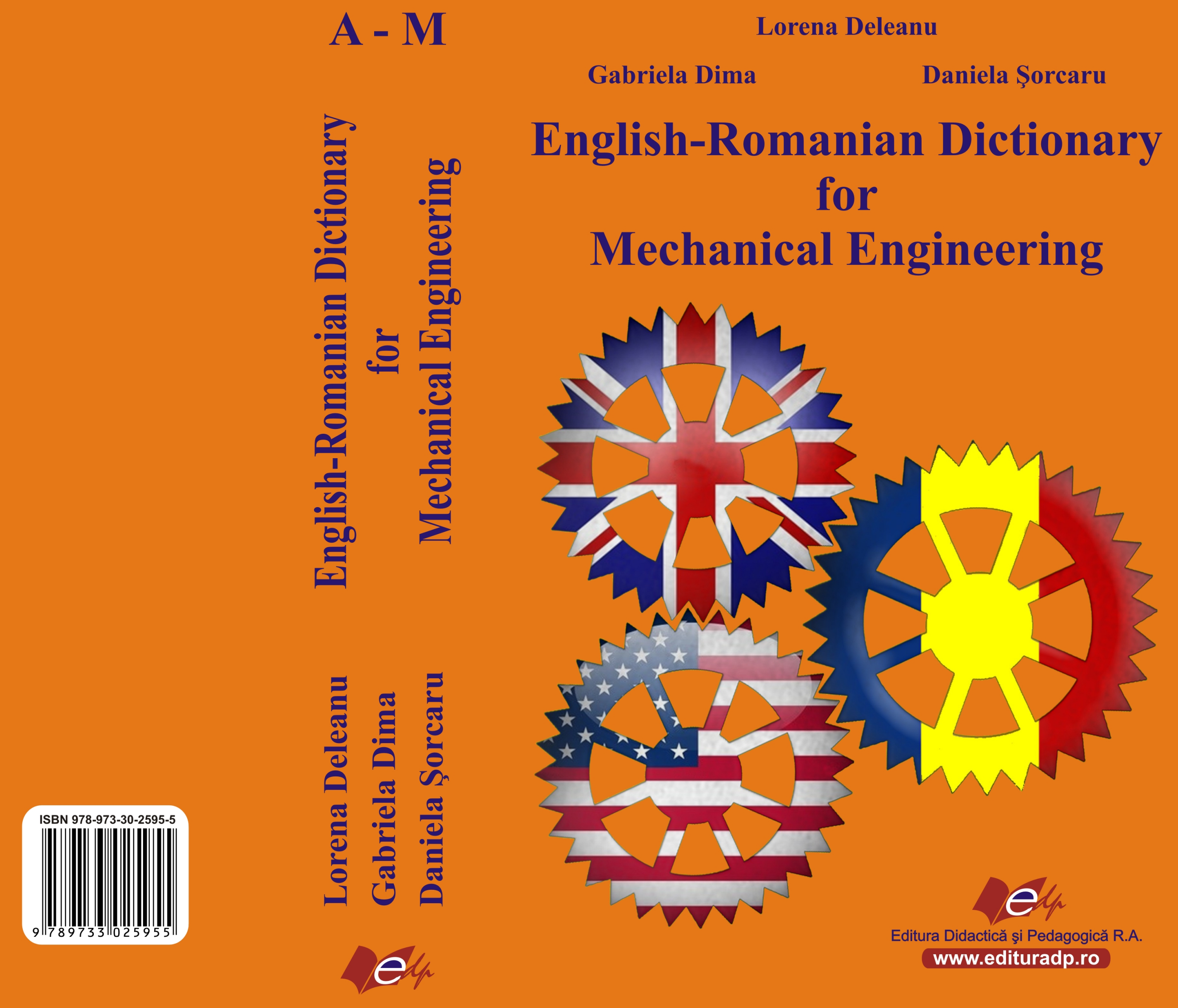




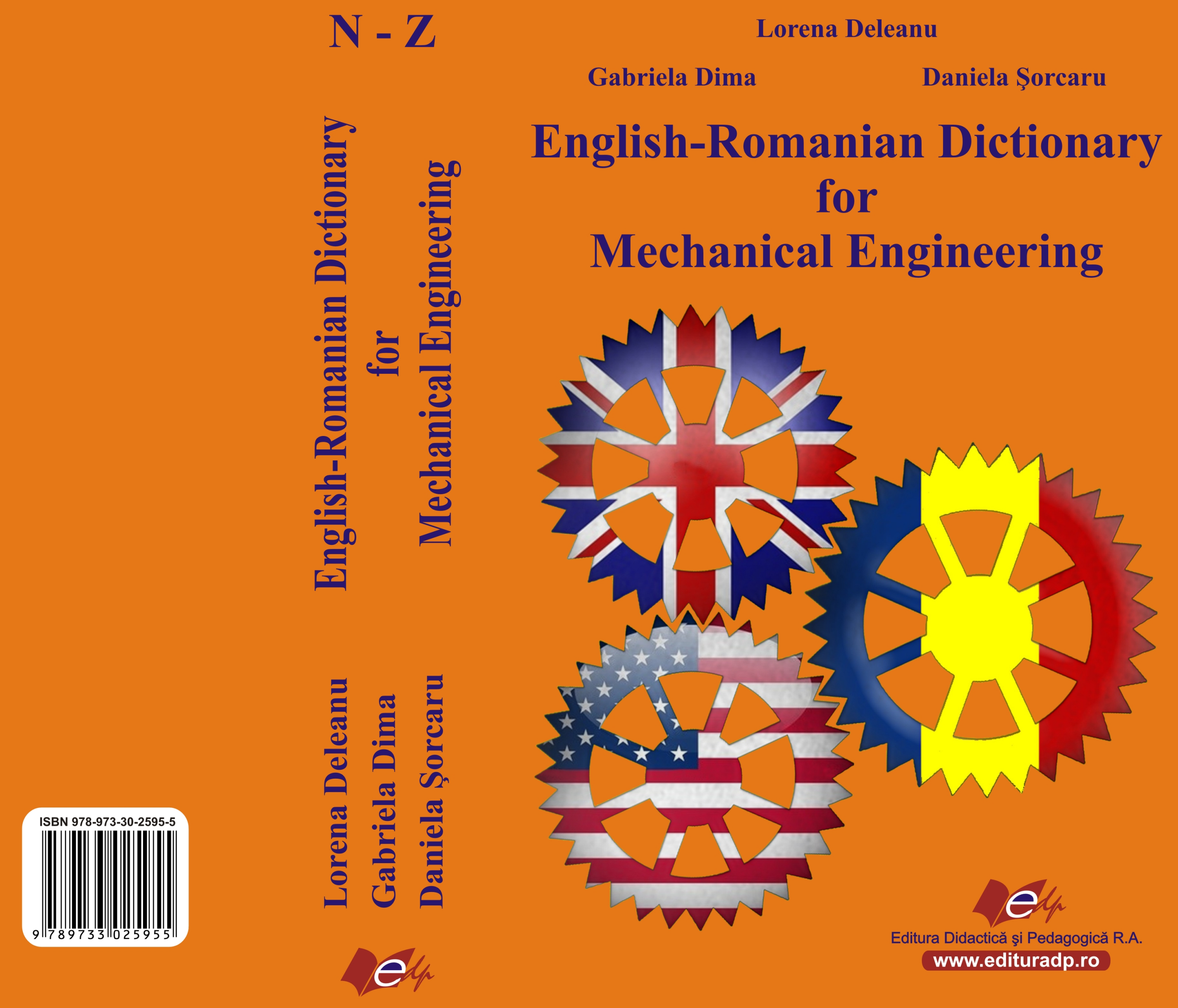




\section{Lorena DELEANU}

Gabriela DIMA

Daniela Şorcaru

English-Romanian Dictionary

for

Mechanical Engineering 

Prof. dr. ing. Lorena DELEANU

Conf. dr. Gabriela DIMA

Lector dr. Daniela Şorcaru

\title{
English-Romanian Dictionary
}

\author{
for \\ Mechanical Engineering
}

\author{
Volumul I \\ A-M \\ Editura Didactică şi Pedagogică
}

2009 


\section{English-Romanian Dictionary for Mechanical Engineering}

Autori: Lorena Deleanu, Gabriela Dima, Daniela Şorcaru

\section{Referenți ştiințifici de specialitate:}

Prof. dr. Michaela Praisler

Prof. dr. ing. Laurenția Andrei

Universitatea „Dunărea de Jos” din Galați

\section{Editura Didactică şi Pedagogică}

Str. Spiru Haret nr. 12, sector 1, 010176, Bucureşti

Tel.: 02131573 98, 0213133470,0213147073

Copyright@2009 Editura Didactică şi Pedagogică

Toate drepturile rezervate

Nicio parte din această publicație nu poate fi reprodusă, înregistrată sau transmisă în nicio formă, prin mijloace electronice, mecanice, fotocopiere sau altele, fără permisiunea scrisă a autoarelor şi a editurii.

Tehnoredactare şi copertă:

\section{Lorena Deleanu, Octaviana Marin şi Daniela Şorcaru}

Tiparul executat la

S.C. Donstar S.R.L. Galați

Str. 1 Decembrei 1918, nr. 23

Tel./ fax: 0236492587

\section{Descrierea CIP a Bibliotecii Naţionale a României} DELEANU, LORENA

English-Romanian Dictionary for Mechanical Engineering Dicționar englez-român pentru inginerie mecanică

Lorena Deleanu, Gabriela Dima, Daniela Şorcaru

Editura Didactică şi Pedagogică, Bucureşti, 2009

ISBN 978-973-30-2595-5

I. Gabriela Dima

II. Daniela Şorcaru

$81^{\prime} 374.2: 621+669=111=135.1$

\section{ISBN 978-973-30-2595-5}




\title{
PREFAȚĀ
}

\begin{abstract}
„Am devenit conştienți de realitatea multilingvistică în Europa. Dar, poate, nu suntem suficient de conștienți de puterea pe care o poate da societății noastre. Pentru că limbile sunt punți esențiale intre culturi. A învăța o nouă limbă străină înseamnă să explorezi noi moduri de gândire, noi sisteme de valori, să deschidem noi orizonturi spre bogăția altor culturi şi idei.

O cultură a multilingvismului promovează o cultură spre deschidere şi toleranță. Acestea sunt valori cruciale nu numai pentru Europa, ci pentru întreaga lume. Orice viziune internațională realistă asupra viitorului lumii noastre trebuie găsită în acceptarea şi aprecierea diferitelor culturi - şi limbile sunt (în) inima oricărei culturi." Din discursul la lansarea Platformei societătii civile pentru promovarea multilingvismului. Brussels, 23 octombrie 2009

Leonard Orban, Comisar European pentru Multilingvism

1987 - 1992 Facultatea de Management, Academia de Studii Economice din Bucureşti, Economist 1981 - 1986 Facultatea de Mecanică, Universitatea din Braşov, Inginer Diplomat
\end{abstract}

Dicționarul englez-român pentru inginerie mecanică a fost realizat cu scopul de a pune la dispoziția specialiştilor din acest domeniu un instrument util în înțelegerea documentației tehnice de limbă engleză. Această lucrare se adresează studenţilor şi profesorilor de la facultățile de mecanică, dar şi inginerilor, care şi-au însuşit deja vocabularul minimal şi structurile de bază ale limbii engleze. Trebuie să recunoaştem, ca specialiști, ca limba engleză este şi va continua să fie preponderentă în domeniile inginereşti din cauze obiective: o gramatică relativ mai uşor de învățat la nivel mediu, comparativ cu cele ale altor limbi de circulație internațională, utilizarea flexibilă a cuvintelor din vocabularul de bază pentru a reda o informație tehnică specifică unui anumit domeniu, şi nu în ultimul rând faptul că este limba oficială sau acceptată, a celor mai multe economii performante pe plan mondial. Alcătuirea acesteia se bazează pe principiul conform căruia un dicţionar bilingv de specialitate trebuie să aibă în primul rând un caracter practic, de aici rezultând alegerea şi organizarea materialului lingvistic prezentat.

Dicționarul cuprinde peste 78000 de termeni (cuvinte simple sau compuse, expresii şi colocații ample) din care domeniului mecanic îi revin aproximativ 55\%.

Din experiența acumulată, autoarele au constatat că ,au câştigat teren” şi în ingineria mecanică, termeni aparținând tehnologiei informației, metrologiei, al testării materialelor şi echipamentelor, metodelor de analiză şi evaluare a calităţii produselor şi serviciilor, din domeniul referitor la protecția mediului, evoluție care evidenţiază dinamica şi ponderea acestora pentru ingineria mecanică, dar şi importanţa studiilor şi realizărilor interdisciplinare, rezultând o creştere procentuală a termenilor din inginerii „,nemecanice”, comparativ cu lucrări similare apărute doar cu câțiva ani în urmă. In plus, s-a considerat necesară introducerea unor cuvinte şi expresii pentru ştiințe exacte (matematică, chimie, fizică), domenii tehnice conexe sau interdisciplinare (electrotehnică, automatizări, metrologie, industria şi exploatarea autovehiculelor, simbolizat - auto, metalurgie etc.), ştiințe economice şi juridice, managementul afacerilor, corespondență, pe care un inginer, indiferent de specialitate, le poate întâlni în activitatea sa. Nu au fost omişi nici termeni generali, „netehnici”, a căror prezență în 
dicționar se justifică în funcție de utilizare prin comparație cu cei tehnici, parcurgând drumul de la lexicul comun la lexicul specializat.

Iată câteva exemple: cuvântul green este adjectiv atât în limba engleză, cât şi în limba română. Sensul lui denotativ de bază indică culoarea, după cum arată şi intra-rea de dicționar; la acest sens s-a adăugat şi cel de crud; sensurile specializate aparțin domeniilor construcțiilor şi utilajelor specifice: construcții - jilav, umed, metalurgie umed, verde (referitor la formele de turnare), (piesă) netratată / nevulcanizată / neîntărită (materiale plastice termorigide) etc. Cuvântul chip este prezentat direct ca termen specializat, cu următorii echivalenți în limba română: ca substantiv, însemnând aşchie în tehnologii mecanice, în special de aşchiere, pastilă, substrat al unui circuit integrat, aşchie de siliciu microelectronică în domeniul electronicii, deșeu rezultat din perforarea unei benzi de hârtie în informatică, birotică, şi aşchie, fragment, surcică, şipcă, draniță, şindrilă în domeniul de tehnică generală (simbolizat prin TH); ca verb, având drept echivalenți verbele $a$ aşchia, a tăia; a dăltui, a ciopli, a rindelui folosite în domeniul ingineriei mecanice în tehnologii de prelucrare pe maşini-unelte (simbolizat prin mas-un). Cuvintele compuse şi sintagmele nominale incluzând colocaţiile unui termen au fost traduse clar, riguros, prin explicitare, tinând cont de specificul procesului fizic, chimic, mecanic, tehnologic etc., prezentat în documentație sau al echipamentului la care se referă: car wheel boring machine (mas-un): strung-carusel pentru strunjirea interioară a bandajelor roților; air extract nozzle cap (auto): căpăcelul de la niplul de aerisire a filtrului de combustibil. Într-un procent destul de mare, dicționarul oferă echivalenți ai termenilor specializați, exprimați prin grupuri nominale şi verbale complexe, selectați prin traducerea directă a documentației tehnice sursă, îmbogățind cu mult informația sumară (făcându-se referire aici la lexemele simple), conținută în alte dicționare, tehnice sau nu.

Selectarea cuvântului sau expresiei celei mai potrivite în limba română ca echivalent al unui termen din textul tehnic în limba engleză depinde de context, dar şi de cultura tehnică generală şi de specialitate a traducătorului (în sens larg) şi de dicționarul avut la dispoziție.

Procedeele lexicografice utilizate în alcătuirea dicționarului au fost următoarele:

- prezentarea termenilor în ordine alfabetică, atât în cazul cuvintelor simple, cât şi al celor compuse, derivate, şi în colocații, toate aparținând atât domeniilor specializate, dar şi limbajului general, prin includerea unor cuvinte şi expresii specifice limbii engleze şi cu frecvență mare în utilizare;

- precizarea domeniului în care se foloseşte un anumit termen din limba engleză se face prin utilizarea parantezelor rotunde ( ) înaintea traducerii şi a sensurilor corespondente din limba română; dacă un cuvânt este folosit în mai multe domenii, acestea sunt separate prin punct şi virgulă (;)

- utilizarea virgulei (,) pentru traduceri care au sensuri apropiate, sinonime sau cu referire la acelaşi domeniu;

- utilizarea barei înclinate simple (/) pentru despărțirea de cuvinte alternative sau sinonime care, prin traducere, se pot schimba între ele; 
- utilizarea semnului punct şi virgulă (;) pentru separarea traducerilor cu sensuri mai îndepărtate (aparținând, eventual, unor domenii diferite cu indicarea, dacă este necesar, a simbolului domeniului respectiv) şi pentru a exprima categorii gramaticale diferite (substantiv, adjectiv, verb etc.); uneori, dacă o familie de cuvinte incluzând substantiv, adjectiv, verb, se referă în mod deosebit la acelaşi domeniu tehnic, acestea sunt enumerate după simbolul domeniului, cu virgulă între ele, facilitând alegerea termenului potrivit în textul tradus;

- precizarea părții de vorbire căreia îi aparține termenul este făcută parțial, numai acolo unde pot apărea confuzii, dar şi pentru economie de spațiu;

- includerea mărcii $a d v$ (pentru adverb) s-a realizat într-o măsură mai mare, ținând cont de rolul predominant al acestuia în determinarea contextuală a verbului indiferent de domeniu şi pentru că în limba română nu există o regulă similară de formare a adverbelor din alte forme lexicale.

Autoarele țin să reamintească utilizatorilor acestei lucrări că dicționarul nu este, totuşi, un instrument absolut, şi că pot întâlni în texte tehnice cuvinte sau expresii care nu se vor regăsi în acest dicționar. În funcție de experiența profesională şi în domeniul traducerii, de cultura tehnică generală, vor putea recurge, în acest caz, la un sinonim sau o expresie echivalentă pentru a ieşi din acest impas.

Orice dicționar ar trebui recomandat şi folosit ca punct de plecare în această călătorie fascinantă printre barierele lingvistice, impuse de limbile străine, alături de utilizarea judicioasă a resurselor internetului în acelaşi scop. Necesitatea unei atenții sporite în selectarea instrumentelor lingvistice adecvate unei traduceri a unui text este cu atât mai evidentă în cazul specialiştilor din domeniile tehnice, dacă se ia în considerare faptul că vocabularul tehnic evoluează într-un ritm extrem de alert. Nu vă recomandăm utilizarea site-urilor şi soft-urilor pentru traduceri „automatizate”, decât cu foarte mare precauție şi cu o verificare foarte atentă a traducerii astfel obținute; pot apărea schimbări de sens care pot compromite parțial sau chiar în întregime textul original, uneori făcându-1 de neînțeles din punct de vedere logic, introducând riscul de a distruge un echipament complex, de a aplica o tehnologie incorect sau/şi ineficient, de a provoca accidente şi pagube, din cauza traducerii „mecanice” a instrucțiunilor de utilizare, a unui contract cu conditii tehnice restrictive etc.

În plus, chiar pentru specialişti o traducere cu un dicționar tehnic lângă tastatură este mai puțin obositoare decât apelarea la dicționare on-line pentru orice cuvânt sau expresie pe care o doresc clar redactată în limba română.

Lista abrevierilor pentru domeniile din care au fost selectate corpusurile în vederea alcătuirii dicționarului este inclusă în pagina următoare abrevieri pentru domenii.

Dacă aveți comentarii sau opinii asupra materialului prezentat, dacă sunteți în fața unei situații care este mai greu de încadrat, după consultarea acestei lucrări, nu ezitați să ne contactați:

lorena.deleanu@ugal.ro,

gabriela.dima@ugal.ro,

daniela.sorcaru@ugal.ro 
Abrevieri pentru domenii

\begin{tabular}{|c|c|c|c|}
\hline $\mathrm{adm}$ & $\begin{array}{l}\text { administrație centrală şi locală, servicii } \\
\text { publice etc. }\end{array}$ & \multirow[t]{2}{*}{$\begin{array}{l}\text { mate- } \\
\text { riale }\end{array}$} & \multirow{2}{*}{$\begin{array}{l}\text { ştiința materialelor, proprietăți (metale, } \\
\text { aliaje, ceramice, materiale plastice, } \\
\text { compozite); rezistența materialelor }\end{array}$} \\
\hline \multirow[t]{2}{*}{ agr } & \multirow{2}{*}{$\begin{array}{l}\text { agricultură (inclusiv zootehnie, } \\
\text { horticultură, viticultură etc.) }\end{array}$} & & \\
\hline & & \multirow[t]{2}{*}{ mec } & \multirow{2}{*}{$\begin{array}{l}\text { mecanică (cinematică şi dinamică), } \\
\text { rezistența materialelor }\end{array}$} \\
\hline \multirow[t]{3}{*}{ alim } & \multirow{3}{*}{$\begin{array}{l}\text { industrie alimentară (produse } \\
\text { alimentare, procese, echipamente), } \\
\text { alimentație publică }\end{array}$} & & \\
\hline & & med & medicină \\
\hline & & \multirow[t]{3}{*}{ mediu } & \multirow{3}{*}{$\begin{array}{l}\text { protecția mediului, poluarea mediului: } \\
\text { colectarea, prelucrarea, reciclarea } \\
\text { deşeurilor etc. }\end{array}$} \\
\hline anat & anatomie, fiziologie & & \\
\hline arhit & arhitectură & & \\
\hline auto & $\begin{array}{l}\text { industria construcției de autoturisme, } \\
\text { exploatare, mentenanță }\end{array}$ & met & $\begin{array}{l}\text { metalurgie, tehnologii pentru obținerea } \\
\text { şi prelucrarea aliajelor metalice }\end{array}$ \\
\hline autom & automatizări, sisteme automatizate etc. & meteo & meteorologie \\
\hline av & aviație, industria aeronautică, aeroport & \multirow[t]{2}{*}{ metr } & \multirow{2}{*}{$\begin{array}{l}\text { metrologie, metode de testare, aparate } \\
\text { de măsură }\end{array}$} \\
\hline biol & biologie & & \\
\hline bot & botanică & mil & domeniu militar \\
\hline $\mathrm{c}$ & ştiința calculatoarelor & minrl & mineralogie \\
\hline ef & căi ferate & \multirow[t]{2}{*}{ nav } & \multirow{2}{*}{$\begin{array}{l}\text { domeniu naval, construcția şi exploata- } \\
\text { rea navelor, instalații portuare etc. }\end{array}$} \\
\hline \multirow[t]{2}{*}{ constr } & \multirow{2}{*}{$\begin{array}{l}\text { construcții civile şi industriale, } \\
\text { drumuri, şosele etc. }\end{array}$} & & \\
\hline & & $\mathrm{OM}$ & organe de maşini, proiectare \\
\hline \multirow[t]{2}{*}{ ec } & \multirow{2}{*}{$\begin{array}{l}\text { economie (management, finanțe, } \\
\text { marketing etc.) }\end{array}$} & opt & optică \\
\hline & & \multirow[t]{2}{*}{ plast } & \multirow{2}{*}{$\begin{array}{l}\text { materiale plastice: proprietăți, tehnolo- } \\
\text { gii de obținere, aplicații }\end{array}$} \\
\hline edu & educație (preuniversitară, universitară) & & \\
\hline fiz & fizică & pol & politică, administrație publică etc. \\
\hline geogr & geografie & radio & radio \\
\hline geol & geologie & SI & sistemul internațional de unități de \\
\hline geom & geometrie & & măsură \\
\hline gram & gramatică & silv & silvicultură, inclusiv utilaje şi procese \\
\hline hidr & hidraulică, pneumatică (aparate, siste- & & de prelucrare a lemnului \\
\hline & me, procese), construcții hidrotehnice & $\mathrm{T}$ & tribologie, lubrifiere \\
\hline & şi echipamente destinate acestora etc. & termo & maşini termice, motoare, maşini cu \\
\hline iht & ihtiologie & & abur, compresoare etc. \\
\hline ind & industrie, în general & textile & textile, industria textilă, de confecții, \\
\hline ind & industria chimică, instalaţii şi procese & & \\
\hline chim & specifice, inclusiv cea a petrolului & $\mathrm{TH}$ & tehnic (în general): tehnologii diverse \\
\hline inf & informatică & $\operatorname{transp}$ & transport (maritim, rutier etc.), instalații \\
\hline jur & domeniu juridic, drept & & de transport şi ridicat \\
\hline mas & maşini în general, maşini şi instalaţii de & TV & televiziune \\
\hline & proces din diverse domenii, mentenanță & univ & mediul universitar \\
\hline mas- & maşini-unelte, scule, dispozitive pentru & zool & zoologie \\
\hline & $\begin{array}{l}\text { diverse procese de prelucrare (aşchiere, } \\
\text { deformare la rece etc.) }\end{array}$ & Nu sunt & $\begin{array}{l}\text { cluse domenii care sunt scrise făă abrevieri, } \\
\text { e, cum ar fi: astronomie, tipografie, }\end{array}$ \\
\hline mat & matematică & & \\
\hline
\end{tabular}

Abrevieri pentru categoriile lexicale şi gramaticale sau pentru diferite registre

\begin{tabular}{|l|l|}
\hline$\sim$ & $\begin{array}{l}\text { cuvântul sau expresia în limba engleză, } \\
\text { scris(ă) la începutul paragrafului }\end{array}$ \\
\hline$a d j$ & adjectiv \\
\hline$a d v$ & adverb \\
\hline$a m e r$ & în engleza americană \\
\hline brit & în engleza britanică \\
\hline conj & conjuncție \\
\hline$d$. & despre \\
\hline fam & familiar \\
\hline fig & (în sens) figurat \\
\hline lingv & lingvistică \\
\hline
\end{tabular}

\begin{tabular}{|l|l|}
\hline$p l$ & plural \\
\hline prep & prepoziție \\
\hline pron & pronume \\
\hline$p t$. & pentru \\
\hline$s$ & substantiv \\
\hline$s g$ & singular \\
\hline$s m b$. & somebody \\
\hline$s m t h$. & something \\
\hline$v$ & verb \\
\hline v. & $\begin{array}{l}\text { vezi (urmează un cuvânt sau o expresie, } \\
\text { scris(ă) boldat) }\end{array}$ \\
\hline
\end{tabular}




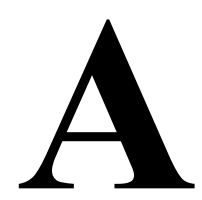

a (=area) arie, suprafată

A (=Ampere) (metr, fiz) amper

AAE (American Association of Engineers) Asociația Americană a Inginerilor

aback înapoi, pe / în spate

abandon abandonare, păăsire; a abandona, a părăsi, a renunța

abandonment (nav) abandon

abate (met) a (se) calma; a reveni, a face o revenire; (termo) a slăbi, a micşora (focul, arderea);

(TH) a risipi (fumul), a abate, a reduce, a slăbi

abatement slăbire, reducere; (chim, met) calmare; (ec) rabat, bonificație; (met) revenire; (termo) slăbirea focului / arderii; risipirea (fumului); descreştere, scădere, diminuare, micşorare; (alim) domolire (şi la limpezire)

abater (OM) amortizor

abattoir (alim) abator

abat-vent (constr, met) apărătoare de coş

Abbe refractometer (metr, fiz) refractometru (tip) Abbe

Abbott-Firestone curve ( $T$, profilometrie) curba portantă a profilului, curba Abbott-Firestone (atenție, poate şi exprimată pentru măsurători ale topografiei suprafeței 2D sau 3D)

abbreviate a prescurta, a abrevia

abbreviation abreviere, prescurtare

ABC elemente de bază, elementar

abeam (nav) (la) travers

abecederaian (edu) în ordine alfabetică; începător; elementar, rudimentar

Abel closed tester (chim, T) aparat Abel-Pensky închis

aberrance aberație, abatere, anomalie, deviație, deviere; vină, greșeală

aberrant aberant, care greşeşte

aberration; abberancy aberatie, abatere, anomalie, deviație, deviere, denaturare

abhesion antiaderență (şi la tehnologii de lipire)

abide a locui; a sta; a rămâne; a persista; a răbda (ceva, pe cineva); a se supune; a aştepta (ceva); a tolera; by a rămâne credincios, a se baza pe abiding trainic, de durată; stăruitor, perseverent ability capacitate, aptitudine, proprietate; posibilitate; putere; tărie; (ec) solvabilitate; abilitate; posibilități; îndemânare; iscusință; $(p l)$ talente; aptitudini ability test (edu, TH, mil) examen de aptitudine ability to flow $(\mathrm{T}, \mathrm{TH})$ fluiditate, capacitate de a curge / de curgere

ability to maintain cutting power (mas-un) durabilitate a sculei / a tăişului, capacitatea de a menține calitatea aşchierii în timp

ability of a film of lubricant to resist rupture (T) capacitatea unei pelicule de lubrifiant să reziste ruperii

ability of a lubricant to reduce friction ( $T$ ) capacitatea unui lubrifiant de a reduce frecarea ability of supply capacitate de aprovizionare ability of the oil to wet the surfaces (T) capacitatea unui ulei de a uda suprafetele ab initio de la început

ABMTM (Associated British Machine-Tool Markers) Societatea Britanică a Producătorilor de Maşini-Unelte

ablation (procedeu / tehnologie de) scoatere / îndepărtare de material de pe suprafața unui corp (prin vaporizare, topire, aşchiere etc.); excludere

ablative material (termo) material special pentru acoperiri asigurând protecție termică

ablaze aprins, cuprins de flăcări; strălucitor able capabil, apt; dotat; competent; calificat

able to work gata / apt / capabil de lucru / de muncă (d. un muncitor / operator etc.)

abnormal anormal, neregulat; $(\mathrm{TH})$ necorespunzător (calitativ, dimensional); aberant; greşit

abnormality, abnormity anormalitate, anomalie, neregularitate; deviere; diformitate

abnormal steel (met) oțel necorespunzător aboard (ship) (nav) la bord

abolish a desființa, a anula; a abroga

abort a renunța la o comandă / acțiune, a întrerupe (brusc) o activitate / o procedură; a eşua; eşec, nereuşită, insucces

abortion eşec, nereuşită, insucces; renunţare (la o comandă / procedură)

about $(a d v)$ circa, aproximativ, cam; ca şi; în jur; (de jur) împrejur; pe ici; pe colo; în diferite părți; peste tot; în toate părțile; aproape; nu departe; prin împrejurimi; (prep) despre, de; cu privire la; în jurul, împrejurul, aproape (de), în preajma, prin, asupra, la, cam pe la, către, pe punctul de a, ocupat cu, în curs de a face; a pierde timpul aiurea; prezent; sus; deasupra; de deasupra; dincolo de, mai mult decât; (în text) de mai sus, de mai înainte, anterior, precedent about length (TH, metr) lungime aproximativă about-sledge hammer (met) baros

above-critical (fiz, el, mec, met) supercritic, supracritic 
above-freezing (alim, fiz, termo) peste punctul de congelare

above-grade de calitate excepțională

above-ground (geol) de suprafață; (de) pe sol; la suprafață, suprateran, aerian

above idle speed (auto) (d. un motor) turat

above-ground suprateran, la / de pe suprafața pământului

above-mentioned mai sus-mentionat

above par de calitate excepțională; peste nivelul obişnuit

above the level deasupra nivelului

abr. (abridged) prescurtat

abradability abrazivitate

abradability index ( $\mathrm{TH}$, mas-un, $\mathrm{T}$ ) indice de abrazivitate

abradant abraziv (rar)

abrade (mas-un) a pregăti o suprafață în sensul măririi rugozității (pentru a facilita următoarea operație: acoperire, placare etc.), a şlefui, a curăța cu material abraziv; a răzui; a poliza; (met) a coji (semifabricate metalice)

abrader $(\mathrm{T})$ maşină de încercat la abraziune abrading curăţire cu abraziv, şlefuire

abraser abraziv, material abraziv

abrasion abraziune, şlefuire, polizare (mec) răzuire; (T) uzură abrazivă; (auto) contuzie

abrasion coefficient ( $T$ ) coeficient (şi parțial) de frecare la abraziune

abrasion hardness $(T$, mec) duritate / rezistență la abraziune

abrasion pattern (mec, $\mathrm{T}$ ) model de (realizare a procesului de) abraziune

abrasion proof $(\mathrm{mec}, \mathrm{T})$ rezistent la abraziune

abrasion resistance $(\mathrm{mec}, \mathrm{T})$ rezistență la abraziune

abrasion resistant / resisting (mec, $\mathrm{T}$ ) rezistent la abraziune / la uzură abrazivă

abrasion test $(T)$ test de rezistență la abraziune

abrasion tester (T) aparat / tester / dispozitiv de încercare la abraziune

abrasion testing (T) încercare / testare la uzură (abrazivă)

abrasive abraziv; (met) nisip de sablare, material de şlefuit; material abraziv

abrasive belt (mas-un) bandă / curea abrazivă

abrasive belt grinding machine (mas-un, T) maşină de rectificat cu bandă abrazivă

abrasive blade disc abraziv

abrasive blasting (met) împroşcare / curățare cu material abraziv

abrasive brick (mas-un) pilă abrazivă

abrasive cleaning (met) curățire prin sablare, sablare abrasive cloth (mas-un) pânză de şmirghel / abrazivă

abrasive cutting(-off) machine (mas-un) maşină de debitat cu disc abraziv

abrasive cutting(-off) wheel (mas-un) disc abraziv pentru debitare

abrasive disc / disk (mas-un) disc abraziv, piatră abrazivă / de polizor

abrasive dust (mas-un) praf de şlefuit, pulbere abrazivă

abrasive hardness (T) duritate la striere / la uzură prin frecare

abrasive material (mas-un, $\mathrm{T}$ ) material abraziv

abrasive paper hârtie abrazivă / de şmirghel

abrasive paste $(T)$ pastă abrazivă / de rodaj

abrasive powder (mas-un, T) pulbere abrazivă, şmirghel

abrasive resistance (materiale, T) rezistență la uzură abrazivă

abrasive surface (mas-un, T) suprafață abrazivă abrasive water (mediu, hidr) apă corosivă / cu impurități mecanice

abrasive wear (T) uzură abrazivă / de abraziune abrasive wheel (mas-un) piatră de rectificat, disc abraziv / de polizor

abridge a prescurta (un cuvânt, o expresie etc.), a reduce, a abrevia; a micşora; a limita, a restrânge (si drepturi); a lipsi

abridgement (pre)scurtare, micşorare; rezumat; conspect

abrogate a abroga, a anula, a suprima; a desființa

abrogation abrogare, desființare

abrupt abrupt, brusc

abruption (met) rupere, spărtură, întrerupere (la sudură)

abruptly $(a d v)$ (în mod) abrupt, brusc, pe neaşteptate

abrutness bruschețe (la comenzi); aspect / caracter abrupt

ABS (Acrylonitrile Butadiene Styrene) (chim, plast) polimer acriconitril-butadien-striren

abscissa, $(p l)$ abscissae (mat) abscisă

absence absență, lipsă

absence of air (TH) lipsă de aer; închidere ermetică

absence of diffusion (fiz) absența difuziei

absence of twist $(\mathrm{OM})$ fără / lipsă de torsiune

absent absent; inexistent; neatent, distrat

absinth wine (alim) vin-pelin

absolute absolut, deplin, total; complet, perfect; nelimitat; curat

absolute accuracy (metr) precizie / exactitate absolută 
absolute accuracy error (metr) eroare absolută, abatere de la valoarea teoretică

absolute calibration (metr) etalonare / calibrare absolută

absolute error (metr) eroare absolută

absolute feedback (autom, el, mas-un) alocarea unei valori unice pentru orice poziție posibilă a maşinii sau a unui dispozitiv

absolute heating effect (fiz, termo) putere calorică absolută

absolute humidity (fiz, TH) umiditate absolută

absolute insensitivity (metr) insensibilitate absolută

absolute level nivel absolut

absolutely dry (fiz) absolut uscat

absolute measurement (metr) valoare măsurată în unități fundamentale de măsură

absolutely dry (alim, ind chim) absolut uscat

absolute permeability (el, fiz) permeabilitate absolută

absolute permitivity (el) permitivitate absolută absolute pressure (hidr, metr) presiune absolută absolute pressure instrument (hidr, metr) manometru / traductor pentru presiune absolută

absolute sealing $(\mathrm{OM})$ etanşare totală / perfectă

absolute temperature (fiz, termo) temperatură absolută

absolute zero (fiz, metr) (temperature) zero absolut $\left(=-273,16^{\circ} \mathrm{C},=0^{\circ} \mathrm{K},=-459,69^{\circ} \mathrm{F}\right)$

absonant discordant; contrar, opus; irațional absorb a absorbi, a aspira, a suge, a prelua, a consuma; (mec, hidr) a amortiza (şi vibrații)

absorbability capacitate de absorbție

absorbable (fiz, hidr) absorbabil; aspirabil, care poate fi absorbit / aspirat

absorbent absorbant, agent de absorbție

absorbance / absorbency (fiz, hidr) absorbanță, capacitate de absorbtie

absorbed absorbit

absorbed heat (met, termo) căldură absorbită, căldură utilă

absorbed power $(\mathrm{TH})$ putere absorbită

absorbent (chim) absorbitor, absorbant, filtru; (met) material absorbant / utilizat în defectoscopie cu raze $\mathrm{X}$

absorbent carbon (chim) carbon activ

absorbent filter (alim, hidr, ind chim) filtru absorbant

absorbent paper sugativă

absorber (fiz, ind chim, T) (mediu / agent) absorbant

absorber cooler (ind chim, termo) răcitor cu absorbție

absorber washer (ind chim) absorbitor absorbing capacity (chim, hidr, termo) capacitate de absorbtie

absorbing effect (fiz) efect de absorbție

absorbing filter (alim, hidr, ind chim) filtru de absorbție / absorbant

absorbing medium (TH) absorbant, mediu absorbant, agent de absorbtie

absorbing power (hidr, mec, el) putere de absorbție

absorptance (fiz, hidr, mec, el) coeficient de absorbție

absorptiometer (metr, chim) aparat de măsurat absorbția

absorption (fiz, mec, hidr) absorbtie, consumare, tragere (rar); amortizare (a sunetelor, a unui şoc)

absorption bulb (chim) pipetă

absorption capacity (hidr, mec, el) putere absorbantă / de absorbție, capacitate de absorbție

absorption characteristics (fiz) caracteristici de absorbție

absorbtion coefficient (alim) coeficient de absorbție

absorption cooling (fiz, termo) răcire prin evaporarea unui lichid

absorption dynamometer (auto, metr) dinamometru pentru frână

absorption factor / coefficient (hidr, mec, el, termo) coeficient / factor de absorbție

absorption heat (met, termo, fiz) căldură de absorbție

absorption of heat (ind chim, met, termo, fiz, T) absorbția căldurii

absorption of light (fiz) absorbția luminii

absorption of power (el) absorbtie / preluare de putere; (chim) capacitate / putere de absorbție

absorption of ultraviolet light (fiz) absorbția luminii ultraviolete

absorption of vibrations (mec) amortizare a vibrațiilor

absorption oil ( $\mathrm{T}$, chim) ulei de absorbție

absorption pipette (chim) pipetă

absorption power (fiz, mec, hidr, termo) capacitate / putere de absorbtie

absorption(-type) refrigerating machine (alim, termo) maşină / instalație frigorifică cu / prin absorbtie

absorptive (fiz, mec, hidr, termo) care absoarbe, absorbant, de absorbție

absorptive form lining (constr) cofraj absorbant absorptive height (hidr) înălțime de aspirație a pompei

absorptive power (fiz, mec, hidr, termo) putere absorbantă / de absorbție 
absorptivity putere de absorbție / absorbantă abs.t. (absolute temperature) (fiz) temperatură absolută

abstain a se abține, a se reține (de la)

abstergent (chim) detergent, curățitor; (med) dezinfectant

abstract extras; rezumat, adnotație; (mat) abstract, abstracție, conspect; teoretic, virtual; a separa, a rezuma, a extrage (şi aur din minereu), a scoate; (chim) a distila; a evacua; a abstractiza; a face un rezumat / conspect; doctrină, teoremă

abstracted heat (met, termo) căldură degajată / evacuată

abstracter referent

abstraction abstracție, teorie; (TH) îndepărtare, extragere, scoatere, eliminare, evacuare; sustragere, furt

abstraction of heat (met, termo) eliminare / evacuare a căldurii

abstract theorem (mat) teoremă, lege

absurd absurd, lipsit de logică, irațional, ilogic

abundance abundență; surplus

abundant abundent, din belşug, excedentar

abusive abuziv, greşit

abut $(\mathrm{OM})$ parte frontală, capăt, aşezare a două piese cap la cap; on / upon a (se) mărgini (cu), a se învecina cu; on / against a se sfầrși, a se termina cu / prin, a se sprijini de / pe

abutment margine; contiguitate; (constr) fundație, contrafort, zid de sprijin, limită, graniță; (OM) reazem lateral, suport, reazem, sprijin, punct de reazem / sprijin, contralagăr, umăr de arbore, capăt de arbore; on / upon mărginire cu, învecinare cu

abutment hinge (constr) articulație pe reazem (la poduri)

abutment joint $(\mathrm{OM})$ îmbinare cap-la-cap

abutment line $(\mathrm{mec})$ latură de închidere a poligonului de forțe

abutment tool-block (mas-un) placă articulată de suport a port-cuțitului; placă rabatabilă

abutment wall zid / perete de sprijin

abutting adiacent, alăturat; (met, $\mathrm{OM}$ ) îmbinat cap-la-cap; mărginaș, vecin, limitrof

abutting beam $(\mathrm{mec})$ grindă în consolă

abutting end (met, OM) suprafață a piesei de prelucrat / de îmbinare

abutting joint (met) îmbinare / asamblare frontală / cap-la-cap

ac (acre) (metr) măsură de suprafață: $1 \mathrm{ac}=0,4047$ ha

a.c. (alternating current) (el) curent alternativ acacia (bot) salcâm

acacia gum (chim) gumă arabică academic (edu, univ) academic, universitar; savant; profesor (universitar), cadru de predare academical academic (adj)

academician academician academics discuții pur teoretice academy academie, universitate accede (to) a fi de acord să / cu; a subscrie (la), a fi instalat în functie

accedence (to) instalare în functie; aderare (la o organizație); consințământ, consimțire

accelerate (mec) a (se) accelera, a(-şi) mări viteza; a (se) ambala; a grăbi (şi un proces)

accelerated ageing (met, plast) (proces de) îmbătrânire accelerată

accelerated ageing test $(T$, met, plast) test / încerare de îmbătrânire accelerată

accelerated combustion (termo) ardere accelerată

accelerated corrosion test ( $T$, met, plast) test de coroziune accelerată

accelerated motion $(\mathrm{mec})$ mișcare accelerată accelerated weathering test (chim, plast, constr) test accelerat de rezistentă la intemperii accelerating accelerator, care accelerează accelerating force $(\mathrm{mec})$ forță de accelerație acceleration (mec) accelerare, accelerație; grăbire (şi a unui proces)

acceleration due to gravity (mec) accelerație gravitațională

acceleration from dead rest / stop (mec, auto) accelerare cu viteză iniţială nulă / de pe loc

acceleration from steady speed (mec, auto) accelerare cu viteză inițială

acceleration gap (fiz) interstițiu / fantă de accelerare

acceleration jet (auto, termo) jiclor de accelerație

acceleration lever (auto) manetă de accelerație

acceleration measurement (metr) măsurarea accelerației

acceleration meter (metr) accelerometru

acceleration nozzle (mas, termo) ajutaj accelerator (la turbine)

acceleration of gravity $(\mathrm{mec})$ accelerație gravitațională

acceleration of upgrade velocity (cf) accelerație în rampă

acceleration pump (OM, hidr) pompă de repriză acceleration transducer (metr) traductor de accelerație

accelerative force (mec) forță de accelerație

accelerator (fiz, constr) accelerator de priză; (mas) pedală / manetă de reglare; (chim, met) accelerator, catalizator 
accelerator control pedal (auto) pedală de accelerator / accelerație

accelerator pedal spindle (auto) axul pedalei de accelerație

accelerator pump (auto) pompă de accelerație accelerator pump jet (auto) jiclorul pompei de accelerație

accelerator pump piston (auto) pistonul pompei de accelerație

accelerometer (metr) accelerometru, traductor pentru accelerație

accent accent, accentuare, subliniere, scoatere în evidență; intensitate; trăsătură distinctivă / particulară, particularitate; (ling) accent, fel particular de a pronunța / vorbi; a acentua, a scoate în evidență / în relief

accentuate a accentua, a evidenția, a sublinia, a scoate în evidență / în relief

accentuation scoatere în evidență, accentuare (şi a unui proces), subliniere

accept a accepta; a fi de acord; a recepționa; a admite; a socoti / considera adevărat; a-şi asuma răspunderea; (ec) a accepta o poliță

acceptability calitate acceptabilă, caracter acceptabil, posibilitate de acceptare

acceptability limit limită de acceptare

acceptance / acceptancy / acceptation (ec) accept; (TH) acceptare, receptie (livrare de marfã), aprobare

acceptable conditions condiții acceptabile (de lucru, de exploatare)

acceptance certificate (ec, TH) certificat de recepție

acceptance delivery test $(\mathrm{TH}, \mathrm{ec})$ probă de recepție-predare

acceptance gange (metr) calibru de recepție

acceptance report $(\mathrm{TH})$ proces verbal de recepție

acceptance run (auto) probă de recepție

acceptance stamp $(\mathrm{TH})$ poanson de recepție acceptance test $(\mathrm{TH})$ probă de recepție acceptance testing $(\mathrm{TH})$ verificare de recepție acceptance trial $(\mathrm{TH})$ proba de recepție accepted acceptat; convențional

access (c, inf) intrare a informației; (TH) acces sau deschidere pentru reglare sau reparație; to acces la, intrare la / în, a avea acces la; of atac, criză, izbucnire de

access door (constr) uşă de acces

access hole gaură / locaş de acces

accessibility (mas) accesibilitate

accessibility of the valves (mas, hidr) accesibilitate la supape

accessible accesibil; abordabil; influențabil accessible bribery (ec, jur, pol) coruptibil, care poate fi mituit

accessories (TH, mas, hidr) furnituri, accesorii, armături

accessory (OM) accesoriu, piesă auxiliară; secundar, auxiliar, adiţional; (TH) adaos; (auto) accesoriu

accessory drive (mas) acționare auxiliară accessory equipment (mas) echipament auxiliar accessory material $(\mathrm{TH})$ material auxiliar access ramp (constr, auto) rampă de acces accident (TH, mas) accident, avarie, deteriorare, pană, întrerupere în funcționare; denivelare accidental accidental, întâmplător, aleator, fortuit; (mat) stocastic

accidental error eroare accidentală / ocazională accident insurance (ec, jur) asigurare împotriva accidentelor

accident prevention (TH) prevenirea accidentelor; protecție; tehnica securității muncii accident-prone predispus la accidente accident sensitive $(\mathrm{TH})$ predispus / sensibil la accidente sau la perturbații

acclimate (to) a (se) aclimatiza, a (se) adapta (la)

acclimatization aclimatizare

acclive (constr) înclinat, oblic, în pantă

acclitivity (constr) urcuş, pantă, taluz, rampă; (fig) dificultate, piedică

acclivious în pantă, povârnit, abrupt

accolade (mat) acoladă

accommodate (to) $(\mathrm{TH}, \mathrm{mec})$ a (se) acomoda, a se conforma (d. materiale), a (se) adapta, a ajusta (două piese conjugate), a avea loc pentru accommodating conditions condiții acceptabile accommodation (TH, T) adaptare, acomodare, conformitate, conformabilitate (d. materiale); aplanare a unui diferend; ajutor, înlesnire; locuinţă (casă şi masă); (ec) împrumut; loc (rezervat, la tren, hotel etc.)

accommodation ladder (nav) scară de bord accommodation train tren personal accompany a însoti, a avea loc odată cu accompanying document (ec) foaie de însoțire accompanying metal / element (met) metal / element însoțitor, impuritate metalică accomplice complice

accomplish a face, a efectua, a executa, a îndeplini, a realiza (şi până la capăt)

accomplished sfârşit, terminat; expert; educat, cult(ivat)

accomplishment facere, săvârşire, efectuare, realizare; execuție; ducere la bun sfârşit; completare, randament (rar); $(p l)$ talent(e), înzestrări 
accord acord, unanimitate, armonie; concordanță; convenție; contract; înțelegere; aprobare, asentiment, consimțământ; a pune de acord (cu); a face să concorde (cu)

accord (with) a pune de acord, a face să concorde (cu)

accordance conformitate, concordanță, acord; corespondență; in with în concordanță cu

accordant (with) care concordă cu, în concordanță cu

according conform, potrivit, care este în concordanță / acord (cu)

according as în măsura în care, după cum, în funcție de, dacă

accordgly în consecință, prin urmare, de accea

according to după, ținând seama de; în funcție de; în concordanță cu

according to law conform legii

according to plane (ec) conform planului

according to a rule conform unei (anumite) reguli

accordion tube $(\mathrm{OM})$ tub ondulat / cutat / tip acordeon, siflon

account dare de seamă, prezentare, raport, relatare; explicație; (ec, mat) cont, socoteală, calcul, raport, referat, recenzie, apreciere, evaluare, acont, factură, notă de plată, folos, profit, beneficiu; semnificație; motiv, cauză; avantaj; a considera; a justifica

accountability responsabilitate, răspundere, (ec) caracter decontabil, decontabilitate

accountable explicabil; răspunzător pentru / de accountancy (ec) contabilitate, profesia de contabil accountancy form (ec) formular contabil accountant (ec) contabil; (jur) reclamat, pârât accountant general (ec) contabil şef accountantship (ec) contabilitate account book (ec) registru contabil account current (ec) cont curent

account for a explica, a lămuri, a motiva, a justifica (cu acte), a răspunde (pentru o eroare) accounting (ec) calcul, calculare; contabilitate, tinerea registrului contabil

acre (ac) (metr) unitate de măsură pentru suprafață, acru: 1 acre $=4046,8564224 \mathrm{~m}^{2} ; 1$ acre (US) $=4046,872609874 \mathrm{~m}^{2}$

acredit a acredita, a împuternici

acre-foot (ac.ft) (metr) unitate de măsură pentru volum / capacitate $1 \mathrm{ac} \cdot \mathrm{ft}=1233,481837548 \mathrm{~m}^{3}$

acre-foot/day (ac.ft/d) (fiz, hidr, metr) unitate de măsură pentru debit: 1 acre-foot/day = $0,014276467 \mathrm{~m}^{3} / \mathrm{s}$

acre-foot/hour (ac.ft/h) (fiz, hidr, metr) unitate de măsură pentru debit:1 acre-foot/hour = $0,342635214 \mathrm{~m}^{3} / \mathrm{s}$ acre-foot/year (ac.ft/y) (fiz, hidr, metr) unitate de măsură pentru debit: 1 acre-foot/year = $0,000039114 \mathrm{~m}^{3} / \mathrm{s}$

acre-inch (ac·in) (metr) unitate de măsură pentru volum / capacitate $1 \mathrm{ac} \cdot \mathrm{in}=102,790153129 \mathrm{~m}^{3}$

accrete (chim, met, plast) a concreşte, a creşte împreună

accretion concreștere; depozitare; creștere, spor, adaos; acumulare; (constr) rambleu natural accretions (met) crustă aderentă / solidificată accumulate a (se) acumula, a colecta, a depozita, a (se) strânge, a aduna, a înmagazina, a îngrămădi, a (se) stoca

accumulated error (autom, metr) eroare acumulată

accumulating chamber (termo, chim) cameră de acumulare

accumulation acumulare, depozitare, îngrămădire, înmagazinare, strângere; cantitate mare; volum (de lucru)

accumulation funds (ec) fonduri din acumulări accumulation of energy (mec, termo, hidr) acumulare de energie

accumulation of gaz (met, termo) acumulare de gaze

accumulative strângător; cumulativ, de acumulare; lacom; zgârcit, avar

accumulative process (fiz, TH) proces cumulativ / de acumulare

accumulator acumulator, dispozitiv de acumulare; (inf) sumator; acapartor, avar

accumulator acid (auto) acid pentru acumulator accumulator box (auto) cuvă de acumulator accumulator can (auto) vas de acumulator accumulator capacity (auto) capacitatea acumulatorului

accumulator car (auto) vehicul electric pe bază de acumulatoare, electrocar

accumulator case (auto) cuvă acumulatorului accumulator cell (el, auto) celulă / element de acumulator

accumulator drive (auto) antrenare / tractiune pe bază de acumulatoare

accumulator jar (auto) vas de acumulator

accumulator metal (met) aliaj pentru acumulatoare (cu mult plumb)

accumulator plant (auto, el) stație de încărcat acumulatoare

accumulator plate (auto, el) separator între plăcile acumulatorului

accumulator switch (auto, el) întrerupător al acumulatorului

accumulator tank rezervor de colectare, bazin colector 
accumulator terminal (auto, el) borne de acumulator

accumulator tester (auto, el) dispozitiv de testat acumulatori

accumulator traction (auto, el) tracțiune prin acumulatoare

accuracy acuratețe, exactitate, precizie; (metr) precizie (expresie globală a aparatului sau metodei)

accuracy class (TH, OM, metr) clasă de precizie / de exactitate

accuracy in measurement precizie în măsurare accuracy of alignment (OM, metr) precizia alinierii (arborilor sau a două piese etc.)

accuracy of measurement (metr) precizie de măsurare

accuracy of regulation (autom, metr) precizie / exactitate de reglare

accuracy of shape precizia formei

accuracy of size exactitate / precizie dimensională, stabilitate / constantă a dimensiunilor

accurate exact, precis, corect

accurate adjustment (OM, metr) ajustaj precis; reglare precisă / fină / exactă a unui aparat sau a unui montaj

accurate to gauge (metr, OM) cu dimensiuni conforme calibrului

accusation acuzare, învinuire; acuzatie, vină

accustomed obişnuit, uzual

accustomed to obişnuit / deprins cu

accustom to a (se) obişnui / deprinde cu

a.c.-d.c. comparator (metr) comparator de curent alternativ - curent continuu

A / C display display / ecran pentru

ace as (în sens de foarte bun); campion; expert; fărâmă, părticică; de prim rang, de prima calitate (d. pise, produse etc.)

acerb (alim) acru, astringent; (fig) aspru, caustic, tăios

acerbity (alim) acreală, gust acru

acetal (chim, plast) acetal(ic)

acetal copolymer (ind chim, plast) copolimer acetal(ic)

acetaldehyde (chim) acetaldehidă

acetate (chim) acetat

acetic (chim) acetic

acetic acid (chim) acid acetic

acetic salt (chim) sare a acidului acetic

acetify (chim) a se oxida

acetone (chim) acetonă

acetylene (chim) acetilenă

acetylene bottle $(\mathrm{TH})$ tub de acetilenă

acetylene burner (met) arzator pentru acetilenă; bec de sudură cu acetilenă acetylene cutting (met) tăiere cu acetilenă / cu flacără

acetylene generator (met) generator de cu acetilenă

acetylene-oxyhydrogen cutting torch ( $\mathrm{TH}$, met) suflai pentru tăiere oxiacetilenică

acetylene welding (met) sudare oxiacetilenică / autogenă

acetyl silk (plast) mătase acetat / artificială

achievable realizabil

achieve a realiza, a efectua, a face, a duce la bun sfârşit; a atinge (un scop); a dobândi un succes

achievement realizare, efectuare, îndeplinire; lucru / sarcină terminat(ă) / îndeplinit(ă)

achromatic (fiz) acromatic, fără culoare

acicular (met) acicular, columnar

acicular gray cast iron (met) fontă cenuşie cu structură aciculară

acicular martensite (met) martensită aciculară

acicular troostite (met) troostită aciculară

acid (chim) acid; acru, acid

acid and basic hearth-converting process (met) proces (acid-bazic) de convertizor

acid-base reaction (chim) reacție între acizi şi baze

acid bath (met, ind chim) baie acidă

acid beach (ind chim) spălare cu acizi

acid Bessemer converter (met) convertizor Bessemer

acid Bessemer pig iron (met) fontă în blocuri pentru convertizor Bessemer

acid Bessemer process (met) procedeu / proces Bessemer (de obținere a oțelului)

acid Bessemer steel (met) oțel Bessemer

acid bottom / hearth (met) vatră acidă (a unui cuptor

acid brick (met) cărămidă antiacidă / rezistentă la acizi

acid brittleness (met) fragilitate acidă

acid concentration (alim, chim) concentrația acidului

acid converter (met) convertizor acid / Bessemer acid converter process (met) procedeu Bessemer acid converter steel (met) otel Bessemer acid-core solder (met) fludor (pentru lipituri)

acid cure (plast) vulcanizare în mediu acid

acid-fast (chim) rezistent la acid

acid fermentation (alim, ind chim) fermentație acidă

acid flux (met) zgură / flux acid

acid free (alim, chim) fără acid

acid-free grease $(T)$ unsoare cu cifră de neutralizare aproape zero / unsoare neutră

acidic (chim) (cu caracter) acid, de acid 
acid fumes (fiz, ind chim) vapori de acid acidification (alim, chim) acidulare, acrire acidified acidulat acidify a acidula, a (se) oxida acidifying (chim) acidulare acidity aciditate acidity index (chim) indice de aciditate acid iron (chim) anion acidizing acidizare acidless (chim) fără acizi acid lining (met) căptuşeală acidă acid-melting process (met) procedeu acid (în cuptor Martin)

acid number ( $\mathrm{T}$, chim) indice de aciditate (la asoluţii / unsori)

acid oil (ind chim, T) ulei acid

acid open-hearth furnace (met) cuptor Martin acid / Siemens-Martin acid (de obținere a oțelului)

acid open-hearth process (met) procedeu Martin acid de obținere a otelului

acid open-hearth steel (met) oțel Martin acid acid pickling (met) decapare (în soluție acidă) acid pig (met) fontă acidă

acid process (met) procedeu acid

acid-proof (chim) rezistent la acid (met) anticorosiv, anti(-)acid

acid-proof brick (chim, met) cărămidă antiacidă / rezistentă la acizi

acid-proof cast iron (met) fontă antiacidă

acid-proof cement ciment antiacid

acid-proof cloth țesătură rezistentă la acizi

acid-proof lining (ind chim, met) căptuşeală / acoperire antiacidă / rezistentă la acizi

acid-proof material / metal (materiale, chim) material / metal antiacid / rezistent la acizi

acid protection (ind chim, met) protectie antiacidă

acid pump (hidr, ind chim) pompă pentru acizi / rezistentă la acizi

acid radical (chim) radical acid

acid rain ploaie acidă

acid reaction (chim) reacție acidă

acid residue (chim) reziduu acid

acid resistance (chim, plast, met) rezistență / stabilitate la acizi

acid-resistant / -resisting (materiale, chim) rezistent la acizi, antiacid, anticorosiv

acid-resistant / -resisting castings (met) piese turnate rezistente la acizi

acid-resistant / -resisting cast iron (met) fontă rezistentă la acizi / antiacidă

acid-resistant / -resisting steel (met) oțel (inoxidabil) rezistent la acizi / antiacid acid-resisting material (ind chim) material rezistent la acizi (fără a preciza natura acestuia)

acid-resisting paint vopsea antiacidă

acid-resisting steel (met) oțel (inoxidabil) rezistent la acizi

acid salt (met) sare acidă (la tratamente)

acid seal paint (ind chim) vopsea de protectie contra acizilor

acid slag (met) zgură acidă

acid sludge nămol acid; (chim) răşină acidă

acid solution soluție acidă

acid steel (met) otel acid

acid strength (alim, chim) concentrație / tărie a acidului

acid tar gudron acid

acid test (auto, metr) încercare cu acid

acid treating rafinare, tratare cu acizi

acid treatment acidizare, tratare $\mathrm{cu}$ acid, afinare cu acid

acidulate a acidula

acidulating agent agent de acidulare

acidulation (alim, chim) acrire, acidulare

acid value indice / cifră de aciditate

acid vapour vapori de acid

acid wash (met) spălare cu soluție acidă (şi de acid fosforic)

acid waste reziduuri / deşeuri acide; gudron acid acid water apă reziduală, apă acidă

acierage (met) acoperire / recondiționare / placare cu oțel, oțelire

ackey (met) soluție pentru decapare

acknowledge a confirma; a recunoaşte, a admite, a socoti adevărat; a accepta, a aproba; a confirma (primirea etc.); a adeveri, a certifica; a multumi, a fi recunoscător

acknoledg(e)ment recunoaştere, luare în considerare; acceptare, aprobare; confirmare (şi de primire), adeverire, certificare

acme culme, vârf, punct culminant, apogeu

acme thread $(\mathrm{OM})$ filet trapezoidal

acnode (mat) punct izolat

acolyte acolit, ajutor; satelit

acorn nut $(\mathrm{OM})$ piuliță-capac

acoustic(al) (fiz) acustic

acoustic board (fiz) placă de fibră acustică / fonoabsorbantă

acoustic chamber (fiz) cameră acustică

acoustic coagulation (fiz, alim) coagulare în câmp acustic

acoustic emission (fiz, T) emisie acustică

acoustic energy dissipation ratio (fiz) viteză de disipare a energiei acustice

acoustic field (fiz) câmp acustic

acoustic filter (fiz) filtru acustic 
acoustic frequency (fiz) frecvență acustică acoustic intensity intensitate acustică acoustic noise zgomot acustic, semnale parazite provocate de vibrațiile acustice externe acoustic property (fiz) proprietate de acustică / în câmp acustic

acoustic responsiveness sensibilitate acustică acoustics (fiz) acustică; efect(e) acustic(e) acoustic signal (autom) semnal acustic, sonerie acoustic sounder (nav) sondă sonoră acoustic wave (fiz) undă sonoră acoustic wave speed viteza undei sonore acoustimeter (mediu, metr) măsurător pentru nivel de zgomot

acoustoultrasonic testing (metr, met) testare $\mathrm{cu}$ ultrasunete

acquirable care se poate obține / dobândi, achiziționabil

acquire (ec) a achiziționa (şi date), a căpăta, a obține; a-şi însuşi (cunoştințe)

acquirement (edu) dobândire; însuşire (a cunoştințelor); (ec, inf) achiziţie (şi de date)

acquisition (ec, inf) achiziționare, colectare, strângere (şi a datelor, a rezultatelor unor măsurători)

acquisitive strângător, lacom, acaparator; receptiv; studios; asiduu; $(\mathrm{TH})$ care poate achiziționa (date, materiale)

acquisitiveness (tendință de) acaparare, lăcomie; repectivitate; caracter studios, dorință de a cunoaşte / de a şti / de a învăța; (inf, autom) capacitate de achiziție (a datelor)

acquit (of) a (se) achita, a plăti; a scuti de; a elibera de

acre (mat, metr) acru, unitate de măsură pentru suprafață, acru: 1 acre $=4046,8564224 \mathrm{~m}^{2}, 1$ acre $\left(\right.$ US) $=4046,872609874 \mathrm{~m}^{2}$

acrid (TH) ascuțit, caustic, corosiv; înțepător, usturător (la gust); neplăcut, supărător

acrilan (plast) fibră polinil-acrilică

acrimonious acru, caustic

across de-a curmezişul, în curmeziş, transversal; de la o margine la alta; pe partea cealaltă; dincolo; în diagonală; (nav) pe malul / țărmul opus; peste, dincolo de

across the line starter (el, autom) demaror direct cu tensiune totală, starter direct

across the line starting (el) demaraj cu tensiune totală / în plină tensiune

acrylamide, acrylic amid (chim) acrilamidă, amidă acrilică

acrylate (chim) acrilat

acrylic acid (chim) acid acrilic

acrylic fibre (ind chim, plast) fibră acrilică, fibre acrilice acrylic glass (plast) sticlă acrilică, plexi, polimetilmetacrilat (PMMA)

acrylonitrile (ind chim, plast) nitril acrilic, acrilonitril

acrylonitrile-butadiene rubber (NBR) (plast) cauciuc butadien-acrilonitrilic

acrylonitrile butadiene styrene (ABS) (plast) acrilonitril-butadien-stiren (ABS)

acryl resin (plast) răşină acrilică

act act, faptă, fapt; acțiune; manifestare, curs, desfăşurare, fenomen, proces; pas, etapă; act, document, hotărâre; a acționa; on / upon a avea efect (asupra), a se purta, a proceda, a functiona, a juca rolul de

act as a îndeplini funţia de, a reprezenta, a servi drept / ca

act for a acționa în numele cuiva

acting activ, care acționează, operativ; eficace; înlocuitor, suplinitor; temporar, provizoriu

Actinium (Ac) (chim) actiniu

actinism (fiz) actinism, fotosensibilitate

acting manager şef de exploatare

actinoid (chim) (element) actinid

actinism fotosensibilitate, actinism, actinitate

actinoid (chim) actinidă, element din familia actinidelor

action acțiune, faptă, manifestare, pas; măsură; purtare, comportare (şi a unei maşini), funcționare; influență, eficacitate, efect rezultat; $(\mathrm{TH})$ mecanism; activitate, proces

actionable pasibil de acțiune judiciară

action at a distance (autom) acționare de la distanță, telecomandă

action of blast (met) acțiune / efect al aerului suflat / în furnal / cuptor

action of force (mec) efect al forței

action of light (fiz, plast) acțiune / efect a(l) luminii

action of rust (met) efect / acțiune a coroziunii; ruginire

action signal (autom) semnal de actionare

activate a pune în mişcare / în funcțiune, a actiona; (chim) a activ(iz)a, a face radioactiv; (el) a iniția un arc electric, a dinamiza; (mil) a forma şi a completa; a crea

activated (chim) activat (d. o substanță, un catalizator etc.), stimulat

activated carbon cărbune activ

activated stock (plast) amestec (de cauciuc) cu acceleratori

activating agent agent de activare

activation (chim, met) activ(iza)are, dinamizare

activation energy (chim, met) energie de activare, reactivare

activation heat căldură de activare 
activator (chim) activator, activant; (constr) aditiv, adeziv

activator in flotation (ind chim, alim), activator de / in flotaţie

active activ; harnic; energic, vioi, dinamic; eficient, eficace (atenție la text); în activitate, în vigoare (d. legi); (chim) activ (chimic), care intră uşor în reacție, radioactiv; (ec) productiv

active device (autom, hidr) component / element activ / care necesită alimentare independentă de semnalul de intrare

active account (ec) cont activ de operațiuni active carbon (chim) carbon activ

active chlorine (chim) clor activ

active coils $(\mathrm{OM})$ spirele active ale unui arc elicoidal

active component (el) componentă activă

active component of the voltage (el) componentă a tensiunii alternative în fază cu curentul

active cooling surface (alim, ind chim, met) suprafață efectivă de răcire

active filler (plast) agent de întărire

active flank (OM) flanc activ (la dinte)

active gas brazing / soldering (met, $\mathrm{OM}$ ) lipire (tare / cu aliaj metalic) în mediu de gaz reducător

active headrest (auto) tetieră activă /reglabilă în funcție de poziția instantanee a şoferului / pasagerului

active hot-metal mixer (met) melanjor de preafinare

active lime (ind chim) var activ

active load (mec) sarcină activă / efectivă

active maintenance time (TH) timp efectiv / util de mentenanță (pentru depistarea defectelor, reparare, reglare, întreținere şi nu timpul total în care s-a realizat respectivul plan de mentenanță) activeness zel, dinamism, caracter activ

active output (autom, hidr) ieşire dependentă numai de alimentare, oricare ar fi starea în care se află componentul

active profile $(\mathrm{OM})$ profil activ (al dintelui de roată dintată / de clichet etc.)

active transducer (metr) traductor activ

activist activist (în orice domeniu); muncitor care a determinat creșterea productivității; persoană activă / energică

activity activitate, acțiune, mişcare, grad de ocupație, ocupație, profesie, serviciu, exploatare, functionare (a unei maşini); energie, dinamism; influență

activize a dinamiza, a acti(viz)a, a influenta cu; a ține seama de

act of dispatching (ec, $\mathrm{TH})$ acțiune de coordonare act on a actiona asupra, a avea efect asupra actual adevărat, real; concret; existent; efectiv, prezent, util

actual air consumption (ind chim, met, termo) consum / efectiv real de aer

actual axial load $(\mathrm{OM})$ sarcină / forță axială reală actual cut (mas-un) partea utilă a cursei cuțitului, cursa activă / de prelucrare (prin aşchiere) actual efficiency $(\mathrm{TH})$ randament efectiv actual error (mat, metr) eroare reală / efectivă actual grain size (met) mărimea reală a grăuntelui (cristalin)

actual force (TH) forță reală /efectivă transmisă (prin tija unui piston, printr-un mecanism etc.) actual horsepower (mas, TH) putere efectivă (exprimată în cai-putere)

actual hydraulic fluid volume (effective cylinder capacity) (autom, hidr) volum real de fluid hidraulic, cilindree efectivă a cilindrului (unei pompe, unui piston etc.)

actual load $(\mathrm{mec})$ sarcină reală / utilă

actually $(a d v)$ într-adevăr, în realitate; de fapt, totuşi, cu toate acestea; în prezent, în momentul de față

actual measurement (metr) măsurare exactă

actual output (ec, mas, mec) producție / putere efectivă / reală; debit real

actual radial load $(\mathrm{OM})$ sarcină / forță radială reală

actual range (TH) gamă / interval efectiv( $\breve{a}) /$ de utilizare

actual size $(\mathrm{OM}, \mathrm{TH})$ dimensiune / mărime reală / efectivă

actual stress (mec) tensiune efectivă / reală

actual value valoare reală

actuate (TH) a actiona, a pune în misçare / în funcțiune; (el) a iniția un arc electric; a activ(iz)a; a impulsiona, a dinamiza; a stimula, a stârni; a determina, a hotărî

actuated position (autom, hidr, mas) poziție finală actuated time (autom, hidr) timp de execuție / de acționare, timp în care se exercită forțele / procesele de comandă (și automatizată)

actuating (TH) acţionare, punere în mişcare, care acționează

actuating lever $(\mathrm{OM})$ pârghie de acționare / de comandă / de pornire

actuating mechanism mecanism de actionare actuating quantity (autom) mărime / cantitate de actionare

actuating range (autom) domeniu / interval de actionare / de influență / în care intervine actionarea (sistemului) / care comandă acționarea

actuating roll (alim, OM, met) rolă (activă) (de ghidare) la un transportor etc. 
actuating signal (el, autom) semnal de acționare / de comandă

actuation $(\mathrm{TH})$ acționare, comandă, punere în funcţiune (a unei maşini)

actuator (autom) element / servomotor de acționare; (mas, OM) pârghie de pornire, mecanism de actionare

act up (TH) a funcționa prost

acurrent rectifier (el) redresor de curent alternativ acute ascuțit; acut; pronunțat; la ordinea zilei acute angle (mat) unghi ascuțit

acute angled (mas-un, OM) cu unghi ascuțit acute bisectrix (mat) bisectoarea unghiului ascuțit

acute fatigue (ec, TH) oboseală acută (a unui operator); (TH, OM, mec) oboseală critică (şi nedorită) / severă / (prea accelerată) (a unui material sau a unui element de maşină)

acutely $(a d v)$ (în mod) acut, sever, cu acuitate, urgent

acute triangle (mat) triunghi ascuțit unghic

acyclic (fiz, mec, el, hidr) aciclic, neperiodic

a.d. (average depth) (nav, geogr, hidr) adâncime medie

adamantine spar (chim) corindon

adapt a (se) adapta; a (se) ajusta; to / for a adapta la / pentru; a (se) potrivi cu / la

adaptability (to) (TH) adaptabilitate (la)

adaptable (to) $(\mathrm{TH})$ adaptabil, care se adaptează (uşor) (la)

adaptation (TH, T) adaptare, ajustare, acomodare adapted adaptat, simplificat; prelucrat; potrivit, ajustat

adapted for cross-country driving (auto) adaptat să circule pe orice teren

adapter / adaptor (met) port-electrod, corp al arzătorului, suport de electrod (la sudură); (el) transformator; (mas-un, OM) adaptor, manşon de reducție, reducție, piesă de ghidare, piesă suplimentară de adaptare la formă, distanțier, bucşă pe care se montează un rulment; (hidr) racord intermediar; (mas) dispozitiv de cuplare

adapter coupling (OM, hidr) manşon de reducție, reducție

adapter plug (el) fişă intermediară

adapter sleever (OM) bucşă intermediară între arbore şi rulment, bucşă de strângere

adapter-type bearing $(\mathrm{OM})$ rulment cu bucşă de fixare

adapting piece (hidr, OM) piesă de adaptare / de racordare, țeavă de racord, fiting, piesă de legătură

adapting pipe (hidr, OM) fiting, racord de tevi, piesă tubulară de asamblare a conductelor

adaptive metallurgy (met) metalurgie fizică adaptive tunning (metr) reglare în funcție de condiții (de lucru etc.)

adapt themselves (T) a se adapta (şi d. două suprafețe în contact)

add (to) a adăuga (la / în), a completa; (mat) a aduna

added material / metal (met) material / metal de adaos / de aport (şi la sudură)

addend (mat) termen al adunării

addenda completări

addend(um) (ec) completare, act adițional; (OM) înălțimea capului dintelui $\left(\mathrm{h}_{\mathrm{a}}\right)$ (la roți dințate); (TH) adaos la o prelucrare; anexă

addendum angle $(\mathrm{OM})$ unghiul de angrenare pe vârful dintelui $\left(\alpha_{a}\right)$, unghiul de cap al dintelui (la orice dinte de roată dințată cu dinți drepți, inclusiv cel evolventic)

addendum circle $(\mathrm{OM})$ cercul exterior / de cap (al roții dințate) $\left(\mathrm{d}_{\mathrm{a}}\right)$

addendum cone (OM) conul de vârf / de cap al danturii conice

addendum flank (OM) flancul capului dintelui

addendum line of the tooth $(\mathrm{OM})$ dreapta de vârf a cremalierei (de referință)

addendum modification (OM) deplasare a danturii (unei roți dințate) / de profil, modificarea / deplasarea capului dintelui $\left(\mathrm{x} \cdot \mathrm{m}_{\mathrm{n}}\right)$

addendum modification coefficient $(\mathrm{OM})$ coeficient de deplasare de profil, coeficientul deplasării capului dintelui (x)

add in a include în, a cuprinde

addition adaos, adăugare, adunare, însumare; (chim, met, plast) corp străin, impuritate, element de aliere; (TH) adaos; completare, adăugire; (constr) dependință, acaret

addition agent (met, plast, $\mathrm{T}$ ) element de aliere / de adaos, aditiv (şi în lubrifianți), material de adaos (la compozite)

additional adițional, suplimentar, complementar, în plus, de adaos

additional air (termo) aer suplimentar additional breaker (mas) concasor de mărunțire additional building ( $\mathrm{TH}$, constr) clădire anexă additional cargo space (auto) spațiu suplimen$\operatorname{tar}$ (şi pentru bagaje)

additional charge (el) încărcare suplimentară, (mas) admisie după punctul mort superior; (mec, mas) încărcătură / încărcare (şi tehnologică) sarcină suplimentară

additional equipment (mas) echipament auxiliar additional load (mec) suprasarcină

additional pressure (mec, hidr) suprapresiune

additional pressure drop (mec, hidr) cădere suplimentară de presiune 
additional voltage (el) tensiune suplimentară addition charge (met, ind chim, TH) încărcare / încărcătură suplimentară (şi la furnal, la procese de prelucrare a materialelor)

addition constant constantă aditivă

addition of reducing agents (ind chim, met) adaos de (agenți) dezoxidanți

addition polymer (chim) polimer de adiţie

addition polymerization (ind chim, plast) polimerizare prin aditiie

additions (alim, met, ind chim) adaosuri, materiale de adaos, fluxuri, fondanți

additive (chim, T) aditiv, agent de adiție; cumulativ, de anunat, care se adaugă

additive action (chim, mec, T) acțiune cumulativă

additive effect ( $\mathrm{T}$, ind chim) efectul aditivului

add-on (OM) adaos prin încleiere; plus de greutate datorat încleierii; a adăuga

address adresare; (inf, c) mesaj, apel, adresă; direcție

addressable (autom) accesibil, care poate fi adresabil, căruia i se poate destina o adresă

addresse (inf) adresă; a se adresa, a lua cuvântul; tact, îndemânare

addressee adresant, destinatar

adduct (fiz, chim) compus chimic cu legături slabe (de exemplu, Van der Waals)

add-up a aduna, a însuma; a completa, a adăuga, a anexa, a (se) alătura; (mas) a cupla

adept $(\mathrm{TH})$ specialist, expert

adeptness (TH) pricepere, calificare (într-o specialitate)

adequacy caracter adecvat, adecvare; (TH, mas) acceptabilitate; proportionalitate

adequate to adecvat $\mathrm{cu} /$ pentru; suficient, potrivit cu, corespunzător la / cu

adequate for destul, suficient (pentru), doar atât cât trebuie; acceptabil; mulțumitor

adequately $(a d v)$ (în mod) adecvat, corespunzător, (aşa) cum trebuie / cum se cuvine; competent, cu competentăă, mulțumitor, satisfăcător; suficient, destul, îndeajuns

adequation of stress (met, mec) detensionare

adhere (met, T) a (se) lipi, a adera

adherence (met, plast, T) aderență, aderare, adeziune, legătură strânsă; capacitate de aderentăă, adezivitate, coeziune

adherent aderent

adherent failure (plast) rupere a aderentului / adezivului

adherent moulding material (met, plast) material aderent de formare în matriță

adhering (fiz, met, plast, T) care aderă, aderent adhering electrode material (met, plast) material de electrod, care aderă / aderent (pe piesă) (şi la procedeul de sudare)

adhesion adeziune, lipire, aderență, capacitate de aderență, adezivitate

adhesion-deformational theory (of friction) (T) teoria adeziunii şi deformării (pentru / la frecare)

adhesion force (fiz, T) forță de adeziune / de aderență / de coeziune

adhesion force due to liquid bridge (fiz, T) forță de adeziune / de aderență / de coeziune datorată punții / legăturii de lichid

adhesion force measurement (fiz, $\mathrm{T}$, metr) măsurarea forței de adeziune / de aderență / de coeziune

adhesion heat (termo) căldură de aderență

adhesion promotor (ind chim, plast) agent de promovare / de îmbunătăţire a adeziunii, diluant reactiv

adhesion of slag (met) aderenta zgurii

adhesion strength (mec, plast, T) forță de adeziune, rezistența la / de adeziune / a asamblării lipite sau numai a adezivului, rezistență a materialului aderat / lipit (şi în procese de frecareşi uzură)

adhesive (material) adeziv, aderent, cleios, lipicios, clei

adhesive batch (plast) şarjă de adeziv

adhesive bonding (OM) legătură / asamblare prin lipire / prin aderență

adhesive capacity capacitate de legătură / de asamblare prin lipire / prin aderență

adhesive coat (plast) strat de adeziv

adhesive failure (plast) rupere adezivă

adhesive film (plast) peliculă de adeziv

adhesive force forță adezivă

adhesive insulating tape (el) bandă izolantă

adhesive material (plast) material de lipit, (material) adeziv

adhesiveness aderență, adezivitate

adhesive power putere adezivă / de lipire / de coeziune

adhesive strength (mec, OM, plast, T) rezistență de aderență (la lipituri)

adhesive substance (chim) substanță adezivă

adhesive tape (el, OM) bandă adezivă izolantă / de lipit / de etanşat

adhesive water (hidr) apă peliculară

adhesive wear (T) uzură adezivă / de aderență

adhesive weight $(\mathrm{cf})$ greutate aderentă

ad hoc $(a d v)$ numai pentru acest caz / scop

adiabat (fiz, termo) adiabată, curbă adiabatică

adiabatic (fiz, termo) adiabatic 
adiabatic (baffle) plate (termo) placă adiabatică adiabatic calorimeter (metr, plast, termo) calorimetru adiabatic

adiabatic compression (fiz, termo) compresiune adiabatică

adiabatic curve / line (fiz, termo) curbă adiabatică

adiabatic dryer (alim, ind chim, termo) uscător adiabatic

adiabatic partition (termo) perete adiabatic adiabatic process (fiz, termo) proces adiabatic adiabatic transformation (fiz, termo) transformare adiabatică

adiabatic wall (termo) perete adiabatic

adipose adipos, gras

adjacency adiacență; vecinătate, apropiere adjacent (mat) adiacent; alăturat, vecin, învecinat; (met, OM) lângă cusătură (la sudură)

adjacent angle (mat) unghi adiacent

adjacent to adiacent la

adjoining învecinat, adiacent

adjoining angle (mat)unghi adiacent

adjoint (ec) adjunct; (mat) asociat, conjugat; a se învecina

adjourn a (se) amâna; a (se) suspenda, a întrerupe (şi o şedință)

adjournment (perioadă de) amânare; suspendare, retragere, întrerupere (şi la o ședință)

adjunct adjunct; ajutor; adaos, anexă; to subordonat la / cuiva

adjunction (mat) completare, asociere

adjust (TH) a ajusta, a regla, a aranja, a adopta, a calibra, a pune la punct, a acorda, a conforma, a potrivi, a pune în ordine, a sistematiza, a se adapta

adjustability (TH) capacitate / posibilitate de reglare

adjustable $(\mathrm{TH})$ reglabil, ajustabil, adaptabil

adjustable baze (mas, OM) postament / batiu / platformă reglabil(ă) (şi cu şuruburi)

adjustable bearing (OM, T) lagăr reglabil

adjustable blade (mas) lamă reglabilă (la buldozer etc.); (nav, termo) pală (de elice / de ventilator etc.) cu pas reglabil

adjustable caliper gauge (metr) calibru-vergea reglabil

adjustable clearance $(\mathrm{OM})$ joc reglabil

adjustable cam $(\mathrm{OM})$ camă reglabilă

adjustable current control (autom, el) reglare a intensității curentului electric

adjustable drill (mas-un) burghiu reglabil

adjustable eccentric excentric reglabil

adjustable feed stop (mas-un, OM) opritor reglabil pentru limitarea avansului adjustable gange şablon reglabil

adjustable index (metr) ac indicator reglabil (la aparate)

adjustable jib (mas-un) braț reglabil (cu diferite poziții de tăiere) (la strung, maşini în industria lemnului etc.)

adjustable lever $(\mathrm{OM})$ pârghie / levier cu braț de lungime variabilă, fixator de poziție

adjustable marker (auto) reper de distributie; (mas) reper de reglare / de potrivire (şi la montaj)

adjustable-(milling) cutter (mas-un) freză reglabilă

adjustable (multiple) spindle drill machine (mas-un) mașină de găurit cu reglarea pozițiilor axelor (multiple) principale

adjustable nozzle (hidr, OM, termo) ajutaj / duză reglabilă

adjustable pin (OM) fus / bolț reglabil

adjustable pitch (mas, OM) pas variabil / reglabil

adjustable play (OM) joc reglabil / ajustabil

adjustable potential system (el) sistem reglabil generator - motor

adjustable pulley $(\mathrm{OM})$ roată reglabilă pentru curele trapezoidale (şi pentru întindere)

adjustable racke angle (mas-un) unghi de atac reglabil al sculei

adjustable reamer (mas-un) alezor reglabil

adjustable resistance (el) reostat, rezistență reglabilă

adjustable restrictor valve (OM, hidr) drosel reglabil, reductor de debit reglabil

adjustable ring $(\mathrm{OM})$ inel de fixare / de reglare

adjustable seat (OM) scaun reglabil (la ventil etc.); suport reglabil

adjustable shock absorber (OM, auto) amortizor reglabil

adjustable spanner (mas-un) cheie reglabilă / universală

adjustable speed motor (mas, el) motor electric de turație reglabilă / variabilă

adjustable starter (auto, el) demaror reglabil

adjustable stop (mas-un, OM) limitator / opritor reglabil

adjustable strap hunger (constr, OM) bridă reglabilă de suspensie

adjustable tap (mas-un) tarod reglabil

adjustable tap wrench (mas-un) cheie universală pentru tarozi

adjustable transformer (el) transformator reglabil

adjustable valve (hidr, OM) supapă reglabilă

adjustable voltage control (autom, el) (sistem de) reglare a tensiunii electrice 
adjustable voltage divider (autom, el) potențiometru / divizor de tensiune, reglabil

adjustable voltage rectifier (autom, el) redresor cu tensiune reglabilă / variabilă

adjustable wrench $(\mathrm{TH})$ cheie franceză / reglabilă

adjust by measuring a măsura, a regla (după măsurare), a dimensiona; a ajusta (un dispozitiv, o maşină etc.) după măsurare / pe baza unor măsurători (ai unor parametri / caracteristici)

adjusted reglat, ajustat, corectat, cu corecție

adjusted life rating factor $(\mathrm{OM})$ factor de corecție dependent de raportul C/P (capacitate dinamică de bază / sarcină dinamică echivalentă, la rulmenți)

adjuster (muncitor) reglor, ajustor, instalator, montator, instalator, cel care face reglarea; dispozitiv de reglare (fină); dispozitiv de ajustare; (OM) tijă / şurub de reglare; (met) dispozitiv pentru fixarea benzii la laminare

adjuster bolt $(\mathrm{OM})$ şurub / bolț de reglare adjuster cotter $(\mathrm{OM})$ pană de reglare

adjust for wear (mas, T) a ajusta / regla (din cauza uzurii); ajustare pentru compensarea uzurii

adjusting (TH) reglare, ajustare, care (se) reglează; reglabil, ajustabil

adjusting clearance (OM) joc de ajustaj, ajustaj cu joc

adjusting clip (el, OM) placă de strângere / clemă reglabilă

adjusting collar $(\mathrm{OM})$ inel de reglare / inel reglabil de montare

adjusting control (autom, mec) reglare (şi automată)

adjusting device (mas, autom) dispozitiv de reglare / ajustare

adjusting ear $(\mathrm{OM})$ ureche de întindere

adjusting gear (OM) mecanism de reglare (posibil cu roți dințate)

adjusting gauge (mas, metr) calibru / şablon de reglare (şi a jocului în rulmenți etc.)

adjusting hand wheel (auto) volan reglabil

adjusting key $(\mathrm{OM})$ pană de reglare; cheie cu deschidere reglabilă

adjusting lever (mas-un) manetă / pârghie de reglare

adjusting nut $(\mathrm{OM})$ piuliță de reglare / piuliță de blocare a inelului interior al rulmentului

adjusting piece $(\mathrm{OM})$ piesă de reglare / care reglează (şi o poziție)

adjusting pin $(\mathrm{OM})$ ştift de centrare / de reglare adjusting plate (mas) liră; placă de îndreptare

adjusting ring $(\mathrm{OM})$ inel de reglare

adjusting screw $(\mathrm{OM})$ şurub de reglare (a poziției, a forței de apăsare etc.) adjusting shim (auto) adaos de reglare

adjusting slider (el) contact alunecător (cu poziție reglare a poziției şi / sau a apăsării)

adjusting spring $(\mathrm{OM})$ arc de reglare

adjusting strip (TH) piesă / fâşie de adaos

adjusting washer $(\mathrm{OM})$ şaibă de reglare

adjusting wedge $(\mathrm{OM})$ pană de reglare (nu se specifică forma acesteia)

adjustment (TH) ajustare, reglare, potrivire; compensare; (OM) ajustaj, păsuire; acordare; asamblare; corectare, corecție, îndreptare; netezire, rectificare; regularizare; reglare; sistematizare; unificare; (ec) reducere / ajustare a prețurilor

adjustment curve curbă de racordare; (metr) curbă de reglare / etalonare (a unui aparat)

adjustment factor (autom, metr) factor de corecţie

adjustment for length of stroke (mas-un) reglare a lungimii cursei (active)

adjustment for position of stroke (mas-un) reglare a cursei în raport cu piesa de prelucrat

adjustment for wear (mas-un, T) reglare pentru compensarea uzurii

adjustment function (autom, OM, mat) funcție de reglare

adjustment mark reper de reglare

adjustment matching (TH) ajustaj

adjustment of rolls (met) reglare a cilindrilor (de laminor)

adjustment of stroke (mas-un) reglare a cursei (active)

adjustment of tappet (auto) reglare a tacheților

adjustment of timing (auto) reglare a distribuției

adjustment pin (OM) stift de reglare

adjustment plate (mas-un) placă / platou de îndreptare

adjustment ring $(\mathrm{OM})$ inel de reglare

adjustment screw $(\mathrm{OM})$ şurub de reglare

adjustment work (TH) (acțiunea / operația de) reglare

adjust to zero (metr) reglare la zero a indicatorului unui aparat

adjust up and down (mas-un, TH) reglare / a regla pe verticală (la curse alternative)

adjuvant ajutător, auxiliar; folositor, util

admeasure a măsura, a distribui (egal); a stabili (limite sau proporții)

admeasurement (metr) măsurare, distribuire, distribuție; mărime, dimensiune

administer (ec) a conduce, a administra; $(\mathrm{TH})$ a pune în funcțiune / acțiune; administrator

administration (ec) administrație, conducere; administrare 
administration building (constr, ec) clădire administrativă

administrative administrativ, executiv

administrator administrator, (bun) organizator; conducător

admiralty brass / bronze (nav, met) alamă / bronz naval(ă)

admiralty law (nav) drept maritim

admiration mark semn de exclamare

admissibility admisibilitate, posibilitate

admissible admisibil, permis, tolerabil, posibil, acceptabil

admissible error (autom, metr) eroare admisibilă

admissible load (mec, TH) sarcină admisibilă

admissible load per axle (cf) sarcină admisibilă pe osie

admissible pressure (hidr) presiune admisibilă

admissible stress (mec) tensiune / solicitare admisibilă, efort admisibil

admission acces; taxă de intrare, acceptare, recunoaştere a unui fapt; (hidr) sosire, intrare; (hidr, mas, termo) admisie, admisiune; (TH) intrare

admission aperture (hidr, mas) fantă / deschidere de admisie / de intrare

admission cam (mas) camă supapei de admisie admission chamber (termo) cameră de admisie admission gear (OM, termo) mecanism pentru deschiderea şi închiderea supapei de admisie (acționat prin angrenaj)

admission opening (auto, hidr, OM, termo) orificiu de admisie

admission pipe (auto) țeavă de admisie

admission port (auto, hidr, OM) canal / orificiu de admisie

admission potential (el) tensiune / potențial de intrare / la sursa de alimentare; (termo) presiunea aerului / fluidului la admisie

admission pressure (termo) presiune de intrare / de admisie

admission stroke (mas, hidr) cursă de admisie

admission valve (mas, hidr, OM) supapă / ventil / robinet de admisie

admissive admisibil, legal, permis

admit (in, into, to) (TH) a deschide admisia, a admite, a permite accesul; a îngădui; a recunoaste ca valabil

admittance (el) admitanță (inversul impedanței) admitted admis, recunoscut, acceptat, permis admix (chim, mediu) a (se) amesteca, a adăuga, a impurifica

admixture (alim, constr, ind chim) amestec(are), adaos, adăugare, impuritate, ingredient; (met) fondant, impuritate admixture heat (chim) căldura amestecului / generată prin amestecarea unor substanțe adnation (chim) adeziune

adopt a adopta; a accepta; a aproba

adoptability acceptabilitate

adoptable acceptabil, adoptabil

adoption $(\mathrm{TH}$, ec) adoptare, primire, receptie, recepționare, acceptare

adrift (nav) în derivă

adroit îndemânatic, iscusit, priceput, abil

adroitness dexteritate, îndemânare, abilitate

adsorb a adsorbi

adsorbate (fiz, T) adsorbit

adsorbed layer strat absorbit (de aer, de apă, de alte substanțe)

adsorbent adsorbant

adsorbent bed strat adsorbant

adsorber adsorbant, care adsoarbe

adsorbing capacity (chim, T) capacitate de adsorbție

adsorbing material (fiz, chim, T) material adsorbant / care adsoarbe (altul)

adsorbing power (chim) putere de adsorbție

adsorption (fiz, chim, T) adsorbție

adsorption capacity (fiz, chim, T) capacitate de adsorbtie

adsorption effect (fiz, chim, T) efect de adsorbție

adsorption film (fiz, chim, T) peliculă adsorbantă / de adsorbție / care poate fi adsorbită (atenție la context)

adsorption isotherm (fiz, ind chim, T) izotermă de adsorbtie

adsorption layer ( $\mathrm{T}$, chim) strat de adsorbție / adsorbant

adsorption property (chim, fiz, T, TH) proprietate adsorbantă / de a adsorbi

adsorption velocity (fiz, ind chim) viteză de adsorbție

adsorptive capacity (chim, fiz, T, TH) capacitate de adsorbție

adsorptive property (chim, fiz, T) proprietate de adsorbție

adsorptivity (chim, fiz, T) putere de adsorbție, adsorbtivitate

adulterate $(\mathrm{TH})$ a falsifica, a contraface; a denatura

adustion inflamabilitate, combustibilitate

advance înaintare, întrecere, depăşire, avans; avansare; dezvoltare, progres; anticipare; decalaj; penetrare; progres; perfectionare; (nav) înaintare (curbă de girație); a împinge în față, a avansa, a promova; (ec) a urca prețul

advance angle (el, mas) unghi de avans 
advance borehole gaură de probă (la tâmplărie) advanced din față / frunte; avansat; înaintat; progresist, modern

advanced ignition (auto, termo) aprindere prematură / timpurie

advancement înaintare, avansare, mers înainte; progres, îmbunătăţire; perfecționare, dezvoltare; succes

advance money (ec) avans, acont

advance of tool (mas-un) avansul sculei

advance payment (ec) acont, avans

advance sparkling (auto) avans la aprindere

advance time (mas-un) timp de avans (al sculei)

advance winding (autom) bobinaj de comandă

advancing avansare, înaintare, care avansează

advantage avantaj, profit, folos, privilegiu; (ec) profit, beneficiu; (mat) preferință, superioritate; a avantaja

advantageous avantajos, favorabil; folositor, util

advaresim (plast) răşină sintetică / poliesterică

adversary adversar; oponent; potrivnic

adversative adversativ

adverse (to) advers, contrar (la / cu); neprielnic, nefavorabil, potrivnic, ostil (față de)

adverse conditions (auto) condiții nefavorabile / adverse / neprielnice

adverse effect efect advers / dăunător

adverse gradient / slope pantă inversă

adversely $(a d v)$ nefavorabil, (în mod) ostil

adverse wind (nav) vânt contrar

advert reclamă, anunț

advertise a face reclamă, a anunța

adverting reclamă, a anunța

advertise a face reclamă; a preveni, a avertiza; a anunța; a da un anunț (la ziar etc.)

advertisment reclamă, publicitate; anunț

advertising publicitate, reclamă, activitatea de publicitate; care face reclamă, de reclamă advice sfat, recomandare; informații; raport advisability recomandabilitate, oportunitate advisable recomandabil, de dorit, oportun, potrivit, adecvat, judicios

advise a sfătui, a consulta, a anunța, a consilia; a recomanda; a informa, a încunoştința, a notifica; with a se sfătui cu, a se consulta cu

advised informat, încunoştiințat; voit, intenționat; prudent, precaut; sfătuit, consiliat

advisedly $(a d v)$ judicios; intenționat; cu bună ştiință

advisorer, advisor (amer) sfătuitor; consilier; consultant

advisory împuternicit să dea sfaturi / recomandări; consultativ advisory body (ec, pol) consiliu consultativ

advisory committee $(\mathrm{TH})$ comisie / comitete de experți

advocate (jur) avocat; susținător, adept

adze teslă, bardă (la tâmplărie)

aegis egidă; under the $\sim$ sub egida

aeolian eolian

aelotropie crystal (chim) cristal anizotrop

aerate a aera, a aerisi, a ventila; a gazifica; a umple cu aer

aerated aerat, $\mathrm{cu}$ aer la interior

aerated ancret (constr) beton aerat

aerated nappe (hidr) curent de apă aerată

aerated water (hidr) apă aerată

aeration aerisire, aerare, ventilație, afầnare, (met) aerare a formelor, afinare; (hidr) aerare a apei, spumare

aeration filter (hidr) aerofiltru, filtru la aerisire

aeration of moulding sand (met) aerarea amestecului / nisipului de formare

aerator (ind chim) saturator, aerator

aerial de suprafață; aerian, suspendat; atmosferic; (radio, mil) antenă

aerial cable (el) cablu aerian

aerial cable pole (el) stâlp de cablu aerian

aerial cableway (constr) macara-funicular (de şantier)

aerial conductor (cf, el) sârmă de contact la locomotivele electrice

aerial contamination (mediu) contaminare a aerului / pe calea aerului

aerial crossing (el) traversare / încrucişare aeriană (de linii electrice)

aerial feeder (el) linie de transport / de furnizare a energiei electrice

aerial leading (el) racord de fir aerian

aerial line (el) linie aeriană

aerially aerian, în aer

aerial railway $(\mathrm{TH})$ funicular

aerial ropeway teleferic, funicular

aerial wire (el) conductor aerian

aerify (ind chim) a gazeifica, a carbura; a vaporiza; a umple cu aer

aeroconcrete (constr) beton-spumă

aerodynamic(al) (fiz, hidr) aerodinamic

aerodynamic diameter (ind chim, alim, hidr) diametru aerodinamic (al unei particule într-o suspensie) (şi la filtrare)

aerodynamic drag (fiz, mec) rezistență a aerului

aerodynamic shape formă aerodinamică

aerodynamics (fiz) aerodinamică

aeroginous (met) coclit

aerology meteorologie 
aero-mixture indicator (ind chim, metr) aparat pentru determinarea compoziției aerului sau a altui amestec de gaze

aeroplane oil (av, ind chim, $\mathrm{T}$ ) ulei de avion aerose (met) de alamă

aerosol aerosol

AESC (American Engineering Standards Committee) Comitetul American pentru Standarde Tehnice

a few câțiva, câteva; nişte; unii, unele affability afabilitate, bunăvoință, cordialitate affable afabil, cu bunăvoință, binevoitor, cordial affably $(a d v)$ afabil, cu bunăvoință

affair afacere, chestiune, problemă;

affect a afecta, a influența (în rău), a avea un efect dăunător, a prejudicia, a dăuna, a vătăma; a simula

affected afectat; nenatural, nefiresc; prefăcut

affective state stare emoțională (la un operator / muncitor)

affiliate (to) a (se) afilia (la), a (se) înscriere (în), a (se) asocia cu; a primi (ca membru); calitate de membru; a stabili legături / surse / origini; a face legătura dintre

affiliation (to) afiliere (la), înscriere (în); primire (ca membru); calitate de membru; stabilirea legăturilor / surselor / originilor

affinage (met) afinare, rafinare

affinated sugar (alim) zahăr rafinat

affining quality (met) grad de afinare

affinition sugar (alim) zahăr rafinat

affinitive afin

affinity afinitate, asemănare, înrudire, legătură

affinity constant (chim) constantă de echilibru a reactiei

affinity for oxigen (chim, met, plast) afinitate față de oxigen

affirm a afirma, a confirma; a susține; a ratifica; a declara

affirmance afirmație, afirmare confirmare; adeverire

affirmation afirmație, confirmare; susținere; ratificare; declarație

affirmative afirmativ, pozity

affirmatively ( $a d v)$ (în mod) afirmativ, pozitv

affix a ataşa (la); a pune (pe); a adăuga (la); aplicare; afix

affixation ataşare; punere; adăugare; aplicare affluence belşug, afluență; prisos; bogație, avere affluent bogat, avut; îmbelşugat, abundent; afluent afflux (a)flux; afluență, curgere, admisie

afford a (-şi putea) permite, a avea mijloacele necesare pentru; a oferi, a da (producție etc.); a aduce (un câştig) affordable posibil, disponibil

afforest a împăduri

afforestation împădurire

affreight (nav) a navlosi

affusion (agr, alim) stropire, udare, aspersiune

afield departe, la mare depărtare; rătăcit, pe un drum greșit

afire arzând, în flăcări

aflame în flăcări

afloat plutind, care pluteşte; dus de curent; (nav) la / pe bord, pe mare; acoperit de apă / ape, inundat; (ec) fără datorii

aflush with $\mathrm{cu} /$ la acelaşi nivel cu

afoam (TH) sub formă de spumă

afloat (nav) pe mare, pe apă, la bord, pe linia de plutire

afloat service (nav) serviciu de bord

afore (nav) spre prora

afore-mentioned mai sus menționat

afds (aforesaid) sus-menționat

aft (nav) pupa, la / din / spre pupa, la cârmă

after după, la sfârşitul (temporal); după, în urma, în spate, dinapoia (spațial); ca / drept urmare; în ciuda, cu toate că; (nav) la pupa

after-acceptance service (TH) service (întreținere) după acceptarea produsului

afteradmission (mas, termo) admisiune, admisie ulterioară / după punctul mort superior

afterbake (chim) întărire ulterioară

after-blow (met) suflare suplimentară (la cuptor Bessemer) / prelungită

afterbody (nav) (jumătatea) pupa

after-burning (ind chim, met) ardere / prăjire suplimentară, supraardere

after-contraction (plast, met) contractie suplimentară / remanentă / reziduală

after cooler (chim, termo) răcitor secundar / final

aftercrop (agr) a doua recoltă

after-damp (chim) gaze de explozie

after deck (nav) punte de la pupa

after-effect remanentă, persistentă; (mec) deformație ulterioară, efect ulterior

after end (met) capătul din spate (al unui semifabricat)

after-expansion (termo) dilatare remanentă

afterflow (plast, mec) curgere / deformare plastică (ulterioară)

aftergeneration (ind chim, met) ieşire întârziată a gazelor din soluție / din materialul topit

after-grass (agr) otavă

after hardening (plast) întărire ulterioară

after-heat încălzire după sudare

aftermarket key (auto) cheie diferită 
after part (nav) pupa

afterpeak (nav) picul pupa

after placing the sample (metr) după amplasa-

rea probei / eşantionului / epruvetei

after post (nav) etambou

after-pour (met) a turna suplimentar

after-pouring (met, plast) turnare suplimentară

afterproduct $(\mathrm{ec}, \mathrm{TH})$ produs secundar

aftersails (nav) far de la pupa

after-sale(s) service (ec, TH) service după vânzare

after-shrinkage (met, plast) contracție remanentă / reziduală

after-teeming (met, plast) turnare suplimentară

after-treatment (met) tratament suplimentar / de completare / după sudare

afterward(s) (nav) spre pupa, în pupa

afterworking (met) efect ulterior (după prelucrare)

aftmost (nav) cel mai din pupa, la extrema pupa

again $(a d v)$ din nou, iar(ăşi); încă o dată; încă pe

atât; pe de altă parte; şi, în afara de acesta, pe

lângă acestea; şi apoi

against împotriva, (în) contra; (cu verbe exprimând ciocnirea / lovirea) de, în; pe fondul / fundalul; prin contrast cu; în comparație cu against theft împotiva furtului

against-theft device / system (auto) dispozitiv / sistem împotiva furtului, (dispozitiv) anti(-)furt

against the sun $(\mathrm{TH})$ în sens invers acelor de ceasornic

agaric mineral (chim) lapte de var

agate (minerl) agat $(\breve{a})$

age vârstă, epocă, perioadă, vechime; $(\mathrm{TH})$ durată de funcționare; a îmbătrâni (şi artificial), a face să îmbătrânească; (alim) a matura age-control (plast) control al îmbătrânirii age hardening (met, plast) durificare prin îmbătrânire / precipitare / afinare / îmbogățire; durificare în timp / din cauza îmbătrânirii (la aliaje neferoase, lubrifianți etc.); creştere a consistenței în timp (d. lubrifianți)

age hardening crack (met, plast) fisură cauzată de durificarea prin îmbătrânire

age of cathodes (met) durata de lucru a catozilor age resister (plast) inhibitor de îmbătrânire aged (plast) îmbătrânit, supus îmbătrânirii ageing (met, plast) îmbătrânire; (alim) maturizare, maturare

ageing apparatus (plast) aparat de încercat / testat la îmbătrânire

ageing induced crack (met, plast) fisură cauzată de îmbătrânire (în sudură şi materiale plastice) ageing of alloy / metal (met) îmbătrânire a aliajului / a metalului ageing of rubber (chim, plast) îmbătrânire a cauciucului

ageing process (alim, chim, plast, met) proces / procedeu de îmbătrânire / de maturizare / de maturare

ageing property (plast) comportare la îmbătrânire, proprietate de îmbătrânire

ageing rezistance (met, plast) rezistență la îmbătrânire

ageing test test de îmbătrânire; (alim) test de maturizare / maturare

agency (ec) agenție, organ (de stat etc.), organizație; (TH) acțiune, factor

agent (chim, TH) agent, mediu, substanță, factor, compus chimic, reactiv; (ec) agent (al unei societăți), reprezentant, intermediar

agent of fusion (met) fondant (la cuptoare), flux (la sudură)

age of cathodes (met, el) durata de exploatare / de functionare / de lucru pentru catozi

age sensitive (met, plast) (material) sensibil la îmbătrânire

agglomerant (met) aglomerant

agglomerate (met) a aglomera, aglomerat; adunat; a aduna, a strânge, a (co)masa; a (se) aduna

agglomerated cake (met) material aglomerat / sinterizat

agglomerating (constr, ind chim, met) (proces de) aglomerare

agglomerating plant (ind chim, met) uzină / instalație de aglomerare

agglomeration (ind chim, met) aglomerare, sinterizare, prăjire de aglomerare; (co)masare

agglutinant (chim) aglutinant

agglutinate (met) a aglutina; a (se) lipi, a (se) încleia; (alim) a se aglutina

agglutination (met) aglutinare, sinterizare; conglomerat

agglutinative cleios, lipicios, aglutinant

aggrandize a mări, a extinde, a lărgi; a întări, a consolida (autoritatea), a face mai autoritar / puternic; a avansa, a promova; a îmbogăți

aggrandizement mărire, extindere, lărgire; întărire, consolidare (a autorității); avansare, promovare; îmbogățire

aggravate a agrava, a înrăutăți; a intensifica (un proces nedorit), a mări, a spori (şi în sens nedorit) aggravation agravare, înrăutățire; îngreunare (în realizare)

aggregate (constr) agregat, amestec natural de nisip şi pietriş (pentru beton); (mat) mulțime, component; colectie; familie; a (se) aglomera, a (se) îngrămădi, a (co)masa; total, adunat la un loc, întreg 
aggregation (constr, TH) agregat, masă, conglomerat; (met) aglomerare; îngrămădire, acumulare; agregare

agitate a agita, a amesteca

agitating (alim, hidr, ind chim, met) agitare, amestecare, care se amestecă / se agită

agitation agitare, clătinare, scuturare; dezbatere publică

agitator (apparatus / device) (alim, ind chim) agitator, amestecător, dispozitiv de agitare / amestecare; (met) melanjor; malaxor

agitator screen (alim, constr, ind chim, met) ciur agitator (de separare / sortare)

AGMA, American Gear Manufacturers Association Asociația Americană a Producătorilor de Angrenaje

AGMA lubricant number (T) număr / cod AGMA pentru lubrifiant, număr arbitrar dat de AGMA pentru desemnarea gradelor de vâscozitate a lubrifianților pentru angrenaje ago $(a d v)$ acum, în urmă (cu)

agraffe $(\mathrm{OM})$ agrafă

agraphitic (chim, met) agrafitic; fără grafit (şi d. compozite)

agraphitic carbon (met) carbon agrafitic / legat agrarian (agr) agrar, agricol; sălbatic (d. plante) agress a începe un atac, a agresa (şi chimic) agression agresiune, atac (și chimic) agressive agresiv; energic, activ; întreprinzător agressiveness agresivitate (şi chimică) agressive slag (met) zgură agresivă

agressive tack (plast) lipire agresivă, lipiciozitate în stare uscată

agreeable (to) dispus să accepte / aprobe / încuviinteze; bun, potrivit, adecvat, coerespunzător agreed de acord, care s-au înțeles / au căzut de acord; agreat; bine; corespunzător agreement înțelegere, acord; aprobare

agree to a accepta (până la urmă, în final), a consimți, a subscrie, a fi de acord, a aproba, a încuviința

agree with a concorda cu; a se potrivi cu, a nu se deosebi de; a se pune de acord cu

agricultural (agr) agricol

agriculturalist (agr) agricultor, agronom

agriculture (agr) agricultură

agrobiologic(al) (agr) agrobiologic

agrobiology (agr) agrobiologie

agrologic(al) (agr) agronologic

agronomic(al) (agr) agronomic

agronomist (agr) agronom

agronomy (agr) agronomie

aground (nav) eşuat, (pus) pe uscat; pe pământ

ahead of în fruntea, în față, înainte ahead $(a d v)$ în frunte, în / din față, înainte, dinainte, (spațial); înainte, în fața, dinainte, pe / de vii-tor (temporal); mai bun decât, superior; go ! înaintează ! avansează !, continuă!; be of a fi înaintea (cuiva, a ceva); look a gângi la viitor; get $\sim$ of a trece înaintea (cuiva, a ceva); get $\sim$ of a depăşi (ceva, pe cineva); straight drept înainte

aid ajutor; a ajuta, a sprijini, a da ajutor

aide consilier; ajutor

aide-memoire agendă, bloc-notes

aidful de ajutor, folositor

aids mijloace auxiliare / ajutătoare, ajutoare

aim scop, obiectiv intentie; a tinti, a ochi, a năzui (spre), a urmări (un scop)

aiming stake tel, pol

aimless fără scop / țintă

aimlessness lipsă de finalitate

air aer, atmosferă, mediu; nesigur; a aerisi, a aera, a ventila, a zvânta, a pune la uscat; de aer, pneumatic, aerian

air-acetylene welding (met) sudare cu acetilenă, în aer

air-arc cutting (met) tăiere arc-aer

air bag (auto) airbag

airbag deployment (auto) deschiderea / umflarea airbagurilor

airbag inflator (auto) sistemul de deschidere (d. airbaguri)

air bag storage (auto) compartimentul airbagului air bag supplimental restraint system (auto) sistemul suplimentar de protecție al airbagurilor air bag warning (auto) indicator EPS (pentru programul electronic de stabilizare); atenționare / avertizare; avertizor pentru airbag

air ball balon (cu aer)

air base (av) bază aeriană / aviatică

air based pe bază de aer, pneumatic

air bed saltea pneumatică, suport pneumatic / pe pernă de aer

air bind buzunar de aer (împiedică trecerea unui fluid peste el)

air blast (met) aer insuflat, vânt (la furnal)

air blast connection pipe (met) conductă de aer (insuflat) / de vânt (la furnal)

air blasting (met) insuflare de aer, vânt (la furnal)

air blast nozzle (met) ajutaj pentru aer insuflat / pentru vânt (la furnal)

air bleed (hidr, OM) purjă de aer, dispozitiv de înlăturare a aerului din instalatii hidraulice

air blower (met) suflantă

air blowing (met) afinare cu aer insuflat, insuflare cu aer (la convertizor) 
air box (met) cutie de vânt (la convertizor) air brake (OM) frână pneumatică / cu aer air bubble (hidr, met, plast, T) bulă de aer air bubbles entrained in a lubricating oil ( $T$ ) bule de aer antrenate / formate în lubrifiantul în exploatare sau prin amestecare / barbotare air case (met) cămaşă de aer (la cuptor) air chamber (met) canal de aer (la cuptoare) air channel (met) cameră de aer (la cuptoare, la furnal)

air chest (met) cutie de vânt (la convertizor) air chill (met) călire în aer

air circulation (met) circulația aerului

air classification (agr, alim, ind chim) sortare în curent de aer

air cleaner (agr, alim, ind chim, met) epurator / filtru de aer, dispozitiv de curățat aerul

air cock $(\mathrm{OM})$ robinet de aer

air comparison pycnometer (metr) picnometru pentru aer, prin comparare

air compression (fiz) comprimarea aerului

air compressor (mas) compresor de aer

air conditioned $\mathrm{cu}$ aer conditionat

air conditioner (unit) (termo) instalație de aer condiționat, unitate de tratare a aerului condiționat / a aerului comprimat (de obicei filtru + detentor + ungător); (auto) dispozitiv de aer condiționat

air conditioner refrigerant (auto) agent de răcire / refrigerant pentru sistemul de aer condiționat

air conditioning (termo) climatizare, condiționare a aerului

air conditioning button (auto) buton pentru (activarea sistemului de) aer condiționat

air conditioning compressor (auto, termo) compresor pentru aer condiționat

air conditioning plant (alim, termo) instalație de climatizare / de conditionare a aerului

air conditioning refrigerant (auto, chim) agent de refrigerare pentru (sistemul de) aer condiţionat

air consumption (auto, termo) consum de aer air contamination (mediu) contaminarea / poluarea aerului

air cool a răci cu aer

air cooler (alim, termo) răcitor cu aer

air cooling (met, termo) răcire cu / în aer

aircraft (av) avion, aparat de zbor

air current (în) curent de aer

air cushion pernă de aer

air cylinder $(\mathrm{OM})$ cilindru pneumatic sau numai partea lui cilindrică

air damper (hidr, OM) amortizor pneumatic

air damping (hidr, OM) amortizare pneumatică air deficiency (termo, ind chim, met) deficiență / lipsă (şi parțială) de aer (la ardere)

air desintegration plant (ind chim, met) instalație de descompunere a aerului

air draft / draught (met, termo) curent de aer, tiraj air drain (met, termo) gură de răsuflare, răsuflătoare

air dry uscare / uscat în aer; a usca în aer

air dryer deshidrator de aer

air drying (alim, constr, ind chim) proces de uscare în aer

air duct (hidr, OM) conductă de aer (şi sub presiune)

air entrainment antrenare (a unui lichid, a unei pulberi) în (jet de) aer; pătrunderea / antrenarea aerului

air exhaust eliminare / evacuare de aer

air exhauster (met, termo) exhaustor

air exhaust port (met, termo) orificiu de evacuare a aerului

air filter filtru de aer

air flap (valve) (hidr, OM) clapetă / supapă de aer air flow (fiz) curent de aer, curgerea/ ieşirea aerului; (auto) flux de aer

air flue (ind chim, met) conductă / aducție de aer (şi la cuptoare)

air for combustion (termo, met) aer de ardere / de combustie

air forging hammer (met) ciocan pneumatic de forjat

air-frame bearing $(\mathrm{OM}, \mathrm{T})$ lagăr cu peliculă gazoasă

air free (ind chim, alim) fără aer, cu aerul scos

air-fuel gas welding (met) sudare aerogaz / în aer cu gaz

air gauge (metr) manometru (pentru aer / gaze), dispozitiv / aparat pneumatic de măsură

air hardening (met) călire / călibil în aer

air heater (met) caupăr, cowper, preîncălzitor de aer

air hole (met, plast) gură de răsuflare, răsuflătoare (și la turnare)

air humidity umezeala / umiditatea aerului

airing aerisire

air ingress (met, termo) admisia aerului

air input debit de aer (la intrare)

air intake admisia / (pre)luarea aerului; (auto) alimentare cu aer

air intake control (auto) control al alimentării cu aer

air intake control button (auto) butonul pentru preluarea aerului (din exterior sau de recirculare); buton de reglare a alimentării cu aer (în interiorul autovehicolului) 
air jarring moulding machine (met) maşină de format prin scuturare pneumatică

air jet jet / curent (dirijat) de aer; (auto, termo) jiclor de aer; (hidr, termo) jet de aer

airless neaerisit, lipsit de aer; îmbâcsit; calm, liniştit, fără curenți de aer

air-line drain port (hidr, OM) orificiu de purjare a apei din circuitele pneumatice

air-locked etanş la aer

air main (hidr, OM) conductă principală de aer

air motor (mas) motor pneumatic

air-operated ram (met) berbec acționat pneumatic (şi la forjă)

air output (hidr) eliminare / evacuare a aerului (debit de) aer la ieşire

air patenting (met) patentare în aer

air permeability (plast, hârtie) permeabilitate la aer

air permeability method metoda cu / prin permeabilitate la aer

aer pillow (hidr, OM) pernă pneumatică / de aer air pipe(line) (hidr, OM) conductă de aer / de ventilație

air pocket (met) gol de aer, suflură

air pollution (mediu) poluare a aerului

air polluting (mediu) care poluează aerul

air port (met) canal de aer la cuptorul SiemensMartin

air preheater (met) caupăr, cowper, preîncălzitor de aer

air pressing (plast) presare (cu sac cu) aer (la lipire); (alim) presare cu sac de aer (la prese de struguri)

air pressure (fiz) presiunea aerului, presiune atmosferică

air-propane welding (met) sudare aeropronică / în aer, cu propan

air-puff blower (termo) dispozitiv de insuflare intermitentă cu aer (şi pentru înlăturat impurități de pe suprafețe)

air puging purjare $\mathrm{cu}$ aer

air pump (OM) pompă de aer

air quenching (met) călire în aer

air refined steel (met) oțel dezoxidat / afinat în convertizor (cu insuflare de aer)

air refining (met) afinare cu aer insuflat (în convertizor)

air release $(\mathrm{TH})$ putere de dezaerare, degajare / eliberare a aerului

air resistance (fiz) rezistența aerului

air sand blower (met) maşină de sablat (cu nisip în jet de aer)

air scrubbler (ind chim) epurator de aer

air seal $(\mathrm{OM})$ etanşare-închidere ermetică air seasoned (termo) aer cu umiditate specifică mediului / anotimpului

air separation (alim, constr, ind chim) separare a aerului

air shaft (TH, termo, OM) canal / cos / burlan de aerisire-ventilare

airship dirijabil

air shrinkage (plast, met) contracție la aer

air silencer (mas) amortizor de zgomot (la vehicularea aerului)

air slide $(\mathrm{OM})$ suprafață pneumatică

air sluice $(\mathrm{OM})$ obturator de aer

air space in grate (termo) gol pentru pătrunderea aerului

air spade (mas-un) ciocan pneumatic (în sens mai larg)

air sparger (hidr) distribuitor de aer

air spring (hidr) arc pneumatic

air squeezer (hidr, met) maşină pneumatică de formare

air squeezing core machine (met) mașină pneumatică de miezuri

air-steam mixture (alim, termo) amestec aerabur

air strainer filtru de aer

air stream (fiz, TH) curent de aer

air suction $(\mathrm{OM}, \mathrm{TH})$ sorb de aer, ventuză

air supply (TH) alimentare cu aer, debit de aer, producerea aerului comprimat

air suspension (auto) suspensie pneumatică

air swept mill (alim, mas) moară / maşină de mărunțit, cu aspirarea aerului

air tank rezervor de aer

air tap (OM) robinet de aer

air throttle $(\mathrm{OM})$ clapetă de aer

air tight închis, ermetic, etanş (la aer)

air tighting packing $(\mathrm{OM})$ etanşare pentru aer

air tint (met) culoare de revenire

air tool (mas-un) sculă pneumatică

air tower post de distributie a aerului comprimat air tube (OM) tub / conductă de aerisire / de aer / de ventilatie; (auto) anvelopă, cameră

air tube radiator (termo) răcitor tubular de aer

air turn over moulding machine (met) maşină pneumatică rotativă de formare

air-type die casting (met, plast) maşină pneumatică, de turnat prin injecție

air uptake (termo) sursă / aducție / priză de aer air valve $(\mathrm{OM})$ supapă pneumatică, ventil robinet (cu sertar) / obturator de aer

air vane $(O M)$ paletă / pală (la ventilator)

air vents (auto) ventilatoare

air vessel $(\mathrm{OM})$ cameră de aer; rezervor / colector de aer; (anat) trahee 
air volume (fiz) volum de aer; (met) debit de aer / de vânt

air washer dispozitiv de spălare a aerului, filtru airy situat în aer; de sus; înalt; (bine) aerisit; cu acces la aer; de / în aer; aerian; ireal, fantastic aisle (constr) deschidere, aripă, paletă

aitchbone (alim) bucată de carne din coapsă (de vacă)

aix gold leaf (met) folie / foiță de aur

ajar întredeschis; (d. o uşă / portieră etc.) întredeschis; nearmonios; discordant

alabaster (minerl) alabastru

alarm alarmă; panică; avertizor; a alarma, a avertiza, a preveni

alarm device $(\mathrm{TH})$ dispozitiv de alarmare

alarmed alarmat, în stare de alarmă

alarm fuse (el) siguranță fuzibilă cu semnalizare

alarm gauge (hidr, metr) manometru cu semnalizare / de alarmare

alarming alarmant, îngrijorător, periculos, primejdios

alarmingly ( $a d v)$ (în mod) alarmant, îngrijorător, periculos (de)

alarm relay (autom, auto) releu de alarmă

alarm signal $(\mathrm{TH})$ semnal de alarmă / alarmare / avertizare

albronze (met) bronz cu aluminiu

albumen (alim) albumină, albuș de ou; (bot) albumen

albumin (alim) albumină

alcohol (chim) alcool, spirt

alcohol factory (alim) fabrică de spirt / alcool alimentar

alcoholization (of the wine) (alim) alcoolizarea (vinului)

alcoho(lo)meter (metr) alcoolmetru

aldehyde (chim) aldehidă

aleatory întâmplător, aleator, stocastic

alembic (alim) alambic

alert sprinten, ager, alert; atent, prevăzător, grijuliu; vigilent; alarmă, alertă; a alerta, a alarma

alertness (stare de) alertă; prevedere, vigilență; vioiciune, agerime

alfa iron (met) fier alfa

alga, $(p l)$ algae (alim, biol) algă

algebra (mat) algebră

algebraic(al) (mat) algebric

algorithm (mat, inf) algoritm

alien străin; înstrăinat; ostil, from diferit de; disjunct; necorespunzător

alienate a înstrăina; a denatura

alight aprins, arzând; luminat

alight (from) a coborî; a ateriza; a ameriza; aprins, arzând; luminat align a alinia, a aşeza în rând; a îndrepta; (TH) a centra; with a (se) pune de acord $\mathrm{cu}, \mathrm{a}(\mathrm{se})$ înțelege cu; a include, a înscrie, a cuprinde

aligning operația de centrare, aliniere etc.; care (se) centrează / aliniază

aligning bar $(\mathrm{OM})$ dorn de centrare

aligning reamer (mas-un) alezor lung pentru prelucrat două găuri concentrice simultan

aligning seat hearing $(\mathrm{OM})$ rulment axial $\mathrm{cu}$ şaibă sferică de aliniere

aligning seat washer $(\mathrm{OM})$ suport pentru şaiba de aliniere a rulmentului axial

alignment aliniere; reglare; îndreptare; aliniament; (TH) aliniere, centrare, directie, paralelism; grupare; jalonare, îndreptare, orientare, nivelare; (mat) regularizare; (mas, mas-un) rectificare, aliniere; (metr) reetalonare, reevaluare

alignment error eroare de reglare / de aliniere

alignment stake $(\mathrm{OM})$ tijă de ghidare

align oneself with a colabora cu (cineva)

align reaming (mas-un) alezare concomitentă a două sau mai multe găuri coaxiale

alike la fel, asemănător; în mod egal, (aproape) la fel

aliment (alim) aliment(e), hrană, a hrăni; (jur) întreținere

alimentary (alim) alimentar, de alimentație, nutritiv, hrănitor

alimentation (alim) alimentare, hrănire, alimentație

alinement jalonare

aliquation (met) stratificare, clivaj, desprindere, exfoliere

aliquot eşation al unei suspensii pentru aparate de măsură

alist (nav) canarisit

aliting (met) alitare

a little ceva, puțin, întrucâtva; nu mult(ă); de scurtă durată; o cantitate oarecare (mică)

alive în viață; (el) încărcat; $(\mathrm{TH})$ în funcțiune; sub tensiune

alkali (chim) alcali(u), bază, substantă alcalină

alkali fastness (chim) rezistență la alcali

alkali free (chim) fără alcalii, nealcalin

alkali metal(s) (chim) metal(e) alcalin(e), $(p l)$ grupul metalelor alcaline

alkalimeter (metr, chim) alcalimetru

alkaline (chim, met) alcalin, bazic

alkaline blaskening (met) brunare

alkaline cleaner (chim) soluție alcalină de curățat alkaline solution (met, chim) leșie, soluție alcalină

alkali neutralisation number $(\mathrm{T}$, ind chim) cifră de saponificare

alkalinity (chim) alcalinitate, bazicitate 
alkali proof (chim) (material) rezistent la alcali alkali-resistant / -resisting rezistent la alcali alkali-resistant / -resisting cast iron (met) fontă rezistentă la alcali

alkali salt (chim) sare alcalină / de metal alcalin alkali-soluble (chim) solubil în alcali

alkali tyre reclaim (plast) (cauciuc şi de anvelope) regenerat cu alcalii

alkalies (chim) alcalii

alkaloid (chim) alcaloid

alkyd (chim) alchid(ic)

all tot, toată (lumea), toți, toate; întreg; fiecare, oricare, orice; tot, maxim

all-American panamerican, fabricat în întregime în SUA

allay (met, chim) a liniști, a calma, a tempera

allayer liniștitor, calmant

all cotton (textile) bumbac 100\%

allege a pretinde, a pretexta

Allen screw (OM) şurub cu locaş hexagonal / cu cap inbus

allergic (med) alergic

allergy (med) alergie

alleviate fitting (OM) ajustaj uşor (de făcut) / slab $/ \mathrm{mic}$

alleviation alinare, uşurare

alliance alianță

allied (met) aliat

alligation (met, ind chim) malaxare, amestecare, aliere (rar)

alligator (mas-un) presă-aligator, concasor cu fălci alligatoring proces de deteriorare a stratului (de vopsea / de acoperire) caracterizat prin crăpături adânci, extinse pe unul sau mai multe straturi, în adâncime, creșterea rugozității unei suprafețe metalice pe durata formării (rezultatul seamănă cu pielea de crocodil)

alligator clip (OM) clamă crocodil

alligator grab $(\mathrm{OM})$ cleşte aligator

alligator shears (mas-un) foarfece cu pârghii

alligator squeeze (mas-un, met) presă aligator alligator wrench cheie pentru tevi "aligator" all-important deosebit / extrem de important all-in inclus; inclusiv

all-inclusive atotcuprinzător; (ec, TH) cu totul (d. preț, pachet de piese / servicii)

all insulated (el) izolat (electric) complet

all-in tariff (ec) tarif universal

all level sample $(\mathrm{T})$ probă medie

all-metal (chim) complet metalic

allocate a aloca (resurse), a destina; a distribui, a repartiza; (autom, inf) a aloca

allocation alocare, destinare, distribuire, repartizare; (ec) alocație; (mat) repartitie, distribuție all-or-none response (autom) răspuns "tot sau nimic"

allot a aloca, a repartiza; a distribui; a destina; a acorda

alloted means (ec) mijloace alocate

allotment (ec) alocare, repartizare, repartiție, distributie, distribuire, contingent, lot; parte, participație; (agr, ec) teren arendat

allotropic alotrop(ic)

allotropic change / transformation (chim, met) transformare alotropică

allotropy (chim, met) alotropie

all over peste tot, în toate părțile; la capăt / sfârșit; terminat; de sus până jos; din toate punctele de vedere

allow a permite, a îngădui; a face posibil; a da, a acorda (bani, timp etc.); a recunoaşte, a nu contesta; a lua în considerare, a ține seama de

allowable admis, admisibil, permis, îngăduit, acceptabil; (ec, jur) legal

allowable $\operatorname{defect}(\mathbf{s})$ toleranță de rebuturi (în selecție); defect admisibil

allowable error (metr) eroare admisibilă

allowable limit limită admisibilă

allowable load sarcină admisibilă

allowable misalignment (mec, mas, OM) dezaxare (nealiniere) permisă (la arbori)

allowable stress (mec, OM) tensiune / solicitare admisibilă

allowable working pressure / load (mec, mas, $\mathrm{TH})$ presiune / sarcină admisibilă de lucru

allowance încuviințare, permisiune; rație, tain (ec) bonificație, alocație, rabat, plată (regulată), indemnizație, reducere, rabat (amer) bani de buzunar; (TH) adaos de prelucrare, toleranță, surplus de material; admitere; recunoaştere, luare în considerare; permisiune, faptul de a permite

allowance for contraction (met, plast) adaos pentru contractie (la model)

allowed permis, admis

allow for a avea în vedere; a tine seama de, a nu pierde din vedere

allow of a permite (ca posibil), a îngădui

alloy (met, plast) aliaj; a alia

alloyage (chim, met) aliere

alloy cast iron (met) fontă aliată

alloy cast steel (met) oțel aliat turnat

alloy deposition (met) depunere de aliaj (la acoperiri)

alloyed (met) aliat

alloyed ferrite (met) ferită aliată

alloy element (met) element de aliere

alloying (met, plast) aliere 
alloying addition (met) adaos de aliere alloying element / component / constituent / metal (chim, met, plast) element / component / compus / metal de aliere

alloying zone (met, plast) zonă de aliere

alloy metal (met) metal aliat, aliaj metalic, metal de aliere

alloy pig iron (met, plast) fontă aliată brută / în blocuri

alloying property (met, plast) capacitate / proprietate de aliere

alloy steel (met) otel aliat

alloy-steel castings (met) piese turnate din oțel aliat

alloy strip (met) bandă din oțel aliat

alloy tool steel (met) oțel aliat de scule

all-position (met) (sudare) în orice poziţie

all-purpose $(\mathrm{TH})$ utilizabil în orice condiții; bun la toate; de uz general

all right perfect, (foarte) bun, în regulă / ordine; satisfăcător, acceptabil; foarte bine, cum trebuie, categoric; destul de bine, mulțumitor

all round din toate punctele de vedere

allseed (alim) ştir, troscot

allusive (to) plin de aluzii (la adresa); aluziv, plin de conotații; simbolic

alluvial aluvionar, aluvial

all-weather oil (ind chim, T) ulei pentru orice vreme / multigrad

all-welded (met, OM) sudat în întregime / complet

all-weld-metal (executat) din metal depus (prin sudură, la recondiționări)

almost aproape (că); cât pe ce

aln (fiz, metr) unitate de măsură pentru lungime 1 aln $=0,593777778 \mathrm{~m}$

alone singur; stingher; neînsoțit; neajutat (de nimeni); doar, numai; exclusiv

along de-a lungul, în lungul; în cursul / timpul (unui proces / fenomen)

alongside chiar lângă, (chiar) alături de, unul lângă altul; pe margine, de-a lungul; (nav) bord la bord, acostat

along with împreună cu, o dată cu

Alnico (met, el) aliaj feros cu nichel şi cobalt, folosit pentru magneți permanenți

alpax (met) silumin, alpax

alpha (litera) alfa, litera $\alpha$ în alfabetul grecesc, primul, prima

alpha and omega alfa şi omega, tot, partea principală / cheie / foarte necesară

alpha iron (met) fier $\alpha$

alpha 2 structure (met) structură alfa 2 care se găseşte în structuri stabile alfa (detectabilă prin difracție cu radiație $\mathrm{X}$, şi nu metalografic) alphabet alfabet; (TH) elemente (de bază)

alphabetic(al) alfabetic

alphabetical listing listare în ordine alfabetică

alphabetically $(a d v)$ ordine alfabetică, alfabetic

alphabetic order ordine alfabetică

alphabetic word cuvânt format din literele aceluiaşi alfabet

alpha-beta structure (met) structură compusă din fază alfa şi fază beta

alphabetize (edu) a alfabetiza; a aşeza în ordine alfabetică

alpha double prime (orphoto-rhombic martensite) (met) martensită ortorombică (obținută la viteze mari de răcire)

alpha prime (met) martensită alfa

alpha-ray spectrometer (fiz, metr, materiale, met) spectrometru cu radiație alfa

alpha stabilizer (met) stabilizator pentru structură / fază alfa

alpha-transus (met) temperatura de graniță între faza alfa şi faza alfa + beta

alpine alpin, de munte

already deja; şi

alsifer (met) alsifer, (fero-aliaj) silico-aluminiu

altar (met) altar (de cuptor)

alter a (se) transforma, a (se) schimba, a altera; a (se) schimba; a (se) modifica, a transforma; (d. animale) a castra

alteration transformare, modificare, alterare, schimbare, rezultat al modificării

alteration of form deformare / schimbare a formei altered structure (chim, met, plast) structură modificată

alternate alternativ, alternant, schimbător; intermitent; (amer) de rezervă / schimb, ca o alternativă; suplimentar, adițional; (mat) altern, fiecare al doilea; (amer) locțiitor, înlocuitor, supleant; a alterna, a se schimba; a se succeda; a face să alterneze

alternate angles (mat) unghiuri alterne

alternate immersion (corrosion) test test de rezistentă la coroziune, prin imersare alternativă alternately $(a d v)$ (în mod) alternativ, succesiv alternating bend(ing) $(\mathrm{T}, \mathrm{OM})$ încovoiere alternantă

alternating current (AC) (el) curent alternativ

alternating current motor (el) motor de curent alternativ

alternating current welding (el) sudare cu curent alternativ

alternating force (mec) forță alternantă

alternating impact test / încercare la şoc repetat alternating joint (constr) rost alternant

alternating load $(\mathrm{mec})$ sarcină alternantă 
alternating motion (mec) mişcare alternativă alternating strain $(\mathrm{mec})$ deformație alternantă alternating stress (mec, OM) efort / tensiune alternant $(\breve{a})$

alternating stress number (mec) număr de cicluri alternante

alternating stress test $(\mathrm{mec}, \mathrm{OM})$ test $\mathrm{cu}$ solicitare alternantă

alternative current shunt motor (el) motor pentru curent alternativ, în derivaţie / şuntat

alternator (el) generator de curent alternativ

although deşi, cu toate că, în ciuda faptului că; chiar dacă

altimeter (metr) altimetru

altitude altitudine, înălțime

altogether cu, întru totul, (în) total, complet; în întregime; în general; până la urmă; întreg, total(itate)

alumina (chim, met) oxid de aluminiu, alumină $\left(\mathrm{Al}_{2} \mathrm{O}_{3}\right)$

alumina fire brick (met) cărămidă refractară din alumină / aluminoasă

alumina-silica brick (met) cărămidă refractară silico-aluminoasă

aluminiferous (met) cu conținut de alumină

aluminise (brit), aluminize (amer) a acoperire / a trata cu aluminiu

aluminising (brit), aluminizing (amer) (met) tratament termo-chimic pe bază de aluminiu, aluminizare, acoperire de protectie prin depunere de aluminiu sau compuşi ai lui

aluminisation (brit), aluminization (amer) (met) alitare, aluminizare, calorizare

Aluminium, Aluminum (chim) aluminiu (Al)

aluminium alloy cage $(\mathrm{OM})$ colivie din aliaj de aluminiu

aluminium-base alloy (OM) aliaj (pe bază) de aluminiu

aluminium boron composites compozite pe bază de (aliaje de) aluminiu şi fibre de bor

aluminium brass (met) alamă cu aluminiu, aliaj $\mathrm{Cu}-\mathrm{Zn}-\mathrm{Al}$

aluminium bronze (met) bronz cu aluminiu, aliaj $\mathrm{Cu}-\mathrm{Sn}-\mathrm{Al}$

aluminium dross (met) zgură cu aluminiu

aluminium dust (met) praf de aluminiu

aluminium graphite composite compozit de aluminiu cu grafit

aluminium hydroxide (chim, met) hidroxid de aluminiu

aluminium impregnation (chim, met) alitare, calorizare, aluminizare

aluminium-magnezium alloy (met) aliaj aluminiu-magneziu aluminium-magnezium-manganese alloy (met) aliaj aluminiu-magneziu-mangan aluminium nitride (met) nitrură de aluminiu aluminium oxide (met) oxid de aluminiu aluminium pig (met) bloc de aluminiu aluminium plating (met) placare / acoperire $\mathrm{cu}$ aluminiu

aluminium shot (met) alice / aşchie / granulă de aluminiu

aluminium silicate (met) silicat de aluminiu aluminium solder (met) aliaj pentru lipirea aluminiului

alumino-thermic process (met) aluminotermie

alumino-thermic welding (met) sudare aluminotermică

aluminous (met) de aluminiu, aluminos, de alumină

aluminous slag (met) zgură aluminoasă

alveolar alveolar (şi la compozite)

alveole (biol) alveolă

alveolus, $(p l)$ alveoli alveolă (şi la compozite)

always $(a d v)$ (în)totdeauna; în orice înprejurare; mereu, încontinuu, fără întrerupere

amalgam (met) amalgam; amestec

amalgamate (met) a amalgama; a (se) amesteca, a (se) combina, a (se) îmbina (d. materiale); (ec) a fuziona, a unifica; a se mări, a extinde (rar)

amalgamating barrel (ind chim, met) amalgamator

amalgamation (met) amalgamare, formarea unui aliaj cu mercur; amestecare, amalgamare; îmbinare, combinare (d. materiale); (ec) fuzionare, fuziune, contopire, unificare; mă-rire, extindere (rar)

amalgamator amestecător

amalgam coating (met) acoperire prin amalgamare

amalgam squeezer (mas, met) presă de amalgamare

amber culoarea ambrei / chihlimbarului; chihlimbar, chihlimbariu; (alim) sunătoare, pojarniță ambience ambianță, mediu înconjurător ambience of air (în) prezența aerului ambient (TH, mediu) ambiant, înconjurător (d. mediu, incintă)

ambient aer (în) aer obişnuit / ambiant

ambient conditions (mediu) condiții normale (de cameră, de laborator)

ambient temperature temperatura mediului ambiant; temperatură generală / ambientă

ambiguity ambiguitate, caracter ambiguu

ambiguous ambiguu, cu dublu înțeles, echivoc; vag, neclar; obscur; problematic; dubios, îndoielnic 
ambiguously $(a d v)$ cu dublu înțeles, (în mod) ambiguu; vag; neclar; obscur

ambiguousness ambiguitate; echivoc

ambivalent (chim) bivalent (rar)

ameliorate a (se) ameliora, a (se) îmbunătăți

amelioration ameliorare, îmbunătățire

amenable to capabil de a fi influențat, influențabil; care înțelege; răspunzător în fața legii; verifical prin, care poate fi verificat

amend îmbunătăți, a pune la punct, a perfecționa; a amenda (un text, o lege); a se îndrepta, a se corija, a se schimba în bine

amendament îmbunătățire; corectare, corijare; amendare (a unui text, a unei legi); amendament; (agr) ameliorare

American English engleză americană, varianta americană a limbii engleze

American National Standards Institute (ANSI) Institutul Național American de Standardizare (SUA)

Americanism americanism

America standard screw thread (OM) filet standardizat în SUA, filet Briggs (pentru țevi)

Americium (chim) americiu (Am)

amide (chim) amidă

amidship (nav) centru al navei, zero cârma, mijloc cârma, la mijlocul navei

amine (chim) amină

aminoplast (chim, plast) aminoplast

amino resin (chim, plast) răşină aminică

ammeter (a.c.) (el) ampermetru (de curent alternativ)

ammonia (chim) amoniac, hidroxid de anomiu, $\mathrm{NH}_{3}$

ammonia pump (hidr, ind chim, OM) pompă de amoniac

ammonia water (ind chim) apă amoniacală

ammonite (minerl) amonit

ammonium (chim) amoniu

ammonium chloride (chim) clorură de amoniu

among printre; între; dintre; din mijloc, în mijloc; la

amorphous amorf, fără structură, necristalizat amorphous deposit depunere / depozit amorf(ă) amorphous body corp amorf

amourphous carbon carbon amorf

amorphous form formă amorfã

amourphous glassy state (fiz, chim, plast) stare amorfă sticloasă / vitroasă

amourphous metal (fiz, chim, met) metal (în stare) amorf(ă)

amorphous state stare amorfă

amortizable (ec) amortizabil, care poate fi amortizat (d. mijloace fixe, investiții etc.) amortizate (ec) a amortiza

amortization (ec) amortizare; (jur) alienare, înstrăinare (a unei proprietăți)

amount cantitate, mărime, sumă, total, valoare; importanță; sens; semnificație; grad, stare; stoc; număr; mulțime; volum; (ec) capitalul plus dobânda

amount of crown sfericitate, convexitate amount of deflection (mec) săgeată de încovoiere (şi mărimea acesteia)

amount of fuel remaining in the tank (auto) cantitatea de carburant rămasă în rezervor

amount of helm (nav) unghi de cârmă

amount of rainfall (auto) cantitatea de apă de ploaie

amount of rudder (nav) unghi de cârmă

amount of unbalance (mec) valoare a dezechilibrului

amount to a se ridica la (o sumă), a atinge; a forma, a alcătui; a fi egal cu, a echivala cu amperage (el) intensitatea curentului (în amperi), amperaj

ampere / ampère (el, metr) amper

ampere hour (el, metr) amper-oră

ampere hour meter (el, metr) aparat de măsurat în amperi-oră

ampere turn (el) amper-spiră

amperometer (el, metr) ampermetru

amphibious amfibiu

amphoteric metal (met) metal amfoter

ample amplu, lărg; vast, cuprinzător, mare; mai mult decât suficient, din belşug, abundent

ampleness amploare, lărgime; vastitate, extindere; bogăţie, abundență

amplification mărire, amplificare, extindere, lărgire; $(\mathrm{TH})$ adaos, material adiţional (în text) amplification coefficient / factor coeficient / factor de amplificare

amplification figure (fiz, metr) cifră / valoare de amplificare

amplifier (autom, el) amplificator (a unei mărimi) (în general)

amplify a amplifica, a mări, a lărgi, a extinde (puterea, autoritatea); a explica amănunțit, a dezvolta (o temă); (TH) a adăuga material; (rar) a exagera

amplify on / upon a dezvolta (o temă)

amplifying vibrograph vibrograf cu amplificare amplifying winding (fiz, autom, el, metr) bobinaj de amplificare

amplitude amplitudine; (mat) unghi polar, argument; rază de acțiune

amplitude increase (fiz, mec) creştere a amplitudinii 
amplitude modulation (autom, metr) modulație / modulare a amplitudinii

amplitude of a complex number (mat) argumentul unui număr complex

amplitude of roll (nav) unghi de ruliu

amplitude ratio raport de amplitudine (raportul între amplitudinea debitului modulat şi semnalul de intrare sinusoidal)

amply amplu; abundent, din belşug / abundență; amănunțit, detaliat

ampoule / ampule fiolă, flacon, ampulă

anachronic anacronic

anachronism anacronism

anaerobe (alim) microorganism anaerob, bacterie anaerobă

anaerobic anaerob

anaerobic adhesive (chim, plast) adeziv anaerob

analog analog, analogic

analog input (autom) semnal analogic de intrare analogic(al) analogic, produs prin analogie analogize a explica prin analogie

analogous analog, similar, asemănător

analogously $(a d v)$ (în mod) analog / asemănător, prin analogie

analog signal semnal analogic

analog-to-digital care transformă datele reale (analogice) în date digitale

analog-to-digital conversion (autom, metr) conversie analog-digitală

analog-to-digital conversion error (autom, metr) eroare a conversiei analog-digitală

analog-to-digital (converter) dispozitiv sau subsistem care transformă datele reale (de la traductori) în date digitale (binare)

analog-to-digital quantization error (autom, metr) eroare dependentă de mărimea convertită analog-digital

analog-to-digital ramp conversion (autom, metr) conversie analog-digitală în pantă

analog-to-digital saturation error (autom, metr) eroare de conversie analog-digitală la saturare

analog-to-digital successive aproximation (autom, metr) aproximare succesivă la conversie analog-digitală

analogue amplifier (autom, metr) amplificator analogic

analogy analogie, asemănare, potrivire (cu)

analysable (brit), analizable (amer) analizabil, care poate fi analizat

analyse (brit), analize (amer) a analiza, a cerceta, a examina (minutios), a studia; a diseca

analyser (brit), analizer (amer) analizator

analysing (brit), analyzing (amer) analizare, care (se) analizează analysis (brit), analyzer (amer) analiză, cercetare, descompunere, examen, examinare, studiere, studiu; disecare; măsurare, identificare analysis of variance analiza variației / dispersiei analyst analist, specialist; (chim) chimist analist / de laborator

analytic(al) analitic

analytic(al) expression (mat) expresie analitică analytical gap spațiul dintre electrozii unui spectrograf

analytic(al) solution (mat) soluție analitică

analytic(al) weights (metr) set de greutăți pentru balanţa analitică

analytically $(a d v)$ (în mod) analitic

analytics logică analitică; (mat) analiză matematică

anatomical alloy / metal (med, met) aliaj folosit în chirurgie

anchor (nav) ancoră, at la ancoră, ancorat; (OM) şurub / bulon de ancorare / de prindere, a prinde, a fixa

anchorage (nav) ancorare, loc de ancorare, cablu de ancorare, ancoraj, staționare la ancoră, taxă de ancoraj; (constr) fixare, consolidare, ancorare

anchorage dues (nav) taxă de ancorare

anchor agitator (alim, ind chim) amestecător cu ancoră

anchor bearing berth (nav) spațiu de evitare

anchor blade (nav) unghie de ancoră

anchor bolt (constr, OM) bulon / bolt / şurub de fundatice / de ancorare

anchor book (nav) cârlig de ancoră

anchor buoy (nav) geamandură de ancoră

anchor cable (constr, nav) cablu de ancorare

anchor capstan (nav) cabestan (de ancoră)

anchor chain (nav) lanț de ancoră

anchor gear (nav) instalație de ancorare (acționată cu transmisie cu angrenaje)

anchor ground (nav) ancoraj

anchor hoy (nav) şalandă pentru manevrat ancore grele

anchor light (nav) lumină de ancoră

anchor loop (nav) buclă de ancoraj

anchor mixer (ind chim, alim) amestecător cu ancoră

anchor nut (nav) bilă de ancoră

anchor plate (constr, OM) şaibă / rondea / placă de ancorare / de fixare

anchor pocket (nav) buzunar de ancoră

anchor pole (constr, el) stâlp de ancorare / de întindere / de fixare

anchor ring (mat) tor; (nav, OM) inel / ochi de ancoră 
anchor rode (nav) cablu de ancoră anchor shackle (nav) cheie / belciug de ancoră anchor shank (nav) fus de ancoră anchor stake (constr) stâlp / pilon de ancorare / de fixare

anchor steel sheeting (constr, met) planşă metalică ancorată / pentru fixare / ancorare anchor tower (constr) stâlp de ancorare anchor trend (nav) gât de ancoră anchor tripper (nav) (sistem) ancorator anchor windlass (nav) vinci de ancoră anchor yoke (OM) brățară de prindere / de ancorare / de fixare

anchoring (OM) fixare; (nav) ancorare anchoring bolt (constr, OM) bolț de ancorare anchoring place (nav) ancoraj, loc de ancorare anchoring rod (constr) tirant de ancorare anchoring strength (plast) capacitate / putere de lipire / de legare (şi între lanţuri moleculare) anchorless (nav) fără ancoră; fără cârmă, dus de curent

ancient antic, străvechi demodat, învechit; clasic and şi; iar; precum şi, aşa că, deci, aşadar and circuit (inf, autom) circuit "şi" and-not circuit (inf, autom) circuit "şi-nu" anechoid chamber (fiz) cameră anecoidă / izolată fonic

anemometer (metr) anemometru

aneroid care nu conține / care nu foloseşte fluid / aer

angle undiță; (OM) țeavă cotită, colț; (mat) vârf, unghi; (met) cornier; (auto) unghi; at an în unghi, înclinat; situație, aspect

angle bar (met) cornier

angle bracket (constr, OM) guseu, colțar (de fixare), cornier (de asamblare); (mat) paranteze în unghi

angle buldozer (constr) buldozer cu lamă regalbilă / orientabilă

angle centrifuge (alim, mas) centrifugă înclinată angle cock (hidr, OM) robinet de colț angle cutter (mas-un) freză unghiulară

angle-cutting (mas-un) aşchierea unei teşituri, teşire, teşitură

angle deflection $(\mathrm{OM}, \mathrm{mec})$ unghi de deformare (a arborelui în reazem), rotire în punctul de reazem

angled piston pump (hidr, OM) pompă cu ax înclinat

angle drive $(\mathrm{OM})$ transmisie în unghi

angle gauge (mas-un, metr) şablon de unghiuri angle indicator (metr) indicator de unghi

angle iron (constr, mec, met) cornier

angle iron with equal sides (constr, mec, met) cornier L cu aripi egale angle joint (met, OM) îmbinare de colț (cu un unghi oarecare între piese)

angle lever shear (mas-un) foarfece cu pârghie / cotită

angle moulding press (mas-un) presă înclinată (de turnare în matriță/ de matrițare)

angle mounting ( $\mathrm{TH}$, mas) montare / fixare la un anumit unghi

angle of action (OM) unghi de angrenare / de presiune $(\alpha)$ (la angrenaj cu roți dințate)

angle of adjustment (mas-un) unghi de atac angle of advance (mas-un) unghi de avans angle of approach (mas-un) unghi de atac angle of backing (mas-un) unghi între tăişuri (la foarfece)

angle of bend unghi de îndoire / de încovoiere

angle of bite / contact (met) unghi de deschidere / de prindere (a cilindrilor de laminare), unghi de contact (semifabricat-cilindru)

angle of convergence (fiz) unghi de convergență

angle of countersink (mas-un) unghi de teşire angle of deflection (fiz) unghi de deviație / de înclinare; (mec) unghi de deformare (la o grindă) angle of entrance (nav) unghi al tangentelor la bordaj / la etravă

angle off a teşi

angle of fall (hidr) unghi de cădere / de pantă

angle of flange (mas-un, OM) unghi de lărgire / de evazare (a unei flanşe)

angle of friction ( $\mathrm{T}$ ) unghi de frecare

angle of glid $(\mathrm{T})$ unghi de alunecare

angle of hearth slope (met) unghi de înclinare al vetrei (cuptorului)

angle of impact (fiz, mec) unghi de impact

angle of incidence (fiz) unghi de incidență

angle of lead (mas-un) unghi de vizare / de avans

angle of lock (mas) toleranță unghiulară la paralelism

angle of mesh (OM) unghi de angrenare/ de presiune $(\alpha)$ (la angrenaj cu roți dințate)

angle of nip (met) unghi de contact (al semifabricatului cu cilindrul), unghi de atac (la cilindrii de laminare); unghi de îndoire al unei sârme (şi pentru încercări)

angle of nonslip point (met) unghi neutru / critic (fără alunecare)

angle of opening (mas, TH) unghi de deschidere / de înclinare

angle of phase difference (el) unghi de defazaj angle of reflection (fiz) unghi de reflexie angle of refraction (fiz) unghi de refractie angle of repose (alim, ind chim, mas) unghi de repaus 
angle of ricochet (fiz, mec) unghi de ricoşare (la o ciocnire)

angle of rolling (met) unghi de atac / de contact / de prindere (între semifabricat şi cilindrii de laminare)

angle of shock (fiz, mec, met) unghi de ciocnire / de impact

angle of sliding (mec, $\mathrm{T}$ ) unghi de alunecare angle of torsion / torque / twist (mec, OM) unghi de răsucire (produs de torsiune / răsucire) angle of unbalance (mec) unghi de dezechilibru angle reference generator (mec, metr) generator de referință de unghi (la echilibrare)

angle reference marks marcaje de referință pentru unghi (la echilibrare)

angle steel (constr, mec, met) oțel-cornier

angle valve (OM, hidr) supapă la care directia de intrare şi cea de ieşire a fluidului formează un anumit unghi, supapă în unghi / înclinată

Anglo-American anglo-american (în special cu referire la sisteme de unităti de măsură)

Ängstrom (metr) unitate de măsură $1 \ddot{A}=$ 1/6438,4696 din lungimea de undă a luminii roșii din spectrul cadmiului $\left(\sim 10^{-10} \mathrm{~m}\right)$

angular unghiular; ascuțit, cu colțuri sau muchii ascuțite

angular acceleration (mec) accelerație unghiulară angular contact ball (roller) bearing (OM) rulment radial-axial sau axial-radial cu bile (role)

angular dimension (mas-un, OM) cotă unghiulară

angularity (mat) unghiularitate, caracter ascuțit; incidență oblică; unghi; ascuțiş; (TH) toleranță unghiulară

angular load (mec, OM) sarcină / forță înclinată / sub un anumit unghi

angularly $(a d v)$ (mat) în unghi ascuțit; (în mod) stângaci

angular misalignment (mas-un, TH) defect unghiular, nealinierea / abatere unghiulară

angular momentum (fiz, mec) produsul dintre momentul de inerție şi viteza unghiulară a unui corp

angular pitch $(\mathrm{OM})$ pas unghiular $(\tau)$ (la roți dințate, roți de lanț / de curele dințate)

angular speed (fiz, mec) viteză unghiulară $(\omega)$

angular tool (mas-un) cuțit cotit

angular velocity (fiz, mec) viteză unghiulară

anharmonic (fiz, mec) anarmonic, nearmonic

anhydride (chim) anhidridă

anhydrous (fiz, chim) anhidru; deshidratat; uscat

anhydrous lime (chim) var nestins

anil (chim, ind chim, plast) grupare anil; culoare şi colorant indigo aniline (phenylamine) (chim) anilină

aniline point $(T$, chim) punct de anilină (la cauciuc, elastomeri, lubrifianți etc.)

aniline test $(T$, chim) test pentru determinarea conţinutului de anilină la arderea unui ulei / unsori etc.

animal (alim) animal, de animal

animal fat (alim) grăsime animală

animal glue (alim) proteină, clei de origine animală

animal oil (alim, T) ulei de origine animală

animate a anima; (inf) a face să fie în mişcare, a simula (pe ecran) un proces / o mişcare

anion (fiz, chim) anion

anionic (fiz, chim) anionic

anion polymerization (chim, plast) polimerizare anionică

anisotropic (fiz, mec) anizotrop

anisometry (fiz, mec, metr) măsurarea anisometriei

anisotropy (mec, met) anizotropie

anisotropy factor (mec, met, OM) factor / coeficient de anizotropie

anise (alim) anason

aniseed (alim) sămânță de anason

ankle joint (med, OM) articulație de gleznă / tip gleznă

annalist analist, autor de anale

annals anale

anneal (met) a reveni, a modera, a arde, a prăji, a calcina, a recoace, a tempera, a normaliza, a decăli, a maleabiliza; a emaila, a smălțui

anneled (met) recopt, revenit

annealed cast iron (met) fontă recoaptă / maleabilă (după tratament) / maleabilizată

annealed copper (met) cupru recopt; aliaj de cupru recopt

annealed steel (met) oțel recopt

annealed wire (met) sârmă recoaptă/ moale

annealer (met) cuptor de recoacere / de revenire

annealing (met) recoacere, coacere, regenerare, refacere, revenire, temperare, normalizare, decălire, maleabilizare; (plast) normalizare

annealing bell (met) cuptor tip clopot de recoacere (a rulourilor de tablă)

annealing box (met) cutie de recoacere

annealing carbon (met) carbon / grafit de recoacere

annealing colour (met) culoare de revenire annealing condition (met) regim de recoacere annealing crack (met) fisură / crăpătură de recoacere

annealing cycle (met) durată / ciclu de recoacere 
annealing furnace (met) cuptor de recoacere / de revenire / de maleabilizare

annealing hood (met, termo) clopot de recoacere (pentru rulouri de tablă)

annealing lacquier (ind chim, plast) lac cu uscare în cuptor

annealing oven (met) cuptor de revenire / de recoacere / de maleabilizare

annealing pot (met) creuzet sau oală de revenire / recoacere / maleabilizare

annealing temperature (met) temperatură de recoacere / revenire

annealing time (met) timp / durată de recoacere

annex adaos; anexă, supliment, completare; (constr) dependinţă $\sim$ to a anexa, a alătura, a adăuga la; a ataşa; a alipi

annihilate a anihila

annotate a face / da notă explicativă; a adnota

annotation adnotare, notă explicativă

announce a anunța; a declara; a semnala

announcement anunt(are), înștiințare

annoy a supăra, a enerva; a deranja; a plictisi annoyance supărare, iritare; deranjare; deranj, necaz, neplăcere; calamitate

annoying supărător, enervant, deranjant (şi d. zgomot de fond); plictisitor; insuportabil

annual anual; anuar

annually $(a d v)$ (în mod) anual, în fiecare an

annual output (ec) producție anuală

annuity (ec) rentă

annul a anula; a desființa; (jur) a declara nul și neavenit

annular inelar, circular, rotund

annular ball bearing $(\mathrm{OM})$ rulment radial $\mathrm{cu}$ bile

annular borer (mas-un) burghiu pentru găurire inelară

annular crucible (met) creuzet inelar / circular annular cutter / drill (mas-un) burghiu inelar annular furnace (met) cuptor inelar / circular annular gear $(\mathrm{OM})$ roată dințată, cu dantură interioară

annular groove (OM) canal / şanț inelar

annular holder (OM) suport inelar

annular kiln (met, sticlă) cuptor circular

annular magnet (el) electromagnet $\mathrm{cu}$ miez toroidal

annular nozzle (mas) ajustaj inelar; (auto) jiclor inelar

annular ring shear tester (mec, mat) tester / dispozitiv de testare / încercare la forfecare, cu inel

annular shape (de) formă inelară

annular stiffener (OM) inel de rigidizare annular type burner (met) arzător inelar annular wave (hidr, mec) undă inelară annulement anulare; desființare annulus fantă inelară, spațiu / rost inelar, cavitate sau deschidere în formă inelară anode (fiz, el) anod; placă anodică anode bar (fiz, el) bară anodică anode butt (met) (restul unui) anod parțial consumat anode copper (met) cupru anodic anode effect (fiz, el, met) efect anodic anode feedback (chim, fiz, el) reacție anodică anode mould (met) formă pentru turnarea anodului

anode mud / slime (el, met) nămol / precipitat anodic

anode strips (met) benzi anodice

anodic (fiz, el) anodic

anodic cleaning (el, TH) curățare anodică

anodic coating (el, met, $\mathrm{TH}$ ) acoperire anodică

anodic effect (met) efect anodic (la acoperiri)

anodic etching (chim, el) corodare / gravare anodică

anodic oxidation (chim, el) oxidare anodică

anodic oxide coating (chim, el) acoperire anodică

anodic pickling (chim, el, met) decanare anodică

anodic stripping (chim, el, met) îndepărtarea prin efect anodic a unei acoperiri

anodise (chim, el, met) a forma prin efect anodic o acoperire

anodising (el, met) acoperire anodică, anodizare (de protecție)

anolyte (chim) anolit (la acoperiri)

anomalous anormal; aberant; neregulat; inconsecvent; contradictoriu

anomaly anomalie

anorganic anorganic

anormalous $(\mathrm{TH})$ contrar normei; anormal

anonymity anonimat, caracter anonim

another un alt, o altă, altul, alta; încă un / o

answer răspuns, replică; to ripostă, contramăsură; (mat) soluție; a răspunde, a replica, a da un răspuns; a reacționa, a corespunde, a satisface; a fi bun / deajuns; a rezolva, a soluționa

answerable la care se poate răspunde, la care se poate da un răspuns; for răspunzător pentru / de; corespunzător la

answerableness posibilitatea de a răspunde / de a riposta; răspundere, responsabilitate

answer for a răspunde de / pentru, a avea răspunderea pentru

answer the helm (nav) a asculta cârma 
answer to a corespunde cu; a răspunde la (nume) antagonism antagonism; conflict; to opoziție / rezistență față de

antagonist opozant, adversar

antagonistic antagonist, advers, opus, potrivnic

antagonize a-şi face un duşman; a contracara; a

lupta împotruva; a se opune, a rezista, a riposta; a fi în opoziție (cu)

antagonistic couple (mec) cuplu antagonist

antecedence precedență, antecedență

antecedent antecedent, anterior, faptă anterioară; (mat) antecedent; precedent

antechamber anticameră; (TH) antecameră

ante meridian, am antemeridian, înainte de amiază / de ora 12 ziua

antenna antenă

antepenultimate al treilea de la sfârşit, antepenultim

anterior anterior, precedent, de mai înainte, din față, de dinainte

anteriority anterioritate; precedentă

anteriorly $(a d v)$ anterior, mai înainte

anteroom (constr) anticameră

antiacid (chim, met, plast) antiacid, resistent la acizi

antiager (plast) inhibitor de îmbătrânire

anticathode (el, fiz) anticatod

antichamber compression ignition engine (auto, mas, termo) motor diesel cu antecameră anticipation anticipare, anticipație, prevedere; perspectivă; (ec) plată anticipată, avans

anticipated anticipat; previzionat

anticlimax anticlimax, gradație descendentă / inversă; cădere, prăbuşire (în carieră); revers

anticlockwise (în sens) antiorar

anticlockwise (left hand) rotation rotație în sens antiorar

anticoagulant (alim, chim, med) (substanță / agent) anticoagulant(ă)

anti-corrosion additive $(\mathrm{T}$, chim) adititiv anticoroziune / anti-corosiv

anti(-)corrosive (chim, met, $\mathrm{T}$ ) anticorosiv

anticorrosive agent (chim, met, $\mathrm{T})$ agent / mediu anticorosiv

anticorrosive coating (met, plast) acoperire / vopsea anticorosivă

anticorrosive paint (nav, met, ind chim, plast) vopsea anticorosivă

anticorrosive plating (ind chim, met, plast) acoperire anticorosivă

anticorrosive protection (chim, $\mathrm{TH}$ ) protectie anticorosivă

anticorrosive quality putere / calitate / proprietate anticorosivă (d. materiale, aditivi etc.) anticreep device (autom, mas) dispozitiv de frânare (la mers în gol); dispozitiv de blocare / antipatinare

antidegradant (plast) inhibitor de îmbătrânire anti-extrusion ring (OM) inel anti extrudare (pentru o garnitură de etanşare)

antifatigue (chim, plast) (material) care îmbunătățeşte rezistența la oboseală antifoam (chim, T) (aditiv, agent) antispumant antifoam additive $(\mathrm{T})$ aditiv antispumant antifoam agent $(T)$ agent antispumant antifouling (alim, chim, plast, met) prevenirea coroziunii (şi organice) (cu referire la piese imersate)

antifreeze (auto, chim) anticongelant; antigel

antifreeze for oil (auto, $\mathrm{T}$, chim) agent antiîngheț pentru lubrifiant, antigel

antifreezing (termo) rezistent la frig

antifreezing agent ( $\mathrm{T}$ ) aditiv anticongelant / anti-îngheț / anti-solidificare

antifreezing compound (auto, $\mathrm{T}$ ) antigel

antifreezing quality (termo) rezistență la frig / înghet

antifreezing solution (auto, $\mathrm{T}$ ) antigel

antifriction $(\mathrm{T})$ antifricțiune

Anti-Friction Bearing Manufactures (AFBMA) Asociația Producătorilor de Lagăre de Antifricțiune

antifriction alloy (met, T) aliaj (de) antifricțiune antifriction brass (met, T) alamă (de) antifrictiune

antifriction insert $(\mathrm{T})$ inserție antifricțiune

antifriction lining $(\mathrm{T})$ acoperire antifricțiune

antifriction material ( $\mathrm{T}$ ) material de antifrictiune (metalic, plastic, ceramic sau compozit) antifriction metal ( $T$, met) aliaj metalic de antifrictiune, babbit (în sens larg)

antifriction state $(\mathrm{T})$ stare de antifrictiune

antifrictional $(\mathrm{T})$ de antifrictiune

antifriction alloy $(\mathrm{T})$ aliaj de antifrictiune / de cuzinet / de lagăr

antifrictional bearing $(\mathrm{OM}, \mathrm{T})$ lagăr de antifricțiune

antifrictional cast iron ( $T$, met) fontă antifricțiune

antifrictional grease (ind chim, T) unsoare antifricțiune

antifrictional metal ( $T$, met) aliaj (rar, metal) de antifrictiune

antifrother (plast, chim) (aditiv) antispumant antigravity filtration (alim, ind chim) filtrare sub vid / în sens antigravitațional

antihunt circuit (autom, el) circuit stabilizator autobasculant 
anti-icing device (termo) dispozitiv de protecție contra gheții / înghețării

antiknock antidetonant

anti-knock index (AKI) (auto, chim) indice anti-şoc

antilock brake system (ABS) (auto) sistem de frânare cu anti-blocare (ABS)

anti-lock brake system (ABS) warning light (auto) semnal luminos de avertizare pentru sistemul ABS de blocare

antimagnetic (fiz) antimagnetic, nemagnetic, amagnetic

antimonial lead (met) plumb dur, aliaj $\mathrm{Pb}+\mathrm{Sb}$

Antimony; Stibium (chim) stibiu (Sb)

antimony bronze (met) bronz cu stibiu

antimony-lead equilibrium diagram (met) diagrama de echilibru a aliajelor stibiu-plumb ( $\mathrm{Sb}$ $\mathrm{Pb})$

antinode (fiz, mec) nod (la unde, vibrații)

antinoise (fiz, $\mathrm{mtr}$ ) antizgomot

anti(-)oxidant; anti-oxident (chim) antioxidant

antiparallelogram (mat) trapez isoscel

antipiping compound (met) pulbere / substanță de protecție împotriva retasurilor

antipodal (mat) diametral opus

antipoison (med) antidot

antipyretic (termo, ind chim) antitermic, antipiretic

antirolling tank (nav) tanc de ruliu

antirust coating (chim, met) acoperire anticorosivă / anti-rugină

antirust grease $(T)$ unsoare anticorosivă (mai mult) de protectie

antirust paint (ind chim) vopsea anticorosivă

antiscuff property $(\mathrm{T})$ proprietate anti-uzură / de reducere a tendinței de distrugere prin scuffing (o formă de uzură adeziv-abrazivă)

antiscoring behaviour $(\mathrm{T})$ comportare bună la uzură adezivă, tip scoring

antiskid (material) (material, suprafață sau acoperire) cu coeficient mare de frecare / care împiedică alunecarea, antiderapant

antisludge additive $(\mathrm{T})$ aditiv detergent

antisoftner (plast) antiplastifiant, împotriva înmuierii

antitheft door handle (auto) mâner de uşă cu antifurt

antitheft steering column lock (auto) blocare anti-furt a coloanei de directie

antithetic(al) (mat) contrar, antitetic

antithrowing agent agent adeziv

antitrigonometric function (mat) functie trigonometrică inversă

antivibrating antivibrator antivibrating spring (el, OM, metr) resort / arc antivibrator (de reținere)

anti vibration mounting montaj antivibrator

antivibrator (autom) amortizor

antizymotic (chim) care împiedică fermentația

antivil (met) nicovală, contact inferior

antivil bed (met) pernă de şoc a nicovalei

antivil block (met) butuc / sabot al nicovalei

antivil cutter daltă lată

antivil face (met) suprafața nicovalei

antivil's stock (met) sabot al ciocanului

antivil tool (met) matriță de forjat

antivil vise (mas-un) menghină cu picior şi nicovală

anti-wear property $(\mathrm{T})$ proprietate de rezistenţă la uzură / de anti-fricțiune

anti-wear vane pump test $(\mathrm{T})$ încercare de uzură a pompei cu palete

anti-weld additive $(\mathrm{T})$ aditiv anti-gripare / de extremă presiune (în lubrifianți etc.)

anti-weld qualities (T) calităti anti-aderentă, anti-gripare

anti-weld quality $(\mathrm{T})$ proprietate anti-gripare $(\mathrm{d}$. lubrifianți etc.)

anvil (met) nicovală (la forjă), placă de absorbție a şocului mecanic / de presiune; (metr) zona staționară de contact, la micrometru

any orice, oricare; toți; indiferent care; vreo, ceva, câteva, unii, unele, nişte; puțin, un pic, vreunul, vreuna; (cu negatiii) nimic, de nici un fel, nici unul / una, deloc defel, câtuşi de puțin anybody oricine, oricare, toată lumea, toți any direction orice direcție, direcție arbitrară anyhow $(a d v)$ oricum, la întâmplare; în dezordine; indiferent

any method other than orice altă metodă decât anyone oricine, toți

anything $(a d v)$ orice

anytime $(a d v)$ oricând; în orice împrejurare

anyway $(a d v)$ oricum; totuşi, cu toate acestea

anywhen $(a d v)$ oricând

anywhere $(a d v)$ oriunde; în orice loc; peste tot, pretutindeni

apart în bucătii; aparte, de o parte, la o parte; în parte, separat; izolat, fără legătură; independent; deosebit, având păreri diferite

apart from cu exceptia, exceptând; dacă nu se ține seama de, lăsând la o parte, făcând abstracție de; nu numai, pe lângă; separat de apartment cameră (mare), apartament

apartment house (amer) (constr) bloc / imobil cu apartamente

apeak (nav) la pic, vertical,drept

aperiodic (fiz, mec, el) aperiodic, neperiodic 
aperiodically damped (autom, mec, metr) amortizat fără oscilații

aperiodic motion (fiz, mec, el) mişcare neperiodică

aperiodic network (autom) circuit aperiodic / de relaxare

aperiodic regime (autom) regim aperiodic

aperiodic stop difragma vibration (el, metr) vibrație aperiodică a diafragmei / membranei (la un traductor)

apertual de deschidere

aperture $(\mathrm{OM})$ orificiu, deschidere, vizor, gură (de vizitare); mărimea ochiului la o țesătură de sârmă aperture angle (mas) unghi de deschidere

apex vârf, culme, creştet, coamă, creastă, punct culminant, apogeu

API, American Petroleum Institute Institutul American al Petrolului

apical angle (mat) unghi la vârf

apiculture apicultură

API engine service classification ( $T$ ) clasificare API a condițiilor de funcționare a motoarelor apolar (mat) apolar

apology scuză; justificare; explicare; apologie (a unei teorii)

apostilb (fiz, metr) unitate de măsură pentru intensitatea luminoasă pe unitatea de suprafață 1 apostilb $=0,318309886$ candela $/ \mathrm{m}^{2}$

apothem (mat) apotemă

apparatus (TH) aparat, instrument, dispozitiv, aparataj, aparatură, sistem

apparatus for direct drying by means of furnace gases (ind chim, met) uscător cu gaze de ardere

apparent aparent, vizibil, imaginar, evident, indiscutabil; virtual, fals; pretins

apparent area of contact $(T)$ aria aparentă a contactului

apparent density (fiz) densitate aparentă

apparent dielectric constant (fiz, el) constantă dielectrică aparentă la ieşire

apparently $(a d v)$ (după cât) se pare; (în mod) aparent, evident, clar, limpede

apparent particle density (fiz, ind chim) densitatea aparentă a particulei

apparent output (mec) putere / productivitate aparentă

apparent powder density densitate aparentă a pulberii

apparent resistance (el) impendanță

apparent strain (mec, metr) deformatie aparentă

apparent time (nav) timp adevărat / real

apparent viscosity (fiz, T) vâscozitate aparentă (şi la emulsii) apparition apariție, ivire (neaşteptată)

appeal to a apela la, a se folosi de, a căuta sprijin; a recurge la; a invoca; a solicita (pe cineva)

appear a apărea, a se ivi, a se vedea, a fi văzut / observabil; a se prezenta; a se tipări, a se publica; a se găsi, a exista

appearance aspect, caracter, aparitie, ivire; venire; publicare, apariţie, tipărire; înfăţişare exterioară, exterior; fenomen; aparență, impresie; aspect exterior; probabilitate

appearance of fracture (mec) aspectul / caracterul ruperii

appear from a reieşi, a rezulta din, a se deduce din

appendage anexă, adaos, apendice; (fiz) fenomen însoțitor

appendix apendice, supliment, adaos, anexă (şi la un document)

apple (alim) măr

appliance (TH) aparat (şi de uz casnic), instrument, dispozitiv, instalatie

applicability for aplicabilitate la / pentru, posibilitate de utilizare / folosire la

applicable aplicabil, care se poate aplica; potrivit, adecvat, bun

applicable temperature range (termo, materiale) interval admisibil de temperatură

applicant solicitant, petitionar

application (to) aplicație (la), aplicare, folosire, întrebuințare, utilizare (la), aplicabilitate, posibilitate de a fi folosit / aplicat (la / pentru); cerere (şi scrisă), solicitare; (med) bandaj, pansament; aplicare, punere, aşezare; adăugare (la); talent, aptitudine; efort, sârguință

application roller (plast) rolă de aplicare / de acoperire (şi pentru adeziv)

application time (plast) timp de aplicare (şi al adezivului)

applied aplicat(iv), practic

applied load (mec) sarcină aplicată (moment şi / sau forță)

apply a aplica (la), a pune (pe), a (se) folosi de / la; a recurge la; a avea aplicabilitate, a fi aplicabil, a se aplica

apply for a se adresa pentru, a cere, a solicita

apply to a apela la, a recurge la; a se aplica la, a se referi la

apportion a împărți, a distribui, a repartiza; a aloca

apportionment împărțire, distribuire, distribuție, repartizare, repartiție; alocare

appraisal stabilire, apreciere, estimare, evaluare appraise a stabili valoarea / calitatea / condiția, a aprecia, a evalua, a estima 
appraiser evaluator

appreciable care poate fi apreciat / evaluat / estimat; apreciabil, considerabil, serios, mare appreciably $(a d v)$ (în mod) considerabil, apreciabil

appreciate a aprecia, a evalua, a estima, a prețui, a recunoaşte valoarea; (ec) a crește / spori valoarea

appreciated apreciat, stimat, recunoscut, valoros, de valoare

appreciation apreciere, evaluare, estimare, caracterizare, părere, punct de vedere; recunoaştere; recunoştință; înțelegere; recenzie favorabilă; crestere, spor; (ec) urcare (a valorii), scumpire apprentice $(\mathrm{TH})$ ucenic

apprise (of / that) a încunoştiința, a înştiința, a informa; a preveni, a avertiza

approach acces, intrare, cale de acces, apropiere, aproximație, asemănare, apropiere, (mod de) abordare (şi a unui subiect), interpretare, mod; a (se) apropia, a fi în vecinătate; a semăna cu; a trata, a se ocupa de; a aborda (un subiect, o temă şi de cercetare etc.); a sesiza; a ataca; a converge spre; $(p l)$ approaches propuneri

approach between surfaces $(T)$ apropierea suprafețelor în contact

approach contact $(\mathrm{OM})$ contact de intrare în angrenare (angrenare antepolară)

approach roller table (met) transportor cu role pentru alimentare

approachability accesibilitate

approachble accesibil, care nu este greu de abordat / de atins, abordabil

approbate (jur) a proba; a confirma; a sancționa approbation aprobare; confirmare; sancționare

appropriate potrivit, adecvat, propriu, specific, deosebit

appropriate a-şi însuşi, a lua, a fura; potrivit, nimerit, destinat pentru

appropriate for a aloca / a destina pentru

appropriately $(a d v)$ (în mod) corespunzător, potrivit, adecvat; oportun, nimerit

appropriateness caracter potrivit, potrivire, adecvare; oportunitate, caracter oportun

appropriation alocare, destinare; (ec) bani alocați, sumă alocată, fonduri; însuşire, luare, furt approvable care merită / poate să fie aprobat approval aprobare; sacționare; consimțământ, asentiment; confirmare

approval test test / încercare / probă de recepție approve a aproba (oficial); a sacționa, a confirma; a se dovedi, a arăta că este

approved booster seat (auto) dispozitiv auxiliar pe banchetă approximate aproximativ, aprope exact; a aproxima, a fi aproximativ / aproape de / la fel cu, a se apropia de

approximately ( $a d v)$ (în mod) aproximativ, cu aproximație, cam, în jur de

approximate to a aproxima (ceva), a fi aproximativ, a se apropia de

approximation aproximare, aproximație, număr / calcul aproximativ

appurtenance apartenență; proprietate; adaos appurtenances $(\mathrm{TH})$ accesorii, anexe, aparatură apricot (agr) cais, zarzăr; (alim) caisă, zarzără a priori a priori

apron sorț (la sudură); (capac de) apărătoare, paravan, prag; dig; (nav) contraetravă

apropos of la subiect; oportun, la timpul potrivit, când trebuia; în locul potrivit, unde trebuie; apropo, referitor la, cu privire la

apropos of apropo de $(\mathrm{fam})$; în legătură $\mathrm{cu}, \mathrm{cu}$ privire la

apt competent, capabil; apt; potrivit, nimerit; at apt la / pentru, competent în

aptitude aptitudine pentru, înclinație spre / pentru, talent, capacitate (pentru)

aptitude test test de aptitudini

aptitude for aptitudine pentru, înclinație spre / pentru

aptness aptitudine, pricepere, competență; oportunitate, caracter oportun / potrivit / nimerit; adecvare

apt to care poate să, gata să, predispus la, capabil de, apt să

aqua( )fortis (chim) apă tare, acid azotic concentrat

aquamarine acvamarin; (culoare) verde-albăstrui

aqua regia (chim) apă regală

aqueous apos, saturat cu apă; acvatic, de apă

aqueous adhesive (plast) adeziv apos / pe bază de apă

aqueous corrosion (chim, met) coroziune din cauza apei / umezelii

aquiculture acvacultură

arbitrary / arbitrarily ( $a d v)$ (în mod) arbitrar; făcut la întâmplare, întâmplător; accidental

arbitrary measure of consistency (hardness)

(metr) măsură arbitrară a consistenței (durității)

arbitrate (ec, jur) a rezolva prin arbitraj

arbitration (ec, jur) arbitrare, arbitraj

arbitration bar (met) bară de testare, obținută odată cu piesele turnate

arbor $(\mathrm{OM})$ arbore (mai rar), piesă cilindrică (în rotație), arbore principal; (met) bară metalică, cilindrică necesară fixării miezului la turnare

arborescent (met) dendritic; arborescent 
$\operatorname{arc}(\mathrm{el}, \mathrm{met}) \operatorname{arc}($ electric / de sudură), a forma un arc, a produce scântei; (mat) arc; a se arcui arc brazing (met) lipire cu arc electric arc cutting (met) tăiere cu arc electric arc cutting machine (mas-un, met) maşină de tăiat cu arc electric

arc discharge (el) descărcare în aer a arcului electric

arc duration (el) durată a arcului electric arc extinguisher (el) stingător de arc electric arc flame (el) flacară de arc (electric / de sudură)

arc furnace (met) cuptor cu arc electric

arch (met) boltă / boltire a cuptorului; (arhit, constr) cupolă, pod, punte; curbură, îndoire, săgeată, arc, arcadă

arch abutment (constr) zid de sprijin, zonă de reazem a boltiii

arch bearing (constr) reazem al arcului

arch brick (met) cărămidă pentru boltă (la un cuptor); (constr) cărămidă-pană; bolțar

arched arcuit, curbat

arched ginder (constr) fermă / grindă principală în arc

arched roof (constr) acoperiș arcuit / boltit; (met, termo) boltă (arcuită) de cuptor

arched roof of hearth (met) boltă de focar (la un cuptor)

archieves arhivă

arc heating (termo, el, met) încălzire prin arc electric

Archimedean conveyor (alim, ind chim, mas) transportor elicoidal

arc ignition (el) amorsarea arcului electric

arch rib (constr) nervură

arch truss (constr) fermă în arc

arch with fixed ends (constr) arc încastrat în ambele părți

arcing (met) arderea arcului (la sudură), topirea marginilor de sudat, scânteiere

arc line curbă; segment de curbă; florar

arc of contact (met) arc de contact; arc rezemat

arc of roll contact (met) arcul de contact al cilindrului cu semifabricatul (şi la laminare)

arcogen (met) sudare electrică cu gaz

arc-striking (el, met) inițierea / aprinderea arcului electric

arc stud welding with initiation by means of a collar (met) sudarea bolturilor cu arc electric amorsat printr-un inel

arc through (el) pierdere a blocării arcului

arc welder (mas, met) mașină / dispozitiv de sudat cu arc electric

arc welding (met) sudare cu arc (electric) arc-welding bimetallization (met) depunere de strat bimetalic prin sudare cu arc

arc-welding depozition (met) depunere prin sudare cu arc

arc-welding transformer (el) transformator pentru sudare cu arc

arc welding using a magnetically moved arc (met) sudare prin topire cu arc electric rotitor

ardometer (metr) aparat pentru măsurarea temperaturii suprafeței metalice încălzite, pirometru optic cu radiație totală

are (fiz, metr) unitate de măsură pentru suprafață: 1 are $=100 \mathrm{~m}^{2}$

area (mat) arie, suprafață; areal; zonă; domeniu, spațiu; gamă; sector; perimetru; (constr) curte interioară; (fig) arie, domeniu, sferă (de interes / de activitate etc.)

area of ball imprimt / of cup (metr) suprafața amprentei (la încercări de duritate, cu bilă)

area of contact (met, OM, T) arie de contact

area of gallery / port $(\mathrm{OM}$, hidr) aria de trecere, aria orificiului

area of heating (termo, met) suprafață / zonă de încălzire

area of identation (metr) suprafața amprentei (la determinarea durității)

area of section suprafața / aria secțiunii

area reduction $(\mathrm{mec})$ gâtuire (şi la rupere)

argentan (met) aliaj $\mathrm{Cu}-\mathrm{Ni}-\mathrm{Zn}$, alpaca, argentan

argil (constr) caolin

argilaceous argilos

Argon (chim) argon (Ar)

argon-arc (el, met) arc (electric) în (mediu de) argon (la sudură)

arguable discutabil, despre care se poate discuta / argumenta (pro şi contra); îndoielnic, dubios; demonstrabil, care se poate demonstra / sustine

argue a argumenta, a aduce argumente; a deduce, a dovedi, a arăta, a atesta

argue into a convinge pe cineva cu argumente

argue out of a convinge pe cineva să renunțe la / să nu mai sprijine

argue that a susține prin argumente / argumentat că, a căuta să demonstreze că

argue with a discuta contradictoriu, a aduce argumente (pro sau contra)

argument dovadă; rațiune; argument, motiv, dispută; (mat) argument, variabilă independentă, unghi polar

argumentation argumentare, argumentație; discuție; dispută (pe bază de argumente)

argumentative căruia îi place să argumenteze / să demonstreze; discutabil, îndoielnic; cu (multe) argumente, argumentat; logic 
argumentative of care demonstrează / dovedeşte că, care pledează pentru

arid arid, uscat, secetos; nefertil, neroditor; arid, sterp, steril (d. teren); sec, neinteresant, plictisitor

aridity ariditate, uscăciune; ariditate, sterilitate (fig), caracter neinteresant / plictisitor

aris $(\mathrm{OM})$ piedică, opritor

arise a lua naştere, a se ridica, a se ivi, a apărea; a se înălța, a se produce, a rezulta

arithlog diagram diagramă cu scară logaritmică pe o axă / semilogaritmică

arithmetical (mat) aritmetic

arithmetical progression (mat) progresie aritmetică

arithmetic mean medie aritmetică

arithmetic mean deviation of the assessed profile (OM, metr) deviaţia / abaterea medie aritmetică a profilului evaluat, rugozitate medie (Ra) (la profilometria suprafeței)

arithmetics aritmetică

arm mână; (OM) braț, umăr, pârghie, mâner, jug, traversă, consolă, spiță, ramură; (nav) braț de ancoră; a arma, a pune o armătură; a (se) activa; armă

armament (constr, nav, mas) armare; (mil) (şi $p l)$ armament, arme, forță armată, forțe armate; $(\mathrm{TH})$ armare

armature $(\mathrm{T})$ contact cu alunecare; cursor, glisant, rotor; (el) indus, corp de iluminat, armătură (la magnet); (OM) garnitură; (mil) blindaj, armatură, armament defensiv

armature bar (el) bară de indus

armature bearing $(\mathrm{OM})$ lagăr de rotor armature bore $(\mathrm{OM})$ alezaj al rotorului armature circuit (el) circuit al indusului armature coil (el) bobină de indus armature core (el) miez al indusului armature core disk (el) tobă de rotor / indus armature cross (el) stea de indus armature current (el) curent de indus armature drum (el) tambur al indusului armature duct (el) crestătură / canal de răcire $\mathrm{a}(1)$ indusului

armature end-connection (el) bornă de indus armature end plate (el) placă frontală a indusului confecționat din tole; cap al indusului

armature field (el) câmp electro-magnetic al indusului

armature flux (el) flux electro-magnetic al indusului

armature head flange (el) flanşă fixă a indusului

armature iron (el) corp de indus din oțel armature lamination (el) tole de indus armature leakage (el) pierderi prin dispersie magnetică a indusului

armature line of force (el) linie de forță a indusului

armature pinion (el, OM) pinion de / pe rotorul motorului

armature quill (el, OM) suport de indus

armature reaction (el) reacție a indusului

armature reaction machine (el) maşină cu reactie de indus

armature resistance (el) rezistență a indusului

armatures (TH, OM, el) armături, accesorii, garnituri

armature shaft (el, OM) arbore de rotor armature slip (el) alunecare a indusului armature slot (el) canal / crestătură de indus armature spider (el) bucşă a indusului armature stray flux (el) dispersie magnetică a indusului

armature stroke (OM, el) joc al indusului, bătaie a indusului

armature travel (OM, hidr, nav) joc al armăturii (pe direcție axială)

armature tooth (el) dinte de indus armature voltage (el) tensiune de indus armature winding (el) bobinaj de indus arm braces (constr, mas-un, OM) contrasuport / reazem-suport

arm bracket (s) (OM) contrasuport

arm clip (OM, el) brățară

armco iron (met) fier pur, fier armco

armed înarmat; cu brațe (şi la scaune etc.)

armed services (mil) forțe armate, categorii ale forței armate (mai ales pe timp de pace)

armed stage blocare; (autom) nivel blocat

Armenian stone (minerl) corindon

arm file pilă pătrată aspră

arming (TH) armătură; (mil) înarmare

armlet (el) brățară

arm mixer (alim, OM, ind chim) malaxor, agitator / amestecător cu brațe / palete

arm of couple (mec) braț al cuplului (de forțe)

arm of mixer braț al amestecătorului

arm of wheel $(\mathrm{OM})$ spiță de roată

armrest (auto) cotieră

armour (constr, mil, nav) construcție de protecție, armură, blindaj, cuirasă

armoured (constr, mil, nav) blindat, armat; (met) zid / perete întărit / căptuşit de furnal

armoured cable (el) cablu blindat / armat / protejat

armoured glass (ind sticlei) geam armat armoured steel (met) oțel pentru blindaje armour plate (met) placă pentru blindaj 
aroma (alim) aromă, parfum, buchet (la vin etc.) aromatic (alim) aromat, parfumat; (chim) aromatic

aromatic amine (chim) amină aromatică

aromatic (aryl) compound (chim) compus aromatic

aromatic hydrocarbon (chim) hidrocarbură aromatică

aromatic substituent (chim) subsituent / înlocuitor aromatic

aromatization (alim, chim) aromare, parfumare; (chim) aromatizare

around de jur împrejur; peste tot, în toate părtile; (amer) prin preajmă / apropiere, nu departe, pe undeva pe-aici, ca la, cam

arpent (fiz, metr) unitate de măsură pentru lungime: 1 arpent $=58,5216 \mathrm{~m}$; unitate de măsură pentru suprafață: 1 arpent $=4041,28224 \mathrm{~m}^{2}$

arrange a aranja, a pune în ordine; a clasifica; a pregăti, a plănui

arrangement aranjare, dispunere, amplasare (a unei maşini), montaj (şi pentru sudare); clasificare, ordine, aranjament, mod de a aranja / distribui; înțelegere, învoială, acord; (TH) reglare, poziție

arrangements (ec, TH) aranjamente, măsuri, pregătiri, (constr) amenajări

arrest interdictie; (mas-un, met, $\mathrm{OM}$ ) oprire, încetare, limitare, frânare, împiedicare, a opri, a împiedica, a fixa, a decupla, a frâna, a capta / a prinde (particule)

arrester (mas-un, met, OM) limitator (şi de cursă), dispozitiv de siguranță / de oprire / de prindere, reazem (rar), obturator, opritor; (ind chim, alim) separator

arresting care frânează / opreşte / limitează / limitează

arresting device (mas-un, met) limitator (şi de cursă), dispozitiv de siguranță / de oprire

arrestive restrictiv, limitativ

arrest point (mas-un, met) punct de oprire / de transformare

arrival venire, sosire; ivire, apariție

arrive (at, in, upon) a veni (la, în), a ajunge (la, în); a fi recunoscut, a se impune; a se întâmpla, a avea loc

arrow săgeată (indicatoare), semn de direcție; cui de lemn

arrowhead vârf de săgreată; (mat) semnul <

arrow-headed ascuțit, cu vârful în formă de săgreată

Arsenic (As) (chim) arseniu; arsenic; de arsen, arsenicat, arsenios

arsenic acid (chim) acid arsenic article (ec) articol, produs (comercial); articol de ziar; articol, punct, paragraf; a expune, a prezenta punct cu punct; (ec) a obliga prin contract

articles (ec) prevederi (într-un contract)

articulated (mec, OM) articulat $(\breve{a})$

articulation (mec, OM) articulație, prindere, balama

artificial artificial, nenatural, nefiresc, făcut de om; simulat

artificial ageing (met, plast) (proces de) îmbătrânire artificială

artificial gas (TH, met) gaz industrial

artificial light lumină artificială

artificiality artificialitate; caracter artificial / nenatural / nefiresc

artificially $(a d v)$ (în mod) artificial / nenatural / nefiresc

artificials (chim) îngrăşăminte artificiale; imitatii

artificial ventilation (met) ventilație / aeraj artificial $(\breve{a})$

as cu privire la, în ceea ce priveşte, cât priveşte; despre; din punctul de vedere al

as annealed tensile strength (met, mec) rezistență (la tracțiune) în stare recoaptă / după recoacere

asbestine de azbest

asbestos (chim) azbest sau amestec de azbest

asbestos board (constr) placă de azbest

asbestos cement corrugated sheet placă de azbociment

asbestos filled PTFE ( $\mathrm{T}$, materiale) (compozit) PTFE umplut cu azbest

asbestos tress şnur de azbest

as cast (met) în stare turnată

ascend a (se) urca (pe), a (se) sui pe

ascendant / ascendent ascendent; influență; care răsare, care se ridică; dominant, stăpânitor; strămos

ascending / ascensional ascendent, crescător

ascension ascensiune; urcare, suire; înălțare

ascensional ascensional, ascendent, urcător, de ascensiune

ascent ascensiune, urcus, urcare

ascertain a stabili, a constata; a lămuri, a se convinge de

ascertainable care poate fi stabilit / constat

ascertainment stabilire, constatare

ASCII (American Standard Code for Information Interchange) cod standardizat american pentru schimbul de informații

as complete în întregime, tot

as concerning în ceea ce priveşte, în legătură cu, cu referire la 
ascorbic acid (chim, alim) acid ascorbic, vitamina $\mathrm{C}$

as delivered (ec, $\mathrm{TH})$ în stare de livrare

as drawn (met) în stare trasă

as-fabricated (o piesă sau un ansamblu) terminat, dar fără (condiții de) tratament (de detensionare, specific sudurii, lipirii, prelucrării prin aşchiere etc.)

as forged (met) în stare brut forjată

ash cenuşă, scrum; (lemn) frasin

ash box (termo, met) cenuşar, cutie de cenuşă

ash content $(T$, chim) conținut de cenuşă (şi d. lubrifianți etc.)

ash free fără cenuşă

ashtray scrumieră

as for uneori, dacă este vorba despre, în ceea ce priveşte

as from începând cu (data de), exact la (data stabilită)

ash inclusion incluziune de cenuşă

ashore (nav) pe / la țărm, de pe țărm / coastă

ash pit (termo) cavitate de acumulare a cenuşii

ash removal (ind chim, met, termo) evacuarea / eliminarea cenuşii

ash residue (chim) reziduu de cenuşă (la procese de ardere)

aside de o parte, la o parte, într-o parte; deoparte; în / ca rezervă

aside from (amer) cu excepția, exceptând, lăsând la o parte

as if ca şi cum, de parcă; că

ask a întreba, a pune o întrebare, a chestiona; a invita, a pofti

ask about a întreba de, a se interesa de, a se informa despre / cu privire la

ask for a cere (cuiva, ceva) (şi credit), a căuta, a reclama, a necesita, a avea nevoie de, a solicita, a pretinde, a reclama; a întreba / se interesa de

asking cerere, rugăminte, care întreabă

as long as atât timp cât, (numai şi) numai dacă; (amer) fiindcă, deoarece, dat fiind că

ASME (American Society for Mechanical Engineering) Asociația Americană a Inginerilor Mecanici

as opposed to atât timp cât; spre deosebire de; cu totul altfel decât; (numai şi) numai dacă; (amer) deoarece, dat fiind că

as of de drept; (în mod) legal, după lege

aspect aspect; expresia feței, mină; latură, parte; poziție, aşezare, vedere; $(p l)$ persective

aspect ratio (OM, hidr) raport de formă aspen (bot) (lemn de) plop tremurător

asperities (T) asperități, rugozitate; accidente de teren, denivelări asperity ( $\mathrm{T}$ ) asperitate, asprime (a unei suprafețe), duritate (rar); (constr) denivelare de teren; (fig) severitate, asprime

aspertion (agr, alim, ind chim) stropire

asphalt (constr, chim) bitum, asfalt, a asfalta, a bituminiza

asphalt mixing plant fabrică / agregat de asfalt asphyxia (med) asfixie, asfixiere, sufocare asphyxiate (med) a (se) asfixia, a (se) sufoca; (TH) a înăbuşi

aspirate a aspira, a absorbi

aspiration aspirație, năzuință; străduință, ambiție; (med) aspirație, inspiraţie, inhalare (a aerului)

aspirator (mas) aspirator, pompă aspiratoare

aspiratory de aspirație / înhalare (a aerului); aspirator, care aspiră, de aspirație / aspirare

as quenched (met) în stare călită

as regards în ceea ce priveşte, cu privire la, din punctul de vedere

as rolled (met) în stare laminată

assay încercare; a încerca, a analiza; (met) prelevare a unei probe; (TH) probă pentru analiză; a testa, a încerca (şi haine etc.)

assay office laborator de încercări

assemblage adunare; grup de obiecte; colecție; (TH) asamblare, montare, grup, agregat; (mat) multime; strângere, acumulare

assemble a aduna, a strânge, a convoca, a pune în ordine; (TH) a monta, a asambla

assembling asamblare, care se asamblează

assembling shop atelier / hală de asamblare / de montaj

assembly asamblare, montaj, montare, instalare; ansamblu, agregat; sfat, consiliu; şedință, adunare (de oameni, specialişti etc.)

assembly drawing $(\mathrm{OM})$ desen de asamblare / de montaj / de ansamblu

assembly line linie de asamblare / de montaj

assembly load $(\mathrm{mec})$ sarcină (mecanică) totală pe ansamblu

assembly mark semn de montaj

assembly room cameră / atelier / hală /spațiu (închis) de montaj

assembly time timp de asamblare / de menținere a amestecului de lipit înainte de presare

assembly tool (mas-un) sculă de asamblare

assent consimțământ; acceptare; acord, a se declara de acord, a consimti

assert a (se) afirma cu hotărâre, a susține, a sublinia; a avea pretenții la; a-şi impune (autoritatea); a arăta, a manifesta, a (se) impune

assertive afirmativ; categoric, insistent, hotărât; dogmatic 
assess (ec) a evalua, a estima, a aprecia, a stabili, a fixa (un pret, o valoare), a taxa

assessable estimabil, evaluabil, impozitabil

assessment evaluare, estimare, apreciere; stabilire; (ec) impunere, taxare, stabilire/ fixare a unei valori, valoare, preț, impozit, taxă; (fig) părere, opinie

assessor evaluator; (jur) consilier juridic

asset bun (de valoare), lucru valoros; calitate, însuşire; bunuri, avere; (ec) investiție; articol (într-o listă); (ec, jur) succesiune, moştenire, valorea bunurilor care se împart creditorilor, în caz de faliment

assignation stabilire, fixare; trasare (de sarcini); (inf) atribuire, alocare, destinare; precizie, delimitare; (jur) cedare, transfer

assignee (ec) reprezentant, împuternicit; agent (al unei firme, instituții); (jur) cesionar, moştenitor de drept

assignment numire (într-o funcție); sarcină, datorie; alocare, distribuire; (amer) temă, lectie

assimilate to a asimila $\mathrm{cu}$, a aduce la acelaşi numitor cu, a adapta la; a echivala $\mathrm{cu}$

assimilation asimilare; omologare; egalizare; (alim) asimilare, digerare, digestie; absorbire, absorbtie

assist a asista, a colabora; a ajuta, a fi ajutorul cuiva

assistance sprijin; (rar) asistență

assistant asistent

assist in a lua parte la, a participa la

associate (ec)asociat; partener; membru (cu drepturi limitate, al unei asociații)

associate (with) a (se) asocia (cu), a stabili o asociație / o legătură (cu), a (se) uni (cu)

associated asociat, care conlucrează

association asociere; unire; legare; asociație; societate; uniune; legătură (şi logică)

assonance (metr) asonanță; analogie, asemănare relativă

assort a sorta, a împărți pe categorii; a grupa, a clasifica; a asorta; a aproviziona; $\sim$ with a se potrivi cu, a fi conform cu; a se armoniza cu assorted asortat, variat, diferit

assorting (met) sortare (a tablelor)

assortment sortare, grupare; clasificare; asortiment; amestec; varietate

assume a presupune, a crede, a bănui; a deduce; a înțelege; a lua în primire (un post); a-şi asuma, a prelua (o răspundere)

assumed fals, fictiv; asumat, arogat, pretins; presupus

assuming care presupune, presupunând, în ipoteza că assumption presupunere, supoziţie; ipoteză; bănuială; asumare, arogare; simulare, mască, fațadă; premisă majoră (în logică)

assurance încredere (în sine); siguranță; asigurare

assured asigurat, garantat, sigur; convins

assuredly $(a d v)$ cu siguranță, sigur, fără îndoială, categoric

assuredness siguranță, certitudine; fermitate; încredere (în sine)

assumption ipoteză, presupunere

assurance factor $(\mathrm{TH})$ factor / coeficient de siguranță

assign a desemna, a atribui

association (chim, ec) asociere

astatic independent de polaritatea Pământului

Astatine (chim) astantiniu (At)

as tempered (met) în stare revenită

as tempered hardness (met) duritate după revenire

as tempered tensile strength (met) rezistență la rupere / la tracțiune în stare revenită

ASTM (American Society for Testing and Materials) Asociaţia Americană pentru Testări şi Materiale

ASTM methods (materiale) metode după standardele ASTM (americane)

ASTM oil (ind chim, T) ulei care respectă norme / condiții de calitate ASTM

ASTM penetration (T) penetrație în sistemul ASTM (unități de măsută, metodă de testare specifice unsorilor lubrifiante)

astronimical unit (AU / UA) (fiz, metr) unitate de lungime: $1 \mathrm{AU}=1,495978707 \cdot 10^{+11} \mathrm{~m}$

as welded (met) în stare sudată

asymmetric(al) asimetric, lipsit de simetrie

asymmetrically ( $a d v)$ (în mod) asimetric

asymmetrical nugget of weld (met) nucleu de sudură asimetrică

asymmetry asimetrie, lipsă se simetrie

asymptotic property (mat) proprietatea de a fi asimptotic / de a avea o asimptotă

asynchonous (fiz) asincron

at la, în

at a glance pe scurt (d. o prezentare etc.)

at a stretch $(a d v)$ fără întrerupere

atm (atmosphere) (metr) atmosferă (unitate de presiune)

atmosphere atmosferă; ambianță, mediu; (metr) atmosferă (unitate de măsură pentru presiune)

atmosphere air aer atmosferic

atmosphere technical (at) (metr) atmosferă tehnică (unitate de măsură pentru presiune: 1 at $=98066,500000003 \mathrm{~Pa})$ 
atmospheric atmosferic

atmospheric corrosion (chim, T) coroziune atmosferică / în atmosferă / în aer

atmospheric pollution poluare atmosferică; conținut de praf (în atmosferă)

atmospheric pressure presiune atmosferică

atmospheric pressure feeding (met, plast, alim) alimentare sub presiune atmosferică

atmospheric pressure head / riser (met) maselotă atmosferică / deschisă

atom (chim, fiz) atom

atomic (chim, fiz) atomic, nuclear

atomic (arc) welding (met) sudare cu hidrogen atomic

atomic arrangement (chim, fiz) aranjamentul atomilor (într-o rețea cristalină, într-o moleculă organică etc.)

atomic dislocation (fiz, met) deplasare / dislocare a unui atom

atomic electron configuration (chim, fiz) configuratia electronilor unui atom (al unui element) atomic energy (fiz) energie atomică / nucleară atomic furnace (constr, fiz) reactor nuclear atomic hydrogen welding (met) sudare cu hidrogen atomic

atomic mass unit (u) (chim, fiz, metr) unitate atomică de masă: $1 \mathrm{u}=1,6605402 \cdot 10^{-27} \mathrm{~kg}$

atomic mass / weight (chim, fiz) masă atomică

atomic number (chim, fiz) număr atomic

atomic pile (fiz) reactor nuclear

atomic power (fiz) energie atomică / nucleară

atomic radius (fiz, chim) raza atomică

atomics (fiz) fizică atomică / nucleară; energie atomică / nucleară

atomic structure (fiz, chim) structura atomului (unui element chimic)

atomic weight (fiz, chim) masa atomică (a unui element)

atomisation (alim, fiz, ind chim, T) atomizare, procedeu de producere a picăturilor fine (de apă / lubrifiant etc.)

atomised atomizat, pulverizat

atomiser, atomizer (amer) atomizor, pulverizator, injector, dispozitiv de împroşcare

atomising jet (hidr, termo) jet pulverizat

atrament black (chim) pigment organic ("ca cerneala")

atrament process (met) parkerizare (la fosfatare)

at rest în repaus

attach (TH) a ataşa, a lega, a adăuga, a anexa, a fixa, a prinde, a anexa (la); (jur) a aresta, a pune sub sechestru

attached coupon (met) bară turnată (apendice) pentru probe attached jet (fiz, OM, hidr) jet ataşat (care se scurge pe un perete prin efect Coandă)

attached to ataşat / prins / fixat de / la

attaching hardware (auto) echipament auxiliar

attachment aderență, ataşare, adeziune, lipire, prindere, fixare, legare (de); anexare (la); (jur) poprire, sechestru, (ordin de) arestare; (TH) accesoriu, remorcă, dispozitiv ataşabil / ataşat attack atac (chimic), corodare; abordare; început; mod de rezolvare; distrugere; a ataca (chimic); a critica

attain a atinge (o limită)

attempt încercare; tentativă; experiență, probă; atentat; a încerca

attend a fi de față / prezent, a frecventa (cursuri); a însoți; a escorta

attendance comandă, conducere; (de)servire, întreținere; mânuire, reglare

attend on / upon a fi în servicul cuiva

attend to a avea grijă de, a se ocupa de; a avea de rezolvat (ceva urgent)

attent atent

attention atenție; concentrare; grijă

attentive atent, care ascultă

attentively $(a d v)$ cu atenție

attentiveness atenție

attenuate a atenua, a slăbi (o intensitate), a micsora; a subția; a înmuia, a dilua; a amortiza

attenuation (fiz, mec) atenuare, slăbire, micşorare; (alim, hidr) subțiere, diluare; (plast, met) înmuiere; (mec, el) amortizare, atenuare

attest a atesta, a dovedi; a demonstra; a confirma, a întări; (jur) a lua drept martor

attestation atestare, confirmare; (jur) legalizare, autentificare, depoziție sub jurământ

attest to a demonstra cu, a dovedi cu, a atesta cu atto (metr) prefix pentru unitătii de măsură: 1 atto $=10^{-18}$

attogram (ag) (fiz, mec, metr) unitate de măsură pentru masă: 1 attogram $=10^{-21} \mathrm{~kg}$ )

attogram/liter (at/L) (fiz, metr) unitate de măsu-ră pentru densitate: 1 attogram $/$ liter $=10^{-18} \mathrm{~kg} / \mathrm{m}^{3}$

attohertz (aHz) (fiz, metr) unitate de măsură pentru frecventă (şi a unei lungimi de undă): 1 attohertz $=10^{-18}$ hertz

attoliter (aL) (fiz, mec, metr) unitate de măsură pentru volum: $\left.1 \mathrm{aL}=10^{-18} \mathrm{~m}^{3}\right)$

attometer (am) (fiz, mec, metr) unitate de măsură pentru lungime: $1 \mathrm{am}=10^{-18} \mathrm{~m} / \mathrm{s}^{2}$ )

attometer/square second (fiz, mec, metr) unitate de măsură pentru accelerație: 1 attometer/square second $=10^{-18} \mathrm{~m} / \mathrm{s}^{2}$ )

attonewton (fiz, mec, metr) unitate de măsură pentru forță: 1 attonewton $=10^{-18} \mathrm{~N}$ 
attopascal (aPa) (fiz, hidr, metr) unitate de măsură pentru presiune: $1 \mathrm{aPa}=10^{-18} \mathrm{~Pa}\left(\mathrm{sau} \mathrm{N} / \mathrm{m}^{2}\right)$ attopoise (aP) (fiz, hidr, metr, T) unitate de măsură pentru vâscozitate dinamică: 1 attopoise $=10^{-19}$ $\mathrm{Pa} \cdot \mathrm{s}$

attostokes (aSt) (fiz, hidr, metr, T) unitate de măsură pentru vâscozitate cinematică: 1 attostokes = $10^{-22} \mathrm{~m}^{2} / \mathrm{s}$

attowat (aW) (fiz, metr) unitate de măsură pentru putere: 1 attowatt $=10^{-18}$ Watt $(\mathrm{W})$

attract (mec, fiz) a atrage

attractable (mec, fiz) care poate fi atras

attraction (mec, fiz) atragere, atracție

attraction / attractive force (fiz, mec) forță de atracție

attrition frecare, frictiune, roadere

attrition strength (constr, textile) rezistență la frecare / la roadere

atypical atipic

atypically $(a d v)$ (în mod) atipic

a.u. / au (fiz, metr) unitate de lungime 1 a.u. (of length) $=5,29177249 \cdot 10^{-11} \mathrm{~m}$

auction sale (ec) vânzare prin licitație

audibility audibilitate

audible audibil; (fiz) fonic, acustic, în domeniul auzibil, care poate fi auzit

audible sound (fiz) sunet auzibil

audible sound warning $(\mathrm{TH})$ semnal sonor (auzi-

bil), avertizare sonoră (de avarie incendiu etc.)

audible warning avertizare sonoră / care poate fi auzită

audibly $(a d v)$ auzibil, care poate fi auzit

audience auditoriu, asitență; public; spectatori, ascultători; (jur) audiere

audio controls (auto) sistem audio şi navigație

audiofrequency audiofrecvență

audio-visual audiovizual

audit (ec) revizie contabilă, (bilanț anual), a revizui, a face o revizie contabilă

auditing (ec) revizie, control

auditing committee (ec) comisia de revizie / de control

auditive / auditory sensation senzație auditivă

auger (constr) distribuitor elicoidal de materiale; (OM) pas al melcului; (mas-un) burghiu elicoidal / lat / lingură, spiral; melc; perforator auger bit burghiu pentru lemn; (mas-un) burghiu elicoidal / cilindric, tăiş al burghiului

auger drill (mas-un) burghiu-melc, perforator tip melc

auger-nose shell racletă, răzuitor

augment a augmenta, a mări (şi la aparte optice), a amplifica, a creşte, a spori; a adăuga, a completa, a multiplica augmentation augmentare, creştere, sporire, spor; (metr) mărire (şi caracteristică de microscop)

augmentation distance distanță / lungime de explorare (şi pentru microscop)

augmentative augumentativ

auriform file (mas-un) pilă triunghiulară mică, cu fața principală semirotundă

ausforming (met) (procesul de) formare a austenitei

austempering (met) călire izotermică, îmbunătățire în trepte

austenite (met) austenită

austenitic (met) austenitic

austenitic cast iron (met) fontă austenitică

austenitic grain size (met) mărimea grăuntelui de austenită

austenitic manganese steel (met) oțel austenitic manganos

austenitic Ni-Cr steel (met) oțel (inoxidabil) $\mathrm{Ni}-\mathrm{Cr}$ austenitic

austenictic stainless steel (met) oțel inoxidabil austenitic

austenitic steel (met) oțel austenitic

austenising (met) austenitizare

austenising temperature (met) temperatură de austenitizare

austenitisation (met) austenitizare, (procesul de) formare a austenitei (prin aliere, tratament)

austerity austeritate; severitate; gravitate; simplitate; restricții, privațiuni

authentic autentic, veritabil, adevărat; original; demn de încredere (referitor la o persoană sau un produs)

authentically ( $a d v)$ (în mod) autentic

authenticate a autentifica, a stabil autenticitatea; a certifica; a adeveri

authentication autentificare, stabilirea autenticității; certificare

authenticity autenticitate; originalitate

author autor; creator; inițiator

authority autoritate, putere

authorisation (brit), authorazition (amer) autorizație (şi document), împuternicire, permisiune authorized autorizat, împuternicit; delegat; aprobat; sanctionat

authorized dealer (auto) dealer autorizat

authorless fără autor; anonim

author's certificate brevet de autor

auto button (auto) buton pentru control automat (la un panou de comandă, un tablou de bord etc.)

auto carrier (auto) remorcă pentru transportat automobile

autocationic plating (ind chim) depunere prin reducere autocatalitică 
autochange (autom, mas-un, mas) schimbare automată (de comandă, a unei piese etc.)

autochanger (autom, mas-un, mas) dispozitiv de schimbare automată (de comandă, a unei piese etc.), schimbător automat

autoclave (alim, chim, plast) autoclavă

autoclave press (plast) presă cu autoclavă

autoclaving tratare în autoclavă

autocrane (mas)automacara

auto cruise indicator (auto) indicator al contro-

lului automat al vitezei

auto cruise system (auto) sistem de controlul automat al vitezei

autofeed $(\mathrm{TH})$ alimentare / alimentator auto$\operatorname{mat}($ izat $)(\breve{a})$

autogenous gazos, autogen (şi la sudură)

autogenous cutting / fusing (met) tăiere autogenă a materialelor metalice

autogenous cutting-machine (met) maşină / instalație de tăiat (prin procedeu) autogen

autogenous cutting shop (met) atelier / loc pentru tăiat (prin procedeu) autogen

autogenous ignition (termo) autoaprindere

autogenous welder (met) aparat / instalație de sudare autogenă

autogenous welding (met) sudare autogenă

autogenous welding by fusion (met) sudare autogenă prin topire

autogenous welding by pressure (met) sudare prin presare şi topire

auto-hoist (auto, mas) elevator pentru automobile auto-ignition autoaprindere

autoignition temperature (AIT) (chim, termo) temperatură de autoaprindere

auto-jack (OM, auto) cric pentru automobile, cric automat / acționat

auto-lathe (mas-un) strung automat

autolight position (auto) poziția pentru sistemul automat de iluminare

autolight system (autom, auto) sistem automat de iluminare

auto-man automat

automate a automatiza

automated machine maşină automată

automatic advanced ignition (auto) avans automat la aprindere

automatically ( $a d v)$ (în mod) automat, automatic; maşinal; involuntar; de la sine

automatically operated (autom, mas) $\mathrm{cu}$ comandă automată, acționat automat

automatic arc welder (autom, met) maşină automat(izat)ă de sudat cu arc electric

automatic balancer (autom, mec) dispozitiv de echilibrare automată automatic blocking (autom) blocare automată / comandată automat

automatic block system (autom, mas) sistem de blocare automată

automatic boiler control (autom, termo) control automat al boilerului / cazanului

automatic brake (autom, mas, OM) frână automată

automatic-brake actuator (autom, mas, OM) organ de acționare a frânei automate

automatic brazing / soldering (autom, plast, met) lipire (tare) automatizată

automatic casting machine (autom, plast, met) maşină automat(izat)ă de turnat

automatic changing switch (autom, el) întrerupător / comutator automat de schimbare

automatic check (autom, el) control / verificare automat(ă) / automatizat(ă)

automatic check sorter (autom, alim, ind chim) sortator automat (cu verificare)

automatic chuck lathe (mas-un) strung automat, cu mandrină universală

automatic circuit breaker (autom, el) întrerupător automat, disjunctor de protecție

automatic climate control system (autom, auto) sistem automat de control al climatizării

automatic clutch $(\mathrm{OM}, \mathrm{mec})$ prindere automată, cuplaj automat

automatic control (autom, el) control automat, reglare / comandă automată

automatic control circuit (autom, el) circuit de control automat

automatic controller (autom, TH) dispozitiv de control automat, regulator automatizat

automatic control system (autom, TH) sistem cu control automat / automatizat

automatic control valve (autom, OM) ventil / supapă cu control automat

automatic counting (autom, metr) numărare / contorizare automat(izat)ă

automatic counting of contamination (autom, mediu, metr) numărare / contorizare / măsurare automată a poluării / contaminării

automatic cross feed (autom, mas-un) avans transversal automat

automatic cut-out (autom, el) întrerupător / disjunctor automat

automatic cutting-out (autom, el) deconectare automată

automatic cycle (autom, TH) ciclu automat

automatic-dimming function (autom, auto) funcția comutatorului de faze

automatic discharge hopper car (autom, met) vagon autodescărcător / cu descărcare automată 
automatic disconnector (autom, el) întrerupător automat

automatic distribution (autom, el, hidr) distribuție automatizată

automatic error correction (autom, metr) corectarea automată a erorii

automatic feed (autom, mas) alimentare automat(izat)ă

automatic feeder (autom, mas) alimentator automat

automatic feeder equipment (autom, alim, ind chim, met) echipament / instalație de alimentare automată

automatic feeding alimentator automat

automatic feeding device / machine (autom, mas, mas-un) dispozitiv / maşină de / pentru alimentare automată

automatic filling machine (autom, mas) maşină automată de umplere / umplut

automatic fire alarm (autom, chim, termo) alarmă autosesizabilă de foc

automatic following (autom, mas-un, robot) urmărire automată

automatic gate lock (alim, autom, ind chim, met) dispozitiv de închidere automată a uşii

automatic gearbox (auto, autom $\mathrm{OM}$ ) transmisie automată (cu roți dințate)

automatic governor (autom) regulator automat automatic inspection (autom) control / inspecție automat(ă) / automatizat(ă)

automatic interlock (autom, OM) dispozitiv de blocare automată

automatic interlocking (autom, mas) blocare / zăvorâre automată

automatic interruption întrerupere automată

automatic lathe (mas-un) strung automat

automatic load indication (autom, mec, metr) indicare automată a sarcinii / greutății

automatic load limitation (autom, mec, metr) limitare automată a sarcinii / greutății / încărcării

automatic lubrication (autom, T) ungere automatizată

automatic machine maşină automată, automat

automatic measurer (autom, metr) aparat de măsură, automat(izat)

automatic milling machine (mas-un) maşină (semi)automată de frezat

automatic mix(ture) control (autom, auto, alim, ind chim) controlul automat al amestecului

automatic opening / tripping (autom, mas) deschidere / declanşare automată

automatic operation (autom, auto, mas, TH) funcționare / conducere / acționare automată automatic operation system (auto) sistemul de funcționare / conducere automată

automatic packaging (autom, hidr, mas, OM) etanşare automată

automatic peak limiter (autom, mas) limitator automat de vârf (de valoare maximă)

automatic phase control (auto, autom) control automat al fazei

automatic powder measuring machine (alim, autom, ind chim) maşină automată pentru dozarea pulberilor

automatic power traverse (autom, mas-un) avans automat (posibil cu acționare / motor $\operatorname{separat}(\breve{a}))$

automatic power window (autom, auto) deschidere şi închidere automată a geamurilor

automatic process control (autom) control automat al procesului (tehnologic)

automatic proportioning (alim, autom, ind chim) dozare automată

automatic reclosing (autom) reînchidere / reanclanşare automată

automatic recorder (autom, metr) înregistrator automat(izat)

automatic recording (autom) înregistrare automată / automatizată

automatic regulation (autom) reglare automată automatic regulator (autom) regulator automat / dispozitiv de reglare automată

automatic remote control (autom) reglare / control / comandă automat(ă) / de la distanță

automatic reversal (auto) schimbare automată a sensului (d. trapă)

automatic roll loader (autom, ind chim, met) dispozitiv de încărcat automat cu cilindru / cu rolă automatic sampling luare / eşantionare automată a probelor

automatic screw machine (autom, mas-un) maşină / strung automat(ă) de filetat

automatic sequence manufacture $(\mathrm{TH})$ fabricație / producție automatizată, în serie

automatic servo-drive (autom) servomecanism automatic shut-off valve (autom, OM, hidr) supapă automată de închidere

automatic soap cutter (autom, mas-un) dispozitiv de tăiat automat săpunul

automatic spark advance (auto) avans automat la scânteie

automatic speed control (autom, mas) control / reglaj automat al vitezei

automatic spot welding (autom, el, met) sudare automată / automatizată, în puncte

automatic stabilization system (autom, el, mas)sistem de stabilizare automată 
automatic starter (autom, el, mas) starter automat / dispozitiv automat de pornire

automatic starting device (autom, mas) dispozitiv automat de pornire

automatic star-up (autom, mas) pornire automată

automatic steel (met, mas-un) oțel pentru automate (pentru prelucrare pe maşini-unelte automate)

automatic stock feed (mas-un) alimentare automată

automatic stop arrangement (mas-un) mecanism pentru decuplare / limitare automată a avansului

automatic stop device (autom, OM) zăvor / dispozitiv automat de oprire

automatic switch (autom, el) întrerupător / comutator automat

automatic switching (autom, el) întrerupere / comutare automată

automatic temperature controller (autom, metr) dispozitiv automat de control / reglare a temperaturii, termoregulator

automatic testing testare automatizată

automatic time switch (autom, el) temporizator automat

automatic titrating apparatus (autom, chim) aparat automat de titrare

automatic tracking (following) (autom, masun) ghidare / reperare / urmărire automată

automatic transaxle (auto) schimbător de viteze, automat

automatic transmission (auto, OM) transmisie automată

automatic tripping (autom, OM) declanşare automată

automatic tube filling machine maşină automată pentru umplerea tuburilor

automatic turret lathe (mas-un) strung automat cu cap revolver

automatic voltage regulation (autom, el) reglare automată a tensiunii (electrice)

automatic weighing (autot, autom, metr, met) cântărire automată

automatic weighing machine (autom, metr) maşină de cântărit automat

automatic weighter (autom, metr) cântar / balanță automat(ă)

automatic weld (autom, met, nav) sudură obținută prin procedeu automatizat

automatic welding (autom, met, nav) sudare automată / automatizată

automatic winch $(\mathrm{OM})$ vinci automat

automatic window reversal (auto) schimbare automată a sensului de mișcare a geamului automating balancing (autom, mec) echilibrare automată

automation automatizare

automating coupling (autom, OM) cuplare, conectare (mecanică) automată

automating welding sudură automată (şi proces de sudare automată)

automation automatizare

automation control gear (autom, OM) echipament / sistem (şi cu tranmisie cu angrenaje) de reglare automată

automation designing (autom, $\mathrm{TH}$ ) proiectare a automatizării

automation plan (autom, TH) plan / proiect de automatizare

automatism automatism (la operator uman)

automatisation (brit), automatization (amer) automatizare

automaton, $(p l)$ automata, automatons model matematic abstract; sistem automat(izat)

automobile (amer) automobil

automobile accessories (auto) accesorii pentru automobile

automobile body (auto) caroserie de automobil automobile-body sheet (iron) (auto, met) tablă de caroserie / de ambutisat caroserii

automobile chassis (auto, OM) şasiu de automobil automobile engine (auto) motor de automobil automobile engineer (auto) inginer în domeniul constructiei de automobile

automobile engineering (auto) construcție de automobile

automobile expert (auto) expert în automobile

automobile factory (auto) fabrică / uzină de automobile

automobile gasoline (auto) benzină de autoturisme

automobile industry industria automobilelor

automobile mechanic mecanic auto

automobile motor (auto) motor pentru automobile / autoturisme

automobile oil (auto, T) ulei pentru automobile automobile plant uzină de automobile automobile radiator radiator auto automobile trade (auto, ec) comerț cu automobile automobile trailer (auto) trailer (de transportat automobile)

automobile tyre pneu / anvelopă (roată) auto automobile works (auto) lucrări (şi de reparare, reglare) la automobile autovehicule etc.

automotive auto, autopropulsat; (termo) cu motor cu ardere internă

automotive engine (auto) motor de automobil de autovehicul 
automotive engineer (auto) inginer specializat în construcția de automobile

automotive engineering (auto) construcția de automobile

automotive engine exhaust (auto, termo) gaze de eşapament

automotive excavator (constr, mas) excavator autopropulsat

automotive fuel (auto) combustibil / carburant pentru automobile / autovehicule / pentru motoare cu ardere internă

automotive industry industria automobilelor automotive truck (auto) autocamion

autonomous autonom, care se autoguvernează autonomy autonomie (neprecizată: de mişcare, energetică etc.)

auto-oiled (T) auto-lubrifiat (cu ulei)

auto-oscillations (mec, el) oscilații întreținute

auto-oxidation (chim) auto-oxidare

autopunch-impact hardness tester (metr) aparat pentru determinare a duritătii prin impact

autoreduction (chim, met) (reacțiede) autoreducere

autorepair shop (auto) atelier de reparații auto auto-repeater (autom, el) generator de semnal repetabil

auto self-excitation (el) autoexcitație

autoslide (auto, mas) autoglisare (d. o trapă)

autotempering (met) (proces de) autocălire, (material) care se autocălește

autotimer (met, metr) ceas automat pentru conectarea sistemelor de ungere (la laminoare)

auto transaxle oil dipstick (auto, OM) tijă de nivel a uleiului, jojă pentru cutia de viteze

auto transformer (auto, el) transformator auto

autotransformer starter (el) starter pentru auto-transformator

auto-truck (auto) autocamion

auto-truck scale (auto) basculă de camion

auto tyre (auto) anvelopă de automobil

auto-tyre casing (auto) anvelopă de automobil (partea metalică)

autovulcanisation stock (ind chim) amestec autovulcanizator

auxiliaries produse ajutătoare / auxiliare; servicii auxiliare (interne ale unei oraganizații / firme)

auxiliary auxiliar; ajutător; suplimentar, adițional auxiliary air intake admisie suplimentară de aer auxiliary anode (met) anod auxiliar / suplimen$\operatorname{tar} /$ de rezervă

auxiliary apparatus (metr) aparat auxiliar auxiliary carrier (mec, constr) grindă auxiliară, suport auxiliar

auxiliary circuit (el) circuit auxiliar auxiliary condenser (termo) condensator auxiliar auxiliary connecting-rod $(\mathrm{OM}$, termo) bielă secundară, bieletă

auxiliary contact contact auxiliar

auxiliary control control auxiliar, comandă auxiliară, dispozitiv (de obicei manual) de comandă, independent de modul normal de comandă

auxiliary department departament auxiliar / secundar

auxiliary device dispozitiv auxiliar

auxiliary drain (hidr) canal / drenaj auxiliar

auxiliary force (mec) forță auxiliară; (ec) personal auxiliar

auxiliary fuel tank (auto, OM, termo) rezervor / tanc suplimentar / auxiliar de combustibil

auxiliary furnace for finishing glass-ware cuptor de uscare (de finisare) a sticlăriei

auxiliary gearbox $(\mathrm{OM})$ transmisie auxiliară (cu roți dințate)

auxiliary grate (termo) focar / grilaj auxiliar auxiliary hoist elevator auxiliar

auxiliary ignition (auto, termo) aprindere suplimentară (la motoare cu ardere internă)

auxiliary implement dispozitiv auxiliar

auxiliary jack $(\mathrm{OM})$ cric / vinci auxiliar

auxiliary jet jiglor de rezervă; (auto, termo) jiclor auxiliar

auxiliary machine maşină auxiliară / secundară

auxiliary material material auxiliar

auxiliary means mijloace auxiliare

auxiliary phase winding (el) înfăşurare suplimentară

auxiliary plane plan auxiliar

auxiliary products $(\mathrm{TH})$ produse secundare / auxiliare

auxiliary quantity $(\mathrm{TH})$ cantitate auxiliară / suplimentară

auxiliary receiver (pneumatic) (hidr, termo) rezervor auxiliar de aer

auxiliary relay (el) releu auxiliar

auxiliary reservoir (alim, $\mathrm{OM}$, ind chim, $\mathrm{TH}$ ) rezervor auxiliar / suplimentar

auxiliary service serviciu auxiliar

auxiliary shaft $(\mathrm{OM})$ arbore auxiliar / suplimentar auxiliary slide valve $(\mathrm{OM}$, termo) sertar / supapă auxiliar(ă) / de expansiune

auxiliary spar (OM) pârghie / bară / traversă auxiliară

auxiliary spark gap (el) distanță auxiliară dintre electrozi; eclator auxiliar

auxiliary spring (OM) arc auxiliar / suplimentar; contraarc

auxiliary switch (el) întrerupător auxiliar auxiliary (testing) electrode (el) electrod suplimentar / auxiliar 
auxiliary theorem (mat) teoremă ajutătoare auxiliary transmission $(\mathrm{OM})$ transmisie / cutie de viteze suplimentară / auxiliară

auxiliary valve (hidr, OM) vană / supapă de avarie / de reparație

auxiliary variable variabilă secundară

auxiliary view (OM) vedere auxiliară / suplimentară (într-un desen tehnic)

av. (average) (mat) medie (implicit aritmetică)

avail a da, o oferi, a prilejui; a dispune de; a folosi; a fi de folos; a ajuta; a avea rost; folos, ajutor; efect; rost

availability folos, utilitate; disponibilitate (a unui sistem), existență; acces; accesibilitate (şi la resurse); posibilitate (de obținere); (inf) probabilitatea ca un sistem informațional să fie operațional; disponibilitate (la maşini şi emulsii etc.)

available utilizabil, disponibil, existent, care poate fi găsit / procurat; la îndemână; accesibil; abordabil; liber, neocupat

available chlorine (chim) clor activ

available electric energy (el) energie electrică disponibilă

available energy (fiz, mec) energie disponibilă / liberă

available heating value (fiz, termo) căldură specifică utilă

available power $(\mathrm{el}, \mathrm{mec})$ putere disponibilă

available storage volum util (de înmagazinare / de depozitare)

available time $(\mathrm{TH})$ timp disponibil (şi al unei maşini etc.)

avalent (chim) avalent; (mat) de valoare nulă avenue stradă, arteră de circulație

average medie; (mat) medie aritmetică, a calcula media aritmetică; mediu, mijlociu, mediat

average agreement $(\mathrm{TH})$ compromis de avarie

average boiling point (fiz) temperatură medie de fierbere

average bond (ec) înscris pentru caz de avarii average calculating operation (autom) calculare automată a mediei

average capacity (mas) capacitate / putere medie average depth adâncime medie

average deviation $(\mathrm{TH})$ deviatie / abatere medie

average diameter (ind chim, alim) diametrul mediu (al particulelor unui amestec)

average error $(\mathrm{TH}$, metr) eroare medie, media erorilor

average fuel consumption (auto, termo) consum mediu de carburant

average grain size (met) mărimea medie a grăuntelui (cristalin)

average local velocity (hidr, met, plast, $\mathrm{T}$ ) viteză medie locală average life / life-time (fiz) viață medie (a unei particule); (TH) durată medie de viață (a unei piese, maşini etc.)

average / mean shear rate (hidr, fiz, T) rata / viteza medie de curgere (a unui fluid într-o conductă, peliculă etc.)

average output producție; $(\mathrm{TH})$ putere medie, debit mediu (la ieşire)

average particle diameter (ind chim, alim) diametrul mediu al particulelor (unui amestec)

average performance (mas, $\mathrm{TH}$ ) putere / performanță medie

average piston speed (auto, hidr, termo) viteză medie a pistonului

average pitch (el) pas mediu (de înfăşurare)

average out a se compensa, a se echilibra

average rate of creep (met, plast) viteză medie de fluaj

average sample probă medie / omogenizată

average speed $(\mathrm{TH})$ viteză medie; (cf) viteză comercială / de marş

average speed between stops (auto, mec) viteză medie între opriri

average value (mat) valoare medie

average vehicle speed (auto) viteza medie a autovehicolului

average velocity $(\mathrm{mec})$ viteză medie

averaging operație de mediere a valorilor

aversion aversiune

aviculture (alim) creșterea păsărilor

avidity aviditate

avid of avid de

Avogadro's number (fiz) numărul lui Avogadro

avoid a evita, a ocoli; a (se) feri de, a se sustrage de la; a preveni; (jur) a anula (o decizie), a declara nul şi neavenit

avoidable ( $\mathrm{TH}$, mas) care poate fi evitat (şi d. defecte, accidente)

avoidance evitare, ocolire; sustragere, eschivare; (jur) anulare

avometer (el, metr) volt-ohm-ampermetru

awake a (se) trezi, a (se) deştepta; (fig) a evoca, a reînvia

awakening trezire, deşteptare; (fig) evocare, a reînviere, stimulare, stârnire

awaken to a face să înțeleagă (pericolul, riscul etc.), a face conştient de

awash la suprafața apei, la nivelul apei, acoperit / spălat de / cu apă; sub / în apă

away $(a d v)$ departe; în altă parte; într-o altă direcție aweigh (nav) smuls (d. ancoră)

AWG (American Wire Gauge) (mas-un, metr) calibru american pentru sârmă

awl (TH) sulă

awning cort; (nav) tendă 
awry strâmb(at), greşit; cum nu trebuie awu (atomic weight unit) (chim) unitate atomică de greutate / de masă

$\mathbf{a x}(\mathbf{e})$ topor; căpuitor, ciocan de nituit

axes (şi $p l$ ) (mat, mec) axă

axes crossing (mat, $\mathrm{OM}$ ) intersecţia axelor

axes of strain $(\mathrm{mec})$ axele principale de deformație

ax handle coadă de topor

axial axial

axial backlash $(\mathrm{OM})$ joc axial $\left(\mathrm{j}_{\mathrm{x}}\right)$ (la angrenaje) axial ball bearing $(\mathrm{OM})$ rulment axial cu bile axial bearing $(\mathrm{OM}, \mathrm{T})$ lagăr axial, crapodină axial (circular) pitch $(\mathrm{OM})$ pas axial $\left(\mathrm{p}_{\mathrm{x}}\right)$ (la dantura cilindrică înclinată)

axial clearance $(\mathrm{OM})$ joc axial

axial component (mec) componentă axială

axial compression (mec, OM) compresiune axială; solicitare la flambaj

axial displacement (mec, OM) deplasare axială

axial extension alungire axială

axial extension test încercare de alungire axială

axial flow compressor (mas, termo) compresor axial

axial flow turbine (mas, termo) turbină axială

axial force (mec) forță / încărcare axială

axial hydraulic thrust (hidr, OM) forță pe directia axială (și la pompe)

axial load (mec) sarcină / înărcare axială

axial load factor $(\mathrm{OM})$ factorul încărcării axiale (la rulmenti)

axial magnification (opt) mărire (pe direcție) axială; grosisment axial

axial modes $(\mathrm{mec})$ vibrații pe direcție axială

axial module $(\mathrm{OM})$ modul axial $\left(\mathrm{m}_{\mathrm{x}}\right)$ (la angrenaje cu dantură înclinată)

axial piston motor (OM, hidr) motor (şi în sens de pompă motoare) cu pistoane axiale

axial piston pump (OM, hidr) pompă cu pistoane / pistonaşe axiale

axial pitch $(\mathrm{OM})$ pas axial $\left(\mathrm{p}_{\mathrm{x}}\right)$ (la angrenaje $\mathrm{cu}$ dinți înclinați)

axial plane plan axial / de simetrie

axial play (OM) joc longitudinal / axial

axial porosity (met) porozitate centrală / axială

(la un lingou)

axial pressure (hidr, mec) presiune axială

axial profile (OM) profil axial (şi la roți dințate, suruburi etc.)

axial pump (hidr) pompă axială / elicoidală

axial ratio raport al axelor

axial runout abatere pe direcție axială la rotația unei piese

axial section $(\mathrm{OM})$ secțiune axială axial spring $(\mathrm{OM})$ arc axial / longitudinal / cu acțiune axială

axial stress (mec, OM) tensiune / efort axial( $\breve{a})$

axial symmetrical flow (fiz, hidr, mec) curgere axial simetrică

axial tension (mec) tensiune / efort axial( $\breve{a})$

axial thrust (mec, OM) apăsare / presiune / forță / încărcare axială

axial tube (hidr, OM) tub axial

axial turbine (mas, termo) turbină axială

axiom (mat) axiomă

axiomatic axiomatic, bazat pe o axiomă, evident, care nu trebuie demonstrat

axiomatically $(a d v)$ (în mod) axiomatic, evident, care nu trebuie demonstrat

axis axă, $(p l)$ axes

axis intercept segment de axă

axis of abscise axa absciselor

axis of buoyancy (nav) axă de carenă

axis of cone (mat) axă a conului

axis of curvature (mec) axă de curbură

axis of incidence (fiz) axă normală (de incidență)

axis of instantaneous rotation (fiz, mec, $\mathrm{T}$ ) axă instantanee de rotatie

axis of ordinates (mat) axă a ordonatelor

axis of oscillation (mac) axă a oscilatiei

axis of pressure (fiz, mec) linie piezometrică (a energiei potentiale)

axis of reference (mat) axă de coordonate

axis of revolution (mat) axă de revoluție

axis of rolling (mec) axă de rostogolire; (met, plast) directie de laminare

axis of rotation $(\mathrm{mec})$ axă de rotație

axis of symmetry (mat, OM) axă de simetrie

axis of weld (met, $O M$ ) axă a sudurii

axis parallel cu axe paralele

axis through center of gravity (mec) linie a centrelor de greutate

axle (mas, OM) ax, arbore, osie

axle base (auto) distanță dintre roți / dintre axe

axle bearing (auto, OM) lagăr al axului; (cf) lagăr al osiei

axle bed $(\mathrm{OM})$ suport de osie

axle box (cf) cutie de unsoare; lagăr de osie; bucşă de lagăr, cuzinet

axle box adjustment wedge (cf, OM) pană de reglare a cuzinetului de osie

axle box bearing (cf) cuzinet / lagăr cu cutie de unsoare pentru osie

axle box cover (mas) capac de lagar; capac al cutiei de unsoare

axle box guide (cf) placă de gardă, furcă de osie, ghidaj al cutiei de unsoare

axle box-keep (cf) contra-cutie de unsoare 
axle bracket $(\mathrm{OM})$ suport / scoabă de prindere a axului

axle breakage (auto, OM) rupere a axului / a osiei axle camber (auto) unghi de cădere a roților; (OM) săgeata arborelui

axle cap (mas) capac de lagăr, capac al osiei / al butucului

axle casing (auto) carter / carcasă a(l) osiei

axle center (cf) osie de mijloc

axle collar (OM) umăr de osie

axle dip (auto) unghi de cădere a roților

axle disk (mas) disc de roată, roată monobloc

axle drive (mas, OM) acționarea osiei, mecanismul de actionare a osiei

axle drive bevel gear (auto, OM) coroană / roată dințată conică (de antrenare) a diferențialului

axle drive bevel pinion (auto, $\mathrm{OM}$ ) pinion conic (de atac / conducător) al diferențialului

axle drive shaft housing $(\mathrm{OM})$ locaş de ghidare a axului planetar

axle end (OM) capăt de osie

axle failure (auto, OM) defectare / deteriorare a axului / a osiei

axle friction (cf, OM, T) frecarea osiei (în reazeme)

axle grease (T) lubrifiant / unsoare de osie

axle guard (cf, OM) placă de gardă, reazem de osie

axle guide stay (cf) legătură a plăcii de gardă

axle head (OM) cap de osie

axle journal (OM) fus; fus de osie

axle lathe (mas-un) strung pentru prelucrarea osiilor

axle load (cf, OM) presiune / sarcină pe osie

axle lubrication pipe $(\mathrm{OM}, \mathrm{T})$ teavă de ungere a axului

axle neck (OM) fus de osie; pivotul axului

axle pin (OM) fus; fuzetă, ax de fuzetă axle pivot steering (auto) direcție cu fuzete axle pressure (mas, $\mathrm{cf}$ ) presiune pe osie axle shaft (auto, OM) semiosie; arbore de planetar / de diferential

axle shaft bearing $(\mathrm{OM})$ lagăr / rulment de arbore planetar

axle shaft casing (auto, OM) locaş de ax planetar / de semiaxă

axle shaft housing (auto, OM) sistem / locas de prindere / rezemare a axului; trompă a semiaxei axle sleeve (auto, OM) arbore tubular de diferențial / de planetar, bucşă de protecție a arborelui axle slide (OM) furcă de osie; placă de gardă axle spring (mas, $\mathrm{OM}$ ) arc de suspensie axle springing (mas, $\mathrm{OM}$ ) suspensie (cu arc) a osiei / a axului

axle stub (auto, OM) capăt de arbore

axle swivel (OM) capăt de arbore

axletree $(\mathrm{OM})$ ax, osie

axle washer $(\mathrm{OM})$ disc / garnitură de osie

axle weight (mec, OM) sarcină / încărcare axială

axle-weight limit (auto, OM) sarcină / greutate admisibilă pe ax

axoid (mat) axoidă

axonometric chart stereogramă

axonometric perspective perspectivă / vedere axonometrică

axphixiation (med) axfixiere

ax stone (minerl) nefrit

axunge (alim) untură de gâscă sau de porc

azolate (chim) azotat

Azote (mai rar); Nitrogen (N) (chim) azot, nitrogen

azotic (chim) azotic

azotic acid (chim) acid azotic

azotize (ind chim, met) nitrurare, a nitrura

azure azuriu, albastru deschis 


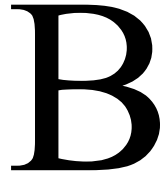

B5 biodiesel (auto, ind chim) amestec diesel cu $5 \%$ biodiesel

babbit (met, T) compoziție / căptuş̧eală pentru lagăre, babbit, aliaj de antifricțiune (numit şi alb, pe bază de Sn-Pb)

babbit alloy / metal (T, met) aliaj de lagăre de tip babbit

babbit bearing $(\mathrm{OM}, \mathrm{T})$ lagăr cu aliaj antifricțiune tip babbit

babbit-line(d) bearing (met, OM, T) lagăr cu acoperire / cuzinet din aliaj antifricțiune (tip babbit)

babbit-lining (met, OM, T) (procedeu de) acoperire cu aliaj moale tip babbit (şi prin turnare)

babbiting jib (met) dispozitiv de centrat dornul la turnarea compoziției de lagăr

baby (mas, TH) de dimensiuni mici, miniatural

babybeef (alim) carne de vițel

baccalaureate (edu) licențiat (aproximativ, în general), (titlul de) bacalaureat (şi pentru prima parte a studiilor universitare)

bacciferous structure (met, materiale) structură granulară

back spate, dos, parte de jos, fund; (mas-un) dos / spate al tăişului (sculei), muchie (din spate); înapoi, în spate; a sprijini, a da / merge înapoi, a andosa, a gira; (nav) a schimba direcția; (mas, OM) suport, spate; spetează, spătar

backacter (shovel) (constr, mec) excavator $\mathrm{cu}$ cupă întoarsă

backacting excavator / shovel (costr, mec) excavator cu cupă întoarsă

back action (mec) acțiune inversă, reacțiune

back-acting excavator / shovel (mas, constr) excavator cu cupă întoarsă

back and fill (nav) a masca şi a umple

back and forth motion (autom, mas-un) mişcare alternativă / înainte-şi-înapoi

back and front pitch of a winding (el) pas parțial al unei înfăşurări în tobă

back angle (mas-un) unghi de aşezare (la scule aşchietoare)

backacter (shovel) (constr, mec) excavator $\mathrm{cu}$ cupă întoarsă

back axle (OM, auto) ax / osie / punte din spate

backbone (med, anat) şira spinării, coloană vertebrală (şi fig); temelie, fermitate; (constr, OM) cadru cu tub central; (cf) linie ferată principală / magistrală

backbone type of frame (auto, constr) cadru cu tub central

back-breaker sarcină / problemă foarte dificilă, corvoadă, muncă istovitoare

back-breaking istovitor

back bridge wall (met, termo) prag de focar (la cuptoare)

back center (mas-un) vârf al păpuşii mobile (la strung)

backcoating (constr, arhit) acoperire pe partea opusă (şi ornamentală)

back cone (mas) con suplimentar; (OM) con conplementar (la dantură conică)

back cone of level gear (mas, OM) con complementar / frontal (la angrenaje conice)

back-connected switch (el) întrerupător cu contacte posterioare

back digger (constr) excavator cu cupă întoarsă back discharge (met) descărcare inversă

back draft (termo) tiraj invers; (met) piesă cu conicitate sau înclinare inversă pentru a fixa un model (la turnare)

backed sprijinit, susținut; $(\mathrm{TH})$ cu susținere în / pe spate (general); $(\mathrm{OM}, \mathrm{T})$ partea mai rigidă pe care se depune / se montează materialul / piesa de antifrictiune

backedfall (geogr) povârniş, pantă; cădere pe spate back edge (met, mas-un) suprafață / față de aşezare (şi la scule)

backed off (milling) cutter (mas-un) freză cu dinţi detalonaţi

backed type of mill (met) laminor cu cilindri posteriori de sustinere

back electromotive force (el) tensiune contraelectromotoare

back end plate (constr, mas) placă / perete din spate / terminală

back face $(\mathrm{OM})$ şaibă la rulmentul axial; suprafață de aşezare (şi la un rulment axial)

back fall (OM, constr) prag, treaptă

back fall slope $(\mathrm{OM}$, constr) panta pragului

backfill (constr) rambleu; (met) metal / aliaj încărcat prin sudură

back(-)fire (met) întoarcerea flăcării (în becul de sudare); (auto) rateu

backfill compactor (constr, mas) utilaj pentru compactarea rambleelor, compactor de ramblee

background fund, fundal (şi la o imagine, un desen), suport (şi pentru o acoperire), fond, material de bază; atmosferă, condiții, mediu, decor; cunoştințe, formație; zgomot de fond; experiența şi pregătirea profesională anterioară 
background noise (fiz, autom, el) zgomot de fond backhand welding (met) sudură peste mână / incomodă / cu flacăra dirijată spre cusătură / înapoi / spre dreapta

backing sprijin, suport; (OM, T) spate, suport, material de bază, placă de bază; mers înapoi / invers, retragere, dare înapoi; (constr) zidărie de umplutură, rambleiere; intrare de serviciu

backing anchor (nav) ancoră de împerechere

backing bead weld (met) cusătură pe dos, executată înainte de sudura principală

backing block (constr, met, mas, termo) căptuşeală, placă-suport

backing cloth pânză-suport, țesătură de întărire (şi la composite)

backing electrode (el, met) contra-electrod (și la sudură)

backing flange (OM) flanşă de susținere

backing frame (constr, mas) cadru suport / de reazem

backing memory / storage / store (c) memorie suplimentară; alimentator auxiliar / de rezervă

backing metal $(\mathrm{T})$ aliaj de turnat pe spate, metal de dublare, material pentru suport de cuzineți turnați

backing-off $(\mathrm{OM})$ înşurubare; (met) îndepărtare (şi a aliajului moale din lagăr, a unei acoperiri); detalonare

backing-off clearance (mas-un) detalonare prin rectificare

backing-off current (el, metr) curent compensator

backing-off device (mas-un) dispozitiv de detalonat

backing-off lathe (mas-un) strung de detalonat

backing-out punch perforator cu coadă

backing pass (met, OM) executare prealabilă a cusăturii pe dosul îmbinării, sudare prealabilă a rădăcinii

backing plate placă intermediară / de presiune (la presă); placă de bază / de fixare la matriță; (el) placă de sprijin la acumulator, contraplacă; (hidr, OM) manşetă de piele, garnitură (plată)

backing pump (mas, OM) prima pompă de vid (legată la atmosferă, într-un montaj cu două pompe)

backing ring $(\mathrm{OM})$ inel interior / de adaos / de rigidizare / de întărire / pentru a întări sudura la țevi

backing roll $(\mathrm{OM}$, ind alim) rolă / valț / cilindru de susținere

backing run (met) sudură de adaos (aplicată în sens invers primei suduri), retrosudură backing strip (met) placă / eclisă (din material neinflamabil) pentru mărirea calității sudurii

backing-up (met, $\mathrm{T}$ ) turnare a aliajului pe spatele piesei, întărirea (de obicei prin turnare / placare) a unei piese din material mai moale (şi la lagăre antifricțiune)

backing-up screw (OM, mas-un) şurub opritor

backing welding electrode (met, el) contraelectrod de sudură

back interest $(\mathrm{ec})$ dobândă neachitată / în restanță

back-kick $(\mathrm{TH})$ întoarcere / descărcare inversă, lovire la întoarcere; rateu

backlash $(\mathrm{TH}, \mathrm{OM})$ mers în gol, joc între elemente / dinți, cursă moartă, alunecare, patinare, rost de dilatație; semnul “/ "; (pol) reacție adversă (la unele măsuri socio-economice)

backlash of the control (autom) joc al comenzilor

backlash on pitch circle (OM) joc la / între flancuri (c) (pe cercul de divizare al roților dințate)

back leg picior din spate; (constr) consolă

backless $(\mathrm{OM}$, constr) fără spate / suport / spetează

backlog butuc solid (din lemn); restanță; sarcini nerezolvate; rezervă, rămăşiţă, rest; (TH) materiale neprelucrate; a se acumula, a se strânge

backlog of orders (ec) portofoliu de comenzi

back mill table (met) cale inversă cu role (plasată sub cilindrul de laminare)

backmost cel mai din urmă / spate, ultimul

back motion (met, mec) mişcare în sens invers; (nav, mas-un) mișcare înapoi

back-moving spring $(\mathrm{OM})$ arc de rapel / de întoarcere

back nut $(\mathrm{OM})$ contrapiuliță, reazem

back of arch (constr) extrados (al arcului)

back of blade (mas-un, ind chim) extrados al paletei / lamei / tăişului (sculei, amestecătorului etc.)

back of seat rezemător de spate; (OM, hidr) suprafața de aşezare a scaunului (supapei)

back of weld (met) dos al cusăturii de sudură, suprafață exterioară a rădăcinii sudurii

back off a deşuruba; (mas-un) a detalona

back out a bate în retragere, a încetini ritmul

back page pagina a doua, contrapagină

back panel wiring (el) cablaj pe spatele unui panou

back payment (ec) restanță (a plății)

back-pedaling brake (OM) frână de bicicletă, cu torpedo 
back pin (OM, mas-un) ştift de blocare (şi la discul divizor al maşinilor-unelte)

back plane vedere din spate (în desen tehnic)

back plate (mas-un) disc al mandrinei

back play (mas) mers în gol / înapoi; a parcurge înapoi un film, o succesiune de imagini

back poppet (mas-un) păpuşă mobilă

backpost (nav) etambou (şi al cârmei)

back pouring (met) turnare a lingotierelor (până la maselotă)

back pressure $(\mathrm{TH}$, hidr) contrapresiune, recul, presiune inversă / dinamică

back-pressure gauge (hidr, metr) manometru de aspirație

back-pressure regulation valve (hidr; $\mathrm{OM}$ ) supapă de reglare a contrapresiunii

back-pressure regulator (hidr, autom) regulator al presiunii de aspirație

back-pressure turbine (termo) turbină cu contrapresiune

back-pressure valve (OM, hidr) clapetă de reținere, supapă / ventil de reținere

back pull (met) trefilare în sens invers

back rabbet (nav) margine exterioară a baturei

back rake (mas-un) unghi de angajare / de ascuțire (a sculei)

back reaction (chim) reacție inversă / reversebilă / de recombinare

back reflection (fiz) radiație inversă / reflectată, reflectare (şi repetată)

back rest (cf, constr) traversă de spate; (mas-un) lunetă mobilă; spetează, spătar

back ring $(\mathrm{OM})$ inel de fund / de rechemare / de rappel / de reazem

back road drum lateral / de țară (neasfaltat)

back roller (alim, constr, ind chim, met) cilindru alimentator

back running $(\mathrm{TH})$ mers înapoi

back saw (mas-un) ferăstrău cu coadă

back-set dare înapoi, pas înapoi; (hidr) curent turbionar; (agr) a ara toamna

backshaft (OM) traversă / arbore de / din spate

back( )shift schimbul 2 / de după-amiază

back shop $(\mathrm{TH})$ atelier auxiliar

back side $(\mathrm{TH})$ latură / parte din spate, revers, pagină cu soț, verso; dos

back slope (mas-un) unghi de înclinare al tăişului principal (la scule aşchietoare)

back-slope angle (of cutting tool) (mas-un) unghi de detalonare (la scule aşchietoare); unghi de panta (de instrumente de decupare)

backspace, backspace $(r)$ / back space key $(\leftarrow)$ (c) tastă de ştergere a caracterului din stânga cursorului, (autom, c) clapă / buton de întoarcere la caracterul anterior / comanda anterioară (şi pe tastatura unui computer)

backstay (auto) tirant, cablu de ancoraj; cală / bloc de sprijin; reazem de pantă; piedică la roată; (nav) patarațină

backstay rope (constr, nav) cablu portant / de ancorare

back steam (termo) contra-abur, abur de contrapresiune

back-step pass (met) rând depus la sudare, în pas de pelerin

back-step welding (met) sudare în pas de pelerin

back stop (mas-un, met) prag, limitator de cursă

back stroke (mas, mas-un) mers / cursă înapoi, recul, contralovitură, reacțiune

back tension bridle (met) dispozitiv pentru întinderea benzii (la laminoare)

back to back $(O M)$ spate în spate, montaj în $O$ la rulmenți

back tool-holder slide (mas-un) sanie port-sculă pe spate

back twist $(\mathrm{mec})$ contratorsiune; rotire în sens invers, moment contrar de rotire

back( )up a sprijini, a susține, a întări; (met, T) a turna un aliaj pe spate; a tipări pe verso

back-up (met, T) turnare a unui aliaj pe spatele altei piese-suport; tipărire pe verso; (OM) piesă de schimb / de reazem

back-up block (constr) bloc de umplutură, suport (metalic)

backup copy (inf, c) copie (de rezervă) a unui fişier

back-up equipment echipament de rezervă

back-up movement (mec, mas) mişcare de recul

back-up protection protectie de rezervă / suplimentară

back-up ring (OM, hidr) inel antiextrudare (a garniturii)

back-up roll (met) cilindru de presiune sau de susținere (la laminor)

back-up safety device (mas) aparat / mecanism / dispozitiv auxiliar de siguranță

backup seal $(\mathrm{OM})$ etanşare exterioară, auxiliară (a unui rezervor) (montată pe partea uscată)

back-up valve (hidr, OM) ventil / supapă de siguranță (la partea de înaltă presiune)

backward înapoiat; retrograd; în sens învers; înapoi; îndreptat înapoi; întârziat; leneş

backward-and-forward bending test probă / încercare de îndoire alternativă / alternantă

backward-and-forward motion / movement (mec, mas-un) mişcare de du-te-vino / alternativă

backward-bladed fan (mas) ventilator cu aripile curbate înapoi 
backward creep / slip (met) întârziere de fază la laminare (între viteza metalului şi cea a cilindrului)

backward curved impeller (alim, ind chim) rotor cu palete curbate înapoi

backward dumping (mas) cu descărcare în spate

backward eccentric (mas, OM) excentric cu mersul înapoi

backward flow (hidr) contracurent

backwardly inclined centrifugal machine (mas, alim, ind chim) centrifugă cu aripile înclinate înapoi

backward movement $(\mathrm{mec})$ mişcare de recul; (auto) mișcare în marșarier / cu spatele

backwardness rămânere în urmă, întârziere; creștere înceată; înapoiere, caracter retrograd

backward offset tool (mas-un) cuțit cotit înapoi

backward push (mec) reacțiune, reacție; $(\mathrm{TH})$ contralovitură

backward recovery time (autom) timp de întârziere a blocării

backward running (mas) mers înapoi

backwards $(a d v)$ înapoi, îndărăt, în spate; invers, de-a-ndoaselea; pe spate

backward stop dog (mas-un) limitator pentru schimbarea sensului de mișcare a mesei

backward welding (met) sudare înapoi / spre dreapta

backwash (alim, ind chim) (spălare în) contracurent; fierbere, clocot, agitație; (nav) apă aruncată de elicea unei ambarcațiuni

backwash effect efect de decalaj (şi economic)

backwater (nav) siaj; remuu; refulare; braț mort (de râu)

backwater curve (nav) curbă de remuu ascendent

backwater envelope curve (nav, geom, geogr) înfășurătoare a curbelor de remuu

backwater pump (hidr, TH) pompă pentru apă de recirculatiie

back weld (met) cusătură de completare (la rădăcină) / pe spatele rostului

back welding (met) (acțiunea de) sudare (şi de completare) la rădăcină

back-wheel brake (auto) frână pe roțile din spate

backyard curte (din spate); teren în perimetrul unei ferme

bacon (alim) slănină

bacteria, $(p l)$ bacterii bacterie

bacteria bed (alim) biofiltru, pat bacterian, filtru biologic

bactericide (alim, med, agr) bactericid, agent de ucidere a bacteriilor

bacteriological bacterian, bacteriological bacteriologist bacteriolog

bacteriology bacteriologie

bacterium, (pl) bacteria bacterie

bad rău, prost; stricat; nepotrivit, nefavorabil; alterat, putred, viciat; periculos, dăunător; defect; urât, neplăcut, rău (d. miros); fals, calp, nevalabil; greşit, incorect; inexact; neizbutit, nereuşit; nesatisfăcător

bad debts reserve (ec) rezerve pentru creanțe nerecuperabile

badge document de identitate codificat, semn distinctiv, marcă, emblemă; insignă; (auto) sticker; (fig) simbol

bad husbandry (ec) administrare incompetentă, risipă

bad influence $(\mathrm{TH})$ influență / afectare negativă nedorită / dăunătoare

badlands (agr) teren sterp / neroditor; teren puternic erodat

badly $(a d v)$ rău, greşit, prost; urât; foarte mult, grozav

badness calitate proastă, stare proastă; caracter vătămător

bad reinforcement angle $(\mathrm{OM})$ defect de racordare (şi la sudare, la proiectarea formelor metalice etc.)

baffle $(\mathrm{TH}, \mathrm{OM})$ ecran, deflector, prag, şicană, taler; (auto) tobă de eșapament; (c) placă / ecran de reflexiee; placă (şi perforată) de regularizare a curgerii; a împiedica; a zăpăci, a deruta, a încurca; a induce în eroare; a arunca într-o parte şi în alta; a dejuca; a necăji; (TH) a filtra, a ştrangula; a devia

baffle blanket (fiz, metr) ecran absorbant de sunet, membrană absorbantă

baffle board (constr, met) perete despărțitor, ecran deflector

baffle chamber (alim, ind chim) cameră / recipient cu şicane

baffle cloth prelată de pânză (şi la platforma unui autocamion)

baffle collar (OM) inel opritor / de retinere

baffle column (alim, ind chim) coloană cu şicane

baffle column mixer (alim, ind chim) coloană de amestecare, cu şicane

baffled încurcat, nedumerit, complicat; şicanat; $(\mathrm{OM}) \mathrm{cu}$ şicane

baffle deflector $(\mathrm{OM})$ ecran deflector

baffle-nozzle amplifier (OM, hidr) amplificator pneumatic (cu ajutaj)

baffle pan $(\mathrm{OM})$ deflector, sicană, taler

baffle piston $(\mathrm{OM})$ piston cu deflector

baffle plate $(\mathrm{TH})$ deflector; $(\mathrm{OM})$ perete al labirintului de etanșare, placă de deviatie, placă 
mobilă pentru reducerea volumului de trecere printr-un tub, taler, şicană, ecran de deviere

baffle-plate column mixer (alim, ind chim) amestecător tip coloană, cu şicane plate

baffle-plate furnace (met, termo) focar $\mathrm{cu}$ şicane plate

baffler (auto, hidr) deflector, regulator al circulației de ulei, tobă de eşapament, regulator de debit

baffle separation (alim, ind chim) separare în aparate cu şicane

baffle-type collector (ind chim, met) colector de praf cu şicane (în instalație de gaze)

baffle washer scrubber (ind chim, met, mediu) spălător cu şicane (şi pentru gaze)

baffling greu, dificil, complicat, derutant; $(\mathrm{TH})$ deviator, care deviază / încursă / perturbă; (nav) (vânt) nefavorabil

bag sac, săculeț, pungă; geantă, valiză, geamantan; (TH) balon, capsulă; (agr, zool) uger; a ambala / pune în saci / pungi; a îndesa; a colecționa; (fam) a şterpeli; a (se) umfla

bag dust filter (TH) filtru de praf cu sac(i)

bag filter / hose (TH) filtru de praf, cu saci

bag filtering / filtration (alim, ind chim, met) separare / filtrare cu saci

baggage (amer) bagaj; echipament portabil baggageroom cameră / magazie de bagaje

bagged goods (transp) marfã în saci

bagging încărcare / ambalare în saci, ambalaj (saci), țesătură pentru saci / ambalaje

bagging machine (mas, constr, alim, ind chim) maşină de ambalat în saci

bagging-up machine (ind chim, auto) presă de formare a anvelopelor

bag house / room (mas, ind chim) cameră / incintă de filtru (cu sac)

bag house fume (constr, met, ind chim) praf din gazele de ardere, depus pe / în filtru cu saci

bag-making machine (mas) maşină de confecționat saci / pungi

bag mould (mas-un) matrită cu sac de cauciuc

bag moulding $(\mathrm{TH})$ formare cu sac de cauciuc

bag-packing machine (mas, alim, ind chim) maşină de ambalat în saci

bag scraper $(\mathrm{OM})$ mecanism de curățare a filtrului cu saci

bag sealing machine (alim, ind chim) maşină de închis pungi

bag-type collector $(\mathrm{OM}, \mathrm{TH})$ filtru / colector cu sac

bail (constr) colier; (ec) garanție, zălog; (OM) mâner, toartă, ureche, buclă

bailing wire (el) sârmă lăcuită bailment (jur) eliberare pe cauțiune; cauțiune, chezăşie, garanție; (ec) mărfuri depuse în păstrare cu garanţie

bail out (constr, TH) a excava, a evacua (şi fluide)

bainite (met) bainită

bainitizing wire (met) sârmă cu structură bainitică / care poate deveni bainitică (prin tratament)

bait momeală, nadă; tentație; (chim) insecticid, otravă; gustare (în călătorie), popas; (agr) nutreț (pentru cai)

bake (met, ind chim, alim) a arde, a prăji, a (se) coace (în cuptor), a calcina, a etuva, a sinteriza, a (se) usca; a (se) usca la soare; a se întări

baked carbon (el, met) electrod de cărbune

baked clay (constr) teracotă

baked core (met) miez uscat (la turnare)

baked permeability (met) permeabilitate în stare uscată (la turnare, după sinterizare)

baked strength (met) rezistență în stare uscată (a formei de turnare)

bakehouse (alim) brutărie, cuptor, rafinărie (de zahăr)

bakelite (plast, el) bachelită

bake on (alim, ind chim) a se lipi, a se prinde prin ardere

bake out a coace (şi pâine)

baker (alim) brutărie, fabrică de pâine, uscător, cuptor de uscare, brutar

bakery hop-yeast (alim) drojdie de panificație

bakery products (alim) produse de panificație

bakery yeast (alim) drojdie de panificație

bakestone (alim, constr, met) podea / vatră de cuptor

baking (alim, ind chim) coacere, uscare, calcinare (mai rar), de copt, care se coace

baking anchor (met) ancoră pentru model de turnare (necesar la uscare); (nav) ancoră de înapoi / de spate

baking apparatus (alim, ind chim) aparatură de ardere / de coacere (şi de laborator)

baking coal (met) cărbune cocsificabil / aglomerat

baking coating (met, ind chim) acoperire cu uscare în cuptor (şi pentru vopsea)

baking loss (alim, ind chim) pierdere la copt / la ardere / la uscare

baking of resin (chim, plast) întărire (şi termică) a răşinii

baking of varnish (chim, plast) uscare a lacului în cuptor

baking oven (alim, ind chim) cuptor / cameră de uscare / de coacere, uscătorie

baking powder (alim) praf de copt 
baking process (alim, met) proces de tratare termică / uscare / coacere

baking soda (alim) bicarbonat de sodiu

baking together during burning lipire la ardere / coacere / întărire

balance $(\mathrm{TH})$ balanță, cântar, echilibru, contragreutate, greutate, pondere, cântărire, cumpănire, considersare; nesiguranţă, şovăială; (el) circuit de echilibrare; (ec) bilanț (şi al conturilor), balanță, rest, sold, a echilibra bugetul; (ec) $\sim$ in hand sold creditor, due sold debitor (TH) a (se) echilibra, a fi în echilibru, a-şi menține echilibrul, a (se) balansa, a egaliza, a egala, a compensa, a cântări, a aprecia, a compara, a ezita; $\sim$ by, $\sim$ against, $\sim$ with a contrabalansa

balance account $(\mathrm{ec})$ rest, sold, bilanț contabil

balance arm (OM, metr) braț al balanței / al balansierului

balance attenuation (autom) atenuare de echilibrare / de compensare

balance axis (mec) axă de echilibrare

balance beam $(\mathrm{OM})$ pârghie (articulată la mijloc), balansier compensator, braț de balanță

balance blade (OM, metr) cuțit (ca) de balanță, lagăr ascuțit

balance-blast cupola (met) cubilou cu aer condiționat / controlat / cu atmosferă controlată

balance bridge (constr, met) pod basculant

balance bridge circuit (el, electr) circuit în punte echilibrată

balance check (autom, metr) controlul reglajului zero

balance cock (metr, OM) consolă a balanței

balanced $(\mathrm{TH}, \mathrm{mec})$ echilibrat, compensat, nivelat, aplanat, ponderat; armonios, simetric

balanced-blast cupola (met) cubilou cu vânt echilibrat

balanced block brake (OM) frână echilibrată / compensată (şi cu saboți)

balanced brake $(\mathrm{OM})$ frână echilibrată

balanced crane (mas) macara cu contragreutate

balanced crank $(\mathrm{OM})$ manivelă echilibrată

balanced crankshaft $(\mathrm{OM})$ arbore cotit echilibrat

balanced error (autom, metr) eroare echilibrată / cu compensare automată

balanced feeder (el) linie de alimentare bifilară

balanced filter (el) filtru compensator (şi în fotografiere)

balanced forces (mec) forțe echilibrate

balanced guard (met) ghidaj suspendat (la laminoare), cu echilibrare

balanced method (metr) metodă de compensare, metodă de zero balanced mixer (alim, ind chim) amestecător echilibrat

balanced peel (alim, met) braț de dozat / de şarjat (şi cu dispozitiv de echilibrare)

balanced pressure blowpipe (met) suflai fără injector, cu presiuni egale (ale gazelor); (hidr) conductă pentru echilibrarea (supra)presiunii

balanced pressure principle (mec, hidr) principiul presiunilor egale

balanced pressure regulator (hidr, OM) supapă de egalizare a presiunii gazelor

balanced reaction (chim, met) reactie de echilibru / reversibilă

balanced rudder (nav, OM) cârmă compensată / echilibrată

balanced running (mas, TH) mers uniform / echilibrat

balanced sample (mat) selecție ponderată

balanced state (mec, met, termo) stare de echilibru

balanced steel (met) otel semi-calmat

balanced to ground / (with respect) to earth raportat la sol / la pământ; (el) echilibrat față de pământ (masă)

balanced twist (mec) torsiune echilibrată / compensată

balance due (ec) sold debitor; datorat echilibrării / echilibrului

balanced vane motor (mas, hidr, OM) motor / pompă motoare cu palete echilibrate

balanced vane pump (hidr, mas) pompă cu palete echilibrate

balance gate $(\mathrm{OM})$ închizător / dispozitiv de închidere cu contragreutate (şi la maşini-unelte)

balance gear $(\mathrm{OM})$ transmisie diferențială, diferențial

balance indicator (metr) indicator de zero / de echilibru / de compensare

balance in hand (ec) sold creditor

balance level (metr) nivelă (cu bulă de aer)

balance lever (OM, mas) pârghie de echilibrare, balansier

balance load (metr, mec) încărcare la echilibru, sarcină de echilibrare

balance meter (metr) balanță, aparat de / cu zero

balance method (autom, metr) metodă a punctului de zero

balance needle (metr) ac indicator al balanței balance of accounts (ec) bilant de decontare balance of heat (termo) bilanț termic

balance out a echilibra, a balansa, a neutraliza, a cântări, a egaliza, a compensa

balance pan (metr) platan / taler de balanță

balance pan (metr) cos / platan de balantă 
balance point indicator (metr) indicator de poziție de echilibru

balance quality grade calitate a echilibrării

balancer (mas) balansier, egalizator, stabilizator, dispozitiv de echilibrare, (element) compensator

balancer booster (autom, mas) regulator / amplificator de compensare / de corectie

balance rope (nav, mas) funie de echilibrare, contracablu, cablu de compensare

balance screw (metr, OM) şurub de echilibrare

balances handle (OM) manivelă cu contragreutate

balance(-)sheet (ec) (foaie / formular de) bilanț, balanță

balance-sheet item (ec) post / articol de bilanţ

balance sheet of materials $(\mathrm{TH}, \mathrm{ec})$ bilant de materiale (în producție, la reparații în construcții)

balance spring (OM, metr) arc (spiral) de echilibrare, dinamometru cu arc

balance staff $(\mathrm{OM})$ ax de balansier, piesă / dispozitiv pentru echilibrare

balance tab (mas) suprafață de balansare / de compensare

balance tank (alim, hidr) rezervor de echilibru / de egalizare

balance tolerance $(\mathrm{TH}$, metr) toleranță de echilibrare

balance weight (met, OM) contragreutate

balance wheel (mas, termo, OM) volant (şi de motor); (metr) balansier (la ceas)

balance with dial (metr) balanță cu cadran

balancing balansare, echilibrare, compensare, simetrizare, neutralizare

balancing apparatus (metr) aparat de zero

balancing arbor / shaft (OM) arbore de echilibrare

balancing battery (el) baterie de echilibrare

balancing chamber (ind chim) cameră de echilibrare / de compensare

balancing coil (el) divizor de tensiune (cu spire)

balancing equipment (mas, metr) echipament de echilibrare (si a rotorilor)

balancing fault $(\mathrm{TH})$ defect / greşeală de echilibrare / de compensare

balancing indicator (metr) indicator de echilibru / de compensare

balancing lever $(\mathrm{OM})$ balansier compensator

balancing machine (mas, metr) maşină de echilibrare (a lagărelor, a rotorilor etc.)

balancing matching (el) echilibrare

balancing method $(\mathrm{TH})$ metodă de compensare / de egalare

balancing of the masses (mec) echilibru al maselor, compensare a maselor balancing piston (in steam turbine) (termo) piston de echilibrare (la turbine cu abur)

balancing plane plan de echilibrare

balancing reservoir (hidr, alim) rezervor de compensare

balancing ring $(\mathrm{TH})$ inel de manevră

balancing speed (mas, TH) viteză de regim / de echilibru / de echilibrare

balancing surface (mas, ind chim, termo) suprafață de compensare

balancing tester (metr) aparat de încercare / de testare a echilibrării, aparat de echilibrat prin încercări

bald chel, pleșuv; gol, golaş; fără pene etc.; deschis; sărăcăcios; simplu; sec, plat, monoton (d. stil, text etc.)

bald tyre (auto) anvelopă cu bandă de rulare uzată

bale balot (şi de marfă); marfă; fascicul; grup; mănunchi; pachet (mare); a face pachete (baloturi), a împacheta, a balota; (met) a bricheta șpan

baled scrap (met) deşeuri metalice (şi fier vechi) în pachet / în balot

bale-out furnace (met) cuptor fix

bale store magazie de baloturi

bale ties (met) sârmă de împachetare / de ambalare, legături de ambalare

baling ambalare în pachete / baloturi, împachetare, ambalaj, balot

baling band / loop (met) (plat)bandă (de oțel) de împachetat

baling machine / press (mas-un, met, alim) maşină / presă de împachetat (semifabricate, pachete etc.) baling wire sârmă de împachetat

balk obstacol, piedică; (mec) lonjeron, grindă longitudinală, bară; a (se) împiedica, a (se) opri, a stânjeni, a îngrămădi, a omite, a scăpa (din vedere), a evita, a pierde (şi ocazia), a refuza (o sarcină), a se sustrage (de la o sarcină / îndatorire), a se împotrivi, a se opune, a aduce argumete contrarii, a dezamăgi, a decepționa; (agr) fâşie de teren nearat; (nav) travers; (constr) apartament la mansardă; înfrângere, decepție

ball bilă, minge, sferă, balon, glonte; $(\mathrm{OM})$ rulment, bilă (şi de rulemnt), flotor; glob, ghem; a se aglomera, a forma sfere, a (se) face ghem; (alim) chiftea; (nav) traversă de punte

ball-and-line float (hidr, ind chim) flotor compus / de adâncime

ball-and-roller bearing $(\mathrm{OM})$ rulment combinat, cu bile și role

ball-and-roller steel (met, OM) oțel de rulment

ball-and-socket (OM) fus / cuzinet sferic, articulație sferică 
ball-and-socket gear control / shifting (auto) manetă de viteze, cu cap sferic / cu articulație sferică

ball-and-socket joint / hinge (OM) articulație sferică / cu nucă

ballast (nav) lest, balast; pietriş; a lesta, a balasta, a încărca cu balast

ballast dragger (nav) şalandă de dragă

ballast pigs (mas) blocuri de fontă folosite ca balast

ballast trip (nav) călătorie cu / în balast

ball attachment (metr) vârf / capăt sferic de măsurare, capăt sferic (eventual detaşabil), bilă prinsă în tija palpatorului sau indentorului

ball bearing $(\mathrm{OM})$ rulment / lagăr cu bile

ball-bearing (-bracket) drop hanger (OM) lagăr oscilant (cu rulmenți cu suprafață exterioară sferică), suspendat în consolă

ball-bearing extractor / puller (OM) extractor de rulmenți (prin tragere sau împingere)

ball-bearing grease $(\mathrm{OM}, \mathrm{T})$ unsoare pentru rulmenți

ball-bearing lead screw (OM, mas-un) şurub conducător cu bile

ball-bearing race / ring (OM) inel / cale de rulare / de rulment

ball-bearing spindle $(\mathrm{OM})$ fus / arbore (rezemat) pe rulmenti

ball-bearing steel (met, OM) oțel de rulmenți

ball-bearing torque test of greases $(\mathrm{T})$ determinare a calității unsorii de rulmenți prin măsurarea cuplului motor

ball-bearing wallbracket hanger (OM) lagăr oscilant cu bile, în consolă

ball burnishing $(\mathrm{TH})$ superfinisarea bilelor (şi de rulment)

ball cage (OM) colivie a rulmentului (cu bile)

ball clay (constr) argilă plastică

ball cock $(\mathrm{OM})$ robinet cu bilă

ball check valve (OM, hidr) supapă / opturator / robinet cu bilă

ball clay (constr) argilă pentru olărit, argilă pentru tuburi

ball closure $(\mathrm{OM})$ obturator cu bilă

ball condenser (termo) refrigerent / condensator cu bule

ball crusher (alim, constr, ind chim) moară cu bule

ball cup $(\mathrm{OM}, \mathrm{T})$ cuzinet / locaş / lagăr sferic

ball cutter (mas-un) freză sferică

ball end (OM) cap / fus / pivot sferic

ball-ended mill (mas-un) freză-deget cu cap sferic

ball-ended pin (OM) fus / ştift cu cap semisferic ball float (auto) flotor sferic

ball float (steam) trap (termo) oală de condensare cu plutitor

ball-forming rest (mas-un) sanie port-cuțit pentru prelucrarea suprafețelor sferice

ball-forming test test de duritate cu bilă / Brinell ball gate (met) răsuflătoare circulară

ball gauge (metr) calibru cu bile

ball-gauge cock $(\mathrm{OM}$, hidr) robinet cu bilă

ball governor (hidr, OM) regulator cu bilă / bile

ball groove $(\mathrm{OM})$ cale de rulare (la rulmenți cu bile)

ball handle $(\mathrm{OM})$ mâner sferic

ball hardness $(\mathrm{mec})$ duritate Brinell

ball-hardness number valoare a durităţii Brinell

ball-hardness test (mec, metr) încercare de duritate Brinell

ball head $(\mathrm{OM})$ cap sferic

ball-headed bolt (OM) şurub / bolț cu cap semisferic / semirotund

ball holder (OM) colivie a rulmentului cu bile

ball-impact hardness tester (met, plast, metr) aparat pentru determinarea durității sclereoscopice / Shore

ball impression (metr) urmă a bilei, amprentă la măsurarea durității Brinell, calotă imprimată

ball-impression test (met, metr) încercare Brinell pentru determinarea durității

ball-indentation test (met, metr) încercare Brinell (cu bilă) pentru determinarea durității

balling formare de bulgări, aglutinare; (chim, fiz) coalescență

balling furnace (met) cuptor cu reverberație

balling machine (mas-un) maşină de prelucrat bile de rulment

balling press (mas-un) presă de brichetat

ball iron (met) fier pudlat

ball joint $(\mathrm{OM})$ articulație sferică, racord / cuplaj tip nucă / bilă / rotulă

ball journal $(\mathrm{OM})$ fus sferic

ball knob $(\mathrm{OM})$ mâner cu cap sferic

ball lead screw (OM, mas-un) şurub conducător cu bile

ball lever (OM) levier cu mâner sferic

ball-like similar cu o bilă, sferoidal, în formă de bilă

ball mill (constr, mas) moară cu bile

ball milling (constr, mas) măcinare în moară cu bile

ball mill pulverizer (alim, ind chim, mas) moară cu bile pentru măcinare fină

ball nut $(\mathrm{OM})$ piuliță cu cap sferic

balloon balon, aerostat; (chim) balon (de sticlă); a ridica, a se umfla 
balloon flask balon de sticlă

balloon tyre (auto) anvelopă balon, pneu de joasă presiune

ball packing (met) umplutură cu / de bile; (plast) presarea bilelor / granulelor

ball-pane iron (met) fier / semifabricat lat

ball-peen hammer ciocan cu cap sferic

ball pin (OM, hidr) ac cu cap sferic (la ventile, supape)

ball plug gauge (metr) calibru tampon sferic

ball plug valve (OM, hidr) robinet / supapă / ventil cu obturator sferic / cu bilă

ball point (OM, metr) vârf bombat / sferic

ball point set screw $(\mathrm{OM})$ şurub de reglare cu vârf bombat / sferic

ball press (met) ciocan de forjat lupe

ball-pressure (met, metr) presiunea exercitată de bilă (la teste Brinell)

ball-pressure hardness (metr) încercare Brinell, cu bilă

ball race $(\mathrm{OM})$ cale de rulare a bilelor (la rulmenți), inel de rulment cu bile

ball race of bearing $(\mathrm{OM})$ inel / cale de rulare (şi la rulmenți)

ball race (thrust) $(\mathrm{OM})$ şaibă / cale de rulare la rulmenti axiali cu bile

ball reamer (mas-un) alezor sferic

ball regulator $(\mathrm{OM}$, hidr) regulator cu bile (în special la acționări hidro-pneumatice)

ball retainer $(\mathrm{OM})$ colivie de rulment

ball retainer ring $(\mathrm{OM})$ colivie inelară a rulmentului

ball retaining valve (OM, hidr) supapă de reținere cu bilă

ball screw $(\mathrm{OM})$ surub cu bile

ball seat (OM, hidr) scaun sferic (la supape, robinete); (metr) reazemul bilei

ball seat coupling (OM, hidr, metr) articulație cu bilă intermediară, cuplare cu racord cu bile / bilă (pe o suprafață plană sau conică), racord cu bile / bilă

ball-shaped de formă sferică, sferic, rotund

ball sizing (mas-un) finisare a bilelor la o dimensiune dată

ball slide (OM, mas-un) ghidaj cu bile, sanie cu bile

ball socket (OM, metr) contra-piesă / suport / suprafață de aşezare / suport pentru bila unei supape / unui robinet, cuzinet pentru fus sferic

ball steel (met) oțel de rulmenți

ball-step / ball-thrust bearing (OM) rulment axial cu bile

ball structure (met, materiale) structură globulară / globoidală / sferică ball stud $(\mathrm{OM})$ bolț cu bilă (şi la articulații de tip cardanic)

ball test (met, metr) încercare a durității, test de călire, cu indentare cu bilă

ball tester (metr, plast, met) sclereoscop, dispozitiv de testare a durității cu bilă

ball-thrust hardness (mec) duritate Brinell

ball-turning lathe (mas-un) strung pentru prelucrarea capetelor sferice

ball-up manşonare (a unei piese sferice)

ball valve $(\mathrm{OM})$ supapă / obturator / robinet sfe$\operatorname{ric}(\breve{a})$

ball viscometer / viscometer (metr, T) vâscozimetru cu bilă

balsa balsa, lemn de plută

balsam balsam; (chim) rășină aromată

baluster (constr) balustru, balustradă

balustrade (constr, nav, met) balustradă, parapet ban interzicere, interdicție, condamnare publică, oprobriu; a interzice, a pune sub interdicție / în afara legii; a opri; a prohibi

banana (alim) banană

banana pin / plug (el) fișă (tip) banană

banbury mixer (alim, ind chim) amestecător (şi de cauciuc) cu două axe care se rotesc în sens contrar

band legătură, banderolă; bandă; chingă; fầşie; cordon, centură; brățară; sfoară de legat; platbandă; grup; $(\mathrm{TH}, \mathrm{OM})$ curea de transmisie (în general), bandă rulantă; (fiz) lungime de undă; a se uni, a se coaliza

bandage (med) pansament, faşă, bandaj; (cf, met, OM) bandaj (şi de roată de rulare)

bandage crown (cf, met) coroana bandajului roții bandage rib (cf, met) talon de bandaj

band between cut-off points $(\mathrm{OM})$ distanța dintre găuri

band brake $(\mathrm{OM})$ frână cu bandă / cu panglică

band broadening (fiz, metr) lărgire / etalare / întindere a benzii

band carrier (alim, ind chim, constr) transportor cu bandă

band charging device (alim, ind chim, constr) dispozitiv de încărcare cu bandă

band coagulation (alim) coagulare pe bandă

band conveyer (alim, ind chim, constr, transp) transportor cu bandă

band coupling (OM) cuplaj cu benzi / cu bandă elastică (şi metalică)

band drier (alim, ind chim) uscător cu bandă

band drive $(\mathrm{OM})$ antrenare / transmisie cu bandă (metalică sau nemetalică)

banded (fiz, T) stratiform, în benzi, în straturi, stratificat 
banded absorbtion (fiz, autom) absorbție în bandă / preferențială pe un anumit interval

banded arrangement / structure (met) structură lamelară / în benzi (şi la compozite)

band edge muchie / margine de bandă (la semifabricate, în transport, în fizică)

band edge (in spectral analysis) (fiz) cap de bandă (în analiza spectrală)

band elevator (alim, agr, constr, ind chim) elevator cu bandă

band expansion clutch $(\mathrm{OM})$ ambreiaj cu benzi band feeder (mas-un, alim) alimentator cu bandă band head (fiz, OM) cap de bandă

band heater (for extruder) (met, plast) element de încălzire inelar (la dispozitive de extrudare)

banding (met) formare a structurii lamelare / în straturi succesive, care se prezintă în benzi / stratificat; (TH, cf, met) aplicarea bandajului la roți (de tren, de macara etc.)

banding steel (met) oțel pentru bandaje (de roți de rulare), otel-bandă (de legat), otel lat

band iron ferăstrău-panglică; (met) fier-balot

band-knife splitting machine (mas-un) maşină de şpăltuit / de tăiat cu cuțit-bandă

band limiting (fiz) limitare a benzii (spectrale, audio etc.)

band magnet (met) lamă / bandă magnetizată; (el) magnet plat / tip bandă

band marking bandă cu semne pentru a contoriza lungimi (și la conductoare); marcare cu bandă (a locurilor de acces etc.)

band of frequency (mec, fiz) bandă / interval / gamă de frecvență

band-pass bandă de trecere (într-o hală); (OM) distantă între găuri

band pillar (constr) stâlp fretat

band ply primul strat de rețea de cord (şi la compozite)

band pulley $(\mathrm{OM})$ roată de curea (lată) / pentru bandă transportoare

band ring $(\mathrm{OM})$ bandă / panglică închisă, inel aplatizat / format din bandă

band rope (met) cablu lat de oțel

bands rânduri, şiruri, linii; (materiale) benzi (la microstructuri, la compozite etc.)

band saw (mas-un) ferăstrău tip bandă / panglică

band-saw file pilă pentru ferăstrău

band-saw steel (met) oțel pentru benzi de ferăstrău

band spring $(\mathrm{OM})$ arc cu secțiune dreptunghiulară / prelucrat din bandă

band steel (met) oțel-bandă, platbandă de oțel

band switching (fiz) comutare de scări / de benzi band turning (mas-un) retezare de benzi din semifabricate plate (prin aşchiere, cu discuri etc.)

band tyre (auto) bandaj plinm de cauciuc

bandwidth (fiz, metr) lărgime de bandă

bandy îndoit în afară, întors, răsfrânt; crăcănat

baneful otrăvitor, nociv, ucigător; primejdios

bang lovitură, izbitură; bubuitură, pocnet, pocnitură; brusc, deodată, drept direct; a se închide cu zgomot, a bubui, a pocni, a răsuna

bang-bang servo (autom) regulator / servomecanism "tot sau nimic"

bang the market $(\mathrm{ec})$ a provoca o scădere a prețurilor / a cursului (pe piață)

banister (constr) coloană / stâlp / baston al balustradei / al parapetului

banjo (OM) cutie, carter

banjo axle (auto) osie-banjo (puntea din spate presată, din două bucăti de tablă, sudate)

banjo lubrication $(\mathrm{OM}, \mathrm{T})$ ungere centrifugă, ungere prin tub radial

bank mal, val (de pământ), dig, tărm, banc de nisip, aluviune; (constr, cf) terasament, taluz (de cale ferată); (TH) baterie, grup de maşini, cale de rulare, magazie, depozit; rând de evidențiat (în text); (met) preîncălzitor (la cuptor SiemmensMartin), a frâna mersul unui furnal, a bătători (la forme de turnare); a îndigui, a zăgăzui, a îngrămădi (în jurul); (ec) bancă, a depune (bani) în bancă, a fi bancher, a avea acțiuni la bancă; up a se îngrămădi, a se strânge (în grămezi); (av) a se înclina (d. un avion); a miza pe

bankable (ec) care poate fi scontat

bank account (ec) cont bancar

banked blast furnace (met) furnal oprit (din mers)

bank bill (ec) bancnotă, bilet de bancă, poliță

bank chain $(\mathrm{OM})$ lanț articulat

bank / banking charges (ec) speze bancare

bank commission (ec) comision bancar

banked together (mas) montat în paralel, grup de (maşini etc.)

bank(ed) winding (el) înfăşurare în serie / cu prize multiple

banker (ec) bancher, director de bancă, funcționar la bancă; (cf) lucrător la terasamente; (constr) varniță, cutie cu mortar

bank fence (constr, cf) rambleu, val

banking (ec) activitate bancară, afaceri / tranzacții bancare, de bancă, bancar; (constr) îndiguire, zăgăzuire

banking engine (cf, met) locomotivă împingătoare; motor de mers în gol (rar) / de oprire

banking file (mas-un) pilă triunghiulară cu vârf teșit 
bankinghouse (ec) (casă / clădire de) bancă banking loss (met, termo) pierdere de căldură la mers în gol

banking period of a furnace (met) oprire de durată la furnal

banking pin $(\mathrm{OM})$ ştift opritor / de limitare

banking screw $(\mathrm{OM})$ şurub de oprire

banking support (ec) sprijin / suport bancar, intervenție bancară (pentru stabilizarea prețurilor)

banking syndicate (ec) consorțiu bancar

bank( )note (BN, B/N) (ec) bancnotă, hârtiemonedă, bilet de bancă

bankocracy (ec) marea finanță, puterea bancherilor, oligarhie bancară

bank of boilers (termo) baterie de cazane

bank of cake-ovens (met) baterie de cocsificare

bank of capacitors (ind chim, alim) baterie de condensatoare

bank of coils (ind chim, alim) baterie / grup de serpentine

bank of contacts (el) panou de contacte, câmp de selecție cu contacte

bank of deposit (ec) bancă de depuneri

bank of keys (c) claviatură, tastatură

bank of lamps (el) panou cu lămpi de semnalizare

bank of machines (TH, mas) grup de maşini

bank of ovens (met) baterie de cuptoare

bank of tubes (met, termo) fascicul de țevi, fascicul tubular

bank pass (ind chim, termo, nav) distanță între cilindrii de alimentare / între tuburi / între țevi

bank rate (ec) scont oficial, taxă de scont

bankrupt (ec) falit, ruinat, (mereu) dator, insolvabil; a (a)duce la faliment, a ruina

bankruptcy (ec) bancrută, faliment; ruină, decădere

banks (met) pereți laterali (la cuptoare)

bankseat (constr) pilon, stâlp (şi de pod)

bankside (geog) pantă / povârniş al țărmului, margine a țărmului

banksman (ec) bancher

banks oil (alim) untură de peşte

bank stock (ec) capital al unei bănci

banquette trotuar; banchetă, bancă

bar rangă, baretă, traversă, bloc, manetă, prag, bară, obstacol, tijă, drug, bârnă, bucată, calup; barieră, piedică, obstacol, discriminare; dungă, fâşie; (mat) diagramă sub formă de coloane; (met) (semifabricat) laminat (cu profil plin sau fasonat), lingou; (metr) bar, lamelă, epruvetă tip bară; (TH) a închide (cu gratii), a zăvorî, a bara, a opri, a exclude, a interzice, a împiedica, a bloca, a despărți (de), a exclude, a dunga; a obiecta împotriva; (jur) judecătorie, curte, tribunal, judecată, banca acuzaților; (fiz, metr) bar

barb (met) bavură, cârlig

barbed nail $(\mathrm{OM})$ cui cu tijă striată

barbed needle $(\mathrm{OM}) \mathrm{ac} /$ ştift cu cârlig

barbed stud (OM) bolț cu țepi, obținut prin imprimare, pentru fixarea materialelor plastice

barbed wire (met) sârmă ghimpată

barbed wire machine (met) maşină de produs sârmă ghimpată

barbel (alim, iht) mreană

bar bending machine (met) maşină de îndoit bare / tevi

barbotage $(\mathrm{OM}$, alim, ind chim, $\mathrm{T})$ barbotare, barbotaj; agitare / amestecare (a unui lichid) datorită mişcării unor piese (şi pentru a realiza ungerea, omogenizarea)

bar capacity (mas-un) diametrul maxim al barei de prelucrat (care trece prin axul principal al strungului)

bar code (ec) cod în / de bare, ataşat unui produs pentru identificare

bar copper (met) cupru în bară

bar cutting machine / shears (met, mas-un) maşină / foarfece de tăiat bare / țevi

bard (alim) felie / bucată de slănină

bar drawing banch (met) banc de tras bare

bare gol; sec; simplu; neacoperit; fără înveliș; ros; teşit; a descoperi; (met) a coji (semifabricate) (mai rar); (el) neizolat; (agr) sterp, neroditor, desfrunzit; $(a d v)$ numai

bare cable (el) cablu neizolat

bare duck belt $(\mathrm{OM})$ curea de transmisie $\mathrm{cu}$ strat textil exterior

bare electrode (net, el) electrod neînvelit (la sudură)

bar feed (mas-un) avans al barei de prelucrat

barefooted netubat

bare pipe $(\mathrm{OM})$ țeavă fără filet

bare shaft $(\mathrm{OM})$ ax de fixare, fără filet

bare welding (met, el) sudare cu electrod-bară

bare welding rod (met) electrod neînvelit (de sudură)

bare wire electrode / rod (met) electrod tip bară / vergea

bare wiring (el) cuplaj cu fir neizolat / blanc

bargain (ec) convenție, înţelegere, câştig, afacere, tranzacție, târg; a negocia, a se târgui pentru; a încheia un târg, a cădea la învoială, a face o afacere

bargain away $(\mathrm{ec})$ a vinde în pierdere

bargain by job / lump (ec) acord global

bargain for a se tocmi pentru, a se aştepta la, a conta pe 
bargaining (ec) tocmeală, negociere, tratative bargain off a scăpa de, a se descotorosi de bargain on a conta pe, a se bizui pe bargain prices (ec) prețuri de sold bargain sale (ec) desfacere, sold, vânzări de solduri, vânzare avantajoasă

barge (nav) barcă / vas de agrement, şlep, barcă (cu pânze), şalupă, şalandă, barjă; a se mişca greoi, a se târâ

barge carrier (nav) navă port-şalande

barge tank (nav) (tanc) petrolier

bar grate $(\mathrm{OM}$, termo) grătar cu zăbrele

bar grizzly (constr, termo) grătar

bar heating furnace (met) cuptor de încălzit platine (semifabricate tip bare)

baric (fiz) baric, barometric

baric step $(\mathrm{TH})$ treaptă barică / de presiune

baring (geol) dezgolire; dezvăluire; dezvelire a unui zăcământ, decoperatre

bar iron (met) (semifabricat) bară din oțel

bar iron rolling train (met) laminor pregătitor pentru profiluri

barite (minrl) barit(in)ă

Barium (Ba) (chim) bariu

barium-base gease $(T)$ unsoare pe bază de bariu bark (nav) barcă mare, şalandă; scoarță, coajă (de copac), cherestea, a coji lemn; toval, a tăbăci, a jupui (pielea)

bark chopper / crusher / cutter (mas-un) sculă de aşchiat, dispozitiv de cioplit (şi lemn)

bark dryer (alim) uscător de coji

barked prop (constr) stâlp cojit (de lemn)

barked timber / wood lemn / buştean cojit

bar keel (nav) chilă masivă

barker (mas) cojitor, cojitoare, maşină de cojit (lemn, piele etc.)

barker (machine) maşină de cojit (lemn şi semifabricate metalice)

barking $(\mathrm{TH})$ cojire (a lemnului sau a unui semifabricat metalic)

barking drum (alim) tambur de cojire, cojitor cu tambur

barking machine (mas-un) maşină de cojit (lemn sau semifabricate metalice)

bark peeling / stripping machine (alim) agregat / maşină de cojit, cojitoare; (met) maşină pentru stripare / cojire

bar lathe (mas-un) strung pentru piese confectionate din bare

barley (alim) orz; (met) antracit (granulat) $(2,5 \ldots 6$ $\mathrm{mm}$ )

barley malt (alim) malț de orz

bar-linear shrinkage (met, plast) contracție liniară, contractia semifabricatului-bară bar link (OM, mas-un) culisă cu pârghie oscilantă, za cu punte, culisă cu două tije barm (alim) drojdie de bere / de hamei bar mill (met) laminor pregătitor pentru profiluri laminate

bar mould (met, plast) matriță cu mai multe cavități (cilindrice), formă de presare cilindrică

bar-moulding machine (mas-un, $\mathrm{TH}$ ) presă de prelucrat din bară (şi săpun)

barmy (alim) în fermentaţie, spumos

bar none nebarat, fără nici o bară

bar of fraction (mat) linie de fractie

bar of rectangular section (OM) tijă / bară de sectiune dreptunghiulară

bar of soap calup de săpun

bar of turn (lathe) (mas-un) tijă de antrenare la strung

barometer (gauge) (metr) barometru

barometer height (geogr, mediu, metr) înălțime / altitudine barometrică

barometer pressure (fiz) presiune barometrică

barometer stock (ec) acțiuni-barometru (la bursa de valori)

barometric(al) (fiz, metr) barometric

barometric column (metr, hidr) coloană barometrică / de mercur

barometric pressure (fiz) presiune barometrică barometric tube (fiz) tub barometric

barometric vacuum (fiz, metr) vid barometric

bar one cu excepția unuia sau uneia

barotermograph (fiz, metr) barometru cu înregistrare

bar pointing machine (mas-un) maşină de ascuțit capete

bar pressure (OMfiz presiune barometrică

barrack (constr) baracă

barrage baraj, dig, a face un baraj împotriva

barred închis, barat, prescris; îngrădit, despărțit prin grilaj

barred box (met) ramă de formare cu nervuri de rigidizare

barrel (OM) butoi, țeavă (şi de armă), butoiaş, tambur, tobă, piesă cilindrică, bobină, cap cilindric (la butoi, pompă etc.), tambur de troliu, bucşă de lagăr (şi cu pereți subțiri), rezervor cilindric (mic, deschis); (met) tăblia cilindrului de laminor; (metr) baril, 1 baril $=163,651$ $(\mathrm{UK}), 1$ baril = 1191 (SUA), 1 baril = 1591 (în domeniul petrolier); a pune în butoi / tobă / tambur

barrel amalgamation (process) (met) (proces de) amalgamare în tobă

barrel arbor $(\mathrm{OM})$ arbore al unui tambur

barrel boiler (termo) cazan orizontal 
barrel bung (OM, alim) cep de butoi barrel casing $(\mathrm{OM}$, termo) cu manta cilindrică barrel cleaning machine (mas) maşină pentru curățarea butoaielor / a recipientelor cilindrice

barrel cooling (termo) răcire tubulară

barrel crankcase (auto) carter tubular / în formă de tunel / nedemontabil

barrel electroplating (met) depunere în tambur / pe suprafață cilindrică

barrel elevator (mas) elevator pentru butoaie

barrel exhausting pump (hidr, OM) pompă de transvazare

barrel file (mas-un) pilă subțire cu secțiune dreptunghiulară şi vârf teşit

barrel filler (alim, ind chim) instalație de umplut butoaie

barrel filling machine (alim, ind chim) instalație / maşină de umplut butoaie

barrel fine borer (mas-un) burghiu pentru tevi de arme

barrelhead (OM, alim, ind chim) fund de butoi

barrel hoist (mas, transp) elevator / troliu pentru butoaie

barrel hoop $(\mathrm{OM})$ cerc de butoi

barrel jacket (termo) căptuşeală / îmbrăcăminte a tubului, manta din țeavă

barrel key $(\mathrm{OM})$ cheie tubulară

barrelled depozitat în butoi / butoaie

barrel length (met) lungime a tăbliei cilindrului de laminor

barrel liner $(\mathrm{OM})$ căptușeală de butoi / de cilindru / de tambur

barrelling umplere a butoaielor; (met) formare a tăbliei cilindrilor de laminor

barrel mixer (alim, ind chim) amestecător cu tambur

barrel nuzzle (OM, hidr) gura tevii

barrel-nut $(\mathrm{OM})$ piuliță-tambur

barrel plating (met, TH) acoperire (şi galvanică) în tobe / în butoi

barrel of gun (OM, mil) țeavă a armei

barrel of micrometer (metr) manşon gradat al micrometrului

barrel of pump (OM, hidr) corp (cilindric) de pompă

barrel of tail-stock (mas-un) bucşă a pinolei

barrel ring $(\mathrm{OM})$ inel de rulare

barrel roll (met) tăblie a cilindrului de laminare

barrel rolling (TH, mas-un) rostogolire a unui butoi / a unei piese cilindrice; (met) curățare în tobă (rotitoare)

barrel shell (met, OM) manta de tambur

barrel-shaped $(\mathrm{OM})$ în formă de butoi / de butoiaş barrel-shaped mixer (alim, met) melanjor / amestecător tip butoi, rotativ

barrel-shaped roller $(\mathrm{OM})$ rolă butoi (şi la rulmenti)

barrel-shaped roller bearing $(\mathrm{OM})$ rulment (oscilant) cu role butoi

barrel support (OM, hidr) sprijin de teavă, suport de butoi / tambur

barrel tumbling (met) curățare în tobă (rotativă) barrel-type converter (met) convertizor cilindric

barrel-type crankcase (termo, OM) carter dintr-o singură piesă / nedemontabil

barrel-type pulley $(\mathrm{OM})$ roată de curea, tip tambur

barren steril, sterp; neproductiv; arid; neroditor; sărăcăcios, fără conținut; searbăd, plictisitor

barrenness ariditate, sterilitate; sărăcie, lipsă de conţinut

barren solution (ind chim, met) soluție reziduală

barricade baricadă, barieră, obstacol, piedică; a opri, a împiedica, a bara

barrier barieră; baraj, barare; îngrădire; balustradă; poartă (în oraș); graniță, hotar, limită; obstacol, piedică

barrier diffusion (ind chim, mediu, alim) difuziune prin barieră / prin perete poros

barrier lake lac de acumulare

barring cu excepția, în afară de; pornire (și la turbine)

barring engine (mas) motor de pornire

barring gear mecanism de demarare (cu angrenaje); (auto) mecanism pentru întoarcerea volanului (la pornire)

barring sets $(\mathrm{OM})$ inel(e) de susținere

bar rolling mill (met) laminor pentru bare

barrow roabă, cărucior; targă

bar screen ciur / grătar cu bare

bar shears (met, mas-un) foarfece pentru tăierea barelor

bar soap calup de săpun

bar solder (met) ciocan / vergea de lipit

bar steadier (met, OM) crapodina / lagărul barei-dorn (la un laminor de țevi)

bar steel (met) oțel în bare (şi semifabricate)

bar stock (met) stoc de semifabricate rotunde / bare

bar strip (met) semifabricat, țaglă

bar support (mas-un) suport al barei (la strung automat sau revolver)

bar tension $(\mathrm{OM}, \mathrm{mec})$ tensiune în bară

bar-tension nut $(\mathrm{OM})$ piuliță de tensionat o bară

barter (ec) troc, schimb în natură, a face troc, a vinde în schimbul 
barter back-to-back (ec) contract-cadru interschimb, după principiul compensării valorice a mărfurilor

barter economy (ec) economie de tip barter / de schimb / de troc

bar tin (met) staniu în bară

barton (agr) curte (de fermă), curte de păsări

bar turning (peeling) plant (met) utilaj pentru cojire prin rotirea barelor

bar voltage (el) tensiune între lamele

bar welding (met) sudare cu electrod-bară

bar work (mas-un) prelucrare a unui semifabricat bară (fără a preciza tehnologia)

barycentre (mec) centru de greutate, centru de masă, baricentru

barycentric(al) co-ordinates $(\mathrm{mec})$ coordonate baricentrice (în raport cu centrul de greutate)

barye (metr) bar

basal cleavage (met) clivaj principal

basal mass masă / substanță / material de bază

basal plane (mas-un) suprafață de sprijin / de bază / de bazare

basalt basalt

basaltic de bazalt, bazaltic

basalt melting furnace (termo, ind chim) cuptor de topit bazalt

bascule $(\mathrm{OM})$ piesă basculantă; basculă (şi în metrologie)

base (TH) bază, suport, postament, pat, talpă, sol, teren, fundament, soclu, temelie, fundație; (chim) bază; (adj) de bază, fundamental; de rând, comun, de proastă calitate; a întemeia, a pune bazele; (ec) fals (d. monede)

base address (c) adresă de bază / de referință

base angle (mat) unghi de (la) bază / adiacent la bază

base bearing $(\mathrm{OM})$ lagăr / cuzinet palier; lagăr principal

baseboard (constr) scândură de podea, platformă, reazem, bordură

base bullion (met) metal nerafinat

base bushing $(\mathrm{OM})$ bucşa interioară

base circle $(\mathrm{OM})$ cerc de bază (şi la roți dințate cilindrice, $d_{b}$ )

base course (constr) strat de legătură

base cylinder $(\mathrm{OM})$ cilindru de bază (la roți dinţate cilindrice)

base data (inf, ec) date de bază / principale

base diameter $(\mathrm{OM})$ diametru de bază $\left(\mathrm{d}_{\mathrm{b}}\right)$ (la roți dințate cilindrice)

base electrode (el) electrod-bază

base exchanger (chim) schimbător de ioni

base helix (OM) elice de bază / pe cilindrul de bază (la roți dințate cilindrice cu dinți înclinați) base helix angle (OM) unghiul elicei de bază / pe cilindrul de bază $\left(\beta_{\mathrm{b}}\right)$ (la roți cilindrice cu dinți înclinați)

base iron (met) fontă inițială / de bază

base lacquer coat lac de grund

base language (c) limbaj de bază

base lead angle (OM) unghiul de înclinare de bază al elicei melcului $\left(\gamma_{b}\right)$ (la angrenaje melcate)

base (lead) bullion (met) plumb impur (nerafinat)

base length lungime de bază

base level (mas-un, OM) nivel de bază / de referință

base line (mec) linie de bază / de referință, linie neutră

base load of production (mec, TH) sarcină de bază (şi în producție)

base machine (ec, TH) maşină de bază; (c) echipamente care execută instructiunile-maşină

base material $(\mathrm{TH})$ material de bază (la un compozit / aliaj), materie primă

base measuring (metr) măsurare de bază / de referință / importantă

basement (constr) fundament, temelie, soclu, subsol, demisol, pivniță

base metal (met) metal de bază, component de bază al aliajului

base mix amestec de bază

base molding (met, plast) tipar, matriță, formă de bază

base of frame (mec, constr) baza cadrului / schelei / batiului

base of hearth (met) vatră a cuptorului

base of nozzle (OM, termo, hidr) alezaj / orificiu al ajutajului

base of structure (constr) fundatie; (met) structură de bază

base of the girder (constr, mas) talpa grinzii

base oil (T) ulei de bază (şi în unsori)

base on a (se) baza pe, a se justifica prin

base onself on / upon a se baza pe

base pitch (OM) pasul de bază / pe cercul de bază $\left(p_{b}\right)$ (la roți dințate cilindrice)

base plate (constr, met) placă de pardoseală / de bază / de fundație / de reazem, piesă de fund, postament

base-plate socket (OM, el) cuzinet / locaş / suport plan

base point punct de bază / de plecare

base projection $(\mathrm{OM})$ proiecție de bază / principală

base rate / pay (ec) salariu de bază, plată tarifară

base ring (constr, mas) inel de fundație; $(\mathrm{OM})$ cerc de bază (și la roți dințate conice) 
base saponification number (chim, T) cifră de saponificare (la unsori)

base shoe (constr) placă de ancorare

base size mărime de bază / de referință; (met, mas-un) dimensiunea piesei brute

base slab (constr, met) placă de bază; (nav) postament

base space (constr, mas) spațiu de bază / de bazare

base strength (chim) concentrație / putere a bazei

base tin (met) aliaj pe bază de staniu

base unit of measurement (metr) unitate de măsură de bază / soluției bazice

base with pins $(\mathrm{OM}$, el) soclu cu ştifturi / cu picioruşe

basic de bază, fundamental; (chim) alcalin, bazic basically $(a d v)$ fundamental, în mod esențial

basic Bessemer process (met) procedeu Bessemer, cu căptuşuală bazică, procedeu Thomas

basic Bessemer steel (met) oțel Bessemer bazic / Thomas

basic Bessemer steel converter (met) convertizor Bessemer bazic

basic Bessemer steel works / plant (met) oțelărie Bessemer bazică / Thomas

basic bottom (met) vatră bazică (la cuptoare)

basic brick (met) cărămidă bazică

basic capacity $(\mathrm{OM}, \mathrm{TH})$ capacitate de bază; (chim) bazicitate

basic cinder / clinker (met) zgură bazică

basic concept concept de bază / fundamental

basic converter (met) convertizor bazic / cu căptuşeală bazică

basic converter process (met) procedeu în / cu convertizor bazic

basic converter steel (met) oțel de convertizor bazic, oțel Thomas

basic data (inf) date de bază / fundamentale

basic diagram diagramă de bază

basic dynamic load $(\mathrm{OM})$ capacitatea dinamică (de bază) a rulmentului (notată cu $\mathrm{C}$ )

basic dynamic rated load $(\mathrm{C} / \mathrm{P})(\mathrm{OM})$ capacitate dinamică (de bază) a rulmentului raportată la sarcina dinamică echivalentă

basic dynamic load rating $(\mathrm{C} / \mathrm{P})$ raport capacitate dinamică / sarcină dinamică echivalentă (la rulmenți)

basic electric melting (met) topire electrică (bazică)

basic electrode furnace (met) cuptor electric şi bazic

basic electrode melting (met) procedeu de topire cu electrod în mediu bazic

basic element (chim, met) element de bază basic flux (met) fondant / flux bazic

basic form line (metr) linie de zero / de referință basic furnace (met) cuptor cu căptuşeală bazică

basic hearth (met) vatră bazică

basic hole $(\mathrm{OM})$ alezaj unitar

basic hole tolerance $(\mathrm{OM})$ toleranță tip alezaj unitar

basic hole system of tolerances (OM) sistemul de toleranțe tip alezaj unitar

basic industry industrie grea

basic ion (chim) cation

basicity (chim) bazicitate

basicity of slag (chim, met) bazicitate a zgurii

basicity ratio (chim) indice de bazicitate

basic level nivel de bază / de referință

basic-lined Bessemer converter (met) convertizor bazic (Bessemer)

basic lining (met) căptuşeală bazică

basic load rating (mec, mas) sarcină de bază, încărcare nominală

basic material material de bază (la un aliaj / compozit), materii prime

basic member $(\mathrm{OM})$ piesă unitară / elementară / de bază

basic metal (met) metal de bază (şi în aliaje)

basic noise (fiz) zgomot de bază / de fond

basic number code $(\mathrm{OM})$ simbolul de bază al rulmentului

basic open-hearth furnace (met) cuptor bazic tip Martens

basic open-hearth steel (met) oțel (elaborat în cuptor) Martens bazic

basic operating system (BOS) (c) program utilitar de gestiune a programelor sistemului

basic ore (met) minereu bazic

basic oxygen steel (met) oțel de convertizor (sau LD), obținut cu insuflare de oxigen

basic patent brevet de bază / inițial / de referință basic pig (iron) (met) fontă pentru convertizor Thomas / (în blocuri) de afinare

basic programming support (BPS) (c) program de regrupare a programelor utilitare

basic process (met) procedeu bazic

basic rack $(\mathrm{OM})$ cremalieră de referință

basic rack tooth profile $(\mathrm{OM})$ profilul cremalierei de referință

basic rack-type cutter (OM, mas-un) sculă tip cremalieră

basic rated file $(\mathrm{OM})$ durabilitatea de bază pentru rulmenți $\left(\mathrm{L}_{10}=10^{6}\right.$ rotații $)$

basic refractories (met) materiale refractare bazice

basic research cercetare fundamentală

basic set (chim) bază 
basic shaft $(\mathrm{OM})$ arbore unitar (pentru sistem de tolerante)

basic shaft tolerance $(\mathrm{OM})$ toleranță în sistem arbore unitar

basic shaft system of tolerances $(\mathrm{OM})$ sistemul de toleranțe tip arbore unitar

basic size (TH) mărime / dimensiune de bază / nominală

basic slag (met) zgură bazică

basic slag grinding plant (met) instalație / moară de mărunțit zgură bazică

basic static rated load $(\mathrm{OM})$ sarcină statică de bază a rulmentului, notată de obicei $\mathrm{C}_{0}$

basic steel (met) oțel (elaborat prin procedeu) bazic

basic steelworks (met) oțelărie cu convertizoare Thomas

basic time (fiz, TH) timp de bază / de referință

basic wage(s) (ec) salariu tarifar

basic word stock fond principal de cuvinte

basin bazin, rezervor, vas; (nav) radă, doc portuar; lac de acumulare; chiuvetă, lighean, castron

basis, $(p l)$ bases bază, temelie, temei, punct de plecare; (ec) bază; a pune bazele

basis metal (met) metal de bază al unui aliaj basis of design (OM) ipoteză / ipoteze de calcul / de proiectare, baze / principii de proiectare

basis soap (ind chim, T) săpun de bază

basis vector (mat) vector de bază

basket cupă; coş; (met) coş al maşinii de decapare; umbrelă; sorb; lingură

basket centrifuge (alim, OM) centrifugă cu tambur perforat

basket charge (constr, met) încărcare cu benă

basket dryer (alim, ind chim) centrifugă de stors, uscător cu tambur perforat

basket strainer (hidr) sorb al pompei

bass (alim, int) biban

Basset-Boussinesq-Oseen equation (mat, fiz) ecuația Basset-Boussinesq-Oseen (la filtrare, sedimentare)

bass notes (fiz) sunete joase / de frecvență mică bast liber

bastard cut(ting) (mas-un) dințare / aşchiere / pilire grosieră / de degroşare

baste a critica, a asalta cu întrebări; a certa

bat sist argilos; bătător, băț, paletă, meliță

batch grămadă, teanc, pachet; $(\mathrm{ec})$ partidă, lot, grup, serie, set; (met) şarjă, grupă, încărcare, încărcătură, amestec, dozare, strat

batch centrifuge (alim, ind chim) centrifugă cu funcționare discontinuă

batch charging (alim, met) alimentare / încărcare discontinuă / periodică (şi la cuptoare) batch cooling / digesting (alim) fierbere discontinuă

batch digester (alim, ind chim) fierbător (cu ciclu) discontinuu

batch dryer (alim, ind chim) uscător discontinuu

batcher dozator

batch freezer (termo, alim) congelator cu intermitență / discontinuu / cu introducerea succesivă a şarjelor

batch grinding (constr) măcinare discontinuă / în şarje

batch-handle switch (el, mec) întrerupător basculant

batching ( $\mathrm{TH}$, alim, ind chim) dozare (şi discontinuă)

batching device ( $\mathrm{TH}$, alim, ind chim) dispozitiv de dozare

batching oil ulei de emulsionat / pentru emulsii batching roller $(\mathrm{OM})$ şaibă / rolă de înfăşurare

batchmeter (alim, metr, ind chim) dozator

batch mill (alim, ind chim) amestecător cu acțiune discontinuă

batch mixer (alim, ind chim, constr) amestecător cu acționare discontinuă, tambur de amestecare

batch(-mix) plant (alim, ind chim, constr) instalație de amestec discontinuu

batch-off mill $(\mathrm{TH})$ valț / cilindru / moară de amestecare (şi discontinuu)

batch operation $\mathrm{TH}$ ) funcționare / operare discontinuă sau în şarje

batch patenting (met) patentare prin imersiune

batch process (fiz) proces intermitent; proces (tehnologic) intermitent / discontinuu / periodic

batch production $(\mathrm{ec}, \mathrm{TH})$ producție de serie mică, discontinuă

batch rectification $(\mathrm{TH})$ rectificare discontinuă

batch sampling luare a probelor pe loturi

batch(-type) drying stove (alim, met, termo, ind chim) etuvă / uscător cu ciclu periodic / discontinuu

batch(-type heating) furnace (met) cuptor cu încălzire cu cameră

batch-type mixer (alim, ind chim) amestecător discontinuu

batch wage(s) (ec) salariu în acord

batchwise (autom, $\mathrm{TH}$ ) tratament discontinuu

bate (met, ind chim) mordant, bait, soluție de decapat

bath cadă, baie, cuvă; spălare; a imersa, a spăla

bat handle switch (el) întrerupător basculant

bath carburizing (met) baie de cementare

bath cyaniding (met) cianurare în baie

bath cover-type furnace (met) cuptoare pentru rulouri, tip baie 
bathe a (se) spăla, a uda, a face baie bath furnace (met) cuptor cu baie

bathing baie, spălare; caracteristicile apei de spălare

bath lubrication $(\mathrm{T})$ ungere / lubrifiere în baie

bath nitriding (met) nitrurare în baie

bath patenting (met) patentare (prin imersiune) în baie

bath plate (met) placă a vetrei (de cuptor); (OM, termo, mas) placă de fund (la unrezervor etc.)

bathroom (cameră de) baie

bating exceptând, (în) afară de

baton baston (si de cauciuc)

batten a (se) îngrăşa, a creşte exagerat; (agr) a deveni roditor

batten of body (auto) nervură / stinghie de caroserie

batten plate (constr, mec) traversă de legătură battening down (nav) închidere a bocaportului battening iron (nav) şină de bocaport

batter înclinare, convexitate, ieşitură, relief, pantă; (alim) aluat nefermentat, a frământa; (constr) taluz, înclinare, lut laminat; (met) bombare / umflare / lărgire a cuvei cuptorului, a lamina (rar); a bate, a lovi, a izbi, a turti, a bătători, a dărâma, a demola, a sfărâma, a zdrobi; a critica aspru, a ataca dur

battered bătătorit, tasat; ponosit, uzat, boțit; deteriorat, stricat

battering of a wall (constr) ajustare la verticală battery (el) baterie, acumulator, element galvanic; (met) baterie de cocs; (auto) baterie

battery accumulator (el) acumulator

battery carrying strap (auto) chingă de transportat acumulatoare

battery cell (el) element de baterie / de acumulator

battery charging equipment (el, mas) echipament de încărcat acumulatoare

battery compound (chim, el) pastă de acumulatoare / de baterie

battery cover capacul bateriei

battery discharge (auto, el) descărcarea bateriei battery-driven vehicle electromobil, (auto) vehicul electric / antrenat cu / de acumulatoare

battery ignition (el) aprindere prin acumulator

battery jack (el) conector de baterie, pârghie de conectare a bateriei

battery of boilers (termo) grup de cazane / de boilere

battery of coke ovens (met) baterie de cuptoare de cocsificare

battery of stills (alim, ind chim) baterie de cazane de distilare

battery-powered instrument (metr, el) instrument / aparat actionat cu baterii

battery replacement (auto) înlocuirea bateriei battery saver (auto) sistem de prevenire a descărcării bateriei / de economisire a bateriei

battery saver function (auto) funcția de prevenire a descărcării bateriei

battery shoe (constr, OM) sabot de concasor; (el) contactor de baterie, papuc

battery spot welding machine (met, el) maşină de sudare prin puncte cu energie acumulată / cu baterie

battery-terminal connection / clip (OM, el) clemă de bornă de baterie / de acumulator

battery vent valve $(\mathrm{OM})$ ventil / buşon de aerisire / de degazare a acumulatorului

batting vatelină, vată

Baudelot cooler (alim, termo) răcitor (până în apropierea punctului de îngheț) prin irigație / prin stropire / prin scurgere / prin ploaie

bauxite (met) bauxită

bay (constr) travee, deschidere, arcadă, nișă, firidă; (TH) secție, hală, sector; $(\mathrm{OM})$ jug, platformă, panou, nişă, stativ, celulă; (cf) stație terminus (pe linie secundară); (alim) dafin, laur

bayonet $(\mathrm{OM})$ baionetă, ştift pentru îmbinare în baionetă

bayonet base / cap (el, OM) dulie / soclu (tip) baionetă

bayonet catch / clutch / coupling (OM) cuplare / asamblare tip baionetă

bayonet joint $(\mathrm{OM}$, constr) îmbinare tip baionetă

bayonet union $(\mathrm{OM})$ închizător tip baionetă

BBC prescurtare de la British Broadcast Corporation

BCE prescurtare de la Bachelor of Civil Engineering sau Bachelor of Chemical Engineering

BCS prescurtare de la Bachelor of Chemical Science

be a fi, a exista, a ființa; a locui; a sta; a rămâne; a persista; a răbda (ceva, pe cineva); a se supune; a aştepta (ceva); a tolera; by a rămâne credincios, a se baza pe; a face; (mat) a valora; a costa; a se simți; a face o vizită; a se afla; se petrece (ceva); a sta în picioare; a se majora

be about to a fi gata să, a fi pe punctul de, a se pregăti să

beach țărm de mare (cu pantă lină), litoral, plajă; (nav) zonă de maree, a pune pe uscat, a eşua, a descărca pe țărm; banc de nisip

beached (nav) tras pe uscat

beacon semnal luminos, avertisment; (nav) far, baliză; a lumina, a străluci (ca un far), a (se) aprine (intermitent)

bead mărgea, perlă, bob, boabă, pic(ătură), strop, băşică (de aer); (OM) talon, umăr, guler, bordură; (OM, met) cordon de sudură, depunere prin sudură / de completare, îngroșare (şi prin sudură); (met) picătură rece (defect de turnare); a fălții, a fasona 
bead bend test încercare / test la îndoire / la încovoiere pe epruvete sudate

bead blasting $(\mathrm{TH})$ curățare cu (împroşcare cu) / cu jet de bile

bead chafing (auto) desprindere a anvelopei de pe geantă

bead core (auto, met, $\mathrm{OM}$ ) miez /armătură metalic( $\breve{a})$ (şi de talon)

bead cover învelitoare de talon

beaded edge $(\mathrm{OM}$, met) muchie cu bordură / bordurată / fălțuită (şi de tablă)

beaded flats (met) oțel cu bulb plat

beaded pearlite (met) perlită globulară

beader knife (mas-un) cutit de rabotat (și profilat)

beading bordurare; (met) încărcarea / depunerea unei cusături înguste de sudură, sudare fără oscilații ale electrodului

beading die (met, mas-un) ştanță de bordurat

beading machine maşină de bordurat / de răsfrânt margini

beading press (mas-un) mașină / presă de făltuit beadless tyre (auto) pneu / anvelopă / cauciuc fără margine răsfrântă

bead in welding (met) sudură în solzi

bead of tyre (auto) talon de anvelopă

bead over a bordura

bead rotation (auto) rotație a anvelopei în raport cu janta pe care este montată

be a drug on the market (ec) a fi (un produs) nevandabil

bead winding machine (auto, mas-un) maşină de nivelat inele de talon

bead wire extruder (mas-un, TH) dispozitiv de extrudare / extruder pentru gumarea sârmelor de talon

beady ca mărgelele, băşicat, cu băşici

be after (ec) a fi (un produs) nevandabil

beak (nav) nas, pinten; (OM) ştift, proeminență, cioc, dinte, corn, gură, vârf

beaked cu cioc, cu vârf, în formă de cioc

beaker $(\mathrm{OM})$ cupă (la transportoare); pahar de laborator

beak head (nav) taie mare

beak iron (met) nicovală de banc

beam (constr) grindă, bară, ax, arbore, bârnă, traversă (şi profilată), şină, rază, jug, stâlp, lonjeron, fermă; (fiz) rază, fascicul de raze; a străluci, a radia; (met) grindă (şi profilată); (nav) traversă (osatură) (şi de punte), travers, lățime a navei; $(\mathrm{OM})$ balansier; (metr) braț de balanță

beam and rail bender (met, mas-un) presă de îndoit bare şi şine

beam balance (metr) balanță cu pârghie beam blank (met) semifabricat (mai mult lung) pentru obținerea de profiluri

beam cantilever (mec, constr) consolă a grinzii

beam compass (metr) şubler

beam-deflection test (mec, metr) încercare / test la încovoiere (a unei grinzi, a unui profil)

beam drill (mas-un) maşină de găurit, radială

beam fixed at both ends $(\mathrm{mec})$ grindă încastrată la ambele capete

beamful cu raze, luminos, strălucitor

beam girder (constr, mec, mas) grindă, bară, traversă, bârnă

beam head (constr, mec, mas) capăt de grindă beam knee (nav) guseu al traversei de punte beam light (fiz) fascicul de raze

beam mill (met) laminor de bare / semifabricate tip grinzi (şi profilate) (cu secțiune mică față de lungime)

beam of light (fiz) fascicul de lumină / de raze luminoase

beam of ship (nav) grindă de rezistentă, coastă

beam packet (constr) pachet de grinzi

beam pivot $(\mathrm{OM})$ fus al balansierului

beam pump (hidr, OM) pompă de adâncime, acționată cu balansier

beam pumping pompaj de adâncime

beam rolling mill (met) laminor pentru / de profiluri

beam rotating fatigue test încercare / test la oboseală la încovoiere rotativă

beam scale (metr) balanță simplă; $(\mathrm{TH})$ basculă

beam sea (nav) mare / valuri de travers

beam steel (met) oțel pentru grinzi / profiluri, pentru construcții metalice

beam support (constr) grindă de planşeu; (nav) grindă de punte

beam valve (OM, hidr) supapă cu lamelă

beam welding (met) sudură cu radiații

beamy strălucitor, radios; greoi, masiv

bean duză; (alim) fasole, bob (de soia), dovleac, bostan

bean-oil (alim) ulei de soia

bean ore (met, minrl) limonit

beans (alim) fasole (boabe); (met) cărbune mărunt

bear (met) urs (la cuptoare), bloc; a purta, a duce, a căra, a (se) ține, a presa, a susține, a rezema, a suporta (sarcini, cheltuieli), a rezista; a (se) naşte, a da naștere la; a exercita (un drept); a se comporta; a rodi

bearable suportabil

bear against a se sprijini de

bear along a trage, a târâ

bear away a lua, a duce, a (se) îndepărta 
bear axle (OM) osie purtătoare / portantă, ax purtător

bear back a da înapoi

beard (OM) cârlig; (mas-un) şanfren

bear down (nav) a se apropia

bearer purtător, care susține; (constr) subgrindă, port-şarnieră, reazem, piesă portantă, purtător; (agr) pom fructifer

bearer bar (constr) bară de suport

bearer cheque (ec) cec la purtător

bearer share (ec) acțiune / titlu la purtător

bear forth a da a produce, a aduce

bearing purtător de, care susține / reazămă; producător de; purtare, ducere, dus; naştere, producere, facere, rod, rodire; comportare, purtare; aer, înfățişare, ținută; răbdare, toleranță, tolerare; sens, semnificație, importanță; (constr) reazem; (OM) lagăr (de orice fel), reazem, punct de rezemare / de sprijinire, locaş de lagăr, cuzinet, palier, pivot, lagăr de alunecare; apăsare, care suportă; (mat) direcție, sens, tendință; (nav) relevment

bearing adjustment (OM, T) reglarea lagărului

bearing alloy $(\mathrm{T}, \mathrm{met})$ aliaj / compoziție pentru lagăre (de alunecare)

bearing area (curve) (T) aria (curba) portantă a profilului lagărului

bearing arrangement (OM) aranjarea rulmenţilor, tipul de montaj al rulmenților

bearing axle (OM) axa lagărului / cuzinetului

bearing backing (OM, T) cuzinet / suport de lagăr

bearing ball (OM, metr) bilă de rulment

bearing beam / carrier (constr, mec) grindă de reazem / de preluare a sarcinii

bearing block (OM) postament / talpă de lagăr, piatră-cuzinet

bearing bore (OM, T) alezajul lagărului

bearing boss (OM) bosaj de lagăr

bearing box (OM) lagăr, cutie de unsoare, cuzinet

bearing bracket (OM) suport al lagărului / scut, consolă de lagăr

bearing brass (met, $\mathrm{T}$ ) alamă pentru cuzineți

bearing bush $(\mathrm{T}, \mathrm{OM})$ bucşa lagărului, cuzinet

bearing capacity $(\mathrm{OM}, \mathrm{T})$ capacitatea portantă a lagărului

bearing cast iron (met, T) fontă (turnată) pentru lagăre

bearing clearance (OM, T) joc al lagărului (de alunecare)

bearing construction / design (OM) construcția / proiectul lagărului

bearing cover (OM) capac de lagăr bearing damage $(\mathrm{OM}, \mathrm{T})$ deteriorarea / defectarea rulmentului / lagărului

bearing depth (OM, T) lățime a lagărului (posibil şi grosimea materialului depus pe un lagărsuport)

bearing design (OM) proiectare / soluție / proiect pentru lagăr(e)

bearing edge (mec) punct de încastrare; (OM, T) muchia / marginea lagărului

bearing extractor $(\mathrm{OM})$ dispozitiv pentru extragerea rulmentului / bucşei

bearing face $(\mathrm{T})$ suprafața de lucru a lagărului, suprafaţa de sprijin / de aşezare

bearing fit (OM) ajustajul lagărului / rulmentului

bearing force $(\mathrm{OM}, \mathrm{T})$ capacitate portantă a lagărului, forța pe lagăr

bearing frame (met, constr) cadru portant

bearing grease $(\mathrm{T})$ unsoare de rulment / ppentru lagăr

bearing hinge $(\mathrm{OM})$ articulatie de reazem

bearing internal clearance (OM) jocul intern al rulmentului

bearing life (OM) durata de viață a rulmentului, durabilitate a lagărului

bearing liner / lining (bushing) (OM, T) cuzinet / acoperire (antifricțiune) a lagărului

bearing lining (met, T) acoperirea cuzinetului / lagărului (procedeu tehnologic dar şi strat de cuzinet)

bearing load (OM) sarcină pe lagăr / pe rulment

bearing load capacity (OM) capacitate dinamică (de bază) a rulmentului (notată cu C)

bearing lock (constr, OM) consolidare / blocare / fixare a reazemelor / lagărelor

bearing metal (met) aliaj pentru lagăre

bearing mounting location (point) (OM) localizarea (punctul, locul) de montare pentru rulmenți

bearing neck (OM) guler de cuzinet / lagăr, fus intermediar

bearing needle $(\mathrm{OM})$ ac de rulment

bearing number $(\mathrm{OM})$ simbolul rulmentului

bearing numbering system (OM) sistemul de codificare / simbolizare a rulmenților

bearing oil $(\mathrm{T})$ ulei pentru lagăre

bearing packing (OM) etanşarea / garnitura rulmentului / lagărului

bearing pile (constr) stâlp portant

bearing pivot $(\mathrm{OM})$ pivot de rezemare

bearing plate (constr) placă de rezemare; $(\mathrm{OM})$ port-cuzinet, scut, suport de lagăr

bearing power $(\mathrm{OM}, \mathrm{T})$ sarcina admisibilă a unui lagăr, portanță 
bearing preload $(\mathrm{OM})$ sarcină de pretensionare a rulmentului / lagărului

bearing pressure $(\mathrm{OM}, \mathrm{T})$ presiune pe / în lagăr

bearing property $(\mathrm{OM}, \mathrm{T})$ capacitate portantă

bearing puller / remover $(\mathrm{OM})$ dispozitiv de demontare a rulmentului / lagărului (prin împingere sau scoatere)

bearing pulley $(\mathrm{OM})$ roată de transmisie, rolă de susținere (a curelei)

bearing race $(\mathrm{OM})$ cale de rulare (şi la rulmenți)

bearing reaction $(\mathrm{OM}, \mathrm{mec})$ reacțiune pe lagăr / în reazem

bearing rigidity $(\mathrm{OM})$ rigiditatea lagărului

bearing ring $(\mathrm{OM})$ inel de fixare a rulmentului

bearing roller $(\mathrm{OM})$ rolă de rulment (cilindrică sau butoi)

bearing seat / sleeve (OM) cuzinet (de lagăr)

bearing separator $(\mathrm{OM})$ colivie a rulmentului, distanțier pentru lagăr de alunecare

bearing shell $(\mathrm{OM})$ carcasă / apărătoare a lagărului / rulmentului

bearing size $(\mathrm{OM})$ mărimea lagărului / rulmentului

bearing speed $(\mathrm{OM})$ viteza (turația) lagărului / rulmentului

bearing spring $(\mathrm{OM})$ arc de suspensie / de tensionare a rulmentului; (met) capră de lagăr pentru cilindri de laminor

bearing's rated load capacity $(\mathrm{OM})$ portanța rulmentului, caracteristica unui element de rostogolire

bearing strength $(\mathrm{OM}, \mathrm{T})$ capacitate portantă a lagărului

bearing support $(\mathrm{OM})$ suport de lagăr

bearing surface $(O M, T)$ suprafată portantă / de reazem / de sprijin / de rulare / de încărcare a lagărului

bearing temperature $(T, O M)$ temperatura lagărului / rulmentului

bearing test $(T)$ încercare / testare a lagărului / a rulmentului

bearing tolerance $(\mathrm{OM})$ toleranța lagărului / rulmentului

bearing value $(\mathrm{OM})$ valoare portantă / a sarcinii (dinamice sau statice) a unui rulment / lagăr

bearing with oil holes $(\mathrm{OM})$ lagăr / rulment cu găuri de ungere

bear market $(\mathrm{ec})$ piață în scădere

bear off a abate, a da la o parte; a lua, a dobândi (şi un premiu)

bear on / upon a se rezema de / pe, a avea legătură / contingență cu, a se referi la

bear out a confirma, a adeveri; a se apăra; a se împotrivi, a rezista bear sale (el) vânzare fără acoperire în marfă

bear towards a fi îndreptat spre

bear up a sprijini, a susține, a încuraja; a rezista, a face față

beat lovire, lovitură; pulsație, ritm; şoc, izbitură; competență, domeniu; (el, fiz) interferență, bătaie, pulsație, oscilație; (med) bătaie a inimii; (met) forjare, batere / îndesare a formei, a forja; (chim, alim) a agita, a măcina, a sfărâma, a frământa; a bate, a lovi, a izgoni, a scutura; a înfrânge, a întrece; a pulsa; a ticăi; a depăşi; (nav) a se izbi de (d. valuri); down a înfrânge, a descuraja; out a dezbate, a forja (un metal); $\sim$ up (alim) a bate (ouă, cremă), a parcurge (o distanță), (mil) a recruta

be at a avea de gând să, a se ocupa de, a fi ocupat $\mathrm{cu}$

beat about a căuta, a o lua pe ocolite

be at a dead end a fi în impas / într-un punct mort / înfundat, a bate pasul pe loc (în muncă, cercetare)

beat down a înfrânge; a reduce la tăcere; a şovăi, a ezita; (constr) a înfige / a bate (piloni); (ec) a face să lase din preț

beaten bătut, bătătorit; învins, înfrânt; obosit, frânt; uzat; cu experiență

beaten aluminium (met) tablă de aluminiu

beaten-staff tester (alim, ind chim, metr) aparat pentru măsurarea gradului de măcinare

beater (met) bătător-îndesător (la formare); (alim) ciocan de moară

beater bar (alim, met) bara / axul bătătorului, bara de prindere a ciocănelului (la mori)

beater chamber (mas) spațiu de fărâmițare al concasorului cu ciocane

beater charging încărcare a holendrului

beater colloid mill (mas, $\mathrm{TH}$ ) moară coloidală acționând prin lovire

beater engine holendru

beater mill (alim, ind chim) moară cu ciocane / ciocănele

beater roll $(\mathrm{OM})$ tambur al holendrului

beater-drum deflector deflector tip tobă

beat in (a nail) a bate (un cui)

beating batere, măcinare

beating engine holendru cu actionare proprie

beating under pressure (alim, ind chim, constr) măcinare sub presiune

beating-up (constr, met) îndesare

beat into a băga / a vârî în

beat off $(\mathrm{mec})$ a despărți prin lovire

beat out a scoate, a face să iasă; a bate, a bătători; a îndrepta (prin lovire), a egaliza; a explica, a lămuri 
beat up a se ridica, a ieşi la suprafață; a se face bine, a se înzdrăveni

beat-up lever $(\mathrm{OM})$ pârghie de ridicare

beaumontage (constr, chim) chit

be bad money (ec) a fi neproductiv / nerentabil (şi d. o investiţie)

be behind a fi / a se plasa în urmă (în producție, într-o competiție, pe piaţă)

be behind the times a fỉ depăşit / învechit, a nu fi actual

be bellow somebody (ec, TH) a fi subordonat ierarhic (cuiva)

be calm a linişti, a potoli, a calma

because pentru că, fiindcă, deoarece, întrucât, cum; of din cauza

because of (conj) din cauza, datorită

becket (nav) sbir, ochi

Beckmann's air comparison pycnometer (metr) picnometru pentru aer, tip Beckmann, prin comparare

be clapped out $(\mathrm{TH})$ a fi complet defectat / scos din uz

become a deveni, a ajunge, a se face; a i se potrivi become of a deveni, a se întâmpla

become coated (met) a se acoperi, a fi placat, a fi căptuşit, a fi capitonat

become darker $(\mathrm{TH})$ a se închide la culoare (şi $\mathrm{d}$. lubrifianti, plastice)

become effective a intra în vigoare, a opera, a avea efect / repercursiuni

become perceptible a se vedea, a se simți, a se percepe, a deveni perceptibil

become rusty (met) a rugini

becoming devenire; potrivit, care se potriveşte; cuvenit

becomingly $(a d v)$ cum trebuie, cum se cuvine; potrivit

be consumed by fire a fi ars / consumat în foc

bed (mas-un) batiu, cadru, suport fix; (met, ind chim) pat, pardoseală (cu diverse acoperiri, perforată sau nu, pentru stocare, răcire etc.), strat, pat, cadru; caroserie, culcus, banc; (constr) temelie, fundație; (met) hală de turnare; (nav, geogr) fund de mare, albie de râu; (cf) terasament, strat de balast; fundament; depunere; a se culca; a rezema, a aşeza, a sprijini, a culca (o piesă mare), a fixa, a fi fixat / aşezat (pe / în ceva), a forma un strat; (agr) răzor, strat, a sădi, a răsădi, a planta, a culca (animalele); out (agr) a semăna într-un strat

bed bearers căi de rulare (la mașini de hârtie și poligrafice)

bed box (mas-un, OM) picior al patului / al postamentului bed charge (met) încărcătură oarbă / de umplutură / fără minereu (la furnal)

bed coke (met) cocs pentru pat / de aprindere, pat de cocs

bed covers (mas-un, OM) placă pentru protecția ghidajelor patului (şi la strung)

bedded (met) stratificat, cu pat (de cocs)

bed deflection săgeată de încovoiere a patului / batiului (la maşini-unelte)

bed die (met) partea inferioară a matriței

bedding bază, fundament; suprafață de sprijin; (constr) executare a fundației, stratificare, strat (met) pat (de cocs)

bedding in layers (met) stratificare în straturi suprapuse

bedding of engine in rubber cushions (auto) instalarea motorului pe tampoane de cauciuc

bedding of pipes montare a țevilor

bed frame (constr, mas-un) batiu, schelet, cadrusuport

bed pig (met) formă (din fontă) pentru turnare

bed plate butuc; ballast; placă de bază, postament, fundație (la o mașină), cadru, soclu, talpă

bedrock rocă-mamă / de bază; temelie solidă / trainică; principii de bază / fundamentale

bedroom dormitor

bedstone (met) vatră de furnal; (constr) piatră cuzinet

bedway (mas-un, OM) glisieră / ghidaj a(l) patului / batiului

bed with gap (mas, mas-un) pat cotit, pat / batiu cu degajare

bee (zool, agr) albină

beech (silv) fag

beechen (silv) de fag

beechwood (silv) lemn de fag

bee culture (zool, agr)apicultură

beef (alim) carne de vită

beef fat (alim) grăsime de vită

beef tea (alim) bulion de carne, supă de vacă

bee garden (zool, agr) stupină, prisacă

beehive (agr, OM) stup

beehive coke oven (met) cuptor celular de cocs

beehouse (agr, OM)stup

beekeeping (zool, agr) apicultură

bee line linie dreaptă

beep a scoate un zgomot (intermitent, ca de sonerie)

be equal to a fi egal cu

beer (alim) bere

beer brewery (alim) fabrică de bere

beer filter (alim) filtru de bere

beer still (alim) coloană pentru distilarea mustului (de bere) 
beery (ca) de bere

beer yeast (alim) drojdie de bere

beerwort (alim) must de bere

beeswax (alim) ceară de albine; a cerui, a da cu ceară

beet (alim) sfeclă (şi de zahăr)

beet chips pump (alim) pompă pentru tăiței de sfeclă

beetle ciocan de lemn; (constr) mai, compactor; a bătători cu maiul; a atârna mult în afară

beet sugar (alim) zahăr de sfeclă

beetroot molasses distillery (alim) fabrică de alcool din melasă

beet pulp (alim) borhot de sfeclă

beetroot (alim) sfeclă (şi de zahăr)

beetroot shredding machine (alim) maşină de tăiat sfeclă

beetroot spirit (alim) alcool din melasă (de sfeclă)

beet sugar (alim) zahăr de sfeclă

befall a se întâmăla (cuiva)

be fool-proof a fi simplu de mânuit

be for a fi pentru; a înlocui; a fi în sarcina cuiva; a incumba (cuiva); a fi în drum spre

before ( $a d v)$ înainte (spaţial sau temporal), în față; în frunte; (mai) înainte; altădată; odinioară; deja; înaintea, în fața, din fața, dinaintea; în prezența, de față cu; (temporal) înaintea, dinaintea, până (la); înainte de a, înainte ca; până ce / când; mai curând, mai degrabă, decât să

before driving (auto) înainte de a conduce

beforehand $(a d v)$ dinainte, anticipat; ( $a d j)$ pripit

be frozen a fi înghetat

beget a naşte, a da naştere la, a genera

be good money (ec) a fi rentabil / productiv

begin a începe, a porni; a se apuca de; a debuta în; to with în primul rând

beginner începător; ucenic

beginning început; debut; pornire; origine, izvor, sursă, început, obârşie; punct de plecare

beginning mark marcaj / semnal / semn de început / de plecare

beginnings principii (fundamentale); elemente de bază

be going to a avea de gând să, a fi pe cale să, a avea intenția să

beg the question a considera adevărat ceea ce trebuie în prealabil demonstrat, a face "petitio principii"

begrime a mânji a murdări, a umple

behalf nume; folos, interes

behave a se purta (bine), a se comporta; (TH) a functiona, a lucra; a sta locului (acțiune dorită)

behaviour (brit), behavior (amer) comportare, comportament, purtare, conduită; ținută, înfățişare; aer; mers; (TH) comportare, regim behaviour in service ( $\mathrm{TH}$, mas) comportare, în functionare / exploatare

behind $(a d v)$ în spate, în urmă, în întârziere de fază; a nu corespunde, a nu face față; în spate, înapoia, în urma; în restanță; în întârziere; (temporal) în urma, după; dos, fund, spate; time întârziat

behold a zări, a vedea

beige bej

be in charge (of) a avea responsabilitate (pentru), a conduce

be in contact a fi / a veni în contact, a atinge

be in for a căuta, a solicita (un post, un serviciu)

being existență, ființare, ființă; viață; faptul de a fi (undeva); prezentăa existent, în ființă; prezent

being a function of (pressure) (mec, OM, T) dependent de (presiune)

be in synchronism a fî în sincronism, a fi în concordantă de fază

be jammed tight $(\mathrm{OM})$ a fixa strâns cu pene

belated întârziat, tardiv

belay (constr) a acoperi, a pardosi (cu scânduri); (nav) a amara

belch a vărsa; a erupe; a da pe afară; a azvârli; erupție

belching (alim, ind chim) debordare la distilare

belittle a micşora, a minimaliza

bell $(\mathrm{OM})$ calotă, clopot, sonerie, manşon, pâlnie; (met) clopot / con de furnal; (bot) caliciu

bell and hopper (arrangement) (met) dispozitv de închidere automată, la gura furnalului

bell-and-spigot connection (OM) racord cu manşon / cu cep şi mufã

bell-and-spigot joint $(\mathrm{OM})$ îmbinare cu cep şi mufă / cu mufă

bell-and-spigot pipe (OM, hidr) conductă îmbinată cu cep și mufă, teavă cu mufă

bell book (mas) jurnal de maşini; (met) registru de furnal

bell-center punch (mas-un, OM) punctator autocentrant

bellchuck (mas-un) mandrină

bell crank (lever) $(\mathrm{OM})$ pârghie cotită / cu articulație / cu genunchi

belled file pilă convexă

belled pipe $(\mathrm{OM})$ țeavă cu mufă / manșonată

belleville spring $(\mathrm{OM})$ arc încapsulat / cu locaş

bell( )hoist (met) troliu de încărcare (la gura furnalului)

bellied (constr) bombat, convex

bell insulator (el) izolator tip clopot

bell jar (OM, termo, met) clopot

bell lifting rod (met) tijă de ridicat clopotul furnalului

bell metal (met) bronz pentru clopotul de furnal / pentru clopote 
bell mouth (chim, met) evazare, difuzor, gură de alimentare (şi la furnal); (OM) mufă, manşon, capăt lărgit (al unei piese, țevi)

bell-mouth center plate (mas-un) lunetă cu orificiu conic

bell-mouth intake (hidr) trompă de admisie la priza de apă sub presiune, tip turn

bell-mouthed în formă de clopot

bell-mouthed elbow (OM) cot cu manșon

bell-mouthed tee $(\mathrm{OM})$ teu cu manşon

bell-mouthing $(\mathrm{OM})$ capăt lărgit / tronconic al unei tevi

bell punch (mas-un) poanson de centrare

bell push buton de apel / de sonerie

bell-operator (operating) gear (met) troliu de încărcare la furnal, cu transmisie cu angrenaje

bellows $(\mathrm{OM}$, termo) foale, membrană, tub ondulat, suflantă, burduf

bellow device (OM, hidr, termo) dispozitiv tip membrană sau burduf

bellows seal (auto, OM) etanşare prin burduf de cauciuc

bell push buton de sonerie

bell seam (OM, met) cusătură de sudură (cu rost) în $U$

bell-shaped în formă de clopot / de con

bell-shaped curve (mat) curbă în formă de clopot / tip Gauss

bell-type distribution gear (met) mecanism / transmisie (cu angrenaje) la conul de închidere a furnalului

bell-type annealing furnace (met) cuptor cu clopot / cu hotă (pentru recoacere sau revenire)

bell-tyre autoclave press (alim, ind chim) autoclavă cu clopot

bell-tyre low pressure manometer (metr) manometru diferențial pentru presiuni mici

belly burtă, stomac, corp, trunchi, umflătură; (nav) cală; a (se) umfla, a se bomba; (met) partea centrală a convertizorului, pântec de furnal, a îngroşa, a lărgi (şi la laminare)

belly band brâu; (nav) întăritură a mijlocului; curea, centură de siguranță

belly brace (mas-un) coarbă, burghiu de mână, maşină manuală de găurit

belly helve (met) ciocan cu pârghie acționată la mijloc

belly out a (se) bomba

bellying umflătură, burtă (şi la curele sau lanțuri), convexitate

belly pipe (met) conductă de aer (la furnal sau convertizor)

belong a fi, a se afla, a se găsi; a locui în; (amer) a fi din, a locui în; a fi bun / de trebuință belongings lucruri, bunuri, obiecte; avere; accesorii; (constr) acareturi, dependinte

belong to a aparține, a ține de, a fi proprietatea cuiva

belong with a avea legătură cu, a ține de

below dedesubt, (de) jos, mai jos; la subsol (de pagină); mai departe, în cele ce urmează; inferior; dincolo de

below freezing (fiz) sub zero grade, sub punctul de îngheț(are)

below ground subteran

below par calitate inferioară / slabă

be low with pressure (auto) a avea presiune (prea) mică / joasă (în pneuri)

belt $(\mathrm{OM})$ curea (de transmisie); centură, chingă, brâu, zonă, cordon, bandă; (met) centură / bandaj de armare (la furnal); (constr) brâu; (mil) cartuşieră

belt adjustment $(\mathrm{OM})$ reglare a tensiunii în curea

belt band $(\mathrm{OM})$ curea (lată), bandă, centură, cordon

belt brake $(\mathrm{OM})$ frână cu bandă

belt brush unit (mas-un) agregat de debavurare cu bandă abrazivă

belt capacity (met, alim, constr) capacitate de transport pentru o bandă

belt clamp $(\mathrm{OM})$ dispozitiv de prindere a curelei

belt composition (OM) compoziția / materialul curelei

belt connector $(\mathrm{OM})$ agrafă de curea

belt conveyor (alim, mas, ind chim) transportor $\mathrm{cu}$ bandă

belt-conveyor tail pulley (OM) roată de întindere la transportoare cu bandă

belt coupling (auto) ambreiaj cu benzi / bandă

belt drive $(\mathrm{OM})$ transmisie / acționare cu bandă / curea / curele

belt drum $(\mathrm{OM})$ tambur pentru bandă

belt dryer (alim, ind chim) uscător cu bandă

belted cable (el) cablu cu izolație înfăşurată

belted occupant (auto) pasager cu / care poartă centura de siguranță

belt elevator (mas, alim, ind chim) elevator $\mathrm{cu}$ bandă

belt fastener (OM) fixator de cablu, agrafă de curea

belt fastener screw $(\mathrm{OM})$ şurub pentru prinderea curelelor

belt feeder (mas) alimentator cu bandă

belt-fork $(\mathrm{OM})$ furcă de conducere a curelei de transmisie

belt freezing (alim, termo) congelare pe bandă transportoare 
belt gearing $(\mathrm{OM})$ transmisie cu curea / cu curele (şi dinţate)

belt guard $(\mathrm{OM})$ apărătoare / protecție a (transmisiei) curelelor

belt guide $(\mathrm{OM})$ ghidaj pentru curea / bandă

belt-guide pulley $(\mathrm{OM})$ rolă de ghidare pentru curele de transmisie

belt hoist (mas) elevator cu bandă

belt hook (OM) agrafă de curea

belt idler $(\mathrm{OM})$ rolă de întindere

belting $(\mathrm{OM})$ țesătură tehnică pentru curele de transmisie, transmisie cu curele, curea de transmisie, montare a unei curele pe roțile transmisiei

belting bolt $(\mathrm{OM})$ bolț / ştift pentru curele / benzi transportoare

belting duck țesătură pentru curele

belting oil $(\mathrm{T})$ ulei / unsoare pentru curele de transmisie

belting press (mas-un, ind chim) presă pentru curele de transmisie (si trapezoidale)

belt joint $(\mathrm{OM})$ împreunare / asamblare a curelei prin agrafare, lipire sau coasere

belt-knife (for) spitting machine (mas-un) maşină de şpăltuit cu cuțit-bandă

belt lace cureluşă de legat

belt lacer $(\mathrm{OM})$ agrafă de curea

belt lacing $(\mathrm{OM})$ coaserea unei curele / benzi

belt line (amer) linie de centură (a unui oraş etc.)

belt load $(\mathrm{OM})$ sarcină pe curea

belt loader (mas, constr) utilaj de încărcat / transportat materiale pe benzi

belt lubricant $(\mathrm{OM}, \mathrm{T})$ lubrifiant pentru curele de transmisii

belt mounter $(\mathrm{OM})$ pârghie pentru aşezat cureaua / banda pe roată

belt ply inserții de pânză / straturi la o curea / bandă

belt pulley $(\mathrm{OM})$ roată de curea

belt-pulley lathe (mas-un) strung pentru roți de curele

belt rapper (met, OM) înfăşurător (acționat cu curele)

belt retractor (auto) locaşul curelei

belt rivet $(\mathrm{OM}) \mathrm{nit} / \mathrm{ştift}$ (şi tubular) pentru asamblarea curelei / benzii

belt roller $(\mathrm{OM}$, met) rolă de sustinere a covorului benzii transportoare

belt sander / sanding machine (mas-un) maşina de şlefuit cu bandă

belt saw (mas-un) ferăstrău-panglică

belt screen sită cu bandă

belt screw $(\mathrm{OM})$ şurub pentru benzi

belt separator (agr, mas) sortator cu bandă belt shifter (OM) dispozitiv de cuplare şi decuplare a curelei

belt sliping / sliding (OM) alunecarea curelei

belt slope plan înclinat cu bandă transportoare

belt speed $(\mathrm{OM})$ viteza benzii transportoare / a curelei

belt speeder $(\mathrm{OM})$ transmisie / multiplicator (de turație) cu conuri de curea

belt strap $(\mathrm{OM})$ curea / bandă tesută, chingă

belt strecher $(\mathrm{OM})$ dispozitiv de tensionare a curelei / a curelelor de transmisie

belt tail section $(\mathrm{OM})$ cap de întindere a unei benzi de cauciuc

belt tension arrangement (OM) dispozitiv de întindere / tensionare a benzilor transportoare

belt tension drum (OM) tobă de tensionare a benzii

belt-tensioning / tightening pulley $(\mathrm{OM})$ roată de tensionare / de întindere a curelei

belt tightener $(\mathrm{OM})$ întinzător de curea, dispozitiv de tensionare a benzii

belt transmission (OM) transmisie cu bandă / cu curele

belt truck loader (mas, constr) transportor $\mathrm{cu}$ bandă mobil

belt (-type) carrier (OM) bandă transportoare

belt-type dehydrator (alim, ind chim) uscător $\mathrm{cu}$ transportor cu bandă

belt vulcanising press (mas-un, ind chim) presă pentru vulcanizarea curelelor

belt webbing (auto) cordonul centurii

belt wiper (OM, met, alim) racletă (a unei benzi transportoare)

bench bancă, banchetă, laviță; banc de lucru / de tragere, masă de tâmplărie; treaptă, fermă, bancă, pat / batiu al maşinii, reper, punct de referintăa (constr) zid, val; (pol) loc în parlament; (jur) funcție de judecător, tribunal

bench (adjustable) clamp (OM) clemă ajustabilă de fixare

benchboard desk pupitru, tablou (şi de comandă)

bench centering device (mas-un) aparat / dispozitiv pentru prindere între vârfuri

bench chisel daltă de mână

benched fall $(\mathrm{OM})$ cădere / variație în trepte (a turației, a formei etc.)

benched transition (hidr) racordare în trepte

bench drill (machine) (mas-un) maşină de găurit de banc / de masă / portabilă (dar cu fixare când lucrează)

bench for cleaning castings (met) masă pentru curățat piese turnate

bench grinder (mas-un) maşină de rectificat, montată pe banc 
bench level (metr, constr) nivelă cu bulă de aer, nivelare după repere

bench-mark (TH) reper, cotă de nivel, punct fix / de reper

bench molding (met) formare pe banc de lucru

bench oiler $(T)$ cană de uns, ungător

bench plate (mas-un) placă de trasare

bench saw ferăstrău mecanic

bench screw menghină cu picior / de lăcătuş

bench vices parallel menghină paralelă

bench work prelucrare pe banc / cu fixare în menghină

bend cotitură, întoarcere, ondulaţie, încovoiere, ramificație, derivatie, curbură, meandră, sinuozitate, curbă; (mas) îndoitură, indoire, strâmbare, cot; înclinație, aspirație; (mat) curbură arc, punct unghiular; (nav) nod, legătură, buclă de parâmă, a fixa, a lega; $(\mathrm{OM})$ cot de țeavă, îndoitură; (mec, met) a (se) încovoia, a (se) îndoi, a (se) curba, a înclina, a apleca, a strâmba, a (se) întinde (si un arc), a ceda

bendable flexibil, care se poate îndoi

bend angle unghi de îndoire (la încercări de îndoire sau încovoiere)

bended tube / pipe (OM, hidr) cot / țeavă în$\operatorname{doit}(\breve{a})$

bender (constr, met, mas-un) maşină / presă de îndoit; (OM) clește

bend in a îndoi, a vira, a frânge

bending (mec) (solicitare la) încovoiere, flexiune, curbură, îndoitură, îndoire, curbare, strâmbare, deformare; care se înconvoaie; (fiz) difracție

bending angle $(\mathrm{mec})$ unghi de încovoiere

bending-back point (mat) punct de întoarcere / inflexiune (al unei curbe)

bending crack (mec) fisură cauzată de încovoiere / îndoire (şi la țevi)

bending cycles (OM) (număr de) cicluri de încovoiere / îndoiri

bending-deflection (mec) săgeată de încovoiere

bending device dispozitiv de îndoit

bending die (met) ștanță / poanson de îndoit, şablon de curbat

bending force $(\mathrm{mec})$ forță de încovoiere / de îndoire

bending-impact test (materiale, mec, metr) încercare / test de reziliență

bending jaw (met) falcă de îndoire

bending load (mec, OM) sarcină (forță sau/şi moment) de încovoiere

bending machine (met) valț / maşină de îndoit

bending measuring device (metr) flexometru

bending modulus (mec) modul (de elasticitate) la încovoiere bending moment (b.m.) (mec, OM) moment încovoietor

bending of a fold (OM, met) îndoitură / formare / îndoire a unei cute

bending-off press (mas-un) maşină / presă de îndoit margini

bending of light (fiz) difracție a luminii

bending pliers (mas-un, OM) cleşte de îndoit (pentru table, tuburi, țevi)

bending point (mat) punct de extrem al unei curbe

bending press (OM, mas-un, met) presă de îndoit margini

bending pressure $(\mathrm{mec})$ efort de încovoiere

bending property (mec) rezistență la încovoiere bending radius (mec) rază de încovoiere

bending resistance (materiale, mec) rezistență la încovoiere

bending roll (met) rolă / cilindru de îndoire / de îndreptare

bending shackle (nav) cheie de ancoră

bending spring $(\mathrm{OM})$ arc solicitat la încovoiere

bending stiffness $(\mathrm{mec})$ rigiditate la flexiune / încovoiere

bending strain (mec) deformare / deformație la încovoiere

bending strain load $(\mathrm{mec})$ sarcină la încovoire (pentru o anumită deformatie)

bending strenght $(\mathrm{mec})$ rezistență la încovoiere / la îndoire

bending stress (mec, OM) tensiune / efort de încovoiere

bending-stress durability durabilitate (limitată) la încovoiere (la solicitari variabile)

bending tensile stress (materiale, mec) efort de tracțiune, generat prin încovoiere

bending test (materiale, mec, metr) test / încercare de încovoiere / la îndoire

bending test on build-up welded joints probă / test de încovoiere a sudurii (pe epruvete sudate)

bending tongs (mas-un) cleşte de îndoit

bending tool (mas-un) matrită de îndoit

bending value număr de îndoituri / îndoiri

bending vibrations $(\mathrm{OM}, \mathrm{mec})$ oscilații / vibratii transversale, de încovoiere

bending-back point (mat) punct de întoarcere (al unei curbe)

bending-deflection (mec) săgeată de încovoiere bending-impact test încercare / test de reziliență bend of lever $(\mathrm{OM})$ cot al pârghiei

bend out a îndoi, a încovoia

bend over a plia, a cuta, a plisa, a îndoi peste

bend pipe $(\mathrm{OM})$ teavă curbă / îndoită

bend sharp a coti (si brusc) 
bend test (materiale, mec, metr) încercare / teste / probă de încovoiere

beneath mai jos, dedesubt; inferior

beneficiation (met) îmbogățire

beneficient generos, darnic; prielnic; folositor

beneficial binefăcător, folositor, util; avantajos, profitabil

beneficiary (ec, $\mathrm{TH})$ beneficiar; funcționar superior; (amer) bursier

benefit (ec) beneficiu, câştig, folos; ajutor; avantaj; uzufruct; (pol) privilegiu, drept special, alocație, ajutor (în bani); ajutor reciproc; a beneficia, a folosi, a trage foloase (de pe urma), a aduce beneficii

bent cot(itură), curbură, pantă; aplecare; îndoit, aplecat, curbat, încovoiat; (constr) capră, fermă de construcție uşoară; (fig) înclinare, aptitudine

bent axle $(\mathrm{OM})$ osie / ax / arbore cotit( $\breve{a})$

bent crank (OM) levier cotit / arcuit

bent down îndoit, cotit

bent for înclinație, aplecare, aptitudine pentru; tendință spre / către

bent frame (nav) coastă deviată

bent lever $(\mathrm{OM})$ pârghie articulată, cotită, cu genunchi

bentone grease $(T)$ unsoare consistentă pe baza de bentonită

bent pipe $(\mathrm{OM}$, termo, hidr) țeavă curbată, racord curbat, cot

bent-tail dog (mas-un) antrenor cu coadă îndoită

benyene (chim) benzen

benzene (chim) benzen

benzine (chim) neofalină; benzină

benzine-resisting hose (chim, plast) furtun (de cauciuc) rezistent la benzină

benzoic acid (chim) acid benzoic

benzol (chim) benzol

benzyl (chim) benzil

be off a pleca, a porni

be off one's beat a nu intra în competența cuiva, a nu fi de resortul cuiva

be on a rula (un film); a fi aprins (d. lumină); a fi deschis

be on the air a transmite, a emite, a fi prezent în emisiune (radio, TV)

be on the bargain counter (ec) a se vinde la un preț scăzut / sub valoare

be on the dole a primi ajutor de şomaj

be on the stocks a fi pe şantier / în curs de execuție

be out a fi plecat; a fi stins (d. lumină); a fi închis

be out of action $(\mathrm{TH})$ a fi $\operatorname{scos} / \mathrm{a}$ ieși din funcțiune, a nu mai funcționa

be out of operation (TH) a nu fi în functiune

be out of phase (el, mec) a nu fi în fază, a fi defazat be out of service a fi şomer, a nu avea serviciu; (TH) a nu mai fi în functiune, a fi scos din producție (d. un utilaj, o maşină etc.)

be out of work a fi desființat, a fi retras din serviciu / exploatare

be out on strike a fi în grevă

be permanently deformed (mec) a fi deformat permanent

bereave (of) a lipsi (de), a priva (de), a răpi, a deposeda (de)

berried (alim) cu boabe

berry (alim) boabă, bob, grăunte, boabă de cafea berth (nav) dană, adapost, cală de constructie / de lansare, ancoraj, a ancora; cuşetă, pat; post, slujbă; a se ține la distanță / parte de

berthage tax (nav) taxă de amarare

berthing (nav) legare la chei, adăpostire, cazare, bordaj exterior deasupra centurii

berthing hawser (nav) legătură, parâmă de legare berthing impact (nav) impact / şoc la amarare (între navă şi chei)

Beryllium (Be) (chim) beriliu

beryllium bronze (met) bronz cu beriliu

beseech a ruga stăruitor, a implora

be serviced a se i face service-ul / verificarea

beset a pune, a aşeza; a asedia; a împresura; a copleşi (cu necazuri); a încurca; a bloca (trecerea)

beside (prep) lângă, aproape de, în apropiere de, nu departe de, la; pe lângă, față de, în comparație cu, în afară de; mai presus de; în afară, dincolo de

besides $(a d v)$ de altfel; în plus; pe lângă toate acestea; mai mult decât atât; pe lângă, în afară de; nu numai, și...; nu numai..., ci și...; inclusiv; cu excepția, în afară de

beslubber a mânji (cu ceva uleios)

besmear a mânji, a murdări

besoil a murdări, a păta

bespeak a arăta; a reține (un loc); a comanda (haine); a prevesti, a prezice; a trăda; a denota

bespectacled cu ochelari

bespoke department (ec) secție / birou / departament de comenzi

besprinkle with a stropi $\mathrm{cu}$

Bessemer charge (met) încărcătură pentru convertizor Bessemer

Bessemer converter (met) convertizor Bessemer

Bessemer ingot iron (met) lingouri de convertizor Bessemer

bessemerising (met) convertizare, prelucrare în convertizor (a otelului)

Bessemer low-carbon steel (met) oțel Bessemer / de convertizor, cu conținut redus de carbon

Bessemer mill / plant (met) instalație / oțelărie Bessemer 
Bessemer pig iron (met) fontă pentru convertizor Bessemer

best cel mai bun; superior; excelent; $(a d v)$ cel mai bine, cel mai mult; maximum; cel mai înalt nivel / grad; (ec) valoare optimă, optim

best bower (nav) ancoră de rezervă, cea mai grea ancoră a bordului

best estimator estimație optimă

bestow a aşeza, a depozita

bestride a sta călare pe; a încăleca; (fig) a fi stăpân (pe o situație); a trece peste (un şanț etc.)

be supported a fí sprijinit

bet pariu; miză; a face pariu

beta $\beta$ (literă grecească)

beta brass / iron (met) alamă / fier beta

beta decay (fiz) dezintegrare beta

betake a recurge la; a se adresa; a se dedica, a se consacra (studiului); a se duce la; a se îndrepta spre

bethanising (met) zincare electrolitică

bethink oneself of a-şi aduce aminte de, a se gândi la

be to a urma să; a trebui să

betoken a însemna, a marca, a arăta; a (pre)vesti

better mai bun, superior; preferabil; mai mare; superioritate; avantaj; ( $a d v)$ mai bine; a mări, a spori; a depăşi, a întrece; a se îndrepta; a se îmbunătăti; a progresa

better hand avantaj, superioritate

betterment îmbunătățire; progres, îndreptare

bettermost cel mai bun

between între; dintre; printre; la mijloc; $(a d v)$ la mijloc, între unul şi altul, între timp / acestea

between-contact space $(T)$ spațiul între suprafetele (rugoase) în contact

between decks (nav) întrepunți

between wind and water (nav) la linia de plutire

be up a stump (ec) a da faliment

bevel $(\mathrm{OM})$ oblicitate, înclinație, teșitură, fațetă, muchie (teşită); (metr) echer mobil; (met) con (la furnal); (mas-un) a tăia oblic, a teși, a fațeta, a şanfrena, a (se) înclina, a fi oblic; (adj) oblic, înclinat

bevel (cone friction) clutch $(\mathrm{OM})$ ambreiaj conic, cuplaj conic, cu fricțiune

bevel angle raportor

bevel cant $(\mathrm{OM})$ muchie teşită

bevel cut $(\mathrm{OM}$, met) tăietură oblică, rost în $\mathrm{V}$ sau jumătate $V$ la sudură

bevel differential $(\mathrm{OM})$ diferențial cu pinioane conice

bevel drive $(\mathrm{OM})$ transmisie prin / cu angrenaj conic

bevel edge $(\mathrm{OM})$ margine teșită

bevel friction wheel $(\mathrm{OM})$ roată de fricțiune conică bevel gear $(\mathrm{OM})$ roată conică, angrenaj conic, angrenaj cu roți dințate conice

bevel gear drive $(\mathrm{OM})$ transmisie cu roți dințate conice

bevel gear hobbing attachment (mas-un) dispozitiv (și detaşabil) pentru frezarea dinților la roți dințate conice

bevel gear pair $(\mathrm{OM})$ angrenaj conic, pereche de roți dințate conice

bevel gear planer (mas-un) maşină de mortezat roți dințate conice

bevel-gear-tooth system (OM) (angrenaj cu) dantură conică

bevel-gear wheel $(\mathrm{OM})$ roată dințată conică

bevel gear with conical pinion (OM) diferențial cu roți conice

bevel geared motor $(\mathrm{OM}, \mathrm{el})$ motor cu reductor cu roți conice

bevel gearing $(\mathrm{OM})$ angrenaj conic

bevel grinding attachment (mas-un) dispozitiv pentru rectificarea suprafețelor conice

bevel joint $(\mathrm{OM})$ racord / cuplare a două piese teşite invers

bevelled $(\mathrm{OM})$ teşit, cu marginea teşită (d. piesa de sudat), conic(ă) (d. o roată, un angrenaj)

bevelled lip of the pulley (mas-un) buza teşită a unei molete / roți

bevelled retaining ring $(\mathrm{OM})$ inel conic, de reținere

bevelled wheel $(\mathrm{OM})$ roată conică

bevelling pregătirea / teşirea marginilor (pentru sudare); prelucrare conică

bevelling-and-cutting machine (mas-un) maşină de executat canturi şi teșituri

bevelling of the edge teșirea muchiei

bevel pinion $(\mathrm{OM})$ pinion conic

bevel rule (metr, hidr) echer reglabil, riglă cu o muchie teşită

bevel-seated valve $(\mathrm{OM})$, supapă cu scaun conic bevel spur gear $(\mathrm{OM})$ roată dințată conică pinion conic

bevel tool (mas-un) cuţit de teşit

bevel washer $(\mathrm{OM})$ şaibă profilată (și conică)

bevel wheel $(\mathrm{OM})$ roată conică (şi dințată)

beverage (alim) băutură (preparată)

beware of a se feri de, a se păzi de; a fi atent la

be within the range (of) a fi în intervalul

beyond (prep) dincolo (de); peste; de / pe partea cealaltă; după (trecerea a) (temporal), după, peste; mai presus de; care depășește; (încă) mai înainte; mai departe, mai încolo; în depărtare, la distantă; pe lângă acestea; mai mult decât atât; (adj) de dincolo, din partea cealaltă

bezel $(\mathrm{OM})$ teșitură, fatetă, locaş, tăis (al unei pietre prețioase); oblic; (mas-un) linetă pentru strung mic; ramă a geamului 
biannual bianual

bias înclinație, înclinare, tendință; preferință, predilecție, simpatie; părtinire, favorizare; prejudecată; (fiz) polarizare; (autom) confuzie, polarizare, eroare sistematică; a influența

bias current curent de deplasare (în instalațiile de vid)

bias cut tăietură în diagonală / cu salt

bias cutter dispozitiv de tăiat în diagonală

biased (autom, OM) cu prag, cu salt

biased error distorsiune

biased estimator estimație deplasată

biasing off (autom, el, metr) blocare

bias mass (mas, mec) masă a dezechilibrului de compensare

bias point (autom, metr) punct de prag, punct de lucru / de functionare

biaxial biaxial

bib cock $(\mathrm{OM}$, hidr) robinet / ventil de golire

bibliographic information search (inf) sortare a informatiei de documentare

bibliography bibliografie

bicarbonate (chim, alim) bicarbonat

bice smalt, glazură

bichromatic (chim) bicromat

bicoil silver bandă cu dublă depunere

becoloured bicolor

biconcave (fiz, TH) biconcav

biconves (fiz, TH) biconvex

bicorn cu două vârfuri

bicurved cu curbură dublă, dublu curbat

bicycle bicicletă

bicyclic biciclic, în doi timpi

bid a invita, a pofti; a oferi, a da; a ura, a dori; a porunci, a ordona; a proclama, a anunta oficial; (ec) ofertă, licitare, a licita, a participa la o licitație, a oferi (un pret), $\sim$ for a face o ofertă pentru; a invita; a dori; a anunța; a publica; a promite să; încercare, tentativă

bid bond (ec) garanție bancară de participare la licitație

bid for (ec) a face o ofertă pentru

bi-directional relief valve (OM, hidr) limitator bidirectional de presiune

bidder (ec) ofertant

bidding (ec) ofertă (şi la o licitație); ordin, poruncă; cerere; licitație

bide a aştepta, a sta (în aşteptare); a continua, a dăinui; a locui, a sta; a înfrunta; a răbda, a suporta

biding așteptare; oprire; haltă

bi-directional drive (mec) transmisie reversibilă

bi-directional motor (termo) motor reversibil / inversabil bifilar bifilar (el) (d. fire)

bifurcate bifurcat; a (se) bifurca

bifurcated launder (met) canal / jgheab bifurcat (la cuptoare)

bifurcation bifurcație, bifurcare

big mare; voluminos; masiv, solid, gros; înalt; mare, vârstnic, matur; important, însemnat

big inch line / pipe (OM, hidr) conductă de diametru mare

big-end (of connecting-rod) (OM) cap de bielă

big-end bearing $(\mathrm{OM})$ lagăr al capului de bielă

big-end-up mould (met) lingotieră cu maselotă

bight (TH) buclă, lanț

bigness mărime, grosime; soliditate

big rolling mill (met) laminor degrosisor

bijection (mat) bijectie

bikern / bick iron nicovală de banc

bilateral bilateral, cu două laturi

bilateral hole $(\mathrm{OM})$ alezaj cu dimensiune nominală între dimensiunea maximă şi cea minimă

bilberry (agr, alim) afin; afină

bilge (alim) burtă de butoi, a scoate fundul unui butoi, a desfunda un butoi; (nav) santină, fund de cală, gurnă, a lua apă în santină

bilge and bilge (nav) stivuire burtă pe burtă

bilge bracket (nav) guseu al gurnei

bilge keel (nav) chilă de ruliu

bilge keelson (nav) carlingă laterală

bilge main (nav) tubulatură principală de santină

bilge pump (nav) pompă de santină

bilge water (nav) apă de santină

bilingual bilingv

bill topor, secure, satâr, târnăcop, colț, cuțit, vârf, foarfece de grădină; proiect de lege, lege, document; listă, inventar; certificat; (ec) calcul al cheltuielilor, socoteală, cont, factură, notă de plată, cambie, poliță; (nav) vârf / gheară de ancoră; (jur) reclamație, plângere, cerere, petiție, proces; afiş, anunţ, înştiinţare; a înregistra, a trece pe o listă, a înştiința, a anunţa (printr-un afiş); (amer) bancnotă; (OM) cioc

billet bilet, notă; (met) lingou, bolt, bloc

billet end (met) capete de țagle, deşeuri (şi din tăierea semifabricatelor la lungimea de livrare)

billet mill (met) laminor pentru tagle

billet roll (met) cilindru de laminor pentru țagle

billet roll stand (met) cajă de laminor de țagle

billet shears (met) foarfecă pentru țagle

billet-reheating furnace (met) cuptor pentru reîncălzirea țaglelor

billet-rolling train (met) laminor de țagle

billhook cosor

billiard-ball collision $(\mathrm{mec})$ ciocnire elastică

billing (ec) facturare 
billion (amer) miliard

billionaire (amer) miliardar

bill of costs (ec) notă de plată

bill of credit (ec) acreditiv, scrisoare de credit

bill of entry (ec) declarație vamală

bill of exchange $(\mathrm{ec})$ cambie, poliță, trată

bill of fare (alim) listă de mâncăruri, meniu

bill of landing (ec, nav) conosament; (amer) (cf) foaie de expeditie

bill of materials specificație / listă de materiale

bill of quantities (ec, TH) deviz estimativ

bill of sale (b.s., BS) (ec) act / contract de vânzare, factură, ipotecă

billow (nav) a se ridica (d. valuri), val mare, brizant, talaz

billowy (constr, agr) neregulat, accidentat (d. teren)

bill poster afişier, avizier, panou de afişaj

bimensal bilunar

bimestrial, bi-monthly care durează două luni, bimestrial

bimetal (met) bandă bimetalică, otel placat

bimetallic bimetalic, din diouă aliate metalice, suprapuse (nu se specifică procedeul sau tehnologia de obținere) (d. benzi, acoperiri etc.)

bimetallic band (met, termo, metr) bandă / platbandă bimetalică

bimetallic bearing (met, T) lagăr cu strat bimetalic

bimetallic conductor (el) conductor bimetalic

bimetallic release / strip (OM, el, termo) declanşator bimetalic

bimetallic strip / band ( $\mathrm{T}$, OM, metr) foaie / platbandă bimetalică, (chim) valență, liant

bimetallic strip compensator (termo) compensator bimetalic (de dilatare termică)

bi-monthly $(a d v)$ bilunar, o dată la două luni, publicație bilunară

bimotored $(\mathrm{cu})$ bimotor

bin dulăpior, ladă, cutie; ladă de gunoi; (agr) hambar, siloz; (constr, met) recipient, cupă, pâlnie de încărcare, buncăr, ladă de alimentare, camere amestec, rezervor, buzunar de laminate; (ec) depozit

binary binar

binary alloy (met) aliaj binar

binary bronze (met) bronz binar

binary cell (c) element binar de memorie

binary compound (chim) compus binar

binary diagram (met) diagramă unui amestec / aliaj binar

binary mixture equilibrium (met) echilibru al unui amestec / aliaj binar

binary number (mat, inf) număr binar

binary variable $(c$, inf) variabilă binară binaxial crystal (chim) cristal biax

bin card (ec, TH) fişă de identificare (a unui produs, pentru conţinut şi calitate)

bind legătură; panglică, fâşie; $(\mathrm{OM})$ piesă de legătură, cerc de bandaj (la roți de rulare); a ataşa, a (se) lega, a (se) fixa (mecanic sau chimic), a strânge (o piesă, un şurub), a uni, a (se) întări, a se solidifica, a intra în angrenare, a consolida, a propti; a obliga, a sili; be binded a fi obligat / constrâns, a fi silit; (constr, chim) a face priză (şi d. adezivi); (ec) a angaja (ca ucenic), a încheia / a ratifica (o convenție); (med) a pansa (o rană), a constipa; a lega (cărţi); to, on a fixa pe / de, a ataşa la / de; a pune o margine la

bind down a sili, a constrânge

binder legătură; panglică, bandă, şnur, sfoară, funie; $(\mathrm{TH})$ şarnieră, liant, material (şi metalic) de lipire / de întărire; (constr) liant, mortar, grindă / strat de legătură; $(O M)$ pârghie de strângere, clemă, legător, maşină / dispozitiv de legat / de capsat; (agr) maşină de capsat snopi

binder beam (cf, constr, mas) traversă de legătură

binder board carton pentru legătorie

binder film (OM, chim) peliculă de liant

binder plug $(\mathrm{OM})$ bolț de strângere / de asamblare

binder twine sfoară

bindery legătorie (de cărți)

binding (med) pansament, faşă, bandaj (medical); (constr, fiz, chim) legătură; (TH) liant, care leagă; $(\mathrm{OM})$ gripare, fretare, înțepenire, înnădire, legare; (met) legătură, balot, colac, aglomerare; obligator, în care obligă; copertă; tiv

binding agent (chim, constr) substanţă / agent de legătură, liant

binding band $(\mathrm{OM})$ centură, bandaj

binding brass (met) alamă de lipit

binding beam (constr) coardă

binding capacity (chim) putere / capacitate de lipire / de legătură

binding clip $(\mathrm{OM})$ clemă de racordare

binding cloth tesătură de legătură (şi în composite şi materiale pentru curele etc.)

binding coal (met) cărbune cocsificabil

binding department / office legătorie

binding handle $(\mathrm{OM})$ manetă de blocare; mâner de fixare

binding hoop (mas-un) fretă

binding joist (constr) coardă

binding material (chim, constr, met) material liant / de legătură, aglomerant

binding matter liant (în general) 
binding nut (OM) piuliță de strângere / de fixare / de legătură (între piese)

binding-off legătură de margine

binding-post voltage (el) tensiune la borne

binding property / quality (chim, constr) capacitate adezivă / de lipit / de priză, proprietate / capacitate de legare / de lipire

binding recess $(\mathrm{OM})$ scobitură / adâncitură / locaş pentru fretă

binding rivet (met, $\mathrm{OM}$ ) nit pentru montaj

binding screw $(\mathrm{OM})$ şurub de strângere / de asamblare

binding substance (chim) substanţă-motrice / de legare; (plast) substanță / agent care favorizează legarea moleculelor, substanță / agent care înlesneşte ataşarea matricei / materialului de bază de cel de adios (la composite)

bind over a obliga, a sili

bin feed (mas-un) banc de alimentare / de încărcare

bin gate (constr, met) gură de descărcare din buncăr

Bingham model (mec, mat, plast) model Bingham (al unui corp)

Bingham plastic model (mec, mat, plast) model plastic Bingham (al unui corp plastic)

bing (met) minereu de plumb bogat, haldă

binocular microscope (fiz, metr, opt) microscop binocular

binomial (mat) binom

binomial expansion (mat) dezvoltare după formula binomului lui Newton

binomial formula (mat) formula binomului lui Newton

binoxide (chim) bioxid

bin stock (ec, TH) materie primă în depozit

bin tag (ec, TH) fişă de evidență a intrărilor şi ieşirilor

biochemical (chim) biochimic

biochemistry (chim) biochimie

biodegradable biodegradabil

biodiesel (auto, chim) carburant biodiesel

biofuel (chim, auto) biocombustibil

biography biografie

biologic(al) biologic

biological treatment tratament biologic

biophysics biofizică

biosphere biosferă

biotechnics biotehnică

bipartite $(\mathrm{OM})$ din două piese, din două părți

biphase (el) bifazat, difazic; cu două faze

biplug (el) fişă dublă

bipolar (fiz, chim, el) bipolar, cu doi poli

bipolar charging (fiz, chim) încărcare bipolară bipolar electrode (el, fiz) electrod bipolar

biquadrate (mat) puterea a patra

birch (silv)mesteacăn; nuia, vergea

birchen (silv) de / din mesteacăn

birdbath (constr) teșitură

bird's mouth (OM, mas-un) îmbinare în furculiță / în coadă de rândunică

birectangular cu două unghiuri drepte

birth naştere, creare, facere; (fig) început, origine; a naşte, a da naştere

birth and death process proces de creare şi distrugere a aceluiaşi lucru (şi a unui produs)

birth certificate certificat de naştere

birthplace locul naşterii

biscuit (alim) biscuit, pesmet

bisecant (mat) bisecant

bisect bisect; (mat) a împărți în două, a înjumătăți

bisecting line, bisector of an angle, bisetrix (mat) bisectoare a unui unghi

bisection (mat) înjumătățire

bisection algorithm (mat) altgoritm de bisectare (prin înjumătățirea sistematică a intervalului de calcul)

bisectrix, $(p l)$ bisectrices (mat) bisectoare

Bismuth (Bi) (chim) bismut

bissextile bisect, an bisect

bistable bistabil, cu două poziții de echilibru

bisulphate (chim) bisulfat

bit bucată mică, bucățică, pic, strop, fărâmă, părticică; ceva, puțin; (c) bit, cifră binară; (mas-un) dinte aplicat / demontabil la freză, bavură, bac, tăiş de sculă aşchietoare (şi de burghiu), margine tăietoare (de sculă), ascuțiş, falcă de menghină; (el, met) letcon (pentru lipit); (OM) floare (a cheii)

bit cutting angle (mas-un) unghi de atac al sculei aşchietoare

bit edge (mas-un) tăiş al sculei (aşchietoare)

bite (met) deschidere a cilindrilor de laminare; a coroda, a ataca (chimic, mecanic), a "muşca" dintr-o piesă; a muşca; a mânca, a arde, a coroda; (alim) a ustura; a calomnia, a defăima, a ponegri; $(\mathrm{TH})$ a prinde; $(\mathrm{TH})$ roadere, ardere, corodare, prindere, îmbucare; (nav) a mușca (d. ancoră)

bite away (mec, $\mathrm{TH})$ a roade; a uza, a strica

bite in a muşca, a ciupi (spre interior)

bite-in muşcare, ciupire (process mecanic sau/şi chimic) (dintr-un material, semifabricat etc.)

biting muşcător, care muşcă / ciupeşte; ascuțit; usturător

bit end $(\mathrm{OM})$ cap al bielei

bit face angle (mas-un) unghi de ascuțire (al unei scule) 
bit gauge (mas-un) şablon pentru ascuțirea sculei bit grinder (mas-un) polizor pentru scule aşchietoare

bit leg (mas-un) falcă

bit of turning cutter (mas-un) cap de cuțit de strung

bit resharpening (mas-un) reascuțirea sculei / muchiei

bit seizure (mas-un) înțepenire a sculei (şi la burghiere)

bit shank (mas-un) cep conic, de fixare a sculei

bitronconic ball mill (alim, ind chim, met) moară bitronconică cu bile

bits (mas-un) fălci de menghină

bitt (nav) baba (de lemn), bintă (de lanț), suport de lanț / de parâmă

bitter (alim) amar, bere amară, bitter (aperitiv); a face amar, a amărâ

bitter almond (alim) migdală amară

bitter salt (alim, chim) sare amară

bitterness of the wine (alim) amăreala vinului

bitting (alim) proces de amărâre a vinului

bitts (nav) baba, suport de ancoră

bitumen (constr, ind chim) bitum natural, asfalt

bituminiferous (ind chim) bituminos

bituminiye (constr) a asfalta

bituminous (ind chim) bituminos

biunique (mat) biunivoc

bivalent (chim) bivalent

bivariate bidimensional

biweekly bilunar, care apare la două săptămâni; care apare de două ori pe săptămână, o dată la două săptămâni, de două ori pe săptămână

black negru, întunecat, închis; a înnegri, a colora sau a vopsi în negru; (chim) negru de fum; (mas, termo) calamină, depuneri cărbunoase, funingine

black-annealed wire (met) sârmă neagră recoaptă

black annealing (met) recoacere primară

black-ash revolver (ind chim) cuptor rotativ pentru soda calcinată

black berry (agr, alim) mur, coacăz negru

blackboard (met) tablă neagră

black bolt $(\mathrm{OM})$ şurub brut / grosolan

black book carte de amenzi; listă neagră

black box (fiz) cutie neagră

black carbon (chim) grafit, negru de fum

black chromium (chim) crom negru

black coal (chim, minrl) cărbune de piatră

black earth (agr) cernoziom

black-edged plate (met) tablă cu margini negre

blacken a înnegri, a întuneca

blackening (met) înnegrirea formelor (la turnare) black finish (met) brunare, a bruna

black flange (OM, hidr) flanşă oarbă

black-heart malleable cast iron (met) fontă maleabilă cu miez negru

black-hot (met) încălzit până la roşu-închis

blacking cremă de ghete; (met) vopsea de grafit (pentru forme de turnare)

black lead (met, chim) grafit

black lead crucible (met) creuzet de grafit

black-lead lubrication $(\mathrm{T})$ ungere cu lubrifiant grafitat / unsoare consistentă cu grafit

black-lead powder (chim, $\mathrm{T}$ ) praf de grafit

black-lead wash (met, chim) vopsea de / cu grafit (pentru forme)

black leg escroc; spărgător de grevă, neparticipant la grevă

back lift (c) mărire a contrastului (şi $\mathrm{d}$. un display, ecran)

black light (fiz) lumină ultravioletă

black-mould dressing (met) (vopsire cu) vopsea de grafit (la forme de turnare)

blackness întunecare, negreală; întuneric

black nickel coating (chim) (acoperire $\mathrm{cu}$ ) nichel negru

black oil (ind chim) păcură, reziduuri petroliere grele

blackon (auto, ind chim) aplicare de substanțe anticorozive pe suprafete metalice de sub caroserie

black-out alarmă aeriană, camuflaj; (el) stingerea luminilor, întreruperea curentului, a întrerupe, a scoate din circuit; a cenzura, a scoate / a tăia (un text)

black patch (met) pete de arsură (la laminare la cald)

black pickling (met) decapare primară

black plate / sheet (met) tablă neagră

black products (ind chim) produse (petroliere) negre

black rope (nav) parâmă cătrănită

black screen (inf, autom, c) eroare critică din sistem, având ca rezultat înnegrirea afişajului / ecranului; (fiz, metr) filtru optic

black screw (OM) şurub brut / grosier

black sheet (met) tablă neagră

black shortness (met) spărtură neagră

black slag (met) zgură neagră

blacksmith fierar, forjor, potcovar

blacksmith's chisel (met) daltă lată

blacksmith's forge (met) forjă (de obicei mai mică)

blacksmith's shop (met) forjă

blacksmith's tongs (met) cleşte de forjă

blacksmith's tool (met) unealtă de forjă 
blacksmith coal (met) cărbune de forjă

blacksmith welding (met) sudare prin forjare manuală

blackwash a înnegri; (met) vopsea de grafit (la forme de turnare)

bladdery cu băşici, băşicat

blade foaie; frunză; lamă, lamă de ras, tăiş de cuțit; (auto, cf, OM) arc lamelar, foaie de arc; (el) lamă a contactorului; (hidr) paletă (de pompă, de turbină); (OM) pală, paletă, aripioară, pană, ic; (mas-un) tăiş, bac, pânză (de ferăstrău), dinte aşchietor, cuțit demontabil; (nav) pană (la ramă), pală a elicei, pană (la cârmă)

blade angle (mas, termo, hidro) unghi al muchiei / al plăcii / al aripii

blade bearing (OM, mas-un) reazem prismatic

blade beater (mec, OM) volant cu lineale / pale

blade clearance $(\mathrm{OM})$ spațiu liber între periferia aripilor unui ventilator / rotor şi carcasa lui

blade crusher (alim, ind chim) valțuri cu cuțite tăietoare

bladed (OM) cu palete, cu lame(le)

blade disk of the diaphragm (OM, hidr) disc de diafragmă, cu palete

blade flutter (mec, termo) vibrație a paletei

blade grader (constr) maşină de nivelat terenul, greder

blade holder (mas-un) port-cuțit

blade maintainer (constr) maşină de nivelat pentru drumuri, cu lamă

blade mixer (alim, ind chim) amestecător cu palete

blade oar (TH) foie, lamă

blade of knife / cutter / shears (met, mas-un) lamă de cuțit / de foarfece

blade of shovel lamă a lopeții

blade-paddle mixer (alim, ind chim) amestecător cu palete

blade pitch (nav, termo) pas al palelor

blade rim bandaj de roată la roți de (căi ferate macarale etc.)

blade switch (el) întrerupător cu lamă / cu cuțit

blade wheel (hidr) roată cu palete

blading (constr) nivelare (a unui drum), paletare

Blake stopper (OM, nav) boț de lanț tip Blake

blame vină, învinuire, răspundere; a învinovăți, a acuza pentru / de; a mustra; a blama pentru

blanch a albi, a înălbi, a vărui; (met) a cositori, a stana

blank orb, gol, pustiu, sec; steril; nefinisat; alb; liber; curat; nescris; (c, autom) blanc, gol, neutilizat; (constr) luft, interstițiu, spărtură, crăpătură, fisură, (teren) viran; (ec) formular, tabel de completat; (met, mas-un) semifabricat, steril, eboşă, piesă brută, țaglă, lingou, bloc, steril; (mat) rubrică

blank assay (metr) probă-martor

blank bending (met) îndoirea bramei (la turnarea continuă)

blank bolt $(\mathrm{OM})$ şurub brut

blank cheque (ec) cec în alb, formular de cec

blank cover (OM, hidr) capac orb

blanked-off pipe (hidr) țeavă blindată / înfundată / cu capac orb / cu flanşă oarbă

blanket (fiz) înveliş; (constr, TH) şapă, îmbrăcăminte rutieră / asfaltică, acoperire, strat, pătură, depozit; a acoperi, a înveli; (nav) a masca; (amer) a include, a cuprinde

blanket drying machine (alim, ind chim) maşină de uscat cu bandă transportoare

blancketed învelit, acoperit

blanketing (autom, metr, el) suprapunere a semnalelor, acoperire a unui semnal cu altul perturbator

blanketing gas (met) (pătură de) gaz de protecție (şi la sudare)

blanket of nitrogen strat / pernă de azot

blanket price (ec) preț global

blanket-type isolation (el) izolație în covor flexibil

blank for blasting caps (met) cupă / epruvetă pentru încercare la ambutisare adâncă

blank form formular

blanking (plast) ştanțare, matrițare, tipar

blanking press (mas-un) presă de decupare / de ştanțare

blanking tool (mas-un) sculă / poanson de decupare / de stantare

blank key (c) clapă / tastă de blanc / de spațiu gol

blankness (fiz) gol, vid, vacuum

blank off (hidr) a blinda o conductă

blank out a ştanța, a decupa

blank page pagină goală

blank pipe (hidr) țeavă neperforată / fără filtru

blank(s) reglete (de lemn)

blank stock (ind chim) amestec de control

blank store (met) loc de depozitare (şi la laminoare), pat de răcire

blank test probă martor

blast $(\mathrm{TH})$ suflu, suflare, insuflare; detunătură, explozie; (met) insuflare de aer (în cuptor), suflantă; (met) a sabla; (termo) aer insuflat, a sufla puternic, a insufla; (fig) a distruge, a ruina, a strica; a arunca în aer, a exploda; a se ofili, a se usca

blast air insuflare a aerului, aer suflat / comprimat; (met) vânt (la furnal) 
blast apparatus (mas-un) aparat cu aer / gaze comprimat(e) / de suflare / de suflat

blast box (met) cameră de aer, cutie de vânt

blast cabinet $(\mathrm{OM}$, met) carcasă a suflantei, cameră de sablare

blast characteristic (met, TH) caracteristica / caracteristicile insuflării cu aer

blast cleaning machine (met) maşină de curățat cu aer comprimat / prin sablare

blast coil assembly (OM, alim, ind chim, met) răcitor cu aer

blast cold (met) vânt / insuflare rece (la furnal, cuptoare etc.)

blast-control valve (OM, hidr) supapă pneumatică, pentru controlul presiunii

blast cooling răcire bruscă / intensă

blast cylinder (met, mas) suflantă de cilindru

blast drying ( $\mathrm{TH}$, plast, alim) uscare în curent de aer

blasted pregătit mecanic (d. o suprafață, pentru lipire, prin sablare etc.)

blast engine (met, mas) suflantă

blaster explozor; (met) maşină de curățat cu alice sau nisip / de sablat

blast-furnace (met) cuptor, furnal, cuptor de topit / cu aer suflat / cu cuvă

blast-furnace blower (met) suflantă de furnal

blast-furnace blowing engine (met) suflante de furnal (inclusiv acționarea ei)

blast-furnace blowout (met) stingere a furnalului

blast-furnace bosh (met) etalaj al unui furnal

blast-furnace bottom (met) fund de vatră la creuzetul de furnal

blast-furnace brick (met) cărămidă pentru furnal

blast-furnace brickwork (met) zidărie de furnal

blast-furnace burden (met) încărcătură / şarjă a unui furnal

blast-furnace casting (met) descărcare a furnalului

blast-furnace cement (met, constr) ciment de furnal / de zgură

blast-furnace charge / charging (met) încărcare / încărcătură a furnalului

blast-furnace cinder (met) zgură de furnal

blast-furnace coal (met) cărbune de furnal

blast-furnace coal tar (met) gudron de furnal

blast-furnace coke (met) cocs metalurgic / pentru furnal

blast-furnace crucible (met) creuzet al furnalului

blast-furnace elevator (met) dispozitiv înclinat, de alimentare la furnal

blast-furnace ferromanganase (met) feromangan de / pentru furnal blast-furnace fittings (met) armătură de furnal blast-furnace flue dust (met) praf de furnal blast-furnace foamed slag (met) zgură spongioasă, de furnal

blast-furnace frame(work) (met) schelet (metalic) de furnal

blast-furnace gas (met) gaz de furnal

blast-furnace gas cleaner (met) epurator pentru gazul de furnal

blast-furnace gas-driven blowing (met) suflantă cu motor cu gaz de furnal

blast-furnace gas main (met) conductă pentru gazul de furnal

blast-furnace gas valve (met) robinet / vană (şi tip sertar) pentru gazul de furnal

blast-furnace gun (met) maşină de astupat orificiul de scurgere de la furnal

blast-furnace hearth (met) creuzet al furnalului

blast-furnace hearth bottom (met) vatră (la furnal)

blast-furnace hearth casting (met) blindaj al etalajului la furnale

blast-furnace hoist (met) ascensor înclinat, de alimentare a furnalului

blast-furnace jacket (met) blindaj al furnalului

blast-furnace lines (met) profilul furnalului

blast-furnace lining (met) căptușeală a furnalului

blast-furnace lump slag (met) zgură de furnal, în bulgări

blast-furnace man (met) metalurg(ist), furnalist

blast-furnace masonry (met) zidărie a furnalului

blast-furnace melting operation / practice (met) conducere a furnalului

blast-furnace mixer (met) melanjor de fontă

blast-furnace mouth / throat / top (met) gură de încărcare a furnalului

blast-furnace of medium height (met) furnal cu cuvă scurtă

blast-furnace operator (met) furnalist

blast-furnace operation (met) mersul / functionarea furnalului

blast-furnace output (met) producție / productivitate a furnalului

blast-furnace pitch (met, chim) smoală de furnal blast-furnace plant (met) secția / uzina de furnale

blast-furnace process (met) procedeu / proces de obținere a fontei prin topire reducătoare în furnal

blast-furnace pumice-stone slag (met) zgură spongioasă de furnal

blast-furnace ring (met) inel de sustinere la (mantaua de la) furnal

blast-furnace salamander / bear / sow (met) fontă răcită în creuzetul furnalului, urs

blast-furnace settler (met) antebazin pentru colectarea fontei topite 
blast-furnace shaft (met) cuvă de furnal blast-furnace slag (met) zgură de furnal

blast-furnace slag cement (met) ciment de furnal din / de zgură

blast-furnace smelting (met) fuziune / topire în furnal

blast-furnace stack (met) cuvă de furnal

blast-furnace stack casing (met) mantaua cuvei de furnal

blast-furnace steel jacket (met) blindaj (metalic / de oțel) al furnalului

blast-furnace steel structure (met) schelet metalic al furnalului

blast-furnace steam blower (met) suflantă cu abur pentru furnal

blast-furnace tar (met) gudron de furnal

blast-furnace throat (met) gură de încărcare a furnalului

blast-furnace top closing device (met) dispozitivul / instalația de închidere automată a gurii furnalului

blast-furnace tuyere (met) gură vânt a furnalului

blast-furnace well (met) creuzet al furnalului

blast gate (met) şuber / gură de aer (la cuptoare şi la furnal)

blast-heating (met, termo) încălzirea aerului vântului (la furnal)

blast-heating apparatus (termo) recuperator (de căldură)

blast hole gaură pentru explozivi

blast in (met) a sufla, a insufla (aer, gaz)

blast indicator (met, metr) aparat de măsurat tirajul

blasting distrugător, care strică; exploziv, explozibil; (met) insuflare de aer în cuptor; împroscare (şi în procesul de sablare)

blasting agent (met) agent de insuflare / împroșcare / de sablare

blasting oil (chim) ulei de împroşcare, nitroglicerină

blasting powder (met) pulbere explozivă

blasting sand (met) nisip de sablare

blast inlet (met) gură de vânt (la furnal)

blast-lamp (termo) suflător, arzător

blast main (met) conductă principală de vânt

blast off a se desprinde de pământ (de. nave spațiale); a sufla în afară

blast opening (met) gură de vânt, deschiderea gurii de vânt

blast pipe (met) conductă de (insuflat) aer, conductă a suflantei

blast preheater (met, termo) caupăr, cowper, preîncălzitor de aer (şi la furnal, cuptor etc.)

blast pressure (met) presiune a aerului / a vântului blast-pressure tank (hidr) cazan de presiune, rezervor de aer comprimat (necesar la insuflare, sablare)

blast regulator / controller (met, ind chim, metr) dispozitiv de control / reglare a aerului insuflat

blast-spout (agr) exhaustor al batozei

blast volume (hidr, met) debit de aer suflat

blast tuyere (met) gură de vânt / de aer

blast wave (fiz) undă expansivă, suflu

blast whistle explozie, suflu

blasty vântos, cu vânt

blaze (fiz) luminozitate, lumină intensă; flacără, foc, vâlvătaie, izbucnire (a focului), explozie; (fiz) plan de incizie; a marca, a lumina, a străluci, a luci, a radia, a deschide, a începe, a iniția; a arde (și cu flacără vie), a pune pe foc

blaze up a izbucni în flăcări

blazing arzând, aprins, care arde, în flăcări; evident; flagrant

bleach (chim, textile) (procedeu de) albire, decolorare; (lichid) decolorant, clorură var; a înălbi, a spăla, a curăța, a decolora, a albi, a oxigena; (constr) a vărui; a păli

bleachery (textile) spălătorie chimică, albitorie

bleary confuz, spălăcit; cețos, încețoşat, întunecat

bled ingot (met) lingou cu miez nesolidificat

bleed (med, anat) sânge; a sângera, a lua sânge de la; a lăsa să curgă; (mas) ajutaj; (mas, termo) a purja; a desfunda, a evacua, a goli, a (se) scurge încet (dintr-o conductă / rezervor, fără etanşare bună); ( for) a-şi da sângele, a se sacrifica (pentru); (d. apă, gaze) a se scurge; (ec) a pierde bani, a fi stors de bani, a stoarce de bani

bleed chock / bleeder (OM, hidr) ventil de purjare, robinet de golire, supapă de siguranță / de golire

bleeder (OM, hidr) supapă de siguranță

bleeder chock (el) bobină de şoc, inductanţă de scurgere

bleeder heater (termo) preîncălzitor cu abur uzat

bleeder resistor (el) rezistență de fugă / de drenare

bleeder turbine (termo) turbină cu priză de aer

bleeder-type condenser (termo) condensator $\mathrm{cu}$ prelevare / sustragere de fluid frigorific

bleeder valve (met) ventil pentru gaz de furnal; $(\mathrm{OM})$ robinet de epurare / de golire / de evacuare a aerului

bleeding (med) sângerare; (hidr) picurare a apei din infiltraţie, picurare (nedorită a fluidului, şi din cauza montajului greșit al garniturilor, a deformațiilor etc.); golire, evacuare, descărcare, exudație, purjare, transpirație, decolorare (şi locală); eflorescență; scurgere (nedorită) (a unui 
fluid); (T) separarea uleiului din structura unsorii, scurgere (lentă) din conducte de ungere

bleeding bulk appearance $(\mathrm{T})$ apariția / separarea uleiului liber pe suprafața unei unsori lubrifiante

bleeding coil (el) bobină de descărcare / de fugă la pământ

bleeding flange (OM, hidr) flanşă de priză

bleeding illustration ilustrație / figură care ocupă întregul format al unei pagini

bleeding of paint (chim, plast) exsudare a vopselei

bleeding tap (OM, hidr) robinet de golire

bleeding test of greases $(T$, metr) determinare a rezistentei la sinereză a unsorilor consistente

bleed-off (hidr, termo) (priză de) golire a fluidului excedentar, evacuare / scurgere a fluidului frigorific (eventual cu substanță de marcare odorizantă sau vizibilă, pentru siguranță)

bleed screw $(\mathrm{OM})$ şurub tubular (şi cu substanță de marcare pentru siguranță)

bleed through (fiz, chim, hidr) migrare printre, extrudare (şi la lipituri), (s)curgere printre / prin

bleed the line (auto) a scurge fluidul din conductă; (TH, OM, hidr) a se scurge dintr-o conductă

blemish defect, viciu, cusur; neajuns, lipsă; pată; a păta; a defăima

blench a înălbi, a albi, a face alb; a păli

blend (alim, ind chim, met) amestec, combinație, îmbinare, potrivire, mixtură, melanj, a (se) mesteca, a elabora amestecul / rețeta, a melanja, a amalgama, a combina (materiale), a (se) îmbina; a (se) asorta, a se potrivi; a (se) uni

blendable miscibil

blendability miscibilitate

blend composition (materiale, alim, constr, ind chim) compoziție a amestecului

blende (minrl) blendă

blended oil $(\mathrm{T})$ ulei aditivat

blender (ind chim, constr, alim) malaxor, amestecător, agitator

blending ( $\mathrm{T}$ ) aditivare; (alim, constr, ind chim) amestec, mixtură, amestecare, dozare, alcătuire a amestecului

blending and mixing device (alim, constr, ind chim) amestecător, agitator, dispozitiv de dozare şi amestecare

blending bin (met) siloz / depozit de amestecare

blending chest (alim, constr, ind chim) bazin / cuvă de amestec

blending feeder (alim, constr, ind chim) ladă amestecatoare, alimentator pentru amestec

blending hopper (met, ind chim, constr) ladă alimentatoare / amestecătoare; buncăr amestecător blending machine (met, ind chim, constr) mașină / instalație de amestecat

blending room (ind chim) cameră de amestec

blending stock (constr, ind chim) componente ale amestecului, produse de amestecat

blending tank (alim, constr, ind chim) rezervor de amestec

bless a binecuvânta

blewing umflare (la refractare)

blind (med) orb, a orbi, go a orbi, care nu distinge culorile, colour $\sim$ daltonist; (constr) stor, jaluzea, wall zid fără uşi şi ferestre, perete orb, door uşă falsă, ditch şanț subteran; (foto) diafragmă; (OM) fără deschizătură, orb, înfundat, flanşă oarbă, (capăt) orb / obturat / închis / înfundat, (piesă tip) diafragmă, (cf) linie moartă; (fiz) a orbi, a obtura (cu diafragmă); lipsit de rațiune; necontrolat; ascuns; obtuz, fără judecată, nechibzuit; neclar, neciteț; (d. obiecte) nelustruit, mat; letter scrisoare greşit adresată; (fig) to care nu vede (ceva), inconştient de

blind alley fundătură; impas, punct mort

blind coal (termo) cărbune care arde mocnit

blind connection (OM, hidr) racord înfundat / obturat

blind core (met) miez pentru obținerea unei găuri cu fund în piesa turnată

blinded orbit (de flacăra de la sudare etc.)

blind end (cf, OM) linie moartă, cap înfundat

blind-end bore $(\mathrm{OM})$ gaură înfundată

blind-end cylinder (auto) cilindru fără chiulasă

blind feeder (met) maselotă oarbă

blind flange (OM, hidr) disc orb, flanşă oarbă / înfundată

blind frame (met) ramă oarbă / mascată (la turnare)

blind hinge $(\mathrm{OM})$ balama îngropată

blind hole $(\mathrm{OM})$ gaură înfundată

blinding ( $\mathrm{TH}$, alim, mediu) colmatare (si a unei site)

blind nut $(\mathrm{OM})$ piuliță oarbă / înfundată, capac orb, filetat

blind off a line (hidr, termo) a blinda / a închide o conductă (şi cu flanşă oarbă)

blind opening (hidr, termo) deschidere oarbă închisă / obturată, canal orb

blind pass fundătură; (met) calibru de laminare orb, trecere goală / în gol; (hidr) conductă de trecere / de ocolire, opturată

blind plug (OM, hidr) dop, flanşă oarbă

blind riser (met) maselotă închisă / oarbă

blind shell (mil) proiectil neexplodat

blind spot $(\mathrm{TH})$ punct mort; (fiz) zonă moartă / de tăcere (radio); punct slab / nevralgic; zonă / punct despre care nu există informații 
blind tuyeres (met) guri de vânt închise blind tyre (auto) bandaj de roată fără buză

blink clipit, clipire; sclipire, licărire; a clipi; a sclipi, a luci; a închide ochii la, a nu vrea să vadă; (auto) a clipi (d. un semnal luminos), a lumina intermitent (şi d. un indicator de bord)

blinker (constr, met) ramă oarbă / mascată; care clipeşte; (cf, auto, TH) semnalizator cu lumină intermitentă

blinkers $(\mathrm{TH})$ ochelari de protecție

blip (fiz) vârf de ecou, impuls scurt, imagine pe ecranul radarului

blister băşică; (met) bulă de aer, gol, suflură, retasură, peliculă (ca defect); a (se) băşica, a arde; a critica aspru

blister copper (met) cupru brut

blistered băşicat, cu băşici

blister(ed) steel (met) oțel cementat

blistering (met, plast) formare de băşici / bule / sufluri / goluri, eflorescență (defecte)

blisters băşici de ardere (şi la sticlă)

bloat a (se) umfla, a face spumă, a (se) umple cu aer; (alim) a afuma (peşte); a se inflama

bloated umflat; excesiv, exagerat; (alim) afumat (d. peşte)

bloating umflare

blob ( $\mathrm{T}$, hidr, plast) picătură, strop (de substanță vâscoasă)

block butuc, buştean; grămadă; barieră, obstacol, piedică; grupare (politică); calotă; (autom) bloc, schemă, diagramă; a bloca, a face obstrucție, a împiedica, a pune piedici, a asigura (o blocare, o închidere etc.) a bloca; (constr) bloc (şi de piatră), lespede, clădire, (amer) corp de case, cvartal; (OM) sabot, scripete, palan, culisă, piesăbloc; (met) bloc de oțel, blum, semifabricat, tambur (de tratament); (nav) macara

block address (autom, inf) adresă în bloc

blockade blocadă; baricadă; a bloca, a împiedica

blockage blocare, înfundare, formare de dopuri

block a line (cf) a bloca o linie

block and block (mas, TH) macara la macara (d. un palan care s-a blocat)

block-and-interlocking arrangement (cf) instalație de centralizare şi de blocare a acelor şi semnalelor

block-and-tackle (mas) scripete multiplu pentru ridicarea greutăților, palan

block bearing $(\mathrm{OM})$ lagăr (radial) monobloc

block brake (OM) frână cu saboți

block chain (OM, mas) lanț articulat / pentru maşini de ridicat

block clutch (OM, cf) ambreiaj cu saboți exteriori (cu volum variabil) block coefficient (ind chim, mas) coeficient de umplere

block cutter (mas-un) cap de frezat, freză frontală, cu dinți demontabili

block diagram schemă-bloc

blocked blocat, închis forțat

blocked grid keying manipulare pe grilă

block engine (auto, termo) bloc (de) motor

blocker (TH) dispozitiv de blocare; (met) eboşă, matriță de preforjare

block file (mas-un) pilă mare cu secțiune dreptunghiulară

block gauge (mas-un, metr) cală plan-paralelă

block gauge holder (mas-un) suport pentru calibre prismatice

block grease $(T$, chim) unsoare în brichete

blockhouse (constr) casă de bârne, baracă

block in a schița, a creiona

blocking blocare, asamblare prin blocare, oprire, împiedicare; (c) asamblare / combinare în blocuri / module, blocare, care blochează; (met) afinarea şarjei, preforjare, corectarea şarjei prin adăugare de fontă (la furnal / cuptoare); (plast) lipirea foilor de plastic (de cilindri, ca defect)

blocking gear dispozitiv de fixare / de blocare blocking of the saw blocarea ferăstrăului

blocking phenomena (chim, fiz) fenomene de blocare (a unei reactii chimice, a unui process fizic etc.)

blocking screw $(\mathrm{OM})$ şurub de blocare / de fixare blocking-up (hidr, mediu) colmatare

block letters majuscule sau litere de tipar, verzale

block motor (termo) bloc motor

block of puchase (met) bloc, lingou

block out a schița (un plan), a retuşa

blockout (constr) nişă, scobitură, firidă

block penetration $(\mathrm{T})$ penetrația unui eşation de lubrifiant (unsoare) suficient de vâscoasă încât să-şi păstreze forma

block press (plast) presă pentru blocuri

block roller (OM, mas) culisă cu role, ghidaj cu role

block shears (met) foarfece pentru lingouri sau blocuri de oțel

block sheave (nav) rai de macara

block slag (met) zgură în blocuri

block slip (ec) cupon (dintr-un carnet de cecuri)

block soap săpun în brichete / calupuri

block soldering (met, termo) lipire cu blocuri de încălzire

block sort (c, inf) clasificare / sortare în bloc

block terminal cutie de distribuție / de derivatie

block tool (mas-un) sculă (mono)bloc

block transfer (c, inf) transfer în bloc 
block type insulant (el, termo) izolant rigid (sau semirigid) în blocuri sau plăci

block-tyre (auto) bandaj plin de cauciuc (la pneuri)

block up a bloca, a zăvorî; (constr) a umple (şi cu cărămidă)

blondin (mas) macara funiculară

blood pressure (med, anat) presiune arterială

bloodstone (minrl) hematit

bloom strălucire, înflorire, floare, luciu; prosperitate; a înflori, a prospera; (chim) eflorescență, fluorescență în lumina reflectată a produselor, fluorescență / ceață pe adeziv; (met) blum, lupă, bloc de oțel, lingou (degroşat), țaglă, a lamina brut, a forja (etapa inițială, brută); a străluci, a înflori; (agr) puf (pe fructe); bujori în obraz

bloom-and-slab yard (met) hală / magazie de depozitat blumuri, sleburi

bloom butts (met) capete care se taie înainte de laminare

bloom (colour) $(\mathrm{T})$ culoare a unui lubrifiant la lumina zilei, reflectată la $45^{\circ}$ față de suprafață

bloom conditioning yard (met) curățătorie (hală, teren) de blumuri

bloom crop end (met) capăt de lingou

bloom shears (met, mas) foarfece de lingouri

bloomer (met) cilindru de laminor pentru blumuri

bloomery (met) cuptor de pudlat

bloomery furnace (met) cuptor de reducere directă

bloomery hearth (met) vatra cuptorului de pudlat

bloomery iron (met) otel de fuziune

bloomery process (met) procedeu de reducere directă

blooming în floare, înflorit, înfloritor, care înfloreşte / prosperă

blooming (mill) (met) bluming, laminor de profiluri grele / de blumuri

blooming pass (met, metr) calibru degrosisor (la laminoare pentru blumuri)

blooming roll (met) cilindru de laminor pentru blumuri

blooming rolling mill (met) bluming, laminor de profiluri grele / groase / de blumuri

blooming(-roll) train (met) linie de laminor de lingouri / blumuri

blooming(-mill) stand (met) cajă de laminor pentru blumuri

bloom strength (mec, OM) rezistența gelului (şi la lipire)

blooper (mas-un) presă de lipit

blossom floare, inflorescență; înflorire; a înflori, a îmboboci; a propăşi, a se dezvolta blot pată (şi pe țesături, de cerneală), a (se) păta, a face pete, a murdări, a mânji, a estompa; (fig) a şterge, a spăla

blotch umflătură; pată

blotchy cu umflături; cu pete, pătat

blot out a anula, a elimina, a înlătura, a şterge (ceva scris, din memorie), a estompa; a ucide, a distruge

blotted pătat

blotter sugativă; tampon; (el) stingător de scânteie; $(\mathrm{ec})$ registru de încasări

blotting paper sugativă

blow răsuflare, suflu; lovitură, izbitură, pocnitură; pumn; (auto) explozie de pneu; (mec) şoc, lovitură, lovire, percuție; (termo) purjare; (el) a arde (o siguranță fuzibilă); (met) (in)suflare, vânt (la furnal), aer insuflat, cantitate de metal prelucrată odată (prin procedeu Bessemer), a (in)sufla (aer etc.), a afina; a împinge, a arunca, a umple, a umfla; a bate; a suna, a răsuna; a sări în aer, a exploda; a atâta focul; a înflori, a da în floare; inflorescență, înflorire

blow-back (auto) rateu în carburator; (fiz) presiune a gazului; (met, termo) întoarcere a flăcării; (mec) recul

blow bending (mec) încovoiere cu şoc

blow bending test (mec, metr) încercare / la test de încovoiere cu / la şoc

blow by (termo) a purja; gaze şi combustibil nears care trec de segmente (inele de compresiune)

blow cold (met, ind chim) a insufla aer rece

blow down (met) a stinge / a opri furnalul

blow-down line / pipe (OM, hidr) conductă de purjare / de evacuare

blow-down valve (termo, OM) robinet de purjare / de evacuare

blower (met, ind chim) suflantă, ventilator, exhaustor

blower (bearing) lubrication $(\mathrm{T})$ ungere (a lagărului) prin împroşcare

blower-cooled răcit prin suflare (şi cu aer)

blower fan ventilator suflant; (auto) sistem de aer condiționat / de ventilație

blower-fed engine (termo) motor cu compresor / cu supraalimentare

blower house (met, termo) camera / casa / incinta suflantei

blower set (termo) grup de ventilator cu motor de actionare

blow-fly (alim) muscă de carne

blow(-)hole băşică; (met, plast) suflură (sferoidală mare), bulă / pori de gaz(e), gol de aer, retasură, gură de vânt, tub de suflare

blow hot (met) a (in)sufla cu aer cald 
blow in / into (met) a sufla, a insufla (într-o incintă); a apărea brusc; a da buzna

blow-in burden (met) încărcătură de pornire a furnalului

blowing înfloritor, prosper; (el) arderea fuzibilului unei siguranțe; (met) afinare (în convertizor), (in)suflare, suflantă, aer suflat

blowing agent (plast) agent porofor / spumant / de umflare / de expandare

blowing cylinder $(\mathrm{OM})$ cilindru de suflantă

blowing engine (mas) suflantă (şi acționarea ei)

blowing fan (mas) ventilator cu refulare

blowing furnace (met, termo) furnal, cuptor cu insuflare de aer

blowing hot (met) suflare cu aer cald (la furnal)

blowing in (met) aprindere / punere în funcțiune a furnalului

blowing iron (TH, ind chim) țeavă de suflat sticlă

blowing operation (met) (in)suflare

blowing out (met) suflare (înspre afară), oprirea cuptorului / furnalului

blowing period (met) perioadă / timp de (in)suflare (la furnal, convertizor etc.)

blow into (met) a (in)sufla (spre interior, în creuzet etc.)

blow lamp lampă / dispozitiv de lipit / de sudat

blow molder (plast, ind chim) maşină de formare prin suflare

blown (in)suflat (d. aer, la furnal, la cuptoare de topire etc.); poros (d. materiale); (auto) explodat (d. un pneu)

blown device dispozitiv răcit cu aer

blown fuse (el) siguranță arsă

blown metal (met) metal pre-afinat

blow nozzle (OM, hidr, termo) duză de suflare

blown oils (mediu, $\mathrm{T}$, chim) uleiuri uzate / oxidate

blown-out tyre (auto) pneu dezumflat

blowpipe (OM, hidr) conductă de aer; (met) arzător, aparat de sudură (şi autogenă)

blow off (termo) a purja, a evacua (aburul); a sufla; evacuare (a apei etc.)

blow-off cock (OM, hidr, mediu) robinet de purjare / de nămol, supapă pneumatică

blow-off (termo) a evacua aburul, a da drumul la abur

blow-off puncture (auto) pană de pneu

blow-off valve (OM, hidr) robinet / ventil de purjare (la cazan) / de siguranță / de descărcare

blow-out suflare; (auto) explozie de pneu, (el) stingerea scânteilor; explozie, evacuare, a erupe, a evacua (forțat), a (se) arde (d. o siguranță); (met) a stinge / a opri furnalul, a sufla (spre exterior); (termo) a purja, a evacua prin suflare, a țâş̧i (aburul), a ieşi cu putere; a erupe blow out (auto) a face explozie (d. un pneu)

blow out a furnace (met) a opri / a scoate din funcțiune un furnal / un cuptor

blow-out valve (termo, hidr) robinet de purjare / de evacuare

blowpipe (OM, hidr) conductă de aer; (met) arzător, aparat de sudură (şi autogenă)

blow-pipe flame (met) flacără de lipit / de suflai (şi la sudură)

blowpipe nozzle (met, termo) bec al arzătorului, cioc al suflaiului

blowpipe size (termo) mărime / putere a arzătorului

blowpipe test (termo) probă / test la suflător / la suflai

blowpipe tube (OM, met) tijă a arzătorului / suflaiului de sudură

blow room (textile, plast) bataj, secție de destrămare-batere

blow stress (mec, OM) tensiune / efort / dina$\operatorname{mic}(\breve{a}) /$ la şoc

blow-through valve (termo, OM) robinet de purjare / de evacuare / de siguranță / de gaze arse

blow torch lampă de lipit / de sudat (cu flacără), suflai

blow up a umfla, a exploda, a face explozie, a sări în aer; a umple cu aer sau gaz; mărire, a mări (d. imagini)

blow-up (ind chim) descărcare, golire; explozie, împuşcare, umflare, fotografie / imagine mărită; izbucnire

blow-up tyre (auto) pneu umplut cu aer / umflat

blowtorch lampă de lipit

blow valve $(\mathrm{OM}$, hidr) supapă de aerisire

blow wash $(\mathrm{TH})$ spălare cu jet de apă

blue albastru, siliniu, azuriu; vânăt; palid; pământiu; învinețit; (met) albastru (culoare de revenire la oțeluri), a bruna oțelul

blue annealing (met) revenire / încălzire / recoacere (până) la albastru

blueberry (agr, alim) afin, coacăz negru

blue brick (constr, met) cărămidă arsă, clincher

blue brittleness (met) fragilitate la albastru / la revenire (d. oțeluri)

blue(d) edges (met) margini oxidate (defect)

blue dip (met) baie de clorură de mercur

blued plate (met) tablă brunată

blue flame (met, chim) flacără albastră / oxidantă

blue for dyed greases $(\mathrm{T})$ albastru caracteristic unsorilor uzate

blue heat of iron (met) temperatură de revenire la albastru (d. oțeluri) 
blueing (met) brunare, albăstrire (după tratament de revenire, la rulmenți - după funcționare la temperaturi prea ridicate, care permit revenirea oțelului de rulment), acoperire prin oxidare

blueing salts (met, chim) săruri de brunare / de acoperire prin oxidare

blue metal (met) mată de cupru

blueness albăstrire, albăstrime

blue powder (met, chim) pulbere de zinc

blue shortness (met) fragilitate la albastru / la revenire (d. oțeluri)

blue steel (met) oțel brunat

blue tempering (met) revenire la albastru

bluff mal abrupt şi înalt, faleză

bluff body (hidr) corp cu contur nehidrodinamic

bluish albăstrui

blunder greșeală; (mat, metr) eroare grosolană; a strica, a nu face cum trebuie, a face o greşeală; (fig) a bâjbâi, a căuta bâjbâind (drumul)

blunder against a se poticni de

blunge a amesteca

blunger (constr, ind chim) malaxor (şi de argilă)

blunt neascuțit, bont; (fig) aspru, necioplit, grosolan, obtuz, greoi, greu de cap; direct tăios, fără menajamente; a (se) toci

blunt angle (mat) unghi obtuz

blunt file (OM, mas-un) pilă lată cu vârf teşit şi cu lătime egală pe toată lungimea

blunting (mas-un) tocire; (de tăişuri de scule); (ind chim) neutralizarea acizilor

blunt mill file (mas-un) pilă fină, cu o față laterală fără tăietură

blunt round file (mas-un) pilă rotundă, cu vârf teşit

blunt square file (mas-un) pilă pătrată paralelă

blur a estompa, a încețoşa, a face neclar (şi un ecran); a păta, a murdări; a întuneca; pată; trăsături confuze / estompate

blurred neclar, încețoşat, cețos; vag, estompat; mâzgălit (şi cu cerneală)

blurry neclar, estompat, vag; pătat, plin de pete boar (agr, alim) porc nejugănit, vier, mistreț

board tablă, scândură, tablou, planşetă, panou, poliță, raft; (constr) pardoseală, cofraj, a acoperi cu scânduri, a pardosi (cu scânduri); mâncare, hrană; (ec) departament, minister, conducere, administraţie, comisie, juriu, consiliu (de conducere), colegiu, comitet, salariu minim; carton, copertă, mucava, scândură, blană, dulap (de lemn); afişier, avizier; (nav) bord, marginea unui vas, a aborda, a urca la bord, by the $\sim$ naufragiat; (amer) (cf) a urca în vagon

boardable abordabil, accesibil board and lodging casă şi masă, pensiune

board arbor (mas-un) braț / pârghie pentru fixarea şablonului rotativ

board drop hammer (met) ciocan de matrițat cu scândură

boarded (OM, mas, constr) căptuşit, blindat

boarding căptușeală, lambriu, îmbrăcăminte de scânduri; (constr) pardosire cu scânduri; (nav) abordare, urcare la bord; întreținere, pensiune

boarding house pensiune, internat

Board of Directors / Managers (ec) direcție, comitet de conducere, consiliu director

Board of Examiners (edu) comisie de examen boat (nav) barcă, ambarcațiune mică, luntre, şalupă, vas, corabie, navă, vapor, submarin

boat bridge (nav) ponton, pod de vase

boat hook (nav) cange, cârlig, harpon

boat oar (nav) ramă

boat-building workings (nav) şantier naval (pentru ambarcațiuni mai mici)

boat-tailed (fiz) în formă de luntre, (formă) hidrodinamică / aerodinamică

bob (fiz) greutate a pendulului; bob; (alim, plast) ciorchine, mănunchi; moț, smoc; (mas-un) disc de piele / pâslă; zdruncinătură; (nav) sondă

bobbin (el) bobină; $(\mathrm{OM})$ tambur de troliu, mosor, bobină (de fir / sfoară etc.), țeavă (de bobinat cabluri electrice)

bobbin target $(\mathrm{OM})$ disc rabatabil

bobby hatch (nav) tambuchi

bob weight (mas) contragreutate

bodied oil (ind chim) ulei polimerizat

bodily corporal, fizic; $(a d v)$ în persoană, personal; în întregime, ca un întreg

body corp, trup, masă, parte principală, consistență, trunchi, bază, suport; cadavru, persoană, individ, om; înfătișare fizică (auto) caroserie; (ec, nav) poliță de asigurare a corpului navei; (mas, OM) batiu, corp, carcasă, cupă, benă, balot, parte principală; (met) tăblie a cilindrului de laminare; (nav) carenă, corp de navă; a concentra, a îngroşa; (agr) tulpină (de pom); (ec, pol) organizaţie, organ politic sau administrativ; masă, mulțime, majoritate; (alim, chim) alambic, retortă; sistem, totalitate; (T) referitor la vâscozitate sau consistență

body back panel (auto) panoul din spate al caroseriei

body bottom (auto) planşeul caroseriei

body brack (met) ruptură / fisură pe tăblia cilindrului de laminare

body cement (auto, chim) chit de caroserie

body-centered cubic lattice (fiz) rețea cubică cu volum centrat 
body-centered grating (fiz) rețea centrată intern (d. cristale)

body-centered structure (fiz) structură centrată, structură cu volum centrat (d. cristale)

body contact terminal (auto) bornă de contact de masă a caroseriei

body corporate (jur) corporație

body counterbore (mas-un) adâncitor pentru lăcaşul capetelor de şurub, lărgitor

body creaking noise (auto) zgomot al caroseriei / datorat componentelor metalice

body designer (TH, auto) proiectant de formă (şi a carcasei auto)

body drill (mas-un) burghiu cu caneluri scurte

body (drying) oils (ind chim) uleiuri care se îngroaşă / se usucă

body finish (auto, ind chim) vopsea de caroserie

body framework (OM, mas) scheletul unei cutii / carcase / caroserii

body heat (termo, med) căldură proprie / animală

body icing (alim) răcire prin stratificare / prin amestecare cu gheață

body-in-black (auto) caroserie grunduită pregătită pentru vopsirea finală / de finisare

bodying ( $\mathrm{T}$, ind chim) îngroşare / concentrare a unui ulei, a unei vopsele; (chim) polimerizare

bodying agent (chim, $\mathrm{T}$ ) agent de îngroşare (pentru ulei, vopsea, unsoare)

bodying up (alim, chim, T) îngroşare

body integral with frame (auto) caroserie autoportantă

body-in-white (auto) caroserie (în tablă brută) pregătită pentru grunduire

body length (met) lungime a tăbliei (cilindrului de laminare)

body of air (fiz) masă de aer

body of oil (fiz, T) vâscozitate, consistența uleiului, component principal al uleiului

body of pump (OM) cilindru / carcasă de pompă

body of revolution (geom) corp de revoluție

body overhang beyond rear axle (auto) consolă din spate a caroseriei

body plan (nav) planul cuplelor, plan de forme (d. o navă)

body resistance (fiz) rezistența corpului (și în aer); (nav) rezistență hidrodinamică de formă (a navei)

body shape (auto, mas) forma carcasei / caroseriei / brațului / corpului

body shell (auto) caroserie autoportană, monococă

body structure (auto) structură interioară

body type literă de rând

body ventilation (auto) ventilarea caroseriei / carcasei body with concealed hood (auto) caroserie cu capotă escamotabilă

bodywork (auto, $\mathrm{TH}$ ) construcție de caroserie

boemite (minrl) boemit

boggy mocirlos, mlăştinos

bogie (cf) boghiu, cărucior

bogie hearth furnace (met) cuptor cu cărucior /

cu vatră mobilă

bogie frame (cf) cadrul boghiului

bogie pin (cf, OM) fus oscilant (şi de boghiu)

bogie pivot (cf, OM) suport de boghiu

bogie truck (cf) vagon de cale ferată, pe boghiuri

bogie(-type) reheating furnace (met) cuptor de recoacere cu cărucior / cu vatră mobilă

bogie wheel (cf) roată alergătoare / de osie

bog ore (met, minrl) limonit

bogus cheque (ec) cec fals

boil fierbere; (fiz) punct de fierbere; (met) (perioadă de) primă afinare; a fierbe, a clocoti, a da în clocot, a pune la fiert, a vaporiza

boil away a lăsa să scadă la foc, a scădea prin fierbere, a se evapora; (fig) a scurta (un text), a prescurta

boil blank (alim) a fierbe sucul de zahăr (în vid), fără cristalizare

boil down (alim, ind chim) a fierbe, a concentra prin fierbere, a îngroșa, a înmuia

boil down to a (se) reduce la (prin fierbere)

boil dry (alim, ind chim) a concentra prin fierbere până la uscare

boiled fiert, clocotit (d. un lichid)

boiled linseed oil (chim, $\mathrm{T}$ ) ulei de in sicativat

boiler (alim, ind chim) cazan de fierbere / de distilare; (termo) boiler, cazan de abur, fierbător, căldare, acumulator de apă supraîncălzită; (alim) verdeturi bune de fiert

boiler back (termo) ecran de / pentru țevi (la cazan, boiler etc.)

boiler bedding (constr, termo) soclu de cazan

boiler blow-down / purging (termo) evacuare / purjare a cazanului

boiler brace (constr, termo) ancorare a cazanului

boiler casing (OM, termo) manta de cazan / recipient

boiler coal (termo) cărbune pentru cazane / industrial

boiler-cleansing compound (chim, termo) (substanță / agent) dezincrustant

boiler drum (OM, termo) partea cilindrică / virolă a cazanului sau a recipientului

boiler end (OM, termo) fund de cazan

boiler feed (termo) alimentarea (cu apă) a cazanului 
boiler feeder (termo, hidr) alimentator / pompă pentru cazane

boiler fireman (termo) fochist

boiler firing (termo) instalația de ardere a unui cazan de aburi

boiler flue (pass) (termo) canalul / pasajul de fum al cazanului, tirajul cazanului

boiler fluid (chim) dezincrustant (lichid)

boiler forge $(\mathrm{TH})$ cazangerie

boiler fur (termo) piatră de cazan, crustă

boiler furnace (termo) focar de cazan

boiler gas (termo) gaze arse / de evacuare

boiler grate (termo) grătar cu bare

boiler head (termo) vatră / fund de cazan

boiler house (termo) sala cazanelor

boiler immuration / jacket / masonry (termo) înzidirea / mantaua / căptuşeala cazanului (şi de abur)

boiler mountings $(\mathrm{OM}$, termo) armătură / armături de / pentru cazan

boiler plate / steel (met, termo) tablă de recipiente (pentru temperatură ridicată) / cazane

boiler-plate planer (mas-un) maşină de rabotat marginile tablelor pentru cazane şi recipiente

boiler scale (termo) piatră de cazan, crustă

boiler scaling hammer (mas-un) ciocan de curățat piatra de pe cazan

boiler shell ring / belt (termo) centură / inel de ridigizare pentru mantaua cazanului / recipientului

boiler shop $(\mathrm{TH}$, termo) cazangerie

boiler slag (termo) zgură de cazan

boiler steam feed pump (hidr, termo) pompă de alimentare cu apă a cazanului

boiler supplies (OM, hidr, termo) accesorii / armături de cazan

boiler tube $(\mathrm{OM}$, termo) teavă de cazan

boiler with corrugated flues (termo) cazan cu tub ondulat de flacără

boiling (alim, fiz) (în) fierbere, care fierbe, care clocoteşte

boiling bed (ind chim, met) strat fluidizat / topit

boiling bulb (alim) cazan de distilare, alambic

boiling capillary (fiz) capilar de fierbere

boiling down (alim) concentrare prin fierbere

boiling fastness (alim, plast) rezistență la fierbere

boiling fermentation (alim) fermentare prin fierbere / pe durata fierberii

boiling flask (alim) balon de distilare

boiling heat (fiz) căldură de vaporizare

boiling limits (fiz, ind chim) limite de fierbere (pentru amestecuri)

boiling liquor (alim, ind chim) soluție de fierbere boiling-off fierbere (şi în autoclavă)

boiling out (the dye) (textile, plast) decolorare (şi la vopsea) (şi prin fierbere)

boiling out pan (alim, ind chim) vas de recoacere / refierbere

boiling over (fiz, alim, ind chim) distilare, debordare (din cauza fierberii lichidului)

boiling pan (alim, ind chim, termo) fierbător, autoclavă de fierbere

boiling plate (el) plită electrică, reşou

boiling point (fiz) temperatură / punct de fierbere

boiling-point depression / lowring (fiz) scăderea punctului de fierbere

boiling-point rising (fiz) ridicarea punctului de fierbere

boiling range / spread (alim, ind chim, termo) interval de distilare, limite de fierbere (exprimate în valori ale temperaturii)

boiling speed (fiz) viteză de fierbere

boiling stage (met) perioadă de primă afinare

boiling station (mediu, ind chim) staţie de evaporare

boiling surface (fiz) suprafață de fierbere

boiling tank (alim, ind chim) fierbător, cuvă / recipient de fierbere

boiling temperature (fiz) temperatură de fierbere

boiling test proba de (la) fierbere

boiling tube (OM, termo) țeavă de fierbere / în care are loc fierberea

boiling vessel (alim) fierbător, vas de fierbere

boil off (chim, alim, ind chim) a concentra / a extrage prin fierbere / prin vaporizare, a vaporiza, a elimina prin vapori

boil-off gas (ind chim) gaz (sii lichefiat) pierdut prin evaporare (pe durata stocării)

boil over transvazarea lichidelor la fierbere, debordare prin fierbere; (termo, alim, chim) a distila; a se revărsa, a da în foc

boilproof (materiale) stabil / rezistent la fierbere

boils (fiz) fierbere, mişcarea dezordonată a particulelor în fluide

boil up a fierbe, a clocoti

boil-up rate (ind chim, alim) viteză de concentrare prin fierbere / vaporizare

boisterous violent, nestăpânit; gălăgois; turbulent bold îndrăzneț, cutezător, curajos; obraznic; abrupt, râpos, stâncos; apăsat, refliefat, citeț (d. scris); (c) comandă pentru scriere cu aldine

bold face (c) (caractere) aldine

bold-faced tipărit / scris cu caractere aldine

bold letter (caracter) aldin, aldină

boldly $(a d v)$ cu curaj / îndrăzneală; obraznic, impertinent; în antă abruptă 
boldness îndrăzneală, cutezanță, curaj; obrăznicie, impertinență; caracter abrupt (al țărmului); caracter proeminent

bole trunchi, tulpină; bolus, argilă fină

boister pernă (mare); (OM) cuzinet, suport, a sprijini, a susține; a ațâța, a îndemna, a susține (pe cineva)

boisterer sprijinitor, susținător

boister up a sprijini, a susține

bollard (constr) bornă, opritor; (nav) baba de chei / de amarare, bolard

bolster (OM) crapodină / bucşa fusului, cuzinet, suport, guler, apărătoare (şi la frecare)

bolster plate $(\mathrm{OM}$, met) placă de presiune / de reazem, suport de matriță

bolt (constr) îmbinare în gât-de-lup, broască, lacăt, zăvor; $(\mathrm{OM})$ bolț, pivot, dorn, deget, ax scurt, şplint, şurub, zăvor, lacăt, broască, buton, bulon, sită, grătar; (mil) percutor; a cerne, a da prin sită, a cerceta, a examina, a fixa cu bolțuri / şuruburi, a îmbina / a asambla cu bolțuri / şuruburi, a scutura

bolt and joint $(\mathrm{OM})$ balama

bolt and nut $(\mathrm{OM})$ şurub cu / şi piuliță

bolt bearing pressure $(\mathrm{T}, \mathrm{OM})$ presiune de strivire pe lagăr

bolt cam (OM, mas-un) camă cu bolț

bolt chisel (mas-un) daltă în cruce

bolt core $(\mathrm{OM})$ tija bolţului

bolt croppers (mas-un, constr) foarfece pentru tăierea / retezarea buloanelor

bolt cutter (mas-un) maşină / dispozitiv de filetare a bolțurilor

bolted (OM) (asamblat) cu bolț(uri) / şurub(uri)

bolted connection / joint $(\mathrm{OM})$ asamblare cu bolțuri / şuruburi

bolted pipe joint (OM, hidr) îmbinare cu tevi filetate

bolted union legătură /îmbinare / asamblare prin buloane, cu cep

bolter (OM, agr, alim) sită, grătar

bolter cloth (ind chim) țesătură pentru site (şi din sârmă)

bolt for T-slot(s) (OM, mas-un) şurub pentru canal în $T$

bolt head (OM) cap de bolț / de şurub

bolt(-hole) circle, bolt-pitch circle (OM, hidr) cercul centrelor găurilor la o flanşă

bolt hook $(\mathrm{OM})$ şurub cu gheară / cu cap ciocan (de strângere), crampon (filetat)

bolting (OM, constr) acțiunea de asamblare cu bolțuri / şuruburi, ancorare cu bolțuri

bolting cloth țesătură pentru site (şi din sârmă, tesătură metalică) bolting lug (OM, mas) bosaj pentru bulon / şurub bolt nab / staple (OM) cârlig de blocare / de închidere

bolt nut $(\mathrm{OM})$ piuliță

bolt of flange (OM, hidr) bolt / şurub de flanşă

bolt stock (met) oțel / semifabricat pentru prelucrat şuruburi / bolțuri

bolt tooth (mas-un) fus al angrenajului în lanternă bolus (met) bulgăre de pământ (şi nedorit); (chim) bol

bomb bombă; a bombarda

bombard (fiz) a bombarda; a asalta

bombardment (fiz) bombardament

bomb oxidation (chim, metr) oxidare accelerată a combustibilului, oxidare în recipient închis

bona fide de bună credință (latină)

bond fixare, adezivitate, legătură, legare, lipire, lipitură; relație; obligație, datorie; (chim) valență, liant; (ec) garanție, gaj, cauțiune, obligație, obligațiune, datorie, contrachitanță, bon, a ipoteca, a amaneta, a emite (bonuri); (chim) valență; a (se) întări, a (se) fixa, a adera, a (se) lipi (şi cu adeziv), a îmbina / a asambla prin lipire

bondability capacitate de lipire (şi la adezivi)

bonded (chim) legat, combinat; (ec) asigurat cu bonuri sau obligații, depozita la vamă; $(\mathrm{OM})$ lipit, ataşat; (auto) ataşat

bonded form of abrazive (mas-un) sculă abrazivă din pulberi dure aglomerate și liat / adeziv

bonded seal (OM, hidr) garnitură de etanşare din material compozit (obținută şi prin lipire)

bonded sealing plate $(\mathrm{OM})$, hidr placă de etanşare din material compozit (fixată şi prin lipire)

bonded strain gauge (metr) traductor / marcă tensiometrică lipit(ă)

bonded washer (OM, hidr) garnitură de etanşare din material compozit (obținută / ataşată şi prin lipire)

bonder (el) legătură la masă / la pământ, şurub de legare la pământ; (met) cărămidă de legătură

bonderising (met) fosfatare

bonding (chim) legatura; (OM) îmbinare (de obicei prin aderență, lipire)

bonding additive (ind chim) adaos adeziv, aditiv pentru realizarea legăturii, lipirii

bonding agent (chim) agent de lipire, agent care măreşte adezivitatea

bonding capacity (constr, chim) capacitate de legătură / de aderență, putere de priză

bonding clay (constr, met) argilă plastică bonding defect lipsă de legătură, defect de lipire 
bonding energy (chim) energie de lipire / de legătură

bonding life ( $\mathrm{TH}$, chim) durată de lipire

bonding material (chim, constr) substanță de legătură, liant, material de lipire

bonding power (chim, constr) putere de aderență / de lipire / de legare, capacitate de priză

bonding capacity / property proprietate / capacitate de aderență / de lipire

bonding range (chim) durată / interval de lipire bonding ribbon (el, OM) bandă adezivă (pentru izolare, etanşare, ambalare etc.)

bonding surface (OM, plast) suprafața de lipire / de legătură / de prindere (a adezivului)

bondless liber, nelegat (mecanic sau chimic)

bond line (OM, plast) linie de îmbinare / de lipire

bond plane (OM, plast) planul de îmbinare / de lipire

bond strength $(\mathrm{OM})$ rezistență la încleiere / la lipire / la smulgere / la împâslire, rezistența la rupere a lipiturii

bond stress (mec) tensiune / efort de aderență / de legătură

bond water (chim) apă de legătură / de reacție / pentru (din) realizarea anumitor legături chimice

bone (alim) os, ciolan, a scoate oasele din

bone black cărbune de oase / animal

boned osos, cu oase

bone-dry absolut / complet uscat

bone-dust / flour / meal (alim) faină de oase

bone glue (chim) clei de oase

boneless (alim) fără oase, curățat de oase

bone-meal (alim) făină de oase

bone oil (alim) ulei de oase

bone processing plant (alim) instalație de prelucrat oase

bones (alim) schelet (de oase)

bone tallow (alim) grăsime de oase

bonfire foc în aer liber

bonnet bonetă; (auto) capotă, husă; (constr) boltă, acoperiş;; (nav) capac de ochi de puț; $(\mathrm{OM})$ manta, capac (şi de robinet), calotă

bonnet catch / fastening-clip (auto) închizătorul capotei motorului

bonnet louvre (auto) fante de ventilație la capota motorului

bonneted cab (auto) cabină retrasă (plasată în spatele motorului, la autovehicule)

bonus (ec) prima, tantiemă, premiu

bony osos, din oase

book carte, volum, broşură, caiet, carnet; (ec) registru, a înregistra (contabil), a trece într-un registru, a angaja, a reține, a solicita; a înscrie, a fi înscris; a prinde; a se retrage (dintr-o societate, club etc.) listă, tabel, inventar; a lua / a elibera bilete, a reține locuri (la spectacol); a rezerva, a reține (o cameră, un loc etc.); a aştepta (un invitat)

bookbinding legatul cărților

bookcase bibliotecă, dulap pentru cărți

book in a ponta la venire (un angajat), a semna în condica de prezență

booking înregistrare; reținere; angajare; (ec) cumpărare; solicitare; rezervare

booking office casă de bilete

booking order (ec) foaie de comandă

bookkeeper (ec) contabil

bookkeeping (ec) contabilitate

boom bubuit, detunătură; reclamă zgomotoasă; (ec) înviorare, (perioadă de) redresare, (perioadă de) avânt, prosperitate, perioadă de succes; agitație; (constr) talpa fermei / grinzii; (mas) fleşa unei macarale; (mec) fleșă, săgeată, braț: (nav) braț de macara, estacadă; a bubui, a hurui, a zumzăi, a bâzâi; (ec) avânt, prosperitate a face reclamă / publicitate, a prospera; (nav) estacadă, bigă

boom bracing (constr, mec) întăritură a tălpii grinzii

boomerang bumerang

boom member (constr, mec) bară a unei tălpi de fermă (metalică)

boom of a girder (constr, mec) talpa grinzii

boom stress (constr, mec) efort în talpa grinzii / fermei metalice

boost sporire; ajutor, sprijin; a ridica, a sălta, a sprijini, a mări, a intensifica, a întări; (met) a comprima, a concentra, a îndesi; (ec) a ridica, a mări (pretul), mărire, sporire (a preturilor)

booster ajutor, sprijin; susținător; (auto) servomotor, motor auxiliar, servomecanism; (fiz) amplificator

booster brake (autom, OM) servo-frână

booster compressor (termo, OM) compresor auxiliar / ajutator

booster pump pompă auxiliară / de suprapresiune

boosting charge $(\mathrm{TH})$ sarcină / încărcare / şarjă parțială

boosting station (hidr) statie de repompare / auxiliară

boost pressure (hidr, termo) suprapresiune, presiune suplimentară / de admisie

boost pressure controller (autom, hidr, termo) regulator de suprapresiune

boost (quick) charge încărcare rapidă (şi a unei şarje de material)

boost voltage (el) tensiune auxiliară / suplimentară 
booth (met) cabină de / pentru sudare; tarabă, dugheană, chioşc; cabină telefonică

boracic acid (chim) acid boric

borating (met) borurare

borazon wheel (mas-un) disc abraziv cu borazon

border tivitură, bord, chenar, bordură, cadru, cant, muchie, limită, margine, linie de demarcație / de despărțire, hotar, frontieră, graniță; (constr) încadrare, înrămare, încastrare, împrejmuire; a împrejmui, a (se) mărgini; a răsfrânge / a îndoi (margini), a bordura, a încadra, a tivi, a înrăma

borderer locuitor de la graniță, vecin

bordering aproape de, care se mărginește cu, limitrof cu; bordare, încadrare, mărginire

borderland zonă de graniță / de frontieră

border-line case (fiz) caz limită

border-line curve curbă limită

border on a se mărgini / învecina cu

border set frontieră; a stabili o frontieră

borderstone (constr) bordură (și de piatră)

bore (OM, mas-un) gaură, alezaj, alezare, forare, diametru interior, a găuri, a sfredeli, a perfora, a fora, a aleza, a săpa; a plictisi, a enerva; (metr) calibru; muncă plicticoasă

bored plictisit

bored cock $(\mathrm{OM})$ dop / cepgăurit

bore diameter $(\mathrm{OM})$ diametru interior / al alezajului (şi pentru un rulment)

bore diameter face $(\mathrm{OM})$ suprafața alezajului interior (şi la rulment)

bored spindle $(\mathrm{OM})$ arbore, ax tubular / găurit

bored tube pump (OM, hidr) pompă cu alezaj / cu ax tubular

bore gauge (met, mas-un) calibru inelar

bore hole (OM, mas-un) orificiu alezat / găurit; gaură, alezaj

bore of boss / of hub (OM, mas-un) alezajul butucului

bore out (mas-un) a aleza, a găuri din nou

bore-hole reaming (mas-un) corectare (şi prin aşchiere) a alezajului

borer (mas-un) burghiu, maşină de găurit, perforator

boric (chim) boric

boride (chim) borură

boring găurire, alezaj; (mas-un) (acțiunea de) găurire, alezare, perforare, gaură, perforator, care găureşte / sfredeleşte; plictisitor, plicticos

boring-and-turning lathe (mas-un) strung de alezat, maşină de alezat (şi orizontală)

boring-and-turning mill (mas-un) strung carusel / vertical

boring apparatus (mas-un) perforator (de mână) boring bar (mas-un) bară / port-cuțit de găurit / de alezat / de strunjit interior, borştangă, arborele maşinii de alezat

boring cutter (mas-un) cuțit de strunjit interior boring depth (mas-un) adâncime de strunjire / de alezare (si prin strunjire)

boring diameter (mas-un) diametrul găurii de alezat / de strunjit

boring dust (mas-un) şpan de la găurire

boring fixture (mas-un) dispozitiv de alezat / de găurit

boring head (mas-un) cap de găurire / de alezare, port-burghiu, păpuşă port-sculă (la maşină orizontală de alezat)

boring kernel carotă

boring lathe (mas-un) strung de alezat; maşină de alezat (şi orizontală)

boring machine (mas-un) maşină de alezat / de găurit

boring mill (mas-un) maşină de găurit / de alezat / de frezat (si alezaje)

boring-milling machine (mas-un) maşină orizontală de alezat

boring operation (mas-un) operație de lărgire / de alezare / de găurire

boring rod (mas-un) bară port-cuțit (pentru strunjit interior)

borings (mas-un) șpan (de la găurire / alezare)

boring saddle (mas-un) cap de găurit

boring sample (mas-un) carotă

boring socket (mas-un) mandrina de găurit

boring spindle (mas-un) ax de găurit

boring template (mas-un, metr) calibru interior / tampon

boring tool for corner work (mas-un) cuțit de strung interior, sculă de găurit

borizing (mas-un) strunjire cu cutit cu diamant / cu plăcuță din aliaj dur; procesul de borurare (şi a oțelului)

boron nitride (chim) nitrură de bor

Boron (B) (chim) bor

boron steel (met) otel cu bor

borrow of / from (ec) a împrumuta de la, a lua cu împrumut

borrower persoană care ia cu împrumut; (ec) debitor

borrowing (ec) împrumut (de la), care împrumută

bort, bortz (mas-un) diamant negru / tehnic, mărunt cu incluziuni

bosh (mas-un) rezervor (cu apă) pentru răcirea sculelor; (met) baie de decapare, etalaj (la furnal)

bosh angle (met) unghi al etalajului (la furnal)

bosh cooling box / plate (met) cutia / placa de răcire a etalajului 
bosh envelope / jacket (met) manta a etalajului (la furnal)

bosh gases (met) gaze din zona etalajului (la furnal)

bosh of a blast-furnace (met) etalajul unui furnal bosh parallels (met) pântecele furnalului bosh plate (met) mantaua etalajului de furnal bosh walls (met) pereți ai etalajului furnalului boss patron, şef, maistru; a conduce; bosaj; (met, $\mathrm{OM}$ ) ieşind, convexitate, butuc, îngroşare, adaos turnat, umflătură

bossage $(\mathrm{TH})$ bosaj

bossed cam / wheel (mas, OM) pinion de distribuție (cu camă)

boss roller (met) maistru laminorist

boosy ieşit în afară, reliefat; autoritar, despotic

botch a cârpi; a lucra prost, a strica; lucru de mântuială; petic

both amândoi, ambii, cei doi

botter rod (met) tija dopului de la oala de turnare

bottle (recipient de) sticlă (în sens larg), butelie, child's biberon; (met) balon cu oxigen (la sudură); a turna / / pune / îmbutelia în sticle; (agr) snop (de grâu), legătură de fân / paie

bottle cap (alim) capsulă / dop pentru sticlă

bottle-capping (alim) (în)capsularea sticlelor

bottle capping machine (alim) maşină de aplicat dopuri la sticle

bottle casting machine (ind chim) maşină de turnat sticle

bottle charging machine (alim) maşină de umplut sticle

bottle closing machine (alim) maşină de capsulat sticle

bottle-corking (ind chim, alim) îmbutelierea sticlelor

bottled gas (ind alim) gaz lichefiat (în recipiente)

bottle draining (alim) scurgerea sticlelor spălate

bottle drying apparatus (alim) aparat de uscat sticle

bottle-filling (alim) umplerea sticlelor

bottle glass (ind chim) sticlă pentru ambalaje (şi alimentare)

bottleneck (cf) umăr de şină; (ec, TH) gâtuire a producției, loc îngust; gât de sticlă; secțiune minimă / ştrangulată / îngustată; (ec) gâtuire a producției; drum îngustat, gâtuire, ştrangulare (a circulației)

bottle rinser (alim) maşină pentru spălarea sticlelor

bottle sampling (alim, mediu) luarea probelor în sticlă

bottle sterilizer (alim, termo) instalație pentru sterilizarea sticlelor bottle tilter (alim) dispozitiv pentru bascularea sticlelor

bottle top mould (met) lingotieră invers conică cu conicitate inversă

bottle washer (alim) maşină pentru spălarea sticlelor

bottling (alim) îmbuteliere / umplere a sticlelor

bottom (constr) sol, fund, teren, bază, fundament, fundație, talpă, temelie; (met) vatră de furnal / de cuptor; (nav) fund de mare, fund de navă, carenă; de la fund, de jos; a goli până la fund

bottom-articulated joint articulaţie de fund / a capacului de fund / de jos (la uşi de instalații metalurgice, chimice, baraje)

bottom belt $(\mathrm{OM}$, alim, constr) curea inferioară (de întoarcere / neîncărcată) a unei benzi transporttoare

bottom blade (mas-un, met) lamă inferioară (la foarfece)

bottom bowing converter (met) convertizor $\mathrm{cu}$ insuflare pe jos / pe la bază

bottom blow valve (OM, hidr) robinet de fund (şi la un rezervor / recipient)

bottom board (met) placă (inferioară / de jos) de model la turnătorie; (nav) panou de barcă; (constr) pardoseală, duşumea, podea, placă de presiune inferioară

bottom boom (constr, mas) talpă inferioară

bottom carriage (mas, OM) şasiu

bottom casing (met, hidr) închiderea capacului de fund (la un cuptor / recipient etc.)

bottom casting (met) turnare prin / în sifon

bottom-charging machine (met) maşină de ştampat vatra (a unui cuptor)

bottom chord (constr, mec) talpă inferioară

bottom clamp plate (mas-un) placă inferioară (a presei) pentru fixarea matriței

bottom clearance (el) rezerva de deplasare în jos, $(\mathrm{OM})$ joc la baza / fundul dintelui (c)

bottom clearance of basic rack profile $(\mathrm{OM})$ joc la baza / fundul dintelui cremalierei de referință $\left(c_{o}\right)$

botttom contact (met) legătură electrică la vatra de cuptor, contact de fund

bottom contraction (hidr) contracția de fund a curentului; (met) contracție la baza unui semifabricat (turnat şi răcit)

bottom current (nav, hidr) curent de fund

bottom dead centre (auto, termo) punct mort inferior (la motoare cu ardere internă / cu piston)

bottom die (mas-un) matriță, partea inferioară a unei matrite

bottom discharge (met, hidr, ind chim) descărcare pe la partea inferioară, golire de fund 
bottom discharge centrifuge (alim, mas) centrifugă cu descărcare la partea inferioară

bottom-discharge conduit (OM, hidr) conductă pentru golirea de fund

bottom-discharge hopper (agr, constr) siloz / depozit cu descărcare pe la fund

bottom-discharge skip (met) schip cu descărcare pe la fund

bottom door (agr, constr, ind chim) uşa de fund a unui depozit de materiale în vrac, a unui siloz

bottom draw (alim, ind chim) reziduu de fund bottom dump (auto) descărcare de fund

bottom-dump bucket (constr) găleată / cupă cu descărcare pe la fund

bottom end (met) capătul piciorului de lingou

bottom fin (met) bavura de la piciorul lingoului

bottom fermentation (alim) fermentație inferioară / la baza recipientului

bottom flange (constr) tablă de centură, flanşă inferioară / de sprijin

bottom floor (nav) varangă-cadru

bottom gear (auto) viteza întâi (la cutii de viteze)

bottom half mold (mas-un) matriță inferioară

bottom heating (met, termo) încălzirea vetrei, încălzire pe la partea inferioară

bottom hole (constr) groapă de fundație

bottom-hole chocke / floe bean (hidr) diuza de fund

bottom-hole pressure (BHP) (hidr) presiune de fund / la talpă

bottom-hole pressure gauge (hidr, metr) manometru de fund

bottom-hole pressure recorder (hidr, metr) manometru de fund cu înregistrare

bottom-hole pump (hidr, nav) pompă de fund / de adâncime

bottom-hole sample probă de fund / luată de la baza recipientului / cuptorului

bottom-hole sample(r) taker (met, hidr) aparat / dispozitiv de luat probe de fund

bottom house (met) pat de turnare

bottoming die (mas-un) matriță / formă pentru finisarea filetului la partea inferioară a piesei

bottoming material (met) material refractar de ştampat vatra (unui cuptor)

bottoming reamer (mas-un) alezor pentru trecerea de finisare

bottoming tap (mas-un) tarod de finisare

bottoming voltage (el) tensiune reziduală / remanentă

bottom land (geol, geogr) pământ aluvionar, luncă (inundabilă)

bottomless fără fund; fără fundament; fără sfârşit / margini bottom loading (TH, met) încărcare pe la fund / pe la partea inferioară / pe jos

bottom-loading belt $(\mathrm{OM})$ bandă transportoare $\mathrm{cu}$ transport pe banda de întoarcere

bottommost cel mai de la fund; ultim; cel mai de jos

bottom nippers (OM, mas-un) falca de jos a cleştelui

bottom note notă de subsol / în josul paginii

bottom of furnace (met) vatră de cuptor / furnal

buttom on a întemeia / a baza pe

bottom packing (hidr) etanşare de fund

bottom plate (constr) placă / dală de pardoseală / de bază / de fundație / de fund, cadru de susținere; (met) placă de turnare / de fund

bottom plating (nav) învelişul / bordajul fundului navei

bottom pouring (met) turnare în sifon

bottom pouring plate (met) placă de turnare în / prin sifon

bottom-pour ladle (met) oală de turnare, cu dop / cu sertar

bottom-pressure casting (met) turnare sub presiune, pe la partea inferioară

bottom product (alim, ind chim) produs rezidual / de fund

bottom rake (mas-un) unghi de aşezare

bottom ramming machine (met) maşină de ştampat

bottom ring $(\mathrm{OM})$ inel de etanşare / de plafon / de punte / de reazem

bottom roll (met) cilindrul inferior (la laminare)

bottom rule linie de închidere la tabele

bottom runner (auto) lonjeron inferior al caroseriei

bottoms (alim, ind chim, mediu) depuneri de fund, reziduuri, sedimente

bottom sediments (alim, ind chim) reziduuri / sedimente / depuneri de fund

bottom slide (mas-un) sanie inferioară

bottom splash (met) suprapunere de material (la laminare)

bottom tap laddle (met) oală de turnare, cu descărcare pe la fund

bottom unloading (met, ind chim) descărcare pe la fund

bottom valve (OM, hidr) robinet / supapă de fund (pentru golire / spălare a unui recipient)

bottom view $(\mathrm{OM})$ vedere de jos (în desen tehnic)

bottom yeast (alim) drojdie de fund

bouchon $(\mathrm{OM}, \mathrm{T})$ lagăr (mic) din alamă

bought scrap (met) fier vechi / deșeuri din comert / din afara uzinei

bouillon (alim) bulion / supă de vacă 
boulder galet, piatră rotundă; bolovan, lespede boulevard bulevard

bounce lovitură puternică, izbitură, împingere, salt, săritură, ricoşeu; a sări, a ricoşa, a trânti (uşa), a izbi (cu zgomot, brusc), a da buzna

bounce into a da buzna în / peste

bouncing efect de dans (la un ecran, display etc.), instabilitate verticală; viguros, robust

bouncing of contacts (el) vibrație a contactelor

bound margine, limită, graniță, piatră de hotar; carte legată; salt, săritură, ricoşeu; legat, ataşat, prins; obligat, silit; (nav) în curs de plecare spre; a delimita; a restrânge

boundary graniță, hotar, margine; (fiz, T) frontieră, limită / suprafață de separație; (mat) frontieră; (met) profil (al calibrului de laminare)

boundary angle (fiz) unghi marginal

boundary angle bar (nav) cornier de contur

boundary behaviour comportare la frontieră / la graniță / la limită (şi în modelare)

boundary condition condiții-limită / de graniță (şi în modelare)

boundary dimensions of bearing (OM) dimensiuni exterioare de montaj ale rulmentului lagărului

boundary film $(\mathrm{T})$ peliculă limită (minimă) (formată prin adsorbție)

boundary friction $(\mathrm{T})$ frecare limită (semiuscată sau semi-fluidă)

boundary layer (fiz) strat / pătură(-) limită, strat de separare; (T) stratul de fluid de lângă corpurile solide în mişcare

boundary-layer motion (hidr) curgere în strat laminar

boundary line (metr) gabarit; linie de delimitare / de separare

boundary lubrication $(\mathrm{T})$ lubrifiere / ungere limită boundary marker (mas-un) limitator, opritor

boundary member (mas-un) limitator

boundary of grain (met) limita grăuntelui (cristalin)

boundary resistance (fiz) rezistență marginală / la limită

boundary stress field (el) câmp de tensiuni în suprafața de baraj (la semiconductoare); (mec) câmp de tensiuni la margine / la muchie

boundary value valoare limită; valoare la limită (în modelare)

boundary-value problem (mat, fiz, mec) problemă la limită, problemă la frontieră

bounded limitat; delimitat

boundedness (mat) mărginire

bound energy (chim) energie latentă

bound for (nav) cu destinația bounding surface (fiz, mec, T) suprafață limită / de separare

boundless nemărginit, nelimitat, infinit

boundlessness nemărginire, infinitate

bound level nivel staționar

bound on a se mărgini / a avea hotar comun cu, a se învecina cu

bound state (fiz) stare staţionară

bound to hotărât / decis să

bound up with strâns legat / ataşat de; având strânse legături cu

bound water (chim) apă de constituție / legată

bounty cadou, dar; (ec) bonificație, gratificație, primă, premiu

bouquet buchet, mănunchi; (alim) buchet / aromă (la vin)

bourn hotar, graniță

bout rând, dat; prindere, apucare

bovine (alim) bovin, de bou, de vacă, de vită

bovines bovine, vite cornute

bow (constr) arc; (el) arc de tracțiune electrică; (mas-un) ramă / cadru de ferăstrău pentru metale; (TH) arc, florar de desen, a (se) înclina, a (se) încovoia, a (se) curba, a se apleca; (nav) proră, provă; fundă, rozetă, nod

bow archor / bower (nav) ancoră de prova / de post

bow girder of a non-circular shape (constr, mec) grindă în formă de arc necircular, grindă curbă

bowing curbare, arcuire, bombare, îndoire

bowing warp arcuire (şi a lemnului)

bowl cupă, ceaşcă, castron(aş), bol, tigaie, vas, lighean, cupă, scobitură, adâncitură (şi a lingurii); glob, sferă, minge, bilă; (hidr) cupă, chiuvetă, bazin, rezervor; (mas) benă, lamă, cos (şi de centrifugă), rulou, rolă (goală la interior), container, recipient, bazin; a arunca, a rostogoli, a face să meargă repede şi lin

bowl feeder (alim, ind chim, constr, met) alimentator cu cupă / cu benă

bowl gedgeon $(\mathrm{OM})$ fus sferic

bowline (nav) bulină, parâmă, prova

bow opening-and-closing plier (mas-un) cleşte pentru format inele

bow saw ferăstrău cu coardă, joagăr

bow-shaped connection (constr, met) conexiune / legătură în formă de arc

bowstring girder (constr, mec) grindă cu talpă superioară curbă

box cutie, cutiuță, casetă, etui, ladă, geamantan, valiză, înveliş, locaş; (constr) boxă, gheretă, cabană, magazie; (mas-un, OM) arbore portsculă, bucşă, manşon, bac, cuzinet; (met) ramă / cutie de formare, cuvă, creuzet; subansamblu 
de maşină, mecanism, a acoperi, a căptuşi, a pune într-o cutie, a împacheta; cadou, dar; fonduri

box and pin $(\mathrm{OM})$ îmbinare cu mufă şi ştift box-annealed (met) recopt în cutie

box-annealed sheet (met) tablă recoaptă în cutii box annealing (met) recoacere în cutie

box annealing furnace (met) cuptor pentru recoacere în cutie / în lăzi

box beam (constr, mec) grindă-dulap, grindăcheson

box bed (mas-un) batiu chesonat / în formă de cutie, pat cu secțiune în $\mathrm{U}$

box bottoming file pilă-disc fină

boxcar (cf) vagon de marfă, acoperit

box casting (met) turnare în cutii de formare

box charging machine (alim) alimentator (în cutii)

box chuck (mas-un) mandrină cu două fălci

box clamp (mas-un) menghină

box column (constr) coloană-cheson

box compound (mas, OM) material de etanşat mufe / manşoane de țevi

box cover (OM) capac de cutie

box dam (hidr, nav) batardou

boxed catch $(\mathrm{OM})$ capac de închidere

boxed heart check (met) debitare din miez / inimă (la forme de turnare)

box (end) wrench $(\mathrm{OM})$ cheie tubulară

boxer engine (termo) motor orizontal, cu cilindrii opuşi

box filter filtru cu camere

boxfoot pipe oven (ind chim, termo) cuptor tubular

box for casting (met) rama de formare

box frame (auto) schelet de caroserie auto

boxful cutie / ladă plină

box-furnace boiler (termo, OM) cazan cu cutie de focar

box groove (met) calibru închis (de laminare)

box hardening (met, chim) cementare / durificare în cutii

box head cap / capac de cutie

box header (hidr) cameră de distribuție (a apei)

box heating furnace (met, termo) cuptor $\mathrm{cu} \mathrm{ca}-$ mere / cameră de încălzire

box hole / pass (met) calibru închis

boxing împachetare în cutii

box keel (nav) chilă-cheson

box key $(\mathrm{OM})$ cheie tubulară

box mould (met) formă de turnare în ramă

box moulding (met) formare în cutii

box nut $(\mathrm{OM})$ piuliță-capac / înfundată / oarbă

box office casă de bilete; clasament

box of fire door (termo) cadrul cutiei de focar

box part (met) parte a ramei de formare box pass (met) calibru închis

box pattern frame (mas-un) cadru cu secțiune chesonată / întărită

box piston (OM, hidr) piston gol la interior

box relay (el) releu în cutie de protecție

box respirator mască de protecție / respiratoare

box scraper (mas-un) răzuitor lat, cu două mânere

box section girder $(\mathrm{mec})$ grindă-cheson / goală pe dinăuntru

box-shaped în formă de cutie

box-sliding feeder (alim, ind chim) dozator $\mathrm{cu}$ sertar

box spar (constr) lonjeron-cheson

box staple (mas) capac de închidere, placă de închidere de formă sferică

box stud (met) suport / susținător de miez (la turnătorie)

box switch (el) întrerupător capsulat, comutator

box table (met) masă de formare

box timber schelet de lemn

box turbine wheel $(\mathrm{OM})$ roată cu cupe

box-type column (constr, mec) montant $\mathrm{cu}$ sectiune în U

box-type design în formă de cutie

box-type impeller (mas) rotor de compresor de supraalimentare, rotorul supraalimentatorului

box-type leg (constr, mas) picior în construcție închisă

box-type pattern (met) model pentru formarea în ramă

box up a îndesa, a înghesui

box wrench $(\mathrm{OM})$ cheie tubulară

boycott boicot, boicotare, a boicota

B-pillar (auto) stâlp B

brace pereche, doi de acelaşi fel; scoabă, clamă, suport, proptea, proteză, şablon; (constr) contrafişă, ancoraj, tirant, a lega; (met) şablon (la turnare), suport montant; (nav) braț (de vergă); a fixa (şi cu scoabă), a întări, a rigidiza, a sprijini, a propti; a îmbina, a lega strâns; a stimula

brace and bit (mas-un) burghiu plat

braced beam construction constructie cu zăbrele braced girder (constr, mec) grindă cu zăbrele brace drill (mas-un) burghiu pentru clame / inele

brace joint (constr) îmbinare în cleşte

bracelet brățară

bracelets cătuşe

bracer (constr) apărătoare pentru braț; scoabă, legătură, întăritură

brace tap (mas-un) tarod pentru cleme

bracing $(\mathrm{TH}$, constr) sprijinire, fixare, întărire, consolidare

bracing of a still (constr, termo) schelet de cuptor tubular 
bracing rib $(\mathrm{OM})$ nervură de rigidizare

bracket $(\mathrm{OM})$ consolă, braț, brățară (şi de țevi), furcă, suport (şi în consolă), scoabă, guseu; a fixa (cu scoabe), a întări, a consolida; paranteză (dreaptă), acoladă (în text), a pune în paranteze (drepte); (nav) brachet, guseu, colțar, a brața; (met) guseu; clasă, categorie; a trata la fel

bracket (jib) crane (mas) macara cu consolă bracket bearing $(\mathrm{OM})$ lagăr în consolă

bracket milling machine (mas-un) maşină de frezat, cu consolă

bracket mounted $(\mathrm{OM})$ montat / fixat cu brățară bracket pin $(\mathrm{OM})$ articulația consolei (cu ştift) bracket plate $(\mathrm{OM})$ placă de fixare bracket pole (constr) stâlp cu consolă / cu braț bracket support $(\mathrm{OM})$ suport în consolă

bracket suspension (TH) suspendare pe suport în consolă

bracket water (mediu) apă sălcie, sărăturată / nepotabilă

bradenhead (hidr, termo) cap de coloană / de teavă

brad (nail) (OM) cui fără cap

braid şnur, panglică împletită, bentiță, tresă, împletitură, toron, şiret, coadă; (el) a împleti (cablul), a bobina

braided huse $(\mathrm{OM})$ furtun / tub cu inserție împletită / de împletitură

braided packing $(\mathrm{OM}$, hidr) garnitură de etanşare din şnur împletit

braided wire (met) sârmă împletită / înfăşurată; (textile) fir, siret împletit; (el) liță

braiding (el) împletitură de cabluri; (met) toron; împletire, împletitură

braiding meshes ochiuri de împletitură

brain creier; judecată, minte

brain creation creație intelectuală (tehnică, ştiințifică sau artistică)

brain drain acaparare a inteligentei (şi prin emigrare)

brainless fără minte

brains aptitudini intelectuale

brainstorm(ing) dezlănțuire / explozie / asalt de idei; discuție între specialiști pentru rezolvarea unei teme

brain thrust (BT) (ec, TH) consiliu / grup de experți

brain work activitate cerebrală, muncă intelectuală braise (alim) a fierbe înăbuşit

brakage rupere

brake $(\mathrm{OM})$ dispozitiv de frânare, frână; piedică; (met) maşină de îndoit tablă; a frâna; a împiedica, a stăvili; meliță, a melita (pentru textile); malaxor; (agr) grapă mare, a grăpa; (alim) a frământa (aluatul)

brake action acțiune a frânei / de frânare

brake actuating care este acționat prin frână, acționarea frânei

brake actuator acționarea frânei

brake adjuster / adjusting gear (OM) mecanism (cu angrenaje) pentru reglarea frânei

brake anchor pin (auto, OM) suport / ax al frânei brake anchor plate $(\mathrm{OM})$ placă / banc de frână

brake apparatus dispozitiv de frânare

brake arm $(\mathrm{OM})$ pârghie / braț de frână

brake arrangement sistem de frânare

brake assembly instalație / sistem de frânare

brake backing plate $(\mathrm{OM})$ disc pentru fixarea saboților de frână

brake-band (lining) (auto, OM) bandă de frână (acoperire tip ferodo)

brake bar $(\mathrm{OM})$ bară a sabotului de frână, tijă / tirant de frânare

brake block $(\mathrm{OM})$ sabot de frână

brake body $(\mathrm{OM})$ corp de frânare

brake booster (autom, OM) servofrână

brake box $(\mathrm{OM})$ banc de frână, carcasa frânei

brake cam (OM, auto) galet de acționare a frânei, camă de frânare

brake check / clutch $(\mathrm{OM})$ sabot de frână, cuplaj pentru frână

brake circuit (hidr) circuit de frânare

brake cock $(\mathrm{cf})$ robinet de frână

brake collar $(\mathrm{OM})$ bandă (inelară) de frână

brake-compensating (mas) egalizare / compensare a frânării

brake connecting hose (cf) acuplare de frână (cu conductă flexibilă / furtun)

brake control device (el, autom) releu de frânare

brake coupling $(\mathrm{OM})$ ambreiaj cu fricțiune

brake crank $(\mathrm{OM})$ manivelă de frână

brake cross lever $(\mathrm{OM})$ levier transversal al sistemului de frânare

brake cylinder (auto, $\mathrm{OM}$ ) cilindru de frână

brake disk $(\mathrm{OM})$ disc de frânare / de frână

brake drag $(\mathrm{OM})$ sabot de frână, tachet opritor

brake dressing $(\mathrm{T})$ unsoare de / pentru frână

brake drum $(\mathrm{OM})$ tambur / roată / tobă de frână

brake drum retarder $(\mathrm{OM}$, mas) încetinitor cu frână pe tobă

brake dynamo (el) frână de încercare cu dinam etalonat

brake dynamometer $(\mathrm{OM}$, metr) frână dinamometrică

brake energy (mec) energie / lucru mecanic de frânare 
brake equalizer (auto) distribuitor de frână brake equalizer shaft $(\mathrm{OM})$ arbore pentru echilibrarea frânării / pentru frânare uniformă

brake failure (auto) nefuncționare / cădere a frânei

brake-field (fiz) câmp de frânare

brake flange $(\mathrm{OM})$ flanşă a tobei de frânare

brake fluid (auto) lichid / fluid de / pentru frână

brake fluid reservoir (auto, mas, OM) rezervor pentru lichidul de frână

brake fluid warning (auto) atenționare asupra lichidului de frână

brake friction area $(\mathrm{OM}, \mathrm{T})$ suprafață de frânare (prin frecare)

brake gear $(\mathrm{OM})$ mecanism de frânare

brake hanger $(\mathrm{OM})$ sabot de frână

brake head $(\mathrm{OM})$ portsabot, sabot de frână

brake horse-power (b.h., BHP) (mec) putere efectivă / utilă / de frânare (în cai putere)

brake hose (auto, OM) furtun de legătură pentru lichidul de frână

brake key $(\mathrm{OM})$ camă de frânare

brake lever $(\mathrm{OM})$ pârghie / levier / mâner de frână

brake-lever connecting rod (OM) bară / pârghie a sabotului de frână

brake lever sector $(\mathrm{OM})$ sector dinţat al pârghiei de frână

brake line (auto, OM) conductă pentru lichid de frână

brake liner / lining $(\mathrm{OM}, \mathrm{T})$ garnitură / acoperire de frână / de ferodo

brake lining (auto) acoperire a plăcuțelor de frână (cu material de fricțiune)

brake looosening $(\mathrm{T})$ slăbire a frânelor

brake lug $(\mathrm{OM})$ adaos turnat pentru fixarea mecanismului de frânare

brake meter (auto, metr) aparat pentru măsurarea distantei de frânare

brake operation (operație de) frânare

brake pedal (auto) pedală de frână

brake plunger (auto, OM) piston / plunjer al sistemului de frânare

brake power (mec) putere de frânare

brake-pressure disk / plate $(\mathrm{OM})$ disc / plăcută de frână

brake-pressure lead (auto) conductă pentru lichidul de frână

brake pulley $(\mathrm{OM})$ disc / roată / tambur de frână brake pull rod $(\mathrm{OM})$ bară a sabotului de frână brake relaxing $(\mathrm{TH}, \mathrm{OM})$ slăbire a frânei brake (release) spring $(\mathrm{OM})$ arc de frână / pentru decuplarea frânei / ambreiajului

brake rigging $(\mathrm{OM})$ sistem al pârghiilor de frână brake rim $(\mathrm{OM})$ tobă / tambur / roată de frână brake rod (auto) tija de tracțiune a frânei; (cf) bară de sabot

brake servo (autom, OM) servofrână

brake(s) fade (TH) scădere a eficacității frânării / sistemului de frânare

brake shaft (auto, mas, OM) arbore de frână / de ambreiaj

brake sheave $(\mathrm{OM})$ disc de frână

brake shoe $(\mathrm{OM})$ sabot de frână

brake-shoe lever (auto) levier pentru desfacerea / acționarea saboților

brake slipper (OM) sabot (de frână)

brake solenoid (el, OM) frână cu magnet, electro-frână, solenoid pentru acționarea frânei

brake spring $(\mathrm{OM})$ arc de rapel al sabotului de frână, arc de frână

brake squeal (auto) zgomot strident la frână

brake stop $(\mathrm{OM})$ limitator al frânei

brake strap $(\mathrm{OM})$ bandă de frână

brake system (auto) sistemul de frânare

brake triangle / truss bar (cf) bară triunghiulară de frână

brake warning light (auto) semnalul luminos pentru frâne

brake wheel $(\mathrm{OM})$ roată frânată / de frână

brake wire $(\mathrm{OM})$ cablu de frână

brake with graduate brake action $(\mathrm{OM})$ frână cu acțiune / frânare treptată / graduală

braking (action) (acțiune / efect de) frânare

braking area $(\mathrm{OM}, \mathrm{T})$ suprafață de frecare (la frână, ambreiaj etc.)

braking axle $(\mathrm{OM})$ osie frânată / de frână

braking bar / club (auto, OM) tijă /mâner de frână

braking couple (mec, OM) cuplu / moment de frânare

braking device $(\mathrm{OM})$ dispozitiv de frânare

braking fan (fiz) ecran de protecție / de frânare

braking force (mec) forță de frânare

braking gear (mas) mecanism de frânare

braking moment $(\mathrm{mec})$ moment de frânare

braking preparation length (cf) lungime de pregătire a frânării

braking resistance (of friction) $(\mathrm{T})$ rezistență la frânare (prin frecare)

braking surface $(T, O M)$ suprafață (activă) de frânare (şi prin frecare)

braking torque (el, mec) moment / cuplu de frânare

braking weight $(\mathrm{mec})$ greutate de frânare

braking work $(\mathrm{mec})$ lucru mecanic de frânare

bramberry (alim) mură

bran (alim) tărâțe 
branch (geogr) creangă, ramură; afluent, braț de râu; branşă, sferă, domeniu / câmp de activitate; (TH) ramificație, bifurcație, derivație, ramură braț, branşament, conductor secundar, ramificat; (ec) sucursală, domeniu, filială, sector, specialitate; fază; a împărți, a diviza, a deriva, a devia, a (se) ramifica, a (se) bifurca, a se lărgi, a se întinde, a se extinde; (pol) organizație de bază branch bank (ec) sucursală de bancă branch box (el) cutie de derivație / de branşament branch chuck (el) circuit derivat / de ramificare branch circuit (el) circuit derivat / de ramificare branch duct (hidr, OM) conductă secundară / de ramificatie

branched (agr, el, $\mathrm{TH}$ ) ramificat

branched chain (chim) catenă / lanț molecular ramificat(ă)

branched chute (hidr) jgheab-pantalon

branched polymer (chim, plast) polimer ramificat

branched structure structură ramificată (și a unui polimer)

branch flange (OM) flanşă de priză

branch haulageway (alim, ind chim) cale / conductă de transport care deversează produsul în calea / conducta principală

branching bifurcație, ramificație, derivație

branching crack fisură ramificată

branching crack in parent metal (met) fisură ramificată în materialul de bază (şi la sudură)

branching crack in the weld (met) fisură ramificată în sudură

branching off bifurcație, derivație

branching trough (hidr) jgheab de deviere

branch joint punct de ramificatie / de derivatie

branch line (el) circuit derivat; (cf) linie deviată, cale ferată secundară

branch office (ec) sucursală, filială

branch of knowledge ramură de cunoştinte, disciplină

branch of manufacture ramură / domeniu (şi de productie)

branch office (ec) filială, sucursală

branch piece $(\mathrm{OM})$ piesă / flanşă de derivație

branch pipe (OM, hidr) branşament, țeavă de derivație, teu, ramificație a conductei principale

branch point (el, hidr) punct de ramificație, nod de rețea; priză

branch resistance (el) rezistență în derivatie branch $\operatorname{rod}(\mathrm{OM})$ bielă motoare, tijă de piston

branch statement (autom, inf) instructiune de salt

branch terminal (el) clemă / bornă de derivație, branșament branch-point stream line (hidr) linie de curent la ramificatie

branch-T (el) cutie de conexiuni / derivație în T

branchy rămuros, cu multe ramificații / derivații; ramificat

brand $(\mathrm{TH})$ marcă de fabricație; calitate, clasă, sort, sortiment, tip; a marca, a însemna

branded goods $(\mathrm{ec})$ mărfuri care poartă o marcă de fabrică

branded oil (T) ulei de calitate

brand manager $(\mathrm{ec})$ director / manager însărcinat cu promovarea şi comercializarea unui produs

brand new perfect nou

brand rating (ec) apreciere a unei mărci de fabrică

brand share (ec) pondere a unei mărci de fabrică pe piață

brands in the running (ec) mărci curente pe piață

brandy (alim) rachiu, coniac, brandy

bran-new nou-nout, foarte nou

branning machine (met, mas-un) maşină de polizat tablă albă

branny (alim) cu tărâțe

brash (constr, mediu) morman de sfărâmături, moloz; resturi; (amer) fragil, sfărâmicios

brass (met) alamă, aliaj $\mathrm{Cu}-\mathrm{Zn}$

brass band (met) bandă de alamă

brass bearing $(\mathrm{OM}, \mathrm{T})$ lagăr / cuzinet din alamă

brass billet (met) semifabricat din alamă (de obicei turnat)

brass brazing (met) lipire tare cu alamă

brass brazing alloy (met) aliaj / alamă pentru lipire tare

brass bushing (OM,T) lagăr de alamă, cuzinet / bucşă din alamă (pentru lagăre)

brass castings (met) piese turnate din alamă

brass foundry (met) turnătorie pentru alamă

brass knuckles (fiz) inel de percuție / de impact / de protecție; cap de baterie

brass latten (met) tablă de alamă

brass plate (met) placă alămită, a alămi

brass plating (met) alămire

brass scraper perie de alamă

brass screw $(\mathrm{OM})$ şurub de alamă

brass sheet (met) tablă, platbandă de alamă

brass tip socket set screw (el) soclu înfiletat din alamă

brass tool (mas-un) cuțit pentru prelucrarea pieselor din alamă

brass tube / tubing (alim, OM, hidr) țeavă / țevărie din alamă

brass varnish (chim) lac pentru alamă

brass wire (met) sârmă de alamă 
brass worker's lathe (mas-un) strung rapid pentru prelucrat aliaje neferoase

brassy de / din alamă; similar cu alama, tare ca alama

brattice drying machine (alim, ind chim) maşină de uscat cu bandă transportoare

bray sunet neplăcut, scrâșnet, hârşăit; bubuit; a măcina, a pisa

brayer (alim, ind chim) valț / cilindru ungător / frecător

braze (met) loc al lipiturii, a lipi tare, a face o lipitură tare (de obicei cu aliaj metalic, alamă)

brazeability capacitate de lipire, comportare la lipire (a unui aliaj)

brazed (met) lipit (cu alamă)

brazed joint (OM, met) îmbinare / rost / asamblare prin lipire tare, lipitură tare

brazed-type carbide tool cuțit / sculă cu plăcuță / plăcuțe de carburi metalice lipită(e)

brazen (met) de alamă, de bronz

brazier (termo) cos pentru jar

brazing (met) (procedeu de) lipire tare (cu alamă), loc al lipiturii, lipire cu material greu fuzibil; sudură tare (mai rar)

brazing alloy (met) aliaj pentru lipire tare

brazing in hot air (met) lipire cu / în aer cald

brazing tongs cleşte de lipit

brazing mixture (met) aliaj pentru lipit (și alamă)

brazing seam shrinking (met) subțiere / contractie (la lipire sau sudare)

brazing with filler metal added while heat is applied (met) lipire cu aliaj aşezat, prin încălzire

brazing with filler metal cladded workpiece (met) lipire cu piese placate cu aliaj de lipit

brazing with flux (met) lipire cu flux

brazing with preplaced filler metal on the heated work-piece (met) lipire cu aliaj aplicat pe piesa preîncălzită

breach (constr, met) breşă, spărtură, deschizătură (într-un zid, la zidărie); ruptură, întrerupere; (jur) încălcare (a legii)

breach of thrust (jur) abuz de încredere

bread (alim) pâine

bread basket (alim) coș de pâine

breadboard setup (el) legătură provizorie (întrun circuit electric)

breadcrumb (alim) miez de pâine

bread factory (alim) fabrică de pâine

bread manufacture (alim) fabricarea pâinii, panificație

breadstuff (alim) făină, ingrediente pentru pâine

breadstuffs (alim) produse de panificație

breadth lățime, lărgime, întindere; generozitate breadthbreak îngustare

breadth of roll material (met) lățime a semifabricatului / materialului laminat

breadthwise în lățime / lat de

break spargere, rupere, ruptură; evadare; erupție; spărtură, deschizătură, crăpătură, breşă; năruire; pauză, întrerupere; izbucnire; schimbare (a vremii); (edu) recreație, pauză; (ec) scădere (a prețurilor etc.); (amer) prăbușire, crah, punct sau moment hotărâtor; cratimă, liniuță, sfârşit de alineat; (inf) cheie de întrerupere, sfârşit de paragraf; şansă; posibilitate; (el) a întrerupe un circuit, a străpunge; $(\mathrm{TH})$ a rupe, a (se) sparge, a (se) strica, a (se) sfărâma, a frânge, a (se) rupe, a (se) zdrobi, a concasa, a degrada, a (se) opri, a încălca, a (se) desface, a (se) descompune, a se dezagrega, a izbucni, a întrerupe, a înceta, a renunța la, a desface (o sticlă), a slăbi (rezistența), a micşora (intensitatea), a concasa, a (se) întrerupe, a lua sfârşit; (ec) a ruina, a face să dea faliment; a nu îndeplini, a călca (o promisiune); a depăşi, a întrece (limite)

breakable fragil, care se poate sparge / strica

breakage $(\mathrm{TH})$ spargere, concasare, mărunțire, fracționare, fărâmițare, zdrobire, măcinare, rupere, ruptură, frângere, stricare, crăpătură (mai mare), distrugere; ciob(uri), spărtură; stricăciune; daune, despăgubire, compensație; reducere, rabat; pagubă, pierdere (din cauza spargerii etc.)

breakage function $(\mathrm{TH})$ funcția de concasare mărunțire

breakage load $(\mathrm{OM}, \mathrm{mec})$ sarcină de rupere

breakage rate $(\mathrm{TH})$ număr de ruperi (şi în unitatea de timp)

break-and-make switch (el) întrerupător pentru închidere-deschidere

break asunder a (se) rupe / a (se) sparge în două

breakaway pornire, punere în mişcare

breakaway pressure (hidr, mas) presiune de pornire / de demarare

breakaway torque (mec, mas) cuplu / moment la pornire / inițial

break bulk (nav) a începe descărcarea

break circuit (el) circuit de ruptură, schemă de deconectare

breakdown epuizare (şi totală); colaps; ruină, prăbuşire; (auto) pană; eşuare, întrerupere (a negocierilor); dezmembrare, împărțire, divizare; (chim, met) descompunere; (TH) măcinare, concasare; (el, TH) pană în functionare, deranjament, defectare, avarie, ruptură, accident, străpungere (a izolației); (TH) plastifiere, vălţuire, distrugere 
break down (met) a lamina lingoul până la țaglă; (TH) a străpunge, a descompune (şi chimic), a separa, a dispersa, a (se) prăbuşi, a (se) surpa, a sfărâma, a distruge, a se deranja, a se strica, a nu mai funcționa; (fig) a dărâma, a doborâ, a ruina, a distruge; a împărți, a diviza, a scinda

breakdown crane (cf) vagon-macara

breakdown field strength (el) intensitate a câmpului electric de străpungere, rigiditate dielectrică

breakdown fluid (fiz, metr) fluid de fisurare (şi ca marcator)

break down group of working stands (TH) deranjamente simultane la mașini

breakdown impulse voltage (el) şoc al tensiunii de străpungere

breakdown in the main supply (el) întrerupere a tensiunii de rețea, pană în rețeaua principală

breakdown lorry (auto) camion de depanare, automacara

breakdown mill (met) laminor degrosisor

breakdown of an emulsion (alim, T) spargere a emulsiei, dezemulsionare, separare a componentelor unei emulsii

breakdown of line (el) demontarea unei linii

breakdown of oil (T) limpezirea uleiului

breakdown of prices (ec) scădere a prețurilor

breakdown pass (met) calibru degrosisor / întinzător

breakdown point (mec, materiale) limită de (rezistență la) rupere; (TH) punct / moment de întrerupere / de cădere a unui utilaj

breakdown roll (met) cilindru degrosisor / întinzător

breakdown service $(\mathrm{TH})$ depanare

breakdown signal (el, TH) semnal de avarie / de pană

breakdown site / spot (mec, el) loc de străpungere

breakdown test (mec) încercare (până) la rupere / distrugere / avariere / test

breakdown temperature (chim, met) temperatură de descompunere

breakdown torque (el) moment de răsturnare (la motoare de inducție)

breakdown train (met) linie de laminor degrosisor / întinzător

break draft (met, plast) laminare preliminară, prima laminare (parțială)

break an emulsion a sparge emulsia, dezemulsionare, separare a componentelor unei emulsii

breaker care sparge; (TH) ruptor, spărgător, concasor, întrerupător, moară; (alim) zdrobitor; (nav) brizant, talaz; (el) întrerupător

breaker arm (auto) braț de ruptor / întrerupător breaker bar (alim) bară a zdrobitorului breaker block (TH, met) spărgător de blocuri breaker cam (auto) camă a ruptorului breaker card maşină de frecat breaker contact-point (auto) platină a ruptorului breaker down (met) laminor degrosisor breaker drawing (met) prima trecere la laminor, prima laminare

breaker drum ( $\mathrm{TH}$, textile) tambur de destrămare

breaker impulse (el, autom) impuls de pornire / de deblocare

breaker jaw (constr, ind chim) falcă de concasor

breakerless ignition (auto) bloc electronic (la sistemul de aprindere fără ruptor)

breaker mouth (constr, ind chim) gură de concasor

breaker plate (auto) platou al ruptorului; of a hammer mill (mec, met) suprafață / placă de ciocnire (şi la forjă)

breaker platinum-contact (auto, el) platină a ruptorului

breaker point punct de rupere

breaker roll (constr, ind chim) valt de concasor

breakers (nav) valuri deferlate, brizanți

breakeven (ec) prag de rentabilitate, punct critic (al rentabilității), a atinge pragul de rentabilitate / punctul critic al rentabilității

breakeven performance (ec) nivel de performanță de la care începe plata primei

break ground (agr, constr) a disloca pământul, a defrişa; (nav) a smulge ancora

break impulse (autom, el) impuls de deblocare / de întrerupere / de deschidere / de separare

break in a irumpe, a rupe, a forța, a întrerupe; a domestici, a îmblânzi; a se năpusti, a intra cu forța sau pe neaşteptate; a căpăta acces; a întrerupe conversatia

break in a curve (mat) punct unghiular / de inflexiune a unei curbe

break in an axle $(\mathrm{OM})$ rupere de osie

breaking ruptură, întrerupere, tăiere, rupere, spărtură, refracție, (constr, ind chim) concasare; (mec) flambaj; deconectare; îndoitură; separare

breaking by overload (el, OM) rupere din cauza suprasarcinii

breaking capacity (el) putere / capacitate de rupere / străpungere

breaking cone (constr, ind chim) concasor conic

breaking delay (el) întârziere de acționare (la relee)

breaking-down mill train (met) linie de laminare pentru profiluri grele

breaking-down pass (met) calibru de degroşare rapidă / degrosisor / întinzător 
breaking-down point $(\mathrm{TH}$, materiale) limită de rupere / de cedare; valoarea unui parametru al unui utilaj peste care apare distrugerea / ruperea / avarierea

breaking-down pressure (hidr) presiunea / de străpungere / disruptivă

breaking-down voltage (el) tensiune de străpungere / disruptivă

breaking-down roll (met) cilindru degrosisor / întinzător

breaking-down stand (met) cajă de bluming / de blumuri

breaking down temperature $(\mathrm{TH}$, termo) temperatură de rupere / de întrerupere / de cădere (a unui utilaj)

breaking drum (constr, ind chim) tambur de concasare

breaking force (mec) forță de rupere

breaking elongation / extension (mec) alungire la rupere

breaking length (mec, metr) lungime de rupere (şi la epruvete)

breaking limit (mec, OM) rezistentă de / la rupere; $(\mathrm{TH})$ valoare limită (a unui parametru) peste care utilajul cedează

breaking load (mec, OM) sarcină de rupere / de flambaj

breaking machine (constr, ind chim, met) concasor, dezintegrator, berbec

breaking mill (met) laminor pregătitor

breaking of an emulsion (T) spargere / separare a unei emulsii

breaking of arc (el, met) întreruperea arcului (electric, la sudură)

breaking-off (met, plast, textile) tăiere cu înlăturarea restului (de material)

breaking of vacuum (fiz) scăderea vidului

breaking of viscosity $(\mathrm{T})$ reducerea vâscozității (şi bruscă)

breaking out $(\mathrm{TH}, \mathrm{mec})$ desprindere forțată, rupere, spargere

breaking plant (constr, ind chim) instalatie de concasare

breaking point $(\mathrm{T})$ punct de spargere / separare a emulsiei; (mec) rezistență limită / la rupere, punct de rupere / de întrerupere

breaking safety (mas) siguranță la întrerupere / la defectare / la dezmembrare / la rupere

breaking shaft $(\mathrm{OM})$ bară de siguranță (prin rupere / de cuplare)

breaking strain (mec) deformație la rupere / la flambaj

breaking stress (mec, plast) rezistență la rupere, efort / tensiune la rupere breaking stress in tension (in shear, in compression) (mec, metr) rezistență la rupere la tracțiune (la forfecare, la compresiune)

breaking switch (el) contactor $\mathrm{cu}$ contacte normal închise

breaking tenacity $(\mathrm{mec})$ tenacitate la rupere, rezistență specifică la rupere

breaking tension (mec) tensiune / efort la rupere

breaking test (mec, materiale) încercare la rupere / la flambaj

breaking up (TH, mas) desfacere forțată, rupere, defectare

breaking weight (mec) sarcină / greutate de rupere break-in period (auto) perioadă de rodaj

break into $(\mathrm{OM}, \mathrm{T}) \mathrm{a}(\mathrm{se})$ infiltra în, a pătrunde, a roda, a intra fortat, a întrerupe, a începe brusc

break length $(\mathrm{OM})$ lungimea ruperii / la rupere

break line rând final (într-un text)

break off (met) străpungere (la furnal); abandonare; rupere; despărțire, separare; defectare; a se întrerupe

break off from a se rupe de, a se desface de / din; a se rupe legăturile cu; a se întrerupe, a se opri (din vorbit)

break open a se deschide, a deschide cu forța, a desface (o legătură, o scrisoare etc.)

break out $(\mathrm{OM})$ deşurubare, smulgere a ancorei; răbufnire, izbucnire; a (se) desface, a sparge, a irumpe, a izbucni, a începe, a se dezlănțui; a exclama; a fugi, a scăpa, a evada

break-out tongs cleşte pentru tuburi

break part way a rupe în două

break point $(\mathrm{T}$, alim) punct de stratificare / separare a unei emulsii, punct de limpezire a unei solutii tulburi; punct de control / de rupere; (fiz, T) prag de absorbție

breakout pressure (mec, hidr) presiune de întrerupere

break shot $(\mathrm{TH})$ proces de întrerupere / de declanşare

break spark (el) scânteie de ruptură / la deconectare

break the joint (mec, $\mathrm{OM}$ ) a rupe legătura / asamblarea

break the joint $(\mathrm{OM})$ a deşuruba, a desface / a distruge $o$ asamblare

break(-)through (chim, fiz, T) punct de ruptură, breşă, spărtură, prag de absorbție, punct critic al ciclului de absorbție; (el, OM) breşă, străpungere, răbufnire;

break through (chim, fiz, T) a pătrunde; a răzbate prin; a învinge dificultăți; (jur) a aplica (legea); a ieşi (din / prin), a apărea, a se ivi; (fig) realizare, progres 
break up (agr) a desțeleni, a ara prima oară; (alim, TH) a deschide (un recipient); (edu) a închide şcoala (pentru vacanță); a se despărți, a se sparge, a (se) sfărâma, a deschide, a descompune, a fărâmița, a dezmembra, a demonta, a separa

break-up (chim, T) descompunere, disociere, dezagregare, dispersie, fracționare; defectare, întrerupere (şi nedorită) (fig) prăbuşire, cădere, ruină; (edu) închiderea şcolii (pentru vacanță); terminare, încheiere

breakwater (constr, nav) dig (de larg (nav) sparge val

bream (alim, iht) plătică

breast piept; a înfrunta

breast high până la înălțimea pieptului

breast beam (mas, constr) traversă frontală

breast box (mas-un, el) cutie de alimentare / de distribuție

breast drill (mas-un) burghiu de mână, maşină de găurit portabilă

breast fast (nav) traversă (parâmă)

breast pan (met) antecreuzet (la cubilou)

breast plate (met) placă / cuirasă frontală, blindaj frontal; (mas, constr) lamă de buldozer

breast shore (nav) pontil lateral

breast wall (constr) zid de sprijin

breast (water) wheel $(\mathrm{OM}$, agr) roată de apă

breastwork (nav) fronton de dunetă; $(\mathrm{TH})$ parapet, balustradă

breath (med) respirație, răsuflare, suflu; adiere; (fig) pată, stigmat

breathe a respira, a răsufla; (fig) a trăi, a exista; a aspira, a trage aer în piept, a inspira; a murmura, a vorbi în şoaptă; a sufla (în); a obosi, a epuiza (o persoană), a lăsa să răsufle / să se odihnească

breather (OM, hidr) supapă de respirație / de aerisire / pneumatică, răsuflător; mască de gaze, ventuză

breather capacity aptitudine / capacitate de răsuflare, debitul de aer care poate trece prin tr-un dispozitiv de răsuflare

breather losses (alim, hidr, ind chim) pierderi prin evaporare / aerisire / respirație

breather plug (met, OM, termo) răsuflătoare, canal de aerisire, orificiu de evacuare

breather valve (OM, hidr) supapă de aerisire

breathing care respiră, viu, veridic; respirație, răsuflare, aerisire; (sunet) aspirat, aspirare

breathing a mould (met, plast) deschidere a formei de presare pentru îndepărtarea gazelor şi a vaporilor

breathing respirație, aerisire beathing a mould (met, plast) deschidere a formei de presare pentru evacuarea gazelor şi vaporilor

breech canal de fum; (nav) tăietură de macara

breech bore gauge (metr, met) calibru inelar

breech door (OM, hidr, ind chim, met) clapă de fund (şi la cuptoare, recipiente)

breech lock $(\mathrm{OM})$ clapă de deschidere / de încărcare

breech plate $(\mathrm{OM})$ nervură / piesă / placă de fund, placă a lacătului / broaştei

breech recess gură a rindelei

breechblock $(\mathrm{OM})$ capac de închidere, închizător

breechblock handle $(\mathrm{OM})$ mâner de închidere

breechblock mechanism $(\mathrm{OM}, \mathrm{cf})$ închidere $\mathrm{cu}$ blocare (şi la vagoane)

breeches piece $(\mathrm{OM})$ piesă de legătură, în formă de furcă

breeches pipe (OM, hidr) racord tip furcă

breeching(s) (termo, met, alim) canal(e) de fum

breechlocking crank $(\mathrm{OM})$ manivelă de închidere / de blocare

breed (agr, zool) rasă, specie; a naşte, a da naştere, a creşte, a prăsi, a spori, a (se) înmulți, a selecționa, a se reproduce; (fig) a avea originnea, a lua naștere

breeder (agr) crescător de animale; animal de prăsilă

breeding (agr, zool) regenerare, reproducere, selecție, înmulțire, creștere a animalelor; bună creştere, educație

breeze (met) zgură (de cărbune), cărbuni sau cocs în bucăţi mici, a sufla în; (nav) briză

breeze coke (met) cocs mărunt

brevet brevet (şi de pilot)

breviary breviar

brevity scurtime; caracter trecător; exprimare concisă, concizie

brew (alim) a fierbe (şi ceai, bere etc.), a fabrica (bere), infuzie

brewage (alim) fierbere, fabricare (a berii); fierbere (a ceaiului); fiertură, infuzie

brewery (alim) fabrică de bere

brewery mash (alim) borhot de bere

brewery yeast (alim) drojdie (de bere)

brewing (alim) fabricare a berii

brewing cup / tun (alim) cuve de brasaj (pentru bere)

brew kettle (alim) fabricare a berii

brewer (alim) fabricant de bere, berar

brewer's copper (alim) cazan / cuvă (de cupru) pentru brasaj

brewer's grain (alim) borhot de bere

brewer's malt (alim) malt de bere 
brewer's wort (alim) must de bere

brewery (alim) fabrică de bere

bribable (pol, ec, jur) care poate fi mituit / corupt, coruptibil

bribe (jur, pol) mită, a mitui, a da mită, a cumpăra (pe cineva), a corupe

bribeless incoruptibil, integru

briber (jur, pol) mituitor

bribery (jur, pol) (acțiunea de a da) mită, mituire, luare / dare de mită

bribetaker (jur, pol) (persoană) care ia mită,

brick (constr) cărămidă, țiglă, ceramică; bucată, tabletă, calup, brichetă; (constr) a construi din cărămidă, a pava cu cărămidă

brick field cărămidărie

brick furnace (constr, ind chim) cuptor pentru arderea cărămizilor

brick grease $(T)$ unsoare consistentă în brichete

brick inclusions (met) incluziuni din materiale refractare / cărămizi

bricking (constr, met) lucrare de zidărie, zidire

brick kiln (ind chim) cuptor de ars cărămizi

brick lined (constr, met) căptuşit cu cărămidă

brick-lined masonry (constr, met) zidărie de placare

brick lining (constr, met) îmbrăcăminte / căptuşeală de cărămidă

brick moulding machine (constr) maşină pentru fasonarea cărămizilor

brick oil (chim, ind chim, constr) ulei pentru ungerea preselor de cărămizi

brick press (mas-un) presă de cărămizi

brickworks (constr, met) zidărie, căptuşire cu cărămidă

brick up (constr) a ridica un zid, a umple cu zidărie (de cărămidă), a suprazidi, a înzidi

bricky (constr) făcut din cărămidă

brickyard cărămidărie

brickworks fabrică de cărămidă

bridge pod; (metr, el) punte de măsurare; (nav) punte (şi de comandă), pasarelă, covertă, castel central, ponton; (transp) slide pod rulant, suspension $\sim$ pod suspendat, swing $\sim$ pod turnant (el) a șunta, a deriva (un circuit); a construi un pod; (fig) a împăca, a concilia, a învinge (o dificultate), a trece peste

bridge across (el) a şunta

bridge capacity (constr) sarcină utilă maximă (pentru pod, drum, pod rulant)

bridge circuit / arrangement (el) circuit / montaj în punte

bridge cock $(\mathrm{OM}$, hidr) robinet de trecere (între conducte altfel separate)

bridge crane (met, mas) pod rulant bridge deck (nav) punte a pasarelei / a comenzii

bridge driving voltage (el) tensiune de alimentare / de acționare a unei punți

bridge floor(ing) (constr) tablier de pod

bridge for supporting pipe (constr) pod pentru conducte tubulare

bridge fuse (el) sigurantă a puntii

bridge girder (constr) grindă a podului (şi rulant)

bridge girder system (constr) sistem portant al podului (şi rulant)

bridge joint (constr) joantă între traverse, joantă de şine la poduri

bridge launching (constr, met) lansare a podului

bridge load (constr, mas) sarcina podului (si rulant)

bridge null detection (el, metr) detectarea nulului punții, aducere la zero a unei punți

bridge of a ship (nav) covertă, punte

bridge of boiler furnace (termo) altar de focar

bridge pile (constr) pilă-culee

bridge railing (constr) balustradă de pod (si rulant)

bridge reamer (mas-un) alezor pentru găuri de nit

bridge relay (el) releu de punte

bridge resistance (el) rezistență a punții

bridges (tank-furnace) (met) baraje (la cuptorvană)

bridge spot weld (met, OM) sudare în puncte cu eclise

bridge stockade (constr) estacadă

bridge wall (constr, mas) corp al podului (şi rulant); (met) prag al cuptorului

bridge wire (el) fir de rezistență calibrat (al unei punți)

bridging (constr) arcuire, tablier de pod (și rulant); proptea, antretoază, planşeu; (met) blocare a şarjei în furnal, lipsă de pătrundere (la sudare); (el) şuntare

bridging over of stock (met) agățarea şarjei

bridging plug (el) fişă / buşon de scurcircuitare

bridging work construcție de poduri

bridle frâu, căpăstru; $(\mathrm{OM})$ bridă, colier; (nav) labă-de-gâscă

bridle chain lanț pentru ghidare / de siguranță la colivii

bridle joint (constr, OM) îmbinare în grindă

brief scurt, concis; rezumat, compendiu; (jur) punctaj al unui dosar, a încredinţa un proces (unui avocat); a rezuma, a expune pe scurt; a da ultimele instrucțiuni (cuiva)

brief acceleration (mec) accelerație momentană / de scurtă durată

briefly $(a d v)$ concis, pe scurt, în câteva cuvinte

brier (bot) măces; mărăcini, mărăciniș 
Briggs(ian) logarithm (mat) logaritm zecimal / comun / ordinar

bright strălucitor, luminos, sclipitor, lucios, lucitor, de culoare deschisă / aprinsă; străveziu, limpede, clar; (met) curat, decapat; (fig) inteligent, ager, spiritual, strălucit, grozav, optimist; bun, prielnic, favorabil; promițător

bright annealing (met) recoacere la alb, în atmosferă controlată

bright annealing furnace (met) cuptor de recoacere (până) la alb (în atmosferă controlată)

bright blue (met) albastru deschis (culoare de revenire)

bright deposit depunere lucioasă

bright-drawn (met) tras la rece (până la luciu)

bright-drawning (met) tragere la rece (până la luciu)

bright-drawn steel bar (met) bară de oțel trasă, lucioasă (blank)

bright dross (met) zgură sticloasă

brighten a face să strălucească; a lumina; a polei, a lustrui, a polei; a deschide la culoare; a ațâța focul

brightener (chim, met) vas de decapare / de limpezire, decantor

brightening $(\mathrm{T})$ limpezire a uleiului; (met, masun) lustruire, obținere a luciului

bright-field illumination (fiz, metr) iluminarea câmpului-obiect (la microscop)

bright finish (mas-un) finisare lucioasă / până la luciu (metalic)

bright finished (mas-un) lustruit, polizat, superfinisat

bright-finished sheet / table (met) tablă polizată la / cu luciu

bright hardening (met) călire (până) la alb

bright light lumină strălucitoare; (auto) fază mare / lungă

bright luster luciu intens / puternic

bright-luster sheet (met) tablă lucioasă

bright metal (met) metal curat / cu luciu / decapat

brightness luminozitate, strălucire, luciu; puritate, limpezime; (fiz) iluminare, luminozitate, claritate (optic); (fig) inteligență (sclipitoare), perspicacitate, pătrundere

brightnessmeter (fiz, metr) exponometru

brightness reversion îngălbenire (şi la materiale plastice), mătuire

brightness temperature (fiz, met) temperatură de incandescență

brightness values (fiz) indice de luminozitate bright nut $(\mathrm{OM})$ piuliță prelucrată / de precizie bright-orange (met) galben-portocaliu (culoare a unui oțel la încălzire la o anumită temperatură) bright parts (OM, mas-un) piesă având toate suprafetele prelucrate

bright pickle (met) a decapa pentru lustruire

bright polished sheet (met) tablă lustruită

bright plating (met, plast) depunere galvanică cu luciu / decorativă

bright plating range (met, plast) depunere $\mathrm{cu}$ luciu

bright red roșu strălucitor / aprins

bright steel (met) oțel tras la rece (cu luciu metalic)

bright stock (ind chim) ulei dezasfaltat rafinat; ( $\mathrm{T}$, chim) ulei cu vâscozitate mare, component (de bază) al unui lubrifiant

bright washer $(\mathrm{OM})$ şaibă prelucrată

bright wire (el) fir incandescent; (met) sârmă albă

bright work (mas-un) piese (şi din alamă) lustruite / prelucrate până la luciu

brilliance strălucire, sclipire, luminozitate, claritate; splendoare, măretie

brilliance display indicare / reprezentare cu mare luminozitate (şi pe ecran / pe display)

brilliant strălucitor (d. o culoare), luminos, briliant, scânteietor; splendid, măreț; eminent, genial, strălucit; brilliant (piatră prețioasă)

brilliant polish (mas-un) lustruire fină

brim margine (de pahar, vas etc.), bordură (mai ales pentru țesături); țărm, mal; bor (de pălărie); a fỉ plin până sus

brimful plin până sus

brim over (with) a se revărsa peste margine, a deborda

brimstone (chim, met) sulf, pucioasă

brine (alim, chim) apă sărată, saramură, solutie de sare, a săra; apă de mare

brine chilling (alim) răcire cu saramură

brine drum (alim, termo) acumulator de saramură, tub de diametru mare, umplut cu saramură răcită, constituind un acumulator de frig

brine gauge (alim, chim, metr) salinometru

brine header (alim) colector de saramură

Brinell's machine (metr, met) durimetru Brinell

Brinel point (metr, mec) unitate Brinell

Brinell (ball-) hardness (metr, materiale) duritate Brinell

Brinell (hardness) number (metr, mec) numărul / valoarea durității Brinell

brinelling $(\mathrm{T})$ brinelare (deteriorare a unui rulment prin amprentare la şoc sau la montaj)

brinelling indentation $(\mathrm{OM})$ indentare prin brinelare (deteriorare la rulmenți)

brine pump (alim, ind chim) pompă pentru saramură 
brine refrigerating plant (alim, termo, ind chim) instalație de răcire cu saramură

brine refrigeration (alim, ind chim) răcire cu saramură

brine tank (alim) rezervor de saramură

bring a aduce (cu sine), a lua, a duce, a aduce, a cauza, a produce; a procura; a convinge; a determina; (jur) a intenta (un proces), a depune o plângere, a furniza (dovezi, argumente); (ec) a reduce (prețuri); a provoca, a da naştere la; a aduce pe lume; a prezenta (argumente, sugestii); a scăpa; a apăsa; a creşte; a pune pe tapet (o problemă); a charge a aduce o acuzare, a acuza; back (si to mind) a aduce aminte; $\sim$ into play a face să acționeze; $\sim$ under a înăbuşi; up to date a aduce (o situație) la zi; $\sim$ to bear a influența; to one's knowledge a aduce la cunoştința cuiva; $\sim$ to pass a provoca bring about a aduce cu sine, a determina, a cauza, a prilejui, a îndeplini, a făptui; a produce

bring along a aduce cu sine

bring away a lua / a duce cu sine

bring back a readuce, a completa, a recupera (şi o întârziere), a înapoia, a aduce înapoi

bring down a aduce jos, a coborâ, a trânti, a scădea; a răni, a omorî; a micşora, a reduce (şi prețuri)

bringer aducător, care aduce

bring forth a naşte, a da naştere la, a produce (rod); (fig) a aduce cu sine, a da naştere la, a cauza

bring forward a pune în lumină, a prezenta, a înfățişa; a favoriza; a recomanda; (ec) a reporta (un total, o sumă), a trece; a aduce

bring home / in (TH) a apropia, a explica, a lămuri, a clarifica; a aduce pe locul de montaj, a introduce un rând (de text)

bringing back damper spring $(\mathrm{OM})$ resort de rapel şi amortizor

bringing out $(\mathrm{TH})$ extragere, tragere în afară

bringing together a aduce aproape, a apropia, a alătura

bring in a importa; a introduce; (ec) a aduce (un beneficiu, un venit); a propune, a prezenta (o propunere); (jur) a declara (şi vinovat)

bring into a aduce în; a pune (în pericol); (ec) a trece (în registre); a pune de acord

bring into fashion / vogue a moderniza, a face ceva conform tendintei / modei în domeniu

bring into service $(\mathrm{TH})$ a pune în funcțiune, a da în exploatare

bring off a săvârşi, a realiza; a smulge; a salva

bring on a aduce; a trage după sine; a pricinui, a cauza; a provoca, a aduce în discutie bring oneself to a se hotărî să

bring out a îndepărta, a scoate (în afară), a scoate în evidență; a produce; a destăinui; a înfățişa; a clarifica, a limpezi; a prezenta, a publica, a tipări, a publica (o carte); a pune în scenă

bring over a face (pe cineva) să-şi schimbe părerea, a convinge, a câștiga de partea sa, a converti; a aduce (de undeva)

bring round / through (med) a (re)pune pe picioare, a însănătoşi; a câştiga de partea sa, a convinge

bring through a scoate dintr-o situație grea, (med) a vindeca (un bolnav);

bring to a face / a determina să, a hotărî / a convinge să; a opri; (fig) a duce la, a aduce în; (nav) a opri, a face să se oprească (o navă)

bring to a standstill a face să se oprească (un mijloc de transport); (ec) a face să stagneze / să înceteze (producția, comerțul etc.)

bring to an anchor (nav) a staționa

bring to boiling (alim, ind chim) a aduce la fierbere

bring to speed (mas) a aduce la viteza normală

bring up (nav) a opri nava, a prezenta, a trage cablul; a ridica, a înălța; a vomita, a vărsa; a educa, a creşte; a aduce în discuție, a atrage atenția asupra (unei chestiuni); a opri

bring up to standard / scratch / the mark (TH) a aduce la nivelul / la standardul cerut

bring up-to-date a actualiza, a moderniza; (c) a uptdata, a îmbunătăți performanțele unui calculator prin schimbarea componentelor hard şi / sau soft

brining (alim) sărare, saramurare

briny (alim) sărat, foarte sărat

briny water (mediu) apă sărată / sălcie

briquette (constr) cărămidă, țaglă, olan; brichetă (şi de cărbune); pachet; a bricheta, a împacheta

briquetted coal (met) cărbune în brichete

briquetting $(\mathrm{TH})$ brichetare

briquetting machine / press / plant (mas-un) maşină / presă / instalație de brichetat (şi span)

bristle (agr, plast) fibră uscată, păr de porc

Britannia joint (el) joncțiune de cablu, sudată fără manșon

British englez, britanic

British gum (chim) gumă, răşină vegetală, solubilă în apă

British mile (metr) milă engleză

brittle casant, friabil, fragil, sfărâmicios (d. materiale solide)

brittle destruction (mec, materiale) distrugere / rupere de tip casant 
brittle failure (mec, materiale) ruptură casantă brittle lacquer (mec, OM) lac pentru identificarea prin fisură (din cauza tensiunilor)

brittleness (d. materiale solide) casanță, fragilitate, friabilitate

brittleness point / temperature (met) temperatură / punct de fragilizare

brittle texture (materiale) textură casantă (şi d. compozite)

brittle when red-hot (met) casant la roşu / la cald (de. oțeluri)

broach deschizătură, spărtură; (alim) frigare, a desfunda un butoi; (amer) broşă; (mas-un) broşă, alezor, a broșa, a aleza, a mări / a lărgi o gaură

broach burnishing (mas-un) finisare prin broşare broaching (mas-un) broșare

broach(ing) press (mas-un) maşină / presă de broşat

broach reamer (mas-un) alezor conic

broach slide / ram (mas-un) sanie / cărucior a(l) broșei

broad larg, vast, lat, întins, spațios, încăpător; vădit, clar, limpede; transparent; (fig) larg, cuprinzător, extins; îngăduitor, tolerant; mare, principal, general; $(a d v)$ pe față, deschis, fără reticente, pe deplin, complet

broadband (fiz, radio) bandă largă

broadcast emisiune radiofonică, program de radio; a (radio)difuza, a transmite (prin radio), răspândi, a difuza

broadcaster crainic de radio, speaker; (fiz, radio) transmițător, emițător; post de radio-emisie; (agr) semănătoare

broadcasting radio, radiodifuziune; (agr) semănat prin împrăştiere

broadcasting range (radio, metr) gamă de unde (radio, aparate de măsură cu unde)

broadcasting station stație de transmisie

broad classes of engine services (termo, auto, T) grupe / intervale largi de funcționare / solicitare a motorului

broaden a (se) lărgi, a (se) extinde, a (se) mări, a dezvolta, a amplifica

broadening lărgire, extindere, amplificare (spațială)

broad-faced steel gear (met) cilindru dințat / de antrenare (la laminor)

broad flange girder (constr, mec) grindă $\mathrm{cu}$ tălpi late

broad flange I beam (constr, mec) grindă lată în formă de I

broad gauge (cf) ecartament (de cale ferată)

broad-gauge railway (cf) cale ferată cu ecartament larg broad iron wedge pană / rangă de despicat

broadish cam larg, cam lat

broadlys $(a d v)$ in linii mari, în mare

broad-minded cu vederi largi

broadness lărgime, lățime

broad nose (mas-un) cleşte cu fălci late

broad-nose tool (mas-un) cuțit lat, de degroșare

broad rib (knitting) (mas-un) patent lat

broadsheet foaie cu text (tipărit) pe o singură parte, foaie volantă, pamflet

boardside (nav) bord, flanc, bordee

broadside sea (nav) mare / valuri de travers

broad strip (met) tablă / bandă lată

broad-strip (rolling) mill (met) laminor pentru tablă / bandă lată

broadways în lățime

broad welt manşetă / bordură lată (şi la textile, curele)

brochure broşură

broil (alim) fript, frigere, coacere (la foc), fritură, carne friptă (la grătar, a (se) frige, a (se) coace (la foc)

broke (TH) rebut, deşeuri; (ec) falit, ruinat, lefter broken $(\mathrm{TH}$, alim) brizură, rupt, sfarâmat, spart, întrerupt, întretăiat; (fig) dărâmat, distrus; frânt

broken-bladed conveyer / mixer (ali, ind chim) amestecător cu paletă segmentată / în segmente cu orientări diferite

broken castings (met) spărturi de turnătorie

broken corner (mas-un, met) margine / muchie rabotată / ruptă (la laminare)

broken-down (med) cu sănătatea distrusă, dărâmat, epuizat; (TH) distrus, stricat; nefolositor

broken down rubber (plast) cauciuc plastifiat (deteriorat)

broken end rupere; fir rupt, bandă / sârmă ruptă

broken glass ciob de sticlă

broken ground (constr) pământ dislocat / săpat

broken hardening (met) călire în trepte / întreruptă

broken iron (met) fontă veche spartă

broken line linie punctată / întreruptă

bronkenly $(a d v)$ întrerupt, intermitent, din când în când; neliniștit

broken number (mat) fractie

broken oxide (met, chim) incluziune / încrustație de oxizi (la laminare)

broken stone (constr) criblură, piatră spartă broken stowage (nav) spațiu pierdut la stivuire

broken wire (el) conductor / fir rupt

broker $(\mathrm{ec})$ comisionar, agent de bursă, negustor de vechituri

brokerage (ec) comision, intermediere, brocheraj brolly umbrelă 
bromate (chim) bromat

bromic acid (chim) acid bromic

bromide (chim) bromură,

Bromine (Br) (chim) brom

bronze (met) bronz, articole din bronz, aliaje de $\mathrm{Cu}-\mathrm{Sn}$, de / din bronz

bronze bushed bearing (OM) bucşă / cuzinet de bronz

bronze brazing (OM, met) lipire / lipitură (tare) cu bronz

bronze casting $(\mathrm{OM}$, met) piesă din bronz turnat bronze foundry (met) turnătorie de bronz

bronze-leaf foiță de bronz

bronze welding (met) sudarea bronzului

bronzing (met, $\mathrm{T}$ ) acoperire cu bronz (procedeul nu este precizat)

brood (agr) a cloci, a scoate (pui); (fig) a (se) pune la cale, a cugeta, a se gândi

brooder (agr, mas, termo) clocitoare, incubator

broom mătură, perie

brooming măturare (de curățare)

brow margine a unei pante; (constr) schelă

brown brun, cafeniu, ocru, culoare închisă, maro (deschis); a colora în brun / ocru / cafeniu; (met) a bruna

brown bread (alim) pâine neagră

brown coal cărbune brun, lignit

brownian coagulation (ind chim, alim) coagulare (în mişcare) browniană

brownian motion (fiz) mișcare browniană

browning (met, chim) brunare, acoperire prin oxidare

brown paper hârtie de ambalaj

brown petroleum (ind chim) țiței degradat

browns hârtii cafenii de ambalaj

brown soap săpun lichid

brownstone (constr) gresie de constructie

brown sugar (alim) zahăr nerafinat

browse a mânca, a roade (din) a mușca (din); a făsfoi cărți; (c) a trece în revistă, a "mătura" (o imagine, un site etc.)

bruise (med) a strivi, a măcina

bruise vânătaie

brush perie, pensulă; periat, periere, dat cu peria; finisare, stilizare; zgâriere; a peria, a şterge cu peria, a netezi; (silv) desiş

brush away a mătura (din cale), a da la o parte, a nu lua în considerare

brush carrier $(\mathrm{OM}, \mathrm{el})$ ax port-perie

brush collar (el, OM) inel port-perie

brush damper (alim, ind chim) umidificator $\mathrm{cu}$ perii

brush deburrer (mas-un) maşină / dispozitiv de curățat cu perie brush gear / holder (el, OM) (dispozitiv) portperie

brushing măturare, periere

brushing attachment (mas-un) dispozitiv de periere / de curățat cu perie

brushing paint (ind chim) vopsea de / pentru pensulă

brushing worm (alim, mas) melc transportor $\mathrm{cu}$ perii, perie elicoidală

brush lead (el) deplasare a periei față de punctul neutru

brush off (ec) a da afară, a concedia

brush on a aplica cu pensula

brush plating (met, el) depunere electrolitică cu perie / prin tamponare

brush polishing (met, metr) lustruire cu tamponul (la acoperiri şi la pregătirea probelor metalografice)

brush ring (el, OM) (inel) port-perie

brush rocker (el, OM) jug port-perii

brush-rocker ring (el, OM) inel al periilor (la maşini electrice)

brush roller (mas-un) cilindru-perie (la curățat)

brush shaft (el, OM) arbore port-perie

brush sparking (el) scânteiere a cărbunilor (de la motor electric)

brush spreader (mas-un, ind chim) maşină de cauciucare / de gumare cu perii

brush yoke (el, OM) jug pentru perii (la maşini electrice)

brush-up periat; lustru, stilizare, finisare

brush up a curăța, a peria; a lustrui, a finisa; (fig) a împrospăta memoria, a pune la punct

brutal brutal, violent, sălbatic

bub (alim) bere tare

bubble băşică; (met) suflură, nivelă, bulă (de gaz), cumpănă, a barbota, a clocoti, a fierbe; a face băşici / bule, a agita, a amesteca (generând bule)

bubble aeration suflare cu aer (printr-un lichid)

bubble boiling (alim, termo) fierbere violentă

bubble flask (alim, ind chim) barbotor / amestecător cu antrenarea aerului / gazelor în lichid

bubble formation (fiz, T) formare a bulelor (la emulsii); (met) formare a suflurilor

bubble gauge (hidr, metr) contor de bule, debitmetru cu bule de gaz

bubble level (metr) nivelă cu bulă

bubble point (fiz) punct inițial de fiebere

bubble-free fără bule de aer (şi la emulsii)

bubble-point pressure (fiz) presiune de saturație / de început de fierbere

bubbler (alim, ind alim, mas) dispozitiv de barbotare / barbotor 
bubbling (fiz, T, met, alim) formare de bule / de sufluri, barbotare, fierbere

bubbly (fiz, alim, ind chim, T) cu băşici, care scoate / face băşici, spumos (d. lichide)

buck (zool) țap, berbec, căprior; (chim) leşie; (fiz) a umezi, a umecta; $(\mathrm{TH})$ a sfărâma, a mărunți; (constr) capră, a sprijini cu o capră; a tăia cu ferăstrăul

bucker (constr, mas, ind chim) concasor

bucket (alim) găleată, vadră, saca; (constr, hidr) racord, rotunjire; (mas) benă, cupă de excavator, graifăr, paletă de rotor; (nav) cupă de dragă

bucket arm $(\mathrm{OM})$ braț al cupei (şi de excavator)

bucket car (met) schip (la furnale)

bucket carrier (met) vagonet de încărcare

bucket chain (OM, alim, nav) lanț cu cupe

bucket-chain dredger / excavator (constr, mas) excavator cu lanț port-cupe / cu elindă

bucket charging (met) încărcare a cuptorului, cu benă

bucket conveyor (alim, mas) elevator transportor cu cupe

bucket crane (constr, mas) excavator

bucket door (OM, mas) clapetă de cupă (la un excavator, transportor)

bucket dredge (nav) dragă cu lingură / cu cupe / cu godeuri

bucket elevator (met, constr, mas) elevator cu cupe / cu bene

bucket excavator (mas, constr) excavator cu cupă / cu cupe

bucket filling (met) încărcare a cuptorului, cu benă

bucket grab (mas) cupă cu graifar

bucket-handling crane (met) macara de şarjare cu cupă / cu benă

bucket-ladder excavator (mas) excavator cu elindă

bucket loader (mas) autoîncărcător cu cupe (şi cu elevator)

bucket nose $(\mathrm{OM})$ muchie de lucru a cupei (şi de excavator)

bucket slide (OM, mas) clapă de cupă (la excavator)

bucket-tipping device (constr, mas, OM) dispozitiv pentru răsturnarea cupei (la excavator)

bucket-type elevator (alim, ind chim) elevator $\mathrm{cu}$ cupe

bucket wheel (constr, termo) roată cu cupe (la turbină, excavator etc.)

bucket-wheel excavator (constr, mas) excavator cu roată port-cupe

bucket-wheel tyre loader (mas, constr) încărcător cu roată port-cupe buckle cataramă; îndoitură, cută, curbură; a ceda; a (se) îndoi, a (se) încovoia, a (se) cuta, a (se) flamba, a (se) curba, a (se) bomba, a (se) umfla; a fixa (cu cataramă)

buckle out a egaliza, a îndrepta

buckle up a (se) turti

buckle-up! (auto) legați-vă centurile de siguranță

buckled (mec) îndoit, încovoiat, flambat, cotit, curbat, bombat, umflat

buckled plate $(\mathrm{OM})$ placă bombată din oțel

buckled plate sheet piling (constr, met) perete / ecran de planșe de tablă ambutisată

buckler (met, termo) scut

buckles (met, plast) cute, ondulații (la laminare)

buckling (constr, mec) flambare, flambaj, curbare (şi la plăci de acumulator); (fiz) curbură; (met, plast) îndoire, deformare, gofrare, ondulare (d. table şi plăci)

buckling coefficient (mec, OM) coeficient de flambaj

buckling criteria (mec) criterii de flambaj

buckling load (mec) sarcină de flambaj, solicitare la flambaj, forță de flambaj

buckling resistance (mec) rezistență la flambaj

buckling stain (mec) deformație la flambaj

buckling strength (mec) rezistență la flambaj / la ondulare / la îndoire

buckling stress (mec) efort / tensiune de flambaj

buckling test încercare / test la flambaj / la îndoire (a tablelor / plăcilor etc.)

buckling vector (mat) vector laplacian

buckram (textile) pânză groasă de legătorie; (fig) formalitate, riditate, formal, rigid

buck( )saw (mas-un) fierăstrău cu arc / cu coadă

buck scraper (mas) screpăr cu roți

buckstay (constr) stâlp de reazem

buck up a reface; a încuraja, a remonta

buck up in front $(\mathrm{TH})$ a răsturna, a bascula

buckwheat coal (met, termo) cărbune mărunt

budge a (se) mișca, a (se) clinti, a (se) urni

budget (ec) buget, a aloca / a repartiza din buget; (fig) rezervă

budgetary $(\mathrm{ec})$ bugetar

budgetary allocation / allotment (ec) alocație bugetară

budgetary deficit (ec) deficit bugetar

buff piele de bou / bivol; culoarea pielii, galben închis; disc din piele, pentru polizat; a lustrui (cu piele); a amortiza (o lovitură)

buffeting oscilație, oscilare

buff stick in leather disc subțire din piele, pentru lustruit

buffer (auto) bară de protecție, circuit-tampon; (autom) circuit tampon; (OM) amortizor, 
tampon, frână, pernă de amortizare, opritor, limitator; (chim) soluție / substanță tampon; (c) memorie intermediară; (fiz) amortizor de oscilații; (mas-un) maşină de lustruit

buffer accumulator (el) acumulator-tampon separator

buffer action (chim) actiune de tamponare (cu soluție); (mec) acțiune de amortizare

buffer base plate (cf) placă de tampon

buffer brake (OM) tampon, amortizor

buffer capacitor (el) condensator capacitiv (pentru atenuarea oscilațiilor)

buffer coating strat intermediar (de vopsea)

buffer drilling (mas-un) perforare / găurire cu amortizor

buffer fluid (auto, ind chim, mas) lichid de frână, fluid pentru amortizor hidraulic sau pneumatic

buffer function (autom) funcție intermediară / tampon

buffer gear (OM) ansamblu-amortizor

buffer head (cf) disc tampon

buffer memory (c) memorie tampon / intermediară

buffer piston (OM, hidr) piston de echilibru / de amortizoare

buffer plunger (cf) tijă tampon

buffer reservoir (hidr, ind chim, OM) rezervortampon

buffer screw (OM) şurub amortizor / cu arc

buffer spring (cf, OM) arc de tampon / de amortizor, arc-amortizor

buffer stock (el) stoc tampon

buffer stop (cf) opritor de linie fix; (constr) grindă de sprijin

buffer store (c) memorie intermediară

buffer tank (nav, hidr, ind chim) rezervor tampon

buffer tube (OM, hidr) tub separator

buffer zone (fiz, med, TH) zonă intermediară / de tranziţie

buffing (mas-un) polizare, şlefuire, lustruire (mecanică şi electro-mecanică)

buffing cone (mas-un) con / dom de polizare

buffing machine (mas-un) maşină de polizat / de şlefuit

buffing powder (mas-un) pulbere de şlefuit buffing wheel (mas-un) disc de şlefuit / de lustruit buff wheel (mas-un) disc de lustruit

bug ploşniță, (amer) insectă, gândac, microfon ascuns; defect, deficiență; a instala microfoane, a supraveghea pe ascuns; (c, autom) indicator de poziție / de deranjament / de eroare, perturbare

bug defect $(\mathrm{TH}$, autom) imperfectiune, eroare

bug dust (constr, mas-un) praf rezultat la perforare sau tăiere buggy ladle (met) oală de turnare, montată pe cărucior / pe vagonet-platformă

buggy casting (met) turnare pe vagonetplatformă

build formă, stil; model; statură, conformație; (constr) construcție, formă, structură; a construi, a clădi, a zidi, a ridica; (fig) a crea, a face, a făuri

builder (constr) constructor, component, antreprenor, arhitect, zidar

builder's diary jurnal de şantier

builder's hoist troliu de construcție

build in (constr) a închide cu zid

building (constr) construire, zidire; clădire, construcție, edificiu, casă, bloc

building block (constr) subansamblu, element de construcție; (TH, mas) modul (într-o instalație sau într-un ansamblu)

building boards carton gudronat

building brick (constr) cărămidă

building contractor (constr, ec) antrepenor, constructor

building crane (constr) macara de şantier

building drum (ind chim, auto) tobă de confecționat anvelope

building engineer (constr) inginer constructor, şef de şantier

building engineering plant (constr) utilaje de construcții / de şantier

building glass (constr, ind chim) sticlă de constructie

building ground (constr) teren sau şantier de construcție

building-in (constr) înzidire

building in series $(\mathrm{TH}, \mathrm{ec})$ fabricație în serie

building limit (constr) limită de gabarit / de constructie

building lumber (constr) lemn fasonat / de construcții

building material (constr) material de construcție

building mortar (constr) mortar

building of rubber compound (ind chim) elaborarea rețetei de amestec pentru cauciuc

building paper carton gudronat

building pit (constr) săpătură, excavație

buildings (constr) dependințe, acareturi

building site (constr) şantier de construcții

building slip (nav) cală de construcție şi de lansare building stone (constr) piatră de construcție building system (constr) regim de construcție building timber (constr) lemn de construcție

building yard (constr) şantier de construcții

building-in (constr) înzidire, fixare în zid (a unei piese etc.) 
building-up process (chim) proces sintetic; (el) proces tranzitoriu

building-up formare, creştere; excrescență; (TH) montaj, asamblare, asamblaj; (T) depunere prin uzură de aderență

building-up current (el) curent tranzitoriu

building-up refacere, (TH) montaj, asamblaj, acumulare, îngrădire

building-up reaction (chim) reacție de polimerizare

building-up process (chim) proces de condensare / de precipitare; (el) proces / fenomen tranzitoriu

building-up rise time $(\mathrm{TH})$ timp de tranzit, timp de cresstere (a unui parametru)

building-up time ( $\mathrm{TH}$, mas, autom) timp / durată de stabilire, perioadă tranzitorie, timp de amorsare a oscilațiilor

building-up transient process ( $\mathrm{TH}$, autom, mas) proces tranzitoriu, generarea / dezvoltarea unui process tranzitoriu

building yard șantier; (nav) şantier naval

build up a crea, a genera, a construi, a ridica; (TH) a forma, a alcătui, a se închega, a se aduna

build-up (el) amorsare a unui generator autoexcitat; (met) creşterea ruloului, încărcare / depunere prin sudură; (T) formare, depunere (prin aderență)

build up a connection (c, el) a face o legătură

build-up factor factor de corectie / de formare

build-up metal (met) metal / aliaj pentru depunere / încărcare (prin sudură)

build-up of pressure (mec, hidr) crearea presiunii

build-up welding (met) sudură cu metal de adaos, depunere / încărcare prin sudură

build-up creștere, dezvoltare, progres; acumulare, sporire, intensificare

build up a construi / a clădi (şi treptat), a zidi; (fig) a întări, a face / a realiza treptat, a acumula, a strange, a ridica

build upon a se baza pe, a conta pe

built beam with keys (constr) grindă îmbinată cu buloane

built-in (constr) înzidit, încastrat, încorporat (şi d. materiale)

built-in beam (constr) grindă încastrată

built-in burner (termo, met) arzător înzidit / încastrat / încorporat

built-in cab (auto) cabină închisă, pentru şofer

built-in check (autom) verificare automată

built-in crankshaft $(\mathrm{OM})$ arbore cotit dintr-o singură bucată

built-in feedback holding brake (OM, autom) frână de blocare cu reacție integrată / la servoelemente de acționare built-in hydraulic jack (OM) cric hidraulic montat permanent / incorporat

built-in magnet (el, autom) magnet încorporat / încastrat

built-in reliability $(\mathrm{TH})$ fiabilitate intrinsecă / internă

built-on piece $(\mathrm{OM})$ piesă ajustată (suplimentar)

built-on pump / built-together pump (el, hidr, mas) motopompă

built soap (chim) săpun cu mai mulți componenți

built-up (constr) construit, clădit, cu multe construcții / clădiri, prefabricat (din. beton etc.)

built-up barrel (fiz) cameră toroidală, toroid

built-up casing (constr) cofraj prefabricat

built-up concrete (constr) beton prefabricat

built-up crankshaft $(\mathrm{OM})$ arbore cotit executat din bucăţi / demontabil

built-up factor (fiz, metr) factor de corecție, factor de formare

built-up girder (constr, mec) grindă compusă

built-up member (constr, mec) bară compusă din mai multe elemente

built-up molding box (met) ramă / cutie de formare demontabilă

built-up propaganda (ec) reclamă pentru un produs

built-up sequence (met) consecutivitate, secvențialitate a depunerii (la sudare în mai multe straturi)

built-up tyre of face mill with inserted teeth (mas-un) freză frontală, cu dinți aplicați

built-up weld(ing) (met) (depunere / încărcare / recondiționare) prin sudare cu metal de adaos

bulb bulb, băşică; (chim) balon, rezervor (şi de termometru); (el) bec electric, lampă cu incandescență; (met) îngroşare, cap de profil; a se umfla; (auto) bec (si de far)

bulb angle (nav) cornier cu bulb

bulb angle iron (met, mec, nav) cornier (din otel) cu bulb

bulbed cu bulb

bulb-iron angle bar (nav) cornier cu bulb

bulb plate (met, constr, mec) oțel lat cu bulb

bulb rail iron (constr, met, mec) profil cu bulb (din oțel)

bulb steel (met) oțel pentru profiluri cu bulb

bulb stopper (OM) dop / obturator sferic

bulge umflare, umflătură, protuberanță, burtă, convexitate, ieşitură, lărgire, bombare; (ec) urcare / ridicare a prețurilor; (met) îngroşare, proeminență; a lărgi, a îngroşa, a rotunji, a umple, a ieşi în afară, a (se) umfla, a (se) proiecta în afară, a se bomba; (met) a evaza, a mandrina 
bulge profile (met, mec, constr) profil (de laminare) cu nervură

bulging bombare, umflare, lărgire, ieşire în afară, rotunjire; proeminent, umflat, bulbucat, protuberant, ieşit în afară, care iese în afară; (constr) deviere a axei unei bare, strâmbare

bulging lathe (mas-un) strung de presat / de planat

bulging out (met) bombare; (plast) umflare

bulk mulțime, masă, majoritate; (în) volum, mărime, majoritate; gros, grosime; (ec) grămadă, (marfă) în vrac, încărcătură; vraf, volum; (fiz) gros, cantitate principală; desfăcut (şi d. marfă); (nav) încărcătură a vasului; a umple, a îndesa, a îngrămădi, a vărsa, a turna; a avea importanță

bulkage (constr) înfoiere / umflare din cauza umidității

bulk analysis analiză generală

bulk appearance aparența materialului întreg

bulk cargo (nav) marfă / încărcătură în vrac

bulk carrier (nav) cargo / navă pentru marfă în vrac

bulk conductivity (el, termo) conductivitate în miez

bulk container (nav) container pentru materiale în vrac

bulk density (fiz) densitate specifică aparentă, densitate specifică în vrac

bulk elasticity (mec) elasticitate de volum

bulk factor (mec, mas-un) factor de compresibilitate

bulk freight (cf) marfã voluminoasă

bulkfreighter (nav) navă cisternă

bulk good material în vrac

bulkhead (constr) perete de dulapi / despărțitor, batardou, acoperiş (al unei scări); (nav) perete etanş; (termo) fund de cazan

bulkhead deck (nav) punte a pereților etanşi

bulking (plast) (acțiune de) înfoiere / umflare, gonflare (la umiditate), umflare, expandare

bulking agent (plast) agent de expandare / de creştere a volumului

bulk liquid storage $(\mathrm{TH}$, hidr, alim) depozitare a lichidelor în rezervoare

bulk lorry (auto) cisternă auto

bulk manufacturing $(\mathrm{TH}, \mathrm{ec})$ producție de serie / în masă

bulk material (ec) material în vrac / afânat / în gramadă; $(\mathrm{TH})$ material de bază, miez

bulk memory / store (c, inf) memorie de mare capacitate

bulk modulus (mec) modul de elasticitate volumic; (hidr) modul de compresibilitate bulk motion (mec, TH) mişcare a sistemului / a întregului în ansamblu

bulk oil (alim, ind chim, ec) ulei vărsat / neambalat bulk plant depozit de produse petroliere / petrol

bulk polymerization (chim) polimerizare în bloc

bulk production $(\mathrm{TH}, \mathrm{ec})$ producție de masă

bulk specific gravity (fiz) greutate specifică aparentă / în grămadă

bulk storage depozitare în vrac / în grămadă

bulk temperature (materiale, fiz) temperatură (în miez) a materialului, temperatura (medie) a masei de substanță

bulk test probă de volum

bulk transportation transport al produselor în $\mathrm{vrac} /$ neambalate

bulk up (materiale) a crește în volum, a se umfla (din cauza umidității, temperaturii sau a unor reacții, şi nedorite)

bulk volume volum total / aparent

bulk weight (fiz) masă specifica în vrac, densitate în grămadă

bulky masiv, voluminos, pufos; greoi

bulky goods marfă voluminoasă

bull (zool, agr) taur, bivol; (ec) speculant la bursă, a se ridica (d. valori), a specula ridicarea valorilor (la bursă); detectiv

bullate poros (d. materiale)

bull bit (mas-un) burghiu lat

bull block (mas-un) maşină de trefilat, filieră de trefilare

bulldozer (constr, mas) buldozer, excavator de nivelat teren; (mas-un) presă de îndoit

bulldozer shovel (constr, mas) autoîncărcător cu cupe

bullet (mil) glont, cartus

bullet headed (OM) cu cap rotund / oval / ca de glonț

bulletin buletin (şi de ştiri)

bullet-proof (mil) rezistent la glonț, blindat

bulletin buletin, fasciculă

bullhead (met) primul calibru (la laminare)

bullhead rail (met, cf) sină cu două coroane

bullion aur sau argint în stare nativă; lingou de aur sau argint; panglică, dantelă, ciucure (din aur / argint sau aurii / argintii)

bullion reserve (met) rezervă metalică

bullish (ca) de taur; (ec) cu tendință urcătoare (la bursă); încăpățânat, îndărătnic

bull landle (met) oală de macara pentru turnare

bull market (ec) piață în urcare

bull-nose tool (mas-un) cuțit normal / de strunjit exterior longitudinal

bull plate (chim) gât al balonului / retortei (de sticlă) 
bull purchase (ec) cumpărare fără acoperire bull ring (el, OM) inel de întindere (la cablu) bull screen (mas-un) prinzător de aşchii bull's eye (nav) hublou, ferestruică rotundă / ovală; (auto) ochi de pisică, reflector din spate; (TH) nod în sticlă; (fiz) lupă

bull's-foot file pilă-disc mică

bulltrout (alim, ht) păstrăv european

bull wheel $(\mathrm{OM})$ roată de transmisie / de întoarcere; (mas-un) roată dințată de antrenare a mesei (la raboteze)

bull wheel brake band $(\mathrm{OM})$ bandă de frână (care acționează pe o roată)

bull wheel brake lever $(\mathrm{OM})$ pârghie de frână cu tambur

bully (alim) conserve de carne de vacă; a intimida; a nu lăsa în pace; a brusca

bulrush trestie, papură

bulwark (constr) zid, val, a întări cu un zid; dig, zăgaz; (nav) parapet, sparge-val

bump ciocnire, lovitură, izbitură, umflătură protuberanţă, curbură, convexitate, proeminență (de piesă, de teren etc.), ieşitură; accident de teren; (auto) şoc, hop, lovitură, izbitură umflătură, a lovi, a izbi; $(a d v)$ brusc, pe neaşteptate

bump against a se ciocni de, a se izbi de

bumped head (OM, hidr) calotă sferică a rezervorului / recipientului

bumper (alim) pahar plin, a umple paharul (până sus); (auto, OM) bară / stâlp de protecție, amortizor, tampon; (persoană sau obiect) neobișnuit de mare; record

bumpily $(\mathrm{a} d \mathrm{v})$ cu smucituri

bumpiness caracter accidentat (al terenului, cu hopuri

bumping (auto, mec) clocotire, tamponare

"bumping" collision (mec) ciocnire elastică

bumping table masă vibratoare / oscilantă

bumpless transfer (el) comutare / transfer fără şocuri

bumps teren accidentat, hârtoape

bumpy cu hopuri / hârtoape (d. drum)

buna (plast) marcă de cauciuc sintetic

bunch mănunchi, grup, grămadă, legătură; ciorchine (şi de struguri), buchet; (el) mănunchi / manşon de cabluri; (fiz) grup, cuib, nor, roi; (met) colac de sârmă, balot; a (se) strânge, a (se) înmănunchia, a lega, a aduna

bunched cable (el,OM) cablu torsadat

buncher (agr, mas) maşină de format şi transportat baloți de paie sau căpițe

bunching (agr) semănat în cuiburi

bunch onion (agr, alim) ceapă verde bunch planting (cf, auto) tren de vehicule bunch together a înmănunchia, a lega împreună bunchy care creşte în mănunchi(uri); ieşit în afară, umflat; cocoşat (şi la lanțuri moleculare, fiere etc.)

bundle ghem, colac (şi de sârmă), buclă, legătură, fascicul, mănunchi, maldăr, snop, balot, pachet, legătură; (fiz) fascicul, grup; sul, val (şi de hârtie); a lega, a înmănunchia, a focaliza, a concentra, a face balot; a se grăbi; boccea; a strânge într-o legătură; a arunca de-a valma, a îngrămădi laolaltă; a expedia, a trimite rapid; a pleca

bundled scrap (met) deșeuri de fier vechi presate în pachete / baloturi

bundle holder $(\mathrm{OM})$ inel de susținere

bundle of fibers (materiale) mănunchi / legătură de fibre / molecule (la polimeri)

bundle of planes (mat) fascicul de plane

bundle of stampings (el) pachete de tole

bundle of tubes (termo, nav) fascicul / mănunchi de țevi

bundle press (mas-un, met) presă de legat pachete (şi pentru deşeuri de fier vechi)

bundle up a strânge laolaltă

bundling legare, balotare; (fiz) concentrare, focalizare

bung $(\mathrm{OM})$ obturator, dop, cep, vană

bungalow (constr) casă cu verandă (la parter)

bunghole $(\mathrm{OM})$ cep, vană

bunker (TH) buncăr, rezervor, recipient, siloz, rezervor de colectare; a umple un rezervor, a alimenta cu combustibil

bunker fuel / oil (termo) combustibil pentru cazane

bunt (nav) burta pânzei, baza vergii; împunsătură, lovitură (cu capul sau cu coarnele); a împunge, a lovi (cu capul sau cu coarnele)

buoy (nav) geamandură, baliză, centură de salvare, a baliza, a menține la suprafață; (fig) a susține, a înviora, a sprijini, a remonta

buoyage (nav) balizare

buoyancy (mec, hidr) forță ascensională / arhimedică / portantă; (nav) flotabilitate, plutire, emersiune, volum de carenă

buoyancy (buoyant) box (nav) cheson etanş de barcă / plutitor

buoyancy level indicator (OM, hidr) indicator de nivel cu flotor

buoyancy tank (nav) cheson etanş de barcă

buoyant (nav) plutitor, flotabil; (ec) în urcare (d. valori de bursă)

buoyant force (fiz) forță ascensională, portanță; (hidr, nav) forță de plutire / de imersiune 
buoyant lift (fiz) forță ascensională buoyant suit (nav) costum de salvare buoy boat (nav) navă de balizaj, balizor buoy rope (nav) gripie, saulă de geamandură bur (biol) ghimpe, țep, scai(ete); belea, pacoste burble point (fiz, met) punct de separație / de tranziţie

burden povară; răspundere; (el, metr) sarcină; (mec) sarcină, greutate, încărcare; (met) şarjă, încărcătură, material de încărcare, pat de fuziune, a umple, a încărca, a alimenta, a îngreuna, a încărca furnalul; a împovăra; a asupri

burden calculation (met) calculare a compoziției încărcăturii la furnal

burdening (auto, cf) încărcare, îngreunare; (met) alcătuirea / dozarea şarjei, încărcare a furnalului

burden of an instrument (el, metr) sarcină totală a unui instrument (volt-amperi consumați în condiții normale de lucru / tensiune şi intensitate a curentului)

burden of proof (el, jur) obligație de a face dovada

burden preparation (met) dozare a şarjei

burden removing (met) îndepărtare a sarcinii sau a rocii nefolositoare

burden yield (met) fontă rezultată din furnal, la o şarjă (în procente)

bureau, $(p l)$ bureaux birou, masă de lucru, oficiu, departament, secție (nu tehnologică)

bureaucracy birocratism, birocrație, birocrați

bureaucrat birocrat

bureaucratic birocratic

bureaucratism birocratism, birocrație

burette (chim) biuretă

burglar alarm (autom) automat de alarmă

burgy (met) cărbune mărunt

buried îngropat (şi în pământ), cufundat, înecat

buried line / pipework (constr, hidr) conductă îngropată

buried tank (constr, hidr) rezervor îngropat / subteran

buried wiring (el, constr) instalație sub tencuială

burl excrescență, nod (textile); a alege, a tria, a scoate defecte / noduri din

burlap (textile) pânză groasă de sac / de ambalaj

burless cut (mas-un, TH) tăietură netedă

burn a pune pe foc, a (se) arde; (alim) a arde (mâncarea), a afuma, a ustura; (met) a arde, a prăji, a calcina; (chim) a oxida; a fi aprins, a fi în flăcări; a dogori, a fi încins; arsură

burnable (met, termo) inflamabil, care (poate) arde

burn away a arde, a distruge prin foc

burn down a arde până la temelii, a distruge prin foc burned (met) ars, supraîncălzit

burned fire clay (met) şamotă

burner (met, termo) arzător (şi la sudură), duză de injecție, muncitor de la cuptor

burner brick (met, termo, ind chim) cărămidă pentru arzătoare

burner head / mouth (termo) duză / ajutaj de ardere / pentru arzător

burner jet (termo) ajutaj pentru arzător, jiclor al arzătorului de injecție

burner nozzle (met) bec de sudură, suflai; (termo) ajutaj / duză de arzător

burner orifice (met, OM) orificiu al becului de sudură

burner pliers (met) cleşte de arzător

burner tip (met) bec / cap de sudură (cu flacără)

burner tube (met) tijă a arzătorului de sudură

burner with nonvariable head (met) arzător simplu de sudură (fără posibilități de reglarea)

burning incendiu; de ardere, care arde, incandescent; fierbinte; (met, chim) ardere, calcinare, prăjire, supratopire (la laminare), arsură (la sudare), călire; (chim) oxidare

burning at sharp fire (termo) ardere $\mathrm{cu}$ foc în plin

burning atmosphere (met) atmosferă care favorizează arderea

burning crevices (met) crăpături de ardere

burning cycle (met, termo) ciclu de ardere

burning gases (met) gaze arse / de ardere

burning hour timp de ardere (aici în ore)

burning kiln (met, ind chim) cuptor de calcinare / de ardere / de prăjire

burning of rubber (ind chim) arderea cauciucului

burning of the surface (met) arsură de suprafață (la sudură)

burning of the vale (auto) arderea supapelor

burning oil (ind chim) păcură, petrol lampant

burning-out (met, ind chim) ardere (şi completă), calcinare; (el) ardere (a unui transformator)

burning oven (met) cuptor de ardere / de calcinare / de prăjire

burning point $(\mathrm{TH})$ temperatură de aprindere / de inflamabilitate; focar (şi de incendiu); (met) temperatură de ardere

burning range (met, ind chim) interval de ardere / de calcinare

burning rate (met, ind chim, termo) viteză de ardere

burning schedule (termo) diagramă de ardere

burning shrinkage (met) contracție la foc

burning space (met, ind chim) spațiu de ardere / de calcinare 
burning temperature (met, ind chim) temperatură de ardere / de calcinare

burning test (chim, met) determinare a timpului de ardere / de calcinare

burning time (met, chim) timp de ardere / de calcinare

burning zone (met, termo, ind chim) zonă de ardere

burnish lustru, strălucire; (met) a bruna (oțelul), a poliza, a finisa (prin şlefuire), a (se) şlefui, a (se) lustrui

burnished steel (met) oțel brunat

burnisher (mas-un) pilă extrafină pentru suprafețe din oțel, lustruitor, polizor, şlefuitor

burnishing $(\mathrm{TH})$ poleire, acoperire bine finisată, superfinisare, lustruire, şlefuire

burnishing by rigid adjustable ball-type trols (mas-un) finisare prin roluire cu dispozitive rigide şi reglabile cu bile

burnishing by rigid run-adjustable with cylindrical roller (mas-un) finisare prin roluire cu role cilindrice rigide, nereglabile

burnishing by spring action single (or multi) ball action (mas-un) finisare prin roluire cu bilă (bile) acționată(e) prin arc(uri)

burnishing by vibrating spring action trols finisare prin dispozitive vibratorii cu arc

burnishing powder (mas-un) pulbere de şlefuit / de lustruit

burnishing tool (mas-un) sculă de polizat

burnishing wheel (mas-un) disc de lustruit

burn off a calcina, a prăji (şi minereu)

burn out a (se) arde complet; (el) a arde, a străpunge; (auto, el) a se arde (şi d. un bec)

burnt ars

burnt brick (constr, met) cărămidă arsă

burnt deposit (met) depunere / depozit ars(ă)

burnt gas (met, termo, chim) gaz de ardere

burn through străpungere, a străpunge (din cauza arderii / temperaturii ridicate)

burn together (chim, met) a cocsifica, a aglutina

burnt iron (met) otel ars / supraîncălzit

burnt plaster (chim) ipsos

burnt products $(\mathrm{TH}$, met) produse arse

burntout (met) străpungere (la sudură)

burnt rubber (chim) cauciuc ars

burnt steel (met) oțel ars

burnt-trough from one side (met) punct de sudură parțial străpuns

burnt-trough weld (met) punct de sudură străpuns

burn up a arde complet

burn-up factor (termo, ind chim) factor de consum (prin ardere) burr (mas-un) bavură de la găurit sau altă operație de aşchiere; (met) probă de perforare, bavură de laminare; (met) a bordura, a debavura

burr gauge (mas-un, metr) calibru-placă pentru măsurat burghie mici

burring (met) debavurare

burring chisel (mas-un) daltă pentru debavurare

burring reamer (mas-un) alezor cu debavurare, alezor pentru prelucrarea finală a găurilor, freză tubulară

burr removing machine (met, mas-un) maşină de debavurat

burrow (met) haldă; a scobi, a fora

bursary casă; trezorerie; bursă (Scoția)

burse pungă, portofel; bursă (Scoția)

burst rupere, ruptură, spargere, aruncare în aer, tensionare; izbucnire, avânt; apariție, ivire bruscă; (chim) explozie, deflagrație; a rupe, a izbucni, a exploda; a crăpa, a plesni, a se desface; a arunca în aer, a face să explodeze; a distruge

burst element (hidr) element (şi filtrant) spart / deteriorat din cauza presiunii diferenţiale

burster care aruncă ceva în aer; exploziv, încărcătură explozivă

burst forth a izbucni, a țâşni

burst forth into a izbucni în, a începe

bursting explozie, izbucnire; plesnire, crăpare, rupere; exploziv; pe punctul de a plesni / izbucni / crăpa

bursting plate membrană de explozie, placă de siguranță

bursting pressure $(\mathrm{mec})$ presiune de plesnire, presiune interioară / internă de rupere / de explodare

bursting resistance (hidr, med, ind chim) rezistență la plesnire / la presiune interioară (şi la recipiente)

bursting shell (mil) obuz brizant

bursting strain (mec) deformare la plesnire (şi d. recipiente)

bursting strength (mec) rezistență la plesnire

bursting strength test (metr, materiale) test / probă / încercare a rezistenței la plesnire

bursting surface (mec, hidr) suprafață de spargere / de rupere sub presiune (la recipiente)

bursting test încercare / test cu presiune statică interioară

burst interval (TH, mil) rază de explozie

burst into a izbucni în, a începe

burst in upon a da buzna peste cineva

burst off (constr, plast) a se coşcovi, a se coji, a se scoroji 
burst open a (se) deschide brusc, a face să sară (broasca uşii, un capac etc.), a plesni, a forța (şi o uşă)

burst out a izbucni (d. război, plâns etc.)

burst pressure (hidr, mec) presiune de plesnire / de spargere (a învelişului unui element hidraulic, recipient etc.), presiune interioară / internă de rupere / de explodare

burst-up (ec) ruină, crah, faliment

bust upon a se ivi pe neaşteptate

burton (nav) palanc simplu

bus (auto) autobuz

bus-bar (el) bară colectoare

bus-bar coupling / tie (el) cuplaj transversal între colectoare

bush (el) bucşă izolatoare, fişă; (OM, T) bucşă, cuzinet, mufă, cutie, ştuţ de țeavă; (mas) a trefila; a aplica o bucşă sau un cuzinet

bush a bearing $(\mathrm{OM}, \mathrm{T})$ a aplica un material de cuzinet, a bucşa un lagăr (prin diferite tehnologii: turnare, presare etc.)

bush-bearing $(\mathrm{OM}, \mathrm{T})$ lagăr monobloc / tip bucşă masivă

bushed bearing $(\mathrm{OM}, \mathrm{T})$ lagăr cu cuzinet (de obicei din alt material decât suportul)

bushel (metr) buşel, 1 busel = 36,36 1 (Marea Britanie); 1 busel = 35,24 1 (SUA)

bushing (OM, T) bucșă, lagăr, cuzinet, manșon, mufă, reducție; (mas-un) bucşă de găurit; (el) bucşă izolatoare, izolator de intrare / de trecere

bushing chain (OM) lanț cu plăcuțe articulate şi bucşe

bushing guide $(\mathrm{OM})$ bucşă de ghidare

bushing / lead-in insulator (el) izolator de intrare

bushing metal (met, T) metal (mai rar) aliaj pentru cuzineți (şi tip babbit)

bushing stone $(\mathrm{OM})$ piatră cuzinet (în mecanica fină)

bushing terminal strip (el, OM) regletă de bucşe / de borne

bush neck $(\mathrm{OM})$ bucşă fixă pentru strângerea garniturii

busiest hour oră de încărcare maximă / supraaglomerată

busily $(a d v)$ preocupat, aferat

business (ec) ocupație, afacere, firmă, magazin, întreprindere, activitate / tranzacție comercială, comerț; chestiune, problemă; profesie, meserie; treabă, datorie, obligație

business at issue chestiune în discuție

business computer $(\mathrm{c}, \mathrm{ec})$ calculator comercial pentru firmă business data processing (ec, inf) informatică de gestiune

business end of tool (mas-un) capăt de lucru al cutitului / al sculei

business executives (ec) personal de conducere

business expansion (ec) dezvoltare a unei afaceri / activități economice

business failure (ec) eşec comercial, faliment

business forecasting (ec) prognoză comercială / economică

business hours ore de lucru, program în birouri şi magazine, ore când magazinele sunt deschise

business interests (ec) interese de afaceri

business like de afaceri (scrisori etc.); practic; metodic, calculat, precis; expeditiv

business logistics $(\mathrm{ec})$ logistică de întreprindere, aplicare a metodelor matematice şi statistice tuturor activităților din întreprindere

businessman (ec) comerciant, negustor, om de afaceri, afacerist

business manager (ec) director / manager (comercial)

business plan $(\mathrm{ec})$ schemă de organizare a unei activități de producție, servicii, desfacere, plan de afaceri

business premises $(\mathrm{ec})$ premise de afaceri

business prospects (ec) perspective în comerț / afaceri

business quarters (ec) sediu comercial / de afaceri bust a sări în aer; (ec) a da faliment; a se face praf; a muri; ceartă

bustard (zool) dropie

bustle pipe (termo) conductă inelară

busy harnic, activ; ocupat (şi d. telefon), prins cu; activat; agitat; aglomerat; plin, încărcat (d. program); greu; plictisitor, sâcâitor, insistent; a da de lucru cuiva

busy-back tone semnal de ocupat (şi la telefon)

busy-flash signal semnal optic "ocupat"

busying (ec) angajare de personal

busy tone ton de "ocupat" (la telefon)

but dar, însă, ci, şi, totuşi, cu toate acestea; fără să, decât, ca să nu; fără a, fără să; că

butadiene rubber (plast) cauciuc butadienic

butane (chim) butan

butcher (alim) măcelar; lucrător prost, cârpaci; a înjunghia, a tăia (animale); a face de mântuială

butcher's stall (alim) măcelărie

butchery (alim) abator, măcelărie

buten, butylen (chim) butilenă

but for fără; dacă n-ar fi (la mijloc)

butt (constr) bandă metalică de închidere a uşilor sau a ferestrelor prin culisare, țâțană, balama; (OM) încheietură, joantă, îmbinare, capăt gros 
(al unei piese); țintă, scop; (metr) butoi cu o capacitate de 490,96 litri; (met) capătul de jos / de picior al lingoului, a îmbina cap-la-cap (prin sudare); a împunge; a se proiecta / a ieşi în afară butt against into a se lovi de, a se izbi de butt and lap joint $(\mathrm{OM})$ îmbinare lipită în trepte butted $(\mathrm{OM})$ îmbinat cap-la-cap (şi prin sudură) butt end final, sfârşit; parte principală, esenţă butter (alim) unt butterball (alim) gogoloş de unt butter-beating / churning (alim) batere a untului butter churn (alim) putinei (de unt)

butter dairy (alim) untărie, secție / atelier de produs untul

butterfly $(\mathrm{OM}$, hidr) fluture, clapetă (în special la robinete, piulițe)

butterfly bolt (OM) şurub cu cap fluture butterfly cock (OM, hidr) robinet fluture / cu clapă

butterfly damper (termo) clapetă de fum butterfly gate $(\mathrm{OM})$ închizător cu clapetă butterfly nut $(\mathrm{OM})$ piuliță-fluture

butterfly screw (OM) şurub cu cap-fluture butterfly throttle (OM, hidr) robinet / clapetăfluture

butterfly valve (OM, hidr) robinet / supapă / ventil / drosel-fluture

butterine (alim) margarină

buttering (met) încărcare a marginilor de sudat cu metal intermediar

butter kneading machine (alim) malaxor de unt butter knife (alim) cuțit pentru unt

buttering (met) încărcarea marginilor cu metal intermediar (diferit de cel de bază şi cel de adaos)

buttermilk (alim) zer, janț, lapte bătut

buttery de unt, untos; (edu) cantină, cămară (la universități)

buttery texture (T) textură untoasă (şi de. unsori) but that ca să nu, încât; că; dacă nu butting $(\mathrm{OM})$ îmbinare cap-la-cap (şi prin sudare) butt ingot (met) capăt de lingou, lingou scurt butting ring (el, mas) inel de pornire butt into a se ciocni / a se izbi de butt joining $(\mathrm{OM})$ îmbinare / înnădire cap-la-cap butt joint (OM) îmbinare / asamblare cap-la-cap (şi prin sudare, lipire), îmbinare la capete butt-joint riveting $(\mathrm{OM})$ nituire cu eclise butt-jointed seam $(\mathrm{OM}$, met) cusătură / sudură cap-la-cap

butt-muff coupling $(\mathrm{OM})$ cuplaj cu manşon

button nasture, a coase nasturi, a încheia (cu) nasturi; $(\mathrm{OM})$ buton, pastilă; (met) relief (la cusătura de sudură) button-control comandă prin butoane

buttoned cu nasturi

button filter filtru cu butoane / pastile

buttonhole (textile) butonieră

button press (mas, OM) buton

button rope conveyor (mas) transportor $\mathrm{cu}$ cabluri şi discuri

button spot weld (met, el) sudare electrică prin puncte prin rezistență

button switch (el) întrerupător cu buton, butonîntrerupător

button welding (met) sudare prin / în puncte

butt pocket nişă

butt out a se proiecta / a ieși în afară

buttress (constr) sprijin, contrafort; proptea; a sprijini, a susține, a propti (și fig)

buttress-(type) thread (OM) filet trapezoidal sau ferăstrău

butts $(\mathrm{TH}$, mediu) reziduuri

butt seam weld (met, OM) sudură cap-la-cap

butt strap $(\mathrm{OM})$ eclisă de îmbinare (şi cap-lacap)

butt weld (met, OM) sudură / cusătură cap-lacap

butt-welded (met, OM) sudat cap-la-cap

butt-welded joint (met, OM) îmbinare sudată cap-la-cap

butt-welded tube (OM, met, hidr) țeavă cu sudură cap-la-cap

butt-welder / welding machine (mas-un, met) maşină de sudat cap-la-cap

butt-welding (met) sudare cap-la-cap

butt welding with cover plates (met) sudare cap-la-cap cu eclisă / eclise

butyl (chim) butil

butyl rubber (IIR) (plast) cauciuc butilic

butyracious uleios, onctuos, untos, unsuros

butyric acid (chim) acid butiric

buy a cumpăra, a face cumpărături; a mitui, a corupe; cumpărătură

buy back $(\mathrm{ec})$ cumpărare de produse rezultate de către furnizorul de echipamente / tehnologie, operație comercială care obligă pe exporttatorul de echipamente să importe de la beneficiar produse realizate cu echipamentul respectiv; a răscumpăra

buy by auction (ec) a cumpăra la licitație

buy for future delivery (ec) a cumpăra la termen

buy in (ec) a acapara, a cumpăra toată cantitatea / în cantităti mari; a face provizii; a achiziționa (la bursă)

buy in bulk (ec) a cumpăra în cantități mari buying capacity $(\mathrm{ec})$ putere de cumpărare 
buy off a cumpăra, a mitui

buy on the installment plan $(\mathrm{ec})$ a cumpăra $\mathrm{cu}$ plata în rate

buyer cumpărător

buy out (ec) a cumpăra toată cantitatea

buy outright / for cash (ec) a cumpăra cu bani gheață / cu plata în numerar

buy up (ec) a acapara, a cumpăra masiv / toată cantitatea

buy wholesale (ec) a cumpăra cu ridicata / en gros

buzz bâzâit, zumzet, (h)uruit; zvon; a bâzâi; a zumzăi; a (h)urui; (TH) a scoate un sunet de avertizare

buzzer claxon (el, TH) buzzer, vibrator întrerupător periodic; avertizor sonor intermitent

buzzing noise (fiz, el) zgomot de fond / de rețea

by (chiar) lângă, foarte aproape de, alături de, în imediata vecinătate a, în preajma; pe lângă, pe la, prin; cu, pe, până (la), până cel mai târziu, nu mai târziu de; în timpul; la; cu, de; câte; după; de la; din; de (către); în; prin mijlocirea / intermediul (cuiva), cu ajutorul; ( $a d v$ ) alături, aproape, în (imediata) apropiere, de / la o parte

by-and-by viitor

by blending alone (T) (numai) prin amestecare simplă

by blending of fluid lubricant components alone $(\mathrm{T})$ prin simpla amestecare a componenților unui lubrifiant

by-blow accident, întâmplare, caz neprevăzut

by-channel (hidr) canal lateral

by-computation prin calcul

bye ceva întâmplător sau auxiliar; secundar; accesoriu; îndepărtat

by-end interes special

by far (cu) mult; de departe

by-groups pe grup, în grupuri

by-jerks (TH) prin şocuri

by-law statut local; (jur) decizie / hotărâre a organelor locale, dispoziție executivă

by means of cu ajutorul

by one touch (auto) la / cu fiecare apăsare

by-pass ocolire, ocol, drum ocolit, canal de scurgere derivat / secundar; (el) şunt, derivație, ramificație; (hidr, OM) tronson secundar de conductă, sector de ocolire în acționări hidraulice, canal de scăpare, canal de transvazare, supapă de branşare, derivație (de țevi); a înconjura, a împrejmui; a ocoli, a evita; (el) a șunta; (hidr) a tranzita debitul

by(-)pass $(\mathrm{TH})$ canal de derivație; drum lateral; (autom) derivație, a ocoli; a înconjura; (mil) a încercui; a împresura by-pass carry (el) transmisie ocolită / de şuntare / cu buclă

by-pass clack valve (OM, hidr) robinet cu clapetă în conductă de ocolire

by-pass cock (OM, hidr) robinet / supapă / conductă de ocolire, de reglare

by-pass conduct / conduit (OM, hidr) conductă de golire

by-pass connection (el) montaj de şuntare

by-pass damper (OM, hidr) regulator de curgere / de debit a(l) aerului (montat pe o conductă de scurtcircuitare)

by-pass discharge path (el) traiect / traseu / circuit de descărcare în derivație

by-pass factor raport / factor / raport de scurtcircuitare (şi în condiționarea aerului)

by(-)pass flow control valve (hidr, OM) regulator de debit cu derivație

by-passing ocolire, înconjurare; (hidr) derivație, by-pass, ocolire

by-pass line / pipe (OM, hidr) teavă în derivatie, conductă de trecere / de ocolire / de scăpare, by-pass

by-pass stop valve $(\mathrm{OM}$, hidr) robinet / supapă de rezervă într-un sistem de ocolire

by-pass switch (el) întrerupător / comutator pentru ocolire / pentru şuntare

by-pass system (el) sistem ocolitor / cu căi ocolitoare, sistem inelar

by-pass valve (OM, hidr) supapă de derivație, robinet, supapă de circulație / de deviere

by-path (el, autom) derivație, şunt, utilizare de linii secundare / indirecte

by-product circuit (el) circuit suprapus / virtual; circuit al produselor secundare / auxiliare

by-product coke-oven gas (met) gaz de cocserie (ca produs secundar la cocserie)

by-product oven (coking) (met, termo) cuptor (de încălzire) cu cameră

by-product reziduu, produs secundar / auxiliar, derivat

by-production productie anexă / auxiliară

by reason of datorită, în virtutea, din cauza

by reflected light (fiz) în lumină reflectată

by-stages în etape, în trepte, discontinuu

bystander spectator, martor

by-steps discontinuu, în trepte

byte (character) (c, inf) octet / secvență de biți, considerată unitate, vector binar cu opt componente

by the head (nav) aprovat

by the naked eye cu ochiul liber

by the stern (nav) apupat (de. navă); cu pupa

by-voltage (el) tensiune într-un circuit de derivatie 


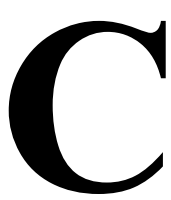

CA $(\mathrm{TH})$ prescurtare de la atmosferă controlată CA, CCA (metr) abrevieri pentru ,cranking amps" - curentul furnizat de baterie la pornirea autovehicolului la $0{ }^{\circ} \mathrm{C}$ şi ,cold cranking amps" - curentul furnizat de baterie la pornirea autovehiocolului la $-17,8{ }^{\circ} \mathrm{C}$, unități înscrise pe bateria autovehicolului în US

cab (auto) taxi, cabină (a şoferului), a lua un taxi; (metr) unitate de măsură pentru volum / capacitate: $1 \mathrm{cab}($ Biblical $)=1,2222221631$

cabbage (agr, alim) varză (de iarnă), căpățână de varză, (mâncare de) varză; a comprima; deşeuri (şi pentru retopire, de la croire); a fura cabbage butterfly (alim, zool) fluture de varză cabbage head (alim) căpățână de varză

cabbage lettuce (alim) lăptuci

cabbaging press (mas-un, mediu) presă pentru comprimat deşeuri

cab floor sfârşit de cursă la ascensoare

cab guard (auto) protecție de cabină

cabin (constr) casă simplă, baracă, gheretă, cabină; (nav) cabină; a înghesui (într-un spațiu mic)

cabin class (nav) clasa a doua

cabined prevăzut cu cabine; înghesuit, ticsit; lapidar, concis

cabinet cabinet (de lucru), cameră, birou; casetă cutie (şi de radio); vitrină; dulap; (pol) cabinet, guvern

cabinet base (mas-un) picior / dulăpior al batiului

cabinet council (pol) consiliu de miniştri

cabinet dryer (TH, alim) etuvă, cameră de uscare

cabinet file (mas-un) pilă semirotundă cu vârf ascutit

cabinet maker tâmplar de mobilă fină, ebenist

Cabinet Minister (pol) ministru plin

cabinet shell cabinet / incintă separată de restul spațiului prin pereți, perete despărțitor al unui cabinet

cabinet work birou / cameră de lucru; tâmplărie de mobilă fină

cabin room interior al cabinei (de ascensor, de macara)

cable (nav) lanț / cablu de ancoră, cablu subțire (şi submarin), ancablură (=185 $\mathrm{m}$ în $\mathrm{UK}$, = 219 m în US); (TH) cablu, frânghie, funie (groasă), odgon, parâmă, cablu de oțel; a cabla, a răsuci mai multe fire, a fixa cu un cablu; a telegrafia; cablogramă, telegramă

cable amplifier (el) amplificator de cablu

cable armature (el) armătură de cablu

cable armouring machine (el, mas-un) maşină de armat cabluri

cable assembly (el) un cablu (de racordare / de legătură) complet, inclusiv piese / componente terminale

cable bearer / bracket (el, OM) suport / consolă pentru cablu(ri), port-cablu

cable bent (mec, el) săgeată a cablului

cable bond legătură de cabluri

cable box (el) cutie / mufă de cablu

cable bracket (el) suport / consolă pentru cabluri, poliță de susținere pentru cabluri cable braiding (el) împletire a învelişului cablului

cable break (el, mec) rupere a cablului

cable buoy (nav) geamandură de cablu submarin cable car cărucior pe cablu, (cabină de) funicular cable cellar (el, ind, constr) subsol pentru cabluri cable channel (el, constr) canal de cabluri cable chute (el, met) puț de cablu / de cabluri cable clamp / clamping (el, OM) clemă / brățară / şarnier de cablu, clemă de legături electrice la conductoare, clemă de strângere (a unui cablu) cable clamping (el, OM) clemă de cablu, acțiunea de prindere a cablului

cable clench (nav) cârlig de puț

cable climp (el) bornă de cablu

cable clip (el) papuc / clemă / brățară de cablu

cable compound (el) (masă) compozit(ă) pentru cablu

cable conductor (el) conductor de cablu

cable conduit (el, hidr, met, constr) canal / galerie pentru cabluri

cable-connecting (el) joncțiune de cablu cable conveyor transportor $\mathrm{cu} / \mathrm{pe}$ cablu cable-cord fabrics tesătură cord (pentru cabluri) cable core (el) inimă / conductor de cablu cable core binder (el) rețea sau învelişuri pentru un cablu cu mai mulți conductori (diferit de cel exterior)

cable covering (el, plast) manta (de etanșare / de izolare) a cablului

cable crane macara funiculară

cable-distribution pillar (el) dulap distribuitor de cabluri

cable drag scraper (nav, mas) racletă / răzuitor / curățitor / screper (foarte rar) acționat prin cablu cable drawing-in (el, constr) tragerea cablurilor / conductoarelor

cable draw pit (met) cămin / puț de vizitare pentru canale de cabluri electrice 
cable dragline / drag(er) (constr, mas) excavator cu cablu, draglină

cable drive $(\mathrm{OM})$ transmisie prin cablu cable-driven car (met, ind) cărucior cu acționare prin cablu

cable drum (mas) tambur / tobă de troliu cu cablu cable duct (constr) conductă de cabluri, canalizare pentru tragerea cablurilor

cable-end connector (el) manşon terminal de cablu cable eye (el) papuc / ochi de cablu cable fan (el) cap de cablu cu fire răsfrânte

cable filler (el, plast) material pentru umplerea cablului / a golurilor la cabluri cu mai mulți conductori

cable filling yarn (el, met) inimă de cablu (şi din mai multe fire)

cable gland (el, plast) garnitură de etanşare a unui cablu

cable-hauled bucket (nav) benă cu / pe cablu (la o dragă)

cable hoist troliu

cable hut (el, met, constr, ind) cămin de vizitare a cablurilor

cable-jacket / -sheathing alloy (met, el) aliaj pentru mantaua de protecție a cablului

cable joint (el) joncțiune de cablu, loc de lipire a cablului

cable laying (el) întindere / instalare / pozare a cablului

cable lay-up (el) cablaj, torsiune a cablului, pas al elicei de cablaj

cable lead-in (el) intrare în cablu

cable loop (el) buclă de cablu

cable lug (el, OM) papuc / bornă de cablu

cable marking (nav) marcare a cablului / a lanțului de ancoră

cable network (el) fascicul de cabluri la instalațiile electrice / rețea de cabluri

cable of bead (auto) inserție de cablu de sârmă / metalică (şi la pneuri)

cable-operated (mec, el) acționat cu / prin cablu cable-protecting tube $(\mathrm{OM})$ tub / manşon de protecție a cablului

cable railway funicular, teleferic

cable reel (el, OM) tambur de cablu

cable ring (el, OM) inel-suport al cablului

cable scraper (nav) racletă / răzuitor / curățitor / screper (foarte rar)

cable shaft (el, met, constr, OM) cămin / gură de vizitare pentru cabluri

cable sheathing (el, plast) mantaua cablului

cable shielding clamp (el, electr) accesoriu / suport de cablu pentru ecranarea câmpului electric al conductorului, la conector cable shoe / socket (el) papuc de cablu

cable sleeve (el) manşon de cablu

cable's length (nav) cheie de lant; (nav, metr) lungime de cablu $(0,1$ din mila marină sau $185,2 \mathrm{~m})$

cable splice (nav) matiseală de parâmă; $(\mathrm{TH})$ înnădire / îmbinare / matisare a cablului

cable stopper (nav) boț al lanțului de ancoră, boț de parâmă

cable strand (el) toron de cablu

cable-stranding machine (mas-un) mașină / dispozitiv de cablat / de torsadat / de împletit izolația pe cabluri

cable strap (el, OM) colier pentru cabluri

cable transmission $(\mathrm{OM})$ transmisie $\mathrm{cu} /$ prin cabluri

cable twist (răsucire de) cablare

cableway funicular, teleferic; (constr) macarafunicular; (el) galerie / canal pentru cabluri

cable wheel $(\mathrm{OM})$ tobă de înfăşurare pentru cablu cable works fabrică de frânghii / cabluri

cabling (TH) cablare, răsucire a mai multor fire

cabling diagram (el) schemă de cablaj / de montaj

caboose (nav) cambuză; bucătărie; (amer) (cf) vagon de serviciu

cab-switch (el) releu de etaj (şi la ascensoare)

cabtyre cable (el, plast) cablu flexibil, izolat în cauciuc

cacao (agr, alim) (arbore de) cacao (boabe sau băutură)

cacao butter (alim) unt de cacao

cacao oil (alim) ulei de cacao

cachalot (zool) caşalot

cache depozit (secret); arhivă de date

cache memory (c) memorie rapidă, plasată între memoria principală și procesor

cachet semn de autenticitate / distinctiv; caşetă

CAD (computer aided design) (OM, inf, c) proiectare asistată de calculator

cadastral cadastral

cadence cadentă; ritm; modulație

cade oil (chim) ulei de ienupăr

cadmia (met) crustă solidificată de zinc, cadmie

cadmiated steel (met) oțel cadmiat / aliat cu cadmiu

Cadmium (Cd) (chim) cadmiu

cadmium plating (el, chim, TH) electro-depunere cu cadmiu, cadmiere, acoperire cu cadmiu cadwelding (met) sudare cu termit (folosind oxidul de cupru în loc de oxid de fier)

Caesium / Cesium (Cs) (chim) cesiu

café ceainărie (UK), restaurant mic (fără băuturi alcoolice); restaurant, bar; cafenea, cafea 
caffeine (alim, chim) cofeină, 1-3-7-trimetilxantină cage $(\mathrm{OM})$ colivie (şi de rulment), cuşcă, carcasă, corp, tambur perforat (la centrifugă); (met) cajă; cabină (de lift); a băga într-o colivie / cuscă

cage bore $(\mathrm{OM})$ alezaj al carcasei

cage coil (el) bobină scurtcircuitată / în colivie cage guidance $(\mathrm{OM})$ ghidarea / ghidajul coliviei (la rulmenți)

cage guide (OM, mas) ghidaj al coliviei / al ascensorului

cage material $(\mathrm{OM})$ materialul coliviei (la rulmenți)

cage rest $(\mathrm{OM})$ tachet

cage screen (constr, OM) grătar-coş, tambur perforat

cage valve (hidr, OM) supapă încasetată

cagey (amer) rezervat; ascuns, închis; precaut, prevăzător; viclean

cagily rezervat; evaziv, pe ascuns

caginess caracter ascuns, secret

caisson (nav) cheson (şi de reparații la carenă), poartă de doc uscat, casetă

caisson blade (nav, constr) cuțit / muchie a(l) chesonului

caisson foundation (constr) fundatie cu cheson

caisson pile pilot-cheson

cake (alim) cozonac, prăjitură, tort, chec, a se aglutina; (met) țaglă, a arde, a prăji, a calcina, a sinteriza; $(\mathrm{TH})$ bulgăre, bucată, calup, turtă (și de filtrare), material sinterizat, material aglomerat, brichetă, pojghiță, crustă; a (se) aglomera, a (se) concentra, a (se) îngroşa, a (se) întări, a prinde coajă, a se încleia, a (se) vitrifia, a se arde (și d. sticlă)

cake bread (alim) franzeluță

cake coal (met, termo) cărbune brichetat

cake cutter (mas-un) maşină de tăiat în calupuri (şi săpun)

caker mixer (alim, ind chim) frământător, amestecător (de pastă, aluat etc.)

cake soap săpun în calupuri

cake upon a se prinde prin ardere, de ceva

caking aglutinare; sinterizare; tasare; (met) cocsificare, aglomerare; prelucrare în brichete; sedimentare, formare de sediment (la filtrare / evaporare); (alim) pregătire / producere a cozonacului, checului etc.

caking capacity (alim, ind chim) capacitate aglutinantă

caking property / quality capacitate de coacere caky (ca) de turtă, ca turta calamine (chim, termo) calamină

calamitous catastrofal, dezastruos; calamitate calamitously ( $a d v)$ (în mod) catastrofal, dezastruos

calamity catastrofă, dezastru

calcareous / calciferous (met, chim) calcaros

calcareous earth (ind chim) piatră de var calcinată, oxid de calciu, var nestins

calcedony (minrl) calcedonie

calcic (chim) de calciu

calciferous (minrl) calcaros

calcification (chim, met) calcificare; pietrificare calcify a calcifia, a calcifica; a pietrifica, a se întări, a se împietri

calcination (met, ind chim) prăjire, calcinare calcinator (met, ind chim) cuptor de calcinare / prăjire, calcinator

calcine (met, ind chim) a (se) calcina, a arde, a prăji, a oxida; a se preface în var

calcin(at)ed bone-meal (alim) făină de oase (calcinate)

calcin(at)ed gypsum (minrl) ipsos

calciner (met, ind chim) cuptor de calcinare, calcinator

calcining (met, ind chim) calcinare, incandescență

calcining drum (met, ind chim) tobă de prăjit / calcinat

calcining furnace / kiln (met, ind chim) cuptor de calcinat / de prăjire

calcining plant (met, ind chim) instalație de prăjit minereu / de calcinat

calcining stall (met, ind chim) cuptor de prăjit minereu

calcining zone (met, ind chim) zonă de decarbonatare

calcite (minrl) calcit

Calcium (Ca) (chim, minerl) calciu

calcium bicarbonate / dicarbonate (alim, chim) dicarbonat de calciu

calcium carbide (chim) carbură de calciu, carbid

calcium lime (chim) var nestins, oxid de calciu

calcium oxide (chim) oxid de calciu

calcium soap grease $(T$, chim) unsoare cu săpun de calciu

calcspar (minerl) calcit, spat de Islanda

calculability (mat, inf) calculabilitate, proprietatea unei functii de a i se putea calcula valoarea sau a unei proceduri de a fi executată

calculable calculabil, care se poate supune unui algoritm, algoritmizabil; previzibil

calculate a calcula, a număra; (amer) a presupune, a anticipa, a prevedea

calculated calculat; premeditat

calculated for destinat / bun pentru 
calculated on / upon a conta pe, a se baza pe calculated value valoare teoretică / calculată calculating care calculează, de / pentru calculat, calculat; (fig) precaut, prevăzător, chibzuit calculating capacity / power capacitate de calcul calculating / calculation statement (c, inf) instrucțiune de calcul în limbaj sursă

calculation (mat) calculare, calcul, socoteală; (fig) apreciere, estimare, evaluare

calculation of mixture (met, ind chim) calculare / stabilire a amestecului

calculation of prospective profits (ec) calcul al rentabilității

calculation table tabel de calcul

calculator calculator; persoană care calculează

calculus of differences (mat, fiz) calcul prin diferențe finite

caldron / cauldron (termo) cazan

calefaction (termo, met, ind chim) proces de încălzire, incandescență, calefacție

calendar calendar; almanah; listă, tabel, opis, catalog; a trece în calendar

calendar setup mode (c) mod de setare a calendarului

calender (plast) calandru; a netezi, a apreta (țesături), a călca, a trece prin cilindri (hârtie, cauciuc etc.); a presa; a calandra

calender bowl (OM, ind chim) valt de calandru

calender coating (ind chim) acoperire pentru calandrare

calender grease $(T$, ind chim) unsoare pentru calandre

calendering $(\mathrm{TH}$, plast) calandrare

calender line linie de calandrare

calender paper hârtie satinată

calender roll (OM, ind chim) valț de calandru (şi la prelucrarea hârtiei)

calender water doctor (ind chim, textile) (valț) umezitor

calf (alim) vițel, pulpă, gambă; piele de vițel

calfdozer (mas, constr) buldozer mic

calf leather piele de vitel

calf's foot (alim) piftie din picioare de vițel

calfskin piele de vițel

calf(-)wheel $(\mathrm{OM})$ tobă / roată de manevră

caliber (metr) calibru, (şi pt. diametru interior), unitate de măsură pentru lungime: 1 caliber $=$ $0,000254 \mathrm{~m}$; (fig) valoare

calibrate (metr) a calibra, a etalona, a grada, a regla, a verifica

calibrated dial (metr, OM) cadran gradat, disc calibrat / etalonat

calibrated flask (chim) balon cotat / cu gradații calibrated nozzle (metr) ajutaj de măsurat calibrated pipette (metr) pipetă gradată / cotată calibrating (metr) tarare, calibrare, etalonare calibrating device (metr) calibru, etalon, dispozitiv de etalonare

calibrating machine (metr) maşină de calibrat

calibrating plot (metr) curbă de etalonare / de calibrare

calibrating procedure (metr) metodă de verificare (şi a etalonării)

calibration (metr) etalonare, calibrare; (autom) control al scării

calibration boring roll tool (mas-un) scule de calibrare pentru rularea interioară a găurilor calibration card / chart (metr) cartelă / tabel de calibrare / de corecție / de deviație / de etalonare calibration curve (metr) curbă / caracteristică de calibrare / de etalonare, caracteristică de conversie (la un traductor)

calibration cycle (metr) ciclu de calibrare, durată între două calibrări succesive

calibration graph (metr) curbă de etalonare

calibration mass (metr) masă de etalonare

calibration roll borer (mas-un, metr) burghiu de calibrare prin rulare

calibrator (metr) (aparat) etalon, aparat pentru calibrare

calibre (metr) calibru, spion, şablon, şubler, (şi pentru diametru interior); (mil) calibrul unei arme

calibre gauge (metr) calibru (şi potcoavă)

calico (textile) pânză crudă, stambă neimprimată calk (chim) oxid de calciu, var nestins; (OM) cui de potcoavă, crampon; a copia pe hârtie de calc; a etanşa, a ştemui, a călăfătui

calked joint $(\mathrm{OM})$ rost / cusătură ștemuită

calking (constr) ştemuire, îmbinare cu prag; (nav) etanşare a unui vas de lemn, călăfătuire

calk weld $(\mathrm{OM}$, met) sudură de etanşare / etanşă calk welding (met) (acțiunea / procesul de) sudură de etanşare

call a chema, a striga, a numi, a zice, a spune, a denumi; a aduna, a strânge; a convoca (o ședință); a atrage atenția; a deştepta (din somn); a considera, a socoti; invitație, sugestie, propunere; căutare, solicitare; somație (pentru neplată); nevoie, necesitate; cauză, motiv; vizită profesională; (c) apelare (şi a unui subprogram); convorbire, apel, a suna (la telefon); (nav) escală, a face escală

call about a veni pentru

call again a veni din nou, a reveni (și cu un telefon)

call away a spune cuiva să plece / să iasă; a abate, a distrage (atenția) 
call back a rechema, a chema înapoi; a lua înapoi; a retracta, a retrage (cuvântul); a reveni, a mai face o vizită; a telefona din nou

call bell sonerie, (ceas) deşteptător

call by adress (inf) apelare prin adresă

call by value (inf) apelare prin valoare (a unui parametru)

call for a veni după; a întreba de(spre); a vizita, a trece pe la; a cere, a reclama; a atrage după sine

call forth a provoca, a determina; a atrage după sine

calligraphic caligrafic

calligraphy caligrafie

call in a scoate din circulatie, a retrage de pe piață; a invita; a pune sub semnul întrebării; (ec) a pretinde / a cere plata (sumei datorate)

call-in (inf) apel, chemare a unui subprogram, a chema un program

calling apel(are); chemare; vocație, profesie, meserie, îndeletnicire

calling card carte de vizită

calling day zi de primire

calling signal semnal de apel (telefonie)

calliper / (beam) / rule (metr) şubler

calliper gauge (metr) spion, şubler

calliper hook foarfece (cârlig)

callipering ( $\mathrm{TH}$, metr) (operația de) verificare, control

callipers (mas-un, metr) calibru, şubler, compas de găuri / de grosime / de exterior

call loan / money (ec) împrumut rambursabil la cerere

call number număr (de telefon) apelat

call off a rechema, a chema înapoi; a anula, a revoca; a contramanda; a opri, a întrerupe

call-off rechemare; anulare, reziliere; oprire, întrerupere

call off a deal (ec) a renunța la o tranzacție

call on a trece pe la, a face o vizită scurtă; a apela la, a solicita; a invita, a pofti; a da cuvântul (cuiva); a trebui să pună în aplicare / să folosească (forța)

callon $(\mathrm{TH})$ strat superficial / de finisare

call out a vorbi tare, a striga; a convoca; a chema la grevă

call sign indicator de apel (telefonie); (nav) indicativ de apel

call together a strânge; a chema; a convoca

call up a chema (la telefon), a suna

call word (inf) cuvânt de apel / de instrucțiune / continut în instructiunea de salt

calm linişte, acalmie, repaus, calm; fără vânt; frumos, senin (d. vreme); a calma, a potoli, a (se) linişti, a domoli calm down a se calma, a se linişti, a se potoli, a se domoli

calming liniştitor, calmant

calming basin (alim, ind chim, mediu) bazin de decantare / de limpezire / de liniştire

calmness calm, linişte

calodorant odorizant

calomel (chim) calomel, clorură de mercur

calor gas aragaz

caloric / calorific (fiz) caloric, termic

caloric balance (termo) bilanț termic / caloric

caloric content (termo) putere calorică

caloric factor (termo) factor caloric / termic

caloricity (termo) putere calorică

caloric power (termo) capacitate / putere calorică

caloric radiation (fiz, termo) radiație termică

caloric unit (metr, termo) calorie, unitate de măsură pentru căldură

caloric value (fiz, termo) putere calorică

calorie / calory (termo, metr) calorie: 1 calorie $(\mathrm{IT})=4,1868 \mathrm{~J}$, calorie tehnică: 1 calorie $($ th $)=$ $4,184 \mathrm{~J}$; (alim, metr) 1 calorie (nutritional) $=$ $4186,8 \mathrm{~J}$

calorie (IT)/hour (metr) unitate pentru flux termic: 1 calorie (IT)/hour $=0,001163 \mathrm{~W}$

calorie (IT)/minute (metr) unitate pentru flux termic / putere calorică, calorie pe minut: 1 calorie $(\mathrm{IT}) /$ minute $=0,06978 \mathrm{~W}$

calorie (IT)/second (metr) unitate de măsură pentru putere calorică, calorie pe secundă: 1 calorie (IT)/second $=4,1868 \mathrm{~W}$

calorie (th)/hour (metr) unitate de măsură pentru putere calorică, calorie tehnică pe oră: 1 calorie (th)/hour $=0,001162222 \mathrm{~W}$

calorie (th)/minute (metr) unitate de măsură pentru putere calorică, calorie tehnică/minut: 1 calorie (th) $/$ minute $=0,069733333 \mathrm{~W}$

calorie (th)/second (metr) unitate de măsură pentru putere calorică, calorie tehnică/secundă: 1 calorie (th) $/$ second $=4,184 \mathrm{~W}$

calorific (fiz, termo) calorific, termic, caloric calorification (fiz, termo) degajare de căldură calorific effect (fiz, termo) efect termic calorific efficiency putere / eficiență calorică, randament termic / caloric

calorific intensity intensitate de ardere

calorific loss (termo) pierdere de căldură

calorific power (tremo) putere calorică

calorific radiation (fiz, termo) radiație termică

calorific value (termo) valoare calorifică (a unui combustibil) (cantitatea de căldură degajată de unitatea de masă a unui combustibil, în condiţii standard)

calorifics termotehnică 
calorifier (termo) calorifer

calorimeter (metr, termo) calorimetru

calorimeter coefficient (metr, termo) coeficient calorimetric

calorimetric detection (metr, termo) detector pe baza măsurării cantității de căldură absorbite

calorimetry (metr, termo) calorimetrie

calorization (met, chim) calorizare, alitare

calorizator (termo, OM) schimbător de căldură tubular

calorize $(\mathrm{TH})$ a produce o acoperire protectoare împotriva căldurii (în general din folii de aluminiu sau aliaje ale lui)

calorized steel (met) otel alitat

calorizing $(\mathrm{TH}$, termo) calorizare, alitare

calorstat (autom, termo) termostat

calory (metr, termo) calorie

calotte calotă

CALS Computer-Aided Acquisition and Logistic Support (inf) sistem logistic bazat pe achiziționarea datelor (pe computer)

cam $(\mathrm{OM})$ camă, excentric, pieptene, pinten, nas, cioc

cam action throw $(\mathrm{OM})$ cursă / excentricitate a camei

cam actuated (OM, mas) cu comandă / actionat prin came

cam adapter $(\mathrm{OM})$ bucşă pentru fixarea camei pe un arbore

cam-and-lever steering gear $(\mathrm{OM})$ mecanism de direcție cu şurub şi levier

cam-and-roller steering gear (OM) mecanism de direcție cu melc şi rolă

camber (auto) unghi de cădere (al roților); (met) ambutisare, bombare, umflare, formă de seceră (a benzii); (nav) convexitate a punţii; (TH, mec) curbură, săgeată la încovoiere, încovoiere, bombare, convexitate, bombament, unghi de cădere, a încovoia, a bomba, a curba, a îndoi

camber angle (auto) unghi de bracaj / de stabilitate / de cădere al roților

cambered girder (mec) grindă curbă / curbată

cambered inwards concav

cambered outwards convex, bombat

cambered roll sferic, bombat, convex, noduros; (met) cilindru profilat / bombat

cambering attachment (mas-un) dispozitiv pentru rectificarea suprafețelor sferice; (met) profilare (a tăbliei cilindrului de laminare)

cambering machine (mas-un, met) maşină de îndreptat / încovoiat şine şi profiluri

camber of an arch (OM) săgeata arcului camber of sheet (met) convexitatea tablei cam bit $(\mathrm{OM})$ bătaie a camei cam bolt $(\mathrm{OM})$ bolț (de blocare) cu camă cam bowl (mas-un, OM) rolă a mecanismului cu camă, rolă a camei

cam brake $(\mathrm{OM})$ frână cu comandă prin camă cam contact $(\mathrm{OM}, \mathrm{T})$ contact cu camă / al camei cam controller (mas-un) controlor cu came, dispozitiv de reglare prin came

cam cutter (mas-un) freză pentru prelucrarea camelor şi a şabloanelor / cu camă de urmărire a şablonului

cam-cutting lathe / machine (mas-un) strung / maşină de prelucrat came (prin aşchiere)

cam design / profile (OM, mas-un) profil al camei cam drawing press (mas-un) presă de tras, cu excentric

cam drive $(\mathrm{OM}$, mas-un) acționare cu camă

camelback (ind chim) bandă de rulare pentru reşapare

camera aparat de fotografiat, cameră de luat vederi / de televizune

cameraman fotograf, operator cinematografic, cameraman

cam follower $(\mathrm{OM})$ tachet de camă

cam follower (stam) guide (OM) ghidaj de tachet

cam gear $(\mathrm{OM})$ distribuție prin came, mecanism cu camă / came, excentric

cam groove $(\mathrm{OM})$ canal de ghidare a camei

camiknikers combinezon-pantalon

cam incline $(\mathrm{OM})$ înclinație a profilului de lucru al camei

camion (auto) camion

cam lever $(\mathrm{OM})$ tachet, pârghie de acționare cu / prin camă

cam milling attachment (mas-un) dispozitiv (și detaşabil) pentru frezarea camelor

cam nose (mas) curbă de lucru a camei

cam-operated controller (mas-un) controlor (actionat) cu came

camouflage camuflaj, camuflare; mască; paravan

camp tabără; a ridica o tabără, a campa, a locui într-o tabără

campaign (met) campanie / durată de funcționare a cuptorului; (pol) campanie (şi electorală)

cam path $(\mathrm{OM})$ canelură curbă pentru camă

camphor (chim) camfor

camphorated (chim) camforat

cam(-)plate (OM, mas-un) disc cu came, placă a camelor

cam (action) press (mas-un) presă cu camă / came

cam profile grinding machine (mas-un) maşină de rectificat prin copiere, cu came

camp site loc de depozitare 
campus (edu) clădirile centrale şi terenul unei universități / unui colegiu, campus

cam regulator (mec, autom) regulator cu excentric / cu camă

cam ring $(\mathrm{OM})$ inel cu came

cam (follower) roller $(\mathrm{OM})$ rolă de tachet

cam roll(er) follower $(\mathrm{OM})$ tachet de camă cu rolă

cam(-)shaft (OM, mas-un) arbore cu came / de distribuție / de excentric

camshaft bearing (OM, mas-un) lagăr de arbore cu came, cuzinet-palier al arborelui cu came

camshaft chain $(\mathrm{OM})$ lanț de distribuție (şi cu came)

camshaft controller (mas-un) regulator cu came camshaft gear (OM, mas-un) pinion de distributie cu camă

camshaft gear wheel (OM, mas-un) pinion al arborelui / al axului cu came

camshaft / cam spindle (OM, mas-un) arbore cu came / de distributie

camshaft thrust pin (OM, mas-un) bolț de oprire / de reazem al arborelui cu came

camshaft timing gear (OM, mas-un) pinion al axului cu came

cam spindle (OM, mas-un) arbore cu came / de distribuție

cam spring (OM, mas-un) arc pentru camă

cam steering (OM, mas-un) distribuție cu came

cam turning lathe (mas-un) strung de copiat / de prelucrat came

cam yoke (OM) jug cu excentric

can cutie (şi de conservă); a conserva, a pune în cutii de conserve; cană, canistră, bidon, oală (el) bac, pahar, ecran metalic; cilindru, tobă de uscat; (TH) a conserva, a înmagazina, a pune în cutie, a închide, a ecrana, a capsula; a (se) putea, a avea voie, a trebui, a fi în stare, a fi capabil, a fi cu putință

canal (hidr) canal artificial; (OM) canelură, canal, tub

canal dredge(r) (nav) dragă pentru canale

canalization (constr) canalizare

canalize a canaliza, a lega prin canale, a îndrepta apa într-o singură direcție, a transforma întrun canal (şi navigabil)

canal lock (nav) ecluză

can carrier (alim, ind chim) transportor de canistre / cutii (si de conserve) etc.

cancel a tăia, a radia; (inf) a şterge (o memorie), a anula (continutul unui registru / o functie comandată anterior); a readuce în repaus, a suprima; a condamna; (mat) a simplifica (o fractie), a reduce (termenii asemenea); a contramanda, a anula, a rezilia (un contract etc.); a neutraliza, a contrabalansa; a compensa; (poligrafie) a reface o pagină, refacere a unei pagini, retipărire

cancellated reticular; spongios

cancellated structure (met, chim, plast) structură reticulară

cancellation ştergere, radiere; (c) ştergere a unei imprimări pe bandă / pe casetă / pe dischetă; (TH) anulare, reducere, contramandare, reziliere, denunțare, suprimare, extincție; neutralizare, contrabalansare; compensare; (mat) simplificare, reducere

cancellation law principiul reducerii

canceling key (TH, mas) buton (cheie) de repunere în poziție

cancel out a (se) anula, a (se) şterge; a echilibra; a neutraliza; (mat) a reduce la acelaşi numitor cancel / cancellation request cerere de anulare candela / candle (metr) candelă (unitate în sistem metric pentru intensitate luminoasă)

candent, candescent (met) incandescent (până la alb); luminos, strălucitor

candid sincer, neprefăcut, onest, cinstit; imparțial, nepărtinitor

candidacy (pol, ec, edu) candidatură

candidate (pol, ec, edu) candidat, pretendent

candidature (pol, ec, edu) candidatură

candidly (în mod) sincer, onest

candidness sinceritate, franchețe

candied (alim) zaharisit, glasat

candied fruits (alim) fructe zaharisite

candied sugar (alim) zahăr candel

candle lumânare

candle / cannel coal (met) cărbune gras / bituminos

candour sinceritate, franchețe; imparțialitate, nepărtinire

can dryer (alim, ind chim, textile) tambur uscător

can dump (alim, ind chim, textile) culbutor / basculator de forme / cutii / ambalaje

candy (alim) zahăr candel, (amer) bomboană, dropsuri, a fierbe în zahăr, a (se) zaharisi, a glasa

candy-maker's wax (alim) parafină pentru cofetărie

cane (agr) trestie de zahăr; (biol) trestie de mare, stuf; baston, nuia; a bate cu bățul

cane sugar (alim) zahăr de trestie

can filler (mas) maşină / dispozitiv pentru umplerea bidoanelor / formelor / conservelor etc.

can filling îmbidonare, umplere a bidoanelor formelor / conservelor etc. 
canicular canicular, de caniculă

can immersion cooling (alim) răcire a bidoanelor (de lapte) prin imersiune

canister (OM, alim, ind chim) canistră, bidon, cutie de tablă

canned (OM, alim, ind chim) ambalat (în cutie de tablă), conservat, închis

caned coil spring $(\mathrm{OM})$ arc cu spire teşite

canned food / products (alim) conserve, alimente conservate

cannery (alim) fabrică de conserve

cannibalize (TH, constr) a demonta (o piesă / un modul) în scopul reutilizării

cannikin cutie de tinichea sau de lemn

canning factory (alim) fabrică de conserve

cannon (mil) tun, artilerie; $(\mathrm{OM})$ bucşă, cuzinet

cannulart $(\mathrm{OM})$ tubular

canopy (auto) apărătoare de cabină; (el) armătură a unei lămpi

can sprinkling milk cooler (alim) răcitor de lapte, prin pulverizare

cant (constr) supraelevație (la curbele drumurilor); (nav) coastă deviată; (TH) înclinare, înclinație, margine tăiată înclinat, împunsătură, lovitură, a tăia pieziş, a şanfrena, a teşi (muchiile), a fasona, a înclina, a (se) răsturna, a se întoarce (pe o parte)

cantaloup(e) (alim) pepene galben

canted nozzle (OM, hidr, termo) ajutaj curbat / teşit

canteen bidon, canistră; cantină; (mil) bucătărie de campanie, gamelă; tacâm, sufertaş

cant frame (nav) coastă deviată

cantilever (mec, OM) (grindă în) consolă, brățară, suport-consolă, brațul unui stâlp; (constr) contrafişă

cantilever beam (mec, OM, constr) grindă în consolă

cantilevered (mec, OM, constr) în consolă

cantilever (gantry) crane (mas) macara cantilever / în consolă

cantilever spring $(\mathrm{OM})$ arc cantilever / în consolă

cantilever truss (constr, mec) fermă în consolă

cantilever / flapper valve (OM, hidr) supapă (cu acționare) cu pârghie, clapetă

canting (mas-un) debitare pe prisme; (d. lemn) (TH) răsturnare, înclinare

can tipper (alim) răsturnător de bidoane (de lapte) / de ambalaje

cant(saw) file (mas-un) pilă triunghiulară

cant scraper (mas-un) răzuitor / racletă / curătitor cu secțiune triunghiulară

cant up (mas-un) a teşi muchiile, a răsturna pe muchii canvas canava, canafas, pânză groasă; prelată; (nav) pânză de vele, velatură

canvas bag sac de iută

canvas belt $(\mathrm{OM})$ curea de transmisie din bumbac

canvas conveyor $(\mathrm{OM})$ transportor cu bandă (din bumbac)

canvas examinare (atentă / amănunțită), cercetare; a cerceta, a examina; a se adresa (cuiva); discuție, dezbatere; a dezbate, a discuta, a analiza; a căuta subscripții / comenzi

canvas tank ambalaj pliant / din prelată

cany (ca) de trestie

caoutchouc (ind chim) cauciuc

cap căciulă, bonetă; (alim) capsulă pentru sticle; (constr) capitel, şapă, coronament (superior) din schelet de grinzi; (el) soclu; (met) dom, boltă, capacul balonului de gaz (la sudare); (mat) calotă (sferică), simbol (al intersecției); (OM) cap, capac (şi de protecție al unui mecanism), calotă, vârf, garnitură de etanşare la (re)montare, duză, înveliş; (literă) majusculă; a pune un capac / un soclu; a întrece, depăşi

capability, capableness capabilitate, aptitudine, pricepere, talent; $(\mathrm{TH})$ posibilitate a unui sistem de a realiza toate performantele la nivelul obiectivelor lui; $(\mathrm{ec})$ productivitate; $(\mathrm{TH})$ randament

capability of being cupped (mas-un) capacitate de ambutisare adâncă

capability of being kneaded (mec, TH) plasticitate

capable capabil, apt, priceput; competent; eficient; (jur) având capacitatea legală

capable of capabil de, în stare de; care nu se dă în lături de la

capable of being cast (met) apt pentru turnare, care poate fi turnat, turnabil

capable of being cemented / hardened (met) cementabil, călibil; (plast) care se poate întări / durifica

capable of being swung open / rised (OM) basculant, rabatabil

capable of being thrown out of gear (mec, OM) decuplabil, care poate fi decuplat

capable of being wrought (met) forjabil, material (metalic) care poate fi tras

capable of dripping / forming drops care poate picura

capable of withstanding (mec) capabil să reziste / susțină / suporte

capably $(a d v)$ cu pricepere / îndemânare; cu competență, competent

capacious încăpător, voluminos; larg, cuprinzător 
capaciousness volum, capacitate, cuprindere capacitance (el) capacitanță

capacitate for a face apt pentru, a califica pentru

capacitive impedance (el) impedanță capacitivă; (hidr) valoarea absolută a impedanței fluide

capacitive storage welding (met) sudare prin acumulare / prin încărcare capacitivă

capacitive traducer (el, metr) captor / traductor capacitiv

capacitor (el) condensator electric; (hidr) capacitate, incintă de înmagazinare

capacitor bank (el) baterie de condensatoare

capacity $(\mathrm{TH})$ capacitate, aptitudine, proprietate, însuşire, calitate; debit, volum, spațiu, mărime, productivitate, randament, putere, sarcină, consum; (hidr) capacitate (a rezervorului, de scurgere, de evacuare), cilindree a unei pompe sau motor; (inf) capacitate (şi de memorare), lungime a cuvântului (la calculator); (mat) număr maxim de cifre

capacity chart (mas-un) schemă a unei maşiniunelte privind dimensiunile maxime ale pieselor de prelucrat

capacity control (termo) reglare / variație a puterii frigorifice / a unui compresor

capacity for decomposition (chim, met) capacitate / putere de descompunere

capacity for hardening (met) călibilitate

capacity-head curve (mas) curbă de presiunerandament

capacity motor (el) motor asincron cu condensator

capacity of pump(ing) (hidr) debit al pompei

cap and gown (edu) ținută universitară, "tichie şi robă"

cap chisel (mas-un) daltă lată

cape cap, promontoriu; capă, pelerină

cap for a casing (hidr, ind chim) cap de coloană

cap head $(\mathrm{OM})$ cap de țeavă

capillarity (fiz) capilaritate

capillarity / cappilary constant (metro, fiz) constantă de capilaritate

capillarity / cappilary hysteresis (metro, fiz) histerezis de capilaritate

capillary (fiz) (tub) capilar, capilară

capillary attraction (fiz, chim) atracție capilară, capilaritate, efect capilar

capillary brazing / soldering (met) lipire capilară

capillary crack (met) fisură capilară

capillary drying (fiz) uscare (a unui solid poros) prin efect capilar capillary feed alimentare prin capilaritate / prin efect capilar; $(\mathrm{T})$ ungere cu fitil

capillary filling pressure (fiz) presiune capilară de umplere

capillary fitting (met) îmbinare sudată / lipită prin capilaritate

capillary flask (chim) balon cu capilar

capillary force (fiz) forță capilară

capillary pressure (fiz) presiune capilară / în capilar

capillary regulator (metr) dispozitiv capilar de reglare, regulator capilar (la frigidere de tip comercial mai mici)

capillary rice (fiz) ridicare, urcare capilară

capillary tension (fiz) tensiune capilară

capillary tube (fiz) tub capilar, capilar

capillary viscometer ( $T$, hidr, metr) vâscozimetru capilar

capillary water $(T$, fiz) apă capilară

capital capitală; (constr) capitel / coronament; (ec) capital, fond, venit, sursă; (în text) majusculă, literă de titlu; principal, fundamental, esential, capital; excelent

capital assets (ec) fonduri fixe

capital costs (ec) cheltuieli de investiție

capital cut-off point $(\mathrm{ec})$ punct până la care se poate dobândi capital în mod rentabil

capital depreciation (ec) amortizare

capital equipment (TH) utilaj / echipament greu, utilaj de bază

capital expenditure (ec) cheltuieli de investiții

capital gains (ec) profituri realizate din vânzarea investitiilor capitale

capital goods (ec) mijloace de producție (maşini, echipament), fonduri fixe

capital intensive industry (ec) industrie $\mathrm{cu}$ investitii mari pe unitate de produs

capital investment (ec) investiții (capitale), plasamente, fonduri fixe

capitalise (ec) a transforma în capital, a valorifica, a profita de un avantaj

capitalise on (ec) a face capital din, a valorifica, a beneficia de pe urma, a profita de

capitalism (ec) capitalism

capitalist (ec) capitalist

capitalistic (ec) (adj) capitalist

capitalization (ec) capitalizare, tranformare în capital, valorificare, rentabilizare

capitalize (ec) a capitaliza, a fructifica, a valorifica, a transforma în capital, a rentabiliza; a tipări cu majuscule

capitalize on (ec) a scoate venituri din, a-și face un capital din, a valorifica un avantaj, a folosi în avantajul său 
capital letter literă mare, majusculă

capital levy (ec) impozit pe capital; consficarea unei părți din avere de către stat

capital market (ec) piață de capital, piață financiară

capital outlay (ec) investiţii capitale

capital output ratio $(\mathrm{ec})$ raport dintre investiție şi producție

capital scrap (met) fier vechi, deşeuri masive

capital stock (ec) acțiuni dând drept de proprietate asupra unei societăți

capitation calculare pe cap / pe om; (ec) capitaţie, impozit pe (cap de) locuitor

cap key $(\mathrm{OM})$ cheie tubulară

capless tyre valve (auto, $\mathrm{OM}$ ) ventil fără capac pentru anvelope / pneuri

cap nut $(\mathrm{OM})$ piuliță înfundată / oarbă / olandeză

cap of connecting-rod big end ( $\mathrm{OM}$, termo) capac al capului de bielă

capote manta cu glugă; (auto) capotă

cap paper hârtie de împachetat

capped end (OM, hidr) extremitate izolată / înfundată (d. o conductă etc.)

capper (mas, alim) maşină de capsulat / de închis sticle cu dopuri

cap piece $(\mathrm{OM})$ capac

capping (met) formare de crustă

caprine (alim) caprin, de capră

caproic acid (chim) acid caproic

capron (plast, chim) capron

cap screw $(\mathrm{OM})$ dop / capac filetat, şurub cu cap / cu dop

cap shore (nav) epontilă, pontil

capsicum (alim) ardei gras

capsize a (se) răsturna, a bascula; a şavira

capsizing (nav) basculare / răsturnare a navei, trecere a fluxului în reflux

capsizing gradient pantă critică

capstan (nav) cabestan, vinci; (TH) rolă, mosor fix, vârtej, troliu, vinci, tambur, raşpel

capstan drive (OM) acționare cu cabestan / cu rolă de transport al benzii

capstan drum (OM) tambur de cabestan

capstan head (hidr) capăt de cabestan; (mas-un) cap revolver / cilindric cu găuri radiale / găurit în cruce

capstan lathe (mas-un) strung revolver (cu cărucior dublu al capului-revolver)

capstan motor motor de antrenare (și al cobestanului)

capstan nut $(\mathrm{OM})$ piuliță rotundă, cu găuri pentru cheie

capstan rest (mas-un) sanie dublă a capuluirevolver capstan saddle (mas-un) cărucior / sanie inferioară a(l) capului revolver

capstan screw (OM) şurub cu cap cilindric găurit în cruce

capstan-turned (mas-un) prelucrat(ă) la strungrevolver

capstan wheel $(\mathrm{OM})$ roată de mână cu brațe / cu spițe

capsular capsular, capsulat

capsulated capsulat, cu capsulă

capsule capsulă; capsă detonantă, carcasă mică; rezumat, compendiu; a capsula; a rezuma, a condensa

captain's bridge (nav) pasarelă de comandă, puntea comandantului

captainship (nav) grad de căpitan, conducere caption titlu (de paragraf, de capitol), legendă (la o ilustrație); generic, titlu, subtitlu

captious delicat; penibil; greu de mulțumit, dificil; insidios

captiously $(a d v)$ (în mod) insidios, prea critic

captivate a capta (şi atenția), a atrage, a captiva

captivation (fiz) captare

captive (fiz, $\mathrm{TH}$ ) captiv, prins

captive device (mas, mas-un) dispozitiv care nu se detaşează, chiar dacă unele elemente de asamblare (filete) se desfac / care nu cade / care nu-și modifică poziția / captiv

captive device fastener $(\mathrm{OM})$ asamblare la care, prin desfacere, elementele componente (şurub, piuliță etc.) nu cad / rămân captive (în piese)

captive float (OM, hidr) flotor captiv, legat de un corp plutitor

captive foundry (met) turnătorie pentru productia de bază a uzinei

captive screw $(\mathrm{OM})$ şurub prizonier / care nu cade la deşurubare

captivity captivitate

capture (fiz) captare, captură, prindere, a capta; (inf) captare a datelor (de pe un document); prinde, a captura

capture area plan de absorbtie

car (auto) maşină, automobil, autoturism, cărucior; (cf, met) vagon(et) (şi de tramvai), boghiu; cabină de ascensor

caramel (alim) zahăr ars, caramel, caramelă

carat (metr) carat, unitate de măsură a proporției de aur din aliaje, egală cu a 24-a parte din masa totală a aliajului; unitate de greutate pentru pietre prețioase, egală cu $0,2053 \mathrm{~g}$, unitate de măsură pentru masă pentru pietre prețioase: 1 carat $=0,0002 \mathrm{~kg} ;($ nav, ec) a $24-\mathrm{a}$ parte din proprietatea unei nave; (ec) cotă de participare la o societate comercială 
caraway (alim) chimen

carbarn depou de tramvaie

carbenes (chim) radical organic care conține carbon bivalent

carbide (chim, met) carbură, carbid

carbide basket (ind chim) retortă a generatorului de acetilenă

carbide capacity (ind chim, met) umplutură de carbid (a generatorului de acetilenă)

carbide carbon (met, chim) carbon de carbid, carbon de cementare

carbide container $(\mathrm{OM})$ casetă / container pentru încărcătura de carbură de calciu

carbide cutter (mas-un) sculă de aşchiere, cu carbură / cu carburi

carbide die (mas-un) filieră din aliaj dur / din carburi

carbide drill (mas-un) burghiu cu plăcuțe din aliaj dur / din carburi metalice

carbide milling cutter (mas-un) freză cu plăcuțe din aliaj dur / din carburi metalice

carbide of iron (met) carbură de fier

carbide planing (mas-un) rabotare cu cuțite cu plăcuțe din aliaj dur / din carburi metalice

carbide-shank boring tool (mas-un) cuțit de strunjit interior, cu corp activ din carbură

carbide slag (met) zgură carbidică

carbide tip (mas-un) placă / plăcuță de aliaj dur / de carburi metalice (montată pe port-cutie etc.)

carbide(-tipped) tool (mas-un) cuțit armat cu plăcuță de aliaj dur (prin lipire), cuțit cu carburi dure depuse pe tăiş

carbide-tool sharpening machine (mas-un) maşină de ascuțit scule / cuțite cu plăcuțe din carburi

carbiding (chim, met) carburare

car body (auto) caroserie de automobil

carbohydrate (chim) hidrat de carbon, hidrocarbonat

carbolic (chim) carbolic, fenic

carbolic acid (chim) acid fenic, fenol

carboloy (met) carboloy, aliaj dur pentru scule aşchietoare

carbon, Carbon (C) (chim), carbon, cărbune pur, electrod, diamant (negru), negru de fum, calamină; (el) cărbune (perie de motor), electrod; (hârtie) indigo

carbonaceous material (chim, met) agent de carburare; substantă / material conținând carbon sau compuşi de carbon

carbon-arc electrode (el) electrod de cărbune

carbon-arc welding (met) sudare cu arc electric, cu electrod de cărbune

carbonate (chim) carbonat carbonated (chim) gazos (d. un fluid)

carbonation (chim) saturare cu acid carbonic

carbon-base material (chim) material pe bază de carbon

carbon-bearing (chim) care conține carbon

carbon black (termo, mas) negru de fum, calamină, funingine

carbon-black stock (ind chim) amestec (de cauciuc) şarjat cu negru de fum

carbon bridge (auto) ancrasare a bujiei; (chim) punte de carbon

carbon carburisation steel (met) oțel-carbon de cementare

carbon concentration (chim) saturare cu carbon carbon content (met) conținut de carbon (şi în oțel)

carbon copy copie cu indigo, copie fidelă

carbon dating datare cu carbon (radioctiv)

carbon dioxide $\left(\mathrm{CO}_{2}\right)$ (chim) dioxid de carbon

carbon drop (met) afinare, eliminare (parțială) / scădere a conținutului de carbon (din oțel)

carbon engineering steel (met) oțel-carbon de construcție / pentru elemente de maşini

carbon electrode (el, met) electrod de cărbune

carbon elimination (met) eliminare (parțială) a carbonului, afinare (la oțel)

carbon equivalent (met) carbon echivalent (la aprecierea sudabilitătii)

carbon feed (TH) aprovizionare cu cărbuni; (el) avans al cărbunelui de contact

carbonic acid (chim) acid carbonic

carboniferous carbonifer

carbonify a carboniza

carbonisation (brit), (met) carbonization (amer) (chim, met) carbonizare, cocsificare, cementare, cărbune

carbonisation at low temperature (chim) carbonizare la temperatură joasă, semicarbonizare carbonisation plant (met) cocserie

carbonise, (met) carbonize (amer) a carbura, a carboniza, a cocsifica

carbonised residue (met, ind chim) cărbune rezidual, reziduu carbonizat

carbonising (chim, met) carbonizare, cocsificare carbonising agent (met) agent de carburare; (chim) agent de carbonizare

carbonising flame (chim, met) flacără reducătoare

carbonising period (met) durată de afinare carbonitriding (met) (procesul de) carbonitrurare carbon loss (termo) pierderi de energie termică, din cauza neoxidării complete a combustibilului; (met) pierderea carbonului din stratul superficial al oțelului din cauza unui tratament greșit 
carbon-molybdenum steel (met) oțel-carbon slab aliat sau aliat cu molibden

carbon monoxide (CO) (chim) monoxid / oxid de carbon

carbon monoxide poisoning (med) intoxicare / otrăvire cu monooxid de carbon

carbon paper (hârtie) indigo

carbon penetration (met, chim) penetrație / pătrundere a carbonului, cementare

carbon period (met) perioadă / interval de carburare (cementare)

carbon pickup (chim) saturare de / în carbon; (met) mărire a conţinutului de carbon (şi la turnare)

carbon-pile pressure transducer (metr, el) traductor de presiune pe baza modificării rezistenței plăcilor de carbon, presate

carbon potential (met) proprietatea mediului de a altera conținutul de carbon din stratul superficial al aliajelor (feroase) expuse

carbon-producing (met) cocsificare, cocsare

carbon-residue test (met) determinare a cifrei de cocs

carbon-resistance thermometer (metr, el) termometru cu rezistență de carbon

carbon restoration (met) recarburare

carbon rod (el, met) tijă / perie de cărbune, bară-electrod (la oțelării electrice)

carbon steel (met) oțel-carbon / nealiat

carbon steel narrow strip (met) bandă îngustă din oțel-carbon

carbon-steel roll (met) cilindru din oțel-carbon

carbon sulphide (chim) sulfură de carbon

carbon tool steel (met) oțel-carbon pentru scule carbonyl (chim) (radical) carbonil

carborundum (chim) clorură de siliciu, carborund

car-bottom furnace (met) cuptor cu vatră mobilă

car-bottom hearth (met) cu vatră mobilă (d. cuptoare)

carboy (chim) recipient / balon de sticlă (pentru acid)

car building (ind, TH) construcție de automobile / de vagoane

carburation (auto, mas) carburație; (met) carburare, cementare

carburet a carbura

carburetted mixture (auto, termo) amestec combustibil

carburetting process (met) (procesul de) cementare / carburare

carburettor, carburetter (auto) carburator

carburettor barrel (auto) tobă a carburatorului carburettor bowl (auto) cameră a flotorului / plutitorului din carburator

carburettor choke (auto) clapetă de aer a carburatorului

carburettor control (auto) tija de comandă a carburatorului

carburettor engine (auto) motor cu carburator

carburettor flange (auto) bridă / flanşă de racord a carburatorului

carburettor float (auto) plutitor al carburatorului

carburettor link / linkage / rod (auto) tijă de comandă a carburatorului

carburettor setting / turning (auto) reglare a carburatorului

carburettor throttle (auto, OM) ştrangulator al carburatorului, difuzor

carburettor ventury (auto) difuzor de carburator, ştrangulator a carburatorului

carburisation (chim, met) carburare, îmbogățire în carbon (și cementare)

carburize (met) a carbura, a cementa carburize partially / slightly / superficially (met) a carbura / a cementa parțial / superficial

carburizer (met) material (de adaos) de cementare; (chim) agent de carburare

carburizing (met) cementare, carburare

carburizing agent (met, chim) agent de carburare, sare de călire

carburizing bath (met) baie de cementare

carburizing box (met) cutie de cementare

carburizing by gas(es) (met) cementare în mediu gazos

carburizing by salts (met) cementare în baie de săruri

carburizing steel (met) oțel de cementare / cementabil

car carrier (auto, transp) remorcă specială pentru transportat automobile

carcass (OM) carcasă, carter, schelet; (auto) carcasa anvelopei; $(\mathrm{TH})$ şasiu, ramă

carcass building (OM) constructie de schelet / de carcasă

carcass chilling process (alim) refrigerare primară, zvântare / uscare prin refrigerare

car-casting (met) turnare pe vagonet

car coupler (cf, OM) cuplă de vagoane

card tichet, bilet; buletin / card de identitate; (TH) fişă, diafragmă, cardă, darac, a carda, a dărăci; (el) suport de înfăşurare; (inf) cartelă (şi perforată); (ec) card (bancar)

cardan $(\mathrm{OM})$ cardan, crude cardanică

cardan axle / shaft (OM) arbore cardanic / articulat 
cardan drive / transmission $(\mathrm{OM})$ transmisie cardanică

cardan joint $(\mathrm{OM})$ articulație / cuplaj carda$\operatorname{nic}(\breve{a})$

cardan wave $(\mathrm{OM})$ arbore cardanic / articulat, ax în cruce

cardboard (de) carton, mucava

cardboard box teacă, cartonaj, cutie de carton / de mucava

card-boxes embossing machine (mas-un) maşină de presat cutii

card-boxes gluing machine (mas-un) maşină de lipit cutii pliante

card catalogue cartotecă, fișier

card dumper (cf, met) culbutor (de vagoane)

cardinal de bază, principal, cardinal; roşu aprins / cardinal; (mat) numeral cardinal

cardinal number (mat) numeral cardinal

cardinal point punct cardinal; reper de bază

card index cartotecă, fişier

car driver (auto) şofer, conducător auto

care întreținere, grijă; îngrijorare; atenție; prevedere; a avea grijă de, a se strădui, a se îngriji; take $\sim$ of a avea grijă de; want of $\sim$ neatenție

careen (nav) carenă, canarisire, înclinare, a abate / a înclina în carenă, a carena, a se canarisi, a se înclina într-o parte

careenage (nav) carenarisire, carenare, abatere în carenă

career carieră, profesi(un)e; înaintare, progres; viață, existență

careerism carierism, arivism

careerist carierist, arivist

care for a arăta interes pentru, a avea grijă de

carefree lipsit de / fără griji

careful atent, grijuliu; prudent; minuțios, migălos; scrupulos

carefully $(a d v)$ atent, cu grijă; cu prudență; minuțios, cu migală

carefulness atenție, grijă, prudență; migală, minuțiozitate, acuratețe

careless lipsit de / fără griji; nepăsător; neatent, indolent; neglijent

carelessly $(a d v)$ (în mod) neatent; neglijent; fără să-i pese; (în mod) nechibzuit; fără să vrea, neintenționat, întâmplător

carelessness lipsă de griji; nepăsare; indolență; indiferență

car elevator / lift (auto, TH) elevator auto, lift (pentru lucrări de întreținere)

car engine (auto) motor de automobil

care of (auto) întreținere; (ec) prin grija / bunăvoința

caret semn de omisiune (în poligrafie) caretaker persoană care are grijă de ceva; responsabil; păzitor; îngrijitor; provizoriu, interimar care to a dori

car feeder (cf, met) alimentator (încărcător) în vagonete

car frame (cf) cadru de osie / de rulare; (mas) suport al căii de rulare (la macarale); şasiu de automobil

car-hearth furnace (met) cuptor cu vatră mobilă cargo (nav) încărcătură, marfă, cargou, caric cargo area (auto) portbagaj

cargo block (nav) macara de bigă

cargo boat / vessel / ship (nav) cargou, cargobot cargo body (auto) caroserie de autocamion cargo boom (nav) bigă de încărcare cargo capacity (nav) capacitate de încărcare cargo-carrier (nav) cargou, cargobot cargo deadweight (nav) capacitate netă / utilă de încărcare

cargo door poartă de încărcare; (nav) sabord de încărcare

cargo fall (nav) cablu al palancului de încărcare cargo gear (nav, ind) instalație de încărcare cargo handling appliances (ind, transp) utilaj(e) de manipulare a mărfurilor cargo hatchway (nav) gură de magazie cargo headlight / lamp (auto) far al unui autovehicul, lumină de semnalizare (în față) cargo hook (nav, transp) cârlig de încărcare cargo in bulk marfã în vrac cargo liner (nav) cargobot de linie cargo net (constr) plasă de încărcare cargo oil pump (nav) pompă de ulei cargo reefer space (alim, termo, nav) magazie / spatiu frigorific $(\breve{a})$

cargo train (cf) tren de marfă

cargo truck / vehicle (auto) autocamion cargo winch (nav) vinci de marfă

car levelling device (cf) dispozitiv automat de nivelare

carload (cf) vagon-cisternă, cisternă

carman şofer; (amer) manipulant, vatman

Carman's tortuosuty model modelul sinusoidal al lui Carman

Carnauba wax (plast) ceară de carnauba (din frunzele arborilor de ceară din Brazilia)

Carnot cycle (termo) ciclu Carnot

carousel carusel; (amer) bandă rulantă pentru bagaje (şi în aeroport)

carpenter dulgher, tâmplar; a fi dungher / tâmplar carpenter's glue (chim, alim) clei de oase carpentry dulgherie, tâmplărie; lemnărie carpet covor, strat superficial / de protecție; (constr) îmbrăcăminte a drumului 
carpet bag sac / geantă de voiaj

car retarder (cf) frână de cale; (el) limitator de viteză a cabinei (la ascensor)

car revision (cf) revizie a vagoanelor

carriage căruţ, car, cărucior, vehicul, sanie; transport, cărăuşie; îndeplinire, executare; $(\mathrm{TH})$ ramă, cadru; (auto) şasiu; (ec) cost al transportului; (mas-un) suport, sanie a unei maşiniunelte, cărucior de macara; (inf) car al unei imprimante; (met) perna cajei (de laminor); (cf) vagon (de pasageri); (mil) afet de tun; (jur) votare (a unui proiect de lege)

carriageable carosabil, practicabil (d. un drum); transportabil

carriage apron (mas-un) placă de zăvorâre, sorț (la strung)

carriage body (auto) caroserie (şi de automobil)

carriage bolt $(\mathrm{OM})$ şurub / bolț cu umăr pătrat sub cap, pentru a evita rotirea lui la strângerea piuliței

carriage delivery (mas-un) dispozitiv de eliminare / de evacuare cu cărucior

carriage examiner (cf) revizor de vagoane

carriage forward (ec, transp) transport de plătit, cu plata la primitor

carriage frame (cf, OM) şasiu de vagoane

carriage free (ec) franco, plătit, francat, gratuit, fără plată; transport gratuit

carriage gain întindere cu căruciorul

carriage gauge $(\mathrm{TH})$ gabarit de încărcare

carriage guide-bar (mas-un) glisieră a saniei, şină de ghidare a saniei

carriage handle (mas-un) manetă pentru deplasare manuală a căruciorului / saniei

carriage rack (mas-un) cremalieră a saniei / a căruciorului

carriage return (c) readucere a carului / a cartuşului unei imprimante la stânga

carriage return mechanism (met) mecanism de întoarcere a căruciorului (şi pentru rulouri)

carriage saddle (mas-un) cărucior (suport)

carriage slide (mas-un) sanie / ghidaj a(1) căruciorului

carriage stop (mas-un) dispozitiv (şi de strung) de poziționare (precisă)

carriage way (auto) parte carosabilă (a drumului) carrick bend (nav) nod de împreunare

carrier persoană care transportă ceva; hamal, comisionar, purtător; (chim) solvent, accelerator (pentru lacuri), suport (flexibil, pentru adezivi); (inf) purtător de date; (ec) societate de transport; (mat) reprezentant, suport, mulțimesuport; (nav) navă de transport, portavion; antrenor (la strung de precizie); (el, autom) frecvență purtătoare; sarcină liberă; purtător (la un semiconductor); $(\mathrm{OM})$ colier, roată dințată de transmisie; (termo) agent termic / caloric; (TH) suport, susținător, crampon, purtător, vehicul, bridă, cărucior, transportor, conveier, consolă

carrier bag sac de mare capacitate (de plastic sau de hârtie)

carrier bar (constr, mec) bară de suport / de susținere

carrier bolt (mas-un, OM) bolț de antrenare, bolț conducător

carrier compound (chim, alim) compus intermediar

carrier frequency (fiz, autom) frecvență purtătoare (a unui semnal)

carrier (idle) $(\mathrm{OM})$ rolă purtătoare / de susţinere carrier of water acvifer

carrier pin $(\mathrm{OM})$ bolt de antrenare

carrier pinion $(\mathrm{OM})$ pinion intermediar

carrier plate (OM, mas-un) flanşă / placă de antrenare carrier ring $(\mathrm{OM})$ inel de reazem / rolă cilindru carrier roll (alim, ind chim) valț de conducere carrier roller $(\mathrm{OM})$ roată purtătoare (pe şenile) carrier set (met) grup de role purtătoare / de susținere

carrier slot $(\mathrm{OM})$ şanț al flanşei / rolei / cilindrului de antrenare

carrier vehicle (auto, transp) mijloc de transport auto

carrot (alim) morcov; de culoarea morcovului (roşcat, roşu)

carrot tool (mas-un) carotier, sculă aşchietoare pentru decupare cu miez

Carr's flowability index (ind chim, alim) indicele de flotabilitate a lui Carr

carry a duce, a purta, a căra; a transporta, a (sus)ține, a sprijini; a suporta; (agr) a întreține, a hrăni, a nutri (d. teren); a avea grijă de, a întreține; (ec) a ajuta bănește, a subvenționa, a reporta, a aduce venit / dobândă; (med) a transmite, a răspândi (boli); (mat) a ține (în minte o cifră etc.); a avea, a dispune de, a avea de vânzare (în comerț); a avea, a conține, a cuprinde; a tipări, a publica (articole); a atrage după sine, a face posibil / necesar; a antrena; a spori, a mări, a duce mai departe, a continua (în spațiu, timp, în mod gradat); a face să ajungă într-o situație; a împinge, a forța; (autom, inf) report, transfer; a conduce, a comanda; a prelungi

carry about a duce / purta cu sine (de colo colo) carryall sac de mână; (auto, transp) camion cu bănci laterale 
carry along a lua / duce cu sine; a duce mai departe, a antrena; a lua, a duce; a trage cu sine

carry away a duce cu / după sine; a transporta; a entuziasma; a smulge; a răpi; a îndepărta; a se rupe, a pierde (şi la transportare)

carry back a (re)aminti (cuiva) trecutul

carry flip-flop (el) circuit basculant de transfer / de report

carry forth a arăta, a prezenta, a expune

carry forward a duce mai departe, a continua; (ec) a reporta

carry further a continua, a duce mai departe

carry in a introduce (date în calculator); a aduce (înăuntru / în interior)

carrying purtător, susținător, care duce / poartă; de transport; portant

carrying agent (chim, mediu, med) agent / mediu purtător / de antrenare

carrying area (mec, OM, T) suprafață portantă / utilă (la transportoare) / care susține sarcina

carrying away antrenare, transportare

carrying capacity (el) intensitate admisibilă; capacitate de trafic; (TH) capacitate portantă / de încărcare / de ridicare, forță ascensională, sarcină admisibilă, portanță

carrying costs (ec, transp) cheltuieli / costuri de transport

carrying frame (constr, mas) schelet purtător, cadru de susținere

carrying-off îndepărtare; (TH) abatere, deviere carrying ring (OM) inel de reazem / de sprijin carrying rope (OM, constr) cablu portant carrying scraper screper pe roți

carrying sling (OM) clemă / buclă de suspensie / de prindere / de suspendare

carrying strap (met, OM) bandă suport / de suspensie, curea purtătoare

carrying tongs (met, hidr) clește de transportat țevi

carry off a lua / duce cu sine, a antrena, a îndepărta; a înstrăina; a evacua, a elimina; a face / executa bine şi cu uşurință; a câştiga (o victorie); a cauza moartea cuiva

carry on a continua; a duce mai departe; $(\mathrm{TH})$ a conduce (un proces tehnologic); a se ocupa cu, a fi angajat (într-o afacere); a întreprinde (o acțiune); a lucra mai departe

carry-out (amer) magazin cu preparate culinare carry out a îndeplini, a executa, a efectua, a face, a exercita; a scoate, a elimina; a realiza; a duce la bun sfârşit, a îndeplini

carry over a duce / trece dincolo; (ec) a reporta carry-over surplus; rest, rămăşițe; (ec) report; (TH) influență (a unei activități asupra alteia) carryover (termo) particule solide şi fluide, antrenate odată cu aburul

carry rudder (metr, nav) a avea tendința de abatere, a avea derivă

carry through a îndeplini, a efectua, a realiza; a ajuta, a sprijini; a scoate din încurcătură; a continua să existe, a nu dispărea

carry to account (ec) a trece în cont

carry up a ridica, a construi; (ec, mat) a reporta; a rămâne, a persista, a continua

car shed (auto) garaj; (amer) depou (de tramvaie, de vagoane)

carsick (auto, med) care suferă de rău de maşină cart camion, cărucior (şi cu două roți), vagon(et), roabă; a duce, a căra (şi cu mâna)

cartage transport cu tracțiune animală, camionaj; (ec) cost al transportului

carte blanche formular necompletat; semnătură în alb; deplină libertate de acțiune

cartel cartel

cartesian (mat, mec) cartezian

cartesian coordinates (mat, mec) coordonate carteziene / ortogonale (în plan sau spațiu)

carton (constr) carton asfaltat; mucava, cutie de carton; cartuş de țigări; centru al unei ținte

cartouche cartuş (şi ornament), celulă; legendă (la desene); (mil) cartuşieră

cartridge (c, mil) cartuş (de armă, de imprimantă etc.)

cartridge case (c) tub / casetă a(1) cartuşului

cartridge clip (mil) lamă de cartuşe

cartridge cylinder (revolver) (mas-un) tambur port-scule la un strung-revolver

cartridge / cellular filter (alim, mediu, ind chim) filtru celular / cu alveole / cu celule / cu site filtrante demontabile

cartridge fuse (el) siguranță fuzibilă tubulară, buşon fuzibil

cartridge heater (termo) cartuş de încălzire, încălzitor / element tubular

cartridge paper (mil) hârtie pentru cartuşe

cartridge plug (el) fişă cu siguranță

cartridge powder tool (constr) pistol pentru fixarea buloanelor prin explozie

cartridge starter (auto) demaror cu cartuş

cartridge valve (hidr) aparat / supapă (tip) cartuş

car trunk (auto) porbagaj

car-type cooling conveyer (met) transportor $\mathrm{cu}$ răcire pe cărucioare (pentru rulouri calde)

car tyre (auto) anvelopă auto / de automobil

car unloader (cf, met) descărcator de vagoane

carus(s)el (el) comutator-adaptor de tensiune; (TH) transportor circular / cu bandă fără sfârşit / continuă 
carve a scobi, a grava, a ciopli, a săpa, a scoate, a decupa, a tăia, a excava; (alim) a tăia carnea

carve out a tăia, a sfârteca, a dezmembra; a-și face o carieră / un drum în viață

carver cioplitor, sculptor, gravor; cuțit de sculptat în lemn; (alim) cuțit de tăiat carne

carve up a tăia (porții); a împărți, a diviza (şi un teritoriu, un teren); a tăia, a răni cu cuțitul

carving scobire, scobitură, tăiere

carving knife (mas-un) cuțit de sculptat în lemn; (alim) cuțit de tăiat carne

car wash (auto) spălare a unui automobil

car washer (auto, mas) aparat / instalație de spălat maşini

car wash pump (auto, OM) pompă pentru (instalație de) spălat automobile

car wheel boring machine (mas-un) strungcarusel pentru strunjirea interioară a bandajelor roților

cascade cascadă, jerbă de cascadă; a face să se reverse, a se revărsa; (cf) zonă de rapiduri; (el) grătar de palete fixe în coroana statorului, legare în cascadă / în serie; (met) dispunere / amplasare în cascadă a băilor (de tratament / de decapare etc.)

cascade circuit (el) legare / legătură în cascadă / în serie

cascade connection (el, mec) montaj / cuplaj în cascadă / în serie

cascade control (el) reglare (a vitezei) prin cuplare în cascadă (a două motoare asincrone); (autom) sistem de control cu două bucle, una fiind subordonată celeilalte

cascade cooler (termo) răcitor în trepte

cascaded (TH) (legat) în serie (d. maşini)

cascaded carry transport în serie / succesiv / în cascadă

cascaded connection (el) conexiune în cascadă, descompunere a unei scheme complexe întrun set de scheme mai simple, conectate în serie

cascade impactor $(\mathrm{TH})$ factor de impact în serie cascade milk cooler (alim, termo) răcitor de lapte prin aspersiune

cascade oiling $(\mathrm{OM}, \mathrm{T})$ ungere cu inele / gravitațională / prin cădere

cascade sequence (met) sudare continuă, cu mai multe treceri

case ladă, dulap, sac, înveliş, corp, carcasă, cameră, vitrină, carter, toc, teacă, cutie, etui, husă, sertar; (constr) schelet de clădire, ramă, pervaz; trusă; situație, caz, întâmplare, incident, accident; (OM) recipient, înveliş, husă, carcasă; (met) strat cementat, cutie pentru cementare; (metr) carcasa (de aparat); a înveli, a acoperi, a pune într-o cutie / în ladă, a căptuşi, a tuba, a aşeza, a amplasa, a plasa; (jur) caz, proces, probe; (med) pacient

case board scândură subțire

case carburizing (met) carburare / cementare în cutie

case-chilled (met) călit (albit)

cased încasetat, cu carcasă, în cutie

cased beam (constr) grindă îmbrăcată în beton, grindă-cheson

cased-butt coupling $(\mathrm{OM})$ cuplaj cu manşon

cased catch $(\mathrm{OM})$ capac de închidere

case depth (met) adâncime a cementării / a stratului cementat

cased glass (ind chim) sticlă / geam compus $(\breve{a})$ din mai multe straturi

case drain flow (hidr) circulație (suplimentară) de răcire a fluidului (realizată printr-un modul ataşat, deservit de o pompă)

casefy (alim) a se brânzi

case girder (constr) grindă îmbrăcată în beton case(-)harden (met) a cementa (în cutii), a căli (prin cementare); a înăspri; a face nesimțitor

case-hardened crossing / frog (met) inimă de încrucişare la oțel turnat

case hardened steel (met) oțel cementat

case hardener (met, chim) agent de cementare case hardening (met) călire / durificare (superficială) prin cementare în cutii

case hardening box (met) cutie de cementare

case hardening carburizer / compound (met, chim) amestec de cementare

case hardening furnace (met) cuptor de cementare case-hardening material / powder (met) material / praf de cementare (pentru cementare în cutii)

case hardening steel (met) oțel durificabil prin cementare / de cementare (în cutii)

casein (alim, chim) proteină, cazeină

case knife cuțit de vânătoare / de masă

case law (jur) precedent juridic, lege bazată pe precedente, jurisprudență

case-making drum (ind chim, OM) tobă de confectionat anvelope

casement window (constr, OM) fereastră batantă, oberliht

case of cock (OM, hidr) corpul robinetului

case of emergency / of need accident, calamitate, situație specială, caz de urgență / de necesitate / de forță majoră

case of loading (mec) caz de încărcare, ipoteză de încărcare

caseous brânzos, ca brânza 
case redressing tool (mas-un, OM) dispozitiv de închidere a carcaselor

cash (ec) bani (gheață), numerar, bani lichizi, fonduri de casă; a încasa, a schimba în bani (un cec), a plăti în numerar

cash a check (ec) a încasa un cec

cash advance (ec) acont în bani

cash and carry (ec) achitare a mărfii şi transportarea ei de către cumpărător, vânzare / livrare direct în depozit (transportul fiind în sarcina cumpărătorului)

cash assets (ec) capital în numerar

cash balance (ec) sold de casă

cash before delivery (CBD) (ec) plată înainte de livrare

cash book (ec) registru de casă

cash crop (agr) recoltă destinată vânzării

cash desk (ec) casă (în magazin)

cashew mahon, acaju (culoare)

cash flow (ec) circuit financiar, flux al numerarului (zilnic / săptămânal), dare de seamă asupra încasărilor şi plăților în numerar pe o anumită perioadă, total compus din profitul net şi amortizări, disponibil de lichidităţi, balanță a disponibilităților

cashier (ec) casier; a îndepărta din serviciu, a da afară; a elimina, a îndepărta

cashier's cheque $(\mathrm{ec}) \mathrm{cec}$, bilet de bancă

cashier's office (ec) casierie

cash in (ec) a încasa un cec

cash in hand (ec) bani disponibili

cash joint (OM, hidr) îmbinare / racord cu mufă din / în corpul țevii (conductei)

cashmere (lână de) caşmir; şal de caşmir

cash note (ec) notă de plată

cash on delivery (COD) (ec) plată la livrare, livrare contra plată

cash register (ec) casă / aparat de înregistrare (a încasărilor)

cash sale (ec) vânzare contra numerar

casing înveliş, husă, toc, teacă; (constr) ramă, pervaz, cofraj; $(\mathrm{TH})$ acoperire, învelitoare, coloană de burlane, tubaj, tubare, armătură, blindaj, înveliş (şi metalic), căptuşire, carcasă, carter, căptuşeală, anvelopă, cămaşă, teacă, manta; încasetare

casing cover $(\mathrm{OM})$ capac al carcasei

casing cutter / knife (mas-un) cuțit / aparat de tăiat țevi

casing head (ind chim, OM) cap de coloană

casing-head flange (OM, alim, ind chim) flanșă de etanşare a coloanei / a recipientului

casing joint (ind chim) îmbinare tubulară, pasul burlanelor, burlan casing machine (alim, ind) maşină de ambalat / de împachetat

casing-off tubare, închidere

casing test (hidr) probă de etanşeitate

cask (alim) butoi, butie, poloboc, butoiaş; baril

cassation (jur) casare

casserole (alim) caserolă

cassette casetă (şi pentru filme / benzi, aparate mici, de măsură)

cassiterite (minrl) casiterit

cast aruncare, azvârlire; risc, şansă; (TH) formă, matriță, aspect (al unei piese), model, mulaj, şarjă, piesă turnată; colorit, nuanță; turnat; a arunca, a îndepărta (si ceva nefolositor), a (a)zvârli, a răspândi; (TH, met, plast) a turna, a modela, a forma, a da o formă; (jur) a condamna la plata despăgubirilor; (d. lemn) a se strâmba, a se scoroji; (d. țesături) a se strânge, a intra la apă; (mat) calcul; lână groasă

castability (met) turnabilitate, capacitate de a fi turnat, fluiditate (la turnare)

castable (met) apt pentru turnare, turnabil

cast about a arunca / turna peste tot (un lichid)

cast alloy (met) aliaj turnat / de turnătorie / turnabil

cast aluminium (met) piese turnate din aluminiu cast aside a arunca, a (se) descotorosi; a nu ține seama de; a renunța la

cast away a arunca; a irosi, a risipi; a înlătura, a scăpa de, a se descotorosi de

castaway paria, desmoştenit al soartei; (nav) naufragiat; nefolositor, inutil

cast brass (met) piese turnate din alamă, alamă turnată

cast bronze (met) bronz turnat

cast chaplet (met) suport de fontă dubluconic, pentru miezuri

cast cold (met) a turna în cochilă

cast down a descuraja; abătut, deprimat, necăjit

castellated / castle nut $(\mathrm{OM})$ piuliță crenelată / moletată

castellated socket-headed cap screw $(\mathrm{OM})$ şurub cu cap crenelat, cu locaş hexagonal (pt. cheie frontală)

castellated / castle washer $(\mathrm{OM})$ şaibă crenelată caster aruncător; (met) turnător, creuzet, aparat de turnat; turnător (în ceramică); (auto) unghi de fugă a rotilor

caster action "on steering" (auto) efect al unghiului de fugă asupra direcției

caster sugar (alim) zahăr pudră

cast house (met) turnătorie, hală de turnare

cast flange $(\mathrm{OM})$ flaşă turnată

cast glass sticlă turnată 
castigate a pedepsi; a critica aspru; a amenda (un text); a corecta, a îndrepta

castigation pedeapsă; corecție; (amendare (a unui text); corectare, îndreptare

casting aruncare, azvârlire; calcul prealabil; scorojire (a lemnului); (met) fontă, turnare, piesă turnată, mulare, cofrare; (constr) turnare în cofraj a betonului

casting alloys (met) aliaje de turnătorie / turnabile casting bay / house (met) turnătorie, hală de turnare

casting bed (met) pat / placă de turnare

casting bogie / car (met) cărucior / vagonet de turnare

casting box (met) vas de turnat, cutie de formare casting brush (met) perie de curățat fonta turnată

casting core (met) miez de turnare

casting characteristics (met) proprietăți de turnare

casting crane (met) macara de turnare

casting defect (met) defect de turnare

casting die (met) formă metalică / montură pentru turnare sub presiune

casting equipment (met) echipament / instalație de turnare

casting form (met) formă / montură de turnare (a metalelor), cochilă

casting furnace (met) cuptor de topit şi turnare

casting gate (met) pâlnie de turnare

casting gutter (met) jgheab de turnare

casting house (met) atelier de turnătorie

casting in chills (met) turnare în cochilie

casting in crucibles (met) turnare în creuzet

casting in flasks (met) turnare în cutii de formare

casting ladle (met) oală de turnare

casting loam (met) argilă de formare

casting machine (met) maşină de turnat (şi continuu)

casting metal (met) metal / aliaj turnat / turnabil / care se toarnă

casting method (met) procedeu / metodă / tehnologie de turnare

casting mould (met) formă / cutie / matriță de turnare

casting moulded in flask (met) turnate în cutii de formare

casting nozzle (met) orificiul / ciocul oalei de turnare

casting on flat (met) turnare în poziție orizontală

cast ingot (met) lingou (turnat)

casting paste (met) pastă de turnare casting pattern (met) model de turnare / de turnătorie

casting pig iron (met) fontă de turnătorie

casting pit (met) loc / groapă de turnare

casting polymerization (chim) polimerizare în bloc / în masă

casting process (met) procedeu / proces / metodă de turnare

casting properties (met) capacitate de turnare (a unui metal, a unui aliaj)

castings (met) piese turnate

castings for general engineering (met) piese turnate pentru construcția de maşini

casting skin (met) crustă de turnare

casting slip (chim) barbotină, substanţă pentru ungerea formelor ceramice de turnare

casting strain / stress (met) tensiune de turnare rezultată din / după turnare

casting temperature (met) temperatură de turnare

casting wheel (met) dispozitiv de turnare rotativ, cu modelele dispuse pe un cerc / radial

casting yard (constr) şantier de cofrare / de turnare a prefabricatelor din beton

cast integral (met) a turna integral

cast into the sea (nav) a arunca în mare

cast iron (met) fontă turnată / de turnătorie

cast-iron cylinder (met, $\mathrm{OM}$ ) cilindru turnat în / din fontă

cast-iron fitting (met, OM) fiting / piesă (de legătură) din fontă turnată

cast-iron founder (met) turnător de fontă

cast-iron ingot mould (met) lingotieră de / pentru fontă

cast-iron malleableizing (met) maleabilizarea fontei (de turnare)

cast-iron mould (met) lingotieră

cast-iron pipe (OM, met) tub / țeavă de fontă

cast iron piston ring $(\mathrm{OM}$, termo) segment de piston din fontă

cast-iron roll (met) cilindru turnat din fontă

cast-iron scrap (met) spărturi de turnătorie, fontă veche / spartă

cast iron sewer pipe (met, OM) tub / țeavă / conductă (de legătură) din fontă turnată

cast-iron splinters (met) aşchii de fontă

cast-iron welding (met) sudare a fontei

cast-iron with euthectic matrix (met) fontă eutectică, de turnătorie

cast-iron with lamellar graphite matrix (met) fontă cu grafit lamelar

castle castel; (OM) crenelat

castle / castellated nut (OM) piuliță crenelată / moletată 
castle / castellated washer $(\mathrm{OM})$ şaibă crenelată cast loose a elibera, a declanşa, a desfăşura, a mola

cast off a arunca; a lăsa; a părăsi; (nav) a mola, a da parâma

cast metal (met) piesă turnată de / din metal, turnare a unui metal / aliaj

cast-metal case (met, OM) carcasă de / din fontă

cast moulding (met) formare prin turnare, obiect / piesă turnată

cast on (met) a completa prin turnare, turnat cast-on test bar (met) epruvetă din acelaşi aliaj / din aceeaşi şarjă de turnare

castor (zool) castor; solniță; rotiță (la mobilă)

CA storage room (termo) cameră (frigorifică) cu atmosferă controlată

castor oil (agr, ind chim) ulei de ricin

castor-oil plant (agr) ricin

cast out a alunga, a izgoni; (met) a scoate din forma de turnare

cast piece (met) piesă turnată

cast plate (met) placă turnată

cast seam (met) bavură de turnare

cast shell process (met) tragere la rece a tevilor turnate fără sudură

cast slab (met) bramă, sleb

cast steel (met) oțel turnat

cast-steel ingot (met) lingou de otel turnat

cast-steel gate (constr, mas) îmbrăcăminte / tablier de oțel turnat

cast-steel manufacture (met) elaborarea / producerea oțelului

cast-steel plate (met, OM) tablă / placă de oțel turnat

cast-steel products (met) piese turnate din otel

cast-steel wire (met) sârmă de oțel de fuziune

cast structure (met) structură a fontei, rezultată după turnare

cast tape / film (plast) peliculă / strat turnat(ă)

cast tooth dinte turnat (fără prelucrare la o maşină-unealtă)

cast up a aduna (o coloană), a calcula, a număra, a socoti, a totaliza, a aduna

cast uphill (met) a turna prin sifon

cast weld / welding (met) sudură / sudare prin turnare / prin topire

casual întâmplător, accidental; neintenționat; nepăsător, delăsător; neglijent, neatent; neoficial (d. tinută); ocazional, provizoriu; temporar; neregulat

casually $(a d v)$ (în mod) întâmplător, accidental; neglijent, neatent; ocazional, provizoriu; ca de fiecare zi, neoficial

casualness nepăsare, delăsare; neglijență cat (mas) pisică, cărucior de macara; (nav) palanc, gheară de pisică, ancorot

cataclysm cataclism; dezastru

catalog(ue) catalog (şi de prezentare a produselor), cartotecă, fişier, listă (şi de prețuri), mapă, broşură; (amer) (edu) plan de învățământ, programă analitică; a cataloga, a trece într-un catalog

cataloguing catalogare, înregistrare a unui fişier (pe un suport extern de informație)

cataloguize a cataloga, a trece într-un catalog

catalysis (chim) cataliză

catalyst (chim) catalizator

catalytic action of metal surfaces (chim) acțiunea catalitică a suprafețelor metalice

catalytic agent / catalyzer (chim) catalizator

catalytic convertor (auto) catalizator; convertor catalitic

catamaran (nav) catamaran

cataphoresis (el, hidr) mişcarea particulelor solide în mediu lichid, sub influența câmpului electromagnetic

catapult catapultă; a catapulta; a azvârli, a arunca

cataract cylinder (auto, OM) cilindru de frână

catastrophe catastrofă

catastrophic catastrofic

catastrophic failure ( $T$, mas) avarie / cădere catastrofală (a unui utilaj)

catch prindere, apucare, capturare; captură; (ec) câştig, venit; truc; pauză, întrerupere; (OM) opritor, pârghie / ştift de oprire, cârlig, tachet, nas; clește de prindere / de angrenare, dispozitiv de prindere, fixator, zăvor, clichet, clemă, clanță; $(\mathrm{OM})$ a prinde, a apuca, a captura, a zăvori, a observa o eroare, a capta, a lua; a ajunge la timp la; a înțelege, a pricepe; a lua foc, a se aprinde; (agr) şanț de scurgere

catchable care poate fi prins / apucat

catch-all (constr) debara, magazie

catch at a încerca să apuce cu, a încerca să se prindă de; a se prinde de

catch crop(s) (agr) culturi intercalate

catcher (met) laminorist din spatele cajei; (OM) opritor, curățitor, prinzător; $(\mathrm{TH})$ capcană, limitator de cursă, dispozitiv de prindere, clichet de blocare; (fiz) cavitate rezonantă, rezonator

catcher mark(s) (met) urme de prindere (şi la rolouri, ca defect)

catcher's side (met) partea de ieşire din laminor (a tablei) şi prindere pentru formarea ruloului catch handler $(\mathrm{OM})$ manivelă de antrenare catch hook (nav, mas) cârlig de prindere 
catching captare;prindere; (met) transmiterea benzii din laminor, prinderea ei în dispozitivul de înfăşurat rulouri

catching piece $(\mathrm{OM})$ clemă / piesă de prindere catching member $(\mathrm{OM})$ prinzător, piesă de prindere

catchment prindere, prins, capturare; $(\mathrm{TH})$ bazin de recepție; zonă pentru o instituţie centrală (spital, şcoală etc.)

catchment area zonă pentru o instituție centrală (spital, şcoală etc.)

catchment of water (hidr, mediu) captarea / colectarea apei

catch on a întelege, a pricepe

catch out a demasca

catch pan (mediu) recipient colector de noroi (în camera de cabluri)

catch pawl $(\mathrm{OM})$ clichet de blocare

catchpenny (ec) marfã proastă

catch pin (OM) bolț, ştift, şplint, ştift de oprire / de prindere

catch ring $(\mathrm{OM})$ inel de antrenare / de prindere

catch up a ajunge din urmă; a prinde, a prelua o idee

catchword cuvânt sau expresie la modă; lozincă; parolă; titlu de pagină; articol de dicționar

catch wrench $(\mathrm{OM})$ furcă de prindere

cate (alim) mâncăruri alese, delicatese

categorical categoric, hotărât; absolut; direct; care tine de o categorie

categorically $(a d v)$ categoric, hotărât; absolut; pe categorii

categorize a clasifica

category categorie, clasă

catena lanț, şir; (chim) catenă

catenary (chim) catenă, lanț; (el) fir de cale; (mat) lănțișor (funcție), catenă; (OM) lanț, lănţişor, arc în formă de coş, cablu de suport, în (formă de) lant, catenar

catenary equation (mat) ecuație a lănțişorului catenation (chim) catenare; șir, lant, înlăntuire cater (ec) a furniza provizii

caterer (alim) furnizor (de alimente), director sau proprietar de restaurant / hotel

cater for a furniza provizii pentru, a se îngriji de aprovizionarea cu; a satisface (un consumator)

caterpillar (zool) omidă; (mas, OM) maşină pe șenile, şenilă

caterpillar chain $(\mathrm{OM})$ şenilă

caterpillar conveyer / conveyor (mas, mil, transp) transportor cu șenile

caterpillar (friction)-clutch (OM) ambreiaj lateral (prin frecare) caterpillar guide $(\mathrm{OM})$ placă de ghidare a şenilei

caterpillar shovel (mas, constr) excavator pe şenile cu lingură / cu cupă

caterpillar tractor (mas) tractor cu şenile

caterpillar transmission (OM) transmisie laterală

caterpillar trunk (auto) autocamion pe şenile

cathead (mas-un) mandrină cu şuruburi de strângere

cathode-base circuit (ec) montaj cu catodul comun

cathode beam (fiz) rază catodică, fascicul catodic / de electroni

cathode bearing a layer of oxide (el, chim) catod stratificat / acoperit cu oxizi metalici

cathode cleaning (el, chim) degresare catodică

cathode copper (el, met) cupru electrolitic

cathode-ray oscillograph (CRO) (fiz, el) oscilograf catodic

cathode sputtering (el) pulverizare a catodului

cathodic bombardment (fiz) şoc / incidență a(l) electronilor, bombardament catodic

cathodic cleaning (el, chim) curățire / degresare / purificare catodică

cathodic coating (el, chim) acoperire catodică

cathodic deposit (met, el) depunere catodică / la catod

cathodic pickling (met, el, chim) decapare catodică / cu catod

cathodic protection (el, chim) protecție catodică (împotriva coroziunii electrochimice)

cation (fiz, chim) cation, ion pozitiv

catoptric(al) (fiz) catoptric

catoptrics (fiz) catoptrică

cat's eye (auto) ochi de pisică

catsup (alim) sos picant (din ciuperci)

cattiness răutate, ură; falsitate, prefăcătorie; agilitate

cattish felin; rău, răutăcios; prefăcut; agil

cattle (agr) bovine, vite

cattle cake (agr) turtă oleaginoasă

cattle house (agr) staul

cattleman (agr) crescător de vite, cioban

cattle run (agr) păşune, izlaz (mare)

cattle suet (alim) seu de vită

catty felin; rău, răutăcios; prefăcut; agil

cat(-)walk (auto) mers foarte încet; (constr) pasarelă, podeț; (nav) culoar, trecere / pasarelă îngustă; scara rezervorului

cauldron (termo) cazan

cauliflower (agr, alim) conopidă

caulk (ind chim) pastă (de cauciuc, cu agent de vulcanizare) de etanşare; a călăfătui, a ştemui 
caulker călăfătuitor, ştemuitor

caulking (met) etanşare a cusăturii de sudură prin forjare

caulking iron (mas-un) dorn de găurit, daltă de călăfătuit

caulking machine for pipes (mas-un) maşină de mandrinat țevi

caulking strips (met) benzi de etanşare

causality cauzalitate

causality condition (s) condiții de cauzalitate

cause cauză; temei; motiv; justificare; (jur) caz,

proces; problemă, chestiune; a cauza, a pricinui

cause beyond control (ec, TH) forță majoră

causeless fără cauză / motiv; nemotivat, nejustificat

causelessly $(a d v)$ fără cauză / motiv; (în mod) nemotivat, nejustificat

causer vinovat; cauză, pricină

cause somebody damage a prejudicia pe cineva

cause to a face pe cineva să; a informa / înştiința pe cineva

causeway dig rutier, şosea

caustic (chim, met) caustic, corosiv

caustic dip (chim, met) soluție puternic alcalină, folosită şi la decapare, baie de hidroxid de sodiu

caustic embrittlement (fiz) coroziune intercristalină (a oțelurilor și aliajelor $\mathrm{Fe}-\mathrm{Cr}-\mathrm{Ni}$ ) din cauza expunerii la soluții caustice; (ind chim, met) fragilitate / fisurare caustică

causticity (chim) causticitate

caustic soda (chim) hidroxid de sodiu (conținând $76 . .78 \%$ oxid de sodiu), sodă caustică, hidrat de sodiu

caustic wash(ing) (ind chim) spălare cu soluții de alcalii

cauterization $(\mathrm{TH})$ băituire

cauterize (med) a băițui, a decapa; a cauteriza

caution a preveni, a avertiza (împotriva); (jur) cauțiune

cautiousness prudență, prevedere; atenție, precauție

cautionary care avertizează

cautioner (jur) garant

cautious precaut, prevăzător; prudent; atent

cave peşteră, grotă, cavernă; (constr) pivniță; (fiz) celulă; (constr) a excava, a săpa, a scobi

caveat avertisment, prevenire, opoziție (împotriva unui brevet de inventie), cerere pentru un brevet provizoriu

cavendish (agr) tutun presat

caviar(e) (alim) icre (ca aliment), caviar cavitation (fiz, hidr, el, T) cavitație (proces dar și rezultat); (met) formare a suflurilor cavitation damage $(\mathrm{T})$ distrugere prin (uzură de) cavitatie

cavitation erosion ( $T$ ) uzură de cavitație şi eroziune cavitation flow (hidr) curgere a unui fluid, cu formare de bule (care ar putea iniția cavitația) cavity cavitate, scobitură; groapă; adâncitură; (met) gol, retasură (într-o piesă turnată); excavație, cavitate (şi într-o piesă), cavernă

cavity brick (constr, met) cărămidă cu goluri

cavity of mould (met) cavitate a formei / a matriței (de turnare)

cavity side part (met) parte fixă a matriței

cavity wall (constr) zid cu goluri / cu pereți dubli

cc (cubic centimeter) (metr) unitate de măsură pentru volum / capacitate: $1 \mathrm{cc}=0,000001 \mathrm{~m}^{3}$

ccf (100 cubic feet) (metr) unitate de măsură pentru volum / capacitate, 100 de picioare cubice: $1 \mathrm{ccf}=2,831684659 \mathrm{~m}^{3}$

c-clamp (mas-un) presă de mână, cu şurub; (OM), clemă cu şurub

cease a înceta, a se opri, a conteni

cease germination (agr) a înceta germinarea

ceaseless neîncetat, continuu

ceaselessly $(a d v)$ (în mod) neîncetat, (în)continuu, fără încetare

cedar cedru

cede a ceda (şi drepturi)

ceiling (constr) tavan, plafon; plafon de nori; (fig) limită

ceiling duct (constr) conducta de trecere prin acoperiş (prin tavan)

ceiling joist (constr) grindă inferioară, subgrindă ceiling lamp plafonieră (şi la autoturism)

celebrate a sărbători, a celebra; a comemora

celebration sărbătoare, celebrare; comemorare; festivitate; oficiere

celebrity celebritate; reputație, faimă; persoană cu renume

celerity iuteală, rapiditate

celery (alim) țtelină

cell $(\mathrm{TH})$ cameră, colivie, sectie, element, celulă; (constr) canal în cărămizile cu goluri; (el) pilă / celulă electrică, element galvanic; (inf) celulă de memorie; (met) celulă de cuptor adânc

cellar (alim, constr) pivniță (şi de vinuri), beci; a ține / păstra în pivniță

cellarage (alim) pivnițe (şi de vinuri), beciuri; păstrare în pivniță; (ec, alim) plată / taxă pentru păstrare în pivniță

cellaret (alim) despărțitură / spațiu pentru sticlă; bar (mobilă)

cellastic tyre (auto, mil) pneu blindat (contra gloanțelor) 
cell concrete (constr) beton celular cell filter (alim, hidr, ind) filtru celular cellophane (alim, plast, chim) celofan cellotape bandă adezivă

cell-pit furnace (met) cuptor adânc, cu celule celular

cell-type în formă de fagure, celular

cellular (plast) celular, poros, spongios

cellular / cartridge filter (alim, hidr, mediu) filtru celular / cu alveole / cu celule / cu site filtrante demontabile

cellular insulant (el, termo) izolant spongios / spumos / poros / celular / expandat

cellular structure (chim, constr) structură celulară

cellular wheel (hidr) roată cu cupe (pentru ridicat apa)

cellule celulă; schelet

cellulose (chim, plast) celuloză

cellulose acetate (chim, plast) acetat de celuloză cellulose ester (chim, plast) ester de celuloză cellulose ether (chim, plast) eter de celuloză cellulose gum (chim, plast) gumă, răşină vegetală, solubilă în apă

cellulosic coating (el, chim) acoperire celulozică (la electrozi)

Celsius degree (metr, termo) grad Celsius

Celtium (Hf) (chim) hafniu, celtiu

cement (constr) ciment, mastic, liant; (ind chim) adeziv, clei; (constr) a cementa, a cimenta, a face priză, a lega; a consolida, a întări

cement-asbestos (constr) azbociment

cementation (constr) cimentare, chituire; (met) (adaos de) carburare / cementare, călire; întărire cementation equipment (met) echipament de cimentare

cementation furnace (met) cuptor de cementare cementation power (met, chim) capacitate de legare / de cementare

cementation steel (met) otel de cementare

cement carbon (met) carbon pentru cementare / pentru călire

cemented armour (mil) cuirasă, blindaj de oțel cemented belt $(\mathrm{OM})$ curea de piele lipită cemented carbide (met) carbură (într-un oțel) obținută după cementare

cemented-carbide alloy (met) aliaj dur, din carburi metalice sinterizate

cemented-carbide (alloy) bit (mas-un) plăcută din carburi metalice (pentru aşchiere)

cemented-lap joint $(\mathrm{OM})$ îmbinare prin lipirea capetelor suprapuse (la curele)

cemented zone (met) zonă / strat cementat(ă) / carburat $(\breve{a})$ cementing (constr) cimentare; (met) cementare, carburare

cementing agent (constr, chim) substanță de cimentare, ciment de legătură; (met) agent ce favorizează cementarea

cementing bath (met) baie de cementare

cementing box / pot (met) cutie de cementare / de carburare

cementing carbon (met, chim) carbon de călire / de cementare

cementing machine (ind chim) maşină de cauciucare / de aplicat soluție de cauciuc

cementing material (constr, chim) ciment de legătură, material liant, substanță liantă

cementing medium (met) mediu (gazos, de săruri) de cementare / de carburare

cementing powder (met) praf / pulbere de cementare / de carburare

cementite (met) cementită, carbură de fier

cementite breakdown (met) descompunerea cementitei

cement mixer (constr, ind chim) amestecător de ciment, mixer, malaxor de clei / de soluție de cauciuc

cement steel (met) otel de convertizor

censored distribution (el, autom) repartitie distribuție controlată

censored sample selectie controlată

censoriousness obiceiul de a critica sever

censorship calitatea / funcția de cenzor; cenzură

censurable care merită să fie criticat; condamnabil

censure dezaprobare, a condamna, a blama, a critica

census recensământ

cent (fiz) interval între două sunete ale căror frecvente se află într-un raport egal cu radical de ordinul 1200 din 2; (ec) a suta parte dintrun dolar (cent)

centenary centenar

centennial centenar; care are loc la o sută de ani center (amer) centru

center console (auto) consolă centrală

centesimal (mat) centezimal

centi (metr) prefix pentru $10^{-2}$ (pt. subunități de măsură)

centigrade (fiz, metr, fiz) centigrad

Centigrade degree (fiz, metr) grad centigrad / Celsius

centigrade heat / thermal unit (metr) centigrad termic (unitate engleză de energie)

centigrade scale (metr) scală centigradă / Celsius centigram(me) (metr) centigram, unitate de măsură pentru masă: 1 centigram $=0,00001 \mathrm{~kg}$ 
centigram/liter (metr) unitate de măsură pentru debit masic: 1 centigram $/$ liter $=0,01 \mathrm{~kg} / \mathrm{m}^{3}$

centigram/second (metr) unitate de măsură pentru debit masic: 1 centigram $/$ second $=0,00001 \mathrm{~kg} / \mathrm{s}$

centiinch (metr) unitate de măsură pentru lungime: 1 centiinch $=0,000254 \mathrm{~m}$

centijoule/second (metr) unitate de măsură pentru putere: 1 centijoule/second $=0,01 \mathrm{~W}$

centiliter (metr) unitate de măsură pentru capacitate, centilitru: 1 centiliter $=0,00001 \mathrm{~m}^{3}$

centimeter, centimetre (cm) (metr) unitate de măsură pentru lungime, centimetru: $1 \mathrm{~cm}=0,01 \mathrm{~m}$

centimeter mercury $\left(0^{\circ} \mathrm{C}\right)$ (metr) unitate de măsură pentru presiune: 1 centimeter mercury $\left(0^{\circ} \mathrm{C}\right)=1333,22 \mathrm{~Pa}$

centimeter water $\left(4^{\circ} \mathrm{C}\right)$ (metr) unitate de măsură pentru presiune: 1 centimeter water $\left(4^{\circ} \mathrm{C}\right)$ $=98,0638 \mathrm{~Pa}$

centimeter/square second (metr) unitate de măsură pentru vâscozitate cinematică: 1 centimeter/square second $=0,01 \mathrm{~m} / \mathrm{s}^{2}$

centinewton (metr) unitate de măsură pentru forță, centinewton: 1 centinewton $=0,01 \mathrm{~N}$

centipascal (metr) unitate de măsură pentru presiune, centipaslcal: 1 centipascal $=0,01 \mathrm{~Pa}$

centiwatt (metr) unitate de măsură pentru putere, centiwatt: 1 centiwatt $=0,01 \mathrm{~W}$

centilitre (cl) (metr) unitate de măsură pentru capacitate / volum, centilitru: 1 centiliter $=0,011$

centimetre-gram-second sistem de unități, de măsură bazat pe centimetru-gram-secundă

centipoise (metr, T) centipoise (unitate de măsură pentru vâscozitate dinamică)

centistoke (metr, T) centistoke (unitate de măsură pentru vâscozitate cinematică

centner (metr) chintal $(=100 \mathrm{~kg})$

central central, din / de lângă centru; fundamental, esențial, principal; accesibil; situat în apropiere

central air-jet (hidr, termo) jet de aer central

central angle (mat) unghi la centru

central back pressure valve (hidr, OM) obturator hidraulic central

central brick (constr, met) cărămidă centrală de închidere / de încheiere a bolții (unui cuptor etc.)

central door lock system (auto) sistemul central de blocare a portierei

central field of vision (auto, mec) câmp la deschiderile din mijloc; (TH) câmp de mijloc / intermediar

central force (mec) forță centrală / centrică central gate (met) pâlnie centrală / principală de turnare central girder (constr, mec) grindă principală / centrală

central heating (termo) calorifer, încălzire centrală

central heating and power plant (termo) centrală electrică de termoficare

centralised centralizat, sub un singur control

centralised greasing $(T)$ ungere centralizată cu unsoare

centralised lubrication $(\mathrm{OM}, \mathrm{T})$ ungere / lubrifiere centrală / centralizată

centralised maintenance shop (met) atelier centralizat de mentenanță

centraliser (OM, mas-un) centrator, ghidaj(e) de centrare, centralizator

centraliser bearing $(\mathrm{OM}, \mathrm{mec})$ rulment / lagăr de centrare

centralising casing $(\mathrm{OM})$ ghidaj de centrare

centralism centralism

centrality poziție centrală / principală

centralization centralizare; concentrare

centralize a (se) centraliza, a (se) concentra

centrally $(a d v)$ la / lângă centru

central motion mișcare centrală

central principal axis of inertia (mec) axă principală de inerție

central principal moment of inerția (mec) moment principal de inertie

central processing unit (CPU) (c, inf) unitate centrală de prelucrare a datelor, parte principală a unui calculator

central roll (met) cilindru intermediar

central wheel $(\mathrm{OM})$ roată intermediară / mijlocie

centre centru, punct central, mijloc; median, central, mediu; vârf; (fiz) nucleu; (mas-un) vârf de strung; a centra, a centrui, a regla la centru, a pune / aşeza la centru; (met) miez, inimă; (constr) centru; (TH) vârf

centre bearing (OM) lagăr de mijloc / intermediar

centre bit (mas-un) burghiu de centrare

centreboard (nav) derivor central

centre cut-end mill (mas-un) freză cu coadă, cu dinți drepți

centred centrat

centre disk-wheel $(\mathrm{OM})$ roată (cu) disc centrat

centre distance (OM, mas-un) distanță între vârfuri / între centre / între axe (a) (a două roți dințate etc.)

centre distance modification coefficient $(\mathrm{OM})$ coeficientul deplasării distanței între axe $(\Sigma)$

centre drill (mas-un) burghiu de centrare / de centruire 
centre gauge (metr) şablon pentru verificarea vârfurilor / centrării

centre girder (mas-un) maşină de rectificat între vârfuri

centre grinding attachment (mas-un) dispozitiv de rectificare între vârfuri

centre hole (mas-un, OM) gaură de centrare

centre irons $(\mathrm{OM})$ lagăr principal al balansierului

centre journal bearing $(\mathrm{OM})$ lagăr intermediar centre lathe (mas-un) strung (paralel) pentru prelucrat piese aşezate între vârfuri

centre line (constr) linie centrală / axă de drum; (mat) linie de centru / mediană, linie centrală, axă; $(\mathrm{OM})$ axă a găurii

centre-line weakness (met) porozitate centrală (la turnare)

centre of attack (mec) centru de aplicație centre of attraction (fiz) centru de atractie centre of bore $(\mathrm{OM})$ axa găurii / alezajului centre of bridging strip (mec) centru fals centre of crystallization (met) germen / nucleu de cristalizare

centre of curvature (auto) centru de viraj; (mat, mec) centru de curbură

centre of displacement (nav) centru de carenă / de deplasament

centre of gravity (fiz, mec) centru de greutate (centru de masă)

centre of gyration (mec) centru de rotație / de girație

centre of inertia system (mec) sistem (de coordonate) al centrului de inerție

centre of lift (hidr, mec) punct de aplicație a forței portante, centru de sustentație

centre of mass (mec) centru de masă / de inerție centre of mass motion $(\mathrm{mec})$ mișcare a centrului de masă

centre of moments (mec) punct neutru al momentelor

centre of projection centru de proiecție

centre of rotation $(\mathrm{mec})$ centru de rotație

centre of support (mec) centru al reazemului

centre of symmetry (mat, mec) centru de simetrie

centre of tooth $(\mathrm{OM})$ linie centrală / centru a(l) dintelui

centre on a se concentra asupra, a se centra pe centre piece obiect principal; $(\mathrm{OM})$ cruce cardanică

centre pin $(\mathrm{OM})$ pivot

centre plug (mas-un, OM) extractor de pană centre of porosity (met) porozitate centrală (la piese turnate) centre point centru; (el) punct median; (mas-un) vârf al burghiului de centrare

centre punch (mas-un) punctator de centrare, dorn de perforat; a puncta

centre ram (constr) stâlp central

centre reamer (mas-un) alezor de centrare

centre rest (mas-un) lunetă fixă

centre riser (met) maselotă centrală

centre roll (met, $\mathrm{OM}$ ) cilindru intermediar, pentru laminor

centre runner (met) pâlnie centrală / principală de turnare

centres (mas-un) vârfuri (şi de centrare a pieselor); distanță maximă dintre vârfuri

centre-slung centrifugal (mas, alim, ind chim) centrifugă acționată de la partea inferioară

centre spine frame (auto) cadru al coloanei centrale (a automobilului)

centre through plate (mec, mas-un) centrul unei plăci

centre-to-centre distance $(\mathrm{OM})$ distanță între centre / între axe (şi la roți dinţate, de curea etc.) centre tubular chassis (auto) şasiu cu tub central / cu grindă centrală tubulară

centre(-web) wheel $(\mathrm{OM})$ roată cu disc, roatădisc, roată centrală / de centru

centricity $(\mathrm{TH}$, mat) centricitate

centrifugal centrifugă; centrifug(al)

centrifugal acceleration (mec) accelerație centrifugă

centrifugal action $(\mathrm{TH}$, alim, ind chim) centrifugare

centrifugal air blower / pump (mas) suflantă centrifugă de aer

centrifugal air compressor (mas, termo) compresor centrifugal de aer

centrifugal atomizer (alim, ind chim) atomizor centrifugal

centrifugal balancing machine (mas-un) maşină de echilibrat centrifugal

centrifugal basket $(\mathrm{OM})$ tobă / tambur de centrifugă

centrifugal basket drier (alim, ind chim, textile) centrifugă cu tobă perforată (pentru stors) centrifugal blender (alim, ind chim) amestecător centrifugal

centrifugal blower (mas) ventilator centrifugal, suflantă centrifugă

centrifugal box (plast) maşină de filare prin centrifugare; (mas) centrifugă

centrifugal breaker (alim, ind chim) moară centrifugă

centrifugal casting $(\mathrm{TH})$ turnare centrifugală (a aliajelor metalice, compozitelor etc.) 
centrifugal casting mould (met) cochilă pentru turnare centrifugală

centrifugal casting process (met) procedeu / metodă de turnare centrifugală

centrifugal crushing-mill $(\mathrm{TH}$, mas, constr, ind chim) dezintegrator, concasor centrifugal

centrifugal discharge (mas) descărcare centrifugală

centrifugal drum $(\mathrm{OM})$ tobă de centrifugă

centrifugal drying (alim, ind chim, textile) uscare prin centrifugare

centrifugal dust collector (mediu, met, ind chim) colector centrifugal de praf

centrifugal effect (mec) efect centrifugal

centrifugal fan (mas) ventilator centrifugal

centrifugal filter (alim, ind chim, mediu) centrifugă filtrantă

centrifugal force (mec) forță centrifugă

centrifugal gas scrubber (mas, met) scruber centrifugal

centrifugal governor (autom, mec, OM) regulator centrifugal

centrifugal growth $(\mathrm{TH})$ creștere a dimensiunii pe direcția forței centrifuge

centrifugal hydro-extracting (alim, textile, ind chim) centrifugare (pentru eliminarea apei)

centrifugal impeller mixer (alim, ind chim) amestecător cu braț centrifugal

centrifugal method $(\mathrm{TH}$, alim, ind chim) metodă prin centrifugare

centrifugally cast concrete (constr) beton centrifugat / turnat prin centrifugare

centrifugally cast (iron) (met) turnare centrifugă

centrifugal machine (mas) centrifugă

centrifugal method $(\mathrm{TH})$ (prin) metodă centrifugală

centrifugal moulding (met, plast) formare/ turnare centrifugă

centrifugal moment (mec) moment centrifugal

centrifugal oil cleaner $(T$, alim) filtru centrifugal de ulei

centrifugal (pressure) casting (met) turnare centrifugă (şi sub presiune)

centrifugal pump (hidr, OM) pompă centrifugă centrifugal roll mill (ind chim) moară centrifugă cu role

centrifugal screen (agr, alim, ind chim) sortator / ciur / sită centrifugal( $\breve{a})$

centrifugal scrubber (met, ind chim) scruber centrifugal

centrifugal separation alim, ind chim) separare centrifugală

centrifugal separator (alim, ind chim) centrifugă de separare centrifugal single-inlet fan (mas) ventilator centrifugal cu o singură intrare de aer

centrifugal speedometer (metr) tahometru centrifugal

centrifugal spinning (plast, ind chim) filare centrifugă

centrifugal spraying $(\mathrm{TH})$ pulverizare centrifugală

centrifugal spray tower (ind chim) coloana centrifugă cu stropire

centrifugal starting switch (el, mec) întrerupător-demaror centrifugal

centrifugal stress $(\mathrm{mec})$ tensiune cauzată de forte centrifuge

centrifugal supercharger (termo) turbocompresor centrifugal; compresor centrifugal de supraalimentare

centrifugal tachometer (metr) tahometru centrifugal

centrifugal tendency (mec) forță centrifugă

centrifugal tray $(\mathrm{OM})$ taler centrifugal

centrifugal-tyre compressor (termo) compresor centrifugal

centrifugal weight $(\mathrm{mec})$ greutate centrifugă (acționată de forță centrifugă)

centrifugal whirler (mas) centrifugă

centrifugal with non-perforated basket (alim, ind chim) centrifugă fără sită

centrifugated milk (alim) lapte degresat

centrifuge (mas) centrifugă, a centrifuga

centrifuge reclaiming (ind chim) regenerare prin centrifugare

centrifuge refining (alim, ind chim) rafinare prin centrifugare

centrifuge test (mediu, ind chim) determinare a sedimentelor prin centrifugare

centrifuging $(\mathrm{TH})$ centrifugare

centring centrare; (constr) calibru, centrare; (inf) centrare a semnelor; (oprerația de) centrare (la prelucrare sau montaj)

centring and facing tool (mas-un) cuțit pentru centrare si strunjire frontală

centring attachment (mas-un) dispozitiv de centrare

centring chuck (mas-un) mandrină de autocentrare / cu centrare automată

centring cone (mas-un, OM) con de prindere centrică

centring control (autom, mas-un) regulator de centrare

centring device (mas-un, OM) dispozitiv de centrare

centring error (OM, mas-un) excentritate, eroare de centrare 
centring guides (mas-un, TH) ghidaje de centrare (la montaj sau la prelucrare)

centring machine (mas-un) maşină de centruit / de dat găuri pentru centrare

centring pivot $(\mathrm{OM})$ fus / cep de centrare

centring rib (mas-un, auto) nervură de centrat (şi anvelope)

centring square (mas-un) echer de centrare

centring (twist) drill (mas-un) burghiu spiral pentru găuri de centrare

centripetal (mec) centripet

centripetal force (mec) forță centripetă

centroid (mat) centroidă, centru de greutate (al unei suprafețe)

centroidal (mec) axă a centrelor de greutate

centroidal axle $(\mathrm{mec})$ axa centroidă / prin centrul de greutate, linia centrelor de greutate

centrum, $(p l)$ centra centru; epicentru

centuple însutit, centuplu; a însuti, a mări de o sută de ori

century secol, veac, sută, o sută de; (metr) unitate de măsură pentru timp, secol: 1 century $=$ $3153600000 \mathrm{~s}$

ceramic (de) ceramică, ceramic

ceramic based circuit (electr) circuit imprimat cu substrat ceramic

ceramic bond (chim) liant ceramic

ceramic coating (chim, T) acoperire ceramică

ceramic composition amestec ceramic

ceramic fibers (ind chim) fibre ceramice (şi pentru compozite)

ceramic filter $(\mathrm{OM})$ filtru ceramic

ceramic industry industrie ceramică

ceramic insert inserție de material ceramic (la scule aşchietoare, lagăre)

ceramic kiln (ind chim) cuptor de ardere a ceramicii

ceramic matrix (materiale) matrice ceramică (la compozite)

ceramic matrix composite (materiale) compozit cu matrice ceramică

ceramic products produse ceramice

ceramics ceramică, produse / obiecte ceramice

ceramic tile (constr) placă / dală ceramică

ceramic tool (mas-un, materiale) scule sau plăcuțe ceramice (de obicei sinterizate)

ceramic transducer (metr, el, materiale) traductor electrostrictiv cu ceramică

cereal (alim) cereală, fulgi de avăz

cereal crops (agr) graminee, (cultură de) cereale cereal harvesting (agr) recoltare a cerealelor cereals (agr, alim) cereale

cerecloth (textile, ind chim) muşama, pânză ceruită / cerată ceremonial de ceremonie; formal; convențional; ceremonie, ceremonial, forme de etichetă

ceremony ceremonie

cerise cireşiu, de culoarea cireşii

Cerium(Ce) (chim) ceriu

cermet $(\mathrm{TH}$, materiale) material metalo-ceramic, cermet; (met) metalurgia pulberilor

cerous (chim) ceros

cert (lucru) absolut sigur; cert

certain anumit, anume; oarecare; sigur, precis, cert; categoric, neîndoios; convins; fixat; definit, determinat

certainly $(a d v)$ (în mod) sigur, cu siguranță, cu certitudine, negreșit, neîndoielnic; (de)sigur, bineînțeles, cum să nu, fireşte, da

certainty fapt cert / sigur, siguranță, precizie, determinare; fixare; definire; convingere

certes $(a d v)$ fără îndoială

certifiable care poate constatat, constatabil

certificate (ec) certificat, titlu (de acțiuni), recipisă; (amer) diplomă, atestat

certificated cu diplomă / atestat

certificate measurement (ec) situație de plată (metr), măsurare, măsurătoare certificată

certificate of acceptance proces-verbal / certificat de recepție (a unei lucrări)

certificate of addition (ec) brevet pentru investiție

certificate of correction brevet pentru invenție complementară

certificate of deposit (ec) certificat de depunere certificate of health (med) certificat medical

certificate of origin (ec) certificat de origine / de proveniență (a mărfurilor de export)

certificate of registry (nav) certificat de naţionalitate (a unei nave)

certificate of utility certificat de utilitate, titlu de protecție, similar brevetului de invenție, eliberat fără aviz de documentare

certification certificare, atestare; adeverire

certification pressure impunerea unor teste de către persoane sau instituții autorizate

certificatory adeveritor, care confirmă / certifică, confirmator

certified adeverit, confirmat; garantat, asigurat; verificat; atestat (de)

certified cheque (ec) cec vizat

certified electrical engine (el) motor electric antigrizuros

certified mail (amer) scrisoare recomandată certified milk (alim) lapte verificat în laborator certified public account (ec), (amer) contabil cu diplomă, revizor-contabil atestat 
certify a certifica, a adeveri; a verifica; (ec) a garanta; a elibera un certificat (şi medical)

certify to a dovedi, a atesta cu

certitude, certainty certitudine

cerulean albastru ca cerul

Cesium (Cs) (chim) cesiu

cessation încetare, oprire, cesionare

cession (jur) cesiune, cesionare

cessioner (jur) cesionar

cesura (metr) cezură

chafe (T) uzură prin frecare, frecare; a uza prin frecare, a freca, a introduce (o substanță) prin frecare, a încălzi prin frecare (în mod voit)

chaff (agr, alim) pleavă, paie tocate, tocătoare de nutreț

chaff cutter (agr, mas) tocătoare staționară

chaffing ( $T$, plast, textile) frecare a firelor, uzura prin frecare a firelor

chaffy (agr) cu pleavă, plin de pleavă; (fig) prost, fără valoare

chafing fatigue (T) uzură tip fretting

chain captivitate; (OM) lanț, lănțişor; (chim) lanț, catenă; (fig) rețea, sistem; (metr) unitate de măsură pentru lungime: 1 chain (US survey) = $20,116840234 \mathrm{~m}, 1$ chain $=20,1168 \mathrm{~m}$

chain-and-ducking dog mechanism (met) transportor cu lanț şi gheară, pentru semifabricate

chain and flight $(\mathrm{OM})$ lanț şi racletă

chain and sprocket transmission (OM) transmisie prin lanț (şi roți de lanț)

chain bar $(\mathrm{OM})$ braț al lanțului de tăiere (industria lemnului)

chain belt $(\mathrm{OM})$ curea articulată / din fişii de piele / din eclise

chain block $(\mathrm{OM})$ palan cu lant

chain box $(\mathrm{OM})$ carter / cutie pentru lant

chain brake $(\mathrm{OM})$ frână cu lanț

chain breaking $(\mathrm{OM})$ (între)rupere a lanțului

chain bridge (constr) pod susținut de lanțuri

chain bridging (chim) formare a punților (între catene)

chain-bucket loader (mas) încărcător / elevator cu cupe

chain cable (nav) lanț de ancoră

chain case (OM, mas-un) apărătoare de lanț, carcasa transmisiei cu lant

chain catalytic polymerization (ind chim) polimerizare catalică în lant

chain company (ec) societate / magazin cu sucursale multiple, grup de agenții de publicitate

chain connecting link (OM) za de înnădire / de legătură (şi la lanțuri)

chain control comandă prin lanț chain conveyor (OM, mas) transportor cu lanț chain-cooling bed (met) pat de răcire, cu (acționare cu) lanțt(uri)

chain coupler $(\mathrm{OM})$ bolț al capătului de lanț, bolț de închidere a lanțului

chain-coupler link $(O M)$ za de închidere a lanțului

chain coupling $(\mathrm{OM})$ cuplaj / cuplare prin / cu lanț

chain cutting machine (mas-un) maşină cu lanțtăietor (industria lemnului)

chain dimensioning $(\mathrm{OM})$ cotare în lant

chain drive $(\mathrm{OM})$ transmisie / acționare prin / cu lanț(uri)

chain drum $(\mathrm{OM})$ tambur pentru lanț

chain elevator for boxes (mas) elevator cu lanț (cu platforme) pentru grinzi

chain ending (chim, OM) întrerupere a lanțului, capăt de lanț

chain gearing $(\mathrm{OM})$ transmisie / antrenare prin / cu lant (si roți de lant)

chain girth (nav) contur al secțiunii transversale a navei

chain grabbing bucket (mas, constr) excavator cu şenile, cu graifăr

chain grate (ind chim, met) grătar rulant cu lanț chain-grate stoker (termo, met) focar cu grătarlant

chain growth (chim) creştere a lanţului / catenei chain guard / housing $(\mathrm{OM})$ apărătoare de lanț chain guide pulley $(\mathrm{OM})$ rolă de ghidare pentru lanț

chain haulage (met, $\mathrm{TH})$ transport prin lanțtractor

chain hawse (nav) nară pentru lant

chain hoist (mas) troliu (de macara); (TH) macara / palan cu lant

chain hook (nav) cârlig de lanț

chain hydrocarbons (chim) hidrocarburi cu catenă / catenate

chaining înlănțuire; (inf) specificare a informatiei de structură; deductie în lant (în luarea deciziilor)

chain initiation (chim) inițiere / formare a lanțului (molecular) / catenei

chain iron $(\mathrm{OM})$ za / verigă de lanț

chain jack $(\mathrm{OM})$ vinci cu lant

chain joint $(\mathrm{OM})$ verigă /piesă de legătură a lanțului

chain leader $(\mathrm{OM})$ dispozitiv pentru întinderea lantului / a ruletei

chainlet lănțişor

chain link $(O M)$ copcă / za / verigă de lanț; (chim, plast) unitate structurală 
chain-link pin (OM) bolțul lanțului, fus de lanț chain lock (om, mas-un) cheie pentru înnădirea lanțurilor

chain man $(\mathrm{OM})$ dispozitiv pentru întinderea lanțului / a ruletei

chain mortizer (mas-un) maşină de frezat cu lanț

chain of command (ec) lanț de conducere / ierarhic, scară ierarhică

chain path $(\mathrm{OM})$ mersul / calea lanțului

chain pick box $(\mathrm{OM})$ cutie susținătoare a unui lanț tăietor (la combină, în industria lemnului)

chain pin $(\mathrm{OM})$ bolț de lanț

chain pipe cutter (mas-un) cleşte cu lanț, de tăiat țevi

chain pipe tongs (mas-un, transp) cleşte cu lanț pentru (prins / transportat) țevi

chain pipe wrench (met, mas-un) cheie pentru țevi, cleşte cu lanț

chain pitch (OM) pasul lanțului

chain plate (nav) placă / eclisă de lant

chain polymerization (chim) polimerizare în lant

chain process (chim) reacție / proces în lanț

chain pull $(\mathrm{OM})$ palan cu lanț

chain pump (mas) pompă cu lanț port-cupe, elevator cu cupe

chain reaction (chim, $\mathrm{TH})$ reactie în lant

chain reel $(\mathrm{OM})$ tambur cu / de lanț

chain reveting $(\mathrm{OM})$ nituire în rânduri paralele

chain road (met, OM) cale de tracțiune, cu lanț(uri)

chain roller $(\mathrm{OM})$ rolă / bucşă de lanț

chain roller bearing $(\mathrm{OM})$ lagărul scripetelui / rotiii de lant

chains $(\mathrm{OM})$ lanțuri

chain saw (mas-un) ferestrău cu lanț

chain saw support $(\mathrm{OM})$ şină port-lanț (în ind lemnului)

chain slotter (mas-un) maşină de mortezat cu lant chain splice $(\mathrm{TH})$ matiseală pe lanț

chain sprocket $(\mathrm{OM})$ pinion de lant

chain starting (chim) inițiere a lanțului (molecular) / catenă

chain steel (met) oțel pentru lanțuri

chain store lanț de magazine (de la aceeaşi firmă)

chain strand $(\mathrm{OM})$ ramură de lanț

chain-stretching device $(\mathrm{OM})$ dispozitiv de întindere a lanțului, întinzător de lanț

chain stud $(\mathrm{OM})$ bolt de lanț

chain suspension bridge (constr) pod (suspendat) cu lanțuri

chain swivel cheie-vârtej, cheie de afurcare chain tackle-block (met) macara / palan cu lanț chain tension-adjuster / tightener (OM) întinzător de lanț

chain termination (chim) întrerupere / terminație a lanțului (molecular) / catenei

chain timber hoist (industria lemnului) transportor cu lant pentru bușteni

chain toggle (nav) lanț de ancoraj

chain tongs (met) clește cu lanț

chain track $(\mathrm{OM}$, mas, mil) şenilă

chain tractor (mas) tractor cu şenile

chain tramway (mas) transportor cu lanț

chain transfer (met) sleper (la laminare), dispozitiv cu lanț, pentru transfer de semifabricate

chain transmission $(\mathrm{OM})$ transmisie prin / $\mathrm{cu}$ lanţ(uri)

chain tub pusher (met) împingător cu lanț (şi la cuptoare)

chain-type traveling grate (met, ind chim) grătar rulant cu lant (și la cuptoare)

chain wale (nav) portsart

chain wheel $(\mathrm{OM})$ roată / rolă / scripete / nucă de lanț; (nav) barbotin

chain winch $(\mathrm{OM})$ troliu cu lant

chair scaun; (OM) cuzinet, placă de reazem; (cf) sabot de şină; (edu) catedră (în învățământ)

chair bed fotoliu-pat

chair lift funicular cu scaune

chairman preşedinte

chairman of the board $(\mathrm{ec})$ președinte al consiliului de administraţie

chairmanship preşedinție

chairperson preşedinte, preşedintă

chair rail (met, cf) şină cu cap dublu / cu două coroane

chalcedony (minrl) calcedonie

chalk (chim) cretă, calcar, carbonat de calciu, var; a trata cu var; (agr) a fertiliza, a îngrăşa; a însemna, a desena, a murdări (cu creta)

chalkiness aspect / caracter de cretă / calcaros chalking (met) defect de acoperire (formarea de straturi sau zone cu pulberi), pulverizare

chalkstone (constr, ind chim) cretă, calcar, piatră de var

chalk test (hidr) probă de etanşeitate cu cretă

chalk up a înregistra, a obține (şi puncte), a ține cont (şi de greşeli)

chalky calcaros, de cretă, cu cretă; alb ca varul

challenge provocare; punere sub semnul întrebării; pretenție; cerere; deziderat; (nav) semnal de recunoaştere; a cere, a pretinde; a necesita, a reclama (atenția), a se îndoi de, a pune sub semnul întrebării, a pune în discuție; a contesta 
challenger persoană care cheamă la întrecere; pretendent; persoană care contestă ceva

challenging interesant; competitiv

chamber (foto, mas, OM) cameră, incintă; sală de şedințe; (jur) birou judecătoresc

chamber dryer (alim, ind chim) uscător de cameră

chamber drying oven (alim, ind chim) uscător compartimentat / cu camere / vertical

chamber envelope $(\mathrm{OM}$, termo) manta a cazanului

chamber filter-press (alim, ind chim) presăfiltru cu camere

chamber(-heating) furnace (met, ind chim) cuptor (de încălzire) cu cameră

chambering shot $(\mathrm{OM})$ virolă de cazan

chambering tool (mas-un) cuțit pentru strunjirea suprafețelor interioare / pentru găuri înfundate

chamber kiln (met, ind chim, termo) cuptor $\mathrm{cu}$ cameră

chamber of a pump (OM) cilindru de pompă

chamber of commerce $(\mathrm{ec})$ cameră de comerț

chamber of gun (met, ind chim) orificiu de încărcare

chamber press (alim, ind chim) presă-filtru cu camere

chamber-type dryer (agr, alim) uscătorie cu camere

chamber welding (met) sudare în incintă

chamfer (hidr, OM) teşirea muchiilor vii ale intrării într-un canal / într-o conductă (pentru mărirea coeficientului de debit); (OM,TH) jgheab, şanț, teşitură, şanfren, fațetă, lungime a conului de atac / de tăiere; a taluza, a teși, a şanfrena, a canela, a nutui, a moleta, a riftui

chamfer dimension (mas-un, OM) dimensiunea şanfrenului

chamfered caisson (constr) cheson teşit

chamfered edge $(\mathrm{OM})$ muchie teşită

chamfered nail (OM) cui cu vârf ascuțit / conic

chamfer groove $(\mathrm{OM})$ canal / canelură cu secțiune triunghiulară

chamfering (mas-un, OM) (acțiunea de) teşire, şanfrenare, teşitură, şanfren; taluz, fațetă

chamfering bit (mas-un) teșitor

chamfering cutting (mas-un, OM) şanfrenare (şi cu rotunjire) pe diametrul exterior

chamfering hob (mas-un) freză-melc pentru rotunjit capetele frontale ale dinților

chamfer key $(\mathrm{OM})$ pană cu colțuri teșite

chamfer on edge of die (mas-un) parte conică de atac a filierei

chamotte (met) şamotă (refractară) chamotte brick (met, termo, constr) cărămidă din şamotă

champagne (alim) şampanie, vin spumos

champaign câmp deschis, şes

champion campion; as, învingător; a apăra, a lupta pentru; excelent, minunat, de frunte

chance întâmplare; noroc, şansă; ocazie (favorabilă), posibilitate

chance cause cauză aleatoare

chance coincidence coincidență accidentală

Chance-cone agitator (ind chim) agitator conic "Chance"

chanceful plin de întâmplări / evenimente, bogat în evenimente

chancellor (pol) cancelar; prim secretar de ambasadă; (edu) rector (la o universitate)

chance move mutare aleatoare

chance of death $(\mathrm{TH})$ risc de deces

chance of injury $(\mathrm{TH})$ risc de accidentare gravă

chancy risca(n)t; nesigur

change schimbare, înlocuire, modificare, transformare, comutare, ciclu, operație, variație, noutate, schimb; transbordare; a (se) schimba, a înlocui, a (se) transforma, a (se) modifica, a comuta, a preface, a converti, a varia; a altera; (auto) a schimba viteza; (ec) rest, bani de schimb, a schimba bani; (cf) a schimba trenul; a face o transbordare

changeability, changeableness schimbare, variabilitate; inconstanță

changeable schimbător, variabil

changeably $(a d v)$ în mod variabil, când într-un fel, când în altul

change down (auto, mas) a trece la o viteză mai mică

changeful plin de schimbări, schimbător, nestatornic

change gear (OM) roată de schimb; (mas-un) cutie de viteze; (auto) schimbător de viteze, cutie de viteze, a schimba viteza

change in charge (mec, met, ind) transfer / schimb / modificare de sarcină / încărcare

change in direction schimbare de direcție

change in structure (met, fiz) schimbare de structură, transformare de fază / structurală

change intervals interval (în kilometri, ore de funcționare) între două revizii (la autovehicule, maşini-unelte)

change into (auto, mas, mas-un) a trece la o altă treaptă de viteză; a se transforma în

change lever $(\mathrm{OM})$ pârghie a unui comutator/ întrerupător

changeless neschimbat, constant, fără schimbări / modificări 
changelessly $(a d v)$ neschimbat, constant, făă schimbări / modificări

change-of-scale theorem (fiz, mec) teoremă de similitudine

change of state (fiz) schimbare de stare

change of volume (materiale, fiz) modificarea / variația volumului

change on gas (met) inversarea / schimbarea gazului (la caupăr)

change over $(\mathrm{TH})$ reconstrucție, transformare; (mas, OM) comutare, mutare, schimbător de viteză; a schimba viteza; a face o schimbare radicală

change-over contact (el) contact de comutare; contact inversor

change-over gear (auto) schimbător de viteză

change-over into a (se) transforma în, a (se) converti în (şi d. materiale)

change-over relay (el) releu comutator

change-over / selector switch (el) întrerupătorcomutator, reversor, inversor

change point $(\mathrm{TH})$ punct de oprire / de încetinire (a unui proces); punt critic, punct de schimbare (şi într-un proces)

changer transformator, schimbător; mecanism de înlocuire; (chim) modificator

changes in consistency ( $T$ ) modificări ale consistentei (d. unsori etc.)

change-speed gear $(\mathrm{OM})$ schimbător de viteză

change-speed motor (el) motor cu mai multe trepte de viteză

change stand (met) cajă de schimb

change the rolls (met) a schimba cilindrii de laminare

change tires (auto) a schimba pneurile

change up a schimba

changing-over comutare

changing the fraction to higher terms (mat) amplificare a unei fractiii

channel (autom, inf) pistă, canal / cale de transmisie; (hidr) jgheab / canal de scurgere; canal, rigolă, albie; (OM) canal, canelură, crestătură, riz; (nav) şenal, canal navigabil; (constr, mas-un) a cresta, a scobi, a canela, a stria, a moleta; (hidr) a canaliza, a riflui; a-şi croi drum; (fig) a canaliza, a îndrepta

channel bar (constr, mec) profil $U$

channel beam (constr, mec) grindă cu profil $U$

channel iron (met, constr, mec) oțel / profil U

channelled plate (met) tablă striată / cutată

channelled roll (OM, met) valț / cilindru striat canelat; (alim) cilindru tăvălug rifluit

channelling producere a canalizării, alunecare (a gazelor); canalizare (a fluidului); (OM) canelură; (mas-un) canelare, formare de canale; (fiz, T) formare a unui canal pe lagărul uns cu unsoare channel lining (termo, ind chim) căptuşeală / îmbrăcăminte a canalului

channel rail (met, transp) şină cu şanț / de tramvai

channel steel (met, mec, constr) grindă / semifabricat cu profil $\mathrm{U}$

channel-type induction furnace (met) cuptor electric de inducție, cu canal inelar

chaos haos; confuzie; anarhie

chaotic(al) haotic

chaotically $(a d v)$ (în mod) haotic

chap crăpătură, fisură fină; (OM, mas-un) falcă de menghină; a crăpa, a fisura, a spinteca, a cresta; a fărâmița, a pisa

chaplet (met) suport / susținător de miez (de turnătorie); (mas-un) broşă

chapped crăpat; (plast) cu tendintă de crăpare a feței; cu față fragilă (şi d. ambalaje)

chapping knife (mas-un) cuțit pentru montarea cablurilor

chapter capitol, episod, pagină; temă, subiect; (inf) capitol / secvență a(l) unui program; capitol al unei lucrări; (amer) (edu) asociație studentească

chapter heading / title titlu de capitol

char (chim) cărbune de lemn, mangal, a carboniza; (alim) ceai, a prăji (la foc mic), a frige; (chim, met) a carboniza, a arde; (ec) muncă menajeră, a munci cu ziua

char-a(à) banc (transp) autobuz (deschis) pentru excursii; (auto) brec

character caracter, fire, natură, aspect, fel, trăsătură caracteristică, caracterizare; reputație, renume; rol, funcție, calitate; (inf, mat) caracter, simbol, semn, succesiune de cifre binare corespunzătoare unui simbol al alfabetului utilizat; caracter de literă (literă, cifră, simbol, semn de punctuație); a caracteriza, a descrie

character-at-a-time printer imprimantă care tipărește caracter după caracter

character font set de caractere

characteristic, characteristical caracteristică, curbă, funcție caracteristică, particularitate; caracteristic, semnificativ

characteristically $(a d v)$ (în mod) caracteristic, tipic characteristic angular momentum (mec) moment cinetic propriu / intrinsec, spin

characteristic curve (fiz, materiale) curbă caracteristică

characteristic curve tracer trasor / trasator de curbe, plotter

characteristic factor indice caracteristic 
characteristic frequency (fiz, mec) frecvență proprie / caracteristică / acustică

characteristic function funcție proprie / fundamentală / caracteristică

characteristic noise parameters (fiz, autom) parametri / caracteristici de zgomot

characteristic number (fiz) valoare proprie / caracteristică; (mat) număr caracteristic, valoare caracteristică

characteristic of fluidity (fiz) caracteristică de fluiditate

characteristic of plasticity (fiz, T, materiale) caracteristică de plasticitate

characteristic property caracteristică, proprietate caracteristică / specifică

characteristic quantity mărime caracteristică, parametru

characterization caracterizare

characterization factor factor de caracterizare

characterize a caracteriza, a descrie, a prezenta

characterless lipsit de / fără trăsături distinctive; comun, şters, fără personalitate

character of service $(\mathrm{TH})$ regim de lucru / de functionare

character wheel (poligrafie) roată de imprimare / de caractere

charactery exprimare prin simboluri; (sistem de) simboluri

charcoal cărbune de lemn, mangal

charcoal brazier (met) cuptor de lipit (cu mangal)

charcoal-hearth steel (met) oțel produs prin afinare cu mangal, oțel Martin

charcoal iron / pig (met) fontă (brută) topită cu mangal

chare a ciopli cu dalta

charge sarcină, grijă; păstrare, supraveghere; ocrotire; (cf) încărcătură, greutate; (ec) preț, plată, cost, taxă, speze, cheltuială, a cere / pretinde plată; (el, fiz) sarcină, încărcare; (met) gură de încărcare a furnalului, alcătuirea / dozarea şarjei, debit (al cuptorului), încărcătură (de exploziv), şarjă; a încărca (arma, acumulatorul, cu electricitate), a șarja, a îngreuna, a umple, a alimenta, a completa, a umple (paharul, cuptorul etc.); învinuire, acuzare; be in $\sim$ of a se îngriji de

chargeable (ec) impozabil, supus la taxă, taxat

chargeable cell (el) acumulator, celulă / unitate de acumulator

chargeable with răspunzător de; învinuit de

charge account (ec) cont personal / curent

charge an expense on / to an account (ec) a trece o cheltuială în cont charge column (met, ind chim) coloana încărcăturii (de materiale) (şi la furnal)

charged controversat, mult discutat; $(\mathrm{TH})$ încărcat

charge density (alim, ind chim, met) densitatea încărcăturii / şarjei

charge distribution of mist (alim, ind chim, met) distribuția încărcăturii / şarjei / amestecului

charged rubber (ind chim) amestec de cauciuc $\mathrm{cu}$ ingrediente / $\mathrm{cu}$ aditivi

charge efficiency (el, met) eficiența de reîncărcare a unei baterii

charge equalization (el, $\mathrm{TH})$ compensare de sarcină / a sarcinii

charge hand ajutor de maistru

charge hole $(\mathrm{TH})$ gură / orificiu de încărcare; (met) gura de încărcare a furnalului

charge independent (mec) independent de sarcină

chargeless $(\mathrm{ec})$ fără plată, gratis, neimpozabil

charge level indicator (el, met) indicator de nivel al încărcăturii / şarjei (la furnal)

charge of pig iron (el, met) încărcătură / de fontă, încărcarea fontei

charged particle (fiz, el) particulă încărcată

charge pressure (hidr) presiune de încărcare / de introducere a unui fluid în echipamentul hidraulic

charge pump (OM, hidr, alim, ind chim) pompă de alimentare

charger (met, alim, ind chim) încărcător, alimentator, dozator; tavă, platou, farfurie întinsă; (jur) acuzator

charger forward (ec) speze care se achită de destinatar

charger sheet (jur) listă de delicte; cazier (la poliție)

charge relaxation (alim, ind chim) relaxarea încărcăturii / şarjei

charge stock materie primă

charge the furnace (met) a încărca cuptorul / furnalul

charge to an account $(\mathrm{ec})$ a pune la socoteală, a trece într-un cont

charge transfer $(\mathrm{TH})$ transferul (şi tehnologic al) încărcăturii

charge with (jur) a acuza, a învinovăți; (ec) a însărcina cu, a încredința (o misiune)

charge with water $(\mathrm{TH})$ a satura cu apă

charging $(\mathrm{TH})$ încărcare, încărcătură, alimentare; (ec) taxare

charging appliance (constr, met, ind chim) dispozitiv de încărcare / de şarjare 
charging basket / bucket (met, alim, ind chim) benă de încărcare

charging bin / bucket (met) oală / benă de încărcare

charging box (constr, alim, ind chim) pâlnie de încărcare / alimentare; (met) troacă

charging by aerial ropeway (met) încărcare cu benă suspendată

charging car / carriage (met, transp) recipient / vagonet de transport / de încărcare

charging cone (met) pâlnie de încărcare / de şarjare

charging conveyer (met, alim, ind) transportor de încărcare / de alimentare

charging crane (met, alim, ind chim) macara de şarjat, pod rulant de încărcare

charging device (met) dispozitiv de încărcare / de şarjare

charging door (met) gură / uşă de încărcare / de şarjare

charging equipment $(\mathrm{TH}$, ind) dispozitiv de alimentare / de încărcare

charging flap (met) uşă / trapă de umplere

charging floor (met) platformă de încărcare a furnalului

charging gantry crane (mas, transp) macara / pod rulant de încărcare

charging gear (met) instalație de încărcare a furnalului

charging hole (met, alim, ind chim) gură de încărcare / de alimentare

charging hopper (met, alim, ind chim) pâlnie de turnare, buncăr de încărcare

charging installation (met) instalație de încărcare a furnalului

charging lorry (met) vagonet / cărucior de încărcare

charging machine (met) maşină de încărcare / de alimentare (cu rulouri)

charging material (ind) material de încărcare

charging mechanism dispozitiv de încărcare

charging opening (met) gură de încărcare / de şarjare

charging pan benă / oală de încărcare

charging period (cursă de) admisie / încărcare

charging pipe (OM, hidr, alim, ind) țeavă / conductă de alimentare / de încărcare

charging platform (met) platformă / rampă de încărcare / de şarjare

charging pot (met) oală de încărcare

charging process $(\mathrm{TH})$ proces de încărcare

charging pump pompă de alimentare / de încărcare / de refulare

charging rate (ind) regim / debit de încărcare charging scales (metr, ind) cântar de amestecuri charging system (auto) sistem de încărcare (cu curent electric), generator

charging system warning (auto) avertizare pentru sistemul de încărcare cu curent electric

charging tank (ind) rezervor de alimentare

charging tipping bucket (met, constr) cupă basculantă de încărcare

charging tower (met) turn de alimentare (la furnal)

charging truck (auto, met) autocamion / buncăr / vagonet / cărucior de alimentare / de încărcare

charging tundish (met) repartitor / distribuitor de încărcare (la turnarea continuă, echipată cu cuptor electric)

charging unit (met, TH) instalație / utilaj de încărcare (şi la furnal)

charging valve (hidr, ind) ventil / robinet de umplere

charily $(a d v)$ precaut, cu grijă

chariness precauție, prevedere, grijă; economie

chariot (mas) cărucior de macara, pisică

charm price (ec) preț atractiv (cu reducere, pentru a atrage cumpărători)

Charpy impact machine (metr) pendul Charpy

charred coal (met) cocs

charring (chim) carbonizare

charry (chim) carbonizat

chart hartă, diagramă

chart drive mecanism de antrenare a hârtiei de înregistrare (la aparate)

charter (jur) privilegiu, drept; statut; (nav) charter, navlosire, a navlosi; închiriere (a unui mijloc de transport); cursă specială; a închiria; a da în folosință; a pune la dispoziție (la cerere); (auto) a angaja pentru un transport

chartered (jur) privilegiat; (ec) concesionat; (nav) navlosit, afretat; închiriat, comandat (d. un avion, o maşină)

chartered accountant (ec) expert contabil, revizor-contabil

chartered company (ec) societate / companie autorizată de stat

chartered vessel (nav) navă navlosită

charterer (nav) navlositor

chartering (nav) navlosire

charter member (amer) membru fondator (al unei organizații)

charter party (nav) (parte în) contract de navlosire

chart scale scară a diagramei / a hărții

chary in / of prudent, prevăzător, cu privire la, econom la 
chase urmărire; canal vertical pentru conducte (de apă, de ventilație etc.); (met) corpul central al matriței cu una sau mai multe cavități; (mas-un) aşchieri succesive (la formarea filetului), curățarea filetului; (OM) jgheab, şanț, renură, a şănțui; a grava, a urmări; a risipi, a îndepărta

chase away a alunga, a izgoni, a îndepărta

chaser (mas) moară chiliană / cu tăvălug; presă moară de fărâmițare; (mas-un) pieptene de filetare; (nav) vas de excortă

chaser grinding machine (mas-un) maşină de rectificat filete, cu pieptene

chaser type of die (mas-un) cap de filetat cu piepteni amovibili

chasing hammer baros, ciocan de ambutisat

chasing jig (mas-un) dispozitiv de ghidare, folosit la filetare

chasing lathe (mas-un) maşină de filetat cu şuruburi amovibile / cu pieptene

chasing tool (mas-un) pieptene de filetat

chasm crăpătură, spărtură; (fig) prăpastie, abis, deosebire, distanță

chassis (auto, OM) şasiu, suport, batiu, cadru, echipament de rulare

chassis ground (el) legătură / conexiune la masă

chassisless body (auto) caroserie fără șasiu / autoportantă

chaste pur, decent, modest; sobru, sever (stil)

chesten a pedepsi; a linişti, a calma, a modera; a îmbunătăti

chattels avere; bunuri (mobile); acareturi; patrimoniu

chatter a clicheta, a ciocăni, a vibra, a trepida; vibrație

chatter free fără vibrații

chatter mark (mas-un) urmă de vibrație de la aşcheiere

chauffer şofer angajat

chaw a mesteca, a rumega

cheap (ec) ieftin, care costă puțin, convenabil ca preț); dobândit uşor; comun, banal, de rând, fără valoare; (fig) superficial

cheapen a (se) ieftini, a deprecia, a vorbi depreciativ

cheaply $(a d v)$ ieftin

cheapness ieftinătate

cheat înșelăciune; înșelător, escroc; a înșela, a păcăli

check control, verificare, oprire bruscă, întrerupere, piedică, oprire, frânare; sigiliu de control, semn de control, etichetă, contramarcă; bun; recipisă; joc; (ec), (amer) cec, a completa un cec; pătrat, carou, stofă în carouri; crăpătură (în lemn); a verifica; a viza; a controla, a (se) opri brusc, a întrerupe, a frâna, a împiedica, a respinge, a da înapoi, a bifa, a despica, a crăpa (şi d. vopsea); (c) a corespunde, a coincide, a fi întocmai

check analysis analiză de control / de verificare

check-back (c, inf, autom) supraveghere (a informației înregistrate)

check ball $(\mathrm{OM})$ clapetă de retinere

check bar (metr) epruvetă de control

check bit (inf) bit de control / de paritate

check book (ec) carnet de cecuri

check chain $(\mathrm{OM})$ lanț de siguranță

check crack (met) fisură de contracție

check determination / test contraprobă

checker verificator, dispozitiv de verificare; (termo) grătar (la regenerator)

checker-brick (met) cărămidă refractară pentru camere regeneratoare; (mas-un) piatră / disc abraziv, cu nervuri

checker-brick superheater (met) supraîncălzitor de şamotă

checker brickwork (met, termo) umplutură (de zidărie) cu grătare

checker chamber (met, termo) cameră a grătarului la generator / recuperator

checker crack (met) fisură capilară, microfisură

checkered brickwork (met) grătar în camere regeneratoare

checkered (iron) plate / sheet (met) tablă striată (de oțel)

checkered wire sârmă ondulată / rifluită

checker fire-brick (met) cărămidă refractară pentru grătar (la generator)

checker heating surface (met) suprafața de încălzire a grătarului (la generator)

checkers (met) grătar (la generator)

checker work (constr) structură / construcție celulară; (met) aranjare specială a cărămizilor în furnal, cu deschideri pentru aer şi gaze

check gauge (metr) măsură, etalon

check in a reține locuri; a se prezenta; a se înregistra

check indicator instruction (metr, inf, autom) instrucțiune pentru conectarea unui aparat indicator de erori

checking verificare, control, frânare, ştrangulare, (re)etalonare; (plast) fisuri mici pe suprafața unui furtun de elastomer, cauzate de mediu; (met) rețea de fisuri mici pe suprafețe metalice (cauzate de prelucrare, mediu și şocuri termice), fisurare superficială fină

checking account (ec), (amer) cont curent

checking case trusă de măsurare / de verificare

checking device (metr) dispozitiv / instalație de control, de încercare 
checking implement (metr) dispozitiv / aparat de control

checking of dimensions (metr) verificarea dimensiunilor

checking operation (operație de) verificare (şi la un autoturism)

checking pin (mas-un, OM) știft opritor

checking station stație de control / de verificare checking strip roll rolă cu bandă de control

checking table (alim, ind) planşă / masă de control

checking the calibration (el, metr) reetalonare a calibrului, recalibrare

check instrument (metr) aparat / instrument de verificare, monitor

checkless de necontrolat, fără control

check lift valve (OM, hidr) robinet cu ventil, de întreținere (şi a presiunii)

check list tabel / listă de control; catalog (şi în ordine alfabetică)

check localization program(me) (inf, c) program pentru depistarea erorilor

check man controlor (şi de tren)

check nut $(\mathrm{OM})$ contrapiuliță

check-off (ec) retinere din salariu

check of shears (mas-un, met) lamă de forfecare de foarfece

check out (amer) a pleca din hotel

check(-)out (TH, metr) verificare, inspecție, control, deconectare, ora de terminare a lucrului / serviciului; casă (în magazin cu autoservire); (inf) a încerca / a verifica un program; oră de plecare din hotel; rezultat satifăcător

check over a examina, a cerceta

check piece (mas, mas-un) limitator al cursei, opritor

check plate (mas) placă de siguranță

check point punct de reper; (inf) punct de reluare / de verificare / de control a(l) unui program

check rail (cf) contraşină, labă de iepure

check reading (metr) citire a indicațiilor aparatelor de control / măsurare

check rod $(O M, T)$ sondă, tijă / jojă (şi de verificare a nivelului unui fluid)

check roll listă nominală, de verificare

check sampling $(\mathrm{TH})$ luare a probelor de control / de verificat

check screw (mas-un, OM) şurub de oprire / de fixare

check shatter crack (met) fisură capilară, microfisură

check stop valve (OM, hidr) ventil / supapă / clapetă de reținere / de oprire / de închidere, ventil de reglare / control (eventual cu închidere) check test contraprobă, verificare de control check the calibration (metr) a recalibra, a (re)verifica un calibru, a reetalona

check totaling control prin totalizare

check-up verificare, control

check up a verifica, a controla

check up on a examina, a cerceta (ceva)

check valve (autom, hidr, OM) supapă de control / de sens unic; ventil / clapetă de retinere / de închidere, robinet de reținere cu ventil

check washer $(\mathrm{OM})$ șaibă / rondelă elastică / de siguranță

check word (inf) cuvânt / cheie / de control

cheddar cheese (alim) varietate de brânză (compactă)

cheek obraz; $(\mathrm{TH})$ față (de macara); $(\mathrm{OM})$ braț de manivelă la arbore cotit; (nav) falcă de coloană

cheek block macara deschisă (cu o față)

cheek brake $(\mathrm{OM})$ frână cu saboți

cheese (alim) brânză; (met) semifabricat pentru bandaje

cheese cake, cheesecake (alim) plăcintă / pateu cu brânză; (bot) nalbă

cheese head (OM) cap cilindric, crestat

cheesing (el) bobinare, înfăşurare

cheesy brânzos, ca brânza; (fig) ieftin, de rând

chef d'oeuvre, $(p l)$ chefs d'oeuvre capodoperă

chemical (chim) chimic; preparat chimic

chemical additive (chim) aditiv (activ) chimic

chemical adsorbtion (chim) adsorbție chimică

chemical affinity (chim) afinitate chimică

chemical agent (chim) reactiv, agent de reacție

chemical attack (chim) atac chimic

chemical balance (chim) echilibru chimic

chemical bond (chim) legătură chimică

chemical change (chim) reacție chimică

chemical cleaning (met, ind chim) curățare chimică, decapare

chemical content (chim) compoziție chimică

chemical conversion coating (chim) acoperire (decorativă) prin reactie chimică

chemical corrosion (met, chim) coroziune chimică

chemical defense (chim, TH) protecție chimică / împotriva unor agenți chimici

chemical engineering (ind chim) tehnologie / inginerie chimică

chemical feed pipe (OM, ind chim) conductă / țeavă centrală într-un vas / recipient pentru introducere / alimentare cu substante de reactie

chemical glass (chim) sticlă pentru aparatură chimică

chemically $(a d v)$ (din punct de vedere) chimic 
chemically active (chim) activ chimic chemically react with oxygen (chim) a reacționa chimic cu oxigenul, a se oxida

chemically resistant steel (met) oțel rezistent la agenți chimici / inoxidabil

chemical passivation (chim) pasivare chimică chemical pickling (chim, met) decapare chimică chemical plant fabrică de produse chimice

chemical preservative (chim, alim) substanță conservantă

chemical processing (ind chim, met) prelucrare / tratare chimică

chemical properties (materiale) proprietăți chimice

chemical surface preparation (met, plast) pregătirea chmică a suprafeței (la lipiri, tratamente etc.)

chemical vapor deposition (CVD) (chim) depunere prin vaporizare chimică

chemism (chim) chimism

chemisorption (chim) chemisorbtie

chemist chimist

chemistry chimie

cheque (ec) cec

cheque book (ec) carnet de cecuri

chequed plate (met) tablă striată

chequer (met) grătar (la regenator)

cheque to bearer (ec) cec la purtător

chequred striat, în carouri; pestriț, amestecat, variat

chernozem (agr) cernoziom

charring (mas-un) frezare sferică / profilată

cherry (agr, alim) vişin(ă), cireş, cireaşă ; (matun) freză profilată cu coadă; vişiniu

cherry brandy (alim) lichior de vişine, vișinată

cherry coal (met) cărbune gras / moale neaglutinant

cherry-red heat / incandescence (met) incandescență până la roşu vişiniu (d. oțeluri)

cherry stone (alim) sâmbure de vişină

chert (geol) şist silicios

cherty silicios

chest ladă, dulap, scrin, sertar, cutie, birou (cu sertare); (ec) casă, fonduri (ale unei societăți firme)

chest freezer (alim, termo) congelator orizontal / ladă (cu capac în balamale)

chestnut (alim) castan( $\breve{\mathrm{a}})$; castaniu, culoare castanie

chestnut coal (met) cărbune brun

chest wheel $(\mathrm{OM}$, hidr) roată cu cupe

chew rumegat, mestecat; a rumega, a mesteca; a pune la cale; tutun de mestecat

chicken (alim) pui (de găină) chicken broth (alim) supă de pui

chicken feed (amer), (agr, alim) hrană pentru pui; $(\mathrm{ec})$ bani mărunți, mărunțiş, sumă mică de bani

chick pea (alim) năut

chicory (alim) cicoare

chide a certa, a dojeni, a mustra

chief şef, conducător; principal; fundamental, de bază; (nav) ofițet unu, ofițer secund, mecanic şef chief constituent (chim, OM, met) piesă componentă principală, component / constituent principal chief designer $(\mathrm{TH})$ constructor / proiectant sef

chiefess conducătoare

chief frame (nav) cuplu maestru

chiefless fără conducător

chiefly $(a d v)$ în principal

chief operator $(\mathrm{TH})$ maistru, operator-șef

chief operator's desk pupitru de comandă

child $(\mathrm{TH})$ produs, rezultat

child restraint (auto) scaun de copii

chlid restraint(s) system (auto) sistemul de protecție pentru copil (inclusiv centură)

child safety item (auto) dispozitiv de siguranță al portierelor din spate

child seat (auto) scaun pentru copil

child seat restraint suitability (auto) adaptabilitatea / potrivirea / reglarea centurii scaunului pentru copil

child seat restraint suitability for seat position using the seat belt (auto) măsuri recomandate pentru scaunul copilului şi utilizarea centurii de siguranță

child seat suitability (auto) adaptabilitatea / potrivire a scaunului pentru copil

chile bar (met) bară de cupru brut

chill frig, răcoare, temperatură scăzută; friguros; înghețat; răceală; (fig) răceală, rezervă, distant; (met) răcitor pentru forme, dispozitiv de răcire, placă de răcire la turnare, lingotieră, cochilă, călire, a căli; răcire bruscă; $(\mathrm{TH})$ a răci, a face / lăsa să se răcească, a îngheța, a congela

chillator (alim, ind chim) răcitor

chill block (met) probă / epruvetă de călire chill casting (met) piesă (de fontă) turnată în cochilă, turnare în cochilă

chill cast ingot (met) lingou turnat în cochilă

chill crack (met) crăpătură de călire (la răcire)

chill crystal (met, fiz, alim) strat de cristale obtinut prin răcire rapidă

chill depth (met) adâncime de călire

chilled (met) călit; răcit (brusc / repede)

chilled castings (met) piese turnate călite / cu crustă dură

chilled cast iron (met) fontă călită / dură 
chilled core (met) miez pentru turnare în cochilie (şi cu răcire)

chilling device (alim, ind) dispozitiv de răcire chilled glass (ind chim) sticlă călită chilled goods material(e) de răcit, produse / mărfuri / bunuri răcite

chilled iron (met) fontă dură / călită

chilled roll (met) cilindru cu coajă dură, turnat în cochilie

chiller (alim, termo) cristalizor, aparat frigorific chilliness frig, temperatură scăzută; (fig) răceală chilling (met) călire; răcire bruscă

chilling layer (met) strat călit / durificat prin călire chilling method (alim, biol) metodă care foloseşte congelarea, metodă de congelare

chill(ing) mould (met) cochilă / formă metalică pentru răcire rapidă

chill(ing) point (fiz, alim) temperatură de înghețare / de congelare, punct de înghețare

chilling roll (alim, ind chim) cilindru de răcire

chilling temperature (fiz) temperatură de cristalizare / congelare / înghețare

chill inserted in mould (met) răcitor exterior / introdus în formă

chill pass roll (met) cilindru cu calibru dur / călit

chill proofing (alim) stabilizare (a lichidelor alimentare) $\mathrm{cu}$ ajutorul frigului artificial

chill ring (OM, met) inel interior / de adaos (la sudarea țevilor)

chill roll (met) cilindru dur / cu crustă dură

chill rubber (ind chim) cauciuc congelat

chill shot bit (mas-un) coroană / freză / cuțit pentru alice

chill test (met) încercare / test de călire

chill test piece / sample (met) epruvetă de călire

chilly (vreme) rece, răcoros; înghețat; (fig) rece, distant, descurajator, deprimant

chime semnal sonor

chimney (met, termo) cămin, coş (de fum / de tiraj), tub de cărămidă / de metal / de beton, horn, burlan de coş, gură de vânt; (constr) şemineu, cămin

chimney base (constr) soclu al coșului / căminului

chimney breast (constr) coronament de coş

chimney cooler (met) turn de răcire

chimney core (constr) tub interior (la coş cu pereți dubli)

chimney cowl capac de coş

chimney damper (met, termo) registru de fum

chimney draught / effect (termo) tiraj al coşului chimney fan (termo) ventilator de activare a tirajului unui coş

chimney flue (termo) canal pentru conducerea gazelor spre coş chimney hood (alim, TH) hotă

chimney pot (met, termo) registru de fum, clapă de reglaj (la coş)

chimney stack / stalk (met, termo) coş, horn, trunchi al coşului de fum

chimney valve (met, termo) clapă de fum

china porțelan, articole de porțelan

china clay caolin brut

china-ink tus (de desen)

chine (alim) şira spinării, bucată de la spate, muşchi, vrăbioară, fileu

chink (met) crăpătură, spărtură; (constr) a cala cu piatră spartă; zăngănit, zornăit, clinchet; a zăngăni, a zornăi

chintz (textile) creton, pânză de bumbac (şi cerată)

chip (el) pastilă, substrat al unui circuit integrat, aşchie de siliciu (microelectronică); (inf, autom) deşeu rezultat din perforarea unei benzi de hârtie; (TH) aşchie, fragment, sur-cică, șipcă, dranită, sindrilă; (mas-un) a (se) aşchia, a tăia; a dăltui, a ciopli, a rindelui; fărâmă, ciob, felie subțire; lucru fără valoare, nimic, fleac, a ciobi, a (se) sparge (şi d. margini), a tăia felii subțiri, a se fărâmița

chip away (mas-un) a aşchia (cu îndepărtare de material / de aşchii (a aşchiilor); a sparge / sfărâma în bucăți

chip bearing surface (mas-un) față de degajare chipboard $(\mathrm{TH})$ placă aglomerată (din aşchii de lemn)

chip breaker (mas-un) dispozitiv pentru fărâmițarea aşchiilor, sfărâmător de aşchii / de şpan

chip breaker (deflecting) shoulder (mas-un) prag / umăr pentru fărâmițarea (şi deviere) aşchiilor

chip curl (mas-un) spirală de aşchiere, aşchie spiralată

chip flow / escape (mas-un) eliminare / evacuare a aşchiilor

chip former (mas-un) răsucitor / înfăşurător / formator de aşchii

chip guard (mas-un) apărătoare contra aşchiilor chip / chipped ice (alim, termo) gheață-aşchii; gheață sub formă de solzi / de aşchii / de cioburi

chipless fără aşchii, (prelucrare) fără aşchiere

chipless shaping (mas-un) prelucrare fără aşchii

chip packer (alim) distribuitor de tocătură (în fierbător)

chip pan (mas-un) tavă pentru aşchii

chipped beaf (alim) carne de vită, tăiată felii

chipped glass fiber (plast) fibre de sticlă, scurte (si la compozite) 
chipper (met) dăltuitor (la laminate), daltă (şi pneumatică), debavurator; maşină de debitat aşchii prin zdrobire; (constr) aparat pentru împrăştierea pietrişului; (alim) tocător, maşină de mărunțit; (mas-un, termo) ciocan de detartrare / de dezîncrustare

chipping detaşare, tăiere, aşchiere, formare de aşchii, despicare, dăltuire; (met) curățare cu dalta a defectelor superficiale

chipping chisel daltă (lată)

chipping hammer ciocan-daltă

chipping machine (mas-un) maşină de debitat aşchii prin zdrobire (ind lemnului)

chipping mark (mas-un) urmă de dăltuire / de detaşare a aşchiei

chippings (constr, TH) țăndări, piatră concasată / spartă mărunt; criblură; sfărâmături; (met) sfărâmătură măruntă de fier; (mas-un) şpan

chipping shop (met) atelier / hală de curățat lingouri

chip production (mas-un) capacitate / productivitate de aşchiere

chippy tocit, bont (d. tăiş, cuțit); ciobit

chip removing process (mas-un) prelucrare prin aşchiere

chip room / space (mas-un) spaţiu pentru aşchii

chip screen (alim, ind chim, constr) sortator / sită (de aşchii, de produse obținute prin tăiere sau mărunțire)

chips cutting machine (mas-un) maşină de debitat aşchii prin tăiere

chip upset (mas-un, met) comprimarea / presare a şpanului / aşchiilor

chisel (mas-un) daltă (simplă sau acționată), cuțit (şi de tip percutant); a dăltui, a percuta, a cizela (cu dalta)

chisel bit (mas-un) tăiş al unei dălți

chisel edge (mas-un) muchie transversală (a burghiului)

chiseller dăltuitor, care dăltuieşte

chiselling spituire, dăltuire, scobire

chisel marking out marcare cu dalta

chisel off a ciopli, a dăltui

chisel pick târnăcop cu tăiş-daltă

chisel point ascuțiş / vârf al unei dălți

chisel pointed nail $(\mathrm{OM})$ cui cu vârf lat

chisel pointing file (mas-un) pilă semirotundă cu margini teşite

chisel shank (mas-un) coadă conică a burghiului chisel-shaped în formă de daltă

chisel steel (met, mas-un) oțel de scule / pentru dălți

chi-square statistic (mat) statistică / repartiție $x^{2}$ chit notă (şi de plată), scrisoare scurtă, bon; recomandare, caracterizare; dispoziție scrisă, ordin, adeverință, dovadă

chitterlings (alim) măruntaie (de porc)

chive (alim, agr) arpagic

chlorate (chim) clorat

chloric acid (chim) acid clorhidric

chloride (chim) clorură

chloridization (chim) clorurare

chlorinated polyvinil chloride (plast) policlorură de vinil clorurată (PVC)

chlorinated rubber (plast) cauciuc clorurat

chlorinating roasting (ind chim) prăjire clorurantă

chlorine(CI) (chim) clor

chlorite (chim) clorit

chlorocarbons (chim) compuşi care includ clor şi carbon, cu sau fără alte elemente

chloroform (chim) cloroform; a cloroformiza

chlorophyl(l) (biol) clorofilă

chloroprene rubber (CR) (plast) cauciuc cloroprenic

chlorosulphonated polyethylene (CSM) (plast) polietilenă clorosulfonată

chlorous (chim) cloros

chlorous acid (chim) acid cloros

chock $(\mathrm{OM})$ sabot, frână, pană, ic; (constr) capră; (nav) cavalet, suport; a opri / sprijini cu pene; (auto) clapetă de pornire, starter, soc; (OM, hidr) duză, drosel, ştrangulare, gâtuire, clapetă de aer; (constr) a umple cu piatră; (TH) a ștrangula, a (se) sufoca, a (se) înăbuşi, a gâtui, a se închide, a se bloca; (agr) a năpădi; a stinge (un foc); (el) bobină (cu reactanță), reactantă

chockfull plin, complet; înțesat, ticsit

chocolate (alim) ciocolată

choice alegere, selecție, selectare, opțiune, alternativă, posibilitate de alegere, predilecție, preferință; sortiment; (adj) ales, cel mai bun / valoros, superior, rar, fin, elegant, de bun gust, rafinat; a alege; at $\sim$ la alegere; for / by $\sim$ de preferință

choice (of material) alegerea / selectarea materialului

choke a înfunda, a sufoca, a colmata; (hidr, T) ştrangulare a unei conducte în care vâscozitatea joacă un rol important în reducerea / căderea presiunii

choke coil (el) bobină de impedanță / cu reactanță

choke rod $(\mathrm{OM})$ tijă a clapetei de aer

choker valve (hidr, OM) robinet de ştrangulare, drosel

chokes (med, TH) efecte ale decompresiei

choke the pipe (hidr, T) a înfunda / a îngusta / a ştrangula conducta din cauza depunerilor 
choke tube (auto, termo) jiclor de aer choke up (agr) a înăbuşi / sufoca (cu buruieni); a umple până sus, a ticsi

choking ( $\mathrm{TH}$, hidr, mediu) colmatare, înfundare, astupare, obstrucție; sufocare; înăbuşitor, sufocant

choky înăbuşitor, sufocant; (alim) acru, verde, necopt (d. fructe)

choleric iritabil, coleric

Cholesky factorization (mat) metodă numerică de rezolvare a sistemelor liniare de ecuații

cholesterol (alim, med) colesterol

choline (chim) colină

choose a alege (şi prin vot), a hotărî, a prefera

chooser care alege; alegător (în magazin)

chop şovăială, ezitare; lovitură cu securea, despicătură; (ec) schimb de mărfuri; a tăia (în bucăți), a ciopli; (alim) a toca, cotlet (cu os, de porc / oaie); a transforma, a schimba

chop at a se repezi la, a căuta să apuce

chop away a tăia, a detaşa / reteza (prin tăiere)

chop down a tăia, a doborî (prin tăiere)

chop off a reteza, a despica, a ciopli, a toca (lemn, carne)

chopped tocat, tăiat în bucăți, retezat, crestat, scobit

chopped meat (alim) tocătură de carne

chopped strands (ind chim) fire scurte de sticlă (şi pentru compozite)

chopper (alim) maşină de tocat, satâr; (autom) modulator, vibrator, întrerupător periodic; (met) daltă de debavuare; (el) întreruptor; (av) elicopter

chopping mărunt, mic, scurt; voinic, viguros; tăiere, care taie / ciopârțeşte; (nav) mare confuză, valuri scurte

choppy (textile, TH) buclat, încrețit, ondulat, plin de crăpături, crăpat; (nav) (mare) agitată, cu hulă, vânt schimbător / variabil

chop through a tăia în bucăți, a despica, a desface (d. lemn, carne etc.)

chop up a toca, a tăia în bucăți, a se despica, a se desface (d. lemn, carne etc.)

chord (geom) coardă (la un cerc); (constr) coardă, funie

chordal / circular pitch (mas-un, OM) pas al dințării, pas pe cercul primitiv / de bază (la dantură evolventică)

chordal tooth thickness $(\mathrm{OM})$ grosime a dintelui, măsurată pe coarda cercului primitiv / de bază

chord bracing (constr, mec) întăritură a unei tălpi de grindă

chord member (constr, mec) bară a tălpii unei grinzi chord plate (constr, mec) platbandă a tălpii unei grinzi

chore treabă / sarcină grea / neplăcută

chores treburi casnice / menajere

chromate (met, chim) cromat, sare a acidului cromic / de crom, a croma (dur sau ornamental)

chromatic cromatic

chromating (met, plast) pregătirea suprafețelor metalice cu soluții cromate, pentru lipire

chromatizing (met) tratament $\mathrm{cu}$ acid cromic a suprafețelor de aluminiu (sau aliaje ale lui) pentru îmbunătățirea aderenței vopselei

chromatography cromatografie

chromatometer (metr) colorimetru

Chrome / Chromium (Cr) (chim) crom

chrome- / chromium-(alloyed) steel (met) oțel (aliat) cu crom

chrome / chromium brick (met) cărămidă de cromit / cromitică

chrome / chromium carbide (chim, met) carbură de crom

chrome / chromium coating / plating (met, plast) acoperire cu crom, cromare (prin electrodepunere sau tratament termo-chimic)

chrome magnesite brick (chim, met) cărămidă refractară de cromo-magnezit

chrome-manganese steel (met) otel $\mathrm{Cr}-\mathrm{Mn}$ chrome-molybdenum steel (met) oțel $\mathrm{Cr}-\mathrm{Mo}$ chrome-nickel steel (met) oțel $\mathrm{Cr}-\mathrm{Ni}$ chrome oxide (chim) oxid de crom chrome-plate (met) a croma, a acoperi cu crom chrome- / chromium-plated (met) cromat chrome sole leather (ind chim) talpă de azbest chrome-tungsten steel (met) otel $\mathrm{Cr}-\mathrm{W}$ chrome-vanadium steel (met) oțel $\mathrm{Cr}-\mathrm{V}$ chrome yellow (chim) galben de crom chromic (chim, met) care conține crom, cromic chromic acid (chim) acid cromic

chromic carbide (chim, met) carbură de crom chromic iron (met) fero-crom (adaos pentru modificarea șarjei în convertizor)

chromiferous (chim, met) cu conținut de crom, cromic

chromize (met) a croma

chromometer (metr) colorimetru

chronograph dispozitiv de măsurare a timpului sau a unui interval de timp

chronologic(al) (adj) cronologic

chronologically $(a d v)$ (în mod) cronologic, în ordine cronologică

chronology cronologie, tabel cronologic

chronometer (metr) cronometru

chrysolite (minrl) crisolit, olivină 
chuck aruncare, aruncătură, azvârlire; (mas-un, OM) mandrină de strângere / prindere, manşon, suport; (el) patron; (constr, mas-un) planşaibă, placă de fixare, manşon, suport, dorn; a prinde, a fixa, a strânge / prinde (în mandrină), a se descotorosi; (alim) antricot (de vită), mâncare

chuck arbor $(\mathrm{OM})$ coadă a mandrinei

chuck coller $(\mathrm{OM})$ bucşă elastică

chucked work piesă prinsă în mandrină

chucking (mas-un) strângere / prindere în mandrină; dispozitiv pentru prinderea piesei de prelucrat; mandrină

chucking capacity (mas-un) diametru maxim al piesei care poate fi fixată în mandrină

chucking grinding machine (mas-un) maşină de rectificat, cu fixarea pieselor în mandrină

chuck(ing) lathe (mas-un) strung cu fixarea pieselor în mandrină / fără păpuşă mobilă / frontal

chucking reamer (mas-un) alezor mecanic / de maşină

chucking rose reamer (mas-un) alezor de finisare, cu porţiune de aşchiere scurtă

chucking table (mas-un) masă de lucru (cu prinderea mecanică / prin strângere a pieselor

chucking turret lathe (mas-un) strung-revolver, cu fixarea pieselor în mandrină

chucking work (mas-un) prelucrare a pieselor strânse în mandrină

chuck key (mas-un) cheie pentru acționarea fălcilor universalului / mandrinei

chuck lever (mas-un) manetă de comandă a mandrinei / universalului (la strung)

chuck out a se descotorosi de, a arunca

chuck plate (mas-un) platou, planşaibă, disc al mandrinei universalului (de strung) cu fălci

chuck-rib (alim) garf (la carne)

chuck vise (mas-un) menghină de maşină

chuck work (ing, mas-un) prelucrare a piesei strânse în mandrină / universal de strung

chuck wrench (mas-un) cheie pentru universal

chump butuc, bloc, bulgăre; (OM) capăt gros (al unei piese)

chunk (alim) bucată / halcă de carne, porție mare

chunky (amer) scund şi îndesat, bondoc

churn (alim) putinei, agitator, amestecător, maşină / aparat de bătut untul; vârtej; a alege; a bate untul; a agita, a înspuma, a tulbura

churner (alim) aparat / dispozitiv de bătut untul

churning machine (alim) maşină / aparat / dispozitiv de bătut untul

churn milk (alim) zer chute (OM) jgheab, plan înclinat, pantă, scoc, topogan; (hidr) cădere (de apă), cascadă; (mas) bandă rulantă, buncăr de alimentare; a aluneca (pe tobogan, pe jgheab etc.), a folosi un jgheab / un plan înclinat

chute blade lamelă de sortare

chute feeder (agr, alim, constr) alimentator cu jgheab

chute riffler (alim) riflu (de tăvălug de moară) înclinat / de evacuare

cibarious alimentar, nutritiv, comestibil

cicatrix, cicatrice $(p l)$ cicatrices (med) cicatrice

cider (alim) cidru, suc de mere

cigarette lighter (auto) brichetă

cinchona (chim) chinină

cinder (met, termo) zgură, cenuşă, arsură, țunder cinder box (met, termo) cameră de zgură / de cenuşă

cinder car (met) vagonet pentru zgură

cinder collector / pocket (met) colector / oală de zgură

cinder cone (termo) con format din cenuşă

cinder frame (termo, met) (grătar) parascântei

cinder hair / wool (ind chim, met) pâslă / lână / vată minerală / de zgură

cinder inclusion (met) incluziune de zgură / de țunder (la laminare)

cinder iron (met) rangă de spart zgura / tunderal cinder notch (met) orificiu / gură pentru evacuarea zgurii

cinder pit (met) groapă de zgură

cinder pot (met) oală pentru / de zgură

cinders (met) zgură, țunder (şi în fragmente)

cinder spout (met) jgheab pentru evacuarea zgurii

cinder tap (met) orificiu (conic) pentru evacuarea zgurii

cindery (met) cu conținut de zgură, cu țunder

cinder yard (met) haldă de zgură (pe un laminat)

cinerary de cenuşă

cinerator crematoriu

cinnabar (bot) cinabru

cinnamon (alim) scorțişoară; (culoare) cafeniu deschis

cipher (inf) cifră, cifru, cod; (mat) zero, nulă; a cifra, a codifica

ciphering cifrare, codificare

cipher key cod

cipher out a socoti, a calcula; a descifra; a decoda circa $(a d v)$ cam, aproximativ

circadian rhytm ritm / ciclu circadian / zilnic

circle (mec) mişcare de rotaţie, orbită; (mat) cerc, circumferință; $(\mathrm{TH})$ platou de mare diametru (şi la maşini-unelte), inel, ciclu, rotație, curs; sferă 
(de influență); a înconjura, a încercui, a se învârti, a se mişca în cerc

circle-cutting machine (mas-un) foarfece circular / cu cuțite-disc; maşină circulară de tăiat (carton, tablă etc.)

circle / circular shears (mas-un) foarfece circular circlet cerc mic, cerculeț, $(\mathrm{OM})$ brățară, inel

circle vision cab(in) cabină cu vedere totală (fără unghiuri moarte), pentru mecanicul care deserveşte un agregat / o macara

circle-wise în cerc, circular

circling machine (met, mas-un) maşină circulară, de tăiat tablă (cu cuțite-disc)

circlip (OM) şaibă arcuită / elastică, inel / rondelă elastic(ă) (şi de siguranţă)

circuit (mec) mişcare circulară / de rotație; (el) circuit, schemă, linie; ciclu, contur; lanț; (mat) pseudovarietate; itinerar, drum, circuit; a merge de jur împrejur, a înconjura, a se învârti

circuit angle (el) unghi de fază (al cuplării convertizorului)

circuit arrangement (el) schemă a circuitelor, schemă de montaj

circuit break (el) întrerupere / deschidere a circuitului (electric)

circuit breaker (CB) (el) întrerupător, disjunctor

circuit closer (el) contactor, conector (de circuit electric)

circuit design (el) structură / construcție, proiectare a schemei electrice

circuit diagram (hidr, el) schemă de circuit (hidraulic sau electric)

circuit fault / failure (el, autom) eroare de conectare / de circuit, cădere a unui circuit

circuit noise meter (electr, el, metr) aparat pentru măsurat zgomotul de fond

circuitous (drum) ocolit; indirect; în circuit

circular (mat, OM) circular, în formă de cerc, de cerc, de arc, cilindric; (ordin) circular, circulară; reclamă, prospect

circular apperture $(\mathrm{OM})$ orificiu / diafragmă circular(ă)

circular mil (metr) unitate de măsură pentru volum: 1 circular mil $=5,067074791 \cdot 10^{-10} \mathrm{~m}^{3}$

circular screwing die (mas-un) filieră (circulară la exterior)

circular arc (mat) arc de cerc

circular axix (mat) cerc axial (la un tor, la o centroidă etc.)

circular bore $(\mathrm{OM})$ alezaj circular

circular cable (met, el) cablu rotund

circular chaser (mas-un) cuțit (cu corp) rotund, cuțit-disc circular continuous milling machine (mas-un) maşină pentru frezare continuă, cu aşezarea pieselor pe o masă rotativă

circular conveyer transportor circular

circular cotter pin $(\mathrm{OM})$ bolț spintecat, asigurat cu şplint

circular curve (mat) arc de cerc

circular cut file (mas-un) pilă cu dinți circulari

circular distributor (mas-un, alim) distributor circular

circular face grinding machine (mas-un) maşină de rectificat plan, pentru suprafețe frontale

circular feed (mas-un) avans circular

circular file (mas-un) pilă-disc, rașpel

circular flanging press (mas-un) presă de bordurat / de răsfrânt marginile (şi pentru țevi) circular forming tool (mas-un) cuțit-disc profilat circular function (mat) funcție periodică / circulară, trigonometrică

circular-grooving saw (mas-un) ferăstrau circular, de canelat

circular helix (geom) curbă elicoidală (pe un cilindru circular); elice cilindrică

circularity (metr, OM) circularitate, caracter circular

circularize a face circular / rotund; (ec) a trimite circulare

circular jig (mas-un) dispozitiv de ghidare cu găuri la periferie (la găurire)

circular key $(\mathrm{OM})$ pană Woodruff / segment (de cerc), pană disc

circular kiln (met, ind chim) cuptor circular / inelar

circular knife (mas-un) cuțit circular / disc

circular letter circulară

circular line cerc (linie); circumferință

circularly $(a d v)$ (în mod) circular, în cerc

circular measure (mat, metr) (măsură în) radiani, radian

circular milling (mas-un) frezare a suprafetelor cilindrice

circular motion (mec) mișcare circulară

circular nut $(\mathrm{OM})$ piuliță rotundă / inelară

circular permutation (mat) permutare ciclică / circulară

circular pipestill (termo) cuptor circular

circular / chordal pitch $(\mathrm{OM})$ pas al danturii (pe cercul primitiv / de bază)

circular planing (mas-un) rabotare a suprafețelor cilindrice

circular recess (mas-un, OM) degajare inelară

circular saw (mas-un) ferăstrău circular

circular-saw bench (mas-un) ferăstrău circular cu masă / de banc 
circular sawing machine (mas-un, met) maşină de tăiat cu disc circular

circular sector (mat) sector circular / de cerc circular shape $(\mathrm{TH})$ profil circular, formă circulară circular shaping (mas-un) prelucrare a suprafețelor cilindrice la şeping (rar)

circular shear blade (mas-un) muchie de disc / de foarfece circular

circular shears (mas-un) foarfece circular / cu discuri

circular-slitting saw (mas-un) ferăstrău circular de canelat

circular slot (T) scobitură circulară

circular slotting (mas-un) mortezare a suprafețelor cilindrice

circular stiffener $(\mathrm{OM})$ inel de rigidizare

circular table (mas-un) masă rotundă

circular tool (mas-un) cuțit disc / rotund

circular tooth thickness at reference diameter $(\mathrm{OM})$ grosimea (lungimea arcului) dintelui pe cercul de divizare (S) (la roti dintate)

circulate a se roti, a avea o mişcare circulară; a rula, a se roti, a functiona, a merge, a circula, a pune în circulație; (ec) a gira (o poliță)

circulate through a străbate, a circula prin care circulă

circulating $(\mathrm{TH})$ circulant, periodic

circulating air aer recirculat

circulating / floating assets (ec) capital circulant, fond de rulment / de rulare

circulating decimal / fraction (mat) fracție zecimală periodică

circulating fan ventilator de recirculare (a aerului)

circulating forced lubrication $(\mathrm{OM}, \mathrm{T})$ ungere / lubrifiere forțată în circuit închis

circulating load (mas) sarcină rotativă (la morile în circuit închis)

circulating lubrication / oiling system $(\mathrm{T})$ sistem de ungere / lubrifiere cu recirculare

circulating medium mediu de circulație / de antrenare (ec) valută, unitate monetară

circulating mixer (alim, ind chim) amestecător cu recirculare / cu pompă de circulație

circulating pipe (hidr, OM) conductă de recirculare

circulating scrap (met) deşeuri metalice interne, fier vechi din circuitul de fabricație

circulating water $(\mathrm{TH})$ apă de circulație / de spălare / circulantă

circulation (el) tensiune magneto-motoare; (mas, mec) circulație, mișcare (și circulară) deplasare, rotație; (mat) integrală pe contur; (ec) circulatie (a banilor / fondurilor etc.), a circula, a fi în circulație; tiraj (de ziar); răspândire

circulation head (ind chim) cap de spălare

circulation lubrication (T) ungere / lubrifiereîn circuit

circulation oven (met, ind chim) cuptor $\mathrm{cu}$ circulatie de gaze de ardere

circulation pump (hidr) pompă de (re)circulație circulation system lubrication (T) ungere / lubrifiere prin circulație / în sistem închis (cu pompă, filtre, drosele etc.)

circulator (termo) conductă de legătură (şi la boilere sau generatoare de abur); propagator, care circulă

circumambience mediu înconjurător / ambiant

circumambient înconjurător, ambiant

circumcentre / circumcenter (geom) centru de cerc circumscris unui triunghi

circumcycle / circumscribed circle (geom) cerc circumscris

circumference (geom) circumferintă, perimetru

circumference gauge (metr) şubler (cu gradații) pentru piese cilindrice

circumference of a sphere (geom) cerc mare al sferei

circumferential circumferențial, circular, de centură

circumferential backlash $(\mathrm{OM})$ joc primitiv $\left(\mathrm{j}_{\mathrm{t}}\right)$ (la angrenaje cu roți dințate)

circumferential diameter (geom) diametru al cercului tangent

circumferential force (mec) forță periferică / tangențială

circumferential groove $(\mathrm{OM})$ canal circular

circumferential joint $(\mathrm{OM})$ inel de etanşare, garnitură inelară

circumferential pitch $(\mathrm{OM})$ pas frontal / aparent (pe cercul de divizare, la danturi înclinate)

circumferential pressure $(\mathrm{mec}, \mathrm{T})$ presiune periferică / pe conturul contactului

circumferential rotor (alim) rotor inelar (la pompe pentru băuturi)

circumferential seam $(\mathrm{OM}$, met) cusătură circulară / inelară de sudură

circumferential speed (mec) viteză periferică / circumferențială / de rotație

circumferential stress (mec) tensiune / periferică / tangentială / pe circumferință

circumflex circumflex

circumgyration $(\mathrm{mec})$ rotire în jurul propiei axe, învârtire

circumrotate $(\mathrm{mec})$ a se roti în jurul axei, a se învârti 
circumrotation $(\mathrm{mec})$ rotire în jurul axei, rotație completă

circumscribe a circumscrie, a (de)limita, a trage o linie în jurul, a restrânge; a defini

circumscription circumscriere, delimitare; limită, hotar, margine; (pol) circumscripție

circumspect circumspect, prudent, precaut

circumspection circumspecție, prudență, precauție

circumsphere (geom) sferă circumscrisă

circumstance circumstanță, împrejurare; formalități, ceremonii; mediu (ambiant / înconjurător)

circumstantial amănunțit, detaliat; circumstanțial; condiționat de împrejurări; neesențial, incidental / circumstanțial suplimentar, adițional; a mănunt, detaliu; (ec) economic

circumstantiality caracter amănunțit / detaliat / neesenţial / incidental; amănunte, detalii; împrejurări

circumstantially ( $a d v)$ amănunțit, în amănunt, detaliat

circumstantial prosperity prosperitate economică de circumstanță / de terminată de o anumită conjunctură

circumstantiate a descrie amănunțit

circumstantiation descriere amănunțită, precizare

circumvent a dejuca; a se sustrage (de la lege), a înşela

circumvention dejucare; sustragere (de la lege); escamotare; înşelare; viclenie, şiretenie

circumvolution circumvoluți(un)e; rotire, învârtire; răsturnare, transformare; îndoire, încovoiere; înconjur, ocoliş

cistern (OM, hidr) cisternă, bazin, rezervor

citation (jur) citație; citare, menționare; enumerare (de fapte)

cite a cita, a menționa, a aminti; a enumera (fapte)

citeable care poate fi citat

citify urbanizare; a urbaniza

citrate (chim) citrat

citric (chim) citric

citrine de culoarea lămâii

citron (alim) arbore de lămâie, citronadă, coajă de lâmâie / de fructe zaharisite

citron melon (alim) specie de pepene verde

citrous (alim) citric

citrus (alim) plantă cictrică, citric

city oraş

city council (pol) consiliu municipal / orăşenesc

city editor redactor financiar şi comercial; (amer) redactor local

city father (pol) consilier orăşenesc / municipal, edil

cityish orăşenesc, de oraş

city planning urbanism, urbanistică city water apă de conductă

civil case (jur) caz civil

civil engineer (constr) inginer constructor

civil engineering (constr) construcții civile, lucrări de construcții

civility politețe, amabilitate

civilization civilizație; cultură

clabber (alim) lapte covăsit, a se covăsi (d. lapte)

clack trosnet, pocnitură; (OM, hidr) supapă, clapetă

clack seat $(\mathrm{OM}, \mathrm{hidr})$ scaun de supapă, clapetă

clack valve (OM, hidr) supapă rabatabilă / cu clapetă, clapetă (de reținere)

clad (met) acoperit, placat

cladding (met) acoperire metalică / prin placare / metalizare, acoperire cu strat relativ mai gros, cu legături obținute prin temperatură, presiune etc.); $(\mathrm{OM})$ armătură, blindaj, protecție

cladding by brazing (met) acoperire / placare prin lipire

cladding by rolling (met, plast) acoperire / placare prin laminare / roluire

cladding by welding (met) placare / acoperire prin sudare

cladding stripper (mas-un) dispozitiv de înlăturare a acoperirii

cladding rolling mill (met, plast) laminor pentru placare

clad material / metal (met, plast) material / metal placat

clad sheet steel (met) tablă (de oțel) placată

claim pretenție, revendicare, drept, reclamație, acțiune, cerere, afirmație, aserțiune; revendicare a priorității unei soluții tehnice; a solicita, a revendica, a reclama / solicita (drepturi), a cere, a pretinde, a afirma, a susține; (jur) a lua ilegal un teren

claimed minimum achivable residual unbalance $(\mathrm{mec})$ dezechilibru rezidual realizabil, declarat

claimer, claimant (jur) reclamant

clam (TH) a încleia, a lipi; (termo) frig umed; umed, lipicios; cleşte cu arc

clamminess caracter lipicios, adezivitate

clammy lipicios, cleios; rece şi umed

clamp $(\mathrm{OM})$ clamă, brățară, cârlig, șurub de strângere; (nav) galet, tachet; (plast) fixare (prin presare, cu cleme, a unui adeziv); grămadă, stivă, morman; a prinde, a strânge, a fixa (cu cleme / brățări etc.), a întări

clamp arm (OM) braț de opritor / de clemă

clamp bucket graifăr

clamp collar $(\mathrm{OM})$ inel de strângere / de fixare, colier

clamp connection (OM) racordare / asamblare / legătură / legare cu colier / prin jug 
clamp coupling (OM) cuplaj cu manşon (din două bucăți)

clamp dog (mas-un, OM) bloc / falcă de fixare laterală

clampdown limitare, interzicere

clamp down a deveni mai sever, a stabili limite

clamped length lungime de prindere

clamp frog (met, mas-un) întinzător de sârmă

clamp-hook (for cranes) (OM) cârlig-cleşte (pentru macarale)

clamping (met) prinderea ramelor după închiderea formei de turnare; $(\mathrm{OM})$ strângere, fixare (şi cu cleme), prindere, încastrare

clamping band $(\mathrm{OM})$ bandă (elastică) de apăsare / de prindere

clamping bolt (OM) bolț / şurub de fixare / de strângere / de consolidare

clamping bush $(\mathrm{OM})$ bucşă de strângere / de asamblare

clamping by screwing up (OM) strângere (prin înșurubare)

clamping chuck (OM, mas-un) mandrină de strângere, gheară de prindere

clamping claw (met, mas-un) cleşte de prins

clamping collar $(\mathrm{OM})$ brățară / colier pentru asamblarea tevilor

clamping device $(\mathrm{OM}$, alim, plast) dispozitiv de prindere (cu cleme, agrafe etc.) (si pt. curele late)

clamping dies (mas-un, OM) bacuri / plăci de strângere

clamping force $(\mathrm{OM})$ forță de strângere (şi pentru un colier)

clamping head (met) cap de prindere (şi la turnare continuă)

clamping-in $(\mathrm{OM})$ prindere, fixare

clamping jaw (el, OM) clemă; falcă de strâns pânze de ferăstrău; (mas-un) falcă de strângere; $(\mathrm{OM})$ sabot / falcă / gheară de strângere / de fixare

clamp(ing) nut (OM) piuliță de presare / de strângere

clamping plate (mas-un) mandrină, placă de fixare / de strângere / de presiune / de legătură a unei matrițe (şi pentru materiale plastice)

clamping pressure (mec, met, plast) presiune de închidere (a matriţei, a colierului) / de menținere a matriței în timpul turnării / matrițării

clamping ring $(\mathrm{OM})$ inel de strângere / de fixare, buşon de bridă

clamping ring stop $(\mathrm{OM})$ opritor (limitator) inelar, inel de strângere al opritorului

clamping spring $(\mathrm{OM})$ clamă elastică, colier elastic clamping time (plast) timp de fixare (presare a unui adeziv); (OM) timp de prindere (cu cleme, inele etc.)

clamping tool (mas-un) sculă de prindere / de fixare

clamp-on vice (mas-un) menghină de banc

clamp stop motion (mas, mas-un) mișcare de oprire cu şurub / cu clemă

clamp up a prinde, a strânge, a fixa (şi cu cleme)

clamshell benă, (macara cu) graifăr

clamshell bucket (nav) graifăr

clamshell dredger (nav) dragă cu graifăr

clamshell excavator excavator cu graifăr

clangur zgomot / sunet metalic, zăngănit

clap pocnet, pocnitură; a lovi, a trânti cu zgomot, a bate; a izbi; a vârî; a îndesa, a închide, a trosni; a aplauda; (ec) a pune impozite

clapper $(\mathrm{OM})$ armătură cu balama

clapper block pin (mas-un) ştift conic al plăcii rabatabile, de suport a port-cuțitului (la raboteză) clapper box $(\mathrm{OM})$ reazem rabatabil

claret (alim) vin roşu (sec); culoare bordo, roşu bordo

clarification (alim, mediu, ind chim) clarificare, limpezire, curățire, purificare, decantare

clarifier (ind chim, alim, mediu) limpezitor, decantor, agent de limpezire, sistem de limpezire / de decantare

clarify (chim, alim, mediu) a (se) limpezi, a (se) decanta, a curăța, a (se) purifica; a (se) clarifica (o problemă)

clarifying (alim) cleiere a vinului, claritate; (ind chim) limpezire, decantare; curățare (a unui lichid)

clarifying basin (alim, mediu) bazin de limpezire

clarifying tank (alim, ind chim, mediu) bazin de limpezire / de decantare, decantor

clarity claritate, limpezime, tranparență

clash ciocnire, lovire; conflict; nepotrivire (a culorilor), lipsă de armonie; a se izbi, a se lovi, a se ciocni; a fi în conflict, a fi în dezacord; a nu se potrivi, a nu se asorta; a coincide, a avea loc în acelaşi timp

clashing of gears (auto, OM) zgomot / scrâşnet / hârâit făcut de dinți, la schimbarea vitezelor

clasp (constr) scoabă, târnăcop; (OM) cârlig, clemă, element de asamblare fără filet, dar cu cârlig / cioc, cataramă; agrafă (şi pentru hârtii); copcă, încuietoare, cârlig; a fixa cu scoabă, a strânge

clasp handle (mas-un) mâner cu fixator cu arc

clasp headed nail (OM) cui cu cap rombic

clasp knife $(\mathrm{OM})$ briceag

clasp nut $(\mathrm{OM})$ piuliță divizată / spintecată 
clasp pin $(\mathrm{OM})$ ac de siguranță, cui spintecat de siguranță

class clasă, grupă, categorie, sortiment; calitate, clasă (superioară), specie; soi; mulțime; (cf) clasă; a clasifica, a sorta, a împărţi pe grupe / clase, a aparține unei clase

classable clasificabil

classic de primă clasă, perfect, desăvârşit; (devenit) clasic; binecunoscut; simplu, sobru; de bază, fundamental, esențial; tradițional

classical V-betlt $(\mathrm{OM})$ curea trapezoidală clasică

classifiable clasificabil, care poate fi clasificat / sortat

classification (sistem de) clasificare, clasare, împărțire în clase, sortare, gradație

classification in air / in liquid (ind chim, alim) clasificare, clasare, împărțire în clase, sortare în aer / în lichid

classification mill (alim, constr, ind chim) instalație de sortare

classified clasificat; (amer) secret

classifier (agr, alim, ind chim) sortator, clasor (de minereuri, de bumbac etc.), clasificator

classifier overflow refuz (de la sortator)

classify a clasifica, a sorta, a clasa; (amer) a considera secret

classifying clasificare, sortare, clasare

classifying cone (agr, alim, ind chim) clasor / sortator conic

classifying drum cilindru de sortare, ciur rotativ classifying jigging screen $(\mathrm{OM}$, alim, constr, ind chim) ciur vibrator / sită vibratoare de sortare

classifying screen (OM, alim, constr, ind chim) ciur / sită de sortare

class list (edu) împărțire pe grupe de studiu (universitar)

class number semn, simbol al grupei / clasei (la clasificare, sortare)

class of fabricated products $(\mathrm{ec})$ serie de fabricație

class of pig iron (met) grupă / sortiment de fontă

clatter zgomot, bătaie (la maşini); zornăit, zăngănit, huruit; a zornăi, a zăngăni, a zdrăngăni, a zurui, a hurui; (TH) a păcăni

clattering zgomotos, $\mathrm{cu}$ huruit, care bate (d. maşini sau organe de maşini)

clause (jur, ec) clauză, punct, articol

claustrophobia claustrofobie

claw $(\mathrm{OM})$ clichet, gheară, dinte, foarfece, cleşte de scos cuie, foarfecă (rar); a zgâria, a râcâi

claw bar $(\mathrm{OM})$ pârghie / cârlig

claw beam (constr) stâlp cu talpă

claw belt fastener $(\mathrm{OM})$ agrafă de curea claw bit daltă-lingură (pt. lemn)

claw elutch $(\mathrm{OM})$ cuplaj / prindere cu gheare

claw coupling $(\mathrm{OM})$ cuplaj cu gheare

claw hammer ciocan cu clichet / cu talpă

claw off (constr) a ciopli

claw wrench (constr) cleşte de scos cuie

clay (met, constr) argilă, lut, humă, pământ galben, noroi

clay-bearing (met, constr) cu argilă, argilos

clayed argilos

clayey de / cu argilă

clay gun (met) maşină pentru astuparea orificiului de descărcare (la cuptoarele metalurgice)

clay plug (met) dop de argilă

clay soil (geol) sol argilos

clay stopper (met) dop de argilă

clay work (met) zidărie refractară

clean curat, pur, neamestecat, îngrijit; imun; clar conturat, pronunțat; (met) neted, decapat; a curăța, a îndepărta murdăria; a epura; a şterge; a lustrui; a spăla, a limpezi; drept, exact, tocmai

cleanable care se poate curăța, lavabil

cleanable element (hidr, alim) element filtrant lavabil

clean air aer pur / curat

clean-cut clar conturat, proeminent, pronunțat; bine format / alcătuit; clar, precis, exact

clean down a curăța de sus până jos

cleaned gas (termo, mediu) gaze epurate

cleaner (el) aspirator electric; (ind chim) epurator; (met) dăltuitor (la laminate), debavurator, curățitor

clean flow (hidr) curgere fără vârtejuri (liniară / laminară)

clean fuel (termo) combustibil / sursă de energie fără poluanți sau impurități

cleaning curățare, epurare, purjare, purificare; (alim) decantare, limpezire; (agr) sortare

cleaning barrel (met) tobă de curățat

cleaning bench (met) masă de debavurare

cleaning brush (met) perie curățitoare (la piese turnate)

cleaning cloth bumbac de șters

cleaning disk disc de curățare

cleaning drum (met) tobă de curățare

cleaning knife (mas-un) cuțit de finisare

cleaning mixture (chim) amestec oxidant / pentru curățire

cleaning needle $(\mathrm{OM})$ ac de deburare

cleaning of blast-furnace gas (met) epurare a gazelor de furnal

cleaning out purificare, rafinare

cleaning power capacitate de curățire 
cleaning-room equipment (met) instalație / echipament de curățat piese turnate

cleaning solvent (chim) solvent pentru curățare chimică

cleaning strainer (ind) filtru

cleanliness puritate; curățenie, ordine

cleanliness factor coeficient de puritate (la materiale)

cleanliness of the environment (mediu) puritatea mediului (cu referire la praf, agenți agresivi etc.)

cleanly $(a d v)$ curat, îngrijit

cleanness curățenie, puritate

clean of burr (met) a debavura

clean off a curăţa (prin îndepărtare), a şterge

clean oil (ind chim, T) ulei pur / fără aditiv / neaditivat

clean out a curăța; a goli, a deşerta; a nu lăsa nimic în / la, a devasta

clean-out door / hole (met) uşă / gură / orificiu de curățare (a unui cuptor)

clean-out valve (OM, hidr, termo) supapă / ventil de purjare

clean room (ind) cameră (cu atmosferă) controlată

cleanse a curăța, a limpezi, a rafina, a spăla; a dezinfecta

cleanser epurator, racletă, arzător, substanță de curățat, detergent, praf de curățat

cleanser drum (met) tobă pentru curățarea pieselor turnate

cleansing agent (chim) agent / substanță de curăţat (şi detergent)

clean sweep schimbare totală / radicală; curățenie totală; (c, inf) scanare si reparare a erorilor în tot calculatorul sau softurile din acesta

clean(-)up curățare / finisare a suprafeței după o prelucrare mai neîngrijită, curățire; (ec) profit enorm

clean up a curăți, a curăța; a pune în ordine; a termina (ceva început)

clear $(\mathrm{TH})$ clar, limpede; neechivoc, luminos, curat, liber, transparent; întreg, plin, complet; (ec) (câştig) curat, a plăti, a achita (datorii etc.), a câştiga netto, a câştiga suficient pentru a achita cheltuielile, a scăpa de datorii; (nav) degajat, ferit; (nav) a evita (un banc de nisip etc.); a (se) limpezi; (nav) a draga; a debloca, a clarifica, a descoperi, a redeschide / a reîncepe (o lucrare); a face formalitățile de sosire şi plecare, a descărca; a curăța, a evacua, a elibera; a clarifica (o problemă); (autom) a repune / a aduce la zero; (inf) a goli (memoria), a şterge (ecranul, registrul), a curăța (şi de viruşi); a strânge (masa etc.); (el) a separa, a deparazita, a întrerupe; a defrişa

clearance curățenie, curățire; gabarit de navigație (la poduri); (ec) cliring; (OM) joc, spațiu liber între două piese, interstițiu; (nav) autorizație de plecare a navei, lichidare în vamă; $(\mathrm{TH})$ spațiu, interval, distantă; verficare; epurare, îndepărtare, înlăturare; defrişare

clearance angle (mas-un) unghi de detalonare la rectificare / la aşezare / la prelucrarea profilurilor

clearance between collars (met, plast) deschidere a calibrului de laminare

clearance between rolls (met, plast) deschiderea cilindrilor de laminare

clearance fit $(\mathrm{OM})$ ajustaj cu joc

clearance for insertion (OM) joc de / pentru asamblare, joc de montare

clearance gauge (metr) spion, şablon de profil; spațiu / interstițiu de izolare

clearance hole(s) (c) grup de găuri coaxiale (la circuite imprimate); (OM) diametrul cercului de trecere, gaură de trecere

clearance-loading gauge (cf, transp) gabarit (dimensional) de încărcare

clearance of piston (auto, OM) joc al pistonului clearance papers (ec) certificat de vamă

clearance sale $(\mathrm{ec})$ lichidare a stocului (de mărfuri), sold, vânzare pentru a termina stocurile rămase

clearance space cameră de compresie

clearance volume $(\mathrm{OM})$ spațiu / de siguranță dar și reglabil, spațiu rezidual între piston şi capul cilindrului, la sfârșitul cursei de compresie

clear away a curăţa, a îndepărta

clear-cut clar conturat, proeminent, pronunțat; bine format / alcătuit; clar, precis, exact

clearer roller (met, ind chim) cilindru curătitor

clear-eyed perspicace, realist

clear glass sticlă transparentă

clear-headed cu capul limpede

clearing (zool, alim) defecare; (cf) deblocare; (chim) limpezire, purificare, curățire; (el) eliberare, deconectare; defrişare; (inf) ştergere; (ec) clearing, decontare; înseninare (a vremii)

clearing agent (alim, ind chim) agent de limpezire / de afinat

clearing cylinder (alim, constr, ind chim) ciur rotativ

clearing device (autom) instalație / aparat de verificat; (inf) dispozitiv de golire (de aducere la zero)

clearing key (autom) buton de readucere în stare de repaos 
clearing of a fault (TH) înlăturare a unui deranjament / a unei greşeli

clearing house (ec) birou de cliring / de decontare clearing station punct de evacuare

clearly $(a d v)$ (în mod) clar, evident, bine înțeles

clearness limpezime; curățenie; (fiz) strălucire; luminozitate; (inf, c) inteligibilitate (a limbajului); (radio) claritate (şi a recepției); (TH) capacitate de funcționare; transparență; claritate, acuitate

clear off a libera, a evacua; a strânge (masa); a se face frumos (d. vreme)

clear of strays fără zgomote parazite

clear opening $(\mathrm{OM})$ spațiu liber, distanță între două reazeme vecine

clear out a curăța, a goli, a evacua, a lua, a îndepărta, a scoate; a duce în altă parte; a alunga, a izgoni; pătrunzător, perspicace

clear sightedness perspicacitate, clarviziune

clear up a curăța, a face curățenie / curat în; a pune în ordine

clear valve opening $(\mathrm{OM}$, hidr) secțiune liberă la o supapă complet deschisă

clear varnish (chim) lac transparent

clear water (ind) apă disponibilă / excedentară; apă limpede / curată (cel puțin vizibil)

clear water dripping (auto) picurare de apă clară / limpede

cleat (constr) sfert de buştean; (el) izolator cu clemă; (OM) pană, clemă, tachet, eclisă; scoabă, şipcă; (nav) tachet de împănare

cleavable care se poate despica / crăpa / despica

cleavage clivaj, despicare, desfacere (la minerale, adezivi); divizibilitate naturală; scindare, spintecare, separare; diferențiere; împărțire (în categorii); (met) exfoliere

cleavage angle (minrl) unghi de clivaj

cleavage brittleness (met) fragilitate intercristalină, tendință de rupere prin clivaj

cleavage plane plan de clivaj / de rupere

cleavage strength (plast) rezistență la clivaj (şi a unei lipituri)

cleave a (se) despica, a spinteca, a se tăia în două, a (se) desface, a despărți, a scinda, a crăpa

cleaved head (OM) cap crestat / cu caneluri

cleaver dispozitiv de tăiat (şi fibre optice); topor, secure, tăietor de lemne

cleave to a se lipi de, a sta lipit de; a rămâne fidel

cleaving despicare, crăpare; clivaj

cleaving ax(e) topor / pană de despicat

cleft fisură, despicătură, plesnitură, crăpătură; slit, fantă clement clement, îndurător; îngăduitor, indulgent; blândă, temperată (d. climă)

clench $(\mathrm{OM})$ clemă, scoabă, nit, strângere, nituire, țintuire; argument hotărâtor; a (se) strânge, a încleșta, a apăsa, a presa, a închide ermetic, a ține strâns, a nitui, a țintui, a (se) agăța, a se comprima; a hotărî (definitiv); a parafa

clench / clinch (TH) a ține strâns / ferm, a închide bine, a înşuruba strâns; a contract (ec) a încheia / a finaliza un contract

clencher strângere; $(\mathrm{OM}$, constr) scoabă, clemă; argument hotărâtor

clever (adj) inteligent, deştept; spiritual, isteț; ingenios; talentat, înzestrat; abil, îndemânatic, dibaci

cleverish $(a d j)$ destul de inteligent

cleverly $(a d v)$ inteligent, cu inteligență

cleverness deşteptăciune, inteligență, istețime; ingeniozitate; dăruire, înzestrare; abilitate, îndemânare, dibăcie

clevis $(\mathrm{OM})$ toartă, inel, brățară, capăt de furcă

clevis bolt $(\mathrm{OM})$ şurub cu gaură pentru cui spintecat

clevis mounting (OM, hidr) montare / fixare cu furcă

clevis pin $(\mathrm{OM})$ ştift cu cap şi gaură pentru cui spintecat

clew ghem, jurubiță; fir călăuzitor; urmaș; făgaș; (nav) colț de şcotă; a face ghem, a înfăşura

cliché clișeu, banalitate, expresie stereotipă

click pocnet, țăcănit, zgomot, pârâitură, pocnitură; $(\mathrm{OM})$ clichet; pârâituri, pocnituri; $(\mathrm{OM})$ clanță, zăvor; a pocni, a țăcăni, a păcăni, a închide cu zgomot

clicker press (mas-un) presă de ștanțat

click spring $(\mathrm{OM})$ resort / arc de înclichetare, arc de clichet

client (ec) client, cumpărător

clientage (ec) clientelă, clienți, relații între client şi patron

climate climat, atmosferă, ambianță

climate control system (auto) sistem de control al mediului

climate maintenance $(\mathrm{TH})$ climatizare, întreținere / menținere a climatului

climatic(al) climatic, climateric

climatic chamber / room cameră climatizată / $\mathrm{cu}$ aer condiționat

climatizer (termo) instalatie de climatizare (și a aerului)

climax punct culminant / de vârf, apogeu

climax with a culmina cu

climb urcare, cățărare, ascensiune; loc greu accesibil; a (se) urca pe, a sui, a se căț̆ra, a se ridica 
climb-down coborâre; cedare; recunoaştere a înfrângerii

climb down a coborî, a se da jos; a cădea; a ceda climbing urcare, cățărare; alpinism; urcător, care urcă

climbing irons gheare de urcat pe stâlp

climbing motion mişcare ascensională

climb milling (mas-un) frezare în sensul avansului

clinch nituire; (nav) îmbinare în baionetă; $(\mathrm{TH})$ a nitui, a țintui; a rezolva (o problemă); (ec) a încheia o afacere

clincher (ec) argument decisiv / hotărâtor, dovadă hotărâtoare / decisivă; $(\mathrm{OM})$ clamă, nit, bulon, scoabă

clincher rim (auto) geantă auto cu talon

clincher tyre (auto) pneu cu talon

cline (autom, TH) ansamblu de caracteristici, exprimând o tranziție

cling a se lipi, a adera, a forma un tot

clinging agățător, care (se) agață

clinging power of fibres putere de aderență a fibrelor (şi la compozite)

cling to a se ține de, a se apuca de, a se prinde de; a adera la, a fi partizanul / adeptul

clingy lipicios, vâscos, cleios, aderent, adeziv

clink clamă, brățară; clinchet; a zăngăni

clink-clank zăngănit

clinker (met) clincher, bulgăre de zgură; a arde, a coace, a sintetiza; (chim) ciment (hidraulic), liant anorganic (sens general)

clinkered dolomite (met) clincher de dolomită, dolomită clincherizată

clinker cooler (met) răcitor de clincher / de zgură

clinkering (met) clincherizare, aglomerare, sintetizare; aglutinare; zgurificare, formare a clincherului, ardere a cimentului / a cărămizilor

clinkery (met) cu conținut de zgură

clinking (met) fisurare, fracturare (la turnare)

clinometer (metr) clinometru

clip agrafã (pentru hârtie); (constr) scoabă; (el) papuc, clemă, brățară (pentru cabluri); (OM) bridă, colier, eclisă, clamă, agrafă, clips, cerc, brățară, şarnieră; (TH) a tăia (şi margini), a forfeca, a scurta, a reteza, a perfora, a decupa, a teşi, a apuca, a prinde; a tunde; a cuprinde; (mas-un) dispozitiv mecanic de prindere; (met) a debavura; a prescurta (cuvinte)

clip bolt $(\mathrm{OM})$ şurub cu gheară / cu cap-ciocan / de strângere; crampon

clip lock $(\mathrm{OM})$ închidere cu pârghie (la buteliile cu dop mecanic)

clip match hook (OM) cârlig foarfece clip nut (OM) piuliță cu clemă (de autoblocare) clip-on (de) prins cu clipsuri / clame / agrafe clipped wire (met) alice obținute prin tăierea sârmei trase

clipper $(\mathrm{TH})$ cleşte, foarfece, maşină de tuns clippers cleşte de tăiat

clipping tăietor, tăios, care taie, ascuțit; (met) debavurare; tundere, tăiere; perforare

clipping bed (met) placă de tăiere (la presa de debavurare)

clipping press (met, mas-un) presă de debavurare

clipping punch (met) poanson de debavurare clippings (met) deșeuri de tablă; tăieturi din ziare

clipping tool (met, plast) sculă / ştanță de debavurare (după turnare, maturare)

cloak mantie, manta, înveliş; a acoperi, a înveli; a ascunde

clock ceas(ornic), pendulă, orologiu, ceas de masă / deșteptător; bază de timp; generator de ritm, sincronizator; semnal utilizat în mod regulat; (auto) kilometraj; pentru controlul sistemelor operative (digitale); a ponta, a cronometra

clock in a începe lucrul, a ponta ora sosirii la serviciu

clocking error (metr, TH) eroare de sincronizare / de ritm

clockmaker ceasornicar

clock out a ponta la plecare de la serviciu

clock setup (auto, autom) setarea timpului / ceasului

clock setup mode mod de setare a ceasului

clockwise (CW) în sensul acelor de ceasornic

clockwise direction (în) sensul deplasării acelor de ceasornic, dextrogir; $(\mathrm{OM})$ cu filet dreapta

clockwise rifling $(\mathrm{OM}$, mil) ghint / filet pe dreapta

clockwise (right hand) rotation rotație în sensul acelor de ceasornic (spre dreapta)

clockwork (metr) mecanism cu ceas(ornic) / cu arc spiral; mecanic, automat (d. jucării); punctual, precis

clod bulgăre, cocoloş; pământ, țărână

clod coal (met) cărbune-bucăți / -bulgări

cloddy, clodish bulgăros, bolovănos; greoi, stângaci, neîndemânatic

clog sabot (de lemn); (TH) piedică, obstacol, a obtura, a împiedica, a opri, a stânjeni, a înfunda, a astupa, a umple (un orificiu, o gaură etc.), a ancrasa, a împovăra, a colmata, a îmbâcsi, a împovăra, a supraîncărca

clogged $(\mathrm{TH}$, mediu) împiedicat, frânat, înfundat, îmbâcsit, astupat 
clogged element (hidr, alim) element filtrant colmatat

clogged strainer (hidr) sorb înfundat (la pompe de aspirație)

clogged up colmatat, înfundat, blocat

clogging colmatare, obturare, înfundare, îmbâcsire, murdărire; (termo) ancrasare

clogging indicator (hidr) indicator de colmatare

cloggy care se face cocoloaşe; cleios, lipicios; dens

clog-nosed vice (mas-un) menghină (specială) cu fălci înguste

clog up a colmata, a înfunda, a bloca

close încheiere, închidere, sfârşit; închis, împrejmuit, îngrădit; închis, încuiat, ascuns, secret; precis, exact; (OM) fidel, strâns (d. un câmp de toleranță); apropiat; amănunțit, detaliat, minuțios, concentrat, atent; des, compact (d. textile); concis, lapidar; a (se) închide, a împrejmui, a îngrădi, a încuia, a aduna, a concluziona, a astupa, a bloca; a interzice trecerea prin; a termina, a sfầrşi, a încheia

close an account (ec) a lichida un cont

close-annealed (met) recopt în cutie / în lăzi

close-annealed sheet (met) tablă recoaptă în cutii

close annealing (met) recoacere în cutie / în lăzi

close annealing furnace (met) cuptor de recoacere în cutii

close-burning care arde înăbuşit

close-burning coal (met) cărbune cocsificabil

close button (auto) buton de închidere (d. o trapă)

close company (ec) societate închisă (controlată de cel mult cinci asociați)

close coupling $(\mathrm{OM})$ cuplaj strâns / rigid

close-cut fraction (ind chim) fracțiune îngustă

closed închis, împrejmuit, îngrădit; încuiat; terminat; restrâns, exclusiv; împrejmuire, loc / teren împrejmuit, curte

closed assembly time (chim, plast) interval scurt de timp de asamblare (la adezivi), intervalul de timp între asamblare şi inițierea prizei

closed centre distance $(\mathrm{OM})$ distantă dintre axe micşorată (la angrenaje deplasate negativ)

closed centre position (OM, hidr) pozitie centru închis (la distribuitoare, toate orificiile obturate când organul de comandă este în poziția neutră sau centrală)

closed chain (chim) ciclu, nucleu

closed-circuit (el, autom) circuit în buclă, (în) circuit închis

closed-circuit arrangement (OM, autom, el) legătură în buclă, circuit închis

closed-circuit crushing (constr, ind chim) sfărâmare / măcinare în circuit închis closed-circuit grinding (TH, alim) măcinare / mărunțire în circuit închis

closed-circuit installation / system (TH) instalație / sistem în circuit închis

closed contact (el) contact normal închis / de repaus

closed crankcase machine (mas, termo) maşină capsulată / cu carter închis

closed-cycle turbine (termo) turbină cu gaze în circuit închis

closed entry (el, c) intrare / suport cu goluri sau proeminențe de anumite mărimi, pentru evitarea introducerii altor elemente

closed die (met, plast), (mas-un) matriță închisă

closed frame (constr, mas) cadru închis / cu secțiune chesonată

closed graph curbă închisă

closed groove (met) calibru închis (la laminare)

closed hole $(\mathrm{OM})$ gaură înfundată

closed-impeller pump (hidr) pompă cu rotor închis

closed-in presuure (mat, hidr) presiune statică, în incintă închisă

closed interval segment, interval închis

closed keyseat $(O M)$ canal de pană, închis

closed linkage (OM) contact prin forță / forțat

closed-loop control (autom, electr) reglaj (în circuit închis), comandă continuă, cu buclă de reacţie

closed-loop servosystem (autom) sistem de reglare cu buclă închisă / cu circuit închis / cu reacție

closed mould (met, plast, mas-un) matriță (de presare) închisă

closed network (el) rețea închisă

close-down încetare (și a muncii, din cauza închiderii întreprinderii)

close down a închide; a lua măsuri represive, a reprima; a înceta (o activitate), a se opri

closed pass (met) calibru închis

closed position (autom, el, TH) poziție de cuplare / de închidere

closed ring $(\mathrm{TH})$ ciclu închis

closed rivet $(\mathrm{OM})$ nit montat

closed shop fabrică în care se angajează numai din anumite sindicate

close-grained (materiale) microgranular, cu granulație mică, cu interval îngust de granulație

closed securely (auto) închis ermetic

closed single-V butt weld (met, OM) cusătură (de sudură) cap la cap în $\mathrm{V}$, cusătură în V fără rost între margini

closed square pressure gas welding (met) sudare cu gaze sub presiune, fără rost între piese closed stand (met) cajă închisă 
closed system (TH) sistem închis closed-tolerance $(\mathrm{OM})(\mathrm{cu})$ toleranță mică / strânsă, (cu) câmp îngust de toleranță

closed-tolerance forging (met) forjare de precizie (la cald)

closed weld $(\mathrm{OM})$ îmbinare prin sudură, fără distanță între piese

close fit (OM) ajustaj cu strângere / strâns / forțat close fractionation (ind chim) funcționare pe interval îngust (de temperatură), fracționare precisă

close-grained cu granulație mică, cu interval îngust de granulație, micro-granular; (plast) microporos

close-grained pig / steel (met) fontă / oțel cu granulaţie fină

close-grained structure (materiale) structură densă / cu granulație fină

close-grained texture structură / textură cu granulație mică / fină, microstructură

close in a se apropia de, a închide în, a împrejmui, a veni, a sosi, a ataca; a se micsora, a se scurta (d. zile etc.)

closely $(a d v)$ atent, cu grijă, minuțios, de aproape, din apropiere, strâns, unul lângă altul

closeness apropiere, vecinătate; (mediu, TH) aer închis, atmosferă viciată; densitate, caracter compact; exactitate, precizie; avariție, zgârcenie; izolare

closeness of contact (el) închidere fermă a contractului

close nipple $(\mathrm{OM})$ racord drept, niplu cu filet pe toată lungimea

close(-)out (ec) lichidare de mărfuri

close out (ec) a vinde la prețuri reduse, a lichida (un stoc)

close packed lattice (materiale) rețea cristalină compactă

close-packed structure ( $\mathrm{TH}$, mas, materiale) structură compactă

close packing ambalare compactă; (cf) rambleiaj dens

closer roll (met) cilindru superior de laminat profiluri

close running fit $(\mathrm{OM})$ ajustaj semiliber / intermediar (dar cu tendiță de joc)

close setting (autom, metr) reglaj fin

close spacing amplasare la intervale mici; (masun) densitate mare a amplasării granulelor (la discuri de rectificat)

close stowing anchor (constr, nav) ancoră cu brațe articulate şi traversă în acelaşi plan

closet cameră, cămară, magazie; dulap (în perete); birou, cabinet (de lucru); toaletă, closet; secret, particular, privat; teoretic, abstract, nepractic; a închide (pe cineva), a ascunde, a pune la loc sigur

close thing accident / eşec evitat în ultima clipă

close to $(a d v)$ în jur de, cam de, lângă; în apropierea

close tolerance forging (met) forjare de precizie / la tolerante strânse

close-up fotografie de aproape, prim-plan; (amer) examen minutios, analiză delicată

close up a închide; a lichida; a termina, a încheia; (med) a se vindeca, a se închide (d. răni)

close up a rivet $(\mathrm{OM})$ a nitui, a îmbina prin nituire

close-up shot / view fotografie de aproape, prim-plan, detaliu

closing (de) închidere (şi a magazinelor / bursei etc.), care închide, ultim, încheiere, sfârşit, capăt; (el) conectare, anclanşare

closing cock (hidr, OM) robinet de închidere

closing device (OM, mas-un) dispozitiv de blocare / de închidere

closing flap (hidr, OM, met) clapetă / clapă de închidere

closing head (OM) dispozitiv / cap de blocare / de închidere / de strângere

closing of accounts (ec) încheiere / închidere a contururilor

closing price (ec) pret / curs la închiderea bursei

closing switch (el) contactor, conector

closing time (el, mas) timp / durată de închidere; (plast) durată de închidere a formei / de coborâre a poansonului; ora închiderii

closing travel (mas-un) cursă de închidere (a presei)

closure închidere, încheiere, sfârșit; (constr, hidr) breşă (de închidere); aderență; (met, mas) închizător, obturator

closure component (hidr, OM) component / element de închidere (şi la supape)

clot bulgăre, cocoloş; cheag (şi de sânge); a se coagula, a se închega, a se face bulgări / cocoloașe, a lăsa să se coaguleze

cloth (textile) postav, stofă, țesătură, pânză; (TH) îmbrăcăminte, căptuşeală (şi de rezervor, recipient)

clothe (TH, met) a (se) îmbrăca, a acoperi, a proteja, a căptuşi

clothes îmbrăcăminte, haine; lenjerie (şi de pat)

cloth filter candle filtru-lumânare (din pânză)

cloth filter dust collector ( $\mathrm{TH}$, mediu) filtru de praf, cu saci

clothier fabricant de stofe; croitor

cloth impregnating machine (mas, ind chim) maşină de împregnat țesături 
clothing acoperire, protejare, căptuşire, îmbrăcare, îmbrăcăminte; $(\mathrm{OM})$ cămaşă (de cilindru), garnitură; (met) manta, înveliş, căptuşeală (şi de cuptor)

cloth laminate stratificat pe pânză (ca suport) (şi la curele pentru transmisii), laminat stratificat cu pânză

cloth shears foarfece pentru textile

clotted cream (alim) smântână grasă

clotting coagulare; floculare

clou un punct de interes major, poantă; indiciu

cloud nor; (el) efect de umbră / pată; (c) părți clare şi părți închise (la o imagine, un display); nervură în marmură; a se înnora, a se întuneca, a marmora

cloud burst rupere de nori, ploaie torentială

cloudbursting / cloudburst treatment (met) curățare (în jet) cu alice

cloud(ed) glass (ind chim) sticlă mată

cloudiness (ind chim) tulbureală, tulburare; (fiz) turbulentăă, turbiditate

cloud point (fiz) punct de turbiditate (început de cristalizare), temperatură de tulburare

cloudy noros, înnourat; tulbure (d. lichide); neclar, confuz (d. idei etc.); tulbure, încețoşat (d. vedere etc.)

clout țintă, lovitură care îşi atinge ținta; scutec; (pol) (fam) putere politică

clout nail $(\mathrm{OM})$ cui pentru asamblat lemn şi tablă

clove (alim) cățel de usturoi, (arbore de) cuişoare

clove hitch (nav) foarfecă simplă

clow (hidr, nav) poartă de ecluză

clowhole (met) retasură

club (mas, OM) piston; (met) țaglă; (el) lob (de radiatie al unei antenei)

club-shaped $(\mathrm{OM})$ îngroşat la un capăt

club steak (alim) muşchi (de vită)

cluck a exprima aprobator; ciocănit; (d. găini etc.) a cloncăni, a-şi chema puii

clue indicație, indiciu, cod, cifru; punct de reper; urmă

clued up about / on bine informat despre, la curent cu

clue in a face să se înțeleagă; (fig) a da o cheie / un indiviu cuiva

clue word cheie a cifrului, cuvânt-cheie (şi în titlu)

clump bulgăre, cocoloş, grămadă, masă, grup; (nav) ancoră de beton / de fontă

clumsy stângaci, neîndemânatic; nehotărât; grosolan; lipsit de tact

clunch (termo, met, ind chim) argilă refractară

clusec (metr) unitate de putere (la pompe de vid) $\left(\sim 1,33 \cdot 10^{-6}\right.$ watt $)$ cluster (constr, hidr) grup de piloți; (fiz) aglomerat (complex) de molecule, grup (cuib, roi, nor); (mat) fascicul; (TH) aglomerare, pensulă, fascicul, mănunchi, ciorchine, grămăjoară, acumulare; (autom, inf) grupă; (el) tiristor (din mai multe discuri); a grupa, a forma un grup, a se strânge, a se aduna, a crește mănunchiuri / în cuiburi (şi d. structuri de materiale)

clustered dirijat, strâns / reunit în fascicul, grupat; aglomerat (d. particule)

clustered flux inclusions (met) incluziuni de flux împrăştiate (la sudură)

clustered slag inclusions (met) incluziuni de zgură împrăştiate (şi la sudură)

cluster gear $(\mathrm{OM})$ mai multe roți dințate montate pe o bucşă

cluster joint (OM, el, hidr) îmbinare a mai multor piese / circuite într-un nod

cluster lattice (materiale) rețea compactă

cluster of plane surfaces fascicul de plane

cluster point (mat) punct limită / de acumulare

cluster rolling mill (met) laminor cu şase cilindri

cluster sampling $(\mathrm{TH})$ prelevare de mostre pe grupuri

cluster set (mat) mulțime derivată, mulțimea punctelor limită

clutch (auto, OM) cuplaj, ambreiaj, manşon, mufă nedecuplabilă, cârlig, apucare, strângere; a ambreia, a cupla, a apuca, a prinde (şi cu o gheară), a ține strâns

clutch barrel $(\mathrm{OM})$ tambur de ambreiaj

clutch casing / case (OM) carcasă / carter a(l) ambreiajului

clutch collar $(\mathrm{OM})$ manşon de cuplare

clutch cone $(\mathrm{OM})$ con de ambreiaj

clutch-coupling sleeve $(\mathrm{OM})$ mufă de legătură / de cuplare / de îmbinare

clutch cover $(\mathrm{OM})$ capac de ambreiaj, capac al carterului de ambreiaj

clutch disengaging spring $(\mathrm{OM})$ arc de debreiere / decuplare (şi a ambreiajului)

clutch disk $(\mathrm{OM})$ disc de frecare (la un ambreiaj)

clutch disk facing $(\mathrm{OM})$ garnitură / acoperire a discului de ambreiaj

clutch dogs $(\mathrm{OM})$ gheare de cuplare

clutch electrohydraulic control valve $(\mathrm{OM})$ supapă electrohidraulică, de comandă a debreierii (şi la vehicule amfibii)

clutch engagement $(\mathrm{OM})$ ambreiere

clutch facing(s) (OM) lamele / garnitură / căptuşeală de ambreiaj

clutch fluid flywheel (OM, hidr) ambreiaj hidrodinamic / hidraulic 
clutch gear $(\mathrm{OM})$ mecanism de cuplare, pinion de arbore primar / de cuplare

clutch housing $(\mathrm{OM})$ carcasă / cutie / carter a(1) ambreiajului

clutch lever (auto, mas-un, mas) levier al schimbătorului de viteză, pârghie de cuplare / de decuplare

clutch magnet (el) (electro)magnet de cuplare (a ambreiajului)

clutch operator (OM) schimbător de cuplu, dispozitiv de operare asupra unui cuplaj / a unui ambreiaj

clutch out $(\mathrm{OM})$ a debraia, a decupla (şi un ambreiaj)

clucth pedal (auto) pedală de ambreiaj

clutch pedal clearance (auto) joc al pedalei ambreiajului

clutch pin $(\mathrm{OM})$ gheară / ştift a cuplajului

clutch plate $(\mathrm{OM})$ disc de ambreiaj

clutch pressure plate $(\mathrm{OM})$ disc al ambreiajului de frictiune, actionat prin presare

clutch release $(\mathrm{OM})$ debreiere

clutch release fork $(\mathrm{OM})$ furcă a pârghiei de debreiere, de decuplare

clutch ring $(\mathrm{OM})$ inel de cuplare

clutch shaft $(\mathrm{OM}) \mathrm{ax} /$ arbore de ambreiaj, arbore de antrenare / primar

clutch spindle $(\mathrm{OM})$ arbore de cuplare (şi pentru ambreiaje)

clutch stop (OM) frână de cuplaj / de ambreiaj

clutch throwout $(\mathrm{OM})$ debreiere, decuplare (și a unui ambreiaj)

clutch wheel $(\mathrm{OM})$ roată de cuplare

clutch with multiple laminated disks (OM) ambreiaj multidisc

clutter dezordine; confuzie; a pune dezordonat, a murdări, a face zgomot, a vorbi repede şi neclar; (c) ecouri parazite pe un ecran

$\mathrm{CO}_{2}$ (-shielded) metal-arc welding (met) sudare cu arc, în atmosferă de $\mathrm{CO}_{2}$

coach autobuz (pentru excursii); (cf) vagon de pasageri; meditator; antrenor, instructor (de sport); (edu) a medita (pe cineva), a antrena, a instrui

coach class (amer), (cf) clasa a II-a

co-acting force $(\mathrm{mec})$ forță care acționează în acelaşi sens

coadjutor asistent, ajutor

coagulable (alim) coagulabil, congelabil

coagulant (chim) (agent) coagulant

coagulate a (se) închega, a (se) coagula; (alim) a se brânzi

coagulating agent (chim) (agent) coagulant coagulating bath baie de coagulare coagulation (alim) brânzire; (chim) coagulare, închegare

coagulation concentration (alim) concentrația de brânzire; (chim) concentrația de coagulare / de închegare

coagulation point (alim, chim) punct / temperatură de coagulare

coagulator (alim, chim) (agent) coagulant

coal cărbune (huilă); a carboniza; (termo) a face plinul de cărbuni

coal ash (met, termo) cenuşă de cărbune

coal-bearing cu cărbune, carbonifer

coal blending (met) amestec de cărbune

coal brick / briquette brichetă de cărbune

coal by-products (met, ind chim) subproduse de la cocsificarea cărbunelui

coal cake brichetă (de cărbune)

coal carbonization (met) cocsificare a cărbunelui

coal-carbonizing plant (met) cocserie

coal-carbonizing practice (met, chim) tehnica cocsificării

coal charger (met) vagon de încărcare a cuptorului de cocsificare

coal chemicals (met, ind chim) produse obținute inițial ca sub-produse la transformarea cărbunelui în cocs metalurgic

coal cutter haveză (de cărbune)

coal deposit zăcământ de cărbune

coal derived gases / fluids (ind chim) gaze / fluide de cărbune / de la procesarea cărbunelui

coal-dust praf / pulbere de cărbune

coal-dust firing (termo) focar pentru cărbune pulverizat

coal-dust furnace installation (termo) instalație de ardere cu cărbune pulverizat

coalesce a concrește, a se suda, a fuziona, a se întrepătrunde

coalescence coalescență, legătură între materiale, cu sau fără topire (la sudură sau lipire prin difuzie), fuziune a suprafețelor, concreştere, sudare, fuzionare, întrepătrundere

coalescence failure (plast) rupere / defect de coalescență

coal face abataj, front de lucru (în mină)

coal field (termo) bazin carbonifer

coal-fired încălzit cu cărbune

coal firing focar pentru cărbuni

coal gas gaz de huilă / de la distilarea cărbunelui / de iluminat

coal-gas tar (ind chim) gudron de gaze

coal hatch (nav) bocaport de buncăr

coal hopper (nav) şalandă de cărbuni

coalification (termo, ind chim) carbonizare 
coaling încărcarea cărbunelui, aprovizionare cu cărbuni

coaling door (met, termo) uşă de focar

coaling station (nav) port de buncher, stație de bunchetare

coalite (met) semicocs, coalit

coalition (pol) coaliție, alianță temporară

coalitionist (pol) membru al unei coaliţii

coal loading trough (met) jgheab de încărcare a cărbunilor

coal mine mină de cărbune

coal mist (met) vapori / gaz de cărbuni

coal mud şlam de cărbuni

coal oil (ind chim) gudron / ulei de huilă, petrol lampant

coal output extracție / transport / producție de cărbuni

coal paste (mixture of coal and oil) pastă de cărbuni (amestec de cărbune şi ulei)

coal pit mină de cărbune

coal slack deșeu de cărbune, cărbune mărunt

coal slurry cărbune fin, cu multă apă

coal-tar (ind chim) gudron de huilă / de cărbune coal-tar pitch (constr, ind chim) smoală (de gudron) de huilă

coaly de cărbune, cărbunos; cum e cărbunele

coaming (nav) ramă (de bocaport)

Coanda effect (fiz, hidr) efect Coandă

coarch bogie (cf) boghiu de vagon

coarch screw $(\mathrm{OM})$ şurub cu cap pătrat

coarch wrench $(\mathrm{OM})$ cheie franceză / reglabilă

coarse rugos, grosier, aspru, brut, neprelucrat, neregulat, grosolan, cu asperităţi mari; macrogranular; (agr) cu bob mare; inferior, de proastă calitate

coarse adjustment (mas, el, metr) potrivire / ajustare / reglare grosolană / brută / aproximativă, acord brut / grosier

coarse aggregate (constr) piatră spartă (cu dimensiuni sub $6 \mathrm{~mm}$ )

coarse breaking / crushing (constr, ind chim) sfărâmare / concasare grosieră / primară

coarse break-up dispersie grosieră (a particulelor etc.)

coarse ceramics (ind chim) ceramică brută

coarse clearance fit $(\mathrm{OM})$ ajustaj foarte larg / cu joc foarte mare

coarse cloth (textile) țesătură groasă

coarse control (autom, $\mathrm{TH}$ ) potrivire / ajustare / reglare grosolană / brută / aproximativă

coarse crushing (constr, ind chim, met) concasare / sfărâmare grosieră

coarse-crystalline (met) cu cristale / grăunți cristalini mari coarse cut (mas-un) dințare aspră / la pile, aşchiere grosolană / de degroşare

coase-drafting (met, mas-un) banc de trefilat sârmă groasă

coarse fish (alim, iht) pește de apă dulce (cu excepția somonului)

coarse-filamentous (textile, plast) cu fire groase coarse file pilă aspră / bastardă

coarse filter (hidr, mediu) filtru cu pietriş; (hidr) prefiltru, filtru brut

coarse-fine relay (autom, el) releu de reglaj brut-fin

coarse finish $(\mathrm{TH})$ finisare, prelucrare grosieră

coarse grain (materiale) granulă / grăunte mare / grosolan(ă) (şi în metalografie)

coarse-grained (materiale) macrogranular, $\mathrm{cu}$ granulație mare, cu fire groase; mărime de grăunte / particule (în aliaje, compozite etc.) de $\sim 5$ (după ASTM); (agr) cu bob mare

coarse-grained cast iron (met) fontă cu structură macrogranulară

coarse-(grained) sand (constr) nisip cu granulație mare / grosier / macrogranular

coarse-grained sandstone (constr) gresie grosieră / macrogranulară

coarse-grained structure (materiale) structură macro-granulară

coarse-grain iron (met) fontă cu grăunți mari / macrogranulară

coarse grind (mas-un) rec tificare de degroşare, şlefuire de degroşare

coarse grinding (alim, constr, ind chim) măcinare grosolană

coarse-ground grist (alim) şrot / măciniş grosier

coarse indicator indicator brut

coarselly $(a d v)$ grosolan; aspru; nepoliticos

coarselly crystalline (materiale) macrocristalin, macrogranular

coarse material material grosier

coarse meshed sleve (agr, alim, ind, constr) sită cu ochiuri mari

coarse mesh wire (agr, alim, ind, constr) sită (din sârmă) cu ochiuri mari

coarse metal (met) mată

coarse movement (mas) ajustaj / calaj brut, mişcare grosolană

coarseness (materiale) granulație / granulare brută, macro-granulație; caracter aspru (al structurii etc.)

coarse pitch cutter (mas-un) freză cu dinți mari / rari, pentru degroşare

coarse pitch tap (mas-un) tarod cu filet cu pas mare 
coarse powder (met, plast) pulbere cu granule / particule mari

coarse ripple (met) crestătură / fisură transversală (defect de sudură)

coarse sieve (agr, alim, constr, ind) sită cu ochiuri rare / mari

coarse-sized carbide carbid în bucăți mari

coarse slurry (agr, mediu, termo) noroi / nămol gros

coarse staple fibră groasă

coarse structure (met, materiale) structură cu granule / grăunți mari / grosolană

coarse thread (OM) filet $\mathrm{cu}$ pas mare, filet grosolan; (textile, plast) fir gros(olan)

coarse-tooth cutter (mas-un) freză cu dinți rari / mari, de degroşare

coarse tuning (mec, autom, TH) reglare / acordare / ajustare grosolană / brută / aproximativă

coarse vacuum (fiz, $\mathrm{TH}$ ) vacuum caracterizat prin presiune de $1 . .760$ torri

coarse yarn (textile, plast) fir gros

coast coastă, țărm de mare, litoral; graniță, hotar, limită; (nav) a naviga de-a lungul coastei, a face navigație costieră; (TH) a merge în gol (d. motor etc.)

coaster brake (OM, auto) roata liberă de frână

coastguard pază a litoralului; gardă de coastă, grăniceri de coastă

coasting (nav) cabotaj / de coastă / de navigație costieră

coasting ship, coaster (nav) cabotier, navă de cabotaj

coast line linie de coastă

coat (chim) strat (de vopsea), acoperire (metalică, ceramică etc.); (constr) liant hidrocarbonat; (el) armatură (de condensator); (TH) manta, îmbrăcăminte, cuvertură, strat depus / de acoperire, căptuşire, înveliş, sediment, precipitat; a aplica un strat, a turna un strat de legătură, a placa, a metaliza, a îmbrăca, a căptuşi, a vopsi, a zugrăvi, a unge, a acoperi (cu ceva); (zool) lână (de oaie), blană (de animal)

coated with $(\mathrm{TH})$ acoperit $\mathrm{cu}$, căptuşit $\mathrm{cu}$

coated abrasive (mas-un, TH) hârtie / pânză abrazivă (obținută prin depunerea / lipirea abrazivului), abraziv pe suport

coated electrode (el, met) electrod acoperit / învelit / cu învelis (şi la sudare)

coated film (plast) film / peliculă aplicată, film / peliculă acoperit(ă) cu alt film / altă folie

coated hard-metal tip (met, mas-un) plăcuță cu acoperire din aliaj dur (pe tăiş)

coated paper hârtie cretată coated rod (met) vergea de metal / electrod de adaos cu înveliș (şi la sudare)

coated with rubber (ind chim) cauciucat, acoperit cu cauciuc

coating (constr) tencuială, învelitoare; (met, TH) acoperire, înveliş (protector), manta, strat, depunere, protectie; (el) izolație

coating constituent (met) constituent al acoperirii / depunerii, component al învelişului electrodului (de sudare)

coating gun (mas-un) pistol de vopsit

coating knife (mas-un) racletă, răzuitor / pentru a îndepărta o acoperiere

coating material (met, alim, plast) material de / pentru acoperire

coating resin (ind chim) răşină de acoperire

coating rolls (met, plast) cilindrii pentru aplicarea unei acoperire

coatings (el, $\mathrm{T}$, ind chim, met) acoperire, strat de protecție, placare, izolație

coating varnish (ind chim) email / lac de finisare / de împregnare

coat with steel (met) a placa cu oțel

co-author coautor

coaxial (mec, OM) coaxial, cu axe suprapuse (ca directie); (el) cablu coaxial

coaxial transmission $(\mathrm{OM})$ transmisie coaxială

cob grămadă, morman; (agr) ştiulete, cocean, nucă; (constr) argilă amestecată cu paie

cobalt (Co) (chim) cobalt

cobalt blue (chim) albastru de cobalt

cobaltic (chim) cobaltic

cobalt steel (met) otel (aliat) cu cobalt

cobble (constr) bolovan (de pavaj), a pava, a pietrui; (met) fărâmătură, cărbuni în blocuri rotunjite, laminare defectuoasă, rebut de laminare, lipitură (material lipit între cilindrii de laminare - defect)

cobblestone (constr) bolovan (de pavaj)

cobbling (met) lipirea materialului între / pe cilindrii de laminare (defect tehnologic)

cobnut (alim) alună

cobweb (plast) pânză de păianjen, țesătură fină; păienjeniş

cobwebbing (plast) pânză de păianjen, scămoşare, țesere (proces sau rezultat al acestuia, la pulverizarea unui adeziv etc.)

cobwebby plin de / acoperit de (ceva ca de) păienjeniş

cock (OM, hidr) robinet, ventil; (agr) căpiță conică; (constr) roza vânturilor

cockbill (nav) a atârna (d. o ancoră)

cockboat (nav) barcă de pescuit

cock handle (OM) cheie de robinet 
cocking $(\mathrm{OM})$ îmbinare cu prag (şi la flanşe) cockle a îndoi, a plia, a şifona; (textile, folii etc.) moluscă comestibilă; (nav) barcă mică; (agr) buruiană, neghină

cockled effect (textile, plast) efect de gofrare / creponare

cockles (met) cute, gofraj, încrețire (defect la laminare)

cockle shell (nav) barcă mică, luntre; cochilie

cockloft (constr) mansardă

cockpit (nav) cocpit

cockpit starter (auto) demaror de bord (pentru pornirea motorului)

cock plug (OM, hidr) cep de robinet

cock system (OM, hidr, constr) baterie cu robinet / de amestec (la băi şi duşuri)

cock wrench $(\mathrm{OM})$ cheie de robinet

cocoa (alim) cacao, arbore de cacao

coconut, cocoanut, coco (alim) nucă de cocos

co-crystallization of two compounds (fiz, chim) co-cristalizare a a două componente

cod, codfish (alim, iht) cod, batog

coddle (alim) a fierbe înăbuşit, a opări

code (autom) cod, cifru, semnal; (inf) cod, succesiune de cifre ale unui sistem de numerație, corespunzătoare simbolurilor unui alfabet; a codifica, a cifra

coded cifrat, codificat

code digit cifră de cod

codeine (chim) codeină

coder codificator, dispozitiv de codificare; (inf) traductor de cod, programator, prelucrător de programe

code wheel disc codificator / de codificare

code word cuvânt de cod / cheie, succesiune de cifre corespunzătoare unui simbol al alfabetului codificat

codification codificare, cifrare

codify a codifica, a cifra

coding (inf) codificare, secvență de instrucțiuni codificate

cod(-)liver oil (alim) untură de pește

coefferdam (constr) val de pământ, ridicătură pentru a nu lăsa apa să pătrundă într-o excavație

coefficient coeficient, indice, factor

coefficient field corp / câmp al coeficienților

coefficient of adhesion (plast, T) coeficient de aderență / de adeziune

coefficient of admission (alim, termo, ind chim) coeficient de umplere

coefficient of compressive strain (mec) coeficient de stabilitate de flambaj

coefficient of contraction (met, plast) coeficient de contracție (la turnare, răcire etc.) coefficient of cubic(al) expansion (termo, fiz) coeficient de dilatare cubică / în volum

coefficient of discharge (hidr, TH) coeficient de debit, factor de descărcare

coefficient of drag (mas, TH) coeficient de frânare / de tracțiune / de antrenare / de tragere coefficient of dry friction ( $\mathrm{T}$ ) coeficient de frecare uscată

coefficient of efficiency / of performance $(\mathrm{TH})$ coeficient / factor de randament / de performanță / eficiență

coefficient of elasticity (mec, OM) modul de elasticitate

coefficient of expansion (materiale, termo) coeficient de dilatare / de expansiune / de destindere / de dilatație

coefficient of expansion by heat (materiale, met, termo) coeficient de dilatare termică

coefficient of friction $(\mathrm{OM}, \mathrm{T})$ coeficient de frecare $(\mu)$

coefficient of hardness (materiale) valoarea durității (Brinell)

coefficient of heat passage (termo) coeficient de conductivitate termică

coefficient of heat transfer / transmission (materiale, termo) coeficient de transmitere a căldurii / de transfer termic

coefficient of hyraulic conductivity (hidr) coeficient de filtraţie

coefficient of hysteresis loss (fiz, mec, T) coeficientul pierderii prin histerezis

coefficient of impact (mec) coeficient dinamic / de impact

coefficient of lengthening (mec) coeficient / factor de (a)lungire

coefficient of linear expansion (materiale, met, termo) coeficient de dilatare liniară

coefficient of load(ing) (mec) factor de sarcină

coefficient of mass transfer (alim, ind chim) coeficient de transfer de masă

coefficient of resistance (mec) modul de rezistență coefficient of roughness (materiale, T) coeficient de rugozitate

coefficient of skew coeficient de asimetrie (a unei dispersii: de particule, de înălțimi ale asperităților etc.)

coefficient of sliding friction $(\mathrm{T})$ coeficient de frecare de alunecare

coefficient of thermal efficiency (termo) randament termic

coefficient of thermal expansion (materiale, termo) coeficient de dilatare termică

coefficient of transfer constant (fiz, termo) constantă de propagare / de transfer 
coefficient of utilization ( $\mathrm{TH}$, mas) coeficient de utilizare

coefficient of variation (materiale) diferența între mărimea celor mai mici şi celor mai mari particule într-un amestec, exprimată funcție de valoarea nominală, coeficient de variație (a granulației etc.)

coefficient of variation in speed (mec, $\mathrm{TH}$, mas) coeficient de neuniformitate (a vitezei)

coefficient of velocity (hidr) coeficient de viteză (caracterizează neuniformitatea vitezei curentului de fluid)

coefficient of viscosity ( $T$, hidr, plast) coeficient de vâscozitate, vâscozitate dinamică

coefficient of wear $(T)$ coeficient / factor de uzură (foarte general)

coefficient region domeniul coeficienților

coequal egal (cu altul)

coerce a constrânge, a impune condiții / restricții; a sili, a obliga, a impune cu forța

coercimeter (metr, fiz) aparat pentru măsurarea intensităţii magnetice

coercion (putere de) constrângere

coercive constrângere, coercitiv

coercive force (fiz, mec) forță coercitivă

coersively $(a d v)$ prin constrângere

coesite (chim) dioxid de siliciu polimorf

coexist a coexista

coexistence coexistență

coexistent coexistent

coffee (alim) cafea

coffee bean (alim) boabă de cafea

coffee mill / grinder (alim, mas) maşină de râşnit cafea

coffee pot ibric de cafea

coffer (nav, constr) ladă (metalică); cheson

coffer dam (nav, constr) batardou

coffin sicriu; cornet (de hârtie); (agr, alim) copită; cisternă de transport; (nav) navă scoasă din uz / inutilizabilă

Coffin-Mawson law (mec) relație pentru estimarea durabilității funcție de deformarea plastică periodică

coffret lădiță

coflexure (mec) săgeată

$\operatorname{cog}(\mathrm{OM})$ dinte, zimt, proeminență, camă, nas, prag, roată dințată, rotiță, rebord; a bloca; (mas-un) a dința, a zimţui, a eboşa, a degroşa; (met) blum, eboşă, a reduce

cog belt $(\mathrm{OM})$ curea trapezoidală, dinţată

cog down (met) a preforja, a reduce, a lamina lingoul la țaglă; (mas-un) a eboşa, a degroşa cogency caracter convingător, putere de convingere cogent concludent, incontestabil; convingător; serios

cogent reason motiv valabil

cogged $(\mathrm{OM})$ dințat, zimţat

cogged belt $(\mathrm{OM})$ curea trapezoidală

cogging (constr) prag (la îmbinări), îmbinare cu crestături; (el) viteză unghiulară fluctuantă / neuniformă a rotorului unui motor electric; (OM) angrenare cu bolțuri; (met, mas-un) degroşare, eboşare, prelaminare, preforjare

cogging-down mill (met) laminor pregătiror / degrosisor (laminor), bluming

cogging-down pass (met) calibru de degroşare rapidă, trecere de degroşare

cogging-down roll (met) cilindru degrosisor cogging-down stand (met) cajă degrosisoare

cogging mill (met) laminor degrosisor, laminor bluming

cogging(-mill) stand (met) cajă degrosisoare

cogging(-mill) train (met) linie de laminor degrosisor / de bluming

cogging pass (met) calibru degrosisor (la laminoare)

cogging roll (met) cilindru de degroşare / de laminor bluming

cogging-roll train (met) linie de cilindri de degroşare / de laminor bluming / de blumuri

cogitate on / upon a gândi, a cugeta despre, a medita la

cogitation gândire, cugetare; gând, idee

cogitative gânditor, capabil să gândească; meditativ cognac (alim) coniac

cognate înrudit, asemănător; (jur) rudă

cognition cunoaştere; percepție

cognitive de cunoaştere, cognitiv

cognitive skil competență pe bază de cunoştințe

cognizable cognoscibil

cognizance cunoaştere, cunoştinţă

cognizant of ştiutor despre, care ştie despre, informat despre; competent în

cog rack (OM, mas-un) cremalieră (şi sculă de degroşare)

$\operatorname{cog}(-)$ wheel (el) rotor cu poli aparenți; (OM) roată cu cepuri / cu fusuri / de lanț / cu bolțuri

cohabitant conlocuitor; colocatar

cohabitation conviețuire

coheir (jur) comoştenitor

cohere a se lipi, a se lega, a se uni; a avea înțeles

coherence, coherency (fiz) coerență, legătură (şi logică), raport; înțeles; (mat) totalitate a punctelor de acumulare ale unei mulțimi care aparțin acesteia

coherence range (mec, el) plajă / interval de sincronizare 
coherent ( $a d j$ ) coerent, având legătură / înțeles; clar, inteligibil; consecvent, logic

coherently $(a d v)$ (în mod) coerent

coherent sheaf / stack (fiz) fascicul coerent

cohesion (fiz, chim) coeziune, aderență, atracție moleculară

cohesion / cohesive strength (fiz, mec, T) rezistență de coeziune / de aderenţă (la lipituri, la straturile transferate prin frecare)

cohesionless incoerent, fără coeziune

cohesionless material material necoeziv

cohesive coeziv, de coeziune, aderent; legat

cohesive failure (mec, plast) rupere coezivă / de coeziune / în adeziv

cohesive force (fiz, chim, mec) forță de coeziune

cohesive material material coeziv

cohesiveness (chim, mec) capacitate adezivă / de lipit

Cohe tester (metr) aparat de testat tip Cohe

coil $(\mathrm{OM})$ bobină, spirală, inel, rolă, serpentină, ghem, colac (de frânghie), spiră, (el) bobină, spiră, înfăşurare; (inf, met) rolă / rulou (de bandă); a (se) înfăşura, a (se) bobina, a rula, a (se) răsuci, a şerpui

coil banding machine (met) maşină pentru legat rulouri (de tablă)

coil breaks (met) mici nervuri pe table, paralele cu direcția de laminare (defect de grosime), îndoituri transversale ale benzii (la desfăşurarea ruloului)

coil conveyer (met) transportor de rulouri

coil cooling conveyer (met) transportor cu rol de răcire a rulourilor (de tablă) / colacilor (de sârmă)

coil downending machine (met) maşină de răsturnat / de întors a rulouri (de tablă)

coil clutch $(\mathrm{OM})$ ambreiaj cu arc

coil condenser (alim, ind chim, termo) serpentină de răcire

coil cooler B (alim, termo) refrigerent / răcitor cu serpentină

coiled electrode (met) sîrmă de sudură / de electrozi

coiled filament (alim, termo) spirală de încălzire

coiled pipe (alim, termo) serpentină

coiled spring $(\mathrm{OM})$ arc elicoidal cilindric

coiled steel (met) (laminate de) oțel în rulouri, tablă în rulouri

coiled strip (met) bandă în rulouri

coiler (device) (mas) maşină de înfăşurat; (alim, ind chim, termo) serpentină; (met) înfăşurător de rulouri (de tablă) / sârmă

coiler drum (met) tambur / tobă de înfăşurare (a ruloului de tablă, a sârmei) coiler gear (met) antrenarea / transmisia înfăşurătorului (de rulouri)

coiler stand (met) batiu / suport al înfăşurătorului (de rulouri)

coil heat-exchanger (alim, termo) schimbător de căldură, cu serpentină

coil-ignition system (termo) aprindere cu acumulator

coil impedance (el) impedanța unei bobine

coiling (met, el) înfăşurare (şi la rulouri de laminate, sârme), bobinaj, spiră

coiling drum (met, plast) tobă de înfăşurare

coil (of) pipe (OM, termo) serpentină

coil "opening" machine (met) maşină de desfacere / de slăbire a ruloului (de tablă) (înainte de recoacere)

coil pitch (el) pas al înfăşurării

coil resistance (el) rezistența unei bobine

coil spring $(\mathrm{OM})$ arc elicoidal

coil transfer car (met) cărucior de transfer / de deplasare al ruloului (de tablă)

coil-type exchanger (alim, termo) schimbător de căldură, cu serpentină

coil up (el, met, plast) a înfăşura / a forma un rulou, o bobină

coil winding lathe / machine (mas-un) maşină de bobinat

coin (ec) monedă (metalică); a bate monedă; (met, plast) a imprima în relief, a ştanța, a presa, a comprima; a născoci, a inventa

coinage fabricare de bani / monede; (ec) sistem monetar

coincide (el) a se afla / a fi în concordanță (de fază); (TH) a coincide, a corespunde

coincidence coincidentă, întâmplare; potrivire; suprapunere

coincidental, coincident (adj) întâmplător, accidental

coincidentally $(a d v)$ printr-o coincidență, întâmplător

coincide with a coincide cu

coining $(\mathrm{TH})$ ștanțare, imprimare (pe ambele fețe, de obicei la rece); comprimare la forma finală, la sinterizare

cokability (met) capacitate de cocsare / de aglutinare

coke (met) cocs, calamină, cărbune bituminos; a cocsifica, a afina

coke ash (met) cenuşă de cocs

coke bed (met) pat de cocs, încărcătură (de cocs) de pornire (la furnal)

coke blast furnace (met) furnal de cocs

coke breeze / cinder (met) praf de cocs, cocs mărunt 
coke bunker (met) siloz / buncăr de cocs coke burden / charge (met) încărcătură de cocs (la furnal)

coke by-product (met, constr, met, ind chim) subprodus de cocs

coke-cement concrete beton de zgură

coke-charging (met) vagonet pentru dozarea cocsului

coke-chemical (ind chim, met) cocsochimic

coke chemistry cocsochimie

coke consumption (met) consum de cocs

coke cooling chamber (met) cameră pentru distilarea uscată a cocsului

coke-discharging / drawing machine (met) împingător de cocs

coked residue (ind chim, met) reziduu de cocs

coke dross / fines (met) cocs mărunt

coke dust (met) praf de cocs

coke extinguisher (met) stingător de cocs

coke firing (termo) focar cu cocs

coke for / per charge (met) cocs în încărcătură / şarjă, pat de cocs

coke furnace / oven (met) cuptor de / cu cocs coke furnace block (met) baterie de cocsificare coke gas (met, chim) gaz de cocserie

coke grading plant (met) instalație pentru sortarea cocsului

coke guide (met) placă de ghidare a cocsului la ieşirea din cuptor

coke knocker (termo) ciocan pentru îndepărtarea pietrei de cazan

coke lump (met) sfărâmătură de cocs

coke number (chim) cifră de cocs

coke oven (met) cuptor de cocs / de cocserie

coke-oven coal tar (ind chim, met) gudron de cocserie

coke-oven gas (met, chim) gaz de cocserie

coke-oven plat (met) baterie de cocsificare, cocserie

coke packing (met) şarjă de cocsificare

coke per charge (met) cocs de încărcătură (la cubilou)

coke pig iron (met) fontă de cocs

coke plant / cokery (met) cocserie

coke producer (met) gazogen cu cocs

coke pusher / coke pushing ram (met) împingător de cocs

coke-quenching car (met) stingător de cocs

coke-quenching tower / station (met) turn de stins cocsul

coke rate (met) modul / rata / viteza de distribuire a încărcăturii de cocs

coke screening plant (met) instalație de ciuruit cocs coke scrubber (met) spălător de gaz, cu umplutură de cocs

coke split (met) cocs de încărcătură (la cubilou)

coke-storage bin (met) siloz / depozit de cocs

coke tar (ind chim, met) gudron de cocs

coke test (metr, chim) determinare a cifrei de cocs

coke-to-metal ratio (met) raport cocs-metal

coke tower (met) coloană cu umplutură de cocs

coke value (metr, chim) cifră de cocs

coke-watering car (met) stingător de cocs

coke wharf (met) rampă pentru descărcarea cocsului

coking (met) cocsificare

coking capacity (met) capacitate de cocsificare

coking chamber (met) cameră de cocsificare

coking coal cărbune cocsificabil

coking index (alim, ind chim) capacitate de coacere; (met) indice de cocsificare

coking mass (met) pilot de cocs

coking oven (met) cuptor de cocsificare

coking plant (met, ind chim) cocserie, uzină de cocsificare

coking power (chim) putere de aglutinare a unui cărbune, capacitate de cocsificare

coking time (met) perioadă / timp de cocsificare colander (ali, constr, met) strecurătoare, sită cold frig, rece; (fiz) fără (radio)activitate; răcoros; slab, abia perceptibil; rece, realist, obiectiv; (med) răceală (boală)

cold-age hardening (met) durificare prin ecruisare / prin prelucrare la rece (şi la aliaje neferoase); (plast) durificare prin îmbătrânire

cold air aer rece

cold(-air) blast (met) (in)suflare cu aer rece (la cuptoare)

cold air inlet (met) admisie / intrare de / pentru aer rece

cold application (OM, met) montare / asamblare la rece

cold bend test (metr, mec) încercare / test de îndoire la rece

cold-blast (met) a (in)sufla cu aer la rece (la cuptoare)

cold-blast furnace (met) cuptor cu aer la rece

cold-blast sliding valve (met, $\mathrm{OM}$ ) vană-sertar pentru aer rece

cold blocking (mas-un, $\mathrm{TH}$ ) matrițare la rece cold blowing (met) (in)suflare cu aer rece cold bonderizing (met) procedeu de fosfatare / bonderizare la rece

cold breakdown (plast) plastifiere la rece cold-brittleness (met, plast) fragilitate la rece cold-brittle steel (met) oțel fragil la rece 
cold carrier (chim, termo) agent frigorific

cold-cast (met) turnat la temperatură joasă, a turna la temperatura joasă

cold-cathode (el) catod rece / a cărui funcționare nu depinde de temperatură

cold charge (met) încărcătură rece (şi la furnal, la cuptoare)

cold chisel (mas-un, met) daltă pentru tăierea capetelor de bară la forjă, daltă de canelat

cold circular saw (mas-un, met) fierăstrău circular, pentru tăiere la rece

cold coating (constr) îmbrăcăminte din mixturi asfaltice, executată la rece

cold composition (ind chim) compoziție (şi nemetalică) la rece / în stare răcită

cold compressing / compacting (TH) presare / compactare la rece

cold crak / cracking (met) fisură / fisurare la rece (cauzată de tensiuni)

cold cream cremă grasă (pentru mâini etc.)

cold crushing strength (materiale) rezistentă la compresiune la temperatură scăzută

cold cure (ind chim, plast) întărire la rece; (alim) conservare / preparare / tratare la rece (a alimentelor); (plast) vulcanizare la rece

cold-curing adhesive (chim, plast) adeziv cu întărire la rece

cold cuts (alim) felii de carne rece

cold cutting (met) tăiere la rece

cold deformation $(\mathrm{TH})$ deformare / fasonare formare / profilare la rece (d. materiale)

cold draw (met) a trage / a trefila la rece

cold drawing (met, plast) laminare / trefilare la rece

cold-drawing bench (met, plast) banc de trefilat / de tras la rece

cold-drawing die (met, plast) calibru de tras la rece, filieră de trefilat la rece

cold drawn (chim, alim) extras la rece prin presare (uleiuri); (met, plast) tras la rece, trefilat

cold-drawn pipe (met, plast) țeavă trasă la rece

cold-drawn steel (met) oțel tras la rece

cold dressing (met) îndreptare la rece

cold drying (alim, ind alim) uscare cu ajutorul deshidratanților

cold end lipitură rece

cold extrusion ( $\mathrm{TH}$, mas-un) extrudare la rece (materiale plastice şi metalice)

cold-finish a finisa la rece

cold-finished prelucrat / tras (d. metale, aliaje) / finisat la rece

cold-finishing $(\mathrm{TH})$ finisare la rece

cold-finishing rolling mill (met) laminor finisor la rece cold-finishing stand (met) cajă finisoare la rece cold flow (plast) capacitate de curgere / de deformare plastică la rece; contracție remanentă; curgere la rece (a unui adeziv)

cold-forge (met) a forja la rece

cold-forging (met) forjare la rece

cold form (met, plast) a forma / a deforma / a profila la rece

cold forming (met, plast) formare / fasonare / deformare / profilare la rece

cold galvanising (met) galvanizare / zincare la rece, acoperire $\mathrm{cu}$ zinc prin vopsire $\mathrm{cu}$ o suspensie cu solvent

cold glue (chim) clei rece de tâmplărie

cold-ground (pulp) pastă obținută la rece, prin amestecare la rece

cold hammer (met) a ecruisa prin forjare

cold hammering (met) ecruisaj, ecruisare prin forjare etc.)

cold-hardened steel (met) oțel ecruisat

cold hardening ( $\mathrm{TH}$, met) durcisare, ecruisare (la rece)

cold-heading (met) refulare / nituire / căpuire la rece

cold-heading die (mas-un) matriță de refulat / de căpuit (şi nituri) la rece

cold-heading tool (met, mas-un) sculă de căpuit (şi nituri) la rece

cold impact forging (met, $\mathrm{TH}$ ) matrițare prin extrudare la rece

cold iron (met) fontă rece, oțel forjat la rece

coldish cam rece, răcoros; foarte rece

cold joint $(\mathrm{TH})$ asamblare la rece; defect de lipire (încălzire neadecvată, adezivul neavând suficientă capacitate de umectare)

cold junction (met) lipitură / sudură (la) rece / de referință (şi la termocuplu)

cold mass masă (de aer) rece

cold metal (met) încărcătură / şarjă rece

cold mill (met, plast) laminor pentru laminare la rece

cold moulding (plast, met, mas-un) formare (prin presare) la rece în matriță

coldness frig, răcoare, răceală

cold piercing (met) perforare la rece

cold pilger rolling (met) laminare la rece în pas de pelerin

cold plasticity (met, plast, mec) plasticitate la rece

cold plate (el, electr) placă cu circuit de răcire, disipator de căldură la circuite electrice cu degajare mare de căldură

cold polymerization (ind chim, plast) polimerizare la rece 
cold-press (met, plast) a matriţa / presa la rece cold-pressing (met, plast) matrițare / extrudare la rece

cold pressure extrusion welding (met, plast) sudare la rece prin extrudare

cold pressure welding (met, plast) sudare la rece prin presare

cold pressure upset welding (met, plast) sudare la rece prin refulare

cold quenching (met) călire la rece

cold reduction (met) deformare / reducere / fasonare la rece

cold reduction mill (met) laminor pentru laminare la rece

cold reserve (equipment) $(\mathrm{TH})$ echipament de rezervă nealimentat

cold reservoir / source (termo) sursă rece / de frig, sursă de căldură cu temperatura cea mai joasă

cold resistance (materiale) rezistență la îngheț / la temperaturi joase

cold reveting (met) nituire la rece

cold-roll (met, plast) a lamina la rece, cilindru pentru laminare la rece

cold-rolled (met, plast) laminat la rece

cold rolled sheet steel (met) oțel (tablă) laminat $(\breve{a})$ la rece

cold-rolled steel (met) oțel laminat la rece

cold-rolled strip (met) bandă laminată la rece

cold-rolling (met, plast) laminare la rece

cold-rolling department (met, plast) secția / uzina de laminare la rece

cold-rolling mill (met) laminor la rece, dresare, îndreptare (prin laminare la rece)

cold-rolling stand (met) cajă a unui laminor de laminare / dresare / îndreptare la rece

cold saw (mas-un) ferăstrău de tăiat la rece

cold sawing (mas-un) tăiere la rece (de obicei cu fierăstrae)

cold setting (plast) întărire la rece (d. materiale plastice termorigide)

cold setting adhesive (plast) adeziv cu întărire la rece

cold settling (alim) decantare la rece

cold shears (mas-un) foarfece pentru tăiere la rece

cold-short / brittle (materiale) fragil la rece / la temperatură joasă

cold-shotness (materiale) rupere / fragilitate la rece

cold shrink fitting (OM) asamblare prin contractie la frig, calare / îmbinare prin răcire

cold shut (met) loc de sudură rece (la piese turnate cu temperatură prea joasă sau turnare prea lentă), lipitură / picătură rece (defect la sudare)

cold solder joint $(\mathrm{OM})$ lipitură (metalică) cu umectare proastă, cu porozitate din cauza încălzirii insuficiente şi necurățării suprafeței

cold spruing (met) decapare la rece

cold stamping $(\mathrm{TH})$ matrițare la rece

cold-start(ing) ability (mas, auto) capacitate de pornire la rece

cold start temperature (hidr) temperatura la care sistemul hidraulic începe să funcționeze (nu neapărat la parametri doriți)

cold storage (agr, alim) antrepozit frigorific

cold-storage meat (alim) carne înghețată / congelată

cold storage room (alim, termo) cameră frigorifică

cold-storage truck (auto, termo) autocamion frigorific

cold strengthening (met) îndreptare / netezire la rece

cold strain (met) a deforma / a întinde la rece

cold-straining (chim, met, plast) întărire / ecruisare, deformare / întindere la rece

cold streching (net, plast) etirare la rece

cold strip (met) bandă laminată la rece

cold-tempering (met) durificare prin ecruisare, revenire „la rece” (cu transformare de fază în stare solidă, la temperaturi relativ joase)

cold test (metr) încercare / testare la rece; determinare a temperaturii de congelare; test la temperatură joasă

cold thickening (alim, T) îngroșare la rece (şi d. lubrifianți)

cold trap (termo) tubulatură care, prin răcire forțată permite captarea vaporilor condensabili cold treatment (met) tratament al metalelor şi aliajelor, sub $0^{\circ} \mathrm{C}$

cold-upsetting (met) refulare la rece

cold-upsetting die (mas-un) matriță de refulat la rece

cold vulcanization (ind chim) vulcanizare la rece

cold-water retting (alim, ind chim) topire în apă rece

cold weather condition(s) (auto) condiții de vreme rece

cold welding (met) sudare la rece / fără preîncălzire

cold wide strip (met) bandă lată laminată la rece cold wide strip mill (met) laminor la rece pentru bandă lată

cold work (met) prelucrare la rece, a prelucra la rece 
cold workability (met, materiale) prelucrabilitate / deformabilitate la rece

cold-work hardening (met) durificare prin ecruisare, prelucrare la rece, durcisare

cold-work hardened steel / metal (met) oțel /metal / aliaj (neferos) durificat / ecruisat la rece cold-working (met) prelucrare / fasonare / deformare la rece; ecruisare

cold working of blast-furnace (met) mers rece al furnalului

cold-work steel (met) oțel pentru prelucrare la rece

Cole pump (hidr) pompă Cole / cu palete fixate pe suprafata unui tambur rotativ

collaborate a colabora, a coopera

collaboration colaborare, cooperare

collaborator colaborator

collagen (alim, chim) colagen, proteină

collapse prăbuşire, sfărâmare; eșec; colaps; a se prăbuşi, a se nărui, a se dărâma, a se sfărâma, a eșua; a se strânge, a fi pliabil; (ec) ruină, faliment; colaps

collapsed prăbuşit, sfărâmat, strivit; (ec) ruinat

collapsed element (hidr, alim) element filtrant strivit / deteriorat

collapsed pressure (mec, hidr) presiune de strivire (şi a unui elemnet filtrant)

collapse strength (OM, hidr) rezistență la presiunea exterioară (la un recipient)

collapsible pliant, pliabil, rabatabil, decapotabil

collapsible mould (met, plast) matriță articulată

collapsible prop (constr, mec) stâlp metalic telescopic

collapsible reamer (mas-un) lărgitor cu bacuri articulate

collapsible steel form (met) formă metalică demontabilă

collapsing turtire, strivire; flambaj; prăbuşire, deformare; decapotare

collapsing force $(\mathrm{OM})$ sarcină / forță de rupere (la compresiune sau flambaj)

collapsing length (mec, OM) lungime critică la care începe flambajul

collapsing load (mec) forța / $\operatorname{sarcină~} \operatorname{critic}(\breve{a})$ de flambaj de / de rupere la flambaj

collapsing of bobbles (T) spargere a băşicilor / bulelor (și la emulsii)

collapsing pressure $(\mathrm{OM})$ presiune de turtire (şi la recipiente)

collapsing tap (mas-un) tarod reglabil / expandabil

collar (el) manșon de cablu, mănunchi (de fire / cabluri); (OM) bridă, şaibă, colier, etrier, flanşă, manşon, brățară, inel, guler, balot, colac, lagăr cu inel de ungere; (met) umăr la calibrul de laminare, topirea metalului în zona influențată termic (la sudură); a curba, a îndoi, a (se) ondula

collar beam (constr) grindă de carpen, riglă

collar bearing / bushing $(\mathrm{OM}, \mathrm{T})$ cuzinet $\mathrm{cu}$ umăr / cu guler

collar bone (anat) claviculă

collar buster sculă de instrumentatie

collar clamp $(\mathrm{OM})$ brățară / colier de prindere / asamblare

collared drill pipe (OM, hidr) conductă / țeavă cu mufă / cu guler

collared nut $(\mathrm{OM})$ piuliță cu guler

collared pin (met) tijă de ghidare a ramei de formare, cu umăr / cu guler

collar end bearing $(\mathrm{OM}, \mathrm{T})$ lagăr cu umăr / cu guler

collargol (chim) colargol; argint coloidal

collaring (met) înfăşurare (de rulou)

collar journal (OM, T) lagăr cu umeri / cu guler collar marks (met) urme inelare / imprimări de la cilindrii de laminare (defecte de laminare)

collar nut $(\mathrm{OM})$ piuliță cu guler / cu umăr / guler

collar of shaft $(\mathrm{OM})$ coroană / umăr a(l) arborelui

collar pin $(\mathrm{OM})$ surub prizonier cu guler

collar pipe (OM, constr) țeavă cu guler / de ancoraj

collar plate $(\mathrm{OM})$ colier, etrier, jug

collar screw (OM) şurub cu bridă / cu guler (la cap)

collar sleeve (OM, mas-un) coloană de ghidaj

collar step (OM) cuzinet inelar, prag / umăr (la o piesă)

collar step bearing $(\mathrm{OM}, \mathrm{T})$ crapodină / lagăr în pieptene / în trepte

collar stud (constr, OM) bulon de legătură / de îmbinare, cu guler

collar thrust bearing $(\mathrm{OM}, \mathrm{T})$ lagăr axial canelat / pieptene; palier canelat, cu umăr axial

collate a compara, a colaționa, a interpola; a confrunta

collateral colateral, secundar, lăturalnic

collateral (security) (ec) garanție / cauțiune suplimentară

collating interclasare; colaționare; interpolare

collation colaționare; confruntare; (alim) gustare, aperitiv

collator (ind) dispozitiv de sortare sau aranjare (şi la birotică); (inf) subrutină de transformare mai multor fişiere într-unul singur

colleague coleg, asociat, partener 
collect a colecta (date, impurități etc.), a strânge, a aduna, a colecta; a colecționa; (ec) a strânge, a încasa (taxe etc.), (contra) ramburs; cu taxă inversă

collected adunat (la un loc), colectat; complet; liniştit, calm

collectedness calm, stăpânire de sine; concentrare

collect in bundles a se aduna în mănunchiuri, smocuri de fibre / fibrile (d. fibre, fire etc.)

collecting channel (constr, hidr, mediu) canal colector

collecting drain (constr, hidr, mediu) dren(aj) colector

collecting electrode (ind, chim, el) electrod de precipitare / colector

collecting funnel $(\mathrm{TH})$ pâlnie colectoare, canal colector

collecting like terms (mat) reducere a termenilor asemenea

collecting main (constr, hidr, mediu) canal colector principal / de drenaj

collecting pipe (constr, hidr, mediu) țeavă / conductă colectoare; linie generală de conexiune, conductă comună

collecting sand (mediu) nisip colector

collecting tank (constr, hidr, mediu) bazin colector / de colectare

collection strângere, adunare, colecți(onar)e, grămadă, morman; $(\mathrm{TH})$ colecție, culegere; colectă (de bani)

collection efficiency (ind chim, alim) randament / eficienţă de selectare / de sortare

collection of samples (metr) colectare de probe / eşantioane

collection sequence $(\mathrm{TH})$ secvență de selectare / de sortare

collective colectiv, grup (social)

collective bargaining (ec, pol) tratative sindicatpatron

collectively $(a d v)$ (în mod) colectiv, cu participarea tuturor

collector $(\mathrm{TH})$ colector, bazin de apă, rezervor de reținere; (el) comutator; (hidr) colector / galerie de drenaj; (mas) cameră colectoare de supraîncălzitor, țeavă colectoare, agent colector; (el) colector (la transistor), electrod de captare; (persoană) care strânge (ceva)

collector bar (el) lamelă de colector; (met) şină colectoare (la baterie de cocsificare)

collector ditch (constr, hidr, mediu) canal / şanț colector

collector line (hidr) conductă de preaplin

collector plate (el) anod / placă colector(oare) collector-shoe gear (el, OM) cursor, piesă alunecătoare

college (edu) colegiu, (aproximativ) facultate; universitate (mică), academie comercială / de marină; (amer) scoală superioară; colegiu (electoral, al avocaților etc.); corporație

collegial de colegiu

collegiate (edu) de / pentru colegiu, universitar, academic, studențesc, student al unui colegiu

collet $(\mathrm{OM})$ manşon conic, inel / mandrină / de strângere / de prindere / de fixare, manşon de prindere, bucşă elastică, guler, jug, cadru

collet chuck (mas-un) mandrină cu bucşă elastică, inel de mandrină, dispozitiv de strângere

collet lathe (mas-un) strung cu (prinderea piesei în) bucşă elastică

collide (mec, TH) a intra în coliziune, a se ciocni collier (nav) navă de cărbuni

collimate (mediu) a colimata; (fiz) a strânge în fascicul paralel; a vizualiza, a face paralel

collimating cone (ind, mediu) con colimator collimating cylinder (ind, mediu) cilindru colimator

collimation (ind, mediu) colimatare; (fiz) concentrare, focalizare, reglare a focalizării unui instrument optic (telescop etc.) cu două sau mai multe elemente optice

collimation line linie de vizare

collimator (fiz) colimator

collinear (geom) coliniar, cu o dreaptă comună collinear load $(\mathrm{mec})$ sarcină liniară / coliniară collinear planes (geom) plane cu o dreaptă comună collision (cf) ciocnire (de trenuri), tamponare; (fiz) ciocnire, şoc; (mat) coliziune; (nav) abordaj, coliziune; conflict; (auto) coliziune

collision activation probability (fiz) probabilitate de dezactivare prin şoc

collisional heating (mec, termo) încălzire la coliziune

collision bulkhead (nav) perete de coliziuneprova

collision coefficient (mec) coeficient de soc / de restituire

collision course directie de ciocnire / de conflict collision damping (mec) amortizare prin ciocniri / prin şoc

collision density (fiz) densitate de ciocniri (și de particule)

collision excitation (fiz) excitare prin şoc / prin ciocnire

collision loss (fiz) pierderi prin ciocniri

collision of the first kind şoc de ordinul / speța I collision rate (fiz) numărul mediu de ciocniri ale unei molecule într-un gaz 
collision sensor (auto) senzor de coliziune collision station (nav) post de gaură de apă collision theory teoria ciocnirilor collocate with a se îmbina, a se asocia cu collocation aşezare, distribuire; grup de cuvinte, sintagmă

colloid (fiz, hidr) dispersie de particule mici, în care fenomenele superficiale joacă un rol dominant, coloid; (chim) substanță coloidală colloidal (chim) coloidal colloidal coal cărbune mărunt colloidal dispersion (chim) dispersie coloidală colloidal solution (chim) soluție coloidală colloidal system (fiz, chim) sistem coloidal colloid mill (alim, ind chim) moară coloidală colloid osmotic pressure (fiz) presiune osmotică coloidală

colloquy colocviu, conversație formală

colmonoy (met, T) aliaj bogat în nichel, pentru acoperiri rezistente la uzură

colonial spirit (chim) alcool metilic

colophony (chim) sacâz, colofoniu

color (amer), colour (brit) culoare

colorless fără culoare, incolor

colorimeter (metr) colorimetru

colorimetric purity (metr) puritate colorimetrică

colorimetry (metr) colorimetrie

colossal (adj) colosal, enorm, uriaș, imens

colossally $(a d v)$ colosal de

colossus colos, gigant

colour culoare, colorit; (chim) cerneală, vopsea, substanță colorată / colorantă; ton, nuanță; caracter, natură; a vopsi, a (se) colora; cromatic, colorat, în culori

colour after burning culoare după ardere

colourant (chim) colorant

colouration (textile, plast) vopsire, colorare

colour break-up (fiz) descompunere a culorilor

colour changing (ind chim, plast) schimbare a culorii, schimbător de culoare

colour depth intensitate a culorii

coloured filter (fiz) filtru de culori

coloured tracer thread (el) fir indicator colorat (pentru marcarea conductoarelor unui cablu)

colour fastness (ind chim, plast) stabilitate / rezistență a culorii

colour filter (fiz, opt) filtru cromatic

colour grinder (ind chim, plast) moară pentru / de măcinat vopsea

colouring (textile, ind chim) colorare, vopsire colouring body (alim, ind chim) colorant artificial / sintetic

colouring pan (textile, ind chim) cadă / baie de vopsire colour insensible emulsion (fiz, chim) emulsie insensibilă (la culori)

colourless incolor, fără culoare, acromatic; palid

colour like metal culoare metalică

colour measurement (metr) colorimetrie

colour response (fiz) sensibilitate spectrală / de culoare

colour reversion (plast, textile) îngălbenire colour-sensitive sensibil la culoare (d. materiale) colour shade nuanţă de culoare

colours in oil (ind chim) pigmenți în ulei

colour stability (materiale) stabilitate a culorii

colour test determinare a culorii

colour tone nuanță de culoare

colour velocity gauging (metr) măsurare a debitului prin metoda colorimetrică

colter (agr, mas) cuțit de plug

Columbium (Nb) (chim) niobiu

column (constr, TH, OM) coloană, stâlp, reazem, stivă; şir; (ind chim) turn de distilare; coloană, spalt, rubrică; coloană (de ziar, de numere); editorial

columnar columnar, în formă de coloană

columnar crystal (met) cristal columnar

column clamp (ind chim) dispozitiv pentru blocarea coloanei

columned (constr, mas-un) cu coloane, în formă de coloană

column evaporation (alim, ind chim) concentrare / evaporare în coloană

column evaporator (alim, ind chim) coloană de concentrare

column filling (alim, ind chim) umplutură / umplere a coloanei

column mixer (alim, ind chim) coloană de amestec

column loading (alim, ind chim) încărcare a coloanei

column packing (alim, ind chim) umplutură a coloanei

column pitch (constr, alim, ind chim) distanță / interval între coloane

column scrubber (ind chim, met) coloană pentru spălarea gazelor

column sleeve (mas-un) manșon (și alunecător) al coloanei (la maşini radiale de găurit), prese etc.

column still (alim, ind chim) coloană de distilare

column-type drilling machine (mas-un) maşină de găurit cu coloană

column washer (met) scruber cu coloană

column ways (mas-un) ghidaje verticale (de batiu) 
colza (agr, bot) rapiță

colza oil (ind chim, T) ulei de rapiță

comb (constr) creastă / coamă de acoperiş; (TH) pieptene; (zool) creastă de cocoş; (textile) spată, darac, meliță, a pieptăna, amelița, a dărăci; (alim, TH) (formă de) fagure; (fig) a cereceta amănunțit, a examina, a scotoci; (nav) a se sparge (d. valuri); (geogr) creastă, coamă (de vale, de deal); țesală; fagure; one's hair a se pieptăna; out a cerceta amănunțit

combat against a lupta împotriva / contra

combative combativ

combination combinație, combinare; îmbinare; (auto) motocicletă cu ataş; (textile) combinezon; combinație / grup de cuvinte, sintagmă combinational tone (fiz) sunet combinat combination atmospheric-vacuum rerun unit (ind chim) instalație combinată de distilare secundară la presiune atmosferică şi în vid

combination cistern and siphon (metr) barometru cu sifon

combination cracking (ind chim) cracare combinată / mixtă

combination diagram schemă combinată (ca desen, reprezentare) (cu simboluri grafice, $\mathrm{cu}$ desene-secțiuni şi simboluri imagine)

combination dies (mas-un) ştanţă combinată (pentru executarea concomitentă a mai multor operații)

combination drill (mas-un) burghiu combinat (pentru găuri de centrare)

combination firing (termo) încălzire combinată

combination gas (termo, ind chim) gaze umede / bogate

combination heat (chim) căldură de formare / de reacție

combination lever (termo) bară de avans a sertarului la motoarele cu abur

combination lock broască, lacăt cu cifru secret

combination of water gas and distillation gas (ind chim) gaz de apă, gaz sărac

combination pliers clește patent / universal

combination probability (chim) probabilitate de combinare (a particulelor, modelculelor etc.)

combination rubber tape (el) bandă izolantă din cauciuc

combinations schimbări simple; (textile) flanelă de corp

combination seal $(\mathrm{OM})$ etanşare combinată (mai multe tipuri la un loc)

combinations of $\mathbf{n}$ things, $\mathbf{r}$ at a time (mat) combinări de $n$ obiecte, luate câte $r$

combination standard gauge (metr) calibru tampon universal combination string (constr, mas-un) coloană combinată / telescopică

combination suit salopetă, halat, combinezon (de lucru)

combination turbine (termo) turbină mixtă cu acțiune şi reacțiune

combinative (mat) combinatoriu

combine (agr, mas) combină; (TH) a lega, a combina, a amesteca, a unifica, a (se) uni, a compune, a îmbina, a fuziona; a (se) amesteca; comunitate de interese; (amer) cartel, sindicat

combined action $(\mathrm{TH})$ actiune combinată

combined carbon (chim, met) carbon legat (chimic)

combined cooling (ind chim, alim) răcire mixtă / combinată

combined compressed-air hydraulic brake (OM) frână hidropneumatică

combined coupling (OM) cuplaj mixt

combined diagram diagramă însumată

combined fuse and switch (el) întrerupător cu siguranță

combined gear pair $(\mathrm{OM})$ angrenaj mixt / cu mai multe perechi de roți (conico-cilindrice, cilindro-melcat etc.)

combined mill (ind chim) moară (cu bile) compartimentată

combined mixer and sifter (constr, ind chim) agregat de amestecare şi ciuruire

combined nitrogen (chim, met) azot legat (chimic)

combined rack-and-adhesion railway (cf) cale ferată mixtă (cu aderență și cu cremalieră)

combined strength (mec) rezistență la deformare complexă / compusă

combined stress (mec, OM) tensiune complexă / compusă

combining heat (chim, termo) căldură de formare / de combinare

combining nozzle (OM, ind chim) ajutaj de amestec

comb out a pieptăna; a percheziționa

comb-type gauge for screw threads (mas-un, metr) calibru, pieptene pentru filetul şuruburilor comburent (termo) comburant

combustibility (chim, TH) inflamabilitate

combustible (chim, TH) inflamabil, combustibil, carburant

combustible composition (chim, termo) amestec combustibil

combustible gas (chim, termo) combustibil gazos, gaz inflamabil

combustion ardere, combustie; (chim) reactie chimică exotermă, acidificare 
combustion chamber (termo) cameră de ardere / de fum / de combustie, focar

combustion conditions (met, termo) condiții de ardere

combustion control (termo, metr) controlul parametrilor care influențează arderea

combustion cut-off (termo) sfầșit / întrerupere a combustiei

combustion degree (termo) grad / eficiență a(l) combustiei

combustion engine (termo) motor cu combustie internă

combustion flue (met, termo) canal al focarului

combustion furnace (termo, ind chim, metr) cuptor de ardere / pentru analize

combustion gases (termo) gaze de ardere

combustion heat (termo) căldură de ardere / de combustie

combustion limits (termo) limite de aprindere / de ardere

combustion mist (termo) combustibil pulverizat

combustion rate (termo) viteză de ardere / de combustie

combustion rate coefficient (termo) coeficient al vitezei de ardere / de combustie

combustion temperature (termo) temperatură de combustie / de ardere

combustion test stand (termo, metr) instalație pentru controlul / verificarea combustiei

combustion value (termo) putere calorică

combustor (termo) cameră de ardere

come a sosi, a veni; a ajunge; a se apropia; a se întâmpla, a se petrece, a avea loc; a se face, a deveni; a se găsi, a fi disponibil

come about a se întâmpla

come again a veni din nou; a se întoarce, a reveni

come along a veni cu, a însoți pe; a face progrese, a progresa

come at a ajunge la, a căpăta acces la; a ataca, a se repezi

come-at-table accesibil, abordabil

come-back revenire; (amer) plată, replică, ripostă come back a se întoarce, a reveni; a răspunde, a riposta

come before a fi (fost) înainte, a premerge; a fi în frunte; a fi în fruntea; a fi înaintea

come by a dobândi, a căpăta; a câştiga; a vizita

comedown cădere, scădere, micsorare, înrăutățire; dezamăgire

come down a veni, a sosi; a coborî, a lăsa în jos; a decădea; a se degrada; a se precipita, a se prăbuşi; (ec) a se ieftini; (edu) a pleca de la universitate (Cambridge, Oxford) come down on / upon a se năpusti asupra; a pedepsi pe cineva; a certa aspru come forward a-şi oferi serviciile come in a intra, a pătrunde; a sosi; a-şi lua postul în primire; a se împărți, a se clasifica, a pune în producție, a începe (o exploatare), a intra (într-o incintă); (fig) a se maturiza, a se coace; a se dovedi (util), a juca un rol, a avea un cuvânt come in on a lua parte la, a participa la come in / on plan / scheme a lua parte / a participa la un plan / la un proiect

come into a intra (în vigoare); a căpăta, a dobândi come into contact a veni (a intra) în contact come it a pricepe, a întelege (ceva) come-off încheiere, rezumat; urmare come off a (se) degaja, a se desprinde, a se desface; a se întâmpla, a se peterece, a se desfăşura; a reuşi, a izbuti; a se achita; a se descotorosi

come on a progresa, a (se) îmbunătăți; (auto) a se aprinde (d. indicatoare de bord)

come on / upon a da de /peste, a întâlni din întâmplare

come out a reieşi, a deveni clar; a apărea, a fi publicat (d. cărți etc.); a face grevă; a ieşi (d. pete); a se termina, a ieşi bine

come out for a se declara de partea

come out to (the) wrong side (ec) a ieși în pierdere (financiară)

come over a veni peste, a se suprapune

comer nou venit; (persoană) care vine

comestible (alim) comestibil

come to a reveni (cuiva), a mosteni; a se ridica la, a se cifra la

come through a rezista; a se descurca, a ieși dintr-o încurcătură / situație

come to a stand still a înceta, a stagna (producția, comerțul, activitatea)

come under a tine de o categorie, a se subsuma (unei categorii etc.); a fi supus (unei influențe) come undone a se desface, a se desprinde come up a se ridica, a se pune (o problemă etc.) come up for auction (sale) (ec) a fi scos / vândut la licitatie

comfit (alim) bomboană

comfits (alim) fructe zaharisite

comfort mângâiere; sprijin, tihnă, odihnă; a mângâia, a consola

comfortable, comfortably confortabil; tihnit, liniştit, comod; (ec) (venit) considerabil / bunicel

comfortably off destul de bogat

coming care vine; viitor; venire, sosire, apropiere 
comma virgulă; pauză

command (TH) (mărime de) comandă; (inf) instrucțiune, ordin; a comanda, a ordona, a ghida; a pretinde, a cere, a stăpâni, a fi stăpân pe situație; (ec) a avea / dispune (de bani), a aduce câştig, a cuprinde cu vederea; rază vizuală, câmp de vedere

commanding aflat la comandă, comandant; dominant; (autom) care comandă

commandment comandament; lege

command module $(\mathrm{TH})$ modul de comandă

command resolution (el, autom) toleranța valorii unui semnal de comandă

command language (inf, autom) limbaj al instrucțiunilor

command word (inf) cuvânt de comandă / al unei instrucțiuni (de intrare / ieşire)

commeasurable comensurabil

commence a începe

commencement început, începere; (edu) ziua acordării diplomelor

commencement of production $(\mathrm{TH}, \mathrm{ec})$ punere în producție, începere a producției

commensurable comensurabil

commensurate with / to corespunzător cu, proporțional cu

comment (c, inf) comentariu (al unui programsursă); explicații, lămuriri, obsevații;

comment on / upon a face comentarii asupra, a comenta, a discuta despre

commentary comentariu

commerce (ec) comerț, circulație (de mărfuri)

commercial (ec) comercial; rentabil, (produs) de serie, de larg consum; reclamă (plătită)

commercial aluminium (met) aluminiu de calitate comercială

commercial casting (met) fontă / piesă turnată de calitate comercială

commercial grade / quality $(\mathrm{TH}$, ec) calitate comercială

commercial iron (met) fier tehnic / de calitate comercială

commercialism (ec) spirit comercial, mercantilism, practică comercială

commercialization (ec) comercializare

commercialize (ec) a comercializa

commercial letter (ec) scrisoare comercială

commercially available (ec) disponibil pe piaţă / comercial

commercially available diesel fuel (auto, chim) carburant pentru motor diesel, motorină care se găseşte pe piață / se comercializează

commercially supplied (ec) furnizat de piaţă commercially supplied biodiesel blend (chim, auto) amestec comercial de biodiesel

commercially supplied biodiesel fuel (auto, chim) carburant biodiesel furnizat de piață

commercial run proces industrial / pentru comerț la scară mare

commercial steel (met, ec) oțel de calitate comercială

commercial value $(\mathrm{ec})$ valoare comercială / la prețul pieței, valoare negociabilă

commingle a (se) amesteca

commingler amestecător

comminute (constr, ind chim) a sfărâma, a fărâmița, a mărunți, a pulveriza

comminution (constr, ind chim) fărâmițare, sfărâmare, zdrobire, pulverizare

comminution rate (constr, ind chim) viteză de fărâmițare / sfărâmare / pulverizare

commission autorizație, brevet; comision; comisie, însărcinare; împuternicire, mandat; efectuare; aplicare; comitere, săvârșire; functie (încredințată cuiva); ordin, brevet, diplomă; (nav) a arma o navă; (TH) a da în funcțiune, a însărcina, a inaugura; (jur) a împuternici, a da mandat, a autoriza

commissioning $(\mathrm{TH})$ punere în funcțiune, prima probă şi reglare a unei instalaţii

commissioning manual ( $\mathrm{TH}$, mas) manualul instrucțiunile (scrise) de punere în funcțiune, prima probă și reglare a unei instalații

commissioner comisar (de poliție); împuternicit; membru al unei comisii

commit a comite, a săvârși, a face, a înfăptui; a încredința; a angaja; a se compromite; a se obliga, a-şi asuma o obligatie

commitment angajament; obligație (şi într-un contract); înmânare, transmitere; (pol) discutarea unui proiect de lege într-o comisie

commit oneself to a se obliga să; a-şi lua angajamentul să, a se ataşa de

committee (ec, pol) comitet, comisie

committeeman (ec, pol) membru al unui comitet al unei comisii

commit to a încredința

commixture amestec, amestecare

commodious comod, uşor de mânuit, practic; încăpător, spațios

commodity lucru folositor; obiect de uz curent; (ec) marfă / articol / bun de larg consum commodity exchange (ec) bursă de mărfuri commodity market (ec) piață a materiilor prime commodity paper $(\mathrm{ec})$ poliță autentică

common (TH) simplu, obişnuit, comun, folosit de toți, general, frecvent, grosolan, ieftin; (el, 
electr, c) punct de conectare comună în receptoare, calculatoare etc.

commonage (jur) drept de folosință în comun, folosință în comun; (agr) drept de păşunat pe păşunea comunală; proprietate comună

commonalty breaslă, corporație; v. commonage common bit (mas-un) burghiu plat, cu fațetă de ghidare

common brass (met) alamă comercială / nealiată / aliaj Cu-Zn simplu

common carriage bolt (OM) şurub de fixare / de blocare

common carrier (transp) societate de transport în comun

common denominator (mat) (cel mai mare) numitor comun

common divisor (mat) divizor comun

common difference (mat) rație (la progresii aritmetice)

commoner om din popor; (edu) student bursier

common fraction (mat) fractie simplă / ordinară common law (jur) drept comun

common logarithm (mat) logaritm zecimal

commonly $(a d v)$ de obicei, în mod obişnuit; prost, rău; mediocru; slab

common main (hidr) conductă colectoare; (el) linie principală, conductor comun

common measure (mat) divizor comun

commonplace banalitate, loc comun; banal, obişnuit; neinteresant; insipid

commonplace book caiet de notițe / însemnări

common ratio (mat) rație (la serii şi la progresii geometrice)

common resin (ind chim) smoală de răşină, colofoniu, sacâz

common room (edu) cancelarie (de profesori)

common salt (alim, chim) sare de bucătărie, clorură de sodiu

common size $(\mathrm{TH})$ dimensiune brută

common slide valve (OM, hidr) (supapă cu) sertar plan / simplu

commonwell (pol) bine public / obştesc

commonwealth (pol) republică, stat; comunitate de națiuni; federație; bunăstare generală

common windlass $(\mathrm{OM})$ troliu cu manivelă

common year an obişnuit (365 zile)

communal comunal, (folosit în) comun

commune comunitate

commune with a fi în strânsă legătură cu, a comunica cu

communicable comunicabil, transmisibil; (med, biol) infecțios, molipsitor

communicate with a tramnsmite la / cuiva, a comunica cu communicating vessels (fiz, hidr) vase comunicante

communication comunicare, comunicatie, transmitere, transfer de informații; (c, inf) dialog între operator şi calculator; legătură; înştiințare, raport, anunț; informație; mijloc de comunicație; (transp) drum, şosea, cale ferată communication cord (cf) semnal de alarmă communicative comunicativ, sociabil community comunitate, proprietate / posesie în comun, asemănare (de interese)

commutable care se poate schimba / comuta; (TH) interschimbabil, comutabil

commutation (autom, el) comutare, comutație; (mat) permutare; înlocuire; (amer) navetă (la tren)

commutator (el, mec) comutator, colector

commutator bar / combar (el) lamelă / pieptene de colector

commutator brush (el) perie colectoare / de colector

commute (el, mec) a comuta, a schimba

compact compact, dens; îngrămădit, înghesuit; concis, lapidar (stil de a redacta / vorbi); a face compact, a compacta; a consolida; înțelegere, acord, învoială

compact construction / design sistem constructiv / solutie (de proiectare) compact( $\breve{a})$

compact disk (c) compact-disc, sistem de înregistrare şi redare prin metode digitale

compacted compact(at)

compact / solid fuel (termo) combustibil solid

compact grained (materiale, alim) cu granulație compactă

compacting (c) (re)compactare, obținere a unei singure zone libere în memoria internă

compacting equipment (constr) utilaj de tasare compacting pressure (constr, TH) presiune de apăsare / de compactare (şi la sinterizare)

compaction method (constr, TH) metodă de compactare

compaction roller (constr, TH) cilindru compresor

compact of plin de

compactor (constr, TH) cilindru compresor / compactor

compact with roller (met, plast) a lamina, a mandrina (cu role), a compacta / presa $\mathrm{cu}$ ajutorul unui cilindru / unei role

companion hatch (nav) capac de tambuchi

companion keyboard (c, autom) tastatură / claviatură la distanță, conectată în paralel

companion way (nav) scară între două punți, tambuchi 
company întreprindere, companie, organizație (economică), societate; asociați (ai unei întreprinderi); vizită, vizitatori, musafiri; (nav) echipaj

company-ownedoutlet, company market (ec) piață de desfacere a unei companii

comparable comparabil

comparable standard standard echivalent / comparabil

comparative (adj) comparat, comparativ, relativ; aproximativ

comparatively $(a d v)$ comparativ (cu), relativ; aproximativ

comparative quality calitate comparabilă; coeficient de calitate

comparative / comparison test (metr) încercare / verificare comparativă

compare to a (se) compara cu, a face / a stabili o comparație între

compare with a compara cu (d. noțiuni asemănătoare)

comparator (metr) comparator; (inf) schemă logică combinațională; $(\mathrm{OM})$ amplificator diferențial

comparing rule (metr) riglă gradată

comparison comparație, asemănare

comparison measurer (metr) aparat comparator

comparison spectrum spectru/ interval de comparație

compartment compartiment, cabină, sector

compartment dryer (alim, ind chim) uscător cu camere

compartment furnace (termo, met) cuptor cu camere

compartimentize (constr) a compartimenta, a împărți pe compartimente

compartment kiln (met, termo) cuptor cu camere succesive (tip Mendheim)

compartment mill (constr, ind chim) moară tubulară, compartimentată

compass $(\mathrm{TH})$ rază, cuprins, întindere; (metr) busolă, compas magnetic; (fig) margine, limită, a realiza, a atinge (un scop); a înțelege, a sesiza; a complota, a pune (ceva rău) la cale

compasses compas de mână

compass gimbals (nav) suspensie cardanică de compas

compatibility compatibilitate

compatible with compatibil $\mathrm{cu}$

compatibleness miscibilitate (a fluidelor)

compel a obliga, a constrânge, a impune (şi ascultare)

compelling care constrânge; captivant, fascinant; convingător, riguros compendious concis, rezumativ

compendium compendiu, conspect, rezumat; schiță

compensate (TH, metr) a compensa, a echilibra, a aduce la zero; a despăgubi, a recompensa

compensated shoe brake $(\mathrm{OM})$ frână cu sabot compensator (care compensează uzura)

compensate for a compensa, a neutraliza, a egaliza, a fi o compensatie pentru

compensating beam (cf) balansier compensator; (OM) pârghie de compensare

compensating device compensator, dispozitiv de compensare

compensating dog (mas-un) antrenor special pentru compensarea erorilor la divizare

compensating gear $(\mathrm{OM})$ angrenaj / mecanism de compensare / diferențial

compensating jet (auto, termo) jiclor compensator

compensating lead (hidr) conductă de compensare / de egalizare

compensating lead wire (el) conductor de compensație / de egalizare

compensating lever $(\mathrm{OM})$ pârghie de echilibrare, compensator

compensating network (el, autom) egalizator; rețea de compensare; dispozitiv de stabilizare

compensating (null-force) balancing machine (mec) maşină de echilibrat cu compensare la forță nulă

compensating pipe (termo, hidr, OM) compensator de dilatație (montat pe conducte)

compensating stuffing box (OM, termo, hidr) presetupă de dilatare / de compensare

compensating tank vas, rezervor de compensare / de egalizare

compesation compensare, compensatie, indemnizație, despăgubire; plată, recompensă; (autom, el, mec) compensare, egalizare, corectare a erorilor datorite componentelor; (amer) salariu, leafă

compensation brake gear $(\mathrm{OM})$ tijă a distribuitorului / mecanismului de frână

compensation for damages (ec, jur) compensare a daunelor

compensation joint (OM, termo) îmbinare / articulaţie (compensatoare) de dilatație / de dilatare

compensation method (autom, metr) metodă de compensare / de zero

compensation of errors (autom, metr) compensare a erorilor

compensator (el) compensator, egalizator, compensator de fază; (autom) corector, regulator; 
(OM) cilindru compensator, / element / organ de maşină, compensator

compensatory compensator; (el, mec) compensat, egalizator

compensatory element (OM, autom, termo) element de compensare (pentru anularea efectului temperaturii / dilatării / deformării) / erorii etc.

compete a se întrece, a concura

conpetence, competency competență, pricepere; calificare; stare (materială)

competent competent, priceput; calificat

competently ( $a d v)$ (în mod) competent, cu competență

competition concurență, rivalitatea; competiție, întrecere; concurs, examen de concurs

competitive competitive, de concurență, de întrecere / concurență

competitor rival, concurent

compilation compilare; alcătuire, redactare; compilație

compile a compila, a întocmi, a redacta, a face, a alcătui (un dicționar, o bază de date)

compiled compilat, calculat, redactat, întocmit

compiler (inf, c) compilator, autoprogramator, procesor specializat pentru translatarea programelor-sursă în programe-obiect; program de traducere pentru limbajele simbolice, program de compilare

compiling (inf, c) compilare, traducere / translatare a unui program sursă într-un program obiect

complacent mulțumit, satisfăcut; afabil, serviabil, prevenitor

complain (ju) a se plânge; a aduce o acuzație, a intenta proces

complaint nemulțumire, plângere, reclamație; (med) durere, boală (cronică)

complanar coplanar

complanant (jur) reclamant, acuzator

complement (mat) complement (al unui număr reprezentat într-un sistem de numerație); complementar (şi d. un unghi); completare; complet, set, garnitură (completă); a complementa, a forma complementul unui număr; (nav) echipaj, efectivul personalului navei; a completa

complementary complementar

complementary angles (geom) unghiuri complementare

complete complet, tot, întreg; total, desăvârşit; terminat, încheiat; a sfârşi, a termina, a isprăvi, a încheia; a perfecționa

complete circle cerc total / complet complete combustion (termo) ardere / combustie completă

completely $(a d v)$ complet, în întregime, cu totul; total, pe de-a-ntregul

completely defined function (mat) funcție definită peste tot

completely elastic (mec, fiz) complet / perfect / ideal elastic (d. un corp ideal, materiale)

completely miscible complet miscibil (d. fluide)

completely purged (auto, $\mathrm{TH}$ ) complet purjat / dat afară / golit (şi d. rezervor)

completely sealed housing (OM) carcasă complet etanşată

completely soluble complet solubil

completeness caracter complet; deplinătate, desăvârşire

complete orthogonal set (mat) sistem ortogonal complet

complete overhaul (mas, met, $\mathrm{TH}$ ) reparație generală / capitală

complete oxidation (chim, met) oxidare completă

completing circuit (el) circuit de închidere

completion completare; împlinire, îndeplinire, extindere, prelungire, terminare; perfecționare

completion bond (ec) garanție (la executarea unei lucrări)

completion date $(\mathrm{TH}, \mathrm{ec})$ termen (de predare a unei lucrări)

completion period / time $(\mathrm{TH})$ termen / durată de execuție a unei lucrări

complex complex; complicat, dificil

complex combination combinatie complexă (şi de materiale / substanțe, tehnologii)

complexing agent ( $\mathrm{T}$, chim) agent complex (la formarea săpunurilor complexe pentru unsori) complexity complexitate, complicaţie complex ore (met) minereu complex complex soap ( $T$, chim) săpun complex (în unsori)

complex valued (mat) complex, cu valori complexe (d. numere complexe)

compliance încuviințare, conformitate, acord; (mec) capacitate de cedare; (rezistență la) arcuire; suspensie / capacitate elastică; maleabilitate; ascultare

compliance coefficient (OM) coeficient de arcuire, factor de cedare / de rezistență la arcuire / de adaptare

compliant îngăduitor; maleabil

compliant elastomer pad (OM, T) cuzinet / palier (de lagăr axial) din compoziție polimerică / elastomerică, la care suprafața se adaptează după forma contrapiesei mai dure 
complicacy complicație

complicate a (se) complica, a (se) încurca

complicated (adj) complicat, complex, dificil

complicatedly $(a d v)$ (în mod) complicat

complicatedness caracter complicat

complication complicare, complicație; încurcătură

complicity complicitate

complimentary laudativ; de felicitare, gratuit, de favoare

comply a consimți; a încuviința, a se supune, a asculta

comply with a ceda, a corespunde la, a face față la, a îndeplini, a satisface, a respecta (reguli etc.), a fi de acord cu, a se supune; a se conforma (cu), (T) a se adapta (d. suprafețe în contact, în special pentru lagăre)

comply with a request $(\mathrm{TH}, \mathrm{ec})$ a se conforma unei cerinte

compo (met) aliaj; (constr) structură, compoziție

component component $(\breve{a})$, termen, reper, piesă, organ al unui ansamblu, element

component analysis analiză factorială

component correction (mec, mas) corecție a componentei (şi la echilibrare dinamică)

component family familie / grup / set de piese (în tehnologia de grup)

component measuring device (metr) aparat specializat pentru măsurarea componentelor

comport a se comporta, a se purta

comport with a se potrivi cu

compose a culege, a redacta, a scrie (un text); (TH) a compune, a forma, a alcătui

composite (chim) amestec, compoziție; montaj foto(grafic); compus; compozit; combinat, mixt; complex

composite beam (mec, materiale) grindă compusă sau din material compozit

composite bearing $(\mathrm{OM}, \mathrm{T})$ lagăr din material compozit

composite body (auto) caroserie mixtă (din oțel şi material plastic sau compozit polimeric)

composite cargo (nav, transp) încărcătură mixtă (şi de mărfuri)

composite electrode (el) electrod dublu / cu două vergele

composite float (hidr) flotor de adâncime

composite force (mec) forță rezultantă

composite function (mat) funcție compusă / de funcție

composite gear (OM) angrenaj executat din compozit, roată dințată combinată (din metal şi fibre, metal şi compozit, numai din material compozit etc.), roată melcată bimetalică composite joint $(\mathrm{OM})$ îmbinare combinată (de exemplu, nituită şi sudată)

composite material (ind chim) material compozit, compozit

composite-metal rod / strip (materiale) bară / bandă de bimetal / de compozit metalic

composite mould (met, plast) matriță cu mai multe cuiburi

composite nozzle (termo, hidro) ajutaj / duză demontabil(ă)

composite number (mat) număr compus / natural neprim

composite roughness $(\mathrm{T})$ rugozitate compusă / echivalentă

composite square linked chain $(\mathrm{OM})$ lanţ (de tractiune) cu articulație cardanică

composite strength rezistență compusă / echivalentă

composite steel (met) oțel placat

composition compunere, formare, alcătuire; (chim) compoziție, amestec, mixtură; (mat) produs; (met) aliaj, compoziție chimică (a unui aliaj); culegere (de text); (TH) constituție, structură, caracter, înțelegere, acord, compromis; (jur, ec) tranzacție

compote (alim) compot

compound compus, complex, compozit, amestec, combinatie, îmbinare, component, masă izolantă, mixtură, substanță sau material omogen(ă) sau nu, cu destinație concretă, cum ar fi curele compoundate pentru transmisii, component, legare, legătură; cu complicații; a compune, a combina, a amesteca, a compounda, a îmbina, a alcătui, a face un întreg din; a ridica, a construi, a clădi, a aplana (o ceartă / o dispută); a aranja, a regla (prin compromis), a ajunge la un compromis, a spori

compound action acțiune compusă de compoundare (formare a unui material / produs)

compound arrangement dispoziție în tandem, aranjament complex (particular)

compound bending dies (mas-un) matriț̆ de îndoit combinată (acţionând atât în plan vertical, cât şi în plan orizontal)

compound body (materiale, OM) compus chimic, corp compus / complex / compoundat

compound casting (met) turnare prin amestecarea a mai multor topituri

compound coking battery (met) cuptoare combinate, de cocs

compound compression $(\mathrm{TH})$ comprimare dublă / în două trepte / în două etaje

compound compressor (termo) compresor polietajat 
compound curvature (mat) curbură spațială (a unei curbe)

compound department (constr, alim, ind chim) secție de cântărire şi dozare (a amestecurilor)

compound die (mas-un) matriță de calibrări / cu prelucrări succesive

compounded oil ( $\mathrm{T}$, chim) ulei cu adaos de ulei animal sau vegetal, ulei aditivat

compound firing (termo, met) încălzire combinată

compound gauge (metr) mano-vacuum-metru, manometru de vid şi de presiune

compound indexing (mas-un) divizare / indexare combinată

compounding amestecare, adăugare, combinare a unor componente (pentru a obține un material, un lubrifiant etc.), compoundare

compound lever (OM) dispozitiv cu o combinație de pârghii

compound load(ing) (mec) încărcare compusă

compound microscope (metr, opt) microscop compus

compound motion (mec) mişcare complexă / compusă

compound movement (mec) mişcare complexă; (mas-un) avans longitudinal şi transversal, concomitent

compound rest (mas-un) port-cuțit cu sanie în cruce, sanie port-cuțit, turnantă

compound-rest bottom (mas-un) sanie inferioară a port-cuțitului, în cruce (cu mișcare după două axe)

compound-rest swivel (mas-un) placă turnantă a căruciorului

compound-rest top (mas-un) sanie superioară a port-cuțitului, în cruce (cu mişcare după două axe)

compound screw $(\mathrm{OM})$ şurub cu capete filetate diferit (ca sens sau pas), şurub cu filete dreapta - stânga (la capete)

compound slide assembly / rest (mas-un) ansamblu al săniilor reciproc perpendiculare

compound state (fiz, met, ind chim) stare intermediară / compusă / nestaționară / complexă

compound steam pump (termo) pompă cu abur de expansiune fracționată

compound steel (met) oțel placat

compound table (mas-un) masă deplasabilă longitudinal și transversal

compound toggle lever stone breaker (alim, constr, ind chim) concasor cu fălci, cu mișcare compusă a fălcii mobile

compound train of gears $(\mathrm{OM})$ tren de angrenaje combinate (conico-cilindrice etc.) compound with a cădea de acord asupra, a se învoi cu privire la; a se compounda, a fi compoundat (d. materiale complexe, de exemplu, curele de transmisie etc.)

comprehend a înțelege, a pricepe; a cuprinde, a include

comprehensible inteligibil

comprehension înțelegere, comprehensiune; cuprindere, includere

comprehensive cuprinzător; larg; încăpător; multilateral, inteligent, comprehensiv

compreg (materiale, ind chim) plăci aglomerate din lemn impregnat cu răşină

compress a culege compact, fără interlinii (un text); (TH) a comprima, a presa, a gâtui, a strânge, a ştrangula

compressed comprimat, presat, ştrangulat

compressed-air (termo) (cu/ de) aer comprimat, pneumatic

compressed-air container rezervor (termo) rezervor / acumulator (cu/ de) aer comprimat

compressed-air drill (mas-un) maşină de foraj / de găurire pneumatică, perforator pneumatic

compressed-air drive (OM, hidr) transmisie pneumatică

compressed-air equilibrator (mas) compensator pneumatic

compressed-air hammer (mas-un) ciocan pneumatic

compressed-air hose (OM, hidr) furtun de aer comprimat

compressed-air jet (fiz, hidr) jet de aer comprimat

compressed-air main $(\mathrm{OM}$, hidr) conductă principală de aer comprimat

compressed-air-operated rod puller (ind chim) elevator pneumatic de prăjit

compressed-air painting apparatus (mas-un, ind chim) pistol de vopsit cu aer comprimat

compressed-air pipe / pipe line (OM, hidr) conductă de aer comprimat

compressed-air plant (termo) stație de compresoare

compressed-air service (termo) instalație pneumatică

compressed-air shock absorber (OM, hidr) amortizor pneumatic

compressed-air spike tongs (cf) cleşte de scos crampoane (acționat cu aer comprimat)

compressed-air tool (mas-un) sculă pneumatică / actionată de aer comprimat

compressed-air tunnel (fiz, metr) tunel aerodinamic de mare presiune

compressed fuel (termo) combustibil presat 
compressed yeast (alim) drojdie de panificație compressibility (materiale) compresibilitate compressibility factor (materiale) factor de compresibilitate

compressibility of gases (fiz) compresibilitate a gazelor

compressibility test (met, plast, hidr) încercare / test de / la compresibilitate

compressible compresibil

compressible aerodynamics (fiz) aerodinamica mediilor compresibile

compressing compresie, care solicită la compresiune, care comprimă

compressing ring (OM, termo) segment de compresie (la motoare)

compressing strain (mec) deformare de compresie / compresiune / comprimare

compression compresiune, compresie comprimare; (inf, c) condensare a datelor; (TH) compresie, strângere, presare, racordare

compressional bar (mec, constr) bară solicitată la compresiune

compresional wave undă de presiune

compression boom / chord / flange (mec) talpă comprimată (în construcții)

compression chamber (termo) cameră / galerie de compresie

compression coefficient (termo) coeficient de compresie

compression condenser (termo, el) condensator ajustabil (cu şurub)

compression coupling (OM) cuplaj-manşon, cuplaj cu manşon (realizat prin strângere)

compression failure (mec) rupere / deteriorare prin compresie / prin comprimare / la flambaj, lipsă de rezistență la presiune

compression fitting (OM, hidr) inel de compresie (pentru etanşare)

compression flow (mec, alim) curgere prin / la comprimare

compression grease cup $(\mathrm{OM}, \mathrm{T})$ ungător $\mathrm{cu}$ capac pentru unsoare consistentă

compression ignition (termo) aprindere prin compresie

compression ignition engine (termo) motor $\mathrm{cu}$ aprindere prin compresie / cu autoaprindere

compression joint $(\mathrm{OM})$ îmbinare cu strângere / cu efect de pană

compressionless fără compresor / comprimare / compresiune

compression limit (mec) limită de / la compresiune

compression load (mec) sarcină / solicitare de compresiune compression member (constr, mec) bară comprimată / sub sarcină de compresiune; (mec, metr) element comprimat, epruvetă de încercat la compresiune

compression modulus (mec) modul de elasticitate la compresiune

compression mould (mas-un) matriță de presare compression moulded blank (plast) semifabricat obținut prin comprimare

compression moulding (mas-un, met, plast) formare prin presare / prin comprimare (în patriță)

compression plant (ind chim, met) instalație pentru comprimare (gaze, lichide)

compression plate (mas-un) placă de presiune

compression pressure presiune, sarcină de comprimare / compresiune

compression pump (OM, hidr) pompă de încărcare / de refulare / de presiune / de compresiune

compression ratio (fiz, met) raport / indice / procentaj / coeficient de compresie / de comprimare; (hidr) raport al presiunilor

compression refrigerating machine (termo, alim) maşină frigorifică cu compresor

compression-release valve (OM, termo) supapă de decompresie

compression resistance $(\mathrm{mec})$ rezistență la compresie / compresiune

compression ring (auto, OM) segment de compresie (la motoare, la etanşări); (OM, termo) segment de motor / cilindru, inel de compresiune

compression set (ind chim, materiale) determinare a contractiei la compresie / la comprimare (şi în procente) (şi la elastomeri)

compression shock (med, hidr) (undă de) şoc (la compresiune)

compression space (termo) cameră de compresi(un)e, volum al spațiului de compresi(un)e

compression specimen (mec, metr) probă de presiune / de comprimare

compression spring $(\mathrm{OM})$ arc de presiune / de comprimare

compression strain (mec) deformație prin / la compresie / compresiune / comprimare

compression strength $(\mathrm{mec})$ rezistență la compresie / la compresiune / la comprimare

compression stress $(\mathrm{mec})$ solicitare la compresiune, tensiune / efort de compresiune

compression stroke (auto, termo) cursă / (timp) de compresie

compression tap (OM, hidr) robinet de compresi(un)e, cu cep 
compression test (metr) probă / test / încercare de refulare, încercare / test la compresie / la compresiune, determinare a compresabilităţii

compression tester (metr) compresometru, aparat de determinare a compresabilității

compression test piece (mec, metr) epruvetă pentru încercare la compresie / la compresiune compression trajectory (fiz, hidr) curbă a presiunii (de comprimare)

compression-type refrigerator (alim, termo) frigider / răcitor cu compresie

compression valve (OM, hidr) supapă de compresie / de compresiune

compression volume (termo) spațiu de compresie / de compresiune

compression yield point (mec, OM) limită de curgere la compresiune

compression zone (mec) zonă comprimată / de compresiune

compressive buckling (mec, OM) flambaj prin compresie / prin comprimare

compressive force forță de compresie / de comprimare

compressive load (mec) sarcină / forță de compresie / de comprimare / la compresiune

compressive property (mec, alim) proprietate la compresie / de comprimare

compressive strength $(\mathrm{mec}, \mathrm{OM})$ rezistență la compresie / compresiune

compressive stress $(\mathrm{mec})$ tensiune / efort de compresiune

compressive yield point (mec, OM) limită de curgere la compresiune

compressive zone (mec) zonă comprimată

compressor (mas) compresor; (el, fiz) compresor de semnal

compressor blade (OM, termo) pale de compresor compressorless injection (termo) injecție fără aer comprimat

compressor lubricant (auto, termo, T) lubrifiant / ulei / unsoare pentru compresor

compression installation (termo) grup compresor

compressor (OM, termo) compresor; (sistem) care comprimă / ridică presiunea unui mediu fluid

compressor pump (OM, termo) pompă cu compresor

compressor unit (termo) agregat de compresie, grup compresor cu motor, (ansamblu) motocompresor

comprisal includere; compendiu, conspect

comprise a cuprinde, a include; a număra, a avea (ca elemente / membri) compromise compromis; compromitere, a compromite, a periclita, a pune în joc, a rezolva prin compromis, a ajunge la un compromis, a renunța la (principii etc.), a face un compromis

compromiser adept al compromisului comptroller (ec) revizor, controlor

compulsoriness caracter obligatoriu, obligativitate

compulsory obligatoriu; cerut, care se cere; de constrângere, coercitiv

compulsory licence licență obligatorie (asupra unui brevet de invenţie)

compulsory sale $(\mathrm{ec})$ vânzare forțată

computable calculabil

computation calcul, calculație, estimație, evaluare, apreciere, estimare, numărare, operaţie aritmetică

computation / computational ability (inf, c) capacitate / putere de calcul

computational numeric, de calcul

compute a calcula, a socoti; a evalua, a estima computed calculat

computed address (inf, c) adresă calculată (obținută prin modificarea câmpului de adrese al unei instrucțiuni în curs de execuție)

computer (inf, c) calculator, socotitor, maşină de calculat (sistem fizic de prelucrare a datelor)

computer aided / assisted (c, TH) asistat(ă) de calculator, excutat( $\breve{a})$ cu ajutorul calculatorului

computer aided design (c, OM) proiectare asistată de calculator

computer-aided manufacturing (mas-un) prelucrare / proces tehnologic (a unei piese) pe maşini asistate de calculator

computer backed / based (mas) asistat / ajutat de calculator

computer-compatible data aquisition / collection (c) culegere de date compatibilă cu prelucrarea pe calculator

computer control (autom, inf, c) comandă / control prin calculator

computer data transmission (inf, c) transmitere a datelor pentru calculator

computer-dependent language (inf, c) limbaj propriu unui calculator

computer expert (inf, c) informatician, specialist în prelucrarea datelor cu ajutorul calculatoarelor

computer field informatică, domeniu al calculatoarelor

computer file (c, inf) fişier de calculator 
computer generation (c) generație de calculatoare (clasificate după tipul componentelor cu care sunt echipate)

computer graphics (inf, c) sistem de calcul grafic, pentru prelucrarea imaginilor grafice; infografie, prezentare sub formă grafică a datelor culese

computer independent language (c) limbaj (de programare) independent de tipul calculatorului

computer information security (c, inf) sistem de securitate împotriva distrugerii sau utilizării neautorizate a computerului

computer instruction (inf, c) instrucțiunemaşină / care poate fi recunoscută de calculatorul pentru care este concepută, instrucțiune de calculator

computerize (inf, c) a computeriza; (TH, autom) a folosi / integra computerul într-un sistem / proces

computerized data (c, inf) date obținute la calculator

computer language (inf, c) limbaj (cuprinzând numai instrucțiuni-maşină)

computer-limited (timp, precizie) $\operatorname{limitat}(\breve{a})$ de computer

computer man (inf) informatician

computer master program(me) (inf, c) program principal al calculatorului

computer network (c) rețea de calculatoare

computer program(me) (inf, c) programmaşină

computer readable (inf, c) lizibil / citibil / care poate fi citit de calculator

computer routine (inf, c) program intern (al unui calculator)

computer scientist (inf) informatician

computer simulation (inf, c, mec) simulare pe calculator

computer systems performance (c) eficiența şi fiabilitatea unui computer

computing (c, mat) calcul (si pe calculator), operație / proces matematic $(\breve{a})$

computing equipment (c) aparat / echipament de calculat, calculator

computing store (c) memorie de lucru (a unui calculator)

comrade tovarăş, prieten; partener, asociat con contra, împotriva; vot / argument contra; (nav) a pilota (o navă)

concatenation (chim) înlănțire, concatenare concave (constr) boltă, cupolă; (fiz, mat) concav concave angle (mat) unghi cuprins între 0 şi $180^{\circ}$ concave bit (mas-un) tăiş de sfredel / de burghiu, cu centrul concav

concave camber (met) formă concavă a tăbliei cilindrului de laminare

concave face $(\mathrm{OM})$ scobitură, suprafață concavă concave fillet weld (met, $\mathrm{OM}$ ) sudură de colț, concavă / scobită

concave milling cutter (mas-un) freză concavă / inelară

concave mould $(\mathrm{OM}$, met) / formă (de turnare) cu racordare concavă

concave planing attachment (mas-un) dispozitiv pentru rabotarea suprafețelor concave

concave roll straightener (met) maşină de îndreptat cu rolă / cu cilindru epilsoidal(ă)

concave weld (met, OM) cusătură de sudură, concavă

concavity $(\mathrm{OM})$ concavitate (şi a cilindrului de laminare)

conceal a ascunde, a masca, a acoperi

concede a concede, a încuviința, a recunoaște; a admite; a garanta un drept, un privilegiu; a ceda; a face o concesie, a se recunoaşte învins

conceivable ( $a d j$ ) de conceput, imaginabil

conceivably $(a d v)$ de presupus, în măsura în care se poate imagina

conceive a concepe, a-şi imagina, a-şi închipui; a întelege, a pricepe; a plănui

conceive of a se gândi la; a concepe, a imagina; a-şi forma o idee despre

concentrate (met) minereu preparat / concentrat; (TH, met) produs concentrat, a concentra, a crește concentrația unui component al unui amestec, a aglomera; a limita, a îngusta; a restrânge; a satura; a îngroșa; (fiz) a focaliza; (chim) a condensa

concentrated concentrat

concentrated acid (chim) acid concentrat (d. minereuri, amestecuri solide, solutiii)

concentrated grape juice (alim) must concentrat / fiert

concentrated matte (met) mată concentrată concentrated wine drawn off after congelation (alim) vin tras după îngheț, inimă de vin concentrate freezing (met) congelare a concentratelor (tratament la metale neferoase)

concentrate melting (met) extragere din concentrate (şi prin topire); topirea concentratelor concentrating (fiz) concentrare, focalizare; (met) concentrare / îmbogățire a minereurilor; care concentrează

concentration (chim, hidr) concentrație, concentrare, creştere a concentrației unui component al unui amestec aglomerare, strângere, 
adunare; (fiz, el) concentrare, focalizare; (met) îmbogăţire, saturație, saturare, concentrare

concentration by boiling (alim, ind chim) concentrare prin fierbere

concentration method (chim, alim) metodă de concentrare (şi a unei soluții)

concentration ratio (met, soluții) raport al concentrației

concentration tank (alim, ind chim) cuvă de concentrare

concentrator (chim) coloană de concentrare, îngroşător, concentrator, agent de îngroşare / de concentrare; (inf) (program) concentrator; (OM) concentrator (de tensiuni) (şi în calculul la oboseală)

concentrator bowl (alim, ind) tobă a centrifugii concentric(al) concentric

concentric angular load $(\mathrm{mec})$ sarcină înclinată concentrică

concentricity caracter concentric; (OM) concentricitate

concentric (jaw) chuck (mas-un) universal cu strângere concentrică / uniformă față de axa de prelucrare

concentric orifice plate (metr) debitmetru $\mathrm{cu}$ placă cu orifiu coaxial cu axa conductei

concentric piston ring $(\mathrm{OM}$, termo) segment de piston concentric

concentric squirrel cage mill (constr, ind chim) dezintegrator cu colivie-veveriță concentrică

concept concept, noțiune abstractă / generală, idee

conception concepție, concepere; embrion; noțiune, concept; înțelegere, comprehensiune; părere, punct de vedere; idee; începere, început; plan

conceptual conceptual; abstract; schematic

conceptualize a conceptualiza, a elabora un concept

conceptual phase $(\mathrm{TH})$ fază de concepție a proiectării, fază zero, fază de studiu, care precede proiectarea

concern (ec) concern, societate (comercială), companie, firmă, întreprindere, afacere; interes, participare la o afacere; a privi; a afecta, a avea legătură cu, a preocupa, a îngrijora, a nelinişti; $\sim$ with participare la, interes în, contingență / legătură cu, relație; importanță, semnificație; preocupare pentru, grijă; rol (în); participare (la); nelinişte; îngrijorare; treabă; a privi (pe); a atinge (un interes), a fi implicat (într-o problemă); that has no $\sim$ with the question nu are legătură cu problema; the parties ed partidele interesate; be $\sim$ ed in a fi interesat în; oneself with / about / in a se interesa de concernedly $(a d v)$ cu îngrijorare concerning despre, privitor la, în ceea ce priveşte concernment importanță, însemnătate; participare, interes; preocupare, grijă, îngrijorare

concern oneself about / in / with a se ocupa de, a se preocupa de, a arăta interes pentru

concert concert; armonie, acord, concordanță, înțelegere

concession concesie, îngăduință; cedare; (jur) concesiune

concessive concesiv, îngăduitor

conch scoică, cochilie

conchoidal fracture (met) rupere / ruptură concoidală

conciliate a împăca, a concilia; a liniști

conciliatory conciliator, conciliant

concillium, $(p l)$ concillia consiliu

concisely $(a d v)$ (în mod) concis, succint, pe scurt

concision, conciseness concizie, caracter concis / succint

conclude a încheia, a termina, a sfârşi; a conchide, a deduce; a hotărî, a stabili

conclusion concluzie, încheiere, terminare, capăt, sfârşit; rezumat; deducție

conclusive de încheiere; definitiv; decisiv, final; convingător

conclusively $(a d v)$ în concluzie / încheiere

concoct (alim, ind chim) a fierbe, a amesteca

concoction (alim, fiz) fierbere, fiertură, amestecare, amestec

concomitance caracter concomitent / simultan, simultaneitate

concomitant concomitent, simultan; însotitor; fenomen însoțitor, circumstanță concomitentă simpton

concomitantly $(a d v)$ concomitent, simultan

concord armonie, înțelegere

concordance concordanță, acord

concordant with concordant, care concordă cu, care coprespunde $\mathrm{cu}$

concordantly corespunzător; în concordanță

concourse aglomerare, aglomerație, afluență, îmbulzeală, mulțime; (amer) hol, sală

concrescence concrescență

concrete $(\mathrm{TH})$ concret, practic, real, material, palpabil; (constr) ciment, beton, a betona, a cimenta, a îndesa, a se solidifica

concrete casting plant (constr) instalație pentru turnarea betonului

concrete filled in bags (constr) ciment în saci

concrete form (constr) cofraj (de beton)

concrete forming (constr) cofraj, cofrare

concrete foundation (constr) fundație de beton concrete fracture (constr) beton spart, spărtură de beton 
concrete grouter (constr) torcretor, maşină pentru injectarea betonului

concrete-gun (constr) maşină / aparat de injectat ciment / de torcretat

concrete hardcore (constr) sfărâmături de beton concrete hardener / hardening agent (constr, chim) agent de întărire a betonului

concrete iron (constr, met) fier- / oțel- beton

concrete mixer (constr) betonieră

concrete pipe (constr) tub de beton

concrete plug (constr) dop de beton

concrete pressure grouting machine (constr, mas) maşină de torcretat / pentru injectarea betonului

concrete testing (constr) încercarea / testarea betonului

concrete waterproofing (constr) zidărie din blocuri de beton rezistent la apă

concretion (fiz, chim) concreştere, concrescență, solidificare, coagulare; masă compactă

concretize a concretiza

concur a coincide, a se întâmpla în acelaşi timp; a concura, a contribui

concur with a fi de aceeaşi părere $\mathrm{cu}$, a fi de acord cu

concurrence, concurrency concurență, concurs de împrejurări; acord, potrivire (de idei); (c) concurență / suprapunere (a mai multor activități într-un sistem de calcul)

concurrent cu un punct comun, concurent, coincident, convergent, asemănător, analog

concurent with simultan cu

concurrent forces $(\mathrm{mec})$ forțe concurente

concurrent jobs (c, inf) rulări / activități desfăşurate în paralel

concurrently $(a d v)$ simultan, în acelaşi timp; totodată

concurrent reactions (chim, fiz) reacții paralele / secundare

concussion spring (OM) amortizor $\mathrm{cu}$ arc, arc de amortizare

concussion test (mec, metr) încercare / testare la şoc

concyclic points (geom) puncte situate pe acelaşi cerc, puncte conciclice

condemn a condamna, a găsi vinovat; a critica, a dezaproba; (nav) a confisca (o navă)

condemnable condamnabil, de condamnat

condemnation condamnare, acuzare

condemned $(\mathrm{TH})$ condammat, cu circulația oprită, rebutat, dat la rebut

condensability (termo) capacitate de condensare condensable (termo) condensabil

condensate (termo) condensat; (fiz, chim) condensat, produs de condensare condensate pump (termo) pompă de condensat condensation (fiz, chim, termo) condensare; condensație, condensat; concluzie, lapidaritate (de stil)

condensation by contact (termo, alim) condensare prin contact / pe suprafață

condensation by mixing (termo, ind chim) condensare prin amestec

condensation centre (ind chim, termo) centru germen de condensare

condensation coefficient (alim, ind chim) coeficient de condensare

condensation curve (ind chim, termo) curbă de condensare

condensation genarator (alim, ind chim, termo) generator de condensare, condensator

condensation heat (ind chim, termo) căldură de condensare

condensation level (ind chim, termo) nivel de condensare

condensation nucleus (ind chim, termo) nucleu de condensare

condensation nucleus counter (alim, ind chim, termo) dispozitiv de numărare a nucleelor de condensare

condensation point (fiz, termo) punct de condensare / de rouă, temperatură de condensare

condensation polymer (ind chim) polimer de condensare

condensation polymerization (ind chim) polimerizare prin condensare

condensation product (ind chim) produs de condensare, condensat

condensation resin (ind chim) răşină de condensare

condensation vacuum pump (termo) pompă de vid de condensare / de difuzie

condensation water (termo, ind chim) apă de condensare, condens

condense a (se) condensa, a (se) comprima, a face mai dens; (c) a concentra date; a exprima succint, a rezuma, a prescurta

condensed gas (termo, ind chim) gaz lichefiat

condensed milk (alim) lapte condensat

condensed water (termo, ind chim) apă de condensare, condens

condenser (el) condensator, capacitor; (fiz) condensor; (termo) condensator, aparat frigorific, dispozitiv / instalatie de condensare; (alim, ind chim) tambur perforat, tambur-sită

condenser boiler (termo) cazan / boiler de formare a aburului prin condensarea de vapori condenser coil (termo, alim, ind chim) serpentină de condensator / condensare 
condenser-discharge arc stud welding (met) sudare a bolțurilor cu arc electric amorsat printr-un vârf fuzibil

condenser duty / heat (termo) căldură cedată / preluată de condensator

condenser plant / system (termo, ind chim) instalație de condensare

condenser tube (termo, OM) țeavă de răcire

condenser water apă de condensare, condens (în instalațiile termice şi chimice)

condensing care (se) condensează, condensându-se condensing coil (alim, ind chim) serpentină de răcire

condensing gas drive (termo, mas) împingere / acționare cu gaze condensabile

condensing jacket (met) manta de răcire (cu condensarea vaporilor rezulțați din preluarea căldurii)

condensing lens (fiz) lentilă condensoare

condensing pipe țeavă de condensare

condensing point temperatură de condensare

condensing pot / vessel (alim, termo, ind chim) oală / separator de condens(at)

condensing programme (inf) program de înregistrare condensată a datelor

condensing rolls (constr, ind chim) cilindri de presare / compactor

condensing steam trap (termo) separator $\mathrm{cu}$ șicane, pentru condensarea aburului

condensing surface (termo, ind chim) suprafață de condensare

condensing temperature (fiz) temperatură de condensare

condensing turbine turbină de condensare

condensing unit (termo) agregat frigorific, grup compresor-condensator

condensing unit capacity (termo) capacitate brută a agregatului frigorific

condensing water (alim, ind chim) apă de condensare

condignly $(a d v)$ pe drept

condiment (alim) condiment

condistillation (alim, ind chim) distilare a lichidelor nemiscibile

condition condiție, stipulație, clauză; stare, situație; antecedent; (gram) propozitịie condițională; $\sim \mathbf{s}(p l)$ circumstanțe; poziție; condiție socială; (amer) reexaminare, corigență; a condiționa, a formula condiții; (termo) a condiționa aerul; a determina, a produce (schimbări); (ec) a verifica (calitatea mărfurilor); on $\sim$ that cu condiția ca; on no $\sim$ în nici un caz; under the present $\sim$ în împrejurările actuale; be in no $\sim$ to a nu fi în stare să

conditional on / upon condiționat de, condițional, dependent, limitat de conditional acceptance acceptare cu rezerve / condiționări

conditional assembly $(\mathrm{TH})$ asamblare condiționată

conditional breakpoint instruction (inf, autom) comandă de oprire condiționată

conditionally $(a d v)$ condiționat

conditional sentence (gram) propoziţie condițională

conditional stability $(\mathrm{TH})$ stabilitate condiționată conditional transfer (inf) transfer conditionat (de îndeplinirea unei cerințe)

condition as forging (met) în stare forjată

condition as rolled (met) în stare laminată

conditioned condiţionat; limitat; determinat, făcut, alcătuit, format

conditioned air (termo) aer condiţionat

condition billet / sheet (met) semifabricat / tablă, cu defectele de suprafață înlăturate

conditioning (alim) odihnă, fermentare finală / secundară, temperare; (inf) instrucțiune condiționată; (termo) umidificare, aclimatizare; (TH) condiționare (şi a aerului etc.), prelucrare, reglare, care poate fi reglat, întocmirea fişelor tehnice

conditioning burner (termo) arzător reglabil

conditioning chamber (termo) cameră de umezire (a aerului condiționat)

conditioning department (met) sectie / atelier / hală de curățare

conditioning of delivery (TH) condiții de livrare, condiționare a livrării

conditioning oven (alim, ind chim) aparat / etuvă / cuptor de condiționare / de umidificare

conditioning room (alim, ind chim) cameră de conditionare / de umidificare

conditioning time (met, plast) timp de condiționare / între aplicarea căldurii şi/sau presiunii pe o îmbinare / pe un material şi obținerea calității dorite

condition monitoring $(\mathrm{TH})$ monitorizarea condițiilor (de lucru, de exploatare), fără a interveni sau regla ceva

condition of material stare a materialului

condition of practice $(\mathrm{TH}$, mas) regim / condiții de exploatare / de lucru

condition of service în ordinea de plecare

conditions of contract $(\mathrm{ec}, \mathrm{TH})$ caiet de sarcini, conditii tehnice / contractuale

condition(s) of delivery (ec, TH) conditiii de recepție / de livrare

condominium (jur) posesiune în comun, coposesie, devălmăşie

conduce to / towards a duce la, a contribui la, a cauza 
conducive to favorabil pentru; care favorizează ceva, care ajută la, care cauzează / determină; (be $\sim$ to a aduce, a determina)

conduct conducere, dirijare; supraveghere, purtare, comportare, conduită; (TH) conductă; a conduce, a purta, a transmite, a dirija, a supraveghea, a îndeplini; a se comporta; a fi bun conducător (de electricitate sau de căldură); a escorta

conductance / conductibility (el, termo) conductanță, conductibilitate

conduct in a introduce în

conducting conduc(ă)tor, care conduce la

conducting coupling (OM) racord; (el) cutie de jonctiune

conducting cylinder / roller $(\mathrm{OM})$ ax / cilindru conducător, valț de ghidare

conducting flux (met) flux granulat pentru sudare (semi)automată

conducting-hearth furnace (met, termo) cuptor cu vatră

conducting media (el) mediu / medii conducătoare (de electricitate)

conducting polymer (el, plast, material) masă plastică / polimer cu conductivitate electrică (apropiată de cea a metalelor)

conducting rod $(\mathrm{OM})$ bară de ghidare

conducting tube $(\mathrm{OM}$, hidr) țeavă de conductă

conducting wheel (mas, OM) roată conducătoare (mai rar)

conducting wire (el) conductor (electric)

conduction $(\mathrm{TH})$ conducere, transmitere, propagare; (hidr) transport de fluid; (el) conducție

conduction band (fiz) bandă de electroni (la metale)

conduction of heat (fiz, termo) conductie / transmitere de căldură, conductibilitate termică

conduction resistance / pressure welding (met) sudare (electrică) / prin presiune prin conducție

conductive (el, termo) conductiv, conductibil, (bun) conducător

conductive adhesive (el, plast, termo) adeziv conductiv / conductibil / (bun) conducător

conductive elastomer (el, ind chim) elastomer (obținut şi prin amestecare cu pulberi metalice, înainte de vulcanizare) cu conductivitate electrică

conductivity (fiz) conductivitate (electrică sau termică)

conductivity type moisture sensor (el, metr) senzor / aparat de determinat umezeala (fibrelor, hârtiei etc.) prin modificarea conductivității

conductivity zone (fiz, el, termo) zonă de conductivitate conductor conducător, director, responsabil; (el) conductor, conductă; (mas-un) dispozitiv de ghidare, coloană de ghidare; (muz) dirijor; (fiz) corp conducător (de căldură); (cf) conductor; bad / non- rău conducător

conductor for moist places (materiale) conductă rezistentă la umezeală

conductor string (constr, mas-un) coloană de ghidaj / de ghidare

conduct over a transmite, a transfera

conduct research a conduce / a coordona cercetări / studii

conductress conducătoare, directoare; responsabilă; taxatoare; (amer) conductoare de tren

conduit (el) conductor, tub protector; (hidr, OM) canal, tub, teavă, conductă, aducție, burlan; (el) canalizare, canal pentru cabluri

conduit coupling $(\mathrm{OM})$ manşon / mufă de legătură conduit duct (hidr, mediu) canal de scurgere conduit elbow (hidr, OM) cot / curbă pentru conductă, cot de teavă

conduit for ventilation $(\mathrm{TH})$ canal de ventilație conduit lock nut (hidr, OM) piuliță de închidere a unei conducte

cone crater (rar); (OM) pivot, con, pâlnie, fus; (geom) con, conic(ă); (textile, el) bobină conică cone bearing $(\mathrm{OM})$ lagăr conic (şi la recipiente, găuri înfundate)

cone belt $(\mathrm{OM})$ curea trapezoidală

cone bottom (OM) fund conic

cone brake $(\mathrm{OM})$ frână cu con de fricțiune

cone breaker (alim, ind chim) malaxor / concasor cu conuri

cone clamp (mas-un, OM) con de prindere, prindere pe con

cone classifier (agr, ind chim) clasor / sortator conic

cone clutch $(\mathrm{OM})$ ambreiaj cu con de fricțiune

cone core $(\mathrm{OM})$ manşon conic, (cu) miez / alezaj conic

cone crusher (constr, ind chim) concasor conic cone grinding wheel (mas-un) disc / piatră de rectificare, $\operatorname{conic}(\breve{a})$

coned milling cutter (mas-un) freză conică / tronconică

cone fire (termo) con de dispersare / de foc

cone-friction brake $(\mathrm{OM})$ frână cu con de fricțiune

cone-friction clutch $(\mathrm{OM})$ ambreiaj cu con de fricţiune

cone gear $(\mathrm{OM})$ roată dințată conică, angrenaj conic

cone head $(\mathrm{OM})$ cap tronconic

cone-headed nail (OM) cui cu cap conic 
cone headstock (mas-un) păpuşă fixă, cu con în trepte

cone impression / imprint (mas-un, met, metr) amprentă / impresiune / urmă conică (şi la măsurarea durității)

cone mill (constr, ind chim) moară conică / cu clopot

cone nut $(\mathrm{OM})$ piuliță conică

cone of dispersion (fiz) con de dispersie

cone of revolution (geom) con de revoluție, con circular

cone-plate for lathes (mas-un) lunetă (cu bacuri / suprafețe conice) pentru strung

cone-plate viscosimeter (metr, T) vâscozimetru cu placă şi con

cone-point set screw (OM) şurub de reglare, cu vârf conic

cone pulley (OM) disc conic, roată de curea / de fricțiune conică / în trepte

cone-screw point $(\mathrm{OM})$ vârf conic al şurubului

cone separator (agr, ind chim) separator conic

cone-shaped (geom, OM) conic, de formă conică, în formă de con

cone speaker difuzor cu pâlnie

cone tank (OM, hidr) rezervor cu fund conic

cone-thrust test (metr, met) încercare / test de duritate Rockwell (cu con)

cone-up (hidr) formare de conuri de apă

cone valve (OM, hidr) ventil cu scaun conic

cone worm (OM) melc / șurub globoidal

confection (textile, construcții metalice) confecție, confecționare; (alim) dulciuri, bomboană, pastilă confectioner (alim) cofetar

confer a da, a conferi, a acorda

confer with a discuta; a se consulta cu, a se sfătui cu

conference conferință, congres, adunare, şedință; discuții, consultări; (ec) cartel, sistem de fixare a prețurilor

conferment conferire, acordare (a unui titlu)

confidence încredere, siguranță, certitudine; convingere fermă, încredințare; confidență; secret

confidence game abuz de încredere, înşelătorie, escrocherie (bazată pe încredere)

confidence interval (metr) limită / interval de încredere (a rezultatului măsurării)

confidence level (metr) nivel de încredere

confidence limits (metr) limitele intervalului de încredere

confidential confidențial, secret; care se bucură de încredere; încrezător, credul

confide to a încredința (şi un secret), a lăsa / a da în grija; a mărturisi; a destăinui; a se bizui pe; in a se încrede în configuration configurație; formă, aspect, structură; poziție (şi a terenului)

configure $(c$, inf) procedura de instalare a softului pentru a functiona pe un anumit calculator sau imprimantă

confine hotar; limită; a confina, a închide, a ține închis, a (de)limita, a restrânge (şi subiectul); a obliga să rămână; a reține

confined flow (hidr) curgere cu curent continuu confined jet (hidr) jet confinat (influenţat de pereții inconjurători)

confinement captivitate, confinare, delimitare; închidere; limitare; arestare; detenție; rămânere (în cameră, în pat); (med) lăuzie

confine oneself a se limita la

confining liquid (OM, hidr) lichid de etanşare confirmation confirmare

confirm a confirma, a dovedi, a adeveri; a întări, a consolida; a autentifica, a sancționa; a atesta; a ratifica

confirmation confirmare, întărire, consolidare (a autorităţii etc.); adeverire; atestare; ratificare

confirmed confirmat, stabilit; convins; (med) cronic (d. boli)

confirming house (ec) firmă de intermediari

confiscate a confisca, a rechizitiona

confiscation confiscare, rechiziționare

confiture (alim) dulceață

conflagration ardere, aprindere, incendiu (mare), inflamare; conflagrație

conflate a combina (d. texte)

conflation combinare (d. texte)

conflict conflict, ciocnire, contradictie; a fi în conflict / opoziție, a diferi, a se bate cap-încap (idei)

conflict with a fi în conflict cu, a fi în contradicție $\mathrm{cu}$

conflicting contradictoriu, care este conflict/ contradicție

conflicting motion(s) (mec, mas) mişcări incompatibile / care nu pot să aibă loc în acelaşi timp confluence confluentă ; convergentăa afluentăă, mulțime; încrucişare (de drumuri etc.)

conform a pune de acord, a armoniza; a se acorda, a fi în acord / concordanță

conformance conformare (la anumite cerințe, specificații)

conformable conform; concordant; corespunzător; ascultător, supus

conformable with comparabil cu, asemănător cu / corespunzător cu

conformation conformație, formă, structură, aspect conformation to conformare la, ascultare de, respectare (a legii etc.), adaptare la 
conformity (TH) concordanță, asemănare, potrivire; conformitate (şi proprietate a materialelor la cuplul fus-cuzinet), caracter corespunzător; (ec) înțelegere

conformity to $(\mathrm{TH})$ confirmare la, acceptare; supunere la

conform oneself a se conforma, a se supune

confound a amesteca, a încurca, a încâlci; a irosi, a consuma; a înfrânge, a distruge; a nărui; a zăpăci; a ului; a confunda

confront a înfrunta; a se confunda (cu); a se opune, a rezista; a confrunta (martori); a compara

confuse a confunda, a amesteca, a încurca (lucruri, idei); a lăsa perplex; a intimida; a ruşina; a ruina

confused confuz, încurcat; perplex

confusion confuzie, încurcătură, dezordine; perplexitate; amestecare (de idei etc.)

confutation respingere (a argumentelor), infirmare

confute a respinge; a dezaproba; a arăta falsitatea, a combate (ceva / pe cineva)

congeal a (se) congela, a îngheța, a (se) solidifica, a (se) îngroşa, a (se) concentra, a (se) coagula, a (se) închega

congealing congelare, care (se) congelează, coagulare, concentrare, închegare

congealing point (fiz, termo) punct / temperatură de congelare

congelation, congealment (alim, fiz, ind chim) congelare, solidificare; coagulare, închegare

congelation temperature (alim, ind chim) temperatură de congelare

congeniality afinitate, conformitate, potrivire

congest a (se) aglomera; (med) a (se) congestiona

congested congestionat; aglomerat

congestion congestie; congestionare

conglobate aglomerat (în bulgări)

conglobe (chim, met) a aglomera (a lua o formă sferică)

conglomerate conglomerat; a congestiona; a (se) aglomera; a (se) aduna, a (se) reuni

conglomeration conglomerare, amestec, aglomerare, transformare într-o masă compactă, amestecătură, conglomerat; congestionare

congratulation (on) felicitări (pentru)

congregate a (se) strânge, a (se) aduna, a (se) întruni; adunat, strâns; colectiv

congregation adunare, întrunire; congregatie; (edu) şedinţă a senatului universitar (Cambridge)

congress (pol, ec) congres; adunare generală

congruence, congruency, congruity (mat, geom) egalitate, congruență; coincidență; acord, concordanță congruent / congruous (mat) congruent, asemenea; corespunzător, potrivit, adecvat

congruently $(a d v)$ (în mod) corespunzător, congruent

conic (mat) de con, conic

conical (mat, OM) conic, în formă conică, în formă de con

conical adapter (mas-un) adaptor conic (pentru scule); (OM) bucşă conică (şi pentru rulmenți)

conical breaker (constr, alim, ind chim) concasor conic / cu conuri

conical crown wheel $(\mathrm{OM})$ coroană de diferențial conic

conical drum $(\mathrm{OM})$ tambur conic, tobă conică

conical-drum hoist (ind chim) maşină de extractie, cu tobe conice

conical fit $(\mathrm{OM})$ ajustaj conic / pe con, asamblare conică netedă

conical helix (mat, OM) curbă / elice conică / de pantă constantă

conical-identation hardness (materiale, metr) duritate Ludwik / determinată cu indentor conic conical journal $(\mathrm{OM}, \mathrm{T})$ fus conic

conical mill (alim, constr, ind chim) moară conică

conicalness $(\mathrm{TH}$, mas-un) conicitate

conical perspective perspectivă axonometrică

conical projection proiecție conică

conical orifice (OM, hidr) orificiu conic

conical roller-bearing $(\mathrm{OM})$ rulment $\mathrm{cu}$ role conice (nu se specifică dacă este radial-axial sau axial-radial)

conical screen (agr, alim, ind chim) sită conică

conical screw (OM) şurub / conic

conical thread $(\mathrm{OM})$ filet conic

conical wheel $(\mathrm{OM})$ roată dințată / pinion co$\operatorname{nic}(\breve{a})$, roată conică (de fricțiune)

conical-wing valve (OM, hidr) ventil cu scaun conic

conifer (silv) conifer

coning (mat) formare de conuri

conjectural imaginabil, de presuspus

conjecture ipoteză, presupunere, bănuială, suspiciune, conjectură; a bănui, a presupune

conjoin a (se) uni, a (se) îmbina, a lega

conjoint unit; comun (d. acțiuni etc.)

conjoint polymer (chim) copolimer

conjugate unit, împerecheat; (mat) conjugat; (chim) a combina; (OM) a îmbina, a lega; (gram) a conjuga; a împerechea

conjugate angle (geom) unghiuri a căror sumă este de $360^{\circ}$, unghiuri suplimentare

conjugate depth (hidr) adâncime conjugată (în saltul hidraulic) 
conjugation conjugare, cuplare, racordare, joncțiune, îmbinare, legare, împerechere

conjunction (el) conjuncție; unire, legătură, îmbinare; conjunctură, coincidenţă

conjuncture conjunctură, concurs de împrejurări

conk (med) nas, cap; lovitură în cap, a leşina

conked-out $(\mathrm{TH})$ scos din circulaţie, bun de dat la gunoi

conn (nav) a da comenzi la cârmă

connate water (geol) apă interstițială

connect (with / to) a uni, a lega (de /cu), a angrena, a cupla, a conecta, a conexa, a anexa (la), a socia cu, a fi în legătură cu

connected conex, cu conexiune, legat, unit; logic, închegat, coerent, înlănțuit logic

connectedly $(a d v)$ (în mod) logic, coerent, cu conexiune, legat de

connecter, conector $(\mathrm{OM}, \mathrm{el})$ piesă de legătură

connect in (el, mec) a conecta, a anclanşa

connecting (el, mec) care se conectează / se leagă, de legătură

connecting angle (met, OM) cornier de asamblare (piesă sau profil)

connecting bolt $(\mathrm{OM})$ şurub / bulon / bolț de asamblare / de legătură

connecting chain $(\mathrm{OM})$ lanț de legătură

connecting device $(\mathrm{OM})$ organ / dispozitiv de cuplare / de legătură

connecting diagram (el) schemă de conexiuni

connecting duct (el, OM) manşon / mufã de legătură (pentru cabluri)

connecting flange (OM, hidr) flanşă de cuplare / de legătură

connecting frame cadru de legătură

connecting gear $(\mathrm{OM})$ angrenaj de transmisie / intermediar

connecting hose (OM, hidr) furtun de cuplare / de racord

connecting line (cf) linie ferată de joncțiune / de legătură; (OM) branşament / conductă de legătură; (el) circuit de conectare

connecting link $(\mathrm{OM})$ culisă, colier, platbandă de legătură

connecting link chain $(\mathrm{OM})$ za de închidere a lanțului

connecting member of link (OM) piesă / organ / element de legătură, verigă

connecting nut (OM) piuliță de cuplare / de asamblare / olandeză

connecting passage (constr) canal / pasaj de legătură

connecting piece $(\mathrm{OM})$ (ştuț de) racord, piesă de legătură connecting pipe (hidr, OM) racord, branşament, conductă de legătură

connecting plug (el) fişă de contact / de legătură connecting rod (auto) bară de direcție / de conexiune; (cf, OM) tijă / bară de conducere, bielă

connecting-rod bearing ( $\mathrm{OM}$, termo) lagăr de bielă

connecting-rod bearing cap (OM, termo) capac al capului de bielă

connecting-rod big end (OM, termo) cap al bielei connecting-rod blade / body $(\mathrm{OM})$ corp al bielei connecting-rod bushing (OM, termo) bucşă / cuzinet / lagăr al bielei

connecting-rod dipper $(\mathrm{OM}, \mathrm{T})$ lingură de barbotaj a bielei

connecting-rod eye (OM) orificiu (de picior) de bielă

connecting-rod small end $(\mathrm{OM})$ picior al bielei connecting shackle (nav) cheie de împreunare / de legare (în navigație)

connecting shaft $(\mathrm{OM})$ arbore de transmisie / de legătură / intermediar

connecting sleeve (OM) cuplaj (mai simplu); racord, manşon de legătură / de cuplare, piesă de cuplare

connecting strap (el, auto) baretă de conexiune / de acumulator

connecting terminal (el) bornă de legătură

connecting-through extension (el) legătură directă, închidere succesivă a contactelor (sau circuitelor)

connecting-tie rod (auto) bară de legătură / transversală de direcție

connecting-up (el, mec) stabilire / efectuare a contactului, conectare

connection corespondență, influență; (el, hidr) conexiune, racordare, legătură, circuit; $(\mathrm{OM})$ cuplaj, cuplare, îmbinare; (ec) clientelă, clienți connection angle $(\mathrm{OM})$ colțar de fixare, cornier de legătură

connection at / to the mains (el, hidr) conectare / racordare la rețea(ua principală)

connection hose (OM, hidr) furtun de legătură connection level (OM, hidr) palier de racordare / de legătură

connection link $(\mathrm{OM})$ inel de suspendare / de legătură

connection of brazing / soldered joint realizare a cusăturii lipite (cu aliaj metalic)

connection of corners (constr, OM) îmbinare / legătură de colț

connection piece (OM, hidr) tubulatură, armătură, piesă de legătură 
connection pipe $(\mathrm{OM})$ conductă de legătură / de conectare

connection plate $(\mathrm{OM})$ guseu, placă de legătură / intermediară

connective de legătură; conectiv; conjunctiv; conector; cuvânt de legătură

connector (el) conector, racord, fişă; (OM) piesă de legătură; (c) selector de linii

connexion, connection conexiune, legătură

connexity conexiune, legătură

connotation conotație, subtext, ceea ce se subînţelege

connote a sugera, a implica (şi ideea de), a atrage după sine

conoid (geom) conoid, trunchi de con, paraboloid / hiperboloid / elipsoid de rotație (în general); conic

conoidal mill (alim, ind chim) moară conică / parabolică / hiperbolodală

conoidal surface (geom) suprafață conoidală

conquer a cuceri, a pune stăpânire pe, a câştiga

conscience conştiință, cuget

consciencious conştiincios, scrupulos; onest, cinstit

conscious (med) conştient, lucid, treaz; inteligent, gânditor; făcut cu bună ştiință, voit

conscious of conştient de, care îşi dă seama, care are cunoştință de

consecution succesiune; desfăşurare (a evenimentelor)

consecutive consecutiv, succesiv, rezultant, ca efect

consecutive index (mas-un) divizare consecutivă / din mai multe reglaje

consecutively $(a d v)$ consecutiv, succesiv

consecutive number număr curent / de ordine consecutive series load (mec, OM) sarcină variabilă periodic / în serii

consensus consens, acord; părere generală

consent acord, încuviințare; permisiune

consent (to) a fi de acord (cu), a se învoi, a consimți (la), a încuviința, a-și da consimțământul (la)

consentant care consimte

consequence consecință, urmare, efect; importanță, însemnătate

consequent consecvent; logic; îndelungat, de durată; (mat) al doilea termen (al unui raport), succesor (al unui număr întreg); consecvent

consequential, consequent important

consequently $(a d v)$ în consecință, prin urmare, de aceea

consequent on / upon care rezultă din, care este o urmare / o consecinț̆ la conservancy (mediu) comitet pentru protecția (apelor etc.); protecția / protejarea naturii

conservation (alim, TH) conservare, păstrare, întreținere, menținere

conservation of energy (fiz, mec) conservarea energiei

consevation of energy law (fiz) legea conservării energiei

conservative amplu, larg; estimat; care se conservă conservator paznic, apărător; custode; tutore conserve (alim) a conserva; a păstra; $(\mathrm{TH})$ a conserva (un utilaj etc.)

conserves (alim) fructe zaharisite, gem, dulceată, zaharicale, dulciuri

consider a se gândi la; a intenționa; a avea în vedere, a lua în considerare, a nu pierde din vedere; a (se) considera, a (se) crede, a socoti; a judeca

considerable considerabil; însemnat, remarcabil considerable load variation $(\mathrm{mec})$ şoc / variaţie mare de sarcină (rar), suprasarcină considerably $(a d v)$ considerabil, mult considerate (to / towards) atent (cu), prevenitor (cu); plin de tact, delicat; circumspect, prudent (față de)

considerately $(a d v)$ (în mod) atent, prevenitor

consideration considerație, stimă, respect; atentie, (luare în) consideratie; judecată, apreciere; considerent; motiv, argument; (răs)plată, recompensă, compensație

considered chibzuit; (amer) apreciat, prețuit, la preț considering privitor la, referitor la, cu privire la, având în vedere, tinând seama de

consideration considerare, observare

consideration of similitude criteriu de similitudine consign (ec) a expedia (mărfuri), a trimite (mărfuri) în consignație, a depune (bani)

consignation $(\mathrm{ec})$ expediere de mărfuri prin consignație, vânzare a unei sume depozitată în bancă

consignee destinatar

consigner expeditor

consignment (ec) consignație, consemnare

consistency / consistence $(\mathrm{T})$ consistentă (d. fluide, unsori etc.); (fiz) consistență, densitate, compactitate, caracter necontradictoriu; (mat) compatibilitate (în logica matematică); (TH) consecvență, stare, grosime, soliditate, densitate, rezistență, continuitate; consecventă, logică

consistency factor $(\mathrm{TH}, \mathrm{mec})$ coeficient / factor de rezistentă

consistent consistent; solid; dens, întemeiat, valabil, compatibil (în logica matematică); consecvent; logic 
consitent with concordant cu, comparabil cu consistent grease $(T)$ unsoare consistentă consistently complet, fără lacună consist in a (con)sta în / din, a se reduce la consist of a consta / a se compune din, a fi alcătuit / compus din

consist with a fi în acord cu, a fi compatibil cu

console (TH) pupitru (de comandă), consolă (prin care un operator comunică direct cu un sistem de calcul); (OM, mec, constr) consolă; (auto) consolă

console desk pupitru de comandă

consoleer operator de consolă

console support (mec) susținere / suport cu grindă în consolă

consolidate a lega, a întări, a (se) consolida, a aşeza, a etanşa, a uni; (ec) a (se) unifica, a contopi (societătii), a fuziona; a întruni la un loc

consolidated balance sheet $(\mathrm{ec})$ situație financiară de ansamblu

consolidated fund (ec) fond consolidat

consolidation consolidare; întărire, etanşare; tasare, compactare; (ec) contopire, fuziune (a unor societăți)

consolidation coefficient $(\mathrm{TH})$ coeficient de consolidare / întărire / etanşare / tasare / compactare

consolidation line (chim, alim) linie de consolidare / întărire / etanşare / tasare / compactare

consolidation surface (chim, alim) suprafață de consolidare / întărire / etanşare / tasare / compactare

consols $(\mathrm{ec})$ bomuri de rentă neconsolidată

consolute (hidr, fiz) lichid miscibil

consortium, $(p l)$ consortia (ec) consorțiu

conspectus conspect, privire generală

constancy (TH) stabilitate, durabilitate, permanență, persistență, constanță, fidelitate

constancy of performance (mas) siguranță / constanță în funcționare

constant constantă, coeficient; constant, fix, durabil, permanent; stabil, invariabil, neschimbător; fidel

constantan (met, metr) aliaj $55 \% \mathrm{Cu}+45 \% \mathrm{Ni}$, folosit la termocuple

constant boiling (termo) constantă ebulioscopică / de fierbere

constant boiling mixture (ind chim, termo) amestecuri cu punct de fierbere constant

constant boiling point (fiz) punct de fierbere constant

constant chord $(\mathrm{OM})$ coarda constantă $\left(\mathrm{S}_{\mathrm{c}}\right)$ (la roți dințate) constant chord height $(\mathrm{OM})$ înălțimea la coarda constantă $\left(h_{c}\right)$

constant-circulation oiling $(\mathrm{T})$ ungere / lubrifiere prin circulație continuă

constant-delivery pump (OM, hidr) pompă cu debit constant

constant-deviation prism (fiz, opt) prismă cu deviație constantă

constant-enthalpy / isoenthalpic process (fiz, termo) proces izo-entalpic

constant-entropy process (termo) proces izoentropic

constant field (el) câmp uniform (în spațiu) / constant (în timp); (mat) corp al constantelor

constant level lubrication $(\mathrm{T})$ ungere / lubrifiere prin împroşcare / barbotare / în baie (cu nivel constant)

constantly $(a d v)$ (în mod) constant, permanent; mereu, într-una

constant-mesh gear $(\mathrm{OM})$ pinion în angrenare continuă / fără întreruperi

constant-mesh gear-box $(\mathrm{OM})$ cutie de viteze cu angrenaje în angrenare continuă

constant of proportionality (TH) coeficient de proporționalitate

constant per unit length constantă liniară

constant pool grup / set de constante

constant pressure (fiz, hidr) presiune constantă

constant-pressure combustion (termo) ardere izobară / la presiune constantă

constant-pressure cycle (fiz, termo) transformare izobară / la presiune constantă

constant-pressure expansion valve (OM, hidr) supapă de presiune constantă, reducător automat de presiune, ventil automat de destindere / cu presiune constantă

constant-presurre line (termo) izobară

constant-pressure valve $(\mathrm{OM}$, hidr) ventil / robinet de presiune (minimă) constantă; (termo) regulator al presiunii de evaporare

constant-speed propeller (nav) elice cu viteză unghiulară constantă (şi prin variația pasului)

constant speed universal joint $(\mathrm{OM})$ articulație dublă cardanică, asigurând viteză unghiulară sau turație constantă

constant stress (mec) tensiune / efort constant( $\breve{a})$

constant use (mas, TH) folosire continuă

constant-volume gas thermometer (metr) termometru cu tub Bourdon

constant / absolute term (mat) termen liber

constituent $(\mathrm{TH})$ (parte) component( $\breve{a})$, piesă componentă, constituent; constitutiv

constituent of structure (met, materiale) constituent structural 
constitute a numi; a constitui, a forma, a alcătui; a institui, a autoriza (funcționarea)

constitution (pol) constituție; (fiz) structură, alcătuire, compoziție, componență; organism constitution(al) diagram (chim, met) diagramă de echilibru / a fazelor

constitutive constitutiv; component; de bază constitutive properties proprietăţi structurale constrain a constrânge, a obliga

constrained supus la condiții, cu restricții, forțat constrained motion (mec, mas) mișcare constrânsă

constrained oscillation (mec) oscilaţie impusă / forțată

constraining (mec) încastrare

constraint (mec, OM) încastrare, calare, fixare, restricție, legătură; (mec, fiz) condiție, limitare, constrângere

constrict a strânge, a contracta, a comprima, a presa (d. materiale)

constricted arc welding (met) sudare cu plasmă constricted passage (constr, hidr) canal îngustat constricting nozzle (OM, hidr) ajutaj / duză de ştrangulare, duză-anod

constriction (materiale, TH) ştrangulare, strângere, gâtuire, contracție, constricție, contractare

construct a construi, a clădi, a proiecta; a imagina, a crea (o teorie)

construction (constr) construcție, clădire, edificiu, construire; execuție, alcătuire; interpretare, explicație

constructional constructiv, construibil, de constructie (d. un defect)

constructional drawing (constr) desen de constructie

constructional element (constr, mas) element / componentă de montaj

constructional steel (met, constr) oțel de construcție / pentru construcții metalice

construction diagram $(\mathrm{TH})$ schemă de montaj

construction element (met, constr) element de constructie

construction equipment / machinery / plant (constr, mas) echipament de construcții

construction line of groove (met) axă a calibrului de laminare

construction material(s) (constr) material(e) / scule / unelte / echipament de construcție

construction time (constr) termen / durată de execuție (a unei lucrări de construcții / montaj)

constructive (constr) de constructie; constructiv; indirect, implicit (d. un refuz)

constructivness caracter constructiv

constructor constructor construe a interpreta, a deduce, a analiza

consul (pol) consul

consulate (pol) consulat

consult a consulta, a se sfătui; a ține seama

cont

consultant consultant, specialist

consultation consultație; discuție; conferință

consultative, consultary consultativ

consulting engineer $(\mathrm{TH})$ inginer consultant

consumable consumabil (şi pentru birotică), care poate fi consumat / distrus

consumable electrode (met) electrod fuzibil / consumabil (pe durata sudării)

consume a consuma, a mânca, a bea; $(\mathrm{TH})$ a consuma, a uza, a folosi (energie etc.); a irosi, a cheltui; a mistui (d. foc)

consummate desăvârşit, perfect; a desăvârşi, a perfecționa; a încheia, a completa

consummation desăvârșire, perfecționare; sfârşit, final, încheiere; rezultat

consumer (ec) consumator

consumer goods (ec) bunuri de consum

consumer's risk (TH) probabilitatea de a accepta un echipament cu un anumit timp mediu estimat între avarii / defectări

consuming consum, care se consumă

consumption (ec) consum, cerere, consumare, cheltuială; (TH) uzură totală, consum (de combustibil, de energie etc.), distrugere

consumption graph / curve diagramă de consum contact atingere; contact, legătură; (geom) tangentă, tangență; (mec, T) contact; a contacta, a pune în contact, a stabili un contact, a intra în legătură / contact, a cupla; a lua legătura cu; intermediar, mijlocitor; (el) întrerupător, şaltăr, contact (electric)

contact adhesive (plast) adeziv de contact (activ la presiune mare)

contact angle (OM, T) unghi de racord / de contact contact arc (el, met) arc cu contact (la sudură)

contact area (mec, $\mathrm{T})$ arie de contact

contact back wipe (autom, el) contactor cu suprafață de curățare (acțiune repetabilă la fiecare ciclu)

contact block $(\mathrm{OM}, \mathrm{el})$ piesă de contact

contact bounce (el) întreruperi accidentale ale contactelor

contact breaker (el) ruptor, întrerupător

contact-breaker cam / shoulder (auto) camă a ruptorului; (el) camă de contact

contact chatter (el) vibrație a contactelor

contact clearance $(\mathrm{T}, \mathrm{el})$ distanța între contacte

contact corrosion (chim, T) coroziune prin contact, cauzată de contact (static sau dinamic) 
contact distillation (ind chim) distilare cu adsorbant / prin contact

contact electrification (el) electrificare prin contact contact filtration (alim, mediu, ind chim) filtrare prin strat adsorbant / prin contactare / prin contact (direct)

contact follow parcurs / traiectorie de urmărire (şi la roboți, manipulatori)

contact icing (alim) refrigerare prin contact (aplicând gheața direct pe produse)

contacting contractare; contactare, care intră în contact cu

contacting peaks $(\mathrm{T})$ vârfurile (asperităților) în contact

contact jaw $(\mathrm{OM})$ clemă / falcă de contact / de prindere

contact laminate (ind chim, plast) material stratificat cu răşină aderență la contact

contact lens (opt, med) lentile de contact

contact line (mec, $\mathrm{T}$ ) linie de contact

contact maker (el, OM) contactor

contact making (el) conectare, închidere a contactelor; (T) aducere în contact

contact making clock (autom, el) temporizator programat pentru închiderea unui circuit contactor (autom, el) contactor, conector contactor starter (el) demaror (cu contactoare)

contact panel (el, autom) panou de contacte; câmp de jacuri

contact pin (OM, el, electr) ştift de contact (la fişe); picioruş de contact (la tuburi electronice şi circuite integrate)

contact pick(-)off (metr, fiz) captor, traducător de / cu contact

contact plane (mat, mec) plan tangent / de contact contact plate (el, mas, mas-un) placă de contact contact plug (el) buşon de contact, fişă de legătură / de contact, conector

contact point (TH, T) vârf de contact (şi la asperități); (el) vârf de electrod

contact-point electrode (el) electrod punctiform contact potential (el) potențial / tensiune de contact

contact pressure (mec, $\mathrm{T}$ ) presiune de contact

contact process proces de contactare, procedeu de contact

contact-potential (el, met) potențial de contact (la acoperiri galvanice)

contact ratio $(\mathrm{OM})$ grad de acoperire $(\Sigma)$ (la angrenaje)

contact resistance (el) rezistența electrică a contactului

contact retainer (el, OM) dispozitiv de menținere a contactului contact roller (el, OM) rolă de contact; rolă de ghidare

contact safety device $(\mathrm{el}, \mathrm{mec})$ protecție contra atingerii unui contact

contact seal $(\mathrm{OM})$ etanşare cu contact

contact screen (el) sită de contact

contact screw (OM, metr) şurub de contact / micrometric

contact separation (el) interval de separare la contractor (în stare deschisă); (T) separarea corpurilor rigide în mişcare prin peliculă fluidă

contact side of the belt $(\mathrm{OM})$ suprafaţă activă (a curelei de transmisie)

contact slag welding (met) sudare cap-la-cap în baie de zgură

contact slider $(\mathrm{el}, \mathrm{mec})$ contact alunecător, culisă

contact slipper / shoe (el) inserție de contact a troliului

contact spacing (el) distanța dintre contacte

contact spot $(\mathrm{T}, \mathrm{mec})$ punct de contact

contact spring $(\mathrm{OM})$ resort / arc de contact; (el) suport arcuit al contactului (electric)

contact stud $(\mathrm{OM}$, el) piesă / buton / plot de contact

contact surface (mec, T, el) suprafață de contact; (mat) plan tangent / de contact

contact thermography (metr, termo) termografie de contact (şi prin studiul stratului luminescent depus pe piesa studiată)

contact thermometer (metr, termo) termometru de contact

contact tube (met) tub care asigură contactul electric între maşina de sudat şi electrodul sub formă de sârmă

contact wear allowance $(T)$ grosimea pierdută prin uzură, a unui contact, peste care funcționarea nu se face corect

contact welding (met, mec) sudare prin contact (direct) / prin presare

contact wipe (el) distanța pe care se deplasează contactul la separare / angajare

contain a conține, a include, a cuprinde; (mat) a fi divizibil cu / prin, a se împărți la, a fi egal cu

contained liniştit, calm, reținut

container (OM, hidr) recipient, container, vas, rezervor, canistră, cutie

containerize $(\mathrm{TH})$ a folosi containere pentru, a pune în containere

containing iron (met) feruginos, cu conținut de fier containing oil (alim, chim, T) cu conținut de ulei, care conține ulei

containment vessel (OM, hidr) recipient / container de siguranță 
contaminant (chim, T, mediu) contaminant, impuritate

contaminate (mediu) a contamina, a impurifica, a mudări, a polua; a strica; (fiz) a face radioactiv; (fig) a corupe

contamination (mediu) contaminare, impurificare, murdărie, poluare; $(\mathrm{T})$ contaminare, poluare (şi a unui lubrifiant)

contamination characteristics (mediu, T) caracteristici ale poluării / contaminării

contamination class (mediu) clasă de poluare

contamination content (chim, mediu) conținutul contaminării

contemplate a contempla; a studia, a considera, a examina; a se aştepta; a intenționa, a avea de gând să; a medita, a gândi

contemporaneity contemporaneitate

contemporaneous with contemporan $\mathrm{cu}$

contemporaneousness actualitate, contemporaneitate; simultaneitate, sincronism

contemporary contemporan; simultan, concomitent; modern; persoană de aceeaşi vârstă

contend a (se) lupta; a se întrece, a rivaliza, a fi rival; a disputa în contradictoriu, a se certa

content conținut, volum, capacitate, compoziție; substanță; mulțumit, satisfăcut; a (se) mulțu$\mathrm{mi}$, a satisface

content-addressable memory / store (c, inf) memorie cu conținut adresabil / asociativă

content by volume (fiz, ind chim, hidr) capacitate, volum, concentrație

content by volatile matter (ind chim) conținut de materii volatile

contention luptă, întrecere; controversă, dispută, discuție, ceartă; subiect de dispută; argument (într-o dispută), punct de vedere; afirmație contentious (adj) litigios, discutabil, de discutat contentiously $(a d v)$ în contradictoriu contentment mulțumire, satisfacție contents conținut, tablă de materii, cuprins conterminous (to / with) având acelaşi hotar / aceeaşi limită; (cu) coincident, care coincide (cu) contest întrecere, luptă, competiție; controversă, dispută; a contesta; a tăgădui, a nega; a căuta să câştige; a dezbate, a disputa; a (se) lupta, a se întrece

contestant concurent, rival, potrivnic

contex context

contextual $(a d j)$ contextual

contextually $(a d v)$ ținând seama de context contiguity contiguitate, atingere, apropriere, proximitate, vecinătate, contingență

contiguous adiacent, limitrof, în contact cu, învecinat, apropiat contiguously $(a d v)$ adiacent, limitrof, unul lângă altul

continental climate (geogr) climat continental

contingence / contingency (mat) atingere, contact, tangență, contingență; (ec) împrejurare neprevăzută; întâmplare, accident

contingencies (ec) (cheltuieli) neprevăzute (întrun deviz, într-o evaluare)

contingent $(\mathrm{TH})$ accidental, întâmplător; posibil; eventual; condiţionat; conjugat; incidental, neprevăzut, fortuit; contingent, lot; neesențial

continual frecvent, repetat, neîntrerupt (în timp), continuu

continually $(a d v)$ (în mod) frecvent, repetat, continuu, fără întrerupere, mereu

continuance continuare, urmare; durată; constanță; permanență; rămânere (în acelaşi loc); (jur) amânare

continuation continuare, urmare; prelungire; reînnoire

continue a continua, a dura, a dăinui, a urma; a prelungi; a duce mai departe; a nu renunța (la); a relua (o activitate), a nu se opri; (jur) a amâna; a rămâne în aceeaşi funcție; a relua (şi discuția)

continued equality (mat) şir / lanț de egalități continued load (mec, OM) sarcină permanentă / constantă

continued product (mat) produs infinit continued proportion (mat) şir de rapoarte egale continuity continuitate, permanență; durabilitate; şir neîntrerupt, înlănțuire neîntreruptă; (TH) listă / ordinea de montaj

continuous neîntrerupt, continuu (în timp sau spațiu), permanent; durabil; constant, stabil

continuous annealing furnace (met) cuptor continuu, de recoacere

continuous beam $(\mathrm{mec})$ grindă continuă

continuous-belt conveyer (OM, mas, transp) transportor cu bandă rulantă

continuous blow-down (termo) evacuare continuă a apei dintr-un boiler / cazan, pentru controlul concentrației de particule solide

continuous bucket elevator (mas, constr, ind chim) elevator contiunuu cu cupe

continuous casting plant (met) (instalație de) turnare continuă

continuous charge furnace (met) cuptor cu încărcare continuă

continuous chip (mas-un) aşchie continuă continuous circulation (hidr, mediu, alim) spălare / circulație continuă (şi a unui fluid) continuous cooker (alim, ind chim) autoclavă continuă, sterilizator-răcitor continuu continuous coring (mas-un) carotaj continuu 
continuous data (c, inf) date independente de timp continuous discharge heating furnace (met) cuptor cu propulsie / împingere / cu funcționare continuă

continuous drawing (met) trefilare continuă

continuous dryer (alim, ind chim) uscător continuu

continuous duty $(\mathrm{TH})$ regim continuu / de lungă durată

continuous-duty rating (TH, mas) putere nominală continuă / de durată

continuous-dying range (ind chim) linie de vopsire continuă

continuous electrode (met) electrod continuu (din sârmă, platbandă)

continuous feed (TH, mas-un) avans continuu, alimentare / încărcare continuă

continuous fillet weld (met, $\mathrm{OM}$ ) cusătură continuă cu sudură în / de colț

continuous filter (alim, mediu) filtru continuu

continuous flow (TH, hidr) continuu, cu functionare continuă, flux continuu, erupție / curgere continuă

continuous footing / foundation (constr) fundație continuă

continuous frame (constr, mas) cadru nedemontabil / monobloc (dintr-o singură piesă)

continuous furnace (ind chim, met) cuptortunel, cuptor cu canale / cu încălzire directă / cu trecere continuă

continuous girder (mec, constr) grindă continuă continuous-heating furnace (alim, met) cuptor cu trecere / încălzire continuă

continuous intensifier (hidr) multiplicator de presiune cu acțiune continuă

continuous impact test (metr) încercare / test la şocuri repetate

continuous joint (met, OM) rost continuu / neîntrerupt, îmbinare continuă (la sudură)

continuous-line production $(\mathrm{ec}, \mathrm{TH})$ producție pe bandă / în flux continuu

continuous load (mec, mas) solicitare / sarcină de durată / continuă

continuous lubricant film $(\mathrm{T})$ peliculă continuă de lubrifiant

continuously $(a d v)$ (în mod) neîntrerupt, continuu

continuously running duty ( $\mathrm{TH}$, mas) serviciu neîntrerupt

continuous mill (met) laminor continuu

continuous mixer (ind chim, alim) mixer / amestecător cu flux continuu

continuous monitoring (autom) supraveghere continuă (cu instalații de măsurare), control continuu continuous motion $(\mathrm{mec})$ mişcare continuă continuous normalising furnace (met) cuptor continuu, de normalizare

continuous note (fiz) ton / sunet continuu

continuous operating ( $\mathrm{TH}$, mas) functionare continuă

continuous operation ( $\mathrm{TH}$, mas) operație / funcționare continuă, producție în flux continuu, funcționare continuă

continuous oscillation (mec, el) oscilație întreținută

continuous output (auto, autom, mas, hidr) debit continuu; (mec) productivitate continuă, putere constantă la ieșire, parametru de ieșire constant

continuous pickling line (met) instalație de decapare continuă

continuous process $(\mathrm{TH})$ proces continuu

continuous production $(\mathrm{TH})$ productie / funcționare în flux continuu (a semifabricatelor, pieselor)

continuous pusher-type furnace (met) cuptor cu propulsie / cu împingere continuă

continuous rating $(\mathrm{el}, \mathrm{mec})$ sarcină nominală în regim neîntrerupt

continuous-recording gauge (metr) manometru cu înregistrare continuă

continuous rope drive $(\mathrm{OM})$ transmisie prin cablu fără sfârşit (considerat o curbă închisă)

continuous rolling mill (met) laminor continuu duo

continuous running $(\mathrm{TH})$ mers regulat, (regim de) funcționare continuă; trecere continuă

continuous running duty $(\mathrm{TH})$ regim continuu de functionare, exploatare continuă a unui utilaj

continuous sampling ( $\mathrm{TH}$, metr) control prin eşantionare continuă

continuous seam cusătură continuă / neîntreruptă (şi la sudură)

continuous series of lines mănunchi / fascicul de linii

continuous service (TH) functionare / deservire / service (de întretinere) continuă

continuous shearing (mec, OM) forfecare lentă continuous spectrum (fiz) spectru continuu, continuum; domeniu / mediu continuu

continuous-speed cone $(\mathrm{OM})$ tambur conic al transmisiei pentru reglarea vitezelor / al unui variator continuu

continuous strand furnace (met) cuptor continuu, pentru benzi

continuous stress (mec, OM) solicitare / tensiune de durată / constantă (în timp), efort constant 
continuous strip galvanising (met) zincare continuă pentru benzi

continuous test încercare la oboseală (rar şi nu este o formulare clară), test continuu (fără întreruperi)

continuous through dryer (agr, alim, ind chim) uscător cu transport (intern) / continuu / cu bandă / cu evacuare continuă

continuous-tooth formation / generation (masun, OM) tăiere / generare a dinților prin rulare

continuous-type furnace (alim, ind chim, met) cuptor continuu / cu propulsie / tip tunel

continuous vacuum brake $(\mathrm{OM})$ frână cu vid, continuă

continuous washer (alim, ind chim, text) maşină continuă de spălat

continuous weld / welded joint (met, OM) cusătură (sudată) continuă

continuous welding $(\mathrm{OM}$, met) sudare continuă

continuous welding process $(\mathrm{OM}$, met) proces / procedeu de sudare continuă

continuous working (OM, met, mas) lucru continuu, funcționare continuă

continuous working conditions (OM, met, mas) condiții de funcționare continuă

continuum, $(p l)$ continua întreg, tot, continuu, întreg, şir neîntrerupt

continuum-wise accessibility ( $\mathrm{TH}$, mas, inf) accesibilitate continuă

contort a distorsiona, a contorsiona, a strâmba, a (ră)suci, a deforma

contortion cortonsiune, strâmbare, (ră)sucire, cortonsionare, deformare; (med) luxație, scrântire

contour contur, curbă de nivel, limită, hotar; contur (pe un desen); (TH) contur, perimetru, profil

contour area of contact $(T$, mec $)$ conturul ariei de contact

contour grinder (mas-un) maşină de rectificat prin copiere

contouring control system (mas-un) comandă numerică (de urmărire a unui contur virtual sau a unui şablon real)

contour(ing) follower ( $\mathrm{T}$, metr) profilometru

contour integral (mat) integrală curbilinie

contour line curbă de nivel; (mat, fiz) dreaptă / curbă de nivel, orizontală, contur, linie de contur

contour lines equidistance ( $\mathrm{TH}$, fiz, metr) echidistanța curbelor de nivel

contour (lines) map hartă cu curbe / linii de nivel

contour of cam compensator (OM, mas) profil al camei de ghidare / de compensare contour of form of groove (met) profil al calibrului de laminare

contour of a groove $(\mathrm{OM})$ profil al canalului / al canelurii

contour of patern (met) formă a modelului; (mas-un) (contur de) şablon

contour pressure $(\mathrm{T})$ presiune pe contur contour tracing apparatus (metr) profilograf

contra $(a d v)$ contra, împotriva

contraclockwise contrar acelor de ceasornic

contract (ec) înțelegere, contract, a face datorii, a micşora / a reduce (datorii etc.), a încheia un contract, a se angaja printr-un contract, a contracta (un împrumut etc.); (mec, met, OM) a (se) contracta, a comprima, a (se) reduce, a freta, a (se) strânge, a (se) micşora, a reduce (un volum), a-şi micşora volumul; (lingv) a contrage, a prescurta; a (se) îngusta, a (se) strâmta

contractant (ec, jur) parte contractantă, contractant contract award $(\mathrm{ec})$ acordare a comenzii contracted contractat; dobândit; contras; (mec) contractat, micşorat; îngustat; (fig) limitat

contracted cross-section (hidr) sectiune transversală contractată / ştrangulată (a curentului)

contract in a declara / a promite că va participa la contractible contractibil, care se poate contrage / prescurta

contractile force (mec, TH) forță de contracție

contraction contractie, contractare; contragere, prescurtare; micşorare, reducere; strâmtare, îngustare; (ec) încheiere pe bază de contract, contractare

contraction allowance (met, plast) adaos de contracție

contraction cavity (met) gol (într-o piesă turnată), retasură

contraction coefficient (met, plast) cifră / coeficient de contractie

contraction crack (met, plast) fisură / crăpătură de contracție

contraction in length (met, mec) contracție longitudinală

contraction in width (met, mec) contracție pe lățime

contraction joint (met, mec) rost de dilataţie, îmbinare / unire din cauza contracției

contraction joints (met, mec) îmbinări / atingeri / lipiri datorate contracției

contraction measure (metr, met, plast) măsură de contractare / a contracției

contraction of area (hidr) îngustare, contracție (a secțiunii conductei etc.); (mec) gâtuire contraction of volume (met, plast) contractie micşorare de volum 
contraction ratio (met, plast) raport / coeficient / factor de contracție

contraction shrinkage (met, plast) îngustare prin contracție (după turnare, matrițare etc.)

contraction strain (met, plast, termo) tensiune / deformație de contracție

contractor (constr, ec) antreprenor; contractant, furnizor, constructor; (anat) muşchi constrictor

contract maintenance $(\mathrm{TH}$, ec) mentenanță realizată de firmă sau atelier specializat (din afara secției / uzinei) / specificată în / prin contract; firmă de mentenanță

contract out (ec) a declara (ofícial) că nu va participa la, a se retrage (dintr-un contract)

contract out of $(\mathrm{ec})$ a rezilia un contract privitor la

contract penality $(\mathrm{ec})$ penalizare contractuală

contract price $(\mathrm{ec})$ preț contractual, valoare contractuală / prevăzută în contract

contractual (ec) contractual

contract work (ec) muncă în acord

contradict a contrazice, a fi în contradicție cu, a contraveni, a nu corespunde

contradiction contradicție, contrazicere; contrast; negare, dezmințire; opoziție; discrepanță, nepotrivire; afirmație contradictorie

contradictious contradictoriu, căruia îi place să contrazică

contradictory contradictoriu, care se bate cap în cap cu, care (se) contrazice (cu)

contradictory to incompatibil $\mathrm{cu}$, care nu corespunde, cu care se bate cap în cap cu

contradistinction contrast, deosebire

contradistinguish a contrasta, a se deosebi prin contrast, a se evidentia prin contrast

contraflow / connterflow (mec, hidr) contracurent contraflow condenser (el) condensator cu contracurent

contrahent contractant, parte contractantă contraposition contrapunere; opoziție; antiteză contrapropeller (nav) elice opusă, contra-elice contraries (ind chim, met) impurități (vizibile) contrariety contrarietate, contrazicere, opoziție contrarily $(a d v)$ invers, de-a-ndoaselea contrariwise $(a d v)$ dimpotrivă, din contră; în sens opus, în direcție contrară; invers, de-andoaselea

contrarotating (mat) în sens contrar (involuție); (mec) care se roteşte / (se deplasează) în sens contrar

contrary contrar, opus; nefavorabil; contra, în opoziție; (gram) antonim; încăpățânat; dificil, greu de mulțumit

contrary to contrar cu, contrar cu, în ciuda contrast contrast; opoziție; deosebire, diferență; a contrasta, a opune, a compara, a forma un contrast

contrasted opus, invers, contrar, contrastant

contravene a contraveni, a contrazice

contravention contravenție, încălcare (a legii)

contribute a contribui cu, a colabora, a scrie pentru, a-şi aduce contribuția

contribute to a contribui la, a-şi avea partea de vină; a colabora la

contribution to contribuție la, participare la, colaborare la; articol; (ec) impozit, taxă pentru contributor (ec) contribuabil

contributor to colaborator la (ziar etc.)

contributory to care contribuie la; (ec) rezultat din (contribuții fonduri etc.)

contrivance invenție, inventivitate, idee nouă; concepere, concepție, plan; dispozitiv, mecanism, maşinărie, aparat

contrive a concepe, a inventa, a descoperi (tehnic)

contrive to a reuşi, a izbuti

control (inf) control, verificare, rulare, comandă; (OM) mecanism de ghidare / de conducere; (TH) control, verificare, supraveghere, examinare; comandă, influențare, reglaj, reglare, revizie, regulator, manipulare, mânuire, normare, mecanism de ghidare; (fiz) modulatie; (TH) a (se) controla, a verifica, a norma (consumul etc.), a examina, a supraveghea, a comanda, a regla, a manipula, a manevra, a modula, a reglementa, a dirija, a conduce, a (se) stăpâni; (agr) a combate (dăunători)

control apparatus (metr) aparat(ură) de control / de reglare

control appliance (metr, autom) aparat / dispozitiv automat de control

control arm $(\mathrm{OM})$ pârghie de comandă

control assembly (autom, mas, metr) bloc / de control / de comandă / de reglare

control bench mark (mas) reper de control

control board (CB) (autom, mas) tablou / pupitru / masă de comandă

control card (autom, inf) cartelă de control, cartelă-parametru (conținând informații destinate sistemului de operare); (TH) fiş̧ă de control

control casing-head (ind chim) vană a capului de coloană

control channel (hidr) canal de comandă (într-o instalație hidraulică)

control characteristic (autom) caracteristică de reglare / de comandă (de obicei caracteristica tensiune de grilă-tensiune anodică)

control chart grafic de control 
control cock (OM, hidr) robinet de reglare control console (mas, autom) panou / consolă de comandă

control crank (OM) pârghie / manetă / manivelă de comandă

control criterion (autom, mas) criteriu de control pentru sistemul de reglare

control cylinder epruvetă cilindrică

control design (autom, inf) sinteza / proiectul sistemelor de comandă

control device (autom, inf) aparat de control, organ / dispozitiv de comandă / de deservire / de mânuire / de reglaj / de reglare

control drive (el, mec) actionare a reglajului

control eccentric (mas-un, OM) excentric al mecanismului de distribuție

control engineering automatică

control experiment contraprobă, experiment / test de control

control flow (hidr) debit modulat

control gate $(\mathrm{OM})$ vană de reglare; (inf, autom) poartă / circuit de comandă

control gauge (metr) calibru-etalon, contracalibru

control gear (mas) mecanism de reglare / de comandă / de ajustare; (el) instalație / dispozitiv de control / de supraveghere (parțial cu acționare mecanică, inclusiv angrenaj)

control handle $(\mathrm{OM})$ bară conducătoare

control hardware (autom, c) echipament / aparatură de reglare / de comandă (partea hard)

control information (inf) informație de control / de verificare a operațiilor de prelucrare sau de transmitere a datelor

control input (inf, autom) mărime / parametru de intrare / de comandă / de referință / cu valoare prescrisă

control instruction (inf) instrucțiune de directionare / de control

control knob (auto) clapetă; buton de reglare

controllability dirijabilitate, proprietate de a fi controlabil / dirijabil

controllable (nav) elice cu pas variabil; (TH) controlabil, reglabil

controllable(-pitch) propeller (nav) (elice) cu pas variabil

controlled ( $\mathrm{TH}$, mas) reglat, controlat, comandat controlled atmosphere (ind chim, met) mediu de gaz de protecție, atmosferă controlată

controlled atmosphere furnace (alim, ind chim, met) cuptor cu atmosferă controlată

controlled chemical wear $(T)$ uzură chimică controlată (rezultatul unor aditivi EP care formează compuşi specifici cu suprafețele în frecare etc.) controlled chilling (alim, met, termo) răcire reglabilă / controlabilă

controlled condition ( $\mathrm{TH}$, mas) mărime (parametru) reglat( $\breve{a})$

controlled cooling (met) răcire controlată / direcționată

controlled crystallization (met) cristalizare controlată / orientată

controlled element (autom, mas) element / sistem / obiect reglat, mărime reglată

controlled initial unbalance (mec) dezechilibru inițial controlat / redus

controlled medium mediu care conține agent de control / de reactie; mediu cu parametri controlați (umiditate, temperatură, presiune etc.)

controlled member (OM, autom) obiect / piesă comandat $(\breve{a}) /$ sub control

controlled reset (metr) reducere la zero, comandată; (inf) resetare controlată

controlled / manipulated variable (OautomM) parametru / mărime / variabilă de referință / de reglare

controlled-volume pump (hidr) pompă cu debit reglabil

controller (autom) combinator, controler, aparat de comandă (propus şi neaprobat); (el) aparat de comandă / de control, controler, regulator, reostat de pornire; (inf) dispozitiv necesar funcționării unei unităţi periferice; (ec) controlor, revizor, inspector

controller action (TH, autom) mod / acțiune de reglare

controller construction diagram $(\mathrm{TH})$ schemă / plan de montaj

controller cylinder / drum (el, autom) cilindru de contacte / de controler

controller output (autom) mărime de reglaj

control lever $(\mathrm{OM})$ manetă / pârghie de comandă / de deservire

control limit (mas, autom) dispozitiv de control cu limitare (a nivelului / presiunii etc.)

control limits limite pentru intervalul de acceptabilitate (la controlul statistic al calității)

control limit switch (autom, mas-un, el) comutator terminal, întrerupător acționat de o valoare limită (cursă, sarcină etc.)

control line (el, autom) conductor de curent de comandă

controlling ( $\mathrm{TH}$, autom) supraveghere, control, reglare, comandă; care controlează / reglează

controlling couple (mec, el) cuplu de reglare / antagonist

controlling depth (hidr, mas-un) adâncime limitatoare / de control 
controlling device (autom, hidr) regulator controlling force (cf) forță conducătoare / de ghidare; (mec) forță de dirijare / de restabilire controlling gear mecanism / dispozitiv de reglare (eventual cu angrenaje)

controlling magnet (el) (electro-)magnet de readucere în poziția inițială

control(ling) mechanism (mec, el, autom) mecanism de conectare / de comutare / de reglare

controlling rod (mas) tijă / bielă de comandă / de reglare

controlling size(s) (metr, mas-un) control dimensional / al dimensiunilor, măsurători de control

controlling spring $(\mathrm{OM})$ arc de readucere / de rapel / de reglare

controlling torque (mec, el) cuplu director, moment de torsiune care reglează

control loop (inf, autom) buclă de control

control memory (c, inf) memorie de instrucțiuni / de comandă

control module (autom) modul de control

control object (autom) sistem / obiect / mărime $\operatorname{reglat}(\breve{a})$

control of operation $(\mathrm{TH})$ control de exploatare al operației (tehnologice)

control of sizing process (mas-un, metr) control dimensional (şi pe durata prelucrării)

control panel (el, autom) tablou de comandă / de control

control parameter / variable (mas, autom) parametru / mărime de reglare

control point post / punct de manevră / de control; valoare prescrisă (a mărimii de reglare); valoare asimptomatică reglată; punct de orientare / de reper (pentru reglare)

control plant $(\mathrm{TH})$ instalație de control (în producție de serie mare)

control platform (met) platformă de control / de comandă

control pressure (hidr) presiune de acționare / de utilizare a unui subsistem hidraulic, presiune de reglare / care declanşează o schimbare / o comandă (în sistem)

control pressure range (hidr) interval al presiunii de acționare / de utilizare / de reglare

control program(me) (inf) program (scris întrun limbaj) de comandă / de gestiune / de control (pentru precizarea functiiilor oferite de programul de sistem)

control pulse (autom, fiz) impuls de comandă / de excitație

control pump (hidr, OM) pompă cu regulator / cu debit controlabil control range bandă / interval / gamă / domeniu / zonă / plajă de reglare

control register (inf) registru de instrucțiuni / de comandă

control resolution (metr, autom) prag / finețe de amorsare / de reglare

control rod (fiz, TH) bară de reglare / de control / de comandă (la reactoare nucleare)

control room (autom, TH) cameră / sală de comandă / de control

control routine (inf) subprogram de gestiune / de comandă / de verificare

controls comenzi; (constr, OM) organe de comandă

control sample probă-martor / de control

control sequence interruption (inf) întrerupere a unui program / a unei secvențe de program

control shaft (auto, OM) arbore secundar din cutia de viteze / de comandă / cu came / de ajustare / de reglare

control sluice $(\mathrm{OM})$ vană de control / de deversare (și la canale de irigatie etc.)

control specimen (metr) etalon de control, probă etalon / martor

control spring $(\mathrm{OM})$ arc de control al mişcării; (metr) arc de reglare a indicatorului în limitele scalei

control stand (mas) pupitru de comandă

control station post de comandă / de control / de reglaj / de manevră

control surface (nav) suprafață de comandă aerohidrodinamică (la cârmă)

control survey expertiză contradictorie, supraexpertiză, supracontrol

control switch (el) întrerupător de comandă

control switch gear / mechanism mecanism de conectare / de control cu conector, controler (şi cu actionare mecanică sau combinată, electromecanică

control tag $(\mathrm{TH})$ fişă tehnologică

control test încercare / probă / test de control / de verificare

control unit (inf, c) unitate / dispozitiv / bloc de comandă (unitate centrală a unui echipament numeric, care furnizează semnale de comandă); (autom) ansamblu / unitate / aparat / element de reglare

control valve (autom) ventil de reglare / de comandă; (hidr, mec, OM) supapă de reglare / de comandă / de distributie; (mas-un) supapă / robinet / registru de distribuție / de reglare

control variable / parameter (mec, el, autom) parametru / mărime de reglare 
control volume $(\mathrm{TH})$ capacitate de comandă (şi prin volum variabil)

control wheel (OM, metr) roată / rotiță a mecanismului de comandă

control window (ind chim) gură / fereastră de vizitare

control with fixed set point (metr, autom) reglare cu valoare fixă de referinţă

control word (inf) instructiune / cuvânt de control / de comandă (decodificată şi executată de canalul de intrare / ieşire)

controversial controversat, discutabil; căruia îi place polemica

controversy controversă, contrazicere, discuție în contradictoriu

controvert contrazicere, controversă; a tăgădui, a nega

contuse a freca; a rade; a măcina, a pisa; (med) a face o contuzie, a contuziona

convection (chim) conducție electrolitică; (el, termo) (curent de) convectie; transmitere a căldurii prin convecție

convection circuit breaker (el, termo) disjunctor cu răcire prin convecție

convection cooling (termo) răcire prin convecție convection efficiency (fiz, termo) coeficient de transmitere a căldurii prin convecție

convection factor (termo) factor de convectie

convection heating (termo, met) încălzire prin convecție

convection section (termo, met) secțiune de convecţie

convection tubular furnace (met, ind chim) cuptor tubular de tip convecție

convective convectiv, prin convectie

convective current (el) curent convectiv / prin convectie

convector (constr, termo) convector

convenanted legat / convenit printr-un acord

convenanter (ec) semnatar al unui acord

convene a chema, a convoca; (jur) a cita; a se aduna

convenience, conveniency oportunitate; confort, comoditate; toaletă, closet; avantaj, profit; interes

convenient (adj) confortabil, comod; uşor, convenabil; avantajos

conveniently ( $a d v)$ (în mod) convenabil, avantajos convenient to în apropierea, lângă, aproape de convenience outlet (el) priză electrică (obişnuită / conventională)

convention convenție, congres, adunare; condiție, regulă, element de condiționare; acord, întelelegere; obicei, uzaj conventional convențional, tradițional; normal, standard; bazat pe o convenție / un acord; artificial, nenatural

conventional aerodynamics (fiz) aerodinamica vitezelor mici

conventionalism convenționalism; rutină conventionally $(a d v)$ (în mod) conventional conventional milling (mas-un) frezare contra avansului

conventional spiral drill (mas-un) burghiu spiral cu unghi normal de înclinare a canalelor elicoidale

conventional twist drill (mas-un) burghiu spiral normal / de tip standard

conventional welding current (el, met) curent nominal de sudură

conventional welding duty (el, met) regim nominal de funcționare la sudare

convention date dată de prioritate, prioritate convențională a unei invenții

converge a converge, a se apropia

convergence (mat, TH) convergență

convergence angle (fiz, opt) unghi de convergență

convergence contour (tremo, fiz) izocoră

convergent (mat) convergent

convergent currents (hidr) curenți convergenți

convergent-divergent nozzle (OM, hidr) ajutaj convergent-divergent

conversation conversație, discuție; purtare, comportare; relații (sociale)

converse (mat) afirmație / teoremă reciprocă; reciproc, invers, opus; parte întregitoare; a discuta, a conversa; conversație, discutie

converse effect efect invers / contrar

conversely $(a d v)$ invers, dimpotrivă

conversion conversie, transformare, (pre)schimbare; (ec) convertire

conversion capacity (of a saw) (mas-un, met) capacitate de debitare (a unui ferăstrău)

conversion constant (mec, termo) echivalent mecanic al căldurii; constantă de transformare conversion motion (mec) transformare a mişcării

conversion / converter routine / program(me) (inf) program de conversie / de traducere / de transformare (a datelor)

conversion table for sieves (agr, constr) tabel de corespondență a sitelor

conversion value (ec) preț de productie, inclusiv profitul aferent

convert a transforma, a modifica, a preface, a schimba (şi structura), a muta, a preschimba, a converti (o mărime în alta); (ec) a converti (o valută în alta) 
converted convertit, transformat; (met) tratat (prin transformare structurală)

converted steel (met) oțel de convertizor

converter / convertor (met) convertizor, convertor; (el) convertizor, etaj de conversie, reactor convertizor / de conversie, transformator

converter air box (met) cutie de vânt a convertizorului

converter bar dispozitiv de stivuire; (met) lance de convertizor

converter bottom (met) fund de convertizor converter charge (met) şarjă de convertizor converter (charging) platform (met) platformă de lucru / de încărcare a convertizorului

converter drying plant (met) instalație de uscare a convertizorului

converter hood (met) cupolă / capac de convertizor

converter iron (met) oțel de fuziune / obținut în convertizor

converter lining (met) căptușeală de convertizor converter mouth / nose (met) gură de convertizor converter nose (met) gât de convertizor converter plant (met) (instalație de) convertizor, oțelărie cu convertizoare (a oțelului)

converter platform (met) platformă de lucru / de încărcare a convertizorului

converter process (met) procedeu de elaborare în convertizor

converter reactor (met) reactor convertizor converter-ring trunnion (met) fus de basculare a convertizorului

converter set / shop / plant (met) grup / secție $\mathrm{cu} /$ de convertizoare, oțelărie cu grup de convertizoare

converter sliver (ind chim) bandă de fibre obținută prin transformare chimică

converter stage (el, ind chim) etaj de conversie / amestecător / de transformare

converter steel (met) oțel de convertizor

converter trunnion ring (met) centură / inel de convertizor

converter unit (met) grup-convertizor (la oțelărie)

convertibility (ec) convertibilitate; posibilitate de a fi convertit / transformat

convertible (ec) convertibil (şi d. valută), transformabil, (pre)schimbabil; (auto) decapota$\operatorname{bil}(\breve{a})$

convertible excavator / shovel-crane (constr, mas) excavator universal

converting (met) afinare cu aer suflat în convertizor

converting process (met) procedeu de afinare / de elaborare în convertizor convex convex; (constr, met) boltit (şi d. o boltă de cuptor)

convex camber (met) formă convexă (a tăbliei de cilindru)

convex / reflex angle (mat) unghi cuprins între 180 şi $360^{\circ}$

convex butt weld (met, OM) sudură cap la cap, convexă

convex fillet weld (met, OM) sudură în / de colț, convexă / bombată

convex fracture (mec) fractură / rupere convexă convex hull (geom) înfăşurătoare convexă

convexity convexitate

convex milling cutter (mas-un) freză convexă convex weld (met, OM) cusătură îngroşată / convexă

convey (el) a transmite, a comunica, a propaga; (TH) a transporta, a (con)duce; (fiz) a transmite (energie etc.); a comunica, a exprima; (jur) a cesiona, a ceda (un bun)

conveyance (auto, cf, TH) (mijloc de) transport, transportare, deplasare; expediție, livrare, transfer; transportor, conveier; (el) conductă; (fiz) propagare, transmisie, transmitere, conductibilitate; comunicare (de idei); mijlocire

conveyer / conveyor (mas, agr, alim, ind) conveier, transportor; de transport

conveyer belt $(\mathrm{OM})$ curea / bandă transportoare conveyer-belt drying machine (alim, ind chim) maşină de uscat cu bandă transportoare

conveyer bucket (mas) benă / cupă de transport conveyer chain (met, constr) lanț pentru transportor cu raclete, transportor cu lant

conveyer drive-head $(\mathrm{OM})$ cap de acționare la transportor

conveyer drying-machine (alim, ind chim) uscător cu transportor

conveyer furnace (alim, met) cuptor continuu / cu trecere continuă a pieselor

conveyer idler (constr) rolă (de transportor cu bandă); (OM) rolă de susținere a covorului unei benzi transportoare

conveyer incline (mas, OM) plan înclinat cu transportor

conveyerised turn-table (mas-un) masă rotativă cu bandă de transport / transportoare

conveyer line (mas) linie de montaj / de asamblare / de transport

conveyer-line production $(\mathrm{TH})$ producție în flux / pe bandă

conveyer pipe-line $(\mathrm{OM})$ conductă de transport (pentru fluide, materiale pulverulente etc.)

conveyer scaffold bridge (OM) rampă / estacadă de transport 
conveyer screw / worm (alim, OM) melc de transport, transportor elicoidal / cu melc / cu şurub conveyer through (constr, alim) jgheab de transport

conveying transport, transportor, de transport conveying agent $(\mathrm{TH})$ mijloc de transport conveying appliance / device (mas) dispozitiv / mijloc de deplasare, instalație de transport

conveying belt (OM, transp) bandă / curea de transportat / transportoare

conveying implement (alim, agr, constr, ind) utilaj / instalație de transport

conveying load (mec, mas) încărcătură de lucru / deplasată / transportată

conveying machinery chain $(\mathrm{OM})$ lanț de transport / de transportor

conveying main $(\mathrm{OM})$ conductă principală de transport (pentru fluide, materiale pulverulente etc.)

conveying spiral (OM, alim) transportor elicoidal, melc transportor

conveying plant (OM, alim, constr, ind chim) instalație de transportat

conveying through (alim, constr, OM) jgheab transportor (şi de lemn)

convey through a tranzita, a trece prin

conviction convingere; siguranță; încredințare; (jur) condamanre

convictions convingeri, idei; crez

convince a convinge de, a încredința de

convinced convins, sigur, încredințat de, hotărât, ferm; înveterat

convincible uşor de convins, credul

convincing convingător, care convinge

convincingly $(a d v)$ (în mod) convingător, cu convingere

convocation convocare; adunare

convolute înfăşurat, răsucit; bobinat; a înfăsura; a răsuci; a bobina

convoluted înfăşurat, răsucit; întortocheat, încurcat

convolution convoluție, răsucire, spirală

convoy însoțire; protecție; escortă; transport, convoi; (nav) a escorta

convulsive a zgudui, a tulbura; a se convulsiona

convulsion convulsie, frământare, zguduire

cook (alim) bucătar; a găti, a fierbe, a coace, a prăji, a fi bucătar

cook the books (ec) a falsifica registrele

cooker (alim) maşină de gătit, vas de bucătărie, oală, fruct bun de gătit; (termo) fierbător cookery (alim) gastronomie

cooking (alim) bun de gătit, copt, care găteşte cooking oil (alim) ulei comestibil / alimentar cooking plate (alim) plită electrică (de gătit)

cooking stove (alim) maşină de gătit, plită

cooking ustensils (alim) vase de bucătărie

cooking vat (alim, ind chim) cazan de fiert / de distilare / de topit

cook-off a (se) arde, a (se) prăji; a (se) distruge prin explozie; încălzire excesivă sau ardere

cooky / cookie (alim) bucătăreasă, prăjitură uscată, fursec, pricomigdală, biscuit

cool răcoros; a (se) răci, a (se) răcori; calm, liniştit; imperturbabil; nepăsător, indiferent; (fig) rece, neprietenos

coolant (alim, met, termo) agent răcitor / frigorific, lichid / fluid / agent de răcire, mediu refrigerent

coolant activity (termo) activitate a agentului de răcire

coolant make-up (termo) regenerare a agentului frigorific

coolant pump (termo, OM, T) pompă la sistemul de răcire / pentru lichidul de ungere şi răcire

coolant reservoir and chip tray (mas-un) tavă pentru colectat aşchiile şî lichidul de răcire coolant system (alim, termo) sistem de răcire coolant temperature (termo) temperatura agentului / mediului de răcire

cool box (auto) cutie frigorifică, torpedou climatizat

cool down a răci; a (se) calma, a (se) linişti

cooler (auto) radiator; (temo) frigider, răcitor; refrigerent, cameră de răcire / de refrigerare; (alim) băutură răcoritoare

cooler condenser (termo) condensator frigorific cooler housing (termo, OM) dulap / carcasă de răcitor

cool hammer (met) a ecruisa prin forjare la rece cool-hammered iron (met) oțel forjat la rece cooling răcoritor; (termo) răcire, refrigerare, extragere a căldurii, coborâre a temperaturii; frigorific, care răceşte, refrigerent, de răcire cooling air (termo, TH) aer de / pentru răcire cooling apparatus (termo) aparat frigorific / frigorifer

cooling baffle (met) tablă / deflector pentru ghidarea aerului de răcire

cooling bank (met, ind chim, termo) banc de răcire

cooling bed (met) pat de răcire

cooling block (auto, termo) bloc de radiator

cooling box (alim) dulap frigorific

cooling brine (alim, ind chim) soluție / saramură de răcire

cooling by gills (OM, termo) răcire prin nervuri (prevăzute pe suprafața de răcire) 
cooling by outspread surface (OM, termo, T) răcire superficială, răcire prin degajarea căldurii pe / prin suprafață

cooling capacity (termo) capacitate de răcire cooling chamber (alim) cameră de răcire / refrigerentă

cooling circuit (termo) circuit / ciclu de răcire, circuit al agentului de răcire

cooling column (alim, ind chim, termo) turn / coloană de răcire

cooling condition (termo, fiz) condiție de răcire cooling crack (met, plast) fisură de contracție; la răcire

cooling crevices (met) crăpături de răcire

cooling curve (met, termo) curbă de răcire

cooling cylinder (alim, termo) cilindru răcitor

cooling down (fază de) răcire treptată

cooling-down period (met) durată / perioadă de răcire

cooling drum (alim, ind chim, termo) răcitor tubular, răcitor tip tambur

cooling effect (fiz, termo) efect de răcire

cooling fan (termo) ventilator (pentru răcirea aerului)

cooling fin / flange / rib (met, OM, termo) aripioară / nervură de răcire

cooling fluid (ind chim, termo) lichid / fluid de răcire

cooling grate (met) grătar de răcire

cooling jacket (OM, termo) husă a radiatorului, cămaşă / manta de răcire

cooling joint (met, plast) (a)lipire / atingere din cauza răcirii (la matrițare etc.)

cooling medium (chim, termo) agent / mediu de răcire, refrigerent

cooling pipe (fiz, termo, T) țeavă / conductă de răcire, tub de răcire

cooling plant (alim, ind chim, termo) instalație de răcire / de ventilare

cooling plate (met) placă de răcire

cooling pond (termo, hidr, mediu) bazin de răcire

cooling press (mas-un, alim, ind chim) presă cu răcire

cooling rib $(\mathrm{OM}$, termo) nervură de răcire

cooling ring (OM, termo) inel de răcire

cooling rate (alim, met) viteză de răcire

cooling space (constr) rost lărgit de răcire (în beton)

cooling strain (mec, termo) deformare la / de răcire

cooling stress efort / tensiune cauzat(ă) de răcire cooling system (alim, termo, ind) sistem de răcire, instalație frigorifică cooling system fan valve (OM, mas) supapă de ventilator a sistemului de răcire (şi la autovehicule amfibii)

cooling table (ind chim, met) pat / masă de răcire

cooling tank (auto, mas, alim) manta / vas / tanc de răcire; (nav) navă frigorifică; (termo) vas / rezervor de răcire

cooling tower (met) turn de răcire

cooling trough (met) jgheab de răcire (la cristalizator)

cooling tube (ind chim, termo, OM) recipient / țeavă / tub / cămaşă de răcire

cooling vane $(\mathrm{OM}$, termo) aripă / aripioară de răcire

cooling-water feed pipe (met, termo) conductă de / pentru intrare a apei de răcire

cooling-water pipe (met, termo) conductă de apă de răcire

cooling worm (alim, OM) răcitor spiralat (în serpentină), melc (amestecător) pentru răcire

coolish răcoros

coolness ( $\operatorname{grad} \mathrm{de}$ ) răcire

cool off / down a (se) răci

cool running of an engine (auto, termo, mas) funcționare a motorului la temperatură joasă de regim

coop (agr) coteț de păsări; loc îngrădit / închis

cooper dogar

cooperage dogărie

co-operant care cooperează, cooperant cooperativ; binevoitor

co-operate a coopera, a conlucra

co-operation cooperare, conlucrare; (ec) cooperație

co-operative comun, de cooperare / conlucrare; (ec) cooperatist, cooperativă (de consum sau în agricultură)

co-operator colaborator; (ec) cooperator

co-opt a coopta

co-optation cooptare

coop up / in a închide în, a zăvorî (în)

coordinate (mat) coordonată, de coordonate, egal, de acelaşi fel; a coordona, a pune de acord, a fi coordonat, a functiona armonios

co-ordinate geometry (geom) geometrie analitică

coordinately $(a d v)$ (în mod) coordonat

co-ordinate reading scale $(c$, metr) scală de citire a coordonatelor

co-ordinate scheme retea de coordonare

co(-)ordinate system sistem de coordonate; (metr) sistem de coordonate (şi la profilometria suprafeței) 
co-ordinate table masă în coordonare (la maşinileunelte automate, cu comandă numerică

co-ordinating staff $(\mathrm{TH}, \mathrm{ec})$ departament / personal de coordonare

coordination coordonare; punere de acord

coordination number număr de ordine / de coordonare

co-ordination of fuse (el) circuit în serie de siguranțe

copartner partener

cope $(\mathrm{TH})$ a secționa, a decupa, a acoperi; (met) parte superioară a formei (de turnare, de matrițare)

cope box (met) ramă superioară de formare (la turnare)

cope chisel daltă de canelat

cope flask (met) parte superioară a ramei de formare (la turnare)

co-phasal (state) (mec, el) în concordanță de fază, sinfazic, sincron

coping (constr) daltă de acoperire, piatră de coronament, creastă (de zid, de baraj etc.), deflector, coamă

coping attachment (OM) dispozitiv de înclichetare

coping piece (constr) grindă de centură, cosoroabă, coardă

copious abundent; copios; bogat, îmbelşugat; prolix

copiously $(a d v)$ din belșug / abundență, abundent, copios

copiousness belşug, abundență; bogăție de idei; prolixitate

coplasticizer (chim) (agent) coplastifiant

copolyamide (chim) copoliamidă

copolymer (chim) copolimer

copolymerisation (chim) copolimerizare

cop-out nehotărâre, şovăială; sustragere, eschivare

cop out a se eschiva, a se sustrage; a şovăi

Copper, copper (Cu) (met, chim) cupru, alamă, a cupra, a arămi; (termo) cazan

copper alloy (met) aliaj (pe bază) de cupru

copper-aluminium alloy (met) aliaj cuprualuminiu

copper asbestos azbest cu cupru (amestec, compozit)

copper-asbestos gasket $(\mathrm{OM})$ garnitură metaloplastică (azbest - aliaj de cupru)

copper assay (met) probă de cupru

copper bar (met) lingou de cupru

copper bath (met) baie de cuprare

copper-bearing (met) cu conținut de cupru; (T) lagăr din de aliaj de $\mathrm{Cu}$ copper beech (silv) fag roşu

copper billet (met) lingou / bară de cupru

copper bit (met) ciocan de lipit

copper blast furnace (met) cuptor cu cuvă, pentru cupru

copper block (met) bloc de cupru

copper cabe (met) placă de cupru, turnată continuu

copper-clad (met, OM) arămit, placat cu cupru copper-clad connecting wire (el) conexiune de continuitate cu fir de oțel-cupru

copper coat(ing) (met) arămire, cuprare, placare / acoperire cu aramă / cu cupru

copper corrosion test (met, chim, metr) probă de coroziune pe placa de cupru

copper corrosion (chim) coroziune a cuprului (sau a aliajelor lui)

coppered (chim) arămit, cuprat, acoperit cu cupru

coppered wire (met) sârmă arămită

copper extraction (met) extragerea / producerea cuprului

copper filings (met) pilitură de cupru

copper furnace (met) cuptor pentru afinarea cuprului

copper gauze $(\mathrm{OM})$ sită de cupru

copper granules (met) granule de cupru

coppering (met) cuprare, acoperire cu cupru (sau cu aliaje de cupru)

copperizing (met) arămire

copper jaw socket (mas-un) falcă de protecție, din cupru (la menghină)

copper loss (el) pierderi electrice în cupru

copper matte (met) mată cuproasă

copper mill (met) laminor de cupru

copper-nickel (met) aliaj $\mathrm{Cu}-\mathrm{Ni}$, nichelină

copper wire (el) conductor de cupru; (met) sârmă de cupru

coppery (met) arămit, cuprat, de cupru

copper oxide (chim, met) oxid de cupru / cupric / cupros (atenție la text)

copper plate (met) placă de cupru, a cupra, a alămi

copper plating (met) (procedeu de) cuprare, acoperire cu cupru sau aliaje de cupru

copper powder (met) pulbere de cupru

copper refing (met) afinarea cuprului

copper scale (met) arsură de cupru (defect)

copper steel (met) oțel placat cu cupru, bimetal oțel-cupru, oțel cu (mult) cupru

copper sulphate test (chim, metr) încercare / testcu sulfat de cupru

copper-tin alloy (met) aliaj cupru-staniu

copper wire (el) sârmă de cupru 
coppery (met) cuprat, de cupru

copper-zinc alloy (met) aliaj cupru-zinc

coprocessor (c) coprocesor, dispozitiv ataşat unui computer pentru îmbunătățirea anumitor funcții sau performanțe

cop skewer (OM) suport de țevi

copunctual cu un punct comun

copy copie, exemplar, model, imitație; machetă; manuscris, ciornă, text; schiță; duplicat, reproducere; a copia, a face o copie, a reproduce; a transcrie; a imita, a lua ca model

copy given to the author exemplar de autor copying multiplicare, copiere, care (se) copie copying apparatus aparat de fotocopiere

copying paper hârtie copiativă / indigo / carbon / pentru copii

copying press presă de copiat, şapirograf

copying roller (mas-un) rolă a dispozitivului de copiere (la freze etc.)

copy milling-machine (mas-un) maşină de frezat prin copiere

copy out a copia întocmai / în întregime; a transcrie pe curat

copy paper hârtie indigo / carbon, hârtie pentru executat copii

copy protection (c, inf) protejare la copiere / împotriva copierii

copyright drept de autor, drept exclusiv de publicare; reproducere, reprezentare, adaptare sau traducere a unei creații știintifice, literare sau artistice; a asigura a apăra dreptul de autor

copyright reserved (jur) drept de reproducere şi difuzare, drept legal exclusiv rezervat autorului sau editorului de a reproduce şi a vinde o publicație

copy spindle (jur) toate drepturile (de publicare) rezervate

copywriter autor de reclame

cor (Biblical) (metr) unitate (veche) de măsură pentru volum / capacitate: 1 cor $($ Biblical $)=$ $219,9999892921 \cong 0,22 \mathrm{~m}^{3}$

cord (metr) unitate de măsură pentru volum / capacitate: 1 cord $=3,624556364 \mathrm{~m}^{3}$

corbel (constr, OM) consolă, nişă, centură, brâu, riglă, prag, pinten, proeminență, rebord; a ieşi în consolă

corbel beam (constr, mec) grindă în consolă corbel piece (constr, OM) suport, consolă, brat cord (el) cordon prelungitor / conector / de alimentare; stânjen (de lemn); cord, cablu / funie din mai multe fire, şnur, sfoară, cordon, şiret, frânghie

cordage (nav) parâme; parâmărie, cabluri, tachelaj; retea de cord cord carcass (auto) carcasă de cord (la pneuri)

corded legat cu funii

cordite (chim) cordit

cordon (constr) brâu; (el, TH) cordon, liță; $(\mathrm{OM})$ inel / cordon (de rigidizare, la recipiente etc.)

cordon off a despărți, a ține la distanță

cord packing $(\mathrm{OM})$ şnur de garnitură de etanşare, etanşare cu şnur

core (el) miez (magnetic / de ferită, din tole) / al bobinei, tor, miez toroidal / de cablu; (fiz) miez de reactor (zona activă); (met) miez de turnare; $(\mathrm{TH})$ con, miez, umflătură, protuberanță, nod, sâmbure, nucleu, inimă; (met) electrod (de sudare) (partea din mijloc la cei înveliți); (c) memoria centrală / principală a unui computer; (alim) miez de fruct, a scoate miezul (unui fruct); esență

core-baking oven (met) cameră / cuptor de uscat miezuri (ale formelor de turnare)

core bar (met, OM) tijă / bară plină

core barrel (met) armătură centrală de miez; tub carotier, carotieră

core-barrel head (mas-un, met) cap de carotieră core binder (met) liant pentru miezuri de turnătorie

core bit (constr, mas-un) (sapă) carotieră, burghiu de centrare; (mas-un) burghiu pentru găurire inelară, burghiu (de) centruit

core blower (met) maşină de suflat miezuri

core-boring crown (mas-un) floare de sfredel / de burghiu, burghiu carotier (partea activă, eventual cu plăcuțe)

core box (met) cutie de miez / pentru carote; tub carotier

core burning (met) ardere a carotei / miezului (la o formă de turnare)

core cast (met) miez de turnare

core catcher (met) reținător de probă; prinzător de probă; ciupitor

core circuit (el) circuit primar

cored casting / work (met) piesă turnată cu miez(uri)

cored hole (mas-un) gură / gaură de centrare; (met) gaură / cavitate în piesa turnată (prin folosirea miezurilor)

core diameter (fiz) diametru al miezului / al nucleului; (OM) diametru interior (la filet)

core diameter of screw thread $(\mathrm{OM})$ diametru interior al unui filet exterior

core die (mas-un) tub carotier; (met) placă pentru formarea miezului, patron de miez; (mas-un) placă pentru filieră

core drill (mas-un) carotieră, cap carotier 
core drilling (mas-un) găurire cu extragere de carote

core dump program(me) / routine (inf, c) subprogram de golire a memoriei

core-end plate $(\mathrm{OM}, \mathrm{el})$ placă de presare (a unui pachet de tole)

core-extractor (mas-un) extractor de carote, carotieră

core extrusion machine (met) maşină de miezuit prin împingere cu melc

core filler wire (met) sârmă tubulară

core flushing (met, mas-un) spălare / stropire a carotei

core-frame (met, plast) carcasă pentru miezuri

core grinding (met) sfărâmare / finisare a carotei / a miezului

core-hole plug (met) dop filetat pentru găuri, în golul pieselor turnate

core iron (met) oțel moale pentru miezuri

core iron / grid (met) carcasă pentru miezuri

core-jarring machine (met) maşină vibratoare pentru miezuri

core jolter (met, mas-un) vibrator de miezuri core lathe (met, mas-un) strung pentru prelucrarea miezurilor (în turnătorii)

coreless (met) fără miez (la turnare); gol

coreless induction furnace (met) cuptor $\mathrm{cu}$ inductie, fără miez

core loss (el) pierderi în miez / în fier; (met) pierdere a carotei (la turnare)

core machine (met) maşină de confecționat miezuri de turnătorie / de miezuit

core-maker (met) miezuitor

core-making department (met) atelier de confectionat miezuri

core-making machine (met) maşină de format miezuri / de miezuit (în turnătorie)

core mark (met) marcă a miezului (la turnare)

core mixture (met) amestec pentru miez (la turnare în forme)

core mould (fiz) formă a nucleului; (met) formă de turnătorie, din miezuri

core moulding (met) formare a miezului (la turnare)

core-moulding machine (met, mas-un) maşină de format miezuri / de miezuit

core nail (met) broşă de turnător, cui pentru sustinerea miezului

core of roll (met) miez / inimă de cilindru (la laminare)

core oil (met, chim) ulei pentru miezuri

core oven (met) cuptor pentru uscat miezuri

core plate (met) placă pentru formarea miezului

core print (met) marcă a miezului (la turnare) core pusher (met) extractor de carote, pompă pentru extragerea carotelor corer (met) reținător de probă core refining (met) recristalizarea miezului prin tratament termic (şi la cementare)

core run (met) extragere a carotei core-sample (met) probă din carotă

core sand (met) amestec de nisip pentru miezuri core sheet strat interior (la materiale stratificate) core shooter (met) maşină de miezuit prin împroşcare

core shop (met) atelier de confecționat miezuri (în turnătorii)

core solder (met) sârmă de lipire / electrod cu cavitate umplută cu flux

core spindle (met) armătură centrală de miez

core splitter (met) divizor de carotă, ruptor

core spring (met) reținător / extractor a miezului de probă

core structure (met) structură în miez

core tank (ind chim) cuvă / recipient / corp al reactorului

core template (met) şablon de miez

core wire (met) cablu bimetalic, la care miezul este învelit în alt aliaj

coriander (alim) coriandru

coring (mas-un) carotare, carotaj, luare / executare a unei carote; $(\mathrm{TH})$ segregare; (met) executare / formare a miezului, segregare intercristalină (şi în miez)

coring up (met) confecționare a miezului

Coriolis acceleration (fiz, mec) acceleratie Coriolis

Coriolis force (fiz, mec) forță Coriolis

Coriolis-type mass flowmeter (fiz, metr) debitmetru masic, pe baza efectului Coriolis

cork (OM, alim) dop (de plută), plută, buşon; a astupa (şi cu un dop), a înfunda; a ascunde, a tăinui

corkage (alim, ec) taxă aplicată băuturilor aduse de consumatori (în restaurante)

corked (alim) cu miros de dop (d. vin)

cork flour făină de plută

corking $(\mathrm{OM})$ (îmbinare cu) prag

cork packing $(\mathrm{OM})$ garnitură de plută

cork press (alim) presă pentru dopuri

corkscrew (alim, OM) tirbuşon

cork slab placă de plută

cork stopper (alim) dop de plută

corn (agr, alim) grăunțe, grăunte, grâu, cereale, grâne, porumb; (amer), rachiu de porumb, ovăz; a săra; (chim) a pulveriza; a granula; (mas-un) a puncta

corn and grain milling (alim) măciniş / măcinare de cereale 
corn cob (agr) (amer) ştiulete de porumb (fără boabe)

cornea (anat) cornee

corned aer (agr) (amer) ştiulete / cocean de porumb

corned beaf (alim) carne de vită sărată

corner colț, vârf, loc retras, loc, parte punct unghiular; (ec) acaparare / stocare de mărfuri, a acapara, a acapara (marfă pentru speculă); a încolți, a înghesui

corner angle (constr, OM) cornier de unghi, guseu

corner bracing (constr, OM) întăritură (şi pentru colț)

corner bracket (met, OM) cot (piesă fasonată), colțar

corner condition (mat) condiție în punctul unghiular (de inflexiune)

corner connection (OM) asamblare în unghi / de colt

corner crack (met) crăpătură / fisură marginală / de colț

corner cramp (OM) colțar / cornier metalic pentru protectia muchiilor

corner-cube prism (geom) prismă dreaptă

corner cutter (mas-un) freză de prelucrat colțuri interioare

corner cutting (mas-un) tăiere a colțurilor; (fiz) umbrire, nuanțare

corner drill (mas-un) maşină de găurit în colțuri greu accesibile

cornered $(\mathrm{OM}) \mathrm{cu}$ colțuri

corner(ing) tool (mas-un) cuțit pentru teşit / prelucrat praguri / colțuri (la interiorul sau exteriorul pieselor)

cornering (auto) virare

cornering maneuvers (auto) manevre de virare / cotire / întoarcere

corner iron (met, OM) (profil) cornier; vinclu corner joint (OM) sudură (de îmbinare), de colț, asamblare în colț

corner on (mas-un) a teși, a prelucra praguri / colțuri

corner-rounding milling-cutter (mas-un) freză de rotunjit muchii / de executat racordări între zone cu dimensiuni diferite ale pieselor

corners rounding (mas-un) rotunjire / racordare a colțurilor (pieselor)

corner stone (constr) piatră fasonată de colț; piatră fundamentală, temelie, bază

cornerwise $(a d v)$ de-a curmezişul, pieziş, în diagonală

corn field (agr) lan, ogor; (amer) lan de porumb, făină de porumb / orez corn flakes (agr) produse / fulgi din cereale / porumb

corn flour (agr) (amer) făină de porumb / orez

corn flower (agr) (amer) neghină; albăstrea

corn-flower blue (met) albastru de cicoare (culoare de revenire)

corn harvester (agr, mas) secerătoare, maşină de secerat

corn husker (agr, mas) maşină de dezghiocat porumb

cornice (constr) cornişă, coronament

cornification (med) cornificare (a pielii)

corning (alim) granulare

corn-lift (alim, constr) magazie de cereale, siloz corn meal (agr) (amer) făină de porumb / orez corn stalk (agr) (amer) tulpină de porumb, strujean corn stone (minrl) calcar silicios

corn tongs pensetă pentru pietre prețioase şi mecanică fină (cu vârfuri aplicate)

cornue (chim) retortă

Cornwall boiler (termo) cazan Cornwall / cu o țeavă de flacără

corny (agr) cerealier, de cereale, de grâne, mănos / bogat în grâne

corollary corolar

Corona discharge (met, plast) pregătirea suprafeței prin tratament Corona (tratament cu flacără)

corporate body (jur) persoană juridică

corporate image (ec) emblemă / imagine-simbol a unei firme

corporation (ec) corporație, societate (anonimă) înregistrată / pe acțiuni, întreprindere; (pol) administrație publică

corporeal corporal, material, fizic

corporate corporativ, corporatist; colectiv care ține de o corporație; comun

corporately în (mod) colectiv

corporation corporație; breaslă; (ec) (amer) societate pe actiuni; municipalitate

corporator membru al unei corporații

corpus parte principală; fond, $(\mathrm{ec})$ fond de bază, capital

corpuscular (fiz) corpuscular

corpuscule, corpuscle (fiz) corpuscul, electron corpus delicti, $(p l)$ corpora delicti (jur) corp delict, dovezi peremtorii privind săvârşirea unui delict

correct corect, exact; just, adevărat; potrivit, corespunzător; cuvenit; a corecta, a îndrepta; a neutraliza; a rectifica, a compensa, a regla; a pedepsi

corrected tooth $(\mathrm{OM})$ dinte cu profil deplasat / corijat (la roți dințate) 
corrected volume $(\mathrm{TH})$ volum real

correcting condition (autom) mărime de comandă / de corecție, condiție care, odată îndeplinită, determină corecția / corectarea / reglarea sistemului

correcting element (autom) element, organ de reglare / de comandă de reglare

correcting wheel (metr) roată corectoare (la aparate de măsură) / de corecție

correction (chim, mat) rectificare; retuş (la desene, imagini); (TH, metr) corectare, corecție, îndreptare, punere la punct; mustrare; corecție, pedeapsă; (chim) neutralizare

correction device (autom, metr) corector de distorsiuni

correction factor (autom, metr) factor / coeficient de corecție

correction mass $(\mathrm{mec})$ masă de corecție (şi la echilibrare)

correction plane interference $(\mathrm{mec})$ interacțiune între planele de corecție (şi la echilibrare)

correction plane interference ratio (mec) raport / nivel de interacțiune între planele de corecție (şi la echilibrare)

correction time (autom) timp de corectare

correctitude corectitudine, cinste

corrective care corectează; (fiz) de corecție; corectiv, rectificator

corrective action (autom) actiune de corectare / de îndreptare (a unui parametru)

corrective equalization (el, autom) egalizare de corecție (a caracteristicii de frecvență)

corrective error (autom, metr) eroare de echilibru / de compensare

corrective maintenance ( $\mathrm{TH}$, mas) depanare, ansamblu al operațiilor efectuate după detectarea unei defecțiuni, întreținere din mers (şi de corectare sau reglare)

corrective measure (TH, mas) măsură de corectare

corrective multiplier (metr, autom) factor de corectie

correctly $(a d v)$ (în mod) corect; bine; cum se cuvine; politicos

correct matching $(\mathrm{TH})$ adaptare corectă

correctness corectitudine, atitudine corectă; exactitate, precizie; cinste

corrector corector (foarte general)

correct type tip / marca adevărat( $\breve{a})$ / corect( $\breve{a})$

correlate (to / with) a corela (cu), a pune în corelație (cu)

correlation corelație, corelare, corespondență correlation coefficient / factor coeficient / factor de corelatie

correlative corelat, în corelatie, corelativ correspond with / to a corespunde (cu); a fi conform (cu), a se potrivi cu / la, a se armoniza cu, a fi asemănător cu

correspondence corespondență, concordanță; asemănare; conformitate; analogie; corespondență, schimb de scrisori

correspondence course (edu) curs prin corespondență

correspondent corespondent, omolog, echivalent; corespondent (la un ziar)

correspondent (to / with) corespunzător (cu)

corresponding (to) corespunzător (cu); corespondent; analog, similar, asemănător $(\mathrm{cu})$

corresponding flanks $(\mathrm{OM})$ flancuri corespondente / omoloage

correspondingly ( $a d v)$ (în mod) corespunzător

corresponding side (mat) latură omoloagă / corespondentă

corridor (constr) coridor, pasaj, pasarelă

corrigible corigibil, care se poate îndrepta / corecta

corroborate a corobora, a confirma, a întări

corroboration coroborare, confirmare, întărire

corrode (chim) a (se) coroda, a (se) oxida, a rugini, a ataca, a decapa, a se dezintegra; a (se) roade (din cauza reactiilor chimice, a coroziunii)

Corrodekote test (metr) test de coroziune accelerată (prin acoperire cu material coroziv şi expunere în mediu umed)

corrodent (chim) corosiv, care corodează; agent / factor coroziv

corrodibility (chim, met) tendință / sensibilitate la coroziune

corrodible (chim, met) sensibil la ruginire / la coroziune, corodabil

corroding (chim, met) coroziune, acțiunea de corodare, care (se) corodează

corroding agent (chim, met) substanță corosivă, agent corosiv

corroding medium / media (chim) mediu / medii corosiv(e), agenti corosivi

corrosion (OM, T) gripare (rar); (met) coroziune, corodare, ruginire; (chim) coroziune, atac chimic

corrosion accelerator (chim) accelerator de coroziune

corrosion allowance $(\mathrm{OM})$ adaos pentru corodare / coroziune (la grosimea pieselor în contact cu substanțe corozive)

corrosion at contact (met, chim, T) coroziune de contact între materiale metalice diferite corrosion cell (chim, T) (micro-)pilă / element de coroziune 
corrosion coating (chim) acoperire de protecție la / împotriva coroziunii

corrosion control (chim, TH) combaterea / reducerea / controlul coroziunii

corrosion fatigue (chim, T) oboseală la coroziune; (mec) slăbire prin coroziune, distrugere / oboseală a materialului prin acțione combinată a sarcinii ciclice şi a mediului corosiv

corrosion-fatigue strength $(\mathrm{OM}$, materiale, chim) rezistență de durată în mediu corosiv

corrosion inhibitor (chim, T) inhibitor de coroziune, substanţă anticorozivă (şi ca aditiv în lubrifianți, combustibil etc.)

corrosion losses $(\mathrm{TH})$ pierderi prin coroziune

corrosion pit (met, chim, T) punct / loc corodat, ciupitură de coroziune

corrosion preventive (chim) substanță de protecție contra coroziunii / de reducere / de întârziere a coroziunii

corrosion-preventing (chim) anticorosiv

corrosion-prevention (chim, TH) protecție / prevenire împotriva coroziunii

corrosion-proof (materiale) rezistent la coroziune, inoxidabil (şi d. oțel)

corrosion-proofing treatment (chim) tratament anticorosiv

corrosion protection (chim) protectie contra coroziunii

corrosion rate (chim, $\mathrm{T}$ ) viteză de coroziune

corrosion resistance (materiale) rezistență la coroziune

corrosion-resisting anticorosiv, rezistent la coroziune (d. materiale)

corrosion-resisting serving $(\mathrm{OM}$, chim) manta rezistentă la coroziune

corrosion-resisting steel (met) oțel rezistent la coroziune / inoxidabil

corrosion spots (chim, materiale) pete / puncte de coroziune

corrosion test încercare / test de / la coroziune

corrosion testing method (metr) metodă / procedeu de încercare la coroziune

corrosive (chim) corosiv, caustic; soluție de băițuit / de decapat

corrosive agent (chim, met) agent corosiv

corrosive brittleness / shotness (chim, materiale) fragilitate provocată la coroziune

corrosive flux (chim, TH) flux corosiv, de curățare a suprafeței înainte de lipire

corrosiveness (chim) corozivitate (a unui agent chimic)

corrosive wear (chim, T) uzură corosivă, tribocoziune corrugate a (se) încreți, a (se)zbârci; (met) a (se) ondula, a (se) stria

corrugated $(\mathrm{OM})$ ondulat, zimțuit, striat, încrețit, gofrat, canelat

corrugated board carton ondulat; (met) margine ondulată (la tablă) (şi defect), tablă ondulată

corrugated fire-tube boiler (termo) cazan $\mathrm{cu}$ țeavă / cu tub de flacără, ondulat( $\breve{a})$

corrugated hose $(\mathrm{OM}$, termo) țeavă flexibilă / ondulată / (tip) burduf, furtun cu profil ondulat corrugated iron (met) tablă ondulată corrugated pipe $(\mathrm{OM})$ țeavă / conductă ondulată corrugated roll (plast) valț canelat

corrugated iron / metal / steel plate / sheet (met) tablă ondulată / striată, metalică / din oțel corrugated sheet rolling mill (met) laminor pentru tablă ondulată / striată

corrugated steel sheet (met) tablă de oțel, ondulată corrugated surface (met, plast) suprafață ondulată (la tablă / bandă) (şi defect)

corrugated transformer tank (met) cuvă de transformator din tablă ondulată

corrugating machine (met) maşină de ondulat cutat tablă

corrugating roll (met) cilindru pentru obținerea tablei ondulate

corrugating stand (met) cajă pentru obținerea tablei ondulate

corrugation cută, cute; cutare; (mas-un) striere; $(\mathrm{mec})$ rifluire, crestare, canelare, ondulare, gofrare

corrugator (mas-un) maşină / dispozitiv de ondulat corrupt corupt, imoral; care ia mită; viciat (d. aer); deformat (d. text); a mitui, a corupe; (alim) a se strica (d. alimente); (c, inf) a introduce erori în programe sau date

corruptibility coruptibilitate, venalitate; alterabilitate; putreziciune

corruptible (pol, ec) coruptibil, care poate fi corupt / mituit: (TH) (sistem tehnic / aparat) care poate fi influențat / „,corupt” de anumiți factori corruption coruptie; putrezire, descompunere; putreziciune; denaturare, falsificare

corundum (minrl) corindon coruscate a scânteia, a străluci

cosecant (mat) cosecantă

cosignatory contrasemnatar, cosemnatar

cosine (mat) cosinus

cosine curve (mat) cosinusoidă, curbă cosinusoidală

coslettize (met) a fosfata, a acoperi cu un strat anticoroziv (şi la rulmenți)

cosmetic defect (TH) defect uşor / nesemnificativ pentru funcționare / estetic 
cosmic (fiz) cosmic; universal; vast, grandios cosmic velocity-first (fiz, metr) prima viteză cosmică: 1 cosmic velocity-first $=7900 \mathrm{~m} / \mathrm{s}$ cosmic velocity-second (metr, fiz, av) a doua viteză cosmică: 1 cosmic velocity-second $=$ $11200 \mathrm{~m} / \mathrm{s}$

cosmic velocity-third (metr, fiz) a treia viteză cosmică: 1 cosmic velocity-third $=16670 \mathrm{~m} / \mathrm{s}$ cosmic rays (fiz) raze cosmice

cosmolene (chim) vaselină

co-sponsor cosponsor, coautor

cost (ec) cost, preț (rar, în sens de cheltuieli), valoare, sumă; cheltuială, cheltuieli (şi de judecată), a costa, a face; a calcula costul, a evalua; a pretui, a stabili prețul; a costa, a cere, a reclama (timp); a pricinui, a cauza; a avea de plătit

cost of a job (ec) a evalua costul unei activități / lucrări

cost-benefit analysis (CBA) (ec) analiza a costului şi a beneficiului (comparație între cos$\mathrm{t}$ (uri) de productie si beneficii)

cost estimate (ec) evaluare, deviz estimativ

cost estimator (ec) normator, evaluator de costuri costiness preț ridicat, scumpete

costing (ec) calcul al costurilor / cheltuielilor necesare

costly costisitor, scump; prețios, valoros, rar; splendid, măret

cost of erection $(\mathrm{TH}, \mathrm{ec})$ cost al montării sau instalării (unei maşini etc.)

cost of expending (ec) cheltuieli de accelerare / de extindere a productiei

cost of goods (ec) costuri directe, sumă a cheltuielilor efectuate pentru un produs / serviciu; cheltuieli de investiții / de instalație / de instalare

cost of operation (ec) cheltuieli de exploatare cost of set-up (ec) cheltuieli de pregătire a productiei

cost price (ec) cost / preț de fabricație (rar); valoare a costurilor

cost reduction (ec) reducere a costurilor

cost standards (ec) nivel de cheltuieli (costuri) prevăzute

cost value (ec) cost, valoare a cheltuielilor de producție

cost variance (ec) discrepanță între costurile estimate şi cele efective

cot (agr) adăpost pentru vite, şopron; cabană; (amer) pătuț, pat de campanie

cotangent (mat) cotangentă

co-tenancy (agr) coarendă

coterminal angles (geom, mat) unghiuri care diferă cu $360^{\circ}$ cottage casă țărănească, casă la țară, reşedință de vară, vilă

cottage cheese (alim) brânză de vaci (presată), sortiment de origine curdă

cottage industry lucru la domiciliu, industrie artizanală, artizanat

cottage loaf (alim) pâine dublă

cottager pie (alim) musaca de cartofi

cottager țăran

cotter (OM) pană (şi înclinată), cui spintecat, ştift, dorn, ic, şplint, cep, zăvor, dorn

cotter blunt file (mas-un) pilă îngustată cu vârf teşit pentru prelucrat canale de pană

cotter bolt $(\mathrm{OM})$ bulon / bolt cu cui spintecat / cu gaură pentru şplint

cotter driver (mas-un) extractor de cui spintecat cottered $(\mathrm{OM})$ asigurat prin cui spintecat cottered pin $(\mathrm{OM})$ bolț asigurat cu cui spintecat cotter file (mas-un) pilă pentru prelucrarea canalelor (de pană)

cotter joint $(\mathrm{OM})$ îmbinare prin pană (înclinată transversal)

cotterless pin $(\mathrm{OM})$ bolț neasigurat cu cui spintecat / cu şplint

cotter pin (OM) cui spintecat, şplint

cotter-pin extractor (mas) extractor / clește de scos cuie spintecate

cotter slot (mas-un) gura / lama rindelei

cotter-taper file (mas-un) pilă îngustă cu vârf ascuțit pentru prelucrat canale de pană

cotton (textile) bumbac, țesătură din bumbac, stambă, vată, ață de bumbac, de bumbac; a înfăşura în bumbac sau în vată; (fig) a se ataşa de; (fam $)$ a pricepe

cotton belt(ing) $(\mathrm{OM})$ curea de transmisie din bumbac

cotton candy (alim) vată de zahăr

cotton cloth (textile) țesătură din bumbac

cotton cord fabrics (for tyres) (auto, textile) rețele cord de bumbac (pentru anvelope)

cotton hard-waste-breaker tenter (textile, mas) destrămător de resturi de fire de bumbac

cottoning (textile, plast) (efect de) scămoşare; țesere (pânză de păianjen) (şi la pulverizarea unui adeziv)

cotton liners (textile) deșeu de bumbac cotton mill (textile) filatură de bumbac cotton on a pricepe, a înțelege

cotton percentage (textile) continut procentual de bumbac (în fir sau țesătură)

cotton print (textile) stambă imprimată

cottonseed (agr) semință de bumbac

cotton(seed) oil (chim) ulei din semințe de bumbac cotton texture (textile) țesătură din bumbac 
cotton together a se înțelege, a fi de acord (unul cu celălalt)

cotton wadding vată de bumbac

cottony (ca) de bumbac

couch sofa, divan, canapea; cuşetă; a exprima, a formula; a redacta; a se culca, a sta culcat; a lăsa în jos, a coborî (ceva)

Couette flow (hidr, T) curgere Couette

Couette viscosimeter (metr, T) vâscozimetru pe principiul curgerii Couette

coulisse $(\mathrm{OM})$ culisă, crestătură, nut

coulomb (el, metr) unitate pentru cantitatea de electricitate, coulomb

Coulomb friction load (T) sarcină / încărcare / forță cauzată de frecarea de tip Coulomb

Coulombic force (fiz, el) forță Columb

Coulombic solid (fiz, el) solid Columb (care respectă legea lui Columb)

Coulomb's law (fiz) legea lui Columb

coulter (agr) cuțit de plug

coumarone-indene resin (chim) răşină cumaron-indenică

council consiliu, sfat; de consiliu; proprietate a conducerii locale (d. constructiii)

council board (şedință de) consiliu

council chamber cameră de consiliu

council estate (pol, constr) cartier (de locuințe) construit de administrația locală

council house (pol, constr) casă în cartier construit de administrația locală

councillor membru al unui consiliu, consilier councillship calitatea de membru al unui consiliu councilman consilier (orăşenesc)

counsel sfat, îndemn; consfătuire, sfat, discuție, dezbatere; consultant; (jur) consielier juridic, avocat (US şi Irlanda); a (se) sfătui, a recomanda (ceva), a se consulta, a discuta

counsellor sfătuitor; avocat (US şi Irlanda)

count (metr) impuls / indicație a(l) unui contor; (mat) calcul, numărare, numărătoare, înregistrare, sumă, total; a calcula, a număra, a socoti, a pune la socoteală, a lua în considerare, a considera, a fi trecut la socoteală; a fi inclus; a fi luat în considerare, a conta; considerație, cont; (jur) cap de acuzare

countable numărabil

count down (el, autom) mod de lucru al unui sistem digital; (a face o) numărătoare inversă count-down numărătoare inversă

count-down counter (autom, metr) contor regresiv / cu numărătoare inversă

counter calculator; contrariu; (TH) contrar, opus, invers; contracarare; (med) antidot; (el) contor; (inf, metr) calculator / dispozitiv de măsurare / numărare; (nav) boltă (pupa); dispozitiv pentru numărare (a ciclurilor etc.); a (se) opune, a contrazice, a contracara, a para (o lovitură); tejghea, ghişeu; parare; duplicat; $(a d v)$ împotriva, (în) contra; a acționa în contra; (fig) a dejuca; go a merge în sens opus

counteract a contracara, a neutraliza; $(\mathrm{TH})$ a reacționa la

counteracting force $(\mathrm{mec})$ forță de reacțiune

counteraction opoziţie, opunere; contracarare, neutralizare; $(\mathrm{TH}, \mathrm{mec})$ reacție, reacțiune

counterbalance (mas, OM) balansier cu contragreutate, contrabalansare, mort / masă de contrabalansare, contragreutate; (mec, ec) a (contra)balansa, a echilibra, a compensa (un dezechilibru)

counter arm (met) săgeata indicatorului (de reducere / de grosime)

counter-attack contraatac, a contraataca

counter(-)balance $(\mathrm{TH})$ contragreutate, contrabalansare, contracarare, compensare, compensație; (mec) a echilibra (cu greutăți / mase); a contrabalansa, a contracara

counterbalanced crank $(\mathrm{OM})$ manivelă echilibrată / cu contragreutate

counterbalanced crankshaft $(\mathrm{OM})$ arbore cotit echilibrat

counter-balance moment (mec, mas) moment de echilibrare

counterbalance valve (hidr) supapă de echilibrare a presiunii (prin contrapresiune)

counter-balance weight $(\mathrm{OM})$ contragreutate (şi de echilibrare)

counter(-)blow contralovitură

counterblow hammer (met) ciocan (de forjă) cu contralovitură

counter body (el) corp / catod al contorului

counterbore (mas-un) adâncitor pentru locaşul capetelor şuruburilor, lărgitor, zencuitor

counterbore facer (mas-un) zencuitor frontal, lamator

counterbore with straight shank (mas-un) adâncitor cu coadă cilindrică

counterboring (mas-un) zencuire, adâncire (a găurii)

counterbrake (OM, mas) contrafrână

counter circuit (el, metr) circuit al contorului

counter-clockwise (direction) în sens contrar acelor de ceas(ornic)

counter clockwise rifling torsiune stânga / inversă; (alim) rifluire inversă

counter connection (el) montaj în opoziție

counter current (el, hidr) (în / cu) contracurent; (în) sens contrar; involuție 
counter-current distillation (alim, ind chim) distilare în contracurent

counter-current extraction (OMalim, ind chim extracție în contracurent

counter-current flow (hidr) curgere în contracurent (şi a două fluide)

counter-current mixer (alim, ind chim) amestecător în contracurent

counter-electrod (met) contraelectrod (la sudură)

counterfeit contrafacere; fals, contrafăcut, falsificat; a contraface, a imita, a plastografia, a falsifica; a simula

counter-flow (hidr) contracurent

counter-flow dryer (alim, ind chim) uscător în contracurent

counter-flowing injection / process $(\mathrm{TH})$ injecție / injectare / proces în contracurent

counter-foil cupon, talon (şi de chitanță)

counter heat exchanger (termo) schimbător de căldură, cu / în contracurent

counter housing (OM, metr) corp al contorului

countering numărare, numerotare, care numără

counterknife (mas-un) contracuțit

countermand a contramanda

countermeasure contramăsură

counter motion mişcare în sens retrograd

countermove mişcare în sens opus; mişcare de control (la măsurare); contramăsură

countermovement mişcare inversă

counter nut $(\mathrm{OM})$ contrapiuliță

counter offer $(\mathrm{ec})$ contraofertă

counter(-)part copie, duplicat; (OM) parte conjugată, contrapiesă, piesă pereche; pereche a unui lucru, obiect-pereche, echivalent; întregire

counter piston (termo, OM, hidr) contrapiston

counterpoise (el) priză de pământ a antenei; (TH) contragreutate; contracarare; echilibru (fig); a contracara, a echilibra

counter-poison (med, chim) antidot

counter pressure (hidr) contrapresiune

counter-pressure steam (termo) contraabur, abur de contrapresiune

counter propeller (alim, ind chim) elice opusă / orientată invers (la amestecătoare)

counter punch (mas-un, OM) placă suport (la ştanțare), contrapoanson

counter reaction (fiz, chim) reacție inversă / reversibilă

counter recoil spring $(\mathrm{OM})$ arc de recul

counter-rotation (mec) mişcare / rotație în sens opus

counter sample (test) contraprobă

counter shaft $(\mathrm{OM})$ arbore auxiliar / de transmisie intermediară countershaft axle (cf) osie falsă / oarbă; (OM) ax liber, osie liberă, arbore intermediar

countershaft cone $(\mathrm{OM})$ con în trepte al transmisiei intermediare

countershaft for ceiling suspension transmisie intermediară, suspendată

countershaft pulley $(\mathrm{OM})$ con antrenat etajat / în trepte (de fricțiune / de curele)

countershaft wheel $(\mathrm{OM})$ roată a transmisiei intermediare

countersign parolă; (OMec; jur contrasemnătură, a contrasemna

countersink (mas-un) zencuitor, teşitor, freză conică, adâncitor, a adânci (prin aşchiere), a (în)cresta, a freza, a puncta, a zencui

countersink bit / reamer / tool (mas-un) zencuitor, teşitor, adâncitor

countersinking (mas-un) zencuire, teşire, adâncire (prin aşchiere)

countersinking bit (mas-un) burghiu de adâncire (pentru găuri adânci)

countersinking fixture (mas-un, met) dispozitiv de teşire (şi pentru table folosite la țevi sudate) counter-slope contrapantă

counterspring $(\mathrm{OM})$ contraarc

countersteam brake (termo) frânare cu contraabur counter-step contratreaptă

counterstream (hidr) contracurent

countersunk $(\mathrm{OM})$ înecat (d. capul unei piese, a unui șurub, a unui nit etc.)

countersunk rivet head $(\mathrm{OM})$ cap înecat de nit countersunk rivet with shallow button head (OM) nit cu cap semirotund înecat countersunk screw $(\mathrm{OM})$ şurub cu cap îngropat / înecat

countersunk serrated toothed lock washer (OM) şaibă conică, cu crestături în exterior counter test contra-probă

counterthrust (mec) contraşoc (şi axial) counter tray (OMTH, el serie / șir de contoare counter tube (metr) tub contor / numărător countervail a acontracara

counterwedge $(\mathrm{OM})$ contra-pană, pană de sigurantă

counterweight $(\mathrm{mec})$ contragreutate

count in a trece la socoteală, a înclude, a nu uita, a nu omite

counting device dispozitiv / mecanism de calculat

counting house birou, oficiu; (ec) contabilitate (ca birou, sectie, departament)

counting rate (metr) viteză de numărare

counting sorter maşină de sortat cu numărător cu contor, sortator cu contorizare 
counting strain gauge (metr) tensiometru / extensometru cu numărare

countless nenumărabil

count off a număra; (amer) a numerota

count on a conta pe, a se bizui pe, a avea încredere în

count out a pune jos bancnote (la numărare); a nu socoti, a nu pune la socoteală; a exclude (şi prin tragere la sorți)

country țară, stat; loc natal; de țară; rural, rustic, provincial

country press (mas-un) presă plan-cilindrică cu o singură turație

county comitat, district (UK, SUA)

county road drum vicinal / de țară

county seat / town capitală / reşedință districtuală

coup a răsturna

couple pereche, doi; (ind chim) cuplu electrochimic; (TH) pereche, cuplu; (auto) a cupla, a ambreia, a lega, a conecta; a împerechea, a uni, a asocia; (el) a cupla

couple action (fiz, chim, el) coroziune electrochimică

couple back (el, autom) a introduce / a conecta un circuit de reacție / de răspuns

couple unbalance (mec) cuplu / moment de dezechilibru

coupled wheel $(\mathrm{OM})$ roată cuplată

couple on a ataşa (şi vagoane)

couple out power $(\mathrm{TH}, \mathrm{mec}$, el) a decupla / a întrerupe alimentarea cu energie

coupler (auto, OM) ambreiaj, cuplaj, cuplare, agrafã pentru curea; (cf, met) aparat de cuplare / de legare, manipulant care cuplează vagoane; (el) element / bobină de cuplaj / de conectare

couple unbalance interference ratio $(\mathrm{mec}) \mathrm{ni}-$ vel / raport de interacțiune al cuplului de dezechilibru

coupler jaw $(\mathrm{OM})$ gheară / cârlig de cuplare

coupling (cf) aparat de legare / cuplare; (OM) cuplare, legare, cuplaj, manşon de legătură, mufă, gheară, cuplă, care cuplează / leagă (mecanic); îmbinare, legare, legătură, asociere

coupling agent (plast) promotor de aderență, agent de lipire / de formare a legăturilor intermoleculare

coupling axle $(\mathrm{OM})$ osie cuplată

coupling bar (constr, mas) tirant

coupling bolt (OM) şurub / bolț de cuplaj

coupling chain (mas, OM) lanț de remorcat / de cuplare

coupling clutch (OM) ambreiaj (şi cu con de fricțiune) de antrenare / cuplare coupling component $(\mathrm{OM})$ organ / componentă de legătură / de cuplare

coupling constant $(\mathrm{OM})$ constantă a unui cuplaj coupling device (OM, mas-un) dispozitiv de cuplare

coupling dimension $(\mathrm{OM})$ dimensiune de asamblare

coupling-disk block $(\mathrm{OM})$ manşon al discului (de ambreiaj)

coupling hook $(\mathrm{OM})$ cârlig de cuplare / de tracțiune

coupling key (OM) pană de cuplare (la pompe submersibile); (el) comutator de poziție

coupling lever (auto) pârghie a ambreiajului; (OM) pârghie / levier de cuplare

coupling lining (OM) garnitură / căptuşeală / acoperire de ambreiaj / pentru discuri de ambreiaj

coupling link $(\mathrm{OM})$ cheie / eclisă pentru înnădirea lanțului

coupling loop (el) buclă de cuplaj magnetic, sondă inductivă

coupling member $(\mathrm{OM})$ organ / element de fixare / de asamblare

coupling muff $(\mathrm{OM})$ manşon de cuplaj / de asamblare

coupling nut (OM) piuliță de fixare / de asamblare

coupling pin $(\mathrm{OM})$ bolț de legătură (şi al lanțului)

coupling pipe (OM, hidr) racord / țeavă de legătură (între conducte)

coupling reaction (mec) reacție la cuplare / asamblare

coupling rod $(\mathrm{OM})$ bielă cuplată

coupling screw (OM) şurub de strângere / de asamblare

coupling sleeve $(\mathrm{OM})$ mufă de cuplare

coupling tappet $(\mathrm{OM})$ camă de declanşare (de cuplare)

coupling through pin (OM) ştift / cui de antrenare, asamblare cu ştift

coupon cupon; probă, epruvetă (pentru încercări, teste); (ec) cupon (de dobânzi), talon, bon de casă

courage curaj; bravadă; cutezanță

courageous curajos, cutezător

courageously $(a d v)$ curajos, cu curaj

course $(\mathrm{TH})$ directie, mers, cursă, curs, drum, cale, albie, procedeu, tendință, desfăşurare, scurgere; durată, timp; linie de conduită, mod de a acționa; purtare, conduită; fel, mod, manieră; a urma o direcție, a circula, a se mişca repede, a curge, a trece prin, a traversa; (alim) 
fel de mâncare; (constr) rând de zidărie, asiză, strat; (nav) cap, cursă, rută; (el, fiz) traiectorie; (inf) derulare / rulare (a unui program); pistă teren (de sport); (edu) curs, cicluri de prelegeri (universitare), a urma un curs; (ec) curs (valutar), curs al pieței

course of the beam (fiz) traiectorie a fasciculului

course of the program(me) (inf) (de)rulare a programului

course of a ship (nav) cursă a unei nave, drum urmat de navă

course of thread $(\mathrm{OM})$ spiră de filet

court curte; (jur) curte, judecătorie, tribunal; ogradă, teren (de sport sau de joacă); stradă înfundată, intrare, fundătură

court house (jur) (amer) tribunal, curte de justiție

courtyard curte, ogradă; şantier

couscous (alim) cuş-cuș

covalent bond (chim) legătură covalentă

cove (constr), chim var nears

covenant învoială, acord; (jur) acord formal

cover (constr) învelitoare, acoperire, plafon, tavan, adăpost, refugiu; (fiz) înveliş, pătură, anvelopă; (hidr) clopot (la vană cilindrică etc.); (OM) manta, înveliş, teacă, capotă, cămaşă, peliculă, acoperire, învelire, clopot, capac, toc, ecran, cutie, căptușeală; copertă; (mat) congruență; (met) pojghiță, coajă, peliculă; copertă plic; îngustare; (fiz, el) a ecrana; a îmbrăca, a tapița, a proteja, a capitona; (TH) a acoperi, a cuprinde, a îngloba, a ascunde, a înveli, a proteja, a apăra (de lovituri), a vopsi, a forma un strat gros, a zugrăvi, a unge, a înnegri, a îmbrăca, a suprapune, a explora, a lumina; a asigura (la o societate de asigurări); (ec) a acoperi, a fi suficient pentru (d. bani); (alim) serviciu (de masă), tacâm

coverage putere de acoperire (d. o vopsea etc.); (el, c) regiune explorată; $(\mathrm{TH})$ domeniu, acoperire, cuprindere, zonă de acțiune / de acoperire, cuprins; (plast) depunere, aplicare (şi a unui adeziv)

coverage analysis $(\mathrm{ec})$ analiză a stocurilor, analiză a sferei publicului căruia i se adresează un suport publicitar

coverall(s) (textile, TH) haină de protecție / de lucru, salopetă

cover bolt $(\mathrm{OM})$ şurub / bulon / bolț pentru fixarea unui capac

cover charge (ec) plată suplimentară, taxă specială (şi la baruri)

covered acoperit, închis, cu capac

covered dented joint $(\mathrm{OM})$ îmbinare în dinți ascunşi covered electrod (met) electrod învelit / cu înveliş

covered-in terminal connection (el) borne protejate / acoperite

covered joint (constr, met) rost ascuns / acoperit (şi la sudură)

covered tenon $(\mathrm{OM})$ cep înfundat

covered wire (el, met, plast) sârmă izolată / protejată (prin tratament sau acoperiri)

covered enamel (chim) email de acoperire

covering (met) acoperire, placare, metalizare, vopsire; (fiz, el) anvelopă, înfăşurătoare (şi de semnal modulat); (TH) strat acoperitor / de protecție, protejare, înveliş, învelire, acoperiș, acoperire; izolație, husă, căptuşire, căptuşeală; care acoperă / protejează; (textile) îmbrăcăminte, cuvertură; teacă, toc

covering ability / capacity / power (ind chim, opt) capacitate / putere de acoperire, grad de opacitate

covering letter (ec) scrisoare de însoțire / de trăsură

covering machine (met, ind chim) maşină de copertat / de executat acoperiri / placări

covering material material pentru învelitori / de acoperire; (plast, ind chim) agent de îngroşare / de acoperire

covering plate $(\mathrm{OM}$, materiale) placă de acoperire

covering power putere / capacitate de acoperire (la vopsire, lipire etc.)

covering shelf (auto) capota portbagajului

covering shelf trim (auto) husă

covering strip (met, alim) bandă metalică de protectie / de acoperire (a unei zone active de la maşini)

covering surface (materiale) suprafață de suprapunere / care se acoperă

cover joint $(\mathrm{OM})$ îmbinarea / articulație a capacului

coverlet învelitoare; plapumă

cover mould (plast) parte fixă a matriței de injecție

cover nut $(\mathrm{OM})$ piuliță înfundată

cover over a astupa (şi o gaură), a pune peste, a acoperi (cu ceva)

cover plate (constr, OM) eclisă de îmbinare, placă / dală de acoperire, piatră de coronament; (mas-un) placă de presiune / de strângere / de acoperire

coversed sine / coversine (mat) funcție convers $\mathrm{x}=1-\sin \mathrm{x}$

cover sheet (met) tablă de acoperire

cover slide (OM, termo) clapă de fund 
cover strip (constr) tablă de acoperire, talpă covert adăpost, refugiu; ascuns

cover up a ascunde (bine), a pune la loc sigur; (constr) a acoperi, a căptuşi

covibrate (fiz, mec) a rezona

covibration (fiz, mec) vibrație de rezonanță

$\mathrm{CO}_{2}$-shielded metal-arc welding (met) sudare protejată în dioxid de carbon

$\mathrm{CO}_{2}$-welding (met) sudare în bioxid de carbon

cow catcher (amer) (cf) curățător de linie, bot de locomotivă

cow house (agr) grajd (de vite), staul

cowl (auto) torpedo (parte fixă între capota motorului şi parbriz), capotă; (nav) trombă (de aerisire); glugă; (TH, OM) capac, deflector, apărătoare de coş

cowl support bracket (auto) suport al torpedoului cowl vent (auto) clapă de aer la torpedo cowl ventilator (auto) ventilație a torpedoului co(-)worker colaborator; asistent cowper (met) cowper, caupăr, preîncălzitor de aer cowshed (agr) staul de oi cozily (amer) (adv) comod, confortabil, tihnit coziness (amer) comoditate, tihnă cozy (amer) comod, confortabil, tihnit C-plus (+) (el) pol pozitiv al bateriei de grilă crab crab, rac; (mas) cărucior de macara, pisică, troliu, autolift, maşină de ridicat, palan electric cu cărucior, elevator; (nav) cabestan mic manual

crabbed, crabby greu de înțeles; neciteț, nelizibil (d. scris)

crack spărgător; hoț; spargere; hoție; (constr) spărtură, casură, fisură; (mat) frântură, frângere, curbură; (met) îndoitură, fisură, spărtură; (plast) riz; (TH) cot, pocnet, pocnitură, detunătură, trosnet, trosnitură, bubuit, bubuitură, crăpătură, ruptură, fisură, deschizătură îngustă, lovitură (puternică) bruscă; de calitate superioară, excelent; îndemânatic, priceput; (chim) a craca; (TH) a (se) crăpa, a face să crape, a (se) sfărâma, a (se) deteriora, a (se) rupe, a trosni, a pocni, a lovi, a (se) sparge, a (se) fisura, a (se) strica, a (se) întrerupe, a plesni; (agr) a (se) desface, a crăpa (semințe); a da greş, a nu reuşi, a-şi pierde controlul / eficacitatea, a claca; a fi făcut de mântuială; a discredita, a strica (reputația cuiva etc.)

crack at the edge of the nugget (met) fisură la marginea nucleului (la sudură)

crack closure închiderea fisurii (de exemplu, la solicitare de uzură)

crack detector (metr, met) detector de fisuri, substanță pentru detectarea fisurilor crack-down (on) interzicere, măsuri de stăvilire (pentru)

crack down (on) a adopta o atitudine mai severă (faţă de)

cracked plesnit, fisurat, cu crăpături, crăpat (d. materiale, piese)

cracked bulk appearance $(\mathrm{T})$ aspect cu crăpături superficiale pe o parte mare din suprafața vizibilă

cracked edges (met) muchii rupte / crăpate / fisurate (şi la laminare)

cracked gas (ind alim) gaz(e) de cracare

cracker (alim) spărgător de nuci, pişcot, biscuit; (ind chim) instalație de cracare;

cracker (roll-mill) (constr, ind chim) valț / cilindru (de) concasor

crack from contraction (met, plast) rost / fisură de contractie

crack geometry (met, $\mathrm{T}$ ) forma fisurii

cracking crăpare (ind chim) cracare / distilare (a petrolului, a hidrocarburilor); care se sparge, spargere; (TH) fisurare; exfoliere (în general)

cracking pressure (hidr) presiune de deschidere a supapei (normal închise), presiune de inițiere a curgerii; (ind chim) presiune în proces de crocare

crack in the joining plane $(\mathrm{OM})$ fisură în planul de separare

crack in the heat affected zone (met) fisură în zona afectată termic (la sudură)

crack in the parent metal (met) crăpătură / fisură în materialul de bază (la sudură)

crackle a pârâi, a sfărâma, a trosni, a pocni

crackleware (vase de) ceramică smălțuită

crackling pocnituri, trosnituri, pârâitură, pocnitură; (alim) piele de porc prăjită

crack off (constr, plast) a se coşcovi, a se coji, a se scoroji

crack open (agr) a desface, a crăpa (şi semințe); a despica; a deschide o fisură

crack opening deschidere a fisurii

crack pattern (met) configurație tipică a fisurilor / de fisurare

crack process (mec) proces de fisurare / de formare a fisurii

crack resistance / strength (materiale) rezistență la fisurare

crack tip (met, T) marginea / buza / vârful fisurii crack-up spărtură, ruptură

crack up a sparge, a fisura (până la separare); prăbuşire; colaps

cracky fragil, casant

cradle (cf, OM, T) cuzinet de reazem, patul sabotului, furcă; (el) rețea de protecție legată 
la pământ; (hidr) jgheab; cap de cuțit (la cupa excavatorului); (nav) utilaj de lansare, cărucior de cală; leagăn; (constr) platformă suspendată, cadru, ramă, batiu, stelaj, cadru; (met) buzunar (al căruciorului de lingouri)

cradle feet $(\mathrm{OM}, \mathrm{T})$ reazem, lagăr (şi cu picior, cu talpă)

cradle frame (cf) cadru pendular

craft meserie, meşteşug; măiestrie, dexteritate; breaslă, corporație, uniune; (nav) ambarcațiune, barcă, vas; avion, vehicul aerospațial; înșelătorie

craft labour (ec) muncă calificată, mână de lucru calificată

craftsman meseriaş, meşteşugar; maestru, artist craftsmanship măiestrie, artă

cram înghesuială, aglomerație; (edu) toceală (a unei materii)

cram into a înghesui, a îndesa în; a umple până la refuz; a sătura, a îmbuiba; a îndopa, a îngrăşa

cram-full ticsit, plin până la refuz

cramp (constr) agrafă, scoabă, a prinde / a fixa / a strânge cu scoabe; (mas-un, OM) clamă, agrafă, scoabă, clemă, a strânge; (plast) a fixa o lipitură prin presare cu cleme

cramped înghesuit, strâns; princ în cleme

cramped construction (constr, mas) construcție compactă

cramping table (mas-un) masă pentru fixarea pieselor (de prelucrat)

cramp(-)iron (cf) crampon; (constr, OM) scoabă, clamă, brățară

cramp joint (mas) macara, pod rulant; (nav) macara de chei, macara, de bord

crane (mas) macara, pod rulant; (nav) bigă de încărcare, macara de bord; a ezita

crane bail ladle (met) oală de turnare cu traversă pentru macara, oală de macara pentru turnare

crane balks (met, $\mathrm{TH}$ ) cale a podului rulant

crane beam (constr, mec) grindă a podului rulant

crane boom (mas) brat de macara

crane brake $(\mathrm{OM})$ frână de macara

crane bridge (constr) pod ridicător; (mas) pod al macaralei, macara-portal

crane carriage / trolley, cărucior de macara, pisică a macaralei

crane carrier (mas) şasiu al macaralei rulante crane centre shaft $(\mathrm{OM}$, mas) arbore central la macara

crane crab $(\mathrm{OM}$, mas) cărucior de macara

crane driver (met, $\mathrm{TH})$ macaragiu crane jib (mas, nav) braț de macara / de gruie elevatoare

crane hoist (mas) macara mobilă

crane ladle (met) oală de macara, pentru turnare, oală de turnare, cu traversă pentru macara

crane load (mas, mec) sarcina (maximă) a macaralei

crane operator macaragiu

crane rail / runway / track (constr, mec, met) cale / şina de rulare a macaralei

crane rope (OM) cablu de macara

crane ship (nav) macara plutitoare

crane skip (mas) benă / cupă de macara

crane stripper (met) macare strip(p)er / pentru scoaterea lingourilor

crane traveling on rails (cf) macara de cale ferată

crank $(\mathrm{OM}, \mathrm{TH})$ manivelă, cot, pârghie cotită, vinci, cric, dereglat, a întoarce, a manevra, a manipula; (constr) a coti, a încovoia; (met) a îndoi, a refula

crank and connecting-rod assembly (OM, termo) mecanism bielă-manivelă

crank angle (OM) unghi de întoarcere / de rotire a manivelei

crank arm (auto) manivelă de pornire; (OM) braț / cot de manivelă

crank axle $(\mathrm{OM})$ ax / arbore cotit

crank bearing $(\mathrm{OM}, \mathrm{T})$ lagăr principal (al unui arbore cotit)

crank brace (mas-un) burghiu cu coarbă / de mână

crankcase (OM, mas, auto) carter (al motorului)

crankcase bottom (OM, mas, auto) cuvă inferioară de carter (de manivelă)

crankcase breather $(\mathrm{OM}$, mas, auto) răsuflător pentru gazele din carter

crankcase heater (termo) radiator pentru încălzit uleiul din carterul unui compresor

crankcase oil $(\mathrm{T})$ ulei de motor

crankcase oil-pan (auto, OM) baie (de ulei) a carterului

crankcase peephole (auto, OM) fereastră / vizor de control a(l) carterului

crankcase pressure regulator (auto, hidr, autom) regulator al presiunii de aspirație

crank cheek $(\mathrm{OM})$ braț de manivelă

crank circle cerc descris de un punct al manivelei / de aza manivelei

crank disk $(\mathrm{OM})$ disc cu bolț de manivelă / cu excentric

crank displacement $(\mathrm{OM})$ unghi de deplasare a manivelei

cranked axle (OM) arbore / ax cotit 
crank(ed) handle (OM) manivelă (de pornire) cranked lever $(\mathrm{OM})$ pârghie cotită

cranked tool (mas-un) cuțit elastic / gât de lebădă / înconvoiat, pentru prelucrarea fundului unei cavități

crank effect diagram (mec, OM) diagramă a variatiei momentului pe arborele cotit

crank end of the connecting-rod (OM) cap de bielă

crank gear $(\mathrm{OM})$ mecanism / transmisie bielămanivelă, roată dințată a culisei

crank guide $(\mathrm{OM})$ mecanism cu manivelă şi culisă

crank guide-way $(\mathrm{OM})$ culisă, şanț al culisei

cranking (constr) piesă cotită; (mas) pornire a motorului cu manivela

cranking bar $(\mathrm{OM})$ manivelă (pt. rotirea unui arbore)

cranking jaw $(\mathrm{OM})$ gheară de acționare / de punere în funcțiune

cranking speed $(\mathrm{mec})$ rotație / viteză necesară pentru pornire

cranking torque (mec, mas) cuplu de demarare

crankled $(\mathrm{OM})$ cotit (d. piese, arbori, conducte etc.)

crank mechanism (mas, OM) mecanism cu (bielă-) manivelă

crankpin (OM) buton / ax de manivelă, fus de bielă / de manivelă, maneton

crankpin journal (OM) lagăr al butonului / brațului manivelei

crankpin lathe (mas-un) strung pentru prelucrarea arborilor cotiți

crank plate $(\mathrm{OM})$ disc al manivelei

crank press (mas-un) presă cu manivelă / cu pârghie articulată

crank roller (mas-un, $\mathrm{OM}$ ) platou / cilindru de siguranță, cu un dinte

crankshaft $(\mathrm{OM})$ ax / arbore cotit (şi cu manivelă); vilbrochen

crankshaft balancer / counterweight (mec, $\mathrm{OM}$ ) contragreutate de echilibrare a arborelui cotit

crankshaft bearing $(\mathrm{OM})$ lagăr palier (şi pentru arbore cotit)

crankshaft-bearing liner (auto, OM, T) cuzinet de lagăr palier (la arbore cotit)

crankshaft grinder (mas-un) maşină de rectificat manetoane / fusuri de arbori cotiti

crankshaft journal $(\mathrm{OM}, \mathrm{T})$ lagăr / palier al arborelui cotit

crankshaft lathe (mas-un) strung pentru prelucrarea fusurilor ale arborilor cotiți

crankshaft press (mas-un) presă cu excentric crankshaft-timing pinion / gear (OM) pinion pe arborele cotit

crank(shaft) web (auto, OM) braț de manivelă al arborelui cotit

crank shaper (mas-un) şeping cu mecanism de acționare cu culisă

crank ship (nav) navă cu stabilitate inițială redusă

crank slotting machine (mas-un) maşină de mortezat cu mecanism de acţionare cu culisă

crank starting (auto, mas) pornire cu manivelă

crank(-)throw (OM) rază a manivelei, cot al arborelui cotit

crank turning moment (mec) moment de rotație al manivelei

crank web (OM) legătura dintre o manivelă / un braț şi arborele cotit

cranky $(\mathrm{TH})$ dereglat, excentric; (nav) lipsit de stabilitate

cranny spărtură, crăpătură

crash (TH) sfărâmătură, sfărâmare, distrugere, ruptură, spărtură, accident, prăbuşire, trosnet, zomot (regim) sever; (ec) faliment, crah, a da faliment, a (se) ruina; (OM, T, met) crăpătură, fisură; a (se) sfărâma, a (se) distruge, a se prăbuşi, a se sparge (şi prin cădere); (auto) accident, ciocnire

crash barrier (constr) grilaj / bare de protectie (la lovire)

crashes (radio) pocnituri (zgomot), paraziți atmosferici

crash halmet $(\mathrm{TH})$ cască de protecție

crash impact (auto) impact în caz de accident

crash program of work $(\mathrm{TH})$ program de lucru în asalt (la intervenții urgente)

crash truck (auto, mas) camion (cu macara) pentru depanare

crate (met) ladă, coş; împletitură, cuşcă

crater coş mare; (constr) îmbrăcăminte cu şipci; cutie (şi din hârtie, carton), ladă (din şipci de lemn); (met) crater (defect la sudură); (masun, T) micro-crater pe suprafata sculei, cauzat de aşchii

crater cavity (met) retasură tip crater

crater eliminator / filter (el) dispozitiv automat pentru stingerea treptată a arcului

crater pipe (met) retasură în formă de crater, pâlnie (şi la sudură)

crawl a (se) târâ, a merge greoi; târât; (TH) mişcare înceată; $(\mathrm{cf})$ a merge foarte încet

crawler (auto) camion / tractor pe șenile; (sistem tehnic) pe şenile

crawler belt (transp, mas, OM) şenilă, lanț de senilă 
crawler drive (transp, mas, OM) propulsie / acționare cu / pe şenile

crawler machine (auto) vehicul / maşină pe şenile

crawler mounted (mas) montat pe şenile

crawler-scraper rig screper remorcat de tractor pe şenile

crawler shoe $(\mathrm{OM})$ placă de şenilă, sabot de şenilă

crawler track $(\mathrm{OM})$ şenilă

crawler transmission (auto, OM, transp) transmisie laterală / pentru acționarea şenilei

crawler unit (mas) şasiu pe șenile

crawling târâre, intrare în sincronizare, acroşare

crawl / guard space spațiu auxiliar, spațiu gol (de siguranță), tampon / vid sanitar crayon creion colorat; cretă colorată; pastel craze (met) fisură capilară, microfisură

crazing (materiale) microfisurare, rețea de microfisuri (mai ales la elastomeri)

crazy nebun; (constr) crăpat, fisurat, gata să se prăbusească; tulburat, mânios; descumpănit; dezechilibrat

creak scârțâit; a scârțâi

creaky scârțâit; scârțâitor, care scârțâie

cream (alim) cremă, frişcă, caimac, smântână, spumă, a lua crema / caimacul; (de culoare) crem

cream cheese (alim) brânză grasă

cream-coloured crem, alb-gălbui

creamed (alim) bătut, (făcut) cremos

creamery (alim) lăptărie, fabrică de unt

cream off (alim) îndepărtare a stratului / cremos / decantat

creame of lime (constr) lapte de var

creamy (alim) cu cremă; (de culoare) crem

crease (constr, met) fractură, cută, surpare; (textile, plast) cută, pliu, încrețitură, dungă; (TH) ruptură, spărtură, îndoitură, falț; a cuta, a face cute, a încreți, a şifona, a plisa; (TH) a îndoi, a fălții

creasing machine (met, mas-un) maşină de zincuit / de cutat tablă

creasing tool (mas-un) sculă de cutare / de fălțuire creasy îndoit, cu pliuri / cute

create a crea, a face; a numi, a acorda un titlu; (c, inf) a deschide, a scrie, a închide un fişier pentru prima oară, a crea un fişier (nou)

creation creare, facere; numire; acordare a unui titlu; creatie, operă; model

creative (adj) creator, inventiv

creatively $(a d v)$ (în mod) creator

creativity, creativeness creativitate, putere creatoare

creator creator, autor, inventator credential (ec, pol) încredere; scrisori de acreditare / recomandare; legitimație

credentials (ec, pol) scrisori de acreditare

credibility credibilitate; probabilitate; posibilitate; veridicitate; crezare; (fig) credit

credible credibil, verosimil, de crezut, plauzibil

credibly din surse credibile / informate

credit crezare; influență; trecere, încredere, nume (bun), reputatie; autoritate; cinste, onoare; (ec) credit, avans, datorie, împrumut, a credita, a împrumuta (pe cineva), letter of $\sim$ scrisoare de credit; a da crezare, a pune pe seama (cuiva); a crede; a se încrede în; a socoti pe cineva (întrun anumit fel)

credit account (ec) cont în credit / creditor, credit

credit card (ec) carte / card de credit

credit item (ec) articol / condiție de credit(are)

credit note $(\mathrm{ec})$ certificat de garanție

creditor $(\mathrm{ec})$ creditor

credit to (ec) a trece în contul (cuiva)

credit with (ec) a credita cu, a acorda un credit; a acorda, a atribui cuiva ceva

creel $(\mathrm{ec})$ uzină furnizoare; ramă; rastel; $(\mathrm{TH})$ coş, paner

creep $(\mathrm{OM})$ alunecare relativă (a inelului rulmentului în carcasă): (met, plast) fluaj, deformare, dilatare, (a)lungire, a se alungi, a curge, a se deforma (d. materiale şi sub sarcină constantă); a se târî, a se strecura; a se cățăra

creep at rated load (metr, el, autom) derivă / abatere în timp a semnalului de ieşire la sarcină nominală; curgere / fluaj sub sarcină cu variație constantă

creep behaviour (materiale) comportare la fluaj / la curgere

creep crack (materiale) rupere / crăpare cauzată de fluaj

creeper (nav) dragă, gheară de pisică; (OM, mas) cărucior, boghiu, bandă-transportor

creep in / into a se strecura în

creeping (constr) cedare lentă; (met, mec, termo) fluaj, curgere lentă / continuă (nedorită)

creeping resistance limit (mec, materiale) rezistență statică de durată, rezistență / limită la fluaj

creep limit (materiale, OM, termo) limită de fluaj; (el) limită / rezistență la conturare

creep rate (met, OM) factor de fluaj, viteză de alungire / de fluaj

creep resistance limit (materiale, $\mathrm{OM}$ ) rezistență statică de durată / la fluaj

creep strain (materiale, termo, mec, $\mathrm{OM}$ ) deformație de fluaj 
creep strength (materiale, termo, mec, OM) limită de fluaj

creep stress (materiale, termo, mec, OM) tensiune de fluaj

creep test (met, OM) test de fluaj

cremaillere (OM, mas-un) cremalieră

cremate a incinera; a preface în cenuşă, a arde

cremation incinerare

crematory, crematorium crematoriu

crenel(I)ate (mas-un) a crenela, a fasona cu dinţi

crenelated $(\mathrm{OM})$ crenelat, cu creneluri

crenellation (mas-un, $\mathrm{OM}$ ) crenelare

crenelle / crenate (constr, OM) crenel

creosote (chim) creozot

crepe, crêpe (textile) crep

crepe paper hârtie creponată

crepe-satin (textile) crep satin

creping (textile, hârtie) creponare

crepitate a trosni, a pârâi, a pocni, a scârțâi

crepitation pârâit, trosnet, scârțâit

crescent pump (OM, hidr) pompă cu sertăraș / cu organ de distribuție în formă de seceră crescent wrench $(\mathrm{OM})$ cheie franceză / reglabilă

crest $(T, O M)$ vârf (de filet), creastă (de asperitate); (el) limită, de vârf; (hidr) prag; (constr) muchie / coamă de acoperiş

crested cu creastă / coamă / vârf

crest of thread (OM) vârf al filetului / dintelui

crest voltage (el) tensiune de vârf / maximă

cretaceous cretos; cretacic

cretonne (textile) creton

crevasse (met) străpungere (la furnal)

crevice (met, plast) crăpătură tip crevasă, fisură

crevice corrosion (chim, T) fisurare corozivă, coroziune în formă de crevasă

crevice corrosion at contact $(\mathrm{T})$ coroziune şi fisurare în formă de crevasă, la contact

crew echipaj, armare; (TH) echipă (de muncitori); grup; companie

crewman (nav, TH) membru al echipajului / echipei

crib pătuț; odăiță, cameră mică; magazin, prăvălie; fițuică, a copia; traducere literară; (constr) fundație de piloți; a închide, a înghesui

cribble (termo) grătar(-ciur)

crib ring $(\mathrm{OM})$ coroană

crimp încrețire la fibre; contracție, ondulare, ruptură; a încreți, a forma cute, a plisa, a ondula (d. fire, fibre, polimeri, textile)

crimped fibre fibră încrețită

crimped metal band (met) platbandă metalică contractată (ondulată, cutată, încrețită, defect)

crimping press (mas-un) presă de ondulat / de cutat (şi tablă) crimp over (mas-un) a fălțui

crimpy încrețit, ondulat (d. textile, plăci, folii etc.)

crimson roşu intens / aprins, stacojiu; a colora, a vopsi în roşu

crinkle încrețitură, fald, pliu (d. textile, table subțiri, plăci şi folii de materiale plastice, şi la nivel micro); a încreți, a împături, a plia, a mototoli

crinkle-resistent (textile, folii) rezistent la şifonare, neşifonabil; (OM) flambaj; (met) rezistent la îndoire / la ondulare / la cutare (şi d. tablă laminată)

crinkling test test la flambaj / la şifonare / la încrețire

crinkly creț, ondulat

cripple infirm, invalid; a mutila, a schilodi, a paraliza; a se deforma, a ciunti, a smulge bucăți mici, a deteriora (parțial), a strica

crippling deformare, deformație, îndoire, inflexiune, încrețire, ondulare, care (se) deformează / (se) ondulează / (se) încrețește

crippling load $(\mathrm{OM})$ sarcină care provoacă o deformație remanentă / flambaj / încrețire

crippling of frame (mec) deformare a cadrului

crippling strain $(\mathrm{mec})$ deformație la îndoire

crippling stress $(\mathrm{OM})$ tensiune la îndoire / la flambaj; tensiune care provoacă o deformație remanentă

crisis criză, moment de răscruce / crucial

crisp (alim) crocant, a prăji bine, a deveni crocant; fragil; întărit, înghețat (d.zăpadă); rece, răcoros, proaspăt (d.aer); clar, precis, vioi (d. stil); a încreți, a ondula, a încreți

crisping criss-cross încrucişat, în zigzag

crispness caracter crocant, fragil

crisps (alim) cartofi pai

criss-cross $(a d j)$ încrucişat, în zigzag (în mod neuniform); de-a curmezişul; a încrucişa, a pune de-a curmezişul; a împleti (în zigzag)

criss-cross structure (met, plast) structură încrucişată (şi la compozite)

criterion, $(p l)$ criteria criteriu, caracteristică, condiție, lege, principiu

criterion of failure (mec) criteriu de rupere; $(\mathrm{TH})$ criteriu de cădere / defectare (a unui utilaj)

criterion of non-interaction criteriu de autonomie (pentru a nu interacționa)

criterion plot (inf, OM) plot de criterii (în proiectare asistată de calculator, folosind metoda elementelor finite)

critical critic, hotărâtor, decisiv; culminant; periculos, riscant

critical build-up speed (mas, auto) viteză critică de demarare 
critical case $(\mathrm{TH})$ caz critic / limită

critical compression ratio (auto, termo) raport critic de compresie

critical cooling rate (ind chim, met) viteză critică de răcire

critical coupling (OM) cuplaj critic (care afectează nefavorabil functionarea sistemului)

critical cross section secțiune critică

critical damping (autom, mec) amortizare critică, aducere la poziția inițială fără oscilații

critical defect (materiale, TH) defect major / critic, avarie

critical flow (mec, hidr) curgere critică

critical frequency (el, mec, autom) frecvență critică / limită

critical grain growth (met) creştere critică a grăuntelui cristalin

critical heat (OMmet, termo, ind chim căldură critică

critical holding value (ind chim, met) valoare critică de menținere

critical humidity (agr, alim, ind chim) umiditate critică

critical interval / range $(\mathrm{TH})$ timp de reținere / de oprire (a unei instalații); (met) durată de menținere la punctul critic (a unui aliaj); (termo) domeniu critic de temperatură

critical item $(\mathrm{OM}, \mathrm{TH})$ piesă / ansamblu care afectează în mod critic siguranța sistemului, piesă / ansamblu cu condiții foarte restrictive de transport / depozitare / exploatare

criticality stare critică (şi a unui sistem tehnic)

critical limit limită critică (în general)

critical load (mec) sarcină limită

critically $(a d v)$ (în mod) critic

critical operating value valoare critică de funcționare / de lucru / d eexploatare

critical path method metoda drumului critic

critical point (fiz) temperatură critică, punct critic; (mat) punct critic, punct de maxim / de minim / de inflexiune al unei curbe, punct singular; (termo) temperatura maximă la care coexistă în echilibru faza lichidă cu cea gazoasă; (met) punct critic / de transformare

critical pressure (OMhidr presiune critică; raportul presiunilor critice (presiunea absolută din amonte şi cea din aval, când curgerea devine sonică, la aparatură pneumatică)

critical range (met) domeniu / interval critic (de temperatură sau sarcină etc.)

critical rate valoare / raport critic( $\breve{a})$

critical Reynolds number (fiz, hidr) număr Reynolds critic critical section (mec, OM, met) secțiune critică

critical-sectional area (mec, $\mathrm{OM}$, met) arie a secțiunii critice

critical shear stress (mec, OM) rezistentă limită la forfecare

critical speed $(\mathrm{mec})$ viteză critică

critical state (chim, termo) stare critică

critical state line (fiz, chim, termo, mec) linie (de demarcare) a stării critică

critical stress (mec, OM) tensiune critică, efort critic

critical temperature (fiz, termo, met) temperatură critică

critical thermal point (chim, met) punct critic de transformare

critical value $(\mathrm{TH})$ valoare critică / la limita de acceptabilitate

critical velocity (mec) viteză critică

criticism critică, criticare, dezaprobare, articol critic

criticize a critica, a dezaproba

crizzly (fiz, plast) netransparent

crock ciob, bucată din spărtură

crockery olărie, vase de lut sau faianță

crocodile (met) despicarea capătului frontal al laminatului

crocodile skin (met) piele de crocodil, aspect solzos (defect de suprafată, la laminare)

crocodile spanner (met) cheie-furcă

crocodile squeezer (alim) presă- / storcător-aligator

crook (mec, OM) îndoitură, îndoire, strâmbare, cârlig; a îndoi, a curba, a încovoia

crooked curbat, deviat, îndoit, încovoiat, strâmb; (mec) deformat, curb

crop (agr) recoltă, cultură, recoltare, seceriş, a recolta, a culege, a stânge, a cultiva, a crește, a paşte, a produce o recoltă; descoperire, tundere, tuns; (fig) serie, masă, număr mare; (met) cap / picior / extremitate de lingou, a şuta (la lingou), a separa (la laminare), a îndepărta, a tăia, a ieși la suprafață; (nav) curbura traversei

crop conveyer (met) transportor de deșeuri (de tablă)

crop end (met) maselotă, cap şutat

crop end (scrap) (met) capete de țagle, deșeuri

crop dusting (agr) stropire cu insecticid

crop out (agr) a ieşi la suprafață

cropper (agr) culegător, secerător, (maşină) secerătoare, combină, plantă care dă recolte bune

crop(ping) shears (met, mas-un) foarfece pentru şutare / pentru tăiet capete 
crop out (agr, TH) a ieşi la suprafață, a se denuda crop rotation (agr) asolament, rotație (a culturilor) crops (agr) semănături, recolte, culturi, lanuri crop spraying (agr) stropire cu insecticid crop up a se ivi, a apărea pe neaşteptate (dificultăți etc.); a se aduna, a se acumula croquette (alim) crochetă

croquis crochiu, schiță, ciornă

cross cruce; încrucişare (şi de drumuri), intersecție, răscruce, trecere; (fig) necaz, supărare; compromis; soluție intermediară; ( fam) fraudă, necinstit, înșelătorie; $(\mathrm{OM})$ cruce, transversal, fiting (şi ramificat), piesă de legătură; (el) atingere; (mat) perpendicular, încrucişat, intersecție; (agr, biol) încrucişare, încrucişat, hibrid, a hibridiza; a încrucişa; a călca (cu un vehicul), a depăşi, a trece (peste), a (se) intersecta, a (se) încrucişa, a străpunge, a traversa, a trece dintr-o parte în alta; a se opune; a contrazice; a hibridiza; a bara (litera t etc.); a scrie de-a latul unei pagini deja scrise; a contracara; a împiedica; a întâlni; a da peste; a se întretăia; a anula; (adj) transversal, în cruce, opus, contrar; supărat, prost dispus; on the $\sim$ în diagonală

cross / transversal axis axă transversală

cross(-)bar, cross(-)beam (constr, met) bară grindă / nervură transversală, traversă; diagonală; (nav) traversă (punte); (c) selector (ortogonal) de coordonate

cross banding (plast) stratificare în cruce / încrucişată, lipire în cruce

cross bearer (met, termo) bară de susținere a grătarului

cross bedding stratificare încrucişată (şi la compozite)

cross bending strength (mec) rezistență la încovoiere / îndoire (alternantă)

cross bit (mas-un) tăiş în cruce; (nav) babá / bintă în cruce

cross bond (chim) legătură încrucişată (şi între lanțuri moleculare)

cross break (met) ruptură / rupere transversală / perpendicular pe direcția de laminare

cross-bred, cross-breed (bot, agr) hibrid

cross-breeding (bot, agr) hibridizare, încrucişare

cross carriage cutting machine (met, mas-un) maşină de tăiere (cu flacără) cu cărucior transversal

crosscheck $(\mathrm{TH}, \mathrm{ec})$ verificare încrucişată / prin metode diverse

cross-country rolling mill (met) laminor cu caje (aşezate) în zigzag

cross coupling (OM) cuplaj parazit

cross crack (met) fisură / crăpătură transversală / perpendicular pe direcția de laminare cross cut $(\mathrm{OM})$ secțiune transversală; drumul cel mai scurt, scurtătură; (mas-un) retezare; (mat) tăietură, intersecție (met) tăiere transversală / perpendicular pe direcția de laminare

cross-cut end (OM, mas-un) suprafață frontală cross-cut saw (mas-un) ferăstrău de retezat / de tăiat transversal

cross-cut shears (met) (foarfece) ghilotină

cross-cutter (OM, mas-un) dispozitiv de tăiat transversal (benzi înguste, hârtie)

cross-cutting (mat) secantă; curmare, încetare; tăiere pe diagonală / în secțiune

cross direction $(\mathrm{TH})$ direcție transversală

crossed $(\mathrm{OM})$ încrucişat, în formă de cruce

crossed-axis helical gearing $(\mathrm{OM})$ angrenare hipoidă pseudoconică

crossed helical gear pair $(\mathrm{OM})$ angrenaj elicoidal

crossed helical gears (OM) angrenaj elicoidal (angrenaj cu roți cilindrice cu axe încrucişate) crossed out wheel $(\mathrm{OM})$ roată cu spițe crossed speed (mas-un, mec) viteză transversală crossed threads (metr, c) reticul, vizor cross eye (med, anat) strabism

cross division clasificare după mai multe caracteristici / criterii

cross drum (termo) boiler / cazan cu axa perpendiculară pe direcția tubulaturii

cross-effect (metr, opt, mec) interactiune între planele de corecție (şi la echilibrare)

cross feed (mas-un) (mecanism de) avans transversal

cross feed system (mas-un) sistem (complex) de alimentare a mai multor posturi de lucru, în ordine dependentă de piese, procese de prelucrare

cross-flow / tangential fan (termo) ventilator tangențial

cross-flow heat exchanger (termo) schimbător de căldură, cu curenți de încrucişare

cross force (mec) forță tăietoare / transversală

cross-grained cu fibră transversală, cu (o anumită) granulație transversală

cross grating ( $\mathrm{TH}$, materiale) retea (de fire / fibre încrucişate)

cross-hatched haşurat încrucişat, cu carouri (în desen tehnic)

cross-hatching haşurare încrucişată; (materiale) structură reticulară; haşurare (în desen tehnic)

cross hawse (nav) lanţuri încrucişate

cross head $(\mathrm{OM})$ cap-în-cruce, cruce cardanică, element care permite transformarea mişcării alternative în mișcare de rotație; (met, masun) traversă superioară (la prese mari)

cross-head bearing / bushing $(\mathrm{OM})$ lagăr / cuzinet / bucşă a capului-în-cruce (şi la cuplaje cardanice) 
cross-head end of connecting rod $(\mathrm{OM})$ picior de bielă

cross-hole nut $(\mathrm{OM})$ piuliță găurită în cruce

crossing traversare, încrucişare (şi de drumuri), intersecție, întretăiere; trecere; traversare; care se încrucişează / se intersectează, care traversează; (cf) punct de încrucişare, inimă de macaz

crossing angle (geom) unghi de intersectare

crossing of the rolls $(\mathrm{OM}$, met, plast) încrucişare / pierdere a paralelismului axelor cilindrilor de laminare

crossjack (nav) vela mare în cruce

cross laminating (plast) laminare în cruce / încrucişată

crosslight tratare a unui subiect din mai multe unghiuri / puncte de vedere; (fiz, metr, opt) surse luminoase

cross line (mat) linie de fracție; linie de demarcație cu fascicule încrucişate

crosslines (metr) reticul; (c) selector (ortogonal) de coordonate

cross link $(\mathrm{OM})$ articulație cardanică; (chim) legătură laterală între catene / lanţuri moleculare

cross-linked structure (materiale, chim) structură reticulară

cross(-)linking (chim, plast) reticulare, legături chimice $3 \mathrm{D}$, stabilite între lanțurile moleculare ale polimerilor pe durata procesului de fabricare

cross(-)linking de legătură (laterală); (chim, plast) agent de reticulare

cross-member (constr, mec, OM) bară transversală, traversă

cross off / out a tăia / șterge (de pe listă) (cu o linie) crossover (cf) macaz (de încrucişare); (constr, met, mec) bară / grindă transversală, traversă, punct de intersecție / nod (de grinzi); (OM) reducție, reducere a secțiunii

crosspiece (TH, OM) traversă, obiect aşezat dea curmezişul altuia, piesă aşezată în cruce

cross point (mas-un) tăiş în cruce (la burghie); (mat) punct critic / staţionar (al unei funcții), punct de intersecție

cross product (mat) produs vectorial

cross purpose intenție contrară, țel opus

cross-rail tool-head (mas-un) suport / cap de ra-

botat (pe traversa rabotezei), suport central (la raboteză)

cross ribs (OM, termo) nervuri încrucişate / transversale

crossroad (constr) drum transversal / lateral

crossroads (constr) intersecție / încrucişare de drumuri; răscruce cross roll (met, plast) a lamina între cilindri înclinați / oblici (în două sensuri)

cross rolling mill (met) laminor cu cilindri oblici

cross roll straightening machine / mill (met) maşină / laminor de îndreptat, cu cilindri oblici

cross roll tube-mill (met) laminor cu cilindri oblici (şi pentru țevi)

cross seam (OM, met) cusătură în cruce (la sudură)

cross screen $(\mathrm{OM}$, termo) grătar (din bare încrucişate)

cross section $(\mathrm{OM}, \mathrm{mec})$ sectiune transversală

cross-sectional area $(\mathrm{OM}, \mathrm{mec})$ aria secțiunii transversale

cross section of a girder (mec) profil / secțiune transversală a unei grinzi

cross-section of passage (met) sectiune de trecere (la laminare)

cross section paper (metr) hârtie milimetrică / caroiată

cross shaft $(\mathrm{OM})$ arbore / ax transversal

cross shafts $(\mathrm{OM})$ arbori cu axe încrucişate (la transmisii)

cross-shaped $(\mathrm{OM})$ în formă de cruce, cruciform

cross sleeve $(\mathrm{OM}$, hidr) mufă în cruce, fiting cu mai multe orificii

cross slide (mas-un) sanie transversală, cărucior cu două sănii, una perpendiculară pe cealaltă, şurub al mecanismului de avans transversal

cross-slide clamping motor (mas-un) motor al mecanismului de blocare a traversei (şi la raboteză)

cross-slide raising and lowering motor (mas, mas-un) motor al mecanismului de deplasare verticală a traversei (la raboteză, la presă etc.)

cross-slide rest (mas-un) sanie transversală (şi la strung)

cross-sliding coupling (Oldham coupling) (OM) cuplaj Oldham, disc intermediar (si de la cuplajul Oldham) care permite preluarea abaterii / excentricității radiale a arborilor

cross-sliding head (mas-un) păpuşă port-sculă, cu deplasare transversală

cross slope pantă transversală

cross spring $(\mathrm{OM})$ arc transversal

cross-staff head $(\mathrm{OM}$, mas-un) placă de încrucişare, cap-în-cruce

cross stop (mas-un) limitator pentru decuplarea avansului transversal

cross stratification stratificare încrucişată (şi la compozite, țesături) 
cross-stratified sand (geol, constr, mediu) nisip cu stratificare încrucişată

cross stud (constr) diagonală (la construcții metalice, ferme); $(\mathrm{OM})$ bară transversală

cross-tie (constr, mec) tirant, etrier, traversă (şi de cale ferată)

cross-tie rod tirant transversal

cross-tip screwdriver $(\mathrm{OM})$ şurubelniță pentru şuruburi cu cap în cruce

cross-tool carriage (mas-un) cărucior al saniei port-cuțit (pe traversa rabotezei)

cross tool-holder slide (mas-un) sanie portsculă, transversală

cross transom (constr) traversă de distanțare

cross travel deplasare transversală; (mas-un) avans transversal

cross-tube boiler (termo) cazan cu țevi fierbătoare transversale

cross wall (constr, termo, alim, ind chim) perete despărțitor, şicană

cross wind (auto) vânt puternic

cross-wire welding (met) sudare prin rezistență electrică, folosită la obținerea sitelor sau plaselor de sârmă

crosswise în cruce, încrucişat

crosswise direction direcție transversală

crotch crăcană, bifurcare

crotchet paranteză dreaptă; (OM) cârlig

crotchet file (mas-un) pilă lată subțire cu vârf ascuțit şi cu fațele laterale rotunjite

crouton (alim) cruton

crow $(\mathrm{OM})$ gheară de prindere

crowbar (alim, ind chim) agitator, amestecător; (met) vătrai, rangă cu gheare, drug (metalic)

crowd mulțime, masă, grămadă (de obiecte); a umple, a înțesa, a presa, a împinge (înainte); (nav) a întinde toate pânzele; a (se) îngrămădi, a se strânge

crowded aglomerat; ticsit, plin; suprapopulat crown coroană; punct culminant, apogeu, încununare; (constr) coronament, cheie de boltă, coroană, creastă, culme, vârf, creștet; (mas) cap (de macara); (OM) coroană (şi dințată), calotă; (masun) a aşchia sferic, a tăia o coroană, partea tăișului de burghiu, acoperită cu praf de diamant sau carburi; (met) parte superioară / boltă de cuptor, bombare la mijlocul tablei sau benzii (defect la laminare), convexitate a cilindrului; (nav) (nod) coroană; (fig) a încununa (eforturi), a încheia, a sfầrşi

crown backing $(\mathrm{OM})$ baza / butucul danturii conice

crown bit (mas-un) tăiş în formă de coroană / de inel crown burner (termo) arzător inelar crown cam $(\mathrm{OM})$ camă inelară dințată

crown cork (OM, hidr) dop cu guler

crowned sferic, bombat, convex, în formă de coroană

crown gear $(\mathrm{OM})$ coroană dințată (şi fără butuc, care se montează prin sudură, şuruburi etc.), roată dințată frontală

crown-grinding wheel (mas-un) disc pentru rectificare, în formă de oală, disc-oală pentru rectificare

crown-head piston $(\mathrm{OM})$ piston cu cap bombat crowning $(\mathrm{OM})$ bombare (a dintelui unei roți dinţate) (C); (met) bombare / convexitate la mijlocul tablei sau al benzii (și defect), bombare a cilindrului de laminare

crowning factor factor de acoperire

crowning machine (alim, ind chim) maşină de capsulat sticle / butelii

crown line / circle (in a gear / toothed wheel) $(\mathrm{OM})$ cerc exterior / de cap al roții dințate, linia de cap a cremaliereei

crown metal (met) aliaj $\mathrm{Cu}-\mathrm{Ni}-\mathrm{Zn}$

crown nut $(\mathrm{OM})$ piuliță crenelată

crown of a furnace (termo, met) boltă a focarului / a cuptorului

crown of piston $(\mathrm{OM}$, termo, auto, hidr) cap al pistonului

crown pulley $(\mathrm{OM})$ roată de curea, cu obadă bombată

crown saw (mas-un) ferăstrău cilindric

crown sheet (met, termo) placă superioară / boltă a unui cuptor

crown wheel (auto, OM) coroană de diferential, roată conică dințată mare de la puntea din spate, coroană a rotii de lant

CRS (auto) child restraint system (auto) sistem de protectie pentru copil

crucial hotărâtor, crucial, decisiv, critic

crucially $(a d v)$ în mod hotărâtor / crucial

crucible (met) creuzet

crucible cast steel (met) oțel de creuzet

crucible charge (met) şarjă de creuzet

crucible coking-test (met) probă de cocsificare în creuzet

crucible furnace (met) cuptor cu creuzet

crucible fusion (met) topire în creuzet

crucible graphite (met) grafit pentru creuzet

crucible melting furnace (met) cuptor $\mathrm{cu}$ creuzet de topire

crucible melting plant (met) topitorie cu creuzete

crucible (process) practice (met) (procedeu de) topire în creuzet

crucible shank (met) furcă a oalei de turnare 
crucible steel (met) oțel de creuzet

crucible tongs (met) cleşte pentru creuzete (şi de laborator)

crucible triangle (met, metr) (suport-) triunghiular pentru creuzete (şi de laborator)

cruciform cruciform, în formă de cruce cruciform curve (mat) curba $x^{2} y^{2}-a^{2} x^{2}-a^{2} y^{2}=0$ cruciform member (constr) traversă în $X$ crud (fiz) infectare, impuritate

crude crud, imatur; (ind chim) țiței brut; $(\mathrm{TH})$ crud, necopt; nefiert, neprelucrat, neterminat, nefinisat, brut, necurățat, grosolan

crude analogy asemănare aproximativă

crude compound (ind chim) amestec (de cauciuc) nevulcanizat

crude copper (met) cupru brut

crude error (metr) eroare grosolană

crude-gas cleaning (met) epurare a gazelor de furnal

crude-gas machine (termo, met) motor cu gaze de furnal

crude-gas main (met) conductă pentru gazul de furnal

crude guess $(\mathrm{TH})$ presupunere / evaluare grosolană

crude iron (met) fontă (brută)

crude metal (met) metal / aliaj brut

crude method (metr, TH) metodă grosieră / neprecisă

crude mix (ind chim) amestec (de cauciuc) nevulcanizat

crude model (met) model grosolan (brut)

crude moment (mec) moment necentrat

crude naphtha (ind chim) țiței brut (cu componenti naftenici în concentratie mai mare)

crude-oil (ind chim) petrol brut, țiței, combustibil greu

crude-oil line / pipe-line conductă de titei crude-oil pump (ind chim) pompă de țiței crude-oil still (ind chim) distilarea țițeiului crude ore (met) minereu brut

crude rubber (ind chim) cauciuc natural / nevulcanizat

crude sampling (TH, mf) selecție neprelucrată (d. date, piese etc.)

crude sewage (mediu, hidr) apă brută, de canal crude sludge (mediu, hidr) nămol crud, noroi crude state (met) stare brută (la forme) crude steel (met) oțel brut / în lingouri crude water $(\mathrm{TH}$, mediu) apă neepurată crudeness, crudity caracter brut; remarcă grosolană cruise (nav) croazieră, navigare, plutire, a face o croazieră, a încrucişa / a patrula pe mare; a călători (de plăcere); (auto) a merge cu viteză economică cruise control (auto) control automat al vitezei cruise control on (auto) functia de control al vitezei, activată

cruise control set speed (auto) viteză setată prin sistemul de control automat al vitezei

cruise control system (auto) sistem de control automat al vitezei

cruise indicator (auto) indicatorul pentru control automat al vitezei

cruise indicator light (auto) lampa / semnalizatorul luminous pentru opțiunea de control automat al vitezei

cruising (auto) economic (d. viteză); (nav) de croazieră (şi d. viteza navei)

cruising power (nav) putere de durată / continuă / în mers de croazieră

cruising speed (nav) viteză de mers / de croazieră / economică

crumb fărâmă, firimitură, pic; (alim) miez de pâine

crumble a (se) face fărâme, a (se) fărâmița, a (se) fărâma; a se dărâma, a se transforma în ruine, a se prăbuşi; (fig) a se spulbera, a se stinge, a se destrăma

crumbled when compressed (mec) fărâmițat / fragmentat când este comprimat / la comprimare / la presare

crumbling (alim, constr, ind chim, met) mărunțire, fărâmițare, dezagregare

crumbly (fiz) (adj) (s)fărâmicios, friabil, fragil, casant

crumple a (se) şifona / mototoli, a se boți, a se cuta (țesături, table subțiri, folii de materiale plastice)

crumpling mototolire, şifonare, boțire, încrețire; care se mototoleşte / se şifonează / se încrețeşte (d. textile, folii, table subțiri etc.)

crunch ronțăit, scârțâit; a roade, a ronțăi; a scârțâi

crunode (mat) punct dublu (al unei curbe)

crush $(\mathrm{mec})$ strivire, apăsare, lovitură zdrobitoare; a zdrobi, a sfărâma, a fărâmița, a sparge, a concasa, a măcina, a strivi, a îndesa; (alim) suc / zeamă de fructe, a stoarce (struguri etc.); a (se) mototoli, a (se) şifona; a se îmbulzi, a se înghesui

crush barrier (constr, OM, termo) grilaj

crush down (constr, alim, ind chim) a zdrobi, a măcina, a fărâmița; a zdrobi rezistenta

crushed aggregates (constr, ind chim, met) agregate de / rezultate din concasare

crushed coke (met) praf de cocs

crushed oven coke (met) cocs sfărâmat, deseu / sfărâmătură de cocs 
crushed rock (constr) agregat, piatră concasată crushed sugar (alim) zahăr măcinat / fărâmițat crusher (constr, alim, ind chim, mas) concasor, mecanism de sfărâmare / de concasare, moară, zdrobitor

crusher-ball (constr, met, ind chim) corp / bilă de măcinat / de dărâmat (ziduri)

crusher-roll mill (constr, alim, ind chim) moară de fărâmițare

crusher rolls (constr, alim, ind chim) valțuri de concasor

crusher-stemmer with pump (alim) zdrobitordezdrobitor cu pompă

crushing măcinare; (mec, constr, TH) strivire, turtire, concasare, sfărâmare, rupere, spargere, crăpare; (adj) zdrobitor, copleşitor, imbatabil; care zdrobeşte / turteşte / concasează

crushing cone $(\mathrm{OM})$ con concasor

crushing cylinder (OM) tambur / valt de concasare crushing jaw (OM) falcă concasoare

crushing load (mec) sarcină / încărcare de rupere / de zdrobire / de măcinare

crushingly $(a d v)$ (în mod) zdrobitor

crushing-mill (alim, constr, ind chim) instalație de măcinat / de morărit, concasor cu valțuri / centrifugal, valțuri zdrobitoare, moară de concasare, instalație de zdrobit / concasat / măruntit

crushing plant (constr, ind chim) instalație de concasare / de sfârâmare

crushing resistance (mec) rezistență la concasare / la sfârâmare

crushing room (constr, ind chim) cameră / incintă / spațiu de concasare

crushing roll(er) $(\mathrm{OM}$, constr, ind chim) valț concasor

crushing-screening plant (constr) concasorcriblor (sortator cu sită / cu ciur)

crushing strain (mec) tensiune / deformație de compresie / de strivire

crushing strength (mec) rezistență la strivire / la sfărâmare, tensiune de compresiune

crushing test (mec, metr) încercare la strivire / la compresiune / la turtire / la sfărâmare / la măcinare / la aplatizare

crushing worm şurub / melc

crushing yield point / limit (mec) limită de curgere la compresiune, limită de strivire / de rupere

crust (materiale) coajă, scoarță, crustă, învelis, strat superficial; strat dur (rezistent la uzură); (met) crustă aderentă solidificată; (termo) piatră de cazan; a se acoperi cu crustă; (alim) coajă de pâine; a (se) acoperi cu crustă / coajă, a prinde coajă crusted (acoperit) cu crustă / coajă, crusty tare, uscat; aspru; tăios (şi d. o replică) crutch cârjă; (constr, OM) suport, furcă, sprijin, proptea; (nav) furchet

crux $(p l)$ cruces esență a unei probleme, punct dificil, dificultate

cry strigăt, țipăt; a țipa, a plânge; a striga; a face reclamă cu glas tare

cry for a plânge după; a dori, a râvni; a cere; a avea nevoie de

cryochemistry (fiz, chim, termo) chimia temperaturilor joase, criochimie

cry off a renunța la, a retrage, a retracta; a nu se ține de promisiune, a nu respecta o înțelegere

cryogen (alim, termo) amestec frigorific

cryogenic fluid (chim, termo) fluid criogenic

cryogenics studiul metodelor de producere a temperaturilor joase şi a comportării materialelor în acest domeniu de temperaturi, criogenie

cryogenic system (fiz, termo) sistem criogenic

cryometer (metr) aparat de măsurat temperaturi joase şi foarte joase

cryosorption (fiz, chim, termo) absorbție la temperaturi joase

cryostat (autom, termo) criostat, termostat / regulator de temperaturi foarte scăzute

crypto gear $(\mathrm{OM})$ angrenaj planetar, epicicloidal

crystal (el, fiz) cristal (şi piezoelectric); cristal, (cristal de) cuarț; aricole de cristal; (amer) sticlă de ceas

crystal axis (fiz, met) axă cristalografică

crystal body (fiz) corp cristalin

crystal boundary (met) limita dintre grăunții cristalini

crystal block cristal monobloc, bloc de cristal

crystal centre (fiz, met) germen / nucleu de cristalizare

crystal cut secțiune / tăietură a unui cristal

crystal edge muchie / colț de cristal

crystal detector (metr) detector cu cristal / cuart crystal dislocations (OMfiz, mec, met dislocări în rețeaua cristalină

crystal face față a cristalului

crystal-forming polymer (plast) polimer cristalizabil

crystal germ (met, plast) germene de cristalizare

crystal glass sticlă cristalină / de cristal

crystal grain (met) grăunte cristalin

crystal growth (met) creştere a cristalului / a grăuntelui cristalin 
crystal lattice (fiz, chim, met) rețea cristalină crystalliform / crystal-like (met, fiz) cristalin, cu structură / cu formă ca de cristal

crystalline cristalin, limpede, transparent

crystalline force / capacity (met, chim) capacitate / posibilitate de cristalizare

crystalline fracture (chim, met) rupere / ruptură cristalină / în cristal

crystalline grain (chim, met) cristalit, grăunte cristalin

crystalline grain size (chim, met) mărimea cristalitului / a grăuntelui cristalin

crystalline group (materiale) formație cristalină crystalline growth (chim) formare a cristalelor; (met) creştere a grăunţilor cristalini

crystalline modification (fiz, met) recristalizare, modificare / schimbare a structurii cristaline

crystalline refinement (met) finisare a granulatiei cristaline (prin tratament termic)

crystalline state (fiz) stare cristalină

crystalline structure (fiz) structură cristalină

crystalline transformation (met) recristalizare, transformare a sistemului de cristalizare

crystallite (chim, fiz, met, plast) cristalit, schelet cristalin, cristaloid

crystallite aggregation (chim, fiz, met, plast) conglomerat de cristale

crystallization $(\mathrm{TH}$, met) cristalizare

crystallize a (se) cristaliza; (alim) a glazura, a zaharisi; (fig) a căpăta o formă definitivă

crystallized sugar (alim) zahăr tos

crystallizer (chim, alim, met) critalizator

crystallizer design (ind chim, alim, met) soluția constructivă a critalizatorului

crystallizing vessel (chim, alim, met) cristalizor crystallographic axes (met) axe cristalografice crystallography cristalografie

crystal metallic lattice (met) rețea (cristalină) metalică

crystal nucleus (chim, met) germen / centru de cristalizare, cristal de priză

crystal orientation (met, plast) orientarea cristalelor

crystal parameters (met, plast) parametri ai cristalului

crystal plane (met) plan cristalografic, suprafață a cristalului

crystal seed (fiz, chim, met) cristal de priză, germene de cristalizare

crystal slab (chim, met) bloc cristalin

crystal spectometer (fiz, met) spectrometru cu cristal

crystal structure (fiz) structură cristalină

crystal systems(fiz) sisteme cristaline crystal water (ind chim) apă de cristalizare

cubage (metr, TH) cubaj, cubatură, calcul al volumului

cubature (metr, $\mathrm{TH}$ ) cubatură

cube (mat) cub, puterea a treia, cub (mod de reprezentare a produselor logice); a ridica la cub / la puterea a treia; (alim) a prăji / tăia în formă de cuburi

cube face (mat) față a cubului

cube root (mat) radăcină cubică, radical de ordinul trei

cube sugar (alim) zahăr cubic

cube test (metr) încercare / test pe cub / pe epruvetă cubică

cube-test specimen (metr) cub de încercare, epruvetă cubică

cubic (mat) (ecuație) cubică, curbă de gradul al treilea, cubic

cubical (fiz, mat) volumetric, spațial, cubic, de gradul al treilea, în formă de cub

cubic body-centred lattice (fiz) retea cubică centrată / cu volum centrat (în cristale)

cubic capacity (mas, termo) cilindree, capacitate cilindrică; $(\mathrm{TH})$ cubaj

cubic centimeter (metr) unitate de măsură pentru volum, centimetru cub: 1 cubic centimeter $=0,000001 \mathrm{~m}^{3}$

cubic centimeter/day (metr) unitate de măsură pentru debit volumic, centimetru cub/zi: 1 cubic centimeter/day $=1,157407407 \cdot 10^{-11} \mathrm{~m}^{3} / \mathrm{s}$

cubic centimeter/hour (metr) unitate de măsură pentru debit volumic, centimetru cub/oră: 1 cubic centimeter/hour $=2,777777778 \cdot 10^{-10} \mathrm{~m}^{3} / \mathrm{s}$

cubic centimeter/minute (metr) unitate de măsură pentru debit volumic, centimetru cub/minut: 1 cubic centimeter $/$ minute $=0,000000017 \mathrm{~m}^{3} / \mathrm{s}$

cubic centimeter/second (metr) unitate de măsură pentru debit volumic, centimetru cub/secundă: 1 cubic centimeter $/$ second $=0,000001 \mathrm{~m}^{3} / \mathrm{s}$

cubic contents cubaj

cubic decimeter (metr) unitate de măsură pentru volum, decimetru cub: 1 cubic decimeter $=0,001 \mathrm{~m}^{3}$ cubic dilatation $(\mathrm{OM}$, termo) dilatație cubică / de volum / volumetrică

cubic expansion (termo) dilatație cubică / volumică

cubic foot (metr) unitate de măsură pentru volum, picior cub: 1 cubic foot $=0,028316847 \mathrm{~m}^{3}$ cubic foot/hour (metr) unitate de măsură pentru debit volumic, picior cub/oră: 1 cubic foot/hour $=0,000007866 \mathrm{~m}^{3} / \mathrm{s}$

cubic foot/minute (metr) unitate de măsură pentru debit volumic, picior cub/minut: 1 cubic foot $/$ minute $=0,000471947 \mathrm{~m}^{3} / \mathrm{s}$ 
cubic foot/second (metr) unitate de măsură pentru debit volumic, picior cub/secundă: 1 cubic foot $/ \mathrm{second}=0,028316847 \mathrm{~m}^{3} / \mathrm{s}$

cubic inch (metr) unitate de măsură pentru volum: 1 cubic inch $=0,000016387 \mathrm{~m}^{3}$

cubic inch/hour (metr) unitate de măsură pentru debit volumic, inch cub/oră: 1 cubic inch/hour $=0,000000005 \mathrm{~m}^{3} / \mathrm{s}$

cubic inch/minute (metr) unitate de măsură pentru debit volumic, inch cub/minut: 1 cubic inch $/$ minute $=0,000000273 \mathrm{~m}^{3} / \mathrm{s}$

cubic inch/second (metr) unitate de măsură pentru debit volumic, inch cub/secundă: 1 cubic inch/second $=0,000016387 \mathrm{~m}^{3} / \mathrm{s}$

cubic kilometer (metr) unitate de măsură pentru volum, kilometru cub: 1 cubic kilometer $=10^{9} \mathrm{~m}^{3}$

cubicle (constr) spațiu, nişă, firidă; (el) carcasă pentru echipament de tensiune înaltă

cubic measure (metr) unitate volumetrică

cubic meter/day (metr) unitate de măsură pentru debit volumic, metru cub/zi: 1 cubic meter/day $=0,000011574 \mathrm{~m}^{3} / \mathrm{s}$

cubic meter/hour (metr) unitate de măsură pentru debit volumic, metru cub/oră: 1 cubic meter $/$ hour $=0,000277778 \mathrm{~m}^{3} / \mathrm{s}$

cubic meter/minute (metr) unitate de măsură pentru debit volumic, metru cub/minut: 1 cubic meter $/$ minute $=0,016666667 \mathrm{~m}^{3} / \mathrm{s}$

cubic mile (metr) unitate de măsură pentru volum, milă cubică: 1 cubic mile $=4168181825,4406 \mathrm{~m}^{3}$

cubic millimeter (metr) unitate de măsură pentru volum, milimetru cub: 1 cubic millimeter $=10^{-9} \mathrm{~m}^{3}$

cubic packing (fiz) rețea spațială cubică

cubic space lattice (fiz) rețea spațială cubică

cubic system (fiz) sistem cubic de cristalizare

cubic yard (metr) unitate de măsură pentru volum, yard cub: 1 cubic yard $=0,764554858 \mathrm{~m}^{3}$

cubic yard/hour (metr, fiz) unitate de măsură pentru debit volumic, yard/minut: 1 cubic yard $/$ hour $=0,000212376 \mathrm{~m}^{3} / \mathrm{s}$

cubic yard/minute (metr) unitate de măsură pentru debit volumic, yard cub/minut: 1 cubic yard $/$ minute $=0,012742581 \mathrm{~m}^{3} / \mathrm{s}$

cubic yard/second (metr) unitate de măsură pentru debit volumic, yard cub/secundă: 1 cubic yard $/$ second $=0,764554858 \mathrm{~m}^{3} / \mathrm{s}$

cubit (metr) unitate de măsură pentru lungime: 1 cubit $($ Greek $)=0,462788 \mathrm{~m}, 1$ cubit $(\mathrm{UK})=$ $0,4572 \mathrm{~m}$

cuboid (mat) paralelipiped dreptunghic, cuboid cucumber (alim) castravete

cud rumegat; amestecat

cudbear (chim) turnesol

cuddy (nav) cabină (de şlep) cue replică; aluzie, semn, sugestie

cuerda (metr) unitate de măsură pentru suprafață: 1 cuerda $=3930,395625 \mathrm{~m}^{2}$

cuff $(\mathrm{OM})$ garnitură a presetupei; manşetă (de etanşare)

cuisine (alim) bucătărie

culinary (alim) culinar, de bucătărie, bun de gătit

cull $(\mathrm{TH})$ deşeu, rebut; $(\mathrm{TH})$ a alege, a selecţiona, a selecta, a tria, a scoate / elimina (defecte); (agr) a strânge, a culege; a spicui (un text)

cullet cioburi de sticlă

cullender (alim) strecurătoare

culling board (alim) masă de sortat peşte

culmination culminare, punct culminant

culpability culpabilitate, vină

culpable culpabil, vinovat

cultivate (agr) a cultiva, a lucra (pământul), a creşte (legume etc.); (edu) a cultiva, a educa, a instrui

cultivated (agr) cultivat, de cultură (d.plante); (edu) cultivat, cult, educat, rafinat

cultivation (agr) cultivare, cultură (a plantelor); educație, cultură, dezvoltare a intelectului

cultivator (agr) cultivator (maşină, persoană)

culture (agr) cultură, semănătură, creştere, cultivare, a cultiva; cultură, nivel intelectual

cultured crystal (chim) cristal sintetic / artificial culvert (constr) canal, rigolă, apeduct, galerie de apă, podeț tubular

cumber a îngreuna, a (se) împovăra, a fi o povară pentru, a stânjeni, a (se) încurca

cumbersome greu, împovărător, stânjenitor cumin (alim) chimion

cumulation cumulare, acumulare, îngrămădire (de particule, defecte etc.)

cumulate a acumula, a cumula

cumulative cumulativ

cumulative distribution distribuție cumulativă

cumulative / chronic fatigue (materiale, mec, termo) oboseală cumulativă

cumulatively $(a d v)$ prin cumulare

cumulative oversize (TH, OM, ec) depăsire / supradimensiune cumulativă / prin cumulare

cumulative undersize $(\mathrm{TH}, \mathrm{OM}$, ec) subdimensiune / depăşire cumulativă

cunial (Cu-Ni-Al) (met) cunial (aliaj pe bază de $\mathrm{Cu}, \mathrm{Ni}$ şi $\mathrm{Al})$

cunico (Cu-Ni-Co) (met) cunico (aliaj pe bază de $\mathrm{Cu}, \mathrm{Ni}$ şi $\mathrm{Co}$ )

cunning viclean, şiret; deştept, priceput, isteț, îndemânatic; inventiv

cup ceaşcă; (chim) capsulă; (constr, mat) calotă; (mat) simbolul U al reuniunii; $(\mathrm{OM}, \mathrm{T})$ cupă, taler; platan, adâncitură (produsă prin lovire), 
manşetă, inel, segment, garnitură de etanşare, gresor, ungător; (metr, fiz) unitate de măsură pentru volum/ capacitate: 1 cup (metric) = $0,00025 \mathrm{~m}^{3}, 1$ cup $(\mathrm{UK})=0,000284131 \mathrm{~m}^{3}, 1$ cup (US) $=0,000236588 \mathrm{~m}^{3}$

cup-and-cone arrangement (in furnace) (met) con de închidere, la furnal

cup-and-cone fracture (mec, materiale) rupere cu una din bucăți concavă şi cealaltă convexă

cupboard bufet, dulap, şifonier

cup core (met, plast) miez-oală

cupel (met) cupelă (creuzet special pentru a separa aurul şi argintul din aliaje), creuzet de cupelare; a face cupelație, a cupela

cupellate (met) a cupela

cupelling furnace (met) cuptor de cupelație / cu creuzete

cup fracture (materiale) rupere la care una din bucăți este concavă şi cealaltă convexă

cupful conținutul unei ceşti

cup grease (chim, T) unsoare consistentă cup-grinding wheel (mas-un) disc de rectificare / abraziv, în formă de oală, disc-oală de rectificare cup-headed nail (OM) cui cu cap (semi)sferic cup holder (auto) suport frontal

cup-leather packing (OM) manşeta de etanşare, din piele

cup nib bolt $(\mathrm{OM})$ şurub / bolțcu cap bombat şi nas

cupola (constr) cupolă, dom; (mat) calotă; (met) cubilou; (nav) turelă

cupola blower (met) suflanta cubiloului cupola cast iron (met) fontă de cubilou cupola charge (met) încărcătură de cubilou cupola charging (met) încărcarea cubiloului cupola furnace (met) cubilou; cuptor de cupelatie / cu creuzete / cu cupolă

cupola gas (met, chim) gaze de cubilou cupola hearth (met) creuzetul cubiloului cupola leg (met, constr) coloana de susținere a cubiloului

cupola lining (met) căptușeală a cubiloului cupola malleable iron (met) fontă maleabilă, turnată din cubilou

cupola mantle (met) manta de cubilou cupola melting (met) topire în cubilou cupola mixture (met) încărcătură de cubilou, compoziția încărcăturii cubiloului

cupola operation (met) functionarea cubiloului cupola receiver (met) bazin anterior, pentru colectarea fontei la cubilou; antecreuzet cupola shaft / stack (met) cuva cubiloului cupola slag (met) zgură de cubilou cupola tender (met) topitor de cubilou cup packing $(\mathrm{OM})$ manşon, manşetă de etanşare, etanşare cu manşetă, manşon-colier

cupped $(\mathrm{OM})$ în formă de cupă

cupping (mas-un) ambutisare (şi adâncă), curbare transversală, prima etapă la ambutisare adâncă

cupping die(s) (mas-un, met) ștanță de tras / de întins

cupping-ductility value ( $\mathrm{TH}$, mas-un) indice de ambutisare-ductilitate

cupping machine (met, metr) aparat de încercat (tabla) la ambutisare

cupping of tape (met, ind chim) curbare transversală (a benzii)

cupping process $(\mathrm{TH})$ procedeu / operația de ambutisare adâncă

cupping test (TH) probă / încercare / test de ambutisare adâncă

cupping value $(\mathrm{TH})$ indice de ambutisare

cup point $(\mathrm{OM})$ vârf cu con interior

cupric (chim) cupric

cupriferous (met) de cupru, care conține cupru

cup screw $(\mathrm{OM})$ şurub cu suprafața frontală concavă

cup-shaped hammer (mas-un) ciocan căpuitor, buterolă (pentru nituire)

cup spring $(\mathrm{OM})$ arc-disc, arc-taler

cup test (met) test turnat / luat cu lingura

cup valve (OM, hidr) supapă cu clopot / cu taler concav

cup wheel (mas-un) piatră-oală, disc abraziv în formă de oală

curatin coater (ind chim) perdea de acoperire (la tehnologii de aplicare a adezivului)

curator custode (de muzeu); (jur) curator, tutore curb (amer) (constr) piatră de bordură; (constr) îngrădire a unei gropi de fundație; (mas-un) limitator, opritor, fixator

curb-ring crane (mas) macara cu placă învârtitoare / rotitoare

curd (alim) coagul, cheag, lapte bătut

curdle (alim) a (se) coagula, a (se) covăsi (d. lapte); (met, anat) a se închega (d. sânge)

curdling (alim) brânzire, covăsire

curds (alim) brânză dulce de vacă

curdy (alim, chim) coagulat, închegat, covăsit (d. lapte)

cure tratament, remediu; (ind chim, plast) vulcanizare, întărire; condensare, tratare termică; (TH) a condiționa, a vulcaniza, a trata termic, a întări, a usca, a zvânta; (alim) conservare, a conserva, a săra, a afuma; (med) a vindeca

cured (alim) maturat; (ind chim) protejat, conservat, vulcanizat 
cured meat (alim) carne sărată / conservată prin saramură, carne afumată

cured-on solid tyre (auto, ind chim) bandaj masiv fixat pe jantă, prin vulcanizare

cure rate (ind chim, plast) viteză de întărire / de vulcanizare

cured resin (ind chim) raşină întărită

cure time (ind chim) timp de vulcanizare / de întărire

Curie (fiz, metr) (Ci) curie, unitate pentru măsurarea radioactivității

Curie point / temperature (fiz, met) punct / temperatură Curie

curing (alim) maturare; (constr) protejare (a betonului până la întărire); (ind chim) întărire, vulcanizare, conservare, păstrare, tratare

curing agent (alim, ind chim) agent de vulcanizare / de întărire / de reticulare, conservant

curing autoclave (alim, ind chim) autoclavă de vulcanizare

curing bag (alim, ind chim) cameră de vulcanizare

curing by drying (alim, ind chim) conservare / întărire prin uscare

curing cellar (alim) cameră / incintă de sărat / de saramură

curing drum (ind chim, OM) tambur de vulcanizare

curing mould (ind chim, OM) matriță de vulcanizare

curing press (ind chim, mas-un) presă de vulcanizare

curing-type sealings $(\mathrm{OM}$, ind chim) materiale de etanşare, cear polimerizează (ireversibil) prin amestecare, prin expunere la apă / aer

curiousity curiozitate, dorință de a şti; indiscreție; lucru neobişnuit; ciudățenie

curious curios, care vrea să ştie; ciudat, neobişnuit, straniu; minuțios, amănunțit, migălos (d. o cercetare)

curium (Cm) (chim) curiu

curl buclă, spirală, colac, ondulație; (hidr) vârtej; (mat) rotor (al unui câmp vectorial); (textile, plast) ondulare, a bucla, a răsuci, a (se) ondula, a (se) încreți, a încolăci (d. fire, folii etc.)

curled buclat, ondulat

curl field (mat, fiz) câmp rotațional (turbionar)

curling încrețire, ondulare, răsucire, buclare (d. țesături şi semifabricate metalice sau nemetalice subțiri, fire, fibre, molecule)

curling die(s) (met, mas-un) stanță de bordurat / de bercluit tabla

curly ondulat, buclat, vălurit; fibros

currant (alim) stafidă (neagră), coacăză, agrişă currency (ec) monedă a unei țări, etalon monetar, valută, devize de valabilitate, devize, valoare, mijloc de plată, valabilitate, circulație, întrebuințare (a valutei), a intra în uz / circulație, intrat în uz / circulație; comun, răspândit

current curent, uzitat, comun, răspândit; (TH, fiz) curent, curgere, flux, şuvoi; (el) curent (electric), circulant; (nav) curent marin / curent, în curs; (ec) circulant, uzual, curent; mers / curs al evenimetelor

current conductor (el) conductor electric

current efficiency (el) randament al curentului electric; (hidr) randament al trecerii fluidului prin sistemul hidraulic

current examination revizie curentă

current instruction (c, inf) instructiune curentă / în curs de execuție

currently $(a d v)$ (în mod) curent, obişnuit, frecvent; acum, în prezent

current meter (metr, el) aparat de măsurat mărimi electrice

current production $(\mathrm{TH}, \mathrm{ec})$ producție curentă current ratio (metr, el, autom) raport / factor de amplificare de curent; (ec) indice contabil curent

current rating (el) intensitate recomandată pentru un anumit conductor sau configurație electrică

current repair (ecTH reparație curentă

current-responsive element (el) element / siguranță fuzibil(ă); (el, metr, autom) element activat de curent electric

current revision $(\mathrm{TH})$ revizie curentă

current sensitivity sensibilitate curentă / momentană (a unui aparat); (el) sensibilitate la parametrii rețelei de curent electric

current shock (el) şoc de curent

current shunt (el) derivație de curent, şunt current-steered (el) comandat prin curent current transformer (el) transformator de curent current velocity (hidr) viteză a curentului curriculum, $(p l)$ curricula (edu) plan de învățământ, programă analitică, orar

curriculum vitae curriculum vitae, scurtă autobiografie, $\mathrm{CV}$

currycomb file pilă rombică

cursive cursiv, italic, (litere) cursive, italice

cursively $(a d v)$ cu litere cursive

cursor (c) cursor (de localizare a elementelor unei imagini); (OM, el) glisor, cursor

cursorily $(a d v)$ (în mod) fugitiv, rapid, superficial, în grabă

cursory trecător; accidental; fugitiv, rapid; superficial 
cursory test (metr) test / încercare în condiții de accelerare (a unui proces)

curt scurt; concis

curtail a tăia, a scurta, a reteza, a restrânge, a reduce; a prescurta (un cuvânt); (ec) a reduce, a micşora (şi cheltuieli)

curtailment scurtare, reducere, micşorare

curtail of a lipsi / priva de

curtain (hidr) diafragmă; (fiz) ecran (subțire); (textile) perdea, draperie, cortină; (c, el) folie de ecranare; perdea de fum / ceață

curtain airbag (auto) airbag tip cortină

curtaining (met) (formare de) crustă de lingou, suprapunere / cutare de material (defect la laminare)

curtain net (el, autom) rețea de protectie curtain wall sheet (met, auto) tablă de caroserie curtate cycloid (mat) cicloidă scurtată curt duration overload capacity $(\mathrm{TH}, \mathrm{mec})$ capacitate de suprasarcină de scurtă durată curvature curbură; (auto) viraj; (TH) arc, curbă, cot

curvature radius of wave crests $(T)$ rază de curbură a vârfurilor asperităților

curve (autom, fiz, mec) grafic, diagramă, curbă caracteristică; viraj; (mat) (linie) curbă, curbură, arc (linie în desen); (alim) a bomba (cutii de conserve); (met) a ambutisa, a curba, a (se) bomba, a îndoi; (TH) cot, a (se) arcui, a (se) bolti, a se îndoi, a se curba, a se bomba

curve cut (mas-un) tăietură curbă / după profil curved $(\mathrm{OM}, \mathrm{mec})$ încovoiat, îndoit, curbat, strâmb, arcuit

curved arm (OM) spiță curbă / curbată, braț curb curved cutfile pilă cu dințare în arc de cerc curved cutting (mas-un) prelucrare a suprafețelor curbe (prin aşchiere)

curved form formă curbă / curbată curved frame (nav, constr) coastă radială curved link (OM) culisă în arc de cerc curved spring washer $(\mathrm{OM})$ şaibă elastică curved trash-rack (termo) grătar-coş curved vane $(\mathrm{OM}$, hidr) paletă curbă (la pompe cu limitare a debitului)

curve-fit (mat) determinare a coeficienților unei curbe (polinomiale de ordin $\mathrm{n}$ )

curve fitting ajustare a unei curbe empirice curve-forming rest (mas-un) sanie port-cuțit pentru prelucrat suprafete profilate

curve gauge (metr) şablon profilat

curve of displacement (nav) curbă a deplasamentului; (mec) curbă de deformații

curve of equal pressure (fiz, hidr, termo) izobară, linie de egală presiune curve of flotation curbă de plutire / de flotare curve of fullness (fiz, hidr) curbă de umplere curvilinear curbiliniu, neliniar, arcuit curvilinear coordinates (mat, fiz, mec) coordonate sferice

curvilinear motion (mec) mişcare curbilinie curving (mec, OM) deformație, încovoiere, curbură, îndoitură, îndoire, curbare

cushion $(\mathrm{OM})$ saltea, pernă, tampon, amortizor; a amortiza, a căptuşi, a capitona

cushioned $(\mathrm{OM})$ amortizat, suspendat prin arcuri

cushioned check valve (hidr, OM) supapă de sens unic, cu amortizare

cushioned clamp (OM) colier (metalic) cu căptusseală de amortizare

cushioned motion (mec, OM, TH) mişcare a unui subansamblu cu amortizare / suspendat prin arcuri

cushioned socket (c, electr) suport antivibrator (de componente electronice)

cushion effect (fioz, mec, el) efect de amortizare cushion feeder (agr, alim, mas-un, ind chim, constr) alimentator vibrator

cushion frame (mec, OM) ramă a pernei de amortizare

cushioning $(\mathrm{OM})$ garnitură elastică, pernă de amortizare; (mec) ciocnire, tamponare, lovire, amortizare

cushioning cylinder (OM) cilindru de amortizare, amortizor (hidraulic sau pneumatic)

cushioning device dispozitiv amortizor

cushioning spring (OM) arc de amortizare / de atenuare

cushion rubber (ind chim, mec) cauciuc spongios pentru amortizoare

cushion-tyre equipment (auto) anvelopă elastică

cushiony (moale) ca o pernă

cushy comod; uşor, care nu cere efort (d. muncă)

cusp vârf, pisc; (mat) punct de întoarcere / de inflexiune; (nav) promontoriu, cap

cusp of second kind (mat) punct de întoarcere de speța a doua

cutaway diagram (hidr) schemă (hidraulică) cu vedere în secțiuni şi conductele de legătură cutaway symbol (hidr) simbol în secțiune custodian custode, tutore, paznic custodianship calitatea sau functia de custode custody custodie, grijă, păstrare; arest, închisoare custom obicei, obişnuință, deprindere; uzanțe, convenții; (ec) clientelă, client, cumpărător, impozit, taxă, plată, comenzi; (nav) uzanță (a unui port); (adj) de comandă 
customary obişnuit, uzual

customarily ( $a d v)$ (în mod) obişnuit, uzual

customary clause (ec) clauză a uzului / uzanței comercial(e)

custom-built (ec, TH) construit / făcut după comandă specială; (amer) comandă la cererea clientului

custom designed $(\mathrm{TH})$ de proiectare / de comandă / de construcție specială, proiectat la comandă

customer (ec, TH) utilizator, consumator, beneficiar, client, cumpărator, abonat

custom-house (ec) vamă

custom-made (ec, TH) făcut de comandă / la comanda clientului

custom of port (ec, nav) vamă / uzanță a unui port

customs (ec) vamă, taxe vamale

customs duty (ec) taxă vamală

custom(s) house (ec) vamă, punct vamal, clădirea vămii

customs union (ec) uniune vamală

cut (ind chim) fracți(un)e (de distilare); (cf) debleu, tranşee, intersecție; săpătură; (mas-un) aşchiere, rectificare, şlefuire, ascuțire, tăiere, retezare, debitare, a așchia, a freza, a reteza, a decupa, a scurta; (mat) tăietură, secțiune (şi printr-o piesă, într-un desen); tăietură, făgaș; (constr) excavație; clişeu, gravură, formă de ilustrații; eliminare / scurtare a unui text; croială; (met) tăiere (cu flacără), decupare de tablă (după contur); (fiz, el) a obtura; (el, TH) a opri, a scoate din funcțiune; (inf) a anula, a suprima, a şterge; $(\mathrm{TH})$ a (se) tăia, a reteza, a debita, a croi, a grava, a ciopli, a fasona, a întrerupe, a secționa (şi în desen tehnic), a intersecta, a întretăia, a înceta; (agr) a recolta, a strânge, a cosi, a secera; (ec) a reduce (salariu, bani); a restrânge; (adj) tăiat, retezat, tuns, cosit, secerat, gravat; reducere, micşorare, scădere; bucată, felie; (textile) croială

cutability (mas-un) capacitate de a fi prelucrat / prin aşchiere, aşchiabilitate

cut across a intersecta, a întretăia

cut adrift (nav) a tăia cablul de ancoră

cutaneous (anat) dermic, cutanat, de piele

cut away a tăia, a reteza, a despărți; tăiat, retezat (cu detaşare a bucăților rezultate)

cut-away model model în secțiune

cutaway stern (nav) pupă dreaptă (la bărci)

cutback retezare, scurtare, tăiere; (amer) reducere, micşorare

cut back ( $\mathrm{TH}$, mas-un) a dilua, a dizolva, a fluidiza; (mas-un) a scurta, a reteza cut-back a product produs diluat, diluare a unui produs

cut by degrees (mas-un) a tăia în trepte

cut a core (mas-un) a carota

cut down a tăia, a separa (şi definitiv); (silv) a doborî / tăia copaci; a reduce din; (agr) a cosi; (ec, $\mathrm{TH})$ a reduce (cheltuieli, prețuri)

cut down incidents (auto, $\mathrm{TH}$ ) reducerea incidentelor; a reduce incidentele

cut-down milling (mas-un) frezare în sensul avansului

cut down the incidents (auto, TH) a preveni incidentele, a împiedica apariţia incidentelor

cut down to (a price) (ec) a determina reducerea (prețului cerut) la

cut edge muchia tăieturii (la table, benzi); (masun) muchie tăietoare

cut edge overhang (mec, OM) creastă a muchiei (şi la sudură, lipire)

cut glass sticlă şlefuită

cut in a însera (într-un text); (TH) a cupla, a anclanşa, a întrerupe, a se amesteca, a interveni; a interveni în discuție; (auto) a face o triplare periculoasă

cut-in insert; (mas-un) cuplat, cuplare

cut-in loop (autom) punere în circuit a frânării automate

cut-in relay (el) releu de anclanşare

cut-in speed (mec, autom) viteză de cuplare

cut length $(\mathrm{TH})$ lungimea tăieturii

cutlery (alim) tacâmuri, cuțite

cutlery steel (alim, met, mas-un) oțel pentru cuțite (tacâmuri)

cutless fără cusătură, fără întrerupere, fără tăietură (d. materiale, piese etc.)

cotlet (alim) cotlet, antricot (de vițel sau berbec), crochetă (din peşte sau carne), bucată mică de carne (pentru o persoană)

cut-meter (mas-un, metr) aparat pentru măsurarea vitezei de aşchiere

cut nipper cleşte ascuțit

cut(-)off scurtătură, drum drept / scurt; $(\mathrm{TH})$ deconectare, separare, întrerupere; (met, termo) pinten, vatră

cut off ( $\mathrm{TH}$, mas-un) a secționa, a separa, a tăia (un material, o legătură electrică, hidraulică etc.), a decupa, a debita, a reteza; a opri (şi brusc), a ciopli, a decupla, a deconecta, a rupe, a întrerupe, a închide, a acoperi; a bloca, a izola

cut-off adjustment (met) reglare a punctului de tăiere / a nivelului de limitare

cut of file dantură / tăietură a pilei

cut-off length (metr) lungime de bază de măsurare a profilului (la profilometria suprafeței) 
cut-off point punct de frontieră, piatră de hotar; punct de întrerupere (a unui proces)

cut-off point of steam (termo) sfârşit al admisiei aburului

cut-off region ( $\mathrm{T}$, met) zonă de rupere

cut-off relay (el) releu de tăiere / de separare / de întrerupere

cut-off rest (mas-un) sanie transversală, sanie port-cuțit (la un strung revolver)

cut-off size $(\mathrm{TH})$ mărime de rebutare

cut-off slide (mas-un) sanie a port-cuțitului de retezare, sanie transversală

cut-off stand (met) dispozitiv de retezare

cut-off tool (mas-un) cuțit de detaşare / de retezare (a piesei din bara din care a fost prelucrată)

cut-off trench (constr) tranşee de drenare (la fundație); (termo, met) vatră

cut-off valve (OM, hidr) ventil / supapă de închidere

cut-off velocity (fiz) viteză limită

cut-off voltage (el, electr) tensiune anodică critică / de blocare (a unei componente electronice), tensiune de închidere a descărcării, tensiune limită de descărcare (a unui acumulator)

cut-off wavelength (metr) lungime de bază de măsurare a ondulației (egală cu lungimea de evaluare) (la profilometria suprafetei)

cut-off wheel (OM) diafragmă de etanşare; (mas-un) disc abraziv subțire (de debitare)

cut oil (chim, T) țiței / ulei emulsionat, țiței / ulei murdar

cut open (mec) a spinteca, a tăia

cut out a tăia, a îndepărta prin tăiere, a separa; a îndepărta, a scoate, a elimina; (el) a scoate din circuit, a deconecta, a întrerupe (curentul); (auto) a depăşi, a se opri brusc (d. motor); a aranja; a pregăti dinainte

cut-out (el) întrerupător, disjunctor, siguranță cu material fuzibil; (OM) profil, contur, schiță, scobitură, decupare

cut-out board (el) tablou de sigurante

cut-out by autogenous method (met) tăiere / debitare prin procedeul autogen

cut-out cock (OM, hidr) robinet de închidere / de oprire

cut-out exhaust (met, hidr) supapă / zonă de evacuare

cut out for (TH, OM) potrivit / nimerit / dimensionat pentru, pe măsură cu

cut-out hole (met) orificiu decupat (spre deosebire de orificiul obtinut la turnare)

cut-out loop (auto, mas) scoatere din circuit a frânării automate cut-out relay (el) releu disjunctor

cut-out switcher (el, autom) întrerupător acționat de o anumită valoare a vitezei

cut-out the feeding bridge (el, autom) a întrerupe circuitul de alimentare

cut-out valve (met, OM, hidr) vană / ventil / supapă de închidere

cut-over tranziție

cut per tooth on broach radius (OM) supraînălțare pe flancul dintelui

cut rate (amer) (ec) preț redus

cuts (met, plast) îngustări, resturi de tăiere

cut short a scurta (prin tăiere, debitare etc.)

cut size (mas-un, el) mărime de tăiere / de întrerupere

cut smaller a tăia, a micşora (prin tăiere etc.)

cutter fisură transversală; (constr, ind chim) tambur de dezagregare (a bulgărilor etc.); (mas-un) cuțit (de aşchiat / de tăiat), sculă așchietoare, freză, frezor, foarfece, filieră, maşină de tăiat hârtie; (met) matriță cu placă de ghidare; filieră, cleşte, dispozitiv de tăiere (şi cu flacără) / de debitare / de decupare; (nav) cuter, şalupă de vamă, vedetă; (inf, c) cuțit (pentru tăierea continuă a hârtiei); (el) cap / dispozitiv de înregistrare electromagnetică a sunetului; $(\mathrm{TH})$ tăietor, care întrerupe

cutter arbor (mas-un, OM) dorn / arbore portfreză

cutter bar (mas-un) dorn port-freză, arbore portburghiu, bară port-cuțit

cutter bit (mas-un) vârf / tăiş̧ de sculă aşchietoare / de burghiu

cutter blade (mas-un) daltă, lamă / muchie tăietoare

cutter block (mas-un, met) cap de frezat / de tăiat; (alim) cilindru de / cu cuțite

cutter-clearance gauge (mas-un) şablon de ascutit freze

cutter disk (mas-un) cuțit-disc, disc de tăiere (la foarfece cu discuri)

cutter for milling half circles (mas-un) freză profilată, semirotundă

cutter for peripheral milling (mas-un) freză radială, maşină de frezat radial

cutter-grinding machine (mas-un) maşină de ascutit freze

cutter head (mas-un) cap port-cuțit, cap de frezat, cap port-burghiu

cutter holder (mas-un) port-cuțit, corp de freză (la freze cu cutite demontabile)

cutter-holder support (mas-un) cap port-cuțite

cutter interference $(\mathrm{OM}$, mas-un) interferența de prelucrare, subtăiere (la danturare - defect) 
cutter jib (mas-un) braț cu lanț tăietor (şi pentru lemne)

cutter mill (mas-un) freză (şi de finisat)

cutter of the borer (mas-un) tăiş al burghiului

cutter oil (ind chim) solvent petrolier

cutter plate (mas-un, met) cuțit tăietor, placă tăietoare

cutter setting (mas-un) aşezare a frezei în fața piesei de prelucrat

cutter shaft (mas-un) corp al cuţitului (şi fără element activ / plăcuţă)

cutter slide (mas-un) sanie a capului de frezat / a capului port-freză

cutter spindle (mas-un) arbore port-cuțit

cutter stock (ind chim) solvent petrolier

cutter tooth (mas-un) dinte de aşchiere / aşchietor (şi la freze cu dinţi demontabili), dinte de sculă aşchietoare

cutter with stem (mas-un) freză cu coadă

cut through (chim) a coroda; (mec, mas-un) a găuri, a perfora, a străpunge; (el) a închide succesiv contactele sau circuitele, a conecta direct

cut-through scurtătură

cut-through resistance (mec, TH) rezistență la aşchiere / la penetrare cu o muchie ascuțită

cutting (constr) excavare, săpare, debleiere, debleu, material rezultat din spărturi; (hidr) tăiere prin dragaj; (mas-un) aşchiere, filetare, tăiere, aşchiere, frezare, fasonare, decupare, debitare, lamă (de cuțit), ascuțit, tăios, care taie / aşchiază, de tăiere; (c, el) schimbare bruscă a secvențelor; $\sim \mathbf{s}$ deşeuri, resturi (de croire, de la aşchiere etc.)

cutting ability (mas-un) capacitate de aşchiere / de a fi aşchiat / prelucrat priun aşchiere

cutting action (mas-un) (procesul / operația de) aşchiere

cutting and bending reinforcement (constr) fasonare a armăturii

cutting-and-loading conveyer (mas) transportor cu lanț exterior, pentru tăierea şi încărcarea cărbunelui

cutting angle (mas-un) unghi de aşchiere; unghi de tăiere (al sculei aşchietoare)

cutting attachment (mas-un) dispozitiv (ataşabil) de tăiere / aşchiere

cutting bed (met) pat de tăiere / debitare cutting bit (mas-un) tăiş / floare de burghiu cutting blowpipe / torch (met) arzător / suflai de tăiat, aparat de tăiat oxiacetilenic

cutting by generation (mas-un) procedeu de aşchiere prin rulare (la prelucrarea roților dințate, roților cicloidale etc.) cutting capacity / property (mas-un) capacitate de aşchiere / de tăiere, productivitate a unei scule aşchietoare

cutting chain (mas-un) lanț tăietor

cutting chip (mas-un) aşchie

cutting compound (mas-un, T) lichid emulsionat de ungere şi răcire la tăiere

cutting die (mas-un) ştanță de decupat

cutting edge (mas-un) muchie aşchietoare, unghi de aşchiere, tăiş, element activ (la scule etc.), vârf tăietor, lamă (de cuțit, în general)

cutting edge of bit (mas-un) tăiş al cuțitului / al sculei, vârf de burghiu / de sfredel

cutting edge of hard metal (mas-un) tăiş / muchie din material dur (carburi metalice) la cuțit / sculă aşchietoare / la vârf de burghiu (şi sub formă de acoperiri)

cutting-edge temperature (mas-un) temperatură a tăişului / pe muchia aşchietoare a sculei

cutting electrode (met) electrod pentru tăiere cu arc

cutting face (mas-un) lamă / tăiş, suprafață de tăiere / de aşchiere

cutting feed (mas-un, met) (viteză de) avans (în procese de aşchiere)

cutting flame (met) flacără de tăiat

cutting fluid (mas-un) lichid de tăiere / de răcire (la aşchiere); (T) fluid de aşchiere/ folosit în procese de aşchiere / de tăiere cu jet

cutting force (mas-un) forță de aşchiere / de tăiere

cutting height (constr, mas) înălțime de acțiune a brațului excavatorului

cutting-in (TH) cuplare; (mas-un) aşchiere interioară

cutting into pieces (mas-un) secționare / tăiere în bucăți

cutting iron daltă tăietoare

cutting knife (mas-un) cuțit de croit / de debitat (tablă)

cutting line (mat) linie de intersecție; linie de tăiere; (inf) linie de sfârşit (de rând)

cutting machine (mas-un) maşină de tăiat bandă de hârtie; maşină de tăiat / de debitat

cutting motion (mas-un) mişcare de aschiere / de lucru, mişcare în cursa activă

cutting-off $(\mathrm{TH})$ închidere, întrerupere, separare (prin tăiere), retezare, debitare

cutting-off the beam (fiz, metr) suprimare a unui fascicul / a unui spot

cutting-off the steam (termo) închidere / oprire a aburului

cutting-off tool (mas-un) cuțit de retezat / de debitat 
cutting oil (mas-un, T) lichid pentru răcire şi ungere (în procese de aşchiere, debitare, tăiere cu jet)

cutting-on croire

cutting-out decupare

cutting-out machine (mas-un, met, autom, nav) mașină de croit / de debitat după contur

cutting-out press (mas-un) presă de decupat cutting plier(s) cleşte ascuțit / de tăiat cutting point (constr) şantier de excavații; (masun) vârf tăietor, element activ, tăiş (de sculă)

cutting power (mas-un) putere consumată / necesară pentru aşchiere

cutting pressure (mas-un) efort / presiune / apăsare de aşchiere

cutting resistance (mas-un) efort / presiune de aşchiere, rezistență la aşchiere

cutting ring (mas-un) poanson inelar

cutting room $(\mathrm{TH}$, nav, met) cameră de decupaj, sală de montaj

cutting root angle $(\mathrm{OM})$ unghiul conului de picior al dintelui (la dantura conică)

cuttings (mas-un, met) şpan, aşchii

cuttings chute / pit / shoot (mas-un) (jgheab) colector de aşchii

cutting section (mas-un) secțiune tăietoare (la scule)

cutting speed (mas-un) viteză de aşchiere / de tăiere / de debitare

cuttings tray (mas-un) tavă de colectare a aşchiilor

cutting strength (mas-un) rezistență la tăiere / la aşchiere

cutting tip (met) bec de tăiat (la tăiere cu flacără)

cutting tool (mas-un) cuțit (aşchietor), sculă aşchietoare

cutting tool(s) dressing (mas-un) ascuțirea sculelor / sculei aşchietoare

cutting tool durability / life / endurance (mas-un) durabilitatea tăişului (şi între două ascuțiri / acoperiri)

cutting torch (met) flacără de tăiere, aparat de tăiat oxiacetilenic, arzător / suflai de tăiere

cutting-up decupare

cutting wheel (mas-un) cuțit-roată pentru mortezarea roților dinţate sau pentru tăierea benzilor în fâşii

cut to length (met, mas-un) retezare / tăiere a bucății / a semifabricatului de o anumită lungime cut to pieces $(\mathrm{TH})$ a distruge prin sfărâmare / rupere în bucăți

cut up (mas-un) a separa prin tăiere, a debita, a secționa, a tăia în bucăţi; a distruge; a afecta profund cut-up milling (mas-un) frezare în contra avansului

cut(-)water (hidr) cumpăna apelor; (nav) spargegheață; cap amonte al pilei; (nav) muchie a chilei / a etravei, pinten

C-washer (OM) şaibă în C, şaibă secționată (pentru înlocuire rapidă)

cyanic acid (chim) acid cianic

cyanide (chim) cianură

cyanide hardening (met) călire în baie de săruri de cianură

cyaniding (met) tratament termo-chimic de carbonitrurare prin imersare în săruri topite sau gazoase, de cianură

cyanoacrylate monomer (ind chim) monomer cianoacrilat

cynite (chim) disten

cyanogen (chim) cian

cybernetics cibernetică

cycle ciclu, timp; (OM, mec) bicicletă, ciclu (şi la oboseală), perioadă, proces ciclic; (inf) grup repetabil, de instrucțiuni; ciclic; a itera, a repeta (periodic); a încheia un ciclu de dezvoltare, a trece printr-un ciclu; a merge cu bicicleta / motocicleta

cycle count (autom, el) progresie a unui contor; (inf) numărare a ciclurilor

cycle index (mec, metr) numărător / numărul de cicluri

cycle of annealing (met) ciclu / durată de recoacere cycle of charges (met, mec) ciclu de încărcări

cycle of operations (TH) ciclu de operații / de lucru (şi de prelucrare prin aşchiere)

cycle of stress (mec) alternanță / ciclu de sarcină; $(\mathrm{OM})$ ciclu de solicitare / de variatie a efortului / tensiunii (la solicitare variabilă; la oboseală)

cycle on (auto, TH) a funcționa în cicluri (d. compresoare etc.)

cycle(s) per second (c/s) (Hz) (metr) perioadă / cicluri pe secundă, frecvență

cycle progress (fiz, chim) derulare / desfăşurare a ciclului

cycle rate $(\mathrm{mec})$ rată a ciclurilor

cycle (rate) counter (metr) contor de cicluri, frecventmetru

cycle reset (metr) readucere la zero a indicatorului de cicluri

cycle stress alternation $(\mathrm{OM})$ ciclu altervativ, de solicitare (mod de) alternare ciclică a tensiunii

cycle through a trece printr-un ciclu, a reveni la un ciclu / la o buclă

cycle tyre (transp) anvelopă de bicicletă 
cyclic(al) periodic, ciclic

cyclic bond (chim) legătură în ciclu / ciclică / care se repetă (într-un lanț molecular)

cyclic course ciclu, parcursul unui ciclu

cyclic fatigue loading (mec) solicitare ciclică (la oboseală)

cycling speed (hidr, mas-un) viteză de parcurgere a unui ciclu / proces ciclic

cyclic motion mişcare periodică / ciclică

cyclic load $(T, O M)$ sarcină periodică / ciclică

cyclic loading (mec, OM, T) sarcină / încărcare periodică / ciclică

cyclic pneumatic programmer (autom, hidr) programator ciclic pneumatic

cyclic shift (autom) decalaj ciclic, deplasare ciclică

cyclic stabilsed conditions (hidr) condiții ciclice, stabilizate

cyclic stress (mec, OM) efort / tensiune (cu evoluție) ciclică / periodică (şi la oboseală)

cyclic timer (autom, metr) programator / temporizator ciclic

cyclide (mat) ciclică (d. curbe)

cycling (inf, c, autom) prelucrare ciclică / în buclă, iterare; pendulare; care este $\operatorname{ciclic}(\breve{a})$

cycling of gas (met, termo) recirculare a gazelor

cyclogram ciclogramă, înregistrarea unui ciclu (de sarcină / frecvență etc.)

cycloid (mat, $\mathrm{OM}$ ) cicloidă

cycloidal (mat) cicloidal

cycloidal gear $(\mathrm{OM})$ angrenaj cicloidal

cycloid check $(\mathrm{OM})$ camă cicloidală

cycloid gear(ing) $(\mathrm{OM})$ angrenaj cicloidal

cyclometer (metr) contor de rotații / cicluri

cyclometry (metr) ciclometrie; (cf) măsurare periodică / ciclică

cyclone (alim, ind chim, mediu) ciclon

cyclone collector ciclon de colectare (şi la desprăfuire)

cyclone dust catcher (mediu, ind) ciclon pentru acumularea / colectarea prafului

cyclone dust separator (mediu, ind) ciclon pentru separarea prafului

cyclone gas washer (mediu, ind) ciclon pentru spălarea / curățarea gazelor

cyclonic flame (termo) flacără turbionară / în spirală

cyclonic motion (mec, hidr) mişcare ciclonică / în spirală

cyclopaedia enciclopedie

cyclopaedic enciclopedic

cyclotomy diviziunea cercului

cyclotron (fiz) ciclotron, rezonator magnetic

cyclysed rubber (plast, ind chim) cauciuc ciclizat cyder (alim) cidru

cylinder (auto) cuzinet, (cămaşă de) cilindru; (mat) cilindru; (OM) tăvălug, cilindru, tambur, butelie; (c) cilindru al unui disc magnetic

cylinder bearing $(\mathrm{OM}, \mathrm{T})$ lagăr cilindric

cylinder body (OM, hidr) partea ciclindrică a unei butelii / a unui recipient / a unei pompe / a unui cilindru hidraulic

cylinder bore $(\mathrm{OM})$ alezaj al cilindrului

cylinder boring machine (mas-un) maşină (şi specializată) de alezat cilindri, maşină de găurit cilindric

cylinder-brushing machine (mas-un) maşină de periat / lustruit cu cilindri

cylinder cap (OM) capac al buteliei (şi de protectie), capac al cilindrului hidraulic

cylinder capacity / displacement (auto, termo) capacitate cilindrică, cilindree

cylinder casing (termo) manta de răcire (şi cu apă) a cilindrului / a recipientului

cylinder cover $(\mathrm{OM}$, termo) chiulasă, capac al cilindrului

cylinder covering (OM) acoperire de protecție a unui cilindru, manta (cilindrică)

cylinder cushion (hidr) amortizor (de şocuri) al cilindrului (şi pneumatic)

cylinder dryer (alim, ind chim) uscător cilindric / cu valturi / cu tambur

cylinder duster (alim, ind chim) desprăfuitor cu tambur

cylinder furnace (met) cuptor cilindric / tubular (şi la laminoare)

cylinder gap (OM) gol / degajare a(l) cilindrului (şi pentru garnituri de etanşare, inele etc.)

cylinder gas (termo, ind chim) gas comprimat / sub presiune / îmbuteliat

cylinder grinder (mas-un) dispozitiv de rectificat cilindri / cilindric

cylinder grinding wheel (mas-un) disc de rectificat, cilindric / inelar

cylinder head (mas, auto) chiulasă / capac al cilindrului; (termo) fund / capăt de recipient / cazan

cylinder head bolt (OM) şurub prizonier în chiulasă

cylinder hone (mas-un) disc de honuit cilindri / cilindric

cylinder honing machine (mas-un) maşină de honuit cilindri / suprafete cilindrice

cylinder lever (OM) pârghie a cilindrului

cylinder liner $(\mathrm{OM}$, termo) căptuşeală / cămaşă de cilindru

cylinder mill (alim, ind chim) moară cu valțuri / cu tăvălugi / cu cilindri / cilindrică 
cylinder planer (mas-un) maşină de rabotat suprafețe cilindrice

cylinder plug (OM, hidr) tampon de cilindru

cylinder port (OM, hidr) fereastră / orificiu a cilindrului

cylinder ring (OM, hidr, termo) inel / segment de cilindru

cylinder saver (OM, hidr) dispozitiv antişoc al cilindrului

cylinder saving (OM, hidr) protejarea cilindrului (hidraulic)

cylinder set-up (termo, hidr, OM) grupare / poziționare a cilindrilor

cylinder shoulder $(\mathrm{OM})$ parte superioară / de rezemare a unei butelii / a unui cilindru

cylinder stand (OM, hidr) picior / suport de butelie / de cilindru (şi hidraulic)

cylinder surface (OM, hidr, termo) suprafața cilindrului (de obicei cea de lucru)

cylinder valve $(\mathrm{OM})$ robinet de butelie

cylinder volume (OM, hidr, termo) cilindree, volumul interior (util) al cilindrului

cylinder wheel(s) gauge (metr) calibru-roată pentru cilindru

cylinder with cooling flanges (OM, hidr) cilindru cu nervuri / aripioare de răcire

cylindric(al) cilindric

cylindrical ball mill (constr, ind chim) moară cilindrică cu bile

cylindrical bearing (constr) reazem cilindric; $(\mathrm{OM})$ cuzinet / lagăr cilindric

cylindrical bloom (met) lingou rotund

cylindrical boiler-shell (termo) cazan orizontal, cilindric

cylinder bore (OM, hidr) alezaj de cilindru

cylindrical brush perie de curățat țevi

cylindrical bushel grindstone (mas-un) piatră cilindrică, de polizor

cylindrical bushing $(\mathrm{OM}, \mathrm{T})$ cuzinet cilindric, bucşă cilindrică

cylindrical caisson (nav, constr) cheson cilindric

cylindrical cam $(\mathrm{OM})$ camă cilindrică

cylindrical cutter (mas-un) freză cilindrică

cylindrical die sinking cutter (mas-un) freză cilindro-frontală, pentru prelucrarea locaşurilor de matrițe

cylindrical drill (mas-un) burghiu cilindric cylindrical drum $(\mathrm{OM})$ tambur cilindric cylindrical-drum hoist (met) maşină de extracție, cu tobe cilindrice

cylindrical fit (OM) asamblare / ajustaj a(l) corpurilor cilindrice netede

cylindrical gear (OM) angrenaj cilindric

cylindrical gear pair $(\mathrm{OM})$ angrenaj cu roți cilindrice, angrenaj cilindric

cylindrical grinder / grinding machine (masun) maşină de rectificat suprafețe cilindrice

cylindrical grinding (mas-un) rectificare cilindrică

cylindrical grinding wheel with recess (masun) corp disc abraziv cilindric, cu degajare

cylindrical harmonic (mat) funcție cilindrică

cylindrical hinge $(\mathrm{OM})$ articulație cilindrică

cylindrical liner $(\mathrm{OM})$ cuzinet cilindric, bucşă (cu pereți subtiri)

cylindrical mill (alim, ind chim) moară cilindrică

cylindrical pin $(\mathrm{OM})$ pivot / ştift cilindric

cylindrical plug gauge (metr) calibru tampon (cilindric)

cylindrical plug valve (OM, hidr) supapă / ventil cu tijă cilindrică (şi la rulmenți)

cylindrical roller $(\mathrm{OM})$ rolă cilindrică

cylindrical roller bearing $(\mathrm{OM})$ rulment (radial sau axial) cu role cilindrice

cylindrical rotary kiln (alim, met) cuptor tubular rotativ

cylindrical screw $(\mathrm{OM})$ şurub cu cap cilindric, şurub cu filet cilindric

cylindrical slide valve (hidr, OM) sertar / plunjer tubular

cylindrical spring (OM) arc elicoidal (cilindric)

cylindrical tank (OM, hidr) rezervor cilindric

cylindrical valve (OM, hidr) supapă / vană cilindrică

cylindrical washer (OMalim, ind chim cilindru spălător

cylindrical waves (fiz) unde $\mathrm{cu}$ fronturi cilindrice, coaxiale

cylindrical wheel $(\mathrm{OM})$ roată dințată cilindrică

cylindrical winding înfassurare concentrică / în straturi suprapuse uniform (şi la transformator)

cylindricity $(\mathrm{OM})$ cilindricitate

cylindro-conical-drum hoist (met) maşină de extracție, cu tobă cilindro-conică

cylindroid (mat) cilindroid, cilindru eliptic drept 


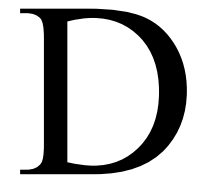

D/A (electr, autom) digital-analog

dab atingere; murdărire; tamponare (cu un burete etc.); picătură, bucățică, strat subțire aplicat, pată (de vopsea), împroşcătură (cu noroi, ulei etc., în sens nedorit); lovitură uşoară; ( $\mathrm{fam}$ ) expert, meşter; (iht) cambulă; a atinge (uşor), a lovi uşor; a tampona, a şterge prin tamponare (cu un burete etc.); a întinde, a aplica, a acoperi cu un strat subțire

dabbed spout (met) gură căptuşită (la cuptoare)

dabber tampon; (met) cui de turnătorie

dabbering / dabbing tamponare

dabble a (se) stropi, a (se) înmuia

dabby umed, jilav; slinos

dactyl (metr) dactil

dactylic (metr) dactilic

dado (constr) soclu, piedestal

daedal ingenios; complicat, încurcat

dag (ind chim) pulbere de grafit

dagger function (inf) functie logica NU-SAU (NOR), funcție Pierce

daily zilnic, cotidian, de fiecare zi; obişnuit; (ziar) cotidian

daily average production (ec, $\mathrm{TH})$ producție medie zilnică

daily chart diagramă zilnică

daily consumption $(\mathrm{ec}, \mathrm{TH})$ consum zilnic

daily delivery capacity $(\mathrm{ec}, \mathrm{TH})$ capacitate de producție zilnică

daily flow (ec, TH) producție zilnică (în flux continuu)

daily mean (ec, TH) medie zilnică

daily output $(\mathrm{ec}, \mathrm{TH})$ producție zilnică

daily paper ziar, cotidian

daily production $(\mathrm{ec}, \mathrm{TH})$ producție zilnică

daily report raport zilnic, jurnal

daily returns (ec) câstig pe zi

daily storage (ec) înmagazinare / acumulare zilnică

dairy (agr, alim) fermă de lapte, laptărie

dairy cattle (agr) vaci de lapte

dairy factory / plant (alim) fabrică de prelucrare a laptelui / de produse lactate

dairy farm (agr) fermă (de vaci) de lapte

dairyman (agr) lucrător la o fermă de lapte

daytime running light (auto) lumină de zi

dairy products (alim) produse lactate dais (constr) podium, estradă; (edu) catedră

dalton (metr) unitate de măsură pentru masă: 1 dalton $=1,66053 \cdot 10^{-27} \mathrm{~kg}$

dam (constr) baraj, dig, stavilă cu clapete, stăvilar, batardou, îndiguire, prag (de bazin); a stăvili, a zăgăzui, a îndigui, a împiedica; (TH) a frâna, a închide, a bara, a opri, a retine

damage (constr) degradare (a constructiei); (ec) pierdere, daună, pagubă, lezare; (TH) avarie, avariere, defect(are), cădere (a unui utilaj etc.), deteriorare, pană, stricăciune; (TH) a deteriora, a defecta, a avaria, a strica, a cădea, a distruge (şi parțial)

damage assessement (ec, $\mathrm{TH}$ ) estimare a pierderilor, a cheltuielilor de reparație sau/şi înlocuire

damage control (nav) control de avarie, serviciu de siguranță a navei

damaged (auto, $\mathrm{TH}$ ) avariat; deteriorat, scos din funcțiune (nedorit) stricat; păgubit; discreditat

damaged component $(\mathrm{OM}, \mathrm{T})$ piesă / componentă deteriorată / distrusă

damage effect (med) leziune; efect al avariei / defectării / distrugerii

damage repairs $(\mathrm{TH})$ depanare, repararea stricăciunilor / avariei

damage report $(\mathrm{TH})$ raport de avarie

damage survey (TH) expertiză a avariei / distrugerii

damage tolerance $(\mathrm{TH})$ capacitatea de a rezista la distrugere o anumită perioadă de timp (d. o maşină, utilaj etc.)

damage threshold $(\mathrm{TH})$ prag de deteriorare (stare, parametri peste care sistemul este considerat avariat / stricat)

damaging action / effect (med) leziune; (procesul de) defectare, acțiunea / efectul deteriorării

Damascus / damask steel (met) oțel de Damasc (şi ca rețetă)

damascene steel (met) oțel de Damasc

damask (textile) (tesătură de)damasc; (met) otẹl de Damasc, a da o culoare închisă oțelului (prin tratament)

damask steel (met) oțel de Damasc

Dammar resin (plast) răşină dammar

damn a condamna; a critica; a considera fără valoare

damp (el, autom) atenuare, amortizare; gaz de mină; (TH) amortizare; umezeală, umiditate, igrasie; descurajare; tristețe; ud, umed, jilav; glacial; (fig) rece; (hidr) a umezi, a umecta, a stropi, a uda, a înmuia; a stinge (focul); (met) a frâna / a atenua / a reduce mersul unui furnal; a înăbuşi (un foc, un sunet etc.); a opri vibrațiile, a amortiza, a slăbi (presiunea); (fig) a descuraja, a potoli (elanul etc.), a deprima 
damp air aer umed; (hidr) aer (coprimat) prin amortizor pneumatic

damp and dust proof rezistent la umiditate şi etanş la praf

damp course (materiale) hidroizolator

damp down a face mai mic, a stinge (d. foc); (mec, autom, metr) a atenua, a amortiza (parțial) (oscilații, vibrații)

damped (autom, mec) amortizat, aperiodic; umezit, înăbuşit (şi un foc); atenuat

damped oscillation (autom, el, mec) oscilație amortizată / atenuată

damped wave (fiz, mec) undă amortizată

dampener (autom, el, mec) amortizor, atenuator; (alim, ind chim, constr) dispozitiv de umezire

dampening (alim, ind chim, constr) umezire

dampening stretch (alim, ind chim, constr) alungire la umezire

dampening unit (alim, ind chim, constr) aparat de umezit

damper (auto) amortizor; (constr) amortizor de zgomot; (el) atenuator; (OM) amortizor, clapetă; (met) registru de coş / fum, şuber; (el, c) surdină; (TH) amortizor, umezitor; (termo) intrare / vană de aer (de combustie); (met) registru de ventilație / de coş; (termo) dispozitiv de climatizare; domeniu, sferă

damper device (mec, autom, el) dispozitiv de atenuare / amortizare

dampering (mec, autom, el) reglare a amortizării / la amortizare

damper loss (OM, hidr) pierdere de presiune statică într-un fluid curgând printr-un amortizor; (autom) pierdere prin atenuare, amortizare

damper plate $(\mathrm{OM})$ placă de amortizor, şuber, clapetă

damper rod $(\mathrm{OM})$ tijă de ridicare

damper ventilation $(\mathrm{OM})$ robinet de ventilatie

damper weight (mec) contragreutate (la sistem de amortizare)

damp heat test (metr, termo) încercare în căldură umedă

damping (autom, mec) amortizare, atenuare; umezire, umectare, înmuiere; (fiz) evaporare, volatilizare, aburire

damping action efect / acțiune de ştrangulare / amortizare / atenuare

damping area $(\mathrm{OM}, \mathrm{mec})$ suprafață de amortizare

damping behaviour (mec, autom, metr) comportare tip amortizor

damping capacity (mec, autom, metr, el) capacitate de amortizare

damping chuck (mas-un, mec) mandrină de strângere, cu amortizare damping coefficient (mec, autom, metr) factor/ constantă de atenuare / de amortizare

damping down tower (met) turn de stingere a cocsului

damping effect (mec, autom, metr) efect de amortizare / atenuare

damping element (mec, autom, metr) atenuator, element amortizor

damping factor (autom, el, metr) factor / coeficient de amortizare / atenuare

damping friction $(\mathrm{OM}, \mathrm{T})$ frecare care are ca efect amortizarea / atenuarea

damping gyro regulator (autom, mec) atenuator / regulator pentur mișcări giratorii

damping period / time (metr, autom, mec) perioadă / timp de liniștire (a indicatorului unui aparat de măsurat, prin atenuare, amortizare a oscilațiilor); timp de stingere (a unei oscilații)

damping pressure (hidr) presiune de amortizare damping ratio (metr, autom, mec) raport / increment de amortizare

damping resistance (el) rezistență de amortizare / atenuare; (mas) rezistență de frânare / de amortizare

damping rolls (constr, alim, ind chim) cilindri de umezire

damping spring (el) arc / resort de amortizare; (mec) amortizor cu arc

damping test probă / încercare la tenacitate / la amortizare (d. materiale)

dampness umiditate, umezeală; igrasie

dampness of walls (constr) igrasie pe perete

damp off (agr, bot) a putrezi (din cauza umidității) (d. plante); a stinge (un foc)

damp-proof $(\mathrm{OM})$ etanş la pătrunderea umidității cu cappacitate de amortizare; $(\mathrm{TH})$ rezistent la umiditate

damp-proofing (mec, constr) etanşare la umiditate / la igrasie

dam stone (met) prag (de furnal)

dampy umed, jilav; (met) necopt, brut

dancer roll(s) (met) role de reglare (la agregate de decapare), regulator de întindere a benzii / foliei

dander (met) zgură; (fam) supărare, mânie, indignare

danger pericol, primejdie

danger alarm $(\mathrm{TH})$ instalație de alarmă / de semnalizare a pericolului

danger arrow (el)săgeată avertizoare pentru înaltă tensiune / paratrăsnet

danger dose (med, fiz) doză periculoasă (şi de radiații)

danger light $(\mathrm{TH})$ semnal optic de pericol 
danger of breaking (mec, TH) pericol de spargere / de rupere

danger of slagging (met) pericol de formare a zgurii

dangerous $(a d j)$ periculos, primejdios, riscant

dangerous goods mărfuri periculoase

dangerously $(a d v)$ (în mod) periculos, riscant

dangerous oils (ind chim, T) produse uşor inflamabile

dangerous section (mec, chim, TH) secțiune periculoasă

dangle a (se) legăna, a (se) bălăbăni, a atârna, a fi spânzurat / agățat; a ademeni

dank umed și rece

dant (met) cărbune de calitate inferioară

dapping die blocks (mas-un) cub cu calote pentru ambutisare (la matrițe)

dare a cuteza, a avea curaj; a se aventura, a risca

daring îndrăzneț, cutezător, care îndrăzneşte / riscă; temerar; riscat; îndrăzneală, cutezanță

dark (fiz) obscuritate, umbră, negru, întuneric; ascuns, obscur, neclar

dark adaptation (anat) adaptare a irisului şi retinei pentru vizibilitate

dark annealing (met) recoacerea neagră / până la negru

darken a (se) întuneca, a face obscur (sensul unui text); a eclipsa, a umbri

darkening of glass (ind chim) opacizare a sticlei dark heat (fiz, termo) căldură iradiată de regiunea invizibilă / infraroşie a spectrului

darkish (cam) întunecos / întunecat

darkness întuneric, obscuritate; culoare închisă; ignoranță; caracter ascuns / secret

dark petroleum oils (ind chim) produse petroliere negre / închise la culoare

dark purple violet închis

dark-red heat (met, termo) incandescență la roşu închis

dark-red heating (met) încălzire până la incandescență la roşu închis

dark yellow galben închis

darn țesătură, cârpitură; a țese, a stopa; a cârpi, a drege

darning needle (textile) ac de stopat

dash izbucnire, țâşnire; picătură; clipocit, plescăit (al apei); pată de culoare; mişcare bruscă; atac, năvală; pic, strop; (alim) deget (de vin etc.); avânt; vioiciune; aparență strălucită; cursă scurtă; (gram) (în punctuație) liniuță de despărțire (auto) separație între motor şi locul de conducere, tăblie de motor; (constr) grindă; (met, mec) ciocnire, şoc, izbire, izbitură, ciocănire, lovitură, şoc; $(\mathrm{OM})$ mâner, coadă de ciocan; (met) aerisire a locului de muncă în subteran sau în hale cu praf şi noxe; linie (de dialog, în text); a lovi, a izbi, a arunca, a lansa, a scoate, a țaşni; (fig) a distruge (un plan), a descuraja; a sublinia; a fugi, a alerga, a goni; a se ivi pe neaşteptate; a azvârli cu putere; a sparge, a zdrobi; a înlătura rapid; (fig.) a nărui (speranțe); a stropi, a împroşca; a amesteca cu apă, a dilua; (off) a scrie în mare grabă; a da buzna; a se precipita; a se prăvăli; a intra cu forța; to pieces a sparge (în) bucăți; $(a d v)$ at a / one $\sim$ dintr-o dată

dash against a se năpusti asupra; a se ciocni de dashboard (auto) tablou de bord

dashboard light (auto) lumina tabloului de bord dash control (mas, TH) comandă prin butoane dash-dot (line) (linie) linie-punct

dash down a coborî val-vârtej

dashed striat, punctat; întreruptă, punctată (d. linii); stropit, împroşcat; zdrobit

dashed-spring washer $(\mathrm{OM})$ rondelă elastică, de oțel (ca o spiră de arc)

dash in a da buzna

dashing energic, hotărât, activ

dashing rule regulă de haşurare

dashpot (auto) amortizor pneumatic sau hidraulic; (el) atenuator; (OM) cilindru de frână, pernă de aer, amortizor, amortizor / tampon pneumatic / cu aer, orificiu de evacuare a fluidului la capăt de cursă (la cilindri hidraulici)

dashpot action (OM, hidr) amortizare hidraulică dashpot piston $(\mathrm{OM})$ piston de amortizor

dashpot-type shock absorber (OM, hidr) amortizor hidraulic

dash shield (auto, termo) tăblie de motor dash to a spray $(\mathrm{TH}, \mathrm{T})$ pulverizare / barbotaj sub presiune

data, datum date, informații (primare), indicii, indicații; caracteristici tehnice; valori caracteristice; parametri; documente de bază

data acquisition / capture (inf) colectare / achiziție (culegere, prelucrare parțială şi înregistrare) de date

data acquisition system (inf, metr) sistem de colectare / achiziție de date

data address (inf) adresă cu / pentru date

data analysis (inf) analiză / procesare a datelor

data bank (inf) bancă / mulțime de date dintr-un domeniu definit, stocate organizat, ansamblu de fişiere înrudite, cu date dintr-un anumit domeniu

data base (inf) bază / mulțime de date, organizată, referitoare la un set anumit de aplicații, ansamblu de date organizate pentru utilizare în aplicații distincte 
data base management system (c, inf) sistem de gestiune a bazelor de date

data block (c, inf) bloc de date, zonă a unui program care concentrează datele utilizate în acesta

data capture (metr, inf, autom, TH) colectare sistematică a datelor

data carrier (c) suport de informații

data collection (inf, $\mathrm{TH}, \mathrm{ec}$ ) colectare a datelor (într-un punct central)

data comparator (inf) bloc de comparare a datelor

data compression (c, inf) comprimare a datelor, codificare a informației pe baza frecvenței de apariție a simbolurilor unui alfabet

data consistency (mat, c) consistență / corectitudine a datelor

data conversion ( $c$, inf) conversie / transformare a formei de reprezentare a datelor

data dictionary (c, inf) dicționar / tabel de corespondenţă şi descriere a datelor

data display / presentation (inf) afişare a datelor

data dump (c) pierdere la transferul informațiilor (între memorii)

data file (inf) fişier de date, mulțime de date utilizate într-o anumită aplicație

data gathering (inf, $\mathrm{TH}, \mathrm{ec}$ ) colectare a datelor

data handling (inf) prelucrare / procesare a datelor / informațiilor

data hold (inf) reținere / memorare / stocare a datelor

data input / output unit (inf) dispozitiv de colectare şi transmitere a datelor

data integration (inf) comasarea datelor din mai multe surse într-un singur fişier

data integrity (c, inf) integritate a datelor, protejare a datelor față de defectarea echipamentelor sau programelor

data link system (c, inf) sistem de transmitere a datelor

data logging (autom, inf) colectare / achiziție / înregistrare de date în timp real

datamation (autom, inf) prelucrare automată a datelor

data name (inf) nume al datei, caracter(e) de identificare a(le) unei date

data of welding (met) regim de sudare

data plate $(\mathrm{TH})$ tăbliță / plăcuță cu date tehnice principale; placă de timbru

data preparation (c, inf) pregătire / înregistrare pe un suport de informații, a datelor

data processing (inf) prelucrare a datelor / informatiilor

data processor (c) unitate centrală a unui calculator, instalație pentru prelucrarea informației, procesor data recorder (inf, autom, TH) înregistrator de informații / de date

data recovery (c) înregistrare / recuperare a datelor

data-sensitive fault $(\mathrm{TH})$ defecțiune pusă în evidență de date / înregistrări

data separation (inf) triere de informații (şi automată)

data sheet scurtă autobiografie; (inf) caiet de sarcini, foaie de date (cu proprietăţi pentru materiale, cu parametri pentru maşini, utilaje etc.)

data simulation (mat, inf) simularea comportării unor modele pe baza datelor statistice

data smoothing (mat, inf) procedură matematică de transformare a unei mulțimi de puncte disperse într-o curbă

data storage (inf) înmagazinare de informații, memorare de date

data transfer (c, inf) transfer de date (sub program specializat)

data transmission chain linie de comunicatie, lanț de transmisie a datelor

data transmitter (inf, autom, ec) terminal pentru transmiterea datelor, transmițător de date

data type (inf) tip de date, mulțime de date unitare din punctul de vedere al informației reprezentate

date dată (calendaristică), perioadă, termen, întâlnire, întrevedere; (alim, bot) curmală, curmal; întâlnire, invitație

date of delivery (ec) dată / termen de livrare

date of grant / of patent dată a brevetării / a publicării unei invenții (brevetare)

date stamp ştampilă cu dată, compostor

dating (fiz, metr) datare, determinare a vârstei (rocilor)

datum, $(p l)$ data punct de referință (autom) dată, informație; (hidr) cotă / nivel inițial(ă) / convențional $(\breve{a})$; (mat) punct de origine al unui sistem de coordonate; (metr) informație de măsurare, rezultat al măsurării; $(\mathrm{TH})$ bază de referință (pentru toleranțe); dată (a unei probleme); $(p l)$ date, fapte

datum deck (nav) punte de compartimentare / la nivelul liniei de plutire

datum dimensioning (OM, mas-un) cotare $\mathrm{cu}$ baze de referinţă

datum error (autom, metr) eroare inițială (a unui aparat de măsurat; eroare a rezultatului măsurării, eroare a informației de măsurare

datum level plan de comparație / de bază / de referință, nivel convențional; (hidr) nivel de referință / inițial; (TH) suprafață de bază / de referință / de cotare 
datum line $(\mathrm{OM})$ linie de referință, nivel convențional, axa neutră

datum plane orizont absolut, plan de bază / de referință, nivel de bază / de referință

datum point punct de referință / de reper

datum surface (TH) suprafață de referință

daub (met) material pentru vatra cuptorului, căptuşire a vetrei cuptorului; (constr) tencuială, a tencui, a unge, a mânji, a vopsi, a murdări, a împroşca, a mâzgăli; desen prost, mâzgălitură

daubing (met) acoperire cu material refractar

daunt a descuraja, a speria, a intimida; a îmblânzi

dawn zori

dawsonite (minrl) mineral din carbonat de aluminiu şi sodiu

day zi; viață, perioadă, epocă

day book jurnal zilnic; (ec) registru (şi de facturi) day labourer $(\mathrm{ec})$ muncitor cu ziua, zilier

daylight (fiz) lumina zilei / naturală; (met, masun) trecere sub presă, înălțime utilă maximă între masa şi cursorul unei prese hidraulice

daylong de o zi întreagă, toată ziua

day-night effect efect diurn

day off zi de repaus, zi de odihnă

day output (ec) producție zilnică

day rate (ec) salariu zilnic / plătit cu ziua

day shift schimb de zi

day-to-day de zi cu zi, zilnic

day work lucru cu ziua / în regie

daywork rate (ec) cost / valoare de regie

dazzle (auto) a deranja (şi d. luminile autovehiculului)

deactivation (chim) dezactivare

dezactivator (chim) (agent /substanță) dezacti$\operatorname{vant}(\breve{a})$, dezactivator

dead mort; paralizat; amorțit; lipsit de zgomot /de viață; liniştit; (fig) insensibil; surd; (bot) veşted, uscat(d. flori); şters, fără strălucire(d. culori); stins(d. un foc, un semnal, un sentiment etc.); învechit, perimat (d. obiceiuri); absolut, deplin; (ec) mort, inactiv (d. capital); care nu s-a putut preda(d. scrisori); $(a d v)$ absolut, deplin, prost, hotărât; (TH) inactiv, stricat, care nu funcționează, care nu mai este bun / utilizabil, neaerisit (d. aer); monoton, neinteresant, plictisitor; (el, electr) fără curent / tensiune, neîncărcat, întrerupt, deconectat; (agr) arid, sterp (d. sol); in the $\sim$ hours, in the $\sim$ of night în toiul nopții; on the $\sim$ categoric; $~$ sure absolut sigur; against împotriva; dead against (nav) drept în față (d. vânt)

dead abutment (constr, mec, OM) suport / reazem fix dead angle unghi mort (la un utilaj, o armă, o macara etc.)

dead-annealing (met) recoacere completă / totală dead axle (mas, OM) osie fixă / alergătoare / legată rigid de sasiu; (TH) ax purtător

dead band (autom, metr) intervalul de variație a unei mărimi pentru care aparatul (de măsură sau control) nu reacționează

dead-beat aperiodic (d. un semnal, un proces)

dead-beat oscillations (mec) oscilații amortizate dead-bold (OM, mas-un) opritor, dispozitiv de oprire

dead-burn (met, chim) a arde total

dead-burning (met, ind chim) ardere excesivă, prăjire totală (a minereurilor)

dead-burnt limestone (met, chim) var stins

dead-centre (DC) (auto, mas) punct mort; (masun) vârf fix / imobil / al păpuşii mobile (la strung)

dead-centre / (hand tool) lathe (mas-un) strung de banc, cu ambele vârfuri fixe (cu acționare manuală)

dead-centre position (mas, termo) poziție în punctul mort

dead-centre puller (mas-un) roată pentru rotirea piesei de rectificat, aşezate între vârfuri

dead certainty siguranță deplină

dead-cold chilling (met) călire (prin răcire rapidă)

dead-drawn wire (met) sârmă trefilată

dead drum (TH, OM) toba / tambur inactiv( $(\breve{a})$

dead-earth (el) legătură la pământ perfectă

deaden (met) a mătui, a pasiva, a pasiviza; $(\mathrm{TH})$ a deconecta, a stabili, a amortiza, a astupa, a înăbuşi / atenua / amortiza (zgomote, o lovitură etc.), a micşora (viteza), a diminua (o sarcină etc.)

dead-end, dead end (TH) fundătură, impas; (cf) linie moartă / închisă; (el, mas) capăt orb / mort, capăt fix al cablului

dead-end anchor / clamp (OM; el) clamă de ancorare

dead-end shut-off (hidr, termo) scurgere la valva / supapa de control (la închidere)

dead-end tie (constr, nav) legătură / capăt de ancorare; (el) legătură de capăt / terminală

dead-end trap (termo) separator de lichid la aspirație

dead-end winding (OM, el) spiră în gol / moartă / de capăt (la bobine şi arcuri elicoidale)

deadeners surdină

dead-engine (mas, TH) motor oprit / stins (şi un sens nedorit)

dead-enginestart (auto, termo) start / pornire $\mathrm{cu}$ motorul oprit la rece 
deadening matisare (d. hârtie, sticlă etc.) dead eye (nav) cap de berbec

dead finish suprafață mată (d. hârtie, sticlă etc.) dead(-)flat (nav) cuplu maestru, coastă de maestru; neted, plan, plat

dead flow (hidr) curgere staţionară

dead-full annealing (met) recoacere completă

dead-ground (el) legătură la pământ perfectă

dead-hard steel (met) oțel foarte dur (şi până în miez)

dead-head (auto) cursă fără pasageri; (met) maselotă / adaos de turnare; (nav) baba (şi de lemn), bolard, geamandură de lemn, căpățană de ancoră

dead market (ec) piață săracă / inactivă

deadhead pressure (hidr) presiune blocată, presiune de ieşire, corespunzătoare unui debit de ieşire nul

dead-joint $(\mathrm{OM})$ îmbinare fixă / rigidă

dead letter scrisoare care nu ajunge la destinație (din cauza adresei greşite)

dead-level (mas, hidr) nivel constant; (TH) nivel de bază

dead-line, deadline limită, hotar; (ec) termen (şi final), margine; (el) linie neutră

dead load (constr, hidr) greutate proprie, sarcină permanentă / datorită propriei mase / greutăți; (mec, TH) sarcină statică / constantă, încărcare / îngreunare prin greutate proprie / moartă

dead-load stress $(\mathrm{mec})$ tensiune cauzată de greutatea proprie

deadlock (inf, TH) blocare / oprire definitivă / totală, situație în care un proces aşteaptă un eveniment care nu se va produce niciodată; impas, punct mort

deadman (nav) stâlp de ancorare

deadman's brake (auto, mas-un) dispozitiv de siguranță / de frână care oprește un vehicul sau o presă dacă piciorul operatorului nu este pe pedală

deadman's handle (mas, TH) buton / pârghie pe care operatorul trebuie să țină apăsat pentru ca utilajul să functioneze

dead-melt (met) şarjă / topitură calmată

dead-melted steel (met) oțel calmat

dead-melting (met) şarjă / topitură calmată

dead-mild steel (met) oțel moale

dead-mould (met) formă pierdută

dead-mould casting (met) piese turnate în forme, turnare în formă

deadness absență; lâncezeală; (ec) stagnare (a afacerilor)

deadness to apatie la, indiferență față de

dead-oil volume (auto, termo, T) cantitate / volum de ulei rezidual, cantitate de ulei din car- terul unui compresor ermetic, al cărui nivel este prea scăzut pentru circulația normală a uleiului şi lubrifierea compresorului în funcționare

dead-point / position (termo) punct mort

dead-pulley $(\mathrm{OM})$ roată de curea, liberă (pe arbore), roată alergătoare

dead reckoning (ec) calcul, estimare; (nav) estimă; presupunere, bănuială

dead roasted (met, chim) ars / prăjit complet / total

dead roasting (met) recoacere totală; (ind chim, mediu) ardere completă

dead room (fiz, metr) cameră anecoidă (fără vibrații)

deads steril

dead slow foarte încet (la maşini) (în sens nedorit, fără a şti cauza)

dead smooth cut (mas-un) dințare dublu fină

dead smooth file pilă dublu fină

dead-soaking pit (met) cuptor adânc, neîncălzit / nepregătit de lucru

dead-soft (met) foarte moale (d. aliaje metalice)

dead-soft annealing (met) recoacere (de înmuiere) completă

dead-soft-mild steel (met) oțel foarte moale / cu continut redus de carbon

dead-soft temper (met) recoacere finală (la table de oțel), recoacere totală

dead sound $(\mathrm{TH})$ zgomot surd

deadspace (mas) spațiu vătămător / periculos / toxic; (mas-un) spațiu mort (în care nu au acces sculele maşinii, căruciorul macaralei etc.)

dead steel (met) oțel calmat

dead stroke (mas-un) cursă moartă / în gol

dead(-)time (TH) timp mort; (autom) timp de răspuns (între momentul efectuării comenzii şi realizarea ei), timp separator

dead true foarte precis

dead twist (mec) torsiune echilibrată

dead wall (constr) calcan, perete fără deschideri

dead-weight (auto, cf) greutate moartă / proprie / netă / fără încărcătură, dara; (metr) tară; (nav) capacitate brută / totală de transport / de încărcare

dead-weight brake $(\mathrm{OM})$ frână cu contragreutate

dead-weight safety valve (hidr, OM) supapă de siguranță, cu contragreutate aplicată direct

dead wind (nav) vânt contrar / din prova

dead-work (cf) rocă sterilă (pentru rambleu); (nav) operă moartă

dead zero (autom, metr) punct zero perfect

dead zone (autom, metr) zonă moartă / de insensibilitate; (el) unghi mort, zonă moartă; (mas) 
zonă moartă / fără acces / de stagnare, pungă de aer de stagnare, deaerator-răsuflator al motorului, ventil de aerisire

de(-)aerater (met, ind, termo, alim) dispozitiv de degazare / de purjare

deaering (alim, termo) dezaerare / scoatere a gazului (aer, oxigen, dioxid de carbon etc.) dintrun lichid sau dintr-un solid (de exemplu, din apa din boiler sau din mâncare)

deaering auger (mas-un) presă cu vid

deafen a asurzi; a înăbuşi / amortiza (un zgomot, sunete); (constr, fiz) a izola de zgomot (d. un perete)

deafener $(\mathrm{OM})$ amortizor

deafening asurzitor

deal (constr) pardoseală, duşumea; (ec) afacere, tranzacție; (silv) de pin, de brad, scândură de pin / brad; a împărți, a distribui, a da, a administra; a trata despre; mod de a trata, comportare, conduită; o mulțime de, o grămadă de; comportament necinstit

dealable cu care se poate discuta / trata; maleabil, înțelegător

dealer (ec) comerciant, furnizor, negustor, distribuitor, angrosist

dealer (delivering materials) (ec) furnizor, distribuitor, negustor (mai rar)

dealer's brand (ec) marcă comercială (a distribuitorului)

deal in $(\mathrm{ec})$ a face comerț cu, a intra în comerțul cu dealing comportare, atitudine; (ec) distribuire, împărțire

dealings (ec) tranzacții, legături comerciale

deallocate $(\mathrm{TH})$ a dezafecta

deal out a repartiza, a distribui; a împărți

deal with (ec) a avea legături comerciale cu, a face afaceri cu; a se ocupa de, a trata despre, a fi vorba despre

dear (fig) scump, costisitor

dear-bought care a costat mult

de-ashing (termo, ind chim) evacuare a cenuşii

death duty (jur) taxă de moștenire

death trap $(\mathrm{TH})$ loc deosebit de periculos

debark (nav) a debarca, a descărca (mărfuri, de pe un vas)

debarkation (nav) debarcare

debarment from $(\mathrm{TH})$ interzicere de a; (jur) excluderea de a beneficia de anumite posesiuni, drepturi sau practici; (pol, jur) interzicere de a deține o funcție publică

debarras a scăpa, a scoate din dificultate

debarred (jur) exclus; (TH) interzis

debase (ec) a devaloriza, a deprecia; a corupe; a înjosi; a degrada debasement devalorizare, depreciere; corupție; degradare

debatable discutabil, controversat, disputat

debate dezbatere, polemică, controversă; a dezbate, a discuta, a polemiza; a se gândi

debater participant la discuții

debenture (ec) obligațiune, titlu de creante

debility debilitate, slăbiciune, slăbire

debit (ec) debit, a debita

debrief a chestiona, a asculta un raport, a examina în paralel, a interoga, a face un interogatoriu încrucișat

debris, débris (chim) reziduuri de substanțe organice; (hidr) materiale / particule solide purtate de curent, grohotiş; (met) sfărâmături, spărturi, deşeuri; (T) particulă / particule de uzură

debt (ec) datorie, debit, datornic; a avea datorii; in $\sim$ cu datorii; out of $\sim$ fără datorii

debtee (ec) creditor

debtless $(\mathrm{ec})$ fără datorii

debtor (ec) debitor, datornic

debts (ec) datorii, debite

debug $(\mathrm{TH})$ a corija, a pune la punct, a corecta, a depana; (c, inf) a localiza şi corecta erori de programare

debugging $(\mathrm{TH}$, autom) corecție, punere la punct, depanare; (c, inf) proces de detectare şi remediere a inadvertentelor în soft

debunching (fiz) degrupare, defocalizare, deconcentrare, tendință de împrăștiere a electronilor (şi în tuburi electronice)

debunk a dezvălui; a arăta în adevărata sa lumină, a coborî de pe piedestal; a prezenta (o persoană etc.); a demasca (un şarlatan)

deburr (mas-un) a elimina bavuri, muchii ascuțite, aşchii (şi din alezaje) (de obicei cu scule abrazive); (met) a debavura

deburring (met, plast) debavurare (fără a specifica procedeul)

deburring machine (mas-un, met) maşină de debavurat şi de montat

decadal alcătuit din zece (elemente); care are loc o dată la zece ani

decade deceniu; (autom) decadă

decadence, decadency decădere, decadență

decadent oscillation (autom) oscilație atenuată

decade scaler (autom) dispozitiv care reduce semnalele de intrare în raport de 10 la 1

decagon (mat) decagon, decagonal

decagram(me) (metr) unitate de măsură pentru masă, decagram: 1 dag $=10 \mathrm{~g}$

decahedral (geom) decaedric

decahedron (geom) decaedru

decalcify (chim) a decalcifia, a decalcifica 
decalescence (met) înnegrirea / întunecarea unui aliaj după o transformare de fază, decalescență

decalibration (hidr) modificare a limitelor de presiune admise; (metr, autom) decalibrare (a unui aparat de măsură)

decalitre, decaliter (metr) decalitru: $1 \mathrm{dal}=101$ decane (edu, univ) decan

decant (alim, hidr, ind chim) a (se) depune, a (se) decanta (şi vin), a turna încet, a filtra, a strecura, a transvaza, a clarifica

decantation (alim, hidr, ind chim, mediu) decantare, filtrare

decantation basin (alim, hidr, ind chim) bazin de decantare

decantation tank (alim, hidr, ind chim) cuvă de decantare

decanter (alim, hidr, ind chim) decantor, aparat de distilat

decanting (alim, hidr, ind chim) decantare

decanting bottle (alim, hidr, ind chim) flacon / sticlă / balon de decantare (si în laborator)

decanting cylinder (OM, alim, hidr, ind chim) cilindru decantor

decanting jar (OM, alim, hidr, ind chim) pahar de decantare

decarbonisation (chim) decarburare; (met) decarburare, decalaminare; (met) a decarbura

decarbonize (auto) a decarbona,

decarburation, decarburisation (met, chim) decarburare

decarburation / decarburisation at the edges (met) decarburare superficială / pe margini

decarburisation depth (met) adâncime de decarburare

decarburise (chim, met) a decarburiza; (met) a decarbura

decarburiser (chim, met) agent / substanță de decarburare

decarburising (effect) (met) proces / efect de decarburare

decay decădere; declin; prăbuşire; destrămare; ruinare, (constr, hidr) ruină, descompunere / degradare / distrugere (a materialelor prin coroziune, a constructiei etc.); (alim, chim) putreziciune, putrefactie, descompunere, a se altera, a putrezi, a se descompune, a mucegăi, a face să putrezească; (med) slăbire (a sănătății); (constr, hidr) a decade, a se descompune, a se strica; a se destrăma; a decădea; a face să decadă; a strica, a distruge; a slăbi, a scădea (şi d. forțe, solicitări etc.); (med) a se îmbolnăvi; (fiz) dezintegrare atomică; a se ruina; fall into $\sim$ a decădea

decay back to zero (autom, metr) cădere pe zero (a unui aparat, a unui regaj etc.) decay constant (fiz, mec) constantă de atenuare $/$ de amortizare

decayed (alim, chim) stricat, putred, putrezit; învechit; decăzut; destrămat

decayedwood (silv) lemn putred

decaying (TH) putrefacție, descompunere, dezagregare; (constr) distrus, ruinat, șubred, dărăpănat, insalubru, care se ruinează / şubrezeşte

decay time (el) timp în care tensiunea se reduce la o zecime din valoarea iniţială

deceive a (se) înşela, a amăgi; a induce în eroare

decelerate $(\mathrm{mec})$ a încetini, a avea accelerație negativă, a frâna, a micşora / reduce viteza, a întârzia

decelerated motion (mec) mişcare încetinită / întârziată

deceleration (auto) încetinire, decelerare; (el, mec) frânare, accelerație negativă, încetinire, întârziere

deceleration curve (mec) curbă de inerție / de oprire / de încetinire

deceleration valve (hidr, $O M$ ) drosel de frânare

decelerator $(\mathrm{OM})$ reductor (în general, mecanic, hidraulic, electronic etc.), (electr) element de incetinire a unui paprametru al sistemului

decelerometer (metr) decelerometru, aparat care măsoară starea de glisare / gradul de frânare al unei piste

decennary, decennium deceniu

decent cuviincios, decent; (ec) mulțumitor, destul de bun (şi d. venituri); bun, făcut cum trebuie (şi d. o lucrare), adecvat, corespunzător

decentralization $(\mathrm{ec})$ descentralizare

decentralize (ec) a descentraliza

decentralized (ec) descentralizat

decentralized maintenance (met, $\mathrm{TH}, \mathrm{ec}$ ) mentenanță descentralizată

decentration (mec, mas) descentrare

decentre $(\mathrm{TH})$ a descentra

decentring descentrare, care descentrează / cauzeză o descentrare

decentring device (mas-un, mas, autom) dispozitiv de descentrare

decern a discerne, a deosebi

decession plecare; despărțire, separare; micşorare, diminuare

decibel (metr, fiz) decibel

decibelmeter (metr) decibelmetru, hipsometru, sonometru

decidable (mat) rezolvabil

decide to a decide să, a (se) hotărî să; a rezolva, a lua o hotărâre / decizie privind / de a

decided precis, clar, bine stabilit; categoric, net, hotărât 
decigram(me) (dg) (metr) unitate de măsură pentru masă, decigram: 1 decigram $=0,1 \mathrm{~g}=0,0001 \mathrm{~kg}$ decilitre (dl) (metr) decilitru: 1 deciliter $=0,11$ decimal (mat) decimal, fracție zecimală, număr zecimal; zecimal

decimeter, decimetre (metr) unitate de măsură pentru lungime, decimetru: 1 decimeter $(\mathrm{dm})$ $=0,1 \mathrm{~m}$

decinewton (metr, fiz) unitate de măsurare a forței, decinewton: 1 decinewton $(\mathrm{dN})=0,1 \mathrm{~N}$

decistere (metr) unitate de măsură pentru volum: 1 decistere $=0,1 \mathrm{~m}^{3}$

decimal base (mat) sistem / bază zecimal(ă)

decimal digit (mat) număr / cifra zecimal(ă)

decimal fraction (mat) fracție zecimală

decimal measure (metr) măsură metrică / zecimală

decimal / decadic (number) system (mat, metr) sistem zecimal de numerație / de măsuri / de unități de măsură

decimal place (mat) (cifră) zecimală

decimal point (mat) virgulă (zecimală), punct care desparte întregul de fracție (în numere din texte de limbă engleză)

decimal point alignment (c, inf) alinierea virgulei zecimale

decipher a descifra, a decodifica

decision (TH) decizie, decret, încheiere, hotărâre, concluzie, terminare; (mat) admitere a ipotezei; tărie, fermitate

decision element (autom, electr) circuit logic, element / circuit de decizie

decision making (ec) luare a unei decizii, competență de decizie

decision-making under certainty (DMUC) (ec) luare de decizii în condiții de certitudine

decision-making under risk (DMUC) (ec) luare de decizii în condiții de risc

decisive hotărâtor, decisiv; precis, ferm (şi un răspuns)

decisively $(a d v)$ hotărâtor, decisiv

deck (auto) platforma superioară a unui autobuz; (el) plan al întrerupătorului, platformă / punte pentru sertare, mecanism de rulare; (constr) tablier (de pod); (nav) punte, covertă, a pardosi (puntea), lower $\sim$ punte inferioară, tread the $\sim$ a fi marinar; (auto, transp) top- imperială (la autobuze)

deck auxiliaries (nav) maşini auxiliare / mecanisme de punte

deck cabin (nav) cabină de punte

decke şariaj

decken structure structură şariată

decker (nav) ambarcație / navă puntată

deck erection (nav) suprastructură (de navă) deckering îngroşare

deck flange (nav) guler de navă (de punte)

deckhead (nav) platformă (la nave)

decking (constr) duşumea, podea

deck pipe (nav) nară de punte (pentru trecerea lanțului de ancoră în puț)

deckplanking (nav) bordaj al punții de lemn

deck plating (nav) bordaj al punții metalice

deckplug (nav) dop al bordajului punții

deck prism (nav) ochi de punte (cu prismă)

deck screen (agr, alim, ind chim) ciur cu mai multe site

deck spillway (agr, alim, ind chim) placă deversantă

deck stopper (nav,OM) boț al lanțului de ancoră

deckstringer bar (nav, OM) cornier lăcrimar de contur

deck superstructure (nav) suprastructură pe/de punte

declaim against a vorbi împotrivă, a ataca vehement (o idee etc.)

declare a declara, a face o declarație, a anunța oficial; (ec) a declara (la vamă); a-şi spune / exprima punctul de vedere

declare against a se declara împotriva

declared value (ec) valoare declarată / pentru care se stabileşte asigurarea (mărfurilor)

declare for a se declara pentru / în favoarea

declassed declasat

declassify a nu mai ține secret, a da publicității

decline $(\mathrm{TH})$ declin, decădere, scădere, micşorare; (OM) a (se) slăbi, a (se) micşora, a scădea, a ceda (un arc, o piuliță), a se înclina, a se apleca; a declina (o răspundere), a refuza; a fi în declin, a decădea; (ec) scădere, a se micşora, a scădea (d. prețuri etc.); (constr) prăbuşire, surpare; (med) ftizie

declivitous abrupt, înclinat (d. o pantă)

declivity declivitate, pantă, înclinare, caracter abrupt, înclinație (mare); povârniş

declivious abrupt, înclinat (d. o pantă), în pantă

decluth (autom, auto, mas) a debreia, a decupla; (cf) a decupla

decoct (alim) a extrage prin fierbere

decoction (alim) fierbere, fiertură; (chim) decocție, decoct

decode a decodifica, a descifra

decoiler (met) desfăşurător de rulou (la laminoare), dispozitiv de derulare (a sârmei, foliei)

decoiling (met, plast) desfăşurare / derulare a ruloului de tablă / de folie

decolorant (chim) decolorant

decolorate (chim) a decolora

decolourize (brit), decolorize (amer) a decolora 
decommissioning (TH) scoatere din uz / dezactivare a unui utilaj / echipament ale cărui performanțe au scăzut atât de mult încât nu mai îndeplineşte scopul inițial

decompose a (se) descompune, a separa, a dezagrega, a analiza; a desface, a destrăma; (OM) a descompune în părți componente, a strica; (alim, chim, mediu) a putrezi, a face să putrezească; (gram) a analiza

decompose in a se descompune în

decomposing descompunere, separare; desfacere; care se desface / se descomppune

decomposition descompunere, dezagregare, dezintegrare, desfacere, destrămare; analiză; putrezire

decomposition point / temperature (chim, alim, met) punct / temperatură de descompunere

decomposition to partial fractions (mat) descompunerea unei fracții în fracții parțiale

decompress (mec, hidr) a reduce tensiunea (de compresiune) / presiunea

decompression (TH, hidr) reducere / scădere a presiunii / a tensiunii, decompresie, decuplare

decompression valve $(\mathrm{OM}$, hidr) supapă de decompresie / de reducere a presiunii

decontaminate (mediu, med) a decontamina, a dezinfecta, a degazifica

decontamination (mediu, med) decontaminare, dezinfectare, curățare, purificare

decontrol (ec) a scuti de controlul de stat, a debloca (o marfã)

decorate a decora, a poavaza, a ornamenta; (constr) a vărui, a tencui, a tapeta (pereți)

decoration decorati(un)e, ornamentatie, ornament, decorare; (constr) văruire, tencuire, tapetare (a pereților)

decorative decorativ

decorative vencer furnir

decoring (met) demieziure, scoatere a miezului: decorare, care decorează

decorticate (alim, agr) a decortica, a de(s)coji, a coji, a, a dezghioca

decorticated rice (alim) orez decorticat

decortication (alim, agr) decorticare, cojire, decojire, dezghiocare

decorticator, decorticating machine (alim) maşină de decorticat / de decojire

decouple a decupla, a deconecta

decoupling, discoupling (OM) decuplare, deconectare

decrease micşorare, descreștere, diminuare, reducere, scădere; declin; a (se) micşora, a descreşte, a (se) diminua, a scădea, a (se) reduce (d. o valoare), a face să descrească; on the în descreștere, în scădere

decrease in weight (transp) scădere în greutate, recepție după greutate

decrease of energy (mec) scădere a energiei

decreasing motion (mec) mişcare întârziată / cu viteză în descreștere / încetinită

decree (pol) decret, hotărâre, ordin, ordonantăa (jur) sentință, hotărâre judecătorească; a decreta, a hotărî, a stabili

decrement (fiz) decrement, descreştere, scădere, reducere, pierdere, amortizare, atenuare, raport de atenuare, parametru de decrementare / de descreștere; (c, inf) un cuvânt-instrucțiune în unele calculatoare binare (un set de digiți)

decremental hardening (met) călire parțială

decrement curve $(\mathrm{TH})$ curbă de scădere / de amortizare / atenuare

decrement of damping (med, el) decrement de amortizare / de atenuare

decremeter (metr) aparat de măsurat amortizarea / decrementul logaritmic

decrepit uzat, vechi

decrepitation (chim) calcinare, ardere, prăjire (fiz) decrepitare

decryptation (c, inf) traducerea datelor într-un format care poate fi citit

dedendum $(\mathrm{OM})$ picior de dinte $\left(\mathrm{h}_{\mathrm{f}}\right)$ (la roți dințate), înălțime a piciorului dintelui

dedendum angle $(\mathrm{OM})$ unghi al conului interior (la roți dințate conice)

dedendum circle / line $(\mathrm{OM})$ cerc interior / de fund (la roți dințate), generatoarea de picior al dintelui (la dantura conică), linia de fund a cremalierei

dedendum flanc $(\mathrm{OM})$ flanc al piciorului dintelui (la roți dintate)

dedendum profile $(\mathrm{OM})$ profil al piciorului dintelui (la roți dințate)

dedicate to a (se) consacra, a (se) dedica

dedication dedicare, consacrare, dedicație, dăruire

deduce a deduce, a trage concluzia că

deducibility deductibilitate

deducible care poate fi dedus, care se poate deduce

deduct (ec) a scădea, a deduce

deduction (TH) scădere, scăzământ; (ec) rabat, reducere, bonificatie / reținere (din plată), remiză; (mat) deducție, concluzie, scădere (dintr-o sumă etc.), scăzător

deductive deductiv

dedusted coal (met) cărbune desprăfuit

dedusting (TH, met, constr) desprăfuire 
deed act, faptă, acțiune, manifestare, realitate; (jur) act, document; in very în realitate; in word and in $\sim$ în vorbă şi faptă

deed act contract

deed of conveyance (ec, jur) act de vânzarecumpărare

deeds atribuții

de-electronating agent (chim), (agent) oxidant

de-electronation (chim) oxidare

deemulsification ( $\mathrm{T}$, alim) dezemulsionare

deemulsified oil (ind chim) țiței / ulei dezemulsionat

deep adâncime; adânc, profund; complicat, greu de înțeles; (nav) adâncime (a mării), adânc, apă adâncă; întunecat; saturat

deep cementing (met) cementare adâncă / profundă

deep corrosion (chim) coroziune pătrunsă / perforată

deep drawing (mas-un, met) ambutisare adâncă, tragere cu raport mare de reducere

deep drawing grade (mas-un, $\mathrm{TH}$ ) calitate a ambutisării adânci

deep drawing ability / property / capacity (materiale) capacitate de ambutisare adâncă / de tragere cu raport mare de reducere

deep drawing steel / sheet / strip (met) oțel / tablă / bandă pentru ambutisare adâncă

deepen a (se) adânci; a aprofunda; a închide la culoare; a face mai grav (un sunet, vocea); (met, mas-un) a adânci, a ambutisa

deep etching (met, chim) atac adânc cu acizi (în metalografie)

deep-etch test (met, chim) probă metalografică, cu atac adânc cu acizi

deep frame (nav) coastă întărită (a navei)

deepfreeze (alim, ind, termo) congelator, a subrăci, a congela; frig adânc

deep-freezer (alim, ind, termo) instalație de congelare, congelator

deep freezing (alim, met, termo) subrăcire (sub $0^{\circ} \mathrm{C}$ )

deep-groove ball bearing $(\mathrm{OM})$ rulment (radial) cu bile, cu cale adâncă de rulare

deep hardening (met) călire pătrunsă (adânc)

deep penetrating electrode (met) electrod $\mathrm{cu}$ pătrundere adâncă (la sudare)

deep pump (OM, hidr) pompă de adâncime

deep pump cup (OM, hidr) garnitură a pompei de adâncime

deep-row bearing (OM) rulment radial-axial, (cu bile) cu cale adâncă de rulare

deep tooth form (OM) înălţimea dintelui, adâncimea dintelui (rar, la dantura interioară) deep-well (piston) pump (OM, hidr) pompă submersibilă / de adâncime / de fund

deer (alim, zool) cerb, căprioară

deerskin, deer skin (zool) piele de căprioară

deface a strica, a deteriora; a degrada; a şterge, a face ilizi-bil; a discredita; a desfigura

defacement stricare, deteriorare; ştergere; desfigurare; degradare

de facto de facto, de fapt

defalcate (ec) a delapida, a sustrage (bani)

defalcation (ec) defícit de casă, deturnare de fonduri, înstrăinare (de bani)

default absență, lipsă; vină, neîndeplinire a obligațiilor; (jur) neprezentare, contumacie, a nu se prezenta (la un proces), a pierde prin neprezentare; a nu(-şi) îndeplini (o obligație); (ec) a nu (putea) plăti, a fi în restanță / întârzi-ere cu plățile; (inf, c) valoarea (implicită) a unui argument, dacă nu se face o specificare anume de către utilizator

defaulter care nu şi-a îndeplinit obligația; (ec) falit, persoană insolvabilă; (jur) care nu s-a prezentat în instanță

defeasible (jur) care poate fi anulat

defeat înfrângere; a învinge, a distruge; (jur) anulare, a anula, a declara nul şi neavenit

defecate (mediu, agr, zool) a limpezi, a curăța (de sedimente), a rafina, a purifica, a defeca

defecator (agr, mediu) căldare de defecare / de limpezire / de purificare

defect defect, lipsă, imperfecțiune; (autom, metr, el) defect, eroare, deranjament, avarie, refuz; (fiz, met) defect (în cristalografie); (mat) defect (algebră, analiză); (met, plast) cicatrice, tăietură puțin adâncă, pete

defect detecting device (metr, met) dispozitiv / aparat de detectare a defectelor

defection defecțiune, deranjament

defective (cu) defect, deficient, incomplet, imperfect, lacunar, defectuos, deteriorat; insuficient; anormal; (gram) defectiv

defective casting (met) defect de turnare, turnare defectuoasă / incorectă / greşită

defence apărare; protecție; mijloc de (auto)apărare; (jur) apărare, pledoarie

defend a apăra (şi idei), a proteja, a se apăra

defendant (jur) acuzat, inculpat

defender (jur) apărător

defensibility (mil) capacitate de apărare; (jur) posibilitate de apărare / de justificare, justificabilitate

deference deferență, considerație, respect

deferential respectuos

deferment amânare, întârziere, suspendare 
defer a ține cont de părerea / de sfatul cuiva; a (se) amâna; a întârzia; (jur, ec) a (se) suspenda (o funcție, o şedință etc.)

deferred amânat, întârziat; (TH) încetinit, cu întârziere

deferred action (TH, ec, jur) acțiune amânată / întârziată

deferred-action alarm (TH) alarmă temporizată / întârziată

deferred examination examinare amânată (a unei cereri de brevet de inventie)

deferred payment (ec) plată eşalonată

deferred results $(\mathrm{TH})$ rezultate de lungă durată

defer to a tine cont de părerea cuiva, a respecta (şi o părere)

defibrator (textile, ind chim) defibrator

deficiency (TH) deficiență, lipsă, omisiune; (ec) manco, deficit, defect, neajuns; (fiz) deficit, deficiență, manco

deficiency of gas (TH, termo) lipsă de gaz

deficient deficient, defectuos; insuficient, sărac

deficient for welding (met) material greu sudabil

deficit (ec) manco, deficit

defile (mediu) a murdări, a contamina, a polua (ape); (geogr) defileu, trecătoare

defilement (mediu) murdărire, contaminare poluare

definable (mat, fiz, metr) care poate fi definit, definibil, determinabil

define a defini, a da o definiție, a preciza, a determina, a fixa, a caracteriza, a descrie, a lămuri, a explica

defining equation (mat) ecuație de definiție

definite precis, clar, limpede, hotărât, categorit, definit (rar)

definitely $(a d v)$ (în mod) precis, clar hotărât, categorit, bineînțeles

definite integral (mat) integrală definită (în analiza matematică)

definiteness determinare, definire, fixare

definite-purpose motor (termo) motor special / cu destinație specială

definite time delay / lag (autom) întârziere / temporizare / independență prestabilită

definition $(\mathrm{TH})$ descriere, definire, definiție, precizare (a înțelesului), caracterizare; (mat) definitie, determinare a noțiunilor; (c) claritate (a monitorului, imaginii etc.)

definition of image (c) claritate (și a imaginii)

definitive definitiv, final; decisiv, hotărâtor; definitoriu, care definește

definitively $(a d v)$ (în mod) definitiv, irevocabil

definitude precizie, claritate

deflagrability inflamabilitate, combustie violentă deflagrate a deflagra, a se aprinde prin explozie deflagration deflagratie, ardere cu explozie deflashing (plast) înlăturarea defectelor de pe linia despărțitoare a unei matrițe modulate

deflate (TH) a goli, a dezumfla, a scădea, a micşora (ca importanţă), a-şi pierde din importanță; (mat) a reduce gradul / ordinul, a reduce dimensiunile; (auto) a (se) dezumfla (o anvelopă, un pneu)

deflated (auto) desumflate (d. airbaguri)

deflation dezumflare; reducere, micşorare, scădere, (ec) oprire a inflației

deflect (fiz) reflectare, a se refracta; (mec, met) îndoire, curbare, strâmbare; (fiz) a refracta; (mas-un, met) a îndoi, a curba, a devia, a strâmba, a încovoia; (mat) a devia (de la o curbă, o dreaptă)

deflect from a devia de la, a întoarce de la, a se abate de la

deflecting bar (OM) tijă pentru mutarea curelei

deflecting force (mec) forță de deviere / de încovoiere / de îndoire

deflecting from true path deviație / deviere / abatere de la drumul bun / corect

deflecting tool (mas-un, OM) deflector, genunchi, sculă / aparat de deviere

deflecting torque (mec) cuplu activ / motor

deflection, deflexion (rar) (autom, metr) deviere, abatere; (auto) îndoire a arcului; (constr, mec) săgeată de încovoiere, complianță; (el, fiz) baleiaj, deviație, deflecție (a luminii), deviere (a acului magnetic etc.)

deflection at mid-span (mec, constr, OM) săgeată la mijlocul deschiderii

deflection indicator (metr) flexometru, aparat pentru măsurarea săgeții de încovoiere

deflection of a girder (mec, constr) săgeată (de încovoiere) a unei grinzi

deflection of the oscillation (fiz) amplitudine a oscilatiei

deflection of the rolls (met) încovoiere / valoare a săgeții cilindrului de laminor

deflection of the vibration (mec) amplitudine a vibrației

deflection spring $(\mathrm{OM})$ îndoire / deviere / încovoiere / curbare a arcului, arc de deviere

deflection test probă de încovoiere

deflectivity (mec, OM, TH) capacitate de a rezista la încovoiere fără defectare

deflectometer (mec, metr) aparat pentru măsurarea săgeții, flexometru; (met) deflectometru

deflector (auto) deflector al pistonului, deflector de aer; (hidr) nas de amorsare (al sifonului deversor); deflector; (mas, termo, $\mathrm{TH}$ ) deflector 
deflector bar (mas, TH) bară de protecție deflector piston (OM, hidr) piston cu deflector deflector plate (mas) deflector

deflocculate (alim, ind chim) a coagula, a flocula, a (se) face fulgi

deflocculated graphite (ind chim) grafit coloidal defluxer (fiz, el) demagnetizator

defloamer (chim, T) produs chimic / aditiv antispumant

defoaming ( $\mathrm{T}$; hidr) spargere / distrugere a spumei defocus (fiz) a defocaliza (un fascicul)

defocusing lens (fiz, opt) lentilă divergentă

defog a dezaburi; (auto) dejivrare; a dejivra

defogging (auto) dezaburire, dejivrare

deforest (silv) a despăduri

deforestation (silv) despădurire

deform a deforma; ( fig) a denatura

deformability ( $\mathrm{TH}$, materiale) deformabilitate, plasticitate

deformation (mec, plast) deformare, deformatie, deformabilitate; (mat, geom, fiz) deformare, curbare (pentru suprafețe)

deformation at low / ambient temperature (mec, plast) deformare / profilare la rece, ecruisare

deformation constant (mec) constantă / factor de deformaţie

deformation due to hardening (met) deformare / deformație (determinată) de călire

deformation energy (mec) energie / lucru mecanic de deformare

deformation-free continuum (mec) continuu nedeformabil

deformation in extension (mec, OM) modificarea lungimii la tracțiune / întindere

deformation potentials $(\mathrm{TH}, \mathrm{mec})$ cauze posibile / potențiale de deformare

deformation rate (mec, plast, mas-un) viteză de deformare

deformation resistance (met, plast) rezistență la deformare

deformation / permanent set (materiale solide) deformație permanentă / remanentă / reziduală (în mecanica solidelor)

deformation work (mec) lucru mecanic de deformare

deformed (mec) deformat

deformed beam lead thickness (OM) grosimea medie a adezivului (într-o îmbinare prin lipire)

deformed (concrete reinforcing) bars (constr, met) armături profilate, oțel-beton profilat

deformeter (metr, mec) aparat pentru măsurarea deformațiilor

deforming (mec, OM, TH) (proces de) deformare, (rezultat) deformație; care (se) deformează defragilisation (ind chim, met) defragilizare, dehidrogenare

defraud a înşela, a escroca (prin înşelăciune)

defraud of a deposeda, de a lipsi de, a priva de

defray (ec) a plăti, a acoperi, a rambursa, a achita (cheltuieli)

defrayal, defrayment (ec) plată, acoperire, rambursare, achitare (a cheltuielilor)

defroster (auto, termo) aparat / dispozitiv de dejivrare a parbrizului

defrost (fiz) înlăturare a gheții (prin topire sau sublimare), (auto) dejivare, dispozitiv de dejivrare (a lunetei); a înlătura gheaţa, a decongela, a dejivra

defroster (alim, termo) sistem de dezghețare / decongelare, sistem de control / reglare a dezghețării / decongelării; (auto) dispozitiv / aprat de dejivrare (a parbrizului sau lunetei); (auto, chim) agent / fluid anti-îngheț, antigel

defrosting (alim, mediu) decongelare, dezghețare, dejivraj, curățirea chiciurii; (auto) dejivrarea; dezghețare

defrosting room (alim, termo) cameră de decongelare

defrost mode (auto) modul pentru dezaburire / dejivrare

defrost pan (termo) bac de dejivrare, colector / cuvă pentru picăturile rezultate din dezghețare

defrost position (auto) poziția de dejivrare (şi la direcționarea aerului condiționat)

defrost timer (alim, metr, termo) cronometru de reglare a decongelării

defrother (chim, T) antispumant

deftness îndemânare, abilitate, dexteritate

deg (metr, termo) abreviere pentru grad hexagesimal

degas(ify) (ind chim, met, termo) a degaza, a degazeifica, a degaja gazul, a dezaera

degasification (met) degazeificare

degasifier (met, ind chim) degazeificator

degassing / degassifying (met, ind chim) degazeificare, extracție / eliminare / îndepărtare a gazului

degassing anneal (met) recoacere de degazeificare

degassing flux (met, ind chim) agent de degazificare, degazificator

degauss (el, electr) a demagnetiza

degaussing, demagnetization demagnetizare

de-gel (alim, ind chim) a se dilua, a-şi pierde consistența, a-şi scădea vâscozitatea (d. soluții, geluri etc.)

degeneracy degenerare, degenerescență, denaturare 
degenerate degenerat; a degenera

degenerative degenerescent

degenerative feed-back (autom) feed-back negativ (nedorit)

degeneration (mat) degenerare, degenerescență, descompunere; (chim) descompunere

degradation degradare, deteriorare, stricare; retrogradare (în funcție); corupție

degradation energy (chim) energie de disipare / de degradare

degradation failure $(\mathrm{TH})$ defectare din cauza deteriorării parametrilor de lucru, încât sistemul nu mai corespunde scopului iniţial

degrade a (se) degrada; a retrograda (în funcție)

degrease (chim) a degresa

degreasing (chim) degresare, care degresează

degreasing agent (chim, met) agent de degresare, detergent

degreasing bath (chim) baie de degresare

degreasing line (alim, met, ind chim) linie instalatie / de degresare

degree (deg) (chim, fiz) grad, treaptă; (el) proporție; gradație, prag / nivel al unei mărimi; (mat) grad (unitate de unghi); (mat) grad (al unei ecuații), ordin, rang, perioadă (a unei fracții); (metr) măsură, grad (şi universitar); (TH) calitate, dimensiune, marcă (de material)

degree Celsius $\left({ }^{\circ} \mathbf{C}\right)$ (metr, termo) unitate de măsură pentru temperatură, grad Celsius: 1 degree Celsius $=274,15 \mathrm{~K}$

degree Fahrenheit $\left({ }^{\circ} \mathbf{F}\right)$ (metr, termo) unitate de măsură pentru temperatură, grad Fahrenheit: 1 degree Fahrenheit $=255,927777778 \mathrm{~K}$

degree centigrade (metr, termo) grad Celsius

degree Clarc (metr, chim, mediu) grad Clarc, unitate de măsură pentru duritatea apei reprezentând 1 gram de calciu într-un galon imperial $(=4,54$ litri) de apă

degree form $(\mathrm{OM})$ unghi de angrenare (rar)

degree of accuracy (OM, mas-un) clasă / grad de precizie

degree of admission (alim, termo, ind) grad de umplere / de admisie

degree of agglomeration (ind chim, alim) grad de aglomerare (a particulelor)

degree of beating (alim, constr, ind chim) finețe / grad de măcinare

degree of compaction (constr, materiale) stare de compactare / de îndesare, grad de compactitate

degree of compression (mec, termo) raport / grad de compresie / comprimare

degree of confidence (TH) nivel / grad de încredere, coeficient de siguranță degree of dip mărimea înclinării

degree of dispersion grad de dispersie (la amestecuri)

degree of dissociation (chim, fiz) grad de disociere

degree of dust extraction / removal $(\mathrm{TH}) \operatorname{grad}$ de desprăfuire

degree of distribution (materiale, $\mathrm{TH}$ ) grad de dispersie / de repartitie

degree of finess (materiale) grad de puritate / de finețe

degree of freedom (mec) grad de libertate

degree of fullness (alim, hidr, ind, $\mathrm{TH}$ ) grad de umplere

degree of hardness (materiale, metr) grad de duritate

degree of homogenity (met) grad de omogenizare (la brame, la turnarea continuă şi în lingotiere)

degree of mixing (met) grad de omogenizare / de amestecare (la brame, la turnarea continuă şi în lingotiere, dar şi în industria alimentară, chimie)

degree of oxidation (OM, met, chim) grad de oxidare

degree of polymerization (ind chim, plast) grad de polimerizare

degree of porosity (constr, materiale) grad de porozitate

degree of purity (materiale, chim) clasă / grad de puritate

degree of ramming (met, plast) grad de îndesare / compactare (şi la materiale poroase)

degree of reading accuracy (metr) precizie de citire (la aparatele de măsurat)

degree of reduction (met, plast, mec) grad de reducere (la laminare, forjare)

degree of reliability $(\mathrm{OM}$, met, $\mathrm{TH})$ nivel de încredere / fiabilitate

degree of resilience (mec) grad de elasticitate / de recul / de reziliență

degree of settling (constr, ind chim, alim) grad de tasare, factor de compactare / de sedimentare

degree of shrinkage (met, plast) grad de contracție / de contractare

degree of sizing (mec, ind chim) grad de încleiere / de îmbinare / de lipire

degree of slope (mec) grad de înclinare

degree of smoothness coeficient / grad de finețe / de netezire

degree of temperature (metr, termo) precizie a temperaturii

degree of unsolvability (mat) grad de nerezolubilitate / insolvabilitate 
degree of wetness (mediu, alim, ind chim) grad de umiditate

degree Rankine (metr) unitate de măsură pentru temperatură, grad Rankine: 1 degree Rankine = $0,555555556 \mathrm{~K}$

degree Reaumur (metr) unitate de măsură pentru temperatură, grad Reaumur: 1 degree Reaumur $=274,4 \mathrm{~K}$

degree rise (termo) creştere a temperaturii

degumming (ind chim) rafinare, degumare (d. uleiuri)

degustation (alim) degustare

dehumidification (alim, ind chim, mediu) dezumidificare, reducerea umezelii, scoaterea apei

dehumidified (auto) dezumidificat (cu umiditatea redusă / eliminată (parțial) (d. aer etc.)

dehumidified heating (auto) încălzire cu dezumidificarea (dezumiditatea) aerului

dehumidifier (alim, met) uscător

dehumidify a usca, a elibera de umiditate

dehumidifying effect (termo, ind chim) putere efect de dezumidificare, putere frigorifică latentă a unui răcitor de aer

dehydrate (alim, ind chim) a (se) deshidrata, a elimina apa

dehydrated alcohol alcool absolut / deshidratat dehydrated fruits (alim) fructe uscate

dehydrated meat (alim) carne deshidratată / uscată

dehydrated vegetables (alim) legume uscate / deshidratate

dehydrating (alim, ind chim) deshidratare

dehydrating catalyst (chim) catalizator de deshidratare

dehydration (alim, constr, ind chim) deshidratare, eliminarea apei

dehydration box / tank (mediu, ind chim) decantor, bazin de decantare

dehydrator (alim, ind chim) deshidrator, evaporator, desicator, exsicator

dehydrogenate (ind chim) a dehidrogena

dehydrogenation (alim, chim) dehidrogenare

deice (auto, av) a dejivra; (termo) a dezgheța

deicer (auto) instalație de jivraj

deicer-switch (auto, av) întrerupător al dejivrorului de parbriz

deicing (auto, av) dejivrare, dezghețare

deionize (chim) a deioniza

deionization (chim) deionizare

deionized water (chim) apă demineralizată / deionizată

dejection descurajare; (agr, zool) defecare, excremente; $(\mathrm{TH})$ dejecție

dejecture (agr) excremente

de jure (jur) de jure, de drept dekagram (dag) (metr) unitate de măsură pentru ma-să, decagram: 1 dekagram $=0,01 \mathrm{~kg}$

dekaliter (dal) (metr) unitate de măsură pentru volum / capacitate, decalitru: 1 dekaliter $=0,01 \mathrm{~m}^{3}$

dekameter (dam) (metr) unitate de măsură pentru lungime, decametru: 1 dekameter $=10 \mathrm{~m}$

dekanewton (daN) (metr) unitate de măsură pentru forță, decanewton: 1 dekanewton $=10 \mathrm{~N}$

dekastere (metr) unitate de măsură pentru volum, 1 dekastere $=10 \mathrm{~m}^{3}$

del (mat) (operator) nabla

delamination (met, plast) exfoliere, delaminare

delay (autom) temporizare, întârziere; amânare; piedică, obstacol; a întârzia, a amâna; a face să întârzie; a opri; a împiedica; without fără întârziere

delay action (autom) (acțiune de) temporizare, acționare întârziată

delayed action (autom) comandă cu întârziere temporizată; (mec) încetinire, efect de inerție; (plast) actiune / reactie întârziată

delayed firing / ignition (auto, termo) aprindere întârziată

delayed pulse tripping cam (mas-un) camă de întârziere / cu mers în gol

delayed radiation effect (fiz, med) efect întârziat al iradierii

delayed response (autom, TH) răspuns întârziat

delayer (chim, plast) inhibitor

delay in boiling (alim, fiz, ind chim) coborâre a temperaturii de fierbere, întârziere a fierberii

delay-interval timer (autom, mas) temporizator de întârziere

deleading (met, chim) eliminare a plumbului

delegate delegat; a delega

delegation delegare, delegație

delete $(\mathrm{TH}, \mathrm{c})$ a anula, a şterge, a elimina; comandă / tastă de ştergere (şi a caracterului de pe poziția curentă a cursorului)

deleterious (TH, med) vatămător, nociv

deletion ştergere (şi cu guma), ştersătură, eliminare; suprimare

delf (met) strat subțire de carbon

deliberate voit, intenționat, gândit dinainte, plănuit, premeditat; prevăzător, precaut; prudent; circumspect (d. persoane); lent, încet (în mişcări); a discuta, a chibzui, a se sfătui / consulta cu privire la; a reflecta; a delibera; a discuta (o problemă

deliberately $(a d v)$ dinadins, intenționat, voit, cu premeditare, gândit, cu grijă; încet, fără grabă

deliberateness premeditare, bună ştiință; chibzuinţă, grijă, atenție; caracter nepripit

deliberation deliberare, consfătuire, dezbatere; prudență, grijă; încetineală (a mişcării) 
deliberative deliberativ, consultativ

delicacy finețe, grad de finețe; rafinament; indulgență, ingăduinţă; delicatețe (şi morală), finețe; (metr) sensibilitate (a unui aparat etc.); (med) constituție delicată, fragilă; modestie; scrupulozitate; (alim) mâncare aleasă, delicatese

delicate delicat, fin; discret; atenuat; fragil, fărâmicios; indulgent, îngăduitor

delict (jur) delict

delimit, delimitate a determina frontierele, a delimita

delimitation delimitare, stabilire de limite

delimiter (inf) caracter care separă o propoziție, o linie într-un program

delineate (mat, mec) a stabili frontiere / dimensiuni; (TH) a schița, a desena, a descrie

delineation schițare, conturare, descriere

delineator proiectant; patron

deliquesce (ind chim) a se topi, a se lichefia

deliquescence (chim) delicvescență, lichefiere, topire (rar)

deliquescent (chim) delicvescent

deliquescent dryer (alim, ind chim) dehidrator / uscător cu higroscopie mecanică / cu produs higroscopic

deliver (autom) a debita; (ec) a distribui, a livra, a furniza, a preda mărfuri; a transmite, a distribui (corespondența)

deliverance părere exprimată public, declaraţie (oficială)

delivered free (ec) livrare franco / la domiciliu / fără taxe (suplimentare)

delivered power (mas, el) putere debitată / de ieşire / livrată din rețea

delivering live-roller table (met) cale / transportor cu role pentru evacuare (după caja de laminare)

delivering under pressure (hidr) refulare

deliver subsequently (ec) a livra suplimentar

deliver up / over a transmite, a preda

delivery (auto) alimentare; (ec) livrare, furnizare, transmitere, predare de mărfuri; (hidr) debit al canalului de legătură între două rezervoare cu niveluri variabile, debit de apă / de curent; (TH) alimentare, debit (de pompare), debitare, livrare, producție, predare, randament; distribuire (a corespondenței)

delivery air $(\mathrm{TH})$ aer insuflat, aer introdus în spațiul condiționat

delivery and receiving document (ec) proces verbal de predare-primire

delivery bill (ec) foaie de livrare

delivery calender (alim, met) cilindru / calandru de debitare / de alimentare delivery cock (OM, hidr) robinet de alimentare / de golire / de scurgere

delivery connection $(\mathrm{OM}$, hidr) racord de evacuare delivery date (ec) data a livrării

delivery end ( $\mathrm{TH}$, ind chim) cap de descărcare a maşinii / a instalației; cap de livrare / de debitare / de ieşire

delivery / discharge gauge (metr, hidr) manometru de refulare

delivery hole $(\mathrm{OM}$, hidr) gură de refulare

delivery hose furtun de golire / de refulare

delivery jet pipe (OM, hidr) ajutaj / duză de scurgere

delivery lattice (mas, alim) pânză transportoare / debitoare

delivery mark (hidr) semn care indică volumul de lichid preluat

delivery mechanism (alim, ind chim) mecanism de alimentare

delivery meter (metr, hidr) contor de trecere, debitmetru

delivery motion (mas-un) mişcare de debitare / de aducere a unui semifabricat în pozitia de lucru

delivery nozzle (OM, hidr) ajutaj de refulare

delivery of current (el) furnizare / livrare de curent

delivery of gas (termo, ind chim, alim) alimentare cu gaze

delivery order (ec) notă de livrare

delivery pipe (constr) țeavă / tub / canal de evacuare; (hidr) conductă de ieşire / de debitare / de refulare sub presiune, țeavă de admisie / de debitare / de presiune; (TH) conductă, burlan de scurgere / de golire / de evacuare

delivery point of a conveyer (mas, alim) punct de deversare al unui conveier / transportor

delivery pressure presiune de refulare

delivery promise $(\mathrm{ec})$ termen de livrare

delivery pump (hidr) pompă de refulare / de debitare / de alimentare

delivery rate (hidr) viteză de pompare / de livrare / de alimentare (cu fluid)

delivery reel (met, plast) dispozitiv de debitare / de derulare (a unui rulou)

delivery requirement $(\mathrm{ec}, \mathrm{TH})$ condiție de livrare delivery roller (mas-un) cilindru debitor, rolă de tăiere / debitare (şi în industria textilă)

delivery roller table (met) cale / transportor cu role pentru evacuare (după caja de laminare)

delivery rolls (mas-un) cilindri / role de debitare delivery side (mec) față de apăsare; $(\mathrm{TH})$ parte de ieşire / de refulare

delivery side of a pump (OM, hidr) gură de refulare a unei pompe 
delivery specification (ec, TH) condiții de livrare delivery table (alim, constr) masă strângătoare / de eliminare; (text, alim) masa de sortare

delivery value $(\mathrm{TH})$ capacitate de alimentare / de transport, valoare la alimentare

delivery valve (mas, hidr) supapă de presiune / de refulare, ventil de golire / de scurgere

dell teşitură; (geogr) dolină, vâlcea

delta (autom) delta; (el) triunghi; (geogr) deltă

delta-brass (met) alamă delta, aliaj $\mathrm{Cu}$-Zn delta

delta bridge (el) punte (electrică) în triunghi, delta

delta connection (el) conexiune în triunghi

delta-delta connection (el) conexiune triunghitriunghi

delta iron (met) fier $\delta$ (delta)

delta metal (brass alloy) (met) metal delta (aliaj de alamă)

delta-star switch (el) comutator stea-triunghi delta voltage (el) tensiune de linie / între faze delta-wire connection (el) conexiune stea-triunghi deltoid (mat) deltoid, romboid, triunghiular

deluge potop, inundație; a inunda, a îneca, a împresura (cu apă)

delustred (mas-un) şlefuit mat / fără luciu

delve in to a cerceta / studia în amănunt

demagnetization, degaussing (fiz, el) demagnetizare

demagnetize (fiz) a demagnetiza

demand cerere, solicitare, revendicare, căutare, necesar (şi de materiale); întrebare, investigație, cercetare; $(\mathrm{ec})$ cerere, necesar, comandă; a cere, a pretinde, a necesita, a reclama, a avea nevoie de

demandant (jur) reclamant

demand bill (ec) poliță plătibilă la vedere

demand factor $(\mathrm{ec}, \mathrm{TH})$ coeficient de încărcare, factor de cerere, coeficient de solicitare

demand power (mec, mas) putere calculată / nominală / teoretică / cerută

demandpull inflation (ec) inflație provocată de cerere

demand security a cere garanție

demarcate a demarca, a delimita, a marca

demarcation hotărnicire, marcare, demarcare, delimitare, bornare, parcelare

démarche demers

demeanour (ec) comportare de merit sau deficiență (a unui produs)

demerit defect, lipsă, scădere; notă proastă

demesne (jur) proprietate funciară, domeniu (şi administrat de către proprietar); regiune, teritoriu; (fig) domeniu, sferă

demijohn (alim) damigeană demister (mas-un, termo) separator de picături / de ceață

demister screen (auto) geam cu dispozitiv contra aburirii

demixing (alim, ind alim) stratificare, separare în straturi

democracy (pol) democrație

democrat (pol) democrat

demography demografie

demolish (constr) a dărâma, a demola; (fig) a distruge, a curăța

demolishing (constr) demolare, darâmare, distrugere, care este demolat / se demolează

demolition (constr) demolare, dărâmare; (fig) distrugere

demonstrable demonstrabil

demonstrate a demonstra, a dovedi, a arăta, a justifica, a prezenta (şi un model); a manifesta

demonstration (mat) demonstrare; prezentare (a unui produs); dovadă, probă (şi în cercetare); demonstratie, manifestare

demonstrative demonstrativ; doveditor, convingător; ostentativ

demonstrativeness evidență, caracter evident

demoralization demoralizare; corupere, coruptie, imoralitate

demote (amer) a degrada, a retrograda (în funcție)

demount (constr) a demola, a dărâma, a sparge un zid; (mas, TH) a demonta

demountable (OM, mas) amovibil, demontabil

demounting (chim) descompunere, depolimerizare; (mas, TH) demontare

demulsibility (alim, T) capacitate de dezemulsionare

demulsification (alim, T) dezemulsionare

demulsifier (chim) (agent) dezelmusionant

demulsify (alim, chim, $\mathrm{T}$ ) a dezemulsiona

demultiplier (OM) demultiplicator, reductor (de orice fel)

demur şovăire, ezitare; obiecție; protest; a şovăi, a ezita; a obiecta, a ridica obiecții; a protesta

denarius (metr) unitate (veche) de măsură pentru masă; 1 denarius (Biblical Roman) $=0,00385 \mathrm{~kg}$

denary zecimal

denaturated alcohol (chim) spirt denaturat

denaturation denaturare

denature a denatura

denatured alcohol (chim) spirt denaturat

dendrite (met) dendrită, structură dendritică

dendritic (met) dendritic

dendritic markings (met) dendrite; structuri dendritice

dendritic structure (met) structură dendritică / arborescente 
dendroid(al) dendritic, (cu aspect) arborescent dendrometric increment (met) creştere dendrometrică

deniable care poate fi negat; contestabil denial negație, negare; contestare; dezmințire; refuz

denicotinize (chim) a denicotiniza, a elimina nicotina

denigrate a denigra, a defăima

denigration denigrare, defäimare

denominate a denumi; concret

denominate number număr concret

denomination denumire, nume; $(\mathrm{ec})$ valoare (a banilor)

denominator (mat) numitor al unei fracții

denotation sens, înțeles (exact)

denote a denota, a indica, a denumi; a însemna, a nota, a marca; a trăda, a dovedi

denotement indicare, arătare; sens, înțeles; semn, indicație

denotive indicativ, indicator; semnificativ

denounce a acuza, a învinui; a denunța

dense dens, des, etanş, compact, fără bule de aer, fără pori; redus

densener (met, ind chim) răcitor (metalic) în formă (pentru grăbirea răcirii)

denseness (materiale) caracter compact / dens, proprietate de a fi dens, densitate

dense smoke fum gros / dens

densimeter, densometer (alim, metr, materiale) densimetru, areometru

densimetry densimetrie, determinare a densității

density (TH, materiale) densitate, impermeabilitate, desime, concentrație; (fiz, mat) densitate; (mas) densitate, etanşeitate

density as pressed $(\mathrm{TH})$ densitate în stare presată / înainte de sinterizare / la crud

density as sintered $(\mathrm{TH})$ densitate după sinterizare

density bottle (metr) picnometru

density function (mat) densitate de repartiție (în teoria probabilităților)

density measurement (metr) măsurare a densității

density of dislocation (fiz) densitate de dislocație (în cristalografie)

density of energy (fiz) densitate de energie

density ratio $(\mathrm{TH})$ densitate relativă

density temperature coefficient (fiz, termo) coeficient al densității în funcție de temperatură

dent $(\mathrm{OM})$ dinte, striu; (met) urmă de lovitură, adâncitură, striu; a tăia, a imprima, a dantura, a cresta, a lăsa urma unei adâncituri

dental alloy (met, med) aliaj dentar dentate (mas-un) a tăia în zigzag, a tăia dinți (nu neapărat evolventici), a zimța, a randalina denticulate $(\mathrm{OM})$ dinţat (nu pentru angrenaje), zimțat, danturat

dentifrice (ind chim, med) pastă de dinți

denting (mas-un) dinţare, randalinare; (met) crestare, crestătură

denuding (chim) desorbție

denumerability, countability numărabilitate

denumerable numărabil

denunciation (ec, jur) denunțare (a unui contract etc.)

deny a nega; a respinge, a contesta; a renunța la; a refuza

deodorant (ind chim) deodorant, dezinfectant, dezodorizant

deodorization dezodorizare, dezinfectare

deodorize a dezodoriza

deodorizing dezodorizare

deoiling (ind chim) dezuleiere, scoatere a / separare (cu eliminare) a uleiului

deoxidant (chim) (agent)dezoxidant

deoxidation / deoxidisation (chim) dezoxidare

deoxidation alloy (met) aliaj dezoxidant

deoxidise (chim, met) a dezoxida

deoxidised copper (met) cupru dezoxidat

deoxidiser (chim, met) dezoxidant

deoxidising agent / element (met, chim) agent / element dezoxidant

deoxidising flux (met) fondant dezoxidant

deoxidising slag (met) zgură reducătoare / de dezoxidare

depart a pleca, a porni; (cf) a pleca din stație

department departament, sector, secție, serviciu, sectie / atelier de fabrică

department head şef de serviciu

department manager (met, ec) şef de secție, conducător tehnic

department store mare magazin, antrepozit, depozit, magazin universal

departure (punct de) plecare; (TH) pornire, despărtire, deviere, deviație, abatere; (hidr, mat) abatere (de la valoarea medie); (nav) plecare (a navei), deplasare est-vest; abordare

departure from plecare din / de la, îndepărate de la, părăsire, abandonare

departure track (cf) linie de ieşire

depend a depinde, a fi condiționat

dependability (fiz) securitate; (ec) dependabilitate

dependable demn de încredere, de nădejde; (maşină / utilaj) cu dependabilitate

dependable in service (TH) disponibil / sigur în exploatare 
dependence, dependency dependință; încredere; sprijin, ajutor

dependence on / upon dependență de, subordonare față de

dependency (autom) funcție dependentă de control / reglaj prin urmărire

dependent dependent, subordonat; atârnat, care atârnă; secundar

dependent variable (autom) mărime dependentă; (mat) variabilă dependentă

depend on / upon a depinde de, a se sprijini pe, a se baza pe; a fi condiționat de; a avea încredere în

dephased (el, autom, metr) defazat

dephlegmation (ind alim) condensare parţială, deflegmare

dephlegmator (ind chim) deflegmator

dephosphorisation (met, ind chim) defosforare

dephosphorise (met) a defosfora

depict a picta, a descrie, a înfățişa

depiling magazine / table (met) masă de încărcare (la laminare)

depinker (chim) antidetonant

deplating (met) îndepărtare a stratului de zinc / a acoperirii

deplete (met) extragere a metalului din minereu; (TH) a goli, a epuiza, a slei, a sărăci

depletion (el, fiz) epuizare, sărăcire, golire, înlocuire; (hidr) secare, epuizare

deploy a desfăşura

deployment (auto) deschidere

depolariser (fiz) depolarizant

depolarisation (fiz) depolarizare

depolish (mas-un, ind chim) a mătui

depolymerization (chim) depolimerizare

depose depunere, sedimentare; a depune; (ec) a concedia, a da afară din serviciu; (jur) a depune mărturie, a face depoziție; a destitui (un funcționar)

deposit (TH) depozit, depunere, strat, zăcământ; (chim) sediment, precipitat, condensat depozit; (el) depunere / depozit de noroi la acumulator; (hidr) depunere, sediment, zăcământ; (ec) avans-garanție, depozit, bani depuşi (în bancă); (met) depunere (şi de recondiționare), strat acoperitor, placare, acoperire, izolație; (T) depozit (la oxidarea uleiului, şi de motor etc.); (chim) a (se) depune, a (se) precipita; (hidr) a sedimenta; (ec) a depune, a depozita

deposit account (DA, D/A) (ec) cont de depuneri cu termen

depositary, depository (ec) depozitar

deposit at call (ec) depunere rambursabilă la cerere deposit by thermal decomposition (met) depunere / acoperire prin descompunere termică

deposited metal (met) metal de adaos / depus în cusătură / pentru încărcare (la recondiționare), metal / aliaj depus

deposit formation ( $\mathrm{T}$, termo) formare a depozitului (şi pe capul pistonului)

deposition concendiere; (jur) depoziție; (ec) depunere, depozitare; $(\mathrm{TH})$ sedimentare, depunere deposition rate (alim, mediu, met) viteză de depunere (la sudură, dar şi la sedimentare)

deposition sequence (met) ordinea de depunere a materialului de adaos la suduri cu treceri multiple

depositor (ec) deponent, depunător

deposit precursors (chim, $\mathrm{T}$, termo) precursori (compuşi chimici rezultaţi din degradarea lubrifiantului) ai depozitelor

deposit welding (met) sudare de încărcare, depunere / încărcare prin sudură (la recondiționări)

depot magazie, hambar; (cf) stație de cale ferată, gară

deprecation critică aspră, condamnare; protest

depreciable care se poate deprecia

depreciate a deprecia; (ec) a deprecia, a se devaloriza (d. monedă), a reduce valoarea; a subestima

depreciation (ec) depreciere, devalorizare; subestimare; desconsiderare

depreciative depreciativ

depress a apăsa, a presa (un buton); a slăbi, a micşora (o mărime); (TH) a depresa

depressant (chim, $\mathrm{T}$ ) depresant, aditiv depresant (în fluide lubrifiante)

depression apăsare, presare (pe un buton); (geogr) depresiune, şes, câmpie; (ec) depresiune economică, stagnare, criză; (med) deprimare, depresie; (OM) adâncitură; afundare

depression of freezing point (fiz, chim) coborâre / depresiune a punctului de înghețare / de congelare (şi la lubrifianți)

deprivation privare, lipsire; pierdere; (ec) concendiere

deprive a concedia

deprived of lipsit de, privat de

deprive of a lipsi de, a priva de

depth adâncime, grosime, înălțime (raportată la o suprafață convențională)

depth at quay (nav) adâncime de cheu

depth contour (geogr, metr) izobată (linie de egală adâncime)

depth effect (nav, hidr) efect de adâncime

depth feed (mas-un) avans de pătrundere / vertical (în aşchiere) 
depth filter (OM, hidr) filtru cu reținerea impurităților pe diferite mărimi, funcție de natura mediului filtrant

depth ga(u)ge (vernier calipers) (mas-un, metr) şubler de adâncime

depth hardening (met) călire pătrunsă / în miez depth of engagement $(\mathrm{OM})$ distanța radială de contact (şi la filete conjugate)

depth of beam (mec) înălțime a unei grinzi

depth of bore / boring (OM, mas-un) adâncime a găurii / de găurire

depth of bore hole (mas-un) adâncime a găurii / adâncimea / lățimea alezajului (butucului)

depth of case (met) adâncime a stratului cementat / de cementare

depth of chill (met) adâncime a stratului călit de călire

depth of cut(ting) (met) înălțime / grosime de tăiere / a tăieturii (la tăierea termică a metalelor); (mas-un) adâncime de aşchiere

depth of drag lines (met) adâncimea rizurilor (la tăierea termică a metalelor)

depth of engagement (OM) înălțime utilă (la filete)

depth of engagement of gears (OM) înălțime de întrepătrundere (la angrenaje)

depth of foundation (constr) adâncime a fundatiei

depth of fusion (met) adâncime a sudurii / de topire, adâncime a zonei topite în materialul de bază (pe durata sudării)

depth of groove (met) adâncimea calibrului (la laminare)

depth of hardening zone (met) adâncime a zonei de călire

depth of hearth (met) adâncime a vetrei (cuptorului)

depth of the hold (nav) înălțime a magaziei / a calei

depth of impression / of indentation (metr) adâncime de pătrundere a unui penetrator (la încercarea de duritate Brinell)

depth of keyway $(\mathrm{OM})$ adâncime a canalului (şi de pană) / a crestăturii / a canelurii

depth of nitrationcase (met) adâncime a stratului nitrurat / de nitrurare

depth of packing space $(\mathrm{OM})$ înălțime a locaşului garniturii de etanşare

depth of page înălțime a paginii

depth of penetration (constr, $\mathrm{TH}$ ) adâncime de pătrundere; (met) adâncime a penetrației / a sudurii / de pătrundere

depth of profile profunzime / adâncime a profilului (topografia suprafetei) depth of quench (met) adâncime de călire, adâncime a stratului albit

depth of roughness $(\mathrm{T})$ adâncime a asperității / a asperităților (în topografia suprafeței)

depth of slide (mas-un) grosime a ghidajului / a glisierei

depth of thread $(\mathrm{OM})$ înălțime a filetului

depth of throat (OM, mas-un) lungime a brațului în consolă, distanța maximă între axa burghiului şi punctul cel mai apropiat de pe suprafața coloanei (la maşini de găurit radiale)

depth of tooth $(\mathrm{OM})$ înălțime a dintelui (h) (la roți dinţate)

depth of welding penetration (met) adâncime de sudare (pătrundere)

depth-tool (metr) compas de angrenare (pentru verificarea roților dințate)

deputy (pol) deputat; (ec. TH) reprezentant

deraliment $(\mathrm{cf})$ deraiere

derange a deranja, a stingheri, a incomoda, a deregla, a strica

deranged deranjat, în dezordine

derangement dereglare, deranjament, deranjare, dezorganizare

derate $(\mathrm{ec})$ a reduce impozitele locale

derating (mas, $\mathrm{TH})$ reducere a sarcinii de funcționare, funcționare în condiții depărtate de cele limită, subregim

derelict (nav) abandonat, epavă abandonată; neglijent, superficial

derivate (autom) derivativ; (chim) derivat, produs derivat; (mat) derivată, număr derivat; secundar

derivation (el, hidr, OM) derivație, branşament, bifurcare (de cabluri electrice, de conducte); origine, proveniență

derivative (chim) produs secundar / derivat

derive a deriva, a deduce, a trage concluzii, a decurge din; a obține, a proveni; a câştiga (un venit)

derived derivat; secundar

derived capacity (hidr, termo) cilindree măsurată (la pompe sau motoare)

derived equation (mat) ecuație obținută prin transformarea unei ecuații date, ecuație obținută prin derivare

derived input / output flow (hidr, termo) debit de intrare / de ieşire ideal, raport între cilindree si frecventa de rotatie

derive from a primi de la, a obține de la, a se trage din, a proveni din

derrick (nav) bigă de marfă; macara

derrick blocks (nav) scripete

derrick crane (nav) macara (de manevră) 
derrick jib (nav) braț de bigă / de macara derust (met) a îndepărta / a curăța rugina, a decapa

derusting agent (met, chim) agent / substanță de îndepărtare a ruginii, decapant

desaccharification (alim) dezaharisire

desactivate (chim) a dezactiva (o substanță etc.)

desactivation (chim) dezactivare

desalter (ind chim) instalație de desalinare

desalting (ind chim) desalinare

desand a deznisipa, a înlătura nisipul

descale (alim, agr) a coji, a decortica; (met) a decapa, a îndepărta zgura / arsura / țunderul, a curăta (un cazan) de piatra depusă; a descuama

descaler rolls (met) spărgător de zgură

descaling (met, termo) îndepărtare a zgurii / a țunderului / a arsurii / a pietrei de cazan, detartrare, desțunderizare

descaling mill (met) laminor spărgător de arsură / de țunder

descaling plant (met) instalație de desțunderizare / de îndepărtare a arsurii

descaling roll (met) cilindru spărgător de arsură / de țunder

descend a (se) coborî, a se da jos, a se lăsa în jos descending coborâre; $(\mathrm{TH})$ tasare; descendent

descent coborâre, afundare; origine, provenientă; (met) golire, gură de golire, pantă

descent of charge (met) coborârea încărcăturii / şarjei (la furnal)

describable care poate fi descris

describe a descrie, a prezenta, a înfățişa, a caracteriza, a se prezenta ca

description descriere, prezentare, înfățişare, caracterizare; fel, categorie

descriptive descriptiv

descriptive geometry geometrie descriptivă

descuming $(\mathrm{TH}, \mathrm{met})$ îndepărtarea defectelor de suprafață; descuamare

desert deşert; a părăsi, a abandona, a se sustrage de la

deserve a merita

deserved meritat

deserving merituos, meritat; care merită

desiccant (chim) agent deshidratant

desiccant dryer (alim, ind chim) desicator, dehidrator (de aer) cu absorbție / cu material absorbant

desiccate (alim, fiz, termo) a usca artificial, a deshidrata

desiccated eggs (alim) praf de ouă

desiccated milk (alim) lapte praf

desiccating (alim, constr, ind chim) (acțiunea de) uscare, desicare, deshidratare, care usucă desiccation (agr, alim) deshidratare, uscare; contracție; (geogr) secare;

desiccation fissure (met, plast) crăpătură de contracție / de uscare

desiccative (chim) desicativ

desiccator (alim, ind chim) exsicator, desicator

desiccator cabinet (alim, ind chim) etuvă

desideratum, $(p l)$ desiderata deziderat, dorinţă

design intenție; tip, model; (TH) plan, proiect, design (şi industrial), desen, schiță, schemă, proiectare, construcție, sinteză, concepție, tip, model, calcul; $(\mathrm{TH})$ a proiecta, a executa / face un proiect / un plan, a desena, a calcula, a plănui, a schița, a destina, a executa un proiect; (met) calibrare; for a destina pentru; $\sim$ s $(p l)$ tipuri (de maşini etc.)

design assumption ipoteză de calcul (în proiectare)

designate a desemna, a indica, a denumi, a marca, a nota, a arăta (d. lucruri); a semna; a numi (într-o funcție); numit, desemnat (pentru o funcție); $\sim$ to, $\sim$ for a indica; a desemna (pt. o functie etc.); a denota

designation (ec) desemnare / numire (a cuiva, într-o funcție) marcare, indicare, etichetare, notare, destinație; (mat) simbol, denumire; scop, menire, destinație; titlu, profesie

designation of weld $(\mathrm{OM})$ geometrie a sudurii

design capacity $(\mathrm{TH})$ capacitatea rezultată din proiectare

design development test verificare a unui proiect (care nu a mai fost realizat practic)

designed intenționat; proiectat, desenat

designed displacement (nav) deplasament de constructie proiectat (la o navă)

designed draught (nav) pescaj de construcție / proiectat

design equation (mat) ecuație de calcul (pentru proiectare)

designer desenator, (inginer) proiectant

design factor coeficient de siguranță

design features (OM, constr, mas) detalii / caracteristici de construcție / de proiectare

design head (mas) înălțime de sarcină pentru proiectare

design in full size desen / plan / schiță în mărime naturală

designing proiectare; (met) calibrare, proiectare a calibrelor (la laminare)

designing engineer inginer proiectant / constructor

design load (mec) sarcină de proiectare / de calcul

design of development phase fază de concepție industrială / în detaliu 
designing of section proiectare a formei / secțiunii

design load (constr) sarcină de proiect, ipoteză de încărcare; (TH) sarcină teoretică / nominală

design of grooves (met) proiectare a calibrelor de laminare

design of pass(es) (met) profil al cablului de laminare

design of rolls (met) calibrarea / profilarea cilindrilor (la laminare)

design power (mec) putere calculată / nominală / teoretică / cerută

design pressure (mec, hidr) presiune nominală, presiune maximă de serviciu (la temperatura nominală / cerută / prescrisă, într-un spațiu dat

design stage stadiu de proiectare / de elaborare a desenului

design stress $(\mathrm{mec})$ tensiune maximă admisibilă (de proiectare)

design thickness (mec, met) grosime stabilită prin proiectare

design to cost $(\mathrm{ec}, \mathrm{TH})$ proiectare după criteriu de cost / de preț / de cheltuieli (pentru o durabilitate impusă)

design value parametru constructiv / de proiectare, valoare proiectată, desemnată

design variables variabile de proiectare

design version variantă de proiectare

desiliconise (met) îndepărtare a siliciului, (chim) a desilicifia

desirabilty oportunitate

desirable de dorit, dezirabil; oportun, bun

desire dorință, rugăminte, cerere; a dori, a vrea

desired value (autom) valoare prescrisă / de referință; (fiz) valoare de consemn / de reper; (metr) valoare nominală / de referință

desk pupitru / masă de comandă

deslag (met) a evacua / a îndepărta zgura

deslagging (met) evacuare / îndepărtare a zgurii

desoxidised steel (met) oțel dezoxidat

desquamation eliminare a cojilor, exfoliere, descuamare

destroy a distruge, a elimina

destroy bacteria (alim, med) a steriliza

destruction distrugere

destruction load (mec, TH) sarcină / încărcare de distrugere

destruction range (mas, $\mathrm{TH}$ ) interval de distrugere

destruction / destructive test (metr) încercare distruc-tivă / cu distrugerea epruvetei

desguarise (alim) a extrage substantele zaharoase, a dezaharisi

desguarizing (alim) dezaharisire desist from a înceta de a mai, a nu mai face (ceva)

desk masă de scris, birou; bancă, pupitru

desolate pustiu, părăsit; (agr) lăsat în părăsire; sterp, neroditor (d. un teren); a pustii, a devasta; a lăsa în părăsire, a abandona

desolation pustiire, devastare; ruină, paragină; părăsire

desorbtion (alim, chim) proces de eliminare a gazelor absorbite

despite în ciuda

dessert (alim) desert

dessertspoon (metr) unitate de măsură pentru volum: 1 dessertspoon $(\mathrm{UK})=11,839 \cdot 10^{-6} \mathrm{~m}^{3}$; 1 dessertspoon (US) $=9,858 \cdot 10^{-6} \mathrm{~m}^{3}$

destination destinație

destroy a distruge, a dărâma; (constr) a demola

destroyable care poate fi distrus, netrainic, şubred destroyer (nav) distrugător

destructible destructibil, care poate fi distrus

destruction distrugere

destructive distructiv, distrugător

destructiveness caracter distructiv

desulphurisation (met, ind chim) desulfurare

desulphurisation plant (met) instalație de desulfurare

desulphurise (met, chim) a desulfura

desulphurising (met, chim) desulfurare

desuperheat (met) a răci după supraîncălzire

desuperheating coil (termo, alim) serpentină de suprarăcire / de răcire a supraîncălzirii, element de prerăcire

desynchronisation (autom, fiz) desincronizare

detach (mas) a decupla; (TH) a (se) detaşa, a desprinde, a separa

detachable (auto, mas, OM) detaşabil, mobil, separabil, schimbabil, demontabil, amovibil; (chim) solubil, detaşabil

detachable back perete din spate, detaşabil (la cuptoare, incinte cu volum variabil, maşiniunelte)

detachable ball journal bearing $(\mathrm{OM})$ rulment radial-axial cu bile, detaşabil

detachable bottom (OM, met) fund demontabil / detaşabil (la oală, la convertizor)

detachable joint (OM) îmbinare / articulație demontabilă

detachable top $(\mathrm{OM})$ parte superioară detaşabilă

detachable valve seat (OM, hidr) scaun de supapă, amovibil / detaşabil

detached liber, izolat, independent, detaşat, separat; imparțial, nepărtinitor, neinfluenţat; indiferent 
detaching (TH, mec) detaşare, separare, declanşare, decuplare; care (se) detaşează

detaching hook $(\mathrm{OM})$ cârlig de declanşare

detachment $(\mathrm{TH})$ detaşare, separare, desprindere; independență, imparțialitate; indiferență

detail $(\mathrm{TH})$ reper, detaliu (şi în desen tehnic), amănunt; a detalia, a descrie amănunțit, a face un detaliu

detail drawing detaliu (într-un desen tehnic), schiță de detaliu, desen (şi de execuție)

detailed detaliat, amănunțit, complet; total

detain a reține, a împiedica, a opri; a deține; a frâna, a face să aştepte / să întârzie, a impiedica, a stingheri (functionarea etc.)

detainer (OM, mas-un) dispozitiv de oprire

detarring plant (ind chim) instalație de degudronare

detect $(\mathrm{TH})$ a identifica, a observa, a descoperi, a constata, a detecta, a găsi; a surprinde; somebody in the act a prinde pe cineva în flagrant delict

detectability (metr) capacitate de detectare / de măsurare, sensibilitate (a unui aparat)

detectable detectabil, care poate fi detectat / sesizat / descoperit, decelabil

detecting detectare; care detectează, detectând

detecting action (autom) acțiune / efect de detectie / de redresare

detecting element (autom) element primar, circuit / element de detectare, detector, element sensibil; (metr) traductor de intrare, detector / traductor / palpator (de măsurare), detector, captor, sesizor

detecting range (autom, metr) interval / distanță de detectare; (auto, autom) interval de detectare, gama obiectelor detectabile

detection $(\mathrm{TH})$ descoperire, identificare, observare; (autom) detectare, detectie; (chim, fiz, metr) identificare (a elementelor sau structurilor)

detector (autom, metr) detector, senzor de detectare

detent $(\mathrm{TH}$, termo, mec) detentă, declanşare; (OM, mas-un) limitator de cursă, dispozitiv de decuplare, mecanism de oprire, clichet de blocare, opritor

detent lever (OM, termo) bară de dilatație, pârghie de declanşare

detent position (auto) poziție de decuplare

detergency (chim, T) capacitate de spălare a unui detergent

detergent (ind chim) detergent, produs de curățat, produs de dizolvat; (T) agent / aditiv detergent detergent additive ( $\mathrm{T}$, chim) aditiv dispersant / detergent, produs incorporat într-un lubrifiant pentru a împiedica depunerea reziduurilor de ardere pe piesele motorului

detergent power (chim) putere / capacitate de spălare a unui detergent

deteriorate $(\mathrm{TH})$ a (se) deteriora, a (se) strica, a (se) înrăutăți

deterioration deteriorare, stricare, înrăutățire

deteriorative care deteriorează / înrăutățeşte / strică

deterioration of lubricant(s) $(\mathrm{T}$, chim) deteriorarea lubrifiantului (lubrifianților)

determinable (mat) determinabil; (metr) sesizabil

determinant (mat) determinant; (factor) determinant, hotărâtor;

determinantal equation (mat) ecuație cu determinanți

determinate determinat, bine definit, precizat; precis; limitat; definitiv

determination stabilire, determinare, calcul; (alim, chim) dozare, măsurare, precizare; hotărâre, fermitate; (mat) definire, determinare, calcul

determination of hardness (metr, hidr, mediu) determinare a duri-tății apei potabile

determination of output (mas, metr) determinarea puterii (la ieşire)

determination of size dimensionare, determinare a dimensiunii (şi prin calcule de proiectare)

determination of the tension (el, metr) determinare a tensiunii

determinative determinant, hotărâtor

determine $(\mathrm{TH})$ a determina, a fixa (un termen, o sumă etc.), a constata, a stabili, a preciza, a contitiona, a delimita; (mat) a evalua; a (se) hotărî, a (se) decide, a lua hotărârea de a; a convinge; a cauza; (jur) a expira

determined determinat, fixat, precizat, stabilit, constatat; hotărât; hotărâtor

determining factor factor determinant

detin (met, ind chim) îndepărtare a staniului, a decositori, a îndepărta cositorul / staniul

detinning (met, ind chim) îndepărtare a staniului, decositorire

detonate $(\mathrm{TH})$ a detona, a exploda, a crăpa, a plesni

detonation detonatie, explozie

detonator (chim) detonant; detonator; amorsă, capsă detonantă

detour, détour ocol, înconjor, întoarcere

detouring ocolire, înconjurare; care ocoleşte / înconjoară 
detoxicate a dezintoxica

detract from a micşora, a diminua, a scădea din (valoare etc.); a reduce (ceva) din

detraction micşorare, diminuare, scădere din (valoare, sumă etc.)

detriment detriment; pagubă; to the $\sim$ of în detrimentul

detrimental nociv, vătămător; (auto, TH) dăunător; păgubitor

detrition (T) uzură prin frecare

detrusion $(\mathrm{mec})$ forfecare, (a)lunecare (de material), deformatie la forfecare

detuning (autom, metr) dezacordare, dereglare

Deuterium (D) (chim) deuteriu

Deuteron mass (fiz, metr) unitate de măsură pentru masă (în fizica atomică): 1 Deuteron mass $=3,343586 \cdot 10^{-27} \mathrm{~kg}$

devaluate (ec) a devaloriza

devaluation (ec) devalorizare

devalue (ec) a devaloriza

devaporation (fiz, termo) condensare a vaporilor

develop (TH) a (se) dezvolta, a desfăşura, a face să crească, a extinde, a stimula (dezvoltarea), a manifesta (şi o tendință); (med) a contracta (o boală); a exploata (resurse); (mil) a desfăşura (trupe), a lansa (un atac); a developa (fotografii), o aptitudine a începe, a progresa, a creşte, a evolua, a (se) mări; a amplifica; a contracta; (mat) a (se) desfăşura (în serie, în produse), a explicita, a dezvolta în serie

developable desfăşurabil, dezvoltabil

developed length / surface (mat) lungime / suprafață desfăşurată (şi la calculul semifabricatelor pentru ambutisare, croire etc.)

developed projection proiecție desfăşurată developing în curs de dezvoltare / de desfăşurare / de manifestare, care se dezvoltă (şi d. un proces)

develop into a se dezvolta, a se transforma în development $(\mathrm{TH})$ dezvoltare, desfăşurare, rulare, rostogolire, formare; perfectionare, extindere, creştere, sporire, progres; (chim) degajare; (constr) şantier, proiect, construcție, ansamblu, lucrare; (mat) desfăşurare a unei suprafețe; (met, chim) degajare / formare / generare de gaze; element, dată; împrejurare, întâmplare, eveniment; (agr) valorificare (a unui teren); dezvoltare / exploatare (a unei regiuni); expunere, prezentare (a unei idei etc.); desfăşurare (de evenimente, procese etc.); $\sim \mathbf{s}(p l)$ evenimente developmental de dezvoltare, al dezvoltării development map plan de amenajare / de dezvoltare (foarte general) development of microstructure $(\mathrm{TH}$, materiale) evidențierea / dezvoltarea / formarea microstructurii

development program (met, constr) program de amenajare / de dezvoltare

development system (c, inf) sistem hard şi soft (care poate îndeplini anumite functiii)

deviance (mat) abatere medie pătratică de selecție deviate abatere de la valoarea medie (în statistică matematică)

deviate from a devia de la, a se abate de la

deviated hole (OM, mas-un) gaură deviată

deviating force $(\mathrm{mec})$ forță deviatoare

deviating (fiz) decalaj; (mat) deviație, care deviază / abate

deviation (OM, autom, metr) deviație, deviere (A), abatere

deviation controller (metr, autom) dispozitiv automat de reglare, care acționează când un parametru deviază de la o valoare impusă

deviation roller $(\mathrm{OM})$ rolă de ghidare / de deviere

device (mas) procedeu, mijloc, dispozitiv, aparat, mecanism, instrument, plan, schemă, proiect, bloc constructiv; (ec) deviz; invenție; emblemă; deviză, mot(t)o

device for adjusting / arresting / locking / setting / stopping (mas, OM) dispozitiv de oprire (prin clichet), opritor; (mas) frână; obstacol

device for counterbending rolls (met) dispozitiv / suport pentru contra-cilindri (la laminoare) / împotriva încovoierii cilindrilor / de împiedicare a încovoierii cilindrilor

devil's claw (nav) gheară de drac (pt. boturile lanțurilor de ancoră)

devil's fork / pitch (mas-un, nav) clește prinzător

devise a concepe, a proiecta, a inventa, a imagina devitrification (chim) devitrifiere, devitrificare devitrify a devitrifica

devolatilization (fiz, alim, ind chim) pierderi prin volatilizare

devoted to devotat, loial față de

devotedly $(a d v)$ cu dăruire

devotedness dăruire; consacrare

devour a devora

dew rouă, ceață, aburire; $(\mathrm{TH})$ a umezi datorită ceții / aburirii

dewars $(\mathrm{OM}$, ind chim) containere pentru gaze lichefiate

dewater (alim, ind chim) a deshidrata

dewaterer (alim, ind chim) aparat de deshidratare 
dewatering (constr, hidr) epuizare / înlăturare / scoatere / eliminare a apei (fără a specifica dacă este prin centrifugare, filtrare etc.); (alim, ind chim) deshidratare

dewatering conduit $(\mathrm{OM}$, hidr) conductă de golire, golire de fund

dewatering conveyer $(\mathrm{OM}$, hidr) filtru continuu / cu bandă

dewetting neumectare, fără umectare (şi la sudare); curgerea adezivului la reîncălzire

dew-point / temperature (fiz) temperatură / punct de rouă / de condensare a vaporilor de apă

dew-point curve (fiz, termo) curbă de condensare

dew-point temperature (fiz) temperatură de condensare, punct de rouă

dextral drept, din dreapta; deprins să folosească mâna dreaptă

$\operatorname{dextrin}(e)($ chim) dextrină

dextorse (mec) cu torsiune pozitivă / la dreapta

dextrorotation (chim) rotația spre dreapta (a planului de polarizare; (mas) rotire la dreapta

dextrose (chim) dextroză

dezinc (met) îndepărtarea zincului, a dezinca, a îndepărta zincul

diacid (chim) acid dibazic

diagnose $(\mathrm{TH})$ a detecta erori / defecțiuni, a diagnostica

diagnosis, $(p l)$ diagnoses diagnoză, diagnostic

diagnostic (med, mas, $\mathrm{TH}$ ) diagnosticare, (de) diagnostic, simptom, stabilire a erorilor / a defecțiunilor

diagnostic routine (c, inf) program de diagnosticare / de detectare a erorilor / a defectelor

diagnostics diagnostic(are)

diagnostic sensivity (mas, $\mathrm{TH}$ ) sensibilitate de detectare a defecțiunilor

diagnostic test (inf) functionare sau rulare a unui program în scopul descoperirii potențialului de defectare

diagonal (mat) diagonală, secțiune diagonală, (adj) diagonal, oblic

diagonally-cut piston ring (OM, termo) segment de piston cu fantă diagonală / oblică

diagonal member (OM) (bară) diagonală; (constr) contrafiş̧ă (în diagonală); contravântuire, contrafort în diagonală

diagonal pitch $(\mathrm{OM})$ pas pe diagonala (nituirii)

diagonal rod $(\mathrm{OM})$ bară / baghetă diagonală sau oblică

diagonal rolling (met) laminare cu cilindri oblici

diagram diagramă, schemă, grafic, organigramă, schemă de calcul, figură, curbă, ilustrație, desen explicativ diagram of component forces (mec) poligonul forțelor

diagram of forces $(\mathrm{mec})$ diagramă a forțelor

dial (TH, metr) limb, cadran, scală, ecran circular cu cifre, scală circulară, disc gradat / selector, disc de reglare; $(\mathrm{OM})$ rondelă / şaibă de potrivire / de ajustare / de reglare; (mas-un) limb; (metr) busolă, scală, diviziune; a forma (un număr de telefon)

dialectics dialectică

dial error (metr) eroare de citire (pe un cadran)

dial extensometer (metr) comparator / extensometru cu cadran, ceas comparator

dial feed (mas-un) cerc gradat al cutiei de avansuri, magazie cu disc de alimentare (la maşiniunelte automate)

dial feed press presă-revolver cu magazie rotativă pentru alimentarea cu piese brute

dial indicating the length of stroke (mas-un) scală pentru reglarea cursei

dial indicator (metr) indicator cu scară și/sau citire circulară

dialling rețea, cadran, centrală (şi de telefoane), formare (a unui număr de telefon); (metr) gradare a unui cadran

dialogue dialog, conversație, discuție

diamagnetic material (fiz) material amagnetic (cu permeabilitate specifică mai mică de 1,00 )

dial micrometer (metr) micrometru cu (ceas / cadran) comparator

dialpointer (metr) ac indicator

dial reading (metr) indicație / valoare citită pe scară

dial scale (metr) scară / scală inelară / în arc de cerc (la aparatele de măsurat)

dialwasher $(\mathrm{OM})$ rondea / şaibă elastică

diameter (geom, OM) diametru

diameter drilled (mas-un) diametru maxim al găurii cu un anumit burghiu

diameter of bore $(\mathrm{OM})$ alezaj, diametru al găurii / alezajului

diameter of furnace throat (met) diametru al gurii furnalului

diameter radial interference $(\mathrm{OM})$ strângere radială

diameter stop (mas-un) limitator pentru prelucrare până la obținerea diametrului cerut

diametral line $(\mathrm{OM})$ diametru, linia / axa care conține diametrul

diametrical (mat) diametral

diametrical clearance $(\mathrm{OM})$ joc diametral

diametrical compression method (ind chim, alim) metoda prin compactare / compresie diametrală 
diamond (mat) rombic, romboidal; (minrl) diamant; (nav) romb

diamond boring (mas-un) alezare cu (cuțit cu) diamant

diamond burnishing (mas-un, termo) distrugerea diamantului din cauza temperaturii ridicate (la rectificare, polizare)

diamond cone (metr) vârf / con de diamant

diamond die (mas-un) filieră cu diamant (la aparate de măsurat duritatea etc.)

diamond drill (mas-un, met) găurire cu carotieră cu diamant; burghiu cu diamant

diamond drilling bit (mas-un) floare de burghiu cu diamant

diamond dust (mas-un, T) praf de diamant (şi ca aditiv în lubrifianți)

diamond hand tool (mas-un) diamant pentru îndreptarea / reascuțirea manuală a pietrei / discului de rectificat

diamond impregnater carboloy (met) aliaj dur „carboloy” / cu pulbere de diamant

diamond-knurl (mas-un) zimțuire în cruce prin rulare, striuri încrucişate, moletare

diamond knurling tool (mas-un) rolă / moletă de zimțuit, cu dinți înclinați

diamond nose vârf ascuțit / fără racordare (la maşini-unelte)

diamond penetrator / pyramid (met, metr) penetrator piramidal de diamant (pentru duritate Vickers)

diamond penetrator / pyramid hardness (met, metr) duritate Vickers (cu penetrator piramidal, de diamant)

diamond pass (met) calibru romboidal de laminare

diamond plate $(\mathrm{OM})$ eclisă romboidală

diamond point engraving cutter (mas-un) freză-deget pentru prelucrarea canalelor cu secțiune triunghiulară

diamond-point tool (mas-un) cuțit cu vârf ascuțit / fără rotunjire

diamond-pyramid hardness (metr) duritate Vickers

diamond-shaped (OM) rombic

diamondspar (minrl) corindon

diamond(-tipped) tool (mas-un) cuțit cu diamant (fixat pe zona de lucru a tăişului), diamant pentru îndreptarea discului de rectificat

diamond(tool) holder (mas-un) montură / portsculă pentru fixarea diamantului sau pplăcuței aşchietoare cu (praf de) diamant

diamond tool lathe (mas-un) strung rapid pentru prelucrare, cu folosirea cuțitelor cu diamant / cu plăci de aliaj dur diamond wheel (mas-un) disc abraziv, cu praf de diamant sintetic

diaphane, diaphanous diafan, transparent

diaphragm (fiz, OM) membrană, diafragmă; (hidr, OM) diafragmă pentru orificiul de scurgere; $(\mathrm{TH})$ perete despărțitor

diaphragm actuator / drive (OM, hidr) actionare cu membrană / diagramă

diaphragm adjustment ring $(\mathrm{OM}$, opt) inel de reglare a diafragmei

diaphragm cap (OM, metr) capac de membrană diaphragm clutch $(\mathrm{OM})$ ambreiaj cu diafragmă / cu disc ondulat / cu disc elastic

diaphragm gas meter (metr) contor (și de gaz) cu diafragmă

diaphragm leaf (OM) lamelă a diafragmei / membranei

diaphragm pressure control valve $(\mathrm{OM}$, autom, hidr) regulator de presiune, cu membrană

diaphragm (pressure) gauge $(\mathrm{OM}$, autom, hidr) manometru cu membrană

diaphragm pump (OM, autom, hidr) pompă cu diafragmă / cu membrană

diaphragm seal $(\mathrm{OM})$ etanşare cu diafragmă diaphragm spring $(\mathrm{OM})$ resort / arc cu / de diafragmă, disc-resort, utilizat în ambreiaje

diaphragm unloading valve (OM, hidr) regulator de presiune, cu membrană, de descărcare

diaphragm valve (OM, hidr) supapă-disc, ventil-disc, supapă cu membrană / cu taler / cu disc / cu ciupercă, supapă plată

diary agendă, jurnal zilnic / de însemnări

dib a lovi uşor, a atinge (uşor), a ciocăni

dibasic (chim) dibazic

dichromate (chim) dicromat

dichromate treatment (met) tratament de acoperire rezistentă la coroziune (la piese din aliaje de magneziu), prin fierbere în soluție de dicromat de sodiu)

dictate a dicta; ordin

dictation dictare; ordin

dictionary dicționar

dictum, $(p l)$ dicta dicton, aforism, maximă

didactic didactic

didactically $(a d v)$ (în mod) didactic

didacticism didacticism

didrachma (metr) unitate (veche) de măsură pentru masă; 1 didrachma (Biblical Greek) = $0,0068 \mathrm{~kg}$

die (mas-un, met) stanță, matriță, clupă, filieră, poanson, cochilie, formă permanentă metalică de turnare; zar

die adapter (mas-un) suport de filieră / matriță 
die approach (mas-un) aproppiere a filierei / matriței de semifabricat; atacarea semifabricatului de prelucrat cu o filieră / matriță; începerea prelucrării cu filiera / matrița

die away a se auzi din ce în ce mai slab, a se stinge (şi d. vibrații), a se potoli

die-away curve (fiz, autom) curbă de scădere / de amortizare

die bed (met, mas-un) placă de bază / pat a(l) matriței (de turnare sau la prese de matrițare)

die-blank (met, plast, OM) semifabricat pentru matriță / filieră

die-body (met, plast) corp principal / carcasa matriței / filierei

die-block (mas-un) matriță / filieră -bloc / nedemontabilă (sau ca subansamnlu cu elemente active, carcasă etc.)

die-bolster (met, plast) suport pentru matriță / filieră

die bolt cutter maşină de filetat buloane (cu cap de filetat)

die case (met, plast, mas-un) inel pentru fixarea filierei, armătură de filieră

die cast / casting formare prin injecție (şi la materiale plastice); (met) turnare sub presiune (în cochilă)

die-casting machine (met, plast) maşină de turnare sub presiune / de format prin presare în matriță

die chaser (mas-un) bac de filetat, filieră

die clamp (mas-un) dispozitiv de închidere / blocare a filierei / matriței

die clearance (mas-un, OM) jocul dintre părțile active ale matriței

die coating (met) vopsea de lingotiere

die cushion (OM, mas-un) pernă a matriței, amortizor pentru matriță

die forged chain (met, $\mathrm{OM}$ ) lanț forjat în matrițe

die forging (met, mas-un) matrițare (şi la cald), forjare în matriță

die-formed part (met) piesă matrițată / formată în matriță

die guide (OM, mas-un) falcă de ghidare (a matriței), ghidaj (de matriță)

die hammer (met) ciocan de matrițare

diehead (mas-un) cap de filetat, filieră

die hob for cutting open dies (mas-un) tarod pentru bacuri de filieră

die holder (mas-un) clupă de filetat, suport al matriței de perforat; (met) port(-)matriță

die hole (OM, mas-un) orificiu al filierei

die impression (mas-un) prelucrare matriței (negativului piesei în matriță)

dielectric (el) dielectric, izolator dielectric breakdown (voltage) (el) tensiune de străpungere a unei izolații

dielectric constant $(\mathrm{el})$ constantă dielectrică

dielectric heating (fiz, el) încălzire dielectrică / prin pierderi dielectrice / prin curenți de înaltă frecvență

dielectric loss (el) puterea pierdută prin transformare în căldură, într-un dielectric supus unui câmp electric variabil

dielectric property (el) proprietate dielectrică

dielectrics materiale dielectrice

dielectric strength (el) tensiunea înainte de străpungere a unui dielectric, rezistența la străpungere

die-maker (met) matrițer; $(\mathrm{TH})$ lăcătuş-sculer

die making machine (mas-un) maşină de frezat prin copiere

die mark (met, plast) urmă / semn / striu după prelucrare în matriţă sau tragere

die of tubing machine (mas-un, met, plast) filieră a maşinii de extrudare

die plate (mas-un) support de filieră, matriță fixă; (met) placă de filetat

diepot (met) matriță (de turnare)

die pressing (met, plast) presare în matriță

die scalping (met) cojire (a semifabricatelor metalice) prin tragere prin filieră

die scar / scratch (met, plast, mas-un) striu / urmă / zgâriere la matrițare sau tragere

Diesel engine (auto) motor diesel / cu motorină

Diesel (cf) locomotivă cu motor Diesel

Diesel engine / motor (termo, autom) motor diesel

Diesel-engine with airless injection / with solid injection (termo) motor diesel cu injecție mecanică, fără compresor pentru injecție

Diesel fuel (auto, ind chim) gazolină, motorină, combustibil pentru motoare diesel

Diesel-fuel index / number (ind chim, termo) indice diesel la motorină

Diesel-liner (OM, termo) cămaşă de cilindru a unui motor diesel

Diesel oil (ind chim, auto, termo) motorină

die set (mas-un) garnitură completă / modulată de matriţă (matriță şi poanson); (met, plast) inel de reglaj al matriței, set de matrițe / de filiere pentru matrițare / tragere în etape succesive

die shaper (mas-un) maşină de mortezat prin copiere

die sinking cutter (mas-un) freză pentru matrițe die sinking milling machine (mas-un) maşină de frezat prin copiere, pentru prelucrarea suprafețelor cu relief complicat

die spinning nozzle (mas-un, plast) filieră în vârtej 
die-stamping press (mas-un, met, plast) presă de ştanțare în matriță

die steel (met) oțel pentru matriţe

die-stock (mas-un) placă de filetat, clupă de lăcătuşerie / de filetat țevi de gaz, filieră

diestock die (mas-un, met) filieră

diet (alim) dietă, regim alimentar, a ține / respecta un regim alimentar

die tap (mas-un) tarod pentru filiere

dietary (alim) de / pentru dietă, regim alimentar, dietetic

dietetical (alim) dietetic

die trap (met) groapă / răzuitor / separator / captator de zgură

die wear (mas-un, T) uzura matriței / filierei

die welding (met) sudare prin forjare în matriță

die work (met, plast) forjare în matriță, matrițare, tragere (prin filieră)

differ from a diferi de, a (se) abate de la, a devia de la, a se deosebi de, a fi diferit de, a nu fi de acord cu

differ with a nu fi de acord cu, a avea altă părere decât

difference diferență, deosebire, creștere, rest; diferend, neînțelegere

difference equation (mat) ecuație cu diferente finite

difference gauge (metr, mas-un) calibru limitativ

difference in temperature (fiz, termo) diferență de temperatură

difference interval pas (în analiza numerică)

difference method (mat) metodă diferențială

difference of gravity diferență de densitate / între greutăți specifice

difference of phase (fiz, el, TH) decalaj de fază, defazaj

different diferit, deosebit, altfel; neobișnuit, special differentiable (mat) diferențiabil, derivabil

differential deosebit, distinctiv; (mas, OM) transmisie diferențială, diferențial; (mat) diferențială

differential amplifier (autom, electr) amplificator diferential / care amplifică diferența dintre două semnalele succesive de intrare

differential attachment (OM) mecanism de diferențial

differential bevel drivegear (OM) transmisie diferențială, cu pinion conic de atac

differential calculus (mat) calcul diferențial

differential case (auto, OM) casetă / carter a(l) diferențialului

differential casing (auto, OM) carter / casetă / trompă a(l) diferențialului

differential coefficient (mat) derivată

differential control (autom) reglaj de urmărire differential cross pin (OM) fus / bolț al crucii sateliților (şi la maşini-unelte)

differential flotation (met, ind chim, alim) flotație diferențială / selectivă

differential gauge (metr, hidr) manometru diferențial

differential gear $(\mathrm{OM})$ mecanism / angrenaj de diferențial

differential gear box $(\mathrm{OM})$ carter de diferențial, diferențial cu angrenaje

differential gearing $(\mathrm{OM})$ diferențial, transmisie diferentială

differential gearsetting mechanism (OM) mecanism de ajustare / de reglare / de blocare a diferențialului

differential gear shaft (OM) arbore al diferențialului

differential gear train $(\mathrm{OM})$ diferențial $\mathrm{cu}$ mai multe trepte (de angrenaje)

differential head (hidr, TH) cădere relativă de presiune, (prag de) presiune dinamică

differential hoist (mas) palan diferențial; (nav) palanc diferențial

differential housing $(\mathrm{OM})$ carter / casetă / trompă a(l) diferențialului

differential indexing (mas-un) metodă diferențială de divizare (la cap divizior)

differential jack $(\mathrm{OM})$ cric / vinci diferential

differential lock $(\mathrm{OM}, \mathrm{TH})$ blocare a diferențialului

differentially $(a d v)$ (în mod) diferențiat

differential master gear $(\mathrm{OM})$ coroană principală a diferențialului

differential mobility analyser (metr, autom) analizor al mişcării diferentiale / relative

differential motion (mec, OM) mişcare diferențială (mișcare relativă suplimentară)

differential pinion $(\mathrm{OM})$ satelit / pinion de atac al diferențialului

differential planet gear $(\mathrm{OM})$ satelit al diferențialului, roată planetară

differential pressure (OM; hidr) diferentă / cădere de presiune, presiune diferențială

differential pressure controller $(\mathrm{OM}$, hidr, autom) regulator de presiune diferențială

differential pressure gauge (metr, hidr) manometru diferențial

differential pressure instrument (metr, hidr) aparat / instrument pentru măsurarea presiunii diferențiale, manometru diferențial

differential pressure switch (hidr, metr) contact / întrerupător acționat de o anumită valoare a presiunii diferențiale, întrerupător acționat de presiunea diferențială 
differential pulley / sheave $(\mathrm{OM})$ rolă / roată diferențială (şi la variatoare prin fricțiune)

differential quantity (mat, metr) diferențială, variația unei mărimi (fără referire la valoarea absolută)

differential quotient (mat) derivată

differential ring gear $(\mathrm{OM})$ coroană de diferențial

differential screw (OM) şurub diferențial, format din două transmisii şurub-piuliță

differential shaft $(\mathrm{OM})$ arbore planetar

differential sidegear (auto, OM) roată planetară la osia din spate, pinion planetar

differential spider $(\mathrm{OM})$ cruce a satelitilor

differential spider pinion $(\mathrm{OM})$ pinion satelit, satelit al diferențialului

differential sun gear $(\mathrm{OM})$ roata centrală de diferenţial

differential temperature expansion valve $(\mathrm{OM}$, hidr, autom) ventil termostatic de reducere a presiunii (utilizat în sistemele frigorifice de joasă temperatură)

differential test masses (mec) mase de încercare diferențiale

differentiate (with respect to) a deriva, a diferenția, a se deosebi (în raport cu), a (se) distinge (faţă de), a face să se deosebească (față de)

differentiating action acțiune de diferențiere / diferențială / derivativă

differentiating solvent (chim) solvent selectiv

differentiation deosebire, diferențire; (mat) derivată, diferențiere; (ec) indice de diferențiere a sortimentului

differentiator (autom) dispozitiv care are funcția de ieşire dependentă de derivata funcției de intrare

differ in phase (fiz, autom) a nu fi în fază, a fi defazat

difficult dificil, greu; susceptibil

difficultly fusible glass (ind chim) sticlă greu fuzibilă

difficultly meltable (met, chim) refractar (şi d. aliaje), greu / dificil de topit

difficult to accesss $(\mathrm{TH})$ greu accesibil

difficult to dissolve (chim) greu solubil

difficult-to-machine job (mas-un) piesă greu de prelucrat la maşini-unelte

difficult to volatilize (fiz) puțin / greu volatil difficulty dificultate, greutate, problemă; necaz diffident neîncrezător (în sine); modestie; rezervă diffract (fiz) a difracta

diffraction (fiz) difracție (a luminii)

diffraction analysis (fiz, metr) analiză structurală (prin difracția radiației $\mathrm{X}$ ) diffraction angle (fiz) unghi de difracție

diffraction beam (fiz) fascicul (împrăş̧iat) după difracție, fascicul folosit în analiză difractometrică

diffraction frange (fiz) franje de difractie

diffraction grating (fiz) rețea de difracție

diffraction spectrum (fiz) spectru de difracție

diffraction X-ray pattern (fiz, metr) röentgenogramă obținută prin difracția razelor $\mathrm{X}$

diffraction X-ray machine (fiz, metr) difractometru cu radiatii $X$

diffractive (fiz) de difracție

diffuse confuz, prolix (d. stil); (fiz) (lumină) difuză; a (se) împrăştia, a (se) difuza, a răspândi, a se propaga

diffused (fiz) difuz, neclar; răspândit, împrăștiat diffuser (auto) difuzor, pulverizator; (el) dispozitiv / refractiv pentru iluminat difuz; (hidr) difuzor (de lichid); (mas, termo) difuzor al compresorului; (met) pâlnie de aer

diffusion (chim, met) difuzie; difuzare, împrăştiere

diffusion battery (chim, met) baterie (tancuri sau coloane etc.) de difuzie

diffusion charging (chim, met) încărcare prin / pentru difuzie

diffusion layer (chim, met) strat de difuzie

diffusion of particles (alim, chim, met) difuzia particulelor

diffusion pump (ind chim, OM) pompă de vid cu efect de difuzie (prin antrenarea gazelor într-un mediu de particule grele, de exemplu, mercur)

diffusion sintering (chim, met) sinterizare prin difuzie

diffusion zone (met) zonă de difuzie

diffusion welding (met) sudare prin difuzie

diffusive difuz; care se poate răspândi, difuzibil

diffusive saturation (alim, ind chim) saturație prin difuzie

diffusivity (hidr, termo) coeficient / capacitate de difuzie; (fiz) difuzivitate

dig (constr) săpătură, a săpa, a excava; (mas-un) a gripa; a băga, a înfige; a înțelege, a aprecia; in a îngropa; up (agr) a desțeleni, a săpa adânc; from a dezgropap din; for information a investiga, a face cercetări

digest compendiu, rezumat; (alim) a (se) digera, a asimila; (chim) a digera, a concentra prin evaporare; (TH) a rezuma, a clasifica, a sistematiza; (alim termo) a fierbe, a trata cu abur; (fig) a întelege

digester (ind chim) autoclavă, cazan fierbător, devulcanizator, bazin de fermentare; (termo) fierbător; (plast) autoclavă de devulcanizarea 
digestion (alim) digestie, asimilare

digestion of emulsion (alim, fiz) maturație a unei emulsii

digest with water a înmuia cu apă

digger (constr, mas) excavator cu linguri, care sapă, săpător

digging (constr) săpare, săpat, săpătură, excavare, debleiere; (hidr) groapă, şanț, canal; care sapă

digging machine (mas) maşină de săpat / de excavat

digging / hand shovel lopată

digging / cutting wheel (constr) roată cu cupe (la excavator etc.)

digit cifră, unitate binară, digit, poziție

digital digital, numeric, cifric, binar

digital clock (auto) ceas digital

digital coding cifrare; (c, inf) codificare prin cifre

digital data (mat, inf) date numerice

digital data processor (inf, c) dispozitiv de prelucrare a datelor codificate numeric

digital fluidics (inf) fluiditate numerică (legată de transmiterea semnalelor şi a informației numerice)

digital measuring instrument (metr) aparat de măsurat cu afişare / semnal de ieşire sub formă numerică

digital position read out (mas, opt) vizualizare numerică a poziției (unui organ mobil)

digital position servo (autom, metr) servomecanism numeric de modificare a poziției

digital program(me) control (autom) comandă după program numeric (a maşinilor-unelte)

digital tachometer (metr) tahometru digital

digital valve (OM, hidr) supapă cu debite variabile în șir binar $(2,4,8,16, \ldots)$

digitise a transforma o mărime fizică într-o valoare numerică

digitizer (metr, electr) dispozitiv de convertire în formă digitală a măsurătorii analogice

digitkey tastă / clapă / cheie cu cifră

digit switch (electr, autom) comutator de poziție

dignify a distinge, a evidenția; a învrednici

dignitary demnitar

dignity demnitate, atitudine demnă, prestigiu

dig out (constr) a dezgropa; a săpa şi a îndepărta materialul excavat

digress from a se abate de la, a devia de la; a face digresiuni

digs (mas-un, T) aşchii mici, particule detaşate de pe suprafețe polizate / rectificate / care se uzează

dig up a săpa, a scoate săpând, a dezgropa, a excava; (fig) a scoate la lumină

dihedral (mat) diedru dike filon; şanț, canal de scurgere; ridicătură de pământ; (fig) piedică, obstacol

dilapidated (constr) în ruină; (TH) stricat, uzat

dilapidation (stare de) ruină; stricăciune, uzură; ruinare, dărâmare

dilatability (materiale, termo) dilatabilitate, extensibilitate

dilatable (materiale, termo) dilatabil, extensibil dilatancy (mec, plast) dilatare (şi a unui polimer, datorită forfecării), proprietate de a-şi mări volumul

dilatant fluid (fiz) fluid dilatant

dilatation (materiale, termo) dilatare, alungire, dilatare fracțională

dilatation hinge (OM, termo) articulație de dilatație

dilatation of length (OM, termo) alungire (prin dilatare)

dilate a (se) dilata, a (se) mări, a (se) extinde

dilate on / upon a (se) extinde asupra, a dezvolta pe larg (un subiect)

dilation dilatare, extindere; dezvoltare (a unui subiect)

dilatometer (metr, termo) dilatometru

dilemma dilemă, situație dificilă

dilettante, $(p l)$ dilettanti diletant, amator

dilettanteism, dilettantism diletantism, amatorism

diligence sârguintă, osteneală, hărnicie

diligent harnic, sârguincios, silitor

dill (alim) mărar

diluent (chim) diluant, solvent

dilute ( $\mathrm{T}$ ) fluid (cu vâscozitate redusă); a dilua, a dizolva, a topi; (fig) a slăbi, a micşora

diluting diluare; ( $f i g)$ slăbire, micşorare

diluting medium (chim) diluant

diluting / water pump (OM, ind chim) pompă de apă

dilution diluare, diluție; slăbire, micşorare, atenuare; soluție diluată

dim slab (luminat); obscur; mat; întunecos, întunecat; abia perceptibil, estompat, vag; neclar, șters, nebulos; confuz

dimension (mat, metr) măsură, dimensiune; $(\mathrm{TH})$ dimensionare, măsurare, (metr) a calibra; a măsura; a dimensiona

dimensional dimensional

dimensional accuracy (OM, mas-un, metr) precizie dimensională

dimensional (as regards size / quantity) dimensional (cu privire la mărime / cantitate)

dimensional data (autom, mas-un) date / informații dimensionale / care definesc pozitia unui organ mobil în raport cu una sau mai multe axe 
dimensional discrepancy / difference $(\mathrm{OM})$ abatere de la dimensiune

dimensional variation (metr, mas-un, $\mathrm{OM}$ ) abatere la dimensiune, toleranță

dimension error (metr, mas-un, OM) eroare / abatere dimensională

dimensional stability (materiale) stabilitate dimensională

dimension cutting (mas-un) croire / tăiere / prelucrare, (şi prin aşchiere) la dimensiuni

dimension figure cotă de desen tehnic

dimensioning (OM, mec) dimensionare, care afectează / determină dimensiunea

dimensioning in engineering dimensionare, cotare în desen industrial / tehnic

dimensionless adimensional

dimensionless coefficient / parameter mărime redusă, coeficient de reducere, coeficient / parametru adimensional

dimension limit system (OM) sistem de toleranțe

dimension of mating part, coupling dimension (OM) dimensiune de asamblare / a piesei pereche / conjugată

dimension of the reciprocal of time (metr) dimensiune / măsură în inversul timpului $\left(\mathrm{s}^{-1}\right.$ etc.)

dimensions chart (mas) desen (schematic) al unei maşini cu dimensiunile de gabarit

dimension stability (materiale) stabilitate dimensională

dimetcote (met, chim) acoperire pe bază de zinc (de obicei din două substanțe care reacționează cu oțelul)

dimethyl (chim) etan

dimethylketone (chim) acetonă

dimetric (proiecție) dimetrică, proiecție axonometrică, cu două unghiuri egale

diminish (TH) a (se) diminua, a slăbi, a (se) miç̧ora, a scădea, a reduce, a (se) atenua

diminishing of the gradient reducere a pantei / a gradientului (unei curbe)

diminution (fiz, el) diminuare, micşorare, scădere, slăbire

diminutive foarte mic, miniatural; diminutiv

dimly $(a d v)$ slab, nedesluşit, neclar; vag

dimple (OM, met) adâncitură, ondulație, încrețitură, gropiță

dimpling $(\mathrm{OM})$ guler mic al unei piese mecanice

dim red heat (met) incandescență la roşu închis

din a răsuna, a face zgomot; zgomot

DIN abreviere pentru standarde germane (după care urmează un număr) DIN (Deutsches Institut für Normung) dinas (met) cărămidă dinas / silica

dine a lua masa (de prânz sau cina)

diner persoană care ia masa; (cf) vagon restaurant

dingey, dinghy (nav) şalupă (mică)

dinginess murdărie

dingot (met) picătură rece (defect de turnare)

dingy şters, spălăcit; învechit, ponosit; murdar, prăfuit; pătat, dubios (d. reputație, rezultatele unor teste etc.)

dining car (cf) vagon-restaurant

dining room sufragerie

dinner (alim) masă (principală), prânz, cină; dineu, masă de gală

dinner service / set (alim) serviciu / tacâmuri de masă

dint $(\mathrm{TH})$ proeminență, ieșitură, dinte, zimț; (met) adâncitură produsă prin lovire

diode (electr) diodă

dioxide (chim) dioxid, bioxid (mai rar)

dip (el) săgeată (la linii electrice); (fiz) declinație magnetică; (mat) înclinare, oblicitate, pantă; (nav) înclinație magnetică; (TH) lumânare de seu, înmuiere (într-un lichid); a (s)cufunda, a imersa, a înmuia; (nav) a atârna o ancoră, a afunda, a băga; (met) decapant; (auto) a micşora lumina farurilor

dip angle unghi de înclinare

dip at high angles înclinare mare

dip at low angles înclinare mică

dip brazing (soldering) (OM, met, chim) lipire în baie de săruri / de aliaj (prin imersiune)

dip-coated electrode (met) electrod de sudură cu înveliş depus prin imersare / prin cufundare

dip coating (met, plast) acoperire prin imersare în baie

diphase bifazat, bifazic, difazic; (met) bifazic

diphase degreasing (alim, chim, met) degresare bifazică / în două etape

diphase equilibrum (el, met) echilibru pe / de două faze

diphenyl (chim) difenil

dip into a-şi arunca ochii asupra

diple semnul ,,>

diploma diplomă, certificat; document oficial

diplomacy diplomație, tact, abilitate

diplomaed cu diplomă, titrat

diplomat (edu, univ) cu diplomă, titrat

diplomatic (adj) diplomatic, cu tact, abil

dipped imersat, cufundat, coborât în baie

dipper (TH) oală, cupă, benă; (alim) polonic; (constr) cancioc; (met) oală de turnătorie

dipper arm / stick (mas, constr) braț / săgeată de excavator 
dipper bucket (mas, constr) cupă-dipper de excavator

dipping (alim, met, chim) cufundare, imersare, coborâre în baie

dipper (stick) shovel (constr, mas) excavator cu cupă dreaptă

dipper tooth (constr, mas, OM, T) dinte de cupă de excavator

dipping (chim, plast) imersiune, înmuiere, impregnare (prin cufundare); (met) cufundare (în baie de tratament / de decapare)

dip pipe (OM, hidr) țeavă cufundată, tub de imersiune / de prelevare

dip rod (auto) tijă de nivel al uleiului, jojă; (mas-un) ştangă de măsurat, indicator de nivel (pentru lichide), spion

dip shift deplasare în jos

dip soldering (met, OM) lipire moale prin cufundare

dipstick (auto, mas-un, OM) tijă de nivel al uleiului, jojă

direct (TH) direct, exact, nemijlocit, drept, neocolit; personal; sincer; (autom) proportio-nal; a dirija, a comanda, a conduce, a îndrepta, a direcționa, a controla, a supraveghea (şi un proces); a ordona

direct access (inf, c) acces direct, localizare directă a informației într-o adresă

direct acting (mas) cu acțiune directă

direct-acting shockabsorber $(\mathrm{OM})$ amortizor telescopic

direct action (fiz, mec) acțiune directă

direct arc-furnace (met) cuptor cu arc electric direct / pentru încălzire directă, cuptor Heroult

direct butt joining $(\mathrm{OM})$ îmbinare dreaptă, capla-cap (prin lipire, sudare etc.)

direct casting (met, plast) turnare directă

direct compression (mec) compresie pură

direct-connected legat (mecanic sau electric) direct (fără elemente / transmisii intermediare)

direct connection $(\mathrm{OM}$, el) racordare / legătură directă

direct control reglare (autom) (cu acțiune) directă

direct-cooling boiling water reactor (ind chim, termo) reactor cu apă fiartă, cu răcire directă

direct coupling (d.c., DC) (el) cuplaj direct; (mas) cuplare directă / mecanică a arborilor a două maşini

direct current (d.c. / DC) (el) curent continuu

direct drive (auto) priză directă (când viteza arborelui de intrare în cutia de viteze este egală cu cea a arborelui de ieşire); (autom) cu comandă directă; (mas) acționare directă directed orientat; direcționat

direct expansion refrigeration (termo) răcire prin detentă directă, sistem direct de răcire

direct extraction (with iron) (met) reducere directă (cu fier)

direct feed evaporator (ind chim, termo) evaporator cu injecție directă, evaporator alimentat cu refrigerent lichid provenind direct de la ventilul de destindere

direct-fire heating (termo) încălzire cu foc direct direct foundation fundație directă

direct fusion (met, termo) topire directă

direct-heating arc furnace (met) cuptor electric cu arc, cu încălzire directă

direct heating steam (termo) abur direct

direct hit (OMmec lovitură directă

direct indexing (mas-un) divizare directă

directing force (cf) forță conducătoare / de ghidare; (el) forță directoare; (mec, autom) forță de dirijare / de restabilire

direction direcție, sens, orientare, tendintă; conducere, îndrumare; control; linie, sferă (de activitate), domeniu

directional direcțional

directional control valve (hidr, OM) distribuitor hidraulic / pneumatic

directional property proprietate (mecanică, fizică etc.) dependentă de directia de măsurare / testare

directional solidification (met, plast) solidificare dirijată / orientată / direcționată

directional stability (auto, mec) stabilitate a traiectoriei unui vehicul în linie dreaptă

direction finder $(\mathrm{mec})$ indicator de direcție; (nav, metr) busolă radiogonimetrică, radiogoniometru

direction of burning (termo) conducere / directionare a arderii

direction of cut (mas-un) direcție a cursei de aşchiere / a cursei utile

direction of feed motion (mas-un) direcție de avans

direction of fire $(\mathrm{TH})$ conducere a focului, directia de propagare a focului

direction of flame path (termo) conducere a flăcării

direction of a force (mec) direcție / sens a(l) unei forțe

direction of gas flow (TH) conducere / distribuire a gazului

direction of grain (met, plast) orientare a fibrelor / a grăunților

direction of hand sens / directie a elicei (la maşini-unelte, la filete) 
direction of primary motion (mas-un) direcție de tăiere

direction of propagation (fiz, termo) direcție de propagare

direction of rolling (met) direcție a laminării

direction of rotation $(\mathrm{OM}, \mathrm{mec})$ direcție de rotație, sens de rotație

direction of slip direcție de lunecare (în cristalografie)

direction of the fibre (met, plast) directia de laminare / fibrelor (într-un compozit sau material fibros)

directions directivă, indicație, normă, instrucțiune, instrucțiuni / prescripții de funcționare

directions for use / application (TH) instrucțiuni / reguli / regulament de utilizare

directive indicator, arătător; dirijat, condus; directivă, instrucțiune; (c) comandă recunoscută de soft; (pol) directivă (europeană)

directive force (cf) forță conducătoare / de ghidare; (mec) forță de dirijare / de restabilire

directly $(a d v)$ (în mod) direct, drept, exact, tocmai; imediat, îndată, peste puțin timp; în linie dreaptă

directly coupled $(\mathrm{OM})$ cuplat direct, calat pe acelaşi arbore (cu altă piesă)

directly operated (mas) reglare / acționare directă; actionat direct

directly operated pressure control valve (hidr, OM) supapă / aparat hidraulic de reglare a presiunii, acționat direct

directly operated unloading valve (OM, hidr) regulator de presiune acționat direct (de diferența dintre forțele la care este supus(ă) pistonul / membrana)

direct maintenance man hours $(\mathrm{TH})$ timp total oameni-ore necesar reparației sau operațiilor de mentenență

directness orientare; caracter direct; sinceritate

direct operated / operating (mas) cu acțiune directă

director director, manager, conducător; administrator; (TH, autom) aparat de comandă; (ec) board of $\sim \mathbf{s}$ consiliu de administratie

directorate (ec) directorat, funcție de director, directie, conducere

directorship (ec) direcție, conducere, directorat

directory registru / carte de adrese; carte de telefon; anuar, ghid

direct power generation (el) producere directă de energie electrică

direct printer (inf) imprimantă directă

direct process proces (tehnologic) de obținere directă a unui material din materia primă direct process (with iron) (met) reducere directă (cu fier)

direct-process malleable iron (met) fier produs prin reducere directă

direct product produs direct; (mat, fiz) produs scalar a doi vectori

direct quotation $(\mathrm{ec})$ cotare directă / certă / în metoda națională

direct reading (metr) (cu) citire directă (la aparate de măsurat)

direct-reading instrument (autom, metr) aparat cu citire directă; (mas-un) instrument de măsurat cu scală / cadran

direct-reading thermometer (metr) termometru înregistrator / cu citire directă

directress directoare

directrix, (pl) directrices (geom) (curbă / dreaptă) directoare

direct shear tester (metr, mec) aparat de testare la forfecare directă / simplă

direct speeds (OM) viteze ale axului / arborelui, cu angrenajul intermediar decuplat

direct spot welding (met) sudare în puncte, directă direct stress (mec) tensiune / solicitare normală

direct sunlight (auto) în soare

direct tax (ec) impozit direct

direct to / towards a îndrepta spre, a dirija spre / către

direct trade (ec) comerț en gros

dirigibility (mas) capacitate de a fi manevrabil, manevrabilitate

diriment care anulează / afectează (negativ)

dirt $(\mathrm{TH})$ noroi, murdărie, gunoi, praf; (constr) sol, teren; (hidr) pământ; (termo) piatră de cazan; rocă sterilă, gangă

dirt capacity (mediu, hidr) capacitate de colmatare dirt coefficient $(\mathrm{TH})$ coeficient de murdărie dirt pits (met) pete (defect al tablei de oțel), ciupituri (provocate şi de coroziune)

dirt removal îndepărtarea murdăriei

dirt-resistent rezistent la murdărie / murdăriei

dirt trap (hidr, ind chim) separator de impurități dirty murdar, plin de noroi / praf; a (se) murdări, a (se) păta

dirty steel (met) oțel impur / cu incluziuni

disability neputință, incapacitate; invaliditate; disabilitate; (jur) lipsă de drepturi

disable a slăbi, a face inapt, a incapacita, a scoate din functiune; (c) a scoate sau a inhiba o caracteristică a hard-ului sau soft-ului; a face inoperant; (jur) a declara incapabil, a lipsi de drepturi; a dezactiva; (med) a schilodi, a face infirm; (mas, auto) a scoate din circulație / functiune o mașină 
disabled inapt; invalid, infirm; (TH) scos din functiune

disablement incapacitate; invaliditate; (mas) stricare, scoatere din funcțiune, dezafectare

disaccord dezacord, neportivire, neconcordanță; a nu fi de acord

disaccredit a discredita

disacidify (chim) a neutraliza acizii

disadjust (autom, TH) a deregla

disadvantage dezavantaj, inconvenient, situație dezavantajoasă; prejudiciu, detriment, pagubă, daune

disadvantageous dezavantajos, nefavorabil, neconvenabil

disadvantageously ( $a d v)$ (în mod) dezavantajos

disaffection nemulțumire; lipsă de loialitate

disafforest (silv) a despăduri

disagree a nu corespunde, a nu coincide, a se contrazice, a nu fi de acord, a nu se înțelege, a avea păreri diferite; a se certa

disaggreable dezagreabil, neplăcut

disaggreement necorespondență, diferenţă; contradicție; dezacord; păreri diferite

disaggree with a nu fi bun / potrivit pentru

disaggregating (constr, ind chim) dezagregare, măcinare, mărunțire

disagio (ec) rabat

disalignment (mas-un, OM) nealiniere, abatere de la aliniere (din montaj şi / sau din funcționare), coaxialitate; (met) deplasare, deviație

disallow a respinge, a nu recunoaşte; a refuza; a dezaproba; a nu permite; a interzice

disallowance refuz; refuzare; respingere; interzicere; dezaprobare

disannul a anula cu desăvârşire

disappear a dispărea, a nu se mai vedea, a se stinge (d. un semnal etc.)

disappearance dispariție

disappearing-filament (optical) pyrometer (metr) pirometru cu dispariția filamentului / cu fir incandescent

disappoint a dezamăgi, a deceptiona

diappointed dezamăgit, decepționat

disappointed of privat de, lipsit de

disappointment dezamăgire, decepție

disapprobation dezaprobare; condamnare

disapprobative dezaprobator

disappropiate (jur) a lipsi de dreptul de proprietate

disapproval dezaprobare

disapprove a dezaproba, a nu fi de acord cu

disapprovingly $(a d v)$ (în mod) dezaprobator

disarm a dezactiva (un circuit, o comandă); (mil) a dezarma disarrange a răvăşi, a deranja, a dezorganiza; a strica (şi un plan, un proiect)

disarrangement răvăşire, deranjare, dezorganizare, stricare; confuzie, zăpăceală

disarray neorânduială, dezordine, dezorganizare, neglijență; a dezorganiza

disarticulate $(\mathrm{TH}, \mathrm{mec})$ a dezarticula, a desface, a dezmembra

disassemble a dezasambla, a demonta (în piese separate), a descompune

disassembling (chim) descompunere, care se descompune; $(\mathrm{TH})$ dezasamblare, demontare, care se demontează

disassembly demontare, demontaj

disassimilation (alim) dezasimilare, denutriţie

disassociate with / from a disocia, a separa de, a despărți de

disaster dezastru, avarie la scară mare

disastrous dezastruos; fatal

disavow a nega, a tăgădui, a nu recunoaşte; a dezavua

disbelieve a nu crede în, a nu avea încredere în

disbranch a tăia, a desprinde; (el, hidr) a debranşa

disc, disk (mas, OM) şaibă, rondelă, disc, roată de curea; (met) disc, taler, lamelă

discard (TH) defect, viciu, rebut, deşeu, a rebuta; (met) șutaj; a îndepărta, a înlătura, a renunța la, a arunca, a renunța; (ec) a concedia

disc auger wheel $(\mathrm{OM})$ roată cu disc

disc-bowl centrifuge (alim, ind chim) separator centrifugal / cu taler, centrifugă cu disc

disc brake pad(s) (auto, T) plăcuță / plăcute de frână

disc brake wear indicator (auto, $\mathrm{T}$ ) indicator de uzură al plăcuțelor de frână

disc crank $(\mathrm{OM})$ manivelă cu disc

disccutter (mas-un) cuțit rotund, cuțit-disc, freză-disc

discern a distinge, a desluşi; a discerne; a deosebi, a face o deosebire între; a judeca limpede

discernible care se poate desluşi / zări, vizibil, perceptibil; care poate fi deosebit

discernibly $(a d v)$ (în mod) perceptibil, vizibil

discerning cu discernământ, pătrunzător; care discerne

discernment discernământ, putere de discernământ; judecată limpede

disc filter (alim, hidr, OM) filtru cu discuri

disc flywheel (OM) volant-disc (plin)

discharge (cf, el, fiz, nav) descărcare, capacitate de descărcare; (hidr) debit, scurgere / evacuare (din rezervor), deversare; (mas, auto) eşapament; (TH) debit, consum, ieșire, descărcare, 
eliminare, scurgere, golire; (el, cf, nav) a descărca; (hidr) a se vărsa (d. râuri, peste marginea recipientului etc.), a deversa; (ec) concediere, plata (unei datorii), a concedia, a rebuta, a plăti, a achita (o datorie); (TH) a goli, a elimina, a debita, a goli; (fiz) a emite, a emana

discharge channel (alim, mediu, constr) jgheab de scurgere

discharge cock (OM, hidr) robinet de scurgere / de golire / de evacuare

discharge connection (hidr, OM) racord de evacuare / de refulare; (el) conexiune de scoatere de sub tensiune

discharged descărcat

discharge end $(\mathrm{TH})$ capăt de livrare / de debitare / de descărcare / de deversare

discharge funnel (OM, met, hidr) pâlnie de scurgere

discharge / delivery gauge (metr, hidr) manometru de refulare

discharge head (ind chim) înălțime / presiune de refulare (a pompei); presiune utilă: raport dintre volumul scurgerii şi suprafața de colectare; (TH) înălțime manometrică / de pompare / piezometrică

discharge hole (met) orificiu de descărcare / de evacuare (la oală / cuptor de turnare)

discharge hopper (chim) pâlnie de descărcare

discharge manifold (termo) cot de refulare al compresorului

dischargement ( $\mathrm{TH}$, hidr, transp) debarcare, descărcare, golire

discharge-meter (metr, hidr) debitmetru

discharge nipple (OM, hidr) ştuț de evacuare

discharge nozzle (auto) injector; (mas) ajutaj de evacuare / de injecție / de refulare

discharge of pump (OM, hidr) debit al pompei

discharge of water scurgere / evacuare a apei

discharge pan (alim, ind chim, met) jgheab / coş de descărcare

discharge partition (hidr) distribuție a debitului de apă

discharge pipe (cf) conductă de refulare / sub presiune / forțată; (constr) tub de refulare; (hidr) țeavă de preaplin; (mas, auto) țeavă de eşapament / de presiune; (TH) țeavă de scurgere, conductă de golire

discharge pressure (hidr) presiune de evacuare / de refulare

discharge (pressure) nozzle (hidr, termo) ajutaj de refulare

discharge pump (hidr) pompă de evacuare

discharger (el) eclator, interval disruptiv, excitator de descărcare; (mas) descărcator discharge rate (mas, transp) capacitate / viteză de descărcare; (el) intensitate a curentului de descărcare

discharge spout (met) canal / jgheab de scurgere / de evacuare, buză de deversare a lichidului dintr-un vas

discharge stroke (mas-un) cursă de comprimare / de refulare / de evacuare a piesei prelucrate

discharge time (hidr, mas) timp de scurgere / de evacuare

discharge valve (OM, hidr) supapă de presiune / de refulare, robinet / supapă / valvă de evacuare / de descărcare / de golire

discharge velocity (mas, hidr) viteză de descărcare / de scurgere

discharging (el) descărcare (a unei baterii); descărcare / golire (a unui cuptor / rezervor / vagon etc.)

discharging agent (chim) agent de corodare

discharging device (constr, mas) dispozitiv de evacuare / de golire / de descărcare / de scurgere

discharging end of furnace (met) vatră mobilă (a unui cuptor, pentru evacuarea pieselor)

discharging funnel pâlnie de golire

discharging gear (alim, constr, ind, transp) instalație de descărcare

discharging hole (OM, hidr) orificiu de golire / de ieşire / de descărcare

discharging spout (alim, constr, ind, transp) jgheab de scurgere

discharging platform (met) platformă de descărcare

disc harrow (agr) plug cu discuri

disc in oil clutch (OM, T) ambreiaj cu mai multe discuri, în baie de ulei

discipline disciplină, ordine; disciplină, ramură a disciplina, a aduce la ordine

disclaim a nu recunoaşte, a renunța (la un drept), a nega, a tăgădui

disclaimer nerecunoaştere, negare, tăgăduire, renuntare (la un drept)

disclose a dezvălui, a releva, a divulga; a aduce la cunoștință, a face cunoscut

disclosure deschidere; aducere la cunoştință, divulgare

discolour a (se) decolora

discolo(u)ration decolorare

discolored decolorat

discomfort lipsă de comfort, disconfort; (ec) jenă financiară, lipsuri; greutate, dificultate, asperitate, duritate (a traiului); a deranja, a stingheri

discomfortable neplăcut; dificil; greu; supărător; stânjenit(or); incomod 
discommend a dezaproba, a nu fi de acord cu discommodity dezavantaj, inconvenient discompose a stingheri, a deranja; a nelinişti disconnect (auto, mas) a debreia, a desface, a separa, a detaşa; (cf) a decupla; (el) a deconecta, a întrerupe, a deschide (un circuit)

disconnectable deconectabil, decuplabil

disconnected desfăcut, separat, detaşat, deconectat; (fig) fără legătură, incoerent

disconnectedness lipsă de legătură; lipsă de logică, ilogicitate; izolare

disconnecting (auto, mas) debreiere; (cf) decuplare; (el) deconectare, întrerupere

disconnecting hook (nav, OM) cârlig de dezagățare

disconnecting key (el) chei de separare / de deconectare

disconnection (auto, mas) debreiere; (cf) decuplare; (el) deconectare, întrerupere, deschidere (a unui circuit)

discontent nemultumire; nemultumit, nesatisfăcut; a nemulțumi

discontentment nemulțumire

discontinuance discontinuitate; încetare; întrerupere

discontinue a înceta, a întrerupe, a renunța la, a se opri, a nu mai continua; discontinuu, întrerupt

discontinuity discontinuitate; întrerupere, gaură; separare, lipsă de continuitate

discontinuity surface (mat) suprafață de discontinuitate

discontinuous discontinuu, intermitent, cu întreruperi, întrerupt

discontinuous conditions (autom) condiții discontinue (parametrii semnificativi nu ajung la stabilitate)

discontinuous load (mec) sarcină intermitentă

discontinuously discontinuu, întrerupt, din când în când

discontinuous operation / running (auto, mas) funcționare intermitentă; (TH) funcționare discontinuă / periodică, mers neuniform / cu pauze

discontinuous phase (fiz, T) fază dispersă (la emulsii)

discontinuous rectifying plant (mas-un) instalație de rectificare discontinuă

discord neînţelegere, conflict; nepotrivire, dezacord; zgomot; (el, metr) dezacord, disonanță, neacordare; a nu fi în acord, a fi în dezacord, a nu se înțelege

discordant discordant, distonant, nepotrivit, în dezacord

discount (ec) reducere, rabat, (mărfuri) fără căutare / care nu se cer, scont, discont, a deconta, a sconta; fără valoare; a micşora valoarea, a nu tine cont de

discountenance a dezaproba, a descuraja, a nu sprijini, a nu susține; a deconcerta; a încurca, a împiedica (realizarea)

discount prices (ec) prețuri reduse

discoupling, decoupling (mas, $\mathrm{TH}$ ) decuplare, deconectare

discourage a descuraja, a combate, a împiedica, a respinge; a şicana

discouragement to descurajare a, piedică pentru, obstacol pentru

discouraging descurajator, care descurajează, descurajant

discourse vorbire, tratat, prelegere, conferință

discourse upon a discuta despre, a conferenția despre

discover a găsi, a descoperi, a revela, a afla, a constata, a stabili

discoverer descoperitor

discovery descoperire, deschidere; explorare

discovery shaft pit (constr)groapă de fundație

disc play $(\mathrm{OM})$ joc al discului

discredit discredit, compromitere, pierderea încrederii, neîncredere, lipsă de încredere; îndoială, bănuială; a discredita, a nu da crezare

discreet discret; prudent, prevăzător

discrepancy divergență; discordantăă, nepotrivire, deosebire, discrepanță, contradicție, dezacord; abatere, inexactitate, lipsă de precizie

discrepancy in weight (alim, TH) abatere (mare) la / de masă

discrepant nepotrivit, discordant, discrepant

discrepant from diferit de

discrete discret, discontinuu; individual, separat; alcătuit din elemente diferite, eterogen; individual, distinctiv

discretely $(a d v)$ (în mod) discontinuu, răzleț, separat

discreteness (mat, inf) distribuție discretă, discretizare

discrete structure (met) structură fină

discretion libertate de acțiune, libertatea de a dispune / hotărî; putere de judecată; maruritate în gândire; prevedere, precauție; discreție, rezervă; înțelepciune

discriminate (adj) distinctiv, deosebit

discriminate against a face deosebire între, a distinge între

discriminate from a discrimina, a defavoriza (pe cineva) în favoarea (altcuiva) / față de (altcineva), a distinge din / dintre, a deosebi, a diferenția, a face diferența (între două lucruri / procese) discriminate in favour of a favoriza pe 
discriminating discriminatoriu, preferențial; distinctiv; care tratează discriminatoriu / preferenţial

discriminating seeking (inf, autom) întrerupere într-o singură direcție

discrimination discriminare, deosebire, distincție; discernământ; (autom) discriminare, demodulare de frecvență; (metr) salt condițional, mobilitate, capacitate a unui aparat de măsurat de a răspunde la variații mici ale semnului de intrare

discriminative distinctiv, caracteristic, special; care face diferența, care ştie să diferențieze / să distingă

discriminator (el, autom) circuit / dispozitiv la care ieşirea depinde de diferența între un semnal de intrare şi o valoare impusă

disculpate a disculpa, a scoate de sub acuzare

discuss (med) a discuta, a judeca (o problemă)

discussion (med) discuție

disease boală; a îmbolnăvi, a molipsi, a infecta

diseased bolnav, bolnăvicios

disembark (nav, transp) a debarca (pasageri), a descărca (mărfuri)

disembarkation (nav) debarcare

disembarass of a despovăra, a elibera de, a scuti de disemulsifyng (fiz, T) dezemulsionare

disengage (auto, OM) a debreia, a decupla, a dezangrena, a scoate din angrenare; (cf) a decupla; (el) a deconecta, a separa; (mas-un) a întrerupe (intenționat), a decupla, a deconecta, a debreia

disengageable $(\mathrm{OM})$ decuplabil, debreiabil, care poate fi decuplat / desprins / decuplat

disengage (a clutch) (OM) a decupla (un ambreiaj)

disengaged $(\mathrm{TH})$ liber, neocupat, nepornit, neangrenat, neantrenat; $(\mathrm{OM}, \mathrm{el})$ decuplat, deconectat

disengaged position (OM, mas-un) poziție de decuplare

disengagement, disengaging (from) (auto, OM) debreiere, dezangrenare, scoatere din angrenare, întreruperea contactului; (cf) decuplare; (ec) scutire de

disengaging clutch (auto, OM, mas) ambreiaj intermitent; (cf) cuplaj debreiabil

disengaging coupling (OM) mufă decuplabilă, cuplaj intermitent / automat de întrerupere a mişcării

disengaging device / gear (OM) mecanism de dezangrenare / de debreiere / de dezanclanşare / de decuplare

disengaging lever (auto) cățel de ambreiaj; (OM) pârghie de decuplare / de debreiere; (mas-un) levier / pârghie a(l) mecanismului de decuplare disengaging surface (termo) suprafața de separare (între apă şi vapori / abur)

disentangle a (se) descurca, a (se) descâlci, a desface de (fire); (fig) a lămuri, aclarifica

disentaglement descâlcire, desfacere (şi d. fire, fibre, molecule etc.); (fig) lămurire, clarificare

disequilibrium dezechilibru, instabilitate

disfigure a desfigura; a strica, a deforma

disfigurement desfigurare; stricare, deformare (şi a unei imagini, reprezentări etc.)

disforest (silv, mediu) a despăduri

disguise deghizare; a deghiza, a masca, a ascunde; ascuns

dish farfurie, vas; (ind chim) cuvă, chiuvetă; (mas-un, met) a ambutisa; (TH) concavitate, a da o formă concavă (unui lucru, semifabricat); (OM) disc

dished (OM) în formă de ceaşcă / de cupă / concavă

dished bottom (OM, met) fund bombat (de rezervor etc.)

dish-ended bombat (la partea terminală)

dishing (mas-un) bombare, ambutisare de adâncime mică şi formă relativ simplă

dishing press (mas-un) presă de ambutisare puțin adâncă / de îndoit

dish of wheels (auto, transp, mas) unghi de cădere (şi al roților de autovehicule)

dish-shaped $(\mathrm{OM})$ în formă de cupă / ceaşcă / o farfurie

dishing (mas-un) ambutisare puțin adâncă (ca la farfurie)

dishonest de rea credință, necinstit, murdar

dishonesty rea credință, necinste

dish water (alim, mediu) apă rezultată de la spălat (vase)

disillusion dezamăgire, deziluzie; a dezamăgi, a deceptiona

disinfect (alim, med) a dezinfecta, a steriliza

disinfectant (alim, chim, mediu) dezinfectant, baiț, decapant

disinfected (alim, med) sterilizat, fără germeni

disinfection (alim, med) dezinfectare, dezinsectie, sterilizare

disinflation (ec) deflație, inflație negativă

disintegrate (fiz, chim) a (se) dezintegra, a (se) descompuse, a (se) disocia, a (se) dezagrega, a destrăma, a (se) fărâmița, a (se) sfărâma

disintegrated descompus, disociat, dezintegrat, fărâmițat, sfărâmat

disintegrating slag (met) zgură sfărâmicioasă / friabilă

disintegration (fiz, chim, constr) dezintegrare, dezagregare, descompunere; fărâmițare, sfărâmare 
disintegration chain (chim) serie / lanț de dezintegrări / descompuneri

disintegrator (alim, ind chim, constr, mas) dezintegrator, concasor, maşină de mărunțit / de pulverizat / de sfărâmat, moară cu ciocane; (TH, met) epurator de gaze, scrubber

disinterested dezinteresat; imparțial, obiectiv; indiferent, nepăsător

disject a împrăştia, a risipi, a dispersa

disjoin (TH) a separa, a desface, a despărți, a distruge o legătură (fără a specifica cum)

disjoint a dezembra, a desface în bucăți / în părți componente; (alim) a tranşa, a tăia felii

disjoint from a despărți de, a separa de, a detaşa de

disjointed $(a d j)$ dezmembrat, separat, despărțit (şi în sens nedorit); (med, anat) scrântit, luxat; incoerent

disjointedly $(a d v)$ fără legătură

disjunct dezmembrat, desfăcut, nelegat

disjunction dezmembrare, desfacere, despărţire, separare; disjunctie; (el) întrerupere; deconectare

disk, disc $(\mathrm{OM})$ şaibă, rondelă, disc, roată de curea; $(\mathrm{TH})$ disc taler, lamelă

disk brake (OM) frână cu disc(uri)

diskbrake motor (mas, OM) motor de frânare, cu frână cu discuri

disk chuck (mas-un) platou de strung

disk clutch / coupling (OM) cuplaj cu lamele / cu disc(uri), cuplaj-disc, ambreiaj cu lamele / cu disc(uri)

disk crusher (constr, ind chim) moară / concasor cu discuri

disk drive (c) mecanismul de introducere a discului / dischetei

diskette (c) disc magnetic, dischetă

disk formating (c, inf) formatare (a discului / dischetei)

disk grinder (mas-un) maşină de rectificat cu disc(uri) de oțel căptuşit(e) cu pânză abrazivă

disk grinding (mas-un) rectificare fină, cu folosirea pânzei abrazive, lipite pe un disc de metal

disk operating system (DOS) (c, inf) program de stocare / gestionare a fişierelor

disk piston (auto) piston cu cap drept; (OM) piston-disc

diskplate $(\mathrm{OM})$ rondelă, disc (plat), şaibă (simplă) plată

disk sander / sanding machine (mas-un) maşină de şlefuit cu disc abraziv

disk skimmer (alim, ind chim, $\mathrm{T}$ ) separator de spumă, cu discuri

disk spring $(\mathrm{OM})$ arc-disc, arc-taler disk type of milling cutter (mas-un) freză-disc, freză ferăstrău

disk valve $(\mathrm{OM}$, hidr) supapă plată / disc / cu taler / cu ciupercă

disk weeder (mas-un) cuțit-disc

diskwheel (auto) roată cu placă / cu disc; (OM) roată-disc; (mas-un) disc abraziv cu profil drept, piatră cilindrică care lucrează cu suprafața plană şi cu suprafaţa cilindrică

dislocate a disloca, a muta, a desprinde, a deplasa; (med, anat) a scrânti, a luxa; (fig) a dezorganiza, a încurca, a deranja

dislocation dislocare; deplasare; (med, anat) luxare, scrântire; deranjare; (fig) dezorganizare

dislocation networks (met, fiz) rețele de dislocație (în cristalografie)

dislodge a îndepărta, a deplasa, a mișca din loc, a disloca

dislodgement îndepărtare, deplasare, scoatere, dislocare

dislodger (alim, mediu) decantor

dismantle (constr) a decofra, a demola, a sparge (un zid); (TH) a demonta (în piese separate)

dismantling (constr) demontare, demolare; (mas, $\mathrm{TH})$ demontare, dezmembrare; (nav) dezarmare (a unei nave)

dismantling point $(\mathrm{TH})$ loc de separare / de desfacere / de demontare

dismember $(\mathrm{TH})$ a dezmembra; a rupe / sfâşia în bucăți

dismemberment dezmembrare, rupere în bucăți dismiss a concedia, a da afară, a lăsa să plece, a îndepărta; (jur) a respinge

dismissal concediere, destituire; concediu, vacanță; pauză, repaus; (jur) respingere (a unui apel); (pol, ec) dizolvare (a unei adunări)

dismission înlăturare, îndepărtare; eliminare; expulzare; concediere

dismount a demonta (în piese separate)

dismountable demontabil, separabil

dismounting demontare; care (se) demontează

dismounting tools scule de demontare (de exemplu, la rulmenți)

disobey a nu da ascultare, a nu se supune (unei reguli etc.)

disorder (fiz, met) dislocație, defect de structură; dezordine, deranjament; confuzie; a dezorganiza, a deranja, a deregla; (med) a îmbolnăvi

disordered deranjat, dezorganizat

disorderly (adj) neîngrijit, dezordonat; şubred; nedisciplinat, turbulent; $(a d v)$ în dezordine

disorganization dezorganizare

disorganize a dezorganiza

disorientation dezorientare 
disparity disparitate, deosebire, diferență; nepotrivire; neconcordanță

dispatch expediere, trimitere; coordonare, conducere; raport oficial, telegramă, corespondență pentru ziar; grabă, rapiditate, promtitudine; a trimite; a dispeceriza, a coordona, a conduce; a expedia

dispatcher expeditor; dispecer

dispel a difuza, a dispersa, a împrăştia

dispensability (mas) disponibilitate, $(\mathrm{T})$ proprietatea unei unsori de a ajunge rapid la proprietăţi bune în exploatare (inclusiv pompabilitate), după ce a fost scoasă din container

dispensable facultativ, neesențial, de care te poți dispensa; de care se poate lipsi; neesențial; pentru care se poate acorda o dispensă

dispensary (med) farmacie, dispensar, ambulanță

dispensation împărțire, distribuire (a hranei etc.); (jur) dispensă, scutire

dispense a împărți, a distribui (hrană etc.); (chim) a prepara

dispense from (jur) a dispensa de (la), a scuti de

dispenser (alim, ind chim, mas) împărțitor, distribuitor, dozator; farmacist

dispense with a se dispensa de

dispergation (chim) peptizare, defloculare, dispersare

dispersability (materiale) capacitate de dispersare (a particulelor în compozite, în solutiii etc.)

dispersal dispersie, împrăştiere

dispersal effect (fiz, materiale) efect de evacuare / de dispersare / de împrăştiere

dispersant (chim, fiz, T) (agent / aditiv) dispersant, agent de dispersare

disperse a (se) împrăştia, a (se) dispersa, a (se) descompune (referitor la lumină)

dispersed dispersat, dispers, împrăstiat

dispersedly $(a d v)$ peste tot, ici şi colo, (în mod) dispers

dispersed shrinkage (met) microporozitate, contracție dispersată

disperse phase (fiz, chim, met) fază dispersă

disperser (fiz, chim, met) agent de dispersare, dispersant

dispersing (chim, T) dispersare; care (se) dispersează / (se) împrăştie

dispersing additive aditiv detergent

dispersing agent (chim) dispersant, agent de dispersie

dispersing machine (alim) afânător; (ind chim) maşină pentru dispersare

dispersing property (alim, ind chim) proprietate / capacitate de dispersare dispersion, dispersal (chim) dispersie, peptizare; (fiz, TH) difuziune, dispersie; răspândire, dispersare, împrăştiere, împărțire, distribuție

dispersion adhesive (chim, plast) adeziv de dispersie (care (se) dispersează

dispersion coefficient coeficient de dispersie

dispersion hardening (met) călire / durificare prin precipitare

dispersion in aqueous media (ind chim) dispersie în mediu apos

dispersion into air / gas (mediu, ind chim) dispersie în aer / în gaz

dispersion medium dispersant, agent de dispersie, mediu de dispersie (atenție latext)

dispersion of hardness value (met) împrăştierea valorilor durității

dispersion of load (mec, transp) repartizarea încărcărilor

dispersion of rotation dispersie de rotație

dispersion prism (fiz) prismă de dispersie (a luminii)

dispersiveness dispersivitate

displaceable mobil, transportabil, portabil, portativ; deplasabil, care poate fi deplasat

displace a deplasa; a decala; a substitui; a muta, a pune în alt loc; a transfera; a înlocui

displaced in phase (fiz) defazat

displacement (TH) înlocuire, împingere, eliminare, translație, deplasare, decalare, mutare, trasnfer(are), înlocuire; (constr) dezlipire / desfacere a liantului bituminos de pe suprafața agregatului, în general sub acţiunea apei; (mas) cilindree, debit; (nav) deplasament

displacement blower (termo) compresor $\mathrm{cu}$ piston

displacement capacity (hidr, termo) cilindree

displacement compressor (termo) compresor volumetric

displacement law (mec) lege de deplasare

displacement motor / pump (mas) motor hidraulic, pompă volumic( $\breve{a})$

displacement of cylinder (hidr, termo) capacitate cilindrică

displacement of foiles (met) deplasare a benzilor / tablelor (şi la sudare)

displacement of phase (fiz, TH) defazare, decalare

displacement of soil (geol, fiz) împingere a pământului (în mecanica solidului)

displacement pump (OM, hidr) pompă cu piston plonjor

displacement volume (auto, hidr, termo) cilindree

displacing deplasare, înlocuire, epuizare 
display etalare, expunere, prezentare; $(\mathrm{TH})$ reproducere, indicator, indicație; (autom, c) afişare, ecran, display, vizualizare (a datelor); (mat) reprezentare, expunere; a etala, a expune, a prezenta, a manifesta, a da dovadă de

display area (c) suprafață de prezentare / de afişare

displaycase (alim, termo) vitrină frigorifică

displayed expus; (inf) aranjat pe un rând separat (de exemplu, titluri, formule etc.), afişat (pe un ecran / display)

display error (c, autom, inf) eroare de afişare (a rezultatelor măsurării)

display image (c) imagine reprezentată / afişată

displaying (c, inf) afişare / prezentare a informației într-o formă direct interpretabilă

display refrigeration (alim, termo) frigotehnică de tip comercial

displease a nu plăcea (cuiva), a nemulțumi

displeasing to nemulțumt pentru, care nemultumenște, neplăcut pentru

displeasingly $(a d v)$ cu nemulțumire

displeasure nemulțumire, neplăcere

disposable disponibil, la îndemână

disposable element (hidr, alim) element filtrant nerecuperabil / consumabil

disposable load (transp, mas) încărcătură / sarcină utilă

disposable waste (mediu) deşeuri recuperabile

disposal dispoziție, aşezare, dispunere, ordine; (hidr, TH) evacuare, îndepărtare; strângere; (ec) dispoziție, rezolvare, cedare / transfer de bunuri

disposal of slag (met) utilizare a zgurii

disposal of waste water (mediu) evacuare a apei reziduale

disposal value $(\mathrm{ec})$ valoare reală

dispose of a dispune de, a aşeza, a aranja, a folosi, a întrebuința, a da o întrebuințare

disputant persoană care ia parte la o dispută / dezbatere / discutie

disputation dispută, discuție, dezbatere; litigiu; arta argumentării

dispute dispută, discuție, dezbatere, controversă; a contesta, a pune în discuție, a se opune, a opune rezistență (cuiva)

disqualification descalificare

disqualify a descalifica, a face inapt

disquiet a nelinişti; nelinişte, agitație

disquieting neliniştitor, alarmant

disquisition on expunere pe larg, cercetare amănunțită, studiu temeinic

disregard a neglija, a nu lua în seamă, a nu ține seama de disregard of indiferență față de, nepăsare față de, neglijare, desconsiderare

disrepair (constr) stare proastă a unei clădiri

disrespect for lipsă de respect / considerație față de

disrupt a rupe în bucăţi, a sfâşia, a disloca, a distruge, a dezmembra, a sparge; a submina; a întrerupe (şi în sens nedorit)

disruption $(\mathrm{T}, \mathrm{TH})$ rupere, distrugere, dezmembrare, dislocare, spargere (de tip casant); subminare; (el) descărcare, întrerupere

disruptive distrugător, de subminare; (el) disruptiv

disruptive oxidation (chim) oxidare distructivă

dissactisfaction nemulţumire, insatisfacție

dissactisfactory nesatisfăcător, nemulțumițor, care nu este satisfăcător

dissatisfied with nemulțumit de, nesatisfăcut de

dissatisfy a nemulțumi, a nu satisface

dissect a diseca, a face o disecție; a analiza

dissection disectie; analiză, cercetare

dissemble a disimula, a masca, a camufla, a ascunde, a se face că nu observă, a trece sub tăcere, a se preface

disseminate $(\mathrm{TH})$ a semăna, a răspândi, a disemina (şi rezultate), a propaga

dissemination diseminare, răspândire, semănare, propagare, difuzare (de idei etc.)

dissension disensiune, neînțelegere

dissent from a avea altă părere decât, a nu fi de acord cu; dezacord, părere diferită, opoziție la

dissertation upon disertație despre / asupra

disservice deserviciu

dissident disident

dissimilar to diferit de, neasemenea cu, neasemănător cu

dissimilitude, dissimilarity lipsă de asemănare; nepotrivire; deosebire, diferență

dissimulate, dissemble a disimula, a masca, a camufla, a ascunde, a se face că nu observă, a trece sub tăcere, a se preface

dissimulation disimulare, mascare, camuflare, simulare

dissipate a risipi, a (se) împrăştia, a irosi, a cheltui; a disipa (şi energie)

dissipated disipat, risipit, împrăştiat

dissipation (TH) cheltuială, risipă, pierdere; (ec) risipă; (el) disipare, disipație; (met) scăpare, dispersie

dissipation of energy (hidr, mec) disipare / disipatie / pierdere de energie

dissipative system $(\mathrm{TH})$ sistem disipativ

dissociate (chim, fiz, met) a (se) separa din amestec, a (se) despărți, a se disocia 
dissociation (chim) disociere, disociație, separare, despărțire

dissolubility (fiz, chim) solubilitate

disssolute solubil; anulabil; netrainic

dissolution (chim, met) dizolvare, descompunere, topire, dezintegrare, fărâmițare; (ec) lichidare

dissolution equation (chim, met) ecuație de dizolvare / de descompunere

dissolution measurement (chim, met, metr) măsurare a dizolvării / descompunerii

dissolution rate (chim, met) viteză de dizolvare / de descompunere

dissolution theory (chim, met) teorie de dizolvare / de descompunere

dissolve (chim) a (se) dizolva, a (se) topi, a dilua, a (se) evapora, a (se) descompune, a (se) dezintegra; (ec) a (se) lichida; a (se) anula, a (se) desființa; a clarifica, a elucida; a dispărea, a pieri

dissolved gasses (fiz) gaze dizolvate

dissolved solid (fiz, chim) solid dizolvat

dissolvent, dissolver (chim) solvent, dizolvant

dissonance (fig) dezacord, nepotrivire; disonanță, stridență

dissonant (fig) nepotrivit, strident; (fiz) disonant

dissymetric(al) asimetric, disimetric

dissymetrical transducer (metr, electr) traductor cu mai multe terminale: la acelaşi semnal de intrare, semnalul de ieşire va fi diferit în, funcție de terminalul ales

dissymmetry asimetrie, disimetrie; (el) grad de dezechilibru al unui sistem trifazat

dissymmetry factor (materiale) coeficient de anizotropie

distance distanță, depărtare; (TH) interval, deschidere; (fig) rezervă; a se distanța de, a lăsa în urmă

distance between centres (mas-un, OM) distanță între vârfuri, distanțe între axe (la transmisii cu roți cilindrice)

distance between clamps (mec, constr) lungime de încastrare

distance between tracks (cf) distanță dintre linii

distance / distant control (autom) telecomandă, reglaj / comandă la distanță, telereglaj

distance-controlled (autom) telecomandat

distance gauge $(\mathrm{OM})$ distantier; (metr) telemetru

distance link $(\mathrm{OM})$ tijă de legătură care menține o distanță constantă între două piese

distance piece (constr) piesă intermediară / antretoază de distanțare; (OM) distanțier, adaos

distance plate $(\mathrm{OM})$ şaibă / placă / rondelă de distanțare

distance ring $(\mathrm{OM})$ inel de etanşare / de distanțare, distanțier inelar / cilindric distance rod $(\mathrm{OM})$ bară de distanțare

distance to empty (auto) distanța (de parcurs) până la golire (a rezervorului)

distant (în)depărtat; (fig) depărtat, vag, aproximativ, oarecare; rece, rezervat

distantly $(a d v)$ la distanță; rezervat; (asemănător etc.) de departe, vag

distend (materiale) a (se) umfla, a (se) dilata

distension, distention (materiale) dilatare, extindere, umflare, umflătură

distil(I) (alim, ind chim) a distila; (fig) a extrage, a scoate esențialul; a picura, a cădea picătură cu picătură

distillate (alim, chim) distilat, produs al distilării

distillate cooler (alim, termo) refrigerent, condensator / răcitor de distilat

distillation (alim, ind chim) distilare, separare prin distilare (a unui amestec de fluide)

distillating (alim, ind chim) (procesul de) distilare; care poate fi distilat

distillation apparatus (alim, ind chim) aparat de distilare, alambic

distillation curve (alim, ind chim) curbă de distilare

distillation film (alim, ind chim) suprafață de fierbere

distillation looss (alim, ind chim) pierdere prin distilare

distillation range (alim, ind chim) limite de distilare, interval de fierbere

distillation residue (alim, ind chim) reziduu de la distilare

distillation still (alim, ind chim) fierbător, alambic

distillation tube (alim, ind chim) țeavă de distilare, deflegmator

distillation with steam (alim, ind chim) distilare cu abur

distillatory vessel (alim) alambic, vas de distilare

distilled (alim, ind chim) distilat

distilled oil (alim, ind chim) ulei distilat

distilled vinegar (alim) oțet de fermentaţie

distilled water (fiz, alim, ind chim) apă distilată

distiller (alim, ind chim) distilator, alambic

distillery (alim,ind chim) distilerie

distinct distinct, desluşit, clar, limpede; deosebit, diferit; individual; anume, precis

distinction distincție, deosebire, diferență; finețe, eleganță; individualitate, personalitate, originalitate; superioritate, renume, celebritate; răsplată distinctive (adj) caracteristic, distinctiv, specific distinctively $(a d v)$ (în mod) caracteristic, distinctiv distinctly $(a d v)$ desluşit, limpede, clar; vădit, vizibil distinctive mark semn distinctiv, reper distinctness caracter distinct, claritate 
distinguish a distinge, a deosebi, a percepe, a desluşi, a vedea, a auzi; a caracteriza

distinguishable care poate fi distins / deosebit, care (se) poate distinge, remarcabil

distinguish between a distinge între, a face deosebire între

distinguish by a se distinge prin, a se remarca prin, a se evidenția prin, a se deosebi prin

distinguished distins, deosebit, remarcabil; ales, renumit

distorsed sound (fiz) sunet bruiat

distort $(\mathrm{TH})$ a deforma, a distorsiona, a strâmba, a desfigura; (mec) a torsada, a deforma prin torsiune (si un model); a denatura

distorted deformat, distorsionat, strâmb, strâmbat; denaturat

distortion (mec) deformare, distorsiune, deformație, strâmbare, desfigurare; denaturare; răsucire (rar)

distortion due to hardening (met) deformare de călire

distortion of grain (met) modificare / deformare a formei grăuntelui cristalin

distract from a distrage, a abate atenția de la, a produce confuzie

distraction neatenție, distragerea atenției, confuzie, absență

distraint (jur) secehestru, sechestrare

distress epuizare, extenuare; (med) suferință extenuare, istovire, oprire temporară a respirației; mâhnire; nenorocire, necaz; $(\mathrm{TH})$ situație grea, catastrofă, avarie; pericol, primejdie; (nav) naufragiu; (ec) lipsă de bani; epuiza; a extenua; in la necaz, în pericol

distressed $(\mathrm{TH})$ avariat

distrees in concrete (constr) fisurare a betonului

distribute $(\mathrm{TH})$ a distribui, a difuza; a diviza, a repartiza, a împărți, a da, a împrăştia (pe o suprafață); a clasifica

distributed load (mec) sarcină distribuită

distributing bell (met) clopot / con de distributie (la furnal)

distributing box (el) cutie de distribuție; (mas) cameră de distribuție

distributing device (mas-un, hidr) mecanism distribuitor

distributing gutter / trough (met) jgheab distribuitor

distributing nozzle (hidro) ajutaj de aducție / de distribuţie

distributing-valve (OM, hidr) sertar / supapă de distribuție

distributing-valve motion (OM, hidr) mişcare a supapei de distribuție distribution împărțire, distribuire, repartizare, difuzare, împrăştiere (pe o suprafață), distribuție; clasificare

distribution board (el) cutie / tablou de distributie

distribution coefficient (el) factor / coeficient de distribuție / de repartizare a unei înfăşurări la periferia statorului unei maşini electrice

distribution conveyer (alim, constr, ind chim) distribuitor / transportor cu bandă (cu funcție de distribuție)

distribution-free method metodă neparametrică

distribution law legea distribuției

distribution number raport / coeficient de distribuție

distribution of sizes (materiale) compoziție granulometrică

distribution of stresses in the place $(\mathrm{mec})$ distribuție a tensiunii în plan

distribution of weight $(\mathrm{mec})$ repartizare a greutății

distribution ratio $(\mathrm{TH})$ raport / coeficient de distribuție

distribution tab (OM, hidr) robinet de evacuare distributive ( $a d j$ ) de distribuire / de împărțire, individual

distributively $(a d v)$ individual

distributivity (mat) distributivitate;

distributor (auto, mas, $\mathrm{TH}$ ) distribuitor, orientator, repartitor, depunător (textile); (ec) unitate de repartizare a mărfurilor

distributor body (el, hidr, OM) carcasă a distribuitorului / a ruptorului; $(\mathrm{OM})$ pinion de distribuție

distributor cap / head (auto, termo, OM) capac al (cutiei) distribuitorului de aprindere

distributor device / mechanism (mec, hidr, el) mecanism de împărțire / de distribuție (şi cu angrenaje)

distributor gear (OM, mas) cutie de distribuție

distributor timing control (auto, autom, termo) comandă a avansului de aprindere

distributor vacuum brake (auto) regulator de avans automat prin depresiune (la automobile)

district district, raion, sector, ținut, zonă, cartier; domeniu, sferă (şi de activitate)

district heating (termo) termoficare

distrust neîncredere, suspiciune, bănuială; a nu avea încredere în, a se îndoi de, a bănui, a suspecta

disturb a (se) deranja, a răscoli, a dezorganiza, a incomoda, a stânjeni; a strica (un plan)

disturbance $(\mathrm{TH})$ anomalie, perturbație, dislocare, deranjament, îngreunare, deranjare, tulburare, 
defectare, dezordine; (hidr) perturbare de straturi / de curenți; remaniere; (mas-un, mas) deranjament, deranjare a funcționării normale, defecțiune, pană

disturbance upset (mas) acțiune perturbatoare disturbed (mas) deranjat, perturbat, bruiat disturbing force (mas) forță perturbatoare disturbing moment (mec) moment perturbator / de răsturnare

disunion despărțire, separare, dezbinare

disunite a (se) despărți, a (se) separa, a (se) dezbina

disunite from a despărţi de, a separa de

disunity, disunion lipsă de unitate

disuse a nu mai folosi / întrebuința; nefolosire, neîntrebuințare, scoatere din uz

disutility lipsă de utilitate, inutilitate

ditch (constr) jgheab, şanț; (hidr) canal, rigolă, tub de drenaj, tranşee; groapă; (cf) a face să deraieze; a se descotorosi, a scăpa de

ditch water (mediu) apă stătătoare (și din canal, şanț)

ditcher (constr) excavator cu cupă întoarsă / de săpat şanțuri / cu lingură de adâncime

dither (el, hidr) semnal de suprapunere

ditto mark simbol pentru idem

diurnal (adj) zilnic, de fiecare zi, diurn

diurnally $(a d v)$ zilnic, în fiecare zi, diurn

diurnal rhythm ritm diurn / circadian

divalent (chim) divalent, bivalent

dive key $(\mathrm{OM})$ pană alunecătoare

diver scafandru; plonjor

diverge from a diverge față de, a (se) abate de la, a devia de la, a diferi de

divergence, divergency (from) divergență (față de), abatere (de la), deviere (de la)

divergence criterion criteriu de divergență

divergence loss pierdere prin divergență

divergent from care se abate de la, divergent față de, diferit de

diverse from diferit de, deosebit de, altfel decât, felurit, variat, divers

diversification diversificare, varietate

diversified diversificat, variat, divers, felurit

diversify a diversifica, a varia

diversion deviere, abatere; $(\mathrm{TH}, \mathrm{el})$ branşament, ramificație; diversiune; (hidr) deviere / deviație a curentului

diversity diversitate, varietate; nepotrivire, diferență, deosebire

divert from a abate de la, a devia de la, a distrage atenția de la

divide (hidr) cumpăna apelor, linie de separație a apelor; $(\mathrm{TH})$ a separa, a grada, a mărunți, a secționa, a diviza, a împărți, a distribui, a repartiza, a (se) despărți, a (se) separa, a se izola; a nu fi de acord; (mat) a divide, a fi divizibil

divide among / between a împărți între

divide from a separa de

divided divizat, împărțit; gradat; secționat, despărțit, separat

divided axle (OM) ax secționat / divizat

divided cell (materiale) celulă cu diafragmă (la acoperiri)

divided circle (mas-un, $\mathrm{OM}$ ) cerc de divizare

divided eccentric excentric demontabil

divided table planer (mas-un) raboteză cu două mese alergătoare

divided wheel (mas-un) disc abraziv cu periferie discontinuă

dividend (mat) deîmpărțit; (ec) divident

dividend warrant $(\mathrm{ec})$ cupon dedivident

divider (mat) divizor; (el) tablou de distribuție; (mas) dispozitiv / mecanism de divizare; (OM) piesă de ramificație

dividers (mas-un) compas de divizare; (met) compas de trasat / de grosime; $(\mathrm{TH})$ compas de mână / diferențial

dividing (el) derivație; (TH) debitare, separare (în bucăți egale), care (se) separă; (mat) care se divide

dividing engine / machine (mas-un)maşină de divizat / de divizare

dividing head (mas-un) cap divizor

dividing rule (metr) riglă cu gradații, scară etalon dividing screw (mas-un, metr) şurub de divizare dividing shears foarfece de debitat

dividing splindle (mas-un) fus / as divizor

dividing worm (OM, mas-un) melc al capului divizor

dividing worm wheel (OM, mas-un) roată melcată pentru divizat

diving (nav) imersiune

divisibility (mat) divizibilitate

divisible by (mat) divizibil cu

division $(\mathrm{TH})$ diviziune, divergență, divizie, divizare, separare, împărțire, distribuire, distribuție, repartitie, repartizare, defalcare, sector, compartiment, raion, secțiune, îngrădire, barieră, secție, linie despărțitoare, hotar; (mas-un) diviziune, gradație; (metr) diviziune a unei scale (la aparate de măsurare); (mat) împărțire, divizare, diviziune; dezacord, păreri opuse, neîntelegeri

division from despărțire, de separare de

division line (auto) linie despărțitoare între două fire / benzi de circulație

division of load (mec) repartiție / distribuție / divizare a sarcinii 
division plane (mas-un) plan de separație; (mat, $\mathrm{TH}$ ) plan de separare / de secționare

divisor (mat) divizor, împărțitor

divorced cementite (met) cementită globulară / liberă

divulgation divulgare

divulge a divulga, a dezvălui

divulgence, divulgement divulgare

divulsion rupere, sfâşiere

divvy (alim) porție, parte, ciozvârtă, halcă

dixie, dixy (fam) cazan

do a face, a săvârși, a înfăptui; (edu) a studia, a învăța; a rezolva; a aranja, a pune în ordine; (alim) a pregăti, a frige, a fierbe (cum trebuie); a traduce; a reda; a fi activ, a lucra, a munci; a se purta, a se comporta; a se petrece, a avea loc

do-all tractor (agr, mas) tractor universal

do away with a scăpa de, a termina cu; a distruge, a nimici

do by a se purta, a se comporta

docent (amer) (edu, univ) conferentiar

docile (adj) docil, ascultător, blând

docilely $(a d v)$ (în mod) docil, cu docilitate

docility docilitate, ascultare; blândețe

dock (cf) platformă de încărcare; (hidr, nav) bazin portuar, doc, a intra în bazin, a (se) ancora, a acosta; a reduce, a micşora (şi salariul etc.); (alim) ștevie, măcriș

dockage (nav) taxă de andocare; (fig) tăiere, reducere, micşorare

docker (nav) docher

docket etichetă (la mărfuri); fişă, listă a problemelor de discutat într-o şedință; chitanță de plată a taxelor vamale, permis de a cumpăra mărfuri sub control sau mărfuri insuficiente pe piață, andosare pe scrisoare sau document indicând conținutul; rezumat, sumar (al unui document); agendă de birou

docking (nav) intrare în bazin, andocare

dock of a priva de, a lipsi de

dock pier (met) rampă / platformă de încărcare

dockyard (nav) santier naval

doctor medic; (el) electrod-burete / macrocelular; (mas) mecanism auxiliar, adaptor, răzuitor; (mas-un, OM) ştift pentru fixarea piesei pe un arbore, mecanism auxiliar, garnitură pentru ajustarea pieselor (la asamblare); (alim) a falsifica / a preface (vinul etc.)

doctoral (univ) de doctor

doctoral dissertation (univ) teză de doctorat doctorate (univ) doctorat

doctor blade (mas-un) lamă de răzuire / a răzuitorului, racletă

doctor holder (mas-un) suport al răzuitorului doctoring (alim) falsificare; (el) acoperire galvanică cu electrod-burete (macrocelular) doctor roller (alim, plast) rolă dozatoare doctor's degree (univ) doctorat (titlu ştiințific) doctorship (univ) doctorat, titlu de doctor, calitatea de doctor (în ştiințe)

doctrinaire doctrinar, teoretic

doctrinal dogmatic

doctrine doctrină, învătătură

document act, document, certificat, a sprijini / dovedi prin acte / documente; (inf) formular de introducere directă a datelor; (ec) document

documentary documentar

documentation documentare

dodecagon (geom) dodecagon

dodecahedral (geom) dodecaedric

dodecahedron (geom) dodecaedru, poliedru cu 12 fete

dodge ferire, evitare, ocolire, salt în lături; a evita, a ocoli, a para (o lovitură), a se feri; (jur) a eluda legea

dodged-up (TH, OM) mecanizat, motorizat, ajustat, adaptat, păsuit (şi d. şuruburi), potrivit

Dodge jaw crusher (constr, ind chim) concasor cu fălci tip Dodge

dog (constr) pârghie, cârlig, scoabă, crampon; (OM) antrenor, clemă, clichet, gheară, declic, dinte, camă, falcă, piedică, opritor, sabot, excentric; deget, piedică, declic, etrier, jug, trăgaci (mas-un) limitator (de cursă), antrenor, falca mandrinei; (met) menghină de mână; (nav) mâner / zăvor de poartă etanşă

dog block (mas-un) opritor al saniei principale (la strung)

dog chuck (mas-un) mandrină cu fălci

dog clutch (auto) ambreiaj cu gheare; (OM) cuplaj cu dinti / cu gheare

dog gearbox $(\mathrm{OM})$ cutie de viteze, cu craboți

dogged încăpățânat; stăruitor, perseverent

dogging (mas-un) prindere, apucare

dogging crane (met) macara cu cleşte / cu dispozitiv de apucare / de prindere

dog headed spike $(\mathrm{OM})$ piron, crampon

dog hook (constr, OM) scoabă, cârlig de prindere

dog house (met) cap de ardere (la cuptor Martin) dogma, $(p l)$ dogmata teorie, doctrină, învățătură dogmatic(al) dogmatic; categoric, fără apel, dictatorial

dogmatically $(a d v)$ (în mod) dogmatic

dog nose plier clește cu capătul ciocului rotund

dog plate $(\mathrm{OM})$ disc cu came

dog point $(\mathrm{OM})$ cep la vârful şurubului

dogs cleşte 
dog screw $(\mathrm{OM})$ şurub de fixare (a unui mecanism, în carcasă)

dog spike (OM, constr) crampon

dog stopper (nav) boț de lanț cu gheară de drac (pentru lanțul de ancoră)

doings comportare, purtare; acțiuni

doit obiect fără importanță / fără valoare

dole subvenție, ajutor, ajutor de şomaj

dole out a împărți / distribui cu economie

dolerite (minrl) dolerit

dollar (ec) dolar

dollop bucată mare şi neuniformă; (alim) halcă de carne

dolly (auto, constr) ax cu două roți şi o platformă pentru rezemarea barei de remorcare a unei remorci, (mic) şasiu rulant; (met, mas-un) cărucior pentru piese grele, nicovală, matriță ştanță; (cf) boghiu, locomotivă de căi ferate înguste; (el) păpuşă (de pastă depolarizantă) la pile electrice; (mas) troliu; (OM) contracăpuitor, contrabuterolă (pentru nituire)

dolly bar (constr) pârghie de oțel, cârlig de oțel, pârghie de susținere a contrabuterolei; (met, $\mathrm{OM})$ căpuitor, buterolă (pentru nituire)

doloma (met) dolomită arsă

dolomite (met) dolomită, magnezit

dolomite brick (met) cărămidă dolomitică

dolomite lime(stone) (met) calcar dolomitic

dolotite (met) dolotit (aliaj dur)

domain domeniu (şi teren), sferă (de activitate)

dome (constr, met) acoperiş, dom, cupolă, boltă, copertină (pe un zid); (auto, mas) capac, dom, calotă, capotă

domed (met) cu boltă sferică

domed cap nut $(\mathrm{OM})$ piulită înfundată înaltă

dome(d) nut $(\mathrm{OM})$ piuliță olandeză

dome-head piston $(\mathrm{OM}$, termo) piston cu cap bombat

domestic domestic, casnic, de casă; (ec) (afaceri) cu caracter intern; indigen; de familie

domestic appliance aparat electric de uz casnic $/$ electrocasnic

domesticate a domestici, a îmblânzi (animale); (agr) a cultiva, a aclimatiza (plante)

domestic fuel (auto, termo) combustibil domestic / menajer (cărbuni fără praf)

domestic gas (chim) gaz aerian

domestic industry industrie casnică

domestic refrigerator (termo) răcitor / frigider de uz casnic

domestics produse indigene

domestic soap (ind chim) săpun de rufe

dome temperature (met) temperatura bolții (cuptorului) domicile domiciliu, reşedință

dominance predominare, influență, înrâurire

dominant (mat) dominant, majorant; care domină, conducător; hotărâtor, dominant, principal, caracteristic, specific

dominate a domina, a predomina asupra, a majora

domination dominare, dominaţie, predominare

don membru al unui consiliu de colegiu; expert, cunoscător, specialist

donate to a dona pentru, a face o donație, a contribui la

donation donație, donare, contribuție

done terminat; (alim) bine gătit / prăjit; obosit, extenuat

donkey (constr) troliu cu tambur dublu, montat pe tractor; (mas) motor auxiliar; (nav) maşină auxiliară (de putere mică); (hidr) pompă de mână, portabilă / auxiliară / de alimentare; (termo) cazan auxiliar

donkey pump (OM, hidr) pompă auxiliară (mică) / pentru alimentarea cazanelor / de mână, portabilă

door (constr) uşă, poartă, acces, oficiu; (auto) portieră (şi de autoturism)

door ajar (auto) uşă / portieră (între)deschisă

door ajar warning (auto) avertizare pentru portieră / portiere deschisă (deschise)

door and rear hatch open display (auto) afişaj / (mini) monitor pentru uşi şi portbagaj deschise

door arch (constr) arc de uşă

door case (constr) toc / pervaz de uşă

door check (OM) amortizorul uşii

door frame (constr) toc / pervaz de uşă

door glass regulator (auto) ridicător de geam de uşă

door handle (auto) mâner de uşă, mânerul portierei; (constr) clanță de uşă

door latch (OM) clanță, zăvor

door lining (met) căptuşeala refractară a uşii (cup-torului), înzidirea ușii

door lock (auto) încuietoare de portieră

door lock switch (auto) telecomandă pentru blocarea / închiderea portierelor

door money (ec) taxă de intrare

door open display (auto) afişaj pentru uşă / portieră deschisă

door post (constr) stâlp de uşă

door sill (constr) prag de uşă

doorstep (constr) prag al uşă, treaptă de la pragul ușii

door stop (auto) opritor de uşă

doorway (constr) uşă, intrare 
door width (met) lărgimea / lățimea / deschiderea uşii (cuptorului)

door wind (constr) canat de uşă

dope (constr) produs adeziv, lac de pensulă (şi pe bază de ester celulozic); (TH) lăcuire, emailare

doped oil (chim, T) ulei aditivat

doping (chim) dopare (şi la semiconductori), dotare, aditivare (pentru lubrifianți)

doping material (met) inhibitor pentru creşterea grăunților

dormer (constr) talpa reazemului, lucarnă, fereastră de fronton

dosage (alim, ind chim) dozare

dosage grid (alim, ind chim) grătar de dozare

dose doză; a doza

dose meter (metr, alim, ind chim) dozimetru

dosimeter (metr) dozimetru; (chim) dozator

dossier (jur) dosar

dot $(\mathrm{TH})$ punct, a puncta; picătură, bulină; a pune punct

dotation dotare, înzestrare

dot curve (mat) curbă care trece printr-un punct dat

dot-dash line linie punct-linie (în desen tehnic)

dots puncte de suspensie

dotted (mas-un) trasat prin puncte (cu punctatorul); punctat

dotted line linie punctată (în desen tehnic)

dotted rule linie întreruptă / punctată

double dublu, îndoit, de două ori mai mare, pereche, (compus) din două părți / elemente; (geogr) cotitură, meandră (de râu); (met) a dubla, a placa; (nav) a dubla, a trece (un cap); (mec) dublu, jumelat, cuplat, schimbare bruscă a direcției; duplicat; a duplica, a face două exemplare; a (se) dubla, a fi dublu

double-acting (mas, hidr, mas-un) cu dublu efect, cu dublă acțiune (d. prese, cilindri hidraulici etc.)

double-acting barring gear (OM, mas) dispozitiv cu dublu efect pentru scoaterea maşinii din punctul mort

double-acting compressor (termp) compresor cu dublu efect / în două trepte / în care compresia se produce de două ori la fiecare rotație a arborelui

double-acting (duplex) pump (OM, hidr) pompă cu două pistoane cu dublu efect

double action (TH) dublu efect, dublă acțiune

double action forming (mas-un) ambutisare cu două operații la o cursă a presei

double action press (mas-un) presă cu dublu efect / cu dublă acțiune double arm kneader (alim, ind chim) malaxor cu două brate

double-armed lever $(\mathrm{OM})$ pârghie cu două brațe

double arm press (mas-un) presă cu doi montanți

double back geared lathe (mas-un) strung cu angrenaj intermediar dublu

double band saw (mas-un) ferăstrău-panglică dublu

double-bar link (OM) culisă cu două ghidaje

double bend (OM, hidr) cot dublu

double bent $(\mathrm{OM})$ îndoit de două ori / în două

double-bevel (OM) margine / rost dublu teşit(ă)

double-bevel butt joint (OM) îmbinare cap-lacap / cu margini dublu teşite (şi la sudură)

double-bevel tee joint $(\mathrm{OM})$ îmbinare în dublu $\mathrm{T}$

double-bladed cutter (mas-un) cuțit cu două tăişuri

double block palan dublu

double-block brake $(\mathrm{OM})$ frână cu doi saboți

double bond (chim) legătură dublă (la atomul de carbon etc.)

double bottom (cf) planşeu dublu; (nav) dublu fund, spațiu de dublu fund

double-bottom ceiling (nav) puncte de dublu fund

double box $(\mathrm{OM})$ racord / manşon dublu

double-butt strap joint (OM) îmbinare cu eclise (pe ambele părți)

double callipers (metr, mas-un) compas / calibru dublu (pentru exterior și interior), etrier dublu

double-casing machine (termo, mas) maşină cu manta de răcire

double-charging bell (met) clopot dublu de încărcare (la furnal)

double(-)check(autom, ec) control dublu, a verifica de două ori

double circular saw (mas-un) ferăstrău circular, dublu

double click (c) dublă apăsare (a aceluiaşi buton al mouse-ului) asupra unui obiect selectat în prealabil (la calculator, pe monitor)

double-coated adhesive tape (plast) bandă adezivă cu fețe duble

double column (mas-un, ind chim) coloană cu manta, coloană dublă

double column milling machine (mas-un) maşină de frezat, tip normal (cu coloană dublă)

double column / standard planer (mas-un) raboteză cu doi montanți

double-cone pulley $(\mathrm{OM})$ roată de curea, în două trepte

double contact freezer (alim, termo) congelator cu dublu contact (produs supus congelării prin presare între două suprafețe reci) 
double cooling bed (met) pat dublu, cu răcire double corner rounding cutter (mas-un) freză disc, cu două fețe (de aşchiere) pentru rotunjire

double / cross cut (mas-un) tăietură / aşchiere încrucişată

double cut file (mas-un) pilă cu dințare dublă

double cutting drill (mas-un) burghiu plat, $\mathrm{cu}$ două sensuri de aşchiere

double-decker panou de afişe, dublu (montat unul deasupra celuilalt); (nav) navă cu două punți

double-deck screen (constr) ciur cu două site; (ind chim) sită dublă

double-deck vibrating screen (alim, constr, ind chim) ciur oscilant cu două site

double detent $(\mathrm{OM})$ clichet dublu

double diameter piston (OM, hidr) piston diferențial

double-disk parallel gate valve (OM, hidr) robinet cu sertar plan-paralel

double dog (OM) clichet de blocare, dublu

double driver chuck (mas-un) antrenor cu două cozi

double-duo (roll-stand) (met) laminor dubluduo

double-duty (mas) cu funcțiune dublă

double-edged (mas-un) cu tăiş dublu

double edger (mas-un) fierăstrău circular dublu

double-effect evaporator (alim, ind chim) evaporator cu efect dublu / cu două corpuri

double elbow (pipe) (OM, hidr) cot dublu (de țeavă / conductă)

double-end control (autom) comandă reversibilă

double-ended bolt $(\mathrm{OM})$ prezon

double-ended calliper (mas-un, auto) dispozitiv de centrare a roților

double-ended dog (mas-un) antrenor cu două cozi

double-ended mill (mas-un) freză-deget, cu două capete

double-ended spanner / wrench (mas-un) cheie fixă dublă

double entry (ec) contabilitate dublă

double fillet weld $(\mathrm{OM})$ sudură în $\mathrm{T}$

double-flanged $(\mathrm{OM})$ cu două flanşe

double-flanged butt joint (OM) îmbinare capla-cap cu dublă răsfrângere

double-flanged butt weld $(\mathrm{OM})$ sudare a bordurii / a flanşei

double-flash evaporation (alim, ind chim) evaporare dublă / în două trepte

double-floor kiln (met, ind chim) cuptor de uscare / uscător cu două grătare

double force mould (mas-un) matriță cu două poansoane double groove weld (met) sudură cu pregătirea rosturilor pe ambele fețe

double halfroundfile pilă ovală

double-handled (cross cut) saw joagăr (beşchie)

double hardening (met) călire dublă

double head box-end wrench (OM, mas-un) cheie inelară dublă

double-head wrench (OM, mas-un) cheie dublă, pentru șuruburi

double helical gear $(\mathrm{OM})$ roată dințată cu dinți în $\mathrm{V}$, roată cu elice dublă

double helical gearing $(\mathrm{OM})$ angrenare / angrenaj cu elice dublă

double helical mixer (alim, ind chim) amestecător cu elice dublă

double helical tooth $(\mathrm{OM})$ dinte în $\mathrm{V}$

double-holed capstan head $(\mathrm{OM})$ cap găurit în cruce

double horizontal milling machine (mas-un) maşină de frezat, orizontală, cu doi arbori principali

double-humped curve (mat) curbă în şa / cu două cocoaşe

double indexing centres (mas-un) cap divizor dublu / cu două axe

double-inlet fan (termo) ventilator cu două intrări ale aerului aspirat

double I-T welded joint $(\mathrm{OM})$ cusătură (sudată) cu completare la rădăcină

double-jawed (OM) cu doi saboți; (mas-un) cu două fălci

double jet carburettor (auto, termo) carburator cu două jicloare

double-lap joint $(\mathrm{OM}$, met) îmbinare prin dublă suprapunere (sudată sau lipită)

double lathe (mas-un) strung dublu / cu doi arbori principali

double-layer belt $(\mathrm{OM})$ curea dublă / cu două straturi

double-layer film (constr, ind chim, met) film / peliculă cu strat dublu

double-layer nickel coating (met) nichel duplex (la acoperiri)

double-lever shears (mas-un) foarfece dublu cu pârghie / cu pârghie dublă

double-motion paddle mixer (alim, ind chim) amestecător cu agitator planetar

double pack furnace (met) cuptor cu cameră dublă de încălzit tabla

double-pass dryer (termo, ind chim) uscător cu două treceri ale gazului de încălzire

double-pipe condenser (termo) condensator de tipul "țeavă în țeavă"

double-pipe head exchanger (termo) schimbător de căldură de tipul "țeavă în țeavă" 
double-piston engine (termo) motor cu două pistoane

double pointed $(\mathrm{OM})$ ascuțit la ambele capete double press (mas-un) presă dublă

double puddle furnace (met) cuptor pentru pudlare dublă

double pump (OM, hidr) pompă cu doi cilindri double-purpose $(\mathrm{TH})$ cu destinație dublă double quenching (met) călire dublă

double ram press (mas-un) presă cu piston dublu double ram vertical broaching machine (masun) maşină verticală, de broşat exterior, cu două cărucioare

double range (metr) (cu) scară dublă, (cu) două domenii de măsurare

double-range instrument (metr) aparat cu două game / scări de măsurare

double recessed wheel (mas-un) piatră de rectificat plană, cu degajare pe ambele fețe laterale

double-reduction gear $(\mathrm{OM})$ reductor în / cu două trepte

double-refined iron (met) fier dublu rafinat

double-refined steel (met) oțel dublu rafinat

double reversing mill (met) laminor duo reversibil

double riveting $(\mathrm{OM})$ nituire cu / pe două rânduri

double rivet(t) ed joint $(\mathrm{OM})$ cusătură în două rânduri de nituri

double-roll crusher (alim, constr, ind chim) concasor / moară cu două valțuri

double-rolling (met) laminare dublă

double-rolling mill (met) laminor duo

double-row ball-bearing $(\mathrm{OM})$ rulment cu două rânduri de bile

double-row bearing $(\mathrm{OM})$ rulment cu două rânduri de corpuri de rostogolire

double-row cross riveting $(\mathrm{OM})$ nituire alternată, dublă / cu două rânduri de nituri în zigzag

double-row riveting $(\mathrm{OM})$ nituire cu două rânduri de nituri

double salt (chim) sare dublă

double screw pump (OM, mas) pompă cu melci double-shaft pugmill (alim, ind chim) amestecător biax

double shaping machine (mas-un) şeping cu două sănii principale

double-sharpened drill (mas-un) burghiu cu ascutire dublă

double-shielded bearing $(\mathrm{OM})$ rulment cu şaibe de protecție pe ambele părți laterale

double shift muncă în două schimburi, schimb dublu (cu număr dublu de muncitori)

double-shoe brake (OM) frână cu doi saboți double-shoulder screw (OM) şurub cu tijă în trepte

double-sided $(\mathrm{OM})$ cu două fețe, bilateral

double-sided adhesive tape (el, plast) bandă adezivă cu două fețe active

double-sided press (mas-un) presă cu cadru dublu / compus din doi montanți

double skin (met) suprapunere de oxizi (la laminare)

double spot welding (met) sudare în puncte duble

double-spread adhesive (plast) adeziv cu dublă aplicare, adeziv pentru lipire pe două fețe

double stage cu două etaje, cu două trepte (d. cilindri hidraulici, prese, transmisii etc.)

double standard $\mathrm{cu}$ doi montanți, cu două coloane ( $\mathrm{d}$ prese, maşini-unelte etc.)

double-stand rolling-mill (met) laminor cu cajă dublă de lucru

double-strand chain $(\mathrm{OM})$ lanț dublu

double-strand roller chain $(\mathrm{OM})$ lant cu două rânduri de zale

double-strap butt joint (OM) îmbinare cap-lacap, cu răsfrângere bilaterală

double-strap joint $(\mathrm{OM})$ îmbinare cu două eclise double strip (met, metr, termo) bandă bimetalică

double stroke (mas-un) cursă dus-întors, cursă completă, lovitură/ solicitare dublă

doublet dublet, duplicat; pereche; (fiz) dublet, lentilă dublă

double-tapered muff (OM) cuplaj cu con dublu double-tapered / compression / Sellers coupling (OM) cuplaj cu con dublu, cuplaj Sellers

double tee (T) joint (OM, met) (cusătură / îmbinare de) sudură (cu rost) în (dublu) T

double tee (T) iron (met, constr) oțel I, semifabricat I din otel

double thread(ed) $(\mathrm{OM})$ (filet) cu două începuturi

double-thread screw (OM) şurub cu două începuturi / cu filet dublu

double-throwcrank-shaft $(\mathrm{OM})$ arbore cotit cu cot dublu

double-throw single-pole switch (el) comutator cu came

double thrust bearing (OM) rulment axial dublu / cu dublu efect

double-T iron (constr, met) profil $\mathrm{T}$ (din semifabricat / otel)

double toolholder (mas-un) port-cuțit dublu / pentru două cuțite

double triangulated system of bracing (mec) construcție / grindă cu zăbrele, formată din triunghiuri 
double-tube heat exchanger (termo) schimbător de căldură de tipul, ,teavă în țeavă"

double tunnel furnace (met) cuptor-tunel dublu double twist (mec) dublă torsiune (la fire textile, cabluri)

double two-high finishing mill (met) laminor dublu-duo finisor

double two-high mill (met) laminor dublu-duo

double two-high stand mill (met) cajă de laminor dublu-duo

double U-leather packing (OM) etanşare cu două manşete de piele

double universal propeller shaft $(\mathrm{OM})$ arbore cardanic, cu două articulații

double up a (se) îndoi, a împături, a strânge; a încovoia, a strâmba

double up with a se strâmba, a locui împreună cu double-V engine (termo) motor cu cilindri în dublu $\mathrm{V}$

double-walled (constr, met, termo) cu pereți dubli

double welded joint (met) îmbinare prin sudare pe ambele fețe

double wheel $(\mathrm{OM})$ roată dințată (cu coroană) dublă

double-wire (el) bifilar

doubling (plast) dublare, placare; (met) cutare, pliere, îndoire, placare; (nav) întăritură, dublaj de lemn; (TH) dedublare; jumelare

doubling test încercare prin îndoire la 180 de grade

doubly dublu, îndoit; de două ori; cîte doi o dată; care face un joc dublu, necinstit

doubt îndoială, nesiguranță; bănuială, suspiciune, neîncredere; problemă nerezolvată, dificultate

doubtable care dă de bănuit, suspect, dubios

doubt if / that / whether a se îndoi de, a nu crede că, a nu fi sigur că

doubt of a îndoi, a nu fi sigur de, a nu se hotărî, a şovăi, a ezita; a se îndoi de, a pune la îndoială, a nu avea încredere, a pune sub semnul întrebării

doubtful of plin de îndoieli cu privire la, nesigur de, şovăitor cu privire la; (sens) nesigur, incert, imprecis, vag; suspect, de reputație dubioasă

doubtfully $(a d v)$ (în mod) nesigur, şovăitor

doubtful operation (TH) funcționare incertă / îndoielnică

doubtlessness neîndoios, sigur; $(a d v)$ fără îndoială, fireşte, bineînțeles

doubtlessly $(a d v)$ fără îndoială, fireşte, bineînteles

doubtlessness certitudine, siguranță

douche duş, stropitoare, jet de apă, spălătură dough (alim) cocă, aluat; (plast) adeziv de cauciuc, pastă, masă densă şi vâscoasă

dough fermentation (alim) dospire (şi d. aluat)

dough-kneading machine / trough (alim) frământator de aluat

dough machine (alim) maşină de împărțit / proportionat aluatul

dough machine portioning (alim) împărţirea / porționarea aluatului cu maşină specializată

doughnut shape formă toroidală

dough-raising (alim) creştere a aluatului

dough roller / -rolling machine (alim) maşină de întins / de rulat aluat

doughy (alim) de consistența unui aluat păstos / cleios, cleios, păstor

do up a pune la punct, a renova, a repara, a schimba forma, a transforma, a împacheta, a face un pachet din; a avea nasturi, a se închide cu nasturi

dour aspru, sever, neînduplecat, încăpățânat

douse a băga în apă, a acoperi cu apă, a arunca apă peste, a înmuia într-un lichid

dove coloured cenuşiu-albăstrui

dovetail (constr, mas, OM) piesă în formă de coadă de rândunică; $(\mathrm{TH})$ a îmbina în coadă de rândunică (şi piese din lemn)

dovetailed $(\mathrm{OM})$ cu canal în coadă de rândunică

dovetailed joint $(\mathrm{OM})$ îmbinare cu cep, în coadă de rândunică

dovetail forming tool (mas-un) cuțit cu tija în formă de coadă de rândunică, pentru fixarea în port-cuțit

dovetailing / dovetail joint (OM, mas-un) îmbinare în coadă de rândunică

dovetail milling cutter (mas-un) freză pentru prelucrarea canalelor în formă de coadă de rândunică

dovetail plane $(\mathrm{OM})$ pârghie arcuită

dowdy neîngrijit, murdar, demodat (d.haine)

dowdyish cam dezordonat / neglijent

dowel (cf) scoabă de traverse; (constr) diblu, pană de fixare; $(\mathrm{OM})$ pivot, ştift, cep

dowel bolt $(\mathrm{OM})$ bulon / bolț de centrare

dowelled joint $(\mathrm{OM})$ îmbinare $\mathrm{cu}$ ştifturi, îmbinare cu şuruburi prizoniere

dowelling jig (OM, mas-un) unealtă pentru montat şi extras pene

dowel pin (cf) scoabă de traverse; (constr, OM) pană de fixare, diblu, prezon, ştift de fixare / de ajustare / de centrare, cep, şurub de fundație $/$ de fixare

dowel screw $(\mathrm{OM})$ şurub de lemn, cu ambele capete filetate, prezon 
do with a se împăca cu, a se descurca cu, a avea nevoie de, a-i trebui

do without a se (putea) lipsi de, a se (putea) descurca fără

down $(a d v)$ (in) jos, la parter, (culcat) pe pământ, la pământ, în partea de jos, pe, de-a lungul; (TH) orice echipament care nu functionează / nu lucrează; chiar, inclusiv; complet, în întregime; încă; (ec) bani în numerar; (adj) în scădere, cu capătul în jos, îndreptat în jos; coborâtor, descendent, situat (mai) jos; sub tipar, dat la tipar; coborâre; a coborî, a lăsa în jos, a nu mai lucra

down comer (met) conductă pentru evacuarea gazului (la furnal); (constr) burlan de scurgere; (hidr) deversor

downcutting and upcutting (mas-un) tăiere atât la cursa de coborâre, cât şi la cea ascendentă

down cutting tool (mas-un) cuțit de mortezat suprafețele verticale

down draft / draught (met, termo) tiraj pe / de jos, tiraj invers(at)

downdraft boiler (termo) cazan cu tuburi curbate / în care gazele de ardere se întorc în jos

downdraft carburettor (termo) carburator inversat / în care aerul trece prin difuzor vertical descendent

downdraft furnace (termo) (cuptor cu) focar cu ardere / cu flacără inversă, focar cu tiraj inversat

dow-draft / -draught sintering (met, termo) aglomerare / sinterizare cu aspirare de aer / de gaze

downdraft-type furnace (termo, met) cuptor cu flacără descendentă

down draught (termo) tiraj invers

downender (met, plast) dispozitiv de întoarcere a rulourilor

down feed (mas-un) avans vertical la coborârea sculei / în jos / descendent

downflow (mas, hidr) conductă de deversare

downflow evaporator (ind chim) vaporizator $\mathrm{cu}$ peliculă descendentă

down(flow) pipe (OM, hidr) țeavă de preaplin

downgate (met, plast) canal / pâlnie / rețea de turnare

downgrade (constr) povârniş, pantă; declin; a micşora, a reduce, a degrada

downgraded (produs, organ de maşină) la care s-a coborât cu o clasă de rugozitate, toleranță, precizie, calitate etc.

downgrading scăderea cu o clasă de rugozitate / calitate / precizie etc.

downhand position $(\mathrm{OM})$ în poziția de jos

downhand position / welding (OM, met) sudare orizontală downhand welding $(\mathrm{OM}$, met) sudare normală (cu electrodul deasupra cusăturii)

down-heart furnace (met, termo) cuptor cu ardere în partea inferioară

downhill $(a d v)$ la vale, în jos; declin

downhill teem (met, plast) a turna pe sus / direct downiness caracter / aspect pufos

download (c) transfer de programe / date de la un computer mai mare la un PC

downpour ploaie torențială

downpull force (fiz) forță de coborâre

downright $(a d v)$ de-a dreptul, pur şi simplu, cu totul; (adj) sincer, direct, deschis, făţiş, onest; (met) canal vertical de turnare, picior de pâlnie

downrights (agr) lână aspră

downshifting (auto) schimbare / retrogradare (dintr-o viteză superioară într-una mai mică)

downside parte inferioară / de jos

downslide motion $(\mathrm{mec})$ alunecare descendentă

downspout (met, hidr) scurgere, descărcare, deversare

downspout conductor (hidr) țeavă de preaplin, deversor

downstairs $(a d v)($ de) la parter, jos

downstream $(a d v)$ în aval, la vale, în josul apei

downstroke (auto, mec) cursă descendentă

downtake (ind, TH) colector

downthrow răsturnare, doborâre

down(-)time (autom) timp de întrerupere, pauză; (ec) gol de producție, oprire, cădere, staționare neproductivă; (fiz) timp de inactivitate; oprire, întrerupere; $(\mathrm{TH})$ timp de oprire / de întrerupere a funcționării / de imobilizare / mort

downturn îndoire, îndoitură; (ec) scădere a activităţii (economice)

down under $(a d v)$ la antipozi

downward în jos, descendent, descrescător, coborâtor, de coborâre

downwards $(a d v)$ în jos

downward motion / movement (mec) mişcare descendentă

downwarping (mec) săgeată de încovoiere; (hidr) submergență, scufundare

downwash (hidr, termo) curent descendent

downy pufos, cu puf, ca de puf

dozen duzină, (set de) doisprezece

dozenth al 12-lea

dozer (auto, constr) buldozer, autoîncărcător cu cupă (montat pe un tractor)

dozzle (constr) adaos, înnăditură; (met) maselotă dozzle metal (met) gâtul maselotei (de la lingou)

drachma (metr) unitate (veche) de măsură pentru masă; 1 drachma (Biblical Greek) $=0,0034$ kg 
draff (alim) borhot, resturi, drojdii, zaț draff-press (alim) teasc pentru borhot draft (ec) cec, cambie, trată, ordin de plată; (mat) conicitate; $(\mathrm{TH})$ proiect, plan, schiță, desen, crochiu, concept, ciornă, redactare, curent de aer, a schița, a proiecta, a face o schiță, a elabora (un concept, proiect etc.), a concepe; punctaj; (met) reducere (la laminare), tragere; (termo) canal de fum al cazanului, tiraj al cazanului, suflare; a elabora, a concepe, a redacta, a schița, a proiecta; (nav) pescaj; (ec) scăzământ, reduce (în comerț); (jur) a întocmi un proiect de lege

draftchange gear (met, plast) roată de schimb a laminajului

draft chimney (met, termo) coş de tiraj

draft constant (met) constantă de laminare / de tragere

draft differential (hidr) diferență de presiune statică între două puncte ale unui sistem hidraulic

draft fan (met) exhaustor, ventilator de tiraj

draft gauge (metr) dispozitiv de măsurat diferența de presiune statică / tirajul

draft hole (met) răsuflătoare, orificiu de ventilare drafting (ec) elaborare de rapoarte; $(\mathrm{TH})$ desen tehnic (şi schiță)

drafting convention convenție, regulă (în desenul tehnic)

drafting paper hârtie milimetrică

draft loss (hidr, met) pierdere de presiune statică din cauza rezistenței la curgere (în cazane sau cuptoare)

draft of drawings desen, proiect, plan, schiță

draft of skip (nav) pescaj

draft preventer (auto) garnitură de etanşare a ferestrei

draftsman (met) modelator, formator; $(\mathrm{TH})$ desenator tehnic, proiectant

draft stage (termo) etaj de presiune (la turbine cu abur)

draft tube (auto) țeavă / conductă de admisie; (OM) teavă de aspirație

drafty expus la curent de aer

drag (hidr, nav) lucrare de dragare, a curăța fundul unei ape, a draga; (mas, OM) dragă, întindere, (sabot de) frână, rezistență la înaintare; (mas-un) fațetă de racordare; (met) formă inferioară de turnare; (nav) rezistență a cârmei, ancoră de mare, înclinare a chilei, a draga; a scoate (greu), a trage, a târâ, a grăpa; (fiz) rezistența aerului; piedică, obstacol; (constr) screper, cilindru compresor

drag acceleration $(\mathrm{mec})$ încetinire, accelerație negativă drag along a antrena (prin tragere)

drag anchor (nav) ancoră-santinelă / plutitoare

drag belt (alim, OM) bandă de transport(or) / transportoare, cu raclete

drag boat (nav) dragă

drag (box) (met) partea inferioară a formei (de turnare)

drag brake $(\mathrm{OM})$ frână de încetinire

drag bridle (met) dispozitiv de întindere a benzii

drag bucket (constr) cupă de excavator, excavator cu cupă întoarsă

drag chain $(\mathrm{OM})$ lanț de remorcare / de tracțiune

drag(chain) conveyer (mas, OM) transport(or) cu lanț

drag classifier (ind chim) clasor cu raclete

drag coefficient coeficient / modul de rezistență / de tragere, coeficient care indică rezistența întâmpinată de un corp care se mişcă într-un fluid

dragcowling (hidr) sorb, crepină

dragée (alim) drajeu

drag effect (fiz, mec) rezistență / efect de atracție / de tragere

drag force (mec, mas-un) forță de antrenare / de tractare / de tragere

drag form (fiz) rezistență aerodinamică

dragging (OM, mas) mişcare în urma unei decuplări incomplete a ambreiajului

dragging device (met) dispozitiv de tragere (a bramei la turnarea continuă)

draghalf of mould (met) jumătatea inferioară a formei (la turnare, matrițare)

drag hook (nav) gheară de pisică

dragline (constr, mas) excavator cu cablu de tracțiune, draglină

drag-in (chim) soluție aderentă

dragline (constr) draglină

dragline bucket (constr) cupă de draglină

dragline excavator (constr) draglină; (mas) excavator cu cablu purtător şi cupă (cutie)

drag lines (mas-un) brazde / urme pe suprafața tăieturii, rizuri (la tăierea metalelor)

drag(-)link (auto) bară de comandă a direcției

drag loading (mec) forță de antrenare / de tragere

drag net năvod

drag of a căra, a remorca

drag of flame-cut lag (met) rămânere în urmă (la tăierea oxiacetilenică)

drag on a trec încet (şi d. timp), a se curge (încet), a trena

drag out a scoate în afară, a trage în afară

drag-out (ind chim) solutie antrenată 
drag-over rolling mill (met) laminor duo ireversibil

drag roll (met) cilindru liber / de presiune (la laminare)

drag rope (nav) cablu de remorcare, barbetă; (TH) cablu de tracțiune

drag scraper $(\mathrm{TH})$ screper cu raclete

drag screen (alim, ind chim) ciur / sită cu raclete

drag shoe $(\mathrm{OM})$ sabot de frână, tachet opritor

drag shovel (constr, mas) excavator cu cupă întoarsă

drag soldering (met) lipire prin tragere

drag the anchor (nav) a derapa pe ancoră

drag theory (fiz) teoria antrenării (particulelor)

drag-type tachometer (metr, el) tahometru de inductie / cu curenți Foucault

drain (el) priză (de curent); (termo) purjare, a drena, a purja; (s)curgere, golire, descărcare; (constr) drenaj, golire, dren, uscare, rigolă, a seca, a asana, a drena; (TH) canal de scurgere, flux, scurgere, a usca, a (se) scurge (încet), a filtra; (agr) asanare, desecare; (constr, TH) drenaj, canal de scurgere, scurgere continuă (dintr-o țeavă); $(p l)$ canalizare; (med) tub de drenaj; cheltuială (mare); (fam) înghițitură; a drena; a asana; a goli (un vas, un pahar); a bea / consuma până la ultimul strop; (alim) a (se) scurge d. (legume); a întinde la uscat (rufe); (fig) a stoarce (de bani); (fig) a secătui (fortele), a epuiza; (d. un lichid) a se scurge; (d. rufe) a se zvânta; a se usca

drainage $(\mathrm{TH})$ drenaj, canalizare, scurgere, golire, impurități, murdărie; (constr) desecare, asana-re; (agr) ameliorarea solului, asanare, uscare

drainage basin $(\mathrm{TH}$, mediu) bazin colector / de drenaj

drainage hose (OM, hidr) furtun de golire

drainage pan (termo, T) țeavă pentru lichid de răcire

drainage pipeline $(\mathrm{OM}$, hidr) conductă pentru drenaj

drainage pump (OM, hidr) pompă de evacuare

drainage tube (constr) conductă de preaplin, țeavă de drenaj

drain arrangement (nav) instalație de santină

drain box (met) cutie de turnare

drain cock (OM, hidr) robinet de golire / de descărcare / de evacuare / de drenaj

drain connection (OM, hidr) conductă de scurgere

drain cup (hidr, alim, mediu) instalație / bazin de decantare, decantor

drained battery (auto) baterie slabă drainer (hidr, alim, mediu) rezervor de decantare / de drenare

drain height (hidr, alim, mediu) înălțimea de decantare

drain hole (OM, hidr) gaură sau orificiu de golire / de evacuare / de scurgere

draining (hidr, constr) drenaj, secare, desecare, canal de scurgere / colector, golire

draining chest (alim, hidr, ind chim) rezervor cuvă de decantare

draining off (constr, hidr) desecare, asanare, drenare

draining out (constr, hidr) evacuare, îndepărtare

draining pipe (OM, constr, hidr) tub de drenaj / de scurgere

draining plant (OM, constr, hidr) instalație de drenare

drain into (hidr) a se scurge, a se vărsa în

drainless nesecat, inepuizabil; (TH) fără scurgere

drainline (constr, hidr) conductă de recuperarea pierderilor (dintr-un rezervor)

drain nipple (OM, hidr) ştuț de scurgere

drain number coeficient / factor / număr de decantare / de drenare

drain off (hidr, constr) a drena

drain (off) the cooling (termo) a goli apa de răcire

drain off the slag (met) a îndepărta / a evacua zgura

drain out (auto) a goli rezervorul (de tot); (hidr) a pierde / scoate lichid, a se scurge în afara (unei conducte)

drain the oil (mas, $\mathrm{T})$ a goli uleiul

drain outlet (OM, hidr, termo) racord de golire

drain pipe (constr) canal, rigolă, tub / conductă de drenaj; (mas, hidr, termo) țeavă de evacuare; de scurgere / de drenare

drain plug (auto) buşon / dop de golire; (OM) dop al orificiului de scurgere / de golire / de descărcare; (met) dop de astupare

drain port (OM, hidr) orificiu de scurgere, drenaj drain sleeve $(\mathrm{OM}$, hidr) stut de scurgere

drain table (alim, ind chim) masă de zvântare / de uscare (şi parțială)

drain tap (OM, hidr) robinet de golire / de evacuare

drain trough (auto) bandă sudată pe caroserie pentru drenarea apei de ploaie

drain valve $(\mathrm{OM}$, hidr) robinet / supapă de golire / de evacuare; (termo) ventil de drenaj / de purjare

dram (metr) unitate de măsură pentru volum: 1 dram $=3,697 \cdot 10^{-6} \mathrm{~m}^{3}$; (în farmaceutică); 1 dram $=3,888 \mathrm{~g}, 1$ dram $=1,772 \mathrm{~g}$; dram, pic, strop 
dramatical dramatic, de efect, care sare în ochi, brusc; sensibil

dramatically (adv) (în mod) dramatic, spectaculos, impresionant

drape forming (met, plast) formare pe matriță pozitivă

draping machine (alim, ind) maşină de ambalat în folie

drastical (adj) drastic, aspru, sever, extrem

drastically $(a d v)$ (în mod) drastic

drastic downshift (auto) schimbare bruscă de viteză (de la una superioară, la una inferioară)

draught $(\mathrm{TH})$ schiță, proiect; (met, termo) titraj, scoatere, tragere

draught bar (mec) bară de tracțiune

draught cup board (met, termo) hotă / nişă de tiraj

draught gauge (nav) indicator de pescaj

draughtiness (expunere la) curent de aer

draught marks (nav) scară de pescaj

draught of ship (nav) pescaj

draught register (termo) registru de tiraj (la coş de fum)

draughty expus la curent (de aer)

draw (hidr) a antrena (de / în curent); (met) microretasură (de turnare), a recoace, a trata prin revenire, a reveni, a supune unui tratament de revenire, a decăli, a trefila, a trage sârma; (TH) scoatere, extragere, extracție, tragere, a desena, a schița, a trasa, a redacta un concept / document, a trage, a extrage, a târî, a scoate, a (se) dilata, a (se) umfla; (alim) a scoate măruntaiele din, a se macera, a se face infuzie; a face, a convinge, a determina; (ec) a aduce (dobândă etc.); a îndoi, a plisa, a face cute; (constr) parte mobilă a unui pod; depresiune (geografică)

drawability (materiale, TH) capacitatea unui material (şi metalic) de a fi tras, ductilitate

draw away a trage deoparte; a distrage (atenția); a se îndepărta, a se retrage

drawback obstacol, piedică; (ec) deficientă, neajuns, lipsă, primă / bonificație de export, rambursare, restituire; (met) revenire

draw back a (se) retrage, a da înapoi

draw-back motion (mec, mas-un) mişcare de tragere înapoi / de retragere

draw band (met) bandă (de margine) pentru control (la laminare), o bandă riglată folosită la controlul curgerii materialului la extrudare sau ambutisare adâncă

draw bar (OM) tijă, bară, bară de tracțiune

draw bench (mas-un, met) banc de trefilare, banc de tras drawbridge pod basculant; (nav) scară de acostare, pasarelă

draw box (met) tren de laminare

draw crack (mec, met) crăpătură cauzată de tensiune / de tragere / la tracțiune

draw die (met) matriță de trefilare

drawdown (hidr) scădere a nivelului apei; (masun, met) micşorarea secțiunii transversale, alungire prin tragere

drawer $(\mathrm{OM})$ sertar, ladă, cutie; proiectant, desenator

draw filing (mas-un) prelucrare fină cu pila

draw-frame (met) laminor

draw-frame sliver (met) bandă de laminor

draw-gear aparat de tracțiune

draw glass (ind chim) sticlă trasă

draw head (met, mas-un) dispozitiv de susținere / fixare a filierei; dispozitiv cu role pentru formarea suprafețelor conice la tuburi sau a suprafețelor plane înclinate

draw hole (met) orificiu al filierei de tragere / de trefilare

draw hook (nav, transp) cârlig de remorcare / de tractiune

draw-hook pin (cf) bulonul cuplei

draw-hook tractive effort (mas) forță / efort de tracțiune la cârlig

draw in (TH) a trage înăuntru, a absorbi, a scurge, a implica în; (ec) a reduce, a micşora (şi cheltuieli)

draw in attachment dispozitiv de detonare

draw-in collet chuck (mas-un) mandrină cu bucşă elastică acționată prin tragere spre interior

drawing desen; (met) ambutisare, tragere, trefilare, revenire, decălire

drawing back (met) revenire (termen popular) (şi pentru reducerea durității)

drawing (wires) bench (met) banc de trefilat (sârmă)

drawing board planşetă de desen

drawing box (met) tren de laminare, laminor (şi finisor, pentru textile, folii)

drawing chalk cretă de desenat

drawing compasses compas de desen

drawing compounds (met, T) emulsii şi amestecuri folosite la trefilare / la tragere

drawing device (mas-un) dispozitiv de trefilare

drawing die (mas-un) filieră / matriţă de trefilare / de ambutisare

drawing documentation $(\mathrm{TH})$ documentație conținând desenele unui proiect (desene de ansamblu şi de execuție)

drawing down (met) reducerea secțiunii (prin tragere) 
drawing effect (met, plast) efect al trefilării / al întinderii

drawing field (met) câmp de tragere / laminare drawing frame settings (met, plast) ecartamente ale trenului de laminare

drawing furnace (met) cuptor de revenire

drawing grease (met, $\mathrm{T}$ ) unsoare pentru tragere / extrudare

drawing hank (met) număr al benzii de laminor drawing mark (materiale) urmă / defect de tragere (zgâriere, ciupituri, urme de la matriță)

drawing model crochiu, proiect, schiță după care se face desenul la scară

drawing nozzle (plast, met, mas-un) orificiu activ de tragere

drawing off of steam (termo) prelevare / priză de aburi

drawing off wine (alim) pritocire a vinului

drawing-out device (met, mas-un) dispozitiv de evacuare (prin tragere)

drawing over mandrel (met, mas-un) tragere pe mandrină / pe dorn

drawing paper hârtie pentru / de desen

drawing pen (TH) trăgător, peniță de desen

drawing pin piuneză

drawing point (mas-un) ac de trasat

drawing press (mas-un) presă de tras / de întins / de ambutisat

drawing pump (OM, hidr) pompă de aspirație

drawing ring (mas-un) inel de trefilare

drawing speed (met, plast) viteză de laminare

drawing stress (met, plast) efort / tensiune de tragere / de tracțiune / de întindere

drawing table masă de desen / de trasare

drawing the dimensions cotare

drawing tool (mas-un) sculă de tras

drawing tongs (mas-un) clește de tras sârmă

drawing tower (ind chim, plast) echipament de tragere / de formare a fibrelor optice

drawingwaste (met) retururi / deşeuri de la laminor

draw in steam a absorbi aburul

draw key $(\mathrm{OM})$ pană alunecătoare

drawn desenat; (mas-un, mec) tras, tensionat, ambutisat; retras / scos din circulație; (alim) topit (d. unt etc.)

drawn arc stud welding (met) sudarea bolțurilor cu arc electric amorsat prin ridicare

drawn draw near a se apropia

drawn fibre (mec) fibră tensionată

drawn glass (ind chim) sticlă trasă

drawn head (met, plast) cap de tragere

drawn-in scale (met) arsură / țunder rezidual(ă) (defect) drawn steel bar (met) bară trasă din oțel drawn pipe / tube (met, plast) țeavă trasă draw off (hidr, mediu) a prelua apa din acumulare, a decanta; (mas-un) a extrage, a aspira, a evacua, a scoate; a distrage (atenţia)

draw off clinker (met) a evacua zgura draw-off cock (OM, hidr) robinet de scurgere de descărcare / de priză

draw-off pan / tray (alim, ind chim) taler de evacuare

draw off slag (met) a scoate zgura

draw out (from) (TH) a scoate (afară din), a extrage, a evacua, a trage afară, a demonta, a ridica, a desena, a schița, a lungi, a dilata

draw-out (endways) (met) trefilare a metalului, întindere

draw piston (OM, hidr) piston de ridicare / de tragere

draw-plate (met, plast) filieră de trefilat

draw radius (mas-un) raza de curbură a muchiei cavității matriței la ambutisare adâncă

draw ring (mas-un) inel de tras (țevi)

draw / tension spring (OM) arc / resort de tracțiune

draw stroke slotter (mas-un) mașină de mortezat cu cursă de aşchiere / de lucru ascendentă

draw together a strânge laolaltă, a (se) aduna

draw-type broaching machine (mas-un) maşină de broşat canale

draw up (TH) a elabora, a proiecta, a trage (în) sus, a (a)trage, a se opri, a se apropia, a se așeza; a redacta (un document); (ec) a întocmi (un bilanț)

draw upon (ec) a extrage (din fonduri), a lua; a se inspira din

draw with back pull / with back tension (met) trefilare în sens contrar

draw works (mas-un) coardă de găurit; (mas) mecanism de ridicat

dray $(\mathrm{TH})$ tălpi de sanie (şi la maşini-unelte), platformă de încărcare; (auto, alim) camion de bere, căruță; (constr) a excava, a draga

dreadnaught, dreadnought (nav, mil) cuirasat, navă de război

dream a visa; vis

dream up a inventa

dreamy fantezist, imaginar, nepractic; neclar, vag, neprecis; tulbure

dredge (nav) dragă plutitoare, a draga

dredged material (nav) material de dragare / dragat

dredge piping (nav, hidr, OM) țevărie / conducte de refulare a unei drăgi aspirante

dredge pump (nav, hidr, OM, mediu) pompă de nămol / de noroi / de dragaj 
dredger (nav, constr) dragă, dragor, muncitor pe dragă; excavator; (hidr, nav) dragă cu lingură; (mas, constr) excavator cu roată port-cupe; (alim, $\mathrm{OM}$ ) cutie cu capac perforat pentru presărat

dredger bucket (mas, constr) cupă de dragă / de excavator

dredger drum $(\mathrm{OM}$, mas) rulou-tambur

dredger for clearing dry earth (constr, mas) excavator de pământ

dredger pump (nav, OM, hidr) pompă de dragare

dredger shovel (constr, mas) lingură / lopată a excavatorului

dredging (nav, OM, hidr) dragare

dredging depth (nav, hidr) adâncime de dragare dredging roll / tumbler (OM) rulou-tambur dregs (alim) drojdii, zaț; reziduuri

drench înmuiere, îmbinare; (chim) saturare; ploaie torențială; (TH) baiț; a înmuia, a îmbina, a uda până la piele

dress îmbrăcăminte, haine; $(\mathrm{TH})$ a rotunji, a îndrepta, a finisa, a prelucra, a îmbrăca, a decora, a aranja, a prepara, a netezi; (ind chim, met) a netezi, a băițui, a finisa, a curăța, a decapa; (constr) a tăia piatra, a prepara minereuri; (el) a aşeza corect conductoarele și elementele componente într-o schemă; (mas-un) a prelucra, a slefui, a poliza, a ajusta, a rotunji, a rectifica (şi (cu) un disc abraziv), a rabota, a îmbogăți, a ameliora, a ascuți (scule), a reface conturul unei scule; (nav) a pavoaza un vas; (met) a ajusta, a netezi, a îndrepta, a fasona; (alim) a pregăti (salata, sosul); (med) a pansa, a bandaja (o rană); (agr) a fertiliza

dress a bit (mas-un) a ascuți un tăiș de burghiu (dar şi altă sculă aşchietoare)

dressed coal (met, ind chim) cărbune preparat

dresser (met, plast) debavurator

dressing îmbrăcat, îmbrăcare; (constr) îmbrăcare (a unei clădiri); (mas-un, met) îndreptare (a tablei), netezire, fasonare, prelucrare, ascuțire a sculei; (met) îmbogățire, preparare, concentrare (a minereurilor), înnegrire a formelor de turnare; $(\mathrm{TH})$ îndreptare, prelucrare; (alim) sos, umplutură; (med) pansament; (agr) îngrăşământ; (nav) pavoazare; (textile) apretare; (alim) pregătire (a salatei, sosului etc.)

dressing by flotation / screening / washing (met) îmbogățire / concentrare prin flotație / cernere / spălare (în industria extractivă)

dressing case (med) trusă sanitară

dressing frame (met) cajă de ecruisare

dressing gown $(\mathrm{TH})$ halat

dressing machine (mas-un) mașină de îndreptat dressing of steel ingots (met) scoaterea lingourilor din lingotiere

dressing room $(\mathrm{TH})$ garderobă, vestiar

dressing shop atelier de finisaj; curățătorie

dressing station (med) punct de prim ajutor

dressing tool (constr) buciardă; (mas-un) cuțit de strunjit plan

dribble (hidr) a picura, a se scurge

drib(b)let $(\mathrm{ec})$ sumă mică; $(\mathrm{TH})$ strop, picătură

dribbling (hidr, termo) scurgere, pierdere

dribs and drabs bucățele, fărâme

dried eggs (alim) praf de ouă

dried fruits (alim) fructe uscate

dried milk (alim) lapte praf

drier, dryer (alim, ind chim) uscător sicativ

drift (TH) derivă, abatere, deplasare, tendință, direcție, sens, curgere; (el, electr) abatere reziduală, derivă / curgere de electroni; (mas-un) mandrină, poanson / dorn / presă / matriță de perforat, pilă de lărgit găuri, alezor; (metr) variație a valorii măsurate, deplasarea indicatorului; (nav, hidr) derivă de curent, curent la suprafață, viteza unui curent, plasă mare de pescuit, a fi în derivă; (met) a perfora, a înfige, a găuri, a lărgi; a fi purtat / dus de ape sau de vânt; a se strânge grămadă (d. zăpadă, praf etc.); a abate, a devia, a deplasa; (constr, geol) (mişcare de) alunecare

driftage (nav) derivă de curent, obiecte aruncate de ape pe țărm

drift angle (nav) unghi de derivă, derivă în unghi; (metr) unghi de deviere (a unei scule etc.)

drift away from a se depărta de, a nu mai avea de a face cu

drift canal (nav) scoc

drift correction (nav, metr, autom) corectie a derivei / a indicației aparatului de măsurat

drifter (nav) drifter

drift hole (mas-un) gaură / canal pentru pană folosită la scoaterea sculei din locaşul arborelui / axului principal, a lărgi o gaură

driftless fără țintă / rost, inutil

drift pin (OM) ştift (şi conic) de centrare / de aliniere a două părți / piese asamblate

drift rate (autom, TH) variația unei mărimi în unitatea de timp, viteza de variație a unei mărimi

drift test (met, plast) încercare de lărgire a tevilor

drift time (TH) timp de punere în serviciu

driftway (nav) derivă de curent

drill $(\mathrm{TH})$ formare, instruire, calificare; (lemn, mas-un) burghiu cu coadă conică; (mas-un) burghiu (şi spiral), maşină de găurit, perforator; (mas-un) a perfora, a găuri 
drill adapter (mas-un, OM) bucşă de reducție drill bit (constr) floare de burghiu; (mas-un) bur-ghiu lat, vârf al burghiului

drill bow (mas-un, OM) dispozitiv de găurit, cu arc drill carriage (mas-un) suport / brat al axului principal (la maşini de găurit), păpuşă a axului principal

drill chuck (mas-un) mandrină (pentru maşini de găurit), cap port-burghiu

drill chuck jaw (mas-un) menghină de prindere a capului burghiului

drill chub (mas-un) ciocan perforator (și pneumatic)

drill drift (mas-un) piesă conică / înclinată pentru scoaterea cozii unei scule (burghiu, freză etc.)

drilled $(\mathrm{OM})$ găurit, perforat

drilled bore / hole (OM, mas-un) gaură executată cu burghiul

driller jig (mas-un, metr) calibru interior, calibru-tampon

driller (mas-un) maşină de găurit

drill finish (mas-un) operație finală de găurire, găurire de finisare

drill grinder / grinding machine (mas-un) maşină de ascuțit burghie elicoidale

drill gun (mas-un) maşină de găurit portabilă

drill hammer (mas-un) ciocan perforator (si pneumatic)

drill hand (mas-un) găuritor, dispozitiv (simplu) de găurire

drill head cap (mas-un) port-burghiu

drill holder (mas-un) mandrină specială pentru burghie (la strunguri automate)

drill hose (OM, hidr) furtun de alimentare a unui perforator

drilling (constr) foraj, forare; (mas-un) proces de găurire, care găureşte; (textile) dril, nanchin (țesătură)

drilling bit (constr) floare / vârf de burghiu

drilling capacity (mas-un) diametru maxim al burghiului care poate fi folosit la o maşină de găurit

drilling depth (mas-un) adâncime de găurire drilling device (mas-un) dispozitiv de găurit drilling jib (mas-un) şablon de găurit

drill(ing) jig (mas-un) dispozitiv de ghidare (folosit la găurire)

drill(ing) lathe (mas-un) maşină orizontală de găurit, strung rapid, folosit la găurire

drilling load (mas-un) forță de avans la găurire

drilling machine (mas-un) maşină de găurit

drilling machine spindle (mas-un) arbore portburghiu drilling mill (mas-un) maşină de găurit

drillings (mas-un) aşchii provenite de la găurire / aşchiere / strunjire

drilling shaft (mas-un) arbore port-burghiu principal al maşinii de găurit

drilling system (mas-un) sistem de foraj, maşină complexă de găurit

drill-jig bush (mas-un) bucşă de găurit

drill out (mas-un) a găuri, a sfredeli, a burghia

drill pad (mas-un) placă de apăsare folosită pentru găurire la strung

drill-pipe coupling $(\mathrm{OM})$ racord special al maşinilor de foraj

drill point (mas-un) vârf al burghiului

drill press (mas-un) maşină de găurit (cu moment constant la burghiu), bormaşină

drill pressure (mas-un) presiune / efort de găurire

drill rocker (mas-un, OM) ax principal (la maşini de găurit)

drill rod (mas-un) bară port-cutit

drill sets (mas-un) set de burghie

drill shank (mas-un) coadă a burghiului

drill sleeve / socket (mas-un) bucşă de ghidare

(a cozii sculei), mandrină pentru maşină de găurit

drill speeder (mas-un) dispozitiv de găurire rapidă, cap de găurit cu mecanism pentru mărirea vitezei de rotație a burghiului

drill spindle carriage (mas-un) sanie a maşinii de găurit

drill stack (mas-un) mandrină (care ține burghiul)

drill steel (met) oțel pentru burghie

drill-steel shank (mas-un) coadă a burghiului (şi din alt otel decât al sculei)

drill stem (mas-un) corp al cuțitului

drillstock (mas-un) mandrină a maşinii de găurit

drill tang (mas-un) trunchi / antrenor al burghiului

drill test (met, metr) probă de găurire

drill thrust (mas-un) presiune / avans al burghiului, forța pe direcția axială a burghiului / frezei

drill with the first bit (mas-un) a găuri preliminar

drink a bea, a absorbi, a adăpa

dinkable potabil

drinking water (alim) apă potabilă / de băut

drinking water supply (alim, constr) alimentare cu apă potabilă

drip picătură, strop; (met) infiltrație, transfer de metal prin picături; (termo) exsudat; (chim) a picura, a se scurge cu picătura, a se prelinge

drip cock $(\mathrm{OM}$, hidr) robinet de picurare 
drip coffee (amer) cafea de filtru

drip condenser (termo, ind chim) condensator cu apă pulverizată

drip cooler (ind chim) răcitor cu apă pulverizată / cu ploaie de apă

drip cup $(\mathrm{OM}, \mathrm{T})$ colector de picături de ulei

drip / drop-feed (T) alimentare prin picături / prin picurare (cu lubrifiant)

drip / drop-feed lubrication (T) ungere / lubrifiere cu picături de lubrifiant

drip / drop(-feed) oiler / lubricator (T) gresor / ungător cu / prin picurare

drip / drop injector (termo) injector cu picurare

drip / drop lubrication $(\mathrm{T})$ ungere / lubrifiere prin picurare

drip moulding (constr) jgheab al acoperişului, cornişă de ploaie

drip nozzle ajutaj de picături

drip off $(\mathrm{OM}$, termo) a se scurge în picături, a picura

drip pan (mas-un, mas) recuperator de ulei; (chim) percolator; tavă pentru captarea picăturilor; (masun) tavă pentru colectarea lichidului de ungere şi răcire

dripping (mas) care picură, picurat; (alim) grăsime care se scurge la frigerea cărnii

dripping edge (nav, OM) muchie de picurat

dripping moisture (alim, ind chim) apă de condensare

dripping pan (alim) tigaie

drippings (met) stropituri, tâşnituri (în producerea aluminiului), stropi de metal (şi la sudură)

drip point (fiz, termo) punct de exsudare, temperatură de începere a fierberii

drip-proof $(\mathrm{TH})$ adăpostit, acoperit / protejat contra picăturilor sau jeturilor de apă

dripstone (constr) lăcrimar; (alim, chim) filtru din piatră poroasă

driptank (mas-un, mas) rezervor pentru colectarea uleiului sau a lichidului de răcire

drip tray (mas-un, mas) tavă pentru capturarea picăturilor

drivability (auto) capacitatea (unui autovehicul) de a fi condus

drivability problem(s) (auto) probleme de condus (un autovehicul)

drivable (auto) care poate fi condus / uşor manevrat

drive $(\mathrm{TH})$ propulsie, acționare, mers, cursă, (mecanism de) antrenare, regim; (autom) comandă, antrenare; (el, electr) circuit electronic care comandă un alt circuit de putere mai mare; (OM) acționare, transmisie, a acționa, a pune în mișcare; (TH, auto) a conduce, a transmite (putere, forță, moment), a acționa, a pune în mişcare, a duce (cu maşina), a transporta, a bate (un cui), a introduce (şi ghidat), a împinge, a duce; a pune la muncă, a solicita, a cere eforturi mari, a extenua, a aobosi; (c) dispozitiv de manipulare a discului / dischetei; (constr) pasaj, drum carosabil

drive ability (auto, mas) motricitate, posibilitate de utilizare a cuplului maxim al motorului în condiții normale de aderență a pneurilor, manevrabilitate, capacitate a unui vehicul de a urma exact traiectoria impusă

drive at a urmări, a căuta să ajungă la, a vrea să, a avea intenția să; (fig) a face aluzie la; a ținti la

drive away (auto) a demara; a (se) îndepărta

drive assembly (OM, mas) mecanism de rulare

drive belt $(\mathrm{OM})$ curea de transmisie

drive bevel wheel of differential $(\mathrm{OM})$ coroană conică de diferențial

drive by compressed air (hidr, OM) acționare pneumatică

drive chain $(\mathrm{OM})$ lanț de transmisie / de acționare

drive current (el) curent de comandă

drivedisk $(\mathrm{OM})$ disc conducător / motor (fixat pe arborele de intrare al unui ambreiaj)

drive fit (mas-un, OM) ajustaj forțat; (TH) ajustaj blocat

drive free-wheel $(\mathrm{OM})$ roată liberă

drive gear $(\mathrm{OM})$ roată dințată conducătoare / a mecanismului de acționare

drive in a nail a bate un cui

drive line (auto, $\mathrm{OM}$ ) transmisie (la autovehicule)

drive link $(\mathrm{OM})$ organ mecanic de transmitere a mişcării

drive mechanism (mas, OM) mecanism motor / de antrenare

driven (mas, $\mathrm{OM}$ ) acționat, antrenat

driven disk (mas, OM) disc condus / receptor (fixat pe arborele de ieşire al unui ambreiaj)

driven gear / geared wheel (OM) roată dințată antrenată / condusă

driven head (OM) cap ornat / bătut (la nituri)

driven-in pin $(\mathrm{OM})$ ştift montat / introdus în gaură

to drive into a-şi vârî în cap; a bate

driven pinion $(\mathrm{OM})$ pinion / roată antrenat $(\breve{a})$

driven pulley $(\mathrm{OM})$ roată de curea condusă / antrenată

driven rivet $(\mathrm{OM})$ nit cu cap ciocănit

driven shaft (auto) arbore secundar; (OM) arbore condus / antrenat / actionat

driven sprocket (wheel) $(\mathrm{OM})$ roată de lanț condusă 
driven wheel $(\mathrm{OM})$ roată condusă

drive out (auto) a pleca, a ieşi cu maşina; (TH) a scoate, a extrage; a izgoni

drive pinion $(\mathrm{OM})$ pinion de antrenare / de atac

drive puller (constr, $\mathrm{TH}$ ) tambur de acționare (a unui transportor cu bandă); $(\mathrm{OM})$ roată de curea, conducătoare

drive pulley force (agr, mec, mas) forță mecanică (a unui tractor) pentru antrenarea unei maşini agricole

drive / control pulse (autom) impuls de comandă / de excitație

driver (auto) conducător auto, şofer; $(\mathrm{OM})$ roată dințată cu un număr mic de dinți, pinion, element de acționare, roată motrice, flanşă de antrenare; (mas-un) platou de antrenare; (nav) randă; (TH) conductor, şef de punct, mecanic, maşinist, piesă de antrenare, antrenor, motor, unealtă de mână pentru asamblare sau demontare; (cf) mecanic (de locomotivă); (el, electr) excitator

drive range (metr, autom) plajă / domeniu de modulație

drive roll $(\mathrm{OM}$, termo) roată motrice (a unui cilindru compresor)

driver's airbag (auto) airbag pentru şofer

driver's and front passenger's seat belt warning light and chime (auto) semnal luminos de avertizare a stării centurilor de siguranță a şoferului şi pasagerului din dreapta

driver's door power window switch (auto) comutator electric pentru geamul stânga față

driver's master control (auto) comandă principală a şoferului

driver's seat (auto) scaunul şoferului

driver's seat cushion (auto) perna scaunului şoferului

driver's seat belt warning light (auto) semnal luminos de avertizare pentru centura de siguranță şofer

driver's side door (auto) portiera şoferului

drive shaft (auto, OM) arbore cardanic / articulat / de transmisie; arbore motor, osie motoare

drive shoe $(\mathrm{OM})$ sabot / papuc condus / acționat drive / driving signal (autom) semnal de comandă / excitator / activant

drive through $(\mathrm{TH})$ a perfora, a înfige, a conduce prin; (jur) a eluda legea

drive tube $(\mathrm{OM})$ tijă tubulară, arbore tubular dispre partea conducătoare a maşinii

drive up a porni; (ec) a mări prețul, a ridica; a se apropia

drive voltage (autom, el) tensiune a unui semnal de comandă driveway into garage (auto) alee către garaj

drive wheel $(\mathrm{OM})$ roată motoare / conducătoare / de acționare

drive winch $(\mathrm{OM})$ troliu acționat mecanic

driving (constr, hidr) baterea unui pilot, drum; (mas, TH) acționare, comandă, motor, conducător (şi d. un element cinematic), conducere, avansare, înaintare, deplasare, transmisie, punere în mişcare, de acționare, motor; (nav) derivă

driving aids (auto, autom) mijloace de conducere, aparate / accesorii care permit optimizarea conducerii automobilului

driving anchor (nav) ancoră plutitoare / de furtună

driving axle (cf) osie motoare; (OM) ax motor / conducător

driving band (OM, mas) bandă alimentatoare / rulantă

driving belt (constr, mas, OM) curea de acționare / bandă / ramură conducătoare (la transmisii cu curele, transportoare c u bandă) / de antrenare / de transmisie

driving blade (mas-un) cuțit /sculă cu partea tăietoare prismatică

driving bogie (cf) boghiu motor, buster

driving bull gear pinion (OM, mas-un) pinion al mecanismului de actionare a culisei (la șeping)

driving chain $(\mathrm{OM})$ lanț de avansare / de transmisie / de acționare

driving circuit (autom) circuit de comandă / de actionare

driving crank $(\mathrm{OM})$ manivelă motoare

driving disk $(\mathrm{OM})$ disc conducător / de antrenare

driving fit (OM) ajustaj forțat / strâns

driving force (mec, mas) forță motoare / motrice / de antrenare

driving gear / gearing (OM) mecanism de antrenare / de acționare (şi cu angrenaje)

driving-gear (wheel) $(\mathrm{OM})$ roată dințată conducătoare

driving jet (hidr, termo) jet propulsiv

driving licence / license (auto, transp) permis de conducere

driving link belt $(\mathrm{OM})$ curea de transmisie, articulată

driving magnet (fiz, el) electromagnet de acționare

driving mechanism (mec) mecanism motor / de antrenare / de actionare; (nav) propulsor

driving member (OM) organ / element motor / conducător

driving mirror (auto) oglindă retrovizoare 
driving moment $(\mathrm{OM})$ moment de rotaţie, moment pe elementul de antrenare al unei transmisii (sau a mecanismului de acționare)

driving motor (mas) motor de acționare

driving part (OM) element al mecanismului de acționare, element conducător

driving pawl $(\mathrm{OM})$ clichet care antrenează o roată dinţată, prin apăsări periodice

driving pin (OM) bulon / bolț de legătură, bolț / cui / ştift de antrenare

driving pinion $(\mathrm{OM})$ roată dinţată conducătoare

driving piston (OM, termo) piston-motor

driving plate $(\mathrm{OM})$ platou, flanşă de antrenare, disc conducător

driving plate pin braț / ştift / ax de antrenare a platoului

driving power (autom, el) putere de acționare / de antrenare / de excitație, putere consemnată în circuitul operativ; (mec) forță motrice (mai rar), putere de acționare

driving pulley $(\mathrm{OM})$ roată de curea conducătoare / motoare, volant-disc

driving rate (met) viteză de trecere (la furnal)

driving rod $(\mathrm{OM})$ bielă motoare

driving roller (mas) scripete mobil

driving shaft $(\mathrm{OM})$ arbore conducător / motor / de acționare / de comandă / de antrenare / de transmisie

driving sheave $(\mathrm{OM})$ roată de antrenare (şi prin fricțiune), şaibă de antrenare

driving signal (autom) semnal (care activează un punct) de comandă / de excitație / de acționare

driving spring $(\mathrm{OM})$ arc motor / de acționare

driving-sprocket (wheel) (OM, mas, transp) roată de lanț conducătoare, roată care acționează şenila

driving square (mas-un) lăcaş pătrat (de antrenare a sculei)

driving stud $(\mathrm{OM})$ bolț de antrenare

driving system (mas) sistem de acționare / de antrenare

driving tape $(\mathrm{OM})$ bandă / cureluşă de antrenare

driving torque (el, mas) cuplu activ / motor; (metr) cuplu activ (al aparatului de măsurat)

driving weight of a piledriver (mas-un, met, constr) greutatea berbecului

driving wheel $(\mathrm{OM})$ roată motoare / conducătoare / de actionare

drogue (nav) ancoră plutitoare / de furtună / de derivă

droop (autom, metr) abatere proporțională / reziduală permanentă (a unui regulator); a face săgeată / fleşă; a atârna în jos, a se lăsa în jos; (agr, bot) a se ofili, a se veşteji drop (TH) cădere, pantă, distanță pe verticală, reducere, scădere, micşorare, coborâre, prăbuşire, pierdere, strop, picătură; (el, fiz) cădere / coborâre (de potențial, a temperaturii); (hidr) înălțime de cădere; (met) incluziune de nisip (defect), deşeu, şutaj, berbec (de forjă); a picura, a se scurge cu picătura, a cădea, a pica, a se prăbuşi, a scădea, a (se) micşora, a se reduce, a restrânge, a se lăsa în jos, a se înclina, a stropi, a lăsa să cadă, a scăpa (din / mână (dintr-o prindere), a arunca, a azvârli, a lansa; (alim) bomboană, drajeu; (nav) cădere la mijloc (a velei); (metr) unitate de măsură pentru volum: 1 drop $=0,00000005 \mathrm{~m}^{3}$

drop-away (el, autom) tensiune de cădere / de acționare

drop axle (cf, OM) osie din față, curbată

drop bottle (OM, T, alim) sticlă cu dispozitiv de picurat

drop bottom (met) fund al vetrei (la cubilou), clapă de fund

drop-counter (metr, hidr) contor de picături

drop down (TH) a răsturna

drop / drip-feed lubrication (T) ungere / lubrifiere cu picături de lubrifiant / prin picurare

drop / drip(-feed) oiler / lubricator (T) gresor / ungător prin / cu picurare

drop forge (met) atelier de forjat în matriță

drop-forged (met) matrițat, forjat în matriță

drop-forge die (met) matriță de forjat

drop forging (met) matrițare la cald, forjare în matriță, piesă forjată în matriță

drop forging press (met) presă pentru matrițare la cald / forjare în matriță

drop frame (auto) ramă curbată / coborâtă a şasiului

drop glass (auto) geam glisant, coborâtor

drop hammer (constr) sonetă

drop-hammer ram (met) berbec (la forjă)

drop hanger $(\mathrm{OM}, \mathrm{T})$ lagăr suspendat

drop hanger bearing $(\mathrm{OM}, \mathrm{T})$ lagăr montat pe un suport suspendat

drop hardness test (materiale, metr) încercare a durității, probă de duritate (cu sclereoscop)

drop height (hidr) înălțime de cădere

drop-in (TH) a picura, a turna în picături

drop / drip injector (termo) injector cu picurare drop-in pin (OM, mas-un) ştift de oprire

drop in pressure (OM, hidr) cădere / pierdere / reducere de presiune

drop in temperature (fiz, termo, T) cădere / gradient de temperatură

drop in tension / voltage (el) cădere de tensiune / de potențial 
drop in the oxygen level (auto, chim, mediu) scădere a conținutului de oxigen

drop in yield strength (mec, materiale) scădere / descreştere a limitei de curgere

drop keel (nav) derivor (construcții navale)

droplet (fiz, T) picătură mică / fină

drop letter (amer) scrisoare locală

drop / drip lubrication (T) ungere / lubrifiere prin picurare

dropmeter (chim) pipetă (şi gradată)

drop off (the roadway) (auto) a ieşi de pe carosabil

drop of potential (el, electr) cădere de potențial / de tensiune

drop of temperature / pressure (OMfiz (s)cădere de temperatură / de presiune

drop / drip oiler (T) gresor / ungător prin / cu picurare

drop out (el) cădere a releului, trecere în repaus; (TH) a da rebut, a scoate un (şi rebut), a elimina; a lăsa; a părăsi (şi o asociație); a renunța, a nu mai lua parte

drop-out line (TH) linie de sigurantă / de evacuare drop out of step (OMmec, el, autom a ieși din sincronism / din fază

dropped axle (auto) osie curbată

dropped frame (auto) ramă curbată / coborâtă a şasiului

dropped nose $(\mathrm{OM})$ vârf basculant

dropper (el) cavaler, calăreț; (ind chim) instilator, pipetă; $(\mathrm{OM}, \mathrm{T})$ ungător / gresor cu picurare, picurător (de lubrifiere), lamelă; breloc; (agr, mas) secerătoare

dropping (TH) scădere, înclinare, cădere, reducere, coborâre, lăsare, aruncare

dropping bottle (chim) picurător

dropping breakage test (metr, materiale) test de spargere / fărâmițare prin cădere

dropping cock (OM, hidr) robinet de picurare

dropping flank (hidr) diagramă de scurgere; (mas-un) curbă / camă de ghidare

dropping funnel (ind chim, termo) pâlnie de picurare

dropping glass (chim) pipetă, picurător

dropping height (mec, fiz, mil) înălțime de lansare

dropping leading edge (OM, mas, constr) vârf basculant

dropping out scurgere, picurare

dropping point $(T$, metr) punct / temperatură de picurare; $(\mathrm{T}, \mathrm{chim})$ punct / temperatura de picurare/ curgere (a unui fluid, lubrifiant etc.): punct / temperatură la care uleiul părăseşte structura agentului de îngroşare (d. unsori lubrifiante) dropping point test $(\mathrm{T}$, metr) determinare a punctului de picurare (la unsori)

droppings ceva care cade în picături, picături; ploaie; (alim) grăsime; (agr) balegă, bălegar dropping vessel (chim, $T$ ) picurător

dropping worm (alim, OM) melc / şurub fără sfârșit, pentru evacuarea materialului antrenat pe la partea inferioară / de jos

drop pipette (chim) pipetă de picurare

drop-plate-type moulding machine (met) maşină de format prin presare

drop-point (mas-un) ac de trasat, însemnător

drop press (mat, mas-un) presă pentru matrițare (şi cu element în cădere liberă)

drop pressure (OM hidr) cădere de presiune

drop seat scaun rabatabil, strapontină

drop shape (streamline) (fiz) formă în picătură, formă aerodinamică

drop shipment (ec) expediere directă, de la uzină la detailist

drop shipper (ec) intermediar angrosist

drop shop (met) forjă

drop shutter (OM) trapă, clapă de semnalizare, obturator tip ghilotină

drop-side body (auto) caroserie cu părți laterale rabatabile

drop stamper (met) ciocan de forjat, cu cădere liberă

drop stamping (met) eboşă, pastilă, piesă brutforjată, matrițare (grosolană) la cald

drop table masă rabatabilă (în perete)

drop test (mec, metr, plast) încercare la şoc prin cădere / de rezistență la şoc

drop tester (metr, mas) dispozitv de testare la şoc drop-type sprag (auto) reazem de pantă

drop-valve engine (termo) maşină cu abur, cu distribu-ție prin supape

drop-weight test (materiale, metr) încercare la şoc prin cădere

drop window fereastră-ghilotină

dropwise (fiz) în formă de picătură, picătură cu picătură

dropwise addition (alim, ind chim) adăugare picătură cu picătură

dropwise condensation (alim, ind chim) condensare în picături

dross (chim) a îndepărta barbotina; (met) spumă, zgură, scorie, țunder

dross coal (met) slacă (corpuri straine eliminate la topirea unui metal)

drossed surface (met) suprafață arsă (şi la tăierea termică a metalelor)

dross filter (met) filtru de zgură, la evacuarea zgurii (la cuptoare, la turnare) 
dross fines (met) mărunțiş obținut prin ciuruirea zgurii (la producerea aluminiului)

dross hole (met) orificiu de zgură (la cuptoare)

drossing (met) îndepărtarea zgurii

dross kettle (met) căldare pentru zgură

dross metallics (met) particule metalice în zgură (la producerea aluminiului)

dross of coal / coke (met) cărbune praf / sfărâmat

dross of liquation (met) zgură din lipitura de cuptor

dross operation (met) prelucrare a zgurii

dross run (met) prelucrare a scoriei / zgurii (la neferoase)

drossy (met) impur, care conține zgură, murdar

drought (agr) secetă, uscăciune

droughty (agr) secetos, uscat, arid, sterp

drove (agr) turmă, cârd, cireadă; mulțime

drover văcar; (nav) navă în derivă

drown a inunda, a (se) îneca, a se scufunda; a înăbuşi (zgomote); a astupa, a acoperi

drowsiness (auto, med) ameteală

drug (med) medicament

druggistrubber sundries (med) obiecte sanitare igienice

drum (auto) butoi, canistră, bidon, butoiaş; (OM) tambur, cilindru, valț, rotor, tobă; (nav) cilindru de semnalizare

drum brake $(\mathrm{OM})$ frână cu tambur

drum baffle (OM, termo) deflector (într-un tambur / rotor / cazan)

drum cell filter filtru celular cu tambur

drum cleaning (met) curățare în tobă

drum cooler (OM, alim, ind chim) tambur de răcire

drumfeeder (OM, alim, ind chim) alimentator cu tambur

drum filter (OM, alim, ind chim, mediu) filtru cilindric / rotativ

drumhead (nav) pălărie de cabestan, tambur de vinci

drum heater (alim, termo) pasteurizator cu tobă rotativă

drum hoist $(\mathrm{OM})$ mecanism de ridicat

drum ladle (met) oală-tambur de turnare

alim, constr, ind chim

drum miller / milling machine (mas-un) maşină de frezat circular cu tambur

drum pulley $(\mathrm{OM})$ roată de curea tip tambur (construcție uşoară, goală la interior)

drum pump (OM, hidr) pompă rotativă

drum read-out meter (metr, OM) aparat de citit

/ de măsurat cu tambur indicator

drum recorder (metr, OM) aparat de înregistrare cu tambur drum sander / sanding machine (mas-un) maşină de şle-fuit cu cilindri

drum screen (alim, ind chim) sită cu tambur / rotativă; (constr) ciur rotativ

drum-shaped (OM) în formă de butoi / de tambur

drum shedder (constr, mas) excavator cu roată port-cupe

drum sieve (alim, constr, OM, ind chim) sită / ciur cu tambur

drum sifter (alim, constr, OM, ind chim) sită cilindrică

drum-type furnace (met) cuptor tubular rotativ

drum-type miling machine (mas-un) mașină de frezat circular, cu tambur

drum-type retort furnace (met) cuptor $\mathrm{cu}$ retorte turnante

drum washer (alim, ind chim) spălator cilindric, tambur de spălare

drum wheel $(\mathrm{OM})$ tambur pentru cablu

drum winch $(\mathrm{OM})$ troliu cu tambur

dry $(\mathrm{TH})$ uscat, care nu este ud, zvântat; (el) fără curent; secat; uscat; secetos; (alim) (vin) sec; sec, neinteresant, plictisitor; a (se) usca, a pune la uscat; a seca

dry-air blast (met) insuflare de aer uscat

dry-air cure (ind chim) vulcanizare cu aer cald

dry-air pump (OM, hidr) pompă cu aer uscat

dry alutriation (alim, ind chim) clasare / separare în curent de aer

dry analysis analiză pe cale uscată

dry assay (chim, fiz, metr) probă uscată; determinare fără folosirea lichidelor de dizolvare sau separare, a conținutului unui element dintr-un aliaj / material

dry basis (materiale, constr, agr) raportat la greutatea în stare uscată

dry battery (el) baterie uscată

dry binder (constr) liant uscat

dry blasting cleaning (met) sablare uscată / pentru curățare

dry (breaking) strength (plast) rezistentă la rupere uscată / în mediu fără umiditate

drybulb (thermometer) (metr) termometru (cu rezervor) uscat

dry bulk density (materiale, metr) densitate naturală / în vrac şi fără umiditate

dry burning coal (met) huilă săracă

dry cargo (nav, transp) încărcătură nerefrigerentă (care nu necesită răcire în timpul transportului)

dry-cargo ship (nav) cargou / navă de mărfuri uscate

dry cell (el) pilă uscată, element uscat 
dry-clean (chim) a curăța chimic / fără apă / cu solvenți organici

dry cleaner (met) scruber pentru epurare uscată

dry cleaning (ind chim) curățare chimică

dry compression (termo) compresie uscată / în regim de supraîncălzire, funcționare a compresorului în regim uscat

dry contact (el) contact fals / greşit

dry cooling (met) stingere uscată (a cocsului)

dry cooling coil (ind chim) baterie uscată, răcitor de aer la care temperatura de suprafață este deasupra punctului de rouă

dry corrosion (chim) coroziune în aer uscat (cu tempe-ratura peste punctul de rouă)

dry crankcase (termo, T) carter uscat / cu ungere forțată

dry crushing (alim, constr, ind chim) sfărâmare / măcinare uscată

dry cylinder liner cămaşă de cilindru, uscată

dry cooling (met) stingere uscată (a cocsului)

dry cyaniding (met) cianurare uscată

dry disk joint $(\mathrm{OM}, \mathrm{T})$ articulație fără ungere

dry distillation (ind chim) distilare uscată

dry dock (van) doc uscat, bazin de radă, cală uscată, a (se) andoca (în doc uscat)

dry-dock and locks (nav) ecluză de doc uscat

dry drawing (met, plast) tragere / trefilare uscată

dry elongation (materiale, mec) alungire în stare uscată

dry enamelling (ind chim) emailare la cald

dryer, drier (alim, ind chim) sicativ, maşină de uscat, uscător

dryer capacity (alim, ind chim, met) capacitate a uscătorului

dryer drum (OM, alim, ind chim) tobă de uscare

dry dust separator (alim, ind chim) desprăfuitor uscat

dryer / drying furnace (alim, ind chim) cuptor de uscat

dry farming (agr) cultivarea pământului fără irigații

dry-film lubricant ( $\mathrm{T}$, chim) lubrifiant solid (şi ataşat de suprafețe, sub formă de pelicule)

dry filter $(\mathrm{OM}$, ind chim, mediu) filtru uscat

dry friction $(T)$ frecare uscată

dry gas (fiz, termo) gaz fără vapori / uscat

dry (gas) cleaning (met, TH) epurare / curățare uscată (a gazelor de furnal)

dry gas filter (OM, ind chim, mediu) filtru pentru gaz fără vapori / uscat

dry goods (agr) marfă uscată; produse pulverulente; (amer) manufactură, îmbrăcăminte dry grind (mas-un) rectificare uscată (fără lichide de răcire)

dry grinding (alim, ind chim) măcinare uscată dry heat cure (ind chim) vulcanizare cu aer cald dryhouse (alim, ind chim, agr) uscătorie dry ice (chim) zăpadă / gheață carbonică dry ice bunker (auto, transpp, chim) compartiment cu gheață carbo-nică (al unui vehicul frigorific)

drying (alim, materiale) uscare, deshidratare

drying agent (alim, chim) agent sicativ / de uscare

drying bottle (alim, ind chim) turn de uscare

drying by reagents (ind chim) uscare pe cale chimică, cu reactivi

drying cabinet (alim, termo) etuvă

drying capacity (alim, termo) capacitate de uscare

drying chamber (alim, termo, ind chim) etuvă, cameră de uscare

drying channel (alim, termo, ind chim) canal de uscare

drying closet (alim) dulap de uscare

drying crevices (materiale) crăpături (fisuri) de uscare

drying curve (termo, materiale, ind chim) curbă de uscare

drying cylinder cilindru uscător

drying drum (OM, termo) tambur de uscare

drying filter (met) scruber uscat

drying furnace (met, alim) cuptor de uscare

drying house (alim, met) cameră de uscare, etuvă

drying hurdle (alim, met) uscător cu rafturi

drying installation (alim, ind chim) instalație de uscare

drying kiln (materiale, ind chim) cuptor de uscat

drying machine (materiale, ind chim) maşină de uscat

drying medium (chim) agent uscător / sicativ

drying oven (alim, ind chim) cuptor de uscare (pentru eliminarea umezelii)

drying place (alim) pod, loc de uscare

drying plant (alim, ind chim) instalație de uscat; (termo) uscătorie

drying press / rolls (alim, ind chim) maşină / presă de stors

drying rate (alim, ind chim, met) viteză de uscare / de deshidratare

drying room (alim, ind chim) cameră de uscat / de uscare

drying schedule (alim, ind chim) diagramă de uscare

drying shelf (alim) raft de uscare 
drying shrinkage (materiale) contracție la uscare drying stove (met) cuptor de uscat / de uscare drying substance (chim) substanță de uscare / care usucă

drying tower (alim, ind chim) turn de uscare drying tunnel (alim, ind chim) tunel de uscare drying up (agr) asanare

drying zone $(\mathrm{TH}$, alim, constr, ind chim) zonă de uscare

drykiln (alim, ind chim) etuvă, cuptor de uscat dry lapping (mas-un) rodare pe cale uscată, lepuire dry measure (metr) măsură de capacitate (pentru materiale pulverulente)

dry method granulation (ind chim) granulare cu aer

dry mix (ind chim) amestec uscat

dry natural gas (ind chim) gaze naturale uscate, gaze de sondă, sărace

dryness ariditate, uscăciune; secetă; caracter sec dryness ratio (alim, materiale, ind chim) grad de deshidratare / de uscăciune, raport de uscare

dry out a (se) usca

dry permeability (materiale) permeabilitate în stare uscată

dry pile (el) element uscat, pilă uscată

dry piston compressor (termo) compresor $\mathrm{cu}$ piston uscat / fără ulei în cilindru şi cu piston având segmente din materiale speciale, cu frecare redusă

drypoint (fiz) punct final de fierbere

dry powder extinguisher $(\mathrm{TH})$ stingător cu praf dry puddling (met) pudlare în stare păstoasă

dry quenching (met) stingere uscată (a cocsului), călire în aer

dry residue ( $\mathrm{TH}$, mediu) reziduu / deşeu uscat

dry run (el) (încercare de) mers în gol; (mec, T) funcționare fără lubrifiant

dry-salt (alim) a usca şi a săra, a conserva

drysaltery (ind chim) magazie de articole chimice şi vopsitorie; (alim) magazin de conserve; (ec) comerț cu articole chimice şi de vopsitorie sau cu conserve

dry sand (constr) nisip uscat

dry-sand mould (met) formă de turnare uscată

dry separation (alim, ind chim) separare uscată

dry slag (met) zgură vâscoasă

dry sludge (TH, mediu) nămol deshidratat

dry steam (termo) abur uscat / supraîncălzit

dry strenght (materiale, mec) rezistență în stare uscată

dry substance substanță uscată

dry sump (OM, T) baie / carter de ulei, uscat(ă)

dry sump lubrication ungere sub presiune, cu evacuare continuă a lubrifiantului din carter dry tack (alim, plast) lipiciozitate în stare uscată, lipire agresivă

dry test (materiale, metr, T) încercare în condiții uscate / fără ungere

dry tons (fiz, termo) necesar de frig pentru compensarea aportului de căldură

dry up a seca (d. un râu)

dry weight (nav, auto, transpp) greutate proprie / fără încărcătură / fără combustibil

dual dual, dublu, compus din doi; împărțit între doi

dual control (autom) dublă comandă, comandă din două poziţii

dual effect compressor (termo) compresor $\mathrm{cu}$ dublă aspirație / cu aspirarea fluidului frigorific la două presiuni diferite

dual fluid intensifier (hidr, mas) multiplicator de presiune bifluid / cu două fluide (fiecare cu circuitul lui)

dualism dualism, dualitate

duality dualitate

dualize a împărți în două, a dedubla

dual meter (metr) aparat de măsurat cu scară dublă

dualpressure controller / switch (hidr, metr) preso-stat combinat, de înaltă şi joasă presiune dual-purpose boiler (termo) cazan mixt (pentru încălzire centrală şi apă caldă menajeră)

dual shaker (agr, alim, constr, ind chim) sită vibratoare jumelată / dublă

dual temperature process procedeu cu două temperaturi

dub a teslui, a ciopli; (fig) a egaliza, a potrivi, a şlefui

dubiety, dubiosity, dubiousness îndoială, dubiu; incertitudine; lucru dubios; (ec) afacere dubioasă

dubious of / about / as to dubios, suspect, nesigur, îndoielnic; vag, ambiguu, neprecis

dubiously $(a d v)$ (în mod) dubios, cu ezitare, nesigur, cu suspiciune

dubitable îndoielnic, nesigur; care poate fi dubios / îndoielnic

dubitation dubiu, îndoială

duck (zool, agr) rață; (alim) carne de rață; afundare, cufundare (bruscă), plonjon scurt; (textile) doc, pantalon de doc; ferire (a capului); (nav) pânză fină de vele; a se feri de, a se eschiva de la, a căuta să nu facă

duckbill drill (mas-un) burghiu-lingură

ducking cufundare în apă, imersiune

duct (constr) canalizare, țeavă; (el) conductor; (termo) aductie de aer; (OM, hidr) canal, conductă, traversare, teavă, tub 
duct-cleaning tool (OM, mas-un) perie de curățat țevi

ducted fan (termo) ventilator închis într-o conductă

ducted radiator (termo) răcitor cu ajutaj / prin destindere

ductile (materiale) ductil, elastic, flexibil, maleabil; (met) forjabil

ductile (cast) iron (met) fontă cu grafit nodular (maleabilă) (termen folosit mai ales în USA)

ductile shaft $(\mathrm{OM})$ arbore flexibil

ductility (materiale) ductilitate, maleabilitate, extensibilita-te; (met) deformabilitate / maleabilitate la rece

ductility at elevated temperature (materiale, met) ductilitate / plasticitate la cald / la temperaturi ridicate

ductility limit (materiale, mec) limită de curgere ductility test (materiale, metr, $\mathrm{TH}$ ) determinare a ductilității

duct keel (nav) chilă-cheson, chilă-tunel

duct work (constr, hidr) rețea / sistem de conducte

due (ec) datorat, de plată, plătibil; cuvenit, corespunzător, potrivit; aşteptat, care trebuie să vină

dues (ec) cotizaţii, taxe (şi vamale)

due to datorat, cauzat de; cuvenit, care se cuvine; datorită, din cauza

duffel bag (nav) sac de marinar

dug iron (met) fier / oțel moale

dug-out (nav) barcă scobită din trunchi de copac; (geogr) iaz mic, eleşteu

dull prost, stupid, obtuz; neascuțit; (TH) întunecat, mat, fără contrast, nelucios; greoi, încet; nelar, cețos, vag; plictisitor, monoton, neinteresant; (mas-un) obtuz, teşit, bont, tocit, neascuțit, a (se) toci, a teși, a înlătura vârful; (met) a mătui; (ec) care stagnează, (marfă) fără căutare; (foc) mocnit; a amorți, a potoli, a (se) micşora, a slăbi

dull bit (mas-un) tăiş tocit, de burghiu

dull depozit (ind chim) depunere / acoperire mată (şi în sens nedorit)

dulled tocit; mat

dull edge (OM, mas-un) teşitură

dull finish (ind chim) mătuire

dull-finish sheet (met) tablă de oțel, mată / neagră

dulling (ind chim, met) (proces / procedeu de) mătuire

dull red (met) roşu închis

dull red heat (met) incandescență la roșu închis

dull to insensibil la, indiferent la

dull white alb mat dully plictisitor

duly cum trebuie, cum se cuvine; la timp, în timp util, când trebuie

dumb barge (nav) şalandă / şlep nepropulsat(ă)

Dumet wire (met, electr) sârmă din $\mathrm{Fe}+$ $42 \% \mathrm{Ni}$, acoperită cu cupru pentru izolarea tuburilor electronice

dummy (inf) adresă fictivă; (TH) machetă, fals, fictiv, artificial, provizoriu; (el, met) catod de epurare (la acoperiri)

dummy bar (met) bramă falsă, de început (la turnarea continuă)

dummy block (mas-un) placă groasă pentru a minimaliza încălzirea părților active ale sculei, la extrudare

dummy joint (OM, termo) rost de dilatare

dummy load (mec) sarcină fictivă / artificială; (el) impedanță

dummy motor (mec, el) motor echivalent (si la echilibrare)

dummy pass (met) trecere în gol, calibru gol

dummy pin (OM) axă falsă, arbore fix

dummy piston (termo) piston de echilibrare (la turbine cu abur)

dummy plug (mas-un, OM) căpăcel / placă de închidere, dop, flanşă oarbă

dummy rivet $(\mathrm{OM})$ nit pentru montaj / provizoriu

dummy roll (met) cilindru liber / de transmisie (la laminor)

dummy sheet (met, OM) placă / tablă de reazem / de sprijin / de suport

dummy stage (termo) etaj inert / fără mijloace de propulsie (care simulează caracteristicile unui etaj propulsor) (la turbine)

dummy strain-gauge (metr) marcă tensometrică inactivă

dummy variable (mat) variabilă de integrare (în integrala definită)

dummy window (constr) fereastră oarbă

dump morman, grămadă (şi de gunoi); (autom) disjunctie, întrerupere de alimentare; (constr, hidr) spațiu de descărcare; (TH) declanşare de avarie (de urgență), zgomot surd (produs de căderea unui obiect greu), depozit (şi de muniții), magazie, parc; (inf) transcriere a conținutului unei memorii interne pe un suport extern; (TH) a arunca (şi cu zgomot), a azvârli (gunoi), a descărca, a răsturna, a bascula; (met) loc de descărcare, haldă (şi de steril, zgură etc.)

dump barge şalandă basculantă / cu clapeți de fund

dump body (OM, mas, constr) cupă basculantă 
dump bucket (constr) cupă de autoîncărcător; (met) schip

dump car (auto) camion cu bară basculantă, autodescărcător; (cf) vagonet basculant

dump cinder car (met) vagon cu oală basculantă, pentru zgură

dumped bale balot presat (de paie, span etc.)

dumper (auto) autobasculantă; (cf, constr) vagonet basculant

dumper friction clutch (met, OM) ambreiaj cu fricțiune, la o maşină de haldat

dumping (mas) dărâmare, răsturnare; descărcare; care descarcă / răstoarnă (ec) dumping

dumping mechanism $(\mathrm{OM})$ dispozitiv de basculare / basculant

dumping radius rază de descărcare a unui excavator / a unui transbordor

dumping site (met) teren destinat unei halde (de zgură etc.)

dump out a goli, a răsturna, a vărsa, a rambleia

dump test (met, plast) probă de refulare

dump trailer (mas, transp) remorcă cu benă basculantă

dump-type lift truck (cf, met) vagon basculant, şi cu ridicare

dump valve (OM, hidr) robinet / supapă de fund / de golire rapidă

dumpy scurt și îndesat, bondoc

dun cenuşiu închis, culoare cenuşie; ( $\mathrm{fam}$ ) creditor care cere plata unei datorii; $(\mathrm{ec})$ cerere a unei plăți, încasator

dungy murdar

dunk a se (în)muia

dunkle-dull red (met) roşu incandescent închis (d. oteluri)

duodecimal (mat) duodecimal, în baza 12

duodecimal notation (mat, inf) notație duodecimală / în baza 12

duo mill (met) laminor duo duplex; (mas-un) dublu, cu două axe principale

duple dublu

duplex dublu (şi stratificat); cu două axe principale; dublat, jumelat

duplex cable (el) cablu dublu

duplex compressor (termo) compresor cu dublu efect

duplexed system (mas) sistem cu două module distincte (care pot fi şi identice) şi separate, unul functionând și celălalt fiind în așteptare

duplex gear cutters (mas-un) ansamblu de freze pentru prelucrarea roților dințate

duplex glass (ind chim, constr) sticlă duplex

duplex horizontal miller (mas-un) maşină de frezat orizontală, cu două axe principale duplex pump (OM, hidr) pompă duplex (cu membrană sau diafragmă)

duplex(ing) process (TH) procedeu combinat; (met) procedeu de obținere a oțelului în cuptor Bessemer, urmat de turnarea în lingouri

duplex region (met) fază de soluție solidă duplex roller chain $(\mathrm{OM})$ lanț dublu, cu role duplex spot welder (met, mas-un) maşină de sudat prin puncte duble

duplex spot welding (met) sudare prin puncte duble

duplex star connection (el) conexiune stea-stea (d. motoare electrice)

duplicate (mas, OM, TH) piesă de schimb / amo-vibilă / de rezervă; reprodus întocmai / analog; duplicat, copie, reproducere; a copia întocmai, a face o copie (după), a duplica, a dubla, a reproduce; (adj) în dublu exemplar, dublu; a scrie în două exemplare; de schimb (d. piese etc.); parts piese de rezervă; made in făcut în două exemplare

duplicate sample (materiale, metr) probă-martor duplicate work ( $\mathrm{TH}$, mas-un) productie de masă a pieselor interschimbabile, copiere (pe o maşinăunealtă)

duplicating (mas-un) copiere automată, care copiază / face copii

duplicating attachment (mas-un) dispozitiv de copiere

duplicating milling machine (mas-un) maşină de frezat prin copiere

duplicating paper hârtie de multiplicat

duplication dublare; duplicat, copie

duplication check verificare a unei copii

duplication punch perforator de copiere

duplicator (mas-un) dispozitiv / aparat de copiere / de multiplicat

duplicity duplicitate; ipocrizie

durability $(\mathrm{TH})$ durabilitate, permanență, rezistență, constanță, viabilitate, stabilitate; trăinicie; (mec, T) durabilitate, timp de folosire, rezistentă de durată / la uzură

durable $(\mathrm{TH})$ durabil, permanent, rezistent, constant, stabil, trainic; (T) rezistent la uzură

durables mărfuri de folosință îndelungată

durably $(a d v)$ (în mod) durabil, trainic

duralumin / duraluminium (met) duraluminiu

duran duran (termo, ind chim) sticlă rezistentă la variatiile bruște de temperatură

duration stare, durată (în timp), perioadă (de timp) duration of blast (met) durată / perioadă de (in)suflare

duration of blow (mec) durată a şocului duration of exposure (TH) timp de expunere 
duration of heat (met) durată de elaborare a unei şarje

duration of holding time ( $\mathrm{TH}$, mas) durată de angajare / de ocupare / de menținere

duration of load application (mec) durata de aplicare a sarcinii / a solicitării

duration of (s)melting (met) durată / perioadă de topire

during în timpul, în cursul

durometer (metr, materiale) aparat de încercat duritatea, durometru

Durville pouring (met) turnare liniștită

dusky întunecat, întunecos

dust praf, pulbere; a acoperi cu praf, a curăța de praf, a şterge praful, a prăfui, a umple de praf; (alim) a pudra

dustability (TH) (capacitate de) prăfuire

dust allaying / alleviation (TH) eliminare a prafului

dust apron (OM, mediu) dispozitiv de protecție contra prafului

dust arrest (mediu, met, ind chim) îndepărtarea prafului

dust arrester (met) pulvocaptor; (OM) obturator de praf

dust bag / catcher (met, constr, ind chim) desprăfuitor, sac / captator de praf

dust bin ladă de gunoi

dust boot (auto, mas-un, met) burduf de protecție împotriva prafului

dust-cart (auto, transp, mediu) autocamion pentru colectat gunoiul menajer

dust catcher (mas) desprăfuitor; (OM) filtru / receptor de praf

dust chamber (met) separator de praf; (ind chim) cameră de desprăfuire

dust cloud nor de praf (la un proces tehnologic, de exemplu, fărâmițare, uscare etc.)

dust-coated electrode (el, met) electrod cu înveliş subțire

dust coke (met) praf de cocs

dust collecter (OM, mediu) colector de praf

dust collecting bag (OM, mediu) sac colector de praf

dust collecting room $(\mathrm{OM}$, mediu) cameră de colectarea prafului

dust collecting system ( $\mathrm{TH}$, constr, ind chim) sistem de desprăfuire

dust collection (TH, constr, ind chim) desprăfuire dust collector ( $\mathrm{TH}$, constr, ind chim) colector de praf, desprăfuitor; captator / colector de praf, filtru / recep-tor / aspirator de praf

dust concentration (mediu) concentrație de praf în aer dust content (mediu) conținut de praf

dust control (mediu) eliminare a prafului

dust core (met) miez mulat / din pulbere de fier sinterizată

dust colour gri-cafeniu

dust counter (metr, mediu, chim) analizor al particulelor de praf

dust cover / jacket (OM) capac de protecție contra pătrunderii prafului, husă

dust deposit depunere de praf

dust disease (med) silicoză

duster aspirator de praf, cârpă de şters praful sondă neproductivă

dust exhaust $(\mathrm{TH})$ desprăfuire

dust explosion (met, ind chim, alim) explozie a prafului (în procese tehnologice)

dust extraction $(\mathrm{TH})$ desprăfuire / eliminare a prafului

dustfall (TH) depunere / cădere de praf

dust generator $(\mathrm{TH})$ generator de praf

dust hole (mediu) groapă de gunoi

dust hood $(\mathrm{OM})$ apăătoare de praf

dustiness $(\mathrm{TH}$, mediu) grad de prăfuire

dusting $(\mathrm{TH}$, mediu) desprăfuire, ştergere de praf, pudrare, presărare, pulverizare, formare a prafului; (met) pudrare (cu talc)

dusting loss (ind chim, constr) pierderi prin praf

dusting machine (alim, constr) maşină de pudrare

dust-laden plin de praf

dust layer ( $\mathrm{TH}$, mediu) strat / depunere de praf

dustless $(\mathrm{TH}$, mediu) neprăfuit, lipsit de / fără praf, care nu face / produce praf

dustless carbon black (ind chim) negru de fum granulat

dustless screenings (constr, ind chim) material ciuruit, fără praf

dust loading (metr, mediu) cantitatea de praf dintr-un gaz (exprimată şi în particule pe unitatea de volum)

dustman gunoier

dust off $(\mathrm{TH})$ a înlătura praful

dust particle particulă de praf

dust pipe $(\mathrm{OM})$ garnitură de etanşare; conductă de evacuare a prafului (la cicloane)

dust pocket (met, ind chim) desprăfuitor, separator / sac de praf

dust precipitation (ind chim, $\mathrm{TH}$ ) precipitarea prafului

dust precipitator (OM, mediu) filtru (de praf)

dust-proof (OM, mediu) rezistent / etanş la praf, protejat contra prafului

dust (protecting) cap (OM, mediu) capac apărător contra prafului 
dust removal ( $\mathrm{TH}$, ind chim, constr) desprăfuire dust removing attachment / plant (met, mas-

un) dispozitiv / instalație de aspirare a prafului / de desprăfuire

dust sampler (metr, mediu) dispozitiv pentru luarea probelor de praf

dust sampling (metr, mediu) luarea probelor de praf dust seal (TH) izolare contra prafului dust separation $(\mathrm{TH})$ separare a prafului dust separator $(\mathrm{TH})$ desprăfuire

dust-separator (mas, ind chim, mediu) instalație de desprăfuire

dust sludging (met) umezire a prafului de cărbune dust suppression $(\mathrm{TH})$ eliminare a prafului dust-tigh $(\mathrm{OM})$ etanş la praf dust trap (OM) obturator de praf dust trunk $(\mathrm{OM})$ conducte de praf dust wetting (met) umezire a prafului de cărbune dust wetting plant (met) umidificator de praf dusty prăfuit, plin de praf, prăfos, în / sub formă de praf, pulverulent; (alim) pudră (d. zahăr); (fig) vag, neprecis, sec, neinteresant

Dutch / shovel nose tool (mas-un) cuțit lat

Dutch tongs (mas-un) întinzător de sârmă dutiable (ec) supus taxelor vamale, impozabil dutiable price (ec) preț impozabil

duties atribuții, îndatoriri

duty datorie, obligație, (obligații de) serviciu, răspundere; regim, funcționare; (mec) solicitare, sarcină; (TH) schimb, debit, serviciu, sarcină, regim de lucru, ciclu de lucru, productivitate, putere utilă; (ec) taxă (şi vamală)

duty cycle raport ciclic; (inf) perioadă / ciclu de lucru, joc; (mas) ciclu de funcționare

duty cycle rating $(\mathrm{TH}$, mas) regim nominal de exploatare

dutyfactor $(\mathrm{TH})$ factor / coeficient de utilizare / de umplere

duty-free (ec) neimpozabil (d. mărfuri), scutit de taxe vamale / fără vamă / impozit, scutit de taxe / de vamă

duty programme program de serviciu

dwell (chim) durată cât matrița este închisă; (mas-un, autom) oprire temporizată; (TH) temporizare, a rămâne, a se opri; $(\mathrm{OM})$ contur de camă pentru menținerea tachetului la înălțime maximă; a locui

dwell angle (OM, el) unghi de închidere, unghi de rotație a camerei unui distribuitor de prindere în timpul parcurgerii căruia contactul ruptorului este închis

dweller locuitor

dwelling (place) (constr) locuință, clădire / casă de locuit, reşedință dwell(-)phase (autom) fază inactivă, perioadă de întrerupere, pe timp prestabilit, a unei acțiuni în curs dwell time (autom, TH) timp de aşteptare / de oprire; (alim, TH, ind chim) timp de menținere a unor parametri constanți (într-un proces tehnologic)

dwindle a se micşora, a se diminua; a-şi pierde importanța; a se înrăutăți, a se agrava

dwindling dispariție, diminuare; agravare

dye (chim) vopsea, colorant, substanță colorantă; culoare, nuanță; a colora, a (se) vopsi

dyed-in-the-wool îmbibat / pătruns de vopsea; (fig) total, perfect, complet

dyed gasoline (auto, ind chim) benzină etilată

dye house (ind chim, auto) vopsitorie

dyeing (ind chim, auto, textile) vopsitorie; vopsit; colorare, colorație

dyeing formula (ind chim, auto, textile) rețetă de vopsire

dyeing house (ind chim, auto, textile) vopsitorie, atelier de vopsitorie

dye marker (nav) pitură / vopsea pentru colaci de salvare

dye number indice de culoare

dye penetrant (met, metr, chim) lichid cu vâscozitate redusă pentru control nedistructiv

dyer vopsitor

dye stuff (ind chim) colorant, materie colorantă, vopsea

dying-downtime (autom) perioada tranzitorie finală / de stingere, durată de amortizare

dying out (fiz, autom) descompunere, dezintegrare, amortizare (şi a unui semnal); (mec) amortizare a oscilațiilor

dying(-out) oscillation (autom, mec) oscilație amortizată

dying out time (autom, mec) durată de dispariție / de amortizare a oscilațiilor

dying-out time (sound) (fiz) timp / durată de amortizare / de revenire la zero / de decontaminare / de relaxare / de atenuare (sunet)

dyke, dike dig epiu, baraj, obstacol, barieră dynamic(al) (sistem) dinamic; activ, energic dynamic balance $(\mathrm{mec})$ echilibru dinamic

dynamic balancer (mec, mas) dispozitiv pentru echilibrare dinamică

dynamic balancing (mec) echilibrare dinamică

dynamic ball-impact test method (metr, constr) metodă de încercare dinamică a betonului, cu bilă

dynamic ball-indentation hardness (metr, materiale) duritate Shore / scleroscopică

dynamic ball-indentation test (metr, materiale) încercare de duritate Shore / scleroscopică 
dynamic braking (el, mec) frânare dinamică / cu curent efectiv

dynamic calibration (metr) calibrare dinamică (de exemplu, la debitmetre care pot măsura în timpul curgerii fluidului)

dynamic capacitance electrometer (electr, metr) electrometru-condensator / cu condensator oscilant / vibrant

dynamic compression (mec) compresie dinamică dynamic compressor (termo) turbocompresor dynamic cooling (fiz) răcire prin expansiune dynamic deflection (mec) încovoiere sub acțiunea unei forțe dinamice

dynamic design (mec, OM) calcul dinamic

dynamic electrode potential (el, met) potenţial dinamic al electrodului (la acoperiri)

dynamic endurance test (materiale, metr) încercare de rezistență la oboseală sub acțiunea sarcinilor dinamice

dynamic equilibrium (mec) echilibru dinamic

dynamic equivalent shape (fiz) formă echivalentă (din punct de vedere) dinamic

dynamic error (autom, mec) eroare dinamică / de reglaj

dynamic friction (T) frecare dinamică / rezultată din regim variabil de solicitare

dynamic hardness (materiale, metr) duritate după Martel

dynamic-hardness testing machine (materiale, metr) aparat pentru încercarea durității

dynamic head (mec, hidr) presiune dinamică

dynamic indentation test (materiale, metr) încercare de duritate, cu aplicarea efortului dinamic

dynamic limit of yield point (materiale, metr) limita de curgere conventională la sarcină dinamică

dynamic load $(\mathrm{OM}, \mathrm{mec})$ sarcină dinamică dynamic loading $(\mathrm{OM}, \mathrm{mec})$ solicitare dinamică dynamic loading capacity (mas, OM) capacitate dinamică de încărcare

dynamic load rating $(\mathrm{OM})$ sarcină dinamică de bază (la rulmenți)

dynamic measurement (metr, mas) măsurare în regim dinamic

dynamic model (mat, fiz, TH) model la care variabilele sunt funcții şi de timp

dynamic modulus (materiale) modul dinamic

dynamic modulus of elasticity (materiale, mec) modul dinamic de elasticitate

dynamic overpressure (hidr, mec) suprapresiune dinamică

dynamic pressure (hidr, mec) presiune dinamică / cinetică, presiune la care sunt supuse corpurile dintr-un fluid aflat în mişcare relativă față de acestea dynamic range $(\mathrm{TH}, \mathrm{mec}$, el) gamă dinamică, raportul între cea mai mică şi cea mai mare valoare a unei mărimi măsurabile cu un aparat

dynamic reaction $(\mathrm{mec})$ reacțiune dinamică

dynamic response (autom, mas) comportare în regim tranzitoriu, caracteristică dinamică

dynamics dinamică

dynamics analyzer (DYANA) (inf) limbaj de simulare DIANA (în limbaj FORTRAN)

dynamic shape formă dinamică

dynamic shape factor (mec, hidr) factor al formei dinamice

dynamic shear modulus (mec, materiale) modul dinamic de forfecare

dynamic stability (mas) stabilitate la sarcină dinamică

dynamic storage / store (c) memorie dinamică / ce necesită reîmprospătarea informației

dynamic strain recording equipment (metr, autom) instalație pentru înregistrarea deformațiilor produse de o sarcină dinamică

dynamic strength $(\mathrm{mec})$ rezistență la vibrații / la eforturi dinamice

dynamic stress $(\mathrm{mec})$ tensiune dinamică / la solicitare dinamică

dynamic tensile test (mec, metr) încercare dinamică la tractiune / la rupere

dynamic test (metr) încercare dinamică / la şoc

dynamic unbalance (mec, mas) dezechilibru dinamic

dynamic vibration reducer $(\mathrm{OM}, \mathrm{mec})$ amortizor dinamic de vibratii / acordat / care reduce vibrațiile unui sistem primar prin transfer de energie către un sistem auxiliar

dynamic viscosity $(T)$ vâscozitate dinamică

dynamism dinamism

dynamite dinamită; a dinamita

dynamo (el) dinam, generator de curent continuu

dynamomagneto (el) dinam-magnetou

dynamometer (metr) dinamometru, aparat pentru determinat rezistența la tracțiune

dynamometer test stand (metr) stand de încercare a unei frâne; cu dinamometru

dynamometer-type wattmeter (metr, el) wattmetru electrodinamic

dynamometric dynamo (OM, metr, el) frână de încercare, cu dinam etalon

dynamo sheet iron (met, el) tolă de dinam

dynamo steelsheets (met, el) tablă de oțel pentru dinam

dynastart (el, auto, mas) maşină electrică reversibilă folosită la autovehicule

dyne (fiz, metr) unitate de măsură pentru forță, dină: 1 dyne $=0,00001 \mathrm{~N}$

Dysprosium (Dy) (chim) disprosiu 


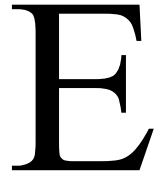

each fiecare (luat în parte); other unul pe altul, reciproc; at an $\sim$ date la o dată apropiată eager for dornic de / să; înverşunat, energic eagerness zel, dorință (puternică)

eagle stone (minrl) limonit

ear (agr) spic, a da în spic; (OM) ureche, toartă, inel, mâner, clemă de suspendare; (met) orificiu, pungă (rar)

eared cu urechi / mânere; (agr) cu spic earing (nav) împuntătură, baieră de învergare earless $(\mathrm{OM})$ fără urechi / ureche / mâner / toartă earliness oră matinală; apariție timpurie; caracter prematur; (agr) precocitate

early (adj) devreme, de dimineață; întâi, prim, de

(la) început; timpuriu, care se petrece devreme; prematur, precoce; grabnic, urgent, neîntârziat; care a venit înainte (de ora fixată etc.); $(a d v)$ (prea) devreme, repede, curând, din timp

early concrete volume charge (const) modificare initială de volum a betonului

early ignition (auto, termo) aprindere prematură early opening of valve (termo, hidr) avans la deschiderea supapei

early slag (met) zgură primară

early spark (auto) avans la aprindere (nedorit)

early strength cement ciment cu întărire rapidă

earmark (ec) a aloca, a distribui, a repartiza (fonduri)

earn a câştiga (prin muncă, merit); a dobândi earnest (ec) acont, arvună, avans, garanție, amanet earnest (money) (ec) acont, arvună, avans earning(s) (ec) venit(uri), câştig, profit(uri), salariu

earning capacity (ec) rentabilitate

earnings related $(\mathrm{ec})$ pe măsura veniturilor earth (georr, fiz) Pământ, Terra, globul terestru; (geol, TH) pământ, sol, teren; (el) legătură / punere la pământ (d. linii electrice), a lega la pământ / la masă; a îngropa, a acoperi cu pământ; (fiz) a face contact cu pământul (d. un meterorit, radiații cosmice etc.): (agr) teren, pământ, țărână, a săpa pământul în jurul rădăcinii; (zool) vizuină (a unui animal), (d. animale) a se băga în vizuină

earth anchor (const) mort, pilot de ancoraj earth bag (const) sac cu pământ / nisip earth brace (constr) eclisă inferioară; (el, OM) scoabă subterană la cabluri

earth bus (el) bară pentru legătură / legare la pământ

earth capacity (el) capacitate față de pământ

earth circuit (el) circuit de legare la pământ, buclă de închidere prin pământ

earth clip (el) bornă de legare la pământ

earth coal cărbune de pământ

earth connection (el) legătură la pământ / la masă, conductă / circuit de legare la pământ earthed (el) legat intenționat la pământ, împământat

earthen de / din pământ

earthenware (constr, ind chim) ceramică, faianță earth fault (el) (deranjament / greşeală prin) punere la pământ

earth flax (constr, termo) azbest

earth flow (geol) alunecare de teren

earth free (el) fără legătură la pământ

earth ground(ing) (el) priză de pământ

earthing (el) legare la pământ, împământare

earthing lead (el) conductor de legare la pământ earthing terminal (el) bornă de legare la pământ

earth interior (geogr) subsol

earth lead / line (el) legătură la pământ, conductor de legare la pământ

earth leakage (el) pierdere / scurgere de curent prin pământ

earth load (constr) împingere / presiune a pământului / a solului

earth location (el) localizare a unei puneri la pământ (şi accidentală)

earth magnetism (geol, geogr) magnetism terestru earth metal (chim) metal pământos

earthmover (constr) utilaj pentru terasamente

earth moving (constr) (lucrări de) terasamente, deplasare de teren / de pământ

earth-nut (alim) arahidă

earth-nut oil (alim) ulei de arahide

earth oil (ind chim) țiței, petrol

earth pitch (ind chim) smoală minerală

earth plate (el) priză de pământ (eventual sub formă de plăcuță)

earth pressure (geol, constr) presiune / împingere a pământului

earthquake-resistant (constr, geol) rezistent la solicitări seismice

earth rammer (constr) mai, compactor pentru pământ

earth shell (geol, geogr) scoarța terestră

Earth's density (fiz, metr) densitate a Pământului, unitate de măsură pentru densitate: 1 Earth's density $($ mean $)=5518 \mathrm{~kg} / \mathrm{m}^{3}$ 
Earth's distance from sun (fiz, metr) distanța Pământ-Soare, unitate de măsură pentru lungime (în astronomie): 1 Earth's distance from sun $=1,496 \cdot 10^{+11} \mathrm{~m}$

Earth's equatorial radius (fiz, metr) rază ecuatorială, raza Pământului la ecuator, unitate de măsură pentru lungime (în astronomie): 1 Earth's equatorial radius $=6378160 \mathrm{~m}$ earth silicon (chim) dioxid de siliciu

Earth's polar radius (fiz, metr) raza Pământului la pol, unitate de măsură pentru lungime: 1 Earth's polar radius $=6356776,9999999 \mathrm{~m}$

Earth's velocity (fiz, metr) viteza Pământului, unitate de măsură pentru viteză: 1 Earth's velocity $=29765 \mathrm{~m} / \mathrm{s}$

Earth's volume (fiz, metr) volumul Pământului, unitate de măsură pentru volum (în astronomie): 1 Earth's volume $=1,083 \cdot 10^{+21} \mathrm{~m}^{3}$

earth tester (el, metr) aparat pentru măsurarea rezistenței electrice a pământului, aparat de încercat împământarea

earth up (constr) a acoperi cu pământ

earthwork (constr) săpături, fundații; rambleu, ridicătură de pământ, terasament

earthy pământos, de / din pământ

earthy brown coal turbă, cărbune brun

earthy calcium carbonate (ind chim) lapte de var ease pace; liniştit; lipsă de constrângere; uşurință, facilitate; naturalețe, dezinvoltură; a (se) linişti; a lărgi; (TH) a uşura, a descărca, a elibera, a calma, a potoli, a reduce / micşora (viteza etc.), a desțepeni, a se micşora (viteza etc.), a se domoli; a înceta, a opri; (med) a alina, a calma; (nav) a slăbi (un odgon); a slăbi din strânsoare; off a se atenua, a se micşora; (mil) stand at $\sim$ ! pe loc repaus!

ease down a-şi încetini mersul / ritmul, a merge mai încet

easement ajutor, sprijin; înlesnire, avantaj

easement curve (hidr) curbă de racordare

ease off a pleca, a porni; a se îndepărta; a deveni mai uşor; (nav) a fila (lanțul de ancoră, remorca), a reduce viteza navei

ease of mounting $\mathrm{(TH}$ ) montaj simplu, construcție simplă, simplu / uşor de montat

ease speed to $(\mathrm{TH})$ a reduce viteza la

ease the engine (TH) a reduce viteza (şi la nave) ease the gas (termo, met) a micşora debitul de gaz (la cuptoare, cazane)

easing (met) deschiderea formei de turnare

easily $(a d v)$ uşor, cu uşurință; liber, nestingherit; liniştit, calm

easily catching fire / easily set on fire (uşor) inflamabil easily cleaning uşor de curăţat (şi manual)

easily fusible / meltable (met, plast) uşor fuzibil, care se poate topi uşor

easely removable $(\mathrm{OM})$ uşor de înlocuit / de scos / de demontat / de înlăturat

easily to machine; easily machined (TH) uşor de prelucrat (şi prin aşchiere)

easiness linişte, tihnă, pace, mulțumire; uşurință, facilitate; uşurință, superficialitate; naturalețe, dezinvoltură, degajare

east (geogr) est

easterly ( $a d j)$ estic, de est; ( $a d v)$ spre / dinspre est eastern (adj) estic, de est; (constr) care dă spre est

easy (adj) uşor, simplu, facil; comod, lejer; liniştit, fără griji; (ec) (d. prețuri) instabil; avantajos, favorabil; (d. o pantă) lin; (d. stil) natural, neforțat; (d. maniere) degajat, neforțat; (d. situații, stări) îndestulat, comod; (d. stări de spirit) calm, fără griji sau temeri; (d. fire) uşor de înduplecat, maleabil; (ec) nesolicitat, care se vinde greu (d. mărfuri); $(a d v)$ uşor, cu uşurinţă, liniştit, fără grabă, fără efort; $(s)$ moment de odihnă, de relaxare, repaus; $\sim$ of access uşor accesibil

easy-change transmission $(\mathrm{OM})$ transmisie $\mathrm{cu}$ schimbare uşoară a vitezelor

easy control (autom, metr) comandă simplă / uşoară (a unui aparat)

easy curve curbă lină / cu rază mare de racordare (d. drumuri, şosele)

easy-going comod, indolent; (d. mers, functionare etc.) lin, negrăbit, lent

easy-machining steel (met, mas-un) oțel uşor prelucrabil prin aşchiere, oțel pentru automate easy push fit $(\mathrm{OM})$ ajustaj alunecător easy running fit (OM) ajustaj cu joc larg easy slide fit $(\mathrm{OM})$ ajustaj semi-liber / $\mathrm{cu}$ joc / alunecător

easy to access $(\mathrm{TH}, \mathrm{OM})$ uşor accesibil eat a mânca; a roade, a măcina

eatable (alim) comestibil, bun de mâncat eatables (alim) mâncare, bucate eat away (met, chim) a coroda, a roade, a distruge eater (chim) corosiv, substanță corosivă eating (alim) care mănâncă; mâncare, hrană eating apple (alim) măr bun de mâncat eating away (chim, met) (acțiunea / procesul de) coroziune

eating house (alim) restaurant, pensiune eating through (chim) coroziune pătrunsă eat into (ec) a înghiți (bani) eat through (chim) a coroda eat up a mânca tot; a preocupa; a absorbi; a captiva eau-de-vie (din franceză) (alim) rachiu 
eaves (constr) jgheab de acoperiş, streaşină, cornişă ebb (geogr, hidr, nav) reflux; (fig) declin, decădere, dare înapoi, schimbare în rău; a se retrage, a fi în reflux; (fig) a fi în declin; be at low $\sim$ a fi în declin

ebb away a fi în declin; a da înapoi; a se schimba în rău; a se scurge

ebb tide (geogr, nav, hidr) reflux

E bend (mec, OM, constr) curbă / cot E, profil E ebeneous (ca) de abanos

ebonite (chim, plast) ebonită

ebonite compound (ind chim) amestec de cauciuc pentru ebonită

ebonise a înnegri, a vopsi în negru

ebony (ca de) abanos, lemn de abanos, negru (de) abanos

ebullience (alim, ind chim) efervescență, fierbere, clocot

ebullient (alim, ind chim) care fierbe, în fierbere / în clocot, clocotitor (d. lichide); (fig) exuberant

ebuliometer (metr, alim, ind chim) ebuliometru ebullioscope (metr, alim, ind chim) ebulioscop

ebullioscopic constant (fiz, ind chim) constantă ebulioscopică

ebullioscopy (fiz) ebulioscopie

ebullition (chim, fiz, alim) fierbere, clocotire, ebuliție, efervescență, barbotare, revărsare, izbucnire eccentric original; $(\mathrm{OM})$ excentric (ca organ de maşină sau ca poziție)

eccentically $(a d v)$ (în mod) excentric

eccentric, off-centre (OM, mas-un) excentric

eccentric-action clamp (OM) dispozitiv cu excentric, descentrat pentru strângere / fixare a pieselor

eccentricality excentricitate, originalitate; $(\mathrm{OM}$, mas) excentricitate

eccentric angular load $(\mathrm{mec})$ sarcină / forță înclinată excentrică

eccentrical(ly) ( $a d v)$ (în mod) excentric

eccentric angle (of an ellipse) (geom) cercuri excentrice (descrise din centrul elipsei, având razele egale cu semiaxa mică şi cu semiaxa mare)

eccentric clamp(ing) (OM, mas-un) dispozitiv de strângere cu excentric, strângere cu excentric

eccentric disk $(\mathrm{OM})$ disc excentric

eccentric distribution distribuție excentrică / necentrată (față de un reper)

eccentric drive / gear / gearing (OM) mecanism / transmisie cu excentric, acționare prin excentric, transmisie cu excentric

eccentric-gear press (mas-un) presă cu angrenaj montat pe un excentric eccentric housing (OM, mas-un) carcasă / manşon al excentricului

eccentricity $(\mathrm{OM})$ excentricitate

eccentricity error (OM, mas-un) eroare de excentricitate, abatere / eroare pe direcție radială, măsurată față de un centru de rotaţie fictiv / teoretic / ideal

eccentric lathe (mas-un) strung pentru prelucrat suprafețe excentrice / necilindrice

eccentric lever $(\mathrm{OM})$ pârghie excentrică

eccentric load (mec) sarcină / forță excentrică

eccentric motion (mec, OM) mișcare excentrică / planetară

eccentric orifice (hidr, OM) orificiu excentric (față de axa conductei / rezervorului etc.)

eccentric press (mas-un) presă cu excentric eccentric reducer $(\mathrm{OM}$, hidr) reducție excentrică (la pompe cu sursă de alimentare în amonte) eccentric ring $(\mathrm{OM})$ inel / colier excentric eccentric rod $(\mathrm{OM})$ bară de excentric / de comandă a culisei, bielă a excentricului

eccentric shaft $(\mathrm{OM})$ arbore (de) excentric

eccentric-shaft press (OM, mas-un) presă cu arbore excentric

eccentric sheave $(\mathrm{OM})$ disc de ridicare, excentric, disc cu camă

eccentric sleeve $(\mathrm{OM})$ manşon al excentricului

eccentric tension (mec) tractiune / efort excen$\operatorname{tric}(\breve{a}) / \operatorname{asimetric}(\breve{a})$

eccentric transmission $(\mathrm{OM})$ transmisie cu excentric

echelle grating (autom) rețea în trepte

echelon eşalon; a eșalona, a repartiza, a planifica; (constr, met) scară metalică la coşuri

echo (fiz, c) ecou, reverberatie; imagine dublă / dublată (pe ecran / dispaly); rezultat, urmare, reacție; imitație, plagiat; a avea ecou; a repeta; a imita

echo box (fiz) cavitate rezonantă

echo check(ing) (fiz) testare tip ecou

echo depth sounding (fiz) sondaj acustic

echo(-)diagram (med, TH, fiz) ecogramă

echography (fiz) ecografie

echometer (metr) ecometru, sonolog, dispozitiv ecometric

echo sound(er) / sounding device (fiz, metr) sondă acustică, sondă ecou, ecometru, sondă cu ultrasunete

éclair (alim) ecler (prăjitură)

eclectic eclectic; compilator

eclipse eclipsă, eclipsare, umbrire; a eclipsa, a umbri, a întuneca

ecologic(al) (mediu) ecologic

ecology (mediu) ecologie 
econometrics (ec, mat) econometrie, economie matematică

economic (ec) economic, privitor la economie, rentabil, practic, aplicat

economical econom, chibzuit; economicos, economic, frugal

economical load of a unit (el) sarcină / putere electrică care corespunde unui consum specific minim

economic alloy (met) aliaj economic

economically $(a d v) \mathrm{cu}$ economie, din punct de vedere economic

economical operation (auto, TH) funcționare / conducere economică

economical running ( $\mathrm{TH}$, mas) regim economic de lucru

economic downturn (ec) criză economică

economic exploitability (ec) exploatabilitate economică / rentabilă / profitabilă (din punct de vedere economic)

economic efficiency (ec) eficiență economică, rentabilitate

economic impact (ec) impact economic

economic lot size (ec) mărime a lotului de produse care menține cheltuielile de producție minime un anumit timp

economics (ec) aspecte economice, economie, economie politică, stiințe economice

economic self-sufficiency (ec) independență economică

economics of scale (ec, $\mathrm{TH}$ ) economie pentru producție în masă / de serie mare

economic survey (ec) expertiză / anchetă / cercetare economică

economic zinc alloy (met) aliaj economic de zinc

economise (ec, $\mathrm{TH})$ a economisi (bani, energie etc.) economiser (termo, met) preîncălzitor, economizor, preîncălzitor de apă / de gaze / de aer, cu gaze de ardere, recuperator de căldură

economiser jet (auto, termo, OM) jiclor economizator

economiser tube (termo) țeavă a economizorului

economist (ec) economist; econom, gospodar; administrator

economize (ec) a economisi, a strânge, a pune de o parte; a valorifica; a face economii

economizer (ec) econom; ( $\mathrm{TH}$, termo) economizor, dispozitiv de economisire a unui material, preîncălzitor

economy (ec) economie

econostat (auto, termo) economizor de combustibil ecru ecru, de culoarea mătăsii nespălate edacious lacom, nesățios; (alim) alimentar, gastronomic

edacity poftă de mâncare, lăcomie

eddy vârtej (de praf); (fiz, hidr) vârtej, curgere turbulență, turbion, mişcare turbionară, anafor eddy current (el) curent turbionar / Foucault

eddy-current braking (el) frânare cu curenți turbionari

eddy-current flow detector (metr) defectoscop cu curenți turbionari / Foucault

eddy-current loss (el) pierdere prin curenți turbionari / Foucault

eddy current tachometer (metr, el) tahometru cu curenti Foucault

eddy diffusity of heat (termo) coeficient de transfer termic, turbulent

eddy field (mat, fiz) câmp turbionar

eddy / eddying flow (hidr) curgere turbulentă, curent turbionar

eddy flux (hidr, el) curent turbionar

eddying / eddy motion (hidr) mișcare turbulentă / turbionară / cu vârtejuri

eddy mill (constr, ind chim) moară / concasor cu turbionare / cu organe de şoc rotative

eddy viscosity ( $T$, fiz) vâscozitate în curgere turbionară

edge frontieră, cant; $(\mathrm{OM})$ bordură, falț, margine, muchie, tăiș, muchie aşchietoare / tăietoare, lamă (de cuțit), tranşăa, ascuțiş; a bordura, a teşi, a rotunji (muchii), a ascuți, a fălți, a netezi, a tivi, a mărgini, a înconjura, a împrejmui, a încadra, a înrăma; chenar, tiv, tivitură; limită; (agr) a tăia / tunde iarba; a strecura, a vârî, a băga, a stimula; a se strecura (în față)

edge abrasion (mas-un, T) uzura / abraziunea muchiei tăietoare / aşchietoare

edge beam (constr, mec) grindă marginală

edge bending (met) curbare a unei benzi (în plan longitudinal); (mas-un) curbare / încovoiere a muchiei sculei

edge bond $(\mathrm{OM})$ îmbinare / legătură de colț edge break (met) fisurarea / ruperea muchiilor (defect şi la prelucrarea la rece a profilurilor)

edged ascuțit, cu muchie ascuțită, tăios

edged tool (mas-un) sculă aşchietoare / cu muchie tăietoare

edge endurance (mas-un) durabilitate a tăişului sculei

edge fin zgârietură (pe piese, pe muchie)

edge forming (mas-un) formarea muchiei active a unei scule, formare / profilare cu îndoirea marginilor

edge fracture (mas-un) fisurare a muchiei (la scule aşchietoare, la benzi prelucrate la rece etc.) 
edge iron (met, mec) oțel cornier

edge joint (met, mec) îmbinare / legătură laterală / de colț / pe muchie / la margine

edgeless (mas-un, OM) fără margine / margini; bont, tocit, neascuțit

edge mill (ind chim, constr) moară chiliană / cu tăvălug; (met) moară de fărâmițare, concasor cu cilindri

edge molding (met) riglă fasonată marginal edge of regression $(\mathrm{OM})$ muchie de întoarcere, linie de regresie

edge of rim (constr, nav, OM) margine, bordură edge part of an ingot (met) crustă a lingoului edge planer (mas-un) raboteză pentru muchii edge preparation (mas-un) teşire a marginilor / muchiilor (şi la pregătirea tablelor pentru sudură)

edge protection (mas-un, met) protecția marginilor / a tăişului

edger (mas-un) maşină de rabotat / de îndoit marginile tablelor; (met) laminor cu cilindri verticali, matriță de rotunjit şi secționat, cajă de refulare

edge runner (mill) (constr, ind chim) moară de fărâmițare, tăvălug de moară chiliană; (met) cale / transportor cu role

edges chipping (mas-un, ind chim) sărire a muchiei (la ceramice, scule etc.)

edge stone (constr) piatră de bordură

edge strength (met, mec) rezistența marginilor (tablei, profilului etc.)

edge stress (mec, met) tensiune marginală, tensiune /efort pe muchie / la margine

edge-strip scanning equipment (met, metr) dispozitiv de control al marginii benzii (pentru detectarea fisurilor etc.)

edge tool (mas-un) unealtă ascuțită

edge trimming (met) tăierea / ajustarea marginilor edgeways $(a d v)$ cu tăişul în față, spre tăiş

edge welding (met) sudarea muchiilor fără teşirea lor

edgewise aşezat pe muchie

edging $(\mathrm{OM})$ margine, bordură, muchie; (textile) franjuri, tiv, tivire; (met) îndoire / pregătire a marginii, eboşare laterală, tăiere

edging circular saw (mas-un) fierăstrău circular edging machine (mas-un) maşină de îndoit margini / de bordurat

edging pass (mas-un, met) trecere de finisare edging saw (mas-un, met) fierăstrău pentru margini

edging mill stand (met) cajă de refulare

edgy tăios, ascuțit; aspru, colțuros

edibility (alim) caracter comestibil

edible (alim) comestibil, bun de mâncat edible fat / oil (alim) grăsime / ulei comestibil(ă)

edibles (alim) mâncare

edification edificare, construire, ridicare; $(\mathrm{TH}$,

mas) instrucțiuni

edifice (constr) edificu, clădire, construcție

Edison lamp / screw holder (OM, el) dulie Edison

edit a edita, a pregăti pentru tipar, a stiliza

editing (inf) editare (a unui program, a unor date), redactare / pregătire a datelor; (mas-un) prelucrare

edition ediție, editare, tiraj

editor editor (de carte), responsabil de ediție; (inf) editor, program de editare

editorial editorial, redactional; articol de fond

editorial board comitet de redacție

editorial staff personal de redacție

editor-in-chief redactor şef

educability însuşirea de a fi educabil

educable educabil, maleabil

educate a educa, a creşte; a cultiva, a forma; a se instrui, a învăța

educated (edu) educat, instruit; calificat

education (edu) educație; creștere, învățătură pregătire; cultură; învățământ; bună creştere, maniere

educational (edu) de educație; educativ; de învățământ, didactic; pedagogic

education for computer (edu, inf, c) instruire în tehnica computerelor

educative (edu) educativ, instructiv

educe a deduce, a conchide, a trage (o concluzie); (chim) a emite, a degaja

educible deductibil

educt (chim, fiz) substanță degajată / eliminată, emanație

eduction dovadă, manifestare (a unui fenomen, proces etc.); (chim) emanare, degajare; evacuare, golire

eduction pipe (OM, hidr) conductă de evacuare eduction valve $(\mathrm{OM}$, termo) supapă de aburi edulcorant (alim) (agent) edulcorat, îndulcitor edulcorate (alim, chim) a îndulci, a edulcora, a purifica, a spăla, a desăra, a dezacidula

edulcoration (alim, chim) edulcorare, îndulcire efface a şterge, a rade; (fig) a eclipsa, a umbri, a întuneca; a se da la o parte, a se retrage

effaceable care se poate şterge / neglija

effaceable element element neglijabil

effacement ştergere

effect efect, consecință, rezultat, urmare; acțiune, influentăa înrâurire; impresie; fenomen; cuprins, conținut, sens; $(\mathrm{TH})$ putere, productivitate, randament; a efectua, a realiza, a îndeplini, a provoca, a cauza; scop, intenție; $\sim \mathbf{s}(p l)$ 
bunuri, lucruri; of no $\sim$ fără efect; give $\sim$ to a face să aibă efect; (jur) with $\sim$ from today intrând în vigoare de astăzi; give $\sim$ to / carry into a duce la îndeplinire, a traduce în viață; in $\sim$ de fapt, în vigoare; to this $\sim$ in acest scop; personal $\sim$ s efecte, bunuri personale

effecter realizator, executant; (ec) parte (într-o convenție)

effectible realizabil, care se poate efectua

effective eficace, util, folositor, efectiv, real; de efect; (jur) având efect / putere, în vigoare, activ; (ec) disponibil bănesc, numerar; (mil) apt, $\sim$ troops trupe apte de luptă

effective address (inf) adresă reală / efectivă / rezultată prin modificarea unei instrucțiuni în curs de executare

effective area (mec, OM) suprafață / secțiune / arie de lucru utilă a unui element, arie reală

effective capacity $(\mathrm{TH})$ capacitate efectivă / reală, putere utilă; (hidr) cilindree reală

effective depth (TH, mas) adâncime / înălțime utilă / efectivă

effective diameter $(\mathrm{OM})$ diametru mediu al filetului

effective discharge (hidr, termo) debit efectiv / real effective equivalent $(\mathrm{OM})$ echivalent de transmisie effective filtration / filtrating area (alim, hidr, ind chim) suprafață efectivă / reală de filtrare

effective flux (hidr, termo) flux / debit util / real

effective head (hidr, termo) presiune hidrostatică / utilă

effective heat (termo, met) căldură utilă

effective horsepower (mec) putere efectivă (exprimată în cai-putere)

effective hydraulic power (hidr, mec) putere hidraulică reală / utilă

effective input / output flow (hidr) debit de intrare / de ieşire efectiv

effective instruction (inf) instructiune efectivă / operatorie

effective length (OM) lungime efectivă / reală, lungime de flambaj

effective length of strut (OM, mec) lungime efectivă de flambaj

effective line differential $(\mathrm{OM})$ decalajul liniei / ramurii active (la transmisii cu curele)

effective load (mec, TH, transp) sarcină / încărcare efectivă / reală, încărcătură utilă / netă

effectively ( $a d v)$ (în mod) eficace / efectiv, de fapt

effectiveness eficacitate

effective output (mec) putere efectivă / utilă / la ieşire; (ec) productivitate reală

effective part of scale (metr) domeniu / interval efectiv / real de măsurare al scalei / scării effective permeability (fiz) permeabilitate efectivă

effective pitch progress $(\mathrm{OM}$, mas-un) pas efectiv / real

effective porosity (met, ind chim) porozitate efectivă / reală

effective power (mec) putere efectivă / utilă

effective pressure (mec, hidr) presiune efectivă

effective rake (mas-un) unghi de degajare real / efectiv (la scule)

effective range (metr) domeniu efectiv de măsurare, gamă / interval efectiv / real de lucru

effective section $(\mathrm{OM}, \mathrm{mec})$ suprafață utilă a sectiunii unui organ de maşină

effective stroke (mas-un, termo) cursă utilă

effective torque (mec) moment de torsiune real / efectiv

effective weight (mec, transp) încărcătură / greutate / sarcină utilă

effective work (mec) lucru mecanic util

effectless ineficace, fără efect / cauză

effector (autom) efectuator, "mână" de robot

effectrix (mec) forță motrice; cauză eficientă

effects efecte, bunuri, avere

effectual eficace (d. un sprijin); real; (jur) valabil, în vigoare

effectual contract $(\mathrm{ec})$ contract valabil

effectualness $(\mathrm{TH}, \mathrm{ec})$ eficacitate

effectuate a efectua, a realiza, a îndeplini

effectuation efectuare, îndeplinire

effervesce (fiz) a fî în stare de efervescență, a spumega, a fierbe

effervescence (fiz) efervescență, fierbere, înspumare

effervescent (fiz) efervescent, în stare de efervescență; care fierbe, gazos, clocotitor (d. băuturi, lichide etc.)

effervescent beverages (alim) băuturi efervescente

effervescent steel (met) oțel necalmat

effete epuizat, uzat; slăbit, stors; (agr) nerodnic, sterp; inutil; decadent

effeteness epuizare, uzare, uzură; caracter sterp / nerodnic; inutilitate

efficacious eficace, folositor, util; rodnic, fructuos, productiv(d. un remediu, mijloc etc.); care are efect; în vigoare

efficaciously $(a d v)$ (în mod) eficace, cu folos

efficaciousness, efficacity, eficacy, eficacitate, randament; folos

efficiency randament, eficiență, operativitate; pregătire, calificare, pricepere; putere de muncă; (TH, hidr) debit; $(\mathrm{TH})$ productivitate (a unui utilaj, a unei secții etc.), bună funcționare, beneficiu, grad de valorificare 
efficiency curve (mec, hidr, TH) curbă de randament

efficiency factor / ratio (ec, TH) factor / coeficient / indice de eficiență / de calitate / de eficiență

efficiency of utilization (ec, $\mathrm{TH}$ ) randament

efficiency test (metr, mec) încercare / test pentru determinarea randamentului / eficienței

efficient $(\mathrm{TH}$, ec) eficient (d. metodă, muncă); operativ; cu randament bun, productiv; capabil, competent, priceput; cauză, agent; (mat) factor, înmultitor

efficient file treatment (inf) prelucrare rațională / eficientă a fișierului

efficiently ( $a d v)$ (în mod) eficient

efficient volume ( $\mathrm{TH}$, transp) volum util

efflorescence (alim, chim) eflorescență, mucegai, erupție

effluence (hidr) scurgere, pierdere, eflux

effluent efluent, care se scurge; (hidr) apă uzată / pluvială / reziduală / de scurgere, scurgere de fluid

effluent conduit / drain / line (OM, hidr) conductă / canal de evacuare / de surgere

effluent pump (OM, mediu, hidr) pompă pentru ape uzate

effluents (mediu, hidr) ape reziduale / uzate, lichide uzate evacuate, efluenți

effluvium, $(p l)$ effluvia (alim, ind chim, mediu) produse secundare (deşeuri), efluviu, emanație, miasmă

efflux scurgere (şi a timpului); izvor, sursă; (mediu) eflux, ejecție, revărsare

efflux coefficient (hidr) coeficient de scurgere / de evacuare

effort (mec) efort, tensiune; efort, realizare, rezultat

effortful care reclamă / cere eforturi

effortless care nu face nici un efort; fără efort, uşor, facil

effuse a (se) vărsa, a (se) revărsa, a (se) răspândi, a (se) împrăştia; (adj) larg răspândit

effusion (hidr) efiziune, vărsare, revărsare; avânt effusive ( $f i g$ ) expansiv

E format (inf, c) tip de scriere a datelor (de exemplu: $543,2=0.5432 \mathrm{E}+03$ )

egality egalitate $(\mathrm{rar})$

egg (zool, med, agr, alim) ou, germen, embrion; (met) brichete mici de minereu sau cărbune (de mărimea unui ou)

egg apple, egg fruit (agr, alim) (pătlăgea) vânătă egg / outside (firm-joint) / leg calippers (metr) compas de exterior, compas simplu de grosime

egg coke (met) cocs sfărâmat, deșeu mărunt de cocs egg-powder (alim) pudră / praf de ou egg-shaped de forma unui ou, oval, ovoidal egg shell (alim) coajă de ou egg-white (alim) albuş de ou eglantine (bot) măceş, răsură

E glass (ind chim) fibre de sticlă (din borosilicați și alcali), folosite la compozite

egress ieşire, pierdere, cedare, scăpare; (TH) gură, eşapament; a ieşi, a scăpa

egress of heat (termo, met) pierdere / scăpare / cedare de căldură

eigenfunction funcție proprie

eigenrotation $(\mathrm{mec})$ rotație proprie

eigenstate stare proprie

eigentone (fiz, mec) oscilație proprie

eigenvalue valoare proprie; (mat) număr caracteristic (la matrici), soluție (complexă)

eight-bit / byte (character) (inf) octet, cuvânt de 8 biți, bait, vector binar cu 8 componente

eightfold twisting(cable) (OM, transp) cablu răsucit din 8 fire

eight-in-line engine (termo) motor cu 8 cilindri în linie

Einsteinium (Es) (chim) einsteiniu

either fiecare, oricare

EITHER-OR (autom, inf) operator logic de disjuncție, SAU-SAU

eject a ejecta, a emite (cu forță), a arunca (cu putere), a da afară, a scoate (fum, o piesă etc.), a extrage, a rebuta, a evacua (o piesă), a respinge; a destitui; (jur) a evacua (dintr-o locuință); a alunga, a expulza; (ec) a concedia; (ec, pol) from office a destitui dintr-o funcție

ejecting piston (OM, mas-un) piston aruncător / ejector

ejection ( $\mathrm{TH}, \mathrm{mec}$, hidr) dare afară, aruncare, tâşnire, evacuare; (ec) destituire, concediere ejection control (mas-un) comandă a ejectării (unei piese) / a emiterii

ejection half (met, plast, mas-un) partea mobilă a unei matrite

ejection key (OM, mas-un) clapă / tastă / buton de ejectare / de aruncare

ejection pin / rod (plast, mas-un, OM) ştift / bară de scoatere a piesei matrițate

ejection plate (mas-un) placă de desprindere / de aruncare

ejection plug tijă aruncătoare

ejection press (mas-un) presă cu aruncător ejection ram (mas-un, OM) piston aruncător ejection seat (av) scaun catapultabil

ejection tie-bar (mas-un, OM) bară de legătură a aruncătorului (la maşini de injectat mase plastice) ejector (mas-un) ejector, aruncător, extractor 
ejector condenser (el) condensator cu ejector ejector cooler (termo) maşină frigorifică cu ejector ejector cycle refrigeration system (termo) sistem frigorific cu ejecție de abur

ejector device (mas-un) dispozitiv cu ejector / cu aruncător

eject dryer (alim, termo, ind chim) uscător cu ejector

eject frame (OM) ramă / traversă de aruncător eject frame guide (OM, mas-un) ghidaj pentru rama aruncătorului

ejector (jet pump) (OM, hidr) pompă cu jet ejector nozzle (OM, mas-un) ejector, ajutaj / duză a ejectorului

ejector pin (OM, mas-un) tijă aruncătoare

ejector ram (OM, mas-un) piston aruncător

ejector spring (OM, mas-un) arc de ejector

eka-cesium (Fr) (chim) franciu

eka-iodine (At) (chim) astatiniu

eka-tantalum (Pa) (chim) protactiniu

eke-out a adăuga la, a lungi, a prelungi

elaborate lucrat cu grijă, minuțios, amănunțit, complicat; a elabora, a întocmi amănunțit; a prelucra, a dezvolta, a intra în amănunte

elaborated prelucrat cu grijă, elaborat minuțios; lucrat fin

elaborately $(a d v)$ (în mod) minuțios, atent, gândit; artistic, cu artă

elaborateness întocmire cu grijă; prelucrare îngrijită / minuțioasă, minuțiozitate

elaboration elaborare (şi minuțioasă), întocmire (cu grijă), alcătuire, redactare, prelucrare, punere la punct

élan avânt, elan, entuziasm

elapse a se scurge, a trece (d. timp)

elapsed (d. timp) trecut

elapsed time (metr) timp trecut / măsurat / scurs; (auto) timp trecut / indicat ca trecut pe un instrument de bord

elastance (el) elastanță, capacitate reciprocă, inversul capacității

elastic elastic, ductil, flexibil; (fig) adaptabil; gumă, elastic

elastic after-effect (mec, materiale) histerezis elastic, acțiune / deformație elastică ulterioară; efect elastic întârziat / ulterior

elastically mounted (OM) montat / suspendat pe suport elastic (şi cu arcuri)

elastically supported bearing $(\mathrm{OM}, \mathrm{T})$ lagăr montat pe un suport elastic

elastic band $(\mathrm{OM})$ bandă elastică, curea de transmisie (fără a specifica materialul)

elastic bearing $(\mathrm{OM})$ reazem / lagăr elastic / deformabil / pe suport elastic elastic behaviour (mec, OM) comportare elastică elastic belt $(\mathrm{OM})$ curea elastică, curea de transmisie din cauciuc

elastic chamber (metr) cameră / spațiu / incintă cu pereți elastici în care intră presiunea de măsurat

elastic chuck (mas-un) mandrină de prindere cu element(e) elastic(e)

elastic collision $(\mathrm{mec})$ ciocnire elastică

elastic come-back of the metal (met, mec) cedare elastică a materialului

elastic constant (mec) constantă de elasticitate

elastic cord (OM) sfoară / şnur de cauciuc / elastic

elastic curve curbă cu rază mare, curbă lină

elastic deflection (mec, OM) săgeată elastică

elastic deformation (mec, met, $\mathrm{OM}$ ) deformare / deformație elastică

elastic drift (mec, met) deformație remanentă a materialului supus tensiunilor din domeniul de elastic

elastic elongation (mec) alungire elastică

elastic expansion (mec) destindere / expansiune ( (a)lungire elastică; dilatare reversibilă

elastic fabrics (textile, ind chim) pânzeturi / tesături elastice / cauciucate

elastic failure (mec) rupere în urma depăşirii limitei de elasticitate

elastic force (mec, OM) forță elastică de rapel / de elasticitate / de restabilire

elastic impact (mec) şoc elastic

elasticity (mec) elasticitate, flexibilitate; (fig) adaptabilitate, flexibilitate

elasticity of compression (mec) elasticitate la compresiune

elasticity of demand $(\mathrm{ec})$ elasticitate a cererii

elasticity of extension (mec) elasticitate la întindere / la tractiune

elasticity of flexure (mec) elasticitate la încovoiere

elasticity of form (mec, OM) elasticitate / stabilitate a formei

elasticity of shearing (mec) elasticitate la forfecare

elasticity of torsion (mec) elasticitate la torsiune / la răsucire

elasticity test (mec, metr) test / încercare / probă de elasticitate

elastic limit (mec, OM) limită de elasticitate (fără a preciza solicitarea, în general pentru tracțiune)

elastic limit under shear (mec, OM) limită de elasticitate la forfecare

elastic modulus $(\mathrm{mec})$ modul de elasticitate (fără a preciza solicitarea, în general pentru tractiune) 
elastic range (materiale, mec) zonă / domeniu / interval de elasticitate

elastic ratio (materiale, mec) grad de elasticitate elastic recovery (materiale, mec) revenire / relaxare elastică

elastic scattering (materiale, mec) împrăştiere elastică / flexibilă (şi la rezultate)

elastic stability (materiale, mec) stabilitate elastică elastic stop nut $(\mathrm{OM})$ piuliță elastică de siguranţă / cu canelură pentru inel de cauciuc

elastic strain (materiale, mec) deformare elastică

elastic stress (mec) tensiune elastică / sub limita de elasticitate

elastic support $(\mathrm{OM}, \mathrm{mec})$ suport / reazem elastic elastic wheel (mas-un) disc abraziv / de rectificat, elastic

elastomechanics (mec) elastomecanică

elastomer (plast) elastomer

elastomeric (plast, ind chim) din elastomer / cauciuc, elastomeric

elastomeric adhesion (ind chim, T) (procesul de) adeziune specific elastomerilor / cauciucului

elasto-plastic beam $(\mathrm{mec})$ grindă elasto-plastică elasto-plastic medium (mec) mediu elasto-plastic elbow (OM) cotitură, cot (şi de țeavă), tub cotit, vinclu, colțar, curbă; a coti, a face o cotitură; a împinge cu cotul; at one's $\sim$ aproape, în apropiere; up to the $\sim \mathbf{s}$ in ocupat până peste cap; out at $\sim$ s cotitură, mevoiaş

elbow bend $(\mathrm{OM})$ cot (şi de țeavă), cotitură, îndoitură (la $90^{\circ}$ )

elbowed (OM) cotit (d. o piesă / conductă etc.)

elbow joint (OM, hidr) articulație tip nucă, îmbinare de colț, racord T sau în unghi, pentru țevi

elbow lever (auto, OM) levier curbat, pârghie cu articulație / cu genunchi / cotită

elbow meter (hidr, metr) debitmetru cu cot

elbow piece $(\mathrm{OM})$ cot (piesă de legătură şi la țevi), colț de chenar, colțar

elbow with flange bellmouth $(\mathrm{OM})$ cot cu picior / cu manşon / cu flanşă

elder (alim) soc

elder berry (alim) boabe de soc

elect (pol, ec) a vota, a alege (prin vot); a numi (în funcție); a prefera; a decide, a hotărî; ales, votat; desemnat

electable eligibil, care poate fi ales

election alegere, opțiune; (libertate de) alegere, latitudine

elective electiv, care poate alege; electoral

elective body (pol) corp electoral

electorate (pol) corp electoral, alegători

electric electric (în general); (fiz) corp electric, izolator, izolant electrical (el) electric (referitor la echipamente electrice, electricitate)

electrical aerosol analyser (metr, fiz) analizor electric pentru aerosoli

electrical charging system (auto) sistem electric de încărcare (pentru baterie)

electrical discharge machining (mas-un, el) prelucrare cu arc electric / prin electroeroziune electrical engineering (el) inginerie electrică, electrotehnică

electrical field strength (el) intensitate a câmpului electric

electrical fitter (el) instalator / montator electrician electrical flow transducer (el, hidr) traductor / contor electric de debit

electrical furnace (met, ind chim) cuptor electric electrical fuse (el) siguranță electrică

electrical industrial truck (el, mas) cărucior acționat electric, electrocar

electrical insulating oil (el) ulei electroizolant

electrically actuated / operated (el) actionat electric

electrical porcelain (el, ind chim) porțelan electroizolant

electrical pressure transducer (el, hidr, metr) traductor electric de presiune

electrical quiescent power (el) putere electrică de repaus

electrical resistivity (el) rezistivitate electrică

electrical saw (el, mas-un) fierăstrău (acționat) electric

electrical soldering bit / iron (el, met) ciocan electric de lipit

electrical sheet (met) tablă pentru elctrotehnică electrical spot weld (met, el) sudură (rezultat al procedeului / tehnologiei) electrică în puncte

electrical spot welding (met, el) sudare (procedeu, tehnologie, mai rar rezultat) electrică în puncte

electrical steel (el, met) otel electrotehnic (otetel cu puțin carbon şi $0,5 \ldots .5 \% \mathrm{Si}$, cu proprietăți electromagnetice)

electrical thermometer (el, metr) termometru electric / cu termocuplu

electric arc (el) arc electric / voltaic

electric-arc furnace (met, ind chim) cuptor $\mathrm{cu}$ arc electric

electric-arc welding (met) sudură cu arc electric electric-arc welding machine (met, el) maşină / utilaj pentru sudură cu arc electric

electric battery (fiz, el) baterie electrică

electric boiler (termo, el) cazan / boiler cu rezistență electrică

electric blast furnace (met) furnal electric 
electric boiling plate (met, el) element de încălzire al unei plite electrice

electric brake switching (el) frânare reostatică

electric brazing (met, el) lipire electrică / cu arc electric

electric bulb (el) bec / tub / lampă cu incandescență / cu filament

electric car (auto, el) automobil cu acumulator (electric) / electric

electric central station (el) centrală / uzină electrică

electric control (el) comandă / acționare / reglare electrică

electric controller (el, autom) servomotor de reglaj, regulator electric

electric convector (el, termo) radiator electric cu convecție

electric cooker (el, alim) bucătărie / aragaz elec$\operatorname{tric}(\breve{a})$

electric coupling (el) cuplaj electric (capacitiv)

electric crane (mas, el) macara electrică

electric current (el, fiz) curent electric

electric current supply system (el) rețea de distribuție a curentului electric

electric cylinder (mas-un, hidr, el) cilindru acționat electric, de poziţionare (integrat în sistem)

electric discharge (el) descărcare / scânteie electrică

electric displacement (el) densitate de flux electric electric distributor (el) distribuitor electric

electric drill (el, mas-un) burghiu electric, maşină de găurit portabilă (cu motor electric), bormaşină

electric drive (el) acționare electrică

electric drying machine (el, fiz) uscător electric

electric energy (el, fiz) energie electrică

electric energy transmission line (el, fiz) linie de trasport a energiei electrice

electric engine (el, fiz) locomotivă electrică

electric eye (fiz, el) celulă (foto)electrică

electric field (fiz, el) câmp electric

electric field strength (el, fiz) intensitatea câmpului electric

electric fitting (el) aparataj electric

electric freight truck (mas, el) cărucior electric de marfă / pentru piese

electric-furnace (met, el) cuptor electric, oțelărie electrică (pentru oțeluri şi neferoase)

electric-furnace annealing (met) recoacere în cuptor electric

electric-furnace iron (met) fontă obținută în cuptoare electrice

electric-furnace steel (met) oțel obținut în cuptoare / la oțelării electrice (numit și oțel electric) electric hardening (met) călire electrică (fără specificarea metodei)

electric hearth (met, el) cuptor electric (pentru oțeluri sau neferoase)

electric heater (el, termo) radiator / încălzitor electric

electric heating (termo, el) încălzire electrică

electric hoist (el, transp) palan electric

electric hygrometer (metr, el) higrometru cu sursă electrică de acționare

electrician (el) electrician, instalator electric

electric induction furnace (met, el) cuptor (electric) cu inducție

electric influence (el) influență electrică, inducție electrostatică

electric insulating material (materiale, el) material electroizolant

electric instrument (el, metr) aparat pentru măsurarea caracteristicilor curentului electric

electricity (el) electricitate, energie electrică

electricity of rolling mill (met, el) echipament electric al laminorului

electricity works (el) centrală electrică

electric jar (fiz, el) butelie de Leyda

electric load(ing) (fiz, el) sarcină / încărcare electrică

electric main (el) rețea / linie electrică principală

electric melting furnace (met, ind chim) cuptor electric de topit

electric meter (metr, el) aparat care indică o integrală de timp a unei mărimi electrice

electric mobility (fiz) mobilitate pe baza proprietăților electrice

electric pig iron (met, el) fontă elaborată în cuptor electric

electric power steering system (EPS) (auto) servodirectie actionată electric

electric power steering system (EPS) warning (auto) indicator / avertizor pentru servodirectie acționată electric

electric power steering system (EPS) warning light (auto) lumină de avertizare pentru servodirecție acționată electric

electric-power-supply network (el) rețea de alimentare cu curent electric

electric potential (fiz, el) potențial electric

electric remote control (auto) reglare electrică

electric resistance (el) rezistență electrică

electric resistance furnace (met, ind chim) cuptor cu rezistență electrică

electric resistance pyrometer (metr, el) termometru cu rezistență electrică

electric resistance welding (met, el) sudură prin rezistentă de contact 
electric rock drill-hammer (constr, met) perforator electric

electric rocking arc furnace (met, el) cuptor basculant cu arc electric

electric separator (alim, ind chim, fiz) filtru / separator electrostatic

electric shaft furnace (met) furnal / cuptor electric cu cuvă

electric sheet (el, met) oțel (tablă) pentru transformatoare

electric shock (el) şoc electric; (med, el) electrocutare

electric smelting (met) topire în cuptor electric

electric smelting furnace (met) furnal / cuptor electric pentru topire

electric soldering (met, el) lipire electrică

electric steel (el, met) oțel elaborat în cuptoare / oțelării electrice

electric steel making process (met) procedeu electric de elaborare a oțelului

electric steel plant / works (met) otẹărie electrică, turnătorie electrică pentru oțel

electric strength (el) rigiditate dielectrică, intensitate a câmpului electric (la străpungere)

electric stroboscope (fiz, el, metr) stroboscop electric

electric supply (el, mas) alimentare cu / sursă de energie electrică

electric tachometer (fiz, el, metr) tahometru electric

electric tempering (met) revenire în cuptor electric

electric transducer (metr, autom) traductor la care semnalele de intrare, intermediare şi de ieşire sunt de natură electrică

electric turbo-blower (met) (modul) turbosuflantă cu motor electric

electric vibrating shears (mas-un, el) foarfece electric, vibrator

electric wave (fiz) undă electromagnetică

electric welder $(\mathrm{TH}$, el) sudor electric

electric welding (met, el) sudură electrică (procedeu, mai rar rezultat)

electric welding plant (el) grup electrogen pentru sudură

electrification (el) electrificare, electrizare

electrified (fiz, el) electrificat, electrizat

electrify (fiz, el) a electrifica, a (se) electriza

electrochemical cleaning (el, $\mathrm{TH}$, chim) curățare electro-chimică

electrochemical coating / deposition (met, el) depunere / acoperire electrochimică

electrochemical corrosion (met, chim) coroziune electrochimică electrochemical equivalent (fiz, chim) echivalent electrochimic

electrochemical machining (mas-un) prelucrare electrochimică / prin electroliză

electrochemical passivity (chim, met) pasivitate electrochimică

electrochemical potential (el, chim, fiz) potențial electrochimic

electrochemical protection (el, chim, met) protecție / acoperire electrochimică

electro-chilled iron foundry (met, el) turnătorie electrică, de fontă dură

electrochromism fenomen (fiz, el) de schimbare a culorii la trecerea curentului electric

electrocoating (el, chim) acoperire galvanică

electrocrystallization (el, chim) electrocristalizare

electrocute (med, el) a electrocuta

electrocution (med, el) electrocutare

electrode (el) electrod

electrod arm $(\mathrm{OM}$, el) braț de susținere pentru electrod, port-electrod

electrod bundle (fiz) pachet / fascicul de electrozi electrode clamp (OM, el) cleşte pentru electrod electrode collar (OM, el) suport (inelar) de electrod

electrode consumption (el, met) consum de electrozi / de electrod

electrode control (OM, el) ghidaj pentru electrod

electrode dissipation (met, el) disipare a electrodului

electrode feed mechanism (met) mecanism de alimentare cu electrod-sârmă

electrode force (met, el) forță de electrod / care tinde să preseze electrodul de piesă (la sudura în puncte)

electrode gap (met, el) distanță între electrozi electrode hearth furnace (met) cuptor cu vatră, cu electrozi

electrode holder / support (el, met, OM) portelectrod, suport de electrod

electrode jib $(\mathrm{OM}$, el) suport pentru electrod electrode lead (el) conductor / fir de conexiune a(l) electrodului

electrodeless tube (el, fiz) tub electronic fără electrozi

electrode metal (el, met) electrod de metal, aliaj metalic pentru electrozi

electrode mixer (ind chim) malaxor / amestecător pentru prepararea învelişului electrodului

electrode nipple (met, $\mathrm{OM}$ ) racord pentru electrozi, piesă filetată care permite asamblarea cap-la-cap a doi electrozi de acelaşi tip la un cuptor electric 
electrode paste (met, ind chim) înveliş / pastă / compoziție a electrodului de sudură

electro-deposition (el, chim) depunere cu ajutorul unui electrod, galvanoplastie

electro-deposit (el, fiz, chim) precipitat galvanic, depunere electrochimică; a depune prin electroliză

electrodeposition (el, fiz, chim) depunere în câmp electric / pe electrod

electrodeposition of tin (met, el) stanare

electroextraction (met, el) extragere / separare electrolitică

electrod potential (el, fiz, chim) potențial de electrod / între electrod şi soluție

electrode process $(\mathrm{el}, \mathrm{TH})$ proces de electrod

electrode shell (met, ind chim) înveliş al electrodului de sudură

electrode short circuit (el) scurtcircuit între electrozi

electrode spacing (met) distanţă între electrozi (şi la oțelăria electrică)

electrode terminal (el, OM) bornă de electrod

electrode voltage (el) tensiune la electrod / între electrod şi catod

electrode waste (met) consum de electrod, capăt $/$ rest de electrod (inutilzabil)

electrodynamic (el, fiz) electrodinamic

electrodynamic instrument (metr, el) aparat electric cu părți mobile, pentru măsurarea tuturor sau a unor caracteristici de curent

electro-dynamics (el, fiz) electrodinamică

electrodynamometer (el, metr) dinamometru electric

electroemissive machining (el, mas-un) prelucrare prin electroeroziune

electroepitaxy (fiz, el) creşterea unui cristal şi datorită trecerii unui curent electric prin soluție

electro(-)erosion (el, mas-un) electroeroziune

electro-erosion metal working process (masun, $\mathrm{TH})$ procedeu de prelucrare prin electroeroziune

electro-forming (el, TH) electrodepunere în strat gros, electroformare (a unei acoperiri), galvanoplastie

electrogalvanising (el, met, $\mathrm{TH}$ ) electrogalvanizare (mai ales cu zinc)

electrogas gaz de protecție (la sudură)

electrogas, welding (met) sudură în atmosferă controlată / cu gaz protector

electrograph (metr) înregistrator cu hârtie sensibilă la trecerea curentului electric

electrohydraulic actuator (hidr, el) sistem motor electric + pompă, motopompă electrohydraulic clutch valve (hidr, nav) supapă electrohidraulică de debreiere (la vehicule amfibii)

electroless chrom / nickel / tin (met) cromare / nichelare / stanare chimică

electroless deposition / plating (chim) depunere / acoperire prin metoda reducerii catalitice controlate

electrolysable electrolitic; care poate fi prelucrat electrolitic / prin electroliză

electrolyse (fiz, el, chim) a electroliza, a face electroliză

electrolysis / electrolyse (el, chim) electroliză

electrolyte (el, chim) electrolit

electrolytic(al) (el, chim) electrolitic

electrolytic cell (el, chim) celulă electrolitică

electrolytic cleaning (el, chim, TH) curățare electrochimică în solutie alcalină

electrolytic copper (met) cupru electrolitic

electrolytic corrosion (chim, T) coroziune electrolitică

electrolytic degreasing (met, el, chim) degresare electrochimică

electrolytic deposition (el, chim) depunere electrolitică

electrolytic grinding (mas-un, el) prelucrare combinată de rectificare şi electrolitică (roata de rectificat poate fi catod)

electrolytic hygrometer (metr, el) higrometru electrolitic

electrolytic iron (met, chim) fier depus electrolitic

electrolytic machining (mas-un, el) prelucrare (şi rectificare) electrolitică

electrolytic parting (chim, el) separare (pe cale) electrolitică

electrolytic polishing (mas-un, el) lustruire electrolitică

electrolytic powder (ind chim, el) pulbere obținută direct sau indirect, prin electrodepunere

electrolytic reduction (met, el) reducere electrolitică

electrolytic refining (met, el) rafinare electrolitică

electrolytic slime (TH, mediu) şlam / nămol electrolitic

electrolytic tinning (met, el, chim) stanare / cositorire electrolitică

electromagnet (el) electromagnet

electromagnetic (el) electromagnetic

electromagnetic clutch (OM, auto) ambreiaj electromagnetic

electromagnetic coupling $(\mathrm{OM}, \mathrm{el})$ ambreiaj electromagnetic, cuplaj inductiv 
electromagnetic gauge (metr, autom, el) traductor / captator (de semnal) electromagnetic

electromagnetic linkage $(\mathrm{OM}$, el) cuplare / conectare electromagnetică

electromagnetic (ore) separation (met, ind chim) separare electromagnetică (a minereurilor)

electromagnetic separator (met, ind chim, el) separator electromagnetic

electromechanical (el, mec) electromecanic

electromechanical actuator (mas, mec, el) sistem de acționare electromecanic (motor electric şi transmisie mecanică)

electromechanical transducer (metr, mec, el) traductor electromecanic

electrometallurgy (met, el) metalurgie prin metode electrice sau electrolitice

electrometer (el, metr) electrometru, aparat de măsurat mărimi electrice

electrometry (el, metr) electrometrie

electromotive (el) electromotor, electromotrice; electromotor; (cf) locomotivă electrică

electromotive force (el) forță electromotoare

electron (fiz) electron

electron beam (fiz) fascicul de electroni / electronic

electron beam brazing (fiz, met) lipire cu fascicul de electroni

electron beam welding (fiz, met) sudare cu fascicul de electroni

electron brake force distribution (EBD) (auto, autom) distribuție electronică a forței de frânare

electron brake force distribution (EBD) system warning light (auto) semnal luminos de avertizare pentru distribuția electronică a forței de frânare

electron cross section (fiz, metr) 1 Electron cross section $=6,6524616 \cdot 10^{-29} \mathrm{~m}^{2}$

electronically $(a d v)$ cu ajutorul electronilor, electronic

electronic brake force distribution (EBD) system warning light (auto) semnal luminos de avertizare pentru sistemul electronic de distribuție a forței pe frâne

electronician (electr) specialist în electronică

electronic deployment/inflation signal (auto) semnal electronic de deschidere a airbagurilor

electronic magnification (electr, fiz) amplificare electronică

electronic engineer (electr) inginer electronist

electronic engineering (electr) electronică

electronic power steering (auto electr) servodirecție asistată electronic

electronic stability program (EPS) (auto) program / sistem electronic de stabilizare electronic stability program (EPS) indicator (auto) indicator al sistemului electronic de stabilizare

electronic stability program (EPS) OFF / ON indicator (auto) indicator de deconectare / conectare a programului electronic de stabilitate / stabilizare

electron metallography (fiz, met) metalografie cu microscop electronic

electron microprobe analysis (fiz, chim) analiză chimică cu ajutorul bombardării cu electroni

electron microscope (fiz, met) microscop electronic

electron microscopy (fiz, met) microscopie electronică

electron radius, electron's classical radius (fiz, metr) rază de electron, unitate de măsură pentru lungime (în fizica atomică): 1 electron radius $($ classical $)=2,81794092 \cdot 10^{-15} \mathrm{~m}$

electron runaway (plasma physics) (fiz, el) disipare de electroni (şi la generarea plasmei dirijate / în câmp electric) (fizica plasmei)

electron spectroscopy (fiz, met) spectroscopie bazată pe emisia de radiații $\mathrm{X}$ a substanțelor la bombardarea cu electroni

electron-volt, electronvolt (eV, EV) (metr, fiz, el), electron(-)volt, unitate de măsură pentru energia atomică: 1 electron-volt $=1,60217733 \cdot 10^{-19} \mathrm{~J}$

electropainting, electrophoretic painting $(\mathrm{TH}$, el, chim) vopsire în câmp electric (piesa este anod)

electrophoresis (el, fiz, med) electroforeză

electrophoresis measurement (fiz, metr) măsurarea electroforezei / a dispersiei particulelor dintr-un fluid sub influența unui câmp electric uniform

electrophoretic velocity (metr, fiz, el) viteză de electroforeză

electro-plate (TH, el, chim) a acoperi cu strat depus galvanic, galvanizat, a galvaniza

electro-plated ( $\mathrm{TH}, \mathrm{el}, \mathrm{chim})$ acoperit cu strat depus galvanic, galvanizat

electroplating (met, el, chim) acoperire electrochimică

electropneumatic valve (OM, hidr) supapă electro-pneumatică

electropolishing (mas-un, TH) lustruire electrochimică

electropositive (fiz, el) electropozitiv

electroscope (el) electroscop

electroslag welding (met) sudare în baie de zgură

electrospark machining (mas-un, el) prelucrare prin electroeroziune

electrostatic(al) (fiz) electrostatic 
electrostatic bond (fiz, chim) legătură electrostatică

electrostatic dispersion (fiz, chim) dispersie electrostatică

electrostatic fibrous filter (fiz, chim) filtru electrostatic cu fibre / fibros

electrostatic field strength (el) intensitate a câmpului electrostatic

electrostatic force (fiz, chim) forță electrostatică

electrostatic painting (fiz, chim, TH) vopsire cu material încărcat electrostatic

electrostatic precipitator (chim, mas-un) agent / dispozitiv de precipitare pe principiu electrostatic

electrostatics (fiz) electrostatică

electrostatic screen (el, met) cuşcă Faraday, ecran electrostatic

electrostatic separation (fiz, ind chim) separare electrostatică / în câmp electrostatic

electrostatic spray(ing) painting (mas-un, fiz, el, chim) vopsire electrostatică prin pulverizare

electrostriction (fiz, el) electrostricțiune

electrostriction transducer (metr, el) traductor care exploatează procese de eletrostricțiune

electrostrictive (fiz, el, materiale) electrostrictiv

electrotechnical (el) electrotehnic

electrotechnics electrotehnică

electrothermal process (termo, el) proces de producere a căldurii cu ajutorul curentului electric

electrothermic instrument (metr, el, electr, termo) aparat care funcționează pe baza proceselor termo-electrice

electrowining (el, ind chim) extracție electrolitică element element (substanță sau organ / element de maşină), parte, factor component, mediu; (el) element, pilă

elemental elemental; elementar, fundamental, de bază, esențial; alcătuitor, component

elementariness caracter elementar, simplitate, stare primară

elementary elementar, primar, primitiv, simplu

elementary body (fiz, mec) corp simplu, substanță simplă

elementary charge (el) încărcătură elementară

elementary gas (fiz) gaz elementar / primar elementary level nivel elementar / de bază elementary particle (fiz) particulă elementară elementary school (edu) școală elementară elementary teacher (edu) învățător, institutor element melt time (el, termo) timp de topire (al unei sigurante / conductor)

elementary probability law (mat, fiz) densitate de repartiție element of area (mat, fiz, mec) element de arie, arie elementară

element of cone / cylinder (geom) generatoare de con / de cilindru

element of integration (mat) expresia de sub semnul integrării, element al integralei / de integrare

element of set (mat) element al mulțimii

elements elemente (de bază), notiuni fundamentale, fond (al unei probleme); (mat) baze

elements of industrial process measurement and control systems (mas, autom) elemente / module (eventual specializate pe funcții) din aparate de măsură și control

elevate a ridica, a înălța; a promova, a înainta (în funcție)

elevated ridicat, înălțat, suspendat; elevat, înalt, superior

elevated railway (cf) cale ferată aeriană / suspendată

elevated tank (constr, hidr) rezervor suprateran elevated train (cf) tren aerian / suspendat elevating belt $(\mathrm{OM})$ bandă elevatoare

elevating capacity (mas, transp) capacitate de ridicare

elevating force (fiz, mec) forță ascensională / de ridicare

elevating grader / belt loader (mas, transp) elevator, greder

elevating mechanism (mas, transp) mecanism / dispozitiv de ridicare

elevating plant (mas, transp) maşină de ridicat

elevating-platform truck (met, transp) cărucior-stivuitor / cu platformă de ridicare

elevating rack (OM, mas-un) sector de cremalieră pentru ridicare

elevating rest (mas-un, metr) lunetă cu reglarea înălțimii

elevating screw (ind chim, alim, $\mathrm{OM}$ ) elevator elicoidal, arbore filetat pentru ridicat (la vinci), şurub de cursă verticală, şurub al mecanismului de ridicat şi coborât (la maşini-unelte)

elevating shaft $(\mathrm{OM})$ bară / arbore al mecanismului / dispozitivului de ridicat

elevating spindle $(\mathrm{OM})$ arbore filetat al mecanismului de ridicat, şurubul vinciului

elevating stops (mas-un) limitatori de cursă verticală

elevation înălțime, profil, secțiune verticală, nivel, ridicare, taluz, ridicătură (de pământ), deal, colină; altitudine, cotă; proiectie verticală; înălțare, ridicare, urcare; (fig) elan, avânt elevation adjustment (mas, metr) avans / reglare / deplasare (pe) verticală 
elevational angle (geogr, fiz) unghi de elevație / de altitudine

elevation error (fiz) eroare de ridicare a fluidului (la aparate care folosesc vase capilare)

elevation handwheel $(\mathrm{OM})$ roată de reglare (de mână)

elevation height setting (mas, metr, autom) reglare pe / în înălțime

elevation mark (constr, hidr) cotă de nivel

elevation motor (mas-un) electromotor pentru cursa verticală

elevator (mas, transp) elevator, ascensor, lift, dispozitiv de ridicat, macara; (av) profundor; (agr, alim) magazie de cereale

elevator belt $(\mathrm{OM})$ bandă / curea de elevator

elevator gear $(\mathrm{OM})$ mecanismul de acționare (eventual cu roți dințate) la elevator

elevator slide (OM, transp) sanie / ghidaj a elevatorului

eleven unsprezece

elicit a smulge, a scoate, a extrage; a provoca (admirație)

elide a evita, a ocoli; a nu menționa

eligibility eligibilitate; calificare; caracter acceptabil, acceptabilitate

eligible for eligibil ca; bun, potrivit, acceptabil; dorit pentru

eliminant (mat) rezultant

eliminate a elimina, a îndepărta, a înlătura; a distruge

eliminate a distortion (autom, mas) a elimina o distorsiune, a compensa, a egaliza, a efectua o corectie

elimination eliminare, îndepărtare, înlăturare; extragere; distrugere

eliminator (hidr, OM) filtru, eliminator; (termo) separator / eliminator de stropi etc.

elinvar (met) aliaj $\mathrm{Fe}-\mathrm{Ni}$ - $\mathrm{Cr}$ (eventual $\mathrm{Mn}$ şi $\mathrm{W}$ ) cu coeficient de dilatare foarte mic şi modul de elasticitate practic invariabil

eliquation (alim, ind chim) licuație, segregare

elite, élite elită, floare, cremă

ellipse (geom) elipsă

ellipsis semnul minus, semn de lipsă; puncte se suspensie

ellipsoid (geom) elipsoid

ellipsoidal harmonic (mat) funcție armonică Lamé

ellipsoid shaving (mas-un) prelucrare cu şever a dinților în formă de butoi, şeveruire pentru bombarea flancurilor

elliptic(al) (geom) eliptic

elliptical bogie spring (cf, OM) arc dublu eliptic, pentru boghiu elipticity (mat) raport între semiaxele unei elipse elm (lemn de) ulm

eloign a se îndepărta

elongate (met, mec) a (a)lungi, a (se) întinde; a prelungi

elongated (mec) alungit, întins

elongated alpha (met) fază alfa, alungită

elongated cavity (met) suflură alungită (la turnare sau sudare) (defect)

elongated hole $(\mathrm{OM})$ gaură ovală

elongating mill (met) laminor elongator

elongation (mec) elongație, întindere, dilatație, (a)lungire relativă (la rupere), alungire longitudinală, depărtare, distanță

elongation at / on break / fracture / rupture $(\mathrm{mec})$ alungire la rupere

elongation per unit length (mec) alungire relativă / specifică / pe unitate de lungime

elongation speed $(\mathrm{mec})$ viteză de alungire

elongation test (mec, metr) încercare la întindere / la tractiune

elongation ultimate (mec) alungire la rupere

elongator (met) laminor de întindere; dispozitiv de tragere / de întindere

eloquence elocvență, elocință, oratorie

eloquent elocvent

else mai încă, în plus; alt, alta; altfel, că de nu elsewhere $(a d v)$ altundeva, în altă parte

eloxation (met, chim) eloxare

elucidate a elucida, a lămuri

elucidation elucidare, lămurire, explicație

elucidative, elucidatory explicativ, lămuritor

elude a eluda, a ocoli, a se feri de

elusion eludare, ocolire, eschivare; chichiță, tertip

elusive evaziv; pe care nu te poti bizui; slab (d. memorie)

elusory iluzoriu, aparent, înşelător

elutriate (alim, hidr, mediu) a elutria, a decanta, a limpezi

elutriation (alim, hidr, mediu) separare particulelor prin curenți ascendenți, levigare, decantare, spălare

elutriation method (alim, hidr, mediu) metodă de separare prin curenți ascendenți, levigare, decantare, spălare

emaciate a vlăgui, a epuiza; a stoarce; a slăbi, a se atrofia, a se atenua (rar)

emaciation epuizare, vlăguire, slăbire

emanate from (ind chim, mediu) a emana de la, a proveni de la, a izvorâ din

emanation (ind chim, mediu) emanație, exalație, exalare, radiație; (fig) proveniență, origine

embank (constr, hidr) a îndigui, a zăgăzui, a taluza (un drum) 
embankment (constr) rambleu, dig de apărare, taluz, umplutură; (nav) cheu, debarcader

embargo, $(p l)$ embargoes (ec) embargou, sechestru, interzicere, prohibiție; piedică, oprelişte; a pune embargou pe, a sechestra, a rechiziţiona; a opri, a interzice

embark (nav) a (se) îmbarca, a încărca (pe un vas); (fig) (ec) a plasa bani

embarkation, embarcation, embankment (nav) îmbarcare, încărcare (de mărfuri)

embarkment (nav) încărcare; obstacol, piedică

embark on / upon a porni pe, a se angaja în

embarass a stânjeni, a jena; a îngreuna, a complica; a împiedica

embarassed jenat, încurcat, stânjenit; (ec) în jenă financiară

embarassing stânjenitor, jenant, penibil, care împiedică / stâjeneşte / încurcă

embarassment jenă, stinghereală; complicație, complicații, încurcătură; (ec) jenă financiară; greutate, dificultate, impediment

embassy (constr, materiale) ambasadă; funcție de ambasador

embed a închide, a îngloba, a introduce, a întipări, a incorpora, a înzidi, a încastra; a insera, a intercala (d. texte, paragrafe), a băga, a vârâ, a fixa în ceva

embedded (constr) înzidit; (mec) încastrat, (s)cufundat; inclus, inserat; (materiale, T) îngropat împins (în) (d. particulele dure în matricea mai moale a unui compozit etc.)

embedded temperature detector (metr) termoelement / termometru / temocuplu incorporat

embedded top gate seat (met, constr) grindă superioară de rezemare

embedding incluziune; (constr, met) înzidire; $(\mathrm{mec})$ încastrare; $(\mathrm{T})$ acțiunea de înglobare a unei particule într-un alt material (la cuzineți din aliaje moi, compozite etc.)

embedding material (materiale) material pentru inserții / de umplut / de înzidit

embedment (materiale, TH) înglobare, încorporare, împachetare, încastrare, mascare; sădire

ember (termo, ind chim) cenuşă fierbinte

embezzle a delapida, a deturna, a-şi însuşi

embezzle funds $(\mathrm{ec})$ a deturna fonduri

embezzlement (ec, jur) delapidare, deturnare de fonduri, sumă delapidată

embezzler (ec, jur) delapidator

embitter a supăra; a irita, a mări (un proces nedorit); a înrăutăți, a agrava

embitterment agravare, înrăutățire

emblaze a aprinde, a face să ardă / să strălucească emblem emblemă, simbol; tip, prototip, mostră emblematic(al) emblematic, simbolic emblemize a fi emblema, a simboliza embodiment aplicare (a unei invenții); întocmire, alcătuire

embody a concretiza; a reprezenta; a alcătui, a forma; a încorpora, a cuprinde în sine; a personifica emboss (TH, mas-un) a gofra, a dăltui / lucra în relief, a stampa, a ştanța (şi monede)

embossed în relief

embossed plate $(\mathrm{OM})$ placă / tablă convexă

embossed plate evaporator (alim, ind chim) evaporator cu plăci ondulate / gofrate / profilate embossing (mas-un, TH) profilare, matritare, gofrare (şi d. materiale plastice), formare de bosaje embossing die (met, plast, mas-un) matriță pentru presarea figurilor în relief

embossing iron (mas-un) daltă de gravat / de aşchiat / de cioplit

embossing (met, plast, mas-un) profilare, gofrare, matritare

embossing die (met, mas-un) matriță de ştanţare embossing press / machine (mas-un) presă / maşină de ştanţat (şi monede)

embossing press for hot process (mas-un) presă de ştanțat / de matrițat la cald

embossment $(\mathrm{OM})$ deformație (umflătură sau adâncitură) pe suprafața unei piese

embosso process (mas-un) matrițare / ştanţare la cald

embound a cuprinde, a include

embowed (OM) arcuit, îndoit

embowel (alim) a scoate măruntaiele din

embrace a îmbrățişa; a primi, a accepta, a adopta, a se ocupa de, a studia (o specialitate); a cuprinde, a include

embranchment (TH, OM, el, hidr) ramificație, branşament; ramură

embrasure (constr) gol (în zidărie)

embrittle (met) a face să fie fragil, a fragiliza, a contribui la / a produce / a provoca fragilitate embrittlement (materiale) fragilitate embrittlement cracking (materiale) rupere fragilă embroider (textile) a broda embroidery (textile) brodare, broderie embroil a încurca, a încâlci (d. fire, fibre etc.); a amesteca, a implica

embroilment amestecare; implicare embrown a înnegri, a închide la culoare embryo (met) nucleu de cristalizare emend a corecta, a îmbunătăti, (un text); (ec, jur) a amenda (un text, o lege)

emendation corectare, amendare (a unui text, a unei legi etc.) 
emerald (minrl) (de) smarald, de culoarea smaraldului

emeraldine verde ca smaraldul

emerge a apărea, a ieşi în evidență / la iveală; a ieşi la suprafață; a se ridica; a reieşi

emergence, emergency (fiz) emergență; ridicare (şi la suprafață), ieşire, apariție, manifestare

emergency urgență; pericol, stare de excepție; de rezervă, de alarmă; (inf) eveniment neprevăzut; avarie, alarmă

emergency brake $(\mathrm{OM})$ frână de siguranță; (cf) frână / semnal de alarmă

emergency control (autom, mas) comandă de avarie

emergency cut-out (el, autom) întrerupător de avarie / de siguranță

emergency exit (constr) ieşire în caz de pericol emergency gate overhead travelling crane (nav, transp) pod rulant (al batardoului) / de reparație

emergency handle (auto) mâner de urgență

emergency maintenance $(\mathrm{TH})$ mentenanță / reparație în regim de urgenţă

emergency outlet / opening (mas, $\mathrm{TH}$, ind) golire / evacuator pentru caz de avarie

emergency power unit $(\mathrm{TH})$ unitate de putere în caz de urgență

emergency rear hatch safety release lever (auto) levier pentru eliberare de urgență plasat în interiorul portbagajului

emergency repair $(\mathrm{TH})$ reparație de urgență / improvizată, depanare

emergency set (mas, ind, nav) grup / agregat de avarie / de rezervă

emergency shut-down oprire / întrerupere de urgență, oprire de avarie

emergency squad (TH) echipă de avarie

emergency stop (auto, TH) oprire de urgență

emergency push stop $(\mathrm{TH})$ buton de întrerupere în caz de avarie / de pericol

emergency valve (OM, termo) vană / robinet / supapă de rezervă a dispozitivului de ocolire (la turbine)

emergency ventilation (met) ventilație de avarie emergent from care iese / apare (pe neaşteptate) din, care survine (pe neaşteptate); (fiz) emergent emery (met) şmirghel, corindon granular emery belt bandă abrazivă

emery cloth hârtie abrazivă / cu şmirghel, pânză abrazivă

emery cutter (mas-un) disc abraziv subțire (de retezat)

emery file (mas-un) bară / pilă abrazivă

emery grinding wheel (mas-un) disc abraziv emery machine (mas-un) maşină de polizat, polizor

emery paper hârtie abrazivă / şmirghel

emery powder (mas-un, TH) praf de şlefuit

emery stand (mas-un) polizor (cu piatră abrazivă) emery wheel (mas-un) disc abraziv / de rectificat, piatră de polizor

emigrant, emigrator emigrant

emigrate a emigra

emigration emigrare

emigratory (materiale) care emigrează; de emigrare; migrator

eminence (geogr) ridicătură de teren, înălțime, colină, dâmb, deal; (fig) rang, situație; proeminență

eminent ridicat, înalt (d. teren); eminent, distins, ales, remarcabil

emission (fiz, autom) emisie (de raze, de particule, de semnale), radiație, expulzare, emanație, degajare, emisiune, propagare, răspândire, difuzare; program; (ec) emisiune de bancnote emission control system (auto) sistemul de control al emisiilor (motorului) / noxelor

emission control system components (auto) componente ale sistemului de control al emisiei de gaze de eşapament

emission control system malfunction indicator light (auto) indicator de avertizare a functionării defectuoase a sistemului de control al emisiilor

emission spectrum (fiz) spectru de emisie

emissive difuzat, emis

emissivity / emmitance (fiz) viteză de emisie a electronilor

emit (fiz) a răspândi, a emana, a exala; a emite, a radia (şi căldură); a scoate sunete; (ec) a emite (bancnote); (TH, med) a secreta

emittance emisivitate, putere de emisie

emitted emis

emitter (fiz, radio) emițător, transmițător; emitent, care emite

emoluments (ec) renumerație, retribuție, indemnizaţie

emotionless impasibil, indiferent

empennage (mas-un) asamblare / montare a cozii (unei scule)

emphasis, $(p l)$ emphases accent, accentuare, subliniere, scoatere în relief; expresivitate, elocvență

emphasize a accentua, a pune accentul pe, a sublinia, a reliefa, a scoate în relief / în evidență emphatic accentuat, subliniat; insistent, stăruitor; autoritar; (d. un refuz) categoric, total; (d. o afirmație) energic; viu (colorat), țipător 
empiric(al) empiric, practic; pragmatic, bazat pe experiență

empirical formula (mat, fiz) formulă empirică empirically $(a d v)$ (în mod) empiric, practic; pragmatic, pe baza pe experienței

empiricism empirism, practicism

emplacement (constr, $\mathrm{TH}$ ) amplasare, aşezare, poziție, punere în poziție (d. utilaje)

emplane (as, transp) a (se) urca în avion

emplanement (av, transp) urcare în avion

employ a folosi, a întrebuința, a utiliza, a încărca (un utilaj); (ec) a angaja (personal), a da de lucru; a se ocupa, a se îndeletnici

employable apt de muncă, utilizabil

employee funcționar, angajat

employees echipă, efectiv, personal

employer patron, antreprenor, beneficiar

employment serviciu, ocupație, folosire, folosință, întrebuințare, utilizare; ocupație, îndeletnicire, post

employment exchange (ec) serviciu / agenție pentru forța de muncă

empower a împuternici, a autoriza; a permite, a da posibilitatea

empowerment împuternicire, autorizare

emptiness (spațiu) gol, vid; nulitate

emptiness of lipsă de

empty gol, neocupat, liber, vid; nelocuit, pustiu; a goli, a deşerta, a descărca, a evacua, a (se) vărsa; (TH) ambalaj

empty glume (agr) pleavă

empty haul (transp) parcurs gol (fără încărcătură)

emptying golire, dezvelire, evacuare, descărcare; (met) descărcare (la cuptor / convertizor)

emptying device (mas) dispozitiv de golire / de descărcare

emptyings (mediu, alim, hidr) depuneri, sedimente empty running (transp) parcurs gol (fără încărcătură); (mas-un) mers în gol

empty seed (alim) sămânță seacă

empty set (mat) mulțime vidă

empty a shell (met) a goli o cochilie (de turnare) empty trip (TH, transp, mas-un) cursă în gol

empty truss (constr) fermă falsă

emulate a rivaliza cu, a căuta să întreacă; a imita; (inf, mas) a permite functionarea unui echipament cu programe destinate altuia

emulation emulare, emulație, întrecere; (c, inf) proprietate a unui sitem de calcul de a executa programe destinate altuia

emulating agent (chim, T) emulsor, agent de emulsionare

emulative de emulaţie; imitativ, de imitaţie emulgator $(\mathrm{T}$, chim) agent emulsificator / de emulsionare, emulgator

emulsification ( $\mathrm{T}$, alim, $\mathrm{TH}$ ) emulsionare

emulsified ( $T$, alim, $T H$ ) emulsificat, emulsionat (şi d. uleiuri lubrifiante sau pentru prelucrări mecanice)

emulsified oil ( $\mathrm{T}$, alim, $\mathrm{TH}$ ) ulei emulsionat

emulsifier (alim, met, $\mathrm{T}$ ) agent de emulsionare

emulsify a emulsiona, a forma emulsii; (met, plast) a acoperi cu un strat protector

emulsifying ( $\mathrm{T}$, alim, $\mathrm{TH}$ ) emulsificare, emulsionare, realizarea unei emulsii, emulsificator, care face o emulsie

emulsifying agent (alim, met, $\mathrm{T}$, chim) agent de emulsionare, agent de emulsificare

emulsifying power / efficiency (alim, chim) putere de emulsionare

emulsion (fiz, T) emulsie

emulsion adhesive (plast) adeziv în emulsie

emulsion breaker (chim, T) (agent) dezemulsionant

emulsion breaking (alim, $\mathrm{T}$, chim) rupere / spargere a emulsiei, dezemulsionare

emulsion degreasing (met) degresare prin emulsionare

emulsion corrosion test (mas-un, met, metr) test / încercare de determinare a coroziunii emulsiei

emulsion inhibitor (chim, T) (agent) inhibitor contra formării emulsiei

emulsion reversal (ind chim, $\mathrm{T}$ ) inversare a emulsiei

emulsion stability (ind chim, T) stabilitate a emulsiei

emulsion stabilizer (ind chim, alim, T) (agent) stabilizator al emulsiei

emulsive (alim) de emulsie; lăptos, untos

emulsor (TH, ind chim, met) aparat / dispozitiv de obținere a unei emulsii

enable to a valida, a face posibil / capabil, a permite să, a da posibilitatea să; (TH, mas) a repune în funcțiune, a permite (şi continuarea funcționării)

enabling care permite, care dă posibilitatea; (jur, pol) care împuterniceşte

enact a legifera, a adopta (o lege); a hotărî, a decreta

enactment (pol) legiferare; adoptare (a unei legi); hotărâre, decret, ordonanță

enamel (ind chim) vopsea de email, email, smalț, glazură; a emaila, a smălțui

enamelled (ind chim) emailat, smălțuit; (textile, hârtie) satinat

enamelled sheet (met) tablă emailată 
enamelling (ind chim) emailare

enamelling kiln / oven (ind chim) cuptor de emailare

enamel lining (ind chim) emailare

enamelling sheet (met) tablă (din oțel) pentru emailare

encapsulate (alim, ind chim) a încapsula, a pune în capsule; a rezuma, a prezenta succint encapsulated capsulat; blindat

encapsulated adhesive (plast) adeziv capsulat / închis ermetic

encapsulation capsulare, încasetare, ecranare

encase a împacheta, a ambala; a acoperi, a înveli; (constr) a cofra; a înveli, a înconjura, a închide, a încaseta, a capsula, a capsa, a aplica capse / capsule; (el) panou, tablou

encased $(\mathrm{OM})$ amplasat în casetă / în carcasă, (în)capsulat (d. o piesă, un element de maşină) encased propeller shaft $(\mathrm{OM})$ arbore cardanic / încasetat / protejat

encasement împachetare, ambalare; (alim, ind, OM) ambalaj, cutie, înveliş; încasetare, carcasă (constr) cofraj

encash (ec) a încasa

encasing (met) manta de cuptor, acțiunea de montare a mantalei, îmbrăcare, căptuşire, închidere, învelire; (constr) cofraj; (OM) carter, carcasă, manta

enchase a şlefui, a cizela, a monta (o piatră prețioasă)

enchaser şlefuitor, cizelator, bijutier

enchisel a dăltui

encipher (inf, mil) a cifra, a codifica

encircle a încercui

encirclement încercuire, înconjurare

encircling împrejmuitor, de încercuire, care încercuieşte

en clair (mesaj) necifrat / necodificat

enclasp $(\mathrm{OM})$ a prinde cu cârlige / copci

enclave enclavă

enclose (ec) a anexa / a alătura un act, o scriesoare; a închide, a îngrădi, a îngloba, a include, a cuprinde, a încadra, a împrejmui, a înconjura, a capsula, a încaseta; a închide, a izola; a pune în plic

enclosed protejat; închis, capsulat

enclosed area zonă / incintă închisă

enclosed blower (termo) suflantă capsulată / tip modul

enclosed RDL compressor ( $\mathrm{TH}$, termo) compresor rotativ, capsulat, cu zonă de lucru uscată enclosed slag (met) incluziune de zgură, (cu) zgură în incluziuni

enclosed type (OM) (de) tip închis / capsulat enclosure închidere, îngrădire, împrejmuire; țarc, curte; conținut (al unui plic), anexă; (constr) gard, împrejmuire, îngrăditură, loc îngrădit; (ec) anexă a unui document; (fiz) incintă, spațiu închis / izolat; inserție, bordură, tivire, ramă, încastrare, montură, armătură, blindaj, acoperitoare, cutie, carcasă, manta; (met) incluziune (defect)

encode a cifra, a codifica

encounter ciocnire, şoc (şi fig)

encroach upon a vătăma, a dăuna; ec, jur) a prejudicia, a păgubi

encrust a încrusta, a (se) acoperi cu o coajă / crustă, a prinde coajă / crustă / rugină

encrustation (met, termo, nav) încrustare (de zgură, produse de uzură / de coroziune / biologice)

encumber a stânjeni, a împiedica, a îngreuna; (ec) a încărca (cu datorii); a împovăra; a fi o piedică / un obstacol pentru

encumbrance obstacol, piedică, povară, greutate; (ec) ipotecă, datorie, sarcină

encryptation (mil, inf) codificare

encyclopaedia enciclopedie

encyclopaedic(al) enciclopedic

end capăt, sfârşit; cap, margine, limită, închidere, încheiere, terminare, partea de la sfârşit; rămășiță, rest, capăt; (met) capăt (de lipit la brame, la turnarea continuă etc.); a sfârşi, a isprăvi, a termina, a încheia

END (inf) tastă care execută saltul cursorului la sfârşit de linie / pagină / document

endamage a strica, a aduce stricăciuni; a teriora; a provoca o distrugere / deteriorare

endamagement păgubire; stricare; pagube, stricăciuni; (procesul de) deteriorare, distrugere

end and means scop şi mijloace

endanger a periclita, a primejdui, a pune în pericol end-around shift (mec, mas-un) deplasare ciclică / circulară

end block (metr) cală plan-paralelă, placă pentru calibrare

end boiling point (fiz, ind chim) temperatură finală a fierberii

end clearance (auto, termo) distanță între capetele segmentului de piston

end cleat (minrl) clivaj secundar / perpendicular

end conditions condiții la capete / la graniță / la margini / la limite (şi la modelare cu element finit)

end device (autom, metr) dispozitiv ultim / final într-un lanț de măsurare

end-dumping truck (met) vagonet basculant $\mathrm{cu}$ descărcare laterală 
endeavour a se strădui, a încerca, a căuta; sforțare, efort, strădanie

ended sfârşit, terminat, gata; finisat

end face $(\mathrm{OM})$ parte / secțiune / suprafață frontală end gauge (metr) calibru vergea

end(-grained) cut secțiune transversală; (masun) retezare

end in a se sfârşi, a se încheia

ending capăt, terminație, (acțiune) de încheiere; sfârşit, final

end item (ec) articol / produs finit

end journal bearing $(\mathrm{OM}, \mathrm{T})$ lagăr frontal / de capăt

end lap weld (met) cusătură / sudură frontală / transversală

end lathe (mas-un) strung pentru prelucrat piese prin prindere în mandrină

end launching (nav) lansare la apă; (pe direcție) longitudinală

endless fără sfârşit, infinit, interminabil, continuu; (OM) cu contur închis (d. curele)

endless belt $(\mathrm{OM})$ curea / bandă (care se livrează) cu contur închis

endless chain $(\mathrm{OM})$ lanț (care se livrează) cu contur închis

endless-chain trench excavator (constr, mas) excavator de tranşee / şanţuri, cu şenile / cu lanț endless conveyer (mas) transportor cu bandă

endless gilled pipe (termo, hidr, OM) țeavă cu aripioare circulare

endlessness infinitate, infinit

endless saw (mas-un) fierăstrău circular / cu panglică

endless screw $(\mathrm{OM})$ şurub tip melc, şurub fără sfârşit

endless track (auto, mil) şenilă, lanț de şenilă end link legătură terminală; $(\mathrm{OM})$ za de lanț, eclisă de închidere a lanțului, cheie terminală

endlong movement (mec, $\mathrm{OM}$ ) mişcare în direcție axială

end-man extremist

end measuring block (metr) cală plan-paralelă, placă de calibrare

end measuring rod (metr) micrometru de interior, calibru-vergea

end-mill(ing) cutter (mas-un) freză deget / frontală, freză cilindro-frontală

end moment (mec, OM) moment de încastrare

end motion (mec, mas) deplasare în directie axială end of a vector (mat) extremitate a unui vector end of the file (inf) sfârșitul fissierului end off a termina (cu succes)

end-of-file statement (inf) propoziție / instrucțiune de sfârşit de fişier end-of-message signal (inf) semnal de terminare a mesajului

end of nozzle (auto, OM, termo, hidr) gură a jiclorului, orificiu de ieşire al unui ajutaj end of tape (inf) sfârşitul benzii (de înregistrare); (mas-un) instrucțiune care opreşte prelucrarea endogenous slag inclusion (met) incluziune de zgură, de proveniență endogenă (defect)

end on (fiz, minrl) perpendicular pe clivaj, în sens longitudinal

endorse (ec) a andosa; a semna pe verso; (fig) a aproba, a fi de acord (cu) a sprijini, a susține (un punct de vedere) a subscrie la; $\sim$ on a scrie pe verso;

endorsee (ec) andosant (al unei polițe)

endorsement (ec) andosare, gir; (fig) aprobare, sancționare, sprijinire; (TH) metodă de adoptare a unui standard internațional (fără modificări, eventual tradus) (și method)

endorser $(\mathrm{ec})$ girant

endothermic reaction (chim, met) reactie endotermă

endow (ec, TH) a dota, a înzestra, a investi, a furniza

endowment (ec, TH) dotare, înzestrare, alocare, talent

end piece $(\mathrm{OM})$ piesă de capăt / terminală, capăt, vârf

end pin $(\mathrm{OM})$ bolț / ştift de legătură / de capăt end plate (el) placă extremă / de capăt (la acumulator); (OM) capac frontal / al orificiului frontal, perete / placă de închidere / terminal(ă); (met) fund de vas / de oală

end play / shake (OM) joc axial / de capăt

end point of meshing $(\mathrm{OM})$ punctul de ieşire din angrenare (notat cu E) (la roți dințate evolventice)

end pressure (hidr, mec) presiune de / la capăt / finală; presare pe muchie / a marginilor

end product $(\mathrm{ec})$ produs finit

end quench (hardenability) test (met, metr) test de duritate prin călire frontală

end reaction (mec, OM) reacțiune în reazem; (plast, ind chim) reacție de încetare a creșterii catenei

end resistance $(\mathrm{TH}$, hidr) rezistență reziduală / de capăt / la sfârşitul unui proces

end restraint $(\mathrm{mec})$ încastrare

end restraint moment $(\mathrm{mec})$ moment de încastrare

end ring $(\mathrm{OM})$ inel cu umăr, etrier inelar, inel de legătură / de închidere / de capăt

end scale value (metr) valoarea maximă a scalei (unui aparat) 
end shears (met, mas-un) foarfece de retezat capete (de semifabricate, profiluri etc.)

end span (constr) deschidere de capăt (la o grindă continuă)

end stage (TH) treaptă / etapă finală, grad final

end stray (met, ind chim) dispersie la capete

end supports (mec, OM) reazeme extreme / de capăt

end thrust (mec, hidr) presiune axială

end thrust bearing $(\mathrm{OM}, \mathrm{T})$ lagăr axial, crapodină

end-to-end (OM) cap-la-cap (d. asamblări etc.)

end-to-end joint $(\mathrm{OM})$ încheietură / rost / asamblare cap-la-cap

end tooling (mec, electr) ansamblu de scule de capăt, graifăr de robot

endurable suportabil; care rezistă / poate rezista un anumit timp

endurance durată, anduranță, rezistență la oboseală, durată de viață (în lucru, în exploatare); longevitate; durabilitate (limitată)

endurance bending strength (mec) rezistență la oboseală la încovoiere / la îndoire

endurance bending test (mec, metr) încercare la oboseală la încovoiere / la îndoire

endurance crack (mec) fisură de oboseală (sens mai larg), crăpătură / fisură de oboseală (din cauza solicitărilor variabile (nu neapărat ajunse în domeniul de oboseală)

endurance failure (mec, $\mathrm{OM}$ ) rupere la / prin oboseală

endurance impact test (mec, metr) încercare de rezistență la oboseală cu şocuri / sub sarcină dinamică

endurance limit (mec, OM) limită de anduranță / de oboseală (limitată)

endurance limit of pulsating stress (mec, OM, metr, materiale) limită de durabilitate (la oboseală limitată) pentru tensiune pulsatorie (fără a specifica tipul de solicitare)

endurance limit of stress (mec) rezistență la oboseală / la durabilitate limitată (în sens larg)

endurance limit on base $\mathbf{N}$ (mec, OM) limită (convențională) de rezistență la oboseală, pentru N cicluri

endurance range (mec) interval (al limitei) de oboseală

endurance run (mec, OM, metr) încercare de rezistență la oboseală / la durabilitate limitată

endurance strength (mec, OM) rezistență la oboseală sau la durabilitate

endurance tension test (mec, OM, metr) încercare de rezistență la oboseală la tracțiune / la întindere endurance test (mec, OM, auto) încercare de rezistență la oboseală / la durabilitate limitată, test de anduranță

endurance torsion test (mec, OM, metr) test de rezistență la oboseală (şi limitată) la torsiune, test de durabilitate la torsiune

endurance traverse-stress test (mec, OM) încercare / test de rezistenţă la oboseală prin încovoiere

endurance trial probă de durată în mers; (nav) probă de rezistență la marş

endure a suporta, a îndura, a suferi, a dura, a ține; a rezista la o solicitare un anumit timp enduring răbdător; trainic, de durată, solid; durabil (o perioadă de timp limitată)

end wall (constr) perete de capăt / frontal

endwise în direcție longitudinală

energetic(al) energic; (fiz) de energie, energetic energetically $(a d v)$ (în mod) energic, cu energie energetics energetică

energisation (fiz, mec) excitare, alimentare, energizare

energize (el) a amorsa, a excita, a lăsa curentul să treacă, a alimenta, a activa, a activiza, a conecta; (TH, mas) a pune în funcțiune, a manipula, a acționa

energized line (el) linie sub tensiune

energizer in carburising (met, chim) agent accelerator de carburare / de cementare

energizing stimulator, care activează

energy energie; forță, vigoare

energy application aport de energie

energy balance / budget (termo, mec) bilanț energetic

energy band (fiz, chim) bandă de energie

energy conversion (fiz, chim) conversie a energiei

energy density (fiz, chim) densitate de energie; (fiz) expunere energetică, expunere radiantă; densitate energetică $\left(\mathrm{H}_{\mathrm{e}}\right)$ - mărime de fotometrie a radiației, (unitate de măsură $-\mathrm{J} / \mathrm{m}^{2}$ )

energy efficiency $(\mathrm{TH}, \mathrm{mec})$ randament energetic energy exchanger (fiz, chim, termo) schimbător / transformator de energie (inclusiv de căldură)

energy limited (el) cu energie limitată (la startere)

energy loss (fiz, mec, el, TH, mas) pierdere de energie

energy output (el) putere dată la borne / la ieşire

energy supply (TH, el) alimentare cu energie

energy storage braking $(\mathrm{mec})$ frânare prin acumulare de energie

energy system sistem energetic 
energy yield ( $\mathrm{TH}$, termo) randament energetic enfeed $(\mathrm{OM})$ introducere a unei piese în altă piesă, cuplare mecanică

enflame (fig) a aprinde

enfold a înfăşura, a înveli; a cuprinde, a plia, a îndoi

enforce a sili, a obliga, a constrânge, a impune; a aplica (o lege); a îndeplini; a întări (o afirmație) enforceable (jur) executoriu; realizabil

enforced forțat, silit

enforcement forțare, silire; constrângere; (jur) executare, intrare în vigoare

enframe a încadra, a înrăma

engage $(\mathrm{TH})$ a cupla, a ambreia, a angaja, a angrena, a conecta, a face legătura (şi mecanică) a prinde; a obliga; a garanta

engaged (ec) angajat, ocupat, rezervat; (OM) angrenat, cuplat, ambreiat, conectat

engaged gear $(\mathrm{OM})$ roată dințată angrenată

engaged in angajat în, ocupat cu

engage in a începe cu, a se angaja în, a intra în, a se apuca (de afaceri etc.), a se lansa în

engagement (ec, pol) angajament, obligație; ocupație, treabă; întâlnire; $(\mathrm{OM})$ cuplare, ambreiere, angrenare, ocupare, angajare / intrare în angrenare; (ec) angajare

engagement mechanism $(\mathrm{OM})$ mecanism de cuplare

engage over a suprapune, a acoperi

engage the parking brake (auto) a activa frâna de mână

engage to a obliga să, a-şi lua obligația de a, a promite să / că

engaging $(\mathrm{OM})$ de antrenare, de angrenare, care angrenează / cuplează

engaging $\operatorname{dog}(\mathrm{OM})$ furcă / gheară de antrenare

engaging friction $(\mathrm{OM}, \mathrm{T})$ frecare care poate bloca o piesă pe suprafața de frecare (şi la ambreiaje)

engaging gear $(\mathrm{OM})$ dispozitiv de cuplare a unui angrenaj / a unei roți dințate

engaging lever $(\mathrm{OM})$ pârghie / levier de conectare / de pornire / de cuplare şi decuplare engaging piston $(\mathrm{OM}$, hidr) piston de cuplare engender a genera, a da naştere la, a produce engine motor, maşină motoare; (cf) locomotivă; (OM) mecanism, dispozitiv, unealtă (mai rar); pompă de incendiu

engine acceptance run / test probă de recepție a unui motor

engine accessory (mas) accesoriu de motor

engine analyzer (metr, termo) oscilograf pentru verificarea motoarelor

engine attendant (cf) mecanic engine base (mas, OM) soclu al motorului

engine bearer / bracket (mas, OM) şasiu / suport al motorului

engine bed (mas, OM) batiu al motorului

engine block (auto, termo) bloc al cilindrilor de motor

engine bogie (cf) boghiu de locomotivă

engine bonnet / cowling / hood (auto, termo) capotă a motorului

engine brake / braking (auto, OM) frână de motor engine breakdown (mas) pană de motor, defectare a motorului

engine builder constructor de motoare / maşini engine compartment (nav, mas) compartiment al maşinilor / motoarelor; (auto) compartimentul motor

engine component ( $\mathrm{OM}$, termo, auto) element, parte a(l) motorului

engine control system's oxygen sensor (auto) senzorul de oxigen al sistemului de control al motorului

engine coolant (system) (auto) (sistem de) răcire al motorului, răcirea motorului

engine coolant reservoir (auto, termo) rezervor al lichidului de răcire

engine coolant temperature (auto) temperatura agentului de răcire al motorului

engine displacement (auto, termo) cilindree, capacitate cilindrică (a motorului)

engine drive (mas) actionare cu motor

engine driver mecanic, maşinist; (cf) mecanic de locomotivă

engine duty cycle (termo, mas) ciclu de lucru al motorului

engineer inginer, tehnician, proiectant, desenator, maşinist, metalurgist; a construi, a proiecta, a inventa, a aranja

engineer-in-charge $(\mathrm{TH})$ (inginer) mecanic de serviciu / de întreținere

engineering inginerie, asistență tehnică, tehnologie, industria construcțiilor de maşini; proiectare şi executie (în domenii diverse, mecanic, electric etc.) (piese, sisteme, tehnologii)

engineering cast iron (met) fontă pentru construcții de maşini

engineering data (mas, $\mathrm{TH}$ ) date tehnice

engineering description (mas, $\mathrm{TH}$ ) descriere tehnică

engineering (design) drawing $(\mathrm{OM}, \mathrm{TH})$ desen tehnic, plan de montaj, desen de ansamblu

engineering education (edu) învățământ tehnic engineering factors ( $\mathrm{TH}, \mathrm{mas})$ condiții tehnice / de serviciu / de exploatare

engineering library (edu) bibliotecă tehnică 
engineering lofting (met, nav) trasare a tablei în vederea decupării

engineering material material de construcție / pentru o (anumită) aplicație inginerească

engineering plastics (materiale, plast, OM) materiale plastice pentru organe sau elemente de maşini

engineering shop $(\mathrm{TH})$ atelier mecanic, secție mecanică

engineering time $(\mathrm{TH})$ durată / timp de întreținere / de reglare / de prelucrare / de asamblare etc.

engineering works $(\mathrm{TH})$ uzină constructoare de maşini

engineer's book jurnal de maşini; (nav) jurnal al motorului (principal)

engineership profesia / funcția de inginer, meseria de tehnician

engine exhaust (auto) gaze de eşapament

engine failure (auto, termo, mas) cădere / avarie de motor

engine fitter mecanic, montor, lăcătuş ajustor (specializat în motoare)

engine flywheel (auto, OM) volant de motor (şi la motoare diesel)

engine foundation (constr, mas) fundație pentru motor

engine frame (constr, mec, mas, OM) batiu al motorului, structură destinată să suporte un motor

engine fuel (auto, ind chim, mas) carburant

engine gear box unit unitate $\mathrm{cu}$ motor şi reductor sau cutie de viteze, motoreductor

engine health monitoring ( $\mathrm{TH}$, mas, termo, cf) monitorizare a funcționării corecte a motorului

engine hold-down bolt $(\mathrm{OM})$ şurub / bolț pentru fixarea motorului

engine hood (auto) capotă

engine house (cf, met) depou de locomotive, compartiment / sală / hală a(l) maşinilor

engine lathe (mas-un) strung cu avans automat, strung de prelucrat piese filetate şi suprafețe cilindrice

engine( )man, engine operator (cf) mecanic de locomotivă; mecanic, maşinist

engine mount (OM, mas) sprijin de motor, batiu al motorului

engine mounting $(\mathrm{TH}$, mas) montare a motorului încorporat, şasiu / suport al motorului

engine-nacelle bracing $(\mathrm{TH}, \mathrm{OM})$ rigidizare a motorului

engine oil (auto, T) ulei de motor

engine oil dipstick (auto) tijă de nivel / jojă pentru ulei engine oil filler cap (auto, mas) capac pentru alimentare cu ulei

engine oil pressure (auto, mas) presiune a uleiului de motor

engine oil pressure warning (auto, mas) avertizare cu privire la presiunea uleiului de motor engine operating cycle (termo) ciclu de funcționare / de lucru, al unui motor

engine output / performance $(\mathrm{mec})$ putere a motorului (la ieşire)

engine part $(\mathrm{OM})$ piesă a motorului

engine room $(\mathrm{TH})$ hală / sală a maşinilor / motoarelor; (nav) compartiment al maşinilor engine room journal (nav) jurnal / registru de evidență a funcționării, pentru sala maşinilor

engine shaft $(\mathrm{OM})$ arborele motorului, arbore motor

engine solar oil (auto, ind chim) motorină engine speed control (auto, autom, termo) limitator de turație (la motoare cu ardere internă) engine strutting $(\mathrm{mec})$ rigidizare a motorului engine temperature (auto, mas) temperatura motorului

engine temperature gauge (auto, metr) indicator al temperaturii motorului

engine test bed / bench / stand banc / stand de probă pentru motoare

engine testing (auto, metr) testare a motorului

engine timing (termo, auto) reglare a distribuției şi a avansului de aprindere

engine torque (mec, auto, mas) momentul de torsiune la motor

engine trouble (auto, mas) pană / defect de motor engine unit ( $\mathrm{TH}$, mas) agregat, grup motor engine versatility (mas) suplețe / flexibilitate a motorului, posibilitate a motorului de a-şi modifica regimul de funcționare, fără a utiliza cutie de viteze

engine with outside guide (mas) motor cu ghidaj exterior de reglare a poziției / cu glisieră

engine with precombustion chamber (termo) motor cu cameră de precombustie

engine with tandem cylinders (auto, mas, termo) motor cu cilindri în tandem

engine works uzină constructoare de motoare

Engler degree ( $\mathrm{T}$ ) grad Engler (de vâscozitate)

Engler viscosity $(\mathrm{T})$ vâscozitate (în grade) Engler

engrain a impregna, a îmbiba; a grava

engrave (met) a grava, a stampa, a cresta (în metal) engraving tool (mas-un) răzuitor pentru strung engross a absorbi, a captiva, a ocupa (atenția); a monopoliza; a masa, a aduna; a scrie cu litere mari; (ec) a monopoliza 
engrossing captivant

enhance a mări, a intensifica, a ridica (calitatea), a creşte, a spori, a amplifica; a atrage atenţia

enhancement amplificare, mărire, creştere, sporire, intensificare

enkindle a aprinde, a ațâța (d. un foc, o flacără)

enlarge a (se) extinde, a (se) mări, a (se) lărgi, a dezvolta, a (se) dilata, a (se) amplifica, a mandrina; a spori

enlarged lărgit; adăugit (d. o ediţie)

enlarged end of link (OM) capăt mărit al plăcuței (de închidere) de lanț

enlarged detail view (OM) vedere de detaliu, detaliu (mărit) (dintr-un desen tehnic)

enlargement lărgire, mărire, sporire, extindere, evazare, amplificare, mandrinare; (constr) anexă, dependințe; creştere, dezvoltare; (pol, ec) extindere (d. Uniunea Europeană)

enlarge on / upon a scrie / vorbi pe larg

enlarger (metr) aparat de mărit

enlarging bit (mas-un) burghiu plat / lărgitor, lărgitor

enlighten a lămuri, a informa; a culturaliza; a explica, a arunca lumină asupra

enlightened instruit, cult; lămurit, edificat

enlightener interpret, persoană care explică (ceva); om bine informat

enlightenment (edu) luminare; instructie, cultură; cunoaştere rațională

enlist a înscrie pe o listă, a înregistra, a face o listă

enlistment înscriere, înregistrare, listare

en masse în masă; cu toții

enmesh a prinde (ca într-o plasă)

enmeshment încurcătură, situatie încurcată

enormous enorm, uriaş, colosal, imens

enough destul, de ajuns, suficient, îndestulător; $(a d v)$ destul, de ajuns, suficient, îndeajuns; (după adj şi $a d v$ ) destul de, foarte, destul (depreciativ), îndeajuns de, suficient de

enounce a enunța, a expune; a proclama enouncement enunțare, expunere; proclamare

enquire, inquire a întreba, a cere; about a se interesa de, a se informa despre; a ancheta, a face $o$ anchetă

enquiry, inquary (inf) interogare, cerere de găsire a unor date stocate; (ec) cerere, chestionar; anchetă, cercetare

enrich a (se) îmbogăți, a concentra (d. minereuri etc.); (agr) a îngrăşa, a fertiliza

enriched gas (termo) gaze bogate / umede

enriched matte (met) mată concentrată / îmbogățită

enriching (met) îmbogățire, concentrare enrichment îmbogățire, înnobilare

enrichment layer (met) strat îmbogățit (la tratamente termo-chimice)

enrichment rate (alim, ind chim) viteză de îmbogăţire / de înnobilare / de modificare a concentrației (în sensul dorit)

enrol(I) a înscrie pe o listă, a înregistra; a împacheta, a face sul; (amer) a se înscrie (la şcoală) enrol(l)ment înscriere, înregistrare

ensilage (agr) ansilaj, însilozare, nutreț însilozat, a însiloza (nutret)

ensile (agr) a însiloza nutreț

ensphere a da o formă sferică

ensue a urma; from a decurge din, a rezulta din

ensuing următor, viitor, care decurge (de aici)

ensure a asigura, a garanta

ensure against a (se) asigura împotriva, a lua măsuri împotriva, a (se) feri de

entail a atrage (după sine), a cauza, a determina; a impune, a reclama, a necesita; (jur) a lăsa moştenire (un bun), moştenire inalienabilă; on a impune cuiva

enter a intra în, a introduce, a băga, a pătrunde în; a fi admis la, a se înscrie în / la; a trece pe listă, a înregistra, a înscrie; (jur) a intenta (un proces); a iniția; (inf) a lansa un program, a înregistra

Enter (inf, c) comandă de introducere în memorie, tastă de execuție a comenzii sau de închidere a liniei curente şi trecere la rândul următor

entering angle (hidr, mec) unghi de intrare / de atac

entering file (mas-un) pilă pentru găuri

entering gear tooth $(\mathrm{OM})$ dinte (de roată dințată) care intră în angrenare

entering side (in rolling) (met) latură de intrare (în laminare)

entering wedge (mas-un) margine / muchie frontală / de atac

enter into a intra în amănunte; a începe, a se angaja (în discuții); a face parte din a desena în, a intra (în calcule); a (se) înscrie în

enter a program(me) (inf) a intra într-un program, a începe rularea unui program

enterprise întreprindere, proiect, plan; inițiativă, spirit intreprinzător; promptitudine (în acțiuni); întreprindere, fabrică, uzină

enterprising întreprinzător, cu inițiativă

enter the armed stage (auto) a activa sistemul de blocare

enter upon (jur) a lua în posesie; a intra, a începe (o discutie etc.)

enthalpy (fiz) entalpie 
entire întreg, tot, deplin; intact, curat, nealterat entirely $(a d v)$ în întregime, complet, cu desăvârşire

entireness, entirety întregime, totalitate, ansamblu; (jur) pământ(uri) în indiviziune

entire rational function (mat) funcție rațională întreagă, polinom

entirety totalitate, întregime, entitate

entitle a (se) intitula, a (de)numi

entitled to îndreptățit la, având dreptul asupra; îndreptățit să, având dreptul de a / să

entity entitate; obiect; esențăl substanță

entrails (alim) măruntaie

entrain a antrena, a cupla

entrained air (met) aer fals (şi la cuptoare); (hidr) aer / gaz antrenat; (T) aer antrenat / amestecat/în lubrifiant etc.

entrainer antrenament; (ind chim, met) agent de antrenare

entrainer disk (OM, transp, mas-un) disc de antrenare

entrainment antrenare, convenţie

entrainment separator / trap (alim, hidr, mediu, ind chim) separator, captator (de impurități etc.) (pentru fluide în mişcare)

entrance intrare, pătrundere, acces, deschidere, admisi(un)e; uşă, poartă; (cf, met) intrare a unui tren, parcurs de intrare; (el) (bornă de) intrare; (hidr) intrare a sifonului (deversor); (met) gură (la cuptor)

entrance angle (met) unghi de prindere / de intrare (a semifabricatului între cilindrii de laminare etc.)

entrance bucket (termo, OM) paletă directoare (statorică) (la turbine)

entrance channel (nav) canal de acces în port

entrance door (constr, mas) uşă de intrare; uşă de urcare / de curățire

entrance examination (edu) examen de admitere entrance fee taxă de intrare; (edu) taxa de admitere (într-o şcoală)

entrance gate (of dry dock) (nav) intrare în docul uscat

entrance pressure (hidr) presiune la intrare (în instalație / pompă etc.)

entrance side (met) latură / parte de intrare

entrance slit (OM, hidr) fantă de intrare

entrance terminal (e; , electr) bornă de intrare

entrance velocity (mec, mas-un) viteză de intrare / de avansare / de început de avans

entrance visa viză de intrare

entrance wire (el) conductor de intrare

entrant candidat, concurent; nou angajat, nou venit entrap a închide, a capta / a separa (apă, ulei, etc.), a prinde în capcană / cursă

entrapment (met) prinderea / rămânerea zgurii în metal (defect)

entrapped air (materiale) aer închis (în ceva), bulă de aer

entrapped slag (met) incluziune de zgură

entrecôte (alim) antricot

entrée intrare, acces; dreptul de a intra; (alim) antreu, gustare; (amer) felul principal de mâncare

entrefer (el) întrefier

entrepreneur (constr, ec) antreprenor

entresol (constr) mezanin

entropy (fiz, termo) entropie

entropy diagram (fiz, termo) diagramă entropică

entruck (transp, auto) încărcare în camion, a încărca în camion

entrust to a încredința (ceva), a da / lăsa în seama entrust with a încredința (cuiva) (ceva), a da / lăsa (ceva) în seama (cuiva)

entry intrare, acces, pătrundere; ivire, apariție; intrare, uşă, poartă; (punct de) trecere; (constr) antreu, vestibul; (inf) parcurs, introducere (a unei date), înregistrare, înscriere; (ec) post, articol (contabil); (met) gură, intrare în cuptor; articol de dicționar; (jur) intrare în posesiune

entry address (inf) adresă de intrare / de lansare entry data (inf, c) date de intrare

entry inwards (ec) declarație vamală de intrare / de sosire

entry loder (mas, transp) maşină de încărcat entry outwards (ec) declarație vamală la ieşire entry side (met) latură / parte de intrare (a semifabricatului între cilindrii de laminare)

entry signal (cf, met) semnal de intrare

entry table (met) transportor-alimentator cu role (la laminoare)

entwist a suci, a răsuci, a împleti

enumerable numărabil, enumerativ

enumerate a enumera, a înşira

enumeration enumerare, numărare, înșirare

enunciate a enunța, a formula

enunciation enunțare, formulare

envelop (mat, geom) a înfăşura (o familie de curbe etc.); (TH) a înveli, a acoperi, a cuprinde, a încercui

envelope $(\mathrm{OM}, \mathrm{TH})$ înveliş, învelitoare, cămaşă, anvelopă, pătură, manta, teacă; copertă; (mat) închidere, înfăşurătoare; plic

envelope curve (mat) (curbă) înfăşurătoare

envelope file mapă

envelope flame (termo, met) zonă exterioară a flăcării 
envelopment (TH) învelitoare, învelire, înveliş, înfăşurare

environ a înconjura, a împresura

environment înconjurare; împrejurimi; mediu ambiant, mediu înconjurător, atmosferă, ambianță; vecinătate

evironmental ambiant, înconjurător, de mediu environmental chamber cameră cu atmosferă controlată

environmental conditions condiții de mediu environmental contaminant (mediu, chim) agent contaminant / poluant, provenit din mediul înconjurător

environmental contamination (mediu) contaminare / poluare a mediului (înconjurător)

environmental damage / deterioration $(\mathrm{TH}$, mediu) deteriorare / avariere din cauza mediului

environmental effects (mediu, $\mathrm{TH}$ ) efecte ale mediului / ale variaţiilor de mediu

environmental engineering (termo) tehnică / ingineria climatizării / condiționării aerului / mediului

environmental influence (mediu) influență a mediului

environmentalist (mediu) ecolog, persoană care luptă împotriva poluării

environmental loss time (TH) timp pierdut (din cauza conditiiilor de mediu de lucru)

environmental proofing / protection ( $\mathrm{TH})$ protecție împotriva influențelor exterioare

environmental stress screening $(\mathrm{TH}$, mediu) test în conditiii (reale) de mediu (pentru corectarea defectelor de operare sau proiectare)

environmental test (metr, $\mathrm{TH}$ ) test în condiții (reale) de mediu

environmental test chamber cameră pentru încercări în mediu controlat

environmentally sealed $(\mathrm{OM})$ etanșat față de mediu

environmental temperature (mediu, termo) temperatura mediului

environs mediu, ambiantă, vecinătate, împrejurimi

envisage a considera, a vedea; a prevedea, a preconiza; privi în față (o primejdie); a lua în considerare (o chestiune)

enwall (constr) a împrejmui cu un zid / perete

enwrap a înveli, a înfăşura, a împacheta; (fig) a ascunde

enzyme (chim, alim) enzimă, ferment

eolation (mediu) eroziune atmosferică / eoliană

EP (extreme pressure) agent ( $T$, chim) agent / aditiv de extremă presiune

EP (extreme pressure) lubricant $(T)$ lubrifiant cu aditivi EP (de extremă presiune) ephah (fiz, metr) unitate (veche) de măsură pentru volum / capacitate: 1 ephah $($ Biblical $)=$ 21,999998929 1

epicyclic / planetary / sun-and-planet gear (OM) transmisie / angrenaj planetar(ă)

epicycloid (mat, OM) epicicloidă

epicycloidal cutter (mas-un) freză-disc pentru roți cu dinţi cu profil epicloidal

epidermis (anat) epidermă

epidiascope epidiascop

EP lubricant ( $T$, ind chim) lubrifiant cu aditivi de extremă presiune / cu aditivi EP

epoch epocă, perioadă, ev

epoxide (chim, plast) epoxid

epoxy adhesive (plast) adeziv epoxidic

epoxy group (chim) grup epoxidic, grupare epoxidică

epoxy matrix composite (materiale) compozit cu matrice epoxidică

epoxy resin (chim) răşină epoxidică

eprouvette eprubetă; (met) lingură folosită la luarea probelor

epuration (mediu, hidr, TH, met) epurare

epure epură, desen la scară

equability simetrie, uniformitate, echilibru; (fig) măsură

equable simetric, uniform; regulat, echilibrat; egal, acelaşi; asemenea; echivalent, corespunzător; imparțial, nepărtinitor, a egala, a fi egal $\mathrm{cu}$, a se compara cu

equal egal, echivalent, de valoare egală, echilibrat (mai rar), identic; a fi egal cu, a egala; to corespunzător, capabil, în stare (să); (d. temperament) echilibrat, ponderat; egal, semen; $\sim$ s $(p l)$ lucruri, cantități egale; not to be ed fără egal, fără a fi egalat

equal angle cutter / symmetrical double angle milling cutter (mas-un) freză unghiulară biconică, simetrică

equal-angle (iron) (OM, met) oțel-cornier / profil cu aripi egale

equal area projection proiectie care conservă ariile

equal friction method duct sizing (hidr) dimensionare a conductelor prin metoda frecării egalizate / a rezistenței echilibrate

equality (fiz) paritate; (mat) egalitate, uniformitate, echivalență (a ariilor)

equality sign semnul egalitătii

equalization egalare, stabilizare, nivelare, echilibrare, egalizare, compensare; (mat) punere în ecuație

equalization network (el, autom) rețea / circuit de egalizare / de corecție / egalizator 
equalize with / to a netezi, a egaliza, a nivela, a egala, a echilibra, a compensa, a face egal (cu), a aduce la acelaşi nivel cu

equalizer (OM, mas) (contra)balansier; (el) conexiune echipotențială; egalizator, compensator; $(\mathrm{OM})$ transmisie diferențială, contrabalansier

equalizer bar $(\mathrm{OM})$ balansier

equalizer bearing end of the pitman (OM) extremitate superioară a bielei

equalizer damper (hidr) registru de aer de egalizare, dispozitiv de menținere a debitului / presiunii statice constant(e)

equalizer spring $(\mathrm{OM})$ arc de reglare

equalizing charge (el) sarcină de compensare / de egalizare

equalizing pipe (hidr, OM) conductă / tub / țeavă de echilibrare / de compensare

equalizing pressure (hidr, OM) presiune de compensare

equalizing system (mec, auto, termo) dispozitiv de echilibrare (şi la motoare cu ardere internă) equalizing time (mec, autom) timp de compensare / de echilibrare

equalling egalizare; finisare

equalling file pilă lată, subțire cu vârf drept, cu tăietură pe toate cele 4 fețe

equalling needle file pilă subțire fină, pilă-ac cu vârf drept

equal-leg angle (met) (profil) cornier cu aripi egale

equally $(a d v)$ deopotrivă, în egală măsură, la fel, la fel de, tot atât de, nu mai puțin; de asemenea, şi; (în mod) egal, uniform

equally loaded (mec, OM) cu sarcină egală, uniform încărcat

equally spaced $(\mathrm{OM})$ echidistant, echispațiat, la distanțe egale

equal mark semn al egalității

equal odds şanse egale

equal-phase (mec, el) în (concordanță de) fază, sinfazic

equal to capabil / apt de, în stare de; la înălțimea, corespunzător cu; dornic de

equal triangle (mat) triunghi echilateral

equanimity sânge rece; indiferență, nepăsare; calm, stăpânire de sine

equanimous cu sânge rece; indiferent, nepăsător; calm, netulburat

equate with / to (met) a egal(iz)a cu, a egala, a pune în ecuație

equated value (met) valoare medie

equation (mat) ecuație; egal(iz)are; echilibru

equational box $(\mathrm{OM})$ diferențial (în carcasă), carcasă de diferential equation of condition ecuație de definiție equation of motion (mat, mec) ecuație de mişcare equation of state (fiz) ecuație de stare

equation of vibrating strings (mec) ecuația coardei vibrante

equator (geogr) ecuator

equatorial (geogr) ecuatorial

equiangular (geom) cu unghiuri egale, izogonal, echiunghiular

equiangular hyperbola (mat) hiperbolă echilaterală

equiangular polygon (geom) poligon regulat equiangular spiral (mat) spirală logaritmică equiareal (geom) cu arii egale, care păstrează aria equiaxed crystal (met) cristal echiaxial equiaxed structure (met) structură echiaxială equidirectional echidirecțional, în acelaşi sens equidistance (mat) echidistanță

equidistant (mat) echidistant, egal distanțat, la distanță egală

equiflux furnace (met, termo) cuptor cu încălzire uniformă, cuptor echiflux

equilateral (mat) echilateral

equilibrate a echilibra, a menține echilibrul

equilibrated echilibrat, compensat, nivelat, aplanat equilibration echilibrare

equilibrator spring $(\mathrm{OM})$ arc compensator

equilibrium echilibru

equilibrium boiling point (fiz) punct / temperatură de fierbere la echilibru

equilibrium composition (met) compoziție de echilibru

equilibrium concentration (met) concentrație de echilibru

equilibrium condensation curve (termo) curbă de condensare în echilibru

equilibrium constant / factor constantă / factor de echilibru

equilibrium curve / diagram (termo, met) curbă / diagramă de echilibru

equilibrium electrode potential (chim, el) potential de echilibru al electrodului (la sudură)

equilibrium flow (fiz, hidr, T) curgere cu energie constantă pe linia de curent

equilibrium moisture (alim, ind chim, termo) content conținut de umiditate la echilibru (şi la adezivi); umiditate de echilibru

equilibrium of forces $(\mathrm{mec})$ echilibrul forțelor equilibrium of moments (mec) echilibrul momentelor

equilibrium pressure (hidr) presiune de echilibru equilibrium separation (alim, ind chim, hidr) separare la echilibru (a unei particule, la decantare etc.) 
equilibrium size (alim, hidr) mărime de echilibru (a unei particule, la decantare etc.) equilibrium state (termo, met) stare de echilibru equilibrium temperature (met) temperatură de echilibru

equilibrium time timp necesar stabilirii echilibrului, timp de relaxare

equilibrium vaporization (fiz) vaporizare în echilibru

equilibrium weight $(\mathrm{mec})$ greutate de echilibrare

equip with a echipa cu, a înzestra cu, a utila cu, a prevedea cu

equipage echipare, înzestrare, (nav) greement, tachelaj

equipartition echipartiție, distribuție uniformă, repartiție egală

equipment $(\mathrm{TH})$ echipament, echipare, înzestrare, utilaj, aparatură, instalație, instalații; (cf) material rulant

equipment compatibility $(\mathrm{TH})$ compatibilitate a echipamentelor / de echipament

equipment failure (TH) greşeală de stabilire a echipamentului / cauzată de utilaj; cădere / avarie / defectare a unui utilaj

equipment number (TH) număr al echipamentului (şi de inventar)

equipment on hire $(\mathrm{TH})$ utilaj / echipament de închiriat

equipment pool $(\mathrm{TH})$ depozit de utilaje

equipment renting $(\mathrm{ec}, \mathrm{TH})$ închiriere de utilaj

equipment repair yard (TH) platformă / şantier / uzină de reparat utilaj

equipment temperature (termo, mas) temperatura echipamentului

equipoise (mec, TH) echilibru, contragreutate, a echilibra, a cumpăni; a contrabalansa

equipollent echipolent, de valori egale

equipotent (fiz, mec) de aceeaşi putere

equipotential echipotențial

equipotential surface (fiz) suprafață echipotentială / de nivel

equipped (TH) echipat, înzestrat, utilat

equipped capacity ( $\mathrm{TH}$, nav) capacitate de echipare

equipressure surface (fiz, hidr) suprafață izobară / de egală presiune

equispaced echispațiat, echidistanțat, la distanțe egale

equitable echitabil, drept, just

equitableness echitate

equitably $(a d v)$ (în mod) echitabil

equity dreptate; (jur) lege nescrisă, drept natural; impartialitate, nepărtinire equities (ec) dividende

equivalence echivalență, corespondență; (fiz, met) echipotență, păstrare a unui parametru la o transformare

equivalence coefficient (fiz) coeficient de echilibru / de echivalență

equivalent echivalent, sinonim, echipotent

equivalent acidity (chim) aciditate echivalentă

equivalent coal (termo) combustibil convențional equivalent concentration (fiz, chim) concentrație echivalentă

equivalent conductivity (el, termo) conductivitate echivalentă

equivalent diameter (alim, fiz) diametru echivalent (al unei particule, într-un anunmit proces) equivalently $(a d v)$ în mod echivalent

equivalent mixture (materiale) amestec echivalent equivalent $n$-th modal unbalance (mec) dezechilibru modal echivalent, de ordin $n$

equivalent of heat (termo) echivalent termic equivalent orifice (termo) orificiu echivalent (aeraj)

equivalent solution (fiz, chim) soluție echivalentă

equivalent specifications ( $\mathrm{TH}$, mas) specificații echivalente

equivalent stopper power (mec, mas) energie / putere echivalentă de frânare

equivalent value echivalență, valoare echivalentă

equivocal echivoc, ambiguu, evaziv; nesigur, îndoielnic

equivocally $(a d v)$ ambiguu

equivocate a vorbi echivoc / evaziv; a se sustrage

equivocation nedeterminare, nesiguranță; caracter echivoc

era eră, epocă

eradiate (fiz) a iradia, a străluci

eradiation (fiz) iradiere, strălucire

eradicable eradicabil, care poate fi eradicat

eradicate a eradica

eradication extirpare, eradicare

eradicator (chim) preparat / substanță care elimină / şterge

erasable storage (inf) memorie care se poate şterge erase a elimina, a (se) șterge, a rade, a răzui; (inf) a goli o memorie, a şterge

erasement, erasion radere, stergere, îndepărtare; (inf) golire, ştergere (a unui program, fişier etc.) eraser dispozitiv de ştergere, radieră, gumă; (inf) program / rutină de ştergere / golire erase signal (c, inf) semnal de eroare / de anulare erasure radiere, ştergere; ştersătură 
Erbium (Er) (chim) erbiu

erect ridicat, perpendicular, drept, vertical; a ridica (vertical), a monta, a înălța, a asambla, a construi; a stabili / construi (o teorie)

erecting instalare, montare, ridicare, care se ridică / se montează (vertical)

erecting bay $(\mathrm{TH})$ hală / secție / atelier de montaj

erecting / erection crane (constr, met) macara de ridicare / de monatj

erecting floor (constr, TH) platformă de asamblare

erecting machinist lăcătuş-montator

erecting scaffold(ing) (constr, TH) schelă de montaj, eşafodaj de schelărie

erecting shop (constr, $\mathrm{TH}$, mas) secție / atelier de montaj

erecting tool sculă de montaj / de lăcătuşerie

erecting truck (constr, $\mathrm{TH}$ ) cărucior de montaj

erecting work (ec, TH, constr) lucru / manoperă de montaj

erection ridicare, construire, construcție, montare, asamblare

erection diagram $(\mathrm{TH}$, mas, ec) schemă de montaj erection drawing desen de montaj

erection platform (constr) platformă de montaj

erection schedule $(\mathrm{TH}$, mas, ec) plan de montaj (incluzând timpul necesar)

erection stress (mec, $\mathrm{TH}$, mas) tensiune cauzată de montaj

erector mecanic, montator

erg (fiz, metr) unitate de măsură pentru energie în sistem CGS (o forță de 1dyne deplasată pe $1 \mathrm{~cm})$, erg: $1 \mathrm{erg}=10^{-7} \mathrm{~J}$

erg on (fiz) ergon

ergonometrics ergonometrie

ergonomics ergonomie, biotehnică

erg/second (fiz, metr) unitate de măsură pentru putere, erg/secundă: $1 \mathrm{erg} /$ second $=10^{-7} \mathrm{~W}$

Erichsen test (mec, metr) test de ambutisare adâncă

erode a eroda, a roade, a spăla, a coroda, a ataca (un material, şi metalic)

erode away a se eroda, a se roade (cu îndepărtare de material)

erodible material material erodabil / corodabil

erosion (fiz, T) eroziune, erodare, spălare, roadere, distrugere

erosion action (hidr, T) acțiune / proces de erodare / eroziune / spălare

erosional cavity (materiale, hidr, T) cavitate rezultată în urma eroziunii

erosion-corrosion (materiale, chim, T) distrugere combinată, rezultat al eroziunii şi coroziunii erosion wear (T) uzură de / prin eroziune, deteriorare superficială din cauza acțiunii erozive erosive (hidr, T) care roade, care distruge; eroziv erratic accidental, întâmplător (referitor la măsurători), eratic; dezordonat, neregulat; straniu, ciudat; schimbător

erratic arc (el, met) arc electric instabil / vagabond (la sudare)

erratic firing (auto, termo) aprindere neregulată erratic flow (hidr) curgere turbulentă, debit neregulat

erratum, $(p l)$ errata erată

erroneous eronat, greşit, fals

erroneously $(a d v)$ (în mod) eronat, greşit, fals, din greşeală

erroneous conclusion concluzie eronată

erroneousness caracter eronat, falsitate

error (autom, metr, TH) eroare, greşeală, abatere de la valoarea reală, deviere, deviație (nedorită)

error-actuated system (autom) sistem cu comandă de / prin eroare

error analysis (mat, metr) analiză / calcul / estimare a(l) erorilor (şi prin metode matematice)

error band (metr) bandă de eroare

error burst (metr) grup de erori

error control (autom, metr, $\mathrm{TH}$ ) detectare / corectare a erorilor

error curve (metr) curbă de repartitie a erorilor

error detection (metr) detectarea / depistarea erorilor

error-free (TH, metr) fără eroare / abatere

error function ( $\mathrm{TH}$, metr) functie a erorilor

error-handling routine (inf) subprogram de prelucrare a erorilor

error in range (metr) abatere longitudinală / de distanță, într-un interval

error level (autom, metr) nivel de eroare

error message (inf) mesaj de eroare

error of centring (OM, mas-un) eroare de centrare, excentricitate (nedorită)

error of construction / design (OM) eroare / defect de constructie / de proiectare

error of shape (OM, mas-un, metr) eroare / abatere de formă

error of straightness / out of straight line (OM, mas-un, metr) abatere de la rectilinitate error of tilt (OM) eroare / abatere de înclinaţie error punching (mas-un, met) perforare greşită error range (metr, autom) interval de eroare error rate (metr, $\mathrm{TH}$ ) factor / grad de eroare, frecvență a erorilor

error removing (autom, $\mathrm{TH}$, metr) corectare / înlăturare a erorilor

error return (inf) revenire în caz de eroare 
error sensing device (metr, autom, mas) dispozitiv de detectare a erorii / abaterii

error signal (TH, autom, metr) semnal de eroare / de corecție / care indică apariția unei erori în funcționarea unui utilaj / dispozitiv

error span ( $\mathrm{TH}$, autom, metr) amplitudine a erorilor / a abaterilor

ersatz (alim, ind chim) material de înlocuire, înlocuitor; surogat

erudite erudit, învățat

erudition erudiție, învățătură

erupt a erupe, a izbucni; a țâşni; (anat) a ieşi (d. dinţi)

eruption erupție; țâşire

escalate a (se) extinde, a (se) ascuți, a spori

escalation extindere, întreținere, sporire

escalator (mas) scară rulantă

escape ieşire, migrație, eliberare; emanație; evadare; evaziune; fugă, ieşire; (auto) eşapament; (hidr, chim, mediu) scăpare, scurgere, descărcare, degajare, pierdere prin scurgere; (met) străpungere (la furnale, cuptoare); scăpare de pericol; (fiz, met) migrație; viitură; a deversa; a se elibera; a fugi; a scăpa; a fugi (din); a rosti fără voie (d. cuvinte etc.), a-i scăpa (cuiva) (şi d. cuvinte, etc.); a scăpa (din)

escape channel (hidr, mediu) canal de scurgere

escape from a scăpa de, a ieşi din, a fugi, a se elibera (şi în sens nedorit), a (se) scurge, a deversa

escape (key) (inf, c) tastă de întoarcere la comanda anterioară

escape ladder (constr, TH) scară de salvare / incendiu

escapeless inevitabil; fără ieşire

escapement (auto) eşapament; ieşire, declanşare, reținere; (hidr, met, mediu) canal de scurgere

escapement file pilă-ac cu coadă (cu secțiune) pătrată

escape of gas (met, chim, mediu) degajare de gaz

escape steam (termo, auto) abur de eşapament, abur evacuat

escape vane (hidr, termo) ventil / supapă de evacuare / descărcare

escape velocity (fiz) viteză de învingere a atracției gravitaționale

escape wheel $(\mathrm{OM})$ roată de oprire

eschew a evita, a ocoli, a se feri; a se eschiva de la eschewal evitare, ocolire; eschivare

escort escortă, pază; însoțitor; a escorta, a însoți

escribe (mat) a exînscrie, a circumscrie

esculent (alim) comestibil

especial special, deosebit

especially $(a d v)$ mai ales, îndeosebi, în special espial urmărire, spionare; observare; descoperire esplanade esplanadă

espresso (alim) cafea espresso

essay probă, încercare, experiență, test

essence (auto) benzină; (alim) esență, extract; parfum

essential esențial, vital, fundamental, elementar; absolut, extrem; esență, substanță; lucru esențial, parte esențială; bază; (chim) volatil, eteric; (mat) integrant, inseparabil, esențial

essentiality esență, caracter esențial

essentially $(a d v)$ în esență / fond, în primul rând, mai presus de toate

essential oil (chim) ulei eteric / volatil

establish a pune la punct, a organiza, a stabili, a pune, a aşeza, a întocmi, a fonda, a întemeia, a pune bazele, a constitui; a stabili, a dovedi, a demonstra; a organiza; (chim, met) a stabili (un echilibru); (mat) a demonstra, a dovedi

established stabilit, demonstrat, dovedit; existent, consacrat; intrat în uz; recunoscut, admis; atestat; (bine) cunoscut

establishment stabilire, aşezare; organizare; instalare, plasare; instalație, amenajare, fixare, întemeiere, fondare, constituire; stabiliment, instituție, gospodărie; consacrare; (ec) venit, încasări, salariu, schemă (a personalului)

establishment charge (ec) cheltuieli de investitie

establishment of a foundation (constr) aşezare / plasare / amenajare a unei fundatiii

estate stare, condiție; proprietate, avere, bunuri; categorie, situație

estate agent (ec) agent de vânzări şi cumpărări bunuri mobile

esteem stimă, considerație; a stima, a respecta; a prețui; a considera, a socoti

ester (chim, plast) ester

ester gum (chim, plast) sacâz, colofoniu

estimable demn de stimă / respect; apreciabil, care se poate aprecia

estimate estimație, apreciere, evaluare, prețuire; deviz, calcul, sumă, total evaluat; părere, opinie; a estima, a aprecia, a evalua, a face un deviz

estimated estimat, calculat, prevăzut, proiectat

estimated design load (mec, termo, TH) sarcină de proiectare / nominală / teoretică

estimated position (autom, TH) poziție estimată

estimated time ( $\mathrm{TH}$, mas) timp estimat / teoretic / calculat

estimated yield (mas) randament estimat / scontat estimate of costs (ec) evaluare, deviz estimativ, cheltuieli estimate

estimate output $(\mathrm{TH}, \mathrm{ec})$ producție / putere teoretică / estimată / calculată la ieșire / nominală 
estimating engineer (inginer) calculator de devize, tehnolog

estimating engineering $(\mathrm{TH})$ calculare a devizelor, calcul de proiectare

estimation estimare, evaluare, calcul; părere, opinie, apreciere; respect, stimă

estimative estimativ

estimative cost (ec) cost estimat / calculat / după deviz

estimator estimator, care (se) estimează

estival estival, de vară

estrade estradă, loc ridicat

etalon (metr) etalon

etch (chim) coroziune, atac (chimic), a ataca (cu acid, probe în metalografie), a decapa, a grava, a băițui

etch angle (mas-un, OM) unghi de înclinare / de atac (şi la scule aşchietoare)

etchant (met, chim) reactiv de atac (al probelor) / de decapare, decapant

etch cleaning (met, chim) curățare cu electrolit sau soluție chimică (şi la probe metalografice)

etch cracks (chim) fisuri în stratul superficial cauzate de procesul de fragilizare la hidrogen sau la atac cu mediu acid

etch depth (met, chim) adâncime de corodare / de gravare

etched wire insulation (el, chim) izolație pe fir atacat chimic (în special acoperirea cablurilor cu fluoroplastice)

etcher gravor

etching (met, chim) decapare, corodare, coroziune, gravare, băițuire, atac(are) cu acizi, metalografie; gravură

etching agent (met, chim) agent / reactiv de atac / de decapare, decapant

etching medium (met, chim) mediu / soluție de atac / de decapare

etching paste pastă decapantă

etching pit (met, chim) gaură / pată / ciupitură / crater mic cauzat de atac chimic

etching solution (met, chim) soluție / de atac (al probelor) de decapare

etch test (met, chim, metr) test de corodare, încercare / atac cu acizi (în metalografie)

ethane (chim, met) etan

ethanol (auto, chim) etanol

ethenyl (chim) (radical de) vinil

ethene (chim) etilenă

ether (chim) eter

ethereal (chim, fiz) eteric; aerian, diafan

etherealize (chim) a eteriza; ( $i g$ ) a face uşor

ethine (chim) acetilenă

ethic(al) etic ethics etică

ethyl (chim) etil

ethyl alcohol (alim, chim) acool etilic

ethylene (chim) etilenă

ethyl fluid (auto, chim) tetraetil de plumb

Euclidean (mat) euclidian

European Norms Norme / Standarde Europene

Europium (Eu) (chim) europiu

eutectic (met) eutectic

eutectic alloy (met) aliaj eutectic

eutectic composite (materiale) composit cu eutectoizi

eutectic composition (met) compoziție eutectică eutectic graphite (met) grafit eutectic

eutectic mixture (met) amestec eutectic

eutectic point (met) punct (de) eutectic

eutectic polymer (ind chim) polimer eutectic

eutectic solidification (met) solidificare eutectică

eutectic solder (met) lipire eutectică / cu aliaj eutectic

eutectic solution (met) solutie eutectică

eutectic state (met) stare eutectică

eutectic structure (met) structură eutectică

eutectic temperature (met) temperatură eutectică

eutectoid (met) eutectoid

eutectoid alloy (met) aliaj eutectoid

eutectoid concentration (met) concentrație eutectoidă

eutectoid point (met) punct (de) eutectoid

eutectoid steel (met) oțel eutectoid

eutectoid structure (met) structură eutectoidă

eutectoid transformation (met) transformare eutectoidă

eutexy (met) eutexie, fenomen prezent la amestecurile eutectice

evacuate (TH, hidr) a evacua, a da afară, a goli; a părăsi

evacuated induction furnace (met) cuptor de inducție în vid

evacuated insulation (termo) izolare sub vid, izolare termică cu pereți dubli, vidați la interior

evacuated space (fiz) spațiu evacuat, depresiune, vid

evacuating equipment (termo, ind chim) echipament / instalație de vidare / de evacuare (şi a gazelor) / de menținut vidul

evacuation (ind chim) evacuare a gazelor / aerului, golire; părăsire

evacuation port (alim, ind chim, hidr) orificiu de evacuare

evacuee evacuat

evadable evitabil

evade a eluda, a se sustrage de la; a evada, a scăpa, a evita, a ocoli; a devia 
evade from / out of a evada din, a fugi din; a devia de la

evaluate a evalua, a prețui, a estima (numeric), a aprecia, a calcula

evaluation apreciere, evacuare, estimare, calcul, prețuire

evaluation length (metr, materiale, $\mathrm{T}$ ) lungime de evaluare (la profilometria suprafeței)

evanescence (fiz) volatilitate; evanescență, dispariție; caracter trecător

evanescent care dispare repede, trecător, efemer; evanescent; (mat) infinitezimal; foarte mic

evaporate (fiz, alim, ind chim, mediu) a (se) evapora, a vaporiza, a se evapora, a produce evaporarea

evaporated (fiz) evaporat; (alim) sterilizat (d lapte)

evaporated make-up (termo) adăugare de apă distilată în boiler / cazan pentru a acoperi pierderile prin condens sau evaporare

evaporate down (ind chim, alim) a concentra (prin evaporare)

evaporated skimmed milk (alim) lapte praf

evaporating column / tower (met, ind chim, alim) coloană de concentrare

evaporating condenser (ind chim, termo) condensator cu evaporare

evaporating pan (alim, ind chim) cuvă / tavă de evaporare

evaporation (fiz) evaporare, vaporizare

evaporation coil (alim, ind chim) serpentină de evacuare

evaporation control (autom, mas) comandă / reglare / control a(l) evaporării

evaporation cooling (termo) răcire prin evaporare

evaporation degree (fiz, ind chim) grad de evaporare

evaporation deposit (alim, hidr) depozit (rezultat) după evaporare

evaporation heat (termo) căldură de evaporare

evaporation loss (alim, ind chim, T) pierdere prin evaporare (d. un fluid, lubrifiant etc.)

evaporation-proof (materiale) impermeabil la gaze

evaporation rate (fiz) viteză de evaporare

evaporation residue (alim, ind chim, mediu) reziduu (de) la evaporare

evaporation station (alim) stație de evaporare (şi la prelucrarea zahărului)

evaporation surface (fiz, termo) suprafață de evaporare

evaporation test (fiz, metr) test de evaporare evaporative cooling (fiz, termo) răcire prin evaporare evaporative surface condenser (termo) condensator cu evaporare forțată / cu economizor de apă

evaporator body (OM, termo) corp al evaporatorului

evaporator coil $(\mathrm{OM}$, termo) serpentină a evaporatorului

evaporator jacket $(\mathrm{OM}$, termo) manta de evaporator

evaporator pressure regulator / valve $(\mathrm{OM}$, hidr, autom) regulator al presiunii de evaporare, ventil de presiune minimă constantă

evasion evaziune; eschivare; ocolire

evasion coefficient (fiz, TH) coeficient de evaporare / de scăpare

evasive evaziv, vag, ocolit

evasively $(a d v)$ (în mod) evaziv, vag, ocolit

evasiveness caracter evaziv

eve ajun

even plan, neted, plat; par, cu soț, egal, uniform, echitabil; (geogr) ses; întins; (mat) egal (d. numere), care se divide exact cu; drept, echitabil, just; a netezi, a nivela, a egal(iz)a; (d. socoteli, datorii) lichidat, încheiat; (metr) (d. măsurători) exact, precis; $(a d v)$ chiar, până şi, întocmai

even bearing (OM, T) lagăr / suprafață cu repartizare uniformă a presiunii

even flow (hidr, met) curgere plană / uniformă

even fracture (met) crăpătură superficială / la suprafață; ruptură / fractură plană

even function (mat) funcție pară

even-handed nepărtinitor, imparțial

even-handedness nepărtinire, imparțialitate

even harmonic (mat) armonică de ordin par

evening seară

evening classes (edu) curs seral

evening school (edu) şcoală serală

even keel (nav) chilă dreaptă

even load (mec) sarcină uniformă

evenly $(a d v)$ (în mod) uniform / egal, regulat; neted, drept; regulat; simetric

evenly distributed load (mec, mas) sarcină uniform distribuită

evenness planitate; (fiz, mat) paritate; netezime, grad de netezime, planietate, uniformitate, egalitate; calm, echilibru; nepărtinire, imparțialitate even number (mat) număr par even-numbered (mata) cu număr par

even out a face egal, a egaliza, a aduce la acelaşi nivel; a ajunge egal, a fi adus la acelaşi nivel

even page pagină cu număr par

even pitch $(\mathrm{OM})$ pas uniform (al danturii, filetului etc.) 
event eveniment, întâmplare, caz, accident, eventualitate; punct în spațiu-timp; in the $\sim$ în cazul

eventless (timp) în care nu s-a întâmplat nimic deosebit, monoton

even to a pune pe aceeaşi treaptă

eventual final, decisiv; eventual, posibil

eventuality eventualitate, posibilitate

eventually $(a d v)$ în cele din urmă, până la urmă

eventuate (amer) a se întâmpla, a avea loc; in a sfârşi prin, a se termina cu

even turning moment (mec) cuplu / moment de torsiune constant

even up a echilibra, a face egal

even wear $(\mathrm{OM}, \mathrm{T})$ uzură uniformă

ever $(a d v)$ vreodată, cândva; într-una, mereu, întotdeauna; and anon din când în când; for $\sim$ pentru totdeauna

everdur (met) everdur (aliaj $\mathrm{Cu}-\mathrm{Si}-\mathrm{Mn}$ )

everglade (amer) (geogr) ținut mlăştinos

evergreen (agr) peren, plantă perenă

everlasting (materiale, $\mathrm{T}$ ) durabil, rezistent la uzură sau la alte solicitări

ever-present omniprezent

ever-ready gata oricând

every fiecare, toți, toate

everybody, everyone fiecare, toți, toată lumea

everyday zilnic, cotidian, de fiecare zi; obişnuit, banal; rutinier

everything tot, toate (lucrurile)

everyway în toate părțile / direcțiile; în toate privințele, din toate punctele de vedere

everywhen întotdeauna, mereu, veşnic

everywhere pretutindeni, peste tot

evict a evacua, a da afară din casă

evict from (jur) a recupera legal de la

eviction evacuare, dare afară din casă; (jur) reluare în posesie

eviction order (jur) ordin de evacuare / de reintrare în posesie

evidence dovadă, mărturie, semn; probă; evidență, caracter evident; claritate; a dovedi, a demonstra, a arăta

evident evident, clar

evidential evident, clar; bazat pe mărturie oculară / observație directă

evidentially $(a d v)$ pe baza dovezilor, în $\bmod$ evident

evidently ( $a d v)$ (în mod) evident, clar, limpede, cu claritate

eviscerate (alim) a eviscera, a scoate măruntaiele din

evisceration (alim) eviscerare, scoaterea măruntaielor

evitable evitabil evolute (mat) evolută, desfăşurată, înfăşurătoare a normalelor unei curbe

evolution evoluție, dezvoltare, progres, degajare, emisie, desfăşurare; (mat) extragere a rădăcinii, desfăşurare (a unei curbe etc.); (nav) manevră la bord

evolutional evolutiv, de evoluție

evolution of gas (ind chim, met) degajare a gazelor

evolution of heat (termo, met) degajare / producere de căldură

evolve a (se) desfăşura, a (se) dezvolta; a elabora; a degaja, a emite (gaze etc.); a evolua; (şi fig) a desfăşura, a dezvolta, a elabora

evolvent (mat) desfăşurătoare, evolventă

evolving (proces de) dezvoltare, degajare, evoluție, care evoluează / degajă / emite

evulsion (mec) smulgere, rupere, extracție

ewe-cheese (alim) caş, brânză de oi

ex (prep) fără, exclusiv; fost

exact exact, corect, precis, riguros; metodic, punctual, corect; a cere, a solicita, a impune, a pretinde exact curve curbă pură / exactă

exact differential (mat) diferențială exactă / totală exact differential equation (mat) ecuație diferențială totală / cu diferențiale totale

exacting exigent, pretențios, sever

exactingness exigență

exaction cerere, pretenție; lucru cerut / reclamat, sumă pretinsă; (ec) impunere fiscală excesivă

exactitude exactitate, precizie, acuratețe, punctualitate

exactly $(a d v)$ exact, întocmai, chiar (aşa), cu exactitate, cu precizie; (d. ore) fix

exactness exactitate, acuratețe, precizie; rigurozitate; (mat) împărțire exactă

exact science ştiință exactă

exact time keeper (metr) cronometru, înregistrator de durată

exactiness exactitate, precizie

exaggerate a exagera, a amplifica, a intensifica exaggerated exagerat

exaggeration exagerare; amplificare, intensificare exaggerative predispus la exagerare, înclinat să exagereze; pompos, bombastic

exagram/second (metr, fiz) unitate de măsură pentru debit masic: 1 exagram $/$ second $=10^{+15} \mathrm{~kg} / \mathrm{s}$

exajoule/second (fiz, metr) unitate de măsură pentru putere: 1 exajoule/second $=10^{+18} \mathrm{~W}$

exaliter (fiz, metr) unitate de măsură pentru volum: 1 exaliter $=10^{+15} \mathrm{~m}^{3}$

examen (edu) examen; (rar) cercetare, studiu

examinable examinabil

examinant examinator; cercetător 
examinate (edu) examinat; candidat

examination examinare, observare, studiere, control, examen; inspectare, inspecție, cercetare, verificare, control, revizie, expertiză

examination by experts expertiză

examination by trepanning (ec, $\mathrm{TH})$ control / examinare prin sondaj

examination paper (edu) chestionar; lucrare scriesă (la un examen)

examine (edu) a examina, a asculta (oral); (TH) a cerceta, a inspecta, a controla; a face o revizie; a verifica, a face o expertiză; (jur) a interoga

examine closely a cerceta / a examina îndeaproape / în amănunt

examinee examinat, persoană examinată, candidat

examiner examinator; (metr, OM) spion (pentru măsurarea jocului între piese, a jocului în rulmenți etc.)

examining machine (metr) maşină de control / de verificare

example exemplu, pildă, exercițiu, model; mostră; precedent; (mat) exemplu, problemă

exanewton (metr, fiz) unitate de măsură pentru forță: 1 exanewton $=10^{+18} \mathrm{~N}$

exapascal (fiz, metr) unitate de măsură pentru presiune: 1 exapascal $=10^{+18} \mathrm{~Pa}$

exawatt (fiz, metr) unitate de măsură pentru putere: 1 exawatt $=10^{+18} \mathrm{~W}$

excandescence (met) călire

ex cathedra oficial

excavate (constr) a excava, a săpa, a dezgropa excavating (constr) săpătură, excavare, debleu exacavating machine (constr, mas) excavator excavation (constr) excavație, cavitate, săpătură excavation of foundations (constr) excavatie pentru fundații

excavator (constr, mas) excavator

excavator bucket (constr, mas) benă / cupă de excavator

excavator / shovel crane (constr, mas) macaraexcavator

excavator crawler / track (constr, mas, OM) şenilă de excavator

excavator grab (constr, mas) cupă cu colți la excavator

excavator hoist (constr, mas) troliu al excavatorului

exceed a depăşi, a întrece; a fi mai bun / mai mare decât; by a depăşi cu; in a întrece (pe cineva) la; a predomina; a excela; a exagera, a face excese

exceeding care depăşeşte, excesiv; excepțional exceedingly $(a d v)$ (în mod) excesiv; extrem de, foarte; extraordinar, teribil exceeding of speed, overspeed (auto, mas) depăşire de viteză / de turație, turație maximă, supraturație, supraviteză

excel a excela, a întrece, a depăşi (pe cineva), a fi superior

excel in / at a excela în (d. un domeniu), a se distinge, a se remarca în / la

excellence desăvârşire, perfecțiune; superioritate; excelență

excellent excelent, ireproşabil

excellently $(a d v)$ excelent, minunat, cât se poate de bine

excenter (geom) centru al cercului circumscris / exînscris

except cu excepția, (în) afară de; minus, mai puțin; (inf) funcție logică ŞI-NU; afară de, cu excepția; a excepta, a exclude, a lăsa la o parte

except against / to a protesta contra, a obiecta împotriva

excepted cu excepția, exceptând, în afară de; exclusiv

except-gate (inf, autom) circuit / poartă ŞI-NU

exception excepție, abatere de la regulă; raritate, caz rar / excepțional; obiecție, opoziție

exceptionable contestabil, criticabil

exceptional excepțional, neobişnuit

exceptionally ( $a d v)$ (în mod) excepțional; exceptional de

exceptionless (realizabil) fără excepții

exception return (inf, mas-un) revenire la program, reluare a execuției unui program întrerupt pentru remedierea unei erori

exceptive excepțional, formând o excepție; critic, care contrazice mereu

except that atât (doar) că

excerpt extras, fragment, citat, pasaj; a extrage, a cita

excess of excedent, exces, surplus; abuz; supradimensionare, preaplin; suplimentar, excesiv, excedentar

excess air (termo) exces de aer (la motoare $\mathrm{cu}$ ardere internă)

excess base (ind chim, met) exces bazic; (el) supratensiune, supracurent, suprasarcină

excess current proof (cf) rezistent la supratensiune / la suprasarcină

excess(-current) switch întrerupător (automat) de supratensiune, de suprasarcină

excess discharge (hidr) debit în exces

excess fare (cf) supliment; suprataxă

excess heat (met, termo) exces de căldură

excessive excesiv, exagerat; exorbitant; extravagant

excessive convexity (met) îngroşare excesivă bilaterală (la sudură) 
excessive current in the wiring (auto, el) curentul în exces din instalația electrică

excessive holding (met) durată de menținere excesivă

excessively $(a d v)$ excesiv, prea mult, excesiv de excessively dry (auto) uscat (în mod) excesiv excessively dry air (mediu, $\mathrm{TH}$ ) aer excesiv de uscat

excessiveness caracter excesiv

excessive penetration (met) exces de pătrundere (la sudură)

excessive stock (ec) stoc supradimensionat / excesiv, adaos de prelucrare în exces / prea mare excessive voltage (el) supratensiune

excessive water droplets (auto) picături de apă în exces

excessive wear (T) uzură excesivă / severă

excess holes goluri / pori în exces (la substanțe / materiale poroase)

excess load (mec) suprasarcină

excess pressure (mec, hidr) suprapresiune

excess rapping (met) dezbatere excesivă

excess level $(\mathrm{TH})$ nivel de depăşire

excess load (el, mec) suprasarcină, supraîncărcare

excess noise factor / figure (mediu, electr) factor de zgomot suplimentar

excess of hatchway (nav) exces al gurilor de magazie

excess of mass (mec) exces de masă

excess power (el, hidr, mec) rezervă de putere, putere suplimentară

excess pressure (mec, hidr) suprapresiune, presiune excedentară

excess slack (transp, mec) greutăți excesive

excess voltage (el) supratensiune, tensiune suplimentară

excess webbing (auto, OM) partea în plus a curelei, curea „cu burtă" / netensionată corect

exchange schimb, schimbare; (mat) substituire; a schimba, a înlocui; (inf) a face schimb de conținut al memoriilor; (ec) bursă

exchangeability $(\mathrm{TH})$ interschimbabilitate

exchangeable înlocuibil, de schimb, interschimbabil, cu care se poate face schimb, care poate fi înlocuit, înlocuibil

exchangeable power (el, med, hidr) putere transferată / disponibilă

exchangeable value (ec) valoare de schimb

exchange area (fiz, chim) zonă de schimb (de natură chimică, structurală etc.)

exchange coupling $(\mathrm{OM})$ legătură / cuplaj de schimb

exchange engine (mas) motor de schimb / de rezervă exchange for (ec) (d. bani) a avea valoarea de, a valora

exchange of heat (termo, met) schimb de căldură exchange prohibitory circuit (el, inf) circuit de blocare

exchanger schimbător; (termo) schimbător de căldură; (ec) agent de schimb

exchange rate (ec) rată de schimb, curs valutar exchange reaction (chim) reacție de substituție / de înlocuire

exchange value (ec) valoare de schimb

exchequer (ec) visteria statului, tezaur; fisc

exchequer bill $(\mathrm{ec})$ bilet de bancă

excircle (geom) cerc circumscris / exînscris

excisable (ec) impozabil

excise a extirpa, a tăia

excitation (fiz, metr) excitare, excitație, sensibilizare (a unui aparat de măsură), agitare; (autom) comandă

excite (el, autom, electr) a excita, a provoca; a agita; a stimula (si un proces fizic, electronic etc.); a emoționa, a impresiona puternic; (chim) a sensibila (un material, la lumină, în câmp electric etc.)

excited (electr) excitat (d. un circuit)

excitement (fiz, electr) excitare, excitație

exciter maşină / dispozitiv de agitat / de excitat (în electrotehnică)

exciting excitant; captivant, foarte interesant

exclamation mark semnul exclamării

exclude a exclude, a elimina

excluding exclusiv, excluzând; care exclude / elimină

exclusion excludere, excluziune, eliminare

exclusion of air $(\mathrm{TH})$ închidere ermetică

exclusive exclusive, unic; întreg, total; la modă; (amer) superior, de calitate superioară; $(a d v)$ exclusiv; articol exclusiv / în exclusivitate al unei firme

exclusively $(a d v)$ (în mod) exclusiv; numai, doar

exclusiveness exclusivitate

exclusive of exclusiv, în afară de

excoriate a jupui; a coji; (fig) a însemna, a marca

excoriation jupuire, cojire (d. lemn, semifabricate etc.)

excorticate (alim) a decortica; (alim, met, lemn) a coji

excortication decorticare; (alim, met, lemn) cojire excosecant (mat) funcția $f(x)=\operatorname{cosec}(x)-1$

excrement (agr, zool) excremente, materii fecale excrescence excrescență, umflătură

excrescent de prisos, inutil

exculpate from a (se) disculpa de, a (se) dezvinovăți de

exculpation disculpare, dezvinovățire 
excursion excursie; elongație, deviere, deplasare, variație, derivație, abatere, cursă totală a unui proces / fenomen oscilant, deplasare din vârf în vârf; digresiune, divagație

excusable scuzabil, care poate fi trecut cu vederea excusatory justificabil

excuse scuză, justificare; scutire (de obligații); a (se) scuza, a ierta, a trece cu vederea, a justifica; a scuti (de obligații); a cere iertare

excuseless de neiertat

executable code (inf) cod-maşină

executable statement (inf) instrucțiune executabilă, al cărei efect poate fi identificat în timpul executării programului din care face parte

executant executant

execute a executa, a îndeplini, a efectua; (jur) a aplica (legea); a redacta, a compune, a scrie; (jur) a valida un act; a sancționa, a viza

execute statement (inf) instrucțiune de execuție execution executare, îndeplinire, efectuare, realizare; executie; (mod de) interpretare, stil; (jur) execuție, executare, validare (a unui act); (fig) distrugere; (c) execuție rulare a unui program

execution cycle (autom, TH) ciclu funcțional / operator

execution error (inf, mas-un) eroare de execuție execution time (inf, c) timp de executare / rulare a unui program

executive authority (pol) putere executivă

executive committee (ec, pol) comitet executiv

executive officer (pol) functionar superior; (nav) marinar de bord

executor, executer executant; (jur) agent judecătoresc

executorial executiv; administrativ, executoriu

executory executiv; (jur) executoriu

exegesis, $(p l)$ exegeses exegeză, interpretare, aplicare

exemplar exemplar; exemplu, model

exemplary exemplar, model; tipic

exemplification exemplificare, ilustrare

exemplify a exemplifica, a ilustra; (jur) a legaliza, a autentifica

exempli gratia (e.g.) de exemplu

exempt from eliberat, scutit de; a scuti de, a absolvi de, a excepta de la; (ec) persoană scutită de impozite; privilegiat

exemption from scutire de, dispensare de, eliberare de

exemptation (ec) scutire

exemptation for duty (ec) scutire de vamă

exempt personnel $(\mathrm{ec})$ personal care nu are dreptul la ore suplimentare / care nu beneficiază de vechime în muncă exercise exercițiu (şi de gimnastică, militar etc.); (edu) exercițiu, temă; exercitare (a unei funcții, drept); aplicare, folosire (a imaginației); antrenament, practică; practicare (a unei profesii, meserii) manifestare, dovadă; temă; a (se) exersa, a (se) antrena, a dezvolta; a exercita (un drept, o functie), a folosi (influența); a instrui; a face exercitiii; (mil) a instrui; a îngrijora; in the $\sim$ of his function în exercițiul funcțiunii sale exercised îngrijorat, neliniştit

exergy (fiz) exergie, entalpie liberă, fracțiune maximă a energiei unui sistem care poate fi transformată în energie utilă

exert a exercita, a face uz de; a se strădui

exertion efort, străduință

ex factory $(\mathrm{ec})$ preț de fabrică

exfoliate (materiale) a exfolia, a desprinde în plăci subțiri, a (se) coji, a (se) scoroji (vopseaua), a (se) desface în staturi, a cliva

exfoliation (materiale) exfoliere, cojire, scorojire, desfacere în staturi, clivaj (mai ales ca defect, deteriorare); (constr) cojire a pereților; (met) exfoliere, defoliere

exfoliation corrosion (materiale, chim) coroziune cu / prin exfoliere

exhalation (TH) degajare, emanație, exalare, evaporare, exalație, abur (degajat), vapori (şi de metal)

exhale a exala, a emana, a degaja (vapori); a face să se evapore; a expira (aer)

exhaling valve (OM, termo, $\mathrm{TH})$ ventil de expirație (şi la măşti de gaze)

exhaust (OM, termo) expirație, (tub de) aspirație, eşapament, (țeavă de) evacuare; a epuiza, a (se) evacua, a ieși, a goli, a purja, a da drumul la(și d. abur, vapori); a (in)sufla, a obosi, a extrage (aer, lichid), a scoate, a aspira; (fig) a epuiza, a istovi

exhaust air (TH, met, termo, ind chim) aer evacuat / uzat

exhaust aperture (OM, hidr) orificiu de ieşire

exhaust blower (met, termo) exhaustor, ventilator aspirant

exhaust box (auto) tobă de eșapament

exhaust chamber (auto, termo) vas / cameră de eşapament, incintă de / pentru evacuarea (gazelor etc.)

exhaust connection (OM, hidr) ştuț / racord de aspirație

exhaust detonation (auto, termo) detonație în eşapament / în incinta de evacuare (a gazelor)

exhausted epuizat; (agr) (d. pământ) secătuit, neroditor; evacuat, dat afară

exhausted of air (TH) golit de aer 
exhaust end (hidr, termo) capăt de evacuare exhauster (auto) rezervor auxiliar; (mas, met) exhaustor (şi de fum), ventilator (şi de aspirație), dezaerator; (hidr) dren

exhaust fume(s) (auto) gaze de eşapament

exhaust gas (met, termo) gaz ars / de evacuare

exhaust fan (termo) exhaustor, ventilator de aspirație

exhaust flue (termo) canal de gaze de ardere / de fum

exhaust-gas condensation point (termo) punct de rouă al gazelor de ardere / de evacuare

exhaust gas(es) (auto, termo, met, ind chim) gaze reziduale / de evacuare / de eșapament / arse / de evacuare

exhausted gases jet (auto, termo, met, ind chim) jet de gaze evacuate

exhaust gas recirculation (auto) recirculare a gazelor de eşapament

exhaust gear (termo, met) mecanism de evacuare (eventual cu roti dintate)

exhaust-heat boiler (termo) cazan recuperator

exhaust hood (alim, met, ind chim) hotă de evacuare

exhaust horn (met) avertizor de evacuare

exhaustible epuizabil; mărginit, limitat

exhausting epuizant, istovitor; $(\mathrm{TH})$ care este evacuat, care se evacuează

exhaustion (alim, termo, hidr, ind chim) golire, epuizare, evacuare, vidare / pompare (a aerului etc.), golire

exhaustive exhaustiv, complet; epuizant

exhaustively ( $a d v)$ (în mod) exhaustiv, complet

exhaust-jacketed carburator (auto) carburator încălzit cu gaze de eşapament

exhaustless nesecat, inepuizabil

exhaust lag (alim, termo, hidr, ind chim) întârziere la evacuare

exhaust lead (alim, termo, hidr, ind chim) avans la evacuare

exhaust main (auto) colector / conductă / țeavă de admisie; (met) conductă de aspiratie

exhaust manifold (auto, termo, met, ind chim) cot de eșapare / de ieșire, țeavă de eșapament; colector / galerie de evacuare

exhaust muffler (auto) tobă de eşapament

exhaust nipple (OM, hidr) ştuț de evacuare

exhaust nozzle (OM, hidr) efuzor

exhaust opening (auto, termo) gură de evacuare a aerului uzat, gură de eşapament

exhaustor (mas, mediu) aspirator, ventilator de evacuare; (met) exhaustor

exhaust orifice (auto, OM, hidr) orificiu de evacuare / de eșapare / de exhaustare exhaust period (TH, hidr, met) cursă / timp de evacuare

exhaust pipe / pipeline (OM, hidr, termo) țeavă / conductă de eşapament / de evacuare / de aspirație / de admisie

exhaust port (OM, hidr, termo) orificiu / canal de evacuare

exhaust process (OM, hidr, termo) proces de evacuare / de epuizare / de exhaustare

exhaust rod $(\mathrm{OM})$ tijă de comandă a evacuării

exhaust silencer (auto, termo) tobă de evacuare

/ de eşapament, cu amortizarea zgomotului

exhaust stack (OM, hidr) racord de evacuare

exhaust steam (termo) abur uzat / de eșapament / de emisie

exhaust-steam condensing-water separator (alim, termo) oală de condens pentru aburul de emisie

exhaust-steam oil separator (termo) separator de ulei pentru aburul de emisie

exhaust-steam pipe (termo, OM) racord / țeavă pentru abur de evacuare / de emisie

exhaust stroke (auto, termo) cursă / timp de eşapament / de evacuare / de emisie / de evacuare

exhaust supercharger (auto) turbocompresor de eşapament

exhaust system (met) instalație de exhaustare de evacuare

exhaust valve (OM, hidr) supapă / ventil de evacuare / de eşapament

exhibit exponat; expunere, expoziție; (jur) probă materială; a arăta, a (se) expune, a (se) manifesta, a demonstra, a fi expus (la o expoziție)

exhibition expunere, prezentare; manifestare; expoziție; târg de mostre

exibitive of care arată, reprezentativ pentru

exibitor expozant

exigence, exigency nevoie, necesitate imperioasă, imperativ; exigență, necesar, cerere; situatie critică, criză

exigent urgent, care nu suferă amânare; insistent exigently $(a d v)$ fără întârziere, urgent; (în mod) insistent, stăruitor

exigent of care necesită / reclamă (ceva)

exigible de încasat, care poate fi încasat

exiguity puținătate; sărăcie

exiguous neînsemnat, mic, puțin; (alim) sărăcăcios (d. mâncare)

exiguously $(a d v)$ puțin, insuficient

exiguousness insuficiență

ex-inscribed circle (mat) cerc exînscris

exist a exista, a trăi; a fi, a se afla

existence existență, ființare; prezență; ființă

existent existent, prezent; real

existing care există / se află / este prezent 
exit ieşire, plecare, evacuare; uşă; (auto, termo) eşapament, gură de ieşire / de evacuare; a ieşi, a pleca

exit gas(es) (met, termo) gaz(e) evacuat(e) / rezidual(e)

exit / output operation ( $\mathrm{TH}$, termo) proces / operație de ieșire / de evacuare

exit pipe (hidr, met) conductă de descărcare / de evacuare / de ieşire / de golire (şi la cuptoare)

exit pressure (hidr, ind chim) presiune de / la ieşire exit ramp (met, TH, termo) rampă de evacuare / de descărcare

exit (roller) table (met, OM, hidr) transportor de evacuare cu role (după caja de laminare)

exit slit / slot (OM, hidr) fantă de ieşire / de evacuare

exit tube (met) conductă de descărcare / de evacuare / de golire

exit visa viză de ieşire

ex mill (ec) preț loco / de fabrică

exoenerg(et)ic / exoergic (fiz, chim) exoergic, exoenergetic, care eliberează energie

exothermal, exothermic (fiz, chim) exoterm(ic), exoenergetic, exoergic

exotermic brazing (met, chim) lipire prin reacție exotermă

exogenous metallic inclusion (met) incluziune metalică, de origine exterioară / exogenă

exogenous non-metallic inclusion (met) incluziune nemetalică, de origine exterioară / exogenă

exothermic feeding material (chim, met) material / agent exoterm

exothermic reaction (chim, met) reactie exotermă

expand (mat) a dezvolta un determinant, a dezvolta în serie; (materiale) a expanda, a umfla, a (se) întinde, a (se) extinde, a (se) dilata, a (se) mări (în volum), a (se) dezvolta, a lărgi, a (se) extruda (mai ales materiale plastice), a amplifica

expandable (materiale) dilatabil, expandabil

expandable plastics (plast) materiale plastice; expandabile (celulare)

expand by mandrel (mas-un) a lărgi o gaură prin mandrinare, a mandrina

expanded contrast (fiz, opt) contrast intensificat expanded flange $(\mathrm{OM})$ flanşă mandrinată expended joint $(\mathrm{OM})$ asamblare prin expandarea / lărgirea unui tub fixat în altul

expanded scale (metr) scară / scală extinsă / dilatată (la aparate de măsură)

expanded slag (met) zgură expandată

expander (mas-un) expandor (și pentru tevi), întinzător, dispozitiv de tensionare, dorn de mandrinare, mandrină, bulon / dorn de dilatare, dispozitiv de îndreptare / de lărgire a tevilor expander cycle (termo) ciclu cu lucru mecanic exterior, ciclu termodinamic în care fluidul cedează energie mecanică exteriorului

expanding (mas-un) procesul de lărgire a unui alezaj / cilindru etc.; care se lărgeşte; (plast) care expandează, care se dilată, extensibil

expanding arbor (mas-un, OM) dorn / arbore extensibil / elastic

expanding-band brake $(\mathrm{OM})$ frână de expansiune, cu bandă

expanding chuck (mas-un) mandrină extensibilă

expending clutch $(\mathrm{OM})$ ambreiaj extensibil

expending die (mas-un) ştanță hidraulică cu pernă de cauciuc fixată pe poanson

expanding drill (mas-un) burghiu reglabil

expanding gas(es) (termo, ind chim) gaz(e) expandat(e)

expanding machine (mas-un, ind chim) presă de formare a anvelopelor

expanding mandrel (mas-un) dorn extensibil

expanding metal (met) metal întins (laminat) / expandat

expanding nozzle (termo, hidr, OM) ajutaj divergent / de expansiune

expanding pipe $(\mathrm{OM}, \mathrm{hidr})$ tub / conductă de dilatatie / dilatare

expanding reamer (mas-un) alezor / tarod reglabil

expanding rolling mill (met) laminor de expandare / de lărgire a țevilor

expanding test (met, metr) test de lărgire / expandare pentru țevi; (plast) test de expandare

expand on a intra în amănunte despre

expanse întindere, întins (de ape); expansiune, lărgire

expansibility extensibilitate, expansibilitate

expansible extensibil; expansibil

expansion expansiune, dilatare, dilație, umflare, detentă, destindere; lărgire; extindere, desfăşurare; întindere; întins, suprafață

expansion bend (termo, OM) compensator de dilatare

expansion bracket (termo, OM) suport alunecător al cazanului

expansion chamber (termo, OM) cameră / spațiu de expansiune

expansion crack (met) fisură / crăpătură de dilatare (defect)

expansion / block clutch $(\mathrm{OM})$ ambreiaj extensibil

expansion coil (OM, termo) liră de compensație, serpentină a vaporizatorului / de vaporizare expansion coupling $(\mathrm{OM})$ cuplaj cu deplasări compensări axiale / de dilatare 
expansion crack (plast, met, termo) crăpătură / fisură de umflare / de dilatare

expansion engine (termo) motor cu detentă / cu expansiune

expansion factor (termo, materiale) coeficient de expansiune / de dilatare

expansion fitting (met, OM) calare / îmbinare prin răcire, asamblare prin suprarăcire şi contracție la frig

expansion gap (OM, termo) joc termic, interstițiu (liber) de / pentru dilatare

expansion girder (constr, mec) grindă cu rezemare liberă a unuia din capete

expansion gland (OM, termo) presgarnitură / presetupă / membrană de dilatare

expansion hand reamer (mas-un) alezor de mână, reglabil

expansion hinge (OM, termo) articulație de dilatare / de compensare (a dilatării)

expansion impact (auto) forță de deschidere (d. airbaguri)

expansion in series (mat) dezvoltare în serie

expansion instrument (termo, metr) instrument termic / cu fir cald / care foloseşte efectul de dilatare

expansion joint (constr, met) rost de expansiune / de dilatare / de tasare; (OM) cuplaj compensator (fără a preciza tipul compensării)

expansion line (termo, met, termo) curbă de expansiune / de dilatare

expansion loop (steam pipe) (termo, OM) buclă / liră de compensare / de dilatație

expansion method (termo) criorefrigerare prin detentă, procedeu discontinuu de lichefiere (şi a heliului) prin dilatare adiabatică a gazului comprimat în prealabil, la temperatura hidrogenului lichid sau solid

expansion pin tap (OM, mas-un) dorn-cep expandabil

expansion pipe (hidr, OM) țeavă elastică / arcuită; (termo) liră compensatoare pentru dilatație

expansion play (OM, termo, met) joc de dilataţie

expansion post / piston (OM) stâlp / piston telescopic (şi la cilindri hidraulici)

expansion pyrometer (OM, metr, termo) pirometru de dilatație

expansion ring / sleeve (OM, termo) manşon / inel de dilatație, compensator cu presgarnitură

expansion screw (mas-un) şurub pentru lărgirea filierei

expansion slot $(\mathrm{OM})$ fantă de dilatare

expansion stage turbine (termo, mas) turbină cu trepte de presiune expansion stroke (auto, termo) cursă / timp de detentă

expansion stuffing box (OM, termo) presetupă / presgarnitură de dilatare / de compensare

expansion support (OM, mas-un) reazem / suport mobil / extensibil

expansion tap (mas-un) burghiu elicoidal reglabil expansion turbine (hidr, termo) reductor de presiune cu turbină, turbină de detentă

expansion valve (hidr) ventil / supapă de reglaj / de destindere / de expansiune

expansion vessel (OM, alim, termo) vas de expansiune

expansive expansiv, întins, vast; (mas-un) de lărgire; (fig) expansiv, comunicativ; (materiale) care poate fi dilatat, extins

expansive bit (mas-un) alezor expandabil, lărgitor reglabil

expansive capacity capacitate de umflare (materiale plastice etc.)

expansive force (termo, mec) fortă de expansiune / de dilatare (d. materiale solide, abur etc.)

expatriation expatriere; emigrare

expect a (se) aştepta ceva / pe cineva / la, a fi în aşteptare, a se aştepta ca, a spera, a presupune că, a considera probabil, a solicita, a necesita; a vrea, a dori, a cere, a pretinde; a cred; it is to be $\sim$ ed este de aşteptat

expectance, expectancy expectativă, aşteptare; probabilitate; previziune, estimare pe baza unor condiții presupuse / probabile / care se pot întâmpla

expectant of care aşteaptă; care are perspectiva să / de a; răbdător, care nu se grăbeşte; de viitor, în perspectivă; solicitant, candidat

expectation aşteptare, expectativă; speranţă (de viață / durabilitate etc.), probabilitate

expectation of life $(\mathrm{ec}, \mathrm{TH})$ durată estimată (medie) de viață (a unui produs)

expected presupus; previzibil; probabil; planificat

expected level nivel probabil / estimat / aşteptat expected value valoare presupusă / estimată / scontată / probabilă / aşteptată

expected yield $(\mathrm{TH})$ randament estimat / scontat expect from / of a se aştepta la, a aştepta de la expedience, expediency promptitudine, iuțeală; caracter expeditiv; eficacitate; folos, utilitate, oportunitate

expedient expeditiv, rapid, eficace, eficient; potrivit, indicat, corespunzător; mijloc auxiliar, ajutor, sprijin, expedient, soluție practică; folositor, util; avantajos, convenabil; oportun; eficacitate; inventivitate 
expedite grăbit, prompt, expeditiv; a grăbi, a urgenta; a expedia; a accelera; a rezolva fără întârziere; liber, nestânjenit; uşor; neîntârziat, prompt, rapid

expedition expediție, expediere, promptitudine

expeditious expeditiv, prompt, rapid; urgent, care nu suferă amânare

expeditiousness promptitudine; rapiditate; caracter expeditiv

expel a expulza, a înlătura, a alunga, a elimina din, a exclude, a da afară din

expend a folosi, a cheltui (bani, mijloace, energie etc.)

expendable (ec, TH) utilizabil, de consum, consumabil (pentru birotică, ca piese de schimb etc.); nerecuperabil, care nu poate fi reparat / recuperat, de unică folosință; ireversibil

expendable mould (met) formă pentru o singură turnare

expendable refrigerant system (auto, termo) echipament cu agent frigorific pierdut / fără recuperarea vaporilor de fluid lichefiat (la vehicule frigorifice)

expenditure (ec) cheltuială, cheltuieli, speze, consum

expenditure of energy ( $\mathrm{TH}$, termo) consum de energie

expense (ec, termo) cheltuială, pret, cost, socoteală

expense account $(\mathrm{ec}) \mathrm{decont}$

expense estimate (ec, TH) deviz de cheltuieli

expense(s) (ec, TH) cheltuială, speze, costuri

expensive scump, costisitor; luxos

expensiveness (ec, TH) cost / preț ridicat; scumpete

experience experiență, eveniment, rutină; întâmplare; calificare, experiență; măiestrie; cunoaştere; a experimenta, a trece prin, a suferi (o influență), a cunoaşte, a simți, a încerca

experienced experimentat, cu experiență; calificat; care a suferit (a influența)

experiment (metr, edu) experiment, test, încercare, experiență (şi de laborator), probă; on, $\sim$ with a experimenta, a face experiențe

experiment on / upon a proba, a testa, a experimenta, a încerca, a face experiente

experimental experimental, de experimentare, prototip

experimental centre centru de cercetări

experimental error (metr) eroare experimentală / datorată modului de experimentare

experimental facilities instalație experimentală / de experimentare

experimental facts fapte stabilite experimental experimentalize a experimenta, a face experiențe experimentally ( $a d v)$ (în mod) experimental, pe baza experienței, din experiență

experimental model model (şi experimental); machetă

experimental plant (ind, cercetare) instalație experimentală / pilot

experimental setup $(\mathrm{TH})$ montaj provizoriu

experimental stress analysis (mec, metr) analiza experimentală a tensiunilor

experimental use aplicație / utilizare experimentală, folosire cu caracter experimental

experimental work studiu experimental, activitatea de realizare a unui experiment

experimentation experimentare; verificare

experimentator / experimenter cel care face un experiment, cercetător

experiment chamber cameră pentru experimente

experimenter experimentator

experiment on a model încercare / experimentare pe model

experiment station institut de cercetări, instalație experimentală

expert expert, specialist; cunoscător

expertise expertiză

expertness caracter expert; pricepere deosebită

expert system (artificial intelligence) (inf, c) program / soft care manipulează informatie simbolică, computer care foloseşte datele pentru a trage concluzii

expert workman (lucrător) specialist, expert

expiration scadență, expirare (şi a unui termen); (anat) expirare, răsuflare

expiratory expirator

expire a expira (aer), a da afară aerul; (anat) a expira; a se termina, a se sfârşi

explain a explica, a lămuri, a interpreta; a (se) explica, a (se) justifica, a motiva, a da explicații

explain away a explica, a lămuri, a elucida, a desluşi

explanation explicare, explicație, lămurire, interpretare; justificare, motivare

explanatory explicativ, lămuritor

explanatory report memoriu / raport explicativ

explement (mat) diferența dintre un unghi și unghiul de $360^{\circ}$

explicable explicabil, de înțeles; care poate fi explicat

explicate a dezvolta (o idee), a expune (un plan); a explica, a lămuri pe larg

explication explicare, lămurire; interpretare

explicative explicativ, lămuritor, de interpretare; clar, lămurit, precis

explicit evident, explicit; a explicita 
explicit data (inf, mas-un) totalitatea informațiilor furnizate de un calculator pentru comanda unei maşini-unelte

explicitly $(a d v)$ (în mod) explicit, clar explodable explozibil, care poate exploda explode (chim, TH) a exploda, a arunca în aer, a face explozie

exploded explodat, secționat, pe părți componente (şi d. un ansamblu desenat în spaţiu)

exploded view (OM) vedere explodată / descompusă a unui ansamblu (în plan sau în spațiu) exploder (mil, TH) focos, iniţiator, detonator exploit a exploata, a valorifica, a utiliza, a extrage; a cerceta

exploitability exploatabilitate (d. maşini, utilaje, resurse)

exploitation exploatare, utilizare, valorificare (d. utilaje, resurse, forță de muncă); reclamă, publicitate

exploitation engineer inginer de exploatare / de întreținere

exploration explorare, cercetare

exploratory cu caracter de tatonare, de probă

explore a cerceta, a studia, a explora, a analiza; a baleia (ecranul)

explorer cercetător

exploring explorare, analizare prin baleiere explosible explozibil

explosion explozie, izbucnire

explosion bomb (termo, metr) bombă calorimetrică

explosion chamber cameră de explozii (controlate) explosion door (TH) uşă de siguranță / de protecție

explosion engine (termo) motor cu explozie explosion hatch $(\mathrm{OM})$ capac de siguranță explosion hazard pericol de explozie explosion in the carburetor (auto, termo) explozie în carburator, rateu, retur de flacără

explosion in silencer (auto) explozie în toba de evacuare / de eşapament

explosion-proof ( $\mathrm{TH}$, chim) antideflagrant, protejat contra exploziei

explosion riveting $(\mathrm{OM})$ nituire prin explozie explosion-type core machine (met) maşină de puşcat miezuri

explosion welding (met) sudare prin explozie explosive (chim) exploziv, explozibil; controversat explosive atmosphere (chim, $\mathrm{TH}$ ) atmosferă explozivă

explosive cladding $(\mathrm{TH})$ formare de bande bimetalice prin explozia unui constituent pe celălalt (considerat suport)

explosive forming $(\mathrm{TH})$ matrițare prin explozie explosive gas (chim, $\mathrm{TH}$ ) gaz exploziv

explosiveness caracter exploziv

explosive oil (chim) nitroglicerină

explosive range of methane (met) limite / interval al(e) amestecului metan-aer, cu caracter exploziv exponent (mat) exponent; putere, factor; ghid, interpret, îndrumător; model, tip; exponat

exponentation (mat) exponențiere, ridicare la putere

exponential (mat) exponențial, funcție exponențială

exponentially spaced holes (OM, hidr) găuri cu aşezare exponențială (la amortizoare hidraulice de şocuri)

exponential notation (mat) reprezentare exponențială a numerelor

exponential rising creştere / dezvoltare exponențială (şi d. un proces etc.)

exponential rule (mat, fiz) lege / funcție exponențială

exponent overflow $(\mathrm{ec})$ depăşire pozitivă a exponentului

export (ec) a exporta; export, articol de export exportable (ec) exportabil, care poate fi exportat exportation (ec) export, exportare; (mat) eliminare exporter (ec) exportator

exporting coil (OM, termo) buclă de cuplaj export trade (ec) comerț exterior, export(are) expose a expune, a (se) dezveli, a (se) descoperi, a iradia, a ieși la suprafață

exposed cardan shaft $(\mathrm{OM})$ arbore cardanic neprotejat

exposed propeller shaft $(\mathrm{OM})$ arbore de acționare, fără cutie / carcasă de protecție

expose to light a expune la lumină

exposition expunere, prezentare, înfățişare; interpretare

exposure expunere (la radiații, la lumină etc.), prezentare, înregistrare, filmare; dezvăluire

exposure factor factor de expunere

exposure fault (fiz, fotografie, materiale plastice etc.) defect / greșeală de expunere

exposure latitude limite de expunere (la unele procedee tehnologice, de exemplu, de iradiere)

exposure range gamă / interval de expunere

exposure test (metr, plast) încercare / test de / la expunere (şi la intemperii)

exposure time (fiz) durată / timp de expunere

exposure to expunere la

exposure to light expunere la lumină

expound a expune, a înfățişa, a prezenta; a explica, a lămuri

express a exprima, a formula, a rosti

express analysis analiză rapidă 
expressed oil (alim) ulei obținut prin presare express highway (auto, constr) autostradă expression expresie (matematică), relație, set de simboluri cu o valoare specificată, grup de variabile legate prin relații, termen, noțiune; exprimare

express train (cf) tren accelerat / rapid / expres

express warranties $(\mathrm{ec}, \mathrm{TH})$ garanții / clauze exprese / speciale / specifice

expropriate a expropia

expropriation expropiere

expulsion expulzare, evacuare, dare afară; (auto) eşapament

expulsive care dă afară / expulzează; de dezlocuire, de înlocuire, de expulzare

expulsive agent (termo, ind chim) agent motor / de lucru / de transport / de dezlocuire / de înlocuire / de expulzare

expulsive energy (mec) energie motrice / de lucru / de expluzare

expulsive force (mec) forță motrice / de impingere

exsecant (mat) functia exsec $(\mathrm{x})=\sec \mathrm{x}-1$

exsiccant (alim, ind chim) agent de uscare / sicativ

exsiccate (alim, ind chim) a usca, a dezhidrata

exsiccator (alim, ind chim) exsicator, desicator, sicativ

extant existent, care se mai găsește

extemporaneous improvizat, nepregătit; prezentat oral; nepremeditat; neprevăzut, întâmplător

extemporary nepremeditat, negândit dinainte; împrovizat, făcut în grabă; provizoriu

extend a (se) extinde, a (se) lăți, a (se) lărgi, a (se) lungi, a (se) mări, a (se) întinde; a prelungi; a (se) răspândi, a extinde (o influență etc.); a acorda (privilegii); a oferi, a da, a acorda (ajutor etc.); a întinde (brațul, mâna); a prelungi (timpul); a transcrie (în limbaj curent); (jur) a sechestra, a evalua în vederea sechestrării; (sport) a supune la un efort maxim

extended întins, extins; dezvoltat, mărit

extended center distance $(\mathrm{OM})$ distanță mărită între axe (de exemplu, prin deplasarea pozitivă a danturii uneia sau ambelor roți dințate)

extended dislocation (fiz) dislocație extinsă / în lanț

extended inner ring $(\mathrm{OM})$ inel interior cu lățimea mai mare decât a celui exterior (la rulmenți)

extended lead (el) (fir / conductor) prelungitor extend (out) stroke (hidr) cursă de ieşire (şi a tijei unui piston)

extended reproduction (ec) reproducție lărgită extended rubber (ind chim) cauciuc spongios extended surface $(\mathrm{OM}$, termo) suprafață nervurată adițională / extinsă prin gofrare, nervurare, pliere extender material de umplutură; (met) sarjă (solidă); (chim) diluant (lichid)

extendible, extensible extensibil

extending capacity / displacement (auto, termo) cilindree de admisie

extend to a exprima ceva, a (se) transmite la, a (se) extinde la

extensibility extensibilitate

extension extindere, mărire, creştere, întindere (şi a braţului, a unui element, dispozitiv etc.), ieşind, extensie, (a)lungire, prelungire, dilatare, lărgire, mărire; mărime, lungime; (el) cordon prelungitor, racord, derivație; (mat, fiz) prelungire a unei aplicații, generalizare; (met, OM) (a)lungire specifică, prelungitor; (constr) extindere, (clădire) anexă; (cf) linie secundară; (TH) branşament; (edu) cursuri în cadrul universității, cursuri serale; acordare (de ajutor), oferire; (med) extensie; (număr de) interior (telefonic)

extension arm (OM) consolă, braț extins

extension (bed) lathe (mas-un) strung cu pat batiu extensibil

extension bellows (OM, mas-un) burduf de extindere (pentru protejarea pieselor în mişcare)

extension bolt $(\mathrm{OM})$ şurub de reglare

extension cable (el) (cablu) prelungitor

extension chain (OM, mas-un) lanț de avansare (la prelucrarea lemnului, a pieselor lungi etc.)

extension cord (el) cordon de racord

extension factor (fiz) coeficient de mărire / de extindere

extension furnace (termo, met) antefocar

extension nipple (OM, hidr) niplu prelungitor

extension of piston $(\mathrm{OM}$, termo) proeminență a pistonului (pentru centrare)

extension piece (OM, mas-un) prelungitor, piesă prelungitoare

extension rod $(\mathrm{OM}$, metr) tijă amovibilă / prelungitor la un aparat de măsură

extension spring $(\mathrm{OM})$ arc de tractiune

extension tube prelungitor din țeavă

extensive întins, extins, vast; (agr) extensiv

extensively $(a d v)$ (în mod) extensiv, extins; mult, considerabil

extensive manufacturing (ec, TH) producție de masă / la scară mare

extensiveness extindere, volum

extensograph (alim, metr, ind chim) extensograf, aparat de măsurat proprietățile reologice ale unei paste, ale unui corp vâscos

extensometer (metr, termo, met) dilatometru; exensometru 
extent (mat) volum, sferă; extindere, întindere, perimetru, circumferință (mai rar), dimensiune, domeniu, mărime, măsură, grad, spațiu, proporții, cantitate

extenuate a slăbi, a atenua; a găsi circumstanțe atenunate pentru, a căuta o justificare

exterior exterior, extern, din afară, lateral, (aspect) exterior, parte exterioară; (mat) mulțime a punctelor exterioare

exteriority exterioritate; obiectivitate; superficialitate

exteriorization exteriorizare

exteriorize a exterioriza; a obiectiva; a concretiza, a materializa

exteriorly $(a d v)$ la exterior, la suprafață; la înfățişare, aparent

exterminate a extermina, a distruge; (agr) a stârpi extermination exterminare, nimicire, distrugere external, exterior extern, (aspect) exterior, aparență; superficial; formă, (lucru) neesențial; împrejurări exterioare

external angle (OM) colț teşit; (geom) unghi exterior / extern

external attemperation (termo, met) răcire exterioară

external audit verificare / control contabil(ă) de către experți externi; audit extern

external bulk store (inf) memorie externă de mare capacitate

external calipper gauge (metr) calibru-potcoavă / -inel

external chill (met) placă de răcire

external cast (met) mulaj extern

external contraction (materiale, constr) contracție exterioară / la exterior

external cylindrical gauge (metr, mas-un, $\mathrm{TH}$ ) calibru-inel

external dovetail (OM, mas-un) piesă cuprinzătoare în îmbinare coadă-de-rândunică

external extension post secundar exterior

external force / load (mec) forță exterioară

external gear $(\mathrm{OM})$ angrenaj exterior

external gearing $(\mathrm{OM})$ angrenare exterioară

external gear pair (OM) angrenaj exterior, pereche de roți dințate cu dantură exterioară

external honing machine (mas-un) maşină de honuit exterior

external leakage flow (hidr) scurgeri externe / în afara sistemului hidraulic / în mediu

external limit gauge (metr, mas-un) calibrupotcoavă limitativ de exterior

external loss time $(\mathrm{TH})$ timp pierdut

externally acting brake (OM) frână cu acționare din afara sistemului externally finned pipe (OM, termo) țeavă cu nervuri / $\mathrm{cu}$ aripioare exterioare

externally fired boiler (termo) cazan cu arzător înconjurat de tuburi din material refractar sau cu răcite (cu apă)

external member (OM, mas-un) piesă exterioară / cuprinzătoare

external memory (inf) memorie externă / auxiliară / secundară

external mould (met) mulaj extern, matriță cu forma la exteriorul ei

external phase (met, plast) fază dispersantă

external plant instalație de / pentru exterior external plasticiser (plast) plastifiant extern external pressure (hidr) presiune exterioară external resistance $(\mathrm{el}, \mathrm{mec})$ rezistență exterioară / externă

external-rotor motor (termo) motor $\mathrm{cu}$ rotor exterior

external scrap (met) fier vechi achiziționat

external shoe brake $(\mathrm{OM})$ frână cu saboți exteriori

external / female taper (ring) gauge (metr) calibru-manşon conic

external-thread $(\mathrm{OM})$ filet exterior (tip şurub)

external-thread gauge (metr, OM) calibrupotcoavă pentru filet exterior

external toothing (of gear) (OM, mas-un) danturare / dantură exterioară

external treatment (termo) tratament al apei înainte de intrare / introducere în cazan

external view $(\mathrm{OM})$ vedere (în desen tehnic)

external wall (constr) zid / perete exterior

external work (constr) prelucrare a suprafețelor exterioare

external zone (constr, TH) zonă exterioară / marginală / externă

extinct stins, care nu mai este activ; a stinge

extinction extincție, stingere, dispariție; distrugere; (inf) ştergere (a conținutului memoriei); (met) stingere (şi a cocsului)

extinction coefficient (el, fiz) coeficient de extincție / de stingere

extinction potential (el) potențial de stingere de blocare

extinguish a stinge; a distruge; (jur) a stinge (un conflict), a achita

extinguisher stingător, extinctor

extinguishing stingere

extinguishing box $(\mathrm{TH})$ stingător, cutia / carcasa extinctorului

extinguishment stingere; distrugere; dispariție; (jur) anulare

extirpation extirpare; stârpire 
extra $(a d j)$ în plus, supliment; suplimentar, extra; $(a d v)$ în plus, peste, suplimentar, extrem de, exagerat de; (ec) plată suplimentară, cheltuieli suplimentare; calitate superioară

extra charge of coal (met) (supra)saturare cu cocs extract (chim) extract; citat, pasaj; (mat) a extrage, a scoate; a lua, a alege, a epuiza (prin extractie)

extract copper (met) a decupra, a extrage cuprul extract a core (met) a extrage un miez extract data (inf) a extrage date extract gas (ind chim) a extrage gazul extraction extragere, scoatere, extracție extraction apparatus (mas-un) aparat / dispozitiv de extractie, extractor

extraction cartridge / shell (ind chim, met) cartuş de extracție

extraction centrifuge (alim, ind chim, mas) centrifugă de extracție / de separare

extraction factor (alim, ind chim, mas) coeficient de extracție (şi la filtrare)

extraction of root (mat) extragerea rădăcinii extraction of sugar (alim) extragerea zahărului extraction pump (alim, hidr, ind chim) pompă de extracție

extraction ratio (fiz, ind chim) grad / raport de extracţie (şi între masa solventului şi masa produsului inițial)

extraction residues (alim) ștrot (la extracția uleiului)

extraction solvent (ind chim) agent / solvent de extractie

extraction tool (mas-un) sculă / dispozitiv de extracție (și în mecanica fină sau electronică)

extraction tube (OM, mas-un) tub al aparatului de extractie

extraction turbine (termo) turbină cu priză de aer extractive extractiv

extractive distillation (alim, ind chim) distilare / fracționare extractivă (şi prin solventare)

extract of book fragment / extras dintr-o carte

extract of materials extras de materiale

extractor (mas-un) extractor, aruncător, dispozitiv de extracție, cleşte

extractor basket $(\mathrm{OM}$, alim, ind chim) tobă / coş al centrifugii

extract yield (ind chim, met, alim) randament la extragere / de extract / de scoatere

extracurricular (edu) în afara programului / programei / curiculei

extra-fine fit $(\mathrm{OM})$ ajustaj fin / de precizie (de clasă superioară)

extra-fine steel (met) oț̣l de calitate superioară / special

extra-hard (met) extradur, prea dur extra-high tensile steel (met) oțel cu rezistență mare la tracțiune, oțel de înaltă rezistență

extra length for machining (mas-un, met) adaos de prelucrare prea mare la lungimea piesei

extra-light drive fit $(\mathrm{OM})$ ajustaj blocat / cu strângere uşoară

extra-light load (mec) sarcină foarte uşoară / mică

extra load $(\mathrm{mec})$ sarcină / greutate suplimentară / peste cea normală

extra-narrow pillar file pilă cu secțiune dreptunghiulară foarte îngustă şi vârf drept

extraneous matter materie / material / component străin( $\breve{a}) /$ extern( $\breve{a})$

extraneous noise (electr, autom) zgomot de fond

extraordinarily $(a d v)$ (în mod) extraordinar, nemaipomenit (de)

extraordinariness caracter extraordinar

extraordinary extraordinar, nemaipomenit, în cel mai înalt grad; extrem de, extraordinar de

extraordinary discharge (hidr) debit de vârf

extra-output (el, mec, mas) putere suplimentară (la ieşire)

extrapolate (mat) a extrapola

extrapolation (mat) extrapolare; (ec) previzionare

extra-red ultra roşu

extra-regular care se abate de la regulă; aberant; neregulat

extra rim (auto) jantă (auto) de rezervă

extras (ec) cheltuieli / lucrări suplimentare (peste deviz, la pret majorat); (mas) echipament / utilaj auxiliar / suplimentar / complementar, accesoriu; extras

extra slack running fit, coarse clearance fit (OM) ajustaj foarte larg

extra-slim taper file pilă (mică) de fierăstrău / triunghiulară / cu vârf ascuțit

extra-soft steel (met) oțel foarte moale / cu continut foarte mic de carbon

extra-strong moulding sand (met) nisip argilos, de formare

extra-violet (fiz) ultraviolet

extra weight (mec) supragreutate

extra wheel (auto, OM) roată de rezervă / suplimentară

extreme (mat) extrem (şi termen într-o relație), extrem (de funcție), cel mai depărtat, cel mai mare / mic; exccesiv; extremă, extremitate, limită, capăt

extreme and mean ratio (mat) raport de aur, raport de medie şi extrem

extreme breadth (nav) lățime maximă a navei

extreme dimension of workpiece (mas-un) dimensiune de gabarit a piesei de prelucrat, dimensiune limită 
extreme fiber stress (mec, OM) tensiune / efort în fibra extremă, tensiune extremă în fibră

extremeless nemărginit, fără limite / limită

extremely $(a d v)$ la extrem, extraordinar, în cel mai înalt grad, extrem de, extraordinar de

extremely high frequency (EHF) (fiz) bandă de frecvente foarte înalte $(30 \ldots 300 \mathrm{GHz})$

extremely humid weather vreme foarte umedă extremely sensitive (metr) foarte sensibil (d. aparate etc.)

extremeness caracter extrem; extremitate; limită; culme

extreme position (mas-un, mas) poziție finală / extremă

extreme pressure (hidr, T) presiune maximă extreme-pressure additive EP ( $\mathrm{T}$, chim) aditiv de extremă presiune (în lubrifianți etc.)

extreme pressure lubricant $(\mathrm{T}$, chim) lubrifiant rezistent la presiuni mari (simbolizat cu $\mathrm{EP}$ )

extreme range distanță / interval / domeniu $\operatorname{maxim}(\breve{a})$

extreme range of use $(\mathrm{TH})$ domeniu extrem de utilizare

extremity extremitate, capăt (şi de piesă), limită, punct extrem / final; situație-limită

extremum value valoare extremă

extricate from / out of a scoate din; (chim, fiz) a degaja; a scăpa, a se descurca

extrication scăpare, descurcare, eliberare

extrude (mas-un) a extruda, a scoate / împinge în afară (d. materiale, ca proces, dar şi defect)

extruded electrode (el, met) electrod format prin extrudare, electrod cu înveliş depus prin presare

extruded goods (met, ind chim) articole extrudate (din mase plastice sau metalice)

extruded section (met, ind chim) profil extrudat extruded tube (met, ind chim, plast) țeavă / tub extrudat $(\breve{a})$

extruder (alim, met, plast, mas-un) dispozitiv de extrudare

extruder / extruding machine (alim, met, plast, mas-un) maşină de extrudat

extruder barrel (OM, alim, met, plast) cilindru de extrudor

extruder core (OM, alim, met, plast) dorn de extrudare

extruder screw (OM, alim, met, plast) şurub / melc (la dispozitiv de extrudare)

extruding (process) (met, plast) (proces) de extrudare

extruding press (met, plast, mas-un) presă de extrudare

extruding speed (mas-un) viteză de extrudare extrusion (met, plast, mec) extruziune, extrudare, fluaj

extrusion billet (met, plast, mec) materialul de extrudat

extrusion die (mas-un, met, plast) matriță pentru extrudare

extrusion head (mas-un, met, plast) cap de extrudare, capul dispozitivului de extrudare

extrusion mandrel (mas-un, met, plast) dorn de extrudare

extrusion moulding (mas-un, met, plast) formare prin extrudare

extrusion plunger (mas-un, met, plast) piston de extrudare

extrudion press (mas-un, met, plast) presă pentru extrudare

extrudion pressing (mas-un, met, plast) extrudare la rece

exudation (fiz, termo) exsudare, transpirație

exude (fiz, termo) a exuda, a transpira, a elimina; (fiz) a iradia, a împrăștia

exuding of the head (met) umflarea maselotei

eye (anat) ochi; ureche (de ac); (hidr) ajutaj de intrare (la compresoare, centrifuge etc.); (OM) ochi, ureche, şurub cu inel / cu ochi, ochet (şi de lanț), vizor; a privi la, a se uita la; a observa, a cerceta, a urmări

eyebar $(\mathrm{OM})$ bară cu ochi la un capăt sau la ambele capete

eye(-)bolt (OM) şurub cu ochi / cu ureche; (nav) ochi de punte cu bolt

eye-catching care reține privirea (şi d. un indicator / panou de semnalizare

eye dropper $(\mathrm{OM}, \mathrm{T})$ picurător

eyeglass (OM, opt) lupă, lentilă, ocular, vizor de sticlă

eyeglasses (opt) ochelari

eyeguard (met) apărător pentru lumină, protecție pentru ochi

eyehole $(\mathrm{OM})$ orificiu de control / pentru vizor eye hook (OM, el, nav) ochet (pentru cablu)

eye joint $(\mathrm{OM})$ articulație, îmbinare articulată

eyelash (anat) geană

eyeless (med) orb

eyelet $(\mathrm{OM})$ ureche, buclă mică, ochi, capsă, ochet, gaură, ferestruică; (el) tub metalic pentru rigidizarea conexiunilor lipite

eye-letter (alim, ind chim) maşină de capsat (sticle, recipiente, ambalaje etc.)

eye letting capsare

eyelet pliers (mas-un) cleşte de apucat, cu gură rotundă

eyeletter (mas-un) maşină de capsat

eyeletting (mas-un) capsare 
eye-lever finder (OM, metr) vizor de corecție eyelid (anat) pleopă

eye mounting (OM, hidr) fixare / montare cu urechi / ochiuri / cu ureche / cu inel (şi la cilindri hidraulici)

eye nut $(\mathrm{OM})$ piuliță cu ochi / cu inel / rotundă eye of connecting rod $(\mathrm{OM})$ ochet cu furcă, ochi / alezaj al bielei

eye of the tuyère (met) gaură a gurii de vânt (la furnale)

eyepiece (fiz, opt) ocular

eyepiece micrometer (metr, opt) micrometru ocular

eye plate (nav) placă cu ochi (construcții navale) eyepore (met, plast) por rotund / lenticular (şi defect)

eye protective lenses ochelari de protecție

eye service aparență

eye shield $(\mathrm{TH})$ vizieră de protecție

eyeshot (anat, opt) câmp vizual / de vedere

eye sight câmp al vederii, orizont; (termo, OM)

fereastră / ochi / gură de observație

eye slit (OM, fiz, metr, mil) vizor

eye tooth (anat, med) dinte canin; (fig) maturitate, experiență

eye wash (med, chim) apă / soluție pentru ochi eyewitness martor ocular, observator direct eyot (geogr) insulă (într-un râu) 


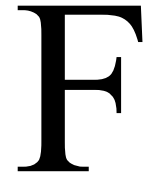

fabric structură, carcasă, schelet, cadru, produs, material; țesătură, stofă; (constr) construcție, clădire, edificiu; mecanism, sistem; structură, alcătuire

fabricant (amer) fabricant; constructor

fabricate a fabrica (rar), a produce, a executa, a prefabrica; a falsifica (un act); a născoci

fabricated falsificat, contrafăcut; prefabricat

fabricated members / parts piese prefabricate

fabricated steel-sheet products (OM, constr) semifabricate de tablă (din oțel)

fabricated steel-sheet structures (OM, constr) constructii de tablă / metalice (din otel)

fabrication fabricare, fabricație, producere, prefabricare, prefabricatie; contrafacere, fals; invenție

fabrication process plan $(\mathrm{TH})$ plan de operații tehnologice

fabric belt $(\mathrm{OM})$ curea țesută / din țesătură, curea textilă

fabric filter $(\mathrm{OM})$ filtru cu țesături

fabric insert inserție textilă

fabric proofing (ind chim) cauciucare a țesăturii, impregnare cu cauciuc a țesăturii

fabric tooth facing $(\mathrm{OM})$ înveliş al dintelui din țesătură (la curele dințate)

fabric-type dust collector $(\mathrm{OM})$ filtru cu saci (textili)

fabulous fabulos, legendar; fantastic, ireal, absurd façade, facade (constr) fațadă

face suprafață, față, aspect exterior; mină; (în) aparență; (constr) fațadă (a unei case), pavament (la o boltă), suprafață frontală, front de lucru, cadran; expresie, înfățişare; îndrăzneală; (met) tăblia cilindrului (de laminor); (metr) cadran de ceas; (tipografie) floare (de literă); a se întoarce cu fața la, a sta cu fața la / spre, a acoperi (partea din față), a înveli, a finisa, a căptuşi; a aranja; a înfrunta / a se confrunta (cu o problemă); a face față; a recunoaşte, a admite; (mas-un) a poliza, a freza; a se arăta; a înfrunta; a recunoaște existența unor fapte etc., a nu nega evidența; a-şi păstra bunul renume; $\sim$ to $\sim$ față în față; full din față; half $\sim \operatorname{din}$ profil; in the $\sim$ of în fața (unui lucru), în prezența, în ciuda, expresie a feței; on the face of it la suprafată ; on the $\sim$ of the earth pe fața pământului; (tipografie) in block / bold $\sim$ cu caractere grase, aldine; $\sim$ down a descuraja, a intimida

face and radius cutter (mas-un) freză frontală, cu tăiş de colț în arc de cerc

face-and-side (milling) cutter (mas-un) freză disc, cu trei suprafețe de aşchiere

face angle $(\mathrm{OM})$ unghi al conului exterior (la roți dințate conice); (mas-un) unghi de degajare (la broşe)

face area $(\mathrm{OM})$ suprafață / secțiune frontală

face belt conveying $(\mathrm{OM})$ transportare cu bandă

face bend test (metr) încercare la îndoire a sudurilor frontale cu cusătură pe una din fețe

face-centred (fiz, chim) cu fețe centrate (d. structură cristalină)

face-centred cube space lattice (fiz, chim) rețea cubică cu fețe centrate

face-centred cubic (lattice) (chim, met) (rețea) cubic $(\breve{a})$ cu fețe centrate (d. cristale)

face-centred grating (fiz, chim) retea cu fete centrate (d. cristale)

face-centred space lattice (fiz, chim) rețea $\mathrm{cu}$ volum centrat (d. cristale)

face-centred structure (fiz, chim) structură cu fețe centrate

face chuck (OM, mas-un) planşaibă, platou, mandrină

face cutting (mas-un) aşchiere a suprafețelor frontale

face-cutting edge (mas-un) tăiş frontal, muchie de aşchiere, de pe fața frontală

face cutter (mas-un) freză frontală

faced cu fața, la fața, având fața

face-floor position (auto) pozitia frontal-podea (şi la direcționarea aerului condiționat)

face gear $(\mathrm{OM})$ roată plană (la angrenaje conice), roată coroană

face grinder (mas-un) maşină de rectificat plan / frontal

face grinding (mas-un) rectificare a suprafeței frontale

face grooving tool (mas-un) cuțit pentru canelat frontal

face guard $(\mathrm{TH}$, ind chim) mască de protecție

face harden (met) a căli (superficial)

face hardening (met) călire / durificare superficială (în general)

face (in lathe) (mas-un) a strunji plan

face / facing lathe (mas-un) strung frontal

face length (met) lungimea tăbliei (cilindrului de laminare)

face machining (mas-un) prelucrare a suprafețelor frontale 
face / facing mill / milling-cutter (mas-un) freză cilindrică / frontală, cap de retezat

face-mill-cutter grinding attachment (mas-un) dispozitiv pentru ascuțirea frezelor $\mathrm{cu}$ dinți demontabili

face milling (mas-un) frezare a suprafețelor frontale face-milling-cutter sharpening machine (masun) maşină pentru ascuțit freze frontale

face mode (auto) selectarea modului de acționare: mod frontal (şi pentru direcționarea aerului)

face of tool (mas-un) față de degajare (a unei scule)

face of weld (OM, met) suprafața cusăturii sudate

face piece (mil, ind chim) mască antigaz

faceplate (mas-un) platou (şi de strung), planşaibă, placă de trasare

faceplate breaker controller (autom) controler combinat, cu întrerupător şi placă cu contacte

faceplate chuck (mas-un) platou / planşaibă cu fălci

faceplate jaw (mas-un) falcă a platoului

faceplate lathe (mas-un) strung frontal

faceplate stud (OM, mas-un) şurub prizonier pentru fixarea piesei pe platou

face position (auto) poziția „frontal” (şi la direcționarea aerului condiționat)

face pressure $(\mathrm{OM}$, hidr, mec) presiune de pe suprafață

face profile $(\mathrm{OM})$ profil frontal

face shield (ind chim) mască de protecție

face side (mas-un) față de degajare (a unei scule); fața unei tesături

face spanner $(\mathrm{OM})$ cheie furcă

facet (fiz) fațetă (a unui cristal); aspect; implicație

face tool (mas-un) cuțit frontal

faceturning (mas-un) strunjire frontală

face up a monta în sus

face value (ec) preț / valoare nominal(ă)

face wall (constr) perete de fațadă

facewidth $(\mathrm{OM})$ lățimea danturii (b)

face work (constr) zidărie aparentă; (met, TH) îmbrăcare, căptuşire

facient (mat) factor

facile facil; uşor, lesnicios; superficial, făcut de mântuială; accesibil; uşor de influențat; maleabil; de înțeles; îngăduitor; conciliant

facilitate a uşura, a facilita, a înlesni; a promova, a încuraja

facilitation uşurare, facilitare; promovare, încurajare

facility $(\mathrm{TH})$ amenajare, instalație, dispozitiv, utilaj; uşurință, facilitate; talent, aptitudine; dezinvoltură; dexteritate facilities $(p l)$ avantaje, înlesniri, comodități; condiții favorabile, facilitătí; privilegii

facing orientare; înfruntare; acoperire, îmbrăcare, placare, finisare, înveliş, strunjire / fațetare pe direcție radială; (met) căptuşire (a unui cuptor), depunere, vopsea / strat final(ă) pentru forme, strat de sudură

facing arm tool (mas-un) cuțit rotativ

facing bar (auto, mas) bară a platinelor

facing brick (constr) cărămidă aparentă

facing-coupled (OM) cuplate, montate (d. piese, rulmenți etc.) în opoziție

facing / outer diameter cutting (mas-un) strunjire frontală / pe diametrul exterior

facing head (mas-un) sanie port-cuțit a aparatului de planare

facing joint rost al măştii (de etanşare)

facing / face lathe (mas-un) strung frontal

facing material (met, $\mathrm{TH}$ ) material de căptuşeală / de fălțuire

facing / face mill / milling cutter (mas-un) freză cilindrică / frontală, cap de retezat

facing plate $(\mathrm{OM})$ placă de fixare

facings (mas-un) şpan; (nav) viraje

facing sand (met) nisip de modelare / de turnătorie, amestec de finisare

facing stone (constr) piatră pentru paviment / pavare; (mas-un) piatră de ascuțit

facing tool (mas-un) cuțit de strunjit plan

facing tool holder (mas-un) sanie port-cuțit a aparatului de planare

facing work (mas-un) strunjire a suprafeței frontale

facsimile reproducere / copie fidelă, facsimil; a reproduce exact

fact fapt, întâmplare, împrejurare, circumstanță, eveniment, fenomen; realitate, adevăr; (fig) esență, miez

fact finder (persoană) care constată fapte(le)

fact finding constatare / stabilire a faptelor

fact-finding board comisie de anchetă

fact-finding mission misiune de constatare

faction facțiune, fracțiune; sciziune, dezbinare

factor factor, element, agent, coeficient, divizor; (mat) factor, coeficient, divizor; (TH) coeficient, factor (şi de siguranță etc.)

factorability (mat) factorizabilitate

factorable / factorisable (mat) care poate fi descompus în factori

factorage comision

factor comparison method metodă a comparării factorilor

factor group grup de factori (în general)

factorial de fabrică 
factorial function (mat) polinom factorial, funcție factorială

factorial series (mat) serie a cărei sumă este egală cu numărul e

factorization (mat) descompunere în operații elementare / în factori, factorizare

factorize (mat) a descompune în factori

factor of adhesion (fiz, chim, T) coeficient de aderență

factor of assurance $(\mathrm{TH})$ coeficient de siguranţă

factor of integer divizor al unui număr întreg

factor of polynomial (mat) divizor al unui polinom

factor of proportionality coeficient de proporționalitate

factor of safety, safety factor $(\mathrm{TH}, \mathrm{OM}$, materiale) coeficient de siguranță

factor out (mat) a da factor comun

factor theorem (mat) teorema diviziunii polinoamelor prin (x-a)

factory fabrică, uzină, reprezentanță comercială într-o țară străină; hand muncitor / operator în fabrică

factory-acceptance gauge (metr) calibru de recepție

factory cost (ec) preț de cost, cheltuieli de producție

factorry farm (agr) fermă industrială

factory hand forță de muncă

factory overheads $(\mathrm{ec}, \mathrm{TH})$ cheltuieli de fabricație

factory process $(\mathrm{TH})$ procedeu / proces / metodă de fabricație

factory railway (cf, met) cale ferată uzinală

factory waste (mediu, ind) deşeuri (industriale)

factual faptic; real, efectiv

facture (ec) factură

facultative facultativ, opțional; întâmplător, accidental

faculties resurse, posibilități, mijloace

faculty (edu) facultate; aptitudine, talent; autoritate, drept

faddy ciudat, straniu; excentric

fade a (se) veşteji, a (se) ofili; a dispărea, a se atenua, a (se) decolora, a se şterge (d.culoare), a slăbi, a scădea

fade away a se şterge, a se stinge, a se estompa

fade-away weld $(\mathrm{OM})$ sudură în $\mathrm{V}$

faded decolorat, şters, îngălbenit

fade-in (autom) intrare progresivă

fade-out (autom) suprimare progresivă

fade out a atenua; a amortiza; a dispărea treptat

fader (autom, metr) potențiometru de reglaj, atenuator, regulator de intensitate sonoră, mixer, amestecător fading (fiz, metr, autom) scădere temporară a unui semnal datorită condițiilor de propagare, atenuare, amortizare; slăbire (a luminii) ofilire, veştejire; decolorare: (autom) mixaj, suprapunere, fading

fading effect (fiz) amortizare, efect de atenuare / stingere

faeces (mediu, geogr) sedimente, depuneri; (agr) materii fecale

fag a trudi, a munci din greu; a obosi, a surmena, a slei; muncă istovitoare / plictisitoare; oboseală, surmenaj, epuizare

fag end rămăşiță; capăt, extremitate; parte finală, sfârşit

fagged out obosit

faggot legătură de lemne, fascicul, snop; îmbinare (prin sudare), legătură; a împacheta

faggoted iron (met) fier / profiluri / semifabricate în legături / împachetat(e)

faggoted scrap (met) deşeuri de fier, în legături / pachet

faggoting (met) împachetare

faggoting furnace (met) cuptor de încălzire a deşeurilor metalice, înainte de împachetare

faggoting press (mas-un, met, plast) presă pentru (îm)pachetare

fag out a istovi, a surmena

Fahrenheit degree $\left({ }^{\circ} \mathbf{F}\right)$ (metr, fiz) unitate de măsură a temperaturii, grad Fahrenheit $\left(1^{\circ} \mathrm{F}=\right.$ $\left.0,556^{\circ} \mathrm{C}\right)$

faience (ind chim) faianță, vase de faiantă

fail nereuşită, eşec; (edu) cădere (la examen); lipsă; a se opri din lucru, a refuza să funcționeze, a se deteriora, a cădea (în sens de avariere), a se nărui, a se prăbuşi, a nu se îndeplini, a avea o avarie, a (se) rupe; a eşua, a da greş, a nu reuşi, a nu face (ceva), a lipsi; a da dovadă de neglijență; a slăbi (d. vedere, stingere, un proces etc.); a se miç̧ora; a se stinge; a se termina; a înșela aşteptările; (agr) a fi sub aşteptări (recolta etc.); (ec) a da faliment; (edu) a nu promova, a nu trece (un examen); a omite, a neglija, a uita să; a dezamăgi; in a fi lipsit de; (ec) a da faliment; a lăsa; a părăsi; a nu fi de ajuns; a lipsi

failed nereuşit, neizbutit, ratat; (ec) falit

failed closed (OM, hidr) nefunctionabil din cauza unei poziții extreme (d. aparatură hidraulică)

failed test piece epruvetă din material necorespunzător, epruvetă necorespunzătoare

fail-functional $(\mathrm{TH}$, mas) cu funcționare limitată, în continuă degradare

fail-hardover (TH) tip de avarie în care elementul distrus se află în condiții limită (de poziție 
sau de sarcină), avarie cauzată de funcționare în conditiii extreme

fail in a-i lipsi, a nu avea ceva

failing lipsă, neajuns, scădere; nereuşită, insucces, eşec; descreştere, slăbire; cusur; defect, greşeală, slăbiciune; (prep) în lipsa, în absența; neîndestulător, insuficient; care slăbește, care se deteriorează;

fail-neutral (autom, metr) tip de cădere sau blocare la zero a aparatului / sistemului de control

fail of a nu izbuti să realizeze ceva; a-i lipsi, a nu avea ceva

fail-open (autom, TH) tip de cădere / avarie în care un element întrerupe calea normală de control

fail-operational (TH) (sistem) care continuă să funcționeze în ciuda căderii, avariei sau a funcționării incorecte a unor componente

fail-passive ( $\mathrm{TH}$, autom) o calitate a dispozitivului căzut / avariat de a nu crea răspuns, chiar dacă rămâne în sistem

fail-safe (autom, TH) autoprotejat, calitate de a înceta funcționarea la defectare; de nădejde, trainic, solid; care nu are opriri

fail-safe device (autom) dispozitiv de protejare în caz de avarie / cădere / de menținere a parametrilor în limite sigure

fail-soft (inf, autom) soft de compensare a căderii parțiale

fail to operate (auto) a nu (mai) funcționa, a înceta să funcționeze

failure absență, lipsă; neajuns; sărăcie, insuficiență; eşec, nereuşită; cădere, prăbuşire; pierdere, pagubă; năruire, rupere, ruptură, avarie, întrerupere, eroare, defect, defectare, oprire (nedorită); falie, dizlocare, surpare, prăbușire

failure analysis analiza căderii / avariei / ruperii failure by shear $(\mathrm{OM})$ distrugere prin forfecare

failure cause $(\mathrm{TH})$ cauza inițierii sau generării mecanismului de distrugere

failure crack crăpătură, fisură (care provoacă o avarie / cădere) sau care este cauzată de o defectare / avarie)

failure criterion $(\mathrm{mec}, \mathrm{TH})$ criteriu de rupere

failure detection $(\mathrm{TH})$ determinare / localizare a avariei / căderii

failure effect $(\mathrm{TH})$ consecința / efectul căderii / avariei / distrugerii

failure-free operation (TH) funcționare fără deranjament / defectare

failure load (mec) sarcină de rupere

failure of lubricating film ( $\mathrm{T}$ ) întrerupere a peliculei de lubrifiant

failure rate period (TH, mas) erioadă între două căderi succesive failure strain (mec, $\mathrm{TH}$ ) deformație la rupere

failure stress (mec, $\mathrm{TH})$ tensiune / efort de / la rupere

failure surface (mec, TH) suprafață de alunecare / de rupere

failure to start rateu / defect de pornire, defectare din start / de la pornire

faint slab, fără putere; mic, slab; şters, lipsit de strălucire; neclar, vag; leşin; (med) pierdere a cunoştinței; a leşina

faintly acid (chim) slab acid

faintly alkaline solution (chim) soluție slab alcalină

fair corect, exact; aproximativ; curat, îngrijit; citeț, lizibil, clar (d. un text); bun, natural, firesc; favorabil; cinstit, nepărtinitor, imparțial, obiectiv; mare, considerabil (d. bani); rezonabil, acceptabil, convenabil, ieftin (d. prețuri); destul de bun, satisfăcător, mulțumitor; $(a d v)$ drept, cinstit, corect, echitabil, direct, tocmai, exact; a da la rindea

fair average quality calitate medie bună

fair copy copie exactă, exemplar corectat

fair dealing comportare corectă, tranzacții corecte; cinste, obiectivitate; imparțialitate

fairing (av, hidr) înveliş aerodinamic, carenaj; material de umplutură

fairlead (el) tub izolator; (OM) piesă de ghidare

fairlead(er) block (mas) macara de ghidare

fairly $(a d v)$ corect, drept, imparțial, obiectiv; destul de, îndeajuns de; foarte, cât se poate de, extrem de; cu totul; citeț, lizibil

fair-mindness imparțialitate, obiectivitate; corectitudine

fairness curățenie, aspect îngrijit; limpezime, claritate; frumusete; cinste, nepărtinire, impartialitate, obiectivitate; caracter acceptabil / convenabil; caracter favorabil; (ec) caracter considerabil (al unei sume de bani); sinceritate; prielnic; culoare blondă (a părului); albeață (a tenului)

fair play corect, regulamentar; corectitudine, obiectivitate, nepărtinire

fair price $(\mathrm{ec})$ preț convenabil

fair quantity cantitate destul de mare

fair trade (ec) comerț exterior pe bază de reciprocitate; comert legal

fairway (nav) şenal de navigație, drum maritim

fair wear and tear $(\mathrm{T})$ uzură normală / acceptabilă

fair yield $(\mathrm{ec}, \mathrm{TH})$ randament bun

faithful exact, fidel, reprezentat exact

fake (met) lipitură moale; (geol) şist nisipos, nisipuri micacee; (nav) rând de parâmă făcută colac; (fam) şiretlic, 2. truc; a contraface, a falsifica; a truca; a înșela (şi buna credință); a 
fura; contrafacere, fals; înşelăciune, escrocherie; fals, simulat

faldstool scaun pliant

fall cădere, picare, prăbuşire, reducere, scădere, (mişcare de) coborâre, pantă, înclinare; $(\mathrm{OM})$ lanțul sau cablul folosit la ridicat; a cădea (şi într-o stare), a pica, a se prăbuşi; a se întâmpla (constr) a cădea, a se dărâma, a se surpa, a se prăbuşi, a se prăvăli; a se desprinde; a scădea în intensitate; a scădea, a se micşora (şi d. prețuri); a se descompune; a descreşte; (mil) a ataca; a coborî (şi d. barometru); a se potoli, a se calma (d. vânt, mare, mânie); a se domoli; a coborî în pantă; a deveni; a ajunge într-o stare de; a se clasifica; a se repartiza; a se poticni; a eşua; a deveni scadent; a întâlni întâmplător; a apela la; a nu reuşi; a se năpusti asupra; a se învrăjbi; a rupe rândurile; (hidr) coloană de apă; (nav) curent de palanc; (silv) tăiere (de copaci etc.); (fig) declin, decădere; precipitații atmosferice; (mai ales la $p l$ ) cădere de apă; (geogr) cascadă, versant, pantă, povârniş̧; have a a cădea; heavy $\sim$ of rain ploaie torențială; $\sim$ (of the year) toamnă; $\sim$ in prices $(\mathrm{ec})$ scădere a prețurilor; $\sim$ of a river scădere a nivelului apei unui râu; to pieces a se sfărâma în bucăți; into $\mathbf{x}$ categories a se împărți în $\mathrm{x}$ categorii; $\sim$ on one's feet a cădea în picioare

fall aboard of (nav) a aborda

fallacious argument argument eronat

fall across a da peste

fallacy paralogism, deducție greşită, raționament greşit

fall among a cădea în mijlocul

fall apart a se descompune; a se destrăma; a se dezagrega

fall asleep a adormi

fall away a scădea, a se micşora, a se diminua; a slăbi, a scădea în greutate; a se desprinde, a dispărea; a se retrage

fallback, fall-back (OM) retragere (şi a unei piese, a unui arc etc.); desprindere; (inf, c) program care permite terminarea unei instrucțiuni în ciuda căderii sistemului / programului primar; (ec) resursă (şi de bani, care poate fi folosită la nevoie)

fall back a reveni, a da înapoi, a se retrage

fall-back circuit (autom) circuit de ajutor / de revenire

fall-back equipment (TH, mas) echipament de rezervă

fall-back pay (ec) salariu minim de subzistență

fall-back possibility (TH, mas) posibilitate de continuare a operației / funcționare fall back upon / on a reveni la, a se reîntoarce la; a recurge la, a a apela la, a căuta sprijin la

fall behind (hand) a rămâne în urmă

fall behind with a rămâne în urmă cu, a fi în restanță cu (livrările, ratele)

fall down a cădea (jos), a (se) prăbuşi, a (se) surpa; a cădea cu fața la pământ

fall down in a nu reuşi în

fall due a fi

fallen căzut, prăbuşit; lăsat în jos; învins, înfrânt; ruinat, distrus

fall foul of (nav) a se ciocni de (d. un vapor); a se certa cu, a avea neplăceri cu; a se debarasa de

fallibility failibilitate; imperfectiune; caracter failibil

fallible susceptibil de a prezenta abateri / erori, supus greşelii, failibil, imperfect

fall in a se prăbuşi, a se dărâma; a expira, a trece (d. un termen); (ec) a fi scadent (d. o datorie); a deveni vacant (d. un post); a se alinia; a ajunge

falling scădere, cădere, defectare; tasare, adâncire, coborâre; (fig) declin, decădere; (mai ales la $p l$ ) precipitații atmosferice, cădere de apă, cascadă; (geogr) versant, pantă, povârniş

falling-ball / falling-sphere viscometer (metr, T) vâscozimetru cu bilă / cu sferă / Hoppler

falling characteristic (fiz, mas, el) caracteristică descrescătoare / de avarie / de defectare

falling due payment $(\mathrm{ec})$ plată scadentă

falling film evaporator (ind chim, termo, alim) evaporator cu peliculă descendentă

falling film heat exchanger (alim, ind chim) schimbător de căldură, cu peliculă descendentă

falling in cădere, înclinare

falling latch $(\mathrm{OM})$ zăvor cu arc / ghilotină

falling needle viscometer (metr, T) vâscozimetru cu ac (în cădere)

falling-out (of step) (mas-un) decroşare; (el, $\mathrm{mec})$ ieşire din sincronism

falling speed (mec) viteză de cădere / de coborâre

falling time (mec) timp de cădere / de coborâre

falling tup (constr) berbec al sonetei

falling water (hidr) apă de întoarcere / de retur

falling weight $(\mathrm{mec})$ greutate de cădere

falling weight test (metr, mec) încercare la şoc (prin căderea unei greutăți)

fall into a fi divizibil cu, a se împărți în, a fi alcătuit din; a începe; a ține de o categorie, a se subsuma (unei categorii); (geogr) a se vărsa în (d. râuri); a ajunge

fall into conversation a intra în conversație

fall into disrepair $(\mathrm{TH})$ a necesita reparații

fall into disuse (TH) a nu mai fi folosit, a ieşi din uz 
fall in with a da peste; a se înțelege cu, a fi de acord cu; a se asocia cu; întâlni din întâmplare, a fi de aceeaşi părere cu; a coincide cu

fall off a scădea, a se micşora; a se îndepărta; a se desprinde; a descreşte, a degenera, (nav) a nu asculta de cârmă

fall on / upon a se arunca

fall-out precipitaţii

fall out a se elimina, a cădea, a se desprinde, a pica; a se întâmpla, a se petrece; a se certa

fall out of a renunta la, a termina cu

fallouts $(\mathrm{ec}, \mathrm{TH})$ piese de calitatea a doua

fall over a se împiedica

fallow galben-cafeniu, roșcat; (agr) ogor necultivat, a desțeleni; (alim) țelină; nedezvoltat

fall short a fi insuficient, a nu atinge tinta

fall short of a nu reuşi

fall sick (med) a se îmbolnăvi

fall time (autom, hidr) timp de coborâre

fall to a se apuca de

fall to pieces a se desface în bucăti

fall to powder a se descompune în praf / pulbere

fall through a da greş, a nu reuşi, a eşua; (edu) a cădea (la un examen)

fall under a cădea sub (influența); a se împărți după / în, a se clasifica după; a fi socotit printre; a fi supus (observatiei etc.)

fall under the heading / head of a fi clasificabil ca

fall way (transp, TH, constr) trapă pentru deplasarea pieselor de la un etaj la altul

false (şi $a d v$ ) fals, greşit, incorect; neîntemeiat, nejustificat; neadevărat; contrafăcut; artificial

false add sumă parțială

false air (met) aer fals (la cuptoare)

false alarm alarmă falsă

false beam (constr, mec) grindă neportantă

false bottom (met) placă de turnare

false brinelling $(\mathrm{OM})$ brinelare falsă (defect la rulmenți); (T) uzură de tip fretting în rulmenți

false core (met) miez exterior

false drop (autom) eroare la înregistrarea / redarea (magnetică) a unei informații, deviere / variație / scădere falsă

falsehood falsitate, neadevăr, caracter fals; minciună, neadevăr

false jaw (mas-un) falcă aplicată, garnitură a fălcii de menghină

false keel (nav) chilă falsă

false key şperaclu

false pass (met) calibru de laminare orb, trecere goală, calibru gol

false pretences aparențe false, falsă identitate; impostură

false start început neizbutit false tenon (OM, hidr) cep fals

false twist (mec) torsiune falsă

false window (constr) fereastră oarbă

falsework (constr) cofraj, schelă

falsification falsificare, contrafacere; denaturare, răstălmăcire

falsifier falsificator

falsify a falsifica, a contraface; a denatura, a răstălmăci; a dezamăgi

falsity falsitate, caracter fals / eronat / incorect

falter a se clătina; a se legăna dintr-o parte în alta; a şovăi, a ezita; a merge prost / din ce în ce mai prost (o întreprindere, o maşină etc.)

faltering şovăitor, nesigur

falt spring $(\mathrm{OM})$ arc lamelar

fame faimă, renume, reputație

famed for renumit pentru, celebru datorită

familiar familiar, binecunoscut; obişnuit, comun

familiarity with bună cunoaştere, stăpânire (a unei discipline etc.)

familirialization with familiarizare cu, deprindere cu; învăţare, însuşire

family familie, sistem

family allowance (ec) alocație de familie

family doctor (med) medic de familie

family curve curbă caracteristică

family name nume de familie

famine foamete

famine of lipsă de, absență a

famish a înfometa, a lipsi de hrană

famn (metr) unitate de măsură pentru lungime: 1 famn $=1,781333333 \mathrm{~m}$

fam-nut $(\mathrm{OM})$ contrapiuliță

famous for renumit pentru / prin, celebru prin; calitatea întâi

fan evantai; (OM, mas) ventilator, exhaustor, suflător, aripă a unei mori de vânt / a unui ventilator etc.; arc (la sudare cu hidrogen); (met) a insufla; (agr) vânturătoare, a vântura; a ațaț̦a focul; fan, admirator; a face vânt (cuiva); a ațâța (focul)

fan blade $(\mathrm{OM})$ paletă a ventilatorului

fan blast (met, termo) aer suflat

fan blower (OM) ventilator cu aripi / cu palete

fancier cunoscător, expert, specialist; (agr) cultivator / crescător de soiuri deosebite

fancies (alim) fursecuri

fan cooling (alim, termo, ind chim) răcire cu aer fan cowling / shroud (OM) cutie a ventilatorului

fancy imaginație; gust, preferință; fantezist; capricios; extravagant, excentric; ornamental; (pret) exorbitant; a avea impresia

fancy alloys (met) aliaje pentru scopuri decorative

fancy cakes (alim) fursecuri

fancy goods articole la modă 
fancy soap săpun de toaletă

fancy work broderie / lucru de mână

fan delivery (termo) debit al ventilatorului

fan diffuser $(\mathrm{OM})$ difuzor al ventilatorului

fan drift $(\mathrm{OM})$ canal de aeraj spre ventilator

fan drive $(\mathrm{OM})$ acționare a ventilatorului

fan duty resistor (el, autom) rezistenţă de autoreglare (la ventilator)

fang (OM) cârlig, dinte; (met) galerie de aeraj, lamă, tăiş

fang bolt $(\mathrm{OM})$ bolț cu cap triunghiular pentru asamblări lemn-metal

fan gate (termo) canal în formă de evantai

fan-in (FAN-IN) ratio (autom, hidr) factor de intrare, număr de intrări de comandă într-un component

fan inversion (el, mas) inversare a ventilatorului

fanlight (constr) fereastră în evantai

fanner (mas) ventilator, suflantă; (agr) vânturătoare

fanning-out distribuire, ramificare

fan out (TH) a matisa (un cablu)

fan-out capability (termo) capacitate de încărcare

fan-out (FAN-OUT) ratio (autom, hidr) factor piramidal, număr de componente identice, comandate prin ieşirea unui component

fan-pad system (termo) răcitor de aer cu tampoane umede / cu bruiaj ventilat

fan performance (termo) caracteristici ale ventilatorului / suflantei

fan performance curves (termo) grafice ale caracteristicilor ventilatorului / suflantei

fan requirements (termo) cerințe / condiții necesare pentru functionarea ventilatorului

fan speed (auto) viteza ventilatorului

fan speed control (auto) control al vitezei ventilatorului

fan speed control knob (auto) buton de control / de reglare al ventilatorului

fantail (nav) punte la extrema pupa; (met) canal de legătură (la cuptoare)

fan-tail die (mas-un) filieră plată

fantail roof (met) boltă în trepte (la cuptoare)

fantastic fantastic, imaginar, ireal; bizar, straniu; capricios

fantasy fantezie, imaginație; bănuială, presupunere (neîmtemeiată); capriciu

fan tip speed (mas, mec) viteză periferică a motorului ventilator

fan wheel $(\mathrm{OM})$ rotor de ventilator

fan-wheel blower $(\mathrm{OM})$ rotor de suflantă

far departe (temporal şi spațial); cu mult, considerabil, infinit, incomparabil; lung; distanță mare; a ajuta mult la; at the $\sim$ end of la celălalt capăt al; on the $\sim$ side of de cealaltă parte a; from $\sim$ de departe; by $\sim$ cu mult; $\sim$ gone avansat; so / thus până acum; so so good până aici e bine; far and near/wide pretutindeni; and away cu mult; as/so as până la; as/so as în măsura în care; go as as to a merge până într-acolo încât să; (in) so as în măsura în care; go $\sim$ a merge departe; go $\sim$ to a contribui

farad (metr, el) farad

Faraday screen / cage (fiz) cuşcă / ecran Faraday, ecran electrostatic

faradmeter (metr, el) faradmetru, capacimetru

faraway (în)depărtat

far beam (auto) fază mare

far-between rar, spațiat

farce (constr, compozite) umplutură, tocătură; a umple cu tocătură

fare cost / bilet de călătorie; mâncare, hrană

Far-East Orientul Îndepărtat, Extremul Orient

Far-Eastern din Orientul Îndepărtat, din Extremul Orient

fare forth a porni, a pleca

farewell rămas bun, adio

far-famed binecunoscut, vestit

far-fatched adus de departe; (fig) forțat, artificial, exagerat, deplasat (şi d. comparații)

far gone (med) foarte bolnav

farina (alim) făină (şi de cartofi), praf, pudră, amidon

farinaceous (alim) făinos, de făină

farina-starch (alim) amidon de cartofi

farinose (alim) farinos, făinos

farm (agr) fermă, gospodărie; locuință de fermier, casă la o fermă; pepinieră; a lucra / cultiva (pământul), a arenda, a lua / da în arendă

farm equipment (agr) utilaj agricol

farmer (agr) fermier, cultivator de pământ, țăran; arendaş

farmer drill (mas-un) burghiu cu caneluri drepte

farmery (agr) fermă, construcții de fermă, curte țărănească

farm hand (agr) muncitor agricol

farm implements (agr) utilaje agricole

farming (agr) agricultură, cultivare / lucrare a pământului; arendare, arendă

farm practices (agr) agrotehnică

farm stead, farm yard (agr) fermă (cu toate dependințele), curtea fermei

far off, far-off (în)depărtat

farrago amesctec(ătură), adunătură

far-reaching cuprinzător, vast; plin de consecințe

far-seeing clarvăzător, prevăzător

far-sightedness (anat) prezbiție, prezbitism; (fig) clarviziune, prevedere 
farther ( $a d v)$ mai departe; (adj) mai îndepărtat, suplimentar, adițional

farthermost cel mai îndepărtat, extrem

farthest $(a d v)$ cel mai departe; (adj) cel mai (în)depărtat

fascia, $(p l)$ fasciae făşie, bandă; (med) faşă, pansament; (constr) cordon, plintă

fascicle (fiz, materiale) fascicul, mănunchi; ciorchine; fasciculă (a unei publicații)

fascicular fascicular

fash (met) bavură (de turnare)

fashion aspect, formă, modă, stil, fel, chip, manieră; croială, formă; obişnuință, uzanță; $(\mathrm{TH})$ a forma, a modela, a fasona, a transforma, a schimba

fashionable la modă, modern, elegant, rafinat

fashionableness eleganță, modă

fashionably elegant, modern; fin, cu finețe

fashioned iron (met) oțel / fier fasonat / profilat

fashioned wire (met) sârmă profilată / fasonată

fashioning formare

fashion to a adapta la, a potrivi la

fast tare, rezistent, solid, durabil, stabil, fix, repede, iute, rapid; strâns, fix, bine fixat, țeapăn; durabil, stabil, trainic; isteț, ager; tenace, stăruitor; dens, compact, repede, (şi $a d v$ ) iute

fast access $(\mathrm{TH})$ acces rapid

fast acting relay (el, autom) releu cu actionare rapidă

fast acting solution (met, plast, ind chim) soluție cu acțiune rapidă (la tratamente, polimerizare)

fast-and-loose pulley $(\mathrm{OM})$ şaibă fixă şi mobilă

fast beside / by chiar lângă, alături de

fast by wedges $(\mathrm{OM})$ fixat cu cală / cu pene

fast coating (met, plast) acoperire aderentă / cu realizare rapidă

fast color (textile, plast) culori rezistente

fast dip înclinare mare

fasten a (se) fixa, a îmbina, a ataşa, a conecta, a racorda; a lega, a asambla; a (se) închide; a încheia, a (se) încuia; a strânge, a înțepeni; (poligrafie) a broșa, a coase; a se întări, a se solidifica; a se prinde, a se lipi

fasten down a face (pe cineva) să de hotărască

fastened (auto) legată (d. centura de siguranță)

fastener $(\mathrm{OM})$ organ de fixare / de asamblare, închizător, agrafă, clemă, bridă, zăvor; cârlig de rufe

fastener head $(\mathrm{OM})$ cap al organului de fixare

fastener tab $(\mathrm{OM})$ aripioară de strângere (şi la piulițe fluture)

fasten in a înfige în

fastening (OM) lacăt, zăvor, fixare, închidere, ataşare fastening iron (met) oțel-beton

fastening lug (OM) gheară / talpă / placă / lamă de fixare

fastening of rails (cf, met) fixare a şinelor

fastening piece $(\mathrm{OM})$ piesă de fixare / de susținere / de sprijin

fastening plate (mas-un) placă de apăsare / de presiune

fastening ring $(\mathrm{OM})$ inel de sustinere

fasten up a lega / închide strâns

fasten upon a se agăța (de o idee)

fasten with blows a fixa prin batere

fast flange (OM) flanşă / bridă fixă

fast-hardening cement (constr) ciment cu întărire rapidă

fast head / headstock (mas-un) păpuşă fixă

fastidious greu de mulțumit, mofturos, dificil

fast increasing repede crescător

fast motion (mas-un) deplasare rapidă

fast-moving cu mişcare rapidă, care se mişcă rapid; trepidant

fastness rezistență, stabilitate, soliditate, tărie, trăinicie; viteză, rapiditate

fastness to alkali (chim) rezistență la alcali

fastness to boiling (chim, plast) rezistență la fierbere

fastness to rubbing $(\mathrm{T})$ rezistență la frecare

fastness to water (materiale, hidr) rezistență la apă

fast-response thermocouple (metr, termo) termocuplu cu acționare rapidă

fast running (met) mers rapid (la cuptoare); funcționare (prea) rapidă

fast setting (ind chim, constr) întărire rapidă (şi d. adezivi)

fast-setting concrete (constr, chim) beton $\mathrm{cu}$ priză rapidă

fast shut închis (ermetic)

fast spiral drill (mas-un) burghiu spiral, cu unghi mare de înclinare a canalelor elicoidale

fast time gain control (autom) reglare rapidă / diferențială a amplificării

fast train (cf) (tren) rapid / accelerat

fat gras, unsuros, plin de grăsime; surplus de materie lucrată; (alim) grăsime; osânză; (T) unsoare; (alim, T, chim) grăsime; ulei vegetal sau animal; (agr) (pământ) gras / roditor, fertil, a (se) îngrăşa; abundent, îmbelşugat; (fig) avantajos, profitabil, rentabil

fatal fatal, inevitabil; mortal

fatal error eroare fatală

fatality fatalitate; determinism; calamitate, dezastru; caracter mortal

fatality rate $\mathrm{(TH})$ procentaj de accidente mortale 
fat boiler (alim) cazan pentru fierberea grăsimilor fat clay (constr) argilă

fat coal (met) cărbune gras, huilă grasă

fat content of the milk (alim, chim) conținutul de grăsimi din lapte

fateful fatal, inevitabil; important, hotărâtor (prin cosecinte)

fat hardening (chim) hidrogenare a grăsimii

fat hardening plant (alim, ind chim) instalație de hidrogenat grăsimi

father file (inf) fişier de origine

father on / upon a atribui paternitatea / a recunoaşte ca autor

fathom (fth) (nav) stânjen marin, braț $(=1,85 \mathrm{~m})$; (metr) unitate de măsură pentru lungime: 1 fathom (US survey) $=1,828803658 \mathrm{~m}$; a sonda, a măsura (o adâncime); (fig) a aprofunda, a cerceta atent

fathomable (nav) sondabil, măsurabil

fathometer (metr, nav) sondă ultrasonică

fathomless fără fund, insondabil; (fig) de neînțeles, incomprehensibil

fathom line (nav) izobară, linie batimetrică

fatigue oboseală; extenuare; a obosi; (met, mec) oboseală, durată la (solicitare de) oboseală

fatigue bending machine (metr, mas, mec) maşină pentru încercare la oboseală prin îndoire / încovoiere

fatigue bending test (metr, materiale) test / încercare la oboseală de încovoiere / prin îndoire

fatigue bending test specimen (metr, OM) epruvetă pentru test de încercare la oboseală prin îndoire / încovoiere

fatigue breakdown / fracture (OM) distrugere / rupere la / prin oboseală

fatigue crack (mec) fisură (cauzată) de oboseală fatigue damage $(\mathrm{OM}, \mathrm{mec})$ distrugere (cauzată) de / prin oboseală

fatigue endurance limit $(\mathrm{OM}, \mathrm{mec})$ rezistență la oboseală (în sens larg), limită la durabilitate / la oboseală limitată

fatigue failure $(\mathrm{OM}, \mathrm{mec})$ ruptură / distrugere / avariere / cădere (cauzată de) oboseală

fatigue fracture $(\mathrm{OM}, \mathrm{mec})$ ruptură / rupere (cauzată de) oboseală

fatigue impact strength (materiale, metr, mec) rezistenţă la oboseală prin lovituri repetate / oboseală de impact

fatigue life (mec) durată la oboseală / la solicitare variabilă, durabilitate

fatigue limit $(\mathrm{OM}, \mathrm{mec})$ limită / rezistenţă de oboseală

fatigue limit under pulsating stress $(\mathrm{O}, \mathrm{mec})$ limită / rezistență de oboseală în ciclu pulsatoriu fatigue loading (OM) solicitare de durată / la oboseală

fatigue notch factor $(\mathrm{OM}, \mathrm{mec})$ factorul concentratorului de tensiune (în calcul la oboseală)

fatigue notch sensivity $(\mathrm{OM})$ estimarea efectului concentratorului asupra rezistenței la uzură

fatigue phenomenon (materiale, mec) fenomenul de oboseală

fatigue-proof rubber (ind chim, mec) cauciuc rezistent la oboseală

fatigue range $(\mathrm{OM})$ interval pentru rezistență la oboseală

fatigue resistance / strength $(\mathrm{OM})$ rezistență de rupere la oboseală (fără a preciza tipul ciclului şi al solicitării)

fatigue-shock test (OM, mec) probă / test / prin impact repetat / încercare la oboseală prin lovituri repetate

fatigue strength for finite life $(\mathrm{OM})$ rezistență la durabilitate limitată

fatigue strength under bending test $(\mathrm{OM})$ rezistență la oboseală de încovoiere (determinată experimental)

fatigue strength under pulsating stress $(\mathrm{OM}$, mec) rezistență la oboseală, în ciclu pulsatoriu

fatigue-stress $(\mathrm{OM}, \mathrm{mec})$ efort / tensiune variabil( $\breve{a}) /$ de oboseală

fatigue-stress concentration factor / coefficient $(\mathrm{OM}, \mathrm{mec})$ coeficient de concentrare a tensiunilor, la oboseală

fatigue tension test (metr, mec) încercare / test la oboseală prin întindere / tracțiune

fatigue test / testing (mec, metr) test(are) / încercare / la oboseală (nu este specificată solicitarea)

fatigue test / testing machine (mec, metr) maşină pentru încercare la oboseală

fatiguing epuizant; obositor, care oboseşte

fat gras

fat images basorefief

fatless (alim) fără grăsime, slab (d. carne)

fatness (alim, ind chim) grăsime, caracter gras / uleios; (agr) fertilitate, rodnicie (a pământului)

fats (chim, alim) grăsimi

fat sand (met) nisip gras

fat-soluble (chim, alim) solubil în grăsimi

fat solvent (chim, alim) solvent de grăsimi

fat spark (el) scânteie caldă

fat splitter (ind chim, alim) autoclavă pentru scindarea grăsimilor

fat splitting plant (ind chim, alim) instalație pentru scindarea grăsimilor

fat stains (alim, met) pete de grăsime

fatten (agr) a îngrăşa, a pune la îngrăşat; (agr) a fertiliza, a îngrăşa (pământul) 
fat tight etanş / în prealabil la unsoare fattening $(\mathrm{OM})$ umflare, umflătură, proeminență (şi la piese din materiale plastice)

fattiness (chim, T) grăsime, onctuozitate

fat trap (alim, ind chim) separator / colector de grăsimi

fatty (ind chim, T) gras, unsuros, uleios; (agr) fertil, gras (d. pământ)

fatty acid (chim, alim) acid gras

fatty acid methyl ester (FAME) (auto, chim) ester metilic din acid gras

fat type (poligr) literă grasă / aldină

faucet (OM, hidr) robinet, ventil, cep, dop, manșon, tubulatură, mufă, canea

faucet pipe (OM, hidr) țeavă cu mufă

fault neajuns, lipsă; cusur; (el) scurtcircuit; falie, defect, fisură, greşeală, eroare, deteriorare (mai rar); (fig) vină; (met) falie, fisură, dislocare; (geol) falie; (TH) avarie, pană, defect; a învinui; be at $\sim$ a fi derutat; find $\sim$ with a găsi cusur; without a $\sim$ fără nici o greșeală; to a excesiv de; in $\sim$ vinovat

fault condition ( $\mathrm{TH}$, mas) stare de avarie

fault current (el, autom) curent de scurcircuitare

fault detection (fiz, metr, materiale) defectoscopie, detectarea / descoperirea unui defect

fault detector (fiz, metr, materiale) defectoscop

fault finder / indicator (fiz, metr, materiale) detector de defecte

faulting care produse defecte, care defectează

fault isolation $(\mathrm{TH})$ localizarea unui defect şi izolarea pentru a nu produce altele

faultily $(a d v)$ greşit, incorect; defectuos

faultiness imperfectiune; caracter imperfect / defectuos; deficiență (şi din proiectare etc.) (c, inf) virusare

faultiless fără greşeală, perfect, ireproşabil; infailibil

faultless ireproşabil; perfect; fără greşeală

faultlessness caracter ireproşabil; perfecțiune; corectitudine

fault line linie de falie, linie de fractură

fault localisation (materiale, mas) localizare a defectului

fault localising / location (metr, autom), localizare a erorilor

fault-location test (materiale), TH) încercare pentru localizarea defectelor

fault locator (fiz, metr, materiale) defectoscop

fault of construction ( $\mathrm{TH}$, constr) greșeală / defect de fabricație / de construcție

fault of current (el) pană de curent

fault signaling (TH) semnalizare a defectelor fault sulphur (met) sulf combinat (nedorit)

fault time (mas, TH) durată de întrerupere

fault tolerance (autom, mas) toleranţă la erori, capacitatea unui sistem de a-şi îndeplini unele funcții după apariția unuia sau mai multor defecte

fault tree (analysis) (TH) o schemă logică (de obicei ramificată) folosită în analiza sau estimarea avariilor / defecțiunilor / căderilor

fault tracing $(\mathrm{TH})$ depistarea erorilor / avariei etc., detectarea avariei / erorii, urmărirea / reconstituirea scenariului unei avarii / defectări

fault water (constr) apă acumulată în fisuri

faulty inutilizabil, defect(at), deranjat, defectuos, greşit, incorect, deficient, cu lipsuri / defecte, stricat, imperfect

faulty cast (met) piesă turnată defectuos

faulty casting (met) turnare defectuoasă

faulty design defect de construcție / de proiectare

faulty operator intervention (TH) manevră greşită a operatorului, intervenție greşită a operatorului

faulty part $(\mathrm{OM}, \mathrm{TH})$ piesă cu defecte

faulty selection selecție falsă

fauna faună

favour (brit), favor (amer) favoare, bunăvoință, trecere, serviciu; aprobare, permisiune; avantaj, folos; patronaj, ocrotire, protecție; distincție, semn, insignă; a favoriza, a fi de partea (cuiva), a privilegia; a sprijini, a susține, a apăra

favourable (brit), favorable (amer) favorabil, prielnic, propice; binevoitor, amabil

favourable to în favoarea (cuiva), pentru (ceva)

favoured favorizat, privilegiat; avantajat

favouring grade marcă (de materiale) avantajoasă

favourite favorit, preferat

fax facsimil, fax; a trimite un fax, a coresponda prin fax

fay a ajusta, a păsui, a pune la punct

faying surface $(\mathrm{OM})$ suprafată de etanşare, suprafața pe care se va executa sudura / lipirea etc., suprafață de depunere / de lipire

faying-surface seal $(\mathrm{OM})$ o etanşare (şi subansamblu) şi cu rol anticorosiv

fear frică, teamă, îngrijorare; a se teme, a fi îngrijorat

fearsance (jur) îndeplinire (a unei datorii)

feasibility fezabilitate, posibilitate de realizare / de executare / de îndeplinire, practicabilitate

feasibility study (TH) studiu de fezabilitate

feasible posibil, realizabil, fezabil, admisibil; probabil 
feasibly $(a d v)$ posibil, $(\mathrm{TH})$ fezabil

feat faptă; agerime, îndemânare, pricepere

feather pană (de pasăre), ( $p l)$ penaj; (zool) egretă; soi; feder (pentru nut); (OM) pană, nervură (de întărire), bavură de turnare, striație, a asambla cu pană / feder; (met) zona de mijloc a flăcării de gaz (la sudură sau tăiere); a acoperi cu pene; a-i creşte penele (d. păsări); a flutura; a fâlfâi

feather coupling $(\mathrm{OM})$ cuplaj cu pană

feathered $(\mathrm{OM})$ îmbinat prin pană de ghidare

feather-edged $(\mathrm{OM})$ cu vârful ascuțit, ascuțit

feather edge / ensiform file pilă rombică

feather-edge file pilă de crestat

feathered shot (met) alice, granule

feathered tin (met) staniu / cositor granulat (fulgi)

feathering pene, penaj; (alim) caimac; (plast) (efect de) pânză de păianjen, scămoşare, țesere (şi la pulverizarea unui adeziv)

feathering propeller (OM, alim, ind chim) elice cu pale reversibile

feather key $(\mathrm{OM})$ pană paralelă, de ghidare

feather of a flame (termo, met) zona mijlocie a flăcării

feather-sliding key (OM) pană culisantă

feather valve (OM, hidr) supapă cu lamelă

featly iscusit

feature trăsătură, caracteristică, particularitate, semn distinctiv; aspect exterior, aparență; piesă, parte; (constr) detaliu de teren; a descrie, a înfățişa; (amer) a scoate în relief, a sublinia, a pune în prim plan; (ec) a vinde / expune un articol special

featureless lipsit de trăsături caracteristice, inexpresiv; inform, fără formă; neinteresant

feature of construction proprietate / caracteristică constructivă / a construcției

features of the vehicle (auto) butoane ale vehiculului

feckless inutil, ineficace

fecklessly $(a d v)$ (în mod) inutil, ineficace

fecklessness inutilitate, ineficacitate (a unei persoane)

fecral (alloy Fe-Cr-Al with high electrical resistance) (met, el) fecral (aliaj de $\mathrm{Fe}-\mathrm{Cr}-\mathrm{Al}$ cu rezistenţă electrică mare, utilizat şi sisteme / elemente de încălzire)

fecula (alim, chim) amidon, fecula

feculence (chim) depunere, sediment

fecund fecund, prolific

fecundate a fecunda, a însărcina; (bot) a poleniza; a face rodnic / fertil, a fertiliza

fecundity (fig) fertilitate, productivitate fee (ec) onorariu, plată, retribuție, taxă (şi şcolară), cotizație; a plăti (o taxă)

feeble slab, debil; imperceptibil, neînsemnat; infim, neglijabil; inferior, necorespunzător

feeble caking coal (met) cărbune slab

feebly $(a d v)$ slab, de-abia perceptibil

feed (alim) aliment, alimentare, alimentație, hrană, hrănire, material de alimentare; a (se) hrăni, a alimenta, a mânca, a împărți (hrană, alimente); a îndopa; (agr) a paşte (d. vite), a da nutreț, nutreț, furaj, porție, rație (de furaj), păşune; a crește; (mas, mas-un, TH) alimentare (a unei maşini, instalaţii etc.), a alimenta (un foc, o maşină etc.), a șarja, a încărca (și un cuptor); (mil) încărcare (a unei arme de foc); a da; on a se hrăni cu; fed up (with) sătul (de); with a desfăta cu; up a îngrăşa

feedability $(\mathrm{T})$ proprietatea unei unsori de a fi pompată în sistemul de ungere, cel puțin la aceaiaşi viteză cu cea dată de pompa de alimentare

feed-and-delivery table (mas-un) masă transportoare, de alimentare şi evacuare

feed-and-take-up sprocket mechanism (OM, met) dispozitiv de prindere a buclei (şi la laminare)

feed angle (met, mas-un) unghi de alimentare

feedback autocontrol; (TH, autom) feedback, reacție, buclă (într-o schemă logică, proces etc.), conexiune inversă, retroacțiune, repercursiune; contracarare; (ec) date extrase dintr-un procesverbal sau dintr-o situație şi folosite în control, planificare sau modificare a deciziilor imediate sau viitoare

feedback circuit (autom) circuit de reacție

feedback control (autom) control în care mărimea controlată poate duce la un răspuns de reglare

feedback control loop (autom) buclă de reglare, feedback

feedback cutter (el, metr, autom) traductor electromagnetic cu reacție

feedback system (autom) sistem cu legătură inversă / autoreglabil / cu buclă de autoreglare

feed belt (alim, OM) alimentator cu bandă, curea de alimentare

feed bin (agr, alim, constr, ind chim) buncăr de alimentare

feed box (el, OM) cutie de alimentare / de distributie

feed bush $(\mathrm{OM})$ bucşă de alimentare

feed change (mas-un) schimbare a avansului

feed (change gear) box (OM, mas-un) cutie de avansuri (cu roți baladoare)

feed change (unit) (mas-un) mecanism de avans 
feed chute (constr, alim) jgheab de alimentare feed circuit (el, TH) circuit de alimentare feed clutch (mas-un) cuplare a avansului feed collet $(\mathrm{OM})$ bucşă elastică de avansare feed cone pulley (OM, mas-un) con în trepte a mecanismului de avans

feed cylinder (plast) cilindru de injectie

feed depth gauge (mas-un, metr) limitator deplasabil al cursei de avans

feed device (mas-un, metr) distribuitor, dispozitiv de alimentare (şi cu piese)

feed / feeding dial / disk (OM, mas-un) alimentator cu disc / cu taler, disc de alimentare

feed disengaging lever (OM, mas-un) pârghie pentru decuplarea avansului

feed drum (OM, mas-un) alimentator cu tambur feed end (mas-un) poziție de încărcare, capăt de alimentare

feed engine (mas-un) motor (al mecanismului) de avans, pompă de alimentare

feed entrance (OM, mas-un) orificiu de încărcare / de alimentare

feeder (mas-un) cablu / linie / dispozitiv de alimentare, distribuitor, mecanism de avans, alimentator, canal de alimentație; (met) maselotă; afluent; canal de alimentare; (alim) biberon; (el) fider; (agr) crescător de (vite), iesle; (geogr) afluent

feeder belt (alim, OM) curea de alimentator

feeder conveyer $(\mathrm{OM})$ transportor alimentator

feeder ear (OM, mas-un) gheară de alimentare

feeder / feeding head (met) maselotă

feeder hopper (alim, met) pâlnie / magazie / buncăr de alimentare / de turnare / de umplere

feeder pot (alim, constr, ind chim, met) gură pâlnie oală / cuvă de alimentare

feeder road (alim, constr, ind chim, OM) drum de acces

feeder roll valt / cilindru de alimentare

feeder rotary (OM, alim, ind chim, constr) valt / cilindru de alimentare

feeder screw (OM, alim) melc de alimentare

feeder table (mas-un) masa de alimentare / alimentatorului

feeder vibration (mas-un) vibrația alimentatorului / încărcătorului

feed forward control (autom) metodă de control prin care o perturbație este compensată înainte ca să ajungă la ieșire

feed finger $(\mathrm{OM}$, metr) palpator

feed function (mas-un) funcția de avans / de alimentare

feed gear (mas-un) roată dințată a mecanismului de avans / de alimentare feed head (met, plast) zonă-rezervor deasupra unei matrițe, pentru compensarea contracției de solidificare

feed hole (OM, plast, met) perforație de contorizare / de numărare / de ghidare, orificiu de ghidaj

feed hopper (alim, constr, ind chim, OM) buncăr / pâlnie / compartiment de alimentare

feed index plate (mas-un) plăcuță cu indicarea avansurilor

feeding hrănire, alimentare; (TH) (orificiu de) încărcare, avans, avansare, alimentare

feeding apparatus (mas-un) aparat alimentator, puitor automat

feeding belt (OM, alim, constr) alimentator cu bandă, bandă rulantă de alimentare

feeding bottle (alim) biberon

feeding box (mas-un) cutie de avansuri

feeding carriage (mas-un) cărucior de alimentare / de avans, cursă verticală (de alimentare cu scule sau semifabricate)

feeding circuit (el, $\mathrm{TH}$ ) circuit de alimentare

feeding connection $(\mathrm{OM})$ ștut de alimentare

feeding cylinders (alim, ind chim) valțuri / cilindri de alimentare

feeding device (OM, mas-un, constr) dispozitiv de alimentare, alimentator, încărcător

feeding elevator (mas-un, alim, constr) elevator de alimentare

feeding funnel (alim, constr, ind chim, met) pâlnie de încărcare / de şarjare

feeding gate of a furnace (met) orificiu / gură de încărcare / de şarjare

feeding gear (mas-un) mecanism de alimentare / avans / debitare

feeding / feed head (met) maselotă

feeding hole (met) uşă / gură de încărcare (la cuptoare)

feeding hopper (alim, met) pâlnie de încărcare / de şarjare / de alimentare

feeding installation $(\mathrm{OM}, \mathrm{TH})$ instalație de încărcare / alimentare

feeding machine (mas, alim, ind chim) maşină de alimentare / de încărcare

feeding mechanism (mas-un) mecanism de avans, cutie de avansuri

feeding of the casting (met) alimentarea formei de turnare, turnare (în formă)

feeding / feed rack (mas-un) cremaliera mecanismului de avans

feeding $\operatorname{roll}(\mathrm{er})(\mathrm{OM}$, alim, ind chim) cilindru de alimentare

feeding roll(er) table $(\mathrm{TH}$, met) transportor de alimentare / alimentator cu role / cu cilindri 
feeding screw (alim, OM) alimentator elicoidal feeding tray (OM, alim, ind chim) tavă de alimentare

feeding worm (OM, alim, ind chim) şurub, melc de alimentare

feed into a introduce; a alimenta (cu o piesă etc.)

feed length (mas-un) avans, lungime de avans (la strunguri automate)

feed line (OM, hidr) linie / conductă de alimentare

feed magazine (alim) magazin de alimentare

feed marking / marks (mas-un) urme de sculă pe suprafaţa prelucrată prin aşchiere

feed material (TH) material primar / inițial / de prelucrat

feed mechanism (mas-un) mecanism de avans

feed mill (termo) vas de preîncălzire

feed motion (mas-un) mişcare de avans

feed motor (mas-un) motor de avans

feed nozzle ajutaj de alimentare

feed on a se hrăni / alimenta cu

feed opening (alim, met, OM) pâlnie de descărcare

feed operating link (mas-un) bielă a mecanismului de avans

feed orifice (OM, hidr) canal de alimentare

feed performance (mas-un) capacitate de alimentare / de avans

feed pin (OM) clichet / ştift de antrenare

feed pipe (OM, mas-un, alim) conductă de alimentare

feed pitch distanță între centrele orificiilor de ghidare ale unei benzi perforate / de alimentare, pas de alimentare

feed plate (OM, alim, ind chim) taler de alimentare a coloanei, masă de alimentare

feed press (mas-un, autom) presă cu magazie, pentru alimentarea automată cu piese brute

feed pump (OM, hidr) pompă de alimentare

feed / feeding rack (OM, mas-un) cremalieră a mecanismului de avans

feed rate (mas-un, autom) viteză de avans

feed rate override (mas-un, autom) corecție a avansului

feed regulator (mas-un, autom) regulator de alimentare

feed reverse (mas-un, autom) inversare a avansului

feed rod (OM, mas-un) ax al avansurilor, bară de alimentare

feed roll(er) (mas-un) ilindru de alimentare

feeds (mas-un) valoare / viteză de avans, (valori pentru) avansuri, gama avansurilor

feed screw (OM, alim, mas-un) şurub de avans / de alimentare feed shaft $(\mathrm{OM})$ arbore secundar din cutia de viteze

feed side (TH, mas-un) parte de intrare a materialului de prelucrat

feed spindle (OM, alim, mas-un) alimentator $\mathrm{cu}$ şurub / cu melc, şurub conducător

feed spout $(\mathrm{OM})$ jgheab de alimentare

feed(-)stock (TH, alim, ind chim) materie primă, stoc de prelucrare

feed stop (OM, autom) opritor pentru decuplarea automată a avansului

feed strainer (OM, hidr) sorb, crepină (la pompe)

feed table (alim, mas-un) alimentator cu taler, masă de alimentare

feed tank (OM, hidr) rezervor de alimentare

feed through $(\mathrm{TH})$ alimentare; a alimenta

feed-through insulator (mas-un) (dispozitiv) izolator de intrare / de alimentare

feed timer (autom, mas-un) regulator de alimentare

feed trip dog (OM, mas-un) camă pentru decuplarea automată a avansului

feed trunk (OM, mas-un) pâlnie de alimentare

feed unit (alim, mas, mas-un) unitate / sistem de avans / de alimentare

feed up (agr) a îngrăşa, a pune la îngrăşat

feed valve $(O M$, hidr) supapă de alimentare

feed vessel (alim, OM, hidr, ind chim) recipient de alimentare

feed water (alim, termo) apă de alimentare (a unui cazan) (adăugată suplimentar, fără referire la apa de circulație)

feed-water deaerator (termo) degazor pentru apa de alimentare

feed-water heater (termo) preîncălzitor al apei de alimentare

feed-water treatment (termo, chim) tratament al apei de alimentare

feed wheel (mas-un) roată de avans

feed worm (OM, mas-un) melc al mecanismului de avans; (alim) melc / şnec de alimentare

feel simțire, senzație; pipăit, pipăire, atingere; impresie, gust; a atinge, a pipăi; a (se) simți, a resimți; a dibui; a tatona; a fi prudent; a fi sensibil la; a-şi da seama de; a da dovadă de; a crede; (mil) a recunoaşte; a presupune; a presimți; a resimți; a fi mișcat / impresionat de; a împărtăşi sentimentele cuiva; (med) (şi fig) a simți pulsul; like a fi dispus să; about / after / for a căuta pipăind; up to a se simți în stare să; soft a fi moale la pipăit; by the $\sim$ după pipăit; the pulse a lua pulsul; $\sim$ the ground a tatona terenul

feel as if / though a avea senzația / impresia că, a părea că 
feeler mustață, tentacul; (metr) palpator, senzor, pipăitor, garnitură de spioni; (zool) antenă, tentacul; încercare, sondare, tatonare; (mil) cercetaş; balon de încercare

feeler gauge / leaf (metr, OM) spion, calibru pentru jocuri (şi pentru verificarea jocului în rulmenți), leră

feeler pin (metr) ac de palpare, palpator

feeler stock (metr) garnitură de spioni

feeling sensibil; senzitiv; senzație, simț; sentiment, emoție; atitudine, atmosferă; sensibilitate; impresie; (metr) palpare; pipăit; palpare; $(p l) \sim \mathbf{s}$ susceptibilitate

feel up to a fi în stare / capabil de

fee-paying (ec) care plăteşte / încasează taxe feet $(p l)$ (metr) picioare (unități de lungime)

feign a simula, a se preface, a pretinde că; a inventa; a născoci; a falsifica (un document etc.)

feigned prefăcut, simulat; inventat, fictiv; orb

feint simulacru; simulare; (mil, atac simulat)

feldspar (minrl) feldspat

felicitate on a felicita pentru

felicitation felicitare, urare

fell a tăia, a doborâ (copaci), a trânti la pământ; piele de animal cu blană; păr des

felloe $(\mathrm{OM})$ obadă

fellow cetățean; ins, individ; coleg; pereche, egal; membru (al unei societăți științifice); (edu) absolvent, angajat temporar al unei universități, membru în conducerea unei universităti

fellows' cutter (mas-un) sculă de mortezat dinți (şi după şablon)

fellows' gear shaper (mas-un) maşină de mortezat roți dințate

fellowship corporație, breaslă; calitate de membru într-o societate ştiințifică

felly (OM, auto) obadă, jantă

felt (textile) postav, pâslă

felt and cotton buff (mas-un) disc de pânză (pentru curățare / şlefuire)

felt ring $(\mathrm{OM})$ inel de pâslă

female (adj) feminin, femeiesc; slab; palid; femeie; (zool) femelă

female fitting $(\mathrm{OM}, \mathrm{c})$ piesa cuprinzătoare într-o asamblare

female adapter (OM) mufă de îmbinare cu filet interior

female centre (OM, mas-un) vârf cu con interior female cone $(\mathrm{OM})$ adâncitură conică, alezaj conic female fastener $(\mathrm{OM})$ organ de asamblare / fixare, tubular

female flange (OM) flanşă cu canelură inelară female gauge (metr, mas-un) calibru interior female mould (mas-un) matriță negativă female nozzle (termo) contraajutaj

female plug (el) conector-mamă

female radius tool (mas-un) cuțit de rotunjit exterior

female sapphire (minrl) safir palid

female screw (OM) şurub tubular, piuliță lungă / înaltă

female (screw) thread (OM) filet al piuliței, filet interior

female socketing $(\mathrm{OM})$ îmbinare tubulară

female / external taper gauge, taper ring gauge (metr) calibru-manşon conic

female thread $(\mathrm{OM})$ filet interior; (hidr) racordare cu filet interior (tip mamă) în aparat (de măsură)

female union $(\mathrm{OM})$ mufă / asamblare cu filet interior

femto (metr) prefix pentru $10^{-15}$ dintr-o unitate

femtogram/liter (metr) unitate de măsură pentru densitate: 1 femtogram $/$ liter $=10^{-15} \mathrm{~kg} / \mathrm{m}^{3}$

femtoliter (metr) unitate de măsură pentru volum: 1 femtoliter $=10^{-18} \mathrm{~m}^{3}$

femtometer (metr) unitate de măsură pentru lungime: 1 femtometer $=10^{-15} \mathrm{~m}$

femtonewton (metr, mec) unitate de măsură pentru forță: 1 femtonewton $=10^{-15} \mathrm{~N}$

femtopascal (metr, mec) unitate de măsură pentru presiune: 1 femtopascal $=10^{-15} \mathrm{~Pa}$

femtosecond (metr) unitate de măsură pentru timp: 1 femtosecond $=10^{-15} \mathrm{~s}$

fence gard, țarc, îngrăditură, parapet, balustradă, cutie de protecție; a îngrădi, a înconjura cu gard fence in a îngrădi, a împrejmui

fence off a împrejmui cu gard; a ține la distanță, a evita (consecinte)

fence wire (met) sârmă pentru împletituri metalice

fencing împrejmuire

fend away / off a para, a respinge

fender (auto) aripă, ecran de îngrădire, paravan protector; (nav) apărătoare, tranchet; (cf) bot de locomotivă; (OM) amortizor

fender marker (hidr, nav) tijă indicatoare de gabarit

fender spar (nav) tranchet plutittor

fennel (bot, alim) mărar

fennel oil (alim) ulei de mărar

fenestral in a door (constr) ferestruică practicată în uşa de la intrare

Fermat's / parabolic spiral (mat) spirală parabolică (a lui Fermat)

ferment (alim, ind chim) ferment, fermentatie, fermentare; a fermenta, a dospi, a face să fermenteze; (fig) efervescență, fierbere, agitație, a se agita 
fermentable (alim, ind chim) fermentabil, care poate fermenta

fermentation (alim, chim) fermentație, fermentație, dospire

fermentation alcohol (alim) alcool de fermentație fermentation cellar (alim) pivniță de fermentare fermentation-inhibiting (alim, ind chim) antifermentativ, care inhibă fermentarea, (agent) inhibitor al fermentării

fermentation plant (alim) instalație de fermentație

fermentation tank / vat (alim) linie / tanc / recipient de fermentare

fermentation test (alim, metr) probă de fermentație

fermentative activity (alim, ind chim) acțiune fermentativă

fermentative power (alim, ind chim) capacitate de fermentare

fermenter (alim, ind chim) agent de fermentare

fermenting (alim) macerare, fermentare

fermenting room (alim) cameră / incintă de fermentare

fermenting tank (alim) bazin / recipient / tanc de fermentare

fermi (metr) unitate de măsură pentru lungime: 1 fermi $=10^{-15} \mathrm{~m}$

Fermium (Fm) (chim) fermiu

fern (bot) ferigă

fernico (Fe-Ni-Co-Mn alloy) (met) aliaj Fe-NiCo-Mn (şi denumire comercială)

fern-leaf crystal (met) dendrită, cristal dendritic ferrate (chim) ferat

ferret panglică de bumbac sau de mătase; (zool) specie de nevăstuică; detectiv, polițist; about a scormoni; a scotoci; a cerceta; a prinde (iepuri etc.); out a descoperi

ferret for a căuta (peste tot)

ferret out a căuta să afle / să descopere, a depista, a afla, a descoperi

ferriage (transp, nav) transport cu feribotul, taxa pentru transport cu feribotul

ferric (met, chim) feric, feruginos

ferric acid (met, chim) acid feric

ferric oxide (met, chim) oxid feric

ferric percentage (met) procentaj de fier în zgură

ferriferrous compound (met) compus care conține fier bivalent şi fier trivalent

ferrite (met) ferită

ferrite / ferritic cast iron (met) fontă feritică

ferrite core (met) miez de ferită

ferrite ghost (met) incluziune de ferită

ferrite / ferritic steel (met) oțel feritic

ferritic stainless steel (met) oțel feritic inoxidabil

ferritic steel (met) oțel feritic ferro(-)alloy (met) feroaliaj

ferro-aluminium (met) (fero-aliaj de) fero-aluminiu

ferro-chrome / -chromium (met) (fero-aliaj de) fero-crom

ferro-concrete (constr) beton armat

ferrodo lining $(\mathrm{OM}, \mathrm{T})$ căptușeală de ferodo

ferrofluid (fiz) lichid magnetic

ferrography (metr, fiz, T) metodă de analiză a particulelor de uzură într-un lubrifiant

ferromagnetic (el, met) feromagnetic

ferromagnetic substance / material (met) material feromagnetic

ferro-manganese (met) (fero-aliaj de) fero-mangan ferrometer (fiz, metr) instrument de măsurat permeabilitatea magnetică

ferro-molybdenum (met) (fero-aliaj de) feromolibden

ferro-phosphorous (met) (fero-aliaj de) fero-fosfor ferrosilicon (met) (fero-aliaj de) fero-siliciu

ferro-silicomanganese (met) (fero-aliaj de) ferosilico(-)mangan

ferrotitanium (met) (fero-aliaj de) (fero-aliaj de) fero-titan

ferro-tungsten (met) (fero-aliaj de) fero-wolfram

ferrous (chim, met) feros

ferrous alloy (met) aliaj feros

ferrous carbide (met) carbură de fier, cementită

ferrous chloride (chim, met) clorură feroasă

ferrous hydroxide (met) hidroxid feros

ferrous metal (chim, met) metal feros

ferrous metallurgy (met) siderurgie

ferrous oxide (met) oxid feros

ferrous scrap (met) deşeuri feroase

ferro-vanadium (met, chim) (fero-aliaj de) ferovanadiu

ferro-zirconium (met, chim) (fero-aliaj de) ferozirconiu

ferruginous (met) feruginos, feros

ferrule $(\mathrm{OM})$ inel de siguranță / de etanşare, bucşă conică pentru presarea garniturii, bandaj, manşon; (cf) linie de centură

ferry (transp, nav) bac, feribot, pod plutitor; a transborda cu feribotul / bacul

ferry-boat (transp, nav) instalație de transbordare pentru trenuri

ferry bridge (transp, nav) bac, transbordor pentru trenuri

ferry vessel (nav) feribot

fertile fertil, rodnic, roditor; fertilizat

fertility fertilitate, rodnicie

fertilization (agr) fertilizare

fertilize (agr) a fertiliza

fertilizer (agr, ind chim) fertilizator, îngrăşământ (artificial) 
fervent fierbinte, aprins; zelos, pasionat; fervent, înfocat

fervour zel, pasiune; fierbințeală, dogoare; ardoare; înflăcărare

fester (med) supurație, supurare; a face să supureze (d. răni, bube etc.), a face să supureze; a chinui (de durere); a putrezi, a se descompune, a se strica; (nav) calea vântului

festooning (of paint) (ind chim) încrețirea suprafețelor vopsite (şi defect)

fetch (ec) a aduce, a scoate, a produce / a aduce (un câştig / venit), a se vinde la / cu (un preț), a valora, a se vinde cu; a se duce după; a aduce; a provoca; a pricinui; a da (o lovitură); a avea efect; a face impresie asupra; a ajunge la; a atinge; a ajunge; a avea efect; $\sim$ and carry a face comisioane; $\sim$ up a se opri brusc; (med) a voma; a leap a face un salt; a compass (nav) a face un ocol

fetch a pump (OM, hidr) a amorsa o pompă

fetch away a se smulge, a se desprinde, a se elibera

fetch programme $(\mathrm{TH})$ program de alimentare

fetch up a ridica

fetch up against a se ciocni de, a se izbi de

fetid fetid, rău mirositor

fetter lanț; $(p l)$ cătuşe; a înlănțui, a opri; a încătuşa; (fig) piedică, obstacol

fettle formă, condiție; condiție (fizică) bună; a pune în ordine, a repara, a pune la punct; (met) a căptuşi cuptorul, a curăţa un lingou

feettler (met) debavurator, muncitor folosit la curățare

fettling (met, plast) curățire, debavurare

fettling bench (met, plast) masă de debavurare

fettling gun (met) pulverizator, dispozitiv de curățare cu jet (de aer sau de lichid)

fettling hole (met) orificiu de golire (la cuptoare)

fettling material (met) material pentru căptuşire (d. cuptoare)

fettling / room shop (met) spațiu / atelier pentru curățirea pieselor turnate

fettling wheel (mas-un) piatră de polizor pentru debavurare

feu arendă

feute (mas-un) muchie principală pe corpul unui burghiu

fever (med) febră, temperatură; nervozitate

fevered (med) febril, cu temperatură

few putini, nu multi

fewness puținătate, număr mic

fisco, $(p l)$ fisco(e)s eșec, fiasco

fiber, fibre (materiale) filament, fibră, țesătură, fir; (fig) caracter, structură fiber / fibre board (materiale) placă din fibre / fibrolemnoasă / aglomerată

fiber bundle (materiale) mănunchi / grup de fibre

fiber composite (materiale) compozit fibros / cu fibre

fibering / fibring fibrare, spațiu fibrat, structură fibroasă

fiber metal (materiale) compozit cu fibre / fire metalice

fiber optics (fiz, opt) transmiterea luminii prin fibre optice

fiber release (chim, plast) eliberarea carbonului sau grafitului la arderea compozitelor (în special cu materiale plastice)

fiber sensor (metr, fiz, opt) senzor cu fibră optică

fibre fibră; filament; (fig) fire; natură

fibre(-)board (materiale) placă din fibre

fibre bonding (materiale) legarea fibrelor prin adezivi

fibre building board (materiale) placă fibrolemnoasă

fibre bundle (materiale) stratificare, spațiu / material fibrat, aglomerare / mănunchi de fibre

fibre cohesion (materiale) adeziune a fibrelor (şî la compozite)

fibre direction (materiale) direcție de fibraj / a fibrelor

fibre drag (mec) întindere a fibrei

fibre filter filtru de fibre

fibre-forming polymer (ind chim, plast) polimer filabil

fibre fracture (materiale, textile) ruptură filiformă / a fibrei / fibrelor

fibre furnish (materiale, textile) compoziția materialului fibros

fibre glass fibră / fibre de sticlă, vată de sticlă, sticlă fibroasă

fibre glass laminate (materiale) stratificat din fibre de sticlă şi răşină sintetică

fibre grease $(\mathrm{T})$ unsoare consistentă cu structură fibroasă

fibre injection process (ind chim, $\mathrm{TH}$ ) procedeu de injecție a amestecului de fibre de sticlă şi răşină sintetică

fibre-length machine (metr, ind chim) aparat pentru determinarea lungimii fibrei

fibre packing $(\mathrm{OM})$ garnitură de etanşare din fibre

fibre stress $(\mathrm{mec})$ tensiune în fibră

fibre structure (materiale) structură fibroasă

fibre suspension ( $T$, ind chim) suspensie fibroasă (d. fluide vâscoase)

fibre texture (materiale) textură fibroasă

fibre washer $(\mathrm{OM})$ garnitură de etanşare din fibre / din material fibros 
fibriform fibros

fibril fibrilă; (fiz, chim, T) fibră mică, de-abia vizibilă şi la microscop electronic (în unsori, compozite etc.)

fibrous appearance (materiale) aparență fibroasă, aspect fibros

fibrous composite (material) compozit fibros

fibrous filler umplutură fibroasă, material de adaos de natură fibroasă (şi în compozite)

fibrous fracture (materiale) ruptură cu aspect fibros

fibrous lubricating grease $(\mathrm{T})$ unsoare $\mathrm{cu}$ aspect fibros

fibrous structure (materiale) structură fibroasă

fickle (chim, fiz) schimbător, nestabil(izat); instabil; nestatornic

fickle colour pattern (c, opt) imagine de televizor (d. display) în culori instabile

fickleness inconstanță; caracter (uşor) schimbător; instabilitate

fictile de olărie, de argilă; de plastic

fictility (mec) plasticitate

fiction fictiune; imaginatie; invenție

fictional fictiv; imaginativ, de imaginaţie

fictitious fictiv, inventat, imaginar

fictitiously $(a d v)$ (în mod) fictiv, inventat, imaginar

fiddle (nav) masă de ruliu

fidelity (metr) fidelitate, acuratețe (d. aparate de măsură)

fiducial (d. un punct) de referință, de reper

fiduciary (ec) fiduciar (d. bani); de încredere, custode, curator

field câmp, domeniu, teren, regiune; (agr) ogor, păşune; sferă, domeniu; (fiz) câmp; (el) excitație

field assembly (constr, mas) montare pe teren

field balancing (mec, mas) echilibrare in-situ / pe loc

field balancing equipment (mec, mas) echipament pentru echilibrare in-situ / pe loc

field calibration calibrare in-situ / pe locul de montaj

field charging înărcarea zonei active (a unei maşini)

field conditions (constr) condiții de şantier

field(-driven) rivet $(\mathrm{OM})$ nit bătut la montaj

field emission microscope (fiz, metr) microscop electronic

field engine (mas) tractor, locomobil

field glass (metr, opt) binoclu, ocular (la microscop)

field gradient (fiz) gradient al câmpului

field gravity (fiz) câmp gravitațional

field husbandry (agr) agricultură, cultivarea pământului field intensity (fiz) intensitatea câmpului

field joint (OM) îmbinare / montare pe loc / la locul de lucru / de funcționare

field magnet (el) inductor de câmp

field of action (OM) câmp de acțiune

field of application domeniu de aplicare

field of competency domeniu de competenţe

field of definition (mat) domeniu de definiţie

field of forces (fiz) câmp de forță

field of study domeniu, specialitate

field of vision (anat, opt) câmp vizual / de vedere

field point punct de măsurare

field-replaceble (OM) uşor de înlocuit pe loc / la fața locului

field-replaceble unit $(\mathrm{OM}, \mathrm{c})$ modul / subsistem uşor de înlocuit pe loc / la fața locului

field strength (fiz) intensitate / gradient a(l) câmpului, densitate de flux

field-test (mas, metr) încercare / test la locul de montare, a testa în condiții de exploatare

field weld (met) sudură (executată) pe şantier / la fața locului

field welding (met) sudare pe şantier / la locul de montaj

field work muncă de / pe teren; activitate practică

field worker tehnician care face muncă de / pe teren

fierce clutch $(\mathrm{OM})$ ambreiaj rapid

fieriness căldură, foc

fiery aprins, arzând, în flăcări; incandescent; inflamabil

fiery fracture (met) ruptură grăunțoasă strălucitoare / lucioasă cu grăunți mari

fifth gear (auto) viteza a cincea, roata a cincea, cuplaj al semiremorcii

fight luptă, întrecere, competiție; a lupta; (jur) a apăra

figment ficțiune; rod al imaginației

figurability capacitate de modelare; plasticitate, maleabilitate

figurable care poate fi modelat; plastic, maleabil figurative figurat, figurativ, grafic; sugestiv

figure cifră; configurație, figură, imagine, diagramă, formă, (mat) cifră, figură geometrică; (ec) preț; înfățişare exterioară, ținută, formă; figură, ilustrație, desen; a reprezenta grafic, aşi reprezenta mintal; a exprima în cifre, a face socoteli; (amer) a socoti, a crede, a considera

figured profilat, fasonat; cu figuri / desene

figured (bar) iron (met) oțel profilat / fasonat

figure-forming circular tool (mas-un) cuțit disc de profil, cuțit profilat, rotund

figure forming tool (mas-un) cuțit pentru format

figure head conducător / şef numai cu numele 
figure in a include, a trece (costul)

figure key (c) tastă / clapă numerică

figure of noise (fiz, autom) coeficient de zgomot figure on (amer) a conta pe, a se bizui pe

figure out (mat) a calcula, a da un rezultat, a scădea (cifre, numere); a înțelege, a descifra, a pricepe

figures (mat) date numerice, aritmetică

figure wheel (mas-un) disc cu cifre

filaceous (materiale) fibros

filament (el) filament, catod cu încălzire directă; fibră, fir

filamentary filiform

filamentary molecule (chim) moleculă filiformă

filament break (el) rupere a filamentului / a lanțului molecular

filament guide (mas) dispozitiv de ghidare a direcției

filamentous filamentos, ca un fir / filament

filament-wound structure structură (de compozit) în care cel puțin unul din materiale este sub formă de filament / filamente / spirale

filament yarn (plast, textile) fir continuu

filar micrometer (metr) micrometru cu fir

filature (textile) filatură

filbert (silv, alim) alun (cultivat), alună

file (c) arhivă, cartotecă, fişier; pilă; arhivă, dosar; a pune la / în dosar, a fişa; (TH) a pili

file across $(\mathrm{TH})$ a pili transversal

file a patent application a depune o cerere de brevet a unei invenții

file away / out (mas-un, TH) a pili, a îndepărta prin pilire

file building routine (inf, c) subprogram de constituire a unui fişier

file cabinet cartotecă, cameră de arhivă

file card perie de curățat pile

file chisel daltă pentru crestarea pilelor

file closing (inf, c) închidere a unui fişier

file compression (inf, c) reducere a volumului unui fişier

file consolidation (inf, c) fuziune a fișierelor

file control processor (inf, c) procesor de control al fisierului

file copying (inf, c) copiere a unui fişier

file creation (inf, c) creare a unui fișier

file cut (mas-un) tăietură / prelucrare cu pila

file cutter (mas-un) maşină pentru dințarea pilelor

file cutting anew (mas-un) redanturare a pilei

file cutting tool (mas-un) sculă pentru dințarea pilelor

file designer (inf) analist

file dust pilitură

file gap (inf) spațiu între fişiere

file hammer ciocan pentru dințarea pilelor file handling (c, inf) manipularea datelor / fişierelor

file inspection (inf) consultare a unui fişier

file interlock (inf) blocare a memoriei

file inventory (inf) listă a înregistrărilor unui fişier

file maintenance (inf) actualizare a unui fişier

file name (inf) nume de fişier

file name extension (inf, c) extensie a unui fişier

file off (mas-un) a pili

file opening (inf) deschidere a unui fişier

filer aparat / muncitor de / pentru pilit; secretar; înregistrator

file reference (c, inf) consultare a unui fişier

file retention period (inf) perioadă de conservare / memorare a unui fişier

file-ring (mas-un) pilă sub formă de inel

files dosare, arhivă; (c) fişiere

file searching (inf) căutare a unui fişier

file sharpening machine (mas-un) maşină de redințat pile

file store (c) memorie pentru (un) fișier

file table tabelă de fişiere, banc de lăcătuşerie

file tang / tail $(\mathrm{OM})$ coadă / mâner de pilă

file toothing (mas-un) danturare a unei pile

file to a template (mas-un) a pili după şablon

file true (mas-un) a pili până la obținerea dimensiunilor dorite

file updating (inf) actualizare a unui fişier

filiation filiație, descendență; derivare; ramură, filială

filiform filiform (d. piese, fire, molecule etc.)

filigree filigranat

filing pilire

filing cabinet cartotecă; fişier, dulap cu acte

filing drawer fişier / fişet pentru dosare

filing dust / filings pilitură

filing mill (mas-un) piatră-cuțit

filing vice / vise (mas-un) menghină de mână

fill umplutură, rambleu; plin; cantitate suficientă; saturație, saț; îndestulare; cantitate necesară pentru a umple ceva; a (se) umple, a completa (şi un formular), a (se) ocupa (un spatiu, o functie); a exercita, a deține (o funcție, un post etc.), a executa; a îndeplini (un ordin); (met) a umple calibrul (la laminoare); a astupa; (med, TH) a plomba (un dinte, o conductă etc.); a hrăni, a alimenta, a satura; a îndestula; a lărgi; a-şi ocupa (timpul); (jur, TH) a satisface (prevederile unei legi etc.); (constr) a astupa (un şanț, o groapă)

fill and ram (met) a umple şi a îndesa o ramă cu amestec de formare

fill / filler / filling cap (OM) capac / gaură de umplere

filled composite compozit cu material de umplutură 
filled-system thermometer (metr) termometru cu element sensibil (tip bulb / tub Bourdon / burduf sau cu membrană) umplut cu un fluid

filled with plin de, umplut cu

filled ground (constr, cf) teren rambleiat

filler material de umplere (şi a lonjeronului, a unui cablu); material de umplere într-un compozit, umplutură; material de umplutură (şi la sudare); (met) căptuşeală (la cuptoare); (nav) tanc petrolier; (constr) filer

filler bit (inf) bit / element de umplere

filler block $(\mathrm{OM})$ pană / piesă de garnitură, distantier

filler brick (constr, met) cărămidă de umplutură / de umplere

filler dispersion (materiale) dispersie a materialului de adaos / a fibrelor (într-un compozit)

filler material material de adaos / de umplere, material filtrant

filler metal (met) metal / aliaj de adaos (la sudare)

filler metal erosion (OM, met) eroziune a materialului care a realizat lipirea

filler metal overflow scurgere de aliaj (şi la lipire)

filler neck $(\mathrm{OM})$ ştuț / gât de umplere

filler particle particulă de adaos (la compozite)

filler plate $(\mathrm{OM})$ placă de adaos / distanțieră

filler rod (met) vergea / tijă suplimentară / de adaos (la sudare)

filler screw plug $(\mathrm{OM})$ dop filetat de umplere

filler sheet (OM, plast) foaie de repartizare (uniformă a presiunii, la lipire)

filler-well adapter assembly (OM) armătură de umplere

filler wire (met) sârmă de aport (electrod de sârmă pentru sudare)

fillet panglică, cordeluță (şi de legat părul), fâşie îngustă şi subțire; $(\mathrm{OM})$ filet, reducție, (rază de) racord(are), guler, şanț, canelură, umăr, flanşă, coamă, jgheab, bandă; (alim) muşchi (filé), a tăia fileuri din, a desface în fileuri (d. carne), (pl) $\sim \mathbf{s}$ muşchi (de animal), fileu (de carne); (hidr) vână (lichidă); (met) piesă de colț într-o matriță pentru minimalizarea tendinței de fisurare, cusătură de colț (la sudură); (plast) parte a adezivului care lipeşte piesele peste planul de îmbinare; a lega cu benzi, cu cordeluțe

fillet corner $(\mathrm{OM})$ racordare, umăr cu racordare (d. o piesă)

fillet joint / weld (OM) cusătură de colț (sudată)

fillet of screw (OM) spiră a filetului, filet de şurub

fillet radius of basic rack $(\mathrm{OM})$ raza de racordare a cremalierei de bază $\left(\rho_{f}\right)$

fillets (met) rotunjirea colțurilor (în calibru) fillet seal $(\mathrm{OM})$ etanşare suplimentară (tip bandă), executată după montarea pieselor

fillet weld (OM, met) sudură de colț

fillet welding (OM) sudare de colt / în unghi

fill in a umple, a alimenta, a astupa, a încărca (şi cu lopata), a turna în; a completa (un formular, un cec)

filling (constr) şpăcluire; umplere, încărcare, alimentare, umplutură, (material) de / pentru umplere; (met) turnare fără miezuri

filling and packing line (alim, ind chim) linie de umplut şi ambalat

filling and weighing machine (alim, ind chim) maşină de umplut şi cântărit

filling brick (constr, met) cărămidă de umplutură

filling cock $(\mathrm{OM}$, hidr) robinet de umplere

filling compound masă / component de umplutură (şi la compozite)

filling degree (met, hidr) grad de umplere (şi la sudură)

filling defect (met) defect de pătrundere / de umplere a rostului (şi la sudură)

filling device (alim, ind chim) dispozitiv de alimentare cu tocătură (în fierbător) / de încărcare (şi a fierbătorului, la fabricarea hârtiei)

filling drawer fişier, cartotecă

filling frame (met) ramă de umplere

filling funnel (alim, constr, ind chim) pâlnie de alimentare / de umplere

filling hole (met) orificiu / gură de umplere / de alimentare

filling hose (OM, hidr) tub / furtun de alimentare (si pentru rezervoare)

filling-in valve (OM, hidr) ventil / supapă de umplere

filling machine (alim, ind chim) maşină de umplere (a ambalajelor)

filling mass masă / material de umplere

filling material (constr) umplutură, material de umplutură / de rambleu

filling out (TH) umplere, umplutură, transvazare

filling period (met, plast) perioadă de umplere (a cuptorului, a matriței etc.)

filling piece $(\mathrm{OM})$ piesă de etanşare, garnitură, piesă de umplere a unui gol, distanțier

filling pipe (hidr) conductă de umplere

filling plant (alim, constr, ind chim) instalație de umplere

filling pressure (hidr) presiune de umplere (şi a buteliilor)

filling pump (alim, OM, hidr) pompă de umplere

filling ratio (hidr, alim, ind chim) raport de umplere 
filling requirements condiții minime de înregistrare a unui brevet de invenție: $(\mathrm{TH}$, alim, hidr, ind chim) cerințe / condiții de umplere / alimentare (a unui rezervor, recipient etc.)

filling riser (OM, mas-un) țeavă de debitare, încărcător (vertical) tip țeavă

filling siphon $(\mathrm{OM})$ sifon de umplere

filling sleeve $(\mathrm{OM})$ racord de umplere

filling slot $(\mathrm{OM})$ canal pentru introducerea bilelor (la şuruburi cu bile)

filling space (met) spatiu de umplere

filling tap (OM, alim, hidr) robinet de umplere / de pritocire

filling tube / vent (OM, hidr) ştuț de umplere

filling with sand (hidr, mediu) înnisipare

fillister (mas-un) rindea de fălțiit

fillister head (OM) şurub cu cap semirotund

fill line (OM, hidr) conductă / linie de umplere / de încărcare

fillmass (constr, materiale) material de umplere / de umplutură

fill material material de umplutură (nisip, material de adaos în compozite etc.)

fill / packing of cooling tower (met) garnisaj al turnului de răcire, ansamblu al dispozitivelor de distribuție şi împrăştiere a apei într-un turn de răcire

fill out (TH) a umple; a (se) mări, a (se) lărgi; a (se) umfla (şi d. materiale plastice); a (se) completa

fill plate (met, plast) tablă de căptuşire, placă de adaos

fill the bill a ocupa locul principal, a îndeplini toate cerințele, a fi suficient

fill up a (se) umple (şi până la refuz, complet), a completa(un cec etc.); a turna, a face plinul (şi cu combustibil); (cf) a rambleia; a ocupa (un post liber), a completa (un formular)

film film, peliculă, membrană, pieliță, strat, înveliş subțire, folie (de plastic); (anat) ceață pe ochi, împăienjenire, încețoşare (a ochilor, a vederii); a acoperi cu un film / cu un strat izolator; (T) a forma o peliculă; a filma; (anat, c) a (se) acoperi (cu negură, ceață), a (se) încețoşa, a (se) împăienjeni (şi d. o imagine pe un display)

film adhesive (ind chim) clei sub formă de peliculă, adeziv peliculogen, peliculă adezivă, adeziv-film

film boiling (fiz, alim, ind chim) ebuliție / fierbere peliculară, barbotare

film building properties $(\mathrm{T})$ proprietăți peliculogene, capacitate de a forma o peliculă (portantă)

film coating $(\mathrm{TH})$ aplicare a peliculei, acoperire peliculară / subțire

film / surface coefficient of heat transfer (termo, T) coeficient de schimb superficial de căldură; coeficient de transmisie termică de suprafață, conductivitate termică, coeficient de transfer termic, specific unei pelicule / unei suprafețe / unui film

film condensation (fiz, termo) condensare peliculară

film dryer / drier (alim, ind chim) uscător cu peliculă / cu film

film drying (alim, ind chim) uscare a peliculei / a filmului; (procedeu de) uscare în peliculă

film evaporator (alim, ind chim) evaporator $\mathrm{cu}$ peliculă / cu film

film flotation (alim, met) flotație peliculară

film force (fiz) forță interfacială; (T) forța portantă a peliculei

film-forming care formează peliculă, peliculogen (d. lubrifiant, vopseluri etc.)

film hardness (mec) duritate peliculei / stratului

film heat transfer coefficient (termo) coeficient de transfer de căldură, specifíc peliculei

film lubrication $(\mathrm{OM}, \mathrm{T})$ ungere cu peliculă (de fluid)

film of oil (T) peliculă de ulei / lubrifiant

film of oxide (chim) strat / peliculă / film de oxid / de oxizi

film of rust (chim) strat de rugină

filmogen (plast, T) proprietate a unui adeziv / vopsele / a unui lubrifiant de a forma o acoperire continuă

film over a se încetoşa, a deveni neclar

film stock film nefolosit

film strength rezistența filmului / peliculei (de lubrifiant etc.) la rupere / la distrugere; (T) capacitate a lubrifiantului de a forma peliculă continuă în anumite conditiii de sarcină și viteză

film strength additive (chim, $\mathrm{T}$ ) aditiv antigripant

filmy cețos, încețoşat; trasparent

filter (OM) filtru, strecurătoare; retea selectivă; a (se) filtra, a (se) strecura, a trece, a (se) limpezi (d. un lichid)

filterable (fiz) filtrabil (d. un fluid)

filterable suspension (alim, ind chim) suspensie filtrabilă

filter accessory acesoriu de / pentru filtru

filter aid (alim, ind chim) material auxiliar de filtrare

filter baffle-plate (alim, ind chim) perete filtrant filter bag (alim, ind chim) sac de / pentru filtru

filter bank (alim, ind chim) agregat de filtrare

filter bed / blanket (constr, chim, alim) strat / pătură filtrant(ă)

filter bottom (OM, hidr, alim) fund de filtru

filter bowl (OM) carcasă / pahar al filtrului

filter box $(\mathrm{OM})$ cutie a filtrului 
filter by suction (fiz, alim, ind alim) a filtra prin absorbție

filter cake (materiale, mediu, alim) turtă de filtrare, strat de colmatare

filter candle (OM, hidr) filtru tip lumânare

filter capacitor (alim, hidr, termo) condensator / tanc de filtrare

filter capacity capacitate filtrantă

filter cell $(\mathrm{OM}$, hidr) celulă de filtru, element filtrant

filter centrifuge (alim, ind chim) centrifugă filtrantă

filter chain (alim, hidr, ind chim, mediu) filtru cu mai multe celule (legate în serie)

filter clogging (alim, hidr, ind chim, mediu) înfundare / colmatare a filtrului

filter cloth (textile) țesătură / pânză pentru filtre

filter cone $(\mathrm{OM})$ con de filtru

filter container / housing $(\mathrm{OM})$ carcasă a filtrului, suport de filtru

filter core $(\mathrm{OM})$ miez de filtru

filter crucible (ind chim) creuzet de filtrare

filter drum (alim, OM, hidr) tambur de filtru

filter efficiency (alim, hidr, ind chim, mediu) eficiență / eficacitate / randament al filtrului

filter element (alim, OM, hidr, mediu) cartuş / element de filtrare, element filtrant

filter fabric țesătură pentru filtru

filter factor (alim, hidr, ind chim, mediu) factor de filtrare

filter flask (alim, OM) vas filtrant

filter frame (OM) cadru (de fixare) / suport a(l) filtrului

filter gauze (textile) țesătură de / pentru filtru

filter holder (OM) suport / montură pentru filtru

filter house (hidr, alim, ind chim) secție / hală de filtrare

filtering (hidr, alim, ind chim) filtrare; (inf) filtrare, izolare / suprimare a unor caractere ale unei înregistrări

filtering action (hidr, alim, ind chim) efect / acțiune / proces de filtrare

filtering apparatus (hidr, alim, ind chim) aparat pentru filtrare, filtru

filtering area (hidr, alim, ind chim) suprafață filtrantă

filtering bag / bed (OM, hidr) strat / sac / cartuş filtrant

filtering basin (hidr, mediu) bazin de filtrare

filtering basket $\cos$ / tambur filtrant

filtering bag of the gas mask (OM, mediu) cartuş filtrant al măştii de gaze

filtering cloth (textile, alim) pânză filtrantă / de filtru

filtering crucible (ind chim) creuzet filtrant filtering flask (alim, ind chim) vas pentru filtrare sub vid

filtering medium (alim, ind chim) masă de filtrare, mediu filtrant

filter out (alim, ind chim) a filtra, a îndepărta prin filtrare

filter paper hârtie de filtru

filtering press (alim, ind chim) filtru-presă

filtering rate (alim, ind chim) viteză de filtrare

filtering surface suprafață filtrantă

filtering tube $(\mathrm{OM}$, hidr) tub filtrant

filter layer strat filtrant

filter liquor (alim, ind chim) filtrat

filter medium (materiale) masă de filtrare, mediu filtrant

filter mesh (textile) țesătură de filtru

filter mud (alim, ind chim, mediu) noroi / reziduuri (vâscoase) de filtru

filter nozzle (OM, hidr) duză / tub de filtru

filter off (alim, ind chim, mediu) a filtra, a separa prin filtrare, a strecura

filter out (alim, ind chim, mediu) a filtra (şi cu evacuarea materialului filtrat)

filter pad (OM) corp al filtrului

filter paper (alim, materiale) hârtie de filtru

filter-paper analysis (chim, metr) cromatografie pe hârtia de filtru

filter passband (fiz) banda / intervalul de trecere a unui filtru

filter performance (fiz) caracteristică / caracteristici pentru un filtru

filter pipe $(\mathrm{OM})$ tub filtrant

filter plant (alim, ind chim, mediu) instalație de filtrare

filter-press (alim, hidr, ind chim) filtru-presă, presă cu filtru

filter-press cake (alim, hidr, ind chim) turtă de filtrare

filter-press cloth / linen (textile, hidr) pânză pentru filtru-presă

filter-press electrolyser (alim, hidr, ind chim) electrolizor cu filtru-presă

filter-press frame $(\mathrm{OM})$ ramă de filtru-presă

filter pressure drop (alim, hidr) căderea de presiune pe filtru

filter pump (alim, hidr, ind chim) pompă de filtrare, pompă cu filtru

filter resistance (hidr) rezistență de filtrare

filter screen $(\mathrm{OM})$ sită de filtru

filter section $(\mathrm{OM})$ element de filtru multicelular, secțiune prin filtru

filter separator (alim, hidr, ind chim) centrifugă / separator cu filtru / filtrant $(\breve{a})$

filter stand (OM) stativ / suport / cadru de fixare pentru filtru 
filter stop band (fiz, hidr) bandă de oprire a filtrului

filter stoppage (fiz, hidr) înfundare a filtrului

filter / suction strainer (OM, hidr, mediu) sorb / epurator filtrant

filter stuff (materiale, mediu, alim) material(e) filtrant(e), masă filtrantă

filter support (OM) reazem / suport de filtru

filter through (hidr, mediu) albie /pat de filtrare

filter unit $(\mathrm{OM})$ element de filtru, cartuş filtrant

filter washing $(\mathrm{TH})$ spălare a filtrului, apă de spălare scursă din filtru

filth (TH, mediu) murdărie, noroi

filthily $(a d v)$ murdar, respingător

filthy murdar, urât

filtrate (hidr, mediu) a filtra, a strecura

filtration (alim, hidr, ind chim, mediu) infiltrare, strecurare, filtrare, filtrație

filtration equation (fiz, alim) ecuația de filtrare / strecurare

filtration machine (alim, hidr, ind chim) instalație / maşină de filttrare / strecurare

filtration rate / velocity (fiz, hidr) viteză de filtrare

filtration ratio (fiz, hidr) coeficient de epurare, raport al cantității de particule de dimensiuni superioare unei valori date care intră într-un filtru față de cea care iese, pentru acelaşi volum de fluid

filtration residue (alim, fiz, hidr, mediu) reziduu de filtrare pe / în filtru

filtration under pressure (fiz, hidr) filtrare sub presiune

filtration vat (alim) cuvă-filtru

filtrator (fiz, hidr) filtru cu vid

fin (alim, iht) aripioară de peşte; $(\mathrm{OM})$ nervură, aripioară de răcire, bavură, muchie; (auto) eleron; stabilizator, derivă; (met) cusătură sudată, bavură de la sudură

finable pasibil de amendă

final final, ultim; hotărâtor, decisiv

final annealing (met) recoacere finală

final balance (ec) sold net; (fiz, termo) echilibru final

final cleaning $(\mathrm{TH})$ curățire fină / finală

final concentration concentrație finală (a unei soluții etc.)

final condition (fiz, $\mathrm{TH}$ ) stare finală

final control element $(\mathrm{OM})$ organ motor, element final de reglare / executor

final controlled condition (autom, metr) mărime finală de control

final finishing (mas-un) finisare finală / ultimă

final hardening (met) călire finală, ultima treaptă într-un tratament de durificare finalist finalist

finality caracter final / definitiv; hotărâre, caracter hotărât, fermitate; final, sfârşit, încheiere; finalitate

finalize a da formă finală, a finaliza; a finisa

finally $(a d v)$ în încheiere, în sfârşit; definitiv

final machining (mas-un) prelucrare finală, finisare

final melting (met) subperioadă de fierbere / de topire liniştită

final output (TH) randament / rezultat final, productivitate finală

final pass (met) calibru finisor (la laminare); trecere / pas de finisare, ultima trecere

final purification (met) afinare finală; (hidr, mediu, alim) (procesul de) purificare finală

final slag (met) zgură finală

final speed (TH) viteză finală / maximă

final stage (fiz, TH) fază / etapă finală; (autom, el) etaj final

final temperature of rolling (met) temperatura finală de laminare

final terminal-stopping device (mas-un) întrerupător de sfârşit de cursă

final total key (c) clapă / tastă de totalizare finală

final twist $(\mathrm{mec})$ torsiune finală (şi la formarea firelor, cablurilor torsadate)

final value (autom, inf) valoare finală / rezultantă / permanentă

finance (ec) finanțe, ştiințe financiare, a finanța, a plăti

finances (ec) finanțe, venituri

financial (ec) financiar

financial difficulties (ec) dificultăți financiare, greutăți materiale

financially $(a d v)$ (din punct de vedere) financiar

financial means (ec) mijloace / resurse financiare / bănești

financial position / standing (ec) situație financiară (a unei firme)

financial year (ec) an financiar

financier (ec) om de finanțe, bancher; capitalist

financing $(\mathrm{ec})$ finanțare

find găsire; descoperire; a găsi (şi prin demonstrație), a descoperi, a inventa; a dezlega / rezolva (o problemă); a constata, a afla, a (se) găsi, a considera; a aproviziona cu, a furniza, a procura, a aduce; a se realiza; a socoti; (jur.) a declara (vinovat etc.); (ec, jur) a acorda (despăgubiri); a acționa independent; a se afla într-o împrejurare; a face rost (de bani, de timp etc.); a vedea; one's feet a fi în stare să meargă, să se țină pe picioare, a sta pe picioarele sale; $\sim$ pleasure / enjoyment in a găsi plăcere / bucurie în; 
it easy to a-i veni uşor să, a obține (o favoare, iertare etc.), a afla; a sum in damages a acorda o sumă ca despăgubire

finder găsitor, aflător; descoperitor, care găseşte; (opt) lentilă, ocular; vizor; (autom) (dispozitiv) căutător; (inf, metr) program de recunoaştere a zonelor unei imagini (pentru microscopie, de identificare / numărare a elementelor structurale)

finder error (metr, opt) eroare de vizare

finder frame $(\mathrm{OM})$ vizor

find for a se pronunța în favoarea cuiva

find in a aproviziona $\mathrm{cu}$

fiding găsire, aflare; (jur) hotărâre, pronunțare, sentință; descoperire; concluzie

findings constatări, rezultate ale unor cercetări, stare de lucruri; (ec, TH) furnituri

find oneself a se simți, a-şi procura singur toate cele necesare, a se descurca singur, a-și descoperi vocația, a se găsi

find out a constata, a descoperi; a dezvălui; a lămuri, a explica; a-şi face o părere despre; a afla, a clarifica, a prinde (pe cineva)

fine amendă, penalizare; a amenda, a penaliza; a amenda; $(p l) \sim \mathbf{s}$ arte frumoase $(\mathrm{TH})$ a rafina, a afina, a înnobila, a îmbunătăți; a (se) face mai fin, a (se) subția, a (se) purifica, a (se) limpezi (adj) fin, pur, rafinat; (d. materiale) subțire, ascuțit; precis, exact; delicat, fragil; deosebit; subtire, ascuțit; bun, de foarte bună calitate, de calitate superioară, excelent; distins, prezentabil; afectat (d. stil, limbă); căutat; (țesătură) cu ochiuri fine; (alim) cu bob mic; timp frumos; $(a d v)$ foarte bine, cu finețe, subtil, (în mod) rafinat, excepțional, excelent, senin; understanding înțelegere pătrunzătoare; in condition în stare perfectă

fine away / down / off a (se) face mai fin, a (se) subția

fine boring (mas-un) alezaj / alezare de precizie

fine break-up dispersie fină (d. emulsii, materiale, de adaos în compozite)

fine breeze (met) praf de cocs / de cărbuni

fine coal (met) cărbune mărunt

fine coke (met) cocs mărunt

fine control (automn, mas) reglare fină / de precizie, comandă exactă

fine-crystalline (met) cu granulație fină

fine crusher (alim, ind chim) concasor fin / de granulație fină

fine crushing măcinare fină

fine cut dințare fină (la pile); (mas-un) aşchiere fină; tăiat mărunt / fin; croit bine / elegant

fine divided (alim, met) măcinat / mărunțit fin

fine down a (se) reduce, a scădea, a (se) micşora fine draw (met) a trage / a trefila cu precizie sârmă subțire

fine drawing (met) tragere / trefilare finală / de precizie

fine drawn (met) tras / trefilat cu precizie / subțire (despre sârmă, semifabricate trase la rece etc.); (textile) cusut fără să se vadă cusătura

fine feed (mas-un) avans mic / fin / de precizie

fine finished work $(\mathrm{ec}, \mathrm{TH})$ produs cu grad de finisare superior

fine fit $(\mathrm{OM})$ ajustaj precis / de precizie

fine grain (materiale) granulație fină

fine(-)grained cu granulație / structură fină, microgranular (d. materiale metalice, ceramice, compozite etc.)

fine-grained fracture (met) ruptură / fisură cu granulaţie fină

fine-grained steel (met) oțel cu granulație fină

fine-grain(ed) structure (materiale) granulație fină, structură microgranulară

fine-grain emulsion (hidr, fiz) emulsie cu granule / picături fine

fine grains (met, plast) granule fine, grăunți cristalini fini / mici

fine grinding (alim, ind chim) şlefuire / măcinare fină; (mas-un) rectificare fină

fine-grinding mill (alim, ind chim) moară pentru măcinare fină

fine jaw crusher (constr, ind chim) concasor $\mathrm{cu}$ fălci pentru concasare fină

fineless nemărginit, nesfârşit

finely $(a d v)$ fin, minunat

finely-adjusting (metr, mas-un, mas, autom) reglaj fin / final

finely crystalline (met) cu structură cristalină fină

finely dispersed fin dispersat (d. materiale de adaos în compozite etc.)

finely ground coke (met) praf de cocs

finely porous (materiale) cu porozitate fină, microporos

finely powdered divizat / mărunțit fin, sub formă de pulbere fină (d. materiale prelucrate)

fine machining (mas-un) prelucrare / rectificare de finisare

fine mechanics mecanică fină / de precizie

fine-meshed cu ochiuri fine (d. site, plase etc.)

fine-mesh sieve $(\mathrm{OM})$ sită fină

fine metal (met) metal afinat / rafinat

fineness finețe; (fiz) calități aerodinamice; puritate a metalelor prețioase, exprimată în părți la o mie; (met) granulatie fină, microstructură

fineness coefficient (nav) coeficient de finețe (al navei)

fineness modulus (materiale granulare) modul de finețe granulometrică 
fineness of comminution (alim, ind chim) finețe de măcinare / mărunțire / de sfărâmare

fineness of grain (alim, ind chim) finețe a granulației

fineness ration (constr, mec, $\mathrm{OM}$ ) coeficient de finețe / de zveltețe / de subțirime

fine-pitch cutter (mas-un) freză cu dinți mărunți

fine-pitched screw (OM) şurub cu pas fin (al filetului)

fine-pored (materiale) mocroporos, cu porozitate fină, cu pori mici

fine print litere foarte mici; text neclar

fine-range diffraction (fiz) difracție într-un domeniu îngust

fine reduction (alim, ind chim) măcinare / concasare fină

finery (met) secție pentru elaborare / extragere / afinare

finery fire (met) cuptor de afinare

finery process (met) proces / procedeu de pudlare

fines particule dintr-un amestec, având mărimea mai mică decât media mărimii tuturor particulelor; particule mai mici decât o anumită valoare, particule care trec prin sită

fine scanning (fiz, metr) explorare / scanare fină / de înaltă rezoluție

fine screen $(\mathrm{OM}$, alim, ind chim) sită / clasor / sortator pentru sortare fină

fine screening (alim, ind chim) sortare fină

fine setting (autom) acord fin / de precizie, acordare / reglare fină

fine sieving (alim, ind chim) cernere fină

fine silicon (met) siliciu de dezoxidare

fine solder (met) aliaj pentru lipire moale

finesse îndemânare, abilitate; finețe, tact; a evita, a se eschiva de la

fine steel (met) otel superior / de calitate

fine structure (materiale) structură fină, microstructură

fine tin (met) cositor rafinat

fine tuning (autom, metr, mas) acord / reglaj fin / selectiv

fine turning (mas-un) strunjire fină

fine vacuum (fiz) vid înaintat

fine wine bouquet (alim) buchet de vin superior

fine wire (met) sârmă subțire

fine wool (textile) lână fină

finger (OM) ştift, bolț, ac (şi al cadranului unui aparat de măsură); deget; a atinge cu degetele; a lua, a fura

fingerbreadth (metr) unitate de măsură pentru lungime: 1 fingerbreadth $=0,01905 \mathrm{~m}$

finger (cloth) (metr) unitate de măsură pentru lungime: 1 finger $($ cloth $)=0,1143 \mathrm{~m}$

fingered cu degete (la dispozitive, roboți) finger hand mână cu degete (a unui robot)

finger joint $(\mathrm{OM})$ articulație cu bolț subțire

finger mark (anat) amprentă digitală, urmă de deget

finger-print (anat) amprentă digitală; a lua amprentele

finger stall $(\mathrm{OM})$ camă

finger tip control (mas) comandă prin buton

finical dificil, pretentios; meticulos; scrupulos; chițibuşar

fining (alim) cleiere a vinului; (met) afinare, rafinare, înnobilare, netezire

fining end (alim, mediu) zonă / compartiment de limpezire

fining furnace (met) cuptor afinare

fining process (met) operatie / proces de afinare

finings (alim, ind chim) clei de peşte

fining substance (alim, ind chim) agent de limpezire

finish şfârşit, capăt; (ind chim) lăcuire, emailare; terminare, completare, finisare, finisaj, calitatea suprafeței, finisaj; (textile) apret; a termina, a sfârși; a epuiza, a distruge; a finisa

finish bore (mas-un) a aleza fin, a efectua operația finală de alezare

finish cut (mas-un) ultima trecere la prelucrare prin aşchiere, trecere de finisare

finished terminat; perfectat, perfect; finisat, pus la punct; excelent

finished article / product produs finit

finished blend (materiale, alim, constr, ind chim) amestec final / utilizabil

finished goods produse finite

finisher (met) laminor finisor, finisor, maşină / utilaj de finisare, cajă finisoare, matriță pentru ultima prelucrare; (textile) finisor, apretor, cardă finisoare

finish extra bright (mas-un) a lustrui până la strălucire (metalică)

finish form formă finală

finish grinding (alim, ind chim) măcinare fină; (mas-un) rectificare fină; (metr) reglare fină

finishing terminare, sfârşit; finisare, prelucrare finală; (met) netezire, rafinare; (textile) apretură, apretare; ultim, de finisare

finishing additions (alim, ind chim) adaosuri pentru prelucrare finală / de finisare

finishing allowance (TH, mas-un) adaos de prelucrare pentru finisare

finishing cut (mas-un) trecere de finisare, danturare fină la pile

finishing die (mas-un) filieră finală, matriță de finisat

finishing drill (mas-un) burghiu-alezor, burghiu de finisare 
finishing floor (met) secție de finisare / de ajustaj

finishing frame (met) cajă de ecruisare / de finisare

finishing gear milling cutter (mas-un) frezămodul, pentru finisare

finishing groove (met) calibru de lustruit la prelucrarea profilurilor fine, calibru finisor

finishing jumper (mas-un) sculă de finisare a filetelor

finishing mill (mas-un) freză de finisat; (met) laminor finisor

finishing (milling) cutter (mas-un) freză de finisat

finishing-mill stand (met) cajă finisoare (la laminare)

finishing (operations) $(\mathrm{TH})$ (operații de) finisare

finishing (oval) pass (met) cilindru finisor (oval) (la laminare)

finishing process proces de finisare; (textile) apretare

finishing rate (el) curent final de încărcare (la acumulatoare)

finishing rolling (met) laminare de finisare

finishing rolling mill (met) laminor de finisare / finisor

finishing rolls (met) cilindri de finisare (la laminare)

finishing room / shop (TH) secție / atelier de finisare

finishing screen (alim, constr, ind chim) sită fină

finishing slag (met) zgură finală

finishing stand (met) cajă finisoare

finishing stand of rolls (met) cajă / linie de laminor finisor

finishing temperature (met) temperatura metalului la ultima reducere (la forjare sau laminare), temperatura la care se termină formarea la cald / forjarea

finishing tool (mas-un) cuțit / sculă de finisare

finishing train (met) laminor finisor

finishing varnish (ind chim) vopsea / lac de finisare / de protecție / de acoperire

finish grinding (mas-un) rectificare finală

finishing work (TH) lucrare de finisaj / finisare

finish lacquer / varnish ultimul strat de vopsea (la caroserii auto, carcase, mobilă etc.)

finish lead (el) conductor / fir de conectare

finish machining (mas-un) prelucrare finală

finish off a planed surface of wood a rindelui, a prelucra fin lemnul cu rindeaua

finish ream (mas-un) prelucrare finală, cu alezor, alezare finală, a finisa prin alezare finish to size (TH) a finisa / a prelucra până la o dimensiune precisă / finală

finish turned (mas-un) finisat la / pe strung

finite finit, limitat, mărginit

finite diamond wire cutting machine (mas-un) maşină de tăiat cu sârmă diamantată finită (în buclă cu mișcare continuă)

finite difference method metoda diferențelor finite

finite difference scheme (fiz, mat, mec) schemă $/$ model cu diferente finite

finite element method (fiz, mat, mec) metoda elementului finit

finite element modelling (fiz, mat) modelare prin elemente finite

finitely separable divizibil în părți oricât de mici

finite set (mat) mulțime cu număr finit de elemente

finless $(\mathrm{OM})$ debavurat, fără bavură

finned $(\mathrm{OM})$ nervurat, cu aripioare

finned cylinder head (auto, OM) chiulasă nervurată, cap de cilindru nervurat, fin prelucrată

finned heat sink $(\mathrm{OM}$, termo) radiator cu aripioare

finned length (OM, termo) lungime nervurată, lungime utilă a țevilor nervurate / a tubului cu aripioare

finned plate $(\mathrm{OM}$, termo) placă cu nervuri

finned tube (OM, termo) tub cu nervuri / cu aripioare

finned tube heat exchanger (OM, termo) schimbător de căldură cu țevi cu aripioare

fin(ned)-type air cooler (OM, termo) răcitor de aer, cu aripi de radiație

finning $(\mathrm{OM})$ nervurare; (met) formarea bavurii

finny (alim) (d. peşte) cu aripioare, de peşte

fin pitch $(\mathrm{OM}$, termo) pas / înclinare a(l) paletei (şi de ventilator)

fin spacing (alim, OM) interval / distanță între palete

fin tube (termo) tub de cazan cu apă la exterior şi cu produse de ardere la interior

fion tool (mas-un) cap de polizare (mecanică fină)

fir (silv) (lemn de) brad, pin

fire foc, flacără, incendiu; strălucire, sclipire; entuziasm, avânt; (termo) grătar, a alimenta cu combustibil; bombardare, bombardament, tragere; a pune pe foc; a da foc la, a incendia, a fi în flăcări; a împuşca, a exploda, a aprinde (un foc), a detona, a încălzi, a preîncălzi, a incendia, a arde; a (se) aprinde, a lăsa să ardă, a întreține focul; (nav, mil) a lansa torpile, a trage (cu o armă); a declanşa impri-marea (birotică); a coace; a arde (cărămidă etc.); (ec) a da afară, a concedia; (med) a cauteriza; catch/take $\sim$ a lua foc 
fire-alarm (TH) alarmă de incendiu

fire-alarm (box) (TH) semnalizator / avertizor de incendiu

fire-alarm signal (TH) semnal de incendiu

fire apparatus stingător, extinctor

fire assay (termo) probă de ardere

fire-bar frame (termo) suport al grătarului

fire barrier (ind chim, met) barieră pentru oprirea unui foc (pânză sau pulverizatoare de apă)

fire boat (nav) şalupă / navă pentru stins incendiile

fire bomb (mil) bombă incendiară

fire-box (met, termo) cutie de foc, cameră de ardere, focar, vatră

fire-box boiler (cf, termo) cazan (şi de locomotivă)

fire brand bucată de lemn aprinsă, lemn aprins

fire break (silv, mediu) teren curățat de copaci pentru a opri extinderea unui incendiu

fire brick (met) cărămidă refractară / de şamotă

firebrick sleeve (met) cărămidă refractară, cu goluri

fire bridge (termo, met) altar de focar

fire brigade / company / department / squad (corp de) pompieri

fire call apel / semnal de incendiu

fire clay (met, termo) argilă refractară, şamotă

fire-clay brick (met, termo) cărămidă refractară, / de şamotă

fire-clay lining (met, termo) căptuşeală refractară / de şamotă

fire-clay mortar (met, termo) mortar de şamotă

fire-clay refractories (met, termo) (materiale) refractare de şamotă

fire cock (met, OM, termo) robinet / gură de incendiu, hidrant

fire control (termo) reglarea focului

fire-control instrument (termo, TH) aparat de stingere / de localizare a incendiilor

fire covering $(\mathrm{TH})$ protecție contra incendiilor

fire crack (met) fisură din cauza arderii / la cald (defect)

fire-crancker welding (met) sudare cu electrod culcat

fire-damp (met, ind chim) metan, grizu, gaz de mină

fire-damp detector / indicator (metr, ind chim) grizumetru, detector de metan

fire danger $(\mathrm{TH})$ pericol de incendiu

fire door (constr) uşă de incendiu; (termo) uşă a focarului

fired refractory products (ind chim, termo) produse refractare arse

fire drencher extinctor manual; instalație de stins incendii fire drill (TH) exerciții de evacuare în caz de incendiu

fire dryer (alim, ind chim) uscător cu încălzire directă

fire engine (OM, hidr) pompă de incendiu

fire equipment (ind chim, termo) instalație de ardere

fire escape / exit (constr) scară / ieşire de incendiu / de salvare

fire extinguisher (chim, TH) extinctor / stingător de incendiu / cu spumă

fire-extinguisher foam (chim, TH) spumă de stingere (a incendiilor)

fire-extinguisher material (chim, $\mathrm{TH}$ ) material de stins incendii

fire-fighting boat (nav) navă de stins incendii (pe chei sau pe o altă navă)

fire-fighting crew echipă de pompieri / de combatere a unui incendiu

fire(-fighting) pump (OM, hidr) pompă pentru stingerea incendiilor

fire foam (chim) spumă de stingere a focului

fire gases (met, termo) gaze de ardere

fire-goods (transp, nav) marfă / încărcătură inflamabilă

fire grate (met, termo) bară de grătar (al focarului)

fire grate bar (met, termo) grătar al focarului, bară de grătar

fire guard (termo) grilaj / grătar pentru foc, apărătoare (la gura de ardere)

fire hazard $(\mathrm{TH}$, termo) pericol / risc de incendiu

fire-hazardous (TH) inflamabil, cu pericol de inflamare

fire-hole (met, termo) gaură / orificiu de scormonire (la focare, grătare)

fire hose $(\mathrm{OM}$, hidr) furtun de incendiu

fire hydrant (OM, hidr) hidrant / gură pentru stingerea incendiilor

fire kiln (alim, ind chim) uscător / cuptor cu foc direct, cuptor de prăjire / de calcinare

fire ladder (constr, TH) scară de incendiu / de salvare

fire losses (ind chim) pierderi prin calcinare

fireman fochist; pompier

fireplace (alim) maşină de gătit; (met, termo) vatră (de cuptor sau forjă), focar; (constr) cămin, şemineu

fire(-)plug (OM, hidr) gură de incendiu, hidrant

fire point (fiz) focar (în optică); (materiale) punct de inflamabilitate / de aprindere; (met) loc pentru scule şi aparate de stins incendiu, focar de incendiu; (termo, hidr) punct de aprindere / de combustie; ( $\mathrm{T}$, chim) punct de ardere (a unui fluid, lubrifiant etc.) 
fireproof (f.p.) (materiale) neinflamabil, refractar, rezistent la foc, ignifug(at); a ignifuga

fireproof brick (met, termo) cărămidă refractară fireproof bulkhead (constr, termo) panou parafoc, perete ignifug

fireproof cement (constr, met) ciment refractar

fireproofed (materiale) ignifugat, refractar, rezistent la foc

fireproof finishing finisare ignifugă (pentur lemn, panouri, țesături etc.)

fireproof glass (ind chim) duran, sticlă rezistentă la foc

fireproofing (ind chim) operație de ignifugare, înveliş / strat ignifug, ignifugare

fireproof mortar (met) mortar refractar

fireproofness (materiale) rezistență la foc

fireproof paint (ind chim) vopsea ignifugă

fireproof substance (chim) substanță ignifugă

fire raising $(\mathrm{TH})$ incendiu (provocat)

fire-refined copper (met) cupru rafinat termic

fire-refining (met) rafinare termică

fire-resistance rezistență la foc (d materiale solide, fluide); (met) refractaritate

fire-resistance cast iron (met) fontă refractară

fire resistance fluid (FR fluid) (hidr, ind chim) fluid neinflamabil

fire resistance test (termo, metr) probă de rezistență la aprindere

fire-resisting lute (chim, constr) chit rezistent la foc

fire-resisting material (ind chim, materiale) material rezistent la foc

fire-retardant (ind chim) produs / substanţă de ignifugare / care întârzie aprinderea

fire-retarding quality (materiale) calitate de ignifugare

fire risk $(\mathrm{TH})$ pericol / risc de incendiu

fire setting (termo) aprindere a focului (la un cuptor etc.)

fire shrinkage (materiale) contracție la ardere

fire station remiză de pompieri

firestone (minerl) cremene, silex; (met) pirită, piatră rezistentă la foc

fire test (materiale, metr) determinare a temperaturii de aprindere, test privind comportarea la foc (deschis)

fire tongs (met) cleşte de forjă

fire tube (met, termo) țeavă de flacără / de fum / fierbătoare / cu apă la exterior şi cu produse de ardere la interior

fire-tube boiler (termo) cazan ignitubular / cu țevi de flacără

fire up a aprinde, a da foc (la instalații termice, cazane, cuptoare etc.)

fire wall (constr, met) perete parafoc fire waste (met) pierdere prin ardere

fire watcher pompier de serviciu

fire water (alim) băutură tare / cu alcool

fire / forge welding (met) sudare la forjă / prin forjare

fire wood (silv, termo) lemne de foc

firing (termo) aprindere; combustibil, lemne (de foc); (autom) excitare (de pornire); (el) amorsare, ardere, ionizare (a unui gaz); aprindere, ardere, încălzire, conducere a focului; (met) calcinare, prăjire

firing angle (termo) unghi de saturație

firing chamber (auto, termo) cameră de ardere / de combustie

firing circuit (termo) circuit de aprindere

firing failure (termo) rateu / defect de aprindere

firing in the silencer (auto, termo) explozie în toba de evacuare / de eșapament

firing pin (mas-un, mil) percutor

firing practice (termo, ind chim, mediu) tehnică a arderii

firing rate control (termo) dispozitiv de reglare a arderii

firing schedule (termo) conducerea focului

firing shrinkage (materiale, termo) contracție la ardere

firing spring $(\mathrm{OM})$ arc de impact

firkin (metr) putinei; unitate de măsură pentru capacitate $(1$ firkin $(\mathrm{UK})=40,91 ; 1$ firkin (US) $=34,11$ )

firm (ec) firmă, casă de comerţ; (TH) a (se) întări, a (se) consolida, a (se) compacta, a (se) fixa; (adj) solid, compact, stabil, rigid, ferm, tare, dur, fix; neclintit; compact; aspru, sever; $(a d v)$ ferm, cu fermitate

firm bottom (constr, OM) fundație tare, fund rigid / stabil

firm offer (ec) ofertă fermă

firmly $(a d v)$ cu fermitate / hotărâre, ferm, hotărât; cu putere

first primul, cel dintâi, principal, de frunte (auto) viteza I

first-aid (med) prim-ajutor

first-aid box / kit (med) trusă de prim-ajutor

first air (termo, met) aer primar

first-class (cf, transp) clasa I; de clasa I, de calitate superioară; superior; $(a d v)(\mathrm{cf})$ cu clasa I

first coat (ind chim) grund; (constr) (prima) tencuială

first-come, first-served (ec) primul venit, primul servit (metodă de ordonare a cererilor dintr-un şir de aşteptare)

first cost (ec) preț de uzină, costuri de investiții, cost (atenție la text)

fist curvature (mat) curbură a unei curbe plane 
first cut (mas-un) dințare inferioară / de bază (la pile); aşchiere de degroşare

first cut screwing die (mas-un) filieră de degroşare

first elavator (agr, alim, met, constr) elevator inferior

firat evaporator (alim, termo) prim corp de evaporare

first floor etajul întâi (UK), parter (SUA)

first fruits (agr) primele produse / fructe, trufandale

first gear (OM) treapta întâi (la o cutie de viteză sau la un reductor)

first-hand direct de la sursă, obținut direct; $(a d v)$ (în mod) direct

first hand distribution (FHD) (ec) distribuție a mărfurilor fără intermediari

first harmonic (mat, fiz) armonică fundamentală

first-in, first-out (FIFO) (inf) primul intrat, primul ieşit (tehnică de manipulare a datelor)

first instalment (ec) acont, arvună, prima plată / rată

first-kind lever (mec) pârghie de gradul întâi

first-layer (brit), neighbor neighbour (amer) (fiz, hidr) stratul vecin cu primul strat

first-line manager şef de echipă / de atelier, contramaistru, manager pe ultima poziție în ierarhia organizației

firsting primul sosit; (agr) primul produs, trufanda

firstly $(a d v)$ întâi, în primul rând

first making-ready ( $\mathrm{TH}$, mas) potrivire / montaj inițial(ă), prepotrivire, prearanjare

first matte (met) mată primară (la neferoase)

first / left member (mat) membru stâng / prim, partea stângă / primă a unei ecuații

first motion (mec) mişcare inițială

first name pronume, nume de botez, numele mic

first pass (met) calibru degrosisor (la laminoare)

first-order lever (mec) pârghie de gradul întâi

first-rate (ec) foarte / extra-fin, de primă calitate (d. produse şi servicii)

first-run slag (met) prima zgură (la topirea staniului sau a aliajelor lui)

first section $(\mathrm{OM})$ secțiune inițială

first slag (met) zgură de topire / oxidantă

first smelting pig iron (met) fontă de primă fuziune

first speed (OM, auto) viteza întâi, primul angrenaj (la reductoare, cutii de viteze etc.)

first-stage graphitization (met) grafitizare primară

first tap (mas-un) tarod de degroşare, tarod N1

fir-tree crystal / crystallite (met) dendrită

fir-tree structure (met) structură dendritică

fiscal (ec) fiscal, financiar fiscally $(a d v)(\mathrm{ec})$ (din punct de vedere fiscal, financiar

fiscal balance (ec) bilanț fiscal

fiscal year (ec) an fiscal

fish (alim, iht) peşte; a pescui, a prinde peşte

fish bellied bar (mec, OM) bară de egală rezistență

fish bolt (cf) bulon / bolț / şurub de eclisă

fish bone (alim) os de pește

fish-bone diagram $(\mathrm{TH})$ diagrama Ishikwa (în analiza cauzelor defectării), diagrama schelet de peşte

fisher, fishman pescar; (nav) navă de pescuit, pescador

fishery pescărie, drept de pescuit, loc de pescuit; cherhana

fish(-)eye (opt) obiectiv superangular de tip „ochi de peşte" (cu redarea imaginii în perspectivă curbilinie); zonă alb-cristalină a unei fisuri (de obicei, la fisurarea cauzată de hidrogen); (plast) zonă neomogenă, vizibilă (mai ales la plastice translucide sau transparente), ochi de pește, deformare globulară (și în adeziv); (met) fulg(i) (defect)

fishing pescuit; (nav) întăritură (a unei vergi); (OM, met) îmbinare cu eclise

fishing net năvod, plasă (de prins peşte)

fishing apparatus / device (autom, electr, mec) aparat / dispozitiv de prindere / de blocare

fishing hook (OM) undiță, cârlig / gheară / sculă de prindere / agățare

fishing piece $(\mathrm{OM})$ eclisă a îmbinării cap-la-cap

fishing plate $(\mathrm{OM})$ eclisă, piesă de prindere / de legătură

fishing socket $(\mathrm{OM})$ bucşă / manşon de prindere

fishing tackle (nov) scule de pescuit, barcă de salvare

fishing tank (OM, hidr, mediu) tanc / rezervor de decantare

fishing tool (nav) unealtă de pescuit; (OM) sculă (telescopică) de prindere a pieselor din locuri greu accesibile

fishing valve (OM, hidr) supapă de blocare / de conectare la un aparat de măsură

fishing-valve socket (OM, hidr) suport al supapei de blocare / de conectare la un aparat de măsură

fishing vessel (nav) navă de pescuit, pescador

fish kettle (alim) oală de fiert peşte

fish ladder / pass (agr, iht) scară de peşti; trecere pentru peşti

fish oil (alim, iht) ulei / untură de pește

fishplate (cf, OM) eclisă de joantă / de îmbinare a şinelor

fishplate bolt (cf, OM) bulon / bolț / şurub de eclisă 
fishplate pass (met) calibru de laminare în formă de V

fish scale (materiale, OM) (defect în) solzi de peşte (la acoperiri)

fish-scale fracture (materiale, mec) rupere în formă de solzi de peşte / solzoasă (la acoperiri)

fish skimmer (agr, iht) separator de peşti

fish skin piele de peşte; suprafaţă solzoasă (la materiale)

fish slice (alim) cuțit de peşte

fish tackle (nav) palanc de manipulat plase (în pescuit ci nave specializate)

fishtail (TH, plast, met) exces de material la exdrudare; (met) coadă de peşte (defect de laminare)

fish-tail burner (termo) arzător plat

fish-tail cutter (mas-un) freză cilindro-frontală cu cap cu degajare

fishy de peşte; cu miros / gust de peşte

fissile (fiz) uşor de despicat, care se desface uşor; fisionabil

fission (fiz) fisiune

fissionable (fiz) fisionabil

fissure (geol) fisură, falie; riz; (TH) crăpătură, crăpare, fisură, fractură, rupere

fissured cu fisuri / crăpături, fisurat (d. materiale, piese)

fissuring fisurare; care (se); care (se) fisurează; (procesul de) fisurare

fist (mas-un) pumn, nicovală cu corn

fit (s) acces; atac; toană; stare trecătoare; (OM, mas) ajustaj, montaj, echipament; potrivit, indicat, ajustat, corespunzător; adecvat; convenabil; gata, pregătit, capabil (să); vrednic, demn; (fam) în formă; competent, în stare să; a (se) potrivi, a adapta, a ajusta, a instala, a monta, a fixa, a pune la punct, a regla, a proba, a fi bun / corespunzător, a corespunde, a fi bun pentru; a pune de acord, a pune în concordanță cu, a face să corespundă cu; a utila, a echipa (o uzină, un vas etc.); (pol, ec, jur).a corupe prin dare de mită; (OM) a se îmbina (bine), a se potrivi, a monta; a $\sim$ of (coughing) un acces de (tuse); be in a (med) a avea un atac / o criză

fit for / to potrivit, cu / pentru, bun pentru / la, adecvat/ corespunzător pentru; a se pregăti pentru, a căuta să corespundă cu, a corespunde cu

fit for / to corespunzător cu / la

fit for bottling (alim, hidr, ind chim) apt pentru îmbuteliere

fitful convulsiv; intermitent, neregulat, sporadic; 1. cu toane, capricios; cu întreruperi; nesigur

fitfully $(a d v)$ convulsiv; intermitent, neregulat, sporadic, cu intermitențe

fitfulness neregularitate, instabilitate, intermitență fit in (OM) a se îmbuca; a se potrivi (forme conjugate)

fit in (with) (constr) a rostui, a introduce, a potrivi, a face să se potrivească cu, a aşeza; $(\mathrm{TH})$ a ajusta (după), a păsui, a monta, a introduce (în)

fit into each other $(\mathrm{OM})$ a (se) potrivi (reciproc) fit into each another a intercala (piese) (şi cu forme conjugate, una cu următoarea)

fit a key $(\mathrm{OM})$ a potrivi o pană

fit loosely (OM) a asambla cu joc

fitly $(a d v)$ (în mod) potrivit, convenabil, la momentul potrivit

fitment $(\mathrm{OM}, \mathrm{TH})$ ajustare, potrivire (şi la montaj) îmbinare; dispozitiv, accesorii

fitness potrivire, caracter potrivit, utilitate, aptitudine, conformitate; calificare; oportunitate

fitness for use $(\mathrm{TH})$ corespunzător pentru utilizare

fit on (TH) a cala; (auto) a echipa o roată; a încerca (o haină)

fit oneself in(to) a se adapta la, a căuta să se obişnuiască (cu)

fit out (TH) a echipa, a înzestra, a utila (o secție, un laborator etc.); (nav) a arma / a dota o navă

fit-out (mas) echipament

fit packing (FP) (alim, ind) constând dintr-un strat protector (folie de polietilenă etc.) fixat de obicei prin termosudare

fitted (TH) montat, fixat; instalat; înzestrat; dotat; echipat

fitted bolt (OM) şurub / bolț păsuit / de păsuire

fitted curve curbă potrivită / adaptată / aviată

fitted piston $(\mathrm{OM}, \mathrm{T})$ piston ajustat prin rodaj

fitted with prevăzut cu

fitter $(\mathrm{TH})$ montor, ajustor, montator, instalator, lăcătuş (ajustor)

fitter's bench (TH, mas-un) masă / banc de lăcătuşerie

fitter's shop (mas-un) secție de montaj; atelier de lăcătuşerie; (TH) lăcătuşerie

fitting bun, corespunzător, potrivit; potrivire; (constr, hidr, mec) aranjare în stație (în punctul de măsurare) a unui aparat; (el) corp de iluminat; (mat) ajustare, trasare (despre o curbă) prin puncte; $(\mathrm{TH})$ păsuire, montare, montaj, asamblare, instalare, ajustare; (OM) ştuţ, niplu, armătură, fiting, garnitură

fitting allowance (OM) adaos pentru ajustare, toleranța ajustajului

fitting area (OM) suprafață de ajustare / corespunzătoare piesei conjugate

fitting edge margine de ghidare la punerea colii (în maşină, în imprimantă etc.)

fitting in (OM) ajustare (a unui arbore) după alezaj 
fitting on $(\mathrm{OM})$ ajustare a unei piese exterioare pe un arbore

fitting out berth (nav) dana de armare

fitting piece (OM, hidr) fiting, piesă intermediară folosită la îmbinare, piesă de ajustare, niplu de fixare; armatura

fitting pin (auto, OM, mas) cui / ştift de ajustare, ştift de centrare

fittings $(\mathrm{OM}$, hidr) garnitură, set; asamblare; fitinguri; armături; articole metalice, feronerie; mobilă, mobilier; (el) corpuri de iluminat

fitting shop (TH) secție de montaj, atelier de lăcătușerie

fitting (up) (TH) montare, potrivire, aşezare

fitting work (TH) operație de ajustare / de montare

fit to apt (pentru); care merită (să); în stare (să)

fit tolerance $(\mathrm{OM})$ toleranță a ajustajului

fit up (TH) a monta, a aşeza, a fixa, a ajusta, a instala, a înzestra cu, a prevedea cu

fit with tyres (auto) a monta pneuri la maşină

five-bearing crankshaft (OM, auto, termo) arbore cotit pe cinci paliere

five-figure accuracy (mat) exactitate pâna la cinci zecimale

fivefold încincit

fix (nav) punct al navei (determinat cu precizie), a face punctul navei, relevment în cruce; a amara; (TH) a (se) fixa, a bloca, a strânge, a îțepeni, a prinde, a lega; a preciza, a stabili, a determina; a monta, a instala, a regla, a repara, a opri, a reține, a întări, a limita; a aşeza, a depozita; a monta în lagăr; a se hotărî; a definitiva, a consolida, (un preț, o dată); a pune în ordine; a se solidifica, a se închega; stare de functionare

fixation (chim, fiz) concentrare, solidificare

fixation-clamping section (OM) sectiune de încastrare

fixation frame (constr, OM) jug de fixare (la cofraje)

fixation of nitrogen (chim) fixarea azotului

fixative (chim) de fixare, fixativ, fixator

fixed $(\mathrm{OM}, \mathrm{mec})$ fix, fixat, staționar, stabil; invariabil, permanent, constant; imobil, stabilizat; definit, determinat, neschimbat neschimbător; (chim) fix, nevolatil

fixed advanced ignition (termo) aprindere cu avans fix

fixed aerial cableway (mas) macara funiculară fixă

fixed air (chim) dioxid de carbon

fixed arch (constr) arc încastrat

fixed assets (ec) fonduri fixe; valori imobilizate

fixed beam (mec, OM) grindă încastrată

fixed bearing (mec, OM) reazem încastrat fixed block format (c, inf) format cu bloc fix în care numărul, lungimea şi ordinea cuvintelor sunt fixe

fixed box pin (OM, met) ştift de ghidare / de centrare (şi la rame de formare, matriţe din mai multe module, carcase)

fixed cableway (mas) macara funiculară fixă

fixed capacity pump-motor (hidr) pompă motor (motopompă) cu cilindree fixă

fixed carbon (met, chim) carbon fixat

fixed centre (mas-un) vârf fix (la strung)

fixed clearance gear motor (OM, mas) motor cu angrenaj cu joc lateral / axial fix

fixed coil (el) bobină fixă; stator

fixed column horizontal boring machine (masun) maşină orizontală, cu montant fix de alezat / de găurit

fixed converter (met) convertizor fix

fixed coupling $(\mathrm{OM})$ cuplare rigidă

fixed cycle (fiz, mec, termo) ciclu constant

fixed-cycle operation operație cu timp fixat

fixed displacement motor / pump (termo, hidr) motor / pompă cu cilindree constantă

fixed-edge moment (mec) moment de / în încastrare

fixed error (autom, metr, mas) eroare sistematică / constantă

fixed field (el) câmp staționar; (inf) zonă fixă

fixed gas (fiz, termo) gas necondensabil

fixed gauge (mas-un) sablon fix

fixed-grate producer (met, termo, ind chim) generator cu grătar fix

fixed grate-type gas producer (met, termo, ind chim) generator de gaz cu grătar fix

fixed grizzly grătar fix

fixed guide vanes (OM, hidr) palete de ghidare fixe (la pompe centrifuge)

fixed head blowpipe (termo) arzător cu debit constant

fixed hinge $(\mathrm{OM})$ articulație fixă

fixed ignition (termo) aprindere cu avans fix

fixed installation (TH, mas) instalație staționară / fixată

fixed interval re-order system (autom, electr) sistem de comenzi la intervale fixe

fixed jaw (OM, metr) falcă a riglei gradate (la şubler)

fixed light $(\mathrm{TH})$ lumină (de intensitate) constantă; fereastră imobilă; (nav) semnal cu lumină fixă

fixed loading point (mec, transp) punct de încărcare fix

fixed mandrel (OM, mas-un) dorn simplu fix cu găuri de centrare

fixed moment $(\mathrm{mec})$ moment de încastrare 
fixed mould (mas-un, plast, met) matriță fixă

fixed nitrogen (chim) azot legat

fixed pan mill (alim, ind chim) amestecător cu cupă fixă

fixed pitch fan ventilator cu elice cu pale fine

fixed point (autom, inf) virgulă fixă; (fiz) focar; (mat) origine a coordonatelor; ( $\mathrm{TH}$, mas-un) reper, punct fix

fixed-point calculation (inf, mat) operație cu virgulă fixă

fixed-point free (TH) fără puncte fixe

fixed pulley $(\mathrm{OM})$ scripete fix, şaibă fixă, roată (şî de curea) cu axă fixă / fixată / imobilizată

fixed range mark generator (el, metr) generator de tensiune de etalonare

fixed residue ( $\mathrm{TH}$, mediu) reziduu solid / depus

fixed restrictor valve (hidr, OM) drosel fix, reductor de debit nereglabil

fixed rule regulament (şi al unei organizații economice)

fixeds (ec) cheltuieli de regie fixe

fixed shear blade (OM, mas-un) lamă de foarfece fixă

fixed size gauge (metr, mas-un) calibru cu o singură dimensiune

fixed tangential rocker bearing $(\mathrm{OM})$ reazem oscilant tangențial, fix

fixed trip (el, mas-un) declanşare / deplasare blocată

fixer (ind chim) baie de fixare

fixing (constr, mec) încastrare; (ec) stabilirea cur-sului valutar; (mas) montare a unei maşini; (TH) fixare, prindere

fixing bolt $(\mathrm{OM})$ şurub / bolț de fixare

fixing device (OM, mas-un) dispozitiv de blocare

fixing needle ac de înțepat (în poligrafie)

fixing of position ( $\mathrm{TH}$, mas, mas-un) stabilire / fixare a poziției

fixings accesorii (şi de fixare); (alim) garnitură

fixing screw $(\mathrm{OM})$ şurub de consolidare / de prindere / de fixare

fixing slot $(\mathrm{OM})$ şanț / crestătură / canal de prindere

fixing strap (constr, OM) etrier, bride de consolidare / de prindere

fixing wedge $(\mathrm{OM})$ pană de fixare

fixity (mec) încastrare

fixture (OM, mas-un) dispozitiv de fixare / de oprire / de prindere; jug, armătură

fixtures (constr) dependințe

fixture stub $(\mathrm{OM})$ bolt de fixare

fix up / upon a repara

fixure fixare; lucru, dispozitiv fixat; (jur) avere mobilă; dată fixată pentru o activitate; (OM, mas) armătură; instalație flabby, flaccid slăbit

flag (cf) fanion; (constr) lespede, pavaj din plăci; (inf) marcaj, reper, indicator; (nav) pavilion, navă de comandant; (TH) steag, bordură, trenă, steguleț, drapel; a semnaliza, a transmite, a marca cu stegulețe

flag bit (c, inf) indicator de recunoaştere, caracter Q

flag bridge (nav) punte de semnalizare

flagging (ec) care stagnează, lipsit de viață; (constr) dale, pavaj din dale

flaggy (constr) de / din dale

flag mosaic (constr) mozaic de plăci

flagrance, flagrancy caracter flagrant; notorietate

flag station (cf) haltă

flastone (constr) lespede / dală de piatră

flagstone floor (constr) dalaj

flagstower (nav, av) turn de semnalizare

flake (OM) fulg, solz, coajă, foiță, lamelă; (nav) buclă plată de parâmă; material plastic sub formă de fulgi / aşchii (care se introduce în matriță); (met) fisură de hidrogen, pulbere metalică sub formă de solzi / fulgi

flake camphor (ind chim) naftalină

flack crack (met) fisură lamelară

flaked solzos, cu solzi

flaked graphite (met, $\mathrm{T}$ ) grafit lamelar

flake formation (ind chim, plast) formarea fulgilor; (T) formarea particulelor de uzură, a plăti rate (asemănătoare solzilor de pește) (rezultate şi la funcționarea rulmenților)

flake-graphite cast iron (met) fontă cu grafit lamelar

flake litharge (chim) oxid de plumb în fulgi

flake off (mec, T) a se exfolia; (T) a (se) exfolia sub formă de particule mici, aplatizate, asemănătoare solzilor de pește

flaker (alim, ind chim) maşină pentru obținerea fulgilor

flakes (met, plast, alim, T) fulgi, solzi (de peste), particule mici şi aplatizate (ca solzii de peşte)

flake soap (ind chim) fulgi de săpun

flakiness (materiale) structură solzoasă, caracter solzos / ca de fulgi; (T) caracter solzos / ca de fulgi pentru paprticule de uzură

flaking (TH, T) cojire, exfoliere, scorojire, detaşare în solzi (defect, formă de uzură)

flaking roller (ind chim) cilindru de solzificat

flaky floconos, pufos, solzos, ca fulgii; (met) lamelar

flaky fracture (met) ruptură lamelară / solzoază

flaky structure / texture (materiale) structură în solzi / solzoasă / în micro-plăci

flamboyant flamboiant; viu colorat; bombastic, exagerat 
flame flacără; a arde cu flacără, a izbucni în flăcări

flame brazing / soldering (met) lipire cu flacără (cu aliaj metalic)

flame / flaming arc (el, met) arc electric

flame annealing (met) recoacere superficială, cu flacără

flame arrester (termo, met) stingător

flame baffling (termo, met) conducere a flăcării

flame black (ind chim) negru de fum

flame bridge (termo, met) altar de focar (la cazane, cuptoare etc.)

flame burning away from nozzle (termo) rupere a flăcării, lângă ajutaj / arzător

flame chipping / cleaning (met) curățare cu flacără / prin ardere

flame cleaning blowpipe ( $\mathrm{TH}$, termo) arzător pentru îndepărtat vopseaua (veche) cu flacără

flame colouration (chim, termo) colorarea flăcării

flame-coloured galben-roşu, portocaliu, de culoarea flăcării

flame contact furnace (met) cuptor cu vatră

flame-cut / -cutting (materiale, metalice) tăiere cu flacără / cu gaze

flame-cutting nozzle (met, termo) suflai de tăiat (cu flacără autogenă)

flame damper (termo, met) amortizor de flăcări

flame descaling / descuming (met) curătire cu flacără / prin ardere a țunderului

flame detector (autom, electr, termo) detector de flacără

flame engine (termo) motor cu gaze

flame envelope (termo) zonă exterioară a flăcării

flame-failure control (autom, termo) sistem de comandă a alimentării cu combustibil, guvernat de flacără-pilot

flame flash-back (termo, met) întoarcere a flăcării

flame flickering (termo) pâlpâire a flăcării

flame flue (met, termo) canal de fum

flame front (met, termo) front al flăcării

flame furnace (met) cuptor cu flacără

flame gases (met, ind chim, mediu) gaze de ardere

flame gauging (met, TH) tăiere a canelurilor cu flacără oxiacetilenică

flame-harden (met) a căli cu flacără

flame hardening (met) călire superficială, cu flacără

flame holder (met, termo) stabilizator de flacără

flame ignition (termo) aprindere cu flacără

flame jet (termo) jet de flacără

flame length (termo) lungimea / înălțimea flacării

flameless (materiale) (care arde) fără flacără

flamelet flăcăruie

flame out / up a (se) aprinde, a izbucni în flăcări flame planing machine (mas-un) maşină de nivelare a suprafețelor, cu flacără

flame plate (termo) placă de deviere / de direcționare a flăcării

flame plating (met) acoperire cu / sub flacără

flame-priming (met, TH) curățire cu flacără

flameproof (chim) antideflagrant, antigrizutos, neinflamabil, rezistent la flacără

flameproof fabric (chim, TH) țesătură ignifugată

flameproof motor (mas) motor antigrizutos

flame propagation (met, termo, $\mathrm{TH}$ ) propagarea flăcării

flame resistance (materiale) rezistență la flacără

flame scarfing (met) curățare cu flacără / prin ardere

flame spray gun / pistol (TH) pistol(et) de pulverizare cu flacără

flame spraying $(\mathrm{TH})$ acoperire prin pulverizare în flacără

flame spread $(\mathrm{TH})$ propagare a flăcării

flame temperature (materiale, termo) temperatură de aprindere

flame test (materiale) probă la flacără

flame trap (met, termo) opritor de flăcări

flame traveling in a horseshoe direction (met, termo) flacără reverberată / întoarsă

flame treating (ind chim, plast) tratament al termoplasticelor prin expunere controlată la flacără pentru a obtine suprafete oxidate (rezistente chimic)

flame tube $(\mathrm{OM}$, turbo) țeavă de flacără

flame velocity (termo) viteza de propagare a flăcării

flaming, flamy (termo) formare a flăcării, în flăcări, cuprins de flăcări; strălucitor; fierbinte

flaming furnace (termo) cuptor cu flacără

flammability (materiale, termo) inflamabilitate

flammability point (materiale, termo) temperatura de inflamabilitate

flammable (materiale, termo) inflamabil

flange (constr) centură, brâu, talpă de grindă; (OM) flanşă, bridă, eclisă, cordon, a asambla prin flanșe; (el) manşon de cablu; proeminență, bordură, ieşitură, cârpă de şters

flange bolt $(\mathrm{OM})$ şurub de flanşă

flange bracing (mec, OM, constr) întăritură a tălpii grinzii

flange connected $(\mathrm{OM})$ îmbinat prin flanşă

flange connection (OM, hidr) bridă de racordare, racordare cu flanșă

flange coupling (OM, hidr) cuplare / asamblare prin flanşă

flanged bearing $(\mathrm{OM})$ lagăr cu flanşă

flanged bushing (OM) bucşă cu flanşă 
flanged butt joint (OM, met) asamblare / îmbinare prin sudură cu margini răsfrânte

flanged connector $(\mathrm{OM})$ cuplaj cu flanşă

flanged-coupling pulley $(\mathrm{OM})$ şaibă / rondelă cu guler, roată cu umăr (pentru cuplare, pentru menținerea curelei (dințate) etc.)

flanged cross cruce cu flanşe

flanged edge $(\mathrm{OM})$ margine răsfrântă a unei piese sau a unei găuri pentru mărirea rigidității

flanged elbow (OM, hidr) cot cu flanşă

flanged(-face) coupling cuplaj cu lamele, cuplaj (rigid) cu flanşe

flanged inward $(\mathrm{OM})$ cu bordurare interioară, flanşe cu umăr la interior

flanged joint $(\mathrm{OM})$ îmbinare / asamblare cu flanşă

flanged nut $(\mathrm{OM})$ piuliță cu guler

flanged outward $(\mathrm{OM})$ cu bordurare exterioară, flanşat

flanged packing (OM, hidr) etanşare cu manşetă / cu guler

flanged pipe (OM, hidr) țeavă cu flanşă (turnată sau sudată)

flanged plate $(\mathrm{OM})$ placă cu margini răsfrânte, fund rotund de tablă

flanged port (OM, hidr) orificiu prevăzut cu flanşă

flanged ring (OM) inel cu aripi / cu guler

flanged sheet (met, nav, constr) tablă pentru bordurare

flanged-tube radiator $(\mathrm{OM}$, termo) radiator din țevi cu nervuri

flanged tyre (auto) pneu cu talon

flanged Y piece (hidr, termo) pantalon / ramificație / bifurcație de țeavă, cu flanşe (direct din turnare sauprin sudate)

flange iron (met, OM) oțel pentru centură / flanşă

flange jig (mas-un) dispozitiv de ghidare în formă de disc cu guler, folosit la găurire

flange joint / union (OM) îmbinare / asamblare cu flanşă / flanșe

flangeless $(\mathrm{OM})$ fără flanşă

flange member (constr, mec, OM) bară / grindă / element cu flanşă / placă de prindere / şi element tubular cu flanşă / guler de fixare)

flange mounting (OM, hidr) fixare / montare / asamblare cu flanşă

flange nut $(\mathrm{OM})$ piuliță cu guler

flange of the fishplate $(\mathrm{OM})$ braț / umăr al eclisei

flange of the rail (cf, OM) talpă a şinei de cale ferată

flange plate (constr) platbandă a tălpii unei grinzi, placă cu flanșă / flanșe / guler de prindere / de fixare

flange pulley $(\mathrm{OM})$ roată de transmisie, cu borduri laterale (pentru menținerea curelei pe roată)

flange rail (cf) şină cu cap rotund flange sleeve $(\mathrm{OM})$ manşon cu flanşă

flange stress (mec, OM) tensiune în flanşă

flange with ring-packing (OM, hidr) flanşă cu etanşare inelară

flange yoke $(\mathrm{OM})$ furcă a articulației unei transmisii

flanging $(\mathrm{OM}, \mathrm{TH})$ flanşare, formare / ataşare a flanşei

flanging die (mas-un) stanță de bordurat

flanging machine / press (mas-un) maşină / presă de îndoit / de bordurat / de răsfrânt marginile / pentru funduri de cazane / pentru formarea flanşelor prin matrițarea capetelor semifabricatelor tubulare

flanging test (materiale, metr) probă / încercare de bordurare / de răsfrângere

flank coastă; versant; parte (OM) pantă, flanc (şi de filet), latură, aripă de clădire, picior / flanc al dintelui; (mas-un) suprafața adiacentă muchiei tăietoare (a unei scule)

flank on / upon a se învecina cu, a se mărgini $\mathrm{cu}, \mathrm{a}$ flanca

flannel (textile) (bucată de) flanel

flannel disk (mas-un) disc de lustruit acoperit cu flanel

flap (OM) rabatabil, zăvor, clapă (şi de plic), lucru care atârnă de un capăt şi flutură; cârpă de şters; prelungitoare de masă; a se mişca încoace şi încolo, a se bălăbăni

flap attenuator (OM) atenuator cu lamă de material absorbant

flap bottom car (cf, met, transp) vagonet $\mathrm{cu}$ descărcare pe la fund

flap door (met) uşă basculantă

flapper (OM) placă rabatabilă

flapper / cantilever valve (OM, hidr) supapă cu balama, rabatabilă

flapping wing (OM, constr) aripă batantă

flap-shatter (OM, constr) clapetă de aer, obturator oscilant pentru aer / gaze

flap valve (OM, constr) clapetă de reținere

flare (nav) torță de semnalizare; (OM) mufă, manşon, pâlnie; (termo) flacără (inegală), pâlpâit, sclipire; evazare, a arde cu flacără inegală, a lărgi, a evaza, a mandrina; a se umfla, a se dilata, a mări

flare angle $(\mathrm{OM})$ unghi de apertură / de deschidere, deschidere a unghiului cornetului / pâlniei

flareback (termo, met) retur al flăcării, întoarcere a flăcării

flared (OM) larg, evazat

flared / flaring cup wheel (mas-un) piatră-oală conică (de rectificat)

flare discharge (el) descărcare sub formă de flacără 
flared fitting (OM, hidr) guler mandrinat flared radiating guide (fiz) ghid de unde cu evazări radiante

flared tube $(\mathrm{OM})$ pâlnie, tub evazat (cel puțin la un capăt)

flare-fat (alim) osânză

flare joint / fitting (OM) îmbinare evazată

flare line (met, termo) conductă spre flacără

flare / flash point punct de aprindere (şi d. lubrifianți)

flare signal (fiz, opt) semnal luminos

flare spot (fiz, opt) pată luminoasă intensivă (şi la aparate optice, microscoape etc.)

flare-up (met, termo) izbucnire a flăcărilor; semnal luminos; a izbucni, a răbufni

flaring izbucnire a flăcării, care arde viu şi intermitent; pâlpâitor; $(\mathrm{OM})$ țeavă lărgită / cu terminație conică; umflat, bombat, ieşit în afară, evazat

flaring tool (mas-un) dispozitiv de lărgit țevi

flash (fiz) scânteiere, fulgerare, strălucire; a fulgera, a scânteia, a străluci, a licări; promt, imediat; clipă, moment; instantaneu; (auto) avertizor de / cu lumină (şi intermitentă); (met, plast) bavură, (TH) jet, inflamare, sclipire, scânteie, fulger, explozie, strălucire, (nav) a da semnale luminoase, a ieşi la suprafață; (plast) a debavura, a demagnetiza, a izbucni; instantaneu; (fiz) a transmite prin radio; (hidr) jet; a se aprinde

flash annealing (met) recoacere rapidă / superficială

flashback privire retrospectivă, amintire; (termo) retur al flăcării

flash baker (alim, met) cuptor / uscător rapid

flash barrier (el) ecran anti-arc

flash butt welding (met) sudare cap-la-cap, prin topire cu flacără

flash coating (met) metalizare / acoperire prin pulverizare (rapidă)

flash column (ind chim) coloană de evaporare pentru distilarea fracțiunilor uşoare

flash distillation distilare prin vaporizare la echilibru

flashdown (hidr) reducere a presiunii

flash drum (alim, ind chim) cameră / tobă / tambur / cilindru de evaporare

flash drying (agr, alim, ind chim) uscare prin pulverizare / rapidă / pneumatică

flashed glass (ind chim) sticlă alcătuită dintr-un strat transparent şi unul opac

flasher (el) dispozitiv de fulgerare, blitz; (masun) maşină pentru debavurarea bilelor forjate la fabricarea rulmenților; (auto, TH) semnalizator luminos intermitent flash evaporation (fiz) evaporare cu detentă

flash evaporator (alim, ind chim) evaporator cu detentă

flash film concentrator / evaporator (alim, ind chim) evaporator cu peliculă

flash gas (fiz) vapori de laminare, gaz încorporat sub formă de bule în masa lichidului

flash grinder (mas-un, met, plast) maşină de debavurare

flash guard (el) ecran protector contra descărcării disruptive

flash heat (termo, met, OM) încălzire rapidă, căldură degajată brusc / în timp relativ scurt

flashing (el) descărcare în arc, (fiz) sclipire, (termo) vaporizare bruscă; (met) pată de arsură (defect)

flashing gap (OM, met) rost înainte de topire / sudare

flashing headlights (auto) lumini de întâlnire (şi intermitente)

flashing light (auto) avertizor luminos / optic; semnal luminos intermitent

flashing test (materiale, metr) determinarea temperaturii de inflamabilitate

flash into steam (fiz) a (se) evapora, a (se) vaporiza (rapid)

flash over (el) conturnare

flash plating (el, met) electrodepunere foarte subtire

flash(ing) point (matriale) temperatură de aprindere / de inflamabilitate, $(\mathrm{T}$, chim) punct de aprindere (şi pentru lubrifianți, fluide etc.)

flash land (OM, constr) margine de sprijin

flash mould (met) matriță de presare, cu retragere pentru bavură

flash nichel plating (met) nichelare preliminară / superficială

flash off a (se) topi

flash of hammer (OM) muchia ciocanului

flash-out angle unghi de alunecare

flash-overflow mould (mas-un) matriță de presare, cu retragere pentru bavuri

flash / flare point (materiale) temperatură de aprindere

flash removing lathe (mas-un) strung de debavurat

flash roasting (met) ardere a piritei praf

flash set (ind chim) priză / fixare rapidă (şi d. adezivi)

flash-set(ting) cement (constr) ciment cu priză instantanee

flash spotting (fiz, opt, metr) metodă fotometrică

flash temperature $(\mathrm{OM}, \mathrm{T})$ temperatură instantanee (de exemplu, a lubrifiantului în zona activă a lagărului, între dinții în contact etc.) 
flash trimmer (met, mas-un) maşină de debavurat

flash-to-pass (auto) semnalizare cu farurile

flash-to-pass position (auto) poziția de semnalizare cu farurile

flash vaporisation (fiz) evaporare instantanee

flash weld (met) cusătură sudată, prin topire intermediară

flash welding (met) sudare cap-la-cap (prin efectul combinat al arcului electric şi încălzirii prin rezistență) (pentru țevi, piese subțiri)

flashy strălucitor, scânteietor; insipid; (d. bani) fals

flashy flow (hidr) curgere rapidă (pe o perioadă scurtă de timp)

flask (TH) butelie, retortă, flacon, sticlă; (chim) balon; termos; (OM) piston; (met) cutie / ramă de formare

flask annealing (met) recoacere în cutii

flask board (met) placă de aşezare a modelului

flask-bottom board (met) fund al ramei de formare

flask casting (met) turnare în cutii de formare

flask-lift machine (met, mas-un) maşină de format cu ridicare a cutiei / ramei de formare

flask-lift-type moulding machine maşină de format cu ridicarea formei de pe placă

flask-lowering device (in foundry) (met) dispozitiv de coborâre a ramei de formare (la turnătorie)

flask lug (OM, met) ureche a ramei de formare

flask moulding (met) formare în cutii

flask neck (OM) gât al balonului / flancului / sticlei

flask nitrogen (ind chim) azot îmbuteliat

flask section (OM, met) parte a ramei de formare

flask with sand rib (met) ramă de formare, cu nervură de nisip

flat (cf) vagon-platformă; (constr) apartament, etaj; (mas-un) fațetă, teşitură, porțiune plană pe o suprafață curbă; (TH) fațetă; plan, plat, neted, lat; orizontal; fără curbură; (met) bandă îngustă, platbandă, laminat, oțel lat; searbăd, plictisitor, monoton, neinteresant; (ec) care stagnează, fără dobândă; slab; (alim) (farfurie) întinsă, stătut, trezit, răsuflat (d. băuturi); exact, precis; direct categoric, hotărât; (d. culori) uniform, fără relief; neclar (d. o imagine); chiar, tocmai; (geogr) şes, câmpie, tărm jos / coborât; (auto) cauciuc / pneu dezumflat

flat abrasion (T) abraziune pe suprafată plană / pentru obținerea suprafeței plane

flat angle (mat) unghi de $180^{\circ}$

flat anode (el) anod plan flat bar (met) platină; (TH) bară lată, bandă

flat-bar steel (met) platbandă de oțel

flat-base rim (auto) jantă auto cu baza plată

flat-base-type instrument (OM, metr) instrument cu soclu plat

flat bed (met) culcuş / pat plan, vatră plană (şi la cuptoare, pături de răcire etc.)

flat-bed belt sander (mas-un) maşină de netezit cu bandă abrazivă, cu pat plan

flat-bed brush deburrer (mas-un) maşină de debavurat, cu perie cu pat / suport plan

flat-bed sanding machine (met, mas-un) maşină de sablat, cu pat plan

flat-bed trailer (transp, auto) remorca cu şasiu coborât / aplatizat

flat-bed truck (auto, transp) autocamion-platformă cu fund plat

flat belt (OM) bandă plată, curea lată

flat-belt conveyer (OM) transportor cu bandă plană / curea lată

flat billet (met) semifabricat plat (şi din oțel)

flat bit (mas-un) burghiu lat; daltă

flat-bit tongs (met) cleşte plat, de forjă

flat blank (met) semifabricat plat

flat boat (nav) ambarcaţiune cu fundul plat, şlep, mahonă

flat bottom (OM) fund plat

flat bottomed $(\mathrm{OM}) \mathrm{cu}$ fund plat

flat-bottom tappet $(\mathrm{OM})$ tachet cu bază plată

flat-bread (alim) lipie

flat brush (ind, TH) pensulă lată, pentru vopsitorie

flat-built tyre (auto) pneu cu bandă de rulare plată / fără nervuri

flat butt strap $(\mathrm{OM})$ eclisă plată

flat butt weld (OM, met) cusătură prin sudare orizontală cap-la-cap

flat cable (mec, OM) cablu de oțel, plat

flat car (cf, met) vagon-platformă

flat channeling file (mas-un) pilă lată pentru canelat

flat chipper (mas-un) maşină de debitat aşchii, prin tăiere plană

flat chisel daltă lată

flat coat (constr) grund (tencuială)

flat column drill (mas-un) maşină de găurit verticală,cu coloană prismatică

flat conveyer (transp, OM) transportor-bandă cu covor plan

flat countersunk head rivet $(O M)$ nit cu cap înecat

flat countersunk nib bolt $(\mathrm{OM})$ şurub cu cap înecat şi nas

flat countersunk square (neck) bolt (OM) şurub cu cap înecat şi gât pătrat 
flat curve (mat, auto) curbă lină / cu pantă mică / dulce

flat die forging (met) forjare cu suprafețe active plane

flat dip $(\mathrm{OM})$ înclinare mică

flat dipping $(\mathrm{OM})$ cu înclinare mică

flat drill (mas-un) burghiu lat

flat driving belt $(\mathrm{OM})$ curea lată pentru transmisii

flat driving pulley $(\mathrm{OM})$ roată de curea, cu față de antrenare netedă / plată

flat expansion pipes (OM, hidr, termo) (conducte) compensatoare de dilatație, plane

flat face pulley $(\mathrm{OM})$ roată de curea, cu obadă cilindrică / fără bombare

flat file pilă lată cu vârf drept

flat fillet welding (met) sudare prin cusătură în / de colț, cu aşezarea în uluc a pieselor

flat fillister head screw (OM) şurub cu cap cilindric / plat

flat filter (OM, alim, hidr) filtru plan

flat fish (alim, iht) pește cu corpul lat, plătică, limbă, calcan

flat gib key $(\mathrm{OM})$ pană plată, cu nas

flat gradient înclinare mică; gradient mic, palier

flat-grate gas producer (termo) generator de gaze, cu grătar plan

flat grinding machine (mas-un) maşină pentru rectificare plană

flat groove (constr) şanț / jgheab plat

flat guide(way) (OM) ghidaj plat / dreptunghiular (la masa unei maşini-unelte)

flat hammer $(\mathrm{OM})$ ciocan de nituit

flat head extruder (mas-un) extruder cu cap plat de extrudat

flat-hearth (type) mixer (met) amestecător / melanjor cu fund plat

flat hinge $(\mathrm{OM})$ articulație plată; balama

flat hollow (OM) canelură, scafă cu gât; (constr) cornişă concavă

flat idler (OM) rolă dreaptă / netedă / cilindrică

flat iron (met) fier / oțel lat; fier de călcat

flat jack (OM) cric / vinci plat

flat-jawed / -nosed pliers cleşte cu cioc lat

flat joint file pilă cu fețe drepte / cu muchii tăiate

flat keel (nav) chilă orizontală / plată

flat lead float file pilă lată cu vârf ascuțit şi cu dințare specială pentru prelucrarea plumbului

flatlet (constr) apartament mic

flat link chain (OM) lanț Gall / cu eclise plate

flatly lat, întins; categoric, hotărât

flat market $(\mathrm{ec})$ piață inactivă

flatness $(\mathrm{OM}$, constr) planietate, caracter plan, netezime; plictiseală, monotonie; caracter categoric, hotărâre, fermitate flat paint (ind chim) vopsea mată

flat pass (met) calibru plat, trecere pe lat (la laminoare)

flat piston (OM, hidr) piston-disc / cu cap plat

flat pivot-point screw $(\mathrm{OM})$ şurub cu cep şi vârf plat

flat plate keel (nav) chilă plată / orizontală

flat pliers cleşte plat, patent

flat pointed tool (mas-un) cutit lat de finisat

flat point set screw (OM, metr) şurub de reglare, cu vârf plat

flat position welding (met) sudare orizontală cu electrodul deasupra cusăturii

flat price (ec) preț unic / fără oscilații

flat rate (ec) preț global

flat reamer (mas-un) alezor în formă de burghiu plat

flat roll(er) rolă dreaptă / netedă; (met) cilindru neted

flat rolled steel (met) oțel laminat plat

flats (hidr, geogr) zonă / zone cu fund mic; (met) bandă / benzi de oțel, laminate plate; (constr) locuintă cu apartamente

flat sawing (mas-un) debitare plană

flat screen (alim, constr, ind chim) ciur plan; sortizor plan, sită plană

flat-shaped $(\mathrm{OM})$ plat, lat, cu formă plată / lată

flat-shaped ingot (met) lingou plat

flat sheet (met) tablă plană / îndreptată

flat sheet extrusion (met, TH, mas-un) extrudare cu filieră plată

flat slide shut-off valve (hidr, OM) robinet de închidere, cu sertar plat

flat slide valve (hidr, OM) distribuitor cu sertar (alunecător), supapă cu sită plată, alunecătoare

flat spiral spring $(\mathrm{OM})$ arc spiral lamelar (cu secțiune dreptunghiulară)

flat steel (met) oțel laminat, profil lat din oțel, platbandă din oțel

flat surface plan, suprafață plană

flat surface grinding machine (mas-un) maşină de rectificat plan

flatten (alim) a se trezi (d. vinuri, bere); (constr) a îndulci panta; (met) a (se) aplatiza, a (se) nivela, a (se) turti, a lamina, a lăți, a (se) netezi, a îndrepta; a se ruina; a se domoli (d. vânt, curent de aer), a deveni plictisitor / monoton / neinteresant

flattened $(\mathrm{OM})$ aplatizat, echilibrat, compensat, nivelat, aplanat

flattened thread $(\mathrm{OM})$ filet aplatizat; (mec, autom) cu vârf şi fund rectilinii (cu profil trapezoidal, cu înălțime mică)

flattener (met, mas-un) maşină / instalație de îndreptat / de netezit 
flattening (TH) aplatizare (la țevi); (mec) turtire; egalizare; (el) aplatizare a unei caracteristici; (met) îndreptare / netezirea tablei (şi între role)

flattening arrangement (autom, electr) dispozitiv de compensare / de atenuare / (mas-un) dispozitiv de planare / îndreptare

flattening hammer ciocan de aplatizare

flattening mill (met) laminor de îndreptare / de netezire / netezitor

flattening pressure $(\mathrm{mec})$ presiune de turtire / de degroşare / de aplatizare

flattening test (materiale, metr) încercare la turtire

flatten out a îndrepta, a aplatiza, a netezi, a turti

flat thread (OM) filet dreptunghiular / pătrat

flat-threaded screw $(\mathrm{OM})$ şurub cu filet pătrat

flatting agent (chim, opt) opacizant, agent de matisare (industria sticlei şi a ceramicii, a materialelor plastice)

flatting mill (met) laminor cu aplatizare / de îndreptare; (textile) maşină de călcat (cu role / cu cilindri)

flat-top alignment guide (OM) ghidaj de aliniere cu cap plat (la articulațiile cu bilă, pentru transmiterea mişcării)

flat trajectory (mec) traiectorie dreaptă / razantă

flat tuning (el, autom, metr) acord brut / grosier, reglaree grosolană / brută

flat turret lathe (mas-un) strung-revolver cu cap revolver plat

flat twin engine (termo) motor cu doi cilindri opuşi (orizontali)

flat-type soldering tab $(\mathrm{OM})$ ochi / pastilă plată lipită / pentru lipire

flat-tyre, flat tyre (auto) pneu dezumflat

flat-tyre insert (auto, plast) inserție din fibre de elastomer termoplastic, care permite rularea în continuare a unui automobil cu pneuri dezumflate

flat varnish (ind chim) lac mat

flatware (alim) tacâm (furculiță, cuțit şi lingură), farfurii întinse

flatways $(a d v)$ de-a latul

flat welding (met) sudare în poziție orizontală

flat wire (met) sârmă plată (şi pentru recondiţionări prin sudare)

flat-wire pincers cleşte pentru sârmă plată

flat-wire sheeting $(\mathrm{OM})$ armătură de sârmă plată

flat wood file pilă lată cu vârf ascuțit pentru prelucrarea lemnului

flavour (alim) aromă; buchet al vinului; gust (plăcut), miros, parfum; condiment, mirodenie; a aromatiza (cu condimente), a drege; (fig) aer, atmosferă

flavoured (alim) condimentat, picant, dres, aromat, având un gust particular flavouring (alim) care are gust / buchet plăcut, care este condimentat / aromat

flavourless (alim) fără gust, lipsit de gust; fără miros; necondimentat; searbăd, neinteresant

flaw (met) defect de turnare, suflură, fisură; (TH) crăpătură, știrbire, defect, ruptură, pată, defectare, deteriorare, imperfecțiune, viciu, discontinuitate (într-un material); rafală (de vânt, ploaie)

flaw detection (fiz, metr, TH) defectoscopie, detectarea defectelor

flaw detector (fiz, metr, TH) defectoscop; detector de defecte

flawed (fiz, mec) friabil, fragil, casant; (TH) rupt, defectuos, greşit, imperfect

flaw in casting (met) defect de turnare

flawless (ing, TH) perfect, fără eroare / fisură, ireproșabil

flawlessly $(a d v)$ (în mod) perfect, fără eroare, ireproşabil

flawy defect, cu defecte

flax (textile) in; țesături / pânză de in

flax fiber (textile) fibră de in

flax oil (agr, ind chim) ulei de in

flax seed (agr, ind chim) sămânță de in

flax tow (textile) câlți de in

flaxy ca de in

flax yarns (textile) fire de in

flay a jupui (de pile); a critica sever

flea (zool) purice

flea bag (amer) hotel prost și ieftin; animal murdar

fleck pată (şi de culoare); (med) eczemă; părticică, particulă; a puncta, a acoperi cu picățele, a presăra

fleck scale (met) pete de arsură / de oxizi

flee a se refugia (la); (fig) a pieri; a dispărea; a părăsi; from / before a fugi, a scăpa cu fuga (de / din fața); to (fig) a fugi (la)

fleece lână; (textile) văl (la cardă); ninsoare abundentă; a acoperi, a înveli

fleecy lânos, mițos, flocos, ca de lână

fleet (auto) parc de mașini sau tractoare; (nav) flotilă, flotă, escadră, convoi remorcat, golf mic; $(a d v)$ la mică adâncime

fleeting care trece repede

fleet wheel $(\mathrm{OM})$ roată de cablu

flesh (alim) carne (crudă), miez / pulpă de fruct, a îngrăşa, a pune la îngrăşat

flesh-coloured de culoarea cărnii, roșu deschis

flesh fly (alim, zool) muscă de carne / albastră

fleshiness caracter cărnos, carne

fleshing (alim) şeruire, fălțuire pe carne / manuală, cărnosire, descărnare, ştrecuire

fleshing knife (alim) cuțit de descărnat

fleshing machine (alim) mașină de descărnat

fleshings, flesh side (alim, ind chim) carne pentru clei 
fleshless fără carne, slab, descărnat (d. animale) flesh worm (alim, zool, med) trichină

fleshy (alim) de carne, cărnos; gras

flex (mat) inflexiune; (mec) a curba, a încovoia; (el) liță

flexibility elasticitate; flexibilitate; adaptabilitate; (mec) rezistență la flambaj

flexibiliser (ind chim, plast) flexibilizant, plastifiant intern

flexibility tester (metr, mec) aparat de încercare la flexibilitate

flexible (el) cordon de alimentare, elastic, ductil, maleabil, pliabil; (mec) flexibil; (OM, TH) adaptabil, îngăduitor

flexible air line (OM, hidr) furtun pneumatic

flexibly $(a d v)$ (în mod) flexibil, elastic

flexible automotive body (auto, ind chim) caroserie de automobil, flexibilă, din elastomer termoplastic

flexible axle $(\mathrm{OM})$ osie autocentrantă flexibilă

flexible bend $(\mathrm{OM})$ arc flexibil, articulație / legătură flexibilă

flexible cord (el, OM) cordon electric flexibil

flexible coupling $(\mathrm{OM})$ cuplare flexibilă

flexible disk (inf, autom) disc magnetic suplu

flexible drive axle $(\mathrm{OM})$ osie oscilantă

flexible fastening (cf, OM, el) suspensie elastică a firului de cale în tractiunea electrică

flexible gangway-bellows (constr) burduf de intercomunicatie

flexible gear(ing) $(\mathrm{OM})$ transmisie elastică, prin curea

flexible hose (OM, hidr) conductă flexibilă, furtun

flexible joint (mas, OM) cuplaj flexibil, îmbinare mobilă / flexibilă

flexible pipe (OM, hidr) furtun / tub flexibil

flexible plate (met, OM) tablă / placă flexibilă

flexible plunger moulding (mas-un) formare $\mathrm{cu}$ poanson elastic

flexible ring $(\mathrm{OM})$ inel flexibil, garnitură de etanşare a unui arbore (mai rar fără contact)

flexible rubber lining (OM, ind chim) căptușeală flexibilă / adaptabilă, de cauciuc

flexible sheeting (OM, ind chim) placă / acoperire flexibilă

flexible (steel) rule (metr) riglă gradată flexibilă (din oțel)

flexible tube (OM, hidr) tub flexibil, furtun

flexible tubing (nav, termo, OM) tubulatură flexibilă

flexible wire (met, el) cablu flexibil, sârmă pentru cablu de otel

flexible working hours (ec) normă flexibilă; program de muncă flexibil flexing armouring $(\mathrm{OM}, \mathrm{el})$ armatură flexibilă a cablului

flexing asbestos (ind chim) azbest flexibil

flexing die $(\mathrm{TH})$ şablon de curbat lemnul

flexing machine (materiale, metr) maşină pentru determinarea rezistentei la încovoiere

flexing test (materiale, metr) probă / test de îndoire

flexing / reed valve $(\mathrm{OM}$, hidr, termo) supapă flexibilă cu lamele, supapă de compresor, formată dintr-o placă cu fante, acoperită de lamele metalice flexibile; ventil cu lamelă elastică

flexion (mec) încovoiere, îndoire, îndoitură, curbare, flexiune; (mat) curbură, derivata a doua

flexivity (OM, termo, metr) variația temperaturii necesară deformării unui element bimetalic / cu geometrie şi materiale date)

flex life (materiale, $\mathrm{TH}$ ) durabilitate la flexiune (exprimată şi prin număr de îndoiri)

flex / inflexion(al) point (mat) punct de inflexiune

flexural fatigue strength $(\mathrm{mec}, \mathrm{OM})$ rezistență la oboseală prin încovoiere

flexural gliding $(\mathrm{OM})$ alunecare (a arborelui din reazem) la încovoiere / din cauza încovoierii

flexural-impact fatigue test (materiale, mec, metr) încercare la oboseală prin încovoiere cu şoc

flexural rigidity rigiditate la flexiune / la încovoiere

flexural strength (materiale, mec, metr) rezistentă la îndoire / la flexiune / la încovoiere

flexural stress (mec) sarcină / tensiune / efort de încovoiere

flexural tensile stress (mec, OM) tensiune de întindere (rezultată) din încovoiere

flexural torque (mec, OM) moment încovoietor

flexural vibration (mec, OM) oscilație de încovoiere

flexure cută, încovoiere, îndoire; (mec, OM) rezistență la încovoiere, încovoiere, îndoitură, flexiune, săgeată (de încovoiere), curbură

flexure produced by axial compression (mec) flambaj

flexure radius (mec, $\mathrm{OM}$ ) rază de încovoiere

flexure test (materiale, mec, metr) încercare la încovoiere / la îndoire

flicker (el) scânteiere, tremurare, scintilație

flier / flyer zburător; (OM) volant; dispozitiv de eliminare a colilor (în poligrafie şi birotică)

fliers (constr) scară suspendată

flight zbor; stol (de păsări); (agr) pleavă, mai ales de ovăz; (constr, hidr) ecluză în trepte, şir de trepte, rampă de scară, etaj; (TH) etalon, şir, deschidere, linie; fugă, refugiu, adăpost

flight-attachment chain (OM, mas, transp) lanț de remorcat 
flight capital (ec) capital transferat în străinătate flight-control surface used for trimming (autom, mas-un, mas) dispozitiv de compensare a devierii față de axa longitudinală

flight conveyer $(\mathrm{OM})$ transportor cu raclete

flighted cu pene (d. păsări)

flight lead $(\mathrm{OM})$ şină portlanț a unei transmisii mecanice

flight on conveyer chain $(\mathrm{OM})$ racletă / răzuitor (de / pe transportor cu lanț)

flighty schimbător, nestatornic, capricios; pe care nu te poți bizui

flimsy fragil, slab, subțire; neîntemeiat, nefondat, nejustificat; de calitate inferioară; foiță, hârtie subțire; (ec) bani de hârtie, bancnote; telegramă

fling a (se) aruna, a (se) azvârli (cu violență), a trânti; a lăsa deoparte; a se repezi, a se năpusti; mișcare violentă, smucitură; remarcă tăioasă

fling away a arunca la o parte, a azvârli în afară

flint (minrl) cremene, silex, sticlă flint; hârtie abrazivă

flint paper hârtie abrazivă

flint tube mill (constr) moară cu corpuri de măcinat din cremene

flinty (geol) silicios

flipover cartridge (el, autom) doză de redare cu două poziții

flipper (auto) bandaj de jantă auto; (zool) aripă, înotătoare; papuc / labă de scufundător

flitch (alim) pulpă de porc, sărată şi afumată, jambon

flitting (mec) ripare, mutare prin translație

flivver (auto, ec) automobil ieftin; lucru mic, neînsemnat, ieftin

float (hidr) plutitor, flotor, flotant; (nav) plută, bac, pod plutitor, centură de salvare, flotă, geamandură, baliză, a pluti, a se menține la suprafața apei, a menține în stare de plutire, a face să plutească, a scoate de pe uscat; (OM, hidr) dop, a flota, a fi în echilibru; a inunda, a îneca; (ec) a emite, a pune în circulație; (alim, iht) băşică (de peşte)

floatability (nav, TH) flotabilitate

floatable (hidr) flotabil; (nav) navigabil sub formă de plută, plutitor

floatage flotabilitate, capacitate de a pluti, plutire, plutit; (nav) epave maritime, varec

float-and-sink process $(\mathrm{TH})$ procedeul plutirecufundare la prepararea minereului

floatation, flotation (hidr) flotabilitate, capacitate de a pluti, plutire, plutit; (ec) fondarea unei întreprinderi; (met) flotație

float a strandel ship (nav) a scoate de pe uscat o navă, a dezeşua float ball (OM, hidr) flotor-glob / sferic

float boat (nav) bac

float bowl (OM, hidr) plutitor

float bridge (nav) bac; pod plutitor

float carburat(t)or (auto, hidr) carburator $\mathrm{cu}$ plutitor, cu nivel constant

float chamber (hidr, OM) cameră a flotorului cu nivel constant

float chamber valve (OM, hidr) supapă din camera plutitorului

float coil (alim, termo, ind chim) evaporator $\mathrm{cu}$ flotor

float collar / coupling (OM, hidr) mufă cu supapă / valvă de cuplare

floated (hidr, nav) lansat la apă, tractat în stare de plutire; flotant

floater (ec) muncitor sezonier; (nav, mil) pod plutitor; care pluteşte

floaters (tank) furnace (met, ind chim) nacele la cuptorul-vană

float gage (hidr, metr) manometru de gaze cu plutitor pentru indicarea nivelului, dispozitiv de redare a poziției flotorului

floating (hidr, metr) plutitor, care pluteşte; flotant; plutire, plutit; (TH) regim tampon, încărcare sub curent constant; (procesul de) flotație; neomogenitate a culorilor

floating address (inf) adresă flotantă

floating anchor (nav) ancoră de furtună

floating / circulating assets (ec) capital circulant, fond de rulment

floating axle (OM) arbore planetar, complet flotant

floating bearing $(\mathrm{OM})$ cuzinet flotant, lagăr liber (şi cu rulmenți)

floating belt $(\mathrm{OM})$ curea de transmisie, cu oscilatie / deplasare laterală

floating body (nav) corp plutitor în derivă

floating bridge (nav, mil) pod de pontoane / plutitor

floating capital (ec) capital circulant

floating debris $(\mathrm{TH})$ corpuri plutitoare, flotanți (în industria extractivă)

floating debt (ec) datorie pe termen scurt

floating decimal point (inf, c) virgulă mobilă, în calcule zecimale

floating die (mas-un) matriță flotantă / amovibilă / deplasabilă

floating dock (nav) doc plutitor

floating dock pontoon (nav) ponton plutitor pentru doc

floating elevator (nav, transp) elevator plutitor

floating knife (mas-un) racletă pneumatică

floating light (nav) far plutitor, geamandură luminoasă 
floatingly $(a d v)$ plutind, în stare de plutire; (în mod) schimbător

floating pan (fiz, metr) evaporimetru plutitor

floating pile (constr) pilon flotant

floating plate (OM, mas-un) placă mobilă

floating point (inf, c) virgulă mobilă

floating-point radix (inf) bază în virgulă mobilă

float position (hidr) poziție flotantă, poziţie a unui distribuitor când toate orificiile sunt legate la retur

floating power engine mounting (mas) (montare / montaj / maşină cu) motorul cu putere fluctuantă

floating punch (mas-un) poanson oscilant

floating ram (nav) sonetă plutitoare

floating reamer (mas-un) alezor pendular

floating roof tank (OM, hidr) rezervor cu capac plutitor

float-level controller (autom, hidr) regulator automat de nivel, cu plutitor

float packing $(\mathrm{OM})$ presgarnitură mobilă

float run (OM, hidr) cursa / funcționarea / deplasarea flotorului

float sand (geol) nisip plutitor

float soap (ind chim) săpun plutitor, cu densitatea mai mică decât cea a apei

float steam trap (termo, hidr) oală de condensat cu plutitor

float switch $(\mathrm{OM}$, hidr) întrerupător cu flotor

float-(type) controller / regulator (autom, OM, hidr) regulator cu flotor

float-type gauge (OM, hidr) nivelmetru cu flotor

float undercarriage (OM, hidr) dispozitiv de plutire

float valve (OM, hidr) valvă de plutire; supapă cu plutitor

float valve needle (OM, hidr) ac al plutitorului

float vibrator (mas, mas-un, met) pervibrator flotant

float viscometer (metr, hidr, T) vâscozimetru cu flotor

float water-level (metr, OM, hidr) indicator cu flotor

flocculant (ind chim) floculant; agent de floculare

flocculate (ind chim) a flocula

flocculating agent (ind chim) agent floculant

flocculation floculare, coagulare

flocculent floconos, pufos, coagulat

flocculent structure (materiale, alim) structură floculară / în fulgi

flock fulg, smoc; (textile) ghemotoc

flock accelerator (alim, ind chim) accelerator de coagulare

flock point (termo) punct de floculare, temperatură de congelare flocks (alim, materiale) fulgi (şi d. polimeri, ca semifabricate de injectat)

flocky (hidr) floconos, pufos, coagulat

flood torent, şuvoi, inundație, viitură; a îneca, a (se) revărsa, a face să se reverse, a se umfla; potop; inundație; revărsare (a unei ape); torent; şuvoi; râu, fluviu mare; a inunda; a potopi; (fig) a copleşi, a năpădi; (agr) a iriga; a face să se reverse; (d. ape) a se umfla, a ieși din albie, a veni în torente, în şuvoaie

floodability (hidr) receptivitate față de apă, posibilitate de a fi inundat, caracter inundabil

floodability index (fiz, geol) indice de receptivitate față de apă

floodable (geogr) inundabil

flood basin (constr) bazin de umplere

flood conditions (geogr, constr) condiții de inundare

flood control (geogr, constr, TH) regularizarea viiturilor

flood coolant (ind chim) lichid de răcire prin injecție

flooded area (geogr) regiune / zonă inundabilă

flooded lubrication $(\mathrm{T})$ ungere prin cufundare în baie de ulei

flooded with lubricant $(\mathrm{T})$ lubrifiat din abundență

flood gate (nav) ecluză (navigabilă)

flooding (hidr, geogr) deversare, inundare, inundatie, înecare

flooding agent (ind chim) agent de spălare

flooding of the engine (auto, termo) înecarea motorului

floodings (nav, hidr) maree, flux

flooding water (hidr, geogr, ind chim) apă de injecție (şi la sonde de petrol)

flood lubrication ( $T$ ) ungere în baie de ulei

flood overflow (hidr) revărsare

flood plain (geogr) câmpie / luncă inundabilă

flood tide (nav, geogr) flux, maree înaltă

flood-type hydrocooling (alim) răcire prin imersiune în apă cu gheață

floor (constr) cat, etaj, podea, duşumea, planşeu, platformă, nivel, dalaj, a podi, a pardosi; pavaj de plăci (d. un drum); (met) culcuş, vatră; (nav) varangă, fund interior la navele cu fund dublu, fund (de mare); (auto) a apăsa accelerația la maxim

floorage (constr) suprafața pardoselii / duşumelii

floor beam (constr) grindă de planşeu

floor board (constr) dulap, scândură pentru duşumea

floor celling (nav) paiol

floor cloth (constr, ind chim) linoleum

floor cement (constr, ind chim) chit de pardoseală 
floor contact (constr, mas) contact de picior / de podea

floor covering (constr) podea

floor-defrost position (auto) poziția (spre) podea şi de dejivrare (la direcționarea aerului condiționat)

floor frame $(\mathrm{OM})$ postament / talpă de lagăr

flooring (constr) podea, duşumea, acțiunea / procesul de formare a podelei / duşumelei, platelaj, podină; (cf) platelaj pe pod

floor level (constr, geogr) nivelul / cota solului

floor load (constr, mec) sarcină pe planşeu

floor mould (met) formă executată în solul turnătoriei

floor moulding (met) formare în solul turnătoriei

floor of dry dock (nav) fund de doc uscat

floor-plate (constr) platelaj; (nav) tablă / tolă / inimă de varangă, varangă de tablă

floor-plate tool (mas-un) maşină-unealtă / dispozitiv / deplasabil(ă) (pentru prelucrarea pieselor grele)

floor(-plate) work (TH, met) prelucrare a pieselor grele, aşezate pe plăci de fontă

floor position (auto) poziția (spre) podea (şi la direcționarea aerului condiționat)

floor projection proiecție orizontală / în plan orizontal (în desen tehnic)

floor space (constr) suprafață a solului / a terenului / a pardoselii; (mas-un) suprafață necesară pentru o maşină-unealtă

floor stand $(\mathrm{OM})$ postament / talpă de lagăr

floor-to-floor time (TH) timp total de prelucrare, timp pentru aşezarea unei piese pe o maşină-unealtă; durată totală de echilibrare

floor-type horizontal boring machine (mas-un) maşină orizontală de alezat, cu masa aproape de nivelul duşumelei / podelei

flop lovitură surdă, bufnitură; plescăit; insucces; a cădea / trânti cu zgomot; a se bălăbăni; a avea o ținută neglijentă; a se trânti greoi; a plescăi; a lipăi; a bufni; (fam) a nu avea succes (d. o carte, o piesă etc.); zgomot (surd); (adv) cu zgomot, fâlfâind, plescăind

flop-in method (autom, TH) metodă de creştere flop-out method (autom) metodă de diminuare

flopper (met, plast) ondulație, val, vălurire (defect la laminare)

flopple nozzle (termo, OM) jiclor cu paletă

floppy lăsat în jos, moale, flasc; neglijent

floppy disk (c) disc magnetic subțire şi flexibil (pentru memorii); dischetă

floppy drive (autom, c) comandă prin dischetă

Florentium (Pm) (chim) promețiu

flospinning ( $\mathrm{TH}$, mas-un) procedeu de formare (cilindrică, conică etc.) prin presarea tablei pe un dorn profilat, care se roteşte floss (met) zgură de pudlaj; (textile) puf, mătase brută; (agr) mătasea porumbului; (geogr) râu

floss hole (met) orificiu de evacuare a zgurii

flossy pufos, ca puful, mătăsos, moale

flot (nav) punte parțială; şalandă

flotation (fiz, TH) flotație (în industria extractivă)

flotation gauge for water level $(\mathrm{OM}$, hidr, metr) flotor indicator al nivelului apei

flotation gear (OM, hidr, metr) (mecanism-) flotor

flotation oil (ind chim) ulei de flotație (în industria extractivă)

flotation plant / machine (TH) instalație / maşină de flotație

flotation pulp (TH, mediu) deșeu de flotație

flotation tailing(s) (TH, mediu) steril / deşeuri de flotație

flour (alim) faină; (constr, hidr) pulbere (făină) de piatră; a măcina

flour detaching machine (alim) detaşor

flour(ing) mill (alim) moară de măcinat grâu

flourish a agita; a expune, a etala; a creşte abudent (d. vegetaţie)

flourishing înfloritor, prosper; sănătos

floor lime (constr, ind chim) var măcinat

floury (alim) făinos, plin de făină

flout dispreț; a respinge, a nu ține cont de; a fi disprețuitor; neglijare, neluare în seamă

flow (TH, hidr) debit, flux, curgere, curent; cută, încrețitură, fald (d. textile, folii, table etc.); (geogr) curs (a unui râu etc.), curgere, (re)vărsare; (hidr) debit (de lichid), erupție, (s)curgere, curent; (nav) flux, a se ridica (d flux); abundență, belşug; caracter fluent, fluență (a exprimării); (plast) fluiditate; (c, inf) ordinea evenimentelor într-o soluțieprogram; (ec) (flux de) productie, a pleca (d. valută), randament; a curge, a se scurge; a inunda; a se umfla; a decurge din; $\sim$ from a rezulta

flowability (alim, met, plast) fluiditate (şi la turnare, filtrare)

flowability index (ind chim, alim) indicele de flotabilitate

flow amplification (hidr) amplificare de debit

flow amplifier (hidr, OM) amplificator de debit

flow area (OM, hidr) secțiune de trecere / de pasaj; secțiune transversală a curentului

flow behaviour (plast) comportare la curgere, proprietăți reologice

flow box (OM, hidr, ind chim) cutie de alimentare flow brazing (met, $\mathrm{TH}$ ) asamblare prin turnarea materialului topit de lipire, peste zona de asamblare

flow by gravity (met, ind chim) curgere liberă

flow chart / diagram schemă bloc / mnemonică; organigramă; (inf) schemă logică de program; (TH) schemă a procesului tehnologic

flow choke (OM, hidr) duză fixă 
flow-combining valve (hidr, autom, OM) sumator de debit, aparat de reglare a debitului, cu compensare a presiunii, care reglează două debite de intrare, astfel încât debitul de ieşire să fie constant

flow constriction (mec) strângere, fixare (întrun proces de asamblare / montaj), care curge

flow-control device $(\mathrm{OM}$, hidr) robinet cu pană, vană pentru cap de erupție

flow controller / governor (OM, hidr) regulator de debit

flow-control valve (OM, hidr) supapă de reglare a debitului

flow criteria (materiale, hidr, mec) criteriu / criterii de curgere

flow down a se prăbuși, a curge în jos

flow dynamics (fiz, hidr) hidrodinamică, dinamica lichidelor şi a gazelor

flow function (materiale, mec) functia de curgere (a unui fluid, pentru o curgere plastică etc.)

flower-gardening / -growing (agr) floricultură; horticultură

flowers of zinc (chim) oxid de zinc

flow from a izvorî din

flow function (hidr) funcție de curent

flow gauge (metr, hidr) debitmetru

flow gate (met, plast) răsuflătoare (la forme de turnare şi matrițe)

flow harden (met, plast, ind chim) ecruisare / durificare / a întărire prin curgerea / laminarea materialului

flow hardening (met) ecruisare prin curgere a materialului / prin laminare

flow heater (termo) boiler în flux continuu; aparat de încălzit instantaneu apa

flow in a curge înăuntru

flow index lin, curgător, care curge; (hidr, met) indice de debit / de curgere

flow indicator (metr, hidr) indicator de debit

flowing (hidr) (s)curgere, erupție; care curge

flowing chip lathe (mas-un) strung de mare productivitate (cu aşchie continuă)

flowing furnace (met) cuptor cu cuvă

flowing power (met) turnabilitate, capacitate / aptitudine de turnare

flow into a se vărsa în (d. fluide)

flow limit $(\mathrm{mec})$ limită de curgere (d. materiale solide)

flow line (autom) linie de legătură între simboluri pe o diagramă de flux; (hidr) conductă de refulare, traiectorie a curentului de fluid; (met, plast) linie de curgere (a materialului, la deformare)

flow-line pressure (hidr) presiune a conductei de evacuare flow lines (materiale) orientare a fibrelor; (hidr) linii de curent

flow(-)meter (hidr, alim, ind chim, metr) reometru, instrument de măsurat caracteristicile de curgere, debitmetru

flow mixer (alim, ind chim) amestecător cu trecere continuă a materialului

flow nozzle (OM, hidr) ajutaj, orificiu îngustat de trecere a fluidului

flow of current (hidr, termo) circulație a curentului

flow of gas (hidr, termo) curent de gaze

flow of metal (met) curgere a metalului / a aliajului (nu se specifică dacaă este în stare solidă sau topită)

flow out (hidr) a se scurge, a se revărsa, a curge în afară

flow over (hidr) a inunda, a se scurge peste un obiect, a se revărsa peste, a inunda

flow path (hidr) traiectorie a curentului de fluid

flow pipe $(\mathrm{OM}$, hidr) țeavă de refulare, conductă de presiune

flow point (plast, $T$ ) punct de curgere (şi la unsori)

flow production $(\mathrm{TH})$ producție pe bandă

flow properties (ind chim, plast) proprietăți reologice / de curgere; (constr, mec) proprietăți de fluaj / de curgere

flow proportioner (alim, hidr, ind chim) dozator de substanțe fluide (chiar în amestec) care poate acționa pe durata curgerii

flow rate (metr, hidr) debit; viteză de curgere (pentru materiale solide şi pentru fluide)

flow-rate range (hidr, mec) interval pentru viteze / debite de curgere (pentru materiale solide şi pentru fluide)

flow recorder (metr, hidr) debitmetru (cu) înregistrator

flow regulation (hidr) reglare a debitului

flow resistance (hidr, mec) rezistență la curgere

flow sheet (hidr) diagramă de curgere; (ind chim) schemă tehnologică / de fabricație; (TH) flux tehnologic

flow shop $(\mathrm{TH})$ atelier cu linii de fabricație în flux

flow soldering (met) lipire în curent de fluid (pentru componente electronice, pentru evitarea supraîncălzirii)

flow strain (mec) deformație de fluaj / la curgere (d. materiale solide)

flow stress tensiune de deformație plastică

flow surface (hidr, mec) suprafața de curgere

flow surge (hidr) variații temporare ale debitului / curgerii

flow temperature (materiale, TH) temperatură de fluiditate / fluidizare / curgere 
flow test (hidr, metr, mec) probă de curgere, determinarea curgerii, test de curgere, determinare a punctului de curgere (d. materiale solide)

flow through (hidr) a străbate curgând, a curge prin ceva

flow through porous medium (hidr) curegere prin mediu poros

flow transmitter (metr, hidr, autom) dispozitiv de măsurare şi transmitere a informațiilor asupra debitului sau a altor caracteristici ale curgerii

flow with a abunda în / de

fluctuant, fluctuating (el, hidr) fluctuant, schimbător, valabil, care fluctuează

fluctuate a fluctua, a varia, a se schimba (d. un parametru al unui proces); a şovăi, a ezita; a fluctua, a pâlpâi

fluctuating load (mec, el) sarcină variabilă (în mod neuniform)

fluctuation (fiz) fluctuație, instabilitate; (mat) variație aleatoare, oscilație

flue (constr) coș industrial, coș / canal de fum, țeavă de fum (la boiler), fum, şemineu; (met) tiraj al cuptorului; (termo) canal de fum, aductie de aer

flue and smoke-tube boiler (termo) cazan combinat cu tevi de foc şi de fum

flue ash (met, termo) cenuşă zburătoare

flue boiler (termo) cazan ignitubular, cu țevi de fum

flue draft (met, termo) tiraj al coşului

flue dust (termo, chim) particule solide rezultate în urma arderii

flue-dust catcher separator de cenuşă

flue gas / gases (met, termo) gaze de ardere / de evacuare / arse, produse gazoase de ardere

flue-gas analysing apparatus / analyser (metr, chim) analizor pentru gaze arse

flue-gas exhaustor (met, ind chim) exhaustor (de fum)

flue-gas register (met, termo) registru de tiraj

flue-gas utilization (met, termo) recuperare a căldurii gazelor de ardere

flue-gas valve (met, ind chim) registru / şuber pentru evacuarea gazelor

flue losses (met, ind chim) pierderi prin gaze de ardere

fluency fluență, uşurință

fluent mărime variabilă, funcție; fluent, curgător

flue of boiler, flue tube (termo) țeavă de ardere / de fum

flueric (autom, el) adjectiv pentru dispozitive / senzori de control, amplificare, fără elemente mecanice în mișcare

fluff puf; a scămoşa (şi un polimer)

fluffing (mas-un) zimțuire, şlefuire fluffy pufos, acoperit de puf

fluid fluid, lichid (substantiv şi adjectiv)

fluid accumulator (hidr) acumulator de lichid sau de gaze / pneumatic

fluid bath (ind chim, met) baie lichidă

fluid bearing (OM, T) lagăr cu fluid sub presiune / lagăr lubrifiant (cu lichid)

fluid-bed drying (alim, ind chim) uscare în pat fluidizat

fluid binder (constr, ind chim) liant lichid

fluid body (fiz) corp fluid

fluid brake (OM) frână hidraulică

fluid clutch (OM, hidr) ambreiaj hidraulic

fluid coupling (OM, hidr) cuplaj hidraulic

fluid dies (mas-un) ştanță hidraulică

fluid drive $(\mathrm{OM})$ transmisie hidraulică

fluid filled shell (OM, hidr) rezervor cu forme de revoluție, umplut cu lichid

fluid film (T) peliculă fluidă

fluid film friction $(T)$ frecare în peliculă fluidă, frecare fluidă / cu film de fluid

fluid flow (fiz, hidr) curgerea fluidelor

fluid flywheel (OM, hidr) cuplaj hidraulic

fluid flywheel clutch ambreiaj hidrodinamic, volant hidraulic

fluid fracturing (mec) fisurare hidraulică / din cauza unui fluid

fluid friction $(T, h i d r)$ frecare fluidă / cu peliculă intermediară de fluid

fluid friction damping (mec, $\mathrm{T}$ ) amortizare prin / cu lichid vâscos / datorată frecării (interne) în fluid

fluid head (hidr) presiune hidraulică

fluidic (adj) fluid, lichid

fluidics (fiz, hidr) domeniu care se ocupă cu dispozitive de control, amplificare, sesizare, care nu au în principal elemente mecanice, ci fluide

fluidity (fiz, hidr) fluiditate, mobilitate, curgere

fluidisation (met) fluidizare

fluidisation state (met, plast) fluidizare, stare fluidă

fluidised-bed (met) (cu) strat / pat fluidizat

fluidised-bed dryer (alim, ind chim) uscător cu strat fluidizat

fluidised-bed furnace (met) cuptor cu strat / pat fluidizat

fluidized-bed mixing (met, ind chim) amestecare în strat fluidizat

fluidised-bed sizing (ind chim) sortare / clasificare în strat fluidizat

fluidised flow (ind chim) curgere fluidizată / în strat fluidizat

fluidiser (chim) (agent) fluidificator; (met) fondant, flux 
fluid loss (hidr, mediu) pierdere de circulație, filtrare de noroi, influx al fluidelor de foraj

fluid lubrication $(T)$ ungere hidrodinamică / cu peliculă de fluid

fluidmeter (hidr, metr) vâscozimetru (mai rar) dar şi debitmetru (atenție la sensul frazei)

fluid method of welding (met) sudare prin topire

fluid ounce (metr) unitate de măsură pentru volum, uncie lichidă: 1 fluid ounce $(\mathrm{UK})=$ $0,000028413 \mathrm{~m}^{3}=0,028413 \mathrm{l} ; 1$ fluid ounce (US) $=0,000029574 \mathrm{~m}^{3}$

fluid pad $(\mathrm{OM})$ patină fluidă, element de susţinere pe pernă de aer

fluid pipe (OM, hidr) conductă de lichid

fluid pressure presiune a lichidului / fluidului

fluid reservoir (auto, OM) rezervor de fluid (şi la sistemul de spălare a parbrizului)

fluid slag (met) zgură fluidă

fluid stiffness (hidr) acțiunea de rezistență a fluidului sub presiune la schimbarea volumului sau la sarcinii exterioare, rezistență hidraulică

fluid tight (OM, materiale) impenetrabil la fluid / la gaz

fluid-type equilibrator (OM, hidr) compensator hidraulic

fluid welding (met) sudare prin topire

fluke (nav) palmă / vârf de ancoră

flume jgheab, canal; uluc (d. transportul lemnului)

flunk (amer) cădere, prăbuşire

flourating agent (chim) agent de florurare (în industria extractivă)

fluorescence (fiz) fluorescență

fluorescent (fiz) fluorescent

fluorescent lamp (el) lampă cu fluorescență, tub luminos

fluoridation (chim) fluorurare

fluoride (chim) fluorură

Fluorine (F) (chim) fluor

fluorine spar (met) fluorină

flurocarbons (plast) fluorocarburi

fluoroplastics (plast) mase plastice $\mathrm{cu}$ fluor. polimeri fluorurați

fluoropolymer grease (ind chim, T) unsoare consistentă cu adaos de polimeri fluorurați

fluorosilicon sealant (OM, plast) material de etanşare, pe bază de polimeri fluoro-siliconici

flurry rafală (de vânt); agitație; (ec) schimbare bruscă a prețurilor (la bursă); a tulbura, a agita

flush a se înroşi; a țâşni, a se revărsa; a spăla în jet de apă; (hidr) evacuare a apei din tanc / bazin, jet de apă; (TH) spălare; încastrat, înecat, îngropat; (met) curățat până la metalul de bază; plat, plan, neted, fără proeminențe

flush again a spăla / a stropi din nou, a clăti (cu un curent / jet de apă) flush bolt of door (OM) zăvor de uşă

flush bushing $(\mathrm{OM})$ bucşă simplă

flush deck (nav) punte rasă / netedă / liberă

flush finish (met) netezirea / curățarea / îndepărtarea îngroşării cusăturii de sudură

flush head (OM, hidr) cap înecat / imersat

flushing (hidr, termo, T) îndepărtare / curățare a depozitelor / particulelor de uzură, a uleiului uzat, prin spălarea fluidului și filtrare

flushing connection (hidr, met) dispozitiv cu conectare la un sistem hidraulic, pentru spălare / curățare periodică

flushing cinder / slag (met) zgură trasă / evacuată odată cu materialul metalic

flushing fluid (chim, hidr) fluid de spălare

flushing hole (met) orificiu pentru evacuarea zgurii

flushing medium (chim, hidr) agent / mediu / fluid de spălare

flushing oil (termo, mas) ulei de spălare

flushing out (alim, hidr) spălare, limpezire

flushing pump (auto, termo) pompă de injecție

flush left a alinia textul la stânga

flush right a alinia textul la dreapta

flush mounted $(\mathrm{OM})$ încastrat

flush mounting $(\mathrm{OM})$ montaj încastrat

flush nut $(\mathrm{OM})$ piuliță înfundată

flush out (alim, hidr) a limpezi

flush rivet $(\mathrm{OM})$ nit cu cap înecat

flush screw $(\mathrm{OM})$ şurub cu cap îngropat / înecat

flush valve (OM, hidr) supapă de (s)curgere

flush weld (met, OM) cusătură / sudură plată

flute $(\mathrm{OM})$ crestătură, jgheab, şanț, adâncitură, scobitură, canelură, renură; (mas-un, met) a moleta, a riflui, a canela, a moleta

fluted $(\mathrm{OM})$ canelat, cu caneluri, nervurat, $\mathrm{cu}$ nervuri, striat

fluted centre reamer (mas-un) alezor canelat

fluted cutter (mas-un) freză cu dinți moletați

fluted cylinder (OM) cilindru zimțuit

fluted filter (OM, hidr) filtru cutat

fluted funnel $(\mathrm{OM})$ pâlnie cu nervuri

fluted land (mas-un) zona / muchia aşchietoare (spiralată) a burghiului

fluted portion (met) parte canelată a cilindrilor de laminare

fluted roll(er) (alim, met, ind chim) valț / cilindru canelat / striat / rifluit

fluted scraper (mas-un) răzuitor canelat

flute-type (OM) striat, brăzdat, rifluit

fluting ( $\mathrm{OM}$, mas-un) canelură; striere, zimțare, moletare

fluting cutter (mas-un) freză pentru canelarea tarozilor şi a burghielor

fluting steel (met, mas-un) (oțel pentru) cuțit de canelat 
flutter (av) vibrație a aripilor, oscilaţii flutter; (fiz) a fierbe; (mec) a agita, a vibra, a trepida

flutter rate ritm al neuniform de deplasare fluvial, fluviatile (geogr) fluvial, de fluviu fluviometer (metr, geogr) fluviometru

flux (hidr) flux, curent; curgere; (met) flux, fondant, a zgurifica, a scorifica, a (se) topi, a deveni lichid /materiale metalice)

flux across the surface (met) flux de fluid prin / pe suprafață

flux coating (met) înveliş care formează protecție prin zgură

flux cored (metal-)arc welding (met) sudare cu sârmă tubulară protectoare

flux cutting (met) tăiere cu oxigen şi flux

flux density (el) densitate a liniilor de câmp

fluxed electrode (met) electrod învelit (cu flux)

fluxes for (galvanizing / pickling) (met) flux / fondanți pentru (galvanizare / decapare)

flux film (met) strat de flux

flux for making slag (met) agent zgurifiant / pentru formarea zgurii

flux guide (el) piesă de ghidare a fluxului (magnetic)

fluxion (mat) derivată

flux inclusion (met) incluziune de flux (la sudare)

fluxing (met) formarea zgurii, zgurificare

fluxing agent (met) (agent) fondant, flux

flux mapping (fiz, el) densitate de flux

flux meter (metr, el) aparat de măsurat intensitatea fluxului magnetic

flux rate (fiz) viteza de generare a energiei, particulelor etc., variație a fluxului (termic / energetic etc.)

fluxshield arc welding sudare electrică sub flux

fly fluturătură; muscă; $(\mathrm{OM})$ pârghie oscilantă, balansor, pendulă; a zbura

fly ash (termo) cenuşă fină "zburătoare" / care nu se depune / care este antrenată în curentul gazelor de ardere

flyback (auto) mers înapoi; (hidr) curent invers, restabilire a poziției anterioare; (nav) macara superioară a fungii gabierului; (hidr) contracurent; (el) retur, reîntoarcere a spotului

flyback timing (metr, autom) metodă / timp de reducere la zero

flyball regulator (OM, autom) regulator centrifug(al)

fly-blown (alim) plin de larve / ouă de muscă; contaminat, murdărit, stricat (d. carne)

fly crank $(\mathrm{OM})$ contramanivelă

fly cutter (mas-un) freză / cuțit cu un singur dinte (generare a suprafeței prin înfăşurare)

fly cutting (mas-un) strunjire / aşchiere oscilantă / cu sculă cu un singur dinte fly-door (constr) uşă care se deschide în ambele părți

flyer / flier (OM) zburător, piesă care se poate deplasa liber, volant; (textile) flaier, aripioară; (nav) focul săgeții

flyer spindle $(\mathrm{OM})$ fus pentru furcă

fly-headed screw (OM) şurub cu cap fluture

fly in a aduce pe calea aerului

flying $(\mathrm{OM})$ flotant, mobil, zburător, volant, care zboară; grăbit, iute, rapid; aerian

flying boat (av) hidroavion

flying bridge (transp) pod rotativ / rotitor / suspendat

flying cutter (mas-un) port-cutit rotativ pentru prelucrarea suprafețelor frontale, alezor rotativ

flying dust (met) praf fin / zburător

flying off $(\mathrm{OM}$, fiz, mec) rupere în bucăți sub acțiunea forțelor centrifuge, detaşarea unei piese dintr-un ansamblu în rotație

flying shears (mas-un) foarfece volant

fly jib (OM) braț oscilant (şi al unei macarale)

fly lever $(\mathrm{OM})$ pârghie oscilantă, culbutor

fly nut $(\mathrm{OM})$ piuliță-fluture

fly press (mas-un) presă cu volant

fly pump (OM, hidr) pompă cu palete

flywheel $(\mathrm{OM})$ volant

flywheel action (mec, OM) acțiune a volantului, moment de inerție

flywheel drive (mec, OM) acționare cu volant

flywheel fan (mec, OM) ventilator cu volant

flywheel flange (OM) flanşă a volantului

flywheel force (mec, OM) forță de inerție a volantului

flywheel mark(ing) (OM) reper pe volant (pentru echilibrare)

flywheel moment (mec) moment de volant / de girație

flywheel pulley (OM) roată de transmisie / volantă / liberă (şi roată de curea)

flywheel regulator (OM, autom) regulator centrifug

flywheel synchronization (mec) sincronizare inerțială / a volantului

foam spumă, material spumos / spongios, zgură; a face spumă, a spumega, a (în)spuma

foamed plastics (ind chim) materiale plastice spongioase / buretoase, materiale plastice tip spumă / expandate

foamed slag (met) zgură spongioasă / expandată, termozit

foamed slag brick (met) cărămidă din zgură spongioasă / expandată

foamer agent (alim, ind chim) agent de spumare foam exclusion (alim, ind chim, $\mathrm{T}$ ) eliminare a spumei 
foam extinguisher (alim, ind chim, T) extinctor / stingător cu spumă

foam formation / forming (alim, ind chim, T) formarea a spumei, (în)spumare

foaminess (alim, ind chim, T) caracter spumos, spumă

foaming stingere a incendiului (cu spumă); (alim, ind chim) (în)spumare, formare a spumei; $(\mathrm{T})$ spumare (şi a unui lubrifiant)

foaming adhesive (plast) adeziv (sub formă de) spumă

foaming agent (chim) agent de spumare / porofor, spumant, substanță spumogenă

foaming inhibitor ( $\mathrm{T}$, ind chim) (aditiv) antispumant, inhibitor al formării spumei

foaming power (chim) putere de spumare (la detergentii)

foam-in-place $(\mathrm{OM})$ etanşare / acoperire cu materiale spumante, după asamblarea pieselor

foamite (chim) spumă de stingere

foam killer ( $\mathrm{T}$, ind chim) (aditiv) antispumant

foamlike spumos, ca spuma

foam material (ind chim) material spumant, material plastic spongios / buretos / celular / expandat

foam plastics (ind chim, plast) poroplaste, materiale plastice spongioase / expandate

foam rubber (plast) cauciuc celular / spongios / buretos

foam separator (alim, ind chim, T, OM) separator de spumă

foamslag (met) zgură spumoasă

foam spray (alim, ind chim, T, OM) pulverizator anti-spumă

foam up (hidr, T) a înspuma, a face spumă (d. fluide, lubrifianți etc.)

foamy spumos; spumegând; buretos; (plast) expandat

foamy structure (materiale) structură spumoasă / spongioasă / buretoasă (d. zgură, materiale plastice)

focal (fiz) focal

focal axis (fiz) axă focală

focal distance / length (fiz) distanță focală

focal point (fiz) punct focal, focar

focal radius (mat) rază vectoare

focus (fiz) focar, focalizare, punct luminos; a converge, a se întâlni în focar, a focaliza; epicentru; punct central, miez, sâmbure

focused spot (fiz, metr) spot luminos / focalizat focusing board (metr, opt) placă de vizare focusing knob (OM, metr, opt) buton de reglare (şi la microscop, aparate optice)

focusing microscope (opt, metr) microscop cu reglare / cu focalizare focus on a se concentra asupra

focus point (fiz) focar

fodder (agr) nutreț, a da nutreț (vitelor)

fodder grain(s) (alim) cereale / grăunțe furajere

fog ceață (şi artificială, la ungerea cu ceață), pâclă; abur, perdea de fum; a încețoşa; (agr) otavă; (auto) a aburi

fog a glass a aburi un geam

fog and drizzle ceață cu burniță

fog bank (nav) banc de ceață

fog bell (nav) clopot de ceață

fogged metal (met) material metalic care şi-a pierdut aspectul lucios din cauza oxidării

fogger (alim, constr, ind chim) umezitor

fogginess caracter cețos, ceață

fogging (met) pierdere a luciului, închidere la culoare, întunecare; (auto) aburire

fogging up the inside of the windshield (auto) aburire a interiorului parbrizului

foggy cețos, încețoşat, neclar, nebulos

fog level (fiz) înnegrirea fondului (la analiză spectrală)

fogless fără ceață, clar, senin

fog nozzle (hidr, OM) ajutaj de pulverizare

fog signal (nav) semnal fonic de ceață

fog up (auto) a (se) aburi; (mas-un) a face ceață (de lubrifiant)

foible punct slab, slăbiciune

foil frunză, (met) foiță de metal, tablă subțire; filă, foaie, folie, film; (fig) contrast, termen de comparație; a împiedica, a răsturna (planuri)

foil brush perie lamelară

foiled $\operatorname{arch}(\mathrm{OM}) \operatorname{arc}$ lamelar / în foi

foil rolling mill (met, plast) laminor pentru folii / table foarte subțiri

foist on (ec) a face să cumpere (ceva inutil)

fold îndoitură, cută, fald, pliu, pliseu, falț, ondulație (şi a terenului / solului / tablei etc.), şant, adâncitură, scobitură; ascunziş̧; cotlon suprapunere; (agr) țarc (de oi), a închide în țarc (oile); (constr) uşă, canat, batant, foaie de uşă̆; a (se) cuta, a plisa, a fălțui, a (se) îndoi, a (se) împături, a (se) înfăşura, a cuprinde; a înveli; a plia; a încolăci (în jurul)

fold about / round a înlănțui

foldaway $(a d j)$ pliant

fold crack / crevice (met) crăpătură / fisură din cauza îndoirii / cutării

folded cutat, cu cute / pliuri, încrețit, gofrat

folded-down (auto) pliat (d. scaune)

folded filter (alim, OM) filtru cutat / burduf

folded joint $(\mathrm{OM})$ asamblare prin suprapunere / prin fălțuire

folded line linie frântă

folded yarn (textile, plast) fir răsucit 
folder mapă, dosar, pliant; (mas-un) fălțuială, maşină de fălțuit; (inf) fişier, director

fold in (alim) a amesteca cu lingura

folding cutare, înfăşurare, convoluție; fălțuire a tablei, contracție; pliere, depunere în pliuri

folding blade (mas-un) cuțit de fălțuit

folding box cutie din carton pliat

folding bridge (transp, constr) pod mobil / rabatabil

folding door (constr) uşă rabatabilă / pliantă / cu două canaturi

folding endurance / strength (met, plast) rezistență la îndoiri repetate

folding finder (metr, OM, opt) vizor rabatabil

folding joint $(\mathrm{OM})$ îmbinare / asamblare prin îndoire / prin fălțuire

folding ladder (constr, OM) scară pliantă

folding machine (mas-un) maşină de fălțuit

folding mandrel (mas-un) dorn de îndoit / de fălțuit

folding mast (mas-un) mast rabatabil / pliant

folding mould (mas-un) dorn de îndoire / de fălțuit

folding money (ec) bancnotă

folding phase (mas-un) fază de cutare

folding of drawing(s) împăturirea desenului / desenelor

folding rule(r) (metr) metru pliant

folding seat strapontină

folding stick (mas-un) fălțuitor, dispozitiv de fălțuire

folding stress $(\mathrm{mec})$ tensiune generată prin îndoire (şi la $180^{\circ}$ ) / cutare

folding table masă pliantă

folding test (materiale, metr) încercare de îndoire la $180^{\circ}$

folding tongs cleşte de îndoit tablă

folding weigher (constr) schip de alimentare (a unei betoniere)

fold-moulding (mas-un) fasonare prin vibrare

fold up (ec) a da faliment

foliated în folii, lamelar (d. materiale)

follow a urma, a merge în urma, a continua, a urmări; a fi atent / prezent, a frecventa; a rezulta; a imita; a înțelege; a se ocupa cu / de; a studia; a arăta interes pentru; a urma (în timp şi în spaţiu); a veni după; a merge de-a lungul (unei cărări); a urmări (un raționament etc.); a însoți; a merge împreună cu; a veni după cineva; a se interesa de; a adopta (o doctrină, idee etc.); a se alătura (unui grup etc.); a proceda; a acționa conform cu; a se conduce după; a respecta (o indicație etc.); a se lăsa dus de; a urma (un impuls, o înclinație); a se apuca de (o meserie); a se angaja (într-o treabă); a rezulta; a decurge; a lua exemplu; a fi perseverent; a completa cu; as follows după cum urmează; it follows that rezultă că; smb.'s advice a urma sfatul cuiva; $\sim$ the fashion a se ține de modă; suit a merge pe urmele; $\sim$ the law a se dedica avocaturii

follow dies (mas-un) matriță cu calibre succesive

follower (inf, autom) dispozitiv de urmărire, cititor de date; $(\mathrm{OM})$ element condus al unei transmisii, roată condusă, rolă de urmărire; (mat) succesor, următor; persoană care e la rând; adept, discipol

follower of eccentric disk $(\mathrm{OM})$ rolă de urmărire a unui disc excentric

follower pin (OM) ştift / cui de antrenare, tachet

follower plate $(\mathrm{OM}$, hidr) placă de presare / de urmărire (a nivelului unui fluid) (şi deasupra suprafeței unei unsori în rezervor, când este pompată în sistemul de ungere etc.)

follow(er) rest (mas-un) lunetă mobilă

follower ring $(\mathrm{OM})$ ochelar (la vană-ochelar)

follower-ring valve $(\mathrm{OM}$, hidr) vană / supapă ochelar

follower roll $(\mathrm{OM})$ tachet

following următor, care urmează; după, la sfârşitul

following pulley $(\mathrm{OM})$ roată de curea / de lanț, condusă

follow-on urmare, continuare

follow on a urma, a continua

follow out a realiza, a face, a pune în aplicare, a duce până la capăt, a urma întocmai; a duce până la sfârşit (un plan etc.); a urmări (un proiect etc.)

follow system (autom, mas-un) sistem de cuplare consecutivă automată, sistem de urmărire / de copiere după model

follow through a urmări până la capăt (un experiment, un proiect etc.)

follow-up urmare, continuare; făcut în continuare; parcurs / traiect (arie) de urmărire (şi la roboți)

follow up a duce la bun sfârşit, a urmări până la capăt; a fi o urmare; a urmări atent / îndeaproape

follow up an advantage a urmări un profit

follow-up draft (met, plast) tragere finală

follow-up letter (ec) scrisoare de confirmare (în urma unei întrevederi) / de revenire (asupra unei scrisori anterioare)

follow-ups (ec) oferte consecutive

follow up with a adăuga

follow-up work muncă complementară

fondant (alim) bomboană fondantă

fondness iubire, afecțiune; dispoziție; înclinare; îngăduință; toleranță 
fondness for predilecție / preferință pentru, înclinație spre

font (c) garnitură completă de litere

fontal originar, primar

food (alim) aliment(e), produs alimentar, hrană, provizii, alimentație

food-bank (termo) frigider cu compartimente de congelare şi depozitare închiriate, instalaţie colectivă de depozitare cu casete individuale de congelare

food chopper (alim) tocătoare de nutreț

food colours (alim, ind chim) coloranți pentru industria alimentară

food industry (alim) industrie alimentară

food processing (alim) prelucrare / obținere a produselor alimentare

food product (alim) produs alimentar

food store (alim) magazin alimentar

foodstuff (alim) aliment, produs alimentar

foodstuff rubber (plast, alim) cauciuc pentru industria alimentară

food stuffs / food supply (alim, ec) (aprovizionare $\mathrm{cu}$ ) alimente, produse alimentare

foody (alim) comestibil, alimentar, hrănitor, nutritiv

fool (alim) cremă de fructe

foolish prostesc, fără rost; pripit

foolproof (autom) asigurat contra greșelilor de manevrare / acționare (şi d. roboți, manipulatori etc.)

foolproofing (autom) blocaj contra utilizării greşite

foot, $(p l)$ feet picior, reazem, talpă, parte (cea mai) de jos; (metr) unitate de măsură pentru lungime: 1 foot $(\mathrm{ft})$ (US survey) $=0,30480061$ m; (anat) labă a piciorului; pas, mers; (mil) infanterie; partea de jos (a unei cizme); (fig) situația, poziția cea mai de jos; feet $(p l)$ reziduuri; a merge; a călca (pe ceva); a tălpui, a pune talpă (la); (ec) a plăti, a achita (o notă); a fi pedestru; a porni ceva; a face totalul; -up to a se ridica la (o sumă); on $\sim$ pe jos, în curs de pregătire, de organizare; on one's feet în picioare, (med) pe picioare (refăcut după o boală), independent materialiceşte; to keep one's feet a-şi păstra echilibrul; miss one's a călca greşit; to set smb. on his feet a da cuiva independență financiară; set smth. on foot a face să funcționeze; at the $\sim$ of a page în subsolul unei pagini; (edu) a pupil at the $\sim$ of the class un elev în coada clasei; it (fam) a merge pe jos; -up (an account) a aduna; the bill a suporta cheltuielile

foot bend (OM, constr) cot cu talpă

foot blower (mas-un) suflantă cu pedală foot board (auto) scară; (constr) pasarelă, podeț; $(\mathrm{OM})$ pedală, treaptă de scară

foot(-)brake (OM, mas-un, auto) frână de picior / cu pedală

footbridge (constr) punte, podeț, pasarelă; (nav) scară de coborâre

foot control unit (mas-un) pedală de comandă

foot drive (mas-un) acționat prin pedală

foothold $(\mathrm{OM})$ reazem (şi pentru picior) (pentru batiu etc.)

foot/hour (metr, mec) unitate de măsură pentru viteză: 1 foot/hour $=0,000084667 \mathrm{~m} / \mathrm{s}$

footing (constr, mec, OM) fundație, bază, reazem, sprijin

footing of the foundation (constr, geol) retragere a fundației

foot lever / pedal (auto, OM) (pârghie de) pedală

foot/minute (metr) unitate de măsură pentru viteză: 1 foot $/$ minute $=0,00508 \mathrm{~m} / \mathrm{s}$

foot(-)note notă de subsol / de picior (într-un text)

foot of line (geom) intersectie a unei drepte (cu o dreaptă / cu un plan), picior al unei perpendiculare

foot of the rail (cf, OM) talpă a şinei de cale ferată

foot-operated switch (el, OM, mas-un) întrerupător (la) pedală

foot passenger pieton, trecător

foot pedals (auto) pedale

foot plate $(\mathrm{OM})$ placă de bază

foot power (attachment) (OM, mas-un) antrenare / acționare cu / prin pedală

foot-pound, foot pound (ft.lbf) (metr, fiz) unitate de măsură pentru energie: 1 foot-pound = $1,355817948 \mathrm{~J}$

foot pound-force/hour (metr) unitate de măsură pentru putere: 1 foot pound-force/hour = $0,000376616 \mathrm{~W}$

foot pound-force/minute (metr) unitate de măsură pentru putere: 1 foot pound-force/minute $=0,022596966 \mathrm{~W}$

foot pound-force/second (metr) unitate de măsură pentru putere: 1 foot pound-force/second $=1,355817948 \mathrm{~W}$

foot (power) lathe (mas-un) strung cu acționare prin pedală

footprint amprentă (în sens larg); (constr, OM) urmă de rezemare a unui batiu a unei piese / a unei role etc.

foot/second (metr, mec) unitate de măsură pentru viteză: 1 foot $/$ second $=0,3048 \mathrm{~m} / \mathrm{s}$

foot/square second (metr, mec) unitate de măsură pentru acceleraţie: 1 foot/square second $=0,3048 \mathrm{~m} / \mathrm{s}^{2}$

footrail (cf, met) şină cu talpă 
foot release $(\mathrm{OM})$ clichet de pedală

foot rest $(\mathrm{OM})$ rezemător de picior

foot rope (nav) grandee de întinsură

foots (met) resturi (şi de lingou / bramă etc.), reziduu(ri)

foot starter (mas-un) pedală de pornire

footstep pas, treaptă (de scară); (OM, mas-un) pedală, limitator de cursă

footstep bearing $(\mathrm{OM})$ crapodină, pivot de rezemare, lagăr axial inferior (la un arbore vertical)

footstep pillow / plate $(\mathrm{OM})$ placă de reazem a crapodinei

footstock (mas-un) păpuşă mobilă

footstock centre (mas-un) vârf al păpuşii mobile (la strunguri)

foot throttle (auto) pedală de accelerație

foot treadle (OM, mas-un) pedală

foot valve $(O M$, hidr) supapă fixă / de aspirație, robinet de fund

footwalk, footway (constr) trotuar

foot wall (constr) zid de fundație; (hidr) zid de picior (de dig etc.)

foot water (metr, mec) unitate de măsură pentru pre-siune: 1 foot water $\left(4^{\circ} \mathrm{C}\right)=1$ foot water $\left(60^{\circ} \mathrm{F}\right) 2988,98 \mathrm{~Pa}$

foot wear încălțăminte

for (prep) pentru, în folosul, de partea, în vederea; împotriva; la, spre, către, în direcția; de din cauza, datorită; ținînd seama de; în ciuda forage (agr) nutreț, furaj

forbear a se feri (de); a fi cu răbdare; from a se abține de la, a se reține de la, a se sustrage de la

forbearance abținere, reținere; răbdare; îngăduință, indulgență

forbid a opri, a interzice, a nu permite; a împiedica, a nu face posibil

forbiddenance, forbiddenness interdicție, interzicere

forbidden interzis, oprit

force constrângere; violență; (ind chim, mas-un) matriță (de materiale plastice); (mec) a forța, a presa, a accelera, a grăbi; (jur) vigoare, putere, valabilitate, validitate, autoritate; (fiz, mec) forță, intensitate, solicitare, putere, efort; influență, putere de convingere; (mil) forță militară, armată, $\sim \mathbf{s}(p l)$ trupe, unităţi militare, forțe armate; (fig) putere; putere de convingere, influență; rațiune; rost; sens; a forța, a-şi face drum; a constrânge, a sili; a viola; a produce, a obține în mod forțat; a grăbi, a accelera (un proces); a fi viguros; a introduce cu forța; join $\sim \mathbf{s}$ with a-şi uni puterea cu; in great $\sim$ în toată puterea; resort to $\sim$ a recurge la forță; yield to $\sim$ a ceda forței; by $\sim$ cu forța; the $\sim$ of circumstances forța împrejurărilor; (mil) in în număr mare; the politiia; of character tărie de caracter; be in $\sim$ a fi în vigoare; come in / into $\sim$ a intra în vigoare; put a law in / into $\sim$ a aplica o lege; smb's hand a-şi impune voința cuiva; $\sim$ smth. upon smb. a impune cuiva ceva cu forta

force account (ec) lucru în regie / cu ziua force account rate $(\mathrm{ec})$ cost de regie

force back a respinge

force balance potentiometer (metr, el) potențiometru de zero / echilibrat

force balance regulator (autom) regulator de compensare a fortei

force cell (metr, el, hidr) traductor de forță (şi hidraulic)

force circulation (hidr) circulație (a unui fluid) sub presiune

force component (mec) componentă a unei forțe force conditions (mec, OM) conditii de aplicare a unei forțe, repartizarea sarcinii / forței

force couple (mec, OM) cuplu de forțe

force delivered (auto, mec) forță rezultată

forced forțat, silit, obligat, obligatoriu; nefiresc, artificial

forced birefringence / double refraction (mec) birefringență mecanică

forced circulation (hidr) circulație forțată (a fluidului)

forced circulation evaporator (alim, ind chim, mas) evaporator cu circulație forțată

forced coding (inf) programare optimă / rapidă

forced cooling (termo) răcire forțată

forced convection air heater (termo) aerotermă, încălzitor de aer cu circulație forțată a aerului

forced draft fan (termo) ventilator / compresor pentru a introduce aer / gaz sub presiune (şi la motoare cu ardere internă)

forced draught / draft (termo, met) insuflare indirectă, tiraj forțat / artificial, curent de aer forțat (la focare), aeraj refulant puternic

forced draught / draft fan / ventilator (termo) ventilator refulant / cu aspirație

forced draught furnace (met, termo) cuptor focar cu insuflare de aer

forced feed (hidr) alimentare sub presiune

forced feed lubrication (T) ungere / lubrifiere forțată în circuit închis

forced fit $(\mathrm{OM})$ ajustaj presat / blocat / cu strângere forced flow (hidr, alim) curgere forțată (a unui lichid, gaz)

force diagram $(\mathrm{mec})$ diagramă a forțelor

forced-induction / induced engine (el) motor supra-alimentat

forced locking device (autom, mas, mas-un) dispozitiv de blocare automată

forced oil air-cooled transformer with blower (el, T) transformator cu circulație forțată de ulei și răcire cu ventilator / cu aer ventilat 
forced oscillation / vibration (mec) oscilație / vibrație forțată

force down (mec) a împinge în jos, a apăsa, a presa forced reversing (OM, autom, mas-un) inversor automat, inversare automată

forced state $(\mathrm{TH}$, mas) regim forțat

forced ventilation (termo) ventilație forțată

forced vibration (mec) vibrație / oscilație forțăă / impusă

force-feed oiler $(\mathrm{OM}, \mathrm{T})$ pompă de ungere

force field (fiz) câmp de forțe

force fit (OM) ajustaj presat / blocat / forțat, ajustaj cu strângere relativ mare, care produce o stare de tensiuni mari în piesele asamblate

force fitted (mec, OM) asamblat forțat / prin forță

force from a smulge de la, a lua cu forța de la forceful puternic, viguros; convingător, eficient

forcefully $(a d v)$ cu forța, prin forță

force in (TH) a presa, a injecta, a ştemui, a introduce forțat, a face să intre cu forța

force intensity (mec) valoare / intensitate a forței, variația forței în unitatea de timp (la studiul proceselor dinamice sau cu şocuri) a forței

force into $(\mathrm{TH}, \mathrm{mec})$ a forța în, a împinge forțat, a înfinge în

forceless slab, fără putere

force lift pump (OM, hidr) pompă de refulare

force-locking (mec) cu contact forțat, blocat (în mod) fortat

force majeure (caz de) forță majoră

forcemeat (alim) umplutură

force of cohesion (fiz) forță de aderență / de coeziune

force of friction (T) forță de frecare

force of reaction (termo, fiz) forță reactivă (şi la turbine); (mec) forță de reacțiune

force of the blow (mec) intensitate / forță de şoc / de lovire

force on / upon (ec) a impune condiții; (mec) a monta o piesă prin presare

force one's way through a străpunge, a pătrunde prin

force out (alim, constr, mec) a dizlocui, a stoarce, a presa, a scoate forțat în afară

force parallelogram $(\mathrm{mec})$ paralelogram al forțelor

force pipe (OM, hidr) țeavă de refulare / pentru fluid sub presiune

force plate (OM, mas-un) plăci de presiune (şi la prese, matrițe)

force plug (OM, mas-un) poanson

force polygon (mec) poligon al forțelor

force pump (OM, hidr) pompă de presiune / de refulare forcer (OM, mas-un) presă cu melc, extruder, pompă de mână

force side part (mas-un) parte mobilă / activă a unei matrite

force through a perfora, a înfige, a străpunge prin presare, a trece forțat prin

force vector $(\mathrm{mec})$ vector-forță

forcible puternic, energic, cu forța, prin forță

forcibly $(a d v)$ cu forța, prin forță; convingător, eficace; puternic

forcing (autom) intensitate a valorii de reglaj; (plast) extrudare; forțare, care forțează

forcing-and-sucking pump (hidr) pompă de aspirație şi de refulare

forcing / force fan (termo) ventilator de refulare

forcing fit $(\mathrm{OM})$ ajustaj cu strângere / forțat / presat

forcing lever $(\mathrm{OM})$ pârghie de presiune / de acționare, brat de susținere al perforatorului

forcing machine ( $\mathrm{TH}$, mas-un) presă pentru montare prin presare (pentru roți, rulmenți etc.); (plast) extruder, presă cu melc

forcing pipe (hidr, OM) țeavă de refulare, conductă sub presiune

forcing press (mas-un) presă pentru calarea / montarea prin presare a pieselor

forcing pump (hidr) pompă de presiune / de refulare

forcing screw (OM, met) şurub de presare / de presiune / de distanţare

forcing valve (OM, hidr) supapă de refulare

ford (geogr, transp) vad, trecere prin apă; a trece prin vad

Ford cup viscometer (metr, ind chim) vâscozimetru Ford (pentru vopsea)

fore din față, anterior; înainte, în față; (nav) prova, extremitate prova, spre / în prova

fore and aft (nav) la prova și la pupa, longitudinal, longitudinal

fore(-and)-aft axis / line (nav) axă longitudinală a navei

fore-and-afters (nav) piese longitudinale ale osaturii navei

fore-and-aft line (nav) axa navei, plan longitudinal al navei

forearm (anat) antebraț

fore axle-tree (cf) osie din față

fore-blow (met) suflare preliminară, a sufla (la început)

fore-blow time (met) timp / perioadă de (in)suflare preliminară

forecast prognoză, prevedere, previziune, anticipare, prevestire; a prevedea, a estima, a planifica; a prognostica, a anticipa

forecasting predicție, prognoză; care face o prognoză / o previziune 
forecasting economic environment (ec) previziune / estimare / prognoză a cadrului economic general

forecastle (nav) teugă, castel (la prova)

fore-cited mai sus amintit, amintit anterior, citat mai sus

foreclose (jur) a declara prescrisă (o ipotecă), a exclude, a respinge; a rezolva dinainte o problemă

foreclosure (jur) presriere (a unei ipoteci)

forecooler (alim, termo) prerăcitor, răcitor inițial / preliminar

forecourt (constr) rte închisă (în fața unei clădiri)

fore-dated antedatat

fore deck (nav) punte (de la) prova

forefinger (anat) deget arătător

fore foot (nav) picior al etravei, extremitate prova a chilei

for free (ec) gratis, gratuit

foregate (constr, TH) intrare / poartă principală (mai ales la zone / hale industriale)

forego a preceda; a fi înaintea

foregoing anterior, precedent, menționat mai sus / înainte, cele mai sus menționate

foregone cunoscut / acceptat dinainte

foregone conclusion concluzie / hotărâre ştiută dinainte / anticipată / inevitabilă

foreground, background (inf, c) sistem de control cu două computere; fundal (de imagine, display etc.)

foreground processing (inf) prelucrare (pe calculator) a programelor prioritare

forehand (cel mai) din față; pregătit / făcut din timp

forehanded pregătit / făcut din timp; prevăzător, precaut; bine situat, prosper

forehand welding (met) (procedeu / tehnică de) sudare înainte / spre stânga (sudare cu flacără orientată înainte, pentru preîncălzire)

forehearth (met) antecreuzet (la cubilou); (termo) antefocar

foreign străin; din altă țară; extern, exterior; (TH) impur, (corp) străin, impuritate; parts țări străine

foreign body corp străin, impuritate (în general)

foreign currency / exchange (ec) valută străină, devize (libere)

foreign current (el) curent independent / de la o sursă independentă

foreigner străin, persoană din altă țară

foreign gas (ec, termo) gaz din exterior

foreign-going ship (nav) navă de cursă lungă

foreign impurities impurități, corpuri străine (în general)

foreign matter corpuri străine, impurități, substanțe / materii străine; obiect(e) străin(e) foreign metal (met) metal însoțitor (ca impuritate)

foreign substance impuritate, substanță străină

foreign to străin de, nefiresc pentru, impropiu pentru

foreign trade $(\mathrm{ec})$ comert exterior

foreknow a şti dinainte; a prevedea

forelock $(\mathrm{OM})$ cui spintecat, şplint, pană transversală

foreman $(\mathrm{TH}$, ind) supraveghetor, şef de echipă / de şantier, maistru

foreman of development $(\mathrm{TH}$, nav) maistru de exploatare / de şantier

foreman of production ( $\mathrm{TH}$, nav) maistru de producție

foremast (nav) arbore trinchet

foremost prim, din față, dinainte; de frunte, de primă însemnătate; $(a d v)$ în / pe primul loc, în primul rând

foremost position (auto) poziția cea mai din față (la reglarea scaunului pentru copil)

forename prenume

forenamed amintit / menționat anterior

forensic (jur) judiciar, legal; indiciu

forensic medicine (jur) medicină judiciară / legală

fore part $(\mathrm{OM})$ parte anterioară / din față; (nav) prova

fore peak (nav) pic prova, compartiment de coliziune prova

foreplate (met, termo) pragul ușii (la cuptoare)

fore pump (termo, ind chim) pompă de vid preliminar / primară

fore-rib-steak (alim) fleică

forerunning (alim, ind chim) distilare primară, separare a fracțiunilor uşoare

foresail (nav) trincă, velă de trinchet

forescattering (fiz) împrăstiere înainte

foreshorten a desena reducând dimensiunile; a prescurta

foreside $(\mathrm{OM})$ parte din față

forest (silv) pădure

forestall (fig) a o lua înaintea (cuiva); a împiedica; a strica (planuri); a anticipa. a preveni; (ec) a stoca mărfuri în scop speculativ, a acapara

forestalling prevenire

forestation (silv) împădurire

foresee a prevedea; a întrezări; a întrevedea

forester (silv) pădurar, brigadier silvic, silvicultor forestry (silv) silvicultură; păduri, ținut păduros

fore stroke (mas-un) cursă înainte

foretell a prezice; a prevesti

forethought prevedere, grijă; anticipare, anticipație

fore top (nav) gabier mic

fore top gallant mast (nav) arbore zburător

fore trawl (nav) dragă de prova 
fore vacuum (termo, ind chim) vid preliminar forever $(a d v)$ pentru totdeauna; mereu forewarmer (termo, ind chim) preîncălzitor fore wheel (auto, OM) roată din față foreword prefață, cuvânt înainte

forfeit pierdut; (jur) pierdere a unui drept, confiscare, bun confiscat; (jur, ec) penalizare, amendă, gaj; (în)călcare a cuvântului $(\mathrm{ec})$ a pierde o ipotecă / garanție, a pierde dreptul asupra; a pierde viața; a fi privat / deposedat de (prin confiscare; a fi amendat

forfeiture confiscare, pierdere (şi a unui drept); amendă; dezicere; (în)călcare a cuvântului

forfend a opri, a interzice, a preveni; a îndepărta (un risc) luând măsuri de prevenire

forge forță; (met) forjă, fierărie, vatră a unei forje, a forja; (ec) a falsifica (un cec, un act etc.), a contraface; a inventa; a minți; a-şi croi drum, a înainta anevoie / treptat; (fig) a progresa; ahead a merge înainte

forgeability (met) forjabilitate

forgeable (alloy) (met) (aliaj) forjabil

forge-and-machined (met, mas-un, OM) forjat şi prelucrat mecanic (la dimensiunile cerute)

forge blower (met) suflantă de forjă

forge coal (met) cărbuni de forjă

forge drawing (met) întindere prin forjare

forged (met) forjat

forged steel (met) oțel forjat

forged steel threaded fitting (met, OM) fiting / racord filetat, din oțel forjat

forge furnace (met) cuptor de forjă

forge hammer (met) ciocan / berbec de forjă

forge lathe (mas-un) strung pentru degroşarea pieselor forjate

forge man, forger (met) forjor; falsificator

forge out (met) a forja, a ciocăni

forge planer (mas-un) maşină de rabotat pentru piese forjate

forger (met) forjor

forgery imitatie, fals, falsificare, contrafacere

forge scale (met) arsură / defect (tip exfoliere) de forjare

forge scrap(s) (met) deşeuri de forjă

forge shop (met) atelier / hală de forjă

forget a uita, a nu-şi aduce aminte, a omite, a neglija

forgetful uituc; neatent

forgetfulness uitare; neatenție, neglijență

forgetive inventiv, descurcăreț

forgettable care se uită uşor

forge tongs (met) cleşte de forjă

forge vice (met) menghină de forjă

forge welded (met) sudat prin forjare

forge / fire welding (met) sudare la forjă / la foc de forjă forging (met, plast) forjare, piesă forjată, matritare la cald

forging billet / stock (met) semifabricat care va fi forjat

forging and dieforging machine (met, mas-un) maşină de forjat şi matriţat

forging coal (met) cărbune de / pentru forjă

forging crack (met) fisură / crăpătură la / de forjare

forging die (met) matriţă de forjare

forging drop (met) forjare în matriță, matrițare

forging furnace (met) cuptor de forjă

forging-grade ingot (met) lingou de forjare

forging-grade steel (met) oțel forjabil

forging hammer (met) ciocan / parte activă de forjă

forging machine (met, mas-un) maşină de forjat

forging press (met, mas-un) presă de forjat

forging range (met) interval optim de temperatură, la forjare

forgings (met) piese forjate

forging shop (met) atelier / hală de forjă, forjă

forging steel (met) oțel forjabil / maleabil / care poate fi deformat la cald

forging test (met) încercare / test de forjare

forgivable scuzabil, care poate fi iertat

forgive a scuza, a trece cu vederea, a absolvi de, a scuti de

forgo a se lipsi de, a renunța la, a se abține de la

fork (cf) branşament, bifurcatie; (inf) ramificare, ramificație, derivare, a (se) bifurca; $(\mathrm{OM})$ furcă; (alim) furculiță; alternativă

fork connection (OM) cuplaj / conexiune cu furcă; (el) conexiune tip furcă

fork distributor (el) distribuitor cu furci

forked $(\mathrm{OM}$, el) bifurcat, ramificat, cu furcă, în formă de furcă

forked bed (mas-un, OM) cadru / batiu în formă de furcă

forked connecting rod (cf, OM) bielă cu cap în (formă de) furcă

forked end lever $(\mathrm{OM})$ pârghie cu cap în furcă

forked stanchion $(\mathrm{OM})$ suport în formă de furcă forked tube (OM, hidr) teu (la conducte)

fork head $(\mathrm{OM})$ cap în formă de furcă / ramificat / bifurcat

forking $(\mathrm{TH}, \mathrm{OM})$ furcă, bifurcație, care se ramifică

fork jointing $(\mathrm{OM})$ articulație / asamblare tip / cu furcă

fork lift / truck (transp, mas) autoîncărcător cu furcă, cărucior / elevator cu furcă

fork mounting (OM, metr) montură cu furcă (şi la aparate de măsură)

fork pin (OM) şplint / bolț de furcă 
fork spanner $(\mathrm{OM})$ cheie-furcă pentru piulițe rotunde

fork-test bar (materiale, metr) epruvetă pentru încercări la coroziune

fork tines $(\mathrm{OM})$ con / dinte de furcă, dinte de furculiță

fork wrench $(\mathrm{OM})$ cheie pentru mecanică fixă

for-list (inf) listă de ciclu

form formă, aspect, înfățişare (exterioară); fel; chip; mod (de a acționa, a vorbi etc.); formalitate; ceremonie; respectare a regulilor de politețe, bunăcuviință; formular; stare; (med) condiție a sănătății, dispoziție sufletească; (edu) clasă (la şcoală); bancă (mai ales fără spetează); formă de prezentare / exprimare; apariție, arătare; contur; stil; varietate, specie, formă; convenientăă, politețe; (constr) cofraj lateral (şi pentru drumuri), bancă (de lemn); (mat, mec) formă, model, element, entitate, schemă, tip, contur, şablon; aspect; imprimat, formular; a (se) forma (şi fig), a lua o formă; a fasona, a profila, a modela; a aconstrui; a alcătui; a compune; a se ivi, a lua naştere, a (se) crea, a (se) alcătui; a închide, a cuprinde (într-un unghi); (edu) a (se) forma, a educa; a (se) dezvolta, a disciplina, a antrena; (ec) a fonda o societate; (cf) a forma un tren; a-şi face (o idee, o părere despre); a făuri (un plan); a nutri; a lua (o hotărâre); a pronunța, a articula (cuvinte); (mil) a dispune; a aşeza; a aranja; (med) sănătos; in due în forma cuvenită; a mere matter of $\sim$ o pură formalitate; stand on $\sim \mathbf{s}$ a respecta formalitățile, formele; good $\sim$ conform buneicuviințe; in în formă; be in great $\sim$ a fi în mare formă; $\sim$ into columns a dispune în coloane

formability (mec, materiale, $\mathrm{TH}$ ) plasticitate, capacitatea unui material de a fi (de)format

formal formal, (făcut) de formă; care ține de formă; exterior; oficial, protocolar; formalist; categoric, precis, expres; simetric, geometric

formal defect $(\mathrm{TH})$ defect de formă

formaldehyde (chim) adehidă formică

formalin (chim) formol

formalism tratare formală, formalism, sistem formal

formalist, formalistic formalist

formality formalitate; formalism; formalizare

formalize a întocmi după toate formele, a da o formă de rigoare

formalizing redactare a unor documente, formulare (după anumite reguli)

formally $(a d v)$ (din punct de vedere) formal

formal system sistem formal, model teoretic

form anchor $(\mathrm{OM})$ rondelă (profilată) / şaibă de ancorare / de fixare format format / mod de prezentare (a datelor / a instrucțiunilor), structură, configurație (şi a unui document)

format error (inf) eroare de format / de formatare

format identifier (inf) identificator de format formation alcătuire; (el) formare (la acumulator); formațiune, formare, structură întocmire, alcătuire, constituire, organizare

formation of blowholes (met, ind chim, plast) formare a bulelor, formare de pori (la sudură / turnare) / de retasuri

formation of burr / of fin / of slag (met) formare a bavurii / a nervurii / a zgurii

formation of cracks (matriale, TH) formare / generare de fisuri, fisurare

formation of fin (met) formarea bavurii

formation of fog $(T)$ formare a ceței (şi pentru ungere în ceață

formation of matte (met) formarea matei

formation of pits (materiale, chim, mec) formare de cratere / de pori, pitting (din cauza coroziunii, oboselii sau a ambelor)

formation of scale (met) formarea țunderului / arsurii

formation of slag (met) formarea zgurii

formation of wrinkles (met) formarea crețurilor / cutelor la tablă

formation permeability (geol, alim, constr, ind chim) permeabilizare (a unui strat)

formative (edu, TH) formator, care formează, de formare

format statement (inf) instrucțiune referitoare la format (în FORTRAN etc.)

formatted data record (inf) înregistrare a unor date prezentate într-un anumit format

formatted statement (inf) instrucțiune având un anumit format

formatting character (inf) caracter de editare

form boards (constr) scânduri de cofraj

form brace (constr) montant (în cofraj)

form bubbles (alim, ind chim, T) a face spumă / băşicuțe, a spumega

form change (TH, OM) schimbare a formei

form cutter (mas-un) freză / cuțit profilat

form distortion (TH, OM) distorsiune / schimbare a formei

formed cutter (mas-un) cuțit / freză profilată

formed in place liquid gasket (OM, plast) garnitură de etanşare pentru lichide (formată direct la locul de utilizare)

formed piece $(\mathrm{OM})$ piesă formată

former fost, trecut; (el) şablon de înfășurare / de bobinare; (mas-un) şablon de copiat / de ghidare, cuțit profilat 
former bar (mas-un) riglă conică, şablon de copiat (şi pentru strung)

formerly $(a d v)$ înainte, altădată, cândva former nose (alim, OM) vârf / gât de pâlnie

former pass (met) calibru pentru profiluri

former roll / tongue (met) cilindru superior de laminat profiluri

former slide (mas-un) sanie a unui strung automat pentru piese profilate

form feed alimentare cu hârtie (şi la imprimante)

form feedout ejectare a hârtiei (şi la imprimante)

form grinding (mas-un) rectificare a suprafețelor profilate, moletare

formic acid (chim) acid formic

forming (edu) formator, formativ, care formează (într-o meserie etc.); (TH) formare (şi fără alterarea grosimii semifabricatului), profilare, fasonare, ştanțare

forming and profiling machine (mas-un) maşină de frezat după şablon

forming bell (met) pâlnie de tras / de formare (la turnare)

forming die (mas-un) matriță de formare (şi fără alterarea grosimii semifabricatului)

forming lathe (mas-un) strung de copiat / pentru prelucrarea suprafețelor profilate

forming operation (met) operație de formare / fasonare / modelare

forming pass (met) pas / trecere de fasonare /de profilare) (la laminare)

forming pressure (mec, met) presiune de formare forming property (materiale, $\mathrm{TH}$ ) deformabilitate, plasticitate

forming roll (met, ind chim, textile) (cilindru) înfăşurător; (met) cilindru superior la laminarea profilurilor, cilindru de fasonare

forming temperature temperatură de formare

form(ing) tool (mas-un) cuțit de formă / profilat $/$ de profilare

formless amorf, fără formă

formlessness (OM) absența / lipsa formei; caracter amorf (d. materiale)

form letter scrisoare tip, circulară

form milling (mas-un) frezare a suprafetelor profilate, frezare prin copiere după şablon

form planing (mas-un) prelucrare după şablon (la raboteze, la morteze)

form of fracture (mec, materiale) formă /aspect al ruperii / rupturii

forms (constr) cofraj(e); formularistică, formulare; $p l$ de la form: forme

form shaping (mas-un) prelucrare după şablon la şeping

form steps (met, plast) a forma / a profila în trepte

form the average (mat) a face media form tool (mas-un) sculă / cuțit profilat(ă) (de obicei, fix)

form tooth (mas-un) şablon pentru mortezarea / frezarea / rectificarea dinților

form turn (mas-un) a strunji profilat

form turning (mas-un) strunjire profilată

formula, $(p l)$ formulae formulă, formulare, expresie

formula for reference formulă de referință

formula function (mat) funcție formală, expressie utilizată ca operand într-o relație

formularize, formulate a formula

formulary formulă, expresie; formular; (adj) formal

formulation formulare

formula translating system (FORTRAN) (inf) sistem traductor de formule, limbaj formal / de programare FORTRAN

formula weight (chim) greutate (mai rar în limba română) / masă moleculară

formwork (constr) cofraj

forrader $(a d v)$ mai departe, înainte

forsake a părăsi; a abandona; a renunța la; a se debarasa de; $\sim$ bad habits a se lăsa de obiceiurile rele

„for” statement (inf) instrucțiune "pentru” în unele limbaje de programare

forswear a abjura; a renega

forth afară, în afară, înainte; mai departe

forthcoming apropiat, viitor; disponibil, existent, la îndemână; apariție, ivire; apropiere

forthright direct, drept; sincer, deschis; înainte, imediat, îndată

fortification (mil) fortificație; fortificare, întărire

fortified întărit, ranforsat (la compozite, cu nervuri la piese etc.)

fortified tyre (auto) pneu întărit

fortified wine (alim) vin alcoolizat

fortify a consolida, a întări; a confirma, a adeveri; a susține, a (se) fortifica; a întări (cu fapte); a confirma; (alim) a adăuga alcool în vin

fortnight (metr) unitate de măsură pentru timp: 1 fortnight $=1209600 \mathrm{~s}$

fortunate norocos, favorizat, prielnic

fortunately $(a d v)$ (în mod) fericit, din fericire

fortune noroc, şansă, întâmplare fericită; succes; avere, bogăție

forum, $(p l)$ fora forum, for, tribunal, adunare

forward (adj) din față, dinainte; (fig) înaintat, progresist, de avangardă; avansat; precoce; aflat în frunte, din frunte, fruntaş; gata să, dispus să; isteț, descurcăreț; (agr) timpuriu, prematur; (ec, jur) (d. un contract) semnat, încheiat din timp, anticipat; to gata de; dispus (să); timpuriu; înfipt; îndrăzneț; încrezut; $(s)$ înaintaş (la un sport de echipă); $(a d v)$ înainte, în față, în evidență, la 
vedere, (nav) la proră, mai departe, în continuare, în față, în perspectivă; în sens direct; a grăbi, a accelera, a trimite (înainte) marfă etc., a expedia (mărfuri, scrisori), a înainta; a face să propăşească; a sprijini; (agr, bot) a grăbi (creşterea plantelor); please rog dați mai departe; be $\sim$ ed de expediat; look $\sim$ to a aştepta; from this time $\sim$ de acum înainte; put $\sim$ a prezenta (un argument); carry $\sim($ ec $)$ a reporta

forward-acting (mas) cu acțiune directă

forward axle (OM; auto, cf) osie din față

forward clutch (OM) cuplaj de sens (înainte)

forward current (el) curent direct / de conducție

forward-curved blade $(\mathrm{OM})$ aripă curbată în față (la ventilatoare, pompe)

forward curve impeller $(\mathrm{OM}$, termo) rotor / elice cu palete curbate în față

forward derivative (mat) derivată la dreapta

forward driving pulley-dumping (wheel) scraper (constr, mas) screper pe roți, cu descărcare în față

forwarder transportor, echer; (ec) expeditor

forward extrusion (mas-un, materiale, $\mathrm{TH}$ ) extrudare directă

forward flow (hidr, fiz) echicurent, curgere înainte, avansare

forwarding transportare, trimitere, expediere, transmisie; accelerare, grăbire; înaintare

forwarding agent expeditor

forwarding agent's notice aviz de expediere

forwarding of freight / of goods transfer / expediere / trafic de mărfuri

forwarding station (cf, transp) stație de expediție

foward gears (auto) viteze, (angrenajele de mers înainte, din cutia de viteze)

forward lead / shift deplasare înainte

forwardly $(a d v)$ în față, (către) înainte; spre partea din faţă

forward motion mişcare înainte

forward move (cf) cale de acces

forwardness (ec) nivel ridicat de dezvoltare / progres; promtitudine, prezumție

forward running curs / mers înainte; $(\mathrm{TH})$ funcționare continuată / continuă

forwards $(a d v)$ înainte, mai departe, în continuare, în față, în perspectivă; în sens direct, înainte

forward sale (ec) vânzare cu livrare la termen

forward shovel (constr, mas) excavator cu cupă dreaptă (în față)

forward slip (met) devansare, alunecare înainte (la laminoare)

forward speed (mas-un) viteză de avans

forward stroke (mas-un) cursă de lucru / directă / înainte

forward tape speed (met) viteză de derulare a benzii înainte forward travel (mas-un) cursă înainte; (met) trecere înainte (la laminoare)

foward welding (met) sudare spre înainte / spre stânga

fossil flax (ind chim) azbest

fossil fuel (ind chim, termo) combustibil mineral

fossil oil (ind chim) petrol brut

Faucault currents (el) curenți Foucault

foul rău; purtare / comportare incorectă, tamponare, defect, ciocnire; de calitate inferioară, murdar, îmbâcsit, putred; (nav) încurcat, angajat, împiedicat (şi d. lanțul de ancoră), a încurca ancora; (alim) rău mirositor, murdar; stricat, viciat (d. aer), (med) molipsitor, contagios; a murdări, a mânji; (mediu, med) a îmbâcsi, a polua (aerul), a strica, a infecta

foul air (mediu, med) aer stricat / viciat

foul-air flue (constr, TH) coş pentru evacuarea aerului viciat

foul bottom (nav) carenă murdară, fund periculos

fouling (TH) tamponare, ciocnire; (metr) indicație greşită a aparatului; lucru defectuos, procesare greşită

fouling of valve (termo) ancrasare a supapei

fouling point $(\mathrm{TH})$ punct periculos

fouling products (alim, ind chim) depuneri mucilaginoase

foulness $(\mathrm{TH})$ funcționare cu defecte; îmbâcsire; (metr) indicaţie greşită a aparatului

foul up (metr) a da peste cap, a indica (total) greşit (d. aparate)

found (mas-un) pilă triunghiulară subtire; a fonda, a întemeia, a înființa; a pili, a topi, a turna (materiale metalice); a justifica, a întemeia; a documenta; $\sim$ on / upon a depinde de

foundation fondare, fundatie, fundament(are), temelie, întemeiere, înființare; (constr, OM) bază, pat, talpă, soclu; organizație, asociație, instituție

foundation base (constr, OM) talpă / placă de fundație

foundation block (constr) bloc de fundatie

foundation bolt (constr, OM) bolț / şurub de fundație / de ancorare

foundation brickwork (constr) zidărie de fundație

foundation by caissons (constr) fundație cu chesoane

foundation cross (constr) placă de fundație cu zăbrele

foundation cutting / excavation (constr) săpătură pentru fundații, excavare a fundației

foundation ditch (constr) groapă de fundaţie

foundation failure (constr) năruire / distrugere a fundației

foundation footing (constr) fundație

foundation frame (constr) cadru de fundație 
foundation grouting (constr) etanşare (a terenului de fundație) prin injecție

foundation of a boiler (termo, alim) cavaleți ai cazanului / fierbătorului

foundation pile (constr) pilot de fundație

foundation piling (constr) pilotare, batere a pivoților de fundație

foundation pillar (constr) stâlp de fundație

foundation pit (constr) groapă de fundație

foundation plate (constr) talpă de fundaţie; (mas) placă de bază / de fundație

foundation rail (constr) şină de fundație

foundation settling (geol, constr) tasare a fundației

foundation stone (constr) piatră de fundație; (fig) bază, temelie

foundation structure (constr) fundament, structură a fundației

foundation washer (constr) adaos sub placa de fundație, placă de ancorare / de fixare

founder fondator; (met) topitor, turnător; (nav) a (se) scufunda, a se duce la fund, a se afunda; (constr) (d. o construcție) a se scufunda / afunda, a se lăsa; a da greș, a eșua

found on a baza / fonda pe

founder's shaft (constr) groapă de fundație

founding (met) turnare, piesă turnată, mulare, turnătorie

founding furnace cuptor de topit / de turnătorie

founding sandblast machine (met, sticlă, masun) maşină / instalație de sablat

foundress fondatoare, întemeietoare

foundry (met) (atelier de) turnătorie (de fontă), topitorie, uzină metalurgică

foundry alloy (met) aliaj de turnătorie, prealiaj

foundry auxiliary material (met) material auxiliar de turnătorie

foundry barrow / cart (met) cărucior de turnătorie

foundry coke (met) cocs de turnătorie / metalurgic

foundry crane (met) macara de turnătorie / de turnare

foundry cupola (met) cuptor cu cuvă pentru turnătorie, cubilou

foundry defect (met) defect de turnare

foundry flask (met) ramă de turnare

foundry floor (met) solul turnătoriei

foundry furnace (met) cuptor de turnătorie (şi cu flacără)

foundry graphite (met) grafit de turnătorie

foundry iron / pig (iron) (met) fontă de turnătorie

foundry jib crane (met, transp) macara pivotantă, pentru turnătorie

foundry ladle (met) oală de turnare

foundry(-)man (met) turnător foundry materials (met) materiale specifice de turnătorie

foundry moulding machine (met) maşină de for-mare pentru turnătorie

foundry pattern (met) model de turnătorie

foundry pig iron (met) fontă brută de turnătorie

foundry pit (met) groapă de turnare

foundry plant (met) instalație de turnătorie / de turnare

foundry-practice (met) tehnica turnării

foundry product (met) produs turnat / de turnătorie, piesă turnată

foundry sand (met) nisip de / pentru (modele de) turnătorie

foundry scrap (met) spărturi de turnătorie

foundry worker (met) muncitor turnător

fount izvor; (met) turnare, topire

fount / font garnitură completă de litere

fountain fântână, puț, rezervor (şi de stilou); (termo) răcitor de apă potabilă; izvor; chei

fountainhead izvor; (fig) izvor primar, sursă directă, origine; rezervor (şi de stilou)

fountain pen stilou

four-ball bearing apparatus, four ball tester (T) aparat cu patru bile pentru testarea uleiurilor lubrifiante, tribotester cu 4 bile

four-bar mechanism mecanism cu patru elemente, mecanism patrulater

four-blade (mas-un) cu patru tăişuri (d. scule)

four-bladed propeller (nav) elice cu patru pale

four-by-four (4 x 4) (auto) vehicul cu tracțiune pe fiecare roată

four-by-two (auto) autovehicul cu tracțiune pe două roți

four-cornered $(\mathrm{TH})$ cu patru colturi; cu participarea a patru părți, cvadripartit

four-cornered shaft $(\mathrm{OM})$ bară pătrată, arbore pătrat / cu secțiune pătrată

four-cusped $(\mathrm{OM})$ cu patru vârfuri / muchii

four-cusped hypocycloid (mat) astroidă, hipocicloidă cu patru puncte de întoarcere

four-cycle (termo) în patru timpi

four-cycle engine (termo) motor în patru timpi

four-cylinder engine (termo) motor $\mathrm{cu}$ patru cilindri

fourfold împătrit, cvadruplu; format din patru părţi

four-gear (4-gear) sequence (auto) secvența trecerii prin 4 viteze

four groove drill (mas-un) burghiu spiral $\mathrm{cu}$ patru caneluri / muchii

four-high rolling mill (met) laminor cuatro

four-high rolling stand (met) cajă de laminor cuatro 
Fourier analysis method (mat) metodă de analiză, prin dezvoltare în serie Fourier

Fourier expansion (mat) dezvoltare în serie Fourier

four jawed (OM, mas-un) cu patru fălci / saboți (de prindere)

four-leafed rose (mat) roză cu patru foi, curba $r$ $=\mathrm{a} \cdot \sin (2 \theta)$

four-light body (auto) caroserie / automobil cu patru geamuri

four-pin driven nut $(\mathrm{OM})$ piuliță rotundă, cu găuri în cruce

four-point attachment (mec, OM) fixare / suspensie / suspendare în patru puncte

four-point bit (mas-un) tăiş de burghiu, în patru colțuri

four-point loading Wöhler machine (mec, metr) maşină Wöhler pentru încercări la oboseală, cu patru posturi de lucru

four prong grapnel (nav) ancoră cu patru brațe

four-ribbed nut $(\mathrm{OM})$ piuliță cu patru nervuri pentru cheie

four-roll calender (ind chim) calandru cu patru cilindri

four-roller mill (met) laminor cuatro

four seater (auto) automobil cu patru locuri

four-stage cu patru trepte / etape (d. un proces tehnologic etc.)

four-stage compressor (termo) compresor $\mathrm{cu}$ patru trepte

four-start $(\mathrm{OM})$ cu patru începuturi (la melc sau la şurub)

four-start worm (OM) melc / şurub cu patru începuturi

four-strike cycle (termo) ciclu în patru timpi (şi la motoare cu ardere internă)

fourteen patrusprezece

forteehtn (al) patrusprezecelea

fourth-power / biquadric equation (mat) ecuație bipătratică / de gradul al patrulea

four-way pipe (OM, hidr) conductă cu ramificații în patru direcții, racord în cruce

four-way (stop) cock (OM, hidr) robinet cu cep, cu patru căi

four-way tool block (mas-un) portcuțit dreptunghiular turnant (la strung)

four-wheel drive (f.w.d., 4WD) (auto) tracțiune integrală (la autovehicule)

four-wheel steering (auto) direcție pe fiecare roată

fox (blană de) vulpe; (mas-un) dispozitiv de filetare la strung; (nav) comandă la bord; (om) şiret; (alim) a se acri, a se trezi (d. bere); a acoperi cu pete roşcate; $(\mathrm{fam})$ a înşela

fox hole (termo) gură de fum fox wedge (OM) contrapană, pană de siguranță / dublă, pereche de pene tangențiale

foxy şiret, isteț; roşcat; (alim) acrit, stătut, nefermentat (d. o băutură)

fractal(s) fractal(i) (figuri geometrice cu grad mare de neregularitate)

fraction (ind chim) fracțiune, produs de distilare; (mat) fracție, parte, porțiune; particulă, fragment, pic, părticică

fractional fracționar; (mat) de fracție; (chim) fractionat; mic, neînsemnat

fractional currency $(\mathrm{ec})$ monedă divizionară

fractional deposition (alim, ind chim) depunere fracționată (la decantare, sortare etc.)

fractional distilling tube (alim, ind chim) deflegmator, coloană de distilare fracționată

fractional gearmotor $(\mathrm{OM})$ motoreductor fracționar

fractional-(horse)power motor (termo, el) micromotor, motor de putere mică / de putere sub $1 \mathrm{CP}$

fractional load (mas, mec) sarcină incompletă / parțială

fractionally $(a d v)$ parțial, în parte; (într-un mod) nesemnifactiv

fractional melting (met) topire / fuziune fracționată, fracționare prin fuziune / topire

fractional part fracție, parte

fractional precipitation (ind chim) precipitare fracționată

fractional recovery curve (alim, ind chim) curba de recuperare fracționată (la decantare, sortare etc.)

fractional turbine (termo) turbină cu admisie parțială

fractionary fracționar, fragmentar; (chim) fracționat

fractionate a fracționa, a fragmenta

fractionating tube (alim, ind chim) deflegmator

fractionation (ind chim) fractionare, rectificare

fractionaze a fracționa

fraction bar / line (mat) linie de fracție

fraction defective $(\mathrm{TH})$ fracție reprezentând numărul pieselor defecte dintr-un lot (şi de 100)

fraction in its lower terms (mat) fracție ireductibilă

fractionize a fracționa, a rupe

fraction stroke (mat) linie de fractie

fractography (mec, metr) studiul ruperilor

fracture fractură; (fiz) refracție; (met) casură, suprafața ruperii; rupere, fracturare, spargere, sfărâmare, concasare, crăpare, spărtură, ruptură, întrerupere, fisură; a fractura, a (se) rupe, a (se) sparge, a crăpa, a (se) fisura, a sfărâma, a concasa 
fracture appearance (met) aspectul ruperii fracture mechanics mecanica ruperii fractured surface suprafață a ruperii fracture load (mec, OM) sarcină de rupere fracture patern (mec, $\mathrm{OM})$ tip de rupere fracture pieces $(\mathrm{mec}, \mathrm{OM})$ fragmente fracture strength $(\mathrm{mec}, \mathrm{OM})$ rezistență la rupere fracture test (materiale, metr) test efectuat până la ruperea epruvetei, în scopul studierii ei

fracturing fracturare, formare de fisuri fragile fragil; fărâmicios; casant; şubred; (TH) netrainic, de scurtă durată

fragilility fragilitate; caracter sfărâmicios; netrăinicie (d. materiale)

fragment fragment, parte (a unui întreg), fracțiune, segment, bucată, bucățică, ciob, sfărâmătură; parte; pasaj (dintr-un text)

fragmentarily $(a d v)$ (în mod) fragmentar

fragmentariness caracter fragmentar

fragmentary fragmentar; incomplet

fragmentation fîşiere, fragmentare (mecanică, dar şi cu referire la calculatoare)

fragmented fragmentat, fragmentar

fragmentize a fragmenta

fragrance mireasmă, miros plăcut, parfum

fragrant parfumat, care miroase frumos

frail fragil, casant, nestabil, şubred, friabil, slab; coş de papură

frame (auto) şasiu; (constr) schelet (de rezistență), cadru, capră, suport, fermă, construcție, corp, toc, cercevea; (fiz) sistem de coordonate; (c) câmp / cadru al imaginii; (OM) batiu, corp, rastel, stativ, carcasă, maşină, cadru, ramă, chenar; alcătuire, structură, organizare; a tivi, a bordura, a încadra, a forma un cadru, a înrăma, a lega, a îmbina; a elabora, a întocmi; a avansa, a propune; a potrivi, a adapta, a ajusta; (mat) reper, sistem de referință / de coordonate; (nav) coastă, osatură de navă, element de osatură; a acuza pe nedrept

frame construction (constr, mec) constructie în cadre, fermă

frame crane (mas, transp) macara-capră

framed building (constr) construcție cu etaje / cu cadre / cu module

framed filter (alim) filtru cu rame

frame dryer (alim) uscător cu rame

framed structure (constr) structură / construcție în cadre

framed system (constr) sistem cu zăbrele / cu cadre

frame field time base bază de timp a cadranului frame filter (alim, OM) filtru cu rame

frame filter-press (alim, mas-un) filtru-presă cu cadru frame floor (nav) varangă de coastă / de cadru (construcții navale)

frame girder (auto) lonjeron de cadru; (constr) grindă cu zăbrele

frame joint (auto) balama-şarnieră; (met) şarnieră

frame kick-up (constr, mec) curbură a cadrului

frameless (constr, mec) fără ramă / cadru, neînrămat, neîncadrat

frame of machine (OM, mas) batiu al maşinii

frame of reference (constr, mec) cadru de referință

frame-plate filter (alim, OM) filtru-presă cu placă şi ramă (şi fig)

frame saw (mas-un) gater, ferăstrău cu cadru

frame shears (mas-un) foarfece paralel, foarfece ghilotină

frame spacing (nav) interval între coaste, distanță intercostală

frame spine coloană a cadrului (la autovehicule cu trei roți)

frame stirrer (alim, constr, ind chim) amestecător cu cadru

frame-type core box (met) cutie deschisă pentru miez

framework (constr) schelet, fermă, grindă (cu zăbrele), paiantă, antablament; (nav) osatură de navă; (TH) batiu, postament, platine, schelet, ramă, cadru, carcasă, şarpantă, jug, structură de rezistență / portantă

framing (constr) chenar, şarpantă, fermă, grindă (cu zăbrele); (OM) batiu; (el, inf, c) cadrare a imaginii, sincronizare, baleiaj de cadru; $(\mathrm{TH})$ cadru, carcasă, schelă, schelet, osatură, lot, serie; (c) încadrare / reglare a imaginii

framing of joists (constr) planşeu de grinzi de lemn

framing restle (constr) capră-suport (şi la macara)

franchise (ec) operatie de franchising, concesiune, privilegiu, prioritate, autorizație de producere / de comerț pentru un produs sau un serviciu al altei companii

franchising (ec) metodă de a produce / comercializa într-o anumită zonă produse şi servicii lansate anterior cu succes în altă parte

Francium (Fr) (chim) franciu

franco (ec) franco, liber de taxe

fragile (materiale) fragil, casant, nestabil, sfărâmicios

fragile disk $(\mathrm{OM})$ membrană / disc / placă de siguranță

frank (mat) strict posibil, posibil dar nu necesar; clar, evident, fățiș: a franca, a timbra

frankness franchețe, sinceritate

frappé (alim) frapat, (puțin) rece 
frapping (nav) parâmă de reținere, legare cu parâme, amarare

fraud înşelătorie, escrosherie; impostor, escroc

fray bătaie; a se uza, a se destrăma, a (se) roade; rosătură; uzură, roadere (şi d. țesături)

frayed uzat, destrămat

fraying destrămare (a unui material fibros)

fray out a destrăma complet (o țesătură etc.)

frazzle (med) stare de epuizare; uzură, roadere (textile); (alim) scrum, ardere; a (se) roade, a (se) uza

freak capriciu; poznă; zbenguială; fantezie; ciudățenie; curiozitate; monstruozitate; of nature fantezie a naturii

freak stocks $(\mathrm{TH})$ produse intermediare

freak value (inf) valoare eratică / instabilă / întâmplătoare

freckles (met) puncte negre / pori la tablă albă laminată (defect)

free (adj) liber; independent, autonom, liber, neocupat; desfăcut; dezlegat; spontan; neîmpiedicat, nestingherit, nestânjenit; neconstrâns (de reguli); degajat (la vorbă, în comportament); nesăbuit; neangajat; generos, darnic; neforțat; nesilit imparțial, nepărtinitor; liber (d. o traducere, un stil etc.); gratuit, gratis, fără plată; neocupat; from / of (ec) scutit de (taxe etc.), franco; separat; (chim) liber; a elibera, a degaja; (el) a deconecta

free abrasing machining (mas-un) prelucrare

de precizie, fără abraziv

free air (mediu) aer atmosferic

free alkalis test (chim, metr) test pentru determinarea alcaliilor liberi

free ammonia (chim) amoniac liber

free and easy neoficial, neconvențional

free ash (termo, met) cenuşă care poate fi antrenată în curentul de ardere / care nu se depune

free atmosphere / air în aer liber

free axle (auto, OM) osie alergătoare

free beam (mec, OM) grindă liber / simplu rezemată

free bearing $(\mathrm{OM})$ reazem articulat, lagăr cu rulment liber sau rulmenti liberi

freeboard (nav) bord liber, franc-bord

freeboard deck (nav) punte de bord liber

freeboard depth (nav) înălțime de bord liber

freeboard zone (nav) zonă de bord liber, zonă de încărcare

free carbon (chim, met) carbon liber / nelegat

free contraction of fiber (plast, textile) contracție liberă a fibrei

free copy exemplar gratuit

free cutting (materiale, mas-un) uşor prelucrabil (prin aşchiere) free-cutting steel (met) oțel pentru maşini / strunguri automate de prelucrat

free-deviation-action turbine (termo, hidr) turbină hidraulică cu acțiune

free-discharge butterfly valve $(\mathrm{OM}$, hidr) vană / supapă / robinet fluture pentru golire de fund free distance $(\mathrm{OM})$ joc, spațiu liber, interstițiu

freedom libertate, îndependență; drept, privilegiu

freedom from bias error of a measuring instrument (metr) exactitate / precizie a unui aparat de măsură

freedom from brittle fracture (met) insensibilitate la rupere fragilă

freedom from scale (met) fără oxizi / arsură / țunder

freedom of movement (mec) mobilitate

free end bearing (mec, OM) lagăr (de capăt) / reazem mobil

free energy (fiz) energie liberă, potențial izocor

free enthalpy (fiz, termo) entalpie liberă

free fall / falling (mec) cădere liberă

free fall acceleration (mec) accelerație gravitațională / de cădere liberă / datorată câmpului gravitațional

free-fall-type batch mixer (constr, mas) betonieră discontinuă / cu cădere liberă

free fit (OM) ajustaj cu joc (şi larg)

free-floating piston (hidr, OM) piston flotant, plunjer

free-flow(ing) (hidr) curgere liberă / cu nivel liber

free-flowing black (chim) negru de fum granulat

free from / of lipsit de, fără, liber de; a elibera, a scuti de

free from average fără avarie (excludere a riscului de avarie în asigurarea mărfurilor cu perisabilitate mare)

free from contagion (alim, med) sterilizat, fără germeni

free from contamination / impurities (alim, med, materiale) fără adaosuri / impurități

free from dross / slag (met) a evacua zgura, fără zgură

free from flaws (TH) fără defecte, perfect, ireproşabil

free from particular average (nav) fără avarie particulară (clauză în contractul de asigurare maritimă, asiguratorul fiind exonerat pentru avarii particulare)

free gases (chim) gaze libere

free-hand de mână, schiță

free handle $(\mathrm{OM})$ manetă detaşabilă

free hand technical sketch $(\mathrm{OM})$ desen / schiță cu mâna liberă

free harbour (ec, nav) port liber; porto-franco

free hung (mec, OM) suspendat liber / fără fixare 
free jet (hidr, termo) jet liber

free labour munca celor neînscrişi în sindicat; muncitori nesindicalişti

free list (ec) listă de mărfuri libere la export

freely movable bearing $(\mathrm{OM})$ lagăr cu mişcare liberă / liber (cu rulment liber)

freely supported beam (mec, OM) grindă simplu rezemată

free-machining material / steel (met) material / oțel cu prelucrabilitate (prin aşchirere) îmbunătățită prin adaos de sulf, fosfor, plumb

free mobility (mec) mobilitate liberă / totală

free motion (mas, TH) mers în gol

free name (ind chim) denumire obişnuită (a produselor chimice)

free of în afara, dincolo de; fără; a elibera de, a degaja de, a scoate (un miros etc.)

free of additives (alim, T) fără aditivi, neaditivat

free of charge (ec) netaxabil, fără taxă, gratuit

free of clinker / of slag (met) fără conținut de zgură

free of duty (ec) scutit de vamă / de taxă vamală

free of ground (el) fără împământare

free of sulphur (materiale) fără sulf

free oscillation / vibration (mec) oscilație / vibrație liberă / proprie

free play (mas-un) joc, cursă moartă

free port (ec, nav) port liber, porto-franco

free position (mas) poziție neutră

free pulley $(\mathrm{OM})$ roată de curea liberă

free radical (chim) radical liber

free reel $(\mathrm{OM})$ rolă liberă

free rotation $(\mathrm{mec})$ rotație liberă

free running (mas, OM) joc, cursă moartă

free-running fit $(\mathrm{OM})$ ajustaj cu joc mare

free-running speed (mas) viteză de regim / de echilibru

free settling (alim, constr, ind chim) precipitare / depunere / sedimentare (prin cădere) liberă

free settling classifier (alim, constr, ind chim) sortator / clasor cu cădere liberă

free shaping (mas-un, TH) fasonare liberă

free speed (mas, mec) viteză unghiulară a unui motor fără sarcină

free spring $(\mathrm{OM})$ arc spiral / elicoidal (care se poate missca pe soclu / reazem)

free stock (ec) stoc disponibil

freestone (constr, geol) gresie

free sulphur (chim) sulf liber / nelegat

free surface (hidr) suprafață liberă (a unui lichid)

free tank (OM, hidr) tank cu suprafață liberă de lichid

free the line (cf, met) a elibera / a debloca linia

free trade (ec) comert liber

free translation traducere liberă free transmission (OM) transmisie cu cuplaj de mers liber

free travel of clutch pedal (auto, OM) cursă a (pedalei) ambreiajului

free valence (chim) valență liberă

free vortex (hidr) vârtej nedirijat

free water (mediu) umiditate în exces

free water circulation (auto) circulație liberă a apei

freewheel, freewheeling $(\mathrm{OM})$ roată liberă, roată a cuplajului, torpedo

freewheeling (roller) clutch $(\mathrm{OM}$, auto) ambreiaj / cuplaj de mers liber, cuplaj torpedo / cu bile / cu role

freezant (alim, termo) mediu / agent congelant

freeze (alim, termo) înghețare, a îngheța, a (se) congela, a refrigera, a (se) solidifica (prin frig), a (se) slei, a se preface în gheață, a face să înghețe; (OM) a gripa, a bloca; (ec) înghețare, stabilizare, a îngheța, a stabiliza (prețuri etc.); a nu mai mișca, a rămâne neclintit; a nu se lăsa de; a boicota; (med) a degera

freeze coagulation (alim) coagulare prin scăderea temperaturii

freeze dryer (alim, ind chim) liofilizator, uscare / uscător prin congelare

freeze in (mediu) a imobiliza cu gheață; a prinde între ghețuri

free drying (alim, termo) criodesicare, liofilizare, uscare prin congelare

freeze grinding (termo, TH) criomăcinare, crioşlefuire, şlefuire în mediu criogenic

freeze out (alim, ind chim) a separa prin congelare

freeze-out (alim, ind chim) separare (a unui component al unui amestec) prin congelarea unuia dintre componente)

freeze over a acoperi cu gheață

freeze proofness (materiale, alimente) rezistență la ger / la gelificare

freezer (termo, alim) răcitor, maşină de înghețat, frigider, instalație de congelare

freezer burn (alim, ind chim, termo) arsură / desicare excesivă prin congelare

freeze resistance (materiale) rezistență la îngheț freeze-thaw resistance (materiale, alimente) rezistență la congelare-decongelare

freeze to death a degera

freeze up a (se) congela, a (se) solidifica, a îngheța

freeze-up (alim, termo, mediu) obturare prin înghet (a unei conducte de fluid etc.)

freezing (alim, hidr, termo) congelare, înghețare, solidificare, care îngheață; $(\mathrm{OM}, \mathrm{T})$ gripare

freezing apparatus (alim, termo) maşină de congelat / de refrigerat / de înghețat, refrigerator 
freezing chamber (alim, termo) incintă congelatoare

freezing constant (termo) constantă crioscopică freezing curve (met) curbă de solidificare / de răcire (la tratamente termice)

freezing interval (fiz, materiale) interval de congelare / de solidificare / de cristalizare

freezing mixture (termo, alim, ind chim) amestec refrigerent / răcitor, (agent) frigorific

freezing of furnace (met) înghețarea cuptorului

freezing plant (alim, termo, ind chim) instalație de congelare / de înghețare / de refrigerare

freezing plateau (termo, alim) punct de oprire a congelării, orizontală de congelare constantă

freezing point (fiz, termo) punct / temperatură de congelare / de înghețare / de solidificare

freezing-point depression (fiz, termo) scădere a punctului de congelare

freezing-point lowering (fiz, termo) coborâre a temperaturii / punctului de congelare / înghețare / solidificare

freezing process (termo, alim) proces de congelare / înghețare / solidificare

freezing range (termo, alim) interval de congelare / înghețare / solidificare; (met) interval de răcire / de solidificare; (auto, termo, mediu) interval de îngheț

freezing segment (auto, termo) indicator pentru intervalul de îngheț

freezing temperature (fiz, termo) temperatură de înghețare / de solidificare

freezing test (materiale, metr) încercare de rezistență la îngheț

freeze-up (termo) a funcționa anormal din cauza depunerii gheții pe elementele de răcire; (mas) a înceta mişcarea din cauza dilatării sau gripării

freight (ec) fraht, încărcătură, (transport de) mărfuri, cost de transport, cheltuieli de transport; (nav) navlu, caric; a încărca, a navlosi

freightage (nav) navlosire, navlu, afretare, capacitatea utilă a navei, încărcătură, cost al transportului

freight car (cf) (amer) vagon de marfă

freight charges / costs (ec) cheltuieli / speze de transport

freight depot (cf) stație / depou de mărfuri

freight elevator (mas, transp) ascensor de mărfuri

freighter (nav) navlositor; cargou, cargobot

freight rate (nav, ec) preț al navlului

freight service (cf) serviciu de mărfuri

freight shed (constr) magazie de mărfuri

freight space / capacity (nav) spațiu pentru mărfuri

freight ton (nav, metr) tonă de navlu / de volum (40 de picioare cubice sau $1,13 \mathrm{~m}^{3}$ ) freight tonnage (nav) tonaj navlosit, capacitate navlosită

freight train (cf) (amer) tren de marfã

freight transit capacity (transpt) capacitate de tranzitare a mărfurilor

freight warehouse (constr) magazie de mărfuri

freight yard (cf) stație de mărfuri

French brandy (alim) coniac

French chalk (chim) (pudră de) talc, talc gras

French coupling (OM) asamblare / cuplare printr-o piesă cu două filete, unul pe stânga şi celălalt pe dreapta

French curve $(\mathrm{TH})$ florar

frenching (met) afinare finală (la neferoase)

frenchman $(\mathrm{OM})$ cheie franceză

French nail $(\mathrm{OM})$ cui de sârmă

French red (chim) carmin, cârmâz

frequency, frequence (fiz, mec, TH) frecvență, repetare; regularitate

frequency function / distribution (mat, fiz) densitate de repartiție, funcție de densitate

frequency modulation (el) modulație de frecvență

frequent des, frecvent; repetat; constant; obişnuit, uzual; a frecventa, a se duce des la

frequentation frecventare

frequently $(a d v)$ frecvent, des, adesea, adeseori, (în mod) obişnuit

fresh proaspăt; nou; de dată recentă; (alim) nesărat, proaspăt, pregătit / gătit chiar acum; sosit recent / de curând; nou, recent, altfel; (d. hârtie) curat, nefolosit; un alt, o altă; reînnoit, în plus, adițional, suplimentar; încă o / un; odihnit, refăcut, împrospătat; tânăr, fraged; (d. culori) viu, curat, strălucitor, (d. vopsea) care nu s-a uscat încă; viu, actual, de actualitate; (d. aer) proaspăt, neviciat, curat; (d. vreme) rece şi cu vânt

fresh air (mediu) aer proaspăt

fresh-air inlet (termo, mas) priză de aer proaspăt

fresh annealing (met) recoacere de maleabilizare cu decarburare

freshen a (se) împrospăta, a înnoi; (d. vânt) a se înteți

freshening împrospătare, înnoire; (mediu) purificare, curătare (a aerului)

fresh to nou în, neexperimentat în, neobişnuit cu freshen up a răcori, a înnoi, a împrospăta

freshet (geogr, mediu) inundație, revărsare

fresh flush (mediu, hidr) jet de apă dulce

freshly $(a d v)$ recent, de curând

freshly distilled (alim, chim) distilat proaspăt

freshly distilled aniline (chim) anilină proaspăt distilată

freshman (edu) student de anul I; începător, novice

freshness prospețime, noutate 
fresh water (alim, mediu) apă dulce / proaspătă fresh water jet (alim, mediu) jet de apă dulce fret agitație; frământare; destrămare; fermentare; (arhit, constr) ornament în unghiuri drepte (mec, T) a freca, a roade, măcinare, a (se) toci (prin frecare); a (se) agita, a (se) uza, a (se) roade; a (se) agita; a tulbura; a irita, a (se) necăji

fret saw (mas-un) ferăstrău coadă-de-şoarece, ferăstrău de traforaj

fret sawing (mas-un, TH) decupare (cu ferăstrău), traforare

fretting (T) uzură tip fretting (cauzată de oscilații / vibrații cu amplitudine mică); (T) fretting; rezultat şi proces de uzură; proces de agitare / frământare / măcinare / roadere

fretting corrosion $(\mathrm{T})$ coroziune / uzură prin frecare, (uzură) fretting, (uzură de) coroziune de tip fretting (fretting-ul provoacă şi o oxidare a materialului detaşat)

friability (materiale) friabilitate, fragilitate

friable (materiale) friabil, (s)fărâmicios, fragil

friction $(\mathrm{mec}, \mathrm{T})$ frecare, frictiune

friction action $(\mathrm{T})$ efect de frecare / de frânare (prin frecare), acțiune determinată de frecare

frictional $(\mathrm{T})$ de frecare

frictional coefficient $(T)$ coeficient de frecare

frictional counter-shaft $(\mathrm{OM}, \mathrm{T})$ arbore intermediar într-o transmisie prin fricțiune

frictional force $(\mathrm{mec}, \mathrm{T})$ forță de frecare

frictional heat $(\mathrm{mec}, \mathrm{T})$ căldură produsă / generată prin frecare

frictional losses $(\mathrm{mec}, \mathrm{T})$ pierderi prin frecare

frictionally held $(\mathrm{mec})$ ținut pe loc prin frecare / datorită frecării

frictional moment (mec, $\mathrm{T}$ ) moment de frecare

frictional resistance $(\mathrm{mec}, \mathrm{T})$ rezistență la frecare / datorată frecării

frictional work (mec, $\mathrm{T}$ ) lucru mecanic de frecare

friction band $(\mathrm{OM}, \mathrm{T})$ bandă de frână; (nav) panglică de frână (la vinci)

friction bevel gear $(\mathrm{OM}, \mathrm{T})$ transmisie cu roți conice prin frictiune

friction board $(\mathrm{OM}, \mathrm{T})$ plăcuță de frână / de ambreiaj

friction brake $(\mathrm{OM}, \mathrm{T})$ frână cu fricțiune

friction calender (mas-un, T) calandru / cilindru de netezire / de lustruit; (plast) calandru de cauciucare prin fricțiune

friction calendering (plast, T) calandrare prin fricțiune

friction clutch pulley $(\mathrm{OM})$ roată de transmisie cu ambreiaj încorporat

friction coefficient $(T)$ coeficient de frecare

friction compound $(T)$ amestec de fricțiune friction coupling (OM, T) cuplare / cuplaj / ambreiaj cu fricțiune / acționat prin frecare

friction disk (OM) disc de frecare / de ambreiaj

friction drag $(\mathrm{T})$ rezistență la / de frecare

friction drive $(\mathrm{OM}, \mathrm{T})$ acționare / transmisie prin fricțiune / cu roți de fricțiune

friction(-driven) roll (mas-un) cilindru de apăsare pentru înaintare; (met) cilindru liber la laminoare

friction facing / lining $(\mathrm{OM}, \mathrm{T})$ garnitură / acoperire pentru frecare

friction factor (hidr, fiz) coeficient Darcy / de rezistență hidraulică de frecare

friction feed motion (mas-un, OM, T) avans prin mecanism cu roți de fricțiune

friction finish (mas-un, T) finisare prin frecare

friction force (mec, T) forță de frecare

friction gear $(\mathrm{OM}, \mathrm{T})$ transmisie cu roți de fricțiune / prin fricțiune

friction head (hidr, T) pierdere de presiune cauzată de frecare (măsurată şi în coloană de apă)

friction hoist (mas, $\mathrm{T}$ ) ascensor prin fricțiune

friction horse power (mas, mec, T) putere consumată prin frecare, putere necesară învingerii / compensării frecării

friction igniter (termo, T) aprinzător prin frecare

frictioning $(\mathrm{T})$ care se freacă

frictionless $(T)$ fără frecare

frictionless liquid (fiz, T) lichid perfect / fără vâscozitate

friction let-off motion (mas, T) mişcare de pornire prin frecare

friction losses $(\mathrm{OM}, \mathrm{T})$ pierderi prin frecare

friction of rest (fiz, T) frecare statică / de aderență în repaos

friction oxidation, fretting ( $\mathrm{T}$ ) uzură fretting, oxidare cauzată de frecare

friction pad $(\mathrm{OM}, \mathrm{T})$ plăcuță de frână

friction plate $(\mathrm{OM}, \mathrm{T})$ placă / disc de frână / de frictiune

friction pressing tool $(\mathrm{OM}, \mathrm{T})$ dispozitiv de presat prin frecare

friction reel $(\mathrm{OM}, \mathrm{T})$ înfăşurător (prin fricțiune)

friction resistance $(\mathrm{T})$ rezistență de / la frecare

friction ring $(\mathrm{OM}, \mathrm{T})$ inel de frecare al unei garnituri, inel de fricțiune (la transmisii prin fricțiune)

friction saw (mas-un, T) ferăstrău cu disc de fricțiune (fără dinți)

friction socket (mas-un) mandrină de fricțiune / cu prindere în fălci de fricțiune

friction spring (OM) arc (de apăsare) al roții de frictiune

friction stock (ind chim, T) amestec de cauciucare prin frecare 
friction stress (mec, T) efort / tensiune tangențial( $\breve{a}) /$ de forfecare, provocat( $\breve{a})$ de frecare

friction stud welding (met, $\mathrm{T}$ ) sudarea prin frecare a bolturilor

friction surface $(T, O M)$ suprafață de frecare

friction tape $(\mathrm{OM}, \mathrm{T})$ bandă de fricțiune (şi la frâne)

friction test $(\mathrm{T})$ probă / test de frecare

friction torque (mec, T) moment / cuplu de frecare

friction welding (met, $\mathrm{T})$ sudare prin frecare

friction wheel $(\mathrm{OM}, \mathrm{T})$ roată de fricțiune

friend prieten; cunoscut, cunoştință; coleg; ajutor; susținător; apărător; partizan

friendlike prietenos

friendliness atitudine prietenoasă, prietenie

friendly prietenos, binevoitor, amabil; favorabil, prielnic; $(a d v)$ prietenos

frieze (textile) pânză moltonată; scamă, pluş

friezing încrețire, ondulare (d. table, folii, textile)

frigorific (termo) frigorific, refrigerent

frigorific mixture (ind chim, termo) amestec refrigerent

frigorimeter (metr, tremo) termometru pentru temperaturi joase

frill (textile, plast) volănaş, cută, pliseu; a plisa, a cuta, a gofra, a încreți, a tivi

frilled (textile) cu volănaşe

fringe (fiz, TH) franjă, margine, franj, bordură, tiv, ciucure, capăt, şuviță; a tivi, a bordura, a pune o bordură (şi la imagine)

fringe benefit avantaj în plus (la salariu)

fringe effect (fiz, mec) efect marginal / de margine

frisk salt, săritură; a țopăi

frit (materiale, TH) a sinteriza, a aglutina; amestec de ceramice fuzibile

frith (geogr, nav) estuar

frit seal $(\mathrm{OM}$, el) etanşare / izolare obținută prin topirea unui amestec de pulberi metalice sau ceramice cu un liant

fritter away a pierde, a irosi, a cheltui (bani, energie etc.)

fritting (ind chim) concreționare, sinterizare, fritare

friz(z) a încreți; a bucla, a cârlionța; crețuri, bucle (d. păr, fire, folii etc.)

frizz a sfârâi

frizzly încrețit, ondulat (d. păr, fire, folii etc.)

frock salopetă, haină de lucru

frog (cf) inimă de macaz / de încrucişare / de ac / de schimbător de cale, macaz de dreapta; $(\mathrm{OM})$ opritor / limitator reglabil

frog cam $(\mathrm{OM})$ camă cardioidă

frog-leg winding (el) înfăşurare în labă de broască / buclat-ondulată frogsuit (TH) îmbrăcăminte de protecție / de siguranță

from de la, din, de pe, (departe) de; din parte, de la; din, de la; după; din cauza

from above de sus; de deasupra

from behind $(a d v)$ din spate; din spatele

from-to-tester (el) aparat electronic de verificare a continuităţii între două puncte într-un circuit

from under pe sub; de sub

front $(s)$ frunte; front, față; (constr) fațadă (de casă), latură anterioară / din față, door uşă principală / din față, room camera frontală pe fațadă, uşă de faţadă; partea principală, partea din față a unui lucru, a tencui fațada (unei case etc.), $\sim$ with a acoperi cu, a consolida cu; vitrină (de magazin); teren care dă spre (un râu etc.); (mil) front, a obliga să facă front spre, a face front spre; cap (al coloanei etc.); pozitie de frunte; îndrăzneală; neruşinare; (adj) frontal; principal; prim; de fațadă; $(a d v)$ din față; de fațadă; (fig) a se distinge, a se face cunoscut; (geogr, nav) țărm de mare, coastă, faleză; a da (în)spre, a fi orientat spre; a fi față-n față cu / vizavi de; a înfrunta; a sfida; a ține piept (la); a face față (greutăților etc.); a se întoarce spre; a fi orientat către; $\sim$ to / towards / upon a fi întors spre; $\sim$ to $\sim$ față în față; in the $\sim$ în rândul întâi

frontage (constr) fațadă

front airbag (auto) airbag frontal

frontal (constr) fronton, fațadă; transversal, frontal

frontal collision (auto) coliziune frontală

frontal impact crash (auto) coliziune frontală

frontal tool-holder slide (mas-un) sanie portsculă din față / frontală

front axle (cf, mas, OM) osie din față / directoare front bridge wall (termo, met) altar de focar

front bumper (auto) bară de protecție

front contact (mas-un, TH) contact de lucru / frontal

front drive (auto) tracțiune pe roțile din față

front edge of the seat cushion (auto) marginea frontală a pernei scaunului

front elevation vedere din faț̆ / frontală

front-elevating drawing $(\mathrm{OM})$ desen al vederii din față, elevație

front end $(\mathrm{OM})$ capăt frontal

front end crawler shovel (constr, mas) autoîncărcător pe şenile, cu cupă frontală

front end loader (constr, mas) încărcător cu cupă frontală

front end plate of a boiler (termo) perete frontal al cazanului / al fierbătorului

front / frontal face suprafață frontală; (mas-un) față de degajare (la scule) 
front fog light(s) (auto) faruri de ceață (față)

front fog light indicator (auto) indicator pentru lumini de ceață față

front gib (OM, mas-un) ghidaj din față, partea din față a ghidajelor

front idler $(\mathrm{OM})$ roată de ghidare

front impact sensor (auto, metr) senzor de impact frontal

frontier frontieră, graniță

frontier property (mat, fiz) proprietate la frontieră

frontispiece (constr) frontispiciu; introducere, prefață, cuvânt inainte,

frontless (constr) fără partea din față, fără fațadă

front member (constr, mec) element frontal

front mill table (met) cale / transportor cu role plat(ă) în fața cajei de laminare

front of cutting (met) front de tăiere (la tăierea termică a metalelor)

front of the piece (met, OM) parte frontală a laminatului / a piesei

front of vehicle (auto) fața vehiculului

front of weld (met) front de sudare

fronton (constr) fronton

front page pagină / foaie de titlu

front panel (constr) panou frontal

front passenger (auto) pasagerul de pe scaunul din față

front passenger position (auto) locul din dreapta şoferului

front passenger's airbag (auto) airbag-ul pasagerului din dreapta (şoferului)

front passenger's air bag off indicator (auto) indicator de oprire / deconectare a airbagului pentru pasagerul din față

front passenger's airbag ON/OFF switch (auto) buton DESCHIS/ÎNCHIS pentru airbagul pasagerului din dreapta (şoferului)

front passenger's door power window switch (auto) comutator electric pentru geamul din dreapta față

front passenger seat (auto) scaunul pasagerului din dreapta

front passenger's seat belt warning light (auto) semnal luminos de avertizare a centurii de siguranță a pasagerului din dreapta

front plate $(\mathrm{OM})$ placă frontală; (met) suport al formei (la turnare sub presiune)

front position $(\mathrm{OM})$ porțiune frontală

front rake (mas-un) unghi de degajare (la scule) front-rank de prim rang; de primă importanță; fruntaş, cel mai bun

front roll(er) $(\mathrm{OM})$ roată / cilindru din față a(l) unui compresor; (met) cilindru degrosisor / de degroşare front seat (auto) scaun din față

front seat adjustment (auto) reglarea scaunului din față

front screen / windshield (auto) parbriz din față front shield (met) scut frontal; (auto) element de caroserie care protejează partea cea mai joasă din față la un autovehicul

frontsight țintă, vedere frontală

front spar $(\mathrm{OM}, \mathrm{mec})$ suport / consolă

front spindle bearing $(\mathrm{OM})$ lagăr principal (la strung)

front tipper (auto, transp) autobasculantă spre față

front track (cf, mas) ecartament frontal

front truck axle (OM) osie alergătoare

front view vedere frontală / din față; proiecție verticală, elevație

front-wheel brake (auto) frână pe roțile din față

front-wheel drive (auto) acționare pe roțile din față

front wheels (auto) roțile din față (ale unui vehicul)

front windshield (glass) (auto) parbriz

front windshield deicer (auto) dispozitiv de dejivrare a parbrizului față

front windshield maximum defrost button (auto) buton pentru dejivrarea (rapidă a) parbrizului

frost îngheț, ger; gheață pe geamuri; (TH) mătuire, finisare prin răzuire; a îngheț; (met) a acoperi cu un strat mat; a se acoperi cu gheață, a îngheța, a congela; a mătui, a glazura, a lua lustrul; (alim) a glazura, a glasa (prăjituri); glazed $\sim$ polei; white / hoar brumă; black ger uscat; hard / sharp ger aspru

frostbite a degera; degerătură

frostbitten degerat

frost-bound (agr) (d. pământ) înghețat

frosted acoperit cu gheață; mătuit, glazurat (d. sticlă)

frost-hardy (agr, bot) (d. plante) rezistent la îngheț / ger / frig

frostiness îngheț, ger; temperatură ca a gheții

frosting (ind chim) lacuri de matisare; mătuire, glazurare, glazură; (met) aspect mat (al alamei); (procesul de) înghețare

frost(-)proof / -resistant (materiale) rezistent la îngheț

frosty geros; acoperit cu gheață; înghețat

froth spumă; clăbuc; a spuma, a face spumă, a fierbe

frother (ind chim) (agent) spumant, substanță spumogenă

froth floatation flotație cu spumare (la prepararea minereurilor) 
froth formation (ind chim) formarea spumei frothing (în)spumare, formare de spumă; formare a unui strat cu bule de gaz / de aer (în procese de flotare)

frothing oil (ind chim) ulei spumant / de spumare froth-over (alim, ind chim) transvazare a spumei, deversare din cauza spumei

froth promotor (ind chim) spumant, agent de spumare, porofor

froth skimming (alim, ind chim) scoatere a spumei frothy spumant, spumos, cu spumă

frowsily neglijent, murdar

frowsiness, frowziness $(\mathrm{TH})$ aer viciat / închis; neglijență, murdărie

frowst (mediu) aer închis; a intra într-o încăpere neaerisită

frowsty (d. aer) stătut, închis, înăbuşitor

frowzy (mediu) cu aer viciat / închis; neglijent, murdar

frozen (alim) înghețat, congelat; înțepenit, prins; (ec) blocat, înghețat

frozen account (ec) cont blocat / înghețat

frozen meat (alim) carne congelată

frozen section (termo) secțiune de înghețare

fructification (agr) rod, rodire; (fig) fructificare

fructify (agr, bot) a face fructe; (fig) a fructifica

fructose (chim, alim) fructoză

fructuous (agr) roditor; productiv

frugal frugal, simplu; economic(os), rezonabil, modic (d. pret); econom, cumpătat

frugality economie, cumpătare; austeritate

fruit (agr, bot) rod, fruct(e); ( $p l$, fig) $\sim$ s roade (fig) rezultat, urmare; (alim) dried $\sim$ fructe uscate, stewed $\sim$ compot; (agr, bot) bear $\sim$ a da roade

fruiter (agr, bot) pom fructifer; (nav) vapor pentru fructe

fruit farming (agr, bot) pomicultură

fruit fly (alim) drosofilă

fruit frame (agr, OM) spalier

fruitful (agr) roditor; (fig) rodnic, fertil, productiv, prolific

fruitfully $(a d v) \mathrm{cu}$ folos, profitabil

fruit-growing (agr) pomicultură

fruition împlinire, realizare, atingere (a unui scop)

fruit knife (alim) cuțit pentru fructe

fruitless (agr) neroditor; sterp, steril, nerodnic; inutil

fruitlessness neproductivitate

fruit pomace (alim) tescovină, turtă de fructe

fruit pulp (alim) pulpă de fructe

fruit sugar (alim) fructoză, zahăr de fructe

fruit tree (agr) pom fructifer

fruit-wine (alim) vin de fructe

fruity (alim) cu miros / gust de fruct(e); (d. vin) cu aromă de struguri frustrate a zădărnici (un plan), a pune piedici; a înşela (aşteptările cuiva)

frustation zădărnicire; învingere (a unui adversar); dejucare (a unui plan etc.)

frustum, $(p l)$ frusta (geom) trunchi (între două plane paralele) (de con, de piramidă)

frustum of a cone (geom) trunchi de con

frustum of a wedge $(\mathrm{OM})$ pană trunchiată

fry (alim) a prăji, a frige (în ulei); carne prăjită, friptură; (alim, iht) icre de peşte, plevuşcă, peşti mici

fryer prăjitor, tavă de prăjit

frying (noise) (el, electr) pocnituri, pârâituri produse de contacte necorespunzătoare, zgomot de fond / de microfon

frying-pan (alim) tigaie / tavă de gătit

fry up a (se) electrocuta, a curenta

fuel (termo, auto) combustibil, carburant; a alimenta cu combustibil (şi lichid), a face plinul

fuel-air mixture (auto, termo) amestec carburant, aer + combustibil

fuel-air ratio (termo, auto) raport combustibil aer

fuel bin (auto, termo) rezervor de combustibil

fuel-burning engine (auto, termo) motor $\mathrm{cu}$ ardere internă

fuel can / canister (auto, termo) bidon de combustibil

fuel consumption (termo, auto) consum de carburant / de combustibil

fuel cycle (termo) ciclu de ardere (a combustibilului)

fuel dust (termo) combustibil pulverizat

fuel efficiency (chim, termo) eficiență / randament a(l) unui combustibil, putere calorifică a combustibilului

fuel element (ind chim) element din combustibil fuel failure (auto) lipsă de combustibil

fuel feed (auto, termo) alimentare cu combustibil

fuel feeding / filling (auto, termo) umplere / alimentare / furnizare de combustibil

fuel feed line (auto, termo) conductă de alimentare cu combustibil

fuel filler cap (auto) buşon

fuel filler lid (auto) capacul rezervorului

fuel filler lid release lever (auto) mâner capac rezervor

fuel filler neck (auto) pompă de alimentare

fuel filter (auto, termo) filtru de benzină / de combustibil

fuel filter warning (auto) indicator / avertizare pentru filtru de combustibil

fuel filter warning light (auto) lumină de avertizare pentru filtrul de combustibil

fuel-fire furnace (met, termo) cuptor cu flacără 
fuel gas (termo, ind chim) gaz carburant / combustibil, combustibil gazos

fuel gauge / indicator (auto, metr) indicator al nivelului de benzină / de combustibil / carburant (şi d. indicatorul de pe bordul autovehicolului)

fuel heater (termo, nav) încălzitor de combustibil

fuel hot spot (termo, nav) preîncălzitor de combustibil

fuel inhibitor (ind chim) antidetonant

fuel-injection nozzle (auto) pulverizator al injectorului de benzină; (termo) conductă de combustibil

fuel jet (auto, termo) jiclor (de carburant), ajutaj

fuel level (auto) nivelul combustibilului (în rezervor)

fuel line / manifold / pipe (auto) teavă de aspirat benzină; (termo) conductă de combustibil

fuelling (auto, termo) alimentare cu benzină (cu combustibil)

fuel nozzle (auto) duză de alimentare

fuel oil (ind chim, termo) păcură, combustibil pentru calorifere

fuel oil equivalent kiloliter (metr) unitate de măsură pentru energie, kilolitru echivalent pentru combustibil/ulei (amestec): 1 fuel oil equivalent kiloliter $=4,019762798 \cdot 10^{+10} \mathrm{~J}$

fuel piping (termo, auto) conductă de combustibil

fuel rating (termo, ind chim) randament de consum

fuel requirements (auto, termo) specificații / cerințe pentru combustibil / carburant

fuel station (constr, ind chim, auto) centru / stație de alimentare cu combustibil

fuel strainer (auto, OM, termo) filtru pentru carburanti lichizi

fuel supply (auto, termo, TH) stoc / rezervă / alimentare cu combustibil

fuel system cleaning agent (auto, ind chim) agent / aditiv de curătare a combustibilului în rezervor

fuel tank (auto, termo) rezervor de combustibil

fuel tank capacity (auto, termo) capacitatea rezervorului de combustibil

fuel value (termo, chim) putere calorifică a combustibilului

fuel wood lemn de foc

fug air (aer) îmbâcsit

fuggy închis, stătut, stricat (d. aer)

fugitive fugitiv, trecător; ocazional

fugitiveness caracter trecător

fugle a conduce, a fi conducător / ghid

fugleman conducător, director; ghid

fulcrum (mec) centru de rotație, punct de sprijin / reazem / echilibru / ridicare / articulație; $(\mathrm{OM})$ ax al articulaţiei, pivot; a pivota; (fig) mijloc de a exercita presiune / influență

fulcrum ball $(\mathrm{OM})$ bilă de sprijin (şi a unei manete, la aparate de măsură)

fulcrum bearing $(\mathrm{OM})$ suport cu prismă de reazem, lagăr-pivot / pivotant

fulcrum bracket $(\mathrm{OM})$ suport al punctului fix al pârghiei

fulcrum of suspension (mec) punct de suspendare / suspensie

fulcrum pin $(\mathrm{OM})$ pivot, şurub prizonier $\mathrm{cu}$ gaură pentru şplint, ax (al unei piese care se poate roti), ax de pivotare / de suspendare

fulcrum plate (OM, mas-un) placă turnantă / pivotantă

fulcrum point $(\mathrm{mec})$ punct de rotire / de pivotare

fulfil, (brit) fulfill (amer) a împlini, a îndeplini, a (se) realiza, a duce la bun sfârşit, a termina; a desăvârşi; a satisface

fulfilment, fulfillment (brit) (amer) realizare, îndeplinire

fulgurate a fulgera; a fulgui

fulgurator (chim, alim) pulverizator, picurător

full plin, încărcat; maxim; întreg, în întregime, total, complet, deplin; limită (ca adjectiv); (alim) sățios, nutritiv; bogat, îmbelşugat; $(a d v)$ direct, drept, tocmai, chiar; a croi larg

full and down (nav) încărcat şi cu pescajul maxim, plin și la marcă

full annealed sheet (met) tablă complet recoaptă (deasupra punctului $\mathrm{A}_{3}$ )

full annealing (met) revenire completă, recoacere de cristalizare / completă

full application of the brake (mas) frânare maximă

full automatic cycle (autom) ciclu complet automat

full automatic temperature control system (FATC) (auto, autom) sistem automat pentru controlul temperaturii

full-automatic turn-table ladder ( $\mathrm{TH}$, autom) scară rotativă automată

full availability (TH) accesibilitate / disponibilitate totală (d. utilaje, maşini etc.)

full bevelled edge (OM) margine / muchie ascuțită / teşită

full-blown (agr, bot) (pe deplin) dezvoltat, matur; înflorit

full board toate mesele; întreținere completă

full-bodied (alim) (vin) tare

full-boiling point (ind chim) temperatură de sfârşit al fierberii, punct final de fierbere

full braking (OM, mas) frânare maximă

full cap literă majusculă / capitală 
full circle (mas) (făcând) un cerc complet, încheind un circuit / parcurs complet

full deck ship / vessel (nav) navă cu punte continuă

full deflection (metr) deviație completă (şi a unui ac indicator)

full diameter bolt tolerance (OM) toleranță a diametrului exterior al filetului şurubului

full-edged $(\mathrm{OM})$ cu muchii neteşite / ascuțite

fuller (met) matriță de întindere; calibru de tăiere (la laminare)

full erase (inf, c) ştergere totală / a tuturor informațiilor

full excursion (metr) deviație completă (şi a unui ac indicator)

full face (poligrafie) caractere negre / aldine

full-feathering propeller (mas, termo, nav) elice dintr-o bucată

full fire / heat (termo) foc principal

full-flame converter blow (met) aprinderea convertizorului

full-fledged (zool) (d. păsări) cu pene; pe deplin dezvoltat, matur, cu drepturi depline

full-floating (nav) descărcat complet, complet flotant

full form tool (mas-un) cuțit profilat pentru finisare

full fusion welding (met) sudare prin topire (totală a materialului de adaos)

full-grown care a crescut; dezvoltat; matur

full hardening (met) călire pătrunsă / completă

full hard temper (met) nivel de duritate şi rezistență (la aliaje neferoase) peste care materialul nu mai poate fi (de)format

fulling mill (textile) piuă cu ciocănele

full length în mărime naturală; neprescurtat

full line linie continuă

fullness deplinătate, plenitudine

full load (mec, mas) încărcare / sarcină totală / plină / maximă / limită / nominală

full-load conditions (mec, mas) regim de solicitare-limită / de plină sarcină

full-load displacement (nav) deplasament de încărcare plină

full-load run / running (mas) funcționare sub sarcină totală / limită

fullness plenitudine, plinătate, volum; perfecțiune

full nut $(\mathrm{OM})$ piuliță cu înălțime normală

full of plin de, având; absorbit de

full of crevices cu fisuri, cu crăpături (d. materiale)

full-open (OM, hidr) deschis complet (şi d. supape, robinete etc.)

full page pagină întreagă

full passengers (auto) cu toți pasagerii, număr maxim de pasageri full-pickled sheet (met) tablă dublu / complet decapată

full-pitch winding (el) înfăşurare cu pas diametral

full point punct de încheiere

full portal crane (mas, transp) macara turnantă pe capre

full power (mas) putere nominală

full pressure (hidr, mec) presiune maximă / nominală

full-pressure lubrication (T) lubrifiere / ungere sub presiune (maximă, la alimentare)

full-purple (met) violet (culoare de trtament)

full-quenching (met) călire completă / pătrunsă

full rate (ec) tarif întreg

full retard (termo) aprindere întârziată

full-rigged (nav) $\mathrm{cu}$ tot greementul, echipat complet

full rotation (mec, mas-un) rotație completă / până la capătul cursei

full-scale deflection (metr) cursă completă a acului indicator al unui instrument / până la capătul scării

full-scale plant instalație industrială

full-scale reading (metr) deviație totală / limită a scării, indicație maximă (d. aparate)

full-scale value (metr) valoare maximă admisibilă de citire (pe scala unui aparat)

full-service leasing $(\mathrm{ec})$ închiriere a echipamentului industrial (cuprinzând în rata plătită și cheltuieli de întreținere şi reparaţii); leasing brut / propriu-zis (în care funcția de prestare de servicii este prioritară)

full-skirt piston (termo, OM) piston cu manta completă

full speed (mas, mas-un) viteză maximă

full-sphere $(\mathrm{OM})$ sferă (şi plină / întreagă)

full-squared tie (constr, mec) traversă pătrată plină

full steam (termo) admisie totală de abur

full stream sampler (alim, chim, metr) dispozitiv de extragere a unui eşation pe înteaga sectiune a curentului

full swing (mas) rotație / balansare completă

full swing rest (mas-un) sanie pentru prelucrarea pieselor, cu utilizarea completă a înălțimii vârfurilor

full swing shovel (mas) lopată mecanică giratorie, excavator giratoriu (care se poate roti $360^{\circ}$ )

full system differential pressure element (hidr) element într-un sistem bazat numai pe presiune diferențială

full-tapered file (mas-un) pilă ascuțită la vârf şi spre coadă 
full temperature control (system) (auto, autom) sistemul automat de control al temperaturii

full time zi de lucru, tot timpul destinat lucrului, cu normă întreagă

full-timer muncitor care efectuează o săptămână completă de lucru; care are o normă întreagă

full throttle (auto, termo) admisie completă

full-throttle start (auto) apăsare la maximum a pedalei de acceleratie

full title titlu principal, frontispiciu

full trailer (auto, termo) remorcă / trailer cu mai multe osii

full up plin până la refuz (d. un recipient etc.)

full view (OM) vedere completă (în desen tehnic)

full-wave vibrator (el) convertor c.c - c.a., cu vibrator

full weight greutate totală

fullword (inf) cuvânt rezervat pentru calculator

fully $(a d v)$ complet, pe deplin, cu totul; chiar, tocmai, exact; amplu, bogat

full(y) automatic / automating (autom, mas, $\mathrm{TH}$ ) complet automat(izat)

fully by-passing position (hidr) poziție de golire completă

fully continuous rolling mill (met) laminor continuu

fully hardened steel (met) oțel călit / complet călibil (martensitic)

fully killed steel (met) oțel (complet) calmat

fully open throttle (auto) accelerare la limita maximă (prin deschiderea completă a admisiei combustibilului în carburator)

fully-tested program(me) (inf) program complet testat / definitiv

fulminate a fulgera

fulminate (with a flame) (chim) a fulmina, a detona, a exploda

fume (termo) fum, abur, gaz puternic mirositor, vapori; a fumega, a face abur, a afuma, a trata cu abur, a face abur, a se evapora

fume extractor (ind chim, mediu) degazificator

fumes (termo) abur, vapori de apă, fum, gaze arse / de evacuare; (met) ca pori de metal

fumigate (alim) a afuma, a curăța prin afumare; a fumiza

fumigation (alim, termo) fumigare, fumizare, degazificare; afumare

function funcție, funcțiune, aplicație, rol; post, activitate; a funcționa, a merge, a îndeplini o funcție / un rol, a lucra

functional functional, destinat unui scop precis; oficial; operator; de funcție

functional compound (mas) compus / modul cu grupări funcționale

functional design proiect funcțional functional design specifications specificațiile totale ale unui proiect şi ale componentelor lui

functional diagram (autom, mas) schemă logică / de funcționare / funcțională, diagramă; (hidr) diagramă de fază / a secvenței operațiunilor unui circuit hidraulic sau pneumatic

functional inspection $(\mathrm{TH})$ control tehnic efectuat după fiecare operație / după un anumit număr de cicluri de funcționare

functionality funcționalitate

functionally $(a d v)$ (din punct de vedere) funcțional

functional requirements cerințe de funcționare, performanțe etc.

functional series (mat) serii de funcții

functional specification $(\mathrm{TH}$, mas) documentație tehnică de funcționare (a unui sistem, inclusiv pornire, lucru la parametri nominali, oprire etc.)

functional symbol (inf) simbol logic / funcțional

function(al) unit (el) bloc functional al unui ansamblu electronic sau electric; (inf) unitate / dispozitiv funcțional( $\breve{a})$, subsistem al unui calculator care efectuează un set bine definit de operații

functionary funcționar; persoană oficială

functionate a funcționa, a acționa

function chart tabelă de funcții

function element (mat, autom) element / variabilă a unei funcții

function hole (TH) perforație funcțională

functioning time (autom, mas) timp de acționare / de revenire (al unui releu, arc etc.)

functioning value (autom) valoare de acționare a unui dispozitiv

function key (autom, c) clapă / tastă de funcționare

function plotter înregistrator de curbe continue, trasator, ploter

fund (ec) fond, capital, rezervă, stoc; a consolida (şi o datorie publică); a plasa în titluri de stat

fundament (constr) fundație, parte dorsală

fundamental fundamental, de primă importantăă, esențial, de bază

fundamental circuit schemă de principiu, circuit fundamental / de bază

fundamental equation (mat, fiz) ecuație principală

fundamental frequency (fiz, mec) frecvență fundamentală

fundamental harmonic (mat, fiz) armonică fundamentală / cu frecvența cea mai mică

fundamental in facts principial, de principiu, de bază

fundamental layer (geom, constrstrat de bază / fundamental / principal 
fundamentally $(a d v)$ esențial, la bază, fundamental

fundamental natural frequency (fiz, mec) frecvență naturală de bază, cea mai mică frecvență naturală

fundamental principle principiu de bază / fundamental

fundamentals fundamente, principii, baze

fundamental sequence (mat) şir Cauchy / convergent / fundamental

fundamental set of solutions, fundamental system (mat) sistem fundamental de soluții (al unei ecuații diferențiale)

fundamental units (metr) unități fundamentale ale unui sitem de unități de măsură

fundamental vibration (fiz, mec) oscilație / vibrație fundamentală

fundamental wave of harmonic (el) lungime de undă corespunzătoare frecvenței fundamentale, frecvență de rezonanță

funds (ec) fonduri, mijloace băneşti

fungicide (agr, ind chim) fungicid

fungus, $(p l)$ fungi (alim) ciupercă

funicular (railway) (mas, transp) funicular

funnel pâlnie; (constr, met) coş de fum / de tiraj, gol într-o piesă turnată, tub / rețea / canal de turnare

funnel connection (OM) racord cu manşon

funnel-flow hopper (alim, ind chim, met) pâlnie cu curgere prin turnare

funnel heater (alim, ind chim, met) pâlnie pentru filtrare / turnare la cald

funnel holder / stand / support (ind chim) suport / stativ pentru pâlnii

funnel-shaped $(\mathrm{OM})$ în formă de pâlnie

funnel tube (alim, met) pâlnie / buncăr de încărcare / de alimentare / de umplere

funnel vicometer / viscosimeter (metr, T) vâscozimetru cu pâlnie

fur blană, piele (de animal); a îmblăni, a căptuşi cu blană; (termo) crustă; (textile) văl, pătură

furane resin (plast) răşină furanică

furbish a lustrui; a renova, a reînnoi

furl (nav) a strânge / înfăşura / desfăşura o pânză / velatura (pe catarg); a (se) înfăşura; a închide (umbrela, evantaiul etc.); a se strânge; a se depărta

furlong (metr) unitate de măsură pentru lungime (1/8 dintr-o milă): 1 furlong (US survey) $=$ $201,168402337 \mathrm{~m}$

furnace (met, ind chim) cuptor de calcinare / de prăjire / de ardere, furnal; focar, sobă, cuptor (în general); (termo) cazan de încălzire

furnace arch (met, termo) boltă a focarului / a cuptorului furnace atmosphere (met) atmosfera din cuptor furnace black (met) negru de fum de furnal

furnace blast (met) aer pentru furnal

furnace body (met) corp de cuptor / furnal

furnace bosh (termo) grătar al cuptorului

furnace bottom (met) vatră (de cuptor sau de forjă); (termo) cameră de ardere

furnace brazing / soldering (met) lipire în cuptor (electric)

furnace brazing / soldering in inert shielded gas (met) lipire în cuptor, în mediu de gaz inert

furnace brazing / soldering in reducing shielded gas (met) lipire în cuptor, în mediu de gaz reducător

furnace brazing / soldering with flux (met) lipire în cuptor (electric), cu flux

furnace brazing / soldering with gas (met) lipire în cuptor electric, cu gaz

furnace brick lining (met, constr) zidire / căptuşeală a cuptorului / a furnalului

furnace brickwork (met, constr) zidărie a cuptorului

furnace bridge wall (met, termo) altar / prag al cuptorului tubular

furnace campaign (met) campania / durata de funcționare a cuptorului

furnace capacity (alim, met, termo) cantitate de căldură utilă a cuptorului, capacitate a cuptorului

furnace carriage (met) vagonet de încărcare (la furnale / cuptoare)

furnace casing (met) carcasa cuptorului

furnace casting (met) turnare în solul turnătoriei

furnace chamber (termo, met) cameră a focarului

furnace charge (met) încărcare a cuptorului, şarjare

furnace-charging carriage (met) vagonet de încărcare (la furnale)

furnace-charging gear (met) mecanismul de încărcare al cuptorului / al furnalului

furnace coke (met) cocs de furnal / metalurgic

furnace column (met) coloană a furnalului

furnace construction / design (met, termo, constr) constructie / proiectare a cuptorului

furnace damper (met) registru de tiraj al cuptorului

furnace door (met) uşa / gura cuptorului

furnace drying (met) uscarea cuptorului

furnace efficiency (met) randament / utilizare a(l) cuptorului

furnace floor (met) vatra cuptorului

furnace flue (met) canal de gaze al cuptorului, gaze de ardere

furnace for heating plates (met) cuptor de recopt tabla / table groase 
furnace for sintering (met, ind chim) cuptor de aglomerare / de sinterizare

furnace front (met, termo) gură a focarului furnace gases (met, termo) gaze de ardere

furnace gases channel (met, termo) canal pentru gaze de fum

furnace grate (met, termo) grătar al cuptorului

furnace gun (met) maşina de astupat orificiul de descărcare

furnace hearth (met) vatra cuptorului, miezul furnalului

furnace-heat capacity (met, termo) capacitate termică a focarului

furnace hoist carriage (met) vagonet de încărcare (la furnale)

furnace-hoisting machine (met) troliu de încărcare (la furnale)

furnace inlet stream (alim, met) curent care intră în cuptor

furnace inlet temperature (alim, met) temperatură de / la intrare în cuptor

furnace installation (alim, met) instalație a cuptorului

furnace life (met, alim) durata (totală sau pentru realizarea unei şarje) de funcționare, campanie a cuptorului

furnace lines (met) profil al cuptorului

furnace lining (met, ind chim, termo) căptuşire / căptuşeală a cuptorului

furnace losses (met) pierderi de metal (prin topire / ardere etc.)

furnaceman (met) topitor, muncitor la cuptoare

furnace mantel (met) manta a cuptorului / a furnalului

furnace mouth (met) gură a furnalului / a cuptorului, clopot de încărcare

furnace operation / practice (met) functionare / mers a(l) cuptorului

furnace outlet stream (alim, met) curent care iese din cuptor

furnace outlet temperature (alim, met) temperatură de / la ieşire din cuptor

furnace output (alim, ind chim, met) capacitate a cuptorului

furnace plant (met) hală a cuptoarelor, instalație cu mai multe cuptoare

furnace platform (met) platformă a cuptorului / a furnalului

furnace pressure (alim, met) tiraj al cuptorului

furnace roof (termo) palfon al focarului; (met) boltă de cuptor

furnace scale (met) arsură / pată de oxizi, formată la menținerea în cuptor (defect)

furnace shaft / stock (met) cuvă a cuptorului

furnace shell (met) manta a cuptorului furnace sow (met) urs, bloc de metal în vatra cuptorului

furnace structural steel (met) schelet / structură din oțel, a(l) cuptorului

furnace throat (met) gură a furnalului, gură de încărcare a unui cuptor

furnace-top bell (met) con de închidere / clopot la gura furnalului

furnace-top distributor / distributing gear (met) mecanismul de alimentare / de distributie de la vârful / gura furnalului

furnace-top flame (met) flacără la gura furnalului furnace-top hopper (met) pâlnie de încărcare a cuptorului (la partea superioară a lui)

furnace working (met, ind chim) conducere a cuptorului

furnacing (met, ind chim) (proce de) ardere, calcinare (în cuptor)

furnish a mobila

furnished room cameră mobilată

furnishing aprovizionare, mobilare, amenajare (interioară)

furnish layer (materiale, alim) strat fibros

furnish with a aproviziona cu, a furniza, a mobila; a da, a oferi, a procura

furniture mobiler, mobilă, utilaj, inventar, furnituri; (met) armătură, utilaj, echipament, inventar; conținut; a piece of $\sim$ o mobilă; a set of $\sim, \mathbf{a} \sim$ set o garnitură de mobilă

furred (met, termo) ancrasat, astupat, acoperit cu o crustă

furrier blănar

furriery blănărie, blănuri

furring (constr) şindrilă; (termo) piatră de cazan; umplutură, concrețiune; blană (de căptuşeală), îmblănire (pentru confecții, haine etc.)

furrow (agr) brazdă, arătură; (constr, OM) şant, făgaş, canal, canelură, cută, rid, falț;(mas-un) a riftui, a cresta, a stria, a zgâria, a brăzda

furrower (agr) marcator

furry cu / din blană; blănuri

further $(a d j)$ mai îndepărtat, următor, celălalt, alt;adițional, suplimentar; în plus; $(a d v)$ mai departe, în continuare, într-o măsură mai mare, în plus, mai mult (decât atât), afară de aceasta; a promova, a încuraja; a favoriza; at the $\sim$ end la celălalt capăt; nothing $\sim$ nimic mai mult; wait for $\sim$ information a aştepta noi amănunte; without explanation fără nici o altă explicație; directions instrucțiuni noi; until notice până la noi instrucțiuni further consideration examinare mai atentă

further credit (ec) credit suplimentar

further enquire anchetă complementară, investigație ulterioară 
further information (ec, TH, jur) informații complementare / suplimentare / ulterioare

further treatment (met) tratament ulterior furthermore $(a d v)$ mai departe, mai mult

furthermost cel mai (în)depărtat

furthest cel mai (în)depărtat; în cea mai mare măsură

fuse (el) siguranță, fuzibil (şi ca adjectiv), a (se) întrerupe (lumina, şi prin arderea siguranței); fitil de amorsare; (met, ind chim) topire, şarjă, amorsă, a (se) topi, a fuziona, a se amalgama, a (se) amesteca

fuse alarm (el, TH) (circuit de) alarmă pentru semnalizarea arderii unei siguranțe

fuse block $(\mathrm{OM}$, el) montură a siguranței

fuse box (auto) cutie cu siguranțe

fuse cap (constr) detonator, capsă

fuse cartridge (el, OM) cartuş, patron fuzibil

fuse clips (el, OM) cleme / contacte pentru legarea / conectarea siguranței

fused carbide tipping (met, mas-un) acoperire a tăişului unei scule prin carburi topite pe el

fused cement (constr) ciment topit

fused flux (met) flux topit

fused lamp (el) lampă de siguranță

fused mass (alim, ind chim, plast) topitură, masă de fluid topit / de topitură

fused-mass casting (met, plast) turnare a masei topite

fused silica (ind chim) sticlă obținută prin topirea oxidului de siliciu de puritate ridicată

fused slag (met) zgură omogenizată prin topire

fuse firing explodare prin aprindere cu fitil

fuse link (el) element fuzibil al siguranței

fuse off a topi, a fluidiza, a face fluid

fuse plug (el) fiş̧ă / patron / cartuş de siguranță

full pull-out (el) suport de siguranță fuzibilă, care poate fi extras

fuse socket $(\mathrm{OM}, \mathrm{el})$ suport al siguranței fuzibile fuse strip $(\mathrm{OM}$, el) lamelă de siguranță fuzibilă

fuse welding (met) sudare prin topire

fuse wire (el) fir fuzibil (al unei siguranțe)

fusibility (met) fuzibilitate, aptitudine de topire

fusible (el) siguranță fuzibilă; (met) fuzibil, care poate fi topit

fusible cut-out (el) siguranță fuzibilă (de întrerupere prin topire)

fusible metal (met) metal (uşor) fuzibil (de topit)

fusible plug (el) siguranță fuzibilă; (met) dop fuzibil fusible slag (met) zgură fluidă, dop fuzibil

fusiform fusiform

fusiform shape formă fusiformă / conică

fusing (el) topire / ardere a fuzibilului unei siguranțe; (met) topire

fusing agent (met) fondant, flux (la sudare)

fusing of the foil surface (met) topire superficială a benzii (la sudare)

fusing / fusion point (met) punct / instalație de topire

fusing temperature (met, chim) temperatură de topire

fussing range (termo, $\mathrm{TH}$ ) interval de topire (pentru amestecuri, materiale plastice)

fusion (fiz, termo) topire, fuziune, fluidizare; contopire, amestec; (met) topitură

fusion electrolysis electroliză în stare topită

fusion heat (met) căldură de topire

fusion plant (ind chim) instalație de topire

fusion welding (met) sudare prin topire

fusion welding with pressure (met) sudare prin topire sub presiune

fusion zone (el) zonă de fuziune / de topire (a cristalului la creşterea / purificarea prin procedeul topirii zonale); (ind chim) zonă de topire; (met) zonă de fuziune a furnalului

fuss agitație; a plictisi; protest, obiecție; a obiecta, a protesta

fustiness caracter / miros de mucegai; carcater demodat

fusty mucegăit, stricat; încins; învechit, demodat; conservator; refractar

futile inutil, van; gol; neserios; superficial

futility inutilitate; neseriozitate, superficialitate

future viitor, următor, care va veni; (ec) contract pentru bunuri / recolte de perspectivă

futureless fără viitor, lipsit de perspectivă

future perfect (tense) viitorul anterior (timp pentru verbe)

futures (ec) cotări, livrări la termen

fuzz (alim) puf (şi de fruct), perişori, scamă, a acoperi cu scamă / cu puf

fuzzily ( $a d v)$ (în mod) neclar, nedesluşit, vag, ca prin ceață

fuzziness caracter sau aspect pufos; neclaritate

fuzzy scămos; flocos; zbârlit (d. păr); fibros (d. lemn); difuz, neclar, estompat, necontrastant, fără contrast; pufos, cu / de puf; scămoşat

fuzzy programming (inf) programare în condiții vagi 


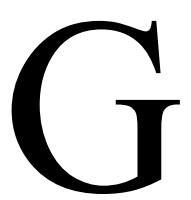

gab vorbire; vorbărie (multă); (OM) cârlig, furcă, orificiu; (met) daltă, cange

gabardine (textile) gabardină, haină, îmbrăcăminte gable (constr) fronton, acoperiş triunghiular, partea din zid, de sub acoperişul triunghiular

gabled (constr) cu acoperiş triunghiular, cu fronton

gable roof (constr) acoperiş mansardat, acoperişmansardă

gabling (el) repartitie în clopot; iluminare triunghiulară

gad $(\mathrm{OM})$ pană; daltă (pentru perforări manuale), vârf, tăiş, ic de metal, piron; (bot) a se întinde şi a creşte stufos (d. plante); about, abroad, out a hoinări (prin)

gadder (constr, mas) perforator (şi pneumatic)

gadget dispozitiv (foarte general), (fam) dispozitiv mic (cu caracter practic), unealtă; truc; fleac gadolinite (chim, minrl) gadolinit, lantanit gaff cange, un fel de harpon; (nav) pic, vergă; complot

Gadolinium (Gd) (chim) gadoliniu gag (met, OM) flanşă oarbă; a astupa gage (amer), gauge (brit) dispozitiv / element de măsurare / comparare (în sens foarte larg); gaj; a lăsa în gaj, a pune gaj

gage block (metr) cală plan-paralelă

gage cock (metr) indicator de nivel

gage glass (metr) tub de sticlă (într-un aparat de măsură)

gage length (metr) lungimea inițială a epruvetei gage point (metr) punct important / de reper într-un aparat de măsură

gage pressure (metr, hidr) presiune măsurată în funcție de presiunea mediului, presiunea statică indicată de un aparat

gagger (met, OM) clemă de prindere, cârlig de formare, maşină de îndreptat cu role

gagging (auto) îndreptare la rece

gag of saw $(\mathrm{OM})$ cordar (la ferăstrău)

gag press (mas-un) presă de îndreptat

gain (autom, fiz) amplificare, intensificare, mărire, creștere, câștig; locaș, scobitură, tăietură; (ec) beneficiu, profit, câştig, spor, avantaj, venit; a câştiga, a profita; a obține; a câş̧iga, a repurta (o victorie, un succes); a cuceri; a se îngrăşa: a creşte; (med) a se face bine, a se însănătoşi; (metr) a o lua înainte (d. ceasuri); a atinge, a ajunge (la); a-şi atinge (scopurile); upon market (ec) a câştiga teren pe piață; one's living a-şi câştiga existența; one's cause a avea câştig de cauză; time a câştiga timp; smb. over a câștiga părerea / aprecierea (cuiva), a convinge (pe cineva)

gain-band merit (el, fiz) lărgime de bandă la amplificare $1: 1$

gain by a câş̧iga la; a profita de; a obține profit sau beneficiu

gain by force a câştiga prin forță

gain control (autom, el) reglajul / comanda amplificării

gainer câștigător, învingător

gainful (ec) rentabil, avantajos; lucrativ; bine plătit

gainings (ec) câştig(uri), profit(uri)

gain margin $(e l, c)$ margine (limită) de securitate în amplificare

gain on / upon a ajunge din urmă, a recupera; a se apropia de; a depăşi

gain over a câştiga / atrage de partea sa; a câştiga sprijinul

gain-phase characteristic (autom) loc de transfer; caracteristica amplitudine-fază

gainsay a nega, a infirma; a contrazice; a pune la îndoială / în discuție, a contesta

gainsayer adversar, oponent; persoană care contrazice / neagă / contestă

gain set (metr) instalație de măsurare a amplificării

gain weight mărirea greutăţii / masei, creştere în greutate

gaiter ghete; şoşon

gal (fiz, metr) gal (unitate de accelerație / de gravitație): $1 \mathrm{gal}=1 \mathrm{~cm} / \mathrm{s}^{2}=0,01 \mathrm{~m} / \mathrm{s}^{2}$; abreviere pentru gallon, $\mathbf{v}$. gallon

gala festivitate, ceremonie, sărbătorire; gală; (adj) de gală / sărbătoare, festiv, sărbătoresc

galalith (plast) galalit

galantine (alim) galantină, rasol de pasăre în aspic gale vânt puternic, vijelie, furtună; (fig) izbucnire galena (met) sulfură de plumb; (minrl) galenă galenic(al) (chim) galenic

galenical iron ore $(\mathrm{min})$ pirită de fier

galileo (metr) unitate de măsură pentru accelerație: 1 galileo $=0,01 \mathrm{~m} / \mathrm{s}^{2}$

gall necaz; ură; rană; amărăciune; a enerva; a necăji, a hărțui; $(\mathrm{TH}, \mathrm{T})$ rosătură, zgârietură, a deteriora, a uza prin frecare, a freca (sârme, cabluri), a zgâria, a roade (şi pielea); uzură tip gall (aderență severă); (met) a ataca, a coroda

Gall chain $(\mathrm{OM})$ lant Gall 
gallery (constr) galerie, coridor, balcon; (el) tunel / canal accesibil pentru cabluri; (OM, hidr) canal longitudinal, pasaj de trecere, traseu de curgere; (met) galerie subterană

gallery port (met) uşă de încărcare galley (nav) cambuză, bucătărie; şpalt (tipografie) galley proof spalt, probă (tipografie)

galling $(\mathrm{T})$ uzură prin sudare locală şi ruperea / forfecarea ei din cauza presiunii mari de contact; formă de uzură adezivă cu urme de rupere şi sfâşiere vizibile, gripare locală, cu desprindere de material; roadere; tocire

gallipot recipient (pentru farmacie, laborator)

Gallium (Ga) (chim, met) galium

gallon (gal) (metr) unitate de măsură pentru volum / capacitate, gal(1)on: 1 gallon $(\mathrm{UK})=$ $0,00454609 \mathrm{~m}^{3} ; 1$ gallon (US) $=0,003785412 \mathrm{~m}^{3}$ gallonage (ind chim) volum, capacitate (în galoane) gallon/day (metr) unitate de măsură pentru debit volumic, galon/zi: 1 gallon (UK)/day (gal UK/d) $=0,000000053 \mathrm{~m}^{3} / \mathrm{s} ; 1$ gallon (US)/day $($ gal $\mathrm{US} / \mathrm{d})=0,000000044 \mathrm{cubic} \mathrm{m}^{3} / \mathrm{s}$

gallon/hour (metr) unitate de măsură pentru debit volumic, galon/oră: 1 gallon (UK)/hour (gal $\mathrm{UK} / \mathrm{h})=0,000001263 \mathrm{~m}^{3} / \mathrm{s} ; 1$ gallon (US)/hour $($ gal US $/ \mathrm{h})=0,000001052 \mathrm{~m}^{3} / \mathrm{s}$

gallon/minute (metr) unitate de măsură pentru debit volumic, gal(l)on/minut: 1 gallon (UK)/minute $=0,000075768 \mathrm{~m}^{3} / \mathrm{s} ; 1$ gallon (US) $/$ minute $=$ $0,00006309 \mathrm{~m}^{3} / \mathrm{s}$

gallon/second (metr) unitate de măsură pentru debit volumic, galon/secundă: 1 gallon (UK)/second $=0,00454609 \mathrm{~m}^{3} / \mathrm{s} ; 1$ gallon (US) $/$ second $=$ $0,003785412 \mathrm{~m}^{3} / \mathrm{s}$

gallons per minute (g.p.m.) (metr) galloni pe minut, $v$. gallon/minute

galloon margine, bordură (şi la textile, plase etc.) galloping mişcare în salturi, galopare; (nav) tangaj galloping motion (mec) mişcare prin impulsuri gallows (mas) capră cu consolă; (mec) susținere în consolă (ca o spânzurătoare)

gallows tool $(\mathrm{OM})$ suport pentru pinioane galmey (chim, met) silicat de zinc; calamină galosh (plast) galoş; şoşon galoshed cauciucat

galvanic (el, met) galvanic, pilă galvanică galvanic(al) (el, met) galvanic

galvanic cell / pile (el, fiz) element galvanic, pilă / celulă galvanică

galvanic coating (met) acoperire galvanică galvanic colouring of metals (el) galvanocromie (colorare electrochimică a metalelor)

galvanic copper bath (el) baie galvanică, de recuperare a cuprului galvanic corrosion (ind chim, T) coroziune electrochimică

galvanic couple (met) cuplu galvanic

galvanic etching (el, chim) gravare galvanică, corodare electrolitică

galvanic silvering (el, chim) argintare galvanică

galvanization (el, met, chim) galvanizare, acoperire galvanică

galvanization pan (el, met) cuvă de galvanizare galvanize (met, el, chim) a galvaniza

galvanized corrugated steel (met) tablă de oțel, ondulată şi galvanizată

galvanized iron (met) fier galvanizat

galvanized-iron wire (met, el, chim) sârmă de oțel, galvanizată

galvanized pipe (met, hidr, el, chim) țeavă / conductă galvanizată

galvanized sheet (met) tablă galvanizată

galvanized sheet metal (met) tablă albă de oțel, galvanizată

galvanized strip (met, chim, el) bandă galvanizată / zincată

galvanizing (met) galvanizare

galvanizing bath (met, el) baie de galvanizare

galvanizing by dipping (met, chim) zincare la cald (prin cufundare)

galvanizing embrittlement (met) fragilitate la galvanizare

galvanizing furnace (met) cuptor de galvanizare

galvanizing plant / shop (met) instalație de galvanizare

galvano cautery (met) corodare galvanică

galvanometer (el, metr) galvanometru

galvanometer constant (el, metr) constanta galvanometrului

galvanometer with ball-shaped shield (el, metr) galvanometru cu blindaj sferic / cu chiulasă sferică

galvanoplastic (chim, el) galvanoplastic

galvanoplastics (chim, el) galvanoplastie

gambit (fig) sacrificiu; iniţiativă, acțiune, mişcare; gambit (la şah)

gamble joc de noroc, aventură, acțiune riscantă, risc; a juca (pe bani), a risca, a pune în joc, a paria, a miza

game (mat) joc (în teoria jocurilor); sport, partidă, repriză, meci; (alim) carne de vânat; vânat, vânătoare; cinegetic, de vânătoare

game(s) theory (mat) teoria jocurilor

gamma literă grecească $(\gamma$ literă mică, $\Gamma$ - majusculă); tip de radiație; (metr) unitate de măsură pentru masă, microgram: 1 gamma $=10^{-9}$ $\mathrm{kg}$; (el, metr) gradație maximă

gamma brass (met) alamă gama, aliaj gama $\mathrm{Cu}-\mathrm{Zn}$ 
gamma carbon (chim) atom de carbon gama gamma distribution (mat) repartiție gama (în teoria probabilităților)

gamma function, $\Gamma$-function (mat) funcție ga$\mathrm{ma} / \Gamma$

gammagraphy (fiz, metr) gama(radio)grafie gamma iron (met) fier gama $(\gamma)$

gamma plus (de) calitatea / categoria a doua, spre a treia

gamma ray(s) (fiz) rază / raze / radiație gama, radiație electromagnetică de frecvență mare

gamma sensitive counter (fiz, metr) contor gama, contor de radiație gama

gamma shield (fiz) ecran de protecție contra radiaţiilor gama

gamma structure (met) structură gama (la aliaje) gammon (alim) șuncă / costiță afumată

gang (constr) brigadă / echipă de lucrători; (masun) set de scule, care lucrează simultan; (ec) schimb de lucru de 8 ore; mineral; (auto, mas) a cupla, a ambreia; a pune laolaltă; a se aduna; serie, șir, ordine

gang blanking die (met) ştanță de decupat cu mai multe poansoane.

gang boss $(\mathrm{TH})$ şef de echipă

gang circuit (autom) circuit de comandă unică

gang control (autom) comandă unică

gang cutter (mas-un) freză de grup / într-o linie tehnologică

gang cutters / mill (mas-un) ansamblu de freze, set de freze

gang drill (mas-un) maşină de găurit multiax / multiplă

gang disconnect (el) conector cu mai multe conectări sau deconectări simultan

gang drilling machine (mas-un) maşină de găurit multiplă, cu funcționare independentă a axelor principale

ganged (mas) cuplat, modulat (într-un întreg)

gang(ed) circuits (autom, mas) circuite cu comandă unică, cuplate mecanic

gang(ed) control (autom) comandă unică

ganged sub-plates (hidr) plăci de bază, cuplate, subsisteme / module ale acționărilor hidraulice ganged valve (hidr, OM) supapă modulată

ganger (constr) maistru, şef de echipă; (nav) parâmă intermediară

gang mandrel (mas-un) dorn demontabil (din mai multe piese)

gang mill (mas-un) ansamblu de freze montate pe un dorn; freză combinată

gang milling (mas-un) prelucrare cu un ansamblu de freze

gang milling cutter (mas-un) freză combinată gang of men $(\mathrm{TH})$ schimb (de zi, de noapte)

gang planing (mas-un) prelucrare simultană a mai multor piese de rabotat

gang(-)plank (nav) schelă, scândura unei punți; (TH) pasarelă

gang punch (autom) perforator, sumator.

gang punching dies (mas-un) ştanță de perforat, cu mai multe poansoane

gang reamer (mas-un) ansamblu de alezoare montate pe un dorn; alezor compus

gang saw (mas-un) fierăstrău circular, cu mai multe discuri

gang-saw frame (mas) ramă de gater

gang shears (met) foarfecare cu mai multe cuțite / tăişuri

gang slitter (mas-un) foarfecare mecanic, cu cuțite rotative pentru tăierea tablelor / hârtiei / foliilor în benzi

gang slitting shears (met, mas-un) foarfecare cu mai multe discuri rotative

gang switch (el, autom) întrerupător de grup / multiplu / pachet

gang toll (mas-un) portcuțit multiplu / pentru mai multe cuțite

gang-type tool rest / holder (mas-un) sanie portcuțite, cu acțiune simultană / cu cuțit multiplu gangue (met) gangă, steril (industria extractivă) gangway (constr) pasarelă, pasaj, coridor, (loc de) trecere; (cf) coridor de mijloc, la vagon; (met) loc de trecere, gang; (nav) schelă de coborâre, pasarelă; tăietură (la scară)

gangway conveyer (mas, transpp) transportor pe un colector (de minereuri)

ganister (brick) (met, constr) cărămidă dinas / silica; piatră de nisip, folosită la tocire; cărămidă silico-calcaroasă

Gant chart (ec) diagramă a producției planificate, suprapusă pe cea de / a executată

gantlet (cf) încrucişare (de linii), pasaj

gantry (constr) capră; (mas, $\mathrm{OM}, \mathrm{mec}$ ) montant, portal, cadru, schelet de macara

gantry crane(s) (constr) macara de schelă / de eşafodaj; (mas) macara-capră, macara pe capre / -portal; (met) pod rulant

gantry robot (mas, autom) robot cu mers înainte şi înapoi

gap interval, gaură, spărtură, gol, deschizătură; spărtură; (geol) prăbuşire de teren; loc vacant / liber, spațiu (gol); lipsă, lacună; omisiune; decalaj, discrepanță; întrerupere, hiat; diferențiere, discriminare; (hidr) breșă de închidere; (OM) distanță, interval, joc, interstițiu, fantă, cea mai mică valoarea a rostului, la sudură; (mas-un) scobitură (a patului de strung etc.); (mat) 
lacună, distanță, discontinuitate; (met) rost de dilataţie, spațiu liber, crăpătură; (inf) spațiu între două informații; spațiu între lobi; minimum în diagramă polară; (auto) bujie

gap bed (mas-un) pat cu scobitură, la strung

gap between rolls (met) spațiu între cilindrii la laminare

gap block / bridge (mas-un) porțiunea demontabilă a patului, cu care se închide deschiderea la strung

gap clearance $(\mathrm{OM}, \mathrm{el})$ lățime / mărime a întrefierului / a interstițiului

gap depth adâncime / lățime (uneori) a interstițiului

gap digits (inf, c) caractere de umplere

gap-filling adhesive (plast) adeziv de umplere gap filter (alim, ind chim, mediu) filtru cu fante gap-graded material (constr) material cu granulometrie discontinuă

gap grading (constr) granulometrie discontinuă gaping (mas-un) interstițiu; joc; (adj) larg deschis, care se deschide, proces de formare / deschidere a unui gol, interstițiu

gap in the rang of miscibility (termo) gol în domeniul de miscibilitate

gap lathe (mas-un) strung cu pat cotit; strung cu pat $\mathrm{cu}$ degajare pentru prelucrat piese mari, fixate pe un platou

gap plate (mas-un) placă cu scobitură / cu adâncitură (la maşini de rectificat rulmenți)

gapless (met) fără rost (la sudură, căptușeli etc.)

gap riveting machine (mas-un) maşină de nituit, cu lungime mare a brațelor

gap section (el) secțiune de separare

gap separation (el) distanță între electrozi; (OM) distanță mică de separare a două piese

gap width (OM, constr) rost între margini, deschidere a rostului

garage (auto, constr) garaj; (amer) service auto, atelier de întreținere şi reparații auto

garage equipment (auto) echipament de garaj / de service auto

garage foreman (auto) şef de garaj

garbage (mediu, ind) resturi, murdărie; (constr) deşeuri menajere; gunoi (menajer); (inf) date / informații fără valoare

garbage can (constr, mediu) ladă de gunoi

garbage chute (nav) trombă de gunoi

garbage collector/ removal truck (auto, transp, mediu) autocamion pentru colectarea gunoiului menajer

garble a trunchia, a deforma (un text)

garbled information (inf) informație trunchiată / deformată garbler persoană care trunchiază / deformează (un text); falsificator

garde (met) reziduu

garden (mediu, agr) grădină; parc; a face grădinărie, a se ocupa cu grădinăritul

garden city (adm, arhit) oraş cu urbanistică modernă / cu spații verzi; oraş-grădină

gardener grădinar

gardenesque ca o grădină; de grădinărit, de grădinărie

gardening (agr) grădinărit, horticultură

gardening tools (agr) unelte de grădinărie

garden roller (mas, OM, agr) tăvălug pentru grădină, sul / mașină de netezit gazonul

garden scissors (agr) foarfece de grădină

garden stuff (agr, bot) legume, zarzavaturi, produse agro-alimentare / de grădină

garden suburb sururbie cu spații verzi

garden village aşezare / localitate cu spații verzi garlic (alim) (căpățână de) usturoi

gare ship (nav) a acosta pe malul unui canal pentru a lăsa liberă trecerea

garland ghirlandă, cunună; premiu, distincție; antologie; (nav) sac de merinde; coroană (de flori); (met) inel colector de apă, la cuva furnalului

garment (textile) (articol de) îmbrăcăminte, confecție (şi de gata), costum, veşmânt; a îmbrăca

garmet industry (textile) industria de confecții garner (agr) a depozita (în hambar), a înmagazina, a însoloza, a aduna, a strânge, a stoca; a aproviziona; a asorta; a culege (prin muncă)

garnet (minrl) granat, minerale $\mathrm{cu}$ silicați $\mathrm{cu}$ cristalizare cubică, culoare rubinie; cu granate, rubiniu

garnet paper (TH) hârtie abrazivă, şmirghel garnish a garnisi, a decora, a înfrumuseța; (TH) a utila, a înzestra; (alim) garnitură; decorație

garnishee (jur) a popri, a ține în gaj; (ec) a emite o ipotecă asupra, persoană asupra căreia grevează o ipotecă

garnishment (jur) ipotecare, oprire; (ec) oprire din salariu, reținere (în contul unei datorii)

garniture (cf) garnitură de tren; $(\mathrm{TH})$ garnitură, ornamentație, decorație, armătură, feronerie; (alim) garnitură

garret (agr) magazie de cereale, siloz; (constr) pod de casă; mansardă, etaj / pod mansardat garret floor (constr) planşeu de pod, mansardă garrret story (constr) mansardă garret window (constr) lucarnă, fereastră de mansardă

garrison $(\mathrm{TH})$ personal, echipă de muncitori 
garter seal $(\mathrm{OM})$ etanşare realizată prin lipire / sudare

gas / gaze (auto, termo) benzină, combustibil; (fiz, chim, termo) gaz(e), gaz de iluminat / aerian; de / pentru gaz(e); a gaza

gas-absorbent (chim, agent) absorbant de gaze

gas-absorbent coal (chim) cărbune pentru absorbția gazelor

gas-absorber oil (chim) ulei absorbant de gaze

gas accumulation (met) acumulare de gaze

gas analyser (metr, chim) analizor de gaz

gas analysis (metr, chim) analiza gazului / gazelor

gas aspirator (met) exhaustor, aspirator de aer / de gaze, instalație de aspirare a aerului / a gazelor

gas aspiring pump (OM, hidr) pompă pentru aspirarea gazelor

gas atomization (fiz) pulverizarea lichidelor în jet puternic de gaze

gas bag (chim) înveliş / pătură de gaze, membrană dublă, cu gaz în interior

gas balance (metr) balanță pentru determinarea greutătii specificare a gazelor

gas balloon (chim, metr) picnometru pentru gaze, aparat pentru determinarea densității unui gaz

gas a balloon $(\mathrm{TH})$ a umple cu gaz un balon gas-bearing (geol, met) gazifer, purtător de gaze gas bearing $(\mathrm{OM}, \mathrm{T})$ lagăr cu (lubrifiat cu) gaz gas-bearing layer (met) intercalație gaziferă, strat cu aer/gaze

gas bell (met, metr) clopotul gazometrului

gas binding (termo) blocare / imobilizare de gaz(e) necondensabil(e) în partea de sus a instalației frigorifice

gas black (plast) negru de fum din gaze / provenit din arderea gazelor

gas blow(-)pipe (termo, met) arzător de gaz

gas blanket (ind chim) strat / pernă de gaze

gasblast switch (el) întrerupător cu gaze sub presiune / cu gaz comprimat / cu stingere în mediul gazos; (met) ventil / robinet de inversare a gazului

gas bleaching (chim) înnălbire cu clor gazos

gas bleeder (met, termo) flacără

gas blower (mas) suflantă de gaze; (met) suflător de metan; suflător de sticlă

gas-blowing engine (met) injector de aer / de gaz (combustibil)

gas blow-out (geol) erupție de gaze

gas blowpipe (met) ciocan de lipit, cu gaz

gas booster (met) instalație auxiliară de compresoare

gas bubble (met) bulă de gaz, suflură gas bubbler (met, mediu, ind chim) vas spălător de gaze (şi prin barbotare)

gas burner (chim) bec Bunsen; (met) bec cu gaz; (termo) arzător de / cu gaze

gas capacity (met) productivitatea gazogeneratorului (la sudură)

gas carburising (met) (procesul de) cementare / carburare cu gaz / în atmosferă gazoasă

gas carburising furnace (met) cuptor de cementare în mediu gazos

gas carrier (nav) navă pentru transportul gazelor lichefiate

gas case-hardening process (met) proces de cementare în gaz, în incintă / în cutie gas casualties $(\mathrm{TH})$ pierdere de gaz gas cavity (met) bulă de gaz, suflură (şi la sudură) gas chamber (met) cameră / incintă de gaze

gas-chamber kiln (met) cuptor cu cameră, încălzit cu gaze, cuptor-cameră cu gaz

gas-charged thermostat (metr, termo) termostat cu vapori supraîncălziți / cu gaz / cu puțin lichid (posibil şi sub formă de vapori)

gas check (termo) etanşare la / pentru gaz(e)

gas checker chamber (met) regenerator cu gaz, cameră regeneratoare de gaz

gas cleaner (met, mediu) epurator de gaz(e); scruber

gas cleaning (met, mediu) epurarea gazelor

gas-cleaning installation / plant (met, mediu) instalație pentru epurarea gazelor

gas-cleaning scrubber for dry(ing) (met) scruber pentru epurare uscată

gas clean-up (chim) extractia gazului; eliminarea / îndepărtarea gazului

gas coal (met) cărbune de gaz; (met, ind chim) cărbune bogat în materii volatile; (termo) cărbune de retortă

gas cock / tap (OM) robinet cu cep, pentru gaze gas coke (met, termo) cocs de gaz

gas collecting bottle (ind chim) recipient de colectare a gazelor

gas-collecting main (ind chim) colector de gaze, conductă colectoare de gaz

gas collection (met, ind chim) colectare a gazelor gas collector (met, metr) gazometru; $(\mathrm{TH})$ colector / captator de gaze

gas compound (chim) amestec de gaze

gas-compression pump (met, termo) compresor de $\operatorname{gaz}(\mathrm{e})$

gas compressor (ind chim, mas, termo) compresor de gaz(e)

gas concentration (chim) concentrația gazului gas conditioning (met) (proces de) condiţionare / tratare a gazelor 
gas conduit (ind chim, met) conductă de gaz(e) gas constant (fiz) constanta gazelor (perfecte)

gas constant per mole (fiz) constantă molară a unui gaz

gas containing (met, ind chim) cu conținut de gaze, care conţine gaz(e)

gas content tube (el) tub electronic cu gaz

gas cooker (alim, termo) plită cu gaze, aragaz

gas cooled (mas, termo) cu răcire / răcit cu (curent de) gaz / aer

gas cooler (ind chim) răcitor de / cu gaze / aer

gas cooling plant (ind chim, met) instalație de răcire a gazelor

gas corrosion (met) acțiunea corosivă a gazelor

gas cure (plast, ind chim) vulcanizare în (mediu de) gaz

gas current (met) curent de gaz(e); (el, fiz) curent ionic

gas curtain / envelope (met) pernă / pătură / cortină / perdea intermediară de gaz

gas cushion pernă de gaz (şi de aer)

gas cutting (met) tăiere cu gaz / autogenă

gas cutting machine (met) maşină de tăiat materiale metalice cu gaz (metan)

gas cylinder $(\mathrm{TH})$ butelie de gaz(e)

gas-cylinder manifold (OM) cap / racord de umplere

gas-cylinder nozzle (mas, OM) ajutaj de gaz (la cilindrii / buteliile de gaze etc.)

gas-cylinder recoil (cf, ind) rezervor de aer comprimat

gas-defence equipment (TH) echipament / aparat de protecție contra gazelor

gas delivery (met, ind chim) emanare / degajare a gazelor, furnizare de gaz

gas delivery tube (met) conductă de evacuare / furnizare a gazului

gas desicator (el) uscător de gaz (la acumulator) gas detection by smelling (chim) detectare organoleptică a gazelor

gas detector (chim) reactiv pentru identificarea gazelor; (metr, met) detector de gaze

gas-detector kit / set (met, ind chim) detector de gaze, aparat de detecție a gazelor

gas development ( $\mathrm{TH}$, auto, ind chim, plast) formare / generare / dezvoltare de bule de gaz (şi la acumulator)

gas diffusion (fiz, met) difuzia gazului / gazelor gas discharge (fiz) descărcare în gaz; (met) debit de gaze

gas discharge chamber (fiz, electr) cameră de descărcare în gaz

gas discharge gap (fiz) spațiu / puncte / interstițiu de descărcare în gaz gas discharge path (el) distanță disruptivă în $\operatorname{gaz}(\mathrm{e})$

gas dispersoid (chim) aerosol

gas displacement (met, ind chim) împingere de gaze

gas displacement method (met, alim, ind chim) metodă care utilizează deplasarea / împingerea de / cu gaze

gas-distributing channel (met) canal pentru distribuția gazului

gas-distributing pipe (met) conductă de distribuire a gazului

gas distribution $(\mathrm{TH}$, ind chim) distribuire (prin conducte) a gazului

gas distribution manifold (met, ind chim) claviatură de distribuție a gazelor

gas-distribution network / system (met, ind chim) rețea de distribuție a gazelor (prin conducte)

gas-distribution plant ( $\mathrm{TH}$, met, ind) instalație pentru distribuția gazelor

gas-distribution system (met, ind chim) retea de distribuție a gazelor

gas distributor (ind chim, termo, OM) distribuitor de gaz

gas downcomer / downtake tube (met) conductă de evacuare a gazelor de furnal

gas downtake (met) eliminare a gazului

gas drain (met) drenaj pentru gaz metan / pentru degazare; (termo) evacuare a gazului / gazelor gas drive (met, ind chim) regim de împingere de gaze / de expansiune a gazelor

gas-driven blowing engine (met) suflător de gaz, suflantă de gaz, cu motor propriu

gas-driven engine (met) motor cu gaze

gas-driven engine blower (mas) moto-suflantă de gaze

gas driving (met, ind chim) împingere de gaze

gas dry cleaning (ind chim, met, mediu) curățare cu gaze / cu aer (uscat)

gas drying device (el) uscător de gaz (la acumulator)

gas duct (ind chim, met) canal / conductă de gaze gas emission (met, ind chim) emanare / degajare a gazelor

gas ends (met) fereastră pentru gaze

gas energy (met, ind chim) energia gazului

gas engine (mas) motor / maşină cu gaz

gas engineering (chim, termo) tehnica / ingineria gazelor

gaseous (fiz, met, ind chim) gazos, cu conținut de gaze

gaseous body (chim, fiz) corp gazos

gaseous envelope (fiz, chim, TH) manta / pătură de gaze, înveliş gazos 
gaseous exchange (chim) schimb de gaze gaseous fluid (ind chim) mediu gazos, fluid gazos gaseous fuel $(\mathrm{TH})$ combustibil gazos

gaseous hydrocarbons (ind chim) hidrocarburi gazoase

gaseous inclusion (ind chim, met) incluziune gazoasă, suflură

gaseous inclusion in glasses (ind chim) băşici / sufluri în sticlă

gaseous mixture (chim) amestec de gaze

gaseous polymerization (ind chim, plast) polimerizare în fază gazoasă

gaseous phase (chim, fiz) fază gazoasă

gaseousness (fiz) stare gazoasă

gaseous state (fiz) stare gazoasă

gas evolution (met) gazeificare, producție / producere / degajare de gaz (e)

gas exhauster (met) exhaustor de gaz(e)

gas-expanded rubber (plast) cauciuc celular / microporos

gas expansion (fiz) destinderea / expansiunea gazelor; (chim, met) explozie de gaz metan sau alte gaze explozive

gas expansion thermometer (metr, termo) termometru cu gaz

gas explosion (chim, termo) explozie a gazului

gas expulsion (chim) extracție a gazului; eliminare / îndepărtare a gazului

gas-filled (fiz) umplut cu gaz

gas-filled thermometer (metr, termo) termometru (umplut) cu gaze

gas filling (ind chim) umplere cu gaz / cu aer

gas filter (OM) filtru de / pentru gaze

gas-fired air furnace (met) cuptor cu flacără, cu gaze

gas fire (termo) arzător de gaz(e)

gas-fired boiler (termo) cazan cu țevi de fum / de evacuare a gazelor de ardere

gas-fired calcining kiln (met) cuptor de prăjit minereu, încălzit cu gaz

gas-fired furnace (met, termo) cuptor cu gaz

gas-fired furnace for hardening (met) cuptor de călire, cu gaz

gas-fired reverberatory furnace (met) cuptor cu reverberație, încălzit cu gaz(e)

gas firing (met) aprinderea gazului, încălzire cu $\operatorname{gaz}(e)$

gas fitter $(\mathrm{TH})$ instalator de gaz

gas fitters (met) cleşte pentru țevi de gaz(e)

gas fitting $(\mathrm{OM})$ armătură pentru țevi de gaz(e)

gas fittings (termo, OM) arzător de gaze, încălzitor cu gaze, instalație de gaze

gas-flask (ind chim) butelie / recipient de / pentru gaz gas-flask container (constr, ind chim, met) depozit de butelii de gaz

gas flow (met) curent de gaz, curgere a gazului; (met) manifestare / erupție de gaze

gas flow controller (met, ind chim, OM, autom) regulator de debit pentru gaze

gas flue (ind chim, met) canal de gaz(e)

gas flue leading (met) conductă de gaz(e)

gas focusing (chim) concentrația gazului; (el) concentrația unui fascicol electronic prin acțiunea gazului ionizat; (termo) concentrarea jetului de gaz(e)

gas formation (el) formare / dezvoltare de bule de gaz (la acumulator)

gas from roasting (ind chim, met) gaz(e) de prăjire

gas fuel (met, ind chim) combustibil

gas fumes (chim, met) gaze asfixiante / toxice

gas furnace (ind chim) cuptor cu gaze (şi pentru producerea sticlei); (termo) instalație de ardere cu gaz $(\mathrm{e})$

gas gap (fiz, el) punte / spațiu / interstițiu de descărcare în gaz

gas gathering (met) captare a gazelor

gas gauge (metr, $\mathrm{TH}$ ) manometru pentru gaze

gas-generating bottle (chim) balon pentru generarea gazelor

gas-generating capacity (chim, met) productivitate a gazogenului

gas generation (met, ind chim) captare / producere / producție de gaz(e)

gas generator (termo) gazogen, generator de $\operatorname{gaz}(\mathrm{e})$

gas generator tractor (auto) tractor cu gazogen gas generator with suction and pressure (termo) generator de gaz(e) sub presiune, cu aspirare

gas goggles $(\mathrm{TH})$ ochelari de protecție contra gazelor

gas governor (OM, met) regulator de gaz

gas grid (met) rețea de alimentare cu gaze

gash (med) tăietură (adâncă), cicatrice lungă; rană adâncă, gol între dinți; (mas-un, OM) canelură, crestătură, crestare; a tăia, a spinteca, a cresta; surplus; risipă; a tăia adânc, a răni (și în accidente)

gas hammer (hidr, mec) lovitură (de berbec) de gaz (la conducte)

gas heater (constr) radiator / încălzitor cu gaz(e) gas heating (termo) încălzire cu gaze

gas-heating operation / regulation $(\mathrm{TH})$ conducere / distribuire a gazului de încălzire gas helmet $(\mathrm{TH}$, mil) mască de gaze gashing tăietor, care taie; risipitor; (mas-un) canelare a golurilor dintre dinți (la freze detalonate) 
gashing cutter (mas-un) cuțit / sculă pentru canelarea frezelor detalonate

gas holder (met, ind chim) rezervor / acumulator de gaz(e); (metr) gazometru

gas-holder bell (ind chim) clopotul rezervorului de gaz(e)

gas-holder tank (ind chim) recipientul rezervorului de gaz(e)

gas holes (met) sufluri în piesa turnată

gas(-)house (met, ind chim) uzină de gaz(e)

gashouse coke (termo) cocs de gaz aerian

gasifiable (met) gazificabil; (termo) volatil

gasification (ind chim, met, termo) gaz(e)ificare, transformare în gaz(e)

gasification rate (ind chim, met, termo) viteză de gaz(e)ificare

gasifier (met) carburator

gasiform (fiz) gazos, în stare gazoasă

gasify (chim, met, termo) a gazifica, a gazifica, a transforma în gaz(e)

gasifying plant (ind chim, met) instalație de producere a gazului

gas in bottle (ind chim, met) gaz în butelii

gas inrush (met, ind chim) degajarea instantanee a gazelor, scăpări bruşte de gaze

gas intake (met) conducte de alimentare cu gaz(e) gas-intake (met, ind chim) injecție / introducere a gazelor

gas-intake pipe (chim) racord / ştuț pentru extragerea gazelor sau pentru extragerea probelor de $\operatorname{gaz}(\mathrm{e})$

gas issue (met) canal pentru evacuarea gazului

gas jet (OM) ajutaj / duză de gaz; bec de gaz; (met, ind chim) jet de gaz(e)

gas jet pump (OM) pompă cu jet de gaz

gasket $(\mathrm{OM})$ garnitură / inel / rondelă de etanşare (cu referire mai ales la elementul flexibil), manşon, material pentru garnitură de etanşare; (met) căptuşeală; (nav) sachet; baieră

gasket board $(\mathrm{OM}, \mathrm{TH})$ placă pentru decuparea garniturilor

gasket for packing (OM, hidr) material împletit pentru etanşare

gasketing ( $\mathrm{OM}$, hidr) etanşare prin folosirea garniturilor (tip şnur, împletite etc.)

gasket joint (ind chim, OM) îmbinare cu garnituri (d etanşare)

gasket ring $(\mathrm{OM})$ inel / şaibă de etanşare

gasket seal paste (auto, chim, hidr) pastă de etanşare

gas kinetics (fiz) cinetica gazelor, gazodinamică gas layer (met) pernă / strat / pătură de gaz(e)

gas leakage (met, ind chim, ind) ivire / scurgere / emanație de gaz(e) (în general nedorită) gas (leak) detector (metr, ind chim) detector de (scurgeri de) gaz(e)

gas lighter (OM, termo) brichetă cu gaze, aprinzător pentru aragaz / gaze

gas line (met, ind chim) conductă de gaz(e)

gas liquefaction (fiz, termo) lichefiere a gazului

gas liquid ratio (GLR) (chim) raport gaz-lichid (RGL)

gas-loaded accumulator (OM, hidr) acumulator hidro-pneumatic

gas lock (met, ind chim) dop de gaze

gas machine (mas) maşină / motor cu gaz(e)

gas main (ind chim, met) colector de gaz(e), conductă principală de gaz(e); conductă magistrală de gaz(e)

gas-main fitting (OM) armătură pentru conducte de gaz

gas-making plant (ind chim, termo) fabrică de gaz aerian

gas man (TH, ind, termo, met) instalator de gaze, muncitor la uzina de gaz; încasator de la distribuitorul de gaze

gas mantle (OM, termo) lampă cu incandescență, dispozitiv de generare a luminii strălucitoare prin încălzirea la flacără a unui material

gas mask (ind chim, mil) mască contra gazelor

gas mask carrier (chim, mil) cutie-filtru (la masca de gaze)

gaz metal-arc welding (GMAW) (met, el) sudare cu electrod continuu şi protecție cu perdea / cortină de gaz(e)

gas meter (metr, met) contor de gaze, gazometru (şi introdus în conducte)

gas mixture (ind chim) amestec de gaze gas motor / engine (termo) motor $\mathrm{cu}$ gaz

gas neck (met) canal de gaz(e), între colectorul de zgură şi regenerator

gas nest (met, ind chim) pungă / cuib de gaze gas nitriding (met) nitrurare în mediu gazos

gas odoriser (ind chim, met) aparat / instalație de odorizare a gazelor

gas off-take (met) evacuare / eliminare a gazelor gas off-take tube (met) conductă de evacuare a gazelor la furnal

gas of high calorific value (termo) gaz(e) cu putere calorifică mare

gasohol (termo) combustibil sintetic din amestec de benzină şi etanol; (chim, auto) gazohol (amestec de benzină şi etanol)

gas-oil (ind chim) motorină

gas-oil ratio (GOR) (ind chim) raport gaze şi țitei (RGT); raport de soluție

gasolene, gasoline (auto, ind chim) gazolină, (amer) benzină 
gasoline balance (auto) nivelul benzinei gasoline can (auto, OM) canistră / bidon de benzină

gasoline containing alcohol and methanol (auto, ind chim) benzină cu alcool şi metanol

gasoline engine (auto, mas) motor cu ardere internă / cu benzină; (cf) locomotivă cu benzină

gasoline filling station (ind chim) staţie de benzină; (auto) contor de benzină

gasoline gauge (auto, metr) contor de benzină

gasoline holder (auto, OM, termo) rezervor de benzină

gasoline (pipe-)line (ind chim) conductă de benzină

gasoline motor (mas, auto) motor de benzină

gasoline-pressure gauge (auto, mas, metr) indicator de nivel benzină a motorului

gasoline propulsion for engine (auto, mas, termo) funcționare cu benzină

gasoline rubber solution (ind chim) soluție de cauciuc în benzină

gasoline pump (auto, mas) pompă de benzină

gasoline scale (auto) nivelul benzinei

gasoline separator (auto) filtru / separator de benzină

gasoline supply (auto, mas) stoc de benzină gasoline-tank (ind chim, OM) rezervor de benzină

gasoline-tank meter (auto, metr) contor de benzină

gasoline trap (OM, auto, termo) separator de benzină

gasoline truck (auto, transp) autocisternă pentru benzină

gasometer (mas) rezervor / colector de gaz(e); (met, ind chim) gazometru

gas outburst (met) degajare / erupție bruscă de gaze

gas outlet (met) orificiu de evacuare a gazelor; (termo) evacuare a gazului / gazelor

gas-outlet line / tube (met, termo) țeavă pentru evacuarea gazelor de ardere

gas oven (met) cuptor cu gaz(e); (alim) aragaz

gas passage (met, termo) trecerea gazului

gas particle (fiz) particulă de gaz

gas pedal (auto) pedală de accelerație

gas-per-mile gauge (auto, metr) contor pentru consum specific de benzină

gas phase (chim, fiz) fază gazoasă

gas permeability (fiz) permeabilitate la gaze / a gazului

gas pipe $(\mathrm{OM}$, met, mas) țeavă / conductă de $\operatorname{gaz}(\mathrm{e})$

gas pipe-line (met, ind chim, termo) conductă de $\operatorname{gaz}(\mathrm{e})$ gas-pipe stock (chim) clupă pentru țevi / conducte de gaz(e)

gas-pipe tap (met, mas-un) burghiu / tarod de filetat țevi pentru transportul gazelor

gas-pipe thread (OM) filet pentru țevi de gaz(e) gas-pipe tongs (mas-un) cleşte pentru țevi de gaz(e)

gas-pipe vice (met) menghină pentru țevi de gaz(e)

gas piping (mas, met, termo) conductă de gaz(e) gas piston blower (met) suflantă cu piston, pentru gaze

gas plant (ind chim, met) instalație gazogeneratoare; statie de gaz; (termo, ind) uzină de gaz(e)

gas pliers / tongs (met) cleşte pentru țevi de gaz(e), dispozitiv pneumatic (şi cu conducte flexibile, ca element activ) de prindere

gas pocket (met) bulă de gaz; suflură, cavitate plină cu gaz; (ind chim) pungă de gaz(e), cuib de $\operatorname{gaz}(\mathrm{e})$

gas poisoning (med, $\mathrm{TH}$ ) otrăvire / intoxicare cu $\operatorname{gaz}(e)$

gas pore (met) suflură sferoidală (şi la sudură); (plast) por de gaz(e) (în materiale plastice)

gas-port block / end (met) (cap de) arzător de gaz / de ardere

gas post (met) cap de ardere a gazelor

gas powder welding sudare cu gaze şi pulbere

gas pressed head (met) maselotă

gas pressure (fiz) presiune de echilibru a gazelor; (ind chim) presiune a gazului

gas-pressure controller / regulator (mas, met, autom) vană; regulator pentru gaze

gas-pressure gauge / meter (metr, ind chim, met) manometru de gaze

gas producer (met, termo) generator de gaz(e); (metr) gazogen; sondă de gaz(e)

gas-producer efficiency (met, ind chim, termo) randamentul generatorului de gaz / gazogeneratorului

gas-producer retort (met) gazogenerator retortă gas-producing (met, plast, alim, ind chim) care degajă / produce gaz(e)

gas-producing coating (met, plast) acoperire cu degajare de gaz(e)

gas production (ind chim) extracție / producție de $\operatorname{gaz}(\mathrm{e})$

gas-proof (met, ind chim) etanş la gaze, impermeabil față de gaze; (met) antigrizutos

gas-proofed protejat contra gazelor

gas-proofness (ind chim) etanşeitate la gaze

gas-protective equipment (met, $\mathrm{TH}$ ) aparat de protectie contra gazelor

gas puddling (met) afinare / pudlare cu gaz(e) 
gas pump (ind chim) suflantă de gaze; (mas, OM) pompă de gaze

gas purification (met, termo, ind chim) epurare / purificare a gazelor

gas purifier (ind chim, TH) epurator de gaze, scruber

gas purifier fan (met) ventilator pentru curățirea gazului.

gas purifying (met, ind chim, mediu) purificare / epurare a gazului / gazelor

gas purifying plant / unit (met, ind chim) instalație / unitate de purificare / epurare a gazului / gazelor

gas-quenching (met) călire în cuptor cu gaze

gas radiator (constr) radiator cu gaz

gas range (alim) aragaz

gas receiver (metr) contor de gaz(e); (termo) gazometru, rezervor de gaz(e)

gas recovery factor (ind chim, met) coeficient de recuperare a gazelor

gas refrigeration machine (termo) maşină frigorifică cu gaz, maşină de răcire a gazului

gas regenerating chamber (met) cameră regeneratoare de gaz

gas regenerator (met) regenerator de gaz

gas registering apparatus (metr, met, ind) aparat de înregistrat debitul de gaze, contor de $\operatorname{gaz}(\mathrm{e})$

gas release (met, ind chim) degajare / erupție de gaze

gas residue (ind chim, met, mediu) gaz rezidual, reziduu gazos

gas retort (chim) retortă de gaze

gas retort carbon (chim) cărbune de retortă

gas reversing valve (met) supapă reversibilă de gaze

gas ring $(\mathrm{OM}$, alim) ochi de aragaz

gas run (met, ind chim) perioadă de gaz(e)ificare

gas sample collector (met) țeavă colectoare de eşantioane de gaz

gas sampling (ind chim) luarea probei de gaz(e)

gas saver (auto) economizor de benzină

gas scrubber (met, ind chim) scruber, spălător de gaze

gas scrubbing (ind chim, mediu) spălare a gazului

gas seal $(\mathrm{OM})$ obturator / garnitură de gaz, etanşare pentru gaze

gas-seal bell (met) închizător de gaz, în formă de clopot

gassed (met, med) gazat (cu gaze toxice)

gas seepage (met, ind chim) iviri / scăpări de gaze gas seeps (met, ind chim) iviri / degajări / emanații / scăpări de gaze gas separator (met, ind chim) separator de gaze gas-shielded arc cutting (met) tăiere (a materialelor metalice) în mediu de gaz protector gas-shielded arc welding (met) sudare $\mathrm{cu}$ arc electric, în mediu de gaz protector

gas shows (met) prezența / apariția gazelor

gassiness (fiz) stare gazoasă

gassing (el) formarea de gaz (la acumulator); (plast) evacuarea gazelor din forma de notificare; (met, ind chim) degajare / emanaţie de gaze, absorbție de gaze într-un material, formare de cavităţi gazoase într-un material; gazare, gazeificare

gassing after the charge (el, auto) fierbere în repaus (la acumulator)

gas singeing gazare, pârlire cu flacără

gassing factor (fiz) constanta gazelor

gas sluice / slide valve (met) capac de închidere pentru gaz(e); robinet cu sertar, de închidere a conductei de gaz(e)

gas soldering copper / iron (met) ciocan de lipit, încălzit cu gaz

gas-solid interaction (fiz, chim, met) interacțiunea dintre gaz şi suprafața solidului cu care vine în contact

gas-solid film (chim) suprafață de separație între gaz şi solid

gas source (met) izvor / sursă de gaz(e)

gas spout (met, ind chim) jet de gaz(e)

gas station (auto) benzinărie, stație de (alimentare cu) benzină / combustibil

gas stove (termo) sobă cu gaze

gaz stream (ind chim, agr) curent de gaz / aer, la cicloane; (fiz) curent ionic

gas-stream separation (agr, alim, ind chim, mediu) separare cu / în curent de gaze

gas strip (met) platbandă laminată pentru țevi de $\operatorname{gaz}(\mathrm{e})$

gas supply (met) alimentare cu gaze, aducție cu gaze

gas-supply pipe (met, ind chim) conductă de alimentare cu gaze

gas sweetening (met, ind chim) desulfurarea / îndulcirea gazelor

gassy (met, ind chim) gazifer, cu conținut de gaze, umplut cu gaz(e)

gas take (met) colector / captator de gaze

gas tank (ind chim, met, OM) rezervor de gaz gas tap / cock $(\mathrm{OM})$ robinet cu cep, pentru gaze gas tar (met) bitum de gaz; (ind chim) gudron de gaz

gas tension (fiz) presiune (de echilibru) a gazului gas testing enclosure (met, ind chim) spațiu cameră de testare a gazelor 
gas testing (fiz, chim) testare efectuată pe gaze (nu se specifică tipul de test)

gas thermometer (metr, termo) termometru pentru gaze / cu gaz

gas thread $(\mathrm{OM})$ filet gaz; filet pentru țevi

gas-throttle (met, ind chim) manetă de gaze / de deschidere-închidere pentru gaz(e)

gas-throttle controls $(\mathrm{OM}$, termo) tijă pentru ştrangularea (debitului) gazului combustibil

gas-throttle valve (auto, OM) clapetă de accelerație, accelerator

gas-tight (chim, met) etanş / impermeabil la gaze gas-tight joint (ind chim) îmbinare etanşă la gaze gas tongs / pliers (met) clește pentru țevi de gaze gas-torch welding (met) sudare cu gaz(e)

gas trap (constr) sas / ecluză pentru gaze (la adăpostul contra gazelor); (ind chim, met) separator de gaze

gas-trap-relief valve (met, ind chim, OM) supapă de siguranță la separatorul de gaze

gastronome (alim) gastronom, specialist în arta culinară

gastronomic(al) (alim) gastronomic, culinar gastronomy (alim) gastronomie, arta culinară gas tube (fiz) tub electronic, umplut cu gaz; tub de descărcări în gaze; $(\mathrm{OM})$ furtun / țeavă de gaz(e); (el) tub de radiații x / cu gaz

gas-tube vice (met, mas-un) menghină pentru țevi de gaz

gas tungsten-arc welding (GTAW) (met, el) sudare cu arc electric, cu electrod neconsumabil din wolfram

gas turbine (mas, termo) turbină cu gaz(e)

gas turbine rotor (mas) rotor al turbinei cu gaz(e)

gas-turbo blower (mas) turbosuflantă pentru gaze

gas tuyère $(\mathrm{OM})$ ajutaj / conductă pentru gaze

gas undersoundness (met, ind chim) formarea incluziunilor gazoase

gas uptake (met) eliminare / evacuare a gazului

gas uptake tube (met) conductă de evacuare a gazelor de furnal

gas valve $(\mathrm{OM})$ robinet cu sertar, de închideredeschidere a gazului

gas-vapour mixture (chim) amestec de gaze şi vapori

gas vent (met, ind chim) supapă de respirație

gas volumeter / volumometer (metr, termo) contor volumetric de gaze, debitmetru pentru gaz

gas volumetric analysis (chim) analiză volumetrică a gazelor

gas vulcanization (plast) vulcanizare în (mediu de) gaz

gas washer (ind chim, met) scruber, spălător de gaze, epurator de gaz(e) umed(e) gas-washing bottle (chim) vas spălător de gaz(e)

gas-washing pump (OM, ind chim) pompă pentru spălarea gazelor

gas-wash tower (met) scruber

gas welding (met) sudare cu gaz

gas-welding machine (met) maşină de sudat cu gaz

gas withdrawal (met, termo) canal de (evacuare pentru) gaz

gas works (met, termo) uzină de gaz

gas yield (termo) producție / debit de gaz(e)

gas zone (met, ind chim) zonă de / cu gaze

gate (constr) poartă, portal; (el, electr, autom, inf) circuit-poartă / condiționat; barieră deplasabilă; (OM) dispozitiv tip poartă (cu deschidereînchidere controlată, de exemplu, o supapă); (met) canalul de legătură între cavitatea matriței şi dispozitivul / utilajul de turnare, canal / rețea de turnare, alimentator, locaş pentru capăt de cleşte (la forjă), trecerea materialului prin cilindri (la laminor), culee, galerie de transport; (hidr) poartă (de ecluză navigabilă), ecluză; (OM, metr) sigurantă pentru manonetru; stavilă; vană; (mas) admisi(un)e; intrare; şuber; registru, închizător; (el, autom) a introduce treptat un semnal peste alt semnal care se atenuează; a realiza un amestec de sunete (prin evidențierea treptată a unora şi estomparea altora); (plast) canal de injecție / de turnare

gate-and-dam discharge (met) instalație de descărcare (a metalului topit etc.)

gate angle (el) unghi de saturație

gate area (met) secțiune a canalului de turnare gate arm (hidr) brațul stavilei-segment gate beams (hidr) grinzi de ridicare a stavilei gate by-pass switch (el) întrerupător de deblocare în caz de pericol (şi la ascensoare electrice)

gate-chain gallery (hidr) canal / galerie pentru cabluri

gate chamber (hidr, met) camera vanelor gate circuit (el, autom) circuit-poartă

gate contact (el, autom) contact de uşă / pentru acționarea unei uşi (la cuptoare, lifturi etc.)

gate crash a intra nepoftit (şi fără bilet sau prin fraudă); (el, autom) străpungere a porții

gate crusher intrus, prezență nepoftită / nedorită gate cutter (mas-un) cuțit de debavurat gate end (met) maselotă

gate-end conveyer (met) terminal de transportor gate for collecting slag and dirt (met) oală de zgură

gate guide (hidr) nişă de ghidare a vanei / porții (la amenajări hidrotehnice etc.)

gate house (constr) gheretă / uşă (a portarului) 
gate interlock (OM, autom, el) zăvorâre a uşilor (şi la instalații de înaltă tensiune)

gate meter (metr) aparat de măsură, cu orificiu variabil / cu diafragmă (şi pentru diferențe de presiuni)

gate operator (el) dispozitiv de închidere a uşii

gate runner (met) culisă pentru antrenarea / deschiderii uşii (cuptorului); (met) canal / rețea de turnare

gate shear (met, mas-un) foarfecare de tăiat tablă (şi tip ghilotină)

gate stirrer (alim, ind chim) amestecător / agitator cu cadru

gate track (met, OM) şină de rulare / de conducere / de ghidare (spre uşa cuptorului etc.)

gate track rack (hidr) cremalieră de acționare a gurii / a porții

gate-turn valve (met, OM) clapetă / supapă rotativă

gate-type gas regulating valve (mas) şuber de gaz; robinet cu sertar de închidere / de reglare a debitului gazului

gate-type shut-off valve (hidr, OM) vană / supapă glisantă de închidere

gate-type slide valve (mas, $\mathrm{OM}$ ) şuber plan; sertar plan

gate-type steam-shut-off valve (termo, OM) robinet cu sertar pentru închiderea aburului

gate valve (hidr) clapetă / vană / supapă glisantă (cu mişcare de translație sau rotație în plan perpendicular pe direcția curentului), robinet cu închidere cu sertar; (OM) vană / ventil de închidere, clapă obturator, robinet cu sertar; (met) registru, şuber

gate voltage $(\mathrm{el})$ tensiune de poartă

gate(-)way poartă de intrare; deschidere, ieşire; (met) galerie colectoare; (inf, c) dispozitiv de interconectare a două sisteme diferite

gate-width (fiz) durată de deschidere sau de blocare

gate window (el, autom) circuit de declanşare periodic / cu impuls periodic

gather (auto) convergența roților din față; a colecta, a (se) aduna, a culege, a (se) strânge; a înțelege, a cuprinde; a dezvolta; (met) a segrega; (agr) a recolta; a plisa, a încreți (textile); a afla; a se întruni; pliseu, încrețitură

gatherer (agr) culegător

gather in a strânge; (agr) a aduna (recolta), a secera (şi cereale)

gathering adunare, întrunire, care se adună / se strâng la un loc; (met) segregatie, suprafată neregulată, lipirea tablelor pe cilindrul de laminare (defect); (ec) colectare a productiei; (inf) colectare / culegere / strângere de date, grupare a datelor

gathering belt (met) bandă colectoare

gathering conveyer (met) transportor colector

gathering line (met, hidr) conductă / linie de colectare

gather up a aduna, a culege, a strânge (laolaltă)

gather way (nav) a căpăta viteză

gating (autom) trecerea printr-o poartă; (inf) selecție; (met) sistem de turnare; (el, autom) deblocare, declanşare, selectare a semnalului

gating practice (met, plast) tehnica / tehnologia de proiectare / de construcție a rețelei de turnare

gating pulse (el, autom) impuls de declanşare gating switch (autom) trecere printr-o poartă, selecție, declanşare, deblocare, selectare a semnalului, întrerupător ciclic / de deblocare; (met) canal / sistem de turnare

gating system (met, ind chim, plast) sistem / retea (de canale) de turnare

gauffer (TH, OM) a gofra, a ondula (hârtie, tablă, membrane pentru aparate de măsură etc.)

gauffer callendar (mas-un) calandru de gofrare / de gofrat

gauge (engl), gage (amer) (auto, cf) ecartament; (metr) aparat de măsurat / de măsură; măsură, dimensiune, scală, calibru, etalon, element de comparație, şablon, spion, indicator de nivel, senzor (în general), manometru, compas de grosime, a măsura, a calibra, a etalona; gabarit; (OM) jojă, distanță dintre axe / piese, pas, finețe, diametrul (fizic) al unei sârme / al unui conductor; (TH) a aprecia, a uniformiza, standardiza; (met, metr, plast) aparat / dispozitiv de măsurat grosimea produsului

gaugeable (metr) măsurabil (cu un senzor, traductor etc.)

gauge atmosphere (metr, mediu) atmosferă standard / etalon (şi în laborator)

gauge bar $(\mathrm{OM})$ bară de distanțare

gauge barometer (metr) manometru, barometru gauge block (mas-un) plăcuță Johansen; (met, metr) placă de calibrare; (metr) cală planparalelă, bloc de cale

gauge board (met) cutie falsă de formare

gauge callipers (mas-un, metr) calibru-potcoavă gauge clock (metr, hidr) contor de apă

gauge cock (metr, hidr, OM) robinet de luat probe gauge condition (metr) condiție de etalonare / de echilibrare / de luat probe / de măsurat / de funcționare (a unei părți) a aparatului de măsură / a traductorului / a senzorului

gauged (met, ind) calibrat, cu senzor / traductor 
gauge datum (hidr, metr) cota zero (a traductorului / senzorului / aparatului, a staţiei hidrometrice)

gauged brick (met, constr) cărămidă profilată gauged mortar (constr, chim) mortar de ciment cu priză înceată / lentă

gauge drill (mas-un) burghiu-lingură

gauge factor (metr) factor de etalonare / de sensibilitate (a unui traductor / aparat de măsură)

gauge finger (met) deget de calibrare

gauge flask (chim) balon cotat

gauge for base (met) calibru inelar

gauge glass (metr) pahar gradat; $(\mathrm{OM})$ indicator de nivel

gauge glass-tube $(\mathrm{OM})$ tub de sticlă al indicatorului de nivel (al lubrifiantului etc.)

gauge height (hidr) înălțimea nivelului apei

gauge length (met) lungimea de măsurare a traductorului; (metr) lungimea (maximă), de măsurat / de bază a traductorului / aparatului

gauge limit system $(\mathrm{OM})$ sistem de toleranțe pentru calibre

gauge loss $(T, O M)$ reducerea diametrului calibrului prin uzură

gauge mark (mas, metr) reper de potrivire / de ajustare / de reglare

gauge measuring device (met, metr) dispozitiv pentru măsurarea grosimii benzilor

gaugemeter (met, metr) dispozitiv de măsurat grosimi (şi de tablă)

gauge of curves $(\mathrm{cf})$ ecartamentul unei căi ferate, la curbe

gauge of plate / of sheet (met, metr) grosimea tablei

gauge of wire (met, metr) dimensiunea / finețea sârmei

gauge pin / plug (met, mas-un) calibru-tampon gauge point $(\mathrm{TH})$ marcare de capăt

gauge pressure (fiz, met, hidr) presiune manometrică / indicată de manometru

gauge protector (hidr, metr) siguranță pentru manometru (sau alt traductor)

gauge pulsation damper (hidr, metr, OM) amortizor de pulsații pentru manometru (sau alt traductor)

gauger (TH) lăcătuş ajustor, măsurător, pontator, normator; (ec) perceptor, încasator

gauge reading (metr) citire a valorii măsurate, la un aparat de măsură

gauge reduction (met) degroşare, eboşare

gauge ring (el, $\mathrm{OM})$ inel de fixare al unui senzor / traductor; (hidr) calibru de cep

gauge rod (auto) tija nivelului de ulei, jojă; (metr) riglă gradată gauges (metr) mijloace de măsurare, traductoare, senzori

gauge saw (mas-un, autom) ferăstrău cu dispozitiv pentru reglarea adâncimii de tăiere

gauge stick (metr) riglă gradată / de măsurat

gauge tank (ind chim, metr) vas / rezervor de măsurat; (metr) vas de măsură

gauge tap (mas-un, metr) robinet de control / de preluat probe

gauge tape (metr) ruletă de măsurat

gauge tolerance (metr) toleranță / abatere tolerată a calibrului

gauge tool (metr) sculă de verificat / de măsurat gauge transformation (fiz, mat) transformare de etalon(are)

gauge tube (fiz, hidr) tub Pitot; (metr) tub manometric / de măsurat presiune

gauge valve $(\mathrm{OM})$ supapă de control (al presiunii sau debitului)

gauge wear (metr) uzura calibrului

gauging (hidr) măsurare a debitelor; (metr) calibrare, etalonare, şablonare

gauging callipers (metr) compas de măsurat

gauging constant (metr) constantă de calibrare / etalonare

gauging error (metr) eroare de calibrare

gauging fixture (mas-un, metr) dispozitiv de montare a traductorului

gauging glass (ind chim) sticlă de nivel, indicator de nivel (cu geam)

gauging tap $(\mathrm{TH})$ tarod de calibrare

gaunt sfrijit, supt; (agr) sterp, sărac, pustiu

gaunlet $(\mathrm{TH})$ mănuşă de protecție, apărătoare pentru încheietura mâinii, manşetă protectoare

gauss (el, metr) gauss $(\mathrm{G})$, (unitate de măsură a câmpului magnetic): 1 gauss $=1$ Maxwell per square centimeter $\left(\right.$ maxwell $\left./ \mathrm{cm}^{2}\right)\left(\mathrm{Mx} / \mathrm{cm}^{2}\right)$

Gaussian curvature (mat) curbură totală, curbură gaussiană

Gaussian distribution (mat) distribuție gaussiană

Gaussian elimination (mat) tehnică de rezolvare a ecuațiilor liniare prin diferențe progresive

Gaussian error curve (metr) curbă gaussiană / normală, de erori

gauze (met, constr) ciur, sită, plasă de sârmă, țesătură metalică; (textile) tifon, voal, văl; pânză gazé; (amer) ceață

gauze filter (OM) sită de filtru, filtru cu pânză țesătură metalică sau din fibre sintetice

gauze-like (textile) subțire ca voalul / tifonul gauze packing (materiale, $\mathrm{OM}$ ) umplutură reticulară (şi la compozite)

gauze screen (constr) sită fină din pânză metalică 
gauze strainer (alim, OM) filtru tip sită gauze wire (met, OM) țesătură / împletitură de sârmă

gauziness transparență; subțirime extremă; finețe gauzy transparent, subtire ca voalul; fin, delicat; imaterial

gazebo (constr) chioşc, pavilion de grădină, foişor, turnulet

gazette monitor / buletin oficial, ziar, gazetă

gear $(\mathrm{OM})$ roată dințată (în general), pinion, angrenaj, mecanism de acționare, transmisie (cu roți dințate); a pune în mişcare (un mecanism), a înzestra cu un mecanism; a cupla; a (se) angrena; a adapta, a ajusta, a se îmbuca; echipament, haine; utilaj

gear assembly (OM) transmisie cu roți dințate (mai des, reductor)

gear blacklash (OM) joc lateral / între flancuri (la angrenaje)

gear blank (mas-un) piesă brută / semifabricat pentru executarea / prelucrarea unei roți dințate

gear box, gear case (mas, OM) cutie de viteze, carcasa unui angrenaj / a unei cutii de viteze

gear box feeding and threading (mas-un) cutie de avansuri şi de filete

gear case / cover / housing (auto, mas, OM) carcasă a cutiei de viteze

gear case oil $(\mathrm{T})$ ulei pentru cutia de viteze / de transmisii

gear casing $(\mathrm{OM})$ carter / carcasă de reductor / a cutiei de angrenaje / de viteze

gear chain $(\mathrm{OM})$ lanț de acționare

gear change (auto) schimbător de viteze

gear change fork (auto) furca pârghiei de debreiere

gear changing (auto, mas-un) schimbarea / cuplarea vitezelor

gear circulator rig $(T$, metr) instalație pentru testarea / verificarea angrenajelor

gear cluster $(\mathrm{OM})$ bloc de roți dințate

gear configuration $(\mathrm{OM})$ configuratie a transmisiei cu roți dințate (cu referire şi la schema ei)

gear control lever (auto) levierul schimbătorului de viteze

gear coupling (OM) cuplaj cu gheare, transmisie incluzând angrenaje şi cuplaje

gear cutter (mas-un) freză-modul

gear cutter sharpening machine (mas-un) maşină de ascuțit dinți la scule / freze de danturat

gear cutting (OM, mas-un) danturare (prin aşchiere, fără a specifica procedeul)

gear cutting machine (mas-un) maşină de danturare / de prelucrat roți dințate gear cutting tool (mas-un, OM) sculă de danturare (prin aşchiere)

gear down (auto) a schimba / a reduce viteza la o treaptă inferioară, a micşora turația unei transmisii / unui arbore, cu ajutorul unui angrenaj

gear drive $(\mathrm{OM})$ transmisie / acționare $\mathrm{cu}$ roți dinţate

gear efficiency (OM) randamentul unui angrenaj $(\eta)$

geared engine / motor (el, OM) motor cu reductor de turație (cu angrenaje), motoreductor

geared feed (mas-un) avans prin folosirea mecanismului cu roți dințate

gear(ed) head (OM) cap de acționare cu roți dinţate

geared locomotive (met, cf) locomotivă pentru cale cu cremalieră

geared plate (mas-un) platou cu coroană dinţată

geared pulley block (hidr, OM) palan cu angrenaje

geared segment $(\mathrm{OM})$ sector dințat

geared shaper (mas-un) şeping cu mecanism de acționare cu pinion şi cremalieră

geared turbine (mas) turbină cu reductor de turație

gear generating machine (mas-un) maşină de danturat prin metoda rulării / rostogolirii

gear grease (ind chim, T) unsoare pentru roți dințate / pentru angrenaje

gear grinder / grinding machine (mas-un) maşină de rectificat roți dințate

gear guard $(\mathrm{OM})$ cutie de protecție a unei transmisii cu roți dințate

gearhead of a machine (mas) cutia de angrenaje a unei maşini

gear hob (mas-un) freză-melc-modul, freză-modul gear hobbing (mas-un) frezare a roților dințate prin metoda rulării (sau rostogolirii)

gear housing (auto, mas) carcasă de reductor / de cutie de viteze; apărătoare la transmisia cu lanțuri gearing $(\mathrm{OM})$ angrenaj, angrenare, cuplaj (dințat), transmisie (şi cu roți dințate), reductor, dinţare; mecanism de acționare; îmbucare; (ec) structură a capitalului unei societăți gearing angle $(\mathrm{OM})$ unghi de angrenare (la roți cilindrice cu dinţi drepți), unghiul format între axele conurilor de rostogolire la angrenaje conice (atenție la text)

gearing down (mas, $\mathrm{OM}$ ) micşorarea turației; cu ajutorul unui angrenaj cu roți dinţate

gearing ratio $(\mathrm{OM})$ raport de transmitere $(\mathrm{u})$ al transmisiei cu angrenaje

gearing up (mas) mărirea turației cu ajutorul unui angrenaj dințat 
gear lapping machine (mas-un) maşină pentru lepuit flancurile dinților (roților dințate)

gear level, gear levelling drive $(\mathrm{OM})$ transmisie cu roți dințate, la care turația de intrare şi de ieşire este aceeaşi $(u=1)$

gearless machine (el) maşină fără angrenaj(e)

gear lever $(\mathrm{OM})$ pârghia mecanismului de acționare a roții dinţate (baladoare); (auto) maneta pentru schimbarea vitezelor, schimbător de viteze

gear lubricant / oil (T, OM) ulei / lubrifiant pentru angrenaje

gear measuring machine (mas-un, metr) mașină / instalație de verificat roți dințate

gear milling machine (mas-un) maşină de frezat roți dințate

gear(-)motor (el, OM) moto-reductor

gear motor with pressure loading (el, OM, hidr) motoreductor cu compensare hidrostatică a jocului

gearless motor (el) motor fără angrenaj

gear pair $(\mathrm{OM})$ angrenaj, pereche de roți dințate gear pair with closed centre distance $(\mathrm{OM})$ angrenaj cu deplasare negativă

gear pair with extended centre distance $(\mathrm{OM})$ angrenaj cu deplasare pozitivă (cu distanța între axe mărită prin deplasarea danturii)

gear pair with intersecting axes $(\mathrm{OM})$ roți dințate cu axe concurente (conice)

gear pair with modified centre distance $(\mathrm{OM})$ angrenaj deplasat / cu distanța între axe modificată / deplasată $\left(a_{w}\right)$

gear pair with non-parallel non-intersecting axes $(\mathrm{OM})$ angrenaj cu axe necoplanare (neparalele şi neconcurente), angrenaj hiperboloidal (în general) / cilindric elicoidal

gear pair without addendum modification (OM) angrenaj nedeplasat / fără deplasare

gear pair with parallel axes $(\mathrm{OM})$ angrenaj (cu roți dinţate) cu axe paralele

gear pair with reference centre distance $(\mathrm{OM})$ angrenaj zero-deplasat, angrenaj de roți dințate, cu distanța dintre axe de referință, nemodificată, dar cu deplasare $\mathrm{x}_{1}$ pe una din roți, şi cu $\mathrm{x}_{2}=-\mathrm{x}_{1}$ pe cealaltă

gear pinion $(\mathrm{OM})$ roata dințată cu număr mai mic de dinţi (mai rar), roata conducătoare dintr-un angrenaj, pinion

gear pitch $(\mathrm{OM})$ pasul dințării / danturii (se subînțelege pe cercul de divizare sau de rostogolire)

gear planer (mas-un) maşină de mortezat / de rabotat roți dințate

gear power wheel $(\mathrm{OM})$ roată conducătoare gear pump (OM, hidr) pompă cu roți dințate gear pump with pressure loading (OM, hidr) pompă cu roți dințate / cu angrenaje, cu compensare hidrostatică a jocului

gear quadrant / rim / segment (auto, OM) sector dințat, coroană dințată

gear rack (auto, OM) cremalieră

gear ratio (auto, OM) raport de angrenare / de transmitere / de transmisie / de reducție / de demultiplicare, raport de transmisie al unui angrenaj (u) (raportul real, între numerele de dinți ale roților în angrenare)

gear reducer / reductor / reduction unit $(\mathrm{OM})$ reductor de / cu angrenaje

gear reduction rate $(\mathrm{OM})$ raport de transmitere / de transmisie / de reducere (a turației)

gear reversing (auto) trecere în marşarier; $(\mathrm{OM})$ schimbarea sensului mişcării (cu ajutorul unui angrenaj)

gear reversing unit / reducer $(\mathrm{OM})$ transmisie reversibilă (cu angrenaje), reductor reversibil

gear selector lever (auto) schimbătorul de viteze gear shaft $(\mathrm{OM})$ arbore-pinion

gear shaper / shaping machine (mas-un) maşină de mortezat roți dinţate

gear shaving (mas-un) şeveruire a roților dințate gear shift (mec) comandă, demarare; (el) comutare; (OM) mecanism de cuplare, angrenaj; (auto) schimbător de viteze

gear-shift bar (mas) bară de cuplare

gear-shift cap (mat) calotă

gear-shift fork $(\mathrm{OM})$ furcă a schimbătorului la cutia de viteze

gear shifting (auto, OM) cuplare / schimbare a vitezelor

gear shift(ing) lever / selector (mas) levier al cutiei de viteze / al schimbătorului de viteze

gear-shift lever shaft (auto) arborele secundar din cutia de viteze; (mas-un, OM) arbore de comandă / cu came

gear-shift sleeve $(\mathrm{OM})$ mufă de cuplare

gear stocking cutter (mas-un) freză-modul pentru degroşare (la prelucrarea roților dințate)

gear tester / testing apparatus (mas-un, metr) aparat pentru verificarea profilului dinților / a roților dințate

gear tooth $(\mathrm{OM})$ dinte de angrenaj / de roată dințată

gear-tooth burnishing machine (mas-un) maşină de polizat dinții roților dințate, aparat / instalație pentru testarea roților dințate (atenție la text)

gear-tooth chamfering machine (mas-un) maşină de rotunjit muchiile fețelor frontale ale dinților roților dințate (roților dințate) 
gear-tooth cutting (mas-un) aşchiere / tăiere a dinților

gear-tooth finishing cutter (mas-un) freză-discmodul (profilată), de finisare

gear-tooth gauge (OM, metr) şubler pentru măsurarea dinților / a lungimii peste $\mathrm{N}$ dinţi

gear-tooth grinding machine (mas-un) maşină de rectificat roți dințate

gear-tooth roughing / stocking cutter (mas-un) freză-disc-modul pentru prelucrare grosieră

gear-tooth system (OM) sistem de angrenaje / de angrenare

gear-tooth vernier cal(l)ipers (mas-un) şubler (vernier) pentru roti dintate

gear train $(\mathrm{OM})$ transmisie / tren de roți dințate, angrenaj cu / în mai multe trepte, angrenaj cu mai multe roți în cascadă (chiar şi parazite)

gear-train diagram (mas, OM) schema cinematică a angrenajelor / a transmisiilor

gear transmission (OM) transmisie prin / $\mathrm{cu}$ angrenaje

gear-type limit switch (mas-un) întrerupător / limitator acționat cu angrenaj

gear up (auto) a schimba viteza într-o treaptă superioară

gear wheel $(\mathrm{OM})$ roată dințată

gear wheel pump (OM, hidr) pompă cu roți dințate gear wheel steel (met, OM) oțel pentru roți dințate

gear whine (auto) cârâitul roților dințate

gear with addendum modification $(\mathrm{OM})$ angrenaj cu deplasare (nu se specifică dacă este negativă sau pozitivă)

gear with negative addendum modification $(\mathrm{OM})$ angrenaj cu deplasare negativă (la cel puțin una din roți)

gear with no addendum modification (OM) angrenaj nedeplasat

gear with positive addendum modification $(\mathrm{OM})$ angrenaj cu deplasare pozitivă (la cel puțin una din roți)

geat (met) culee, rețea de turnare

geese $(p l)$ gâşte

gefilte fish (alim) peşte / ştiucă umplut(ă)

Geiger-Müller counter / tube (fiz, metr) contor Geiger-Müller

gel (chim, met) gel, suspensie (coloidală); a forma un gel / o suspensie coloidală

gelatination (ind chim, alim) gelatinare

gelatine (alim, ind chim) piftie, gelatină

gelatine-tannin treatment of the wine (alim)

clei(e)re a vinului

gelatinisation (alim, chim, plast) gelifiere

gelatinous (alim, chim) gelatinos gelatinous precipitate (chim) precipitat gelatinos

gelation (alim, chim) gelifiere, gelatină, gelatinizare, înghețare, solidificare prin răcire, formare a unui gel / a unei soluții coloidale

gelation time (alim, chim) timp de gelifiere

gel formation, gelification, gelling (alim, chim) gelatinizare; (plast) gelifiere, formare a gelului / a unei substanțe vâscoase / gelatinoase

gelid înghețat, rece ca gheața, glacial

gelignite, gelly (chim) exploziv cu fulmicoton

gelling action (alim, chim) acțiune de gelificare / de înghețare (mai rar)

gelling agent (alim, chim) agent de gelificare, gelatinizant

gelling properties (alim, chim) capacitate de gelatinizare / de gelifiere

gel point (alim, chim, plast) punct de gelifiere

gel strength (alim, chim) rigiditate / rezistență a gelului

gel structure (alim, chim) structură a gelului / gelatinoasă

gel temperature (plast) temperatura gelului (şi la adezivi)

gel-time (alim, chim) timp de gelifiere / de gel

gem (minrl) piatră prețioasă, gemă, bijuterie; (bot) boboc, mugur

geminate a îngemăna, a împerechea; a (se) dubla, a repeta; îngemănat, împerecheat; pereche

gemination îngemănare, împerechere; geminație; dublare, repetare

gender (mat) gen

genemotor (el) motor-generator, convertizor rotativ de curent continuu

general (mat, TH) general, complet, universal, total, (larg) răspândit, obişnuit, comun; vag, general, nespecific, nedefinit, nespecificat; principal, şef

general agent $(\mathrm{ec})$ reprezentant general

general arrangement plan $(\mathrm{TH}$, constr, ind) plan general de montare

general assembly $(\mathrm{ec})$ adunare generală

general failure (nav) avarie generală

general cargo (nav) mărfuri generale; încărcătură mixtă

general contractor (constr) antreprenor general general corrosion (met) coroziune generalizată / generală, pe / în tot materialul

general dealer (ec) proprietar de magazin general, distribuitor de talie mare

general delivery poștă / corespondență obişnuită; (amer) post restant

general drive (mas) acționare de la un motor (comun, pentru mai multe maşini) 
general duty (mec) universal, cu destinație generală

general equation (mat) ecuație generală

general expenses (ec) speze / cheltuieli diverse / generale

general extension (mec) alungire uniformă (relativă) la rupere

general gain coefficient (autom) coeficient / raport de amplificarea totală

general integral (mat) integrală generală

generalisation (mat) generalizare

generalise (mat) a generaliza

generalised function (mat) distribuție / funcție generalizată

generalised project $(\mathrm{TH}$, constr) proiect tip(ic) / general

generality generalitate, considerație cu caracter general; universalitate, aplicabilitate generală; majoritate; masă, gros

generalization generalizare, abstractizare, absolutizare; generalități; inducție

generalize a generaliza, a absolutiza, a abstractiza; a răspândi; a stiliza, a schematiza; a vorbi în termeni generali

general knowledge (edu) cunoştințe generale general layout (constr, $\mathrm{TH}$ ) amplasare / plan / general(ă); conținut (al unei cărți, broşuri etc.) generally $(a d v)$ în (mod) general; vag; peste tot, pretutindeni, în majoritatea cazurilor

generally valid (mat) universal valabil, identic adevărat

general maintenance (ec, TH) mentenanță generală

general management $(\mathrm{TH})$ direcție generală, management

general manager $(\mathrm{TH})$ şef de exploatare

general meeting adunare generală

general memory (inf, c) memorie principală / primară

general overhaul $(\mathrm{TH})$ revizie, reparație capitală / generală

general plan (constr, TH) plan de ansamblu / general (al unei instalații / utilaj etc.)

general post-mortem program(me) (autom, auto) program universal de diagnosticare

general program(me) (inf) program general / maşină

general purpose $(\mathrm{TH})$ pentru mai multe scopuri, universal, de uz (tehnic) general

general purpose computer (c) calculator universal general purpose instrument (metr) sculă / instrument (de măsură) universal( $\breve{a})$

general purpose machine (mas-un) maşinăunealtă universală general repair work $(\mathrm{TH}$, met) reparație generală general store $(\mathrm{ec})$ magazin universal

general strike grevă generală

general topic (constr) temă generală (a proiectului)

general trend $(\mathrm{TH})$ tendință generală (de modernizare etc.)

general utility truck (auto, el) electrocar

general ventilation (met) aeraj principal, ventilație generală (în toată secția, hala etc.)

generant (mat, OM) generatoare

generate a genera, a produce, a dezvolta; a degaja; a stârni, a provoca; a da naştere la

generated generat, produs, dezvoltat; degajat, inițiat (d. un proces etc.)

generated contamination (mediu, ind chim) poluant provocat

generating angle (hidr) unghi de divergență al orificiului triunghiular; (OM) unghi de deschidere, de angrenare

generating circle (mat) cerc generator; $(\mathrm{OM})$ cerc de bază (la dantura evolventică, cicloidală)

generating cone $(\mathrm{OM})$ con de bază (la roți dințate conice)

generating function (mat) funcție generatoare generating line (mat, OM) (dreaptă) generatoare; (mas-un) linie generatoare

generating machine (mas-un) maşină de frezat / de generat scule / danturi etc.

generating method (mas-un) metodă de prelucrare prin rulare / rostogolire a roților dințate / suprafețelor profilate; (mat, OM) metodă de generare (a suprafețelor etc.)

generating milling cutter (mas-un) freză-melc, freză rostogolitoare

generating motion (mas-un) mişcare de rulare la tăierea dinților roților dințate

generating motion press (met) presă cu mişcare impusă

generating plant / station (el) stație / uzină generatoare; centrală electrică; generator

generating process (mas-un) metode de rulare (la tăierea dinților), proces de danturare prin rulare

generating set (el) grup electrogen, generator

generating station (el) stație / uzină generatoare; centrală electrică

generating station capacity (el) putere instalată a unei centrale electrice

generating unit (termo) instalație de generator generation generare; generație; formare, producere, producție

generational generativ; referitor la diferența între generații 
generation gap decalaj între generații, deosebiri de concepții între grupe (de vârste)

generation of gas (chim) generare de gaz(e); formarea / generarea gazelor

generation of oscillations (fiz, autom) genera-re a oscilațiilor

generation of powder (chim, met, alim) producere / generare de pulbere / pudră

generation of power (el) producere / generare de energie / de putere

generator (el, electr, autom) generator (şi de semnal); dinam; (mat) (curbă) generatoare; generator (element operator); (inf) programgenerator, sursă; (termo) generator de gaz

generator boiler (termo, OM) cazan (generator) de abur

generator drive belt (auto, OM) cureaua generatorului (electric)

generator gas (met, termo) gaz (de) generator/ de gazogen

generator-gas firing (met, termo) încălzire cu gaz de gazogen / de generator

generator hum (mas) zgomot de maşină

generator magneto crank / handle (el) manivelă de inductor

generator plant (mas, el) instalatie de generator generator program(me) (c, inf) program generator de cod

generator protective relay (el, autom) releu de protecție al generatorului

generator rating $(\mathrm{el})$ putere nominală a generatorului

generator set (el) grup electrogen

generator unit (el) generator

generatrix (geom) dreaptă / linie generatoare

generic generic; general, universal

generically $(a d v)$ generic, vorbind în general

generic efficiency $(\mathrm{ec})$ productivitate relativă

generosity, generousness generozitate, mărinimie; altruism; spirit de sacrificiu; abundență, bogăție

generous generos, mărinimos, darnic; altruist; abundent, bogat; copios

genesis, $(p l)$ geneses geneză, naştere; origine; apariție

genesis of crystalline structure (met) formarea structurii cristaline

genetics genetică

geneva (alim) gin olandez, băutură de ienupăr

genial plăcut, agreabil; favorabil, propice; binevoitor, amabil; coridal; blând, calm, dulce (d. aer, climă etc.); înnăscut; natural, firesc; vesel, voios; (fig) rodnic, fertil

geniality caracter plăcut / agreabil; caracter favorabil; veselie, bunăvoință, amabilitate, cordialitate; blândețe (a climei) genially $(a d v)$ plăcut, agreabil; favorabil, propice; binevoitor, cordial; blând

gentle binecrescut, manierat; binevoitor; liniştit, domol; cu înclinare mică; plan cu pantă lină; (fig) a îmblânzi

gentle dip (geol) înclinare mică

gentle gradient (met) pantă lină

gentle heating (met, termo) încălzire treptată / lentă

gentle oxidation (chim) oxidare blândă

gentle slope pantă mică / dulce / redusă

gentle slope arch (constr) arc pleoştit

genuine autentic; veritabil; original, adevărat; curat, pur, nefalsificat; sincer, cinstit, onest, deschis; natural, neprefăcut; document document autentic

genuineness autenticitate

genuine purchaser (ec) cumpărător serios

genuine soap (textile, T) săpun care nu conține substanțe de îngreunare

genuine spare part (auto, OM) piesă de schimb, originală

genus gen, speță, soi

geode (minrl) geodă

geographic mile (metr, nav) unitate de măsură pentru lungime, milă marină / geografică: 1 geografic mile $\cong 1855,4 \mathrm{~m}$

geography geografie; topografie, înfățişare a unui loc

geology geologie

geometric(al) (geom) mărime geometrică, geometric

geometrical form tolerancing $(\mathrm{OM})$ tolerarea formei geometrice

geometrical magnitude / dimension (mat) mărime geometrică

geometric(al) mean / average (mat) medie geometrică

geometrical position / locus (mat) loc geometric geometrical progression (mat) progresie geometrică

geometrical proportion (mat) proporție geometrică

geometrical representation (mat) reprezentare geometrică

geometrical shape $(\mathrm{TH}, \mathrm{OM})$ formă geometrică geometric average / mean (mat) medie geometrică

geometric buckling (fiz, mat) curbură (laplacian) geometrică a reactorului

geometric capacity (hidr) cilindree geometrică (teoretică)

geometric distortion (fiz) distorsiune geometrică geometric distribution (fiz) repartizare geometrică; (mat) repartiție în progresie geometrică (în statistica matematică) 
geometric figure (geom) figură geometrică geometric form (geom) formă geometrică geometric hydraulic power (hidr) putere hidraulică geometrică (teoretică)

geometric input flow (hidr) debit geometric de intrare

geometric lathe (mas-un) strung semiautomat pentru lucrări de gravare

geometric mean (mat) medie geometrică

geometric mean diameter (mat, chim, fiz) diametru (ca) medie geometrică

geometric mean value (mat) valoare a mediei geometrice

geometric object (geom) obiect geometric

geometric output flow (hidr) debit geometric de ieşire

geometric progression (mat) progresie geometrică geometric solid (mat, mec) solid format din corpuri geometrice (simple)

geometric torque (hidr) moment geometric (calculat cu puterea geometrică)

geometry (mat) geometrie; formă, structură, amplasare, compoziție

geosphere (geol) scoarța terestră, geosferă

geotechnical engineering (mediu) inginerie care are efect asupra mediului (constructii, hidrotehnică etc.)

geothermal geotermal

gerah (Biblical Hebrew) (metr) unitate de măsură (veche) pentru masă (din ebraica veche): 1 gerah $($ Biblical Hebrew $)=0,00057 \mathrm{~kg}$

germ (med, zool) germen, embrion, microb, agent patogen, spor; (fig) sâmbure, sământăă, nucleu, început

germane înrudit, legat, apropiat; relevant, pertinent, adecvat

German silver (met) alpaca, argentan, aliaj $\mathrm{Cu}-$ $\mathrm{Ni}-\mathrm{Zn}$

Germanium (Ge) (chim) germaniu

germicides (substanțe) bactericide

germinal (agr, bot) germinativ, embrionar; incipient; în germene / faşă

germinate (agr, bot) a germina, a încolți; (met) a creşte (d. cristale în aliaj etc.), a forma / a iniția nucleu de cristalizare; a naşte, a da naştere la

germinating ability (agr, met) / calitate / capacitate germinativă / de a forma nuclee de cristalizare

germinating layer (agr, bot) strat germinativ

germination (agr) germinație, încolțire; (fiz) formare a miezului / a nucleului; (el) formarea filamenului; (met) crestere / germinare / formare (a cristalelor); dezvoltare

gersdorffite (met) nichelină

get a căpăta, a obține, a dobândi; a face rost de, a procura, a pune mâna pe; a găsi (un rezultat la un calcul); a primi; a lua, a-şi acorda; a determina (să fie făcut / să facă ceva), a pune (să facă), a duce (la realizarea unui lucru); a da la; a convinge; a forța, a sili; a realiza, a repurta; a câștiga (prin muncă); a înțelege, a pricepe; (med) a contracta, a lua (o boală); a nimeri, a atinge, a lovi; a aduna, a culege, a strânge; a ajunge să aibă; a prinde, a apuca, a ajunge în; a cuceri, a captura; a duce, a conduce, a trece; a ajunge, a izbuti să vină, a reuşi; a se duce, a merge, a se pune, a se aşeza; a mări, a spori, a crește; a se face, a se aranja; (cu un infinitiv) a ajunge la, a fi constrâns să; (met) a tăia, a extrage, a recupera; zămislire; (agr, zool) fătare, naştere, pui, animal fătat, reproducere (la animale); a zămisli, a da naştere la; a-şi imagina; a-şi băga ceva în cap; a fi preocupat de ceva; (edu) a învăța pe dinafară; a răpune; a sosi; a începe să; a se sfârşi prin; (fam) a păcăli; a aduce într-un anumit loc / într-o anumită stare; have got to a trebui, have got a avea; old a îmbătrâni; fat a se îngrăşa; rich a se îmbogăți; angry a se înfuria; tired a obosi; dizzy a ameți; married a se căsători; a blow a primi o lovitură; wind of a avea ştire de, a se răspândi (d. o ştire etc.); well / better a se face (mai) bine, a se însănătoşi; $\sim$ smth. mended a da la reparat; $\sim$ killed a fi omorât; one's own back a-şi lua revanşa

get about a călători, a voiaja, a umbla, a se deplasa; a circula, a se răspândi

get across a face să treacă / să traverseze, a trece (dincolo)

get afloat (a ship) (nav) a scoate de pe uscat (o navă)

get along a transporta, a duce, a face să înainteze, a înainta, a progresa, a face progrese; a se descurca; a se înțelege; a pleca; with smb. a se înțelege cu cineva

get aside (mas-un) a devia de la poziția normală get at a ajunge (până) la, a atinge; a găsi, a descoperi, a izbuti să găsească, a obține get-at-able accesibil, abordabil

get-at-ableness accesibilitate, caracter abordabil get at the truth a încerca să afle adevărul; a reuşi să-şi procure (documente), să descopere (fapte)

getaway fugă, evadare, scăpare; start, demaraj, plecare

get away a pleca; a elibera; a scăpa, a fugi, a evada; a dispărea; a ieşi cu bine dintr-o afacere, a o scoate la capăt

get away from a scoate, a smulge din / de la; a scăpa de, a se sustrage de la / din

get away with a fugi / dispărea cu

get back a recăpăta, a redobândi, a reintra în posesie; a recâştiga, a recupera, a reface; a readuce, a aduce înapoi, a face să revină; a pune 
la loc (un lucru); a restabili; a se întoarce, a reveni; a (se) da înapoi; a reprimi

get beyond a depăşi, a trece peste; a lăsa în urmă, a întrece

get by a se strecura, a reuşi să treacă; a trece pe lângă; a depăşi, a trece peste, a trece dincolo de

get clear a scăpa (cu bine) de, a depăşi (cu bine) o dificultate; (nav) a pleca de la chei

get down a da jos, a coborî; a nota, a însemna, a lua note după; a doborî (la pământ); a înghiți; a (se) coborî, a se da jos

get down to a coborî (la fapte); a se apuca de

get foward a merge mai departe, a înainta, a progresa, a avansa

get from a veni de la

get hold of a (se) apuca de, a (se) lega de; a înşfăca, a prinde, a pune mâna pe, a face rost de get home a-şi reveni (după o pierdere, lovitură etc.) get hot (auto, termo) a se (supra)încălzi

get in a strânge, a colecta, a aduna; a face provizii de; a aduce; (agr) a strânge (recolta); a include în program, a reuşi să realizeze; (edu) a educa, a învăța, a trece (la un examen etc.); a aduce înapoi, a face să se întoarcă; (agr) a planta, a semăna, a strânge (recolta); a intra, a pătrunde, a se infiltra, a se strecura, a ajunge; a se întoarce (acasă), a reveni; a se urca (în tren etc.); (pol) a fi ales (deputat etc.); (ec) a încasa (bani); a plasa (un cuvânt, o lovitură)

get into a se urca, a se sui în, a (se) strecura în; a (se) obişnui cu, a (se) deprinde cu; a fi primit în, a căpăta acces la; a înțelege, a pricepe; a se afla (în vehicul); a-şi lua, a-şi pune (o haină); a intra (în încurcătură etc.); debt a face datorii; a mess a se vârî într-o încurcătură

get into slag (met) trecere în zgură

get loose (mas-un, OM) a se slăbi; a se deşuruba; a elibera, a (se) desprinde

get next to a afla de, a descoperi; a se informa asupra; a înţelege, a-şi da seama de; a se apropia de

get-off decolare; (fig) chițibuş

get off a pleca de pe / de la, a părăsi; a scoate, a (se) dezbrăca; a curăța (o pată); a scăpa de (ceva), a se debarasa de; a scoate din încurcătură; a da drumul la; a salva; a isprăvi, a încheia; a expedia în grabă, a lichida; (edu) a învăța pe de rost; a (se) coborî, a (se) da jos (dintr-un vehicul etc.); (av) a decola; a porni; a pleca, a dispărea din; a se libera de

get on a înainta, a progresa; a merge înainte, a nu sta pe loc; a scoate, a extrage, a publica; a îmbătrâni; a se descurca, a-i merge bine; a se înțelege, a se împăca; a izbuti, a reuşi, a junge să facă ceva; one's nerves a enerva

get on in a reuşi în viață, a progresa în, a înainta în get on to a ajunge să înțeleagă, a ajunge (la un subiect)

get on with a progresa la, a reuşi la; a continua, a persevera; a se înțelege cu

get-out fugă, scăpare, evadare

get out a ieşi (în afară / din), a scoate, a extrage (din), a smulge, a face să iasă; a scoate la iveală; a publica; a rosti, a pronunța; a lua de la bibliotecă; a rezolva, a solutiona; a coborî (dintrun vehicul); a scăpa (cu bine) (de cineva); (d. ştiri etc.) a se răspândi, a transpira; a ieşi (din casă); a se sustrage (unei urmăriri etc.); of a habit a se debarasa de un obicei; $\sim$ of hand a scăpa din mână, a nu mai putea stăpâni; of sight a dispărea

get out of a scoate din, a smulge de la; a stoarce; a estorca; a face să dea / să producă; a câştiga de pe urma; a salva de la; a evada din; a scăpa de datorii

get out of alignament a ieşi din rând; (mas) a nu mai fi aliniat (d. linia de axe motor - cuplaj maşină etc.)

get out of commission (about a motor) (mas) a ieşi din funcțiune (d. motor)

get out of line a ieşi din rând

get out of order (mas) a se defecta, a nu mai funcționa

get over a face să treacă; a termina, a isprăvi, a încheia; a trece peste, a sări peste, a trece dincolo de, a escalada (un zid etc.); a străbate, a parcurge, a traversa; (med) a-şi reveni (dintr-o boală, emoție etc.), a se vindeca de, a scăpa de; a ocoli, a eluda, a evita; a uita de, a nu se mai gândi la; a înfrânge; a se consola, a se resemna, a ierta (ceva cuiva), a tolera, (fam) a digera, a înghiți; (fam) a duce cu vorba, a încânta

get paid (şi fig) a fi plătit / răsplătit

get rotten a putrezi (d. lemn)

get rough a se înăspri (şi d. vin)

get round (med) a înzdrăveni, a face sănătos; a convinge; a ocoli, a evita; get smb. round a se aduce pe cineva în simţiri

get round to a trece / ajunge pe rând, pe la; a coti (un colț de stradă etc.); a înşela, a îmbrobodi (cu vorbe)

get a shock (el, med) a (se) electrocuta

getter (chim) degazor; ghet $(t) e r$ (substanță absorbantă de gaze); reductor de sorbție; (ec) achizitor, procurist; (chim, fiz) substanță de evacuare, purificator, (d)epurator, a (d)epura, a evacua, a purifica

getting-down roll (met) cilindru de degroşare / degrosisor (la laminor)

get through a duce la bun sfârşit, a termina cu bine, a sfârşi; a asigura succesul; a face să treacă; a răzbate, a ieşi cu bine; (edu) a trece 
(la un examen); a parcurge, a străbate; a face față la, a dovedi; a trece prin, a scăpa dintr-o încurcătură; (pol) (d. o lege etc.) a fi introdus, a fi votat; a ajunge la fârşit

get through to a străbate până la, a ajunge până la; a obține (legătura), a găsi (la telefon)

get through with a termina, a încheia; a face față, a reuşi să facă; a trece prin

get together a se întruni, a se aduna; a se înțelege, a cădea de acord

get to work a se apuca de lucru, a începe lucrul

getting achiziție, obținere, căpătare, achiziționare; realizare, îndeplinire

getting away fugă, evadare; scăpare, eliberare; (auto) pornire, demaraj

getting back întoarcere, reîntoarcere; (jur) recăpătare, redobândire, reluare (în posesie)

getting in (agr) recoltare, strângere a recoltei, seceriş; (ec, jur) strângere, colectare (a impozitelor)

getting off pornire; decolare; (jur) scăpare, achitare

getting out scoatere, smulgere, extracție; (nav) lansare; publicare; alcătuire, elaborare, întocmire

getting over trecere, străbatere, parcurgere; escaladare; (med) însănătoşire, vindecare

getting through trecere, răzbatere; pătrundere; reuşită, succes; promovare

getting together culegere, strângere, adunare, colecatre; întrunire, reunire

getting up deşteptare, sculare, trezire; pregătire, preparare; aranjare; instigare, născocire

get to a ajunge la, a se apuca de

get-together reuniune, întrunire, adunare

get together a (se) aduna, a (se) strânge, a pune laolaltă, a cădea de acord, a se înțelege

get under a localiza, a stinge (un incendiu); a învinge, a înfrânge; a stăpâni, a supune; a se strecura dedesubt; a trece pe sub

get up îmbrăcăminte, ținută; machiaj; deghizare; (ec) prezentare; prezentare grafică; apretare; a sălta, a (se) urca, a (se) ridica, a înălța; (nav) a ranflua, a scoate la suprafață; a ațâța, a irita; a pregăti, a prepara, a elabora; a pune la cale, a organiza; a stârni, a monta; a născoci, a inventa; a pune în funcțiune; a aranja, a împodobi; (fig) a înscena; a simula; a se inteți; a se agita (şi d. mare); a pregăti (un discurs); a pune la punct

get up steam (termo) a pune / intra sub presiune (de abur), a se încălzi; (fig) a se înfuria

get up to a ajunge până la, a se apuca de gewel hinge $(\mathrm{OM})$ cârlig ataşat la o buclă

geyser (geol) gheizer; (termo) boiler, cazan de baie

G force (mec) forță gravitațională

gherkin (alim) castravecior, cornişon ghost fantomă; umbră, urmă; cantitate (foarte) mică; (met) zonă de incluziuni nemetalice; (el, c) imagine dublă / fantomă

ghost effect (c, fiz) efect secundar / parazitar

ghost line(s) (fiz) linie spectrală falsă (linii spectrale false); (met) şir de incluziuni nemetalice / de zgură, linii / benzi de segregare

ghost picture (el, c) dedublarea imaginii

ghost signal (fiz, autom) semnal accidental / fals

GHz (metr) gigahertz, unitate de măsură pentru frecvență $1 \mathrm{GHz}=10^{3} \mathrm{~Hz}$

giant uriaş, gigant(ic), colosal; (hidr) treaptă de amortizare la căderea apei

giant molecule (plast, chim) macromolecule giant-powder (chim) dinamită

giant rolling mill (met) laminor mare (referitor la capacitatea de prelucrare şi de reducere)

giant tyre (auto) pneu gigant

gib $(\mathrm{OM})$ prismă de ghidare; pană de fixare / de siguranță, scoabă, clemă; contrapantă; pană cu călcâi / cu nas, clemă; (met) platbandă; placă

gib and cotter $(\mathrm{OM})$ pană dublă

gib arm (met) săgeată

gibbet $(\mathrm{TH})$ braț de macara; a spânzura

gibbosity gheb, cocoaşă $(\mathrm{OM})$ protuberanță, umflătură

gibbous cocoşat; proeminent; (mat) convex giblets (alim) măruntaie (de pasăre), potroace gib screw (mas-un, OM) şurub pentru reglarea jocului dintre ghidaje şi piesa ghidată

giddy amețitor, care dă amețeală; zăpăcit, aiurit; nechibzuit, nesocotit; nestatornic, inconstant; sovăitor, şovăielnic, nesigur; a ameți, a năuci, a zăpăci

gift cadou, dar; sarcină uşoară, fleac; talent, înzestrare; (ec) primă; a dărui, a face cadou, a avea un talent

gift away a dărui, a face cadou

gift coupon (ec) cupon pentru premii (la magazin) gifted talentat, înzestrat; iscusit, priceput, capabil gift with a dărui, a face (ceva) cadou, a înzestra cu gig (met) troliu; (met) cărucior / mic vagonet pe două roți; pieptene mecanic, scaiete pentru scămoşat (şi pentru lână); (nav) barcă de bord, şalupă, harpon, ostie, a pescui cu harponul, a harpona

giga (metr) giga (prefix pentru $10^{9}$ unități)

gigacalorie (fiz, termo, metr) unitate pentru energie termică, gigacalorie: 1 gigacalorie = 4185799999,9932604 J

gigacycle (autom, metr) $10^{9}$ cicluri pe secundă gigagram (metr) unitate de măsură pentru masă: 1 gigagram $=10^{6} \mathrm{~kg}$

gigagram/liter (metr) unitate de măsură pentru densitate, gigagram/litru: 1 gigagram/liter = $10^{9} \mathrm{~kg} / \mathrm{m}^{3}$ 
gigagram/second (metr) unitate de măsură pentru debit masic, gigagram/secundă: 1 gigagram $/ \mathrm{second}=1000000 \mathrm{~kg} / \mathrm{s}$

gigajoule (metr) unitate de măsură pentru energie, gigajoule: 1 gigajoule $=10^{9} \mathrm{~J}$

gigajoule/second (metr) unitate de măsură pentru putere, gigajoule/secundă: 1 gigajoule/second = $10^{9} \mathrm{~W}$

gigaliter (metr) unitate de măsură pentru volum: 1 gigaliter $=1000000 \mathrm{~m}^{3}$

gigameter (metr) unitate de măsură pentru lungime, gigametru: 1 gigameter $=10^{9} \mathrm{~m}$

giganewton (metr) unitate de măsură pentru forță, giganewton: 1 giganewton $=10^{9} \mathrm{~N}$ gigantic gigantic, uriaş

gigapascal (metr) unitate de măsură pentru presiune, gigapascal: 1 gigapascal $=10^{9} \mathrm{~Pa}$

gigaton (Gton) (metr) unitate de măsură pentru energie: 1 gigaton $(\mathrm{Gton})=4,184 \cdot 10^{18} \mathrm{~J}$

gigawatt (metr) unitate de măsură pentru putere, gigawatt: 1 gigawatt $=10^{9} \mathrm{~W}$

gigawatt-hour (metr) unitate de măsură pentru energie: gigawatt-oră: 1 gigawatt-hour $=3,6 \cdot 10^{+12} \mathrm{~J}$

gild (poligrafie) a auri, a polei cu aur; a decora, a înfrumuseța; breaslă, corporație

gilded aurit, poleit cu aur; înfrumusețat

gilding (met, poligrafie) aurire, poleire

gill (c) gill (unitate de timp de milisecunde, la maşinile de calcul); (OM, auto) clapetă de reglare a aerului, ac, nervură; (alim) branhii, urechi, guşă, a curăța (peşte, ciuperci), pahar de băutură $(\sim 111 \ldots 142 \mathrm{ml})$; (geogr) viroagă, vâlcea, ravină (împădurită); torent, pârâu de munte; (metr) unitate de măsură pentru volum / capacitate: 1 gill $(\mathrm{UK})=0,000142065 \mathrm{~m}^{3} ; 1$ gill (US) $=0,000118294 \mathrm{~m}^{3}$

gilled (auto, OM) nervurat

gilled pipe / tube (hidr, termo, met OM) țeavă cu nervuri / cu aripioare

gillion miliard; (fig) mulțime / număr mare

gilt aurire, suflare cu aur

gilt-edged investment (ec) investiție sigură

gimbal (auto, OM) articulație cardanică

gimbal joint $(\mathrm{OM})$ articulație cu nucă / cardanică

gimbal mounting / suspension (auto) suspensie cardanică

gimbal pivot $(\mathrm{OM})$ ştiftul articulației cardanice

ghimbals (nav) balansiere, suspensie giroscopică (şi a busolei)

gimbal system $(\mathrm{OM})$ sistem cardanic

gimcrack fleac, bagatelă; ieftin, de nimic, fără valoare, de proastă caliatte; țipător, strident

gimlet sfredeluş, coarbă de găurit locaşuri de dibluri (la piese din lemn); (mas-un) burghiu, sfredel, a sfredeli, a găuri; (met) perforator

gimlet of auger type (mas-un) burghiu pentru cuie gimmick inovație, invenție, expedient; idee genială / năstruşnică; şarlatanie, păcăleală

gimp vitalitate, energie, vigoare; (textile) şiret, fir(et), ceapraz, galon; (anat) şchiop, schilod, infirm; a şchiopăta

gimpy şchiop

gin (alim) gin, rachiu de fructe (de ienupăr); (hidr) fulie; (OM) troliu, scripete; palan, macara; vârtej; (nav) macara de bigă; (textile) maşină de egrenat (bumbac), a egrena; capcană, cursă

gin block (mas) scripete; (nav) macara de bigă ginger (alim) ghimbir

gingerale (beer) (alim) băutură răcoritoare din ghimbir

ginger bread (alim) turtă dulce

gingerly $(a d v)$ (în mod) prudent, precaut, cu tact / prudență, cu băgare de seamă; delicat, tiptil; (adj) precaut, grijuliu

ginger nut / snap (amer) (alim) biscuit / pesmet cu ghimbir, turtă dulce

gingery (alim) aromatizat / condimentat cu ghimbir; (fig) irascibil

gingham (textile) pânză vărgată / cadrilată; hârtie cu pătrățele

gingile oil (chim, alim) ulei de susan

gin pole (constr) capră; (nav) bigă improvizată

gin sling (alim) gin cu apă şi zahăr

Giorgi system (of units) (metr, fiz, el) sistemul Giorgi; sistem electromagnetic de unități

gipsy (nav) tambur de vinci

Girard furnace (met, ind chim) cuptor electric cu încălzire directă (tip Girard)

gird a încinge, a strânge (cu o curea); a înconjura, a împresura; a (se) pregăti, a (se) prepara; a echipa, a înzestra; a ridiculiza

girded (nav) tras travers

girder (constr) grindă, bârnă, fermă, traversă de pod, antretoază, bară; $(\mathrm{OM})$ capră cu consolă; (mec) grinda armăturii / de acoperiș; (met) drug, profil greu; (nav) traversă (osatură); riglă; (el) antenă

girder and rolling mill (met) laminor pentru profiluri grele şi / pentru şină

girder beam (met, mec) grindă cu zăbrele, grindă principală

girder bracing (met, mec) legătură / prindere între grinzi

girder bridge (constr) pod de grinzi / de ferme girder mill (met) laminor de profile

girder mill train (met) laminor de bare, linie de laminare pentru profiluri grele

girder network (constr, mec) rețea de grinzi

girder on two supports (constr, mec) grindă simplu rezemată

girder pass (met) calibru pentru bare / pentru profiluri grele (la laminor) 
girder pole (el) stâlp cu zăbrele

girder rail (met) şină cu şanț

girder rolling mill (met) laminor pentru profiluri grele

girder roll stand (met) cajă pentru profiluri grele girder section (constr) profilul / secțiunea grinzii; (met) secțiunea barei

girder train (met) linie de laminor pentru profile grele

girdle (constr) centură, brâu; (met) ciclu; inel; (nav) centură de remorcă; curea; a încinge, a înconjura

girdle-shaped surge (hidr, fiz) undă inelară

girt (nav) ancorat cu cap fix (cu ancorare prova şi pupa)

girth (geom, OM) contur, circumferință; perimetrul secțiunilor transversale; (met) muchie; centură de strângere (şi pentru un recipient etc.); (nav) perimetru; bară orizontală; talie, măsură a taliei; a înconjura, a împrejmui; a măsura circumferința

girth-joint (met) îmbinare transversală

girth pulley $(\mathrm{OM})$ roată pentru chingă

gist esență, fond, miez al lucrurilor; punct nevralgic; motiv principal

git (met) canal / pâlnie de turnare

git cutter (met) aparat de tăiat rețele de turnare

give $(\mathrm{OM})$ elasticitate, pierdere parțială a elasticității unui arc (în mecanica fină); a da, a dărui, a dona, a face cadou; a acorda, a transmite, a remite, a încredința, a comunica, a încredința; a investi (cu autoritate), a atribui, a conferi, a oferi; a ceda, a lăsa, a se retrage, a (se) slăbi, a permite, a repartiza, a distribui, a aloca; a plăti; a transfera (sub altă autoritate); a rosti, a pronunța; a scoate, a da drumul la; a face, a produce, a realiza; a consacra, a dedica; a sacrifica; a anunța, a comunica, a informa despre; (jur) a lăsa prin testament / mostenire; a duce la, a avea drept consecințe; (mat) a da ca rezultat; a oferi, a furniza, a aduce; a expune (argumente); a concede, a recunoaşte, a admite; a arăta, a indica, a prezenta; a ceda, a se da bătut; a fi moale / elastic, a se lăsa; a se umezi, a se muia de la ploaie / de la umezeală; a-şi acorda, a-şi rezerva; a-și face, a-și crea

give-and-take compromis, concesii reciproce; concurență; schimb(uri); a oferi în schimb, a propune pentru schimb; a plăti reciproc; a-şi face concesii unul altuia

give an expert opinion ( $\mathrm{TH}, \mathrm{ec})$ a aviza, a da un aviz competent

give an incrustation (met) a incrusta, a depune un strat subtire, a acoperi

give a quarter turn (met) a răsturnam a răsuci (cu $90^{\circ}$ ) give-away dovadă / probă evidentă / clară; cadou, dar; trădare, denunt

give away a da gratis / degeaba; a distribui, a împărți; a trăda, a da de gol

give back a restitui, a înapoia, a da înapoi; a reda, a readuce; a reflecta, a răsfrânge, a oglindi; a reproduce; a se retrage, a bate în retragere

give forth a produce, a face, a crea; a emite (un sunet); a degaja, a răspândi (un miros); a reproduce (un text)

give in a preda, a înmâna; a anunța, a face cunoscut; a adăuga, a aduce în plus; a ceda, a capitula, a se da bătut; a se supune

give in exchange (ec) a schimba, a da în schimb give in to a se supune la, a se pleca în fața

give into a da înspre / către (d. o fereastră, o deschidere)

given (mat) dat, determinat, oferit, furnizat, stabilit, precizat; (jur) făcut, dat, executat; stabilit, fixat

given diameter (nav) diametru la tubul etambou given name (amer) nume de botez, nume mic give off a preda, a emite; (met) a degaja; a emana, a răspândi; a produce, a emite (un sunet)

give out a scoate, a elibera; a edita, a anunța, a declara (public), a proclama, a face cunoscut; a emite, a răspândi, a produce, a degaja; a împărți, a distribui; a fi obosit; a se termina, a se epuiza

give over a abandona, a părăsi; a înceta, a termina cu, a renunța la; a se vindeca

give over to a abandona, a lăsa pe seama (cuiva) give to a se deprinde cu, a se obişnui cu

give up a renunța (la), a ceda, a părăsi; (ec) a face donații; a demisiona din; a se lipsi de; a ceda (un loc); a lăsa; a se lăsa de (fumat etc.), a se opri din, a înceta; a se dezice de, a abandona (şi idei); a remite, a preda, a înmâna; a divulga, a denunța, a da pe mâna autorităților; a declara pierdut; a socoti insolubil / de nerezolvat; a renunța la (orice) efort; a se retrage (şi din afaceri), a închide (firma etc.)

give upon a da înspre (d.o deschidere)

give way a face loc; (met) a irupe; a rupe, a forța; (nav) a rama; înainte! (rame)

giving off of gas (chim) degajare de gaz(e); formare / generare de gaz(e)

gizzard (alim) pipotă, rânză

glancé (met) blendă; glasat, acoperit cu glazură, zaharisit; înghețat, jivrat; lucios, lustruit, glancé; (textile) satinat

glacé coal (met) antracit

glacéing (alim) glazurare, glasare

glacial glacial, de gheață, înghețat, rece, geros; (fig) neprietenos, ostil

glacing collision $(\mathrm{mec})$ ciocnire oblică 
glad bucuros; dispus, gata (să facă ceva) gladly $(a d v)$ bucuros, cu dragă inimă; de bună voie glair (alim) albuş de ou; substanță vâscoasă glance strălucire, licărire; (foto, el) diafragmă; (met) blendă; a luci, a străluci

glance at a arunca o privire, a se uita în treacăt glance coal (met) cărbune cu luciu metalic

glance off a ricoşa de, a aluneca peste (şi d. un text etc.)

glancing collision (mec) ciocnire oblică (faţă de o suprafață)

gland (auto) presetupă, presgarnitură; $(\mathrm{OM})$ bucşă de presare a garniturii, cavitatea sau spațiul pentru garnitură, manşon tip membrană, membrană

gland box $(\mathrm{OM})$ cutia presgarniturii sau membranei

gland cock $(\mathrm{OM})$ robinet cu cep şi cu presetupă

gland follower $(\mathrm{OM})$ capac (ce se poate deplasa în locaş) al presetupei

glandless cock $(\mathrm{OM})$ robinet fără presgarnitură

glandless compressor (termo, OM) compresor fără presgarnitură

glandless pump (hidr, OM) pompă fără presgarnitură

gland packing $(\mathrm{OM})$ garnitură de etanşare a presetupei, presgarnitură (ca sistem: etanşare, capac, elemente de asamblare etc.)

gland seal connection $(\mathrm{OM})$ racord cu etanşare

glare strălucire, lumină orbitoare, puternică / supărătoare; (fiz) orbire, ebluisare; (auto) efectul de orbire (d. faruri); a orbi; (foto, c) a diafragma, amodifica deschiderea diafragmei; a produce o lumină orbitoare, a străluci orbitor; (adj) sticlos şi strălucitor, neted şi lucios

glare light (auto) lumină orbitoare

glaring orbitor, care orbeşte (d. o lumină prea intensă); viu, strălucitor; evident, prea vizibil, bătător la ochi; grosolană (d. o eroare etc.)

glary strălucitor, orbitor

glaser (mas-un) placă de polizat

glaser's diamond (mas-un) diamant de tăiat geamuri

glass (ind chim) sticlă; pahar, geam (şi de ceas, de aparat de măsură etc.), conținutul unui pahar; oglindă; (nav) barometru; lunetă; telescop; ochean, binoclu; (ind chim) a acoperi cu sticlă; $(a d j)$ de sticlă, făcut din sticlă

glass annealing furnace (ind chim) cuptor de recoacere a sticlei

glass base (el, electr) soclu / placă de bază de sticlă (şi la circuite integrate

glass beads (ind chim, OM) bile de sticlă

glass bell (ind chim, OM) glob / clopot de sticlă

glass blower (ind chim) sticlar, muncitor la o fabrică de sticlă glass blowing (ind chim, OM) fabricare / prelucrare a sticlei (şi prin suflare)

glass-bonded mica seal $(\mathrm{OM})$ garnitură de etanşare din mică cu liant de sticlă

glass bulb (ind chim) balon de sticlă

glass case $(\mathrm{ec})$ vitrină

glass cleaner (auto) ştergător de parbriz

glass cloth (constr) pânză de sticlă / din fibră de sticlă; glaspapir, (hârtie) de şmirghel; cârpă de şters paharele

glass composition (chim) compoziţia sticlei

glass cover (metr) lamelă de acoperire; $(\mathrm{OM})$ capac de sticlă

glass crack (ind chim) defect în sticlă, crăpătură glass cup $(\mathrm{OM}, \mathrm{T})$ ungător $\mathrm{cu}$ picurare $\mathrm{cu}$ vizor din sticlă (pt. a vedea nivelul lubrifiantului)

glass cutter (mas-un) diamant de tăiat geamuri glass dial cover $(\mathrm{OM}$, metr) capac de sticlă (şi al unui aparat de măsură)

glass disk (OM) disc de sticlă; geam de reflector glass drill (mas-un) burghiu pentru sticlă

glass electrode (el, metr) electrod de sticlă (la $\mathrm{pH}-$ metre)

glasses (opt, med) ochelari

glass faults (ind chim) defecte la sticlă

glass fiber fibră de sticlă

glass fiber binder întăritură cu fibră de sticlă (la compozite)

glass fiber board placă din fibră de sticlă

glass fiber insert inserție cu fibră de sticlă

glass fiber laminate (compozit) laminat din fibră de sticlă

glass fiber mat (materiale) pătură / strat din fibră de sticlă

glass fiber paper hârtie cu fibre de sticlă (pt. şlefuit)

glass fibre (constr) țesătură de fibre de sticlă; (ind chim) fir / fibră de sticlă

glass fibre reinforced plastics (materiale) plastice ranforsate / întărite cu fibre de sticlă (echivalent cu compozite cu matrice polimerică şi ranforsant - fibre de sticlă

glass filter (OM) filtru de sticlă

glass flask (ind chim) balon de sticlă

glass for hygienic uses (ind chim, med) sticlă pentru scopuri igienice

glass for pharmaceutical uses (ind chim, med) sticlă pentru scopuri farmaceutice

glassful conținutul unui pahar

glass funnel (ind chim) pâlnie de sticlă

glass gauge $(\mathrm{OM})$ (indicator din) sticlă pentru nivelul unui fluid

glass grinding marble $(\mathrm{TH})$ bilă de sticlă pentru şlefuit

glass half-cell (el, ind chim) electrod de sticlă (şi la $\mathrm{pH}$-metre) 
glass-hard solid; dur; cu duritatea sticlei glass hardened (met) călite forțat (prea dur, defect) glass-hardening (met) călire forțată (uneori proces condus defectuos / greşit)

glass-hard steel (met) oțel foarte dur

glass house (agr) seră; (ind chim) fabrică de sticlă, sticlărie

glassily $(a d v)$ ca sticla, sticlos, ca de sticlă (fragil, casabil sau transparent - atentie la text)

glass industry (ind chim) industria sticlei glassine foil (ind chim) peliculă transparentă glassine paper hârtie de copiat, transparentă / pergaminată

glassiness (ind chim) aspect / caracter sticlos / vitros

glass insulator (el) izolator de sticlă

glass jar (chim) pahar (de sticlă) de laborator

glass-lift (auto) dispozitiv de ridicare a geamului (portierei)

glass lining (ind chim) emailare; căptuşire cu plăci de sticlă, acoperire cu sticlă

glass making ( $\mathrm{TH}$, ind chim) fabricarea sticlei

glass marble (OM, materiale) bilă de sticlă

glass melt (ind chim) topitură de sticlă

glass melting (ind chim) topirea sticlei

glass pane $(\mathrm{OM}$, opt) disc de sticlă, geam reflector

glass panel (auto) panou de geam

glass paper $(\mathrm{TH})$ hârtie abrazivă / sticlată, şmirghel, glaspapir

glass pipe (ind chim) tub de sticlă

glass plates (ind chim, metr) sticlă plată de ceasornic

glass-pot furnace (ind chim) cuptor pentru tratamentul vaselor din sticlă

glass printing (TH, ind chim) tipărire pe sticlă

glass rod (ind chim) baghetă de sticlă

glass-roll machine (ind chim, mas-un) maşină de laminat sticlă

glass sand (materiale) nisip pentru obținerea sticlei

glass screen (auto) parbriz; (c, metr, autom) partea transparentă a unui ecran

glass shade $(\mathrm{OM})$ clopot de sticlă

glass silk (ind chim) fibră / vată de sticlă

glass slip (fiz, opt) lamelă de acoperire (şi pt. microscop)

glass smelting (ind chim) topirea sticlei

glass-smelting kiln (ind chim) cuptor de topit sticlă

glass stick / stirrer (ind chim) baghetă de sticlă glass stopper (ind chim) dop de sticlă

glass strip (auto, OM) curea de ridicat geamul parbrizului glass suitable for laboratory ware (ind chim) sticlă de laborator / refractară

glass trasion (plast, termo) tranziţie vitroasă

glass-to-metal seal (el) sudură / etanşare între sticlă şi metal

glass tube (ind chim) tub de sticlă

glass wadding (constr) vată de sticlă

glassware aparatură de laborator de sticlă, (articole de) sticlărie

glass wastes (ind chim, mediu) deşeuri de sticlă

glass wool (ind chim) vată de sticlă; fibre de sticlă necardate

glass work (ind chim) fabrică de sticlă, (articole de) sticlărie

glassy sticlos, lucios, vitros; ca sticla, ca de sticlă, lucios şi neted; fragil

glassy alloy (materiale) material metalic având şi stare amorfă / sticloasă, sticlă metalică

glass yarns (ind chim) fibre / fire de sticlă

glassy state / structure stare / structură sticloasă (d. materiale în stare amorfã)

glaze (alim) glazură; polei; (materiale, chim, met) email, zgură, smalț, verniu; lustru, luciu; ceramică smălțuită, vase emailate; a glasa; a satina (hârtie, țesături); a smălțui, a emaila, a glazura, a pune glazură, a lustrui; a pune geam(uri); a deveni sticlos

glazed satinat, neted (d. hârtie, țesături); (alim) glasat, glazurat

glazed brick (ind chim, constr) cărămidă smălțiită

glazed frost polei

glazed powder (ind chim) pulbere grafitată

glazer (met) placă de şlefuire

glazier's diamond (materiale) diamant pentru tăiat geamuri

glazier's putty (constr) chit

glazing (alim) glasare; satinare (a hârtiei, a unui material textil); glazurare (a sticlei), smălțuire, emailare, lustruire; punerea geamurilor, sticlă (de geamuri)

glazing wheel (mas-un) disc de lustruit / de rectificat

gleam licărire, licăr, rază (de lumină); urmă; întrezărire; strălucire, scânteiere, luciu, lustru; a licări, a străluci (slab), a luci, a sclipi

glean (agr) a spicui, a culege, a aduna (spice, boabe etc.); (fig) a spicui, a culege (de ici şi de colo), a strânge, a aduna, a colecta

Gleason tooth $(\mathrm{OM})$ dinte în arc de cerc, dinte Gleason (la dantură conică)

glib volubil, rapid, fluent; facil, superficial; cu aparență de adevăr, credibil; nesincer

glide alunecare, alunecător; a ploua; $(\mathrm{TH})$ a (a)luneca, a culisa, a glisa, a plana, a trece uşor (peste) 
glide along a pluti, a aluneca pe / peste glide past a se strecura (alunecând)

glide-path angle (mec) unghi de coborâre pe pantă, unghi al planului înclinat

glide plane (fiz) plan de lunecare; (mas) plan de înclinare

glider $(\mathrm{OM})$ piesă alunecătoare, culisă

glide reflection (fiz) reflecție cu translație

gliding $(\mathrm{TH})(\mathrm{a})$ lunecare, glisare, alunecător, glisant, care alunecă,

gliding angle (mas, T) unghi de alunecare

gliding plane / surface (mas) suprafață / plan de alunecare.

gliding quality $(\mathrm{T}, \mathrm{OM})$ capacitate de alunecare glim lumină, luminiță, licăr(ire)

glimmer strălucire, licăr(ire), scânteiere; pâlpâire; a licări, a pâlpâi, a luci; a se vedea slab

glimmering strălucire, licăr(ire), scânteiere; pâlpâire; $(a d j)$ pâlpâitor, care licăreşte, care luminează slab

glint licărire, strălucire (metalică); a licări, a scânteia, a străluci (metalic)

glissade (a)lunecare; a aluneca, a glisa

glisten a (stră)luci, a scânteia

glitch (c, metr, autom) distorsiune / perturbare a unui impuls (rezultând erori de prelucrare a datelor); (el) pană, defecţiune, cădere

glitter strălucire, sclipire, scânteiere, luciu; fast; a sclipi, a scânteia, a (stră)luci

gloaming (fig) crepuscul, asfinţit

global total, global; mondial, universal

global error (metr) eroare totală / globală

global gear (OM) angrenaj (melcat) globoidal

globally $(a d v)$ global, în bloc, în ansamblu; total

globe glob, sferă; glob pământesc / terestru; (mat) sferă; (met) capac tip calotă

globe boiler (termo) cazan / fierbător sferic (sau numai cu capete / capace sferice)

globe calotte (mat, TH) calotă sferică

globe / straightway coke (OM, hidr) robinet drept / de trecere cu elemente activ de formă sferică

globe mill (ind chim) moară cu bile

globe pliers (mas-un) cleşte cu deschidere sferică; (met) cleşte de țevi

globe-roof tank (ind chim, OM) rezervor cu acoperiş / capac sferic

globe valve (cf) sertar cilindric / circular; (OM, hidr) vană / supapă sferică / cu bilă; ventil de trecere, cu element activ sferic

globoid worm-gear / worm-drive (OM) angrenaj cu melc globoidal

globose (OM) sferic, globular, aproape sferic / globular (d. formă a piesei, particulei etc.) globular globular, sferic; rotund, circular; (met) granular, granulos, sferoidal

globular pearlite (met) perlită globulară

globular structure (fiz) structură sferoidală; (met) structură glanulară / globulară

globule globulă; pilulă

globulitic (met) globular, sferoidal

glonoin (chim) nitroglicerină

gloomy întunecos, întunecat; înnorat (d. vreme)

glop (fiz) substanță lichidă vâscoasă, lichid vâscos

gloss luciu, lustru, strălucire (şi superficială, aparentă); aparență înşelătoare; (ind chim) email, glazură, smalț; a lustrui, a da luciu; observație, notă marginală, adnotare; glosă, exegeză, explicație, parafrază; a interpreta, a răstălmăci, a denatura; a comenta nefavorabil

glossarial cu caracter de glosar / lexicon / glosă, interpretativ

glossary vocabular; glosar

gloss finish (ind chim) finisare cu luciu

gloss paint (ind chim) vopsea lucioasă

glossology terminologie, glosologie

glossy lucios, lustruit, cu luciu / lustru

glossy black bituminous coal (met) antracit

glossy coal (met) cărbune lucios

glove (textile) mănuşă

glove box (fiz) cameră izolată pentru manipularea materialelor periculoase, cu ajutorul mănuşilor

glove box (auto) torpedou

glove compartment (auto) torpedou

glow iluminare, iluminat, incandescență, strălucire, lucire, licărire, scânteiere, strălucire; foc, flăcăruie, flacără; (fiz) luminescență, lumină, căldură; (met) încălzire; a licări, a scânteia, a străluci, a radia; (met) a (se) (în)roşi, a fi incandescent / încins; (fig) entuziasm; a arde; (auto) bujie

glow cathode (el) catod incandescent

glow column (el) filament

glow cooking plate (el, alim) plită electrică

glow-discharge tube (el, electr) tub / lampă cu descărcare luminescentă

glow indicator (auto, autom) indicator (luminos) / avertizare pentru bujii

glowing (el) incandescență; (met) încălzire; incandescență, care este incandescent / încălzit / încins (până la roşu), fierbinte, dogoritor, luminos, strălucitor

glowing cathode (el) catod incandescent

glowing furnace (met) cuptor de călire

glowing heat (met) incandescență de culoare albă-gălbuie (strălucitoare)

glowing red (met) încălzire la roşu 
glowing wire (el) fillament; (met) sârmă recoaptă glow light (el) luminescență

glow plug (auto) bujie incandescentă / de preîncălzire

glucide (alim, chim) zaharină

glucinium (Be) (chim, met) beriliu

glucose (alim, chim) glucoză

glue (ind chim, met) clei, adeziv; (TH) a lipi cu clei, a încleia

glue applicator (ind chim, plast) maşină / dispozitiv de aplicare / aplicator de întins / de aplicat clei / adeziv

glue boiler (ind chim) cazan de fiert clei (d. lemn) glue brush $(\mathrm{TH})$ perie / pensulă pentru aplicarea adezivului / apretului

glued belt $(\mathrm{OM})$ curea de piele, lipită (şi în straturi)

glue digester (ind chim) autoclavă pentru fierberea cleiului

glue dryer (ind chim) uscător pentru clei / adeziv

glue line $(\mathrm{OM})$ suprafață de lipire

glue mixing machine (ind chim) malaxor pentru adezivi

glue on $(\mathrm{TH})$ a lipi cu clei, a încleia

glue pot $(\mathrm{TH})$ borcan / recipient / borcănaş cu clei / adeziv / pentru pregătirea adezivului

glue powder (chim) praf de clei, clei praf

glue press clemă cu şurub pentru încleiat (şi pentru asamblat piese din lemn)

glue resins (ind chim) răşini pentru adezivi sintetici

glue spreader (mas, OM) maşină / dispozitiv de întins clei

glue spreading (ind chim) întinderea cleiului / adezivului

glue stock (alim) carne pentru clei

glue up a lipi, a încleia

gluey lipicios, cleios

gluing $(\mathrm{TH})$ lipire, încleiere

gluing binding $(\mathrm{OM}, \mathrm{TH})$ legare / asamblare prin încleiere (şi a cărților)

gluing clamp clemă de şurub pentru încleiat (și pentru asamblat piese din lemn)

gluing machine (mas-un, TH) mașină de întins clei

gluing roll (mas-un) tobă / cilindru de întins clei (în fabricarea pânzei abrazive)

glut îndestulare; saturare, saț; astupare, închidere, înfundare; (met) pernă (înfundare) transversală; a suprasatura; (ec) supraabundență, supraproducție, a inunda (piața), excedent, prisos; a sătura, a ghiftui; a împovăra, a încărca; a incomoda, a plictisi

gluten (ind chim) gluten glutinous(chim) cu gluten; lipicios, cleios

glut with / upon / on a umple, a satura, a suprasatura, a supraîncărca; (ec) a inunda piaţa

glycerin(e) / glycerol (chim) glicerină glycerin brake (cf, OM) frână cu glicerină glycine (chim) glicocol, acid aminoacetic glycogen (chim) glicogen

glycogenesis (chim) glicogeneză, formarea glicogenului din zahăr

glycolysis (chim, alim) glicoliză, fermentație enzimatică

gnarl nod, ciot (de lemn)

gnarled cu noduri, noduros, cioturos; răsucit, strâmb (d. lemn); butucănos

gnaw at a roade din

gnawing form inside out (materile, $\mathrm{T}$, chim) erodare din interior spre exterior

gnaw into a acorda; a roade; a mânca (şi un metal), a uza, a distruge

go a merge, a călători, a circula, a se duce, a pleca, a se îndepărta; a trece (timpul); a funcționa, a merge, a acționa, a fi în funcțiune; a proceda; a se comporta; a se desfăşura, a se petrece; a reuşi, a izbuti; a intenționa, a avea de gând; a se integra, a intra, a-şi avea locul, a aparține de, a sta; (mat) a intra, a cuprinde; (ec) (d. mărfuri) a se vinde, a se da; a se îmbrăca; mișcare, actiune, agitație; modă; încercare, probă; întâmplare; afacere, tranzacție; reuşită, succes; (univ) examen, probă; a rula, a se roti, a funcționa

goad strămutare; a îmboldi; a stimula

go after a merge în urmă; a urmări; a imita, a urma; a căuta (să obțină), a ținti spre / la

go against a contrazice, a contraveni la / $\mathrm{cu}$; a se împotrivi la, a fi împotriva

go-ahead (cf) semnal de cale liberă; verde (la semafor); activ, dinamic, întreprinzător

go ahead a merge în frunte, a o lua înainte

go ahead of a o lua înaintea (cuiva)

goal țintă; țel, scop, obiect; misiune, sarcină, obiectiv

go along a pleca, a se duce, a porni

go alongside (nav) a acosta cu bordul

go along with a se potrivi (bine) $\mathrm{cu}$

goal programming $(\mathrm{ec})$ programarea unei activități pe bază de scop

go aside a se da la o parte, a face loc; a se abate din drum

go astray a se rătăci, a rătăci (şi drumul); a se împrăştia; a se desface în bucăți

go-as-you-please liber, neîngrădit; degajat, lejer, nepăsător; nedisciplinat

goat (alim, agr, zool) capră 
go at a se apuca de, a lucra la

goatskin, goat skin piele de capră, şevro, marochin; burduf din piele de capră

gob grămadă, cantitate mare; a scuipa

go back a se întoarce (din drum), a reveni, a se reîntoarce; a regresa, a da înapoi

go back on a retracta, a se dezice de; a nu se tine de promisiune

gobbing (ec) rocă sterilă; grohotiş; (ind, mediu) rambleu de steril

go before a trece înainte, a merge în frunte; a avea prioritate asupra

go behind a întârzia, a fî în întârziere (de fază), a fi defazat în urmă

go between a mijloci între, a intermedia

go-between $(\mathrm{ec})$ intermediar, broker

go beyond a depăşi, a întrece, a trece de

gob feeder (OM) alimentator (din sticlă) de picături

goblet (OM) cupă (la transportoare)

go-by indiferență, lipsă de atentie

go by a trece (pe lângă), a se scurge; a întrece, a depăşi; a se ghida / conduce după

go by electricity (mas) a funcționa / a fi acționat $\mathrm{cu} /$ de curent electric

go-cart țarc cu rotile (pentru copii), cărucior de copil; (auto) automobil mic pentru carting

go cheap (ec) a (se) vinde ieftin

go down a cădea, a (se) coborî, a (se) lăsa în jos, a scădea; a apune, a asfinți; a decădea; a se scufunda, a se duce la fund, a se îneca; (fiz) a scădea în intensitate, a slăbi; (ec) a scădea (d. prețuri)

go downhill (auto) a coborî o pantă

go down to a merge până la, a continua până la (în timp)

goer călător, pasager, trecător, pieton

gofer (agr, alim) fagure de miere

goffer (mas-un) cleşte / dispozitiv de ondulat / de încrețit / de plisat (şi textile), foarfece de gofrat; a gofra, a ondula, a încreți, a cuta, a plisa

goffer calender (OM) calandru de gofrare / de ondulare / de încrețire / gofrare (pt. țesături, folii, hârtie etc.)

goffered paper hârtie grofată

gof(f)ered plate (met, TH) tablă ondulată / gofrată

gof(f)ering gofrare, gofraj, care se ondulează / se gofrează

go for a se duce după, a se duce să aducă, a pleca la; a urmări, a căuta să obțină; a intra în funcție; a ataca; a prețui, a face, a avea valoarea de, a se vinde cu prețul de go forth a ieşi înainte, a porni, a pleca, a se duce; a se răspândi; a-şi face apariția

go forward a înainta, a avansa; a progresa, a face progrese

go(-)gauge (metr) calibru ,trece”

goggles (met) ochelari de protecție

go in a intra, a pătrunde (înăuntru); a se înscrie, a se angaja; a sosi, a veni; a parveni, a ajunge

go in for a se apuca de, a se îndeletnici cu, a se ocupa cu; (edu) a se prezenta, a se înscrie (la un examen etc.)

going mers; plecare, dus, ducere; viteză de mers; stare a drumului; în mers, în mişcare, în acțiune, care merge / funcționează / se mişcă; existent, în viață

going-over trecere, tranzit, cercetare, verificare, inspecție

goings-on întâmplări, fapte, evenimente; acțiuni, comportare

go into a intra în, a pătrunde în; a se ocupa de, a ajunge la; a îmbrăca

go into servic / use a fi dat în funcțiune / în folosință, a intra în exploatare

gold (Au) (chim) aur; auriu, de / din aur; (fig) avere, bani

gold alloy plating (el, met) depunere galvanică a aliajelor de aur

gold-bearing (geol) aurifer

gold dust (geol) praf de aur; nisip aurifer

golden aurit, de aur, din aur, auriu; (fig) excelent, favorabil, prosper, înfloritor

golden mean cale de mijloc

golden rule proporție de aur $1: \sqrt{2}$

gold finger / number indice de aur

golding $(\mathrm{TH})$ aurire

gold leaf folie / foiță de aur, poleială

gold plate (alim, OM) veselă şi tacâmuri de aur

goldsmith bijutier

gold standard (ec) etalon aur

gongola (cf) vagon platformă; stand cu produse (în magazin cu autoservire)

gone plecat, dus, dispărut; distrus; pierdut; înaintat, care a mers departe

gong medalie, decorație

goniometer (metr, fiz) goniometru

goniometry (fiz, metr) goniometrie

good bun, de bună calitate; în bună stare, solid; sănătos; corect, just, drept, atractiv; valabil, veritabil, autentic; capabil, în stare, apt; amabil, agreabil; de nădejde; cuminte, ascultător; propice, prielnic; serios, solid; $(a d v)$ tare, destul, (foarte) bine, cu adevărat; bine, serviciu, ajutor; folos, avantaj, profit

good at priceput, iscusit la, abil, expert în 
good cause îndreptăţire; justificare; motiv good driving judgement (auto) conducere preventivă/ prudentă

good driving practice(s) (auto) practici / sfaturi de conducere prudentă

good earth connection (el) legătură la pământ, fermă / eficientă

good for corespunzător, potrivit, bun, folositor pentru

good-for-nothing fără valoare, care nu e bun de nimic; prost

good-looking care arată bine

goodly prezentabil; bunişor; potrivit, convenabil; mare, măricel, apreciabil

good money (ec) salariu mare

goodness bunătate; calitate bună, valoare

goodness of fit (mat) concordanță

good penetration (OM, met) sudură cu pătrundere în toată adâncimea cusăturii

goods marfă, bunuri (mobile), lucruri, obiecte, valori; (ec) mărfuri, articole comerciale; tesături, materiale, stofe; (cf, nav) încărcătură, marfă, bagaje, coletărie; (jur) probe materiale, corp delict; calități / proprietăți necesare

goods circulation (ec) circulație a bunurilor / a mărfurilor

goods service (ec, transp) serviciu de / pentru mărfuri

good works opere de caritate / filantropice

good working of the blast furnace (met) mers normal al furnalului

gooey unsuros, liupicios, cleios; grețos

go-off plecare, pornire; început, începere; încercare, tentativă

go off a (se) descărca, a detona, a exploda; a izbucni; a se aprinde; a se desfăşura (evenimente), a se întâmpla; a se diminua, a se micşora; a înceta; a pleca, a porni, a se pune în mişcare; (ec) a se vinde bine; a ieşi din

go on a se prelungi, a se întinde, a se lungi; a merge înainte / mai departe, a continua; a face progrese, a progresa, a avansa, a merge mai bine, a avea succes, a reuşi; a avea loc (d. evenimente), a se petrece, a se întâmpla; a trece, a expira (d. timp); a porni în, a pleca în; a începe; (metr) inscripție în partea „trece” a calibrului potcoavă

go on for a se apropia de

go on strike a face / a declara / a intra în grevă

go on the short time a trece la regim de lucru redus

go on to a trece (mai departe) la

go on to overtime $(\mathrm{ec})$ a trece la program de ore suplimentare goose, $p l$ geese (alim, agr, zool) gâscă

goose flesh (alim) carne de gâscă

goose neck obiect curbat; (OM) pârghie în formă de S; (met) gură de ardere la cauper, partea superioară a axului dispozitivului de blocare a oalei

gooseneck coupling (hidr, OM) luleau a capului hidraulic

gooseneck tool (mas-un) cuțit gât-de-lebădă

go out a ieşi (în) (afară), a pleca, a porni; a demisiona, a-şi da demisia; a se afla, a se răspândi; a apărea, a se publica; a se termina

go out of a ieşi din, a părăsi

go out of blast (met) oprire a vântului (la furnal) go out of control (auto) pierderea controlului, a pierde controlul asupra autoturismului

go over a trece dincolo, a traversa, a străbate, a trece peste; a se răsturna; a parcurge (cu privirea), a revedea, a reciti; a examina, a cerceta, a studia; a recapitula; a învinge, a întrece

go over into (chim) a se transforma în

gore (textile) clin (de rochie, de haină etc.); a străpunge, a găuri; (med) sânge închegat, cheag de sânge; (zool) a împunge cu coarnele

gorge trecătoare, defileu, chei, pas; stomac

gorgeous minunat, strălucitor, splendid, bogat; luxuriant, abundent

gorgeousness strălucire, splendoare, măreție

gormangize a devora; a înfuleca

gormless prostesc, stupid

gormlessness prostie; stupiditate

go round a merge de la unul la altul; a face un ocol / înconjur; a se schimba; a se rostogoli; (nav) a-şi schimba direcția (d. vânt)

go side (metr) partea ,trece" a calibrului

gosling (alim) pui / boboc de gâscă; (fig) prost, tont

go-slow strike grevă scoțiană

gossamer (textile) țesătură ca borangicul, voal, gaz; fin, subțire, transparent; (fig) superficial

gothic groove / pass (met) calibru ogival (la laminare)

go-thread ring gauge (metr, OM) calibru inelar „trece”, pentru filete

go through a merge până la capăt; a se realiza, a se îndeplini; a se aproba, a fi adoptat / aprobat; (ec) a se vinde bine pe piață; a trece prin; a examina / cerecta amănunțit; a percheziționa; a face față la

go through a loop (inf, autom) a parcurge o buclă go through with a duce până la bun sfârșit

go to a se adresa la; a recurge la; a ajunge la; a porni la / în

"go-to" assignment (inf) instrucțiune de dirijare 
go to dross (met) trecere în zgură

go together a se ântâlni, a se întruni, a se aduna; a se potrivi, a se îmbina

go-to statement (inf) instrucțiune de dirijare gouge (constr) daltă de aşchiat / de cioplit / de şpițuit piatră; sol argilos-nisipos; daltă concavă; (met) daltă de gravat / în cruce / semicirculară, scobitură făcută cu dalta; smulgere; a dăltui, a scobi cu dalta

gouge(on) $(\mathrm{OM})$ tijă cilindrică, filetată la capete, folosită pentru a asambla două piese

gouging (mas-un) executare a unei adâncituri / unui canal într-o piesă; (TH, mas) înlăturarea (mecanică, electro-mecanică, termo-mecanică) a defectelor de suprafață (şi înainte de sudare) goulash (alim) gulaş, tocană, mâncare de carne cu legume

go under a (se) scufunda, a (se) duce la fund; a suferi un insucces, a fi o cădere, a cădea; a pieri, a dispărea; a decădea

go up a urca, a creşte, a (se) mări, a (se) ridica; a (se) urca (pe scări); (nav) a naviga în susul unei ape

go upon a se sprijini pe, a se baza pe

gourmet (alim) expert gastronomic

govern a conduce, a administra; a stăpâni (şi un proces), a comanda, a regla, a controla, a determina, a reglementa

governable ascultător, docil; uşor de mânuit / condus / controlat

governance (pol) guvernare, conducere; administrație; putere

governess (edu) educatoare, învățătoare

governing guvernant, de guvernământ; $(\mathrm{TH}, \mathrm{ec})$ conducere, reglare, reglaj, comandă, control; conducător, de conducere, de administrație; care conduce / controlează (un proces etc.)

governing factor factor decisiv / de comandă / de comandă

government (pol) guvern, putere executivă; stat; guvernare, conducere; regim

government agent (pol) funcționar de stat

governmental (pol) guvernamental, de stat

government industry $(\mathrm{pol}, \mathrm{ec})$ întreprindere de stat

guvernment issue (echipament) furnizat de stat / de guvern

government of / over (autom) stăpânire a, control asupra, dominare a

government paper / securities (ec) obligații / bonuri de tezaur (emise de guvern / de stat)

governor conducător, comandant; director, patron; (autom) dispozitiv de stabilizare / de comandă (şi automată), supapă regulatoare; (el) regulator (pt. motoare de putere / de turație), magnet corector

governor centrifugal pendulum (OM, hidr) regulator cu pendul centrifugal

governor deflection $(\mathrm{OM})$ amplitudine / cursă a regulatorului

governor relief valve (hidr, OM) supapă / robinet de reglare / de ştrangulare / de laminare (a curentului)

governor slide valve (hidr, OM) supapă de reglare, cu sertar

governor throttle (auto) clapetă regulatoare (la carburator); (OM, hidr) orificiu reglabil

go with a merge cu. a însoți, a conduce

go without a se lipsi de, a nu avea nevoie de, a fi lipsit de, a nu avea, a duce lipsă de

gown robă, mantie, pelerină; haine civile; a se îmbrăca în robă

gownman persoană care poartă o robă (universitar, jurist); civil

grab apucare; acaparare, lăcomie; (constr) benă, (cupă de) excavator; (nav) dragă; (mas) dispozitiv de prindere, graifăr, cupă cu gheare; (plast) lipiciozitate; a apuca, a smulge, a (se) gripa, a se înțepeni

grabber acaparator

grabbing dispozitiv de prindere, care prinde grabbing clutch $(\mathrm{OM})$ ambreiaj brusc / total

grabbing excavator (mas, constr) excavator $\mathrm{cu}$ graifăr

grab bucket (met, mas) graifăr, benă aruncătoare / cu gheare, excavator cu graifăr / cu benă, graifăr de macara

grabby apucător; lacom

grab container (met, mas) container apucător / cu dispozitiv de prindere

grab crane (met, mas) macara cu graifăr grab dredger (nav) dragă cu graifăr / cu cupe; (mas, constr) excavator cu cupe / cu benă

grab excavator (mas, constr) excavator cu cupe / cu benă

grab iron $(\mathrm{OM})$ cârlig de apucare

grab jaw $(\mathrm{OM})$ lingură / gheară apucătoare

grab of crane $(\mathrm{OM})$ dispozitiv de apucare (la macara), graifăr, benă cu graifăr

grabs (OM, mas) graifăr-polip / cu fălci multiple grab sampling $(\mathrm{TH})$ metodă de testare cu alegere la întâmplare a probei

grace farmec, eleganță, suplețe; favoare, bunăvoință; politețe, bună cuviință; păsuire, amânare, termen de grație

graceful grațios, elegant; suplu

graceful degradation (OM, mas) degradare treptată / imperceptibilă / lentă 
gracile zvelt, subțire

gracious binevoitor, condescendent; îngăduitor; grațios, elegant

gradate a grada; a nuanța; a aşeza într-o anumită ordine; a fi nuanțat

gradation (constr) sortare a agregatelor; gradație; progresie; nuanțare; $(\mathrm{TH})$ marcă de verificare

gradations trepte / etape succesive (ale unui proces etc.), grade

grade sort(iment), clasă, categorie, fel, calitate, treaptă, marcă (şi de oțel); pantă a unui drum, înclinație; (amer) (fig) ascensiune, dezvoltare; (mat) clasă, grad (de unghi), putere, rang, valoare a funcției de repartiție; (metr) reper, semn de diviziune; notă, calificativ (amer); a clasa, a sorta, a clasifica, a grada, a tria; (agr) rasă ameliorată de vite, a ameliora (o rasă)

grade against the load contrapantă

gradebuilder (mas, constr) buldozer cu lamă orientabilă

grade-crossing (constr) pasaj / trecere de nivel

graded gradat; sortat; clasificat

graded aggregate (constr, ind chim, met) agregat calibrat (cu granulometrie strânsă / în interval îngust)

graded coal (met) cărbuni sortați

graded crushing (met, ind chim) concasare fracționată, sfărâmare în trepte

graded hardening (met) călire în trepte

graded junction (electr, autom) joncțiune treptată / graduală

graded material material calibrat (cu granulometrie strânsă); material standardizat (despre fonte, oțeluri etc.)

graded slope (mec) pantă cu înclinare mică

grade efficiency (materiale, alim, hidr) grad / eficiență / finețe de filtrare / de clasificare

grade of coke (met) calitate a cocsului

grade of concentration (chim) conținut, clasă / grad de concentrare / de concentrație

grade of fit $(\mathrm{OM})$ tip de ajustaj, grad de ajustare

grade of service $(\mathrm{TH})$ calitate a serviciului a întreținerii / a service-ului

grade of steel (met) marcă / calitate de oțel

grade of tolerance $(\mathrm{OM})$ clasă / treaptă de precizie

grader (alim) separator; (mas, constr) greder, excavator / maşină de nivelat, plug nivelator; sortator, discriminator, maşină de profilat drumul; (agr) trior, selector

grade school (amer) şcoală primară / elementară grade standards standarde (americane)

grade up (agr) a ameliora (o rasă de animale) gradient pantă, înclinare, unghi / înclinare / pantă a taluzului; (fiz, mat) gradient gradient of pressure (hidr, T) gradient de presiune grading clasificare, sortare, selectare; (constr) (lucrări de) nivelare; (met) compoziție granulometrică, granulometrie; (el) gradare, multiplicare, legare în cascadă

grading analysis (metr) analiză granulometrică grading curve (metr) curbă granulometrică, granulometrie (d. materiale)

grading factor $(\mathrm{TH})$ coeficient de sortare (1 este pentru sortare perfectă)

grading fraction fracție granulometrică

grading limit $(\mathrm{TH})$ curbă granulometrică tip / prescrisă

grading machine (constr, ind) maşină de sortat

grading of grain (constr, met, ind chim) sortare granulometrică

grading of oils (ind chim) clasificare a țițeiurilor / a uleiurilor

grading plant (ind chim) instalatie de sortare

grading room $(\mathrm{TH})$ sală de sortare

grading screen (OM, alim, agr, ind chim) ciur / sită de sortare

grading shield (el) inel de protecție împotriva arcului electric

gradometer (metr) indicator de pantă

gradual gradat, treptat, progresiv, gradual, succesiv

gradual brake $(\mathrm{OM})$ frână cu frânare treptată / graduală

gradual expansion (termo, materiale) dilatare treptată / progresivă

gradually $(a d v)$ (în mod) gradat, treptat, progresiv

gradually applied load (mas, OM) sarcină aplicată treptat

graduand (univ) doctorand, candidat la un titlu academic

graduate (univ) licențiat, absolvent (de învățământ superior), diplomat universitar, titrat; calificat, cu calificare superioară; de licențiat; (fiz, chim) cilindru gradat; a grada, a etalona, a se transforma treptat, a diviza, a împărți; a doza, a proporționa; (edu) a conferi o diplomă, a scoate (absolvenți)

graduated gradat, împărțit în grade, divizat; (univ) titrat, licentiat, diplomat (universitar); (edu, univ) absolvent, în posesia unei diplome graduated circle (autom) circuit de gradare (a unui proces etc.); (mas-un) cerc de divizare

graduated cylinder (chim) cilindru gradat graduated dial (metr) cadran gradat graduated drum (metr) tambur gradat graduated flask (metr, chim) balon gradat / cotat 
graduated pipette (metr, chim) pipetă gradată graduated plate (mas-un) disc divizor graduated ring inel gradat / secționat graduated scale (metr) scară / scală gradată (la aparete de măsură)

graduated slide-wire (el, metr) fir etalon cu contact alunecător

graduated tube (hidr, metr) tub de măsurare / manometric / gradat

graduated vessel (chim, metr) vas gradat

graduate from (univ) a-şi lua diploma de licență la, a fi absolvent de la

graduate school (univ) secție / specialitate postuniversitară pentru doctoranzi

graduate student (univ) (amer) absolvent care urmează cursuri postuniversitare

graduation (materiale, procese) clasificare, calibrare, etalonare, gradare, gradație, divizare, diviziune, scară (şi gradată); dozare, proporționare; (edu, univ) decernare, acordare (de diplome); (mat) gradare, trasare a curbei prin puncte; graduare (în statistica matematică); ajustare, ansamblu al reperelor; $(\mathrm{TH})$ triere, sortare

graduation from / of (edu) absolvire (a unei şcoli)

graduation line / mark (mas-un, TH) linie / semn de divizare, linie divizoare; (metr) reper de scală

graduation tower (ind chim) turn de răcire graduator (edu) absolvent (al unui curs)

graft (agr) altoi, altoire; a grefa, a altoi; (med) grefă, a grefa, a face o grefă; mită, a primi mită

graft copolymer (ind chim) copolimer grefat grafter (agr) cuțit pentru altoit, specialist în altoire grafting (agr) altoire, grefare; (OM) îmbinare cap-la-cap

grafting-clay / wax (agr, ind chim) amestec (tip ceară, clei) pentru acoperirea altoiului

grail (constr) pietriş mărunt

grain structură granulată / granulară, granulă, granulație, fibrozitate; (alim, agr) bob, grăunte, sămânță, cereale, grâne; (met, chim) grăunte cristalin, granulă, fir, fibră, bob (sare); fibră (în țesături, compozite, lemn etc.) a granula, a mărunți, a măcina, a fărâmița, a şangrina, a vopsi în lungul fibrei; (metr) unitate de măsură pentru masă, dram: 1 grain $=0,000064799 \mathrm{~kg}$; părticică; $(\mathrm{OM})$ nervură; (alim, ind chim) $\sim \mathbf{s}(p l)$ reziduu(ri) (de la distilerii), borhot; cantitate minimă; culoare stacojie; (ind chim) vopsea rezistentă; aspect granulos; fire, caracter; înclinație; a da un aspect granulat (d. piele naturală sau înlocuitori de piele); a vopsi trainic; a marmora; a imita fibra lemnoasă; large powder praf cu grăunțe mari grain-alcohol (alim, chim) alcool etilic / din cereale

grain-alcohol distillery (alim) distilerie de alcool (etilic)

grain boundary (met) limită de granulație, limită / graniță a grăuntelui cristalin / cristalului

grain boundary attack (met) atac / coroziune la limita grăuntelui cristalin / grăunților / cristalelor

grain colony (met) formație cristalină

grain composition (materiale) compoziţie granulară

grain crops (agr, alim) cereale

grain/cubic foot (metr) unitate de măsură pentru densitate: 1 grain $/$ cubic foot $=0,002288352 \mathrm{~kg} / \mathrm{m}^{3}$

grain deformation (met) deformarea grăuntelui cristalin

grain density densitate a granulelor (la compozite)

grain diameter (met) diametru al grăuntelui cristalin; (plast) diametru al granulei

grain direction sensul de orientare a fibrelor / a grăunților (d. aliaje sau compozite)

grain dryer (alim) uscător de cereale

grained grăunțos, zgrunțuros, fibros, granulos, granulat, granular; şagrinat; vopsit în lungul fibrei

grained sand (constr) nisip grăunțos

grain elevator (agr) siloz, elevator de siloz (de cereale)

grainer (agr, alim, ind chim) granulator, valț de granulare

grain flow orientare a fibrei / a grăuntelui (d. aliaje, materiale compozite etc.)

grain formation (met, plast) formarea granulei / a cristalului / a grăuntelui cristalin

grain/gallon (metr) unitate de măsură pentru densitate: 1 grain $/$ gallon $(\mathrm{UK})=0,014253768 \mathrm{~kg} / \mathrm{m}^{3}$; 1 grain $/$ gallon $(U S)=0,017118061 \mathrm{~kg} / \mathrm{m}^{3}$

grain growth (met) creşterea grăuntelui cristalin / a cristalului

graininess granulație, caracter granular, grad de granulație

graining (chim, met) formare de cristale / de grăunți cristalini, granulare, granulație, cristalizare; scămoşare; formare a boabelor / grăunțelor; care se granulează (d. un material)

grain junction line (chim, met) linie de contur a granulelor, limita grăuntelui

grain of crystallization (chim, met) centru / germene / nucleu de cristalizare

grain of wood (silv) textură a lemnului

grain oriented sheet (met) tablă cu grăunți (cristalini) orientați 
grain refinement (met) micşorare / finisare a grăunților cristalini / a structurii (prin tratament termic)

grain refining (met) micşorare / fărâmițare / măcinare a grăunților cristalini / a structurii (mecanic sau prin tratament termic)

grain separator (agr, ind chim, alim) selector, sortator

grain shape (met) formă a grăunților cristalini; (plast) formă a granulelor

grain silo (agr) siloz pentru cereale

grain size (met) mărimea a grăuntelui cristalin; (plast) mărime a granulelor

grain-size distribution (met, plast, ind chim, constr) repartiție granulometrică

grain-size distribution curve (constr, met, plast) curbă granulometrică

grain-size fraction (met, plast, ind chim, constr) fracție granulometrică

grain size number (met) granulație, mărime a grăunților (exprimată simbolic prin numere)

grain sizing (met, plast, ind chim, alim, constr) clasificare granulometrică

grain store (alim, agr) magazie / depozit de cereale, siloz

grain structure (met) structură granulară / a grăuntelui cristalin

grany granular, grăunțos

gram, gramme (g) (mai rar) (metr) unitate de măsură pentru masă, gram: 1 gram $=0,001 \mathrm{~kg}$

gram-calorie, gramme-calorie, small calorie (metr, termo) calorie mică, calorie-gram, energia necesară creşterii cu temperaturii uni gram de apă cu $1^{\circ} \mathrm{C}(\sim 4,184 \mathrm{~J})$

gram/cubic centimeter (metr, fiz) unitate de măsură pentru densitate, gram/centimetru cub: $1 \mathrm{gram} /$ cubic centimeter $=1000 \mathrm{~kg} / \mathrm{m}^{3}$

gram/cubic meter (metr) unitate de măsură pentru densitate, gram/metru cub: 1 gram/cubic meter $=0,001 \mathrm{~kg} / \mathrm{m}^{3}$

gram/cubic millimeter (metr, fiz) unitate de măsură pentru densitate, gram/milimetru cub: 1 gram $/$ cubic millimeter $=10^{6} \mathrm{~kg} / \mathrm{m}^{3}$

gram/day (metr) unitate de măsură pentru debit masic, gram/zi: 1 gram $/$ day $=0,000000012 \mathrm{~kg} / \mathrm{s}$

gram-force, gramme-force (gf) (metr) unitate de măsură pentru forță, gram-forță: 1 gramforce $=0,00980665 \mathrm{~N}$

gram-force centimeter (metr) unitate de măsură pentru energie sau lucru mecanic: 1 gramforce centimeter $=0,000098066 \mathrm{~J}$ sau $\mathrm{N}$ meter

gram-force meter (metr) unitate de măsură pentru energie sau lucru mecanic: 1 gram-force meter $=0,00980665 \mathrm{~J}$ sau N m gram-force millimeter (metr) unitate de măsură pentru lucru mecanic, gram-forță-milimetru: 1 gram-force millimeter $=0,000009807 \mathrm{~N} \mathrm{~m}$

gram-force/square centimeter (metr) unitate de măsură pentru presiune, gram-forță/centimetru pătrat: 1 gram-force/square centimeter = 98,0665 Pa

gram/hour (metr) unitate de măsură pentru debit masic, gram/oră: 1 gram $/$ hour $=0,27810^{-6} \mathrm{~kg} / \mathrm{s}$

graminaceous, gramineous (agr) graminaceu, din familia gramineelor

gram/liter (metr) unitate de măsură pentru densitate, gram/litru: 1 gram $/$ liter $=1 \mathrm{~kg} / \mathrm{m}^{3}$

grammar gramatică; notiuni elementare (într-un domeniu); (inf) totalitate a regulilor de structurare corectă a unui limbaj

gram-mass (fiz, chim) gram-masă, gram; volumul moleculei-gram

grammatical gramatical; (inf) care respectă reguli de structurare

gram/minute (metr) unitate de măsură pentru debit masic, gram $/$ minut: 1 gram $/$ minute $=$ $0,000016667 \mathrm{~kg} / \mathrm{s}$

gram-molecule (chim) moleculă gram

gram-molecular volume (chim, fiz) volum molar gram-molecular weight (chim) masă molară

grampus cleşte mare

gram/second (metr) unitate de măsură pentru debit masic, gram/secundă: 1 gram $/$ second = $0,001 \mathrm{~kg} / \mathrm{s}$

grams per square meter (metr) grame pe metru pătrat $\left(\mathrm{g} / \mathrm{m}^{2}\right)$

granary (alim, agr) grânar, siloz / magazie / depozit de cereale, hambar

granary silo (alim, agr) siloz de cereale

granat(e) (minrl) granat

grand mare, important; suprem; grandios, impresionant; splendid; generos; principal; capital, foarte însemnat / important; total, general; final

grand result rezultat final, total general

grand sum sumă totală, total general

grand total total general

grange (agr) fermă, gospodărie; (amer) asociație a fermierilor

granger (agr) administrator al unei ferme

granite (geol, minrl) granit

granitic de granit

grant (ec) donatie, subventie, alocatie, alocare, acordare (a unei bonificații, a unei compensații, a unui credit); concesiune; concesie, acordare (a unei favori); (edu, univ) bursă; a acorda, a da; (jur) (act de) donație, cesiune, transmisiune; bun transmis / transferat; aprobare, admitere; 
îndeplinire; încuviințare, permisiune; a ceda, a dona; a încuviința, a permite; a recunoaşte, a admite, a accepta (un argument); a aproba, a îndeplini (ceva), a admite (o cerere etc.); a garanta; a acorda; a împlini, a satisface; a concesiona; a îngădui; a lua drept bun / valabil; a request a aproba o cerere; take for $\sim$ ed a admite, a lua drept bun

grantable acordabil, care poate fi acordat; permisibil, permis; tolerabil; (jur) transmisibil, transferabil

grant-aided (pol, ec) subvenționat de stat

grant-aided school (edu) şcoală subvenţionată de stat

grant a permit a acorda un permis / o autorizatie

grantee concesionar, cesionar, donator, persoană căreia i se acordă ceva, persoană căreia i se transferă / transmite ceva

granter persoană care acordă / aprobă ceva, donator

grant-in-aid (pol, edu) ubvenție guvernamentală (şi pentru şcoli)

grant of license (ec) acordare / concesionare a unei licențe, protecție / garantare a unui brevet grantor donator

granular granular, granulos, grăunțos, cu structură granulară (d. materiale)

granular fracture suprafață rugoasă de rupere (şi la rupere fragilă) (la materiale solide)

granularity granulozitate (la materiale solide)

granular pearlite (met) perlită granulară / globulară

granular structure (met, materiale) structură granulară / globulară

granular ash (ind chim) sodă (calcinată) granulată

granular concentrate (ind chim) concentrat granular

granular-crystalline (met) cu grăunte mare, macro-granular, macro-cristalin

granularity grad de granulatie, granulozitate

granular membrane (OM, hidr) filtru cu umplutură granulară

granular powder (materiale) pulbere granulară granular precipitate (chim) precipitat granulos granular refractory materials (met) materiale refractare granulare

granular residue (met) nisipuri (ca reziduu la formare, după turnare); (chim) reziduuri granulare

granular-resistor furnace (el, termo) cuptor cu rezistență din material granulat

granulate (met) a (se) granula, a (se) fărâmița; (constr) a buciarda; (mas-un) a puncta granulated (material) granulat, sub formă de granule

granulated (blast furnace) slag (met) zgură granulată (de furnal)

granulated metal (met) metal / aliaj granulat granulated rubber (ind chim) cauciuc granulat granulated slag (met) zgură granulată

granulated slag brick (constr, met) cărămidă din zgură granulată

granulated structure (materiale) structură granulară

granulated sugar (alim) zahăr granulat / tos granulates (alim, plast) produse granulate granulating granulare (a zgurii, a materialelor plastice etc.)

granulating basin (met) bazin de granulare a zgurii

granulating drum (met, ind chim) tambur de granulat

granulating machine (met, ind chim) maşină de granulat, granulator

granulating mill (met, plast) valț de granulare; (alim, constr) moară de mărunțit / de măcinat

granulating pit (met) bazin de granulare a zgurii

granulating spout (met) jgheab de granulare

granulating tower (met) turn de granulare

granulating worm (alim, OM) melc pentru granulare / măcinare

granulation $(\mathrm{TH})$ granulare, granulație, formare a granulelor; structură granuloasă, fărâmițare, măcinare (d. materiale)

granulation curve (materiale, metr) curbă granulometrică

granulator granulator, aparat de granulat; (met, constr) concasor

granule (chim, met) granulă, grăunte, bob, fir; (c, el) particulă luminescentă pe ecranul tubului catodic

granulitic structure structură granulară (d. materiale)

granulometric (metr, $\mathrm{TH})$ granulometric

granulosity granulație

granulous granular, grăunțos (d. materiale)

grape (alim, agr) boabă de strugure, viță-de-vie

grape cluster (alim) ciorchine de struguri

grape brandy (alim) rachiu de vin

grape crusher / press (alim, mas) zdrobitor /

teasc / presă de struguri

grape cutting (agr) butaş de viță-de-vie

grape fruit (bot, agr, alim) pom care produce grefe, grefă, grapefrut

grape gathering (agr) culegerea viilor

grape grower (agr) viticultor 
grape growing (agr) viticultură

grapes (alim, agr) struguri

grape scissors (agr) foarfecă de vie (pentru tăiat ciorchini de struguri)

grape-seed oil (alim) ulei din semințe de struguri grape stalk (agr) butaş de viță-de-vie grape-stone (agr, alim) sâmbure de strugure grape sugar (alim, chim) glucoză, dextroză, zahăr de struguri

grape vine (agr, bot) viță-de-vie, butuc de vițăde-vie

graph (TH) grafic, desen, diagramă, curbă, reprezentare grafică, nomogramă; (mat) complex unidimensional

graph chart diagramă, grafic

graphic(al) grafic, ilustrativ, figurat; elocvent, expresiv

graphical diagram (hidr) schemă grafică / simbolică

graphical image imagine / reprezentare grafică a informației

graphically $(a d v)$ (în mod) grafic, în formă scriesă, în scris, prin grafic / diagramă; elocvent, expresiv

graphic plotting trasare a unui grafic

graphical programming aids (c, inf) asistență grafică a programării, metodă de corectare a unui program, direct pe imaginea monitorului

graphical representation reprezentare grafică

graphical symbol simbol grafic

graphic design proiectare grafică (şi pe computer), desen, grafică pe computer

graphic displaying (c) afişarea graficului / curbei, schiței / diagramei (inclusiv simboluri) pe ecranul calculatorului

graphic example exemplu ilustrativ / grafic

graphic formula (chim) desenul / schema formulei structurale

graphic input device (c) dispozitiv de intrare grafică / pentru introducerea datelor sub formă grafică (creion fotosensibil, tablă a unui terminal etc.)

graphic pattern recognition (c, inf, metr) recunoaştere a formelor grafice (şi în microscopie)

graphic recorder aparat de trasat curbe

graphics calcul grafic, (set de) grafice

graphic terminal (c) terminal pentru trasarea de grafice

graphite (fiz, chim, T) grafit

graphite blacking (chim) pudră de grafit; înnegrire cu grafit (a materialelor plastice etc.); (met) vopsire cu grafit (pentru forme)

graphite block (met, chim) bloc de grafit

graphite bronze (met) bronz grafitat graphite carbon cărbune grafitizat; (met, chim) carbon grafitic

graphite crucible / pot (met) creuzet de grafit graphited (met, plastic) grafitat, cu grafit (d. aliaje, materiale plastice şi compozite)

graphited bronze (met) bronz grafitat

graphite deposit (ind chim, T) depunere / acoperire de grafit

graphite-epoxy composite (chim) compozit epoxidic, cu grafit

graphite eutectic (met) grafit eutectic

graphite flakes (chim) solzi / funli de grafit

graphite formation (chim, met) grafitizare, formare a grafitului

graphite gasket $(\mathrm{OM})$ garnitură de grafit

graphite grease $(\mathrm{T})$ unsoare grafitată / cu grafit

graphite lubrication $(\mathrm{T})$ ungere cu lubrifiant grafitat / cu grafit

graphite nodule (met) grafit nodular (în fonte)

graphite oil (ind chim, T) ulei cu grafit

graphite packing $(\mathrm{OM})$ umplutură cu grafit (şi pentru etanşări)

graphite pebbles (chim) bile / conglomerate de grafit

graphite-polyamide composite (ind chim) compozit grafit + poliamidă

graphite pot (chim) creuzet de grafit

graphite rosette (met) grafit stelat (în fonte)

graphitic carbon (met) carbon grafitic, grafit de recoacere

graphitic cast iron (met) fontă grafitică / cu grafit / grafitată

graphitic corrosion (met) coroziune (și în medii apoase sau umede) a fontei cenuşii, rezultând o structură poroasă cu compuși de coroziune

graphitic pig iron (met) fontă cenuşie de furnal, fontă cenuşie brută

graphitic steel (met) oțel cu carbon parțial sub formă de grafit

graphitiferous grafitic, care conține grafit (d. materiale)

graphitizable steel (met) otel grafitizabil

graphitization (met, chim) grafitizare, formare a grafitului de recoacere (în oțeluri, fonte)

graphitized electrode (el, chim) electrod din grafit

graphitized packing $(\mathrm{OM})$ garnitură de etanşare cu grafit

graphitizer (met) element (de aliere sau de adaos în şarjă) grafitizant

graphitizing (met) recoacere de grafitizare

graphitoidal (met) grafitic, care participă la grafitizare

graph paper hârtie milimetrică / cu grilă 
graph plotter (birotică) ploter pentru grafice, dispozitiv de trasat grafice

graph representation reprezentare grafică

grapnel (met) cleşte mare; (nav) ancoră cu gheare de pisică / cu patru brațe / de barcă

grapple (constr, met) graifăr tip polip; dispozitiv de prindere, gheară apucătoare; a prinde, a apuca

grapple bucket (OM, constr, met) graifăr, benă cu gheare

grappling fixare, apucare, prindere; (nav) ancoră cu gheare de pisică / cu patru sau mai multe gheare; care prinde, care apucă

grappling iron (nav) ancoră cu mai multe brațe / tip gheară de pisică

grappling irons $(\mathrm{OM})$ degete / dinți / palete de prindere (la macarale, manipulatoare)

grasp apucare, strângere, înşăcare; pricepere, înțelegere, pătrundere; stăpânire, dominație, putere; (OM) mâner, coadă (de unealtă); a apuca, a prinde, a (se) agăța, a smulge, a ține strâns; a pricepe, a înțelege, a sesiza

grasp at a (se) prinde de, a (se) agăța de; a încerca să prindă / să fixeze, a nu se desprinde de graspingness zgârcenie, avariție; aviditate grass iarbă; (alim) sparanghel, salată, legume; (agr) păşune, păşunat, păscut; a se acoperi cu iarbă

grass cutter (agr, mas) foarfecare / maşină de tuns iarba

grass cutting (agr) cositul / tunsul ierbii

grass-grown (agr) ierbos, acoperit cu iarbă / gazon

grass land (agr) pajişte, păşune

grass plot (agr) spațiu verde, pajişte mică

grassy (agr) ierbos, cu iarbă; buruienos; verde ca iarba

grate $(\mathrm{OM}, \mathrm{mec})$ grătar (şi de cuptor) grilă, grilaj, zăbrele, plasă; (termo) grătar cu bare; (masun, met) a răzui, a rade, a freca cu un abraziv; a râcâi, a freca (cu zgomot), a zgâria; (alim) a rade (pe răzătoare)

grate area (termo, met) suprafață a grătarului (cu bare)

grate bar (met, termo) bară de grătar

grate cooler (alim, termo, met) răcitor cu grătar

grate fire (termo) focar cu grătar

grate firing (met) prăjire, calcinare; (termo) focar cu grătar

grateful recunoscător, cu recunoştință; reconfortant, întăritor, odihnitor

gratefulness recunoştință, gratitudine; caracter plăcut / odihnitor

grate furnace (termo) focar cu grătar; (met) cuptor cu grătar

grate like reticular (d. materiale) grate opening (met) rost de dilatare între bare; (termo) gol pentru pătrunderea aerului grater (alim) răzătoare; $(\mathrm{TH})$ raşpel, pilă mare grate skid-plate (termo) placă de grătar grate stoker (termo) dispozitiv pentru încărcat focarul

grate surface (termo) suprafață a grătarului (cu bare)

grate with water circulation (termo) grătar cu răcire prin ciruclarea apei

graticulate (metr, fiz) grilă (a colimatorului); rețea / grilă reprezentând meridianele şi paralele

gratification satisfacție, mulțumire, satisfacere; gratificație, recompensă, primă

gratify a satisface, a mulțumi; a recompensa, a răsplăti

gratifying plin de satisfacții; plăcut, agreabil; care satisface

gratin (alim) gratinare

grating gratie, închidere cu gratii, zăbrele, grilaj, plasă, scârțâit; (constr) grătar, radier de piloți, sită, umplutură, fundație; (fiz) grilă, rețea; (met) rețea (de turnare); sită; aspru, supărător, strident, discordant

grating constant (fiz) distanță între planele unei rețele, constantă a rețelei, parametru reticular

grating of gears $(\mathrm{OM})$ scârțâit al pinioanelor la schimbarea vitezei

grating patent acordare a unui brevet de invenție

grating space (fiz) constantă a rețelei, distanță reticulară; (met, termo) distanță între barele grătarului (la un cuptor)

grating spectrograph (fiz, metr) spectrograf cu rețea de difracție

gratis $(a d j, a d v)$ gratuit, pe gratis, făă bani / plată gratitude recunoştință, mulțumire, gratitudine

gratuitous $(a d v)$ gratuit, gratis, făă bani / plată; benevol; în mod arbitrar, pe nedrept

gratuitousness gratuitate, caracter gratuit / arbitrar; lipsă de justificare

gratuity gratificație, primă, recompensă

gratulatory caracter de felicitare

graupack (ind chim) hârtie de maculatură grave grav, serios, îngrijorător, periculos; groapă, mormânt; a sculpta; a grava (o inscripție); (fig) a imprima în memorie, în suflet

gravel (constr) prundiş, nisip grosier / necernut, pietriş (între 2 şi $20 \mathrm{~mm}$ ); balast; a balasta cu pietriş; a prundui, a acoperi cu pietriş

gravel pit (constr) balastieră, carieră de pietriş gravel sand (constr) nisip grosier, pietriş mărunt gravel walk cărare / alee acoperită cu pietriş graveness gravitate 
graver (mas-un) cuțit de strung

graveyard (working) shift schimb de la ora 0 la ora 8

gravimeter (metr) gravimetru

gravimetric gravimetric

gravimetric analysis (metr) analiză gravimetrică (a materialelor granulare)

gravimetroscope gravimetroscop

gravimetry (metr) gravimetrie, analiză gravimetrică

graving dock (nav) doc uscat / de reparații

graving tool (mas-un) răzuitor

gravitate (fiz, hidr) a gravita, a curge liber prin gravitație; a cădea la fund, a trage în jos

gravitate to / towards a tinde spre / către

gravitation (fiz) gravitație, forță de gravitație, greutate

gravitational attraction (fiz) atracție gravitațională

gravitational balancing machine (mec) maşină de echilibrat prin gravitație / nerotativă

gravitational drainage (hidr) scurgere / deplasare gravitațională

gravitational dust collector (mediu) colector gravitațional de praf

gravitational energy (fiz) energie gravitațională

gravitational exploration / prospecting prospecție gravimetrică (a materialelor granulare, cu particule de densităţi diferite)

gravitational field (fiz) câmp gravitațional

gravitational force forță de gravitaţie

gravitational flow (fiz, hidr) curgere în câmp gravitațional / datorită forței de gravitație / datorită greutății (proprii)

gravitational separation (agr, alim, ind chim) separare / sortare gravimetrică

gravitational settling (agr, alim, ind chim) sedimentare gravitațională

gravitation constant (fiz) constantă / accelerație gravitaţională (g), constanta gravitaţiei universale gravitation field (fiz) câmp gravitațional

gravitation force (fiz) forță de gravitație / gravitațională

gravitation settler (fiz, metr) gravimetru

gravitation thickening $(\mathrm{TH})$ clasificare / sortare a minereurilor după greutatea specifică

gravitation transporter $(\mathrm{OM}$, transp) transportor gravitațional

gravitic field (fiz) câmp gravitațional

gravity gravitate, importanță; (fiz) (forță de) gravitație, pondere, greutate; (fig) profunzime, adâncime

gravity acceleration (fiz) accelerație gravitațională $(\mathrm{g})$ gravity arc welding (with covered electrode (met) sudare gravitațională (cu electrod învelit)

gravity-balance (metr) gravimetru

gravity bucket conveyer (OM, transp) transportor cu cupe basculante

gravity circulation (fiz, mec) circulație gravitațională prin cădere liberă; (termo, hidr) circulația apei prin termosifon

gravity closing (mas-un, mec) închidere (a presei / matriței) prin cădere liberă

gravity concentration (TH, fiz) concentrare / sortare gravitațională

gravity concentrator (met, $\mathrm{TH}$, fiz) fabrică de concentrate pe cale umedă, datorită gravitatiei gravity constant (fiz) constantă gravitațională, accelerație gravitațională $(\mathrm{g})$

gravity conveyer $(\mathrm{OM}$, transp) transportor gravitațional

gravity-die casting (met, plast) turnare în câmp gravitațional

gravity-discharge furnace (met, termo) cuptor cu autodescărcare / cu propulsie

gravity distribution (met, constr) distributie / distribuire prin gravitație / prin segregare gravitațională

gravity drainage (hidr, agr) drenaj gravitațional, desecare gravitațională

gravity dressing (met, alim, ind chim) concentrare gravitațională (la amestecuri lichide sau solide, cu componenți cu densități diferite), aranjare / distribuire după greutate specifică

gravity feed (mas-un, hidr, alim) alimentare prin cădere / curgere liberă, alimentare prin diferență de nivel; alimentare cu circulația normală a metalului

gravity feed furnace (met, alim, ind chim) cuptor cu deplasare gravitațională a sarcinii

gravity filter (OM, hidr) filtru gravitațional, fără presiune (cu curgere liberă)

gravity filtration (alim, ind chim, hidr) filtrare gravitațională / prin curgere liberă

gravity flow (fiz, mec) curgere gravitațională / prin cădere liberă

gravity haulage ( $\mathrm{TH}$, transp) transport prin gravitație (şi pe plan înclinat cu frână)

gravity head (hidr) presiune hidrostatică, presiune a coloanei

gravity high (fiz, hidr) înălțime (în câmp gravitaţional)

gravity loading (fiz, mec) încărcare liberă, sub gravitație / prin cădere (liberă)

gravity lubrication $(\mathrm{T})$ ungere prin cădere / prin scurgere liberă

gravity meter (metr) gravimetru 
gravity oil system (T) ungere cu ulei, prin cădere / prin scurgere liberă

gravity pawl $(\mathrm{OM})$ clichet în angrenare $\mathrm{cu}$ o roată dințată, cu acțiune prin greutate proprie

gravity plane (met) suprafață de alunecare, plan înclinat cu frână

gravity preparation preparare prin gravitaţie (d. minereuri, amestecuri cu componente cu densităţi diferite)

gravity separation (agr, alim, met, ind chim) separare / sortare / clasare gravitațională / gravimetrică / prin gravitație

gravity separator (alim, ind chim, met) separator gravimetric

gravity settling (alim, met) sedimentare / decantare gravitațională / după greutatea specifică a componentelor amestecului lichid sau lichid + solid

gravity spiral conveyer (alim, constr) transportor elicoidal, cu cădere liberă / sub greutate proprie

gravity-system water-cooling (termo) sistem de răcire prin termosifon

gravity tank (met) cadă / baie tampon; rezervor cu scurgere liberă / prin gravitație

gravity test (fiz, metr) determinare a densității

gravity tube (OM, hidr) burlan de scurgere; (fiz, T) tub de cădere în vâscozimetre

gravy (alim) zeamă / suc de carne, sos de friptură

gravy boat (alim) sosieră

gravy soup (alim) supă / bulion de carne

gray / grey cenuşiu, gri

gray cast iron (met) fontă cenuşie (turnată în piese)

gray-iron foundry (met) turnătorie de fontă cenuşie

gray pig iron (met) fontă cenuşie brută

gray spiegel iron (met) fontă albă / oglindă

gray tin modification (met) (modificare / transformare cu / la) staniu cenuşiu

graze (agr) a paşte, a păşuna, a duce la păscut; a zdreli, a zgâria, a juli, a jupui; jupuitură, julitură, zgârietură; against, along, through, by a atinge în treacăt

graze along / by / past a trece, a merge, a se strecura pe lângă

grazier (agr) crescător de vite, fermier

grazing (agr) iarbă, nutreț; păscut, păşunat; care paşte

grazing ground / land (agr) păşune, islaz, imaş grazing angle (fiz) unghi razant

grease (alim) untură, seu topit, grăsime, osânză; (T) unsoare consistentă, lubrifiant semi-solid; a unge (cu unsoare), a gresa, a lubrifia, a uleia; a păta cu unsoare / grăsime

grease baffle / retainer $(\mathrm{OM}, \mathrm{T})$ deflector de unsoare (şi într-o carcasă de transmisii etc.)

grease box (cf, OM, T) cutie / bucşă cu unsoare, gresor, ungător

grease cock $(\mathrm{OM}, \mathrm{T})$ robinet pentru unsoare / pentru unere

grease cup (cf) cutie cu unsoare; (OM, T) gresor, ungător (şi cu pahar), bucşă de lubrifiere, ungător (cu unsoare)

grease distribution line $(\mathrm{OM}, \mathrm{T})$ conductă de distribuție a unsorii

grease extracting plant (alim, ind) instalație de degresare / de extras unsoarea / grăsimea

grease extractor / trap (alim, ind chim) separator de grăsime / de componenți graşi

grease filter (for greasy water) (OM, fiz, chim) filtru separator (pentru apă cu grăsimi / ulei / unsoare)

grease gun $(\mathrm{OM}, \mathrm{T})$ tecalemit, pompă de uns de gresat, niplu de ungere

grease hardening resistance (chim, T) rezistență a unsorilor la întărire

grease lubrication $(\mathrm{OM}, \mathrm{T})$ lubrifiere cu unsoare

grease of bones (alim) grăsime de oase

grease oil (ind chim, T) lubrifiant, ulei de ungere, uleiul de bază al unsorii

grease-proof impermeabil la grăsimi, etanş la unsoare (d. materiale, filtre etc.)

grease-proofing (textile) tratare oleofobă a țesăturilor

grease-proofness impermeabilitate la grăsimi / la unsori (d. materiale, țesături etc.)

grease-proof paper hârtie pergament

grease pump $(\mathrm{OM}, \mathrm{T})$ pompă de unsoare

greaser $(\mathrm{OM}, \mathrm{T})$ ungător, gresor (pentru unsoare)

grease remover $(\mathrm{T}$, ind chim) degresant, detergent (mai mult pentru curățare)

grease seal ring $(\mathrm{OM})$ inel de etanșare pentru unsoare

grease separator (alim, ind chim) separator de grăsimi / de ulei / de unsoare (şi din emulsii)

grease solvent (chim) solvent pentru grăsimi / unsori

grease structure $(\mathrm{T})$ structura unsorii

greasiness $(\mathrm{T})$ onctuozitate; caracter unsuros / gras

greasing station (met, T) stație (centralizată) de ungere (cu unsoare, ulei)

greasing $(\mathrm{T})$ ungere, gresare, lubrifiere; care unge / asigură ungerea / lubrifierea

greasy unsuros, gras; (alim) gras, tulbure (d. vinuri); pătat cu grăsime, murdar; noroios

greasy luster luciu gras (d. suprafețe) 
great mare, grandios; intens, puternic, imens, uriaş, enorm; (extrem de) important, vital, esențial; remarcabil, ilustru; minunat, excelent; iscusit, priceput; îndelungat, lung, de lungă durată; total, întreg

great circle (geom) cerc mare / principal

great coat (textile) palton

greatest common divisor (g.c.d.) (mat) cel mai mare divizor comun (c.m.d.c.)

greatest lower bound (g.l.b.) (mat) cel mai mare minorant, margine inferioară

greatest upper bound (mat, OM) limită superioară

greatly $(a d v)$ foarte (mult), foarte (tare), în mare măsură

great-minded cu concepții / vederi largi, deschis la minte; generos

greatness mărime (ieşită din comun), măreție; importanță, însemnătate; gravitate, seriozitate; măreție, faimă

greats (edu) examen de absolvire

great-sized mare, cu / de dimensiuni mari; impresionant

great span saw (mas-un) ferăstrău de debitat

great toe (anat) degetul mare de la picior

greaves (alim) jumări

greed lăcomie, aviditate, avariție

greedy of lacom de, avid de, avar

Greek type caractere / litere greceşti

green verde, crud, necopt; înverzit; verdeață, vegetație; (constr) jilav, umed, de abia tencuit, văruit, turnat (d. beton); (met) umed, verde (la formare); (piesă) netratată / nevulcanizată / neîntărită (d. materiale plastice termorigide); a înverzi; a vopsi în verde

green bond strength (met) rezistența amestecului crud de formare

green bones (alim) oase brute

green card (auto) document de asigurare casco, carte verde

green cheese (alim) urdă, caş proaspăt

green cloth (textile) postav verde

green crop (agr) plantă / cultură furajeră, nutreț verde

green compact (alim, ind. chim) material compactat inițial / neprelucrat / crud

green core (met) miez crud

green core-making method (met) metodă de formare a miezurilor crude, procedeu de formare cu miez crud

green density (materiale) densitate la crud / înainte de sinterizare / de tratare / de vulcanizare / de întărire (d. materiale plastice termorigide) greenery (bot, agr) verdeață, vegetație verde, frunziş, seră

greed food (agr) nutreț verde

greengage (agr, alim) renglotă, prună verzuie

green goods (alim) zarzavaturi, verdețuri

green goose (agr, zool) boboc de gâscă

greengrocery (alim, ec) comerț cu legume şi

fructe; zarzavaturi, fructe

greenhouse (agr, termo) seră

greenhouse effect (mediu) efect de seră

greenish verzui

green light (cf, auto, TH) verde (ca la semafor), cale liberă, permisiune, autorizație

green matte (met) mată neprăjită / brută

green meat (alim) carne crudă; (agr) nutreț verde

green-mould casting (met) turnare în forme de nisip crud

greenness verdeață; culoare verde; imaturitate, stare necoaptă; lipsă de maturitate / experiență, nepricepere

green oxide (chim) oxid de nichel

green roasting (met) recoacere incompletă

green roll (met) cilindru (de laminor) netratat

greens (alim) verdețuri, legume

green sand (met) nisip / amestec de formare, crud

green-sand core (met) miez crud

green-sand mould (met) formă crudă de turnare (de nisip crud)

green-sand moulding (met) formare cu nisip crud

green soap (chim, T) săpun de potasiu

green state stare crudă (în industria sticlei şi ceramicii)

green stock (ind chim, plast) amestec de cauciuc nevulcanizat

green strength (met) rezistența mecanică a miezului crud, rezistența mecanică a unui amestec ceramic sau din pulberi metalice, după compactare, dar înainte de tratare termică sau sinterizare; (plast) rezistență inițială / înainte de întărire / vulcanizare (d. elastomeri, materiale plastice termorigide)

green stuff verdețuri, zarzavaturi, legume verzi greensward pajişte, gazon, peluză de iarbă / gazon green timber / wood (silv) lemn verde greet a saluta greeting salutare; bun venit grège, greige (culoare) greige, gri-bej grey / gray gri, cenuşiu; a vopsi în gri / cenuşiu; a (se) întuneca, a umbri (o imagine); a se face cenuşiu

greying (met, chim) grafitizare; umbrire; (c, TV) transformare a unei imagini colorate într-una alb-negru 
greyish bătând în gri / cenuşiu

grey matter materie cenuşie; (fig) minte, inteligență

grey pea (alim, agr) mazăre furajeră

grey spiegel (iron) (met) fontă oglindă

grid grilaj, grătar, grilă, rețea, caroiaj; (cf, el) rețea de fire sau căi ferate, grila unui tub electronic; caroiaj; (mat) rețea de curbe; (met) armătură a miezului; sită

grid bar (OM, met, termo) bară de grătar

grid base (mat) bază rețea; (el) polarizare de tăiere

grid cleaning (met, el) curăţire electrolitică

griddle (alim) tavă / formă de copt; (met) ciur, sită

grid gas (met, ind chim) gaz transportat la distanțe mari (prin rețea de conducte)

gridiron (el) rețea de bare colectoare; (nav) grătar de carenaj, schelă de reparație

gridiron divider (metr) riglă gradată

grid map retea / hartă gradată / caroiată

grid mash (OM) ochi de grilaj / de plasă / de sită

grid piling (met) stivuire în formă de grătar

grid system (el) sistem interconectat (de rețele electrice / electronice

grievance plângere, revendicare, doleanță; nedreptate, abuz

grill (alim) grătar, friptură la grătar, rotiserie; (constr) grilă, rețea; (met) rețea, grilaj

grillage (mec, OM) grilaj, grătar, zăbrele; (met) rețea

grill closure valve (OM, termo, met) supapă de închidere a grătarului

grille grilă; gard, grilaj; (auto) mască (de motor, radiator etc.)

grilled tube (OM, termo) țeavă cu nervuri

grime (ind chim, mediu) funingine, praf de cărbune; negreală, murdărie; a înnegri, a murdări (cu funingine)

grimy murdar de funingine / cărbune

grind (alim, TH) măcinare, fărâmițare, mărunțire, mărime a produsului măcinat; scârțait, scrâşnet; a (se) măcina, a râşni, a pisa; (masun) ascuțire, reascuțire; a granula, a mărunți, a sfărâma, a poliza, a şlefui, a lustrui, a rectifica, a (se) ascuți (şi prin frecare); a se freca, a se roade, a se subția; a scârțâi, a scrâşni

grindability (chim, alim, met) capacitate de măcinare / de sfărâmare; (mas-un) capacitate / abilitate de rectificare / de a fi rectificat

grindability index (chim, alim, met) indicare al capacității de mărunțire

grind and mix (TH) a prelucra la moara cu tăvălug / la kollergang grind away at a munci serios la

grind down (TH, mas-un, constr, alim, ind chim) a măcina, a şlefui, a poliza

grinder (alim) piatră / tăvălug de moară; defibrator, râşniță, măcinătoare; mecanism de măcinat, moară, concasor; (mas-un) maşină de ascuțit unelte / scule, maşină de rectificat / de şlefuit / de polizat, polizor, piatră de rectificat / de polizor, şlefuitor, rectificator, tocilar

grinder-polisher (mas-un) rectificator(-lustruitor); dispozitiv de rectificare / de lustruire

grinder rest (mas-un) lunetă a maşinii de rectificat

grinder stone (mas-un) piatră de polizor

grinder wheel (mas-un) disc / piatră de rectificat

grindery (mas-un) secție de rectificat

grind fine (alim, ind chim) a măcina fin

grinding care macină / zdrobeşte / turteşte; care scârtâie / scrâşnește; (alim) măciniș; (constr) măcinare, sfărâmare; defibrare; (mas-un) şlefuire, rectificare, ascuțire, abraziv, de polizat; (met) debavurare a pieselor turnate; (proces de) defibrare (textile, plast)

grinding addition / allowance (mas-un) adaos de rectificare

grinding and bagging plant (alim, mas, ind chim) instalație de măcinare şi punere în saci

grinding and sifting plant (met, mas) instalație de măcinare şi cernere

grinding apparatus (alim, ind chim) dispozitiv de măcinat; (mas-un) polizor, dispozitiv de ascuțit sau şlefuit

grinding arbor (mas-un, OM) ax al discului de rectificat

grinding ball (OM, constr, ind chim) bilă de măcinare

grinding board (mas-un) placă de şlefuit / de lustruit

grinding burn (met, mas-un) supraîncălzire locală, la rectificare

grinding capacity (materiale) capacitate / capabilitate de a fi măcinat / de a se măcina

grinding carriage (mas-un) sanie de rectificat, port-piatră

grinding centre (mas-un) centru de rectificare / de prindere a piesei de rectificat

grinding chamber (alim, ind chim) cameră / incintă de măcinare (a unei mori / instalații etc.)

grinding check / crack ( $\mathrm{TH}$, materiale) fisură produsă la rectificare

grinding compound (mas-un) lichid de răcire pentru rectificare 
grinding cone (mas-un) piatră conică de rectificat

grinding disk (alim) disc de măcinat; (mas-un) disc de rectificare / de şlefuire

grinding drum (alim, ind chim) tambur de măcinare

grinding dust (mas-un, mediu) praf rezultat din rectificare / polizare

grinding face (mas-un) suprafață de rectificat / de lucru a pietrei de rectificat, suprafaţă de măcinare a cilindrului unei mori

grinding fineness (alim, ind chim) finețe de măcinare

grinding finish (OM, mas-un) suprafață rectificată, calitate a suprafeței rectificate

grinding fluid (mas-un, T) fluid pentru rectificare

grinding gauge (mas-un, metr) calibru pentru verificarea unghiului de aşezare (la scule de rectificare)

grinding machine (mas-un) maşină de rectificat / de polizat, polizor, maşină de ascuţit unelte / scule; (alim, ind chim) maşină de sfărâmare / de măcinare

grinding mark (mas-un) urme de şlefuire; (alim, ind chim) urme (abrazive) pe cilindrii / elementele active de măcinare

grinding material (mas-un) material de şlefuit / de rectificat, material abraziv

grinding media (mas, alim, ind chim) corpuri de măcinare, mediu de măcinare (uscat, lichid etc.)

grinding mill (constr, mas) concasor; maşină de măcinat, moară cu discuri; (mas-un) atelier de ascutit scule

grinding mortar (chim) mojar

grinding pan (alim, ind chim) cuvă de moară chiliană / de kollergang; moară chiliană cu cuvă

grinding paste (mas-un) pastă de rectificat / de rodat / de şlefuit

grinding plant (alim, ind chim) instalație de măcinat / de morărit / de mărunțit; (mas-un) linie de maşini de rectificat, agregat complex de prelucrat suprafețe de rectificat pe o singură piesă

grinding plate (mas-un, alim, ind chim) disc de măcinare / de şlefuit

grinding powder (mas-un) praf abraziv, pulbere abrazivă

grinding pressure (mas-un) presiune la rectificare / la şlefuire

grinding property (mas-un) proprietăți abrazive (ale materialului sculei de rectificat); (met, alim) capacitate de măcinare

grinding rest (mas-un) sanie de rectificat grinding ring (mas-un, alim) disc / inel de măcinare / de şlefuit

grinding roll (alim, ind chim) tambur / cilindru / rolă de măcinat; (mas-un) piatră de rectificat cilindrică (de lățime mare), cilindru de şlefuit, sul abraziv

grinding roller (mas-un) cilindru de polizat / de rectificat, polizor plin

grindings (mas-un) praf de rectificat; (met) pilitură

grinding size (mas-un) dimensiune a piesei de rectificat, inclusiv adaosul de prelucrare

grinding stock abraziv, material abraziv; (masun) adaos de prelucrare la rectificare

grinding stone (mas-un) piatră abrazivă / de rectificat / de ascuțit

grinding surface (alim, mas-un) suprafață de măcinare / de rectificare / activă a discului abraziv / a sculei de rectificat / măcinat

grinding table (mas-un) masă de rectificat / de şlefuit

grinding test (metr, alim, ind chim) încercare de măcinare; (mas-un) test / încercare / de rectificare

grinding wheel (mas-un) piatră / disc abraziv(ă) / de şlefuit, piatră de polizor / de polizat, tocilă grinding wheel dresser (mas-un) freză pentru îndreptarea / profilarea discului de rectificat

grinding wheel head (mas-un) păpuşă a pietrei de rectificat

grinding wheel slide (mas-un) sanie a pietrei de rectificat

grinding worm ( $\mathrm{OM}$, mas, alim, constr, ind chim) melc de concasare / de măruntịe / de măcinare

grind off (mas-un) a şlefui (prin înlăturarea / îndepărtarea adaosului de rectificare)

grind of paint (ind chim) frecare a vopselei

grindstone (mas-un) piatră de polizat / de polizor, tocilă, disc abraziv (pentru rectificare, polizare etc.); (alim) piatră / tăvălug / cilindru de moară

grind superficially a zgâria fin, la suprafață

grind with emery a şlefui cu şmirghel

grip strângere, apucare, prindere; stăpânire, control; înțelegere (a unei probleme); (OM) gheară apucătoare, graifăr, manetă, mâner, clemă, a strânge, a prinde, a cuprinde, a fixa, a ambala, a împacheta, a (se) agăța; (mas-un) cap de prindere; (met) dispozitiv / cleşte de prindere; (fig) putere, autoritate, influență; capacitate de înțelegere; (amer) valiză, sac de voiaj; (nav) a se prinde de fund (d. ancoră); a reține atenția (cuiva)

grip check (OM, mas-un) sabot de strângere / de blocare / de prindere 
grip conditions (auto) aderență la sol (a unui pneu); ( $\mathrm{TH}$, transp) condiții de prindere (a unei piese în dispozitivul de prelucrat / de ridicat)

grip device (OM, mas-un) dispozitiv / mecanism de prindere

gripe a apuca, a strânge, a prinde, a presa, a apăsa; (nav) a lega de țărm; apuce, strânsoare

gripes (nav) parâme, odgoane

grip gear (OM) dispozitiv de prindere (cu dinți, cu clicheți), cleşte, menghină

grip hold angle (mas-un, transp) unghi de înfăşurare / de prindere / de cuprindere (la prinderea unei piese)

grip holder (el) clemă; (OM, mas-un) fălci de strâns pânza de ferăstrău; (mas-un, met) falcă sabot de strângere / de prindere / de fixare

grippe (med) gripă

gripper (OM, mas) graifăr, „mână” (la roboți), dispozitiv de prindere / de apucare; (met, OM) cleşte de prindere, gheară, clapă, graifăr

gripper die (mas-un) matriţă de / cu strângere gripper roller $(\mathrm{OM})$ rolă de avans / de alimentare, cu gheare, rolă de prindere / de strângere

gripping (constr, mec) încastrare, prindere, fixare, apucare; care apucă / prinde; (met) dispozitiv de prindere; $(\mathrm{OM}, \mathrm{T})$ gripare

gripping angle (met; $\mathrm{TH}$ ) unghi de prindere (la laminare)

gripping appliance (OM, mas-un) dispozitiv de apucat / de prindere / de prins

gripping capacity / power (mas, mas-un) capacitate de prindere / de apucare (şi la roboți, manipulatoare)

gripping chuck (mas-un, OM) mandrină / cap de prindere a piesei de prelucrat

gripping clutch (OM, auto) ambreiere bruscă

gripping device (OM, mas, mas-un) dispozitiv de strângere / de prindere / de fixare, apucător; benă

gripping face $(\mathrm{OM})$ suprafaţă de reazem / de prindere / de apucare (a piesei sau a dispozitivului de prindere)

gripping fork $(\mathrm{OM})$ furcă de prindere, dispozitiv de prindere în furcă

gripping head (met, mas-un) cap de prindere

gripping jaw (mas-un, $\mathrm{OM}$ ) falcă de strângere, falcă a menghinei

gripping jaw device (el) clemă; dispozitiv cu falcă, de strâns pânza la ferăstrău; (mas-un) dispozitiv cu falcă de strângere / de fixare

gripping surface (OM, mas-un) suprafață de strângere / de fixare (a piesei sau a dispozitivului de prindere) gripping tongs (met) cleşte plat, cleşte de apucat / de prins

gripping wedges (OM, mas-un) fălci de prindere a pieselor

grip resistance (mec, $\mathrm{T}$, mas-un, transp) forță de frecare la alunecare, forța necesară fixării / prinderii (fără alunecare)

grip ring $(\mathrm{OM})$ inel de fixare

grips (OM, mas-un) fălci ale menghinei; (med) colici

gripsack sac de voiaj, bagaj de mână

grip strip spion (pentru reglarea jocului dintre ghidaje şi piesa ghidată)

grip vice (mas-un, $\mathrm{OM}$ ) menghină, dispozitiv de prindere

grissini (alim) grisine

grist material boabe / grăunțe / granular, de măcinat; (alim) grâu măcinat, malț

grist-mill (alim) moară

grit (alim) urluială, şrot (de la măcinarea cerealelor, de la extractia uleiului), crupe; nisip grosier, pietriş fin, prundiş; (mas-un) material abraziv (și sintetic, din particule cu unghiuri ascuțite), pilitură; (met) granulație, alicare (şi pentru sablare); a scârțâi, a scrâşni (ca nisipul)

grit blasting (met) alitare, prelucrare / împroşcare / curățare cu alice

grit catcher (hidr, mediu) separator de nisip, denisipator

gritstone gresie (cu granulație mare)

gritty grăunțos, granulos, cu pietriș, cu nisip, nisipos; cu pietricele, cu nisip

grizzle cărbune de calitate inferioară; (ind chim) cărămidă insuficient arsă

grizzly cenuşiu, sur; (constr) grătar / ciur cu bare; transportor cu role

groats (alim) urluială, şrot (de la măcinarea cerealelor), crupe (de cereale)

grocer băcan

grocery (shop) băcănie, magazin alimentar

grocery paper (alim, ind chim) hârtie de ambalat alimente

grog (met) şamotă măcinată; (alim) grog, rachiu amestecat cu apă, băutură tare, alcool

grog refractories (met, ind chim) cărămidă de şamotă

grogs particule de pământ / de rocă, granule de nisip, bulgări de noroi

grommet (el) trecere (izolată); (OM) manşon (şi de trecere), garnitură (inelară) de cauciuc, inel de etanșare (din cauciuc) (așezată / lipită sub capul şurubului sau sub piuliță), inserție, disc; (nav) ochet (la parâmă), zbir, cârlig de fixare pentru frânghii 
groove (constr) uluc, canelură, nişă; şanţ, făgaş; (el) crestătură / şanț de izolator (pentru fixarea conductorului); (OM) canal, canelură, nut, crestătură, şanț, şliț, jgheab, locaş, culisă, canal al roții de curea trapezoidale, racordare concavă, degajare, riz, tăietură, striuri, încrețitură (la piese / table / folii subțiri); (mas-un) moletă; (metr) calibru; a scobi, a canela, a şănţui, a brăzda, a riftui, a cresta; (met) calibru, a calibra (cilindrii de laminor), pregătirea marginilor (înainte de sudare)

groove-cutting machine (mas-un) maşină de canelat (prin aşchiere)

grooved $(\mathrm{OM})$ canelat, cu canelură / caneluri, striat, riftuit, zimțuit, brăzdat, cu nervuri; (met) cu margini pregătite de sudare

grooved anvil (met) nicovală ajutătoare, matriță de forjă

grooved drum tambur canelat / cu caneluri; (met) cilindru canelat (cu nervuri)

groove depth adâncime a calibrului / a canelurii / a şanțului

groove designing calibrare

grooved finishing roll (met) cilindru finisor pentru lamonoare de profile

grooved friction wheel $(\mathrm{OM})$ roată de fricțiune cu canale / şanțuri trapezoidale

grooved pulley $(\mathrm{OM})$ roată cu canale pentru curele (rotunde sau trapezoidale)

grooved rail (cf, met) şină cu şanț / de tramvai

grooved ring $(\mathrm{OM})$ inel canelat

grooved roll (met) cilindru profilat de laminor; (alim, ind chim) valț / cilindru canelat / striat / calibrat

grooved roller $(\mathrm{OM})$ rolă canelată, valt randalinat / cu şanțuri, rolă de ghidare pentru cordon / cablu

grooved wedge $(\mathrm{OM})$ canal de pană

grooved wheel (OM, mas-un) mandrină specială pentru roți

grooved wire electrode (met, el) electrod cu înveliş presat în canelurile longitudinale ale sârmei

groove radius $(\mathrm{OM})$ rază de racordare la rădăcină / la bază (între suprafața unui canal şi pereții acestuia)

groove rolling mill (met) laminor de calibrare / de tablă striată

groove row (metr, met) serie de calibre

grooves $(\mathrm{OM})$ striuri, canale (în piese)

groove stand (met) cajă de laminor, de calibrare / de tablă striată

groove wheel $(\mathrm{OM})$ roată de curea (cu secțiune) rotundă grooving (mas-un) prelucrare / tăiere a canelurilor, canelare; rindeluire în uluc; (met) calibrare grooving and tonguing (joint) $(\mathrm{OM})$ îmbinare cu lamba si uluc (nut si feder)

grooving and tonguing moulder $(\mathrm{OM})$ maşină de frezat nut şi feder

grooving and tonguing plane (mas-un) rindea pentru lambă şi uluc

grooving chisel (mas-un) daltă îngustă de tăiat şanţuri, daltă în cruce

grooving cutter (mas-un) freză pentru canale

grooving machine (mas-un) maşină de prelucrat / de ştanţat canale / caneluri

grooving (milling) cutter (mas-un) freză pentru canale / caneluri

grooving of rolls (met, plast) calibrare a cilindrilor (de laminare)

grooving plane (mas-un) rindea de canelat / de fălțuit / de nut

grooving saw (mas-un) ferăstrău de şănțuit

grooving tool / iron (mas-un) cutit de canelat / de riftuit

gross gros (12 duzini); mare, voluminos, global, brut, grosolan; măcinat mare; (ec) total, global, brut; (d. aer) greu, viciat, stricat; cantitate mare

gross average heat rate (termo, met) consum specific mediu brut de căldură

gross caloric / heat power / value (termo) putere calorifică superioară

gross cash flow (ec) total al beneficiilor (inclusiv amortizarea)

gross disposal income (ec) venit disponibil total gross domestic / national product (ec) produs national global

gross effect (mas) putere efectivă

gross error (metr, mas-un) eroare grosolană / cumulativă

gross formula formulă empirică

gross heating value (termo) putere calorifică superioară

gross lift (fiz) forță ascensională totală

gross load (met, mec) încărcătură obişnuită; greutate / sarcină brută

gross loading (mec, transp) greutate brută (a unui vehicul)

gross national product $(\mathrm{ec})$ produs național brut grossness grosolănie, caracter grosolan, gravitate (a unei erori); grosime, desime

gross oil (ind chim) țiței brut, după deshidratare

grosso modo $(a d v)$ aproximativ, groso modo, circa, cam

gross output (el) putere la bornele generatorului; (ec) productie globală; (mas) putere brută 
gross porosity (met) defect major de sudare, cu găuri multe şi mari

gross power (mec) putere brută

gross production $(\mathrm{ec})$ producție brută / totală / globală

gross profit (ec) venit global

gross registered tons (nav, metr) tone-registru brut

gross register tonnage (metr, nav) tonaj-registru brut, tonaj brut

gross sample eşantion grosier

gross ton (nav, metr) unitate de măsură pentru masă, tonă-registru, tonă englezească $(=1016 \mathrm{~kg})$

gross vehicle weight (auto, transp) greutate totală a vehiculului (inclusiv încărcătura)

gross weight (cf) greutate în serviciu a locomotivei; greutate brută / totală (şi a unui mijloc de transport); (met) greutate / masă brută

ground (porțiune de) pământ, teren (de sport etc.), sol; (constr) fundație, temelie, podea, bază; pretext; (el) masă, punere / legare la pământ / la masă, a lega / a pune la pământ, a face legătura la pământ; (geol) scoarță terestră, rocă; (mat) bază; (met) grund, şlefuit mat / făă luciu; (nav) fund de mare, a se pune pe uscat, a eşua uşor, a se împotmoli, a da de fund (d. ancoră), a se scufunda; (av) a ateriza, a reține (un avion etc.); (fig) temei, bază, motiv, justificare, a întemeia, a justifica, a motiva, a sprijini (o instituție), a susține; a pune / aşeza jos, a depune; a poseda (cunoştințe); (edu) a învăța, a preda temeinic; (mil) a depune (armele); $\sim \mathbf{s}(p l)$ parc în jurul casei; $\sim \mathbf{s}(p l)$ (alim) drojdie, zaț; fond (al unei picturi, țesături); fall to the $\sim$ a cădea la pământ, a se prăbuşi; gain (fig) a câştiga teren; give / lose $\sim$ (fig) a pierde teren, a da îndărăt; on the $\sim$ of pe motiv că, pretextând că; on the $\sim$ of ill health din motive de sănătate groundage (nav) taxă / locație portuară ground-based (constr, mas) cu baza la / pe sol ground basic slag (met) zgură bazică din convertizorul Thomas

ground beam (constr, mec) grindă de fundație, longrină

ground cable (el) cablu de legare la masă / la pământ

ground circuit (el) buclă de închidere prin pământ

ground clamp / lug (el) bornă de legare la pământ; clemă / menghină de racord la pământ

ground clearance (auto) gardă la sol, distanța minimă până la sol

ground coat (auto, ind chim) vopsea grund, prim strat de vopsea; (constr) grund, tencuială ground color culoare de fond

ground connection (el) instalație de legare la pământ, legare / conectare la pământ

ground constant (constr) coeficient de tasare

ground deposit (geol) sediment(e)

ground detector (el, metr) indicator de pierderi la pământ

ground down (mas-un) ajustat prin rectificare / prin rodare

grounded (el) legat / conectat (intenționat) la pământ; (mas-un) rectificat, ajustat

grounded simplex circuit (el) linie simplă cu pământare, circuit cu punere / conectare simplă la pământ

ground electrode (el) electrod / placă de legare / conectare la pământ

ground elevation (geogr, constr) cotă a terenului ground-floor (constr) parter

ground glass (ind chim) sticlă mată / şlefuită; $(\mathrm{OM})$ dop rodat (din sticlă)

ground-glass joint $(\mathrm{OM})$ îmbinare cu sticlă şlefuită

ground-glass plate (ind chim) geam mat, sticlă şlefuită

ground-glass stopper (OM) dop din sticlă şlefuită, dop rodat

ground-glass stopper flask (chim) balon / butelie cu dop şlefuit, ambele din sticlă

ground-glass view finder $(\mathrm{OM})$ vizor $\mathrm{cu}$ geam mat

ground grip tyre (auto) pneu pentru orice teren ground humidity (geol, constr) umiditatea solului ground-in (mas-un, T) ajustat prin rodare / prin rectificare

ground-in ball-and-socket joint $(\mathrm{OM})$ articulație sferică cu bilă, rodată sau cu ambele suprafețe sferice rectificate

grounding (el) legare / punere / conectare la pământ; (nav) punere pe uscat, eşuare; (mas-un) (procesul de) rectificare

grounding conductor (el) cablu de împământare

grounding sleeve (el) manşon / bucşă / bornă de punere / de legare / conectare la pământ

grounding-in piston $(\mathrm{OM}, \mathrm{T})$ piston ajustat prin rodaj

ground law lege de bază / fundamentală

ground lead (el) conductă / conductor de legare / conectarela pământ, linie subterană de cabluri

ground leakage current (el) curent de pierdere / de scurgere la / în pământ

groundless nejustificat, nemotivat; arbitrar groundlessness lipsă de justificare, netemeinicie; caracter arbitrar 
ground level (constr) nivelul solului; (fiz) energie zero (a atomului etc.)

groundmass (met) masă fundamentală / de bază (în metalografie)

ground moisture (constr) umiditatea solului ground net / network (el) priză de pământ, retea de legare la pământ

ground-nut (alim) arahidă

ground-nut oil (alim) ulei de arahide

ground outlet (el) priză de curent, legată la pământ / cu împământare

ground plan (TH, constr, ind) plan de ansamblu ground plane (geogr, constr) suprafață plană, teren / pământ plat

ground plate (el) priză de pământ / de împământare; (constr) placă de bază / de fundație, soclu

ground plate of a framework (constr, mec) traversă / prag de legătură

ground point of control (metr, $\mathrm{TH}$ ) punct fix de reper / de control

ground pressure (constr) presiune a terenului / a solului, presiune asupra terenului de fundație

ground product (alim, ind chim) material / produs măcinat

ground relay (el,autom) releu de punere la pământ / de împământare / care acționează în cazul punerii la pământ

ground rent $(\mathrm{ec})$ rentă funciară

ground resistance (el) rezistență a prizei de pământ / de legare la pământ / de împământare

ground rule principiu / regulă fundamental(ă) / esențial( $\breve{a}) /$ de bază

grounds (ind chim) reziduu(ri), sediment(e); (alim) zaț, drojdie

ground screen (mas) contragreutate; (el, radio) priză de pământ a antenei

ground sill (cf) traversă de bază / de cale; (constr) longrină / talpă de fundație, grindă

ground slide $(\mathrm{OM})$ suprafață şlefuită

ground-speed indicator (metr, mec) vitezometru (pentru viteza la sol)

ground state (fiz) stare fundamentală / normală

ground stopper (OM) dop şlefuit / rodat

ground submergence (geogr) depresiune

ground subsidence (geogr) depresiune; lăsare a terenului

ground sugar (alim) zahăr pudră

groung surface (geogr, constr) suprafața terenului / solului / podului / pardoselii

ground swell (nav) hulă

ground switch (el) întrerupător de legare la pământ / împământare

ground tackle (constr, mas) instalație de ancorare ground tax (ec) impozit funciar

ground terminal (el) bornă de pământ / de împământare

ground thread (OM, mas-un) filet rectificat

ground timber (constr) grindă de fundație, longrină

ground tool (mas-un) sculă de rectificat

ground-type charging machine (transp) maşină de încărcat, cu bandă rulantă

ground varnish (ind chim) vopsea / material pentru grunduire

ground water (geol) (pânză de) apă freatică

ground wave (fiz) undă terestră

ground wire (el) fir / conductor de legare la masă / la pământ, reîntoarcere prin pământ, linie subterană de cabluri

groundwood (pulp) (silv, ind chim) pastă mecanică de lemn

groundwork (constr şi fig) temelie, fundație; bază, fundament; (cf) infrastructură, terasament

group grupă, grup, grupare; (fiz) fascicul / grup de linii / raze etc.; (mat) grup; mănunchi, grupare (în statistică); a (se) grupa, a clasifica, a sorta; (chim) radical, grup

group drive / driving (mas) acționare / antrenare în grup

group(ed) control / operation ( $\mathrm{TH}$, autom) comandă unică, reglaj grupat

grouped cutter (mas-un) ansamblu de freze, freză combinată

grouping (mas, chim) grupare, care (se) grupează group of conductors (el) fascicul / grup de conductoare / de fire

group of disconnected cracks (materiale) fisuri în rețea (şi la sudură)

group selection selecție de grup, alegere a grupului

group standard (metr) serie de standarde / de etaloane

group teeming bottom plate / stool (met) placă de bază, de turnare

grouser (nav) pilot provizoriu de ancorare pentru dragă; (OM) sabot / pinten de şenilă, nervuri antiderapante ale şenilei

grout (alim) sediment, drojdie; (constr) mortar, reziduu de mortar, pastă / lapte de ciment / de var; a lega, a cimenta, a tencui

grouter (constr) cărămidă cu goluri

grouting compound (el, termo) masă izolantă, compozit de turnare

grouting tube (ind chim, hidr) țeavă de injecție

grouts (alim) drojdie, zaț, sedimente, terci subțire

grout valve (OM, plast) clapetă pentru injecție 
grow a creşte, a (se) mări, a spori, a (se) dezvolta, a se face mare; a se coace, a se maturiza; a progresa, a face progrese, a înainta; a proveni din, a rezulta din; (agr) a creşte, a cultiva, a produce; (met) a creşte (fonta), a (se) umfla

grower (agr) cultivator, crescător, producător; (OM) şaibă / inel Grower

grow from a proveni din, a-şi avea originea în grow hot a (se) încălzi, a deveni (mai) cald, a-şi ridica temperatura

grow in a creşte în; a ajunge la / să

grow in bulk a creşte în volum, a se face mai voluminos (d. materiale)

growing crescând, din ce în ce mai mare, care creşte, în curs de creştere / dezvoltare

growing pains (fig) dificultăți inerente începutului / dezvoltării

grow into a ajunge să fie, a deveni, a se transforma în

grown-up adult, mare

grow out a creşte (mai) mare

grow out of a ieşi din, a rezulta din, a creşte din, a se dezvolta din, a fi o consecință a

grow rich (in) (met, plast) a (se) îmbogăţi (în)

growth creştere, mărire, dezvoltare, progres, sporire; suire, urcare; afluență, aflux; (mat) creştere, ordin de creştere; produs, rezultat

growth industry industrie în plină dezvoltare

growth of cast iron (met) creştere / umflare a fontei

growth rate $(\mathrm{TH})$ viteză / rată de creştere / de dezvoltare (d. un proces, un parametru etc.)

growth stock (ec) acțiuni destinate să sporească investițiile / capitalul

grow to a ajunge să fie, a deveni, a se transforma în, a ajunge până la; a se apropia de

grow together a creşte dependent unul de altul / împreună, a fi strâns legați / influențați

grow towards a se apropia de

grow up a creşte, a se face mare; a se coace, a se maturiza; a se naşte, a lua naştere

groyne (nav) dig, sparge val, etravă, pinten

grub (alim, agr) larvă, vierme, râmă, a desțeleni, a curăța pământul de rădăcini; a dezgropa, a aduce la suprafață; (fig) a descoperi, a scoate la iveală

grubber (agr) plug de desțelenit, săpător

grubby (alim, agr) plin / mâncat de viermi; murdar, neglijent

grub screw (OM) şurub autofiletant / de blocare, fără cap (eventual cu şanț pentru şurubelniță)

grub-stake (ec) materiale / echipamente oferite în schimbul acțiunilor, a furniza materiale / echipament în schimbul acțiunilor grub up a dezgropa, a scoate la suprafață gruel (alim) terci, fiertură de cereale gruel(l)ing istovitor, extenuant gruff aspru, sever; brutal; grosolan grummet $(\mathrm{OM})$ garnitură de cânepă pentru etanşarea conductelor

grummet joint (OM) îmbinare cu inel de etanşare (din cânepă)

guarantee, guaranty $(\mathrm{ec}, \mathrm{TH})$ garanție, garant, girant, creditor (care primeşte garanția), a garanta, a depune garanție

guarantee against / from a asigura împotriva guarantee load (mec, TH) sarcină garantată guarantee period $(\mathrm{TH})$ termen de garanție guarantee test (metr) încercare / test pentru verificarea caracteristicilor garantate

guarantor (ec) garant, girant

guard pază, paznic; vigilență, apărare; (constr) balustradă; (OM) dispozitiv / cutie de protecție, grătar de siguranță, apărătoare, mâner de protecție; (met) ghidaj, cuțit de ghidaj; a proteja, a apăra, a păzi; (fig) reținere, rezervă, neîncredere; (cf) şef de tren, conductor

guard boat (nav) şalupă din paza de coastă

guard cradle (el) plasă / rețea / cuşcă de protecție pentru înaltă tensiune

guarded păzit, apărat; prudent, precaut guardedness prudență, precauție, măsură guard fence (constr, mas) balustradă, îngrădire / gard de protectie

guardian custode (de muzeu); protector guardianship (jur) tutelă; pază, supraveghere guardless lipsit de pază / de apărare / de apărătoare

guard net (mas, constr, el) plasă protectoare guard pin $(\mathrm{OM})$ ştift de siguranță

guard plate $(\mathrm{OM})$ placă de siguranță, apărătoare plană

guard position (mas) poziție de rezervă / de siguranță

guard rail (cf) contraşină; (constr) bază / şină de ghidare, parapet, balustradă

guard ring (el) inel de gardă; (OM) inel de susținere / distanțier; (met) inel de protecție guard screen / shield (el) ecran de gardă / de protecție; (OM, met) ecran / scut de protecție guard ship (nav) navă de pază (a coastei) guard sleeper (cf, transp) longrină de deraiere guardsman paznic

guard vacuum (mas, ind chim) spațiu vidat, intermediar între zona vidată dorită şi atmosferă cu rol de siguranță

guard valve (OM, hidr) supapă / vană de oprire / de protecție 
gubbins maculatură; fleacuri; vechituri; gunoaie gudgeon (OM) cep / dop de protecție, ax, bolt, bulon, pivot, fus de capăt; (nav) balama de cârmă

gudgeon pin $(\mathrm{OM})$ fus cu umeri, bolt de piston; (nav) ax de cârmă

guess a ghici, a găsi (un răspuns); a presupune, a-şi închipui, a bănui; (amer) a crede, a socoti, a bănui; apreciere estimativă

guesstimate bănuială (puternică), apreciere formată pe ghicite, evaluare aproximativă

guest oaspete, invitat; chirias

guidable $(\mathrm{TH})$ care poate fi ghidat

guidance ghidare, îndrumare, comandă; îndrumar, ghid; (constr) sfoară de trasat, direcționare; (met) regim, mers, conducere (a furnalului / a cuptorului)

guide îndrumător, consilier; (OM) piesă / dispozitiv de ghidare, ghidare, ghidaj, patină, glisieră, manşon de protecție; a conduce, a ghida; a dirija, a conduce

guide bar (OM) linie / tijă / bară de ghidare / de conducere

guide bearing $(\mathrm{OM})$ lagăr de ghidare

guide bearing supporting ribs $(\mathrm{OM})$ nervuri de ghidare pentru reglarea poziției lagărului, glisieră

guide blade (OM, mas-un) paletă / muchie directoare / de ghidare

guide block (OM) sabot de ghidare, culisou, sanie / cadru de ghidare

guide box/ bush / bushing / cage (OM) bucşă / manşon / cuzinet de ghidare; (met) cutie de ghidaje

guide cable cablu de ghidare

guide column (mas-un, OM) coloană de ghidare (și la matrițe)

guide comb (mas-un, OM) pieptene / cremalieră de direcție / de ghidare

guide conduit (met) ghidaj / ghidare (la laminare)

guide eye (fiz, opt, metr) fotocelulă de ghidare

guide face (mas-un, OM) suprafaţă de ghidare / de alunecare (la ghidaje)

guide finger $(\mathrm{OM})$ bolț de ghidare, ştift al brațului / dispozitivului de copiere

guide fork $(\mathrm{OM})$ furcă / etrier de ghidare

guide groove $(\mathrm{OM})$ şanț / canal de direcție / de ghidare, nut / gaură de ghidare

guide hole $(\mathrm{OM})$ gaură / orificiu / perforație de ghidare

guide iron $(\mathrm{OM})$ manşon / bară de ghidare

guide jaw (met, OM) ghidaj închis, gheară / falcă de ghidare (la laminor) guide mark semn, marcaj, punct de reper

guide needle $(\mathrm{OM})$ ştift / ac de ghidare

guide nozzle (OM, hidr) ajutaj de conducere / de dirijare (a jetului de aer / apă etc.)

guide path (OM) ghidaj; (mas-un) față / cale de ghidare

guide pilot $(\mathrm{OM})$ cep de ghidare / de centrare

guide pin (OM) ştift / bolț / cep de ghidare / de centrare; (el, c) picior / nut de ghidare pentru introducerea corectă a unui tub electronic sau a unei fişe în suportul său

guide pipe (constr) burlan de ghidare

guide pivot $(\mathrm{OM})$ vârf / pivot de ghidare

guide plate $(\mathrm{OM})$ placă / riglă / bară de ghidare

guide-plate bracket $(\mathrm{OM})$ port-glisieră

guide post (auto) indicator / semn rutier; (masun) ghidaj al poansonului

guide prism (mas-un, OM) prismă de ghidare, ghidaj prismatic

guide pulley $(\mathrm{OM})$ roată / rolă de ghidare, ghidaj pentru curea, roată de curea conducătoare; rai (de macara) de ghidare

guide rail (cf, met) şină conducătoare; şină de rulare / de ghidare / de conducere; (auto) şină de ghidare (d. trapă)

guide ring (OM, met) inel de ghidare (şi cu gheare)

guide rod (auto) tijă / bară de directie; (OM) tijă / bară / falcă de ghidare, ghidaj

guide roll(er) (met, OM) valț / cilindru / rolă de ghidare / de conducere

guide rolling mill (met) laminor $\mathrm{cu}$ ghidare mecanică

guide rope (constr, $\mathrm{TH}$ ) cablu de ghidare

guide runner (met) canal / jgheab de ghidare (la laminor)

guide screw (OM, mas-un) şurub de ghidare / conducător

guide shaft (OM) arbore / fus conducător / de ghidare

guide sheave (OM, met) rolă de ghidare / conducătoare (și la laminor)

guide surface (OM, mas-un) suprafață de alunecare / de ghidare

guide table (OM, mas-un) placă de ghidare / de conducere

guide vane $(\mathrm{OM}$, termo) paletă culisantă de ghidare (la compresoare volumice rotative)

guide vane axial fan (termo) ventilator axial $\mathrm{cu}$ palete directoare

guide vane ring $(\mathrm{OM}$, termo) coroană directoare / inel de ghidare la turbine

guidewall (hidr) perete deflector / de ghidaj (şi la deversor) 
guideway $(\mathrm{OM})$ ghidaj, culisă de ghidare guide wheel $(\mathrm{OM})$ roată conducătoare / de ghidare (şi la transmisii cu curele sau cu lanț) guiding (OM) ghidare, ghidaj, care ghidează guiding axle $(\mathrm{OM})$ ax motor / conducător guiding bar / rail $(\mathrm{OM})$ riglă / bară conducătoare / de ghidare

guiding control dispozitiv de control / de ghidare / de conducere

guiding frame (mec, met, OM) cadru de ghidare guiding mark reper, semn indicator guiding roller (met, OM) rolă de ghidare / conducătoare

guild (ec) breaslă, corporație; organizație, asociație, societate

guillotine (met, mas-un) maşină de tăiat / de retezat rețele de turnare, foarfece ghilotină

guillotine shears / cutting machine (met, masun) foarfece ghilotină (şi pt. tablă în foi, blumuri)

guilt, guiltiness vină, culpă

guiltless nevinovat; inofensiv; ignorant

guiltlessness nevinovăție

guilty of vinovat de

guise aspect, înfăţişare, formă; paravan, pretext; under/in the $\sim$ of pretextând că

guich (amer) (geogr) viroagă, vale formată de un torent

gulf (geogr) golf; vârtej

gullet (geogr) defileu

gulletting file pilă rotundă cu vârf drept (pentru ascuțirea dinților de ferăstrău, în formă de dinte-de-lup)

gully (geogr) viroagă, rigolă, tranşee, cotlon, râpă, vâlcea, defileu; (OM) gaură, canal îngust; (hidr) sifon de decantare; (alim) cuțit mare

gully hole (hidr, constr) puț de scurgere, gură de canal

gulp a înghiți; a accepta, a lua drept bun; (inf, c, autom) mai mulți biți, grup de octeți

gum (ind chim, plast) gumă, răşină fluidă, cauciuc, liant; a lipi, a încleia; (alim) gumă de mestecat; (bot, silv) secreție răşinoasă, a secreta răşină; a (se) lipi, a încleia

gum arabic (plast) gumă arabică, răşină vegetală solubilă în apă

gumbo (alim) bame; (constr) argilă grea

gum elastic (ind chim) cauciuc

gum inhibitor (plast, ind chim) inhibitor de formare a gumelor / cerurilor

gummer (mas-un, ind chim) maşină / dispozitiv de gumat

gumminess (fiz, TH) adezivitate, putere de încleiere (d. adezivi) gumming (plast) formare / depunere a răşinilor sau a gumelor, cauciucare, gumare

gumming of piston rings (auto, termo) gumare / calare / cocsificare a segmenților de piston (proces nedorit)

gumming-up ( $\mathrm{T}$ ) creştere a vâscozității uleiului din cauza oxidării, ,gumare" a lubrifiantului

gummosity (plast) adezivitate, putere de încleiere

gummy cleios, vâscos; răşinos, care secretă clei / răşină; gumat, cu gumă / răşină / clei; lipicios gumption ingeniozitate, pricepere, spirit practic; îndrăzneală, inițiativă

gum resin (plast) sacâz, colofoniu

gum shoe galoş, şoşon

gum shoes încălțăminte de cauciuc

gum tragacanth (plast) gumă, răşină vegetală solubilă în apă

gum up a înțepeni, a strica, a deteriora

gun (mil) armă de foc, tun, puşcă; (constr, met) perforator, tecalemit; (el) tun în tub catodic; (met, mas-un) pistol de sudare (şi în puncte), pistol de pulverizat vopsea, cleşte de sudat

gun-barrel drill / boring machine (mas-un) maşină de găurit şi alezat țevi de tun / de arme gun boat (met) vagonet basculant (cu capacitate de $5 . . .8$ tone); (nav) vas înarmat cu tunuri, canonieră

gun-core drill (mas-un) burghiu de găurit țevi de tun / pentru găuri adânci

gun metal bush (met) cuzinet din bronz roşu / din aliaj pentru țevi de tun

gunnel (nav) parapet de navă, copastie

gun potential (fiz, el) tensiune de acceleraţie

gunshot (met, mil) alice

gun tube (mil, OM) țeavă de tun

gun (turning) lathe (mas-un) strung pentru tevi lungi (şi de tun)

gunwale (nav) parapet de navă, copastie, bord

gun welding machine (met, mas-un) maşină de sudat cu pistolet

gurgitation (fiz, hidr) bolboroseală, clocotire (a unui lichid)

gorgle (fiz, hidr) a bolborosi, bolborosit (al unui lichid)

gush (hidr) a țaşñi, a izbucni; a împroşca (cu lichid); şuvoi, torent, jet

gushing (hidr) tâşnitură, şuvoi, torent; care tâşnește / se revarsă, debordant, revărsat

guss concrete (constr) beton turnat

gusset (met) tablă de dublură; $(\mathrm{OM})$ guseu; clin, baghetă, îmbinare (cu guseu)

gusset plate (OM) guseu; (nav) guseu orizontal, de gurnă 
gustation (alim) degustare gut (alim) a scoate intestinele, intestin guts (alim) măruntaie, organe interne gutta, $(p l)$ guttae (fiz, chim) picătură gutta-percha gutapercă

gutter (ind chim, met) preaplin, deversor, jgheab de turnare, locaş de bavură; (constr) jgheab de acoperiş, canal de scurgere, rigolă, uluc, streaşină; $(\mathrm{OM})$ canelură, şanț, jgheab; margine a paginii; a riftui, a cresta, a canela

gutter collar / stirrup (constr) brățară de burlan guy tip, individ; ghidaj, funie de ancorare; (nav) braț de bigă, sart, otgon, parâmă; a fixa cu parâme; (mec, constr) tirant, ancoră

guy anchor (mec, constr) ancoră (a tirantului) guy attachment (nav) fixare a cablului de ancorare; $(\mathrm{el}, \mathrm{mec})$ consolă de ancorare

guy clamp (OM) bornă / clemă / scoabă de susținere; (el) colier de ancorare / de prindere guying (mec) ncorare

guy rope $(\mathrm{OM}, \mathrm{mec})$ tirant, ancoră, cablu de ancorare

guy wire (OM) sârmă de ancorare / de rigidizare gymbals (OM, mas) suspensie la cardan gymnasium, $(p l)$ gymnasia (edu) sală de gimnastică / de sport, liceu

gyn $(\mathrm{OM})$ vinci manual, tripod

gypseous, gypsous ghipsos, ca ghipsul / ipsosul gyps / gypsum (minrl) selenit, g(h)ips, ipsos gypsy (nav, OM) tambur al vinciului de ancoră gyrate (mec) a (se) învârti (şi în spirală), a merge în cerc, a pivota, a avea o mişcare giratorie, a gira, a se roti

gyrating rotativ, circulant, cu mişcare de girație gyrating crusher (constr, ind chim) concasor girator

gyrating mass (mec) masă în rotație / cu mişcare giratorie

gyrating vanner $(\mathrm{mec})$ masă de girație

gyration (mec) mişcare circulară / de rotație / giratorie, giratie, rotație, rotire

gyration moment $(\mathrm{mec})$ moment de girație

gyrator (OM, mas) girator, mecanism de rotire

gyratory (mec) giratoriu

gyratory (cone) crusher / breaker (constr, ind chim) concasor giratoriu / rotativ conic

gyratory fixed-spindle crusher (constr, ind chim) concasor rotativ, cu valturi verticale fixe

gyratory screen / sifter (mas, agr, alim) sită / ciur cu mişcare giroscopică / vibratorie

gyro bearing $(\mathrm{OM}, \mathrm{T})$ determinare / orientare giroscopică a direcției / a unui lagăr

gyro-compass (metr, nav) busolă giroscopică, compas marinăresc

gyro frequency (metr, mec) frecvență de rotație gyrometer (metr, mec) girometru, indicator de viteză de rotație

gyropilot (nav) pilot automat / giroscopic

gyroscope (mas) giroscop

gyroscope control (autom, mas) conducere / comandă giroscopică

gyroscopic giroscopic

gyro(-)stabilizer (mas, mec) giroscop; (nav) stabilizator giroscopic

gyrostatic effect (mec) efect girostatic, acțiune giroscopică

gyrostatic thermometer (metr, termo) termometru-praştie / care se roteşte în aer 


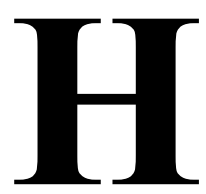

h (Planck's constant) (metr, fiz), constanta lui Plank: $\mathrm{h} \cong 6,62606896 \cdot 10^{-34} \mathrm{~J} \mathrm{~s}$

habile abil, îndemânatic, iscusit; isteț, deştept; capabil, competent

habilitate (ec) a furniza capital rulant, a finanța; a (se) califica (pt. un post); a înzestra

habilitate for a califica pentru, a îndreptăți (la un titlu)

habilitation (edu, univ) calificare superioară

habilitative care conferă o calificare superioară

habit obicei, deprindere, obişnuință; purtare, conduită, comportare; mentalitate; aspect exterior, fizic; specific, particularitate, (trăsătură) caracteristică; be in the $\sim$ of a avea obiceiul de a

habitability caracter locuibil (d. locuințe)

habitable locuibil

habitant locuitor

habitat (mediu) habitat, areal, arie de răspândire

habitation locuire; folosire pentru locuit; reşedinţă; aşezare

habit-forming care duce la deprinderi, care formează deprinderi; formativ

habit of mind mentalitate, mod de gândire, structură psihică

habitual uzual, obişnuit, comun, curent; deprins

habitually $(a d v)$ de obicei, (în mod) obişnuit, (în mod) curent

habitualness caracter obișnuit / frecvent / repetat; obişnuință, deprindere, obicei

habituate to a (se) obişnui, a (se) deprinde, a (se) învăța cu / să

habituation (to) obişnuiță (faţă de), obişnuire, deprindere, acomodare la / cu

habitude obişnuinţă, obicei, deprindere; particularitate; psihologie; mentalitate; comportare, fel de a fi; constituție fizică

habitudinal obişnuit, (ținând de) obişnuință, făcut din obișnuință

habitus constituție, fizic; tip, structură; trup; alcătuire; deprindere, comportament (tipic); mentalitate; capacitate mintală

hachure haşură, haşurare; a haşura

hachured haşurat (în desen tehnic)

hachuring haşurare, care haşurează (în desen tehnic) hack (agr) săpăligă, sapă, târnăcop; (TH) tăietură, crestătură, ştirbitură, daltă; a (se) uza, a (se) toci, a strica, a cresta, a ştirbi, a tăia cu toporul, a rupe, a desprinde (aşchii), a ciopli (piatra), a toca, a ciopârți; uzat, ros, tocit; (amer) taxi, automobil, a conduce un taxi, a fi şofer de taxi; a exploata, a pune la muncă grea; a se banaliza

hacker târnăcop, topor (şi de piatră); muncitor cu târnăcopul / cu toporul; (inf) persoană care intră fără permisiune într-un program / calculator

hack file pilă-cuțit

hack hammer teslă

hack iron târnăcop, daltă

hack knife (el, mas-un) cuțit pentru tăiat cabluri hackle a tăia, a ciopărți; (fig) a poci, a strica, a stâlci

hackneyed uzat, tocit, ros; (fig) banalizat

hack-saw (mas-un) ferăstrău coadă-de-vulpe / cu coardă; (met) ferăstrău de mână pentru metale / pentru tăiere la rece a metalelor, bomfaier

hack-saw blade (mas-un) pânză de ferăstrău pentru metale

hack-saw(ing) machine (mas-un) ferăstrău mecanic pentru metale, cu mişcare alternativă de translație

hack upon a roade, a uza, a toci, a strica

hackwork muncă monotonă / neinteresantă

hade unghi de înclinație (la teren, zăcământ etc.); a se înclina, a avea înclinație

haematite (met, minrl) hematit

haematoma (anat, med) hematom

haemorrhage (anat, med) hemoragie

Hafnium (Hf) (chim) hafniu

haft $(\mathrm{OM})$ mâner de unealtă, coadă; a pune mâner hag (geogr, constr) (teren) mlăştinos; teren; excavare / săpătură într-un zăcământ de turbă

haggle tocmeală

hail grindină; a bate ploaia / grindina; (nav) a semnaliza, semnalizare; apel (telefonic)

hail from a fi originar din, a veni de la / din; a fi născut la / în

hailstone grindină

hailstorm ploaie cu grindină

hair (fir de) păr; păr de animal, blană, puf; a curăța de păr

hair-breadth grosime de un fir de păr

hair-crack (met) fisură fină

hair crackings (materiale) fisuri fine / capilare

haircross încrucişare de fire, reticul (d. materiale fibroase, lanțuri moleculare etc.)

hairiness pilozitate

hair-hygrometer (metr) higrometru cu fir de păr hairlike ca părul subțire; ca un fir de păr 
hairline (fiz) reticul; (metr) fir de vizare (la instrumente de măsurare; (c) (linie) foarte subțire / fină, liniuță

hairline crack (met) crăpătură fină / capilară, fisură subțire şi lungă

hairline distinction distincție / diferențiere fină

hairpin agrafă de păr; (constr) (drum) cotit / șerpuit; (d. o cotitură) brusc, periculos

hairpin bend (auto) curbă periculoasă / în ac de păr

hairpin tube (metr, hidr) tub în formă de $U$

hairpin tuning bar (fiz, muz) bară de acord în formă de $\mathrm{U}$, diapazon

hair's breadth (metr) o unitate de măsură informală pentru lungime: 1 hair's breadth $=100 \mu \mathrm{m}$

hair shaped filiform, subțire ca firul de păr

hair sieve (alim, ind chim) sită fină (şi din păr)

hair space spațiu foarte mic, ca firul de păr

hairspring stud tong plier (metr) cleşte pentru diametre foarte fine

hairsplitting despicare a firului în patru, chițbuş(ărie); care despică firul în patru; prea exagerat, prea subtil

hairstroke linie foarte subțire / fină

hairy din / de păr

halation (fiz) voalare; halo (d. imagini etc.)

halbe (metr) unitate de măsură pentru capacitate (în industria berii) 1 halbe $\cong 0,51$

half jumătate, semi-, doime; (edu) semestru (de şcoală); (jur) parte contractuală; a face jumătatejumătate; (adj) (pe) jumătate, parțial, incomplet; $(a d v)$ (pe) jumătate, pe din două

half-adjust (mat, inf) a rotunji ultima cifră de la un număr zecimal în plus sau în minus, funcție de valoarea cifrei (de exemplu, 3,534 devine $3,53)$

half-and-half incomplet, parțial, insuficient; nu prea mare, moderat; în părți egale, jumătatejumătate; $(a d v)$ jumătate-jumătate, pe din două; (alim) băuturi amestecate

half-and-half solder (met) aliaj de lipit $\mathrm{Pb}+\mathrm{Sn}$, în proporții egale

half-automatic (autom) semiautomat

half baked (alim) pe jumătate crud, rămas necopt; făcut numai pe jumătate; neterminat; (fig) nepus la punct; imatur, nematurizat

half beam $(\mathrm{OM}, \mathrm{mec})$ semigrindă

half-bearing $(\mathrm{OM}, \mathrm{T})$ semilagăr, reazem de arbore în formă de semicerc, lagăr deschis / de $180^{\circ}$

half-black semiprelucrat

half-calmed steel (met) oțel semi-calmat

half cell (chim) electrod; (el) electrod de sticlă (la $\mathrm{pH}$-metre)

half-closed $(\mathrm{OM})$ întredeschis half-compression cam (termo, OM) camă de decompresie

half-cooling time (met) timp de semirăcire, durată de înjumătățire a temperaturii de răcire

half-covered joint (OM) îmbinare semiacoperită

half-countersunk small rivet $(\mathrm{OM})$ nit cu cap semiînecat, mic

half-crossed belt $(\mathrm{OM})$ curea semiîncrucișată

half cycle (termo, OM) jumătate de ciclu (de solicitare, termic etc.)

half-dog screw point (OM) vârf de şurub, cu cap bombat

half-done (alim) pe jumătate crud, nefiert, nefript, nefiert / nefript bine

half face profil

half fare (cf) tarif redus, jumătate de bilet

half-finished good / material / product (ind) semifabricat(e)

half-fused (met) semi-aglomerat, netopit complet

half-gas firing (met, termo) focar de semi-gaz (la cuptoare)

half-groove (met, OM) falt, îmbinare cu falt

half-hard (met) semidur

half hourly $(a d v)$ cu durata de o jumătate de oră; $(a d v)$ din jumătate în jumătate de oră

half-joint $(\mathrm{OM}$, met) semi-sudură, una din cusături la sudarea pe ambele fete ale pieselor

half lap (OM, met, plast) îmbinare / asamblare parțial suprapusă

half life (fiz) timp / perioadă de înjumătățire (la materiale radioactive)

half-light semiîntuneric, penumbră; înserare

half-loop (autom) semibuclă

half-measures măsuri de compromis, politică de compromis / inconsecvență

half-normal bend (OM, hidr) cot cu unghi de $135^{\circ}$

half nut $(\mathrm{OM})$ contrapiuliță

half of pattern (met, plast) jumătate a modelului / a matriței

half-open întredeschis

half-part moulding box (met) jumătate a ramei de formare

half-period (fiz) semiperioadă

half plane (geom) semiplan

half pound (metr) jumătate de livră / funt, (aproximativ) sfert, litră

half-price pret redus

half-quad jumătate de cuadrat (în reprezentări grafice)

half-roasted lumps of iron ore (met) minereu de fier semi-prăjit

half round semirotund 
half-round blunt scraper (mas-un) răzuitor cu car în arc de cerc

half-round chisel (mas-un) daltă semirotundă

half-round file (mas-un) pilă semirotundă

half-round hammer (mas-un) ciocan cu cap bombat / semirotund

half-round head nib bolt $(\mathrm{OM})$ bolț / şurub cu cap semirotund şi nas

half-round iron (met) profil semirotund

half-round nose plier (mas-un) cleşte cu cioc semirotund

half-round reamer (mas-un) alezor cu cap sferic

half-round tread $(\mathrm{OM})$ bandă / curea de rulare cu profil semirotund

half-shade (fiz) penumbră

half-side milling cutter-(straight) line (masun) freză-disc cu două suprafețe de tăiere / de aşchiere

half speed (mas) cu viteză redusă

half storey (constr) mansardă

half-term (edu) vacanță la jumătatea semestrului / trimestrului

half thick file (mas-un) pilă grea cu o față convexă şi celelalte trei fețe plate

half-tide (nav) perioadă de echilibru dintre flux şi reflux

half time (sport) pauză între reprize; (ec) jumătate de normă, program redus; şomaj parțial

half time life (fiz) timp de înjumătăţire (d. elemente radioactive)

half-timer, half-time worker (ec) şomer parțial; muncitor cu jumătate de normă

half tin (met) aliaj de lipit 50\% $\mathrm{Sn}+50 \% \mathrm{~Pb}$

half title titlu prescurtat

half-track (auto, mil) autoblindat cu roți şi şenile

half-truss (constr) semifermă

half truth afirmație care ascunde o parte din adevăr, lucru spus doar pe jumătate

half-turn socket (mas-un) dispozitiv de scos scule (dacă s-au rupt / blocat în alezaj etc.), sfredel cu lingură

half versine function, half-versed function, haversine function (mat) semiversus, funcția $\operatorname{hav}(\mathrm{x})=\operatorname{vers}(\mathrm{x}) / 2=[1-\cos (\mathrm{x})] / 2$

have-wave (fiz) semiundă

half-wave length (fiz) jumătate de lungime de undă

half-way $(a d v)$ la jumătatea drumului, la jumătate de drum; partial, pe jumătate, oarecum; (adj) situat la jumătatea drumului, parțial, incomplet

half-way unit instalație semiindustrială

half-width (fiz) semilărgime; (mat) jumătate a intervalului de încredere centrat, semiamplitudine

half-word lucru spus pe jumătate, aluzie, insinuare half-wrought material (met) semifabricat, tras half year jumătate de an, semestru

half-yearly $(a d j)$ semestrial, bianual, care are loc de două ori pe an; $(a d v)$ semestrial, de două ori pe an

halide (chim) halogenură, haloid

halide lamp (fiz) lampă haloidă / cu halogeni; (fiz, metr) detector de scurgeri de flacără

halite (chim) sare gemă, halit $(\mathrm{NaCl})$

hall (constr) coridor, culoar; hală (de mărfuri), hol, sală (şi de tribunal), salon, amfiteatru, auditoriu; edificiu public, instituție publică; cămin studențesc

halliard (nav) fungă

hall-mark marcaj, marcă (pt. pietre prețioase); amprentă, semn distinctiv; particularitate, însuşire caracteristică; poanson de titlu (d. metale prețioase), marcă / semn de control; a marca (pietre prețioase), a-şi pune amprenta pe, a marca

hallway (amer) (constr) coridor, culoar, vestibul, antreu, hol, gang

halo, $p l$ halo(e)s (fiz) nimb, aureolă, halo, a face o aureolă / un halo în jurul

halocarbon (chim) compus cu atomi de halogen si de carbon

halogen (chim) halogen

halogenous (chim) halogen

haloid (chim) haloid, halogenură

halt oprire; (cf) haltă; (autom) a întrerupe (din funcționare, din mers), a (se) opri; a înceta să se mişte; a şchiopăta, a merge prost, a nu merge prea bine; a se clătina; a ezita, a şovăi, a oscila; a se bâlbâi; a merge clătinându-se, cu nesiguranță; (d. un argument) a şchiopăta

halter opritoare, piedică; persoană care opreşte

halting care şchioapătă; şchiop; care se împleticeşte; şovăitor, şovăielnic; (d. vorbire) împleticit, greoi

halting point (cf, transp) punct de oprire

halt instruction (inf) instrucțiune de oprire / de întrerupere (a unui program)

halva(h) (alim) halva

halve (met, OM) a îmbina / a lega prin eclise; (mat) a înjumătăți, a împărți în două; a reduce la jumătate; a tăia / despărți în două

halved belt $(\mathrm{OM})$ curea semiîncrucişată

halyard (nav) fungă

ham (alim) şuncă, jambon; (fig) fraier, ageamiu

hammer ciocan, ciocănaş, baros; percutor; (met) a ştemui, a forja, a ciocăni, a lovi, a bate (şi cu ciocanul), a fasona (un metal), a distruge (şi prin batere); (ec) a declara falit, a reduce / coborî (prețuri)

hammer anvil (met, mas-un) nicovală de forjă 
hammer at a lovi la / în, a ciocăni la / în; a pistona, a asalta (pe cineva)

hammer band $(\mathrm{OM}, \mathrm{mec})$ piesă metalică de protecție / de apărare (contra loviturilor)

hammer blow (mec, hidr) lovitură (ca) de ciocan, şoc, impact

hammer break / interrupter (el) întrerupător vibrant / cu ciocan

hammer breaker (constr, met) ciocan pneumatic pentru spart roci tari / căptuşeli uzate (la cuptoare etc.)

hammer-cog (met) a preforja

hammer crusher (mas, constr) concasor $\mathrm{cu}$ ciocane

hammer down a netezi (prin lovire) (şi asperităţi)

hammer-dressed (met) modelat / lucrat cu ciocanul

hammer drill (mas-un, constr, met) perforator, picamăr, ciocan pneumatic

hammer drill stopper (mas-un) perforator (şi pentru minereuri)

hammered (met) forjat

hammered glass (ind chim) sticlă mată, geam mat

hammered into the surface (met) forjat la suprafață

hammered resistance welding (met) sudare prin forjare cu încălzire prin contact

hammered steel (met) oțel forjat

hammerer (met) forjor

hammer even (met) a netezi prin ciocănire

hammer face (met) suprafața (activă) a unui ciocan (şi de forjă)

hammer forging (met) forjare liberă

hammer frame (met, OM) batiu al ciocanului mecanic (şi la forjă)

hammer (grinding) mill (alim, ind chim) moară cu ciocane / cu ciocănele

hammer guides (met, OM) ghidaje de ciocan (şi la forjă)

hammer head $(\mathrm{OM})$ cap de ciocan; (met, $\mathrm{OM})$ partea activă a forjei

hammer handle $(\mathrm{OM})$ tijă / coadă a ciocanului (de mână)

hammer-harden (met) a ecruisa prin forjare / prin lovire, a ciocăni, a bate la rece

hammer-hardened (met) ecruisat prin forjare / prin batere

hammer-hardened iron (met) oțel forjat la rece

hammer hardening (met) durcisare, ecruisare, forjare la rece

hammer head $(\mathrm{OM})$ piston / cap al perforatorului; (met) berbec al ciocanului, cap-ciocan (la forjă) hammer-head crane (transp, mas) macara-ciocan hammering ciocănire, batere cu ciocanul; (hidr) şoc hidraulic, lovitură de berbec; (met) forjare liberă

hammering press (met) presă de forjat / cu şoc hammering spanner $(\mathrm{OM})$ cheie de strâns prin lovire

hammering test (met) încercare de lărgire / de extindere / de lățire / de forjare

hammer into a bate în, a înfige în

hammerlock mooring / moor (constr, OM) ancorare zăvorâtă / asigurată

hammer man (met) forjor

hammer mill (met) valt de forjare; (alim, chim) moară cu ciocănele

hammer of a pile driver (constr, met) berbec

hammer out (met) a forja

hammer peen $(\mathrm{OM})$ pană a ciocanului

hammer pick sapă, târnăcop

hammer piston piston-berbec (la ciocane pneumatice)

hammer press (mas-un) presă cu ciocan / cu berbec

hammer roll (constr, ind chim) concasor cu ciocane

hammer scale (met) zgură / țunder de forjă

hammer shaft (OM) tijă a ciocanului mecanic

hammer shears (mas-un) foarfece de tăiat tablă

hammer shop (met) atelier de forjă

hammer sledge $(\mathrm{OM})$ glisieră de / pentru berbec

hammersmith (met) forjor

hammer stud (OM, metr) ax de fixare a unui ciocănel

hammerswing mill (alim, ind chim) moară cu ciocane / cu ciocănele

hammer test (metr) încercare la şoc

hammer together a fixa / prinde laolaltă (prin batere)

hammer top (met) berbecul ciocanului (de forjare) hammer welding (met) sudare prin forjare

hammock hamac; movilă, ridicătură de pământ hammock chair șezlong, scaun de pânză

hamper coş cu capac (de nuiele), coşuleț de alimente; (nav) accesorii grele ale echipamentului naval; a stânjeni, a împiedica; a restrânge, a limita (libertatea de acțiune)

hand (anat) mână, brat; palmă; îndemânare, dibăcie, dexteritate; antrenament, practică; scris, scriere; păstrare, influență; sursă (de informație); proveniență; muncitor; individ, tip, figură, persoană; parte, latură; direcție; mână de ajutor; (fiz, metr) ac (indicator); (OM) săgeată; (nav) marinar, matroz, echipaj; indicator, parte laterală; $(\mathrm{OM})$ ac indicator, arătător, limbă; (ec) 
profit, câştig, beneficiu; conducere, control, autoritate; dirijare; răspundere; cantitate, lot de marfă; avantaj; a înmâna, a preda; a expedia, a trimite; a conduce; a mânui, a manipula, a manevra; (metr) unitate de măsură pentru lungime: 1 hand $=0,1016 \mathrm{~m}$

hand about a da / transmite din mână în mână, a răspândi, a face să circule

hand adjustment (mas) reglare manuală

hand and foot total, complet; cu desăvârşire

hand anvil (met) nicovală de mână

hand auger (mas-un) sfredel-lingură de mână

handbag sac de voiaj; trusă (de medic); geantă, poșetă

hand barker (alim) cojitor manual

hand barrow cărucior; (med) targă, brancardă

hand bellows (met) foale de mână, suflantă de forjă

handbill (ec) reclamă distribuită trecătorilor

hand blower ventilator manual; (met) foale de mână

hand blowpipe $(\mathrm{OM})$ suflantă / ventilator cu actionare manuală

handbook $(\mathrm{TH})$ manual, ghid de utilizare / de pro-iectare, memorator

hand boring $(\mathrm{TH})$ perforare / găurire manuală

handbowl (alim) polonic, lingură mare

handbrake (auto, mas) frână de mână, levier de comandă a frânei (de mână)

hand-brake pawl rod (auto, OM) tijă a clichetului de blocare a frânei de mână

handbreadth, hand breadth un lat de palmă, lătime de o palmă; (metr) 1 handbreadth = $0,0762 \mathrm{~m}$

hand capacitance / capacity effect capacitate a mâinii, efect de capacitate al mâinii

hand cart cărucior cu două roți, roabă

hand centrifuge $(\mathrm{OM})$ centrifugă cu acționare manuală

hand charging (cf, met) încărcare manuală

hand chisel daltă de mână

hand control comandă de mână / manuală

handcraft meserie; muncă manuală; articol de artizanat

hand crusher $(\mathrm{OM}, \mathrm{mec})$ concasor manual

handdolly (mas-un) ştanță

hand draw tong (met) cleşte de tras sârmă

hand dressing (alim) sortare manuală; (met) reglare / ajustare manuală

hand drill (met, mas-un) coarbă, maşină de găurit manuală; sfredel / burghiu de mână

hand drive (mas) acționare manuală

hand-driven chuck (mas-un) mandrină cu strângere manuală hand feed (mas-un) (cu) avans manual

hand-feed drill (mas-un) maşină de găurit cu avans manual al burghiului

hand feed (mas-un) alimentare manuală, avans manual

hand finisher $(\mathrm{TH})$ finisor de mână

hand finishing finisare manuală

hand fire extinguisher stingător (de incendii) manual

hand firing (termo) focar alimentat manual

hand forged (met) forjat manual

handful (cât încape într-o) mână, pumn

hand gear (mas) comandă manuală, mecanism / angrenaj actionat manual

hand glass (opt) lupă cu mâner; (agr) clopot de sticlă (pentru plante)

hand governing (mas, aparate) reglare manuală

handgrip apucare cu mâna, strângere în mână / cu mânal; (OM) mâner

hand hammer $(\mathrm{OM})$ ciocan de mână, baros

hand-held probe (metr) cap de măsurare portabil

handhold, hand-hold $(\mathrm{OM})$ manivelă, manetă, mâner, priză / loc de apucat cu mâna

hand hole orificiu / ochi de observare; (OM) gură de vizitare

hand hollow punch (OM, mas-un) poanson

handicap handicap; dezavantaj; obstacol, piedică; a handicapa, a dezavantaja; a stânjeni, a deranja

handicraft meşteşug; meserie; muncă manuală; artizanat; artă meşteşugărească; îndemânare, artă, pricepere

handicraft article obiect de artizanat

handicraft cooperative cooperativă meşteşugărească / de artizanat

handicraft industry producție meşteşugărească, industrie manuală

handicraftsman meşteşugar, artizan, meseriaş

handily $(a d v)$ cu uşurință, uşor, comod; cu îndemânare / abilitate, abil

hand in a prezenta, a înmâna, a depune, a preda; a remite, a da, a înainta

handiness maniabilitate, manevrabilitate; comoditate, uşurință; îndemânare, dexteritate

handing over predare

hand input (inf) introducere manuală a datelor

handiwork muncă manuală / artizanală, lucru de mână, produs meşteşugăresc

hand jack $(\mathrm{OM})$ cric / vinci de mână

hand ladle (met) lingură / oală de mână (pentru turnarea metalelor sau luarea probelor)

hand lance (met) lance / conductă de suflat aer / abur etc., de dimensiuni mici, manipulată manual 
handlamp lanternă / felinar de mână; (el) lampă portabilă

hand lapping $(\mathrm{TH}, \mathrm{OM})$ lipire manuală

hand lathe (mas-un) strung cu comandă manuală

handle ajutor; $(\mathrm{OM})$ manivelă, levier, manetă, toartă, ureche, mâner, coadă, mişcare, manipulare, buton; a mânui, a manipula, a transporta (manual), a conduce, a dirija, a comanda, a manevra, a manipula, a face să funcționeze, a prelucra, a trata, a administra; a pune mâna pe, a lua în mână; a pipăi, a atinge cu mâna; (ec) a vinde; prilej, ocazie (favorabilă); pretext convenabil; a trata, a discuta, a rezolva (o problemă)

handle bar $(\mathrm{OM})$ bară de ghidare / de comandă a direcției, ghidon (de bicicletă / de motocicletă)

handler agent, intermediar; mânuitor

hand lever $(\mathrm{OM})$ nivelă, manetă, cocoş, pârghie basculantă manuală

hand-lever shifter $(\mathrm{OM})$ comutator manual cu pârghie

hand-lever squeezing (mas-un) presă cu pârghie de mână

handling manipulare, transport manual; (av, transp) complex de servicii oferite pasagerilor şi avioanelor în timpul staționării pe aeroporturi; $(\mathrm{TH})$ tratare, tratament, prelucrare manuală; (auto) manevrare

handling ability $(\mathrm{TH})$ proprietăți tehnologice, posibilitate de manipulare

handling break ( $\mathrm{TH}$, transp) deteriorare / rupere (şi a muchiilor) la manipulare / din cauza manipulării / transportării

handling bridge (transp, ind) pod de încărcaredescărcare

handling holes (OM, met) găuri / orificii / urechi de ridicare (la matrițe, piese grele etc.)

handling qualities calități controlabile, controlabilitate a unor calități / parametri

handling device (OM) dispozitiv de manipulare, manetă

handling facilities (mas) instalație de manipulare handling failure ( $\mathrm{TH}$, metr) eroare / incident cauzat $(\breve{a})$ de prelucrare / manipulare defectuoasă

handling strength (plast) rezistență la manipulare

handlist listă bibliografică

hand loaded scow (met) screper-ladă, cu încărcare manuală

hand luggage bagaj de mână

hand-made lucrat manual / de mână; artizanal, meșteșugăresc

hand milling machine (mas-un) maşină de frezat, cu avans manual

hand mould (met, plast) matrită manuală hand-moulded (met) format manual

hand-moulder (met) formator manual

hand moulding (met) prelucrare / fasonare / formare manuală

hand-moulding shop / work (met) (atelier de) formare manuală (la turnătorii)

hand mucking (cf, transp) încărcare manuală a vagoanelor / a vagonetelor

hand nut $(\mathrm{OM})$ piuliță moletată / striată

hand of helix (OM) sens al elicei (la roți dințate cu dinți înclinați, la filete, la canalele sculelor)

hand of rotation (mec) sens de rotatie

hand of a tool (mas-un) caracteristică a cuțitului (pe stânga sau pe dreapta)

hand-operated / -actuated (mas) acționat manual, cu acționare manuală

hand-operated crane (mas) macara manuală

hand operation acționare / comandă manuală

hand out a remite; a elibera; a înmâna; a da; a ajuta la coborâre

handout dar, cadou; comunicat de presă / oficial; rezumat, conspect (distribuit auditorilor de un conferențiar)

hand over a preda; a transmite; a da, a remite; a ceda, a lăsa din mână

hand over fist $(a d v)$ până peste cap; uşor şi repede, expeditiv

hand over hand $(a d v)$ repede, expeditiv; conştiincios; până peste cap

hand peeler (alim, met) cojit manual

handpick a selecționa / alege / culege manual / cu mâna / cu grijă

hand-picked (alim) ales / sortat / selectionat cu mâna / manual / cu grijă; de soi, de elită

hand picking sortare manuală

hand plane rindea de mână

hand post (auto) indicator rutier, stâlp indicator

hand power manual, cu acționare manuală

hand-power crane truck $(\mathrm{OM})$ cărucior de macara cu acționare manuală

hand press $(\mathrm{OM}, \mathrm{alim})$ teasc, presă de mână

hand pump pompă (hidr) de mână / manuală

hand rail (constr) rampă, bară, balustradă, parapet

hand ramming (met) bătătorire / îndesare manuală (a formei de turnare)

hand reamer alezor de mână

hand regulation reglare / comandă manuală

hand-reset (autom) cu repozitionare manuală

hand rest (mas-un) sanie manuală, suport pentru mână la polizor

hand rounds (met) oțel rotund, forjat manual

hand safety guard (OM) dispozitiv / apărătoare pentru protejarea mâinilor 
hand saw (mas-un) ferăstrău de mână / coadăde-vulpe

hand-saw file pilă pentru ferăstrău / triunghiulară, cu vârf teşit

hand-saw pad (mas-un) ferăstrău coadă-devulpe

hand-setting (met) îndreptare manuală

handshake strângere de mână; (c) acțiunea de recunoaştere a două computere care pot comunica

hand shank ladle (met) oală de turnare, acționată manual

hand shears foarfece de tinichigerie / de mână

hand shield / screen (met) ecran / mască de protecție, ținută în mână (şi la sudură)

hand shift comandă manuală; (nav) guvernare manuală

handshifting comandă manuală

hand shovel lopată de mână

hand slide rest (mas-un) sanie manuală / acționată manual

hand sorting (alim) sortare manuală

hand-sorting table (alim) masă de / pentru sortare manuală

hand specimen (met) probă de minereu, luată manual

handspike (OM) pârghie

hand starter (auto) demarare / starter manual / de mână

hand stocking (alim, met) dozare / încărcare manuală

hand tap (mas-un) tarod pentru filetare manuală / de mână

hand teeming (met) turnare manuală a lingourilor

hand throttle (auto, mas) accelerator / accelerație de mână

hand-tilting / -tipping device (OM) dispozitiv manual de basculare

hand tool sculă manuală, cuțit de strung pentru prelucrat manual piese din lemn

hand tool rest $(\mathrm{OM}$, mas-un) suport pentru mână (la polizor, strung etc.)

hand towel prosop (mic)

hand traversing gear (mas-un) mecanism de avans manual

hand truck $(\mathrm{OM}$, transp) cărucior acționat manual

hand turnover moulding machine (met) mașină manuală de formare, cu placă rabatabilă / basculantă

hand vice $(\mathrm{OM})$ menghină de mână

hand walking beam (OM) pârghie basculantă manuală handwelding (met, TH) sudare manuală (şi cu arc electric)

handwelding transformer (el, met) transformator pentru sudare manuală, cu arc electric

hand wheel (auto) volan (de direcție); (hidr, $\mathrm{OM}$ ) roată de mână / de manevră; (nav) cârmă de mână, timonă

handwork lucru de mână

handwriting expert (expert) grafolog

handwritten scris de mână / cu mâna; (jur) olograf

handy comod, uşor de mânuit; la îndemână, apropiat; disponibil; (aflat la locul) potrivit; îndemânatic, priceput, abil

handy device $(\mathrm{OM})$ dispozitiv de prindere

handyman om priceput la toate

hang linie, a închide telefonul; (TH) a atârna, a agăța, a suspenda, a prinde, a face să atârne, a lăsa în jos; a pune în cui, a prinde / pune pe perete, a fi atârnat / suspendat / agățat / spânzurat; a fi înclinat, a oscila, a pendula; a fi în aşteptare / suspensie, a rămâne în aer; (constr, $\mathrm{OM}$ ) a pune (o fereastră etc.); a lăsa în jos (urechile, capul etc.); a pluti; a fi nesigur; a rămâne, a stărui, a persista; a zăbovi, a întârzia; a şovăi, a ezita; a fi expus, a se găsi; (jur) a fi în disensiune, a nu cădea de acord, a nu ajunge la o înțelegere; a spânzura; poziție, aşezare; linie; tinută, conduită; sens, înteles, esență; punct nevralgic; înclinare, pantă; atârnare în jos; tendință; sens, rost; get the $\sim$ of a prinde sensul; $\sim$ a leg a tărăgăna

hang about / around a da târcoale; a vagabonda hangar (constr) hangar, adăpost, şopron

hang back a da înapoi, a bate în retragere; a şovăi, a ezita

hang behind a rămâne în urmă; a fi înclinat, a fi în pantă (d. un drum); a nu se desface, a nu se disloca (d. lucruri, piese etc.)

hang down a atârna, a apleca, a se înclina (în jos)

hanged platform platformă suspendată

hanger umeras (de haine); cuier; (el) suport / placă de sticlă (la acumulator); (OM) consolă; brățară; etrier de suspendare; agățător; agățătoare; cârlig (de agățare); inel de suspensie, ureche de prindere, bară de suspensie / de ridicare; traversă laterală

hanger bearing $(O M, T)$ lagăr suspendat / în consolă

hanger bracket (constr) schelă / capră suspendată

hanger screw point $(\mathrm{OM})$ capăt al şurubului cu ochi de suspendare

hangfire explozie întârziată 
hanging suspendare; atârnare; agățare; care atârnă; atârnat în afară; pantă; înclinație; suspendat; în pantă; înclinat (în jos); de atârnat; de care se poate agăța / atârna ceva

hanging beam (constr) grindă suspendată; traversă de legătură (la o structură suspendată)

hanging guard ghidaj / apărătoare $\operatorname{suspendat(\breve {a})}$

hanging gutter jgheab suspendat

hanging room (alim) încăpere de uscare

hanging scaffold (constr) schelă în consolă

hanging stage (constr) eşafodaj / schelă suspen$\operatorname{dat}(\breve{a})$

hanging tie (cf) şină suspendată

hang off a nu fi dispus să înainteze, a rămâne în aşteptare

hang on a se agăța de; a se ține strâns de; a adera; a se ține (bine) de; (fig) a depinde de; a fi dependent / condiționat de; a rămâne / sta în aşteptare; a persevera, a nu se da bătut (cu una, cu două); a insista; a nu da drumul la; a se crampona de

hang on / upon a se sprijini pe, a se agăța de, a se crampona de, a trage greu în cumpănă

hang out a atârna în afară; a-și pierde timpul; a arbora, a desfăşura (un steag); a întinde rufe etc.

hangover time (autom) timp de postacțiune / de blocare

hangtag (ec) (amer) etichetă prinsă de articol / de produs

hang together a sta / se ține laolaltă; a rămâne uniți / nedespărțiți; a fi solidari; a nu se despărți; a se îmbina; (fig) a avea coerență / logică

hang up a atârna; a agăța (sus); (inf) oprire neprevăzută (a calculatorului); a (se) opri; a închide telefonul; a pune receptorul în furcă; a suspenda; a amâna; a ține lăsa în suspensie; a reține; a întârzia

hang up in a loop $(c$, inf) a rula în buclă (şi fără a putea să iasă din buclă)

hang with a tapisa cu (hârtie etc.); a împodobi (cu perdele etc.)

hank (textile) scul; jurubiță; împletitură, nod (şi d. fibre în compozite); coc; (metr) unitate de măsură pentru lungime (pt. fire, fibre): 1 hank of cotton yarn $\sim 768 \mathrm{~m}, 1$ hank of wool yarn $512 \mathrm{~m}$; 1 hank of woolen yarn (US) $\sim 1463 \mathrm{~m}$

hanse breaslă, corporație; taxă de primire în breaslă / corporație

haphazard ( $a d j)$ întâmplător; ocazional; petrecut din întâmplare

haphzardly $(a d v)$ la / din întâmplare; aleatoriu, întâmplător

haplessly $(a d v)$ dintr-o / printr-o întâmplare nefericită; din păcate happen a se întâmpla; a se petrece; a se produce, a avea loc; a surveni; a se întâmpla între timp; a se nimeri (să fie)

happening întâmplare; eveniment; accident; eveniment imprevizibil

happen on / upon a da peste; a se întâlni cu; a nimeri (din întâmplare)

happen to a i se întâmpla; a trece prin; a deveni happy fericit; încântat; vesel; optimist

happy about bucuros; încântat; satisfăcut de

harbour (nav) port; bazin / radă portuar(ă); adăpost; loc adăpostit; a (se) adăposti; a ocroti; a proteja; a conține; a cuprinde; a trăi; a locui; a sta

harbour dues taxe portuare

harbour master (nav) căpitan / comandant al portului

harbour of departure port de plecare

hard dur; tare (la pipăit, la tăiat etc.); ferm; rigid; greu; (fiz) solid, compact, rezistent, penetrant; puternic; contrastant (imagine); (met) călit, oțelit; (d. sunete) aspru, tare; strident; discordant; (ec) (d. prețuri) inaccesibil; ridicat; mare; (alim) (d. băuturi) alcoolic; tare; $(a d v)$ (cu / din) greu; cu dificultate, cu efort, din toate puterile; imediat, curând, îndeaproape; dificil; dificil de înțeles; greu (de făcut etc.); aspru; fără îngăduință; sever; crud; dureros; harnic, destoinic; obositor, greu; aspru; crud, nemilos; încăpățânat, rezistent (la oboseală); neplăcut; dur (d. consoane)

hard aluminium (met) aluminiu dur

hard alloy (met) aliaj dur

hard-and-fast strict; rigid; sever; fix; ferm; de neschimbat

hard-back carte cartonată; exemplar / volum cartonat

hard-backed cartonat (d. carte)

hard bake (alim) pralină, caramelă cu lapte şi suc de lămâie

hard bearing $(\mathrm{OM})$ lagăr dur / rigid, reazem rigid hard bearing balancing machine (mas, metr) maşină de echilibrat, cu lagăre rigide

hardboard placă dură (de fibre, de compozit) / aglomerată / fibrolemnoasă

hardbrass (met) alamă dură

hard brazing (met, OM) lipire tare / cu alamă / cu aliaj cu temperatură (mai) ridicată de topire hard caoutchouc (plast) ebonită

hard cash (ec) numerar; bani lichizi; monede metalice

hard-chromium plating (met) cromare dură

hard clad silica fibers (ind chim, opt) fibre optice (din oxid de siliciu) acoperite cu plastic dur 
hard coal (termo) antracit, cărbune sărac în gaze hard core nucleu solid; central, principal, care constituie miezul; absolut, fără rezerve; total; (met) cu miez dur / călit

hard court teren (de tenis) cu zgură

hard cover carte cartonată; copertă cartonată

hard-covered cartonat (d. cărți), cu coperți tari

hard currency (ec) monedă / valută-forte

hard-cutting alloy (met) aliaj metalic dur folosit la scule aşchietoare

hard disk (c, inf) disc (magnetic dur / fix / Winchester) (pentru stocarea informațiilor)

hard disk drive (HDD) (inf, c) unitate de disc

hard drawn (met) tras la rece

hard drawn copper wire (met) sârmă trasă de cupru, ecruisată

hard drawn wire (met) sârmă trasă la rece / trefilată

hard-earned câştigat cu greu / cu efort(uri)

harden a (se) întări; a (se) solidifica, a (se) face tare; (met) a căli; a durifica; a (se) oțeli; a consolida

hardenability (met) călibilitate; (plast) capacitate de întărire / de solidificare, capacitate de termorigidizare (d. materiale plastice termorigide)

hardenability test (met, metr) test / probă de călibilitate

hardened (met, ind chim) călit, durificat; (plast) întărit, rigid; consolidat

hardened case (met) cutie / incintă pentru călire

hardened cast iron (met) fontă călită

hardened oil (met, ind chim) ulei pentru tratament termic / pentru călire

hardened point (met) punct / temperatură de călire hardened resin (plast, ind chim) răşină dură / întărită / cu punct înalt de topire; smoală / bitum cu temperatură înaltă de topire

hardened steel (met) oțel călit

hardened steel roller $(\mathrm{OM})$ rolă / cilindru din oțel călit

hardener (plast, chim) agent de întărire; întăritor; agent de reticulare

hardening (constr) priză (la ciment); (met) călire, ecruisare; întărire (şi la materiale plastice şi aliaje neferoase); durificare (şi prin călire); solidificare

hardening accelerator (constr, plast) accelerator de priză / de întărire

hardening agent (met, plast) agent / mediu de călire / de întărire

hardening and heat treatment plant (met) instalație de durificare şi tratamente termice

hardening and tempering (met) (tratament termic de) îmbunătăţire, călire urmată de revenire hardening alloy (met) aliaj durificabil (şi prin călire)

hardening bath (met) baie de călire

hardening capacity (met) călibilitate; (plast) capacitate de întărire / de solidificare, capacitate de termorigidizare (d. materiale plastice termorigide)

hardening compound (met) compus / mediu de călire; (plast) compus de / pentru întărire

hardening constituent (chim) substanță care determină duritatea apei; (met) constituent / mediu de călire

hardening crack (met) fisură / crăpătură de călire hardening crucible (met) creuzet de călire

hardening cycle (met) ciclu de călire; (plast) ciclu de întărire

hardening depth (met) adâncime de călire

hardening flaw (met) crăpătură / fisură de călire

hardening furnace (met) cuptor de călire; (plast) cuptor de întărire

hardening heat (met) căldură necesară pentru călire

hardening in oil (met) călire în ulei

hardening in salt bath (met) călire în baie de săruri

hardening in water (met) călire în apă

hardening layer (met) strat călit / dur / care se durifică

hardening liquid (met) lichid de călire

hardening medium (met) mediu de călire

hardening oil (met) ulei pentru călire

hardening outfit / plant (met) instalație de călire / de durificare

hardening power (met) călibilitate, putere de călire

hardening process (met) proces de călire / de durificare; (plast) proces de întărire / de solidificare

hardening room (met) secție / spațiu / incintă de călire

hardening shop (met) atelier de călire

hardening stock (met) produs călit / durificat

hardening stress (met, mec) tensiune de călire

hardening tank (met) bazin pentru călire

hardening temperature (met) temperatură de călire

hardening time (met) timp de întărire (a cimentului)

hardening through (met) cuvă de călire

harden off a deveni rezistent, a se durifica, a se întări

harden right out (met) a căli complet

harden through (met) a căli în profunzime / (până) în miez 
hard facing (met) încărcare / acoperire prin sudare cu material dur (proces şi rezultat)

hard-facing alloy (met) aliaj dur (şi pt. acoperiri)

hard-facing electrode (e; met) electrod pentru suduri de încărcare rezistente la uzură

hard glass (ind chim) sticlă călită / dură

hard-goods (ec, ind) mărfuri / bunuri de folosință îndelungată

hard-grained (met, plast) macrogranular, cu granulație cristalină mare (d. aliaje metalice)

hard-head (met) urs (la furnal)

hard-headed practic; pragmatic; lucid; insensibil; încăpățânat, inflexibil

hard iron (met) fontă albă (dură)

hard lead (met) plumb dur / tare, aliaj $\mathrm{Pb}-\mathrm{Sb}$ $(1 \ldots 12 \% \mathrm{Sb})$

hard line inflexibilitate; intransigență; intransigent; dogmatic; inflexibil; de mână forte

hard liner intransigent; inflexibil; conservator; (OM, met) acoperie dură, suport dur (şi pentru un cuzinet / un lagăr)

hard liquor (alim) băuturi spirtoase / tari

hardly $(a d v)$ abia (dacă / de), prea puțin, deloc; puțin probabil; tocmai; abia; aspru; cu asprime; rău; crud

hard metal / alloy (met) metal / aliaj dur

hard metal draw die (met, mas-un) filieră pentru aliaje dure

hard money (ec) (amer) mărunțiş; monezi; bani metalici

hardness (mec, materiale) duritate; tărie; rigiditate; rezistență, consistență; soliditate; rigoare, severitate; dificultate

hardness degree (of water) grad de duritate (al apei)

hardness(-drop) tester / gauge (metr, materiale) aparat de încercare a durității; scleroscop, durometru

hardness measuring (met, plast, metr) măsurare a durității

hardness number (metr) cifră de duritate; valoare a durității, grad de duritate (depinde de metoda de măsurare)

hardness penetration (depth) (met) călibilitate; adâncime de călire; grosimea stratului călit

hardness reversal (met) scădere a durității, revenire la o duritate anterioară (de obicei mai redusă)

hardness scale (met, metr, plast) scară pentru / de duritate

hardness test (materiale, metr) test / încercare $\mathrm{a}(1)$ durității; probă de călire

hardness tester (metr, met) aparat de încercare / de măsurare a durității hardness-testing machine (metr, materiale) durometru; maşină / aparat de încercat / măsurat duritatea

hardometer (metr, materiale) scleroscop; aparat pentru determinarea durității

hardpan (constr) strat compact / rigid; (fig) temelie, fundație solidă

hard pewter (met) staniu dur

hard plastic (plast) textolit; țesătură bechelitizată, material plastic dur (termorigid)

hard plating (met) acoperire dură

hard porcelain (ind chim) porțelan tare / dur

hard rubber (plast) ebonită, cauciuc vulcanizat / rigid

hard rubber mixt (plast) amestec de / pentru ebonită

hard rubber mould (plast) matriță pentru vulcanizarea / întărirea ebonitei

hard rubber scraps (plast) deşeuri de ebonită

hards (met) zgură de sudare

hard sell (ec) vânzare agresivă; comert agresiv

hard-set întărit (şi d. materiale plastice termorigide); consolidat; care a făcut priză; fix, rigid; (agr) incubat, clocit (d. ouă)

hard-shell cu coajă / acoperire tare; ferm; rigid, care nu face compromisuri

hard shoulder (auto) bandă suplimentară de circulatie, refugiu

hard soap (chim) săpun de sodiu

hard solder (met) aliaj pentru lipitură dură / tare; brazură; a lipi (tare)

hard soldering (OM, met) lipire tare

hard spelter (met) aliaj pentru lipire tare

hard spring $(\mathrm{OM})$ arc rigid / cu rigiditate mare

hard steel (met) otel dur

hard stock (met) clincher

hard stop (auto) oprire bruscă

hard surfacing (met) încărcare / recondiționare prin sudură (a suprafeței uzate) (după prelucrare și răcire, suprafața se durifică)

hard tissue (plast) textolit; țesătură bachelitizată hard-top (auto, TH) capotă demontabilă rigidă; acoperiş rigid / metalic; automobil decapotabil

hard twist (mec) torsiune / mare, fire (prea) răsucite (la cabluri) (defect)

hard up for lipsit de / fără (bani etc.)

hard upon imediat după; curând după; chiar în urma

hard vacuum (fiz) vid înaintat

hardware (inf) material, elemente componente ale unui calculator, suport pentru soft, hardware; articole de fierărie, obiecte de uz casnic, articole de menaj; (autom) echipament, utilaj

hardware bug / failure (c) incident-maşină 
hardware check (c, autom) verificare / control prin elemente cablate

hardware compatibility (c) compatibilitate a două calculatoare sau a două echipamente periferice

hardware configuration (c) configurație / compunere a unui sistem de calcul

hardware bugging (c) deteriorare a componentelor unui sistem de calcul

hardware diagnostic (c, inf) diagnostic (are) pentru hard, program pentru localizarea defectelor unui subsistem hardware

hardware division (c) împărțire cablată / realizată prin elemente cablate

hard water (chim) apă dură

hard wax (chim) parafină tare

hard wearing surface $(T)$ suprafață rezistentă la uzură

hard wheat (agr, alim) grâu cu conținut ridicat de gluten

hardwood (silv) (copac cu) lemn de esentă tare

hard-working harnic, muncitor, care munceşte din greu

hard-wrought (met) prelucrat / durificat prin tragere la rece

hardy daltă lată; viguros, robust, rezistent

hardy annual (agr, bot) plantă perenă / rezistentă; problemă care revine în fiecare an

hare (zool) iepure de câmp

harm deteriorare; daună, lezare; vătămare; atingere (a intereselor); rău; avarie; stricăciune; dăunare; a avaria; a dăuna; a strica; a face un rău; a răni

harmful dăunător, rău, vătămător, nociv, stricător; periculos, primejdios; supărător

harmfully $(a d v)$ (în mod) dăunător, nociv, primejdios

harmfulness nocivitate, caracter dăunător, rău

harmless to inofensiv, neprimejdios, nepericulos pentru; nevinovat

harmless component (materiale) component nedăunător

harmless component of the exhaust from an internal combustion engine (termo) component nedăunător al gazelor de eşapament de la motorul cu ardere internă

harmlessness caracter inofensiv / neprimejdios, lipsă de nocivitate

harmonic armonios; (mat) (funcție) armonică; (mec, fiz) armonic

harmonic balancer (OM) amortizor de vibrații

harmonic curve (mat) curbă armonică, sinusoidă

harmonic motion (mec) mişcare armonică / sinusoidală harmonic response (autom, mec, hidr) răspuns în frecvență / armonic

harmonics (mec, fiz) armonică, armonice, oscilații harmonious armonios; bazat pe înțelegere / pe armonie

harmoniousness armonie; caracter armonios; omogenitate; concordanță

harmonisation, harmonization armonizare; punere de acord / în armonie

harmonise (with), harmonize (with) a (se) armoniza; a pune de acord / în armonie / a fi în concordanță, a (se) omogeniza (d. amestecuri); a (se) potrivi; a (se) înțelege

harmony armonie; întelegere, acord; concordanță; punere de acord, concordanță

harness (el) grup de cabluri care poate fi instalat / montat împreună

harpings (nav) întăritură pentru provă, capre pentru cala de construcție

harpoon (nav) harpon; a prinde cu harponul

harp-shape shackle (constr, nav) cheie de ancoră cu traversă

harrow (agr) grapă; a grăpa; a zgâria; a scrijeli; a cresta

harrowing (agr) grăpare

harry a distruge; a strica; a spolia; a jefui; a hărțui, a chinui

harsh (chim) dur (referitor la apă); aspru (la pipăit); (mat) aproximativ; (TH) grosier, rigid, aspru, rugos; cu rugozități; discordant; sever, strident, supărător; dezagreabil, respingător

harsh blowing flame (met) flacără pentru tăiere (şi grosolană)

harsh clutch $(\mathrm{OM})$ ambreiaj prea brusc / prea brutal

harsh flame (termo, met, ind chim) flacără tare / suierătoare

harshly $(a d v)$ aspru; cu asprime; crud; sever; riguros; supărător; dezagreabil

harshness asprime; severitate; rigoare; rigurozitate; cruzime

harsh picture imagine contrastantă / dură

harsh taste (alim) gust astringent / acru

harsh wine (alim) vin aspru

hartley (Hart) (metr, inf) unitate pentru informație: 1 hartley $=\log _{2} 10=3,321928$ shannons (bits)

hartree (energy), atomic unit of energy (simbol $\mathrm{E}_{\mathrm{h}}$ ) (metr, fiz) 1 hartree $\approx 4,359744 \cdot 10^{-18} \mathrm{~J}$

hartshorn oil (alim) ulei de oase

harvest (agr) seceriş, recoltare, cules, strânsul recoltei, recoltă, producție agricolă; (fig) roade, rezultate, consecințe; timpul recoltării; a recolta, a strânge, a culege, a secera 
harvester (agr) secerător, culegător, muncitor agricol la seceriş, combină de recoltat cereale, secerătoare-legătoare

harvester oil (alim) ulei agricol / vegetal

hash (alim) tocătură; carne tocată; a toca (carne) (şi cu o maşină); a mărunți; (c) ecouri parazite pe ecran

hashing (inf) dispersare (a datelor)

haslet (alim) carne de fript (de porc)

hasp (mas-un) articulație pentru ridicarea automată a cuțitului (în timpul cursei de înapoiere la raboteze; (OM) clamă, brățară, balama, cataramă, încuietoare, scoabă; scul, jurubiță, mănunchi de fire

Hassium (HS) (chim) hasniu

haste grabă (exagerată), precipitare, mişcare precipitată, agitație

hastelloy (met) aliaj $\mathrm{Ni}-\mathrm{Fe}-\mathrm{Mo}$, cu variante: hastelloy $\mathrm{B}(66,7 \% \mathrm{Ni}+5 \% \mathrm{Fe}+28 \% \mathrm{Mo}+$ $0,3 \% \mathrm{~V})$, hastelloy C (59\% Ni $+5 \% \mathrm{Fe}+16 \%$ $\mathrm{Mo}+4 \% \mathrm{~W}+16 \% \mathrm{Cr}$ )

hasten a (se) grăbi, a face / îndemna să se grăbească; a accelera; a face să se producă mai repede / mai devreme; a fi grăbit

haste to a se grăbi să

hastily $(a d v)$ grăbit; repede; în mare grabă; pripit; fără chibzuială; fără să se gândească

hastiness grabă; repezeală; nechibzuință

hastings naphtha (chim) alcool metilic

hasty grăbit; rapid; iute; repezit; irascibil; nechibzuit

hasty pudding (alim) budincă / fiertură de cereale, (amer) mălai dulce cu lapte

hat pălărie; $(\mathrm{OM})$ capac

hatch (constr) trapă; (hidr) dig, stăvilar, batardou; (nav) gură de magazie, bocaport, tambuchi, capac al gurii de magazie, chepeng; partea de jos a uşii cu două tablii; linii paralele; (TH) gură, deschizătură, ferestruică, capac (şi la cuptor), încuietoare, haşură; a cresta, a îndigui, a haşura, a face umbre (la desene), a grava; a cloci, a scoate pui, a ieşi din ou

hatch beam (nav) traversă de bocaport

hatch-coaming (nav) ramă a gurii de magazie

hatchery (agr, alim) incubator, crescătorie de pui; (agr, iht) crescătorie de peşti (păstrăvi)

hatchet bardă; topor (şi de barcă), secure

hatch hood (nav) muşama / prelată a gurii de magazie

hatching umbrire cu haşuri, haşurare

hatcure haşuraă (şi în desen tehnic)

hatchway (nav) bocaport, tambuchi

hatch(way) cover (nav) capac al gurii de magazie

hat nut (OM) piuliță oarbă / înfundată haul captură (şi la pescuit); (TH) târâre, tragere, remorcare, transport (de mărfuri); (cf) cursă, parcurs, cantitate transportată; a târî, a trage, a remorca, a tracta, a transporta; câştig, profit

haulage (transp) transport (mai ales pe orizontală), tracțiune, remorcare, camionaj

haulage gear (met, plast) înfăşurător

haulage equipment / installation instalație / echipament de remorcare

haul at / upon a-şi schimba direcția, a (se) schimba

haulier camionagiu

hauling (auto, cf) remorcare

hauling cable (OM, transp) cablu de tracțiune / de tragere

hauling device (OM, transp) dispozitiv de remorcare

hauling equipment $(\mathrm{OM}$, transp) utilaj / mijloace de transport

hauling installation $(\mathrm{OM}$, transp) troliu de ridicat

hauling output (mec, transp) putere / capacitate de tracțiune

hauling rope funie de tractiune pe orizontală; (nav) parâmă de remorcare, remorcă

hauling scraper (met) screper montat pe roți

hauling tractor (auto, transp) tractor remorcher

hauling winch $(\mathrm{OM}$, transp) troliu de transport

haul road (constr) drum de serviciu / de acces pe şantier

haulm (agr) tulpini de păioase / de legume

haunch (alim) pulpă, but; şuncă

haunt a frecventa, a vizita des; a obseda

have a avea, a poseda; a dispune de; a manifesta; a arăta; a dovedi; a da dovadă de; a reține, a păstra; a permite; a tolera; a da voie; a suporta; a lua; a cuprinde; a fi înzestrat cu; a primi; a lua; a obține, a face rost de; a consuma; a trece prin; a susține; a necesita; a solicita; a cere; a concepe; a se gândi la; a avea (în minte); a menține; a ține (minte); a păți; a cunoaşte; a întâmpina; a dispune de; a cum-păra; a afirma; a zice; a spune; a exprima; a face; a îndeplini; a încerca; a determina; a pu-ne să facă; a-şi face; a-şi comanda; a dori; a voi; a ține

have back a primi înapoi; a recăpăta; a reintra în posesie

have done with a termina cu; a înceta; a termina; a sfârşi; a se opri din

have in a chema, a solicita să vină; a aduce, a se aproviziona cu; a-şi face provizii de

have it out with a discuta deschis cu; a ajunge la o înțelegere cu (cineva)

have leeway a avea libertate de acțiune

have many strings a dispune de multe resurse 
haven (nav) port, loc adăpostit; (fig) liman, adăpost, refugiu

have on a purta; (mas, autom, inf) a avea în program / programat; a avea superioritate avantaj asupra

have out a scoate la iveală; a face să apară; a da pe față; a dezvălui; a extrage; a scoate (o piesă); a duce până la capăt

haversack raniță

have to a trebui să; a fi obligat să; a fi necesar să

have what it takes a avea (toate) calitățile necesare (îndeplinirii unei funcții)

havoc ravagii; devastare; distrugeri; pagube; dezastru; catastrofă; dezordine

hawkbill(-pliers) (met, OM) cleşte de sudare

hawse (nav) nară, porțiune de punte unde se află nările, distanța de la nară la ancoră

hawse(-)hole (nav) gaură / gură de nară

hawsepipe (nav) nară de ancoră, nară de punte

hawser (OM) cablu de oțel; (nav) cablu de remorcă, saulă, parâmă, otgon

hawser-laid rope (nav) parâmă simplă / răsucită "în parâmă"; (OM, transp) toron de cablu

hay (agr) fân; culoarea fânului; sumă infimă; a transforma în fâneață, a usca (iarbă); a hrăni cu fầ; împrejmuire, gard (viu); loc împrejmuit; parc

hay bale (agr) balot de fân presat

haycock (agr) căpiță de fân

hay elevator / loader (agr, mas) elevator de fân

hayfever (med) alergie (şi la fân)

hayfork (agr, mas) furcă de fân

haymaker (agr) cosaş, maşină de uscat fânul

haymaking (agr) încărcare a fânului cosit, uscare a fânului

haymou (agr) şură pentru fân

haystack (agr) șură de fần

hayward (silv) şef de ocol silvic

haywire (agr) sârmă pentru legat baloturile de fân; încurcat; în dezordine; agitat

HAZ (heat affected zone) (met) zona afectată termic (la sudură)

hazard şansă; întâmplare; hazard; joc aleator; risc; a risca; a se aventura; a înfrunta; a expune la riscuri, a pune în pericol; (auto) avarie

hazard lights ( auto) faza scurtă

hazardous periculos (toxic, otrăvitor, exploziv etc.); risca(n)t; bazat pe noroc

hazardous location (auto) zonă cu pericol crescut / ridicat

hazardously $(a d v)$ în mod riscant / periculos

hazardous material material periculos (toxic, otrăvitor, exploziv etc.)

hazardousness caracter riscant / periculos hazard warning flasher (auto) lumini de avarie hazard warning lights (auto) lumini de avarie (şi intermitente)

haze (fiz) tulbureală, opacitate; ceață, negură, pâclă; (c) voal (la imagine); a se încețoşa

haze filter (fiz) filttru de tăiere a radiației ultraviolete, filtru UV

hazel (alim) alun (turcesc), alună; culoare maronie; (d. ochi) căprui

hazel nut (alim) alună (turcescă)

hazelnut oil (alim) ulei de alune

hazily $(a d v)$ ca prin ceață, nedeslușit

haziness (med, fiz, c) încețoşare, caracter cețos

hazy cețos, încețoșat, înnorat; nedeslușit, voalat

H-beam (met) grindă / semifabricat / profil cu tălpi late / în formă de H

head (anat) cap, craniu; (med) coacere (d. un abces etc.), loss of $\sim$ pierdere de sarcină; psihic; intelect; minte, înțelepciune, inteligență, capacitate intelectuală; imaginație, inventivitate; persoană, locuitor; frunte, prim rang; parte de sus; şef, conducător, lider; şefie, conducere, comandă; capăt, extremitate (şi superioară, principală sau cea mai avansată); parte de sus; avangardă; categorie, clasă; (fiz, hidr) presiune, presiune hidrostatică / a coloanei de apă, cădere, înălțime / cădere manometrică, înălțime de cădere, sarcină de apă; (OM) parte de sus, cap (de cui, bulon, nit, ciocan etc.), oală / tobă de evacuare, silențiator, culee; atenuator de zgomot(e), fier (al ciocanului, al securei), ascuțiş (al săgeții), măciulie, fund (de butoi, de recipient etc.), tavă; (termo, OM) corp (de piston); (mas-un) păpuşă port-sculă; ed with prevăzut / înzestrat cu un vârf / cap cap; (met) zgură de metal; umplutură, maselotă, capăt pierdut, cap de berbec (la forjă), a refula; (nav) extremitate prova, cap (al navei), proră, bot, cap de ecluză (navigabilă), $\sim \mathbf{s}(p l)$ latrină; (el) cap magnetic; (alim) spumă (la bere), smântână (la lapte); (auto) capotă, far din față; $(\mathrm{TH})$ vârf (de piesă sau al unui proces); (ec) față, cap, efigie (a unei monede); capitol (de text); (silv) coroană de copac; (geogr, nav) promontoriu, cap; (zool) căpățână (de mistreț etc.); mănunchi, buchet; capăt, căpătâi (al patului); piele (a tobei); (fig) izvor, sursă; capăt (al unui dig, al unui zăgaz); antet, început (de capitol); titlu (al unui discurs etc.); punct critic; criză; forță; a se situa / înscrie în frunte, a fi primul; a conduce; a depăşi, a întrece; a atinge un punct culminant (d. un proces); a pune, a așeza; a se împotrivi, a se opune; a se îndrepta spre / într-o direcție; $(\mathrm{TH})$ a înzestra, a prevedea cu un cap, a pune fund / capac (unui butoi, unui 
recipient etc.); a fi în capul / fruntea; a merge în fruntea; a călăuzi (trupe, coloane etc.); a înfrunta; a abate, a schimba direcția; a para; (fig) a preveni; a se trage, a-şi avea originea; a alcătui un cap / un capăt; make a înainta, a progresa; from $\sim$ to foot din cap până-n picioare; of a school (edu) director al unei şcoli; gather $\sim$ a prinde forță, a lua proporții; river $\sim$ iaz de moară; under the same $\sim$ sub acelaşi titlu, în aceeaşi categorie; $\sim$ of a department şef al unui serviciu / departament

headache (med) durere de cap, nevralgie; problemă care dă dureri de cap; complicație; dificultate

head back a întâmpina; a ieşi în fața (cuiva) pentru a-l obliga să dea înapoi

headband majusculă; (OM) lamelă / bandă de fixare pe cap a căştilor (de protecție)

head beam (constr, met) grinda principală superioară, grindă de umplutură; coronament (superior) din schelet de grinzi

head bearing $(\mathrm{OM})$ crapodină superioară, lagăr de cap

headblock $(\mathrm{OM})$ sabot de frână

headboard (constr, met) grindă, traversă

head bolting $(\mathrm{OM})$ înşurubare a capacului

head cheese (alim) (amer) piftie / răcitură de porc

head circle $(\mathrm{OM})$ cerc exterior (de cap) (la roți dinţate cilindrice) $\left(d_{a}\right)$

head countersink (mas-un) adâncitor de capete de nit / de şurub, zencuitor, teșitor

head down (silv) a tăia vârful (unui copac); a tăia / elimina un capăt (şi dintr-o piesă)

head draft (termo, met) tiraj (la focare)

headed cu cap (despre organe de maşini)

head end (alim, mas-un) capăt de încărcare / de alimentare, cap de antrenare a maşinii; (hidr) capac din spate, fund de cilindru hidraulic

header (agr) dispozitiv de tăiere al combinei; (constr, hidr) colector de apă, bazin de colectare, cărămidă aşezată perpendicular / în lat, fermă; (inf) titlu al unui listing, titlu pentru fiecare pagină, header; (met, OM) recipient sub presiune, autoclavă, (cap) colector (la cazane, cicloane), distribuitor, claviatură; (met) maselotă, canal de alimentare a sistemului de turnare

header / heading block (inf) bloc de început

header die (met) poanson de refulare; partea superioară a unei matrițe

headered etajat, suprapus

header information (inf) început de informatie

header / heading statement (inf) instructiune de început de fişier

headfast (nav) parâmă, odgon head file pilă-cuțit

head for talent, pricepere, aptitudine, înclinație pentru; a îndrepta spre

head for side extrusion (mas-un) cap de extrudare, oblic

head fraction (ind chim) (fracțiune de) frunte; fracțiune uşoară

headgate (hidr) poartă / vană de ecluză

head gauge (metr) manometru de refulare

headgear troliu, vinci (la gura unui puț)

headgrip with toolchuck mâner cu mandrină de prindere a pilelor

head hunter agenție / agent de recrutare; racolare a personalului foarte calificat

head hunting recrutare / racolare a personalului foarte calificat

head hydrostatic (hidr) presiune hidrostatică

heading (constr) lemn de pardoseală; (met) aşezare a maselotei, cap (de lărgit) la extrudare, formare a unui cap refulat, refulare, înaintare, galerie mică; (nav) directie de deplasare a navei; titlu de rubrică / capitol, antet (într-un text); (el, c) cursă, traiectorie, direcție

heading die (met, plast) matriță de refulare, superioară

heading in the moving die of horizontal forging machine (met) acumulare în pastilă glisantă, la mașina orizontală de forjat

heading line (inf, c) linie de început / de antet

heading machine (met) maşină pentru refularea capetelor

heading slide (met, OM) berbec al maşinii de refulare

heading tool $(\mathrm{OM})$ căpuitor, buterolă

headlamp (auto) far de automobil (în față); lampă de mână (purtabilă şi pe cască)

headless wire nail $(\mathrm{OM})$ cui subțire fără cap

headlight (auto, cf) far de automobil / principal (fază lungă), far de locomotivă; fază de întâlnire

headlight aim (auto) alinierea farurilor

head light beam indicator (auto) indicatorul pentru fază lungă

headlight bulb (auto) becul farului

headlight high beam (auto) fază lungă

headlight lens (auto) lentile ale farurilor

headlight levelling device (auto) dipozitiv de reglare a înălțimii farurilor

head light position (auto) poziția pentru faza de întâlnire

headline titlu (de ziar), ştire principală

head loss $(\mathrm{OM}$, hidr) pierdere de presiune (exprimată ca înălțime de coloană de apă etc.)

head made during (process of) reveting cap de nit, închis / format la asamblare prin nituire 
headmaster (edu) director de şcoală / liceu headmistress (edu) directoare de şcoală / liceu head metal (met) maselotă head money (ec) sumă / taxă pe persoană / locuitor headmost de frunte, fruntaş

head note notă inserată la începutul paginii; preambul, expunere de motive

head of draught (termo, met) intensitate a tirajului head off a preveni, a preîntâmpina

head office (ec) sediu / birou / oficiu central (al unei societăți); centrală telefonică principală

head of hammer (met, OM) cap (de) ciocan (şi la forjă)

head of ingot (met) cap de lingou

head of rail ( $\mathrm{cf}, \mathrm{OM})$ ciuperca şinei

head of the anchor $(\mathrm{OM})$ diamant de ancoră (mecanică fină)

head of tubing machine (mas-un, OM) cap de extrudare pentru țevi

head on (d. o ciocnire) frontal, cap în cap; $(a d v)$ direct, frontal; fără ocolișuri

head-on collision (mec) coliziune / ciocnire frontală (centrală)

head page pagină de început

headphone (radio) cască radio

headpiece, head piece cască; intelect, minte, cap; intelectual; (met) adaos; cască; (TH) coronament

head pivot (OM, mas) fus superior

head-planing machine (constr) maşină de nivelat terenul, greder

head pulley (OM) tambur / roată de capăt

headquarters (ec, mil) cartier general; comandament, centru al operațiunilor, sediu central

head recovery structure (hidr) (dispozitiv) recuperator de sarcină hidraulică

head roller (met) maistru laminorist

headrace (constr) scoc de moară

headrest (auto) tetieră, rezemătoare de cap

headrest adjustment (auto) reglare a tetierei

headrest pole (auto) suportul tetierei

headrest removal (auto) îndepărtarea tetierei

headroom (constr) înălțime constructivă / de construcție; înălțime interioară a unui volum; înălțime liberă

headroom under a bridge (nav, transp, constr) înălţime de gabarit sub pod

head screen (met, TH) cască prevăzută cu mască (pt. sudură)

headset căşti

head shaft $(\mathrm{OM})$ arbore principal

headspring (fig) izvor principal, sursă principală

head step bearing $(\mathrm{OM})$ crapodină / lagăr superioar( $\breve{a})$ headstock (mas-un) păpuşă fixă, cap de antrenare al maşinii

headstock centre (mas-un) vârf al păpuşii fixe (la strung)

head tank (hidr, OM) rezervor de / sub presiune, bazin decantor

head tax (amer) (ec) taxă / impozit pe locuitor

head temperature (mas, termo, TH) temperatură principală / de regim

head-to-head polymerization (chim, plast) polimerizare cap-la-cap

head-to-tail polymerization (ind chim, plast) polimerizare cap-la - coadă

head tube nipple thread $(\mathrm{OM})$ filet de înșurubat ciocul / becul de sudat

head wall (constr, met) zid / perete de închidere headway (auto, cf) interval (în spațiu sau în timp) între două vehicule care se deplasează pe acelaşi fir de circulație; (nav) viteză înainte, inerție înainte

head windless $(\mathrm{OM})$ vinci / cric cu şurub

headword cuvânt principal

headwork activitate / muncă intelectuală, efort intelectual, gândire; (OM) berbec (mecanic); (met) înălțime a bolții (cuptorului)

heady impetuos; violent; isteț, ager

heal (med) a (se) vindeca; (fig) a îndrepta, a remedia, a ameliora; a asana; a (se) reface; a restaura; a cimenta; a consolida; a întări; a-şi reveni

healling (med) vindecare, care vindecă / se reface

health sănătate; bunăstare, stare înfloritoare

health food (alim) hrană / alimentație sănătoasă, dietă ratională

healthfulness (mediu) caracter sănătos / salubru, salubritate

health physicist (medic) specialist în protecția contra radiațiilor

health physics (med, ind) protecție contra radiațiilor

health protection (med, TH) ocrotire a sănătătii health security (med, TH) securitate a sănătății

health service (med) servicii de asistenă medicală / sanitară

health visitor funcționar de la prevederile / asigurările sociale

healthy sănătos, robust; rezistent, viguros; (fig) viabil, viu; fără primejdii; sigur; înfloritor, prosper; benefic, pozitiv, salutar; considerabil; masiv

heap (constr) cantitate de material care depăşește marginile unei cupe, încărcare cu vârf; $(\mathrm{TH})$ grămadă, morman, teanc; (met) haldă (de zgură) 
heaped bushel (metr) uitate tradițională pentru capacitate / volum în SUA, oficial, 1 "struck" bushel $=45,0361$; în practică $1=44,0491$

heap coking (met) cocsificare în bocşe; a îngrămădi, a face grămadă; a stoca, a aduna; a agonisi; a face teanc

heap of debris (mat) îngrămădire / depozitare (de minereu), haldă de steril / de zgură

heap up a îngrămădi; a acumula; a stivui, a aglomera; a aduna; a strânge

heap with a umple până la refuz; a încărca cu

hear a auzi; a afla; a asculta (cu bunăvoință); (jur) a audia

hearer auditor, ascultător

hearing (med) auz, simţul auzului; distanţă până la care poate auzi cineva, rază auditivă; audiere; audiție

hearing aid (med, mecanică fină, fiz) aparat auditiv (p. surzi)

hearing distance distanță de audibilitate

hear out a asculta cu bunăvointă până la capăt

heart (anat) inimă, cord; (constr) lemn obținut din miez de buştean; (fiz) miez; nucleu; sâmbure; centru; (mas-un) inimă de strung / de antrenare; (met) miez al piesei cementate; (nav) inimă de parâmă

heart block (nav) țest (la construcții navale)

heart-felt sincer, deschis; cordial, din inimă

hearth cămin, şemineu; (met) vatră de forjă / de furnal; focar; creuzet; cadă; cuvă; spațiu util; (termo) (la cuptoare cu reverberație), focar

hearth area (met) suprafață a creuzetului furnalului / a vetrei cuptorului

hearth block (met) vatră de creuzet

hearth bottom (met) fund al creuzetului furnalului, vatră a cuptorului (a unui furnal)

hearth casing (met) manta / blindaj de creuzet, căptuşeală a vetrei (unui cuptor)

hearth cinder (met) zgură de sudare (la furnal)

hearth dimension (met) dimensiune a creuzetului

hearth electrode (met, el) electrod inferior / de vatră, la un cuptor electric

hearth fettling (met) căptuşeală a vetrei / a creuzetului

hearth furnace (met) cuptor cu vatră

hearth jacket (met) manta / blindaj a(l) creuzetului (la furnal)

hearth layer (met) strat de material de vatră (pentru cuptoare)

hearth lining (met) căptuşeală / zidărie a vetrei (la cuptoare), căptuşire

hearth load (met) încărcare (specifică) a creuzetului hearth maintenance (met) întreținere / reparare a vetrei (creuzetului, cuptorului etc.)

hearth mould (met) formă executată în solul tur-nătoriei

hearth of cupola (met) vatră de cubilou

hearth plate (met, termo) placă de focar, placă de armare a vetrei; plită

hearth refining (met) limita fontei în vatra cuptorului pentru lupe, afinare în cuptorul Siemens-Martin

hearth sole (met) vatră a cuptorului

hearth steel (met) otel Martin

hearth stone (constr, termo, met) fund de vatră / de cămin

hearth-type (smelting) furnace (met) cuptor cu topire pe vatră

hearth wall (met) perete lateral al cuptorului, zidăria cuptorului

hearth zone (met) zona de fuziune în furnal

heartily din toată inima, cu sinceritate; cu zel, zelos; total, din plin, absolut, foarte

heartwhole netulburat, impasibil; neafectat; sincer, deschis, cinstit

heat (fiz, termo) căldură, energie calorică, a încălzi; (met) topire, şarjă (mai rar), încărcătură, foc, termic, a (se) încălzi, a inflama, a aprinde, a face să ardă; (plast) a (se) vulcaniza; vreme călduroasă, caniculă, arșiță, căldură puternică; fără a se opri; (med, anat) pată roşie pe piele, pistrui; ardoare, zel; (zool) călduri, rut (la animale); efort neântrerupt; a (se) încălzi; (fig) a (se) înfierbânta, a (se) înflăcăra; at a dintr-o lovitură;

heat-absorbent surface (termo, met, ind chim) suprafață cu absorbție de căldură

heat-absorbing (termo) absorbant de căldură, care absoarbe căldură

heat-absobing reaction (chim) reacție endotermică

heat-absorbtion (termo, met) absorbție a căldurii

heat-absorbtion capacity (met, termo) capacitate de absorbție a căldurii

heat abstraction / delivery (termo, met) cedare (şi forțată) / evacuare / eliminare de căldură

heat accumulator (termo, met) acumulator de căldură

heat activated adhesive (plast) adeziv reactiv la cald / la o anumită temperatură

heat activation (plast) activare / la căldură

heat affected area / zone (met) zonă afectată termic / de tranzitie (la sudură)

heat ageing (plast, met) îmbătrânire la cald / artificială; (alim, chim) maturare la temperatură ridicată / prin încălzire 
heat alarm (termo, ind) semnalizator de alarmă la căldură anormală

heat application (met, plast, ind chim) aport de căldură, încălzire

heat available (met, termo) energie termică disponibilă

heat baffle (met, termo) ecran termic

heat balance / budget, balance sheet (termo) bilanț termic

heat barrier (materiale, fiz, termo) barieră termică

heat-bodied oil (ind chim) ulei polimerizat la cald

heat bodying of oil (ind chim) polimerizare a uleiului la temperatură înaltă

heat booster (alim, termo) încălzitor

heat bridge / channel (termo) punte termică / de căldură

heat calculation (termo) calcul al bilanțului termic

heat capacity (fiz, met) capacitate calorică, căldură specifică

heat capacity at constant pressure (fiz, met) capacitate calorică, căldură specifică la presiune constantă

heat capacity at constant volume (fiz, met) capacitate calorică, căldură specifică la volum constant

heat carrier (termo, T) agent termic, purtător de căldură

heat change (fiz, met, termo) schimb de căldură heat coil (alim, ind chim, termo) serpentină de încălzire, bobină termică; (autom, termo) întrerupător termic automat

heat colours (met) culori de incandescență

heat conductance (fiz, termo) conductibilitate termică

heat-conducting care transmite / conduce căldura, conduc( $\breve{a})$ tor termic (d. materiale, indiferent de stare)

heat conductivity (fiz, termo) conductivitate termică

heat conductor (termo, net) conductor termic / de căldură, element bun conducător de căldură

heat constant (termo) constantă termică

heat-consuming (termo) consumator de căldură, care consumă căldură

heat-consumption (termo) consum de căldură

heat-contact welding (met, termo) termosudură prin contact

heat content (termo) entalpie, conținut de căldură heat convection convecție a căldurii

heat conversion factor (termo) factor de echivalență termică

heat-convertible (plast) termoreactiv (d. materiale plastice termorigide) heat convertible resin (plast) răşină termoreactivă

heat crack (met) fisură cauzată de călire / de încălzire excesivă

heat current (termo) curent de încălzire

heat damage (mas, met, OM, termo) avariere / deteriorare din cauza căldurii

heat deficit (termo, met, plast) deficit / lipsă de căldură / de energie termică

heat delivery surface (termo, OM) suprafață de transmitere a căldurii

heat density (fiz, termo) densitate de căldură, cantitate de căldură pe unitatea de suprafață sau volum

heat deperdition (termo, met) pierdere / pierderi de căldură

heat dissipation (termo, met) disipare de căldură

heat distortion (met, plast) deformare / distorsiune la cald (şi nedorită)

heat distortion point (met, plast) temperatură de deformare la cald, punct de înmuiere

heat distribution (met, termo) repartitie / distribuție a căldurii

heat drill (termo, mas) perforator termic

heat drilling (met) perforare la cald

heat drop (termo, met) (s)cădere / diferență de temperatură

heated încălzit, aprins (d. un foc, un material etc.)

heated channel injection moulding tool (plast) matriță de injecție, cu canale încălzite

heated filament (termo, met, fiz) filament încălzit (şi incandescent)

heated to glowing (met) încălzit la roșu (strălucitor)

heated tool welding (met) sudare prin termocompresiune / cu ciocan de lipit

heated wire (termo, el) fir incandescent, filament

heat effect (termo) efect termic / caloric

heat efficiency (termo) randament termic

heat-eliminating medium (termo) mediu / agent refrigerent / de răcire / de eliminare a căldurii

heat elimination (alim, ind chim, met, termo) eliminare / evacuare / degajare de căldură

heat embossing press (met, mas-un, plast) presă de ştanțare la cald

heat emission (fiz, met, termo) emisie de căldură

heat endurance (plast) (durată de) rezistență la cald, stabilitate la cald

heat energy (fiz) energie termică, căldură

heat engine (termo) motor termic, mașină termică

heat engineering termotehnică

heat equation (termo, fiz) ecuația căldurii

heat equivalent (termo, fiz) echivalent termic 
heater (alim) pasteurizator, sistem de încălzire (a unui tanc, recipient, cuvă etc.); (auto) sistem de încălzire al habitaclului; (constr) cazan de topire (pentru lianți hidrocarbonați / smoală etc.); (el) filament, catod; (termo) radiator, corp de încălzire, încălzitor, schimbător de căldură, boiler; (hidr) aparat care adaugă căldură fluidului utilizat, reîncălzitor

heater cable / strip / tape (alim, termo) cablu / cordon încălzitor / cu conductoare de încălzire, bandă termoforă

heater hose (auto) furtun de încălzire pentru circulația fluidului încălzit

heater reclaiming (plast, ind chim) regenerare cu abur (şi a cauciucului)

heater temperature (termo, met, el) temperatură a filamentului / a elementului de încălzire

heat evolution (alim, ind chim, met, termo) degajare a căldurii, evoluția cantității de căldură în timp şi / sau spațiu (şi într-un proces tehnologic sau accident, avarie)

heat evolved (fiz, met) aport de căldură

heat exchange / interchange (termo) schimb de căldură

heat exchange by convection (termo) schimb de căldură prin convecție

heat exchange by radiation (termo) schimb de căldură prin radiație

heat exchanger (termo) schimbător de căldură

heat-exchanger tube sheet (termo) schimbător de căldură tubular

heat exhaust (termo) evacuare a căldurii

heat expansion (fiz, met, termo, plast) dilatare / dilatație termică

heat-fast (fiz, termo, plast) termostabil

heat flow (termo) flux de căldură / termic, transmitere a căldurii, direcția de evacuare a căldurii (într-un sistem complex, într-un material etc.)

heat flux / gain / uptake (termo, met, plast) aport / aflux de căldură

heat-generating reaction (chim) reactie exotermă

heat index (HI or HX) (metr) indice al efectului combinat al căldurii şi umidității, indice al confortului termic

heather mixture (textile) stofă ecosez

heating (termo) încălzire, care încălzește, termic

heating agent (termo) agent purtător de căldură, agent termic / de încălzire

heating bath (alim, plast) baie de încălzire

heating body / element (termo, met) corp / element încălzitor, (element de) radiator

heating by arc (termo, el, met) încălzire prin / cu arc electric heating capacity (met, termo) capacitate de încălzire

heating chamber (alim) cameră / incintă de încălzire; (met) spațiu de lucru al cuptorului; (termo) focar, cameră de ardere

heating channel (termo, met) canal (conductă mai mare) de încălzire (la cuptoare etc.)

heating coil (auto, termo, ind chim) spirală / serpentină de încălzire; (el) bobină de încălzire

heating conductor surface rating (termo) putere pe unitatea de suprafață a unui element încălzitor

heating connection (termo, OM) racord / branşament de încălzire / de termoficare

heating curve (met, plast, termo) curbă de încălzire (a unui matrial, a unui cuptor etc.)

heating cycle (termo, met, ind chim) ciclu de încălzire

heating effect (termo) efect de încălzire

heating surface (termo) suprafață expusă la încălzire / care primeşte căldură

heating system (auto, termo) sistem de încălzire

heat efficiency (termo, met) randament termic / de încălzire

heating element (termo) element de încălzire

heating flame (termo, met) flacără (şi directă) de încălzire

heating flue (termo, met) canal de încălzire / de fum / de gaze arse

heating from bottom (constr, met, termo) încălzire prin podea / prin pardoseală

heating furnace (met) cuptor de recoacere / de încălzire (şi la forjă)

heating furnace for billet(s) / for bloom(s) (met) cuptor de recoacere / de încălzire pentru tagle / pentru blumuri

heating gas (ind chim, termo, met) gaz de încălzire / pentru ardere

heating gas conduit (met, termo) conductă pentru gaz de încălzire / de ardere

heating grill (termo) grătar incandescent

heating installation (alim, ind chim, met, termo) instalație de încălzire

heating jacket (alim, ind chim, met, termo) manta de / pentru încălzire

heating medium (alim, ind chim, met, termo) agent calorific / purtător de căldură / termic

heating pad (el, termo) pernă electrică

heating passage (termo, met) canal de încălzire

heating pattern (fiz, met, $\mathrm{T}$ ) distribuție de temperatură

heating-pipe coupling (cf) (a)cuplare de încălzire; (plast) furtun de cauciuc pentru încălzirea vagoanelor

heating plate (alim, el) plită electrică, reşou 
heating plug (termo, auto) bujie incandescentă heating power (termo) capacitate de încălzire, putere calorică

heating radiator (termo) radiator / element de calorifer

heating rate (met, termo) viteză de încălzire

heating resistance pad / mat / collar (alim, termo, met) învelitoare / manta (cu rezistențe) pentru încălzire

heating spiral (el, termo) spirală de filament / de rezistență pentru încălzire

heating station (ind, termo) centrală termică / de termoficare

heating stove (met) cuptor de recoacere

heating surface (met, termo) suprafață de încălzire

heating system (termo) sistem de încălzire

heating temperature (met, termo, alim) temperatură de încălzire

heating time (termo) timp de încălzire

heating tongs (el, OM) cleşte pentru (încălzit) nituri

heating tube (termo) țeavă fierbătoare / de fum / de încălzire (la cazane)

heating unit (termo) unitate / element, şi modulat(ă), de încălzire

heating up (termo, met, plast) încălzire, creştere a temperaturii

heating-up period / time (termo, met) perioadă / durată / timp de încălzire; (el) timp de formare (a catodului)

heating value (termo) putere calorică

heating wire (termo, el) filament, rezistență (pt. încălzire)

heat input (termo, chim) aport / absorbție de căldură

heat installation (termo) instalație de încălzire

heat insulating (termo, met) izolare termică, termoizolant (şi ca adjectiv)

heat insulation (termo, met) izolație termică

heat interchange / exchange (termo) schimb de căldură

heat lag (termo) decalaj în transmiterea căldurii, timp termic mort, inerție termică

heat leakage (termo, met) pierdere / disipare de căldură, pierdere termică, infiltrație / aport / pătrundere de căldură (nedorită)

heatless (termo) fără căldură

heatless regeneration (hidr) regenerare cu încălzire redusă (la sisteme pneumatice)

heat load (alim, termo) necesar de frig, sarcină de refrigerare

heat loss(es) (el) pierderi ohmice / prin efect Joule; (termo) pierderi de căldură heat of absorbtion (fiz, termo) căldură de absorbție

heat of carburisation (met) căldură de carburare / de cementare

heat of combustion (termo, met) căldură de ardere / de combustie

heat of decomposition (met, chim) căldură de descompunere / de dezagregare

heat of dissociation (met, chim) căldură de disociere

heat of evaporation (alim, termo) căldură de evaporare

heat of fusion (termo, fiz) căldură specifică de topire

heat of immersion (termo, fiz) căldură la / de imersare

heat of reduction (chim, met) căldură de reducere / rezultată în reacția de reducere

heat of oxidation (chim) căldură de oxidare

heat of separation (alim, met, plast) căldură de separare / de descompunere

heat of solidification (termo) căldură de solidificare

heat of sublimation (termo, met) căldură de sublimare

heat of the drawing off air (termo) căldura aerului la ieşire

heat of transformation (met, termo, fiz) căldură de transformare / rezultată la transformare / de fază / de stare

heat of vaporization (fiz) căldură de vaporizare

heat of wetting (alim) căldură de umectare / de udare

heat output (termo) putere calorifică / calorică

heat passage (termo, alim, fiz) transmitere / transport / trecere de căldură, conductibilitate termică

heat polymer (plast) polimer (obținut prin polimerizare) la cald

heat polymerization (chim, plast) polimerizare la cald

heat power plant (termo) centrală de termoficare

heat-producing reaction (chim, met) reacție exotermă

heat-proof, heat proof (termo) rezistent / etanş la căldură, termostabil, refractar, termorezistent

heat-proof cast iron (met) fontă refractară

heat protecting screen (met, termo) ecran de protecție termică

heat pump (termo) pompă termică / de căldură

heat radiating (termo, met) care radiază căldură, (element) radiant de căldură

heat radiation (termo, met) radiație termică 
heat radiation pyrometer (metr, termo) pirometru optic

heat radiator (termo, met) radiator de căldură; disipator termic

heat rate (mec, termo) raport între energia termică / calorică la intrare şi lucrul mecanic la ieşire; eficiență / randament termic( $\breve{a})$

heat rays (fiz, termo) radiații calorice

heat reactivation (plast) reactivare la căldură

heat reactivator (plast, chim) reactivator termic

heat record card (met) diagrama procesului de topire

heat recovery (met, termo) recuperare a căldurii heat red-hot (el, met) a încălzi (până) la incandescență

heat-reflecting paint (termo, plast) vopsea care reflectă căldura

heat regeneration (termo) regenerare prin căldură (eliminarea apei prin căldură)

heat regulation (termo, met) reglaj al căldurii / al flăcării

heat regulator (termo, metr) termoregulator, termostat (met) comutator / regulator al maşinii de sudat prin puncte

heat rejection / release (termo) cedare / evacuare / degajare de căldură

heat removal / removing (termo) disipare / evacuare a căldurii

heat requirement (alim, termo, met, ind chim) cantitate de căldură cerută / necesară

heat reservoir (alim, termo) acumulator de căldură

heat resistance (termo, plast, met) rezistență la căldură / la temperaturi înalte, stabilitate termică, refractaritate

heat-resistant, heat-resisting (met, plast) refractar, rezistent la căldură, termorezistent, termostabil

heat-resistant alloy (met) aliaj refractar

heat-resistant cast iron (met) fontă refractară

heat-resistant quality (materiale) rezistență la temperaturi înalte (în general)

heat-resisting steel (met) otel refractar / termostabil

heat-resistor element refractar; (el) rezistență de încălzire

heat retainer (termo) acumulator de căldură

heat run (met) mersul topirii / al încălzirii

heat-sealable termosudabil (d. materiale metalice)

heat sealing (plast) sudare / lipire la cald; (OM) etanşare la cald (cu întărirea materialului de etanşare, când se răcește); care izolează termic

heat sealing adhesive (plast) adeziv termocolant heat sealing adhesive (plast) adeziv termocolant (folosit și pentru etanşare) heat sensibility (materiale, aparate) sensibilitate termică, termosensibiliate

heat sensitive (materiale) sensibil la căldură, termosensibil

heat-sensitised mix (ind chim, plast) amestec (şi de cauciuc) termosensibil(izat)

heat-setting resin (plast) răşină termoreactivă / termorigidă

heat shield (termo, met) ecran / scut termic

heat shielding (alim, met, termo) protejare / ecranare împotriva căldurii

heat shock (met, termo) şoc termic

heat sink (termo, met) mediu / element absorbant de căldură

heat sink loading (termo) cantitate de energie absorbită pe unitatea de masă sau volum (caracterizează mediul termic absorbant)

heat spreading (termo) propagare / împrăştiere a căldurii

heat storage (alim, termo, met) acumulare / înmagazinare de căldură

heat stress (mec, met) tensiune termică / provocată de modificarea temperaturii

heat supply (alim, met, termo) aport / furnizare de căldură, alimentare cu căldură

heat strength (plast) rezistență la căldură

heatstroke (med) insolație, moleşeală cauzată de căldură

heat switch (alim, termo, el) întrerupător al circuitului de încălzire

heat test (materiale, metr) probă de încălzire, probă / test la cald / de topire

heat-tight (termo) impermeabil la căldură, izolator termic (d. materiale)

heat tint (met) culoare de revenire

heat tone (met) culoare de încălzire

heat tracing (termo) dispozitiv auxiliar de încălzire a unui element, încălzire suplimentară a unui element (prin rezistență, conductă cu agent termic etc.)

heat transfer (fiz, alim, termo, met) transfer / transmisie / transport de căldură

heat-transfer agent (alim, termo, fiz) agent de transfer termic (de încălzire, frigorific sau răcitor)

heat-transfer coefficient (termo, met) coeficient al transferului de căldură / de transmitere a căldurii

heat-transfer fluid (alim, termo, met) (agent) fluid de transfer termic, fluid purtător de căldură

heat-transfer medium (alim, termo, met) agent / mediu de transfer termic (şi fluid); purtător (fluid) de căldură 
heat-transfer rate (alim, termo, met) viteză de transmitere a căldurii, viteză a transferului de căldură

heat-tranferred per unit surface (termo) încărcare a suprafeței de transfer de căldură, căldură transferată pe unitatea de suprafață

heat-transfer surface (alim, termo, met) suprafață de transfer termic

heat transition (alim, termo, met) transmisie / trecere a căldurii

heat transmission (termo) transmitere de căldură

heat transmission by conductivity (termo) transmitere de căldură prin conductivitate

heat transmission by convection transmitere de căldură prin convecție

heat transmission by radiation (termo) transmitere de căldură prin radiație

heat-treatable steel (met) oțel care poate fi tratat termic

heat treating (met, plast, ind chim) tratament termic, procesul de tratare termică

heat-treating department (met) atelier de tratamente termice

heat-treating furnace / plant (met) cuptor / instalaţie de tratamente termice

heat treatment (met, plast) tratament termic (foarte general)

heat treatment crack (met) fisură cauzată de tratamentul termic

heat-treatment furnace / oven (met, plast, alim, ind chim) cuptor de / pentru tratament termic

heat unaffected zone (materiale, $\mathrm{OM}$ ) zonă neafectată termic (şi la sudură)

heat unit (termo, metr) unitate termică / calorică / de căldură / de energie termică, denumnirea în SUA pentru British thermal unit (Btu)

heat up a încălzi, a ridica temperatura

heat uptake / flux / gain (termo) aflux / aport de căldură

heat value (termo) putere calorică

heat vulcanisation (plast) vulcanizare la cald

heat wave val de căldură; (fiz) rază calorică, undă termică

heave umflare; urcare; ridicare; aruncare, azvârlire; înfoiere; deplasare, dislocare (şi de teren); (nav) ridicare, virare, deplasare, grad de montare al mării; a trage, a aduce (într-o poziție); a (se) ridica (greu); a umfla, a face să se umfle / ridice / înalțe a deplasa; a înălța; a trage în sus; a fi agitat; a gîfâi; a face un efort; a se strădui (fiz) unduire

heave down (nav) a abate în carenă, a carena, a răsturna vasul pentru curățare

heave in (nav) a vira, a ridica la bord heave to (nav) a opri vasul cu vântul în față, a se opri cu vântul în față

heave up umflare, mărire a volumului; (nav) a remorca, a ridica

heavier-than-air (fiz) mai greu ca aerul

heavily $(a d v)$ (foarte) greu, din greu; greoi, cu greutate, cu efort, lent

heavily tapered solid core box (met) cutie cu miez nedemontabilă

heaviness greutate; sarcină; dificultate; pondere; apăsare

heaving umflare, înfoiere; (geol) ridicare (a terenului)

heaving up remorcare

heavy greu, greoi, masiv; cu pondere / greutate mare; încărcat; (OM) (serie) grea (la rulmenți etc.); apăsător, greoi; (constr) (d. pământ) cleios, lutos, lipicios; (alim) (d. pâine etc.) cleios, necopt, necrescut; stângaci; corpolent; impozant; plicticos, neinteresant; somnoros; dificil, laborios; puternic, violent; de o fortă neobișnuită; (auto) vehicul greu; considerabil, mare; plictisitor, greu (d. o carte); (d. cer) încărcat, acoperit; adânc, greu (d. somn); înțepenit, greoi

heavy accumulation (mediu) acumulare / aglomerare considerabilă / mare (de materiale, particule etc.)

heavy air aer comprimat

heavy alloy (met) aliaj greu

heavy and medium plate mill (met) laminor pentru table groase şi mijlocii

heavy anode (met, el) anod masiv

heavy benzene / benzol (chim) benzen greu, benzină grea, solvent nafta

heavy-bodied (fiz) dens, consistent, vâscos

heavy-bodied oil ( $T$, fiz) ulei vâscos

heavy body $(\mathrm{T})$ corp cu vâscozitate mare

heavy breaking (auto) frânare bruscă

heavy burden (met) încărcătură / şarjă cu conținut ridicat de minereu (la furnal)

heavy case (met) grosimea stratului superficial (şi la cementare adâncă)

heavy casing (met) cementare adâncă (d oțeluri)

heavy casting (met) piesă mare / voluminoasă, turnată, turnare a unei piese mari / voluminoase

heavy coating $(\mathrm{TH})$ înveliş gros, acoperire groasă heavy crude oil (ind chim) țiței greu

heavy cut (ind chim) fracțiune grea; (mas-un) aşchie de mare secțiune, prelucrare / aşchiere cu îndepărtare de aşchii cu secțiune mare

heavy damping (mec) amortizare puternică / intensă 
heavy-duty $(\mathrm{TH})$ condiții grele de lucru, regim sever / cu condiții grele, (de) tip greu, (de) serie grea, de mare putere, de mare capacitate / rezistență, destinat pentru lucru greu / sarcină mare; (auto) de mare tonaj, greu; foarte robust; utilizat intens

heavy-duty boiler (alim, termo) cazan / boiler / fierbător de mare capacitate / cu debit mare

heavy-duty crane (nav, met, transp) macara de mare capacitate

heavy-duty forging (met) forjare grea

heavy-duty milling (mas-un) degroşare la maşina de frezat, frezare în regim sever

heavy duty relay / contactor (el) releu / contactor pentru curenți mari / puternici

heavy-duty thread $(\mathrm{OM})$ filet de forță / care rezistă la solicitări mari

heavy-duty tool (mas-un) cuțit / sculă pentru degroşare / eboşare

heavy-duty trailer (transpt, auto) remorcă pentru greutate mare

heavy-duty truck (transpt, auto) camion greu

heavy-duty tyre (auto) pneu pentru sarcină mare

heavy ends (ind chim) fractiii petroliere grele (cu cel mai ridicat punct de fierbere)

heavy force / driven fit (OM) ajustaj presat / forțat / cu strângere (mare)

heavy forging (met) forjare grea

heavy-fuel oil (termo) combustibil greu, păcură

heavy-fuel furnace (termo) focar pentru păcură

heavy gauge (met, metr) calibru / grosime mare (a tablei, sârmei, profilului) (la laminoare)

heavy-handed stângaci; greoi; cu mână grea; brutal; sever; aspru; dur

heavy hydrogen (D) (chim) hidrogen greu, deuteriu

heavy imports (ec) importuri masive

heavy industry industrie grea

heavy keying fit $(\mathrm{OM})$ ajustaj blocat / cu strângere

heavy-laden (mas, OM) încărcat până la refuz, greu, împovărat; supraîncărcat

heavy lathe (mas-un) strung mare / de tip greu

heavy liquor pump (alim, ind chim) pompă pentru suspensie îngroşată

heavy lorry (auto, transp) autocamion greu / pentru greutate mare

heavy machine oil ( $T$, ind chim) valvolină

heavy mass (fiz) masă grea / gravifică / gravitatională

heavy merchant mill (met) laminor de serie mare

heavy metal(s) (chim, met) metal(e) rare, cu masă atomică mare, metale grele

heavy mill (met) laminor greu / cu coeficient mare de reducere heavy naphta (ind chim) benzină grea

heavy oil (T) ulei lubrifiant greu / mai vâscos

heavy-oil carburattor (auto) carburator pentru motorină

heavy-oil engine (auto, nav) motor pentru combustibil greu

heavy pitch $(\mathrm{OM})$ pas mare / grosolan (la filete)

heavy plant (mas) utilaj greu

heavy plate (met) tablă groasă

heavy plate product (met) produs din tablă groasă

heavy pressure (hidr, met) presiune înaltă

heavy rain ploaie puternică / torențială

heavy repair $(\mathrm{TH})$ reparație capitală

heavy residue (ind chim) reziduu greu

heavy scrap (met) bucăţi mari de fier vechi

heavy-section / heavy-shape mill (met) laminor pentru profiluri grele

heavy sections (met) profiluri grele

heavy shade nuanță închisă

heavy shape (met) profil greu (laminat)

heavy-sized $(\mathrm{OM})$ de dimensiuni mari, se serie mare / grea (implicit dimensiuni mai mari)

heavy starting duty (mas, TH) pornire în condiții severe / dificile / grele

heavy storm (nav) furtună mare

heavy stroke linie groasă

heavy structural mill (met) laminor de profiluri grele

heavy swell (nav) hulă, valuri mari

heavy traffic (auto, transp) trafic greu / intens, vehicule grele, circulație intensă

heavy water (chim) apă grea

heavy-web drill (mas-un) burghiu spiral cu miez mai mare decât burghiul standard

heavy weight serie / categorie grea

heavy welding (met) sudare în secțiuni mari / cu rosturi mari

hebdo- (metr, mat) prefix metric pentru 10 milioane $\left(10^{7}\right)$

hebdomadal săptămânal, hebdomadar

heckle a bombarda / sâcâi cu întrebări

hect-, hecto- (h-) (metr) prefix metric prefix pentru 100

hectare (agr, metr) unitate de măsură pentru suprafață, hectar $\left(=10000 \mathrm{~m}^{2}=2,5\right.$ acri $)$

hectare meter (ha·m) (metr) unitate de măsură pentru volum: 1 hectare meter (ha $\mathrm{m})=10000 \mathrm{~m}^{3}$

hectobar (hbar) (metr) unitate de măsură pentru presiune: 1 hectobar (hbar) $=100$ bari $=10 \mathrm{MPa}$

hectogram (hg) (metr) unitate de măsură pentru masă: 1 hectogram $(\mathrm{hg})=100 \mathrm{~g}$

hectogram/liter (metr) unitate de măsură pentru debit masic, hectogram/litru: 1 hectogram/liter $=100 \mathrm{~kg} / \mathrm{m}^{3}$ 
hectogram/second (metr) unitate de măsură pentru debit masic, hectogram/secundă: 1 hectogram $/ \mathrm{second}=0,1 \mathrm{~kg} / \mathrm{s}$

hectojoule/second (metr, mec, fiz) unitate de măsură pentru putere, hectojoule/secundă: 1 hectojoule/second $=100 \mathrm{~W}$

hectoliter (hL or hl) (metr) unitate de măsură pentru volum / capacitate, hectolitru: 1 hectoliter $(\mathrm{hL}$ or $\mathrm{hl})=100 \mathrm{l}=0,1 \mathrm{~m}^{3}$

hectometer (hm) (metr) unitate de măsură pentru lungime, hectometru: 1 hectometer $(\mathrm{hm})=$ $100 \mathrm{~m}$

hectometer/square second (metr, mec) unitate de măsură pentru accelerație, hectometru/ secundă la pătrat: 1 hectometer/square second $=100 \mathrm{~m} / \mathrm{s}^{2}$

hectopascal (hPa) (metr) unitate de măsură pentru presiune: 1 hectopascal $(\mathbf{h P a})=100 \mathrm{~Pa}$

hectowatt (metr, mec, el) (metr) unitate de măsură pentru putere: 1 hectowatt $=100 \mathrm{~W}$

hedge gard viu, împrejmuire; obstacol, barieră; (fig) afirmație ambiguă, răspuns echivoc; a împrejmui (cu un gard); a se asigura contra riscurilor; a (se) eschiva; a(se) ascunde; a da răspuns echivoc

hedgehog arici; obstacol de sârmă ghimpată

hedgerow (agr) spalier

hedge-trimmer (agr. OM) foarfece de grădină

heed atenție, băgare de seamă; a băga de seamă, a acorda atenție; a ține sema de

heel (anat) călcâi; toc de pantof; (mas-un, metr, OM) călcâi (la micrometru), bază (la cuțit); (nav) bandă, înclinare transversală temporară a navei, unghi de bandă, a (se) carena; (OM) sabot, pinten, talon de anvelopă; a se înclina, a (se) apleca

heel block $(\mathrm{OM})$ bloc / piesă de protecție la flambaj (a poansonului, coloanei unei matrițe)

heeling (nav) bandă, înclinare transversală temporară a navei

heeling experiment (nav) probă de stabilitate

heeling indicator (metr) înclinometru

heeling tank (nav) tanc de canarisire, înclinare transversală

heel knee (nav) guseu de etambou

heel of keel (nav) călcâi al chilei

heel of tool (mas-un) fața inferioară, liberă a cuțitului

heel over (nav) a se înclina, a lua banda (d. o navă)

heelplate blancheu; potcoavă

heel top flec; (alim) drojdie, zaț

heer (metr) unitate tradițională pentru masurarea lungimii firelor / fibrelor: 1 heer $=73,152 \mathrm{~m}$
Hefner candle (HC), Hefnerkerze (HK) (metr, fiz) fostă unitate de măsură pentru intensitatea luminii: 1 Hefner candle $\sim 0,902$ candela (cd)

heft greutate, pondere; împingere; impuls; a cântări (în mână); a ridica (sus), a înălța

hefty robust; viguros, tare, puternic; abundent, copios, bogat

he-goat (agr) țap

hefter (agr) vițică, vițea, juncă, junică

height cotă, înălțime, nivel, altitudine, elevație; statură; ridicătură, culme; (fig) vârf, punct culminant; zenit

height above sea-level (geogr) cotă absolută, înălțime deasupra nivelului mării

height and/or spacing discrimination (metr) discriminare a înălțimii şi/sau a pasului (la profilometria suprafeței)

heighten a înălța, a ridica; a (se) mări, a spori, a creşte, a ridica; a (se) intensifica; a ascuți; a ațâța; (fig) a exagera; a deveni mai intens

height gauge (mas-un) şubler de trasat; (metr) altimetru, riglă verticală

height indicator (metr) altimetru

height of the curve (mec, OM) săgeată a curbei (şi la lanţuri)

height of the level (hidr) înălțime / nivel (a(l) lichidului)

height of the level / of lift (TH, mas-un) înălțime / cursă de ridicare

height of oscillation (mec) amplitudine a oscilației

heights $(\mathrm{TH})$ cote, înălțimi (la construcții, utilaje metalurgice, în desen tehnic)

height under the cross slide (mas-un) înălțime de rabotat, caracteristică a rabotezei

heir moştenitor, succesor

heiress mosstenitoare, succesoare

helek (hl), $(p l)$ halakim (hl) (metr) veche unitate iudaică de timp: 1 helek $=1 / 1080 \mathrm{~h}=1 / 18$ minute $=10 / 3 \mathrm{~s}$

helfy profits (ec) beneficii / profituri considerabile / substantiale

heliarc welding (met, el) sudură cu arc şi electrod de wolfram, în atmosferă controlată

helical (TH, OM) elicoidal, în formă de elice / de spirală, în spirală, spiral

helical auger (mas-un) burghiu elicoidal

helical-blade stirrer (alim, ind chim) amestecător cu elice / cu pale / cu palete elicoidale

helical blower (met) suflantă elicoidală

helical conveyer (transp, ind chim) transportor elicoidal; (alim) şnec, (transportor cu) melc

helical / helicoidal gear (OM) roată / angrenaj cu dinți înclinați 
helical / helicoidal gearing (OM) angrenaj cu dinți înclinați, angrenare la roți între dinți înclinați

helical groove $(\mathrm{OM})$ canal elicoidal

helical mill (mas-un) freză cu dinți elicoidali / aşezați în spirală

helical milling (mas-un) frezare a canalelor elicoidale (cu cap divizor)

helical motion $(\mathrm{mec})$ mişcare elicoidală / pe o elice / pe o spirală

helical plain milling cutter (mas-un) freză cilindrică, cu dinți elicoidali / înclinați

helical rack $(\mathrm{OM})$ cremalieră cu dinți înclinați

helical rack type cutter (mas-un, OM) sculă aşchietoare, tip cremalieră cu dinți înclinaţi

helical rolling (met) laminare elicoidală

helical spring $(\mathrm{OM})$ arc elicoidal

helical spur gear (OM) angrenaj cu roți cilindrice cu dinți înclinați

helical stripe (met) bandă înfăşurată elicoidal (pe cabluri, la suduri de reconditionare etc.)

helical teeth $(\mathrm{OM})$ dinți înclinați / elicoidali

helical-toothed wheel $(\mathrm{OM})$ roată dințată cu dinți înclinați / elicoidali (rar în limba română)

helical wire $(\mathrm{OM})$ spirală de sârmă, bobină

helicoidal toothing (OM, mas-un) dantură înclinată / elicoidală (rar în limba română), generare a danturii înclinate / elicoidale

helicopter (av) elicopter

helicopter screw (av, fiz) elice sustentoare portantă / de elicopter

heliotope heliotrop; culoare purpurie

heliport, helidrome (av) aeroport pentru elicoptere

Helium (He) (chim) heliu

helium arc welding (met) sudare cu arc, în atmosferă / mediu de heliu

helix (ind chim) serpentină; (mat) elice, curbă elicoidală; $(\mathrm{OM})$ elice, spirală, linie curbă elicoidală (în plan sau în spațiu); (geom) suprafață elicoidală, elicoid; (OM) arc spiral / elicoidal

helix angle $(\mathrm{OM})$ unghi al elicei, unghi de înclinare al elicei (la filete, la dantură înclinată)

helix pump (OM) pompă elicoidală

helm (constr) acoperiş turlă; (nav) cârmă, eche, timonă, transmisie de cârmă, instalație de guvernare; $(\mathrm{TH})$ cască; (fig) a cârmui, a călăuzi

helmet (met) cască de protecție (la sudură etc.)

helmeted ( $\mathrm{TH}$, met) cu casca de protectie pe cap (d. un muncitor)

helmsman (nav) timonier, cârmaci

help sprijinire, suport, ajutor, asistență; persoană care ajută; remediu, soluție; salvare; a ajuta; a fi folositor; a sprijini; a vindeca; a remedia, a îndrepta, a ameliora; a folosi, a fi de folos / ajutor; (c) fişier care conține informații, explicații de utilizare

helper ucenic, ajutor de muncitor

helper spring $(\mathrm{OM})$ arc auxiliar / ajutător

help in / with a ajuta să / la; a sprijini în / la

help to a ajuta la; a sluji, a servi la; a fi de ajutor pentru; a trebui; a fi obligat

helper (persoană care dă) ajutor; (cf) locomotivă suplimentară / auxiliară

helpful util, folositor; de ajutor / nădejde; serviabil, îndatoritor

helpful information informatii utile

helpfully $(a d v)$ (în mod) util / folositor

helpfulness caracter folositor, utilitate

helpless neajutorat, lipsit de ajutor; neputincios, incapabil; lipsit de apărare; inutil, ineficace; nul; nedumerit, uluit

helplessly $(a d v)$ neajutorat, fără ajutor; în imposibilitatea de a face ceva, fără apărare

helplessness neajutorare; nevoie / lipsă de ajutor; lipsă de apărare; ineficacitate

help out a scoate din încurcătură; a ajuta la nevoie; a fi de folos / ajutor

helve $(\mathrm{OM})$ coadă / mâner de unealtă

helving hammer $(\mathrm{OM})$ ciocan cu pârghie acționată la mijloc

hem volută; tiv, bordură (şi de tesătură); manşetă; a tivi; a înconjura, a împresura; a închide; a împrejmui

hematite (minrl) hematit (mineral care conține oxid feric)

hematite pig iron (met) fontă-hematit

hemicompact semicompact (d. un material, subansamblu)

hemicycle (fiz, TH) semiciclu, jumătate dintr-un ciclu (şi de producție, de solicitare, tehnologic)

hemicyclic(al) semiciclic

hem in a îngusta; a limita; a delimita; a înconjura; a face un tiv / o bordură; a închide

hemina (metr) unitate romană pentru volum (pentru lichide): 1 hemina $\sim 265,6$ mililitri

hemisphere

hemisphere emisferă; (geom) semisferă; (metr, geom) unitate tradițională pentru unghiul solid 1 hemisphere $=0,5$ dintr-o sferă, 2 pi steradiani, 20 626,48 grade de unghi solid

hemispheric(al) emisferic, în formă de emisferă hemispherical part emisferă; pătură / capsulă sferică

hemiterpene (plast) izopren

hemoglobin (anat, chim) hemoglobină

hemp (agr, textile) cânepă; (nav) parâmă de cânepă 
hemp belt $(\mathrm{OM})$ curea din țesătură de cânepă hempen de cânepă; cânepiu

hemp jointing / packing $(\mathrm{OM})$ garnitură de cânepă hemp oil (agr, ind chim) ulei din semințe de cânepă

hemp rope (nav) parâmă / frânghie de cânepă hen (agr) găină, cloșcă

hence (adv) de aici / acum înainte; de acum încolo, în viitor; pornind de aici, pornind de la aceasta, de unde; de la / din care; aşadar, deci, prin urmare; $\sim$ it was that din cauza asta

hendecagon (geom) endecagon, poligon cu unsprezece laturi

henry, $(p l)$ henries $($ brit), henrys (amer) $(\mathrm{H})(\mathrm{SI}$ unit) (metr, fiz) unitate de măsură a inductantei electrice, henry: $1 \mathrm{H}=1 \mathrm{~Wb} / \mathrm{A}=1$ $\mathrm{kg} \cdot \mathrm{m}^{2} /(\mathrm{A} \cdot \mathrm{s})^{2}$

hepatic pyrite (met, minrl) marcasit; (chim) disulfură de fier

heptachlor (chim) heptaclor, insecticid puternic heptad heptadă, grup de şapte; (metr) unitate pentru cantitate 1 heptad $=7$ bucăți

heptagon (geom) heptagon, poligon cu şapte laturi

heptagonal (geom) heptagonal

heptahedron (geom) heptaedru

heptavalent (chim) heptavalent

her ei; său, sa, săi, sale; pe ea; (a / al; ai / ale) ei, său / sa / săi / sale; pe ea

herb (bot) iarbă, plantă ierboasă

herbage (agr, bot) ierburi, buruieni, măduvă (la plante); (jur) drept de păşunat

herbal referitor la ierburi; ierbos; tratat despre plante; manual de botanică

Herbert hardness (metr, materiale) duritate Herbert

herbicide (agr) ierbicid

herbivore, $p l$ herbivores, herbivora (zool, agr) animal ierbivor / rumegător

herbivorous $(a d j)$ ierbivor

herborization (bot, edu) erborizare; colectare de plante

herb tea (bot, med) ceai medicinal / din plante medicinale

here $(a d v)$ aici, în locul acesta; (arată direcția) încoace, aici; în acest moment, aici, acum; la care; aici de față / prezent; momentul acesta / de față / prezent

hereabout(s) $(a d v)$ pe aici (pe aproape), (pe) undeva prin apropiere

hereafter $(a d v)$ în viitor, mai târziu; viitor

hereditary mechanics $(\mathrm{mec})$ mecanică cu condiții la limită

here and now $(a d v)$ acum şi aici here and there $(a d v)$ (pe) ici colo, încoace şi încolo

hereat la care, drept care; din care cauză

hereby prin care mijloc, drept care, prin aceasta; în felul acesta

hereditariness caracter ereditar / moştenit; ereditate

hereditary ereditar; moştenit

heredity moştenire, ereditate

herein $(a d v)$ aici, în acest loc; în cele de față, alăturat; prin / în această

hereinabove, hereinbefore mai sus, mai înainte hereinafter mai jos; mai departe; în continuare

hereto (aici) alăturat; la aceasta; în această privință

heretofore până acum, anterior, înainte de aceasta; de mai înainte, de până acum; în această privință, la aceasta

hereunder $(a d v)$ mai jos; mai departe; tot aici

hereunto până aici; cu referire la aceasta

hereupon $(a d v)$ la care, drept care; drept urmare, ca rezultat, în consecință; cu acestea; între timp

herewith $(a d v)$ (aici) alăturat; în acelaşi loc; în felul acesta, prin aceasta, în acest mod

heritable (jur) care poate fi moștenit / transmis prin moştenire / succesiune; transmisibil; ereditar

heritage moștenire, succesiune; patrimoniu, avere; drept legitim; tradiție, datină

heritor (jur) moștenitor, succesor

hermetic(al) (OM) ermetic, etanş; (fig) obscur

hermetically $(a d v)$ (în mod) ermetic, etanş

herring (alim) hering, scrumbie (şi de Atlantic)

herringbone $(\mathrm{OM})$ în unghi; în $\mathrm{V}$; model în zigzag; a aranja în zigzag (d. elemente de maşini, forme); (arht) împletituri, mozaic; şiră / schelet de spinare de pește

herringbone gear cutter (mas-un) freză-degetmodul, freză-modul cu coadă

herringbone gearing $(\mathrm{OM})$ angrenare / angrenaj în V

herringbone masonry (constr) zidărie cu cărămizi aşezate în spic

herringbone parquet floor (constr) pardoseală de parchet în spic

herringbone paving (constr) pavaj de piatră cioplită în formă de spic (şiră de spinare de pește)

herringbone pattern (autom) diagramă de perturbare în spic; diagramă / schemă de cauzalitate / cauză-efect (v. fishbone chart, Ishikawa chart); (TV, c) interferentă care apare pe ecranul televizorului ca o bandă orizontală de linii în formă de $\mathrm{V}$ sau de $\mathrm{S}$

herringbone strut (nav) contravântuiri în cruce 
hers al ei / său, a ei / sa; ai ei / săi, ale ei / sale herself (pe) (ea) însăşi

hertz (Hz) (SI unit) (metr, fiz) unitate de măsură pentru frecvență, numărul de cicluri pe secundă; 1 hertz $=1 \mathrm{~s}^{-1}$

Hertz(ian) contact (mec, T) contact hetzian

hesitance, hesitancy, hesitation ezitare, şovăială, nehotărâre, nesiguranță; bâlbâială

hesitant ezitant, şovăielnic, nesigur, nehotărât

hesitate a şovăi, a ezita, a fi nehotărât

hesitate to / at a şovăi, a ezita, a nu se putea hotărâ să; a avea ezitări, a se da înapoi de la; a se bâlbâi

hesitater, hesitator (om) nehotărât, persoană care ezită

hesitating care ezită, ezitant, şovăielnic, nesigur, nehotărât

hesitation ezitare, şovăială, nehotărâre, nesiguranță; bâlbâială; (inf, c) ezitare, suspendare (temporară) a execuției unui program / a unei secvente de calcul în favoarea alteia

heteroclite anormal, care manifestă anomalii; neregulat; (cu) anomalie

heterocoagulation (ind chim, alim) coagulare eterogenă

heterochromatic (fiz, plast) policrom, heterocromatic

heterogeneity neomogenitate

heterogeneous eterogen, neomogen; divers, diferit

heterogeneousness neomogenitate, caracter eterogen, eterogeni(e)tate

heterotropic anizotrop, heterotrop (d. materiale)

heuristic euristic, (cu caracter) de descoperire / cercetare (practică)

heuristics euristică, metodologia descoperirilor / cercetărilor; (inf) (metodă) euristică (bazată pe experiența, intuiția sau inspirația programatorului); (ec) metodă de selectare a alternativelor în luarea deciziilor

hew a ciopli (lemn); (met, mas-un) a degroşa, a tăia, a reteza, a extrage

hew asunder a despica, a tăia în două

hew away a reteza

hewing cioplire (a lemnului); (constr) excavație

hewn timber (silv) cherestea brută / nefasonată

hew off a reteza, a tăia

hew to a adera la; a se conforma cu

hexad hexadă, serie / grup de 6; (metr) unitate pentru cantitate: 1 hexad $=6$ bucăți

hexadecanoic acid (chim) acid palmitic

hexadecimal number system (mat, inf) sistem de numeratie hexazecimal / cu baza 16

hexadic în număr de 6 , formând un grup de 6 hexagon (geom) hexagon

hexagonal (geom, OM) hexagonal

hexagonal bar (met) semifabricat / bară cu secțiune hexagonală

hexagon(al) bolt / screw (OM) şurub / bolt cu cap hexagonal

hexagonal close-packed lattice / system (fiz, met) sistem hexagonal compact (de cristalizare)

hexagonal drawn bar (met) bară trasă, hexagonală

hexagonal-head bolt (OM) bolț / şurub cu cap hexagonal

hexagonal-head nut $(\mathrm{OM})$ piuliță hexagonală

hexagonal system (fiz, met) sistem hexagonal (de cristalizare)

hexagonal wire (OM, met) sârmă cu secțiune hexagonală

hexagon and pentagon broaches (mas-un) alezor hexa- şi pentagonal

hexagon bar iron (met, mas-un) bară / semifabricat hexagonal( $\breve{a})$

hexagon bolt / cap / head screw (OM) şurub cu cap hexagonal

hexagon flangenut $(\mathrm{OM})$ piuliță hexagonală cu gât / cu flanşă / cu bază mărită de aşezare

hexagon head $(\mathrm{OM})$ cap hexagonal (și la şuruburi)

hexagon head bolt $(\mathrm{OM})$ șurub cu cap hexagonal

hexagon head with washer face $(\mathrm{OM})$ cap hexagonal cu guler / umăr de aşezare

hexagon nut $(\mathrm{OM})$ piuliță hexagonală

hexagon steel (met, mas-un) semifabricat / bară cu secțiune hexagonală

hexagon tool (mas-un) cuțit pentru rabotarea profilului hexagonal, al deschiderii la cheie

hexagon turret (mas-un) cap revolver cu turelă hexagonală / cu şase posturi de lucru

hexahedral (geom) hexaedric

hexahedron (geom) hexaedru, cub

hexangle (geom) poligon cu şase laturi, hexagon hexit (metr, inf) unitate pentru informatie: 1 hexit $=4$ bits sau $1 / 2$ byte

H fixture (constr) stâlp în formă de $\mathrm{H}$

hiatus discontinuitate, lacună, omisiune (în text) hi-bulk voluminos (d. fibre sintetice şi compozite)

hickey $(\mathrm{OM})$ adaptor

hidden latent; ascuns; în repaus

hidden crack (met) fisură ascunsă

hidden energy (fiz, chim) energie potențială / latentă

hidden feature $(\mathrm{OM})$ muchie ascunsă / invizibilă (în desen); (autom, mas) caracteristică ascunsă / neevidentă 
hide a (se) ascunde, a ține ascuns; a camufla; a acoperi; a împiedica să fie văzut; piele de animal, piele crudă / brută; (metr, agr) lot de pământ (25...50 ha)

hide (metr) unitate de măsură pentru suprafață: 1 hide $=4,046856 \cdot 10^{5} \mathrm{~m}^{2}$

hideaway ascunzătoare, (loc de) refugiu

hide behind a se refugia, a se ascunde

heding ascunzătoare, refugiu

hiding-place ascunzătoare; depozit / refugiu secret

hierarchic(al) ierarhic

hierarchy ierarhie, organizare ierarhică; (mat) clasificare după rang / clasă, ordin

hieroglyph hieroglifã

hieroglyphic(al) hieroglific; simbolic; plin de simboluri; (fig) greu de înțeles / descifrat etc.

higgle a se tocmi, a se târgui

high (s) cer; (zi de) sărbătoare; înalta societate; (adj) înalt, ridicat, mare, înălțat; elevat, distins; (fiz) (d. sunete) înalt, ascuțit, acut; intens, puternic, tare; (foarte) mare; superior; complet; acut; principal, important, însemnat; remarcabil; avansat, înaintat (d. timp); în toi; apoape de punctul culminant; maxim barometric; ieşit din comun, neobişnuit; deosebit; (foarte) favorabil, foarte bun, propice; grav, serios; îngrijorător; scump, costisitor, cu preț ridicat; abundent, copios, bogat, luxos; care urcă; nedecoltat (d. rochii); suspus; înalt; superior (d. sentiment, limbaj etc.); ales; semeț, mândru; viu, intens; plin, foarte înaintat; furios, mânios; strident, ascuțit (d. voce, sunet); (alim) aproape stricat, care a început să se strice (d. mâncare) înălțime; ridicătură de teren; deal, movilă; cer; anticiclon; centru de mare presiune; (auto) treaptă de viteză superioară / multiplicativă; $(a d v)$ înalt, la înălțime mare, la înălțime de, scump, din belşug, puternic, violent, furios, îndepărtat, în vremurile trecute, din plin; în mare măsură; and dry (nav) fără vânt, împotmolit; bid (ec) a pune prețuri mari; and low pretutindeni

high abrasion furnace black (met) negru de fum, cu rezistență mare la abraziune

high-activity file (inf) fişier cu modificări frecvente

high alloy (met) aliaj bogat / înalt aliat

high-alloyed steel (met) oțel înalt aliat

high-altitude engine (termo) motor de înălţime

high aluminium (met) defect, zonă-defect în aliaje de aluminiu, cu prea mult aluminiu-alfa

high-antichock gasoline (ind chim) benzină cu cifră octanică superioară, benzină superioară

high-ash coal (met, termo) cărbune cu conținut mare de cenuşă high beam (auto) fază mare / lungă

high-beam operation (auto) funcționarea / acționarea fazei lungi

high blood pressure (med) hipertensiune (arterială)

high-boiling (fiz) greu volatil, cu punct de fierbere ridicat

high body $(\mathrm{T})$ corp cu vâscozitate mare

high brass (met) alamă de calitate superioară / bogat aliată

high-carbon steel (met) oțel $\mathrm{cu}$ conținut ridicat de carbon

high-carbon steel casting (met) piesă din oțel turnat, cu continut ridicat de carbon

high class $(\mathrm{TH})$ de calitate superioară, de mare valoare

high-compressing ( $\mathrm{TH}$, termo) cu compresie înaltă, care comprimă mult / puternic

high-compression engine (auto, termo) motor cu compresie înaltă / puternică

High Court (jur) Curtea Supremă

high-cycle fatigue $(\mathrm{OM})$ (distrugere prin) oboseală la nivele de tensiuni mai mici decât limita elastică, în general sub $5 \cdot 10^{4}$ cicluri

high damping (mec) amortizare mare / intensă / rapidă

high density (c, plast) de mare densitate

high density alloy (met) aliaj de mare densitate

high-density (-weight) polyethilene (plast) polietilenă de mare densitate

high density pulp (alim, ind chim) pastă concentrată

high dip înclinare mare

high dumper (OM, mas) benă basculantă cu dispozitiv de ridicare simultană / cu mecanism foarfece

high-duty (TH) de tip greu, de mare putere, de serie grea (d. organe de maşini, caneluri, rulmenți etc.)

high-duty / high-strength cast iron (met) fontă rezistentă / de calitate superioară (turnată în piese)

hight-duty cooling bed (met) pat de răcire cu randament mare

hight-duty machine ( $\mathrm{TH}$, met, mas) maşină de mare putere / pentru industrie grea

hight-duty mill / roll (met) laminor / cilindru (de laminor) de mare putere / greu

hight-duty steel $(\mathrm{TH})$ oțel de rezistență mare / de înaltă rezistență

high efficiency (mas) (de / cu) mare eficiență / randament

high efficiency mill (met) laminor cu randament mare / ridicat 
high early strength cement (constr, ind chim) ciment cu întărire rapidă

high-energy (mas, TH) de mare energie, cu energie multă

high-energy particle (fiz) particulă de mare energie

high-energy physics (fiz) fizica de mare energie

higher mai înalt, superior, mai sus

higher-degree de grad superior (d. calitatea produselor)

higher derivative (mat) derivată de ordin superior $(\geq 2)$

higher education (edu, univ) învățământ superior

higher education(al) establishment (edu, univ) institut de învătământ superior

higher hydrocarbons (ind chim) hidrocarburi superioare

highest common factor (mat) cel mai mare factor comun

highest output $(\mathrm{TH}$, mas) putere maximă la ieşire

highest pressure (hidr) presiune maximă

highest stress (mec, OM) solicitare / tensiune / efort $\operatorname{maxim}(\breve{\mathrm{a}})$

high explosive (chim) exploziv puternic, cu potențial exploziv mare

high farming agricultură intensivă

high fidelity (mas, autom) înaltă fidelitate; de înaltă fidelitate / precizie

high finish $(\mathrm{TH})$ finisare / prelucrare finală de calitate superioară

high flash solvent (chim) solvent cu punct de inflamabilitate ridicat

high flow (fiz, T) fluiditate mare, vâscozitate mică

high frequency (mec, el) frecvență mare / înaltă / ridicată

high-frequency furnace (met, el) cuptor metalurgic, cu curenți de înaltă frecvență

high-frequency induction furnace (met, el) cuptor cu inducție, cu curenți de înaltă frecvență

high-frequency hardening (met) durificare / călire prin / cu curenți de înaltă frecvență

high-frequency heating (termo, el, met) încălzire prin curenți de înaltă frecvență

high-frequency moulding (met) formare / matrițare prin (încălzire cu) curenți de înaltă frecvență

high-frequency vibrator (mas) vibrator de înaltă frecvență

high-frequency welding (met, el) sudare cu curenți de înaltă frecvență

high furnace (met) cuptor vertical / cu cuvă high gas pressure switch (termo, met, hidr) întrerupător de gaz, la presiuni mari

high gear (OM) angrenaj multiplicator; (auto) viteză superioară / mare

high gloss lamination (alim, plast) celofanare, caşetare cu pelicule transparente

high gloss paper hârtie cu luciu superior

high-grade (TH) de calitate superioară, de bună calitate, cu conținut ridicat, de mare valoare, mult îmbogățit, marcă superioară (de material)

high-grade steel (met) oțel de calitate superioară

high-grade zinc (met) zinc rafinat

high headlight (auto) fază lungă

high-heating value (termo) putere calorică mare / superioară

high helix drill (mas-un) burghiu spiral, cu unghi mare de înclinare al canalelor elicoidale

high humidity and condensation test (materiale, metr) încercare / test la coroziune în aer umed

high impact polystyrene (plast) polistiren antişoc / rezistent la şoc

high in sulfur $(\mathrm{T}, \mathrm{chim})$ cu concentrație mare de sulf

high interstitial defect (met) defect intergranular (cauzat de concentrații locale mari de azot, oxigen sau carbon)

high-key imagine / picture (c) imagine luminoasă (pe display)

high-level (hidr, ind chim) suprateran (d. rezervoare, conducte etc.)

high level language (inf) limbaj (de programare) de înalt nivel, limbaj evoluat

high-lift pump (hidr, OM) pompă de presiune mare / ridicată

highlight parte luminoasă, punct de maximă luminozitate; (TV, c) arie de intensitate luminoasă; a scoate în evidentă / relief, a releva, a evidenția; a sublinia

highlights trăsătură esențială / principală, element de bază; atracție principală (şi la $p l$ )

high-low bias test (autom, metr) verificare / test la valori extreme / marginale

high-lustre polish (mas-un) lustruire fină / cu luciu puternic

highly acid (chim) (agent / substanță) puternic $\operatorname{acid}(\breve{a})$

highly basic (chim) (agent / substanță) puternic $\operatorname{bazic}(\breve{a})$

highly compressed comprimat la presiune mare (d. materiale, şi sinterizate)

highly conductive (termo, el) de mare conductivitate / conductibilitate (termică sau electrică)

highly poisonous gas (chim, med) gaz foarte toxic / otrăvitor 
highly polished (mas-un) polizat fin, lustruit oglindă; satinat; neted

highly refractory (met) foarte refractar

highly resistive / resistant (el) de / cu mare rezistență electrică

highly volatile (fiz) uşor volatil

high melt (met, plast) topire intensă / la temperatură ridicată

high-melting greu fuzibil; (met) refractar, care se topeşte la temperaturi ridicate

high melting-point alloy (met) aliaj cu punct / temperatură de topire ridicat( $(\breve{a})$

high mirror finish (mas-un) finisare oglindă, luciu puternic / intens

high mirror finish sheet (met) tablă polizată / lustruită-oglindă

high-molecular (chim) macromolecular

high-molecular compound (chim) compus macromolecular

high-molecular weight compound (chim) compus cu masă moleculară mare

high mounted stop bulb light (auto) becul celei de-a treia lumini de stop

high mounted stop light (auto) lumină de stop suplimentar spate

high-octane gasoline / petrol (ind chim) benzină cu cifră octanică superioară

high-octane rating (ind chim) cifră octanică ridicată / superioară

high ohmic (el) de rezistență (ohmică) mare

high-ohmic resistance (el) rezistență ohmică mare

high-order position poziție de rang superior (a unei cifre)

high output (mec) putere mare, la ieşire

high-output penstock (hidr) conductă forțată, de mare debit

high output slow speed, marine diesel engine (nav) motor diesel naval, de viteză mică şi putere mare

high part $(\mathrm{OM})$ parte superioară / de sus (a unui organ de maşină)

high-pitch tone (fiz) ton / sunet înalt

high polymer (ind chim, plast) polimer cu grad mare de polimerizare / cu lungime moleculară mare / cu greutate moleculară mare

high potential (el) (de / cu) înaltă tensiune

high power $(\mathrm{TH})(\mathrm{de} / \mathrm{cu})$ putere mare

high precision $(\mathrm{TH})(\mathrm{de} / \mathrm{cu})$ precizie ridicată

high pressure $(\mathrm{TH}, \mathrm{hidr})(\mathrm{de})$ presiune mare / înaltă

high pressure accesories / fittings (hidr, OM) armături / accesorii de presiune mare / înaltă

high pressure boiler (alim, termo) cazan / fierbător (de) presiune mare / înaltă (în sistem hidraulic) high pressure compressor (termo) compresor de înaltă presiune

high pressure die-casting (met) turnare sub presiune (în matriță)

high-pressure exhauster (met, termo) suflantă de gaze sub presiune

high pressure lubricant $(\mathrm{T})$ lubrifiant pentru presiuni / sarcini mari

high-pressure moulding (met plast) (procedeu de) formare / turnare sub presiune înaltă / mare

high-pressure oil $(\mathrm{T})$ ulei antigripant / pentru contacte greu încărcate

high pressure oil saver $(\mathrm{T})$ dispozitiv de prevenire şi recuperare a uleiului sub presiune (din circuit)

high-pressure pipe / piping (OM, hidr) conductă / sistem de conducte de / sub presiune mare / înaltă

high pressure polyethylene (plast, ind chim) polietilenă obtinută la presiune mare

high pressure shuttle valve (hidr, autom) selector de circuit de înaltă presiune

high pressure spray test (hidr) probă de jet pulverizat cu presiune înaltă

high-pressure steam reclaiming process (ind chim) procedeu de regenerare a cauciucului, cu abur de înaltă presiune

high-pressure valve (OM, hidr) supapă de presiune înaltă

high production (mas, $\mathrm{TH}$ ) de mare productivitate

high pressure pump (OM, hidr) pompă de presiune mare / înaltă

high rate terminal (hidr) terminal cu debit ridicat / cu capacitate sporită

high pressure tank (hidr, alim, ind chim) tanc / recipient sub presiune mare

high-purity (de / cu) puritate ridicată (d. materiale)

high-quality (TH) de calitate ridicată / superioară high-quality cast iron / steel (met) fontă turnată / oțel de calitate superioară

high-quality steel sheet (met) tablă din oțel, de calitate superioară

high rate trickling (alim, mediu) biofiltru de mare încărcare

high ratio gear (OM) angrenaj (şi dințat) cu raport mare de transmisie

high /-highly refractory brick (met) cărămidă de înaltă refractaritate

high resistance rezistență mare (în general)

high resolution (HR) (inf, c) rezoluție înaltă / mare (în prelucrarea imaginii) 
high Reynolds number (hidr, T) număr mai mare decât numărul Reynolds critic

highroad (auto) şosea, autostradă

high road drum principal

high-rubber mix (ind chim, plast) amestec cu conținut mare de cauciuc

high school (edu) curs superior al liceului, liceu, colegiu

high sea (nav) mare agitată

high-silicon cast iron (met) fontă de turnătorie, cu conținut mare de siliciu

high-silicon pig iron (met) fontă brută, cu conținut mare de siliciu

high-sintering (met, ind chim) sinterizare la temperaturi ridicate

high speed, high-speed (auto) viteză multiplicată; (mas-un) viteză / turație mare / înaltă; mers rapid; de /cu viteză mare, rapid

high-speed auxilary jet (auto, termo) jiclor compensator

high speed balancing (mec) echilibrare la viteză / turație mare

high-speed camera (metr) aparat pentru filmare rapidă

high-speed carry (auto, cf, hidr, transp) transport / report rapid

high-speed car wash brush (auto) perie de mare viteză (pentru spălarea mașinilor)

high-speed centrifuge (alim, ind chim) centrifugă de mare viteză

high-speed cutting (mas-un) aşchiere / debitare cu viteză mare / rapidă

high-speed evaporator (alim, ind chim) evaporator / vaporizator cu circulație intensă / rapidă

high-speed machine-tool (mas-un) maşinăunealtă de viteză mare / rapidă / pentru scule din oțel rapid

high-speed mill (met) laminor rapid / cu viteză mare

high-speed plunger moulding (plast) formare prin transfer, cu două pistoane

high-speed reamer (mas-un) alezor din otel rapid

high-speed roll (met) cilindru de viteză mare, cilindru rapid

high-speed shooting filmare rapidă

high-speed steel (met) oțel rapid

high-speed (tool) steel (met) oțel rapid (pentru scule)

high street strada principală

high strength $(\mathrm{mec})(\mathrm{cu})$ rezistență mare $(\mathrm{d}$. materiale)

high-strength nodular cast iron (with spheroidal graphite) (met) fontă cu grafit nodular / sferolitic, de mare rezistență high-strength steel (met) oțel de mare rezistență (mecanică)

high-temperature alloy / steel (met) aliaj / oțel termostabil / refractar

high-temperature oxidation (chim, met) oxidare la temperatură înaltă

high-temperature strength (mec, met) rezistență la temperatură înaltă

high-temperature tempering (met) revenire (la temperatură) înaltă

high-temperature (tensile) strength (materiale) rezistență la temperatură înaltă (sub sarcină de tracțiune)

high tensile $(\mathrm{mec}) \mathrm{cu}$ rezistență mare la tracțiune (d. un material)

high-tensile bolt $(\mathrm{OM})$ bulon / bolț cu rezistență mare la tractiune

high tensile brass / steel (met) alamă / oțel cu rezistență mare la tracțiune

high-tensile structural steel (met) oțel de construcții, cu rezistență mare la tracțiune

high tension / voltage (el) tensiune ridicată / înaltă

high-tension ignition (auto, termo) aprindere (prin magnetou) la / cu înaltă tensiune

high tension system (el) sistem de înaltă tensiune

high-test metal (met) metal de înaltă calitate / testat cu acuratețe

high tide (nav) maximum al fluxului, maree înaltă, cotă maximă a fluxului; (fig) punct culminant, apogeu, culme

high-tin babbit (met, T) aliaj $\mathrm{Cu}-\mathrm{Sn} /$ babbit / aliaj alb cu conținut mare de Sn (şi pt. lagăre)

high top heat (met) temperatură excesivă a gazelor la gura furnalului

high vacuum (fiz) vid înaintat

high-vacuum distillation (alim, ind chim) distilare în vid (înaintat) / moleculară

high-vacuum melting furnace (met) cuptor de topire, cu vid înaintat

high-vacuum pump (OM, termo) pompă pentru vid înaintat

high-velocity flow (hidr, fiz) curgere rapidă

high-velocity tension impact test încercare / test dinamic(ă) la tracțiune cu şoc, cu viteză mare

high-velocity wash (alim, ind chim) spălare sub presiune / cu jet

high viscosity $(\mathrm{T})$ vâscozitate mare / ridicată high volatility (fiz) volatilitate uşor de realizat

high voltage (el) tensiune înaltă, voltaj ridicat

high voltage lines / equipment (el) linii / echipament electric(e) de tensiune înaltă 
high water (hidr, geogr) apă mare, cotă maximă a apei

high water mark (hidr, metr) cotă maximă a apei, nivel maxim al apelor; punct culminant, apogeu; cu capul în nori (d. persoane)

highway drum național, autostradă, magistrală (rutieră), rută principală

high wearing feature (T) rezistență mare la uzură high-webbed (met) cu inimă înaltă (la profile)

high-webbed tee iron (met) profil $\mathrm{T}$ înalt / cu inimă înaltă

high wind vânt violent

high-Z element (fiz, chim) element cu număr atomic mare

hike plimbare (de agrement), excursie; ridicare, urcare, sporire (de prețuri, salarii etc.); a (se) ridica, a (se) înălța, a urca; a împinge în sus; a mări, a spori; a lua la plimbare; a călători

hiker excursionist, călător

hill (geogr) colină, deal, movilă, grămadă, morman, muşuroi, munte, cotă, pantă, povârniş; a îngrămădi, a aduna într-un morman, a face morman / grămadă; (agr) muşuroi

hillock (geogr) deluşor; ridicătură de teren; mamelon

hillocky (geogr) deluros; acoperit cu deluşoare; accidentat

hillside (geogr) coastă de deal

hilly (geogr) deluros, acoperit de dealuri / coline; colinar; abrupt, în pantă; accidentat, cu hârtoape

hilly ground (geogr, auto) teren accidentat

hilt mâner, coadă, prăsele; a pune mâner

hin (Biblical) (metr) veche unitate iudaică de măsură pentru capacitate / volum (lichide): 1 hin $($ Biblical $)=0,003666667 \mathrm{~m}^{3}$

hind de dinapoi, posterior; (agr) muncitor agricol; țăran; (zool) căprioară, ciută

hinder a împiedica; a stânjeni; a stingheri; a îngreuna; a întârzia; a reține; a face obstrucții la; a opri; a constitui un obstacol / o piedică

hindered settling (ind chim, alim) decantare / cădere ştrangulată a granulelor

hindered settling classifier (constr, alim, ind chim) clasor / sortator cu cădere ştrangulată a granulelor

hindering împiedicare, obstacol, piedică

hindlay worm $(\mathrm{OM})$ melc globoidal

hindmost cel mai din spate / urmă; posterior; ultimul; cel din urmă

hindquarter (alim) but (de vacă, de oaie etc.), picioarele din spate

hindrance împiedicare; obstrucție; obstacol, piedică; impediment; reținere
Hindu-Arabic number cifre arabe

hinge (constr) balama, şarnieră; (OM) pivot, (punct de) articulație, joantă, legătură, (fig) principiu / element de bază

hinge connection $(\mathrm{OM})$ îmbinare articulată

hinge coupling $(\mathrm{OM})$ cuplaj cardanic

hinged (constr, OM) rabatabil; articulat

hinged beam (mec, OM) grindă cu articulație

hinged bearing $(\mathrm{OM})$ lagăr basculant

hinged bolt $(\mathrm{OM})$ şurub articulat

hinged-bottom door $(\mathrm{OM})$ clapă / trapă de fund

hinged bucket (OM, transp) benă apucătoare, graifăr

hinged cantilever $(\mathrm{OM})$ consolă articulată

hinged collar $(\mathrm{OM})$ brățară articulată

hinged cover (OM) capac rabatabil, chepeng

hinged door (constr, OM) uşă turnantă / rabatabilă

hinged frame (constr, OM) cadru articulat / rabatabil

hinged girder $(\mathrm{mec})$ grindă cu articulație

hinged guard (OM, met) capac de protecție, rabatabil

hinged guide blade (mas, mil) lamă / aripă de ghidaj rabatabilă / articulată

hinged jib (OM, transp) brat oscilant de macara

hinge(d) joint (OM) îmbinare articulată

hinged moulding box (met) cutie / ramă de formare, cu balamale

hinged pier $(\mathrm{mec})$ reazem pendular

hinged plate (OM, mas-un) placă rabatabilă / rabatabilă (şi la port-cuțit)

hinged shutter (constr, OM) oblon rabatabil

hinged support $(\mathrm{OM})$ suport articulat / rabatabil hinged tool holder (mas-un) port-cuțit articulat

hinged tracing lever (mas-un, nav) braț trasor articulat

hinge truss (mec) fermă articulată

hinged valve (OM, hidr) supapă cu clapetă (rotitoare sau rabatabilă pe max)

hinge fitting $(\mathrm{OM})$ racord articulat

hingeless arch (constr, met) arc încastrat (si la bolta de cuptor)

hinge on (fig) a atârna de, a depinde de

hinge pin $(\mathrm{OM})$ bolț al unei articulații, ax (de basculare / de înclinare / de răsturnare)

hinge pivot $(\mathrm{OM})$ pivot articulat, crapodină cu articulație

hinge plate / strap (OM) balama

hinge up a suspenda

hinge washer $(\mathrm{OM})$ rondelă / distanțier de articulație

hinge with hook $(\mathrm{OM})$ balama cu cârlig, balama-coltar 
hinge zone of earth (geol, constr) zonă seismică hint aluzie (directă), insinuare; sugestie / indicație indirectă; indicație prețioasă; indiciu, cheie; cantitate infimă; urmă; idee, picătură; a lăsa să se înțeleagă; a spune direct; a sugera; a insinua hint at a face aluzie la, a insinua că

hip (met) bavură; (alim, bot) măceaşă, fruct de măceş

Hipparchic cycle (metr) unitate de măsură pentru timp: 1 Hipparchic cycle $=9,593424 \cdot 10^{9} \mathrm{~s}$

hippopede / horse fetter (mat) lemniscată sferică hire închiriere, luare / dare cu chirie; a închiria, a lua / da cu chirie; angajare; a angaja (şi muncitori); a se angaja; (ec) închiriere pe termen scurt a unor mijloace de transport, utilaje sau aparate, inclusiv service-ul aferent, plată, salariu; (amer) a lua cu împrumut; angajament, slujbă, serviciu

hireable de închiriat, care se poate închiria

hire charge (ec) cheltuieli de închiriere a utilajelor

hired labour (ec) lucru în regie / cu ziua

hire labour rate $(\mathrm{ec})$ cost de regie

hire onself out a se angaja, a intra în serviciu

hire-purchase buying (ec) cumpărare în rate

hire purchase (system) (ec) (sistem de) cumpărare / vânzare cu plata în rate

H iron (constr) traversă metalică în formă de H; (met) profil / oțel laminat în $\mathrm{H}$

hiss (fiz) zgomot de audiofrecvență, sâsâit

histogram histogramă, diagramă statistică / a repartiției (culorilor, frecvențelor etc., şi în trepte), poligon al frecventelor

historical (cu caracter) istoric

historical costing (ec) postcalculatie

hit lovitură; atac; ciocnire, coliziune; şoc; lovire, lovitură; izbire, izbitură; atingere; a (se) lovi; a pocni; a (se) izbi, a (se) ciocni; a bate; a apăsa (un buton, o clapă etc.); a face să se lovească / ciocnească; a atinge ținta, a găsi, a descoperi; a nimeri (în plin); a afecta; a frapa, a şoca; a ajunge, a atinge; a da din întâmplare peste; a potrivi, a armoniza, a pune de acord; a se întâmpla, a se petrece, a se produce; a izbuti, a reuşi

hit against / upon a se ciocni de, a se lovi de

hitch smucitură; oprire bruscă; împiedicare; impediment, obstacol, piedică; (OM) cuplaj, cuplare, ataşare, agățător, cârlig, nod la legarea unei funii de punct fix; (mas-un) oprire spontană a unui mecanism în timpul funcționării; a agăța, a prinde, a fixa, a atârna, a lega, a mişca, a smuci, a (se) zgâlțâi, a (se) zgudui, a hurduca; a trage, a muta, a împinge hitch crossbar (auto, OM) bară de remorcare / de tractiune

hitch into a vârî, a băga, a introduce

hitch up a înălța, a ridica

hit it a nimeri în plin; a face tocmai ceea ce trebuie

hit off a reproduce exact, a imita perfect; a caricaturiza; a se potrivi, a se armoniza, a fi potrivit

hit-on-the-fly / hit-on-the-run printer (c) imprimantă cu deplasare continuă / cu mişcare continuă

hit out a da o lovitură puternică; a izbi; a lovi

hit the roof (ec) (d. prețuri) a crește vertiginos / peste măsură; a bate toate recordurile (d. un sportiv)

hitting force (mec, met) forță de lovire / de izbire

hoar chiciură, promoroacă

hoard comoară, tezaur; (ec) monetar, bani adunați; (TH, ec) stoc, rezervă, fond; a stoca, a aduna, a strânge; a face provizii / stoc(uri)

hoarding păstrare, tezaurizare; stocare, adunare, strângere

hob cot; poliță (de mobilă); țăruş de lemn; (OM) melc, şurub fără sfârşit, butuc; (mas-un) butuc al unei roți, freză-melc; (plast) poanson (pt. presare la rece); (mas-un, transp) talpă (la sanie)

hobbing (mas-un) tăiere a dinților cu freză-melc (modul) prin rulare; (plast) presare la rece

hobbing cutter (mas-un) freză-melc

hobbing machine (mas-un) maşină de frezat cu freză-melc(-modul), prin rulare

hobbing punch (mas-un, plast) poanson de perforare

hobble a șchiopăta (și fig); a merge șchiopătat; a face să şchiopăteze; a împiedica; a înlănţui; mers greu / împiedicat

hobby pasiune pentru o activitate în timpul liber hob method (mas-un) metodă / procedeu prin rulare

hob nail $(\mathrm{OM})$ caia

hob-type milling cutter (mas-un) freză-melc(modul), freză care prelucrează (dantură) prin rulare / rostogolire

hock (alim) vin alb din Germania, aprox. risling; a pune amanet, a amaneta; amanet; îndatorat mult

hod cadă, troacă; (constr) targă, varniță, cuvă

hodometer (metr) odometru

hoe (agr) sapă, săpăligă; a plivi, a săpa, a reteza / tăia cu sapa; a mărunți (pământul); a lucra cu sapa

hoe-cake (alim) (amer) (budincă de) mălai / crupe (din porumb / mălai) 
hog (alim) porc (îngrăşat); (TH) arcuire, încovoiere, deformație; (nav) arcuire (a corpului navei), a se arcui (nava); raşchetă; a se deforma, a (se) arcui (şi în sus), a (se) încovoia, a raşcheta; a acapara, a lua (totul) pentru sine, a nu lăsa pentru alții

hogged (nav, mec) arcuit (despre corpul navei)

hogging (met) debavurare cu flacără

hog nose drill (mas-un) burghiu cu un singur tăiş

hogshead (hhd) (metr) unitate tradițională pentru volum / capacitate (pt. lichide): 1 hogshead (US) (hhd US) $=1$ traditional British wine hogshead $=238,481$; 1 hogshead (Imperial) (hhd Imp) $=0,327318 \mathrm{~m}^{3}$

hog's lard (alim) untură de porc

hog-tie (fig) a împiedica, a ține în frâu, a pune bețe în roate

hoist bob; maşină de ridicat, elevator; ridicare, urcare, înălțare; (OM, mas) troliu de intervenție, vinci, lift (de materiale); ruinat, distrus; a înălța, a ridica, a sălta, a urca

hoist brake (OM, transp) frână a unei instalații de ridicat

hoist chain (OM) lanț de avansare / de ridicare

hoist crane (mas, transp) macara

hoist gearing / gear train (OM) mecanism / transmisie (şi cu roți dințate, cu mai multe trepte), de ridicat

hoisting $(\mathrm{TH}, \mathrm{ind})$ extragere, ridicare, care ridică hoisting apparatus / gear aparat, mecanism de ridicat (eventual cu roți dințate reductor etc.)

hoisting block $(\mathrm{OM})$ palan

hoisting cable (OM) cablu de ridicat / de palan / de extracție

hoisting capacity (mas, transp) capacitate de ridicare

hoisting carriage (met, $\mathrm{cf}$, transp) vagonet $\mathrm{cu}$ dispozitiv de ridicare

hoisting chain (OM, met) lanţ de ridicat / de avansare

hoisting clevis (OM, transp) gheară de prindere (la mecanism de ridicat sau de avans)

hoisting crab $(\mathrm{OM})$ cric, vinci, macara, troliu; (nav) vinci de ranfluare

hoist crane (mas, transp) macara

hoisting device (Om, transp) dispozitiv de ridicat

hoisting engine maşină de ridicat, troliu; (nav) vinci de ridicare (cu acționare proprie)

hoisting equipment (mas, transp) utilaj de ridicat

hoisting force (mec, $\mathrm{TH}$ ) forță de ridicare

hoisting hook $(\mathrm{OM})$ cârlig al macaralei

hoisting jack $(\mathrm{OM})$ cric, vinci

hoisting platform (auto, mas, transp) platformă de ridicare, elevator pentru autoturisme, autolift hoisting rope (OM) funie / cablu de transport hoisting speed (mec, mas-un) viteză de ridicare / de extragere / de avans

hoisting time (el) timp de atragere (la relee); timp de ridicare, durată a cursei

hoisting unit (OM, transp) dispozitiv / instalație / mecanism de ridicat

hoisting wheel (OM, transp) roată de irigație; (hidr) roată cu cupe de ridicat apa; $(\mathrm{OM})$ roată de ridicat

hoist pan (OM, transp) benă / oală de încărcare

hoist out (nav) a lăsa o barcă la apă; a extrage, a instrumenta

hoist structure (OM, transp) cadru de elevator

hold ținere; strângere; apucare; păstrare; putere; influență; menținere; autoritate; (OM) ochi, (punct de) sprijin, reazem; ochet, ureche, dispozitiv de prindere; (nav) cală, magazie; $(\mathrm{TH})$ a (men)tine, a dura, a persista; a fixa; a cuprinde; a conține; a susține; a deține, a poseda, a avea (în mână); a ocupa; (met) parte orizontală a curbei de echilibru; a stăpâni, a avea drepturi / autoritate asupra; a opri, a stăvili, a împiedica, a ține în frâu, a reține; a preocupa, a reține atenția; a avea în minte, a nu uita; a considera, a socoti potrivit / de cuviință; a susține, a afirma; (jur) a hotărî, a decide, a stabili; a rezista, a se mentine; a dăinui, a continua; a se aplica, a fi valabil; a se socoti; a se considera; (metr) denumirea a două unități ungureşti pentru suprafață (pt. teren): 1 magyar hold (Hungarian acre) $\cong 0,4314$ ha; 1 kataszteri hold (cadastral hold) $\cong 0,5752$ ha (utilizată la impozitare)

hold-all cutie pentru scule şi dispozitive; sac de voiaj

hold(-)back retenție, reținere; a reține, a opri, a stăvili; a nu da, a păstra; a ascunde, a ține secret; a şovăi, a ezita; a (se) da înapoi, a avea o reținere / rezervă; a manifesta o reținere / rezervă

hold-back valve (OM, hidr) regulator al presiunii de aspirație, ventil / supapă de reținere

hold by a adera la; a ține la, a insista asupra

hold depth (nav) înălțime a calei / a magaziei

hold down (autom, mas) a menține (un buton) apăsat, a ține aplecat / în jos; a(-şi) păstra un serviciu

hold-down bars (constr, mec) bare de fixare / de presiune

hold-down plate $(\mathrm{OM})$ placă de fixare / de presiune / de strângere

hold-down screw $(\mathrm{OM})$ şurub de fixare / de oprire 
holder (ec) deținător, posesor (de titluri, valori, cambii etc.); ocupant; păstrător; (mas-un) portcuțit, prelungitor; (termo) acumulator de căldură; (OM) stativ, mâner, manşă, toartă, suport, casetă, recipient, montură, dorn, dulie

holder die (mas-un) cap de filetat, suport de filieră

holder for (screwing) dies (mas-un) placă de filetat

holder or licence titular al unui brevet de invenție / al unei licențe

hold fast (constr, OM) aplică / scoabă de prins în perete; (mec) priză puternică, apucare / ținere fermă

hold in a stăpâni, a ține în frâu

holding tinere, apucare; (inf) blocare, înmagazinare / reținere (a informației); (ec) holding, grup de întreprinderi subordonate unei societăți pe acțiuni, pachet de acțiuni; stare, proprietate, posesiune / deținere de bunuri / de pământuri; pământ, teren; (TH) fixare, mențnere, întindere, prindere, durabilitate, rezistență; (agr) proprietate (mică), fermă; (jur) drept de proprietate funciară

holding at heat (alim, met, plast) menținere la temperatură

holding brake (OM, mas) frână de fixare / de blocare

holding capacity (mas) capacitate (şi de rezervor / recipient), capacitate de menținere (la anumiți parametri)

holding charge (mas, ind) sarcină de repaus / de nefunctionare; umplere de aşteptare

holding company (ec) societate care controlează alte societăți mai mici, holding

holding cover for bearing (OM) capac portlagăr

holding device (OM) dispozitiv de frânare / de oprire; (mas-un) dispozitiv de prindere

holding-down bolt (OM, constr) şurub / bolț de ancorare

holding-down plate (OM, met, plast) placă de presiune / de strângere / de fixare / de întindere / de îndreptare

holding freezer (alim, termo) cameră frigorifică de depozitare (sub $-7^{\circ} \mathrm{C}$ )

holding furnace (met) cuptor pentru menținerea metalului topit / şarjei topite la temperatura necesară, melanjor

holding key (OM, el) întrerupător de blocare, comutator-suport

holding load (mec, mas) sarcină stabilizată / menținută constantă

holding position (mas) poziție de cuplare holding power (chim, OM) putere de lipire holding range (autom, el, electr) gamă de comandă / de reglare; domeniu de sincronizare

holding ring $(\mathrm{OM})$ inel de fixare

holding rope (OM) cablu de ancorare

holding screw (OM) şurub de oprire / de fixare / de mentinere

holding tackle $(\mathrm{OM})$ dispozitiv pentru prinderea sarcinilor

holding tank (OM, ind, mediu) rezervor colector

holding the line (ec) menținere a prețurilor / a tendintei

holding time (met, ind chim, alim) timp de mentinere

hold on putere, influență, autoritate (asupra); a (men)ține în aceeaşi stare; a nu se da bătut

hold out a întinde mâna; a oferi, a da; a dăinui, a persista, a ține; a ajunge, a ține (d. rezerve)

hold over acumulator, acumulare; (termo) rezervă de frig; a reține, a păstra; a menține (în serviciu etc.), a reînnoi angajamentul cuiva, a rămâne mai departe (în funcție); a amenința, a face să planeze asupra

holdover key (TH) cheie de oprire / de gardă / de blocare, buton (al semnalului) de oprire

holdover position (mas) poziție de oprire

hold pen / pound (nav) compartiment de cală (al calei)

hold range (mas, autom, el, electr) gamă de reglare / de comandă, domeniu de sincronizare

hold time ( $\mathrm{TH}$, met, ind chim) timp de menținere / de ocupare / de stabilizare

hold to a face să respecte

hold together a uni, a lega, a ține uniți / asamblaț / fixati; a nu se desface

hold-up jaf; oprire, stagnare; pană

hold up a arăta, a expune; a tine sus / drept; a opri, a stăvili, a reține; a jefui; a întârzia; retenție

hold-up time (TH) durată / timp de mentinere / reținere / oprire

hold with a accepta; a sprijini; a fi de acord cu, a fi pentru, a fi în favoarea

hole (fiz) gol (electronic), loc electronic vacant, vacanță, lacună; (constr) groapă (şi în drum); (geol) peşteră; (inf) perforație; (OM) gaură, deschidere, orificiu, scobitură, cavitate, alezaj, ochet, locaş; perforație, defect; (nav) gaură de apă la bordaj; (el, c) zonă moartă (a unei imagini etc.); (met) suflură; a găuri, a săpa, a scobi, a perfora, a străpunge, a excava; încurcătură, situație grea

hole boring cutter (mas-un) freză de alezat

holed $(\mathrm{OM}$, met) găurit, perforat 
hole gauge (metr, mas-un) calibru pentru găuri / pentru alezaje

hole making (mas-un) sfredelire, executare a unei găuri (fără a specifica procedeul)

hole-punching machine (mas-un) maşină de perforat (cu poanson)

holes (OM, transp) găuri de transport / de ghidaj (al unei benzi)

hole stamping (mas-un) ştanțare de perforare hole tolerance $(\mathrm{OM})$ toleranța găurii / alezajului hole up a (se) ascunde

hole vacancy (in lattice) (fiz) spațiu gol, loc vacant (într-o rețea)

holey (OM) găurit, perforat, cu găuri

holing (mas-un, met) găurire, perforare (şi nedorită)

hollander (ind) holendru

hollow scobit, concav; cu scobituri, cu găuri; (constr) groapă (şi în drum); depresiune, vale, peşteră; bazin; (TH) gol, adâncitură, excavație (și mică), racordare, cavitate, scobitură; concav, tubular, scobit, gol; a adânci, a ambutisa, a săpa, a excava (şi ca urme de uzură), a scobi; (d. sunet) dogit, sec; fals, necinsitit, nesincer; lipsit de / fără valoare

hollow arbour $(\mathrm{OM})$ arbore tubular

hollow axle (OM) osie / ax tubular( $\breve{a})$

hollow billet (met) semifabricat concav

hollow bit daltă concavă

hollow body (OM) corp celular / cu cavitate / scobit; (auto) flotor

hollow bored spindle (OM) arbore principal tubular

hollow brick (constr, met) cărămidă cu goluri

hollow casting (met) turnare / piesă turnată cu miez

hollow core (met) miez gol la interior

hollow cylinder $(\mathrm{OM})$ cilindru tubular, tobă; (OM) tub cilindric

hollow-disk reversing valve (hidr) supapă reversibilă, cu disc inelar

hollow drift (mas-un) poanson tubular

hollow drill (mas-un) burghiu tubular (şi pt. găurire tubulară)

hollow edged equalling file pilă lată, cu vârf teşit şi cu fețele laterale concave

hollow forging (met) forjarea corpurilor cu cavități

hollow girder (constr, mec) grindă cu goluri

hollow ground scraper (mas-un) răzuitor triunghiular cu fețe concave / canelate / cu trei tăişuri şi fețe concave

hollowing chamfering tool (mas-un) sculă de şanfrenare şi găurire hollowing file (mas-un) pilă concavă

hollowing hammer (constr, met) bătător, mai

hollowing knife (mas-un) cuțit cu tăiş curb(at)

hollow journal $(\mathrm{OM})$ fus tubular

hollow key $(\mathrm{OM})$ pană concavă

hollow mandrel lathe (mas-un) strung cu ax principal tubular

hollow mill (mas-un) freză cu gaură / inelară

hollow mill die (mas-un) bac de filetat în vârtej / tubular

hollow mould (met, plast) formă de turnare (goală)

hollowness goliciune, concavitate, scorbură

hollow out (TH) a scobi, a broşa, a excava, a adânci, a săpa

hollow pin $(\mathrm{OM})$ ştift tubular

hollow pinion $(\mathrm{OM})$ pinion găurit / care nu este dintr-o bucată cu arborele

hollow piston (OM, hidr) piston gol la interior

hollow pivot (OM) pivot gol la interior / inelar / tubular

hollow punch (mas-un) presă / maşină de perforat; perforator; preducea

hollow ram pump (hidr, OM) pompă Norton cu piston tubular

hollow rod $(\mathrm{OM})$ tijă / bară tubulară

hollow roll (met) cilindru tubular

hollow shaft (OM) arbore tubular

hollow space cavitate, cavernă, vid

hollow sphere sferă goală, strat sferic

hollow spoke $(\mathrm{OM})$ spiță goală

hollow steel (mas-un) sfredel cu gaură centrală, semifabricat tubular

hollow-type rivet (OM) nit tubular

hollow valve stem (hidr, OM) tijă goală, de supapă

hollow weld (OM, met) cusătură de colț, concavă holm, holme (geogr) ostrov, insulităă, luncă inundabilă

Holmium (Ho) (chim) holmiu

hologram (fiz) hologramă

holograph (jur) olograf, document olograf; (fiz) a face o hologramă

home cămin, casă; domiciliu, locuință; areal, habitat; familie; sediu (principal); cartier general; domestic, legat de locuință / cămin / domiciliu, de acasă, de familie; intern, interior; a adăposti

Home, HOME (c, inf) tastă care efectuează saltul cursorului la început de linie / pagină / document (la calculator personal, procesoare de text)

home-born băştinaş, localnic

homebound care merge spre casă; (nav) care se îndreaptă spre portul de origine

home-bred făcut în casă, de casă, domestic; indigen, făcut în țară 
home brew (alim) băutură făcută în casă home economics economie domestică, gospodărie homelike familial; ca (de) acasă, agreabil; comod, comfortabil; simplu, obişnuit, normal

homelikeness caracter familiar / obişnuit; simplitate, naturalețe; caracter plăcut; (amer) urâtenie, caracter dizgratios

homely familial, ca (de) acasă; agreabil; familiar, obişnuit, banal; simplu, natural; (amer) plat, neinteresant, urât, dizgrațios

home-made de casă, lucrat / făcut în casă, domestic

homemaker gospodar, gospodină

homemaking gospodărie, treburi gospodărești; conducerea / administrarea casei

home market (ec) piață internă

home port (nav) port de origine

home products produse naționale

homer (Biblical) (metr) veche unitate de măsură pentru volum / capacitate: 1 homer (Biblical) $=0,22 \mathrm{~m}^{3}=219,991$

home scrap (met) fier vechi recuperat / din circuitul de fabricatie

home signal (cf) semafor, semnal

homespun (textile) țesut / lucrat / făcut în casă, țesătură de casă; simplu, modest

homestead (agr) gospodărie țăănească, fermă, casă de tară (cu acareturi); (metr) unitate de măsură pentru suprafață: 1 homestead (US) = $647497,027584 \mathrm{~m}^{2}$

homesteader fermier, gospodar

home trade (ec) comerț intern; (nav) cabotaj

home traffic trafic / transport intern

homeward-bound (nav) care se îndreaptă spre țară, în drum spre casă

homework (edu) lecții / teme / lucrări / exerciții pentru acasă

homing device (autom) dispozitiv de (tele)ghidare

homocentric (mec) homocentric, cu același centru

homogenate (alim, ind chim) rezultat al omogenizării, substantă produsă prin omogenizare

homogeneity, homogeneousness omogenitate, uniformitate; similitudine; identitate

homogeneous omogen, similar, uniform

homogeneous body (fiz) corp omogen

homogeneous liquid (fiz) lichid omogen

homogeneous mixture (fiz) amestec omogen

homogeneousness omogenitate

homogeneous strain (mec) deformație omogenă / uniformă / aceeaşi pe orice direcție

homogeneous system sistem omogen

homogenization $(\mathrm{TH})$ omogenizare

homogenize $(\mathrm{TH})$ a omogeniza, a uniformiza homogenizer (constr, alim, ind chim) omogenizator, aparat / dispozitiv de omogenizare

homogenizing (met) recoacere de omogenizare; (alim, ind chim) omogenizare

homologate a omologa, a aproba, a admite, a accepta; a recunoaşte, a accepta; a confirma

homologation omologare, aprobare, acceptare; confirmare, recunoaştere

homologize (amer), homologise (brit) a omogeniza, a uniformiza; a (se) potrivi; a egaliza; a corespunde, a fi omolog

homologous omolog; corespunzător

homologue (element) omolog

homonym omonim

homopolymer (chim, plast) homopolimer, polimer rezultat dintr-un singur monomer

hone (mas-un) bară / piatră abrazivă fină, cap de honuit, a honui, a şlefui, a ascuți

honed finish (mas-un) finisare prin honuire

honer (mas-un) maşină de honuit

honest cinstit, onest, corect; real, veritabil, adevărat; sincer, deschis; integru; respectabil; cuminte; inocent, nevinovat; simplu, modest

honestly $(a d v)$ (în mod) cinstit / corect / onorabil; sincer, deschis, pe față

honesty cinste, corectitudine, onestitate, probitate; caracter onorabil; integritate; nevinovătie; sinceritate

honey (alim) miere (de albine); nectar, lucru dulce; dulceață; a îndulci cu miere; ca mierea

honeybee albină

honeycomb fagure de miere; gaură de nod (în lemn / în fagure); în (formă de) fagure, hexagonal (ca un fagure); a aşeza în fagure

honeycomb capping (alim) căpăcirea mierii

honeycomb core $(\mathrm{OM})$ miez al unei piese, în formă de fagure, pentru mărirea rezistentei

honeycomb corrosion $(\mathrm{T})$ coroziune în formă de fagure

honeycombed poros; (met) cu retasuri, cu structură în fagure; ca la fagure

honeycombed casting (met) turnare / lingou cu pori în formă de fagure

honeycomb furniture $(\mathrm{OM})$ suport cu goluri / economic / cu găuri în formă de fagure

honeycomb lattice-like structure (fiz, T) structură asemănătoare fagurelui

honeycomb texture structură în fagure, textură / aspect ca de fagure

honey dew (agr) tutun îndulcit cu miere

honeyed cu / de miere, plin de miere, îndulcit cu miere

honey extractor (alim) centrifugă de miere

honey flow (agr) recoltare a mierii 
honey plant (bot) plantă meliferă honey sweet (alim) dulce ca / din miere honing (mas-un) (prelucrare prin) honuire honorarium plată onorifică, onorariu oferit (fără a fi cerut)

honorary onorific, de onoare; nerenumerat, fără plată, neplătit; voluntar, neobligatoriu

honour cinste, onoare; reputație, faimă; autoritate; privilegiu; stimă, cinstire; respect; prețire; gest de respect; distincție, onor(uri); (edu) curs special / facultativ de specializare; (univ) distinție academică, diplomă de onoare / de merit; premiu, distincție, mențiune (univ); a conferi distinctii; a respecta, a(-şi) onora, a(şi) îndeplini o obligație; (ec) a plăti, a onora (o notă de plată etc.)

honorable onorabil, cinstit, de onoare; corect, drept; respectat, demn de respect; înalt (ca titlu), distins

honour system (edu) sistem de educație bazat pe încredere şi libertate

hood (auto) capotă, husă; (OM) învelitoare; coviltir; nişă, hotă; (constr) boltă; (hidr) clopotul / mantaua sifonului deversor; (OM) calotă, cap $(\mathrm{ac})$ (şi protector); (textile) glugă, bonetă

hood catch (auto) susținător de capotă

hood clamp / fastener (auto) închizător de capotă hood cover (auto) husă a capotei

hooded acoperit cu glugă, în formă de glugă; (TH) acoperit, protejat

hooded anode (auto) anod protejat

hood handler (auto) mâner de capotă

hood hinge (auto) balamaua capotei

hood louvre (auto) fantă de aerisire a spațiului de sub capotă

hood release lever ( auto) mâner de capotă

hood-type annealing furnace (met) cuptor (tip) clopot / cu hotă, pentru recoacere / revenire

hoodwink a păcăli, a înşela; a induce în eroare

hoof picior de animal

hook obiect încovoiat; cuțit încovoiat; croşetă; copcă (la haină); (fig) capcană, cursă; momeală, nadă; promontoriu; (geogr) cotitură bruscă (de râu), limbă de pământ în mare; reaping (agr) seceră; (OM) ochi de lanț pentru agățat, za de agățat, agrafă, copcă, ac de îngustare, croşetă, capsă, cârlig (şi de undiță), mâner, ureche, undiță, țațână, seceră, a fixa / prinde prin cârlige / agrafe, a suspenda, a îndoi, a încovoia, a agăța, a prinde, a anexa, a face cârlig, a (se) încovoia, a se îndoi; a încopcia (o rochie etc.); (argou) a fura, a ciordi; be off the $\sim$ s a fi scos din răbdări; a fi bolnav; a fi abătut; by $\sim$ or by crook prin toate mijloacele posibile; on one's own $\sim$ pe socoteala / răspunderea lui; prin propriile sale mijloace

hook and handle rope $(\mathrm{OM})$ cârlig cu cablu / cu funie

hook and hinge (OM) țâțână şi balama

hook and ladder (mas) maşină de pompieri (cu tot echipamentul)

hook belt fastener (OM) bulon, agrafă pentru curele de transmisie

hook bolt $(\mathrm{OM})$ bolț al cârligului

"kook" crack (met) fisură de refulare a marginii (la sudură)

hooked (OM) în formă de cârlig, încovoiat, (prevăzut) cu cârlige

hooked tie plate $(\mathrm{OM})$ placă pentru crampon

hooked wrench / spanner (OM) cheie cu dinte / cu cârlig

hook engagement $(\mathrm{OM})$ cuplă cu cârlig, prinderea cu cârlig

hooker (OM) agățător, agățătoare; (nav) vas de pescuit, pescador, vas vechi şi greoi

Hooke's joint / coupling (OM) articulație / cruce / cuplă cardanică

Hooke's law (mec) legea lui Hooke (materiale elastice)

hook guard (OM, mas) consolă de siguranţă

hook housing / casing $(\mathrm{OM})$ casetă a cârligului, mufă de suspendare a cârligului

hook holder (auto) capsă de fixare (a scaunului)

hook lifter (alim, OM) elevator cu cârlige (și la un abator etc.)

hook link chain (OM, alim) lanț cu / de cârlige (şi la un abator etc.)

hook load (mec, OM) sarcină de / la cârlig

hook nail crampon; cui cu cârlig

hook-off (met, TH) dispozitiv de dezagățare, a dezagăța; a decupla

hook on a agâța (pe); a suspenda; a se agăța de, a se lipi de; a se îndoi, a se încovoia

hook out (TH) a dezagăța, a decupla, a scoate de pe cârlig

hook scraper (mas-un, met) răzuitor curbat

hook screw (OM) şurub cu cârlig, cârlig cu filet

hook-shaped $(\mathrm{OM})$ în formă de cârlig

hook spanner / wrench (OM) cheie cu cârlig / cu dinte

hook spring ring (auto) inel de siguranță la cârlig (de sarcină); (OM) şaibă de siguranță, cu cârlig

hook switch (mec, el) întrerupător cu cârlig

hook tilter (alim, OM) răsturnător cu cârlige

hook tool (mas-un) cuțit încovoiat / curbat, de strung

hook tooth $(\mathrm{OM})$ dinte al angrenajului cu clichet, dinte de agățare 
hook tooth file (mas-un) pilă de ferăstrău, semirotundă paralelă

hook-type bottom block $(\mathrm{OM})$ scripete cu cârlig

hook(-)up (TV, radio) rețea de radio / televiziune; program comun; (TH) schemă de montaj / de conexiuni, instalație, mecanism, sistem, conexiune, cuplare, montaj; înlănţuire (a unor elemente opuse); a conecta, a cupla, a înlănțui; a încătuşa, a lega cu lanț

hoop (constr) inel metalic (în capul piloților de lemn); cerc de butoi, doagă; (OM) şină / geantă / obadă de roată, colier de excentric, etrier, bandaj (de roată), cerc, inel, obadă, geantă, brățară, fretă; (nav) armătură; a lega (cu bandă metalică), a încercui, a înconjura

hooped concrete (constr) beton armat

hooped reinforcement $(\mathrm{OM})$ fretă, întărire cu inel / bandaj (la corpuri cu pereți subțiri, tip recipient etc.)

hooping $(\mathrm{OM})$ fretaj, fretare, îmbinare cu bandaje, consolidare cu bandaje / cu cercuri / cu inele

hoop iron (met) oțel de bandaje (semifabricat tip platbandă), fier-balot

hoop-iron sheathing $(\mathrm{OM})$ armătură cu bandă de oțel

hoop rolling mill (met) laminor de platbande / de benzi (în rulouri)

hoop tension (mec, el) tensiune inelară / în inel / în bandajul de rigidizare

hoop-up (autom, el) schemă de montaj / de conexiuni

hooter (TH) sirenă de fabrică / industrială

hoover (mediu) aspirator de praf; a curăța cu aspiratorul

hop (alim) hamei, fructe de hamei, a aromatiza berea cu hamei, a culge hamei; (el, c) salt, traiectorie de reflexie

hop bind, hop bine (bot) lujer de hamei, curmei hope speranță, nădejde; încredere; probabilitate, şansă, perspectivă; sprijin, reazem; a spera; a aştepta

hope for a spera la, a avea speranțe în / că / să

hopeful plin de speranțe, optimist; îmbucurător, încurajator, dătător de speranțe; care promite

hopefully $(a d v)$ (în mod) optimist, cu curaj, cu speranță; în mod încurajator / promițător

hopefulness optimism; curaj; speranță; caracter încurajator / promițător / îmbucurător

hopeless disperat, fără speranță; incurabil, nevindecabil; imposibil (de rezolvat)

hopelessness situație disperată; caracter insolubil / incurabil / de nerezolvat

hop garden (agr) lan / plantație de hamei hopper (nav, constr) magazie de material dragat; (OM) pâlnie, buncăr, magazin, magazie de scule (la maşini unelte) bară de încărcare, siloz, rezervor, recipient; (agr) culegător de hamei

hopper bale breaker (met, OM) desfăcător de baloturi

hopper barge (nav) şalandă cu clapete de fund

hopper body (alim, ind chim, OM) tomberon / buncăr cu descărcare prin greutate

hopper car (auto, cf) vagon-pâlnie, vagon-buncăr

hopper casement / light (constr) fereastră cu oberliht

hopper chute (OM, constr, mas-un) tobogan

hopper cooler (alim, OM) sită de răcire, răcitor cu pâlnie

hopper dredger (nav) dragă purtătoare

hoppered bottom (OM) fund conic

hoppered cargo (nav) magazie cu pereți înclinați

hopper feed (OM, constr, alim) cutie / ladă de alimentare / de dozare

hopper feeder $(\mathrm{OM})$ ladă / pâlnie alimentatoare, alimentator-amestecător

hopper mill (alim) moară cu pâlnie

hoppers (alim, mas-un) magazii de semifabricate (de exemplu la maşini poligrafice / de umplut etc.)

hopper-shaped $(\mathrm{OM})$ în formă de pâlnie

hopper tank (constr, alim, ind chim) tanc (conic) de depozitare / de alimentare

hopper truck (auto, transp) autocamion cu buncăr de alimentare

hopper waggon (cf, met) vagon-pâlnie, vagonbuncăr

hoppet coş de nuiele

hop picker (agr, mas) culegător de hamei, maşină de recoltat hamei

Höppler viscometer ( $\mathrm{T}$, metr) vâscozimetru Höppler

hoppus foot, hoppus board foot (metr, silv) unitate traditională britanică pentru volum (de lemn): 1 hoppus foot $=0,036054 \mathrm{~m}^{3} ; 1$ hoppus board foot $=0,00300 \mathrm{~m}^{3}$

hop up (amer) a stimula; (auto) a supraalimenta, a supune la supercompresie

horizont orizont, plan de referință

horizontal orizontal; plat, întins, neted; (dreaptă / linie / bară) orizontală

horizontal bar (mec, constr) bară orizontală

horizontal belt conveyer (OM) transportor orizontal, cu bandă

horizontal boiler (alim, termo) cazan / boiler / fierbător orizontal

horizontal chamber (met) cameră orizontală de recuperare (la cuptoare) 
horizontal clearance (nav) lățime de trecere a vaselor / gabarit pe sub pod

horizontal component (mec, OM) componentă orizontală, element ori metal (la o piesă, la un subansamblu etc.)

horizontal converter (met) convertizor orizontal horizontal-cylinder drying machine (agr, alim, ind chim) maşină cu tambur orizontal de uscare

horizontal deal frame gater orizontal

horizontal drying cylinder cilindru orizontal de uscare

horizontal extruder head (mas-un, plast) cap orizontal de extrudare

horizontal forging machine (met) maşină orizontală de forjare

horizontal hot shears (met) foarfecă orizontală pentru tăiere la cald (şi la laminoare)

horizontal line (mat) (linie) orizontală

horizontal moment $(\mathrm{mec})$ moment în plan orizontal

horizontal plane $(\mathrm{OM})$ plan orizontal (în desen tehnic)

horizontal plane-milling machine (mas-un) maşină de frezat longitudinală, cu arbore orizontal

horizontal position welding (met) sudare orizontală

horizontal power (c, fiz) frecvență a liniilor, număr de linii explorate pe secundă

horizontal / floor projection with index numbers $(\mathrm{OM})$ proiecție orizontală cotată

horizontal sawmill (mas-un) gater orizontal (şi pt. lemn)

horizontal slotter (mas-un) şeping

horizontal speed $(\mathrm{mec})$ viteză orizontală

horizontal-spindle pump (hidr, alim) pompă cu tijă orizontală de piston

horizontal stand (met) cajă orizontală

horizontal stress (mec, OM) tensiune / presiune orizontală / în plan orizontal

horizontal thrust $(\mathrm{mec})$ împingere orizontală

horizontal-tube evaporator (alim, ind chim) vaporizator / evaporator cu tub orizontal

horizontal vulcanizer (ind chim, plast) autoclavă orizontală, de vulcanizat

horizontal weld $(\mathrm{OM})$ sudură orizontală (rezultat)

horizontal welding $(\mathrm{OM}$, met) sudare orizontală (procedeu)

hormonal (med) hormonal

hormone (med, chim) hormon

horn (auto) claxon; (met) braț inferior (al maşinii de sudat în puncte; (OM) corn, cornet, pâlnie, volută; (geogr) braț de râu / de mare

hornbeam (silv) (lemn de) carpen

hornblock (patches) (cf) furcă de osie horn book (edu) abecedar, manual elementar / rudimentar

horned cornut; crestat; cu ciufuri

horned nut $(\mathrm{OM})$ piuliță crenelată

Horner's method (mat) metoda Horner / de determinare aproximativă a rădăcinilor reale ale unui polinom

horn-gap switch (el) întrerupător cu coarne / cu furcă

horning tool (mas-un) ştanţă de bordurat

horn plate $(\mathrm{OM})$ furcă de osie

horn-(shaped) radiator (termo) radiator în formă de pâlnie

horn-shaped roller lightning arrester (el) descărcător cu coarne tip Bendmann

horn spacing $(\mathrm{OM})$ distanțe între brațe (la o furcă sau la maşina de sudat în puncte)

horologe (metr) orologiu, ceasornic

horloger, horlogist (metr) ceasornicar

hors d'oeuvre (alim) aperitiv, antreu

horse (zool) cal; (constr) suport, capră, cadru, carcasă; (met) urs, bloc de metal întărit în vatra cuptorului (defect, avarie); (nav) şablon de coaste, "țin-te bine" (la scara de pilot)

horse fetter / hippopede (mat) lemniscată sferică horsepower horse-power (HP sau hp) (metr, mec, el) unitate de măsură pentru putere, calputere: 1 horsepower (European electrical) (metr) $=736 \mathrm{~W}$; 1 horsepower (Imperial electrical) (metr) $1 \mathrm{hp}=746 \mathrm{~W}$; horsepower (Imperial mechanical $)=745,699871 \mathrm{~W}$; horsepower $($ metric) $=735,49875 \mathrm{~W} ; 1$ horsepower (boiler) $=$ 9809,5 W; 1 horsepower (water) $=746,043 \mathrm{~W}$

horsepower (metric) hour (metr) unitate de măsură pentru energie: 1 horsepower (metric) hour $=2647795,5 \mathrm{~J}$

horsepower hour, horse-power-hour (hp-hr, hp·r) (metr) unitate de măsură pentru energie, cal-putere-oră: 1 horsepower hour $(\mathrm{hp} \mathrm{hr}) \cong$ 2,685 MJ, 2545 Btu sau 745,7 Wh

horse's head (metr) liră (la maşini-unelte)

horse shoe potcoavă; $(\mathrm{OM})$ obiect în formă de potcoavă

horseshoe bend meandru

horseshoe gauge (metr, mas-un) calibru-potcoavă

horseshoe mixer / stirrer (alim, ind chim) amestecător cu ancoră

horticultural (bot) horticol

horticulture (bot) horticultură

horticulturist (bot) horticultor

hose ciorapi (ca marfă); (OM) furtun, tub; a stropi / uda cu un furtun; (geogr, nav) canal, strâm-toare; a înzestra cu un furtun, canal; half- şosete 
hose assembly (OM) furtun de umplere, racord flexibil cu tot cu furtun, ansamblu furtun + racord, tulumbă; a stropi / uda cu furtunul

hose(-building) machine (mas-un) maşină pentru confectionare furtunurilor (flexibile)

hose clamp / clip (OM) colier / bridă / piesă de legătură pentru furtun

hose connection (OM) racord de furtun

hose coupling $(\mathrm{OM})$ cuplare a furtunurilor, racord (olandez) pentru furtun

hose duck (textile, OM) pânză pentru furtun

hose filter (OM, hidr, mediu, alim) filtru cu pânză / cu sac(i)

hose insert (met, OM) insertie a furtunului

hose nipple $(\mathrm{OM})$ îmbinare pentru furtun, cu piese filetate, niplu pentru furtun

hose-nozzle (nav, OM) cioc de barză, ştuț (de incendiu, la nave)

hose pipe (OM) furtun (flexibil) / de cauciuc

hose reel (OM) tambur de înfăşurat furtunul

hose sandblast (met) furtun de sablare

hose tube (OM, plast) inimă / tub de cauciuc a(l) furtunului

hose-type-sandblast tank machine (met) maşină de sablat cu furtun şî tanc de nisip

hose with braided inserts (OM) furtun cu inserții împletite

hose woven around with wire (OM, met) furtun armat, tub blindat flexibil

hospitable ospitalier, primitor

hospital (med) spital, clinică (universitară); (ind) atelier de reparații (rar)

hospitality ospitalitate, caracter ospitalier / primitor

hospitalization (med) spitalizare

hospitalization insurance (med) asigurare pentru caz de boală (inclusiv spitalizarea)

hospitalize (med) a spitaliza

host gazdă; patron (de local)

host computer (inf, c) calculator gazdă / principal

hostel han; cămin (studențesc)

hostess gazdă (la feminin)

hostil duşman, inamic; neprietenos, neospitalier; antagonist; ortil (d. mediu etc.)

hostile to ostil față de

hostility (to) ostilitate faţă (de), antagonism, opoziție (față de), împotrivire (la), rezistență (la)

hostler (agr) grăjdar, îngrijitor (de cai); (TH) mecanic (de massini, macarale); hangiu

hot cald; încălzit; fierbinte, încins; foarte cald; arzător; aprins; febril, cu temperatură / febră; nervos; violent (despre un proces); puternic; foarte radioactiv; contaminat; proaspăt, nounouț; absurd, de necrezut, de neconceput; (el) de înaltă tensiune; (d. un vehicul) rapid; clandestin, ilegal, ilicit, obținut pe căi ilegale, de furat; a încălzi

hot activity (fiz) (radio)activitate înaltă

hot-air apparatus (termo, met) preîncălzitor de aer

hot-air balloon (termo) balon cu aer cald (şi de laborator)

hot-air blast (met) suflare cu aer cald

hot-air blower (met, termo) aparat de suflat, aer cald, suflantă cu aer cald

hot-air cupola furnace (met) cubilou cu aer cald

hot-air welding (met) sudare în jet de aer cald

hot-air cure (ind chim, plast) vulcanizare / întărirecu aer cald

hot-air dryer (alim, met) uscare cu aer cald

hot-air drying slasher (mas-un) maşină de încleiat cu aer cald

hot-air steam cure (plast) vulcanizare / întărire cu aer cald

hot-air blast $(\mathrm{TH})$ aer cald suflat, insuflare cu aer cald

hot-air blower (termo) aparat de suflat aer cald, suflantă de aer cald

hot-air cure (plast) vulcanizare / întărire / fixare cu aer cald

hot-air dryer (alim, met) uscător cu aer cald

hot-air steam cure (plast, ind chim) vulcanizare la cald cu abur / cu aer cald

hot-air / hot-blast stove (met) cauper, cowper, aparat de preîncălzire regenerativă a aerului

hot air vulcanisation (plast, ind chim) vulcanizare / întărire / fixare cu aer cald

hot bank / bed (met) pat de răcire

hot bearing $(\mathrm{OM})$ lagăr / rulment care se încălzeşte anormal în funcționare

hotbed (agr) pat cald, seră, răsadniță; (fig) focar; (met) pat de şine (pt. răcirea semifabricatelor)

hot bending test (met) test de îndoire la cald

hot-blast cupola (met) cubilou cu preîncălzire a aerului de insuflare

hot-blast furnace (met) cuptor cu (insuflare de) aer cald

hot-blast main (met, termo) conductă de aer cald hot-blast pig iron (met, termo) fontă brută, obtinută la mersul cald al furnalului

hot-blast (slide) valve (met) registru / şubăr de aer cald

hot-blast stove (met) caupăr, cowper, preîncălzitor de aer

hot-blast temperature (met, termo) temperatura aerului cald / de vânt

hot-blast valve (met) registru / şubăr de aer cald (la cuptoare) 
hot blower (met, termo) (dispozitiv de) insuflare / suflantă de aer cald

hotbox lagăr supraîncălzit

hot breakdown (plast) plastifiere / înmuiere la cald

hot brick (met) maselotă exotermă

hot brittleness (met) fragilitate la cald / la roşu

hot bulb (termo) cap incandescent / de aprindere

hot-bulb engine (termo) motor cu cap incandescent / semi-diesel

hot cell (fiz, hidr) recipient protejat impotriva radiațiilor; clopot

hot chemistry (chim) chimie radioactivă

hotchpotch (alim) ghiveci; (fig) amestecătură, amestec; (jur) fuziune / unire a proprietăţilor

hot corrosion ( $\mathrm{T}$, chim, termo) coroziune (accelerată) la temperaturi înalte

hot crack (met, plast) fisură / crăpătură la cald

hot (-)curing adhesive (plast) adeziv cu întărire / fixare la cald

hot cutting (met) tăiere la cald (la turnarea continuă şi la laminoare)

hot deep metal coating (met) acoperire (metalică) termică / realizată la temperatură ridicată

hot die steel (met) oțel pentru matrițare la cald

hot dip (met, plast) acoperire prin imersare în baie

hot dip galvanisation (met) zincare la cald

hot dipping (met, plast) metodă / procedeu de acoperire prin imersare / cufundare, la cald

hot dip aluminium (met) depunere / placare la cald de / cu aluminiu

hot-dip silver-plating (met) argintare la cald

hot-dip tinning (met) cositorire prin cufundare în baie

hot dip zinc coating (met, chim) zincare termică (în strat adânc)

hot drawing (met) tragere / trefilare la cald

hot drawn tube (met, plast) tub / țeavă tras(ă) la cald

hot drying (alim, met, plast) uscare la cald

hot ductility (met) ductilitate / forjabilitate la cald hotel hotel

hot electrode (el, met) electrod la cald, catod incandescent

hotelier, hotel-keeper (turism) hotelier, proprietar de hotel

hot embossing (met) matrițare la cald, formare de bosaje la cald

hot embritllement (met) fragilitate la cald (d. aliaje)

hot etching test (met, plast, metr) încercare de atac (cu acizi) la cald

hot forging (met) forjare, forjabil la cald, care se forjează la cald hot-forming property (met) capacitate de deformare la cald, prelucrabilitate la cald

hot galvanised (met) galvanizat / zincat la cald

hot galvanising (met) galvanizare la cald, zincare (galvanică) la cald

hot gas (met, termo) gaz cald / brut

hot gases (met, ind chim, termo) gaze de ardere / fierbinți

hot-gas recycle process (met, termo) procedeu cu recircularea gazelor calde

hot-gas valve (OM, met, termo) supapă de aer cald

hot-gas welding (met) sudare cu gaz cald

hot hardness (met) duritate la temperatură ridicată / la cald

hot head (met) cap de aprindere / incandescent

hot house (agr, alim) seră, uscătorie

hot iron (met) fontă lichidă

hot-iron lever-type saw (mas-un, met) ferăstrău cu pârghie de tăiat semifabricate din oțel, la cald

hot-iron saw (met, mas-un) ferăstrău de tăiat (otel) la cald

hot isostatic press (mas-un) presă izostatică de temperatură înaltă

hot isostatic pressing (met, ind chim) procedeu termo-mecanic (presare izostatică) de formare a materialelor din pulberi

hot job (inf) lucrare / rulare urgentă / cu prioritate hot junction (metr) jonctiune caldă a termocuplului; (OM) lipitură tare / la cald

hot masticated (alim, plast) plastifiat / amestecat la cald

hot-melt adhesive (plast) adeziv termofuzibil

hot metal (met) metal lichid

hot-metal charge (met) topitură, şarjă, încărcătură de fontă lichidă

hot-metal charge steel-making (met) elaborare a otẹlului cu încărcătură lichidă

hot-metal ladle (met) oală pentru turnarea fontei lichide

hot-metal ladle and car (met) vagon de transportat oale cu fontă lichidă

hot-metal mixer / receiver (met) melanjor de fontă / de metal lichid

hot-metal working (met, $\mathrm{TH}$ ) prelucrare la cald

hot-metal process (met) procedeu / tehnologie cu metal lichid / cu topitură

hot money (ec) capital vagabond / de speculație / foarte mobil

hot moulding (met, plast) formare / mulare / matriţare la cald

hot news ultimele stiri

hot plate (alim) vatră, fierbător, cratiță, plită

hot polymerization (ind chim, plast) polimerizare la cald 
hot pot (alim) musaca de cartofi

hot-press (TH) a presa la cald, a gofra; (mas-un) presă / maşină care lucrează la cald, maşină de gofrat

hot-pressed $(\mathrm{TH})$ presat la cald

hot-pressing (met) (procedeu, tehnologie de) presare la cald

hot pressure welding (met) sudare prin presiune la cald

hot oil quenching (met) călire în ulei încălzit $\left(90 \ldots 230^{\circ} \mathrm{C}\right)$

hot quenched (met) călit în trepte / în ulei încălzit

hot quenching (met) călire în trepte / în ulei încălzit

hot riveting $(\mathrm{OM}$, met) nituire la cald

hot roll (met, plast) a lamina la cald

hot-roll (met) laminare la cald

hot-rolled (bar) (met) (bară / semifabricat) laminat $(\breve{a})$ la cald

hot-rolled steel (met) otel laminat la cald

hot-rolled steel for reinforced concrete (met, constr) otel-beton, laminat la cald

hot-rolled strip (met) bandă laminată la cald

hot-rolled seamless casing burlan (laminat) fără (cusătură de) sudură

hot-rolling (met) laminare la cald

hot-rolling mill (met) laminor pentru laminare la cald

hot-rolling train (met) linie de laminare la cald

hot run $(\mathrm{TH})$ supraîncălzire în timpul funcționării; (met) mers / funcționare (la) cald (d cuptoare etc.)

hot runner mould (met, plast) matriță cu canale încălzite

hot saw (met, mas-un) ferăstrău pentru tăierea metalelor la cald

hot sawing (met, TH) tăiere / debitare a metalelor la cald

hot scarfing (met) curățire cu flacără / prin ardere hot scarfing machine (met) maşină de curătat semifabricate metalice, cu flacără și / sau mecanic şi încălzirea semifabricatului

hot setting adhesive (ind chim) adeziv cu întărire / priză la cald

hot setting glue (ind chim) clei (care se întărește la) cald

hot setting resin (plast) răşină termorigidă / termoreactivă (la temperatură ridicată)

hot shaping (met, plast) fasonare / formare / deformare la cald (și pt. unele materiale plastice)

hot shears (met) foarfece de tăiere la cald

hot short / brittle (met) fragil / casant la roșu

hot shot (cf) marfar rapid; expert, om îndemânatic hot-shotness (met) fragilitate / rupere la cald / la roşu

hot spot (fiz, TH) zonă periculoasă / primejdioasă / de radiații

hot spring (geol) izvor termal / cald

hot stamping (met, plast) ştanţare la cald

hot stereotyping mulare / stereotipare la cald (ind hârtiei)

hot straightening (met) îndreptare / dresare / ajustare la cald

hot strip (met) (plat)bandă laminată la cald

hot strip mill (met) laminor de benzi la cald

hot strip instrument (metr, termo, el) aparat de măsurat termo-electric cu bandă

hot tear (met, plast) crăpătură / fisură / sfâşiere (și locală, a materialului) la cald

hot-temperature zone (met, termo) zonă de temperatură înaltă / ridicată

hot tensile test (met, metr) încercare la tractiune la cald / cu epruveta încălzită

hot test (met, metr) test la temperatură ridicată (şi pentru determinarea stabilităţii)

hot trimming (met) tăiere / debavurare la cald (a metalului, semifabricatului, piesei)

hot tinning (met) cositorire / stanare la cald

hot up a încălzi, a pune pe foc

hot water (alim, ind chim) apă fierbinte

hot water cure (ind chim) vulcanizare cu apă caldă

hot-water reservoir (met, termo) acumulator / rezervor de apă supraîncălzită

hot well (termo) recipient pentru condensat cald / aburi; (geol) izvor termal / cald

hot wire (metr, termo) manometru Pirani / termic; (el) fir incandescent, filament (de rezistentă, care se încălzește puternic)

hot wire gauge (metr, termo) manometru Pirani / termic

hot workability (met) capacitate de deformare / prelucrabilitate la cald

hot work(ing) (met) prelucrare / fasonare / deformare la cald

hot yield point (met, termo, mec) limită de curgere la cald

hour (h)oră; (edu) lecție, oră de clasă / de curs; (metr) unitate de măsură pentru timp, oră (siderală): 1 hour $($ sidereal $)=3590,170416667 \mathrm{~s} ; 1$ hour $=3600 \mathrm{~s}$

hour circle meridian, fus orar

hourglass worm $(\mathrm{OM})$ melc globoidal

hour hand (geogr) ac orar

hour-long de o oră; $(a d v)$ timp de o oră, pe parcursul / durata unei ore

hourly $(a d v)$ (care se petrece) din oră în oră, orar; repetat, frecvent, la un ceas o dată 
hourly capacity / efficiency (ec, TH, mas) productivitate orară

hourly output randament / producție orar(ă)

hour of relief oră de schimbare a turei / lucrului

house (constr) casă, imobil, clădire; sală de spectacole, teatru; locuință, domiciliu; gospodărie; (constr) adăpost, hangar, garaj, şopron; de casă; casnic; $(\mathrm{OM})$ carcasă; (ec) firmă comercială, casă de comerț, birou comercial, întreprindere; (nav) ruf, a pune ancora la post în nară; a depozita, a în-magazina; a găzdui, a (se) adăposti, a caza; a cuprinde, a include; a ține; a domicilia, a sta, a locui

house agent $(\mathrm{ec})$ agent de vânzări-cumpărări

house brand (ec) marcă comercială (a angrosistului)

house-clean a face curățenie (în casă); a curăța, a epura; a împrospăta

house doctor, house physician (med) intern de spital, doctor rezident

house fly (zool) muscă

househould gospodărie; familie, oameni dintr-o casă; gospodăresc, de gospodărie; administrativ; domestic, casnic; familiar, obişnuit, comun

household appliance (mas) aparat de uz casnic householder cap de familie, gospodar

househould management gospodărie; economie domestică; arta conducerii gospodăriei

housekeeper menajeră

housekeeping (inf) ansamblu al operațiilor de gestiune internă care nu fac parte din prelucrare, program de repartizare preliminară a memoriei; (autom) operație auxiliară / accesorie; (ec, TH) operații administrative pentru menținerea controlului; menaj, gospodărie; economie domestică; gospodărire; administrare, administrație

house of call birou / agenție de informații

house painter (constr) zugrav

house pipe drains (constr) instalație de canalizare la o casă

house pole (constr) sistem de grinzi în acoperiş house style (ec) marcă a întreprinderii / firmei / companiei; stilul casei (în reclame / marketing)

housewares (mas, OM) articole de menaj / gospodărie, obiecte de gospodărie / bucătărie

house water pipe (hidr, mediu, OM) conductă de apă menajeră

housework treburile gospodăriei / casei / domestice, menaj

housing locuință, adăpostire, adăpost, găzduire, cazare; $(\mathrm{OM}$, hidr) lagăr, corp, montură, carcasă, cutie, toc, teacă corp de robinet / de supapă etc.); (mas-un) carter, corp; (met) cadrul laminorului; (nav) picior al coloanei de catarg housing base $(\mathrm{OM})$ soclu / talpă a(1) carcasei housing cap (met) capac de batiu (la laminor) housing chain stopper (nav) boț de nară; boț de lanț cu întinzător

housing clamp stiffener $(\mathrm{OM})$ piesă (şi de tablă) folosită pentru fixarea mantalei / armăturii unui cablu

housing of the closed (open) top type (met) cadru închis (deschis) al cajei de laminor

housing problem (pol, adm) problema locuințelor pentru populație

housing project (constr) proiect pentru construcții de locuințe

housing screw $(\mathrm{OM})$ şurub pentru asamblat părțile carcasei

housing pin (met, OM) știft / bolt de centrare a carcasei / a cadrului cajei

hove (nav) în pană (d. navă)

hover(ing) craft (nav) ambarcațiune pe pernă de aer

hover plane (av) elicopter

hovertrain (cf) tren care circulă pe pernă de aer how $(a d v)$ cum (?), în ce fel / sens (?), pe ce cale (?); de ce (?), din ce cauză (?); cum, felul cum / în care, după cum, aşa cum, în orice fel; că, cum că; mod, fel, metodă

howbeit $(a d v)$ şi totuşi, cu toate acestea, orice ar fi, oricum (ar fi); deşi, cu toate că; măcar că

however $(a d v)$ oricum, în orice mod / fel; deşi, cu toate că; oricât de mult; oricum, în orice caz; (şi) totuşi, cu toate acestea; pe de altă parte; dar, însă

hoy (nav) gabară, şlep, ponton, şalupă comercială

H section (constr, mec, met) grindă cu profil în $\mathrm{H}$

H-section armature (constr, mec) armătură / întăritură în (formă de) H

HSV color system, (metr, c) sistem de descriere a culorilor prin trei variabile: hue, saturation, and value (nuanță de culoare, saturație şi valoare)

hub (constr) țăruş, parte a căminului / sobei; (el) bornă, bucşă, plot; (inf) butuc purtător de rolă; (ec) centru de activitate / de interes; (OM) butuc / bucşă de roată, miră de nivelment, sabot de frână, cămaşă, manşon, tălpige de sanie; (mas-un) cap de frezat; (fig) centru, punct central

hubble (metr, fiz) unitate de măsură pentru lungime, în astronomie: 1 hubble $=10^{9}$ ani lumină $=9,4605 \cdot 10^{21} \mathrm{~km}$

hubcap (OM) capac (de fixare / de protejare) al butucului; (auto) capac de roată

hub drawer / extractor / puller (OM) extractor al butucului 
hub flange (OM) butuc cu flanşă, piesă circulară cu umeri (şi pentru montarea frezelor)

hub-mortising machine (mas-un) maşină de găurit butuci (de roți), maşină de mortezat / alezat şi alezaje poligonale

hub of armature (el) miez de indus

hub of flywheel $(\mathrm{OM})$ butuc al volantului

hub seat $(\mathrm{OM})$ port-butuc, piesă / reazem care susține butucul unei roți / unui motor etc.; (mas-un) suport pe care se montează semifabricatul cu alezaj (de exemplu, la danturare)

huckle (anat) şold

huckster (ec) vânzător ambulant; autor de reclame / emisiuni publicitare; a (re)vinde (şi cu amănuntul), a face reclamă pentru; a falsifica; a strica

huddle grămadă, morman; masă confuză / incoerență, mulțime; dezordine, răvăşeală, deranj; confuzie

huddle into a îngrămădi, a înghesui în; a pune de-a valma

hue nuanță, tonalitate cromatică; tentă; culoare; scară / gradație a culorilor; strigăt, chiot; (metr c) o măsură a nuanțelor de culoare, codificată numeric

huff a umfla cu aer

huge uriaş, imens, colosal, enorm

hugeness mărime imensă, imensitate

hugger clivaj

hulk (nav) navă dezafectată, ponton dormitor, navă de lucrări portuare, cocă veche, carcasă de vas cu altă destinație (depozit etc.), vas greoi; morman, grămadă

hulking hammer (constr) ciocan pentru demolare / pneumatic

hull (alim, agr, bot) păstaie, coajă (de fruct), teacă (de mazăre, fasole), înveliş, a coji, a de(z)coji, decortica (orez), a curața (de coajă); (nav) carenă; (av) fuzelaj; (OM, met) înveliş, coajă; (ec, nav) poliță de asigurare a corpului navei; (mat) înfăşurătoare; (nav) corp de navă, cocă, carenă, carcasă, parte exterioară, a deriva pe furtună; (TH) a coji (şi de vopsea)

Hull cell (el, chim) celulă Hull / pentru îmbunătățirea electrodepunerii / electroacoperirii

hulled rice (alim) orez decorticat

hull of ship (nav) coca navei, corp de navă

hull / shell plating (nav) bordaj exterior, platelaj

hull shop (nav) atelier de reparat şalupe, hală de construcții navale

hum, humming (TH, el, autom) bâzâit, vâjâit; brum, zgomot de alimentare / de retea / de fond; a produce acest zgomot, perturbare electrică

human omenesc, uman humane omenos, uman; indulgent, îngăduitor human engineer economist specializat în sociologie industrială

human engineering (ind) ergonomie, adaptare a muncii la om, antropotehnică, biotehnică, sociologie industrială, studiul relațiilor industriale humanity omenire, umanitate; caracter omenesc humanized milk (alim) lapte de vacă prelucrat (pt. a semăna cu cel de mamă)

human race omenire, umanitate

human rights (pol) drepturile omului

humdrum banal, monoton, stupid; banalitate, monotonie, stupiditate

humectation (alim, constr, ind chim) umectare, umezire

humic acid (chim) acid humic, amestec de acizi organici (din humus)

hum (alim, constr, ind chim) effect de umectare; (el, autom) zgomot de rețea

humid umed, jilav

humid air (mediu) aer umed

humid gas (termo, chim) gaz umed

humidification (alim, constr, ind chim) umezire, umectare, umidificare

humidified (alim, constr, ind chim) umidificat, umezit

humidifier (mas, alim, constr, ind chim) umezitor, umidificator

humidistat (metr, mediu) umidostat

humidify (alim, constr, ind chim) a umezi

humidity (fiz) umiditate, umezeală

humidity element (OM, metr) element sensibil la umiditate

humidity of the air (mediu) umiditatea aerului humidity recorder (metr, mediu) higrometru humidity resistance (plast) rezistență la umiditate humidometer (metr, mediu) higrometru

humid weather vreme umedă

hump (cf) cocoaşă de triaj; (met, OM) proeminență, umflătură, bombare; (mat) cocoaşă a unei curbe; (geogr) movilă / ridicătură (de pământ)

humpage hob (mas-un) freză-melc elicoidală, cu dinți demontabili

humpback (met, OM) proeminență, umflătură, bombare; (mat) cocoaşă a unei curbe

humpback bridge (constr) pod în spinare de măgar

hump blind track (cf) linie moartă a cocoașei

hump's crest (mat, fiz) vârf al cocoaşei

humpy separation (met, plast) neregularități în piesa turnată, separare cu proemiențe vizibile

humus (agr) humus, pământ vegetal

hum voltage (el, electr, autom) tensiune de zgomot 
hunch bucată groasă / mare; bănuială, suspiciune, intuiție, fler; a curba, a îndoi (în afară)

hunch pit (met) groapă de zgură

hundred (mat) (o) sută; (metr) unitate britanică, veche, pentru suprafață: 1 hundred $=5000$ ha; unitate comercială pentru cantitate (denumită şi cent): 100 bucăți, 120 buncăți "great hundred" (în funcție de produse)

hundred-cubic foot (metr) (metr) unitate de măsură pentru volum, 100 de yarzi cubici: 1 hundred-cubic foot $=2,831684659 \mathrm{~m}^{3}$

hundred-cubic foot/day (metr) unitate de măsură pentru debit volumic: 1 hundred-cubic foot $/$ day $=0,000032774 \mathrm{~m}^{3} / \mathrm{s}$

hundred-cubic foot/hour (metr) unitate de măsură pentru debit volumic, 100 de picioare cubice/oră: 1 hundred-cubic foot/hour = $0,000786579 \mathrm{~m}^{3} / \mathrm{s}$

hundred-cubic foot/minute (metr) unitate de măsură pentru debit volumic, 100 picioare cubice/minut: 1 hundred-cubic foot $/$ minute $=$ $0,047194744 \mathrm{~m}^{3} / \mathrm{s}$

hundredfold însutit

hundredth (mat) al o sutălea, a o suta; sutime

hundreds digit (mat, inf) cifră poziție a sutelor

hundreds place (mat) ordin al sutelor

hundred to one unu la sută (procent)

hundredweight, hundred weight (hwt) (metr) unitate de măsură pentru masă, chintal: 1 hundredweight (long) (long cwt or cwt) (UK) = $50,80234544 \mathrm{~kg} ; 1$ hundredweight (short) (cental sh cwt) $(\mathrm{US})=45,359237 \mathrm{~kg}$

hung ceiling (constr) plafon / tavan suspendat

hunk halcă, bucată (informă / groasă); felie

hunkers (alim) pulpe, sunci

hunky muncitor necalificat

hunt a vâna; a urmări; a căuta; vânătoare (şi de greşeli etc.); (mas, el) variație mică a turației unui motor

hunter vânător

hunt for a căuta, a umbla după, a fi în căutarea

hunting vânătoare; (autom) autoechilibrare, oscilație pendulară, pompaj, căutare, selecție; (termo) fluctuație excesivă în dozarea refrigerentului (la admisie); (cf) mişcare de şerpuire a locomotivei; (mas-un) funcționare neuniformă, vibrații periodice

hurdle (constr) gard împletit / mobil, bucată / panou de gard, obstacol, barieră, piedică, împletitură, grătar; a înconjura cu gard, a separa print-un gard; (fig) a trece peste, a depăşi o dificultate

hurdle-type washer (met, termo) grătar de spălare, spălător cu grătar hurl a (se) arunca, a azvârli; a înfige, a împinge înainte; a se repezi înainte; aruncare, azvârlire hurler (OM, mas-un) dispozitiv aruncător hurling pump (hidr, OM) pompă rotativă hurricane uragan, furtună, vânt puternic hurried grăbit, fugitiv, făcut în grabă; pripit, repezit; rapid, iute

hurry grabă (şi exagerată); precipitare, repezeală; (motiv de) grabă, urgență; pripeală; a se grăbi; a zori; a da peste cap (din grabă)

hurry along a lua / duce repede, a face să se grăbească, a zori, a se grăbi, a merge repede

hurry for / to nerăbdare să, grabă să; a se grăbi să hurry up a se grăbi

hurst (geogr) deluşor (împădurit), pădure; banc de nisip

hurt (med) rană, durere, a răni; lovitură; a srtica, a lovi, a avaria; (fig) a face un rău, a strica; a împiedica, a stânjeni

hurtful dureros; supărător; dăunător, păgubitor

hurtle a izbi, a lovi; a trânti, a dărâma; a arunca repede, a (se) repezi; a cădea, a se prăbuşi cu zgomot; prăbuşire / cădere cu zgomot

hurtle against a se izbi de, a se ciocni de

hurtless teafăr, neatins, nerănit

husbandry economie (la scară mică), administrație, gospodărire

hush-hush (fiz, autom) reducere a zgomotului de fond

husk (alim, agr) coajă, pleavă, păstaie, a (de)coji, a decortica, a îndepărta pleava

husker (agr, mas) decorticator

husks of grapes (alim) coji de struguri, boască

husky (alim) plin de coji / de pleavă; scorțos, aspru, uscat

hustle into a decision a forța luarea unei decizii

hut (constr) baracă, cabană

hüvelyk (metr) unitate de măsură pentru lungime, deget unguresc: 1 hüvelyk $\sim 2,63 \mathrm{~cm}$

hyaline (fiz) hialin, vitros, sticlos; amorf, necristalizat; corp / obiect transparent

hyaline structure / texture structură vitroasă / stricloasă

hybrid (agr) (d. plante, materiale) hibrid, amestecat; bastard

hybrid computer (c) calculator hibrid / analogic-numeric

hybridity hibriditate, caracter hibrid

hybridization (agr, bot) hibridizare, încrucişare

hybridize (agr, bot) a hibridiza, a încrucişa

hybrid structure $(\mathrm{mec})$ structură hibridă (formată din elemente rigide şi elastice)

hybrid transformer (el) transformator diferențial echilibrat 
hydracid (chim) acid care nu conține oxigen hydrant (hidr, OM) hidrant, gură de apă hydrargyrum (chim) mercur, hidrargir $(\mathrm{Hg})$ hydrate (chim) hidroxid, hidrat; a hidrata, a hidrogena

hydrated lime (chim) lapte de var, hidroxid de calciu; (constr) var stins

hydrated oxide (chim) hidroxid

hydrated soap ( $T$, chim) săpun format (şi) cu apă (la săpunuri pentru unsori)

hydration (chim) hidratare, hidrogenare

hydraulic hidraulic; cu apă

hydraulic actuator (hidr) element de acţionare hidraulică

hydraulic amplifier (hidr) amplificator hidraulic

hydraulic cement (chim) liant / ciment hidraulic / cu priză la apă

hydraulic clutch (OM, hidr) ambreiaj hidraulic hydraulic control (OM, hidr) comandă hidraulică hydraulic conveying transport(are) hidraulic(ă)

hydraulically operated (autom, hidr) actionat / comandat hidraulic

hydraulically smooth (perete) neted (din punct de vedere hidraulic)

hydraulic barking (met) cojire hidraulică

hydraulic binder / binding matter liant hidraulic / rezistent la apă sau alt fluid (şi sub presiune)

hydraulic booster (hidr) dispozitiv hidraulic de amplificare a comenzilor (manuale) de forță sau de reducere a forțelor pentru a putea controla / comanda o maşină

hydraulic bulldozer (hidr, mas) buldozer cu comenzi hidraulice

hydraulic circuit circuit hidraulic

hydraulic classification $(\mathrm{TH})$ clasare / sortare hidraulică

hydraulic classifier clasor / sortator hidraulic

hydraulic coupling (OM, hidr) cuplaj hidraulic, turboambreiaj

hydraulic cutt-off device obturator hidraulic

hydraulic cylinder $(\mathrm{OM})$ cilindru hidraulic

hydraulic descaling (met) curățare / îndepărtarea arsurii / țunderului cu jet de apă

hydraulic dozer (hidr, mas-un) dozator hidraulic, autoîncărcător cu comandă hidraulică

hydraulic dredge(r) dragă de nămol / aspiratoare hydraulic energy (hidr) energie hidraulică

hydraulic engineering hidraulică

hydraulic excavator excavator (cu comandă) hidraulic( $\breve{a})$

hydraulic fluid (hidr, T) fluid sub presiune, fluid (şi cu vâscozitate mică) (pt. instalații hidraulice

hydraulic fluid volume (hidr, T) volum fluid sub presiune / hidraulic hydraulic forging (met, hidr) forjare / presare (a metalelor) prin acționare hidraulică (a presei matriței etc.)

hydraulic forging press (met) presă hidraulică de forjare / presare (a metalelor)

hydraulic glue (plast) clei rezistent la apă

hydraulic gradient (hidr) gradient hidraulic, treaptă hidraulică, linie piezometrică (a energiei potențiale)

hydraulic hammer (hidr) şoc hidraulic; lovitură de berbec

hydraulic head (hidr) presiune hidraulică; înălțime a coloanei de lichid / apă

hydraulic impact (hidr) lovitură de berbec; şoc hidraulic

hydraulic ironing press (mas-un) presă hidraulică de călcat (țesături)

hydraulic jack (OM, hidr) vinci / cric hidraulic hydraulic jet (hidr) jet hidraulic / sub presiune hydraulic jump (hidr) salt hidraulic / de presiune hydraulic jump surge (hidr) undă de salt / şoc hidraulic

hydraulic knife (mas-un, hidr) cuțit hidraulic, cu jet de apă (sub presiune)

hydraulic lever (hidr, OM) amplificator hidraulic hydraulic lock (hidr) blocare hidraulică hydraulic motor (hidr) motor hidraulic hydraulic oil brake (OM, hidr) frână hidraulică cu ulei

hydraulic operating gear (OM, hidr) mecanism cu acționare hidraulică

hydraulic power (hidr) putere hidraulică

hydraulic press (mas-un) presă (cu acționare) hidraulică

hydraulic pressure (hidr) presiune hidraulică

hydraulic pressure extruder (hidr, plast, masun, met) extruder actionat hidraulic

hydraulic-pressure head (hidr) înălțime piezometrică, presiune a coloanei de fluid

hydraulic-pressure test (hidr, metr) probă de presiune la rece, test de / la etanşeitate

hydraulic pump (OM, hidr) pompă hidraulică

hydraulic pump-motor $(\mathrm{OM}$, hidr) motopompă hidraulică; deversor

hydraulic radius (hidr) rază hidraulică

hydraulic ram (hidr, met, plas) cilindru / berbec hidraulic

hydraulic resistance (hidr) rezistență hidraulică hydraulics hidraulică

hydraulic sammying press (alim, ind chim) presă hidraulică de stors

hydraulic screw (alim) elevator elicoidal de apă hydraulic servovalve (hidr, autom) servovalvă hidraulică, servodistribuitor hidraulic 
hydraulic shock (hidr) şoc hidraulic, lovitură de berbec

hydraulic shovel(-)up (mas, hidr) excavator cu comandă hidraulică

hydraulic slip (hidr) pierderi de fluid

hydraulics of open channels (hidr) hidraulica canalelor deschise / cu nivel liber

hydraulic stepping motor (hidr, mas) motor hidraulic, pas cu pas

hydraulic supply (hidr) sursă de fluid (apă) sub presiune

hydraulic system (autom, hidr) sistem hidraulic

hydraulic tractor loader / shovel (mas, hidr) autoîncărcător cu cupă acționat hidraulic

hydraulic transducer (metr, hidr) traductor de presiune (hidraulică), manometru

hydraulic tripping device (OM, hidr, autom) declanşator hidraulic

hydraulic vice (mas-un, hidr) menghină acționată hidraulic

hydraulic vulcanising press (mas-un, plast, hidr) presă hidraulică de vulcanizat

hydraulic wheel $(\mathrm{OM})$ roată hidraulică / de apă

hydrazide (chim) hidrazidă

hydric (chim) hidric

hydride (chim) hidrură

hidride phase (met) fază cu conținut mărit de hidrogen (peste limita de solubilitate)

hydrocarbon (chim) hidrocarbură; compus pe bază de carbon şi hidrogen

hydrocarbon black (chim) negru de fum

hydrocarbon fuel-air mixture (termo) amestec carburant pe bază de hidrocarburi şi aer

hydrocarbon pavement mixture (chim) mixtură / amestec asfaltic( $\breve{a})$

hydrocarbon resin (plast) răşină hidrocarbonată hydroclassifier (hidr, alim, ind chim) clasor / sortator hidraulic

hydrochloric (chim) clorhidric

hydrochloric acid (chim) acid clorhidric

hydrochloride (chim) clorură, sare a acidului clorhidric

hydrocooling (termo) răcire cu apă cu gheață, răcirea unor produse prin contact direct cu apa

hydrocracking (ind chim) hidrocracare, hidrogenare distructivă

hydrocracker (ind chim) instalație de cracare hidrocyclone (alim, chim, mediu) hidrociclon hydrocyanic (chim) cianhidric

hydrocyanic acid (chim) acid cianhidric

hydro drive (OM, hidr) acționare hidraulică

hydrodynamic film $(\mathrm{T})$ peliculă / film hidrodinamic(ă)

hydrodynamic (fiz, hidr, T) hidrodinamic hydrodynamic loss (OM, hidr, T) pierdere hidrodinamică

hydrodynamic (fluid film) lubrication (T) lubrifiere hidrodinamică (cu peliculă portantă)

hydrodynamic pressure $(\mathrm{OM}$, hidr, $\mathrm{T})$ presiune hidrodinamică

hydrodynamics hidrodinamică

hydrodynamic theory of fluids teoria hidrodinamică a fluidelor

hydroelectric hidroelectric

hydroelectric generating set (el, hidr) grup generator hidraulic

hydroelectric power (el, hidr) energie hidroelectrică

hydroelectric power plant / station (el, hidr) hidrocentrală, instalație hidroenergetică, centrală hidroelectrică

hydroelevator elevator de apă

hydroextracting (alim, ind chim) îndepărtare a apei din materiale prin centrifugare

hydroextractor (alim, ind chim) centrifugă de uscare

hydrofluoric (chim) fluorhidric

hydrofluoric acid (chim) acid fluorhidric

hydrofoil (fiz, hidr) aripă portantă / imersă / subacvatică, (navă) cu aripi portante / imerse / subacvatice

hydrofuge hidrofug

Hydrogen (H) (chim) hidrogen

hydrogen acceptor (chim) (atom/radical) acceptor de hidrogen

hydrogenant agent (alim, chim) agent de hidrogenare

hydrogenate (alim, chim) a hidrogena

hydrogenated fat / oil (alim, ind chim) ulei hidrogenat

hydrogenation (alim, ind chim) hidrogenare

hydrogen attack (met, chim) agresivitate a hidrogenului, coroziune de hidrogen

hydrogen carrier (chim) purtător de hidrogen

hydrogen controlled covering (chim) înveliş cu conținut redus de hidrogen

hydrogen cracking (chim) hidrocracare

hydrogen cylinder (OM, met, chim) butelie (cilindrică) de hidrogen

hydrogen damage (met) deteriorare / distrugere cauzată de hidrogen (în general, fără precizarea formei de distrugere)

hydrogen deuterium oxyde (chim) apă grea

hydrogen dicarbide (chim) metan

hydrogen dioxide (chim) apă oxigenată

hydrogen embrittlement (met, chim) fragilizare acidă / cauzată de hidrogen / prin incluziuni de hidrogen 
hydrogen-evolution type of corrosion (met, chim) coroziune (cu degajare) de hidrogen

hydrogen equivalent (chim) echivalent de hidrogen

hydrogen generator (chim) generator de hidrogen hydrogen ion (chim) ion de hidrogen

hydrogen-iron resistance (met) rezistență a aliajelor feroase la hidrogen

hydrogenize (chim) a hidrogena

hydrogen nitrate (chim) acid azotic

hydrogen nitride (chim) amoniac

hydrogenous (chim) hidrogenos, hidrogenic

hydrogen oxide (chim) apă

hydrogen peroxide (chim) perhidrol, apă oxigenată

hydrogen sulfide / sulphide (chim) hidrogen sulfurat

hydrogen welding (met, chim) sudare cu hidrogen atomic

hydrographic (geogr) hidrografic

hydrography (geogr) hidrografie, geografia apelor

hydrokinetic (hidr) hidromecanic

hydrokinetics (hidr) hidromecanică, hidrodinamică; mecanica fluidelor

hydrokinetic / hydraulic transmission (hidr, OM) transmisie hidrodinamică

hydrologic(al) hidrologic

hydrologist hidrolog

hydrology hidrologie

hydrolyse, hydrolize (chim) a hidroliza, a descompune prin hidroliză

hydrolysis (chim) hidroliză

hydrolytic adsorbtion (fiz, chim) adsorbție hidrolitică

hydromechanical efficiency (hidr, mec) randament hidromecanic

hydromechanics hidromecanică, mecanica fluidelor

hydromel hidromel

hydrometallurgy (met) hidrometalurgie, spălarea minereurilor, obținerea metalelor prin spălare / prin procedeu lichid

hidrometer (metr, hidr) aparat de măsurat greutatea specifică a unui lichid, hidrometru, densimetru

hydrometric hidrometric

hydrometry (metr) hidrometrie, densometrie

hydroperoxide hidroperoxizi

hydrophile, hydrophilic (chim) hidrofil, având afinitate cu / pentru apă, dizolvabil / care reacționează în apă

hydrophilic binder (chim) liant hidrofil

hydrophilic emulsifier (chim) emulsificator / emulgator hidrofil

hydrophilic emulsion (fiz, chim) emulsie hidrofilă hydrophilic surface $(\mathrm{T})$ suprafață hidrofilă

hydrophilous, hydrophylic delicvescent, care necesită multă apă (şi pentru creştere); (bot) avid de apă

hydrophobe, hydrophobic (fiz) hidrofob, nemiscibil cu apa, care nu absoarbe apa

hydrophobic material (fiz) material hidrofob hydrophobic surface $(\mathrm{T})$ suprafață hidrofobă hydrophone (metr, fiz) ecometru, detector sonic hydrophyte (bot) plantă acvatică, plantă care crește numai în mediu umed

hydroplane (av) hidroglisor, hidroavion, a glisa pe apă

hydroplaning (auto) hidroplanare, acvaplanare hydropneumatic hidropneumatic

hydroponics (agr) cultivarea plantelor fără sol

hydropower (fiz) energie hidroelectrică

hydropower plant / station (ind) hidrocentrală, centrală hidroelectrică

hydroquinone (chim) hidrochinonă

hydroscope (nav, OM) periscop

hydroscopic higroscopic

hydroscopic substance substanță higroscopică

hydroseparator (alim, ind chim) separator hidraulic

hydrosol (fiz) hidrosol, dispersie coloidală în apă hydrosphere hidrosferă

hydrostatic(al) (hidr) hidrostatic

hydrostatic(al) press (mas-un, hidr) presă hidrostatică

hydrostatic(al) pressing / pressure (hidr) presiune hidrostatică

hydrostatic balance (hidr) balanță hidrostatică, echilibrul presiunilor (hidrostatice)

hydrostatic gradient (hidr) gradient hidrostatic

hydrostatic head (hidr) presiune hidrostatică (exprimată ca înălțime a unei coloane de lichid, de obicei apă)

hydrostatic level (hidr) nivel hidrostatic

hydrostatic lubrication (T) lubrifiere hidrostatică hydrostatics hidrostatică

hydrostatic test $(\mathrm{OM}$, metr, hidr) test / încercare de etanşeitate la presiune constantă

hydrothermal (geol) hidrotermal

hydrothermal stress analysis analiza efectului combinat al mediului şi solicitărilor (şi variabile)

hydrous apos, care conține apă

hydroxide (chim) hidroxid, hidrat

hydroxyl (chim) hidroxil, oxidril

hydroxyl group (chim) grupare hidroxilică

hydroxyl ion (chim) (ion de) hidroxil / oxidril

hygiene igienă

hygienic igienic

hygienics igienă, știința igienei 
hygienist igienist

hygral property proprietate de a absorbi umezeala / apa (d. materiale)

hygrometer (metr) higrometru

hygrometric (metr) higrometric, capabil să absoarbă apă sau umezeală (d. materiale)

hygrometry (metr) orice procedeu de determinare a conținutului de apă / umezeală, higrometrie

hygroscope (metr) higroscop

hygroscopic higroscopic (d. un material)

hygroscopicity higroscopicitate (d. un material)

hygroscopic moisture umiditate higroscopică

hygroscopic water apă higroscopică

hygrostat higrostat

hyl (metr) unitate de măsură pentru masă (CGS unit) (metr) 1 hyl $=9,80665 \mathrm{~g} ; 1$ hyl (MKS unit) $=9,80665 \mathrm{~kg}$

hyper acid (chim) hiperacid

hyperacidity (chim) hiperaciditate

hyperactive (chim) exagerat de / foarte activ, hiperactiv

hyperbolas (mat) hiperbolă

hyperbolic (mat) hiperbolic; exagerat

hyperbolical gear $(\mathrm{OM})$ roată dințată hiperboloidală

hyperbolic law (mat) dependență / lege hiperbolică (de variaţie)

hyperbolic logarithm (mat) logaritm natural

hyperboloid (geom) hiperboloid

hypereutectoic (met) hipereutectic

hypereutectoid (met) hipereutectoid

hypereutectoid steel (met) oțel hipereutectoid

hyperfine superfin, hiperfin

hyperfine structure (met, plast, compozite, materiale sinterizate) structură superfină

hyperinflation (ec) inflație galopantă

hyperme (met) aliaj feromagnetic (Fe-Si, $\mathrm{Fe}-\mathrm{Ni})$

hypermetropic, hyperopic (anat, opt) hipermetropic, presbit

hyperopia, hypermetropia (anat) hipermetropie hypernik (met) invariu (aliaj Fe-Ni)

hyperox (met) material tip ferită

hyperquench (met) călire cu răcire bruscă

hypersensibility (autom, metr) sensibilitate mare, hipersensibilitate

hypersensitive (mas, aparate) foarte sensibil

hypersonic (fiz) ultrasonic, supersonic, hipersonic

hypersonic frequency (fiz) frecvență ultrasonică (mai mare de $20 \mathrm{kHz}$ )

hypersorption (fiz) proces de hipersorbție

hyphen liniuță de unire, cratimă

hyphenate a lega cuvinte prin liniuță, a despărți în silabe

hyphenation (inf) tăiere a unui cuvânt

hyphened word cuvânt compus / cu liniuță de unire hypochlorite (chim) hipoclorură, sare a acidului hipocloros

hypochlorous acid (chim) acid hipocloros hypocycloid (mat, OM) hipocicloidă

hypodermic seringe (med, OM) seringă pentru injecții subcutanate

hypoeutectic (met) hipoeutectic

hypoeutectic alloy (met) aliaj hipoeutectic

hypoeutectoid (met) hipoeutectoid

hypoeutectoid alloy (met) aliaj hipoeutectoid

hypoeutectoid steel (met) oțel hipoeutectoid

hypoid bevel gear (OM) angrenaj conic hipoidal /pseudoconic

hypoid gear (OM) angrenaj hipoid(al)

hypoid gearing $(\mathrm{OM})$ angrenare hipoidă / pseudoconică

hypoid gear lubricant (T) lubrifiant pentru angrenaje hipoide (şi pt. diferențiale de autovehicule)

hyposulfite, hyposulphite (chim) hiposulfit

hypotenuse (geom) ipotenuză

hypothecate $(\mathrm{ec})$ a ipoteca

hypothecation $(\mathrm{ec})$ ipotecare

hypothek (ec) ipotecă

hypothesis (mat, fiz) ipoteză

hypothesize a face / emite ipoteze, a presupune, a bănui

hypothetical ipotetic, bazat pe supoziție; presupus

hypothetically $(a d v)$ (în mod) ipotetic

hypoxia (med) hipoxie, insuficientă oxigenare a țesuturilor

hypsometer (metr) hipsometru

hysteresigraph (metr, fiz) histerezigraf, aparat pentru vizualizarea / înregistrarea curbei de magnetizare / de histerezis

hysteresimeter (metr) aparat pentru măsurarea histerezisului (mecanic, magnetic)

hysteresis (el, mec) histerezis; (inf) caracteristică a memoriei magnetice

hysteresis constant (fiz, el, mec) constantă de histerezis

hysteresis curve recorder (fiz, el, mec, metr) histerezigraf, aparat pentru vizualizarea / înregistrarea curbei de magnetizare

hysteresis error (el, mec) eroare de histerezis

hysteresis loop (fiz, el, mec, plast) buclă / curbă / ciclu de histerezis

hysteresis losses (el, mec, plast) pierderi prin histerezis

hysteresis test (metr, el, mec) test de histerezis

hysteretic (el, mec, plast) cu histerezis puternic / accentuat

hysteretic lag (el) întârziere de fază, provocată de histerezis

Hz (hertz) (metr, fiz) hertz; v hertz 


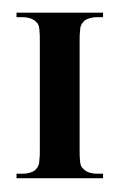

i, imaginary unit (mat) număr imaginar unitar: $\mathrm{i}=\sqrt{-1}$

IACS abreviere pentru International Annealed Copper Standard, o măsură a conductivității folosită să compare conductorii electrici cu un conductor standard de cupru: 100\% IACS reprezintăconductivitate de 58 megasiemens pe metro $(\mathrm{MS} / \mathrm{m})$, echivalentă cu rezistivitatea de $1 / 58$ ohmi pe metru, pentru un concductor cu secțiunea de $1 \mathrm{~mm}^{2}$

I-beam / I-beam (constr) grindă în I / cu tălpi; (met) oțel / profil I (sau dublu T)

I-beam axle (OM) osie cu secțiune I / dublu T

I-beam girder (met, mec) oțel / profil I, grindă I

I-beam section (met, mec) secțiune a unui profil / semifabricat I

ibidem $(a d v)$ în / din acelaşi loc

IBU (metr, agr, alim) abreviere pentru international bitterness / bittering unit, unitate în industria berii: $1 \mathrm{IBU}$ este egală cu $1 \mathrm{ppm}$ de izohumulen, un acid derivat din hamei

ice gheață, strat / pojghiță de gheațắ; înghețare; (alim) înghețată, glazură de zahăr; a îngheța, a congela, a (se) acoperi cu gheață, a pune la gheață, a (se) răci, a frapa, a glasa, a face o glazură; a se jivra

ice bag pungă de gheață

iceberg (geogr) aisberg, ghețar; (fig) simbol, semn vizibil (al unui proces important)

ice boat (alim, termo) vehicul pentru deplasare pe gheață, sanie cu pânze; (nav) spărgător de gheață

ice-bound (transp, mas) prins / blocat de ghețuri ice box (alim, termo) răcitor; (amer) frigider ice-breaker (nav) spărgător de gheață ice-cold rece ca ghața; înghețat; de la gheață ice cream (alim) înghețată ice crystal (fiz) cristal de gheață

ice day zi cu temperatură maximă sub 0 grade Celsius

ice drag ancoră de gheață (cu un singur braț)

iced road (auto) drum înghețat / cu polei

icefall (geogr) perete de gheață; ghețar, morenă glaciară, cascadă de gheață

ice formation (mediu) jivraj, formare de gheață (pe o suprafață) icehouse (alim, iht) siloz pentru gheață

ice on road segment (auto) indicator „drum cu gheață"

ice point (fiz) punct de îngheț / de congelare

ice point depression (termo, fiz, T) scădere a punctului de congelare (şi la unsori)

icetray (alim) tăviță pentru (cuburi de) gheață

ice water apă (rece) de la gheață

ice wool (textile) lână fină

icfm, inlet cubic feet per minute (metr) unitate pentru măsurarea capacitătii unui compressor: picior cubic (de interior) pe minut: 1 inlet cubic foot $/$ minute $=0,000471947 \mathrm{~m}^{3} / \mathrm{s}$

ichthyologic(al) ihtiologic

ichthyologist ihtiolog

ichthyology ihtiologie

icing înghețare; (alim) glazură

icon (c) icoană, icon, imagine simbolică (pt. un (sub)program) pe ecranul calculatorului

iconic iconic, imagistic, cu caracter figurativ

iconometer (opt, OM) vizor (optic) direct; (metr) iconometru, telemetru

icy de gheață, înghețat, ca gheața, rece

idea idee, noțiune; imagine; gând; părere, concepție; bănuială, presupunere; mod de a gândi, mentalitate

ideal ideal, perfect, desăvârşit, excelent; nereal; mintal; ideal, perfectiune; tintă, scop

ideal articulation inteligibilitate / articulare ideală

ideal black body (fiz) corp absolut negru

ideal combustion (termo, chim) ardere completă

ideal elastic behaviour (mec) comportare idealelastică

ideal gas (fiz) gaz ideal

idealess lipsit de ideal; fără imaginatie

ideal liquid (fiz) lichid / fluid ideal / newtonian

idealist idealist

idealization idealizare

idealize a idealiza

ideal point (mat) punct impropriu / de la infinit

ideal simple pendulum (mat, mec) pendul matematic

ideal value (autom) valoare ideală; (mat) valoare adevărată

ideate a concepe, a(-şi) închipui; a-şi forma concepții / idei

ideation ideație, formare a ideilor; proces de gândire; idei, mod de a gândi

idem acelaşi cuvânt / autor; $(a d v)$ idem, la fel, de asemenea

identic(al) with (mat) identic, congruent, absolut la fel

identically $(a d v)$ (în mod) identic cu, în acelaşi fel, la fel cu 
identifiable identificabil, uşor de identificat identification identificare, egalare, marcare identification card $(\mathrm{TH})$ etichetă cu caracteristicile piesei, legitimație

identification colour $(\mathrm{TH})$ culoare distinctivă / de identificare

identification record (jur) cazier, dosar

identification tag (auto) număr / placă de circulație identifier ( $\mathrm{c}$, inf) identificator, nume simbolic (într-un limbaj de programare)

identify (TH) a (se) identifica; (mat) a identifica, a egala

identifying information (inf, TH) informație de identificare / de recunoaştere

identifying operator action (TH) precizare a sarcinilor lucrătorului / operatorului

identity identitate, congruență, transformare identică, asemănare; unicitate; (mat) ecuație identică, identitate

identity card (TH) legitimație, buletin / card de identitate

identity matrix (inf) matrice-identitate (de rang n); (el, mat) matrice unitară / unitate / unificată

id est (i.e.) adică

idiosyncrasy idiosincrasie, particularitate; (med) hipersensibilitate, alergie

idiosyncratic bazat pe idiosincrasie, cu totul deosebit, particular; (med) hipersensibil, alergic

idle inutil, zadarnic; neântemeiat, neocupat; indolent; (TH) inactiv, inert, leneş; şomer; nefolosit, inutil, nefolositor, (d. muncitor) fără ocupație, inactiv; fără temei / bază, neîntemeiat, nefondat; nelalocul lui; stupid, prostesc; (auto) regim de ralanti; (mec, mas) repaus, mers în gol; (ax) liber, neocupat; a funcționa / merge în gol; a irosi; a nu face nimic, a şoma, a nu avea de lucru, a nu avea ocupație, a rămâne / ține nefolosit; a lenevi; a risipi, a irosi; away one's time a-şi pierde vremea lenevind / nefăcând nimic

idle adjustment ( $\mathrm{TH}$, mas) reglarea mersului în gol / la mers în gol

idle capacity (mas, ec) capacitate neutilizată

idle capital (ec) capital neproductiv

idle component $(\mathrm{OM})$ componentă reactivă

idle convolution (OM) spiră inactivă (la arcuri)

idle frequency (mas, fiz) frecvență de mers în gol

idle gear / run(ning) (mas, TH) funcționare / mers în gol, cursă moartă / în gol

idle hours (mas-un) întrerupere în functionare; (TH) timpi morți

idle market (ec) piață inactivă cu lipsă (totală) de afaceri

idle money (ec) lichidități, bani nefolosiți

idleness (mec) inerție; inactivitate; lene idle operation (met, TH) mers în gol (al laminorului etc.)

idle pass (met, TH) pas / trecere în gol (la laminare) idle period (met, mas, ind) perioadă în circuit deschis / de mers în gol, timp de blocare / de repaus / mort / inactiv

idle position (mas) pozitiie de repaus

idle pulley $(\mathrm{OM})$ fulie / roată de întins cureaua; roată liberă pe ax

idler leneş; hoinar; $(\mathrm{OM})$ rolă de ghidare (şi de transportor cu bandă), rolă de întindere a benzii, rolă, roată (şi de curea), liberă pe arbore / conducătoare / de ghidare, rolă / roată dinţată intermediară, întinzător de curea; cursă în gol; (met) cilindru neacționat / liber

idler nozzle (auto, termo) jiclor de ralanti / de mers încet

idle roll $(\mathrm{OM})$ cilindru de mers liber / cu rotire liberă; (met) cilindru liber / neacționat (la laminoare)

idle roller (constr, met, $\mathrm{OM}$ ) rolă de sustinere a covorului unei benzi, transportoare rolă liberă

idler pulley $(\mathrm{OM})$ roată de curea, liberă

idler reverse gear $(\mathrm{OM})$ roată dințată intermediară (pt. inversarea sensului de rotație într-o transmisie)

idler rope sheave $(\mathrm{OM})$ roată liberă pentru cablul de transmisie

idlers $(\mathrm{OM})$ dispozitiv de tensionare a curelelor de transmisie (cu role / roți libere)

idler rubber (ind chim, mediu) deşeuri de cauciuc

idle run / running $(\mathrm{TH})$ mers / trecere / funcționare în gol, cursă moartă; $(\mathrm{OM})$ joc liber

idle-running current (el) curent (la mers) în gol idle-running regime (mas) regim de mers în gol idler wheel $(\mathrm{OM})$ roată de ghidare, roată de curea, liberă pe arbore, roată intermediară (întro transmisie de roți dințate), roată parazită (care nu influențează raportul de transmisie)

idle shift schimb în care nu se lucrează

idle speed (mas, mec) viteză (de mers / de functionare) în gol

idle stroke (mas, mas-un) cursă de înapoiere, mers în gol, cursă moartă

idle time (TH) timp inactiv / mort, întrerupere (în funcționare); (ec) gol în producție; timp mort; (mas) timp de mers în gol

idle turn (OM) spiră moartă (la arcuri)

idling ( $\mathrm{TH}$, mas) regim de ralanti, mers / funcționare în gol

idling adjustment / setting ( $\mathrm{TH}$, mec, autom, mas) reglarea mersului în gol / la mers în gol

idling control ( $\mathrm{TH}$, autom, mas) supravegherea mersului în gol 
idling cycle (mas-un, met) ciclu de mers în gol idling gear $(\mathrm{OM})$ roată dințată intermediară idling jet / nozzle (auto) jiclor de ralanti / de mers încet

idling speed (OM, mas) turație de mers în gol / de ralanti

idling wheel $(\mathrm{OM})$ roată intermediară (într-o transmisie)

IE (metr) simbol pentru International Einheit, numele german al unității internaționale; $v$. international unit (IU)

if (conj) dacă, de, că; deşi, cu toate că; presupunând că, în cazul în care; cu condiția ca; (c, inf) comandă pentru introducerea unei condiții (in anumite limbaje de programare); $(s)$ condiție, presupunere, supoziție; even chiar dacă; as ca şi cum

if and only if (mat, autom, inf) dacă şi numai dacă (condiție necesară şi suficientă)

if equipped (auto, mas) dacă este prevăzut / dotat

if-statement (inf, autom) instrucțiune "dacă" / condițională

I-girder (constr, mec) grindă cu secțiune în I sau dublu $\mathrm{T}$, oțel profil I sau dublu $\mathrm{T}$

igneous de foc; arzând; fierbinte; eruptiv

igneous metallurgy pirometalurgie

ignitability inflamabilitate

ignitable / ignitible (plast, termo, hidr) inflamabil ignite a arde; a (se) aprinde; a da foc; a lua foc; a (se) inflama; a încălzi până la incandescență, a fi incandescent

igniter (auto, termo, el) aprinzător, electrod / dispozitiv de aprindere

ignition (termo, met, chim) inflamare, aprindere, igniție, calcinare, ardere, combustie; (el) aprindere, initierea arderii / combustiei; (auto) contact; activare

ignition adjustment (auto, termo) reglarea aprinderii

ignition advance (auto, termo) avans la aprindere ignition delay (auto, termo) timp de întârziere la aprindere

ignition distributor (auto) cap distribuitor, delco

ignition failure(s) (auto) întreruperi la aprindere; rateuri

ignition key (auto) cheie de contact; (mas) cheie de cuplaj / de pornire

ignition key removal (auto) scoaterea cheii din contact

ignition lag (mas, auto, termo) aprindere întârziată / cu întârziere, întârziere la amorsare / la aprindere, timpul între descărcarea electrică scânteie și aprinderea combustibilului ignition lock (auto, termo) contact de aprindere ignition loss(es) (met, ind chim) pierderi la calcinare / prin calcinare / prin ardere

ignition map (mas, termo) diagramă de funcționare a motorului

ignition on motor at a variable compression rate (termo, ind chim) probă test de rezistentă la aprindere prin compresie cu raport de compresie variabil

ignition plug (auto, termo) bujie

ignition point / temperature $(\mathrm{T}$, termo) temperatură / punct de inflamabilitate / de aprindere (a lubrifianților, a furnalului etc.)

ignition quality (chim) inflamabilitate (pt. hidrocarburi, fluide hiraulice etc.)

ignition range (chim, termo) limită de inflamabilitate / de aprindere

ignition residue (met, termo, mediu) reziduu de calcinare / de ardere

ignition switch (auto, mas) buton / cheie de contact, întrerupătorul de pornire; comutator / contact de aprindere; (el) comutator de magnetou

ignition switch ON (auto) buton PORNIRE

ignition switch key (auto) cheie de contact

ignition temperature (met, ind chim, termo) temperatura minimă de auto-întreținere a arderii ignition timer (auto) distribuitor de aprindere; (mas, termo) regulator de avans

ignition timing / adjustment (auto, termo) reglare a aprinderii / a intrării în conducție

ignition tube (termo, met) țeavă de aprindere

ignition wire (auto) cablu de aprindere; fişă de bujie; (el) cablu de aprindere

ignitor (termo, ind chim) aprinzător

ignorable neglijabil

ignorance (of) ignoranță, neştiință; necunoaştere (a ceva)

ignorant ignorant, neştiutor, lipsit de învățătură

ignorantly $(a d v)$ ca un ignorant; în necunoştință de cauză

ignorant of necunoscător a ceva; ignorant în (domeniul etc.)

ignore a ignora, a refuza să țină seama de; (jur) a respinge ca nefundat

IGPM (metr) abreviere pentru Imperial gallons per minute: v. Imperial gallons per minute

I iron (met, OM) fier / oțel laminat, cu profil I sau dublu T

ill (med) bolnav, nesănătos, într-o stare proastă; rău, rău intenționat; aspru; nefavorabil; ostil; dificil; plin de dificultate; greu de mânuit; refractar; necorespunzător; prost; urât; de calitate inferioară, ordinar, grosolan; prea puțin, abia, mai deloc; imperfect; stricăciune; daună; pagubă; necaz 
ill-advised prost sfătuit, imprudent, nesocotit, nechibzuit

ill-affected prost dispus

ill-affected towards nefavorabil

ill-at-ease stânjenit, stingherit

illation deducție, concluzie; deducere, tragere a concluziilor, metodă deductivă

illative deductiv, bazat pe deducție

ill-being (med) stare proastă

ill-conditioned într-o stare proastă

ill-considered nechibzuit, nesocitit, grăbit, pripit, nepotrivit, inoportun

ill-defined neclar, insuficient (de clar) definit

illegal nelegal, nepermis, neautorizat, ilicit, clandestin

illegality (jur) nelegalitate, ilegalitate, caracter nelegal, acțiune ilegală

illegally $(a d v)$ (în mod) ilegal, ilicit

illegibility caracter neciteț / indescifrabil

illegible ilizibil, neciteț

illegibly necitet, indescifrabil

illegitimacy caracter nelegitim, nelegimitate

illegitimate (jur) nelegitim; ilegal, nelegal; neîntemeiat; ilogic; neobişnuit; contrar convențiilor

ill-founded fără temei, nefondat, neîntemeiat, nejustificat

illiberal fără orizont, îngust la minte, mărginit, încuiat; intolerant; neîngăduitor; incult

illiberality lipsă de orizont, concepții înguste, mărginire; intoleranță; lipsă de îngăduință

illicit (jur, ec, TH) ilicit; interzis, clandestin, ilegal, nepermis, neautorizat

illicit commission (ec) mită, şperț

illicitly $(a d v)$ (în mod) ilicit

illimitable (mat) nemărginit, nelimitat

illimitableness (mat) caracter nemărginit / nelimitat, infinit

Illinium (Pm) (chim) promețiu

illiquid (ec) (d. valori) care nu poate fi transformat în bani lichizi

illiquidity (ec) lipsă de fonduri lichide / disponibile

illiteracy (edu) analfabetism, incultură; greşeală de ortografie / gramatică

illiterate (edu) analfabet; incult; (TH) ignorant, nepriceput, incompetent

illness (med) boală, maladie, indispoziție, stare proastă, have a return of one's $\sim$ a avea o recădere / o recrudescență a maladiei a maladiei

illogical ilogic, nelogic; nerezonabil

illogicality lipsă de logică, ilogicitate

illogically $(a d v)$ ilogic, lipsit de logică

ill-qualified (TH) incompetent

ill-sorted prost împerecheat / aranjat; nesortat, nepotrivit, sortat în mod eronat ill-spent cheltuit irațional, irosit, risipit (d. bani, materiale, resurse etc.)

ill-suited nepotrivit; impropriu; inoportun, nelalocul lui

illth (ec) bunuri şi servicii inutile societății

ill-timed inoportun, făcut când nu trebuie

ill-treat a trata prost, a se purta urât

illuminance (fiz) iluminare, flux luminos pe unitatea de suprafață

illuminate (fiz) a ilumina, a iradia, a lumina; a face să strălucească, a străluci; a lămuri, a explica; a elucida; a se aprinde

illuminated arrow pointer (metr) indicator / ac arătător luminos

illuminated sign (TH) indicator luminos

illuminating (fiz) care luminează / străluceşte, luminos, de iluminat; lămuritor, edificator

illumination (fiz) iluminație, iluminat; lumină

illuminator (fiz) corp de iluminat

illusive iluzoriu, amăgitor; nereal, ireal

illustrate a ilustra; a exemplifica; (fig) a lămuri, a explica

illustration figură; ilustrație; ilustrare, exemplificare; lămurire, clarificare; exemplu

illustrative of lămuritor pentru, reprezentativ pentru

illustrator grafician, ilustrator

ill will rea vointăa ostilitate; antipatie

image (fiz, c, el, inf) imagine, figură, poză; portret, chip; reprezentare; copie; formă identică, replică; concepție; descriere; figura de stil, metaforă; idee; înfățişare; întrupare; (mat) valoarea $\mathrm{f}(\mathrm{a})$, valoare, valoare a funcției $f$ pentru argumentul a, simbol; a descrie, a prezenta; a oglindi, a reflecta; a simboliza, a reprezenta; a proiecta (o imagine); a semăna cu; a portretiza; a prezenta (un film etc.); a reflecta

image area (c) suprafața imaginii; ecran

image processing $(\mathrm{c}$, inf) procesarea / prelucrarea imaginii

image resolution (c, TV) rezoluția imaginii

image rotation $(\mathrm{c})$ rotirea imaginii

imagery (set de) imagini, reprezentări; ilustrare, exemplificare prin imagini

imaginable imaginabil, de conceput

imaginarily $(a d v)$ (în mod) imaginar

imaginary (TH) imaginar, ireal, nereal; (mat) (număr) imaginar, complex, impropriu

imaginary component (el) componentă imaginară / reactivă

imaginary number (mat) număr imaginar / complex $(a+i b, b \neq 0)$

imaginary point (mat) punct impropriu (în geometrie) 
imaginary unit, square root of minus one, $i$ (mat) numărul imaginar $i=\sqrt{-1}$, unitate imaginară imagination imaginație, închipuire imaginative inventiv, plin de fantezie, fantezist imaginativeness inventivitate, imaginație fertilă imagine a(-şi) imagina, a-şi forma o imagine; a concepe, a-şi forma o idee / concepție despre; a înțelege, a deduce; a presupune, a bănui; a-şi folosi imaginația; a face presupuneri, a emite ipoteze

imaging formare de imagine; imagine; care îşi imaginează

imbalance (TH, fiz, mec) instabilitate, labilitate, echilibru instabil, dezechilibru; (ec) balanță de plăți, deficitară

imbed a încrusta; a fixa, a prinde, a înfige; a împinge (un corp dur într-unul mai moale, ranforsanții în matricea compozitului etc.)

imbibe a (se) îmbiba, a impregna; a suge, a aspira, a absorbi; a sorbi, a bea; a inhala, a respira, a inspira; (fig) a asimila, a (se) deprinde

imbibition (fiz, TH) îmbibare, absorbție, absorbire; sorbire; (anat) inspirare, inhalare

imbricate a suprapune; (adj) suprapus

imbue with a îmbiba cu, a impregna; a colora; a vopsi; a satura cu; a umple de; a păta de / cu imitable imitabil

imitate a copia, a reproduce, a imita; a falsifica; a urma exemplul; a simula

imitation imitație, imitare; falsificare, fals, copie; machetă; copiere, reproducere; reprezentare; replică

imitational, imitative imitativ; fals

immanence, immanency imanență, caracter imanent

immanent in permanent, imanent, remanent în; inerent; general, universal

immaterial neesențial; imaterial

immature imatur, nematur; (agr, alim) necopt, crud

immaturity imaturitate, lipsă de maturitate

immeasurability incomensurabilitate, nemărginire; caracter incomensurabil

immeasurable nemăsurat, incomensurabil; nemărginit, nelimitat, fără margini

immeasurableness incomensurabilitate; nemărginire

immeasurably ( $a d v)$ (în mod) nemăsurat, incomensurabil; nemărginit, nelimitat

immediacy caracter imediat / direct; urgență

immediate direct (în matematică); nemijlocit; direct; instantaneu, dat / făcut pe loc, fără întârziere; urgent; iminent; imediat următor, cel mai apropiat immediate access ( $\mathrm{TH}$, autom, inf) acces imediat / direct / instantaneu

immediate addressing (inf) adresare directă

immediate inference concluzie directă

immense imens, colosal, uriaş; nemărginit; nemăsurat, incomensurabil

immerse in a imersa, a (s)cufunda în, a afunda în

immersion (nav) afundare, imersiune; imersare, (s)cufundare; (fiz) coborâre / scufundare întrun lichid; îngropare, afundare

immersion degreasing (met, $\mathrm{TH}$ ) degresare prin imersie

immersion gas burner (termo) arzător imersibil immersion hardening (met) călire / durificare prin imersare (în baie)

immersion heater (el, termo) încălzitor electric cu imersiune; (ind chim) încălzitor prin imersiune; (termo) arzător / fierbător plonjor, termoplonjor

immersion length (TH) lungime / cotă de imersare (şi la aparate de măsură)

immersion plating $(\mathrm{TH})$ placare / acoperire prin imersiune (în galvanotehnică)

immersion pump $(\mathrm{OM}, \mathrm{hidr})$ pompă submersibilă

immersion test (met, metr) test de coroziune prin imersarea probei (în mediul corosiv)

immi (metr) unitate elvețiană de măsură pentru volum / capacitate (pt. lichide): $1 \mathrm{immi}=1,51$

immigrant (pol) imigrant; (agr) aclimatizat (d. plante şi animale); care imigrează

immigrate into (pol) a imigra, a se stabili (într-o țară)

immigration (pol) imigrare, imigrație

imminence iminență, caracter iminent; lucru / eveniment iminent

imminent iminent, apropiat, pe punctul de a se produce, inevitabil; amenințător

immiscibility (fiz) imiscibilitate

immiscible liquid (fiz) lichid nemiscibil

immix a amesteca, a mixa

immixture (in) amestec(are) (în), implicație (în); confuzie; imixtiune

immobile imobil, fix, nemişcat

immobility imobilitate, fixitate

immobilization imobilizare; fixare; nemişcare; inactiune

immobilize a imobiliza, a fixa; (ec) a retrage din circulație (bani)

immobilizer (auto) imobilizator (al motorului), dispozitiv de blocare a pornirii motorului

immobilizer indicator (auto) indicator al dispozitivului de blocare a pornirii motorului

immobilizer system (auto, autom) sistem electronic de blocare a motorului 
immovability inamovibilitate, nemişcare

immovable imobil, fix, nemişcat; (jur) imobi1(iar); inamovibil, care nu poate fi deplasat; rece; impasibil; pasiv; imobil

immovable in neabătut, ferm în

immovables (jur) bunuri imobiliare, proprietate imobiliară

immuninity rezistență la coroziune; (TH) pasivitate; (med) imunitate

immuration (constr, mec) încastrare în zid

immutability caracter imuabil / neschimbător / de neschimbat; imuabilitate, permanență; inflexibilitate; caracter inflexibil

immutable imuabil, invariabil, neschimbător; ferit de schimbări; constant; permanent; inflexibil; neabătut

impact (on, against) (mec, TH) impact, (cu) ricoşare (pe / de), izbire de, şoc, ciocnire (cu), lovitură, lovire, impuls; a lovi, a izbi, a ricoşa (de), a ciocni

impact acceleration (electr) accelerare prin şoc; (mec) accelerație de impact

impact amplifier (hidr) amplificator cu impact

impact-ball hardness (metr, materiale) duritate (la scleroscop)

impact bending test (metr, materiale) încercare / test de încovoiere prin şoc / de reziliență

impact block (OM, met) pernă / bloc de şoc / de preluare a şocului

impact breaker (mas, constr) concasor cu impact / cu ciocane

impact cleaning (met) curățire prin împroşcare cu alice / cu nisip

impact compression test (matriale, metr) încercare / test la compresie prin soc

impact cross section (mec) secțiune (eficace) de ciocnire

impact crusher (mas, constr, ind chim) concasor cu impact

impact crashing test (metr, materiale) încercare / test la şoc (şi până la spargere / sfărâmare)

impact ductility / elasticity (mec, OM, met) reziliență

impact effect (mec) efect de şoc; efect de batere (şi la teren, țesături)

impact endurance text (mec, metr, materiale) încercare la oboseală prin şoc

impact energy (fiz, mec) energie de şoc

impact extrusion (met, plast) injectare la rece; extrudare prin impact

impact extrusion press (met, plast, mas-un) presă de injectare la rece / de extrudare prin impact impact fatigue tester (metr, mas) aparat pentru încercare la oboseală prin şoc impact force (mec, met) forță de izbire / de şoc / de impact

impact-free (mec, met, TH) fără şoc

impact hardness (metr, plast) duritate scleroscopică / Shore

impact hardness test (metr, plast) test / încercare de duritate scleroscopică / Shore

impact head (hidr) presiune dinamică maximă (de scurtă durată, şoc hidraulic, variație bruscă a presiunii (dinamice)

impacting (met) forjare rotativă / prin lovire (repetată); care loveşte /aplică un şoc / un impact

impact load (mec, TH) solicitare, sarcină de şoc / dinamică

impact mill (mas) moară cu impact

impact moulding (met, ind chim) formare / matriţare prin şoc

impact number (mec) valoare a rezilienței (specifice)

impactor (met) maşină de forjat rotativă, cu lovituri

impact plate (TH, met) placă / ecran de lovire / de prindere / de impact

impact pressure (fiz) presiune de şoc; (mec, plast, hidr) presiune dinamică, presiune generată la aplicarea unei sarcini dinamice

impact pulling test (metr, materiale) încercare / test de rupere la sarcini dinamice

impact resistance (mec, materiale) rezistență la şoc, reziliență, rezistență dinamică

impact screen (constr, ind chim, met) sită vibratoare, ciur cu impact

impact sensing door unlock system (autom, auto) sistem de deblocare a portierelor la impact

impact shortness (met, plast) fragilitate la şoc / la impact

impact sound (fiz) şoc sonor / acustic, sunet zgomot la impact

impact-sound level (fiz, mediu) nivel de şoc sonor / acustic

impact spring (OM) resort / arc de impact

impact strength (mec, plast, met) reziliență, rezistență la şoc / la impact

impact stress $(\mathrm{mec})$ tensiune cauzată de şoc

impact tearing test încercare / test de rupere (destrămare) prin şoc (şi la țesături, materiale plastice, compozite)

impact tensile stress (mec) efort / tensiune de rupere la tracțiune prin şoc

impact tension test (mec, metr) încercare / test de rupere la tracțiune la sarcini dinamice / prin şoc / prin lovire / prin impact

impact test (metr, materiale) încercare / test de rezilientă / de încovoiere cu şoc 
impact testing machine (mas, metr) maşină de încercat la încovoiere cu şoc / pentru determinarea rezilienței

impact test on notched specimen / test bar (metr, materiale, mec) test / încercare de reziliență / de încovoiere cu şoc pe epruvete crestate / cu crestătură

impact torsion test (metr, materiale) încercare / test dinamică de torsiune

impact toughtness / value (materiale) valoare a rezilienței

impact transducer (metr) traductor pentru impact / fenomene perturbatorii

impact tube (hidr, met) tub Pitot

impact value (materiale, mec) (indice de / valoare pentru) rezistență la şoc, reziliență

impair (ec) a dăuna, a păgubi, a prejudicia; $(\mathrm{TH})$ a defecta, a deteriora, a slăbi, a strica, a avaria, a afecta; a stânjeni, a împiedica; a submina, a ruina; a diminua

impaired cu defect, defectuos

impairment ( $\mathrm{TH})$ deteriorare, deranjament, stricare, avariere; (ec) dăunare, păgubire, prejudiciere; (el, inf) indice / valoare a(l) calității transmisiei; subminare

impalpabel $(\mathrm{TH}, \mathrm{metr})$ insesizabil, care nu poate fi sesizat de un aparat / de un palpator; imperceptibil

impart a împărți; a împărtăşi; a atribui, a da, a acorda; a face cunoscut, a comunica

impart to a împărți cu, a da o parte / o cotăparte; a comunica (cuiva); a informa despre

impartial imparțial, nepărtinitor; ferit de / fără prejudecăţi

impartiality impartialitate

impasse impas, fundătură, situație fără ieşire

impassibility impasibilitate, caracter impasibil; indiferență

impassible impasibil; nepăsător, indiferent

impatience nerăbdare; nervozitate, iritare; intoleranță, lipsă de ingăduință

impatient nerăbdător, impacient; nervos, iritat

impatient of neîngăduitor cu, intolerant cu / față de; dornic de

impeccability caracter impecabil / ireproşabil, impecabilitate

impeccable impecabil, ireproşabil, ferit de greşeală

impedance (el) impedanță

impede a împiedica, a opri, a întârzia, a frâna, a opune rezistență; a stânjeni; a reține; a întârzia, a pune bețe în roate

impediment împiedicare, impediment, oprelişte, piedică, obstacol, stavilă; întârziere; rezistență impedimenta $(p l)$ lucruri care te încurcă, piedici impedor impedanță (ca element constructiv) impel a împinge; a grăbi; a forța; a pune în mişcare; a constrânge, a obliga; a da un impuls, a propulsa

impelled ramming (met, ind chim, alim) îndesare / compactare / formare prin centrifugare

impellent forță de propulsie

impeller (hidr) rotor (şi cu pale / cu palete), rotor de turbină / cu cupe; (OM, met) rotor de ventilație / de suflantă, elice de ventilator / de exhaustor, agitator (pt. fluide); (nav) roată cu zbaturi

impeller blade $(\mathrm{OM}$, termo) paletă de rotor, la turbine

impeller channel / passage (termo, OM) canal al rotorului (la turbine)

impeller head (alim, met) cap de aruncare centrifugă

impeller impact (grinding) mill (mas, constr, ind chim) concasor cu ciocane articulate

impeller impact (type) breaker / crusher (mas, constr, ind chim) concasor cu impact

impeller pump (OM, hidr) pompă centrifugă

impeller rotor $(\mathrm{OM}$, termo) rotor al compresorului de supraalimentare

impel (to) a împinge (la), a îndemna (la)

impenetrability, impenetrableness (fiz) impenetrabilitate, caracter impenetrabil

impenetrable impenetrabil, de nepătruns

impenetrate a pătrunde adânc (în)

imperative imperativ, imperios (necesar), (absolut) necesar; fără replică; esențial, sine qua non; urgent, presant; ordin; necesitate imperioasă; cerință; obligație; (gram) (modul) imperativ

imperativeness caracter imperios / urgent, urgență, necesitate absolută

impercievable imperceptibil

imperceptibility caracter imperceptibil

imperceptible imperceptibil, insensibil; treptat, gradat; uşor; delicat

imperfect imperfect, cu defect; incomplet, insuficient; defectuos

imperfect combustion (termo, met) ardere imperfectă / incompletă

imperfect gas (fiz) gaz real

imperfection imperfecțiune, caracter incomplet; defect, lipsă, deficiență

imperfection in separation (alim, ind chim, $\mathrm{TH}$ ) imperfectiune la separare

imperfect shape defect de formă; formă imperfectă / realizată cu defecte

imperial, methuselah (metr) sticlă mare de vin de $\sim 6$ litri 
Imperial gallon (gal, IG) (metr, fiz) unitate de măsură pentru volum / capacitate: 1 Imperial gallon $\cong 4,5461$

Imperial Units System (metr) sistem de unități de măsură oficial în Marea Britanie şi în unele țările de limbă engleză; unitățile de bază ale sistemului sunt: foot, pound, Imperial pint

imperil a periclita, a primejdui, a pune în primejdie

imperious imperios (necesar); urgent; de comandă, imperativ

imperishable indestructibil

impermanent nepermanent, trecător, efemer impermeability, impermeableness (fiz, OM) impermeabilitate, caracter de impermeabilitate, etanşeitate; (caracter de) monolit

impermeabilisation (hidr) izolație; (constr) stăvilire; (fiz) impermeabilizare

impermeable (fiz, OM) impermeabil, etans

impermeable bed / seam / layer (mediu, constr) strat impermeabil

impermissible inadmisibil, care nu este permis, nepermis

imperturbable imperturbabil; calm, nepăsător

impervious (to) $(\mathrm{TH})$ impermeabil, etanş, impenetrabil (pentru / la); (fiz) etanș la lumină, insensibil la, inaccesibil pentru

impervious joint $(\mathrm{OM})$ îmbinare etanşă

impervious lining (constr, met) căptușeală / tencuială de impermeabilizare

imperviousness impermeabilitate, impenetrabilitate

imperviousness due to sizing $(\mathrm{OM})$ impermeabilitate / etanşeitate a încleierii

impervious riveting $(\mathrm{OM})$ cusătură nituită de etanşare

impervious to heat (termo, materiale) rezistent / impermeabil la căldură, termo-izolant

impervious to light (fiz, opt) netransparent la lumină

impetus impuls, stimulent; forță dinamică, elan

impinge on / upon a (se) lovi, a bate; a ricoşa de; a se ciocni de, a se izbi de, a veni în contact cu; a avea efect / inflență asupra, a influența

impingement (mec) lovire, izbire, batere, mişcare de izbire a unui fluid de un perete; (mas) admisie; (fiz) şoc, bombardare; (met) (in)suflare a oxigenului

impingement area (met) zonă de (in)suflare cu oxigen

impingement attack $(T$, chim) coroziune şi/sau uzură accelerată (a unei piese / suprafețe) de mişcarea unui fluid, coroziune şi / sau uzură de cavitație impingement baffle (OM, hidr) şicană, membrană deflectoare

impingement separator (mas, mediu, agr, ind chim) separator (de praf) prin lovire; aparat de separat praful prin inerție

impinging face suprafață de ciocnire / de lovire

implant implantare, implant; a implanta; (agr) a (ră)sădi

implantation implantare; (agr) (ră)sădire

implate $(\mathrm{OM})$ a căptuşi cu tablă

implausible neplauzibil, neverosimil

implement unealtă, instrument, ustensilă, trusă, dispozitiv, echipament; obiect; articol, lucru, mijloc; a aplica; a îndeplini; a executa, a implementa, a pune în aplicare, a îndeplini, a face, a utila, a echipa

implementation, implementing îndeplinire; implementare, punere în practică, aplicare, traducere în viață, realizare, efectuare; (c) îndeplinire, executare (a unui angajament, a unui program)

implementing (procesul / acțiunea de) aplicare / omplementare; care aplică / implementează. care pune în practică (în proiect etc.)

implicate lucru implicat / sugerat; sugestie, aluzie; (element survenit ca) implicație; a implica; a amesteca; a spune în mod implicit, a sugera, a lăsa să se înțeleagă

implication implicare; amestec; amestecare; includere; implicație; lucru subînțeles; aluzie, sugestie

implicit subînțeles, implicit, exprimat (ca atare), care nu necesită explicații; potențial; virtual, posibil; (d. încredere) absolut, total, fără rezerve

implicit differentiation (mat) derivare a funcției implicite

implicit function theorem (mat) teoremă de existentă pentru functiia implicită

implicitly $(a d v)$ (în mod) implicit, fără a fi exprimat direct; în mod absolut, total, fără rezerve

implicitness caracter implicit / neexprimat direct

implode a exploda în interior, a face implozie

implosion (mec) implozie

implosive cu implozie; care face implozie

imply a presupune, a implica; a necesita; a sugera, a indica în mod implicit; a însemna că; a insinua, a face aluzie

impolicy (pol) politică greşită, greșeală politică / diplomatică; lipsă de diplomație; lipsă de eficacitate, ineficiență

impolite nepoliticos

imponderability (fiz) imponderabilitate

imponderable (fiz) imponderabil

imponderables elemente imponderabile, factori imprevizibili 
imporosity lipsă de porozitate, structură compactă (fără pori) (d. materiale)

import (ec) (marfă de) import, importare; sens, înțeles, semnificație; însemnătate, importanță; $\sim \mathbf{s}(p l)$ mărfuri de import; a importa; a însemna, a avea sensul de; a declara, a aduce la cunoștință; a avea importană (pentru)

importable (ec) importabil, corespunzător pentru import

importation import; mărfuri de import

import into a aduce din import

importance importanță, însemnătate, semnificație; emfază

important to important pentru, însemnat pentru; influent; plin de consecințe, de mare importanță importation import, importare, marfă importată importer importator

import into (ec) a importa mărfuri, a face import import to a fi important pentru

import trade (ec) comerț de import

importunate insistent, supărător, stăruitor (d. persoane); presant, urgent (d. lucruri); apăsător; plictisitor

importune a inoportuna, a deranja

importunity caracter supărător / inoportun, insistență

impose (upon) a impune; a pretinde, a cere (insistent), a solicita; a aranja pagini; a pune, a aşeza pe; a profita, a se folosi de, a trage profit de pe urma; a înşela

impose on / upon (ec) a pune, a impune (taxe) pe imposing impunător; impresionant; care (se) impune

imposition (ec) impunere, impozit, stabilire (de taxe); aşezare în formă a paginilor; lucru impus, obligație, sarcină impusă; pedeapsă; impostură; înşelătorie

impossibility imposibilitate; neputință; lucru imposibil

impossible imposibil (de realizat), cu neputință; de neconceput, de neatins; extrem de greu / dificil, inacceptabil, inadmisibil, imposibil de admis

impossibly $(a d v)$ imposibil, prin absurd; inadmisibil, inacceptabil

impost (constr) postament

impostor impostor, escroc

imposture impostură, escrocherie, fals

impound (hidr) a bara; a zăgăzui; (met) a reține în siguranță; a confísca

impoverish a sărăci, a pauperiza; a face să-şi piardă calitățile; a împovăra

impoverished sărăcit, pauperizat, secătuit

impoverishment sărăcire, pauperizare; secătuire, pierdere a calităților impracticability, impracticableness inaplicabilitate, caracter inaplicabil, imposibilitate de realizare, caracter nerealizabil; impracticabilitate (d. drumuri)

impracticable inaplicabil, imposibil de pus în practică, nerealizabil; nerealist; nepractic; (d. drum) impracticabil, neutilizabil; dificil

impractical (amer) nepractic; ineficace; nepotrivit; imposibil de practicat, inaplicabil

imprecise neprecis, vag, nedefinit

impreciseness, imprecision imprecizie, lipsă de precizie

impregnant (ind chim) material de impregnare, impregnant, agent / substanță de impregnare

impregnate with (fiz, chim) a impregna $\mathrm{cu}$, a îmbiba, a satura, a umple

impregnated bit (mas-un) tăiş impregnat cu pulberi de diamant sau sinterizate

impregnated wood (constr) lemn impregnat

impregnating agent (ind chim) substanță de impregnat

impregnating / impregnation compound (met, ind chim, plast) amestec / masă / compound / pentru impregnare

impregnating machine (mas-un, ind chim) maşină de impregnat

impregnating resin (plast, ind chim) răşină de impregnat

impregnation (alim, plast, ind chim) impregnare, îmbibare, saturare

impregnation by dipping (ind chim, textile) impregnare prin imersare / cufundare (în baie de lichid)

impress (met) a (se) imprima; a introduce apăsând; a imprima (o ștampilă), a ștanța; a impresiona, a face impresie asupra; a imprima (în memorie), a influența (o persoană); fixare, imprimare (în memorie); urmă (lăsată de / imprimată); semn, amprentă; sigiliu; caracteristică (distinctivă), amprentă personală, impresie; efect

impress on a lăsa o urmă / (fig) amprentă

impressibility imprimabilitate

impression impresiune; (met) amprentă, urmă; (birotică) presiune de tipărire; tipar; ediție; copie (pt. trasarea contururilor); tiraj, imprimare; (TH) imprimare, ştanțare, amprentă, întipărire, marcă, urmă (lăsată / imprimată); impresie, imagine creată

impressional strength (metr, mec) rezistență la amprentare / la imprimare / la ştanțare

impression area (met, metr) suprafața amprentei / urmei

impression cylinder (OM) cilindru de imprimare / de ştanțare 
impression moulding (mas-un) imprimare / ştanțare / formare prin contact

impressive impresionant, care produce o impresie profundă

imprint urmă; amprentă; imprimare, tipărire; a (se) imprima, a ştanța; a fixa (în memorie); a aplica, a lipi, numele editorului / tipografiei

imprinter imprimator, imprimantă

imprint the pattern in the sand (met) a imprima modelul în amestecul de formare

improbability improbabilitate, caracter improbabil

improbable improbabil, (prea) puțin probabil, greu de presupus, neverosimil

improbably $(a d v)$ prea puțin probabil, cu prea puține şanse (de realizare), (în mod) neverosimil, improbabil

improbity necinste, lipsă de probitate

impromptu improvizație; improvizat; făcut pe moment; $(a d v)$ pe neaşteptate, (în mod) improvizat

improper impropiu, nepotrivit; necorespunzător, inadecvat, impropriu; incorect, inexact; nelalocul lui, deplasat; indecent; ordinar, grosolan

improper fraction (mat) fracție supraunitară improper handling (auto, TH) manevrare greșită

improper increased load (auto) încărcare excesivă

improperly $(a d v)$ (în mod) impropriu, necorespunzător, nu aşa cum trebuie

impropriety caracter impropriu / necorespunzător; folosire incorectă, incorectitudine (în utilizare)

improvability posibilitate de ameliorare / de îmbunătătire

improvable perfectibil, susceptibil de ameliorare / îmbunătătire

improve a (se) îmbunătăți, a (se) ameliora, a (se) perfecționa; a desăvârşi; a îmbogăți (în conținut); a corecta, a îndrepta; a valorifica, a pune în valoare; a profita de, a se folosi de, a trage folos din; a folosi; a opri, a extinde, a mări; a progresa, a face progrese; a evolua favorabil; a crește (în valoare); a merge mai departe; a se dezvolta; a înainta

improve away a lichida prin ameliorări / îmbunătăţiri, a îmbunătăţi / ameliora prin îndepărtarea unor lucruri / procese nedorite

improvement îmbunătătire, (lucrări de) ameliorare, perfecționare; progres, corectare, îndreptare; (agr, constr) ameliorări, amenajări, lucrări de ameliorare / de îmbunătățire funciară; (ec) sporire în valoare; valorificare (superioară); amendament, modificare (şi d. o lege) improvement maintenance ( $\mathrm{TH}$, mas) mentenanță îmbunătățire / ameliorată / mai redusă dar mai eficientă

improve on / upon a ameliora, a îmbunătăți; (jur, pol) a amenda, a modifica; a încerca să depăşească; a şti mai bine decât, a întrece, a depăşi

improver perfectionist; reformator; ucenic, practicant (cu salariu mic sau benevol)

improve the ocasion a profita de ocazie improvidence nechibzuință, risipă; lipsă de prevedere, neprevedere; imprudență

improvident nechibzuit, risipitor; neprevăzător, imprudent

improvidently ( $a d v)$ (în mod) nechibzuit, imprudent, fără spirit de prevedere

improving (met) afinare primară; îmbunătățire, care îmbunătățeşte

improving furnace (met) cuptor de afinare

improvisation improvizație, improvizare

improvisional, improvisatorial improvizat, $\mathrm{cu}$ caracter de improvizatie; improvizatoric, care improvizează

improvise a improviza; a face pregătiri la repezeală, a face improvizații

imprudence imprudență, lipsă de prudență / prevedere; nechibzuință; gest imprudent

imprudent imprudent, lipsit de prevedere / prudență; nechibzuit

impugn (jur, ec) a contesta (şi autenticitatea), a pune la îndoială; a suspecta / acuza de fals, a nega

impulse împingere, mişcare înainte; (autom, el) impuls, excitaţie; (fiz, mec) cantitate de mişcare, impuls; şoc; mobil, motiv, stimulent; motivare, motivatie; îndemn; a da un impuls, a impulsiona, a îndemna

impulse counter (metr, electr) numărător / contor de impulsuri

impulse function (mat) functie delta

impulse generator (autom, hidr) generator de impuls(uri), convertizor de semnal / treaptă / impuls impulse neutraliser $(\mathrm{OM})$ amortizor de vibratie (la arborele cotit)

impulse pressure (mec, hidr) creştere rapidă / vârf de presiune

impulse reflection method (fiz, metr) metodă nedistructivă cu ultrasunete pentru detectarea defectelor (la piese turnate; sudate etc.)

impulse sealer (met, el) maşină de sudat cu impulsuri

impulse stroke (termo) cursă de detentă / de expansiune

impulse strength (el) tensiune de străpungere a unei izolații 
impulse timer (metr) cronometru cu impulsuri; întrerupător sincron comandat prin impulsuri; temporizator / sincronizator cu impulsuri

impuls transmitter (elctr, autom) emițător / traductor / generator de impulsuri

impulse welding (met, termo) sudare cu impulsuri termice

impulsion împingere înainte; îndemnare, impulsionare; îndemn; constrângere, silire, forțare

impulsive impulsiv, repezit; nerațional, instinctiv; făcut pe moment / la repezeală

impulsively ( $a d v)$ (în mod) impulsiv, nerațional, la repezeală, fără chibzuință, pe negândite

impulsive load (mec) sarcină dinamică

impulsiveness caracter impulsiv / nerațional / repezit

impure impur, cu impurități, lipsit de puritate; falsificat, contrafăcut; murdar, stricat; (mediu, material) a impurifica, a contamina

impurity (mediu, material) impuritate, caracter impur, lipsă de puritate; contaminare; improbitate

imputable imputabil

imputable to care poate fi atribuit / imputabil (cuiva)

imputresciblity (agr, bot, alim, silv) rezistență la putrezire

in în; la, înăuntrul, în interiorul; cu, din, de la; prin

inability incapacitate, nepricepere, incompetență; imposibilitate, neputință

inaccessibility inaccesibilitate, caracter inaccesibil

inaccessible to inaccesibil pentru, inadmisibil

inaccessible area (met, el, OM) zonă inaccesibilă / neaccesibilă (şi greșeală de proiectare la sisteme complexe)

inaccuracy (metr) inexactitate, imprecizie, eroare; neregularitate, greşeală; incorectitudine; caracter / lucru inexact

inaccurate (metr) inexact, incorect; neconform cu realitatea

inaction inertie; lipsă de activitate; lene

in action în funcţiune (d. maşini, istalaţii etc.)

inaction inacțiune, inerție, imobilitate

inactivate a inactiva, a neutraliza, a reduce la inactivitate; a opri activitatea / funcționarea

inactivation (fiz, chim) inactivare; neutralizare

inactive (fiz, chim) inactiv, inert, fără activitate, pasiv; lenes, sedentar

inactive filler (mec, chim) ingredient inactiv, material de umplutură care nu influențează (chimic şi / sau fizic) un compozit etc.

inactive output (autom, hidr) ieşire pasivă (depinde numai de semnalul de intrare) inactivity inactivitate, lipsă de activitate

inadequacy, inadequateness nepotrivire, inadecvare, caracter inadecvat / necorespunzător / nepotrivit; caracter insuficient; disproporție; imperfecțiune, insuficiență

inadequate to neadecvat $\mathrm{cu}$, necorespunzător / nepotrivit pentru, insuficient pentru, imperfect, prea puțin pentru

inadequately $(a d v)$ (în mod) neadecvat, nepotrivit, necorespunzător, insuficient; nu îndeajuns (de)

inadmissibility caracter inadmisibil / inacceptabil, neadmitere; neacceptare

inadmissible inadmisibil, inacceptabil

inadmissibly $(a d v)$ (în mod) inadmisibil, inacceptabil

in advance of centre (mas-un) cu unghi de degajare inactiv (la scule aşchietoare)

inadvertence, inadvertency inadvertență; nepotrivire; neatenție, lipsă de atenție; neglijență; caracter necugetat; greșeală provenită din neatenție, scăpare

inadvertent neatent; neglijent; necugetat

inadvertent connection (mas, $\mathrm{TH}$ ) conectare neintenționată / accidentală / din neglijență / din greşeală

inadvertently $(a d v)$ (în mod) neatent; neglijent; necugetat

inadvisability caracter nerecomandabil; imprudență

inadvisable nerecomandabil

inaliennability caracter inalienabil

inalienable inalienabil

in all $(a d v)$ în total, cu totul; cu toții

inalterability caracter neschimbător / constant, imuabilitate, permanență

inalterable de neschimbat; inalterabil

inalterably $(a d v)$ (de) neschimbat, (de) nemodificat; constant

in-and-out reheating furnace (met) cuptorcameră; cuptor de încălzire cu vatră înclinată

inanimate neînsuflețit; fără viață; monoton, insipid; inert, mort, inactiv, lipsit de vitalitate

inanimateness lipsă de viață, monotonie; inerție; lipsă de vitalitate

inapparent prea puțin evident; nedesluşit, neclar inappelable (jur) inatacabil; irefutabil; fără drept de apel

inapplicability caracter inaplicabil / nerealist

inapplicable inaplicabil, greu de aplicat / de pus în practică; nerealist

inapplicable to nepotrivit $\mathrm{cu} /$ pentru, necorespunzător pentru, inaplicabil la, inaplicabil la, fără legătură cu 
inapposite deplasat, nepotrivit; inoportun inappositeness inoportunitate, caracter nepotrivit / inoportun

inappreciable imperceptibil, infim, infinitezimal inappreciative of care nu apreciază; insensibil la (d. aparate, senzori etc.)

inapprochable inaccesibil, inabordabil

inappropiate necorespunzător, nepotrivit, inadecvat, impropriu; insuficient

inappropiately $(a d v)$ (în mod) necorespunzător, / nepotrivit; în mod insuficient

inappropriateness caracter necorespunzător / nepotrivit / impropriu; insuficiență, caracter neîndestulător

inapt inapt, neîndemânatic, nepriceput; nepotrivit, impropriu; irelevant, fără legătură cu; stupid

inaptitude, inaptness nepricepere, neîndemânare; caracter inadecvat; stupiditate, inepție, prostie

inarticulate nedesluşit, neclar; prost articulat; incoerent, incapabil să se exprime clar

in as far as, in as much as în măsura în care; întrucât, deoarece, dat fiind că

in a straigth-line motion (mec, $\mathrm{OM})$ în mişcare rectilinie

inattention neatenție, lipsă de concentrare / atenție, distracție; nepăsare

inattentive neatent, distrat

inattentiveness neatenție, distracție, lipsă de atenție

inaudability (fiz, edu) imposibilitatea de a fi auzit, sonoritate prea scăzută

inaudible abia auzit, prea slab să fie auzit

inauspicious nefavorabil; neospitalier, ostil; ghinionist

in bad repair (mas) reparatie incorectă; deteriorat in block $(\mathrm{OM})$ din aceeaşi bucată

inborn înnăscut, congenital; nativ; de la natură, ereditar

in-built, inbuilt (TH) incorporat, integrat

inbuilt compartment for luggage (auto) compartiment de bagaje în caroserie

inboard între; (mar) interior (adv) înăuntru

inboard rotor (mec) rotor între lagăre / reazeme incalculability incomensurabilitate, caracter incalculabil, incalculabil, incomensurabil, nemăsurat

incalculable incalculabil, care nu poate fi calculat incalescence (termo) încălzire (şi puternică)

incandesce (termo) a aduce la incandescentă, a fi incandescent, a arde; a face să ardă

incandescence incandescență

incandescent incandescent

incandescent lamp (el) lampă cu incandescență, bec electric incandescent mantle (met) manta incandescentă, înveliş incandescent

incandescent welding (met, el) sudare prin rezistență electrică aducându-se la incandescență zonele care urmează să fie sudate

incandescent zone (met) zonă încălzită până la alb / la incandescență

incapability incapacitate, neputință

incapable of incapabil să / de, nepriceput, incompetent; nepotrivit, nepregătit să / pentru

incapable of solution (mat) nerezolvabil, care nu are solutie

incapacitate for / from a face incapabil de / să, a împiedica să; (jur) a priva de un drept, a face să decadă dintr-un drept

in cash (ec) în numerar, cu bani gheață

incendiary (chim, termo) incendiar; care aprinde / inflamează; incendiator, bombă incendiară

incentive stimulent

incentre (geom) centru al cercului / sferei înscris(e)

inception început, începere; întemeiere; iniţiere; incipient, inițial

inception of knock (TH) început de detonare

incertitude incertitudine, nesiguranță; îndoială, dubiu; instabilitate

incessant neîncetat, permanent, continuu

incessantly $(a d v)$ neîncetat, fără încetare, permanent, continuu, în permanență

inch (in, ") (metr) unitate de măsură pentru lungime, inch, tol: 1 inch $=0,025400051 \mathrm{~m}$; unitate de măsură pentru presiune, v. inch (of) mercury, inch of water column

inching (autom) comandă prin închideri succesive rapide / prin impulsuri ale unui circuit; (mas-un) mişcare lentă, prelucrare la şeping prin executare de curse scurte; (plast) încetinirea închiderii matriței

inching controller (autom) conjunctor (cu relee) cu întreruperi succesive

inching speed control (autom) control automat pentru reducerea vitezei de tăiere a unei combine în poziții dificile de strat

inchoate incipient, abia început, în stadiu inițial; nedezvoltat; rudimentar; incompălet; a începe, a iniția, a porni; a da naştere la

inch (of) mercury $\left(32^{\circ} \mathrm{F}\right)$ (metr) unitate de măsură pentru presiune, inch / țol de coloană de mercur la $32^{\circ} \mathrm{F}$ : 1 inch mercury $\left(32^{\circ} \mathrm{F}\right)=$ $3386,38 \mathrm{~Pa}$

inch (of) mercury $\left(60^{\circ} \mathbf{F}\right)$ (metr) unitate de măsură pentru presiune, inch / tol de coloană de mercur la $60^{\circ} \mathrm{F}$ : 1 inch mercury $\left(60^{\circ} \mathrm{F}\right)=$ $3376,85 \mathrm{~Pa}$ 
inch (of) mercury (in Hg) (metr) unitate de măsură pentru presiunea atmosferică, inch / țol de coloană de mercur: 1 inch of mercury = $3,38638 \mathrm{KPa}$

inch (of) water $\left(4^{\circ} \mathrm{C}\right)$ (metr) unitate de măsură pentru presiune, inch / țol de coloană de apă la $4^{\circ} \mathrm{C}: 1$ inch water $\left(4^{\circ} \mathrm{C}\right)=249,082 \mathrm{~Pa}$

inch (of) water $\left(60^{\circ} \mathbf{F}\right)$ (metr) unitate de măsură pentru presiune, inch / țol de coloană de apă $\left(60^{\circ} \mathrm{F}\right): 1$ inch water $\left(60^{\circ} \mathrm{F}\right)=248,843$ pascal

inch (of) water column (in WC) (metr) unitate de măsură pentru presiune, inch / țol de coloană de apă: 1 inch of water column = 249,0889 Pa

inch (of) water gauge / gage (in wg, "wg) (metr, fiz) altă denumire pentru inch of water column; cuvântul „gauge” (brit) sau ,gage" (amer) arată că presiunea citită este de fapt diferenta de presiune dintre presiunea absolută reală şi presiunea atmosferică

inch-ounce (metr) unitate de măsură pentru energie: 1 inch-ounce $=0,007061552 \mathrm{~J}$

inch per second (in/s) (metr) unitate de măsură pentru viteză, inch/secundă: 1 inch per second (in $/ \mathrm{s})=0,0254 \mathrm{~m} / \mathrm{s}$

inches per year (in/yr) (metr) unitate de măsură pentru viteza de coroziune, inch/an; 1 inches per year (in/yr) $=2,54 \mathrm{~cm} / \mathrm{an}$

inch-pound, inch pound-force (in-lbf) (metr) unitate de măsură pentru energie şi lucru mecanic, tol-livră-forță: 1 inch-pound = 0,112984829 J

inch/square second (metr) unitate de măsură pentru acceleratie: $1 \mathrm{inch} /$ square second = $0,0254 \mathrm{~m} / \mathrm{s}^{2}$

inch stress (metr, mec) tensiune raportată la un țol pătrat (efort pe un țol pătrat)

inch taper thread (Briggs) (OM) filet conic (Briggs) în inci

inch thread (OM) filet în țoli / Whitworth

incidence (fiz) (unghi de) incidență; rază de acțiune; frecvență (a unui fenomen etc.);

incident incident, eveniment (colateral / concomitent), eveniment nedorit; fapt, întâmplare; (jur) privilegiu, sarcină, servitute (legată de o proprietate); incidental, întâmplător

incident to legat de, firesc pentru, inerent pentru incidental incidental, întâmplător, accidental; ocazional; suplimentar, adăugat, pe deasupra; mărunt, mic, neesențial, neînsemnat; amănunt neesențial; neesențial, secundar

incidental to legat de, inerent

incidente angle (hidr) unghi de atac critic; (fiz) unghi de incidență

incident ray (fiz) rază incidentă incinerate (met, ind chim) a incinera, a arde, a calcina

incineration (met, ind chim) calcinare, incinerare, ardere

incinerator (termo, ind chim, mediu) cuptor de ardere / calcinare / prăjire, crematoriu de gunoi

incipience, incipiency stadiu inițial / incipient

incipient incipient, la început, în stadiu iniţial

incipient crack (met, materiale) fisură / crăpătură incipientă

incipient failure rupere / avarie / cădere incipientă (a unui utilaj)

incipient fusion (fiz) sinterizare incipientă

incipient shrinkage (met, plast) contracție iniţială incipient tear (geogr, plast) rupere / sfâş̧iere inițială / incipientă

incircle (mat) cerc înscris

in-circuit (el, electr, autom) incorporat / integrat în circuit / în schemă

incise (med) a face o incizie în, a tăia; a grava, a imprima

incision (med) incizie, tăietură, tăiere; (fig) incisivitate, caracter incisiv

incisive tăios, incisiv, ironic; clar, precis, bine definit; pătrunzător, penetrant; percutant

in clear lumină; $(\mathrm{OM})$ diametrul interior al unei țevi; luminos, clar, deschis

inclinable to înclinabil spre; (OM) rabatabil, basculant; favorabil

inclination înclinare, pantă; dispoziție, tendință

inclination to / for / towards înclinație spre, tendință spre, aplicație pentru

incline a (se) înclina, a (se) apleca, a aşeza oblic, a fi în poziție înclinată, a avea o înclinare; ( $f i g$ ) a convinge, a determina; a decide, a hotărî; pantă, înclinație, înclinare; (fiz) plan înclinat

inclined înclinat, oblic, în pantă

inclined asymptote (mat) asimptotă oblică

inclined bucket conveyer (OM, alim, ind chim) elevator înclinat, cu cupe

inclined carrier (OM, alim, constr, ind chim) transportor înclinat

inclined-disk conveyer (OM, alim, ind chim) transportor cu discuri înclinate

inclined-disk mill (OM, alim, ind chim) moară cu discuri înclinate

inclined-disk mixer (OM, alim, ind chim) amestecător cu discuri înclinate

inclined elevator / hoist (met, constr, transp, $\mathrm{OM}$ ) elevator / transportor înclinat

inclined plane (fiz, mec) plan înclinat

inclined track $(\mathrm{mec})$ traiectorie înclinată

inclined-tube gauge (metr) manometru $\mathrm{cu}$ tub înclinat 
incline plane tester (metr) dinamometru cu plan înclinat

incline to a tinde să, a avea tendința să, a fi predispus să

inclining experiment (nav, metr) probă de stabilitate inițială (construcții navale)

inclinometer (metr) inclinometru, aparat pentru măsurat înclinația

include a include, a cuprinde, a număra; a conține; a pune la socoteală / număr, a ține seama de, a nu uita de; a închide, a îngrădi; (geom, mat) a circumscrie, a mărgini

included cuprins, inclus

included slag (met) incluziuni de zgură

including inclusiv, cu tot $\mathrm{cu}$, care include

inclusion includere, cuprindere; (mat) incluziune, implicație; închidere; (met) incluziune

inclusion of decomposition products (met, ind chim) incluziune de produse de descompunere (şi la sudură)

inclusive (atot)cuprinzător; total, general, referitor la tot; inclusiv; cu totul, per total, în ansamblu

inclusively $(a d v)$ inclusiv, (în mod) cuprinzător, cu totul

inclusiveness caracter (atot)cuprinzător

inclusive of (d. prețuri, tarife etc.) cuprinzând / incluzând / inclusiv (şi); precum şi, care cuprinde / include

inclusive OR (inf, mat, autom) SAU inclusiv, SAU SI; disjuncție

inclusive OR circuit (inf, mat, autom) circuit SAU inclusiv; poartă de amestec

inclusive terms (ec) preț / cost total, tarif cuprinzând toate serviciile / cu toate serviciile incluse (d. hoteluri etc.), termeni incluşi în contract / licitație

incoagulable (alim, ind chim) necoagulat, care nu se poate coagula

incoherence, incoherency incoerență; exprimare incoerentă

incoherent incoerent

in cold storage (alim) congelat, depozitat în stare congelată

incombustible (chim) incombustibil; necombustibil, care nu arde, neinflamabil, refractar (rar)

incombustible dust (TH) praf inert / incombustibil

income (ec) venit(uri), câştig(uri)

income tax (ec) impozit pe venit

incoming care intră / vine; în creștere / dezvoltare; venire, sosire

incoming message holding unit (c) memorietampon de intrare

incoming power (mec, el) putere absorbită incoming tide (nav) flux

incommensurability incomensurabilitate, caracter incomensurabil

incommensurable incomensurabil, nemăsurabil, nemărginit, nemăsurat; incomparabil; (mat) irațional

incommensurable with incomparabil / care nu se pretează la / în comparație cu

incommensurate incomensurabil, nemărginit; necorespunzător, insuficient; disproporționat

incommensurateness incomensurabilitate, caracter incomensurabil / nemăsurat; enormitate

incommode a incomoda, a stânjeni, a stingheri, a deranja

incommodious incomod, neconvenabil; supărător, care deranjează

incommodiousness caracter neconvenabil / incomod / supărător

incommunicable incomunicabil, necomunicativ incommunicative necomunicativ

incomparable to / with de necomparat cu, incomparabil

incomparability, incompatibleness incomparabilitate

incompatibility ( $T$, chim) incompatibilitate

incompatible with incompatibil $\mathrm{cu}$, nepotrivit cu; distonant, necorespunzător pentru; ireductibil, ireconciliabil; neomogen, eterogen; care vine în conflict / contradicție cu

incompatibly $(a d v)$ (în mod) incompatibil, nepotrivit, necorespunzător

incompetence, incompetency incompetență, lipsă de competență; lipsă de calificare / pricepere / pregătire, nepricepere; nepotrivire, caracter necorespunzător / nepotrivit

incompetent incompetent, necompetent; necalificat, nepriceput, slab pregătit; necorespunzător, nepotrivit

incomplete incomplet

incomplete combustion (met, termo, chim) ardere / combustie incompletă

incomplete equilibrium (mec, met) echilibru instabil

incomplete reduction (met, ind chim) reducere incompletă

incompletly $(a d v)$ (în mod) incomplet, nu îndeeajuns (de)

incompletly annealed (met) (oțel călit) incomplet revenit

incompleteness caracter incomplet; nedesăvârşire; neterminare, neîncheiere (a unui proces, a unei acțiuni etc.)

incomprehensibility caracter incomprehensibil / de neînțeles 
incomprehensible incomprehensibil, ininteligibil; de nepătruns

incompressibility (fiz) incompresibilitate

incompressibility modulus modul de elasticitate (d. materiale incompresibile)

incompressible (fiz, hidr, mec) incompresibil, necomprimabil; rigid, țeapăn; rezistent la compresiune

incompressible volume (fiz, chim) constanta $b$ în ecuația lui Van der Waals; volum incompresibil

inconcievable de neconceput, inimaginabil; greu de crezut, neverosimil; remarcabil, ieşit din comun, extraordinar

inconclusive neconcludent; neconvingător; fără efect / rezultat / consecințe, care nu duce la nimic

inconclusively ( $a d v)$ (în mod) neconvingător, neconcludent

inconclusiveness caracter neconvingător / neconcludent

incondensable (fiz) de necondensat, imposibil de lichefiat / solidicat; care nu poate fi condensat / rezumat / comprimat

incondite (d. un text) rău construit / compus; deficitar din punct de vedere al compoziției / al structurii; necizelat; inform; neprelucrat inconel (met) aliaj inconel (aliaj $\mathrm{Ni}-\mathrm{Cr}-\mathrm{Fe}$ )

inconformity lipsă de conformitate, neconformitate, caracter neconform (d. un produs etc.)

incongruence, incongruity nepotrivire, lipsă de potrivire; distonanță; incompatibilitate, nepotrivire; (mat) necongruență

incongruous nepotrivit, în dezacord, distonant; nearmonios; necorespunzător, incompatibil; absurd; (mat) necongruent

inconsecutive fără şir; dezlânat; nelogic, fără logică; fără legătură

inconsecutiveness lipsă de legătură / logică; irelevanță, lipsă de importanță / valoare

inconsequence lipsă de importanță / valoare

inconsequent neînsemnat, fără importanț̆ / valoare; mărunt; irelevant, fără legătură; nelogic, lipsit de logică, nefiresc

inconsequently ( $a d v)$ (în mod) irelevant, fără legătură / logică; dezlânat; (în mod) neînsemnat

inconsiderable fără valoare, neînsemnat; neinteresant, lipsit de interes; de neluat în considerare

inconsiderate nechibzuit, pripit; lipsit de înțelepciune, neînțelept; nepăsător (față de alții), care nu ține seama de nimeni / nimic, egoist

inconsiderateness, inconsideration nechibzuință, nechibzuială; lipsă de înțelepciune; nepăsare (față de alții) inconsistence, inconsistency inconsecvență, lipsă de consecvență; nepotrivire, caracter eterogen, lipsă de armonie; incoerenţă; caracter schimbător / contradictoriu, inconstanță; şubrezenie; inconsistență

inconsistent inconsistent, neconsecvent, inconstant; eterogen, lipsit de armonie

inconsistent with nepotrivit $\mathrm{cu}$, necorespunzător, incompatibil cu

inconspicuous (aproape) inobservabil; neobservat; greu de remarcat, care nu sare în ochi, nu prea evident; lipsit de strălucire, şters, palid; obscur; modest, retras

inconspicuousness lipsă de strălucire / distincție, obscuritate, caracter şters / obscur / inobservabil inconstant inconstant; inconsecvent, schimbător; nesigur, pe care nu poți conta

incontestable incontestabil, indiscutabil, mai presus de orice discuție

incontrollable (de) necontrolat, greu de stăpânit, care nu poate fi controlat

incontrovertible incontestabil, indiscutabil, irefutabil; convingător

inconvenience inconveniență, incomoditate, caracter incomod; neplăcere, dificultate; dezavantaj; a incomoda, a stingheri, a stânjeni

inconvenient incomod, supărător; inoportun; nepotrivit; neconvenabil

inconvenienetly $(a d v)$ (în mod) supărător, nepotrivit, inoportun, neconvenabil

inconvertibility (ec) lipsă de convertibilitate, caracter neconvertibil

inconvertible (ec) neconvertibil

incorporate a incorpora, a integra; a primi, a grupa (într-o asociație, societate etc.); (adj) integrat, îmbinat, unit (într-o asociație / societate / sistem)

incorporate in a îmbina, a uni, a strânge laolaltă în, a incorpora în

incorporated incorporat, integrat; (ec) organizat sub forma unei societăți pe acțiuni, asociat

incorporated retard oxidation agent / additive (of lubricant) (chim, T) inhibitor al oxidării, încorporat / adăugat în lubrifiant

incorporation incorporare (şi a unei asociații într-o societate comercială), integrare

incorrect incorect, eronat, greşit; inexact; neadevărat, fals; nepotrivit, necorespunzător, nelalocul lui, impropriu; necorectat

incorrectly $(a d v)$ (în mod) incorect, necorespunzător, impropriu, fals

incorrectness incorectitudine; inexactitate; neadevăr, falsitate; nepotrivire, caracter impropriu / nepotrivit 
in correct scale cu respectarea dimensiunilor (în proiectare, execuție); (metr) utilizând scara / scala corectă (a unui aparat de măsură)

inorrigible incorigibil, incapabil de îndreptate / corectare; corupt; refractar; dificil; greu de mânuit; hotărât, ferm

incorrodible (met, chim) necorodabil

incorruptible (pol) incoruptibil, integru, imposibil de corupt; cinstit; (alim, silv) care nu poate putrezi, care nu se strică

increase mărire; majorare, suire; urcare, ridicare, creştere, sporire, înmulțire (a ființelor vii etc.), spor, dezvoltare; adaos, adăugire; a creşte, a (se) înmulți, a (se) mări, a majora, a urca, a spori (un parametru, producția), a augmenta; a intensifica, a îmbogăți; a promova, a favoriza; a se înălța, a deveni mai mare; a se dezvolta; wage $\sim$ (ec) sporire de salarii; on the $\sim$ în creştere; $\sim$ tenfold a înzeci, a creşte de zece ori

increased delivery (ec) surplus de producție, producție suplimentară

increased efficiency eficientă sporită

increased height (constr, $\mathrm{OM}$ ) supraînălțare

increase in a se dezvolta

increased output producție sporită; putere mai mare la ieşire

increased safety siguranță sporită

increase gear (OM) angrenaj multiplicator

increase in efficiency (mas) mărire / creştere a puterii / a randamentului / a eficienței

increase in elongation $(\mathrm{mec}, \mathrm{OM})$ creştere a alungirii

increase in load $(\mathrm{TH}, \mathrm{mec})$ creştere a sarcinii / a solicitării

increase in performance (mas) mărire a randamentului / a performanței

increase in thickness $(\mathrm{OM}$, ind chim, met) îngroşare, mărirea / creşterea grosimii

increase in volume $(\mathrm{OM}$, ind chim, met) creştere în volum, mărire a volumului

increase of grain size (met) creştere a grăuntelui cristalin

increaser $(\mathrm{OM}$, hidr) țeavă / conductă cu creştere continuă a diametrului

increasing crescând, din ce în ce mai mare, care creşte / se dezvoltă; în creştere / dezvoltare

increasingly $(a d v)$ din ce în ce mai mult, tot mai mult; sporit

increasing motion mișcare accelerată

increasing oscillation oscilație crescătoare

increasing returns randament în creștere

increadible incredibil, de necrezut, neverosimil, neplauzibil; greu de crezut, neobişnuit, extraordinar; surprinzător, uluitor increment adaos, adăugire, cantitate adăugata; creştere, dezvoltare, mărire, sporire, ridicare; (mat, inf, autom) increment, creştere (a unei funcții, a unei variabile), mărire, majorare, dezvoltare; (ec) beneficiu, profit, câştig, spor (de salariu etc.); mărire, creştere, ridicare, sporire (de salariu etc.); (mat) creștere a unei funcții; adaos, adăugire, supliment; cantitate adăugată; (TH, autom) incrementare, majorare, mărire; supliment

incremental control (autom, mas) reglaj diferenţial

incremental cost (ec) cost suplimentar pentru o creștere a unui parametru într-un proces

incremental dimensioning $(\mathrm{OM})$ cotare relativă increment feedback (autom, inf) control / feedback bazat pe poziția / parametrii anteriori, buclă de reglare pe baza unor parameti anteriori

increment cut (mas-un) frezare a canelurilor, cu pas neuniform (la fabricarea alezoarelor)

increment-cut file pilă cu dințare neuniformă / cu rânduri de dinți deplasați

incriminate a acuza, a incrimina, a implica; a condamna

incrimination acuzare, acuzație, incriminare, reproş

incrust (termo, hidr, T) a depune / a acoperi cu piatră; a incustra

incrustation (met) crustă (si aderentă), coajă, pojghiță; incrustație, incrustare, coajă tare; (constr) fațadă de marmură

incrustation of boiler (termo) depunere de piatră pe cazan; depunere a crustei

incrusting matter (met, termo) incrustă, depunere de crustă, material încrustat

incubate (agr, med) a supune la incubatie; a incuba, a face să crească, a dezvolta; a fi supus incubatiei

incubation (agr, med) clocire, incubație; (perioadă de) incubație; proliferare

incubator (agr, med, termo) clocitoare (artificială), incubator

incult incult, necizelat, inform; nepoliticos, necivilizat, grosolan

incumbancy caracter obligatoriu, obligativitate; iminență, caracter iminent

incurability, incurableness (med) caracter incurabil / nevindecabil

incurable (agr, med) incurabil, nevindecabil

incur debts a face datorii

incuriosity lipsă de curiozitate / de interes

incurvation (mat, $\mathrm{OM}$ ) curbură

incurve $(\mathrm{TH})$ a curba, a îndoi 
in d., daily abreviere din limba latină pentru in die, (metr, med) unitate pentru frecvență pentru administrarea medicamentelor; pe zi

indebded to dator / îndatorat (față de); (fig) obligat, recunoscător

indebteness to (ec) datorie față de, sumă datorată; (fig) îndatorire, obligație, recunoştință față de

indeciphrable indescifrabil, neciteț

indecision nehotărâre, nesiguranță; ezitare, şovăială

indecisive nehotărât, şovăielnic; nesigur; indecis, nedecis, îndoielnic; neconcludent, neconvingător

indecomposability (mat) nedecompozabilitate, ireductibilitate

indecomposable (mat) care nu se poate descompune, care nu poate fi descompus

indeed $(a d v)$ într-adevăr, cu adevărat; sigur, fireşte; foarte, extrem de, cât se poate de; ba chiar (şi), (ba) mai mult decât atât; pe de altă parte, totusi, cu toate acestea

indefeasibility (jur) caracter irevocabil / definitiv; caracter imprescriptibil, imprescriptibilitate

indefeasible (jur) imprescriptibil; definitv, irevocabil

indefensibility (jur) netemeinicie, lipsă de temei / justificare; lipsă de apărare, neajutorare

indefensible nejustificat; (jur) lipsit de temei / justificare, imposibil de apărat

indefinable nedefinit, imposibil de definit, sine die; imprecis, vag

indefinite nedefinit, nedeterminat, indefinit; nehotărât, vag, nedesluşit; nelimitat

indefiniteness (mat, TH) caracter nedefinit / nedeterminat / vag; nerezolvare, lăsare în suspensie, nedeterminare; caracter nelimitat

indefinite value valoare nedeterminată

indemnification (jur, ec) compensarea daunelor, despăgubire; garanție, garantare

indemnify for (jur, ec) a despăgubi, a compensa pentru

indemnify from / against a asigura, a garanta contra / împotriva; a pune la adăpost, a feri de

indemnity despăgubire, compensație, indemnizație; asigurare, garanție; (jur) scutire de pedeapsă, imunitate (penală)

indemnity bond (ec) scrisoare de garanție

indemonstrability (mat, fiz) caracter nedemonstrabil, imposibilitate de a fi demonstrat

indemonstrable (mat, $\mathrm{TH}$ ) nedemonstrabil, imposibil de demonstrat / dovedit, de nedovedit; evident, vădit

indent (OM, TH) a zimțui, a avea / face zimți, a fi crestat / zimtuit, a dantela, a cresta, a știrbi, a lăsa urme pe, a dința, a cresta, a face adâncituri în, a scobi; a face un semn în; a lăsa o amprentă pe; (poligrafie) a spația, a începe un paragraf / de la capăt (de rând), a paragrafa (un început de rând); (jur, ec) a întocmi în două exemplare (un act etc.), a face duplicat după; a angaja (prin contract), a tocmi; a întocmi un contract (în dublu exemplar); (OM) zimț, crestătură, adâncitură, urmă, dantelare, indentație, indentare, crestătură, ştirbitură; (ec) comandă de mărfuri; (tipografie, poligrafie) aliniat, spațiu netipărit, cap de rând, paragraf, alineat; (jur, ec) act în dublu exemplar / cu duplicat; (adm, mil) ordin de rechiziție, a rechzitiona;

indentation $(\mathrm{OM})$ indentație, indentare, zimțuire, intrând, adâncitură, dinte, crestătură, zimț, cavitate, crestare, crestătură, intrând, scobitură, spațiere, ştirbitură, zimțuire; (poligrafie) alineat (în text); v. indention (poligrafie), spațiere; (metr, OM) amprentă (defect / rezultat al unei deteriorări și / sau deformări plastice, urmă lasată de aparate pt. măsurarea durității); (mas-un) ambutisare, imprimare, zimțuire, dințare; (ec) contract de angajare (ca ucenic)

indentation hardness (metr, materiale) amprentă pentru măsurarea durității Rockwell, duritate determinată prin indentare (şi de tip Rockwell), amprentă de duritate / Rockwell

indentation cup (met, metr) calotă imprimată

indentation depth (met, metr) adâncime a amprentei

indented $(\mathrm{OM})$ dințat, indentat, zimțat, zimțuit, amprentat, crestat, $v$. indent

indented chisel daltă cu dinţi

indented line început de alineat; stare

indented size $(\mathrm{OM})$ dimensiune nominală

indented wheel $(\mathrm{OM})$ roată dințată (fără specificarea formei dinților)

indention (tipografie, poligrafie), rând intrat, retragere a rândurilor, spațiu netipărit, v. indentation (poligrafie); stare

indent on / upon a identa pe, a amprenta pe; (ec) a tocmi, a angaja, a rechizitiona

indentor (metr) indentor (la aparate pt. caracterizarea durității)

indenture crestătură, ştirbitură, dantelare; (ec, jur, adm) contract de angajare (ca ucenic), document / act oficial; (perioadă de) ucenicie; a angaja prin contract (un ucenic)

indent with a se îmbuca cu, a se îmbina cu

independence independență, autonomie; avere, stare

independent of independent, de sine stătător, autonom; înstărit; neafiliat 
independent axle (OM) osie independentă independent ballast (nav) încărcare independentă

independent chuck (mas-un) mandrină cu fălci simplă / cu deplasare independentă a fălcilor

independent drive (mas, OM) acționare individuală

independent variable (mat, fiz) mărime / variabilă independentă; argument

independent yield $(\mathrm{mec})$ randament primar

indestructibility indestructibilitate, caracter indestructibil

indestructible indestructibil; inexpugnabil; de nezdruncinat; (ec) fix (d. fonduri)

indeterminable indeterminabil, de nedeterminat; interminabil, nesfârşit; iremediabil, de nerezolvat, fără soluție

indeterminancy, indeterminateness (mat, fiz) caracter nedeterminat; stare nedeterminată

indeterminate (mat) nedeterminat, neprecizat, nerezolvat, fără soluție; vag, nedefinit; în suspensie

indeterminately ( $a d v)$ (în mod) nedeterminat, neprecizat, neclar; nedecis, fără rezultat

indetermination (TH, metr) lipsă de precizie, imprecizie; (mat) nedeterminare; şovăială, nehotărâre; caracter nerezolvabil, lipsă de soluție

index, $(p l)$ indices (anat) deget arătător; $(\mathrm{TH})$ săgeată, index, indice; (metr) (ac) arătător; fixator; reper; $(\mathrm{OM})$ ac indicator; manetă pentru rotirea capului revolver la un anumit unghi; (mat) index; indice; coeficient; exponent; indiciu, semn; ordin; indice alfabetic; tablă de materii; repertoar; cartotecă; marcă, registru, tabelă, cuprins; (el) indice; (mas-un) a roti discul capului divizor; a diviza; a grada; (mat) a numerota; (c, în texte) a indexa, a alcătui/ întocmi un index etc., a insera într-o tablă de materii etc.; a clasa; (el, fiz) a împărți în elemente de scală

index bord (TH, mas) tablou / panou indicator

index card fişă de catalog / cartotecă

index centres (mas-un) ansamblu compus din cap divizor şi păpuşă mobilă

index dot (electr) reper reglabil; (mas) marcaj de punere la punct / de reglare

index driving shaft (mas-un) arbore / ax de acționare a mecanismului de divizare

index error (ec) eroare de indice; (metr) eroare de instrument / de aparat; (nav) eroare de index / instrumentală (a sextantului)

index finger (anat) deget arătător

index gear / plate (mas-un) placă de indexare, disc divizor index head (mas-un) cap divizor

indexing (mas-un) avans circular periodic; divizare a cercului

indexing attachment (mas-un) dispozitiv de divizare, care poate fi montat şi demontat

indexing chance gears (OM, mas-un) angrenaj de schimbare în trepte a indexării

indexing gear / wheel $(\mathrm{OM})$ roată de cuplare / de clichet; (mas-un) mecanism de divizare

indexing machine (alim, ind chim, mas-un) mașină de divizare

indexing movement (mas-un) mișcare de divizare

indexing position (mas-un) poziţie de cuplare (a divizorului / a mecanismului de divizare)

indexing ring (mas-un) inel de divizare (al capului revolver)

indexing unbalance (mas-un) dezechilibru de indexare

index milling (mas-un) frezare cu folosirea capului divizor

index move (mas-un) mișcare de divizare (la maşini de frezat roți dinţate etc.)

index number (ec, mat) coeficient; indice (numeric); indicator

index of deep drawing ( $\mathrm{TH}$, mas-un) indice de ambutisare (adâncă)

index of friction $(\mathrm{T})$ coeficient / factor de frecare, indice pentru frecare (la forță de frecare etc.)

index of refraction (fiz) indice de refractic

index pin $(\mathrm{OM})$ știft de blocare

index pin holder (mas-un) manetă a capului divizor, cu ştift de fixare

index point $(\mathrm{TH})$ punct de reper

index ring (mas-un, metr) inel / tablou circular cu divizare / cu diviziuni / cu gradatii, limb

indexterity stângăcie, lipsă de îndemânare

index wheel (mas-un) disc de divizare / divizor; roată indicatoare

Indian blue indigo

Indian red (chim) oxid roșu de fier

India rubber (ind chim) radieră, gumă de şters; cauciuc, gumă

indicate (TH) a indica; a arăta; a trasa, a schița; a menționa, a pomeni; a fixa, a stabili; (fig) a exprima, a denota; (med) a recomanda, a prescrie, a indica; a dovedi; a justifica; (mas) a măsura cu un aparat indicator; (mat) a indica; a marca; a însemna; (metr) a indica; a afişa (rezultatele măsurării); a fi indicat, a se recomanda

indicating indicator, arătător; care indică / arată / exprimă

indicating apparatus (metr, autom, mas) indicator, instrument de măsurat cu ac indicator; (fiz) trasor (d. elemente radiactive) 
indicating circuit (metr, autom) circuit de indicare; (inf, autom) circuit de informare

indicating control switch (el, autom) întrerupător de comandă a confirmării

indicating device (metr) instrument / dispozitiv de măsurat cu ac indicator

indicating flowmeter (metr, hidr) debitmetru cu indicator

indicating fuse (el) siguranță cu semnalizarea topirii fuzibilului

indicating gauge (metr) calibru cu comparator

indicating, indicator, pointer $(\mathrm{OM}$, metr) arătător; ac / săgeată; arătător(-oare)

indicating instrument (metr) aparat indicator, indicator (autom, mas); (fiz) trasor (d. elemente radiactive)

indicating lamp (autom, metr, el, mas) lampă de semnalizare

indicating mechanism (metr, OM) mecanism al indicatorului (la aparate cu ace indicatoare)

indicating micrometer (calipers) (metr) micrometru (cu ceas comparator)

indicating peg (el) fişă indicatoare

indicating plug gauge (metr) pasametru (pt. măsurarea dimensiunilor interioare)

indicating pointer (metr) ac arătător / indicator, săgeată arătătoare; arătător

indicating relay (el, electr) releu de indicare / de semnalizare

indicating self-balancing potentiometer (el, autom) compensator cu autoechilibrare şi citire directă

indicating snap gauge (metr) pasametru (pt. măsurarea dimensiunilor exterioare)

indicating switch (el) cheie / contact de confirmare; (el, autom) întrerupător de confirmare

indication indicație; indicare; semn vizibil la instrumente de detecție nedistructiv; indiciu, semn; manifestare; (med) simptom; (TH, metr) citire, indicație (a unui aparat)

indication error (autom, metr) deviație de măsurare; eroare de indicatie / de citire

indication of surface texture $(\mathrm{OM})$ notarea / indicarea stării suprafeței, simbolizarea stării suprafeței (în desen tehnic)

indicative of elocvent pentru, care vădește / trădează / dovedeşte

indicator (at, fiz) (atom / substanţă / agent) trasor; (auto) indicator de directie; (autom, TH) panou de semnalizare; (chim) hârtie-indicator; (metr) (aparat) indicator; semnalizator, ac (de ceas / de cadran gradat); (el, c) indicator / prezentator vizual; (metr) contor de producție; (TH, OM) ac indicator; indicator (de direcție / de sens) indicator arm braț al indicatorului de direcție (la afişaje în industrie, clădiri etc.)

indicator cock $(\mathrm{OM}$, hidr, metr) robinet-indicator

indicator diagram (autom) diagramă indicatoare; (mas) diagramă indicată / de indicare

indicator light (auto) indicator luminos

indicator / indicating pointer (metr, TH) arătător; ac / săgeată indicator(-oare)

indicator / indicating relay (el, autom) releu de indicare / de semnalizare

indicator paper (chim) hârtie indicatoare / de turnesol

indicator spring (OM, metr) arc (legat) de indicator

indicatory indicator, elocvent

indicatrix indicatoare

indicial response (autom, mat) funcție treaptă de transfer

indicium, $(p l)$ indicia indicație, semn / indicator de identificare; (amer) ștampilă atestând plata taxei poştale

indict for / as (jur) a inculpa pentru, a pune sub acuzare pentru / ca, a deschide proces penal pentru; a acuza de

indictable (jur) condamnabil, care poate fi pus sub acuzare, susceptibil de a fi acuzat; condamnabil, incriminabil (d. acțiuni)

indictee (jur) inculpat, acuzat

indicter (jur) acuzator, denunțător

indictment (jur) inculpare, punere sub acuzație; acuzare, acuzație, rechizitoriu, incriminare

indifference to / towards indiferență, nepăsare, pasivitate față de; lipsă de importanță / însemnătate; mediocritate; nepărtinire, impartialitate

indifference dose (mediu, med) doză admisibilă indifferent to indiferent la, nepăsător față de; neînsemnat, fără valoare; banal, care lasă indiferent; mediocru, nici bun, nici rău; (chim) neutru, inert; nediferențiat

indifferent admixture (materiale, ind chim) adaos / aditiv inert

indifferent gas (chim) gaz inert

indiffusible nedifuzibil, care nu poate difuza

indigo culoare indigo

indigo blue (chim) albastru de indigo, indigotină indigo purple (chim) fenicină

indigotic $\mathrm{cu} /$ legat de indigo

indirect indirect, prin ricoseu, prin intermediar(i); evaziv, (fig) ocolit (d. un drum, o soluție etc.); nesincer, necinstit (d. un răspuns)

indirect access $(\mathrm{OM}, \mathrm{TH})$ acces indirect (la o piesă, subansamblu etc.); (inf) acces prin înregistrări care conțin valorile adreselor 
indirect action (ec) acțiune publicitară indirectă (care urmăreşte prestigiul şi nu vânzarea imediată a produsului)

indirect-acting (mas) acționare indirectă / cu mecanisme, transmisii intermediare

indirect aggression (pol, ec) agresiune indirectă (nemilitară)

indirect aiming (fiz, opt) vizare inversă (şi la un microscop optic)

indirect-arc furnace (met) cuptor cu arc elctric, cu încălzire indirectă

indirect back scatter (fiz, radio) retrodifuzare indirectă / prin reflexie difuză a semnalelor spre antena de emisie

indirect call (radio, fiz) comunicație în tranzit (şi în telefonie)

indirect contact (termo) contact prin pereți

indirect cooking (termo) fierbere indirectă (în ind. hârtiei etc.)

indirect drive (OM) (transmisie cu) acționare / antrenare indirectă (prin curele etc.)

indirect echoes (fiz) ecouri false (în radiolocație)

indirect elections (pol, adm, ec) alegeri prin reprezentanți, alegeri prin vot indirect

indirect electrode furnace (met) cuptor cu electrozi, cu încălzire indirectă

indirect explosion $(\mathrm{TH})$ explozie prin simpatie

indirect fire (mil) foc / tir indirect; (termo) foc / aprindere indirectă

indirect firing (termo) încălzire cu flacără indirectă indirect flushing (alim, ind chim) spălare inversă în curent invers (avansării produselor de spălat)

indirect foundation (constr) fundaţie indirectă

indirect gap tunnelling (fiz) efect indirect de tunel al distantei dintre benzi

indirect heated mould (termo, mas-un, plast) matriță cu placă încălzită

indirect heat exchange (termo) schimb de căldură indirect / prin piese sau medii intermediare / prin pereți

indirect lighting surge (el) supratensiune datorită descărcărilor atmosferice indirecte

indirect light-spot scanner (metr, fiz) explorator / scanner / analizor (prin scanare) indirect, cu spot luminos mobil

indirect load $(\mathrm{OM}, \mathrm{mec})$ sarcină indirectă / aplicată prin intermediul unui element

indirectly controlled system ( $\mathrm{TH}$, autom) sistem controlat / comandat indirect

indirectness caracter indirect

indirect object (gram) complement indirect

indirect passive (gram) formă pasivă indirectă (cu subiectul provenind dintr-un complement indirect) indirect pressure control (hidr, autom) comandă hidraulică indirectă prin distribuitor pilot

indirect proof (mat) demonstrație prin reducere la absurd

indirect question (gram) întrebare (in vorbire) indirectă

indirect registering (inf, c birotică) înregistrare amânată, înregistrare efectuată după compunerea cifrelor

indirect scanning (metr, fiz) analiză / explorare indirectă

indirect sighting (fiz, opt) vizare inversă (şi la un microscop optic)

indirect speech (gram) vorbire indirectă

indirect speeds (OM, mas-un) viteze ale arborelui / axului principal la cuplarea transmisiei intermediare

indirect stress, induced stress (mec) tensiune indirectă / indirectă / cauzată de altă tensiune; stare de tensiuni induse

indirect sulphonation (ind chim) sulfonare indirectă

in direct sunlight (auto) în soare

indirect tax (ec) contribuție, impozit indirect

indirect taxation $(\mathrm{ec})$ impozite indirecte, impunere indirectă

indirect taxes (ec) impozit indirect

indirect tripping (el, autom) declanșare indirectă / prin releu intermediar

indirect wave (meteo) undă atmosferică; (fiz, radio) undă indirectă,undă ionosferică, undă reflectată, undă spațială

indiscernible de nedesluşit, indistinct; greu de desluşit / deosebit / distins

indispensability necesitate absolută / imperioasă; caracter indispensabil; caracter obligatoriu, obligativitate

indispensable to / for indispensabil pentru / la, de primă necesitate / urgență, absolut necesar pentru; esențial, de bază, vital, imperios, obligatoriu; ineluctabil, inevitabil

indispose a dispune nefavorabil; (med) a (se) îmbolnăvi, a produce o indispoziție

indispose for a face incapabil să / de a

indispose from a abate de la, a face să se abată de la

indisputability caracter indiscutabil / incontestabil

indissolubility (chim) insolubilitate, caracter insolubil, incapacitate de a se dizolva / descompune; caracter indestructibil / indisolubil, indestructibilitate

indissoluble (chim) insolubil, imposibil de descompus; (fig) indistructibil, indisolubil, trainic 
indistinct indistinct, nedistinct, nedesluşit, neclar; vag, confuz, obscur

indistinctive banal, cu nimic ieşit din comun, necaracteristic, nedistinctiv

indistinctness caracter nedeslușit / neclar, neclaritate

indistinguishable imperceptibil, insesizabil; care nu se poate distinge / deosebi, nedesluşit

Indium (In) (chim) indiu

indium plating (met) indiere, acoperire cu indiu

indivertible de neabătut, imposibil de deviat; inflexibil

individual individ, persoană, om; personalitate, individualitate; $(a d j)$ individual, personal; caracteristic, specific; personal, original; separat, izolat, răzleț

individual control (autom) comandă separată; acționare / reglare individuală

individual cut (mas-un) aşchiere printr-o singură trecere

individual motor drive (el, mas) comandă acționare cu motor individual

individual spot welding (met, $\mathrm{TH}$ ) sudare prin / în puncte

individual weld spot $(\mathrm{OM})$ punct de sudură

individuate a individualiza

indivisibility, indivisibleness indivizibilitate, caracter indivizibil

indivisible indivizibil, nedivizabil

indoor (de) interior, de cameră, de sală

indoor air pollution (mediu, TH) poluare în mediu / spatiu închis

indoor paint (ind chim) vopsea pentru interior

indoors $(a d v)$ în casă, în interior

indoor sanitation (constr, OM, hidr) instalații sanitare

indorsation (ec, $\mathrm{TH}$ ) andorsare (şi d. standarde internationale)

indorse (ec) a andorsa

indorsement (ec) andorsare, girare, gir

indorser (ec) girant

indraft, indraught (hidr) aflux, aspirație, admisie; (met) aer aspirat, curent (şi de aer)

indubitability certitudine, caracter neîndoios / neîndoielnic / sigur / cert; caracter incontestabil / indiscutabil; indubitabil

indubitable neîndoielnic, neîndoios, cert, sigur; indiscutabil, incontestabil

indubitably $(a d v)$ fără îndoială, fără doar sì poate; neîndoios, sigur

induce to a convinge să, a determina să, a face să; a îndemna să, a împinge la; a stârni, a provoca; a deduce; a conchide, a trage concluzia că; (el) a produce prin inducție induced convins, determinat, îndemnat; (el) indus; (TH) forțat, articifial

induced current (el) curent indus / de inducție

induced draught / draft (ind chim) tiraj artificial / forțat; (met) curent de aer indus

induced (draft) fan (ind chim, met) ventilator / exhaustor cu tiraj artificial / forțat

induced pressure (hidr, mec) presiune indusă (de exemplu, printr-o forță exterioară, aplicată unui cilindru hidraulic)

inducement persuadare, convingere, îndemare; îndemn; ispită; stimul, stimulare; mobil (care îndeamnă la), motiv (care îndeamnă la); tentație

inducer (el) inductor; care induce

inducing current (el) curent inductiv

induct into a instala; (jur) a pune în posesie; a antrena în, a atrage în; a iniţia în; (el) a produce prin inducție

inductance (el) inductanță, reactanță

inductance(-type) pressure transducer (el, metr) traductor de presiune, bazat și pe un element cu inductanță

inductile (materiale) neductil

inductility neductilitate (d. materiale)

induction instalare; (el, mat) inducție, metodă inductivă; (TH, termo, hidr) admisie, aspirație; (ec) inițiere (a unui salariat nou angajat), instalare; (jur) punere în posesie; (med) cauză generatoare; (amer) (mil) incorporare; (jur) punere in posesie

induction accelerator (fiz) accelerator cu inducție / inductiv, betatron, accelerator de particule, prin inductie

induction ammeter (metr, el) ampermetru de inductie

induction arrangement (el) protecție contra inducției

induction brazing, inductive brazing (met) lipire tare prin inducție

induction channel (termo, OM, met, ind chim) jgheab la cuptorul cu inducție

induction clutch $(\mathrm{OM}$, el) cuplaj cu inductie

induction coil (el) bobină de inducție, inductor, bobina Ruhmkorff

induction cup (el, OM) miez de inducție (la magneți-oală)

induction current (el) curent de inductie / indus induction-current relay (el, autom) releu de inducție

induction detector (metr, autom) detector prin / cu inductie

induction device (el) protecție contra inducției induction flowmeter (metr, hidr, el) debitmetru cu inducție 
induction furnace (met, termo, el) cuptor (electric) de inductie

induction generator $(\mathrm{el})$ generator asincron induction hardening (met, el) călire prin (curenți de) inducție

induction heating (termo, el, met) încălzire prin curent electric indus, încălzire prin (curenți de) inducție

induction instrument (metr, el) aparat de inducție, aparat de măsurat de tip inductiv

induction interference (fiz, el) interferență prin inducție / cauzată de inducție

induction logging (metr, el) carotă inductivă / prin inducție, carotaj geofizic prin metodă inductivă

induction logging apparatus (metr, el) aparat de carotaj geofizic, care funcționează pe principiul inducției

induction loudspeaker (el) difuzor cu paletă liberă / cu inducție

induction magnetic separator (alim, ind chim) separator magnetic cu inducție

induction manifold (OM, termo, hidr) conductă colectoare / de admisie

induction meter (metr, el) contor de / bazat pe inducție

induction method (el, metr) metodă inductivă (pt. localizarea defectelor la cabluri)

induction mixture (auto) amestec de combustibili

induction motor (el) maşină de inducție, motor asincron

induction motor meter (metr, el) contor (cu motor) de inducție

induction magnetic separator (met, agr, mas, mediu) separator magnetic, cu inducție

induction period (el, fiz, chim) perioadă de inductie

induction pipe (auto) țeavă / conductă de admisie; (OM) țeavă de aspirație

induction port $(\mathrm{OM}$, hidr, termo) orificiu / canal de admisie

induction predicate (gram) predicat inductiv

induction of facts aducere de fapte / probe, producere de fapte / probe

induction side $(\mathrm{OM})$ partea prin care se face admisia / intrarea

induction signalling (fiz) semnalizare prin inducție (în telefonie)

induction stroke (OM, auto, termo) cursă de admisie (a pistonului)

induction system (termo, Om, hidr mas) conductă / sistem de admisie

induction tachometer (metr) tahometru Ferraris / cu inducție / de curent alternativ induction transmitter adapter (electr, metr) adaptor pentru captatoare / transmițătoare cu inducție

induction valve (OM, hidr) supapă de intrare / de admisie / de aspirație

induction vessel heating (termo) încălzire indirectă prin încălzirea unui creuzet, încălzire indirectă prin inducție

induction welding using rod inductors / using a surrounding inductor (met, el) sudare prin inducție cu inductor-bară / cu inductor-spiră

inductive (el) de inducție, inductiv, bazat pe inducție; (OM, termo, hidr) de admisie, de aspirație, de absorbție

inductive / induction brazing (met, el) lipire tare prin inductie

inductive capacity (fiz, el) constantă dielectrică; permitivitate

inductive coupling (el) cuplaj inductiv / magnetic inductive impedance (autom, el, metr) impedanță inductivă

inductive rail connection (el) conectare / conexiune / legătură cu bobină de amortizare inductivity (el) inductanță, constantă dielectrică inductor (el) inductor, bobină de şoc / inducție; (hidr) drosel

indulge in a îngădui să, a permite să; a încuraja la indulgence to / of indulgentă, toleranță pentru / față de; tolerare, îngăduire; privilegiu, favoare indulgent indulgent, îngăduitor, tolerant indurate a (se) întări

indurated fabric (ind chim, plast) textolit; țesătură bachelitizată

induration (plast) solidificare, întărire

industrial industrial; de productie, de muncă; industriaş; (ec) acțiuni ale unei societăți industriale industrial accident $(\mathrm{TH}$, ind) accident de muncă industrial alcohol (chim) alcool / spirt industrial, alcool tehnic

industrial capital (ec) capital industrial

industrial / process computer (c) calculator industrial / folosit în procesele tehnologice / de proces

industrial disease (med, TH) boală profesională industrialist industriaş, fabricant

industrialization industrializare

industrialize a industrializa

industrial naphtha (chim) solvent petrolier

industrial psychology psihotehnică

industrial revolution revoluție industrială

industrial sanitation (med, $\mathrm{TH}$ ) igiena muncii

industrial school (edu, TH) şcoală profesională de meserii

industrial union sindicat industrial (de ramură) 
industrious harnic, muncitor, silitor; destoinic; priceput, abil

industry industrie, ramură industrială; întreprindere, fabrică, uzină; hărnicie; studiu specializat, cercetare a unui subiect

industry standard(s) (colecție de) standarde referitoare la o ramură industrială

inedible (alim) necomestibil, de nemâncat

inedible oil (ind, alim) ulei necomestibil

ineducable (edu) needucabil

ineffaceable (de) neşters, de neuitat

ineffective ineficace, zadarnic, infructuos, fără rezultat; incapabil, incompetent; lipsit de efect, nereuşit, plat, searbăd; ineficient, moale, nepriceput

ineffectively $(a d v)$ zadarnic, inutil, fără efect

ineffectiveness ineficacitate, lipsă de efect; incapacitate, nepricepere, incompetență

ineffectual fără efect / rezultat / succes; zadarnic, inutil, van, infructuos; anost, plat, searbăd, sters; incapabil, ineficient, nepriceput

ineffectually $(a d v)$ zadarnic, fără rost / efect / rezultat; necorespunzător

inefficacious ineficace, care nu dă rezultate, necorespunzător

inefficaciousness, inefficacy lipsă de eficacitate, ineficacitate

inefficiency ineficiență, lipsă de efect; lipsă de randament; incapacitate, ineficiență, nepricepere

inefficient ineficient; lipsă de rezultat / randament; incapabil, incompetent, nepriceput, lipsit de randament

inefficiently $(a d v)$ inutil, fără rost / efect / rezultat / randament; neîndemânatic, fără pricepere, fără eficiență

inelastic (mec, materiale) lipsit de elasticitate / suplete, rigid, neelastic; lipsit de maleabilitate; inadaptabil, refractar; ferm, constant, fără fluctuații

inelastic behaviour (mec) comportare neelastică (d. un corp)

inelastic collosion $(\mathrm{mec})$ ciocnire neelastică

inelasticity $(\mathrm{mec})$ lipsă de elasticitate, rigiditate, neelasticitate

inelastic scattering (el) împrăştiere neelastică

inelastic stress $(\mathrm{mec})$ tensiune neelastică / care produce deformări permanente

ineligible (pol, jur, ec) care nu poate fi ales, ineligibil; inapt, necalificat; nepotrivit, inadecvat, inapt

ineluctability inevitabilitate, caracter ineluctabil ineluctable ineluctabil, inevitabil, de neînlăturat inept stupid, prost(esc), absurd, inept; nepotrivit, deplasat, inoportun; (jur) nul (şi neavenit), fără efect ineptitude stupiditate, absurditate, caracter prostesc / stupid / absurd; incapacitate, nepricepere; prostie, inepție; caracter inoportun / deplasat

ineptitude for incapacitate pentru, lipsă de aptitudini pentru

ineptly $(a d v)$ (în mod) stupid / absurd, prosteşte inequable (distribuit) neuniform; eterogen, lipsit de omogenitate, neomogen (d. componente într-un material, un proces în timp şi / sau spațiu)

inequality (mat) inegalitate; părtinire, parțialitate; disproporție, decalaj; deosebire, diferență; asperitate, neregularitate (şi de teren); instabilitate; insuficiență, caracter insuficient / neîndestulător inequitable inechitabil, injust, nedrept inequity nedreptate, injustiție, inechitate inerrability infailibilitate, lipsa oricărei greşeli / deficiente

inerrable infailibil, incapabil de greşeală, care nu dă greș (niciodată)

inert indiferent, inert, nemişcat; mort; fără viață, fără vigoare; (chim) inactiv, inert (si gaz nobil); (mec) inert, inactiv, neutru; (mas) mort, fără să functioneze / să poată fi pornit

inert anode (el) anod inert

inert atmosphere (ind chim, met) atmosferă inertă

inert cell (el) pilă activată cu apă, pilă electrică inertă

inert filler (materiale, chim) material de umplutură, inactiv / inert (şi d. compozite)

inert gas (met, ind chim) gaz inert / nobil

inert gas brazing / soldering (met) lipire tare / moale, în mediu de gaz inert

inert gaseous components (termo, met) constituenti gazoși inerti (chimic) / necombustibili

inert gas generator (ind chim) generator de gaze inerte / nobile

inert-gas metal-arc welding (process) (met) (procedeu de) sudare cu arc în mediu gazos inert (protector)

inert-gas shielded-arc welding (process) (met) sudare cu arc în mediu gazos protector / inert

inert gas tungsten arc welding (met) sudare cu arc electric în mediu de gaz inert, cu electrod de wolfram

inert gas welding (met) sudare cu arc în atmosferă inertă

inertia (mec, chim) inerție, forță de inerție; (fig) încetineală, indolență, apatie

inertia about (mec) moment de inerţie în raport cu inertia balance (mec) echilibru dinamic inertia bonding $(\mathrm{OM})$ lipire prin frecare şi presare inertia clamping (mec) funcție compensatoare a inerției, fixare produsă prin forțele de inerție 
inertia constant (mec, mas) constantă de timp a funcționării datorită inerției până la oprire în sarcină nominală, constantă de timp a maşinii, constantă inerțială a maşiniii

inertia field (fiz) câmp de inerție

inertia of electrons (fiz) inerție a electronilor

inertia of mass force (mec) forță de inerție datorată maselor elementelor în mişcare

inertia pinion $(\mathrm{OM})$ pinion al demarorului

inertia starter (el, mec) demaror prin inerție / cu volant

inertia-type starter (mec, el) demaror cu volant, demaror prin inerție

inertia-free switch (el) întrerupător fără inerție

inertia clamping (autom) funcție compensatoare a inerției, compensator al inerției

inertia constant (autom, mas) constantă de timp a funcționării datorită inerției până la oprire în sarcină nominală

inertia equivalent (energy) (mec, OM) (energie-) echivalent de inerție (la frâne)

inertia field (fiz) câmp de inerție

inertia-free switch (el, electr, autom) întrerupător fără inerție

inertial (mec) de / referitor la inerție, inerțial; (chim) inert; (nav) automat, făcut în virtutea inerției

inertial dust collector (mediu, mas) colector inerțial de praf

inertialess (mec) fără / lipsit de inerție

inertial force (mec) forță de inerție

inertial lock (auto, OM) încuietoare activată prin inerție

inertial locks (auto) sistem de blocare prin inerție

inertial separator (agr, ind chim, mediu) separator de praf prin inerție

inertia moment (mec) moment de inerție

inertia of mass force (mec) forță de inerție

inertia pinion (OM, auto) pinion al demarorului

inertia selling (ec) vânzare din inerție (fără activități de susținere / influențare), vânzare fortată, forțarea mâinii cumpărătorului

inertia welding (met) sudare prin frecare cu inerție inertness inerție

inert shielding gas (met) gaz inert de protecție (la sudare etc.)

inessential neesențial, secundar; mărunt, neînsemnat, neglijabil; mărunțiş, fleac, lucru mărunt / secundar / neesential

inestimable (de) neprețuit, inestimabil, de mare valoare

inevitability caracter inevitabil / ineluctabil

inevitable inevitabil, ineluctabil, de neînlăturat, fatal; inerent inevitable to inerent pentru, specific pentru; propriu (unui sitem, material etc.)

inevitableness caracter inevitabil / fatal / ineluctabil

inexact inexact, incorect

inexactitude inexactitate; incorectitudine

inexactly $(a d v)$ (în mod) inexact, incorect

inexactness inexactitate

inexhausted nesecat, inepuizabil

inexhaustive neexhaustiv, incomplet, care nu epuizează problema, care nu duce lucrurile până la capăt

inexpectant of luat prin surprindere de, care nu se așteaptă la; care nu speră la / în

inexpedient inoportun, nepotrivit, dezavantajos; zadarnic, fără rost / sens

inexpensive ieftin, convenabil, modest, necostisitor

inexpensiveness caracter ieftin / convenabil, ieftinătate

inexperience of lipsă de experientă în / de

inexperienced in lipsit de experiență în, nepriceput la

inexpert at nepriceput la, neîndemânatic la; ignorant, incompetent

inexplicable inexplicabil, de neîntẹeles

inexplicit neexplicit; neclar; neprecizat

inextricability, inextricableness caracter inextricabil / de nedescurcat; (mat) caracter insolubil / de nerezolvat

inextricable inextricabil; încâlcit; de nerezolvat, irezolvabil, fără soluție / ieşire

infallibility, infallibleness infailibilitate, caracter infailibil, imposibilitate de a greşi

infallible care nu dă gres (niciodată); infailibil, incapabil să greşească; iminent, inevitabil, de neînlăturat; fără greș; sigur

infeasible irealizabil, nefezabil; imposibil; nerealist (şi d proiecte etc.)

infect (with) (med, mediu) a infecta (cu) / (de), a molipsi, a contamina (cu); (fig) (jur) a vicia, a corupe $\mathrm{cu}$

infection (med) infecție, proces infecțios, infectare; (fig) infectare, molipsire, contaminare; (jur) viciere, corupere

infectious, infective (med) infecțios, infectat; (fig) molipsitor, contagios, transmisibil

infectiousness, infectiveness (med) natură infectioasă; (fig) contagiozitate, caracter infecțios / molipsitor / contagios

in-feed (mas-un) avans transversal

infer (from) a deduce (din), a implica; a conchide, a trage concluzia (din); a presupune, a necesita; a indica, a arăta; a dovedi 
inferable (from) deductibil (din), care poate fi dedus / presupus (din)

inference (mat) deducție, concluzie; deducere, tragere a unei concluzii; implicație, lucru subînțeles

inferential bazat / întemeiat pe deducție, deductibil, uşor de dedus; dedus

inferential meter (metr, hidr) debitmetru

inferior (to) cu valoare redusă (față de), inferior; situat / plasat mai jos; mai de jos; de calitate inferioară; inferior, subaltern, subordonat

inferiority (in) inferioritate față de, capacitate redusă (în privința); caracter inferior; calitate proastă

inferior limit $(\mathrm{cu})$ limită inferioară

inferred zero (metr, autom) dispozitiv (al unui instrument de măsurat) pentru mărirea sensibilității într-un domeniu limitat de măsurare; cu gradație fără zero; zero suprimat / decalat

infertile (agr) nefertil, neroditor, sterp; infructuos

infest (agr, med) a infesta; a invada, a năpădi, a împânzi; a sâcâi

infestation (med) infestare, invazie; (agr) năpădire

infill a umple (o cavitate); (constr) a plomba, a construi (pe un loc gol)

infilling umplere (a unei cavități); (constr) plombă, construcție între alte clădiri

infiltrate a trece; a pătrunde; a (se) infiltra; a impregna; a îmbiba; a strecura; infiltrare, infiltrație; (med, chim) inflitrat

infiltrate into a trece prin (ceva); a pătrunde în; a (se) infiltra în; a (se) strecura în / prin (d. fluide, prin materiale solide etc.)

infiltration infiltrare, infiltrație, îmbibare, impregnare (d. fluide, prin materiale solide etc.)

infiltration by dipping (met, plast) impregnare prin imersare / prin cufundare

infimum infimum, margine inferioară; (mat) cel mai mare minorant (în analiza matematică)

infinite infinit, fără sfârşit, nelimitat, nemărginit, nesfârşit, fără margini

infinite dilution (fiz, chim) diluție infinită

infinite integral (mat) integrală cu limite infinite

infinite loop (inf, c) buclă repetabilă la infinit (proces de blocare a unui program)

infinitely fine control (autom, metr) comandă / reglare fină continuă

infinitely variable (metr, autom) cu reglare continuă

infinitesimal infinit mic; infinitezimal; infim, minuscul, neînsemnat, mărime / valoare infinitezimală

infinitesimals analiză infinitezimală infinity, infiniteness (of) (mat) infinit, infinitate (de), nemărginire

infirm neputincios, firav; şovăielnic, fără voință; (jur) a infirma, a invalida, a declara nul

infirmity, infirmness neputință, slăbiciune; (med) debilitate, boală, maladie; caracter slab, lipsă de voință, (jur) nulitate

inflame (chim, termo) a (se) aprinde, a da foc la, a lua foc; (med) a produce o inflamație, a (se) inflama

inflamed în flăcări, arzând, cuprins de flăcări; (med) inflamat, (d. ochi) injectat

inflammability, inflammableness (chim) inflamabilitate; capacitate de aprindere, caracter inflamabil; (fig) iritabilitate

inflammability test (metr) test / încercare de inflamabilitate (foarte general)

inflammable inflamabil; substanță inflamabilă, combustibil, carburant; (fig) iritabil

inflammable dust ( $\mathrm{TH}$, ind, met) praf fin de cărbune inflamabil (capabil de a produce o explozie)

inflammable materials $(\mathrm{TH})$ materiale inflamabile inflammation (termo, $\mathrm{TH}$ ) inflamare, aprindere

inflammable mixture (termo, chim) amestec combustibil

inflammatory incendiar; (med) inflamator

inflate a umple (cu aer); (ec) a umfla (d. preturi, costuri etc.), a încărca (nota de plată, un deviz etc.); (auto) (d airbag) a se umfla, a se deschide

inflated (auto) umflat (d. un pneu); (ec) umflat, încărcat, mărit (şi d. prețuri)

inflated slag (met) zgură cu pori şi sulfuri

inflater, inflator (auto, OM) pompă pentru (umflat) pneuri

inflate the air bag (auto) a deschide airbagul

inflating agent / medium (plast) agent porofor / spumant / de umflare

inflation (TH) umflare, umplere; (ec) inflație

inflationary (ec) inflaționist

inflation pressure (hidr) presiune de preîncărcare / de umplere; (auto) presiunea pneurilor

inflation strength (plast) rezistență la umflare

inflect a devia; (mec) a încovoia, a îndoi, a curba; (fiz) a refracta

inflected încovoiat, curbat, îndoit; (fiz) refractat

inflection, inflexion (fiz) difracție; (mas-un) inflexiune, îndoitură, curbură; (mat) inflexiune (d. o curbă)

inflexibility inflexibilitate, rigiditate, fermitate

inflexible inflexibil, rigid; ferm

inflexion, inflection (mec, OM) încovoire, îndoire, curbare, curbură, îndoitură 
inflict on / upon a pricinui, a cauza, a produce (cuiva, ceva); (jur) a aplica, a da (o amendă); a se impune, a se băga cu de-a sila

infliction pricinuire, cauzare; suferință, neplăcere; (jur) aplicare, administrare (a unei amenzi etc.)

inflorescence (agr, bot) inflorescență, înflorire

inflow, (fiz, hidr) curgere spre interior, a curge în; v. influx

inflowing (fiz, hidr) aflux, pătrundere, intrare, vărsare (în interior); care pătrunde / intră / se varsă (în interior)

influence on / upon influență asupra; (fig) autoritate, trecere; factor influent; (el) inducţie; a influența, a înrâuri

influencer factor influent, care influențează

influence quantity (metr) mărime care influențează în mod nedorit indicațiile unui aparat de măsurat

influent care se varsă, care se revarsă, afluent

influent tide (nav) flux, maree

influenza (med) gripă

influenzal (med) gripal, de gripă

influx (into) aflux (în / spre), afluență (către spre); val (către / spre), năvală (către / spre); (auto, mas, av) admisie / intrare de aer; (fiz, hidr) afluență, aflux, curgere; (geogr) vărsare, gură (de râu); (ec) încasări

influx of oil (geol, ind chim) aflux de titei

infolded (OM) cu marginile îndoite spre interior inform inform; amorf

informal neoficial, fără formalitate; neprotocolar, neceremonios; liber, degajat; familiar; a înştiința (despre / de); a anunța, a comunica, a face cunoscut

inform (of) a informa, a da informații (despre)

informatics informatică; (inf) sumă a activităților legate de prelucrarea automată a datelor

information informații; informație (inf) date; informare, luare la cunoştință; cunoştințe (întrun domeniu, cultură

information bureau / desk birou de informații

information monitor / display (auto) monitor pentru informații (pe panoul de bord)

informative, informatory (cu caracter) informativ

informed informat, în cunoştinţă de cauză, la curent; încunoștiințat; documentat

infraction (jur, ec) încălcare, violare (a legii / regulamentului)

infrangible incasabil; ( $f i g$ ) inviolabil

infra(-)red (fiz) infraroșu

infra(-)red dryer (alim, ind chim) uscător cu radiații (infraroşii)

infrared radiation heating (termo, fiz) încălzire prin radiații infraroşii infrared radiation furnace / oven / stove (alim, ind alim) cuptor cu radiații infraroşii

infrared response (fiz, materiale) sensibilitate la infraroşu

infrasonic (fiz) infrasonic, subsonic

infrastructure (constr, ind) infrastructură, temelie, fundație

infrequency rarietate, lipsă de frecvență

infrequent rar, ocazional, lipsit de frecvență

infringe a încălca, a viola (o lege etc.)

infringement încălcare, violare; contrafacere (şi a unui patent)

in front de față; frontal, în față

infructuous (agr) neroditor, sterp; (fig) steril, infructuos

infundibular $(\mathrm{OM})$ în formă de pâlnie

infuse (in into) (TH) a turna (în), a vărsa (în), a injecta, a inculca, a infiltra; a sugera; (alim) a face o infuzie, a opări, a macera

infuse with a imbiba cu, a umple de / cu

infusibility capacitate de infuzie

infusible infuzibil, nefuzibil; greu de topit, refractar; ignifug, rezistent la foc, insolubil, greu de dizolvat (d. substanțe)

infusion turnare, vărsare; (alim) infuzie, fiertură, extract, opărire, fiebere; (TH) amestec, adaos, injecție, injectare, în introducere (a unei substanțe etc.)

infusion pump (termo, OM) pompă de injecție ingate (met) picior al pâlniei de turnare, canal de alimentare / de turnare, rețea de turnare; (hidr) orificiu de intrare

ingather a (se) aduna, a culege, a (se) strânge (şi recolta), a recolta

in gear $(\mathrm{OM})$ angrenat, în angrenare, ambreiat; (mas) în funcțiune; (el) în priză

ingeminate a repeta, a relua, a reitera

ingenerate originar, înnăscut; a genera, a crea; a produce

ingeneration generare, producere, provocare

ingenious ingenios, iscusit, inventiv, priceput, bogat în idei

ingenuity, ingeniousness ingeniozitate, inventivitate; iscusință, talent, pricepere; inteligență, agerime, geniu

in-going intrare, pătrundere; care intră / pătrunde în; de intrare; pătrunzător; care vine / soseşte; care intră în funcțiune, care se instalează; nou

ingot (met) lingou, bloc (turnat), în lingouri, sub formă de lingouri

ingot blank (met) semifabricat sub formă de lingou

ingot breaker (met) spărgător de lingou

ingot buggy (met) vagonet pentru lingou(ri) 
ingot butt (met) capăt / rest de lingou ingot iron / steel (met) oțel în lingouri ingot car (met) vagonet pentru lingouri ingot chair (met) dispozitiv de răsturnare a lingoului

ingot charger (met) dispozitiv de încărcat lingouri (la laminoare)

ingot-charging crane (met, transp) macara / pod rulant de încărcat lingouri (la laminoare)

ingot chariot (met) vagonet pentru lingouri

ingot crane (met, transp) macara / pod rulant (şi cu cleşte) pentru manipulat lingouri

ingot crop end (met) maselota lingoului

ingot crusher (met) spărgător de lingou

ingot dogs (met, OM) cleşte pentru prinderea lingoului

ingot drawing crane (met, transp, termo) macara / pod rulant de manipulat lingouri în cuptoare adânci

ingot form (met) bloc turnat (semifabricat)

ingot gripper (met, OM) clește pentru prinderea lingoului

ingot handling crane (met, transp, termo) macara / pod rulant de manipulat / transportat lingouri

ingot heating furnace (met) cuptor adânc de încălzire a lingourilor

ingot iron (met) otẹl în lingouri

ingotism (met) segregație în lingouri

ingot lathe strung pentru prelucrarea blocurilor / lingourilor

ingot metal (met) lingou de metal, bară neprelucrată, semifabricat (brut) obținut prin turnare

ingot mill (met) laminor degrosisor, slebing

ingot mould (met) lingotieră

ingot mould blackening (met) ungerea lingotierei (înainte de turnare)

ingot mould bottom-plate / stool (met) placa de fund / de bază a lingotierei

ingot mould coating / dressing material (met, chim) material pentru ungerea / acoperirea lingotierei (la interior)

ingot mould glazing (met, chim) glazură pentru lingotieră

ingot mould scrap (met, chim) spărtură de lingotieră (ca fier vechi)

ingot mould varnish (met, chim) lac / vopsea / material / glazură pentru lingotiere (la interior)

ingot parting machine (met, mas-un) maşină de tăiat lingouri

ingot pit (met) cuptor adânc, de încălzire a lingourilor

ingot-rolling mill (met) laminor de blumuri, bluming ingot scum (met) spumă de lingou

ingot shears (met) foarfece pentru blocuri (de oțel) / lingouri

ingot skin (met) crustă a lingoului

ingot slab (met) bramă / sleb brut(ă)

ingot slab mill (met, mas-un) laminor de blumuri şi sleburi

ingot slab mould (met) cochilă pentru brame ingot-steel (met) lingou de oțel, oțel în lingouri ingot-steel plate (met) tablă de oțel de fuziune

ingot stirrup (met, $\mathrm{OM}$ ) cleşte pentru prinderea lingoului

ingot stripper (met) striper

ingot stripping crane (met, transp) macarastriper

ingot suitable for rolling (met) lingou gata / pregătit de laminare

ingot tilter (met, mas) dispozitiv de răsturnare a lingourilor

ingotting (met) turnare în lingotiere

ingot-tipping device (met, mas) dispozitiv de răsturnat lingouri

ingot tongs (met, $\mathrm{OM}$ ) cleşte de prins lingoul ingot topping (met) tăierea maselotei lingoului ingot transfer car (met, transp) vagonet de transportat lingouri

ingot yard (met, constr) depozit de lingouri

ingraft (agr) a folosi ca altoi, a altoi

ingrain a fixa, a întipări, a imprima; (textile) vopsit în fibră / fir; vopsit durabil; fire / fibre vopsite înainte de prelucrare, covor vopsit în fibră; vopsit în culoare închisă, vopsit în culori diferite pe cele două fețe; caracter înnăscut

ingrained (textile) impregnat / imprimat (profund, în fir, în fibră); întipărit, înrădăcinat

ingredient (chim, met, plast, alim) (element) component, constituent, ingredient, parte componentă

ingress pătrundere, infiltrare (în), penetrație, admisie (în); intrare; sosire; taxă de intrare, cost al biletului de intrare; poartă de intrare / de acces ingress into acces, (drept de) intrare în / la

ingress gate (met, plast, alim) pâlnie / canal de turnare

ingression intrare, acces; pătrundere; incursiune, invazie

ingressive care intră / pătrunde

ingrowing care creşte spre / în interior ingrown întipărit, crescut spre / în interior ingulf (agr) a îneca, a cuprinde, a covârşi (d. buruieni etc.), a năpădi

inhabit a locui, a domicilia (în), a sta

inhabitable locuibil, corespunzător pentru locuit; salubru 
inhabitancy, inhabitation reşedință, locuință, domiciliu; şedere, domiciliere

inhabitant locuitor, locatar; (zool) viețuitoare specifică unui areal

inhabited locuit, ocupat; populat

inhalant (chim, med) inhalant; inhalator; de / pentru inhalat

inhalation (anat) inhalare, inspirare, aspirare; (med) inhalație

inhalator (med, OM) inhalator

inhale a inhala; a inspira; a absorbi; a trage (aer, fum) în piept; a respira; a răsufla

inhaler (med, OM) inhalator; (TH) mască de protecție (contra prafului, fumului); filtru de aer

inhaust a absorbi (aer, gaze)

inherent (in) inerent, intrinsec, propriu; realizabil în condiții ideale / de proiectare; inseparabil, inalienabil; de la sine înțeles

inherent acceleration (el, electr, autom) accelerație naturală (la acționări electrice)

inherent ash (termo) cenuşă intrinsecă (neseparabilă prin spălare)

inherent characteristic data (autom, inf) date / valori caracteristice ale buclei de reglare

inherent damping $(\mathrm{mec})$ capacitate proprie de amortizare (a unui material, cum ar fi cauciucul)

inherent error (metr, autom) eroare inițială, transmisă pas-cu-pas

inherent failure causes $(\mathrm{TH}$, deteriorări) cauze de rupere / de distrugere, datorate factorilor de exploatare (de exemplu: şocuri, fluaj, oboseală termică etc.)

inherent lag (mas, autom) întârziere proprie / inerentă

inherently stable cu stabilitate inerentă

inherent noise figure (el, metr, autom) factor de zgomot inerent / propriu

inherent regulation (autom) autoreglare; durată de adaptare naturală; reglare inerentă

inherent regulation rate (autom) viteză de autoreglare

inherent reliability (mas, $\mathrm{TH}$ ) fiabilitate intrinsecă (în condiții normale / nominale de lucru)

inherent stability (mas, TH) stabilitate proprie / naturală / intrinsecă; autoreglare

inherent stable cu stabilitate inerentă / intrinsecă

inherent stress / tension (mec) tensiune internă / proprie

inherent strength (materiale) rezistență naturală / proprie

inherent time (autom) timp propriu

inherent value valoare proprie / intrinsecă

inherited error (metr, autom) eroare acumulată inhesion caracter inerent, inerență

inhibit (chim, autom) a inhiba; a opri, a împiedica; a interzice; a inhiba (o persoană); a paraliza (şi un proces tehnologic etc.); a bloca; a reține; a nu permite

inhibit gate (electr) poartă de blocare

inhibit line (autom) linie de oprire / de blocare / de inhibare

inhibit pulse (autom) impuls de oprire / de blocare / de inhibare

inhibit to / from a împiedica să, a opri să / de la; a interzice să, a nu permite să

inhibition $(\mathrm{TH}$, mas) oprire, împiedicare, reținere, blocare; (agr, chim) inhibiție; interzicere, interdicție; (jur) sechestru, poprire; inhibare

inhibition from împiedicare de la, oprire de la, reținere de la; inhibare de a

inhibitor (autom, plast, chim) element / agent / substanță de blocare (a unei reacții chimice), inhibitor, stabilizator, element de blocare; (OM, TH, mas) dispozitiv de încetinire / frânare, element de blocare / încetinitor, stabilizator; factor de inhibiție / reținere; (chim) agent / substanță care încetineşte / împiedică anumite reacții chimice

inhibitory, inhibitive (chim, fiz) inhibitor, care inhibă; prohibitor, care interzice / împiedică

INHIBITORY-gate (autom) circuit / poartă CU EXCEPȚIA LUI; circuit / poartă ŞI-NU

inhibit oscillations (mec, electr) oscilații blocate / suprimate

inhomogeneity neomogenitate, caracter neomogen / eterogen (d. materiale)

inhomogeneous (materiale) neomogen, lipsit de omogenitate

inhour (ih, inhr) (metr, fiz) o unitate în ingineria nucleară pentru a descrie ,reactivitatea” unui restor nuclear; raportul R între numărul de neutroni creați şi cei copnsumați în fiecare ciclu de fisiune trebuie să fie foarte apropiat de 1 pentru ca reactorul să fie controlat; reactivitatea $\mathrm{k}=\mathrm{R}-1 ; 1$ inhour este reactivitatea care va face ca numărul de neutroni să crească de un număr de ori egal cu e $=2,71828$ într-o oră; valoarea exactă a unității depinde de tipul reactorului

in-house (al său) propriu; intern, local; autohton, indigen

in-house facilities (ec) resurse / mijloace proprii / interne

in-house maintenance (met) mentenanță efectuată de personalul unității / fără contract

inimitable inimitabil; incomparabil, fără pereche, care nu poate fi imitat 
in inverse ratio to în proporție inversă, invers proporțional $\mathrm{cu}$

initial (poligrafie) (în text) (literă) inițială, a nota cu inițiale / cu o inițială; (TH) inițial, original; de plecare, de pornire; primar, primordial; de bază, de referință, de început, de plecare; a parafa, a aproba, a aviza; a viza, a-şi pune parafa pe, a parafa; a nota cu o iniţială

initial abstraction (agr) pierderi inițiale de apă din precipitații (reținută de vegetație şi acumulată în depresiunile solului)

initial acceptivity (mec, mas, el) putere absorbită normală; $(\mathrm{TH})$ recepție nominală

initial adjustment (autom, el, metr) reglare inițială, reglaj inițial / la zero; aducere la zero (a indicatorului unui aparat de măsurare)

initial body retention (fiz, chim) coeficient / factor de retenție inițială

initial boiling point (alim, ind chim, met, fiz) punct inițial de fierbere; temperatură inițială de fierbere

initial break-away torque (of engine) (mec, mas) moment de rupere (la pornire, eventual sub sarcină) (a unui motor)

initial bubble point (fiz, alim) punct inițial de fierbere (d. amestecuri de lichide)

initial boiling point (fiz) punct inițial de fierbere

initial capacitance (electr, TH) capacitate inițială / reziduală

initial capital (poligrafie) literă inițială majusculă initial cell (biol) celulă embrionară

initial charge (el) sarcină de bază; (mec) sarcină inițială

initial contamination (mediu, chim) poluare / contaminare inițială

initial costs (ec) costuri initiale, costuri cu investiția, investiții

initial daily production (ec) producție zilnică inițială

initial depth (mec, hidr) adâncime a apei înaintea saltului hidraulic (în hidraulică)

initial dialling delay (electr) durată inițială de selectare (în telecomunicații)

initial driving gear $(\mathrm{OM})$ prima roată dințată, de antrenare a unei transmisii de roti dinţate

initial excitation response (fiz, autom) viteză inițială de excitație

initial function (mat) funcție-original, original

initial heating (met, alim, termo) preîncălzire (înainte de prelucrare mecanică, de sudare etc.)

initial ingot (met) lingou inițial

initial investment $(\mathrm{ec})$ investiție inițială, sumă care include taxa de concesionare la care se adaugă un capital minim necesar pentru demararea unei operații de franchising

initialize (c, inf) a inițializa, a începe (un program / o subrutină etc.); (autom, metr) a readuce la zero

initial line aliniament inițial; (poligrafie) cap de pagină

initial load (mec) sarcină iniţială / prealabilă / de prestângere (la şuruburi etc.)

initial loading (mec) încărcare inițială / prealabilă, pretensionare, prestrângere (la asamblări cu şuruburi)

initially $(a d v)$ inițial, la origine, la început, mai întâi

initial material (TH, ind) material de bază, materie primă

initial oscillation time (mec, autom, el) timp de amortizare a oscilațiilor / de oscilație inițial / de stabilizare a oscilațiilor

initial pass (met) pas / trecere inițial(ă) (la laminare)

initial phase (fiz, chim, termo) fază iniţială, fază la originea timpului

initial pitch (mec, OM) pantă iniţială (şi de evoluție a unui parametru caracteristic unui proces tehnologic), pas inițial

initial point (mec, mas, metr, $\mathrm{TH}$ ) poziție de plecare / de zero, poziție inițială, punct inițial / de plecare

initial position (mas, $\mathrm{TH}$ ) poziție de plecare / de zero / inițială; (metr) poziție zero (la aparate de măsurat)

initial production $(\mathrm{TH}, \mathrm{ec})$ productie inițială debit inițial

initial program loader (inf, c) program de încărcare inițială (a unui sistem de calcul)

initials (TH) parafă / viză de control

initial section (mec, TH) secțiune inițială (înainte de orice tip deformare)

initial slope (electr, autom, TH) pantă inițială (și de evoluție a unui parametru caracteristic unui proces tehnologic)

initial set (constr) priză / întărire inițială, contracție inițială, începutul tasării, tasare de început / inițială

initial speed / velocity (mec, mas) viteză inițială / de început / de pornire

initial stage stadiu inițial, etapă inițială, început (d. un proces etc.)

initial starting (mas) punere în funcțiune, pornire inițială

initial state (fiz) nivel de ieşire (la lasere), (mec, fiz, TH) condiție / stare inițială (a unui sistem, corp) 
initial stress (mec) efort, iniţial, tensiune / solicitare inițială (şi la îmbinări cu şuruburi cu prestrângere la asamblare etc.), solicitare inițială, tensiune de pretensionare (la rulmenți etc.)

initial substance (alim, ind chim) material de bază

initial temperature (termo, TH) temperatură de bază / de referință / iniţială (la începutul unui proces tehnologic la care se cere o anumită temperatură la început)

initial temperature of rolling (met, termo) temperatură la începutul laminării

initial thickness / width (TH) grosime / lăţime inițială (la laminare sau alt proces de prelucrare)

initial transconductance (electr, autom) pantă inițială

initial unbalance (mec) dezechilibru inițial

initial value valoare inițială, dată inițială (într-o problemă)

initial value problem (mat, fiz) problemă Cauchy; problemă cu condiții / valori inițiale (la limită)

initial velocity $(\mathrm{mec})$ viteză de început / de pornire / inițială

initiate inițiat, inaugurat; început; pornit; $(\mathrm{TH})$ a introduce, a declanşa, a iniția, a începe, a porni, a deschide (şi un studiu de cercetare, un proiect etc.); (autom, inf mas) a comanda; a declanşa; a avea / lua initiativa; a inaugura, a lansa; a introduce; a fi admis / iniţiat / introdus (într-o societate secretă); început, pornit; inaugurat; (jur) a intenta, a deschide, a introduce

initiate in admis în; inițiat în; pus la curent cu

initiate into a iniția în (într-o taină, problemă etc.); a primi (într-o societate secretă etc.)

initiate into a iniția (într-o problemă); (edu) a instrui (într-un domeniu)

initiation (inf) inițiere; începere, deschidere, inaugurare; introducere

initiation fee (amer) taxă de înscriere

initiation into inițiere, introducere (într-un domeniu)

initiator inițiator, promotor

initiatory introductiv, pregătitor, preliminar, de început; de / pentru inițiere

inject (into) $(\mathrm{TH}$, termo, plast) a injecta (în), a introduce prin injecție; (met) a sufla (în), a insufla; (med) a face o injecție; (amer) a intercala, a interpola

inject conduit (termo, met, plast, OM) conductă de injectare / de (in)suflare

injected (med) injectat, congestionat; (TH, plast) injectat, introdus prin injectie

injected gas $(\mathrm{TH}$, termo) gaz injectat / de injecție injecting nozzle (termo, $\mathrm{OM}$ ) injector

injection (constr) injectie (de beton etc.); (mat) aplicație injectivă; (hidr) injectare de apă sub presiune, injecție, pompare; (plast, TH, med) injectare; (fig) sugerare; (amer) observație / remarcă intercalată / forțată

injection cock $(\mathrm{OM}$, termo, hidr) injector, robinet / ajutaj de injectare

injection condenser (OM, termo, hidr) condensator prin injecție

injection conduit (alim, ind chim, plast) conductă de suflare / de injectare

injection engine (termo, auto) motor diesel / cu injector

injection mould (mas-un, plast) matriță de injecție / de injectare; formă de injecție / de injectare

injection moulded part (plast) piesă formată prin injecție

injection moulding (alim, plast) formare prin injecție / prin injectare; (met) turnare sub presiune

injection moulding machine (plast, mas-un) maşină de injectat / de injecție; presă de injecție

injection moulding nozzle (OM, mas-un, plast) duză de injecție

injection moulding with screw plasticising (alim, plast) formare prin injecție cu preplastifiere cu melc / cu şnec

injection oil engine (termo, auto) motor cu injecție / diesel

injection pump (auto, OM, termo, mas) pompăinjector; pompă de injecție

injection ram (OM, mas-un, plast) piston de injecție

injection seal (OM, plast) etanşare formată prin injectarea unui material

injection syringe (med) seringă

injection system (auto) sistem de injecție (la motoare diesel)

injection valve (OM, hidr, mas) supapă de injecție, injector

injector (OM, termo, hidr) injector, pompă de injectie

injudicious nesocotit, nechibzuit, nesăbuit, imprudent; lipsit de discernământ; neînțelept

injure a vătăma, a (se) răni; a lovi; a ofensa, a leza; a prejudicia; a păgubi; a dăuna; a strica; a înrăutăți; (TH) a avaria

injured rănit, vătămat; lovit; ofensat, lezat; prejudiciat, păgubit; avariat, stricat

injury (TH) avarie, pană, defect, defectare, deteriorare, stricăciune; (med) rană, rănire, leziune; ofensă, injurie, lezare; pagubă; nedreptate, prejudiciu

injustice nedreptate, inechitate, injustiție 
ink cerneală, tuş; $(\mathrm{TH})$ fluid de marcare (prin colorare în urma evaporării fluidului); tipar; a păta cu cerneală, a mânji

ink spot, ink stain pată de cerneală

ink-spot remover (chim) detergent / substanță pentru petele de cerneală

ink up a unge cu cerneală, a aplica cerneală

inlaid introdus; încrustat; inserat, intercalat; marchetat; furniruit, placat, parchetat; lucru în mozaic; (fig) bogat, înstărit

inlaid work marchetărie; mozaic de lemn; incrustație

inland interior, regiune / parte centrală (şi a unei tări); din / în interiorul tăriii; interior, intern; autohton, indigen; $(a d v)$ spre / în interiorul / centrul (țării)

inland coin $(\mathrm{ec})$ monedă națională

inland commodities (ec) produse indigene

inland duty (ec) vamă internă; taxă de consum, impozit pe circulația mărfurilor

inland mail (transp) poștă internă

inland navigation (nav) navigație fluvială / interioară

inland produce $(\mathrm{ec})$ produs $(\mathrm{e})$ indigen(e)

inland revenue (ec) impozite directe şi indirecte; fisc(alitate), venituri provenite din impozite

inland revenue stamp (ec) timbru fiscal

inland trade $(\mathrm{ec})$ comert interior

inland waters (geogr) ape interioare / continentale

inland water transport / transportation (nav, transp) transport fluvial, navigație fluvială

inland waterways (nav) căi navigabile fluviale, interne

inlay încrustare; marchetare, mozaicare; intercalare, inserare; încrustatie (în lemn); (plast) inserție; (el, c) mascare / mixaj electronic(ă) a(l) imaginilor; (med, TH) plombă (şi dentară); a încrusta, a acoperi cu încrustații; (constr) a marcheta, a parcheta, a pardosi (cu mozaic); a intercala, a introduce, a insera; a orna, a împodobi, a decora

inlaying (TH) incrustatie; marchetărie; (constr) pardosire în mozaic, parchetare; lambriu

inleakage air (met, termo) aer fals

inlet intrând; (el) racord, bornă de intrare; (geogr) braț de mare, golf mic; strâmtoare îngustă; (hidr) canal pentru priză de aer din lac sau din mare, spre uscat; (OM, hidr) orificiu / gură de admisie / de aspirație / de intrare / de scurgere, admisie, intrare, ştuț de intrare / de umplere; alimentare, dispozitiv de alimentare; de intrare, de admisie

inlet angle of impeller (el, termo) unghi de intrare al rotorului inlet blade / edge (OM, termo) muchie de admisie / de intrare

inlet cam $(\mathrm{OM}$, termo) camă a supapei de admisie inlet cubic feet per minute (metr) unitate pentru capacitatea / debitul volumic a(l) unui compressor, picior cubic (la admisie) pe minut: 1 inlet cubic foot $/$ minute $=0,000471947 \mathrm{~m}^{3} / \mathrm{s}$

inlet fitting (OM, hidr) racord de umplere

inlet flow (hidr) debit de intrare

inlet funnel (OM) pâlnie (de intrare)

inlet gate (met, plast) pâlnie / canal / gură de turnare

inlet governor (auto, termo, autom) distribuție a admisiei

inlet manifold $(\mathrm{OM})$ colector de admisie

inlet nozzle (OM, termo) ajutaj de admisie / de aducție

inlet of pass (met) partea de intrare în calibru

inlet opening (OM, hidr) orificiu de admisie / de intrare

inlet-pipe connection $(\mathrm{OM})$ ștut de intrare / de admisie

inlet port (hidr) orificiu de alimentare

inlet pressure (hidr, OM) presiunea statică echivalentă de intrare (a unei pompe), presiune la de intrare

inlet silencer (met) amortizor de zgură la admisie inlet sliding plug (OM, hidr) sertar de admisie

inlet stroke (termo) cursă de admisie

inlet table (met) transportor (cu role) de alimentare

inlet temperature $(\mathrm{TH}$, termo) temperatură initială / la intrare

inlet valve (OM, termo) supapă de admisie / de intrare / de aspiratie

inlet velocity head (hidr, termo) presiune dinamică, la intrare

in-line (autom, inf) fără întârziere; fără stocare / memorie; (el) pe un singur rând; unul după altul; succesiv, în linie; în rând; pe aceeași axă; aliniat; (mas-un) coaxial, paralel; (nav) în linie; în aliniament; (în text) liniar

in-line engine / motor (termo) motor cu cilindrii în linie

in-line piston pump (OM, hidr) pompă cu pistoane în linie

in-line processing (inf) prelucrare aleatorie / fără sortare prealabilă

in-line setting (autom, mas-un) căutare (automată) a poziției pieselor care urmează a fi decupate dintr-o bandă, astfel ca deșeurile să fie reduse la minim

inlying intern, (din) interior

inmiscible (fiz) nemiscibil, imiscibil (d. un lichid) 
inner interior; intern, dinăuntru, ascuns; slab, stins; înăbuşit

inner brake $(\mathrm{OM})$ frână interioară

inner circumference $(\mathrm{OM})$ perimetru interior, circumferință interioară / la interior

inner cone (termo) nucleu al flăcării, zonă primară a flăcării

inner dead centre (termo) punct mort interior / superior

inner diameter $(\mathrm{OM})$ diametru interior / al găurii / al alezajului

inner friction ( $T$, plast, hidr) frecare interioară / internă

inner heat (termo) căldură acumulată (în interior)

inner lining of a furnace (met) căptuşeală de uzură a cuptorului (care se înlocuiește periodic)

inner mixer (ind chim) malaxor capsulat

inner point punct interior

inner product (mat) produs scalar; produs interior; produs contractat a doi tensori

inner race $(\mathrm{OM})$ inel interior (la rulmenti)

inner side $(\mathrm{OM})$ interior, parte interioară

inner spring mattress (amer) somieră

inner-toothed crown wheel $(\mathrm{OM})$ coroană cu dantură interioară

inner tube (auto) cameră de aer; (OM) tub interior

inning (agr) asanare; (geogr) pământ aluvionar

innocuous inofensiv, nevătămător

innocuousness caracter inofensiv / nevătămător; lipsă de nocivitate

innovate in a aduce inovații în, a fi inovator; a înnoi

innovation inovație, invenție; înnoire, lucru inedit; inovativitate, spirit inovator

innovator inovator, inventator; reformator, înnoitor, adept al inovațiilor

innoxious inofensiv, nevătămător

innumerability caracter nenumărabil; imposibilitate de a fi numărat; multitudine

innumerable nenumărabil, fără număr

innutritious (alim) nehrănitor, netrutitiv, nesubstanțial

inobservable inobservabil, care nu poate fi observat

inobservance, inobservancy (jur) nerespectare, încălcare; neîndeplinire; lipsă de atenție, neatenție

inobservant of (jur) care nu respectă, care încalcă; neatent la, care nu observă

inoccupation lipsă de ocupație, şomaj

inoculant (met, plast) modificator

inoculate a inocula; (met) a modifica

inoculated cast iron (met) fontă modificată

inoculating agent (met, plast) (agent) modificator inoculating crystal (met) cristal de amorsare a cristalizării

inoculation inoculare; (met) modificare

inodorous lipsit de miros, inodor

inodorousness lipsă de miros, caracter inodor

inoffensive inofensiv, nevătămător; nesupărător

inoffensiveness caracter inofensiv / nevătămător

/ nesupărător

inofficial neoficial

in one part $(\mathrm{OM})$ nedemontabil, dintr-o singură bucată, monobloc

in one piece $(\mathrm{OM})$ monobloc; dintr-o bucată; cu o singură parte

inoperable inoperabil

inoperating contact (mas) contact de repaus

in operation (auto) în functiune, activ, activat

inoperative inoperant; nevalabil, ineficace, fără efect; inactiv, inert, neoperativ; (autom) insensibil; (mas-un) inactiv; (mec) stare de repaus

inoperative pass (in rolling) (met) calibru gol / orb de laminare

inopportune inoportun, neoportun; deplasat, prost plasat; nepotrivit, nelalocul lui; supărător, neplăcut, plicticos

inopportuneness, inopportunity inoportunitate, caracter inoportun / nepotrivit

in order to prevent (accidents etc.) pentru a evita (accidente etc.)

inordinate nemăsurat, exagerat; excesiv, exorbitant; necumpătat, nechibzuit, fără măsură; dezordonat, neregulat

inordinateness exagerare, caracter excesiv / exagerat; neregularitate, caracter neregulat / dezordonat

inorganic (chim) anorganic, neorganic; (mas, TH) neintegrat; străin; exterior

inorganic chemistry (chim) chimie anorganică

inorganic material (chim) material anorganic

inorganic salt (chim) sare anorganică

inorganizable (ec) dezorganizat, imposibil de organizat

inoxidability (chim, material) neoxidabilitate, inoxidabilitate

inoxidable, inoxidizable (chim, met, plast) inoxidabil, care nu oxidează

in phase (fiz, mec, el) sinfazic; în fază

in-phase opposition (fiz, mec, el) în opoziţie de fază / în antifază

in place (TH) pe loc; la locul de lucru; "in situ" (în locul în care s-a format / montat)

in-plant system (mas) sistem tip modul / într-o singură constructie (unitară)

inpour aflux, aluență, revărsare; potop, ploaie; a se revărsa, a curge (mult) 
inpouring (hidr) aflux, aluență, revărsare; care intră / vine / năvăleşte

in-process $(\mathrm{TH})$ aflat în pregătire / în prelucrare / pe linia de prelucrare

in-process material $(\mathrm{TH})$ produs intermediar in proportion to în raport cu; proporţional cu input ( $\mathrm{TH}$, ind) mărime de intrare, intrare, introducere; alimentare, furnizare, absorbție, admisie, alimentare, consum de putere, energie / putere consumata / necesară / furnizată / de alimentare (la intrare în sistemul tehnic); (el) putere absorbită; lampă de intrare; consum de putere; (mas) putere absolută, putere / energie absorbită de / la alimentare (electrică, mecanică); (inf) date de intrare; (mas) parametri de intrare; (autom) mărime de intrare; (autom, el) lampă de intrare

input-power (el, mec) energie / putere absorbită/ necesară (la intrare)

input - output $(\mathrm{TH})$ intrare - ieşire (referitor la putere, informatiii, parametri etc.)

input resistance (hidr, el) rezistenţă de intrare

input current (autom, el) curent / semnal de intrare

input flow (hidr) debit de intrare

input impedance (autom, el) impedanță de / la intrare

input port (hidr, OM) orificiu de intrare

input-power (mec, el) energie absorbită; putere necesară; putere la intrare

input pressure (hidr) presiune de intrare

input-quantity (autom, inf) mărime de intrare

input resistance (metr, el) rezistență de intrare

input shaft $(\mathrm{OM})$ arbore primar al cutiei de viteze, arbore de intrare

input signal (autom) semnal de intrare; (mas) mărime de reglaj / de reper

input store (inf) bloc de intrare

input terminal (autom, el) bornă de intrare

input value (mas, autom, inf) valoare a mărimii de intrare

input quadrature (mas, autom) în cvadratură, defazat cu 90 grade

inquest anchetă

inquire a întreba, a se interesa de, a se informa despre

inquire about a se interesa / întreba despre / de

inquire into a cerceta, a investiga, a examina; a lua informații despre; (jur) a ancheta, a face cercetări cu privire la

inquirer solicitator; persoană care întreabă / anchetează / studiază; anchetează

inquiring întrebător, iscoditor, care întreabă, curios; interesat inquiry anchetă; cercetare, investigare, investigație; întrebare, solitare de informații; (c, inf) tehnică de interogare a unui computer

inquiry for cerere de / pentru

inquiry office birou / ghişeu de informații

inradius (geom) rază a cercului înscris

in rapid traverse (mas-un) avans rapid, apropiere rapidă (spre piesa de prelucrat)

in-rolling box pass (met) calibru închis de laminor

in rotation consecutiv; unul după altul; prin rotatie

inrush năvală, aflux, potop; izbucnire, irupere, răbufnire; ruptură, rupere; năruire, prăbuşire; (TH, mas) impuls, putere de pornire, demaraj

insalubrious (med) insalubru, nesănătos; neigienic

insalubrity (mediu, med) caracter insalubru / nesănătos / neigienic, insalubritate

inscape chintesență, esență, caracteristică / calitate esențială

inscattering (fiz) împrăștiere către interior

inscribe (geogr) a înscrie în cerc; (ec) a înregistra / înscrie acționarii

inscribed stock (ec) acțiuni / efecte nominale înregistrate

insect (zool) insectă; (TH) mic defect (ascuns)

insecticide (ind chim, agr) insecticid

insect powder (ind chim, agr) insecticid

insecure nesigur, prea puțin sigur; şubred, instabil; primejdios, periculos; critic, supus pericolului

insecurity (condiții de) nesiguranță, caracter nesigur, situație nesigură / periculoasă; instabilitate

insensibility (to) lipsă de sensibilitate (față de), insensibilitate, indiferență (față de); (med) pierde a cunoştinței, leşin

insensible to / of insensibil fată de, indiferent la, nepăsător; apatic; fără cunoştință; imperceptibil, făcut pe nesimțite; neobservabil

insensitive to insensibil la, indiferent la

insensitiveness (autom, metr) lipsă de sensibilitate (si a unui aparat); insensibilitate

insensitive time (mas, mas-un, c) timp de inactivitate / mort

insensitivity (metr, autom) insensibilitate; $(\mathrm{TH}$, mas) inactivitate

inseparability caracter inseparabil, legătură indisolubilă; inseparabilitate

inseparable from inseparabil de, indisolubil legat de

insert (hidr) piesă de racord (la canalizare); (OM) inserție, bucşă, element de intercalație; adaos; completare (a textului iniţial); a introduce, a intercala; (constr) a înzidi, a încastra; 
(plast) a încorpora (şi adaosuri în compozite); a intercala; a introduce suplimente; (el) a introduce, a lega (în circuit); a insera (şi întrun text), a înscrie, a înregistra, a trece; inserție, intercalare, introducere

insert die (met, plast, OM, mas-un) matriță detaşabilă, pastilă detaşabilă (la o matriță)

inserted inclus, inserat

inserted blade (mas-un) cuțit demontabil; (alim, constr) lamă demontabilă / aplicată

inserted blade face milling-cutter (mas-un) freză frontală, cu dinți aplicați; freză cilindrofrontală cu dinți demontabili

inserted chaser die (mas-un) cap de filetat cu piepteni amovibili

inserted cover (OM) capac adâncit / îngropat / încorporat

inserted cutter tool (mas-un) portcuțit cu cuțit demontabil

inserted joint $(\mathrm{OM})$ îmbinare fără manşon

inserted key $(\mathrm{OM})$ pană îngropată

inserted nut $(\mathrm{OM})$ piuliță inserată / care blochează şurubul prin deformare plastică

inserted tooth (mas-un) dinte demontabil / aplicat, cuțit demontabil

inserted tooth milling cutter (mas-un) freză cu dinți demontabili, cap de frezat

inserted tooth shell hole boring cutter (masun) zencuitor / burghiu / lărgitor demontabil, cu dinți aplicați

inserted tooth tipped cutter (mas-un) freză cu dinți demontabili, cu tăişuri cu plăci din carburi metalice

inserted (valve) seat (OM, hidr) scaun de supapă inserat / aplicat

insertion, inserting (TH) inserție, garnitură; intercalare, element intercalat, căptușeală; incorporare (d. adaosuri în compozite); căptuşeală; garnitură; (constr) element de intercalare; (şi într-un text) inserție, înserare, introducere; adaos; intercalare; dantelă

insertion attenuation (mec) atenuare / amortizare de / prin inserție

insertion mark semn de inserție / introducere / intercalare

insertion process $(\mathrm{TH})$ regim tranzitoriu; (plast) proces de inserție (a materialelelor de adaos în compozite)

insertion point (c, inf) punct de inserare (a unui caracter)

insert of metal inserție metalică (şi d. compozite)

in service (mas) în functiune

in-service education (edu) continuarea studiilor în timpul producției; calificare la locul de muncă inset map cartuş (la o hartă)

inseverable inseparabil, indivizibil

inshore (nav) la țărm, aproape de tărm / mal, spre țărm / mal; (nav, geogr) costier, de coastă; care se apropie de țărm / mal

inshore navigation (nav) cabotaj, navigație costieră

inshore of foarte aproape de, în preajma

inside (situat în) interior, dinăuntru; partea interioară; dos (de haină); ( $a d v)$ înăuntru, în interior

inside boring tool (mas-un) cuțit de strunjit interior / de alezat

inside calliper(s) (metr, mas-un) compas / calibru de interior / pentru găuri / de adâncime

inside chaser / chasing tool (mas-un) pieptene de filetat interior

inside-corner tool (mas-un) cuțit încovoiat pentru strunjirea fundului unei cavități

inside corner weld (met, OM) sudare interioară de colt

inside diameter (metr, OM) calibru / diametru interior (al țevii)

inside die (mas-un, OM) matriță interioară (de extrudare)

inside gauge (metr, mas-un) calibru pentru măsurătoare de interior, calibru tampon, pasimetru

inside gearing $(\mathrm{OM})$ angrenare / dantură interioară

inside jaw chuck (mas-un) mandrină de prindere pe suprafața interioară a piesei

inside micrometer (metr) micrometru de interior

inside of în cadrul; în mai puțin de; (cel mult) până în

inside out pe dos, cu susul în jos

inside-out flow element (hidr) element filtrant, cu curgere centrifugă (spre exterior şi perpendicular pe axă)

inside rearview mirror (auto) oglindă retrovizoare interioară

inside track (cf) linie interioară

insight perspicacitate, intuiție; discernământ

insight into pătrundere; înțelegere; bună cunoaştere; privire

insigne, $p l$ insignia insignă

insignificance, insignificancy insignifianță, lipsă (totală) de însemnătate / importantă, caracter neimportant / neînsemnat; inconsistență, lipsă de conținut

insignificant neînsemnat, nesemnificativ, lipsit de semnificație, neimportant, minor, fără importanţă, insignifiant; neglijabil, infim

insipid insipid, fără gust, searbăd; (fig) nesărat, plat, banal, anost, plicticos; stupid, prostesc

insist a insista, a stărui, a fi insistent; a pretinde, a sustine (cu convingere) 
insistence upon, insistency upon insistență asupra, stăruință asupra, accent pus pe, accentuarea; stăruință asupra, perseverență asupra

insistent insistent, stăruitor; perseverent; imperios; puternic; de urgență, imediat; plicticos; evident; strident; violent

insist on / upon a insista asupra / să, a pune accent deosebit pe; a nu se lăsa de, a nu renunţa la, a persista în

insofar ( $a d v)$ (într-)atât

insofar as în măsura în care

insolation expunere la soare; (med) insolație

insolubility, insolubleness (chim, met) insolubilitate, caracter insolubil; (mat) caracter de nerezolvat, imposibilitate de rezolvare

insoluble (chim, met) insolubil, care nu se dizolvă; (mat) de nerezolvat, fără soluție / rezolvare, imposibil de rezolvat

insoluble phase (met) fază insolubilă (la aliaje)

insoluble wax molecules (chim) molecule insolubile de ceară

insolvency (ec, jur) insolvabilitate, faliment, bancrută

insolvent (ec, jur) insolvabil, falimentar, în stare de faliment

insolvent act / law (ec, jur) legea falimentului

insomuch as ... that $(a d v)$ într-atât(a) încât; aşa de mult / tare încât, aşa de / atât de... încât să

inspect a inspecta, a face o inspecție, a controla; a cerceta, a examina, a privi îndeaproape; (metr) a citi un contor; a verifica, a revizui, a face o revizie

inspecting (TH) (acțiunea / procesul de) inspectare, inspecție; care inspectează / controlează / verifică / cercetează, cercetător, de cercetare

inspection $(\mathrm{TH})$ inspectare, inspecție, examinare, cercetare, verificare, control, revizie, vizită; examen; (ec) luare de mostre / de probe; (auto) revizie

inspectional de inspectie / revizie

inspection board (ec, $\mathrm{TH})$ comisie de recepție

inspection box (OM) fereastră / ochi de control / de observare

inspection chamber (met, ind chim, constr) cămin de vizitare

inspection cover (OM, hidr) capac al orificiului de vizitare, chepeng de vizitare

inspection gauge (metr) calibru de control / de recepție

inspection hole (auto) orificiu de vizitare / de control / de observare; (OM, met) gaură de vizor, gură de control / de vizitare

inspection manhole (met) gură de acces / de vizitare pentru control (prin care poate trece un om) inspection of parts (TH) verificare / control al pieselor

inspection panel $(\mathrm{OM})$ orificiu de control, vizor inspection pit (met) canal de revizie / de vizitare / de întreținere

inspection plate $(\mathrm{OM})$ placă / capac demontabil( $\breve{a})$ de examinare si control

inspection record $(\mathrm{TH})$ proces verbal de verificare (a unei mașini)

inspection stamp (TH, mas) ştampilă de verificare / control / garanție

inspection tools (metr) instrumente de control / verificare

inspection window / porthole ( $\mathrm{cf}$ ) orificiu de control; (OM) gură de control, vizor; (met) gură pentru vizor

inspector recepționer, controlor (de calitate), inspector, diriginte de şantiere; (cf) supraveghetor

inspectorate inspectorat, corp de control

inspector of taxes (ec) inspector financiar

insphere (geom) sferă înscrisă

inspirable (mediu) respirabil, care poate fi inspirat / respirat

inspiration inspiraţie, inspirare; $(\mathrm{TH}$, termo) aspirare

inspirator $(\mathrm{TH})$ aspirator, injector; (med, $\mathrm{OM})$ (aparat) respirator

inspissate (fiz) a se condensa; a se îngroșa; a se concentra (d. o soluție)

instability instabilitate, labilitate, lipsă de echilibru; şubrezenie; lipsă de soliditate; inconstanță

instability of mix (ind chim, met) instabilitate a amestecului

instable (chim) instabil, nestabil; (mec) fără echilibru; inconstant, schimbător

install (TH) a monta, a asambla; a (se) instala, a amenaja; a (se) stabili; a se aşeza

installation ( $\mathrm{TH}$, mas) instalație, instalații, utilaj, aparatură (şi de instalare); montaj, montare, asamblare; echipament; instalare, stabilire, intrare, mutare (într-o casă, clădire etc.)

installation costs $(\mathrm{ec})$ investitiii capitale, costuri de instalare / de montaj

installation drawing(s) $(\mathrm{TH})$ desene de montaj

installation manual ( $\mathrm{TH}$, mas) manual de instalare

installation work (TH, mas) lucrări de montaj / asamblare

installed ( $\mathrm{TH}$, mas) construit, montat, instalat

installed capacity / power ( $\mathrm{TH}$, mas) putere instalată

installer reglor, montator

installing (ind) montaj, asamblare, instalare, care (se) instalează, care se montează / asamblează 
installment (ec) rată, vărsământ, plată în rate; fasciculă (de carte); pay on $\sim(\mathrm{ec})$ a da un acont, a plăti / vărsa o rată; by (ec) eşalonat, în rate; by easy $\sim(\mathrm{ec})$ eşalonat convenabil, în rate convenabile; annual $\sim(\mathrm{ec})$ anuitate, sumă fixă de bani cu dobândă plătibilă anual sau la intervale regulate de timp

installment credit $(\mathrm{ec})$ credit rambursabil în rate installment plan / system (ec) sistem de încasare, cu plata eşalonată / în rate

instance exemplu, exemplificare; dovadă, probă; cerere insistentă, insistență; a da exemplu, a cita ca exemplu, a exemplifica, a ilustra cu un exemplu / printr-un exemplu

instancy caracter insistent / stăruitor, insistență; urgență, caracter imperios; iminență, caracter iminent

instant clipă, moment; neîntârziat, imediat, urgent, grabnic, presant; insistent, stăruitor; (chim, alim) uşor solubil

instantaneity caracter instantaneu; simultaneitate, concomitență

instantaneous instantaneu, momentan; simultan, concomitent

instantaneous conditions (fiz) condiții instantanee / momentane

instantaneous energy (fiz) valoarea momentană a energiei

instantaneous fuel consumption (auto, termo, mas) consum instantaneu de carburant

instantaneously (adv) (în mod) instantaneu

instantaneously operating (mas) cu funcționare imediată

instantaneous output putere / productivitate instantanee

instantaneous shutter (hidr, OM) obturator instantaneu; (el) întrerupător rapid

instantaneous speed (mec) viteză instantanee

instantaneous strength $(\mathrm{mec})$ rezistență instantanee / la un moment dat

instantaneous value (TH) valoare reală / instantanee

instantaneous / flash vaporisation (fiz, termo) evaporare bruscă / instantanee / cu detentă; vaporizare prin laminare

instant coffee (alim) nescafé, ness

instant of failure (TH, mas) moment al avariei al defectului

instant-start circuit (el) circuit de pornire directă instate (jur) a pune, a repune; a conferi; $(\mathrm{TH}$, mas) a dota, a înzestra

instead $(a d v)$ în schimb, în loc; mai degrabă

instead of în loc de, în locul

in-steps $(\mathrm{TH})$ în trepte, treptat instil(l) (fig) a inculca, a infiltra, a insufla (cuiva), a întipări (în), a strecura

instil(l) (into) a picura, a turna cu picătura, a instila (în); a întipări (în)

institute institut (şi de învățământ superior), aşezământ, societate; instituție, asociație; (amer) (edu) curs scurt, serie de cursuri; ordine / normă stabilită, sistem; a institui, a instaura, a stabili; a întemeia, a fonda; (jur) a pune în posesie, a intenta, a deschide

institution instituție, aşezământ; (jur) doctrină, cutumă, norme, instituire, deschidere (a unei anchete, a unui proces), intentare, punere în posesie; creare, fondare, instaurare, întemeiere; investitură

institutional instituțional, instituit; referitor la instituție

in storage la depozitare, pe durata depozitării (d. produse, semifabricate etc.)

instruct in (edu) a instrui, a învăța, a iniţia (întrun domeniu); a da instrucțiuni / dispoziții / informații; a însărcina, a pune să facă ceva

instruction (c, inf) instrucțiune; (edu) învățătură, învățământ, instrucție; s $(p l)$ instrucțiuni, ordine, sfaturi, indicații; dispoziție

instructional (edu) de învătământ / instrucție, educativ; de aplicație (d. şcoală)

instruction book(let) ( $\mathrm{TH}$, mas) manual de instrucțiuni / de întreținere, carte tehnică, instrucțiuni de folosire (sub formă de carte, broşură)

instruction by remote control (autom, el) teletransmitere / transmitere la distanță de instrucțiuni / de ordine

instruction complement ( $\mathrm{TH}$, mas) listă de instructiuni

instruction cycle (c, inf) ciclu al instrucțiunii, succesiune de operatii în executarea unei instrucțiuni-maşină; timp necesar executării unei instrucțiuni-maşină

instruction for hardening process (met) instrucțiune / fişă tehnologică pentru (tratament de) călire

instruction format (c, inf) model / formă / dispunere a(l) unei instrucțiuni

instructions $(\mathrm{TH})$ instrucțiuni, dispoziții, directive, indicații, prescripții

instructions for operation and maintenance instrucțiuni de funcţionare şi mentenanță; carte tehnică (a unei maşini, a unui utilaj etc.)

instructions for use (mas, ind) instrucțiuni de exploatare / de utilizare

instructions to operator (mas) instrucțiuni de funcționare / pentru operator

instructive instructiv 
instruct of / that a înştiința, a informa, a enunța despre / că

instructor $(\mathrm{TH}, \mathrm{mil})$ instructor; (edu) institutor, preceptor, profesor; (amer) (univ) asistent universitar

instructress (edu) instructoare

instrument (metr) instrument (şi de măsură); aparat, dispozitiv, mecanism, unealtă, sculă; a traduce în viață, a înfăptui

instrument absolute (measurement) (metr) aparat de măsurat (etalonabil) / măsurare în unități absolute

instrumental instrumental

instrument board $(\mathrm{TH})$ pupitru de comandă

instrumental dial (metr, OM) cadran / disc cu scară gradat $(\breve{a}),(\mathrm{ac})$ indicator

instrumental error (metr) eroare de instrument / de aparat / a instrumentului de măsurat, orare tehnică, datorată aparatelor

instrumental in / to folositor la, util pentru, esential pentru, indispensabil pentru

instrumentally $(a d v)$ ca instrument, ca unealtă; ca intermediar, în calitate de reprezentant / intermediar

instrumental observation (metr, $\mathrm{TH}$ ) observare cu ajutorul aparatelor / aparatului

instrumentation (metr) aparate de măsură şi de control, aparataj; aparatură; instrumentație; dotare cu mijloace de măsurat, folosire a aparatelor / instrumentelor

instrument board / panel ( $\mathrm{TH}$, mas) tablou / panou cu aparate / de comandă; (auto) tablou de bord; (el) tablou de distribuție

instrument carrier plate / panel (autom, mas) tablou cu instrumente / cu aparate

instrument case trusă (pt. instrumente), ladă / cutie cu scule; (OM) cartercarcasă, casetă; osatură, schelet, montură

instrument cluster (auto) consolă indicatoare; panou de bord

instrument constant (metr) constantă a aparatului de măsurat

instrument headed screw $(\mathrm{OM})$ şurub cu cap semi-înecat

instrument layout (mas) montaj al aparaturii

instrument maker sculer

instrument man topometru, topograf

instrument oil ( $T$, ind chim) ulei pentru mecanică fină și aparate (rezistent la oxidare şi cu proprietăți stabile în timp)

instrument opening (OM, metr) orificiu de măsurat / pentru instrumente

instrument panel (auto) tablou de aparate / de bord, panou de bord; (autom, metr) tablou / pupitru de comandă; (mas-un) tablou de distribuție / cu aparataj şi instrumente de măsurat

instrument panel illumination (auto) sistemul de iluminare al panoului de instrumente / aparate

instrument panel vents (auto) ventilatoare / evacuări de aer din panoul de bord

instrument range (metr) domeniu / gamă / interval de măsurare

instrument reading (metr) indicație (la aparatul de măsură)

instrument specification(s) (metr) specificații (de proiectare, utilizare, reglare) a unui aparat

instrument table ( $\mathrm{TH}$, metr) masă / pupitru cu aparate pentru verificări

instrument with locking device (metr) aparat cu dispozitiv de blocare

insubmersible insubmersibil, care nu se poate scufunda

insubordinate nesupus; refractar; insubordonat

insubordination insubordonare, neascultare

insubstantial inconsistent, nesubstantial, neconsistent; imaterial, fără substanţă; neîntemeiat, nefondat, nejustificat; ideal

insufficiency insuficiență, caracter neîndestulător insufficient insuficient, neîndestulător, incomplet; nesatisfăcător, necorespunzător

insufficient-fed jet (hidr, termo) jet insuficient alimentat

insufficiently $(a d v)$ (în mod) insuficient, nu destul (de), nu îndeajuns de

insuflate a (in)sufla

insuflation insuflare

insufletor (OM, mas) pulverizator, aparat pentru insuflații

insulance (el, termo) izolanță, rezistență la izolatie

insulant (el, termo) (material) izolant

insulate a izola, a separa; a transforma într-o insulă; (el) a izola

insulated izolat; izolant; etans

insulated clip (el, OM) clemă cu ureche izolată

insulated conduct (el, hidr) tub izolat

insulated runner mould (mas-un) matriță cu canalul de injectare izolat

insulated suspending tie-bar (OM, mec, constr) tirant / dispozitiv de legătură, izolant; bară de suspensie izolantă

insulated train (cf, termo) tren frigorific

insulated wire (el) cablu izolat

insulating (el, termo) izolare; izolant, izolator, care izolează, de izolare

insulating base (el) placă / talpă izolantă; (mas) suport / soclu izolant

insulating fibre board (el, termo) placă de fibră, izolatoare 
insulating brick (ind chim, met) cărămidă izolatoare

insulating compound (el) masă izolantă; (plast) amestec izolant

insulating concrete (constr, termo) beton izolant insulating course (el, termo) strat izolator insulating fire brick (constr, termo) cărămidă refractară izolatoare

insulating glass (el, termo) sticlă izolantă insulating gloves (el) mănuşi izolante de cauciuc insulating lacquer (ind chim, el) lac izolant insulating layer (constr) strat izolator; (el) strat izolant

insulating material (materiale, el, termo) material izolant; masă izolantă, izolator

insulating oil (el) ulei izolant, ulei de transformator

insulating refractories (constr, termo, met) refractare termoizolatoare

insulating strength (el) rigiditate dielectrică / a izolației

insulating strip / tape (el) bandă izolantă / izolatoare, izolirband

insulating varnish (auto, ind chim) vopsea izolantă; (el, ind chim) lac izolant

insulation (fiz) izolație, izolare (şi fonică); desprindere, separare; (el) izolație, izolare; insonorizare

insulation crimp (OM, el) izolator care prin strângere / presare este modelat / deformat

insulation failure (el, chim, plast) defect de izolație; îmbătrânire a izolație

insulation fault (el, met, termo) defect de izolație insulation resistance (el, termo) izolanță, rezistentă de izolatie

insulation rubber (plast, el) cauciuc pentru izolație

insulation / insulating tester / testing set (metr, el) aparat pentru măsurarea rezistenței izolației, megohmetru, megger

insulation voltage (el, metr) tensiune de încercare a izolatiei

insulator (fiz) izolant (termic, fonic, electric); (el) izolator (dispozitiv sau material), dielectric; (termo) materie calorifugă

insulativity (el) rezistență specifică de izolare insulator (termo sau el) izolator, izolant; (el) dielectric

insulator arc-over (el) străpungere a unui izolator insulator bolt (el) şurub izolant

insulator bracket / pin / spindle (el, OM) portizolator, consolă / suport de izolator

insulator chain / string (el) lanț de izolatoare

insulator clip (OM, el) clemă / agrafã de izolare insulin (med, chim) insulină

insupportable insuportabil, de neîndurat / suportat; intolerabil; inacceptabil

insurance (ec) asigurare (la contracte); social (adm, pol) asigurări sociale; life- asigurare de viață; fire- asigurare împotriva incendiilor; hospitalization $\sim$ (amer) asigurare pentru caz de boala (inclusiv spitalizare); officer (adm) funcționar la asigurări sociale / la o societate de asigurări; social $\sim($ pol, adm) prevederi sociale; effect / buy / make an $\sim$ a face o asigurare; transport $\sim$ asigurare (contra riscurilor) de transport; on hull / equipment (auto, mas) asigurare casco

insurance agent / broker (ec) agent de asigurare insurance carrier $(\mathrm{ec})$ asigurat

insurance company (ec) societate de asigurare

insurance money $(\mathrm{ec})$ primă de asigurare insurance note $(\mathrm{ec})$ talon de asigurare

insurance officer (ec) funcționar la o societate de asigurare / la asigurări sociale

insurance policy (ec) poliță de asigurare insurance premium $(\mathrm{ec})$ primă de asigurare insurant (ec) asigurat

insure a (se) asigura, a încheia o asigurare, a garanta

insured party asigurat, persoană asigurată

insurer (ec) agent de asigurare

insurmontable insurmontabil, de netrecut

intake (TH, OM) (dispozitiv de) admisie / aspirație, intrare, introducere, acces; aspirație, aspirare, captare alimentare, culee; ştrangulare; (hidr) gură / orificiu de admisie; priză (de apă); captare; (met) pâlnie de încărcare / de şarjare; (el) sub tencuială, putere consumată / cheltuită, consum; (alim) rație alimentară; (agr) lot cultivat între mlaştini

intangible intangibil, care nu poate fi atins; (fig) imperceptibil, insesizabil

intangible assets $(\mathrm{ec})$ valori / bunuri materiale

intake (for steam, water) intrare, priză (de abur, apă)

intake line (termo, hidr, OM) conductă de recepție; țeavă de aspirație; niplu de refugiu

intake manifold (auto) colector / țeavă / conductă de admisie; (hidr, OM) țeavă de distribuție; colector de aspirație / de admisie

intake muffler / silencer (OM, termo) amortizor de zgomot la admisie

intake port $(\mathrm{OM}$, hidr, termo) orificiu de admisie / de aspirație; gură de intrare

intake pressure (termo, plast) presiune de injecție / de admisie

intake sluice (OM, hidr, termo) vană de admisie 
intake stroke (auto, termo) cursă de admisie / de aspirație (a pistonului)

intake valve (OM, hidr) supapă de aspirație / de admisie, robinet / ventil de admisie

in tandem consecutiv, succesiv; în cascadă, în serie (şi d. rulmenți montați unul după altul, pe acelaşi reazem / lagăr)

integer (mat) (număr) întreg, întreg (tip de variabilă); întreg, tot (unitar), unitate; factor of (mat) divizor al unui număr întreg; complex (mat) număr gaussian, număr întreg complex; negative $\sim$ (mat) număr întreg negativ

integrability (mat) integrabilitate; sumabilitate

integrable differential equation (mat) ecuație cu diferențială totală exactă

integral (mat) integrală; întreg; integral, complet, total; integrant, indispensabil, esenţial; întreg, tot, totalitate

integral absolute error (metr) eroare totală absolută (a unui aparat)

integral bearing $(\mathrm{OM}, \mathrm{T})$ lagăr turnat în bloc cu corpul piesei

integral-blower burner (termo, OM) arzător cu ventilator / suflantă încorporat(ă)

integral body and frame construction, integral chassis and body construction (auto) construcție integrată de ramă şi caroserie

integral calculus (mat) calcul integral

integral cast iron flange (OM) flanşă din fontă turnată

integral correction factor (mat) factor de corecție prin / la integrare

integral counterweights $(\mathrm{OM})$ contragreutăți dintr-o bucată cu arborele cotit

integral error method (metr) metoda abaterilor de reglare (pt. determinarea calității re-glării)

integral exhaust manifold (OM, hidr, termo) colector de evacuare, turnat odată cu cilindrul

integral fin (OM) nervură / aripioară forjată / laminată

integral flange (OM) flanşă turnată / formată odată cu corpul tevii / recipientului, flanșă integrată

integral instalation (mas) instalare completă / integrală

integrality întregime, totalitate; plenitudine, caracter plenar / integral; deplin

integral key $(\mathrm{OM})$ pană şi arbore dintr-o bucată (rar)

integrally $(a d v)$ integral, total, în întregime integral multiple (mat) multiplu întreg integral part $(\mathrm{OM})$ parte integrantă, componentă integer programming (inf) programare în numere întregi

integral ring (mat) domeniu de integrare integral tank (constr, hidr) rezervor structural / ai cărui pereți fac parte din structura construcției

integral tooth milling cutter (mas-un) freză dintr-o bucată / integrală

integral transmission $(\mathrm{OM}, \mathrm{mec})$ variator (şi hidraulic), convertizor de moment

integrant component, constitutiv; indispensabil, esențial, integrant; parte integrantă; (OM) element component / constitutiv

integrant / integrating factor factor integrant; (metr) multiplicator

integrate (with / to) (mat) a integra; a rezolva o ecuație diferențială; a integra (în); a reuni, a strânge laolaltă; a alcătui, a constitui; a îngloba, a cuprinde; a totaliza, a însuma; a sintetiza; a prelucra în mod creator; integral, complet, total, întreg; compus, alcătuit din mai multe părți; component, constitutiv

integrated integrat

integrated circuit (electr) circuit integrat

integrated data processing (inf) prelucrare integrată / coordonată a datelor

integrated iron and steel work (met) combinat metalurgic

integrated management planning and control technique (IMPACT) (ec) tehnică de planificare şi control pentru management integrată integrate drive (auto) tractiune integrală integrating (mat) integrant; care (se) integrează

integrating action (TH) acțiune integrală / de integrare

integrating constant (mat, autom) constantă de integrare

integrating flowmeter (hir, metr) debitmetru / contor totalizator

integrator (autom, electr) integrator, dispozitiv / schemă / circuit de integrare

integrity integritate; (inf) date nealterate / nemodificate; întregime, deplinătate, onestitate

integument coajă, scoarță

intellect intelect, inteligență, minte, rațiune

intellection activitate intelectuală / mentală; gândire, rațiune; cunoaştere; idee, gând, noțiune

intellective mintal, intelectual, rațional; cognitiv, de cunoaştere; abstract

intellectual intelectual; mintal

intellectuallity intelectualitate; intelect, minte, capacitate intelectuală; caracter intelectual

intelligence informație, ştire, veste, lămurire; inteligență, rațiune, înțelegere

intelligent inteligent, deștept, ager la minte

intelligent of conştient de, cunoscător în, priceput la

intelligibility caracter inteligibil, inteligibilitate 
intelligible inteligibil, care poate fi înțeles; desluşit intend a intenționa, a plănui, a avea de gând, a avea intenția; a avea drept scop, a avea în vedere, a urmări; a face în mod voit / intenționat; a vrea să spună, a înțelege

intendance, intendancy (pol, ec) administrație, administrare, gospodărire; control

intended (for) destinat (pentru / la / să); intenționat, deliberat, făcut intenționat (ca să); plănuit, proiectat (să)

intended size $(\mathrm{OM})$ dimensiune nominală

intendent (ec) administrator; controlor; inspector

intending presupus, prezumtiv

intense puternic, tare, viguros; intens; extrem

intenseness intensitate; putere, forță, tărie, vigoare; agerime; concentrare intensă, atenție încordată; susceptibilitate

intensification intensificare, întărire; sporire, creștere; încordare, concentrare

intensified pressure (hidr) presiune amplificată (şi produsă la limitarea debitului de ieşire)

intensifier (el, metr, autom) multiplicator, intensificator, amplificator, întăritor

intensify a (se) intensifica, a mări, a crește, a spori, a (se) întări, a deveni mai intens

intensity intensitate, putere, vigoare; (el) intensitate (a curentului, a câmpului); (el, fiz) densitate, tărie / intensitate (a radiației); (fig) concentrare, atentie

intensity of bending stress $(\mathrm{mec})$ mărime a tensiunii de încovoiere

intensity of compressive stress (mec) tensiune la flambaj

intensity of current (el) intensitate a curentului electric

intensity of draught (met, termo) intensitate a tirajului

intensive intens, puternic, viguros, tare; concentrat, atent; intensiv

intensive heating (termo) încălzire rapidă / intensivă

intensively ( $a d v)$ (în mod) intensiv

intensiveness intensitate

intensive shearing action (mec) acțiune intensă de forfecare

intent atent, concentrat, absorbit; hotărât; avid (de), dornic (de); înflăcărat (de), pasionat (de); intenție; plan; scop; gând

intent on / upon îndreptat spre / asupra, atent la intention intenție; plan, scop, țel; proiect; (med) cicatrizare

interact a interacționa, a fi interdependent, a fi în interacțiune, a acționa unul asupra altuia, a se influența / condiționa reciproc interacting interdependent, în interacțiune, acționând combinat / conjugat / unul asupra altuia, care interacționează, care sunt interdependenți

interaction interacțiune, acțiune mutuală, influență / acțiune / condiționare reciprocă, interdependență

interaction range rază / domeniu / interval de interacțiune

interaction region / zone ( $\mathrm{TH}$, met, ind chim) regiune / zonă de interacțiune

interactive interactiv; intercalat; interdependent, condiționat reciproc

interactive drawing (c, TH) trasare interactivă, reprezentare grafică a rezultatelor prelucrării

interactive graphics $(c, T H)$ grafică interactivă, utilizare în timp real a unui sistem grafic

interannealed wire (met) sârmă supusă unei recoaceri intermediare

interannealing (met) recoacere intermediară

interatomic (fiz) interatomic

interbedded interstratificat; intercalat (la compozite, între straturi etc.)

interbedding interstratificație, interstratificare, intercalare

interblend a (se) amesteca, a mixa; a (se) combina, a (se) îmbina

intercalar, intercalary intercalat; inserat

intercalate a intercala; a interpola; a insera; a introduce în (program etc.)

intercalation intercalație; interpolare; inserare; intercalație

intercede (with) a interveni la, a face o intervenție (la / pe lângă)

intercede with / between a (inter)media, a mijloci, a se interpune între

intercept (mat) segment (al unei dreapte între axele de coordonate), intersecție a dreptei cu una din axe; (nav) interceptare; diferență de înălțimi; a intercepta; a capta, a prinde; a surprinde; a asculta; a controla; a spiona; a tăia (şi comunicații); a mărgini; a delimita; a împiedica; a opri, a stăvili

intercepted water (hidr, mediu) apă colectată

intercept form of the equation of a straight line (mat) ecuația dreptei prin tăieturi / prin coordonatele punctele de intersecție cu axele de coordonate

interception interceptare, intercepție; captare; capturare; împiedicare, oprire, stăvilire; tăiere, întrerupere, barare (a legăturilor etc.)

interception range (fiz, autom) plajă / interval de sincronizare / de antrenare

interceptor (hidr) separator, obturator hidraulic, sifon de scurgere; care face o interceptare 
intercession $(\mathrm{TH})$ intervenție; mijlocire, intermediu; demers, mediere

interchange comutare, schimb, schimburi reciproce; succesiune, alternanță; transbordare; (constr) bretea (şi de drum), comutare, intersecție amenajată, (şosea de) racord; a înlocui; a interschimba; a permuta; a schimba; a alterna; a face sa se succeadă; a încurca (cu); a schimba (cu)

interchange with a (inter)schimba $\mathrm{cu}$, a face schimb (reciporc) (mărfuri etc.), a înlocui; a alterna; (mat) a permuta; a alterna cu, a face să se succeadă

interchangeability $(\mathrm{TH})$ interschimbabilitate, caracter interschimbabil, posibilitate de înlocuire reciprocă; (mat, fiz, $\mathrm{TH}$ ) comutativitate

interchangeable interschimbabil, care se pot schimba / substitui între ei; alternativ, în alternanță / succesiune

interchangeable (item / piece /element) $(\mathrm{OM})$ articol / piesă / organ de maşină interschimbabil( $\breve{a})$

interchangeable gears / wheels $(\mathrm{OM})$ roți dințate amovibile

interchanger (termo) schimbător de căldură interchapter capitol intercalat / intermediar intercollegiate (edu) între colegi; (univ) interuniversitar; comun mai multor colegii / universități intercommune a avea relatii reciproce intercommune with a intra în relații cu intercommunicable (inter)comunicabil, comunicat, care se pretează la intercomunicație

intercommunicate a fi în (inter)comunicație / legătură, a avea relații reciproce

intercommunication intercomunicație, intercomunicare, relații / legături reciproce, schimburi reciproce; (TH, fiz) interfon, aparat de comunicație la mică distanță, transmisiuni

intercondenser (termo) condensator intermediar interconnect a conecta, a lega; a pune în legătură interconnecting piece $(\mathrm{OM}$, el) piesă de legătură / de racordare

interconnection, interconnexion interconexiune, conectare, legare, punere în legătură, legătură reciprocă; comunicație

interconnection pattern schemă de conexiuni

intercontinental intercontinental

intercoolant; intercooler (termo) refrigerent / răcitor intermediar, schimbător de căldură pe traseul fluidului

intercornversion transformare din unul în altul intercostal plate / stringer (nav) tablă intercostală, stingher intercostal

intercourse raporturi, relații, legături, relație, legătură; limbaj comun, mesaj intercrescence (materiale) concreştere, întrepătrundere (a grăunților cristalini etc.)

intercross a (se) încrucişa; a (se) întretăia, a (se) intersecta; hibrid, corcitură, produs al unei încrucišări

intercrystalline brittleness / friability (met) fragilitate intercristalină

intercrystalline corrosion (met) coroziune intercristalină

intercrystalline crack / fracture (met) fisură intercristalină

intercrystalline embrittlement (met) fragilitate intercristalină

intercrystalline segregation (met) segregație intercristalină

intercurrence caracter intermediar (al unui eveniment, proces) (med) suprapunere, supraadăugare (a unei boli), recurență

intercurrent din intervalul respectiv; intervenit pe parcurs (d. un eveniment, proces etc.); (med) supraadăugat / intervenit în cursul unei boli, recurent

intercut (mat, geom) a întretăia, a intersecta

interdendritic (met) interdendritic

interdendritic graphite (met) grafit interdendritic

interdendritic segregation (met) segregație interdendritică

interdepend a fi interdependent, a depinde unul de altul, a se condiţiona / influența (reciproc)

interdependence, interdependency interdependență, caracter interdependent, dependență / influență reciprocă

interdict a interzice, a prohibi, a nu permite, a nu îngădui; a opri; a împiedica; (jur) a pune sub interdictie, interdictie, interzicere

interdiction interzicere, interdicție, prohibiție; neîngăduire

interdictive prohibitiv, de interdicție, de interzicere

interdimers (plast) copolimeri

interdisciplinary (edu, univ) interdisciplinar

interest interes, avantaj, profit, folos; importanță, valoare; punct de atracție; aspect interesant; lucru care stârnește interesul; (ec) dobândă, acționari, cotă (din), cotă-parte (din), investiții, participare (la), procente, proprietari, finanțatori, sumă investită (în); camătă; a fi interesat, a prezenta interes / importanță; (jur) interese materiale (în), drept (asupra); punct de atractie; pasiune; lucru care stârneşte interesul / pasiunea cuiva; (ec) oameni legați prin aceleași interese materiale; rate of $\sim(\mathrm{ec})$ cuantumul dobânzii, dobândă, procent(e); loan (ec) dobânda creditului; simple $\sim(\mathrm{ec})$ dobândă simplă; 
security $\sim$ (ec) drept de proprietate al unui creditor, garanție pentru o datorie reprezentata de o proprietate; life $\sim$ (ec, jur) renta viagera, uzufruct; principal and $\sim(\mathrm{ec})$ capital şi dobândă; self- egoism, propriul interes

interest account $(\mathrm{ec})$ calculul dobânzilor, cont de dobânzi

interested in / by interesat de / în, plin de curiozitate pentru

interestedly $(a d v)$ (în mod) interesat, din interes, cu interes

interested parties (ec, jur) părți interesate / în cauză, cei interesați

interest in interes / curiozitate pentru, atenție pentru / la; (ec) investiții în, sumă investită în; a interesa în, a atrage în / la

interesting interesant, care interesează; important, însemnat; decisiv, hotărâtor

interestingly $(a d v)$ (într-un mod) interesant

interest rate $(\mathrm{ec})$ rată a dobânzii

interest warrant (ec) cupon de dobânzi

interest with / at influență / putere / control asupra

interface (fiz) suprafață de separație / de secționare / de rupere / limită; (inf) dispozitiv de interfață; (T) interfață (a contactului), suprafață / zonă de frecare; suprafață de contact; graniță, frontieră (ca suprafatăă); caracter interdisciplinar, interdisciplinaritate, corelație (strânsă), legătură reciprocă, (inter)conexiune

interface device (autom, el, hidr) component / dispozitiv de legătură (şi pentru trasformarea unui semnal)

interface fit $(\mathrm{OM})$ ajustaj cu strângere

interface layer (electr) strat intermediar (la semiconductoare)

interface position (met, T) curbă a conturului de contact

interface with a fi interdependent / în interdependență / în strânsă legătură cu; a fi indisolubil legat de; a integra, a lega strâns de interfacial interfacial; (geom) (d. unghi) diedru interfacial angle (geom) (unghi) diedru interfacing conex, înrudit, apropiat

interfere (in) a interveni (în), a mijloci, a face pe mijlocitorul (în); a interacționa (cu), a interfera (cu), a face interferență (cu)

interfere in / with a se amesteca în, a se băga în, a interveni în; a interfera cu

interference (fiz) interferență, paraziți, bruiaj; (el) bruiaj; perturbare de la alt post; (TH) influență perturbatoare, amestec (nejustificat), deranjament, intervenție, imixtiune, ingerință; obstacol, piedică interference effect acțiune de interferență / interferențială, efect al interferenței

interference fit / tight (OM) ajustaj cu strângere / cu presare

interference point (mec, el) nod de vibrații, punct de interferență; punct nodal

interference-proof (mas) imun la perturbații / la paraziți

interference seal $(\mathrm{OM})$ etanşare de completare a unui gol / între două piese care au, inițial, joc

interferential interferent, de interferență,

interferer (persoană) care se amestecă / intervine, inoportun; intrus; mijlocitor

interfere a impiedica, a influența, a interfera

interfere with a împiedica, a stânjeni, a deranja, a pune bețe în roate; a se opune; a contraveni la, a veni în conflict cu; a se bate cap în cap cu; a dăuna, a vătăma; a inoportuna, a plictisi

interfering care intervine / se amestecă; (fiz) interferent, de interferență, care interferează; amestec (nejustificat), interventie

interfering field (el, autom) câmp perturbator interferometer (metr) interferometru

interferometry (metr) interferometrie

interferometry of length (metr, fiz) măsurare interferometrică a lungimii (de undă)

interfingering întrepătrundere; (fiz) formarea franjelor de interferentă

interflow scurgere; confluență; a (se) scurge între, a (se) vărsa unul în altul, a se amesteca

interfuse a (se) amesteca, a intercala; a (se) îmbina, a fuziona

interfusion (fiz, TH) amestecare, amestec, îmbinare; fuzionare, fuziune, topire, sudare

intergradation (mat) metodă bazată pe aproximație succesivă / treptată

intergrade schimbare treptată a formei, transformare treptată / pas cu pas / gradată, a se transforma / schimba treptat / gradat / încet

intergrain intergranulare

intergranular (met) intergranular, intercristalin intergranular beta (met) fază beta, intergranulară intergranular corrosion (met) coroziune intergranulară / intercristalină

intergranular fracture (met) fisură intergranulară intergrown crescut laolaltă, concrescut, intercrescut (d. grăunţi cristalini, cristale etc.)

intergrowth concreştere; (chim) concreştere (la cristale); (met) creştere (a grauntelor), întrepătrundere prin creştere (a grăunților)

interior interior, dinăuntru, situat în interior, intern; parte interioară; (mat) intern

interior angle (geom) unghi interior; (mec, OM) colt interior 
interior decoration (constr) decorațiuni interioare, decorație interioară

interior decorator (arhitect) decorator de interioare

interior features (auto) caracteristici ale interiorului

interior light housing notches (auto) locaşurile pentru carcasa luminilor de interior

interior lights (auto) lumini interioare

interiorly $(a d v)$ înăuntru, în interior

interior overview (auto) privire din interior

interior screw $(\mathrm{OM})$ piuliță, piesă cu filet interior

interior strutting and bracing $(\mathrm{OM})$ rigidizare interioară şi prindere / asamblare

interjacent aşezat la mijloc / între mai multe obiecte; intermediar

interknit, a (se) împleti (laolaltă, cu mai multe fire etc.), a (se) îmbina

interknitted împletit (din fire etc.)

interlaboratory standard (metr) etalon de transfer / de comparatie

interlace întrețesere, încrucişare, împletire, amestecare (d. compozite, țesături etc.); (TH) a amesteca, a (se) împleti, a (se) întrețese, a încrucişa; a intercala; (plast) a (se) reticula; a intercala; v. interlard; a (se) întrețese; a amesteca; a îmbina

interlaced understructure ramă de zăbrele (la autovehicule)

interlacery (textile, compozite) împletitură, urzeală

interlace sequence (autom, inf, telecomunicații) secvență intercalată

interlacing întrețesut, împletit, care se împletește / întretese; întretesere, împletire; împletitură; (fig) amestec, îmbinare; (TH) încălecare, suprapunere, intercalare, distribuție intercalată

interlaid intercalat

interlard a împăna

interlard (with) (fig) a împăna (cu), a împestrița (cu), a presăra (cu)

interlattice plane distance (fiz) distanță între planurile unei rețele; (materiale) distanță între straturi succesive (la materiale sandwich, compozite stratificate etc.)

interlineation intercalare, înserare printre rânduri

interliner (plast) foaie de acoperire / intermediară, interlinie în materiale stratificate)

interlayer strat intermediar în materiale stratificate

interleaf friction $(\mathrm{OM}, \mathrm{T})$ fricțiune / frecare între foi de arc / între straturi

interleave (inf) distributie intercalată; a intercala interliner (plast) interlinie, foaie de acoperire interlink (with) a lega de a (se) lega unul de altul; a pune în legătură, a conecta, a stabili / face o legătură (cu); (TH) a cupla, a înlănțui

interlinkage, interlink (mec, el) cuplaj, interconectare, legătură (şi reciprocă)

interlinked (el) interconectat; (mas-un) cuplat (prin articulație), conjugat

interlinking (mas, TH) legătură (între sisteme), interconectare

interlining spațiere între rânduri de text, între straturile materialelor tip sandwich

interlock (inf) interblocare; (mas-un) dispozitiv de blocare / de sincronizare; (TH) a înclesta, a îmbuca; a prinde, a conecta, a (se) lega, a (se) îmbuca, a se împleti, a se încrucișa; (el, c) a sincroniza; a se amesteca, a se uni; (auto, OM) a (se) cupla, a (se) angrena, a ambreia, a sincroniza; a încleşta; a uni prin strângere sau articulație

interlock circuit (el, autom) circuit de protectie / de blocare

interlocking $(\mathrm{TH})$ blocare, concreştere (a grăunților cristalini, a cristalelor etc.); (auto) zăvorâre; (hidr, constr) prindere / solidarizare reciprocă (a elementelor de construcție); (inf) sincronizat, integrat

interlocking current curent de anclanşare / de cuplare

interlocking device (OM, mas-un) dispozitiv de blocare, dispozitiv contracuplare concomitentă a mișcărilor incompatibile

interlocking levers (mas-un) pârghii / manete cu blocare reciprocă

interlocking mill (mas-un) freză-disc reglabilă pentru canelat

interlocking side milling cutter (mas-un) freză disc combinată; ansamblu de freze disc

interlock time timp de zăvorâre / de blocare

interlocutor interlocutor, partener de conversație

interlope a se amesteca (şi în sens nedorit); a face contrabandă / trafic

interloper intrus, nechemat; clandestin; traficant; (nav) vas care face contrabandă

intermediary intermediar, mijlocitor; care mijloceşte / (inter)mediază

intermediate (în stadiu) intermediar; indirect, mijlocit, făcut prin intermediar; mediat; semiavansat; auxiliar, ajutător; mediu; (edu) (in stadiul) intermediar, mediu, semiavansat; a intermedia între, a face pe intermediarul / mijlocitorul; mijlocitor, (in stadiul) intermediar; (jur) in perioada dintre / între 
intermediate aggregate (constr) pietriş concasat; piatră spartă

intermediate annealing (met) recoacere intermediară

intermediate compound compus intermediar intermediate / interstage cooler (alim, termo) recipient de răcire / răcitor intermediar

intermediate course (edu) curs intermediar / semiavansat / mediu / pentru elevi semiavansați, curs semiavansat

intermediate draft (met, plast) laminare intermediară

intermediate examination (edu, univ) examen intermediar / parțial

intermediate gear $(\mathrm{OM})$ roată dinţată intermediară, angrenaj intermediar

intermediate grades $(p l)$ (amer) (edu) clasele 4 ...6 ale unei scoli elementare

intermediate frame (nav) coastă intermediară / suplimentară; (el) repartitor intermediar

intermediate frequency (IF, i.f.) (fiz) frecvență intermediară / medie

intermediate frequency furnace (met) cuptor cu inducție de frecvență mijlocie / medie

intermediate gear plate / quadrant $(\mathrm{OM})$ liră, inversor al sensului de rotație

intermediate grinding (alim, chim) măcinare / sfărâmare intermediară; (mas-un) rectificare intermediară

intermediate level maintenance (level 2 maintennace) (met, TH, mas) mentenanță de nivel mediu (calibrare, reparare, înlocuire de piese de schimb, asistență tehnică)

intermediate materials produse intermediare

intermediate member (of series) element medial / de mijloc (al unei serii)

intermediate metal (met) metal / aliaj intermediar

intermediate mill (met) laminor pentru profiluri mijlocii

intermediate motion (mec, OM) mişcare impusă de un mecanism intermediar

intermediate oxide (chim) oxid amfoter

intermediate pass (met) pas / calibru / trecere intermediar(ă) (la laminare)

intermediate phase (met) fază intermediară

intermediate piston (OM, hidr) piston al cilindrului de presiune medie

intermediate position $(\mathrm{OM}$, hidr, metr) poziție intermediară

intermediate-pressure turbine (termo) turbină de presiune medie

intermediate product (met, alim, ind chim) produs intermediar intermediate resistance (alim, hidr) rezistenţă de trecere

intermediate rolling mill / train (met) laminor degrosisor / pentru profiluri mijlocii

intermediate roll(ing) stand (met) cajă intermediară (de laminor)

intermediates produse intermediare, (produse) semifabricate

intermediate shaft (auto, OM) ax / arbore intermediar (la cutia de viteze, transmisii etc.)

intermediate space (mat) spațiu intermediar; (TH) dimensiune interioară

intermediate stress $(\mathrm{mec})$ tensiune intermediară intermediation (ec) (inter)mediere, mijlocire intermediator (ec) mijlocitor, (inter)mediator intermedium, $(p l)$ intermedia intermediu, mijlocire; intermediar, mijlocitor; mijloc de comunicație; spațiu intermediar; perioadă intermediară

intermesh (OM) a se angrena; a se îmbuca, a se întrepătrunde (la rețele de fibre, fibre şi compozite)

intermetallic compound (met) compus / combinație intermetalic(ă), fază

interminate nelimitat, nemărginit, fără limite / granițe

intermingle among a strecura prin, a introduce prin, a amesteca printre

intermingle (with) (materiale) a (se) amesteca (cu), a (se) îmbina (cu), a se confunda cu

intermission pauză; întrerupere

intermit $(\mathrm{TH})$ a face / se repeta periodic / cu intermitență; a (se) întrerupe, a (se) opri (şi temporar), a suspenda (producerea etc.), a fi intermitent (d.un proces)

intermittence (TH) intermitentăa caracter intermitent; întrerupere, pauză

intermittency effect $(\mathrm{TH})$ efect de intermitentă intermittent intermitent; (mat, inf) recurent; întrerupt, periodic, cu întreruperi / pauze; discontinuu; instabil

intermittent blow-down (met, termo. hidr, mediu) insuflare / evacuare intermitentă (de gaze, apă etc.)

intermittent ceramics kiln (termo, ind chim) cuptor pentru ceramice intermitent / periodic

intermittent conditions $(\mathrm{TH}$, mas) conditii intermitente (de funcționare)

intermittent control (autom, mas) reglare discontinuă

intermittent duty ( $\mathrm{TH}$, mas) funcționare intermitentă, operație discontinuă; regim intermitent; destinat pentru funcționare discontinuă

intermittent-duty rating ( $\mathrm{TH}$, mas) randament în regim intermitent 
intermittent firing (termo) aprindere / ardere intermitentă / în ciclu

intermittent grinding (alim, constr, ind chim) măcinare discontinuă

intermittent integration (mat) integrare pe intervale

intermittent kiln (alim, ind chim, met, termo) cuptor cu funcționare periodică / intermitentă / discontinuă

intermittent line (TH, ind) linie discontinuă (de producție etc.)

intermittent lubrication $(\mathrm{T})$ ungere periodică / intermitentă / discontinuă (din proiectare)

intermittently ( $a d v)$ (în mod) intermitent, discontinuu

intermittent operation / running ( $\mathrm{TH}$, mas-un) operaţie discontinuă, funcționare periodică

intermittent shock load (mec) încărcare cu întreruperi, sarcină cu şocuri

intermittent sprocket $(\mathrm{OM})$ roată stelată pentru acționare intermitentă

intermittent-type grinder (ind chim, textile, mas-un) defibrator cu acțiune periodică

intermittent weld (met, OM) cusătură discontinuă / întreruptă (la sudare) (din proiectare)

intermix a (se) amesteca (d. materiale)

intermixture amestec, mixtură

intermodal transport (transp) transport combinat (cu diverse mijloace succesive: camion, cale ferată, şlepuri, nave, avion etc.)

intermolecular (chim, plast) intermolecular

intermolecular swelling (plast) umflare intermoleculară

internal (din) interior; dinăuntru; intern; intrinsec; implicit

internal aerial (radio, TV, fiz) antenă de cameră

internal (block) brake (OM) frână cu saboți interiori, frână de expansiune

internal calliper(s) (metr) calibru pentru găuri / de interior

internal cast (met, plast) mulaj intern

internal chamfering tool (mas-un) cuțit pentru teşirea marginilor interioare (la prelucrarea pieselor la strung automat)

internal chill (met) răcitor interior (la forme)

internal circular planing (mas-un) rabotarea suprafețelor cilindrice concave / interioare

internal(-) combustion engine (auto, termo) motor cu ardere internă, motor cu benzină

internal compensation (mec, el, autom) compensare internă

internal condensation (met, termo, chim) cementare, carburare internă

internal crack (met) fisură interioară / internă internal cylindrical gauge (mas-un, metr) calibru tampon, calibru cilindric interior

internal defect (met) defect interior / intern

internal diameter (constr) lumină; (mat, OM) diametru interior

internal dovetail $(\mathrm{OM})$ piesă dintr-o îmbinare "în coadă de rândunică"

internal energy (fiz, chim) energie interioară / internă

internal fissure (materiale) fisură interioară

internal-flue boiler (termo) cazan ignitubular

internal-flush (tool) joint (OM) îmbinare cu mufă din corp, racord special cu gaură largă

internal force (fiz, chim, hidr, plast) forță interioară / internă

internal friction ( $\mathrm{T}$, hidr, plast) vâscozitate; frecare internă

internal friction angle ( $T$, materiale, hidr) unghi al frecării interne

internal furnace boiler (tremo) cazan cu focar interior

internal gas counter (metr, ind chim, met) contor de gaz în conductă

internal gauge (metr) calibru de interior; calibru tampon

internal gear $(\mathrm{OM})$ roată dințată cu dantură interioară, angrenaj cu roată dințată la interior, transmisie (dințată) cu angrenare interioară

internal gearing $(\mathrm{OM})$ angrenare / dantură interioară

internal gear motor $(\mathrm{OM}, \mathrm{el})$ motor(reductor) cu transmisie cu angrenare interioară

internal grinding (mas-un) rectificare interioară

internal grinding machine (mas-un) maşină de rectificat interior

internal hardening stress (met, mec) tensiuni interne la călire / cauzate de călire / de durificare

internal heating (fiz, termo) încălzire internă; (termo, met) focar interior

internal latent heat (fiz, termo) căldură latentă de vaporizare

internal leakage (hidr) scurgeri în interiorul unui dispozitiv / sistem hidraulic (defectare)

internal leakage flow (hidr) debit intern / de curgeri interiorul unui sistem hidraulic

internally fired gas heated soldering iron (met, termo) ciocan de lipit, combinat cu arzător / bec de gaze

internal gear $(\mathrm{OM})$ roată cu dantură interioară

internal gear pair (OM) angrenaj interior

internal helical gear $(\mathrm{OM})$ angrenaj cu angrenare interioară, cu dinți înclinați

internal member $(\mathrm{OM})$ piesă interioară / cuprinsă 
internal member coupling dimension $(\mathrm{OM}) \mathrm{di}$ mensiune a piesei cuprinse

internal milling cutter (mas-un) freză pentru prelucrat suprafețe interioare

internal mixer (alim, ind chim) malaxor / amestecător închis / capsulat / intern

internal oxidation (chim, met) oxidare intramoleculară (şi prin difuzia oxigenului în interior)

internal plasticiser (plast, chim) flexibilizant, plastifiant intern

internal pressure (hidr, mec) presiune interioară / internă

internal resistance (hidr) rezistență internă

internal revenue (pol, adm, ec) venit național, venitul statului

internal shrinkage (met, plast) retasură / contracție interioară

internal spur gear $(\mathrm{OM})$ roată dințată cilindrică, cu dinți drepți, cu dantură interioară

internal stress (mec, $\mathrm{TH})$ tensiune / efort remanent(ă) (si după tratament termic etc.)

internal student (univ) student căminist internal surface area aria suprafeței interioare internal thread $(\mathrm{OM})$ filet interior (tip piuliță)

internal-thread-measuring instrument (metr, $\mathrm{OM}$ ) aparat de măsurat găuri, micrometru de găuri, verificator pentru alezaje

internal trade $(\mathrm{ec})$ comert interior

internal treatment (hidr, termo, chim) tratarea apei sau a altui fluid de lucru chiar în instalația / sistemul în care lucrează

internal triggering (autom, el, mec) autodeclanşare

internal voltage (el) tensiune electromotoare

internal water (geol) apă de adâncime

internal welding (met) sudare (la partea) interioară

internal width $(\mathrm{OM})$ deschidere interioară

internal wiring (el) instalație electrică interioară $/$ de interior

internal work (mas-un) prelucrarea suprafețelor interioare

international internațional

International Annealed Copper Standard (metr) o măsură a conductivității folosită să compare conductorii electrici cu un conductor standard de cupru: $100 \%$ IACS reprezintă conductivitate de 58 megasiemens pe metro (MS/m), echivalentă cu rezistivitatea de $1 / 58$ ohmi pe metro pentru un concductor cu sectiunea de $1 \mathrm{~mm}^{2}$

international bitterness / bittering unit (agr, alim, metr) unitate în industria berii: 1 IBU este egală cu 1 ppm de izohumulen, un acid derivat din hamei international wine bottle (alim, metr) sticlă internațională de vin: 1 international wine bottle $=750 \mathrm{ml}$

International Bitterness Units scale (metr) scala / scara unităților internaționale pentru bere

international foot (metr) unitate de măsură pentru lungime, picior, în țările de limbă engleză: 1 foot $=0,3048 \mathrm{~m}$

international nautical mile (metr, nav) unitate de măsură pentru lungime, milă marină internatională: 1 international nautical mile $=1852 \mathrm{~m}$

International Organization for Standardization, ISO (metr) Organizația Internațională pentru Standardizare

international rubber hardness degree (IRHD) (metr, materiale) unitate de măsură a durității cauciucului sau elastomerilor; rezultatele sunt similare dar nu identice cu cele obținute cu durometru Shore A

international steam table calorie (metr) unitate de măsură pentru energie: $1 \mathrm{IT}=4,1868 \mathrm{~J}$

International System of Units (metr) Sistemul Internațional de Unități (de măsură)

international unit (IU) (metr, med, chim) unitate pentru măsurarea activitătii (efectului) medicamentelor şi vitaminelor, pe baza unui acord internațional; exemple: 1 IU reprezintă $45,5 \mu \mathrm{g}$ de insulină standard sau $0,6 \mu \mathrm{g}$ de penicilină standard

Internet time (metr) un sistem global pentru timp propus de Swatch Corporation

internuclear (fiz, chim) internuclear, dintre / între nuclee

interpass annealing (met) recoacere intermediară, între două treceri / trageri

interpass temperature (met) temperatura minimă atinsă de metalul depus / de semifabricat între două treceri / depuneri succesive

interpenetrate a pătrunde în / prin / printre, a cuprinde, a se răspândi în / prin; a se întrepătrunde, a se interpenetra, a pătrunde unul în altul

interpenetration (materiale, compozite) întrepătrundere; pătrundere, penetrație

interphone interfon

interplait a (se) împleti, a (se) îmbina

interplay interacțiune, influență reciprocă; interdependență; efect combinat / de ansamblu

interpolate (mat) a interpola, a face o interpolare; (el) a conecta, a anclanşa; a intercala, a insera, a introduce (d. materiale, inclusiv în compozite)

interpolated (mat) interpolat

interpolating polynomial (mat) polinom de interpolare

interpolation (mat) interpolare; intercalare, introducere, inserare (d. materiale, compozite) 
interpose a intercala; a insera; a aşeza (între), a (se) interpune, a (se) băga la mijloc; a media,a juca rol de intermediar; a opune, a ridica; a interveni cu, a face uz de, a recurge la

interposition interpunere, intercalare, aşezare la mijloc; introducere; inserare; intervenție; mediație, mijlocire

interpolymerisation (chim) copolimerizare

interpret a interpreta (şi rezultate), a traduce; a explica, a desluşi, a înțelege; a considera, a lua; a traduce (oral), a fi traducător

interpretable interpretabil

interpretation interpretare, lămurire, explicare; acceptare; traducere, interpretare (a unui text); descifrare, desluşire

interpreter interpret, traducător; comentator interpretship calitate / muncă de interpret / traducător / translator

interrelate a pune în legătură, a fi legat / în legătură, a se lega unul de altul, a interrelaționa

interrelationship relatie; legătură

interrogate a interoga, a chestiona, a întreba

interrogation interogare, chestionare, întrebare, interogație, (jur) interogatoriu

interrogative interogativ, întrebător; întrebare, interogație

interrogator (persoană) care interoghează, examinator; anchetator

interrupt întrerupere; a (se) întrerupe (şi silit); a deranja

interrupted intermitent, întrerupt

interrupted duty ( $\mathrm{TH}$, mas) regim permanent, în care se succed diferite operații sau întreruperi tehnologic necesare

interrupted hardening (met) călire / durificare întreruptă

interrupted pour / cast(ing) (met) turnare intermitentă / discontinuă / întreruptă

interrupted quenching (met) călire întreruptă

interrupted screw (OM) şurub cu filet discontinuu / cu tijă cu caneluri longitudinale

interrupter (el) întrerupător, manetă de întrerupere, ruptor

interrupter blade $(\mathrm{OM}$, el) lamelă / contact lamelar de întrerupător

interrupter shaft (auto) arbore secundar din cutia de viteze; (mas-un, OM) arbore de comandă / cu came

interrupt handling $(\mathrm{TH})$ funcționare / manipulare cu întreruperi

interrupting rating (capacity) (el) capacitate de întrerupere, putere de rupere (a unui întrerupător)

interruption $(\mathrm{TH})$ întrerupere, oprire, pauză; separare; deranjare, împiedicare interruption arc (el) arc de separare / de întrerupere interruption cable (el) cablu de rezervă

interruption key $(\mathrm{TH}, \mathrm{c})$ tastă / cheie de întrerupere / de separare

interruption voltage (el) tensiune de stingere (a unei descărcări)

interrupt key (inf, c) cheie de întrerupere / de separare, caracter care anunță terminarea introducerii datelor curente

interruptor, interrupter (el) întrerupător, comutator; (persoană etc.) care întrerupe

intersect a (se) intersecta; a se încrucişa, a se întretăia (d. linii, cabluri electrice, conducte etc.)

intersecting care se intretaie / se intersectează / se încrucişează

intersection (mat, inf) (functia) intersectie, punct de intersecție; (TH) intersectare la rețele de cabluri / conducte; (constr) încrucişare de drumuri, intersecție, răscruce

interspace interval, interstițiu, spațiu liber / intermediar; interval / perioadă de timp; a spația, a distanța, a rări

intersperse (with) (alim, constr, TH) a presăra, a umple, a împestrița (cu), a stropi, a umezi, a umidifica, a răspândi, a amesteca (între, printre) interspersion (alim, constr, ind chim, fiz) presărare, răspândire; amestecare, împletire, îmbinare

interstage (autom) între două etaje; între două stări / etape

interstage / intermediate cooler (alim, termo, ind chim) recipient de răcire intermediară, răcitor intermediar

interstage / intermediate pickling (met) decapare intermediară

interstand (met) cajă intermediară (la laminare) interstice (OM, el) interstițiu, interval îngust

interstitial interstițial

interstitial solid solution (met) soluție solidă interstițială / de pătrundere

interstitial water (fiz) apă interstițială / în pori

interstratification interstratificare (d. compozite), situare între straturi; împănare; (mat) interpolare

interstratified (with) intercalat (cu) (d. straturi cu caracteristici diferite), interstratificat; împănat (cu)

intertangle (el, materiale, textile) a încurca, a încâlci

interterminal capacitance (el) capacitate între borne

intertexture întrețesere, împletire; (textile) țesătură, urzeală

intertripping (el, autom) declanşare interdependentă 
intertwine a (se) împleti, a se răsuci, a se întrețese (d. fire, cabluri, lanțuri moleculare, fibre etc.), v. intertwist

intertwining ( $\mathrm{d}$. fire, cabluri, lanțuri moleculare, fibre etc.) care se împleteşte / încolăceşte; împletire, împletitură

intertwist a (se) împleti, a (se) răsuci

intertwisted conductors / fibers (el) conductori răsuciți între ei; fibre răsucite între ele (la compozite)

interurban interurban; suburbii, suburban; (transp, cf, auto) mijloc de transport pentru suburbii

interval (TH) interval, pauză, întrerupere; distanță; segment; (fiz, mat) interval; (mas) repaus de funcționare; (el, autom) interval de impulsuri, decalaj; (edu) recreație; (teatru) antract, pauză; at regular $\sim \mathbf{s}$ la intervale regulate; at $\sim$ s din când în când, ici şi colo

interval counter (metr) contor cu sursă internă, pentru intervale (şi de timp)

interval of retardation (fiz, chim, $\mathrm{TH}$ ) interval de întârziere

interval rule (fiz, metr) regula intervalelor (în spectroscopie)

interval timer, intervalometer (autom) întrerupător de interval de timp; cronometru de interval / de pauză / a cărui conectare poate fi programată în timp; (inf) contor de intervale, ceas de timp real

intervalve coupling (hidr) dispozitiv de cuplare a tuburilor; (el, autom) circuit de cuplare între etaje (şi nedorit)

intervene (in) a interveni, a surveni, a se întâmpla între timp, a se amesteca (în)

intervener (persoană) care intervine

intervening care survine / intervine / s-a întâmplat între timp

intervention $(\mathrm{TH})$ intervenție; (pol, ec) amestec

interview întrevedere, întâlnire; convorbire, interviu; a intervieva, a lua un interviu; a avea o întrevedere

interviewee (d. fire, cabluri, lanțuri moleculare, fibre etc.)interviewer reporter / persoană care ia un interviu

intervine (auto, $\mathrm{TH}$ ) a interveni

interweave (chim, el) a (se) întrețese, a (se) împleti (d. cabluri, fire, fibre în compozite etc.); (OM) a (se) îmbina, a (se) lega strâns unul de altul

interwind (el, OM) a (se) răsuci laolaltă, a (se) împleti (d. fire, cabluri etc.)

interworking interacțiune, conlucrare

interzonal interzonal

in that prin aceea / faptul că, întrucât, pentru că in the event în cazul în care

in-the-loop (element) (autom) (element) component al unei bucle / sistem de control, fără de care funcționarea / controlul este între$\operatorname{rupt}(\breve{a})$

in three parts $(\mathrm{OM})$ triplu, din trei părți

intimate contact (mec, OM) contact bun / perfect / intim

intimate mixing (mec, alim, constr, ind chim) amestecare foarte bună

intimate mixture (mec, alim, constr, ind chim) amestec intim

into în; spre, înspre; (mat) cu

intolerable intolerabil; inadmisibil; nepermis

intorelably $(a d v)$ (în mod) intolerabil, inadmisibil

intolerance (towards) intoleranţă la, lipsă de toleranță față de

intracrystalline / intragranular fracture (met, materiale) fisură intracristalină / intragranulară

intractability caracter refractar / dificil / intratabil; caracter ireductibil, lipsă de maleabilitate / docilitate; (mat) dificultate de rezolvare, insolubilitate; (agr) neputință de a fi cultivat; (med) caracter incurabil

intractable refractar, dificil, intratabil; neascultător, lipsit de docilitate / maleabilitate; de nerezolvat, insolubil; (agr) necultivabil; greu de lucrat / tratat (d. un material)

intramolecular (fiz, chim) intramolecular

intramolecular chain (chim, plast) lanț / catenă intramolecular( $\breve{a})$

intramolecular change (chim, plast) transformare intramoleculară

intramolecular rearrangement (chim, plast) transpoziție intramoleculară, rearanjare a moleculei

intranational național, intern

intransferable intransferabil, netransferabil

intransigency intransigență, refuzul oricărui compromis

intransigent intransigent, care refuză compromisul intransitive intranzitiv; (mat) netranzitiv

intransmissible netransmisibil

intransparency lipsă de transparență, netransparenţă

intrant novice, nou venit; membru nou / de curând primit

intraplant în interiorul unei întreprinderi, de uz intern

intraplant transportation (transp) transport / manipulare intern(ă) / în interiorul unei întreprinderi

intrasystem în interiorul unui sistem

intreprid îndrăzneț, întreprinzător 
intricacy complexitate, complicație, caracter complex / complicat

intricate complicat (şi d. forma unui element de maşină), complex; încâlcit, încurcat; a complica

intricately $(a d v)$ (în mod) complicat / complex / încâlcit

intricate casting (met, plast, $\mathrm{OM}$ ) piesă turnată, cu configurație complicată

intricate cored casting (met) turnare în miezuri fasonate

intricate mixture (alim, ind chim) amestec complet

intricate shape die (met, plast, OM) matriță compusă / pentru formă complicată

intrinsic(al) intrinsec, în sine, propriu; interior, intern; natural

intrisic basicity (chim) bazicitate internă

intrinsic derivative (mat) derivată absolută

intrinsic permeability (el) susceptibilitate electrică / magnetică

intrinsic pressure (mec, hidr) presiune interioară / internă

intrinsic viscosity (hidr) vâscozitate intrinsecă

introduce (into) $(\mathrm{TH})$ a introduce, a băga, a vârî (în); (mat) a înlocui; (inf) a introduce (o valoare); a stabili, a înființa, a iniția

introduce into / before a aduce în discuție, a prezenta înaintea / în fața

introduce to a (se) prezenta, a (se) recomanda, a face cunoştință cu

introducer inovator; inițiator; prezentator

introducing box / socked (electr, telecomunicații) manşon / bucşă de intrare

introduction (into) introducere (în); prefață, introducere, cuvânt înainte la; aducere la / în; iniţiere, lansare

introduction to introducere, inițiere în; prezentare, recomandare

introductive, introductory introductiv, preliminar intromission $(\mathrm{TH}, \mathrm{ec})$ admisie, intrare, pătrundere; (jur) imixtiune, ingerință, intervenție

intrude a veni nepoftit / nechemat, a fi un intrus; a deranja

intrude into a băga forțat / cu de-a sila în

intrude on / upon a impune, a-şi impune prezența; a deranja, a stingheri, a stânjeni

intruder intrus, nepoftit, nedorit; impostor

intrusion intruziune

intrusion into amestec în, ingerință în, intervenție asupra / în

intrusion on / upon intrare / venire nedorită în / la, deranj(are), stingherire

intrusion of water (hidr, chim, TH) intruziune / pătrundere a apei intrusive $(\mathrm{TH}) \mathrm{cu}$ caracter de intruziune; care vine nedorit; supărător, care deranjează

intuition intuiție, intuire

intuitional intuitiv

inturned întors / răsucit (spre) înăuntru

inundate (hidr) a inunda, a revărsa

inundation (hidr) inundare, inundație

inundator (hidr, OM) inundator, dozator de apă

inure to a (se) deprinde, a (se) obişnui, a învăța, a face să se deprindă cu

inurement to deprindere a, obişnunță cu, obişnuință cu / să

inuring deprindere, obişnuire, obişnuinţă; (jur) punere / intrare în vigoare

in use $(\mathrm{TH})$ în exploatare, în funcționare

invade a invada, a năvăli; a copleși

invading care invadează / cuprinde (nedorit)

invading fluid ( $\mathrm{TH}$, hidr) fluid de injectie

invalid (med) bolnav cronic, infirm, invalid, inapt, incapabil de muncă; a reduce la invaliditate, a face să rămână infirm, a face inapt pentru muncă; (jur) nul (şi neavenit), lipsit de valabilitate; fără valoare / efect

invalidate a invalida; (TH) a casa; a infirma; a anula; (jur) a declara nul (şi neavenit) / fără valoare / valabilitate; a dezminț

invalidation invalidare; anulare; ( $\mathrm{TH}$, mas) casare; infirmare, dezmințire

invalid chair (med, OM) scaun cu rotile / pentru invalid

invalid diet / food (alim, med) regim dietetic, alimentatie pentru bolnavi

invalidity (TH, metr) nevalidare, lipsă de valabilitate; nulitate, caracter inoperant; (med) invaliditate, infirmitate, incapacitate de muncă, sănătate precară

invaluable neprețiit, inestimabil, incalculabil

invaluably $(a d v)$ nemăsurat / extrem de

invar (met) invar, aliaj $\mathrm{Fe}+\sim 36 \% \mathrm{Ni}$

invariability (mat) invariabilitate, caracter invariabil / neschimbător; continuitate; constantă, durabilitate, permanență

invariable invariabil, neschimbat, neschimbător; constant, permanent; continuu

invariably $(a d v)$ (în mod) invariabil, fără nici o schimbare; mereu, neîncetat, într-una; fără nicio exceptie

invariance (mat) invarianță

invariant (mat) invariant

invar steel (met) oțel invar

inval strut piston (termo, OM) piston (cu manta) cu fâşie de / plecat cu invar

invasion (mil) invazie, incursiune; (geogr) viitură; (fig) deranj(are); (jur) încălcare, violare 
invent a inventa; a imagina, a născoci; a descoperi

invention invenție; descoperire; inventare

inventive inventiv, ingenios

inventiveness inventivitate, ingeniozitate, spirit inventiv

inventor inventator; descoperitor, autor al unei invenții

inventorize $(\mathrm{TH}, \mathrm{ec})$ a inventaria, a face inventarul

inventory inventar; a inventaria, a face inventarul

inventory book $(\mathrm{ec})$ registru de inventar

inventress inventatoare, descoperitoare

inverse invers; contrar; reciproc; opus; inversare, element invers

inverse chill (met) călire inversă a fontei (albire) inverse cosecant (mat) (funcția) arccosecantă (x)

inverse cosine (mat) (funcția) arccosinus (x)

inverse cotagent (mat) (funcția) arccotangentă (x)

inversly $(a d v)$ (în mod) invers

inverse value valoare reciprocă / inversă

inverse feedback (mec, autom) contrareacție, reacție inversă

inverse function (mat) funcție / transformare inversă / reciprocă

inverse logarithm (mat) antilogaritm, inversul unui logaritm

inverse mapping (mat) funcție inversă

inverse proportion / ratio (mat) proporție inversă

inverse response (metr, autom) răspuns inversat (parametrul de intrare are o anumită variație / direcţie, cel de ieşire este inversat)

inverse secant (mat) (funcția) arcsecantă (x)

inverse segregation (met) segregare inversă

inverse sine (mat) (functia) arcsinus ( $\mathrm{x}$ )

inverse tangent (mat) (funcția) arctangentă (x)

inverse time-limit release (autom) declanșator cu temporizare dependentă

inversion (inf, electr, c) transformare inversă; inversare, răsturnare; invertire, schimbare, inversiune; (chim) invertire

inversion of sugar (alim) inversiune a zahărului inversion point (mat) punct de inversiune / de întoarcere / inflexiune (a unei curbe)

invert a inversa, a răsturna; (chim) a inverti; (mat) a schimba ordinea; a interveni

invert a motion (mec) a modifica sensul de mişcare

invertase (chim) invertază

inverted $(\mathrm{TH}, \mathrm{fiz}, \mathrm{mec})$ răsturnat, invers, inversat inverted commas ghilimele

inverted engine (termo, OM) motor inversat / cu chiulasa în jos

inverted image (c) imagine răsturnată inverted position (mas, mas-un) poziție inversată / basculată

inverted / invert sugar (alim) zahăr invertit

inverted taper spigot (OM) fus în formă de con invers

inverted tooth rocker joint chain $(\mathrm{OM})$ lanț Morse; lanț cu articulații de rulare / de rostogolire

inverted-type carburettor (termo) carburator cu flux de aer inversat

inverted valve (OM, hidr) supapă cu ciupercă inversată / în jos, clapetă inversă

inverted $\mathbf{V}$ form slide (OM, mas-un, metr) ghidaje prismatice / în V răsturnat

inverted $\mathbf{V}$ guide (OM, mas-un, metr) prismă de ghidare în $\mathrm{V}$ răsturnat / triunghiulară

inverted welding (met) sudare peste cap / pe plafon

inverter (el, electr) invertor; ondulator; (inf) circuit de negație / NU; inversor, schimbător de semn

invertible inversabil, reversibil

invertible matrix (mat) matrice inversabilă

invert sugar (chim) combinaţie de dextroză şi levuloză

invest (in / with) (ec) a investi (în), a face investiții (în), a plasa, a băga (bani etc.), a imputernici să, a atribui; a acorda, a conferi; a numi

investigate a investiga, a cerceta, a face investigații / cercetări / un studiu; (jur) a ancheta; (cu caracter) de anchetă / cercetare

investigation (TH) investigație, anchetă, studiu, cercetare, investigare

investigation / investigating committee $(\mathrm{TH})$ comisie de investigație / de anchetă

investigator cercetător; anchetator

investiture investitură, instalare; (jur) punere în posesie

investment (ec) investiție de capital, plasament, plasare, titluri la purtător

investment bank (ec) bancă de investiții

investment charge (ec) costuri / cheltuieli de investiție

investment casting (met) turnare în modele fuzibile (şi din mercur)

investment moulding (met) formare cu modele fuzibile

investment pattern (met) model fuzibil

investment stock (ec) valori clasate

investor (ec) investitor

inveterate adânc înrădăcinat, învechit, vechi, cronic; tradițional; inveterat; vicios; încăpățănat

invigilate a sta de pază; a fi supraveghetor 
invigilation pază; supraveghere invigilator paznic, supraveghetor inviolability inviolabilitate, caracter inviolabil inviolable inviolabil, intangibil inviscid fluid (fiz) fluid ideal / fără frecare invisibility (fiz, chim) invizibilitate, caracter invizibil

invisible invizibil, nevăzut; imperceptibil, insesizabil

invisible / intangible assets (ec) valori intangibile / imateriale (brevete, mărci de fabrică, licente, drepturi de autor, clientelă)

invisible heat (fiz, termo) radiaţii infraroşii

invisibly $(a d v)$ (în mod) invizibil, nevăzut, imperceptibil, insesizabil

invisible spectrum (fiz) domeniu invizibil al spectrului

invitation invitație; invitare; solicitare, apel

invite a invita; a solicita, a ruga; a interveni la; a provoca; a atrage după sine; a face o invitație

invitee invitat, oaspete

invoice (cf) foaie de expediție; listă de mărfuri; (ec) factură; a factura, a trece în factură

invoice book (ec) facturier

invoicing (ec) facturare

involuntarily $(a d v)$ (în mod) involuntar, neintenționat, fără să vrea

involuntariness caracter involuntar / neintentionat

involuntary involuntar, neintenţionat, fără voie / intenție

involute (geom) desfăşurătoare, evolventă, evolventic

involute gear $(\mathrm{OM})$ roată dințată cu dinți / cu profil în evolventă

involute gear cutter (mas-un) freză-modul (pt. roată dințată cu dinți cu profil în evolventă)

involute spline(s) (OM, T) limită de uzură (admisibilă / care nu afectează funcționarea) pentru grosimea dintelui

involute-tooth gear / system (OM) dantură în evolventă

involution (bot, zool) involutie; degenerescentăa stagnare, nedezvoltare; înfăşurare; încâlceală; încurcătură; complicație

involutory involutiv, de evoluție

involve a antrena, a conține; a include a implica; a atrage; a cuprinde; a produce; $\mathrm{TH}$ ) a încolăci, a încâlci, a încurca, a complica, a înveli; (mat) a ridica la putere; a atrage după sine; a cere; a complica; a comporta; (med) a implica, a interesa; a necesita

involve in a amesteca în; a antrena în, a băga în; a implica în; a încurca în; a înfăşura în; a îngloba în; a înveli în; a vârî în involved implicat, amestecat; încurcat; închis, necomunicativ

involvement implicare, amestec(are); încurcătură, încâlceală, amestecătură; (ec) complicații financiare, înglodare în datorii; (med, mediu) contaminare, atingere

invulnerability invulnerabilitate, caracter invulnerabil

invulnerable invulnerabil

inwall (constr) perete interior; (met) zidărie de căptuşire, perete interior (la cuptor)

inwall batter of stack (of blast furnace) (met) pântece (de furnal)

in want of repair (mas) care necesită reparații

inward intern, interior; îndreptat spre interior; familiar

inward cargo (ec) mărfuri de import

inward directed force (mec) forță centripetă

inward opening $(\mathrm{OM})$ orificiu spre interior

inwards $(a d v)$ înăuntru

inward ship (nav) navă care face o călătorie de întoarcere

inweave (textile, compozite) a întrețese

in welding layer (met) strat de sudură în solzi

in work (mas) în funcțiune

iodate (chim) a iodura, iodat

iodic (chim) iodic

iodide (chim) iodură

Iodine (I) (chim) iod

iodize (chim) a trata cu iod, a prepara cu iod

ion (fiz, chim) ion

ion binding / bond (chim) legătură ionică / hetero-polară

ion beam cutting tăiere (met, $\mathrm{TH}$, fiz) cu fascicul de ioni

ion exchange (chim) schimb de ioni

ion exchange adsorbtion (ind chim) adsorbție cu / pe răşini schimbătoare de ioni

ion exchange column (ind chim) coloană cu schimbători de ioni

ion exchanger (chim) schimbător de ioni; (plast) răşină schimbătoare de ioni

ion exchange resin (chim, plast) răşină schimbătoare de ioni

ion-exchange softening (chim) dedurizare prin schimb de ioni

ion gauge (metr, hidr, fiz) manometru cu ionizare ionic (fiz, el) ionic

ionic bath (chim) baie de electroliză

ionic bond / link(age) (chim) legătură ionică

ionic charge (chim, fiz) sarcină (ionică)

ionic quantimeter (chim, metr) dozimetru de ioni / ionic

ionization (fiz, chim) ionizare 
ionization heat (termo) căldură de disociere / de ionizare

ionize (fiz, chim) a (se) ioniza

ionising (fiz, chim) ionizare

ionogenic (fiz, chim) ionogen

ion spectrometer (fiz) spectrometru ionic / masic

iota literă grecească; iotă, câtime, părticică

ips (metr) abreviere pentru inches per second

(in/s), unitate de măsură pentru viteză 1 ips = $0,0254 \mathrm{~m} / \mathrm{s}$

ipy (metr, OM) abreviere pentru inch per year (in/yr), unitate de măsură pentru viteza de coroziune (la recipiente, conducte etc.)

IRHD durometer (metr) durometru pentru cauciucri şi elastomeri

iridesce (fiz) a iriza

Iridium (Ir) (chim) iridiu

iris (OM, metr) diafragmă

irisated (fiz) irizat

Irish acre (metr) unitate irlandeză pentru suprafață (de teren): 1 Irish acre $=0,6555$ ha

Irish mile (metr) o unitate irlandeză pentru lungime, milă irlandeză: 1 Irish mile $=2,048256$ km

iris out $(\mathrm{OM})$ a diafragma

Iron, Ferrum (Fe) (chim, met) fier (Fe)

iron feric, feros, de fier; (met) oțel, fontă, material / aliaj feros (în general); (textile) a călca, a netezi (tesături); $(\mathrm{OM}$, termo) fier de călcat; (OM, mil, met) a blinda; (metr) o unitate tradițională pentrua grosimea tălpii din piele a pantofilor: 1 iron $=0,5292 \mathrm{~mm}$

iron and steel mills / plant / works (met) uzină metalurgică

iron anode (chim) anod de fier

iron ball (met) lupă

iron band (met) (plat)bandă de oțel (rar, de fier)

iron bar (met) bară de oțel, oțel în bare

iron bear (met) urs (şi de fontă)

iron black sheet (met) tablă neagră

iron block (met) bloc de oțel, blum

iron bloom (met) blum, lupă de fier

iron borings (met, mas-un) aşchii de material feros (şi de la găurire)

iron-boron (met) ferobor

iron box $(\mathrm{OM})$ manşon / cutie de oțel

iron bronze (met) bronz cu fier

iron carbide (met, chim) cementită; carbură de fier; fier cementat (rar)

iron-carbon alloy (met) aliaj fier-carbon, otel iron-carbon diagram (met) diagramă fier-carbon iron-cased $(\mathrm{OM}, \mathrm{mil})$ blindat (cu oțel)

iron casting (met) turnare a fontei, fontă turnată iron castings (met) piese din fontă turnată iron channel (met) profil $U$ (din oțel) iron charge (met) parte metalică a încărcăturii iron chill (met) cochilie, pod de turnare (pt. oțel / sau fontă)

iron chips (mas-un, mediu) aşchii de oțel provenite de la strung

iron circuit (el) circuit magnetic

iron clad (met) placat / blindat cu oțel; (el) blindat; (nav) cuirasat

iron cladding $(\mathrm{OM})$ armătură, blindaj (şi de oțel), înveliş fero-magnetic, blindare

iron clad plate (met) placă de blindaj din oțel

iron-clad transformer (el) transformator ecranat / blindat

iron cladding (met) blindare cu oțel, armătură, blindaj, înveliş metalic (din oțel)

iron clad plate (met, $\mathrm{OM}$ ) placă de blindaj (din oțel)

iron coating (OM, mil) acoperire cu oțel

iron-constantan couple (metr, met) termocuplu oțel constantan

iron construction (constr, mec) constructie metalică din oțel

iron cooper sulphide (chim) calcopirită

iron core (el, met, OM) armătură / miez meta$\operatorname{lic}(\breve{a}) /$ de fier / din aliaj de fier

iron core armature (el, met) armătură / indus din fier moale

irondolomite (met) ankerit

iron drill (mas-un) sfredel / burghiu de mână

iron dross (met) zgură

ironer (textile termo) călcător, netezitor

iron filament ballast (nav) rezistență de balast

iron fallings / filings pilitură de fier

iron founder (met) turnător (de fontă)

iron foundry (met) turnătorie de fontă

iron frame (constr, mec) schelet metalic

iron glance (minrl) hematit; luciu metalic

iron gray / grey (culoare) gri-fier

iron group (chim, met) grupă (de metale) a fierului

iron hoop (met) fretă, bandă de foi, bandă de oțel iron hydroxide (chim) hidroxid de fier iron industry (met) siderurgie

ironing (TH, mas-un) ambutisare adâncă; (textile) călcare / netezire (a textilelor)

ironing fastnes (textile) rezistență la călcat iron hydroxid (met, chim) hidroxid de fier iron ingot (met) lingou de fier iron jacket (met, OM) manta de fier iron-lead matte (met) mată de fier-plumb ironless (met, chim) fără / lipsit de fier iron loop (met) lupă de fier

iron losses (met) pierderi de fier (prin ardere); (fiz) pierderi prin curenti turbionari / prin histerezis 
iron making (met) elaborarea fontei

iron mass (fiz, el) miez de fier

iron mill (met) turnătorie de fontă, uzină metalurgică

iron mould (met) lingotieră, cochilie, cochilă

iron notch (met) gură / orificiu de scurgere a zgurii iron of granular fracture (met) fontă cu granu-

lație mare / macrogranulară

iron ore (met) minereu de fier

iron out (textile) a netezi

iron oxide (chim, met) oxid feric

iron-oxide formation (chim) formarea oxidului de fier / a ruginii

iron pattern (met) model / şablon metalic

iron pig (met) fontă brută / de (la) furnal, urs / bloc de fontă

iron plate (met) placă metalică (din otẹl)

iron plating (met, $\mathrm{OM}$ ) acoperire / placare $\mathrm{cu}$ oțel / cu fier

iron Portland cement (constr) ciment Portland cu adaos de zgură

iron-pot furnace (met) cuptor-creuzet pentru fontă iron powder (chim) pulbere de fier

iron precipitation (met) precipitarea fierului

iron protoxide (chim) oxid feros

iron puddling (met) afinarea fontei

iron pyrite (chim, minrl) pirită

iron rail (cf) şină (de cale ferată)

iron refining (met) afinare a fontei

iron reinforcement $(\mathrm{OM})$ adaos interior / căptuşeală / armătură de oțel

iron rolling mill (met) laminor de tablă (de oțel)

iron runner (met) jgheab de turnare / de evacuare a fontei (din furnal)

iron rust (met, chim) rugină de fier; oxid de fier iron salts (chim) săruri de fier

iron saturated (met) saturat în fier

iron scale (met) țunder, arsură, scorie de fier

iron scrap (met) fier vechi, deşeuri de metal feros

iron sesquioxide (met, chim) oxid feric

iron sesquisulphide (met, chim) sulfură ferică

iron sheathed $(\mathrm{OM})$ blindat / armat cu fier / cu oțel

iron-shield instrument (metr) aparat / instrument cu ecran / blindaj feromagnetic

iron shot (met) alice de oțel (pt. curățarea pieselor turnate)

iron silicide (met, chim) siliciură de fier

iron slab (met) bramă, sleb

iron-slag (met) zgură de fontă / de furnal / de fier / cu mult fier

iron sleeper (cf, met) traversă metalică

ironsmith (met) forjor, fierar iron stain (met) pată de rugină / de fier

iron-stone (met) minereu de fier; (minrl) siderit; sideroză

iron sulphate (chim, met) sulfat de fier

iron-tapping hole (met) gură de evacuare a fontei la furnal)

iron tie (constr) ancoră

iron turnings (mas-un) aşchii de oțel (provenite de la strunjire)

iron tyre $(\mathrm{OM})$ bandaj metalic (din oțel) (şi la pneuri)

iron up (auto) a pune lanțuri la roți; (textile) a călca (rufe etc.)

iron ware (met, $\mathrm{TH})$ feronerie, articole de fierărie / lăcătuşerie

iron waste (met) pierdere de fier (şi prin ardere)

iron wire (met) sârmă de oțel

ironwood (silv) lemn de esentă tare

ironwork (articole de) fierărie; (constr) schelet metalic

iron worker (met) metalurgist, siderurgist

iron works (met) uzină metalurgică / siderurgică, turnătorie

irony ca fierul, de fier

irradiance (fiz) iradianță, iradiație, iradiere, iluminare, luminozitate, putere pe unitatea de arie

irradiant (fiz) iradiant, care radiază, luminos, strălucitor

irradiate a iradia, a expune; a fi luminos, a străluci; a face să strălucească; (fig) a limpezi, a clarifica, a lămuri

irradiation (fiz) iradiere, iradiație; expunere (la radiații); strălucire, luminație, luminare, difuzare a razelor / a luminii

irrational irational, nerational, nelogic; absurd, fără sens; inexplicabil, nerezonabil; (mat) (număr) irational

irrationality iraționalitate, caracter irațional / nerațional, absurditate, lipsă de rațiune / logică; prostie

irrationally $(a d v)$ (în mod) iraţional, absurd

irrational number (mat) număr irațional

irreclaimmable irecuperabil, nerecuperabil; incorigibil, imposibil de îndreptat

irrecognizable de nerecunoscut, imposibil de recunoscut

irreconciliable ireconciliabil, de neîmpăcat

irreconciliably $(a d v)$ (în mod) ireconciliabil, incompatibil

irrecoverable (mediu) nerecuperabil; ireparabil; iremediabil

irrecoverably $(a d v)$ (în mod) nerecuperabil; ireparabil; iremediabil

irreducibility (mat) caracter ireductibil 
irreducible, irreductible (mat) ireductibil; care nu mai poate fi descompus, indecompozabil

irreducible polynomial (mat) polinom ireductibil irrefragable incontestabil, indiscutabil; (jur) irefutabil

irrefutable incontestabil, de necontestat, irefutabil

irregular dezordonat, în dezordine; incidental, neregulat, asimetric, neuniform; defect; nereglementar; clandestin, ilicit

irregular bedding (alim, constr, ind chim) depunere / stratificare dezordonată / neregulată / neuniformă

irregular cut (mas-un) prelucrare a unei suprafețe cu profil complicat

irregular distribution $(\mathrm{TH})$ distribuție neregulată (de presiune, temperatură etc.)

irregular flow (hidr) curgere neregulată / neuniformă

irregular fracture (materiale) ruptură / crăpătură neregulată

irregularity $(\mathrm{TH})$ neregularitate, caracter neregulat; neuniformitate, lipsă de uniformitate; (d. structura unui material, d. funcționare etc.) funcționare neregulată / dereglată (a cilindrilor unui motor etc.); (T) asperitate, rugozitate

irregularity accelerated motion (mec) mişcare neuniform accelerată

irreguraly $(a d v)$ (în mod) neregulat, neuniform, inegal, fără regularitate; în dezordine

irregular motion $(\mathrm{mec})$ mişcare variată / neuniformă

irregular outline (OM) profil complicat / neregulat (şi d. topografia suprafeței)

irrelevance, irrelevancy lipsă de legătură / relevantă / însemnătate / importantă, irelevantă

irrelevant irelevant, lipsit de legătură, fără nici un raport cu problema; lipsit de importanță / însemnătate, neînsemnat

irremediable iremediabil; incorigibil; (med) incurabil, nevindecabil

irremovable (jur) inamovibil, nerevocabil; implacabil; permanent, ireversibil, imuabil

irreparable $(\mathrm{TH})$ ireparabil, de nereparat; iremediabil, nerecuperabil

irreplaceable de neînlocuit; neprețuit

irreproachable ireproşabil

irresoluble insolubil, nerezolvabil

irresolute (mat) nehotărât, nedecis; şovăielnic, şovăitor

irresoluteness, irresolution lipsă de hotărâre, nehotărâre, şovăială, ezitare

irresolvable (mat) irezolvabil, de nerezolvat; (mat, chim) de nedescompus, neanalizabil, care nu (mai) poate fi analizat irrespective(ly) of independent de, indiferent de, făcând abstracție de, fără a ține seama de irrespirable (med, mediu) irespirabil, de nerespirat irresponsability iresponsabilitate, lipsă de responsabilitate

irresponsible iresponsabil, lipsit de răspundere

irresponsive to (mec, autom, metr) insensibil la, indiferent la

irresponsiveness to insensibilitate la / față de, indiferență la

irretention incapacitate de reținere (a unui fluid etc.); lipsă de ținere de minte, memorie slabă

irretrievable irecuperabil, de necompensat / înlocuit; ireparabil, iremediabil

irreversibility (TH) ireversibilitate, caracter ireversibil

irreversible ireversibil; nereversibil; $(\mathrm{OM}) \mathrm{cu}$ autofrânare (filet)

irreversible element (el, autom, mec) element unidirectional

irreversible gear (OM) transmisie ireversibilă / cu un singur sens de mişcare

irreversible steering (auto) direcție autoblocantă / ireversibilă

irrevocable irevocabil

irrevocable letter of credit (ec) acreditiv irevocabil, scrisoare de credit care nu poate fi contramandată / anulată fără acordul beneficiarului

irrigable, irrigatable (agr) irigabil

irrigate (agr) a iriga, a umezi, a drena, a uda

irrigation (agr) irigare, irigație, umezire, udare, stropire

irrigation engineering (agr) lucrări de irigare / stropire

irrigator (agr, OM) stropitoare, aspersor, irigator

irritability (autom, metr) excitabilitate, sensibilitate; iritabilitate

irritant (med, chim) iritant, care produce iritație, substanță iritantă; gaz iritant

irritate a irita, a agasa, a supăra; (med) a irita, a produce iritație

irritating gas (ind chim, med) gaz iritant

irritation (med) iritație, iritare, enervare, supărare

irrotational flow (fiz) curgere irotațională

irruption irupere, năvală, năvălire

irsing deposit (fiz) depunere irizată

I-section (constr, met) profil cu secțiune (în formă de) I

isentrope (hidr, mec) linie de echipresiune isentropic flow (fiz, hidr) curgere adiabatică

isentropic factor / exponent (termo, fiz) raport între căldura specifică la presiune constantă şi cea la volum constant 
isinglass (alim, iht) ihtiocol; clei de peşte; gelatină pentru prăjituri; mică (mineral)

island insulă, ostrov; (fig) insulă, regiune / zonă izolată, a izola, a transforma într-o insulă

ISO abreviere pentru International Organization for Standardization, Organizaţia Internatională de Standardizare

isobar (fiz) izobară

isobaric (fiz) izobar, izobaric

isochore / isochoric (fiz) izocoră, curbă de volum constant

isochromatic (fiz) izocromatic

isochromatic light (fiz) lumină izocromatică de aceeaşi culoare

isochronous izocron, sincron(ic); simultan, concomitent

isochronous governer (el) dispozitiv de mentinere a turatiei constante indiferent de sarcină

isoclinal izoclin(al) (cu aceeaşi înclinare) (d. cute şi falii)

isoclinic izoclinal

isoelectric point punct izoelectric

isogonal (geom) cu unghiuri egale, izogon

isohumulone (chim) izohumulen (substanță care dă gustul amărui al berii)

isokinetic sampling probă izoelectrică

isolable izolabil, separabil, care poate fi izolat / separat

isolate (el, termo) a izola, a separa; a deconecta; a ține deoparte; (med) a izola, a ține în carantină

isolated izolat, separat

isolated singularity (mat) punct singular / izolat

isolated slag inclusions (met) incluziuni izolate de zgură (și la sudură)

isolated spacer (auto) garnitură izolantă plasată între carburator şi blocul motor

isolating izolant, care izolează / separă, izolator, (acțiunea de) izolare

isolating switch separator, întrerupător

isolation (el) izolare; material izolant; deconectare, întrerupere; degajare; (TH) izolatie, separare

isolator (el, termo) întrerupător-separator; izolator; (electr, fiz) conductor directiv (în tehnica microundelor)

isolator handle pârghie a separatorului

isomer (chim) izomer

isomeric (chim) izomeric

isomerisation (plast) izomerizare

isomeriser instalație de izomerizare

isomorph(ous), isomorphic izomorf

isopiestic izopiezometric, izobaric

isopren rubber (plast) cauciuc izoprenic isosceles (mat) isoscel isosceles crank mechanism patrulater articulat cu laturi egale

isostatic pressing presare izostatică

isostructural izomorf, izostructural

isotherm (fiz) linie de egală temperatură, izotermă

isothermal, isothermic izoterm, izotermal

isothermal annealing (met) recoacere izotermă

isothermal change (termo) proces izoterm

isothermal process (termo) transformare izotermă, proces izoterm

isothermal transformation (met) transformare izotermă

isotime / izochrone curve (fiz) curbă de intervale de timp egale

isotope (chim) izotop

isotropic (adj) izotrop

isovolumic process (fiz) proces izocor

issuance eliberare, emitere (de adeverință, permis etc.); publicare, editare, apariție; ieşire la iveală; (ec) emitere / emisiune de acțiuni

issue deşertare, descărcare, vărsare, scurgere; (med) hemoragie; rezultat, deznodământ, sfârşit, consecinţă; concluzie, rezolvare; controversă; (ec) emisiune / emitere de acțiuni (şi de timbre); ediție (a unei cărți, ziar etc.), număr (de ziar), apariție, publicație; eliberare (de bilete); (jur) litigiu, chestiune controversată; dispută, controversă; dezbatere, discutare în contradictoriu; (pol) decret, hotărâre, decizie; faptă; a rezulta, a proveni; a emite; a publica, a edita; (pol) a promulga; a vinde; a emite, a elibera (bilete), a sfârşi, a încheia, a termina

issue from a se scurge, a porni din / de la; a descinde, a se trage din

issue from / out of a decurge, a rezulta din issuer (ec) emitent; distribuitor

issuer price (ec) preț de emisiune, valoare inițială (a unei acțiuni etc.)

I-strut (met) bară laminată cu secțiune în I

it el, ea (pt. obiecte, noțiuni abstracte)

IT calorie, international steam table calorie (metr) unitate de măsură pentru energie: 1 IT $=4,1868 \mathrm{~J}$

italic (poligrafie) cursiv, italic; literă cursivă / italică

italics (poligrafie) caractere cursive / italice

item paragraf, alineat, punct, articol (dintr-o listă); articol, element; număr, punct (din program); chestiune, subiect, punct; material, informație, articol (de ziar); a bifa, a însemna, a nota; (adv) idem, la fel, de asemenea

item $(\mathrm{TH})$ articol, piesă, element, produs, material, subansamblu, modul, accesoriu 
item counter (mas-un, metr) contor de operații itemize (amer) a specifica, a enumera, a înşira pe puncte / pe articole

item levels (mas, TH) nivele de complexitate (piesă, subansamblu, ansamblu, unitate, subsistem, sistem etc.)

iterance, iterancy (mat, inf) iteratie; iterare, repetare, repetiție; recapitulare

iterant (inf) recurent, care se repetă; repetat

iterate (inf) a itera, a repeta, a reitera; a recapitula

iteration (mat, edu) iterație, iterare, repetare, repetiție; recapitulare

iteration loop (inf, c) buclă / de iterare / de repetare

iteration statement (inf) instructiune de ciclu repetabil / de lucru în buclă / de iterare

iterative (mat, inf) iterativ, repetat, repetabil, recurent, reiterat

iterative method (mat, inf) metodă iterativă iterative propagation constant (inf, mat) constantă iterativă de propagare

itinerancy turneu, tur, vizită; caracter itinerant

itinerant ambulant, voiajor; călător; itinerant

itinerary itinerar, rută, drum; plan de călătorie; călător

itinerate a călători, a voiaja

itself se; (pe) el însuşi, chiar (pe) el, chiar lui, lui / sie însuşi, (pe) ea însăşi, chiar (pe) ea, ei / sie însăşi; singur; în sine; fără ajutor; prin sine însuşi / însăşi; de la sine etc.

ivory fildeş; culoare ivorie, ivoriu; din fildeş

izett steel (met) oțel cu $0,05 \% \mathrm{Al}$ (rezistent la îmbătrânire)

Izod impact (metr, materiale) duritate după Izod

Izod impact machine (OM, metr, plast) maşină cu berbec / pendul Izod

Izod test (metr, materiale) încercare / probă / test de duritate după Izod 


\section{J}

jab lovitură (bruscă), şoc

jab into a băga / vârî forțat, a împinge în

jack muncitor, ucenic; (constr) capră, pârghie, suport; (el) fişă (de conectare), jack, contrafişă, bucşă; (OM) cric, vinci, troliu manual, jac; a ridica cu un cric / vinci; (mas-un) a degroşa

jackass (nav) dop de nară

jack bar (auto, OM) bară a cricului

jack barrel / bushing (el, OM) bucşă a jacului (a fişei)

jackbit (mas-un) floare / tăiş / vârf a(l) burghiului

jackbit insert (mas-un) tăiş, muchie tăietoare (plăcută ataşată / lipită)

jack body / support / socket (el, OM) corp al jacului

jackboot cizmă impermeabilă (înaltă)

jack disk $(\mathrm{OM})$ disc cu clichet

jacket (OM, mas) cămaşă, manta, înveliş, învelitoare, teacă, clopot, perete dublu, armătură; (met) blindaj; (termo) izolație; (el, termo, met) a acoperi, a izola, a îmbrăca, a înveli; supracopertă, a pune în supracopertă; piele de animal; (alim) coajă de cartof

jacket-cooling (termo) răcire prin manta, refrigerare cu pereți dubli; (met) răcire cu cămaşă de apă (la cuptoare)

jacketed (met, termo) căptuşit, blindat, echipat cu cămaşă / cu manta

jacketed cold room (alim, termo) cameră frigorifică cu pereți dubli, prin care circulă aer rece

jacketed crystallizer (alim, ind chim) cristalizator cu manta cu apă

jacketed cylinder (auto, termo) cilindru cu manta de răcire (la autovehicule)

jacketed dryer (alim, termo) cilindru uscător cu manta

jacketed hot air press (mas-un, plast) presă de vulcanizare, cu manta cu aer cald

jacketed wall (OM, met, termo) perete dublu cu circulaţie de fluid

jacket-heating (termo) încălzire prin manta

jacketing îmbrăcăminte, căptuşeală, blindaj (din diverse materiale)

jacket stave (OM) doagă / inel de manta

jacket water cooling (termo) răcire cu cămaşă de apă staționară / fără circulație jack hammer (mas-un) ciocan / perforator pneumatic jacking ridicare cu cric(uri) jack-in-place $(\mathrm{TH})$ a monta cu ajutorul cricurilor jack key switch (OM) clichet, (el) jac jack-knife cuțit de buzunar, briceag jack lamp (el, mas) lampă de siguranță jack latch (OM) zăvor / clichet cu arc jack lift (mas-un) cărucior cu dispozitiv de ridicat jack nut $(\mathrm{OM})$ contrapiuliță

jack-screw / winch $(\mathrm{OM})$ cric / vinci cu şurub; ansamblu şurub-piuliță, ataşat conectorilor

jackshaft (OM) arbore intermediar (şi la planetar sau diferențial)

Jackson turbidity unit, JTU (metr, fiz, hidr) unitate pentru măsurarea turbidității apei

jack spring $(\mathrm{OM})$ arc cu / de clichet, (el) arc / resort al jacului

jack up a ridica cu cric / cu vinci / cu troliu; (ec) a ridica prețuri; (auto) a ridica vehiculul (pt. a-1 verifica)

jack wheel $(\mathrm{OM})$ pinion de diferenţial

jade (minrl) jad, nefrit

jag (OM) colț, vârf ascuțit, dinte (şi de ferăstrău); breşă, spărtură, crestătură, zimț, teşitură; (el) oscilație în formă de dinți de ferăstrău; a tăia în zigzag, a cresta, a zimța; zigzag; (metr) unitate britanică de măsură pentru volum (şi de fân), nestandardizată: $1 \mathrm{jag} \sim 0,7 \ldots 1,0 \mathrm{~m}^{3}$

jagged crestat, dințat, zimțat, cu / în zigzag

jagging board (mas) masă de concentrare pentru noroi rezidual la minereuri

jam (alim) dulceață, marmeladă, gem; (auto) încurcătură de circulație; $(\mathrm{T})$ gripare, înțepenire, blocare; (TH) a (se) bloca, a (se) întepeni, a prinde, a strivi, a (se) strânge, a îndesa; $(\mathrm{OM})$ a fixa prin pene, a apăsa, a (se) presa, a comprima; a-şi prinde (degetul etc.); a (se) aglomera; (el) legătură la borne; a aduna, a îngrămădi; a pune brusc frână; (auto) ambuteiaj, încurcătură de / în circulație; strângere, apăsare, presare; îmbulzeală; blocare a circulației; $(\mathrm{TH})$ pană, defect; a zdrobi; a bloca (un culoar etc); a vârî brusc (în); a băga cu forța (în); a (se) înghesui, a se îmbulzi etc.; (radio) a bruia; a fi blocat

jamb (met) deformare; proptea, suport (şi temporar) jam into a băga cu forța / putere în, a îndesa în, a împinge în

jam jar (alim) borcan de dulceață

jammed (auto) încurcat (d. centură, circulație etc.) jamming $(\mathrm{OM}, \mathrm{T})$ gripare, înțepenire, blocare; fixare (şi la borne electrice)

jamming roller $(\mathrm{OM})$ rolă de blocare

jammy (alim) lipicios (ca dulceața) 
jam nut (OM) contrapiuliță

jam on a apăsa brusc pe (frână etc.)

jam plate (mas-un) placă de filetat, filieră simplă

janitor portar; (amer) administrator (de bloc); om de serviciu

January ianuarie

jansky (Jy), flux unit (metr, astronomie) unitate pentru măsurarea densității de flux a semnanelor radio din spațiu; 1 jansky este egal cu un flux de $10^{-26} \mathrm{~W} / \mathrm{m}^{2}$ pe aria de receptie (a unei antene) pe unitatea benzii de frecvență $\left(\mathrm{W} / \mathrm{m}^{2} \mathrm{~Hz}\right)$

Japanese japonez

japanning a lăcui, a acoperi cu lac fin

jar (TH) recipient, vas, oală, cană, borcan; (metr) măsură pentru volum: 1 jar $=4,541$; (metr, el) unitate de măsură pentru capacitate electrică: 1 jar $\cong 1,1$ nanofarad; vibrație neplăcută, țăcănit; (el) butelie de Leyda, vas de acumulator; (mec) şoc, vibrație, trepidație, scuturare, izbire, lovire; a vibra puternic, a scutura; a produce un sunet neplăcut, a hurui, a face să huruie / să trepideze, a trepida, a scârțâi, a lovi, a izbi; (fig) (d. păreri) a se ciocni; a diferi; a fi în dezacord; ciocnire, nepotrivire, conflict; a nu se asorta; sunet aspru / discordant / neplăcut, disonanță; dezacord

jargon zirconiu

jar ram a vibra

jar ramming $(\mathrm{TH})$ scuturare, vibrare, vibrație

jar-ramming machine (met) maşină de format prin vibrare / scuturare în turnătorie

jar-ramming turn-over / roll-over (plate) machine (met) mașină de format prin vibrare / scuturare cu placă rabatabilă, în turnătorie

jar-ram moulding machine (mas) maşină vibratoare, vibrator; (met) maşină de format prin vibrare / prin scuturare

jarring vibrare, scuturare, vibrație, trepidație jarring blow lovitură bruscă, şoc prin lovire jarring moulding machine vibrator; (met) maşină de format prin vibrare / prin scuturare

jarring plate / table (alim, mas, ind chim) masă vibratoare / oscilantă

jars dispozitiv cu cădere liberă (şi foarfecă)

jar-squeeze machine (met) maşină de format prin scuturare şi presare

jaw (OM) falcă, gheară, pană, camă, braț de cleşte / de foarfece; (mas-un) dispozitiv de strângere

jaw brake (OM, cf) frână de saboți

jaw breaker (constr, mas) concasor cu fălci

jaw clutch / coupling (OM, auto) ambreiaj / cuplaj cu gheare

jaw crusher (constr, mas) concasor / maşină de sfărâmat, cu fălci jaw crushing (constr, TH) sfărâmare / concasare grosieră / primară

jaw mandrel (mas-un) dorn cu fălci longitudinale

jaw plate (OM, mas) falcă a concasorului

jaw press (mas-un) presă cu fălci

jaw-shaped (OM) în formă de gheară, cu gheară jaw speeder screw driver şurubelniță cu coarbă jaw vice (mas-un) menghină

jejune (fig) slab, subțire; (agr) sterp, neroditor; (d. sol) neinteresant, plictisitor; (amer) pueril, copilăresc

jell (alim, chim) gel; (fig) a (se) cristaliza, a (se) definitiva (un plan)

jellification (alim, plast, ind chim) gelificare, gelatinizare

jellify (alim) a face piftie din; (alim, chim) a (se) gelatiniza, a trece în stare de gel

jelly (alim) jeleu, peltea, piftie, gelatină, aspic; substanță gelatinoasă; a se face jeleu / peltea / piftie, a face jeleu / piftie / peltea

jellylike gelatinos

jemmy şperaclu, bară mică

Jena glass (ind chim) sticlă de Jena / termorezistentă

jenny (mas) macara mobilă, troliu mic şi mobil

jeopar(ize) a primejdui, a periclita, a pune în primejdie

jeopardy risc, pericol, primejdie

jerk (auto, mas) zdruncinătură, săritură, lovitură (bruscă), izbitură, hurducătură; (mec) şoc, smucitură; salt brusc; a smuci, a zdruncina, a porni din loc brusc, a urni, a (se) mişca / înainta (cu smucituri); (metr, mec) unitate de măsură pentru viteza de variație a accelerației: 1 jerk $=$ $0,3048 \mathrm{~m} / \mathrm{s}^{3}$

jerkin vestă

jerking (mas) şocuri, smucituri, lovituri rapide repetate, vibrații

jerking motion (mas, mas-un) mişcare intermitentă (şi nedorită)

jerky sacadat, cu impulsuri, smucit, intermitent

jerky drawing (met) tragere / trefilare cu trepidatii

jeroboam, double magnum (alim, metr) sticlă de vin de $\sim 31$

jerry building (constr) clădire şubredă / din material prost

jerry-can (alim, ind chim) bidon / canistră

jet (auto) jiclor; (autom) jet, rază; (hidr) jet / vână de fluid, jgheab, canal; (OM) ajutaj, alezaj, orificiu al ajutajului, canal de rotor la turbine; (termo) duză / ajutaj pentru arzător, jiclor; (TH) a pulveriza, a arunca, a azvârli (un lichid); (av) avion cu reacție; lignit

jet apparatus (mas-un) ejector 
jet blower (met, ind chim) suflător cu jet (şi de abur)

jet bore (OM, hidr) ajutaj de pulverizator jet carburettor (auto) carburator cu jiclor jet chamber (alim, ind chim) cameră de pulverizare

jet condensation (chim) condensare prin injectie

jet condenser (termo) condensator termic prin injecție, condensator de amestec

jet conveyer (mas, mas-un) încărcător prin aruncare

jet cooling (termo) răcire / refrigerare prin jet (de aer rece)

jet deflector (fiz, hidr) deflector de jet / de fascicul

jet engine motor cu reacție, reactor

jet engine steel (met) oțel pentru motoare cu reacție

jet exhaust (hidr, termo) efuzor

jet freezing (alim) congelare (rapidă) prin jet de aer

jet gas scrubber scruber cu jet

jet injection injectare cu jet

jet injector injector cu jet

jet mill (alim, constr, ind chim) moară cu jet

jet mixer amestecător cu jet

jet motion (hidr) mişcare în jet

jet moulding (mas-un, plast, met) extrudare

jet needle (auto) gură a jiclorului, jiclor; $(\mathrm{OM})$ duză

jet nozzle (auto) ajutaj al jiclorului, jiclor; (OM) duză

jet piercing $(\mathrm{TH})$ străpungere prin jet de apă sub presiune

jet pipe (fiz, hidr, av) ajutaj de reacție

jet-pipe regulator $(\mathrm{OM}$, hidr) regulator hidraulic, cu tub / plunjer oscilant

jet-propelled cu reacție / jet

jet propeller (nav) elice cu ajutaj

jet propulsion propulsie cu jet (şi de aer)

jet propulsion engine motor cu reacție

jet propulsion fuel combustibil pentru motoare cu reacție

jet pump (hidr) pompă cu jet, ejector

jet radiator (termo) răcitor cu ajutaj / prin destindere / cu detentă

jet reaction (mec) forță de respingere / de recul

jetsam (nav) bunuri aruncate peste bord, obiecte aruncate de apă la țărm; resturi, lucruri inutile, rebut

jettison (nav) a arunca peste bord, aruncare peste bord; a arunca, a scăpa de lucruri inutile

jetton jeton, fisă

jetty (nav) dig, chei, debarcader; negru ca abanosul / smoala jetty for fuel-oil bunkering (nav) dană de alimentare cu combustibil lichid

jet-type gun (mas, hidr) perforator cu jet

jewel piatră prețioasă; bijuterie

jewelled bearing montare de pietre pretioase ca lagăre, lagăr din pietre prețioase (mecanică fină)

jewellery bijuterii

jewellery alloy (met) aliaj pentru bijuterii

jew's harp cheie de ancoră

jib (constr, mec) braț, fleşă (şi de macara); (nav) foc, trincă; a se opri brusc, a nu mai vrea să meargă

jib at a refuza să, a nu fi dispus să, a nu vrea să, a se opune; a şovăi să, a ezita să

jib crane macara pivotantă

jibe a se înțelege, a fi de acord; a fi în concordanță, a corespunde

jib sheete (nav) şcotă de foc

jiffy (fiz) interval de timp foarte scurt, moment instanataneu; (metr, inf) lungimea unui cilclu al ceasului computerului: 1 jiff (standardizat) = $0,01 \mathrm{~s}$, v. tick; (metr, chim, fiz) unitate de măsură pentru timp, timpul necesar luminii să parcurgă $1 \mathrm{~cm}: 1$ jiffy $\cong 33,3564$ picosecunde, $\mathrm{v}$ light centimeter; mai recent, timpul necesar luminii să parcurgă 1 femtometru / fermi: 1 jiffy $=3,33564$ zeptosecunde

jiffy tools set de scule cu destinație specială

jig (mas) capră de montaj; (mas-un) dispozitiv de strângere / de prindere / de fixare, dispozitiv de ghidare pentru găurire; (metr) calibru, şablon; (nav) palanc de manevră (de mică putere); $(\mathrm{TH})$ gabarit, şablon, calibru, matriţă (poligrafică)

jig borer / boring machine (mas-un) maşină de găurit în coordonate, maşină de găurit şi alezat

jig bushing $(\mathrm{OM})$ bucşă de ghidare

jig down $(\mathrm{TH})$ a fixa, a strânge

jig drill (mas-un) maşină / dispozitiv de găurit de precizie

jigger (alim, OM) sită oscilantă; (TH) vibrator, sită, ciur; (el) transformator de cuplaj; (nav) velă în cruce, brigantină

jigging oscilant, oscilatoriu

jigging point punct de referință (şi la prelucrare prin aşchiere)

jig(ging) screen (agr, alim, constr, ind chim) sită oscilantă

jiggle a legăna; a zgâlțâi, a scutura

jiggle pin (hidr) supapă în formă de ac

jig grinding machine (mas-un) maşină de rectificat în coordonate

jigger (metr, alim) unitate de măsură pentru volum (şi pt. lichior): 1 jigger $=44,36 \cdot 10^{-3} 1$ 
jig lathe (mas-un) strung de copiat

jig plate (mas-un) dispozitiv de ghidare la găurit, cu placă

jig saw (mas-un) ferăstrău mecanic pentru metale cu mişcare alternativă

jig vice (mas-un) menghină de maşină, dispozitiv de ghidare (folosit și pt. fixarea pe masa maşinii-unelte)

jig welding (met, OM) sudare pe contur

jig work / working (mas-un) prelucrare cu folosirea dispozitivelor de ghidare

jimmy (met) spărturi, deşeuri; (TH) rangă

jin (metr) unitate chinezească de măsură pentru masă: 1 jin $=500 \mathrm{~g}$

jingle a suna, a zornăi, a zdrăngăni; a face să sune; sunet metalic, zornăit, zdrăngănit

jitro (metr) unitate de măsură pentru suprafață (de teren) în Republica Cehă, identică cu josh: 1 jitro $=0,5755$ ha, $v$. joch

jitter (autom) instabilitate de scurtă durată, variatie rapidă a caracteristicilor unui semnal

jitter-free operation (TH) funcționare precisă / stabilă / fără vibrații

jo (metr) unitate tradițională japoneză pentru măsurarea suprafeței (camerelor): 1 jo $=1,62 \mathrm{~m}^{2}$

job $(\mathrm{TH})$ lucru, muncă (şi în acord), operație, funcție, post, activitate, treabă, meserie, însărcinare; (inf) lucrare, înlănțuire a execuției mai multor programe; (ec, adm) loc de muncă, serviciu, slujbă, funcție, post; (ec) afacere (şi rentabilă), profit, speculă, achiziție, îndeletnicire, lucrări mărunte, ocupație, (muncă) în acord; realizare; (mas-un, TH) piesă de prelucrat, operație de prelucrare; (ec) a angaja într-un post, a da / primi (de lucru) în acord, a face speculă cu; be on the $\sim$ a lucra cu pasiune; work by the $\sim$ a lucra cu bucata; out of $\sim$ (rămas) fără lucru, şomer

job analysis analiza muncii

jobber muncitor în acord / cu ziua, zilier; (ec) speculant la bursă, comerciant cu amănuntul

jobbery (adm, ec) abuz de putere, afacere necinstită; speculă; mită

jobbing (ec) lucru în acord, lucru ocazional, muncă măruntă, comerț cu acțiuni, joc la bursă, speculă

jobbing casting (met) piesă brut-turnată

jobbing foundry (met) turnătorie pentru piese brute, livrabile

jobbing mill (met) laminor pentru profiluri uşoare / comerciale

jobbing plant / shop (TH) atelier de reparații (şi nespecializat)

jobbing plate rolling-mill (met) laminor pentru tablă comercială / de grosime mijlocie jobbings (met) piese turnate, gata de livrare (în stare brută)

jobbing sheet (met) tablă (de grosime) mijlocie

jobbing sheet rolling mill (met) laminor pentru tablă (de grosime) mijlocie

job breakdown (TH) analiză / defalcare a componentelor unei activităti

job characteristic / grading / factor particularitate a unei activități (calificare, condiții fizice şi intelectuale necesare, răspundere, condiții de muncă)

job family grup de activități analoage, familie / grup de lucrări / de operații

job flow control $(\mathrm{TH})$ urmărire / monitorizare a unităților de lucru în curs de funcționare

jobless fără serviciu, şomer

job line (ec) solduri, marfã de ocazie

jo-block (metr) cală plan-paralelă

job management organizare a şantierului (şi de construcții)

job-mix formula formulă de fabricatie

job order number (ec) număr de comandă a unui lot de marfã

job private (ec) lucru în acord

job rates (ec) norme de producție

job run (TH, constr) executare a unei lucrări

job site (constr) şantier (de construcții)

job specification $(\mathrm{TH}, \mathrm{ec})$ specificare / precizare a sarcinilor; caiet de sarcini

job step etapă de lucru

job stream flux / fişier de lucrări

job work $(\mathrm{TH})$ reparație, lucru în acord

joch, $(p l)$ joche (metr) unitate tradițională de măsură a suprafeței (de teren) în țările de limbă germanică, inclusive Austria: a traditional unit of area in German speaking countries, especially in Austria. 1 joch $\sim 0,5755$ ha

jockey $(\mathrm{OM})$ dispozitiv de cuplare, ambreiaj

jockey pulley / roller / wheel (OM) roată de întindere pentru transmisii cu curele, rolă întinzător

jog (TH) zguduitură, zdruncinătură, obstacol, piedică; (fiz) discontinuitate, salt; (mas-un) avans normal; (mat) cot de curbă, curbură; (mec) șoc; a împinge, a zgâlțâi, a scutura, a zgudui, a zdruncina, a se mişca încet

jogged line linie discontinuă

jogging (autom, c) comandă prin impulsuri, acționare prin taste

jogging control (autom, metr) reglare progresivă / prin impulsuri

joggie $(\mathrm{TH})$ încheietură, îmbucătură; $(\mathrm{OM})$ cep (de îmbinare), prag, umăr; a îmbina prin pene, a fălțui; a vibra 
joggle $(\mathrm{OM})$ degajare sau cavitate complementară piesei cu care vine în contact; etanşare prin injectare; scuturare; îmbucătură, încheietură; cep de îmbinare; (constr) îmbinare cu lambă şi uluc; a împinge (uşor); a zgâlțâi, a vibra; a îmbina prin împănare

joggled-built beam (constr, mec) grindă cu pene

joggled lap joint $(\mathrm{OM})$ îmbinare prin suprapunere

joggle joint $(\mathrm{OM})$ îmbinare cu canal şi pană (şi la flanşe)

joggling machine / press (met, mas-un) mașină / presă de bordurat

join punct / linie de întâlnire; (el, hidr) de joncțiune, punct sau linie de împreunare; împreunare; unire; (TH, OM) combinație, reuniune, asociere; a îmbina, a asambla, a atârna, a agăța, a anexa, a uni; a (se) alătura, a cupla, a racorda, a împreuna, a lega; (el) a lega; (mat) a reuni; a (se) întâlni; a intersecta; a deveni membru, a se înscrie în, a intra în; a veni la / lângă, a însoți, a intra în; a se uni cu, a se strânge, a se aduna, a se întâlni; a se mărgini (unul cu altul); a se ataşa (unui grup etc.); (mil) a se ataşa (regimentului), a(-şi) regăsi (regimentul); a strânge (trupe); a ralia; a se amesteca în; from the $\sim$ of prin / din unirea / alaturarea / anexarea

join by casting (met) a îmbina prin turnare

joinder combinație, îmbinare; reunire, asociere; (jur) conexare de acțiuni, aglomerare de reclamații; $(\mathrm{OM})$ punct de îmbinare

joined $(\mathrm{TH})$ îmbinat, legat, asamblat joiner tâmplar, maşină de prelucrat lemnul joinery tâmplărie

join in a intra în, a lua parte la, a se asocia la, a participa la

joining îmbinare; (el) legare, conectare; (mas) acuplare; (TH) racordare, înnădire

joining by brazing (OM, met) asamblare prin lipire (cu aliaj metalic), lipire de îmbinare / de asamblare

joining frame (constr, mec) cadru de legătură

joining methods metode convergente / de legare / de racordare / de asamblare (mai rar)

joining piece $(\mathrm{OM})$ piesă de legătură

joining tenon (OM, constr) cep de îmbinare

joining traverse (constr) traversă de legătură

joining with expansion joint / piece / device (OM) îmbinare cu rost / cu piesă / cu dispozitiv de dilatare

joining with smooth joint $(\mathrm{OM})$ îmbinare cu rost neted

joint (adj) (în) comun; (OM) combinat, îmbinat; (jur) solidar; (anat) articulație; (OM) conexiune, joncțiune, racord, nod, țațână, balama, punct de lipire / nodal, ansamblu, încheietură, legătură, îmbinare, îmbucare, articulație, rost, asamblare, falț, racord, sudură, cusătură de sudură, asamblare sudată / lipită, lipitură; (auto) garnitură de etanşare; (mec, constr) nod de fermă, articulatie, rost, punct / linie de îmbinare, a rostui; (cf) joantă; (alim) bucată (mare) de carne, parte, halcă, ciozvârtă, a tăia în bucăți (d. carne); (silv) ciot (într-un pom); (geol) crăpătură în stâncă; (el) loc de legare a cablurilor, a lega, a cupla; (ind chim) umplutură; (met) cusătură (de sudură); (OM, TH) a potrivi, a adapta, a ajusta, a articula, a îmbuca, a uni, a îmbina, a combina, a asambla (şi prin lipire), a etanşa, a rostui; (constr) a tencui (crăpături)

joint action acțiune concomitentă / de formare a unei legături (mecanice)

joint board (met, constr, ind chim) fund basculant (pt. golire)

joint bolt $(\mathrm{OM})$ bolt de articulație

joint-box (el) cutie de joncțiune, manşon de cablu joint-box compound $(\mathrm{OM})$ masă (compozită) de umplere / de etanşare

joint distribution (el) distribuție cu mai multe variabile

jointed articulat, legat, unit

jointed cross-shaft axle (auto, OM) osie oscilantă

jointer $(\mathrm{OM})$ piesă metalică de închis rosturi; (agr) antebrăzdar; rindea

joint estate (jur) bunuri deținute în comun

joint face / surface (TH) suprafață de îmbinare / de separare; (met) suprafață a rostului (de sudură)

joint file pilă lată cu fețele laterale rotunjite, pilă cu vârf drept şi cu dințare numai pe fețele laterale rotunjite

joint fitting $(\mathrm{TH})$ centrare a îmbinării / a rostului joint gap $(\mathrm{OM})$ rost / distanţă între marginile / piesele de sudat

joint geometry $(\mathrm{OM})$ geometria / forma rostului (la sudură)

joint grease $(\mathrm{T}, \mathrm{OM})$ unsoare consistentă pentru etanşare

joint hinge $(\mathrm{OM})$ îmbinare articulată, articulație, balama

jointing $(\mathrm{TH})$ îmbinare, înnădire, rostuire, operația de executare a rosturilor; $(\mathrm{OM})$ (garnitură de) etanşare

jointing filler (chim, OM) chit de etanșare

jointing plane (OM) suprafață / plan de îmbinare / de asamblare

jointing sleeve $(\mathrm{OM})$ clemă tubulară de legătură, manşon

jointless fără rosturi, fără cusătură 
joint lever $(\mathrm{OM})$ pârghie cotită

joint line $(\mathrm{OM})$ linie de îmbinare / de separare

joint line of a mould (met, plast) linie de separare a formei (la turnare)

joint liner $(\mathrm{OM})$ garnitură, presgarnitură de îmbinare

jointly în comun, în cooperare

joint nut (OM, met) piuliță de cuplare / de legătură / de asamblare

joint of the bed (constr, OM) rost de rezemare

joint of piston ring (auto, OM, termo) fantă de segment (la motoare de autovehicule)

joint of rupture rost de rupere

joint of (a) truss (mec) nod de fermă / de grindă cu zăbrele

joint owner (ec, jur) coproprietar

joint packing $(\mathrm{OM})$ garnitură de etanşare

joint piece $(\mathrm{OM})$ piesă de legătură

joint pin (OM) şurub oscilant; bolț / ştift de articulație; (mas-un) prezon de strângere (la asamblare)

joint pusher (mas-un) dorn mic

joint ring $(\mathrm{OM})$ garnitură inelară, inel de etanşare joint rubber (plast, $\mathrm{OM}$ ) cauciuc pentru garnituri joint sealing închidere / strângere a rosturilor joint sealing compound (OM, hidr) masă (şi compozită) pentru etanşarea rosturilor

joint statement (pol, ec) declarație comună

joint stock (ec) capital social

joint-stock company (ec) societate pe acțiuni

joint surface (OM, met) suprafață de separare / de îmbinare

joint up a conecta, a anclanşa, a uni

joint use utilizare conjugată / în comun

joist (constr, met, mec) grindă transversală, bară, traversă metalică (şi din profile)

joist rolling mill (met) laminor pentru profiluri grele

joist shears (met, mas-un) foarfece pentru laminate profilate

jolly balance (metr) balanță pentru determinarea greutății specifice

jolt (auto) lovitură, scuturătură, smucitură, izbitură $(\mathrm{mec})$ şoc; $(\mathrm{TH})$ jgheab vibrator, vibrare; a scutura, a vibra, a zdruncina

jolter / jolting moulding machine (mas) vibrator; (met) maşină de format prin scuturare

jolting scuturare, vibrare; scuturător

jolting knock-out grid (met) grătar vibrant de dezbatere / de scuturare (a formei de turnare, a piesei turnate etc.)

jolt moulding machine (met) maşină de format prin scuturare / prin vibrare

jolt / jolting table (mas, met) masă vibratoare oscilantă jolting vibratory squeeze moulding machine vibrator; (met) maşină de format prin scuturare

jolt rammer mai compactor

jolt ramming îndesare prin scuturare / prin vibrare

jolt ramming (moulding) machine (mas) vibrator; (met) maşină de format prin scuturare

jolt roll-over moulding machine (met) maşină de format prin scuturare cu masă rabatabilă

jolt squeezer moulding machine (met) maşină de format prin scuturare şi presare

Jominy test (metr, plast) test Jominy

Jones, $\mathbf{c m} \cdot \mathbf{H z}^{1 / 2} / \mathbf{W}$ (metr, electr) unitate de măsură a detectivitătii (abilitatea unui sistem electronic de a detecta energie radiantă

jostle ciocnire, lovire; înghesuială, aglomerație; a (se) împinge; a (se) înghesui

jot iotă; pic; urmă

jot down a nota, a însemna, a trece; a schița, a face o ciornă

jotter carnețel, blocnotes

jotting însemnare, notă, notiță; care notează

joule (J) (fiz, metr, mec) unitate SI de măsură pentru energie şi lucru mecanic, joule

journal jurnal (zilnic), cotidian revistă, ziar; (autom) gheară de comandă; (OM) lagăr (foarte general), pivot, fus (de osie), cep, gât, ax scurt; (ec) jurnal de contabilitate, proces verbal (la o ședintăa); (nav) jurnal de bord; (metr) unitate tradițională de măsură a suprafeței (de teren) în Franța: 1 journal 0,3 ..0,45 ha

journal axis $(\mathrm{OM})$ axa fusului de reazem

journal bearing $(\mathrm{OM})$ lagăr de alunecare, lagăr de reazem / de sustinere / de osie, cuzinet

journal-box guide (auto, OM) furcă de osie journal centre $(\mathrm{OM})$ centrul fusului de reazem journalist jurnalist, ziarist

journalize (ec) a înregistra într-un jurnal

journal milling machine (mas-un) maşină de frezat fusuri

journal neck (OM) fus, cep, capăt / guler de arbore / de fus

journal of an axle $(\mathrm{OM})$ pivot

journal pin (OM) fus, pivot, ax (de dimensiuni mici, într-o articulatie etc.)

journal pressure presiune aplicată pe fus (nu se specifică tipul: maximă sau medie)

journal turning machine (mas-un) strung pentru prelucrat arbori cotiți

journey work lucru cu ziua

joystick (inf) dispozitiv pentru specificarea coordonatelor unui punct; (TH) pârghie / mâner, manşă de comandă

joystick selector switch (el, mec) comutator-selector cu pârghie 
JTU (metr, fiz, hidr) abreviere pentru Jackson turbidity unit, unitate pentru măsurarea turbidității apei

juchart, juchert, tagwerk ("day's work") (metr) unitate tradițională de măsură pentru suprafață (de teren): 1 juchart $\sim 4000 \mathrm{~m}^{2}, 1$ juchart $($ Bavaria $)=3407.27 \mathrm{~m}^{2}, 1$ juchart $($ Elveția $)=$ $3600 \mathrm{~m}^{2}, 1$ (Roman) jugerum $\cong 2500 \mathrm{~m}^{2}$

judder trepidație

judge (jur) judecător, magistrat, a judeca; cunoscător (de); a aprecia, a evalua, a judeca, a face o judecată; a-şi da seama; a considera, a fi de părere că; a presupune; a hotărî, a decide; a critica; a arbitra, a face parte dintr-un juriu (fig) critic, judecător, cunoscător, expert

judge by a judeca după; a considera după

judge by its flavour (alim) a degusta

judge from a judeca după, a deduce din

judgement (jur) judecată, judecare; sentință, hotărâre, pedeapsă; judecată, discernământ; părere, opinie; apreciere; raționament; bun-simt

judgement delay întârziere în gândire / în luarea unei decizii

judicatory (jur) (adj) judecătoresc

judicial (jur) (adj) judecătoresc, judiciar, juridic, de judecător / magistrat; judicios, cu discernământ; principial, nepărtinitor, imparțial; critic judicious judicios, rațional, logic, chibzuit judiciously $(a d v)$ (în mod) judicios, rațional, logic, chibzuit

judiciousness rațiune, logică, caracter judicios jug ulcior; ibric; cană

jug, Scots pint (metr) unitate scoțiană de volum: 1 jug $\cong 1,701$

jugged (alim) înăbuşit, călit (d. mâncare)

juggle with a falsifica, a denatura (fapte)

juice (alim) suc, zeamă, a face / obține zeamă / suc, grape $\sim$ must

juice centrifuge (alim) centrifugă pentru zeamă juice cooker (alim) fierbător de zeamă / de suc juice delimiting (alim, chim) decalcifiere a zemurilor / sucurilor

juice diffusion (alim) difuzie / difuzare a zemii juice filtration (alim) filtrare a zemii juiceless (alim) fără suc / zeamă, uscat juice pump (alim) pompă pentru zeamă juicer storcător juiciness suculență, caracter zemos juicy suculent, zemos; (fig) interesant jumble amestec, harababură; zăpăceală, confuzie; a amesteca; a zăpăci, a încurca; a fi amestecat jump (inf, mat) salt; săritură; discontinuitate; tranziție; creştere; trecere bruscă; tresărire; a sări peste / de pe / din; a tasa, a îndesa; a suda cap- la-cap; (cf) a deraia (d. tren); a tresări; a sălta, a sări; a face să tresară; a pune să sară (un copil, un cal); (fig) a omite; a sări (un obstacol); a coincide; a se arunca asupra; (alim) a prăji (cartofi); a întrece, a i-o lua (cuiva) înainte

jump about a sări ici şi colo

jump at a ajunge pripit la o concluzie, a accepta pripit (o idee etc.); a sări la; a prinde (din zbor)

jump at a conclusion a trage o concluzie pripită jump attenuation atenuare a saltului

jump clear a sări deoparte

jump control (autom) comandă pas cu pas / prin salturi, (hidr) control sau măsurare a saltului hidraulic

jump discontinuity (mat) punct de discontinuitate cu salt finit / de prima speță

jumper care sare, legătură / fir temporar(ă)

jumper bar rangă, drug

jumpering (el, hidr, OM) legare, interconectare, racordare, joncțiune

jumper tube $(\mathrm{OM}$, hidr) conductă de legătură pentru devierea (temporară) unui fluid

jump function funcție de salt / treaptă jumping refulare, compresiune

jumping of the brushes salt al periilor (la maşini electrice)

jumping out săritură (şi un rând la text)

jumping-up refulare, îngroșare

jumping up test încercare la turtire (prin forjare)

jump instruction / order (inf) instructiune de salt jump-off salt din

jump-off line linie de pornire

jump of spark formare a scânteii

jump of temperature (termo) salt de temperatură

jump out ieşire / salt din cadru (şi la calculatoare)

jump over a scânteia

jump-over continuare / urmare pe pagina următoare

jump-over spark (el, fiz) descărcare superficială / de suprafață

jump relations (inf) relatii de salt la ecuatii cu derivate parțiale

jump roughing rolling mill (met) laminor duo fără echilibrarea cilindrilor superiori

jump saw (mas-un) ferăstrău mecanic pentru metale cu mişcare de translație alternativă

jump seat strapontină

jump spark scânteie disrumptivă

jump test (metr, materiale, TH) test / încercare de refulare / la compresiune

jump clear a sări deoparte

jump together a se potrivi

jump upon a se năpusti asupra 
jump weld (OM, met) sudură în $T$, sudură de colț jump welding $(\mathrm{OM}$, met) sudare în $\mathrm{T}$, sudare în colț

jump wire connection (el) punte de lipituri jumpy nervos, iritabil; enervant, supărător; (ec) (d. prețuri) instabil, fluctuant

jumpy market $(\mathrm{ec})$ piață instabilă

junction (cf) încrucişare, nod de cale ferată; (ec) asociație, (el) joncțiune; (met) lipitură; (TH) racordare, îmbinare, legătură; confluență

junction board (el) comutator

junction box (el) cutie de racord / de branşament / de derivație / de joncțiune, colector, doză de derivație

junction curve (geom, OM) curbă de racordare (şi la căile ferate)

junction line (metr) linie de delimitare; $(\mathrm{TH}$, hidr) conductă de legătură

junction plate $(\mathrm{OM})$ eclisă (şi la sudură)

junction point punct nodal / de legătură, nod juncture moment, clipă; situatie, stare de lucruri; criză, perioadă de criză / critică; punct / loc de legătură; $(\mathrm{OM})$ încheietură, cusătură sudată, sudură, îmbinare, element de legătură, articulație

June iunie

juniper oil ulei de ienupăr

junk vechitură, obiecte uzate; (met) metal vechi, fier vechi, deșeuri, (nav) parâmă uzată; (alim) carne uscată, pastramă; a tăia în bucăți

junket (alim) cheag de lapte, smântână, lapte gras junk ring $(\mathrm{OM})$ inel de etanşare

junk scrap (met) fier vechi, deşeuri (metalice)

Jupiter (astronomie) Jupiter; (metr, astronomie) unitate de măsură pentru masa planetelor: 1 Jupiter $\sim 1,899 \cdot 10^{24}$ tone

juridic(al) juridic

jurisconsult jurisconsult, jurist

jurisdiction jurisdicție, competență juridică; competență; autoritate; putere; domeniu, sferă (de activitate, de interes etc.)

jurisdictional jurisdicțional, de jurisdicție jurist jurist, student la drept, cunoscător al legilor; autor de lucrări cu caracter juridic; (amer) avocat juristic(al) (jur) juridic, legal

jury mast (nav) catarg improvizat

jury pump (mas, hidr) pompă auxiliară

jury strut (constr, OM, mas) piesă de sprijin, suport (pt. piese înalte)

jus $(p l)$ jura lege, principiu / drept legal

just drept, just, corect; meritat, cuvenit; (d. o opinie) întemeiat, fondat, justificat; ( $a d v$ ) exact, tocmai, precis, chiar; doar, numai

just about aproape, cam pe la

just gap (fiz, el) distanță / interstiţiu de aer

justice (jur) justiție, judecător (de pace sau la Curtea Supremă)

justifiability justificare, motivare, caracter justificabil; legalitate

justifiable justificabil; admis; legal

justification împlinire; (constr, TH) limitare a înălțimii, justificare

justificative justificativ

justificatory justificare

justify a justifica, a motiva; a scuza, a îndreptăți; a explica, a lămuri; a confirma, a adeveri

justly $(a d v)$ just, drept, corect; pe bună dreptate; pe merit, meritat

justness justețe, dreptate; exactitate, precizie

jut $(\mathrm{OM})$ ieşind, ieşitură; convexitate, proeminență; proiectare; a ieşi în afară, a fi proeminent jute (bot, textile) iută

jute bag sac de iută

jute canvas pânză tare, de iută

jute fibre fibră de iută

jut out (constr) a depăşi în consolă

jutro, $(p l)$ jutra (metr) unitate tradițională de măsură a suprafeței (de teren) în Croația: 1 jutro $=5754,64 \mathrm{~m}^{2}$

jutty (nav) debarcader; dig; a ieşi, a proiecta în afară

juxtapose a juxtapune, a alătura; a suprapune

juxtaposition juxtapunere, alăturare; suprapunere 


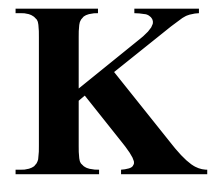

kaiac (nav, sport) caiac

Kaldo-process (met) proces / procedeu Kaldo (la oțelării)

kale (agr, bot) varză furajeră, varză creață, nap; (alim) ciorbă

kalendar calendar

kali (chim) oxid / carbonat de potasiu

Kalium (K) (chim) potasiu sau kaliu

kaolin (chim) (de) caolin

kaolin sand (geol, constr, ind chim) nisip argilos / caolinos

kaplan turbine (mas, termo) turbină elicoidală / Kaplan

kappa curve (mat) curbă $x^{4}+x^{2} y^{2}=a^{2} y^{2}$

karat (kt) (amer, Canada) (metr) carat, măsură a purităţii aliajelor prețioase (şi de aur); 1 karat $=1 / 24$ masă de metal prețios din masa totală a aliajului

kathod (el) catod

kayac (nav) caiac

kebab (alim) kebab

kedge (nav) a se trage pe ancoră

keel (hidr) carenă; (nav) chilă, a întoarce (vasul) cu chila; a răsturna, a arunca pe spate, a se răsturna cu chila în sus; over a cădea pe neaşteptate; $\sim$ up a pune cu chila în sus

keel block (met) lingou; (nav) tacadă de chilă

keel corridor (constr) coridor circular

keel line (nav) linia chilei(desen)

keelson (nav) carlingă

keen tăios, ascuțit, care taie bine; (mas-un) a ascuți; (fig) aspru, tăios, pătrunzător, caustic, ascuțit, inteligent, subtil, energic, activ, sever; (ec) (d. prețuri) coborât, redus; pasionat; zelos; înfocat; aprig

keen edge (nav) margine ascuțită / vie

keenly $(a d v)$ ascutit, cu putere, puternic, foarte (mult)

keenness (mas-un) grad de ascutire, finețe, ascuțiş keep hrană; întreținere; grijă; îngrijire; păstrare; (OM) capacul corpului de lagăr, tachet; stare, condiție; (agr) rezervă de nutreț; a păstra, a avea în păstrare, a ține (ceva, dar şi în închisoare sau captivitate etc.), a deține; a reține; a întreține (o mişcare); a susține; a poseda; a administra; a respecta; a apăra, a păzi, a feri; a ascunde; a tăinui; a rămâne (şi închis); a continua; a face; a vinde; a (se) menține; a avea grijă de, a avea; a respecta (o promisiune), a nu se abate de la; a opri; a nu restitui; a păstra (pentru mai târziu); a pune deoparte; a economisi; a avea de vânzare; a întârzia; a nu se băga în; a împedica să crească (prețurile etc.); a nu se despărţi; a nu ceda; a-şi menține pozițiile; a întârzia; a împedica să înainteze; a nu mărturisi; a stăpâni; a ține închis (o persoană); a se stăpâni; a împiedica să scadă / să cadă (şi d. prețuri); a nu abandona; a obliga să stea treaz

keep at a continua să lucreze la, a nu renunța la ceva, a munci intens

keep away from a se tine la distanță de, a sta de o parte, a nu avea de-a face cu, a se feri de, a ascunde de

keep back a opri, a ascunde

keep back from a ascunde de, a tine secret, a retine, a nu da din salariu, a păstra pentru sine, a opri (la distanță), nu lăsa să înainteze

keep down a continua să stea (culcat), a nu se scula; a opri / împiedica creşterea / dezvoltarea; a reprima

keeper paznic, gardian, custode, supraveghetor; (OM) contrapiuliță, piesă de reținere; (el) armătura unui magnet; (ec) detinător, titular

keepership funcția de tutore / paznic

keep from a (se) feri de; a ține la adăpost de, a nu arăta (cuiva); a se ține de o parte / la distanță; a evita, a ocoli; a sta departe de; a se abține de la

keep in a nu dezvălui; a înăbuşi (un sentiment etc.); a opri să iasă; a întreține (un foc etc.); a nu ieşi; a reține, a lăsa să ardă (focul)

keeping grijă, protecție; întreținere, păstrare, conservare, menținere; conformitate; pază, supraveghere; concordanță, armonie, înțelegere; hrană; care păzește; care respectă; care tine; care se conservă; be in $\sim$ with a fi în concordanță cu

keep in motion a menține în mişcare

keep in stock a stoca, a păstra în stoc

keep in view a nu scăpa din vedere

keep in with a rămâne în bune relații cu, a căuta să rămână în bune relatii cu

keep late hours a avea obiceiul de a se culca sau a veni acasă târziu; a sta / rămâne până târziu (la serviciu)

keep off a nu se apropia, a fi departe, a (se) ține la distanță, a nu lăsa să se apropie

keep on a continua, a nu se opri; a mentine, a întreține (focul, mişcarea), a nu se întrerupe (o functionare, un proces etc.) 
keep one's accounts a-şi ține la zi socotelile keep one's countenance a nu-şi pierde stăpânirea de sine

keep one's temper a nu se înfuria

keep one's word a-şi respecta cuvântul

keep out a sta de o parte, a nu se amesteca, a nu lăsa să intre

keep out of a se feri de, a nu lăsa să, a evita, a ocoli

keep pin $(\mathrm{OM})$ şplint

keep somebody from falling a împedica pe cineva să cadă

keep the course (nav) a ține ruta

keep the peace a păstra liniştea / ordinea publică

keep to a se ține de; a respecta (prevederi etc.); a rămâne la, a nu se abate / depărata de la

keep together a sta împreună; $(\mathrm{OM}, \mathrm{mec})$ a menține elemente asamblate

keep to $\operatorname{program}(\mathrm{me}) /$ schedule a se respecta programul

keep under a supune; a ține la respect; a disciplina; a supraveghea, a ține sub control; a stăpâni

keep under lock and key a păstra sub cheie

keep up a (se) menține, a nu scădea; a nu ceda, a rezista; a continua, a dura, a nu se termina; a ține pasul, a nu rămâne în urmă; a continua să întrețină, a întreține (şi curățenia); a nu se lăsa doborât; a sustine; a procura pe cheltuiala cuiva; (mas, TH) a menține în stare bună; a împedica să se culce

keep up with a se menține la același nivel cu / față de, a merge tot aşa de repede ca şi; a ține pasul cu, a nu rămâne în urma (cuiva)

keep watch a veghea (şi continuu)

kefir (alim) chefir

keg (alim, OM) butoiaş (de lemn); (nav) butoi sub 10 galoane, butoi de heringi

kelly (OM) tijă de antrenare

kelly bushing (OM) bucşă / dispozitiv de antrenare

kelly bushing gradle (OM) bucşă / dispozitiv de antrenare cu rame

kelp (nav) iarbă de mare

kelsen (nav) carlingă

Kelvin degree (fiz) grad Kelvin $(\mathrm{K})$

Kelvin double balance / bridge (el, metr) punte dublă Kelvin / Thompson

Kelvin effect (el) efect Kelvin / pelicular

kelvinometer (el) calorimetru Kelvin

kemidol (chim) oxid de calciu

kempy lungă, bătoasă, groasă (d. fibre)

ken cât vezi cu ochii; vedere; cunoaştere; care nu poate fi cunoscut; out of $\sim$ în afara câmpului vizual; out of $\sim$ inaccesibil cunoaşterii; beyond one's $\sim$ dincolo de puterea de pricepere a cuiva; (metr) unitate de măsură pentru lungime: $1 \mathrm{ken}=2,11836 \mathrm{~m}$

kenching (nav, alim) sărarea peştelui

kennedy key $(\mathrm{OM})$ două pene înclinate, complementare, pene tangențiale

kentledge (nav) balast din fontă / metal

kentledge goods (nav) marfã grea, cu rol de lest

keps (OM) clichet de siguranță, opritor

keramics, ceramics ceramice

keratin (chim) cheratină

kerb (drum) bordură

kerb plate $(\mathrm{OM})$ placă de ghidaj

kerbstone (auto) piatră de bordură

kerf (mas-un) tăietură, fantă; (met) profil, secțiune; crestătură; urmă de ferăstrău (şi defect); (silv) vârf tăiat (al unui arbore doborât)

kernel (fiz) nucleu, sâmbure; (agr, alim) sâmbure, miez (de nucă, sâmbure, de sămânță), boabă, bob de cereale, grăunte; (met) miez (rar); (fig) miez, esentă, nucleu, centru, parte principală / esențială

kerosene, kerosine (ind chim) petrol lampant; cherosen

ketchup (alim) sos picant (cu roşii)

ketone (chim) cetonă

ketonic (chim) cetonic

kettle ibric, vas / oală de fiert apă, depresiune; (mas-un) cazan de încălzire; (termo) cazan, fierbător, boiler, autoclavă; depresiune, dolină

kettle casing (termo) mantaua cazanului

kettle of the compass (OM, nav) cutia busolei

kenel (nav) braț de ancoră, tachet mare

kenel head (nav) babá de lemn, în cruce

key (el) conector, comutator, buton, întrerupător; (OM) pană (de fixare), cheie, cui de siguranță, zăvor, splint, clapă de presiune; clapă, clește mecanic, ic (pt. despicat), a fixa (cu o pană), a încuia, a închide cu cheie, cleşte mecanic; a asambla cu pene; (met, constr) cărămidă-pană (c) cheie, tastă; (fig) cheie, soluție, cod, cifru; principiu de bază, explicatie (la o problemă etc.); (geogr) insulă joasă, banc de nisip, atol, recif; (muz) mod, ton, cheie, clapă (la pian, la flaut), a acorda (instrumente muzicale); (el, electr) manetă (a întrerupătorului), manipulator; ton, manieră de a se exprima etc.; filodormă; inel pentru ținut cheile; (adj) cheie, de bază, fundamental; a stârni; skeleton / master $\sim(\mathrm{OM})$ şperaclu

key adress (c) adresă-cheie

key assembly $(\mathrm{OM})$ asamblare cu pană

key bed (auto, OM) suport / lăcaş de pană, locul penei 
keyboard (c) claviatură, tastatură, panou cu fişe, tablou de comandă

keyboard unit (c) tastatură

key bugle $(\mathrm{OM})$ piston

key bolt $(\mathrm{OM})$ şurub cu cap prismatic / în formă de pană, şurub de fundație

key button (mas, OM) buton (de comandă); manipulator, clapă

key driver $(\mathrm{OM})$ extractor de pene

keyed (c) manipulat; (OM) asamblat / blocat cu pană / pene

keyed bush (OM) bucşă fixată cu pană

key file (mas-un) pilă lată (prismatică)

key groove $(\mathrm{OM})$ canal de pană

keyhole $(\mathrm{OM})$ canal pentru pană, canelură (golul canelurii); gaura cheii

keyhole saw (mas-un) ferăstrău coadă de şoarece / de traforaj (pentru lemn)

key industry industrie-cheie

keying (OM) asamblare cu pană / pene, calare, (piese) care se asamblează cu pene

keying device (c) claviatură, taste de comandă

keying-on $(\mathrm{OM})$ fixare / asamblare cu pană

key instruction (inf) instructiune cheie

key joint $(\mathrm{OM})$ asamblare cu pană

keyless entry system (auto) sistem de deschidere automată, fără cheie

key lever (OM) pârghia unei clape

key making attachement (mas-un) dispozitiv pentru rabotarea penelor

keyman personalitate, specialist, expert

key money filodormă

key note idee fundamentală; esență, miez

key on (OM) a cala, a fixa cu pană, a monta cu pană, a conecta prin pană / pene, a bloca cu pană

key operations (auto) operațiuni ale cheii

key position poziție-cheie

key punch (mas) maşină / dispozitiv de perforat cartele

key point punct cheie / important

keys (c, TH, inf) claviatură, tastatură

key seat $(O M)$ canal de pană, ajustaj blocat

key-seat cutter (mas-un, OM) freză pentru canal de pană

key-seater (mas-un, OM) dispozitiv de broşat canale de pană

key-seating machine (mas-un) maşină de prelucrat canale de pană (prin mortezare, frezare sau broşare)

key set $(\mathrm{c})$ claviatură, tastatură

key shaft $(\mathrm{OM})$ arbore canelat / cu canal de pană

key socket (el) comutator cu cheie

key steel (met) otel pentru pene key stone (constr) piatră spartă; (fig) cheie de boltă, esență, miez, frincipiu fundamental, sprijin / reazem principal

key up a monta / asambla (şi cu pană / pene); (fig) a stimula; a încuraja; a spori, a ridica, a mări

keyway $(\mathrm{OM})$ canal (şi de antrenare), canelură, locaş / canal de pană; (mas-un) canal de antrenare, a prelucra canalul de pană

keyway chisel $(\mathrm{OM})$ daltă pentru canal de pană

keyway cutter (mas-un) freză pentru canale de pană

keyway file pilă lată, prismatică

keyway gauge (metr) calibru pentru canal de pană

keyway milling cutter (mas-un) freză pentru canale de pană

keyway milling machine (mas-un) maşină de frezat canale de pană

keyway planing (mas-un) (operația / procesul de) rabotare a canalelor de pană la interior

keyway shotting ştanțarea canalelor de pană

key wedge $(\mathrm{OM})$ pană tangențială

key word, keyword (c, inf, autom) parolă; cuvânt cheie (şi pentru documentație)

kick izbitură; lovitură (cu piciorul, cu copita etc.); (mas) pornire uşoară a motorului; (mec) lovitură, şoc; (nav) abatere / curbă de giratie; a lovi (cu piciorul); a azvârli; 1. (mec) (fam) forță de reacție; (mil, fiz) recul (la pușcă), a face / avea recul, a smuci (d o armă); elan; energie, vigoare; a da (cu piciorul, cu copitele etc.); a zvârli din copite; a lovi cu piciorul; a da afară

kick out a arunca (în afară), a ieși din cauza unei lovituri / izbituri (d. o piesă etc.)

kick over the traces (fig) a-și tăia craca de sub picioare

kick at / against a protesta, a-şi arăta nemulțumirea față de; a se împotrivi la; a reacționa (la)

kick back a da brusc înapoi

kicker (met) dispozitiv de aruncare a buclei (la laminorul de tablă subțire)

kick fuse (el) siguranță fuzibilă

kicking-off amorsare, pornire

kicking tackle (nav) palane de cârmă

kick metal (met) oțel de convertizor, obținut prin procedeu duplex

kick off a porni, a amorsa; a arunca (cu ceva); (sport) a începe meciul de fotbal (cu prima lovire a mingii)

kick-off (mas) pornire, amorsare; (met) dispozitiv de evacuare / de îndepărtare, împingător (şi la laminoare) 
kick-off for crop ends (met) dispozitiv de evacuare / îndepărtare a capetelor debitate (la laminor)

kick(-)off pressure (mas, hidr) presiune de pornire / de amorsare

kick press (mas-un) presă cu pedală

kick sorter (metr, autom, mec, el) analizator de amplitudine

kick starter (auto) pornirea motorului la pedală

kick-up (mas-un) răsturnător, basculator; (met) culbutor, răsturnător

kick up frame (auto) şasiu curbat; ramă curbată

kick out a uza, a roade, a face ferfeniță

kick start (auto) pornirea motorului cu pedala

kidney (anat) rinichi; (constr) pietriş

kidney oil (met) minereu de fier în brichete

kidney stone prundiş, piatră mică şi rotundă; nefrit; piatră la rinichi

kier autoclavăkiering fierbere în autoclavă

kieselgu(h)ur (minrl) tripoli, kiselgur, dialomit

kies (minrl) pirită

kife switch (el) comutator, întrerupător

kill a omorî; a distruge; a sacrifica, a ucide, a tăia (animale); (el) a deconecta (tensiunea); (met) a calma oțelul, a decapa; (fiz) a atenua , a amortiza (sunete)

killed lime (constr, met) var stins

killed spirits (met) soluție de lipit; (chim) acid saturat, acid clorhidric descompus

killed steel (met) oțel calmat

killick (nav) ancoră

killing (alim) sacrificare (a animalelor); (TH) distrugere, anihilare, care distruge / anihilează (un efect, un element etc.); (met) calmare, liniştire, dresare, laminare cu reduceri mici, (agent / proces / procedeu) care calmează (oțelul); (TH) răcire (rar); (alim) (dispozitiv/ instalație) care omoară / sacrifică (animale); (chim, med) ucigător (d. o substanță, un virus etc.)

killing period (met) perioadă de liniştire / de dezoxidare / de calmare

killing pickle (met) baie / soluție (de decapare) sărăcită / epuizată

kiln (met) cuptor de ardere / de calcinare / de ardere / de uscare; uscare; etuvă; a usca, a arde (cărămidă, var)

kiln brick (met, termo) cărămidă refractară pentru cuptor

kiln dried (alim, termo, plast) uscat în cuptor

kiln dry (alim, met, termo, plast) a usca în cuptor

kilner jar borcan mare cu capac etanş

kiln with ascending flame (termo, met) cuptor cu flacară ascendentă

kiln with horizontal flame (termo, met) cuptor cu flacără orizontală kiln with overlying beds (met, termo) cuptor vertical cu etaje

kiln with turned-up flame (termo, met) cuptor cu flacără răsturnată

kilo (metr) prefix pentru unități de măsură, kilo (=1 000 unităţi)

kilobarrel/day (metr, hidr) unitate de măsură pentru debit volumic: 1 kilobarrel (US)/day = $0,001840131 \mathrm{~m}^{3} / \mathrm{s}$

kilocalorie (metr, termo) unitate de măsură pentru energie termică, kilocalorie: 1 kilocalorie $(\mathrm{IT})=4186,8 \mathrm{~J}$

kilocalorie (IT)/hour (metr, termo) unitate de măsură pentru energie termică: 1 kilocalorie (IT)/hour = 1,163 W

kilocalorie (IT)/minute (metr, termo) unitate de măsură pentru putere termică: 1 kilocalorie (IT) $/$ minute $=69,78 \mathrm{~W}$

kilocalorie (IT)/second (metr, termo) unitate de măsură pentru putere termică 1 kilocalorie (IT) $/$ second $=4186,8$ watt

kilocalorie (th) (metr) unitate de măsură pentru energie, kilocalorie tehnică (termochimică): 1 kilocalorie (th) $=4184 \mathrm{~J}$

kilocalorie (th)/hour (metr) unitate de măsură pentru putere, kilocalorie tehnică/oră: 1 kilocalorie (th)/hour $=1,162222222 \mathrm{~W}$

kilocalorie (th)/minute (metr, termo) unitate de măsură pentru putere, kilocalorie tehnică (termochimică)/minut: 1 kilocalorie (th)/minute $=$ 69,733333333 W

kilocalorie (th)/second (metr, termo) unitate de măsură pentru putere, kilocalorie tehnică (termochimică)/secundă: 1 kilocalorie (th)/second $=4184 \mathrm{~W}$

kilocycle (per second) (fiz, metr) unitate de măsură pentru frecvență, kilohertz $(\mathrm{Khz})$

kiloelectron-volt (metr, fiz) unitate de măsură pentru energie (în fizica nucleară): 1 kiloelectron-volt $=1,60217733 \cdot 10^{-16} \mathrm{~J}$

kilogram (kg) (fiz, metr) unitate SI de măsură pentru masă, kilogram

kilogram/cubic centimeter (metr) unitate de măsură pentru densitate, kilogram/centimetru cub: $1 \mathrm{kilogram} /$ cubic centimeter $=1000000 \mathrm{~kg} / \mathrm{m}^{3}$

kilogram/day (metr) unitate de măsură pentru debit masic, kilogram/zi: 1 kilogram/day = $11,574 \cdot 10^{-6} \mathrm{~kg} / \mathrm{s}$

kilogram/hour (metr, hidr, alim) unitate de măsură pentru debit masic: 1 kilogram $/$ hour $=$ $277,778 \cdot 10^{-6} \mathrm{~kg} / \mathrm{s}$

kilogram/liter (metr, materiale) unitate de măsură pentru densitate, kilogram/litru: 1 kilogram $/$ liter $=1000 \mathrm{~kg} / \mathrm{m}^{3}$ 
kilogram/minute (metr, hidr, alim) unitate de măsură pentru debit masic, kilogram/secundă: $1 \mathrm{kilogram} /$ minute $=0,016666667 \mathrm{~kg} / \mathrm{s}$

kilogram-force (metr, mec) unitate de măsurare a forței, kilogram-forță: 1 kilogram-force = $9,80665 \mathrm{~N}$

kilogram-force centimeter (metr, mec) unitate de măsură pentru energie şi lucru mecanic, kilogram-forță.centimetru: 1 kilogram-force centimeter $=0,0980665 \mathrm{~J}$ sau $\mathrm{N} \mathrm{m}$

kilogram-force meter (metr, mec) unitate de măsură pentru energie şi lucru mecanic, kilogramforță $\cdot$ metru: 1 kilogram-force meter $=9,80665$ $\mathrm{J}$ sau $\mathrm{N} \mathrm{m}$

kilogram-force millimeter (metr, mec, el, fiz) unitate de măsură pentru energie şi lucru mecanic, kilogram-forță.milimetru: 1 kilogramforce millimeter $=0,00980665 \mathrm{~J}$ sau $\mathrm{N} \mathrm{m}$

kilogram-force/square centimeter (metr, mec. hidr) unitate de măsură pentru presiune, kilogram-forță /centimetru pătrat: 1 kilogramforce/square centimeter $=98066,5 \mathrm{~Pa}$

kilogram-force/square meter (metr, mec, hidr) unitate de măsură pentru presiune, kilogramforță/metru pătrat: 1 kilogram-force/square meter $=9,80665 \mathrm{~Pa}$

kilogram-force/square millimeter (metr, mec, hidr) unitate de măsură pentru presiune, kilogram-forță /milimetru pătrat:1 kilogramforce/square millimeter $=9806650 \mathrm{~Pa}$

kilogram-molecule (chim, metr) kilomol (kmol) kilogram of TNT (metr, fiz) unitate de măsură pentru energia eliberată prin explozie: 1 kilogram of TNT $=4.184 \cdot 10^{6} \mathrm{~J}$

kilohertz (fiz, metr) unitate de măsură pentru frecvență, kilohertz $(\mathrm{Khz})$

kilojoule (kJ) (metr, mec, fiz) unitate de măsură pentru energie: 1 kilojoule $=1000 \mathrm{~J}$

kilojoule/hour (kJ/h) (metr, mec, fiz) unitate de măsură pentru putere: 1 kilojoule/hour $=$ $0,277777778 \mathrm{~W}$

kilojoule/minute (metr, mec, fiz) unitate de măsură pentru putere, kilojoule/minut: 1 kilojoule $/$ minute $=16,666666667 \mathrm{~W}$

kilojoule/second (metr, mec, fiz) unitate de măsură pentru putere, kilojoule/secundă: 1 kilojoule/second $=1000 \mathrm{~W}$

kiloliter (metr) unitate de măsură pentru capacitate / volum, kilolitru: 1 kiloliter $=1 \mathrm{~m}^{3}$

kilometer, kilometre (metr) unitate de măsură pentru lungime, kilometru: 1 kilometer $=1000 \mathrm{~m}$

kilometer/hour (metr, mec) unitate de măsură pentru viteză, kilometru/oră: 1 kilometer/hour $=0,277777778 \mathrm{~m} / \mathrm{s}$ kilometer/minute (metr, mec) unitate de măsură pentru viteză, kilometru/minut: 1 kilometer/ minute $=16,666666667 \mathrm{~m} / \mathrm{s}$

kilometer/second (metr, mec) unitate de măsură pentru viteză, kilometru/secundă: 1 kilometer/ second $=1000 \mathrm{~m} / \mathrm{s}$

kilometer/square second (metr, mec) unitate de măsură pentru accelerație, kilometr/secundă la pătrat: 1 kilometer/square second $=1000 \mathrm{~m} / \mathrm{s}^{2}$

kilometer-train (cf, transp) tren-kilometru

kilomol (chim) kilomol

kilonewton (kN) (metr) unitate de măsură pentru forță, kilonewton: 1 kilonewton $=1000 \mathrm{~N}$

kilonewton meter (metr, mec) unitate de măsură pentru lucru mecanic: 1 kilonewton meter $=1000 \mathrm{~N} \mathrm{~m}$

kilonewton/square meter (metr, mec, hidr) unitate de măsură pentru presiune, kilonewton/ metru pătrat: 1 kilonewton/square meter = $1000 \mathrm{~Pa}$

kiloparsec (metr) unitate de măsură pentru lungime (în astronomie), kiloparsec: 1 kiloparsec $=3,085677581 \cdot 10^{+19} \mathrm{~m}$

kilopascal (metr, mec, hidr) unitate de măsură pentru presiune, kilopascal: 1 kilopascal $(\mathrm{kPa})$ $=1000 \mathrm{~Pa}$

kiloohm $(\mathbf{k} \Omega)$ (el, fiz) unitate de măsură pentru rezistența electrică: kilo-ohm

kilopond (metr) unitate de măsură pentru forță, kilogram-forță: 1 kilopond $=9,80665 \mathrm{~N}$

kilopond meter (metr) unitate de măsură pentru energie şi lucru mecanic: 1 kilopond meter $=$ 9,80665 J sau N m

kilopound (metr) unitate de măsură pentru masă: 1 kilopound $=453,59237 \mathrm{~kg}$

kilopound-force (metr) unitate de măsură pentru forță: 1 kilopound-force $=4448,221615255 \mathrm{~N}$

kiloton (metr) unitate de măsură pentru masă, kilotonă: 1 kiloton (metric) $=10^{6} \mathrm{~kg}$; (metr) unitate de măsură pentru energie eliberată prin explozie: 1 kiloton $=4,184 \cdot 10^{+12} \mathrm{~J}$

kilovolt (kV) (metr, el) unitate de măsură pentru tensiune electrică, kilovolt

kilovolt-ampere (kVA) (metr, el) unitate de măsură pentru putere (d. curent electric alternativ): 1 kilovolt-ampere $=1000 \mathrm{~W}$

kilowatt (kW) (metr, mec, el) unitate de măsură pentru putere, kilowatt: 1 kilowatt $=1000 \mathrm{~W}$

kilowatt-hour (kWh) (metr, el, mec) unitate de măsură pentru energie, kilowatt-oră: 1 kilowatt-hour $=3600000 \mathrm{~J}$

kilowatt-second (kWs) (metr) unitate de măsură pentru energie, kilowatt·secundă: 1 kilowattsecond $=1000 \mathrm{~J}$ 
kiloyard (metr) unitate de măsură pentru lungime: 1 kiloyard $=914,4 \mathrm{~m}$

kind binevoitor, amabil; rasă, familie; gen, tip, fel, soi, categorie; blând, prietenos; (ec, TH) tip, sortiment, calitate, familie, clasă; trăsătură caracteristică / distinctivă; esenţă, natură, caracter; bun, drept, legitim

kindle (termo) a (se) aprinde (focul), a începe să ardă a da foc la, a amorsa

kindler aprinzător, cărbune aprins, care aprinde

kindling (termo) aprindere, amorsare

kindling point / temperature (termo, T) punct / temperatură de aprindere / de inflamabilitate / de inflamare

kindness bunătate, bunăvoință; amabilitate, prietenie; favoare

kind of aşa, într-un fel, până la un punct, parcă, într-o anumită măsură

kind to bun, amabil cu, binevoitor cu, bun cu

kinematic(al) cinematic

kinematic coefficient of viscosity $(T)$ coeficientul cinematic al vâscozităţii

kinematics cinematică

kinematic viscosity $(\mathrm{T}$, hidr) vâscozitate cinematică

kinetic cinetic

kinetic control system (autom, TH) sistem de reglare dinamică

kinetic energy $(\mathrm{mec})$ energie cinetică

kinetic head (hidr) presiune dinamică

kinetic quantity / magnitude (mec) cantitate de mişcare

kinetis cinetică, cinematică; (mas) teoria mecanismelor

kinetic theory of gases (fiz) teoria cinetică a gazelor

kink nod; răsucitură (în cabluri, odoane, funii); fundă; (fig) toană, capriciu; (mec) flambaj, a flamba; (met) curbură, îndoitură (a benzii), a curba, a (se) îndoi, a (se) răsuci, a (se) înnoda

king bolt (auto) pivot de fuzetă; (cf) bară de crapodină, leagănul boghiului; (OM) pivot, bolț central / principal

king bolt bush $(\mathrm{OM})$ bucşă de pivot / de bolț

king-bolt lock (OM, auto) siguranța pivotului

king pillar bolt (mas) bolț al pivotului principal

king pin (auto) pivot de direcție / de fuzetă; (OM) pivot, fus central, arbore vertical

king pin bearing $(\mathrm{OM})$ crapodină pivotului / fuzetei

king pin bush (OM) bucşă (lagăr) de pivot

king pin camber $(\mathrm{OM})$ unghiul de înclinare laterală a pivotului

king pin geometry (auto) geometria direcției king pin lock (auto) siguranța pivotului

king pin offset (auto) suportul axei de fuzete

king pin sidewise inclination (auto) unghiul de înclinare laterală a pivotului

king pin steering assembly (auto) ansamblul de direcție cu fuzete

king pin support (auto) suportul fuzetei

king post (nav) catarg de încărcare; (constr) stâlp de agățat

king-size mare, de format mare; neobişnuit, extraordinar (d. piese, sisteme tehnice etc.)

kingston valve (nav) priză de apă

kink nod, răsucitură; buclă; creț; întorsătură; a (se) suci; a (se) răsuci; (el) nod, răsucitură (de cabluri, de odgoane); (mat) punct unghiular; (mec, OM) flambaj, a flamba; (met) încovoiere, îndoitură (la benzi), a îndoi, a curba; a face nod; a se încurca, a se încâlci; (nav) ochi, buclă; velină

kink cable (el) buclă de cablu, cablu îndoit / înnodat

kinking $(\mathrm{OM})$ buclare, distorsiune temporară sau permanentă a unui furtun / cablu; (met) rupere prin / cauzată de deformare / buclare

kinky creț, încurcat

kiosk chioşc, pavilion; cabină telefonică

kp (metr) simbol pentru unitate de măsură pentru forță, v. kilopond sau kilogram-force: 1 $\mathrm{kp}=9,80665 \mathrm{~N}$

kip (metr) unitate de măsură pentru masă: 1 kip $=453,59237 \mathrm{~kg}$

kip-force (metr) unitate pentru forță: 1 kip-force $=1000$ pounds-force $=4448,221615255 \mathrm{~N}$ (simbol: kipf sau klbf)

kip-force/square inch (metr) 1 kip-force/square inch $=6894757,2931783 \mathrm{~Pa}$

kipper (alim) scrumbie afumată, peşte afumat; a săra, a afuma (peşte)

kipp relay (autom) releu basculant

kish (met, chim) grafit de solidificare, grafit în fulgi / primar, spumă de grafit

kish graphite inclusions (met) incluziuni de grafit sub formă de cuiburi (defect de turnare)

kisser (met) pete de arsură / de tunder (defect)

kit set, ansamblu; (TH, mas) garnitură / trusă de scule, echipament; container simplu sau dublu pentru materiale de etanşare; articol / piesă pentru modificarea funcționării; (c) modul, kit; cadă, găleată

kit bag geantă / sac de voiaj; rucsac

kitchen bucătărie, fel de a găti

kitchen garden (agr) grădină de zarzavat

kitchen range (alim, termo) plită de bucătărie, maşină de gătit 
kitchenry (alim) bucătărie, gastronomie

kitchen stuff (agr, alim) produse / zarzavaturi de gătit; gunoi (de la bucătărie)

kitchenware ustensile de bucătărie

kit of tools ladă / trusă de scule

klaxon (auto) claxon

K-monel (met) aliaj $\mathrm{Cu}-\mathrm{Ni}$

knack îndemânare, dexteritate; abilitate, pricepere, iscusință (profesională), merșteșug; talent; (textile) cută, pliu, încrețitură; tic, gest specific

knacky îndemânatic, abil

knaggy noduros, cioturos (d. lemn)

knap (constr) a sfărâma, a concasa

knar nod, ciot; protuberanță

knarred noduros, cioturos (d. lemn)

knead (alim) a frământa (aluat), a malaxa; (met, mas-un) a deforma plastic

kneadable maleabil

kneader (alim, ind chim) frământător, malaxor, amestecător; (ind chim) maşină de amestecat şi plastifiat; (met) melanjor

kneader bar brațul malaxorului

kneading (alim, ind chim) (proces / operație de) frământare, amestecare, malaxare, plastifiere

kneading and mixing machine (alim, ind chim, mas) malaxor cu pale

kneading machine (alim, ind chim) frământător, malaxor / amestecător cu palete

kneading blade (alim, ind chim, OM) paletă / pală / aripă de amestecare / de amestecător / de malaxor

kneading device (alim, ind chim, OM) dispozitiv / subansamblu de amestecare

kneading mill (alim) dispozitiv / subsistem tip malaxor sau frământător, care poate încorpora cantități mari de făină în aluat

kneading through(ly) (alim, ind chim) (proces de) amestecare în adâncime / în toată masa; care amestecă în toată masa (d. dispozitive de amestecare, axe de malaxoare, de diferite forme etc.)

knead (the) dough (alim) a frământa aluatul

knee (anat) genunchi, cot; frântură; legătură; $(\mathrm{OM})$ colțar, consolă, cot de legătură, guseu, a întări cu un colțatr / guseu; (mec) flambaj; (mat) punct unghiular, inflexiunea unei curbe; (nav) curbă (la construcții navale, a corpului navei)

knee-action suspension (mas, OM) suspensie cu articulatie / cu genunchi (rar)

knee braced bracket $(\mathrm{OM})$ consolă întărită

knee brake $(\mathrm{OM})$ frână cu articulație / cu genunchi (rar)

knee-bracket $(\mathrm{OM})$ consolă

knee clamp $(\mathrm{OM})$ clemă / scoabă articulată kneed $(\mathrm{TH})$ cotit, cu genunchi, îndoit (d. un profil, o placă etc.)

knee-deep adânc până la genunchi

knee-halter $(\mathrm{TH})$ a cupla

knee-high înalt până la genunchi

knee iron (met) oțel cornier, colțar

knee joint $(\mathrm{OM})$ articulație tip nucă

kneel a îngenunchea; a sta în genunchi

kneeler $(\mathrm{OM})$ pârghie cotită, îmbinare articulată

knee pipe $(\mathrm{OM})$ țeavă / conductă cotită

knee plate $(\mathrm{OM})$ guseu, colțar, placă în consolă

knee-type miller / milling machine (mas-un) maşină de frezat, cu consolă (radială)

knee-voltaje (el, metr) tensiune de saturatie

knife (alim) cuțit; (mas-un) dinte / tăiş de freză / de cutit, dinte de freză

knife-blade contact $(\mathrm{el}, \mathrm{OM})$ contact baionetă

knife clip (mas-un) port-cuțit

knife disk (mas-un) cuțit-disc, disc tăietor

knife driving shaft (mas-un) arbore port-cuțit

knife edge lamă de cutit; (mas-un) tăișul cutitului, muchie ascuțită, muchie tăietoare; (OM) lagăr tip cuțit

knife-edge bearing (OM) lagăr tip cuțit

knife-edge (în unghi) ascuțit (d. o muchie)

knife edge of balance (metr) prisma balantei

knife-edge load $(\mathrm{mec})$ sarcină liniară

knife-edge stright line (mas-un, metr) riglă cu margine ascuțită

knife-edge support (OM) suport cu prisme

knife file pilă-cuțit

knife grinder (mas-un) maşină de ascuțit cuțite

knife-grinding attachament (mas-un) dispozitiv de ascuțit cuțite

knife-grinding machine (mas-un) maşină de ascuțit cuțite

knife grooving tool (mas-un) cuțit îngust, de canelat

knife of piow rindea (de lemn)

knife pass (met) calibru secționat (pt. laminare)

knife reaper file pilă-cuțit

knife section (alim, mas-un) lamă de cutit

knife steel (met) oțel pentru cuțite (rar)

knife switch (el) întrerupător tip cuțit / lamă

knife-switch prong (el) lamă de contact; cuțitul întrerupătorului cu pârghie

knife tool (mas-un) cuțit îngust, sculă sub formă de lamă

knifing (met) laminare cu calibru sectionat

knit (textile) a tricota, a împleti

knitter (textile, mas) tricoteză, maşină de tricotat

knitting (textile) tricotare, împletire, împletitură; lucru de mână 
knitting needle (textile, $\mathrm{OM}$ ) andrea, ac de tricotat knob (autom, cf) clapetă de bloc; (el) izolator cilindric; nod de lemn, ciot; (mas) buton rotativ; $(\mathrm{OM})$ proeminență, convexitate, bombare; movilă, dâmb

knobbed noduros, cu noduri, cu proeminență

knobbled iron / steel (met) oțel Martin (rar), oțel elaborat prin procedeul de pudlare

knobbling fire (met) vatra cuptorului pentru lupe

knobbling rolls (met) cilindri de prelucrare grosieră / degrosisori

knobbly noduros, cioturos (d. lemn)

knock ciocănitură, bătaie (în uşă) (mec) lovitură, izbitură; a lovi (în), a (se) lovi, a se ciocni, a (se) izbi, a bate (în), a ciocăni (în); (fam) a face impresie puternică asupra; a ciocăni (la uşă); (OM, mec) a bate (d. un motor, o piesă în rotație etc.); a doborî; (ec) a scădea, a reduce (d .prețuri); a face de mântuială; a fura; a bate complet (un cui etc.); a pregăti în pripă, a strânge în grabă; a se istovi; a face în grabă, la repezeală; take the $\sim(\mathrm{ec})$ a fi lovit greu (din punct de vedere financiar)

knock about a vagabonda; a brutaliza; (ec) a adjudeca (la licitație)

knock-about (amer) (nav) iaht mic

knock against a se lovi cu (ceva) de (ceva), a da peste, a întâlni din întâmplare

knock down $(\mathrm{TH})$ a demonta, a dezasambla, a desface; a reduce; demontabil; (ec) a reduce, a micşora (prețul), a face (pe cineva să micşoreze prețul), (preț) minim, cumpărare / livrare de produse montabile de către cumpărător; (constr) a demola; a adjudeca (la licitație)

knocked down (nav) angajată (d. navă)

knocked down test (met, metr) încercare de refulare / la compresiune

knocker (chim) detonator; (constr) bătător, mai

knock-free (chim) nedetonant

knocking ciocnire, lovire; (mas) bătaie, abatere (prea mare) în funcționare, detonare; (met) îndepărtare / scoatere (prin lovire) a țunderului / a arsurii (la laminoare)

knocking-in device (met, OM) dispozitiv de împingere (şi la cuptoare)

knock loose (mec) a despărți prin lovire

knock-off oprire, respingere, îndepărtare; reducere; încetare a lucrului; micşorarea / reducerea vitezei; (ec) scăderea / micşorare (d. prețuri)

knock off a opri, a respinge, a îndepărta; a reduce; a înceta lucrul; a micşora viteza; (ec) a scădea / micşora (prețul etc.); (TH) a da afară / demonta cu lovituri / prin lovire knock-off stop (mas-un, OM) limitator de cursă knock-on collision (mec) coliziune directă

knock out (met) dezbatere (la forme), a scoate prin lovire, a dezbate (în turnătorie); a scoate din luptă (sport)

knock out by jolting (met) dezbatere prin vibrare (a formelor de turnare)

knock out grid (met) grătar de dezbatere (a formelor de turnare)

knock-out key $(\mathrm{OM})$ extractor de pană

knock-out of mould (met) dezbatere (a formei) (la turnătorie)

knock-out rod (mas) aruncător (la presă), tija mecanismului de decuplare; (plast) tijă aruncătoare

knock producer (chim) detonator, substanță detonatoare

knock property (chim) proprietate de detonare

knock-sedative dope (chim) adaos antidetonant

knock test (chim, metr) încercare la detonare

knock the bottom out of an argument a combate un argument

knock together a face repede / de mântuială; a înjgheba; a asambla / monta (prin lovire / batere); a aduna (laolaltă); a se lovi unul de altul

knock under a ceda (la o lovitură / izbitură etc.)

knock up a scula; a câştiga prin muncă; a se istovi

Knoop hardness (materiale, metr) duritate (măsurată prin metoda) Knoop

Knorr air brake (auto, cf) frână Knorr

knot nod; (el) buclă; (nav) nod (la parâmă), nod marinăresc; defect de fir, a înnoda, a lega, a face noduri; (fig) nod, miez; grup, ceată, mănunchi; (textile) nod, defect de fir; (metr) unitate de măsură pentru viteză egală cu o milă marină pe oră, nod: 1 knot $(\mathrm{UK})=$ $0,514773333 \mathrm{~m} / \mathrm{s} ; 1 \mathrm{knot}=0,514444444 \mathrm{~m} / \mathrm{s}$

knot hole gaură de nod (în lemn)

knot of the truss (constr, mec) nod de fermă

knot strength (constr, mec) rezistență în nod

knotty cu noduri; noduros, cioturos (d. lemn)

knotty wood (silv) lemn noduros

know a cunoaşte, a ști; a avea experientă; a recunoaşte, a-şi reaminti; a avea cunoştinţă despre; a recunoaşte; a deosebi de; a fi în rela-ții; a vedea; a fi de față; a fi informat (despre); a fi la curent (cu); a putea; a fi hotărât

knowable care poate fi cunoscut, cognoscibil; care se poate recunoaşte; sociabil, prietenos

know about a şti despre

know all about it a fi la curent

know better than a avea destul bun simț față de; a avea destulă experiență în legătură cu, a ști mai bine decât; a fi mai prudent / prevăzător decât, a avea suficientă experiență ca să nu 
know from a distinge de, a deosebi de / între know how a se pricepe, a avea cunoştințele necesare pentru a face un anumit lucru

know-how informații / cunoştințe tehnice utilizate în industrie, experiență / competență practică, pricepere, dexteritate, abilitate; savoir-faire; secret profesional / de productie; $(\mathrm{TH})$ totalitatea cunoştintelor practice necesare pentru o bună utilizare a metodelor sau/şi maşinilor

knowing informat, care ştie, care se pricepe; cunoscător, priceput, abil; cunoaştere; înțelegere, pricepere; putere de înțelegere

knowingly $(a d v)$ (în mod) conștient, cu bună ştiință, intenționat

knowledge știintăă, cunoaștere / cunoștințe (întrun domeniu), informație

knowledgeable (bine) informat, inteligent; versat

knowledge engineering proiectare pe baze fundamentate / documentate

known ştiut, cunoscut (d. un proces, o informație)

known as cunoscut ca

known from experience cunoscut din experiență / din practică

know-nothing ignorant, neştiutor

known to cunoscut de către

know of a şti despre

knuckle (OM) articulație, cot; curbă; (mas-un) clichet de cuplare; (nav) cot; (met) canal / rețea de turnare

knuckle joint (auto, OM) articulație cardanică de tip nucă / genunchi

knuckle joint press (mas-un) presă mecanică cu genunchi

knuckle pin (OM) bolț de articulație; bolțul capului de cruce

knuckle post (mec) reazem articulat

knuckle thread (OM) filet rotund

knuckle under a ceda knurl (mas-un) randalinare, moletare, rolă de striere / de zimțuit, moletă; a stria, a moleta, a zimțui; nod, ciot

knurl (mas-un, met) a cresta, a zimțui, a stria, a moleta

knurled button (mas) buton randalinat / moletat knurled-head (mas, OM) cap (de piesă) moletat / randalinat

knurled-head screw (OM) şurub cu cap moletat knurled nut $(\mathrm{OM})$ piuliță randalinată

knurled screw $(\mathrm{OM})$ şurub cu cap randalinat

knurling (mas-un) moletare, randalinare, crestare, zimțuire, striere

knurling and corrugating machine (mas-un) maşină de bordurat

knurling machine (mas-un) maşină de moletat

knurling pitch (mas-un) pasul randalinării

knurling tool (mas-un) sculă / rolă de randalinat, moletă

knurling turret tool (mas-un) cutie cu o set de role de zimţuit(la strung revolver)

knurl pitch (mas-un) pasul randalinării

kohm (kilo-ohm) (el) kilo-ohm

konel (met) konel (aliaj Ni-Co-Fe-Ti)

koniscope (metr, fiz, mediu) aparat de măsurat de detectat praful în aer

krylene (plast, ind chim) copolimer butadienstirenic (denumire comercială)

Krypton (Kr) (chim) cripton

ksi, kilo-pound(-force) per square inch (metr) unitate de măsură pentru presiune: $1 \mathrm{ksi}=$ $6894757,2931783 \mathrm{~Pa}$

kurtosis of the assessed profile (metr) factor / parametru de aplatizare a profilului evaluat (la profilometria suprafeței) (simbol Rku pt. profile 2D şi Sku ca parametru 3D sau spațial)

kynar (plast) denumire comercială a polifluorurii de viniliden 


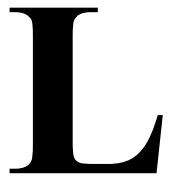

L (mat) numărul 50, în simbolizare romană

L, I (metr) simboluri SI pentru litru, v. liter; se preferă L pentru a nu se confunda cu numărul 1

lab, laboratory laborator

láb (metr) unitate de măsură pentru lungime în Ungaria, Hungarian foot, 1 láb $\sim 31,6 \mathrm{~cm}$ (= 1 Viennese fuß)

label placă, tăbliță / placă / plăcuță indicatoare; marcă a fabricii; plumb de garanție; etichetă, inscripție, denumire, semn distinctiv; a eticheta, a pune o etichetă / inscripție pe, a prevedea cu o inscripție / etichetă; a marca (un produs etc.), a prevedea cu o inscripție; (inf) adresă din memorie (mai rar); (fig) caracterizare (a cuiva), a face o caracterizare (cuiva), a caracteriza, a califica, a eticheta; (jur) codicil, adaos la un document; (constr) streaşină; (cf, av, transp) a înregistra un bagaj; (TH, transp) plumb de garanție; semn distinctiv

label coding indicator de cod (pt. produse, piese etc.)

label information (auto) etichetă informativă / cu informații

labelled (fiz) marcat (cu un izotop); etichetat, care are marcajul sau eticheta aplicat( $\breve{a})$

labelled molecule (chim) moleculă marcată (cu elemente / constituenți uşor de detectat etc.)

labelled statement (inf) instrucție / instrucțiune generală marcată

labeller (ind) maşină de etichetat / de pus etichete

labelling $(\mathrm{TH})$ etichetare, denumire, indexare, tabelare; (fiz, metr) marcare, marcaj (cu un izotop, cu un anumit simbol sau cod)

label punching machine (mas, ind) maşină de decupat etichete

labile (chim, met) instabil, labil; (constr) bitum cu plasticitate redusă (casant)

labile compount (chim) compus labil

labile oscillator (autom, electr) oscilator telecomandat

labile point (fiz) punct nestabil / instabil

lability (chim, fiz, mas) labilitate, instabilitate

labor (amer) (nav) balans puternic (al navei pe mare rea), a avea ruliu şi tangaj puternice, a lupta cu furtuna / valurile (d. navă); (med) travaliu, chinurile naşterii; (ec) lucrători, munci- tori, mână de lucru, muncă (grea), muncă fizică; (metr) unitate tradițională pentru suprafață (de teren) în America Latină: 1 labor 71,685 ha (şi în Texas)

laboratory laborator; (met) baie, cadă

laboratory ambient conditions (metr) condiții de laborator $\left(18 \ldots 24^{\circ} \mathrm{C}\right.$ şi $45 \ldots 55 \%$ umiditate)

laboratory beater (metr) holendru experimental / de laborator (în industria hârtiei)

laboratory bench (metr) masă de laborator

Labor Day Ziua muncii (în SUA, prima luni din septembrie)

laboratory engine test (metr, termo) încercare a motorului pe banc / în laborator

laboratory equipment (metr) aparatură / echipament / instalaţie de laborator

laboratory frame / system (metr) sistem de referință (de coordonate), de laborator

laboratory glass-ware (metr, ind chim) sticlărie de laborator

laboratory grade instrument (metr) aparat de precizie / de laborator

laboratory scale (metr) scală / scară de laborator

laboratory size (metr) macroscopic, dimensiune de laborator

laboratory standard (metr) etalon de măsură

laboratory system (metr) sistem de referință (de coordonate) de laborator

laboratory technician laborant

labour, (brit) labor (amer) muncă (grea); muncă fizică, efort, lucru, trudă; (ec) mână de lucru, forță de muncă, muncitori, lucrători; produs al muncii; produs al muncii; a munci, a lucra; (nav) balans puternic (al navei pe mare rea), a avea ruliu și tangaj puternice, a lupta (din greu) cu furtuna / cu valurile (d. navă); (pol) clasă muncitoare; (pol) (fam) laburiştii, laburism; (fig) $(s g$ şi $p l))($ med) facere, naştere, chinurile / durerile nașterii, (d. femei) a naște, a fi în chinurile naşterii / durerile facerii; a (se) trudi, a munci, a îndeplini o muncă; a munci la (un plan dificil etc.); a lucra cu atenție la, a trata amă-nunțit (un obiect etc.); a redacta amănunțit; a elabora amănunțit; a expune amănunțit; a lupta; (mec, mas) a funcționa cu greu; to a se strădui (să), a face eforturi (pentru a); lost $\sim$ muncă zadarnică; manual $\sim$ muncă manuală; skilled muncitor calificat; shortage of $\sim$ criză de mână de lucru / forță de muncă; employer of patron; demands of $\sim(\mathrm{pol})$ revendicări ale laburiştilor / stângii

labour question (pol, ec, adm) problemă a forței de muncă

labour troubles (pol, ec, adm) conflicte între muncitori şi patroni

labour under an illusion a fi victima unei iluzii 
labour up a hill a urca greu o pantă labour along a înainta cu greu (şi fig)

labour at/over smth. a munci la ceva labour contract $(\mathbf{e c})$ contract de muncă labour cost(s) (met, ec) cheltuieli / costuri pentru manoperă / cu forța de muncă

laboured (med) (d. respirație) greu, greoi; (d. stil) greoi, artificial

labourer (constr, hidr) salahor; (ec) muncitor necalificat, zilier

labour exchange / market (pol) piața forței de muncă

labour for smth. a se trudi pentru ceva

labour hoarding (ec) angajare de forță de muncă peste necesitățile imediate (pt. a preîntâmpina o lipsă în viitor)

labouring muncitor, care muncește; (med) (d. respirație) îngreunată

labour intensive industry industrie bazată în special pe muncă / manoperă (cu un cuantum redus de capital)

labour legislation (jur) legislație a muncii

labourless uşor, care nu cere efort

labour of love serviciu gratuit, serviciu făcut cu plăcere

labour protection $(\mathrm{TH}$, ind) protecția muncii

labour safety $(\mathrm{TH}$, ind) siguranța muncii

labour safety rules $(\mathrm{TH}$, ind) prescripții de securitate a muncii

labour saving (ec) economie de muncă, mărirea productivității muncii, care face / presupune economie de forță de muncă

labour saving device (mec) dispozitiv mecanic

labour through a înainta greu prin

labyrinth labirint; impas, situație fără ieşire, încurcătură; (OM) etanşare tip labirint (fără contact)

labyrinth compressor (termo, $\mathrm{OM}$ ) compresor cu labirint

labyrinth gland / packing / seal(ing) (OM) etanşare cu / prin labirint, presgarnitură-labirint

labyrinthine, labyrinthic labirintic, de labirint; încurcat, încâlcit

lac (chim) lac

lace dantelă; (textile) şiret (şi de pantof), şnur, panglică, rețea, plasă; a lega cu şireturi / sfoară; a dunga, a fi prevăzut cu şireturi; (alim) a adăuga coniac / lichior

lacer igliță

lacerate a rupe; a sfâşia (d. textile, folii, compozite cu fibre); (med) a schilodi

lacery dantelărie, dantelă

laches (jur) nerespectarea termenului legal; întârziere nejustificată; incurie; neglijență, nepăsare lacet road (auto) drum în serpentine

lachrymator (chim) gaz lacrimogen

lacing board $(\mathrm{el}, \mathrm{mec})$ şablon pentru formarea cablurilor

lacing panglici, dantelărie; (med) pansamente

lacing machine (textile, mas) maşină de şnuruit

lacing messenger (el, mec, OM) cablu suport în zigzag

lack (of) lipsă, absență; neajuns, nevoie (de), trebuinţă; articol care lipseşte; a lipsi, a avea nevoie de, a-i trebui; a fi lipsă (de), a fi lipsit de, a nu exista, a nu se găsi; a da greş, a nu reuşi; for $\sim$ of money din lipsă de bani; experience a fi lipsit de experiență, a-i lipsi experiența

lacking absent, lipsă, care nu se găseşte / lipseşte

lack of interrun fusion (met) lipsă de topire între straturi (la sudură, defect)

lack of fusion / penetration (met, TH) lipsă de pătrundere a sudurii, sudură nepătrunsă / incompletă

lack of root penetration (met) lipsă de pătrundere la rădăcina sudurii, sudură nepătrunsă / incompletă la rădăcină

lack of side wall fusion (met) lipsă de topire laterală (la sudură)

lacmus (chim) turnesol

laconic laconic, concis

laconism laconism, exprimare laconică; concluzie

lacquer (ind chim) lac, smalț, verniş; glazură; a lăcui, a glazura, a emaila; acoperire cu lac

lacquer curing furnace (met, termo, chim) cuptor pentru uscarea tablei lăcuite

lacquered lăcuit

lacquer finish (ind chim, TH) vopsea, lac (ca strat final sau de finisare)

lacquer for bronze (ind chim) lac de bronz

lacquering (ind chim, TH) lăcuire

lacquering stove (ind chim, termo) cuptor de emailat / de ars / de uscat lacuri

lacquer solvent (ind chim) solvent pentru lacuri

lacquer thinner (ind chim, TH) diluant pentru lacuri

lactase (chim) lactază

lactate (chim) lactat

lactic acid (chim) acid lactic

lactic salt (chim) sare lactică

lactodensimeter (alim, metr, chim) lactometru, galactometru

lactometer (alim, metr, chim) lactometru

lactose (chim) lactoză

lacuna, $(p l)$ lacunae lacună, întrerupere (şi întrun text) 
lacunar(y), lacunal lacunar (în analiza matematică)

lacustrine lacustru

lac varnish (ind chim) lac, lac de ulei

ladder (OM) scară, scară mobilă, bridă, jug, punte amovibilă, jug, diagonală de macazuri; (constr) elindă; (textile) ochi deşirat / scăpat (într-o împletitură, la un ciorap, un tricot etc.), ochi de încheiat, a (se) deşira (d. un fir); (nav) punte amovibilă; (cf) diagonală de macazuri

ladder attenuator atenuator în trepte / iterat / multicelular

ladder bucket dredge (nav) elindă, dragă cu cupe ladder chain (OM, alim) lanț de / cu cârlige (la abatoare etc.)

ladder chain carrying buckets (alim, constr, ind chim) lanț / transportor cu cupe / cu cârlige

ladderditcher (mas, constr) excavator cu elindă / pentru şanțuri

ladder dredge (nav) dragă cu godeuri / cu cupe

ladder peg $(\mathrm{OM})$ treaptă la o scară de lemn

ladder-proof (textile) indeşirabil, care nu se deșiră

ladder scafold (constr) schelă de fațadă

ladder step (OM, constr) treaptă (de scară)

ladder stringer $(\mathrm{OM}$, constr) montant

ladder trailer (auto) remorcă cu scară

ladder-type filter (autom, hidr, mediu) filtruscară / multicelular / iterat, lanț de filtre

lade (nav, transp) a încărca, a umple (nava); a goli, a scoate (lichide)

laden in bulk (nav, transp) încărcat în vrac

laden with (nav, transp) încărcat cu / de, plin de

lader (nav) încărcător, hamal

lading (nav, transp) încărcătură (de navă), caric, navlu, încărcare

ladle (constr) cancioc; (mas) cupă, benă; (met) oală de turnare, lingură de turnare; (alim) lingură mare, polonic, a scoate cu lingura / polonicul

laddle addition (met) adaos (direct) în oală

laddle analysis (met, metr) analiză din oală / din creuzet

ladle bail (met, constr) traversă cu brațe pentru suspendarea oalelor de turnare

ladle barrow / bogie (met, cf, transp) vagonet de transportat oala de turnare

ladle bowl (met) creuzet-oală

ladle brick (met, ind chim) cărămidă pentru înzidirea / căptuşirea oalei de turnare

ladle capacity (met) capacitate de turnare a oalei

ladle car / carriage (met, cf, transp) cărucior / vagonet de transportat oală / oale

ladle casing (met) mantaua / carcasa oalei ladle crane (met, transp) macara de turnare ladle deoxidising (met, $\mathrm{TH}$ ) dezoxidare în oală ladle drying plant (met) instalație de uscat oale ladle emptying time (met) timp de golire al oalei ladle forchearth (met) antecreuzet

ladle heating plant (met) instalație de încălzit oale

ladle heel (met) crustă aderentă la oală, urs

ladle inoculation (met) modificare în oală (prin adaosuri de fiero-aliaje etc.)

ladle lining (met) căptuşeală (refractară) a oalei

ladle lip / nozzle (met) cioc al oalei de turnare / al lingurii de turnare

ladle out (met) a scoate, a evacua, a epuiza (topitura etc.); a împărți (generos)

ladle sample (met, metr) probă (de metal) din oală

ladle scull / skull (met) crustă aderentă la oală, urs (la furnal)

ladle shank (met, OM) jug / furcă a(l) oalei de turnare

ladle shell (met, OM) manta a oalei de turnare

ladle support (met, OM) cârlig pentru ridicarea oalei de turnare

ladlet (met) oală de turnare; (constr) sand mistrie

ladle truck (met, cf, transp) vagonet de transportat oala de turnare

I(a)evo(-)rotation (mec) rotație la stânga

lag (TH, autom) întârziere (de reacție a operatorului sau/şi a sistemului), rămânere în urmă, încetinire, decalaj; (autom, el, electr, c) defazare / defazaj în urmă; întârziere (de fază), întârziere de reproducere, rămânere în urmă (a unui semnal etc.); doagă, şipcă (de lemn), a pune doage / şipci; (mat) întârziere; (constr, termo) a căptuşi (şi cu izolație termică); (autom, el, mas) a întârzia, a fi în întârziere de fază, a fi defazat în urmă; $(\mathrm{OM})$ garnitură, înveliş (rău conducător de căldură $)$, şurub cu capul pătrat; $(\mathrm{OM}, \mathrm{cf})$ bulon de fixat şina în traversă; (mas, chim) retard de reactie; a rămâne în urmă; (jur) detenție, deținut, infractor, întemnițare, a întemnița, a aresta, a închide; (OM) a aresta / bloca (o piesă de prelucrat, defect sau operație impusă tehnologic); (textile) ancoşă; (mas-un, TH) decalaj între două operații; (met, TH) rămânere în urmă (la tăierea oxiacetilenică); of the tide (geogr, nav) întârziere a mareei

lagan (nav) bunuri aruncate în mare (scufundate şi balizate în vederea recuperării)

lag-and-lead lever $(\mathrm{OM})$ pârghie oscilantă

lag behind a nu corespunde; a nu face față; a rămâne în urmă 
lag compensation (electr, autom) compensare de remanență

lager beer (alim) bere tare, de fermentație inferioară (germană)

lag error (nav) eroare de antrenare (a rozei compasului, la schimbări de drum); (el) eroare de sincronizare / de urmărire

lagged-demand meter (el, metr) contor de maximum cu indicație întârziată; (metr) aparat de înregistrare cu întârziere

laggers (ec) indicatori comerciali care apar ulterior unei activități comerciale

lagging $(\mathrm{TH})$ încetinire, întârziere, defazaj; (OM) căptuşeală, bandaje (şi de roți), înveliş de protecție, căptuşeală, manta; eşalonare; deplasare, rămânere în urmă, decalaj (între operații); (el) strat izolant / izolator, întârziere de fază, circuit de curent alternativ în care vârfurile de curent apar întârziat față de vârfurile de tensiune, rămânere în urmă (a unui semnal); (termo) izolatie / izolare termică; (ind chim) temporizare, izolare termică, încetinire (a unei reacții); (nav) întârziere a mareei, corecție a orei portului (de producere a mareei înalte); (met) întârziere în prinderea metalului / semifabricatului între cilindri (defect de sincronizare a sistemelor tehnice sau al calității materialului şi/sau cilindrilor)

lagging coil (el, metr) bobină de întârziere (la contoare)

lagging crankshaft $(\mathrm{OM}$, transp) manivelă de tracțiune

lagging efect $\mathrm{TH}$, chim) fenomen / efect / proces de încetinire a unui proces într-un anumit punct (într-o anumită etapă)

lagging load (el) sarcină inductivă

lagging plank scândură (bandaj)

lagging power factor (el) factor de putere inductiv

lag ignition (auto, termo) aprindere întârziată

lag-lead equalizer (autom, electr) corector / compensator de defazare

lag of ignition (chim) perioadă latentă de aprindere (de exemplu, la metan)

lag of release (autom) perioadă de temporizare, timp de declanşare

lag of the tide (nav) întârziere a mareei

lagoon (geogr) lagună

lag period (chim, ele, autom) perioadă de latență / de întârziere (a unei reacții, semnal etc.)

Lagrange correlation coefficient (mat) coeficient de corelație Lagrange

Lagrange particle trajectory (mat, fiz) traiectoria particulei tip Lagrange
Lagrange's / Lagrangian funtion (mat) funcția lui Lagrange; (mec) potențial cinetic

Lagrange's theorem (mat) teorema lui Lagrange, formula creşterilor finite, formula mediei, prima formulă a creșterilor finite

lag regression (mat) regresie $\mathrm{cu}$ argument întârziat

lag time, dead time ( $\mathrm{TH}$, autom) timp mort / de decalaj

laid-down (TH, el, constr) pozat, aşezat, depus; (poligrafie) aşezat în pagină

laid-in key $(\mathrm{OM})$ pană îngropată

laid length of pipe (OM, hidr, termo) lungime (aşezată a) conductei

laid paper hârtie liniată

laid rope $(\mathrm{OM}$, transp) parâmă de sârmă cu 6 vițe a 7 fibre, cablu rigid din fire de oțel

laid shroud rope (nav) parâmă de sart

laid-up ship (nav, mil) navă dezarmată (scoasă din serviciu)

lake (geogr) lac, iaz, ieleşteu, ghiol; (chim) lac, pigment

lake copper (met) cupru nativ

laked (ind chim) lăcuit (d. o suprafață)

lake tool (mas-un) port-cuțit pentru fixarea cuțitelor mici

Lalande cell (el, chim) pilă / element Lalande / cu zinc şi fier

lam (drum) argilă grasă; a bate, a lovi

lamb (alim) (carne de) miel

lambda denumire pentru litera mică grecească $\lambda$, (metr, chim) unitate SI de măsură pentru volum: 1 lambda $=1 \mathrm{~mm}^{3}$ sau 1 microliter $(\mu \mathrm{L})$; (metr, electr) unitate relativă de măsură în proiectarea microcircuitelor integrate, de ordinul zecimilor de micron

lambda calculus (inf) calcul lambda, model formal al limbajului LISP

lambent (d. lumină) licăritor, pâlpâitor; sclipitor

lambert (La, Lb, L) (metr, fiz) unitate în sistemul CGS pentru luminanță / strălucire luminoasă, strălucire luminoasă: 1 lambert este luminanța unei suprafețe care emite / refelectă 1 lumen $/ \mathrm{cm}^{2}$

Lamb shift (fiz) deplasare Lamb

lambskin pielicică de miel

lame (met, metr) placă subțire de metal, lamelă metalică; defect

lamella, $(p l)$ lamellae (mas-un, met) placă, plăcuță, lamelă, cristal / grăunte lamelar strat, folie, foaie, felie, tablă, placă, ştraif

lamellar (OM) lamelar (şi d. compozite), cu lame / lamele; foios, folios, foliform, cu plăci, cu aripioare 
lamellar chisel (mas-un) dalta dublă

lamellar field (mat, fiz) câmp nerotațional / neturbionar / lamelar

lamellar fracture (mec, materiale) ruptură / fractură lamelară

lamellar heat exchanger (termo) schimbător de căldură cu lamele

lamellar martensite (met) martensită lamelară

lamellar pearlite (met) perlită lamelară

lamellar structure (materiale) structură lamelară / cu lamele

lamellate lamelat, cu lamele / folii

lame şchiop, schilod; defectuos; incapabil; imperfect; fără valoare; care şchiopătează; a schilodi

lame duck (ec) (fam) falit

lame excuse scuză cusută cu ață albă

lamely $(a d v)$ şchiopătând; fără finisare, nelucrat

lameness (anat) infirmitate; şchiopătat (şi a unui argument; imperfecțiune, defectuozitate

lamina $p l$ laminae (OM, compozite, el) lamelă, placă, strat, foită, foaie, tablă

lamina of wood placaj, placă de furnir (d. lemn)

laminar boundary layer (hidr, T) stratul laminar de margine / de lângă margine, strat de viteză nulă

laminar flow (mec, hidr) curgere / curent lami$\operatorname{nar}(\breve{a})$

laminar insulation (termo, el) izolație stratificată

laminar motion (hidr, mec) mişcare laminară curgere laminară

laminar stratum (hidr, materiale) strat laminar

laminar sublayer (hidr, plast) strat laminar, film laminar

laminate (met, plast) laminare în foi subțiri, (produse) laminate, stratificat(e); a (se) lamina; (OM) cu lamele

laminated (met, plast) laminat; lamelar, foios; (el) din tole

laminated board panel (de lemn)

laminated channel section (materiale, $\mathrm{OM}$ ) profil $U$ din material stratificat

laminated cloth (plast) textolit

laminated coal (met) cărbune lamelar (care se exfoliază)

laminated epoxy resin (plast, ind chim) răşină epoxidică stratificată / laminată în straturi

laminated film (plast) foaie / folie stratificată / obținută prin laminare

laminated fuse (el) siguranță lamelă / cu bandă fuzibilă

laminated glass (ind chim) sticlă securit / stratificată

laminated-iron core (el) miez din tole de oțel

laminated material (material) laminat laminated moulded section (plast) profil stratificat, secțiune obținută prin turnare şi laminare laminated moulding (plast) formare / matrițare prin stratificare

laminated paper hârtie dură

laminated plastics materiale plastice stratificate

laminated preform semifabricat stratificat

laminated sheet placă stratificată

laminated sheet iron (met) tablă de oțel, laminată

laminated spring (OM) arc lamelar / din / în foi

laminated spring hammer $(\mathrm{OM})$ ciocan $\mathrm{cu}$ arc din foi

laminated spring valve $(O M)$ supapă cu arc lamelar

laminated stucture (materiale) structură laminată / lamelară

laminated tape (materiale) bandă din unul sau mai multe straturi laminate

laminated thermosetting plastics (plast) materiale plastice termoreactive / termorigide stratificate

laminated wire core (el) miez din fire (de oțel) laminate

laminated wood lemn impregnat, placaj de lemn

laminates (plast) materiale plastice stratificate / laminate

laminating (plast) stratificare

laminating press (mas-un, plast) presă pentru materiale plastice stratificate

laminating resins (plast) răşini pentru materiale plastice stratificate

laminating roller (met, plast, metr) role de reglare (pt. obținerea tablei / foliei la diferite grosimi)

laminating rolling mill (met) laminor de tablă subțire (pentru metale pretioase)

laminating wax $(\mathrm{TH}$, chim) parafină pentru stratificare

lamination $(\mathrm{TH}$, materiale, $\mathrm{T})$ stratificare, exfoliere, laminare, strat; încrețire, suprapunere (defecte de laminare); (plast) material stratificat, vălțuire

lamination core (met, materiale) miez laminat

laminations (met) defecte la laminare, sub formă de discontinuităţi fine, aplatizate, la marginea, muchia sau capătul semifabricatului

lamp (ec) lanternă, lampă / bec electric( $\breve{a})$, corp de iluminat; (electr) tub electronic; (TH) a lumina, a privi la

lamp bar (auto) bară de legătură dintre suporturile farurilor

lamp base / cap (OM, el, electr) soclu cu borne al unei lămpi electrice / al unui tub electronic 
lamp( )black (chim) negru de fum / de flacără; (mas) calamină; (termo) funingine

lamp body (auto) carcasă a farului

lamp bulb (auto) bec pentru far; (el) lampă electrică / bec cu incandescență

lamp bump circuitry (auto) circuite ale becului lămpii

lamp call (mas, $\mathrm{TH}$, opt) apel optic

lamp current (fiz) flux luminos

lamp equipment (fiz, el) reflector (al unei lămpi) pe un echipament

lamp fitting corp de iluminat

lamp flashing ( $\mathrm{TH}$, ind, transp) semnal luminos, lampă de semnalizare

lamp-holder (el, OM) dulie, fasung

lamp-holder switch (el, OM) întrerupător fixat pe suportul lămpii

lamp housing (el) corp de iluminat

lamp oil (ind chim) petrol lampant

lamp post (constr, el) stâlp pentru iluminat

lamp press, lamp squash $(\mathrm{OM}, \mathrm{el})$ soclu de lampă electrică

lamp rating (el) tensiune nominală a unei lămpi

lamp sealed beam unit $(\mathrm{OM}$, el) reflector, filament, lampă ca sistem etanş

lamp shade $(\mathrm{OM})$ abajur, protecție a unui bec / a unui corp de iluminat

lamp signal (fiz) apel / semnal optic

lamp socket (el) soclu / dulie de lampă electrică

lamp switchboard (el) tablou de semnalizare luminoasă

lamp tripod $(\mathrm{OM})$ stativ de lampă

lamp wick (textile) fitil de lampă

lamp with solid carbons (el) lampă cu electrozi de cărbune

lanac (metr) unitate de măsură pentru suprafață în fostele state yugoslave: 1 lanac (Serbia) 0,56 ha, 1 lanac (Croația) $=0,7193$ ha

lance (met) lance (pt. insuflat oxigen, argon etc.) lance cutting (met) tăiere cu oxigen / cu flacără lance pole (constr, mec) prăjină / drug / vergea / bară / tirant / pentru construcții

lancet (constr) săgeată a bolții, arc în ogivă; (met) rangă pentru destupat cuptorul / furnalul

lancet window (constr) fereastră în ogivă

lancing (met) tăiere cu oxigen / cu flacără

land $(\mathrm{TH}, \mathrm{ec}$, geogr) pământ, uscat, ținut, teren, sector, sol; proprietate funciară; (ec, geol) resurse / bogății naturale; (mas-un, OM) fațetă / suprafață de ghidare / de contact / de presare / de sprijin; (şi fig) glie, moşie, pământ; provincie; regiuni rurale; (fig) țară; (adj) de uscat, terestru; (nav) a debarca (pasageri), a descărca (mărfuri), a coborâ la uscat (d. echipaj), a acosta, a trage la mal (o barcă), a ancora, a face escală; a sosi, a ajunge; (av) a ateriza; a pune (pe cineva) într-o anumită situație; a realiza; a cădea, a se pomeni (într-un şanț etc.)

a acosta; (fam) a ajunge

land agent $(\mathrm{adm})$ administrator (funciar)

land (area) (OM, mas-un) suprafață de sprijin / de presare / de contact

land bank (ec) bancă de credit funciar

land betterment (constr, agr) îmbunătățire funciară, ameliorare a terenului

land carriage (transp, ec) transport de / pe uscat land carrier (transp, ec) cărăuș (răspunzător) pentru mărfurile transportate pe uscat

land clearing (agr, silv) defrișare

land cofferdam (nav) batardou

land cruiser (transp) autobuz interurban

landed care posedă pământ; $(a d j)$ funciar

landed force (mas-un) poanson cu margine de presare

landed price (ec, nav) preț la debarcarea mărfurilor

landed terms (ec, nav) condiții de plată a mărfii descărcate în portul de destinație

landfall aterizare; (nav) apropiere de uscat (dinspre larg); apariție a uscatului (în vedere sau pe ecranul radarului); (geogr) alunecare / surpare de teren

landfall light (av) lumină de aterizare, far luminos land fog ceață continentală / de uscat

land form (constr, geol) configurație a terenului land gas turbine (termo) turbină stabilă, cu gaze landholder proprietar de pământ; arendaş

land improvement ameliorare a terenului; îmbunătățire funciară

landing (nav) debarcare, acostare, debarcader, loc de debarcare; aterizare

landing account (ec) cont de debarcare (al antrepozitelor)

landing apron (transp, OM) planşă de securitate a cabinei (la ascensoare)

landing barge (nav) şlep / ponton de debarcare

landing boat (mil, nav) ambarcație de desant / de debarcare

landing book (ec, nav) registru al mărfurilor debarcate

landing-call push $(\mathrm{Om}$, transp) buton de apel pe etaj (la ascensoare)

landing charges (ec, nav) speze de debarcare

landing craft (nav) şlep de debarcare autopropulsat, mijloace de desant (şi mil)

landing deck (nav, av) punte de apuntare / de decolare (la portavioane); punte de elicopter (pt. apuntarea elicopterelor)

landing field (av) teren / câmp de aterizare 
landing gear (av) tren de aterizare

landing light (el, av) baliză de aterizare

landing nipple (OM, hidr) niplu de fixare / de reglare, racord interior

landing order (nav, mil) permis de debarcare

landing pier (nav, constr) chei de debarcare, debarcader

landing place (nav, constr) loc de debarcare, debarcader

landing platform (transp, constr) rampă de descărcare

landing pontoon (nav) ponton de acostare / de debarcare

landing ship (nav, mil) navă de desant / de debarcare

landing skid $(\mathrm{OM})$ patină (la maşini)

landing spot (nav, constr) debarcader

landing stage $(\mathrm{TH})$ rampă de descărcare; (nav, constr) chei de debarcare, ponton-debarcader

landing switch (el, transp) întrerupător de etaj (la ascensoare)

landing wheel axle (cf, OM) osie alergătoare (şi la locomotive)

landing wire (nav, mec) contracablu

landing zone (nav) zonă de debarcare; (av) zonă de aterizare

land league (metr) unitate de măsură pentru lungime, leghe terestră: 1 land league $=3$ statute miles $(4828,03 \mathrm{~m})$

land mile, ordinary statute mile (metr) unitate de măsură pentru lungime, milă terestră: 1 land mile $=1609,344 \mathrm{~m}$

land locked înconjurat / protejat de uscat (d. radă); fără ieşire la mare (d. țări)

landmap hartă

landmark (geogr) bornă de hotar, punct topografic; baliză; reper; (nav) reper la uscat; semn terestru; jalon; (fig) punct de cotitură, moment hotărâtor

landmeasurement geodezie

land office (amer) cadastru

Landore-Siemens process (me, $\mathrm{TH}$ ) procedeu Landore-Siemens

landowner proprietar de pământ

land purchase (ec) cumpărare / achiziționare de terenuri

land reclamation (agr, constr) asanare / ameliorare a terenurilor / solului, îmbunătățiri funciare

land register (ec, adm) registru funciar, carte funciară, cadastru

landscape peisaj

landscape gardening (arht) arhitectură / amenajare peisagistică landscape office (constr) birou comun / necompartimentat / amenajat estetic

landslide (geol, geogr) alunecare de teren

land storage tank $(\mathrm{OM}$, hidr, ind chim) rezervor de suprafață, rezervor suprasol

land subsidence (geol, constr) cufundare a suprafeței deasupra unui gol subteran; tasare, subsidență

land survey ridicare topografică

land surveyor (geol, TH) topograf, geodez; topometru, inginer de cadastru

land-type boiler (OM, hidr, ind) cazan stabil / pe sol

land use agrotehnică; exploatarea terenului

land vehicle (transp) vehicul terestru

landsward(s) $(a d v)$ spre coastă, în direcția uscatului

lane (constr) alee, cărare (între pomi, garduri vii etc.); stradă îngustă; trecere, pasaj, coridor; (nav) drum navigabil; (auto) fir / bandă de circulatie

lane meter (metr, nav, transp) unitate pentru aria (utilă) a punții la nave „roll on/roll off” (port-containere): 1 lane este o bandă de punte de $2 \mathrm{~m}$ lățime, 1 lane meter este aria punții cu o lăţime de 1 lane şi $1 \mathrm{~m}$ lungime $\left(2 \mathrm{~m}^{2}\right)$

lane change signals (auto) semnalizare a schimbării benzii de circulatie

lang lay (electr) cablaj direct / paralel

lang-lay-rope (nav) parâmă de sârmă, cu răsucire în acelaşi sens cu a vițelor; (mec, OM) cablu cu înfăşurare directă / torsadat paralel

langley (Ly) (metr, fiz, termo) unitate în sistemul CGS pentru măsurarea trasmiterii căldurii: 1 langley $=41,84 \mathrm{~kJ} / \mathrm{m}^{2}$

language limbă, limbaj (şi inf), exprimare, stil; (c) cod / limbaj al maşinii

language translation (inf) traducere a limbajului (dintr-un limbaj sursă într-un limbaj obiect)

language translation computer (c, inf) calculator pentru traducerea limbajului

Lanthanum (La) (chim) lantan(iu)

lantern (TH) felinar, lanternă; (mas-un, $\mathrm{OM}$ ) inel de ungere din presetupă, roată dințată cu fusuri; (ind chim) lanternă de observație / de control

lantern gear (OM) angrenaj cu fusuri, angrenaj în lanternă, angrenaj cu role

lantern pinion $(\mathrm{OM})$ pinion cu fusuri, roată dințată cu fusuri, pinion cu dinți din bare

lantern slide dispozitiv de sticlă (care alunecă)

lantern wheel $(\mathrm{OM})$ roată dintată, cu fusuri

lanyard (textile) şnur (şi pt. garnituri de etanşare); (nav) capăt de parâmă

lanyard stopper (nav) boț de parâmă cu nucă 
lap $(\mathrm{TH}, \mathrm{OM})$ falț, genunchi, învelitoare, înveliş, pătură, joc; suprapunere, petrecere; (mas-un) sculă de rodat / de lepuit; (met) cusătură (şi de sudură), îmbinare cu margini suprapuse, îmbinare prin suprapunere, încrețire / suprapunere (defecte la laminare), cusătură, falț; (mas-un) sculă de şlefuit / de lepuit / de rodat / pentru efectuarea rodajului, şaibă / disc de şlefuit, a şlefui, a lepui, a (se) suprapune; (OM) a (se) îmbina prin suprapunere, a (se) îmbina, a se îmbuca, a face să se îmbuce, a se înfăşura (în jurul); (hidr) acoperire (la distribuitoare); (metr) unitate informală de lungime, în atletism, tură (de stadion etc.), 1 lap (UK) $402,336 \mathrm{~m}$, la înot 1 lap $=100 \mathrm{~m}$ (o lungime de bazin olimpic), 1 lap $=50 \mathrm{~m}$ in bazine acoperite sau de agrement; (anat) lob (al urechii); (textile) pânza groasă, pătură, înfăşurare pe cilindri (la trenul de laminaj); (textile, OM) sul la bataj; (sport) partidă, etapă, tur (de stadion, de bazin etc.), a depăşi (adversarul) cu o rundă; (geogr) şa, poală; (fig) apă chioară, băutură slabă; plescăit, clipocit (al apei), a clipoci, a pleoscăi (d. valuri etc.), a lovi (țărmul) cu un pleoscăit (d. valuri etc.); a linchi, a linge (d. animale); lipăit; a lipăi, a plescăi (d. cineva); (fig) a se ridica (deasupra altora)

lap belt (auto) centura pentru şold

lap butt $(\mathrm{OM}$, met) îmbinare (metalică) prin suprapunere, îmbinare cu margini suprapuse

lap cutter (mas-un) freză pentru curățirea / netezirea locului de lipire la ferăstrăul-panglică

lap-ended piston ring (termo, T) segment de piston cu fantă în treaptă

lap gate (met) rețea de turnare în fante

lap grinder (mas-un) maşină de rectificat pentru netezirea îmbinărilor lipite (la fierăstrăul panglică)

lap in a înveli în, a împături în, a înfăşura în

lapis lazuli (minrl) lapislazul, lazulit

lap-joint (auto) fantă în treaptă; (met, OM, plast) îmbinare prin / cu suprapunere, îmbinare cu margini suprapuse (şi apoi sudate sau lipite); (el) legătură / conexiune a doi conductori prin suprapunerea lor

Laplace distribution (mat, fiz) distribuție normală / exponențială Laplace-Gauss

Laplace operator (mat) laplacian, operator a lui Laplace

Laplace's law (mat, fiz) legea fluxului total, legea lui Laplace

Laplace theorem (mat) teorema Laplace

Laplacian (mat) operator al lui Laplace

lappet $(\mathrm{OM})$ clapetă

lap of the slide valve (OM, termo, hidr) acoperire a sertarului (la motoare termice) lap over (met, OM) a îmbina / asambla prin suprapunere

lapped (OM) suprapus (la sudură), îmbinat prin suprapunere

lapped armouring (el, OM) armătură închisă a unui cablu

lapped butt $(\mathrm{OM})$ îmbinare (metalică) prin suprapunere, îmbinare cu margini suprapuse

lapped corner joint $(\mathrm{OM})$ îmbinare de colt, cu margini răsfrânte

lapped finishing (mas-un) rectificare prin frecare, lepuire

lapped in (fig) înconjurat / învăluit în (ceață etc.)

lapped seam (OM, met) cusătură de sudură prin suprapunere

lap(ped) winding (el) înfăşurare în bucle / buclată

lappet (mas-un, OM) clapetă, suport al conducătorului de fir la maşină de debitat cu fir

lappet rail (mas-un, OM) bancă / traversă a clapetelor

lap pin $(\mathrm{OM})$ tijă / vergea a sulului (de hârtie / de folie etc.)

lapping $(\mathrm{OM})$ înveliş, manta, îmbinare prin suprapunere, rodaj; (mas-un) lepuire

lapping abrasive (mas-un, materiale) substanță / (amestec) abraziv pentru lepuire

lapping in ajustare a unei piese după alta, prin lepuire

lapping machine (mas-un) maşină de lepuit / de suprafinisat / de rodat

lapping movement (mas-un) mişcare de lepuire

lapping over (met, $\mathrm{OM}$ ) îmbinare prin suprapunere

lapping plate (mas-un) sculă tip placă, de rodat $/$ de lepuit

lap(ping) tool of gear lapping (mas-un) sculă de rodat / lepuit roți dințate

lap riveting $(\mathrm{OM})$ nituire prin suprapunere

lap rod $(\mathrm{OM})$ dorn / vergea a(l) sulului (in industria textilă şi alimentară)

lap roll (alim, plast, $\mathrm{OM}$ ) dorn / valț / mandrină a(l) sulului

lap round a înfășura în jurul

laps (met) suprapuneri (la laminare), spire ale ruloului

lapse $(\mathrm{TH})$ eroare, scăpare, greșeală; curgere; cădere; răstimp; lapsus; neglijare (a datoriei); interval de timp, perioadă; scădere a temperaturii / presiunii (şi nedorită); întreruprere, discontinui-tate; (jur) decădere (a unui drept), pierdere a unui drept prin prescriere, a decădea, a-şi pierde valabilitatea, a se perima, a cădea în desuetudine; 
(fig) decădere, declin, distrugere; a se anula; (d. timp) răstimp, perioadă de vreme, a se scurge, a trece; a pieri; călcare (a cuvântului dat); apatie; (hidr) scurgere (a apei); a se împiedica; a face un pas greşit; after a $\sim$ of months / days după o absență de luni / zile; with the of time cu timpul

lap seam weld $(O M$, met) cusătură sudată prin suprapunere

lap seam welding (met, OM) sudare (electrică) prin suprapunere

lapse away (d. timp) a trece, a se scurge

lapsed fost; învechit; (jur) căzut în desuetudine, care nu mai este în vigoare

lapsed patent (jur) brevet de invenție decăzut

lapse from duty a nu-şi îndeplini datoria

lapse into obscurity a cădea în umbră

lap shear strength (mec, plast) rezistență la forfecare longitudinală, rezistență la forfecare a unei îmbinări cu acoperire, rezistență la desprindere (şi a unui adeziv)

lap belt, shoulder belt (auto) centură de siguranță (în diagonală, peste umăr)

lap spot weld $(\mathrm{OM})$ cusătură suprapusă de sudură, prin / în puncte

laptop (c) laptot, calculator personal, portabil (cu alimentare independentă / cu acumulator încorporat)

lap-weld (OM, met) sudură (ca rezultat) cap-lacap, a suda cap-la-cap

lap-welded (OM, met) sudat cap-la-cap

lap welding (met, $\mathrm{OM}$ ) sudare prin suprapunere

lap-weld process $(\mathrm{OM}$, met) procedeu de sudare prin suprapunere

larboard (nav) babord

lard (alim) untură, grăsime animală

lardaceous unsuros

large $(a d j)$ întins, spațios, încăpător, mare (d. un producător, comerciant etc.), vast, larg, încăpător; cuprinzător; puternic; numeros; considerabil; avântat, plin de vervă (d. stil etc.); darnic; grosolan, vulgar; pompos; trufaş; $(a d v)$ în larg; cu emfază, cu îngâmfare; cu litere mari; (nav) (d. vânt) favorabil; large sum (ec) sumă impor-tantă; as as life în mărime natu-rală; on a $\sim$ scale pe / la scară mare / întinsă; in a measure în mare măsură; views (fig) $(\mathrm{cu})$ vederi largi; sail $\sim$ (nav) a naviga cu toate pânzele desfăşurate; by and $\sim$ în general

large bell (met) clopot / con mare (la furnal)

large bit (mas-un) daltă lată

large body size corp mare de literă

large calorie (kcal) (metr, fiz, termo) unitate de măsură pentru energie termică, kilocalorie, calorie mare large chip area (electr) suprafața mare a unei microplăcuțe modulare

large countersunk head rivet $(\mathrm{OM})$ nit cu cap îngropat

large crystalline precipitate (chim, met) precipitat macrocristalin

large edition ediție de masă

large enough destul de mare / larg

large face plate (OM, mas-un) platou, planșaibă

large flat-top countersunk-head rivet $(\mathrm{OM})$ nit cu cap înecat, pentru rezistență şi etanşare

large-grained (l.g.) macrogranular (d. materiale)

large heart trowel (met) mistrie de netezit miezuri

large hexagon nut $(\mathrm{OM})$ piuliță hexagonală cu deschidere mare de cheie

large in bore / diameter $(\mathrm{OM})$ de diametru mare, cu alezaj mare (d. un element de maşină etc.)

large-hearted darnic, generos, binevoitor

large-heartedness mărinimie, generozitate; bunăvoință

large kettle (alim, termo) cazan de fiert / de distilare

largely $(a d v)$ foarte mult, în mare măsură; generos

large-mindedness vederi largi, lipsă de prejudecăți; toleranță

largeness mărime, amploare, extindere, dimensiuni mari; vederi largi; mărinimie, generozitate

large pore (met) suflură mare; por mare / gol (în materiale sinterizate etc.)

large primary jaw crusher (mas, constr) concasor primar cu fălci

large reduction micşorare / reducere puternică / mare / considerabilă; (met) reducere mare

large requirement necesitate, necesar, cerere

large run tiraj mare

large-scale la / pe scară mare; în mărime naturală

large-scale digital computer (c) calculator numeric, cu capacitate mare de memorare

large-scale industry marea industrie, industrie de serie / de masă

large scale experiment / test (metr, mas) experiență / încercare în natură, la scară reală / industrială

large-scale series production $(\mathrm{TH})$ fabricație în serie mare

large-size cable $(\mathrm{OM}, \mathrm{mec})$ cablu cu număr mare de fire

large-size coke (met) cocs în bulgări mari

large-sized $(\mathrm{OM})$ mare, de dimensiune / de format mare

large-space soaking pit (met) cuptor adânc de capacitate mare

large sprinkler for irrigating (OM, hidr, agr) duză de stropire (la irigații) 
largest particle passed (hidr, T) particulă trecătoare maximă, finețe de filtrare absolută

large vice (met, OM) menghină de forjă lark's head (nav) nod de inel (nod marinăresc)

larmier (nav) lacrimar (în construcții metalice şi navale)

larry (met) cărucior de alimentare / de încărcare / de distribuție

lase (fiz) a produce radiații / lumină coerentă (cu ajutorul laserului)

laser (fiz) laser

laser annealing (met) încălzire rapidă cu laser (şi pt. tratament termic superficial)

laser-beam machining device (fiz, mas-un) dispozitiv de prelucrare cu fascicol laser

laser-beam brazing ( $\mathrm{TH}, \mathrm{fiz})$ lipire cu laser

laser computer / computing machine (c) calculator cu laser

laser cutting (mas-un) tăiere cu laser

laser detection and ranging (LADAR) (fiz) radiolocator cu laser (laser radar)

laser disk (LD) (c) disc compact (care poate fi citit $\mathrm{cu}$ ) laser (pt. informații video)

laser doppler flowmeter (metr) aparat pentru măsurarea vitezei fluidului cu ajutorul efectului Doppler, în radiație laser a particulelor de marcare

laser frequency correction (fiz) corectare a frecvenței laserului

laser guidance (mec, constr, mas) ghidare (de precizie) prin fascicul laser

laser printer (c) imprimantă (cu) laser

laser range finder / ranging device (metr) telemetru cu laser

laser spectometer (metr) spectrometru cu laser

laser welding (met) sudare cu laser

lash bici; (anat) geană; $(\mathrm{OM})$ batere a curelei, joc, a (se) destinde cu o mişcare bruscă (şi d. arcuri); (nav) a lega, a amara încărcătura navei, (d. valuri) a bate țărmul; a bate, a biciui, a plesni; a critica

lashing biciuire; (constr) îmbinare cu platbande / cu eclise (la cofraje); (nav) amarare, amaraj, parâmă de amaraj, legătură, socar; legătură, chingă

lash-up (metr, $\mathrm{TH}$ ) aparat improvizat

lassitude (med) oboseală, moleşeală; lâncezeală

last (adj) ultim; precedent, trecut; cel mai mic; extrem; (cel) din urmă, care a mai rămas; trecut; cel mai puțin probabil; final, definitiv; cel mai recent, modern; $(s)$ calapod (pt. ghete); rezistență, abilitate; sfârşit; ultima răsuflare / clipă (şi fig); încetare, sfârşit; capăt; (nav) încărcătură (a unui vas); a dăinui, a ține, a dura; a ajunge; a continua; a rămâne; a rezista; $(a d v)$ ultima dată, ultima oară; la urmă; stand on one's legs a fi la capătul resurselor; night aseară, ieri seară; azi noapte, noaptea trecută; the night before alaltăieri seară, alaltăieri noapte; of the $\sim$ importance de extremă importanţă; in the degree intr-un grad extrem; the $\sim$ ultimul; trial of skill and $\sim$ dovadă de îndemânare şi rezistență; at în sfârşit; at long în cele din urmă; the $\sim$ ultimul semn (de existență a cuiva); come $\sim$ a veni ultimul, a veni târziu

last (în limba germană), ballast (metr) unitate de măsură pentru masă sau volum: 1 last $\approx 1800$ kg sau 1 last $\approx 3 \mathrm{~m}^{3} ; 1$ last of wool (US) $\approx$ $1981,3 \mathrm{~kg} / \mathrm{sac}, 1$ last (Olanda) $=3 \mathrm{~m}^{3}, 1$ last $($ Germania $)=2,819 \mathrm{~m}^{3}=2$ metric tons, 1 Riga last of timber $(\mathrm{UK})=2,265 \mathrm{~m}^{3}$ de buşteni

last brine pit (met, ind chim) bazin de cristalizare

last but one penultimul

last but two antepenultimul

last but not least ultimul (ca ordine), dar nu cel mai puțin important (dar nu cel din urmă)

last come-first served (ec, inf) ultimul venitprimul servit (metoda de servire în teoria şirurilor de aşteptare)

last diamond pass (met) calibru finisor (la laminor)

last difusser (alim) difuzor terminal

last finishing pass (met) trecere finală de finisare

last groove / pass (met) calibru finisor

last-in first-out (LIFO) (inf) ultimul venit-primul servit (tehnica de manipulare a structurilor de tip stivă)

lasting durabil, rezistent, persistent; permanent, trainic, de durată; durată, trăinicie, rezistență

lasting accuracy (mas-un) perioadă lungă a păstrării preciziei iniţiale

lastingness (mas, OM) durabilitate

lasting power (mec, el) putere de durată / continuă

lasting qualities $(\mathrm{T})$ rezistență la uzură; $(\mathrm{OM})$ durată de serviciu, calități de durabilitate

last-in last-out (LILO) (ec) ultimul articol primit, ultimul vândut / dat la vânzare

last line (inf, text) rând final (la o subrutină, un program, la o pagină etc.)

lastly $(a d v)$ în cele din urmă, în sfârşit, în ultimul rând

last-mentioned menționat ultimul, mai sus amintit / mentionat

last pass (met) calibru finisor (la laminor); (TH) ultima trecere (la laminare, la finisare etc.) 
latch (constr) zăvor; clanță; încuietoare; (OM) opritor, declic, clichet, cățea, zăvor de blocare (şi cu resort / arc), a zăvorî, a încuia; a (se) închide (cu un zăvor, cu clanță etc.); (met) zăvor cu bolț şi cu arc; (hidr) zăvorâre; (auto) încuietoarea capotei; (textile) limba / vârful indoit a(l) acului de tricotat

latch contact (el, mec) contact cu blocare

latchet $(\mathrm{OM})$ cureluşă, curea

latch hook $(\mathrm{OM})$ cârlig cu clichet

latching relay $(\mathrm{OM}, \mathrm{el})$ releu cu zăvorâre mecanică

latch-in relay $(\mathrm{OM}, \mathrm{el})$ releu cu blocare / cu opritor

latch jack $(\mathrm{OM})$ cârlig pentru instrumentație

latch key (OM) cheie de zăvor cu arc

latch machine (mas-un) multicircular pentru tăiat şipci de lemn

latch plate (plast, mas-un) placă de sprijin

late $(a d j)$ târziu, întârziat; fost; răposat, defunct; recent, ultim; din ultima generație / vreme, recent; de curând, recent; $(a d v)$ cu întârziere, târziu; recent, de curând, nu de mult; at a late $\sim$ la o oră târzie; keep $\sim$ hours a se culca târziu, la ore mici; of $\sim$ years în ultimii ani; of $\sim$ de curând; better $\sim$ than never mai bine mai târziu decât niciodată; get up a se scula târziu; in the day spre sfârşitul zilei; in life la o vârstă înaintată; sooner or later mai devreme sau mai târziu

late combustion (termo, met) ardere întârziată

late contacts (autom, el) contacte de urmărire, contacte eşalonate în ordinea repaus-lucru / care se închid şi se deschid succesiv

late cut-off the admission (mec, hidr, termo) închidere întârziată a supapei de admisie

late failure $(T)$ întrerupere / defect din cauza uzurii, după o perioadă de funcționare, cădere târzie / întârziată

late ignition / spark (auto, termo) aprindere întârziată

lately $(a d v)$ recent, de curând; în ultima vreme

laten a reține, a face să întârzie; a întârzia

latency (chim, fiz) latență, stare latentă; (inf) timp de aşteptare; potențialitate

latency time (chim, fiz) timp / perioadă de latență

lateness întârziere; oră târzie

latent latent; în repaus; ascuns; potențial

latent effect / defect (metr, materiale, OM) efect / defect latent (greu detectabil)

latent enery $(\mathrm{mec})$ energie potențială, energie latentă

latent heat (fiz, ind chim, termo) căldură latentă latent heat load (termo) sarcină termică latentă, necesar de frig corespunzător căldurii latente, sarcină frigorifică pentru îndepărtarea / prelevarea / compensarea căldurii latente

latent heat of crystallisation (fiz, termo) căldură latentă de cristalizare

latent heat of evaporation (fiz, termo) căldură latentă de evaporare

latent heat of fusion (materiale, termo) căldură latentă de topire

latent heat of liquefaction (materiale, termo) căldură latentă de topire / de lichefiere

latent heat of melting (materiale, termo) căldură latentă de topire

latent heat of sublimation (materiale, termo) căldură latentă de sublimare

latent heat of transition (materiale, termo) căldură latentă de tranziție

latent heat of vaporization (materiale, termo) căldură latentă de vaporizare

latent oscillations (autom, mec) oscilații interne latent partner $(\mathrm{ec})$ comanditar, partener / asociat puțin cunoscut (care nu ia parte activă la afaceri)

latent period $(\mathrm{med}, \mathrm{T})$ perioadă de incubație $(\mathrm{d}$. o boală, deteriorarea prin oboseală etc.)

latent root of a matrix (mat) număr caracteristic / valoare proprie a(l) unei matrici

latent solvent (chim) solvent inert

latent steam (termo, met) abur indirect

latent time (termo, chim) perioadă de latență / latentă

latent vector (mat) vector propriu

lateral $(\mathrm{TH}, \mathrm{OM})$ lateral, dintr-o parte, accesoriu, secundar orizontal; (mat) secundar, auxiliar; colateral

lateral acceleration (mec) componentă laterală a accelerației

lateral axis $(\mathrm{OM})$ ax lateral / transversal

lateral blow (met) (in)suflare laterală

lateral buckling $(\mathrm{OM})$ flambaj lateral

lateral channel $(\mathrm{OM}$, constr, hidr) canal lateral

lateral compliance (electr, fiz) forță de deviație laterală (a unei particule, a unui electron etc.); $(\mathrm{mec})$ capacitate de cedare în lateral

lateral contraction (met, plast) gâtuire, stricțiune, îngustare, contracțoie transversală

lateral discharge (el) descărcare secundară

lateral expansion (termo, materiale, $\mathrm{OM}$ ) dilatație / dilatare transversală / laterală

lateral feed (mas-un) avans transversal

lateral flexure (mec, OM) flambaj, încovoiere transversală; (met) îndoitură 
laterally $(a d v)$ (în) lateral, dintr-o parte; pe linie colaterală

lateral oscillation (auto, mec) oscilație laterală / transversală

lateral pipe-line (hidr, termo, OM) conductă secundară

lateral play $(\mathrm{OM})$ joc lateral

lateral point (mat) punct neesențial

lateral reinforcement $(\mathrm{OM}$, met, constr) armătură transversală

lateral section $(\mathrm{OM})$ secțiune transversală, profil

lateral shear (mec, met) forfecare transversală

lateral spread (met, plast) lățire transversală (şi la laminare)

lateral standard (constr, mas-un) montant lateral

lateral strength $(\mathrm{mec})$ rezistență la forfecare

lateral stress (mec, OM) tensiune normală / perpendiculară pe axa elementului

lateral thrust (mec) presiune laterală, efort tangențial

lateral tilt (auto, transp) înclinare transversală (la autovehicule), pantă laterală

lateral vibration $(\mathrm{mec})$ vibrații transversale

later development eveniment ulterior

later impact $(\mathrm{mec})$ impact ulterior

laterite (minrl) laterit, ferulit

latex, $(p l)$ latices (chim) adeziv în dispersie (stabilă), latex

latex adhesive (chim) adeziv / clei de latex

latex-foamed rubber (plast) cauciuc celular (obținut prin spumarea latexului)

latex froth building machine (ind chim, mas) maşină pentru spumarea latexului

latex impregnator maşină de impregnat cu latex de cauciuc

latex mix (ind chim) amestec pe bază de latex

latex paint (ind chim) vopsea de latex

latex proofing (ind chim) cauciucare / impregnare cu latex

latex rubber (ind chim) cauciuc de latex

latex-sprayed rubber (ind chim) cauciuc natural obținut prin pulverizarea latexului

latex thread (ind chim) fir de latex

latex vulcanisated (ind chim) vulcanizat din amestec de latex

lath (constr) şipcă, riglă, palplanşă, lat; a fixa şipci

lathe (mas-un) strung, a stunji, a prelucra la strung

lathe axis indicator (metr, mas-un) aparat pentru verificarea coaxialității centrului marcat pe piesa de prelucrat, cu axa vârfurilor strungului

lathe carriage / saddle / scale / slide (mas-un) cărucior al strungului, cărucior-suport lathe centre (mas-un) vârf pentru / de strung (şi de centrare)

lathe chuck (mas-un, OM) universal / mandrină pentru strung

lathe cricket (mas-un, OM) placă de bază a păpuşii mobile

lathe dog (mas-un, OM) antrenor / inimă de strung lathe fixture (mas-un, OM) dispozitiv de rotire (la strung)

lathe hand / operator (mas-un) strungar

lathe headstock (mas-un, OM) păpuşă a strungului

lather spumă (de săpun), clăbuc; a săpuni, a da cu săpun

lathering (alim, ind chim, T) spumare

lathery spumos, cu spumă / clăbuc

lathe tool (mas-un) cuțit de strung

lathe with horizontal face plate (mas-un) strungcarusel vertical

lathe work (mas-un) piesă de prelucrat la strung

lathe worm (OM, mas-un) melc prelucrat prin strunjire

lathe wrench (mas-un) cheie dublă a port-cuțitului de strung

lathing şipci (din lemn)

lathing hammer $(\mathrm{OM})$ ciocan de bătut cuie

lathlike (geol) aciform (şi d. cristale)

latish $(a d j, a d v)$ cam târziu

latitude lățime, lărgime, întindere; latitudine; libertate de acțiune / opinie / interpretare; (geogr) latitudine; north $\sim$, northern $\sim$ (geogr) latitudine nordică, in $\sim \mathbf{3 0}$ grade north (geogr) la 30 grade latitudine nordică

latitudinal (dependent) de latitudine

Latour motor (el) motor monofazat colector, $\mathrm{cu}$ excitație internă, motor cu repulsie, compensat, motor Latour

latten (met) tablă subțire laminată la cald

latten brass (met) foaie / tablă de alamă

latter cel din urmă, ultimul (din doi), cel de-al doilea

lattermost ultim, din coadă

lattice (TH, materiale) zăbrele, grătar, grilaj, rețea cristalină, cadru; (constr, mec) grindă cu zăbrele; (mat) rețea, structură, configurație de linii, schelet; (geom) suprafața desfăşurată a unui solid; (el, c) structură reticulară; zăbreli, a pune zăbrele / grilaj

lattice / latticed anode (el) anod cu ochiuri / cu retea

lattice apron (constr) masă de alimentare / de transport (formată din şipci de lemn, eventual de metal) 
lattice arm / branch (fiz) ramură / braț a(l) unei rețele (cristaline)

lattice boom (constr, mas) săgeată de excavator cu zăbrele

lattice bridge (constr, mas) pod cu zăbrele

lattice chart hartă caroiată

lattice coil (el) bobină-fund de coş / fagure

lattice column (ind chim) coloană cu grătare

lattice column mast (ind chim) mast cu zăbrele

lattice constant parametru / constantă a(l) rețelei (în microstructură)

lattice covering (radio, fiz) acoperire în rețea

latticed în formă de gratii / de zăbrele / de rețea / de grilaj, zăbrelit, în rețea, prevăzut cu grilaj / zăbrele

latticed bar (OM) zăbreluță, bară cu zăbrele lattice defect (fiz) defect de rețea (şi cristalină)

lattice distorsion (fiz, met) distorsiunea rețelei (cristaline)

latticed member (mec, OM) zăbrea, bară (în grilaj)

lattice dryer (alim, ind chim) maşină de uscat cu bandă transportoare

lattice enery (fiz, chim) energie reticulară / de rețea

lattice feeder (OM, alim, transp) masă de alimentare, transportor de alimentare din plăci, pânză alimentatoare

lattice fence grilaj de şipci

lattice frame (termo, alim) cadru cu sită pentru filtrarea lichidului de răcire

lattice framework $(\mathrm{OM})$ ramă din bare / zăbrele încrucişate

lattice girder / gland (mec) grindă cu zăbrele; $(\mathrm{OM})$ membrană cu rețea / reticulată

lattice-girder construction (mec, constr) construcție cu zăbrele, fermă (metalică)

lattice imperfections (materiale) neregularități ale unei retele ale unui cristal

lattice jib $(\mathrm{OM})$ braț cu grindă cu zăbrele

lattice-like (materiale) în formă de rețea, ca o rețea, reticular

lattice network (el) rețea alcătuită din patru impedanțe în circuit închis, montaj în punte

lattice of infinite (mat, fiz) rețea infinită

lattice ordered ring (mat) inel structural ordonat, inel ordonat în matrici

lattice parameter (fiz, met) constantă / parametru a(l) rețelei cristaline

lattice pattern (mat, fiz) rețea / familie de linii de poziție (şi în cartografie)

lattice pitch (fiz) perioadă / pas al rețelei

lattice points (fiz) puncte / noduri în rețea lattice spancing (fiz) constantă / parametru a(l) rețelei cristaline

lattice spectrograph (metr, fiz) spectograf cu rețea sau pentru identificarea rețelelor cristaline

lattice structure (fiz) structură a rețelei / reticulară

lattice suspension bridge (constr) pod suspendat, cu zăbrele

lattice texture (minrl) structură (minerală) reticulară

lattice tower (constr) turn în construcție cu zăbrele; (el) stâlp cu zăbrele

lattice transformation (fiz, met) transformare / modificare a rețelei (cristaline)

lattice truss (mec, constr) grindă cu zăbrele, fermă

lattice unit (fiz) celulă elementară a rețelei

lattice vacancy (fiz) loc liber în rețeaua cristalului

lattice vacant site (met, fiz) loc vacant în rețea

lattice vibration (electr) oscilații parazite pe grilă

lattice work (mec) grătar, zăbrele, fermă cu contrafișe, grindă cu zăbrele, construcție / structură în zăbrele; (constr) îmbrăcăminte cu şipci

latticework in space (constr) construcție cu zăbrele, în spațiu / spațială; (fiz) rețea (cristalină) spațială

latus rectum (geom) parametru focal (pt. sectiuni conice)

launch (nav) lansare la apă (a navei noi), barcă cu motor, şalupă, barcaz, a lansa la apă (o navă); (mil) a arunca un proiectil, a lansa (torpile), a arunca; (fig) a lansa, a întreprinde; a pune în mișcare, a da curs

launch control (nav) control al lansării / pornirii launch engine (nav) motor de ambarcație launching (nav) lansare a unei nave la apă launching basin (nav) bazin (al calei de lansare) launching grease (nav, T) unsoare pentru lansarea navelor / pentru cale de lansare

launching platform (nav) rampă de lansare

launching site (nav) poziție de lansare; instalație de lansare

launching slip / way (nav) cală de lansare

launch into a se lansa în, a începe cu

launch out (nav) a pleca pe mare; (fig) a se avânta, a se aventura

launder (met) jgheab de scurgere, canal de turnare / de scurgere (din cuptor); rigolă; (ind chim) detergent (pentru uz industrial sau pt. textile); a (se) spăla cu maşina (d. obiecte confecționate, rufe); a spăla și a călca (rufe) 
launder classifier (ind, constr) clasor / sortator cu jgheab

launderette (mas) spălătorie automată laundry (textile) spălătorie, rufe spălate laundry washing $(\mathrm{TH})$ spălare în maşini de uz casnic sau industrial (se referă în special la spălarea obiectelor confecționate)

laureate laureat; distins, de seamă, eminent lautering (alim) filtrare (a berii)

lauter tub (alim, OM) cuvă de limpezire (pt. bere) Lauth three-high hot mill (met) laminor trio Lauth, pentru laminare la cald

lava (geol) lavă

lavender oil (chim) ulei de lavandă

law lege; autoritate; justiție; regulă, regulament; principiu; formulă, teoremă; (jur) legi, jurisprudență, drept, judecată, proces

law-abiding (jur) care se supune legilor

law-breaking (jur) violare a legii, infracțiune

law court (jur) instanță de judecată, tribunal

law expenses (jur, ec) cheltuieli de judecată

lawful (jur) legal, legitim

lawful contract $(\mathrm{ec})$ contract valabil

lawful currency $(\mathrm{ec})$ monedă legală

lawfully $(a d v)$ (în mod) legal, pe temeiuri legale

lawfullness (jur) legalitate, caracter legal

lawless (jur) fără legi, ilegal, anarhic

lawlessly $(a d v)$ nelegal, în pofida legii

law maker (jur, pol) leguitor, legislator, care face legea / regula

law-making (jur) legislativ

law merchant legislație comercială

lawn pajiște

law of action and reaction (mec) legea acțiunii şi reacțiunii, legea a treia a lui Newton

law of areas (mec) legea ariilor, legea constantei vitezelor sectoriale, a doua lege a lui Kepler

law of conservation of momentum (mec) legea conservării cantității de mişcare, legea conservării impulsului

law of constant heat summantion (fiz, termo) legea constantei căldurii totale de reacție, legea lui Hess

law of constant / definite proportions legea proporțiilor definite

law of degradation of energy (fiz, mec) legea transformării energiei

law of electrostatic attraction (el) legea lui Coulomb, legea atracției electrostatice

law of energy conservation (fiz, mec) legea conservării energiei

law of the equivalent / reciprocal proportions legea proportiiilor echivalente / multiple law of equivalents legea echivalenţelor

law of excluded middle (mat) principiu / legea terțului exclus (în logica matematică)

law of extreme path (fiz) legea traiectoriei luminii între două puncte, principiul lui Fermat

law of falling bodies (mec) legea căderii corpurilor

law of gravity (fiz) legea atracției gravitaționale

law of induction (fiz) legea inducției electromagnetice, legea lui Faraday

law of large numbers (mat) legea numerelor mari (în teoria probabilităților)

law of least squares (mat) legea celor mai mici pătrate

law of mass action (fiz) legea actiunii maselor

law of mass conservation (fiz) legea conservării masei

law of matter conservation (fiz) legea conservării materiei

law of the mean (mat) teorema mediei

law of moment of momentum (mec) teorema momentului cinetic / impulsului / momentului cantității de mișcare

law of multiple proportions legea proporțiilor multiple

law of nations (jur, pol) drept internațional

law of proximity theory legea teoriei efectului de proximitate, legea acțiunii din aproape în aproape

law of refraction (fiz) legea refractiei

law of similarity lege de similitudine

law of the situation cale de urmat într-o situație

law of small numbers (mat) legea repartitiiilor rare, repartiția / legea lui Poisson

law of superimposed stresses $(\mathrm{mec})$ principiul suprapunerii tensiunilor

law of superposition (fiz) legea superpoziției straturilor / legea suprapunerii efectelor

law of supply and demand (ec) legea cererii şi ofertei

law of the trivial many and the critical few (ec) regula 80 la 20 (în controlul stocurilor)

Lawrencium (Lr) (chim) Lawrentiu

laws in force (jur) legislație în vigoare

laws of electric networks (fiz, el) legile lui Kirchhoff / rețelelor electrice

laws of motion $(\mathrm{mec})$ legile mişcării / cinematicii lawsuit (jur) proces (si civil), litigiu judiciar

law term (jur) termen juridic; sesiune judecătorească

lay (adj) laic, mirean, profan, neinițiat; neprofesionist, neprofesional, (de) nespecialist, amator; (s) întindere, aşezare (şi a unui cablu, a unei 
conducte etc.), situare (a unui teren, a unei clădiri etc.), direcție, poziție; înfățişare, contur; ocupație; specialitate; (TH) cablare, strat de cablaj, pas de torsiune; a depune, a impune, a înlătura, a situa, a acoperi cu (vopsea, strat etc.), a pune, a întinde (vopsea pe ceva); (nav) răsucire a unei parâme; (constr, TH) a pune (şi jos), a aşeza, a poza (cabluri), a întinde (un cablu etc.); a regla (aşezarea unei piese / probe, în metrologie, la artilerie), a culca, a aşeza; a plasa; a doborî, a răpune; a potoli, a linişti; a calma (spiritele etc.); (nav) a trasa / ruta (pe hartă); a răsuci, a staționa (d. navă); (agr) a culca la pământ (păioase, semănături etc.); (zool, agr) a oua, a face ouă (d. păsări); a scăpa de, a îndepărta (griji etc.); a pune / aduce într-o anumită stare; (ec) a impune, a fixa (impozite); (ec, jur) a estima, a fixa (despăgubiri); with a acoperi (o suprafață cu); a aduce (într-o anumită stare); a aranja, a pregăti; a stabili (un plan); a urzi (o intrigă); a atribui; a impune, a aplica; a revendica, a reclama; (mil) a îndrepta spre țintă (un tun); a fi gata să parieze, a paria cu / pe; be laid up with (med) a fi bolnav de; well-spaced out montaj / montare bine spațiat(ă)

lay a course a trasa un drum pe hartă; (nav) a guverna pe drumul stabilit (în navigație)

lay a floor (constr) a pune un parchet

lay a plot a urzi un complot

lay a ridge (constr) a aşeza / a construi o şarpantă, a acoperi coama şarpantei / acoperişului

lay aside by a pune de / la o parte, a lăsa de / la o parte, a abandona; (ec) a strânge bani, a pune deoparte, a economisi

lay a snare a pregăti o cursă

lay a tax / an obligation / a penalty on (ec, adm, jur) a impune o taxă / o obligație (cuiva); a aplica o pedeapsă (cuiva)

lay back a da pe spate, a aşeza pe spate

lay bare (fig) a dezvălui; a dezgoli; (el) a dezizola, a scoate izolația

lay-by linie de garare, linie moartă; a pune de / la o parte, a pune lângă; (auto) (loc de) parcare

laydays, laying days (nav) stalii (zile afectate navei pentru încărcare / descărcare)

lay down a introduce (canalizarea), a instala, a fixa (o cale ferată etc.); (TH) a băga în reparații (o navă, o maşină etc.); a stabili (o regulă, un principiu); (nav) a trasa (în sala de trasaj); (hidr) a aşeza / poza o conductă / un cablu; a întocmi, a alcătui (un plan etc.); a pune fundația unei clădiri; a renunța la (un post); a enunta, a stabili, a formula (un principiu etc.); (mil) (şi fig) a depune armele; a trasa linia de conduită, a întocmi harta (unei regiuni); a renunța la (o speranță); a sacrifica ceva pentru, a-şi da viaţa pentru

lay down rules a stabili / formula reguli

lay down smoke a produce ceață

lay down the law a porunci

layer (constr) asiză, strat, pat al drumului; (OM, el) strat, înveliş, peliculă; (mas, OM) banc, batiu, pat; depunere de fire (şi la compozite); zăcământ; (agr) pasăre ouătoare; a aşeza în straturi / stive, a stivui

layer cathode (electr, fiz) catod din mai multe straturi / stratificat

layer-corrosion ( $T$, met) coroziune prin infiltrare în strat, coroziune în straturi / stratificată

layered stratificat (d. materiale)

layered structure (d. materiale) alcătuire stratigrafică

layering (d. materiale) stratificare

layer lattice (chim) rețea stratificată; (fiz) rețea în straturi / în paturi

layer lines linii în etaje / în straturi; linii de demarcație între straturi (şi de compozit etc.)

layer of air strat de aer

layer of columnar crystals (met) zona cristalelor columnare (într-un lingou, într-o piesă turnată, de volum mare)

layer of slag (met) crustă de zgură

layer of wood placaj de lemn, placă de furnir layers (met) spirele ruloului (de tablă)

layer shortening (el, mas) scurtcircuitare a unui strat (la maşinile de bobinat)

layer tablet tabletă din mai multe straturi layer-welding (TH, met) sudare în straturi layer winding (met, el) înfăşurare în straturi

lay flat (constr) a aplana, a nivela, a netezi, a întinde mortar, a egaliza; (mec) a plana, a netezi, a nivela

lay gauge (mas-un) opritor (mecanic)

lay great emphasis on a insista mult asupra

lay great store upon / by a atribui o mare valoare (unui lucru, unui fapt etc.)

lay guide $(\mathrm{OM})$ broască

lay hands on a lovi, a pune mâna pe, a găsi, a sili să facă ceva

lay hands on a lua, a fura, a-şi însuşi

lay in (ec) a se aproviziona cu, a face / aduna (provizii de) a strânge (provizii)

laying (mec, OM) răsucire / împletire a toroanelor unei funii; $(\mathrm{TH})$ instalare / montare (a unui cablu, a unei conducte etc.); (agr, zool) ouare, depunere a ouălor 
laying down (el) pozare (la cabluri); pozare a conductei / aşezare a conductei

laying down a formula (mat) punere în ecuație laying off (nav) trasaj naval, staționare a navei laying off of works (TH, ind, constr) scoatere din funcțiune / din exploatare, oprire a lucrărilor

laying of form (met) aşezare a formei

laying of pipe line (constr, hidr) pozare a conductei

laying out (constr) întocmire a planului lucrărilor, trasare, amplasare; (ec) etalare (de mărfuri); cheltuială bănească

laying-out machine / reel (constr, mas) cărucior pentru pozat cabluri; (mas-un) maşină de trasat

laying-out of a line (cf, constr) trasare a liniei (de cale ferată)

laying-out, lay-out plate (nav, met) placă de trasare

laying-out table (nav, met) masă de trasaj

laying up (nav) scoatere din exploatare a navei, dezafectare

laying-up basine (hidr, mediu) bazin de retenție / de acumulare

laying-up machine (mas-un, el, TH) maşină de cablat / de torsionat / de torsadat / de înfuniat

lay into a se lovi de, a da de, a se întâlni cu; (fam) a fi pe ducă; (sport) (la scrimă) a descoperi

lay out montaj

lay-off concediere temporară; încetare a lucrului, grevă; şomaj, lipsă de lucru (temporară)

lay off a opri; (nav) a trasa pe hartă (rute şi relevmente), a aştepta în radă; (ec) a concedia; $(\mathrm{TH})$ a scoate, a dezbrăca (o căptuşeală, un strat); a concedia (temporar); a nu mai lucra (o perioadă), a se odihni; (mas-un) a raporta (un unghi)

lay off a course (nav) a trasa o rută (pe hartă) (în navigație)

lay off the anchor (nav) a da ancora; a fundarisi ancora

lay of wire (el) strat de conductoare / de bobinaj lay on (tipografie) a potrivi foaia (la maşină); (nav) a azvârli (ancora); a explica; a instala (și conducte de gaze, de apă etc.); a aplica, a pune, a întinde (vopseaua etc.); a aşterne; (ec) a impune (un impozit)

lay-on roller $(\mathrm{OM})$ rolă de presare / de întindere lay open a deschide; a expune, a arăta; a da la iveală

lay-out $(\mathrm{TH})$ traseu, amplasare, pichetaj; proiectare, proiect, machetă; plan (general); înscriere; dispoziție; plan general / de ansamblu; schemă; utilaj; traseu; configurație; organizare; echipament, instalație; tehnoredactare

lay out a aranja; a împodobi; a înfăşura (un mort, ca defect la compozite cu fire lungi etc.); a schița (un plan etc.); (mas) a scoate din funcțiune; a expune, a arăta; a se vedea; a trânti, a doborî, a culca la pământ; (nav) a transporta parâma de legare la mal (cu barca); a amenaja un parc; a amplasa; a planifica, a proiecta; (fam) a omorî

lay-out block (nav, met) placă / dispozitiv de trasare

lay-out man (constr) proiectant, decorator

lay out money (ec) a cheltui, a debursa bani

lay-out of circuit (el, hidr) instalare a unui circuit / a unei scheme

lay-out of construction work (constr) organizare a şantierului de construcții

lay-out (plan) (ind, constr) plan general / de ansamblu / de situatie

lay-over oprire, haltă (în călătorie etc.); zi liberă prin rotație

lay over a aşterne, a acoperi (complet); a amâna (o şedință); a se opri, a face un popas / o haltă (în călătorie)

lay rails (cf, constr) a instala şine de cale ferată

lay ratio (el) raport al pasului de înfăşurare

lay / levy a tax on a percepe taxă / impozit pe

lay the blame on smb. a arunca vina asupra cuiva

lay the foundation of a aşeza fundația (unei clădiri); (şi fig) a pune bazele pentru

lay the table (alim) a pregăti masa

lay to (nav) a (con)duce o navă în port

lay under contribution a pune la contribuție

lay up a pune, a aşeza; (ec) a acumula, a strânge, a aduna (provizii), a pune deoparte, a economisi, a strânge (bani etc.); a înmagazina; a scoate din circulație / funcțiune (şi pt. reparații); (nav) a răsuci o parâmă; a scoate nava din exploatare; (nav, mil) a dezarma (o navă)

lay-up, layingup (plast) a fi bolnav; acoperire / stratificare de întărire a plasticelor (şi cu fibre)

lay waste a devasta

laziness (mec, med) inerție

lazuli (minrl) lapis lazuli, lazulit

lazy inert, leneş, indolent; încet, domol; fără activitate (o zi etc.)

lazy jack $(\mathrm{OM})$ balansier, element al unui mecanism care poate oscila în jurul unui punct al său, diferit de extremități

lazy scissors (mas) (mecanism cu) pantograf 
lb, lbf, lbm (metr) simbol pentru pound în limbile engleză, spaniolă şi italină, v. pound

lbf, lbm (metr) simbol pentru pound of force, în limbile engleză, spaniolă şi italină, v. pound of force

lbm (metr) simbol pentru pound of mass, în limbile engleză, spaniolă şi italină, v pound of mass

LD (metr) v. lunar distance

LD plant (met) oțelărie LD

LD process (met) procedeu LD de elaborare a oțelului / în convertizor

lea, skein (rar) (metr, textile) unitate tradițională de lungime pentru fire / fibre, variind în functie de masa fibrei; tipic, 1 lea of wool (lână) $=73$ m; 1 lea of cotton or silk (bumbac sau mătase) $=110 \mathrm{~m} ; 1$ lea of linen $=274 \mathrm{~m}, 1$ lea of cotton $/$ wool $=1 / 7$ hank, $v$ hank

leach (chim) bază, leşie; (ind chim) percolator, aparat de extractie prin dizolvare; a trata cu leşie, a lixivia, a percola, a extrage prin dizolvare; a filtra (un lichid); (alim, mediu) filtrare; (nav) cădere a unei vele

leached (ind chim) dezalcalizat, dezalcalinizat, supus îndepărtării substanțelor alcaline

leaching (met) extracție prin dizolvare, lixiviere, percolare

leaching barrel (ind chim) tambur de caustifiere / de dizolvare

leaching by agitation (ind chim) solubilizare / dizolvare prin agitare

leaching drum (ind chim, OM) tobă de leşiere / de lixiviere

leaching out (chim) dezalcalizare, dezalcalinizare, acțiune de îndepărtare a proprietăților alcaline

leaching plant (alim) instalație de macerare; (met) instalație de tratare cu leşie

leaching vat (ind chim) cuvă pentru solubilizare, extractor (prin dizolvare); cuvă de lixiviere

leach out (alim, ind chim) a macera, a extrage prin dizolvare

leach residue (alim, ind chim) reziduu de leșie

leachy poros (şi d. sol)

lead conducere; indicație; avans, prioritate; mină (de creion); (tipografie) interlinie, a interlinia; (auto, termo) avans (la aprindere etc.); zgardă; (agr, alim, OM) canal de moară; (teatru) (şi fig) rol principal; (autom) anticipare; (el) avans de fază; (conductor de / pentru) cablu; (mas-un) avans, devansare; linie; (nav) distanță dintre centrul de efort şi centrul de rezistență laterală, sondă (şi de mână); (geol) filon (de minereu, dar şi fig); exemplu, pildă; (pol, adm, ec) directive, îndrumare, îndrumări, instrucțiuni (şi tehnice); rezumat introductiv (al unui articol); (OM) pas elicoidal / al elicei / al filetului, pas axial al danturii cilindrice înclinate $\left(\mathrm{p}_{\mathrm{z}}\right)$; $(\mathrm{TH})$ a conduce, a dirija, a comanda; a îndrepta, a îndruma, a ghida; a avansa; a decala în avans; a comanda; a căra, a transporta; a determina a determina (un proces, un efect, pe cineva să facă); (met, chim) a plumbui, a acoperi cu plumb; a (a)duce (la), a face; (med) plombă; a fi în fruntea, a deschide (un drum); a împinge; a pune plumb la (un năvod etc.); a lua cu sine, a duce; a fixa (cu precizie); a hotărî (o dată, un termen etc.); (mil) a comanda (o armată etc.); a călăuzi, a conduce, a dirija; (mil, OM) (d. țevile armelor de foc) a se ancrasa cu plumb; $\sim$ to a duce la, a provoca, a da loc la; all roads $\sim$ to Rome toate drumurile duc la Roma; have the $\sim$ a fi în frunte; $\mathbf{a} \sim$ of (sport, trasp) un avans de; be led by one's passions a se lăsa condus de pasiunile sale; follow the $\sim$ of a se lăsa condus de cineva; on the $\sim$ tinut în zgardă; take the $\sim$ a lua conducerea, a se aşeza în frunte; give smb. a a încuraja pe cineva prin exemplul propriu; a sări primul un obstacol

Lead, Plumbum $(\mathrm{Pb})$ (chim) plumb

lead acetate (chim) acetat de plumb

lead-acid battery (auto) acumulator cu plăci de plumb şi acid sulfuric

lead admisson (auto, termo) avans la admisie lead alloy (met) aliaj tipografic / cu plumb lead amalgam (met) amalgam de plumb

lead-and-go (c) funcționare a unui calculator fără întreruperi sau întârzieri între fazele de încărcare şi de executare a programului

lead and lag method (ec) metodă a avansului și a întârzierii (în prognoza economică)

lead angle (el) unghi de defazaj înainte; (masun) unghi de înclinare a elicei / a porțiunii de avans (la tarod); (met) unghiul dintre axa electrodului şi axa cusăturii de sudură; $(\mathrm{OM})$ unghiul (de pantă al) elicei spirei melcului (la angrenaje melcate) $(\gamma)$

lead angle (of phases) (el) unghi de avans (al fazelor)

lead annealed wire (met) sârmă recoaptă în baie de plumb

lead anode (el, ind chim) anod de plumb (în instalatii electrochimice)

lead-antimony alloy (met) aliaj plumb-stibiu

lead-antimony-tin alloy (met) aliaj plumbstibiu-staniu

lead away a duce cu sine, a purta dintr-un loc în altul 
lead back a întoarce

lead base antifriction alloy ( $T$, met) aliaj antifricțiune, pe bază de plumb

lead bath quench (met) călire în baie de plumb lead bath vat (met) cuvă pentru baie de plumb lead-bearing (met) cu conţinut de plumb

lead blast furnace (met) cuptor cu cuvă pentru plumb

lead block (transp, mas) macara

lead bronze (met) bronz cu plumb

leadburning outfit (met, mas) aparat / lampă de sudat

lead cable (el) cablu în manta de plumb

lead cam $(\mathrm{OM})$ camă de ghidare

lead captive a duce în captivitate, a lua în captivitate

lead clamp / jaw (OM) falcă de protecție din plumb (pt. menghină)

lead-coat (met) a plumbui, a căptuşi cu plumb

lead-coated (met, OM) plumbuit, căptuşit / acoperit cu plumb

lead-coated steel sheet (met) tablă de oțel plumbuită / acoperită cu plumb

lead coating (chim, TH) căptuşire cu plumb, căptuşeală de plumb; (met) acoperire cu plumb, plumbuire

lead colic (med) intoxicație cu plumb

lead core (el) miez de plumb

lead-covered (met) acoperit cu plumb; plumbuit

lead-covered rubber cable (el, OM) cablu cu izolație de cauciuc, în manta de plumb

lead covering (el) manta de plumb (la cabluri); (met) acoperire cu plumb

lead cut-out (el) siguranță fuzibilă de plumb

lead dioxide (chim) dioxid de plumb

lead deposit (met, mediu) nămol cu plumb, depunere de plumb

lead dress (constr, el) tragere / montare a conductelor electrice

lead dross (met) zgură / cenuşă de plumb

lead dust (met) pulbere de plumb

leaded $(\mathrm{TH}$, met) plumbuit, căptuşit / acoperit cu plumb

leaded bronze (met) bronz de plumb

leaded fuel / gasoline (ind chim) benzină etilată / cu plumb

leaded gun metal (met, mil) aliaj pentru tunuri (aliaj cu plumb)

leaden (met, fiz) plumbuit, (ca) de plumb, căptuşit / acoperit cu plumb; plumburiu, cenuşiu

leaden end box of cable (met, el) mufă terminală de plumb

leaden pipe cable (el) cablu cu manta de plumb leader (pol, adm, ec, TH) conducător, şef, comandant; lider; (autom, metr) porțiune de bandă nefolosită, la începutul ei; (el) conductor; (hidr, constr, OM) conductă, țeavă, canal (de scurgere), amorsă; (ec) articol de fond / de atragere a clientelei; (mas-un, OM) şurub / element / organ (de maşină) conducător, roată motrice / conducătoare / princilapă, canal / conductă de scurgere (a lichidului de răcire şi ungere); (nav) navă conducătoare / directoare; articol de fond (într-un ziar); (jur) avocat principal (într-un proces); $\sim \mathbf{s}(\mathrm{pl}),($ tipografie) linie punctată

leader and follower (mas-un, OM) dispozitiv de ghidare pentru filetare

leader cable (el) cablu director / de ghidaj; (nav) cablu-pilot

leader merchandising (ec) comercializare „lider” (prin publicitate intensă și expunere a unui produs ieftin, care să atragă atenția spre celelalte articole)

leader mill (met) laminor finisor

leader pass (met) calibru finisor

leader pipe (hidr, constr) burlan / conductă de scurgere

leader points puncte-puncte (în text)

lead error (OM, mas-un) abatere a pasului elicei filetului

leaders (ec) indicatori comerciali

leader screw (OM, mas-un) şurub conducător

leader-stroke discharge (el) descărcare / efect corona

lead extraction (met) extracția plumbului

lead extruded round tube (met, $\mathrm{OM}$ ) țeavă rotundă extrudată, din plumb

lead extruding press (mas-un) presă pentru plumbuit / pentru extrudat plumb şi aliaje lui

lead ferrite (met, chim) ferită de plumb

lead file raşpel, raşpilă

lead foil (ind chim) foiță / folie de plumb

lead gasoline (ind chim) benzină cu plumb (conținând tetraetil de plumb pentru ameliorarea cifrei octanice)

lead glance (met, chim) galenă, sulfură de plumb

lead glass (met, chim) sticlă cu plumb

lead grease (ind chim, T) unsoare consistentă pe bază de săpun de plumb

lead grid $(\mathrm{OM})$ grătar de plumb

lead grip (el) fir de continuitate electrică (la mantaua de plumb a cablului)

lead hammer $(\mathrm{OM})$ ciocan de plumb

lead hardening / quenching (met) călire în baie de plumb

lead hole (OM, mas-un) gaură de ghidare 
lead(-)in (el) racord; intrare în post, tronson de linie care leagă aparatul cu exteriorul; (metr) intrare

lead-in / leading cable (el) cablu de introducere / de intrare / de racord

leading (adj) principal, de primă importanţă; (TH, mas) (element) conducător, conducere, direcție, dirijare, avans; (ind chim, TH) plumbuire; directivă, instrucțiune, îndrumare; (cf) plumb de legare / de siguranță / de sigiliu; (el) avans de fază; (mat) principal, dominant; (met) articole / obiecte de / din plumb; $(s)$ influență; sugestie; exemplu; take the $\sim$ part (teatru) (şi fig) a juca rolul principal; article articol de fond (într-un ziar)

leading address (inf, autom) adresă de bază / inițială

leading article articol de fond

leading axle (cf) osie alergătoare; (OM) ax motor / conducător

leading block (met, transp) macara de direcție / de ghidare

leading bogie (cf) boghiu alergător

leading channel (constr, mediu) canal principal de scurgere / de asanare

leading circuit (autom) buclă / circuit de anticipare / diferențial(a)

leading current (el, autom) curent defazat înainte leading dimensions $(\mathrm{OM})$ dimensiuni principale leading edge (av) bord de atac; (mas-un) muchie activă (a sculei aşchietoare)

leading element (in a determinant) (mat) element de pe diagonala principală (într-un determinant)

leading end $(\mathrm{OM})$ capătul din față / anterior

leading hand (constr, ind) şef de echipă

leading idea idee principală

leading-in (metr) introducere / conectare a unui aparat (prin cablu); (el) izolator de intrare / de racord / de trecere

leading-in cable (el, mas) cablu de intrare (în instalație)

leading double bracket / spindle (el) consolă dublă pentru intrarea într-un post de transformare

lewading drop wire (electr) intrare a liniei unuzi abonat (la televiziune / internet prin cablu)

leading-in insulator (aerial) (el) izolator (aerian) de trecere / de intrare / de racord

leading-in point (el) introducere / intrare / branşament a(l) circuitului

leading light (nav) far de aliniament

leading line (nav) aliniament (în navigația costieră) leading load (el) sarcină capacitivă

leading mark baliză; (nav) reper / semnal de aliniament

leading-off rod $(\mathrm{OM})$ tijă de legătură

leading of phase (el, fiz) avans de fază / al unei faze, defazare înainte

leading (of a polynomial) (mat) termen de gradul cel mai înalt (al unui polinom)

leading out (el) ieşire (dintr-o stație electrică)

leading phase displacement (el, fiz) defazare înainte

leading pulley $(\mathrm{OM})$ roată conducătoare la curele, rolă de ghidare / ghidaj / conducere

leading question întrebare care sugerează răspunsul

leading reactive (el, fiz) curent reactiv, defazat înainte / capacitiv

leading roll (OM, alim) valț / cilindru de conducere

leading screw (OM, mas-un) şurub conducător

leading shaft $(\mathrm{OM})$ arbore conducător

leading spindle $(\mathrm{OM})$ fus de ghidare; şurub conducător

leading strings hamuri (pt. copil); conducere, îndrumare exagerată

leading tip (av, fiz) bord de atac

leading tongs $(\mathrm{OM})$ cleşte de plumbuit

leading truck (transp, mas) macara-călăuză; macara de ghidare; $(\mathrm{OM})$ rolă de ghidare

leadling variable (autom) variabilă principală / independentă

leading voltage (el, fiz) tensiune în avans / defazată înainte

lead-in insulator (el) izolator de intrare

lead-in phase (el, fiz) avans de fază; a fi defazat înainte

lead-in spiral $(\mathrm{OM})$ rilă / şanț de început / de intrare

lead into / to (fig) a induce în

lead-in wire (el) conductor de intrare (a curentului) de fază; conductor de conexiune a unui electrod

lead jacket (el) manta de plumb (a unui cablu)

lead jaw (socket) (mas-un, OM) falcă de protecție din plumb (pt. menghină)

lead joint(ing) $(\mathrm{OM})$ impermeabilizare cu plumb; garnitură de etanşare de plumb

lead ladle (met) lingură pentru plumb topit

lead-lag circuit (autom) circuit integrat-diferențial; (el) circuit dublu

lead line (constr) fir cu plumb; (nav) saulă de sondă; (hidr) conductă de recepție; (met) a acoperi / a căptuşi cu plumb; sondă 
lead lined căptuşit cu plumb, plumbuit

lead lining (met, OM) căptuşeală / îmbrăcăminte de plumb

lead-loaded insulating sleeve $(\mathrm{OM}$, fiz) mufã izolatoare, din răşină sintetică cu plumb (la tuburi cu radiații $\mathrm{X}$ )

lead matrix (mas-un) matriță de plumb

lead matte (met) mată de plumb

lead mine mină de creion

lead mould (met) cochilă pentru (turnat) plumb

lead number (mas-un) raport de transmitere constant al unui strung de filetat, caracteristică a angrenajelor strungului de filetat

lead of brushes (el) decalare a periilor înainte lead of current (el) avans de fază, decalaj înainte lead off a aduce, a lua cu sine; a începe, a deschide (balul etc.) (şi fig)

lead of helix (OM) unghi de înclinare al elicei filetului / melcului

lead of milling machine (mas-un) caracteristică a angrenajului unei maşini-unelte (şi freze), avans longitudinal pentru piesa aşezată între vârfuri (la freze)

lead of thread $(\mathrm{OM})$ pasul filetului

lead on a conduce la; a antrena la; a decide, a obliga (pe cineva la ceva); a arăta drumul; a târî cu sine

lead one a dance a-i da cuiva multă bătaie de cap

lead out a începe; a conduce la o ieșire / solutie lead-out (el, mas) ieşire; (electr) conductor de conexiune scos afară (la circuitele imprimate)

lead-out groove (constr, OM) şanț / canal de ieşire lead oxide (chim, met) oxid de plumb

lead packing $(\mathrm{OM})$ garnitură de etanşare pe bază de plumb

lead paint (ind chim) vopsea cu plumb

lead pateting (met) tratament de patentare în baie de plumb

lead pencil creion (obişnuit, cu mină)

lead-pig (met) plumb în blocuri, calup / bloc de plumb

lead-pin $(\mathrm{OM})$ știft de ghidare

lead pipe $(\mathrm{OM})$ țeavă de plumb

lead plate (met, fiz) placă / tablă de plumb

lead plate rolling mill (met) laminor pentru tablă de plumb

lead plating (met, ind chim) plumbuire, acoperire cu un strat de plumb

lead poisoning (med, $\mathrm{TH}$, mediu) intoxicație cu plumb, saturnism

lead polarity of a transformer (el) polaritate a bornelor transformatorului lead quenching (met) călire în baie de plumb

lead rate (ec) tarif de excepție (pt. calificare sau muncă de excepție)

lead refing plant (met) instalație de rafinare a plumbului

lead ring $(\mathrm{OM})$ inel de ghidare

lead safety plug (OM) dop de plumb, siguranță (moale) (la asamblări filetate etc.)

lead scavengers (ind chim, auto, termo) compuşi de crom şi clor, incluşi în compuşii antişoc pentru a ajuta la îndepărtarea compuşilor de plumb, după arderea combustibilului

lead scoria (met) zgură de plumb

lead screw $(\mathrm{OM})$ şurub conducător / de acționare / de avans

lead seal (transp, ec, jur) sigiliu de plumb; (OM) etanşare cu plumb

lead sheath (el) manta de plumb (la cabluri); înveliş de plumb

lead sheet (met) tablă de plumb

lead shot (met) alică de plumb

lead skim (met) spumă de plumb (la neferoase)

lead slag (met) zgură de plumb

lead smeltery (met) turnătorie / topitorie pentru plumb şi materiale pe bază de plumb

lead smelting (met) elaborare / prelucrare / topire a plumbului

lead-smelting furnace (met) cuptor pentru topirea plumbului

lead soap (T) săpun de plumb

lead softening furnace (met) cuptor de rafinare a plumbului

lead solder (met) aliaj cu plumb pentru lipit; (TH) fir cu plumb

lead soldering (met) lipire cu (aliaj de) plumb

lead spar (minrl) ceruzit (mineral de plumb)

lead speiss (met) mată la topirea plumbului

lead sponge (el, auto, met) plumb spongios (pt. acumulatoare)

lead-stamping punch pliers $(\mathrm{OM})$ clește de plumbuit / de sigilat

lead storage battery / cell (auto, el) acumulator cu plăci de plumb

lead-strip (met) bandă de plumb

lead-strip fuse (el) siguranță lamelară de plumb

lead sulphate (chim) sulfat de plumb

lead sulphide (chim) galenă, sulfură de plumb

lead tapper (met) muncitor în metalurgia plumbului

lead tempering (met) revenire în baie de plumb lead tempering bath (met) baie de plumb, pentru tratament de revenire

lead through a tranzita, a conduce prin 
lead-through electrode (el) electrod de tranzit / de trecere

lead-through insulator (el) izolator de trecere

lead time (ec) timp total (între darea dispoziției şi îndeplinirea / controlul ei)

lead time compensation avans; (autom) parte derivativă a unui regulator

lead-tin solder (met) aliaj de lipit staniu-plumb

lead to a duce la, a avea ca urmare (ceva); (d. drumuri etc.) a (con)duce la

lead tubing $(\mathrm{OM})$ țeavă de plumb

lead up to a fi o introducere la; a vedea terenul pregătit pentru

lead voltage drop (el) cădere de tensiune în / pe conductor / în linie principal( $\breve{a})$

lead wire (el) conductor, cablu; sârmă de plumb, conductă de legătură

leady bogat în plumb, plumburiu, (ca) de plumb

leady matte (met) mată de plumb

lead zirconate titanates (materiale, chim) ceramică densă cu coeficient piezoelectric mare şi permitivitate relativă mare, pe bază de plumb, zirconiu şi titan; titanați cu zorconiu şi plumb

leaf (bot) frunză, frunziş, petală; filă, foaie (şi de carte), pagină; (constr) canat (şi de uşă), batant, tăblie (a uşii, a mesei), cadru, aripă a podului basculant; (met) tablă subțire, foaie, (şi metalizată), tolă; (bot) a avea frunze / foi; a înfrunzi; a frunzări (o carte)

leafage (bot) frunziş, frunze

leaf aluminium rolling mill (met) laminor pentru folii de aluminiu

leaf edge joint $(\mathrm{OM})$ îmbinare frontală a tablei

leaf filter (alim, ind chim) filtru cu plăci / cu discuri, filtru-cartuş

leafless (silv, bot) fără frunze / foi, desfrunzit

leaflet (silv, bot) frunzuliță; foaie volantă, prospect; (ec) circulară

leaf of grasshopper spring $(\mathrm{OM})$ foaie de arc lamelar

leaf out (bot, silv) a înfrunzi

leaf shale (geol, minrl) şist lamelar

leaf spring $(\mathrm{OM})$ arc în foi / lamelar

leaf / beam / feather valve $(O M)$ clapetă / ventil / supapă de reținere (cu lamelă)

leafy (bot, silv) frunzos, cu (multe) frunze; înfrunzit; cu frunza mare

league leghe ( 1 leghe terestră $=4,83 \mathrm{~km}, 1$ leghe marină $=5,56 \mathrm{~km}) ;($ pol, adm, ec) ligă, alianță, asociație; a face o ligă, a se alia

league (metr) unitate tradițională de măsură pentru lungime, milă: 1 Celtic league $\sim 1,5$ Roman miles $\sim 2275 \mathrm{~m}$; în multe cazuri înseamnă 3 miles; pe mare, 1 league $=3$ nautical miles $=$ $5556 \mathrm{~m} ; 1$ league $(\mathrm{SUA}, \mathrm{UK})=3$ statute miles $\sim 4828,03 \mathrm{~m}$ pe uscat sau 3 nautical miles pe mare, 1 lieue $($ Franța $)=4000 \mathrm{~m}$

league (statute) (metr) unitate tradițională de măsură pentru lungime, leghe: 1 league (statute) = $4828,041656083 \mathrm{~m}$

leak (TH) fugă, scăpare, crăpătură, pierdere prin scurgere (a unui lichid), dispersie, infiltraţie; (el) şuntare, derivație; (nav) spărtură (în corpul navei, pe unde pătrunde apa), gaură de apă, a lua apă (d. o navă); (nav, hidr, ind) a fi neetanş, a avea scăpări / scurgeri; (met) a curge, a (se) scurge (d. fluide, un metal topit), a (se) strecura; (fam) a transpira (d. secrete etc.); stop a $\sim$ a opri înfiltrarea apei; spring a $\sim$ a i se face o spărtură

leakage (TH, hidr, OM) scăpare, răsuflare, derivație, infiltrație, atenuare, neetanşeitate, pierdere prin scurgere, dispersie; (el) pierdere prin dispersie; (hidr) pierdere prin infiltraţie sau neetanşeitate (etanşare defectă); (nav) spărtură, gaură de apă, pătrundere a apei (în navă); (termo) exsudare (la cazane)

leakage conductance (el) perditanță, conductanță de scăpări

leakage current (el, hidr) curent de scurgere / de fugă / de dispersie, scurgere / pierdere de curent

leakage factor (el, hidr) factor de pierdere (şi la o maşină electrică) / de scăpări / de scurgere

leakage flow (hidr, TH) scurgere, curgere nedorită leakage flux (fiz) flux de scăpări / de dispersie (şi la câmp magnetic)

leakage indicator (el, autom, metr) verificator al contactelor de punere la masă / de împământare, verificator de pierderi, indicator de contact electric cu pământul; (mas, el, hidr) indicator al scurgerilor

leakage loss (hidr, $\mathrm{T}$ ) pierdere prin scurgere (şi la instalații de ungere)

leakage meter (el, metr) aparat pentru măsurarea curentului de scurgere / pierderilor (şi de putere)

leakage on one phase (el) punere la pământ a unei singure faze

leakage path (el) linie de fugă (pe suprafața unui izolator); linie de curent de fugă

leakage pipe (OM, hidr) conductă de prea-plin

leakage rate $(\mathrm{TH}$, hidr) pierderi / scurgeri în unitate de timp, viteză de scurgere / de pierdere

leakage relay (el) releu de protecție împotriva punerii la pământ / acționat de curentul de scurgere la pământ 
leakage test (metr, OM, hidr) probă / test / încercare de etanşseitate (conducte, recipiente etc.)

leakance (el, fiz) conductanță de izolație, perditanță (inversa rezistenței de izolație)

leakance current (el) scurgeri, curent de scurgere

leakance loss (el) atenuare de scurgere / de perditanță

leak circuit (el) circuit de legare/ (scurgere) la pământ / de împământare

leak coil (el) bobină de şuntare / transversală

leak conductance (el) constantă / coeficient al liniei (electrice)

leak detector (el, OM, hidr, metr) aparat pentru determinarea locului neetanșeității, detector / indicator de pierderi / de scurgeri (de curent, de fluid etc.)

leaker (hidr) fisură prin care se scurge un fluid, sursă / loc de scurgere (a unui fluid)

leak exit (OM, hidr) locul (de la exteriorul unui rezervor etc.) de ieşire a fluidului / unde apare scurgerea

leak free / tight (OM, hidr) etanş, impermeabil, fără pierderi / scurgeri

leak hunter (metr, autom, el) locator / detector de pierderi de curent

leak impedance (el) impedanță paralelă / de şuntare / a şuntului

leakiness (hidr) neetanşeitate

leaking (TH) scăpare, răsuflare, scurgere; (met) nedens, neetanş, permeabil

leaking carburettor (auto) carburator înecat

leaking float $(\mathrm{OM}$, hidr) flotor găurit / neetanş

leaking radiator (auto) radiator care curge

leak instrument (metr, el, hidr) instrument de control (în special pt. pierderi sau scurgeri de curent electric, fluide etc.)

leak into a (se) infiltra, a se scurge (încet) prin

leakless $(\mathrm{OM})$ ermetic, etanş, fără pierderi / scurgeri

leak loss (el) pierdere prin scurgere / prin curent de fugă

leak-off (hidr) pierdere de fluid prin scurgere

leak out a se strecura, a se scurge, a se infiltra; a se răspândi, a se împrăştia, a transpira

leak pressure (hidr, nav) presiunea de scurgere (şi printr-o fisură)

leak(-)proof (OM, hidr) ermetic, etanș, asigurat împotriva pierderilor prin scurgere, impermeabil

leakproof fit (OM, hidr) ajustaj cu strângere / cu frecare, asigurând etanşeitatea îmbinării

leak resistance (el) rezistenţă / şunt în derivație / în paralel / de scurgere leak stopper (nav) dop de gaură de apă; (OM, hidr) piesă / dispozitiv care împiedică scurgerea leak source (OM, hidr) locul în care începe fisurarea prin care se va scurge fluid, sursă de scurgere

leak transformer (el) transformator uscat cu câmp de dispersie

leaky neetanş, permeabil (şi în sens nedorit), care are scurgeri / scăpări

leaky tube (electr) tub electronic neetanș; (OM, hidr) țeavă neetanşă

lean înclinare, înclinație, aplecare; sărac, slab; a (se) înclina, a (se) apleca, a (se) sprijini, a (se) rezema; (alim) carne macră

lean back a se lăsa pe spate

lean coal cărbune sărac în gaze, huilă săracă

lean concrete (constr, met) beton slab

lean flammability (materiale) limită inferioară de inflamabilitate

lean gas (chim, termo) gaz sărac

leaning înclinare, pantă, aplecare; înclinat, aplecat, care se înclină; tendință

lean material (chim) degresant

lean mixture (termo, chim) amestec sărac în combustibil (la motoare cu ardere internă)

lean moulding sand (met) amestec slab de formare (la turnătorie), nisip sărac

leanness slăbiciune; (alim) lipsă de grăsime (a cărnii); (ec) neproductivitate; (agr) lipsă de fertilitate (a solului)

lean on a se sprijini / bizui pe

lean ore (met) minereu sărac

lean over a se înclina, a se apleca; (nav) a se banda, a se înclina transversal

lean sand (met) amestec slab de formare (la turnătorie), nisip sărac

lean-to (constr) acoperiş cu un versant, anexă, pavilion, şopron cu un versant

lean to(wards) a fi înclinat spre, a avea o tendință spre

leap salt, săritură, pas; a sări, a sălta, a face un salt, a înainta prin salturi; a sări de la un subiect la altul; a acționa pripit; pripit; foarte repede; (metr) unitate tradițională galeză de măsură pentru lungime 1 leap $=2,0574 \mathrm{~m}$

leap second (metr, fiz) o secundă suplimentară, adăugată la sfârşitul unei zile (pe 30 iunie sau 31 decembrie) pentru a realinia cronometrul la viteza de rotație a pământului

leap year (metr) o unitate de timp egală cu 366 zile

leap at a se agăța de, a accepta (o propunere)

leaper care face salturi, care sare, săritor 
leapfrog, leaping frog (constr) compactor / mai (tip) broască

leaping săritură, salt, care sare, care face un salt leaping frog test (c) program / test de verificare internă (cu controlul funcționării memoriei), revizie a unui calculator

leap year an bisect

learn a învăţa (singur), a instrui, a studia, a deprinde; a se deprinde cu; a reține, a memor(iz)a, a învăța pe de rost; a exersa; (fam) a auzi, a afla (o ştire); by heart a învăța pe de rost

learnable care se poate învăța, care poate fi învățat

learned învățat, erudit, savant

learner (edu) ucenic, student, persoană care învață leaning (edu) învățare, studiere, studiu; învățătură, cunoştințe (într-un domeniu); informație

learning ability (edu) capacitate / abilitate de învățare

learning machine (edu, univ) calculator pentru învățare (în învătăământ asistat de calculator)

learn of a afla / auzi despre

leasable (agr) arendabil, de dat / luat în arendă

lease drepturi, perspectivă; (ec) arendă, arendare, concesiune (a unei exploatări), chirie, dare / luare în arendă; contract; şantier; închiriere; a arenda, a concesiona, a închiria, a da / lua în arendă / cu chirie; rost (la textile), a despărți sau a împleti fire (şi în textile sau compozite); on $\sim$ în arendă

lease back $(\mathrm{ec})$ vânzarea unei instalații către o societate care are obligația de a o închiria celui care a vândut-o

leasehold pământ / teren arendat; casă închiriată lease peg / pin $(\mathrm{OM})$ cui cu cap în cruce

leasee / leaser (ec) beneficiar de licențe sau bunuri care fac obiectul unui contract de leasing

leash lesă, curea; a ține lagat cu lesa / cureaua

leasing (ec) arendare, concesionare, închiriere (a unor mijloace de producție, bunuri, utilități)

leasor $(\mathrm{ec})$ proprietar de licențe sau bunuri care fac obiectul unui contract de leasing

least cel mai mic, cel mai puțin, minimum

least cost estimating and scheduling system (LESS) sistem de evaluare a costului minim şi de planificare (inițiat de IBM)

least curvature (mat) curbură minimă

least-energy principle (fiz) principiul minimei energii

least significant bit (LSB) (c) cel mai mic bit semnificativ, cea mai mică valoare a datelor prelucrate de un calculator least-squares method (mat) metoda celor mai mici pătrate

least upper bound (l.u.b., lub) (mat) margine superioară, supremum, cel mai mic majorant

leastways, leastwise $(a d v)$ sau cel puțin; sau măcar; sau mai curând

leather piele, piele tăbăcită; articol din piele, curea; a acoperi cu piele

leather belt (OM) curea (de transmisie) de piele leather-binding $(\mathrm{OM})$ legătură de piele, (adeziv pentru) lipirea pielei

leather board carton imitatie de piele

leather-bound legat în piele

leather cuff $(\mathrm{OM})$ garnitură / manşetă (de etanşare) de piele

leatherette (ind chim) imitație de piele

leather-flap valve $(\mathrm{OM})$ robinet cu clapetă din piele

leather gasket $(\mathrm{OM})$ garnitură de etanşare din piele

leather lace / strap $(\mathrm{OM})$ cureluşă pentru cusut curele din piele

leathern de piele, ca de piele

leather ring $(\mathrm{OM})$ inel de etanşare din piele

leather roller $(\mathrm{OM})$ cilindru de presiune, $\mathrm{cu}$ piele (la exterior) (pt. şlefuire, antrenare a materialelor fără a fi deteriorate)

leather seal $(\mathrm{OM})$ manşetă / garnitură / etanșare din piele

leather sealing strip $(\mathrm{OM})$ fâşie / garnitură / bandă din piele (şi pt. etanşare)

leather strap (OM) curea de piele

leather strip fâşie / bandă de piele

leathery ca pielea; (alim) (d. carne) tare (ca pielea)

leave rămas bun; (mil) permisie, concediu; permisiune; autorizație, permis; învoire, plecare; a lăsa (o urmă, într-o anumită stare); a nu lua; a uita, a părăsi, a abandona, a pleca (din / de la), a se duce; a porni din / de la; a renunța la, a întrerupe; a rămâne; a încredința, a înmâna; a depune, a depozita; a lăsa la o parte, a respinge; a omite; a neglija, a nesocoti; a-și da demisia; a termina, a isprăvi; a lăsa în aceeaşi stare; (bot) a înfrunzi, a avea frunze; (jur) a lăsa prin testament

leave behind a lăsa (în urmă), a uita, a întrece

leaved (bot) înfrunzit, cu frunze

leaven (alim) plămădeală, maia, ferment, drojdie, a face să fermenteze, a pune aluatul la dospit; (fig) înrâurire, influență, a supune influenței

leavening influențare

leave off a lăsa, a nu mai purta; a înceta; a termina, a isprăvi, a lăsa (munca); a se opri 
leave out a omite, a lăsa pe dinafară, a elimina; a sări peste, a nu include, a lăsa de o parte

leave over a amâna, a lăsa în suspensie (o problemă)

leave to a lăsa în seama, a încredința

leave untouched a lăsa neatins

leavings (ind, mediu) reziduuri, rest(uri), deşeuri, rebuturi

le Chatelier-Braun principle (fiz) principiul le Chatelier-Braun, legea echilibrului mobil

lection lectură, citire, citit; variantă (a unui text)

lector (univ) lector (străin)

lecture (univ) prelegere, curs; conferință; cuvântare

lecture on (univ) a tiine o prelegere / un curs, a conferentia, a tine o conferintă despre

lecturer (univ) lector, asistent, conferențiar

lecture room (univ)sală de cursuri, sală de lectură, amfiteatru

lectureship (univ) post de lector / asistent

ledeburite (met) ledeburită

ledeburitic steel (met) oțel ledeburitic

ledge ieşitură, proeminență; (TH, constr) terasă, margine, bordură, strat, lisă; (mas-un) linie, rigletă, riglă; (met) rețea de turnare; $(\mathrm{OM})$ culee; (constr) poliță, pervaz

ledge of plane talpă a rindelei

ledger (constr) grindă / scândură orizontală, stinghie (de lemn); (ec) registru contabil

ledger card cartelă cu piste magnetice

lee sub vânt, la adăpost de vânt; (nav) bordul de sub vânt; apărare, protecție, adăpost; loc ferit / adăpostit

lee anchor (nav) ancoră nefundarisită / inactivă / de sub vânt

lee board (nav) derivor lateral, bord de sub vânt

leech (nav) margine de cădere

lee gauge (nav) poziție sub vânt

leek (alim, bot) praz

leer (ind chim, termo) cuptor-tunel de recoacere a sticlei

lees (ind, alim, mediu) sediment, produs decantat; drojdie, drojdii, pleavă

lee share (nav) coastă de sub vânt

lee side, leeward (nav) bordul de sub vânt

leeward (nav) (bordul de) sub vânt

leeway (nav) derivă

left stânga, stâng, din / la stânga

left-bent tool (mas-un) unealtă / sculă înclinată pe / la stânga

left drive / driving (auto) conducere pe dreapta (Europa, SUA etc.)

left flank (OM) flancul stâng (al unui dinte) (simbol L) left-hand action (mas-un, OM) acționare pe stânga, pe stânga (şi d. filete)

left-hand cutter (mas-un) freză pentru aşchiere spre / pe stânga

left-hand deviation (cf) ramificație / deviație spre / pe stânga

left-hand drive / steering (auto) conducere / volan pe stânga

left handed stângaci, neîndemânatic; contrar acelor de ceasornic; (OM) (filet) pe stânga; (mat) la stânga

left-handed bolt $(\mathrm{OM})$ şurub / bolț cu filet pe stânga

left-handed coordinate system (mat, fiz) sistem de coordonate pe stânga

left-handedly $(a d v)$ cu stângăcie, neîndemânatic

left-handed moment (mec) moment de rotatie contrar acelor de ceasornic

left-handedness stângăcie, neîndemânare; ipocrizie; lipsă de sinceritate

left-handed twist (auto) cablaj la stânga; (OM) răsucire la / spre stânga

left-hand lay $(\mathrm{mec})$ torsiune pe stânga; (c) parcurgere de la dreapta spre stânga

left-hand limit (mat) limită la stânga

left-hand mill(ing) cutter (mas-un) freză cu coadă, pentru aşchiere pe stânga

left-hand rule (fiz) regula mâinii stângi

left-hand page pagina pe stânga

left-hand side (mat) membrul stâng al unei ecuații

left-hand switch / turnout (cf, el) macaz / întrerupător / ramificație pe stânga

left-hand teeth $(\mathrm{OM})$ dantura înclinată (spre) stânga (simbol L)

left-hand welding (met) sudare înainte / spre stânga

left identity (mat) element neutru la stânga (în algebră)

left lay (el, OM) cablaj (pe) stânga, înfăşurare S (stânga)

left lay rope (el, OM) cablu torsadat la stânga

left-luggage office (cf) (depozit de) bagaje (pierdute)

left / first member (mat) membru stâng / întâi, prim membru, partea stângă a unei egalități

left offset tool (mas-un) cuțit cotit pe / la stânga

left-overs (mediu, ind) resturi (şi de mâncare)

left-right tuning (autom, metr) reglare / reglaj stânga-dreapta

left-right volume (metr, radio) reglaj stângadreapta al intensității sonore

left-sided de pe partea stângă 
left-side view $(\mathrm{OM})$ vedere din stânga (în desen tehnic)

left turn (mat, mec) rotație / răsucire la stânga

left turning (mat) (întoarcere) la stânga; (masun) strunjire sore / la stânga

leftward din stânga, din partea stângă, îndreptat spre stânga

leftwards $(a d v)$ din(spre) stânga, din partea stângă, de la stânga, (în)spre stânga, în stânga

lefty stângaci

leg picior, gambă; (el) piesă polară; picior de compas; (mat) catetă, latură; (met) latură a profilului cornier; $(\mathrm{OM})$ latura / cateta cusăturii de colț (la sudură), picior (de la o masă etc.), suport, picior suport, flanc; (alim) picior (de miel), ciosvârtă; crac (de pantalon); (constr) bretea, ramificație de şosea; a împinge cu piciorul, a mişca cu piciorul

legacy moştenire

legal (jur) juridic, judecătoresc; legal, permis, îngăduit, conform unei legi, după lege

legal adviser (jur) juristconsult, consilier juridic legal aid (jur) servicii juridice gratuite

legal charges (jur) speze pe contencios

legal constraint (jur) restricție legală

legal department (jur) contencios

legal expert (jur) juristconsult

legal filing depozit reglementar (al unei cereri de brevet de invenție)

legality legalitate

legalization (jur) legalizare, autentificare

legalize (jur) a legaliza, a autentifica

legally $(a d v)$ (din punct de vedere) juridic / legal

legal person (jur) persoană juridică

legal profession (jur) profesia de jurist

legal tender / currency $(\mathrm{ec})$ monedă legală, curs legal, instrumente de plată legale

legal time timp legal, oră oficială

leg callipers (metr) compas simplu de exterior / de grosime

legend explicație, legendă (la desene tehnice, diagrame etc.), inscripție

legend of a map legenda unei hărți

legibility (mas-un, metr) claritate (a gradațiilor); lizibilitate (a unui text)

legging filare, filamentare (şi la ruperea unui adeziv) (şi mod de deteriorare)

leggy cu picioare lungi

legibility lizibilitate

legible citeț, lizibil; clar

legibly (adv) (în mod) citeț

legislate (jur) a legifera, a elabora legi

legislation (jur) legislație

legislative (jur) legislativ; putere legislativă lagislator (jur) legiuitor, legislator

legist (jur) legist, jurist

legitimacy (jur) caracter legitim, legitimitate

legitimate, legitimize (jur) legitim, legal; drept, justificat, îndreptățit; a recunoaşte ca legal

legitimation legitimare, justificare; (jur) adoptare, înfiere

legua (metr) unitate tradițională spaniolă pentru lungime, leghe spaniolă: 1 traditional legua $=$ $4,2 \mathrm{~km}, 1$ legua $($ Texas $)=4233,4 \mathrm{~m}, 1$ traditional Spanish legua $=4179,4 \mathrm{~m}$; în prezent se folosește în Argentina şi alte țări de limbă spaniolă ca unitate în sistem metric: 1 legua $=5 \mathrm{~km}$; (metr) unitate tradițională spaniolă pentru suprafață în America Latină și America de Sud: 1 legua $($ Texas $)=1792$ ha, 1 legua $($ California $)=$ 1796 ha, 1 legua (Mexic şi Texas) $=1$ sitio, v. sitio

légua, legoa (metr) unitate de măsură pentru lungime, leghe portugheză: 1 Portuguese league = $6174,1 \mathrm{~m}$

legume (alim) păstaie

legumes (alim) legume

leg length $(\mathrm{OM})$ lungimea / mărimea catetei la cusătura de colt

leg of a circuit (el) parte a unui conductor aflat sub tensiune maximă

leg of fillet $(\mathrm{OM})$ cateta cusăturii de colt (la sudură)

leg pipe (OM, hidr, termo) cot (şi de țeavă), țeava condensatorului barometric

leg room / space (mas-un, auto) loc / spațiu pentru picior

leg work muncă de teren; aplicare în practică

lehr (met) cuptor de răcire

Leibnitz's theorem / formula (fiz) formula / teorema lui Leibnitz

leisure răgaz, timp liber; liber, neocupat

leit-motif, leit-motive laitmotiv

lemma, $p l$ lemmata (mat) lemă, propoziție auxiliară

lemniscate (mat) lemniscată, curba $\varphi^{2}=a^{2} \cdot \cos 2 \theta$

lemon (alim, bot) lămâie, lămâi; galben-lămâie

lemon acid (chim) acid citric

lemonade (alim) limonadă, citronadă

lemon drop (alim) bomboană acidulată

lemon squash (alim) limonadă

lemony (ca) de lămâie

lend (to) a da cu împrumut (cuiva), a împrumuta (cuiva); a da (cuiva), a închiria (cuiva), a acorda (cuiva); a adăuga; a se preta (la)

lender (ec) creditor, împrumutător

lending (ec) împrumut, creditare, $\operatorname{credit}(\mathrm{e})$ 
lending circuit (el, hidr) circuit / linie de tranzit lending library bibliotecă cu împrumut

lend-lease (jur, ec) (legea de) împrumut şi închiriere

length lungime; distanță; întindere; bucată; (textile) cupon; metraj; durată, timp; măsură; a trata un subiect în mod amănunțit; at pe larg, detaliat, în cele din urmă; of service vechime în muncă, (mas) durata de funcționare efectivă (a unei maşini)

length (lg) (metr) unitate de măsură pentru lungime, ca distanță între concurenți în curse hipice sau nautice, egală cu lungimea medie a unui cal, bărci etc.: 1 length $\sim 2,4 \mathrm{~m}$, uneori 1 legth $\sim 1 / 5 \mathrm{~s}$

lengthen a (se) (a)lungi, a deveni (mai) lung, a (se) prelungi (şi temporal), a întinde; (d. zile) a se mări, a creşte

lengthened alungit

lengthened pulse (electr, autom) impuls prelungit lengthening piece $(\mathrm{OM})$ alonjă, prelungitor, piesă cu reglarea lungimii

lengthening rod $(\mathrm{OM})$ tijă / bară de prelungire / prelungitoare

lengthening tube (ind chim, OM) alonjă, tub cu lungime variabilă, tub prelungitor

length feed (mas-un) avans longitudinal

lengthiness lungime, întindere (mare); (fig) prolixitate

length measuring system (metr) sistem de măsurare a lungimii

length modulation (autom) modulație a duratei impulsurilor

length of action ( $\mathrm{TH}$, mas, radio) rază de acțiune

length of approach path (OM) segment de intrare în angrenare, lungimea segmentului de angrenare (la roți dințate)

length of brake path (auto, OM) distanță de frânare

length of break (el) cursa contactului de întrerupere

length of endsection (OM, met) lungime terminală / de capăt

length of engagement (OM) lungime de asamblare / de prindere

length of grip $(\mathrm{OM})$ lungime de prindere

length of jib (mec) lungimea / mărimea săgeții

length of lay (el) pas de înfăşurare

length of life (TH) durată de viață / de functionare

length of life test (metr, mas) durata testului / încercării în funcționare / de durabilitate

length of operation ( $\mathrm{TH}$, mas) durată de funcționare / de operare / de serviciu length of overhang (mec, OM) lungime în consolă, lungimea consolei

length of path of contact $(\mathrm{OM})$ lungimea petei de contact (şi la roți dințate)

length of run (nav) distanta dintre perpendiculara la pupa şi extremitatea de la pupa a părtii cilindrice a navei

length of support (mec, OM) distante între reazeme, lungime de rezemare, lungimea suportului

length of taper (OM, mas-un) lungimea conicității / conului / suprafeței conice (şi la cozi de prindere pt. scule)

length of thread $(\mathrm{OM})$ lungimea filetului

length of undercut (OM, mas-un) lungime de degajare a filetului, lungime de scoatere a cutitului / sculei de filetat

length of (a) vector (mat, fiz) modul al unui vector length of weld (OM, met) lungimea cusăturii sudate / a sudurii

length overall $(\mathrm{OM})$ lungime totală (cotă de gabarit); (nav) lungime maximă / totală (a navei)

length-preserving mapping $(\mathrm{OM})$ proiectie echidistantă / care păstrează lungimile

length trip (mas-un) limitator de cursă

lengthwise $(a d v)$ în lungime; (met) în lung, în sensul lungimii / laminării, în lungul sudurii

lengthwise seat (constr, OM) bancă / aşezare longitudinală (şi la laminare etc.)

lengthwise streaks dungi / urme în direcție longitudinală

lengthy foarte lung, întins; deşirat; (fig) prolix, interminabil, plictisitor

lens (fiz, opt) lentilă, obiectiv; (med, anat) cristalin lens distance (fiz, opt) distanța obiectivului lenslike în formă de lentilă

lens power (fiz, opt) puterea lentilei

lens ring $(\mathrm{OM})$ garnitură lenticulară

lens-ring cooler (termo) răcitor lenticular

lens-shaped $(\mathrm{OM})$ lenticular, în formă de lentilă lens tabs (auto) umerii lămpilor

lens turret (metr, opt, fiz) turelă rotitoare, cu lentile (la microscop)

lenticular (fiz, opt) lenticular, biconvex

lentil (alim) linte

lentil head $(\mathrm{OM})$ cap semi-înecat / semirotund

lentitude încetineală, inerție

Lenz's law (fiz) legea lui Lenz

lepton (Biblical Roman) (metr) unitate veche de măsură pentru masă, lepton: 1 lepton $($ Biblical Roman $)=0,000030078 \mathrm{~kg}$

less mai puțin, mai mic, mai neînsemnat; inferior; minor; minus, fără

lessee (ec) chiriaş, arendaş, concesionar 
lessen a (se) micşora; a scurta; a (se) reduce; a slăbi; a îngusta; a (se) diminua; a (se) împuțina; a minimaliza, a subestima; a descreşte

lessening micşorare, slăbire, reducere

lesson lecție; oră de predare; prelegere; temă; a da lecții, a medita, a învăța, a instrui

lessor (jur, ec) persoană care dă cu chirie / în arendă

lest ca nu cumva; ca să nu; de teamă să nu; să nu

let a lăsa; a admite; a presupune, a permite, a îngădui; a închiria, a da cu chirie; a face, a pune în situața să

let-down încetinire; relaxare; declin, regres; deziluzie; descurajare

let down a lăsa (în) jos, a coborî; a lungi (o rochie); a dezamăgi; a face un rău; a dezumfla (un pneu); a încetini, a relaxa

lethal (med, chim, TH, mediu) (cu efect) mortal, letal, fatal

lethal dose (LD) (metr, famacologie) unitate de măsură pentru a exprima procentajul unei populații (de insecte etc.) ucise de o doză dintr-o anumită substanță: exemplu doza $\mathrm{LD}_{50}$ este cantitatea din acea substanță care ucide $50 \%$ din populația supusă testului

lethargic (med) letargic, apatic, inert; de moarte lethargy letargie, inerție, amorțeală; apatie

let in a deschide (admisia etc.), a admite; a introduce, a lăsa să intre / să pătrundă; a primi

let in the clutch (mas, OM) a ambreia let-in piece $(\mathrm{OM})$ piesă de (la) intrare let it be fie; se admite; se presupune

let(-) off pornire, scurgere; a goli, a elibera, a lăsa să curgă (un lichid)

let off a da drumul la; a descărca; a lansa; a elibera; a da cu chirie, a închiria

let out a da drumul; a goli; a lăsa să iasă afară

let out on lease a închiria, a da cu chirie

let slip the clutch (mas, OM) a permite patinarea / alunecarea ambreiajului

letter scrisoare, literă, caracter, tip; instruit, educat, cultivat, cult; exprimat prin litere; imprimat, tipărit

letter box portofel; cutie de scrisori

letter carrier factor poştal, poştaş

letter code cod literal

letter designation simbolizare / desemnare prin literă / litere

letterhead antet, scrisoare / hârtie cu antet

lettering notatie $\mathrm{cu}$ ajutorul literelor; titlu, antet

letter mark ştampila poştei

letter nail (el) marcă distinctivă

letter of advise aviz, înştiințare letter of credit (ec) acreditiv, scrisoare de credit letter of indemnity / guaranty (ec) certificat / scrisoare de garanție

letter pad (bloc de) hârtie de scrisori

letter paper hârtie de scrisori

letter-spacing (tipografie) spațiere / rărire a textului

letters patent brevet de inventie

let through a lăsa să treacă (prin)

letting locuință de închiriat

letting-off motion of worm type (fiz, materiale) mişcare de eliberare de tip melc (şi la polimeri, țesături, fire)

lettuce (alim, bot, agr) lăptucă, lăptuci

let-up încetinire; stagnare; oprire; pauză

let up a încetini; a stagna; a se opri, a se întrerupe

levee (hidr, constr) zăgaz, dig; chei, debarcader; a îndigui

level nivel; întindere, suprafață; (fiz) nivel de energie; (constr) netezitor, nivelator, treaptă, etaj, cotă, nivelmetru, nivelă cu bulă de aer; (mat, mec) linie de nivel; (geogr) câmpie, șes; a nivela, a aduce la acelaşi nivel, a netezi, a îndrepta (și table, profile); a plana; a regla pe orizontală; a egaliza, a uniformiza; plan; drept; orizontal

level away a nivela, a aduce la acelaşi nivel

level bar (metr) clinometru

level bottle (metr, chim) sticlă de nivel / gradată

level characteristic (el, autom) zgomot de fond

level chuck (mas-un, OM) mandrină cu dispozitiv de strângere cu pârghie

level controller (autom, hidr) regulator / stabilizator de nivel

level crossing (cf) pasaj de nivel

level curve / line (mat, fiz) curbă de nivel

level decrease (autom, hidr) scădere a nivelului

level difference diferență de nivel

level down a coborî nivelul

level dyeing $(\mathrm{TH})$ vopsire uniformă

level error (metr) eroare de înclinare

level gauge (OM, metr, hidr) indicator de nivel

level housing $(\mathrm{OM})$ carcasa nivelei / indicatorului de nivel

level hunting (autom) selecție pe mai multe niveluri / trepte

level indicator (met, OM) indicator de nivel (și pt. fluide şi pt. buncăre cu materiale)

level input (el, electr, autom) intrare a semnalului de referință

level (instrument) (constr, metr) nivelă cu bulă de aer 
leveller (constr, TH, mas) dispozitiv / maşină de uniformizare / de nivelare / de îndreptare

levelling nivelare, uniformizare, egalizare; (met) dresare, îndreptare, putere de nivelare (la acoperiri); (constr) nivelment

levelling bench (constr) placă de trasare / de îndreptare

levelling course / underlay strat de egalizare / de îndreptare

levelling cross (cf) cruce de nivel, intersecție la (acelaşi nivel)

levelling device (OM, mas-un) dispozitiv de îndreptat / de nivelat / de egalizat

levelling indicator (OM, hidr) indicator de nivel, nivelă

levelling jack (mas-un) dispozitiv pentru aşezarea piesei de prelucrat la raboteză (cu reglare a poziției orizontale)

levelling machine (mas-un) maşină de îndreptat (şi tablă)

levelling of ground (constr) nivelarea pământului

levelling screw (auto, OM) șurub de reglare (și la maşini-unelte); (mas) elice cu pas reglabil

levelling vessel (OM, hidr) vas de nivel, vas pentru păstrarea nivelului constant

liveliness uniformitate, egalitate, netezime

level measurement (metr) măsurarea nivelului (unui fluid etc.)

level number (inf, OM) număr de nivel, număr de referință care arată poziția unui articol întrun ansamblu ierarhizat

level of energy (fiz) nivel de energie

level of program(me) (inf) treaptă / nivel de program

level of repair analysis (TH, ec) tehnică / analiză de stabilire a nivelului de reparare / de mentenanță

level out (constr, mas-un) a nivela (şi prin îndepărtare de material)

level plane (cf) nivel de platformă cu cale

level regulator (hidr, OM) regulator de nivel

level surface (hidr) suprafață de nivel

level track (cf, met) linie ferată orizontală

level tube (hidr, OM) tub de nivel

level vessel (hidr, OM) vas de nivel

level with plummet (metr, OM) nivelă cu fir cu plumb

lever $(\mathrm{OM})$ pârghie, levier, mâner, manetă, rangă; (auto) vinci, cric; (hidr) sifon

level action (mec) efect de pârghie

lever (OM) pârghie, levier, braț, mâner (şi de uşă); punct de sprijin / de reazem leverage (mec, OM) mecanism cu pârghii, transmisie prin pârghii, efect de pârghie, forță a pârghiei

leverage coefficient (mec) coeficient de amplificare al pârghiei

leverage of load (mec, OM) braț de acționare al forței

lever apparatus $(\mathrm{OM})$ aparat / dispozitiv cu pârghie

lever arm (mec) braț al pârghiei

lever arrangement $(\mathrm{OM})$ poziția / aranjamentul pârghiei

lever-arresting device $(\mathrm{OM})$ dispozitiv de oprire cu pârghie

lever brake $(\mathrm{OM})$ frână cu pârghie / cu manivelă

lever chuck (OM, mas-un) mandrină cu strângere prin pârghii

lever control (OM) comandă cu / prin pârghie

lever controlled switch (el, OM) întrerupător cu pârghie

lever drill (mas-un) burghiu cu pârghie de apăsare (de avans)

lever for quick lubrication $(T, O M)$ pârghie de comandă a sistemului de ungere

lever guide (OM) ghidaj de pârghie / de balansier

lever head (el) contact cu pârghie (de acționare)

lever jack $(\mathrm{OM})$ cric, vinci

lever key clapă / alezaj de manivelă

lever latch (OM) zăvor / blocare cu pârghie

lever of first / second kind (mec) pârghie de ordin unu / de ordinul al doilea

lever-operated (knife) switch (el, OM) întrerupător tip cuțit acționat prin pârghie

lever press (mas-un) presă cu pârghie

lever pump (OM, hidr) pompă cu pârghie

lever punch (met) ştanță de decupat / de poansonat, cu pârghie

lever ratio (mec) raport de transmitere al forței (la pârghii)

lever-reversing gear $(\mathrm{OM})$ schimbător de sens cu pârghie (şi la transmisii dințate)

levers (mec, OM) sistem de pârghii

lever safety valve $(O M$, hidr) supapă de siguranță, acționată cu pârghie

lever scale (metr) balanță simplă, basculă

lever shears (mas-un) foarfece cu pârghii

lever system $(\mathrm{TH}, \mathrm{mec})$ sistem acționat prin pârghie / pârghii

lever table shears (mas-un) foarfece de banc, cu acționare prin pârghie

lever-type (TH, OM) cu pârghie 
lever-type clamp $(\mathrm{OM})$ dispozitiv de strângere cu pârghie

lever-weighted safety valve (OM, hidr) supapă de siguranță, acționată cu pârghie şi cu o greutate

leviable (ec) impozabil, care poate fi perceput (d. impozit)

levigate (ind, mediu) a pulveriza; a leviga; a spăla; a decanta; a limpezi; a măcina

levigation (TH) levigare; spălare; decantare; pulverizare; măcinare; limpezire

levigation melting (met) topire în pat fluidizat, topire în câmp electromagnetic, piesa de topit fiind menținută în câmp prin forțe Lorentz

levulose (chim) fructoză, levuloză

levy (ec) percepere a impozitelor; sumă impusă; (jur) sechestru judiciar, a lua în stăpânire o proprietate (pe baza unei hotărâri judecătoreşti); contribuție, cotizație; a percepe, a strânge (taxe, impozite)

levy / lay a tax on a percepe impozit / taxă pe, a strânge / a ridica un impozit / o taxă

Lewis key $(\mathrm{OM})$ sistem de două pene tangențiale

Lewis number (termo) numărul lui Lewis, raport între difuzibilitate termică şi masă

lexical lexical; de vocabular; de dicționar; lexicografic

lexicon lexicon; dicționar

Leyden jar (el, electr) butelie Leyda, condensator cu sticlă

L-head engine (termo) motor cu supape laterale

LH thread (OM) filet pe stânga

li (metr) unitate tradițională chinezească pentru lungime; $1 \mathrm{li}=0,5 \mathrm{~km}, 1$ metric $\mathrm{li}=1 \mathrm{~km}$

liabilities (ec) pasiv, datorii

liability răspundere, responsabilitate; obligație, îndatorire; posibilitate; susceptibilitate; piedică; (constr) aderență a betonului la oțelul-beton; (ec) răspundere, garanție; $(\mathrm{TH})$ adeziune, aderență, siguranță în exploatare

liability insurance (auto) asigurare de răspundere civilă

liability to (TH) tendință / susceptibilitate la

liability to the formation of / to form hot spots (met) tendință / susceptibilitate la formare de pete moi

liable for răspunzător pentru / de

liable to obligat să; care poate să; (care este) pasibil de; expus la; predispus la

liaison legătură; (mil) (ofițer de) legătură

liang (metr) a traditional Chinese weight unit. In modern China, 1 liang $=50 \mathrm{~g}$ liberal (pol) liberal; larg, liberal; generos, larg liberate a elibera; (chim) a elimina, a degaja liberation eliberare; (chim) eliminare, degajare liberation of gas (met, ind chim) eliberare / degajare de gaz

liberty libertate; voie, permisiune; risc, şansă libra, pound (lb) (metr) unitate de măsură pentru masă în Marea Britanie şi Cmmonwealth, livră, pfund (unitate de masă $1 \mathrm{lb}=0,4536$ $\mathrm{kg}$ ); (ec) liră sterlină

libra, libbra (lb) (metr) unitate de măsură tradițională pentru masă în țările de limbi italiană, spaniolă şi portugheză: 1 Roman libra $\sim 0,722$ English pound $\sim 1$ traditional Italian libbra, 1 Spanish libra $\cong 1$ Portuguese libra $\sim 460 \mathrm{~g}$

librarian bibliotecar

librarianship funcția de bibliotecar

library bibliotecă, librărie (şi colecție de programe, bănci de date, disponibile pe computer)

licence (ec) licență, brevet, patent, licență, autorizație, permis, permisiune; (univ) licență; (auto) număr (la maşină)

license (auto) permis de conducere; a autoriza, a permite; a da un brevet

license bracket / holder (auto, TH) suport pentru licență / numărul de înregistrare / înmatriculare

licensed $(\mathrm{ec})$ care are autorizație (să vândă ceva)

licensee $(e c)$ concesionar, persoană căreia i-a fost acordată o licență / un permis

license-lamp (auto) lanternă / lumină pentru numărul de înmatriculare

license number (auto) număr de circulație / înmatriculare; (ec) numărul licentei

license plate (auto) plăcuța numărului de circulatie / înmatriculare

license plate light (auto) lumină pentru plăcuță de înmatriculare

license plate light bulb (auto) becul de la sistemul de iluminat pentru plăcuța de înmatriculare

licentiate (univ) licențiat

lichen (bot) lichen

licit (jur) licit, legal

lick (met) a scurge, a (se) strecura; (constr, TH) vopsire, vopsit, zugrăveală

licking clamp (OM) pârghie de strângere

lid $(\mathrm{OM})$ capac, cap, clapă de închidere, calotă

lid of luggage boot (auto) capac de portbagaj

lid-operated switch (el, autom) întrerupător actionat de capac

lie minciună; situație; aşezare, poziție; a minți; a zace; a se afla; a se întinde; a staționa; a se menține; a sta (întins / culcat); a constitui; a consta; a fi, a se afla (într-o situație); a fi situat 
lie at anchor (nav) a sta / a staționa la ancoră lie by a sta / se ține deoparte; a rămâne pasiv lie down a se culca, a se întinde; a nu se împotrivi

lien (ec) drept de retenție / de sechestru, garanție lie off (nav) a se menține la distanță, a rămâne în larg, a fi ancorat în larg; a întrerupe temporar lucrul, a şoma

lie time (TH) timp / durată de întrerupere / de stationare

lie to (nav) a fi în derivă

lieue (metr) unitate de măsură pentru lungime, leghe franceză: 1 lieue (recunoscută internațional $)=5556 \mathrm{~m}, 1$ metric lieue $($ Franța $)=4000 \mathrm{~m}$

life viață, existență; trai; ființă; mod / fel de viață; (TH) durată de viață / de serviciu / de funcționare, durabilitate (d. elemente de maşini, maşini, echipamente etc.); (met) campanie (la cuptoare); biografie

life annuity (ec) rentă viageră

life assurance / insurance (ec) asigurare de persoane, asigurare pe durata de viață (a unui utilaj)

life belt (nav, constr) centură de siguranță / de salvare

life boat (nav) barcă de salvare

life buoy (nav) colac de salvare

life curve / characteristic (TH, mas) curbă de siguranță / de fiabilitate / de durabilitate, caracteristica duratei de funcționare

life cycle cost (ec) suma cheltuielilor de achiziție şi mentenanță pentru un produs, pe toată durata lui de viață

life cycle of product $(\mathrm{TH}$, mediu) durată de viață a unui produs

life expectancy (TH) durată de viață estimată

life interest (jur) uzufruct; rentă viageră

life jacket (nav, TH) vestă de salvare / de protectie

lifeless rubber (plast, ind chim) cauciuc fără insertie / moale

lifelike colours culori naturale

life line (nav) țin-te bine, balustradă; (fig) ancoră de salvare

life long pe viață; $(\mathrm{TH})$ pe toată durata de viață (a produsului, echipamentului etc.)

life of a furnace (met, ind chim) campania / durata de viaţă a cuptorului / a furnalului

life of mould (met) durata de utilizare a matriței, durabilitatea formei / matriței

life pension pensie viageră

life-saving station (nav) punct de salvare

life span (TH, mas) durată de serviciu / de exploatare life test (TH, mas) încercare / test pentru determinarea duratei de funcționare, test la care interesează durata de funcționare a unui produs în anumite condiții, până la rupere

lifetime durata vieții; (TH) timp de funcționare / de utilizare, durată de viață a unui produs

life unit (TH, metr, mas) unitate de măsură pentru durata de viață a unui produs (pot fi ore, zile, cicluri, distanțe etc.)

life work muncă de o viață; operă capitală (a cuiva)

lift forță ascensională, portanță; (TH, mas) cursă, ascensor, lift, elevator, ridicare, înălțare; avânt; înălțime, ridicătură de teren; flec de toc; (masun) înălțime de ridicat; (hidr) cursa supapei / a ventilului; (transp) stivuitor, dispozitiv de ridicat; înălțime de depresiune / nivel; (nav) scădere a pescajului (pe măsura descărcării); porție; a (se) ridica, a înălța; (agr) a dezgropa, a săpa, a defrişa; a scoate; a se împrăștia, a se risipi (şi d. un gaz etc.); a plagia; (ec) a ridica (un embargou etc.), (amer) a urca, a mări, a ridica (prețuri etc.); (av) a decola, a se desprinde (de sol)

lift area (of valve) (hidr, OM) suprafaţa ventilului sau a supapei de actionare sub presiune

lift automatic shut down device (autom, OM, transp) întrerupător automat al mişcării de ridicare / al motorului liftului

lift axis (mec) axă / direcție a forței portante

lift brake (OM, transp) frână prin cădere / de ascensor

lift bridge (transp, ind) pod basculant

lift cabin / car (transp, ind) cabină de ascensor / de elevator

lift cage / case (constr) put / casă a(l) liftului

lift car annunciator ( $\mathrm{TH}$, transp) panou cu semnale de etaj (la ascensoare)

lift-check valve (hidr, OM) clapetă de reținere ghidată / cu mişcare verticală

lift coefficient (mec) coeficient al forței portante / ascensionale; (hidr) coeficient de contrapresiune

lift conveyer (alim, constr, transp, mas) elevator, transportor cu ridicarea materialului

lift distribution (mec) distribuție a forței ascensionale / portante

lift (elevating-platform) truck (mas, transp) cărucior de transport cu platformă ridicătoare, stivuitor, cărucior de ridicat

lifter (met, OM) clește de prins creuzete, cârlig pentru demulare, ridicător, dispozitiv de ridicat

lifter cam $(\mathrm{OM})$ camă ridicătoare

lifter valve (auto, OM) tachet de supapă 
lift force (mec) forță de ridicare / ascensională lift fork $(\mathrm{OM})$ furcă de ridicare

lift guide track $(O M)$ patină / ghidaj de ascensor / de dispozitiv de ridicat

lift hammer (met, OM) ciocan de forjă cu / prin cădere

lift heating (termo) încălzire cu circulație prin termosifon

lift hoisting cable (mec) cablu al ascensorului / al dispozitivului de ridicat

lift hysteresis (fiz, mec) histerezisul forței ascensionale

lifting $(\mathrm{TH}$, transp) ridicare, instalație de ridicat

lifting apron (alim, ind chim) curea ridicătoare, masă înclinată, pânză ridicătoare

lifting beam / bar (OM, transp) traversă pentru ridicat materiale, bară ridicătoare

lifting capacity (transp) capacitate de ridicare / portantă

lifting contrivance $(\mathrm{OM})$ dispozitiv de scoatere / de ridicare

lifting craft (nav) ponton de ridicare / ridicător

lifting device ( $\mathrm{TH}, \mathrm{OM})$ dispozitiv de ridicat

lifting expenses (met, ec) cheltuieli de extracție / de exploatare

lifting eye $(\mathrm{OM})$ inel / ochi / ochet de ridicare, buclă de suspendare

lifting eye bolt $(\mathrm{OM})$ şurub cu ochi de ridicare

lifting force (mec) forță ascensională / de sustentație; (hidr) forță de ridicare

lifting frame (constr, mec) schelet / cadru de ridicare

lifting gate $(\mathrm{cf})$ barieră

lifting gear (OM) mecanism / dispozitiv de ridicare (posibil cu angrenaje)

lifting height (mec, transp) înălțime de ridicare (şi la macarale)

lifting holes (OM, met) găuri de ridicare (a modelului / matriței / carcasei etc.)

lifting hook (OM, transp) cârlig de macara / de ridicat

lift(ing) jack (OM) trepied, cric, vinci (pt. ridicarea unei sarcini)

lifting lever $(\mathrm{OM})$ pârghie de ridicat

lifting magnet (device) (met, el, transp) dispozitiv electromagnetic de ridicare

lifting medium (mec) mediu portant, organ de ridicare

lifting motor (el, mas) motor al mecanismului de ridicat

lifting movement $(\mathrm{mec})$ mișcare ascensională / ascendentă / de ridicare (met) extragerea / ridicarea modelului lifting-out device (met, OM, mas) dispozitiv de evacuare / de ridicat (la paturi de răcire, matrite mari etc.)

lifting pins (met) ştifturi de ridicare (la ramele de formare)

lifting plate $(\mathrm{OM})$ placă-extractor, placă de extractie

lifting platform (transp, mas) elevator, autolift, platformă-ascensor, masă ridicabilă

lifting pontoon (nav) cilindru / ponton / flotor de ranfluare

lifting power (mec, hidr) portanță, putere / capacitate de ridicare

lifting pressure (hidr) presiune de refulare, presiune de ridicare (a ventilului etc.)

lifting pressure (valve of oil engine) (auto, termo) presiune de pornire (la supapa motoarelor diesel)

lifting property $(\mathrm{mec})$ proprietate de portanță / de ridicare

lifting pump (hidr, transp) pompă-elevator

lifting rod $(\mathrm{OM})$ bară de crapodină

lifting-screw (OM) cric, vinci (cu şurub), şurubul de la vinci; (mas-un) (mecanism cu) şurub de ridicare (la cursa verticală a unei maşini-unelte)

lifting ship (nav) navă de ranfluare

lifting spindle $(\mathrm{OM})$ arbore filetat pentru ridicat, vinci cu şurub

lifting surface (mec) suprafață portantă

lifting table (mas-un) masă ridicătoare / cu mişcare (şi) pe verticală

lifting tackle $(\mathrm{OM})$ palan de ridicare

lifting time (mec) timp de ridicare / de urcare

lifting trough $(\mathrm{OM}$, transp) troc elevator

lifting truck (transp, mas) cărucior elevator (și pt. stivuire), încărcător automat, stivuitor

lifting wheel $(\mathrm{OM})$ roată elevatoare / ridicătoare

lift motor (el, mas) motor de ridicat / de ascensor

lift of cam (OM, mas-un) cursă / excentricitate a camei

lift off a scoate, a ridica

lift of key (OM) joc al manipulatorului, cursă a clapei

lift of pump (hidr) înălțime de refulare a pompei lift of sleeve $(\mathrm{OM})$ cursă de decuplare (la cuplaje)

lift of valve (hidr, OM) cursă / ridicare a ventilului / a supapei

lift out a ridica din; a scoate din paranteze

lift over a ridica peste (o limită)

lift over arrangement $(\mathrm{OM})$ dispozitiv de siguranță contra ridicării peste o anumită cotă

lift per unit area (mec, mas) sarcină portantă / portanță pe unitatea de arie 
lift platform (OM, mas) platformă de ridicare lift platform track (mas, transp) cărucior cu platformă ridicătoare

lift pump (OM, hidr) pompă de refulare / ridicătoare (de presiune)

lift shaft (constr) puț / casă a(l) ascensorului

lift truck (mas, transp) cărucior elevator (şi pt. stivuire), încărcător automat, stivuitor

lift up a sălta; a trage în sus; a ridica; a ridica cu troliul

lift valve $(O M$, hidr) supapă ridicătoare

lift ventilation (mediu, termo) ventilație forțată

lift well cabină de ascensor / de elevator

lift wire $(\mathrm{OM}$, transp) cablu principal de ridicare / de sustinere, cablu purtător

ligament $(\mathrm{OM})$ secțiunea minimă într-un corp de piesă, între două găuri adiacente (la recipiente, nituire, table asamblate cu şuruburi etc.); (anat) ligament

ligan (nav) bunuri aruncate în apă şi balizate în vederea recuperării

light lumină; iluminare; foc; flacără; lampă; felinar, far; (constr) fereastră, ferestruică, lucarnă; zi; lumina zilei; (el) sursă de lumină, corp de iluminat; semnal luminos; lampă; far; litere subțiri; a lumina, a ilumina, a (se) aprinde (şi lumina); a lua loc, a se aprinde; a se însenina; a se lăsa; a coborî; luminos, bine luminat, strălucitor; uşor (ca greutate, intensitate, concentraţie, complexitate etc.); deschis (d. o culoare)

light-absorbing (materiale, fiz) absorbant de lumină

light absorption (fiz) absorbție de lumină light ageing (plast) îmbătrânire la lumină light alloy (met, $\mathrm{T}$ ) aliaj uşor, material slab aliat light annealing (met) recoacere albă / până la incandescență albă

light aperture / opening / slit / slot (fiz, metr) deschidere / fantă / gol de lumină / de iluminare, deschidere / fantă mică

light ash (met, termo) cenuşă volatilă / fină / zburătoare

light barrier (autom, fiz, el) releu fotoelectric

light beam (fiz) rază / fascicul de lumină

light beam brazing / soldering $(\mathrm{TH})$ lipire cu radiații luminoase

light brick (met, constr) cărămidă uşoară

light brightness (fiz, opt, c)luminozitate

light bulb (el) bec electric

light buoy (nav) geamandură luminoasă

light car (auto) autoturism mic / uşor; (cf, met) vagonet

light casting (met) turnare a pieselor mici light cell (fiz, el, opt) celulă fotoelectrică, foto element

light-coated electrode (el, met) electrod cu înveliş subțire

light cold-rolled sheets (met) tablă subțire, laminată la rece

light colour culoare deschisă

light-coloured de culoare deschisă

light colouring colorare uşoară

light concrete (constr) beton uşor

light constituents (chim) constituenți volatili; (met) constituenți cu densitate mică

light construction (constr) construcție uşoară

light control / turn signals (auto) lumini / semnalizare de schimbare a directiei

light-coupled switch (autom) întrerupător comandat printr-un fascicul de lumină

light crude (oil) (ind chim) țiței parafinos / ușor

light current (fiz) flux luminos; curent fotoelectric, fotocurent, curent slab

light-current engineering electronică, electrotehnică a curentilor slabi

light cut (mas-un) aşchie de secțiune mică, prelucrare cu aşchii mărunte; (ind chim) fracținne uşoară

light day (metr, fiz, astronomie) unitate de măsură pentru lungime, zi-lumină: 1 light day $\sim 25,90210^{9} \mathrm{~km}$ )

light dimming (fiz) slăbire / atenuare a luminii

light distance (fiz) distanță față de sursa de lumină

light duty $(\mathrm{TH}$, ind) condiții uşoare de lucru, uşor, pentru sarcini uşoare

light duty contact (el) contact pentru putere mică / pentru curent slab

light-duty vehicle (auto, transp) camionetă, camion uşor

lighted dial (metr) cadran cu sistem / bec de iluminare

lighten a (se) (i)lumina; a uşura, a face mai uşor, a slăbi; a micşora; a domoli; (nav) a descărca parțial o navă (pt. micşorarea pescajului); a deschide o culoare; a lămuri

light-ends (alim, ind chim) fracțiuni uşoare (la distilare)

lightening pocket $(\mathrm{OM})$ cavitate prevăzută / prelucrată pentru micşorarea greutății piesei / de uşurare

lighter aprinzător, dispozitiv de aprindere, brichetă, fitil; (nav) şlep, şalandă

lighterage (nav) prețul alimbării / mahonării

lighter bar $(\mathrm{OM})$ vinci cu cremalieră

light-fast (plast) rezistent la lumină

light-fingered îndemânatic 
light fitting / fixture / unit (el) corp de iluminat, lampă

light flux (fiz) flux luminos

light fraction (alim, ind chim) fracțiune uşoară (la distilare)

light from vertical sources (el, fiz) lumină directă verticală

light fuel (ind chim, auto, mas) combustibil uşor light-fugitive (materiale) instabil la lumină light fuse (el) siguranță

light gauge $(\mathrm{OM})$ cu secțiune mică, subțire light-gauge sheet (met) tablă subțire

light gauge steel construction (constr, mec) construcție metalică uşoară (din oțel)

light grey cenuşiu deschis

light-handedness dexteritate; tact

lighthouse (nav) far

light industry industrie uşoară

lighting aprindere; iluminare, iluminat

lighting aperture (constr) luminator; (fiz, metr) deschiderea fantei de iluminare

lighting by daylight iluminare / iluminat natural

lighting control (auto) control al sistemului de lumini

lighting equipment $(\mathrm{el}, \mathrm{TH})$ instalație de iluminat lighting fitting / fixture / unit (el) corp de iluminat, lampă

lighting gas (ind chim) gaz de iluminat

lighting mains / network (el) rețea de iluminat

lighting of blast furnace (met) aprinderea / pornirea furnalului

lighting of cupola furnace (met) aprinderea cubiloului

light-off (termo) inițierea arderii în camera de combustie (a unei turbine)

lighting of instruments (auto, el, metr) iluminare a bordului, a tabloului cu indicatoare

lighting panel (el) tablou electric de iluminat lighting system (el) sistem / instalație de iluminat lighting switch (auto, el) întrerupător de lumină lightish uşurel, destul de uşor; (d. culoare) palid, şters, deschis

light keying fit $(\mathrm{OM})$ ajustaj cu strângere mică

light lathe (mas-un) strung mic / pentru mecanică fină

lightless întunecat, întunecos, neluminat

light load (pentru) sarcină uşoară (d. elemente de maşini, maşini etc.)

light lorry (auto) camionetă, camion uşor lightly $(a d v)$ uşor, încet, fără zgomot; neserios; lesne, fără efort; cu uşurință, nechibzuit

lightly-coated electrode (met) electrod cu înveliş subtire (la sudare) light metal (met) metal / aliaj uşor

light-metal rim (auto) jantă auto din aluminiu

light minute (metr, fiz, astronomie) unitate de măsură pentru lungime, minut-lumină: 1 light minute $\sim 17987547 \mathrm{~km}$

light motorcycle (auto) motoretă

lightness (fiz) luminozitate, lumină, strălucire, uşurință; greutate mică; uşurință, facilitate

lightning arrester / conductor / rod (fiz, constr) paratrăsnet

lightning stroke (lovitură de) trăsnet

light off (chim) țiței uşor, ulei uşor

light pitch înclinare mică

light plant $(\mathrm{el}, \mathrm{TH})$ instalaţie de iluminat

light plate (met) tablă mijlocie / subtiire

light plate rolling mill (met) laminor pentru tablă mijlocie

light pointer (metr) arătător / punctator / indicator luminos

light positive (fiz) fotoconductor

light press fit $(\mathrm{OM})$ ajustaj presat uşor, ajustaj cu strângere mică

light-proof (plast) rezistent la lumină

light railway (cf, met) şină uşoară

light ray (fiz) rază de lumină

light refractories (met) refractare uşoare

light relay (el, opt) releu optic / fotoelectric

light resistance (fiz, plast) rezistentă la lumină, fotorezistență

light-resistant (fiz) rezistent la lumină (și d. materiale plastice)

light running (TH, mas) mers în gol / uşor / fără sarcină

lights (auto) semafor, stop

light scattering (fiz, opt) împrăştiere / difuzie a luminii

light second (metr, fiz, astronomie) unitate de măsură pentru lungime, secundă-lumină: 1 light second $=299792458 \mathrm{~m}$

light-section rolling mill (met) laminor pentru profiluri uşoare

light-section steel (met, OM) profil uşor de oțel light-sensitive sensibil la lumină (d. ochi, materiale plastice etc.)

light-sensitive cell (fiz, opt, el) fotocelulă, celulă fotoelectrică

light shape (met) profil uşor

light sheet (met) tablă uşoară

light ship (nav) navă fără încărcătură, navă-far, far plutitor

light signal (opt) semnal luminos

lightsome luminos, luminat; limpede, clar; neîntunecat; uşor, delicat 
light spot spot luminos (şi la aparate optice, microscopice etc.)

light stop (fiz, metr, OM) diafragmă / obturator de lumină

light stroke linie subțire

light-structural mill (met) laminor de profiluri uşoare

light switch (el) întrerupător de lumină / al iluminatului

light-tight (materiale, fiz) etanş la lumină, netransparent, opac

light tower (nav) far

light track urmă subțire / uşoară

light transmitting (fiz, materiale) transparent

light up a lumina

light watt (metr, fiz) unitate de măsură pentru puterea relativă la ieşire a unei surse luminoase

light wave (fiz) undă luminoasă

lightweight (materiale) uşor, cu greutate specifică mică; (auto) deplasament neîncărcat

lightweight alloy (met) aliaj uşor / cu greutate specifică mică

lightweight construction (constr) construcție uşoară / cu greutate redusă

lightweight steel shape (met, OM, constr) profil uşor din oțel

light wiring (el) instalație de iluminat

light year (ly) (metr, fiz, astronomie) unitate de măsură pentru lungime, an-lumină: 1 light year $=9,4607304725808 \cdot 10^{+12} \mathrm{~km}$

ligne, French inch (metr) unitate tradițională pentru măsurarea lungime în țări de limbă franceză: 1 ligne = 1 English line, 1 Swiss ligne (industria de ceasuri, Elveția) $\cong 2,256 \mathrm{~mm}$

ligneous lemnos

lignify a (se) lignifia

lignin (plast) răşină fenolică (PF), lignină

ligneous coal (met) cărbune brun, lignit

lignification lignificare

lignite cărbune, cărbune brun, lignit superior

lignite power plant (el, termo) centrală electrică pe bază de cărbune superior / cu lignit

lignum vitae gaiac

ligula (metr) unitate romană de măsură pentru volum de lichid: 1 ligula $\sim 11,07 \mathrm{ml}$

like a-i plăcea; a vrea, a dori; asemănător, analog, egal, similar, asemenea; probabil, verosimil; ( $a d v)$ (într-un mod) asemănător, în acelaşi mod / fel; (prep) ca, (la fel) ca şi, la fel cu; întocmai ca, precum; aşa cum, ca

likelihood verosimilitate, probabilitate

likelihood estimation (mat) estimare probabilistică likely probabil, verosimil; potrivit, adecvat; convenabil; $(a d v)$ probabil, după toate probabilitățile, după cum / cât se pare

liken to a compara cu

likeness (between / to) asemănare (între / cu), analogie; egalitate; înfățişare, chip, formă

like terms (mat) termeni asemenea

likewise $(a d v)$ în acelaşi mod / fel, la fel; de asemenea; mai mult decât atât; pe lângă acestea, în plus

liking simpatie; plăcere, preferință

lillliput socket (el, OM) dulie pitică

lily (bot) crin

Lithium (Li) (chim) litiu

lithium battery baterie de litiu

limaçon (mat, geom) melcul lui Pascal, curba $\rho(\theta)=a \cdot \cos \theta+b$

limb $(\mathrm{OM})$ membru, arc, braț, limb, piesă, flanc; (agr) cracă, creangă; a dezmembra, a face bucăți

limber flexibil, pliant, (fig) înțelegător; prompt, expeditiv; (nav) canal de santină

limber hole, limbers (nav) orificiu de scurgere al santinei

lime (bot) tei, specie de lămâi; (chim) oxid de calciu, var nestins, calcar, piatră de var; a vărui, a trata cu var

lime base grease ( $T$, chim) unsoare pe bază de calciu

lime basic covering (met) înveliş bazic de var

lime bright annealed wire (met) sârmă recoaptă în mediu neutru

lime brush (constr) bidinea

lime burner / burning kiln (met, ind chim) cuptor de var

lime carbonate (chim) carbonat de calciu

lime-coat a trata / a acoperi cu var, a vărui

lime-coating (met, constr) tratare / acoperire cu var, a văruire

lime cream (constr) lapte de var

lime fluorspar covering (mat) înveliş de tip bazic (la electrozi de sudură)

lime juice (alim) suc / zeamă de lămâie

lime kiln (met, ind chim) cuptor de ars var

lime milk (chim) lapte de var

limen linie despărțitoare, limită (în sens larg); (el) prag electric

lime pit (constr) carieră de calcar

lime residue (met) şlam

lime roasting (ind chim, met) arderea / calcinarea varului

lime set (met, TH) deranjament din cauza excesului de var (la furnal)

lime slag (met) zgură calcaroasă 
lime slaking (ind chim) stingere a varului lime soap ( $T$ ) săpun de calciu

lime spar (minrl) calcit

limestone calcar, piatră de var; (chim) carbonat de calciu

limestone flux (met) fondant / flux de calcar lime-wash (constr) lapte de var, a vărui lime water (chim) apă de var

limit (el, inf) toleranță, valoare limită, adresă finală / limită (în programare); limită, margine, hotar, semn de margine / de hotar, (mat) domeniu; (ec) preț plafon, a stabili / fixa prețul; a limita, a mărgini, a restrânge, a delimita, a micşora

limitable limitabil, care poate fi limitat

limitary limitat, restrâns, mărginit; limitrof, mărginaş; restrictiv, limitativ

limitation condiție, (de)limitare, restricție; rezervă; mărginire; frontieră; restrângere; vecinătate

limitation of mobility limitare a mobilității

limitation of warranty rights (ec) limitare a garanției / a drepturilor date de garanție

limitative limitativ, restrictiv

limit bridge (electr, metr) punte de măsurare rapidă

limit-check (autom, TH) compararea datelor cu valoarea limită

limit contact (autom, mas) contact-limită (la dispozitive de comandă)

limit control (autom, mas) dispozitiv care întrerupe functionarea când se atinge o limită impusă

limit design $(\mathrm{OM}, \mathrm{mec})$ proiectare / calcul la (rezistență) limită

limited limitat, delimitat, micşorat, mărginit, restrâns, finit; (ec) cu răspundere limitată, anonim

limited amount of oxygen (termo, chim) cantitate limitată de oxigen

limited availability accesibilitate / disponibilitate parțială (d. maşini, echipamente etc.)

limited company (ec) societate pe acțiuni, cu răspundere limitată, societate anonimă

limited creep stress (mec, OM) limită de curgere / de fluaj valoarea rezistentei / tensiunii / efortului pentru curgere / fluaj impus( $\breve{a})$

limited liability $(\mathrm{ec})$ responsabilitate limitată

limited partner $(\mathrm{ec})$ comanditar

limited rotary motor (mas) motor cu unghi de rotatie limitat

limited short-circuit (el, autom) scurt-circuit amortizat / atenuat

limited slip differential (OM) diferențial autoblocant

limiter (OM) limitator, care limitează; (TH, autom) regulator (cu limită de viteză etc.) limit exceedance (TH, mas) depăşire a limitei / a unui parametru-limită

limit gauge (metr) calibru limitativ

limit gradient pantă / gradient limit(ă) / $\operatorname{critic}(\breve{a})$

limiting limitare, care limitează; limitativ, restrictiv; (metr, autom) limitarea semnalului de ieşire, chiar dacă parametrul de intrare creşte

limiting amplifier (autom) amplificator de limitare / limitator

limiting angle of rolling mill (met) unghi de contact al semifabricatului cu cilindrul de laminare

limiting compressive stress $(\mathrm{mec})$ rezistență la rupere / la compresiune, limită la compresiune

limiting-conditions condiții la limită (şi la metode cu element finit)

limiting creep stress (mec, met) limită de fluaj, efort / tensiune pentru o valoare limită a deformației la fluaj

limiting current (el) limită de curent, curent de limitare; (hidr) curent în stare critică

limiting date line linie de demarcație, termenlimită (pt. o acțiune); (nav, geogr) linie / meridian de schimbare a datei

limiting deflection (metr) deviaţie completă / limită (şi a acului unui instrument de măsurat)

limiting device (OM, autom) dispozitiv de limitare, limitator (a mişcării, a înălțimii de ridicare etc.)

limiting distribution repartiție / distribuție extremă / limită (d. materiale, frecvențe etc.)

limiting forward overload current (el) curent limită de suprasarcină, în sens direct

limiting forward peak repetitive on-state current (el) curent limită periodic de vârf, de durată, în sens direct

limiting line $(\mathrm{TH})$ linie de delimitare

limiting load (mec) încărcare / sarcină limită / limitatoare

limiting maximum stress (mec) limită (tensiune / efort) maximă de solicitare

limiting minimum stress $(\mathrm{mec})$ limită (tensiune / efort) minimă de solicitare

limiting no-damage current (el) curent de nefuzibilitate, curent maxim fără pericol de distrugere / deteriorare

limiting point (mat, TH) punct limită / la frontieră limiting quality (metr) cantitate / mărime limită de influență (asupra unui aparat de măsură)

limiting rabbet (mas-un) limitator de cursă

limiting range of stress $(\mathrm{mec}, \mathrm{OM})$ interval de limitare a tensiunilor

limiting resistance (mec, $\mathrm{OM}$, materiale) rezistență-limită, rezistență limitatoare

limiting screw $(\mathrm{OM})$ şurub-limitator 
limiting slope (mec, constr) pantă limită / critică limiting surface (mas-un, OM) suprafață de limitare / care limitează (ceva)

limiting value valoare-limită / de limitare limiting viscosity ( $T$, hidr) vâscozitate limită limitless nelimitat, infinit, fără limite, nemărginit limitlessness caracter nelimitat / nemărginit limit load (mec, OM) sarcină-limită

limit of adhesion (materiale) limită de aderență / de adeziune (şi d. adezivi, compozite etc.)

limit of capacity $(\mathrm{TH}$, mas) limită a unei capacităti, limită de putere, capacitate maximă

limit of density (materiale) limită de densitate

limit of detection (metr, autom) limită de detectare, cea mai mică valoare a cantitătii măsurate care determină modificarea poziției indicatorului / răspunsului sistemului

limit of elasticity (mec, OM) limită de elasticitate limit of elongation (mec, OM) limită de alungire / de curgere

limit of endurance (mec, TH) limită de anduranță / de durabilitate

limit of error (metr) eroare limită

limit of linear elasticity $(\mathrm{mec})$ limita elasticității liniare

limit of proportionality (mec) limită de proportionalitate

limit of range (mat, autom) limită de interval

limit of resistance $(\mathrm{mec})$ limită de rezistență

limit of rollability (met) limită de laminare

limit of sensibility (metr, autom) limită de sensibilitate

limit of solubility (chim, met) limită de solubilitate

limit of stability (mec, met) limită de stabilitate

limit of stress (mec, materiale) limită de tensiune, rezistență la rupere (fără a preciza tipul de solicitare sau, implicit, la tracțiune)

limit of stretching strain (mec) limită de alungire (mai ales la materiale plastice)

limit of wear $(\mathrm{T})$ limită de uzură

limit point punct-limită

limit resistor (el) rezistență limitatoare

limitrophe (to / with) limitrof, învecinat (cu)

limit side load (mec) sarcină transversală limită

limit signal (autom, mas, TH) semnal pentru valoare limită

limit snap gauge (metr) calibru-potcoavă limitativ limits of accuracy (metr) limite de precizie / acuratețe / exactitate (d. un aparat de măsură etc.)

limits of effective current range (el) limitele curentului maxim şi minim, de lucru limit speed (auto, mec) viteză-limită, limită de viteză

limit stop (mas-un) limitator de cursă

limit stress (mec, OM) tensiune / efort limită

limit superior limită superioară

limit system $(\mathrm{OM})$ sistem de toleranțe

limit testing (metr) testare la limită (d. materiale, sisteme tehnice)

limit velocity viteză-limită

limit value valoare limită

limit value of the stimulus (autom) limită de excitabilitate

limoid (ind chim) var stins

limonite (minrl) limonit

limous calcaros, de var, vâscos, tulbure

limousine (auto) limuzină

limp moale, flasc; mototolit; şchiopătare, mers neregulat; a şchiopăta

limp growth rates viteze (neregulate) de creştere (d. parametrii unui proces tehnologic etc.)

limpid transparent, limpede

limpidity limpezime, claritate

limy cleios, lipicios; calcaros, de var; tulbure

linage număr de rânduri (pe pagină)

linchpin $(\mathrm{OM})$ fus, fuzetă, şplint

Lincoln type milling machine (mas-un) maşină de frezat longitudinală

line curbă, dreaptă, linie, direcție (de demarcație, comunicație, de creion etc.); (auto, transp) rută, cale, traseu, parcurs (de mașină); graniță, contur, limită, drum, magistrală, căptuşeală, conductă, şir, rând (şi de litere), in (fibră textilă); aliniere; frânghie, şnur, sfoară; instrucțiune, regulă; domeniu, ramură, sferă; ordine, serie, şir; descendență, linie; (şi fig) specialitate, profesie, ocupație; articol; condiții, situație; parte; informație; (nav) cale de apă, parâmă, saulă, tubulatură navală, otgon, companie de navigație; (geogr) the Line ecuatorul; (cf) linie, cale ferată; linie, fir, legătură (telefonică, de comunicații etc.); (anat) rid, încrețitură, trăsătură (a feței), linie (în palmă), trăsătură; (arte) contur, schiță; (metr) unitate de lungime (USA) $=0,635 \mathrm{~m}$; (fig) limită; (mil, nav) front, linie, lanț, linii (de apărare), poziții; (OM, TH) a căptuşi (un cazan etc.), a haşura, a linia, a alinia; (met) a bătători, a îndesa (la formare), a acoperi, a căptuşi, a îmbrăca; a tapisa a placa, a dubla; a aşeza în linie, a înşirui; a regla / ajusta (un mecanism); (zool) (d. lup etc.) a străbate o distanță; (fig) a umple; a linia; (mil) a alinia (soldați etc.); a brăzda; come into / to the $\sim$ a (se) alinia; get $\mathbf{a} \sim$ on a obține 
informații despre; in smb.'s line în specialitatea cuiva; head $\sim$ titlu; read between the $\sim \mathbf{s}$ (fig) a citi printre rânduri; in the natural $\sim$ of things în ordine firească / normală a lucrurilor; all along the $\sim$ pe toată linia; (mil) of battle linie de bătaie, line firing foc desfăşurat (al lanţului de trăgători), serve in the $\sim$ a fi pe front; ship of the $\sim$ (nav, mil) vas de linie; cross the Line a trece ecuatorul; with iron a blinda

line (li, "') (metr) unitate tradițională de măsură pentru lungime; 1 line $=1 / 12$ inch $(\sim 2,1167$ $\mathrm{mm}), 1$ (smaller) line $=1 / 40$ inch $(0,635 \mathrm{~mm})$ pentru măsurarea grosimii nasturilor; (metr) (li) nume anterior pentru maxwell - unitate de măsură în sistem CGS pentru flux magnetic; (metr) unitate tradițională pentru măsurarea suprafeței în tipografii şi reclame: $1 \mathrm{li}=1,814$ mm multiplicat cu lățimea liniei tipărite

line a bearing $(T)$ a turna un cuzinet, a acoperi un lagăr (cu compoziție antifricțiune)

lineal of (jur) descinzând direct (din); ereditar, succesoral; linear

lineal scale length (metr) lungimea unei scale liniare

line amplifier (autom, metr) amplificator de linie / de cale

line and staff $(\mathrm{ec})$ conducere şi personal responsabil cu execuția

linear, lineal liniar

linear calibration curve (metr) curbă liniară de calibrare, caracteristică liniară de conversie

linear contraction (met, plast) contracție liniară

linear distribution of bending stress (mec) repartizare liniară a efortului de încovoiere

linear element element liniar

linear energy transfer (LET) (mec) transfer de energie pe unitatea de lungime

linear equation (mat) ecuație liniară

linear expansion (materiale, termo) dilatare liniară

linear expansivity (materiale, termo) coeficient de dilatare liniară

linear extension (mat, fiz) alungire / extensie liniară

linear flow (hidr) curgere liniară

linear foot ("lineal" foot) (ft, lf) (metr) termeni pentru o lungime de 1 picior la corpuri lungi şi subțiri / înguste (conducte, garduri etc.)

linear functional (mas) (cu) funcționare liniară

linear meter (metr) termen pentru a descrie o lungime de 1 metru la corpuri lungi şi subțiri / înguste (conducte, garduri etc.), metru liniar

linear yard (metr) termen pentru a descrie o lungime de 1 yard la corpuri lungi şi subțiri / înguste (conducte, garduri, panouri etc.)

linear gate (autom, electr) circuit liniar de intrare linear indexing (mas-un) divizare liniară linear induction motor (el) motor de inducție cu mişcare liniară

linearity (mas) liniaritate (şi între parametri)

linearity error (metr) eroare / abatere de la liniaritate

linearisation, linearising action (mat) liniarizare (a unei curbe, evoluții a unui parametru etc.)

linear load (mec, T) încărcare / sarcină liniară / pe unitatea de lungime, sarcină liniară specifică

linearly / serially / simply ordered set (mat) lant, multime liniar ordonată

line arm (el, mas, electr, autom) ramură longitudinală / liniară (a unei scheme)

linear magnification (autom) amplificare liniară

linear measure (metr) dimensiune liniară, măsură de lungime

linear misalignment (mas) defect de aliniere

linear molecular chain (chim, plast) lanț molecular liniar

linear momentum (mec) impuls (cantitate de mişcare) liniar( $\breve{a})$

linear movement $(\mathrm{mec})$ mișcare rectilinie

linear pitch $(\mathrm{OM})$ pasul danturii la cremalieră (cu dinți drepți)

linear polymer (plast) polimer liniar

linear programming (inf) programare liniară

linear range interval liniar, interval pe o axă / pe o dreaptă

linear rate (mec) viteză liniară; (mas, TH) rată de modificare liniară (a unui parametru)

linear shim (el) separator (tip / cu) lamelă; (TH) adaos (de prelucrare) liniar / pe o directie

linear space (mat) spațiu liniar / vectorial

linear speed of rolling (met) viteză liniară a laminorului / de laminare

linear strain (met) deformație liniară

linear system (el, hidr) rețea liniară

linear taper (el) rezistență cu variație liniară

linear transducer (metr) traductor liniar (dependență liniară parametru de intrare - parametru de ieşire)

linear velocity (mec) viteză liniară / pe aceeaşi direcție

line authority $(\mathrm{adm}, \mathrm{ec})$ autoritate ierarhică

line assembly work (TH) asamblare pe bandă

line bar (el) conductor tip bară

line breaker (el) întrerupător principal de linie

line clogging / plugging (hidr) înfundare / colmatare a unei conducte

lined $(\mathrm{OM}, \mathrm{T})$ căptuşit, acoperit, cu compoziție aplicată (pe un cuzinet); liniat; cutat; brăzdat; (mil) blindat 
line electrical parameters (el) parametri electrici ai liniei

line element (OM, hidr) element de conductă; (mat) element de linie

line filling (hidr, alim) a umple / umplere până la semn

line-free circuit (el) circuit electric de blocare

line header section (met, hidr) stație de repompare pe conductă

line hum (el) zgomot de retea

line load (mec) sarcină liniară

line loss (el) pierderi pe linie

lineman (cf) picher; (nav) om la manevră pe chei

lineman's instrument (el, metr) instrument / aparat de montaj / de aliniere

line material (constr) material de construcție; (T) material pentru acoperiri pe lagăre

linen (textile) pânză (şi de in), olandă, rufărie, lenjerie

linen draper (textile, ec) comerciant de pânzeturi linen drapery (textile) pânzeturi, albituri; lenjerie

line noise (el) zgomot de fond / de linie

line of action / of engagement (OM) linie / dreaptă de angrenare

line of balance (LOB) (inf) linie de echilibru (metodă de analiză în rețea)

line of contact $(\mathrm{OM}, \mathrm{T})$ linia contactului / de contact, linie de angrenare

line of curvature linie curbă / de curbură

line of dip (fiz, mec) linie de cădere / de incidență / de înclinare

line of flow (hidr, fiz) linie de curent

line of flux (fiz) linie de flux (termic, electric etc.)

line of force (el) linie de forță

line of fusion (met) limită de topire

line of load (mec) linie de sarcină / de încărcare

line of segregation (met) curbă / linie de segregare

line of solidification (met) curbă / linie de solidificare

line of strike(s) (geol, materiale) direcție a straturilor; (mas-un) direcție de acțiune

line of trace (fiz, metr) urmă / pistă luminoasă (la osciloscoape)

line of vision (opt) direcție a privirii / de privire

line of zero variation (el) linie de variație zero

line pair (mat) pereche de drepte

line pipe $(\mathrm{OM}$, hidr) (țeavă de) conductă

line plate $(\mathrm{OM}$, met) placă de căptuşeală / acoperire

line pressure (hidr) presiune în conductă line production (ec) productie în flux (liniar) liner (el) strat intermediar (la bobine de şoc); (OM) cuzinet, cămaşă, manşon, căptuşeală, garnitură, material pentru acoperire la lagăre, țeavă interioară / de căptuşire, bucşă; (nav) vas de linie, pachebot, transatlantic; țesătură în inserție; (met) bandă metalică pentru garnituri, material de acoperire (foarte general); (av) avion care face curse regulate, avion de linie

line reaming (mas-un) alezarea găurilor coaxiale, la piese asamblate

line regulator (el, autom) regulator al tensiunii de retea / de sector

line replaceable unit $(\mathrm{OM}$, ind) element / modul / subansamblu care este proiectat / asamblat astfel încât să fie înlocuit ca un singur articol / modul

liner of a pump / cylinder (OM) cămaşă de pompe / cilindru

line segment segment de dreaptă, bară

line service (constr) (d. drumuri) serviciu de întreținere

line-shaft $(\mathrm{OM})$ arbore conducător / de antrenare / de transmisie

line-shaft bearing (OM) lagăr al arborelui (unei transmisii)

line shape (fiz) forma liniei spectrale

line sharpness claritatea liniilor

line system (el) rețea electrică

linesman (nav, TH) tehnolog / muncitor la masa / instalația de trasaj

lines of ferrite (met) linii / benzi de ferită

lines of self-intersection (geom) linii de intersecție a două suprafețe

line spectrum (fiz) spectru de linii

line standard (metr) riglă-etalon / cu scară gradată; (OM) standard pentru linii în desen tehnic

line straight box (OM, hidr) manşon de racord drept, mufã

line surge (el) şoc de tensiune pe linie

line system (el) rețea electrică

line-to-neutral voltage (el) tensiune pe fază / între fază şi nul

line through a bifa; a şterge; a însemna

line through-put (hidr) capacitate de transport a conductei

line up a (se) alinia, a pune în linie, a aduce în aliniere, a centra; (mas-un) a centra; (termo, T, met) a căptuşi, a acoperi (un cuzinet, un cuptor etc.); a pune de acord; a se aşeza în şir

line up the bearing $(\mathrm{OM}, \mathrm{T}, \mathrm{TH})$ a verifica concentricitatea lagărului, a alinia lagărul, a căptuşi un cuzinet (prin turnare, acoperire etc.) 
line-up period $(\mathrm{TH})$ perioadă de reglare a liniei (şi de producție), timp necesar acoperirii unui lagăr de alunecare

line up with a adera la, a se apropia de, a se alipi line voltage (el) tensiune de linie / între faze

line welding $(\mathrm{OM}$, met) sudare continuă / longitudinală, sudare cu role

line wire (el) conductor electric

line with bricks / lead / rubber ( $\mathrm{TH}$, ind) a căptuşi cu cărămizi / cu plumb / cu cauciuc, a cauciuca, a aplica un cauciuc (şi prin lipire), a căptuşi cu zidărie (un cuptor etc.)

linger a continua; a rămâne; a întârzia; a dura, a dăinui, a persista; a şovăi; a acționa încet

lingerie (textile) pânzeturi, albituri; rufărie, lenjerie

lining (constr) rambleiere, sprijinire; (OM, T) blindaj, cuzinet (și numai acoperirea cu proprietăți tribologice), căptuşire, acoperire (pt. diferite piese, de protecție, pt. rezistență la uzură etc.); garnitură; (met) bătătorire, îndesare (la formare), căptuşeală (şi refractară), dublură, procesul de căptuşire, placare; (nav) călăfătuire; (poligrafie) caşerare, aliniere; (textile) albitură

lining mass / material material pentru căptuşire / pentru acoperiri de protecție / de lagăre; material de umplutură

lining out trasare

lining-up (OM, hidr) centrare a țevilor; (mas) alinierea arborilor

lining wall perete căptuşit, manta (şi de zidărie)

link (autom) legătură, conexiune, instrucțiune de înlănțuire; (chim) legătură chimică; $(\mathrm{OM}) \mathrm{za}$, ochi, verigă, sector, culisă, cercel, tijă, articulatie, balansier, legătură, lant, manivelă, element / piesă (de legătură); (inf) a stabili o legă-tură (în programare); a lega (şi cu un lant), a face legătura, a uni, a se lega; (metr) unitate de măsură pentru lungime: 1 link (US) $=0,201168402 \mathrm{~m}$, 1 link $(\mathrm{UK}) \cong 20,12 \mathrm{~cm}, 1$ link $(\mathrm{US})=1$ foot (pt. lanțuri simbolizate 66 / 100 -foot chains)

linkage (chim) legătură; (el) înlănțuire, legătură, cuplare; (inf) codificare care leagă două (sub)programe separate; $(\mathrm{OM})$ cuplare, legătură, element de legătură, mecanism cu pârghii, lanț cinematic / mecanism cu articulație sau cu pârghii, transmisie prin pârghii, lanț cinematic; (hidr, OM) racord; (met) aderență

linkage segment (inf) segment de program care conține informații alterabile în cursul executării acestuia

link belt $(\mathrm{OM})$ curea articulată, lant articulat

link belt conveyer $(\mathrm{OM})$ transportor cu bandă articulată link block $(\mathrm{OM})$ corp de culisă, parte / bloc de legătură

link box (el) cutie de distribuție; (OM) manşon articulat, mufă articulată

link bracket $(\mathrm{OM})$ lagăr de culisă

link chain $(\mathrm{OM})$ lanț articulat / cu articulații; lant cu eclise

link connection $(\mathrm{OM})$ conexiune / îmbinare prin articulație / cu balama

link-crank $(\mathrm{OM})$ culisă-manivelă

linked $(\mathrm{OM})$ cuplat, legat

linked circuits (el, electr) circuite cuplate / legate

linked connecting rod $(\mathrm{OM})$ bielă secundară

linked subroutine (inf) subrutină / subprogram

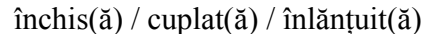

link fuse (el) siguranță lamelară

link grinding machine (mas-un) maşină de rectificat suprafețe plane / de culise

link holder (OM) suport de culisă

linking (chim) fixare, lagăre, prindere (între molecule etc.); (inf) legare (a unui spațiu de nume); (mec) asamblare, legare

link joint $(\mathrm{OM})$ articulație cu furcă / cu culisă

link leather belt $(\mathrm{OM})$ curea articulată / din bucăti de piele

link lever $(\mathrm{OM})$ pârghie de culisă

link line (cf) linie ferată de joncțiune

link motion mișcare a culisei

link pin (of chain) (OM) bolț de articulație (şi al lanțului)

link plate $(\mathrm{OM})$ placă de legătură, eclisă de lanț

link-plate chain (OM) lanț cu eclise

link / knuckle rod $(\mathrm{OM})$ bară articulată, bieletă, bielă secundară

link up a lega, a conecta, a conexa, a uni

link-up (punct de) legătură; conexiune

linkwork $(\mathrm{OM})$ levier de distributie

link wrench $(\mathrm{OM})$ cheie articulată

linoleum linoleu

linseed (agr) sămânță de in

linseed oil (alim, TH) ulei de in

lint (textile, plast) fibră, puf, fibră de bumbac, scamă, fir; (textile, mil) fitil

lint blower / cleaner (textile) suflător de scame

lint cotton (textile) bumbac fibră

lintel (constr) buiandrug, prag (al uşii)

lintol seating (constr) grindă superioară de rezemare

lint recovery $(\mathrm{TH}$, textile) recuperarea fibrelor din deșeuri, randament de fibră din bumbac neegrenat; bridă; (anat) cataractă; (OM) flanşă, ieşitură, margine, gură de turnare, muchie, prag, protuberantă; (mas-un) tăiș de sculă 
liny vărgat, dungat, încrețit, brăzdat, ridicat; subțire, slab, firav

lip (TH, constr, OM) buză, margine, muchie, bridă, ieşitură, prag, nervură, nas, bot, cioc; (mas-un) tăiş, muchie activă; (met) gură / buză / cioc de turnare (la o oală)

lip angle (OM) unghiul penei sau al piesei înclinate; (mas-un) unghi al muchiei / tăişului (sculei)

lip clearance (mas-un) unghi de aşezare

lipids (chim) lipide

lip lower (hidr, OM) adâncitură la ieşire / la golire de fund (a unui recipient etc.)

lip / edge of a casting ladle (met) gură / buză de turnare

lippie (metr) unitate tradişională scoțiană pentru volum: 1 lippie 2,27 1 (făină, boabe de masăre sau fasole) şi $\sim 3,041$ pentru orz sau ovăz

lip-poured ladle (met) oală (basculantă) cu cioc de turnare

lip pouring (met) turnare prin ciocul oalei

lip surface (mas-un) suprafață de degajare (a sculei)

lip-type of packing $(\mathrm{OM})$ manşetă de etanşare tip buză

liquate a topi, a (se) lichefia, a segrega, a separa

liquated surface (met) suprafață de segregare

liquate out (met) a separa (metale) prin fuziune

liquation (fiz, termo, met) lichefiere, segregație, topire

liquefaction (fiz, termo, met) lichefiere

liquefaction heat (fiz, termo, met) căldură de lichefiere

liquefaction of gases (fiz, termo, met) lichefiere a gazelor

liquefy (fiz, termo, met) a (se) lichefia, a fluidiza, a (se) fluidifica

liquefying (fiz, termo, met) (acțiunea de) lichefiere / fluidizare

liqueur (alim) lichior, a doza şampania

liquid (fiz, hidr) lichid, fluid, soluție, lichefiat; (ec) lichid, disponibil; (TH) hidraulic

liquid air (fiz, termo) aer lichefiat

liquid ammonia (chim) apă amoniacală

liquid assets (ec) disponibilități, lichidități, active lichide / disponibile

liquidate a lichida, a regla (socoteli); a achita (o datorie); (ec) a lichida, a desființa (o întreprindere), a intra în lichidare; a scăpa de

liquidation (ec) lichidare; achitare; desființare; terminare

liquidator (ec) lichidator

liquid barometer (metr) barometru cu lichid liquid bath baie de lichid

liquid binder (chim) liant / adeziv lichid

liquid body (fiz) corp lichid

liquid brake $(\mathrm{OM})$ frână hidraulică

liquid bridge (fiz, T) punte de lichid (şi între două corpuri solide)

liquid bridge force (fiz) forța punții de lichid

liquid carburising (met) cementare în mediu lichid / în baie

liquid charge (met) încărcătură / şarjă lichidă

liquid column (ind chim, hidr) coloană de lichid

liquid column manometer (metr) manometru cu coloană de lichid

liquid controller (OM, hidr) regulator / distribuitor hidraulic

liquid-cooled (termo, TH) răcit cu lichid

liquid (cooled) collector (termo, ind chim) captator / colector de lichid (răcit)

liquid cooled dissipator (termo) disipator termic cu răcire cu lichid

liquid crystal display (metr) afişaj cu cristale lichide

liquid damping (hidr) amortizare lichidă / hidraulică

liquid displacement method (metr) metodă care utilizează deplasarea unui lichid

liquid-filled $(\mathrm{OM})$ umplut cu lichid

liquid-filled machine (alim, ind, chim) maşină de umplut sticle / recipiente

liquid-filled thermometer (metr) termometru cu lichid

liquid film ( $T$, chim) peliculă fluidă / de lichid

liquid film lubrication $(\mathrm{T})$ ungere / lubrifiere cu peliculă de lichid

liquid flow meter (metr) debitmetru

liquid gas (fiz, chim) gaz lichefiat

liquid-gas interface (fiz) suprafața de separare dintre un lichid şi un gaz

liquid gas plant (ind chim, met) instalație / fabrică de gaz lichefiat

liquid-gas system (fiz) sistem / amestec gazlichid

liquid glass (chim) sticlă solubilă

liquid head (hidr) înălțime a coloanei de lichid

liquid header (OM, hidr) rezervor / colector de lichid

liquid hold-up (ind chim) retenție a coloanei

liquidity (ec) fonduri lichide / disponibile, lichiditate; (met, fiz) fluiditate, stare fluidă / lichidă

liquidity ratio (ec) coeficient de lichiditate / de trezorerie

liquid jet (hidr, termo) jet / vână de lichid 
liquid joint seal (OM, hidr) material lichid pentru etanşare

liquid layer (fiz, T) strat / peliculă de lichid

liquid level (hidr) nivel al lichidului; (metr) nivelă, cumpănă

liquid level manometer (metr) manometru $\mathrm{cu}$ tub U / cu tub de lichid

liquid level measuring instrument (hidr, metr) aparat pentru măsurarea nivelului unui lichid

liquid level switch (OM, hidr) întrerupător cu flotor

liquid limit (hidr) limită de curgere, limită (de nivel) a lichidului

liquid lubrication ( $\mathrm{T}$ ) ungere / lubrifiere lichidă / cu lubrifiant lichid

liquid measure (metr) măsură pentru capacitate / pentru volum de lichid

liquid metal embrittlement (met) fragilizare sau scădere a rezistenței unui material metalic, cauzată de contactul cu un metal topit

liquid metal charge (met) încărcătură de metal lichid, şarjă lichidă

liquid paraffin (chim) parafină lichidă

liquid-phase (met, chim) fază lichidă

liquid phase epitaxy (chim, met) transformare de fază pe durata creşterii cristalului

liquid-phase refining (met, chim) rafinare în fază / stare lichidă

liquid pitch (ind chim) smoală lichidă

liquid power (ind chim, auto) benzină, combustibil lichid

liquid-pressure pick-up (metr, hidr) element / captator de presiune a lichidului

liquid remnant (mediu, alim, chim) reziduu lichid

liquid resistance (hidr) rezistență lichidă / specifică a lichidului

liquid rubber (ind chim) latex, cauciuc nevulcanizat / pastă

liquid seal (OM, hidr) etanşare lichidă / cu material lichid / prin presiunea sau prezența lichidului, închizător hidraulic

liquid sloshing (hidr) mişcarea unui fluid într-un rezervor (în mişcare) (de navă, autovehicul, vagon-cisternă etc.)

liquid soap $(T$, chim) săpun lichid

liquid-solid interface (fiz) interfața / suprafața de separare lichid-solid

liquid spray diffuser (OM, hidr) dispozitiv / duză de pulverizat lichide

liquid spring (OM, hidr) ,arc” lichid, amortizor cu lichid compresibil

liquid state (fiz) stare lichidă liquid-suction heat interchanger (termo) schimbător de căldură vapori-lichid de aspirație, supraîncălzitor

liquid-tight (OM) ermetic, etanş, impermeabil la lichide

liquid trap (termo, hidr) separator / captator de picături

liquidus (line) (met) linie lichidus

liquid-vapour interface (fiz, termo) interfaţă / suprafată de separare lichid-vapori

liquid waste (ind chim, hidr, met, mediu) pierdere / risipă / irosire de lichid, deșeuri lichide, soluție de deșeuri lichide

liquor soluție, leşie, baie alcalină; (alim) băutură spirtoasă, zeamă, suc (de carne), sos

list (inf) listă, enumerare de simboluri, structură de date; tabel, tablou, tabelă; registru, catalog. (ec) stat de plată, catalog, anuar; (TH) specificație, enumerare, fâşie, margine, bordură, chenar, brâu; a enumera, a face o listă, a înscrie într-o listă, a înregistra; a specifica; (c) a lista, a trece în revistă /a imprima rezultate / programe; (amer) (agr) brazdă (trasă cu plugul); (nav) a se înclina, a se canarisi

listel (constr) plintă

listen to a asculta; audiție, ascultare

listener ascultător (la radio), auditor, ascultător

listen in a fi pe receptie, a asculta, a intercepta (un semnal audio)

listening ascultare, audiție; (radio) interceptare; de ascultare, de recepție

lister (agr) plug-rariță

listing (c) care listează, listare, rezultat al operației de listare; (nav) canarisire, înclinare transversală permanentă, unghi de canarisire

listless nepăsător, indiferent, apatic

listlessness nepăsare, indiferență, apatie

list of contents cuprins, index, tabelă de materii

list of queries chestionar

list of spar parts (mas, TH) listă / catalog de piese de schimb

list price (ec) preț de catalog

list processing (LISP) (inf) prelucrare a listelor, prelucrare cu liste

literate cu carte, cult, învățat; literat

liter (amer), litre (brit) (L, l) (metr) the common metric unit of volume.

liter atmosphere $(\mathbf{L} \cdot \mathbf{a t m})$ (metr, fiz) unitate de măsură pentru energie sau lucru mecanic, utilizată în studiul gazelor închise în incinte: 1 liter atmosphere $=101,325 \mathrm{~J}$ sau $0,09605 \mathrm{Btu}$

literal (mat) simbol literal netraductibil; greşeală mică de redactare a unui text 
literal equation (mat) ecuație algebrică / cu coeficienți literali

literature literatură; biografie, material informativ; lucrări de referință

liter per 100 kilometers $(\mathrm{L} / 100 \mathrm{~km})$ (metr) o măsură a vitezei / ratei de consum al combustibilului pentru autovehicule, echivalentul acesteia în sistemul SI fiind centilitru pe kilometru $(\mathrm{cL} / \mathrm{km})$

liter per mil (L/mil) (metr, auto) unitate de măsură pentru consumul de combustibil al autovehiculelor, folosită și în Scandinavia: 1 liter per mil $=0,11$ per $100 \mathrm{~km}$

liter/day (metr) unitate de măsură pentru debit volumic, litru pe zi: 1 liter/day $=0,0012 \cdot 10^{-6} \mathrm{~m}^{3} / \mathrm{s}$

liter/hour (metr) unitate de măsură pentru debit volumic, litru pe oră: 1 liter $/$ hour $=0,278 \cdot 10^{-6} \mathrm{~m}^{3} / \mathrm{s}$

liter/minute (metr) unitate de măsură pentru debit volumic, litru pe minut: 1 liter $/$ minute $=$ $16,667 \cdot 10^{-6} \mathrm{~m}^{3} / \mathrm{s}$

litharge (chim, met) oxid de plumb, litargă

lithia (chim) oxid de litiu

Lithium (Li) (chim) litiu

lithium (base) grease (T) unsoare pe bază de litiu

lithosphere (geol) litosferă

litmus (chim) turnesol

litmus paper (chim) hârtie de turnesol

litre, liter (metr) litru

litter targă; (mediu) gunoi, murdărie; resturi; lucruri împrăştiate; dezordine; a murdări; a arunca hârtii / resturi prin / pe; a umple cu resturi; (agr) a aşterne paie (pt. un animal)

litter bin (mediu) sac / cutie de gunoi

little puțin; nu mult; câtva; ceva; oarecum; cam puțin; mic, neînsemnat; aproape deloc

little / small end (OM) picior al bielei

little finger (anat) degetul mic

little knob / node (silv) nodozitate (la arbori)

littoral litoral

lituus (mat, geom) spirala $\sigma^{2}=\mathrm{a} / \theta$

litz (wire) (el) liță

live (el) parcurs de curent, aflat sub tensiune; (OM) aflat în mișcare, mobil, activ, în funcțiune; în direct; în exploatare; real (şi d. sarcină, solicitare etc.); a trăi, a exista, a viețui; a locui, a trăi; a se întreține; a rezista, a supraviețui; viu, în viață; real, din viață; (d. culori) viu, aprins; (TH) mobil

liveable locuibil, în care se poate locui; (d. condiții de viață) acceptabil, suportabil; sociabil

live axle $(\mathrm{OM})$ arbore planetar, osie motoare, arbore de antrenare / conducător live boom (nav, constr) elindă de dragă, cupă / săgeată de excavator ce poate fi ridicată sau coborâtă fără a întrerupe funcționarea acestuia

live centre $(\mathrm{OM})$ vârf rotativ; (mas-un) vârf al păpuşii mobile (la strung)

live circuit (el) circuit sub tensiune

live conductor (el) conductor neizolat

live gas (ind chim) gaz proaspăt

live lever $(\mathrm{OM})$ pârghie pentru transmiterea mişcării / de acționare

live line tester (el, metr) detector de tensiune

live load(ing) (mec, mas) sarcină mobilă / temporară / variabilă / activă / utilă / dinamică

live load stress (mec, mas) efort / tensiune dato$\operatorname{rat}(\breve{a})$ unei sarcini în exploatare şi variabil( $\breve{a})$

lively strălucitor (d. lumină), intensiv (d. un proces), viu, aprins

live off a-şi câştiga existanța din; a trăi de pe urma

live part (el) element activ, piesă parcursă de curent electric

liver (alim, anat) ficat

live rail (met, cf) şină prin care circulă curent electric

live rear axle (auto) punte motoare din spatele autovehiculului

livered oil ( $\mathrm{T}$, chim) ulei uzat / oxidat / cu conținut mucilaginos

livering (alim, T, chim) îngroşare (şi a uleiului), concentrare

live roller gear bed (met) (cale cu) role de alimentare (acționată şi cu transmisii dinţate)

liver starch (chim) glicogen

live soaking pit (met) cuptor adânc de încălzire

live spindle / axle (OM) ax / arbore rotativ (în functiune)

live stock (agr) vite, şeptel; inventar viu

live storage (OM, hidr) volum util (al unui recipient etc.)

live storage bin (alim, chim) siloz de extracție

live weight (transp) încărcătură utilă; (alim) greutate a animalului viu

live wire (el) conductor sub tensiune

living viu, în viață; (d. culori) viu, aprins, luminos; vioi, energic, activ, harnic; (mod de) viață, existență, trai; locuință, domiciliu

livre (metr) unitate tradițională pentru masă în țări de limbă franceză şi în Grecia, livră; 1 livre $($ Franța $)=0,5 \mathrm{~kg}, 1$ Greek livre $\sim 500 \mathrm{~g}$

lixiviate (chim) a trata cu leşie, a extrage prin dizolvare, a lixivia (la neferoase)

lixiviation (met, chim) extracție prin dizolvare, lixiviere (la neferoase)

lixivium (chim) leşie 
load (mec, mas) sarcină, încărcătură, greutate, solicitare (în general, fără a specifica tipul: presiune, forță, moment etc.), randament (rar); debit (în hidraulică); (met) şarjă, încărcătură de cuptor / de furnal / de melanjor etc.; (inf) introducere de date; a încărca, a alimenta; a solicita, (met) a şarja; (nav) caric; a (se) încărca; (metr) unitate tradițioală pentru măsurarea volumului: 1 load (US) $=1$ cubic yard $=$ $0,764555 \mathrm{~m}^{3}$

loadability (mec, mas) capacitate de încărcare

load action (mec, mas) actiune perturbatoare / efect perturbator a(l) unei sarcini

load area (mec, OM) suprafață / zonă / loc de încărcare / solicitat( $\breve{a})$

load at proportional limit (mec, OM) limită de proporționalitate (la solicitări mecanice)

load-bearing pile (constr) pilot portant / de fundație

load-bearing wall (constr) zid / perete portant / de rezistență

load brake $(\mathrm{OM})$ frână de / la sarcină

load break cut-out / switch (el, autom) dispozitiv / întrerupător care asigură întreruperea la sarcină

load cable $(\mathrm{OM})$ cablu de ridicare

load capacity / carrying ability (mec, mas) capacitate de încărcare / portantă / de ridicare, capacitate de sarcină

load carrier (mas) transportor

load-carrying $(\mathrm{mec}, \mathrm{T})$ care poate suporta o sarcină

load-carrying additive ( $\mathrm{T}$ ) aditiv antigripant / pentru presiuni mari

load-carrying capacity (constr, mec) capacitate portantă; (TH) sarcină-limită, capacitate de ridicare

load-carrying equipment (mas, transp) instalație de transportat sarcini

load cell (mec, fiz) celulă / element de transportat / de sarcină; (metr) traductor de forță

load centre (fiz, mec) centru (de aplicare) al sarcinii

load chain $(\mathrm{OM})$ lanț de ridicat / de tracțiune

load change $(\mathrm{mec})$ variatia sarcinii

load characteristic / diagram (mec, mas) caracteristică / diagramă de sarcină / de încărcare

load-circuit power input (el) putere de intrare în circuitul de sarcină

load compensation (mec) echilibrarea / compensarea sarcinilor; (el) compensare / egalizare de sarcină

load continuously (mec) a încărca continuu load current (el) curent de sarcină

load curve $(\mathrm{TH})$ curbă de sarcină / de încărcare

load cycle (OM) ciclu de încărcare / de solicitare

load-deflection diagram (mec, OM) diagrama deformație(tip săgeată)-sarcină

load-deformation diagram (mec, $\mathrm{OM}$ ) diagramă deformație-sarcină

load diagram (mec, OM) diagramă / caracteristică de sarcină, schema distribuției sarcinii

load distribution (mec, OM) distribuția sarcinii

load draught (nav) pescaj cu nava încărcată

load due to snow / wind (constr, meteo) sarcină datorată zăpezii / vântului

load duration (mec, OM) durata sarcinii / solicitării

loaded (mec, OM) încărcat, îngreunat, plin; (mil) (armă) încărcată

loaded circuit (el) circuit sub sarcină

loaded mud $(\mathrm{TH})$ noroi încărcat în timpul procesului tehnologic

loaded weight (mec, mas) greutate de lucru / în serviciu

loaded wheel (OM) roată încărcată / solicitată

loaded with blanks / with inert filling (nav) încărcare cu balast / cu umplutură

load equalisation (el) echilibrare / compensare a diferenței de sarcină; (mec) echilibrare a sarcinii

loader (OM) încărcător; (nav) hamal, docher, muncitor portuar; (TH) încărcător, dispozitiv sau maşină de încărcat / de alimentare (şi la maşiniunelte, pentru piese de prelucrat sau scule)

loader boom $(\mathrm{OM})$ parte în consolă a transportorului

loader with grab bucket (OM, transp) încărcător cu graifăr

load-extension diagram / curve (mec, materiale) diagramă / curbă sarcină-deformație, determinată, de obicei, pentru tracțiune

load factor (autom, el, mec) sarcină-limită, factor / coeficient de sarcină / de încărcare, grad de solicitare / de încărcare

load graph (mec) diagramă de sarcină / de încărcare

load hook (OM, met) cârlig de macara / la maşini de ridicat

load increase / increment (mec, el) treaptă de sarcină

load index (mec, el) procentaj de sarcină

loading (mec) încărcare, îngreunare, îngreuiere, sarcină, încărcătură, solicitare; (ec) fraht, caric, primă suplimentară (la asigurări); (autom, el) alimentare, încărcare; (nav) caric, încărcătură 
loading aperture (alim, ind chim, met) orificiu de încărcare

loading bank (transp) rampă / platformă (pod de încărcare

loading berth (nav) dană de încărcare

loading bin (mas-un) buncăr al sistemului de alimentare cu piese brute

loading boom (nav) bigă de încărcare

loading broker (ec) broker / agent de încărcare și navlosire

loading bunker (alim, met) buncăr de încărcare

loading capacity $(\mathrm{TH}, \mathrm{mec})$ capacitate de încărcare

loading case $(\mathrm{TH}, \mathrm{mec}) \mathrm{caz} / \mathrm{tip} / \mathrm{schemă} \mathrm{de}$ încărcare

loading chamber $(\mathrm{OM}, \mathrm{mec})$ cameră de încărcare

loading chute (mas-un) jgheab de alimentare cu piese brute

loading coil (el) bobină de sarcină / de încărcare

loading condition (auto) încărcătură, conditịi de încărcare

loading crane (met) macara de încărcare / de şarjare

load(ing) curve (mas, mec) diagramă de sarcină

loading days $(\mathrm{TH})$ zile de încărcare

loading device (OM, mas) dispozitiv de încărcare, încărcător

loading diagram (met, mec) diagramă de încărcare

loading end $(\mathrm{TH})$ capăt de alimentare

loading frame (OM) stativ / cadru de încărcare

loading funnel (OM, alim, ind chim) pâlnie de încărcare

loading gauge gabarit (de încărcare); (metr) traductor de sarcină / de încărcare (pt. forță şi / sau moment)

loading gear $(\mathrm{OM})$ instalație de încărcare (şi cu transmisie cu roți dințate)

loading hatch (nav) gură de magazie

loading hopper (met, alim, ind chim) buncăr / pâlnie de încărcare

loading inductance (el) bobină de inductanță / de sarcină

loading ledge (cf) rampă (de încărcare)

loading line (cf) linie de încărcare; cablu de ridicare a cupei de excavator; (el) linie / caracteristică de sarcină

loading list (transp) foaie de încărcare

loading machine (transp) maşină / instalație de încărcare

loading material (transp) material de umplutură / de încărcare

loading platform (transp) platformă de încărcare loading point (mec) punct de încărcare / de aplicare a sarcinii (mecanice) concentrate

loading port (nav) port de încărcare

loading procedure (inf) procedură de încărcare (şi lansare în execuție) a unui program

loading rack / ramp (transp) rampă de încărcare

loading range (mec, mas) interval de încărcare / de variație a sarcinii

loading rate (mec, mas) viteză de încărcare

loading regulator (el) reostat de sarcină

loading resistance (mec) rezistență de sarcină, balast

loading routine (inf) program de încărcare / de înmagazinare

loading scraper (OM, transp) screpăr încărcător

loading shoe (OM, transp) sabot de încărcare

loading shovel (OM, transp) lopată, cupă de încărcare

loading siding / track (cf) linie de încărcare

loading test probă / test de încărcare, test sub sarcină

loading time (inf, $\mathrm{TH}, \mathrm{mec}$ ) timp / perioadă de încărcare

loading tray (constr, alim, ind chim) cupă de alimentare / de încărcare; troacă de încărcare

loading through (constr, alim, ind chim) jgheab de încărcare

loading weight $(\mathrm{mec})$ greutate a încărcăturii / a sarcinii

loading winch $(\mathrm{OM})$ vinci de încărcare

load inrush current (el) vârf / maxim al curentului de pornire în sarcină

load isolator (mec) separator de sarcină

load-levelling / -limiting relay (el) releu de limitare a sarcinii

load life (mas) durată de funcționare sub sarcină / în sarcină completă

load lift ascensor de mărfuri

load-lifting capacity (mec, transp) capacitate de ridicare

load limit (mec, transp) limită de sarcină / de încărcare, sarcină-limită / maximă

load limiter (auto) limitator de tensiune

load line (hidr) linie de sarcină, funcția presiune de ieşire - debit de ieşire; (nav) linie de încărcare, linie de plutire de plină încărcare

load-line mark (nav) marcă de bord liber, marcă de încărcare; semn de limitare a sarcinii / greutății etc.

load module (inf) element de program / modul încărcabil (pt. executare)

load on soil (constr) presiune pe teren / pe sol, presiune asupra terenului de fundatie 
load per unit surface (mec, OM) sarcină / încărcare pe unitatea de suprafață

load platform (transp) platformă / rampă de încărcare

load point $(\mathrm{mec})$ punct de sarcină, punct de aplicare a sarcinii

load pressure (OM, hidr) presiune de încărcare / solicitare

load pressure drop (hidr) presiune diferențială de sarcină, diferență de presiune între două puncte de tilizare

load pulley $(\mathrm{OM})$ scripete

load range (mec, TH) domeniu / interval de încărcare / de sarcină

load rate $(\mathrm{mec}, \mathrm{TH})$ viteză de încărcare / de aplicare a sarcinii

load rating $(\mathrm{el}, \mathrm{mec})$ capacitate nominală de încărcare, sarcină nominală, coeficient de încărcare

load reversal $(\mathrm{mec})$ alternanță de sarcină / de încărcare

load rope $(\mathrm{OM})$ cablu de ridicat / de tracțiune

load side (mec, OM) capăt la care este aplicată sarcina, capăt de suspendare a unei greutăți

load stability (OM, mas) stabilitate în sarcină

loadstone (met, el) magnet natural, magnetit

load stress (mec, OM) tensiune / efort datorat unei sarcini

load test (metr, mas) probă de încărcare, încercare în sarcină

load torque (mec) cuplu rezistent, (sarcină sub formă de) moment de torsiune

load up (mec, transp) a încărca

load voltage (el) tensiune în sarcină; (metr) tensiune de ieșire a traductorului

load water line (nav) linie de plutire a navei încărcate

loaf (alim) pâine (de o anumită formă), franzelă, căpățână de zahăr, cocean

loaf sugar (alim) căpățână de zahăr, zahăr cubic

loam (constr, geol) lut (şi pt. cărămizi), argilă grasă / nisipoasă, humă, sol argilos; (met) amestec de formare cu argilă

loam brick (constr) chirpici, cărămidă nearsă / crudă

loam casting (met) turnare în amestec de formare / de argilă / în forme de argilă

loam core (met) miez argilos

loam floor (constr) pardoseală de lut

loam mill / mix (met) malaxor / amestecător de argilă (la turnătorii)

loam mould (met) formă (de turnătorie) de argilă nisipoasă loamy (geol) argilos, lutos, humos loamy sand (met) nisip argilos

loan împrumut; a împrumuta

loan bank (ec) bancă de credit

loan on mortgage $(\mathrm{ec})$ credit ipotecar

loan society (ec) societate de credit

lobate $(\mathrm{OM})$ lobat, cu lobi

lobby anticameră, vestibul, coridor, culoar; (nav) culoar către mai multe compartimente; (ec, pol) grup de persoane cu interese comune care ar putea exercita presiuni; a influența

lobe $(\mathrm{OM})$ lob, ieșind, camă; (met) proeminență, adaos turnat, bosaj; alveolă

lobe(d) bearing $(T, O M)$ lagăr cu lobi

lobed-impeller $(\mathrm{OM})$ paletă rotitoare lobată

lobe-shaped hole $(\mathrm{OM})$ gaură / alezaj poligona1(ă) (şi pt. arbori K) / cu lobi, (în sens nedorit) abatere poligonală de la forma cilindrică

lobster (alim, zool) rac de mare, homar

lobster box (nav) vas de transportat homari

lobster shift schimb de noapte

local local; (cf) tren local

local buckling (mec, materiale) flambaj local, turtire / umflare / bombare locală

local contraction (met, plast) contracție locală

local control (autom, mas) comandă directă, reglaj local

local correction (autom) corecție parțială / locală a unui semnal

local element (mec) element local; ( $\mathrm{T}$, chim) pilă locală / elementară

local end $(\mathrm{OM})$ ansamblu terminal

local error (inf) eroare locală / care afectează doar parțial executarea unui program

local extension of fracture (mec) alungire relativă locală a epruvetei la rupere

local hardening ( $T$, met) călire / durificare locală / parțială

local inquiry (ec) întrebare, reclamație, anchetă (cu extindere relativ redusă)

locality localitate; loc, poziție; situație; punct sector, zonă

localization localizare; limitare, mărginire, delimitare; detecție; descentralizare; sediu, loc

localization corrosion (met, T) coroziune localizată

localization of heat (termo) acumulare de căldură localization test $(\mathrm{TH})$ încercare de localizare a defectelor

localize a localiza, a detecta; a restrânge, a limita; a descentraliza; a stabili locul, a preciza locul

localized annealing (met) recoacere locală $/$ selectivă 
localized corrosion (chim) coroziune locală / localizată

localized elongation (mec, met) alungire / elongație locală (şi la laminare)

localized hardening (met) călire locală / parțială

localized heating (met) încălzire locală (la laminare)

localized oxidised pinholes (met, chim) pori eterogeni oxidați, localizați

localized pressure (met) presiune locală (la laminare)

localized reaction pinholes (met) pori eterogeni de culoare albastră (rezultat din reacții chimice, defect)

localized / bound vector (mat, fiz) vector legat

localize on / upon a concentra / îndrepta (atenția) asupra

localizing trouble (mas, $\mathrm{TH}$ ) localizarea defectelor / deranjamentelor

local line (met, cf) linie de circulație locală

locally $(a d v)$ (în plan) local, într-un anumit spatiu

local losses of head (hidr) pierderi locale de sarcină / de presiune

local mass eccentricity $(\mathrm{mec})$ excentricitate locală a masei (şi la echilibrare)

local overheating (ind chim, met, T) (supra)încălzire locală

local slope ( $T$, mas-un) pantă locală (a profilului) (la profilometria suprafeței)

local-stress $(\mathrm{mec})$ tensiune locală / concentrată (într-un loc)

local-stress relief heat-treatment (met) tratament termic pentru înlăturarea tensiunilor (remanente) locale

local tax (ec) impozit local / comunal

local thickness (met) grosime locală

local time ora locală

locate a amplasa, a localiza, a delimita, a mărgini; a (se) stabili locul; a amplasa; a instala; (masun) a trasa, a regla, a potrivi, a fixa o piesă de prelucrat într-o poziție convenabilă

locate centres (mas-un) a centra piesa de prelucrat între vârfuri

located localizat, amplasat, stabilit (d. o piesă etc.) locate from centre hole (mas-un) a centra o piesă după o gaură deja existentă

locate from outside diameter (mas-un) a centra după diametrul exterior al piesei de prelucrat

locating amplasare, localizare; reperare; punctare; actiunea de centrare

locating bearing $(\mathrm{OM})$ lagăr axial, crapodină, de centrare locating cones for mould / housing assembly (met, OM) ştifturi conice de fixare / de ghidare / pentru asamblarea componentelor unei matrițe / unei carcase etc.

locating device (mas-un) dispozitiv de aşezat piesa de prelucrat în poziţia dorită

locating pin $(\mathrm{OM})$ știft / bolț de montaj / de fixare / de ghidare (la montarea a două piese)

locating slot (OM, mas-un) canal pentru fixarea unei piese (şi la dispozitive de prindere, mese de lucru la maşini-unelte etc.)

locating surface (OM, mas-un) suprafață de prindere / de aşezare

location locație, loc, localizare, amplasare, amplasament, aşezare, delimitare; situație; (mas-un) piesă de bază, linie sau suprafață de bazare a pieselor de prelucrat, a monta, a aşeza

location line (TH, metr) traseu, linie de aşezare / de reglare

location of defect (met) localizarea unui defect (la sudură, turnare, laminare etc.)

location of instruction / of order (inf) amplasarea / locul adresei (într-un program etc.)

location tolerance $(\mathrm{OM})$ toleranță de poziție

locator (OM) fixator, ştift de fixare / de control; (metr) detector

lock buclă; mănunchi; (OM) închizător, lacăt, zăvor, opritor, piedică (și de armă), prag de ghidare (al matriței), fixator, siguranță; (nav) ecluză, trecere prin ecluză, a trece prin ecluză; stăvilar; blocare; a (se) închide, a obtura, a zăvorî, a încuia, a fi încuiat; a împiedica, a (se) bloca (mecanic), a (se) înțepeni; a frâna

lockage (nav) ecluzare, taxă de ecluzare

lock box / case (mas-un) cutia căruciorului la strung

lock button (auto, mas) buton de blocare

lock cylinder $(\mathrm{OM})$ cilindru de broască / de yală

lock die (met, plast) matriță cu dispozitiv de blocare

locked (mec, OM) fixat, blocat, încuiat, închis, zăvorât; (autom) blocat, aservit

locked in place (auto) fix / blocat pe poziție

locked-in system (autom) sistem aservit / blocat prin comandă internă / localizată (fără a putea fi redistribuită)

locked nut $(\mathrm{OM})$ piuliță blocată

locked rotor current (el) curent în rotorul scurtcircuitat

locked-rotor torque (el) cuplu inițial de pornire locked-up stress (mec, OM) tensiune internă

locker dulap; ladă pentru scule; vestiar; paznic; pontator; (nav) cheson, magazie de materiale 
locker coils (termo, alim) evaporator cu serpentine fize, al compartimentelor de congelare

locker plant (termo, alim) instalație de congelare cu casete

locker room vestiar cu dulapuri individuale

lock in a închide, a bloca

lock-in feature (mec, el) sincronizare

locking (mec) înzăvorâre, încuiere, (acțiunea de) blocare, oprire (a rotației); (el) sincronizare cu frecvența retelei

locking bayonet $(\mathrm{OM})$ închizător tip baionetă

locking bolt / pin (OM) bolt de blocare / de fixare, surub de asamblare

locking box (cf) cutie cu înzăvorâri

locking clamp (OM) gheară / clemă de blocare / de fixare / de închidere

locking clip (auto) clemă de fixare

locking device (mas-un, OM) mecanism de blocare / de închidere / de oprire / de fixare

locking gas cap (auto, mas) capac de rezervor cu cheie

locking gear (OM) dispozitiv de închidere / de blocare du dinti

locking hook $(\mathrm{OM})$ clemă de închidere, cârlig de blocare

locking in antrenare, închidere, blocare

locking-in relay (el) releu de sincronizare prin efect de antrenare / de târâre a frecventelor

locking key $(\mathrm{OM})$ pană înclinată / de blocare

locking mechanism (OM, mas-un) mecanism / dispozitiv de blocare / de oprire / de limitare / de fixare

locking of axles / of wheels (OM, T) blocarea osiilor / a roților (şi din cauza frecării)

locking of the turntable (mas-un) blocarea / fixarea / înzăvorârea plăcii / mesei turnante

locking pressure (hidr, metr) presiune de blocare

locking ring $(\mathrm{OM})$ inel de strângere / de prindere / de fixare, inel opritor, inel de siguranță

locking screw (OM, mas-un) șurub de blocare / de fixare / de închidere, şurub opritor

locking switch (el) întrerupător cu capac încuiat / cu cheie / cu blocare

locking tab (auto) capac (al consolei)

lock-in range (autom) plajă / domeniu / interval de reglare / de sincronizare

lock nut $(\mathrm{OM})$ contrapiuliță (şi de siguranţă)

lock-out (met) întrerupere, deconectare, blocare a liniei (de turnare / laminare); a opri (accesul), a deconecta; (ec) închidere a întreprinderii de către patron

lock pin (OM) şplint / ştift / bolț de blocare / de cuplare lock plate (auto) dispozitiv de blocare a portierei lock-points (mas, autom) puncte (de reglare) blocabile

lock ring (OM, mas-un) inel de blocare / de fixare (a poziției unei piese)

lock roller (OM, plast) rolă de acoperire (la lipire)

locksmith lăcătuş

locksmithery / locksmith's shop (ind) atelier de lăcătuşerie

locksmith's vice (mec) menghină de banc / de lăcătuş

lock stitch $(\mathrm{OM})$ cusătură făcută la maşină (și la asamblarea curelelor late), punct de cusătură

lock-up (oră de) închidere / încetare a lucrului; (ec) capital mort

lock up a împiedica, a (se) închide, a încuia, a zăvorî care se încuie; (ec) a imobiliza, a bloca (un capital)

lock washer $(\mathrm{OM})$ șaibă arcuită (cu scop de blocare), disc obturator / de blocare, inel arcuit de siguranță

lock wire $(\mathrm{OM})$ sârmă de siguranță (la deșurubare)

locomotion (mec) locomotie

locomotive (cf) locomotivă

locomotive changing point (cf) punct / stație de schimbare a locomotivei

locomotive shed (cf) depou / remiză de locomotive

locomotive underframe (cf) şasiu de locomotivă

locum tenens locțiitor, înlocuitor; suplinitor

locus (mat) loc geometric al punctelor

locus of concentration (materiale) loc de aglomerare / de concentrare

locus tree (silv) salcâm

lode (geol) filon, vână

lodestone (met) magnetită, magnet natural

lodge (constr) gheretă, locuință (provizorie), boxă; a stabili (temporar); a caza, a depozita, a locui, a adăposti; (ec) a investi, a plasa (bani)

lodge in a pătrunde în; a se opri în

lodgement, lodgment adăpost, loc; prezentare (a unei cereri)

lodger locatar; chiriaş

lodging găzduire; locuință

lodging house (constr) casă cu apartamente / camere de închiriat

loess (geol, constr) loess

loft (constr) pod (de casă); (nav) sală de trasaj naval

lofting (nav) trasaj naval 
$\log$ (constr) grindă, bârnă; (silv) buştean, butuc, buturugă, material lemnos; (nav) loch, jurnal de bord, a înregistra în jurnalul de bord; (metr) a etalona

$\log$ (Biblical) (metr) unitate veche de măsură pentru volum: $1 \log ($ Biblical $)=0,000305556 \mathrm{~m}^{3}$

logarithm (mat) logaritm

logarithmic(al) (mat) logaritmic

logarithmic cosine (mat) cosinus logaritmat

logarithmic deformation ratio (met) grad de deformare logaritmic (la forjare)

logarithmic series (mat) serii logaritmice

logarithmic-series distribution (mat) distribuție în serii logaritmice

logarithmic sine (mat) sinus logaritmat

logarithmic tipper (el) rezistență (cu variație) logaritmică

log band sawing machine (mas-un, silv) ferăstrău-panglică pentru lemn / buşteni

log barker (mas-un, silv) dispozitiv de cojit buşteni

log book (nav) jurnal de bord

log cabin (constr) colibă / casă / cabană din bârne

log characteristic / curve (mas) curbă / caracteristică logaritmică

log conversion (mas-un, silv) debitare a buştenilor

log conversion defects (mas-un, silv) defecte de debitare a lemnului

log conversion in frame / gang saws (mas-un, silv) gater / fierăstrău cu mai multe pânze

loge lojă

log-exponential sum (mat) sumă logaritmicexponențială

logger (autom, inf) înregistrator cronologic (automat) de date; (nav) specialist în etanşarea tubulaturii (maşinilor şi motoarelor navale)

logging (inf) tehnică de organizare a unei baze de date, înregistrare de date / de rezultate; (nav) înscriere în jurnalul de bord, înregistrare a parametrilor

logging system (inf, c) sistem de colectare / de înregistrare a datelor

log house (constr) casă de bârne

logic logic; logică

logical logic, rațional

logical algebra / calculus (mat) algebră logică

logical branch (inf) salt condiționat logic, ramură de circuit logic

logical constraints (inf) restricții / constrângeri logice

logical data (inf) date logice, date nenumerice care arată o stare binară logical defogging (auto) dejivrare automată logical design (inf, autom) proiect logic, proiectare / sinteză logică

logical diagram (inf, ec) schemă logică / funcțională, organigramă

logical error eroare logică; (inf) algoritm defectuos, de rezolvare a unei probleme

logical expression (inf) expresie logică, calcul / expresie cu operatori logici

logical file (inf) fişier logic, înregistrări logice cu organizare definită

logical level (autom) nivel logic, pozitie a unui circuit logic față de un terminal

logically $(a d v)$ (în mod) logic

logical record (inf) înregistrare logică

logical symbol (inf) simbol logic / funcțional

logical unit (ec, inf) unitate / element $\operatorname{logic}(\breve{a})$, unitate / element de decizie

logic / logical element (c, inf) element logic / de decizie logică

logic / logical function (inf, autom) funcție logică / de comutare

logic module (inf) modul logic

logic operation (inf) operație logică (de tip NU, SI, SAU etc.)

logic product (mat, inf) produs logic / Boole, conjuncție

logic shift (inf) decalaj / deplasare logic(ă)

logic sum (mat, inf) sumă logică / Boole, disjuncție

logic threshold (autom, inf) prag logic, număr minim de semnale, necesar comutării unui elemente cu intrări multiple

logic variable (mat, inf) variabilă logică

logistic (inf, ec) logistic; (mat) logaritmic, proporțional, calculabil (în logica matematică)

logistics logistică, logică simbolică, artificiu de calcul aritmetic; (ec) tehnică a aprovizionării şi transportului, servicii

logistic spiral (mat) spirală logaritmică

log-log paper hârtie cu caroiaj dublu logaritmic

log-log scale (mat, fiz) scară dublu logaritmică

log-log transformation (mat) transformare prin aplicarea repetată a logaritmilor

$\log (-)$ normal distribution (mat, fiz) repartitie / distribuție logaritmic normală

$\log (-)$ normal probability graph (mat, fiz) grafic al probabilității logaritmic normală

log paper hârtie cu caroiaj logaritmic

log recording înregistrare logaritmică

log seal $(\mathrm{OM})$ lemn de etanşare

long lungime; lung, prelungit; lung (temporal), îndelungat, de lungă durată 
long arc (el) arc electric lung

long boat (nav) barcă mare / de transport

long bolt (OM, constr) bulon / şurub de ancorare / cu tijă lungă

long-chain polymer (chim) polimer cu lanț molecular lung / cu catenă lungă

long cross $(\mathrm{OM})$ raclet / eclisă de mijloc / la lanțuri cu număr impar de paşi

long cubit (metr) unitate de măsură pentru lungime: 1 long cubit $=0,5334 \mathrm{~m}$

long day zi de muncă cu ore suplimentare

long-distance call convorbire interurbană

long-distance cruise / service (nav) probă de durată în mers, călătorie de cursă lungă

long-distance gas supply (ind, termo) alimentare cu gaz(e) la mare distanță

long-distance heating (met, termo) încălzire industrială / pe zone mari, termoficare

long-distance power station / plant centrală electrică de interes național

long-distance trial (mas) probă de durată în mers; (nav) probă de marş pe distanță mare

long-drawn (out) de durată; prelungit

longeron (constr) lonjeron, grindă longitudinală / principală

longevity (mas) durată de serviciu / de exploatare / de functionare

long fiber (textile, plast, compozite) fibră lungă

long-flame (gas) coal (termo) cărbune cu flacără lungă

long grinding (mas-un) rectificare longitudinală / în lungime

long-haul traffic (transp) transport de mărfuri la mare distanță

long-hole drilling (mas-un) găurire / burghiere adâncă / pentru găuri lungi

long hundredweight (metr) denumire pentru British hundredweight, o unitate de măsură pentru masă: 1 long hundredweight $=112$ pounds, v. British hundredweight, long hundredweight

longitude longitudine

longitudinal longitudinal

longitudinal arch / belt (constr, met) centură longitudinală (de întărire)

longitudinal axis (mec, OM) axă longitudinală

longitudinal ball-bearing (OM) ghidaj cu bile

longitudinal beam (mec, constr) grindă longitudinală

longitudinal bond / bracing (OM) îmbinare / legătură în lung, prindere / asamblare pe lungime

longitudinal bulkhead (nav) perete longitudinal la navă longitudinal bus-bar (el, OM) cuplă longitudinală (la bare colectoare ale instalațiilor electrice)

longitudinal carrier cable $(\mathrm{OM})$ cablu purtător / de susținere

longitudinal clearance (OM, mas-un) joc longitudinal / axial

longitudinal corner crack (met, OM) crăpătură / fisură longitudinală marginală / în zona colțurilor (defect la laminarea profilelor şi la sudură)

longitudinal corrugation (met) striuri longitudinale (la laminare) (defect)

longitudinal crack (met) crăpătură / fisură longitudinală (defect)

longitudinal crystal (fiz) cristal cu oscilație longitudinală

longitudinal deck beam (nav) curent longitudinal de punte

longitudinal dihedral angle (mas-un) unghi de detalonare

longitudinal direction (met, mec) sens / direcție longitudinal(ă) (şi la laminare)

longitudinal ductility (met) ductilitate / deformabilitate în direcție longitudinală

longitudinal facial crack (met) crăpătură fisură longitudinală pe fețele laterale (defect)

longitudinal feed (mas-un) avans longitudinal

longitudinal force (mec) forță longitudinală / în lungul axei

longitudinal framing (nav) osatură longitudinală

longitudinal girder (auto) lonjeron; (mec, constr) grindă longitudinală

longitudinal gradient gradient / pantă longitu$\operatorname{dinal}(\breve{a})$

longitudinally gilled / ribbed cylinder (OM) cilindru cu nervuri longitudinale

longitudinal groove $(\mathrm{OM})$ canelură / canal longitudinal(ă); (met) urmă / adâncitură longitudinală (şi defect)

longitudinal member (of frame) (OM, mec, constr) element longitudinal (la grinzi cu zăbrele, la construcții sudate, la un cadru etc.)

longitudinal motion / movement (mec) mişcare longitudinală / în lungul axei

longitudinal outtrigger (constr, mec) lonjeron, grindă longitudinală

longitudinal pitch $(\mathrm{OM})$ pas longitudinal (la nituire, asamblări cu multe şuruburi etc.)

longitudinal planer (mas-un) raboteză longitudinală

longitudinal profile $(\mathrm{OM})$ profil longitudinal / în lungul axei / piesei 
longitudinal profiling machine (met, mas-un) maşină de executat profiluri lungi

longitudinal rib (met, OM) nervură longitudinală longitudinal runner (mec, constr) lonjeron longitudinal sampling (met, plast) luarea probelor în direcție longitudinală, probă / eşantionare longitudinală

longitudinal seam $(\mathrm{OM})$ cusătură longitudinală de sudură

longitudinal section $(\mathrm{OM})$ profil în lungime, secțiune longitudinală

longitudinal shear strength (plast) rezistență la forfecare longitudinală (şi a unei îmbinări lipite)

longitudinal sloping hearth furnace (met) cuptor cu vatră înclinată în sens longitudinal

longitudinal stay (el, OM) ancoră de linie electrică aeriană

longitudinal streak (met, plast) striație longitudinală / în lungime (şi defect)

longitudinal strength (mec, OM, met) rezistență pe direcție longitudinală

longitudinal stress (mec, OM, met) efort / tensiune pe direcție longitudinală

longitudinal system ship (nav) navă cu osatură longitudinală

longitudinal tie (constr) grindă longitudinală, lonjeron de pod (şi rulant)

longitudinal travel / traverse (mas-un) avans / deplasare longitudinal( $\breve{a})$

longitudinal turning (mas-un) strunjire longitudinală

longitudinal vibration (mec) vibrație longitudinală

longitudinal weld $(\mathrm{OM})$ cusătură (de sudură) longitudinală

long jumper (mas-un) burghiu pentru finisarea ghinturilor / găurilor / alezajelor lungi

long-lasting $(\mathrm{TH})$ de durată mare, cu durabilitate mare, care durează mult

long-length delay (autom, ec) întârziere de lungă durată

long life (mas, OM) durată mare de viață, (cu) durabilitate mare

long-life mould (met, plast) matriță cu durată mare de utilizare, cochilă, formă permanentă

long-link chain $(\mathrm{OM})$ lant cu zale lungi

long loop device (textile) dispozitiv pentru producerea ochiurilor lungi

long nose over pliers (OM) cleşte cu cioc lung, curbat

long oil (ind chim) ulei polimerizat

long-oil varnish (ind chim) lac gras / preparat pe bază de ulei cu grad înalt de polimerizare long-period recording (mas, autom, inf) înregistrare pe o durată mare

long-pitch screw (OM) şurub cu pas mare, şurub grosolan

long-pitch winding (el) înfăşurare cu pas mare

long pug mill (alim) malaxor cu un braț lung

long-pull magnet (el) electromagnet cu forță de tracțiune constantă la mare distanță

long radius (of a regular polygon) (geom) rază a cercului circumscris (unui poligon regulat)

long-range $(\mathrm{TH})$ cu rază mare de acțiune, cu parcurs lung, la mare distanță, cu interval mare; de largă perspectivă; cuprinzător

long-range force (fiz) forță cu rază mare de acțiune

long-range interaction (fiz) interacțiune la distantă mare

long reed (metr, fiz) unitate de măsură pentru lungime: 1 long reed $=3,2004 \mathrm{~m}$

long run (termo) tiraj mare; functionare de lungă durată

long-run test (mas) încercare / test la funcționare de lungă durată

long-service wear (T) uzură după funcționare de lungă durată

long shank machine tap (mas-un) tarod cu coadă lungă, de maşină

long sight (anat) prezbitism

long-sighted (anat) prezbit, care vede departe; perspicace; pătrunzător

long-sightedness (anat, opt) hipermetropie; (fig) prevedere, clarviziune

long stem funnel (OM, alim) pâlnie cu gât lung

long-stroke (mas-un) cu cursă lungă

long-stoke press (mas-un) presă cu cursă lungă

long tackle $(\mathrm{OM})$ palanc lung

long-tackle block (mas, transp) macara-vioară

long-tail block (nav) macara de sart

long-tailed (mas-un) cu coadă lungă (parte de fixare a sculelor)

long taper die tap (mas-un) tarod pentru filiere

long-term pe termen lung, de durată

long-term average discharge (hidr, $\mathrm{TH}$ ) debit mediu (calculat pe o perioadă mare de timp)

long-term station (autom, ind) secție / stație cu observare / înregistrare de date pe durată îndelungată

long tern plate (met) tablă cositorită / mată

long-time (TH) de lungă durată, pe timp îndelungat long-time creep strength $(\mathrm{mec})$ rezistență statică de durată la fluaj / la curgere

long-time test (metr, materiale) test / încercare de lungă durată 
long ton, gross ton (metr, fiz) unitate de măsură pentru masă, tonă engleză: 1 long ton = $1016,047 \mathrm{~kg}$

long(-vista) shot (constr, ind) plan general / de ansamblu

long-wearing ( $T$, materiale) rezistent la uzură longword (metr, inf) unitate de măsură în informatică, în general egală cu 2 cuvinte

look privire; înfăţişare, aspect; observare; expresie; a arăta; a părea

look about for a căuta / urmări cu privirea; a căuta; a fi în căutarea

look after a avea grijă de, a supraveghea

look ahead a privi înainte

look at a privi la, a se uita la; a examina; a cerceta; a urmări; a lua în considerare (ceva)

looker privitor, observator; paznic; telespectator

look for a căuta, a se uita după; a se aştepta la; a prevedea, a anticipa

look foward to a aştepta cu nerăbdare

look(ing) box $(\mathrm{OM})$ gaură de observare

looking-for căutări; aşteptări, speranțe

looking glass (opt) oglindă

looking-stick (OM) jojă de control al nivelului (lubrifiantului, fluidului etc.); (met) rangă pentru controlul topiturii metalice

look into a cerceta (în interior), a examina, a studia; a se uita prin, a răsfoi

look like a semăna cu; a arăta; a fi

look on a avea vedere spre, a da înspre; a privi, a fi spectator

look-out atenție, băgare de seamă, vigilență; veghe, pază; paznic; observare; grijă; supraveghere; observator; post de observare; perspectivă; punct de vedere, opinie

look out a privi / se uita în afară; a fi atent; a căuta, a alege, a selecta

look-over examinare, cercetare

look over a examina, a cerceta; a trece în revistă

look-through (fiz, opt, c) transparență

look through a se uita prin, a căuta prin; a cerceta, a examina

look-up (ec, inf) căutare în tabel (în listă)

look up a privi / se uita în sus

look upon a considera, a socoti; a privi / vedea (o problemă)

look up the logarithm of (mat) a logaritma

loop (TH, autom, inf) buclă, ciclu; curbură, arc, deschidere, nod, contur; (hidr) conductă de derivație / de ocolire; (OM) balama, belciug cârlig, jug, etrier, clemă, bridă, brățară, agrafă, ochi de prindere, lat, inel, ureche, colier, contact de alunecare / glisant, gaură, alezaj, orificiu, ochi, arc, resort; (nav) nod simplu; (el) buclă, spiră; a înfăşura, a conecta în buclă; a înnoda, a lega

loop and hook $(\mathrm{OM})$ tendon cu cârlig / cu copcă / cu agrafă; balama-colțar

loop-and-trunk layout (el, hidr) schemă / plan (de situație) al unei rețele

loop chain (OM) lant închis

loop connection (el, autom) legătură în buclă

loop cut (mas-un) secțiune / tăiere ciclică

loop dryer (alim, ind chim) uscător în buclă / în circuit închis

looped circuit (electr, autom) circuit în buclă

looped tape (OM) bandă lipită (cu contur închis)

looper (met) suport de buclă, dispozitiv de întindere a buclei, jgheab de ghidare pentru bucle; (textile) maieză

loop gain (el, autom) câştig / amplificare a buclei / a trecerii prin buclă (deschisă)

loop hanger (OM) ochi / buclă de suspensie / de atârnare

loophole $(\mathrm{OM}$, constr) deschizătură, crăpătură; crenel; fisură

loop ident (el) număr / identificare a circuitului / buclei de reglare

looping (OM, met) formare de bucle, asamblare, încheiere

looping channel (met) dispozitiv de întindere / jgheab de ghidare a buclelor

looping floor (met) jgheab înclinat în buclă (între cuptor şi laminor)

looping pit (met) groapă / spațiu pentru buclă / bucle

looping rolling mill (met) laminor deschis

loopknot nod simplu

loop initialisation (inf) instructiuni, date, valori iniţiale, care preced o buclă repetabilă / iniţializarea unui ciclu

loop length (met, OM) lungime a buclei / a spirei

loop lifter (met) suport al buclei (la laminare)

loop line (cf, met) ramificație, linie de derivație / de ocolire; (hidr) conductă de ocolire

loop mill rolling (met) laminare în formă / cu formare de buclă (dorită sau nedorită)

loop mode (autom) mod de acționare / funcționare în buclă

loop of an oscillation / of vibration (mec, fiz) ventru al unei oscilații

loop of wire (el, OM) buclă a sârmei, spiră (de arc, de bobină)

loop oscillograph (fiz) oscilograf cu buclă

loop rectangularity (fiz) rectangularitate a ciclului (de histerezis) 
loop resistance (el) rezistență a buclei

loop-reversing method (inf) metodă de comutare / de parcurgere în sens invers al buclei / al ciclului

looproad (constr) linie de derivare, drum de ocolire; (hidr) meandru

loops (materiale) ventre, umflături, bucle (şi defecte de laminare)

loop signal (autom) semnal al unei bucle

loop system $(\mathrm{TH})$ sistem închis

loop test bar (metr, chim) epruvetă în formă de buclă / potcoavă, pentru teste de coroziune

loop testing (inf) testarea buclei de program pentru a verifica dacă este completă / utilizabilă

loose $(\mathrm{OM})$ dezlegat, desfăcut, detaşat, degajat, destins, liber, larg, cu joc, neexact; slab, slăbit; nefixat, vag; lipsit de constrângere; rar; (ec) dezlegat, neambalat (d. marfă); (mat) nedeterminat, necompact, nedens; a dezlega, a slăbi (o legătură), a desface; a scăpa, a lăsa să scape; (d. scris) neglijent, neciteț

loose axle (cf, OM) osie falsă / alergătoare, osie cu încastrare la unul din capete

loose bottom (met, OM) fund detaşabil / demontabil (la cuptoare, recipiente, matrițe etc.)

loose bushing (OM) bucşă de mers în gol; (masun) bucşă amovibilă (a dispozitivului de ghidare)

loose collar $(\mathrm{OM})$ inel de fixare (şi cu şurub)

loose connection $(\mathrm{OM})$ îmbinare neetanşă, legătură / conexiune întreruptă

loose coupling $(\mathrm{OM})$ cuplare flexibilă / largă; cuplaj / cuplare (prea) largă

loose deposits (termo, ind chim, T) calamină afânată, material depozitat neconsolidat / cu tendință de împrăştiere

loose ends $(\mathrm{ec}, \mathrm{TH})$ probleme mărunte / mărunțişuri de ultimă oră

loose fibre (textile, plast) fibră în masă, fibre destrămate

loose fill type (material) de umplutură / în vrac

loose flange $(\mathrm{OM})$ flanşă liberă

loose freezing (alim) congelare în masă divizată / necompactă, congelare de produse neambalate

loose gear $(\mathrm{OM})$ roată dințată amovibilă / baladoare / liberă pe arbore

loose ground (geol, constr) sol afânat / neconsolidat

loose headstock (mas-un) păpuşă mobilă

loose key $(\mathrm{OM})$ pană îngropată

loose leaf $(\mathrm{OM})$ foaie liberă (şi de arc)

loose mould (mas-un) matriță mobilă / amovibilă / independentă loosen a (se) desface, a (se) dezagrega, a (se) detaşa; a disloca; a (se) slăbi (d. un arc, o piuliță etc.), a ceda, a (se) deşuruba; (agr) a afâna (pământul)

looseness desfacere, slăbire; lărgire; fragilitate, instabilitate (şi a terenului); prolixitate, neclaritate

loosen the brake (OM, auto) a slăbi frâna

loosened coal (met) cărbune dezagregat

loosening slăbire; relaxare; destindere; desfacere; degajare; care se relaxează / se slăbeşte; (chim) dizolvare; (OM) deşurubare, gripare (a unui lagăr), eliberare (şi parțială) din prindere / strângere; (agr) afânare

loosening machine (agr, ind chim) afânător loose nut $(\mathrm{OM})$ piuliță slăbită / deşurubată

loose part $(\mathrm{OM}$, met) piesă amovibilă / detaşabilă / demontabilă / separabilă (a unui model, a unui ansamblu)

loose pattern (met, plast) model demontabil

loose piece $(\mathrm{OM}, \mathrm{met})$ parte amovibilă / detaşabilă (a unui model etc.)

loose pin (met, OM) ştift de ghidare (şi la rame de formare), cap mobil

loose pinion $(\mathrm{OM})$ pinion mobil, roată dințată liberă

loose powder (alim, met, plast) pulbere nepresată loose pulley $(\mathrm{OM})$ roată (de curea) liberă

loose punch (mas-un) poanson mobil loose running (mas) mers în gol / liber loose (running) fit (OM) ajustaj foarte larg

loose sand (constr, met) nisip neconsolidat / necimentat

loose standard $(\mathrm{ec}, \mathrm{TH})$ normă nerigidă

loose twist $(\mathrm{mec})$ torsiune slabă

loosing $(\mathrm{OM})$ deblocare / slăbire

lop (agr, silv) a curăța de ramuri, a tunde (un pom); a clipoci; clipocit

lop-sided (OM) asimetric; strâmb; înclinat; aplecat (într-o parte)

lorry (auto, transp) autocamion, camion; (cf, met) vagonet, vagon-platformă

lorry body (auto, OM) caroserie de camion lorry scale (auto, OM) basculă de camion lorry tractor (transp, mas) tractor-remorcher lorry trailer (transp, OM) remorcă de camion lorry-trailer combination (transp, mas) tren rutier, ansamblu autocamion-remorcă

lorry tyre (auto, OM) anvelopă de autocamion lose a (se) pierde; (d. o propunere) a fi respins; a fi zadarnic / inutil; a ieşi în pierdere; a avea / suferi pierderi; (d. ceas) a întârzia, a rămâne în urmă 
lose colour (plast, textile) a (se) decolora, a pierde o culoare, a (se) albi

loser păgubaş, învins

lose way / on speed (auto, mas) a pierde din viteză

losing care pierde; învins; necâştigător; pierdere loss $(\mathrm{TH})$ pierdere (şi de energie, a unui obiect), scurgere, atenuare, amortizare; (ec) pierdere, daună, daune, lipsă, risipă; încurcătură, impas; (textile, met) deșeuri (și la decupare, tăiere); (fig) încurcătură

loss angle (el, metr) unghi de pierderi, unghi de atenuare

loss by pierderi prin

loss by burning (met) pierderi prin ardere

loss by percolation (hidr) pierderi prin infiltrație

loss current to earth (el) curent (de pierderi) prin punere la pământ

loss damping (hidr, el, mec) atenuare datorită pierderilor

loss due to cutting (mas-un) pierdere de material datorită retezării / prelucrării prin aşchiere / prin decupare

loss due to diffusion (hidr, ind chim) pierderi prin difuzie

loss due to friction $(\mathrm{T})$ pierderi datorate frecării loss due to drying (alim, ind chim, agr) pierderi din cauza uscării, pierderi prin uscare

losses pierderi; (met, ind) deşeuri, pierderi (tehnologice)

losses of circulation (hidr) pierderi la circulația unui fluid

losses on no land (el) pierderi în gol / în circuit deschis

losses through breathing (constr, $\mathrm{TH}$ ) pierderi prin respirație (şi a unui perete)

losses through standing $(\mathrm{TH})$ pierdere prin / la depozitare, pierderi din cauza staționării

loss-free fără pierderi

loss in bends (hidr) pierdere de sarcină / de presiune (în cot sau la curbe); pierdere de presiune prin frecare (la coturi şi derivații)

loss in efficiency (mas) pierdere de randament / de energie / de putere

loss in energy / in power ( $\mathrm{TH}$, mas, mec) pierdere de energie / de putere

loss in measure scăzământ; $(\mathrm{TH})$ pierdere în dimensiune

loss in reverse direction (electr, autom) pierdere de blocare / în sens invers

loss in weight (ec) scăzământ; pierdere în greutate / de masă

lossless fără pierderi loss meter (el, metr) contor de pierderi, aparat de măsurat (unghiul de) pierderi

loss of charge method (metr, el, mec) metodă de măsurare a pierderilor prin descărcare a sarcinii (electrice sau mecanice)

loss of core (met) pierdere de carotă / de miez (la turnare)

loss of efficiency (mas, TH, ec) scădere a productivității / a eficienței / a randamentului

loss of gauge $(\mathrm{OM}, \mathrm{T})$ reducere a diametrului prin uzură

loss of / in head (hidr, mec) pierdere de sarcină / de presiune

loss of life (mas, OM) micşorare a durabilității / a duratei de viață / de serviciu

loss of power $(\mathrm{el}, \mathrm{mec})$ pierdere / scădere de putere loss of pressure (met, hidr) pierderi / scăderi (nedorite) de presiune

loss of returns ( $T$, hidr) pierdere prin recirculare (și la sisteme de ungere / de răcire etc.)

loss of synchronism (mec, el) ieşire din sincronism, desincronizare

loss of temperature (met, termo) pierderi / scăderi (nedorite) de temperatură

loss of visibility (auto) pierderea vizibilității

loss on ignition (ind chim) pierderi la calcinare / ardere / încălzire; (met) pierderi la recoacere

loss on purification (alim, ind chim) pierdere la purificare

loss per pass (met) pierdere la fiecare trecere

loss resistance $(\mathrm{el}, \mathrm{mec})$ rezistență de amortizare, rezistență echivalentă a pierderilor

loss-summation method (mas, metr) metoda pierderilor separate (pt. măsurarea randamentului)

loss tangent (el) tangentă a unghiului de pierderi

loss through diffusion (alim, ind chim) pierdere prin difuzie

lossy circuit element (el) componentă de circuit cu pierderi

lossy network (el) rețea cu pierderi

lost pierdut

lost cluster (c) sector / sectoare de disc care nu mai sunt disponibile pentru memorare

lost head (hidr) pierdere de sarcină / de presiune; (met) maselotă

lost metal (met) pierdere (tehnologică) de metal lost motion (mas-un) joc, cursă moartă, mers în gol, porțiune neutilizată a cursei

lost shuttering (constr) cofraj pierdut

lost time (mas, TH) timp pierdut / neutilizat, timp mort, întrerupere a lucrului

lost volts (el) cădere de tensiune 
lost-wax casting (met) piesă turnată / turnare în formă / în model fuzibil(ă) / în ceară pierdută

lost wax moulding / process (met) formare cu modele fuzibile (din ceară)

lot lot (de piese, de pământ etc.), serie; grămadă; parcelă; partidă; parte; porțiune; (plast) şarjă (de adeziv); (ec) lot, livrare; (mat) grupă; mulțime; cotă; parte; a parcela, a împărți (un teren etc.); (metr) unitate tradițională de măsură pentru masă în țări germanice: 1 lot $15 \mathrm{~g}$

lot number mulțime, număr de lot

lot production $(\mathrm{TH}, \mathrm{ec})$ productie de serie

lot size $(\mathrm{TH})$ mărimea lotului (de piese / de semifabricate

lottery sample / sampling (metr) eșantion ales / eşantionare prin tragere la sorți / aleatoare

loud (d. sunete) tare, puternic, sonor, răsunător; (d. culori) strident, țipător; (d. mirosuri) tare, pătrunzător

louden (fiz) a amplifica (un sunet)

loudness (fiz) intensitate auditivă, impresie sonoră, nivel / volum sonor, sonoritate

loudness counter (fiz) curbă de intensitate sonoră / auditivă

lounge a se odihni; a lenevi; pierdere de vreme, lenevie; fotoliu, şezlong, divan, sofa; loc de odihnă; foaier (de teatru), hol (de hotel); plimbare, hoinăreală

loupe (fiz) lupă

louse, $p l$ lice (zool) păduche

louver tăietură; deschizătură; crestătură; jaluzea; oblon; reinură; fantă / gol / canal de ventilație (şi la maşini electrice); gaură de aer / de ventilație / de tiraj; (termo) gaură a coşului de fum

louvered cover (OM) capac de protecție, cu fante pentru ventilație

louvers (OM) jaluzele, oblon

lovage (alim, agr) leuștean

Lovibond color units (metr, fiz) unităţi de culoare Lovibond

Lovibond tintometer (metr) colorimetru Lovibond low jos, scund, mic; scăzut, redus, micşorat; (d. o notă) grav, încet, şoptit, jos; adânc; decoltat, decupat; răsfrânt; ieftin, comun, vulgar; (electr) nivel mic / zero în circuite digitale; slab, slăbit; prost, de proastă calitate; $(a d v)$ jos, la pământ, până la pământ

low-access memory / storage (c) memorie cu timp redus de acces, memorie rapidă

low-alloyed (met) slab aliat

low-alloy(ed) steel (met) oțel slab aliat

low average productivity $(\mathrm{ec})$ productivitate medie redusă / mică low-battery indicator (auto) indicator de descărcare a unei baterii

low / lower beam (auto) fază scurtă

low-bed / low boy trailer (transp) remorcă cu platformă joasă / pentru sarcină mare

low binding (fiz, chim) legătură slabă între atomi / molecule

low-boiler (fiz) compus volatil, cu punct de fierbere jos / redus

low-boiling (alim, ind chim) cu temperatură joasă de fierbere

low bracket gasoline (ind chim) benzină cu cifră octanică redusă

low brake fluid (auto) lichid de frână în cantitate (prea) mică / puțină

low brake fluid level (auto) nivel (prea) mic al lichidului de frână

low brake fluid level warning (auto) atenționare asupra nivelului prea scăzut al lichidului de frână

low built chassis (auto) şasiu de construcție joasă

low calorific power (termo) putere calorică redusă / inferioară

low-carbon (met) cu continut redus de carbon

low-carbon cast iron (met) fontă decarburată / moale

low carbonisation coke (met) semicocs

low-carbon steel (met) oțel cu conținut redus de carbon

low-class de calitate inferioară (d. produse)

low-current protector (el) siguranță pentru curent slab

low cycle fatigue (mec) oboseală (şi rupere) la un număr mic de cicluri (sub $10^{5}$ )

low dip înclinare mică

low distillation (alim, ind chim) distilare la temperaturi joase

low-down scund, jos

low duty $(\mathrm{TH}$, mas, $\mathrm{OM})$ de mică putere, cu regim uşor de funcționare, de tip uşor, de serie uşoară (d. rulmenți, caneluri etc.)

low-duty-cycle source (el, electr) sursă cu durată mică de anclanşare / declanşare (şi de putere mică)

low-duty goods (ec) mărfuri cu tarif vamal scăzut low-enriched (met) uşor îmbogăţit (d. aliaje etc.)

lower (mat) inferior; (TH) a coborî, a (se) reduce, a micşora, a scădea (şi un preț), a degrada, a lăsa în jos; de jos; (nav) a lansa la apă; a se înnora, a (se) întuneca

lower / low beam (auto) fază scurtă, lumină de întâlnire 
lower a boat (nav) a lansa / a lăsa o barcă la apă lower boom (constr, mec) talpă inferioară a grinzii (în construcții metalice)

lower bound margine inferioară; (mat) minorant lower calorific value (termo) putere calorifică inferioară

lower-case (letter) literă minusculă / obişnuită / de rând

lower chord (mec, constr) talpă inferioară a grinzii

lower chord member (mec, constr) bară inferioară (într-o constructie metalică)

lower control arm (mas-un) brat oscilant inferior lower crankcase (OM) baie / carter de ulei, partea inferioară a unei carcase, carcasă inferioară lower cut (mas-un) prima trecere (la danturare, pilire)

lower dead centre (auto, termo) punctul mort inferior

lower deck (nav) punte inferioară

lower deviation (metr, OM) abatere inferioară (şi la toleranțe)

lower die (OM, mas-un) partea inferioară a unei matrițe

lower flange $(\mathrm{OM})$ flanșă inferioară / de jos

low friction loss(es) $(\mathrm{T})$ pierderi reduse prin frecare (de putere, material, de energie etc.)

lower heating value (termo) putere calorifică inferioară

lower hold (nav) cală, magazie inferioară

lowering coborâre, lăsare în jos; descreştere, care descreşte

lowering casing $(\mathrm{OM})$ perete rabatabil

lowering-in coborâre, reducere

lowering motion (transp, mec) mişcare de coborâre (la o macara)

lowering movement (geol, constr) tasare, coborâre, adâncire a suprafeței terenului

lower layer (geol, TH) strat inferior

lower leg of siphon (hidr) tub de aspirație al sifonului

lower members of the series (mat) membri inferiori ai unei serii

lowermost cel mai de jos

lowermost bed (constr, TH) strat-talpă, pat, strat inferior / cel mai de jos, strat-culcuş

lower panel (auto) şorț al caroseriei

lower platen (mas-un) masă inferioară a presei

lower pump box (OM, hidr) piston de pompă

lower roll (ind chim, met) cilindru / valt inferior

lower shaft (of furnace) (met) parte inferioară a cuvei (şi la furnal)

lower slide $(\mathrm{OM})$ glisieră lower stone (alim, ind chim) piatră inferioară la o moară

lower tool slide (mas-un) sanie inferioară (a port-cuțitului la strung)

lowest cel mai de jos; cel mai scăzut; cel mai îngust

low-expansion alloy (met, termo) aliaj cu coeficient mic de dilatare

low explosive (chim) exploziv lent

low explosive limit (TH) limită inferioară de explozie

low fermentation (alim, ind chim) fermentatie inferioară

low flow year (agr) an cu apă puțină

low-freezing liquid (fiz) lichid cu punct de înghețare scăzut

low frequency (fiz) (de) frecvență joasă

low-frequency damping (fiz) atenuare a sunetelor / a frecvențelor joase

low-frequency end / final / output stage (fiz, electr) etaj final de joasă frecvență

low-frequency self-excitation (el, autom, electr) auto-excitare în domeniul frecventelor joase

low fuel (auto) carburant / combustibil puțin

low fuel consumption (mas, auto) consum redus de combustibil

low fuel level (auto) nivel (prea) scăzut al carburantului / combustibilului

low fuel warning (auto) atenționare pentru carburant putin / insuficient

low gear (auto, OM) viteza întâi, treaptă inferioară de viteză, angrenajul vitezei întâi

low grade inferior, de valoare / calitate inferioară, inferior calitativ; marcă inferioară; pantă cu înclinare mică

low grade ore (met) minereu sărac

low gravity crude (ind chim) țiței crud, ulei vâscos

low gravity oil (ind chim) țiței greu

low ground (geogr) șes, câmpie, teren jos

low-ground type (mas-un) cu batiu la nivelul podelei

low hardening steel (met) oțel uşor / slab călit

low headlight (auto) faza scurtă

low-head screw (OM) şurub cu cap înecat

low helix drill (mas-un) burghiu în spirală cu unghi mic de înclinare al canalelor elicoidale

low in carbon (met, chim) cu conținut redus de carbon

low-inertia $(\mathrm{mec})$ inerție redusă

low intake pump (OM, hidr) pompă de alimentare, de joasă presiune

lowland (geogr) zonă depresionară 
low-leakage transistor (electr) tranzistor $\mathrm{cu} \mathrm{cu}$ rent rezidual mic

low level $(\mathrm{TH}, \mathrm{el}, \mathrm{mec})$ nivel coborât, de slabă putere / intensitate

low-level amplifier (electr, metr) amplificator de semnal slab

low-level contacts (el) contacte pentru curenți slabi

low-level controller (hidr, el) regulator / întrerupător al nivelului de minim

low-level magnetic detection (metr, electr) detectare a câmpurilor magnetice slabe

low-lift pump (OM, hidr) pompă de presiune joasă

low limit $(\mathrm{TH})$ dimensiune minimă, limită inferioară

low-limit selector (metr, OM, autom) selector / clasor pentru limită inferioară

low-load adjustment (autom, hidr, mec) dispozitiv de reglare pentru debit / sarcină mică

low loader (auto, transp) camion / remorcă cu platformă joasă

low-load rate $(\mathrm{TH}$, ind) viteză redusă de încărcare

low-loss cu pierderi mici (şi pt. dielectrici)

low-lying trap capcană / trapă aflată în adâncime / la nivelul de jos (al utilajului etc.)

low-melting (materiale, termo) uşor fuzibil

low-melting alloy (met, termo) aliaj uşor fuzibil

low melting compound / element (met, plast) compus / element cu punct de topire scăzut

low-molecular polymer (plast) polimer cu greutate moleculară scăzută / cu grad redus de polimerizare

low-molecular weight compound (chim) compus cu masă / greutate moleculară scăzută / mică

low oil alarm ( $\mathrm{T}$, aujtom) semnal care indică scăderea nivelului de ulei sub nivel normal

low output (TH, mec, autom) nivel / parametru mic de ieşire, putere redusă (la ieşire)

low-pass filter (LPF) (autom) filtru care permite trecerea frecventelor joase, filtru trece-jos

low phosphorous pig iron (met) fontă cu conținut scăzut de fosfor

low-pitched note (fiz) sunet grav / de frecvență joasă

low position (mas-un) poziție joasă

low potential source of supply (el) sursă de alimentare de joasă tensiune

low power(ed) (mas, mec, el) de / cu putere mică, alimentat cu putere mică

low pressure (hidr) (de) presiune joasă low-pressure area (hidr, T) zonă de joasă presiune

low-pressure compressor (termo) compresor de joasă presiune

low-pressure cut-out switch (hidr, OM) întrerupător de contact de joasă presiune, presostat acționat la scăderea presiunii

low-pressure / low side float valve (OM, hidr) ventil de expansiune cu flotor la presiune joasă, regulator de joasă presiune cu flotor

low / back pressure gauge (OM, hidr) manometru de aspirație, depresiometru

low-pressure moulding (plast) procedeu de formare la presiune joasă presiune

low-pressure piston (OM, hidr) piston al cilindrului de joasă presiune

low-pressure polyethylene (plast) polietilenă de joasă presiune

low-pressure safety cut-out (OM, hidr) presostat de contact joasă presiune, presostat de siguranță, acționat de scăderea presiunii

low-pressure torch (termo) arzător cu injecție de joasă presiune

low-priced (ec) ieftin, cu preț mic / redus

low-Q specimen (metr) eşantion / epruvetă / probă cu factor de calitate mic

low-quality (de) calitate inferioară (d. produse)

low-quality goods $(\mathrm{ec})$ bunuri / mărfuri de calitate inferioară

low red roşu închis

low-reflection coating (ind chim, fiz) acoperire cu strat antireflectorizant

low-refief basorelief

low resistance $(\mathrm{el}, \mathrm{mec})$ rezistență mică / joasă / scăzută

low-resistance forward direction (el) sens de trecere (şi la un redresor)

low Reynolds number (hidr, fiz) număr Reynolds sub numărul Reynolds critic pentru o sferă

low-rubber compound (chim) amestec cu conținut scăzut de cauciuc

low season (ec) sezon mort

low shear strength $(\mathrm{mec})$ rezistență mică la forfecare

low slider $(\mathrm{OM})$ culisă inferioară

low sound (fiz) sunet grav / de joasă frecvență

low speed (de / cu) viteză mică / redusă; viteză minimă; cu mers încet; cu viteză mică; cu turație joasă / lentă

low speed balance $(\mathrm{mec})$ echilibrare la viteză redusă / joasă

low-speed jet (auto, termo) jiclor de turație mică low-speed mill (met) laminor cu viteză mică 
low-speed nozzle (auto, termo) jiclor de mers încet, jiclor de turație mică

low spot depresiune; (met) gol (în suprafața cusăturii sudate); (T) adâncitură punctiformă pe suprafața piesei

low suction temperature cut-out (OM, metr, termo) termostat de siguranță, la aspirație

low temperature behaviour (materiale, termo) comportare la temperaturi joase

low-temperature carbonization (chim, met) semicarbonizare, semicocsificare; (termo) carbonizare la temperatură joasă

low-temperature coke (met) semicocs

low-temperature distillation (chim, met) semicocsificare, distilare la temperaturi joase

low-temperature oxidation (chim, met) oxidare la temperatură joasă

low-temperature polymerisation (ind chim) polimerizare la rece / la temperatură joasă

low-temperature rubber (ind chim) cauciuc polimerizat la rece

low tension (el) tensiune mică / joasă

low-tension ignition (auto) aprindere prin magnetou, la temperatură joasă

low-tension voltage (el) tensiune mică / joasă (şi la transformator)

low-test gasoline (ind chim) benzină de calitate inferioară

low thermal mass furnace (TH) cuptor cu inerție termică mică / cu încălzire rapidă

low tide (nav) reflux

low tin solder (met, OM) aliaj cu conținut redus de staniu, pentru lipire moale

low tone (fiz) sunet grav / de joasă frecvenţă

low vaccum (fiz) vid slab (corespunzător unei presiuni mai mici de 760 torri sau presiunii vaporilor de apă la $\left.25^{\circ} \mathrm{C}\right)$

low viscosity ( $\mathrm{T}, \mathrm{OM}$, hidr) fluiditate, văscozitate redusă / mică

low volatility (fiz) volatititate greu de realizat

low voltage (el) joasă tensiune

low-voltage protection (el) protecție minimală de tensiune / protecție împotriva tensiunii joase

low-voltage release (el) declanşare la tensiune minimală / la subtensiune

low water (nav) maree / apă joasă

low-water mark (nav) limită de jos / inferioară de apă

low washer fluid level (auto) nivel (prea) scăzut al lichidului de spălare

low weir (OM, hidr) prag de fund, deversor înecat low with pressure (auto) cu presiune (prea) mică / joasă (d. pneuri)
low-Z element (chim, fiz) element cu număr atomic mic

loyal loial, credincios

lozenge (chim) tabletă, pastilă; (mat) romb

lozenge file pilă rombică

LP constraints (inf) limitări / restricții la programarea liniară

Lpf (metr) simbol pentru liters per flush, parametru pentru toalete, litri la o acționare a sistemului de spălare: $1 \mathrm{Lpf}=0,264$ US gallon per flush (gpf)

Ipi (metr, fiz, c) abreviere pentru lines per inch, o unitate de măsură pentru rezoluția monitoarelor; (metr, tipografie, c) unitate de măsură pentru spațierea rândurilor (unui text)

L-shaped iron / steel (met, OM) oțel cornier cu aripi inegale

L-shell (chim) pătură L (cu opt electroni)

lubber mark (OM) linie de reglare, reper reglabil

lube oil / luboil (T) lubrifiant, ulei de ungere (foarte general)

lubricant $(T)$ ulei de ungere, lubrifiant (indiferent de starea de agregare), lichid de răcire şi ungere, unsoare; (met) material pentru ungerea formelor de turnare

lubricant additive (chim, $\mathrm{T}$ ) aditiv pentru lubrifianți

lubricant blend $(\mathrm{T})$ amestec lubrifiant, lubrifiant cu mai multe componente

lubricant bloom $(\mathrm{T})$ exsudare a lubrifiantului lubricant dope (ind chim, T) aditiv pentru lubrifianți (inclusiv uleiuri)

lubricant incompatibility ( $\mathrm{T}$, chim) incompatibilitate între lubrifianţi

lubricant / lubricating grease $(\mathrm{T})$ unsoare consistentă

lubricant / lubricating grease for general use ( $\mathrm{T}$, ind chim) unsoare consistentă, de uz general

lubricant / lubricating pump ( $\mathrm{T}$, met) pompă de gresare (tecalemit)

lubricant ring $(\mathrm{OM}, \mathrm{T})$ inel (liber) de ungere

lubricate $(\mathrm{T})$ a unge, a gresa, a lubrifia

lubricated $(\mathrm{T})$ uns, lubrifiat

lubricating / lubrication ( $\mathrm{T}$ ) (acţiunea de) lubrifiere, gresare, ungere, care unge / lubrifiază

lubricating can $(\mathrm{OM}, \mathrm{T})$ gresor, ungător

lubricating capacity / power $(\mathrm{T})$ onctuozitate, capacitate de ungere (a unei suprafețe)

lubricating cup (T, OM) ungător, lubrificator

lubricating cushion $(\mathrm{T})$ pernă de ungere (şi cu fitiluri)

lubricating fluid ( $\mathrm{T}$, ind chim) fluid de ungere / de lubrifiere 
lubricating graphite $(\mathrm{T})$ grafit (pt. ungere / cu rol de lubrifiere)

lubricating grease for general use $(\mathrm{OM}, \mathrm{T}$, ind chim) unsoare pentru uz general

lubricating grease structure $(\mathrm{T}, \mathrm{chim})$ structura unei unsori lubrifiante

lubricating grease thickener $(T$, chim) agent de îngroşare pentru unsori lubrifiante

lubricating / lubrication nipple (OM, T) ungător cu bilă

lubricating oil ( $\mathrm{T}$, chim) ulei lubrifiant

lubricating oil gauge $(\mathrm{OM}, \mathrm{T})$ jojă pentru ulei, indicator al nivelului de ulei (lubrifiant)

lubricating ring $(\mathrm{OM})$ inel pentru ungere

lubrication by gravity $(\mathrm{T})$ ungere prin scurgere / cădere liberă

lubrication by oil circulation $(\mathrm{T})$ ungere prin circulația (şi forțată) a uleiului

lubrication by splashing $(\mathrm{T})$ ungere prin barbotare / prin stropire / prin bălăcire

lubrication by submersion ( $\mathrm{T}$ ) ungere prin imersare / prin cufundare (în baie)

lubrication chart / diagram $(\mathrm{T}$, mas, $\mathrm{TH})$ diagramă / schemă de ungere

lubrication grease $(T)$ unsoare lubrifiantă

lubrication pipe $(\mathrm{OM}, \mathrm{T})$ conductă de ulei / de lubrifiant, țeavă de ungere

lubrication piping ( $\mathrm{T}$, hidr, met) sistemul de conducte / țevi de ungere, canale / conducte de ungere

lubricator ( $\mathrm{T}, \mathrm{OM}$, met) cutie cu unsoare, gresor, ungător, aparat pentru lubrifiere, muncitor însărcinat cu ungerea

lubricator fitting $(\mathrm{OM})$ niplu pentru ungere, la pompa de mână

lubricator piston $(\mathrm{OM})$ piston al pompei de ulei (în sistemul de ungere)

lubricity $(\mathrm{T}$ ) onctuozitate; (hidr) putere / capacitate lubrifiantă; capacitate de protecție antiuzură; (fig) abilitate de a scăpa / de a se sustrage; caracter alunecos; lubricitate; lascivitate; caracter instabil, inconstanță

luce (alim) ştiucă

lucerne (agr, bot) lucernă

lucidity luminozitate; luciditate, rațiune; (fiz) transparență, claritate

luck noroc, şansă; întâmplare

lucky norocos

lucrative lucrativ, avantajos, profitabil

lucrativeness rentabilitate

lucrative transaction (ec) afacere / tranzactie rentabilă / avantajoasă

luff (nav) margine de învergare; a veni în vânt

luff tackle (nav) palanc simplu luffing (mas, trasp) înălțime de ridicare a brațului macaralei

luffing crane (mas, trasp) macara cu braț mobil în plan vertical

luffing davit (nav) gruie radială / rotativă / pivotantă

luff tackle (OM) palanc simplu cu cârlig

luff upon luff (OM, trasnp) palanc pe palanc, palancuri în serie

lug (constr) capră, consolă; (el) bornă, piesă polară, ureche (la acumulator); (OM) opritor, inel de agățat, nas, știft, pivot, camă, mâner, ureche, ochi (de prindere), proeminență, dinte, ridicătură, scobitură, canelură, limbă, labă, toartă, manivelă; smucitură, tragere; (met) adaos de turnare, bosaj, ureche a ramei de formare; (el) bornă pentru sudură; a târî, a trage cu putere, a smuci

lug (metr) denumire veche englezească pentru rod: 1 lug $=5,0292 \mathrm{~m}, 1$ great $\operatorname{lug}=6,4008 \mathrm{~m}$; (metr) unitate de măsură pentru masă (pt. fructe: struguri, piersici etc.) 1 lug $\sim 7 \ldots 13 \mathrm{~kg}$ de produs într-un volum de 121 (şi în SUA)

lug-angle (mec, constr) cornier de legătură / de asamblare (şi într-o construcție metalică)

lug boss $(\mathrm{OM})$ bosaj

lug brick (constr) cărămidă cu nut şi feder / cu suprafețe conjugate (când se montează)

luggage bagaj(e)

luggage boot / carrier (auto, transp) portbagaj, compartiment de bagaje

luggage darrier (auto) portbagaj

luggage compartment (cf) compartiment de bagaje

luggage depot / storage (transp) magazie de bagaje

luggage grid (auto) portbagaj exterior

luggage net (auto, el) plasă bagaje

luggage office (transp) depozit de bagaje

luggage rack (auto, cf) plasă de bagaje

luggage room lamp (auto) lampă de portbagaj

luggage truck (transp) cărucior de magazie / de bagaje

luggage van (cf) vagon de bagaje

lugged $(\mathrm{OM}, \mathrm{met}) \mathrm{cu}$ nervuri, cu adaosuri de turnare

lug head (OM) cap cu nas (la şuruburi)

lug nut tighting (auto) strângerea şuruburilor de fixare a supapelor

lug of insulator (el, OM) eclisă / pivot de consolă la un izolator

lug of a moulding box (met) ureche a ramei de formare

lug shackleer (nav) cheie de ureche 
lug support (constr) proptea, reazem; montant lukewarm călduț

lumbar support (auto) suport lombar

lumber (constr, silv) cherestea (nesortată), material lemnos neprelucrat, lemn de construcție; mobilă veche; a îngrămădi, a arunca de-a valma; a se mişca greoi / stângaci; a hodorogi, a hurui

lumber carrier (mas, transp) autovehicul / autocamion de transportat cherestea / lemn

lumberg (metr, fiz) denumire veche pentru talbot, o unitate pentru măsurarea energiei luminoase: 1 lumberg $=1$ lumen second, v. lumen second

lumbering (silv) exploatare forestieră

lumber mill (silv, ind) fabrică de cherestea

lumber preservation (ind chim) impregnarea lemnului

lumber yard (silv, ind) depozit de cherestea

lumen (Im) (metr, fiz) unitate SI pentru măsurarea fluxului de lumină produs de o sursă luminoasă sau primit pe o suprafață, lumen

lumen hour (Im h) (metr, fiz) o unitate de măsură pentru cantitatea de lumină: 1 lumen hour $=1$ lumen de flux luminos continuu, timp de o oră

lumen second (Im s) (metr, fiz) o unitate de măsură pentru cantitatea de lumină, lumen secundă: 1 lumen secund = 1 lumen de flux luminos continuu, timp de o secundă

luminaire (el) corp de iluminat

luminance (fiz) Luminanță luminoasă, strălucire luminoasă

luminescence luminescență, a străluci, a deveni luminescent

luminescent dial (metr) scară / scală luminoasă, disc selector luminos (la aparate de măsură şi control)

luminescent digital (metr) indicator numeric luminos

luminosity (fiz) luminozitate, strălucire

luminosity coefficient (fiz) coeficient de luminozitate

luminous area (fiz) zonă / arie iluminată

luminous (fiz) luminos, strălucitor; incandescent; (fig) clar, limpede, desluşit; inteligent; (fiz, chim) luminescent, fosforescent

luminous beam (fiz) fascicul de lumină

luminous brightness of a surface (fiz) strălucire luminoasă a unei suprafețe

luminous cone (fiz) con de lumină / luminos

luminous dial (metr, OM) scală / cadran luminos

luminous efficiency (fiz) coeficient de eficacitate luminoasă, raport între fluxul luminos emis şi energia consumată, randament luminos luminous emittance, exitance (fiz) emitanță, emitanță luminoasă, radiație luminoasă specifică

luminous energy (fiz) energie luminoasă, lumină, cantitate de lumină

luminous exposure, light exposure (fiz) expunere, cantitate de iluminare

luminous flame (termo, chim, TH) flacără luminoasă

luminous-flaming semibituminous coal of high rank (met, termo) cărbune semibituminos cu flacără lungă

luminous flux (fiz) flux luminos

luminous-flux density (fiz) densitatea fluxului luminos

luminous intensity (fiz, metr) intensitate luminoasă

luminous paint (ind chim) vopsea luminescentă $/$ fosforescentă

luminous pointer (metr) (ac) indicator luminos

luminous power (fiz) intensitate luminoasă

luminous reflectance (fiz) grad de reflexie

luminous signal table (cf, met) schemă luminoasă

luminous source (fiz) sursă luminoasă

luminous spot (fiz) punct luminos

lump bloc; bulgăre; bucată; masă; grămadă; umflătură; (met) lupă, bloc de metal, lingou; (nav) şalupă portuară; ghemotoace; umflătură; $(\mathrm{ec})$ angro, en-gros, a plăti dintr-o dată; a aduna, a strânge, a pune laolaltă; a lua / considera în bloc; a concentra; a îngrămădi, a (a)cumula, a reuni; a (se) face bulgări

lump coal (met) cărbune bulgări, a aglomera

lump coke (met) cocs bucăți

lumped capacitance capacitate concentrată

lumped characteristic (mas) caracteristică compusă / generală / echivalentă

lumped constants (inf) constante localizate / determinate

lumped loading (mec, OM, T) sarcină concentrată / punctiformă

lumper (nav, transp) lucrător în port, docher

lumpish greoi, stângaci; obtuz, greoi la minte

lump lime (met) var în bulgări

lump of ore (met) bulgăre de minereu

lump ore (met) minereu în bulgări

lump slag (met) zgură-bucăti / concasată

lump sugar (alim) zahăr cubic / bucăți

lump sum (ec) sumă forfetară / globală

lumpy (material) format din bucăți mari; plin de cocoloaşe / bulgări, zgrunțuros

lunar lunar, al lunii; (fig) abstract, fără rezultat practic, fantezist

lunar caustic (chim) azotat de argint 
lunar day (metr) denumire pentru tidal day, o unitate de măsură pentru timp: 1 lunar day = 24 ore şi 50 minute

lunar distance (LD) (metr, astronomie) unitate de măsură pentru lungime egală cu distanța medie dintre Lună şi Pământ, utilizată pentru a exprima distanta unui asteroid care trece foarte aproape de Pământ

lunar month, lunation (metr) denumiri pentru intervalul mediu între două luni noi: 1 lunar month $=29,53059$ zile

lunch (alim) masă de prânz, a prânzi, a lua o gustare

lung (anat) plămân

lunge against a se izbi de

lurch legănare; a se legăna, a se clătina, (nav) ambardee, bandă bruscă / neaşteptată, unghi de înclinare (limită), a se înclina (d. navă); a sta ascuns; ascunziş

luscious (alim) suculent, zemos; mălăieț; dulce, savuros, delicios

lusec, $\mathbf{L} \cdot \boldsymbol{\mu m H g} / \mathbf{s}$ (metr, fiz) acronim pentru litermicron/second, unitate de măsură pentru putere, utilizată pentru a exprima performanța sau scurgerile din pompele de vid; 1 lusec $=1$ 1/s la o presiune de $1 \mu \mathrm{m} \mathrm{Hg} ; 1$ lusec este echivalent cu $133,3 \mathrm{~Pa} \cdot \mathrm{cm}^{3} / \mathrm{s}$, sau $133,3 \cdot 10^{-3} \mathrm{~W}$

luster luciu

luster, lustre, lustrum (metr) unitate traditională pentru timp: 1 luster $=5$ ani

lustre $(\mathrm{TH})$ lucire, luciu, lustru, sclipire; strălucire; (el) lustră; (fig) renume, faimă; (textile) lustrin; (el) lustră; candelabru, policandru; (pielărie) lustru pentru piele; v. lustre lustreless fără luciu / strălucire; mat (d. suprafețe)

lustrous lucitor, lucios, lustruit

lute (auto) chit de etanşare; (constr) material de lipit; chit, mastic, îndreptar, netezitor, lut

Lutetium (Lu) (chim) lutețiu

luting (constr) chituire; $(\mathrm{TH})$ etanșare

luting agent / material (OM) material de lipit / de etanşare

lux (Ix) (metr, fiz) unitate SI de măsură pentru iluminare luminoasă, lux

luxate (med) a luxa, a scrânti

luxation luxație, scrântitură

lye (chim) leşie

lye solution (chim) (soluție de) leşie

lying orizontal; care stă (şi aşezat)

lying ancillary time (ec, TH) timp de nefunctionare a echipamentului (pt. curățenie şi reorganizare)

lying attention time (TH, mas) timp de supraveghere a funcționării maşinii

lying down time (ec, TH) timp de nefuncționare a echipamentului (din cauza unei defecțiuni sau pt. întreținere)

lying flow diagram $(\mathrm{TH}$, ind) diagramă de flux a maşinilor

lying-time (ec) timp scurs între terminarea săptămânii de lucru și ziua plății salariilor

lyre (metr) liră

lysimeter (metr, geol) instrument de măsurare a pătrunderii apei în sol şi de determinare a materialelor dizolvate 


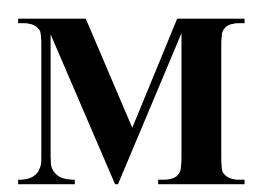

M (metr) abreviere pentru million: $\$ 500 \mathrm{M}$ pentru 500 milioane de dolari; (inf) (în context binar, memoria unui calculator) $M$ reprezintă $2^{20}=1048$ 576; (metr, mat) nume-ralul roman 1000 (a nu se confunda cu sim-bolul pemtru milion); (metr, chim) simbol pentru ,molar”

Ma (metr, geol, astronomie) simbol pentru 1 milion de ani (a - de la annum din limba latină)

mab (metr, nav) simbol pentru ,,metri (de apă) deasupra fundului (mării)" (fund de mare)

macadam (constr) (drum cu) macadam

macadamize (constr) a face un (drum cu) macadam, a macadamiza

macadam roller (constr) cilindru compresor

macaroni, $(p l)$ macaroni(e)s (alim) macaroane, spagheti; (termo, hidr) țevi cu diametru mic

macaroon (alim) procomigdală

mace (alim) nucşoară; (metr) unitate chinezească tradiţională pentru masa pietrelor şi metalelor prețioase: 1 mace $\sim 3,78 \mathrm{~g}$

macerate (alim, chim) a (se) macera; a emacia, a slăbi

maceration (alim, chim) macerare, macerație; emaciere, slăbire; istovire, sleire

maceration extract (alim, chim) macerat

Mach, mach (M, Ma) (metr, fiz) unitate de măsură pentru viteză relativă față de viteza sunetului: $1 \mathrm{Mach}\left(0^{\circ} \mathrm{C}, 1 \mathrm{~atm}\right)=331,6 \mathrm{~m} / \mathrm{s} ; 1$ Mach $\left(20^{\circ} \mathrm{C}, 1 \mathrm{~atm}\right)=343,6 \mathrm{~m} / \mathrm{s} ; 1$ Mach $($ SI standard $)$ $=295,0464 \mathrm{~m} / \mathrm{s}$

machinability (mas-un) prelucrabilitate (şi prin aşchiere); (met) prelucrabilitate (la rece sau la cald) machinable (mas-un) prelucrabil

machine (mas) maşină, aparat, dispozitiv, mecanism; (transp, mas) bicicletă, motocicletă, automobil; a prelucra, a uzina; (fig) (adm) mecanism, aparat (de stat)

machine address (inf, mas-un) adresă (de) calculator / (de) maşină, adresă permanentă

machine alphabet (inf, mas-un) alfabet pentru calculator / maşină

machine-available time (OM, mas) timp de exploatare a unei maşini, timp disponibil al maşinii

machine brazing / soldering $(\mathrm{OM}, \mathrm{TH})$ lipire tare / moale, mecanizată machine builder (mas, mas-un) constructor de maşini

machine-building industry industrie constructoare de maşini

machine-by-machine (mas-un, ec) evidența producției pe fiecare maşină-unealtă / pe fiecare utilaj de productie

machine casting (met) piesă turnată pentru construcții de maşini

machine components $(\mathrm{OM})$ piese / organe de maşini, componente

machine construction $(\mathrm{TH})$ construcție de maşini machine construction steel (OM, met) oțel pentru constructia de maşini

machine current (el) curent absorbit de maşină machine cut (mas-un) prelucrat prin aşchiere, prelucrare / tăiere cu maşină-unealtă (şi prin aşchiere)

machine cycle (autom, mas-un) ciclu al maşinii

machine element $(\mathrm{OM})$ organ / parte / element de maşină

machine department (constr, mas, TH) sală a maşinilor

machine divided (mas-un) cu gradații trasate la dispozitivul de divizare

machined parts $(\mathrm{OM})$ piese prelucrate (prin aşchiere), organe / elemente de maşini

machined plate (constr, hidr, mec, met) tablă prelucrată (mai ales prin aşchiere)

machined rib (constr, OM) nervură rabotată / prelucrată

machined sliding face (hidr, mec, OM) grindă de alunecare rabotată; glisieră / suprafață prelucrată prin aşchiere

machined surface (mas-un, OM) suprafață prelucrată (prin aşchiere)

machine element $(\mathrm{OM})$ organ / element de maşină, piesă

machine equation ( $\mathrm{TH}$, mas) ecuaţia maşinii

machine for drawing off (alim, ind chim) instalație de îmbuteliere şi agitare

machine foundation (constr) fundație pentru o maşină, instalație, utilaj etc.

machine gun (mil, OM) mitralieră

machine house (nav, ind) hala / sala maşinilor

machine industry (mas-un) industria constructiilor de maşini

machine inertia constant (mas) constantă de timp (inerțială) a maşinii

machine language (autom) limbajul maşinii

machine lathe (mas-un) strung universal

machine-limited system (autom) sistem limitat de viteza maşinii

machine loading (mas) încărcare mecanizată 
machine-made (OM, mas-un) făcut / prelucrat / mecanic / de mașină

machineman (mas-un) (lăcătuş) mecanic; mecanic, oprator

machine member $(\mathrm{OM})$ piesă / element / organ de maşină

machine mixing ( $\mathrm{TH}$, alim, constr, ind chim) amestecare mecanică

machine moulding (met) formare mecanică / cu maşina

machine oar (OM, alim, ind chim) paletă amestecătoare

machine oil (TH, T) ulei de maşină; valvolină

machine operation (mas) funcționarea mașinii, operație caracteristică maşinii

machine part $(\mathrm{OM})$ organ / element de maşină

machine plant (ind) uzină constructoare de maşini

machine programming (c, mas-un) programarea maşinii

machine revise ( $\mathrm{TH}$, mas) revizie a unei maşini machine riveting (constr) nituire mecanică

machine room $(\mathrm{TH})$ sala maşinii

machinery $(\mathrm{OM})$ piesă / organ / element de maşină; (TH, mas) mecanism, maşinărie, utilaj, instalație mecanică / de exploatare, maşini; (fig) combinație, intrigă, complot

machinery casing (nav) cămaşa / puțul maşinii

machinery house (mas, ind) hala / sala mașinilor

machinery oil (ind chim, T) ulei de maşină (prea general, rar utilizat)

machinery parts $(\mathrm{OM})$ organe / elemente de maşini, piese, subansamle (de maşini)

machine screw tap (mas-un) tarod pentru filetarea găurilor

machine shop $(\mathrm{TH})$ atelier mecanic

machine short tap (mas-un, OM) tarod scurt de maşină

machine sorting $(\mathrm{TH}$, mas) sortare mecanică

machine spindle (mas-un) arbore de maşină

machine steel (met) oțel de construcții (de maşini), oțel de scule (atenție la text)

machine straightening (met) îndreptare mecanică / cu maşina

machine tap (mas-un) tarod / burghiu de maşină machine time ( $\mathrm{TH}$, mas-un) timp mecanic / de maşină

machine time lost due to mechanical failure (TH, mas) timp pierdut din cauza defectării mecanice

machine-tool (mas-un) maşină-unealtă

machine-tool control (autom) comandă a maşiniiunelte

machine-tool spindle (mas-un, OM) arbore al maşinii-unelte machine vise (mas-un, OM) menghină de maşinăunealtă

machine welding (met) sudare automată

machine work (mas-un) prelucrare mecanică; lucru mecanic; (ind) uzină constructoare de maşini machining (mas-un) prelucrare (mecanică), uzinare, aşchiere

machining allowance (constr) toleranță de fabricație / de uzinare / de prelucrare; (masun) adaos de prelucrare

machining operation (mas-un) prelucrare / operație pe maşini-unelte

machining property / quality (mas-un) parametri de prelucrabilitate, calitate / calități ale prelucrării (pe o anumită maşină-unealtă)

machining step (mas-un) etapă / grad de prelucrare, trecere (la aşchiere)

machining time (mas-un) timp / durată de prelucrare / pentru o operație

machinist $(\mathrm{TH})$ maşinist, operator, mecanic, lăcătuş

machinist's tools (TH) scule de lăcătuşerie

mackerel (alim, iht) macrou, scrumbie

mackintosh (plast) manta de cauciuc

mackled sheets (mediu, ind chim) maculatură

macro-acicular structure (met) structură macroaciculară

macrobiotic (biol) macrobiotic

macro(-)crystalline (met) macro-cristalin, cu grăunte mare (d. structura aliajelor)

macroetching (met) gravare / corodare brută / grosieră

macro-examination (met, metr) examinare (cu ochiul liber) (şi a macrostructurii)

macrograin (met) grăunte mare (cristalin)

macro-granular structure (met) structură macrogranulară (d. aliaje)

macrography (met, metr) macrografie

macromolecular (chim) macromolecular

macromolecule (chim) macromoleculă

macropore (met, fiz, plast) macropor

macroscopic(al) (fiz, materiale) macroscopic, macrostructural

macroscopy (met) cercetarea / analiza macroscopică a structurii (d. aliaje)

macrosegregation (met) macrosegregare (d. aliaje) macrostructure (met) macrostructură, macrogranulație (d. aliaje)

maculate a păta, a macula

maculation pătare, maculare

made făcut; instruit; creat, inventat

made of $(\mathrm{TH})$ făcut / format / alcătuit / prelucrat din

made-up confecționat, de gata; inventat; fabricat; artificial 
maf, Maf (metr) simbol pentru pentru 1 milion de acre feet: $1 \mathrm{Maf} \sim 1,233510^{9} \mathrm{~m}^{3}$

magazine (mas-un) buncăr, magazie de alimentare (cu scule sau semifabricate) la maşini automate; (nav) magazie de muniție; (met) magazie de matrițe; revistă, magazin, publicație periodică; $(\mathrm{TH})$ magazie, depozit, magazin

magazine clip (OM, met) fâşii de încărcare / de ambalare; (mil, mas-un) încărcătoare (pentru arme, pentru maşini-unelte automate)

magazine creel (ind) rastel de magazie

magazine feed (mas-un, TH) alimentare (cu piese brute) din magazie, sistem de alimentare cu magazie

magazine mechanism (mas-un) dispozitiv de încărcare multiplă

magazine tool holder (mas-un) bucşă pentru fixarea cuțitelor, port-cuțit (la strung revolver), port-cuțit cu mai multe posturi de prindere

magenta (chim) fucsină; purpuriu

maggot (zool) larvă de insectă, vierme; (fig) excentric

magic eye (fiz, opt) celulă fotoelectrică

magisterial (jur) judiciar; juridic; de magistrat; de magistru

magistracy (jur, adm) magistratură

magistral (jur) judiciar; juridic; de magistrat; de magistru; profesoral

magistrate (jur, adm) judecător, magistrat; (adm) funcționar (public)

magnaflux (inspection) method (met) procedeu / metodă de cercetare magnetică

magnalium (aluminium-magnesium alloy) (met) magnaliu (aliaj Al-Mg)

magnate magnat; potentat

magnesian (chim) care conține magneziu

magnesis (chim) oxid de magneziu; magnezie

magnesic (chim) magnezic

magnesite (chim) carbonat de magneziu; (minrl) magnezit

Magnesium (Mg) (chim) magneziu

magnet (el, fiz) magnet; (fig) punct de atractie

magnet carrier (el) port / suport de magnet

magnet case /casing (fiz) carcasă / încasetare magnetică

magnet chuck (mas-un) mandrină magnetică

magnet cradle (el, OM) port-magnet, suport de magnet

magnet-holder (el, OM) port-magnet, suport de magnet

magnet housing (el, OM) carcasă pentru magnet magnetic(al) (el) magnetic

magnetic after-effect (autom, fiz) postacțiune magnetică magnetic ageing (fiz) stabilizare magnetică / în câmp magnetic

magnetic axis (el, fiz) axă magnetică

magnetic brake (auto) frână magnetică

magnetic bridge (el) punte magnetică

magnetic compass (fiz, metr) busolă; (nav) compas

magnetic core (autom) tor magnetic, miez (de bobină)

magnetic disk spindle $(\mathrm{OM})$ axul discului magnetic

magnetic dispersion (fiz) scăpări magnetice, dispersie magnetică

magnetic domain (fiz) domeniul magnetic (al unui material)

magnetic drill (mas-un) burghiu cu mandrină magnetică

magnetic element (hidr, OM) element filtrant, care nu reține decât particule feromagnetice; (el) magnet, element cu proprietăți magnetice

magnetic fatigue (autom, materiale) postactiune magnetică, oboseală cauzată de funcționarea în câmp magnetic (şi variabil)

magnetic field (el) câmp magnetic

magnetic field flux (el) flux de câmp magnetic

magnetic field strength (el) forță magnetică, intensitate de câmp magnetic

magnetic figure (el) spectru (de linii de forță magnetică)

magnetic flow water (metr, OM, hidr, fiz) debitmetru magnetic

magnetic fluid (fiz) fluid magnetic

magnetic flux (fiz) flux magnetic

magnetic flux density (metr, fiz, el) densitate de flux magnetic

magnetic flux intensity (el) intensitatea fluxului magnetic

magnetic flux saturation (fiz) susceptibilitate magnetică

magnetic flywheel (auto, OM) volant magnetic, magnet construit în volant

magnetic force (el) forță magnetică, intensitate de câmp magnetic

magnetic hardness comparator (metr, materiale) durometru care funcționează prin compararea răspunsului materialului testat în câmp magnetic, cu un semnal etalon

magnetic holding device (mas-un, OM, el) dispozitiv / masă de fixare magnetică (a sculei sau a semifabricatului); (metr, OM) dispozitiv magnetic de fixare

magnetic holding-down plate (el, OM) placă de strângere (cu acționare) magnetică magnetic hysteresis (el) histerezis magnetic 
magnetic hysteresis loop (el, fiz) buclă / ciclu de histerezis, ciclu de magnetizare

magnetic induction (el) inducție magnetică magnetic insert (hidr, fiz, OM) buşon magnetic (pentru reținerea particulelor feromagnetice); (metr, el) inserție cu proprietăți magnetice magnetic inspection (fiz, metr, TH) defectoscopie magnetică

magnetic iron (el) magnet natural; (met) fier moale magnetic iron-ore (met, minrl) magnetit, minereu feromagnetic

magnetic leakage (el, fiz) flux magnetic de dispersie, dispersie / fugă magnetică, scăpări magnetice magnetic memory scaling unit (electr, c, metr) element de contorizare cu memorie magnetică magnetic needle (fiz, OM) ac magnetic / de busolă magnetic permeability (el) permeabilitate magnetică

magnetic pick-up (metr, fiz) traductor / captor / receptor magnetic

magnetic plug ignition (el) aprindere prin bujie magnetică

magnetic pole (el, fiz) pol magnetic

magnetic proximity sensor (metr, fiz) senzor de distanță, pe baza răspunsului elementului mobil într-un câmp magnetic

magnetic repulsion (el, fiz) respingere magnetică magnetic saturation (el, fiz) saturatie magnetică magnetic screening (metr, fiz) ecranare magnetică

magnetic separation (met, alim, ind chim) separare magnetică

magnetic separator (el, met, ind chim) separator magnetic

magnetic steel (met) oțel magnetic

magnetic steel bar (el) bară de oțel magnetic

magnetic susceptibility (el) susceptibilitate magnetică

magnetic tester (metr, fiz) magnetometru, histerezimetru, permeametru

magnetic time relay (el, autom) releu magnetic temporizat

magnetic transition temperature (el, fiz, materiale) punct Curie; temperatură de tranziție magnetică

magnetic tube of force (el) tub magnetic de forță magnetic valve (autom, OM, hidr) ventil magnetic

magnetic viscosity (fiz) vâscozitate magnetică

magnetic wave (fiz) undă magnetică

magnetisation (el, materiale) magnetizare

magnetism (fiz) magnetism

magnetite (minrl) magnetit

magnetizable (fiz) magnetizabil magnetization (el, fiz) magnetizare magnetization curve (el) curbă de magnetizare magnetize (fiz) a magnetiza

magnetizing force (el, fiz) forță magnetică, intensitate de câmp magnetic

magnetic keeper (el, fiz) armătură / suport de magnet

magneto (auto) magnetou; (el) inductor

magneto armature (auto) indus de magnet

magneto bearing (auto, $\mathrm{OM}$ ) rulment de magnetou magneto booster (auto) magnetou de pornire magneto breaker (auto, electr) ruptor de magnet magneto-breaker cam (auto, $\mathrm{OM}$ ) cama ruptorului de magnet

magneto (carbon) brush (auto) perie de carbon, de magnet

magneto coupling (auto) cuplajul magnetoului magneto-dynamo (auto) magnet-dinam combinat magneto ignition (auto) aprindere prin magnetou magnetometer (metr, fiz) magnetometru

magnetometry (metr, fiz) magnetometrie magnetomotive force (M.M.F., MMF) (fiz) forță magneto-motoare (f.m.m., fmm)

magneton (fiz) magneton

magneto spanner (el, auto) cheie de magnetou magnetostarter (el, auto, mas) demaror magnetic magnetostrictive relay (el) releu magnetostrictiv magneto timing (auto) reglarea avansului aprinderii la magnet(ou)

magnetron (fiz) magnetron

magnet separator (mas, fiz) separator magnetic magnet steel (met) oțel magnetic / pentru magneți

magnet support (el, OM) suport de magnet; port-magnet

magnet valve (autom, hidr, OM, fiz) ventil magnetic, electro-ventil

magnet yoke (el) jug magnetic

magnico (Mg-Ni-Co-alloy) (met) magnico (aliaj $\mathrm{Mg}-\mathrm{Ni}-\mathrm{Co})$

magnification (fiz, metr, opt) mărire / grosisment (în optică); amplificare; exagerare

magnification coefficient (autom) coeficient de pătrundere

magnifier (fiz) lupă, amplificator

magnify a mări, a amplifica; a exagera

magnifying glass / lens (fiz, opt) lupă

magnifying power (fiz, metr, opt) mărire, grosisment

magnitude (TH, OM) mărime, dimensiune; importanță, însemnătate; magnitude (mag) (metr, astronomie) unitate pentru exprimarea strălucirii aparente a stelelor, planetelor sau a altor corpuri cereşti; (metr, geol, fiz) unitate pentru 
măsurarea intensității cutremurelor; (mat, fiz)

$\sim$ of a vector modulul unui vector

magnum (metr, alim) unitate de măsură pentru volum (pentru vin): 1 magnum $=1,51$

magnum opus (alim) operă principală, capodoperă mahnd (metr) unitate tradițională arabă, de măsură pentru masă: 1 mahnd $\cong 925 \mathrm{~g}$

mahogany (silv) (lemn de) mahon

maiden nut $(\mathrm{OM})$ piuliță principală (spre deosebire de contrapiuliță)

mail poştă, corespondență; a expedia prin poştă

mail bag sac de poștă

mail boat (nav) navă de poştă

mail box $(\mathrm{OM})$ cutie poştală

mail carriage (cf) vagon poştal

mailing list listă cu adrese poştale

mail order comandă (de mărfuri) prin poştă

mail train (cf) tren poştal

mail van (auto) furgonetă poștală

main (geogr) uscat, continent, insulă principală; (constr) canal principal de scurgere, corp principal de clădire;(el) cablu de distribuție; (TH) conductă principală / magistrală; (cf) linie principală; principal, esențial, mare, important; fundamental, de primă importanță; predominant

main adjustement (autom, el) reglaj principal

main anchor (nav) ancoră principală

main arbor $(\mathrm{OM})$ arbore principal

main axis of inertia $(\mathrm{OM}, \mathrm{mec})$ axa principală de inerție

main bang (auto) impuls de pornire

main barrel (of carburettor) (auto) gură principală de aer (la carburator)

main bearing (auto, OM) lagăr principal (şi de arbore cotit) crapodină

main bearing shell (auto, OM, termo) cuzinetul lagărului palier

main blast line (met) conductă principală de aer (la furnale)

main boiler (mas, termo, OM) cazan principal

main boom (nav) ghiul mare

main brake airpipe (cf, OM, hidr) conductă generală a frânei

main brake cylinder / braking (auto, OM) cilindru principal de frână

main bush (mas-un, OM) bucşă fixă pentru strângerea garniturii, contrabucşă

main cable duct (el, constr, OM) canalizare țeavă (de protecție) a cablului principal

main carriage (mas-un) sanie longitudinală a căruciorului

main check valve (OM, hidr) ventil principal de închidere main clutch (cf) cuplare principală; $(\mathrm{OM})$ cuplaj principal

main concept concept / principiu de bază / fundamental / important

main connecting-rod (mas, OM, termo) bielă principală

main course (nav) vela mare; (alim) fel principal

main crank $(\mathrm{OM})$ manivelă principală

main crosshead $(\mathrm{OM})$ capul de cruce al bielei principale

main cutting-edge (mas-un) tăiş principal, muchie principală (la scule)

main deck (nav) punte principală

main direction (cf, mat, $\mathrm{TH}$ ) direcție principală

main drive $(\mathrm{OM})$ transmisie principală

main drive shaft (mas-un) arbore principal al acționării

main engine (mas) maşină / motor principal(ă)

main file (autom) registru de bază / principal

main foundation (constr) talpă / bază de fundație, fundație principală / de bază

main frame (nav) cuplu maestru

main framework (auto, cf) cadru principal

main fuel filter (auto, OM) filtru principal de combustibil

main fuse (el) siguranță principală

main gear (mas) mecanism principal de acționare (şi cu angrenaje)

main gear drive $(\mathrm{OM}$, mas) acționare principală, cu angrenaje

main generating station (el) centrală / uzină electrică principală

main governor (autom, el) regulator principal

main hoisting tackle (mas, transp) mecanism principal de ridicare

main jet (hidr) jet principal; (auto, termo) jiclor principal

main journal $(\mathrm{OM}, \mathrm{T})$ fus de reazem, fus principal (şi la arborele cotit), lagăr principal

main leaf of spring (auto, OM) lamă / foaie principală de arc în foi

mainly $(a d v)$ în special, îndeosebi; mai ales

mainmast (nav) arbore mare, arbore prova / pupa main motion (mec, mas-un) mişcare principală / de lucru / de aşchiere

main operating rod (constr, hidr, mec) tijă de suspendare (la stavilă, clapetă echilibrată cu contragreutate)

main part $(\mathrm{OM})$ parte / piesă / organ / element $\operatorname{principal}(\breve{a})$

main pivot (constr, hidr, mec, OM) ax de rotatie, pivot central

main plate of spring (auto, OM) lamă / foaie principală de arc în foi 
main (pneumatic) receiver (hidr, OM) rezervor principal de aer / de gaz

main road (constr) magistrală, stradă principală, şosea; (cf) cale ferată / linie principală

mains (el, hidr) conducte / linii magistrale; (el) rețea / sector de alimentare cu electricitate

mainsail (nav) vela / randa mare

mains connection (el, hidr) alimentare de la rețea, racord la rețea

main section (nav) secțiune maestră; (OM) secțiune principală (şi în desen tehnic)

main shaft $(\mathrm{OM})$ ax / arbore principal

mains hold (el) acroşare a rețelei; sincronizare cu frecventa retelei

main slide valve (mas-un, OM, hidr) sertar / supapă principal(ă)

main spindle (OM, mas-un) arbore / ax principal

main spring $(\mathrm{OM})$ arc / resort motor; (fig) cauză principală

mains supply (el) alimentare de la rețea

mainstay (nav) straiul arborelui mare, parâmă de susținere a catargului; (fig) sprijin de nădejde / principal

maintain a menține, a păstra (ordinea etc.); a întreține; a susține, a afirma; a susține (o competiție etc.); a întreține (relații, maşini etc.); (TH) a face operații de mentenanță; a asigura (cuiva) mijloace de existentă; a întreține (un copil, o familie); a susține (o cauză etc.); a păstra, a conserva (un produs, o maşină etc.); a confirma o afirmație etc.; correspondence a întreține corespondență

maintainable (mas) care se poate repara / întreține / menține; (mil) care se poate menține / apăra; care se poate susține (d. o opinie etc.)

maintainability (mas) mentenalibilitate

maintaining constant (mas, $\mathrm{TH}$ ) mentinere la o valoare constantă; (autom) stabilizare

maintain pressure (hidr, mec) a menține presiunea maintain stationary $(\mathrm{TH})$ a menține staționar / constant)d. un proces, un parametr etc.)

maintenance apărare (a drepturilor etc.); conservare; (TH, mas) întreținere, conservare, păstrare, susținere, menținere, mentenanță; (auto) service, întreținere (a autoturismului); (ec, adm) menținere, păstrare (a ordinii, a unui serviciu etc.); susţinere; software $\sim(\mathrm{c}$, inf) activitate de depanare, dezvoltare şi documentare a sistemului de programe

maintenance chart (nav, TH, mas) jurnal de evidență a întreținerii tehnice, schemă de întreținere / de mentenanță

maintenance charge (auto, ec) cheltuieli / speze de întreținere / pentru mentenanță maintenance conditions $(\mathrm{TH})$ condiții de realizare a mentenanței

maintenance control (autom, ec, TH) reglarea / verificarea / inspectarea (rezultatelor) întreținerii / mentenanței

maintenance costs / expenses (ec, TH) costuri / cheltuieli / speze de întreținere / de mentenanță

maintenance event $(\mathrm{TH})$ acțiune de / inclusă în mentenanță

maintenance indirect costs $(\mathrm{TH})$ costuri / cheltuieli indirecte cu mentenanța / cu servicii / secții / departamente auxiliare producției directe

maintenance instruction $(\mathrm{TH}$, mas) instrucțiuni de întreținere / de mentenanță

maintenance level $(\mathrm{TH}, \mathrm{ec})$ nivel al mentenanței (determinat pe baza dificultătiii executării acesteia, a valorii cheltuielilor, a calificării personalului, dar şi funcție de cine execută lucrarea de mentenanță, din întreprindere sau din afara ei etc.)

maintenance log (nav, TH) jurnal de evidentă a întreținerii tehnice / a operațiilor de mentenanță / verificare / reglare

maintenance manual $(\mathrm{TH})$ manual de întreținere / de mentenanță

maintenance moving parking ring (hidr, OM) inel mobil de etanşare pentru închidere la revizie / verificare (la vana sferică pt. turbine etc.)

maintenance period $(\mathrm{ec}, \mathrm{TH})$ termen de garanție a programului de mentenanță, perioada de timp necesară mentenanței, perioada în care se asigură mentenanța (unui utilaj, de către furnizor / proprietar)

maintenance plan ( $\mathrm{TH}$, mas) plan / program de mentenanță, organizare a mentenantei

maintenance ratio $(\mathrm{TH}$, mas) raport de mentenanță (egal cu raportul dintre numărul de oremuncitori şi numărul total de ore ca durabilitate totală a utilajului (estimată sau cunoscută) maintenance seating ring (hidr, mec, $\mathrm{OM}$ ) inel fix de etanşare, pentru închidere la revizie / verificare (la vana sferică pentru turbine)

maintenance section $(\mathrm{TH}$, ind) secție de întreținere / de mentenanță

maintenance service $(\mathrm{TH}$, ind, mas) serviciu de întreținere / de mentenanță

maintenance schedule (auto, mas) plan de mentenanță / de întreținere

maintenance significant $(\mathrm{TH})$ element / subansamblu / modul (considerat) important pentru siguranța, fiabilitatea și/ sau impactul financiar asupra întregului sistem tehnic, semnificativ pentru mentenanță (d. un subansamblu, un modul, un element al sistemului tehnic) 
maintenance task (TH, mas) sarcină / obligație / în-datorire / efort de mentenanță

maintenance test $(\mathrm{TH}$, metr, mas) încercare / test în exploatare, test de mentenanță / după efectuarea mentenantei

maintenance time (TH) timp de mentenanță

maintenance tools (mas-un) scule pentru lucrări de reparație / de mentenanță

maintenance work $(\mathrm{TH})$ întreținere curentă, lucrări de mentenanță

main top (nav) gabia mare

main topgallant mast (nav) arboret mare, arboretul zburătorului mare

main topmast (nav) arborele gabier mare

main topsail (nav) gabier mare, vela gabierului mare

main trunk sewer (hidr, OM) colector principal main valve $(\mathrm{OM}$, hidr) robinet principal

main voltage fluctuations (el) variațiile tensiunii rețelei / sectorului

main yard (nav) verga (arborelui mare)

major mai mare; major, mare, de mare importanță; semnificativ; persoană majoră

majorant (mat) funcție majorantă, majorant

major axis axa mare; (nav) axă de ruliu; (OM) arbore principal; (mat) axa mare (a elipsei etc.)

major components (c, autom) componente fundamentale / de bază

major diameter $(\mathrm{OM})$ diametrul exterior al filetului (la şurub)

major feedback (autom, mas) reacție principală de feedback

major in a se specializa in

majority (pol, adm, ec) majoritate, cea mai mare parte; (jur) majorat

major overhaul (repair) (auto) revizie / reparație generală / capitală

major repair $(\mathrm{TH})$ reparație capitală / cu impact deosebit asupra producției / utilajului etc.

major semi-axis (fiz) semiaxă mare

majuscule (literă) majusculă

make formă, structură fason; (anat, textile) talie (a unui om); constituție; alcătuire; (textile) tăietură, linie (a hainei), croială (a unei rochii etc.); caracter, fel, tip, gen, calitate; (TH) fabricație, produs, producție; (el) închidere (a unui circuit); marcă (a unui produs); alcătuire; a face, a fabrica, a construi, a confectiona, a produce, a conecta, a executa; a crea, a elabora; a destina; a transforma în; a sili; a determina; a atinge, a se ridica la; a reprezenta, a înfățișa; a face să arate / pară (într-un anumit fel); a cauza, a prilejui, a ocaziona; a pune în valoare, a scoate în evidență; a scrie; a aranja; a prepara; a formula; $(f i g)$ a începe; a câştiga; a evalua; a aprecia; a merge; a nimeri; a avea un efect / un rezultat; a deveni; a se preface că; a se pregăti să; (mat) a face, a fi egal cu; a câştiga bani; a realiza; a căpăta; a considera; a determina, a hotărî, a obliga; a încerca, a vrea (să facă ceva); a se întinde, a se extinde, a acoperi o suprafată ; (nav) a ajunge într-un punct dorit, a ajunge în apropierea (unui port etc., d. o navă); (nav, geogr) (d. maree) a începe să urce sau să scadă, a creşte (d. flux); at $\sim$ în circuit (şi de fabricație etc.); of Romanian $\sim$ de fabricație românească

make a claim $(\mathrm{ec})$ a ridica o revendicare, a revendica

make a fortune a face avere

make against a fi defavorabil, a fi în defavoarea; a face rău; a fi dăunător pentru

make a living a-şi câştiga existența

make allowance for a ține seama de

make amends for a despăgubi pentru; a compensa

make a motion a face o miscare

make an attempt a face o încercare

make-and-brake current (auto, el) contact de întrerupere

make-and-brake (device) (auto, el) contactordisjunctor

make-and-brake mechanism (autom) întrerupător comandat

make answer a răspunde, a da un răspuns

make a rough calculation $(\mathrm{TH})$ a estima, a face un calcul / o socoteală în linii mari

make a screwed joint (mas-un) a asambla o îmbinare în şuruburi, a face o asamblare cu şuruburi

make a start a porni la drum

make away with a se debarasa de; a face să dispară (prin omor); a înstrăina (valori, bunuri etc.); a risipi

make-before-break contact (el) contact eşalonat, precontact

make believe (to / that) a se preface că

make complaint a se plânge, a face o plângere / o reclamație

make contact (el) contact de lucru; a face contact

make dead (el, mas) a deconecta, a tăia / întrerupe contactul

make-do $(\mathrm{TH})$ provizoriu; care înlocuiește (ceva)

make fast (mas-un) a fixa / lega (strâns), a îmbina, a întări; (nav) a se lega, a amara

make for a se îndrepta spre; a face posibil; a mijloci (ceva), a înlesni; (nav) a guverna pe, a pune capul pe; a fi favorabil pentru, a fi în avantajul (cuiva)

make free with a fi îndrăznet fată de 
make fun / game of a râde de; a-şi bate joc de make good (met) a îmbunătăți, a înnobila; (TH) a repara; a reduce (o cheltuială); a înlocui (un lucru pierdut); a îndeplini (un angajament); a dovedi (o afirmație etc.); a săvârşi (o tentativă); a ocupa şi a deține (o poziţie); a se reabilita make good / bad weather a nimeri vreme bună / rea

make haste a se grăbi; a înainta

make head against a ține piept

make heavy a îngreuna (şi funcționarea unei maşini etc.)

make into (chim) a se preface / transforma în

make lean (TH, OM) a slăbi (şi o asamblare, o strângere etc.); (chim) a dilua, a sărăci (d. soluții, minereuri etc.)

make light of a trata cu uşurință; a da puțină importanță

make like a face ca, a imita pe

make money a câştiga bani

make much of a face mare caz de

make no doubt (of / that) a nu se îndoi (de / că)

make noise a face zgomot

make of a crede (despre)

make off a pleca

make one's escape a se salva, a evada

make out a înțelege cu greutate; a elibera (un act), a întocmi, a emite (un act); a redacta (un proces verbal, un document, o listă, un cont etc.); (TH) a identifica, a recunoaște; a pretinde, a susține; a dovedi, a demonstra; a considera, a crede; a redacta; a forma; a compune (din diferite elemente); a scoate în evidență; a demonstra; a înțelege, a sesiza sensul; a descifra

make out for a avea legături / relații cu

make over into a transforma, a preface în

make over to a transfera (o proprietate etc.) (la); a ceda (cuiva)

make poor (alim, met, ind chim) a dilua, a sărăci (o soluție / un amestec)

maker (mas-un) furnizor, producător, fabricant, constructor, executant

makeready (mas-un) a pregăti (de funcționare etc.) maker's name plate (mas) plăcuța fabricii constructoare

make sail (nav) a naviga

makes-and-breakes (OM, TH) operație de înșurubare-deşurubare

makeshift (TH) improvizație, (înlocuitor) provizoriu, temporar; (folosit ca) expedient, paliativ

make shift to a se înțelege asupra

make spring (el) resort de contact

make tight $(\mathrm{TH})$ a ermetiza, a închide etanş, a etanşa, a face etanş make time (el) durata de închidere / de anclanşare make true (mas-un, OM, metr) a îndrepta, a regla, a aduce la zero, a regla (un aprat de măsură etc.)

make-up fard, machiaj; invenție, născocire; alcătuire, structură; compoziţie; construcție; constituție; (poligrafie) paginație, machetă (de carte etc.), tehno-redactare; (auto) admisie ulterioară / după punc-tul mort; (TH) reîncărcare (cu semifabricate, ca recondiționare etc.); (termo) apă adăugată la boilere pentru compensarea pierderilor

make up a face; a aplana (o divergență); a farda, a (se) machia; a inventa în întregime (o poveste etc.), a născoci; a prepara (pe baza unei rețete); a completa; (ec) a plăti (o datorie), a înapoia; (textile) a confecționa (o haină), a coase; (ec) a aduna, a strânge (o sumă de bani etc.), a balansa (conturi), a încheia (un bilant); a împacheta, a face un pachet din; (TH) a aranja, a finisa, a monta, a confectiona (d. constructii metalice etc.); (tipografie) a culege, a face şpaltul, a pagina, a face macheta, a forma, a alcătui; a întocmi; a face (o listă, un document etc.); a încheia; a pune capăt (unei neânțelegeri); a pune la cale (o împăcare etc.); a compensa; a repara (o pierdere etc.); a completa (un număr etc.); (ec) a acoperi un deficit

made up according to preparat / făcut / executat după (norme, instrcuțiuni, rețetă etc.)

make-up for a recupera; a recompensa, a fi în compensație pentru; a înlocui

make war (mil) (şi fig) a se război

make water (nav) a lua apă; (nav, hidr, OM) a avea o spărtură

make way a avansa

make way for smb. a face loc cuiva, a se da la o parte pentru a putea trece

make-weight $(\mathrm{TH})$ adaos (de prelucrare, de compensare a pierderii în greutate etc.), supliment; câtime (pentru completare)

making facere, creare; construire; alcătuire, întocmire; mână de lucru; devenire; $(\mathrm{TH})$ fabricație, executie, constructie, confectionare

making capacity (autom) putere de închidere; (TH) capacitate de producție

making current (el) curent de închidere

making good (hidr, mec) refinisare, care este refinisat / retuşat

making mould (met) formare

makings (ec) câştiguri, venituri; aptitudini, înzestrare, talente

making-up alcătuire, formare, compunere (şi a trenurilor; confectionare (textile) 
making-up room (plast) secție de asamblare mål (metr) măsură în limba norvegiană şi denumire pentru diferite unități de măsură: pentru suprafață (de teren): 1 mål $=100 \mathrm{~m}^{2}$, pentru volum: 1 mål $=101$

malachite (minrl) malahit

malajusted (OM, TH) prost adaptat / ajustat / reglat, inadaptabil

maladjustment (OM, TH) adaptare / ajustare defectuoasă; inadaptabilitate

maladministration (ec, adm) proastă administrare / administrație / conducere

maladroit stângaci, neîndemânatic; lipsit de tact

maladroitly $(a d v)$ cu stângacie / neîndemânare; fără tact, (în mod) stângaci

malady (med) boală, maladie

malapropos nepotrivit, inoportun; cuvânt / act nepotrivit / inoportun

malax (alim, constr, chim) a malaxa, a amesteca

malcontent, malcontented nemulţumit, nesatisfăcut

male collar (met, OM) patriţă

male die (mas-un, plast) poanson

male fitting $(\mathrm{OM})$ piesă cuprinsă într-o asamblare (şi filetată)

male friction cone (mas-un, $\mathrm{OM}$ ) con interior al ambreiajului de fricțiune

male gauge (mas-un, metr) calibru tampon / de interior

male member (met) poanson

male mould (mas-un, plast) matriță pozitivă

male (screw) thread (OM) filet exterior

malfunction (autom) deranjament, defect; $(\mathrm{TH}$, mas, autro) funcționare defectuoasă, a funcționa defectuos; (TH) defectiune

malfunction indicator (auto) indicator pentru funcționare defectuoasă

malfunctioning $(\mathrm{TH}$, mas) funcționare cu întrerupere, funcționare nesatisfăcătoare / defectuoasă

mall (met) baros

malleability (met) maleabilitate, plasticitate, deformabilitate, fasonare, forjabilitate; adaptabilitate

malleability test (met) încercare / test de maleabilitate

malleability when cold (met) forjabilitate la rece, deformabilitate la rece

malleable (fiz, met) maleabil, ductil, flexibil, deformabil, forjabil; adaptabil

malleable alloy (met) aliaj maleabil / deformabil malleable annealing furnace (met) cuptor pentru maleabilizare

malleable brass (met) alamă / aliaj $\mathrm{Cu}-\mathrm{Zn}$ maleabil( $\breve{a})$ malleable casting (met) piesă turnată din fontă maleabilă

malleable cast iron (met) fontă maleabilă / recoaptă

malleable hard iron (met) fontă maleabilă dură malleable iron (met) fier forjabil, fontă maleabilă malleable iron foundry (met) turnătorie de fontă maleabilă

malleabl(e)ize (met) a maleabiliza, a face un tratament de maleabilizare

malleableizing (met) maleabilizare

malleableizing anneal (met) recoacere de maleabilizare

malleableizing oven / furnace (met) cuptor de maleabilizare

malleable white iron (met) fontă maleabilă albă

mallet mai (şi de lemn); (mas-un) ciocan de lemn; (met) bătător-îndesător

mall mane (met) baros

malnutrition (med, alim) subnutriţie, alimentatie defectuoasă

malobservation (mas-un) greşeală de observare malodorous rău / urât mirositor

malpractice incompetență (în serviciu), abatere de la îndatoririle de serviciu; (jur) infracțiune, delict; tratament greşit

malt (alim) malț; a malțifica

malt dryer / drying installation (alim) uscător de malț, instalație de uscare a malțului

Maltese cross (OM) cruce de Malta

Maltese-cross mechanism (OM) mecanism cu cruce de Malta

Maltese-cross transmission (mas) transmisie cu cruce de Malta

malt-extract (alim) extract de malt

malt-kiln (alim) uscător / cuptor de malț

maltose (chim) maltoză

malversation (ec, jur) delapidare, fraudă; abuz

mammiferous (zool) mamifer

man, $(p l)$ men bărbat, om, adult; ființă omenească, persoană, individ, ins

manage manej (pt. cai); (ec, adm) a conduce, a dirija, a coordona, a mânui, a guverna; a drege; (ec) a manageria, a gospodări, a administra (o întreprindere, firmă etc.), a se descurca; a rezolva, a izbuti, a face față la; a supraveghea; a duce la capăt / la bun sfârşit, a reuşi (să facă ceva); (nav) a cârmui (un vas); a manevra; a conduce (o maşină etc.); a stăpâni, a ține în frâu; a îmblânzi (un animal); a mânui, a folosi (o unealtă)

manageability, manageableness capacitatea unui sistem de a fi condus / manageriat / administrat, maniabilitate (a unui sistem tehnic); posibilitate 
de realizare / efectuare; (fig) docilitate, supunere; flexibilitate

manageable maniabil, uşor de mânuit / de condus / de organizat; realizabil, posibil; docil, ascultător; înțelegător, flexibil; acomodabil

management (ec, adm, TH) management, organizare, exploatare, administrație (a unei întreprinderi, firme etc.), serviciu, secție de exploatare, direcție, dispoziție, conducere (a uneri afaceri), administrare, gospodărire, direcție, directori, colectiv de conducere; (TH) mânuire (a unui instrument); abilitate; talent de conducător; iscusință, pricepere, dibăcie, îndemânare; orientare; îmblânzire (a unui animal); intrigă, uneltire

management expenses (ec) cheltuieli de administrație şi de regie / pentru management

management science ştiința managementului, management

manager (ec, adm) manager, conducător, director, administrator, gospodar; persoană care conduce o actiune; (teatru) impresar

manageress (ec, adm) manager (femeie, în context), conducătoare, directoare, administratoare

managerial (ec, adm) managerial, de conducere

managership conducere; funcție de conducere / de manager / de conducător / de director / de impresar

manage to a se înțelege să, a cădea de acord să; a se pricepe să; a reuşi să; a găsi mijlocul să

manage with blade (hidr, mas) a monta pale (pe rotorul turbinei)

managing (ec, adm) managerial, de conducere, de direcție; energic, activ, gospodar, întreprinzător; care conduce / administrează / manageriază

managing board (ec) consiliu / comitet de conducere / administratie

managing director $(\mathrm{ec})$ director / manager general (de fabrică)

managing staff $(\mathrm{ec})$ personal de conducere

mandate mandat, procură, împuternicire; ordin, dispoziție; a delega; a mandata, a acorda un mandat pentru

mandatory împuternicit, care are un mandat; (amer) obligatoriu, constrâns, forțat; mandatar

mandel (metr) unitate germană pentru cantitate: 1 mandel $=15$ (bucăţi)

mandrel, mandril (constr, OM, met) dorn (şi de echilibrare), mandrină, fus, poanson, montură, târnăcop

mandrel block (mas-un) suport de introdus dornul (în gaura piesei de prelucrat)

mandrel for shaping machine (mas-un) dorn port-freză mandrel press (mas-un) presă de mandrinat, presă de demontat şi montat piese de prelucrat pe dorn

mandrel rod (OM, mas-un) tija mandrinei

mandrel work (mas-un) prelucrarea pieselor pe dorn / cu ajutorul unei mandrine

maneuverability (mas, auto) manevrabilitate (la vehicule de orice fel)

manganate (chim) manganat

Manganese (Mn) (chim) mangan

manganese addition (met) adaos de mangan

manganese alloy (met) aliaj pe bază de mangan

manganese bronze (met) bronz cu mangan

manganese concentrate (met, chim) concentrat de mangan

manganese-killed steel (met, chim) oțel calmat cu mangan

manganese ore (met) minereu de mangan

manganese steel (met) oțel (aliat cu) mangan

manganic (chim) manganic

manganiferous (chim, met) cu conținut de mangan, manganos

manganin resistance (el) rezistență din fir de manganină

mange (med) râie, scabie

mangel-wurzel (agr) sfeclă furajeră

manger (agr) iesle, troacă

mengle $(\mathrm{OM})$ calandru; a sfâșia, a rupe în bucăți; (med) a mutila; a denatura; a deforma (pronunțând greşit)

mangle gear $(\mathrm{OM})$ angrenaj cu fusuri / cu role

mangle roll (met) rolă de îndreptat, maşină cu role de îndreptat

mangling $(\mathrm{TH})$ cilindrare, calandrare, mandrinare; (met) îndreptare (a tablelor cu maşina de îndreptat cu role)

manhandle (mas-un) a întreține, a îngriji (o maşină)

manhead (OM) gură de vizitare / de om (prin care poate trece un operator uman)

manhole (el) puț de cablu; (nav) gură de om; (OM, hidr, termo) gură de vizitare a cazanului / a recipientului, gură de observare / de acces, trapă, fereastră de observație, deschizătură, gură de canal; (cf) nişă, adăpost (în tunel)

manhole cover (termo, OM, hidr) capul gurii de vizitare (prin care poate trece un om)

manhole door $(\mathrm{OM})$ capacul gurii de vizitare

manhole junction box (el, OM, hidr) cutie de joncțiune, cu gură de vizitare

man hour, man-hour, person hour, person-hour (mai nou acceptată) (metr, ec, TH) o unitate pentru măsurarea muncii, egală cu munca unei persoane timp de 1 oră, om-oră 
manhours (ec, TH) manoperă exprimată în om-ore manifest vădit, clar, limpede; manifest; evident; listă a încărcăturii (în transporturi); a (se) manifesta, a dovedi, a da dovadă de, a arăta, a exprima, a declara; (nav) a declara la vamă; a demonstra, a lua parte la o manifestație

manifestation manifestare (şi a unui sistem tehnic), declarare, exprimare; manifestație, demonstrație; manifestare, simptom; proclamare, publicare

manifest of cargo and cargo books (nav) certificat de încărcătură

manifold $(a d j)$ variat, diferit, felurit, divers; varietate, diversitate; multime, colectie; colector, distribuitor; a multiplica; (OM) tuburi, țevi, sistem de conducte, rezervor; multiplu, numeros; copie multiplicată

manifold block (hidr, OM) bloc colector

manifold classification (mat) clasificare după mai multe caracteristici

manifold ignition test (hidr) test de aprindere pe metal / suprafață cald( $\breve{a})$

manifold port (hidr, OM) orificiu colector

manifold pressure (mec, hidr) presiune în conductă / tub / incintă

manifold-pressure gauge (metr, hidr, OM) manometru de conductă

manipulate ( $\mathrm{TH}$, metr) a manipula, a mânui (aparate etc.), a acționa, a manevra; a măslui (şi rezultate)

manipulated value (metr) mărime de reglare manipulated variable (autom) variabilă reglată

manipulation manipulare (şi fig), mânuire, operație manuală; manevră

manipulator (met) manipulator de blocuri, dispozitiv de răsturnare a lingourilor, răsturnător (de lingouri, rulouri)

manipulator arm (mas-un) brațul de manipulator manipulator for turning sheets (met) răsturnător de tablă

mankind omenire, umanitate

man-made făcut de om; artificial

man-made rubber (plast) cauciuc sintetic

manner mod, fel, manieră, stil; obicei, deprindere; categorie, soi; fel / mod de viață

manner of fastening (auto, OM, mas-un) mod de fixare / de strângere, fel de fixare / de strângere

Mannesman process (met) procedeu Mannesman (pt. laminarea țevilor cu cilindri oblici)

Mannesman rolling mill process (met) laminor pentru tevi, cu procedeu Mannesman (cu cilindri oblici)

Mannesman roll-piercing process (met) procedeu Mannesman de laminare a tevilor cu cilindri oblici manoeuvrability (auto, mas) manevrabilitate manoeuvre (TH) manevră; a manevra; (nav) a manevra, a evolua

manoeuvring manevrare; care (se) manevrează, care face o manevră

manoeuvring apparatus (mas) dispozitiv de deservire / de comandă / de manevrare

manoeuvring device (cf) instalație de manevrat manoeuvring valve (mas-un, OM, hidr) supapă de reglare

manoeuvring winch (cf, ind) troliu de manevră; (mas) troliu de deservire

manometer (metr, OM, hidr) manometru

manometer pressure (hidr) presiune manometrică

manometric fluid (chim, metr) lichid manometric

manometric head (hidr) înălțime manometrică man power, manpower (ec) mână de lucru, forță de muncă; oameni; (metr) unite de măsură pentru putere, om-putere: 1 manpower $=74,57 \mathrm{~W}$

man rope (nav) strajă, balustradă

mansard(roof) (constr, mec) acoperiş mansardat

mansbridge capacitor (el) condensator în rulouri / suluri

mantel, mantelpiece (OM, termo) carcasă, înveliş, manta

mantissa (mat) mantisă

mantle (textile) mantou, manta (şi de protecție), pelerină, perdea, văl; strat, înveliş; (constr) fațadă, parte exterioară, a acoperi (cu un strat / înveliş), a înveli; (d. lichide) a face spumă, a spumega mantle ring (constr, met) coroană / inel de susținere (la recipiente, cuptoare, furnal etc.)

manual (TH) manual( $\breve{a})$, de mână; manual, ghid, carte tehnică (a unei maşini etc.); claviatură

manual adjustement (auto) reglaj manual

manual brazing / soldering $(\mathrm{TH})$ lipire tare / moale, manuală

manual carbon arc welding (met) sudare manuală, cu electrod de cărbune

manual climate control system (auto) sistem manual al climatizării

manual control (mas) comandă manuală (neautomată); (autom) comandă / reglare manuală, organe de comandă manuală

manual controller (autom) regulator manual manual cutting $(\mathrm{TH})$ tăiere manuală $(\mathrm{cu}$ ferăstrău / cu flacără etc.)

manual cycle $(\mathrm{TH})$ comandă manuală, periodică (şi a unui proces tehnologic ciclic)

manual drive (mas) acționare manuală, periodică manual governing ( $\mathrm{TH}$, mas) reglare / comandă manuală 
manual intervention (autom, TH) intervenție manuală

manual labour (ec, TH) muncă manuală

manually (mas-un) manual, cu mâna

manually operated (autom, mas-un, hidr) cu comandă manuală, acționat manual

manually operated circuit breaker (el) întrerupător manual

manual operation (autom) comandă manuală; (el) manevrare manuală; (mas-un) fabricație manuală; (auto) operare / acționare manuală

manual regulation $(\mathrm{TH})$ reglare manuală

manual remote control (autom) comandă manuală la distanță; (auto) reglare manuală

manual spark advance (auto) avans manual de aprindere

manual steering (auto) direcție manuală

manual switch (auto) comutator / întrerupător (acționat) manual

manual transaxle fluid (auto) lichid pentru cutie de viteze cu schimbare / actionare manuală

manual welding (met) sudare manuală

manual window (auto) geam activat / acționat manual

manual work muncă / lucru manual(ă)

manual worker meseriaş, meşteşugar, muncitor manual (fără dispozitive, maşini)

manual working manual

manufactory manufactură; fabrică, uzină

manufactural fabricație; de fabricare

manufacture fabricare, producere, confectionare (de produse industriale, haine etc.) fabricație, producție; manufactură; prelucrare; fabricat, produs fabricat (industrial); (ramură de) industrie; fabricație în serie fără valoare; a fabrica, a manufactura, a produce, a confecționa; ( fam $)$ a născoci; (peiorativ) a fabrica (cărți etc.)

manufactured produs (industrial), manufacturat; manufacturier; fabricat, confecționat; artificial, sintetic

manufactured article $(\mathrm{ec})$ produs manufacturier manufactured good $(\mathrm{TH})$ fabricat, produs manufactured head of rivet $(\mathrm{OM})$ cap original al nitului

manufacture looms (TH) maşini de producție

manufacturer $(\mathrm{ec}, \mathrm{TH})$ industriaş, producător, fabricant; furnizor; executant

manufacturer's mark (mas-un) marca fabricii

manufacturer vehicle warranty (auto) garanția autovehiculului

manufactures warranty (ec, ind) garanție dată de producător(i)

manufacturing fabricare, producere, confecționare; de fabricatie, industrial manufacturing calibre (met, metr) calibru de fabricație

manufacturing costs (ec, TH) costuri / cheltuieli de fabricație

manufacturing district $(\mathrm{ec}, \mathrm{adm})$ regiune industrială

manufacturing engineer $(\mathrm{TH})$ inginer de exploatare / de producție / tehnolog

manufacturing expenses (ec) cheltuieli de fabricație / de producție / tehnologice

manufacturing industry $(\mathrm{ec})$ industrie prelucrătoare

manufacturing lathe (mas-un) strung pentru productie de serie

manufacturing machine ( $\mathrm{TH}$, mas-un) maşină pentru producție în masă / în serie

manufacturing method $(\mathrm{TH})$ procedeu $/ \bmod /$ metodă de fabricaţie

manufacturing plant $(\mathrm{TH})$ instalație industrială / pentru fabricație pe scară industrială, fabrică, atelier

manufacturing operation $(\mathrm{TH})$ operație (din metoda / tehnologia) de fabricație

manufacturing process $(\mathrm{TH})$ procedeu / proces / metodă de fabricație

manufacturing program(me) (constr, $\mathrm{TH}$ ) program / gamă de fabricație

manufacturing time $(\mathrm{TH}$, ind) timp / perioadă durată de fabricație / de prelucrare, timp tehnologic

manufacturing tolerance $(\mathrm{TH})$ toleranță de fabricație / obținută în fabricație

manure (agr) îngrăşământ (natural), gunoi, bălegar; a îngrăşa (pământul)

manurial (agr) de / privitor la îngrăşământ (natural) manuring (agr) îngrăşare (a pământului)

manuscript manuscris

many un mare număr; mulți, multe; numeroşi, numeroase, o mulțime de; majoritatea

many-bodied vaporizer (alim, ind chim, termo) vaporizator multiplu / cu mai multe corpuri many-coloured multicolor, pestrit

many-line spectrum (fiz) spectru cu linii multiple many one function switch (autom) întrerupător de funcții multiple

many-sided (OM) (şi fig) cu mai multe muchii / fețe / fațete; multilateral; complex, complicat manysidedness diversitate, caracter multilateral manystage etajat, cu mai multe etaje / trepte (d. un sistem de automatizare, un sistem de reglare, un proces tehnologic etc.)

many-valued function (mat) funcție multiformă many-valued logic(s) (mat) logică cu mai multe valori, logică polivalentă 
map (constr) plan, hartă, reprezentare cartografică; (mat) aplicație; $(\mathrm{TH})$ a proiecta, a întocmi o hartă / o diagramă / un plan, a înfățişa sub formă de plan; questions off the $\sim$ învechit, neactual

map case porthartă

map-coordinates system (geogr, mas) sistem de coordonate al hărții / al diagramei / al maşinii (de prelucrat în coordonate)

map-cracking (materiale) fisurare în formă de hartă

maple (silv) arțar

map maker cartograf

map making cartografiere

map measurer (metr) cubimetru

map out a plănui, a prevedea, a trasa, a schița

mapper cartograf

mapping cartografiere; cartografie; cartare, releveu; (mat) aplicație

mar (mas-un) zgârietură; (met) deteriorare exterioară

maraging (met) îmbătrânire martensitică / la martensită

marathon maraton; (fig) probă / acțiune de lungă durată care solicită efort deosebit; (metr) unitate de lungime (în atletism): 1 marathon = $42195 \mathrm{~m}$; distanţa reală dintre Marathon şi Atena $\cong 36,75 \mathrm{~km}$

marble (constr, geol) marmură; a marmora, a perla

marbled (ca) de marmură

marble plate / slab (constr) placă de marmură

marc (alim) boască, boștină, borhot, tescovină; rachiu de tescovină

marc, marco, mark (metr) unitate tradițională de măsură pentru masă în Europa de Vest: 1 French marc $\cong 244,75 \mathrm{~g} ; 1$ Spanish marco $\cong$ $230 \mathrm{~g} ; 1$ German mark $\cong 280,5 \mathrm{~g} ; 1$ English mark $\cong 226.8 \mathrm{~g}$ (pt. metale prețioase)

marcasite (minrl) marcasit

march out a pleca

marchpane (alim) marțipan

marc of fruit (alim) tescovină de fructe

margarine, marge (alim, chim) margarină

margin joc, interstițiu; hotar, graniță, frontieră; țărm; (OM, met, TH) joc, toleranță, spațiu liber, margine, marjă, muchie, limită, toleranță, bordură, rezervă, coeficient de siguranță, zonă; (ec) acoperire; (fig) deosebire, diferență; a mărgini; a adnota (o carte)

marginal marginal, de (pe) margine; periferic; (agr) (d. sol) sărăcăcios

marginal beam (constr) grindă marginală / de centură marginal check / test(ing) (mas, TH) procedură preventivă de mentenanță prin verificarea unor condiții de operare în intervalul lor normal, pentru detectarea şi localizarea erorilor marginal checking (autom) verificarea toleranței; (metr) încercare (de material) la limită marginal current (el) curent limită; (hidr) curent în stare critică

marginal point (mat) punct limită, punct de contur, extremitate

margin line (nav) linie de supraimersiune

margin of atention limită de atenție (a unui operator)

margin of energy (fiz) exces / rezervă de energie

margin of manufacture $(\mathrm{TH})$ adaos de ajustare, limită de producție (nu se specifică dacă este superioară sau minimă, din cauze tehnologice etc.)

margin of power (TH, mas) rezervă de putere

margin of safety $(\mathrm{TH})$ coeficient / marjă de siguranță, raport între sarcina maximă de lucru şi sarcina care ar cauza deformarea / ruperea sistemului

margin plate (nav) tablă marginală

marina (nav) port de ambarcații

marinade (alim) marinată, a marina

marine (nav) marin, de mare, maritim, naval, navigatie, marină (comercială); albastru marin, bleumarin

marine belt (nav, geogr) ape teritoriale

marine diesel engine (nav, termo) motor diesel naval

marine board (nav) inspectorat maritim / marin marine cable (el) cablu submarin

marine engine (nav, mas) mașină navală, motor naval

marine league (metr, nav) unitate de măsură pentru lungime, leghe marină: 1 marine league $=5556 \mathrm{~m}$

marine packing (nav, transp) ambalaj pentru transport maritim

marine pump (mas, nav) pompă pentru construcții navale

mariner (nav) marinar, matroz

marine railway (nav) cală de hală

marine superintendent (nav) inspector de navigație

marine transport (nav) transport maritim

maritime (nav) maritim, marin

mark (ec) marcă (monedă germană, înainte de adoptarea monedei euro); (constr) martor; (mec, OM) imprimare, amprentă, semn, întipărire, impresiune, pată; (TH) semn, reper, marcă, marcare, marca fabricii, poanson de marcare, urmă 
(şi superficială), emblemă, indiciu; simptom, trăsătură (şi caracteristică), semn distintiv; semn de punctuație; notă, punct; a marca, a lăsa un semn / o pată, a indica, a arăta, a denumi, a însemna, a face un semn pe / în, a desemna (pe cineva), a picheta; a ştampila, a păta; a califica, a nota, a aprecia prin notă / calificativ; a fi atent, a ține minte; a desemna, a alege; a caracteriza, a defini; a sărbători; (fig) semn, urmă, dovadă; scop; (auto) semn rutier, (stâlp) indicator, bornă; calitate, tip, sort, fel; (textile) cută, îndoitură

mark-down (ec) scădere a prețului, preț scăzut

mark down a nota; a însemna, a scrie; a reduce la; a scădea nota / calificativul

marked marcat; însemnat; ştampilat; pronunțat; clar; vizibil; evident; sensibil, apreciabil; (mas-un) marcat, trasat (cu gradații)

marked effect efect important / deosebit

markedly $(a d v)$ deosebit de, apreciabil; considerabil

marker semn, indicator; (constr) reper; (hidr) sondă; (hidr, nav) semn pe cablul de măsură; (agr, chim) (substanță) marcator; (ec) persoană care marchează / notează, pontator; semn de carte marker buoy (nav) geamandură de ceață

marker light (auto) lanterne de gabarit / de poziție / laterale

marker-off (mas-un) trasator

market (ec) piață, târg, obor, debuşeu, cerere, vânzare, a pune în vânzare, a vinde, a lansa pe piață

marketable products $(\mathrm{ec})$ produse-marfă / comercializabile

market brass (met) alamă obişnuită / comercială

marketer (ec) cumpărător sau vânzător într-o piață, vânzător de firmă

market garden (agr) grădină de zarzavat (cu producție pentru piață)

market house (constr, ec) hală de piață

marketed existent pe piață, comercializat

marketing (ec) marketing; comerț, vânzare; (amer) cumpărături

marketing expenses (ec) cheltuieli de marketing / de vânzare

marketing station (ind chim) stație / centru de desfacere (pt. produse petroliere, lubrifianți, vopsea etc.)

marketplace piață (ca loc)

market price (ec) prețul / cursul pieții market research $(\mathrm{ec})$ sondaj de piață market value (ec) curs / valoare de piață mark for location (mas-un) a marca pentru indicarea poziției reciproce a pieselor marking însemnare, marcare (d. metale prețioase); (constr) reperare; ( $\mathrm{TH})$ trasare, jalonare, marcare, reperare, marcaj, poansonare, bornare marking awl (mas-un) ac de trasat, trasator paralel marking compass $(\mathrm{TH})$ compas de trasare

marking gauge (mas, $\mathrm{TH}$ ) trasator paralel, şablon de trasaj

marking light (auto) lumină de gabarit / de pozitie / laterală

marking machine (mas-un) maşină de trasat / de marcat / pentru marcarea pieselor

marking needle handle file (mas-un) pilă-ac semiovală, pentru marcat

marking off (met, nav) trasare

marking-out (constr) pichetare

marking pointer (el) indicator fix (cu poziție reglabilă pe scală)

marking punch $(\mathrm{TH})$ poanson de marcare

marking scriber (mas-un) ac / şubler de trasat

marking stamp $(\mathrm{TH})$ poanson de marcare

marking tool $(\mathrm{TH})$ ac de trasat

mark off a delimita, a demarca; a mărgini, a hotărnici; a însemna, a bifa; a măsura, a trece (pe hârtie, hartă etc.); (mas-un) a trasa

mark of test ball (met, metr) calotă imprimată (şi pt. determinarea durităţii)

mark out a marca, a însemna cu marcaje; a determina locul; a trasa, a evidentia

mark out for a alege, a selecționa, a selecta pentru markup of (ec) scumpire cu

mark up (ec) a scumpi, a ridica prețul la (o marfă, un produs etc.)

Marcovian process (mat) proces Marcov

marks and deeps (nav) gradațiile saulei sondei

marla (metr) unitate traditională pachistaneză pentru suprafaţă (de teren): 1 marla = 25,2929 m²

marlinespike (nav) cavilă de matisat

marline spike hitch (nav) nod de plasă

marmalade (alim) marmeladă, gem, magiun

maroon castaniu, culoare castanie; (mil) petardă; artificii

marplot piedică, obstacol; nepoftit

marque (auto) marcă

marquee (constr) cort mare (în formă de umbrelă), marchiză

marquenching (met) călire la martensită

marquetry inscrustație; intarsio

marquisette (textile) marchizet

marriage problem (mat) problema selecționării

marrow (alim) măduvă

marsh (geogr) ținut / pământ mlăștinos, mocirlă, mlaştină

marshalling yard (cf) (stație de) triaj

marsh gas (ind chim) gaz metan / de mlaştină 
martempering (met) tratament de călire izotermă, la martensită

martempering and tempering (met) tratament de îmbătrânire / îmbunătățire (călire şi revenire) martensite (met) martensită

martensite cast iron (met) fontă martensitică martensite formation (met) formare a martensitei

martensite steel (met) oțel martensitic

martensite / martensitic transformation (met) transformare martensitică

martensitic quench (met) călire martensitică / la martensită

martensitic stainless steel (met) oțel inoxidabil martensitic

Martin furnace (met) cuptor Martin

Martin process (met) proces / procedeu Martin

Martin steel (met) oțel Martin

marzipan (alim) marțipan

mas (metr, astronomie) simbol pentru milliarcsecond, unitate de măsură pentru unghiuri mascot (auto) mascotă, figură / simbol pe radiator maser (fiz) maser, amplificator cuantic

mash amestecătură; (alim) decocție de malț, amestec de malț cu apă fiartă, must de vin, tescovină, pastă, terci, plămadă, pireu de cartofi (sau alte legume, fructe); a plămădi, a terciui, a zdrobi, a face piureu, a muia; a face o infuzie (de ceai) în; (met) amestec de minereuri; amestec(ătură); (fam) simpatie, dragoste; (fig) amestec(ătură), lucru încurcat

masha (metr) o unitate tradițională de măsură pentru masă, în India şi Pakistan, 1 masha = $0,972 \mathrm{~g}$ (utilizată încă pt. metale prețioase)

mashed potatoes (alim) (cartofi) piuré, pireu de cartofi

mashing of the massecuite (alim) transformarea masei în pastă (la prelucrarea zahărului)

mash off (alim) a pune malțul (la fermentat); (constr) a netezi prin frecare

mash tun (alim) cuvă pentru brasaj

mash weld (met) cusătură (sudură) cu role

mask mască, cadru; (fig) pretext, paravan; a masca, a acoperi, a (se) ascunde

masking effect (fiz) efect de mască / mascare / ecranare

masl (metr, geol, geogr) simbol pentru „metri desupra nivelului mării"

masonry (constr, met) zidărie, căptușeală din zidărie / cărămizi

mansory joint (constr) rost de zidărie

masout (ind chim) păcură

mass grămadă, morman; cea mai mare parte (din ceva); mulțime; (TH) material, pastă, greutate, masă, substanță; (mat) mulțime; a concentra, a (se) masa, a comasa, a (se) strânge, a se aduna; (mil) a concentra, a masa (trupe); a comasa

mass, maß (Bavarian maß) (metr) unitate de măsură pentru capacitate (pt. bere, în Germania şi Austria): 1 mass 1,07 1

mass-action law (chim, mec) legea acțiunii maselor

mass axis (mec) axă a masei

mass balance (TH, mas, transp) echilibrare de greutate / a greutăților (unui sistem, unei încărcături etc.)

mass centring (mec) centrare a masei

mass concentration (chim) concentrație masică

mass connection (el) legare la masă

mass defect (TH, met) defect în masă / mare / la multe produse

mass density (mec, materiale) densitate

mass distribution (fiz) distribuție de masă

massecuite (constr, TH) masă de umplere, material de umplutură, filer

mass electrode (el) electrod (legat) la masă / la nul

mass equilibrium (mec) echilibru de masă, compensarea maselor

mass excess (fiz) exces de masă

mass flow (fiz, hidr) debit masic

mass flowmeter (alim, ind chim, metr) debitmetru pentru măsurarea debitului masic

mass flow rate (hidr) debit masic

mass group grupă de vârstă

massic force (fiz) forță masică

mass group (auto) grupă de copii (după greutate)

massif $(\mathrm{TH})$ masiv

mass-impregnated insulation (el) izolare cu hârtie impregnată

massing masare, concentrare

massive masiv; robust; solid; greu; compact; mare; voluminos; vast

massiveness masivitate, caracter masiv

mass moment of inertia (mec) moment de inerție al masei

mass number (fiz) suma numărului de protoni şi neutroni dintr-un nucleu, număr de masă

mass of flywheel (auto, OM, mas) masa volantului

mass point (mec) centru de masă

mass polymerization (plast, ind chim) polimerizare în bloc / în masă

mass pressure (mec) presiune de inerție / a masei

mass-produce (TH) a produce în masă, a fabrica în serie 
mass productibility (mas-un) posibilitatea de fabricație în serii mari (în masă)

mass production $(\mathrm{TH})$ producție / fabricație în serie / în masă

mass-scattering coefficient (fiz) coeficient de împrăştiere masică / a maselor particulelor (unui amestec etc.)

mass sensitive parameter/ quantity $(\mathrm{TH}$, fiz, chim) mărime / parametru dependent(ă) de masă

mass-spectrometry (fiz, metr) spectrometrie masică

mass spectroscope (fiz, metr) spectroscop de masă (prin împrăștierea ionilor în câmp electromagnetic)

mass spectrum (mec, fiz, metr) spectru / distribuția masei (într-un amestec)

mass-transfer coefficient (chim) coeficient de transfer de masă

mass transit (transp, adm) transportor public

mass transportation facilities (transp, adm) mijloace de transport public / în masă

massy masiv, solid

mast (nav) catarg, arbore; prăjină; coloană (de macara etc.), instala / monta arborii / catargele; (constr) stâlp, pilon; (mas) coloană de macara; (bot) ghindă, jir; (el) stâlp de linie electrică

mast cap (nav) butuc

master proprietar, patron; maestru, meșter, artist; (TH) maistru, (mecanism) conducător; model, şablon de precizie; etalon (principal); a stăpâni; a mânui cu pricepere; (nav) căpitan (de vas comercial), comandant; (edu) învățător, intitutor, dascăl, profesor, director de colegiu, licențiat; (ec) şef, conducător, director, administrator; (adj) principal, conducător, călăuzitor; a invinge (greutăți); (edu) a-şi însuşi (o materie), a învăța, a deprinde; a conduce; a gospodări master alloy (met) aliaj intermediar, prealiaj master batch (plast) preamestec

master batching (plast, ind chim) pregătirea preamestecului

master block (met) port-matriță (la forjă)

master brake cylinder (auto) cilindru principal de frână

master builder (constr) antreprenor, arhitect

master chuck (mas-un, OM) corpul mandrinei, cu strângere prin şuruburi

master clock (inf) schemă principală de sincronizare; (metr) pendulă-etalon

master cone sub-unit (OM) subansamblul inel interior + role (cu colivie) la rulmentul radialaxial, cu role conice master connecting-rod $(\mathrm{OM}$, termo) bielă motoare / principală

master control (autom, met) pupitru central de comandă

master control (room) (autom, met) cameră principală de comandă

master cup sub-unit $(\mathrm{OM})$ inelul exterior la rulmentul radial-axial, cu role conice

master cylinder (auto, OM) cilindru principal

master form (mas-un) şablon de copiat

master gauge (mas-un, metr) calibru etalon / de control, contra-calibru, dispozitiv de reglare spațială a poziției (piesei / sculei)

master gear (mas-un, OM) roată dințată etalon / de referință

master key $(\mathrm{TH})$ cheie principală, ssperaclu; (auto) cheie principală

master / slave manipulator (autom) dispozitiv mecanic / hidromecanic / electromecanic care reproduce mişcările mâinii sau brațului operatorului

master mariner (nav) căpitan de navă comercială

master mechanic (mas-un) mecanic şef, şeful atelierului mecanic

master meter (metr) instrument etalon

master operation (mas-un) operații principale

master pattern (mas-un) model-etalon; (met) model de bază, pre-model

masterpiece capodoperă

master pilot lamp (autom) lampă principală de control

master power window switch (auto) panou principal de activare a geamurilor acționate electric

master regulator (autom) regulator principal master rotor rotor de control (la echilibrare) master's certificate (nav) brevet de comandant mastership conducere, direcție, administrație, functie de conducere / director; (edu) functie / post de învățător; măiestrie

master spring leaf (auto, OM) foaie principală de arc (la arcuri în foi)

master straight edge (mas-un, metr) riglă / linie de control / de ghidare

master switch (autom, el) întrerupător principal / de linie

master tap (mas-un) tarod de calibrare / pentru filiere

master tool (mas-un, metr) instrument / sculă etalon de mare precizie

master vibrator (auto) trambler / vibrator principal; (alim) vibrator principal (la sisteme de cernere etc.) 
master vibrator ignition (auto) aprindere prin trambler

masthead (constr, el) vârf de stâlp; (nav) vârf de catarg

mast hole (nav) (tub) etambou

mastic $(\mathrm{TH})$ mastic

masticated rubber (plast) cauciuc plastifiat

masticating mill (plast, ind chim) valț de masticat, malaxor de plastifiat

mastication (plast, ind chim) masticare

masticator (alim) frământător; (plast, ind chim) maşină de amestecat şi plastifiat, malaxor

mast of derrick (mas) catarg de macara

mast yoke (nav) butuc inferior

Masurium (Te) (chim) tehnețiu

mat $(\mathrm{TH})$ saltea, mască, covoraş, suport, muşama; (agr) mărăcini, mărăciniş; gard de nuiele; (adj) mat (nepolizat); (met) a mătui; a (se) încâlci; a întări cu un gard de nuiele

match chibrit; fitil, focos, amorsă; potrivire; pereche a unui lucru, piesă-pereche, obiectpereche, piesă / formă conjugată; a se asorta, a se armoniza; a opune; a rivaliza cu; a corespunde; (autom) a echilibra, a adapta; (mas) a selecționa, a (se) potrivi; (met) a ajusta; (TH) a asambla, a monta; (d. culori) a se potrivi, a se asorta, a se armoniza

match box cutie de chibrituri

matched (OM) ajustat, păsuit, potrivit (la / cu)

matched assembly (mas, OM) ansamblu compus din piese ajustate / cu ajustaje conform desenului de ansamblu

matched samples (mat) selecție cu elemente comparabile între ele

matching (mas-un, $\mathrm{OM}$ ) ajustare, păsuire, potrivire, îmbinare; combinare; împerechere; (met) adunarea tablelor în pachete

matching efficiency (el) randament de adaptare (a rețelei electrice etc.)

matching pad (el) dispozitiv de adaptare, adaptor matchmark (mas-un, OM) semnul pe piese de asamblat, pentru indicarea poziției reciproce

match pattern (met) cutie falsă de formare

match plate (met) placă de model / de formare; $(\mathrm{OM})$ placă conjugată

matchstick (băț de) chibrit (şi folosit)

match up to a fi pe măsura aşteptărilor

matchwood (ind, mediu) aşchii / țăndări de lemn

mate ucenic; tovarăş, coleg; prieten; însoțitor; (ind) ajutor, asistent, laborant; (OM) piesă ajustată / pereche (şi a unui obiect), a (se) angrena; (nav) ofițer în marina comercială, ofițer secund; (TH) a (se) lega, a agăța, a (se) cupla, a (se) îmbuca, a (se) uni mated (with) conjugat (cu); care face pereche (cu), potrivit (cu)

material material, corporal, fizic; material, real, concret; materialist; substanțial, considerabil; (ec) marfă, material, articol; (fiz) material, materie, substanţă; (met) (produs) laminat; subiect de discutie; (textile) material, țesătură

material damage $(\mathrm{ec})$ pagubă materială, deteriorare / distrugere a unui material

material defect $(\mathrm{TH}$, ind, materiale) defect de material

material delivered (ec) material transportat / livrat

material for construction (constr) material de construcție / construcții

material handling (mas-un, TH) încărcare-descărcare, transport de material, manipulare a unui material

material inspection (TH) control / încercare / verificare a(l) materialului

materialization materializare, concretizare; realizare

material loader (OM, transp) încărcător

material(s) dressing / processing (alim, ind chim, met) prepararea / pregătirea materialului (materialelor)

material(s) recovery (mediu, $\mathrm{TH}$ ) recuperare de material(e)

material(s) testing (materiale, metr) încercarea / testarea materialelor

materials science (materiale, metr) ştiința materialelor

material's tendency (materiale, metr) tendința materialului

material strength (materiale, metr) rezistența materialului

material testing (materiale, metr) încercarea / testarea materialului, defectoscopie

material-testing machine (mas, materiale, metr) maşină / instalaţie de testare a materialelor

material to be ground (constr, alim, ind chim, met) material de măcinat

material to be mixed (alim, constr, ind chim, met) material de amestecat

material to be roasted (met, ind chim) material de prăjit

material transfer (alim, ind chim, TH) transfer de material

materiology (materiale, met, metr) încercarea materialelor / defectoscopie (foarte rar)

math, maths matematică

mathematical matematic, de matematică; riguros, exact

mathematical check (mat) verificarea calculelor 
mathematical constant (mat) constantă matematică

mathematician matematician

mathematics matematică

mating flanc $(\mathrm{OM})$ flanc conjugat

mating gear $(\mathrm{OM})$ angrenaj $\mathrm{cu}$ roți dințate; roată conjugată

mating member (mas-un, OM) piesă / element pereche / conjugat $(\breve{a})$

mating parts $(\mathrm{OM}, \mathrm{T})$ părți (piese) conjugate / cu profiluri sau suprafețe conjugate / în contact / care se influențează reciproc

mating profile $(\mathrm{OM})$ profil conjugat (şi la dantură, dinți de cuplaj etc.)

mating surfaces $(\mathrm{OM}, \mathrm{T})$ suprafețe conjugate / în contact

mat of rubber (el, TH) covor de cauciuc

matriculate (univ) candidat admis într-o facultate, student; (univ, edu, ec) a admite (la o facultate), a fi înmatriculat, a înregistra, a înmatricula, a (se) înscrie (şi într-o asociație etc.)

matriculation înmatriculare; înscriere (într-o organizare)

matrix, $(p l)$ matrices (mat, inf) matrice; (materiale)matrice, bază, material de bază (şi într-un aliaj, compozit etc.); (mas-un) ştanță, matriță; (alim, met, plast) cochilă, formă (permanentă)

matrix algebra (mat) algebră matricială, calcul matricial

matrix inversion (mat) inversarea unei matrici

matrix material (materiale) material (matrice) pentru un compozit

matrix metal (met, materiale) metal de bază, matrice metalică (într-un compozit)

matrix moulding press (mas-un, plast, met) presă pentru matrițare

matrix sticking press (mas-un, met) presă de forjat

mat-surface glass (ind chim) sticlă mată

matte (met) mată; (fiz) (suprafață) mată

matted (TH) şlefuit mat / fără luciu (materiale metalice și plastice, sticlă)

matte ladle (met) oală de turnare pentru mată

matter conținut, fond; chestiune, problemă; lucru, afacere; importanță, însemnătate; prilej, ocazie; subiect de discuție; (med) puroi, a supura; (chim, fiz) materie, material, substanță masă; (ec) afacere, problemă; (c) culegere (de text); (poligrafie), material de cules / de redactat; a conta, a avea importanță; in the $\sim$ of cât priveşte

matter-of-course (adj) de la sine înțeles; firesc; natural

matter of course lucru de la sine înțeles / firesc matter-of-fact prozaic; realist; lipsit de imaginatie; practic

matter of fact realitate

matter of study obiect de studiu

matte refining (met) rafinarea matei

matte scrap (met) deşeuri de mată

matte smelting (met) topirea matei

matt glass sticlă lăptoasă

matting (chim) matisare (fibre); pierderea luciului

matting furnace (met) cuptor pentru topirea matei

mattress saltea, somieră

maturate (med) a supura, a provoca / stimula colectarea (unui abces); a se coace; a se maturiza

maturated rubber (plast) cauciuc natural maturat mature matur; perfect, desăvârşit; scadent, ajuns la scadență; a (se) maturiza; 2. a (se) coace; a perfecționa, a desăvârşi; (ec) a fi scadent (d. datorii, obligații); plans planuri bine gândite, chibzuite; after $\sim$ deliberation după o matură chibzuire

matured slag (met) zgură matură

maturated wine (alim) vin matur

maturation (med) puroiere, supurare; coacere; (agr) maturație; (alim) maturizare, maturare

maturing properties (met, plast) caracteristici / proprietăți mecanice după îmbătrânire (d. aliaje neferoase, materiale plastice etc.)

mature matur; copt, pârguit; bine gândit; (ec) scadent (d. o poliță etc.), a deveni scadent, a ajunge la scadență; (alim) a matura, a (se) maturiza, a (se) coace, a (se) pârgui

matured slag (met) zgură matură

matureness maturitate (a gândirii etc.)

maturing properties (materiale, mec, metr) proprietăți mecanice după îmbătrânire (d. aliaje neferoase, materiale plastice etc.)

maturity maturitate; (agr) coacere; (ec) scadență, termen

mAU, milli-absorbance unit (metr, fiz) simbol pentru unitatea de măsură pentru absorbanță: o creștere a absorbantei cu $1 \mathrm{mAU}$ corespunde unei reduceri a transmitanței cu $\sim 0,2305 \%$

maul (constr) mai manual, sonetă manuală cu berbec; a lovi cu maiul

maund (metr) unitate tradițională de măsură pentru masă în Asia de Sud-Est: 1 maud = 37,3242 $\mathrm{kg}$ (India sub dominația britanică); 1 maund = $40 \mathrm{~kg}$ (Pakistan, din 1980)

mauve mov, liliachiu

max v. maximum

maxi maxi

maximal maxim, maximal

maximal ideal (mat) ideal maxim(al) 
maximal value (mat) valoare maximă; $(\mathrm{TH})$ limită superioară

maximize a maximaliza, a mări / spori / aduce la maximum

maximum, $(p l)$ maxima (mat) maxim; maximum; (ec) maximal (d. prețuri etc.)

maximum allowable concentration (chim, met) concentrație maxim admisibilă

maximum allowable working pressure (ind chim, met, hidr) presiune maxim admisibilă de lucru

maximum amplitude (el, mec) amplitudine / deviație maximă

maximum and minimum current relay (el) releu de curent, de maximum şi minimum

maximum and minimum power relay (el) releu de putere, de maximum şi minimum

maximum and minimum voltage relay $(\mathrm{el}) \mathrm{re}-$ leu de tensiune, de maximum şi minimum

maximum angle of dumping (auto) unghi maxim de basculare / răsturnare

maximum aperiodic oscillation (el, fiz) oscilație aperiodică maximă

maximum axle load (auto, OM) sarcină maximă pe osie

maximum boiling point (fiz, termo) punct maxim de fierbere

maximum capacity type ball bearing (OM) rulment radial cu bile, de capacitate maximă

maximum circuit-breaker (el) întrerupător de maxim (al unui circuit electric)

maximum clearance (mas-un, OM) joc / interstițiu / spațiu liber maxim

maximum condition (mat) condiție de maxim

maximum continuous load (mas, mec) sarcina maximă continuă

maximum current (el) curent de maxim, supracurent (al unui circuit electric)

maximum current relay (el) releu de supracurent (al unui circuit electric)

maximum cut-out (autom, el) întrerupător (automat) de supracurent

maximum deflection (el) deviație maximă; (mec, $\mathrm{OM})$ săgeată maximă

maximum cycling speed (hidr, mec, el) frecvență maximă a ciclurilor

maximum demand (autom) consum maxim, sarcină maximă; (ec) maxim al cererii, vârf de cerere (pe piață)

maximum demand indicator (metr, hidr, el) contor cu indicator de maxim

maximum demand recorder (metr, hidr, el) înregistrator de maxim

maximum efficiency (mas) randament maxim maximum flow control valve (hidr, OM, autom) supapă de închidere automată

maximum form / shape error eroare maximă de formă

maximum freezing point (fiz) punct / temperatură maxim(ă) de solidificare / înghețare / congelare

maximum height of profile irregularities $(\mathrm{OM}$, T) înălțimea maximă a asperităţilor profilului

maximum input current (el, metr) curent maxim de intrare / de alimentare

maximum input voltage (el, metr) tensiune maximă de intrare / de alimentare

maximum likelihood (mat) verosimilitate maximă

maximum load (TH, mas, mec) încărcare / sarcină maximă

maximum load rating (auto) valoarea maximă de încercare; (metr) viteza maximă de variație a sarcinii / încărcării (şi la maşini de testat proprietăți mecanice)

maximum moment (mec) moment maxim

maximum open time (plast, chim) timp maxim deschis, interval după care adezivul îşi pierde capacitatea de lipire

maximum output ( $\mathrm{TH}$, mas, hidr) putere maximă, debit maxim, parametru maxim la ieşire (în general)

maximum overshoot (autom) depăşire maximă maximum period of idleness (el, mas) durată maximă de nefuncționare

maximum permissible maximum admisibil (d. un parametru al unui sistem tehnic)

maximum permissible concentration (MPC) (fiz) concentratie admisibilă maximă maximum permissible inflation pressure (auto) presiunea maximă permisă (în pneuri) maximum permissible load / pressure $(\mathrm{TH}, \mathrm{mec})$ sarcină / presiune maximă admisă

maximum permissible residual unbalance (mec) dezechilibru rezidual maxim admis

maximum permissible speed (auto, mas) viteză maximă admisă / permisă

maximum power $(\mathrm{TH}$, mas) putere maximă

maximum pressure (hidr, mas) presiune maximă maximum range (fiz, $\mathrm{TH}$ ) parcurs maxim, interval maxim

maximum relay (el) releu maximal / de maxim maximum revolution (mas, mec) turație maximă

maximum speed (mas, mec) viteza maximă

maximum speed governor ( $\mathrm{TH}$, autom, mas) limitator de viteze / de turație 
maximum static equivalent load $(\mathrm{OM})$ sarcină statică echivalentă maximă (şi la rulmenți)

maximum stress (mec, OM) tensiune / efort $\operatorname{maxim}(\breve{a})$

maximum tensile load (mec, materiale, OM) sarcină-limită / maximă de rupere (la tracțiune)

maximum time of repair ( $\mathrm{TH}$, mas) timp maxim de reparare / de mentenanţă

maximum torque (mec) cuplu maxim, moment maxim de răsucire

maximum value valoare maximă (în general)

maximum voltage $(\mathrm{el}, \mathrm{mec})$ tensiune maximă

maximum weight $(\mathrm{TH})$ greutate maximă

maxwell (Mx) (metr, el) unitate de măsură a fluxului magnetic în sistemul CGS: 1 maxwell $=10^{-8}$ Weber

may ( $v$ auxiliar) a putea, a avea voie (să); a-i fi permis / îngăduit; a se putea, a fi posibil; s-ar putea ca etc.; probabil că, nu e imposibil să; a avea îngăduința / bunăvoința să

maybe $(a d v)$ poate, posibil, poate că

mazy ca un labirint, ca de labirint; şerpuit, întortocheat; (fig) încurcat, încâlcit

MBF, MBM (metr, silv) simboluri pentru 1000 board feet, o unitate de măsură pentru volum (pt, lemn, buşteni): $1 \mathrm{MBF}=2,360 \mathrm{~m}^{3}$; $\mathrm{BM}$ este abrevierea pentru ,board measure"

MBH, MBtuh (mega British thermal unit per hour) (metr) simboluri pentru 1000 Btu (British thermal unit) per hour, unitate de măsură pentru putere în sisteme de încălzire şi condiționare a aerului din SUA, pentru aprecierea vitezei de răcire sau de încălzire: $1 \mathrm{MBH} \cong$ $0,293071 \mathrm{~kW}$

mbsl (metr, geol) simbol pentru „metri deasupra nivelului mării"

mc, MC (TH) abreviere pentru maşină (machine); (mas-un) abreviere pentru maşină-unealtă; (metr) o abreviere pentru cubic meter în limbile latine (metro cubico în italiană, metru cub în română etc.); simbolul standard este $\mathrm{m}^{3}$

mc-, mc (metr, c, inf) simbol alternativ pentru micro- (rar, în soft-uri care nu au simbolul $\mu$ )

MCF (metr) simbol tradiţional pentru 1000 cubic feet, 1000 de picioare cubice, o unitate de măsură pentru volum: 1000 cubic feet $\cong 28,317 \mathrm{~m}^{3}$

Mcfd (metr) un simbol pentru 1000 cubic feet per day, 1000 de picioare cubice pe zi, o unitate de măsură pentru debit volumic (de apă, folosită în SUA): $1 \mathrm{Mcfd}=19,665 \mathrm{l} / \mathrm{min}$

Mcfe (metr, ind chim, termo) simbol utilizat în industria gazului natural pentru 1000 cubic feet of gas equivalent (cfe), 1000 picioare cubice de gaz echivalent, unitate de măsură pentru energie în industria petrolieră şi chimică: 1 Mcfe $\cong 1,091 \mathrm{GJ}$

MCM, kcmil (mai nou) (metr, el, met) simbol pentru 1000 circular mils, mega circular mil, o unitate de măsură pentru suprafață: $1 \mathbf{M C M}=$ $0,5067 \mathrm{~mm}^{2}$ (utilizată pentru calibre de sârme, conductori etc.); v. circular mil

$\mathbf{m}_{\mathbf{e}}$ (metr, fiz) simbol pentru masa unui electron mead (alim) mied

meadow (agr) pajişte, livadă, fâneață; (geogr) luncă meadow ore (minrl) limonit

meagre slab, costeliv; (fig) puțin, sărac; insuficient, rar; (alim) (mâncare) de post

meal (alim) masă, mâncare, făină (şi integrală); praf, pudră, pulbere, material(e) măcinat(e) (şi d. alimente, cereale etc.)

mean medie; mijloace, mijloc; metodă; principal; mediu, mijlociu, de mijloc; a însemna; se referi la; a intentiona; a destina

meal beetle (agr, alim) gândac de făină

mealiness (alim) caracter făinos; onctuozitate

mealy (alim) făinos; (materiale) poros, afânat; alb, palid

mean a însemna, a avea sensul / înțelesul / semnificația; a vrea sa spună, a se referi la, a avea în vedere, a vrea, a avea intenția, a intenționa; sărăcăcios, deplorabil; inferior (d. intelect), fără valoare; mijlociu, mediu, de mijloc; mijloc, cale de mijloc; (mat) valoare medie, medie

mean clearance $(\mathrm{OM})$ joc mediu, valoare medie a unei fante / a unui interstitiu

mean convergence (mat) convergență în medie

mean corrective maintenance time $(\mathrm{TH}, \mathrm{mas})$ timp mediu de realizare a unei activități de mentenanță

meander (geogr) meandră, cotitură, șerpuitură; a face meandre / cotituri; a şerpui (d. un râu, un furtun etc.)

meandering şerpuire, care şerpuieşte, şerpuit, cotit

mean deviation (mat, fiz) deviație / abatere medie mean diameter $(\mathrm{OM})$ diametru mediu mean effective pressure (m.e.p.) (hidr, mec) presiune medie efectivă

mean error (metr, autom) eroare principală / importantă

mean for a meni, a destina să

meaning (mat) a face media; care semnifică / înseamnă, semnificativ, cu înțeles; intenționat; înţeles, sens, semnificație; intenție, plan, scop

meaningful semnificativ; având / cu înțeles meaningless fără înțeles / sens; inexpresiv

meaningly $(a d v)$ semnificativ, cu înțeles; voit, dinadins, cu bună ştiință 
mean life (TH, mas, OM) durată medie de viață, durabilitate medie (a unui produs / modul, a unei piese, a tăişului de sculă între două ascuțiri etc.)

mean line $(\mathrm{OM}, \mathrm{T})$ (la rugozitate) linia față de care deviația pătratică a profilului este minimă mean load (mec) sarcină / încărcare medie

mean maintenance time (TH, mas) timp mediu de mentenanță (suma timpilor de mentenanță preventivă şi corectivă, împărțită la numărul total de evenimente care necesită intervenții de mentenanță)

mean motion (mec) deplasare medie

mean piston speed $(\mathrm{OM}$, hidr, termo) viteză medie (liniară) a pistonului (de cilindru)

mean pitch (circle) diameter $(\mathrm{OM})$ diametrul mediu de divizare (la roți conice) $\left(\mathrm{d}_{\mathrm{m}}\right)$

mean pressure $(\mathrm{OM}$, hidr, $\mathrm{T})$ presiune medie mean proportional (mat) medie proporțională mean proximity (mat) vecinătate medie

mean rate of hydraulic fluid flow (hidr) debit mediu al fluidului hidraulic

means mijloc, cale, metodă, mijlocire, ajutor, intermediu; agent; (ec, TH) mijloace, resurse, posilibilități; (chim) agent / agenți

means of circulation (ec) mijloace circulante

means of production (ec) mijloace de producție

means of transportation (transp) mijloc / mijloace de transport

mean spacing of profile irregularities (OM, T) distanța medie dintre asperități

mean speed (mec, transp) viteză medie

mean stress (mec, $\mathrm{OM}$ ) tensiune medie, tensiune / efort mediu (pe ciclu, pe durata unei solicitări variabile etc.)

mean surface temperature $(\mathrm{OM}, \mathrm{T})$ temperatura medie a suprafetei

mean temperature difference $(\mathrm{OM}, \mathrm{T}$, termo) diferență medie de temperatură

mean tensile strain $(\mathrm{mec})$ deformație medie la tracțiune (şi la rupere) (mai rar, în sens de tensiune medie la tractiune)

meantime $(a d v)$ între timp, deocamdată, până una alta

mean time (nav) timp mediu

mean time between (critical) failure ( $\mathrm{TH}$, mas) timp mediu între avarii / întreruperi (grave / mari / critice)

mean time between maintenance $(\mathrm{TH}$, mas) timp mediu între reparații / operații de mentenanță

mean time between removals $(\mathrm{TH}$, mas) timp mediu între două înlocuiri succesive ale unei piese / ale unui subansamblu mean time between unschedule removals $(\mathrm{TH}$, mas) timp mediu între două înlocuiri succesive neplanificate, ale unei piese / ale unui subansamblu

mean-time-to-failure (MTTF) (TH, mas) timp mediu până la prima defectare (TMPD) (pentru loturi de piese, motoare, rulmenti etc.) mean time to repair (MTTR) (TH, mas) timp mediu până la reparare

mean value (mat) valoare medie, medie

mean velocity $(\mathrm{mec})$ viteză medie

mease (metr, iht) unitate pentru cantitate: 1 mease 620 (bucăţi / peşti dintr-un coş)

measurability (metr) comensurabilitate

measurable (mat, metr) măsurabil, comensurabil

measurable variable (mat, metr) variabilă măsurabilă

measurably $(a d v)$ într-o anumită măsură; (în mod) perceptibil

measurand (el, fiz, metr) mărime / cantitate măsurabilă, măsurand

measure strat (mai rar); măsură, proporție, capacitate, volum, mărime, dimensiune, întindere; măsură, procedeu, mijloc, dispoziție; unitate de măsură, sistem de măsură, dimensiune, riglă gradată; (mat) împărțitor, divizor; a măsura, a face o măsurătoare, a stabili, a avea o anumită mărime, a verifica, a dimensiona; a evalua, a cântări, a aprecia

measured măsurat, stabilit; cântărit; regulat, uniform, ritmic; (d. proporții) egal

measured feedback (autom, metr) reacție (de răspuns) măsurată

measured mile (nav, metr) bază de viteză, milă măsurată

measured response (autom, metr) reacție măsurată, răspuns măsurat

measured response control reglaj cu reacție / răspuns măsurat(ă)

measured sea mile (nav, metr) milă marină măsurată

measured value (metr) valoare măsurată, parametru măsurat

measured variable (metr, TH) mărime / variabilă măsurată

measure equipment (metr, OM, mas) echipament / dispozitiv de măsurare

measure expansion (fiz, termo) dilatație de volum / cubică

measureless nemăsurat, vast, nemărginit

measurelessness incomensurabilitate, caracter nelimitat

measurement (metr) măsurătoare, măsurare, măsură (proces şi rezultat al procesului) 
measurement accuracy (metr) precizie de măsurare

measurement certificate (nav) certificat de tonaj; (ind) certificat de etalonare (a unui aparat de măsură), certificat de atestare a rezultatelor măsurătorilor

measurement device / mechanism dispozitiv / mecanism de măsurare

measurement error (metr) eroare de măsurare

measurement in radians (geom, fiz, metr) măsură / măsurare în radiani

measurement range (metr) domeniu / interval de măsurare

measurement result (metr) rezultat al măsurării / măsurătorii

measurement ton (MTON, MT) (metr) unitate pentru măsurarea volumului de mărfuri, încărcat pe o navă, un camion, un tren etc.: 1 measurement ton $\cong 1,1326 \mathrm{~m}^{3}$

measure off (metr, TH) a măsura, a tăia (după măsurare)

measure of hardness (metr, materiale) grad de duritate (atenție la metoda de măsurare şi la scara utilizată)

measure out (metr, fiz, autom) a măsura (prin separare), a distribui, a împărți

measurer (metr, OM, electr) dispozitiv de măsurat

measure throughout (metr) a măsura

measuring (metr) măsurare, dozare, măsură, doză, care (se) măsoară

measuring accuracy (metr) precizia măsurătorii measuring anvil (metr, OM) nicovala micrometrului

measuring apparatus (metr) aparat de măsurare measuring appliance (metr) instrument de măsură

measuring arrangement (metr, $\mathrm{TH}$ ) dispozitiv / ansamblu de măsurare, dispunere a aparatelor de măsură (într-un lanț de măsurare)

measuring bottle (chim, metr) balon cotat / gradat measuring bowl (chim, metr) vas gradat measuring bridge (el, metr) punte de măsurare measuring burette (chim, metr) biuretă gradată measuring chain (metr) lanț de măsură / cote / măsurat

measuring circuit (metr, electr, $\mathrm{TH}$ ) circuit de măsurare

measuring cylinder (chim, metr) cilindru gradat measuring device (metr, OM, electr) dispozitiv / instrument de măsurat

measuring element (metr) element cu celulă / dispozitiv de măsurat (în general pentru un singur parametru) measuring equipment (metr, TH, mas) echipament de măsurare

measuring error (metr) eroare de măsurare

measuring eyepiece (metr, OM, opt) micrometru ocular

measuring face (mas-un, metr) suprafața de lucru a aparatului de măsură

measuring fault (metr) eroare / greşeală de măsurare

measuring flask (chim, metr) vas / balon gradat measuring hopper / pocket (metr, OM) dozator, dispozitiv de dozare, tanc mic de măsurare measuring instrument (metr) instrument / aparat / dispozitiv de măsurare

measuring-instrument error (metr) eroare datorată instrumentului / aparatului de măsură measuring jaw (metr, OM) falca / ciocul unui instrument de măsurat

measuring level (metr) scară nivelmetrică, nivel de măsurare

measuring line (el, metr, electr) linie / circuit de măsurare, marcă de verificare

measuring machine (metr, mas) maşină / echipament de măsurare

measuring magnifier (metr, opt) lupă de măsurare

measuring mark reper, semn (folosit pentru măsurători)

measuring means (metr) mijloace de măsurare

measuring nozzle (metr, OM, hidr) ajutaj de măsurare

measuring pin (OM, metr) ştift de calibrare, cioc de măsurare

measuring pipette (chim, metr) pipetă gradată measuring plane (metr) plan de măsurare

measuring pocket (metr, OM) dozator, rezervor mic necesar măsurării

measuring point (metr) punct de măsurat, punct în care se măsoară

measuring pressure (metr, hidr, mec) presiune de măsurare

measuring range (metr) interval de măsurare, gamă / domeniu de măsurare, limitele scării sau etalonării unui aparat de măsură

measuring relay (metr, el, electr) releu de măsurare

measuring rod (metr, OM) riglă de măsurare, calibru-vergea

measuring rule (metr) riglă gradată, regulă de măsurare

measuring screw (OM, metr) şurub de măsurare $/$ micrometric

measuring set (metr) aparat / instalație de măsurare 
measuring spring (OM, metr) arc pentru măsurare, arc etalonat

measuring surface (metr) suprafață de măsurare measuring table (metr, TH) masă de măsurat / de control, planşetă

measuring tank (metr, OM) vas / rezervor (întrun aparat de măsură)

measuring tape (metr, OM) ruletă pentru măsurat

measuring technique (metr) tehnică de măsurare measuring tool (metr) mijloc / unealtă / aparat de măsurat, parte principală a aparatului de măsurat measuring tube (metr, fiz, hidr, OM) tub manometric

measuring vassel (metr, chim, fiz) vas de măsurat measuring voltage (el, electr, metr) tensiune de măsurare

meat (alim) carne, aliment, hrană, masă, prânz, miez (de nucă); green $\sim$ regim vegetarian

meat broth (alim) bulion de carne

meat carving (alim) tranşarea cărnii

meat chopper / grinder (alim, OM, mas) satâr, maşină de tocat carne

meat grower (agr) crescător de vite (de carne)

meatless (alim) fără carne, de post

meatman (alim) măcelar

meat meal (alim, ind chim) făină de carne (îngrăşământ)

meat mincer / mincing machine (alim, mas) maşină de tocat carne

meat pie (alim) plăcintă cu carne

meaty (alim) cărnos, din / de carne

mebi- (Mi-) (metr, el, c) prefix pentru $2^{20}=$ 1048576 (din 1998)

mechanic mecanic, montator, lăcătus mecanic

mechanical mecanic, de maşină; maşinal, automat

mechanical adhesion (plast) adeziune mecanică mechanical adjustment (mas, metr) punere la punct / ajustare / reglare mecanică

mechanical agitation agitare mecanică

mechanical agitator (alim, constr, ind chim) agitator / amestecător mecanic

mechanical ashing (met, tremo) evacuare mecanică a cenuşii / a zgurii

mechanical atomiser burner (termo, OM) pulverizator de combustibil lichid

mechanical balance (mec, mas) echilibru de mase, compensarea maselor

mechanical brake $(\mathrm{OM})$ frână mecanică

mechanical centring (mas-un, OM) centrare mecanică

mechanical characteristic $(\mathrm{mec})$ caracteristică mecanică mechanical charger (mas-un, OM) dispozitiv de alimentare / de încărcare

mechanical classification (alim, constr, ind chim, hidr) sortare / clasare mecanică (şi în curent de apă)

mechanical classifier (alim, constr, ind chim, hidr) clasor / sortator mecanic

mechanical cleaning (alim, constr, ind chim, hidr) curățare mecanică

mechanical clearance $(\mathrm{OM})$ joc mecanic (între piese)

mechanical coke-pusher ram (met, mas) împingător de cocs

mechanical component of coefficient of friction (T) componenta mecanică a coeficientului de frecare

mechanical conductor loading (el, mec) încărcare mecanică a unui conductor

mechanical control (mas) comandă / control

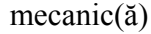

mechanical control system (mas, mec) reglare dinamică, sistem de reglare mecanică

mechanical counter (metr, OM) contor mecanic

mechanical cushioning (OM, hidr) amortizare mecanică

mechanical damping (mec, OM) amortizare mecanică (prin absorbție de energie mecanică) mechanical disengagement (mec, OM) decuplare mecanică

mechanical draft (termo) tiraj artificial; (met, mec) laminare mecanică, valoare calculată a laminării / tragerii

mechanical drawing $(\mathrm{OM})$ desen tehnic (în special în construcția de maşini)

mechanical drive (OM, mas, mec) comandă mecanică, acționare mecanică

mechanical effect (mec, mas) putere utilă / efectivă, efect mecanic

mechanical efficiency (mec, mas) randament mecanic, eficiență mecanică (mai rar)

mechanical engineer inginer mecanic (şi în constructii de mașini)

mechanical engineering inginerie mecanică, teoria mașinilor, construcții de maşini, domeniul aplicaţiilor inginereşti mecanice

mechanical equivalent (of heat) (termo, mec) echivalentul mecanic al căldurii

mechanical exhaust (mec, mas) evacuare mecanică mechanical feeder (OM, mas-un) alimentator automat (acționat mecanic)

mechanical filter $(\mathrm{OM})$ filtru mecanic

mechanical force (mec) forță mecanică

mechanical four-wheel brake (auto, $\mathrm{OM}$ ) frână mecanică pe patru roți / pe fiecare roată 
mechanical fret saw (mas-un) ferăstrău mecanic (şi pentru decupat)

mechanical grate (met, termo) grătar cu bare mobile (la cuptoare)

mechanical hygrometer (metr, OM) higrometru mecanic (cu arc, cu element cu lungime dependentă de umiditate etc.)

mechanical impurity / impurities $(\mathrm{TH}$, materiale, hidr, T) impuritate / impurități mecanice (şi în lubrifianți etc.)

mechanical interlocking $(\mathrm{OM})$ protecție / blocare mecanică

mechanical jack $(\mathrm{OM}) \mathrm{cric} /$ vinci mecanic

mechanical life $(\mathrm{TH}, \mathrm{OM})$ durată de viață (în special pt. componentele mecanice)

mechanical linkage (OM) legătură mecanică (între componentele unui sistem, element întrun mecanism, bielă etc.)

mechanical loader (alim, mas-un) încărcător mecanic, dispozitiv mecanic de încărcare

mechanical lock (mas-un, OM) dispozitiv cu închidere mecanică, blocare mecanică

mechanical loss(es) (TH, mec, mas) pierderi mecanice / de energie mecanică

mechanical lubrication (T) ungere / lubrifiere sub presiune (rar)

mechanically actuated (mec, mas) acționat / comandat mecanic

mechanically controlled (mec, mas) acționat / comandat / reglat mecanic

mechanical mixing (alim, constr, ind chim) amestecare mecanică

mechanical mixture (alim, constr, ind chim) amestec mecanic

mechanical moulding (met, mec, mas) formare mecanică / cu utilaj specializat (şi pentru sinterizare ulterioară)

mechanical oil-atomiser burner (termo, OM) arzător cu pulverizator de ulei sub presiune

mechanical operation $(\mathrm{OM}$, mas, $\mathrm{TH})$ comandă / operație mecanică

mechanical pick (constr, met, OM, hidr) ciocan pneumatic

mechanical pillar (mas) stivuitor mecanic

mechanical plating (plast, met, $\mathrm{TH}$ ) placare mecanică (prin presare, laminare etc.)

mechanical power / output (mas, mec) putere mecanică (la ieşire, a unei maşini)

mechanical property (materiale) proprietate mecanică

mechanical puddling furnace (met, termo) cuptor de pudlaj, cu acționare mecanică

mechanical pusher (met, mec) împingător mecanic de cocs mechanical rabber (alim, constr, met, ind chim) agitator mecanic

mechanical rubber (ind chim, OM) cauciuc tehnic mechanical rectifier (el, OM) redresor cu reglare mecanică

mechanical repair shop $(\mathrm{TH})$ atelier de reparatii mecanice

mechanical rubber goods (OM, ind chim) articole din cauciuc tehnic

mechanical sampling (met, mas-un) luare automată a unei probe

mechanical saw (mas-un) ferăstrău mecanic

mechanical seal $(\mathrm{OM})$ etanşare care funcționează pe baza deformării materialului / garniturii datorită unei presiuni / forțe mecanice

mechanical scrubber (met, hidr, mas) scrubăr / spălător (de gaze) mecanic

mechanical shock resistance (materiale, OM) rezistență la şoc mecanic

mechanical sleeve $(\mathrm{OM})$ bucşă

mechanical stability (materiale, mec) stabilitate mecanică (a unui fluid, lubrifiant etc.), stabilitate la forfecare

mechanical stirrer (alim, ind chim, OM) amestecător / agitator mecanic

mechanical straightening (met, $\mathrm{TH}$ ) îndreptare mecanică

mechanical strength (materiale, mec) rezistență mecanică (fără a specifica la ce solicitare, prea general, atenție la text)

mechanical surface preparation (met, plast) pregătire mecanică a suprafeței (la tratamente, la lipire etc.)

mechanical technology $(\mathrm{TH})$ tehnologie mecanică / bazată pe procese mecanice (aschiere, deformare etc.)

mechanical test (materiale, metr) încercare / test(are) mecanic( $\breve{a}) /$ pentru determinarea unei proprietăți mecanice

mechanical transmission $(\mathrm{OM}, \mathrm{mec})$ transmisie mecanică

mechanical treatment $(\mathrm{TH}, \mathrm{mec})$ prelucrare / tratament mecanic

mechanical trip $(\mathrm{OM})$ organ de actionare pentru frână automată

mechanical vehicle $(\mathrm{OM}$, transp) vehicul antrenat mecanic

mechanical ventilation (mec, termo) ventilație forțată / mecanică / artificială

mechanical washer (met, ind chim, mediu) scrubăr / spălător mecanic de gaze

mechanical work (mec, fiz) lucru mecanic

mechanical work done (mec, fiz) lucru mecanic consumat 
mechanical working (mec, TH) solicitare / prelucrare mecanică

mechanical zero (metr, OM) zero mecanic (la aparate mecanice)

mechanics mecanică

mechanics of moulding making (met, $\mathrm{TH}$ ) tehnica / mecanica formării

mechanician mecanic; constructor de maşini

mechanic's tools $(\mathrm{OM})$ scule de lăcătuşerie

mechanism (OM, TH) mecanism (cu elemente cinematice, dar şi în sensul de proces / mecanism de deteriorare, formare, generare etc.); aparat; tehnică

mechanist mecanic

mechanization (mec, $\mathrm{TH}$ ) mecanizare

mechanize (mec, $\mathrm{TH})$ a mecaniza

mechano-chemical dehydration (alim, ind chim) dezhidratare mecano-chimică

meddle-proof (OM, autom, mas) protejat împotriva defectării (mecanice) din cauza acționării greșite (de exemplu, prin blocare)

medial (OM, geom) median, de mijloc

median (mat) mediană (în geometrie), de mijloc, median; mediu

median corrective maintenance time $(\mathrm{TH}$, mas) timpul în care se execută 50\% din acțiunile de mentenanță corectivă, în anumite condiții specificate

median diameter (OM, geom) diametru median / mediu

median perpendicular (geom) mediatoare (a unui segment, a unei laturi etc.)

median preventive maintenance time $(\mathrm{TH}$, mas) timpul în care se execută $50 \%$ din acțiunile estimate / preventive de mentenanță, în anumite condiții specificate

mediate intermediar; a intermedia; a ocupa o poziție intermediară; a fi mediator / intermediar; a mijloci, a media

mediation (ec) mijlocire, mediere; intermediere mediatrix, $(p l)$ mediatrices (geom) mediatoare medic (med) medic, doctor; student la medicină medical (med) medical; examen medical medical aid (adm, med) asistență medicală medical board (adm, med) comisie medicală medicament (med, chim) medicament; remediu medicamentary (med) medicamentos; curativ, terapeutic

medicate (med) a administra medicamente; a strânge plante medicinale

medicated (med, chim) medicinal

medicine (med) medicină

medicine dropper (med, chim) pipetă

mediocre mediocru, banal, comun mediocrity mediocritate

medium, $(p l)$ media medie; cifră medie; termen mediu; mediu, (de) mijloc, mijlociu, de mijloc; (chim, fiz, met) agent, mediu, ambianță; împrejurări; (mat) medie, valoare medie; agent, mijlocitor, intermediar; mijloc, cale, intermediu; metodă, procedeu; (ec) marfă de calitate intermediară; (poligrafie) aldine

medium carbon steel (met, $\mathrm{TH}$ ) oțel carbon cu conţinut mediu de carbon

medium drawing (met) trefilare intermediară

medium effective pressure (mec, hidr) presiune medie efectivă

medium fit (OM) ajustaj intermediar

medium force fit (OM) ajustaj intermediar (spre strângere), ajustaj blocat

medium granular (materiale) cu granulație mijlocie

medium grinding $(\mathrm{TH})$ sfărâmare / rectificare intermediară

medium-hard (met, mas-un) semidur, cu duritate mijlocie (şi la pietre de rectificat)

medium-hard steel (met) oțel semidur

medium heavy $(\mathrm{OM})$ semigreu (şi d. o serie de elemente de maşini, rulmenți etc.)

medium-heavy load (mec) sarcină medie

medium keying fit $(\mathrm{OM})$ ajustaj forțat

medium-lift pump (OM, hidr) pompă de presiune medie

medium plate (met) tablă (de grosime) mijlocie

medium plate rolling mill (met) laminor pentru tablă (de grosime) mijlocie

medium pressure $(\mathrm{OM}$, hidr) presiune medie

medium shape / section (met) profil mijlociu

medium sheet (met) tablă mijlocie

medium-sized $(\mathrm{OM})$ de mărime mijlocie / medie (şi d. semifabricate, elemente de maşini)

medium-sized mill (met) laminor pentru profiluri mijlocii

medium sizing (ind chim, met, metr) sortare / clasare intermediară

medium solder (met) aliaj de lipit (pt. lipire moale), cu conținut mediu de plumb

medium-temper steel sheet (met) tablă de oțel semidur, laminată la rece

medium term (mat) termen mediu, termenul de la mijloc

medium wave (fiz) undă medie

medium-wide strip mill (met) laminor pentru bandă (de grosime / lățime) mijlocie / medie

medium wire drawing (met) trefilare intermediară

meet (mat) intersecție a mulțimilor; competiție; a (se) întâlni cu; a (se) cunoaşte; a întâmpina; 
a înfrunta, a face față; (fig) a găsi, a da de / peste; a satisface, a mulțumi; a fi în concordanță cu; (ec) a onora (o poliță); a se întruni, a se aduna; (d. drumuri) a se întâlni, a se încrucişa; a fi de acord, a avea păreri comune, a ajunge la aceleaşi concluzii; a se uni, a se asocia, a stabili legături; (amer) întâlnire, întrunire; potrivit; nimerit; indicat; coerespunzător; smb. half-way a întâmpina pe cineva la jumătatea drumului, a face concesii cuiva

meeting întâlnire, întrunire; miting, adunare; şedință; întrecere, competiție; (geogr) confluență (a apelor); (auto) încrucişare (de vehicule), joantă; (OM) încheietură, îmbinare

meet the rudder (nav) a opri întoarcerea (punând cârma în bordul opus)

meg (metr, c, inf) abreviere informală pentru megabyte; v. megabyte

mega- (M-) (metr) prefix metric pentru $10^{6} \mathrm{sau}$ 1 milion; (metr, c) prefix în informatică şi industria calculatoarelor pentru memorie sau stocarea informației: $2^{20}=1048576$

megabar (Mbar) (metr, fiz, hidr) unitate de măsură pentru presiune: 1 megabar $=100 \mathrm{GPa}$

megabarrel (Mbbl, Mbo, MMb, Mb) (metr, termo, el) unitate de măsură pentru volum, din industria energetică: 1 megabarrel $\cong 158,987$ megalitri (Ml)

megabecquerel (MBq) (metr, fiz) unitate pentru măsurarea radiocativității: 1 megabecquerel = $10^{6}$ dezintegrări atomice pe secundă sau 27,027 microcurie

mega Btu (IT), (mega British thermal unit) (metr, fiz, termo) unitate de măsură pentru energie, în sisteme de încălzire şi condiționare a aerului din SUA, pentru aprecierea vitezei de răcire sau de încălzire: 1 mega Btu (IT) = $1055055852,62 \mathrm{~J}$

megabyte (MB) (metr, inf, c) unitate de măsură pentru informatie, în calculatoare; deseori 1 megabyte $=10^{6}$ bytes, dar uneori 1 megabyte $=2^{20}=1048576$ bytes

megacycle (Mc) (metr, fiz) denumire informală pentru megahertz, v. megahertz

megacycle per second (Mc/s) (metr, fiz) denumire mai veche pentru megahertz, v. megahertz

megadalton (MDa) (metr, fizică nucleară, chim) unitate de măsură pentru masă: $1 \mathrm{MDa}=10^{6}$ unităti atomice de masă

megaelectron-volt (metr, fiz) unitate de măsură pentru energie, utilizată în fizica nucleară: 1 megaelectron-volt $=1,60217733 \cdot 10^{-13} \mathrm{~J}$

megagram (Mg) (metr, fiz) unitate SI de măsură pentru masă: 1 megagram $=1000 \mathrm{~kg}=1$ tonă megagram/liter (metr) unitate de măsură pentru densitate, megagram pe litru: 1 megagram/liter $=1000000 \mathrm{~kg} / \mathrm{m}^{3}$

megagram/second (metr) unitate de măsură pentru debit masic, megagram pe secundă: 1 megagram $/ \mathrm{second}=1000 \mathrm{~kg} / \mathrm{s}$

megahertz (MHz) (metr, fiz, radio) unitate de măsură pentru frecvență, megahertz: $1 \mathrm{MHz}=$ $10^{6} \mathrm{~Hz}$

megajoule (MJ) (metr, fiz, mec) unitate de măsură pentru energie şi lucru mecanic: $1 \mathrm{MJ}$ $=10^{6} \mathrm{~J} \cong 0,277778 \mathrm{~kW} \cdot$ oră

megajoule/second (metr, fiz) unitate de măsură pentru putere: 1 megajoule $/$ second $=10^{6} \mathrm{~W}$

megakelvin (MK) (metr, astrofizică) unitate de măsură pentru temperatură: $1 \mathrm{MK}=10^{6} \mathrm{~K}$; reciprocal $\sim\left(\mathbf{M K}^{-1}\right)$ se foloseşte în calorimetrie

megalerg (metr) unitate de măsură în sistemul CGS pentru energie: 1 megalerg $=10^{6}$ erg $=0,1 \mathrm{~J}$

megaliter (MI, ML) (metr, fiz) unitate de măsură pentru volum / capacitate, megalitru: 1 megaliter $=1000 \mathrm{~m}^{3}$

megameter (Mm) (metr) unitate de măsură pentru lungime, megametru: 1 megameter $=10^{6} \mathrm{~m}$

megampere (MA) (metr, fiz, el) unitate de măsură a intensității curentului electric: $1 \mathrm{MA}=$ $10^{6} \mathrm{~A}$

meganewton (MN) (metr, fiz) unitate de măsură pentru forță: $1 \mathrm{MN}=10^{6} \mathrm{~N}$

megaohm (megohm) (metr, fiz, el) unitate de măsură pentru rezistența electrică: 1 megaohm $=10^{6} \mathrm{ohmi}$

megaohm (megohm) centimeter (metr) unitate de măsură pentru rezistivitate (folosită pt. substanțe cu rezistivitate mare, ca apa pură): 1 megaohm centimeter $=10^{4} \mathrm{ohm} \mathrm{m}$

megaparsec (Mpc) (metr, astronomie) cea mai mare unitate de măsură pentru lungime: 1 megaparsec $=10^{6}$ parseci sau 3,2616 milioane de ani-lumină $=30,857 \cdot 10^{18} \mathrm{~km}$.

megapascal (MPa) (metr, fiz, hidr, mec) unitate de măsură pentru presiune şi tensiune: $1 \mathrm{MPa}$ $=10^{6} \mathrm{~Pa}=1 \mathrm{~N} / \mathrm{mm}^{2}$

megapixel (metr, c) o unitate pentru descrierea mărimii sau rezoluției unei imagini digitale: 1 megapixel $=10^{6}$ pixeli (sau ,puncte")

megapond (Mp) (metr) unitate de măsură în sistem metric, pentru forță: 1 megapond = $1000 \mathrm{kgf}=9806,65 \mathrm{~N}$

megaton (Mton, Mt) (metr) unitate de măsură pentru energia degajată prin explozie (şi nucleară): 1 megaton este cantitatea de energie degajată după explozia a 1 milion de tone de TNT: 1 megaton $=4,18 \cdot 10^{15} \mathrm{~J}$ 
megatonne (Mt) (metr) unitate de măsură pentru masă, megatonă: 1 megatonne $=10^{6} \mathrm{t}$

megatron (fiz) megatron

megavolt (metr, el) unitate de măsură a tensiunii electrice, utilizată şi pentru caracterizarea centralelor energetice, megavolt: 1 megavolt $=10^{6} \mathrm{~V}$

megawatt (MW) (metr, mec, fiz) unitate SI de măsură pentru putere, utilizată şi pentru caracterizarea centralelor energetice, megawatt: 1 megawatt $=10^{6} \mathrm{~W}$

megawatt day $(\mathbf{M W} \cdot \mathbf{d}$, MWD) (metr) unitate de măsură pentru energie, utilizată pentru centrale şi arme nucleare: 1 megawatt day = $86,410^{9} \mathrm{~J}$

megawatt hour, megawatt-hour (MW·h) (metr) unitate de măsură pentru energie (electrică), megawatt oră: 1 megawatt hour $=3,6 \cdot 10^{9} \mathrm{~J}$

megayear (Myr, Ma) (metr, geol, astronomie) unitate de măsură pentru timp: 1 megayear $=1$ milion de ani

megohm (metr, fiz, el) unitate de măsură pentru rezistența electrică: 1 megohm $=10^{6} \mathrm{ohm}(\mathrm{i})$

meile (metr) unitate de măsură pentru lungime în țările cu limbi germanice: 1 meile (Austria) $=7586 \mathrm{~m} ; 1$ meile (Germania de nord) = $7532,5 \mathrm{~m} ; 1$ geographische meile (în germană) $=7412,7 \mathrm{~m}$

melchior (metr, alim) sticlă mare de şampanie, de $\sim 181$

Mercalli intensity scale (metr, geol) scara Mercalli, o scară empirică pentru ierarhizarea efectelor cutremurelor

-merous (metr) un sufix însemnând „cu n părți / elemente”; exemplu: „8-merous” înseamnă „care are 8 părți / elemente)"

mesh (metr, textile) unitate tradițională pentru măsurarea fineții țesăturilor din lână sau a plaselor de pescuit, reprezentând numărul de ochiuri / noduri pe inch: $\mathbf{n}$ mesh $=25,4 / \mathbf{n}$ (noduri / ochiuri) pe milimetru

Meitnerium (Mt) (chim) meinteriu

melamine-formaldehyde resin (MF) (plast, ind chim) răşină melaminforaldehidică

meliorate a îmbunătăți, a ameliora; (met) a înnobila, a purifica (d. un aliaj)

melioration îmbunătățire, ameliorare; înnobilare melliferous (bot) melifer; dulce ca mierea (d. produse apicole)

mellification melificație, pregătirea mierii

mellow (agr, bot) copt, matur, maturizat; suculent, moale (d. fructe); afânat; delicat (d. culori); a (se) coace; a (se) (în)muia, a face / deveni mai moale; a îndulci, a atenua, a micşora; a (se) afâna; a liniști mellowness (alim) suculență, maturitate (şi a vinului), friabilitate; (agr) pârg (al fructelor); bunăvoință, bunătate

melon (agr, bot) pepene galben sau verde melon field (agr) pepenărie, bostănărie

melonite (minrl) melonit

melon-seed oil (alim) ulei din semințe de pepene galben

melt (met, chim) topitură, topire, fuziune, şarjă, cantitate de material topită odată; (met, chim) a (se) topi, a fuziona, a (se) dizolva (material solid într-un lichid), a (se) lichefia, afiziona; a amesteca (culori); (fig) a mişca, a (se) înmuia, a (se) îndupleca, a (se) înduioșa, a dispărea, a se şterge, a transpira, a se topi (de căldură), a fi mişcat; ( $\mathrm{fam}$ ) a toca / topi (bani)

meltable (met, materiale) fuzibil, care poate fi topit, care se poate topi

melt away (fiz, materiale) a se topi complet

melt-doped (chim, materiale, electr) dopat în topitură (d. materiale pt. semiconductori)

melt down (termo, met) a (se) topi (complet), a retopi, a fluidiza; a se estompa, a dispărea încet melted (fiz, materiale) topit, aflat în fază lichidă (d. un metrial); v. molten

melted butter (alim) unt topit

melted fat (alim) untură / grăsime topită

melted snow and ice (meteo, alim) apă cu gheață (şi rezultată la / din topirea gheții zăpezii)

melter (met) topitor, oțelar, creuzet

melt extrusion (TH, materiale) extrudare când materialul a depăşit punctul de topire sau de înmuiere (şi la formarea izolatoarelor)

melt-grown crystal (met, chim, electr) cristal format în topitură (d. semiconductoare)

melting (met, chim) topire, topitură, fuziune, retopire, care (se) topeşte

melting accelerator (chim, fiz) accelerator de topire

melting aggregate (met) instalație / agregat pentru topirea metalelor

melting and refining of cast iron (met) topirea şi afinarea fontei

melting bath (met) baie de topire / de metal lichid

melting capacity (met) capacitatea de topire (a cuptorului); (plast) capacitate de plastifiere

melting charge (met) şarjă / masă topită, topitură melting condition (met) condiții / regim de topire / de elaborare a şarjei

melting crucible (met) oală de topire, creuzet

melting curve (met, termo curbă de topire

melting down (met) (re)topire; (meteo) dezgheț; (alim) dezghețare 
melting-down power / efficiency (met) producție de metal topit / lichid, eficiența / randamentul utilajului de topit

melting furnace (met) cuptor de topire melting hearth (met) vatra cuptorului de topire melting heat (termo) căldură / de topire melting house (met) topitorie, turnătorie melting kettle (ind chim) vas de topit melting loss (met, TH) pierderi prin topire sau ardere

melting medium (met) mediu de topire, atmosfera vasului de topit

melting operation (met) operație de topire

melting pan (chim) vas de topit

melting plant (met, plast) instalație de topire

melting point (fiz, chim, met) punct / temperatură de topire

melting-point curve (met) curba temperaturilor de topire; (fiz) punct / temperatură de topire

melting pot (ind chim, met) creuzet / oală de topire

melting practice (met, $\mathrm{TH}$ ) regim / tehnologie de topire

melting process (met, $\mathrm{TH}$, ind chim) proces / procedeu de topire

melting range (plast, met, ind chim) interval de topire / de înmuiere

melting rate (met) viteză de topire

melt into (alim, ind chim) a se preface (în ceva) prin topire; a se preschimba încet

melting stock (met) material de încărcare, şarjă, încărcătură pentru şarjă

melting-stock column (met) coloană de încărcare / de încărcătură la furnal

melting tank (ind chim, termo) cazan de topit, (vas) topitor; (met) oală de topit, creuzet

melting temperature (chim, met, termo) temperatură de topire

melting under a white slag (met) topire sub zgură albă

melting unit (met) instalație / unitate de topit

melting waste (met) pierderi la / prin topire

melting zone (met) zona de fuziune din furnal, zonă de topire / cu material topit

melt off / on a (se) topi

melt out a se topi (şi a curge în afară), a (se) îndepărta prin topire

melt spinning ( $\mathrm{TH}$, plast, materiale) proces de formare a fibrelor de materiale plastice şi de sticlă prin trefilare (şi rotativă) din topitură melt spun (plast) filare din topitură

melt time (met, plast) timp de topire, durată de realizare a topiturii (la anumiţi parametri)

melt (with) a se contopi (cu); a fuziona (cu) member membru (şi al unui partid), participant, asociat; cetățean, individ; (OM) piesă, element (de construcție sau de maşină), reper, parte, piesă componentă sau de schimb, organ de maşină, bară (într-o structură mecanică, în grinzi cu zăbrele); (mat) membru (al unei ecuații etc.), element al unei mulțimi, termen; (anat) membru, organ

member by member (mat) membru cu membru member card (ec, adm) carnet / legitimație de membru

member of an equation (mat) membrul unei ecuații

member of cinematic chain $(\mathrm{mec})$ element al lanţului cinematic

membru of the board (ec, adm) membru al consiliului de administrație

membership calitatea de membru; număr de membri; comunitate, societate

membrane $(\mathrm{OM})$ membrană, învelitoare, diafragmă, peliculă; (met) pojghiță, coajă

membrane actuated mechanism (OM, autom, metr) organ / mecanism de comandă (cu acționare prin membrană / cu diafragmă)

membrane filter (OM, alim, metr) filtru cu membrană

membrane pump (OM, hidr) pompă cu membrană

membrane valve (hidr, OM) supapă / robinet cu membrană

membrane water-proofing (materiale, $\mathrm{OM}$ ) membrană (izolatoare / de etanşare pentru / rezistentă la apă)

memorandum (ec) notă, minută, convenție; (adm, pol) memorandum

memorization memorizare

memorize a înregistra, a pune în memorie, a memora; (c) a memora, a înregistra în memorie, a introduce în memorie; a memoriza, a reține, a învăța pe de rost / pe dinafară

memory memorie, ținere de minte; amintire, aducere-aminte; reminiscență; commit to $\sim$ a memora, (c) echipament pentru înmagazinarea / păstrarea / stocarea informației, memorie, memorie pentru înmagazinarea / păstrarea / stocarea informației, a introduce în memorie; (autom) subsistem (bazat / rămas / introdus) pe / în memorie; comemorare; document biografic / istoric; reputatie; suvenir

memory access controller (c) regulator de acces la memorie

memory address register (c) registru care conține adresa cuvântului căutat, registru de adresă a memoriei 
memory array (c) aranjament în rânduri, al memoriei; (el, electr) aranjament în rânduri al miezurilor magnetice

memory bit (inf, c) unitate de măsură a capacității de memorare, bit de memorie

memory capacity (c, inf) capacitate de înmagazinare / de memorare / de stocare (a informației)

memory cell (c) celulă / element de memorie, locaţie de memorie

memory chips (electr, c) circuite de memorie memory circuit (c, autom) circuit de memorare (şi d. roboți)

memory cycle (c, inf) ciclu al memoriei (exprimat ca interval de timp sau succesiune de operații)

memory cycle time (c) durată a ciclului memoriei

memory device (c) memorie (ca subansamblu a unui calculator); (metr) aparat dispozitiv cu capacitate de memorare / stocare a datelor înregistrate / măsurate

memory dump (c) extragere a informației din memorie în cazul abandonării execuției unui program, vidare a memoriei

memory guard (c, inf) dispozitiv care împiedică accesul în anumite zone ale memoriei, protejare / protecție a memoriei

memory hierarchy (c) ierarhie pe niveluri diferite a memoriilor unui calculator

memory location (c) localizare în memorie, locație de / în memorie (d un calculator, un robot etc.), adresă, celulă de memorie

memory lockout register (c) registru conținând anumite adrese dintr-o zonă a memoriei la care programul nu are acces, registru de blocaj al memoriei

memory loss (med) amnezie; (c) pierdere a informației din memoria unui calculator

memory management (c, inf) gestiune a memoriei (ansamblu de funcții ale sistemului de operare)

memory overlay $(c)$ reutilizare a aceleiaşi zone a memoriei interne în diferite faze ale unui program; suprapunere a memoriei

memory paging (c) transferare a segmentelor unui program din memoria internă într-un mediu cu memorie virtuală şi invers

memory port (inf, c) legătură logică prin care datele sunt transferate din / în memoria principală

memory power (c) raport între vitezele de acces ale diferitelor zone de memorie, putere a memoriei memory print (c) extragere a informației din memoria internă şi trimiterea ei unei unități externe de memorare, listare a memoriei

memory protect (c, inf) dispozitiv / soft care împiedică accesul în anumite zone ale memoriei, protejare / protecție a memoriei

memory register $(\mathrm{c})$ registru de memorie

memory resident (c) memorie rezidentă (programe care rămân în memorie şi după executarea ei)

memory search register (c) registru de căutare în memorie

memory search routine (c) rutină / progam pentru căutarea memoriei / pentru căutarea și înlăturarea greşelilor

memory segmentation control (inf) calculul adreselor şi protecţia sistemelor de memorie, control al segmentării memoriei

memory space (c) locații disponibile pentru memorarea informațiilor, spațiu al memoriei interne

memory word (inf) cuvânt memorie

menace amenințare; pericol, primejdie; a amenința; a periclita, a primejdui, a pune în pericol

menacing amenințător, care pune în pericol, care periclitează / amenință

mend $(\mathrm{TH})$ ameliorare, îmbunătățire (a unei situații etc.), cusătură, reparație; (TH) a îmbunătăți, a ameliora, a corecta, a perfecționa, a (se) în-drepta (d. un drum, suprafețe în construcții etc.), a finisa, a repara, a drege, a cârpi; a corija, a (se) corecta, a se schimba în bine, a se corija; a accelera; a înfrumuseța; (auto, mas) reparație, a repara, a repune în stare de functionare; (textile) cusătură, a stopa, a tese (o gaură), a repara (un defect de țesătură sau de croială), a remaia, a cârpi; (ec) a se mări, a crește (d. prețuri); (med) ameliorare / îmbunătățire a sănătății, însănătoşire, întremare, a se face bine, a se îndrepta, a se însănătoși; a se schimba în bine; a accelera (pasul); a ațața (focul), a pune lemne / cărbuni pe foc; matters a drege / repara lucrurile; on the $\sim$ în curs de ameliorare, pe cale de vindecare / însănătoşire; be on the $\sim$ a fi în curs de îmbunătățire / normalizare (d. lucruri, procese tehnologice), a fi în curs de însănătoşire restabilire / ameliorare (d. sănătate, persoane)

Mendelevium (Md) (chim) mendeleviu

Mendeleev's periodic system tabloul periodic al elementelor

mender $(\mathrm{TH})$ reparație curentă, maistru pentru reparații; (textile) repansatoare, dispozitiv de remaiere / reparare / stopare 
menders (TH, ec, metr) piese rebutate (şi la maşini-unelte)

mending $(\mathrm{TH})$ reparare, reparație, îmbunătățire, îndreptare, material(e) pentru reparat; cârpire (şi peiorativ), cârpit; (textile) remaiat, remaiere, repansare; ( $\mathrm{fam}$ ) lucruri de dat la reparat

mending yarn (textile) ață de țesut / de reparare (a unei țesături)

mensurable (metr) măsurabil; onest, corect, cinstit

mensurate (metr) a măsura

mensuration (fiz, metr) măsurare

mental mental, mintal; intelectual

mentality intelect, capacitate intelectuală; mentalitate; mod de a gândi; concepție; stare de spirit, dispoziție

mention mențiune; menționare; amintire, referire; a menționa, a aminti; a cita; a vorbi (despre); a releva, a sublinia

mentionable de mentionat

mentor mentor; (edu) îndrumător; dascăl, profesor, învățător; tutore; (sport) antrenor

mercantile mercantil, comercial; interesat; meschin

mercantile house (ec) casă de comert

mercantile marine (nav) marină comercială

mercerization (textile) mercerizare

mercerize (textile) a merceriza

mercery (textile, ec) mercerie, manufactură

merchandise (ec) marfă, mărfuri

merchant (ec) comerciant

merchantable (ec) vandabil

merchant bar iron (met) aliaje feroase (oțel) în bare, destinat pieței

merchant fleet / navy (nav) flotă comercială

merchant marine (nav) navă comercială

merchant mill (met) laminor de profiluri (cu destinație comercială)

merchant mill train (met) trenul laminorului de profile

merchant navy (nav) navă comercială

merchant rolling mill (met) laminor de profiluri comerciale

merchant steel (met) otel comercial / pentru piață / de calitate comercială

mercurial vioi, iute, ager, isteț; nestatornis, schimbător; (ec) comercial; (chim) mercurial, (preparat) cu mercur

Mercury, Hydrargyrum (Hg) (chim) mercur; mercury (metr) coloana de mercur a barometrului; ghid, călăuză

mercury alloy (met) aliaj de mercur

mercury column (fiz, metr) coloană (de mercur)

mercury contact (el) contact cu mercur

mercury manometer $(\mathrm{OM}$, hidr) manometru $\mathrm{cu}$ mercur, barometru mercury oxide (chim) oxid de mercur / mercuric mercury porosimeter (metr) porozimetru $\mathrm{cu}$ mercur

mercury vapour (fiz, chim) vapori de mercur

merge a (se) amesteca, a fuziona, a (se) uni, a îmbina (două sisteme), a se amalgama, a contopi, a fuziona, a (se) îmbina; (c) denumirea unei comenzi pentru transformarea mai multor celule dintr-un tabel într-una singură (Windows);

merge in / into a (se) transforma treptat în, a trece în

merger (chim, TH) contopire, fuzionare, fuziune, amestecare

merging joncțiune; (met) dizolvare, fuziune, contopire, amalgamare

meridian meridian; zenit, apogeu, culme; culminant

merit merit, valoare; calitate, însuşire; a fi vrednic de, a merita

merited meritat

meritorious meritoriu

mesh (alim) ochi de sită / plasă; (cf) retea de căi ferate; (el) priză, buclă; (OM) angrenare a dinților, montură (a unei pietre prețioase), sită, a angrena; (mat) celulă, element, nod, diviziune; (cf) rețea de căi ferate; (nav) ochi de plasă; (textile) buclă, împletitură, plasă, ochi, număr de ochiuri al unei site pe inch sau pe suprafață unitară (d. o sită, un filttru, o tesătură etc.), a face ochiuri, a împleti năvoade; ochi (de plasă de pescuit, de sită, într-o rețea electrică; a face ochiuri din; (fig) a prinde în cursă, a se prinde în capcana, a fi prins în capcană; coarse(textile) cu ochiuri mari / grosolane, (mec, inf) cu divizare grosieră, cu elemente mari (în metoda elementului finit); silent $\sim(\mathrm{OM})$ angrenare fără zgomot / silențioasă; out of (OM) decuplat, scos din angrenare; in $\sim$ în priză

mesh aerial (radio) antenă din plasă de sârmă

mesh analysis (materiale, metr) analiză granulometrică, analiză pe site

mesh anode (el) anod în ochiuri

mesh antenna (radio) antenă din plasă de sârmă

mesh connection (el) conexiune buclată, conexiune poligonală / delta / în triunghi

mesh currents (el) curenți ciclici (în lanțuri electrice), curenți închiși (în lanțuri electrice)

meshed cu ochiuri, cu rețea (d. plase, site, rețele electrice; (model) împărțit / divizat în elemente finite (în metoda elementului finit etc.)

mesh filter (OM, hidr, alim) filtru de sită meshing (OM) angrenare / cuplare a roților dințate 
meshing angle $(\mathrm{OM})$ unghi de angrenare (în special la roți dințate) $(\alpha)$

meshing interference $(\mathrm{OM})$ interferență la angrenare / în funcționare

meshing with backlash $(\mathrm{OM})$ angrenare $\mathrm{cu}$ joc meshing without backlash $(\mathrm{OM})$ angrenare fără joc, angrenare forțată

mesh layout (el) rețea închisă

mesh line / surface strat al rețelei (în analiza numerică 2D sau 3D)

mesh network (electr, inf) rețea în care un nod este conectat cu celelalte astfel încât comunicarea se face peste circuitele dedicate dintre noduri; rețea de noduri (în metoda elementului finit)

mesh number (metr, agr, constr, ind chim) numărul ochiului, numărul sitei (în gama standardizată sau tipizată); numărul de noduri / de elemente finite (în metoda elementului finit)

mesh points (mat) puncte reticulare, noduri ale rețelei (şi la modele în metoda elementului finit); (OM) puncte de angrenare (de exemplu, pe dreapta de angrenare a roților cu dinți evolventici)

mesh of railways (cf) rețea de căi ferate

mesh reinforcement (materiale, constr) armătură din rețea / plasă metalică sau din fibre, ranforsare tip rețea / plasă (şi la compozite)

mesh rule (el) legea a doua a lui Kirchhoff meshs (nav, agr) plasă, năvod; (el) rețea / rețele mesh screen / sieve (OM, metr, agr, constr, ind chim) ciur, sită

mesh size mărimea ochiului sitei

mesh structure (plast) structură reticulară

mesh substation stație de transformare cu bare în buclă şi disjunctoare în serie

mesh texture (plast) textură reticulată

meshwork (el) rețea; (fiz, mec, termo) rețea (a unui model, în metoda elementului finit)

meshy cu ochiuri; (plast) reticular, reticulat

mesic atom (fiz) mezoatom

meson (fiz) electron greu, mezon

mess murdărie, gunoi; dezordine, harababură; bătaie de cap, încurcătură; a murdări, a mânji; a face dezordine, a răvăşi; a face de mântuială; (alim) fel de mâncare; (agr) nutreț; (nav) careu; comeseni; masă comună

message mesaj, ştire, veste; apel; a transmite / comunica prin semnale, a semnaliza; a telegrafia

messenger trimis, mesager, curier; cablu portant messenger strand (el, OM) fir de suspensie pentru cabluri aeriene

messenger wire (el, OM) cablu purtător messenger wire clamp (el, OM) placă / clemă (de strângere a firului de suspensie)

messy murdar; dezordonat, în dezordine; răvăşit mestron (fiz) mezotron

met (metr, med) o unitate de măsură pentru metabolism: 1 met este metabolismul unei persoane în repaus, echivalent cu $58,15 \mathrm{~W} / \mathrm{m}^{2}$, indiferent de mărimea persoanei

metacentre (mec, nav) metacentru

metacentric high (nav) înălțime metacentrică

metal (met, OM) metal, aliaj metalic (deseori); de metal, metalic; a acoperi cu metal; a pune pietriş pe, a macadamiza

metal alloy (met) aliaj metalic

metal-arc cutting (met, el, TH) decupare / tăiere cu cu arc şi electrozi metalici

metal ball (OM) bilă de metal (şi de rulment etc.)

metal base (el, OM) soclu metalic

metal bath (met) baie metalică / de metal

metal-bearing metalifer (d. minereuri)

metal block (met) bloc / lingou de metal sau aliaj metalic

metal board (constr) planşeu metalic

metal borings (mas-un) aşchii de metal (mai ales din procesul de găurire)

metal brush (met, mas-un) perie metalică

metal castings (met) piese (metalice) turnate

metal-ceramic (compound) (materiale) compozit metalo-ceramic

metal-ceramic bearing $(\mathrm{OM}, \mathrm{T})$ lagăr (cu cuzinet) metalo-ceramic

metal charge (met) încărcătură metalică, şarjă (pt. un cuptor etc.)

metal chips (mas-un) aşchii metalice (provenite mai ales din procese de aşchiere, decupare, ştanţare etc.)

metal-clad (met) placat (cu metal), acoperit $\mathrm{cu}$ plăci metalice; blindat

metal cloth (met) țesătură de metal / metalică, manta / acoperire metalică

metal coat (met) acoperire metalică (de protecție) metal coating (met, $\mathrm{TH}$ ) (acțiunea / procesul de) acoperire metalică

metal constructions (constr, mec) construcții metalice, ferme

metal content (met) conținutul de metal

metal core (met, el) inimă de metal (la cabluri)

metal covering (met) metalizare, placare cu un metal sau aliaj metalic (pt. protecție)

metal cutting (mas-un, $\mathrm{TH}$ ) prelucrare prin aşchiere, tăiere / decupare a metalelor (indiferent de procedeu)

metal-cutting band saw (mas-un) fierăstrău cu bandă (pentru tăierea metalelor) 
metal deactivator (chim, $\mathrm{T}$ ) aditiv dezactivator metalic (pentru combustibili, lubrifianți etc.)

metal deposit (met) depunere / placare metalică (în general de protecție)

metal door (constr) uşă (metalică)

metal drain (met) jgheab de turnare

metal drawer (met) trăgător la trefilare, dar şi la turnarea continuă, trefilor

metal dross (met) zgură (metalică)

metal drum $(\mathrm{OM})$ tambur / tobă metalic $(\breve{a})$

metal enveloping facing acoperire metalică (la suprafață), înveliş metalic (ornamental sau de protecție)

metal extrusion (mas-un, met) extrudare a materialelor metalice

metal extrusion press (mas-un) presă pentru extrudat materiale metalice

metal facing (TH, met, OM, T) acoperire metalică, manta / blindaj de protecție

metal fatigue (met, OM) oboseala metalului sau a unui aliaj metalic

metal fitting(s) (auto) fierăria caroseriei; (OM) garnitură, armături din metal

metal foil (alim, met) folie metalică

metal foil rolling mill (met) laminor pentru folii metalice / semifabricate / table (foarte) subțiri

metal foundry (met) turnătorie de metal

metal frame (mas-un, OM) cadru / batiu / suport metalic

metal gauge (met, metr) calibru pentru grosimea tablei / semifabricatului

metal goods articole de metal (nu neapărat tehnice)

metal hub $(\mathrm{OM})$ bucşă metalică, butuc / sabot metalic

metal impurity (met, materiale) metal însoțitor, impuritate metalică, impuritate într-un material metalic / aliaj

metal insert (plast) inserție metalică

metal jacket (met, termo, OM) carcasă / manta / înveliş de metal

metal latch plate (auto) încuietoare de metal metalled glass (ind chim, TH) sticlă metalizată

metallic (met) de metal, metalic

metallic arc (el, met) arc electric între electrozi de metal

metallic-arc welding (el, met, $\mathrm{TH}$ ) sudare $\mathrm{cu}$ arc, cu electrozi metalici

metallic bead (met) picătură rece de metal (defect de turnare)

metallic bond (chim, met) legătură metalică

metallic case (met, OM) carcasă / casetă / cutie de metal (şi pt. tratament termic sau termochimic)

metallic charge (met) încărcătură metalică metallic clip $(\mathrm{OM})$ bridă metalică

metallic coating (met, $\mathrm{TH}, \mathrm{T}$ ) acoperire metalică

metallic compound (chim, met) compus meta-

lic, combinație metalică

metallic foil (met) foaie / folie metalică

metallic glass(es) (met) aliaje metalice amorfe (pe bază de $\mathrm{Fe}, \mathrm{Ni}$, Co etc., prin răcire rapidă)

metallic hose (met) furtun metalic

metallic inclusions (met) incluziuni metalice

metallic ores (met) minereuri metalice

metallic oxide (chim, met) oxid al unui metal, oxid metalic

metallic packing $(\mathrm{OM})$ garnitură metalică de etanşare

metallic resistor $(\mathrm{el})$ rezistență metalică

metallic ribbon (met, $\mathrm{OM}$ ) platbandă / bandă / panglică metalică

metallic salt of short-chain organic acid (chim) sare metalică a unui acid organic cu catenă scurtă (şi pt. unsori)

metallic shot (met) alice de metal

metallic soap (chim, T) săpun cu metal în compoziție, săpun metalic

metallic sponge (met) metal / aliaj spongios, burete metalic

metallic stearate (chim) stearat al unui metal / metalic

metalliferous (met) cu conținut de metal, metalifer (d. minereuri)

metalling coating by hot dipping process (met) metalizare / acoperire prin cufundare în baie caldă

metal lining (met) placare metalică (nu se specifică procedeul)

metallization (met, chim) metalizare (şi cu rol de protecție), acoperire metalică

metallize (met) a metaliza; (el) a galvaniza

metallizing (met) metalizare, acoperire metalică

metallizing gun (met) pistol de / pentru metalizare / acoperire metalică

metallographic etchant (met, chim, metr) reactiv metalografic (pt. evidențierea structurii)

metallographic examination (met, metr) cercetare / examinare metalografică

metallography (met, metr) metalografie

metalloid (chim, met) metaloid

metalloid cutting tool (met, mas-un) sculă de aliaj dur

metallurgic(al) metalurgic, metalurg (d. o persoană)

metallurgical chemistry (met, chim) chimie metalurgică

metallurgical coal (met) cărbune metalurgic / cocsificabil 
metallurgical coke (met) cocs de furnal / metalurgic

metallurgical condition (met) micro-structură (a unui material metalic, a unui aliaj)

metallurgical engineer (met) inginer metalurg

metallurgical engineering (met) metalurgie, inginerie metalurgică

metallurgical furnace (met, termo) cuptor metalurgic

metallurgical plant (met) uzină / combinat metalurgic $(\breve{a})$

metallurgical product (met) produs metalurgic metallurgical waste gases (met) gaze de furnal metallurgical works (met) uzină metalurgică

metallurgist (met) metalurgist

metallurgy (met) metalurgie

metallurgy of iron (met) siderurgie, metalurgia fierului

metallurgy of iron and steel (met) metalurgie feroasă

metallurgy of non-ferrous metals (met) metalurgie neferoasă

metal mike (nav) giropilot, pilot automat

metal mixer (met) melanjor

metal mould (met) cochilă; (plast) formă / matriță metalică

metal notch (met) gură de scurgere a metalului (la cuptor)

metal package $(\mathrm{OM})$ cutie metalică, container metal plate (met) placă / tablă metalică metal plating (met) metalizare, acoperire metalică metal plate rolling mill (met) laminor pentru tablă groasă

metal pot (met, termo) cazan (mic) de topit plumb metal powder (met) pulbere metalică

metal powder rolling mill (met) laminor pentru laminarea benzii din pulberi metalice

metal-protecting cage (met, el, fiz, OM) cuşcă de protecție din împletitură sau din plăci metalice

metal purifying (met) rafinarea metalului / aliajului

metal purifying process (met) proces / procedeu de rafinare a metalului / aliajului

metal radiography (met) analiză metalografică cu radiații $\mathrm{X}$

metal rectifier (el, met) redresor metalic (uscat)

metal removed per cut (mas-un) metal / aliaj îndepărtat la o trecere

metal research (met) cercetare în domeniul metalurgic

metal residues (met, chim) reziduuri / deșeuri metalice

metal rib $(\mathrm{OM})$ nervură metalică

metal ring $(\mathrm{OM})$ virolă, inel metalic metals (cf) şine de cale ferată; (constr, OM) profile (şi ca semifabricate metalice)

metal saw (mas-un) fierăstrău metalic / pentru metale (şi de mână)

metal science (met) metalografie, studiul metalelor metal scrap (met) deşeuri de metal

metal seal $(\mathrm{OM})$ garnitură metalică de etanșare

metal shavings (mas-un) aşchii de metal

metal sheathing (met, TH) metalizare, placare metalică

metal sheet (met) placă / tablă de metal

metal sheet covering (met, constr) tablă de învelit (de protecție, nu de rezistență)

metal sheet (met, OM) placă / tablă de metal

metal shell (met, OM) manta din tablă de oțel metal shielding (el, fiz) ecranare metalică; protecție prin ecran / foaie metalică

metal-slitting saw (mas-un) fierăstrău circular pentru metale

metal-soap complexes (chim, T) combinații complexe ale săpunurilor pe bază de săruri metalice (şi pt. unsori)

metal-sprayed coating, metal spraying (met) acoperire metalică prin pulverizare (de protecție sau anti-uzură) (tehnologie şi rezultat)

metal-spray gun (met) dispozitiv de pulverizare a metalelor, pistol de metalizare

metal spraying $(\mathrm{TH})$ pulverizarea unui metal / material metalic

metal strip (met) fâşie / bandă de metal / metalică metal strengthening durificarea metalului, creşterea rezistenței (mecanice) a metalului (fără a preciza d. ce rezistență este vorba sau prin ce procedeu / tehnologie se obține)

metal structure (met, constr) constructii / structuri metalice

metal tape (met) bandă / panglică metalică

metal to be melted (met) metal de / pentru topit metal-to-metal brake (auto, OM) frână / ambreiaj cu frecare uscată (metal-pe-metal)

metal-to-metal clutch (OM) ambreiaj cu frecare uscată (metal-pe-metal)

metal-to-metal fit (mas-un, OM) ajustaj fără joc şi fără strângere, ajustaj cu joc sau strângere mici (realizat prin selectarea loturilor de piese care se montează)

metal-to-metal joint $(\mathrm{OM})$ îmbinare a două suprafețe metalice fără joc între ele, îmbinare cu contact direct între piesele metalice

metal trim (constr, OM) ornament metalic / de metal

metal tube (met, OM) țeavă / tub de metal

metal turbulence (met) mişcare turbulentă a metalului lichid 
metal turning lathe (mas-un) strung pentru metale / aliaje metalice

metal turnings (mas-un) aşchii de metal (mai ales de la strunjire)

metalware (met, OM) articole / produse din metal metal waste (met) deşeuri metalice, pierderi metalice (la turnare, transvazare etc.)

metal wheel (auto) jantă

metal weld (met) sudură metalică

metal welding (met) sudarea metalelor / aliajelor / metalică

metal wing (met, OM) aripă / parte metalică

metal wire (met, OM) sârmă de metal / metalică

metal work $(\mathrm{OM})$ piese de / din metal / aliaj metalic

metal worker (met) muncitor în metalurgie

metal working (met) prelucrarea metalelor (fără a specifica procedeul: turnare, forjare, laminare) metal-working industry (met) industria metalurgiei prelucrătoare

metal-working machine (mas-un) maşină-unealtă pentru prelucrarea metalelor (fără a preciza tehnologia: deformare la rece, aşchiere etc.)

metamer (chim) metamer

metamorphosis metamorfoză

metastable (chim) metastabil (şi d. o fază întrun aliaj)

metastable beta (met) fază beta metastabilă

metastable diagram (met) diagramă metastabilă metastable equilibrium (met) echilibru nestabil mete limită, margine, hotar, graniță; a măsura, a împărți, a distribui

meteoric iron (met) fier meteoric

meteorologic(al) meteorologic

meteorologist meteorolog

meteorology meteorologie

meter (el) contor; (metr) aparat de măsură, a măsura; (metr) meter (m) (amer), metre (m) (brit) metru, unitate SI de măsură pentru lungime

meter armature (el) indusul contorului

meter-atmosphere (metr) v. atmo-meter

meter base (el, OM) soclu de contor

meter board (el, metr) panou de contoare, panou de aparate de măsură

meter bottom bearing (el, OM) lagăr-suport al contorului

meter box $(\mathrm{OM})$ cutie de contor / aparat de măsură meter braking element (el, OM) dispozitiv de frânat al contorului

meter calibrating equipment (metr, el) echipament de etalonat contoare sau aparate de măsură

meter case (OM, metr) carcasa contorului / aparatului de măsură meter constant (metr) constanta contorului / aparatului de măsură

meter display (metr, OM) afişajul contorului / aparatului de măsură

metered (metr) măsurat, contorizat

meter error (metr) eroare de măsurare

meter/hour (metr) unitate de măsură pentru viteză, metru pe oră: 1 meter $/$ hour $=0,000277778 \mathrm{~m} / \mathrm{s}$

metering (metr, $\mathrm{TH}$ ) măsurare, contorizare, dozare meter-in circuit (hidr, autrom) circuit de reglare a vitezei de alimentare

metering device (metr) aparat / dispozitiv / instrument de măsurat (foarte general)

metering equipment (metr) echipament de măsurat (în general, mai complex)

metering error (metr) eroare de măsurare

metering hole jet (auto) ajutajul jiclorului

metering orifice (metr, OM, hidr) ajutaj de măsurat

metering panel (metr, autom) panou de măsurare, panou de control

metering pin (hidr, Om) plunjer / ştift care prin formă şi poziționare poate varia secțiunea de curgere a unui fluid

metering pump (alim, hidr, metr, OM) pompă dozatoare

metering rod (auto, OM) ac de dozare pentru benzină

metering zone (TH, mas) zonă de măsurare; (plast, ind chim) zonă de omogenizare / de plastifiere

meter kilopond, mkp (metr, fiz) o unitate de măsură pentru moment: 1 kilopond $=9,80665 \mathrm{~N} \cdot \mathrm{m}$

meterlambert, meter-lambert (metr, fiz) unitate SI pentru măsurarea luminantei: 1 meterlambert $=1$ candela $/ \mathrm{m}^{2}$

meter/minute (metr, fiz, mec) unitate de măsură pentru viteză, metru pe minut: 1 meter/minute $=0,016666667 \mathrm{~m} / \mathrm{s}$

meter of seawater, msw (metr, hidr) unitate convențională de presiune, metru de coloană de apă de mare: 1 meter of seawater $=10 \mathrm{kPa}$

meter-out circuit (hidr, autom) circuit de reglare a vitezei pe retur

meter per second $(\mathbf{m} / \mathbf{s})$ (metr) unitate SI de măsură pentru viteză, metru pe secundă

meter/square second, $\mathbf{m} / \mathbf{s}^{2}$ (metr, mec) unitate SI de măsură pentru accelerație, metru pe secundă la pătrat

meter rule (metr) riglă gradată

meter terminal cover (el) capac de protectie la contor / aparat de măsură

methacrylate(s) metacrilați

methane (chim) (gaz) metan / de baltă 
methane gas (chim) (gaz) metan

methanol (chim) metanol, alcool metilic methanol coolant (auto) agent de răcire pe bază de metanol

method metodă, sistem, organizare; procedeu methodic(al) metodic, sistematic; ordonat methodically $(a d v)$ (în mod) metodic, sistematic methodize a ordona, a sistematiza

method of random sampling (metr) metoda controlului prin sondaj

method of approximation (mat, metr) metodă de aproximare

method of firing (termo) conducere a focului method of gas attack (met, termo) procedeu de suflare (a gazului)

method of least squares (mat, metr) metoda celor mai mici pătrate

method of operation $(\mathrm{TH}$, ind) metodă de exploatare; procedeu / regim / proces de lucru / de fabricație

method of similitude metoda similitudinii

method of test(ting) (metr) metodă de testare / de cercetare

method of travel of the flames (termo) conducerea flăcării

methodological metodologic

methodologically $(a d v)$ (din punct de vedere) metodologic

methodology metodologie

methoxides (ind chim, plast) metilați

methuselah (metr, alim) sticlă mare de vin, de $\sim 61$

methyl (chim) metil

methyl acetate (chim) acetat de metil

methyl acrylate(s) (chim), acid acrilic, metil ester, acid 2-propenoic

methyl alcohol (chim) alcool metilic

methylate (chim) metilat

methylated spirit / spirits (chim) alcool metilic, spirt denaturat

methyl-butadiene (plast, ind chim) izopren, metilbutadienă

methylene (chim) metilen

methyl-metacrylate (chim) metacrilat de metil

methyl polymethacrylat (plast) polimetacrilat de metil

methyl rubber (ind chim) metil cauciuc

meticulosity meticulozitate, scrupulozitate

meticulous meticulos, scrupulos; minuțios

metre (brit) (metr) metru

metric (metr) metric (şi cu referire la unități din sistemul metric / internațional de unităti de măsură); (mat) metrică

metrical (metr) metric

metric calculation (mat) calcul zecimal metric carat (metr) unitate recunoscută internațional, pentru masă în bijuterie, carat: 1 metric carat $=200 \mathrm{mg}$

metric coarse pitch (OM) pas metric (normal) (la filete)

metric fine pitch $(\mathrm{OM})$ pas metric fin (la filete) metric gear $(\mathrm{OM})$ roată dințată cu pas / modul exprimat în milimetri

metric grain, pearl grain (metr) unitate de măsură pentru masă, în bijuterie: 1 metric grain = $50 \mathrm{mg}=1 / 4$ carat

metric horsepower (metr) unitate de măsură pentru putere, cal-putere metric: 1 metric horsepower $\cong 735,499 \mathrm{~W}$

metric hundredweight, centner (brit) (metr) unitate neoficială de măsură pentru masă: 1 metric hundredweight $=50 \mathrm{~kg}$

metric lattice (mat) structură metrică

metric measure (metr) măsură metrică / zecimală metric mile (metr, atletism) unitate informală pentru lungime: 1 metric mile $=1500 \mathrm{~m}$

metric pound (metr, fiz) denume neoficială a unei unități de măsură pentru masă: 1 metric pound $=0,5 \mathrm{~kg}$

metric quintal (metr) unitate de măsură pentru masă, chintal: 1 metric quintal $=100 \mathrm{~kg}$

metric slug, engineering mass unit, simbol TME (din germană - Technische Mass Einheit) (metr) unitate de măsură pentru masă, în inginerie, 1 metric slug este masa accelerată la 1 $\mathrm{m} / \mathrm{s}^{2}$ de o forță de $1 \mathrm{kgf:} 1 \mathrm{TME}=9,80665 \mathrm{~kg}$

metric system (metr) sistem metric de unităţi de măsură, sistem internațional (SI) de unități de măsură

metric taper reamer (mas-un) alezor pentru conuri metrice (ale cozilor de scule etc.)

metric thread $(\mathrm{OM})$ filet metric

metric ton, tonne (t) (metr) unitate de măsură pentru masă, tonă (metrică): 1 metric ton $=10^{3} \mathrm{~kg}$

metric ton unit (mtu) (metr) unitate de măsură pentru a evalua valoarea unui minereu: $1 \mathrm{me}$ tric ton unit este o tonă de minereu cu $1 \%$ metal $(=10 \mathrm{~kg} / 1000 \mathrm{~kg})$

metrological (metr) metrologic

metrological reliability (metr) fiabilitate mettrologică

metrological repeatability (metr) repetabilitate metrologică

metrology (metr) metrologie, teoria, ştiința şi tehnica măsurării

MeV (metr, fizică nucleară) simbol pentru un milion de electronvoltit; unitate pentru energie: $1 \mathrm{MeV}=160,2176462$ femtojouli; unitate de masă: $1 \mathrm{MeV}=1,782662 \cdot 10^{-27} \mathrm{~g}$ 
mezzanine (constr) mezanin

$\mathbf{m g} / \mathbf{d l}$ (metr, med) simbol pentru milligram per deciliter, unitate US pentru a măsura concentrația unei substanțe în sânge: $1 \mathrm{mg} / \mathrm{dl}=0,01 \mathrm{~g}$ (de substanță) pe litru (g/L, g/l)

$\mathbf{m g} / \mathbf{k g}$ (metr, med) simbol pentru milligram per kilogram, unitate de măsură pentru dozarea medicamentelor în funcție de masa (greutatea) pacientului: $1 \mathrm{mg} / \mathrm{kg}$ (corp) este echivalent $\mathrm{cu}$ $10^{-6} \mathrm{~g} / \mathrm{g}$ (corp) sau $1 \mathrm{ppm}$

mg-at (metr, chim) simbol pentru milligram atom sau millimole (mmol)

Mgd (metr, hidr) abreviere pentru million of gallon per day $(\mathrm{Mgal} / \mathrm{d}): 1 \mathrm{Mgd} \cong 3,78543$ megalitri pe zi

mg-eq (metr) simbol pentru milligram chimic equivalent (mai vechi) sau milliequivalent (mEq); v. milliequivalent

mgon (metr, geom, astronomie) simbol pentru milligon (milligrad), unitate de măsură pentru unghiuri: 1 milligon $=10^{-5}$ din unghiul drept sau $0,0009^{\circ}$ sau 15,708 microradians ( $\left.\mu \mathrm{rad}\right)$

m-graduated in metric (metr) cu gradații în milimetri (d. cadrane / afişaje ale aparatelor de măsură)

mho (metr, el) denumire veche pentru siemens, unitate definită ca inversa pentru ohm; v. siemens

mic (metr, fiz) denumire neoficială pentru microgram; v. microgram

mica (chim) mică

mica spark(ing) plug (auto) bujie cu izolator de mică

mica washer (auto, el) şaibă de mică

mickey (metr, c) unitate de măsură în programarea mouse-ului şi a sistemor similare: 1 mickey este cea mai mică lungime detectabilă, a mişcării mouse-ului (tipic $\sim 0,1 \mathrm{~mm}$ )

micro- ( $\boldsymbol{\mu}-$, mc-, u-) (metr) prefix metric pentru $10^{-6}$ (o milionime) (dintr-o unitate de măsură)

microadjustment device (mas, autom, metr) dispozitv / aparat pentru reglare fină/ de precizie

microampere $(\boldsymbol{\mu A})$ (metr, el) unitate de măsură a intensității curentului electric, microamper: 1 microampere $=10^{-6} \mathrm{~A}$

microanalysis (chim) microanaliză

microarcsecond ( $\mu$ as) (metr, astronomie) unitate pentru măsurarea unghiurilor: 1 micro-arcsecond $=10^{-6}$ arcsecond $\cong 4,8481 \cdot 10^{-12} \mathrm{rad}$

microbar ( $\mu$ bar) (metr, fiz, acustică) unitate de măsură pentru presiune în sistem CGS, microbar: 1 microbar $=0,1 \mathrm{~Pa}$

microbe (biol, med) microb

microbial, microbic (biol, med) microbian microbiology (biol, med) microbiologie

microcamera (fiz, opt) microcameră

microcell (fiz, el, T) microcuplu, microcelulă (nu se specifică principiul de funcționare), microelement (şi galvanic)

microcellular rubber (plast, ind chim) cauciuc microporos

microclimate microclimat, microclimă

microcomputer (el, autom, c) microcomputer (de obicei dedicat / specializat)

microcomputer-controlled driver information gauge (auto, c) instrument controlat de un microcomputer pentru informații asupra parametrilor autovehicolului

micro-corrosion (chim) microcoroziune, coroziune neobservabilă cu ochiul liber / vizibilă la microscop

micro(-)crystallography (met) microcristalografie microcurie $(\mu \mathrm{Ci})$ (metr, fizică nucleară) unitate de măsură pentru radioactivitate, microcurie: 1 microcurie $=10^{-6}$ curie (corespunde unei radioactivități de 37000 dezintegrări atomice pe secundă)

microdefect (met) microdefect (şi la sudură)

microdegree ( $\mu \mathrm{deg})$ (metr, geom, astronomie) unitate de măsură pentru unghiuri, micrograd: 1 microdegree $=10^{-6}$ grade

microeinstein $(\boldsymbol{\mu E})$ (metr, fiz) unitate pentru a măsura concentrația energiei luminoasă sau a radiației electromagnetice: 1 microeinstein $=$. $10^{-6}$ einstein

microeinsteins per second per square meter $\left(\mu \mathrm{E} / \mathrm{s} \cdot \mathrm{m}^{2}\right)$ (metr, fiz) unitate de măsură pentru densitatea radiației luminoase, microeinstein pe secundă pe metru pătrat

microencapsulation (materiale) incapsulare la nivel micro (şi d. compozite)

microequivalent ( $\boldsymbol{\mu E q}, \boldsymbol{\mu e q})$ (metr, mediu, alim) unitate de măsură pentru cantitatea rela-tivă de substanță: 1 microequivalent $=10^{-6}$ equivalent weight

micro-examination (met, metr) examinare metalografică / micrografică

microfarad $(\boldsymbol{\mu} \mathbf{F})$ (metr, fiz, el) unitate de măsură pentru capacitatea electrică, microfarad: 1 microfarad $=10^{-6} \mathrm{~F}$

microfinish (mas-un, TH) prelucrare finală de precizie şi fină

microfissure microfisură

microfuse (el) siguranță de precizie (şi mică, miniaturizată)

microgram, microgramme ( $\mu \mathrm{g}$, mcg) (metr, med) unitate de măsură pentru masă, microgram: 1 microgram $=10^{-9} \mathrm{~kg}$ 
microgram/liter (metr) unitate de măsură pentru densitate, microgram pe litru: 1 microgram $/$ liter $=0,000001 \mathrm{~kg} / \mathrm{m}^{3}$

microgram/second (metr) unitate de măsură pentru debit masic, microgram pe secundă: 1 microgram $/ \mathrm{second}=10^{-9} \mathrm{~kg} / \mathrm{s}$

micrographic micrografic

micrography micrografie

microgray ( $\boldsymbol{\mu G y}$ ) (metr, fiz, mediu) unitate pentru a măsura doza de radiație: 1 microgray $=10^{-6}$ gray sau 0,1 millirad

micro(-)hardness (met, metr) microduritate (atenţie la metoda şi aparatul folosit)

microinch ( $\mu$ in) (metr, T) unitate de măsură pentru lungime (în țările de limbă engleză): 1 microinch $=10^{-6}$ inch $=25,4$ nanometri $(\mathrm{nm})$ (şi în profilometria suprafețelor)

microinch (metr) unitate de măsură pentru lungime (în țările de limbă engleză): 1 microinch $=0,000000025 \mathrm{~m}$

microjoule (metr, fiz) unitate de măsură pentru energie: 1 microjoule $=0,000001 \mathrm{~J}$

microjoule/second (metr, fiz) unitate de măsură pentru putere, microloule pe secundă: 1 microjoule/second $=0,000001 \mathrm{~W}$

micro-lathe (mas-un) strung de masă (pt. lucrări de mecanică fină / de precizie)

microliter, lambda ( $\mu \mathrm{l}, \mu \mathrm{L}, \mathrm{mcl}, \mathrm{mcL})$ (metr, chim, med) o unitate de măsură pentru volum / capacitate, microlitru: 1 microlitter $=10^{-6} 1$ sau $1 \mathrm{~mm}^{3}$

micrometer, micron $(\boldsymbol{\mu m})$ (metr) unitate de măsură pentru lungime, micron, micrometru (rar utilizat): 1 micron $=10^{-6} \mathrm{~m}$

micrometer calliper (metr, OM) micrometru de exterior, calibru de precizie

micrometer callipers with dial indicator (metr) micrometru cu comparator

micrometer depth gauge (metr) micrometru / calibru de adâncime / de interior

micrometer feed (mas-un, metr) (mecanism de) avans fin (poate include un micrometru)

micrometer gauge (metr, OM) micrometru (de exterior)

micrometer-gauge screw (OM, metr) şurubul micrometrului

micrometer knob (OM, metr) buton micrometric

micrometer ring (mas-un, metr) inel cu gradație micrometrică

micrometer screw (OM, metr) şurub micrometric micrometer screw gauge (OM, metr) micrometru de precizie (cu şurub)

micrometer slide gauge $(\mathrm{OM}$, metr) şubler micrometric micrometer/square second (metr, mec) unitate de măsură pentru accelerație, milimetru pe secundă la pătrat: 1 micrometer/square second $=0,0001 \mathrm{~m} / \mathrm{s}^{2}$

micrometer stop dog (mas-un, metr) limitator / opritor cu şurub micrometric (pt. reglarea precisă a poziției)

micrometer with dial indicator (mas-un, metr) micrometru cu comparator tip ceas

micrometric (metr) micrometric, de ordinul micronilor

micrometrical screw (OM, metr) şurub micrometric

micrometric gauge $(\mathrm{OM}$, metr) şubler micrometric

micrometric measurement (metr, TH) măsurări micrometrice

micrometric screw (OM, metr) şurub micrometric

micromicro- $(\mu \mu-)$ (metr) prefix pentru $10^{-12}$, înlocuit de pico- (p-)

micromicrofarad $(\mu \mu \mathrm{F}, \mathbf{m m f d})$ (metr, el, fiz) denumirea veche pentru picofarad: 1 picofard $=10^{-12} \mathrm{~F}$

micromicron $(\mu \mu \mathrm{m})$, picometer (pm) (metr) unitate de măsură pentru lungime, micromicrometru, micromicron, picometru (acceptat acum): $1 \mu \mu \mathrm{m}=1 \mathrm{pm}=10^{-12} \mathrm{~m}$

micromole $(\mu \mathrm{mol})$ (metr, biol, chim) unitate de măsură pentru cantitatea de substanță, micromol, egală cu o milionime dintr-un mol

micron, micrometer $(\mu \mathrm{m})(p l)$ micra (metr) unitate de măsură pentru lungime, micron, micrometru (rar utilizat): 1 micron $=10^{-6} \mathrm{~m}$; (metr) unitate neoficială pentru presiune, în tehnologia vidului: 1 micron of mercury ( $\mu \mathrm{m}$ $\mathrm{Hg})=1,333$ microbar $(\mu \mathrm{bar}, \mu \mathrm{b})=133,3 \mathrm{mPa}$; 1 micron de mercur (presiunea unei coloane de mercur de $1 \mu \mathrm{m})=1$ millitorr (mTorr)

micronewton $(\mu N)$ (metr, fiz) unitate de măsură pentru forță, micronewton: 1 micronewton $=$ $10^{-6} \mathrm{~N}$

microorganism (biol, med) microorganism

micropascal $(\mu \mathrm{Pa})$ (metr, fiz) unitate SI de măsură pentru presiune, micropascal: 1 micropascal $=10^{-6} \mathrm{~Pa}$

micropoise $(\boldsymbol{\mu P}, \boldsymbol{\mu P o}, \boldsymbol{\mu P s})$ (metr, hidr, T) unitate de măsură pentru vâscozitate dinamică, micropoise: 1 micropoise $=10^{-7} \mathrm{~Pa} \cdot \mathrm{s}$

micropore (materiale) micropor

microporosity (materiale) microporozitate microporous (materiale) microporos, cu pori mici microporous ebonite (ind chim, plast, el) ebonită microporoasă 
microporous rubber (ind chim, plast) cauciuc microporos

micropressure gauge (metr, OM, hidr) manometru pentru presiuni / variații de presiuni mici

microrad ( $\mu$ rad) (metr, fizică nucleară) unitate de măsură pentru doza de radiație, microrad: 1 microrad $=10^{-6} \mathrm{rad}$

microradian ( $\mu$ rad) (metr, geom) unitate de măsură pentru unghiuri, microradian: 1 microradian $=10^{-6} \mathrm{rad}$

microrem ( $\mu$ rem) (metr, fiz, med) unitate pentru măsurarea dozei efective de iradiere, microrem: 1 microrem $=10^{-6}$ rem

microscope (fiz, opt, metr) microscop

microscopic(al) (fiz, opt, metr) microscopic

microscopically $(a d v)$ la microscopic, cu ajutorul microscopului; minuțios, exact, precis; amănunțit, detaliat

microscopical structure (materiale) structură microscopică

microscopy (metr, opt) microscopie

microscrew $(\mathrm{OM}$, metr) şurub micrometric

microsecond ( $\mu$ s, $\mu$ sec) (metr, fiz) unitate de măsură pentru timp, microsecundă: 1 microsecond $=10^{-6} \mathrm{~s}$

microsection (fiz, met) secțiune metalografică

micro-segregation (met) microsegregare

microshrinkage (met, plast) microretasură, microcontracție

microsievert ( $\boldsymbol{\mu S v})$ (metr) unitate a dozei de radiație / iradiere: 1 microsievert $=10^{-6}$ sievert $=0,1$ millirem

microslice (met, metr) probă metalografică

microstrain ( $\mu$ strain) (metr) unitate de măsură pentru tensiune, în inginerie: 1 microstrain este tensiunea care produce o deformare relativă de $10^{-6}$

microstructure (materiale) microstructură

microTesla $(\boldsymbol{\mu} \mathbf{T}, \mathbf{m c T})$ (metr, fiz, electr) unitate de măsură pentru intensitatea câmpului magnetic, microTesla: 1 microTesla $=10^{-6}$ Tesla

microtron (fiz) microtron

micro-Vickers hardness (metr, materiale) microduritate Vickers

microvolt $(\mu \mathbf{V}, \mathbf{m c V})$ (metr, fiz) unitate de măsură pentru tensiunea curentului electric, microvolt: 1 microvolt $=10^{-6}$ volt

microwatt (metr, fiz) unitate de măsură pentru putere, microwatt: 1 microwatt $=10^{-6} \mathrm{~W}$

microwave (fiz) microundă

mid-boiling point (termo, materiale) temperatură medie de fierbere (d. amestecuri de lichide, polimeri lichizi)

mid channel (nav) firul apei, şenalul central middle mijloc, medie, mijlociu, de (la) mijloc; (ec) marfă de calitate medie; a aşeza / pune la mijloc

middle band (nav) întărirea mijlocului; (fiz, radio) bandă de unde medii

middle bearing $(\mathrm{OM})$ lagăr intermediar

middle body (nav) porțiunea cilindrică

middle cut (mas-un, TH) dinţare aspră la pile

middle file (mas-un) pilă cu tăiere grosolană

middle gear $(\mathrm{OM})$ treaptă intermediară (la cutii de viteze şi reductoare în mai multe trepte)

middle ground (nav) banc central

middle-hard cast steel (met) oțel semi-dur, turnat

middle line (nav) axa navei

middle line keelson (nav) carlingă centrală

middleman (ec) intermediar

middle mill (met) linie de profiluri mijlocii (la laminoare)

middlemost centrat, cel mai apropiat de mijloc / centru

middle (neutral) position (hidr) poziţie neutră / la mijloc / medie (d. distribuitoare etc.)

middle of stroke (mas, OM, termo) mijlocul cursei pistonului

middle pass (met) calibru / trecere intermediar(ă)

middle roll (met) cilindru de mijloc / intermediar (la laminare)

middle sample (metr, TH) probă medie / de la mijloc

middle-sized $(\mathrm{OM})(\mathrm{de})$ mărime mijlocie

middle-shot wheel (OM, hidr) roată de apă

middle slider $(\mathrm{OM})$ culisă intermediară

middle speed $(\mathrm{OM})$ viteză intermediară (la o cutie sau la un reductor cu trei trepte)

middle standing pillar (auto) stâlp central de caroserie (situat între două uși)

middle support (mec, OM) reazem / suport intermediar

middle traverse (constr, mec) bară de mijloc, traversă

middle wheel $(\mathrm{OM})$ roată intermediară

middling mijlociu, potrivit, mediocru; (alim) irimic middlings (ec) produse intermediare / de calitatea a doua; (met) minereuri impure / mixte

midget miniatură; uzină mică

mid-line capacitor (el, electr) condensator logaritmic

midpoint (mat) punct de mijloc, centru, jumătate

midportion $(\mathrm{OM}$, mas) parte centrală

mid-position (mas-un, OM) poziție centrală / de mijloc

midrange (mat, fiz) semi(-)amplitudine; rază medie de acțiune, distanță medie 
mid-section $(\mathrm{OM})$ parte / secțiune centrală (a unei piese, element de maşină etc.)

midship (nav) mijlocul navei

midship bend / frame (nav) cuplu maestru midshipman (nav) elev ofițer, aspirant

midships (nav) la travers / centru, mijlocul navei midship section (nav) secțiune maestră

mid-square method (mat) metoda pătratelor medii

mid-temperature coking (met) cocsificare la temperatură medie

midway $(a d v)$ la jumătate de drum

might putere, forță, energie; autoritate

migrane (med) migrenă, durere de cap

migrant, migratory (fiz, el, materiale) nomad; migrator

migrate (fiz, el, materiale) a migra; (zool) a migra (d. păsări, animale)

migration (fiz, el, materiale) migrație, migrare, mobilitate

mil (metr) miime dintr-o unitate (mai ales de lungime) (rar); unitate tradițională pentru lungime (în țările scandinave): 1 Danish mil $\cong 7,5$ $\mathrm{km} ; 1$ mil (Suedia, Norvegia) $=10 \mathrm{~km}$; (metr, mil) unitate de măsură pentru unghiuri, pentru reglarea dispozitivelor de ochire: $1 \mathrm{mil}=$ $1 / 1600$ din unghiul drept sau $0,05625^{\circ}$; uneori 1 mil $=0,001$ radian $=1$ milliradian $\cong 0,0573^{\circ}$; 1 milliradian sau angular mil (brit) corespunde unei tinte de $10 \mathrm{~mm}$ aflate la $10 \mathrm{~m}$

mil, milli-inch, thou (amer) (metr) unitate de măsură pentru lungime: $1 \mathrm{mil}=0,001$ inch / țol $=0,0000254 \mathrm{~m}$

milch cow (agr) vacă de lapte / de muls

mild lin, domol; temperat, moderat (şi d. uzură); liniștit; slab, moale; (met) moale; domol, lin, liniştit; (alim) necondimentat, nepiperat

mild (carbon) steel (met) oțel moale, oțel cu conținut redus de carbon

mildew (bot, alim) ciupercă producătoare de făinare; mucegai

mildewy (agr, alim) cu mucegai, mucegăit

mild soap (chim) săpun slab

mild-steel sheet rolling mill (met) laminor pentru table din oțel moale

mild wear $(\mathrm{T})$ uzură medie / intermediară (între cea severă şi cea foarte mică)

mild wire (met) sârmă moale

mile (mi) (metr) unitate de măsură pentru lungime, milă: 1 Roman mile $\cong 1480 \mathrm{~m} ; 1$ medieval England mile $\cong 1524 \mathrm{~m}, 1$ modern English mile $=1609,344 \mathrm{~m}, 1$ French mille $/$ mile $=1949 \mathrm{~m}$, uneori se înțelege 1 mille (nautical mile (mille marin $\hat{\imath}$ franceză $)=1852 \mathrm{~m} ; 1$ Scottish mile $=1814 \mathrm{~m} ; 1$ the Irish mile $=2048 \mathrm{~m} ; 1$ statute mile $=1609,344 \mathrm{~m} ; 1$ survey mile (US) sau 1 mile (US survey) (milă terestră) $=1609,3472 \mathrm{~m}$; 1 milla $($ Spanish mile $)=1392 \mathrm{~m}$; (nav) 1 milă marină $=1,8533 \mathrm{~km}$

mileage distanță în mile; (nav) distanța parcursă (în mile); primă calculată pe baza distanței parcurse; cheltuieli de deplasare (calculate pe mile); kilometraj (exprimat în mile)

mileage counter (auto, transp, metr) contor de parcurs (în km sau mile)

mileage meter / recorder (auto, transp, metr) înregistrator / contor de parcurs (în mile sau $\mathrm{km})$, kilometraj

mileometer (auto, metr) instrument de înregistrat distanțele parcurse (în mile sau kilometi)

mile per gallon (mi/gal, mpg) (metr, auto) unitate pentru măsurarea eficienței combustibilului pentru motoare auto, milă / mile (parcurse) pe galon (de combustibil): 1 mile per US gallon $\cong 0,4252 \mathrm{~km} / 1 ; 1$ mile per US gallon $=235,215$ litri la $100 \mathrm{~km}$; (metr) unitate utilizată în Marea Britanie şi Commonwealth pentru a măsura eficienta combustibilului pentru motoare auto, înlocuită cu liters per $100 \mathrm{~km}$; 1 mile per Imperial gallon = 282,481 litri la $100 \mathrm{~km}$; 1 mile per Imperial gallon $\cong 0,8327$ mile per US gallon

mile per hour, mile/hour (mi/h, mph) (metr, mec) unitate de măsură pentru viteză, milă pe oră: 1 mile per hour $\cong 1,609 \mathrm{~km} / \mathrm{h}=0,44704 \mathrm{~m} / \mathrm{s}$

mile/minute (metr, mec) unitate de măsură pentru viteză, milă pe minut: 1 mile/minute $=$ $26,8224 \mathrm{~m} / \mathrm{s}$

mile/second (metr, mec) unitate de măsură pentru viteză, milă pe secundă: 1 mile/second = $1609,344 \mathrm{~m} / \mathrm{s}$

mile/square second (metr, mec) unitate de măsură pentru acceleratie, milă pe secundă la pătrat: 1 mile/square second $=1609,344 \mathrm{~m} / \mathrm{s}^{2}$ milestone (auto) bornă kilometrică, jalon important mil-foot, circular mil-foot (metr) unitate de măsură pentru volum (utilizată pentru fire, conductori etc.) 1 mil-foot $\cong 0,6178 \mathrm{~cm}^{3}$

milha (metr) unitate portugheză pentru măsurarea lungimii, milă potugheză: 1 milha $=2087,3 \mathrm{~m}$

military pace, step (metr, mil) unitate de măsură pentru lungime: 1 US military pace $=$ $76,2 \mathrm{~cm}$ pentru marş obişnuit sau $91,44 \mathrm{~cm}$ pentru marş în timp dublu

millenary (metr) unitate pentru cantitate 1 millenary $=1000$ (bucăți)

millennium, $(p l)$ millennia sau millenniums (metr) unitate de măsură pentru timp, mileniu: 1 millennium $=1000$ ani 
millimetre (brit), millimeter (amer) (mm) (metr) unitate de măsură pentru lungime, milimetru: 1 millimeter $=0,001 \mathrm{~m}$

millisecond (metr) unitate de măsură pentru timp, milisecundă: 1 millisecund $=10^{-3} \mathrm{~s}$

military installations (mil, mas) instalații militare military vehicle (auto, mil, transp) vehicul militar milk (alim) lapte; (ind chim) latex, lapte de var; lichid lăptos; (agr) a mulge

milk a battery (el) a supravolta o baterie milk collecting (agr, alim) colectare a laptelui milk fat (alim) grăsime din lapte milkiness (materiale) aspect lăptos milk (of) lime (constr, chim) lapte de var milk of magnesis (chim) hidroxid de magneziu milk of starch (chim) soluție de amidon milk scum (alim) caimac milk separator (alim, mas) separator de lapte milk-skimming (alim) smântânirea laptelui milk skin (alim) caimac

milk storage (alim, mediu) depozitarea laptelui milk sugar (alim) lactoză

milk transporter (alim, auto, transp) cisternă de transportat lapte

milky lăptos, ca laptele; alb ca laptele; cu lapte mill (constr, ind chim) concasor; (alim) moară, râşniță; (mas-un) freză, presă-ciocan, presă (şi de ulei), polizor, piatră de polizor, randalină pentru zimțare; (met) laminor, a lamina; $(\mathrm{TH})$ fabrică, uzină, filatură, instalație, întreprindere; a măcina, a sfărâma, a moleta, a zimțui, a zimța, a freza, a şlefui, a plastifia; a (se) învârti, a (se) roti)

mill accident accident de exploatare

mill approach table (met, transp, mas) transportor cu role, de alimentare (la laminor)

mill bar (met, OM) platină (semifabricat sau ghidaj şi neprelucrat)

mill blunt scraper (mas-un) răzuitor cu secțiunea dreptunghiulară şi cap drept

mill board (constr, ind chim) carton asfaltat

mill centre (mas-un) axa unei maşini de frezat / unei freze

mill cinder (met) țunder (la laminoare), arsură de laminare

mill coil (met) rulou de bandă / de tablă

mill-cutter (mas-un) sculă specială de rifluit tăvălugi de moară

mill drive (met) actionarea laminorului

milled (alim) măcinat; (met) laminat (mai rar)

mill edge (met, $\mathrm{TH})$ muchie / margine naturală la laminare

milled nut $(\mathrm{OM})$ piuliță moletată / randalinată / zimțată (pe suprafața laterală exterioară) milled rubber (ind chim, plast) cauciuc plastifiat milled slot (mas-un) frezare / crestare cu freză milled soap (chim) calup de săpun, săpun în fulgi (atenție la text)

milled tooth (mas-un) dinte frezat

mill effluents (mediu, alim, ind) ape reziduale din fabricație

miller (alim) morar; (mas-un) maşină de frezat, frezor, freză

mill file (mas-un) pilă fină / lată, cu vârf ascuțit

mill-finished (mas-un, OM) (suprafață) cu prelucrare prin aşchiere (şi prin frezare)

mill floor (level) (met, constr) nivelul / cota uzinei / pardoselii

mill for grouts (alim) moară de crupe

mill for rolling circular shapes (met) laminor cu discuri

mill for rolling shapes (met) laminor pentru profile

millgrain tool (mas-un) randalină, moletă fină

mill grating (alim, ind chim) maşină de măcinat; (mas-un) maşină de răzuit / de frecat

mill grinding (alim, ind chim) maşină de măcinat mill hand (mas-un) frezor

mill-head screw $(\mathrm{OM})$ şurub cu cap zimțat striat / moletat / randalinat

mill hopper (met, OM) pâlnie de încărcare / de şarjare

mill housing (met) cajă de laminor

millammeter (el, electr, metr) miliampermetru, aparat pentru măsurarea amperajului / a intensității curentului electric

millampere (rar) (metr, fiz, el) miliamper; v. milliampere

milli- (m-) (metr) un prefix metric pentru 0,001 (o miime)

milli-absorbance unit (metr, fiz) simbol pentru unitatea de măsură pentru absorbanță: o creştere a absorbanței cu $1 \mathrm{mAU}$ corespunde unei reduceri a transmitantei $\mathrm{cu} \sim 0,2305 \%$

milliampere (mA) (metr) unitate de măsură pentru intensitatea curentului electric, miliamper: 1 millampere $=0,001 \mathrm{~A}$

milliampere hour $(\mathbf{m A} \cdot \mathbf{h})$ (metr, fiz, el) unitate de măsură pentru sarcina electrică, miliamper oră: 1 milliampere hour $=3,6$ coulomb $(\mathrm{C})$

milliarcsecond (metr, astronomie) unitate de măsură pentru unghiuri: 1 milliarcsecond $=$ $4,84813710^{-9} \mathrm{rad}$

milliard (mat) miliard $\left(10^{9}\right)$; (metr, hidr) unitate de măsură pentru volum (pt. volume mari de apă, în amenajări hidrotehnice, baraje, hidrocentrale etc.) 1 milliard $=1 \mathrm{~km}^{3}=10^{9} \mathrm{~m}^{3}$ milliard, billion (amer) (metr) miliard, $10^{9}$ 
millibar (mb, mbar) (metr, fiz) unitate de măsură pentru presiune (şi atmosferică), milibar: 1 millibar $=100 \mathrm{~Pa}$

millicandela (mcd) (metr, electr, fiz) unitate de măsură pentru intensitatea luminoasă, microcandela: 1 microcandela $=0,001$ candela

millicurie (mCi) (metr, fiz) unitate de măsură pentru radioactivitate: 1 millicurie reprezintă radioctivitatea la viteza de 37 milioane de dezintegrări atomice pe secundă

millidegree (mdeg) (metr) unitate de măsură pentru unghiuri, miligrad: 1 millidegree $=0,001^{\circ}$; (metr) unitate de măsură pentru temperatură, miligrad: 1 millidegree $=0,001^{\circ}$, de obicei ${ }^{\circ} \mathrm{C}$

milliequivalent (mEq, meq) (metr, chim) unitate pentru măsurarea cantității relative de substanță: $1 \mathrm{mEq}=0,001$ equivalent weight; equivalent weight - unitate de masă chimic echivalentă a unei substanțe este masa acelei substanțe care ar reacționa sau ar înlocui $1 \mathrm{~g}$ de hidrogen

millifarad (mF) (metr, fiz) unitate de măsură pentru capacitate electrică, milifarad: 1 millifarad $=0,001 \mathrm{~F}$

milligal, milligalileo (mGal, mgal) (metr, fiz) o unitate pentru măsurarea variației accelerației, utiliztaă în geologie, miligalileo: 1 milligal = $10 \mu \mathrm{m} / \mathrm{s}^{2}=10^{-5} \mathrm{~m} / \mathrm{s}^{2}$

milligauss (mG) (metr, fiz) unitate pentru măsurarea densității fluxului magnetic, miligauss: 1 milligauss $=0,001$ gauss $=0,1$ microTesla

milligon, milligrad, mgon (metr, geom, astronomie) unitate de măsură pentru unghiuri: 1 milligon $=10^{-5}$ din unghiul drept sau $0,0009^{\circ}$ sau 15,708 microradians ( $\mu \mathrm{rad})$

milligram, milligram(me) (mg) (metr) unitate de măsură pentru masă, miligram: 1 milligram $=0,001 \mathrm{~g}=0,000001 \mathrm{~kg}$

milligram per deciliter $(\mathrm{mg} / \mathrm{dl}, \mathbf{m g} / \mathrm{dL}$ ) (metr, med) unitate convențională pentru măsurarea concentrațiilor de substanțe în sânge, miligram pe decilitru; unitatea SI este millimole per liter (mmol/L, mmol/l)

milligram/cubic centimeter (metr) unitate de măsură pentru densitate, miligram pe centimetru cub: 1 milligram $/$ cubic centimeter $=1 \mathrm{~kg} / \mathrm{m}^{3}$

milligram/cubic meter (metr) unitate de măsură pentru densitate, miligram pe metru cub: 1 milligram $/$ cubic meter $=0,000001 \mathrm{~kg} / \mathrm{m}^{3}$

milligram/cubic millimeter (metr) unitate de măsură pentru densitate, miligram pe milimetru cub: 1 milligram $/$ cubic millimeter $=1000 \mathrm{~kg} / \mathrm{m}^{3}$

milligram/day (metr) unitate de măsură pentru debit masic, miligram pe zi: 1 milligram/day = $1,157407407 \cdot 10^{-11} \mathrm{~kg} / \mathrm{s}$ milligram/hour (metr) unitate de măsură pentru debit masic, miligram pe oră: 1 milligram/hour $=2,777777778 \cdot 10^{-10} \mathrm{~kg} / \mathrm{s}$

milligram/liter, mg/l (metr) unitate de măsură pentru densitate, miligram pe litru: 1 milligram $/$ liter $=0,001 \mathrm{~kg} / \mathrm{m}^{3}$

milligram/minute (metr, mediu) unitate de măsură pentru debit masic, miligram pe minut: 1 milligram $/$ minute $=0,000000017 \mathrm{~kg} / \mathrm{s}$

milligram/second (metr, mediu) unitate de măsură pentru debit masic, miligram pe secundă: 1 milligram $/$ second $=0,000001 \mathrm{~kg} / \mathrm{s}$

milligray (mGy) (metr, fizică nucleară, med) unitate de măsură pentru doza de iradiere, miligray: 1 milligray $=0,001$ gray $=0,1 \mathrm{rad}=10^{-3}$ J pe kg de substanță

millihenry (mH) (metr, fiz) unitate de măsură pentru inductanța electrică, milihenry: 1 millihenry $=0,001$ henry

millihorsepower (mhp) (metr, electr) unitate de măsură pentru putere, mili-cal-putere: 1 millihorsepower $=0,7457 \mathrm{~W}$

millijoule (mJ) (metr, fiz, mec) unitate de măsură pentru energie şi lucru mecanic, milijoule: 1 millijoule $=0,001 \mathrm{~J}$

millijoule/second (metr, fiz, mec) unitate de măsură pentru putere, milijoule pe secundă: 1 millijoule/second $=0,001 \mathrm{~W}$

millikelvin (mK) (metr, criogenie) unitate de măsură pentru temperatură, milikelvin: 1 millikelvin $=0,001 \mathrm{~K}$

millilambert (mLb) (metr) unitate SI de măsură pentru iluminare (luminoasă), mililambert: 1 millilambert $=10,001$ lambert $=10 \operatorname{lux}(\mathrm{lx})$

milliliter $(\mathbf{m l}, \mathbf{m L})$ (metr) unitate de măsură pentru volum, mililitru: 1 milliliter $=10^{-6} \mathrm{~m}^{3}$

milliliter/day (metr) unitate de măsură pentru debit volumic, mililitru pe zi: 1 milliliter/day $=$ $1,157407407 \cdot 10^{-11} \mathrm{~m}^{3} / \mathrm{s}$

milliliter/hour (metr) unitate de măsură pentru debit volumic, mililitru pe oră: 1 milliliter/hour $=2,777777778 \cdot 10^{-10} \mathrm{~m}^{3} / \mathrm{s}$

milliliter/minute (metr) unitate de măsură pentru debit volumic, mililitru pe minut: 1 milliliter $/$ minute $=0,000000017 \mathrm{~m}^{3} / \mathrm{s}$

milliliter/second (metr) unitate de măsură pentru debit volumic, mililitru pe secundă: 1 milliliter $/$ second $=0,000001 \mathrm{~m}^{3} / \mathrm{s}$

millilux (mlx) (metr, fiz) unitate SI de măsură pentru iluminare (luminoasă), mililux: 1 mililux $=0,001$ lux

millimass unit (mu), millidalton (mDa) (metr, fiz, chim) unitate de măsură pentru masă: 1 millidalton $=0,001$ unități atomice de masă 
millimeter (amer), millimetre (brit) (mm) (metr) unitate SI de măsură pentru lungime, milimetru: 1 millimeter $=0,001 \mathrm{~m}$

millimeter/hour (metr, mec) unitate de măsură pentru viteză, milimetru pe oră: 1 millimeter $/$ hour $=0,000000278 \mathrm{~m} / \mathrm{s}$

millimeter mercury $\left(0^{\circ} \mathrm{C}\right)$ (metr, hidr, fiz) unitate de măsură pentru presiune: milimetru coloană de mercur la $0^{\circ} \mathrm{C}: 1$ millimeter mercury $\left(0^{\circ} \mathrm{C}\right)=133,322 \mathrm{~Pa}$

millimeter/minute (metr, mec) unitate de măsură pentru viteză, milimetru pe minut: 1 millimeter $/$ minute $=0,000016667 \mathrm{~m} / \mathrm{s}$

millimeter (of) mercury, torr (mm Hg) (metr, fiz) unitate de măsură pentru presiune, milimetru coloană de mercur: 1 millimeter of mercury $\cong 133,3 \mathrm{~Pa}$

millimeter of water $\left(\mathrm{mmH}_{2} \mathrm{O}, \mathrm{mm} \mathrm{WC}, \mathrm{mm}\right.$ CE, mm WS) (metr) unitate pentru măsurarea presiunii, milimetru coloană de apă: 1 millimeter of water $\cong 9,8067 \mathrm{~Pa}$

millimeter of water gauge (brit) / gage (amer) (mm WG) (metr) milimetru coloană de apă, unitate pentru măsurarea presiunii relative, cuvântul gauge /gage indicând că presiunea citită este diferența dintre presiunea absolută şi presiunea aerului la momentul citirii

millimeter water $\left(4^{\circ} \mathrm{C}\right)$ (metr, fiz) unitate pentru măsurarea presiunii, milimetru coloană de apă la $4^{\circ} \mathrm{C}$ : 1 millimeter water $\left(4^{\circ} \mathrm{C}\right)=9,80638 \mathrm{~Pa}$

millimeter/second (metr, mec) unitate pentru măsurareavitezei, milimetru pe secundă: 1 millimeter $/ \mathrm{second}=0,001 \mathrm{~m} / \mathrm{s}$

millimeter/square second (metr, mec) unitate pentru măsurarea accelerației, milimetru pe secundă la pătrat: 1 millimeter/square second $=0,001 \mathrm{~m} / \mathrm{s}^{2}$

millimicro- $(\mathbf{m} \mu-)$ (metr) prefix metric pentru $10^{-9}$, înlocuit de nano- (n-)

millimicron $(\mathbf{m} \mu)$, nanometer $(\mathbf{n m})$ (metr) unitate de măsură pentru lungime, milimicron, înlocuită cu nanometru: 1 millimicron $=10^{-9} \mathrm{~m}$

millimole (mmol) (metr, chim) unitate de măsură pentru cantitatea de substanţă, milimol: 1 millimole $=0,001 \mathrm{~mol}$

millimole per liter $(\mathrm{mmol} / \mathrm{l}, \mathrm{mmol} / \mathrm{L})$ (metr, med) unitate SI unit pentru măsurarea concentrațiilor unei substanțe în sânge, milimol pe litru

millinewton (mN) (metr, fiz) unitate de măsură pentru forță, milinewton: 1 millinewton $=0,001 \mathrm{~N}$

milling (alim) măcinare; (mas-un) frezare; (textile) piuare

milling apparatus (mas, OM) dispozitiv de măcinat (şi de laborator) milling arbor (mas-un, OM) dorn / arbore portfreză

milling carriage (mas-un) sania maşinii de frezat milling contraction (plast, met) contracție la laminare

milling cutter (mas-un) freză (sculă), frezor

milling cutter arbor (mas-un, OM) dorn / arbore port-freză

milling fixture (mas-un) dispozitiv de frezare milling head (mas-un) capul frezei

milling industry (alim) industria morăritului milling jig (mas-un, OM) dispozitiv de strângere pentru maşina de frezat

milling machine (mas-un) maşină de frezat, freză (maşină); (textile) maşină de piuat

milling-machine operator (mas-un) frezor

milling machine with chain cutter (mas-un) maşină de frezat cu lanț (pt. prelucrarea lemnului) milling ore (met) minereu fărâmat

milling pitch (mas-un) pas de moletare / de randalinare

milling plant (alim) instalație de măcinat / de morărit

milling process $(\mathrm{TH}$, alim, ind chim) proces / procedeu de măcinare

milling room ( $\mathrm{TH}$, alim, ind chim) secție / incintă de morărit / de măcinat

milling shop $(\mathrm{TH})$ atelier / secție de freze

milling slide (mas-un) sania capului port-freză

milling spindle (mas-un, OM) arbore port-freză, arborele principal la maşini de frezat

milling support (mas-un) sania maşinii de frezat milling to break down the structure (constr, ind chim) măcinare de dezagregare

milling tool (mas-un) sculă de frezat, randalină

milling wheel $(\mathrm{OM})$ roată cu camă

milling work (mas-un) (operație de) frezare

millioersted (mOe) (metr) a name sometimes used for the milligauss as a unit of magnetic flux density

million (mat) milion

millionaire (ec) milionar

millionfold (mat) de un milion de ori mai mare

million of gallons per day (Mgal/d) (metr) unitate de măsură pentru debit volumic, milion de galoane pe zi: $1 \mathrm{Mgd} \cong 3,78543$ megalitri pe zi

million particles per cubic foot, mppcf, $\mathrm{mp} / \mathrm{f}^{3}$ (metr, mediu) unitate pentru măsurarea concentrației de particule de praf din aer (şi în medii industriale), milion de particule pe metru cub

million particles per cubic meter (metr, mediu) unitate pentru măsurarea concentrației de particule de praf din aer (şi în medii industriale), milion de particule pe metru cub 
million pounds (metr) unitate de măsură pentru masă (în țări de limbă engleză): 1 million pounds $\cong 373241,7216 \mathrm{~kg}$

milliosmole (mOsm) (metr, med, biol) unitate pentru măsurarea presiunii osmotice, miliosmole: 1 milliosmole $=0,001$ osmole

millionth al milionulea, a milioana; milionime

milliparsec (mpc) (metr, fiz, astronomie) unitate de măsură pentru lungime, miliparsec: 1 milliparsec $=0,001$ parsec $\cong 206,265$ unități astronomice $=11,913$ zile-lumină $=30,8568$ terametri

millipascal (mPa) (metr, fizică) unitate SI de măsură pentru presiune, milipascal: 1 millipascal $=0,001 \mathrm{~Pa}$

millipascal second (mPa·s) (metr, fiz) unitate de măsură pentru vâscozitatea dinamică, milipascal secundă, centipoise $(\mathrm{cP}): 1$ millipascal secund $=0,001 \mathrm{~Pa} \cdot \mathrm{s}$

milliphot (mph) (metr, fiz) unitate de măsură pentru iluminare (luminoasă), miliphot: 1 milliphot $=0,001$ phot $=10$ lux

millipoise (mP, mPs, mPo) (metr, hidr) unitate de măsură pentru vâscozitatea dimanică, milipoise: 1 millipoise $=0,001$ poise $=0,1 \mathrm{mPa} \cdot \mathrm{s}$

millirad (mrad) (metr, fizică nucleară) unitate pentru măsurarea dozei de iradiere, milirad: 1 millirad $=0,001 \mathrm{rad}$

milliradian (mrad), angular mil (brit) (metr, geom, astronomie) unitate de măsură pentru unghiuri, miliradian: 1 millirad $=0,057296^{\circ}$

millirem (mrem) (metr) (metr, fizică nucleară) unitate pentru măsurarea dozei de iradiere, milirem: 1 millirem $=0,001$ rem

millisecond (ms, msec) (metr) unitate de măsură pentru timp, milisecundă: 1 millisecond $=10^{-3} \mathrm{~s}$

millisiemens (mS) (metr, fiz) unitate de măsură pentru conductanță, milisiemens: 1 millisiemens $=0,001$ siemens

millisievert (mSv) (metr) (metr, fizică nucleară) unitate pentru măsurarea dozei de iradiere, milisievert: 1 millisievert $=0,001$ sievert $=0,1$ rem

milliTesla (mT) (metr, fiz) unitate de măsură pentru intensitatea cîmpului magnetic, miliTesla: 1 milliTesta $=0,001$ Tesla $=10$ gauss

millitorr (metr, fiz) unitate neoficială pentru presiune, în tehnologia vidului: 1 millitorr $(\mathrm{mTorr})=1$ micron de mercur (presiunea unei coloane de mercur de $1 \mu \mathrm{m})$

millivolt (mV) (metr, fiz, electr) unitate de măsură pentru potențialul electric / tensiune electrică, milivolt: 1 millivolt $=0,001 \mathrm{~V}$

millivoltammeter (metr, fiz, electr) unitate de măsură pentru putere dezvoltată de un curent electric alternativ, milivoltampermetru: 1 millivoltammeter $=0,001 \mathrm{VA}$

millivoltmeter (el, metr) milivoltmetru

milliwatt (metr, fiz, electr) unitate de măsură pentru putere, miliwatt: 1 milliwatt $=0,001 \mathrm{~W}$

milliwatt hour $(\mathbf{m W} \cdot \mathbf{h})$ (metr) unitate de măsură pentru energie şi lucru mecanic, miliwatt oră: 1 milliwatt oră $=3,6 \mathrm{~J}$

mill layout (met) schema laminorului

mill length (met) lungimea laminorului / liniei de laminare

mill limit (met) toleranță la laminare

mill-masticated rubber (ind chim, plast) cauciuc plastifiat pe valt

mill off (mas-un) a freza, a prelucra prin frezare mill recess (mas-un) frezare / crestare cu freză

mill (roll) scale (met) țunder (la laminoare), arsură de laminare

mill saw (mas-un, silv) gater

mill scale powder (met) arsură de laminare sub formă de pulbere (defect)

mill schedule (met) program de laminare

mill scrap (met) deşeuri de recirculație / interne (la laminoare)

mill stand (met) cajă de laminor

mill-stone (alim) piatră de moară

millstone runner (alim) piatră de moară rotitoare mill tolerance (met) tolerantă la laminare mill train (met) linie / tren de laminare mill waste water (mediu, ind) ape reziduale provenite din fabricatie

mill with disk-type rolls (for tube making) (met) laminor cu cilindrii în formă de discuri mill with multiple (many) rolls (met) laminor cu mai multi cilindri / cu cilindri multipli mill with smooth rolls (met) laminor cu cilindri netezi

mill with stones (alim) moară cu pietre

mill work (met) produse de laminare

mill worker (met) laminator, laminorist

mill wright proiectant, montator

milt (iht, alim) lapți (de pește)

mimic diagram board (el) tablou de distribuție cu schemă de conexiuni

mimic diagram panel (el, mas, $\mathrm{TH}$ ) panou cu schemă (tehnologică sau a unei instalații)

mina (metr) unitate veche de măsură pentru masă: 1 mina (Biblical Greek) =0,341 kg; 1 mina $($ Biblical Hebrew $)=0,57 \mathrm{~kg} ; 1$ Hebrew mina $\cong$ $0,499 \mathrm{~kg}$

mince (alim) tocătură, carne tocată, a toca (carne); (alim, TH) a tăia mărunt, a fărâmița, a mărunți mincemeat (alim) tocătură de carne, umplutură din carene tocată, mirodenii etc., carne tocată 
mincing mic, mărunt, mărunțel; afectat; care mărunțeşte; prețios

mincing machine (alim, mas) maşină de tocat mind memorie, amintire; conştiință; minte, rațiune, intelect, cunoştință; părere, opinie, idee, concepție, punct de vedere; gând; atracție, înclinatie, intenție; gândire; atenție; dispoziție sufletească; suflet; hotărâre, decizie, rezoluție; dorință, poftă; gust, plac; a fi atent la (ceva); a da atenție (cuiva), a-i păsa de; a se ocupa de; a se amesteca în; a se deranja; a se îngriji (de), a avea grijă (de) (copii etc.); a păzi (animale); a găsi ceva de obiectat, a avea ceva împotrivă; a nu pierde din vedere; a nu uita; a tine seama de; a ține minte; a se supăra; bear / keep smth. in $\sim$ a ține minte ceva; bring / call to $\sim$ a-şi aduce aminte; be of the same $\sim$ as smb. a fi de aceeaşi părere cu cineva; to my după părerea mea; make up one's $\sim$ a se hotărî; change $\sim$ s about smth. a fi nehotărât cu privire la chestiune; change one's a se răzgândi; have smth. in $\sim$ a avea ceva în vedere; state of stare de spirit; presence of $\sim$ prezență de spirit

mine al meu, a mea, ai mei, ale mele; mină, mină explozivă; a săpa, a face săpături; (fig) a submina, a slăbi

mine layer (nav, mil) puitor de mine

miner miner

mineral (minrl) mineral (d. roci etc.); (ind chim) mineral (d. ulei lubrifiant etc.)

mineral-based oil (ind chim) ulei mineral

mineral filler (materiale, constr) material mineral de umplutură (şi în compozite)

mineral filter filtru (cu material) mineral mineralization (chim) mineralizare (şi d. apă) mineralize a prospecta, a explora; (chim) a satura mineral lard oil (mas-un, $\mathrm{T}$, ind chim) ulei mineral de răcire la scule aşchietoare

mineral matter (chim) substanță anorganică mineralogy (geol) mineralogie

mineral oil (ind chim, T) ulei mineral (şi lubrifiant), titei, produs petrolier

mineral resource / wealth (geol) bogăţia solului, resursă minerală

minerals (geol, met) minereu

mineral spring (geol) izvor natural

mineral water (geol, alim) apă minerală

mineral wax (minrl, chim) ceară minerală, ozocherită

mine sweeper (nav, mil) dragor, dragă

-minex (metr) suffix pentru numere mici: numărul n-minex este $10^{-\mathbf{n}}$; o milionime este 6 -minex mingle a amesteca

mingle with a se amesteca (cu) miniature miniatură

miniature screw $(\mathrm{OM})$ şurub cu filet fin

miniaturisation miniaturizare

minibus (auto, transp) minibus

minify a minimiza

minim (m, min) (metr, farmacie) unitate de măsură pentru volum (pt. lichide): 1 minim (UK) $=59 \cdot 10^{-9} \mathrm{~m}^{3} ; 1$ minim $(\mathrm{US})=62 \cdot 10^{-9} \mathrm{~m}^{3}$

minimal (mat) minim, minimal

minimal curve (mat, fiz) curbă izotropă

minimal surface (mat) suprafaţă minimă

minimization (mat) minimizare

minimize a minimiza, a subestima, a reduce la un minimun; a diminua, a minimaliza

minimum minim, valoare minimă; foarte mic, minimal

minimum achievable residual unbalance (mec) dezechilibru rezidual realizabil

minimum bend $(\mathrm{mec})$ încovoiere minimă

minimum circuit breaker (el, autom) întrerupător de / la minim

minimum clearance $(\mathrm{OM})$ joc minim

minimum condition (mat) condiție de minim

minimum content (materiale) conținut minim (d. un constituent etc.)

minimum control flow (hidr, autom) debit minim de comandă

minimum current (el, electr) curent minim

minimum cut-out (el) întrerupător de / la minim minimum elongation (mec, materiale) elongație / (a)lungire (relativă) minimă

minimum interference (OM, mas-un) interferența minimă (a dinților), strângere minimă

minimum limit (mat, TH) limită de minim / inferioară

minimum load (mec, $\mathrm{OM})$ sarcină minimă

minimum measure $(\mathrm{OM})$ dimensiune minimă, limită inferioară a unei dimensiuni

minimum open time (plast, chim) timp minim deschis, timp minim de mentinere a adezivului pentru a avea capacitate de lipire

minimum pressure (mec, hidr) presiune minimă

minimum section (met) secțiune minimă

minimum speed (mec, TH) viteză minimă (a unei maşini, a unui proces etc.)

minimum starting voltage $(\mathrm{el})$ tensiune minimă de pornire

minimum stress $(\mathrm{mec})$ tensiune minimă

minimum thickness $(\mathrm{OM})$ grosime minimă

minimum value valoare minimă / de minim

minimum wage $(\mathrm{ec})$ salariu minimal

minimum weight $(\mathrm{mec})$ greutate / masă minimă (atenție la text)

mining minerit, exploatare minieră 
mining industry minerit, industrie minieră / extractivă

minipin (metr) o unitate britanică de măsură pentru volum (pt. bere, băuturi alcoolice): 1 minipin $=101$

minister (pol, adm) ministru

ministration, ministry (pol, adm) serviciu, sprijin, ajutor

minium (chim) miniu de plumb

minnow (iht) plevuşcă, peşte mărunt; (agr, iht) momeală pentru peşte

minor (mat) minor, determinant minor, subdeterminant; mai mic, mai puțin important; minor, nesemnificativ, neimportant

minor axis (mat, fiz) axă mică (de exemplu a elipsei)

minor caloric (metr, fiz) calorie mică

minor cycle (autom, c) ciclu / buclă secundar(ă)

minor diameter (OM) diametru interior (la filet); (met) diametrul miezului / interior al formei

minor distributor $(\mathrm{OM}$, hidr) conductă secundară, distribuitor secundar / auxiliar

minor graduation (metr, mas-un) diviziuni secundare ale scalei, gradații secundare

minor part $(\mathrm{OM})$ piesă secundară / auxiliară / de mai mică importanță

minor segregation (met) micro-segregație, segregație intercristalină

minor semi-axis (geom, fiz) semiaxă mică

minor thread diameter $(\mathrm{OM})$ diametrul de fund $/$ interior al filetului

mint (bot) mentă, izmă; (ec) monetărie; sumă / cantitate mare; izvor, sursă; a bate / fabrica monedă; a inventa, a născoci

minuend (mat) descăzut

minus (mat) minus; fără; lipsă; neajuns; deficiență, defect

minuscule, minuscular minuscul, foarte mic, imperceptibil; (literă) minusculă

minus plate (auto, el) placa negativă a acumulatorului

minus post (el) bornă negativă

minute minut, clipă, moment; (ec) minută, notă; a cronometra; a trece într-un proces verbal; minuscul, foarte mic; amănunțit, detaliat; minuțios; de mică importanță; minute (min, ', m) (metr) unitate de timp, minut: 1 minute $=1 / 60$ $=60 \mathrm{~s} ; 1$ minute $($ sidereal $)=59,836173611 \mathrm{~s}$; minute (', m) (metr, astronomie) unitate de măsură pentru unghiuri (la divizarea ecuatorului în 24 de ore): 1 minute of right ascension $=$ 15 arcminute; $v$. arcminute

minute of arc, minute of angle, arcminute (') (metr) unitate de măsură pentru unghiuri, minut de arc: 1 minute of arc $=1 / 60$ grade $(\mathrm{de}$ unghi drept)

minute adjustment (mas-un, metr) reglare precisă (şi cu folosirea unui şurub micrometric)

minute current (el, electr) curent slab

minute finish (mas-un, met) polizare / şlefuire până la luciu oglindă

minuteness caracter minuscul, micime; caracter amănunțit / detaliat

minutes (ec) proces verbal, protocol, minută

minute surface (mas-un, OM) suprafață lustruită oglindă

mips (metr, c) unitate pentru a măsura puterea de programare a unui computer, egală cu $10^{6}$ instrucțiuni pe secundă

mire noroi, clisă; (geogr) ținut mlăştinos, mlaştină; încurcătură; a umple de noroi, a murdări cu noroi; a se înnămoli, a se afunda în noroi; a nu mai putea ieşi din noroi

mired, reciprocal megakelvin $\left(\mathrm{MK}^{-1}\right)$ (metr, termo) acromin pentru micro-reciprocal degree

mirror oglindă; reflectare; a oglindi, a reflecta; (auto) oglinda retrovizoare

mirror-finish (mas-un, OM) suprafață lustruită oglindă

mirror housing (auto) montura oglinzii

mirror image (c) imagine simetrică / în oglindă

mirror iron (met) fontă oglindă

mirrorlike (mas-un, OM) finisare ca oglinda

mirror scale (metr) scară / scală cu oglindă / de precizie

mirror symmetry (geom) simetrie tip oglindă miry plin de noroi, noroios, murdar; mlăştinos misaddress adresă greşită (şi la o scrisoare); a confunda, a se adresa (cuiva) din greșeală

misadjustment $(\mathrm{TH}$, mas, $\mathrm{OM})$ plasare / reglare / ajustare greșită

misadvise a sfătui greşit

misalignment nealiniere, dezaliniere; (OM) abatere de la coaxialitate / paralelism, excentricitate

misapply (TH) a aplica / folosi greșit (d. un rezultat de calcul, un procedeu, o tehnologie etc.)

misapprehend a înțelege greșit

misapprehension neînțelegere, înțelegere greşită

misbecoming nepotrivit, impropriu; nelalocul lui; nepoliticos

misbehave purtare / comportare urâtă / greşită; (jur) contravenție, delict

miscalculate (mat, logică) a calcula / judeca greşit miscalculation (mat) eroare de calcul, calcul eronat / greşit

miscarrriage (jur) eroare, greşeală (şi judiciară); eşec, nereuşită; (med) avort; (ec) livrare greşită 
miscellaneous amestecat, multilateral

misch metal (met) amestec de metale, aliaj

miscibility miscibilitate (d. fluide, elemente de aliere etc.)

miscible miscibil; (fiz, T) care se pot amesteca / dizolva etc.

misconceive a înțelege greșit, a avea o părere greşită despre

misconception neînțelegere, înțelegere / concepție greşită

misconduct comportare proastă; (ec, adm) conducere / administrare proastă; a conduce / administra prost; a nu se purta bine / corect

misconstruction interpretare / înțelegere greșită; neînțelegere, răstălmăcire

misconstrue a interpreta greşit; a răstălmăci

miscount (mat) a număra / calcula greşit

misdate dată greşită, a greşi data (de livrare etc.)

misdirect a îndruma greşit; (inf, TH) a da instrucțiuni greşite; (transp) a expedia greşit; (fig) a canaliza greşit

misemploy $(\mathrm{TH}, \mathrm{adm})$ a folosi / utiliza greşit / abuziv

misemployment $(\mathrm{TH}, \mathrm{adm})$ folosire / utilizare greşită / proastă / abuzivă

misestimation estimare / apreciere greșită; calcul greşit

misfire (auto) rateu (și la aprindere); (el) omisiune de aprindere

misfire (ignition) (auto) rateuri la motor

misfit (TH, OM) nepotrivire, neajustare; nepotrivit, necorespunzător; piesă / element (de maşină) / modul prost ajustat; inadaptabil; neadecvat

misfit cast (met) şarjă rebutată

misgovern (TH, adm) a guverna / conduce greşit (şi un proces tehnologic)

misgovernment $(\mathrm{TH}, \mathrm{adm})$ guvernare / conducere greşită (şi un proces tehnologic)

misgrowth (materiale, bot, agr) concrescență, umflătură (nedorită)

misguidance (ec, adm) îndrumare proastă; inducere în eroare; $(\mathrm{TH})$ ghidare greşită / necorespunzătoare, conducere greșită / necorespunzătoare (a unui proces tehnologic etc.)

misguide a îndruma greşit; a duce în eroare; (OM) a ghida prost / greşit; (TH) a conduce greşit (un proces tehnologic etc.)

misguided îndrumat prost; negândit, nechibzuit; (TH) ghidat prost / necorespunzător

mishap (auto, mas) pană, avarie, ruptură

misinterpretation interpretare greșită; răstălmăcire

mislay a rătăci; a pierde mislead a conduce greşit, a îndruma greşit; a induce în eroare, care duce la o concluzie greşită misleading greşit, care conduce / îndrumă greşit; amăgitor, fals

mismachined (mas-un) prelucrat greșit

mismanage (ec, adm, pol) a conduce / administra greșit / prost

mismanagement (ec, adm, pol) conducere / administrare greșită / proastă

mismatch $(\mathrm{TH}, \mathrm{OM})$ nepotrivire, deranjament, dereglare, dezechilibru, dezacord, neadaptare

mismeasurement (metr) eroare de măsurare

misoperate $(\mathrm{TH})$ a opera greşit (d. un operator uman), a opera / funcționa greșit (d. un sitem de reglare / automatizare etc.)

misoperation $(\mathrm{TH})$ oprerație greşită

misphased (el, c) defazat, cu fază greşită

misplace (TH, OM) a aşeza greşit, a deplasa

misplaced $(\mathrm{OM})$ aşezat greşit, deplasat (în sens nedorit) (d. o piesă, un semifabricat etc.)

misplaced core (met) miez de turnătorie deplasat

misrepresent a denatura, a prezenta greşit / întro lumină falsă

misrepresentation denaturare

misrule conducere / guvernare proastă; dezordine, neorânduială

misrun casting (met) turnare greşită, piesă turnată rebutată

miss a lipsi; a(-i) scăpa, a pierde, a simţi lipsa; a nu nimeri, a trage în gol; a nu avea succes, a nu reuşi; insucces, nereuşită, eşec; (med) avort mission misiune, delegație; chemare, țel, scop; problemă, sarcină, însărcinare; dispoziție

miss out a scăpa, a omite; a trece peste; (alim) a nu mânca

mispend a irosi, a cheltui prost / greşit; a risipi

mist (meteo, mediu) ceață (şi ca amestec de ungere), negură, pâclă, aer cețos; a încețoşa, a fi ceață, a burnița

mistake eroare, greșeală, (c) instrucțiune incorectă, defect; a greşi; a interpreta greşit, a face o greșeală

mistake for a confunda cu, a lua drept

mistaken greșit, eronat, incorect

mistimed inoportun, nepotrivit

mistiness (mediu) atmosferă cețoasă; aer cețos; nebulozitate

mistranslate a traduce greşit / eronat

mistranslation traducere greșită / eronată

mistrust of / in neîncredere în; bănuială, suspiciune față de; a nu avea încredere în; a bănui, a suspecta

misty (mediu) cețos, neguros; înnegurat, încețoşat; aburit; nebulos, confuz, vag 
misunderstand a înțelege greşit, a interpreta greşit; a răstălmăci

misunderstanding înțelegere greşită, interpretare greşită; neînțelegere, dazacord

misusage $(\mathrm{TH})$ folosire / întrebuințare greşită; (ec, adm, pol) abuz; maltratare, brutalitate

misuse (TH) a folosi / întrebuința greşit; (ec, adm, pol) a abuza de; a maltrata, a brutaliza; folosire / întrebuințare greşită / abuzivă

miter $(\mathrm{TH})$ îmbinare în unghi ascuțit; (mat) unghi de $45^{\circ} ;(\mathrm{OM})$ roată dințată conică

mitigate a calma, a potoli, a atenua (vibrații, neînțelegeri etc.), a tempera, a linişti, a slăbi; a micşora, a diminua

mitigating circumstances (jur) circumstanțe atenuante

mitigation micşorare; temperare; atenuare (a unei dureri, a unui proces etc.); slăbire

mitre (mat) unghi de $45^{\circ} ;(\mathrm{OM})$ roată dințată conică cu semi-unghiul conului de divizare de $45^{\circ}$, îmbinare în unghi ascuțit

mitre angle (geom) unghi de $45^{\circ}$

mitred $(\mathrm{OM})$ teşit / îmbinat / tăiat sub un unghi de $45^{\circ}$

mitred butt joint (el) legătură oblică

mitred joint (OM) îmbinare în unghi de $45^{\circ}$, îmbinare înclinată (şi la sudură)

mitre gear $(\mathrm{OM})$ roată dințată conică, pinion conic

mitre line linie de mijloc, linie la $45^{\circ}$

mitre seam (nav) cusătură diagonală

mitre sill's foundation (nav) prag la porți de ecluze navigabile

mitre valve $(\mathrm{OM}$, hidr) ventil cu scaun conic

mitre wheel $(\mathrm{OM})$ roată conică (rar)

mitre wheel gearing $(\mathrm{OM})$ angrenaj conic (rar)

mitring $(\mathrm{OM})$ îmbinare / asamblare la $45^{\circ}$

MIU (metr, med) simbol pentru 1 milion de unităţi internaţionale (pt dozarea unor medicamente)

mix (TH) dozaj, amestec; a mixa, a suprapune, a (se) amesteca, a (se) combina, a (se) îmbina, a prepara; a confunda; (met) a alcătui şarja; (alim) mâncare din mai multe ingrediente; a se asocia, a avea relații (d. cineva); (bot, zool, agr) a încrucişa (animale, plante); (c) mixaj / suprapunere de imagini, a suprapune / mixa imagini, a schimba succesiunea unor imagini; (fig) a amesteca, a băga (pe cineva într-o afacere etc.)

mixable miscibil, amestecabil

mix composition (materiale) compoziție a amestecului

mix consistency (materiale) compoziția / consistența amestecului mix design (constr) proiectarea / alcătuirea rețetei amestecului / betonului

mixed (materiale) amestecat, eterogen, mixt; (mat) combinat, mixt

mixed bag (alim) ghiveci, amestecătură

mixer circuit (electr, autom) circuit / montaj de conversie / modificare / schimbare a frecvenței

mix conduit (alim, ind chim) conductă de amestec

mixed crystal (met, fiz) cristal de soluție solidă

mixed expression (mat) expresie cu polinoame şi fracții raționale

mixed farming (agr) mai multe feluri de muncă la o fermă, agricultură mixtă

mixed feed (mec, el, mas) alimentare în paralel

mixed friction $(\mathrm{T})$ frecare mixtă

mixed gas (chim) gaz mixt / de amestec

mix iron / metal (met) fontă de melanjor

mixed metal (met) amestec / aliaj de metale

mixed polymer (plast) copolimer

mixed scrap (met) deșeuri de fier vechi amestecate (ca forme şi compoziţii)

mixed spirit (ind chim) spirt / alcool amestecat cu benzină

mixed train (cf) tren mixt

mixed up (in) amestecat (în); implicat (în)

mixer (constr) maşină de amestecat mortar, malaxor (şi de mortar), betonieră; (ind chim, alim) amestecător, mixer, malaxor (de mortar, pt. adezivi etc.), agitator, aparat / dispozitiv de amestecare, cilindru amestecător, shaker, mixer (pt. cocteiluri); (met) melanjor (şi de fontă); (electr, autom) etaj de amestec, schimbător; malaxor; (textile) mixor; ( fam) persoană sociabilă

mixer for the massecuite (alim) malaxorul pentru masa groasă de zahăr

mixer hopper (constr) schip de alimentare (a unei betoniere)

mixer metal (met) fontă de melanjor

mixer unit (alim, ind chim) aparat de amestecat, mixer

mixer valve (OM, ind chim) supapă de amestecare mixer with double blade (alim, ind chim) malaxor cu palete duble

mix formula (alim, met, ind chim) formula / reteta amestecului

mix in (alim, constr, ind chim) a introduce (prin amestecare), a adăuga, a încorpora, a introduce (o altă substanță) (într-o rețetă de material / de mâncare etc.)

mixing (TH) (acțiune / proces de) amestecare, care amestecă; (textile) amestec de fibre; (c, fiz) mixaj, schimbare / conversie a frecvenței mixing agitator $(\mathrm{OM})$ braț de amestecător 
mixing apparatus (alim, OM, ind chim) aparat de amestecat

mixing arm $(\mathrm{OM})$ braț de amestecat

mixing bin $(\mathrm{OM}$, ind chim) cameră / incintă de amestec

mixing burden (met) alcătuire a şarjei

mixing can (auto) bidon / canistră pentru amestecarea benzinei cu ulei

mixing chamber $(\mathrm{OM}$, ind chim) cameră / incintă de amestec; (auto, termo) carburator

mixing condenser (termo) condensator prin amestecare

mixing cone (injector) (OM, alim, ind chim) ajutaj de amestecare

mixing control (OM, alim, ind chim, $\mathrm{TH}$, autom) regulator de amestecare, controlul amestecului

mixing degree (materiale) grad de amestecare, calitate a dispersiei constuenților amestecului

mixing drum (OM) tobă / tambur de amestecare mixing formula (TH, materiale) compoziția / reteta amestecului

mixing ladle (met) oală de amestecare

mixing limit (ind chim, met) limită de amestec(are) / de concentrație etc. (pt. un constituent)

mixing machine (alim, ind chim, mas) maşină / instalație de amestecare; (constr) betonieră

mixing mechanism (ind chim, alim, met) mecanism de amestecare

mixing method $(\mathrm{TH})$ metodă de amestecare

mixing mill (alim, constr, ind chim) malaxor (şi deschis), amestecător

mixing motion (mec, $\mathrm{TH}$ ) mişcare de malaxare / de amestecare

mixing nozzle (OM) duză, ajutaj, (auto, termo) jiclor de amestec

mixing paddle $(\mathrm{OM})$ paleta amestecătorului

mixing pan amestecător; (met) oală de turnare cu dispozitiv de amestecare

mixing process $(\mathrm{TH})$ proces / procedeu de amestecare

mixing proportion / ratio (ind chim, met) proportie de amestec

mixing ratio (materiale, $\mathrm{TH}$ ) raport / procent de amestecare, componentă procentuală a amestecului

mixing tank (ind chim, OM) tanc / recipient de amestecare (de formare a unui amestec)

mixing rolls (plast, ind chim, OM) valțuri de amestecare

mixing time (TH) timp de amestecare; (met) timp de şarjare

mixing through (alim, OM) cuvă de amestecare mixing vessel (alim, chim) vas pentru amestecare mixing water (alim, chim) apă de amestecare mixing wing (alim, ind chim, OM) pală amestecătoare

mixing worm (alim, ind chim, OM) melc / şnec amestecător

mixture (materiale) amestec, adaos, umplutură; melanj; (chim, constr) amestec, compoziție; (met) alcătuirea / dozarea şarjei

mixture chamber (ind chim) cameră / incintă de amestec(are)

mixture control ( $\mathrm{TH}$, materiale) reglarea / corectarea amestecului

mixture corrector (autom, ind chim, constr) regulator de amestec

mixture distribution distribuirea amestecului mixture gas (me, chimt) gaz de amestec / mixt mixture making (alim, met, plast) alcătuirea / dozarea şarjei

mixture formation ( $\mathrm{TH}$, materiale) formarea amestecului

mixture-method lubrication (auto, T) metodă de ungere / lubrifiere prin amestec benzină-ulei

mixture of gasoline and ethanol (auto, chim) gazohol, amestec de benzină şi etanol

mixture of ores (met) alcătuirea şarjei (mai mult la furnal), amestec de minereuri (pt. uniformizarea şarjei la furnal)

mixture ratio $(\mathrm{TH})$ raport de amestec; (met) proporție de amestec

mixture temperature $(\mathrm{TH}$, termo) temperatură de amestecare

mix-up ciocnire; harababură; confuzie

mix up a amesteca (bine / complet); a încurca, a încâlci (şi fig); a răvăşi

mix up in / with a implica (într-o afacere), a amesteca în

mix well a (se) asorta, a (se) armoniza (d. lucruri) mizzen (nav) brigantină, arbore artimon, arbore pupa, velă artimon

mizzen mast (nav) arbore artimon, arbore pupa

mkp (metr) simbol pentru meter kilopond, o unitate de măsură pentru moment: 1 kilopond $=9,80665(\mathrm{~N} \cdot \mathrm{m})$

MM (metr) abreviere pentru un milion, $\mathbf{M}-$ de la numeralul roman 1000; în numerotația romană MM înseamnă 2000 (atenție la text)

$\mathbf{m} / \mathbf{m}$ (metr, chim, farmacologie) abreviere pentru „masă/masă”, pentru descrierea concentratiei unei substante într-un amestec sau într-o soluție: $2 \% \mathrm{~m} / \mathrm{m}$ înseamnă că masa substanței de interes este $2 \%$ din masa tolată a amestecului / soluției

MMb, MMbo (metr) simbol pentru 1 milion de barili de petrol 
MMBtu, dekatherm (metr, termo) simbol pentru 1 milion Btu $(\sim 1,055057 \mathrm{GJ})$, o unitate de măsură, folosită în industria energetică

MMcf (metr) simbol pentru un milion de picioare cubice $\left(28316,85 \mathrm{~m}^{3}\right)$.

MMMcf (metr) simbol pentru un miliard de picioare cubice

MMcfe (metr) simbol folosit în industria gazului natural pentru un milion de picioare cubice de gaz echivalent, o unitate de măsură pentru energie: $1 \mathrm{MMcfe} \cong 1,091$ terajoule (TJ)

MMMcfe (metr, fiz) simbol folosit în industria gazului natural pentru un miliard de picioare cubice de gaz echivalent, o unitate de măsură pentru energie: $1 \mathrm{MMMcfe}=1,091$ petajoule $(\mathrm{PJ})$

mmHg (metr, fiz) simbol pentru millimeter of mercury, milimetru (coloană) de mercur, unitate de măsură pentru presiune: $1 \mathrm{mmHg}=133,3 \mathrm{~Pa}$

MMM (metr) simbol pentru un miliard $\left(10^{9}\right), \mathrm{M}-$ numeralul roman 1000 (atenție, conform sistemului roman de numărare, MMM înseamnă 3000)

m.m.p., mmp (metric module pitch) (OM) pas exprimat prin modul metric (de exemplu, la roți dințate)

MMscfd (metr) simbol pentru one million standard cubic feet per day - un milion de picioare cubice standar pe zi, unitate uzuală de măsură pentru producția şi debitul de gaze naturale la temperatură standard $\left(15,6^{\circ} \mathrm{C}\right)$ şi o presiune atmosferică

Mlb (metr) simbol pentru million of pounds

moa (metr, mil) acromin pentru minute of angle sau arcminute, unitate pentru măsurarea mărimii unghiulare a țintelor; în unități metrice, 1 moa $=2,9089 \mathrm{~cm}$ la $100 \mathrm{~m}$

mobile (mec) mobil, transportabil, mișcător; schimbător, neconstant; migrator; (chim) foarte fluid, mobil (d. un atom, un ion, un radical etc.); (OM) parte mobilă

mobile hearth (met) vatră mobilă

mobile load (mec) sarcină mobilă / deplasabilă

mobile phone (elctr, ing, radio) telefon mobil, mobil

mobility (fiz, mec) mobilitate

mock (nav) model de lemn al unei nave sau al unei porțiuni de navă

mock window (constr) fereastră oarbă

modal balancing $(\mathrm{mec})$ echilibrare modală $(\mathrm{d}$. rotori flexibili)

modal value (mat) valoare probabilă maximă mode mod, fel, manieră; caracteristică; aspect; procedeu; formă; (c) mod; (mat) metodă, procedeu; (mas) formă / regim de funcționare; modă, obicei; formă, aspect; stil; (gram) mod; (fiz, autom, electr) mod, formă de undă, mod de oscilație, mod de propagare (în ghidurile de undă); (textile) modă; obicei; (muz) tonalitate

model tip, model, machetă, tipar; (ec) mostră; (el) schemă; (metr) normă; desen, tipar, şablon; (met) a modela; a imita; perfect, desăvârşit

modelling modelare (și matematică)

model (on / upon) (TH) a (se) modela (după), a fasona (după), a da forma dorită; a influența, a înrâuri

model test testarea modelului; $(\mathrm{T})$ test pe model mode of action mod de lucru

mode of crystallisation (fiz) formă / $\bmod /$ sistem de cristalizare

mode of operation mod de funcționare, regim de lucru

moderate moderat; temperat; reținut; mijlociu, mediu; potrivit; mediocru; (ec) (d. prețuri) modic, rezonabil, accesibil; a (se) modera; a (se) domoli; a (se) tempera; a (se) linişti; a prezida; a fi presedinte; a arbitra, a fi arbitru

moderate cooling (termo) răcire la temperatură medie

moderating glass (ind chim) sticlă mată / opacă moderation moderare; temperare; liniştire; moderație, cumpătare; reținere, stăpânire de sine; (fiz) frânare, încetinire

moderator arbitru, mijlocitor; președinte (al unei adunări, conferințe); (univ) examinator (în universitate, Oxford); (fiz) moderator; (mas-un) regulator de mişcare

modern modern; nou; contemporan

modernise a moderniza

modernising modernizare, care este în curs de modernizare, care (se) modernizează

modernity caracter modern, contemporaneitate, modernitate

modernization modernizare

modernize a (se) moderniza

mode selection knob (auto, OM) buton pentru selectarea modului de distribuție a aerului

mode shift (fiz, autom) alunecare a frecvenței

modest modest; nepretențios; simplu; neînsemnat; ieftin; decent; pur, curat

modesty modestie; simplitate; decență; puritate, curățenie

modifiable modificabil, care poate fi modificat

modification modificare, transformare, schimbare; (chim) modificație

modification of quality modificare a calității / calitativă (d. produse, servicii etc.)

modification of quantity $(\mathrm{TH})$ modificare a cantități / cantitativă

modifier (chim, met) modificator 
modify a (se) modifica; a (se) transforma, a (se) schimba; a modera, a tempera

modular (mat, TH) modular

modulate a (se) modula

modulation modulare; modulație

modulator (fiz, autom) modulator

module (mat, OM) modul; (metr) unitete de măsură pentru volum (pt. bumbac în pachete): 1 cotton module $\cong 36,25 \mathrm{~m}^{3}$.

module gear $(\mathrm{OM})$ angrenaj cu modul metric module pitch $(\mathrm{OM})$ pas exprimat prin modul modulus, $(p l)$ moduli modul (în mecanică şi rezistența materialelor), coeficient; (mat) valoare absolută, modul; (hidr) modul de debit; (constr, arhit) modul

modulus of compressibility (mec, materiale) modul de elasticitate la compresiune

modulus of elasticity (mec, materiale) modul de elasticitate

modulus of elasticity for / in shear (mec) modul de elasticitate la forfecare, modul de elasticitate transversal

modulus of elongation (constr) modul (de elasticitate) de alungire / la tracțiune

modulus of extension (materiale, termo) modul de extensie / de dilatare

modulus of precision (mat) modul de precizie modulus of resistance (mec) modul de rezistență modulus of rigidity (mec) modul de rigiditate modulus of rupture (mec, materiale) modulul (de elasticitate) la / înainte de rupere

modulus of section (mec) modul de rezistenţă al secțiunii

modulus of shear(ing) (mec) modul de elasticitate la forfecare / transversal

modulus of sliding (mec) modul de elasticitate la forfecare (rar)

modulus of sliding movement (constr) coeficient de elasticitate transversală

modulus of specific compression (materiale, mec) modul de elasticitate la compresiune

modulus of stiffness (mec, materiale) modul de rigiditate

modulus of strain hardening (met) coeficient de ecruisare la deformare

modulus of torsion (mec) modul de elasticitate la răsucire / transversal

modulus of torsional shear (mec) modul de elasticitate la forfecare / la răsucire / la torsiune / transversal

modulus of a vector (mat, fiz) modul al unui vector

Mohr circle (geom, mec) cercul lui Mohr

Mohs hardness (materiale, mec) duritate Mohs
Mohs hardness scale (metr) o scală 1-10 pentru estimarea durității mineralelor: diamant 10 , corindon 9 , topaz 8 , quarț 7 , ortoclaz 6 , apatită 5 , fluorită 4 , calcit 3 , gips 2 şi talc 1

moiety (metr) jumătate (din franceză, moitié) (rar) moire, moiré (textile) moar; (fiz, c, opt) moarat, efect moiré (la imagini)

moist umed, jilav, ud

moist air (mediu) aer umed

moisten a (se) umezi, a umecta; a (se) (în)muia; a (se) uda; a se jilăvi

moistening (acțiunea / procesul de) umezire, umectare

moistness umiditate

moisture umezeală, umiditate

moisture apparatus (metr, fiz) aparat pentru de-terminarea umidității

moisture barrier (fiz) barieră antivapori (material sau dispozitiv), ecran de etanşare față de vapori

moisture capacity capacitate / proprietate de a reține umezeala

moisture carry-over (met, ind chim) antrenare a picăturilor de apă de către un curent de aer sau gaz

moisture chamber (alim, ind chim, met) cameră / incintă de umezire / de umidificare

moisture content (mediu, materiale, plast) conţinut / grad de umiditate

moisture curing adhesive (plast, chim) adeziv cu întărire la umiditate

moisture determination method (plast, alim, metr) metodă de determinare a umidității

moisture eliminator (alim, chim) agent de uscare

moisture expansion (plast, mediu) înfoiere / mărire a volumului din cauza umezelii, gonflare

moisture free (materiale, mediu, met) uscat, lipsit de umezeală

moisture head (autom, metr) element sensibil la umiditate, sesizor de umiditate

moisture loss (agr, alim, mediu) pierdere de umiditate

moisture meter (metr) aparat pentru măsurat umiditatea (materialelor, mediului), umidometru

moisture percentage procent de umiditate

moisture permeability (materiale, mediu) permeabilitate la umezeală

moisture sampling (met) luarea unei probe pentru determinarea umidității

moisture sensitivity (materiale, aparate) sensibilitate la umezeală

moisture tester (metr, fiz) aparat pentru determinarea / testarea umidității 
moisture tons (termo) sarcină frigorifică datorită căldurii latente, sarcină termică de condensare

moisture-proof (materiale) rezistent la umiditate, hidrofug, etanş, protejat contra umezelii moisture-repellent (materiale) hidrofob

moisture-resistant (materiale) rezistent la umezeală, impermeabil (d. un material, un lubrifiant etc.)

moisture-sensitive (materiale, aparate) sensibil la umezeală

moisture-testing oven (metr, termo) etuvă pentru determinarea umidității

molad, lunar (synodic) month (metr) denumire din ebraica veche pentru luna (sinodică): 1 lunar (synodic) month $=29,53059$ zile

molal (m), molar (M) (metr, chim) măsură pentru descrierea concentrațiilor soluțiilor, în moli pe $\mathrm{kg}$ de solvent (mol/ $\mathrm{kg})$; molar descrie concentrația unei soluții în moli pe litru $(\mathrm{mol} / \mathrm{L}$, $\mathrm{mol} / \mathrm{l})$

molar (metr, chim) molar, măsură pentru descrierea concentrațiilor soluţiilor, în moli pe litru, gram-molecular

molar volume (metr, fiz, chim) unitate pentru măsurarea volumului unui gaz: volumul unui mol de gaz ocupat la temperatură standard $\left(0^{\circ} \mathrm{C}\right)$ şi presiune standard (normală) (1 atmosferă): 1 molar volume $=22,4141$

molasses (alim) melasă

molasses for forage (alim) melasă furajeră

mold (amer) v. mould

molecohesion (chim) forță de coeziune între molecule polare

mole (mol) (metr, chim, fiz) mol, moleculă-gram; (nav, constr) baraj, chei, dig portuar

molecular (chim) molecular

molecular action (chim) actiune la nivel molecular

molecular adhesion (chim) adeziune moleculară

molecular attraction (chim, T) atracție moleculară

molecular beam (chim) fascicul molecular molecular boiling-point elevation (chim) constantă ebulioscopică

molecular boiling-point elevation (chim, termo) ridicare moleculară a punctului de fierbere

molecular bond (chim) legătură moleculară molecular cluster (chim) aglomerare moleculară molecular colloid (chim) coloid molecular molecular decomposition (chim) descompunere a moleculei

molecular depression of freezing point (chim) constantă crioscopică, scădere moleculară a punctului de congelare molecular diameter (chim) diametru al unei molecule

molecular diffusion (chim) difuzie moleculară

molecular dissymmetry (chim, $\mathrm{T}$ ) asimetrie moleculară

molecular electronics (electr, chim) electronică care utilizează moleculele ca elemente constructive, electronică moleculară

molecular film (chim, T) peliculă monomoleculară

molecular flow (chim) curgere moleculară molecular forces (chim) forțe moleculare

molecular fraction (chim) fracțiune moleculară (într-un amestec)

molecular functional block (electr, chim) circuit integrat complet format dintr-un cristal semiconductor

molecular heat (chim, termo) căldură molară / specifică moleculară

molecular link (chim) legătură moleculară

molecular linkage (chim) legătură moleculară

molecular mass (chim) masă moleculară

molecular motion (chim, fiz) mişcare / agitație moleculară

molecular network (chim) rețea moleculară

molecular pump (OM, chim) pompă (de vid) moleculară

molecular ray (chim) rază moleculară

molecular scattering (chim) difuzi(un)e / împrăştiere / dispersie moleculară

molecular sieve (chim) sită moleculară

molecular solution (chim) soluție moleculară, soluție reală

molecular spectrum (chim) spectru molecular

molecular still (chim, mas) aparat pentru distilare moleculară

molecular structure (chim) structură moleculară

molecular transposition (chim) transpoziție intramoleculară

molecular volume (chim) volum molecular

molecular weight, mol wt, (chim) masă moleculară

molecule (chim) moleculă, particulă, mol

moleskin (textile) moleschin

mollify a potoli, a alina; a înmuia (d. sentimente, durere etc.)

molten (met) topit, lichid, topitură

molten bath (met) baie topită / lichidă

molten charge (met) încărcătură / şarjă lichidă

molten charge steel-making (met) elaborare cu încărcătură lichidă

molten layer (materiale, T, TH) strat topit

molten metal (met) metal / material metalic topit / lichid 
molten-metal dyeing process (met, $\mathrm{TH}$ ) procedeu de acoperire, cu folosirea unor băi de metale topite

molten-metal fluidity (met) fluiditatea metalului lichid

molten state (fiz, met, materiale) stare topită / lichidă

molten test sample (met) probă din metal lichid

Molybdenum (Mo) (chim) molibden

molybdenum disulphide $(\mathrm{T}$, chim) disulfură de molibden

molybdenum steel (met) oțel aliat cu molibden

moment (mec) moment; importanţă, însemnătate; of no fără importanță, fără consecințe, $(\mathrm{mec})$ care nu generează moment

moment about point support (mec) moment față de un punct de reazem

momentarily $(a d v)$ momentan, pentru o clipă moment equation (mec) ecuație de momente moment area $(\mathrm{mec})$ suprafața determinată de / sub curba momentului

momentariness caracter momentan / trecător moment arm (mec) braț al cuplului (de forțe) / al momentului / al forței (care generează un moment)

momentary de scurtă durată, trecător, momentan, care nu durează

momentary duty (mec) putere instantanee, lucru / funcționare de scurtă durată

momentary high-power effort (mec) efort determinat de o creştere scurtă a puterii

momentary load (mec) sarcină instantanee / de scurtă durată

momentary output (mec, mas, hidr) putere de / la ieşire instantanee / de scurtă durată, debit instantaneu / de scurtă durată

momentary velocity (mec) viteză instantanee momentană

moment at fixed end (mec) moment de încastrare moment at the joint (mec) moment în articulație (de obicei încovoietor)

moment at the point of fixation (mec, $\mathrm{OM}$ ) moment de / în încastrare

moment curve (mec, OM) curba (de variație a) momentului (pe un arbore etc.)

moment digram (mec) diagramă de moment moment distribution (mec) distribuția momentului

moment equation (mec) ecuatie de momente moment equilibrium (mec) (ecuație de) echilibru al momentelor

moment generating function (mat, fiz) funcție generatoare de momente

moment line (mec) linie de moment moment of couple (mec) momentul cuplului (de forțe)

moment of deflection (mec, $\mathrm{OM}$ ) moment încovoietor / de încovoiere

moment of double source (chim, hidr) momentul dipolului

moment of elasticity (mec) moment de inertie de elasticitate

moment of external forces (mec) momentul forțelor externe / exterioare

moment of flexure (mec) moment încovoietor

moment of force (mec) moment al fortei

moment of force tending to capsize (mec) moment al fortei de / la răsturnare

moment of friction (mec, $\mathrm{T}$ ) moment de frecare moment of gyration (mec) moment de girație moment of inertia (mec, OM) moment de inertie

moment of load (mec) moment (ca sarcină), momentul datorat sarcinii / forței

moment of (a) magnet (el) moment magnetic moment of momentum (mec) moment cinetic unghiular al cantității de mişcare / al impulsului moment of reaction (mec) moment (generat) de reacțiune

moment of resistance (mec) moment de rezistență moment of rotation (mec) moment de rotație / de torsiune, cuplu motor

moment of rupture (mec) moment (încovoietor sau de torsiune) de / la rupere (atenție la text)

moment of shearing (mec) moment de forfecare moment of torsion (mec) moment de / la torsiune

moment of twisting (mec) moment de / la răsucire moment on the pin joint / the support (mec) moment în articulație / în încastrare (de obicei cu referire la încovoiere)

moment-resisting (mec) rezistent la încovoiere moment rotation $(\mathrm{mec})$ rotație generată de un moment (de rotire / de torsiune)

moment taken about the point of fixation (mec) moment în raport cu punctul de fixare / de reazem (al grinzii)

momentum, $(p l)$ momenta (fiz, mec) moment mecanic, cantitate de mişcare, energie cinetică, inerția unui corp în mişcare, impuls

mometum amplifier (hidr, autom) amplificator de moment / de mişcare (bazat pe fluidul de alimentare și de comandă)

momentum conservation theorem (mec) teorema conservării cantitătii de mișcare

momentum (mass velocity) (mec) cantitate de mişcare

momentum of a body (mec) moment cinetic 
momentum-transportation (transformation) theory $(\mathrm{mec})$ teoria transmiterii impulsului momme (metr, bijuterie) unitate tradiţională japoneză pentru masurarea masei, corespunzând celei chinezeşti (Chinese mace): 1 momme = $3,75 \mathrm{~g}$ (şi pt. masa perlelor de cultură); (metr) unitate pentru măsurarea masei unității de suprafață (pt. țesături, mătăsuri): masa în momme a unei tesături din mătase cu lungimea de 25 yarzi şi 1,49 inch lățime $(\sim 0,8652$ $\mathrm{m}^{2}$ ): 1 silk momme $\cong 4,33 \mathrm{~g} / \mathrm{m}^{2}$

MON (metr) abreviere pentru numărul octanic al motorului

mondo point (metr) denumire pentru milimetru, ca măsură pentru pantofi

Monel metal (met) aliaj $\mathrm{Cu}-\mathrm{Ni}$, metal Monel monetary (ec) monetar, financiar; pecuniar monetize (ec) a transforma în monedă, a da o valoare monetară

money (ec) (sumă de) bani

money bill (pol, adm) proiect de lege financiară moneyed (ec) bănesc, financiar

moneyless (ec) fără bani

money maker (ec) persoană care câștigă bine, afacere bănoasă

money-making (ec) câştig(uri), profit(uri), (fam) care face bani; acaparator

money office (ec) casierie

money order (ec) ordin de plată, mandat poștal monition prevenire, avertisment

monitor (c) monitor, display; (autom, mas, c) dispozitiv de comandă / de control / de reglare; ( $\mathrm{TH}$, ind) a supraveghea, a urmări, a controla, a verifica, a asculta, a monitoriza, a urmări (pe un monitor), monitor (şi cu ecran); (mas-un) cap revolver; (nav) hidromonitor

monitor desk (c, autom) pupitru pentru monitor monitored control system (autom, mas) sistem de reglare în circuit închis, sistem monitorizat monitor(ing) (pol, ec, adm, TH) monitor(izare), control, supraveghere, informare, comandă monitoring circuit (el, autom) circuit de control / de monitorizare

monitoring feedback (autom, mas) buclă de (auto)reglare, feed-back

monitoring of process variables (autom, TH) reglarea / monitorizarea parametrilor unui proces tehnologic

monitor switchboard (mas, autom) tablou de comandă

monitor lathe (mas-un) strung revolver monitor signal (c, autom) semnal de comandă monkey (constr) berbec (de sonetă), mai; cărucior de macara; (met) ciocan cu cădere liberă (la forjă), cutie de răcire (la un cuptor etc.), inel de răcire al orificiului de zgură; (mas, termo) cărucior de macara

monkey bridge (nav) punte etalon, pasarelă

monkey (of a pile driver) (constr) berbec (la o sonetă)

monkey spanner / wrench $(\mathrm{OM})$ cheie universală, cheie franceză / reglabilă

monobloc (OM, hidr) monobloc (d. un element de maşină, un modul, un subansamblu, un bloc hidraulic etc.)

monoblock casting (met) piesă turnată monobloc

monochromathic (fiz) monocromatic

monodisperse particles (fiz) particule monodisperse

monolith (constr, TH) monolit

monolithic (constr, $\mathrm{TH}$ ) monolitic, de monolit

monomer (chim) monomer

monomial (mat) monom

monophase (chim, met) monofazic; (el) mono-

fazic, monofazat

monopolist (ec) monopolist

monopolistic $(a d j)$ monopolist

monopolize (ec) a monopoliza (piața etc.)

monopoly (ec) monopol

monorail (cf) monoşină, monorai

monostable (fiz, hidr) monostabil, univibrator

monotectic alloy (met) compozit metalic cu o fază dispersă a produselor de solidificare, distribuită într-o matrice, aliaj monotectic

monostable (mec) cu o singură stare stabilă monotone monotonie, caracter monoton

monotonous monoton; plictisitor

monotonously $(a d v)$ (în mod) monoton, plictisitor

monotony monotonie; repetare / uniformitate plictisitoare; plictiseală

monotype monotip (poligrafie)

monotonicity (mat) monotonie

monovalent (chim) monovalent

monoxide (chim) monoxid

month lună (calendaristică); month (mo, mon) (metr) unitate de timp care marchează durata unei revoluții a Lunii în jurul Pământului: lunar / synodic month este media intervalelor dintre două momente succesive cu lună nouă: 1 month $($ synodic $)=2551443,84 \mathrm{~s} ; 1$ month $=$ $2628000 \mathrm{~s}=29,53059$ zile; (metr, adm) o lună $\sim 1 / 12$ an, variind între 28 şi 31 zile monthly $(a d v)$ lunar, în fiecare lună monument monument mood dispoziție, stare de spirit; supărare; mod (gramatical) 
moody schimbător, cu toane; supărat, indispus; capricios

moon lună

moon-knife (pilărie, mas-un) disc de înmuiat moon-struck neatent, distrat, lunatic; nebun moon sail / raker (nav) vela lunii (la veliere) moor (nav) a afurca, a acosta, a amara, a se lega, afurcare

moorage (nav) acostare, amarare, afurcare, loc de ancorare, ancoraj

moor coal turbă

mooring (nav) amaraj, post de ancoraj, dană de acostare, legare, acostare, afurcare

mooring anchor (nav) ancoră de geamandură

mooring bitts (nav) bintă de lanț

mooring bridle (nav) legătură de cap mort

mooring clamp (nav) ancoră de beton

mooring equipment (nav) instalație de manevră

mooring force (nav) forță de amarare

mooring line (nav) cablu de ancorare

mooring mast (nav) stâlp de ancorare

mooring pipe (nav) nară de bordaj

mooring rope (nav) cablu de amarare, parâmă de manevră

moorings (nav) ancoră de port / de geamandură, mijloace de ancorare / legare

mooring screw (nav) ancoră şurub

mooring stern to a jetty (nav) a acosta cu pupa la chei

mop $(\mathrm{OM})$ coadă cu mâner; spălător (de podele), mop; (met) disc de lustruit din postav / pânză; a spăla, a şterge (de praf), a curăța (cu un mop)

moped (auto, transp) motoretă

mop polishing lap disc de lustruit cu marginea din tesătură

mop up a curăți (umed, cu un mop), a absorbi, a şterge (umed)

morass (geogr) mlaştină; (fig) situație grea, încurcătură

mordant (met, chim) baiț, mordant, soluție de decapare

more mai mult

morello (cherry) (alim) vişină

moreover $(a d v)$ mai mult decât atât; în plus; pe lângă acestea; de asemenea

morgen (metr) unitate tradițională de măsură pentru suprafață (de teren) în nordul Europei; 1 Dutch morgen, $\cong 0,850$ ha, 1 morgen (Africa de Sud) $=0,8567$ ha, 1 morgen (Scandinavia şi Germania de nord) $\cong 0,25$ ha; 1 Prussian morgen $=2553,22 \mathrm{~m}^{2} ; 1$ morgen (Germania de sud şi Austria) $=0,5755$ ha

morning (de) dimineață; matinal morphine (chim) morfină morphism (mat) morfism

morsel (alim) bucată, bucățică (de hrană); fărâmă; (d. persoane) nulitate; a împărți / distribui în părți mici

Morse taper (shank) (mas-un, OM) con Morse

Morse taper gauge (mas-un, metr) calibru pentru conuri Morse

Morse taper reamer (mas-un) alezor pentru con Morse

mortar (constr) mortar; (TH) mojar, piuliță

mortar mixer (constr, mas) malaxor de mortar

mortgage (ec) ipotecă, ipotecare, amanetare; amanet, ipotecă; drept de ipotecă; a amaneta, a ipoteca; a lua un împrumut ipotecar de la; a se angaja, a-şi lua angajamentul

mortgage bond / deed (ec) titlu de garanție

motagee (ec, jur) creditor ipotecar

mortager (ec, jur) datornic ipotecar

mortise $(\mathrm{OM})$ sanț, canal, canelură, crestătură, locaş, deschidere; a morteza, a decupa, a executa un locas, a îmbina cu cep, a ștemui mortise chisel daltă

mortise joint $(\mathrm{OM})$ îmbinare cu cep

mortiser (mas-un) maşină de mortezat

mortising (mas-un, TH) scobire, mortezare

mortising machine (mas-un) maşină de mortezat mortmain (jur) bun inalienabil, avere inalienabilă

mosaic (constr) mozaic; (met) structură tip mozaic

mosaic structure (met) structură tip mozaic moselle (alim) vin de Mosela mosquito, $(p l)$ mosquito(e)s (zool, mediu) țânțar

mosquito craft (nav) vedetă torpiloare

mosquito net (OM, mediu) plasă de țânțari

moss rubber (plast) cauciuc buretos

mossy lead (el, chim) plumb spongios (pt. acumulatoare)

mossy zinc (met) zinc granulat, alice de zinc

most cel mai mult, cea mai multă, cei mai mulți, cele mai multe; cel mai, cea mai, cei mai, cele mai; cât se poate de, foarte, extrem de; cu totul; (amer) aproape

most favo(u)rable (ec) valoare optimă / favorabilă, optim, favorabil

mostly $(a d v)$ de cele mai multe ori, în general; de obicei; în special, îndeosebi, mai ales, mai cu seamă

most powerful test (mas) test / încercare de / la putere maximă

motel (constr, turism) motel

moth (zool, mediu) fluture de noapte; molie

moth ball granulă de naftalină 
mother mamă; (fig) izvor, sursă; a îngriji ca o mamă; a înfia

mother disk $(\mathrm{OM})$ piuliță, disc conjugat (cu altă piesă)

mother of mould (met, OM) tipar-mamă, tipar pentru executarea modelului (de turnare) / matriței

mother-of-pearl, mother of pearl (materiale) sidef

mother of vinegar (alim) drojdie de oțet

mother oil (geol) țiței primar

mother tongue limbă maternă

mother tree (agr) semincer

mother vat (alim) butoi de bază

mother wit bun-simț înnăscut

mothery (alim) mucilaginos, care a prins mucegai

mothy plin de molii; ros / mâncat de molii

motif motiv; idee, subiect; (textile) desen, motiv

motion (mec) mişcare, mers, deplasare; $(\mathrm{TH})$ mecanism, funcționare; impuls, inițiativă; propunere

motion energy (mec) energie de mişcare / cinetică motion quantity / magnitude (mec) cantitate de mişcare

motion equation (mec, mas) ecuația mișcării

motionless (mec) imobil, nemişcat, în repaus

motion of translation (mec, mas-un) mişcare de translație

motion screw (OM) şurub de mişcare / pentru transmiterea mişcării

motion thread $(\mathrm{OM})$ filet pentru transmiterea mişcării; (mas-un) filetul șurubului conducător motivation motivare; imbold, impuls

motive motiv, cauză, mobil; (TH) motor, (adj) motrice (d. o forță, un motor etc.); a dicta, a inspira; a stimula; a motiva, a justifica; a fi cauza / motivul

motive fluid (hidr, T) fluid motor, agent / fluid / lichid de lucru

motive force (mec) forță motoare / motrice

motiveless fără motiv; nefondat, neîntemeiat, nejustificat

motive power (mec) forță motoare / motrice / de acționare / de antrenare, sursă de energie

motivity (mec) forță motoare, rezervă de energie motley multicolor, de diferite culori; pestriț, divers, amestecat; amestecătură; dezordine, harababură

motoplough (agr, mas) motoplug

motor motor, mașină, automobil; a merge cu maşina; (anat) nerv / muşchi motor

motor barge (nav) şlep (cu) motor

motor bicycle (transp) motocicletă, motoretă motor boat (nav) motonavă, şalupă, ambarcatiune cu motor

motor bogie (cf) boghiu motor

motor brake / braking (auto, OM) frână de motor

motorcade (amer) coloană de maşini

motor car (auto) automobil, maşină

motor-car battery (auto, chim, el) baterie auto

motor-car body (auto) caroserie de autovehicul

motor-car body sheet (met, auto) tablă (lamina-

tă) de caroserie

motor-car boot portbagaj (auto)

motor-car chassis (auto) şasiu de autoturism

motor-car engine (auto, termo) motor pentru automobil

motor-car repair shop (auto, TH) atelier de reparații auto

motor-car sheet rolling mill (met, auto) laminor pentru tablă de caroserie

moto(r-)compressor (termo) motocompresor

motor concrete mixer (constr, transp, mas) betonieră auto

motor controller (autom, termo) regulator de viteză (pentru un motor)

motor converter (el, mas) grup convertizor, motor-generator

motor couple (mec, mas) cuplu activ

motor crane (auto, transp) macara auto

motorcycle (auto) motocicletă

motorcycle oil (auto, T) ulei pentru motociclete

motor distribution diagram (termo, mas) diagrama de funcționare a unui motor

motor drive (mas) actionare cu motor; (mec) antrenare mecanică

motor-driven / -actuated / -operated (TH, mas) acționat / antrenat / comandat prin motor electric

motor-driven pump (mas, hidr) motopompă motor-driven welding set / machine (el, met) generator de sudură cu motor electric, convertizor de sudură

motored (mas) (prevăzut) cu motor

motor failure (mas, auto) pană / avarie de motor, cădere / defectare a motorului

motor fastener (auto, OM) închizătorul capotei

motor field (el, fiz) câmp magnetic / de excitație al unui motor electric

motor field control (el, autom) reglare a turatiei unui motor electric prin variația curentului de excitație

motor fuel (ind chim, auto, termo) combustibil pentru motoare, carburant

motor-generator (el) motor-generator, convertizor motor-generator set (el) grup motor-generator electrogen 
motor hood (auto, OM) capota motorului motoring (auto) automobilism; motociclism motorization (mas) motorizare motorize (mas) a motoriza motorized (mas) motorizat; autopropulsat motorized head pulley (OM) tambur motor, rolă motoare (la transportoare cu bandă) motorized speed reducer $(\mathrm{OM})$ motoreductor, ansamblu motor-reductor

motor knocking (auto) bătaia motorului motor lorry (auto, transp) autocamion motorman vatman, manipulant de tramvaie; conducător auto, şofer

motor number (mas, auto) număr (de fabricație) al motorului

motor oil (ind chim, mas, T) ulei pentru motoare motor operated (mas) actionat cu motor motor operated valve (ind chim, OM) ventil / robinet (actionat) cu motor

motor operator demaror

motor protection switch (electr, el, termo, mas) întrerupător automat de protecție a motorului motorpump (OM, hidr) motopompă motor road (auto, constr) autostradă motor service (auto) service auto motorship (nav) motonavă

motor speed control (OM, el) variator de turație motor spirit (auto, ind chim) benzină

motor terminal board (el) placă cu borne a motorului (electric)

motor trouble (mas, el) pană / avarie la motor, defectare, functionare defectuoasă

motor-truck (auto, transp) autocamion

motor-truck crane (auto, transp) macara auto motor-truck engine (auto, termo) motor de camion motor truck scale (metr, OM) basculă / dispozitiv pentru cântărit autocamioane

motor tyre (auto, OM) pneu de automobil

motor vehicle vehicul motorizat, autovehicul, automobil

motorway (auto, constr) autostradă

motor winch (OM, mas) vinci / troliu / macara cu motor

motor with series characteristics (el) motor cu caracteristică-serie

motor with shunt characteristic (el) motor cu caracteristică-paralel

motor workshop (auto, TH) atelier de reparații auto

mottle a păta, a bălța, a împestrița, a marmora mottled pătat, băltat, împestrițat, pestrit, marmorat mottled (pig) iron (met) fontă brută pestriță mottled structure (met) structură pestriță / perlitică (la fontă) mottled white (pig) iron (met) fontă semi-albă / cu structură intermediară între fonta albă şi cea perlitică

motto motto

mould (alim) mucegai, a (se) mucegăi, a se umple de mucegai; (agr) humus, sol, pământ afânat / roditor; (constr) cofraj; (met) mulaj, matriță, formă (şi de turnare), tipar, cochilie, cochilă, formă de turnare, lingotieră, calibru de formă, şablon; gabarit; (TH) a ambutisa, a presa (adânc), a forma, a matrița, a turna, a modela, a face după şablon; a ştanța; (nav, constr) dig de larg; (fig) structură, caracter, a modela (un caracter)

mouldability (met) plasticitate, turnabilitate, maleabilitate

mouldable (met) maleabil, ductil, plastic, modelabil, turnabil

mouldable insulating material / substance (el, plast) masă / substanță izolantă turnabilă / matritabilă / injectabilă

mould and die copying machine (mas-un) maşină de frezat prin copiere (pt. matrițe, forme de extrudare etc.)

mould assembling (met) asamblarea formei matriței (la turnare)

mould board (met, OM) placa ramei de formare mould box (met, OM) ramă / cutie de formare

mould casting (met, TH turnare în matriță / cutii de formare

mould castings (met) piese turnate

mould cavity (met, plast, OM) cuibul / golul cavitatea matritei / formei

mould charge (met, plast) încărcarea / umplerea matriței

mould cooling jacket (met) manta de răcire a formei

mould core (met, plast) miez al formei (de turnare) / matriței

mould cure (plast) vulcanizare în matriță

mould dilatation (met, plast) dilatare a formei / matritei / cochilei

mould-drying oven (met) cuptor de uscat forme (de turnare)

moulded article / body (met) piesă turnată; (plast) articol obținut prin presare / turnare / injectare în matriță

moulded breadth (nav) lățime de construcție / de calcul a navei

moulded capacitor (el, electr) condensator presat în material plastic

moulded core (met) miez de turnare

mouled depth (nav) înălțime a bordului, înălțime de calcul (a bordului) 
moulded laminate (plast) piesă formată din material stratificat / laminat

moulded piece (met, plast, OM) piesă turnată / matrițată; (plas) piesă obținută prin injectare în matriță

moulded plastic pirn (OM, plast, textile) țeavă de fir, mulată, din material plastic

moulded plastics (materiale) materiale plastice care se pot matrița / injecta în matriță

moulder a se preface în praf (d. o clădire), a se ruina, a se nărui; a se descompune; a nu face nimic; (met) formator

mouldering mocnire

moulder (met) (muncitor-) formator

moulder's peel (met, OM) lopată de turnătorie

moulder's pin (met, OM) cui de turnătorie

moulder's rule (met, metr, termo) riglă / metru de modelărie; scară de contracție

moulder's shovel (met, OM) lopată de formare

moulder's spring (met, OM) cui / arc de turnătorie (la articulația dintre capac şi matriță)

moulder tool(s) (met, mas-un) instrumente / scule de formare

mould face (met) suprafață de turnare, perete al formei de turnare

mould finish (met, chim) vopsea pentru forme

mould fungus (alim) mucegai

mouldiness (alim) mucegăire

moulding (alim) plămădire; (met, plast) formare, modelare, fasonare, mulare, matrițare (la cald); (constr) ciubuc, mulură; material profilat (pt. piese)

moulding batch (met) amestec de formare; (TH) masă de fasonat

moulding bay (met) atelier de formare (si turnare)

moulding bench (met) masă de formare moulding bed (met) pat / placă / pod de turnare moulding blackening (met, chim) vopsire cu vopsea de grafit pentru forme

moulding board (met) placă de formare

moulding box (met) cutie / ramă de formare, cuvă / formă de turnare

moulding-cinder pot (met) oală pentru zgură moulding clay (met, chim) argilă de formare moulding core (met) miez pentru formare moulding die (met, mas-un) formă / matriță pentru turnare sub presiune

moulding equipment (met) instalație de formare moulding file (mas-un) pilă cu fața de lucru concavă

moulding flask (met) ramă de turnare

moulding floor (met) atelier de formare

moulding in die (met) formare pentru turnarea sub presiune moulding ink (met, chim) vopsea de grafit pentru forme

moulding job (met, TH) operație de formare (la turnătorie)

moulding loam (met) argilă de formare

moulding machine (met, mas-un) maşină / presă de formare

moulding machine with power lift (met) maşină de format cu extragerea automată a modelului

moulding machine with swing-out-type squeezing head (met) maşină de format, cu cap de presare rabatabil

moulding machine work (met) formare cu maşină de format

moulding material(s) (met) material(e) de formare moulding mixture for steel castings (met) amestec de formare pentru turnarea pieselor din otel

moulding oil (met, plast, ind chim) ulei pentru matrițe

moulding operation (met) operatia de formare

moulding paste (met, chim) pastă pentru ungerea formelor; (mas-un) pastă de rectificat

moulding pit (met) groapă de turnare

moulding powder (plast) pulbere pentru presare (în matriță)

moulding practice (met) formare (a matriței, formei de turnare)

moulding press (met) presă de formare

moulding process (met) operație / proces / procedeu de formare (la turnătorie)

moulding rapper (met) aparat / dispozitiv de dezbătut forme

moulding sand (met) (amestec cu) nisip pentru formare

moulding sand sieve (met) sită (la turnătorie)

moulding shop (met) atelier de formare

moulding spade (met) lopată de formare

moulding technique (met) tehnică de formare

moulding wax (met, plast) unsoare consistentă pentru ungerea formelor / matrițelor

mould into (met, plast, TH) a transforma în, a turna în, a matrița (în formă, matriță)

mould jacket (met) ramă de formare

mould joint (met, plast) suprafața de separare dintre părțile componente ale unei forme / matrițe

mould loft(floor) (nav) sală de trasaj

mould maker (met) (muncitor-) formator

mould mark (met) bavură de turnare

mould on / upon a forma după model

mould paint (met, chim) vopsea pentru forme / pentru turnătorie

mould part (met, OM) semiformă, o parte a formei 
mould plate

movable-disk relay

mould plate (met, plast) placă de model / matriță / formă

mould press (met, plast) presă de format

mould pressing (met, plast) presare/ formare în matriță

mouldproof (plast) rezistent la mucegai

mould ramming (met) îndesarea formei

mould release agent (chim, plast) ulei / substanță pentru matrițe, agent pentru uşurarea scoaterii din matriță

mould scrap (met) spărturi de turnătorie / de lingotiere / de cochile

mould skip depth (auto, OM) adâncimea canalelor dintr-un pneu

mould splits (met, OM) părțile componente ale unei forme / ale unei matrite

mould stamping (met) îndesarea formei

mould stool (met) fund de lingotieră

mould table (met) masă de formare

mould unloading (met, plast) descărcarea matriței

mould vulcanisation (ind chim) vulcanizare în matriță

mould wash (met, chim) vopsea pentru forme mould weight (met) masa / greutatea încărcăturii mound zid de pământ, val; rambleu; (geogr) colină, dâmb, movilă; morman, teanc; a împrejmui cu zid de pământ, a forma un zid de pământ / o ridicătură / o movilă

mount munte, deal; (TH) suport, montură; a monta, a asambla, a instala, a se urca în / pe, a ridica, a sălta, a pune, a fixa; (ec) (d, prețuri) a creşte, a se ridica; (poligrafie) suport

mountain munte

mountain cork / leather (minerl) azbest

mountainous (geogr) muntos, de munte; (fig) uriaş

mounted $(\mathrm{OM})$ construit, montat, asamblat, instalat

mounted axle $(\mathrm{OM})$ osie montată

mounted die (OM, met, plast) matriță (deja) montată

mounted drill (mas-un) burghiu montat

mounter montator, instalator

mount guard a prelua schimbul, a schimba tura mounting (TH, OM) dispozitiv de ancorare / de rezemare, montaj, montare, asamblare, montură, suport, cadru, şasiu, soclu, piesă auxiliară

mounting bracket $(\mathrm{OM})$ brățară / clemă de fixare

mounting bracket for roof carrier (auto, OM) suport pentru portbagaj extern

mounting drawing $(\mathrm{OM}, \mathrm{TH})$ desen de montaj mounting hole $(\mathrm{OM})$ gaură de prindere / de montare / necesară la montaj mounting joint (constr, mec) rost de montaj (zidărie şi construcții sudate)

mounting ladder (constr, mec) schelă / scară de montaj

mounting pad (mas-un) suprafața (prelucrată) pentru aşezarea pieselor conjugate ale unui ansamblu

mounting plate $(\mathrm{OM}, \mathrm{TH})$ placă portantă, masă de montaj

mountings (OM) piese auxiliare / accesorii, armătură, garnitură

mounting shoe (OM) talpă / sabot de fixare

mounting shop $(\mathrm{TH})$ atelier de montaj

mounting strip (constr, OM) şipcă de reazem / de susținere (provizorie)

mounting stud $(\mathrm{OM})$ bolt de fixare

mounting support $(\mathrm{OM})$ suport

mounting table $(\mathrm{OM}, \mathrm{TH})$ masă de montaj

mounting tool $(\mathrm{OM})$ sculă de montaj / de asam-

blare / de instalare

mouce, $p l$ mice (zool) soarece; (c) mouce

mouse sight (anat, opt) miopie

mouth (anat) gură; (constr) bot, cioc; (geogr) gură de vărsare (canal, râu); (met) deschidere, gură, orificiu, gât (de convertizor); deschizătură

mouthing $(\mathrm{OM})$ capăt lărgit al unei țevi

mouth of a furnace (met) gură / orificiu de încărcare / de şarjare

mouth of funnel capătul lărgit al pâlniei

mouth of hook gura cârligului

mouth of pipe (OM, hidr) capătul unei țevi, capăt de admisie al unui tub

mouth of spanner $(\mathrm{OM})$ deschiderea cheii

mouth of tongs $(\mathrm{OM})$ ciocul graifărului; (met) deschiderea clestilor de prindere a semifabricatelor la forjă, la slebing etc.

mouthpiece purtător de cuvânt, exponent; (OM) ajutaj, muştiuc

mouth screen (met) manta de captare a gazului la furnal

mouth skull (met) lipitură la gura convertizorului movability (mec) mobilitate

movable (OM) transportabil, mobil, care se poate mişca, care poate fi mișcat

movable bearing $(\mathrm{OM}, \mathrm{T})$ reazem / lagăr mobil, lagăr liber (cu rulmenți)

movable charging machine (met) maşină mobilă de încărcat

movable crushing jaw $(\mathrm{OM})$ falcă mobilă de concasare

movable disk discharger (el) eclator $\mathrm{cu}$ electrozi mobili / rotitori

movable-disk relay (el) releu cu disc, releu de curent alternativ cu inductie 
movable element (OM) element / parte mobil(ă) / amovibil( $\breve{a})$

movable fit (OM) ajustaj cu joc

movable frame $(\mathrm{OM})$ cadru mobil

movable hinge $(\mathrm{OM})$ articulație mobilă (posibil cu glisieră)

movable jaw (mas-un, OM) falcă mobilă

movable load (mec, OM) sarcină mobilă / fără punct fix de aplicare (şi la rulmenți)

movable parts $(\mathrm{OM})$ organe de maşini / piese în mişcare

movable / moving plate (met) placă port-cochilă mobilă

movable platform (met) platformă mobilă

movable poppet (mas-un) păpuşa mobilă / de centrare

movable pulley $(\mathrm{OM})$ roată liberă (şi de curea) pe arbore

movables mobilă, mobilier; (jur) bunuri mobile, avere mobilă

movable system (mas) sistem mobil; (TH) echipaj mobil

move $(\mathrm{TH})$ mişcare, deplasare, mutare, pornire, plecare; schimbare; măsură; pas, acțiune; mutare (cu locuința); (fig) măsură; (TH) a (se) mişca, a deplasa (ceva), a se deplasa cu, a (se) urni, a (se) clinti, a împinge, a pune în mişcare, a fi (pus) în mișcare, a agita, a înainta; a (se) muta, a-şi schimba reşedința, a strămuta; a lua măsuri; a înainta, a progresa, a avansa, a face progrese; a acționa, a întreprinde o acțiune; a face o propunere; a se învârti, a se roti, a merge, a funcționa; a porni, a nu sta pe loc; (ec) a se vinde, a avea desfacere / căutare; (şi fig) a mişca, a clinti, a însufleți, a face să-și schimbe părerea, a îndemna, a împinge (la, să), a emoționa, a mișca; (pol, adm) a propune, a depune (o rezoluție, o moțiune); a provoca, a stârni (mânie etc.); a face o mişcare / un gest, a merge, a păşi, a pleca (d. o persoană); a juca, a deplasa o piesă (la şah); a acționa, a se pune pe treabă; a face o propunere; (jur, adm, ec) a face / formula o reclamație / o cerere

move away a da la o parte; a îndepărta; a înlătura; a se îndepărta, a pleca

move back a da înapoi; a se retrage

move down a coborî, a lăsa jos; a se mișca în jos; a trece într-o clasă inferioară, a retrograda, a fi retrogradat

move for a interveni pentru; a face demersuri pentru; a cere

move in a se muta în; a lua inițiativa

move in step (el) a funcționa în fază

moveless fix, nemişcat, imobil movement (mec) mişcare, avansare, deplasare; înaintare; functionare; parcurs; mutare; gest; (ec) acțiune organizată, circulație, debit; (TH) mers (al motorului etc.), funcționare; $\sim \mathbf{s}(p l)$ acțiuni; mișcare (socială, politică etc.); (mil) mişcare (de trupe etc.); gest, mers; dezvoltare, evolutie; tempo, ritm

movement coil (el, metr) bobină mobilă a unui mecanism de măsurare

movement from copy (mas-un) mişcarea unei scule comandate după şablon / prin copiere

movement in a curved line (mec, fiz) mişcare după o curbă, mişcare curbilinie

movement of gyroscope (mec) miscare giroscopică / a giroscopului

movement of stroke (transp) mişcare de ridicare / ascendentă / ascensională; (mas-un) mişcare principală, cursă activă

move off a da la o parte, a îndepărta, a înlătura; a pleca, a se îndepărta; (ec) a se vinde

move on a se mişca, a circula; a merge mai departe; (d. timp) a trece, a se scurge; a nu sta în loc

move out (of) a se muta (din)

move out of the mud (auto) a ieşi (cu maşina) din noroi

move over a (se) da la o parte, a face loc; a ceda, a renunța

mover motor, sistem de acționare

move to a face / determina / hotără să

move to and fro a (se) balansa, a oscila

move up a merge în sus, a (se) ridica, a creşte, a urca; a aduce (rezerve); (edu) a promova (la şcoală), a fi promovat

moving în mișcare, care se mişcă, deplasare, mişcare, mobil, deplasabil

moving along mișcare de translație, deplasare, care se mișcă / se deplasează în / de-a lungul

moving-bar grizzly (met, ind chim) grătar cu bară movilă

moving bed (alim, ind chim, mediu) pat instabil (si la sedimentare), pat cu miscare

moving blade $(\mathrm{OM})$ paletă de rotor, lamă (şi tăietoare) mobilă

moving contact rod (el, OM) tija mobilă a contactorului

moving element (OM, mas) element în mişcare / mobil

moving force (mec, OM) forț̆ mobilă / care nu este fixă ca punct de aplicație, forță motoare moving-iron ammeter / meter (metr, electr, $\mathrm{OM}$ ) contor electromagnetic (mai rar)

moving load (mec, OM) sarcină mobilă / deplasabilă 
moving part logic (hidr) parte din logica fluidelor, care utilizează piese mobile

moving part(s) $(\mathrm{OM})$ piesă / / element(e) / piese în mișcare

mow mutră; strâmbătură; (agr) a cosi, a secera (cereale etc.), a tunde (iarba); a se strâmba; (agr) căpiță, claie, hambar

mower (agr) cosaş, secerător, cositoare, secerătoare

MPa (metr, hidr, mec) simbol pentru megapascal, unitate de măsură pentru presiune sau tensiune /efort (mecanică)

mppcf, $\mathbf{m p} / \mathbf{f}^{\mathbf{3}}$ (metr, mediu) abreviere pentru million particles per cubic foot, unitate pentru măsurarea concentrației de particule de praf din aer (şi în medii industriale): 1 mppcf $\Leftrightarrow$ 35,315 million particles per cubic meter; $v$. million particles per cubic meter

msl, MSL (metr) abreviere pentru above mean sea level - deasupra nivelului mării

Mstb (metr, ind chim) simbol utilizat în industria petrolului pentru 1000 stock tank barrels; v. stock tank barrel

M\&S tyre (mud and snow tyre) (auto, OM) pneu pentru noroi şi zăpadă

msw (metr, hidr) simbol pentru meters of seawater, unitate convențională de presiune, metru coloană de apă de mare: 1 meter of seawater = $10 \mathrm{kPa}$

Msym/s (metr, radio) unitate pentru viteza de transmitere a informație: $1 \mathrm{Msym} / \mathrm{s}=10^{6} \mathrm{sim}$ boluri transmise pe secundă

MT (metr) (amer) abreviere pentru metric ton sau tonne $(1000 \mathrm{~kg})$

MTS system, meter-ton-second system (metr) sistem de unități de măsură metru-tonă-secundă, corespunzător sistemului centimetru-gramsecundă

mtu (metr, fiz) simbol pentru metric ton unit; v. metric ton unit

mu, mou (metr) unitate pentru suprafață (de teren): $1 \mathrm{mu}($ China $)=1 / 15$ ha

much mult; $(a d v)$ foarte, cu mult, de departe, incontestabil; categoric

much as oricât de; deşi; cu toate că

muchy (met, materiale) poros

mucilage (alim, plast, ind chim) mucilagiu, soluție de gumă în apă

muck (mediu) noroi, nămol, gunoi; (agr, mediu) bălegar, murdărie; a încărca (nedorit); (met) a pudla; (agr) a îngrăşa cu bălegar; a murdări, a strica

muck-bar pile (met) bare de fier pudlat

muck iron (met) oțel pudlat, lupă

muck (rolling) mill (met) laminor de fier pudlat mud (mediu) lut, mâl, nămol, noroi; a murdări / împroşca cu noroi, a tulbura (un lichid), a vârî în noroi; (metr) unitate tradițională daneză pentru volum (pt. cereale sau alte materiale uscate): $1 \mathrm{mud}=1$ hectolitru

mud boat (nav) şalandă de dragă

mud box (OM, alim, hidr, mediu) cameră de decantare; (met) saci de praf (la furnal), habă de noroi

mud cock (OM, hidr, mediu) robinet de nămol

mud-collector (OM, hidr, mediu) colector de nămol

mud cover (auto, OM) şorțul aripii, apărătoare laterală

mudded murdar, mânjit, plin de noroi

muddiness caracter noroios / nămolos; murdărie muddle zăpăceală, confuzie; harababură; $(\mathrm{TH})$ a amesteca (un lichid); (materiale, el) a încurca, a încâlci (ițe, fỉre etc.); (alim) a zăpăci (şi un vin), a tulbura (un lichid); a face de mântuială; a strica; a lucra prost / de mântuială

mud dredger (nav) dragă de nămol

mudguard (auto, OM) aripă, apărătoare împotriva stropirii cu ceva, sorț de aripă

mudguard flap (auto) şorțul aripii, apărătoarea laterală a aripii

mud gun (met, mas-un) maşină / dispozitiv pentru astupat orificiul de descărcare / de evacuare

mud gun mix (met, materiale) masă / amestec pentru astupat orificiul de descărcare / de evacuare

mud lighter (nav) şalandă de dragă

mudd off (mediu, hidr) a colmata

mud silting (mediu, hidr) înnămolire, colmatare muff $(\mathrm{OM})$ cuplaj, manşon (de legătură), bucșă

muff coupling (OM, el) cuplare / cuplaj cu dulie muffle (met) muflă; (TH) a înfășa, a înveli

muffle furnace (met, termo) cuptor cu muflă cu retortă

muffin (alim) prăjitură rotundă, brioşă

muffler (fiz, OM) amortizor de zgomot; (auto, OM) tobă de eşapament

muffler explosion (auto) explozie în toba de eșapament

muffling (fiz, TH) amortizarea zgomotului (şi la autovehicule)

mug (OM, chim) cană, pahar (cilindric); a machia, a farda (şi fig); (alim) halbă, băutură răcoritoare (metr) o denumire scurtată pentru metric slug; $v$. slinch

muggy (d. atmosferă) umed şi cald; (d. aer) înăbuşitor

mulberry (alim, bot) dud, dudă

mule catâr; şablon; (constr) tractor electric; papuc fără călcâi

mule pulley $(\mathrm{OM})$ roată de întins cureaua 
mull (textile, med) tifon; (alim) a încălzi şi a pune mirodenii în vin

muller (alim) piatră de moară alergătoare / liberă pe arbore

muller (mixer) (alim) malaxor

mullion (constr) montant, stâlp, şipcă verticală (la fereastră)

multigrade oil ( $\mathrm{T}$, ind chim) ulei multigrad / care îndeplineşte condiții de limite de vâscozitate pentru mai mult de o clasă (de vâscozitate)

multiaccelerator (ind chim, plast) amestec de acceleratori

multiaccess, multiple access (c) acces multiplu; capacitate a unui sistem de calcul de a accepta cereri de prelucrare simultane prin intermediul mai multor terminale

multi-axle drive (auto) automobil cu antrenare pe mai multe osii

multi-axial stress condition (mec) stare de tensiuni multiaxială / spațială

multi-blade (mas-un) cu mai multe tăişuri / lame, cu mai multe cuțite aşchietoare

multi-blade circular saw (mas-un) ferăstrău multicircular / cu mai multe benzi

multi box (auto) compartiment multifuncțional

multi-bucket excavator (constr, mas) excavator cu cupe

multi-cavity mould (met, plast) matriță multiplă / cu mai multe cuiburi

multi-cellular pump (OM, hidr) pompă cu mai multe etaje

multi-chamber furnace / kiln (met) cuptor cu mai multe camere / celule

multi-circuit switch (el) comutator multiplu

multicoloured multicolor

multicone divider (OM) divizor / dozator multiconic

multicore multifilar (d. conductori electrici, cabluri, ranforsări în compozite etc.)

multicore cable (el, OM) cablu cu mai multe conductoare / fire, cablu multifilar

multicut lathe (mas-un) strung cu mai multe puncte de lucru / cu prelucrare simultană a mai multor suprafețe

multi-cutting bar (mas-un) bară de alezat / de găurit, cu mai multe cuțite

multi-diameter (OM, mas-un) cu mai multe diametre (d. o piesă, o maşină-unealtă, o sculă)

multi-dimensional system $(\mathrm{TH}, \mathrm{ec})$ sistem $\mathrm{cu}$ mai multe variabile

multi-drilling machine (mas-un) maşină de găurit, cu mai multe axe / multi-ax

multi-edged (mas-un) cu mai multe tăişuri / muchii tăietoare multi engine (mas, mas-un) motor multiplu multiflame blowpipe (met, termo) arzător cu mai multe flăcări (la cuptoare)

multiform $(\mathrm{OM})$ cu forme variate, multiform multi-functional multifuncțional, polifuncțional (d. module, piese, elemente, lubrifianți etc.) multi-grade oil ( $\mathrm{T}$, ind chim) ulei lubrifiant pentru orice anotimp, ulei multifuncțional / multigrad

multi-head automatic welding machine (el, mas-un, autom) maşină automată de sudat cu mai multe posturi de sudare

multi-head welder (el, mas-un, autom) dispozitiv de sudat cu mai multe posturi de sudare

multi-hole brick (constr, met) cărămidă celulară / cu goluri

multi-hole nozzle (auto, termo, OM) jiclor cu găuri multiple, pulverizator cu mai multe găuri multi-impression mould (mas-un, met, plast) matriță (şi de ştanțat) cu mai multe cuiburi / posturi

multi-jet nozzle / spray (auto, termo, OM) jiclor cu găuri multiple, pulverizator cu mai multe găuri

multilateral multilateral

multi-layer (materiale, OM) cu mai multe straturi, multistrat, stratificat (şi d. compozite stratificate, lamelare etc.)

multi-layer coating (met, plast) acoperire din mai multe straturi / stratificată

multi-layer structures (materiale) laminate, materiale (cu structuri) stratificate, structuri multistrat (d. semifabricate multistrat)

multi-layer welding ( $\mathrm{TH}$, met) sudare în mai multe straturi

multi-machining operation (mas-un) prelucrare simultană cu mai multe scule, executarea simultană a mai multor operații de prelucrare

multi-motion (mas-un) (subansamblu / modul) cu mai multe mișcări (mai rar)

multi-motored cu mai multe motoare

multinomial, multinominal (mat) polinom

multioperator, multioperating (mas-un) cu mai multe posturi (de sudare, trefilare etc.)

multi-part adhesive (plast, chim) adeziv multicomponent

multipass (TH) (prelucrare / proces) în / cu mai multe treceri (la sudare, laminare etc.); cu mai multe straturi (d. o sudură, o acoperire etc.)

multipass exchanger (termo) schimbător de căldură, cu mai multe trepte

multiphase system (el) sistem polifazat

multiplane balancing (mec, mas) echilibrare în mai multe plane 
multiplate (OM) (piesă / modul / element) cu mai multe discuri / plăci (d. ambreiaje etc.)

multiplate clutch $(\mathrm{OM})$ ambreiaj cu mai multe discuri / lamele / multi-disc

multiplaten press (mas-un) presă cu mai multe etaje / plăci

multiple multiplu; numeros, felurit; alcătuit din mai multe părți; compus, complex; $(\mathrm{TH})$ paralel multiple action (mas-un, TH) acțiune multiplă / compusă

multiple arc (el, met) arc multiplu (la sudare)

multi-axle drive (mas-un) acționare multi-ax (la maşini de găurit multi-ax etc.)

multiple bar chart $(\mathrm{TH}$, ec) diagramă după mai multe criterii

multiple blade frame saw (mas-un) fierăstrău / gater cu lame multiple (şi pt. lemn)

multiple blow test (met, metr, materiale) probă / test / încercare la şoc repetat

multiple-cage mill (alim, constr, ind chim) moară cu ciocănele

multiple casting (met, TH) turnare multiplă / în mai multe cuiburi / matrițe, odată

multiple-cavity mould (met, OM) matriță multiplă / cu mai multe cuiburi

multiple chucking (mas-un, OM) prinderea simultană a mai multor piese de prelucrat, cu aceeaşi mandrină

multiple connection (el) legare / conexiune în paralel, comutare multiplă

multiple contact (el) contact multiplu

multiple control (autom, mas) comandă complexă / compusă / multiplă / paralelă; (mas-un) comandă complexă

multi-core box (met, plast) cutie / matriț̆ cu mai multe miezuri

multiple-crucible furnace (met) cuptor cu mai multe creuzete

multiple-cutter lathe (mas-un) strung cu mai multe cutite

multiple-daylight press (mas-un) presă etajată

multiple dies (mas-un, met, plast) ștantă / matriță cu mai multe poansoane

multiple-die tubing machine (mas-un) presă cu mai multe posturi de lucru, maşină cu mai multe filiere; maşină de profilat tuburi / țevi, prelucrare simultană în mai multe posturi

multiple-disk brake $(\mathrm{OM})$ frână cu mai multe discuri, ambreiaj / frână multi-disc

multiple-disk clutch $(\mathrm{OM})$ ambreiaj / cuplaj multi-disc / cu mai multe lamele

multiple-drafting / drawing (met, plast, $\mathrm{TH}$ ) (procedeu / tehnologie de) trefilare multiplă / cu trageri multiple multiple-drawing machine (met, plast, mas-un) maşină de trefilat multiplu / cu trageri multiple (simultan)

multiple drill head (mas-un) cap de găurit multiax

multiple-electrode furnace (met, el) cuptor (electric) cu mai mulți electrozi

multiple-electrode welding (met, $\mathrm{TH}$ ) sudare $\mathrm{cu}$ mai mulți electrozi simultan

multiple failures (TH, mas) apariția simultană a mai multor avarii / defecte independente

multiple-flight screw conveyer (transp, alim, ind chim) transportor elicoidal multiplu / cu mai mule snecuri

multiple gauge calibru multiplu

multiple gearing $(\mathrm{OM})$ transmisie în mai multe trepte (şi de roți dinţate)

multiple-grooved pulley $(\mathrm{OM})$ roată de curea, cu mai multe canale

multiple-head welding (met, TH) sudare cu mai multe capete

multiple-hearth furnace / roaster (met) cuptor cu vatră multiplă, cuptor cu mai multe vetre

multiple impact accident (auto, TH, mas) accident în lant

multiple impeller (OM, hidr) pompă cu mai multe etaje / cu mai multe rotoare

multiple impression die (mas-un) matriță cu mai multe poansoane (şi identice) / cu locaş multiplu

multiple jig (mas-un) dispozitiv de ghidare pentru mai multe operații sau/şi piese de prelucrat

multiple joint (mec, OM) legătură / îmbinare multiplă, nod de articulație (la construcții metalice)

multiple layer adhesive (plast) adeziv multistrat multiple machining (mas-un) prelucrare simultană a mai multor piese

multiple metering (metr, TH) măsurare multiplă multiple milling (mas-un) frezarea simultană a mai multor piese, cu un singur ax principal

multiple motor (el, hidr) motor multiplu (cu un arbore de ieşire)

multiple mould (met, plast) matriță multiplă / cu mai multe cuiburi

multiple operation tool (mas-un) sculă pentru mai multe operații

multiple-operator welding machine (met, el) maşină de sudat cu mai multe posturi de lucru multiple-plate brake (OM) frână cu lamele / cu mai multe suprafețe de lucru

multiple point welding (met, TH) sudare în prin puncte

multiple projection weld $(\mathrm{OM})$ cusătură de sudură punctiformă 
multiple pump (OM, hidr) pompă multiplă, ansamblu de două sau mai multe pompe, acționate de acelaşi arbore / motor

multiple purpose $(\mathrm{OM})$ pentru mai multe scopuri, multifuncțional (d. piese, elemente de maşini, lubrifianți etc.)

multiple-radial engine (el) motor în stea multiplă multiple range transmission $(\mathrm{OM})$ transmisie cu mai multe viteze

multiple-ring grinding (mas-un) debavurare prin prelucrare cu mai multe scule de lucru

multiple-ring valve $(\mathrm{OM}$, hidr supapă inelară / cu inele multiple

multiple roll crusher (constr, ind chim, mas) concasor cu mai multe valțuri

multiple roll mill (met) laminor cu mai multe treceri

multiple root (mat) rădăcină multiplă

multiple series-connection (el) conexiuni serieparalel

multiple-shear rivet $(\mathrm{OM}, \mathrm{mec})$ nit $\mathrm{cu}$ mai multe secțiuni de forfecare

multiple-slide (mas-un) cu mai multe sănii portcuțit (port-sculă)

multiple-speed gear box (OM) cutie de viteze

multiple spindle drill (mas-un) maşină / dispozitiv de găurit multi-ax

multiple spindle drill machine (mas-un) maşină de găurit multi-ax

multiple spindle machine (mas-un) maşină multi-ax / cu mai multe axe principale

multiple-spot weld $(\mathrm{OM})$ sudură în puncte (multiple) / în mai multe puncte (pt. prindere)

multiple-spot welding machine (mas-un, met, el) maşină de sudat în puncte multiple

multiple spring (OM, cf) arc multiplu / format din arcuri elicoidale concentrice, arcuri-taler suprapuse etc., grupare de arcuri (la amortizoare, tampoane de vagoane etc.)

multi(ple)-stage etajat, cu mai multe trepte / etape / etaje (d. pompe, alte sisteme tehnice, sisteme de automatizare etc.)

multiple-stage gas cleaning (met, mediu) epurarea gazului în trepte

multiple-stage pump (OM, hidr) pompă cu mai multe etaje

multiple-stand rolling mill (met) laminor cu mai multe caje

multiple start (mas-un, OM) filet / melc cu mai multe începuturi

multiple-steps impression die (mas-un, met, plast) matriță (de ștanțat / ambutisat) cu mai multe locaşuri / cu acționare în mai multe trepte / cu prelucrare succesivă multiple-step valve (OM, hidr) distribuitor / supapă etajat(ă)

multiple stops (mas-un) sistem de opritoare / limitatoare

multiple-story furnace (met) cuptor etajat

multiple sub-plate (hidr, OM) placă de bază, multiplă (la un bloc hidraulic etc.)

multiple testing machine (metr, mas) maşină pentru încercări multiple / cu mai multe posturi de încercare

multiple thread (OM) filet cu mai multe începuturi

multiple-thread screw (OM) şurub cu filet cu mai multe începuturi

multiple tool holder (mas-un) port-cuțit multiplu, dispozitiv pentru montat mai multe cuțite

multiple tooling (mas-un, $\mathrm{TH}$ ) prelucrare simultană cu mai multe scule

multiple tool slide (mas-un) sanie port-cuțit cu mai multe posturi de prindere a cuțitelor

multiple-torch machine (met) maşină de tăiat cu gaz, cu mai multe dispozitive de tăiat cu flacără (care pot fi acționate / comandate simultan)

multiple-unit control (autom) reglare / comandă multiplă

multiple-valued (mat) care ia mai multe valori

multiple $\mathbf{V}$ gear $(\mathrm{OM})$ transmisie cu roți de fricțiune cu mai multe canale în $\mathrm{V}$, transmisie cu mai multe trepte, cu roți dințate în $\mathrm{V}$

multiplex (mat) compus, multiplu

multiplex wave (el) înfăşurare serie-paralel

multiple-zone furnace (met) cuptor cu mai multe zone (active)

multipliable (autom, fiz) multiplicabil (d. un parametru, un proces, o reacție etc.)

multiplicable multiplicabil, care poate fi înmulțit

multiplicand (mat) deînmulțit

multiplication (mat, TH, fiz, chim) înmulțire, multiplicare

multiplication factor (mat) factor de multiplicare

multiplication table (mat) tabla înmulțirii

multiplicity multiplicitate; număr mare; mulțime

multiplier (mat) coeficient (de multiplicare / înmulțire), multiplicator, înmulțitor; (chim) agent / substanță de multiplicare a unei reacții etc.

multiply (mat) a (se) înmulți, a multiplica; a spori, a creşte, a mări; a (se) înmulți

multiplying (mat, chim, fiz) care se înmulțeşte / se multiplică

multiplyingout the expression in brackets (mat) înmulțirea cantităților din paranteze multiply through a înmulț / a multiplica cu 
multi-point ignition (auto) aprindere cu scântei multiple

multi-purpose (el, OM) multifuncțional, general, cu întrebuințări / destinații multiple, universal

multi-purpose machine (mas-un) maşină-unealtă universală, multifuncțională

multi-purpose oil ( $\mathrm{T}$, ind chim) ulei (lubrifiant, tehnologic etc.) multifuncțional

multi-purpose rolling mill (met) laminor universal / cu destinații multiple

multi-purpose shears / shearing machine (masun) foarfece multifuncțională / universală

multi-range (metr, autom) cu mai multe intervale (de reglare / de acționare) / scări (de citire)

multi-range meter (metr) aparat de măsură cu scară multiplă / cu mai multe domenii de măsurare

multi-roll bar straightening machine (met, mas-un) maşină de îndreptat profile, cu role multe / multiple

multi-roll cold rolling mill (met) laminor cu mai mulți cilindri pentru laminare la rece

multi-roll crusher (constr, ind chim) concasor cu mai multe valțuri

multi-roll straightening machine (met, mas-un) maşină de îndreptat cu role multe / multiple

multiskilled (muncitor / personal) policalificat

multi-speed (OM, mas-un) cu mai multe viteze

multi-speed motor (el, electr) motor electric cu reglare a turației / cu mai multe turații

multi-spindle machine (mas-un) maşină multiax / cu mai multe axe

multi-stage cu mai multe trepte / etaje, etajat (d. un proces, un sistem etc.)

multi-stage amplifier amplificator în mai multe trepte / în cascadă

multi-stage bloer (met) suflantă multietajată / în trepte

multi-stage evaporator (alim, ind chim) vaporizator în trepte

multi-stage expansion (termo) expansiune în trepte

multi-stage fatigue test (metr, materiale) test / încercare la oboseală, la sarcină variabilă ciclic în blocuri / în trepte

multi-stage press (mas-un) presă cu acțiune în trepte

multi-stage pump (OM, hidr) pompă cu mai multe etaje

multi-stage turbinbe (termo) turbină în trepte multi-step-cone pulley (mas-un, OM) con în trepte, roată de curea, în trepte

multi-step control (autom, mas-un) reglare cu poziții / trepte multiple, reglare / control în trepte multi-step expansion (termo) expansiune în trepte multistorey (constr) cu mai multe etaje

multi-throw crankshaft $(\mathrm{OM})$ arbore cotit, cu mai multe manivele (rar)

multi-tool (mas-un) cu mai multe cuțite

multitude mulțime; multitudine

multi-turning tool (mas-un) port-cuțit cu mai multe cuțite

multi-valent (fiz, chim) polivalent, multivalent

multi-valued (fiz) polivalent, cu mai multe valori

multi-valued function (mat) funcție multiformă multi-variable control system (autom) sistem cu mai multe variabile

multi-variate (mat) multidimensional

multi-variate moment (mat, mec) moment mixt

multivarious variat, felurit, divers

multi-voltage control (autom) comandă / reglare / control prin variatia tensiunii

multi-way switch (el, autom) comutator cu mai multe căi

multi-wheeler (auto) vehicul cu mai multe roți sau axe

municipal (adm) municipal, orăşenesc; cu / de autoguvernare

municipality (adm) municipalitate; autoritate municipală / orăş̧enească; municipiu

Muon mass (metr, fiz) unitate de măsură pentru masă, utilizată în fizica nucleară: 1 Muon mass $=1,8835327 \cdot 10^{-28} \mathrm{~kg}$

muriatic acid (chim) acid clorhidric

murmur murmur; foşnet; zumzet; a murmura; a rosti încet

muscat(el) (alim) vin / strugure muscat / tămâios

mush (alim) terci, păsat; (ind chim, constr) masă vâscoasă / semilichidă

mushroom (alim, bot) ciupercă (comestibilă); (OM) con de închidere a supapei sau robinetului, piesă în formă de ciupercă

mushroom anchor (nav) ancoră ciupercă

mushroom head of valve (OM) ventil de supapă, de forma unei ciuperci, ventil-ciupercă

mushroom head nib bolt (for wood) (OM) şurub cu cap bombat şi nas (pentru lemn)

mushroom head rivet $(\mathrm{OM})$ nit cu cap bombat mushroom head square neck bolt (for wood) $(\mathrm{OM})$ şurub cu cap bombat şi gât pătrat (pt. lemn)

mushroom insulator (el) izolator tip ciupercă mushroom tappet (auto, OM) tachet în formă de ciupercă

mushroom-type follower (auto, OM) tachet cu ciupercă 
mushy poros; ca terciul; (fig) fără putere, slab, moale

mushy zones (met) zone cu amestec de fază lichidă şi solidă în aliaje care se solidifică întrun interval de temperaturi

muslin (textile) muselină

must (alim) must (de struguri); mucegai, putregai; (arată obligația / necesitatea), a trebui; a fi obligat să

mustard (alim) muştar; (culoare muştar), galben închis

mustard-oil (alim) ulei de muştar

mustard seed (alim) sămânță de muştar

muster a trece în revistă

musty încins, mucegăit, stătut; învechit, prăfuit; searbăd, plicticos, fad

mutability mutabilitate

mutable mutabil; transformabil; nestatornic, schimbător

mutate a schimba, a transforma

mutation $(\mathrm{TH})$ schimbare, transformare; (biol) mutație

mutator (el) (co)mutator

mutchkin (metr) unitate tradițională scoțiană de măsură pentru volum (pt. lichid): 1 mutchkin $\cong 426$ mililitri

mutilate (med, anat) a mutila, a răni, a desfigura; (TH) a deteriora, a ciunți, a distruge parțial mutilation (med, anat) mutilare, rănire, desfigurare; $(\mathrm{TH})$ deteriorare, ciunțire, deformare, avarie motton (alim) carne / cotlete de berbec / oaie motton chop (alim) cotlet de berbec, cotlete mutual reciproc, mutual; comun

mutual action interacțiune, influențare reciprocă mutual inductance (el) inductanță mutuală mutual induction (el) inducție mutuală mutually $(a d v)$ (în mod) reciproc mutually exclusive events (mat) evenimente incompatibile; evenimente care se exclud reciproc mutually exclusive sets (mat) mulțimi disjuncte mutual reaction (mec, fiz) acțiune reciprocă mutual solubility (chim, met) solubilitate reciprocă (d. fluide, elemente dintr-un aliaj etc.) muzzle bot; botniță; (OM) gura țevii (şi de armă), orificiu; mască antigaz

mwe (metr) abreviere pentru metru echivalent de apă, unitate folosită în fizica nucleară pentru descrierea scutului din jurul reactorului / acceleratorului / detectorului: 1 mwe din orice material (rocă, pietriş etc.) este grosimea acelui material care asigură o protecție echivalentă cu 1 metru de apă

MWe (metr, el, ind) simbol energiei livrate de o centrală electrică, megawatt (de energie electrică) mycosis, $(p l)$ mycoses (med) micoză

myocarditis (med) miocardită

myocardum (anat, med) miocard

myope, myopic (anat, opt) miop

myopy, miopia (anat, opt) miopie

myria- (my-) (metr) prefix pentru 10000 (denumire veche, provenită din limba greacă, rar utilizată)

myriad (metr) număr (foarte) mare; în limba greacă, numărul 10000

myriagram (myg) (metr) o unitate de măsură pentru masă: 1 myriagram $=10 \mathrm{~kg}$

myriameter (mym) (metr) unitate de măsură pentru lungime: 1 myriameter $=10000 \mathrm{~m}$ 


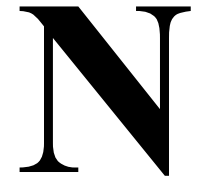

$\mathbf{N}$ (metr, fiz) simbol pentru newton - unitate SI de măsură pentru forță, v. newton; (metr) o unitate pentru indicele de refracție, folosită pentru atmosferă (care exprimat astfel este puțin mai mare decât 1); valoarea indicelui $\mathrm{N}$ este numărul de milionimi cu care se depășește valoarea 1 , adică un indice de refracție $n$ este echivalent cu $(n-1) \cdot 10^{6}$ unități $\mathrm{N}$

nacelle nacelă

nacre sidef

nacred sidefat

nacreous (materiale) irizat

nadir nadir; (fig) punct / nivel cel mai de jos; limită inferioară

nail (anat) unghie; (zool) gheară; (OM) cui, ştift, țintă, piron; (fig) țigară; (metr) unitate veche englezească de măsură pentru lungime pentru confectii; 1 nail $=5,715 \mathrm{~cm}$; $(\mathrm{OM})$ a bate $/$ fixa în cuie, a țintui, a pironi; (fig) a prinde, a captura (un hoț etc.), a înhăța, a înşfăca, a fixa / aținti atenția; door $\sim(\mathrm{OM})$ cui cu cap lat (pt. ornamentarea uşii); French $\sim(\mathrm{OM})$ cui de sârmă; to a / the la perfecție; drive a a bate un cui; hit the $\sim$ (right) on the head a da o explicație justă, a lovi drept la țintă

nail bed (anat) lojă unghială

nail biting obiceiul de a-şi mânca unghiile

nail brush perie de unghii

nail claw / drawer (met, OM) rangă cu gheare

nail clippers $(p l)$ cleştişor de unghii, unghieră

nail down a țintui

nail down to a fixa de; (fig) a stabili; a sili să spună care are de gând

nail drawer $(\mathrm{OM})$ ciocan de scos cuie, extractor de cuie, rangă / extractor cu gheare

nail up a bate în cuie (un capac, o uşă etc.)

nailed (OM) fixat / bătut în cuie / ținte, pironit

nailed-up făcut / scris / organizat în grabă; cârpăcit

nail enamel (ind chim) lac de unghii, ojă

nailer (OM, met) dispozitiv de forjat / matrițat cuie

nailery, nail factory fabrică de cuie

nail file pilă de unghii

nail hammer $(\mathrm{OM})$ ciocan de scos cuie

nail head $(\mathrm{OM})$ cap / floare de cui nail head bond(ing) (electr) conexiune tip „floare de cui”

nail parings $(p l)$ (resturi de) unghii tăiate

nail scissors $(p l)$ foarfece de unghii

nail varnish (ind chim) lac de unghii, ojă

nailing (OM) fixare / asamblare în cuie / ținte

nail maker (mas-un) dispozitiv de executat / prelucrat cuie / ținte etc.

nail making machine (mas-un) maşină de fabricat cuie / ținte etc.

nail mould / tool (mas-un) dispozitv (şi matriță) de făcut cuie

nail puller $(\mathrm{OM})$ cleşte de scos cuie

nail (rolling) bearing, needle (rolling) bearing

(OM) rulment cu ace

nail scissors $(\mathrm{OM})$ foarfece de unghii

nail varnish (ind chim) lac de unghii, ojă

naive, naïve naiv

naïvity, neivity naivitate

naked gol; dezvelit; dezgolit; nud; (OM, TH) neprotejat, neacoperit; dezbrăcat; (bot, silv) (d. arbori) desfrunzit, golaş; (el) neizolat; gol, nemobilat (d. o cameră etc.); (fig) deschis, fără apărare, gol, liber, neapărat; dezbrăcat, dezgolit; with the $\sim$ eye cu ochiul liber; invisible to the $\sim$ eye invizibil cu ochiul liber

naked cable (el) cablu electric neizolat / neprotejat

naked facts fapte nude, faptele - aşa cum sunt naked lamp (TH) lampă cu flacără deschisă (lampă cu carbid etc.)

naked light $(\mathrm{TH})$ lampă cu flacără deschisă, lumină cu / de la flacără deschisă

naked model (nav) model / machetă de navă pentru probe în bazin

nakedness (of) lipsă (de), sărăcie

naked reactor (ind chim) reactor fără reflector

naked pile (ind chim) reactor fără reflector

name nume, denumire; termen, titlu; reputație, faimă, renume; (gram) substantiv; personalitate (renumită, influentă); mențiune, indicație; inscripție; vorbă, cuvânt; familie; (ec) firmă, nomenclatură (a valorilor), titlu (de cont); (inf) termen utilizat pentru identificarea unui articol; (fig) aparență a (de)numi, a boteza; a chema pe nume; a menționa; a indica (şi un preț); a stabili; a alege; a recunoaşte; a da ca exemplu; a fixa (o oră, o sumă etc.); a-şi face un renume; Christian prenume, nume de botez; family nume de familie; maiden $\sim$ nume de fată; in the $\sim$ of în numele (legii, cuiva etc.); go by the $\sim$ of a fi cunoscut sub numele de; make a $\sim$ a deveni renumit; proper $\sim$ (gram) substantiv propriu, common $\sim$ (gram) substantiv comun 
nameable care poate fi numit; de scris / amintit / menționat

name board / plate (ind, OM) emblemă, plăcuță / tăbliță cu marca fabricii

name for / to (ec, adm) a numi (într-o funcție)

nameless fără nume, necunoscut; anonim; de nedescris, extraordinar

namelesssness lipsa numelui; anonimat; caracter de nedescris / extraordinar

namely $(a d v)$ cu alte cuvinte, adică, şi anume

name no names a nu menționa nume

name of an account (ec) titular de cont

name plate (TH, OM) plăcuță / tăbliță cu marca fabricii, emblemă; ecuson

name index (inf) index de nume

nankeen, nankin (textile) nankin

nano- (n-) (metr) prefix metric pentru $10^{-9}$, nano-, o miliardime (dintr-o unitate)

nanoacre (metr, c, electr) o unitate de măsură pentru suprafață (utilizată pentru a caracteriza suprafața unui chip): 1 nanoacre $\cong 4,047 \mathrm{~mm}^{2}$

nanobar (nb, nbar) (metr, meteorologie) unitate în sistemul CGS pentru măsurarea presiunii, nanobar: 1 nanobar $=10^{-9} \mathrm{bar}=0,1 \mathrm{mPa}$

nanocurie (nCi) (metr, fizică nucleară) unitate de măsură pentru radioactivitate, nanocurie: 1 nanocurie $=10^{-9}$ curie sau 37 becquerel, corespunzând unei radioactivități de 37 de dezintegrări atomice pe secundă

nanofarad (nF) (metr) unitate SI de măsură pentru capacitatea electrică, nanofarad: 1 nanofarad $=10^{-9} \mathrm{~F}$, denumire anterioară: millimicrofarad $(\mathrm{m} \mu \mathrm{F})$

nanogram (ng) (metr) unitate de măsură pentru masă, nanogram: 1 nanogram $=10^{-9} \mathrm{~g}$

nanogray (nGy) (metr, med, fizică nucleară) unitate pentru măsurarea dozei de radiații (şi inhalate), nanogray: 1 nanogray $=10^{-9}$ gray sau 0,1 microrad ( $\mu \mathrm{rad})$

nanoliter (nl, nL) (metr) unitate în sistem metric pentru măsurarea volumului, nanolitru: 1 nanoliter $=10^{-9} 1=0,001 \mathrm{~mm}^{3}$

nanometer (nm) (metr) unitate de măsură pentru lungime, nanometru: 1 nanometer $=10^{-9} \mathrm{~m}$

nanomole (metr, chim, biol) unitate de măsură pentru cantitatea de substanță, nanomol: 1 nanomole $=10^{-9} \mathrm{~mol}$

nanon (metr) denumire informală pentru nanometru, $v$. nanometer

nanonewton (nN) (metr, fizică nucleară) unitate de măsură pentru forță, nanonewton: 1 nanonewton $=10^{-9} \mathrm{~N}$

nanoradian (nrad) (metr, astronomie, geol) unitate de măsură pentru unghiuri, nanoradian: 1 nanoradian $=10^{-9}$ radian $\cong 0,208533$ milliarcsecond; v. milliarcsecund

nanosecond (ns) (metr) unitate de măsură pentru timp, nanosecundă: 1 nanosecund $=10^{-9} \mathrm{~s}$

nanosievert (nSv) (metr, fizică nucleară) unitate pentru măsurarea dozei de radiații: 1 nanosievert $=10^{-9}$ sievert sau 0,1 microrem

nanostrain (nstrain) (metr, inginerie, geol) unitate relativă de măsură a deformației ca raport între mărimea deformării şi mărimea iniţială a unei dimensiuni nedeformate a unui element: 1 nanostrain este deformația relativă de $10^{-9}$

nanotesla (nT) (metr, geol, fiz) unitate de măsură pentru intensitatea câmpului magnetic, nanoTesla: 1 nanoTesla $=10^{-9}$ Tesla sau $10^{-5}$ gauss

nap (textile, plast) scamă, fulg, pluş (la catifea, stofe compozite etc.); a scămoşa, a flauşa; ațipeală, somn scurt; a aţipi, a dormita, a moțăi, a trage un pui de somn

napalm (chim) napalm

nape (anat) ceafă, grumaz

napery (textile) pânzeturi / albituri pentru masă

nap finish (textile, plast) scămoşare, flauşare

naphtha (ind chim) petrol, țiței, păcură, benzină grea, benzină-solvent

naphta column (ind chim) coloană cu reflux de benzină grea

naphtalene, naphthalin (ind chim) naftalină

naphtalic (chim) naftoic

naphta soap (chim) săpun din acizi naftenici / naftenic

naphta solvent (chim) solvent naftenic

naphtha solution of rubber (ind chim) soluție de cauciuc în benzen

naphtene base crude oil (ind chim) țiței naftenic

naphtenes (ind chim) hidrocarburi naftenice

naphthenic (chim) naftenic

naphtenic-base oil (ind chim) țiței naftenic

napkin (alim) şervețel, şervet; cârpă de vase

nappe (mat) pânză a unei suprafețe (şi conice); (mat, mas-un, TH) pânză de încălecare / de şariaj; (OM, T) strat superior / de acoperire; (hidr) pânză / lamă de apă; (geol) strat de acoperire, strat superior

napper (textile, plast) maşină de scămoşat napping (textile, plast) scămoşare, pluşare napple (hidr) vână de fluid scurs din deversor nappy (textile, plast) scămos; scămoşat naps (plast, compozite, textile) butoni / mici aglomerări, defect de fibră (şi la bumbac)

narcosis narcoză

narcotic (med) narcotic, soporific

narcotical adormitor, soporific (d. plante, medicamente etc.) 
narcotize a narcotiza; a adormi; a amorți (d. plante, medicamente etc.)

narration relatare; narațiune; povestire

narrow (adj) îngust, strâmt; mic, restrâns; limitat, mărginit (şi d. intelect); minuțios, atent; strict; dificil; amănunțit (d. o cercetare); sever, strict, precis, exact (şi d. un examen); parte îngustă; meschin; neânsemnat; a (se) îngusta; a restrânge; a limita; a mărgini; a (se) strâmta; a micşora; a strânge; (geogr) defileu, $\sim \mathbf{s}(p l)$ strâmtoare; in the narrowest sense of the word în sensul cel mai strict al cuvântului narrow beam (fiz) fascicul îngust / subțire narrow bit (mas-un) daltă / tăiş / muchie (de sculă) îngust $(\breve{a})$; (OM) muchie ascuțită

narrow-boiling range (alim, ind chim, termo) interval îngust de fierbere

narrow boat (nav) luntre îngustă

narrow dimension (metr, autom) dimensiune necritică / strânsă / care variază într-un interval îngust

narrow down a (se) îngusta; a (se) limita; a gâtui; a strâmta; a se ştrangula; (mat) a strânge, a restrânge

narrow examination (edu, metr) examinare minuțioasă / atentă

narrow gauge (cf) ecartament îngust

narrow gauge railway $(\mathrm{cf})$ linie $\mathrm{cu}$ ecartament îngust

narrowing micşorare; reducere; îngustare; scădere; descreştere; diminuare; heel $\sim$ (textile) îngustare a călcâiului; (geol) efilare

narrowing chain (textile) lanț al capacelor de cardă, lanț de îngustare

narrowing cutter (mas-un) freză pentru scaune de supape

narrowing point (textile, OM) ac de îngustare

narrow-limit control / gauging (metr, $O M$ ) control cu limite / tolerante severe

narrowly $(a d v)$ cu greutate, (de-)abia

narrowing machine (mas-un) maşină (textilă) cu dispozitiv de îngustare

narrow majority (ec, pol) majoritate mică / deabia formată

narrow meshed $(\mathrm{OM})$ cu ochiuri mici / înguste (d. site, țesături, plase, dar şi la modele pentru analiză cu element finit)

narrow-minded îngust (la minte), mărginit, limitat, făă orizont, obtuz

narrow-mindedness îngustime (la minte), mărginire, limitare, lipsă de orizont, obtuzitate

narrow-mouth bottle / flask (OM, chim) sticlă / balon (de sticlă) cu gât îngust

narrow pillar file pilă îngustă cu vârf teșit narrows trecere îngustă (şi în navigație); (hidr, materiale) gâtuitură, ştrangulare, ştrangulări (ale unui curent de fluid etc.)

narrow search cercetare amănunțită

narrow size format mic / îngust (la cărți); $(\mathrm{OM})$ de / cu dimensiuni mici, mărime / formă redusă / micşorată (d. piese, elemente de maşini etc.)

narrow strip (met) bandă îngustă

narrow strip rolling mill (met) laminor de bandă îngustă

nacency naştere; apariție

nascent nativ, în stare născândă, în formare, care se naşte / apare

nascent hydrogen (chim, TH) hidrogen nativ / în formare / în stare născândă

nascent state / stage stare născândă / nativă

nasty murdar; dezgustător; imoral; indecent; obscen; nepoliticos, obraznic; vătămător, dăunător; primejdios, periculos; malițios; urât; rău(voitor); neprietenos

nasty taste (alim) gust neplăcut

nasty weather (meteo) vreme urâtă

natal natal, de naştere

natality natalitate

natant (hidr) plutitor

natation natație, înot (ca sport)

natatorial de înot

natatorium (constr, sport) bazin de înot (de interior)

natheless $(a d v)$ totuşi, cu toate acestea; în ciuda

nation (pol) națiune; țară, stat

national (pol) național; de stat; cetățean

national anthem imn național

national assistance (pol, adm) asistență socială

national bank $(\mathrm{ec})$ bancă națională

national coarse (NC) thread (OM) filet normal, cu pas mare (standardizat în SUA)

national debt $(e c$, pol) datorie publică / națională

national devidend / income (ec, pol) venit național

national expenditure (adm, pol) cheltuieli de stat national fine (NF) thread (OM) filet cu pas fin (standardizat în SUA)

national flag (pol) steag / drapel național

national form thread $(\mathrm{OM})$ filet cu profil normal (standardizat în SUA)

national(ity) plate / tag (auto, OM) plăcuță / tăbliță de înmatriculare cu simbolul țării

national government (pol, adm) guvern de coaliție

national income (ec, pol) venit național national insurance (adm, pol) asigurări sociale nationality naționalitate 
national park (mediu, geogr) parc național national round thread $(\mathrm{OM})$ filet normal $\mathrm{cu}$ profil rotunjit

national standard (metr) standard / etalon națonal

national tag (auto) plăcuță cu indicativul țării de înmatriculare a autovehicolului

national taper pipe thread (OM) filet normal conic pentru tevi (standardizat în SUA)

national wealth (ec) avuție națională

native natal; de naștere; înnăscut; natural; în mod natural; nativ; (chim) în stare pură, necombinat; originar, indigen; (agr) plantă indigenă; animal indigen

native metal (chim) metal nativ pur

natrium (Na) (chim) sodiu, natriu

natron (chim) carbonat de sodiu cristalizat, sodă cristalizată, oxid de sodiu

nat unit, natural unit (metr, inf) unitate de informație, similară cu shannon, dar utilizând logaritmul natural (cu baza e) în locul celui în baza 2, v. shannon

natural natural, înnăscut (d. un talent, etc.); natural, firesc, normal; explicabil, de înțeles; real, viu; în stare naturală; normal; (bot) necultivat, sălbatic; viu; simplu; înnăscut; original, veridic; obişnuit; firesc; dispoziție / înclinație naturală; expert (în); geniu; idiot; înzestrare; (persoană) înzestrată de la natură, (persoana) calificată (pentru); prost; talent; din flori, nelegitim (d. un copil); din natură; neprefăcut

natural admittance (el, electr) admitanță naturală / proprie

natural ageing (met, plast) îmbătrânire naturală / în conditii naturale (d. aliaje, materiale plastice, lubrifianți etc.)

natural attenuation frequency (fiz, mec, autom) frecvență proprie de amortizare

natural bed (geogr) albie naturală (a unui râu)

natural boundary condition (mat, fiz) conditie la limită naturală

natural cement (ind chim) ciment natural (prin calcinarea calcarului argilos), ciment roman

natural circulating water cooling (auto, termo, hidr) răcire prin termosifon

natural circulation (auto, termo, hidr) circulație de apă prin sistemul termosifon

natural color reception (TV) recepție de înaltă fidelitate, receptie naturală a culorilor

natural coloured leather piele colorată natural natural condition test (mec, mas, metr) încercare / test în condiții de funcționare

natural contour of tire / of tube (auto, OM, metr) contur / sectiune de pneu / de cameră neumflat( $\breve{a}) ;(O M$, metr) secțiunea iniţială a unui tub Bourdon nesolicitat

natural convection (mediu, termo) convecție naturală (în atmosferă)

natural cooling $(\mathrm{OM}$, termo) răcire naturală, autorăcire

natural crack (in wood) crăpătură de vânt (în lemn)

natural current (el) curent teluric

natural detector (metr, electr) detector $\mathrm{cu}$ contacte

natural draft (termo, mediu) (curent de) aeraj / tiraj natural

natural draft / draught (met, termo) curent (şi de aeraj) natural, tiraj natural

natural draught cooling tower (termo, constr) turn de răcire cu tiraj natural

natural drying (alim, plast) uscare naturală / în aer

natural dye (alim, chim) colorant natural

natural equations of a curve (mat) ecuatii intrinseci ale unei curbe

natural excitation (el, electr, autom) autoexcitare, excitație proprie / naturală

natural fall cădere naturală, pantă naturală

natural fermentation (alim) fermentație naturală

natural flow (hidr) curgere naturală; (geol) erupție naturală (de gaze, petrol etc.)

natural frequency (fiz, mec, autom) frecvență fundamentală / naturală / frecvență proprie

natural frequency of oscillation (fiz, mec, autom) frecvență proprie de oscilație

natural gas (ind chim, geol) gaz natural

natural gas firing (termo) încălzire cu gaz natural

natural gasoline (auto, ind chim) benzină din gaze naturale

natural graphite (chim) grafit natural

natural ground (geol, geogr) continent; teren solid

natural hardness (mec, materiale) duritate inițială (a unui aliaj, material plastic); duritate naturală (a apei)

natural language limbaj natural / folosit pentru comunicarea informatiilor între oameni natural latex (chim) latex natural / îngroşat natural levee (geogr) baraj natural (pe un curs de apă)

natural light (fiz) lumină naturală / solară / de zi natural lightening (fiz, $\mathrm{TH}$ ) iluminare naturală natural lighting iluminat natural natural limit of stress (mec) rezistență / limită (naturală) inițială de tensiune 
natural logarithm (mat) logaritm natural / Neper(ian)

natural magnet (fiz, materiale) magnet natural natural moisture content (materiale) (conținut de) umiditate naturală, conținut natural de umiditate (d. materii prime etc.)

natural motion (fiz, mec) oscilație / vibrație proprie natural mud (geol) noroi de foraj natural natural noise (fiz, autom) zgomot natural / propriu natural noise (fiz, autom, electr) zgomot propriu natural number (mat) număr natural / pozitiv întreg

natural obstacle (geogr, constr) obstacol natural natural occurring isotope (fiz) izotop natural natural oscillation / vibration (fiz, mec, autom) oscilație / vibrație proprie / naturală

natural period (fiz, mec, autom) perioadă a oscilațiilor proprii, perioadă proprie

natural person (jur) persoană fizică

natural phenomena fenomene naturale

natural pruning (silv, agr) elagaj natural, curățare de crengi, recepare

natural rubber (NR) (plast) cauciuc natural

natural scale $(\mathrm{OM})$ mărime naturală / la scara 1:1 natural silk (textile) mătase naturală

natural ventilation (mediu, termo) aeraj / ventilație naturală

natural wastage $(\mathrm{ec})$ pierdere naturală a forței de muncă

natural water (mediu, chim) apă nelimpezită / netratată

naturally allied cast iron (met) fontă aliată natural

naturally aspired engine (termo, mas) motor fără supra-alimentare

nature $(\mathrm{TH}, \mathrm{fiz})$ natură; stare; dispoziție; caracter, temperament; fire; fel, categorie; structură; trăsătură caracteristică; esență; forțele naturii; lume materială; natură (exterioară); univers; organism; viață in aer liber; by $\sim$ din fire

nature of the ground (geol, constr) compoziția solului

naught nimic; (mat) zero, nulă; eşec, nereuşită, fiasco; neimportant, neînsemnat

naught line (mec, metr) linie / axă neutră / de zero / de referință

naughtily $(a d v)$ (în mod) obraznic; şocant; neascultător

naughtiness proastă creştere; lipsă de decență; imoralitate, obrăznicie

naughty obraznic; neascultător; mofturos; stricător; nepoliticos; şocant; indecent (d. un cuvânt etc.)

nausea (med, nav) rău de mare, greață nauseating (med, TH) vătămător; neplăcut, scârbos, grețos

nautical (nav) nautic, naval, maritim

nautical mile (nmi, naut mi, n mile, NM) (metr, nav, av) unitate de măsură pentru lungime, folosită în special în navigație maritimă şi aeriană, milă marină: 1 nautical mile (UK) sau Admiralty mile $=1853,188 \mathrm{~m}, 1$ US nautical mile (până în 1954) $=1853,249$ m, 1 international nautical mile $\cong 1,1508$ statute mile, 1 true nautical mile $=1852,216 \mathrm{~m}(1980$, the Geodetic Reference System)

naval (nav) naval, maritim

naval academy (nav, univ) academie / școală de marină

naval architect (nav) inginer constructor de nave

naval architecture (nav) arhitectură navală

naval constructions (nav) construcții navale

naval dockyard / shipyard (nav) şantier naval, doc

navally $(a d v)$ din punct de vedere naval / maritim

naval officer (nav, mil) ofițer de marină; (amer) funcționar vamal portuar (superior)

naval school (nav, univ) şcoală navală / de marină (superioară)

naval stores (nav) ulei, trebetină, smoală

nave $(\mathrm{OM}$, auto) butuc de roată

nave borer (maş-un) maşină de găurit butuci (de roți)

navel iron / pipe (nav) nară de punte / de puț navigability (geogr, nav) navigabilitate

navigable (geogr, nav) navigabil

navigate (nav) a naviga (pe), a pilota (un vas), a pluti

navigational (nav) de navigație, marin

navvy (TH, constr) săpător; terasier; lucrător la construcții civile, muncitor necalificat; (constr, mas) excavator

navy (nav) flotă (maritimă), personal de marină navy-blue bleumarin, albastru marin

navy yard (nav, mil) şantier / arsenal naval (şi militar)

Ncm, N.cm (metr, mec) simbol pentru newton centimeter - newton-centimetru, o unitate în sistem metric pentru măsurarea momentului: $1 \mathrm{Ncm}=$ $0,01 \mathrm{~N} \cdot \mathrm{m}$

NC-thread (OM) filet normal cu pas mare, standardizat în SUA

$\mathbf{N d m}^{\mathbf{3}}$ (metr) simbol utilizat pentru normal liter - litru normal, v. normal liter

nebuchadnezzar (metr, alim) sticlă de vin de 151 
neap(tide) (nav, geogr) maree joasă / moartă / de cvadratură

near $(a d v)$ aproape, nu departe, în apropiere, în preajmă, încă puțin, puțin lipseşte ca, atât cât, cu puțin, cu zgârcenie, apropiat (în spațiu sau în timp); (prep) lângă, aproape de, pe, de, spre; (adj) (d. o traducere) aproape, destul de corect / fidel, aproximativ; (d. loc, timp) apropiat; apropiat, intim (ca rudă, prieten); scurt; direct; zgârcit; meticulos; (d. animale de tracțiune, vehicule etc.) de / din stânga / partea stângă, stâng; (d. drum) direct, cel mai scurt; a se apropia (de); in the $\sim$ future în viitorul apropiat; a $\sim$ er road un drum mai scurt; near work lucru migălos; be at hand a fi la îndemână; draw a se apropia; far and $\sim$ pretutindeni; as near as smb. can judge atât cât (cineva) poate judeca; live $\sim$ a trăi cu puțin

near-beer (alim) bere nealcoolizată

nearby, near-by $(a d v)$ aproape; $(a d j)$ apropiat

near-by interference (el, electr, autom, radio) perturbație locală / în apropiere

near critical (fiz, chim) aproape critic, cvasicritic

near empty (auto) aproape gol (d. carburant în rezervor etc.)

nearest neighbour (fiz, met) atomul vecin cel mai apropiat

nearest neighbo(u)r spacing (fiz, met) spațiul până la cel mai apropiat vecin / atom

nearly $(a d v)$ aproape, aproximativ

nearness apropiere; proximitate, vecinătate

near on / upon $(a d v)$ aproape de, în preajma

near side (auto) partea stângă

near sight, near-sightedness (anat, opt) miopie

near-sighted (anat, opt) miop

near to aproape de (locul), lângă

neat curat, îngrijit; pur; net; neted; ordonat; aspectuos, plăcut; grațios; inteligent, spiritual (d. un răspuns); (alim) simplu, neamestecat (d. băuturi); (d. stil) clar, precis, concis, laconic neatly $(a d v)$ (în mod) îngrijit, cu acuratețe; clar, limpede; abil

neatness grijă; îngrijire; acuratețe; exactitate; claritate, limpezime; îndemânare, abilitate

neat's-foot oil (alim) ulei de oase; (ind chim) grăsime / ulei de copite

neat'leather piele de vită

nebuliser (fiz)

nebulosity (fiz) nebulozitate, neclaritate; nebuloasă

nebulous înnorat; nebulos, cețos, (fig) confuz, vag nebulousness (fiz) nebulozitate

necessarily $(a d v)$ (în mod) necesar, inevitabil necessariness caracter necesar; inevitabilitate necessary (mat) necesar; necesar, obligatoriu, inevitabil; esențial, fundamental; evident

necessary condition (mat) condiție necesară

necessitate a necesita; a cere; a avea nevoie de; a reclama

necessity necesitate; nevoie; imperativ, inevitabilitate

necessities nevoi(e), sărăcie, lipsă / lipsuri

neck (anat) gât; (alim, chim) gât (de sticlă, de vas etc.); (geogr) gură (a unei strâmtori), istm, limbă de pământ, coş vulcanic; $(\mathrm{OM})$ gât (de piesă), guler, degajare inelară, orificiu; fus pe porțiune de mijloc a unui arbore; fus de osie / de arbore, parte îngustă a unei piese / a unui tub, fus (al unei axe), axă (a unui cilindru etc.), degajare inelară; (hidr) parte filetată, pentru montaj, concentrică cu axa cilindrului hidraulic; (met) porțiune îngustă a unui cuptor / furnal; (fig) alură, aspect, aer (al cuiva); ( $\mathrm{fam}$ ) tupeu, îndrăzneală; neck (nk) (metr) unitate de măsură pentru lungime, utilizată în curse hipice, reprezentând $\sim 1 / 4$ din lungimea unui cal: 1 neck $\sim 0,6 \mathrm{~m}$ neck band $(\mathrm{OM})$ guler (şi d. piese, confecții etc.) neck bearing $(\mathrm{OM}, \mathrm{T})$ lagăr intermediar, $(\mathrm{OM}$, textile) crapodină a fusului

neckbone (anat) vertebră cervicală

neck bush(ing) (OM) guler de cuzinet / bucşă

neckcloth (textile) fular; cravată

neck collar journal (OM) fus / lagăr cu prag

neck down $(\mathrm{OM})$ a îngusta (o piesă, o trecere de conductă etc.), a micşora o dimensiune

necked part $(\mathrm{OM})$ porțiune îngustă a arborelui (sau a osiei)

neck flange (OM, hidr) franşă cu gât / cu guler

neck groove $(\mathrm{OM}, \mathrm{el})$ şanț pentru conductor (la izolatoare)

neck groove binding $(\mathrm{OM})$ legătură a unui conductor pe gâtul izolatorului

neck growth $(\mathrm{OM}, \mathrm{TH})$ creşterea / îngroşarea gâtului (unei piese)

necking (down) $(\mathrm{OM}, \mathrm{mec})$ gâtuire; ştrangulare; (fiz) stricțiune

necking tool (maş-un) cuțit de canelat

neck journal (OM) fus / lagăr cu diametru mai mic decât diametru arborelui)

neck journal bearing $(\mathrm{OM}, \mathrm{T})$ lagăr intermediar; lagăr pentru un fus intermediar

necklace clap $(\mathrm{OM})$ închizătoare / clamă de închidere pentru coliere (pt. țevi, conductori, cabluri etc.)

neck moulding $(\mathrm{OM})$ mufă redusă

neck (nose) mounting (hidr, OM) fixare / montare cu capac filetat 
neak of bulb (chim) gât al balonului / retortei (de sticlă)

neck out $(\mathrm{TH})$ a fălțui

neck ring of stuffing box $(\mathrm{OM})$ inel / bucşă de fund / de aşezare (şi la garnituri tip presetupă) necktie (textile) cravată

necrose (anat, med) a se necroza

necrosis (med) necroză

nectar (alim) băutură răcoritoare, nectar; sifon, apă gazoasă

nectarial (agr) de nectar, nectarifer

nectarine (alim, agr) nectarină, piersică cu coaja netedă

nectarious (alim) nectarifer, melifer; (d. miros) plăcut, aromat

nectarous (alim) de nectar, ca nectarul

need lipsă; nevoie; dificultate; (ec) necesitate; necesar; criză; sărăcie, lipsă materială, strâmtoare; (anat) $(p l)$ necesități (ale corpului); a trebui (din necesitate), a fi necesar să; a avea nevoie de să; a reclama, a necesita, a cere, a pretinde; $a(-i)$ lipsi, a fi nevoie de; have $\sim$ of a avea nevoie de; if $\sim$ be dacă e nevoie; in case of $\sim$ în caz de nevoie

needed necesar; util, folositor

needful to / for necesar pentru / la

neediness lipsă, sărăcie, necesitate

needle $(\mathrm{OM}) \mathrm{ac}$, andrea; (metr, $\mathrm{OM}$ ) (ac) indicator, ac de busolă; săgeată (şi indicatoare); (hidr, $\mathrm{OM})$ con de închidere (a vanei); (OM) ac (de cusut, de rulment, de tricotat etc.), piesă cilindrică subțire; (met) particulă aciculară; (masun, met, OM) dorn de perforat; (bot) ac (de conifer); (textile) andrea, ac (de tricotat); (OM, hidr) con de închidere (a supapei); (materiale) cristal în formă de ac; (constr) obelisc, daltă, proptea, sprait; (geogr) pisc / vârf ascutit; (OM, med) ac / seringă hipodermic, injecție; (fig) glumă (la adresa cuiva), discuție dură / ironică / sarcastică, remarcă critică; (textile) a coase cu acul; (constr) a şpăițui; (met) a forma ace (la cristalizare), a (se) cristaliza în formă de ace; a se strecura; a bate la cap, a cicăli, a sâcâi, a enerva; a îndemna; (alim) a întări cu alcool, a învechi artificial (o băutură), a ridica tăria unei băuturi (prin adăugare de alcool rafinat); a stimula

needle beard (OM, textile) ac cu cârlig

needle bearing $(\mathrm{OM})$ rulment $\mathrm{cu}$ ace

needle bottom (met) placa duzelor; fundul convertizorului

needle case (OM) bucşă cu ace

needled steel (met) oțel cu structură aciculară

needle eye (OM, textile) ureche de ac needle file $(\mathrm{TH})$ pilă-ac; pilă subțire fină; pilă coadă-de-şoarece

needle fracture (met, materiale) ruptură aciculară needleful (textile) (bucată de) ață

needle gap, point spark gap (el) eclator cu vârfuri

needle ice (alim) gheață aciculară / aciformă

needle-like / -shaped (met) aciform; acicular (d. structuri cristaline, la aliaje etc.)

needle lubricator $(\mathrm{T}, \mathrm{OM})$ ungător cu ac

needle nozzle (OM) ajutaj cu ac; (plast, OM) duză (cu închidere automată) cu ac

needle oiler $(\mathrm{OM}, \mathrm{T})$ ungător cu ac

needle point (OM, metr, textile) vârf de ac; (textile) dantelă de ac

needle port (hidr, OM) deschidere (îngustă) a vanei conice

needle pusher (OM, hidr) culisor / împingător de plunjer subțire

needle roller $(\mathrm{OM})$ rulment / bucşă cu ace

needle (roller) bearning $(\mathrm{OM})$ rulment cu ace

needle-shaped (met) aciform; acicular (d. structuri cristaline, la aliaje etc.); (OM) în formă de ac; (bot) acicular

needless de prisos, nenecesar; inutil

needlessness inutilitate

needle steel (met) oțel cu structură aciculară

needle stem (hidr, met, OM) tijă centrală (lungă față de diametru) (a vanei conice)

needle tear resistance (plast, textile) rezistență la zgâriere / sfâşiere cu acul

needle throw (metr) deviația acului indicator (la aparate de măsură)

needle valve (auto) poantou; (hidr, OM) vană / supapă inelară, supapă / robinet cu ac, ac obturator

needlework lucru de mână; (ec) muncă manuală needling (constr, mec) grinzi transversale, traverse (de poduri)

need of repair (auto, mas) nevoie de reparatie

NEF-thread (OM) filet normal foarte fin, standardizat în SUA

negate a nega; a respinge; a anula; $(\mathrm{TH})$ a neutraliza (un efect)

negation (mat) negație; negare

negational de negație; negativ

negative negativ, negație, refuz; trăsătură negativă; (el) (pol) negativ, catod; (foto) negativ; (mat) (număr / termen) negativ

negative acceleration $(\mathrm{mec})$ decelerație

negative adsorbtion (plast, hidr, T) adsorbție negativă, desorbție

negative allowance $(\mathrm{OM})$ strângere, abatere / toleranță negativă (față de dimensiunea nominală) 
negative area (el, electr) zonă de intrare (a curenților vagabonzi)

negative azeotrope (hidr, termo) amestec azeotrop cu temperatură minimă de fierbere

negative battery terminal (auto) bornă negativă baterie

negative bias (el, metr) negativare

negative collar (met) patriţă (şi la forjă)

negative damping (mec, el) acțiune inversă amortizării, propagare (cu amplificare) a oscilațiilor

negative deviation (autom, metr) abatere / deviație negativă

negative die (OM, mas-un) matriță negativă

negative distorsion (OM, autom) distorsiune negativă / în formă de semilună

negative electrode (el) electrod negativ

negative eye piece (fiz, opt) ocular negativ / cu două lentile divergente

negative feedback (autom, fiz) reacție negativă; (el) conexiune inversă negativă; (met) reacție inversă negativă; (el, electr) contrareacție

negative feedback loop (autom, fiz) buclă de contrareacție / de reacție negativă

negative-going edge (autom) flanc coborâtor / spre negativ al impulsului / al mărimii variabile

negative image (fiz, c) imagine negativă / inversată (cu referire la culoare)

negative integer (mat) număr întreg negativ

negative ion (met, chim) ion negativ

negative lead (el) conductor negativ, minus

negative leg (el, fiz, electr) picior negativ / minus (la un termocuplu etc.)

negative lens (fiz, opt) lentilă divergentă

negative matrix (OM, mas-un, el) matriță / formă negativă (în galvanotehnie, electroeroziune)

negative movement (geol, constr) tasare a terenului

negative number (mat) număr negativ

negative picture (fiz, c) imagine negativă

negative plate (el) placă negativă de acumulator negative pressure (hidr) subpresiune (presiune mai mică decât cea atmosferică); contrapresiune; (mec, fiz) vid; vacuum; depresiune

negative proton (fiz, chim) antiproton

negative rake (mas-un) unghi de degajare negativ (la scule)

negative rake milling (mas-un, $\mathrm{TH}$ ) frezare cu o freză cu unghi de degajare negativ

negative replica $(c, O M)$ copie negativă / în oglindă (d. un profil, o imagine etc.)

negative report (autom) semnal negativ / eronat / nedorit negativ sign (mat) semn negativ; minus negative segregation (met) segregație inversă negative sweep-back (mec, OM) săgeată negativă / inversă

negative temperature coefficient thermis (electr) tor cu coeficient de temperatură negativ, tor termistor cald

negative thrust $(\mathrm{OM})$ sarcină axială (care nu încarcă rulmentul axial)

negative valence (chim) valență negativă

negativity negativitate

negator (autom) element NU; care neagă

negatory negator; negativ, negativist

negentropy (fiz, termo) entropie negativă

negistor (el) rezistență negativă

neglect a neglija; a nu se îngriji de; a nu avea grijă; a ignora; a omite; a desconsidera, a nu ține cont de, a nu acorda atenție; neglijare; desconsiderare; neîndeplinire

neglected uitat, părăsit, neglijat; ignorat

neglectful of neglijent cu, neatent cu; nepăsător, fără griji

negligeable (mat) neînsemnat ca valoare; neglijabil

negligence neglijență, neatenție; scăpare; omisiune; delăsare, nepăsare, aspect neglijent

negligent of neglijent $\mathrm{cu}$, neatent cu; delăsător, nepăsător, indolent

negligently $(a d v)$ (în mod) neglijent, neatent negligibility caracter neglijabil, lipsă de importanță / valoare

negligible neglijabil, neînsemnat

negociability negociabilitate; accesibilitate (a unui drum)

negociable (ec) negociabil; care poate fi trecut / învins (d. un obstacol); accesibil (d. un drum); aplanabil, care se poate rezolva / media / negocia

negociate a negocia, a trata; a duce tratative; a discuta; a învinge (un obstacol), a trece de / peste

negociator (pol, adm, ec) negociator; intermediar, mijlocitor

negus (alim) vin fiert

neighbour vecin; (mat) valoare apropiată; a se învecina cu

neighboured cu împrejurimi; învecinat

neighbourhood (mat) vecinătate; preajmă, apropiere; regiune, zonă, parte; cartier; vecini; care se învecinează

neighbouring învecinat, vecin; care se învecinează

neighbouring position $(\mathrm{OM})$ poziție adiacentă / vecină, care se învecinează 
neighbour upon a se învecina cu nenuphar (bot) nufăr

Neodynium (Nd) (chim) neodim neohexane (chim) trietiletilmetan neologism (gram) neologism

Neon (Ne) (chim) neon neon lamp (el) lampă cu neon neon light (el) lumină de neon neopentane (chim) neopentan, tetrametilmetan neper (Np) (metr, fiz) unitate care exprimă raportul a două numere sub forma unui logaritm natural; raportul $r$ corespunde valorii (1/2). $\ln r$ neperi; două mărimi diferă cu 1 neper dacă una este de $\mathrm{e}^{2}(7,389056)$ ori mai mare decât cealaltă: 1 neper $\sim 8,685890$ decibeli

neoprene (chim, plast) neopren (elastomer) neosyl (chim) dioxid de siliciu amorf

nep (textile, plast) buton, defect de fibre (încâlcire) (şi d. fire fibre în compozite), nopeu nep count (textile, plast) număr de nopeuri nep-counting tamplate (textile) placă de numărare a nopeurilor

nephelometric turbidity unit (NTU) (metr) o unitate de măsură utilizată în măsurarea calitătii apei (apa potabilă are 1 NTU, dar este considerată sigură până la 5 NTU)

nephelometer (metr) aparat pentru măsurarea turbidității apei

nephrite (minrl) jadeit

neppy (textile, plast) cu noduri / cu încâlcire (a fibrelor)

neptunium (Np) (chim) neptuniu

nerve (mat) nerv (în topologie); (plast) „nerv” / elasticitate / revenire elastică a cauciucului

"nerviness" of rubber (plast, chim) elasticitatea cauciucului (nevulcanizat)

nervosity nervozitate

nervous breakdown (med) epuizare / depresiune nervoasă

nervously $(a d v)$ (în mod) nervos, agitat

"nervy" rubber (plast, ind chim) cauciuc (nevulcanizat) cu revenire elastică bună

nervure (bot, OM) nervură

nest (zool) cuib (de pasăre), cuibar, vizuină, a cuibări, a pune în cuib, a-şi face cuib; colț, adăpost; set / grup de obiecte de acelaşi fel; (fiz) grup (cuib, roi, nori); pungă; cavernă; (met) incluziune, cuib (şi de grafit); (nav) grup de nave legate de aceeaşi dană, bărci ancorate una de alta; (TH, OM) set; garnitură; a îmbuca, a încastra, a încorpora; (inf) a include o subrutină / un subprogram într-un program mai mare; (mat) a evalua un polimon de grad n, prin (n-1) operații de multiplicare și adunare; multime; colecție; (metr) veche unitate englezească pentru cantitate de 3 (bucăți); (alim) garnitură; grup / serie de obiecte de acelaşi fel; set; (geol) incluziune în rocă, pungă; (fig) adăpost, colț, cuib, viespar; a îmbuca; a încastra; a încorpora

nest egg (agr) ou pus la clocit; (fig) bani puşi deoparte (pt. concediu etc.), bani albi pentru zile negre

nestle a se cuibări, a (se) adăposti (d. păsări)

nestling (zool) pui (în cuib); (inf) un program cu bucle în bucle

nest of boiler tubes (mas, termo, OM) fascicul de tevi / tubular

net (adj) (ec) net, curat; fără adaosuri (d. greutate, preț etc.); (textile) tul; (TH, c) rețea (şi de televiziune, radio etc.); (OM) plasă; net, neto; $(s)$ plasă, năvod; (pt. vânat) laț; fileu, plasă; rețea; împletitură; (agr) a acoperi cu o plasă (pomi dintr-o livadă); (fig) cursă, capcană; a prinde (pești etc.) cu năvodul, a pune plasa (într-un râu); (ec) a plăti net (în bani), a primi net, a produce net; (sport) a trimite (mingea) în plasă; a lucra (un hamac, un năvod etc.); a acoperi / proteja cu o plasă; a prinde în plasă; (fig) a prinde în cursă; fall into the a cădea în cursă; (inf, mec) rețea (pentru modelare cu element finit)

net actual load $(\mathrm{TH})$ încărcătură / sarcină utilă (netă)

net area (mas) suprafață de lucru / utilă

net calorific / heating power (termo) putere calorifică inferioară

net calorific value (termo) valoare calorifică inferioară (d. combustibili, substanțe inflamabile)

net charge (mec, el) sarcină rezultantă / totală

net control station (el) stație de emisie principală

net cost (ec) cost(uri) net(e)

net current assets $(\mathrm{ec})$ mijloace circulante

net dredger (mas, constr) excavator cu cupe

net efficiency (fiz) eficacitate totală; (mas, mec) randament net / util; putere utilă

net equivalent (el) echivalent net; atenuare reziduală

netful (iht) plasă plină, năvod plin

net head (hidr) cădere netă (exprimată în presiunea coloanei de fluid), înălțime utilă de cădere (la hidrocentrale)

net heating power (chim, termo) putere calorifică inferioară netă (d. combustibili, substante inflamabile etc.)

net heat of combustion (termo) putere calorifică măsurată prin răcirea produselor de ardere la temperatura inițială şi fără condensarea vaporilor de apă formați 
nether inferior, de jos

nethermost cel mai de jos

netlike reticular, reticulat, în formă de rețea (d. structuri, modele cu element finit etc.)

net load (cf) încărcătură / greutate netă / reală; (fiz, mec) sarcină / încărcătură utilă / netă

net loss echivalent de transmisie; (el) pierdere totală / netă / a rețelei

net masonry (constr) legătură / îmbinare / aşezare / zidire în formă de rețea

net method (mat) metoda rețelelor (în analiza matematică)

net polymer (plast) polimer reticulat

net positive suction head (hidr, termo) presiune de aspirație pozitivă netă (d. combustibili, substante inflamabile etc.)

net profit / proceeds (ec) profit / venit net

net of squares (mat) rețea de pătrate (în analiza numerică)

net receipts (ec) încasări nete

net refrigerating effect / power (termo, alim) putere frigorifică netă

net register tonnage (NRT) tonaj registru net

net returns (ec) venituri nete din vânzări

net sales $(\mathrm{ec})$ sumă netă a vânzărilor

net-shaped (fiz) în formă de rețea; reticular (d. structuri de materiale etc.)

net structure (met) structură reticulară / celulară netted (materiale, el, textile) în formă de rețea, cu ochiuri

netting $(\mathrm{OM})$ plasă, rețea; fileu, țesătură, urzeală; împletitură; (constr, OM, textile, componente cu fibre lungi) plasă de armătură / de protecție; (textile) fileu, împletitură, plasă, țesătură, urzeală; (constr, compozite) plasă de armătură netting knot $(\mathrm{OM})$ nod de plasă / de sită

netting yarn $(\mathrm{OM}$, textile) fir de plasă / de rețea / de sită

nettle rash (med) urticarie

net ton (NT) (metr) poate avea cel puțin două îțelesuri: (1) denumire pentru US ton sau short ton (2000 pounds), şi (2) o altă denumire pentru register ton - unitate de măsură pentru volum, utilizată în descrierea capacității de transport pentru o navă (în opoziție cu exprimarea volumului total al acesteia): 1 net ton $=100$ cubic feet (picioare cubice); pentru evitarea confuziei se recomandă termenul ,short ton" pentru (1) şi ,net register ton” pentru (2)

net tonnage (nav) tonaj net

net transfer function (autom) functie de transfer echivalentă

net weight $(\mathrm{mec})$ greutate (sau masă) netă; greutate proprie / fără încărcătură net weight hauled (nav, transp) încărcătură utilă tractată / remorcată

net weight taring (jur, ec, transp) greutate netă legală

network rețea (şi de calculatoare, de cabluri etc.); plasă; schemă; circuit; grătar; zăbrele; (cf, hidr) rețea (de căi ferate, de canale, de conducte); (constr) ornament în formă de rețea; paiantă; (el) rețea electrică; (met) rețea de fisuri (defect superficial); rețea de radioteleviziune; împletitură de / tip plasă

network analyser (autom) analizor / simulator de rețea

network application (c, inf) aplicație de rețea

network data base $(c$, inf) rețea / structură de baze de date, cu elemente legate prin indicatoare de adresă

network driven (mas, c, autom) alimentat / condus de la rețea

network hard disk (c) hard-disc al unei rețele (de calculatoare) la care pot avea acces toți utilizatorii

network hum (el, autom) zgomot de rețea / de sector

net working capital (ec) capital net de rulare network intrinsec application (c, inf) aplicație / program special pentru a lucra în rețea

network layout (c) formă / configuratie de retea network loss $(\mathrm{el}, \mathrm{c})$ pierdere în / pe rețea

network map / plan $(\mathrm{TH}$, ind) plan de situare / amplasare al unei rețele; plan / schemă de rețea

network master relay (el, autom) releu de protecție al unei rețele

network mesh $(\mathrm{OM})$ verigă; za; (el, autom) element de filtru multicelular / iterativ; (mec) retea de noduri / elemente finite la modelare cu soft-uri dedicate

network of bench marks rețea de repere network of capillary (fiz) rețea de capilare network of pipe-lines (hidr) rețea de conducte network parameter (el, electr, autom, inf) parametru / element de rețea

network relay (el) releu disjunctor de rețea network structure (plast) structură reticulară network tolerant application (c, inf) aplicație tolerată de rețea, program care poate fi rulat într-o rețea de calculatoare, fără a beneficia de avantajele resurselor acesteia

net yield $(\mathrm{ec})$ venit net; $(\mathrm{TH})$ randament net

neutral $(\mathrm{TH}, \mathrm{fiz}, \mathrm{mec})$ neutru, indiferent, neîncărcat, neangajat; neprecis, intermediar; (el) conductor de nul / neutru; (metr, el) poziție neutră a unui releu / buton etc.; (pol) cetătean 
al unui stat neutru, stat neutru, neangajat; (nav, pol) vas al unui stat neutru; cenuşiu, sur (d. culori)

neutral atmosphere (met) atmosferă neutră / inertă

neutral axis (mat, mec, fiz) axă de coordonate, axă neutră

neutral balance (mec) echilibru indiferent

neutral brought out (el) punct neutru accesibil / cu conexiunea scoasă în exterior

neutral conductor (el) conductor / cablu / fir de nul / neutru, linie deutră / de nul

neutral earthing capacitor (el) condensator de legare la pământ a neutrului

neutral equilibrium (fiz, mec) echilibru indiferent

neutral flame (met) flacără neutră (la sudare)

neutral fiber (mec) fibră neutră

neutral gear $(\mathrm{OM})$ angrenaj neutru / cu raport de transmitere $1 /$ care nu modifică parametrii de intrare

neutral hue (c, TV) nuanţă cenuşie / neutră

neutrality (el) poziție neutră a unui releu; (pol) neutralitate)

neutralization (chim) desfacerea legăturii chimice; neutralizare; (el) neutralizare; neutrodinare

neutralization number / value (chim) indice de neutralizare / de aciditate

neutralize a neutraliza; (chim) a desface legătura chimică; a face inofensiv, a anihila, a desființa; a paraliza

neutralizer (chim) neutralizator

neutralizing (chim) dezacidulare, (actiunea de) neutralizare care neutralizează; (el) legare la nul / la neutru

neutral leach (ind chim) extracție (prin dizolvare) cu solutie neutră

neutral line (el) linie neutră (şi a unui magnet); $(\mathrm{mec})$ linie a nodurilor

neutral line of a magnet (fiz, el) linie neutră a unui magnet

neutral anode magnetron (fiz) magnetron cu anod neutru

neutral medium (met, chim) mediu neutru (şi la tratamente)

neutral-meson (fiz) mezon neutru

neutral oils (ind chim) uleiuri distilate cu vâscozitate medie

neutral oxidation (chim) oxidare cu substante neutre

neutral phase (hidr) fază neutră, prima şi ultima fază a unui ciclu

neutral phosphate (chim) fosfat neutru / fosfat tribazic neutral plane of a direct current machine (el) linii neutre ale unei maşini de curent continuu cu colector

neutral position $(\mathrm{el}, \mathrm{mec})$ poziție de repaus

neutral point (fiz) punct neutru / zero / inițial; punct pe curba de titrare a unei soluții în care concentrația ionilor de hidrogen este egală cu cea a ionilor de hidroxil

neutral-point resistance (metr, el) rezistență de zero / de nul; (el) rezistență în punctul de nivel zero; rezistență conectată între punctul neutru al unui transformator şi pământ; (hidr) poziție neutră a unui motor / a unei pompe, poziție de cilindree nulă

neutral position (el) poziție neutră / de repaus; (mat) poziție medie; (metr) poziție de zero (la aparate de măsură); (auto) poziția de mijloc neutral reaction (chim) reacție neutră neutral red (chim) aminodimetil aminotoluenfenazoniu

neutrals (chim, petr) uleiuri distilate cu vâscozitate medie

neutral soda (chim) amestec de carbonat şi bicarbonat de sodiu

neutral sulphite pulping (ind chim) (procedeu / proces de) fierbere cu sulfit neutru de sodiu

neutral value (mec) valoare de repaus

neutral wire (el) conductor / cablu / fir neutru, linie neutră; $(\mathrm{mec})$ linie neutră

neutral zone (autom) zonă neutră / de inefícacitate; (el) unghi mort; zonă moartă / neutră

neutrino (fiz) neutrin

neutron (fiz) neutron

neutronics (fiz) fizică neutronică

never $(a d v)$ niciodată, nicicând, doar nu;

never-ending decimal (mat) fracție zecimală infinită

nevermore $(a d v)$ niciodată (din nou)

nevertheless $(a d v)$ totusi, cu toate acestea

new (constr) nou; recent, de curând; nou, novice, neexperimentat, necunoscător

new-built nou construit, reconstruit

new candle (metr, fiz) denumire mai veche pentru candela - unitate pentru măsurarea intensității luminoase, v. candela

new-comer nou-venit; străin, necunoscut

new-day (amer) contemporan, nou, modern

new dimensions system miniaturizare, reducere a dimensiunilor

new-found nou descoperit

newish destul de nou

new lining (mas-un) reglare / acoperire din nou; (met) căptuşire / căptuşeală nouă (la convertizor, cuptor etc.) 
newly mixed sand (met) nisip proaspăt newness noutate; prospețime; lipsă de experiență

new paragraph alineat nou

news ştire, noutate, ştiri, noutăți

news agency agenție de ştiri / de presă

newscast buletin de ştiri, radiojurnal, telejurnal

news conference conferinţă de presă

newspaper ziar, revistă

newsprint hârtie de ziar

news stall chioşc de ziare

new style (NS) (metr) stil nou, un sistem de notație pentru dată, care aplică calendarul gregorian

newton (N) (metr) unitate SI de măsură pentru forță, newton

Newtonian flow (hidr, T) curgere newtoniană / în care caracteristicile fluidului (vâscozitate, tensiuni de forfecare) sunt în dependență liniară

Newtonian fluid / model (hidr, T) fluid / model newtonian

Newton's law (mec) legea lui Newton

Newtonian viscosity (hidr, T) vâscozitate newtoniană / a unui fluid newtonian

newton meter $(\mathbf{N} \cdot \mathbf{m})$ (metr, fiz, mec) unitate SI de măsură pentru moment

newton second $(\mathbf{N} \cdot \mathbf{s})$ (metr, fiz, mec) unitate SI de măsură pentru impuls, newton-secundă

new use aplicație nouă a unei soluții tehnice

newsworthy interesant, important, care merită să fie publicat / difuzat

new wine (alim) vin nou

next următor, care urmează; cel mai apropiat, vecin, învecinat; (temporal) următor, viitor, care vine; $(a d v)$ pe urmă, apoi, după aceea; iar, din nou; altădată; lângă, alături

next state equation (fiz) ecuație de stare

next to aproape de, de lângă, din apropierea; (imediat) după

nexus nex; legătură, apartenentă

N fixture (constr) stâlp în formă de N

NF-thread (OM) filet normal fin (standardizat în SUA)

niacin equivalent (NE) (metr, med, alim) unitate de măsură utilizată în nutriție; un nutrient esenţial - niancinul, este furnizat în dietele normale, din tryptophan, un amino acid: 1 niacin equivalent $=1 \mathrm{mg}$ niacin $=60 \mathrm{mg} \mathrm{de}$ tryptophan

nib (zool) cioc; vârf; peniță, vârf de peniță (de stilou); (constr) nas (la țigle); (OM) vârf; ac de ajutaj, nas (la suprafața de reazem a capului de şurub); (met) carbură pentru filieră; ochi (vizor) nibble (alim) mâncare foarte puțină; a roade (cu dinți), a muşca; muşcătură; (metr, inf) unitate de informație: 1 nibble $=4$ bits $=1 / 2$ byte; un grup de 4 bits este denumit uneori quadbit sau hexit

nibble at a muşca din; (fig) a arăta interes pentru nibble at an offer a fi atras / tentat de o propunere / ofertă (fără a se putea hotărî)

nibbling (mas-un) operație de prelucrare / de tăiere / de ştanţare (cu avans mic de tăiere)

nibbling machine (met) maşină de ştanțat

niccolite (met) nichelină (Ni-As)

nice plăcut, drăguț; simpatic, binevoitor, prietenos, agreabil; atent; scrupulos, atent, amănunțit, migălos; (d. auz) fin, ascuțit, bun; elegant; (d. un mecanism) fin, sensibil

nicety precizie, exactitate; acuratețe; punctualitate; scrupulozitate; finețe, subtilitate; (constr) rafinament; susceptibilitate

niche (const) nişă, firidă, semicupolă, adăpost, refugiu, ungher; ( $f i g)$ loc potrivit

nichrome (alloy Ni-Cr) (met) nicrom (aliaj Ni$\mathrm{Cr}$ )

nichrome wire (met) sârmă de nicrom / din aliaj crom-nichel

nick crestare; crestătură; crăpătură; tăietură; $(\mathrm{OM})$ canelură, gât (de piesă, de arbore etc.), gâtuire; îngustare; strictiune; crestătură (transversală), urmă de indentare pe filetul piuliței, cauzată de abraziune sau impact; a cresta, a face o crestătură / crestături; (geogr) vale îngustă; (jur) (fam) închisoare, puşcărie, a aresta, a jefui, a prăd ${ }_{2}$ a pune mâna pe; (ec) a reține banii unui salariat (pentru că nu a lucrat tot timpul); s $(p l)$ (ant, sport) condiție fizică, formă

nick bend test (met, metr) încercare / test de îndoire cu probe crestate

nicked $(\mathrm{OM})$ crestat, ştirb, cu zimți, ciobit

nicked-fracture test (materiale, metr) încercare

/ test la rupere pe epruvete crestate

nicked teeth taper reamer (mas-un) alezor conic cu dinti crestati

nicked tooth (mas-un) dinte crestat

nickel (Ni) (chim) nichel; (met) a nichela

nickel alloy (met) aliaj de nichel

nichel-aluminium bronze (met) bronz $(\mathrm{Cu}-\mathrm{Sn})$ (aliat) cu Ni și Al

nickel bearing (met) (aliaj) cu conținut de / bogat în nichel

nichel brass (met) alamă cu Ni, aliaj $\mathrm{Cu}-\mathrm{Zn}-\mathrm{Ni}$

nichel bronze (met) bronz cu $\mathrm{Ni}$, aliaj $\mathrm{Cu}-\mathrm{Sn}$ $(\mathrm{Pb})-\mathrm{Ni}$

nickel carbide (chim) carbură de nichel

nichel cast iron (met) fontă turnată, aliată cu Ni 
nichel cast steel (met) oțel turnat, aliat cu Ni nichel-chrome steel (met) otel (înalt) aliat cu $\mathrm{Ni}-\mathrm{Cr}$

nichel-chromium (chrome) -nichel-aluminium (met) cromel - alumel

nichelic compound (chim, met) compus al nichelului trivalent / nichelic

nickel coat (met) acoperire cu nichel; nichelare

nickel coating (auto, met) strat / acoperire de nichel

nichel converting (met) rafinare a matei de nichel

nickeline (met) nichelină

nickel iron (met) fero-nichel

nickel-iron battery (auto) acumulator feronichel

nickel-manganese steel (met) oțel nichel-mangan nicehl matte (met) mată de nichel

nicehl matte refining (met) rafinare a matei de nichel

nichel nitride (chim, met) nitrură / azotură de nichel

nickelous compound (chim) compus nichelos / al nichelului bivalent

nickel oxides (chim) oxizi de nichel

nickel pellets (met) nichel granulat

nickel plating / cladding (met) nichelare; acoperire cu nichel

nickel shot (met) granulă de nichel

nickel silver (met) alpaca; argentan, aliaj $\mathrm{Cu}-\mathrm{Ni}$ $\mathrm{Zn}$, neusilber, maillechort

nickel steel (met) oțel cu / aliat cu nichel

nichel sulphate (chim) sulfat de nichel

nichel sulphide (chim) sulfură de nichel

nichel trimmings (met) feronerie de nichel

nichel-wire rolling mill (met) laminor pentru sârmă de nichel sau aliajele lui

nicker (mas-un) vârful burghiului de centrare

nicking (met, OM) crestare, canelare, striere

nicking file $(\mathrm{TH})$ pilă lată subțire, pentru canelat

nicking tool (mas-un) cuțit de canelat

nicklad (met) tablă de oțel nichelată

nick out a brăzda; a încreți

nicotine (chim) nicotină

niello engraving (met) nielare

nigger head (met) concrețiuni dure, rotunde de steril în straturi de cărbuni; (nav) tambur de vinci; baba / bintă de remorcă

nigger heads (met) bucăți netopite (în baia cuptorului Martin)

night noapte; seară; (fig) întuneric

night charge (transp, ec) tarif de noapte

night frost îngheț nocturn

night gang / shift / turn (ec, TH) schimb / muncă de noapte night light (el) lampă, bec de noapte; lumină de serviciu (pe coridor etc.)

night-load tariff $(\mathrm{ec})$ tarif de noapte

nightman lucrător din schimbul de noapte

night rate (el) tarif de noapte

night school (edu) şcoală serală, cursuri serale

night shift schimb de noapte

night time timp de noapte; noaptea, în timpul nopții

night watch pază de noapte; paznic de noapte

night watchman paznic de noapte

nightwork (ec, TH) muncă / schimb de noapte

nil (inf) listă vidă

nil balance (ec) sold nul

nile (metr, fizică nucleară) unitate utilizată în energetica nucleară pentru a descrie reactivitatea unui reactor nuclear: 1 nile este o reactivitate de 0,01 sau $1 \%$; în practică se utilizează millinile: 1 millinine $=10^{-5}$ sau $0,01 \%$

nil load (el, mas) mers în gol, cu sarcină zero

nimbed nimbat, aureolat

nimble (d. mişcare) vioi, sprinten, agil; (d. răspuns) prompt; (d. un ascultător) receptiv

nimbly $(a d v)$ vioi, sprinten, cu agilitate; prompt; inteligent

nine nouă; (metr) o măsură a fineții / purității aurului sau a altor metale prețioase: aurul de puritate $99,99 \%$ are 0,9999 , sau finete de "4 nines fine"; (metr, inf, OM) o măsură a fiabilității sau disponibilitătii: un element sau o componentă este descris( $\breve{a})$ cu o fiabilitate "3 nines" dacă funcționează corect $99,9 \%$ din timp

ninefold din nouă părți; de nouă ori mai mare; $(a d v)$ de nouă ori mai mult

nine point circle (geom) cercul lui Euler

nineteen nouăsprezece

nineteenth al nouăsprezecelea

ninetieth al nouăzecilea

ninety nouăzeci

ninth noime, a noua parte

Niobium (Nb) (chim) niobiu

nip muşcătură; pişcătură; ciupitură; a mușca; a ciupi; a distruge; (plast) distanță dintre cilindri; linie de contact; joc dintre valturi; $(\mathrm{OM}, \mathrm{TH})$ prindere; apucare; strângere; presare, comprimare; (mas-un) loc de strângere; diferență dintre dimensiunile pieselor conjugate; punct (linie) de prindere; presiune între valturile de prindere / de stoarcere; a prinde, a apuca; a presa; a comprima; a muşca, a tăia; (met) a sparge cu explozivi, distanță / joc între cilindri (la laminare); a sparge roci prin înghețare; $(\mathrm{TH})$ a tăia cu cleştele, a strânge cu cleştele; a înghesui; a distruge, a vătăma; (alim) cantitate mică (de lichid); 
(metr, alim) unitate de măsură pentru volum de lichid (şi pt. băuturi alcoolice) 1 nip (US) 59 ml, 1 nip of spirits (UK) $\sim 22,95 \mathrm{ml} ; 1$ nip of beer $\sim 117,7 \mathrm{ml} \mathrm{sau} \sim 189,4 \mathrm{ml}$

nip guards $(\mathrm{OM})$ apăratoare (la calandru)

nipper (mas-un, OM) dispozitiv de strângere, clește, (falcă de) menghină; (met) muncitor auxiliar

nipper pliers (mas-un) cleşte ascuțit; cleşte de tăiat / de îndoit

nippers (mas-un) cleşte de tăiat sârmă; pensetă nippers knife $(\mathrm{OM})$ falcă a cleştelui

nippiness iuțeală, sprinteneală; (ec, TH) operativitate; asprime, frig

nipple (OM, hidr) niplu; racord; (auto, OM) duză; ajutaj; jiclor; tub de legătură; capul de protecție a unui monitor; zencuitor (sculă); (TH) a cresta; suzetă, biberon

nipple joint $(\mathrm{OM})$ îmbinare cu niplu

nipple plate (met) tablă striată

nip off $(\mathrm{TH})$ a reteza

nip pressure (plast) presiune între valțuri nip rolls (plast) valțuri / cilindri finisori

nip up (TH) a prinde, a strânge, a presa, a reteza (şi cu un cleşte)

Niresist (met) fontă cu nichel $(12 \ldots 15 \% \mathrm{Ni}+$ $5 . .7 \% \mathrm{Cu})$

nirosta (met) otel inoxidabil (rar)

nit (nt) (metr, fiz) o unitate de măsură în sistem MKS pentru iluminanță luminance, numită şi meterlambert: 1 nit $=1$ candela $/ \mathrm{m}^{2}$

nital (chim) nital (amestec de acid azotic şi alcool metilic sau etilic); (met) nital (reactiv pentru atacul probelor metalografice)

nitinol alloy (met) aliaje $\mathrm{Ti}-\mathrm{Ni}$, cu memorie

nitralising (chim, met) imersare în nitrat de sodiu topit

nitralloy steel (met) oțel nitrurat

nitrate (chim) nitrat; azotat; a nitra; a azota; (met) a nitrura

nitrated case (met) strat / casetă de nitrurare

nitration (chim) nitrare, azotare; (met) nitrurare

nitration bath (chim) baie de nitrare, azotare; (met) baie de nitrurare

nitration / nitride / nitrated case (met) strat de nitrurare

nitration / nitriding furnace (met, chim, termo) cuptor de nitrurare

nitration / nitriding process (met) procedeu proces de (călire prin) nitrurare

nitre, niter (chim) azotat de potasiu (nativ); salpetru, silitră; a nitra

nitre cake (chim) disulfit de sodiu

nitric acid (chim) acid azotic, apă tare nitric acid pickle (met, $\mathrm{TH}$ ) baie de decapare cu acid azotic

nitric acid test (met, metr) încercare / test cu acid azotic

nitric oxide (chim) oxid de azot

nitridation (met, chim) nitrurare

nitride (chim) nitrură; azotură; (met) a nitrura; (met) strat de nitrurare

nitride(d) steel (met) oțel nitrurat

nitriding (chim) nitrare; (met) (călire prin) nitrurare

nitriding atmosphere (met, chim) atmosferă de nitrurare

nitriding box (met) cutie de nitrurare

nitriding equipment (met) instalaţie de nitrurare

nitriding / nitration furnace (met, chim, termo) cuptor de nitrurare

nitriding process (met) procedeu / proces de călire prin nitrurare

nitriding steel (met) oțel de nitrurare

nitrification (agr) nitrificare; (met) nitrurare

nitrify a azota, a îmbogăți în azot; (agr) a nitrifica

nitrile (chim) nitril

nitrile butadiene (plast) cauciuc butadien nitrilic

nitrile rubber (ind chim, plast) cauciuc (butadien-)nitrilic

nitrite (chim) azotit, nitrit

nitrocompounds (plast) nitroderivați

nitro-dyes (chim) nitrocoloranți

Nitrogen (N) (chim) azot, nitrogen

nitrogen atmosphere (ind chim, met) atmosferă de azot

nitrogen chain (chim) catenă din atomi de azot

nitrogen group (chim) grup(are) cu azot

nitrogen hardening (met) durificare prin (călire prin / după) nitrurare

nitrogen oxide (chim) oxid de azot

nitro(-)glycerin(e) (chim) nitroglicerină

nitrohalogen compound (chim) derivat nitrohalogenat

nitrohydrochloric / nitromuriatic acid (chim) apă regală

nitro-lacquer (ind chim) nitrolac, lac de nitroceluloză

nitron (chim) nitron

nitrous (chim) azotos, nitros

nitrous compound (chim) compus al azotului trivalent

nitrous oxide (chim) protoxid de azot, gaz ilariant nix nimic, zero; nimeni

NLGI, National Lubricating Grease Institute Institutul Național pentru Unsori Lubrifiante (SUA) 
NLGI number (T) număr pentru clasificarea intervalului de consistență a unsorilor, bazat pe numărul de penetrație ASTMĂ

$\mathbf{N m}, \mathbf{N} \cdot \mathbf{m}$ (metr, mec) simbol pentru newton meter, unitate de măsură pentru moment de torsiune

Nm (metr, textile) abreviere pentru normal metric, o unitate care măsoară densitatea firului lung de lână care, după pieptnare, are o uniformitate deosebită; lâna pieptănată descrisă printr-un fir de $a / b \mathrm{Nm}$, şi are $a$-fire individuale şi $b-(\mathrm{k}) \mathrm{m}$ de fir (număr de dublaje ale firelor) pe kilogram; dacă firul nu este dublat, calitatea lânii se exprimă în $b \mathrm{Nm}$

no account (ec) cont descoperit, fără cont

nobbing, nobbling, nobling (met) îndepărtare a țunderului

Nobelium (No) (chim) nobeliu

noble gas (chim) gaz inert / nobil

noble metal (met) metal nobil

noble metal thermocouple (materiale, metr, termo) termocuplu din platină sau platină-rodiu, rezistent până la $+1500^{\circ} \mathrm{C}$

no-bounce switch (el) întrerupător fără dispozitiv de protecţie

no-break emergency power-supply (el) alimentare neîntreruptă cu curent de rezervă / de siguranță

no-charge loss (el, mas) pierdere la mers în gol

no charge machine-fault time (autom, cib) timp de întrerupere din cauza unei erori a maşinii

no charge non-machine-fault time (autom, inf) timp de întrerupere care nu este din cauza maşinii

nock $(\mathrm{OM})$ crestătură (şi la epruvete), adâncitură no-constant variabil, neconstant

no-constant boiling mixture (alim, ind chim) amestec cu temperatură de fierbere variabilă

nocturnal nocturn, de noapte

nocturnal frost (mediu) îngheț nocturn

no-current trip (el) declanşator de curent nul / cu curent de repaus

nodal nodal, esențial, fundamental

nodal line / plan (mec, el) linia / planul nodurilor / nodal( $\breve{a})$

nodal point (fiz, el) punct nodal, nod (de oscilație); punct de joncțiune a fazelor

nodal shifting (electr, autom) decalaj / decalare a(l) nodurilor

nodal surface (fiz) suprafață nodală

nodal width (fiz) distanță între noduri

node $(\mathrm{OM})$ nod de asamblare; (materiale) umflătură, îngroşare, nodul; (mat, mec) punct, nod (al unui grafic, al unei rețele sau al oscilației); dilemă; problemă; complicație; (cf) nod de cale ferată; îngroşare; excrescenţă

node of vibration (mec, fiz) nod de vibrație

nodose (silv) cu noduri, noduros (d. lemn)

nodosity nodozitate, nod

no doubt $(a d v)$ fără îndoială, indiscutabil

nodous noduros, cu noduri

no-draft / no-draught ventilation (termo) ventilație fără curent

nodular, nodulated noduros; în formă de nod; nodular; globular; sferic; cu noduri

nodular cast iron (met) fontă cu grafit nodular

nodular cementite (met) cementită globulară

nodular graphite (met) grafit nodular

nodular structure (met) structură cu nodule / reniformă

nodule nodozitate (la lemn); (met) nodul; aglomerare de cristale; geodă; nodul; (anat) ganglion

nodulising (met) nodulizare, sferoidizare

nodulising drum (met) tambur granulator (de exemplu, pentru zgură)

nodulising installation (met) instalație de granulare (şi pentru zgură)

noeud ( $(\hat{n}$ franceză) (metr, nav) unitate de măsură pentru viteză, nod: 1 noeud $=1$ knot $=$ $1,852 \mathrm{~km} / \mathrm{h})$, v. knot

nog $(\mathrm{OM})$ pană de lemn, ic; ciot, bloc mic (paralelipipedic) de lemn

nogging piece (constr) antretoază, traversă

no-glare (metr, fiz, opt) ) lumină neorbitoare

no-go (mas-un) „nu trece” (inscripție pe calibrul limitativ), semn de marcare pentru ,respins”

noil (textile) deşeuri de la pieptănat

noise (el, electr, fiz) zgomot; gălăgie; (autom) paraziți, perturbații; (inf) documente nepertinente

noise abatement / elimination (auto, autom, mas) combaterea / eliminarea zgomotului noise analyser (fiz, metr) analizor de zgomot noise-balancing circuit (autom) circuit de deparazitare / de eliminare a zgomotului

noise criterion (NC), noise rating (NR) (metr) unități utilizate în inginerie pentru a măsura acceptabilitatea nivelului sonor (zgomotului) în spații închise; numeric NR este egală cu nivelul zgomotului în decibeli la o frecvență de $1000 \mathrm{~Hz}$; criteriul de zgomot este similar dar este utilizat pentru evaluarea calității comunicației (şi radio)

noise damper / suppressor (fiz, autom) amortizor / atenuator de zgomot, insonorizator

noise due to transients (autom, mas) zgomot produs de fenomene tranzitorii 
noise elimination (auto, autom) combaterea / eliminarea zgomotului

noise figure (fiz, autom) sensibilitate limită, factor de calitate; (el) factor de zgomot

noise filter (fiz, autom) filtru antiparazit / de zgomot

noise-free (mas, el) fără zgomot, silențios

noise helmet $(\mathrm{TH})$ cască de protecție împotriva zgomotului

noise intensity (fiz, el, autom) intensitate a perturbațiilor / a zgomotului

noise killer (electr, autom) rețea anti(-)parazită; circuit de filtrare / de netezire a zgomotului

noiseless care nu face zgomot, tăcut; (auto) silențios; (metr, electr, autom) fără zgomot de fond

noiseless chain $(\mathrm{OM})$ lanț silențios

noiseless run (mas) funcționare fără zgomot

noiseless running (mas) mers fără zgomot; mers liniştit (al unui motor)

noiseless shift(ing) (auto) schimbarea (vitezelor) fără zgomot

noise level (auto) nivel de zgomot; (metr, autom) nivel de zgomot de fond

noise measuring meter (auto, fiz, el) sonometru; măsurător de zgomot

noise meter (metr) decibelmetru

noise muffler (fiz, OM) surdină, amortizor de zgomot

noise of exhaust (auto, met) zgomot de evacuare noise of suction (auto) zgomot de aspirație noiseproof (fiz, mediu) izolat acustic

noise suppression ( $\mathrm{TH}$, autom, el) deparazitare / eliminare a zgomotului; antibruiaj

noise suppressor ( $\mathrm{TH}$, autom, el) amortizor de zgomot

noisily ( $a d v)$ zgomotos, cu zgomot; gălăgios

noisome (med) vătămător, dăunător; otrăvitor; urât / rău mirositor

noisy zgomotos, care face zgomot, cu zgomot; (d. culori) țipător

no-lead gasoline (ind chim) benzină fără tetraetil de plumb

no-load (mec) mers în gol / cu sarcină nulă

no-load time (mec, mas, TH) timp / etapă de mers în gol, timp în care sarcina este nulă

no-load current (mec, el) curent mers în gol

no-load cut(-)out (el) disjunctor de curent nul / de mers în gol

no-load draft / draught (nav) pescaj în gol / de navă neîncărcată

no-load friction (mas, mec, T) frecare de mers în gol

no-load loss(es) (el) (la mers) pierderi în gol; (mas, mec) pierderi la mers în gol no-load operation (mas) funcționare (de mers) în gol

no-load regime ( $\mathrm{TH}$, mas) regim de mers în gol

no-load run / running (auto) funcționare fără sarcină / în gol; (mas, mec) mers în gol

no-load start / starting (mas) pornire / demarare în gol / fără sarcină

no-load switch (el) întrerupător de zero

no-load test (el) încercare / test la mers în gol

no-load trip (mas) decuplare la mers în gol

no-load work (el) funcționare în gol; (mas) lucru mecanic de mers în gol

no longer blocked (mas, autom) deblocat

nomenclature nomenclatură; terminologie; denumire; nume

nominal nominal, convențional, oficial; nominal, mic, neînsemnat

nominal admissible load (el, mec, mas) sarcină nominală admisibilă

nominal bore (OM, metr) alezaj / calibru nominal, diametru nominal interior (la o teavă etc.)

nominal capacity (mas) capacitate / putere nominală

nominal capital (ec) capital nominal

nominal collector ring voltage (el) tensiune nominală a inelului colector

nominal control ampere-turns (el, metr) toleranță / diferență de amper-spiră

nominal diameter $(\mathrm{OM})$ diametru exterior / nominal (şi de filet)

nominal dimension dimensiune nominală

nominal filtration rating (autom el, electr, hidr) putere nominală de filtrare, finețe (nominală) de filtrare

nominal force (mec) fortă nominală

nominal full scale (metr) valoare nominală la capătul scalei (unui aparat de măsură)

nominal gauging constant (metr) constantă nominală de calibrare (unui aparat de măsură)

nominal horse power (n.h.p., nhp) (metr, mec) unitate de măsură pentru putere, cal-putere nominal

nominal load (auto, mas) încărcătură / sarcină nominală

nominal mains variation (el) variație nominală a tensiunii în rețea / în rețeaua principală

nominal output (el) putere nominală la ieşire; (hidr) debit nominal (la ieşire)

nominal power $(\mathrm{TH}$, mas, el) putere / productivitate nominală; (hidr) debit nominal

nominal pressure (hidr) presiune nominală

nominal pull-in torque (el) moment nominal de sincronizare / de acroşaj al unui motor sincron nominal range interval nominal 
nominal rang of use (autom, el) interval / domeniu nominal de utilizare

nominal size $(\mathrm{OM})$ dimensiune nominală

nominal speed (mas) viteză nominală

nominal upset force (met, mas-un) forță nominală de refulare

nominal value (autom, ec) valoare prescrisă / de referință / nominală

nominal width (met, metr) lățime nominală

nominator (mat) numitor (de fracție)

nominee (pol, adm) candidat

nomogram, nomograph, nomographic chart nomogramă, grafic

non-absorbent (materiale) neabsorbant, hidrofob

non-active maintenance time (ec, $\mathrm{TH}$, mas) timp în care nu se pot executa operații de mentenanță din cauze logistice sau/şi administrative (aprovizionare, recondiționări etc.), timp de mentenanță

nonadiabatic (fiz, termo) neadiabatic

non-ageing (met, plast) care nu îmbătrâneşte; (alim) inalterabil

non-ageing steel (met) oțel rezistent la îmbătrânire

non(-)alcoholic (alim, chim) nealcoolic; fără alcool non-alloy / non-allied steel (met) oțel nealiat non-approved fuel additive (auto, chim) aditiv neaprobat pentru combustibil / carburant

non-aqueous (chim) neapos, fără apă

non-arcing property (materiale) rezistență la arc electric

non-associated liquids (materiale, chim, fiz) lichide neasociabile

non-attendance nefrecventare; (edu, univ) absente (la cursuri); neprezentare

non-attended $(\mathrm{TH})$ (instalație) nesupravegheată

non-automatic (mas) neautomat(izat)

non-automatic opening / tripping (mas, el) deschidere / declanşare liberă / neautomată

non-availability nedisponibilitate (şi d. maşini, utilaje etc.); absență

non-baking / -caking coal (met) cărbune necocsificabil

non-balanced (mec, el) necompensat; neechilibrat non-bleeding (hidr) fără scurgeri

non-blooming (bot, plast, agr) (ingredient) neeflorescent, care nu se dezvoltă

non-burning ( $\mathrm{TH}$, chim, termo) neinflamabil, care nu arde

non-carbonate hardness (chim) duritate permanentă a apei

non-central (mat) necentral; (OM, TH) asimetric, necentrat

non-central force (fiz) forță necentrată non-changeover system (termo) sistem de climatizare automatizat / autoreglant

non-circuital vector field (mat, fiz) câmp vectorial nerotaţional

non-clashing gear set (auto) cutie de viteze cu aranjamente permanente / fară zgomot la schimbarea vitezelor

non-clinkering coal (met) cărbune fără zgură

non-closed loop control (autom) reglare în buclă deschisă

non-coagulable necoagulabil

non-cohesive material (constr) material necoeziv non-cohesive soil (constr) pământ necoeziv

non-coking coal (met) cărbune necocsificabil / neaglutinant

non(-)colinear forces (mec) cuplu de forțe, forțe necoliniare

non-comittal care nu angajează (d. un răspuns etc.) non-combustible (chim) incombustibil, care nu arde / nu degajă energie prin ardere

non-/ not-completely reversed stress (mec) tensiune pulsatorie

non-compliance neascultare, neconformare

non-compliance with (în) dezacord cu / față de; neacceptare; nerespectare (a unor dispoziții)

non-corrosive petroleum jelly (ind chim, T) vaselină necorosivă

non-concentrie (mec, $\mathrm{OM}$ ) excentric

non-condensable (fiz, termo) necondensabil

non-conducting (fiz, termo) neconductor, rău conducător (de căldură, electricitate etc.), izolant, izolator

non-conductive / -conductor (el) izolator, izolant, dielectric; (fiz) neconductor (termic / electric)

non-conforming product (ec, $\mathrm{TH}$ ) produs necorespunzător (calitativ)

non-conformity $(\mathrm{T})$ neconformabilitate (a unui contact); (ec) neconformitate a unui produs / serviciu

non-congealable oil (alim, T) ulei necongelabil non-consumable $(\mathrm{TH})$ neconsumabil, care nu se consumă (d. piese, electrozi etc.)

non-consumable electrode (el) electrod metalic neconsumabil / nefuzibil

non-contact (fiz, electr) fără contact (cu referire mai ales la contact între corpuri solide, de exemplu: acționări etanşări etc.)

non-contact electric relay (el, fiz) releu elctric de rezonantă (fără contact)

non-contact gauging (metr) (metodă de) măsurare a dimensiunilor, fără contact direct între piesă şi aparatul de măsură

non-contacting tachometer (metr, electr) tahometru fără contact direct 
non-contrasty (c) fără contrast, şters (d.imagini) non-contributory (ec) (d. pensii) plătit de patron; fără cotizații

non-convex (geom) concav

non-corrodibility (chim, materiale) rezistență la coroziune

non-corrodible (chim, materiale) incorodabil, (material) chimic anticorosiv, protejat contra ruginii / coroziunii; inoxidabil (d. oțeluri)

non-corroding, non-corrosive (chim, materiale) necorosiv; anticorosiv; incorodabil, care nu (se) corodează; inoxidabil (d. oteluri)

non-corosive coating (OM, chim, materiale) acoperire necorosivă / anticorosivă / inoxidabilă

non-corrosive grease (auto, chim, T) unsoare consistentă neutră

non-corrosive metal (met, chim) metal / aliaj anticorosiv / care nu corodează

non-corrosive protection $(\mathrm{OM}$, chim) protecție contra coroziunii

non-corrosive steel (met) oțel inoxidabil

non-creasable (textile) neşifonabil

non-critical dimension ( $\mathrm{TH}$, mas) dimensiune care poate fi modificată fără a afecta funcționarea

non-crystalline (chim) amorf, necristalizat non-cutting stroke (mas-un) cursă de înapoiere non-cyclic (mat, fiz) neciclic; neperiodic non-dazzing light (auto) lumină de fază scurtă / neorbitoare

non-deflecting (mec, OM) rigid, nedeformabil nondeformability ( $\mathrm{mec}$ ) indeformabilitate

non-deforming steel (met) oțel nedeformabil / neprelucrabil prin deformare

non-degenerate (agr, autom) nedegenerat (d. plante, caracteristici, semnale în automatizări)

non-dense nedens; dens neuniform (d. materiale, semnale în automatizări, câmp electromagnetic etc.)

non-descriptive greu de definit / de scris / de clasificat; fără o ocupație / profesie precisă

non-destructive (method of) test(ing) (mec, metr) (metodă de) încercare / testare fără distrugerea epruvetei / a probei, test nedistructiv

non-detactable (fiz, metr, materiale) nedectetabil

non-detactable failure defect / eroare nedetectabil(ă) / fără a-i putea determina cauza

non-diaphanous (materiale, textile) netransparent la lumină, opac

non-diathermic (fiz, termo, materiale) impermeabil la căldură, nediatermic

non-directional independent de direcție; (inf) nedirijat; (el) nedirecțional non-dissipative ideal, fără pierderi, nedisipativ (d. un sistem, o linie electrică, o rețea hidraulică etc.)

non-dissipative stub (hidr) secțiune de adaptare nedisipativă; $(\mathrm{OM})$ element de adaptare coaxial non-dissociated (chim) nedisociat

non-distorting steel (met) oțel nedeformabil, neprelucrabil prin deformare

non-drying oil (chim) ulei nesicativ

none niciunul, niciuna; $(a d v)$ câtuşi de puțin, deloc, defel

none but numai, doar, nimeni altul decât, nimic altceva decât

non-empty (mat) nevid (d. multimi)

non-enclosed motion parts (mas-un) piese în mişcare, fără cutie de protecție / fără carter

non-erasable storage $(c$, inf) memorie care nu se şterge / permanentă

non-essential neesențial, neimportant

non-essential auxiliary circuits (el, electr, autom) circuite secundare / auxiliare, fără alimentare de rezervă

nonevent $(\mathrm{TH})$ eveniment nesemnificativ

non-executable (statement) (c, inf) (instrucțiune) neexecutabilă

non-expanding nozzle $(\mathrm{OM})$ ajutaj convergent

non-extractable care nu poate fi extras (şi în procedee de prelucrare la care piese, scule (rupte) sau materiale rămân în produs)

non-extractable plasticiser (plast, ind chim) plastifiant neextractibil

non-factory neproduse de producătorul de la care s-a cumpărat sistemul (autovehicul, maşini-unelte etc.) (d. piese de schimb etc.); (piese, materiale) produs / prelucrat artizanal / nu cu tehnologie de serie etc.

non-factory installed care nu este instalat / montat de producător

non-fading (plast) rezistent la lumină

non-fatal error (c, inf) eroare nefatală / după care calculatorul poate funcționa

non-felting (materiale) care nu poate fi împâslit

non-ferrous (met) neferos

non-ferrous alloy (met) aliaj neferos

non-ferrous castings (met) piese turnate din metale neferoase

non-ferrous metal (met) metal neferos

non-ferrous-metal alloy (met) aliaj de metale neferoase

non-ferrous metallurgy (met) metalurgie neferoasă

non-ferrous rolling mill (met) laminor pentru neferoase

non-ferrous scrap (met) deşeuri neferoase 
non-ferrous sheet (met) tablă din (aliaje / metale) neferoase

non-fibrous (plast, chim) nefibros (şi d. structura unsorilor compozitelor etc.)

non-flammable (chim, materiale) neinflamabil

non-fluid oil ( $T$ ) lubrifiant nefluid, unsoare consistentă

non-folded nefălțuit, necutat (d. table, folii)

non-fractioning distillation (ind chim, met) distilare fără rectificare

non-freezing (termo, materiale) rezistent la frig / la îngheț (d. lubrifiant, fluide etc.)

non-freezing lubricant $\mathrm{TH}$ ) lubrifiant / unsoare antigel / pentru temperaturi joase

non-freezing mixture (chim) amestec necongelabil / antigel

non-functional (mas) nefuncțional

non-fusible (chim) infuzibil, nefuzibil

non-fusible electrode (met) electrod nefusibil

non-fusible electrode welding (met) sudare $\mathrm{cu}$ electrod nefuzibil

non-geared (mas) legat direct la motor (fără transmisie intermediară sau angrenaj)

non-glare glass (ind chim) geam protejat contra efectului de orbire, geam cu tentă

non-halating (metr, c) fără halo (la aparate optice, fotografii)

non-hazardous $(\mathrm{TH})$ nepericulos

non-hydraulic lime (ind chim) var gras

non-hydrogenous (chim) fără hidrogen

non-hygroscopic (materiale) hidrofob, nehigroscopic

non-ideal liquid (fiz) lichid nenewtonian / neideal

non-ignitable (materiale) neinflamabil

non-impact printer (c) imprimantă cu jet

non-inductive (el) neinductiv, fără inductantă

non-inherent failure causes $(\mathrm{TH}, \mathrm{mas})$ avarii / deteriorări / căderi datorate cauzelor externe, neasociate cu defecte de proiectare, de material sau de mentenanță

non-isothermal (fiz, termo) neizotermic, care nu este izoterm (d. un proces)

non-interactive (mas, $\mathrm{TH}$ ) care nu (inter)actionează / funcționează împreună (d. module / subansamble ale unui sistem tehnic)

non-interactive control system (autom) sistem autonom de control / reglare

non-intervention (pol) neamestec, neinterventie non-interference (pol) neamestec non-ionized (fiz, chim) neionizat non-isotropic (materiale, fiz) neizotropic nonisotropy (fiz) anizotropie nonius (metr) vernier nonius zero (metr) reper / punct zero al vernierului

non-kinking $(\mathrm{TH})$ fără torsiuni / distorsiuni

nonlevel (constr, OM, mas-un) neorizontal, înclinat, nenivelat

non-lifting (fiz, mas) care nu creează forță ascensională / de ridicare, care nu ridică

non-lifting injector în sarcină

non-linear (mat) neliniar, de grad mai mare decât unu (ecuații, funcții etc.)

non-linear distorsion (electr, autom) distorsiune neliniară / de neliniaritate

non-linearity attenuation (mec, autom) atenuare neliniară / de neliniaritate

non-linearity compensation (autom, metr) compensare neliniară / de neliniaritate

non-linear scale (el, metr) scală neliniară

non-linearity (autom, fiz, el, c) nelinearitate

non-load (mec, mas) fără sarcină

non-load current (el, mas) curent de mers în gol

non-local nelocal, nelocalizat, (pe un spatiu, o suprafață) extins(ă) (şi d. procese de deteriorare etc.)

non-locking key (mas, autom) cheie / tastă cu revenire

non-machined (met, mas-un) brut, neprelucrat (prin aşchiere, mecanic)

non-magnetic (fiz) nemagnetic, amagnetic

non-magnetic cast iron (met) fontă nemagnetică / antimagnetică / amagnetică

non-magnetic steel (met) oțel nemagnetic / antimagnetic / amagnetic

non-merchandable (ec) necomercializabil, nevandabil

non-merchandable by-products $(\mathrm{ec}, \mathrm{TH})$ produse secundare necomercializabile / nevandabile

non-metal (chim) metaloid

non-metallic (met) nemetalic

non-metallic inclusion (met) incluziune nemetalică

non-metallic mould (met, plast) formă / matriță nemetalică

non-migratory (chim, met) nemigrator, care nu migrează (d. particule, fibre în compozite, constituienți în aliaje etc.)

non-miscible (chim) nemiscibil

non-moving (mec) în repaus

non-natural artificial, nenatural; nefiresc; bombastic, umflat

non-negative (mat) nenegativ (d. numere, funcții) non-negociable paper $(\mathrm{ec})$ efect de comert, care nu este negociabil

non-newtonian liquid (fiz, hidr, T) lichid nenewtonian, neideal 
non-numerical data (inf) informații cu caracter nenumeric

non-obedience neascultare, nesupunere

non-observance nerespectare (a regulilor etc.)

non-occupational exposure ( $\mathrm{TH}$, med) expunere neprofesională (la iradiere / substanțe toxice etc.)

non-operate current (el, metr, autom) curent inactiv / mai mic decât curentul de acționare

non-operate value (mas, autom) valoare limită / critică / la care nu mai funcționează

non-operating (mas, OM) nefuncțional, care nu funcţionează

non-operating conditions $(\mathrm{TH})$ condiții nefavorabile de lucru, condiții în care nu se lucrează

non-operational (TH) nefuncționabil, nefuncționare, care nu functionează

non-operational conditions ( $\mathrm{TH}$, auto) condiții nefuncționabile / în care nu funcționează

non-operative (mec) stare de repaus

non-oscillating (mec, autom, metr) fără oscilații, care nu oscilează / nu are oscilații

non-oscillatory (mec, autom) neoscilant

non-overlapping ( $\mathrm{TH}$, ind) care nu se suprapun (d. semnale în automatizări, comenzi, prelucrări, operații, procese etc.)

non-overlapping sets (mat) mulțimi disjuncte non-oxidable, non-oxidizable (chim, materiale) inoxidabil, care nu oxidează

non-oxidizing (chim, materiale) neoxidant, care nu oxidează

non-payment (ec) neachitare, neplată

non-periodic (fiz, autom) neperiodic; aperiodic

non-periodic decimale (mat) fracție zecimală neperiodică

non-permanent nepermanent; schimbător; în schimbare

non-permanent (magnet) (fiz) (magnet) nepermanent

non-persistent nepersistent

non-picking spirit (auto, ind chim) benzină nedetonantă

nonplus impas; strâmtoare; dificultate; a pune în încurcătură, a zăpăci

non-polar (fiz, chim) nepolar, apolar

non-polar bond (fiz, chim) legătură nepolară / apolară

non-polarizable (fiz, chim) nepolarizabil

non-polarized (fiz, chim) nepolarizat, neutru

non-polar link(age) (fiz, chim) legătură nepolară / apolară

non-polar molecule (fiz, chim) moleculă nepolară / apolară

non-porous (met) fără bule; (plast) neporos non-positive (mec) elastic; nerigid; (el) negativ (rar)

non-positive compressor (termo, OM) compresor non-volumic (rotativ, la care compresia se realizează fără modificarea volumului camerei de compresie)

non-productive (ec, $\mathrm{TH})$ neproductiv

non-productive operation (TH) operație auxiliară / secundară / neproductivă

nonquantized necuantificat

non-random (mat) nealeator

non-recognition (inf, c) nerecunoaştere (d. o instrucțiune, un program etc.)

non-recoverable (inf) nerecuperabil

non-recurring irepetabil; neregulat; extraordinar non-refractory (met) nerefractar

non-regenerative (chim) fără reacție de regenerare, neregenerabil (d. un catalizator, o resursă etc.)

non-reinforced (plast) neranforsat / neîntărit (d. compozite, fără ranforsanți, doar cu materiale de adaos cu alt scop decât ranforsarea)

non-removable flange (TH, OM) flanşă fixă / nedemontabilă

non-repeatability (metr) nerepetabilitate (în testare, încercări)

nonresponse (autom, metr) răspuns nul, fără răspuns

non-return cam locking device (OM, mas-un) dispozitiv de blocare cu camă fără revenire

non-return flap (hidr, TH) clapetă (cu sistem) de reținere

non-return valve (auto, hidr, OM) clapetă / supapă / ventil de reținere, supapă de sens unic (fără revenire la poziția inițială, indiferent de evoluția ulterioară parametrului de acționare)

non-reversing (met) ireversibil, nereversibil (și d. laminoare)

non-reversible ireversibil (d. un proces)

non-reversible process (plast, temo) proces ireversibil

non-reversible rolling mill (met) laminor ireversibil

non-rigidity (mec) elasticitate

non-rigid sheeting (plast) folie elastică / nerigidizată

non-rising necrescător (d. un parametru, o variabilă etc.)

non-rotational field (fiz, hidr) câmp nerotațional / neturbionar

non-rusting (met) care nu ruginește / nu oxidează, inoxidabil (cu referire mai ales la aliaje feroase)

non-saponificable (chim) nesaponificabil 
non-scaling (met) inoxidabil; refractar; stabil la temperatură ridicată

non-saturated (chim) nesaturat

non-self-maintained / -sustained discharge (mas, el) descărcare neautonomă

nonsense absurditate, nonsens

nonsensical fără sens, absurd; de neînțeles; prostesc

non-sensitive (metr, autom) insensibil

non-shatterable glass (auto) geam incasabil / de siguranță / care nu face țăndări; geam securit

non-scheduled maintenance ( $\mathrm{TH}$, mas) mentenanță neplanificată / după de o avarie neprevăzută

non-shock (mas) fără şoc(uri)

non-shock chilling (met, termo) răcire lentă non-shrinkable (plast) neşifonabil; (met) necontractabil, nedeformabil

non-shrinking steel (met) oțel fără contracție

non-singular (mat) nesingular; nedegenerat

non-singular form (mat) formă nedegenerată

non-singular matrix (mat) matrice nedegenerată / nesingulară

non-skid (auto) antiderapant

non-skid chain (auto, OM) lanț antiderapant

non-skid / non-slip device (auto, mas) dispozitiv antiderapant

non-skid tyre (auto) pneu antiderapant

non-slip (auto) antiderapant / antialunecare

non-slip point / line (OM, met, T) punct (teoretic) / linie / zonă neutră (şi la laminare) (fără alunecare relativă)

non-sludging oil (ind, chim, T) ulei nedegradabil / care nu formează depuneri

non-smoker nefumător; (cf) vagon / compartiment pentru nefumători

non-smooth (materiale, TH, T, OM) cu asperități, care nu este neted

non-soluble (fiz, chim) insolubil

non-spillable accumulator (el, OM) acumulator etanş

non-spinnable (textile, plast) nefilabil

non-spinning rope / cable (mec, el) cablu netorsadat

non-stainable (materiale) inoxidabil (d. oțeluri), nepătabil (d. materiale plastice şi textile)

non-standard (TH, ind) în afara normelor / standardului, nestandardizat

non-stationary state $(\mathrm{TH}$, ind) regim nestaționar

non-steady (autom, mas, electr, fiz) nestaționar; instabil, tranzitoriu

non-steady flow (chim, fiz, hidr) curgere nestaționară / neuniformă non-steady state (chim, fiz) regim nestaționar; stare intermediară / nestaționară

non-stop (TH, mas) fără oprire, continuu

non-substantial nonsubstantial; nematerial

non-swelling (plast) fibră / material textil / plastic care nu se umflă (în apă sau alte lichide)

non-symmetrical (geom, OM) asimetric, nesimetric

non-symmetrical profile (met, OM) profil asimetric

non-synchronous motor (el) motor asincron

non-tacky (materiale) nelipicios

non-tarnish paper (ind chim) hârtie anticorosivă

non-tension joint (el, electr) legătură / racord care nu se află sub tensiune

non-terminating infinit; fără sfârşit, care nu se termină

non-tilt(ing) drum mixer (constr, mas) betonieră cu ax orizontal, cu descărcare prin schimbarea sensului de rotatie

non-toxic (chim, med) netoxic

non-transferable (inf) netransferabil

non-transferred arc plasma torch (met, fiz) arzător cu plasmă cu arc interior

non-transportable (med, mas) netransportabil

non-twisting $(\mathrm{OM})$ fără răsuciri, care nu (se) răsuceşte

non-uniform inegal; neuniform (d. materiale, procese etc.)

non-uniformity (autom, mat) neuniformitate; variabilitate; neomogenitate

non-uniform movement (mec) mișcare neuniformă

non-vacuous (fiz) nevid, nevidat

non-valent (mat) de valoare nulă; fără valoare

non-vanishing (fiz, mat) nenul; diferit de zero; (autom) neanulabil, care nu se anulează (şi d. un semnal)

non-vanishing vector (mat) vector nenul / care nu se anulează

non-variable-head (welding) torch (met) arzător simplu de sudură

non-varint system sistem invariant

non-vibratile (mec, fiz) fără vibrații / trepidații

non-viscous (fiz) lipsit de vâscozitate, nevâscos

non-void nevid; fără gol(uri) (d. un material)

non-volatile (chim) nevolatil

non-volatile (random-acces) memory (c, inf) memorie (cu acces aleatoriu) permanentă / de durată / nevolatilă / al cărei continut nu este pierdut la deconectarea alimentării

non-volatility (fiz, inf) fără volatilitate, nevolatilitate 
non-volt release (el) declanşare la tensiune nulă non-vortical field (fiz) câmp irotațional; câmp fără vârtejuri

non-vulcanisable (plast, ind chim) nevulcanizabil

non-warping steel (met) oțel nedeformabil

non-wettable / -wetted (chim, met) hidrofob (d. materiale, țesături)

non-working flank $(\mathrm{OM})$ flanc care nu lucrează / inactiv

non-yielding (mec) rigid, care nu cedează, care nu curge / nu se deformează

non-zero (fiz, mat) nenul; diferit de zero

noodles (alim) tăiței, fidea

nook (TH) loc îngust, îngustime; colț; ungher; (geogr) golf mic, baie; (metr) o unitate tradițională englezească pentru măsurarea suprafeței (de teren): 1 nook of land $\sim 8,094$ ha; ascunzis

noon amiază; ( $f i g$ ) apogeu, culme, înflorire

noose nod; laț; $(\mathrm{OM})$ inel, ureche, culisă; a prinde; a înnoda

noplace nicăieri, niciunde

noria elevator cu cupe

norm (mat) normă; (metr, TH) normă (standard), tipar

normal normal; regulat; obişnuit; conform, corespunzător; reglementar; (mat) normal, distanță între două puncte ale unui spațiu vectorial; cu repartiție normală (în teoria probabilităților); perpendicular, normal; perpendiculară, normală; (metr, TH) normă (şi în sens de standard), corespunzător / conform standardului; condiție / stare normală; tip / model normal; normal (N) (metr, chim) termen pentru descrierea unei soluții având o concentrație de 1 gram echivalent pe litru

normal axis $(\mathrm{OM})$ axa verticală

normal ajustment (mas, OM) reglare la poziția normală de lucru

normal backlash $(\mathrm{OM})$ jocul normal între dinţi $\left(\mathrm{j}_{\mathrm{n}}\right)$

normal base pitch $(\mathrm{OM})$ pasul de bază normal, pasul normal pe cercul de bază $\left(\mathrm{p}_{\mathrm{bn}}\right)$ (la roți cilindrice cu dinți înclinați)

normal base thickness $(\mathrm{OM})$ grosimea de bază a dintelui în plan normal pe dinte $\left(\mathrm{s}_{\mathrm{bn}}\right)$ (pe cilindrul de bază) (la roți cilindrice)

normal calomel electrode (el) electrod etalon cu calomel, electrod Ostwald

normal carbon chain (chim) catenă normală (de hidrocarbură)

normal chordal tooth thickness (OM) grosimea dintelui pe coada în plan normal $\left(\mathrm{s}_{\mathrm{n}}\right)$ normal clear cale liberă, normal - cale liberă (semnal de acces)

normal component of force (mec) componentă normală / perpendiculară a forței

normal conditions condiții normale / standard / obişnuite

normal co-ordinates (mat) coordonate ortogonale / rectangulare

normal cubic meter $\left(\mathrm{Nm}^{3}, \mathbf{m}^{3}\right.$ normal) (metr, fiz) unitate de măsură pentru masa gazelor, egală cu masa unuimetru cub de gaz la presiune de 1 atmosferă și la $0^{\circ} \mathrm{C}$ sau $20^{\circ} \mathrm{C}$, echivalent cu termenul stan-dard cubic meter, v. standard cubic meter; simbolul $\mathrm{Nm}^{3}$ nu este admis în SI pentru că înseamnă ,newton cubic meter”, dar se acceptă ,"m normal”

normal derivative (mat) derivată (după) normală

normal diameter $(\mathrm{OM})$ diametru normal

normal distribution $(\mathrm{TH}, \mathrm{fiz})$ repartiție distribuție normală / exponentială / tip GaussLaplace (d. frecvența amplitudinilor unui proces, frecvența înaltelor suprafețelor reale etc.)

normal distribution curve (TH, fiz) curbă de repartiție distribuție normală / tip GaussLaplace

normal efficiency ( $\mathrm{TH}$, mas) putere / eficiență nominală

normal fluid temperature (termo, hidr) temperatura (stabilizată) a unui flui de lucru, în regim continuu de lucru

normal force $(\mathrm{mec})$ forță perpendiculară / normală

normal gauge railway (cf) cale ferată cu ecartament normal

normal idle speed (auto) turație (la) ralanti; (mas) turatie normală

normality normalitate (stare fizică); aspect / caracter normal

normalization (fiz, mat) normalizare; normare; aducere la forma normală

normalize a normaliza; a norma; a standardiza; (met) a normaliza (d. tratamente termice); (inf) normalizare, ajustare a exponentului și a mantisei unei cantități cu virgulă mobilă

normalized normalizat; normat

normalized state (fiz) stare fundamentală normală

normalizing (met) normalizare (tratament pt. oțel) normalizing furnace (met, termo) cuptor pentru normalizare

normal line (geom) perpendiculară; normală normal linear dimension (OM, geom) dimensiune liniară, normal perpendiculară; normală 
normal liter (NL, Nl, $\mathbf{N d m}^{3}$ ) (metr) unitate de măsură pentru masa gazelor, egală cu masa unui litru de gaz la presiune de 1 atmosferă şi la $0^{\circ} \mathrm{C}$ sau $20^{\circ} \mathrm{C}$. Air flow is often stated in normal liters per minute $(\mathrm{Nl} / \mathrm{min})$

normal liters per minute $(\mathrm{Nl} / \mathrm{min})$ (metr, fiz, hidr) unitate de măsură pentru debit de aer, litru normal de gaz pe minut, egală cu litri normali de aer la presiune de 1 atmosferă și la $0^{\circ} \mathrm{C}$ sau $20^{\circ} \mathrm{C}$, pe minut

normal load (el) sarcină normală; (mec, T) sarcină / încărcare normală

normally $(a d v)$ (în mod) normal, obişnuit; de obicei

normally closed (autom, hidr) normal închis normally open (autom, hidr) normal deschis normally ordered (mat) bine ordonat (în teoria mulțimilor)

normal mode (mec, el) oscilație proprie

normal module $(\mathrm{OM})$ modul normal $\left(\mathrm{m}_{\mathrm{n}}\right)$ (la roți dințate)

normal operating conditions $(\mathrm{TH})$ condiții normale de lucru / de funcționare

normal operating current (el) curent normal de regim

normal operation (mas, TH) funcționare în limite normale (prevăzute în proiect / catalog de producător etc.)

normal output (mec, ec) putere / productivitate normală / nominală; (hidr) debit normal

normal overload $(\mathrm{TH})$ suprasarcină normală (pentru un anumit proces tehnologic)

normal pitch $(\mathrm{OM})$ pas normal (şi la filete), pasul în plan normal pe dinte $\left(\mathrm{p}_{\mathrm{n}}\right)$ (la roți dințate)

normal plane (mat, OM) plan perpendicular / normal (pe axă, pe dinte etc.)

normal position poziție normală / de bază / de pornire; (mas) poziție de echilibru; (mec, el) stare / poziție de repaus

normal pressure (fiz, hidr, mec) presiune normală

normal pressure angle $(\mathrm{OM})$ unghi de presiune / de angrenare în plan normal (pe dinte) $\left(\mathrm{d}_{\mathrm{n}}\right)$

normal pressure angle at point $\mathrm{Y}(\mathrm{OM})$ unghi de angrenare în plan normal (pe dinte) în punctul Y $\left(\alpha_{Y_{n}}\right)$ (la roți dințate)

normal profile $(O M)$ profil (în plan) normal (şi la dantură)

normal rake (mas-un, OM) unghi normal de degajare (şi la scule pentru generarea danturii) normal running fit $(\mathrm{OM})$ ajustaj liber / cu joc normal running temperature $(\mathrm{TH})$ temperatură normală de lucru / de exploatare normal salts (chim) săruri neutre normal section $(\mathrm{OM})$ secțiune normală / în plan normal pe dinte (la roți dințate)

normal segregation (met) segregare normală normal size (OM) mărime de referință / normală normal school (edu) şcoală normală / pedagogică normal scores test (mat) test / încercare în trepte normale (în statistică matematică)

normal section $(\mathrm{OM}, \mathrm{TH})$ secțiune normală / perpendiculară (pe o axă, un plat)

normal soap (chim, $\mathrm{T}$ ) săpun normal / obişnuit normal space width $(\mathrm{OM})\left(\mathrm{e}_{\mathrm{n}}\right)$ mărimea spațiului dintre dinţi în plan normal

normal speed (auto) viteză / turație normală; (autom, mas) turație de funcționare / de regim normal start-up (auto, mas) demaraj normal, pornire normală

normal state (fiz, termo) stare fundamentală / normală

normal stress $(\mathrm{mec})$ tensiune / solicitare normală

normal subgroup (mat) divizor normal, subgrup invariant

normal supply price $(\mathrm{ec})$ preț al ofertei normale normal tangent length (OM) lungimea (cota) peste $\mathrm{N}$ dinți, pe direcție normală / în plan normal pe dinte $\left(\mathrm{W}_{\mathrm{nN}}\right)$ (la danturi cilindrice)

normal temperature (autom, fiz, termo) temperatură normală / de bază

normal temperature and pressure (autom, fiz, termo) condiții normale de temperatură şi presiune, temperatură şi presiune normale

normal terminal-stopping device (autom, electr) dispozitiv întrerupător automat, de siguranță

Normal Thermometric Scale (metr) scală de temperaturi în grade Celsius ( 0 pentru punctul de îngheț al apei pure și 100 pentru punctul ei de fierbere)

normal tooth thickness $(\mathrm{OM})$ grosimea dintelui în plan normal $\left(\mathrm{s}_{\mathrm{n}}\right)$

normal to surface (mat) normală / la suprafață

normal value (ec, metr) valoare nominală

normal weld (met, OM) sudură normală (rezultat al sudării, mai rar procedeu / proces)

normal welding (met, TH) sudare normală (procedeu, proces, mai rar rezultat)

normal width $(\mathrm{OM})$ lățime standardizată / normală

normative $(\mathrm{TH})$ normativ, prescriptiv

normator $(\mathrm{TH}, \mathrm{ec})$ normator

normed linear space (mat) spațiu vectorial / liniar normat

norming $(\mathrm{TH})$ normare

Norton cone (mas-un, OM) con Norton (pt. scule) 
north (geogr) nord north-east (din / de) nord-est; ( $a d v)$ spre / către / la nord-est

north-easter (geogr, mediu) vânt de nord-est north-eastern de nord-est, situat la nord-est northern nordic, de nord; vânt de nord

Northrup furnace (met, termo) cuptor cu inducție de înaltă frecvență

northwards $(a d v)$ spre / la / către nord

north-west nord-vest; de / din nord-vest; $(a d v)$

la / spre / către nord-vest

nose (anat) nas; (zool) bot, nas, miros (la câinii

de vânătoare); (ind chim) ajutaj de alambic; (constr) nas, bot; (hidr) cap amonte al pilei; (OM) cioc, camă, cep, proeminență, ieşind, ştift; cioc (la roată), mufă (a unei țevi), ajutaj, vârf, capăt; (mas-un) vârf de cuțit, cioc (de sculă); (nav) proră, prova, extremitate prova, bord anterior; nas (de navă); (met) gât / gură de convertizor, cioc / gură la oala de turnare; ( fam) fler, perspicacitate; mireasmă (mai ales de fân); (av) bot (al unui avion etc.) a mirosi, a simţi mirosul; a descoperi după miros; (fig) a adulmeca, a se uita în / spre; (ec) (fig) a-și băga nasul (într-o afacere); a adulmeca (pt. a descoperi ceva); a se conduce după miros; a-şi şterge nasul

nose cap (OM) cap; capăt

nosed $(\mathrm{OM})$ cu proeminență; cu nas

nose ender (nav) vânt de prova

nose end of tuyère (met) partea frontală a gurii de vânt

nose-heavy $(\mathrm{OM})$ cu centrul de greutate în față; (nav) aprovat

nose key $(\mathrm{OM})$ pană cu călcâi, cu vas

nose-mounted refrigeration unit (auto) agregat frigorific frontal / montat în partea din față a unui vehicul

nose of the punch (mas-un, OM) cap (activ / de lucru) al poansonului

nose piece $(\mathrm{OM})$ partea / piesă frontală

nose pipe (auto, OM) duză; ajutaj; (auto, termo) jiclor

nose radius (mas-un) rază de racordare a vârfului tăişului (unei scule)

no-signal value (mec, autom, electr) valoare de repaus / fără semnal

nosing (constr) căptuşeală metalică a buzei unei trepte

nostrils (for burners) (termo) orificii (pentru arzătoare)

NOT (autom, inf) NU (instrucțiune)

notable notabil; remarcabil, de seamă; personalitate notably $(a d v)($ chim) considerabil, remarcabil, foarte

not-acidified neacidulat

notarial (jur) notarial

notary public (jur) notar public

not at all deloc, câtuşi de puţin; ba, dimpotrivă

not-at-intermediate position (metr, mas-un)

fără poziție intermediară

notation notă; notare; notație; denumire; însemnare; înregistrare; (mat) notaţie; sistem de notație / de calcul / de numerație

notational notațional, de notație / notare

not blistered (met) fără sufluri

not-busy (inf) neocupat, liber

not but that / what cu toate că, deşi

notch semn; (constr) crestătură; tăietură (în), scobitură; (el) ancoşă; depresiune; (hidr) orificiu de măsurare a debitului; fantă în peretele deversorului (unui baraj); (OM) canelură, renură, crestătură, şanț, canal de pană, nut, adâncitură, tăietură, dinte, jgheab; (nav) şant pentru zbir (pe o macara); a cresta; a dantela; a crenela, a tăia; (mas-un) spărtură (făcută cu o unealtă), a dința, a freza şanțuri / intrânduri; a dantela, a ştirbi (o unealtă, o sculă, o muchie a unei piese etc.); (geogr) defileu, trecătoare; top excelent, de primă mână / calitate, splendid, nobil; ed quadrant $(\mathrm{OM})$ sector dintat

notch bending test (met, plast) încercare la încovoiere pe epruvetă cu crestătură

notch bend-test specimen (materiale, metr) epruvetă cu crestătură, pentru încercare la încovoiere notch britlleness (met, mec) fragilitate la crestare / la concentrator tip crestătură

notched $(\mathrm{OM})$ crestat, zimțat

notched bar $(\mathrm{mec})$ epruvetă crestată; platină

notched-bar bend test (met) încercare / test de îndoire cu probe crestate

notched-bar impact - bending test / specimen (met) încercare de îndoire prin lovire, pe / cu epruvete crestate

notched-bar impact-endurance / fatigue test (met) încercare de durabilitate / de oboseală prin şoc, pe epruvete crestate

notched-bar impact strength (met, metr) reziliență (determinată pe epruvete crestate)

notched-bar impact test (met) încercare / test la reziliență pe epruvete crestate

notched-bar strength (mec, materiale) reziliență determinată pe epruvete crestate

notched-bar tensile test (met, materiale, metr) încercare la tracțiune pe epruvetă crestată

notched-bar toughness (mec, materiale, metr) rezilientă (determinată pe epruvete crestate) 
notched disk $(\mathrm{OM})$ roată de cuplare / de clichet; disc de clichet

notched ingot (met) bloc de metal / lingou cu crestătură

notched specimen (materiale, metr) epruvetă cu crestătură

notched (taper) pin (OM) ştift (conic) crestat

notched wheel (mas-un) roată dințată a unui angrenaj cu clichet

notch effect (met) efect de crestare, influența crestăturii

notch fatigue factor $(\mathrm{OM})$ factorul concentratorului de formă (aici - crestătură) (în calculul la oboseală)

notch impact strength / tenacity (mec, met) reziliență (determinată pe epruvete cu crestătură)

notch impact - bending test (met) încercare de îndoire prin lovire, cu probe / epruvete crestate

notching (el) comutare în trepte / eșalonată; $(\mathrm{OM})$ canal de pană, crestare, crestătură; (mas-un) crestare, zimtuire, dintare, prelucrarea unui canal de pană, danturare (mai rar)

notching controller (el) comutator / controler în trepte

notching die (maş-un) ştanță pentru dințarea periferiei unei piese

notching filter (el, autom) filtru de absorbție a vârfurilor semnalelor

notch off $(\mathrm{TH})$ a tăia, a decupa

notching ratio (el, autom, metr) finețe de reglare

notching tool gardină (la doage de butoi)

notch sensitivity (plast, met, $\mathrm{OM}$ ) sensibilitate la crestătură

notch toughness / value (mec, met) reziliență determinată pe epruvete crestate

notch with root radius $(\mathrm{ON})$ crestătură / canal cu fundul rotunjit (la epruvete crestate)

not / non completely revered stress (mec) tensiune pulsatorie

note notă, notiță, însemnare; (ec) bancnotă, bilet de bancă; semn (caracteristic), notă distinctivă / caracteristică; simbol; însemnare; informare, scurt comentariu; scurtă explicație; adnotare; sunet; a nota, a însemna; a designa; a remarca; a denumi; a adnota

notebook agendă, blocnotes, agendă, caiet de notițe

noted de seamă, renumit

notedly $(a d v)$ (în mod) considerabil

noteless neînsemnat; şters; obscur

notelet notită, însemnare

note paper hârtie de scrisori

noteworthy demn de atenție, care reține atenția; remarcabil not-flat (met, OM, electr) inegal (d. un semnal), neplanitate (la table, piese)

NOT-gate (autom, inf) circuit NU; poartă NU

nothing nimic; zero; nul; inexistență; neființă, ireal; nulitate

nothingness lipsă de însemnătate, nimic, fleac no-thoroughfare fundătură

"not-go" gauge (metr) calibru ,nu trece"

notice informație; înştiințare; notă; aviz; anunț avertisment; observație; recenzie; cronică; (ec) preaviz; a observa; a remarca; a scrie despre; a recenza; a mentiona, a se referi la; a fi atent

noticeable vizibil, perceptibil, observabil; remarcabil; demn de atentie, care retine atentia

noticeably $(a d v)$ (în mod) considerabil; sensibil, vizibil

notice board avizier

notice deposits (ec) depuneri cu avizarea retragerilor

notice of abandonment (ec) aviz de abandon

notice of delivery $(\mathrm{ec})$ confirmare a primirii

notice of meeting (adm, ec) aviz de convocare (şi a acționarilor)

notice of readness (ec, nav) aviz „gata de operare" (la încărcare sau descărcare)

notice signal $(\mathrm{TH})$ semnal de atenționare

notice to pay $(\mathrm{ec})$ avizare a scadenței

notifiable (transp, jur) care trebuie declarat

notification notificare, aducere la cunoştinţă; înştiințare; aviz

notify a notifica; a anunța; a avertiza; a înştiința; a informa

not go in (metr, mas-un) ,nu trece” (inscriptie pe partea de rebutare a calibrului-tampon)

not go on (metr) „nu trece” (inscriptie pe partea de rebutare, a calibrului-potcoavă)

"not go" side (metr, mas-un) partea „nu trece” a calibrului

notion (of) (mat) noțiune (despre), părere, conceptie (asupra), idee; concept; intentie

notional noțional, speculativ; teoretic; imaginar

not-machined (met, mas-un) brut, neprelucrat (mecanic, prin aşchiere etc.)

not only... but (also) nu numai... ci şi...

not-operating time (mas) timp în care un modul / subansamblu nu funcționează, timp de repaus (la funcționări intermitente)

not-saturated (chim) nesaturat

not sensitive at light (fiz, plast) insensibil la lumină

not suitable necompatibilă; nepotrivit

not under command / control (nav) nestăpân pe manevră; (mas) care nu (mai) este sub control not that nu că 
no-twist yarn (textile, plast) fir nerăsucit notwithstanding deşi, cu toate că; $(a d v)$ totuşi, cu toate acestea; în ciuda, fără a ține seama de notwithstanding any provision to the contrary (ec, jur) în ciuda oricăror prevederi / clauze contrarii

nougat (alim) nuga

nought (mat) zero; nimic

nought check / checking (autom, metr) control de zero

noun (alim) substantiv

nourish (alim) a alimenta, a nutri, a hrăni

nourishing (alim) hrănitor, nutritiv

nourishment (alim) aliment, alimentare, nutrire, hrănire; hrană, alimentație

nourrice tank (OM, hidr) tanc / rezervor de alimentare

not usually obtainable care nu se (poate) obține în mod obişnuit (d. un produs, o resursă etc.)

novolak (chim, plast) novolac

novelty noutate, lucru nou; caracter nou, prospețime; schimbare, inovație; ciudățenie

novelty (of invention) noutate (a unei invenții)

no-voltage circuit breaker (el, autom) întrerupător / disjunctor de tensiune nulă

no-voltage release (el) deconectare automată la căderea tensiunii

now $(a d v)$ acum, în prezent, în momentul de față; în zilele noastre; îndată, imediat, chiar acum

nowadays $(a d v)$ în vremea noastră, astăzi, în zilele noastre

nowel (met) ramă inferioară

nowhere $(a d v)$ nicăieri, niciunde

nowise $(a d v)$ nicidecum, în nici un caz, cu nici un chip

now that acum că, acum când; întrucât; de vreme ce, fiindcă, cum

nox (metr, fiz) unitate de măsură pentru măsurarea iluminării (slabe): 1 nox $=0,001$ lux

noxious (chim, med) nociv; vătămător, otrăvitor

noy (metr, fiz, acustică, med) unitate pentru măsurarea zgomotului perceput, nivel standard de zgomot: 1 noy este zgomotul produs de un semnal în banda de frecvență de $910 \ldots 1090$ $\mathrm{Hz}$ la o presiune a sunetului de 40 decibeli

nozzle (OM) ajutaj, duză, (şi de gaze), duză de egalizare; jiclor; efuzor; nas; cioc; vârf; bot; muştiuc de furtun; ştut; capul unui injector sau monitor; (nav) cioc de bază; (el, fiz) deschidere / fantă a unui ghid de unde; (met) ciocul / gura oalei de turnare; ajutaj de sudură nozzle adapter (OM, hidr, termo) suport de duză nozzle arangement $(\mathrm{OM})$ orificiu de ieşire, al unui ajutaj

nozzle bore (auto, OM) ajutaj de jiclor / de injector

nozzle brick (constr) bloc / cărămidă cu găuri nozzle flapper (hidr, OM) dispozitiv duză paletă / obturator cu clapetă

nozzle holder (auto) suport de ajutaj / de jiclor; (mas, OM) tub de ajutaj

nozzle inlet (OM, hidr, termo) orificiu de intrare al unui ajutaj

nozzle mixing burner (termo) arzător cu curent în cruce

nozzle needle (auto) gură de jiclor; (OM, termo) orificiu de ieşire, al ajutajului

nozzle of ladle (met) ciocul oalei de turnare

nozzle radiator (termo) răcitor cu ajutaj / prin destindere

nozzle ring $(\mathrm{OM})$ coroană directoare, inel director (al unui ajutaj)

nozzle-ring segment (OM, termo) segment de ajutaj (la turbină)

nozzle tip (OM) cap de ajutaj; cap de duză / de filieră; (auto, termo) jiclor

nozzle type radiator (termo) radiator / răcitor cu detentă (cu ajutaj)

n.p. (normal pitch) (OM) pas normal (al filetului)

Npole (constr) stâlp în formă de $\mathrm{N}$

N.R. thread $(\mathrm{OM})$ filet normal cu profil rotunjit (standardizat în SUA)

n-space (mat) spațiu n-dimensional

n.t. (number of teeth) $(\mathrm{OM})$ număr de dinți (şi la roți dințate)

n-terminal network (c, electr) rețea cu n borne / utilizatori

$\mathbf{n}^{\text {th }}$ order derivative (mat) derivată de ordinul $\mathrm{n}$

N thread (OM) filet cu profil normal, folosit în SUA.

NTP thread (OM) filet normal conic pentru tevi (standardizat în SUA)

NTU (metr, mediu) abreviere pentru nephelometric turbidity unit, o unitate de măsură utilizată în măsurarea calității apei; în afara USA unitatea este denumită şi FNU (formazin nephelometric unit)

nu (metr, fiz, opt) măsură (şi simbol al măsurii) pentru dispersivitatea (constringența) lentilelor

nuance nuanță de culoare

nubble (met) bulgăre mic de cărbune

nub twist (textile, plast) fir cu efect răsucit / cu noduri

nuclear (fiz) nuclear 
nuclear energy (fiz) energie nucleară nuclear fission (fiz) fisiune nucleară / a nucleului nuclear fusion (fiz) fuziune nucleară, reacție termonucleară

nuclear particle (fiz) particulă nucleară

nuclear physics (fiz) fizică nucleară

nuclear power (fiz) energie nucleară

nuclear-powered (fiz) cu energie / propulsie nucleară, cu combustibil nuclear, cu instalație de energie nucleară

nucleated (fiz, chim) nucleat

nucleating centre (fiz, chim) centru / nucleu de cristalizare, germen de cristalizare

nucleation (fiz, chim) formare / inițiere de germeni / de nuclee de cristalizare, nucleaţie

nucleon (fiz) particulă nucleară, nucleon

nucleic acid (chim) acid nucleic

nucleus, $(p l)$ nuclei (fiz) nucleu (de atom); (met) nucleu / germen de cristalizare; (mat) centru, nucleu

nucleus of condensation (fiz, termo) nucleu de condensare

nucleus of crystallisation (fiz, materiale) nucleu / germen de cristalizare; cristal de priză

nuclide (fiz, chim) nuclid, izotop

nugacity inutilitate, lipsă de importanță / semnificație

nugatory zadarnic; inutil; van, fără rost; ineficace, fără efect

nugget (minrl) pepită (de metal nativ); (met) centrul / nucleul punctului sudat; punct de sudură

nuisance neplăcere; bătaie de cap; daună; detriment

nuisance value $(\mathrm{TH})$ indice / grad de periculozitate

null (mat) nul; zero; vid; (jur) nul, nevalabil; fără valoare / continut, gol; inexistent; inexpresiv

null and void (jur) efect nul, nul şi neavenit

null balance device (autom, mec) dispozitiv de echilibrare automată

null-bench mark (autom, metr) reper de zero

null bias (metr, autom) decalare a zeroului

null circuit (electr, autom, metr) circuit de compensare / de aducere la zero

null connection (el) legare la nul

null curve (mat) curbă izotropă

null detector (metr, electr) indicator / detector de zero / de nul

null device (metr, electr) indicator de zero

null drift (metr, autom, electr) derivă / deviere zero / a punctului de zero

null electrode (el) electrod de zero

null event (mat) eveniment cu probabilitate nulă (în teoria probabilităților) nullification (ec, autom) anulare

nullifier (inf, autom) funcție care anulează

nullify (inf, autom) a anula; (pol, adm) a abroga;

(metr) a reduce la zero

null indicator (metr, electr) indicator de zero

null instrument (metr, autom) indicator de zero; aparat de măsură bazat pe metoda de zero

nullity (jur) nulitate, anulare; ineficacitate, lipsă de efect

null leakage (hidr) scurgeri (din supape etc.) când debitul exterior este neglijabil (nul)

null method of measurement (metr) metodă de măsurare prin zero, metoda punctului de zero, metodă de compensare

null off-set (metr, autom) decalaj de zero

null point (fiz, metr, autom) punct zero / neutru / iniţial

null pressure (hidr, metr) presiuni egale, existente la două orificii de ieşire, în poziţia de zero

null region (hidr, metr) zonă de zero, zonă moartă null set (mat) mulțime vidă / cu măsură nulă

null shift (hidr, metr, autom) deriva valorii de zero

null-type bridge (fiz, metr) punte cu punct de zero

null valency (chim) valență zero

null vector (mat) vector de lungime nulă

number număr; cifră; serie; mulțime; (autom) număr; cuvânt; (nav) numire de navă; a numerota; a număra; a însuma; a se ridica la (un număr); fasciculă; a numerota; a însemna cu cifre; a număra; a calcula

number base (mat) bază de sistem de numerație number-checking arrangement (mas, OM) dispozitiv de susținere; (el, autom) dispozitiv de blocare a unei comunicații

numbered numerotat

numbered dial (metr) scară / scală / cadran numerotat $(\breve{a}) /$ cu cifre

numbering (mat) numerație; numerotație, numărare; (el) formarea unui număr (pe disc, pe taste); (sistem de) numerotare

numbering apparatus (metr) aparat de numerotat, contor

numbering die (met, plast) matriță de marcare

numbering head (mas) cap de marcare

numbering machine (mas) automat de marcat / de numerotat

numbering system (mat, inf) sistem de numerotatie

numberless fără număr, nenumărat; infinit; fără număr, nenumerotat

number nail marcă distinctivă 
number of a logarithm (mat) antilogaritm number of cycles (mec, fiz) număr de cicluri (la solicitări variabile / de oboseală)

number of cycles per second (fiz, OM) număr de cicluri pe secundă

number of gears $(\mathrm{OM})$ număr de trepte (la un angrenaj / la o transmisie)

number of layers $(\mathrm{OM})$ număr de straturi (de vopsea); (el) număr de straturi (de înfăşurări, la un transformator)

number of load alternation (mec) număr / frecvență de alternare a sarcinii

number of scanning lines (c, metr) număr al liniilor de explorare (şi la profilometre etc.)

number of revolutions / rotations (mas) turație; (plast) număr de rotații / de răsucituri

number of rotations per minute (mas) număr de rotații pe minut

number of strokes (mas-un) număr de curse (active)

number of the degrees of freedom (mec) numărul gradelor de libertate

number of the wire (constr, alim) număr al sitei number of teeth $(\mathrm{OM})$ număr de dinți $(\mathrm{z})$ (la o roată dințată)

number of turns (auto, el) număr de spire; (nav) coeficient de moment (al elicei); (chim) valoarea unghiului de rotatie (al planului de polarizare); (mas) turație

number period (autom) perioadă de număr

number plate (auto) plăcuță pentru numărul de înmatriculare; (el) disc de apel

number-theoretic formula (mat) formulă aritmetică / cu constante

number variable variabilă numerică

number wheel $(\mathrm{OM}$, metr) rolă / roată de numărare / cu cifre

numerable numărabil, care se poate număra

numeral (mat) cifră, numeral, simbol (al numărului); aritmetic, numeric, cifric

numerate (mat) a număra, a calcula, a enumera; a exprima prin cifre / numere

numeration (mat, inf) numărare, calcul, sistem de numerație

numerator (mat) numărător

numeric(al) (mat) numeric; cifric, digital

numerical action (autom, mas-un) acțiune / operație comandată numeric

numerical analysis (mat, inf, c) analiză numerică numerical branch (inf) salt condiționat numeric numerical check (inf, mat) verificare a calculelor numerical command / control (autom, c) comandă numerică, control cu ajutorul calculatoarelor numerical computation (mat, inf, c) calcul numeric, determinarea valorii unei expresii matematice

numerical constant constantă numerică

numerical control (mas-un, autom) control numeric

numerical data (inf) date numerice

numerical differentiation (mat) diferențiere numerică, metodă de calcul aproximativ al derivatei

numerical display (autom, inf, metr) indicație numerică, afișaj numeric (al rezultatelor măsurătorii)

numerical integration method (mat) metodă de integrare numerică / de aproximare a unei integrale în care intervin valorile functiei întrun număr finit de puncte

numerically controlled (mas-un, inf, autom) cu reglare numerică, comandat numeric

numerically controlled (machine-) tool (masun, inf, autom) (maşină-) unealtă cu comandă numerică

numerical positioning control (mas-un, inf, autom) comandă numerică de poziționare, reglare pozițională numerică

numerical process control system (autom, mas) sistem de comandă / de reglare numerică

numerical programming (inf) programare numerică / cu date cu caracter numeric

numerical ratio raport numeric

numerical read-out system (autom, inf) sistem / dispozitiv de afişare numerică

numerical keypad (c) tastatură numerică care poate prelua şi funcții speciale (controlul cursorului, stergerea caracterului curent etc.)

numerical setting-up (c) afişare numerică

numerical value (mat) valoare numerică

numerics (inf) date numerice

numerous numeros

numinous (alim) nutritiv, hrănitor

nursery (bot, agr) pepinieră; răsadniță; incubator; (iht) bazin pentru crescut pești

nursery garden (agr, bot) pepinieră

nursery school (edu) grădiniță

nursing (med) îngrijire; pregătire sanitară medie

nursing bottle biberon

Nusselt number (fiz) număr Nusselt

nut $(\mathrm{OM})$ nucă, piuliță, manşon, mufă, bucşă; (alim) nucă, alună

nut-and-lever steering (auto, OM) direcție cu şurub şi piuliță

nutation (mec, electr) oscilație periodică

nutating-disk flowmeter (metr, OM) debitmetru cu disc rotitor 
nut bolt $(\mathrm{OM})$ şurub cu piuliță

nut-brown castaniu, maro

nut capable of disengagement $(\mathrm{OM})$ piuliță de decuplare

nut coal (met) cărbune în brichete (ouşoare)

nut coke (met, termo) mărunţiş de cocs; cocs mărunt / în brichete / bulgări mici

nut flare (OM, hidr) piuliță de racord

nut for keyed end $(\mathrm{OM})$ piuliță crenelată

nut for T-slots (OM, mas-un) piuliță pentru canale $\mathrm{T}$

nut key (OM) cheie pentru piuliță, cheie fixă

nut lathe (mas-un) strung de prelucrat piulițe

nut lock (OM) şaibă de siguranță, contrapiuliță

nut locking (OM) siguranță de piuliță, asigurarea piuliței

nut machine (mas-un) maşină de frezat / prelucrat piulițe

nutmeat (alim) nuci fără coajă, miez de nucă nutmeg (alim) nuc(u)şoară

nutrient, nutritious (alim) nutritiv, hrănitor nutriment (alim) hrană; (agr) nutreț; (alim) aliment; produs alimentar

nutrition (alim) alimentare, hrănire, nutriție nutritional (alim) de nutriție / hrană, alimentar; nutritiv, hrănitor; dietetic

nutritive (alim) alimentar, nutritiv, hrănitor

nutritive quality (alim) valoare nutritivă

nutritive value (alim) valoare nutritivă

nut runner $(\mathrm{OM})$ dispozitiv de înşurubat piulițe nut screw $(\mathrm{OM})$ ansamblu şurub-piuliță

nutshell (alim) coajă de nucă

nut shearing machine (mas-un) maşină pentru prelucrarea piulițelor

nut tap (mas-un) tarod pentru piulite; burghiu de filetat piuliţe

nut tapping machine / device (mas-un) maşină / dispozitiv de filetat piulițe

nut tap with curved shank (mas-un) tarod pentru piulițe, cu coadă curbă

nutted up (mas-un) reținut / asamblat / fixat prin strângere cu piulița

nut thread $(\mathrm{OM})$ filet de piuliță / interior

nut threading machine (mas-un) maşină de filetat piuliţe / interior

nut tree (agr, bot) nuc

nutwood (silv) (lemn de) nuc

nut-wrench $(\mathrm{OM})$ cheie pentru piulițe

Nw (metr) simbol pentru normal worsted, o unitate care măsoară densitatea firului lung de lână care, după pieptănare, are o uniformitate deosebită; lâna pieptănată descrisă prin $a / b \mathrm{Nw}$ are $a$-fire individuale şi $b$-jurubițe (număr de dublaje ale firelor) pe pound; dacă firul nu este dublat, calitatea lânii se exprimă în $b \mathrm{Nw}$

nybble (metr) v. nibble

nylon (plast) nailon, nylon (denumire comercială a unor mărci de poliamidă)

nylon fibre (plast) fibre de nylon / de poliamidă 


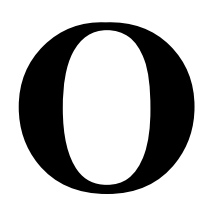

oak (silv) (lemn de) stejar

oakum (textile) pieptănătură, câlți; (nav) calafat, câlți gudronați

oar (chim) agitator, amestecător; (nav) ramă; vâslă; lopată; vâslaş; a rama; a vâsli; a trage la rame; (TH) a se opri din lucru

oar blade (nav) pana ramei / vâslei

oarlock (nav, OM) suport de ramă

oarpin (nav, OM) cui de strapazan

oar stroke (nav) lovitură de vâslă

oat (bot, agr) ovăz

oatcake (agr) turtă de ovăz

oaten (agr, alim) de / din ovăz

oat flakes (alim, agr) fulgi de ovăz

oatmeat (alim, agr) făină / urluială / terci de ovăz

obedient ascultător, supus; docil

obese (anat) obez, foarte gras

obesity (med) obezitate

obey a asculta; a satisface condiții; a respecta (reguli); (c) a executa (o comandă); (nav) a evita (o lovitură), a apăra

object $(s)$ obiect (şi de studiu), lucru (material); preocupare; țintă, scop; obiectiv, țel; lucru important / care contează; piedică, obstacol; (gram) complement; spectacol, privelişte; a obiecta (la); a contesta; a se împotrivi la; $\sim$ of / for subiect, motiv, obiect de / pentru; an $\sim$ of interest un obiect / lucru interesant; an $\sim$ for meditation un subiect de meditare; $\sim$ of admiration obiectul admirației; the $\sim$ in view ținta / scopul urmărit(ă); no $\sim$ nu contează, nu are importanță

object glass (fiz, opt) obiectiv

objectification concretizare

objectify a concretiza, a materializa; a întruchipa objection obiecție; reclamație; neacceptare

objectionable criticabil; inacceptabil; nedorit; neplăcut, supărător

objective $(s)$ scop, țintă; (mil) obiectiv (de operatie); (opt) obiectiv (la microscop, aparat de fotografiat etc.); (adj) obiectiv, de obiect; (mat) obiectiv, real, inductiv (d. metodă); concret; obiectiv (şi de proiectare); impersonal, imparțial, nepărtinitor; scop, țel, țintă; (gram) complement; case (gram) cazul complementului, cazul obiect

objectively $(a d v)$ (în mod) obiectiv objectiveness obiectivitate

objective parameter $(\mathrm{TH}, \mathrm{fiz}, \mathrm{ec})$ caracteristică / parametru real(ă)

objective table (metr, OM) măsuță port-obiect la microscop

objective variable (autom) mărime de reglaj auxiliară

objectivity obiectivitate; imparţialitate; realitate obiectivă

objectless fără obiect; fără scop / țintă; (d. un loc) gol, pustiu

object to a se opune (la); a ridica o obiectie; a nu admite

oblate (materiale, OM) turtit, aplatizat, comprimat, presat

oblate spheroid (mat) sferoid de rotație, axa mică fiind axa de revoluție

obligate a obliga

obligated obligator

obligation (ec) legătură; datorie, sarcină, îndatorire; obligatie, titlu de rentă

obligatory obligatoriu

oblige a obliga, a constrânge; a sili; a îndatora; a fi obligatoriu; a fi de dorit

obliged to îndatorat, recunoscător (cuiva)

obligee (jur) creditor

obligor (jur) debitor

oblique oblic, înclinat, pieziş

oblique angle (mat) unghi diferit de unghiul drept, unghi ascuțit sau obtuz

oblique cutting edge (mas-un) tăiş înclinat

oblique filled weld $(\mathrm{OM})$ cusătură / sudură oblică, de colt

oblique load (mec, OM) sarcină / forță înclinată obliquely-cut piston ring (OM, termo, $\mathrm{T})$ segment de piston, cu fantă oblică

obliqueness oblicitate

oblique position (OM, mas-un) aşezare / poziție înclinată / oblică

oblique projection $(\mathrm{OM})$ proiecție oblică

oblique sawing (mas-un) tăiere oblică (la ferăstrău)

oblique section $(\mathrm{OM})$ secțiune oblică

oblique setting (mas-un) aşezare oblică; înclinare față de poziția normală

oblique triangle (mat) triunghi ascuțitunghic

obliquity oblicitate, înclinare, poziție oblică; deviere, abatere (de la normă); caracter pieziş

obliquity factor (fiz) factor cosinus

obliquity of (the) wheels (auto) unghi de cădere a roților

obliterate a şterge, a rade; a distruge; a îndepărta; (fig) a şterge / distruge orice urmă

obliterated şters, ras, distrus (d. o urmă etc.) 
obliteration extincție; lichidare; anulare; ştergere, îndepărtare; distrugere; uitare

obliviousness uitare; capacitate de a uita; distracție, neatenție

oblong (OM) alungit, întins, lunguieț, prelung; (geom) dreptunghiular

oblong hole $(\mathrm{OM})$ gaură longitudinală / alungită, ovală

obol, obolos, obolus (metr) unitate veche de măsură pentru masă: 1 obolos (Grecia antică) $\sim, 5$ g, 1 obolus (Roma antică) $\sim 0,57$ g, 1 obolos $($ Grecia modernă $)=1$ decigram $=0,1 \mathrm{~g}$

obscure neclar; întunecos; ascuns, obscur, neştiut; nedesluşit; nelămurit, de neînțeles, enigmatic; complicat; a întuneca; a ascunde; a complica (şi mai mult)

obscure glass (ind chim) sticlă mată / fumurie

obscurity obscuritate, întuneric; (fig) lipsă de claritate, anonimat

observable observabil, vizibil, perceptibil; remarcabil; care se face respectat

observance of (jur, ec, adm) respectare (a legii, normelor etc.)

observant of atent la, bun observator

observation observație, observare, percepție, privire, examinare; constatare, remarcă; supraveghere, control

observational bazat pe observație (nu pe experiență)

observational equation (metr, mat) ecuație de erori, ecuație de corecție / de compensare

obsevation(al) error (metr) eroare de observație observation hole $(\mathrm{OM})$ orificiu de control, gură de control / de vizor, vizor

observation instrument (metr) instrument de observație

observation mirror (auto) oglindă retrovizoare observe a asculta de; a observa, a remarca, a băga de seamă; a examina (un fenomen, un proces); a face o observație (despre); a studia; a constata, a nota; a controla, a supraveghea; a vedea; a fi observator; a respecta (întocmai) (o lege, un regulament, o procedură etc.); a sărbători, a celebra (o aniversare etc.); a comenta; a fi atent

observed data $(\mathrm{TH})$ date obținute prin observație observed mean time between failure ( $\mathrm{TH}$, mas) timpul total de funcționare împărțit la numărul de avarii / defecte, media timpului între două avarii / defectări

observe on / upon a comenta, a face comentarii asupra, a face o remarcă în legătură cu / referitor la

observed value (mas, $\mathrm{TH}$ ) valoare observată

obsess a obseda, a persecuta, a urmări obsession obsesie, persecuție; idee fixă

obsessive obsedant

obsolete (lucru) învechit, ieşit din uz, desuet; perimat, demodat; a nu mai fi potrivit din cauza schimbărilor în tehnologie şi cerințe, a fi depăşit uzat / moral

obstacle (to) obstacol (pentru), piedică (la)

obstruct a astupa (o trecere etc.), a înfunda; a bloca (un drum, un proces etc.); a împiedica (dezvoltarea etc.); a întârzia (înaintarea) (d. un proces etc.); a opri; a îngreuna, a face dificil (dezvoltarea, inițierea unui proces etc.); (pol) a face obstrucție (d. parlament, etc.); a înfunda (o conductă, o trecere etc.); a îngreuia (dezvoltarea etc.); a obtura (o conductă, un orificiu etc.)

obstruct a bill (pol) a face obstructie (în parlament) obstructing $(\mathrm{OM}, \mathrm{TH})$ obturare, care obturează, care împiedică

obstruction obstrucție; piedică, barieră, obstacol; împiedicare; blocare; oprire

obstructive de obstructie, care obstructionează, obstructiv

obstructively $(a d v)$ (în mod) obstructiv

obstructiveness obstrucție; obstrucționism

obtain a obține, a căpăta, a dobândi, a câştiga; a procura, a face rost de; a realiza; a exista; a fi la curent, a fi în uz / vigoare; a se folosi; a fi recunoscut

obtainable accesibil; realizabil; care se poate obține

obturate $(\mathrm{OM})$ a astupa, a etanşa, a obtura (o conductă etc.)

obturating needle $(\mathrm{OM})$ ac obturator

obturating ring $(\mathrm{OM})$ inel deflector / de oprire

obturation obturatie, obturare

obturator (OM) obturator

obturator ring $(\mathrm{OM})$ inel de etanşare

obtuse obtuz; (fig) mărginit, care pricepe greu, obtuz; redus

obtuse angle (geom) unghi obtuzunghic

obtuse triangle (geom) triunghi obtuzunghic

obtuseness obtuzitate, mărginire, îngustime; stupiditate, prostie

obverse revers; (OM) față, parte frontală; față exterioară; din față; exterior; celălalt; (ec) cap (de monedă)

obviate a îndepărta, a înlătura; (jur, ec) a eluda; a preveni; a preîntâmpina; a scăpa de

obvious evident, clar, limpede, vădit

obviously $(a d v)$ (în mod) evident, clar

obviousness caracter evident / vădit

occasion prilej, ocazie, moment potrivit; motiv; pretext (invocat); eveniment; circumstanță; a prilejui; a produce, a cauza 
occasional ocazional, accidental, întâmplător; de ocazie; (met) (caracteristică) care apare în mai puțin de $10 \%$ din structura metalografică

occasionally $(a d v)$ din când în când, uneori; rar; (în mod) ocazional

occidental occidental, vestic, apusean

occlude a astupa, a închide, a bloca; (chim) a absorbi gaze

occluded gases (met) incluziuni de gaze, sufluri

occluded water (fiz, met) apă izolată în masa unui material

occlusion ocluzie, astupare, închidere, blocare; (chim) absorbție (de gaze); (met) incluziune, por occlusion of gas (met) suflură; (plast) incluziuni de gaze în volumul de material plastic

occupancy ocupare, luare în posesie; posesiune temporară; arendă; domiciliere; reşedință

occupant ocupant; locatar; arendaş; deținător (al unui post); (auto) pasager

occupation (ec) ocupație, îndeletnicire, meserie, profesie, luare în posesie

occupational profesional, ocupaţional

occupational desease (med) boală profesională occupational hazard $(\mathrm{TH}, \mathrm{med})$ risc profesional occupied ocupat

occupier ocupant; deținător

occupy a ocupa; a lua în posesie; a locui; a închiria, a arenda; a acoperi; (TH) a exploata; a preocupa

occur a avea loc; a se întâmpla; a se petrece, a se produce; a surveni; a se ivi, a apărea; a se găsi; a se afla; a(-i) veni în minte / gând, a(-i) trece prin minte

occurrence existență, prezență, răspândire, pozitie, ocazie, eveniment, caz, întâmplare, lucru; fenomen; apariție, ivire, manifestare; incident

occurrence of spark (auto) formarea / apariția scânteii

o.c. (open circuit) (hidr, mas) circuit deschis

ochre (minrl) ocru, limonit

o'clock fix (d. timp); „10 o'clock” - ora 10 (fix); (metr) unitate de măsură pentru unghiuri, având ca referință ora 12 pe un cadran (clasic) de ceas; astfel, unghiul format între două ore consecutive (de pe cadran) este de $30^{\circ} ;$, ,4 o'clock” este un unghi de $120^{\circ}$, măsurat în sens orar

octad (metr) unitate pentru cantitate, egală cu 8 octagon (geom) octogon

octagonal (geom) octogonal

octagon(al) steel (met) semifabricat din oțel cu secțiune octogonală

octahedral (geom) octaedric, cu opt fețe, octoedric octahedron (geom) octaedru

octane (chim) octan octane number, octane rating / value / ratio (metr, ind chim, auto) cifră octanică, indice octanic, măsură utilizată pentru a arăta capacitatea combustibilului / benzinei de a reduce bătaia motorului

octane (chim) octan, hidrocarbură octanică; iso$\sim(2,2,4-t r i m e t h y l p e n t a n e)$ (ind chim) izooctan, compus chimic care previne bătaia motoarelor cu ardere internă

octane rating (chim, metr) determinare a cifrei octanice

octant (metr, geom) unitate de măsură pentru unghiuri, egală cu $1 / 8$ dintr-un cerc sau $45^{\circ}$ ( $\pi / 4$ radiani); (metr) unitate de măsură pentru unghi solid: loctant este un unghi solid care cuprinde $1 / 8$ dintr-o sferă sau $\pi / 2$ steradiani

octarius (metr, med) denumire veche pentru British Imperial pint $(\sim 568,261 \mathrm{ml})$

octave (metr, muz) unitate pentru descrierea raportului între frecvențele a două note succesive; două note diferă print-o octavă dacă cea înaltă are frecvența dublă față de cea joasă

octavillo (metr, fiz) unitate tradițională spaniolă pentru măsurarea volumui (uscat): 1 octavillo $\sim 289 \mathrm{ml}$

octennium (metr) unitate de timp, egală cu 8 ani octet (metr) unitate de cantitate, egală cu 8 ; (metr, inf, telecomunicații) unitate pentru informație, egală cu 8 bits

octuple, octuplet (metr) un grup de 8 articole, în special identice 8 ; membru al unui grup de 8

ocular (anat) ocular, al ochiului; optic; vizibil, palpabil; (OM, metr) ocular la aparate optice

odd impar, fără soț; neegal; neregulat, accidentat; excedentar, suplimentar, adițional; în plus; întâmplător (d. un proces, o întâlnire etc.); sporadic; curios, ciudat; neobişnuit, excentric; de ocazie (d. muncă etc.); de răgaz (d. un moment etc.); desperecheat (d. un volum etc.); liber, neocupat (d. un moment etc.); nepereche; răzlet (d. un volum, etc.); şi ceva; straniu; an $\sim$ thing ce se nimerește, indiferent ce, un lucru la întâmplare; at $\sim$ moments $(a d v)$ când şi când, din când în când, în clipele libere, în momentele de răgaz, în timpul liber, printre picături, în răstimpuri

odds and ends mărunţişuri, vechituri

odd angle cutter (mas-un) freză biunghiulară asimetrică

odd-come-shortly zi / termen apropiat(ă)

odd-come-shorts $(p l)$ (mediu, ind) resturi, rămăşițe; (textile) zdrenţe

odd control (inf) control al imparitătii

odd course (textile) rând de ochiuri aruncate / libere 
odd-electron molecule (fiz, chim) moleculă cu număr impar de electroni

odd-even impar-par

odd-even check (inf) control de paritate, verificare impar-par

odd fluted mill (mas-un) freză cu număr impar de caneluri

odd frequency motor (el) motor cu frecvență neuzuală

odd function (mat) funcție impară

odd harmonic (autom, mat) armonică de ordin impar

odd-harmonic distortion (autom) distorsiune datorită armonicelor impare

odd in shape $(\mathrm{OM})$ cu formă greşită / neregulată odd job (ec) activitate neregulată

odd-job man (ec) muncitor necalificat, om care face de toate

odd jobs $(p l)($ ec) munci ocazionale / de tot felul odd legs (metr) compas cu un picior drept şi unul curb

odd-line interlace (TV) întrețesere de linii impare odd man out lucru / persoană care a rămas în afara grupului; lucru răzleț; persoană izolată

odd money (ec) primă de completare

odd-mass (number) (fiz, chim) număr de masă impar

oddness ciudătenie, caracter impar

odd number (mat) număr impar

odd-odd (mat, inf) impar-impar

odd parity check (inf) control impar de paritate odd parts $(\mathrm{OM})$ piese dezasortate / neasortate, piese diferite

odd permutation (mat) permutare impară, substituire impară

odd picks (textile) bătăi impare

odds şanse; avantaj; diferență, distanță, decalaj; (metr, mat) formulare a probabilităților pentru un eveniment, probabilitate, şansă: dacă probabilitatea ca evenimentul să aibă loc este $a /(a+$ $b$ ) iar probabilitatea ca evenimentul să nu aibă loc este $b /(a+b)$, atunci şansele sunt $a-b$ (sau $a$ la $b$, sau $a: b)$ în favoarea evenimentului şi $b$ $a$ (b la $a$, sau $b: a)$ în defavoarea lui ( $\mathrm{a}+\mathrm{b}$ tinde spre 1): 4-1 odds arată că probabilitatea evenimentului de a avea loc, este $1 / 5$

odd shape (OM, materiale) formă neregulată

odd side (met) ramă falsă / de formare auxiliară

odd-side board (met, OM) placă de sub rama de formare

odd size $(\mathrm{OM})$ dimensiune specială

odd sorts (tipografie) caractere neuzuale

odd-toothed $(\mathrm{OM})$ cu număr de dinți fără soț, cu număr impar de dinți odd work (ec) lucru la / în ore suplimentare, lucru ocazional

odometer (metr, auto) contor de parcurs

odorisation (ind chim) odorizare

odorless (chim) fără miros, nemirositor

odour (alim, TH) miros, parfum; (fig) renume, reputație

odourless inodor

Oechsle degree (metr, alim) unitate pentru măsurarea conținutului de zahăr din must, în Germania şi Elveția: 1 degree Oechsle (sau Öchsle) este echivalent cu $\sim 0,2 \%$ zahăr (masic)

oelotropic (materiale) anizotrop

oenology (alim) oenologie, știința vinificației

oenolog (alim) oenolog, specialist în ştiinţa vinificatiei

oersted (Oe) (metr, fiz) unitate de măsură în sistem CGS pentru intensitatea câmpului magnetic (până în 1930 această unitate era numită gauss)

of ample size (TH, OM) cu dimensiuni mari, cu coeficient de siguranță exagerat

of commercial size (ec, ind) uzual, corespunzător uzanțelor comerciale

of contrary sense care se mişcă / se deplasează în sens contrar

off (alim) alterat, expirat (d. un produs alimentar); (prep) din, departe, de, deoparte; deschis; ca prefix descrie o stare de nefuncționare; din dreapta; din afară; în plus; stins; stricat, terminat; epuizat; desprins (d. o piesă etc.); (mas, TH) ,decuplat" (ca inscripție pe maşini, aparate); issue chestiune secundară; street stradă laterală; ward a îndepărta; a bate; a para; keep smb. a tine pe cineva la distanță; right $\sim$ fără a ezita; straight $\sim(a d v)$ îndată, numaidecât; and on cu intermitente, cu întreruperi; be well $\sim$ a fi înstărit, a o duce bine; be badly a fi sărac, a o duce rău; run $\sim$ the rails (cf) a deraia; be $\sim$ duty a nu fi de serviciu, a fi liber

offal (ind, mediu) deşeuri; rămăşiţe, resturi

off-balance dereglat (d. aparate, sisteme de control, automatizare); scos din echilibru, cu echilibrul pierdut (d. maşini, piese / elemente de mişcare etc.)

outside windshield (auto) exteriorul parbrizului

off cast (met) piesă turnată, rebutată

off-centre (OM) $(s, a d j)$ excentric

off-centred descentrat, excentric

off-centre loading (mec, OM) sarcină excentrică / necentrată

off-centre stop (mas, termo) dispozitiv pentru prevenirea opririi manivelei în punctul mort off-chance șansă minimă, fără şansă 
off-colour de o culoare neobişnuită; nepotrivit, de prost gust; nesărat; defect, stricat; de cea mai proastă calitate; indispus; care nu este în formă; culoare care nu corespunde mostrei

off-contact (mas, T) contact de repaus

off-corn (agr) tărâțe

offcut tăietură; decupaj

off-cuts (mediu, ind) deşeuri

off-cycle (TH, mas) perioadă de nefuncționare / de staţionare (specifică unei tehnologii)

off-delay (el) întârziere de cădere / de eliberare / la revenire (a unui releu)

off-diagonal elements (of a matrix) (mat) elemente diagonale (ale unei matrice)

offending (mas) defect care provoacă funcționare neregulată / defectuoasă

offensive ofensiv, agresiv; (ec, mil) ofensivă

off equipment work $(\mathrm{TH})$ toate operațiile de mentenanță executate cu utilajul nefuncționând / oprit

offer (ec) ofertă; propunere, preț; a (se) oferi; a propune; a acorda, a da; a încerca; a manifesta; a se produce; a prezenta

offerer (ec) ofertant

offering (ec) propunere, ofertă; care oferă

off-gas (ind chim, met, mediu) gaze reziduale

off gassing (plast) pierdere de gaze / de masă (mai ales în vid)

off-gauge (metr) care nu menține dimensiunea (d. un aparat de măsură); fără cote, în afara dimensiunilor, (dimensiune / cotă) care nu se încadrează în norme / în toleranțe, nestandardizat

off-gauge material (met) material nestandardizat / care nu se încadrează în norme

off-going (auto) accident provocat de ieşirea vehicolului în afara carosabilului

off-grade (ec, TH) material de calitate inferioară / proastă care nu se încadrează în normă

off-grade (cast) iron (met) fontă de tranziție / care nu este corespunzătoare standardului / normei, fontă pestriță (rar)

off-grade steell (met) oțel care nu se încadrează în standard / în norme

off-hand (mas) care funcționează fără deservire; improvizat, nepregătit; fără pregătire (d. operatori, muncitori etc.)

off heat (met, termo) căldură evacuată / de pierdere; (met) (şarjă) în afara normelor / limitelor tehnologice, şarjă rebutată

office (ec, adm) birou; serviciu, post; funcțiune; oficiu; cabinet; (amer), cabinet medical

office automation (inf, ec, adm) automatizare a administrației / a lucrărilor administrației

office building (constr, ec, adm) clădire cu birouri office code (inf) cifru, cod

office copy (jur, adm) copie efectuată de instituția unde se află originalul; copie care rămâne la arhivă; copie autentificată de notariat

office test (metr, TH) verificare în fabrică

official test (metr, ind) încercare / test de recepție

of fine porosity (materiale) microporos

office holder (pol, adm) funcționar (de stat)

officeman functionar

officer (pol, adm) ofițer; funcționar; membru al unui comitet de conducere; polițist; (nav) ofiter, comandant (pe vas comercial)

officer of health (adm, med) inspector sanitar

officership (mil, nav) grad de ofițer; îndatoriri de ofițer

official oficial; formal; de serviciu (sarcini etc.); profesional; (ec, adm) funcționar (de stat, superior, de bancă)

offing (nav) largul mării (văzut de pe mal); (fig) în perspectivă; iminent, curând; keep the (nav) a se ține în larg, a se menține departe de coastă

off-iron (met) fontă brută obişnuită / fără caracteristici impuse

offlet (OM) canal / țeavă de scurgere

off-licence local unde se vând băuturi pentru acasă

off-limit piece $(\mathrm{OM}, \mathrm{TH})$ piesă prelucrată fără respectarea toleranțelor prescrise

off-limits (ind, adm) ,intrarea interzisă” (d. zone protejate în jurul maşinilor birouri în care nu au acces persoane din afara firmei, instituției), ,accesul interzis"

off-line indirect; (c) care nu este în legătură directă, continuă cu calculatorul, subsistem care este operabil, dar în mod curent deconectat

off-line equipment (mas, c) echipament periferic (auxiliar)

off-line operation (TH) operație indirectă / auxiliară

off load (mec, mas) a descărca, a elimina sarcina off-load (mas) fără să fie încărcat / solicitat (d. un element de măsură, întreg sistemul tehnic etc.)

off-load start (mas) pornire în gol

off-melt (met, plast) topire / topitură necorectată după analiză

off-normal (OM, TH) anormal, nenormal (d. elemente de maşini, comportarea unor sisteme, procese şi fenomene în producție)

off-oil (ind chim, T) ulei de calitate inferioară

off-peak hour (el) ore în afara perioadei consumului de vârf

off-peak periods (el, mas) perioadă de încărcare în afara vârfului 
off-peak rate / tariff (el) tarif de noapte redus off-peak time (el) ore în care se micşorează consumul (de curent electric)

off-period (el) perioadă în care curentul este întrerupt

off-position (el) poziție de oprire / de deconectare / de repaus / de zero (d. aparate, mașini, rețele electrice etc.); (mas) poziția închis

off-print extras

off-region (autom, metr) zonă / domeniu de blocare

off-road driving (auto) condus / conducere în afara şoselelor asfaltate

offscurrings (mediu, ind) deşeuri, gunoaie, gunoi, murdărie

off-the-road tyre (auto, OM) pneu pentru orice teren

offset compensație; (ec) plată, socoteală, decontare; mlădiță, vlăstar; (el, autom, OM) deviație remanentă (de la valoarea prescrisă), deplasat, ramificatie, ramificare, branșament (și de tevi), deplasare, decalare, compensare; îndoire, curbare, încovoiere; (constr) terasare; (met) deplasare (a cajelor / a utilajului greu); a îndoi; (TH, mas, autom) a compensa, a contrabalansa, a echilibra; (ec) a compensa, a plăti; tipar

offset beam (fiz) fascicul descentrat / excentric / deviat

offset behaviour (autom) comportare proporțională (a unui element)

offset characteristic ( $\mathrm{TH}$, autom) reglare cu domeniu parțial suprimat

offset coefficient ( $\mathrm{TH}$, autom) coeficient de deviație reziduală (permanentă) la reglare

offset connecting rod (auto, $\mathrm{OM}$ ) bielă deplasată

offset crank drive (OM) mecanism cu manivelă dezaxată

offset deviation (TH, autom) deviație / diferență permanentă la reglare

offset grinding wheel (mas-un) piatră de rectificat / disc abraziv pentru prelucrarea în poziție oblică

offset holder (mas-un) port-cuțit cotit / curbat

offset oil (ind chim) ulei de tipografie

offset ratio (autom, metr) raport de deviație

offsets (nav) coordonate ale planului de forme

offsetting (mas, OM) dezaxare

offset plate (OM) eclisă călită (la lanțuri)

offset tool (mas-un) cutit încovoiat

offset yield strength (mec) limită de curgere

offshift (ec) schimb în care nu se lucrează

offshoot (agr, bot) mlădiță, vlăstar; $(\mathrm{OM})$ parte alungită, braț, ramificație (a unei piese, a unui modul etc.) offshore (nav) depărtat de țărm / coastă, din larg, (d. vânt) dinspre uscat, zonă de apă din vecinătatea coastei, $(a d v)$ în larg

offside (OM, mas) parte din dreapta, partea dreaptă (la autovehicule)

off-size (OM, mas-un) prelucrat cu nerespectarea dimensiunilor prescrise, abatere de la dimensiune / toleranță

off-size condition $(\mathrm{OM}, \mathrm{TH})$ abatere de la dimensiune

off-smelting (met) topire / şarjă în afara analizei / rebutată

off-sulphur iron (met) fontă desulfurată

offtake (OM, hidr) canal de fugă; branşament; canal de evacuare; (ec) vânzare, (cantitate de) marfă vândută; (poligrafie) copie

offtake pipe (OM, hidr) țeavă de evacuare

off-the-spot controller (autom, hidr) regulator care nu se află în punctul de reglare

off-time (met, TH) timp între două cicluri / depuneri la sudură; (TH, mas) timp de întrerupere a funcționării, timp de repaus

offward (nav) (în)spre larg

off-white alburiu

of high carbon content (met) cu conținut mare de carbon (şi d. oțeluri)

of a high degree de grad înalt

of high early strength (constr) cu priză rapidă (la beton)

of high frequency (fiz) de înaltă frecvență

of high speed (mec) de viteză / turație înaltă

of low light intensity (fiz, metr) întunecat, puțin luminos

of low noise (fiz, autom, mas) cu nivel de zgomot redus

of low pressure (hidr) de joasă presiune

of particular section $(\mathrm{OM})$ cu secțiune specială, de o anumită formă

of small bore $(\mathrm{OM})$ de calibru mic, cu diametru mic

of smithing quality (met) forjabil

often $(a d v)$ adesea, adeseori, frecvent

ogdoad (metr) o altă denumire pentru octad, v. octad

ogival (constr) ogival

ohm (metr, fiz) unitate SI de măsură pentru măsurarea rezistenței electrice, a reactanței şi impedanței, ohm

ohm meter (metr, fiz) unitate de măsură pentru rezistivitate, ohm.metru

ohm per square (metr) unitate de măsură a rezistivității suprafețelor corpurilor subțiri (tip folii etc.), ohm pe unitatea de suprafață

ohm loss (fiz, el) pierderi ohmice 
ohmic drop (el) cădere de tensiune ohmică / rezistivă

ohmic heating (el, termo) încălzire prin efect Joule ohm(ic) loss (el, fiz) pierdere ohmică / prin efect Joule

ohmic resistance (el) rezistență în curent continuu (ohmică)

ohmmeter (metr, el) ohmmetru

Ohm's law (el) legea lui Ohm

oil (alim, ind chim, T) ulei (vegetal, mineral sau sintetic), untdelemn, țiței, petrol, produs petrolier; (T) a unge, a lubrifia (cu ulei), a gresa, a alimenta cu ulei (o instalație de ungere), a impregna cu ulei

oil absorbtion $(\mathrm{T})$ absorbție de ulei

oil accumulation acumulare de petrol, zăcământ de petrol

oil actuary expert în statistica petrolieră

oil additive (ind chim, $\mathrm{T}$ ) aditiv pentru ulei

oil ageing (brit) / aging (amer) (chim, $\mathrm{T}$ ) oxidare / degradare în timp / „îmbătrânire” a uleiului

oil area (geol) perimetru / sector petrolifer, zonă petroliferă

oil asphalt (ind chim) bitum moale (cu penetrație ridicată)

oil atomiser (brit) / atomizer (amer) (OM, T) ajutaj / pulverizator / atomizor de ulei

oil baffle / deflector / slinger (OM, T) deflector de ulei

oil base (ind chim) caracterul / natura țiteiului

oil-base mud (geol) noroi (de foraj) negru / pe bază de produse petroliere

oil bath $(\mathrm{OM}, \mathrm{T})$ baie de ulei

oil-bath air cleaner / filter (auto, OM, T) filtru de aer pentru baie de ulei

oil-bath lubrication $(\mathrm{T})$ ungere / lubrifiere prin barbotare / în baie (de ulei) / în carter

oil-bearing (ind chim) petrolier; (geol) (strat) purtător de țiţei, petrolifer

oil-bearing formation (geol) formațiune petroliferă

oil-bearing layer (geol) strat petrolifer

oil-bearing rock (geol) rocă petroliferă / purtătoare de titei

oil-bearing sand (geol) nisip petrolifer

oil-bearing stratum (geol) strat petrolifer

oil-bearing structure (geol) structură petroliferă

oil black (ind chim) negru de fum de petrol

oil-blast circuit breaker (el) întrerupător cu curent de ulei

oil-bleaching apparatus (alim, ind chim) aparat de înălbire a uleiului

oil body ( $T$, fiz) viscozitate a uleiului

oil bodying $(T$, chim) polimerizare a uleiului oil-boiling pot (ind chim, alim) cazan pentru fierberea uleiurilor

oil bonding sand (met) nisip aglutinat cu petrol / cu produs petrolier

oil box $(\mathrm{OM})$ incintă / baie de ulei

oil brake $(\mathrm{OM}$, hidr) frână hidraulică

oil breaking (ind chim, alim) limpezirea uleiului

oil-break switch (autom, T, OM) întrerupător de / cu / în ulei

oil breathing capacity (el, chim) posibilitate de răsuflare a uleiului (dintr-un cablu)

oil bunker (OM) tanc de combustibil lichid

oil burner (termo) arzător / injector cu combustibil lichid / cu țiței / cu petrol, arzător cu țiței; (fig) rable (d. o maşină)

oil cable (el) cablu cu izolație de ulei

oil cable head (OM, el) capăt (mufă) de cablu cu izolație de ulei

oil cake (OM) bidon de ulei, biuretă de ulei, cană de ulei, pompă de ulei; (agr, alim) turtă de oleaginoase

oil can $(\mathrm{OM}, \mathrm{T})$ gresor, ungător (şi cu capac)

oil cap (OM, T) ungător cu capac

oil car (cf, transp) (vagon-) cisternă

oil carbon (termo, $\mathrm{T}$, chim) calamină

oil carburising plant (met) instalație de cementare în (baie de) ulei

oil carrier (nav) petrolier

oil carry-over antrenare (nedorită) de ulei (în circuitul sistemului frigorific)

oil-catalyst slurry (chim) suspensie de catalizator în ulei

oil catcher $(\mathrm{OM})$ deflector / separator de ulei

oil-catch ring $(\mathrm{OM})$ inel deflector de ulei

oil centrifuge (mas, alim, ind chim) centrifugă de ulei

oil-chalk test (metr) test cu lichide penetrante (la suduri etc.)

oil chamber $(\mathrm{OM}, \mathrm{T})$ cutie de ungere

oil change (mas, auto, T) schimbare / înlocuire a uleiului (din baia de ulei, carter etc.)

oil-change period $(T, T H)$ perioada înlocuirii uleiului din baia de ulei

oil circuit breaker (autom, T) întrerupător în ulei

oil circulating lubrication $(\mathrm{T})$ lubrifiere prin (re)circulație de ulei

oil-circulating reactor (ind chim) reactor cu circulaţie de ulei

oil circulation (hidr, T) circulatie de ulei / a uleiului (hidraulic sau lubrifiant)

oil clarifier / cleaner $(\mathrm{OM}, \mathrm{T})$ filtru / epurator de ulei

oil cloth (ind chim, textile) muşama; pânză uleiată, linoleum 
oil clutch (OM, hidr, T) ambreiaj (care funcționează) în ulei

oilcoat (textile) impermeabil, manta de ploaie oil coating (chim, T) acoperire cu ulei, strat protector de ulei

oil cock (OM, hidr) robinet de ulei, cu cep

oil coke (ind chim) cocs de petrol

oil cold test (metr) determinare a temperaturii de congelare a produselor petroliere

oil collecting pit (geol) batal de captare (de scursori)

oil collector (OM, hidr, $\mathrm{T})$ colector de ulei oil colour (poligrafie, ind chim) cerneală pe bază de ulei; (ind chim) vopsea de ulei

oil colours $(p l)$ (ind chim) vopsele de ulei oil condenser (OM, termo) condensator de ulei oil conduit $(\mathrm{OM})$ conductă de ulei

oil cone $(\mathrm{T}, \mathrm{OM}$ ) ajutaj pentru ulei (la lubrifiere cu jet de ulei, la pulverizatoare)

oil connection $(\mathrm{OM}$, hidr) conductă / țeavă de ulei

oil conservator $(\mathrm{OM}$, termo) vas de compensare (a dilatării) uleiului (la cabluri şi transformatoare)

oil consumption (auto, $\mathrm{T}$, mas) consum de ulei oil container $(\mathrm{OM})$ rezervor / colector de ulei oil content (alim, T) conținut de ulei (în materiile prime, în emulsii etc.)

oil control (piston) ring $(\mathrm{OM})$ segment / raclor de ulei

oil control ring $(\mathrm{OM}, \mathrm{T})$ inel deflector de ulei oil cooled transformer (el) transformator cu răcire în ulei

oil cooler (termo, auto) răcitor / radiator de ulei

oil cooling ( $T$, termo, mas) răcire cu ulei

oil corrosion (chim, T) coroziune provocată de componenții acizi ai uleiului (hidraulic, lubrifiant, alimentar uzat etc.)

oil-corrosion test (metr, ind chim) test / încercare pentru determinarea corozivității uleiului, test de coroziune cu ulei

oil country (geol, geogr) zonă petroliferă

oil cover (OM, auto, mas) capac de ungere / de ungător, capac ungător; clapetă de ulei

oil crust (OM, auto, mas, $\mathrm{T})$ crustă de ulei ars

oil cup $(\mathrm{OM}, \mathrm{T})$ cană de ulei, cutie de unsoare, gresor, ungător, canal de ulei, ungător cu pahar / prin picurare, cupă de captare a picăturilor de ulei; (cf, T) cutie de unsoare; ungător; (textile) dispozitiv de uleiere / ungere / lubrifiere

oil cushion $(\mathrm{OM}$, hidr, $\mathrm{T})$ pernă de ulei

oildag $(\mathrm{T})$ emulsie de grafit în ulei; lubrifiant cu adaos de grafit

oil damping (OM, hidr) amortizare cu ulei (a unui mecanism) oil dash pot (OM, hidr) amortizor cu ulei oil decomposition (chim, T) oxidarea uleiului oil deflector / baffle / slinger (OM, T) deflector de ulei

oil dehydrating (mas, $\mathrm{TH}$ ) deshidratare a uleiului; (ind chim) deshidratare a țiţeiului / a uleiului, instalație pentru deshidratarea tițeiului

oil delivery (transp, ind chim) distribuire / livrare / transport de petrol / de ulei (mineral)

oil delivery truck (auto, transp, ind chim) autocisternă pentru produse petroliere

oil deposit (chim, termo, auto, T) crustă de ulei (îngroşat, fenomen nedorit); (geol) zăcământ de petrol / de țițel

oil derrick (constr) turlă de sondă de petrol

oil detection (geol, ind) descoperire a petrolului

oil deterioration (chim, T) îmbătrânire / modificare (în rău) / deteriorare a uleiului

oil diffusion pump (OM, hidr) pompă de difuzie cu ulei

oil dilution $(\mathrm{T})$ diluarea uleiului (pentru scăderea vâscozității şi a punctului de curgere)

oil dipper rod $(\mathrm{OM}, \mathrm{T})$ jojă, tijă pentru măsurat nivelul uleiului

oil dipper / scoop (auto, termo, OM, T) linguriță de ulei pe capacul bielei (pentru barbotaj)

oil dish (OM, T) farfurie / tavă pentru colectarea picăturilor de ulei

oil dispenser (OM, hidr, $\mathrm{T})$ distribuitor / picurător de ulei

oil dispersion $(\mathrm{T}, \mathrm{TH})$ dispersie în / de ulei (în alt lichid) ulei

oil displacement (geol, ind) dezlocuire a petrolului (din rocă), împingere a petrolului (din rocă)

oil-dissolving solvent (chim) solvent pentru ulei (mineral, alimentar sintetic)

oil dope (chim) aditiv pentru ulei (nu se specifică tipul uleiului)

oil drain (OM, hidr) dispozitiv / orificiu de golire / de evacuare a uleiului

oil drainage (ind, geol, hidr) curgere a petrolului spre sondă, drenaj al petrolului din zăcământ; (ind chim) dezuleiere, îndepărtare a uleiului

oil drain cock (OM, hidr) robinet de golire pentru ulei

oil drain plug $(\mathrm{OM})$ buşon de golire pentru ulei

oil-drain valve (OM, hidr) robinet cu cep pentru scurgerea uleiului

oil-dressed leather (ind chim) piele tăbăcită cu grăsimi

oil drop $(\mathrm{OM}, \mathrm{T})$ picătură de ulei

oil-drop method (metr) metodă a picăturilor de ulei (pt. stabilirea gradului de degradare şi/sau impurificare) 
oil drowned $(\mathrm{OM}, \mathrm{T})$ în baie de ulei

oil duct $(\mathrm{OM}$, hidr, $\mathrm{T})$ canal de ungere; canal conductă de ulei

oil duet $(\mathrm{OM})$ canal / conductă de ulei / de ungere oil-insoluble materials $(\mathrm{T}$, fiz, chim) materiale / substanțe insolubile în ulei

oiled finish (met) tratament (termic) final în ulei; (mas-un) prelucrare cu / în ulei; (T) uns cu ulei

oiled paper (ind chim, OM) hârtie uleiată / îmbibată cu ulei (p. ambalare de protecție)

oil-electric drive (termo, el) propulsie dieselelectrică

oil emulsion (alim, T, TH) emulsie de ulei

oil engine (auto, termo) (termo, auto) motor cu combustibil greu / cu motorină

oil equipment (ind chim, mas) utilaj petrolier oiler autocamion cu motor diesel (rar); $(\mathrm{T})$ gresor, ungător (cu ulei); (nav) (tanc) petrolier

oiler and wiper $(\mathrm{OM}, \mathrm{T})$ pungă de ulei, cutie de unsoare cu pernă din pâslă / cu picurare

oilery (ind chim) (magazin de) articole chimice şi vopsitorie; fabrică de ulei; produse din ulei sau petrol

oil expansion tank / vessel (termo, hidr, OM) vas de expansiune / de dilatare a uleiului

oil expeller / interceptor (OM, T) separator / captator de ulei

oil exploration (geol) prospecțiune a zăcămintelor de petrol

oil extended rubber (ind, chim, plast) cauciuc diluat / întins în ulei

oil-extraction plant (alim, ind chim) instalație pentru extractie a uleiului

oil extractive industry industrie extractivă (a petrolului, industria de extracție a uleiurilor vegetale şi animale)

oil extractor (mas-un, hidr, mas) centrifugă pentru recuperarea uleiului din aşchii şi material de şters; (alim) centrifugă de extragere a uleiului; (mas, ind chim, alim) centrifugă pentru recuperarea uleiului din aşchii şi material de şters

oil exudation (geol) supurare / infiltratie a titeiului; (OM, T, hidr, chim) infiltrare (nedorită, prin materialele cu care vine în contact), exudare a uleiului

oil face $(\mathrm{OM}, \mathrm{T}$, fiz) nivel / suprafață liberă de ulei / a uleiului / lubrifiantului (în rezervor etc.)

oil failure safety switch (autom, hidr) presostat de sigurantă a circuitului de ulei

oil feed $(\mathrm{T})$ alimentare cu ulei

oil-feed pump (OM, T, hidr) pompă de ulei

oil field (ind, geol) schelă petrolieră, teren petrolier / petrolifer, zăcământ de petrol (constr, mas) sondă petrolieră / de petrol oil-field development (cons, ind) construcție a sondelor de petrol

oil-field exploitation (ind) exploatare a zăcămintelor de petrol

oil-field rotary bit (OM, mas-un, ind) sapă / freză / tăiş rotativ(ă) pentru foraj petrolier

oil-field waters (geol) ape de zăcământ (asociate petrolului)

oil-filled cable (el, ind chim) cablu (izolat) $\mathrm{cu}$ ulei sub presiune

oil filler (OM, T) ş̧uț / racord / gură (scobitură, cavitate) pentru umplere cu ulei

oil-filler inlet $(\mathrm{OM})$ orificiu de umplere cu ulei (hidraulic sau lubrifiant)

oil filler screw $(\mathrm{OM})$ şurubul orificiului de umplere cu ulei

oil film (T) peliculă / film de lubrifiant (mai ales de ulei)

oil filter (OM, mas, hidr) filtru / epurator de ulei oil filter element $(\mathrm{OM})$ cartuş (la filtru de ulei)

oil-fired furnace (met) cuptor încălzit cu combustibil lichid / cu păcură

oil-flame control installation (termo, autom) instalație pentru supravegherea flăcării unui arzător

oil flat (nav) tanc de buncherare (cu combustibil lichid)

oil-flotation process (met) procedeu de flotare (a minereurilor) cu ulei

oil flow (OM) intrare a uleiului (în baie), curgere a uleiului / lubrifiantului

oil flow control valve (OM, hidr) supapă (sau drosel) de reglare a curgerii uleiului

oil-fly pump (OM, hidr) pompă de ulei cu palete oil foam ( $T$, hidr) spumă a uleiului (efect nedorit la ungere în baie sau în instalatii hidraulice)

oil foaming $(\mathrm{T})$ spumare a uleiului (hidraulic sau lubrifiant)

oil for axles ( $T$, ind chim) ulei (lubrifiant) pentru osii

oil for fine mechanisms ( $T$, ind chim) ulei pentru mecanisme de mecanică fină

oil for switches (el, ind chim) ulei pentru întrerupătoare

oil fraction (ind chim) fracți(un)e de țiței (din prelucrare)

oil-free (alim) fără ulei; (T) fără ungere, nelubrifiat oil-free compressor (mas, termo) compresor fără ulei / nelubrifiat

oil-free petrolatum (ind chim) petrolatum dezuleiat

oil fuel (termo, ind alim, ind chim) combustibil lichid, păcură, titẹi

oil fuel tank (OM, termo, ind chim) tanc de combustibil lichid 
oil funnel $(\mathrm{OM})$ ştuț / racord de umplere cu ulei, pâlnie pentru turnarea uleiului

oil furnace (met, termo) cuptor (încălzit) cu combustibil lichid / cu păcură / cu motorină

oil gas (ind chim) gaz de sondă / petrolier / de petrol

oil gauge (metr, hidr, T) indicator de ulei, manometru de ulei

oil gauge rod / stick (OM, T) tijă de nivel de ulei oil gear (OM, T) dispozitiv / transmisie de / pentru circulare a uleiului, cu pompă cu angrenaje

oil grinding $(\mathrm{T})$ rodare $\mathrm{cu}$ ulei; (mas-un, $\mathrm{TH}$ ) rectificare în ulei / sub jet de ulei

oil groove $(\mathrm{OM}, \mathrm{T})$ canal de ungere (şi la rulmenți)

oil groove drill (mas-un, T) burghiu (şi spiralat) cu canal periferice de ungere

oil groover / grooving machine (mas-un) strung special pentru canelat / prelucrat cuzineți de lagăre şi canalele de ungere

oil grooving (mas-un, T) tăiere / prelucrare (prin aşchiere) a canalelor pentru ulei / ungere

oil gun ( $\mathrm{T}, \mathrm{OM})$ pistol de stropit ulei, tecalemit oil harbour (nav) port petrolier

oil hardening (ind chim) hidrogenare a uleiului; (met) călire în ulei (a oțelurilor)

oil hardening steel (met) oțel călibil în ulei

oil header $(\mathrm{OM})$ distribuitor de ulei (în sistemul de ungere)

oil heater (termo, hidr) încălzitor de ulei

oil heating (termo, hidr) încălzire cu păcură

oil hole (OM, T) orificiu de uns / de ungere

oil hole drill (mas-un, T) burghiu (spiral) cu canal(e) de ungere

oil hole screw, oil plug (OM) dop filetat al orificiului de ungere

oil hydrometer (metr, ind chim) areometru hidrometru pentru produse petroliere

oil-immersed apparatus (el, metr) aparat cu / în baie de ulei

oil immersion (ind chim) imersiune / imersare / scufundare în ulei

oil-immersion objective (fiz, opt) obiectiv cu imersiune în ulei

oil immersion test (metr, chim, plast) încercare / test prin imersiune / imersare în ulei

oil impregnation ( $T$, materiale) impregnare cu ulei (şi a materialelor poroase)

oil-impregnated $(\mathrm{T})$ impregnat de ulei, saturat cu ulei; (geol) impregnat / saturat cu petrol / țiței

oil-impregnated limestone (geol) calcar petrolifer / saturat cu petrol

oil-impregnated sand (geol) nisip îmbibat cu petrol oil-impregnated sandstone (geol) gresie impregnată cu petrol

oil index $(\mathrm{T})$ indice de onctuozitate

oil indicator (auto, metr) manometru de ulei

oil industry (ind chim) industria petrolului

oiliness ( $T$, fiz) onctuozitate, caracter uleios; vâscozitate

oiliness dope (chim) adaus (şi aditiv) de ulei

oiliness (lubricity) ( $\mathrm{T}$ ) lubricitate

oiliness index $(\mathrm{T})$ indice de onctuozitate

oil inflow ( $\mathrm{T}$ ) adaos / completare a uleiului; (geol, ind) aflux de țiței

oiling (mas, T) gresare, lubrifiere, ungere, uleiere; $(\mathrm{OM}, \mathrm{T})$ ungător de ulei, care unge (cu ulei) / lubrifiază

oil-in-gasoline lubrication (auto, mas, T) ungere prin amestec de ulei şi benzină

oiling attachment $(\mathrm{OM}, \mathrm{T})$ dispozitiv de ungere oiling chart (mas-un, $T$ ) schema ungerii

oiling device $(\mathrm{OM}, \mathrm{T})$ dispozitiv de ungere $(\mathrm{cu}$ ulei) (foarte general)

oiling hole $(\mathrm{OM})$ orificiu de uns / ungere

oiling tube $(\mathrm{OM}, \mathrm{T})$ țeavă / tub / conductă de ulei / de ungere

oil inlet (auto, hidr) intrarea uleiului

oil-insoluble (ind chim, plast) insolubil în ulei

oil-insoluble materials ( $\mathrm{T}$, fiz, chim) materiale / substanțe insolubile în ulei(uri) (și impurităti)

oil insulator (el) izolator cu ulei

oil interceptor / expeller (mas-un, hidr, OM) separator / captator de ulei

“oil-in-water" emulsion (ind chim, fiz, T, TH) emulsie ,ulei-în-apă“ (ulei mai puțin decât apă)

oilite bushing (OM, T) bucşă din bronz poros, care lucrează fără ungere / autolubrifiantă

oil jack (mas, OM) balansier jack / de transmisie (la extractia petrolului)

oil joint $(\mathrm{OM}$, hidr) etanşare cu ulei

oil lagging (metr, OM) teacă cu ulei pentru termometru

oil lamp lampă cu ulei

oil land (geol) perimetru / teren petrolifer

oil layer (OM, T) peliculă / strat / film de ulei; (geol) strat petrolifer

oil leather (ind chim) piele tăbăcită în vârtej (de / cu ulei)

oil length (ind chim) grad de polimerizare a uleiului

oil length of varnish (ind chim) continut de ulei al lacului, ,grăsime" a lacului

oil lens (geol) lentilă (acumulare naturală) de petrol oil level (auto, mas, OM, T, TH) nivel al uleiului (şi din baia de ungere / de tratament etc.); (geol, ind) nivel al țiteiului în sondă 
oil level indicator (metr, OM) nivelmetru de ulei oil level meter (metr, OM) nivelmetru de ulei oil length (ind chim) grad de polimerizare a uleiului

oil length of varnish (ind chim) conținut de ulei în vopsea

oilless fără ulei (d. sistem fără ungere, din proiectare sau din cauza unei defecțiuni în sistemul de ungere)

oilless bearing / bushing (OM, T) lagăr / cuzinet / bucşă (şi din material / bronz poros), fără ungere (sau cu lubrifiant solid încorporat)

oilless circuit breaker (el) întrerupător (de putere) fără ulei

oil level (auto, mas) nivelul uleiului

oil-level dipstick, oil gauge rod / stick (auto, metr) tijă de nivel de ulei, jojă

oil level gauge $(\mathrm{OM})$ indicator de nivel

oil lifting (ind) liftare a țițeiului; (OM) pompare a uleiului (hydraulic, lubrifiant) în sus, în sistemul de (re)circulare

oil-like (chim) uleios

oil line (OM, ind chim, hidr, T) conductă de țiței / de ulei

oil-line pump (mas) pompă pentru conductă de tiței / de ulei

oil-liver (alim, ind chim) formare de depuneri mucilaginoase în ulei

oil-loading rack (transp) rampă de încărcare a produselor petroliere

oil locating (geol) detectare a (existenței) unei acumulări de petrol, prospecțiune

oil $\log$ (ind, TH) fişă geologică-tehnică de foraj

oil lubrication (T) ungere / lubrifiere cu ulei

oilman (TH, mas, T) (muncitor) ungător; (ind chim) petrolist

oil manifold (hidr, OM) distribuitor / conductă de ulei

oil market (ec) piață a acțiunilor petroliere / a petrolului, piața uleiurilor (hidraulice, lubrifiante)

oil mat (constr, auto) îmbrăcăminte rutieră bituminoasă

oil measure (geol) strat petrolifer

oil menstruum (ind chim) solvent petrolier

oil migration (geol) migrație a petrolului (din locul de formare)

oil-measuring stick (auto) tijă de măsurat nivelul uleiului, jojă

oil-mill (alim) presă / fabrică de ulei

oil mist (auto, T, mas) ceață / vapori de ulei

oil-modified resin (ind chim) răşină modificată cu ulei

oil-moistened air filter (auto) filtru de aer, umezit de / cu ulei oil nozzle (auto, termo, OM) jiclor de ulei oil of bitter almonds (alim) ulei de migdale amare oil of fir (ind chim) terebentină (obținută prin antrenare cu vapori de apă)

oil of mirbane (ind chim) nitrobenzen

oil of vitriol (chim) acid sulfuric

oil-operated power cylinder (hidr, OM) cilindru / motor hidraulic, comandat hidraulic (cu ulei), servomotor hidraulic cu ulei

oilostatic cable (el, hidr) cablu izolat cu ulei sub presiune

oil outlet (auto, OM, hidr, T) (conductă) ieşire a uleiului

oil overflow pipe (OM, hidr, mas) țeavă de preaplin, pentru ulei

oil oxidation stability (ind chim) stabilitate a uleiului la oxidare

oil oxidation stabilizer (ind chim, $\mathrm{T}$ ) aditiv antioxidant, agent de stabilizare, agent de inhibare a oxidării

oil package (alim, ind chim) ambalaje pentru uleiuri

oil pad $(\mathrm{T}, \mathrm{OM})$ pernă de ungere, perniță de ungere cu fitiluri

oil paint (ind chim) vopsea pe bază de ulei

oil painting (constr) pictură in ulei, zugrăveală / vopsire în ulei

oil paints (ind chim) vopseluri de ulei

oil pan (auto, mas, T) carter / colector / baie de ulei oil pan tray (mas-un, OM) tavă pentru lichid de ungere şi răcire

oil paper (ind alim, OM) hârtie îmbibată în ulei (pt. protecția elementelor de maşini)

oil passageway (hidr, OM) conductă de ulei, canal de ungere

oil performance ( $T$, chim) performanța uleiului oil pipe(-line) (hidr, OM) conductă de ulei oil piping (mas-un, OM, T) conductă / conducte / linie de ulei / de circulație a uleiului (de ungere sau hidraulic)

oil piping layout $(\mathrm{TH})$ schemă / plan a(1) conductelor de ulei

oil piston ring $(\mathrm{OM}$, termo, $\mathrm{T})$ segment de ungere oil plant (agr, bot) plantă oleaginoasă

oil plug, oil hole screw (mas-un, OM) dop filetat al orificiului de ungere

oil pointer (mas-un, T) indicator de nivel al uleiului

oil pot (mas-un, $T$ ) rezervor de ulei, ungător

oil pool (geol) zăcământ de țiței

oil-pool repressuring (ind) presiune de refacere oil-pool waters (geol) ape de zăcământ

oil-poor (T) cu ulei puțin, (cu) insuficient ulei pentru ungere 
oil-poor circuit breaker (el) întrerupător (de putere) fără ulei sau cu ulei în cantități mici (proiectat sau ca defect)

oil-press (alim) presă de ulei (din semințe, fructe, plante etc.)

oil pressure (auto, hidr, T) presiune a uleiului (lubrifiantului lichid), presiune oleohidraulică; (poligrafie) oleografie

oil pressure cut-out (auto, hidr, T, metr) presostat de siguranță a circuitului de ulei

oil pressure gauge / indicator (auto, metr) manometru de ulei

oil-pressure pipe (mas, OM) conductă de presiune pentru ulei / oleohidraulică

oil pressure safety switch (autom, hidr) presostat de siguranță a circuitului de ulei

oil processing (ind chim) prelucrare a petrolului brut

oil-processing unit (ind chim) instalație de prelucrare a petrolului brut

oil-producing area (geol) perimetru petrolifer

oil-producing formation (geol) formațiune petroliferă

oil production (ind chim) extracție / producție de petrol

oil-proof (materiale) rezistent la acțiunea uleiului, impermeabil la ulei, care respinge uleiul, oleofob (care respinge uleiurile)

oilproofness (ind chim, plast) rezistență la uleiuri (d. elastomeri pentru etanşări etc.)

oil prospecting (geol) prospecțiune a petrolului oil protection / shield (el) izolație / protecție de / cu ulei; (met) protectie cu ulei

oil pump (mas) pompă de ulei

oil pumping (hidr) pompare a uleiului

oil purging (ind chim) dezuleiere, îndepărtare a uleiului

oil purifier (OM, hidr, T) filtru / epurator de ulei oil putty (constr) chit uleios

oil-quenched and tempered (met) călit şi revenit în ulei (d. oțeluri)

oil-quenched fuse (el) siguranță fuzibilă, cu extincție în ulei

oil-quenching (met, TH) călire în ulei

oil radiator (auto) radiator de ulei

oil receiver $(\mathrm{TH}, \mathrm{OM})$ rezervor de ulei

oil reclaimer / regenerator (ind chim, T) regenerator de ulei

oil reclaiming / reclamation (ind chim, $\mathrm{T}$ ) regenerare a uleiului

oil receiver $(\mathrm{OM})$ rezervor de ulei

oil recovered from waste oils and fats (alim, ind chim, mediu) ulei recuperat din deşeuri de ulei şi grăsimi oil recovery (ind chim, T, mediu) recuperare / regenerare a uleiului; (ind) exploatare / recuperare a petrolului (din zăcământ)

oil rectifier / still (alim, mas, OM) epurator / filtru de ulei

oil-recycle process (ind chim, $\mathrm{T}$, hidr, $\mathrm{TH}$ ) proces cu recircularea uleiului

oil refinery (ind chim) rafinărie de petrol

oil refining (ind chim) rafinare a țițeiului / a uleiului, tehnologia țițeiului

oil regenerator (ind chim) instalație pentru regenerarea uleiului

oil region (geogr) regiune petroliferă

oil relief valve $(\mathrm{OM}$, hidr) supapă de suprapresiune pentru ulei

oil research (ind) cercetare / prospectiune a petrolului

oil reserves (geol) rezerve de petrol; (hidr, T, mas) rezerve de ulei (pt. acționări hidraulice şi ungere) oil resinification (ind chim) rezinificare a uleiului oil reservoir / tank (OM, hidr) rezervor / tanc de ulei

oil residue (alim, ind chim, T) reziduu de ulei

oil resistance (plast) rezistență la ulei

oil-resistant (plast) rezistent la ulei

oil-resistant / oil-resisting rubber (plast) cauciuc rezistent la ulei(uri)

oil resisting (materiale) rezistent la actiunea uleiului

oil retainer ring (auto, OM) simering, manşetă de etanşare; garnitură de reținere a uleiului / de împiedicarea pierderii de ulei

oil retaining rim (mas-un, $\mathrm{OM}$ ) rebord pentru reținerea uleiului

oil-return line (hidr, OM) returul uleiului, conductă de retur

oil-return pipe (hidr, OM) conducta de retur a uleiului

oil rig (ind, mas) echipament / instalație de foraj oil ring $(\mathrm{OM}, \mathrm{T})$ segment / inel raclor / de ungere oil-ring bearing $(\mathrm{OM}, \mathrm{T})$ lagăr cu inel(e) de ungere

oil run $(\mathrm{OM}, \mathrm{T})$ orificiu de uns, canal de ungere oils (ind chim) vopsea de ulei / de ungere oil salvage (ind chim) regenerare a uleiului oil sampler (metr, OM) aparat de luat probe de țiței

oil sand (geol) nisip petrolifer

oil sandstone (geol) gresie petroliferă

oil saponification value (chim, metr) indice de saponificare a uleiului

oil-saturated sand (geol) nisip saturat cu petrol oil-saturated sandstone (geol) gresie saturată cu petrol 
oil saturation value (geol) grad de saturaţie cu petrol (al unei roci)

oil saver (ind, met) instalație / dispozitiv de prevenire a pierderii de ulei

oil-scal(ing) ring $(\mathrm{OM}, \mathrm{T})$ inel pentru împiedicarea pierderii de ulei, inel pentru reținerea uleiului, simering

oil scoop / dipper (OM, T) linguriță de ulei pentru barbotare (montată şi pe capacul bielei)

oil scraper (OM, termo) segment raclor

oil scraper (piston) ring $(\mathrm{OM}$, termo, $\mathrm{T})$ segment (piston) raclor de ulei

oil seal $(\mathrm{OM}, \mathrm{T})$ etanşare cu ulei

oil search (geol) cercetare şi explorare a petrolului, prospecțiune şi explorare a petrolului

oil sediment (auto, mas, $\mathrm{T}$, chim) reziduu / depunere de ulei

oil-seed cake (alim) turtă de oleaginoase

oil seepage (geol) infiltrație / susurare a țițeiului; (T) infiltrare a uleiului în materialele cu care vine în contact

oil seeps (geol) infiltrație a țițeiului, manifestări de țiței

oil separator $(\mathrm{OM})$ separator / decantor de ulei

oil shale (geol) şist bituminos / petrolifer

oil ship (nav) tanc petrolier

oil shipment (nav, transp) transport de țiței cu petroliere

oil shock absorber (OM, hidr) amortizor oleohidraulic

oil siphon $(\mathrm{OM}, \mathrm{T})$ ungător de ulei cu fitil

oilskin (nav, textile) haină de ploaie

oil slinger / baffle / deflector $(\mathrm{OM}, \mathrm{T})$ deflector de ulei

oil slip (mas-un) piatră de şlefuit / de tras

oil sludge (termo, OM, hidr) crustă de ulei

oil solubility (alim, plast) solubilitate în ulei

oil-solvent blend (ind chim) amestec de ulei cu solvent

oil-solvent solution (ind chim) amestec de ulei cu solvent

oil splash guard (OM) deflector de ulei, cutie / apărătoare împotriva stropirii cu ulei

oil splitting (alim, ind chim) scindare a grăsimilor oil-spot $(T)$ ungere prin picurare / cu lubrifiant antrenat în jet de aer

oil squirt $(\mathrm{OM}, \mathrm{T})$ pompă manuală de uns, piston de stropit ulei

oil-stained $(T$, chim) îmbibat cu ulei, pătat de ulei oilstone (mas-un) piatră / disc abraziv(ă), îmbiba$\mathrm{t}(\mathrm{a})$ în ulei sau care functionează în baie de ulei

oilstone grinder (mas-un) maşină de ascuțit scule, cu disc abraziv îmbibat în ulei sau care functionează în baie de ulei oil storing (chim, TH) colectare / depozitare a uleiului

oil strainer (OM, mas) filtru de ulei

oil substitute (chim) înlocuitor de ulei

oil sump (auto, OM) baie de ulei

oil sump tank (OM, $T$, hidr) rezervor pentru colectarea uleiului

oil supply (mas, T) sursă de ulei, alimentare cu ulei; rezervă / stoc de ulei

oil switch (hidr, OM, T) întrerupător de curgere a uleiului

oil tank (auto, OM, hidr) rezervor / baie de ulei, carter

oil-tanker (nav) petrolier, navă-petrolier, tanc petrolier

oil tar (ind chim) gudron de petrol / de ulei

oil temperature cut-out (auto, termo, hidr) termostat de siguranță pentru circuitul de ulei

oil tempered (met) revenit / călit în ulei

oil tempering (met) revenire / călire în ulei

oil terminal (ind chim) depozit de transbordare, stație de pompare finală, terminal (de petrol)

oil tester (metr, chim) aparat Abel-Pensky

oil thief (metr, OM) aparat de luat probe de petrol, canciog, grădelniță

oil thinning (OM, T, termo, ind chim) diluare / subțiere a uleiului (d. o unsoare, vopseluri etc.)

oil thixothropic behaviour (fiz, T) comportare tixotropică a uleiului

oil thrower $(\mathrm{OM}, \mathrm{T})$ deflector / aruncător de ulei, dispozitiv de barbotare

oil-tight (OM) etanş la ulei, (material / incintă) în care nu pătrunde uleiul

oil trace(s) urme de ulei (defect la textile)

oil transferring (hidr, termo) pompare / transferare / transvazare a uleiului

oil transformer (el, hidr) transformator cu ulei

oil trap $(\mathrm{OM})$ separator / captator de ulei, cavitate pentru acumularea picăturilor de ulei (şi pt. redistribuire la puncte de ungere)

oil-tray of crankcase (auto, termo, OM) baie a carterului

oil tray (under motor) $(\mathrm{OM})$ tablă deflectoare de ulei (sub motor)

oil trucking (auto, transp, ind chim) transport de produse petroliere cu autocisterne

oil tube drill (mas-un, OM) burghiu cu tuburi de ungere

oil varnish (ind chim) lac de ulei, acoperire cu ulei, strat protector de ulei

oil-water boundary (fiz) limită de separare între apă şi ulei / țiței

oil-water contact (fiz) contact apă-ulei; (geol, fiz) contact apă-titei (la un zăcământ) 
oil-water emulsion (T) emulsie ulei-în-apă; (fiz, ind, geol) emulsie de tipul țiţei-în-apă, emulsie de țiței hidrofobă

oil-water interface (fiz) interfața ulei-apă; (fiz, geol) linie / plan / interfață de separație apățiței (în zăcământ)

oil-water line (fiz) linia de separare apă-ulei

oil-water sludge (fiz, mediu, T) emulsie de apă cu ulei

oil-water surface (fiz) suprafața de separare apăulei; (fiz, geol) suprafața de contact țiței-apă

oilway $(\mathrm{OM}, \mathrm{T})$ canal de ungere

oil well $(\mathrm{OM}, \mathrm{T})$ cutie de ungere; (constr, ind chim) sondă de titei / petrol

oil-well blowing (hidr, T) erupție / împrăştiere a uleiului; (ind) erupție a sondei de petrol

oil-well cementing (ind) cimentare a sondei de petrol

oil-well derrick (constr, ind) turlă de sondă de petrol

oil (well) drill-boat, oil (well) driller (ind, nav) platformă (şi plutitoare) de foraj marin

oil well gas (ind chim) gaz de sondă

oil-well industry (ind) industrie de petrol, industrie petrolieră

oil-well (plunger) pump $(\mathrm{OM})$ pompă de adâncime / fund (pentru țiței, ulei)

oil-well pumping (ind) exploatare a petrolului prin pompare

oil-well shooting (ind) torpilare a unei sonde de petrol (în erupție necontrolată)

oil-well swab $(\mathrm{OM})$ piston de extracție

oil wiper $(\mathrm{OM}, \mathrm{T})$ inel deflector de (picături de) ulei

oil with little body (ind chim, T) ulei nevâscos

oil without additives ( $T$, ind chim) ulei (hidraulic sau lubrifiant) fără aditivi / neaditivat

oily uleios; îmbibat cu ulei; unsuros, gras, onctuos; (fig) alunecos, mieros, insinuant

oil zone (geol, geogr) zonă petroliferă

ointment (chim) unsoare, unguent, cremă, alifie

oitavo (metr, fiz) unitate tradițională portugheză pentru măsurarea volumului (de lichid): 1 oitavo $\cong 1,731$

oka or oke (metr) unitate tradițională de măsură pentru masă în Turcia şi țări mediteraneene: 1 oka $\sim 1,28 \mathrm{~kg}$; uneori unitate de măsură pentru volum de lichid, reprezentând volumul $(\sim 1,25$ 1) ocupat de 1 oka (masă) de vin sau apă

okta (metr, mediu) unitate pentru exprimarea proporțiilor, egală cu $1 / 8$, utilizată în meteorologie pentru a exprima fracția ocupată de nori pe cer

öl (metr) unitate tradițională din Ungaria pentru a măsura lungimia traditional: 1 öl $\cong 1,896 \mathrm{~m}$ olf (metr) olf, unitate empirică pentru măsurarea intensității mirosului în interior

old bătrân, vârstnic, având etatea de, care are vârsta de (d. persoane); vechi (d. lucruri); de altădată, de odinioară; trecut, vechi; antic; inveterat; experimentat, $\mathrm{cu}$ experiență, priceput; of $\sim$ de demult, de mult

old-fashioned anchor (nav) ancoră cu traversă tip amiralitate

old metal (met) metal vechi, spărturi metalice

old rags cârpe vechi (în industria hârtiei)

old sand (met) amestec de formare refolosit, nisip de turnătorie, uzat

old style (OS) (metr) pe stil vechi, notare a datei pe stil vechi sau după calendarul iulian

old timber (silv) lemn îmbătrânit

old waste paper (ind chim, mediu) maculatură

old wine (alim) vin vechi / matur

old workings (ind, geol) zăcăminte exploatate și părăsite

oleaginous (bot, alim) oleaginos; (chim, TH, T) uleios, onctuos

oleaginousness (fiz) onctuozitate

oleander (alim) oleandru

olefin (chim) olefină

olefin polymer oil (ind chim) ulei sintetic (obținut prin polimerizarea olefinelor)

oleic acid (chim) acid oleic

oleiferous (chim) cu conținut de ulei

oleomargarine (chim) oleomargarină

oleo-pneumatic $(\mathrm{OM}$, hidr) hidro-pneumatic (pe bază de ulei)

oleo-pneumatic shock-absorber (OM, hidr) amortizor hidro-peumatic (pe bază de ulei)

oleophilic (fiz, chim) oleofilic

oleophobic (fiz, chim) oleofob

oleoresin (ind chim) răşină fluidă

oleo strut (OM, hidr) picior / suport cu amortizor hidraulic

oligiste (met) fontă oglindă

olive (alim) măslină; culoare măslinie, oliv, măsliniu

olive oil (alim) ulei de măsline

olive-oil cake (alim) turtă de măsline

olivine (minrl) olivină

olk (metr) unitate tradițională irachiană pentru măsurarea suprafeței (de teren): 1 olk $=1$ are $=100 \mathrm{~m}^{2}$

olympiad (metr) unitate de timp de 4 ani; în Grecia Antică - intervalul de timp (4 ani) între două olimpiade consecutive

omega (met) fază omega, fază submicroscopică care poate apărea la formarea fazei alfa din faza beta

omelet(te) (alim) omletă 
omer (metr, agr) unitate veche, din Biblie, pentru măsurarea volumului de cereale etc.: 1 omer $\sim 4,0321$

omicron (literă grecească) omicron

omissible care poate fi omis

omission omisiune; omitere; lipsă; neglijență; scăpare

omit a omite; a neglija; a nu face; a uita să

omnicompetent cu puteri / împuterniciri depline

(şi d. un expert, inspector etc.)

omn. bih. (metr, med) abreviere pentru omni bihorio (în latină), o dată la fiecare două ore, unitate de frecvenţă în prescripții medicale, echivalentă cu alt. h. - abreviere pentru alternis horis (în latină) - (la) fiecare oră următoare

omn. hor. (metr, med) abreviere traditională pentru omni hora (în latină), o dată la fiecare oră, unitate de frecvență în prescripții medicale; o abreviere echivalentă: q. h. (quaque hora, (la) fiecare oră)

omnidirectional (fiz) în toate directiile

OMS (output per man shift) (ec) putere / producție pe om şi schimb, productivitate a muncii

on pe; (el) închis, în circuit; (TH) cuplat; în funcțiune (întâlnit ca inscripție)

on-again, off-again (amer) (mas) care porneşte şi se opreşte brusc; care nu mai porneşte, care nu începe, care nu este aplicat

on an average în medie

on approval (materiale) de probă, ca mostră

ON button (auto, OM) buton de deschidere / pornire / de acționare

onça, once, oncia, onza (metr) uncie, unitate tradițională de măsură pentru masă, în țări cu limbi latinice: 1 onça (Portugalia) $=1$ onza $($ Spania $)=28,69 \mathrm{~g} ; 1$ once $($ Franța $) \sim 30,59$ g 1 oncia / onza (Italia) 27,3 g

once $(a d v)$ o (singură) dată; odată, altădată; odată ce; dacă; în / din momentul în care

on centre (mas-un, OM) fixat pe axă

on centre distance $(\mathrm{OM})(\mathrm{cu})$ distanță între axe (de)

once-over ochire; privire; examinare sumară

once-through boiler (el, termo) încălzitor electric, cu circulație forțată

once-through control (autom, electr) modulare / reglare directă

once-through cooling (termo, T) răcire cu circulare fortată

once-through process $(\mathrm{TH})$ proces într-un singur ciclu / fără recirculare

on-coming apropiat, care se apropie

on-coming of apropiere, sosire apropiată; care se apropie de on-condition unit (TH) sistem tehnic la care mentenanța nu este planificată sau estimată, depinzând de una sau mai multe condiții impuse şi respectate

on-cost(s) (ec) cheltuieli indirecte / de regie

ondometer (fiz, metr) undametru, frecvențiometru on-duty ( $\mathrm{TH}$, ind) de serviciu

one unu, unul, una; prim, prima, întâi; (mat) cifra / numărul unu; unitate; aceeaşi, acelaşi; unul şi acelaşi lucru; unic; $\mathbf{A} \sim$ (clasa) întâi; un / oarecare; oarecare; tot una; unul singur; (în unele cazuri) se (impersonal): pays - se plăteşte; rolled into $\sim$ combinat, $(\mathrm{OM}$, hidr, mec) îmbinate într-un singur modul / sistem; of unul / una dintre; $\sim$ another unul altuia; $\sim$ way or another într-un fel / mod sau altul, pe o cale sau alta

one-aloner (om, persoană) singuratic(ă)

one-amplifier (autom) circuit schemă (de telecomunicații) cu un singur amplificator

one-armed $(\mathrm{OM}) \mathrm{cu}$ un singur braț

one-armed lever $(\mathrm{OM})$ pârghie cu un singur braț one-axis $(\mathrm{OM})$ monoaxial (elemente de maşini, scule şi dispozitive)

one-class boat (nav) navă monotip

one-cycle bandwidth (fiz, electr, radio) lățime de bandă de $1 \mathrm{~Hz}$

one-decker (nav) navă monopuntată, vas cu o singură punte

onedesign (nav, $\mathrm{TH}$ ) proiect monotip

onedesign boat $(\mathrm{OM})$ navă monotip

on edge (OM, TH) (aşezat pe) pe muchie

one-dimensional (mat) cu o dimensiune, unidimensional

one-directional compression efort de compresie pe o singură direcție

one-directional tension (mec, $\mathrm{OM}$ ) efort (de tracțiune) pe o singură direcție

one-eyed (OM) (piesă)cu un singur ochi (de prindere)

one-flue boiler (termo) cazan cu o singură țeavă de flacără / Cornwell monotubular

one gram sample (metr, mec, T) eşantion de 1 gram (de fluid etc.)

one-hole nozzle (auto, termo, T, OM) injector / jiclor cu un singur orificiu

one-horse (mec, mas) de un cal putere

one-ideaded (fig) limitat, mărginit (d. concepții etc.), stăpânit / blocat de o idee

one-legged $(\mathrm{OM}) \mathrm{cu}$ un singur picior

one-loop control system (autom) sistem de reglare cu o singură buclă / cu buclă unică one-man (mas) (acționat) de un singur om oneness unitate, identitate 
one-one (mat) injectiv (d. o funcție), în care un element al celei de a doua multimi are un antecedent în plus (în analiza matematică)

one-parameter (fiz, TH) care depinde de un singur parametru

one-part cu o singură parte, (piesă / element de mașină) dintr-o singură bucată / material

one-part adhesive (plast, chim) adeziv monocomponent

one pass (mas-un, TH) o singură trecere; (sudare) printr-o singură trecere; într-un strat; (plast, ind chim, met) laminare cu o singură trecere

one pass weld $(\mathrm{OM}, \mathrm{TH})$ sudură executată dintro singură trecere

one-phase (el) monofazat; (met) cu o singură fază one-phase current (el) curent monofazat

one-phase ground / grounding (el) punere la pământ a unei faze

one-piece $(\mathrm{OM})$ (piesă) monobloc, dintr-o singură bucată (d. un element de maşină, un bloc hidraulic), modul nedemontabil

one-piece bearing (OM) lagăr monobloc

one-piece casting (met) turnare a unicatelor

one-piece crankshaft $(\mathrm{OM})$ arbore cotit dintr-o singură bucată / monobloc

one-piece flywheel $(\mathrm{OM})$ volant solid (nedemontabil)

one-piece rim (auto) jantă dintr-o singură bucată one-piece wheel $(\mathrm{OM})$ roată monobloc one-pole (el) plug fișă monopolară / unipolară

one-port (el, chim) dipol; uniport

onerous oneros, împovărător, apăsător

onerously ( $a d v)$ (în mod) oneros, dezavantajos

ons (metr, fiz) unitate olandeză de măsură pentru masă: 1 ons $=1$ hectogram $=100 \mathrm{~g}$

oneself ( $p r$ refl) se, (pe) sine însuşi

one-sheet (mat) cu o singură pânză (d. corpuri geometrice)

one-shot lubrication system ( $\mathrm{T}$ ) sistem de lubrifiere / de gresare / de ungere centrală / centralizată one-side o parte, o față

one-sided, single-sided (textile, hârtie, birotică) imprimat pe o singură față; (mat) unilateral; lateral, cu o singură față; (electr) circuit imprimat cu un singur strat metalic

one-sided unilateral; (mat) cu o singură latură; (fig) unilateral, limitat, părtinitor; aplecat întro parte

one-sided limits (mat) limite laterale

one-stage resin (plast, med, chim) răşină termoreactivă

one state (autom, c) stare „unu" la circuite binare one-sheet (geom) cu o singură pânză one-storyed (constr) cu un singur etaj / nivel one-story furnace (alim, met) cuptor cu un singur nivel

one-syllabled (lingv) cu o (singură) silabă

one-term(ed) (mat) cu un singur termen

one-thread worm $(\mathrm{OM}$, alim) melc cu un singur început (într-un angrenaj melcat, prese etc.)

one-throw crankshaft $(\mathrm{OM})$ arbore cotit cu un singur cot

one-to-one injectiv (d. o functie)

one-to-one correspondence (mat) corespondență biunivocă / injectivă, injecție, injectivitate

one-to-one mapping (mat) aplicație / reprezentare bijectivă, în care un element al celei de a doua multimi are un antecedent în plus

one-track (cf, met) (cale ferată) cu o singură linie one-valued function (mat) funcție uniformă one-valuedness (mat) uniformitate

one-way (el, hidr, OM) unidirecțional, cu o singură direcție / cale; (mas-un) unilateral; cu sens unic; (el, fiz) monoalternanță

one-way classification clasificare după un singur criteriu

one-way stick adhesive (plast, OM) adeziv pentru lipire pe o față

one-way valve (OM, hidr) supapă de sens

onflow (fiz, hidr, el) curgere, flux

on-going care continuă; neîntrerupt

onglette file (mas-un) pilă rombică

onion (alim, bot) ceapă

onisotropy (fiz, mec) anizotropie (d. materiale, câmpuri)

on-line (inf, c) on-line, aflat sub control, cuplat direct cu unitatea centrală, direct, functionând în circuit comandat de calculatorul central, sistem de calcul la care utilizatorul are acces în timp real / în mod interactiv, operabil, cuplat şi gata de lucru, (existent / accesibil) pe internet; (monitorizare / reglare) activ(ă) / în timp real

on-line computer (autom, c, TH, ind) calculator direct de proces / cuplat cu maşinile din procesul (tehnologic)

on line maintenance ( $\mathrm{TH}$, mas) mentenanță executată fără întreruperea funcționării sistemului tehnic

on-line operation (TH, mas) exploatare directă

on-line system (autom, c) sistem (de calcul, de monitorizare) care asigură comanda directă a unei operații, a unui proces

on-load changer (autom, el, electr) comutator de reglare sub sarcină

on-load starting (mas, mec, el) demarare / pornire în sarcină

onlooker privitor, spectator

only singur, unic; $(a d v)$ numai, doar 
on-off (autom, el) conectat-deconectat, închisdeschis, tot-sau-nimic

on-off action (autom) reglare tot-sau-nimic / închis-deschis / în două puncte

on-off controller / regulator (autom) regulator / comutator cu două poziții / bipozițional / totsau-nimic

on-off keying (autom, hidr, mec) manipulare bipozițională / închis-deschis

on-off mechanism (mec) mecanism de pornireoprire / de conectare-deconectare

ON/OFF switch (el, electr) comutator / buton deschis/ închis

on-off (two step) action (autom, el, electr, hidr) acțiune de tip închidere-deschidere

on or off attachement (mas-un, OM) dispozitiv de prindere-desprindere

on a percentage sampling basis pe baza unui sondaj; (TH) prin sondaj / control procentual

on period (mas, el, termo) interval de timp de actionare / de conductie

“on” position (mas) poziție „cuplat” / de lucru / de cuplare (a unei manete sau buton de comandă); (TH) poziția deschis

on-push button (OM, mas) buton de comandă acționat prin apăsare

on-sale (ec) cu vânzare de băuturi alcoolice

on-screen distortion (c) distorsiune pe ecran

onsetter (el) electrician de serviciu

onset time (fiz, chim, constr) timp de amorsare

onshore (nav) de coastă / litoral; ( $a d v)$ spre coastă on site (ind) pe loc; pe şantier; la fața locului on-state current (el) curent (care circulă) direct on the job (constr) pe şantier / pe teren on-the-job assembly (OM, TH) asamblare montare pe loc

on the road test (metr, auto) încercare / testare (a autovehiculelor) în conditiii de drum / de teren

on-the-spot calibration (metr, ind) calibrare la fața locului

on-the-spot control (metr, ind) control la fața locului

on (the) port bow (nav) în prova babord

on (the) port quarter (nav) în pupa babord

onus sarcină, răspundere, obligație

onward înainte, în față; (fig) înainte, progresiv

onwards (adv) înainte, în față, mai departe

onyx (minrl) onix

oolitic ore (met, minrl) limonit

ooze (med) supurare; infiltrație; noroi; nămol; mâl; sol nămolos; aluviune; (hidr) (s)curgere foarte lentă; a strecura; a (se) infiltra; a se prelinge; a se scurge foarte lent oozy (mediu) nămolos, mâlos; ud, transpirat opacimeter (metr, opt) opacimetru, aparat de măsurat transparența la lumină

opacity (materiale, opt) opacitate, caracter mat; întuneric; (fig) opacitate, obtuzitate, mărginire

opacity tester (metr, fiz) opacimetru

opal (minrl) opal

opalescence (fiz) opalescență

opaline (ind chim, fiz) sticlă opală / lăptoasă; opalescent

opaque opac, întunecat, nedesluşit, neclar mat (d. materiale) (şi fig); (fig) opac, obtuz, mărginit

opaque container (OM) container opac

opaquely $(a d v)$ (în mod) neclar, abscons

opaqueness opacitate, putere de acoperire (d. vopseluri etc.)

opaque rubber (ind chim, fiz) cauciuc cu plumb (de protecție la raze Röentgen)

open aer / spațiu liber, spațiu deschis; (silv, mediu) luminiş (în pădure); (el) deschis, întrerupt, deconectat; (mat) strict posibil, posibil dar nu necesar; (ec) deschis (d. o sedintă etc.); deschis, nesoluționat, discutabil (d. o problemă etc.); deschis, mare (d. ochi); desfăcut, deschis (d. o scrisoare, o carte, un braț, o mână etc.); fără obstacole; fățiş, pe față (d. o ceartă, atitudine etc.); întins (d. mână, braț, etc.); neapărat, deschid (d. un oraş etc.); nerezolvat, rămas deschis (d. o problemă etc.); fără intervenția poliției; (TH, OM) deschizătură, declanşat, scos din circuit, deschis, desfăcut, destrămat, liber, neîncuiat, accesibil, dat la o parte (d. uşi, capace etc.); deschis, neîmprejmuit, neîngrădit (d. un teren); nezăvorât neîncuiat (d. uşi, lăzi, panouri de comandă etc.); (ec) liber, neocupat, vacant (d. un post); (nav) larg, mare liberă, a descoperi o intrare în port, a apărea; a deveni foarte vizibil; (auto) decapotabil, deschis, neacoperit (d. un vehicul etc.), a scoate capota; (meteorologie) fără zăpadă şi geruri (d. iarnă), (d. vreme) dulce, blând; evident, manifest, vizibil; public, scos la iveală, publicat; declarat; generos, darnic; (mil) desfăşurat; dispersat; (mas-un, OM) a (se) deschide, a (se) descuia, a da la o parte, a rostui, a desface / îndoi / rostui (capetele unui cui spintecat), a rupe, a (se) desface, a destrăma, a (se) slăbi (d. un şurub, o piuliță, o frână), a forța, a (se) da la o parte; (textile) a desface, a destrăma, a bate (fibrele); (fig) a releva; a începe; (geol) a irupe (d. petrol etc.); cinstit, deschis, direct, sincer (d. felul de a fi al cuiva); a (se) deschide, a începe, a declara deschis (d. o ședință, o discuție, un eveniment etc.); a se deschide, a se înfățişa (d. o privelişte); a deschide (ochii, gura etc.); a deschide, a desface (o scrisoare, o carte etc.); 
a deschide (sufletul, inima, etc.); a descoperi; (fig) a desface (mâna, brațul etc.); a destăinui (sufletul, inima, un secret etc.); (fig) a da publicității, a face public; a rări (rândurile) (d. un text, o formație militară etc.); a comunica, a înştiinţa despre; in the air în aer liber; fire (mil) a deschide focul; half- (OM) întredeschis; push / throw a deschide brusc; open road cale deschisă; in order în ordine desfăşurată; have an $\sim$ hand a fi generos, a avea inimă largă; be $\sim$ to many objections a risca să întâmpine multe obiecții; to attack expus unui atac; lay $\sim($ fig) a demasca, a scoate la iveală, a descoperi

open account (ec) cont deschis (în baza unui credit)

open-air în aer liber

open-air drying (agr, constr) uscare în aer liber

open-air piping (OM, hidr, ind chim) conductă în aer liber / de exterior

open-air transformer plant (el) stație de transformatoare în aer liber

open-and-shut foarte clar, evident

open and shut action (autom) reglare tot-saunimic, acționare închis-deschis

open annealing (met) recoacere în aer liber

open arc (el) arc electric descoperit / în aer liber (şi la sudare)

open assembly time (chim) timp de asamblare deschis, intervalul de timp după care adezivul îşi pierde capacitatea de lipire

open berth (nav) loc de ancoraj neadăpostit (într-o radă deschisă)

open building pit (constr) groapă de fundație (fără întărire)

open burning coal (termo) cărbune cu flacără lungă

open butt joint $(\mathrm{OM})$ îmbinare cap-la-cap / cu joc open butt weld (OM) sudură cap-la-cap, cu rost între margini

open by boring (mas-un, $O M$ ) lărgire a unei găuri (cu burghiu sau lărgitor)

open calibre (metr) calibru deschis

open car (auto) automobil decapotabil

open carriage trăsură descoperită

open centre (hidr) sistem (hidraulic) care, dacă nu lucrează, permite evacuarea fluidului de lucru în rezervor

open chain hydrocarbons (chim) hidrocarburi nesaturate

open calliper (metr) calibru deschis

open chamber needle valve (OM, hidr) supapă (de deschidere) cu ac

open cheque (ec) cec nebarat open chock $(\mathrm{OM})$ ureche de ghidare / de prindere deschisă

open circuit (hidr) circuit deschis / neoperabil din cauza unei avarii sau scurgeri; (mas, el) mers în gol

open-circuit grinding (alim, constr) măcinare în circuit deschis

open-circuit operation (TH) proces tehnologic în circuit deschis

open contact (el, hidr) contact de lucru / normal deschis

open credit (ec) credit descoperit / deschis

open-cup flash point (metr) temperatura / punctul de inflamabilitate (determinat) în vas deschis (pt. fluide)

open-cup tester (metr) aparat pentru determinarea temperaturii de inflamabilitate în vas deschis (pt. fluide)

open cure (plast, ind chim) vulcanizare liberă / fără matriță

open cycle control (autom) comandă în circuit deschis

open die(s) (mas-un, plast) matriță deschisă (ce permite formarea bavurii)

open-door (mas) accesibil pentru control şi curățare, (cu) uşă de acces

open dye kettle (OM, met, textile) bazin / incintă de vopsire $\operatorname{deschis}(\breve{a}) / \operatorname{neprotejat}(\breve{a})$

open-ended line (hidr, OM) linie / conductă cu terminație deschisă / neobturată / deconectată la capăt

open-ended question întrebare / chestionar care admite o infinitate de răspunsuri

open-ended spanner (OM) cheie fixă, cu cap deschis

open end hole $(\mathrm{OM})$ gaură pătrunsă / fără fund open end wrench $(\mathrm{OM})$ cheie simplă (cu gură deschisă)

opener (alim, OM) tirbuşon; cheie, deschizător (pt. conserve); (mas-un, OM) dispozitiv de deschidere

open equipment (mas, mediu) echipament neprotejat (contra actiunilor exterioare sau atmosferice)

open exhaust (hidr) evacuare liberă

open-eyed vigilent, atent

open-flame furnace (met) cuptor cu flacără

open flow (hidr) curgere liberă

open furnace (met) cuptor deschis

open-fuse cut-out (el) siguranță cu topire directă / liberă

open-grain structure (matriale) structură cu granulație mare

open hearth (met) vatră deschisă (la cuptoare) open hearth furnace (met) cuptor Martin 
open hearth iron / steel (met) oțel obținut în cuptor Martin

open hearth pig iron (met) fontă pentru cuptor Martin

open hearth plant (met) secție de oțelărie Martin open hearth process (met, $\mathrm{TH}$ ) procedeu siderurgic Martin

open hearth refining (met, TH) afinare în cuptor Siemens-Martin

open hearth steel furnace (met) cuptor Martin, pentru elaborarea oțelului

open hearth steel plant (met) oțelărie Martin

open hole $(\mathrm{OM})$ gaură pentru nituire la locul de montaj

open hostilities (mil, şi fig) război declarat, ostilități deschise

open-impeller pump (OM, hidr) pompă cu rotor deschis

opening breşă; descoperire; începere a unui exploatări; (ec) debuşeu (pt. o marfă); (OM) interstițiu, spațiu liber, gaură; lumină; deschidere, deschizătură, descoperire, explorare, excavație, străpungere, breşă, spărtură, orificiu, cavitate; declanşare; început; inaugurare; parte introductivă; şansă, prilej favorabil; post liber / vacant; de început / deschidere; (sport) loc / spațiu / poziție neapărat(ă); (fiz) lumină; (fig) (deschidere spre) soluționare; (silv) luminiş, poiană; ocazie fericită / favorabilă; oficiu; (geogr) pas, chei, trecătoare; (cinematografie) premieră; fericit; inițial; de deschidere, de început, de inaugurare, inaugural; incipient; preambul (la un discurs); intrare, ieşire (în sens de trecere în orice sens); (fig) prima apariție, debut; for ocazie favorabilă pentru, oportunitate pentru

opening-and-lap-forming machine (met, constr) bătător

opening between rolls (met, OM) jocul între cilindrii de laminor

opening bridge (mas, transp) pod mobil

opening capacity (met, mas, TH, hidr) deschidere maximă, capacitate de deschidere

opening capital (ec) capital inițial

opening cut $(\mathrm{TH})$ spintecare

opening delay (el, autom) întârziere la declanşare / la deschidere / la deconectare

opening die-holder (mas-un, OM) cap de filetat cu deschidere automată

opening line (c, inf) rând de început

opening material (chim) degresant

opening of an angle (geom) deschidere a unui unghi

opening of the break (OM, termo) dilatare (a frânei) opening of the circuit (el, hidr) deschidere a circuitului

opening of a connection (el, autom) deconectare opening of the groove (met) profil / deschidere de calibru (la cilindri de laminor)

opening of the ring (chim) deschiderea ciclului / radicalului ciclic

opening of the spanner (OM) deschidere a cheii / a gurii (cheii)

opening pipe (OM, hidr) conductă de trecere / de intrare / de deschidere

opening pressure (hidr) presiune (statică) de deschidere

opening price (ec) curs de deschidere (la bursă)

opening section (of the swing bridge) (constr) orificiu / loc de trecere

opening time $(\mathrm{el}, \mathrm{mec})$ timp / întârziere de întrerupere / de deconectare / de deschidere a(l) unui întrerupător; (ec) oră de deschidere

opening wedge (constr) breşă

open into a da înspre, a se deschide spre, a avea vedere spre

open into / on / to a da spre / în, a comunica cu open joint (OM, hidr) asamblare (de conducte) cap-la-cap, îmbinare cu joc

open-joint fissure (materiale) crăpătură / fisură deschisă / ajunsă la suprafaţă

open keyseat $(\mathrm{OM})$ canal de pană, deschis

open link $(\mathrm{OM})$ culisă deschisă / fără protecție

open-link chain $(\mathrm{OM})$ lanț articulat

open-loop control (autom) reglare / control în buclă deschisă

open-loop control system (mas, autom) sistem cu funcționare cu reglare / control în buclă deschisă

open-minded cu orizont larg; lipsit de prejudecăți; receptiv (la nou etc.)

openness deschidere; disponibilitate; poziție expusă; sinceritate; evidență, caracter vădit / manifest

openness of scale (metr) sensibilitate pe unitatea de lungime; increment între diviziunile scalei

open out a (se) deschide; a lărgi; a mări (găuri, alezaje etc.); a (se) desface; a releva; a face cunoscut; a vorbi deschis

open out a hole (mas-un) a lărgi o gaură / un alezaj open out the throttle (auto) a accelera motorul open pass (met, metr) calibru deschis

open-phase protection (autom) disjunctor de fază; (el) dispozitiv de protecție contra întreruperii unei faze

open pipe (hidr, OM) conductă deschisă / fără presiune

open piston $(\mathrm{OM})$ piston deschis / neprotejat 
open pit (met) groapă de turnare open polygon (mat, geom) linie poligonală / frântă / deschisă

open porosity (materiale) porozitate aparentă deschisă

open position (autom, hidr) poziție (total) deschisă open-pot melting (met) topire în creuzet deschis opening price (ec) valoare / preț de deschidere la bursă

open quarry carieră la suprafață, sub cerul liber open question chestiune discutabilă open resistance (el) rezistență infinită open roastead (nav) radă deschisă open sand (materiale, met) nisip poros / permeabil open sand casting (met) turnare în solul turnătoriei

open sand mould (met) formă executată în solul turnătoriei

open sand moulding (met) formare în forme de amestec deschise

open scale (metr, OM) cadran / scală fără gradatii intermediare / cu intervale mari între gradațiile principale

open sea service (nav) navigație în largul mării open set (mat) multime deschisă

open sheet delivery (OM, tipografie) dispozitiv de eliminare a colilor

open shop (ec) loc de muncă necondiționat de apartenența la un sindicat

open side planer (mas-un) raboteză cu un singur montant

open space exterior, spațiu liber (ca interstițiu între două piese sau față de mediul exterior); suprafață liberă

open spacing amplasare la intervale mari; densitate mică a amplasării granulelor (la discuri de rectificat, compozite etc.)

open spillway (hidr) deversor liber

open spreader $(\mathrm{OM})$ întinzător deschis

open square butt weld $(\mathrm{OM})$ sudură cap-la-cap fără teşirea marginilor, cu distanță mare între piese

open-steam cure (ind chim) vulcanizare cu abur direct

open-steam oven (ind chim) autoclavă de vulcanizare cu abur direct

open-steam reclaiming process (ind chim) proces / tehnologie de vulcanizare cu abur direct

open system sistem deschis

open tapped $(\mathrm{OM})$ cu capac demontabil

open-tee joint $(\mathrm{OM})$ îmbinare în $T$, cu joc între margini (şi la sudură)

open the connection(s) (mec, el, hidr) a deschide, a deconecta open the mould (met, plast) a scoate o piesă turnată din formă / matriță, a deschide matrița forma

open throttle (termo) admisie completă a gazului, deschidere completă a orificiului de admisie open time (plast, chim, TH) timp (de asamblare) deschis, interval de timp între aplicarea adezivului şi realizarea asamblării

open to receptiv la; care primeşte uşor; pasibil de; supus; accesibil pentru, expus la

open top feeder (met) maselotă directă / deschisă open top side feeder (met) maselotă deschisă lateral

open town oraş deschis

open truck (cf) vagon de marfă deschis / platformă open-type (constr, mas) construcție de tip deschis / neprotejat

open-type compressor unit motocompresor (de tip) deschis / necapsulat

open up a (se) deschide; (OM) a (se) desface; (el, hidr) a deconecta

open up the engine (auto, termo) a accelera motorul; a deschide clapeta unui motor

open up on hinges a rabata, a bascula

open vulcanisation (ind chim) vulcanizare liberă (fără matriță)

open water-cooling tower (met, el) turn de răcire descoperit

open window unit (owu) (metr, fiz, acustică) denumire inițială a unității pentru absorbția sunetului / acustică, denumită acum sabin, v. sabin open wire (el) fir neizolat, linie aeriană operability (mas, ec) operabilitate

operable realizabil, executabil; care funcționează, în funcți(une); (c) operabil; funcționabil, gata de lucru

operand (mat) (număr) operator; (c, inf) operand, dată implicată în efectuarea operațiilor la calculatoare, număr operator, mărime de calcul, adresa unei instructiuni

operand fetch (c, inf) citire / extragere a operandului (dintr-o memorie)

operand register $(\mathrm{TH}$, ind) registru de operand / de operator

operate ( $\mathrm{TH}$, ind) a produce; a functiona; a manipula, a mânui; a excita; a acționa; a pune în functiune (o mașină); (ec, TH) a prelucra, a exploata; a opera; a lucra; a conduce, a administra, a avea în subordine; a avea, a produce efect (şi d. un medicament, o schimbare etc.); (mil) a desfăşura operații strategice, a opera; a efectua, acuza; (adm, pol) a actiona a administra, a avea în subordine, a gestiona; a opera, a produce (schimbări etc.) 
operate current (el, autom, electr) curent de acționare / de comandă / de declanşare / de excitație / de pornire; non- curent inactiv (al unui releu), curent mai mic decât curentul de acționare (al unui releu)

operated (mas) acționat, comandat, alimentat

operate delay (autom) întârziere de răspuns / de declanşare

operate for a rise (ec) a specula în speranța unei urcări (a cursurilor)

operate margin (el, autom, mas) limită de acționare / declanşare / de răspuns (la relee)

operate on / upon a acționa, a exercita influență asupra (cuiva); (fig) a profita de, a exploata (naivitatea, încrederea cuiva); (med) a face o operație (cuiva)

operate power windows (auto) a deschide ferestrele automat

operate speed (mas, TH) viteză de lucru / de actionare

operating (mas) de exploatare, de lucru, de funcționare, de acțiune, de regim, care lucrează / funcționează, curent (d. reparații etc.); de comandă, de deservire, (condiții / regim) de exploatare / de funcționare / de lucru; pentru / de operații; tehnic; (med) chirurgical

operating accident (mas, TH) accident de / în exploatare / în functionare

operating alternating-current voltage (el) tensiune de regim (în curent alternativ)

operating ampere-turns (el, metr) amper-spire active

operating bias (electr, fiz) polarizare de funcționare (a unui tub electronic etc.)

operating break-time (autom, el) timp de acționare / de răspuns al unui contact de închidere /de repaus

operating button (OM, mas) buton de acționare operating by hand (mec, mas) operație / acționare manuală

operating characteristic (mas) caracteristică de lucru / de functionare

operating circuit $(\mathrm{TH}, \mathrm{el})$ circuit de lucru

operating code regulations (ec) regulament de funcționare / intern al unei organizații / unei întreprinderi

operating coil (el, metr, autom) bobină de acționare (a unui releu)

operating contact (el) contact de închidere, contact de lucru

operating conditions (mas, TH) condiții / regim de exploatare / de lucru / de functionare

operating control (autom, metr, ec) control în exploatare; $(\mathrm{OM})$ levier de comandă operating control cab (mas) cabină / cameră de comandă (la macarale etc.)

operating costs (mas, ind, ec) cheltuieli de exploatare (exclusiv costul sistemului)

operating current (el, mas) curent de regim / de lucru / de funcționare / de acționare

operating datum / data (mas, $\mathrm{TH}$ ) parametru / parametri de lucru / de exploatare

operating delay (autom, mas) întârziere în acționare

operating desk (mas) masă de lucru, pupitru de comandă

operating device (autom, mas) dispozitiv de manevră / de acționare / de deservire / de comandă operating diagram (mas) diagramă de funcționare

operating differential (value) (autom, mas, metr) valoare operativă / efectivă de reglare

operating distance limit (auto) limita distanței de deschidere

operating duty (mas, el, mec) sarcină / regim nominal( $\breve{a}) / \operatorname{normal}(\breve{a})$

operating duty test (mas) încercare / test de funcționare în condiții de lucru

operating efficiency (mas) de randament în / de exploatare

operating element (OM) element / organ de lucru / de actionare

operating engineer $(\mathrm{TH})$ inginer de exploatare / de secție, inginer tehnolog

operating error ( $\mathrm{TH}$, autom) eroare de comandă / de manipulare

operating expenses (ec) cheltuieli indirecte, cheltuieli generale neproductive şi pentru forța de muncă, cheltuieli de exploatare

operating experience experiență de exploatare

operating fault (mas, TH) greşeală / eroare / defect de funcționare, cădere din cauza condițiilor de functionare

operating frequency $(\mathrm{TH}, \mathrm{el})$ frecvență de lucru / industrială / normală / de regim

operating gear $(\mathrm{OM}$, mas) mecanism de actionare / de comandă (şi cu roți dințate)

operating gear for saddle (mas-un) mecanism pentru deplasarea saniei principale

operating handle $(\mathrm{OM})$ manivelă / manetă de acționare / de comandă / de deservire

operating handle tappered pattern (OM) mâner cu cap sferic

operating hours (mas) ore de functionare

operating hours counter (metr) contor de ore de functionare

operating installation instalație de fabricație, utilaj de fabricație 
operating installation (ind, mas) instalație / utilaj de producție

operating instruction(s) (auto, mas) instrucțiune / instrucțiuni de exploatare; (inf, autom) instrucțiune operațională, instrucțiuni operaționale

operating instructions form (ec, mas) document / ghid prin care sunt precizate condițiile de executare a lucrărilor pe calculator / pe o mașină cu comandă numerică etc., foaie de operare

operating key (mas, autom) cheie / tastă de acționare

operating knob (OM, autom) buton de comandă operating leasing (auto, mas, agr, ec) arendare, închiriere (cu recuperare parțială a prețului de vânzare al obiectului contractului)

operating lever (OM) pârghie de acționare; (termo, hidr) nivel (de fluid / de presiune etc.) care condiționează întrarea în funcțiune

operating life (mas, OM) durată de exploatare / de viață

operating line (mas, TH) linie de exploatare / de operație / de prelucrare

operating load (mas, mec) sarcină / solicitare de regim

operating machinery (mas, OM) mecanism / maşină de antrenare / de acționare

operating magnet (el, electr) magnet de manevră / de reglare

operating make-time (el, mas) timp de funcționare al unui contact de lucru

operating mode (el, autom) mod de lucru / de acționare / de exploatare; (inf) mod de execuție (a unui program)

operating nut on (ball) thrust bearing (OM) piuliță de acționare pe rulmenți axiali (cu bile) operating observation $(\mathrm{TH})$ supraveghere a procesului tehnologic / a operației / a exploatării / a funcționării (de către un operator uman)

operating overload (mec, mas) suprasarcină în exploatare / de funcționare

operating part (OM) organ (activ) de lucru operating pedal $(\mathrm{OM})$ pedală de comandă / de actionare

operating performance (mas) performantă în exploatare

operating personnel / staff $(\mathrm{TH}$, ec) personal de deservire / tehnic / de exploatare

operating plan $(\mathrm{TH}, \mathrm{ec})$ plan de productie

operating point (mas) punct de funcționare

operating pole (el, mas, transp) bară (izolantă)

de comandă / de manevră, prăjină (izolantă) de comandă / de manevră

operating position (mas, mas-un) poziție de lucru operating power (el) putere de acționare / de anclanşare / de funcționare (a unui releu)

operating pressure (hidr, mec) presiune de lucru / de regim (nominal)

operating pressure range (hidr) interval al presiunii de lucru / de regim (nominal), limite de presiune între care sistemul funcționează

operating principle (mas, $\mathrm{TH}, \mathrm{OM}$, el) principiu de functionare / de lucru

operating procedure (mas, $\mathrm{TH}$ ) procedură de functionare

operating process $(\mathrm{TH})$ proces tehnologic

operating range (mas, autom, radio, electr) domeniu de functionare / de actionare / de reglare; (mas, TH) rază de acțiune (la manipulatoare, poduri rulante etc.)

operating rate (mas) viteză de lucru / de funcționare / de exploatare / de regim

operating repairs $(\mathrm{TH}$, mas) reparații curente / de întreținere / uzuale

operating room (ind) sală / cameră de manipulare / de comandă, cabină de protecție

operating rules $(\mathrm{TH}$, mas) reguli de exploatare operating safety (TH, mas) siguranță în funcționare, care lucrează în siguranță

operating space (TH, mas) spațiu de operare / de lucru al dispozitivului / al brațului robotului, manipulatorului etc., ansamblu al pozițiilor de lucru al unui robot, spaţiul din jurul unei maşini-unelte necesar operatorului şi depozitării semifabricatelor şi pieselor prelucrate; (inf, c) ansamblu al pozitiilor adresabile ale unui dispozitiv de afişare

operating speed (autom, el) viteză / timp de răspuns (al unui releu); (TH, mas) viteză de lucru, turație de regim; (metr, mas) cadență / frecvență de măsurare

operating staff (ind, mas) personal de deservire / de exploatare, personal tehnic

operating standards laboratory (metr) laborator metrologic

operating station (autom, TH) stand / pupitru / tablou de comandă

operating superheat (termo, autom) (valoare de) supraîncălzire (exprimată prin temperatură, dilatare etc.) care acționează dispozitivul de reglare / de comandă

operating switch (el, mec) întrerupător de comandă, controler

operating system (OS) (c, mas, autom, inf) sistem de operare / de exploatare / de comandă a executării programelor; ansamblu / set de programe care realizează interfața dintre utilizator şi sistemul de calcul 
operating tap voltage (el) tensiune a unei prize de functionare / de lucru

operating temperature $(\mathrm{TH}, \mathrm{mas}$, termo) temperatură de lucru / de funcționare

operating theatre (med) sala de operații; $(\mathrm{TH})$ hală / spațiu de lucru; (mil) teatru de operații

operating threshold sensitivity (autom, metr) sensibilitate la pragul de funcționare

operating time (TH, mas) durată de lucru / de serviciu (a unei instalații, al unei maşini, al unui releu etc.); (el) timp de acționare / de funcționare (al unui releu)

operating time ratio ( $\mathrm{TH}$, mas) factor al timpului de serviciu / de functionare

operating trouble $(\mathrm{TH}$, mas) defect de exploatare, avarie, deranjament, pană, cădere, defectare

operating unit (mas) dispozitiv de comandă / de deservire

operating units sparing (c) economie de celule ale memoriei, economie de elemente ale memoriei

operating value (autom, mas) valoare de reglaj / de comandă

operating / operation voltage (el) tensiune de funcționare / de lucru / de anclanşare / de acționare (a unui releu), tensiune de amorsare (a unui arc electric)

operating watts / power (el) putere (electrică) de funcționare / de anclanşare / de acționare (şi a unui releu)

operating winding (el, electr) înfăşurare de excitație

operating with (mas) funcționare cu; care operează cu / în timpul

operating with alternating current or direct current (el) funcționare universală (cu curent alternativ sau continuu)

operation operație (logică, tehnologică etc.), lucru, muncă, proces (sau mai multe operații), activitate, desfăşurare; manevrare; acțiune, efect (asupra); acționare (inf) acțiune definită de o singură instructiune / de un singur element logic, rezultat obținut de la un operand; (mat) calcul, operație; (TH) muncă, operație, mânuire, acționare, punere în functiune, exploatare; forță, putere; influență; (ec) producție, procedeu, tranzacție financiară; (mil) operație; (med) operație, intervenție (chirurgicală); (mat) operatie; unddergo an $\sim$ a suferi o operatie; perform an $\sim$ a face o operație; come into $\sim$ a intra în vigoare; be in $\sim$ a fi în vigoare

operational operațional, de exploatare, care poate fi pus în funcțiune; disponibil; gata de funcționare / de lucru operational availability ( $\mathrm{TH}$, mas) disponibilitate de functionare

operational altitude (mas) înălțime / sarcină utilă de exploatare (în hidrotehnică, la macarale, poduri rulante etc.)

operational chart (mas) schemă funcțională / operațională / de instructiune

operational distance (mas, transp) distanţă de operare (a unui manipulator, pod rulant etc.)

operational efficiency (mas) eficiență, randament în exploatare

operational factors (mas) caracteristici de lucru, parametri de funcționare

operational hazard ( $\mathrm{TH}$, mas) pericol de / în exploatare

operational limit (mas) limită operațională / de functionare

operationally ready (mas) disponibil, gata de funcționare / de lucru (aşa cum a fost proiectat) operational reliability (mas) fiabilitate efectivă / operatională, sigurantă în exploatare / în funcționare

operational research cercetare operațională; activitate de analizare, modelare matematică şi măsurare a proceselor cu caracter repetitiv

operational seating ring $(\mathrm{OM})$ inel fix de etanşare

operational unit (mas) modul / subsistem / unitate operațional $(\breve{a})$

operation breakdown (analysis) (TH, ec) analiză prin defalcare / a componentelor unei activități operation control circuit (autom) circuit de reglare / de control / de comandă a(l) funcționării operation delay (autom, ec) timp de întârziere (între comandă şi executarea ei)

operation details (mas) dispozitive de deservire sau comandă

operation knob (OM, mas) buton de comandă operation line (TH, ind) linie tehnologică operation period $(\mathrm{TH}$, mas) timp (efectiv) de lucru / de funcționare / de exploatare

operation register ( $\mathrm{TH}$, mas) registru de operare / de instrucțiuni

operation office ( $\mathrm{TH}$, mas) serviciu de exploatare operation sheet $(\mathrm{TH})$ fişă tehnologică operation smoothness (mas) funcționare lină / fără vibrații / suprasarcini etc.

operations plan $(\mathrm{TH})$ plan de operații operations research cercetare operațională operations section ( $\mathrm{TH}$, mas) secție de exploatare operation voltage (el) tensiune de functionare / de lucru / de anclanşare / de acționare (a unui releu / aparat), tensiune de amorsare a unui arc electric 
operative $(s)$ muncitor (calificat), lucrător, operator, conduc(ă)tor, angajat; operativ; de acțiune; eficace, practic; în funcțiune; activ, productiv; mecanic; expeditiv; (ec) bun / apt de exploatare; $(\mathrm{TH})$ în bună stare de functionare

operator (auto) şofer, conducător auto; (inf) operator, simbol terminal al gramaticii unui limbaj de programare; (mat) operator; (ind, TH, mas) lucrător, operator, conductor, mecanic, maşinist, motorist, manipulant; (ec) proprietar / administrator de firmă; (med) chirurg; (fig) speculant

operator controls (OM, autom) butoane de comandă / de acționare

operator('s) cage (met) cabina macaragiului / operatorului

operator's console / desk (autom, mas) pupitru / consolă de comandă

operator's handbook (mas) manual / instrucțiuni de utilizare / exploatare

operator's platform (met, el) post / loc de comandă; dispecerat

opinion opinie, părere (şi a unui specialist); punct de vedere; convingere; apreciere; concluzie; verdict

opponency (ec, adm) opoziție; rezistență

opponent opus, contrar; aşezat față în față; ostil; oponent; adversar; partener (în negocieri)

opportune oportun; adecvat; potrivit; nimerit opportunely $(a d v)$ la momentul potrivit / oportun opportuneness oportunitate, caracter oportun opportunity prilej favorabil, ocazie favorabilă, moment potrivit

opposable opozabil; contrastabil

oppose (with / against) a opune (şi rezistență), a se opune (la); a contrasta; a fi împotriva

opposed opus; invers; contrar

opposed blade damper (termo, met) registru (de aer) cu palete opuse / cu palete de compensație

opposed cylinder-type engine (termo) motor $\mathrm{cu}$ cilindrii opuşi, orizontali

opposed force (mec, fiz) fortă opusă / reactivă / acționând în sens invers

opposed / ordinary milling (mas-un) frezare în contra avansului

opposed to ostil față de; în dezacord cu

opposer opozant, adversar; potrivnic

opposing cu înțeles contrar, antonimic, în sens opus; care (se) opune

opposing electromotive force (el, mec) forță / tensiune electromotoare opusă / contrară

opposing force (fiz) forță opusă / reactivă / de sens contrar

opposing reaction (chim) reacție reversibilă opposing spring (OM) arc cu revenire / de rapel opposing winding (el) înfăşurare diferențiată / antagonistă

opposite opus; invers; (mat) contrar, de semne contrare

opposite angles (geom) unghiuri opuse la vârf opposite flanks (OM) flancuri opuse opposing forces (mec) cuplu de forțe opposite (to) opus; contrar (cu); invers (față de); raport de opoziție; lucru / cuvânt opus; (prep) vizavi de, de / pe / în partea cealaltă

oppositely directed (fiz, OM) (care se mişcă se deplasează) în sens contrar; direcționat în sens invers

oppositely phased voltages (el) tensiuni în opoziție de fază

opposite phase (fiz, el) fază opusă / antagonistă opposite poles (el) poli opuşi

opposition opozitie, deosebire izbitoare; contrast marcat; opunere, rezistență; (el) opoziție de fază, antifază, defazaj de $90^{\circ}$

optation optiune

optic (metr, opt) ocular, optic

optical (fiz) optic, de optică, ocular; vizual

optic(al) blokage technique (fiz, metr) tehnică de blocare optică

optical comparator (metr, opt) comparator optic optical glass (fiz) sticlă optică

optical index (fiz) indice de refracție; (metr, TH) indicator luminos

optical illusion iluzie optică

optical method (fiz) metodă optică

optical microscopy (fiz, metr, opt) microscopie optică

optical phenomena (fiz) fenomen optic

optical plastic (plast) material plastic (transparent) utilizabil în aparate optice

optical pyrometer (metr, termo, opt) pirometru optic

optical scanning (metr) scanare / verificare optică, vizualizare

optical sight $(\mathrm{OM})$ vizor

optical signal (mas) semnal optic

optical signalling (mas) semnalizare optică

optical spectrum (fiz) spectru vizibil

optical view finder (metr, OM) vizor optic

optimal optim, optimal

optimal adjustment (autom, mas) acord / reglare / ajustare optim(ă)

optimal setting (autom, mas) reglare optimă

optimization (mas, ind) optimizare; proiectare de optimizare

optimization problem $(\mathrm{TH}$, ec) problemă de optimizare 
optimal setting (autom, mas) reglare optimă optimal vehicle performance (auto) funcționare optimă a vehicolului

optimize a optimiza

optimizing (TH, ec) optimizare; (inf) alocare optimă, care optimizează alocarea

optimum, $(p l)$ optima optim, cel mai bun, cel mai favorabil; cele mai favorabile condiții, soluție optimă; valoare maximă

optimum coupling (OM) cuplaj optim / critic optimum cure (ind chim) tratare / conservare optimă; vulcanizare optimă

optimum form / shape $(\mathrm{OM})$ formă optimă

optimum test (metr) test optim

optimum value valoare optimă; optim

option opțiune, alegere, selecție; alternativă

optional opțional; la alegere; facultativ; neobligatoriu

optional equipment (ind, $\mathrm{TH}$ ) echipament special / opțional (livrat la comanda beneficiarului)

optional feature (ind, TH) dispozitiv auxiliar facultativ; (c) caracteristică opțională / la cerere optionally $(a d v)$ (în mod) facultativ, la alegere optional sampling selecție facultativă

optometer (fiz, metr) optometru

or (inf, autom) funcție logică SAU, SAU inclusiv oral oral, verbal; (med) bucal; (edu) examen oral orally $(a d v)$ oral, verbal; (med) pe cale bucală orange (alim, bot) portocală, portocal; portocaliu orangeade (alim) oranjadă

orange oil (alim) ulei de portocale

orange-peel bucket $(\mathrm{OM}$, transp) cupă cu graifăr formată din segmente (ca feliile unei portocale)

orb (fiz) orbită; rotație; corp ceresc; planetă; glob; (mat) sferă, cerc

orbicular sferic

orbit (fiz) orbită, traiectorie; (mat) suprafaţă de tranzitivitate; orbital; a se deplasa pe o orbită, a se învârti

orbital (fiz, mec) orbital

orbital moment (mec) impuls orbital

orchard tractor (mas, agr) tractor de grădină or-circuit (autom) circuit SAU

order ordine, disciplină; (autom, inf) instrucțiune, comandă, ordin; ordine, succesiune, secvență, serie, stare; (mat) şir, ordin, ordonare, grad; stare de funționare; regulament, regulă, statut; ordin, clasă, fel, categorie; rang; (pol, adm) ordonanță, pătură socială; poruncă, dispoziție, hotărâre; (inf) instructiune; (ec) ordin, instructiune, decizie, comandă, scrisoare de comandă, mandat de bani; (mil) ordine, formație; obicei; (bot, zool) clasificare; (fiz) ordine, stare; succesiune, ordine; a aranja, a sistematiza, a organiza, a pune în ordine; a ordona; a comanda, a face o comandă; a delega; a face ordine; a porunci, a comanda, a da ordin; a conduce, a dirija; a supraveghea; (med) a prescrie (un tratament etc.); a trimite; (ec) a face comandă (pt. ceva, unui furnizor etc.); keep a păstra ordinea; out of în dezordine; obey $\sim \mathbf{s}$ a se supune ordinelor, hotărârilor; until further $\sim$ s până la noi dispoziții sau ordine; by $\sim$ prin ordin superior dat de autorități; give an $\sim$ (mil) a da ordin, a ordona; open $\sim$ ordine desfăşurată; in marching $\sim($ mil) în formație de marș; postal $\sim$ mandat poștal; in $\sim$ în ordine, bun; out of $\sim$ (mas, OM) stricat, defect, care nu poate functiona; in chronological $\sim$ în ordine cronologică; the $\sim$ of events succesiunea evenimentelor; standing $\sim$ s regulament (al unei instituții etc.); away a da ordin să plece; back a ordona să se întoarcă; down a dispune să vină jos; $\sim$ in a dispune să intre; out a dispune să iasă, a da afară

order blank / form (ec) formular / foaie de comandă

order book (ec) caiet / registru de comenzi

ordered (mat, TH) ordonat, pus în ordine; comandat; (ec) formular / foaie de comandă ordered field (mat) câmp ordonat

ordered mixing (chim, alim) amestecare ordonată ordered set (mat) mulțime ordonată, şir order element (inf) element de instrucțiune ordering ordine; ordonare; care (se) ordonează order in hand $(\mathrm{ec})$ comandă acceptată

orderless dezordonat

orderliness ordine; rînduială; acuratețe; (jur, ec, $\mathrm{adm})$ respectare a legilor/ a regulamentelor de ordine interioare (la o organizație economică, instituție etc.)

orderly ordonat; regulat; metodic; sistematic; organizat

order note (ec) notă de comandă

order of an equation (mat) ordinul / gradul unei ecuații

order of differentiation (mat) ordin de derivare order of error (metr) ordin de mărime al erorilor order of forbidenness (ind) grad de interdicție order of harmonics (fiz, mec) ordin / număr de ordine al armonicelor

order of magnitude (metr, mat) ordin de mărime, unitate logaritmică de comparare a cantităților: două cantități diferă cu un ordin de mărime dacă una este de 10 ori mai mare decât cealaltă, cu două ordine de mărime dacă una este de 100 de ori mai mare decât cealaltă etc. 
order of a radical (mat) ordin de radical ordin of root (mat) ordin de multiplicitate al unei rădăcini (în ecuații diferențiale)

order of sequence (inf, autom, TH, mas) succesiune a comenzilor

order of switching (el, mas) ordine de comutare (releelor / a întrerupătoarelor)

order-preserving care lasă ordinea invariantă order register (mas, $\mathrm{TH}$ ) registru de instrucțiuni order relation (mat) relație de ordine order signal (autom, inf) semnal de comandă / de instructiune

order transmission (ec, mas, inf) transmitere de comenzi / de instrucțiuni

order word (ec, mas, inf) instructiune

ordinal (mat) (numeral) ordinal / de ordine

ordinal number (mat) număr ordinal

ordinance ordin; decret; hotărâre

ordinariness normal, uz, obișnuință

ordinary $(\mathrm{TH})$ obișnuit, uzual, comun, simplu, condiții obişnuite / normale de lucru; regulat; cotidian

ordinary chain $(\mathrm{OM})$ lant necalibrat

ordinary condition (mas) condiție normală

ordinary key $(\mathrm{OM})$ pană longitudinală

ordinary lay (el) cablare în cruce

ordinary link(age) (el, OM) legătură simplă

ordinary seaman (nav) marinar necalificat

ordinate (mat) ordonată; ordonat, regulat, metodic

ordinate line ordonată

ordinate value (metr, T) valoarea ordonatei (şi

la profilometria suprafeței)

ordonnance (pol, adm, ec) ordonanță, instructiune, ordin, hotărâre

ore (met) minereu (brut)

ore assay (met, metr) probă de minereu

ore-bearing (met) cu conţinut de minereu ore-bloom (met) lupă (de oțel)

ore boil (met) reactie de afinare cu minereu ore breaker / crusher (met) concasor de minereu ore-bucket-handling crane (met) macara cu benă pentru minereu

ore-bulk-oil carrier (nav) vrachier combinat (minereu mărfuri solide în vrac-petrol) ore bunker (met) buncăr pentru minereu ore burden (met) amestec de minereu şi fondant (la furnale)

ore burdening (met) dozare a minereului ore carrier (nav) mineralier, navă mineralieră ore charge (met) încărcătură de minereu ore-concentrating plant (met) instalație de concentrare / aglomerare a minereului

ore concentration (met) concentrare / aglomerare a minereului ore crusher (met, mas) concasor de minereu ore crushing (met, $\mathrm{TH}$ ) concasare a minereului ore discharging plant (met) instalație de descărcare a minereului

ore dressing (met) preparare / îmbogățire a minereului

ore dressing plant (met) instalație de preparare / aglomerare / îmbogăţire a minereului ore dryer (met, mas) uscător de minereu ore fines (met) minereu mărunt

ore furnace (met, termo) cuptor pentru topirea minereurilor

ore grab $(\mathrm{OM}$, met) graifăr pentru minereu

ore handling equipment / plant (met, transp) instalație de manipulare / de transportare a minereului

ore homogenising (met, $\mathrm{TH}$ ) omogenizarea minereului

ore leaching (chim) leșiere a minereului

or-else (inf) (funcție logică) SAU-SAU; SAU exclusiv

ore mixture (met) amestec de minereu

ore preparation (TH, met) preparare / îmbogățire / aglomerare a minereului

ore process (met) procedeu / proces / tehnologie de elaborare a oțelului din fontă + minereu

ore pulverizer (met, mas) moară de măcinat minereu

ore reduction (met, chim) reducerea minereului ore reduction plant (met) instalație pentru reducerea minereului

ore roasting (met, $\mathrm{TH})$ prăjire a minereului ore sample (met, metr) probă de minereu ore separation (met, $\mathrm{TH}$ ) sortare a minereului ore separator (met, mas) ciur / separator de minereu

ore ship (nav) mineralier, navă mineralieră

ore sintering plant (met) instalație de aglomerare a minereului

ore sizing (met, mediu) clasificare / sortare a minereului (după granulație)

ore slime (met) slam de minereu, reziduu ore sludge (met, mediu) şlam de minereu ore smelting $(\mathrm{TH})$ topire a minereului ore-smelting (met) topirea minereurilor ore-smelting furnace (met) cuptor pentru topirea minereurilor

ore sorting (met, $\mathrm{TH}$ ) sortare a minereului ore stock yard (met) depozit de minereu ore storage bunker (met) buncăr de minereu ore wash(ing) (met, TH) spălare a minereurilor ore washer / washing room (met, mas) instalație / incintă de spălare a minereului ore yard (met) depozit de minereu 
organ (alim) organ

organic (chim) organic; (fig) unitar, inseparabil, constitutiv; (agr, bot) (d. legume etc.) crescut fără îngrăşăminte artificiale, natural

organic acid (chim) acid organic

organic chemistry chimie organică

organic compound (chim) compus organic

organic coating (ind chim) acoperire organică / celulozică

organic origin (chim) de origine organică

organic glass (ind chim, plast) sticlă organică (pe bază de polimetilmetacrilat)

organic group (chim) grupare organică

organic radical (chim) radical organic

organic solvent (chim) solvent organic

organizable $(\mathrm{ec}, \mathrm{TH})$ organizabil, care poate fi organizat / sistematizat

organization organizare, organizație (economică, administrativă etc.); formare; alcătuire; creare; întocmire; structură; asociație, unitate

organizational de organizare, organizatoric

organisational maintenance ( $\mathrm{TH}$, mas) mentenanță executată de firmă specializată / atestată (personal şi echipament)

organize a (se) organiza, a alcătui, a forma; a crea, a întemeia; a institui; a (se) sistematiza; a aranja; (amer) a organiza într-un sindicat; a se planifica; a deveni organic; a-şi face ordine în gândire

organized (pol, ec, adm) organizat

organizer organizator (şi sindical)

organoleptic test / analysis (alim, metr) test / analiză organoleptic(ă)

“or" gate, OR gate (inf, autom) trecere SAU

orient răsăritean, oriental; a (se) orienta; a da direcția; a dirija; a direcționa

orientable $(\mathrm{OM}, \mathrm{ec})$ care poate fi direcționat / dirijat

orientability orientabilitate

oriental oriental; estic, răsăritean

oriental lathe (mas-un) strung de banc, cu ambele vârfuri fixe

orientation orientare; (c) reperare; (fiz) direcție, sens (şi d. vectori)

orientation angle (mas, fiz) unghi de orientare

oriented (fiz) orientat, direcționat

orienting line linie de orientare / de reper

orifice $(\mathrm{OM}$, hidr) orificiu, gaură, gură, deschidere, răsuflătoare, duză

orifice column (ind chim) coloană reticulară / cu talere perforate

orifice flange union $(\mathrm{OM})$ asamblare $\mathrm{cu}$ flanşe (identice), care strâng o placă intermediară cu orificiu orifice meter (metr, OM, hidr) dispozitiv de măsurat orificii / găuri; debitmetru cu orificiu orifice flowmeter (metr, hidr) dispozitiv de măsurat debitul de fluid cu orificii / cu diafragmă orifice mixer $(\mathrm{OM})$ amestecător cu diafragmă, orificiu de amestecare (a două fluide sub presiune)

orifice of exit (OM, hidr, termo) orificiu de emisie / de ieşire

orifice plate $(\mathrm{OM}$, hidr) diafragmă cu orificiu, taler perforat, membrană, perete separator cu orificiu

origin (mat, fiz, metr) origine, punct zero / neutru / initial / de referință; izvor

original iniţial, prim(ar); original; autentic; nou; (mat) funcție original; personal; (OM) desen original; (fiz, autom, metr) punct zero / inițial

original accumulation $(\mathrm{TH})$ acumulare inițială / primară / primitivă

original address (inf) adresă originală / de ieşire original (base) material (TH) material de bază original equipment manufacturer $(\mathrm{ec}, \mathrm{TH})$ producător al utilajului / echipamentului original

originality autenticitate; caracter original; originalitate; personalitate; noutate; ciudățenie

originally $(a d v)$ la origine, inițial; (în mod) original; în primul rând, mai ales

original parts (auto, OM) chei / piese originale

original spare parts $(\mathrm{OM})$ piese de schimb originale

original stock (alim, constr, ind chim) amestec inițial / de bază

original structure (materiale) structură inițială / primară

original tire (auto, $\mathrm{OM}$ ) pneu original

original tire size (auto) dimensiunea pneului original

originate a lua naştere; a iniția

originary originar

originate a fi creatorul; a inventa, a crea

originating de origine, de plecare; inițial, care începe (din), care (se) formează / inițiază (d. un proces etc.)

origination inițiere, concepere; origine

originator inițiator (al unei acțiuni, al unei reacții chimice etc.); autor, creator

origin distorsion (autom, metr) deviație de la zero, distorsiune / anomalie de origine / iniţială

origin of coordinates axes (mat) originea axelor de coordonate

origin of force $(\mathrm{mec})$ punct de aplicare al unei forțe

origin of a vector (mat, fiz) punct de aplicație al unui vector 
O-ring $(\mathrm{OM})$ inel $\mathrm{O}$ (în formă de tor) (de etanşare) O-ring seals $(\mathrm{OM})$ inel $\mathrm{O}$ de etanşare, etanşare cu inele $\mathrm{O}$

orlop deck (nav) punte falsă, ultima punte (de jos), punte inferioară

ornament ornament, podoabă; a ornamenta; a împodobi; a înfrumuseța

ornamental ornamental; decorativ

ornamental hub cap (auto, OM) capac ornamental de roată

orsat (metr, fiz) analizor de gaze prin metoda absorbtiei selective

or so $(a d v)$ sau cam aşa ceva

ort (ind, mediu) fragment, deşeu

orthocentre (geom) ortocentru

orthogonal (geom) perpendicular, ortogonal

orthogonality (geom) perpendicularitate, ortogonalitate

orthogonal projection (geom) proiecție ortogonală

orthogonal tests (metr) teste independente

orthogonal trajectories (fiz) traiectorii ortogonale, normale

orthographic (geom, OM) ortogonal, care formează unghiuri drepte; (mat) (curbe) ale căror tangente sunt perpendiculare

orthographic projection (OM) proiecție ortogonală

orthographic view $(\mathrm{OM})$ vedere ortogonală

orthography (gram) ortografie

orthorhombic (geom) (adj) ortorombic(ă), prismă dreaptă, cu baza un romb

orthorhombic packing (fiz, materiale) aranjament / structură ortorombic(ă) (la rețele cristaline)

orthorhombic crystal (fiz) cristal ortorombic / rombic

orthotropy (fiz, materiale) ortotropie (proprietate a materialelor de a avea proprietăți diferite pe direcții diferite / pe direcția axelor unui sistem ortogonal)

oscillate (fiz) a oscila, a pendula; a vibra; a se legăna; (fig) a oscila, a ezita, a şovăi

oscillate about the steady position (mec) a oscila în jurul unui punct fix / unei poziții fixe

oscillate continuously (mec, autom) a oscila neamortizat / continuu

oscillating (el, mec) oscilant, oscilator

oscillating adaptive control system (autom, mec) sistem de reglare cu adaptare prin oscilare

oscillating agitator (alim, constr, ind chim) amestecător vibrator

oscillating circuit (el, autom) circuit oscilant oscillating circular saw (mas-un) ferăstrău circular/pendular oscillating conveyer (el, autom, OM) jgheab / scoc oscilant

oscillating crank lever culisă oscilantă

oscillating current (el) curent oscilant

oscillating cylindrical valve $(\mathrm{OM}$, hidr) sertar rotativ, supapă cilindrică oscilantă

oscillating distributor (OM, hidr) distribuitor oscilant

oscillating field (fiz) câmp oscilant

oscillating mill (met, alim) moară vibratoare

oscillating motion / movement (mas, mas-un) mişcare oscilatorie / alternativă / de du-te-vino oscillating / vibratory motion of limited amplitude (mec, T) misscare oscilatorie sau vibratorie, de amplitudine mică / limitată

oscillating process (fiz, el, mec) proces oscilatoriu, alternativ

oscillating quantity mărime oscilantă

oscillating riddle (agr, alim, constr, ind chim) ciur oscilant / cu mişcare alternativă

oscillating saw (mas-un) ferăstrău pendular / cu mişcare alternativă

oscillating sieve (agr, alim, constr, ind chim) ciur / sită oscilant(ă)

oscilating table $(\mathrm{OM})$ masă vibratoare / oscilantă oscillation (fiz) oscilație; vibrație; pendulare; fluctuație; (mas, fiz, chim), instabilitate; (fig) oscilare, ezitare, sovăire

oscillation absorber (OM, autom) amortizor de vibrații

oscillation about a centre (mec) oscilație de răsucire / cu rotație (şi parțială) în jurul unui punct

oscillation amplitude (fiz, mec) amplitudinea oscilației

oscillation analyser / analizer (metr, electr) analizor de oscilatii

oscillation choke (OM) amortizor de vibrații

oscillation detector (electr, metr) detector de oscilatii

oscillation frequency (mec, el) frecvența oscilației oscillation generator (OM, electr) generator de oscilații

oscillation motion $(\mathrm{mec})$ mișcare oscilatorie

oscillation node / nodal point (mec, fiz) punct nodal al oscilației, nod de oscilație

oscillation period (fiz, mec) perioada oscilatiei / de oscilație

oscillation range (fiz, mec) interval / domeniu de oscilare / de pendulare

oscillation time (fiz, mec, el) timp / durată / perioadă de oscilație

oscillator (autom, el, metr) oscilator, generator de oscilații / de semnale cu o anumită frecvență 
oscillator crystal (fiz) cristal piezoelectric oscillatory (fiz, mec) oscilant, oscilatoriu, vibrator; (fig) ezitant, oscilant, şovăitor oscillatory current (el) curent oscilant oscillatory field (fiz) câmp oscilant oscillatory motion (mec) mişcare oscilatorie oscillatory power $(\mathrm{mec})$ putere a oscilațiilor oscillatory surge (mec) undă de şoc oscilantă oscillatory waves (fiz) valori oscilatorii, unde oscillogram (fiz, metr) oscilogramă, înregistrarea oscilațiilor

oscillograph (metr, fiz) aparat de înregistrat oscilații

oscilloscope (metr, fiz) osciloscop

osmic (chim) osmic

osmium (Os) (chim) osmiu

osmolal, osmolar (metr, chim) notații pentru a descrie concentrația ionilor în soluții chimice: „osmolal” descrie o concentraţie de ioni într-o soluție, în moli pe kilogram de solvent (mol/kg), „osmolar” descrie o concentraţie de ioni într-o soluție, în moli pe litru (mol/L)

osmosis (chim, fizică, biol, med) (proces de) osmoză

osmotic (chim, fiz) osmotic

osmotic pressure (chim, fizică, biol, med) presiune osmotică

osmole (Osm) (metr, chim, fizică, biol, med) unitate de măsură pentru presiunea osmotică: 1 osmole este presiunea osmotică a unei soluții molare (concentrația soluției este de $1 \mathrm{~mol}$ pe litru de solvent) a substanței care nu disociază în apă

ostentation ostentație, atitudine de paradă

ostentatious ostentativ, de paradă

other (adj) alt, altă, alți, alte, cealaltă, ceilalți, celelalte; (pron) altul, alta, alţii, altele; $(a d v)$ altfel; the $\sim$ celălalt, cealaltă

otherness deosebire; diferență; neasemănare

Otto engine (termo) motor Otto / cu benzină / cu carburator

otherwise $(a d v)$ altfel, într-un mod diferit; (într-) altfel; prin alte mijloace; (conj) sau, de / dacă nu, altminteri, altfel; (adj) diferit; altfel; altul; alții; altele; de altă categorie

ought un pic, puțin, ceva; $(a d v)$ cât de cât, până la un punct

ounce (oz, oz av) (metr, fiz) unitate tradiţională pentru măsurarea masei, uncie: $\mathbf{1}$ avoirdupois ounce (US) $\cong 28,3495 \mathrm{~g}$

ounce (oz, oz t, toz, oz ap) (metr, farmacologie) o altă unitate tradițională pentru măsurarea masei: 1 troy ounce, $\cong 31,1035 \mathrm{~g}$ ounce (oz, fl oz) (metr, hidr) unitate tradițională de măsură pentru volumul de lichid, denumită şi fluid ounce (fl oz), uncie fluidă: 1 (fluid) ounce $=29,573531 \mathrm{ml}$; (metr) denumire veche pentru 1/12 (dintr-un întreg)

ounce avoirdupois (oz av) (metr) uncie, unitate de măsură pentru masă: $1 \mathrm{oz}$ av (US) = $28,3495 \mathrm{~g}$

ounce force (ozf, oz) (metr, fiz) unitate tradițională de măsură pentru forță: 1 ounce force $\cong$ $0,278014 \mathrm{~N}$

ounce mole (ozmol) (metr, chim) unitate de măsură pentru cantitatea de substanță, 1 ounce mole (of a chemical compound - de compus chimic) este exprimată în acelaşi număr de uncii ca și masa moleculară a acelui compus chimic, măsurată în unități atomice de masă: 1 ounce mole $=28,34952 \mathrm{moli}$

ounce per gallon (oz/gal) (metr, fiz) unitate tradițională pentru măsurarea densității, uncie pe galon: 1 ounce per US gallon $=7,489152 \mathrm{~g} / \mathrm{l}, 1$ ounce per Imperial gallon $(\mathrm{UK})=6,236023 \mathrm{~g} / 1$

ounce per square foot $\left(\mathbf{o z} / \mathbf{f t}^{2}\right)$ (metr, textile, pielărie, ind chim) unitate tradițională pentru măsurarea densităţii țesăturilor, semifabricatelor tip folii subțiri, utilizată mai ales în USA: 1 ounce per square foot $=0,305152 \mathrm{~kg} / \mathrm{m}^{2}$

ounce weight (oz) (metr, textile) unitate traditională pentru măsurarea densității unei țesături; există variante: (1) 1 stated ounce density este densitatea în uncii pe iarzi pătrați $\left(\mathrm{oz} / \mathrm{yd}^{2}\right): 1$ ounce per square yard $=33,9057 \mathrm{~g} / \mathrm{m}^{2} ;$; (2) ounces per linear yard - uncie pe iard liniar (lățimea țesăturii fiind cunoscută); de exemplu, pentru un val de lână cu lățimea de 1,524 $\mathrm{m}, 1$ ounce per linear yard corespunde la $31,0034 \mathrm{~g}$ pe metru liniar sau, luând în considerare lățimea, $20,3434 \mathrm{~g} / \mathrm{m}^{2}$

ounce per linear yard (metr, textile) unitate de măsură pentru densitatea tesăturii, uncie pe iard liniar (lățimea țesăturii fiind cunoscută)

ounce per square yard (metr, textile) uncie pe iard liniar (lățimea țesăturii fiind cunoscută); de exemplu, pentru un val de lână cu lățimea de $1,524 \mathrm{~m}, 1$ ounce per linear yard corespunde la 31,0034 grame pe metru liniar $(\mathrm{g} / \mathrm{m})$ sau, luând în considerare lățimea, $20,3434 \mathrm{~g} / \mathrm{m}^{2}$

ounce troy (oz tr) (metr, farmacologie, fiz) uncie, unitate de măsură pentru masă, pentru metale prețioase şi produse farmaceutice: $1 \mathrm{oz}$ tr $=31,1035 \mathrm{~g}$

our (adj) nostru, noastră, noştri, noastre

ours (pron) al nostru, a noastră, ai noștri, ale noastre 
oust a elimina, a da afară, a exclude; a alunga; a scoate; (jur) a evacua

out $(a d v)$ (în) afară, în exterior; departe, în altă parte; absent de la locul de muncă; (d. foc, lumină etc.) stins; demodat, plecat, ieşit, scos la iveală, scos, eliminat, în larg, în străinătate, departe; în eroare, scrântit, dislocat; fără rețineri, deschis, pe față; până la capăt, în întregime, tot; complet, consumat, terminat; (prep) (în)afară, afară din, din (cauza), din, la (distanță determinată), în dezacord cu, printre, din(tre), fără, lipsit de; $(a d j)$ care se petrece în afară; care este îndepărtat (de patrie, de țărm); anormal, neobişnuit, extraordinar, excesiv, neobişnuit, depărtat, exterior, din afară; outs $(s, p l)$ partid care nu este la putere; (tipogroafie) omisiune la culegere; (TH) defect, deplasat, deconectat; deschis; omisiune; ieşire, deschizătură; (amer) lipsă, neajuns; a da afară, a elimina; an size în afara seriei, mai mare sau mai mic; the ins and $\sim$ s cavităţile şi proeminențele, aspectele, amănuntele (unei probleme etc.); worn $\sim($ fig) epuizat; knock $\sim$ a scoate din funcțiune prin şoc; put $\sim$ at sea (nav) a porni în largul mării, a fi în larg, a fi pe mare; tired $\sim$ istovit, la capătul puterilor; worn $\sim(\mathrm{OM}, \mathrm{T})$ complet uzat; at rupt, găurit, gol, descoperit la; and away cu mult; $\sim$ and $\sim$ perfect, desăvârşit, în întregime, cu totul; of it neglijat, rău informat; of order de-a valma, stricat, scos din functiuonare; of place nelalocul lui, nepotrivit; from $\sim \operatorname{din}$ (afară); of danger în afara pericolului; of sight în afara vederii, scăpat din vedere; of necessity din necesitate; of proportion peste măsură, depăşit; be of money a fi fără bani; of date demodat, învechit; of doors în exterior, în aer liber; of doubt fără îndoială; of hand pe loc, imediat; of order defect(at), deranjat; of place în afara timpului; of place fără slujbă, fără situatie; of print epuizat (d. o carte); of work fără lucru, şomer

outage (ec, TH) stagnare, pierdere, perisabilitate; (mas-un, met) perioadă de inactivitate, întrerupere a lucrului

outage time timp de pană / de avarie / de stagnare, durată a ieşirii din funcțiune

outbalance a cântări mai mult decât; $(f i g)$ a întrece, a depăşi

outbid (ec) a supralicita, a oferi mai mult (la o licitație)

outboard (nav) suspendat / în afara bordului / în consolă, (în) exterior

outboard engine / motor (nav) motor suspendat / în afara bordului / în consolă outboard wing $(\mathrm{OM}$, nav) aripă exterioară outbreak afloriment; descoperire; erupție; explozie; izbucnire

outbuilding (constr) acaret, dependință outbuildings dependințe, clădiri anexe outburst degajare bruscă; erupție; izbucnire outclass a depăşi cu mult, a lăsa cu mult în urmă outcome ieşire; rezultat; consecință; urmare; efect; (el) avarie, ieşire din funcțiune

outcrop afloriment; descoperire, deschidere; a (se) descoperi, a ieşi la suprafață

outdated învechit, demodat; (TH, OM, ec) în afara termenului / intervalului de timp prescris (pentru garanție, reparație etc.), depăşit

outdistance a se distanţa de, a lăsa în urmă outdo a întrece, a învinge; a epuiza

outdoor (mas, mediu) exterior; destinat pentru funcționare în aer liber, de câmp

outdoor / outside air (mediu) aer proaspăt / din exterior / de înlocuire

outdoor-air supply (termo) alimentare cu aer din exterior

outdoor-indoor bushing trecere din exterior la interior / din afară înăuntru

outdoor temperature (mediu) temperatură exterioară / de afară / din aer liber

outdoor storage $(\mathrm{TH})$ depozitare în aer liber outer (în / de) exterior, extern, din afară, periferic outer arbor support $(\mathrm{OM})$ contrasuport outer / outboard bearing (OM) lagăr auxiliar / exterior / montat pe un suport exterior (separat)

outer casing (auto, OM) anvelopă; $(\mathrm{TH})$ carcasă (pentru tot sistemul tehnic)

outer cover (auto) anvelopă; înveliş exterior, protecție exterioară; $(\mathrm{OM})$ capac exterior

outer covering (constr, OM) învelire, placare (la exterior)

outer curve $(\mathrm{OM})$ parte exterioară a unui corp îndoit; (geom) curbă înfăşurătoare la exterior

outer dead centre (termo) punct mort superior / exterior

outer diameter $(\mathrm{OM})$ diametru exterior

outer diameter / facing copying (mas-un) copiere pe diametrul exterior / frontală

outer diameter / facing cutting (mas-un) strunjire pe diametrul exterior / exterioară / frontală outer electrons (fiz) înveliş de electroni outer form fața întâi (a unei file, a unui formular)

outer hull (nav, mil) corp exterior (la submarine) outer inspection (metr) control vizual (dinspre exterior)

outer main (hidr, OM) conductă exterioară; (el) conductor exterior 
outer member $(\mathrm{OM})$ piesă cuprinzătoare outermost cel mai din afară, extrem outermost oxide layer (chim, materiale) stratul de oxid de la exterior

outer race $(\mathrm{OM})$ inel exterior (la rulmenți) outer roads / roastead (nav) radă exterioară outer skin (OM) înveliş; placaj (exterior) outer support (OM) reazem exterior, lagăr palier, contralagăr; lagăr opus

outer wall perete / zid exterior out facing (mas-un) strunjire a suprafeței frontale outfall (geogr) gură (de vărsare), loc de vărsare outfall channel (OM, hidr) canal de scurgere / de evacuare

out feed (mas-un) avans de la centrul piesei de prelucrat spre periferie

outfield câmp îndepărtat; (fig) teren necercetat outfit (nav) armare, echipare (a navei); (mas) instalație, echipament, dispozitiv, utilaj; echipare, utilare, înzestrare; instrument, agregat, aparat, aparataj, serie, set, ansamblu; (TH, ind) a echipa, a utila, a înzestra

outfitter (ec) comerciant; furnizor

outflank a înconjura, a flanca (din exterior)

outflow (hidr) flux, eflux, scurgere, izvorâre, erupție; debit; eşapament, evacuare, gură de scurgere, producție; a se scurge

outflow tube (hidr, OM) tub / țeavă de scurgere

outgas (met, ind chim) a degaza

outgo ieşire; (ec) cheltuieli; a ieşi (în afară)

outgoing evacuare, de ieşire, de plecare, de expediere; care iese afară / în exterior (d. un modul, element de maşină etc.)

outgoing air (met, termo, mediu) aer evacuat / uzat

outgoing output (el) putere disponibilă / la ieşire outgoing side (of rolls) (met) fața de ieşire (a cilindrilor de laminare)

outgoings (ec) cheltuieli

outgrow a deveni prea mare; a depăşi (o fază)

outgrowth rod, rezultat, consecință, efect; excrescentă

outgush a erupe

outhouse (constr) dependință, acaret; aripă de clădire

outlay (ec) investiții, cheltuieli, a cheltui (bani)

outlet (el) bornă de ieşire; (hidr) izvor al unui curs de apă, evacuare, scurgere; (OM) dispozitiv / orificiu / gură de golire / de evacuare, gaură de ieşire, supapă; (pol, adm) emisar; (auto, termo) eşapament; (ec) debuşeu, debit, livrare, piață de desfacere; (hidr, OM) debit (la ieşire); emisar

outlet air aer evacuat outlet automatics (autom, transp) automatizare a descărcării

outlet bellmouth (OM, hidr) con de ieşire (şi la supape-fluture)

outlet box (hidr) cutie de distribuție

outlet bucket $(\mathrm{OM})$ adâncitură pe fund (la un recipinet, pentru golire etc.)

outlet chamber (OM, hidr) cameră de evacuare outlet connection (OM, hidr) racord de evacuare outlet elbow (OM, hidr) cot de ieşire

outlet entrance (OM, hidr) orificiu de ieşire outlet funnel (OM, hidr) pâlnie de scurgere outlet nipple (OM, hidr) ştuț de evacuare outlet nozzle (OM, hidr) ajutaj / gură de scurgere outlet opening / orifice (OM) orificiu de evacuare / de golire / de ieşire / de scurgere, deschidere (spre) înafară

outlet passage (OM, hidr) canal de evacuare

outlet pipe (OM, hidr) țeavă / conductă de evacuare / de golire / de eşapament / de scurgere / de preaplin / de deviație

outlet port (OM, hidr) orificiu de evacuare

outlet pressure (hidr) presiune de / la ieşire / de evacuare

outlet slide (hidr, OM) vană / robinet de golire / de evacuare / de scurgere

outlet temperature ( $\mathrm{TH}$, termo) temperatură de / la ieşire

outlet tube (auto, OM, hidr) țeavă / conductă de evacuare / de golire / de eşapament / de scurgere / de preaplin / de deviație

outlet valve (hidr, OM) supapă / ventil de evacuare / de golire

outlet velocity (alim, hidr) viteză de scurgere la golire, viteză la ieşire

outline contur; schiță; schițare; plan; proiect; desen; crochiu; descriere; rezumat; conspect; a scoate în evidență; a contura; a schița; a proiecta; a sublinia; a prezenta în linii generale

outline drawing (OM) desen de ansamblu (cu cote de gabarit şi montaj)

outline of scanned area (metr, c) perimetru al ariei scanate / explorate

outline specification schiță a condițiilor tehnice outline system (OM) ansamblu specific

outlining conturare, subliniere

outloading platform (mas, transp) platformă de descărcare

outlook concepție generală; perspectivă, vedere, privelişte; punct de observație / de vedere; prevedere; prognoză

outlying periferic, (în)depărtat de centru out of (arată extragerea, proveniența, materialul) din; fără, din lipsă de, scos din 
out of action / of operation / of service (mas, OM) scos / ieşit din funcțiune / din serviciu, oprit (şi din cauza unei avarii), care nu mai funcționează

out-of-balance (mec, mas, OM) dezechilibrat, neechilibrat, scos din echilibru

out-of-balance wheels (auto, OM) pneuri neechilibrate

out of centre with $(\mathrm{OM})$ deplasat față de centru cu out of a commodity (ec) rămas fără marfă în stoc be $\sim($ ec $)$ a nu avea marfă în stoc

out of control (OM, mas, $\mathrm{TH})$ cu nerespectarea limitelor stabilite, cu caracteristică care iese din câmpul de toleranțe; (autom) (sistem) ieşit de sub control

out-of-date învechit; demodat; depăşit (şi uzat moral)

out-of-door în aer liber

out of doors în aer liber, afară

out of flatness $(\mathrm{OM})$ abatere de la planitate

out of gear $(\mathrm{OM})$ debreiat; scos din angrenare; decuplat

out-of-gear falling worm (OM, transp) melc de cădere

out of level (constr, mas) neorizontal

out of mesh (OM) decuplat, scos din angrenare

out of operation (mas, OM) scos din funcționare / din lucru

out of order (mas, OM) dereglat, deranjat, defect, scos din functiune

out-of-order signal / tone (autom, mas) semnal de deranjament / de dereglare

out of parallel / of step falling (el, mec) decroşare, ieşire / desprindere din sincronism

out of phase (fiz) defazat

out of position (OM, mas) aşezat greşit, deplasat de la poziția corectă

out-of-range number (c) număr care depășeşte capacitatea sistemului de calcul

out of repair (constr) şubred, dărăpănat, insalubru, nereparabil; (OM, T) uzat, care nu mai este reparabil

out of round (OM, mas-un) oval, cu abatere de la circularitate (mai rar de la cilindricitate)

out-of-roundness (OM, mas-un) ovalizare, abatere de la circularitate

out of service (OM, mas-un) deranjat, avariat, scos din functiune

out-of-service record înregistrare (şi statistică) a deranjamentelor / avariilor

out of shape (OM, mas-un) deformat, cu abateri de formă

out of size (OM, mas-un) cu abateri de la toleranțele prescrise; ieşit din intervalul de dimensiuni out of square (OM, mas-un) oblic, neperpendicular out-of-step (el) asincron

out-of-step falling (el, mec) desincronizare

out-of-step protection (autom, el) dispozitiv de protecție contra ieşirii din sincronism / contra pendulării

out-of-the-way (în)depărtat; izolat, greu de găsit; neobişnuit; necunoscut

out of tolerance (metr, OM) în afara toleranței, depăşire a toleranței, în afara câmpului de toleranță

out-of-true (mas-un, OM) aşezat greşit, imprecis, neprecis, descentrare, bătaie, dezaxare

out-of-trueness (auto, termo) deformare a cilindrului sau cămășii acestuia datorită poziției oblice a bielei

out of true wheel $(\mathrm{OM})$ roată descentrată

out-of-tune dezacordat; (mas, metr, autom) nereglat, dereglat

out-of-use scos din functiune, învechit

out of work (mas, el) inactiv, oprit, decuplat, care nu lucrează

outphasing (el, mec, autom) defazare

outport deschidere / lumină de ieşire; (nav) port exterior

outpour revărsare, şuvoi; a vărsa, a turna, a deşerta, a goli

output (inf) ieşire (a unor rezultate, a unui circuit, a unui subsistem); (TH, mas, ec) putere, capacitate, producție, debit (şi final), semnal / putere de ieşire, rezultat, productivitate, randament, fabricație, capacitate de producție

output amplifier (autom, el, mas) amplificator de / la ieşire / final / de putere

output area (ec) sferă de producție

output at the drawbar (auto, met, OM) putere la cârligul de tractiune

output buffer (c) zonă de ieşire (a memoriei interne), zonă din care datele sunt transferate echipamentelor periferice

output capacity (mas) randament, debit / capacitate (la ieşire)

output cascade (autom) treaptă finală, etaj final / de ieşire

output coefficient (ec) coeficient de utilizare / de eficiență; productivitate; (met) coeficient de scoatere

output data (c, inf) date de ieşire; date / caracteristici (şi de putere) la o maşină

output disturbance (autom, electr) perturbatie la ieşire

output error (metr, autom) eroare a valorii de ieşire / finale 
output factor (ec) coeficient de eficiență / de utilizare, productivitate

output file (inf) fişier în care sunt memorate rezultatele unei prelucrări de date

output function (autom) funcție (a semnalului) de ieşire

output of hearth area / surface (met) productivitatea cuptorului, raportată la suprafața vetrei, producție în unitatea de timp pe $\mathrm{m}^{2}$ de vatră

output per day / hour (ec, TH) producție / productivitate pe zi / zilnică / pe oră / orară

output per man-hour (ec, TH) producție / productivitate pe om şi oră

output per man-shift (ec, TH) producție / productivitate pe om şi schimb

output per unit of displacement (hidr, mas, termo) putere litrică / pe unitatea de volum

output power (mas, termo, auto) putere la ieşire output rating (mas, termo, auto) putere (nominală) la ieşire

output regulator (autom, hidr) element de execuție, regulator de / la ieşire

output resistance (metr, hidr) rezistență la / de ieşire

output signal (autom) semnal de / la ieșire

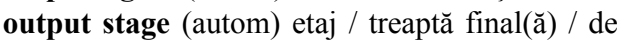
ieşire

output standard $(\mathrm{ec}, \mathrm{TH})$ normă de producție output terminal noise (autom, mas, el) zgomot de / la ieşire

output test (metr, ec, TH) încercare de putere / de productivitate

output value (mas, el) valoare (şi a puterii) la ieşire

output valve (OM, hidr) supapă finală

output voltage (el) tensiune de ieşire / finală

outreach (nav) raza de acțiunii a bigii; (TH, OM, transp) deschidere a brațului, rază de acțiune (şi a macaralei)

outrigger $(\mathrm{OM})$ lonjeron; (el, $\mathrm{OM})$ consolă, brățară; grindă în consolă; (nav) suport exterior al vâslei, furchet, barcă cu furchet

outriggers $(\mathrm{OM})$ console de reazem, picioare pentru macara

outright (adj) deschis, direct, sincer; categoric, hotărât, indiscutabil; complet, desăvârşit; $(a d v)$ total, complet; deodată, dintr-o dată, imediat, pe loc; pentru totdeauna, din prima lovitură, în întregime, de-a-ntregul, în mod sincer, deschis

outrival a întrece, a depăşi

outrun a întrece, a depăşi; a căuta să scape de, a fugi de

outsell (ec) a se vinde mai scump decât, a vinde în cantităti mai mari decât outset început

outshot $(\mathrm{OM})$ proeminență, ieşind; (mediu) deşeuri

outside $(s)$ suprafață, exterior; aparențe; spațiu situat în afară (de casă etc.), extremitate; imperială (a unui omnibuz); înfăţişare exterioară; latură exterioară; lumea exterioară; parte din afară, parte exterioară, suprafață exterioară; realitatea obiectivă; (fig) lumea exterioară; (adj) adițional; care nu face parte (dintr-o organizație etc.); din afară; din afara (unei organizații etc.); excesiv (d. prețuri etc.); exterior; extern (unei organizații etc.); extrem; mărginaş; profan; străin; superficial; maxim; periferic; suplimentar; afară; în aer liber; $(a d v)$ (din) afară, în / la exterior, (în) afară de, în afară, cu excepția, pe dinafară, dincolo de (şi fig); (fig) dincolo de limitele; (prep) afară din, în afara, în exteriorul, (şi fig) peste; (OM) latură / parte / suprafață exterioară / de afară, exterior, extern; (nav) în larg; (ec) (maximal (d. preturi, etc.); (nav) în larg; the $\sim$ cel mult, maximum; opinion (pol) opinia publică (din afara parlamentului); the $\sim$ cost $(\mathrm{ec})$ prețul maxim; judging from the $\sim$ judecând după aparență; the sphere of influence în afara sferei de influență; at the (very) cel mult, maximum; engine with $\sim$ guide maşină / motor cu cap de cruce; exterior $\sim$ screw chaser (mas-un, OM) pieptene de filetat pentru filet exterior; inside and $\sim$ caliper (metr) compas dublu (pt. exterior şi interior); on the $\sim$ în exterior, pe dinafară

outside air (auto, termo, mediu) aer de afară, aer de înlocuire, aer din exterior, aer proaspăt

outside ambient temperature (auto, mediu) temperatura mediului ambiant (extern autovehicolului)

outside box (OM, T) lagăr exterior

outside broadcast (TV, radio) reportaj de pe teren, reportaj din exterior, transmisie exterioară

outside callipers (metr, mas-un) compas de exterior / de grosime

outside chance posibilitate îndepărtată

outside chaser (mas-un) sculă-pieptene, sculă pentru filet exterior

outside circular thread tool cuțit-disc de filetat exterior cu un singur profil activ

outside circulation circulație exterioară

outside clamping $(\mathrm{OM})$ prindere exterioară (şi cu cleme)

outside clinch (nav) nod de scaun simplu

outside corner weld $(\mathrm{OM})$ sudură exterioară, de colt

outside crank (OM) manivelă exterioară / care iese din carcasă (şi pt. acționare manuală) 
outside diameter $(\mathrm{OM})$ diametru exterior outside director / manager (ec) membru al consiliului de administrație, neangajat permanent outside door handle (constr, OM) uşă acționată din exterior; (auto) mânerul exterior al portierei outside (firm-joint) callipers (metr) compas de exterior / de grosime, simplu

outside (fresh) air position (auto) poziția pentru aer curat

outside-in filter (alim, ind chim, mediu, OM) filtru cu deplasarea materialului care se filtrează, de la periferie la centru

outside junction plate $(\mathrm{OM}$, constr) guseu (fixat la) exterior

outside key hole (auto, OM) încuietoarea externă a portierei

outside light lumină externă, lumină străină outside line of the tooth $(\mathrm{OM})$ dreapta / linia de vârf (a cremalierei)

outside micrometer $(\mathrm{OM}$, metr) micrometru de exterior

outside mirror (auto, OM) oglinda exterioară

outside mirror defroster (auto) dispozitiv de dejivrare a oglinzii exterioare

outside of (amer) cu exceptia

outside of tubes (OM, hidr termo) spațiu intertubular, spatiu între tevi / tuburi

outside one's ken dincolo de ceea ce se cunoaşte, dincolo de ceea ce se stie; mai presus de cunoștințele noastre / de ştiința noastră

outside pipe cutter (mas-un) cuțit de burlane exterior

outside planking (constr, nav) bordaj exterior, placare exterioară (şi de lemn) (la nave)

outside plant (el, hidr) instalație / rețea de linii / conducte exterioare

outside plating (nav) bordaj exterior (şi metalic) (la nave); placare exterioară

outside proofed (plast, ind chim) cauciucat la / pentru a rezista la, impermeabilizat la (exterior, apă etc.)

outsider străin; (fig) spectator, privitor; nepoftit, nechemat; nespecialist; amator

outside rearview mirror control switch (auto) comutator pentru oglinda retrovizoare externă outside repairs (nav, constr, mas) reparații exterioare / în aer liber

outside right (sport) extremă dreapta

outside screw chaser (mas-un) cuțit-pieptene de filetat pentru filet exterior

outside screw cutting tool (mas-un) cuțit de filetat pentru filet exterior outside (screw) thread $(\mathrm{OM})$ filet exterior outside shoe brake $(\mathrm{OM})$ frână cu saboți exteriori

outside spring callipers (metr, mas-un) compas de exterior / de grosime, de arc

outside storage ( $\mathrm{TH}$, ind) depozit deschis, depozitare în aer liber

outside strake (nav) filă exterioară (la nave)

outside stripping section (met) sectie de stripare exterioară

outside temperature (mediu, termo) temperatura exterioară (a mediului)

outside the door pe uşă afară; (fig) în afara casei, dincolo de uşă

outside the garden în afara grădinii

outside the pale (of smth.) în afara limitelor (unui lucru)

outside the pale of civilization în afara hotarelor civilizatiei, departe de orice civilizație outside the radius of knowledge depăşind / dincolo de sfera cunostintelor (cuiva) outside the town / walls în afara oraşului outside the town plecat din oraş (d. o persoană) outside thread (OM) filet exterior outside turning tool (mas-un) sculă de filetat la exterior, cuțit pentru strunjire exterioară outside wall (constr, OM) perete exterior outside windshield (auto) exteriorul parbrizului outside work muncă în aer liber outsize (textile) număr foarte mare, măsură neobişnuită; în afara dimensiunilor outskirts periferie (de oraş) outsole (OM, mas-un) talpă (exterioară) outspeed (auto, mas) a depăşi viteza outspoken explicit; realist; enunțat; rostit outspread a întinde, a răspândi; (adj) intins, desfăcut, răspândit outsqueezing (materiale, $\mathrm{TH}$ ) extrudare outstanding remarcabil, important; nerezolvat, de rezolvat, nesoluționat, restant, neîmplinit; (constr) proeminent, în relief; (ec) neachitat, litigios; pendinte, în suspensie; neîndeplinit, neefectuat; rezistent; care atârnă

outstanding debt $(\mathrm{ec})$ creanță

outstanding payment (ec) plată neachitată / neefectuată

outstanding shares (ec) actiuni detinute de public outstrip a depăşi, a întrece

out-stroke (mas-un) cursă de evacuare

out time (of machine) (mas, TH) timp de întreruperi, timp mort

out-to-out (measured) (OM, metr) (măsurat) la exterior

outturn (ec, TH) productie, randament, greutate netă (şi a caricului descărcat la sosirea navei) 
outturn sample (metr, materiale) mostră din marfa preluată

outvalue (ec) a valora / costa mai mult decât

outward în / de / din afară, (de) exterior; vizibil; material; aspect (exterior); în străinătate, peste hotare; (OM) exterior, parte exterioară

outward-bound (nav) cu destinație spre un port straăin

outward opening $(\mathrm{OM})$ orificiu spre exterior

outwards $(a d v)$ spre exterior, în afară; peste hotare; la înfățişare / vedere, ca exterior; la suprafață; pe din afară

outwear a istovi; a dura mai mult decât; a-și petrece vremea trândăvind; a uza

outweight a cântări mai mult decât, a depăşi în greutate, a avea mai multă greutate / influență decât, a prevala asupra

outworn $(\mathrm{OM}, \mathrm{T})$ uzat, impropriu de folosit, inutilizabil

oval (geom, OM) oval, elipsoidal

oval flange (OM, hidr) flanşă ovală / eliptică

oval head (OM) cap oval / bombat la şurub

oval-head countersunk wood screw $(\mathrm{OM})$ şurub pentru lemn, cu cap oval semi-înecat

ovalisation ( $\mathrm{TH}, \mathrm{OM}$, mas-un) ovalizare

oval lathe (mas-un) strung pentru prelucrarea profilelor / secțiunilor ovale

oval pass / groove (met) calibru oval (la laminoare)

oval screw $(\mathrm{OM})$ şurub cu secțiune ovalizată (şi din materiale plastice)

oval screw point $(\mathrm{OM})$ vârf bombat al filetului

oval-square-oval method (met, TH) metodă / tehnologie de laminare / de calibrare ovalpătrat-oval

oval turning device (mas-un, $\mathrm{OM}$ ) dispozitiv de strunjit oval

oven (alim) maşină de gătit, cuptor; (constr, met) cuptor, furnal (mai mic), sobă, etuvă

oven battery / block (met, ind chim) baterie de cuptoare

oven brickwork (met, constr) zidărie a cuptorului

oven charge (met, TH) încărcare a cuptorului, şarjă

oven control (alim, met, autom) reglare / comandă / termoreglare a unui cuptor

oven cure (ind chim) vulcanizare în etuvă

oven-dried (termo, OM, materiale) uscat în cuptor / în etuvă

oven-drying (ind chim, alim, TH) uscare în etuvă oven-dry weight (materiale) greutate după uscare (în etuvă / în cuptor)

oven gas (met, chim) gaze de cocserie

oven plant (met, ind chim) secție / instalație de cuptoare oven sole (met, constr) vatră / fundație a cuptorului

over (prep) deasupra, peste, pe (de)asupra, asupra, dincolo de, până la, pe, prin, în (cursul / decursul), pentru, de, din cauza, la, mai mult de, mai presus de, la; despre, cu privire la; $(a d v)$ dincolo, de partea cealaltă, pe deasupra, peste tot, peste, la, peste, în plus, de la un capăt la altul, în întregime, desăvârşit, terminat; (adj) gata, terminat, isprăvit; prea mult, exagerat, excesiv (de), peste tot, de sus până jos; $(s)$ surplus, prisos; excedent; fall $\sim$ a se năpusti asupra, a cădea peste; lean $\sim$ a se apleca peste; hang $\sim$ a atârna peste; there în partea aceea, acolo, încolo; painted $\sim$ with acoperit peste tot cu; run $\sim$ a da peste margini, a curge peste; $g 0 \sim$ to the enemy a trece la inamic; make $\sim$ smth. to smb. a înmâna cuiva o sumă de bani; against în fața (cuiva, a ceva); smth. and $\sim$ peste (o cantitate); $\sim$ and $\sim$ again în repetate rânduri; be nearly a fi pe sfârșite (d. un test); and above fără a socoti, fără a număra, fără a ține cont de; head and ears până peste cap; look a trece cu privirea peste; jump $\sim$ a sări peste; from $\sim$ the Atlantic de dincolo de Atlantic; the road de peste drum; $\sim$ a period of pe o perioadă de; all $\sim$ the world / all the world $\sim$ pe întreg pământul, în întreaga lume

overabundance (ec) supraabundență

overabundant $(\mathrm{ec})$ supraabundent

over-active (chim) prea activ

over again $(a d v)$ încă o dată, din nou

over against opus, contrar; în / prin contrast cu

overageing (met) supraîmbătrânire

overall (ind) salopetă, combinezon / halat de lucru, îmbrăcăminte de protecție; (TH) total, global, general; $(a d v)$ peste tot, pretutindeni; în întregime, complet, cu desăvârşire

overall agreement $(\mathrm{ec})$ acord global

overall attenuation (mas, autom) atenuare tota-

lă (d. oscilații, vibrații, perturbații etc.), echivalent de transmisie

overall coefficient of heat transfer (termo, OM) coeficient total / global de transfer de căldură

overall contrast ratio (c) contrast total, raport mediu al contrastelor

overall dimensions $(\mathrm{OM}$, mas) dimensiuni de gabarit / exterioare

overall efficiency (ec, mas) eficacitate totală, randament total / global

overall equivalent (autom, electr) echivalent (total) de transmisie, atenuare totală

overall estimate (ec, pol, adm) estimație globală / bazată pe întreaga informație 
over-all formula (TH, fiz, chim) formulă empirică

overall heat transfer coefficient (termo, mas) coeficient total / global de transfer de căldură

overall height (OM, mas) înălțime totală / de gabarit

overall housing (constr, ind) construcție provizorie de protecție (şi încălzită)

overall length (OM, mas) lungime totală / de gabarit

overall net-loss measurement (mas, OM) măsurare a echivalentului total de transmisie

overall noise factor / figure (fiz, autom, el) factor mediu de zgomot

overall output (ec, $\mathrm{TH})$ productie totală / globală; (mas) putere totală la ieşire

overall reduction (met, $\mathrm{TH}$ ) reducere totală a secțiunii

overall rate of heat transfer (termo) viteză globală / totală de transfer termic

overall rigidity $(\mathrm{mec}, \mathrm{OM}$, mas) rigiditate globală / a ansamblului

overall size (OM, mas) gabarit, dimensiune de gabarit

overall transmission loss (mec, OM) atenuare efectivă, pierderi totale / globale de energie (pe o transmisie)

overall voltage $(\mathrm{el})$ tensiune totală

overall width (OM, mas) lățime totală / de gabarit overamplification (autom, metr) supraamplificare over and above $(a d v)$ pe lângă acestea, în plus over-and-under current relay (el) releu de maxim si minim (pentru intensitatea curentului)

over-and-under power relay (el) releu de maxim şi minim (pentru putere)

over-and-under voltage relay (el) releu de maxim şi minim (pentru tensiune)

over-arm (OM) contrasuport; (mas-un) braț al maşinii de frezat

overbaking (alim, ind chim) încălzire / coacere excesivă (şi defect tehnologic)

overbalance (mec, mas) greutate suplimentară pentru echilibrare, surplus de greutate; a cântări mai mult decât, a întrece în greutate, a avea preponderență asupra; a strica echilibrul, a-şi pierde echilibrul, a se răsturna

overbear a birui; a dovedi; a înlătura (obiecții); a întrece (prin forță); a răspunde la (argumente)

overbending (mec, OM) inflexiune, strâmbare, îndoire / încovoiere prea mare

overbid (ec) a supralicita

overblenching (ind chim, c) înnălbire, supraînălbire

overblow (met, TH) a sufla suplimentar (aer în cuptor)

overboard (nav) ( $a d v)$ peste bord overboil (alim, ind chim) a răsfierbe, a da în foc overboiling (alim, ind chim, TH) răsfierbere

overbridge (constr, autom) pasaj superior

overbunching (fiz) supragrupare, supraconcentrare a unui fascicul

overburden ( $T$ ) strat superior / protector; depuneri superficiale; (alim, met, ind chim) a supraîncărca (un cuptor), a suprasolicita

overburdening, overcharging (alim, ind chim, met) supraîncărcare, suprasarcină (la cuptor etc.) overbuy (ec) a cumpăra o cantitate prea mare de overcapitalization (ec) supraevaluare a capitalului (unei firme)

overcapitalize (ec) a supraevalua capitalul (unei firme)

overcast a întuneca, a pune în umbră; (textile) a îmbrăca, a tivi, a face tiv la; (meteo) cer acoperit de nori, cer înnourat / noros; acoperit cu / de nori, mohorât (d. cer); (fig) mohorât, posomorât, sumbru; a se acoperi cu nori, a se înnoura (d. cer); a înnoura; (fig) a (se) întuneca, a (se) mohorî, a (se) posomori

overcautious exagerat de prudent

overcharge (mec) supragreutate, greutate suplimentară (față de cea proiectată, estimată etc.); (ec) suprapreț, preț exagerat / excesiv, suprataxă, navlu excesiv; supraîncărcare; a supraîncărca, a suprasolicita, $(\mathrm{ec})$ a cere un preț prea mare; (TH) suprasarcină, supraîncărcare

overcoat (met, materiale, ind chim, T) acoperire; (textile) manta, palton

overcoating (constr) tencuire; (met, ind chim, T) (operația de) acoperire

overcome a înfrânge, a învinge; (d. oboseală) a doborî, a învinge, a înfrânge; a birui, a câştiga; a copleşi

overcoming învingere

overcompensation (autom, electr) compensare excesivă

overconfident prea încrezător

overcooling (met) suprarăcire

over-cooking (alim, ind chim) suprafierbere, răsfierbere

overcritical (fiz, termo) supracritic

overcrop (agr) a secătui / degrada solul prin culturi intense

overcrowd (adm, agr) a suprapopula; a aglomera; a se îngrămădi

overcure (plast, ind chim) a supravulcaniza, a postvulcaniza; (porces și rezultat) postvulcanizare, supravulcanizare

overcuring (ind chim, TH) supraîntărire, supravulcanizare, întărire excesivă prin reticulare / vulcanizare (şi defect tehnologic)

overcurrent (el) supracurent, supraintensitate 
overcurrent protection (el, autom) protecție la depăşirea intensității

overcurrent release / tripping (el, autom) declanşare / deconectare la supraintensitate

overcurrent-undervoltage circuit breaker (el, autom) disjunctor de supracurent şi subtensiune / cu protecție maximală de intensitate şi minimală de tensiune

overcut $(\mathrm{OM})$ dantură superioară a pilei

overdamping (OM, fiz, mec el) supraamortizare, amortizare supracritică / aperiodică

overdetermination (mat) supradeterminare (la sisteme de ecuații, de exemplu)

overdeveloped supradezvolat, dezvoltat excesiv

over die (met, OM, mas-un) poanson, contramatriță, stâlp superior

overdo a exagera; (ind chim, alim) a arde, a prăji (prea tare); a întrece măsura

overdone supradezvoltat; (alim) prea făcut, prăjit / fiert prea tare

overdraft (ec) descoperit în cont, neacoperire (a unei plăţi), depăşire de cont în bancă, sumă cu care s-a depăşit contul în bancă, cont fără acoperire, sold debitor; $(\mathrm{TH})$ supraincărcare, supraexcitare

overdraw $(\mathrm{OM})$ a forța un filet; (ec) a elibera un cec fără acoperire; $(\mathrm{TH})$ a supraîncărca, a supraexcita; a exagera

overdriven (mas, mec, el) supraîncărcat, supraexcitat, funcționând cu turație prea mare

overdrying (alim, ind chim) suprauscare, uscare excesivă (şi a electrozilor de sudură)

overdue întârziat, depăşit ca termen

overdue debts $(\mathrm{ec})$ arierate, debite rămase restante după expirarea scadenţei

overdue delivery (ec) livrare cu întârziere

overeat a mânca prea mult

overestimate (ec) a supraevalua, a aprecia exagerat, a face un deviz exagerat

overestimation (ec) supraevaluare, deviz exagerat, apreciere exagerată (şi în proiectare de sisteme, tehnologii)

overetch (met, chim) a ataca adânc cu acid (şi pentru analize metalografice)

overexert (mec, OM) a supraîncărca, a supratensiona, a exercita peste limită

overexpose (fiz, termo) a supraexpune, a expune prea mult

overexposed (fiz, termo, OM) supraexpus, expus excesiv

overfall (OM, hidr, nav) deversare, deversor; (geogr) prag submarin

overfall coefficient (hidr) coeficient de deversare

overfall gap (hidr, OM) deschidere de deversare overfalls (nav) valuri de maree deferlante, valuri produse de curenți contrari

overfastness (ind chim, materiale) rezistență la supravopsire

overfeed (auto, termo, mas.un) a supra-alimenta, a alimenta prea mult sau prea repede (cu semifabricate)

overfeed arrangement (termo, auto) dispozitiv pentru supraalimentare

over feeding supra-alimentare; (mas-un) avans excesiv

overfill (ind) a umple excesiv, a supraîncărca (ceva); (met) supraîncărcare, umplere excesivă, bavură din laminare

overfilling (met, ind chim, alim, constr) exces / surplus de material; umplere excesivă; supradozare, supraumplere; care (se) umple excesiv

overflow (autom) depăşire; (hidr) deversare, debit, scurgere, ape excedentare, deversor; (inf) depăşire a posibilității de prezentare corectă a unui rezultat / a capacităţii de memorare; (OM) țeavă de deversare / de preaplin, prea-plin; a deversa, a deborda, a (se) revărsa, a îneca, a inunda, a se scurge (peste), a fi prea plin

overflow cock (OM, hidr) robinet de deversare

overflow hole (OM, hidr) orificiu / gură de scurgere / de deversare

overflowing (hidr) deversare, debordare

over-flowing (from mould) (met) revărsare din forma de turnare / din matriță

overflow mill (alim, ind chim) moară cu descărcare centrală

overflow nipple (OM, hidr) ştuț / tub de deversare overflow-oil line $(\mathrm{OM}$, hidr) conductă de deversare a uleiului

overflow outlet (OM, hidr) racord de prea-plin

overflow pipe (OM, hidr) țeavă / conductă de preaplin / de deversare

overflow slag (met) zgură evacuată prin deversare / scursă din preaplin

overflow tube (OM, hidr) tub de preaplin, deversor overflow valve (OM, hidr) supapă de preaplin / de deversare / de descărcare

overflow water apă excedentară / disponibilă

overflux relay (autom, el) releu de siguranță / de declanşare

overfold (textile, met, plast, TH) cută răsturnată / dublă (şi ca defect)

overform a copia

overglaze (ind chim) email, smalț, glazură

overglazing (ind chim, TH) emailare, smălțuire, glazurare

overground (materiale) măcinat fin, pulverizat; (constr) suprateran, deasupra solului 
overground building / work (constr) construcție supraterană

overgrow (bot, agr) a acoperi (cu plante); a crește mai mare decât, a crește prea mare

overgrown prea mare, crescut peste măsură; (agr) năpădit de buruieni, lăsat în paragină

overgrowth supracreştere, creştere excedentară / excesivă / prea rapidă (d. aluat sau dendrite la aliaje metalice etc.); (agr, bot) năpădire a buruienilor

overgrowth of liabilities (TH, ec) creștere excesivă a obligațiilor / angajamentelor

overhand coborâtor, de sus în jos

overhand knot (nav) jumătate de nod

overhand method (met, TH) metodă de extracție sau de folosire a grămezii de minereu de jos în sus, pentru omogenizarea şarjei

overhang (auto, OM) consolă-spate; $(\mathrm{TH})$ consolă; (constr) proeminență, ieşind, streaşină, ieșitură; (el) cap de bobinaj; (mas-un) lungime a brațului în consolă; $(\mathrm{OM})$ consolă, prelungire; ieşire din rând; a atârna deasupra / peste

overhang beam (of a rotating crane) (OM, transp) consolă, braț (de macara)

overhanging $(\mathrm{OM})$ proeminent, ieşit în afară, în consolă

overhanging arm $(\mathrm{OM})$ grindă / braț în consolă, contrabrat, contrasuport

overhanging stairs $(\mathrm{OM})$ scară suspendată

overhanging standard (mas-un, OM) cadru în formă de C; (met, OM) batiu de ciocan cu o singură coloană

overhaul $(\mathrm{TH}, \mathrm{mas})$ reparație capitală, revizie generală, inspecție (şi cu demontarea unor elemente tip capace etc.), cercetare, examinare, depăşire, întrecere; a examina, a verifica, a revizui, a repara, a face o revizie / o reparatie capitală, a cerceta amănunțit, piesă cu piesă (o maşină); a verifica (calcule); a întoarce (pe o parte şi pe alta); (ec) a controla din nou; a ajunge din urmă; (med) a supune unui examen medical; (nav) a lăsa în jos (o macara)

overhauling (cf) punct de trecere înainte (la calea ferată)

overhaul manual (TH, mas) manual / ghid pentru reparații / revizii

overhaul stand (TH, mas) banc pentru revizii / reparații capitale

overhead de sus, superior, deasupra; (ind chim, alim) frunți de distilare; (inf) suprasarcină, timp consumat de un sistem de calcul pentru operații neproductive; (ec) cheltuieli generale, cheltuieli fixe şi variabile cu excepția celor pentru materii prime şi forță de muncă, global (d. prețuri etc.); (termo) curent de abur; (constr) de suprafată, suprateran, fixat de plafon; supra- teran, aerian, de sus; ( $a d v)$ sus, (de) deasupra, la etaj, la etajul de deasupra

overhead beam (mec, constr) grindă de plafon / superioară

overhead bridge (constr) pod / eşafodaj de serviciu overhead brine spray deck (termo, constr) plafon fals de răcire prin aspersiune; (alim) tavan fals (sub răcitorul de aer cu injector de saramură)

overhead bunker refrigerated railcar / truck (cf, termo) vagon frigorific cu rezervor de gheață / cu răcire în tavan / de plafon

overhead cableway (transp, mas) macara funicular overhead camshaft (mas-un, OM) arbore cu came în cap

overhead charges / expenses (ec) cheltuieli fixe / de regie / de întreținere / indirecte / generale / suplimentare

overhead console (auto) consolă pe plafon

overhead conveyor (alim, ind, transp) transportor suspendat

overhead / general costs (ec) cheltuieli generale overhead cover (constr) acoperiş suspendat

overhead crane (mas, transp, nav, met) pod rulant, macara portal

overhead crossing (cf) încrucișare aeriană, pasaj superior, trecere denivelată; (el, OM) clemă de legătură pentru încrucişări, încrucişare de linii aeriene

overhead cut / distillate (alim, ind chim) fracțiune de vârf (la distilare)

overhead exhaust valve (OM, termo, hidr) supapă de evacuare în cap

overhead framework (OM, mec, constr) suport-cadru suspendat în partea superioară

overhead gear / transmission (OM) transmisie intermediară / de tavan (şi cu roți dințate)

overhead grinding machine (mas-un) maşină de rectificat cu brat suspendat / pendular

overhead hand travelling crane (mas, transp) pod rulant cu antrenare manuală

overhead ingot feeding run-way (met, trasnp) cale aeriană pentru transportat lingouri

overhead inlet valve (OM, hidr) supapă de admisie, cu orificii la partea superioară

overhead light source iluminare de sus / de deasupra

overhead loader (mas, constr) încărcător cu cupă (cu descărcare peste cap)

overhead plate bank (alim, termo) ansamblu de evaporatoare tip placă montate pe tavan (în depozite frigorifice)

overhead position welding (met, $\mathrm{TH}$ ) sudare peste cap / pe plafon

overhead rail(way) (cf, transp) cale aeriană, monorai 
overheads (met) capete de lingou (şi de la partea superioară); (ec) (amer) cheltuieli de regie

overhead seam / weld (OM, met) (cusătură de) sudură peste cap

overhead shovel (mas, transp) autoîncărcător cu cupă (cu descărcare peste cap)

overhead transmission / gear (OM) transmisie intermediară suspendată (şi cu roți dințate)

overhead travelling-crane (met, transp, constr, ind) pod rulant

overhead travelling drilling machine (mas-un) maşină de găurit suspendată, deplasabilă

overhead valve (OM, hidr, termo) supapă actionată de sus, supapă de / în cap

overhead valve engine (termo) motor cu supape acționate de sus / cu supape în cap

overhead / overheated vapours (ind chim, alim) vapori din partea de sus a coloanei (de distilare)

overhead weld $(\mathrm{OM}, \mathrm{TH})$ sudură peste cap

overhead welding (met, TH) operația de sudare peste cap / pe plafon

overhear a auzi neintenționat / fără să vrea, a auzi (ceva) fără ca vorbitorul să ştie; a intercepta (o convorbire)

overheat (termo) supraîncălzire; a supraîncălzi

overheated (materiale, termo) supraîncălzit

overheated neck (OM) fus (de arbore) încălzit anormal / prea tare

overheater (termo) supraîncălzitor

overheating (termo, met) supraîncălzire

overheating sensitivity (met) sensibilitate la supraîncălzire (d. aliaje)

overhung crank $(\mathrm{OM})$ manivelă de capăt / fixată la capătul unui arbore

overhung pinion $(\mathrm{OM})$ pinion în consolă

overidentification (inf, mat) supradeterminare (stohastică)

overinvoicing (ec) facturare la o sumă excesivă

overland (geogr) pe deasupra pământului, aerian, pe uscat

overland transport (transp) transport pe uscat

overlap (TH) suprapunere, acoperire parțială, întretăiere, întrepătrundere; coincidență parțială; a acoperi, a suprapune; a întretăia; a coincide în parte cu; (el) histerezis (la regulatoare bipoziționale); (mat) a intersecta, a întretăia; (met, OM) îmbinare / sudură prin suprapunere, scurgere de material (din cauza excesului de material, la sudură), a îmbina / a suda prin suprapunere, a (se) acoperi (în parte)

overlap action (autom, OM) acțiune de suprapunere

overlap angle (OM) unghi de suprapunere

overlap control (autom, metr) reglare prin acoperire / prin suprapunere / de recuperare

overlap factor $(\mathrm{el}, \mathrm{mec})$ factor de acoperire overlap joining $(\mathrm{OM})$ îmbinare prin suprapunere overlap of shear blade $(\mathrm{OM})$ suprapunere a lamelor de foarfece

overlapped joint weld (OM, met) asamblare prin sudură, prin suprapunere

overlapping (constr, cf) îmbinare cu eclise / prin suprapunere; suprapunere, superpoziție, acoperire, întindere; (met) încrețire (şi cu suprapunere) (defect la laminare)

overlapping distillation curve (alim, ind chim) curbă de distilare cu suprapunere

overlapping sets (mat) mulțime cu puncte interioare comune

overlap ratio $(\mathrm{OM})$ grad de acoperire axial (suplimentar, datorită înclinării danturii) $\left(\varepsilon_{\beta}\right)$

overlap welding (met, $\mathrm{TH}$ ) sudare prin suprapunere

overlay (OM, materiale) strat de acoperire, căptuşire; (inf) segment de acoperire (a unui program), utilizare repetată a memoriei; (met, chim) acoperire, metalizare, depunere (la sudare), a acoperi (şi cu vopsea), a metaliza, a depune prin sudare; (inf) a reacoperi, a modifica încărcarea unui segment de program într-o memorie; a suprapune; față de masă

overlaying welding (met, TH) încărcare prin sudură, sudare prin suprapunere, cu depunere de material (la recondiționări, şi strat peste strat)

over length (mas-un) adaos de prelucrare la lungime

overleaf $(a d v)$ pe pagina următoare

overleap a sări (peste); a omite; a neglija; a merge mai departe; a întrece măsura; a exagera; a sări mai departe decât; a se întinde mai mult decât îi este plapuma; a se întrece pe sine

overlie a sta (culcat) pe; (fiz, mec, autom) a suprapune (oascilații etc.)

overlift a ridica peste limită

overload (el, mec, cf) supragreutate, suprasarcină (şi de curent), supraîncărcare; (el) supracurent; a supraîncărca, a suprasolicita, a încărca excesiv

overload capacity (el, mec) capacitate de supraîncărcare / de suprasolicitare / de suprasarcină

overload circuit breaker / switch $(\mathrm{el}, \mathrm{mec})$ întrerupător de maxim (electric sau mecanic) / maximal / de suprasarcină

overload clutch $(\mathrm{OM})$ cuplaj cu declanşare la suprasarcină (oprire sau pornire)

overload current intermittent operation (el, mas) funcționare intermitentă, cu curent de suprasarcină

overloader (OM, transp) încărcător / dispozitiv de încărcare cu cupă (cu descărcare peste cap)

overload indicator (el, OM, autom) indicator de suprasarcină 
overloading (mec, el) suprasarcină, suprasolicitare, supraîncărcare

overload level (el, OM, mec) limită de suprasarcină, putere limită admisibilă

overload protection device / valve (OM, hidr, autom) supapă / dispozitiv de protecție la suprasarcină

overload relay (el, autom) releu declanşat la suprasarcină

overload release (el, autom) declanşare / deconectare la suprasarcină

overload shearing clutch (OM) cuplaj de siguranță (cu decuplare prin ruperea / forfecarea elementului de siguranță)

overload spring $(\mathrm{OM})$ arc suplimentar, contraarc, arc pentru suprasarcină

overload switch (el, mec) întrerupător de / la suprasarcină

overload test (mas, metr) test / încercare la suprasarcină

overload trip (el, OM, autom) decuplare la depăşirea limitei de sarcină

overlong prea lung; prea îndelungat; $(a d v)$ prea mult (timp)

overlook a se ridica deasupra; a domina; a vedea / privi de sus; a trece cu vederea peste, a nu ține seama de; a supraveghea, a avea grijă de; a examina, a cerceta

overlubrication $(\mathrm{T})$ ungere / lubrifiere excesivă, supraungere

overly $(a d v)$ prea; prea mult; excesiv

overlying suprapunere

overlying bed (constr, met) strat protector / superior; (constr) acoperiş

overlying measure strat acoperitor / superior

overman maistru

overmastication / overmilling (alim, ind chim) supramasticare, amestecare excesivă

overmatching (autom) supraadaptare

overmaturing (alim, ind chim) răscoacere, maturare excesivă

overmeasure $(\mathrm{OM})$ supradimensionare

over motoring folosirea motorului la o putere excesiv de mare (pt. acționarea unei maşini)

overmuch $(a d v)$ prea mult, exagerat

overoxidation (chim) peroxidare

overpass (constr) pasaj superior

over-passed limit (mas, TH) limită depăşită

overpay (ec) a plăti mai mult decât, a plăti prea mult

overpeopled suprapopulat; supraaglomerat over pickled (met, chim) (prea) puternic decapat overplus (ec, TH) surplus, excedent, prisos; exces, cantitate prea mare

overpoint (alim, ind chim) temperatură / punct inițial de distilare / de fierbere overpoling (fiz, el) schimbare a polarității

overpower a copleşi; a fi mai puternic decât; a învinge; a supune; a pune stăpânire pe overpowering copleşitor; prea autoritar overpressure (hidr, OM) suprapresiune, presiune excesivă

overprint (tipografie) a supratipări

overproduction (ec) supraproducție

overpunch (mas-un) superperforare, supraferforare (şi ca defect), supraştanțare, a supraperfora, a supraştanța

overquenching (met) suprarăcire la călire

overrange (mas) parcurs anormal, evoluție anormală (a unui proces, parametru etc.); (metr) depăşire a domeniului de măsurare

overrate a supraevalua, a supraestima, a supraaprecia

overreach a ajunge la / până la; a se întinde până la / dincolo de; a depăşi (în timp); a se extinde până după; a păcăli; a (se) înșela; a dobândi ilegal; a calcula greşit; a ținti prea departe

overregulate (mas, autom) a supraregla, a regla excesiv, a supracomanda

over relay releu de maxim / maximal

overrich extrem de bogat (d. concentrație)

override (autom) suprareglare; (auto) a depăşi, a întrece; (ec) a avea prioritate asupra; a asupri, a oprima, a prigoni; a călări peste; (fig) a călca in picioare; a se extinde peste, a se întinde peste; a nu lua în seamă, a nu ține cont de

overring (OM) inel extins; (mat) suprainel (în algebră)

overripening (alim, ind chim) răscoacere

overrule a conduce; a respinge (o propunere); a anula; (jur) a considera nul şi neavenit; a nesocoti

overrun a invada; a năpădi; a se revărsa peste; a inunda; a trece peste (o limită)

overrunning (el) supraîncărcare; (hidr) debordare, deversare; (mas) trecere peste o limită (normală)

overrunning clutch (OM, auto) ambreiaj de mers liber / în gol, cuplaj unilateral / de depăşire

overrun(ning) brake $(\mathrm{OM})$ frână prin inerție / inerțială

oversaturate (alim, chim) a suprasatura

oversaturation (alim, chim) suprasaturare

overscore linie trasată peste un caracter

oversea (geogr) de peste mare / ocean, de dincolo de ocean; străin, de peste hotare; (d. comerț) exterior

oversee a supraveghea, a controla

overseer supraveghetor

oversensitive (autom, metr) supersensibil 
overset a nelinişti; a tipări în exces; a tulbura; a zădărnici; a zăpăci; v. upset

overshoot (autom) supracreştere, supra(-)modulație; (amplitudine de) supraoscilaţie; suprareglare, depăşire a domeniului de reglare; a nu nimeri, a greşi (o țintă etc.), a depăşi, a suprasolicita, a întrece măsura

overshoot impulse (el, autom) impuls de demarare / de pornire

overshoot period (autom, mas-un) timp de suprareglare / de reglare suplimentară

over shop / plant (TH, met) atelier / uzină pentru reparații şi revizii

overshot (hidr) cu admisie superioară

overshot loader $(\mathrm{OM}$, transp) autoîncărcător cu cupă (cu descărcare peste cap)

overside $(a d v)$ (nav) peste bord

oversight omisiune, neglijență; (ec, TH) supraveghere

oversimplification simplificare excesivă / exagerată (în proiectare, tehnologii etc.)

oversimplify a simplifica prea mult / exagerat

oversize supradimensionare; a supradimensiona (la proiectare); supradimensiune; supragabarit; gabarit depăşit

oversize(d) part $(\mathrm{OM})$ piesă cu dimensiuni mai mari / care depăşesc limite stabilite, supradimensionare; (constr) refuz pe / de sită

oversize(d) grain (met, materiale) grăunte grosolan / mare

oversize hole $(\mathrm{OM})$ gaură lărgită / cu diametrul mai mare decât cel cerut

oversize product (alim, constr) produs / material care nu trece prin sită; refuz / reziduu de la cernere

oversleep a dormi mai târziu decât (o anumită oră), a dormi prea mult, a nu se scula la timp, a nu se trezi la timp

overslung worm (OM) melc aşezat deasupra roții melcate

overspeed (mas-un, mas) depăşire a vitezei normale; ambalare; a merge / a funcționa cu supraturație / cu turație prea mare

overspeed device (autom) dispozitiv de protectie la supraviteză / la depăşirea limitei de viteză

overspeed drive $(\mathrm{OM})$ dispozitiv cu multiplicarea vitezei, multiplicator (de viteză şi unghiulară)

overspeed governor (autom) dispozitiv de deconectare la viteză peste o limită, limitator de ambalare

overspeed limiter (OM) limitator de viteză

overspeed protection (mas) protecție la depășirea unei viteze

overspread a (se) desfăşura, a (se) întinde, a (se) răspândi, a (se) împărți, a (se) împrăştia (mai mult decât tre-buie, exagerat etc.) oversquare engine (termo) motor cu cursă scurtă (la care cursa pistonului este inferioară alezajului cilindrului)

overstate a exagera; $\sim$ smb.'s case a exagera in favoarea cauzei sale, a-şi prezenta cauza într-o lumină (exagerat) favorabilă

overstatement exagerare

oversteering (auto) supravirare (caracteristica autovehiculelor de a prezenta, în curbe, o derivă mai mare la roțile din spate față de cele din față) overstock (ec) suprastoc, stoc excedentar / supranormativ; a suprastoca, a aproviziona excesiv (piața, un magazin, o secție etc.)

overstrain (mec, OM, met) deformație remanentă, supratensionare, supraîncărcare; a aplica o sarcină peste limita de elasticitate, a supraîncărca, a suprasolicita, a deforma mai / prea mult / remanent

overstrain ageing (met) îmbătrânire după ecruisare

overstraining (mec, OM) supratensionare, tensionare suplimentare, supraîncărcare

overstraining of equipment (mas, TH) suprasolicitare a utilajului

overstress (mas) a suprasolicita (mecanic), a supratensiona

overstressing (mas) suprasolicitare (şi statică)

overstreching (mec, plast) supraîntindere, supraelongaţie

oversupply (ec) supraproductie

overtake (auto) a depăşi (în circulație), a dubla; a depăşi; a ajunge din urmă; a îndeplini / efectua în cele din urmă, a face față

overtaking depăşire

overtaking light (auto) lumină de semnalizare a depăşirii; (nav) lumină de pupa

overtax (ec) a supraevalua; a taxa suplimentar; a obliga să se plătească impozite prea mari; a suprasolicita

over-the-counter (ec) vândut direct / fără intermediar / în magazin

overthrow (constr) a răsturna, a demola, a trânti; a da jos; (fig) (pol) a răsturna (guvernul etc.); (fig) înfrângere, răsturnare

overthrust şariaj; transgresiune; încălecare; suprapunere

overtighten $(\mathrm{OM})$ a strânge excesiv de tare

overtime (ec) timp / ore suplimentar(e), (plată pentru) ore suplimentare / muncă suplimentară overtime goods (ec) mărfuri neridicate la termen / expirate

overtone (fiz) armonică (a unei unde)

overtravel (autom) suprareglare; (mas-un) depăşire a capătului cursei

overtravel wiper path $(\mathrm{OM}$, el) suprafața de contact a periei (la mașini electrice) 
overtreating (met) suprarafinare (a oțelului) overturn (auto) a capota; (met, TH) a teşi muchii, a inversa, a bascula, a (se) răsturna, a da peste cap; (nav) a (se) răsturna (d. o barcă etc.); a distruge, a ruina; (fig) a învinge, a răsturna (planuri) overturning (met, $\mathrm{TH}$ ) răsturnare; dat peste cap; basculare

overturning moment (mec) moment de răsturnare

overturning skip (met, constr) schip cu golire prin basculare (peste cap)

overturn the thread $(\mathrm{OM})$ a forța filetul

overuse (OM, mas) a întrebuința / folosi / utiliza prea mult

overtwist $(\mathrm{OM})$ a răsuci prea tare (şi o piuliță / un şurub etc.)

overevaluation (ec) supraevaluare

overvoltage (el) supratensiune

over-voltage protection (el, autom) protectie la supratensiune

overvoltage release / tripping (el, autom) declanşare la supratensiune

overvulcanisation (ind chim) supravulcanizare

overweight supragreutate, exces de greutate; (mas) a supraîncărca; preponderență; (adj) în (sur)plus

overweighted (mas, OM) supraîncărcat

overwind (el) a depăşi bobinarea; (termo, met) insuflare incorectă

overwork (ec) ore suplimentare, muncă excesivă; a supraîncărca, a munci în plus / suplimentar / exagerat, a (se) extenua; a exploata (personal)

overwrite (c) a scrie peste, a elimina / a şterge date prin scriere peste ele a altor date

overwriting error (inf, c) eroare datorată suprapunerii instrucțiunilor

overwrought extenuat, foarte obosit, muncit; încărcat de amănunte, elaborat

oviform (OM) oviform, oval

ovine (zool, agr) ovin, de oaie

ovoid (OM) ovoidal, oval

owe (ec) a datora, a fi dator / îndatorat

owing (ec) rămas de plată (d. o sumă de bani), datorat

owing to (prep) datorită, din cauza, în urma

own $(s)$ proprietate, $\sim \mathbf{s}(p l)$ rude; $(a d j)$ propriu, personal; a poseda, a avea, a stăpâni; a mărturisi; a recunoaşte, a admite (ca al său); a face destăinuiri, a se destăinui; of one's ceea ce i se cuvine cuiva, care apartine cuiva

owner (nav) proprietar, armator

owner driver proprietar şi conducător al massinii owner-occupied ocupat de proprietar

ownership (jur) proprietate, posesiune, drept de proprietate; (jur, nav) proprietar de navă, armator owner's risk (ec) pe riscul proprietarului own scrap (met) fier vechi din circuitul intern / recirculat intern

ox, $(p l)$ oxen (zool, agr) bou, taur, bivol

oxalic acid (chim) acid oxalic, sare de măcriș

oxbow (geogr) braț mort; meandră; albie veche;

(OM) jug (în formă de U)

oxbow lake (geogr) braț mort (de apă)

oxgang (metr) unitate veche britanică pentru măsurarea suprafeței (de teren): 1 oxgang $=6$ ha

oxidability (chim) capacitate de oxidare

oxidant (chim) oxidant

oxidiser (chim) oxidant, care oxidează

oxidising atmosphere (chim, met) atmosferă oxidantă

oxidation (chim) oxidare

oxidational losses (chim, met) pierderi prin oxidare

oxidation film (materiale) peliculă rezultată la după oxidare, peliculă de oxizi

oxidation heat (chim, termo) căldură de oxidare oxidation inhibitor (chim, T) (aditiv) antioxidant, inhibitor de oxidare

oxidation period (chim) perioadă / durată de oxidare

oxidation preventive (chim) anti-oxidant (și aditiv în lubrifianți)

oxidation process (chim, met) proces de oxidare oxidation promotor (chim) promotor de oxidare oxidation-proof (met, chim) rezistent la oxidare, anticorosiv (şi ca aditiv în lubrifianți)

oxidation rate (chim, met) viteza de oxidare

oxidation ratio (chim, met) grad de oxidare

oxidation reaction (chim, met) reactie de oxidare

oxidation reclaiming process (ind chim, $\mathrm{TH}$ ) procedeu de regenerare (a cauciucului) prin oxidare

oxidation-reduction (chim) oxi(dare)-reducere, oxido-reducere

oxidation-reduction reaction (chim) reacție de oxi(dare)-reducere / oxido-reducere

oxidation-resistant (materiale) rezistent la oxidare oxidation-resisting (materiale) care rezistă la oxidare

oxidation-resisting steel (met) otel inoxidabil

oxidation retarder (chim) anti-oxidant, inhibitor de oxidării

oxidation stability ( $\mathrm{T}$, chim) stabilitate la oxidare (şi d. lubrifianți)

oxidation stability test (metr, chim) test de stabilitate la oxidare

oxidation susceptibility (chim) susceptibilitate la oxidare

oxidation test (metr, chim) încercare / test la oxidare

oxidation tint (met) culoare de revenire 
oxidation value (chim) indice de oxidare oxidative (chim) oxidativ

oxidative attack (chim) atac oxidativ oxidative degradation (chim) degradare oxidativă oxidative polymerization (ind chim) polimerizare oxidativă

oxide (chim) oxid; (met) arsură (defect)

oxide coating (chim, met) acoperire cu peliculă de oxid, protecție cu peliculă de oxizi / prin oxidare oxide drosses (chim, met) zgură de metal / de acoperire

oxide film / skin (chim, met) film / peliculă de oxizi

oxide-free (chim) fără oxizi, fără conținut de oxizi oxide inclusions (chim, met) incluziuni de oxizi oxide layer (chim) strat de oxizi / de oxid oxide skin / film (chim) peliculă / film de oxid oxide passivisation layer (chim) strat de pasivare de / cu oxid / oxizi

oxide trap (electr, chim) capcană de oxizi

oxidimetric method (chim, metr) metodă oxidimetrică

oxidizable oxidabil, care se poate oxida (d. materiale)

oxidizability (chim) oxidabilitate

oxidizable (chim) oxidabil

oxidization (chim, met) oxidare

oxidize (chim, met) a (se) oxida, a rugini (d. materiale feroase)

oxidized (drying) oil (chim) ulei oxidat / suflat

oxidized starch (alim) amidon oxidat

oxidizer (chim) (agent) oxidant

oxidizing action (chim) actiune de oxidare

oxidizing agent (chim, met) (agent) oxidant

oxidizing atmosphere (chim, met) atmosferă oxidantă

oxidizing burning (chim) ardere în oxigen / oxidantă

oxidizing colour (chim, met) culoare de revenire oxidizing effect (chim, met) efect oxidant oxidizing flame (met) flacără oxidantă oxidizing fusion (chim, met) topire oxidantă oxidizing losses (chim, met) pierderi prin ardere / prin oxidare

oxidizing medium (chim) mediu oxidant oxidizing mixture (chim) amestec oxidant oxidizing period (chim, met) perioadă de afinare / de oxidare

oxidizing roasting (chim, met) prăjire oxidantă oxidising slag (met) zgură acidă / oxidantă / de afinare

oxidizing substance (chim) substanță oxidantă oxime (chim) oximă

oxomethan (chim) aldehidă formică oxyacetylene (chim) oxiacetilenă

oxyacetylene blowpipe (termo, chim, met) arzător oxiacetilenic

oxyacetylene cutter (met, mas-un, chim) dispozitiv de tăiat cu flacără oxiacetilenică

oxyacetylene cutting (met, $\mathrm{TH}$, chim) tăiere (cu flacără) oxiacetilenică / autogenă

oxyacetylene cutting torch (met, mas-un, chim) arzător oxiacetilenic pentru tăiere

oxyacetylene / oxy flame (chim) flacără oxiacetilenică

oxyacetylene scarfing machine (met, mas-un) maşină de curățat, cu flacără oxiacetilenică

oxyacetylene / oxy welder (met, $\mathrm{TH}$ ) aparat de sudură cu flacără oxiacetilenică, sudor autogen

oxyacetylene welding (met, $\mathrm{TH}$ ) sudare oxiacetilenică

oxyacid (chim) oxiacid

oxy-cutting (met) tăiere cu oxigen

oxycompound (chim) compus al oxigenului

oxydic film ( $\mathrm{T}$, chim) peliculă de oxid

oxy-electrode (el, fiz) electrod care formează şi mediul gazos oxidant

oxyflame welder (mas, met, $\mathrm{TH}$ ) aparat de sudare cu flacără (şi oxiacetilenică)

oxyfluoride (chim) oxifluorură

oxygasoline welding (met, TH) sudură oxibenzenică

Oxygen (O) (chim) oxigen

oxygen acid (chim) acid oxigenat

oxigenate (chim) a oxigena, a oxida

oxygen attack (met, chim) atac al oxigenului, coroziune cauzată de oxigen

oxygenated water (chim) apă oxigenată

oxygenation (chim) oxigenare, oxidare

oxygen bottle (ind chim) tub de oxigen

oxygen carrier (chim) comburant, carburant, oxidant (în procesul de combustie)

oxygen compound (chim) compus al oxigenului oxygen consumption (auto, mas, termo) consum de oxigen

oxygen cutting (met, $\mathrm{TH}$ ) tăiere cu oxigen

oxygen cutting torch (met, mas-un) aparat de tăiat oxiacetilenic

oxygen cylinder (OM, ind chim) cilindru / container pentru oxigen

oxygen cylinder manifold ( $\mathrm{OM}$, ind chim) colector tubular pentru legarea mai multor butelii de oxigen într-o baterie

oxygen de-seaming (met, TH) îndepărtare a defectelor de pe suprafața laminatelor cu flacără oxiacetilenică

oxygen enriched air blast (met) aer suflat / vânt (la furnal) îmbogățit cu oxigen 
oxigen evaporator (met) gazogen / instalație pentru gazeificarea oxigenului lichid

oxygen filling truck / plant (ind chim, met) stație / instalație de încărcat oxigen

oxygen-free (chim) fără (conținut de) oxigen oxygen gauging $(\mathrm{TH}, \mathrm{met})$ tăiere a unei caneluri / a unui canal într-o piesă, cu flacără oxiacetilenică

oxigen ignition temperature of metal (chim, termo) temperatura de aprindere a metalului în oxigen

oxygen in cylinders (ind chim) oxigen îmbuteliat

oxygen-induced chain reaction (chim) reacție în lanț indusă de oxigen

oxygen lance (met, OM) lance de (insuflat) oxigen

oxygen machining (met, TH) prelucrare (și tăiere) cu flacără oxiacetilenică

oxygen mask mască de oxigen

oxygen producing / production plant (met, ind chim) fabrică de oxigen

oxygen pull-down (met, ind chim) reducere a conținutului / procentului de oxigen

oxygen refined steel (met) oțel LD (obținut după insuflare cu oxigen)

oxygen relationship afinitate față de oxigen (d. materiale) oxygen steel plant (met) oțelărie LD (cu insuflare cu oxigen)

oxygen surface planing $(\mathrm{TH}, \mathrm{met})$ prelucrare / planare / rabotare a suprafețelor cu flacără oxiacetilenică

oxygen uptake (chim) absorbție de oxigen

oxy(-)hydrogen flame (chim, termo) flacără oxihidrică

oxyhydrogen (chim) gaz detonant

oxy-hydrogen welding ( $\mathrm{TH}$, met) sudare cu flacără oxihidrică

oxymethylene (chim) formaldehidă

oxynitrides ceramice (refractare) pe bază de nitruri de $\mathrm{Si}$ şi $\mathrm{Al}$

oxy-welded (OM, constr) obținut prin sudare cu gaz

oxy-welding (met, TH) sudare cu gaz / autogenă / oxiacetilenică

oyster (zool) stridie; (OM) în formă de scoică / de lentilă, lenticular

ozone (chim) ozon

ozone ageing (plast) îmbătrânire în / la ozon

ozone resistance (plast) rezistentă la ozon

ozonide (chim) ozonidă

ozonization (mediu, chim) ozonizare

ozonize (chim) a ozoniza

ozonizer (chim, mas) ozonizor, aparat de ozonizare

ozonosphere (geogr) ozonosferă 


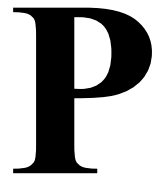

P, p (metr) formă scurtă pentru PM sau pm (post meridian), pentru exprimarea timpului

p.a. (per annum) pe an

paardekracht (pk) (metr) cal-putere metric în flamandă, v. metric horsepower

pabular (alim) nutritiv, hrănitor

pace pas, mers, viteză; ritm; (TH) mărimea unui pas; viteză de mers, a măsura cu pasul; (constr) repaus, treaptă (şi de scară); a ține pasul cu, a fi la acelaşi nivel cu; a paşi peste; a merge, a se plimba; (metr) unitate tradițională de lungime egală cu doi paşi făcuți consecutiv: 1 (Roman) $\sim 148 \mathrm{~cm}, 1$ pace (în tări de limbă engleză) = $152,4 \mathrm{~cm}=1$ great pace $=1$ geometrical pace, 1 (metric) pace $=1,5 \mathrm{~m}$; (metr, mil) pas, în limba engleză echivalent cu ,step”; v. military pace

pace voltage (el) tensiune de pas

pachymeter (metr, mec) dispozitiv pentru măsurarea limitei de forfecare sau a grosimilor mici (pt. hârtie, folii, tablă subțire etc.)

Pacific Standard Time (PST, PT) (metr) oră pe al 120-lea meridian

pack (agr) legătură, balot; (fiz) fascicul; grup; raniţă (şi de militar); (autom, inf, fiz) a comprima, a grupa (date), disc detaşabil, depunere a mai multor unități de informație în aceeaşi unitate de stocare, împachetare (a datelor, informației); (OM) container, balot, pachet, ambalaj, mănunchi; grămadă, stivă, teanc; (alim, ind) a ambala, a împacheta, a balota; a înfăşura; a lega; a etanşa; a îngrămădi; a astupa; a înmănunchea, a face mănunchi; a lega; (alim) a conserva, a pune în cutii de conserve; a se solidifica; a înțesa, a umple, a (se) înghesui, a se îmbulzi; a (se) strânge, a aduna; a face bagaje; (cf, constr) a rambleia; a căra; a duce; (fig) a da o lovitură; a da un pumn; (d. haine, produse etc.) a (se) împacheta (bine etc.); (fig) a pleca în grabă; (ing, med) a împacheta; (med) a înfăşa; a împovăra

pack (pk) (metr) unitate comercială pentru numărul de articole (identice) dintr-un ambalaj / pachet: 4 articole într-un pachet se poate scrie „4 pack” sau ,4pk”

package pachet; colet; cutie; ladă; împachetare, ambalare; capsulă; încapsulare; balotare, legare; modul; grupă de montaj; grup de elemente tipizate, parte / bloc premontat(ă); (ind, transp) spațiu minim necesar pentru depozitare; (inf) parte a unui mesaj; (ec) taxă vamală pe balot / pachet; mobil, transportabil

packaged împachetat, balotat; legat

packaged air conditioner (termo, mediu) aparat autonom (monobloc) de aer conditionat

packaged circuit module (ind) modul / element functional tipizat

packaged boiler (termo) boiler de abur sau apă caldă, construit, testat, garantat de producător (ca modul autonom)

package deal (pol, adm) acord global, set de reglementări (în Uniunea Europeană)

packaged unit (autom, c) unitate gata de funcționare / preasamblată; modulată (gata de asamblare); sistem autonom / monobloc

package freight / goods (nav, transp) mărfuri generale

package mobil locomobil, transportabil; (ec) ambalaj, pachet, colet; (fiz) pachet, format

package store (amer) magazin în care băuturile se vând exclusiv închise

package system (ec, $\mathrm{TH})$ sistem complex de produse (materiale, servicii, know-how etc.)

packaging $(\mathrm{TH}$, ind) (proces / tehnologie de) ambalare; îmbidonare; îmbuteliere

packaging / packing machine (ind chim, alim) maşină de îmbidonare / de îmbuteliere; (TH) maşină de împachetat

packaging paper (ind chim, ind) hârtie de ambalaj pack annealing (met, $\mathrm{TH}$ ) recoacere în cutii / în pachete

pack builder (met) care construieşte o stivă (maşină sau operator uman / muncitor)

pack calorizing (met) alitarea pulberilor în cutii pack carburizing (met) cementare / carburare în cutii

packed împachetat; făcut (d. bagaje); gata; plin până la refuz; înțesat, aglomerat

packed bed (ind chim) umplutură (coloană); strat / pat compact

packed bottom (met) vatră ştampată / îndesată

packed high $(\mathrm{OM})$ înălțimea garniturii / umpluturii

packed joint $(\mathrm{OM})$ îmbinare cu garnitură de etanşare

packed-out ticsit, plin până la refuz

packed scrap (met, mediu) deşeuri în pachete (de şpan, de resturi de la decupări etc.)

packed space (OM, hidr) spațiul / volumul garniturii / umpluturii

packen (metr, fiz) unitate tradițională rusească pentru masă: 1 packen $=491,4 \mathrm{~kg}$ 
packer $(\mathrm{TH})$ împachetator, persoană / maşină care împachetează; (cf) ciocan de burat; (mas) presă / dispozitiv de împachetat / ambalat

packer body (auto, mediu) caroserie pentru colectarea gunoiului, cu dispozitiv de compactare

packet pachet; (fiz) grup (cuib, roi, nor); (inf) pachet, cea mai mică unitate de date care poate fi manevrată ca o entitate logică; $(\mathrm{TH})$ balot; a ambala; a împacheta; a balota

packet assembly (OM, ind, c) asamblare, pachet, ansamblu modulat / de pachete

packet boat (nav) navă de pasageri cu mesagerii la bord, pachebot

packet cam-operated switch (el, OM) întrerupător modulat acționat cu camă

packet file (mas-un) pilă de braț (bastardă)

packet switching (inf) comutare a pachetelor de mesaje, transfer dinamic al mesajelor divizate în pachete între sursă şi destinație

packfong (met, $\mathrm{TH}$ ) packfong, alpaca, argentan, aliaj $\mathrm{Cu}-\mathrm{Ni}-\mathrm{Zn}$

pack-hardening (met) cementare în cutii

pack heating furnace (met) cuptor pentru încălzirea pachetelor (de table)

pack in a atrage în număr mare; (ec) a termina (munca)

packing ( $\mathrm{TH}$, alim, ind) împachetare; ambalare; ambalaj; (inf) comprimare a datelor / componentelor; (TV, c) comprimare a imaginii; (OM) garnitură, etanşare (cu referire în special la materialul deformabil / activ în etanşare), umplutură (de etanşare), manşonare, îmbrăcăminte a cilindrului; (met) bătătorire, îndesare, compactare; (constr, cf) rambleiere

packing agent (met, OM) material de umplutură

packing block (mas-un) suport, bloc de strângere / de formare a pachetului (de piese) de prelucrat

packing board $(\mathrm{OM})$ carton pentru garnituri

packing box $(\mathrm{OM})$ presgarnitură / cutie / modul de etanşare

packing case (OM, agr, ind) ladă de ambalaj (si din lemn); (met) cutie de împachetare / de cementare

packing cloth (textile, ind) pânză de saci de ambalaj

packing cord (textile, ind) sfoară de ambalare; (OM) şnur de etanşare

packing defect (fiz) defect de masă; (alim) defect de împachetare

packing density (autom, c) densitatea informațiilor

packing drawer (mas, OM) cârlig de scoatere a garniturii de etanşare packing drum (mas-un, OM) cilindru / tobă de etanşare

packing extra (ec) facturare separată a ambalajului

packing flange $(\mathrm{OM})$ bridă / flanşă de etanşare

packing fraction (plast) fracție a materialului aflat în stare cristalină (în rețea)

packing gland $(\mathrm{OM})$ presetupă, presgarnitură, garnitură / membrană de etanşare

packing industry / trade (alim) industria conservelor

packing lath (constr) filată

packing linen (textile, ind) pânză de ambalaj

packing machine (met, ind chim, alim) mașină de împachetat / de ambalat

packing material $(\mathrm{TH})$ material de etanşare / de ambalare / de umplutură

packing / fill of cooling tower (met, OM) dispozitiv(e) pentru distribuţia şi împrăştierea apei într-un turn de răcire

packing nut $(\mathrm{OM})$ piuliță de etanşare

packing paper (ind chim, alim) hârtie de ambalaj packing piece (mas-un, OM) garnitură de etanşare, element / modul de etanşare

packing plant (alim) fabrică de conserve

packing plate $(\mathrm{OM})$ şaibă / placă de etanşare; (met) tablă / platbandă de ambalaj

packing pot (met) oală de cementare

packing press (mas-un) presă de împachetat / de balotat

packing ring $(\mathrm{OM})$ inel de etanşare, segment de compresiune, garnitură inelară

packing room (constr, ind chim, alim, met) hală / sală de ambalaj / de ambalare

packing sheet (ind, alim) material / foaie pentru împachetat

packing space (mas-un, OM) grosimea / spațiul presgarniturii

packing spring (mas-un, termo, $\mathrm{OM}$ ) arcul segmentului de piston, segment elastic de piston

packing stick (mas-un, $\mathrm{OM}$ ) bară de montare a presetupelor şi de înlocuire a materialului de etanşare

packing surface $(\mathrm{OM}, \mathrm{T})$ suprafață de etanşare packing surface with tongued and grooved joint (OM, hidr) suprafețe de etanşare, cu canal şi pană

packing twine (textile) sfoară de împachetat

packing up block (mas-un, OM) placă de reglare a înălţimii (sculei, piesei de prelucrat, pachetului de piese de prelucrat)

packing washer $(\mathrm{OM})$ inel de etanşare, şaibă de presiune

packing up împachetare 
packing-up block / piece (mas-un) piesă / placă pentru reglarea înălțimii sculei / piesei / pachetului de piese de prelucrat, placă intermediară (de menținere în pachet etc.)

packing washer $(\mathrm{OM})$ inel de etanşare, şaibă de presiune (a presgarniturii)

packless (mas-un, OM) fără presetupă / presgarnitură, fără garnitură de etanşare

packless joint $(\mathrm{OM})$ îmbinare / asamblare fără garnitură de etanşare

pack off a da afară; a pleca

pack out (mas-un) a aşeza la o anumită distanță prin piese de distanțare / distanțiere

pack rolling (met) laminare în pachete

pack rope (textile) frânghie de împachetat / de ambalaj

packset (metr) aparat portabil

packthread (textile) sfoară de legat

pack up (cf) a bura (balastru sub traverse); (TH, ind) a fixa; a strânge; a împacheta; a ambala; a nu mai merge / functiona (d. o maşină etc.)

pack with leather $(\mathrm{OM})$ a etanşa cu piele

pack year (metr, med) unitate pentru numărul de țigări, folosită pentru a evalua istoria unui pacient fumător: 1 pack year (1 pachet pe an) este echivalent $\mathrm{cu}$ fumatul unui pachet de 20 de țigări pe zi, timp de un an

pact (pol) pact, tratat

pad (TH) căptuşeală, acoperire cu un prim strat de vopsea; suport, talpă; (med) pachet de vată, tampon; pernă; bloc de foi de scris; pilulă, tabletă; pat; $(\mathrm{OM}, \mathrm{T})$ căptuşirea cuzinetului cu compoziție, pernă, zonă (inel) de întărire la ieșirea din recipientele sub presiune; (met) strat depus (si la recondiționări prin sudare); (nav) placă, ochi; (OM) suport, reazem, garnitură, flanşă, manșon, tampon de amortizare, bucşă, mâner de unealtă; a căptuşi, a acoperi cu un prim strat de vopsea / de sudură, a depune prin sudare; a decapa; a nivela (un drum), a capitona; a umple cu vată; bloc cu foi detaşabile, mapă; (sport) plastron de protectie (la scrimă), jambieră, apărătoare (la fotbal etc.); (zool) perniță cărnoasă (la patrupede), labă (de iepure etc.); (cf) tampon de amortizare

pad an account (ec) a încărca un cont

pad blotting (OM, med, hidr, mediu) tampon

pad cover (auto, OM) capac

padded plate (met) tablă striată

padding (mas-un, OM) material de etanşare / de umplutură, căptuşeală; (met) încărcare prin sudură a suprafeței în formă de pernă; (TH) capitonare, umplere, astupare; pânză groasă; acoperire cu un prim strat de vopsea (grund); decapare; (inf) umplutură, adăugare de caractere fictive nesemnificative

paddle (nav) zbat, padelă, vâslă, poartă de ecluză; lopată; ramă; racletă, paletă, pală, aripă, aripioară, lopată, rangă; a vâsli

paddle agitator (ind chim, alim) agitator cu palete paddle-bladed / radial-bladed impeller (OM) rotor cu palete radiale

paddle-blade-type mixing machine (alim, constr, ind chim) malaxor cu pale / cu palete

paddle mixer (constr, ind, alim) malaxor / agitator / amestecător cu pale / cu palete / cu aripi paddle shaft (constr, OM) ax / arbore cu palete paddle steamer (nav) navă cu roți cu zbaturi

paddle stirrer (alim, ind chim) amestecător cu palete

paddle valve (hidr, OM) vană / supapă plată de închidere

paddle-wheel $(\mathrm{OM}$, hidr) roată cu cupe / rotor la turbina Pelton; (nav) roată cu zbaturi

paddle worm conveyer (alim, ind chim) malaxor / transportor elicoidal

paddy (alim) orez nedecorticat / pe pai

padlock $(\mathrm{OM})$ lacăt; a încuia cu lacăt

pad roll(er) (cf, OM) rolă de presiune / de ghidare / de conducere / de apăsare

pad saw (mas-un) ferăstrău cu pânză

page pagină; filă; foaie; coloană; a pagina; a numerota (pagini)

page depth înălțime a paginii

page imposition / make-up paginație

page size (inf, c) format de pagină

pages per inch, ppi (metr) abreviere pentru numărul de coli / pagini pe inch / țol, unitate de măsură pentru grosimea hârtiei; (metr, materiale) abreviere pentru pores per inch (pori pe inch / țol); unitate de măsură pentru porozitatea spumelor (poliuretanice etc.) şi a produselor de filtrare

pagination paginație; paginare; numerotare a paginilor; aşezare în pagini

paid (ec) plătit, achitat

paid-up (ec) plătit / achitat integral

pail găleată, vadră; (met) oală; (TH) benă, cuvă

pain killer (med) calmant

paint vopsea; (nav) pitură; (TH) a picta, a vopsi, a zugrăvi, a colora; (fig) a descrie, a prezenta, a înfățișa

paint blower $(\mathrm{OM})$ pulverizator de vopsea

paint brush $(\mathrm{OM})$ pensulă (de vopsea)

paint coat (met, auto, $\mathrm{TH}$ ) vopsire; strat de vopsea; acoperire cu vopsea

painted (ind) vopsit; (constr) zugrăvit, colorat; pretins; fals

painter zugrav; vopsitor; (nav) barbetă 
painter's naphtha (ind chim) diluant (pt. vopsea) paint ports (nav) saborduri false

painting (constr) zugrăveală; (nav) piturare; $(\mathrm{TH})$ vopsire, vopsitorie; coleire (ind pielăriei); (nav) piturare; (artă) pictură, tablou

paiting medium (ind chim) agent de vopsire, vopsea, strat pe care se aplică vopseaua

painting nozzle (chim, OM) pistol / pulverizator de vopsit / de vopsea

paint out (TH, auto) a acoperi cu vopsea, a vopsi (pe deasupra)

paint remover (chim) compoziție pentru ştergerea vopselei, dizolvant; (met) agent / material de decapare

paint room / shop (mas-un, auto) vopsitorie, incintă pentru vopsirea (caroseriilor euto)

paint sprayer $(\mathrm{OM})$ pistol-pulverizator (duco) de vopsea

paint spraying (auto, $\mathrm{TH}$ ) vopsire prin stropire / prin pulverizare

paint spraying pistol / gun (auto, OM) pistol de stropit vopsea

paint thinner (chim) diluant; diluant de vopsele paintwork (auto, ind) vopsire; lăcuire, suprafață vopsită

painty proaspăt vopsit

pair pereche; (mat) cuplu; a împerechea; a face perechi; a aranja doi câte doi; a forma o pereche; a fi pereche

pair (pr) (metr) unitate pentru cantitate, egală cu 2 , pereche (de obiecte / piese identice)

pair heating furnace (met) cuptor pentru încălzit platine / cu două camere

pairing $(\mathrm{OM})$ împerechere (a două piese conjugate, a platinilor la laminor etc.); potrivire

pair furnace (met) cuptor cu două camere

pair (of) perechi (de)

pair of gears $(\mathrm{OM})$ pereche de roți dințate

pair of nippers (mas-un) cleşte de tăiat sârmă

pair of plates (el) pereche de plăci

pair of poles (el) pereche de poli

pair of tongs (mas-un) clește

pair of tweezers (mas-un) pensetă

pair of wedges (mas-un, OM) pană dublă

pair royal (metr) unitate pentru cantitate, egală cu 3, (în jocul de cărți)

pairwise în perechi, câte doi; perechi-perechi palladium (Pd) (chim) paladiu

palladium plating (chim) placare cu paladiu

pale deschis (la culoare); pal; spălăcit; şters; palid; par, stâlp; pilot; a îngrădi

Palermo scale (metr,a stronomie) scară de estimare / evaluare a riscului de impact al Pământului cu o cometă sau un asteroid, scară Palermo palette (mas-un, OM) paletă; (c) gamă / paletă de culori (pe un ecran)

palette conveyer (alim, mas-un, OM) transportor cu plăci / cu palete

palisade (constr) palisadă; a împrejmui, a îngrădi, a înconjura cu piloți / stâlpi

Palladium (Pd) (chim) paladiu

pallet (mas-un, OM) paletă, pală (de elice / rotor etc.) placă de transportor, crapodină, pat de scânduri, lopată, diblu

palletainer boxpalet, ladă cu fund dublu pentru manipulare

pallet box / crate (alim, OM, transp) paletăladă, boxpalet

pallet conveyor (alim, ind chim) transportor $\mathrm{cu}$ plăci / cu palete

palletisation, palletization, pallet operation (alim) formarea paleților, paletizare

palletise, palletize (met, plast, $\mathrm{TH}$ ) a peletiza, a face / a forma granule

palletised / palletized rubber (plast, ind chim) cauciuc granulat / în granule

palletiser, palletizer (mas, transp) utilaj pentru împachetat în boxpaleți

palletising / palletizing drum (ind chim, OM) tambur de gra-nulare, tobă de peletizare

pallet load (alim, transp, ind) încărcătură de palet pallet loader / truck $(\mathrm{OM}$, mas) cărucior de ridicat şi stivuit cu furcă, pentru boxpaleți, stivuitor pallet posts $(\mathrm{OM})$ suporți pentru rigidizarea stivei pallet staff (nav, OM) ax al ancorei

pallox $(\mathrm{OM})$ boxpalet

palm (metr, fiz) unitate tradițională de măsură pentru lungime, palmă, mână: 1 palm $\sim 7,5 \mathrm{~cm}$; 1 palm $(\mathrm{UK})=22,86 \mathrm{~cm}=1$ span; denumire utilizată uneori în flamandă pentru decimetru

palmful (metr, alim) an informal unit of volume 1 tablespoon $\sim 15 \mathrm{ml}$

palmo (metr) unitate tradițională de măsură pentru lungime, palmă: 1 palmo (Spania, tradițional) $\sim 20,9 \mathrm{~cm}, 1$ palmo (Texas) $21,17 \mathrm{~cm}, 1$ metric palmo $($ Spania $)=20 \mathrm{~cm}, 1$ palmo (Portugalia) $\sim 22,0 \mathrm{~cm}$

palm oil (alim) ulei de palmier

palnut (OM) contrapiuliță ștanțată din tablă / elastică cu umeri / cu cioc, cui spintecat, şplint palpate (med, OM, metr) a palpa

pamphlet (mas-un, TH) catalog cu descrieri şi date tehnice; foaie volantă, broşur

pan (constr) scripete pe roți; (hidr, OM) bazin, rezervor, jgheab; (mas-un) tavă, rebord (de aşchii sau ulei); (TH) castron mic, farfurioară, cadă; (met) cuvă / vatră de cuptor; taler / platan (al balantei); adâncitură, vale; băltoacă, ochi de apă 
pan charger (OM, alim) încărcător cu cupe pan conveyor (ind, transpp, OM) transportor $\mathrm{cu}$ scocuri (oscilante)

pan down (c, TV) descentrare pe verticală în jos a imaginii

pane geam; placă de sticlă; panou; (mat, OM) fața unui corp poliedric (a unei piulite, carou, pătrat

paned (constr, OM) cu geamuri, alcătuit din pătrate

panel (OM, mas) panou; tăblie; pupitru; placă frontală; comisie; structură sau suprafață pe care se montează un aparat; (autom, el) tablou de comandă / de distribuție; (constr) panel; dală rutieră de beton, casetă (de tavan), perete despărțitor, lambriu; (ochi de) geam, sticlă; (ec, TH) grup de experți consultanți; a căptuşi cu lambriuri; foaie de pergament; listă, tabel, enumerare; (textile) aplicație (la o rochie etc.); cadru tipografic al reclamei; comisie (de anchetă etc.); (jur) complet de judecată, (listă de) jurați; fotografie format mare; (med, adm) listă de doctori în serviciu public; masă rotundă; (foaie de) pergament

panel braces (el, OM) echere / colțare de fixare al unui panou

panel cabinet (el, autom) dulap / panou de distribuție / de comandă

panel cooler (termo, OM) panou de răcire / radiant / de refrigerare

panel frame mounting (autom) montare pe panou panel lamp (autom) lampă de panou

panelling (constr) căptuşeală (cu plăci de lemn); panou de lemn, lambriu

panel method (hidr, fiz) tehnică de analiză şi simulare în dinamica fluidelor (denumire rar utilizată astăzi), metoda elementului finit, metodă FEM

panel of experts (ec, TH, edu) grup de experți panel (of switchboard) (el) tablou de comandă / de distribuție (cu întrerupătoare)

panel-point load (mec) nod de asamblare, sarcină în nod

panel screen $(\mathrm{TH})$ tablou (de comandă, tip schemă pt. o instalație etc.)

panel stock (met) foaie de tablă

pane of glass (constr, ind chim) geam

pan grinder / mill (mas, alim) moară chiliană / cu tăvălug / cu role verticale; malaxor-amestecător panhead (OM) cap conic / tronconic panhead rivet $(\mathrm{OM})$ nit cu cap tronconic pan mill (mas, alim, ind chim) moară de fărâmițare; kollergang

pan mixer (constr, mas) betonieră, malaxor pentru mortar panning (inf) panoramare, translatare continuă pan of a balance (OM, metr) taler de balanță pan-shaped base (mas-un, OM) placă de bază, cu bordură formând un canal sau o tavă de colectare panting (nav) vibrația corpului navei datorită balansului

pantograph (el, mas-un) pantograf; (transp, el) troleu

pantograph engraving machine (mas-un) maşină de frezat prin copiere, cu pantograf

pantry (constr) cămară; (nav) oficiu

pan-type annealing furnace (met) cuptor de recoacere, cu creuzete / cu mufle

pan vulcanisation (plast, ind chim) vulcanizare în autoclavă

pap (ind chim, alim) pastă, terci; $(\mathrm{OM})$ butuc, bucşă; (alim) griş cu lapte

paper hârtie; ziar, gazetă; articol; (univ, edu) referat, comunicare (și ştiințifică); disertație; lucrare scrisă / ştiințifică, teză, bilet de examen, teză; (constr) tapet, a tapeta; pungă de hârtie; (ec) bancnote, efecte, titluri, bani de hârtie, valori; bigudiu; pungă de hârtie; (poligrafie) document; permis (la teatru etc.) a împacheta / înfăşura în hârtie; a scrie pe hârtie

paper advance knob $(\mathrm{OM})$ rolă pentru avansul hârtiei (birotică)

paperback carte broșată, volum broșat

paper-backed broşat

paper bag (alim, ind chim) pungă / sac de hârtie paper band / strip / tape (alim, birotică, metr) bandă de hârtie (şi perforată)

paper-clip / fastener (OM) clemă, agrafă (pt. hârtie) paper currency / money (ec) monedă de hârtie, cu valoare conventională numai în interiorul țării paper cutter $(\mathrm{OM})$ ghilotină (poligrafică), maşină / cuțit de tăiat hârtie

paper deformation (autom, birotică) deformarea hârtiei

paper-fastener $(\mathrm{OM})$ agrafă pentru hârtie paper feed (c, birotică) alimentare cu hârtie paper feeding (c, birotică) avansul hârtiei

paper file mapă, dosar (de hârtie, cu documente pe hârtie)

paper gasket garnitură din hârtie sau carton paper industry (ind) industria hârtiei

paper knife / cutter (mas-un, OM) cuțit de tăiat hârtie

paper laminate (plast) material plastic, laminat, stratificat cu hârtie

paper mill (ind chim) fabrică de hârtie

paper moving system (mas, ind chim) sistem de antrenare al hârtiei

paper reel / roll (birotică, alim) sul de hârti 
paper refuse (mediu, ind) deşeuri de hârtie, maculatură

papers hârtii; documente; acte

paper-sack machine (mas) maşină de fabricat saci de hârtie

paper size (birotică) formatul hârtiei

paper slip (metr) bandă de hârtie pentru înregistrare (la un aparat)

paper supply roll (metr) rolă de derulare a hârtiei paper take-up roll $(\mathrm{OM})$ rolă de înfăşurare a hârtiei

paper tape input, paper threading (birotică, metr) intrare / introducere a benzii de hârtie

papery (ca) de hârtie; subțire ca hârtia

parabola (mat) parabolă

parabolic (mat) parabolic; curbat

parabolic distribution of stress (constr, mec) distribuție parabolică a tensiunilor

parabolic law (TH, fiz, chim) dependență parabolică

parabolic load (constr, mec) sarcină / încărcare parabolică

parabolic spiral (mat) spirală parabolică / a lui Fermat, funcția $\varphi^{2}=a \cdot \varphi$

parabolize (mat) a paraboliza, a transforma în parabolă, a aduce la formă de parabolă

paraboloid, parabolic body (heom) paraboloid

parachute (av, mil) paraşută; a paraşuta, a coborî cu parașuta

parachute jumper paraşutist

parade defilare; faleză; esplanadă; trecere în revistă; apel; marş, demonstrație, manifestație; promenadă, loc de plimbare; trecători; a face paradă de, a etala; a defila

paradigm exemplu; model; tipar; paradigmă

paradox paradox; fapt / părere care contrazice ceva în general acceptat

paradoxical paradoxal

paraffin (chim) parafină, ulei de parafină, gaz, petrol lampant; a parafina

paraffin acids (ind chim) acizi din seria alifatică / parafinelor

paraffin-base crude / oil (ind chim) țiței parafinos

paraffin distilate (ind chim) distilat parafinos

paraffin hydrocarbons (ind chim) hidrocarburi parafinice / saturate; parafine

paraffinic (chim) parafinic

paraffinic oil ( $T$, ind chim) ulei parafinic

paraffin jelly $(T$, ind chim) vaselină

paraffion oil (ind chim) ulei de parafină, țiței parafinos, petrol lampant, gaz

paraffinum liquidum (ind chim) ulei de parafină paraffin wax (ind chim) ceară parafinică, parafină (transparentă)

paraffin wax sizing (ind chim) parafinare

paragraph paragraf; alineat; notă; notiță; articol scurt; semn de alineat; a paragrafa; a împărți în paragrafe (d. texte)

paragraphic(al) format din paragrafe; puncte / note disparate

paragraph mark (c, inf) semn de paragraf

parallax (fiz) paralaxă

parallel (to) (geom) paralel(ă) (cu); (fig) asemănător, analog; paralelă, latitudine; in în paralel; to draw a $\sim$ between a trasa / stabili / face o paralelă între, a face o analogie între; with a compara, a asemăna cu, a putea face o comparatie; a egala; a fi / merge paralel

parallel acces (autom, c) acces simultan (paralel)

parallel alignment $(\mathrm{OM})$ paralelismul axelor

parallel-arc welding (TH, met) sudare cu electrozi legați în paralel

parallel actuators, side-by-side actuators (mas, autom) acționări paralele pentru a comanda acelaşi sistem (pt. siguranță)

parallel axiom / postulate (mat) axioma / postulatul paralelelor

parallel bench vice (mas-un, $\mathrm{OM}$ ) menghină de banc, paralelă

parallel carrier (mas-un, OM) transportor / flanşă de antrenare cu brațe paralele

parallel circuit (el) circuit şunt / paralel / derivație parallel circular saw (mas-un) ferăstrău circular, cu mai multe discuri

parallel connection (mec, el) legare / conectare în paralel / în derivație

parallel crank mechanism (mas, OM) mecanism dublu, cu bielă şi manivelă

parallel displacement dislocare paralelă; (mec) translatie

paralleled (el) legat în paralel / în derivație; (fiz, mec) în paralel

parallel elements (el, hidr) elemente legate în paralel

parallelepidal product (mat) produs mixt a trei factori

parallelepiped(on) (geom) paralelipiped

parallelepipedal, parallelepipedic, parallelepipedonal, parallelepipedous (geom) paralelipipedic

parallelepipedal product (mat) rezultatul compunerii a trei vectori perpendiculari doi câte doi

parallel fence (mas-un) riglă de ghidare

parallel flanged beam (met, mec, OM) profil / grindă I 
parallel flow (el) curent în derivație; (hidr) curent laminar / paralel, curgere laminară; $(\mathrm{TH})$ echicurent, curgere unidimensională (d. fluide vâscoase, materiale topite etc.)

parallel forces (mec) cuplu de forțe

parallel gear drive (mas) transmisie prin paralelogram de pârghii articulate

parallel hand vice (mas, $\mathrm{OM}$ ) menghină de mână cu fălci paralele

parallel helical gear pair (OM) angrenaj cu roți cilindrice cu dinți înclinați

parallel hobbing cutter (mas-un) freză-melc cilindrică

paralleling (el, mec) legare / cuplare / conectare în derivație; care este (în) paralel cu

parallelism (between) / parallelness (OM, masun) paralelism; analogie, asemănare (între)

parallel jaws (mas-un, OM) fălci paralele (la menghină sau la dispozitiv de prindere)

parallel jointing sleeve (el, OM) cutie / manşon de derivatie

parallel key $(\mathrm{OM})$ pană paralelă

parallel key with fastening holes $(\mathrm{OM})$ pană paralelă, cu găuri de fixare

parallel laminate (plast) (produs) stratificat paralel

parallel lathe (mas-un) strung paralel / normal

parallel light rays (fiz) lumină orientată

parallel middle / square body (nav) porțiune cilindrică a corpului navei, porțiune / zonă maestră

parallel milling machine (mas-un) maşină de frezat verticală, cu doi arbori principali

parallel misalignment $(\mathrm{OM})$ abatere de la paralelism; neparalelism

parallel motion $(\mathrm{mec})$ mişcare paralelă

parallelogram (mat) paralelogram

parallelogram of forces $(\mathrm{mec})$ paralelogramul forțelor

parallel of latitude (geogr) paralelă de latitudine

parallel operation (autom) operație paralelă; (el) funcționare / operare / operație în paralel

parallel planing machine (mas-un) raboteză

parallel plate shear tester (metr) dispozitiv de testare la forfecare cu plăci paralele

parallel processing (mas-un) prelucrare simultană (de exemplu, găurire cu cap multi-ax, aşchieri simultane la strunguri revolver etc.)

parallel-precision gauge (mas-un, metr) bloc cală plan-paralelă, calibru prismatic

parallel projection $(\mathrm{OM})$ proiecție paralelă (în desen tehnic)

parallel resistance (el) rezistență paralelă / în derivație; şunt

parallel rule linie dublă (în desen tehnic)

parallel ruler (met) paralel de trasare parallels (met, plast) nervuri / distanțiere pentru a regulariza curgerea materialului turnat şi pentru a evita fisurarea componentelor matritei / formei de turnare

parallel shank (mas-un, $\mathrm{OM})(\mathrm{cu})$ coadă cilindrică (la scule)

parallel-slide steam stop valve (cf, OM, termo) robinet cu sertar pentru închiderea aburului parallel slide valve (OM, hidr) robinet cu sertar parallel splice (OM, hidr) armătură capabilă să lege conducte paralele sau adiacente

parallel square body (nav) porțiune cilindrică parallel surface (geom, OM) suprafață paralelă parallel task execution (c) executarea în paralel a mai multor programe

parallel terminals (el) borne pentru conectare în paralel

parallel type worm (mas-un, OM) melc cilindric (în angrenaje melcate etc.)

parallel vice (mas-un, OM) menghină paralelă parallel winding (el) înfăşurare în derivație parallel working (el, mas) funcționare în paralel paralogize a raționa fals / ilogic

paralyse, (brit) paralyze (amer) a paraliza paralysing paralizant

paralysis, $(p l)$ paralyses blocare; paralizare; paralizie; $(\mathrm{TH})$ stagnare

paralysis time (autom, $\mathrm{TH}$, mas) timp mort paralysing voltage (el) tensiune de blocare paramagnet / paramagnetic material (el) material paramagnetic

paramagnetism (fiz, met) paramagnetism

paramagnetic (el, met) paramagnetic / amagnetic

parameter $(\mathrm{TH})$ parametru, constantă, factor, coeficient, caracteristică, indice, variabilă, mărime de stare / de determinare

parametric analysis (TH, metr) analiză parametrică, analiză prin variația unui parametru

parameter device (electr) dispozitiv cu reactanță neliniară

parametric subharmonic oscillator (fiz, elctr) oscilator parametric / neliniar subarmonic

parametric variation (autom, fiz) variație parametrică

paramount extrem; suprem; maximum

paramountcy caracter suprem/ exceptional, unicitate

paraphrase parafrază; interpretare (liberă); a parafraza; a interpreta (liber); a reda cu alte cuvinte parasang (metr) unitate veche de măsură pentru lungime, comparabilă cu o leghe europeană: 1 parasang $\sim 3,5 \ldots 4,0$ mile sau $\sim 6 \mathrm{~km}$

parasite (agr, bot, biol) parazit: (fiz) parazit, perturbator (d. un semnal etc.)

parasitic(al) (agr, bot, biol) parazitar; parazit, de parazit 
parasitism (agr, TH, autom) parazitism, caracter parazitar

parasol umbrelă de soare

parastrophic structural

paratape (el, ind chim) bandă izolatoare

paratrooper (av, mil) paraşutist

paratroops (av, mil) unități de parașutiști

paravane (nav, OM) paravan

parboil (alim) a opări; a fierbe pe jumătate; (d. soare) a încinge, a înfierbânta

parbuckle (nav) parabuclă; a ridica prin saule

parcel pachet, livrare, parte, porțiune; grup; (constr) parcelă, lot de pământ; (cf, transpp) colet; (nav) a înfășura o parâmă; (ec) partidă / lot de marfă; (agr) parcelă; a parcela, a împărți în loturi (pământul sau piese); a ambala, a împacheta, a face un pachet / colet

parcelling (constr, agr) parcelare, împărțire în loturi

parcel net / rack $(\mathrm{OM})$ plasă pentru bagaje

parcel out (agr, constr) a împărți; a diviza; a parcela (pământ)

parcel paper (ind) hârtie de împachetat

parcel plating (met, pplast) depunere parțială / limitată

parcel post (transp) mesagerii; colete; by $\sim$ prin coletărie

parcel receipt / ticket $(\mathrm{ec})$ recipisă / foaie de încărcare

parce lup a face un pachet din

parcener (jur) comoştenitor

parch (alim) a prăji, a (se) coace, a rumeni; (d. soare) a pârjoli, a arde; (ind chim, alim) a (se) usca (prin încălzire); a face să înghețe, a îngheta; a se scoroji

parched paper (alim) hârtie pergament parchment (alim) pergament, hârtie pergament parclose (constr) a împrejmui, a înconjura par-cook (alim) a fierbe puțin / pe jumătate pardonable de iertat; scuzabil

pare a tăia / îndepărta partea exterioară, a coji, a scoate / tăia coaja (unei portocale etc.), a curăta; a reduce treptat, a micşora (economii etc.); (agr) a dezmiriști, a tăia (iarba), a tunde (un gard viu); a rade (părul); a tăia (unghii, gheare)

pare down (ec) a reduce, a micşora (costul etc.)

paregoric (med, chim) analgezic, substanță analgezică

parent (autom, fiz) (atom) primar / inițial / de plecare; de bază; (fig) izvor, sursă, origine

parent-cell (biol) celulă-mamă

parent company (ec) societate-mamă / de bază parent distribution repartiție teoretică; repartiția întregii populații (în statistică matematică) parenthesis, $(p l)$ parentheses paranteze (rotunde); paranteză; completare; precizare, explicație patent metal (met) metal de bază

parenthezise a pune (în) paranteze, a include între paranteze; a preciza într-o paranteză

parenthetic(al) (mat) parantetic, între paranteze, menționat într-o paranteză / în treacăt

parenthetically $(a d v)$ ca o paranteză, într-o paranteză

parent metal (met) metal de bază

parent population populație (în general, în statistica matematică)

parent solution (chim, met) soluţie de bază / inițială (şi la decapare)

parent stock (agr, bot) portaltoi

parent substance (chim) substanță de bază / inițială parent unit unitate de bază

paresis (med) pareză

parfait (alim) parfe

paring (ind, silv) talaş

paring knife cutit de derulat / de sculptat în lemn; (mas-un) cuțit de cojit / de tăiat piele

Paris foot (metr) denumire în limba engleză pentru Paris point, v. Paris point

parison (mas-un, TH) piesă brută, semifabricat intermediar

Paris point (metr) unitate de măsură pentru lungime, folosită pentru a evalua mărimea pantofilor în majoritatea țărilor Europei: 1 Paris point $=2 / 3 \mathrm{~cm}$

parity (ec, fiz) paritate, egalitate valorică, simetrie a funcției de undă; (inf) număr total de biți, cu valoarea 1 din cadrul unui cuvânt (caracteristica unui vector binar utilizată pentru verificarea corectitudinii transmiterii datelor)

park parc, loc de parcare / de staționare; a parca; (c) program / rutină de dezangajare a harddiscului pentru protecție

parkerizing (met, chim) fosfatare, parchetizare

parker (rustproofing) process (met, $\mathrm{TH}$ ) procedeu / proces / tehnologie de fosfatare (antiruginire)

parker screw $(\mathrm{OM})$ şurub autoînfiletant

parking staționare; parcare; (auto, transp) parc de autovehicule

parking brake (auto, OM) frână de mână / de parcare

parking brake warning (auto) atenționare / avertizare asupra frânei de parcare / de mână parking light (auto) lumina de parcare

parking light position (auto) poziția luminii (indicatorului luminos) de parcare

parking lot (auto) parcare

parking strip (constr) zonă / linie de staționare 
parlon (plast, ind chim) denumire comercială a clorcauciucului

par of exchange (ec) paritate de schimb (d. valute) parry (nav) a evita, a apăra

parsec (pc, psc) (metr, astronomie) unitate nemetrică pentru distanțe: 1 parsec $\sim 3,26156$ ani lumină $\sim 30,85678 \cdot 10^{12} \mathrm{~km}$

pars pro / per mille miime, părți la mie

pars per million (ppm) (chim, fiz) părți / particule la un milion

part parte (dintr-un întreg); (ec) datorie, obligație, contribuție; fragment; $(\mathrm{OM})$ reper, piesă / organ / element de maşină, subansamblu; element de construcție; (nav) fir de palanc; fasciculă; (jur) parte, cauză; datorie; (teatru) rol; (TH) a (se) împărți; a diviza; a fracționa, a (se) separa; a înlătura, a tăia, a îndepărta; a (se) rupe (d. o funie, o parâmă); >s (geogr) regiune, loc, împrejurimi, (fig) talent, posibilități; a despărți; a se frânge; (fam) a plăti; for the most cea mai mare parte, cel mai adesea; spare $\sim \mathbf{s}$ piese de schimb; in $\sim \mathbf{s}$ demontat; come out in $\sim \mathbf{s}$ a apărea în fascicule; publi-shed in $\sim$ s publicat în fascicule; from all $\sim \mathbf{s}$ din toate părțile; for $\mathbf{m y} \sim \operatorname{din}$ partea mea; take $\sim$ in a discussion a lua parte la o discutie; a man of $\sim \mathbf{s}$ un om de talent; of weak $\sim$ s cu puține posibilități, puțin dotat; (metr, chim, alim) unitate pentru exprimarea proporțiilor sau în rețete de amestecuri; fractia unui ingre-dient reprezintă numărul de părți al acestuia din amestec: exemplu: 1 parte apă şi 2 părți făină (cantitatea de făină este dublă față de cea de apă); (metr) unitate medievală de măsură pentru timp: 1 part $=1 / 15$ ore; (metr) altă denumire pentru helek, unitate ebraică de timp: 1 part $=10 / 3 \mathrm{~s}$

part and parcel of parte integrantă din

partake a se atinge de; a consuma; a împărți; a lua parte, a participa; a profita de; a uza de

paratake of a aduce a, a aminti de; a avea (un anumit caracter, un gust oarecare etc.); a se folosi de (ospitalitatea cuiva); a împărtăşi (o idee etc.), a lua parte la, a fi părtaş la, a participa la, a nu refuza (ospitalitatea cuiva)

part chill roll (met) cilindru (de laminor) semidur / semicălit

parted (geom) cu două pânze

partial parțial; local; incomplet; părtinitor, subiectiv; to care nu este indiferent la, amator de partial automatic (autom) semiautomat partial carbonisation (met) semicarbonizare partial carbonisation of coal (met) semicocsificare

partial cementation (met) cementare parțială partial coking (chim, met) cocsificare parțială partial combustion (chim) ardere incompletă partial condensation (chim) deflegmare partial condenser (ind chim) condensator parțial partial derivative (mat) derivată parțială partial differential (mat) diferențială parțială partial differential equation (mat) ecuație cu derivate partiale

partial dismantling (auto, mas, $\mathrm{OM}$ ) demontare parțială

partial error (metr, mas-un) eroare parțială

partial liquefiation (fiz) lichefiere parțială

partial load $(\mathrm{mec})$ sarcină parțială

partially $(a d v)$ în parte, parțial; părtinitor

partially alloyed powder (met) pulbere parțial aliată

partially carbonized lignite (met) semicocs de cărbune brun, semicocs de lignit

partially miscible (fiz. chim) parțial miscibil (d. o substanță)

partially throttled (mas, mas-un, OM, hidr) ştrangulat partial

partial mission capable (system) (mas, TH) (sistem) parțial disponibil / care își poate îndeplini doar o parte din funcțiile pentru care a fost proiectat

partial oxidation (chim, met) oxidare parțială partial plating (met, plast) depunere / acoperire parțială / limitată

partial pressure (fiz) presiune parțială (a unui gaz dintr-un amestec) / locală

partial-pyritic process (met) topire semipiritică partial radiation pyrometer (met, metr) pirometru cu radiație parțială

partial reduction (met, ind chim) reducere parțială

partial section $(\mathrm{OM})$ secțiune parțială (în desen tehnic)

partial separation efficiency (alim, chim) eficiența parțială a separării

partial sequence (mat) şir parțial; secvență succesiune parțială (a unui proces)

participant participant; abonat

participate a participa

particle (constr) granulă; (fiz) particulă, corpuscul, granulă (d. materiale)

particle board (constr) placă aglomerată (din aşchii de lemn, rumeguş etc.)

particle concentration (fiz, hidr) concentrația particulelor (într-un fluid) (şi d. impurificarea unui fluid)

particle density (fiz, chim) densitatea particulei particle deposition (fiz, alim) depunere a particulei / particulelor (d. sedimentare, limpezire etc.) particle diameter (fiz, chim, alim) diametru al particulei

particle difusion equation (fiz, chim) ecuația de difuzie a particulei / particulelor 
particle flux unit (pfu) (metr, fiz) unitate de măsură pentru a evalua fluxul de particule energetice (protoni etc.) pe o suprafață în spațiu: 1 pfu este un flux de 1 particulă pe centimetru pătrat al ariei pe steradian scanat într-o secundă: $1 \mathrm{pfu}=10^{-4} \mathrm{~m}^{-2} \mathrm{sr}^{-1} \mathrm{~s}^{-1}$

particle form factor (met, plast) factor de formă a particulei

particle motion (fiz, chim) mişcarea particulei (şi la sedimentare, limpezire etc.)

particle precipitation (fiz, chim) precipitare a particulelor (solide)

particle Reynolds number (fiz, hidr) numărul Reynolds pentru o particulă

particle shape (met, plast) formă a particulei / a granulei

particle size (materiale, mediu, hidr, T) dimensiune a particulelor / granulelor (şi de praf, impurități)

particle size analysis (materiale, metr) analiza granulometrică / dimensională a particulelor / a granulelor

particle size distribution (materiale) distribuție granulometrică / dimensională a particulelor / granulelor

particle size distribution curve (materiale) curba distribuției granulometrice

particle size fraction (materiale) fracțiune granulometrică

particle-size histogram (materiale) curbă / histogramă a distribuției granulometrice

particle size range (materiale) interval / clasă granulometric $(\breve{a})$

particle velocity (fiz, ind chim, met) viteza particulelor

particular detaliu; articol; particular, special, distinct; personal; neobisnuit, individual; exact; dificil

particular as to size and location (mas-un) (piesă) care trebuie să fie prelucrată şi montată după desen

particular average / failure (nav) avarie deosebită

particularity particularitate; proprietate; trăsătură caracteristică

particular solution (mat) soluție particulară (a unei ecuații diferențiale)

particulate (macro) particulă

particulate assembly (materiale) aglomerare / conglomerat de particule

particulate filter (auto, hidr, T) filtru de / pentru particule (solide)

particulate filter system (auto, hidr) sistemul filtrului de particule (solide)

parting (mas-un) retezare cu cuțit, linie de separație; (TH) separare, separație, rost, clivaj, des- părțire, distanță între piese sau părți separate; (chim, met) descompunere, afinare (neferoase)

parting agent (chim, plast) agent care previne lipirea garniturii pe suprafața de frecare

parting cut (mas-un) micşorare locală a diametrului, gât

parting device (met, alim) dispozitiv de separare, separator

parting force (mec, electr) forță de separare

parting limit ( $\mathrm{T}$, met, chim) limită de coroziune selectivă

parting line (OM, constr) rost / linie de separație / / de separare / de delimitare

parting line of the pattern (met) linie / plan de separatie a modelului (ppt. form a de turnare)

parting medium / powder (met) pudră de presărat formele / pentru detaşare uşoară a piesei prelucrate

parting of a mould (met) suprafața de separare a formei de turnare / a matritei

parting off (mas-un) separare, retezare; porționare (prin separare completă)

parting off lathe (mas-un) strung de retezare / de debitare

parting off slide (mas-un) sanie / dispozitiv de retezare (şi la strunguri automate)

parting-off tool holder (mas-un) port-cuțit pentru scula de retezare

parting plane (materiale, alim, constr) plan de stratificare; plan de separare

parting sand (met, constr) nisip fin

parting shear(s) (met, mas-un) foarfecă de debitat / de porționat

parting silver (met) argint de separație

parting surface (fiz, met) suprafață de separare (a două faze)

parting tool (mas-un) cuțit de retezat / de debitat

parting tool slide (mas-un) sanie transversală / cu port-cuțit de retezare

parting wall (mas-un, OM) perete despărțitor, prag

partition (fiz, OM) diafragmă; (mat) divizare, partiție; $(\mathrm{TH})$ perete despărțitor, sector, parte; (inf) zonă a memoriei interne, spațiu de hard-disc

partition chromatography (chim) cromatografie de repartiție / de distribuție

partition coefficient (chim) coeficient de repartiție / de distribuție

partition law (fiz) lege de distribuție / de repartiție

partition of load (mec, OM) distributie a sarcinii

partition wall $(\mathrm{OM}$, constr) perete despărțitor / interior; (met) prag al cuptorului

partly paid capital $(\mathrm{ec})$ capital parțial vărsat

part-machined (mas-un) prelucrat parțial 
partner (ec) partener, asociat, societar partnership (ec) participare, parteneriat, calitate de a fi partener, asociere

partnership deed $(\mathrm{ec})$ contract de asociere part number (auto, mas, OM) număr al unei piese de schimb, număr de catalog

part off (mas-un) a reteza, a debita (cu cutitul)

part of a mould (met, plast) parte a unei forme / matrițe de turnare / de injectare

part of speech (gram) parte de vorbire

part order (auto, mas, ind) comandă de piese de schimb

part payment (ec) plată parțială

part per billion (ppb) (metr) unitate pentru exprimarea proporției, egală cu $10^{-9}$

part per million (ppm) (metr) unitate pentru exprimarea proporției, egală cu $10^{-6}$

part per quadrillion (ppq) (metr) unitate pentru exprimarea proporției, egală cu $10^{-15}$

part per thousand (ppth, ppt) (metr) unitate pentru exprimarea proporției, egală cu 0,001 , denumită şi per mill

part per trillion (ppt) (metr) unitate pentru exprimarea proporției, egală cu $10^{-12}$

part pressure (mec, hidr) presiune parțială

parts catalogue / list (auto, mas) listă / catalog de piese de schimb, tabel de componență (în desen tehnic)

parts management $(\mathrm{TH}$, mas) controlul şi supravegherea duratei de viață a ansamblelor cu durabilitate limitată

part-sectioned view (mas-un, $\mathrm{OM}$ ) vedere cu secționare parțială a piesei (în desen tehnic)

parts per million (ppm) (fiz, chim, T) părți la un milion

part symbol No. (OM) reper nr.

part time (mas-un) timp incomplet / partial

part-time job (ec) post cu normă incompletă, part-time

party echipă, grup; (ec) parte contractantă / contractuală

party to a case (ec, jur) parte în cauză

party to a dispute (jur) parte în litigiu

par value $(\mathrm{ec})$ valoare la paritate

pascal / Pascal (metr, fiz) unitate SI (în sistemul MKS), de măsură pentru presiune $(1 \mathrm{~Pa}=1$ $\mathrm{N} / \mathrm{m}^{2}$ )

pascal second (Pa·s) (metr, hidr, T) unitate SI de măsură pentru vâscozitatea dinamică a unui fluid, pascal.secundă

pass $(\mathrm{OM})$ orificiu de trecere, canal (într-un bloc hidraulic), trecere (tehnologică), pas, fază / etapă de prelucrare; (constr) pasaj, trecere, coridor, canal; (geogr) defileu, pas, trecătoare (de munte); (textile) năvădire; (sport) centrare (la fotbal), pasă; (adm) paşaport, permis (de liberă de trecere); (mil) permisie; (edu, univ) promovare, notă de trecere; punct critic; situație periculoasă; (fiz) tranzit; (nav) şenal, canal navigabil (pe râu), traversare (a mării), partea navigabilă marcată a fluviului; (met, mas-un) calibru, trecere, şablon, cusătură / strat de sudură; (ind, TH, ind chim) ciclu; (auto) a depăşi, a lăsa în urmă, a întrece; a se deplasa; a avea loc, a trece, a circula, a traversa; a înceta; a contraface, a preface; (fig) a fi acceptat / îngăduit (d. o atitudine etc.); (pol, adm) a fi aprobat / adoptat (d. un proiect de lege etc.); a avea circulatie, a circula, a avea curs (d. bani, monedă etc.), a plasa (bani falşi); (med) a avea sfârşit (d. o durere etc.); a se duce; a se scurge, a trece (d. timp etc.); (OM, mas) a ieşi din uz; a se întâmpla, a se petrece; a se învechi, a se perima; a merge; over to the enemy a trece la inamic; free- (teatru) bilet de favoare; -key șperaclu; a înainta, a avansa; a fi transmis; a transmite, a da mai departe; a dispărea; (d. o teorie, o părere) a fi acceptat; a emite (o părere, o critică etc.); (jur) (d. verdicte, sentințe) a fi pronunțat, a fi votat / acceptat de; a fi admis; a trece neobservat; (fig) a depăşi, a întrece, a fi mai presus decât

passable (auto, transp) carosabil, transportabil; (nav) navigabil (d. cursuri de apă)

pass a certain figure a trece de / a depăşi o anumită cifră / valoare

pass across a traversa

passage cale; drum; (hidr) canal / conductă de ocolire; transbordare; (TH) trecere; traversare, pasaj; (OM, hidr) diametru al orificiului de trecere (al scaunului supapei); (nav) şenal; (met) trecere (la laminor), mers (la cuptor)

passage for steam (termo) canal de conductă de abur

passage opening (mas-un, OM) gaură / gură de acces, gură de vizitare

passage probability (metr, alim) probabilitate de trecere

passage way (constr, cf, met) pasaj; (mas-un) canal de egalizare / de traversare / de preaplin; culoar

pass along a trece (ceva) din mână în mână; a trece de-a lungul

pass angularity (met) unghiul la vârful calibrului (rombic) (la laminare)

pass a sentence (jur) a pronunța o sentință

pass away a muri, a deceda; (d. lucruri) a dispărea

pass-by (autom, hidr, auto) ocol, ocolire 
pass by a trece pe lângă; a omite; a neglija pass design (met, plast) calibrare, proiectarea / construcția calibrului (la laminare)

pass direction (auto, hidr) direcție / sens de trecere

pass down a coborî

passenger pasager; călător

passenger and cargo ship (nav) navă mixtă (pentru pasageri şi mărfuri)

passenger-car (auto) autoturism; (cf) vagon de călători

passenger car trailer (auto) remorcă de autoturism passenger compartment (auto, transp) compartimentul pasagerilor

passenger ropeway (mas, transp) teleferic / funicular pentru persoane

passenger's airbag (auto) airbag pentru pasager passenger side (auto) bancheta din spate

passimeter (metr) pasimetru, instrument de măsurat cavitățile din piese

pass for a trece drept, a fi considerat drept

pass in a introduce

passing beam (auto) fază scurtă / de întâlnire

passing contact $(\mathrm{T}, \mathrm{OM})$ contact prin alunecare

/ frecare / trecere

passing over $(\mathrm{TH}$, hidr) trecere, tranzit

passing place (ind) loc de trecere / de depăşire / de evitare

passing shower (meteo) aversă, ploaie trecătoare

passing sliding (cf, met) linie de formare a garniturii unui tren

pass interval (met) durată / timp / interval de trecere (printr-un calibru)

pass into a se transforma în

passivate (met) a pasiviza, a decapa

passivating (met, chim) pasivizare, oxidare, decapare

passivating agent (met, $\mathrm{T}$ ) agent de pasivizare

passivating dip / solution (met, chim) soluție de pasivizare / de decapare

passivating film (met) film de pasivizare

passivation (met, chim, $\mathrm{T}$ ) pasivizare, decapare

passivator (chim) agent de pasivizare

passive (el, chim) pasiv, inactiv, inert; (autom) dispozitiv care funcționează numai la un anumit semnal (de putere, frecvență etc.)

passive device (hidr, autom) component hidraulic pasiv (fluidul de ieşire provine din fluidul de comandă)

passive electrode (el) electrod colector / pasiv passive failure (mas) avarie / defectare în care dispozitivul sau elementul căzut nu afectează functionarea sistemului sau îi permite să functioneze cu o eroare tolerabilă passive hardness (mas-un, T) rezistență la uzură passive metal (met, chim) metal pasiv

passive paralleling (mas, OM) tip de redundanță simplă, cu două elemente în paralel; dacă unul cade, începe să funcționeze celălalt (arcuri, etanşări)

passivity (chim, met) pasivitate

pass mark (edu, univ) notă de trecere

passmeter (mas-un, metr) pasimetru

pass off a ieşi; a scăpa; a înlătura; a evacua; (fig) a da / trece drept (ceea ce nu este); a trece; a se potoli (d. senzații)

pass on a trece (ceva) mai departe; a trece mai departe, a nu se opri

pass out a ieși (dintr-o încăpere); a trece în afară; (fam) a muri; a leşina

pass-out back pressure turbine (termo) turbină cu contrapresiune

pass over $(\mathrm{TH})$ a traversa; a transporta, a trece peste ceva (şi fig), a transfera, a transmite, a da; a lăsa să treacă (neobservat), a închide ochii (la); a nu insista asupra; a trăda

pass-over rolling mill (met) laminor duo ireversibil

pass parting (met) deschiderea calibrului (la laminare)

pass reduction (met) reducerea secțiunii la o (singură) trecere de laminare

pass-reject mechanism mecanism de clasare / sortare

pass schedule / sequence (met) program / succesiune a trecerilor de laminare

pass template (met) şablon pentru calibrul de laminare

pass-template drawing (met, $\mathrm{OM}$ ) desenul şablonului pentru calibrul de laminare

pass through (mat) a intersecta, a străpunge; (TH) a parcurge, a traversa, a trece

pass to account $(\mathrm{ec})$ a trece în cont

pass up (nav) a trece în sus, a naviga în amonte; a renunța

pass valve (met, hidr) ventil / supapă de trecere pentru variatia / reglarea debitului

pass-word, password, pass word (mil) parolă; (inf, c) parolă

pass the word (nav) a repeta o comandă

password, pass word (c, inf, mas) parolă, cod de acces

password checking legitimare, verificare a unei parole

paste (alim) pastă, terci, aluat, cocă; (ind chim) clei, pap; (el) masă activă a plăcilor de acumulator, a încărca cu pastă o placă de acumulator; (ind chim, TH) a aplica clei / lipici, a cartona, a lipi 
paste adhesive (plast) adeziv pastă pasteboard (constr) carton asfaltat; mucava paste-brush $(\mathrm{OM})$ pensulă de aplicat clei / lipici paste carburising (brit) / carburizing (amer) (met) cementare / carburare cu pastă

paste cathode (TH, fiz) catod cu pastă (de material emisiv)

paste consistency (alim, ind chim, plast) consistența pastei / masei vâscoase

pasted plate (el) placă umplută cu pastă (la acumulatori)

paste solder (ind chim) pastă de lipit

pastel pastel, culoare deschisă

pastel shade nuanță deschisă

paste lubricant $(\mathrm{OM}, \mathrm{T})$ unsoare consistentă (pastă)

paste mill (ind chim, plast) malaxor de pastă

paste-mould casting (met) turnare în forme de ghips

paste on a lipi pe / de

paste roller mill (ind chim, alim) valț pentru pastă paste up a lipi, a încleia (hârtie)

pasteurisation (alim, med) pasteurizare

pasteurise, pasteurize (alim, med) a pasteuriza

pasteurizer (alim) pasteurizator, instalație de pasteurizare; biorizator

pasteurizing column (alim) pasteurizator tip coloană

paste wax (chim, mas-un) pastă de lustruit

pasting (alim, ind chim) prepararea unei paste; (TH) încleiere; (utila) care formează pasta

past process (alim, met, ind chim) (proces de) formare a pastei

past question în afară de orice discuție / îndoială

past solder (met, ind chim) pastă de lipit

pasty (alim, ind chim) păstos, cleios

pasty process (met, alim) proces semilichid / vâscos

pat (metr, alim) unitate / măsură / porție individuală de unt; în US untul se serveşte 48 pats (porții) pe pound (1 pat $~ 9,45 \mathrm{~g}$ ); în afara US, 1 pat (porție) $\sim 10 \mathrm{~g}$ (pentru 100 porții la kilogram), dar şi în porții / pachețele de 125 la kilogram: 1 pat (porție) $\sim 8 \mathrm{~g}$ sau 150 pe kilogram: 1 pat (porție) $\sim 6,67 \mathrm{~g}$; în rețete culinare: 1 pat of butter (o porție / măsură de unt) (US) 10 ml

patch (inf, autom) semnal / instrucțiune de corecție; (constr) parte superioară a balamalei, toc de balama; spațiu verde, parcelă de pământ, strat; (mas) petic, cârpitură; (nav) întăritură; a pune un petic, a petici, a cârpi, a repara (şi un cuptor)

patchboard (autom) panou de conexiune / de programare; (el) tablou de conexiune patchcord (autom) fir / cablu / şnur / cordon de conexiune

patching cârpire, reparație; (mas) reparație prin aplicare de eclise; (met) refacere parțială a căptuşelii cuptorului; (el) conectare suplimentară prin cablu de legătură

patching material (chim, plast) material de umplutură, masă de reparaţie; (met) material refractar de ştampat / de reparație a vetrei cuptorului

patch panel (autom) panou de programare; (el) panou, repartitor

patch weld $(\mathrm{OM}$, met) sudură de acoperire a unui orificiu, orificiu acoperit cu sudură

patch welding (met, TH) sudură a ecliselor (şi la reparații)

patch work cârpăceală, peticire; (mas-un) produs realizat prin utilizarea deşeurilor

patent (ec, TH) patent, brevet, autorizație; a breveta, a patenta (şi sârma)

patentability brevetabilitate

patent application (ec) înscrierea unui brevet, cerere de brevet

patent block (nav) macara cu rulmenți

patent cancelation anulare a unui brevet

patented (ec) brevetat, patentat

patented defect (mas, OM) defect (de proiectare sau de exploatare) care poate fi detectat prin inspecție, teste, fără solicitare

patented steel wire (met) sârmă patentată, de oțel patented wire (met) sârmă patentată

patent fee (ec) taxă de brevet(are)

patent flattening (met) planare prin tragere

patent fuel (termo, met) combustibil brichetat

patent granting acordare a unui brevet

patenting, patentising (met) (tratament) de patentare

patent law (ec) legea brevetelor

patent letter $(\mathrm{ec})$ certificat de brevet

patent link (nav, OM) cheie Kenter, za demontabilă (la lanțuri)

patent of addition brevet pentru o invenție complementară

patent office (ec, adm) oficiu de brevete

patent owner, patentee titular de brevet de invenție patent rights drepturi de autor (al unui brevet)

patent slip (nav) cală de andocare (pt. ambarcațiuni)

patent specification descriere a invenției

patent statutes $(\mathrm{ec})$ legea brevetelor

patent tax (ec) taxă de brevet

paternity paternitate; sursă

paternoster (bailing) work, paternoster elevator (mas) elevator cu cupe 
path cale, drum, traiectorie, parcurs, cărare; (met) galerie / cale de transport; (inf) cale, traseu, în MS-DOS, instrucțiune de localizare a unui anumit fişier

path amplitude (mec, mas-un) amplitudine a cursei / a traiectoriei

path length (autom) lungime / parcurs de programare sau de calcul

path of contact $(\mathrm{OM})$ linie de angrenare

path of current (el) cale de curent

path of the flames (termo, met) canal de flăcări / de gaze arse

path of integration (mat) metodă de integrare

path of lines of forces (el, fiz) spectru / imagine / figură a liniilor de câmp, direcția liniilor de forță

path of motion (mas-un, fiz) traiectorie, cale de mişcare

path of propagation (fiz) parcurs / cale / direcție de propagare

pathway (fiz) traiectorie, parcurs; (mas-un) platformă pentru deservirea unei maşini

patina (met, chim) patină, strat subțire de oxizi patinate (met) a patina, a acoperi cu patină

patten (cf, met, OM) talpă a şinei; (constr) fundație în curs de ridicare, postament, suport al unui zid

pattens $(\mathrm{TH})$ patine

pattern (mas, TH) model (la turnare, la prelucrare prin copiere), formă, textură; schemă; şablon; sistem; probă, eşantion, specimen; calibru; tipar; caracteristică; mostră; schiță; proiect; sistem de amplasare; machetă; (poligrafie) moarare (a hârtiei); (textile) desen (în țesătură, în tricot), model (de rochie etc.); armură; (c, TV) imagine; formă, diagramă; mod, modalitate, stil (de viața etc.); caracter (al unei opere literare etc.); pildă, exemplu (demn de urmat); gabarit

pattern dowel (met) diblu de model

pattern draw(ing) (met, OM) ridicarea / extragerea / dezbaterea modelului

pattern-drawing piston (met) piston pentru extragerea modelului

pattern draw machine (met) maşină de formare cu masă de ridicare

pattern drum (alim) tambur desenator, tambur cu tipare (la maşini de biscuiţi)

pattern failures (mas, OM) avarii / căderi ale aceluiaşi element în situații similare, cu acelaşi mecanism de distrugere şi care sunt mult mai frecvente decât viteza estimată de avarie

pattern flow (hidr) căi de curgere a fluidului pentru o poziție dată (într-un distribuitor, circuit hidraulic) pattern frame (met) cadru de model

pattern half (met) jumătate (detaşabilă) de model

pattern lathe (mas-un) strung pentru prelucrarea modelelor

pattern maker (met) modelator

pattern-maker's rule (met) scară de contracție, metru de modelărie

pattern-maker's shop (met) modelărie

pattern-making (met) confecționare / executare a modelului, modelare

pattern moulding (met) formare cu model(e)

pattern of the field (fiz) linii de câmp

pattern of intricate external shape (met) model complex

pattern plate (met) placă de model

pattern plate moulding (met) formare pe placă de model

pattern recognition (metr, autom) identificare automată a formelor şi dimensiunilor

pattern setting (ec) acord tip, regulament tip / standard

pattern scrap (met) deşeuri de la modele

pattern shop (met) modelărie

pattern tie bar (met, $\mathrm{OM}$ ) nervură de rigidizare pattinsonizing (met) (tratament de) patinsonare pause pauză

pause of charging (met) pauză la / de încărcare pavement (constr) pavare, pavaj, trotuar, îmbrăcăminte rutieră

pavement / paving breaker $(\mathrm{OM})$ ciocan pneumatic pentru pavaj

paving (constr) (acțiune de) pavare, pavaj, pietruire, podea; care pavează / acoperă (un drum etc.) paving slab (constr) dală de beton / de pavaj paw (OM) gheară; (zool) labă

pawl (TH) clichet; închizător; cățea; declic pawl click (autom) clichet de comandă; (OM) clichet de cuplare / de înaintare (şi cu arc)

pawl coupling $(\mathrm{OM})$ cuplaj / cuplare cu clichet pawl mechanism $(\mathrm{OM})$ mecanism cu clichet pawl with roller $(\mathrm{OM})$ clichet cu rolă

pawn (ec) amanet, gaj, ipotecă, garantie; a amaneta, a garanta cu, a ipoteca

pay $(\mathrm{ec})$ salariu, productiv, diurnă, rentabil, exploatabil; (nav) a turna smoală, a gudrona, a cătrăni; (ec) a plăti, a achita, a depune bani; a recompensa, a răsplăti; a se achita de (o obligație etc.); a aduce (omagii etc.); (ec) a aduce (un venit etc.), a da (un procent etc.), a aduce beneficii, a fi rentabil; one's debt a-şi plăti datoria; one's way a-şi acoperi cheltuielile

payable at sight $(\mathrm{ec})$ plătibil la vedere payable on delivery (ec) plătibil la livrare payable to bearer (ec) plătibil la purtător 
pay back (ec) a rambursa

pay-back period $(\mathrm{ec})$ perioadă de recuperare a banilor (cheltuiți pt. un produs)

pay by / in instalments (ec) a plăti în rate paychymeter (met, metr) dispozitiv de măsurare a grosimilor

pay down a achita (prima rată)

payee $(\mathrm{ec})$ beneficiarul unei plăţi

payer (ec) plătitor, platnic

pay in a vărsa (bani) (într-un cont etc.)

pay in full (ec) a plăti integral

pay in kind (ec) a plăti în natură

payload (mas, transp) sarcină utilă / care se plătește / netă / rentabilă

payload bed (transp) platformă de încărcare (de camion / vagon)

payment (ec) vărsământ, plată

payment on account (constr) acont

payment on delivery (ec) plată ramburs, plată / achitare la livrare

payment pause (ec, pol, adm) înghețare a plăților (pe bază de decret)

pay off (ec) amortizare, rentabilizare, plată, despăgubire, a amortiza; (nav) a dezarma (o navă), a debarca (un echipaj); (mil) a plăti (solda)

pay off a debit (ec) a plăti / a achita o datorie

pay-ore (met) minereu exploatabil industrial

pay-out reel (met, OM) tambur pentru desfăşurarea cablului / sârmei

pay package (ec) plată globală

pay up (ec) a achita (o sumă), a plăti integral (o restanță)

p.c. (pitch circle) (OM, mas-un) cerc de divizare (la roți dințate / de lanț)

p.c.d. (pitch circle diameter) $(\mathrm{OM})$ diametrul cercului de divizare (d) (la roți dințate / de lanț)

pcf (metr) simbol pentru pound per cubic foot, unitate tradițională pentru densitate, în inginerie: $1 \mathrm{pcf}=16,01846 \mathrm{~kg} / \mathrm{m}^{3}$

pci (metr) simbol pentru pound per cubic inch, unitate tradițională pentru densitate în inginerie: 1 pci $=27679,90 \mathrm{~kg} / \mathrm{m}^{3}$

p.d. (per day) (metr, farmacologie, med) unitate de măsură pentru frecvență, pe zi, o dată pe zi

p.e. (plane-edge) (mas-un) margine prelucrată la raboteză

pé (metr) unitate tradițională portugheză pentru lungime, picior protughez: 1 pé $\sim 0,33324 \mathrm{~m}$

pea coke (met) cocs mărunt

pea gravel (constr) pietriş / prundiş fin / mărunt peak (TH, mat) vârf, pisc, maxim (şi al unei curbe / functiii), valoare de vârf

peak clipping (fiz, autom) retezare / tăiere / nivelare a vârfurilor (unor semnale) peak current (el) curent de vârf

peak demand $(\mathrm{TH}, \mathrm{ec})$ cerere de vârf (de apă / curent etc.)

peaked ascuțit(ă) (despre un grafic, o curbă); cu vârf; slab, prăpădit

peak efficiency ( $\mathrm{TH}$, mas) randament maxim, productivitate maximă

peak factor (autom) coeficient de amplitudine; (el) factor de vârf

peak flame temperature (met, termo) temperatură maximă / de vârf a flăcării

peak hours (el, auto) ore de vârf

peaking network (el, autom) circuit / rețea de corectie (a vârfului) / de diferentiere

peak limiter (autom, electr, el) limitator de putere / de amplitudine

peak load / of the loading (mec) sarcină / încărcătură maximă sau de vârf

peak making current (el) curent maxim la închidere / de anclanşare

peak music power output, PMPO (metr, electr, media) măsură neoficială, utilizată de producătorii de module electronice, pentru evaluarea puterii efective la ieşire, a amplificatorilor stereo de sunet etc., fără a avea corespodență cu unități recunoscute în domeniu

peak of a curve (mat) vârful (unei curbe)

peak of a load (el, mas) vârf de sarcină

peak off-state voltage (el, autom) tensiune maximă de blocare

peak of the loading (el, mec) sarcină maximă

peak output (auto) putere / debit maxim(ă) (în regim forțat); (ec) producție maximă

peak power (el, mec) putere maximă / de vârf

peak-power measurement (metr, el, mas) măsurarea puterii de vârf

peak-power output (el, mec) putere de vârf, putere maximă de ieşire

peak pressure (hidr) vârf / impuls de presiune

peak-reading voltmeter (metr, el) voltmetru de valoare maximă

peak shaving (el) nivelare / reducere a vârfurilor (de consum de energie)

peak-to-peak amplitude (fiz, mec) valoare între un maxim şi un minim succesive al unei funcții / a unui parametru

peak-to-peak value (fiz, mec) diferența algebrică între două valori extreme ale unei funcții variabile

peak torque (auto, OM) cuplu / moment (de torsiune) maxim

peak value $(\mathrm{TH}, \mathrm{mec}$, el) valoare de vârf, maxim

peak voltage (el) tensiune de vârf

peak voltmeter (el, metr) voltmetru de maxim 
peak wavelength (fiz) lungime de undă maximă peaky cu picuri, cu vârfuri, cu maxime (d. curbe, o suprafață cu asperități înalte) peal (bot, alim) coajă (şi de fructe, legume) pea-ore (met, minrl) limonit pear (alim) pară; (met) pară (la convertizor) pear-head rail (cf, met) şină cu cap umflat / cu profil de bară / de bulb

pearl barley (alim) arpacaş

pearled perlat, sidefiu

pearled cereals (alim) crupe (de cereale) pearled / peeled millet (alim) mei decorticat pearl grain (metr, fiz) unitate de măsură pentru masă: 1 pearl grain $=1 / 4$ carat $=50 \mathrm{mg}$ pearlite (met) perlită

pearlite area (met) suprafață / zonă perlitică pearlite ghosts (met) perlită lamelară pearlite grain (met) grăunte de perlită pearlitic (met) perlitic pearlitic cast iron (met) fontă perlitică pearlitic-ferrite (met) ferito-perlitică pearlitic ghosts (met) perlită lamelară pearlitic iron (met) fontă perlitică

pearlitic malleable iron (met) fontă maleabilă perlitică

pearlitic steel (met) otel perlitic

pearlitic structure (met) structură perlitică

pearl polymerization (ind chim) polimerizare în perle / granule

pearl spar (met) dolomită

peat (met) turbă

pebble (constr) prundiş; galeți; (minrl) cremene, silex, cristal de stâncă, agat $(\breve{a})$

pebble mill (met, constr) concasor; (plast, ind chim) moară cu bile

pebbly (materiale) grăunțos, granulos

pebi- $(\mathbf{P i}-)$ (metr, c, inf) prefix binar pentru $2^{50}=$ 1125899906842 624; din 1988 înlocuieşte termenul peta- în aplicatii binare; contractie a termenului petabinary; v. petabinary

peck (pk) (metr, alim) unitate de măsură pentru capacitate / volum (pt. produse uscate: cereale, fructe etc.): $1 \mathrm{pk}=9,09$ l; în sistemul comercial US: 1 peck $\sim 8,80981,1$ peck (UK) 9,0923 1; 1 peck (Scoția) $\sim 9,1$ pentru grâu, mazăre, fasole şi 1 peck (Scoția) 12,1 1 pentru orz, ovăz etc.

pecker / pecking motor (autom, electr) motor pas cu pas

Peclet number (termo, fiz) număr / parametru adimensional în transferul căldurii în fluide, numărul lui Peclet

peculation $(\mathrm{ec})$ însuşire ilegală, delapidare, deturnare

peculiar specific (pt. ceva, cuiva); particular; individual; special; ciudat; caracteristic (pentru); deosebit; distinct; exclusiv; extraordinar; neo- bişnuit; propriu; straniu; unic; interes privat, prerogativă; privilegiu; proprietate exclusivă

peculiarity particularitate; trăsătură caracteristică; proprietate; individualitate; ciudățenie; originalitate

peculiar support equipment ( $\mathrm{TH}$, mas, autom) echipament specific / compatibil doar cu un anumit sistem

pedal (mas, OM) pedală, pârghie de picior; a pedala, a apăsa pe o pedală

pedal brake (auto, OM, mas) frână de picior, frână cu / prin pedală

pedal bracket (auto, OM) suport de pedală

pedal change-over switch (el, OM) întrerupător acționat cu piciorul / de pedală

pedal clearance (auto) joc al pedalei (de ambreiaj); (mas-un) cursă moartă a pedalei (la prese)

pedal driven (mas-un) cu acționare prin pedală

pedal gear (mas-un) mecanism / transmisie cu pedală

pedal gear change (auto) schimbarea vitezelor prin pedală

pedal grip / pad / rubber (auto, OM) adaos / pernuță de cauciuc pe pedală

pedal jack (auto, OM) cric acționat de picior

pedal lever (mas-un, OM) pârghia pedalei, pedală

pedal of clutch (auto, OM) pedală de ambreiaj

pedal operation (mas-un) acționare / comandă prin pedală

pedal pin $(\mathrm{OM})$ ax de pedală

pedal rod (auto, OM) pârghia pedalei

pedal treadle (mas, OM) pedală

pedal switch (el, OM) întrerupător / comutator acționat cu piciorul / de pedală

pedal triangle (geom) triunghi ortic (vârfurile lui sunt picioarele înălțimilor triunghiului dat)

pedestal $(\mathrm{OM})$ piciorul suportului, baza pilonului; (constr) bază de coloană; capră, soclu, fundație, plintă, postament; (TH) piedestal

pedestal base (mas-un) cadru, montant

pedestal bearing $(\mathrm{OM})$ lagăr cu picior

pedestal frame (cf, OM) furcă de osie

pedestrian pieton, trecător

pedestrial fork-lift (mas, OM) cărucior de ridicat şi stivuit cu furcă

pedestrian subway (met, constr) trecere subterană / tunel / pasaj (pentru muncitori)

PEEK (plast) simbol pentru polietereterchetonă peel coajă; (alim, bot) coajă, pieliță (de fructe); (OM, alim) lopată (de brutar), a (se) coji, a dizolva; a (se) desface, a dezghioca, a scoate coaja / pielița / pielea de pe, a curăța de coajă / de pieliță, a jupui; a se desprinde (și d. un adeziv); (met) crustă, coajă, a (se) coji (d. un semifabricat), a (se) exfolia; a (se) dezbrăca 
peel adhesion (plast, OM) rezistență la desprindere (a unei asamblări lipite)

peeled cereals cleanser (alim, mas) vânturătoare de crupe

peel resistance (plast, OM) rezistență la desprindere (a unei asamblări lipite)

peeled steel bar (met) bară de oțel (de)cojită

peel strength (plast, OM) rezistență (limită) la desprindere (a unei asamblări lipite)

peeled wood lemn cojit

peeler (met, mas) maşină de cojit (metale dar şi lemn); (agr, bot) soi de bumbac american cu fibră lungă; (alim) decojitor, dispozitiv de cojit / de îndepărtat coaja

peeling (alim, silv) cojire (a lemnului, fructelor, legumelor); (met) cojire, stratificare, exfoliere

peeling and streinghtening machine (met) maşină / instalaţie de cojit şi îndreptat

peeling device (alim, met) dispozitiv de cojire (pt. fructe, metale, lemn)

peeling knife / tool (mas-un) cuțit de cojit

peeling lathe (mas-un) strung de cojit

peel off (alim, met) a ridica, a scoate (coaja), a (de)coji, a îndepărta coaja

peel test test de îndepărtare a materialului de etanşare prin cojire, pentru a determina locul de forfecare (în materialul etanşării sau la suprafața de lipire)

peen (mec, TH) a ciocăni, a forja (la rece)

peening (met, TH) ciocănire a cusăturii sudate, ecruisare

peening shot (met) alice de oțel

peening test (met) încercare de ciocănire

peen hole (cf) orificiu de control; (OM, met) gaură de control / pentru vizor, fereastră / ochi de control / de observație

peen of a hammer (cf) cui de şină

peep door (termo) vizor de observare a arderii

peer-to-peer network (c) rețea in care fiecare calculator poate împărți în mod egal datele şi resursele cu altul

peg $(\mathrm{OM})$ cuier (de haine), cârlig (de haine, de rufe), cui (de lemn), diblu, dop, buşon de siguranță, ic, pană, stâlp, țăruș; bolț, știft de oprire, dorn, pichet, țintă, jalon, cep, şplint, picior; (cf) scoabă de traversă; (OM, el) fişă de siguranță; grad; (constr) ghermea; (fam) păhărel (de whisky), picior de lemn; par, pichet; pretext; (TH) a fixa (cu pană, cu cuie, cu țarus, cu știft etc.), a bate în cuie; (ec) a stabiliza

peg and worm steering (auto, OM) direcție cu şurub şi deget

peg and worm steering gear (auto, $\mathrm{OM}$ ) casetă de direcție cu şurub şi deget peg gate (met, plast) canal de turnare, cotit pegging (textile) lustruire a unei suprafețe scămoşate; $(\mathrm{OM})$ asamblare cu ştifturi

pegging out trasare, jalonare; pichetare pegging / pelican hook $(\mathrm{OM})$ cârlig pelican peg the exchange (ec) a susține cursul pell (agr) crustă

pellet (chim) granulă, tabletă; $(\mathrm{OM})$ bilă, peletă; bilă, alice, pastilă; (met) perlă / picătură la sudură pelleter (mas-un) maşină de tabletat

pellet feeder (met) alimentator cu alice pelleting / palletising $(\mathrm{TH})$ tabletizare

pelleting machine (plast, ind chim) maşină de granulare (pt. cauciuc)

pellicle $(\mathrm{OM}, \mathrm{T}$, hidr, fiz) peliculă, membrană (foarte subțire)

Peltier cooling (fiz) răcire prin efect Peltier

Peltier effect (fiz) efect Peltier

Pelton turbine (hidr, mas) turbină cu cupe Pelton

pen (ind) țarc (de piese etc.), îngrăditură, cuşcă; (birotică) trăgător, trasator (de desen), peniță toc, (vârf de) stilou; (constr) groapă / bazin (de var); (fig) artă scriitoricească, scriitor, scris; (zool) lebădă (şi femelă); (agr) ocol, țarc, a închide într-un țarc; (nav) refugiu pentru nave; țarc (pt. copii); (fig) închisoare, puşcărie; a compune, a redacta

penalty (ec) daună penalizatoare, amendă, penalizare; (ind) rebut (în producție)

penalty factor $(\mathrm{el}, \mathrm{ec})$ factor de creştere a prețului energiei (electrice) din cauza pierderilor

penalty for nonfulfillment of a contract (ec) penalizare pentru nerespectarea clauzelor unui contract

pencil creion, pensulă, a schita în creion; (fiz) fascicul / mănunchi (îngust) de raze; (OM) stift de trasare; (mat) familie de curbe / de suprafețe depinzând de un parametru

pencil gate (met, plast) alimentator în formă de creion (la piciorul pâlniei de turnare)

pencil hardness (metr) unitate tradițională pentru măsurarea duritătii minelor de creion (în prezent, din grafit); scală / scară de duritate începe de la cel mai moale material spre cel mai dur: ..., 3B, 2B, B, HB, F, H, 2H, 3H, 4H, ....; literele sunt pentru Black - negru, Hard dur, Firm - ferm; în US unii producători folosec o scală numerică $\mathrm{B}, \mathrm{HB}, \mathrm{F}, \mathrm{H}, 2 \mathrm{H}$, corespunzătoare aproximativ numerelor 1,2 , $2 \ldots 2,5,3$, şi 4 ; notațiile se folosesc şi pentru acoperiri semi-dure şi vopseluri, pe principiul unei scale Mohs de zgâriere, dar cu un creion pencil-type thermocouple (metr, termo) termocuplu tip creion 
pendant (el) lampă suspendată; (hidr, metr) semn pe cablu de măsurare; (mas-un) cutie suspendată cu butoane de comandă; (nav) atârnător, flamură, cablu de vinci; $(\mathrm{OM})$ piesă care atârnă pendent $(\mathrm{OM})$ atârnat, suspendat

pending în timpul / cursul, până la, înainte de, suspendat, atârnat; (ec) care aşteaptă o rezolvare, pendinte

pen drive (autom, metr, birotică) mecanism de antrenare a peniței

pendular circular saw (mas-un) ferăstrău circular pendular

pendulary motion (fiz) mişcare pendulară

pendulate (fiz, mec) a pendula, a se balansa, a oscila

pendulum bearing $(\mathrm{OM})$ reazem prismatic / oscilant

pendulum bucket conveyer ( $\mathrm{OM}$, met) transportor cu cupe basculante

pendulum governor (autom, mas) regulator $\mathrm{cu}$ pendulă, regulator oscilant

pendulum hammer (met) ciocan pendular

pendulum hardness $(\mathrm{mec})$ duritate Herbert

pendulum impact test (mec) încercare / test de reziliență cu pendul Charpy; $(\mathrm{mec})$ încercare prin lovire

pendulum impact testing-machine (mas, metr) pendul Charpy

pendulum saw (mas-un, met) ferăstrău pendular pendulum shears (mas-un, met) foarfece pendular pendulum table (mas-un) masă oscilantă / basculantă

pendulum tup (met, metr) ciocan pendul pentru încercări la şoc, pendul Charpy

penetrability (met, T) penetrabilitate (la tratamente şi unsori), permeabilitate, capacitate de pătrundere

penetrable (met) penetrabil, permeabil

penetrance (metr) factor de pătrundere (la unsori)

penetrant (plast) agent de umplere, penetrant

penetrate (mec, TH) a străpunge, a pătrunde, a avansa, a străbate (şi un strat)

penetrating oil (auto, mas) ulei pentru degripare; (ind chim) ulei de impregnare

penetrating power (met) capacitate de pătrundere / de penetrare (a sudurii), forță de perforare

penetration $(\mathrm{mec})$ pătrundere, penetrație, penetrare; infiltrare; (ec) străpungere; (mas-un) adâncime de pătrundere; $(\mathrm{TH})$ avansare; traversare

penetration advance (mec, chim) viteză de pătrundere / de avansare (şi la procese corosive)

penetration depth (met) adâncime de pătrundere (la sudare sau tratament termic) penetration hardening (met) călire pătrunsă

penetration heat (met) penetrația / pătrunderea căldurii

penetration index $(\mathrm{T})$ indice de penetrație (la unsori)

penetration of tool (mas-un) pătrunderea cuțitului / a sculei

penetration rate (mas-un) viteza de avans (şi la găurire) pe directie axială

penetration speed $(\mathrm{TH}$, mas-un) viteza de pătrundere / de penetrare / de avans

penetration tension (fiz, mec) tensiune adezivă / de aderență

penetration weld (met, OM) (adâncime de) pătrundere a stratului de sudură, sudură pătrunsă

penetrator $(\mathrm{OM}$, metr) penetrator

penetrometer (metr, $\mathrm{T}$ ) penetrometru, aparat pentru determinarea indexului de penetrație (a unsorilor)

penstock (met, OM) cot al conductei de vânt (la furnal, cuptoare)

penny (p) (metr, ec) peni, unitate monetară britanică: $1 \mathrm{p}=1 / 12$ shilling; (metr, ec) (brit) altă denumire pentru part, cu referire la sume de bani: de exemplu ,the fourth penny” înseamnă $1 / 4$ din suma avută în discuție

penny stock (ec) acțiuni emise la prețuri mici (pt. speculație)

pennyweight (dwt, pwt) (metr, fiz) unitate tradițională de măsură pentru masă: 1 pennyweight $\sim 1,5552 \mathrm{~g}$

pen recorder (mas, metr) aparat înregistrator $\mathrm{cu}$ peniță; înregistrator automat

pensile $(\mathrm{OM})$ suspendat, care atârnă

penstock (hidr, OM) vană, stăvilar, conductă forțată / de evacuare, jgheab, cot

penstock pipe (cf, hidr, OM) conductă de refulare, țeavă de presiune

penta (cu) cinci; (el) dispozitiv cu cinci contacte / poziții; (hidr) distribuitor cu cinci poziții

pentad (el, autom) pentadă, ansamblu de cinci elemente (relativ) identice; (metr) unitate pentru cantitate, egală cu 5; (metr, meteo) unitate de timp, egală cu 5 zile - durata pentru care se face, de obicei, o prognoză meteorologică

pentehedron (geom) pentaedru, poliedru cu cinci fete

pentadecagon (geom) poligon cu cincisprezece laturi

pentagon (geom) pentagon

pentagonal (geom) pentagonal

pentavalence (chim) pentavalență

pentavalent (chim) (element) pentavalent, penta atomic 
pent-up demand $(\mathrm{ec})$ cerere controlată penultimate penultim penumbra penumbră penury (ec) penurie, lipsă

peonage (ec) muncă efectuată pentru plata unei datorii sau obligații

pepper blisters (met, plast) pori de suprafață, porozitate superficială (defect)

per capita output $(\mathrm{ec})$ producție pe locuitor pepper (alim) piper

per annum (PA) (metr) unitate tradițională pentru frecvență, o dată pe an

per capita output (ec) producție pe locuitor / pe muncitor

perceived values valori observate

percent, per cent, per centum (\%, pet, pc, p.c., pct.) (metr) la sută, \%, procent, procentaj, unitate (adimensională) pentru exprimarea proporției, procent, egală cu 0,01 din valoarea mărimii considerate, scrisă echivalent cu $1 \%$

percentage procentaj, proportie

percentage by weight / volume procentaj masic / volumic (d. amestecuri, compozite)

percentage composition (chim, met) compoziție procentuală

percent(age) elongation (mec, materiale) alungire relativă (în procente)

percentage error eroare relativă / procentuală / proporțională

percentage inspection $(\mathrm{ec}, \mathrm{TH})$ verificare prin sondaj

percentage of elongation (mec, materiale) alungire relativă în procente

percentage of load (mec) sarcină parțială, în procente

percentage of moisture (mediu, materiale) procent(aj) de umiditate

percentage of saturation (fiz) grad de saturare

percentage point (metr) procent, procentaj, unitate (adimensională) pentru exprimarea proporției, egală cu 0,01 din valoarea mărimii considerate, scrisă echivalent cu 1\%; (rar) punct procentual

percent by volume (metr) procent / raport de volum

percent by weight (metr) procent / raport în / de greutate / masă

percent conductivity (termo) conductivitate procentuală (exprimată ca procent din conductivitatea a cuprului)

percent defective $(\mathrm{TH}$, ec) numărul pieselor defecte dintr-un lot, exprimat în procente

percentile (mat) funcție de repartiție; (metr) a suta parte din intervalul total al frecventelor (în statistică); un scor / o valoare 78th percentile este mai mare de $78 \%$ dar mai mică de $79 \%$; astfel intervalul de repartiție este împărțit în 100 subintervale (percentiles), numărate de la 0 (0th) până la 99 (99th)

percentile curve (mat) ogivă, curbă a funcției de repartiție

percent of dilution (alim, chim) procent de diluare

percent reduction (met) procent de reducere (a secțiunii semifabricatului prin laminare)

percent slip $(\mathrm{OM}, \mathrm{T})$ viteza de alunecare (la angrenaje evolventice, frâne etc.) viteza de alunecare, exprimată ca procent din viteza de rostogolire (în polul angrenării, la angrenaje) sau ca procent din valoarea teoretică (fără alunecare) a pieselor în mişcare relativă

perception percepere

perception head (metr, OM) cap de măsurare, palpator

perceptual skills abilitate de perceptie (a informațiilor, evenimentelor, faptelor etc.) în contextul unei munci

perch (arhit, constr) antablament, ornament, cornişă, coronament; (nav) baliză; (iht, alim) biban; (OM, constr) oiște, stinghie, prăjină; (fig) poziție (înaltă), situație, loc înalt; (constr) subgrindă (la tuneluri); a așeza sus; a (se) cocoța, a se aşeza (sus); (metr) unitate de măsură pentru lungime, stinghie, prăjină: 1 perch $=5,0292 \mathrm{~m}$, unitate de suprafață $\left(=25 \mathrm{~m}^{2}\right)$; (metr) unitate de măsură pentru arie, unitate de arie egală cu o prăjină pătrată: 1 perch of area (square perch) $\sim 25,29285 \mathrm{~m}^{2}$; (metr) unitate tradițională de măsură pentru volum în constructii / zidării: 1 perch of masonry $\sim 0,700842 \mathrm{~m}^{3}$; (metr) unitate tradițională de măsură pentru lungime, 1 perch (Irlanda) $=6,4008 \mathrm{~m}>1$ (English) perch

perche, perch (metr) unitate tradițională de măsură pentru lungime sau arie, în zona franceză a Americii de Nord: 1 perche (Canada) $=$ $5,84713 \mathrm{~m} ; 1$ perche of area (square perche) $=$ $34,189 \mathrm{~m}^{2}$

perched ground water (geol) apă subterană cu nivelul ridicat spre suprafață

perchloron (chim) hipoclorit de calciu

percolate (alim, chim) a strecura; a percola; a filtra; a extrage prin dizolvare

percolating filter (chim) percolator, filtru fără presiune / cu scurgere liberă

percolation (hidr) scurgere subterană, percolare, infiltrare, filtrare, strecurare

percolation treatment (alim, ind chim) filtrare prin percolare, percolare 
percolation vat (alim, ind chim, OM) cuvă percolatoare

percussion $(\mathrm{TH}, \mathrm{mec}$, mas) lovitură, şoc, percuție, ciocnire; zguduire

percussion riveting (met, $\mathrm{TH}$ ) nituire prin ciocănire / percuție

percussion test $(\mathrm{mec})$ încercare (dinamică) prin lovire / de perforare / la şoc

percussion tool sculă percutantă

percussion wave (mec) undă de şoc

percussive welder (met, mas-un) dispozitiv / maşină de sudat prin lovire / prin percuție

percussive / percussion welding (met, $\mathrm{TH}$ ) sudare prin rezistentă de contact / prin ciocănire

per diem; by the day (p.d., PD) (ec, metr, med) unitate tradițională pentru frecvență, o dată pe zi, cu ziua, pe zi, salariu zilnic, diurnă

perfect perfect; impecabil; complet; corect, desăvârşit, exact, excelent, fără cusur; identic; intact, întreg; ireproşabil; minunat; (gram) perfect; a perfecționa; a îmbunătăti; a desă-vârși, a încheia, a perfecta (un contract etc.)

perfect combustion (chim, termo) ardere completă

perfect crystal (fiz) cristal ideal / perfect / a cărui rețea nu a fost perturbată

perfect elasticity (mas-un) elasticitate maximă; (mec) limită de elasticitate, elasticitate perfectă (la un corp ideal)

perfect fluid (fiz) fluid perfect / ideal

perfect gas (fiz) gaz perfect / ideal

perfect (in) a (se) perfecționa (în), a-şi perfecționa cunoştințele (de)

perfecting finisare, care finisează; care perfectează

perfecting engine (alim) frământător; (mas) moară conică, concasor conic; (plast, ind chim) maşină de amestecat şi plastifiat

perfection perfecțiune; perfectare

perfect participle (gram) participiu perfect

perfect ream (metr) v. printer's ream

perfect solution (chim) solutie ideală

perfect vacuum (fiz) vid perfect

perforate (mas-un, TH) a găuri, a perfora, a străpunge, a pătrunde (în)

perforated (mas-un, OM) perforat, găurit, străpuns

perforated basket centrifuge (alim, ind chim, mediu) centrifugă cu tambur perforat

perforated bottom / cage (ind chim, met) fund perforat

perforated brick (constr, met) bloc / cărămidă cu goluri

perforated disk (met) şablon găurit perforated dragline bucket (constr) cupă de draglină

perforated file (mas-un) pilă cu găuri (pentru îndepărtarea materialului de prelucrat)

perforated pipe $(\mathrm{OM})$ țeavă perforată

perforated plate (ind chim, met, $\mathrm{OM}$ ) placă perforată, taler-sită

perforated-plate column (alim, ind chim) coloană cu talere reticulare; coloană cu talere perforate (site)

perforated screen $(\mathrm{OM})$ sită matrițată

perforated seat $(\mathrm{OM})$ placă de sprijin cu gaură

perforated sheet (met) tablă perforată

perforated slip / tape (met) bandă perforată

perforated spray (ind) amestecător cu orificii

perforated steam spray (termo) barbotor de abur

perforated strip recorder (metr, OM) înregistrator-perforator de bandă

perforated wall (met, constr) zid perforat (la cuptoare etc.)

perforated water spray $(\mathrm{OM}$, hidr) pulverizator de apă

perforating perforare, care perforează

perforating apparatus $(\mathrm{OM})$ aparat de perforat

perforating die (mas-un, plast, OM) poanson perforator, matriță de perforare

perforating machine (mas-un) aparat / maşină de găurit

perforation $(\mathrm{TH})$ perforare, gaură pătrunsă, perforație; (met) străpungere

perforator (mas-un) maşină / dispozitiv de perforat, perforator

perform (mat) a face / a efectua o operație; a calcula; $(\mathrm{TH})$ a efectua, a executa, a îndeplini, a realiza, a functiona foarte bine, a răspunde la comenzi (d. maşini); a se achita foarte bine (într-un domeniu de activitate); a face (tot felul de) figuri, a răspunde la comenzi (d. animale dresate); (adm, ec, TH) a efectua, a executa, a face, a îndeplini, a săvârşi, a aduce la îndeplinire (o sarcină etc.); (teatru) a interpreta, a juca (o piesă, un rol), a prezenta un spectacol, a se produce; a se ține de, a îndeplini (o promisiune)

performance desfăşurare, derulare, mers (d. un proces), funcționare, operație, productivitate, randament, performanță (d. maşini şi personal); executie, realizare, efectuare; (mas) caracteristică, calitate de exploatare; putere, capacitate; (av) capacitate de zbor; (artă) concert, expoziție; (teatru) interpretare, joc, piesă; prestidigitație; executare (a îndatoririlor etc.); faptă urâtă reprobabilă; (adm, ec, TH) îndeplinire (a îndatoririlor etc.); (fam) munca grea, pacoste, pedeapsă; (sport) performanță 
performance apprasail (ec) apreciere a capacității (unui salariat, a posibilităților sale şi a salariului său); apreciere a execuției / a realizărilor

performance bond (ec) scrisoare de garanție bancară de bună execuție (a contractului)

performance calculation (mas) calculare a puterii / a performanței / a capacității

performance characteristic / graph (mas, TH, ind) caracteristică de performanță / de putere /de lucru (care se poate măsura sau evalua calitativ doar în funcționare)

performance criterion (autom, mas) criteriu de performanță / de calitate

performance curve (autom) curbă de performanță; (met) curba caracteristicilor de lucru (ec, TH) curbă de productivitate

performance data (mas, ind $\mathrm{TH}$ ) caracteristici / date de exploatare

performance factor / index (mas, TH) factor / indice de calitate

performance graph (TH, mas) caracteristică grafic de putere / de performanţă / de lucru, caracteristică / evoluție a unui parametru al maşinii / al elementului de maşină etc., în funcționare

performance limit (autom, mas) limită de performanță

performance-linked pay $(\mathrm{ec})$ plată în funcție de producția realizată

performance load (mas) greutate / încărcare pe unitate de putere (a unei maşini)

performance monitor (autom) monitor de urmărire a funcționării (unei mașini etc.)

performance number (metr, mas) indice de performantă / de control

performance optimized with enhanced risk personal computer (POWERPC) (c) Power PC, serie de procesoare cu mai multe unități independente care pot funcționa în paralel, computer optimizat

performance per litre (auto, mas) putere pe litru / volumică / litrică

performance rating $(\mathrm{TH}$, mas) randament

performance specification (mas) specificație tehnică de utilizare

performance test / testing (el, mas) încercare / testare pentru determinarea caracteristicilor; (TH, mas) probă de exploatare / de funcționare, încercare / testare a puterii / a unei performante (a unei instalații, a unei maşini etc.)

perfume parfum

perhalides (chim) compuşi complet halogenați

perhalocarbon (chim) hidrocarbură complet halogenată perhydrol (chim) perhidrol

perhydrous coal cărbune care conține peste $6 \%$ hidrogen

perigon (mat) unghi complet / de $360^{\circ}$

peril pericol, primejdie; a pune în pericol, a primejdui; in of în pericol de

peril point (ec, pol) punct periculos (sub care reducerea tarifului vamal prejudiciază industria națională)

perils of the sea clause (ec, nav) clauza pericolelor mării / de risc pe mare

perimeter (mat) lungime a unei curbe închise; (TH) perimetru; contur

period (fiz, TH) perioadă, timp minim după care o mărime repetitivă urmează aceeaşi evoluție; ciclu; timp, durată, interval de timp; durată de oscilaţie; punct (în texte)

period cost (ec) costuri / cheltuieli fixe / periodice

periodic(al) revistă; publicație periodică; (fiz, mec, ec) periodic; ciclic

periodical decimal (mat) fracție zecimală periodică

periodic(al) motion (mec, mas-un) mişcare periodică

periodic(al) pass (met) trecere periodică

periodical supplementary charging (el) încărcare periodică, suplimentară în repaus (la acumulatoare)

periodical system (fiz) sistem periodic

periodic(al) system / chart (chim) sistemul / tabloul periodic (al elementelor)

periodic annealing furnace (met) cuptor de recoacere cu mers / funcționare periodic(ă) / discontinu $(\breve{a})$

periodic duty (mas, TH) funcționare periodică / intermitentă

periodic function (mat) funcție periodică

periodic increment creştere periodică (d. un parametru etc.)

periodic inspection (auto, mas) revizie periodică

periodicity (mat, $\mathrm{TH}, \mathrm{ec}$ ) periodicitate; (fiz) frecvență

periodic kiln (met, alim) cuptor cu funcționare discontinuă / periodică / ciclică

periodic law (chim) legea lui Mendeleev

period meter (metr, fix) aparat pentru măsurarea perioadei; periodmetru

periodic motion $(\mathrm{mec})$ mișcare periodică

periodic oil / lubricant change (auto, T, met) schimbare periodică / regulată a uleiului / a lubrifiantului

periodic process cycle proces periodic, ciclu (foarte general) 
periodic pulse-train (autom, electr) serie / tren de impulsuri periodice

periodic resonance (fiz) rezonanță periodică / proprie

periodic system (chim) sistemul periodic (al elementelor)

periodic time $(\mathrm{el}, \mathrm{mec})$ perioadă

period meter (metr, electr) aparat pentru măsurarea perioadei

period of acceleration (auto, mec) durată / interval de accelerare

period of admission (mas, termo) timp / perioadă de admisie

period of blowing (met) durată de insuflare (la cuptoare metalurgice)

period of braking (auto) perioadă / durată de frânare

period of combustion (auto, termo) durată a arderii period of exhaust (auto, mas) perioadă de eşapare period of expansion (termo) perioadă / durată de detentă

period of grace concerning novelty perioada permisă de exploatare a unei invenții (fără a-i afecta noutatea)

period of heating (termo) durată de încălzire period of intake (termo) perioadă de aspirație period of loading (mas, TH) durată a aplicării unei sarcini, perioadă de încărcare

period of operation (mas, TH) perioadă de operare / de funcționare, timp de exploatare; durată de utilizare

period of oscillation (fiz) perioadă de oscilație period of rest ( $\mathrm{TH}$, mas) timp de repaus

period of running (mas) perioadă / timp de funcționare

period of service (mas) durată de folosire / de functionare / de serviciu

period of starting engine (auto, mas) perioadă / durată de pornire a motorului

period of time perioadă / interval de timp

period of wear out (failure rate) (mas, ind, T) perioada în care viteza / rata de scoatere din uz a pieselor creşte din cauza distrugerilor (prin uzură), perioada uzurii accelerate (a unui sistem) periodogram (fiz, mat) grafic al funcției spectrale; periodogramă

period(s) per second (metr, fiz) perioadă / perioade pe secundă, unitate de măsură pentru frecventă; v. Hertz

peripheral (fiz, OM, mas-un) periferic, de circumferintă

peripheral addressing (c, autom) adresare a perifericului, selecționare a unui anumit echipament periferic peripheral blowhole (met) suflură marginală / periferică

peripheral component interconnect (PCI) (c, autom) interconectare a componentelor periferice (permițând) transfer rapid între diferite periferice conectate la o magistrală sau între procesor şi periferice

peripheral component of velocity (mec) componentă tangentială a vitezei

peripheral control unit (autom, c) unitate de legătură, unitate periferică de control (a sistemului de intrare / ieşire al unui calculator)

peripheral-discharge mill (ind chim) moară cu descărcare periferică

peripheral device / unit (c) echipament periferic, unitate periferică (dispozitiv de intrare, de ieşire sau de stocare al unui calculator)

peripheral equipment (c) echipament periferic

peripheral event (c) eveniment periferic / în afara celor care se produc în unitatea centrală (şi de calcul)

peripheral / periphery force (mec) forță periferică / tangențială

peripheral jet (hidr, termo) jet periferic

peripheral line $(\mathrm{TH})$ linie de delimitat, periferie (ca linie)

peripheral milling cutter (mas-un) freză radială peripheral procession (met) proces de devansare / periferic / de margine (la laminare)

peripheral resistance unit, PRU (metr) unitate periferică de rezistență, utilizată în medicină pentru a evalua curgerea sângelui prin vase capilare; măsurarea în PRU este egală cu raportul dintre presiunea sângelui în $\mathrm{mmHg}$ şi viteza acestuia în $\mathrm{mm} /$ minut: 1 PRU $=1$ $\mathrm{mmHg} \cdot \mathrm{min} / \mathrm{mL} \cong 8 \mathrm{GPa} \cdot \mathrm{s} / \mathrm{m}^{3}$ )

peripherals (c) aparate periferice / auxiliare (ale calculatoarelor)

peripheral speed / velocity (mas-un, mec, OM, T) viteză periferică (și de aşchiere)

peripheric periferic, marginal

periphery (mat, OM) periferie, circumferință, contur

perish a pieri, a se distruge; a se perisa, a se degrada, a dispărea

perishable load (cf, transp) încărcătură perisabilă perishables (transp, ec) (mărfuri) perisabile perishing degradare, care (se) degradează peritectic change / transformation (chim, met) transformare peritectică

peritectic reaction (chim, met) reacție peritectică peritectic system (chim, met) sistem peritectic peritectic temperature (chim, met) temperatură peritectică 
per linear foot, plf (metr) unitate adimensională, pe metru liniar (d. o sarcină etc.): 1 plf = 3,280840 pe metru $(/ \mathrm{m})$

perlite (met) perlită

perlite area (met) secțiune / zonă perlitică

perm (metr, fiz) unitate pentru permeabilitatea la vapori de apă (abilitatea unui material de a permite trecerea vaporilor de apă prin el): un material are permeabilitatea de 1 perm dacă permite trecerea a $0,065 \mathrm{~g}$ vapori de apă (1 grain of water vapour) printr-o arie de 1 picior pătrat, la o diferență de presiune de 1 țol coloană $\mathrm{Hg}$, într-o oră, valoare care depinde de temperatură: la $0^{\circ} \mathrm{C}, 1 \cong 5,721 \cdot 10^{-11} \mathrm{~kg} /\left(\mathrm{m}^{2} \cdot \mathrm{Pa} \cdot \mathrm{s}\right)$; la temperatura camerei 1 perm $\cong 5,745 \cdot 10^{-11} \mathrm{~kg} /\left(\mathrm{m}^{2} \cdot \mathrm{Pa} \cdot \mathrm{s}\right)$

permalloy (met) permaloi (aliaj cu $40 \ldots 80 \% \mathrm{Ni}$ şi $60 \ldots 20 \% \mathrm{Fe}$ )

permanence permanență; durabilitate; fixitate; (mat, fiz) constanță; permanență; (mec) stare de inerție, stabilitate, trăinicie

permanence relation (mat, fiz) relație de conservare / de invarianță

permanency (chim) stabilitate; (mec) durabilitate; (lucru) permanent

permanent permanent; durabil; constant; fix; continuu

permanent action (autom) acțiune permanentă permanent capital (ec) capital / activ imobilizat permanent charging (el) încărcare de durată / continuă (la acumulatoare)

permanent connection / joint (OM) asamblare / îmbinare nedemontabilă / fixă

permanent coupling $(\mathrm{OM})$ cuplaj fix

permanent current (el) curent permanent

permanent deformation (mec) deformație reziduală / remanentă / permanentă

permanent elongation (materiale) alungire remanentă / permanentă

permanent elongation load (mec, materiale) limită / sarcină de curgere

permanent extension (mec, materiale) extensie / alungire permanentă

permanent fender $(\mathrm{OM})$ apărătoare fixă

permanent file (c) fişier permanent (păstrat pe durata mai multor acțiuni de prelucrare)

permanent gas (fiz) gaz necondensabil

permanent hardness (chim, met) duritate permanentă

permanent jacking system (auto, OM) cric fix / permanent

permanent load (el, mec) sarcină permanentă

permanent lubrication $(\mathrm{T}, \mathrm{OM})$ ungere / lubrifiere continuă

permanently convergent series (mat) serie peste tot convergentă permanent magnet steel (met, el) oțel pentru magneți permanenți

permanent marking $(\mathrm{TH})$ marcare permanentă (a unei piese) pentru identificare, monitorizare continuă a uzurii etc.

permanent memory (autom, c) memorie permanentă

permanent mould (met) formă permanentă

permanent-mould casting (met) turnare în cochilie / în formă permanentă

permanent motion (mec) mişcare continuă

permanent output $(\mathrm{TH}, \mathrm{ec})$ producție continuă / de durată

permanent overload capacity (mas, el) capacitate de sarcină permanentă

permanent pressure drop (hidr) cădere permanentă de presiune, inevitabilă la trecerea prin rezistențe hidraulice

permanent repair (mas, TH) reparație curentă permanent set (mec, OM) deformație reziduală / remanentă, armătură definitivă

per man-hour (ec) pe om-(şi-)oră

per person-hour (ec) pe persoană-(şi-)oră, pe operator-(şi-)oră

permeability (fiz) permeabilitate

permeability alloy (met, el) aliaj cu permeabilitate mare

permeability of free space (fiz) permeabilitate absolută a vidului

permeability test (metr, constr) probă de (in)filtrație; (metr, el) determinarea permeabilității

permeability to air (fiz) permeabilitate în aer

permeability to gas (chim) permeabilitate la gaz(e)

permeability to heat (termo) conductibilitate termică

permeable permeabil

permeable bed / formation / layer (met, geol, ind) strat / pat permeabil

permeable plastic (material) plastic permeabil permeable to gas (chim) permeabil la gaz permeable to light rays (fiz) transparent permeametry (metr, fiz) măsurarea permeabilității

permeate $(\mathrm{TH}$, fiz) a trece prin ceva, a pătrunde

permeation (chim, fiz) pătrundere, penetrație, îmbibare

per mensem (metr, med) unitate pentru frecvență, o dată pe lună

per mill (amer), per mil (brit), per mille, permill (rar), permil (rar) (metr) unitate pentru exprimarea proproției, egală cu 0,001 (din valoarea mărimii în discuție) sau o miime, simbolul $\% 0$ nu este disponibilă pe unele site-uri şi soft-uri 
perm inch (metr, fiz, materiale) unitate tradițională pentru permeanța vaporilor de apă (ca produs al valorii permeabilității şi a grosimii materialului în țoli / inchi): 1 perm inch $\cong 1,453 \cdot 10^{-12}$ $\mathrm{kg} /(\mathrm{m} \cdot \mathrm{Pa} \cdot \mathrm{s})$ la $0^{\circ} \mathrm{C}$ şi 1 perm inch $\cong 1,459 \cdot 10^{-12}$ $\mathrm{kg} /(\mathrm{m} \cdot \mathrm{Pa} \cdot \mathrm{s})$ la temperatura camerei

perm value (metr, fiz, materiale) valoare a permeabilității vaporilor de apă pentru un material, exprimată în perm (nu depinde de grosimea materialului utilizat ca barieră pentru vaporii de apă); v. perm

perminvar (met) perminvar (aliaj $\mathrm{Ni}-\mathrm{Co}-\mathrm{Fe}$ )

permissible admisibil, permis

permissible deviation ( $\mathrm{TH}, \mathrm{OM}$, mas) abatere admisibilă (a unui parametru etc.)

permissible dose (fiz, TH) doză permisă de iradiere / de substanțe toxice (într-un anumit timp de expunere)

permissible equipment ( $\mathrm{TH}$, mas, jur) echipament aprobat de autoritatea în domeniu

permissible limits limite admisibile, toleranță (în orice domeniu)

permissible load (mec) sarcină admisibilă

permissible overload (mec, mas) suprasarcină admisibilă / admisă / permisă

permissible speed (mas, mec) viteză admisibilă

permissible stress (mec, OM) efort / tensiune admisibil(ă)

permissible usage load (mec, mas) sarcină permisă de utilizare

permissible variation variație / abatere / toleranță admisă / permisă / admisibilă (foarte general)

permissible velocity (auto, mas, mec) viteză permisă / admisă / admisibilă

permission permisie; voie; învoire; permis; îngăduire; autorizație

permit permis, licență; autorizație; a permite, a îngădui; a permite, a autoriza (ceva); of a admite permitivity (el) permitivitate (şi magnetică)

permit restarting (mas) a permite repornirea (unui motor etc.)

permit to lade (nav, transp) permis de încărcare

permit to unlade (nav, transp) permis de descărcare

perms (ec) personal permanent, salariați permanenți permutation (mat) permutare

permute (mat) a permuta, a face o permutare peroxidation (chim) ozidare cu peroxizi, peroxidare perpendicular (to) (geom) perpendicular (pe) perpendicular alignment $(\mathrm{OM})$ aşezare / reglare a unei poziții perpendiculare

perpendicular bisector (geom) plan bisector perpendicular, mediatoare perpendicularity (geom) perpendicularitate, verticalitate (mai rar)

perpendicular line (geom) linie perpendiculară, perpendiculară

perpendicular load $(\mathrm{mec})$ sarcină perpendiculară / normală

perpendicular to (geom) perpendicular pe

perpetual permanent

perquisite, perk (ec) câştig suplimentar / întâmplător, indemnizație specială, beneficii marginale (neoficiale)

per revolution feed (mas-un) avans pe o rotație / la o revoluție (a piesei sau a sculei)

perseverance perseverenţă

persistence permanență; statornicie; durabilitate; stare de inerție; (fiz, mec) persistență (pe retină, pe display etc.), durata luminozității remanente

persistence characteristic (fiz) caracteristică de extincție

persistency constanță; continuitate; constantă de timp; inerție; postluminație; (fiz) persistență

persistent current (el) curent remanent

personal (gram) pronume personal; individual; particular

personal account $(\mathrm{ec})$ cont personal

personal computer (PC) (c) computer personal / individual

personal error (metr) eroare de observare / de citire (a operatorului uman)

personal probability probabilitate subiectivă

personal safety siguranță personală

person hour (metr, ec) unitate pentru evaluarea muncii, egală cu munca unei persoane timp de o oră, versiune agreată în loc de man hour

personnel (ec) personal, echipă de muncitori

personnel file / record (ec) dosar personal al salariatului

personnel policy (ec) politică de personal

personnel specification $(\mathrm{ec})$ fişă a salariatului (studii, experiență etc.)

perspective perspectivă

perspective drawing $(\mathrm{TH})$ plan / desen în perspectivă

perspex (plast) material plastic transparent, dur şi incasabil, plexiglas

perspire a asuda; a transpira; a exsuda

pertaining to commercial customs (ec) corespunzător uzanțelor comerciale

perthousand (metr) altă denumire pentru per mill; (tipografie) la mia de caractere (sau per mill character)

pertinax material (el, plast) electroizolant $\mathrm{cu}$ bachelită

pertinent în legătură cu; obiectiv; esențial, pertinent; adecvat, conectat cu 
perturbance, perturbation (fiz, autom, mas) mărime perturbatoare, perturbație

perturbing perturbator, care perturbează

per unit specific; raporat la unitate (de supra-față, de putere, de lungime, de volum etc.), de exemplu: per unit of area / of length / of volume pe unitatea de arie / de lungime / de volum

perusal examinare vizuală; cercetare; citire / lectură atentă

peruse a răsfoi; a cerceta (cu privirea); a examina, a studia; a citi atent

pervade a trece prin (ceva); a pătrunde în; a se răspândi (în / pe)

pervasion (fiz) penetrație; răspândire

pervious permeabil; accesibil

pervous bed / stratum / blanket (hidr, mediu) strat permeabil / de drenaj

pervious to light rays (fiz) transparent

pes (metr) unitate romană de măsură pentru lungime, picior roman: 1 Roman foot, $=29,67 \mathrm{~cm}$

pest (bot, biol) parazit, dăunător

pesticide (ind chim) pesticid

pestle (OM, alim) pisălog; (bot) pistil; a pisa, a fărâmița

pestle mill (chim) mojar

peta- (P-) (metr) sufix metric prefix pentru $10^{15}$ (amer) (one US quadrillion); exemplu: 1 parsec $=30,857 \cdot 10^{15} \mathrm{~m}$

petabecquerel (PBq) (metr, fiz) unitate de măsură pentru radioactivitate, egală cu $10^{15}$ dezintegrări atomice pe secundă sau 27027,03 curie

petaflops (Pflops) (metr, c) unitate de măsură a puterii de calcul, egală cu $10^{15}$ operații în virgulă mobilă pe secundă

petagram (Pg) (metr, fiz, astronomie) unitate de măsură pentru masă: 1 petagram $=10^{15} \mathrm{~g}=1$ gigatonă

petahertz (PHz) (metr) unitate de măsură pentru frecvență: 1 petahertz $=10^{15} \mathrm{~Hz}$ (pentru unde luminoase infraroşii şi vizibile)

petajoule (PJ) (metr, fiz) unitate în sistemul metric pentru energie: 1 petajoule $=10^{15} \mathrm{~J}=$ 277,7778 gigawatt oră

petameter (Pm) (metr, fiz, astronomie) unitate de măsură pentru lungimi mari: 1 petameter $=$ $10^{15} \mathrm{~m}$

pet-cock $(\mathrm{OM}$, hidr) robinet de scurgere / de siguranță / de decompresie

petrification (termo) pietrificare, întărire

petrify a (se) întări, a se împietri

petrochemistry (ind chim) petrochimie

petrol (ind chim) benzină auto

petroleum (ind chim) țiței, hidrocarburi naturale

petrolatum (ind chim) vaselină petroleum allied products (ind chim) produse derivate din petrol

petroleum industry specification(s) (ind chim) specificații / cerințe ale industriei petroliere

petroleum jelly (rar) lubrifiant

petrolatum liquidum (med, chim) ulei medicinal

petrol barrel / drum (OM) butoi de benzină petrol economizer (auto) economizor de benzină petrol engine (auto, termo) motor pe benzină petroleum, crude oil (ind chim) petrol brut / natural, țiţei

petroleum ether (ind chim) gazolină

petroleum fluid (ind chim, hidr) fluid petrolier, ulei mineral

petroleum fuel (termo, ind chim) combustibil extras din țiţei

petroleum naphta (ind chim) benzină grea

petroleum pitch (ind chim) smoală de țiței

petroleum products (ind chim) produse petroliere

petroleum refining (ind chim, $\mathrm{TH}$ ) rafinare a petrolului brut

petroleum residue (ind chim) reziduuri petroliere

petroleum sluice valve $(\mathrm{OM}$, ind chim) robinet cu sertar pentru o conductă de petrol

petroleum solvent (ind chim) solvent petrolier

petroleum tar (ind chim) gudron

petroleum-type oil (ind chim, T) ulei (lubrifiant) din petrol

petrol feed pump (termo, auto) pompă de alimentare cu benzină

petrol filler (OM, auto) gât de umplere (la rezervorul de benzină)

petrol-filling station (auto, ind chim) stație de benzină

petrol injection (PI) (auto, termo) injecție de benzină

petrol level gauge (OM, auto, mas) indicator de nivel de benzină

petrol lubrication $(\mathrm{T})$ ungere prin amestec de ulei şi benzină

petrol pump (auto, OM) pompă de benzină

petrol separator (auto) separator de benzină petrol strainer (auto) filtru de benzină

petrol supply (ind chim) alimentare cu benzină

petrol tank(er) (OM, ind chim) rezervor / cisternă de benzină

petrol vaporizing oil (auto, ind chim) benzină grea de tractor

petticoat pipe (cf, OM) cap de emisie cu conuri etajate; (OM) țeavă evazată / cu mufă

petties $(\mathrm{ec})$ cheltuieli mărunte

pet valve (OM, hidr) robinet / supapă de probă 
pewter (met, T) compoziție pentru lagăre; aliaj alb (de staniu şi plumb)

pF (metr, fiz, el) simbol pentru picofarad; (metr) simbol pentru unitatea folosită în agricultură pentru a măsura „absorbția în sol” sau tensiunea provocată de umiditate în sol (care este presiunea aplicată umezelii din sol pentru a o aduce la un echilibru cu cea a apei dintr-un bazin deschis); se măsura în unităti $\mathrm{pF}$ - logaritm din presiunea exprimată în $\mathrm{cm}$ coloană de apă; astăzi se măsoară direct în $\mathrm{kPa}$

Pfiff (metr) unitate tradițională de măsură pentru volum de lichid (bere), în Austria: 1 Pfiff of beer $\sim 177 \mathrm{ml}$, dar şi $200 \mathrm{ml}$

pfu (metr) simbol pentru unitatea de flux de particule; v. particle flux unit

pfund (pfd) ( $s g$ şi $p l)$ (metr) unitate tradițională de măsură pentru masă: 1 English pound = $454 \mathrm{~g}, 1$ Viennese pfund $\sim 560 \mathrm{~g} ; 1$ pfund (Germania contemporană) $=500 \mathrm{~g}$

pH (potential of Hydrogen) (metr, chim) $\mathrm{pH}$, simbol pentru unitatea logaritmică de măsură a acidității sau bazicității soluțiilor; $\mathrm{pH}$ unei soluții este o măsură a concerației de ioni de hidrogen, adică logaritmul negativ al concentrației, măsurată în moli pe litru; valorile $\mathrm{pH}$ variază între 0 şi 14 ; apa pură la $25^{\circ} \mathrm{C}$ are $\mathrm{pH}$ $\sim 7,0$; un $\mathrm{pH}<7$ indică aciditate, iar $\mathrm{pH}>7$ indică alcalinitate

Ph Eur unit (metr) unitate utilizată în Uniunea Europeană pentru a măsura puterea unei vitamine sau a unui medicament, adică efectele biologice așteptate; 1 doză $\mathrm{Ph}$ Eur unit este determinată pentru fiecare substanță; în multe cazuri $1 \mathrm{Ph}$ Eur unit =1 international unit (IU), $\mathrm{v}$. international unit

phi unit (metr, constr) unitate logaritmică pentru măsurarea mărimii particulelor / grăunți de nisip, pietriş etc.; $1 \mathrm{~mm}$ corespunde valorii 0 ; o creștere cu 1 phi indică descreșterea cu un factor de 0,5: 1 phi unit este mărimea unui grăunte de $0,5 \mathrm{~mm}, 2$ phi units corespunde $0,25 \mathrm{~mm},-1$ phi unit corespunde unui grăunte de $2 \mathrm{~mm}$ etc.

phon (metr) o măsură logaritmică a intensității auditive (a unei persoane), similară decibelului, dar spre deosebire de acesta, reflectă măsurători subiective

phacoidal structure (materiale) structură lenticulară

phantom lines (met) şiruri / benzi de incluziuni nemetalice

phase aspect; etapă; (fiz, astronomie) fază; latură, perioadă, stadiu; unghi; (el) fază, a aduce în concordantă de fază; (inf) etapă a executării unei activităţi de calcul; (met) fază; a introduce (metode noi etc.)

phase adapter (el) transformator de fază

phase advance / lead(ing) (autom) avans de fază; defazaj înainte; (inf, c) etapă a executării unui calcul

phase advancer (el, electr, autom) compensator de fază

phase angle (el) unghi de fază

phase angle error (el, electr, autom) eroare de defazaj

phase (angle) meter / (difference) indicator (el, metr) fazmetru; cosfimetru

phase balance (met, el) echilibru / coincidență de faze

phase bridge (el, metr) punte pentru măsurarea unghiului fazei / de defazare

phase boundary (met, chim) suprafață de separare între faze, limită de faze

phase change (met) schimbare / transformare de fază

phase changer / shifter (electr, autom) schimbător / convertizor de fază; defazor

phase coincidence (fiz) concordanță / coincidență de fază

phase conductor (el) conductor de fază / de linie / de exterior

phase-contrast microscope (metr, opt) microscop cu contrast de fază

phase-control factor (el) coeficient de reglare a fazei

phase current (el) curent pe fază

phase delay / lag(ging) (el, electr, autom) întârziere de fază; defazaj în urmă

phase-delay error (electr, autom) distorsiune de întârziere de fază

phase diagram (met) diagramă a fazelor / de echilibru

phase difference / displacement / shift(ing) (electr, autom) defazaj; decalaj de fază

phase (difference) indicator / (angle) meter (el, metr) fazmetru; cosfimetru

phase displacement (met) deplasare filoniană (a fazei / fazelor)

phase delay / lag(ging) (el, electr) întârziere de fază, defazaj în urmă

phase diagram (met) diagramă de faze

phase equalizer (el, electr, autom) egalizator / corector / compensator (al distorsiunilor) de fază phase equilibrium (met) echilibru de fază phase fading (el) dispariție a tensiunii pe fază

phase failure protection (el, autom) protectie contra întreruperii unei faze

phase field (met) domeniu al fazei / de fază 
phase (group) velocity (mas, TH, ec) timp de funcționare (pe grupuri de maşini)

phase jump (el) schimbare bruscă a fazei; salt de fază

phase lag / lagging / delay (autom, fiz) defazaj în urmă; întârziere de fază

phase lead / leading / advance (fiz) avans de fază, defazaj înainte

phase margin at gain crossover (autom, fiz) limită de fază la frecvență de intersecție / de suprapunere a amplificării

phase opposition (fiz, el) opoziție de fază; antifază phase-out (mil, mas-un) retragere succesivă / treptată

phase out a opri succesiv / treptat, a reduce succesiv / treptat; a retrage succesiv / treptat

phase-propagation ratio (fiz, el) constantă de propagare a fazei

phase quadrature (fiz) cvadratură (de fază); defazaj de $90^{\circ}$

phaser (el, electr, autom) fazor, regulator de fază; încadrator, sincronizator de încadrare / de centrare a imaginii

phase recorder (el, metr) fazmetru înregistrator phase recovering time (el, autom) timp de restabilire a fazei

phase-related output signals (autom) semnale de ieșire raportate / comandate în fază

phase response (el, autom) caracteristică / dependență / răspuns de fază

phase reversal (el, autom) inversiune de fază

phase rule (met) regula fazelor

phase-segregated terminal box (el) cutie terminală, cu / pentru separarea fazelor

phase-senzitive (autom) sensibil la fază

phase-sensitive detector / demodulator / rectifier (autom) detector / demodulator / discriminator sensibil la fază

phase separation (met) segregație, separare de faze / de fază, licuație

phase-shift (fiz, autom) defazare

phase-shifted (fiz) defazat

phase shifter / changer (el, electr) defazor, convertizor / schimbător de fază

phase shift(ing) / difference / displacement (el, electr, autom) decalaj de fază, defazaj

phase-shifting circuit (el, electr, autom) circuit de defazare

phase swinging (el) oscilații pendulare (ale vitezei unei maşini sincrone)

phase-to-phase voltage (el) tensiune între faze / de linie

phase transformation (met) transformare de fază (într-un sistem fizic eterogen) phase transition (met) tranziţie / transfer de fază phase variation (el) oscilație / variație de fază phase velocity (fiz) viteză de fază

phase voltage (fiz, el) tensiune pe fază phase wave (fiz) undă a lui de Broglie phase winding (el) înfăşurare a unei faze

phasing (constr) program de construcții, etapizare a executării lucrărilor; (el) sincronizare, sinfazare, reglare a fazelor; (chim, plast) separare / formare de faze

Phelps vacuum gauge (metr, fiz) aparat de măsurat presiuni în intervalul $10^{-5} \ldots 1$ torr (prin ionizarea unui filament incandescent)

phenol (chim) fenol

phenolformaldehyde resins (chim) răşini fenolformaldehidică

phenolic resins, phenolics (PF) (chim) răşini fenolice

phenomenon, $(p l)$ phenomena fenomen, fapt (şi neobişnuit)

phenoxy resin (plast, ind chim) rășină phenoxy

phenyl (chim) fenil

phenylamine (chim, T) anilină

phenyl benzoate (chim) benzoat de fenil

phenyl cacodyl (chim) tetrafenilarsină

phenyl carbinol (chim) alcool benzilic

phenyl carbonate (chim) carbonat de fenil

phenyl chloride (chim) clorbenzen

phenyl chloroform (chim) ofeniltriclormetan

phenyl cyanate (chim) cianat de fenil

phenyl dichloroarsine (chim) fenildicloroarsină phenyl ether (chim) eter fenolic

phenyl ethylene (chim) stiren

phenyl fluoride (chim) fluorbenzen

phenyl hydrate (chim) fenol

phenyl isocyanate (chim) fenilizocianat

phenyl ketone (chim) benzofenonă, fenilcetonă

phenyl mercaptan (chim) tiofenol

phenyl methane (chim) toluen

phenyl monohalide (chim) monohalogenbenzen

phenyl phosphate (chim) fosfat de fenil

phenyl phosphine (chim) fenilfosfină

phenyl polyhalide (chim) polihalogenbenzen

phenyl rhodanate (chim) feniltiocianat

phenyl sodium (chim) fenilsodiu

phenyl-sulphonic acid (chim) acid benzensulfonic

phenyl thiourea (chim) feniltiouree

phenyl urea (chim) feniluree

phenyl-ethyl mustard oil (chim) izotiocianat de feniletil

phenyl-magnesium halide (chim) halogenură de fenil magneziu

phenyl-mercuric salt (chim) sare fenilmercurică phenyl-methyl ketone (chim)fenilmetilcetonă 
phenyl-mustard oil (chim) fenilsenevol, fenilizotiocianat

phenyl-propyl ketone (chim) fenilpropilcetonă phenyl-styryl ketone (chim) benzilidenacetofenonă

phenyl-styryl ketone (chim) fenilstirilcetonă phenyl-sulphonic acid (chim) acid benzensulfonic phial (chim) flacon, fiolă

Phillips gauge (metr, fiz) aparat pentru măsurarea indirectă a presiunilor mici, cu ajutorul unei descărcări luminoase

Phillips screw (OM) şurub cu cap în cruce

pH meter (chim, fiz, T) pHmetru

pH number (metr, chim, fiz, T) exponent de hidrogen, valoare a $\mathrm{pH}$-ului; valorile $\mathrm{pH}$ variază între 0 şi 14; apa pură la $25^{\circ} \mathrm{C}$ are $\mathrm{pH} \sim 7,0$; un $\mathrm{pH}<7$ indică aciditate, iar $\mathrm{pH}>7$ indică alcalinitate

phonometer (metr, fiz) fonometru, aparat de măsurat intensitatea sunetului

phos-copper (met) bronz fosforos

phosphate (chim) fosfat

phosphate coating (chim, met) fosfatare

phosphate-treated (chim) fosfatat, supus unui tratament de fosfatare

phosphating (met, chim) fosfatare, care fosfatează (d. o substanță activă)

phosphatizing (met, chim) (proces / tehnologie de) fosfatare

phosphide (chim) fosfură

phosphite (chim) fosfit

phosphor (chim) substanță fosforescentă

phosphorate (chim, met) a mări conținutul de fosfor

phosphor-bronze / -copper (met) bronz / cupru cu fosfor / fosforos

phosphorescence (chim, fiz) fosforescență

phosphorescent fosforescent (d. un material)

phosphoretic steel (met) oțel fosforos

phosphoric (chim) fosforic

phosphoric pig iron (met) fontă fosforoasă

phosphoric acid (chim) acid fosforic

phosphorise (chim, met) a mări conținutul de fosfor

phosphorised-bronze / -copper (met) bronz cupru cu fosfor / fosforos

phosphorogen (met, chim) fosforogen

phosphorous (met, chim) cu conținut de fosfor, fosforos; fosfor

phosphor(o)us acid (chim) acid fosforos

phosphorous bronze (met) bronz fosforos

phosphorous pig iron (met) fontă fosforoasă

phosphorous soap $(T$, chim) săpun pe bază de fosfor

phosphors (chim) substante fosforescente
Phosphorus (P) (chim) fosfor

phosphorus-bearing slag (met) zgură fosforoasă

phosphorus doped (chim, electr) (semiconductor) dopat cu fosfor

phosphorus segregation (met, chim) segregare a fosforului

phot (ph) (metr, fiz) unitate de măsură în sistemul CGS pentru iluminanță sau iluminare: 1 phot $=1$ lumen $/ \mathrm{cm}^{2}=10000$ lux

photo fotografie

photo(electric)cell (fiz) fotoelement, celulă fotoelectrică, fotodetector

photochemical effect (chim) efect fotochimic

photochemical oxidant (chim) agent oxidant, activ în prezența luminii

photoeffect (fiz) efect fotoelectric, fotoefect

photoelastic stress analysis (metr, fiz) analiză foto-elastică a tensiunilor, fotoelastometrie

photoelectric pyrometer (metr) aparat de măsurat temperaturi prin măsurarea emisiei fotoelectrice a obiectului incandescent

photology (fiz) optică

photomacrograph (met) macrofotografie

photomicrograph (met) microfotografie

photon (fiz, metr) foton, o cuantă de energie luminoasă sau orice formă de energie electromagnetică cu o singură lungime de undă, direcție şi polarizare; photon (metr) nume anterior pentru unitatea de iluminanță retinală, numită acum troland; $v$. troland

photon correlation spectometry (fiz) spectrometrie prin corelare fotonică

photophoresis fotoforeză

phrase in parentheses intercalare; text în paranteze

phreatic (geol) freatic

physical (fiz) material, fizic

physical adsorbtion (fiz) adsorbție fizică / prin procese fizice

physical arrangement of the component particles (fiz) aranjamentul (fizic) al particulelor componente (d. unsori, compozite etc.)

physical distribution management (PDM) (ec) supraveghere a distribuției mărfurilor (ambalare - transport - înmagazinare)

physical metallurgy (met) metalurgie fizică

physical vapor deposition (PVD) (fiz) depunere a vaporilor prin procese fizice

physical weathering (fiz, met) dezagregare / alterare / îmbătrânire fizică din cauza agenților de mediu / atmosferici (şi d. materiale plastice)

physicist fizician

physico-chemical analysis (metr, fiz, chim) analiză fizico-chimică 
physics fizică

Pi (mat, metr) (munărul) pi, simbolizat şi cu litera grecească $\pi: \pi=3,141592$; unitate de măsură pentru unghiuri: $\pi$ radiani este un unghi de $180^{\circ}$

pi, pic (metr) unitate de măsură pentru lungime în țările mediteraneene şi în Orientul Apropiat, braț: valoarea tipică este $\sim 0,71 \mathrm{~m}$

pic (metr) v. pik

pica (metr) unitate de măsură egală cu o şesime dintr-un inch; pica (pi, pc) (metr, topografie, topografie) unitate de măsură pentru lungime 1 pica $=4,22 \mathrm{~mm}$

pica type (tipografie, metr) tip / stil de scriere a unui text cu 6 linii pe țol / inch

pick alegere, selecție; (fig) elită; (constr) târnăcop, sapă, cazma, şpiț; (nav) vârf al ghearei de ancoră); (textile) pic, bătaie, a îndepărta nodurile / nopeurile din țesătură; a smulge; a culege (flori, fructe); a alege (dintr-o multime), a sorta, a tria, a selecționa; a săpa, a scobi; a curăța (de coajă); a jumuli (de pene); a ciuguli (d. păsări); a pune la cale; a căuta; (fam) a mânca, a se îndopa; a deschide (cu un şperaclu); (d. persoane) a face mofturi la mâncare; a fura (din buzunare)

pick acquaintance with smb. a face cunoştință cu cineva

pickax(e) $(\mathrm{OM})$ cazma, hârleț, târnăcop

pick counter numărător, contor

picked sortat; ales; clasat; triat

picker (met) ciocan de selectare, bătător, tachet

picker beater (OM, mas) volant

picker cam, picking tappet (OM) camă cu excentric

picket țăruş, jalon; bară de lanț; post de pază, pichet

pick holes in a găsi de obiectat, a critica

picking separare; selecționare; (met) sortare manuală a minereului; culegere (şi de text); bătaie; batere

picking belt (alim, OM) bandă de sortare

picking drum $(\mathrm{OM})$ ciur rotativ

picking out $(\mathrm{TH})$ sortare (prin scoatere dintr-o mulţime)

pickings (ind, mediu) resturi, rămăşiţe

picking table $(\mathrm{OM})$ masă de sortare

picking up ridicare (a unui obiect dintr-o mulțime) extragere

pickle (alim) saramură; (met) soluție pentru decapare, decapant, a decapa, a băițui; piclu (ind pielăriei)

pickle brittleness (met) fragilitate la decapare pickle inhibitor (met, chim) inhibitor de decapare pickle liquor (met, chim) soluție de decapare pickler (met, chim) agent de decapare, decapant pickling (alim) murare, baie de saramură; (met, chim) tratament de decapare / de băițuire, decapare, băițuire, atac cu reactivi

pickling acid regeneration (met, chim) regenerarea / refacerea soluției de decapare

pickling acid waste (met, chim) soluție de decapare epuizată / uzată

pickling agent (met, chim) agent / soluție de decapare, decapant

pickling bath (met, chim) baie de decapare

pickling blistering / holes (met) sufluri de decapare (defect)

pickling department / plant (met) secție / instalatie de decapare

pickling embritllement (met) fragilitate la decapare

pickling line (met, mas) linie (continuă) de decapare

pickling solution / fluid (chim) soluție de decapare

pickling paste (chim) pastă de decapare

pickling tank (met) cadă de decapare

pick oakum / to pieces a face bucăți; a critica aspru

picklock $(\mathrm{OM})$ şperaclu

pickoff (s) (metr) senzor(i) (în general)

pick-off $(\mathrm{OM})$ detaşabil, de schimb, demontabil, amovibil

pick-off gear $(\mathrm{OM})$ roată dințată amovibilă, angrenaj selector

pick pockets a fura, a buzunări

pick out a selecta; a selecționa; a sorta; a culege; a elimina prin sortare, a alege, a tria; a descifra (sensul unei fraze)

pick-up (auto, transp) autofurgonetă, camionetă uşoară; (autom) element sensibil; (ec) creştere; seismograf; (mas-un, metr, OM) dispozitiv de prindere, senzor, adaptor, palpator, traductor

pick up a scoate; a extrage; a recepționa; a ridica; a înregistra; a aduna, a strânge; a ridica de jos; (edu) a învăța repede, a prinde; a găsi, a regăsi; a capta (un mesaj etc.); (med) a restabili, a întrema (după boală) (met) metal aderent, aderență

pick-up pump (OM, fiz) pompă de vid

pick-up roller (plast, OM) rolă de curățare la lipire

pick up speed (mec) a accelera; (auto) a intra în viteză; a mări viteza, a lua viteză

pick up strength a prinde puteri

pick-up time (el, autom) timp de acționare (al unui releu)

pick-up transducer (metr) convertor / traductor de explorare 
pick-up unit (OM, metr) palpator; (mas-un, autom) emițător de comandă, unitate de selectare (a valorilor etc.)

pick-up velocity (metr) viteză de explorare / de analiză

picnometer (metr, fiz) picnometru, instrument de măsurat densitatea

pico- (p-) (metr) pico-, prefix metric pentru $10^{-12}$ dintr-o unitate (provine din piccolo - mic în limba italiană)

picocurie (pCi) (metr, fiz) unitate de măsură pentru radioactivitate, utilizată pentru a măsura radioactivitatea naturală a mediului: 1 picocurie $=10^{-12}$ curie sau 0,037 becquerel, adică o dezintegrare atomică la fiecare $27 \mathrm{~s}$ (foarte lentă)

picofarad (pF) (metr, el, fiz) unitate de măsură pentru capacitanță electrică, picofarad: 1 picorafad $=10^{-12} \mathrm{~F}$; denumirea anterioară era micromicrofarad $(\mu \mu \mathrm{F})$; $\mathrm{v}$. micromicrofarad

picogram (pg) (metr, fiz) unitate de măsură pentru masă, picogram: 1 picogram $=10^{-12} \mathrm{~g}$

picoliter (pl, pL) (metr, fiz) unitate de măsură pentru volum, picolitru: 1 picoliter $=10^{-12} 1$

picolo (metr, alim) unitate de măsură pentru volum, pentru şampanie: 1 picolo $=1 / 4$ dintr-o sticlă $\sim 187,5 \mathrm{ml}$

picomole (pmol) (metr) unitate de măsură pentru cantitatea de substanță, picomol: 1 picomole = $10^{-12} \mathrm{~mol}$

picosecond (ps) (metr) unitate de măsură pentru timp, picosecundă: 1 picosecond $=10^{-12} \mathrm{~s}$

picotesla (pT) (metr) unitate de măsură pentru intensitatea câmpului magnetic, picoTesla: 1 picoTesla $=10^{-12}$ Tesla sau $10^{-8}$ gauss

picric acid (chim) acid picric

pictograph ideogramă; simbol grafic

pictorial diagram (edu, TH) schemă / diagramă cu imagini

pictorial quality (c) calitate a imaginii

pictorial symbol simbol-imagine

picture imagine, desen; pictură, portret; poză; ilustrație; figură; tablou; (inf) descriere a unui lant de caractere într-un limbaj de programare; (poligrafie) figură; film cinematografic, imagine (cinematografică), fotografie, cadru; (c, TV, fotografie) imagine (electro-optică), imagine (vizibilă), poză, fotografie; (fig) întruchipare, personificare, cadru, frumusete; (fig) a descrie, a explica, a ilustra, a imagina, a închipui, a oglindi, a reflecta; a desena; a fotografia; a picta; a (re)prezenta (prin desen, pictură etc.)

picture area (c) câmp / suprafață a(l) imaginii

picture cycle (c, cinematografie) / succesiune a imaginilor / cadrelor, durata de schimbare a imaginilor, frecvență de repetare a imaginilor picture definition (c) rezoluție / definiție a imaginii

picture element, pixel (c) element / punct de imagine, pixel; (PEL, pel) (c, TV) ,punct” care formează o imagine în televiziunea digitală

picture field (c, foto) suprafață / câmp a(l) imaginii

picture gate (c) cadru delimitator al imaginii

picture line / strip (c) linie de explorare a imaginii

picture ratio / shape (c) format al imaginii

picture scanning (c, opt) scanare / explorare / baleiaj a(l) imaginii

picture sharpness (c) acuitate, claritate a imaginii

picture unit (fotografie) aparat de telefotografiat (şi inclus într-un sistem tehnic)

picture unit area (c) unitate / element de imagine

picul (metr) unitate de măsură pentru masă, comparabilă cu chintalul european, utilizată în Asia de Est, în perioada colonială: 1 picul $\sim 60,5 \mathrm{~kg}$; astăzi în sistem metric: 1 picul (Tailanda) $=60 \mathrm{~kg}, 1$ picul (China) $50 \mathrm{~kg}$

pie (metr) unitate tradițională spaniolă de măsură pentru lungime, picior: 1 pie (Spania) $=$ $2,86 \mathrm{~cm}, 1$ pie (Argentina) $=28,89 \mathrm{~cm}, 1$ pie $($ Texas $)=28,22 \mathrm{~cm}$

piebald tărcat; bălțat; pestriț

piece bucată; element; articol; parte, piesă; fragment; epruvetă; parcelă, lot (de pământ); (alim) butoi (de vin); a înnoda, a înnădi; a completa; a pune la un loc; piece (pc) (metr) unitate pentru cantitate, egală cu 1 / o unitate / o bucată; strategy (ec) strategie lipsită de vedere de ansamblu; (mil) armă de foc

piecemeal (făcut) din bucăți, parțial, bucata cu bucata, (a lucra, etc.) cu bucata, treptat

piece production $(\mathrm{ec})$ productie individuală

piece rate / wage(s) (ec) plată / salarizare la bucată / în acord

piecemeal reaping (agr) recoltare fracționată

piecewise pe bucăți, parțial

piece work (ec) muncă în acord

piece worker (ec) muncitor în acord

piece-work rate(s) (ec) salariu în cord

pie chart diagramă circulară / sectorială

piecing of broken threads (textile) legare a firelor rupte

pied (metr) (în franceză - picior) unitate tradițională de măsură pentru lungime, picior francez; 1 royal foot (pied de roi, v. Paris foot) $=1$ foot (French measure) în Canada: 1 pied de roi $\cong$ $32,48 \mathrm{~cm} ; 1$ official Canadian pied $=32,48406$ $\mathrm{cm}, 1$ pied (Franța) $=0,30 \mathrm{~m}$; în Canada franceză: 1 pied = 1 English foot: $v$. foot 
piede (metr) (în italiană - picior) unitate tradițională de măsură pentru lungime, picior italian: 1 piede $\cong 29,8 \mathrm{~cm}$, dar 1 piede (Veneția) $\cong 34,8$ $\mathrm{cm}, 1$ piede $($ Bologna $) \cong 38 \mathrm{~cm}$

pier (constr) stâlp, pilon; (nav) dană, chei

pierce a străpunge, a perfora, a găuri; a pătrunde (în); a-şi face loc prin, a face o deschizătură / gaură în; (fig) a pătrunde in / prin; a răzbate prin pierced perforat; găurit; străpuns

piercement $(\mathrm{mec})$ străpungere, găurire, perforare

piercer (met) dorn de perforare, perforator, laminor perforator

piercer rod (met) dorn de laminor perforator

piercer rolls (met, $\mathrm{OM}$ ) cilindri perforați, pentru laminare elicoidală

pierce the tap hole (met) a destupa / perfora gura de evacuare (la un cuptor, la o oală de turnare)

piercing (met) perforare, străpungere, poansonare, formare a unei găuri necirculare cu scule speciale de presare / aşchiere; (mat) intersecție piercing die (mas-un, OM) matriță de perforat

piercing machine (mas-un) presă de perforat; (met) maşină de perforat (la oale de turnare continuă sau la cuptoare)

piercing mandrel (met, OM) dorn de perforat, poanson

piercing point (of a line) (geom) punct de intersecție / de înțepare (a unei drepte cu un plan)

piercing rolling mill (met) laminor perforator

pieze (pz) (metr, fiz) unitate metrică pentru presiune, în sistemul metru-tonă-secundă, utilizată în inginerie: 1 pieze $=10$ milibari

piezoelectric (fiz) piezoelectric

piezoelectric accelerometer (metr, mec) accelerometru (cu senzor) piezoelectric

piezoelectric ceramics (materiale) ceramice piezoelectrice

piezoelectric gauge (metr) traductor piezoelectric piezoelectric pressure transducer (metr, hidr) traductor piezoelectric de presiune

piezoelectric transducer (metr) traductor piezoelectric

piezoelectric voltage transformer element (electr, metr) element piezoelectric pentru transformarea tensiunii

piezoid (material) cristal piezoelectric de cuarț (bun de folosit ca traductor)

piezometer (metr, mec) piezometru, manometru cu efect piezometric

pig (cf) locomotivă auxiliară; (met) lingou, bloc (brut / pentru retopire), fontă, calup, bară, piesă brută, țaglă, lupă de metal; (hidr) dispozitiv interior de curăţat depunerile din conducte; (agr, zool) (d. scroafe) a făta

pig-and-ore process (met, $\mathrm{TH})$ procedeu minereu + fontă, de elaborare a oțelului

pig-and-scrap process (met, $\mathrm{TH}$ ) procedeu / proces fontă+fier vechi, de elaborare a oțelului

pig back (met) a recarbura baia de fontă

pig bed (met) pat de turnare (a blocurilor de fontă brută)

pig boiling (met) afinare / pudlare cu fontă

pig breaker (met) spărgător de blocuri

pig-casting machine (met, mas-un) maşină / instalație de turnat blocuri

pigeon hole $(\mathrm{OM})$ casetă, compartiment mic

pigging (met, $\mathrm{TH}$ ) turnare în lingotiere

pigging up (met) adaos de fontă brută

piggy-back control (autom) control / comandă / reglare în cascadă

pig-iron (met) fontă brută / de turnătorie / de furnal, fontă (în general)

pig-iron brand / grade (met) marcă de fontă (şi brută)

pig-iron for steel making (process) (met) fontă pentru afinare (pt. obținerea oțelului)

pig-iron ladle (met) oală de turnare pentru fontă brută

pig-iron ladle car (met) vagonet pentru transportul oalei de fontă brută

pig-iron mixer (met) melanjor de fontă brută lichidă

pig-iron-ore process (met, $\mathrm{TH}$ ) proces de afinare fontă-minereu

pig-iron output (met) evacuare a fontei, nivel / procent / randament de scoatere (în producția de fontă)

pig-iron purifying process (met) proces de afinare a fontei

pig-iron refining (met) afinare a fontei (brute)

pig-iron-scrap process (met) procedeu fontă +fier vechi, de elaborare a oțelului

pig-lead (met) plumb în blocuri / în lingouri

pig machine (met) maşină / instalație de turnat fontă în blocuri

pigment (ind chim) colorant, pigment

pigmentation (ind chim) pigmentare; colorare; vopsire

pig metal (met) metal în blocuri

pig mould (met) lingotieră, formă de turnat blocuri

pig process (met) (proces de) afinare a fontei

pigs (met) blocuri de fontă

pig tail (el, metr) conductor de conectare; (termo, hidr) cot de conductă de $270^{\circ}$ sau $360^{\circ}$ (folosit şi pt. captarea condensului) 
pig tin (met) staniu în blocuri

pig tongs (met) cleşte de prins blocuri metalice / lingouri

pike (bot) ghimpe, spin, pisc, vârf; (OM) furcă, vârf ascuțit; (auto) autostradă cu plată

pile snop, morman; păr; pluş, smoc; (constr) pilot, stâlp, par; (el) pilă electrică, baterie, element galvanic; (TH) grămadă, stivă, pachet; a îngrămădi, a umple, a acumula, a rambleia, a ambala, a împacheta, a jalona, a stivui

pile bent $(\mathrm{OM})$ dispozitiv de fixare transversală, jug, travee

pile cocking (met) cocsificare în bocşă

pile driver (constr) berbec, sonetă

piled steel (met) oțel sudabil

piled-up group (fiz, met) aglomerare de dislocații

piled weight (met) greutate / masă în vrac

pile hammer (constr) sonetă, berbec pentru baterea piloților

piler (mas, transp) stivuitor, dispozitiv de stivuit

pile(-)up a îngrămădi; a stivui; a acumula; a umple; a rambleia; (nav) a eşua, a se pune pe uscat; (el) grup de conectare (cu arcuri)

pilger mill (met) laminor cu pas de pelerin (pilger)

pilger roll (met) cilindru pentru laminor, cu pas de pererin (pilger)

pilger (step-by-step) rolling mill (met) laminor cu pas de pelerin

pilger step-by-step welding (met, TH) sudare cu / în pas de pelerin

piling (constr) batere a piloților, stivuire (şi de marfă), formare de grămezi de material; (met) (îm)pachetare (a tablei)

piling device (mas, transp) dispozitiv de stivuit, stivuitor

piling furnace (met) cuptor pentru încălzirea pachetelor de tablă

piling hammer (constr) sonetă, berbec pentru baterea piloților

piling machine (mas, transp) maşină de stivuit

piling scrap (met) deșeuri de metal / fier vechi pentru pachetare

piling steel (met) oțel pentru palplanşe

piling-up stivuire, îngrămădire, aglomerare

pill (med, OM) pilulă, pastilă; fibre încolăcite formând mici ghemotoace pe suprafața unui compozit sau a unei țesături

pillar (el) stâlp, coloană de distribuție; (nav) pontil; (constr, OM) stâlp de reazem, montant, tijă, bară, coloană

pillar bolt $(\mathrm{OM})$ şurub distanțier

pillar bracket bearing $(\mathrm{OM})$ lagăr pe suport în consolă pillar circular saw (mas-un) ferăstrău circular pe coloană

pillar crane (mas, transp) macara cu coloană

pillar die (mas-un, OM) matriță cu coloane de ghidare

pillar drilling machine (mas-un) maşină de găurit verticală, cu coloană

pillar file pilă lată mică (mecanică fină)

pillar jib crane (mas, transp) macara turnantă, cu rază de acțiune constantă

pillarlike $(\mathrm{OM})$ în formă de coloană

pillar press (mas-un) presă cu coloană

pillar shaper (mas-un) maşină de mortezat, cu coloană

pillar support $(\mathrm{OM})$ coloană de reazem / de sprijin, suport vertical

pillar-type drill (mas-un) maşină de găurit, cu coloană

pilling (textile, plast, compozite) încolăcire a firelor sau fibrelor, ghemotoc de fibre format pe suprafata unei tesături sau a unui compozit

pill of aluminium (met) granulă de aluminiu pentru procese de reducere

pillow pernă; $(\mathrm{OM})$ cuzinet de lagăr (din material moale), suport moale

pillow block (OM) lagăr (principal), placă de reazem

pillow block bearing $(\mathrm{OM})$ lagăr cu cuzinet moale

pillow distorsion / strain (OM) distorsiune / deformare în formă de pernă

pilot (nav) pilot, pilotină, a pilota; (av) pilot, a pilota; (autom) semnal de comandă, a comanda, a dirija; (constr) stâlp, pilot; (el) fir pilot, întrerupător de forță; (OM) supapă-pilot / auxiliară, cep de centrare, fus de ghidare (şi la scule); a dirija, a conduce, a ghida

pilotage, piloting (nav) pilotare; (hidr) pilotaj; $(\mathrm{OM})$ ghidare

pilot bar $(\mathrm{OM})$ axă / tijă de ghidare

pilot beam (fiz) fascicul de ghidare

pilot bearing $(\mathrm{OM})$ lagăr / rulment de ghidare

pilot boat / cutter / launch / vessel (nav) pilotină, şalupă de pilot

pilot bushing (OM, mas-un) bucşă de ghidare / de conducere

pilot cell (el) element de control (la acumulatoare electrice); (metr, autom) celulă de comandă

pilot circuit (el, hidr, autom) circuitul de comandă (la un distribuitor cu comandă electrică etc.)

pilot controlled check valve (OM, hidr, autom) supapă de sens unic, pilotată

pilot controlled valve $(\mathrm{OM}$, hidr, autom) robinet / supapă / ventil pilotat/ cu servocomandă 
pilot controller (hidr, el, autom) controler de comandă; întrerupător de comandă, acționat direct pilot (control) port (OM, hidr) orificiu de comandă / de pilotare

pilot die (OM) matriță cu ştifturi / coloane de ghidare

pilot duty rating (el, autom) putere de închidere (la relee de timp)

pilot engine (met, cf) locomotivă de pilotare / de manevră

pilot flame (met) flacără de aprindere / de control (la suflai)

pilot hole (OM, mas-un) gaură / alezaj de ghidare

pilot indicator (autom, radio) semnal de ghidare piloting (nav, hidr) pilotare; ghidare; cercetarepilot; teste restrânse

pilot jet (auto, OM) jiclor de mers încet / de ralanti

pilot jet screw (auto, OM) şurub de reglare a aerului (la carburator)

pilot lamp / light (auto) lumină / lampă martor; (mas-un) lampă de semnalizare / de control

pilot model model-pilot / incomplet al unui sistem

pilot-operated (hidr, autom) pilotat (d. dispozitive hidraulice)

pilot-operated device (hidr, autom) dispozitiv de reglare a presiunii, pilotat

pilot pin $(\mathrm{OM})$ ştift de ghidare

pilot plant / unit instalație-pilot / experimentală

pilot pressure (OM, hidr) presiune pilot / de pilotare

pilot ray (fiz) fascicul de ghidare

pilot reamer (mas-un) alezor cu fus / cep de ghidare (şi la degroşare)

pilot relay (el, autom) releu de control / de supervizare / de semnalizare

pilot's bridge (nav) cabină de navigație / de comandă

pilot shoulder reamer (mas-un) lărgitor cu bacuri (de ghidare) în trepte

pilot signal (fiz, hidr, autom) semnal pilot / de comandă

pilot study studiu pilot / prealabil / de început

pilot tap (mas-un) tarod cu cep de ghidare

pilot test probă preliminară, test preliminar

pilot valve (OM, hidr, autom) ventil-pilot, supapa servomotorului, supapă-pilot / de comandă

pilot wave (fiz, autom, radio) undă-pilot / de comandă

pilot wheel $(\mathrm{OM})$ roată de mână

pilot wire regulator (termo, autom) compensator termic; regulator cu fir auxiliar / pilot pin (el) port-izolator, suport de izolator, pol, contact, ştift (de fişă); (OM) bolț, diblu, dorn, bulon, ştift, țăruş, pivot, ac (şi cu gămălie, de rulment), bold, deget, şplint, poanson, fus, cui, cep; (electr, OM) picioruș de componentă electronică; a bate în cuie, a fixa cu ştifturi / ace etc., a prinde cu; (metr, alim) unitate tradițională britanică de măsurare a volumului, utilizată pentru bere: 1 pin $\cong 20,457 \mathrm{l}$; v. polypin

pin base / cap (el, c) soclu cu picioruşe / cu contacte

pin bearing $(\mathrm{OM})$ rulment cu ace

pinboard (el) tablou de conexiuni

pin bushing $(\mathrm{OM}$, el) manşon / bucșă pentru fişă / ştecher

pincers $(\mathrm{OM})$ pensetă; (met) cleşte de tăiat / de trefilat / de tras sârmă

pinch (mec, OM) ştrangulare; ciupit(ură); ciupire; sfărâmare; a tăia cu cleştele; a strânge, a comprima; a ciupi; a apăsa; (met) încrețire la laminare; ondulație (de tablă); (metr, alim) unitate de măsură pentru volum, utilizată în rețete alimentare, „cât prinzi între degete”, vârf de cuțit, pic (propus şi neaprobat): 1 pinch $=1 / 16$ lingurițe $\sim 0,3 \mathrm{ml}$; (fig) criză, moment critic; (d. frig) a întepa; (d. foame) a chinui; (d. încălțăminte) a strânge, a jena; a roade; a fi strâmt; (d. încălțăminte) a jena; a fi zgârcit, avar; (geol) (d. un filon) a se îngusta

pin chain (auto) lănțiş̧or pentru prevenirea pierderii unei piese; (OM) lanţ articulat / cu eclise, lanț Gall

pin chanferer (mas-un) freză pentru pivoți

pinch bar (OM) pârghie; rangă; fier; drug

pinch bolt $(\mathrm{OM})$ surub de prindere / de strângere (la asamblarea pieselor secționate)

pinch(ed) base (OM, electr) picior reglabil / ajustabil (la piese electronice); (OM) postament, bază, suport

pincher $(\mathrm{OM})$ dispozitiv de prindere / de strângere pinch cock $(\mathrm{OM}$, hidr) robinet de ştrangulare pinch effect (fiz, OM) efect de ciupire (şi la aplicarea unei forțe electromecanice)

pinchers $(\mathrm{OM})$ cleşte, gheare

pinching screw (OM) şurub de strângere

pinch off die (OM, mas-un) ştanță pentru tăierea marginilor unei piese

pinch pass (met) calibru de laminare

pinch pass mill (met) laminor de dresare / de netezitor / de ecruisare

pinch pass rolling (met) dresare / laminare de ecruisare, netezire, planare

pinch pass rolling mill (met) laminor de dresare / de ecruisare / netezitor 
pinch roll (met, OM) rolă / cilindru de apăsare / de presare / de presiune

pinch roller unit (met, $\mathrm{OM}$ ) dispozitiv pentru tragerea benzii

pinch rolling (met, $\mathrm{TH}$ ) dresare / laminare de ecruisare, netezire, planare

pinch valve (hidr, OM) robinet de închidere cu manşon deformabil

pinch welder (mas-un) cleşte de sudat în puncte

pinch wheel (OM, plast) roată de presare (mecanică fină)

pin clamp (OM, mas-un) placă de presiune cu bolț / ştift de ghidare

pin clutch $(\mathrm{OM})$ cuplaj cu pană opritoare (la prese)

pin coupling $(\mathrm{OM})$ cuplaj cu bolțuri, asamblare cu ştifturi

pin drill (mas-un) burghiu cu fus de ghidare

pin-ended $(\mathrm{OM})$ articulat (cu ştift)

pine-tree (crystal / crsytallite) (met, chim) (cristal) dendrită

pine-tree structure (met, chim) structură dendritică

pin extractor (OM) extractor de cui spintecat / de ştift

ping (metr) unitate tradițională de măsură pentru arie în Taiwan: 1 ping $\sim 3,305 \mathrm{~m}^{2}$ (aceiaşi unitate este numită pyong în Korea); v. pyong

pin gauge (metr, OM) calibru vergea

pin groove-type of broach shank (mas-un) cap de antrenare, cu fixare prin ştift (la broşă sau alte scule)

pinguid (agr) gras, uleios, fertil (d. sol)

pin hinge $(\mathrm{OM})$ balama

pinhead blisters (met, plast) pori de suprafață, porozitate superficială

pin hole (fiz, metr) orificiu mic, por; carie (în lemn); (mas-un) gaură mică / pentru ştift; (met) bulă de gaz, suflură, retasură dispersă, defect ca rezultat al micilor pori prinşi, iniţial, într-o acoperire / sub suprafață

pinhole arrangement (OM) colimator, dispozitiv cu diafragmă îngustă

pinhole detector (metr, met, plast) detector de defecte / de pori mici (în table, folii în mișcare)

pinhole plug (of converter) (met) placă a duzelor (de turnare), fund de convertizor

pinholes (met) pori (şi de suprafață), porozitate superficială

pin insulator (el, OM) izolator şi cu rol de suport sau bolt

pinion (OM) pinion; (met) cilindru de antrenare / dințat (rar) pinion-and-rack $(\mathrm{OM})$ angrenaj pinion-cremalieră pinion-and-rack steering (auto) direcție $\mathrm{cu}$ pinion şi cremalieră

pinion gauge (metr, OM) calibru pentru măsurarea pinioanelor

pinion housing $(\mathrm{OM})$ carcasă de reductor / de angrenaj, transmisie cu roți dintate (și numai carcasa ei); (met) batiul cajei de laminare, cajă de angrenare

pinion leaf $(\mathrm{OM})$ dinte de pinion (rar)

pinion neck $(\mathrm{OM})$ fusul pinionului; (met) fusul cilindrului dințat

pinion shaft $(\mathrm{OM})$ arbore-pinion

pinion(-shaped) cutter (mas-un) cuțit-roată de mortezat roți dințate

pinion stand $(\mathrm{OM})$ carcasă (pt. angrenaj), reazem al arborelui-pinion; (met) cajă de angrenare

pinion steel $(\mathrm{OM}, \mathrm{met})$ oțel pentru pinioane

pinion type cutter (OM, mas-un) (sculă) cuțitroată

pin jack $(\mathrm{OM})$ bucsă miniaturală

pin / pinned joint (OM) asamblare cu ştifturi

pink roz, trandafiriu

pinking (auto, termo) bătaie, detonare, funcționare cu bătaie sau detonații (la motoare cu ardere internă)

pin-lift moulding machine / stripper (met) maşină de format cu ridicarea ramei prin știfturi pin mounting (hidr, OM) montare / fixare cu bolț(uri)

pinning $(\mathrm{OM})$ prindere, întărire, îmbinare / asamblare (şi cu ştifturi, pene), țintuire

pinpoint a indica cu precizie

pin(-)point weld (OM, met) sudură în punct

pin(-)point welding $(\mathrm{OM}$, met) sudare în puncte pin remover $(\mathrm{OM})$ dispozitiv de scos ştifturi

pin riveting $(\mathrm{OM}, \mathrm{TH})$ nituire cu formare concomitentă a ambelor capete ale nitului

pin spanner $(\mathrm{OM})$ cheie cu dinte

pint (p., pt.) pintă, halbă' unitate de măsură pentru volum: 1 pint $(\mathrm{UK})=0,571,1$ pint $(\mathrm{US})=0,47$ 1 ; pint (pt) (metr) a traditional unit of volume: 1 liquid pint $(\mathrm{US}) \cong 473,176 \mathrm{ml} ; 1 \mathrm{US}$ dry pint $\sim 550,611 \mathrm{ml} ; 1$ British Imperial pint $\sim 568,261$ $\mathrm{ml}$; (metr) a traditional unit of volume in Scotland: 1 Scots pint $\sim 1,708$ 1; pint (pt) (metr) unitate de măsură pentru volum, în Australian: 1 pint of beer $\sim 425 \mathrm{ml}$ în South Australia, 1 pint glass $\sim 560 \mathrm{ml}$ în Queensland

pin terminal (electr, OM) bornă cu picioruşe

pintle $(\mathrm{OM})$ ax vertical; pivot; fus; coadă cilindrică (la scule)

pintle nozzle / valve (OM, hidr, termo) injector supapă cu ac 
pintle-type atomizer / fuel (OM, hidr, termo) injector injector cu ac pentru combustibil

pin tongs (OM, mas-un) mandrină

pinwheeling (nav) întoarcere din maşini (la nave cu două elici)

pin wire (met) sârmă pentru cuie

pin with thread $(\mathrm{OM})$ fus (subțire / mic) filetat

pip, tick (metr, ec) cea mai mică valoare măsurabilă de variație pentru conversia unei valute; aceasza depinde de valută: în convertirea euro $\rightarrow$ dolar, 1 pip $=0,0001$, dar în convertirea US dolar $\rightarrow$ yen japonez, 1 pip $=0,01$; v. tick

pipa (metr, fiz) unitate tradițională portugheză de măsură pentru volum de lichid: 1 pipa $=5001$

pipe (el) tub de protecție, țeavă de legare la pământ; (met) pori de gaze, retasură dispersă, pâlnie de aerisire; (OM, hidr) conductă, țeavă, tub, canal, cilindru (gol) de ghidare; a curge / trece prin conductă; (constr) burlan, a instala într-o casă țevi-le; (bot, agr) a butăşi; a tivi; a vorbi pițigăiiat; (d. păsări) a cânta, a piui, a ciripi; a fluiera; (nav) fluier (de manevră), a comanda (prin semnale de fluier); (geol) filon; ciripit; pipă, lulea; (metr) unitate tradițională de măsură pentru volum de lichid: 1 pipe (US) $\cong 476,961$; 1 British pipe - unitate de măsură pentru volum pentru vin, va-loarea depinzând de regiune şi de tipul vinului

pipe arrangement (hidr) rețea de conducte pipe bearing pile (constr) stâlp / pilot tubular pipe bend / elbow /knee (OM, hidr) cot de conductă / de țeavă

pipe bender / bending machine (mas-un) maşină de îndoit țevi

pipe-bending bench (mas-un) banc pentru îndoirea țevilor

pipe bending tongs $(\mathrm{OM})$ cleşte de îndoit țevi

pipe billet (met) semifabricat pentru țevi

pipe blockage (hidr, mediu) înfundare / blocare a conductei

pipe branching (OM, hidr) branşament de țevi pipe bridge clip $(\mathrm{OM})$ brățară pentru suspendarea unei conducte

pipe buckling $(\mathrm{OM})$ flambaj de conductă

pipe bundle (termo, OM, nav) mănunchi / fascicul de țevi

pipe capacity (hidr) capacitate de transport a conductei

pipe carrier (OM) suport / reazem / şarnieră pentru conductă / țeavă

pipe casting (met) turnare a țevilor

pipe cavity (met) retasură de contracție

pipe choking / clogging (hidr, mediu) înfundarea conductei pipe clamp $(\mathrm{OM})$ brățară pentru prinderea țevii / conductei

pipe classifier (termo, OM) registru / catalog de țevi

pipe closer (OM, hidr) capac / dop pentru teavă / conductă, obturator (în general, dar şi flanşă oarbă de închidere a unei conducte)

pipe coat(ing) (OM, termo) izolație / acoperire a conductei / țevii

pipe coil $(\mathrm{OM}$, termo) serpentină de țeavă

pipe column (termo, nav, $\mathrm{OM}$ ) fascicul vertical de țevi / tubular

pipe conduit (hidr) rețea de conducte

pipe connection (OM, hidr) îmbinare între țevi / conducte, racord, ştut

pipe conveyor (ind chim, alim, termo) transportor tubular

pipe cooler (ind chim, alim) răcitor tubular

pipe cramp / crampet / hook (OM) crampon pentru tuburi izolante

pipe culvert $(\mathrm{OM}$, mediu) colector tubular pentru canalizare

pipe cutter / cutting machine (met, mas-un) maşină de tăiat țevi

pipe-cutting die (mas-un, OM) bac / filieră de filetat țevi

pipe dip $(\mathrm{TH})$ vopsire a țevilor prin cufundare

pipe key $(\mathrm{OM})$ cheie tubulară

pipe $\operatorname{dog}(\mathrm{OM})$ cheie pentru țevi

pipe drain (OM, hidr) tub / conductă de drenaj / de drenare

pipe drill (mas-un) burghiu tubular, carotieră

piped-type thermocouple (metr, termo) termocuplu tubular

pipe duct $(\mathrm{OM}$, hidr, termo) conductă

pipe elbow (OM, hidr) cot de conductă, racord circular

pipe elbow meter (metr, hidr) aparat pentru măsurarea curgerii în coturi de conducte / în conducte neliniare

pipe eliminator / eradicator (met, chim) substanță de protecție contra retasurilor

pipe extension (OM) adăugarea unei bucăți de țeavă

pipe fitter / layer / liner, pipeman (TH) instalator de țevi sau conducte

pipe fitting (OM, hidr) fiting, racord, îmbinare de conducte, garnitură, ştuț (tubular)

pipe fittings (OM, hidr) armături / fitinguri de conducte

pipe flange (OM) flanşă pentru conducte / țevi pipe formation (met) formare de retasuri pipe for fluids (OM, hidr) conductă pentru fluide pipe for pipe-line $(\mathrm{OM})$ țeavă pentru conductă 
pipe fracture (OM, hidr) rupere / spargere a unei țevi

pipe furnace (met, alim) cuptor tubular

pipe gang echipă de instalatori de țevi

pipe grip $(\mathrm{OM})$ cheie de țevi; cleşte cu lanț / articulat; cheie articulată

pipe hammer (hidr) şoc hidraulic, lovitură de berbec

pipe hanger (OM) agățător / suport suspendat pentru tevi

pipe hook (el, OM) crampon pentru tuburi izolante; $(\mathrm{OM})$ cleşte pentru țevi

pipe (hydraulic) casing-head (OM, hidr) cap de scurgere

pipe installation / work (OM, hidr, nav, termo) rețea de țevi / de conducte, conductă, (schema / planul de) aşezare a conductelor, ansamblu de conducte, de furtunuri sau țevi

pipe joint (OM, hidr) îmbinare a conductelor, mufă pentru un tub, manşon de țeavă

pipe laying / stringing (OM, hidr, termo, nav) aşezare / pozare a conductelor

pipe leading (OM, hidr, termo) țeavă de conductă

pipe-line (OM, hidr) conductă (lungă) (şi pentru transport de fluide la distanță)

pipe-liner cleaner $(\mathrm{OM}$, hidr) curăţitor de conducte pipe-line layout (OM, hidr) schemă de instalare / amplasare a conductelor

pipe-line run (materiale, transp) cantitate de propdus transportat prin conducte

pipe-line maintenance (met, OM) întreținere a rețelei de conducte

pipe-line orifice (OM, hidr) diafragmă

pipe-line processing $(\mathrm{TH}$, ind) prelucrare în cascadă / în linie

pipe-line pumping station (ind, hidr) staţie de repompare în conducte

pipe-line run (hidr) cantitate / volum de material transportat prin conductă

pipe-line scraper $(\mathrm{OM})$ racletă pentru curățarea țevilor

pipe-line strainer (OM, hidr) dispozitiv de separare / separator de impurități din conducte

pipe-line transportation (transp, hidr) transport prin conductă (de fluide)

pipe-line wrapping (OM, termo) izolație de conducte

pipelining (OM, hidr) pozare a conductei, pompare prin conductă

pipe manifold (OM, hidr, termo) claviatură, colector

pipe mill (met) laminor de țevi

pipe-moulding machine (met, mas-un) maşină de format țevi pipe nail (met, OM) cui / bucată de țeavă pentru susținerea miezului

pipe network / system (OM, hidr, termo, nav) rețea de conducte

pipe nipple (OM, hidr) niplu, racord pentru țevi pipe opener (termo) (activitate de) încălzire, dispozitiv / sistem de deschidere al conductelor pipe pile (constr, OM) pilot tubular (de susținere) pipe pitch (hidr) pantă hidraulică a conductei pipe plug (OM, hidr) dop (şi filetat) pentru țevi pipe precipitator $(\mathrm{OM}$, fiz, hidr) filtru electrostatic, tip țeavă

pipe prover / tester (metr, OM) dispozitiv de testat etanseitatea tevilor

pipe reamer (mas-un) alezor pentru țevi

pipe reduction / reductor $(\mathrm{OM}$, hidr) reducție pentru țevi

pipe rolling mill (met) laminor pentru țevi

pipe saddle $(\mathrm{OM})$ brățară / colier pentru țevi

pipe sampling (met, OM) luarea unei probe din teavă (prin țaiere)

pipe seal (OM, hidr) dop / capac de țeavă, obturator, etanşare a conductei

pipe section (met, hidr, termo, OM) tronson de țeavă

pipe schedule $(\mathrm{OM})$ specificație pentru tevi, grosime normală / nominală pentru peretele țevii pipe sealing compound $(\mathrm{OM}$, ind chim) material (compozit, amestec) pentru etanşarea țevilor pipe section (OM, hidr) tronson de țeavă pipe segregation (met) segregare în jurul retasurii de contracție

pipe sewer (constr, OM) canalizare cu tevi / conducte

pipe slicing $(\mathrm{TH})$ tăierea țevilor

pipe-slicing lathe (mas-un) strung pentru retezat țevi

pipe socket (OM, hidr) flanşă / manşon de țeavă, mufă de tub

pipe spanner $(\mathrm{OM})$ cheie pentru țevi (cu lanț)

pipe-spinning machine (met, mas-un) maşină de turnat țevi, centrifugal

pipe still cuptor tubular

pipe stock (OM) filet pentru țevi, clupă

pipe-stock die (mas-un) cap de filetat

pipe strap $(\mathrm{OM}$, termo, hidr) brățară / colier pentru țevi

pipe string (met, termo, OM) grup de țevi paralele pipe stringing / laying (OM, constr) pozare / aşezare a conductelor

pipe support (OM) suport de țeavă

pipe tap (mas-un) tarod pentru țevi; (hidr) orificiu într-o conductă pentru montarea unui aparat de măsură 
pipe thread (OM, hidr) filet de etanşare (pt. țevi), filet la o țeavă

pipe threading lathe / machine (mas-un) maşină / strung de filetat țevi

pipe threading tool (mas-un) clupă / sculă de filetat țevi

pipe thread protector $(\mathrm{OM})$ protector de filet la țevi (în transport sau înmagazinare)

pipe thread tap (mas-un) tarod / dispozitiv de filetat la interior, pentru țevi

pipe thread where pressure-tight joints are made on the threads (OM, hidr) filet pentru țevi cu etanşare în / pe filet

pipe tongs (met, $\mathrm{OM}$ ) cleşte pentru țevi

pipette $(\mathrm{OM}$, chim) pipetă

pipe-type precipitator $(\mathrm{OM}$, fiz) filtru electrostatic cu țevi / tip comandă

pipe union (OM, hidr) racord (olandez) de conductă

pipe union nipple (OM, hidr) racord / niplu de legătură / de racordare a tevii

pipe vice $(\mathrm{OM})$ menghină pentru țevi

pipeway (met, constr) galerie / tunel pentru conducte

pipe welding (met, $\mathrm{TH}$ ) sudare a țevilor

pipe welding machine / plant (met) maşină / instalație pentru sudarea țevilor

pipe wrench $(\mathrm{OM})$ cheie (cu lanț) pentru țevi; cleşte pentru țevi

piping (OM, hidr, termo, nav) tubulatură, țevărie, instalație de conducte (pentru gaze, fluide), tevi, tuburi, pompare prin conducte, pozare a conductelor; (met) formare a retasurilor

piping diagram / layout (constr, nav, OM) schemă de amplasare a conductelor / a tubulaturii

piping effect (ind chim, plast) formare de goluri (la turnarea răşinilor izolante)

piping pressure (hidr) presiunea de deschidere a unei supape de siguranță

piping system (OM, constr, termo) rețea / sistem de conducte

piquancy (alim) caracter picant / condimentat; (fig) caracter nostim; picanterie

piquant (alim) picant, înțepător, condimentat, iute; (fig) nostim, picant

piqué (textile) pichet

piracy (nav) piraterie; plagiat, furt literar; (hidr, constr) captare a unui curs de apă

Pirany gauge (metr, constr) manometru cu fir cald / tip Pirany

pirn (textile) cops; (OM) țeavă de fir

pisciculture (iht, alim) piscicultură

piscine piscină; bazin de înot pisolite (minrl) pisolit, oolit

pissasphalt (ind chim, constr) asfalt, bitum natural

pistachio (alim) fistic; (culoare) fistic

pistil (agr, bot) pistil

pistol (OM, TH) pistol (şi de pulverizat / vopsit, pentru sudură), revolver; (mil) a trage / împuşca cu pistolul

pistol-shot noise pocnet, detunătură

pistol stock $(\mathrm{OM})$ mâner al pistolului de vopsit / de pulverizat

piston (OM, termo, hidr) piston, poanson

piston air motor (hidr) motor pneumatic cu piston / pistoane

piston area (OM, hidr, termo) suprafața pistonului (hidraulic, de motor)

piston blast engine (met, OM) suflantă cu piston

piston clearance (OM, auto, nav, termo) joc al pistonului

piston compressor (termo) compresor cu piston

piston crown (OM, termo) cap de piston, fund / calotă de piston

piston displacement (hidr, termo, auto) cilindree, capacitate cilindrică, debit al pompei

piston drive (hidr, plast) acționare cu piston

piston engine (termo, auto) motor cu piston / pistoane

piston head / top (OM) cap / fund de piston

piston head capacity (auto, termo, hidr) capacitate cilindrică

piston motor (OM, hidr, termo) motor cu piston / pistoane (şi hidraulic)

piston packing (OM, termo) garnitură (şi de etanșare) de piston

piston-packing leather (OM, termo, hidr) garnitură de etanşare a pistonului

piston path stroke / travel $(\mathrm{OM}$, termo, hidr) cursă a pistonului

piston pin (OM, termo, hidr) bolț de piston

piston pin boss $(\mathrm{OM}$, termo, hidr) umăr pentru bolt de piston, ureche de piston

piston pin bush(ing) (OM, termo, hidr) bucşă a bolțului de piston

piston pin knock (OM, termo, hidr) bătaie a bolțului de piston

piston pin locking screw (OM, termo, hidr) şurub de fixare a bolțului de piston

piston pin lock ring (OM, termo, hidr) inel Seeger / de fixare a bolțului de piston

piston-position time diagram $(\mathrm{OM}$, termo, hidr) diagramă cursă (a pistonului) - presiune

piston pressure $(\mathrm{OM}$, termo, hidr) presiune de piston 
piston pump (OM, termo, hidr) pompă cu piston (mai rar, cu pistonaşe)

piston ring $(\mathrm{OM}$, termo, hidr) segment de piston piston ring clearance $(\mathrm{OM}$, auto, termo) joc al segmentului de piston

piston ring compressor compresor / cu piston şi segmenți

piston ring expander $(\mathrm{OM}$, termo) cleşte pentru montat segmenții în canalele lor

piston-ring flutter $(\mathrm{OM}$, termo) vibrare a segmenților în canalele lor

piston-ring gap $(\mathrm{OM})$ joc al segmentului de piston

piston-ring grinding machine (mas-un) maşină de rectificat segmenti de piston

piston-ring groove $(\mathrm{OM}$, termo) canal pentru segment de piston

piston-ring joint / lock $(\mathrm{OM})$ siguranță a segmentului de piston

piston-ring removing pliers $(\mathrm{OM})$ cleşte pentru demontat segmenți

piston ring seal (OM, termo) segment de piston, pentru etanşare / etanşare-ungere

piston-ring side clearance $(\mathrm{OM})$ joc lateral al segmentului în canal

piaton-ring spreader dilatator de segmenți

piston ring tightener $(\mathrm{OM}$, termo) dispozitiv de strâns / montat segmenți de piston

piston-ring tongs $(\mathrm{OM})$ clește pentru demontarea segmenților de piston

piston rod $(\mathrm{OM})$ tija pistonului

piston rod area $(\mathrm{OM})$ suprafața / aria tijei pistonului

piston rod attachment (OM, hidr) (dispozitiv de) fixare a tijei pistonului

piston rod coupling $(\mathrm{OM})$ articulație a tijei de piston

piston-rod end $(\mathrm{OM})$ cap al tijei de piston

piston rod guide $(\mathrm{OM})$ ghidaj al tijei de piston

piston rod knuckle $(\mathrm{OM})$ articulație (şi sferică) a tijei pistonului

piston scraper ring (OM, termo) segment raclor al pistonului

piston skirt / cap $(\mathrm{OM}$, termo) cămaşă / manta de piston

piston skirt slot $(\mathrm{OM})$ fantă a cămășii pistonului piston speed $(\mathrm{OM})$ viteza pistonului

piston ring spreader $(\mathrm{OM})$ dilatator de segmenți piston spring (OM, hidr) arc de piston (la pompe)

piston stroke / path / travel (OM, termo, hidr) cursă a pistonului

piston surface $(\mathrm{OM}$, termo, hidr, T) suprafață a pistonului

piston-type engine (hidr, termo) motor / pompă cu piston / cu pistoane piston-type variable-area flowmeter (metr, hidr) debitmetru cu piston, deplasarea lui fiind proporțională cu mărimea de măsurat

piston valve (OM, hidr) supapă de distribuție tip piston, sertar cilindric, piston de reglare a presiunii

piston with baffle (OM, hidr) piston cu deflector

piston with double rod (OM, hidr) piston $\mathrm{cu}$ dublă acțiune (la cilindri hidraulici, prese etc.)

pit (constr) groapă, gaură, adâncitură, scobitură, cavitate; tranşee, parter; (met) retasură (într-o piesă turnată), pată de rugină, coroziune punctiformă, a coroda punctiform; carieră, balastieră, canal / puț de vizitare; a îngropa (şi legume etc pentru păstrare), a face gropi în; (amer) sâmbure (de fruct); a scoate sâmburii din; (T) ciupitură (cu referire în special la uzură, coroziune), a ciupi; a îngropa; a scobi

pit against a-şi concentra toate forțele împotriva; ( $\mathrm{T}$, chim) a ciupi dintr-un material

pit casting (met, constr) turnare în sol(ul turnătoriei)

pit for cables (met) canal / puț de cabluri

pitch (geol, av) înclinare (şi longitudinală), pantă; (nav) tangaj, pas (axial) al elicei, a avea tangaj, a tanga; (ind chim) răşină, smoală, gudron, catran, răşină; a asfalta, a gudrona, a smoli; (el) pas al înfăşurării; (fiz) înălțime a sunetului, grad, nivel, treaptă; $(\mathrm{OM})$ divizare, diviziune, pas (la filet, dantură etc.), modul, camă de ghidare, a (se) angrena, a se îmbuca; nivel, treaptă, grad; aruncare, azvârlire; ridicare, înălțare; (textile) finețe a mașinii; a ridica, a înălța, a (se) instala; a se stabili; a arunca, a azvârli; a fixa / pune / aşeza la un anumit nivel / într-un anumit punct; a se apleca, a se lăsa, a se înclina (d. un acoperiş etc.); (metr, tipografie) altă denumire pentru ,,characters per inch"-, ,caractere pe inch / țol”; (bot, anat) măduvă; (muz) a acorda; (fig) energie, putere esență, miez, importanță; (mil) (şi fig) a aşeza în ordine de bătaie; a cădea (cu capul în jos); a face (un cort), a face tabăra, a instala (o tabără)

pitch angle (nav) unghi de tangaj; (OM, masun) unghi de divizare / de înclinare

pitchblende (minrl) pehblendă

pitch circle (p.c.) (OM) cerc de divizare (la roți dinţate / de lanţ / de curele dințate etc.), cerc primitiv (la roți de curea trapezoidală)

pitch cylinder $(\mathrm{OM})$ cilindrul de divizare pitch coke (met) cocs de bitum

pitch cone $(\mathrm{OM})$ con de divizare / de rostogolire (la angrenaje conice)

pitch cone angle $(\mathrm{OM})$ unghiul conului de divizare (la o roată dințată conică) 
pitch cone run out $(\mathrm{OM})$ bătaie / abatere a conului de divizare

pitch control (nav) reglare a pasului elicei; (OM, mas-un) reglare / control a(l) pasului (la danturare), controlul divizării

pitch-control box (nav) mecanism de reglare a pasului elicei; (mas-un) mecanism de reglare a divizării / a pasului

pitch diameter $(\mathrm{OM})$ diametru de divizare $(\mathrm{d})$ (la roți dințate) diametru mediu (şi la arcuri elicoidale) / inițial / primitiv (la roți de curea)

pitched face (chim, T) suprafață impregnată

pitch factor (el) factor de scurtare (al unui bobinaj)

pitcher ulcior; (constr) târnăcop, piatră de pavaj

pitch error (OM, mas-un) eroare a pasului / a divizării

pitch feed (mas-un) avans pe dinte

pitchfork (agr, OM) furcă

pitch formation (termo, auto) ancrasare

pitch indicator (OM, metr) dispozitiv de măsurat pasul unui filet

pitching (constr) blocaj, blocare fundație pentru drumuri; înclinare; (nav) tangaj; (av) cabrare

pitching bore (mas-un) burghiu-daltă

pitching moment (mec) moment de răsturnare; (av) moment longitudinal

pitching motion mișcare de galop; (nav) tangaj

pitch into a se năpusti asupra; a se repezi la

pitch line $(\mathrm{OM})$ linie divizoare (mediană / de rostogolire (la cremalieră), cerc primitiv / de rulare / de divizare (rar)

pitch line of groove (met) axă a calibrului de laminare

pitch line of spur gear (OM) cerc de divizare (la roți cu dinți drepți)

pitch of centres (mas-un) înălțime a vârfurilor / axei strungului

pitch of chain (OM) pas al lanțului

pitch of fins (termo, hidr) desime a nervurilor; număr de nervuri / de aripioare pe unitatea de lungime a tevii, pas al aripioarelor

pitch of holes $(\mathrm{OM})$ pas al găurilor (pe cercul de distribuire a şuruburilor de fixare, pe un guseu, la nituire, la asamblarea pieselor cu şuruburi etc.)

pitch of propeller (OM, nav) pas al elicei

pitch of rivets $(\mathrm{OM})$ pas al nituirii

pitch of screw (OM) pas al filetului / al şurubului / al melcului

pitch of teeth $(\mathrm{OM})$ pas al danturii (între dinţi)

pitch of thread (OM) pas al filetului

pitch of tone (fiz) înălțime / frecvență a sunetului pitch of weld $(\mathrm{OM})$ pas al sudurii (discontinue sau în puncte)

pitch of winding (el) pas de înfăşurare

pitchover (OM, mas-un) (punct de) basculare

pitch point $(\mathrm{OM})$ punct de rostogolire / pe cercul de divizare / de rostogolire, polul angrenării (la roți dințate)

pitchpole (agr) scarificator

pitch radius $(\mathrm{OM})$ raza cercului de divizare (la roți dințate) / cercului primitiv (la roți de curea)

pitch ratio (nav) pas relativ al elicei

pitch residuu (ind chim, mediu) reziduu de smoală

pitchstone (geol) rocă bituminoasă; (constr) piatră cioplită

pitch-to-foot indicator (metr) dispozitiv de verificat pasul danturii la ferăstrău

pitch tolerance $(\mathrm{OM})$ toleranța pasului (la filete, roți dințate etc.)

pitch trimmer (nav, autom) dispozitiv automat de reglare a pasului elicei

pitch upon a se opri la; a alege; a se hotărî asupra

pitchy cu smoală; smolit; (ca) de smoală; negru; foarte întunecos

pit coal (termo) cărbune bituminos, huilă

pit corrosion (met, $\mathrm{T}$, chim) coroziune în puncte / punctiformă / în pete

pit fire (met) cuptor cu creuzet

pit for cables (met, el, constr) canal / puț pentru cabluri

pit foundry work (met) groapă de turnare

pit furnace (met) cuptor cu cuvă / vertical / adânc / cu creuzet (pt. încălzire sau topire)

pit furnace cover (met) capacul cuptorului $\mathrm{cu}$ cuvă / vertical / adânc / cu creuzet

pit furnace crane (met) pod rulant (cu macara care deserveşte cuptorul adânc)

pit gas (indchim, termo) gaz metan

pit gravel balast de carieră, pietriş

pith (el) miez; sâmbure; nucleu; inimă; măduvă (de lemn); (alim) măduvă; (fig) esență; importanță; putere; energie

pit heating furnace (met) cuptor adânc de încălzire (a lingourilor)

pit kiln (met) cuptor de cocs / adânc

pit lathe (mas-un) strung cu batiu îngropat

pitman (OM, mas-un) bielă a balansierului / excentricului

pit moulding (met) formare în sol

Pitot tube (metr, hidr) tub Pitot

Pitot-Venturi tube (metr) tub combinat PitotVenturi

pit planer (mas-un) raboteză cu groapă / cu canal pits (met, T, chim) pori; pete / puncte de coroziune; ciupituri; rezultatul pitting-ului 
pit saw (mas-un) ferăstrău de despicat

pittance (ec) salariu derizoriu, câștiguri derizorii, venituri modeste; parte / cantitate neînsemnată

pitted (materiale, OM, T, chim) cavernos, ciupit (prin uzură sau/şi coroziune în puncte), cu gropi / gropițe

pitted contact / surface ( $T$, chim) contact / suprafață prezentând uzură pitting / de ciupitură sau / şi cu coroziune în puncte

pitted valve (OM, hidr, T) supapă / corodată / ciupită / roasă (neuniform)

pitticite (met) arsură de fier

pit timber (constr) lemn de cofraj

pitting formare de ciupituri / microcratere; (met) formare a petelor / cavităților / adânciturilor de coroziune; $(\mathrm{OM}, \mathrm{T})$ uzură de ciupitură, pitting (la contacte de rostogolire sau rostogolire cu alunecare, de exemplu, la roți dințate), uzură (tip) pitting / ciupitură (şi de natură chimică)

pivot $(\mathrm{OM})$ pivot, ax, articulație, lagăr oscilant, axă / punct de rotire, a pivota, a monta un pivot pivotal (TH) axial, central

pivotal interval (OM, mas) pas de pivotare

pivotally attached $(\mathrm{OM})$ îmbinat / ataşat prin articulație / prin mișcare de pivotare

pivotal points (mec, el, hidr) noduri de rețea (şi la modelare cu element finit)

pivot axis $(\mathrm{OM}, \mathrm{mec})$ axă de rotație / de pivo$\mathrm{t}($ are)

pivot bearing $(\mathrm{OM}, \mathrm{T})$ lagăr oscilant / pivotant / basculant, crapodină

pivot bolt $(\mathrm{OM})$ bolț rotativ / pivotant

pivot cent(e)ring and drilling tool (mas-un, auto) dispozitiv de găurit şi înlocuit pivotii

pivoted $(\mathrm{OM})$ rotativ, oscilant, pivotant

pivot gauge (metr, auto) calibru pentru pivoți pivoting $(\mathrm{TH}, \mathrm{mec}, \mathrm{OM})$ pivotant turnant, rotativ, care pivotează

pivoting arm (constr, met) grindă pivotantă (şi la poduri rulante)

pivoting motion (mec, OM) (mișcare de) rotire / pivotare / pivotare / oscilare în jurul unei axe

pivot jaw (el, OM) contact pivotant / rotitor al unui întrerupător-cuțit

pivor joint $(\mathrm{OM})$ articulație cu pivot

pivot mounting $(\mathrm{OM})$ fixare oscilantă / pe pivot

pivot on a depinde de (fig) a se învârti în jurul (unei chestiuni, soluții)

pivot pin (auto, OM) ax de fuzetă; $(\mathrm{OM})$ ax de pivot / de pivotare, fus de basculare, rotulă

pivot pin bush (auto, OM) bucşă / cuzinet pentru pivot (şi al fuzetei)

pivot reamer (mas-un) alezor autocentrant pivot seat $(\mathrm{OM})$ scaun turnant / rotitor

pixel, picture element (PEL, pel) (metr, c) element / punct de imagine, unitate de date, „punct” în televiziunea digitală, unitate de măsură a rezoluției unei imagini; diametrul pixel-ului se măsoară în $\mu \mathrm{m}$

pk (metr) simbol pentru pack; v. pack

placard placardă, pancardă, afiş; a pune afişe / plancarde pe / în

place spațiu; loc; situație; (geogr) punct terestru; poziție; regiune, stațiune; locuință, casă, vilă; ordin; loc de naștere; oraș; serviciu, rang, loc; a pune; a aşeza, a situa; a aranja (într-o anumită ordine); a stivui; a plasa; a numi, a pune (într-un post); (ec) a plasa (şi mărfuri), a investi (bani), a încheia (un contract), a vinde; a recunoaşte; a localiza, a determina locul; $(\mathrm{TH})$ a amplasa

place an order $(\mathrm{ec})$ a face o comandă

place in the circuit (autom, electr, hidr) a introduce / a conecta în circuit

place in matrix a încorpora, a însera, a intercala (şi material de adaos într-un compozit)

placement, placing $(\mathrm{TH}$, ind) amplasare; punere (în operă); plasare; (ec, adm) plasament; aranjare

place of application (mec, fiz) punct de aplicare / de atac

place of contact (el, mec) punct / loc de contact / de atingere

place of embarkation (nav) loc de îmbarcare

place on a plasa; a aplica

place setting (alim) tacâm; (constr) amplasare / montare pe teren / în situ

placing aşezare, plasare; plasament, loc; situație; poziție; (auto) depozitare, parcare

placing of concrete (constr) punere în operă / turnare a betonului

placing out of operation / running ( $\mathrm{TH}$, mas) scoatere din functiune / din actiune / din functionare

placings (ec) emitere de acțiuni la preț fix

placket (textile) şliț (la rochie), buzunar (şi la fustă)

plagiarize a plagia

plagiary plagiat, furt literar; plagiator

plaid (textile) pled, pătură

plain (el) sârmă blanc; (geogr) câmpie, şes; plan; neted; clar; simplu; obişnuit; $(\mathrm{OM})$ fără filet; (mas-un) fără gradații; (corp / piesă) plin(ă); limpede, evident, clar; (textile) (d. scris) citeț, lizibil, inteligibil; (d. o haină) simplu, uni, făă imprimeuri; $(a d v)$ (în mod) clar, limpede, cu claritate 
plain basic steel (met) oțel bazic, nealiat plain bearing $(\mathrm{OM}, \mathrm{T})$ lagăr (de alunecare) monobloc / plin

plain bed (mas-un) pat simplu (fără degajare / scobitură etc.)

plain bending die (mas-un) ştanţă simplă de îndoit

plain border chenar simplu (şi în desen tehnic)

plain butt weld (met, OM) sudură cap-la-cap, cu margini drepte

plain cable (el, met) cablu fără înveliş de protecție

plain carbon steel (met) oțel carbon / nealiat

plain chocolate (alim) ciocolată simplă

plain coil (el, electr) bobină de inducție fără vibrator

plain concrete (constr, met) beton simplu, nearmat sau slab armat

plain dealing cinste, corectitudine; sinceritate, franchețe

plain die (met, OM) matrită deschisă

plain division $(\mathrm{TH}, \mathrm{OM})$ divizare a suprafeței (şi la modelare cu element finit)

plain drawing dies (OM, mas-un) ştanță simplă de tras

plain-end pipe $(\mathrm{OM})$ țeavă simplă nefiletată, burlan drept

plain fit (OM) ajustaj obişnuit / clasa de precizie 4 ...6

plain flour (alim, agr) făină simplă

plain (friction) bearing $(\mathrm{OM}, \mathrm{T})$ lagăr de alunecare, monobloc

plain girder (mec, constr) grindă cu inimă plină

plain grinder (mas-un) maşină de rectificat rotund (la exterior)

plain grinding (mas-un) rectificare cilindrică

plain grinding machine (mas-un) maşină de rectificat circular, la exterior

plain grinding wheel (mas-un) corp abraziv cilindric, roată cilindrică de rectificare

plain harmonic (mec) mişcare sinusoidală

plain indexing (mas-un) indexare directă

plain joint $(\mathrm{OM})$ îmbinare / lipire cu clei, încleiere

plain jolting machine (OM, alim, agr, ind chim) masă vibratoare / oscilantă

plain-laid rope (nav) parâmă simplă

plain language text / limbaj clar

plain milling (mas-un) frezare simplă / obişnuită / paralelă cu axa frezei

plain milling-cutter (mas-un) freză simplă / obişnuită / cilindrică

plain milling-machine (mas-un) maşină de frezat / freză orizontală, simplă plainness simplitate (de stil etc.); lipsă de ornamentație; claritate; inteligibilitate, caracter inteligibil; caracter limpede / evident; caracter deschis / evident / direct

plain piston ring (auto, termo, OM) segment de piston, cu suprafața exterioară cilindrică

plain rest (mas-un) sanie simplă

plain ring gauge (metr, $\mathrm{OM}$ ) calibru-inel

plain rod $(\mathrm{OM}$, met) electrod neînvelit pentru sudură

plain roll / roller (met, OM) cilindru neted (de laminor)

plain roof (met, termo) boltă fără nervure (la un cuptor etc.)

plain running fit $(\mathrm{OM})$ ajustaj simplu larg / cu joc mare

plain sheared end $(\mathrm{OM})$ vârf plat, fără teşitură (la asamblări filetate)

plain sifter (OM, agr, constr) sită plană

plain sliding fit (OM) ajustaj simplu alunecător

plain soldering iron $(\mathrm{OM})$ ciocan de lipit

plain solid mandrel (OM, mas-un) dorn simplu (fix) cu găuri de centrare

plainspiral $(\mathrm{OM})$ înfăşurat / înfăşurare pe muchie / plat, spiră / spirală plană (la arcuri, bobine, termorezistențe etc.)

plain steel (met, el) tub plin din oțel, (semifabricat plin din) otel carbon obișnuit

plain surface $(\mathrm{OM})$ suprafață netedă, fără aripioare sau nervuri de răcire

plain thermite (met) termit simplu

plaint (jur) acuză, acuzație, plângere, învinuire

plaintiff (jur, ec) reclamant

plain time rate $(\mathrm{ec})$ tarif de plată simplu (fără prime, pe unitatea de timp / oră, zi etc.)

plain tube / pipe (OM, hidr, termo) tub / țeavă neted(ă) / fără nervuri

plain turning (mas-un) strunjire simplă a suprafetelor exterioare

plain turning tool (mas-un) cuțit de strung normal / de trecere

plain view $(\mathrm{OM})$ vedere (totală) în plan (fără secțiuni) (în desen tehnic)

plain web girder (mec, constr) grindă cu inimă plină / continuă

plain writing scriere clară

plait (textile, OM) şnur; împletitură; pliu (la confecții), fald; bandă împletită; a împleti; a plia, a îndoi, a face falduri (d. semifabricate subțiri, folii, hârtie, țesături)

plaiting împletire

plaiting thread (textile) fir de vanisare

plaiting thread guide (textile, $\mathrm{OM}$ ) conducător / ghidaj al firului de vanisare 
plan proiect; schemă; schiță; desen; diagramă; intenție; presupunere; anticipare; sistem; plan (de ansamblu); (geogr, constr) hartă la scară mare; desen (tehnic), secțiune sau proiecție orizontală; gând(uri); $(\mathrm{TH}$, ec) a proiecta; a schița; a planifica; a face un plan, a plănui; a intenționa; (fig) a ascunde ceva

plan approach angle (mas-un, OM) unghi de atac principal (la scule aşchietoare)

planar (mat) plan; (OM) plat

plan area $(\mathrm{OM})$ aria secțiunii (transversale)

Planck's constant (fiz) constanta lui Planck

plane (geogr) câmpie, şes; platou, podiş; $(\mathrm{OM})$ fată, fatetă; (mas-un) raboteză, mașină / dispozitiv de şlefuit; (geom) plan, suprafață plană; rindea (pt. lemn); (silv) platan (copac); (fiz) față / faţetă a unui cristal; (av) aeroplan, (aripă de) avion, a merge în zbor lin, a plana, a zbura (cu avionul); (adj) plan, neted, plat; întins; (TH) a rabota, a netezi, a şlefui, a aplatiza, a face plată (o suprafată), a nivela, a îndrepta, a rindelui, a se rindelui (uşor, greu) (d. lemn); a gelui; a egaliza; (fig) plan, bază, nivel (de cunoştințe etc.)

plane angle (geom) unghi (plan) al unui diedru

plane cutter (mas-un) cuțit de raboteză / de rindea

plane defformation / strain (mec, OM) deformație plană / în plan

planed goods (ind, silv) cherestea geluită

plane down a egaliza; a aduce în acelaşi plan

planed tooth (mas-un, OM) dinte obținut prin rabotare / mortezare

plane frame(work) (OM, constr) cadru plan

plane geometry (geom) geometrie plană

plane grate (termo, OM) grătar plan

plane grating (el, hidr, OM) rețea plană (și de noduri în modelare cu element finit)

plane grinding machine (mas-un) maşină de rectificat plan

plane iron / knife (mas-un) cuțit de rindea / de geluit (lemn)

plane milling (mas-un) frezare plană

planeness $(\mathrm{OM})$ planitate, planietate

plane of action $(\mathrm{OM})$ planul de acționare

plane of bedding (alim, OM, mediu, hidr) plan de stratificație (şi la filtre)

plane of bending (mec, OM) plan de încovoiere

plane of buoyancy (nav) plan de carenă / de plutire

plane of cable layout (el, constr) plan de traseu / de pozare a cablurilor

plane of clivage (fiz) plan de clivaj

plane of contact $(\mathrm{mec}, \mathrm{T})$ plan de contact plane of cross section $(\mathrm{OM})$ plan al secțiunii transversale

plane of curvature (osculating plane) (mat, mec) plan osculator

plane off (mas-un) a degroşa

plane of failure / fracture (OM, mec) plan / suprafață de rupere / de fractură

plane of flexure (mec, OM) plan de încovoiere

plane of oscillation (mec, OM, fiz) plan al oscilației

plane of projection $(\mathrm{OM})$ plan de proiecție (în desen tehnic)

plane of reference (metr, opt) plan de referință / de focalizare

plane of shear (mec, OM) plan de forfecare

plane of sighting (OM, metr, opt) plan al vizorului

plane of symmetry (mat, fiz, OM) plan de simetrie plane of vision (anat, fiz, opt) plan / câmp vizual plane-parallel (OM) plan-paralel

plane-parallel flow (hidr, materiale) curgere bidimensională / în 2D / plan-paralelă

plane problem (mec, geom) problemă plană / în plan

planer (constr) mai, maşină / agregat de îndreptat / nivelat (un drum); maşină de îndreptat / de rindeluit, rindeluitor; (mas-un) raboteză, (dispozitiv, muncitor) rabotor; (poligrafie) bătătoare, călfuță

planer and shaper gauge (mas-un, metr) dispozitiv pentru reglarea precisă a cuțitelor de raboteză sau şeping

planer and shaper vice (mas-un, OM) menghină de maşină (la raboteză sau şeping)

planer centres (mas-un, OM) păpuşi cu vârfuri la raboteză

planer chuck (mas-un, OM) menghină a rabotezei planer dog (mas-un, OM) limitator la schimbătorul de sens al mesei (la raboteze)

planer fixture (mas-un, OM) dispozitiv de rabotat planer jack (mas-un, OM) cric pentru aşezarea pieselor pe masa rabotezei

plane-round (mas-un, TH) a rabota o suprafață cilindrică

planer rail (mas-un, OM) traversă a rabotezei

planer shoe (mas-un, OM) sabot de fixare a piesei de prelucrat pe masa rabotezei

planer table (mas-un, OM) masa rabotezei

planer tool (mas-un) cuțit de rabotat / de şeping

planer-type milling machine (mas-un) maşină de frezat longitudinal (tip raboteză)

planer-type surface grinder / grinding machine (mas-un) maşină de rectificat plan tip portal 
planer vice (mas-un, OM) menghină de maşină planer work (mas-un, TH) operație de rabotare, lucru la raboteză / şeping

plane sealing surface $(\mathrm{OM})$ suprafață plană de etanşare

plane-sided (OM, constr) cu pereți plani

plane sifter / sifting apparatus / machine $(\mathrm{OM})$ sită plană (cu acţionare mecanică)

plane stress $(\mathrm{mec}, \mathrm{OM})$ stare plană de tensiuni

plane surface (geogr) teren plat, platou, câmpie, şes; (OM) suprafață frontală; (geom) suprafață plan, plan

plane table (ec) bază de proiectare / de planificare

plane-table sheet (metr, OM) placă de verificare

planetary planetar; (chim) orbital

planetary gear(ing) $(\mathrm{OM})$ transmisie planetară, planetar

planetary gear train $(\mathrm{OM})$ angrenaj planetar, tren de angrenaje planetare

planetary mixer amestecător planetar

planetary motion $(\mathrm{OM}, \mathrm{mec})$ mişcare planetară

planetary (motion) paddle agitator planetar

planetary mill (alim) moară cu mecanism planetar

planetary pinion (OM) satelit la angrenajul planetar, pinion /roată central(ă) (la o transmisie cu mai multe ieşiri / ramuri)

planetary rolling mill $(\mathrm{OM})$ laminor planetar

planetary shaft $(\mathrm{OM})$ arbore planetar

planetary spindle $(\mathrm{OM})$ ax / arbore cu mişcare planetară, arbore port-satelit

planetary / planet wheel (auto, OM) pinion / roată de planetar, (roată-)satelit

planet gear $(\mathrm{OM})$ roată planetară

planet gearing $(\mathrm{OM})$ angrenaj planetar

planet motion (mec, OM) mişcare planetară

planet pinion gear $(\mathrm{OM})$ angrenaj planetar $\mathrm{cu}$ roată centrală / cu pinion / transmisie planetară

planet power drive $(\mathrm{OM}$, mas) actionare $\mathrm{cu}$ planetar de putere

planet stirrer (alim, ind chim) agitator planetar planet (wheel) carrier (OM) port-satelit

planimeter (metr, OM) planimetru

planimetry (geom) geometrie plană; (metr) planimetrie

planing geluire, rindeluire (pt. lemn); (mas-un) rabotare, prelucrare la şeping; glisare

planing cut (mas-un) aşchiere plană, rabotare

planing fixture (mas-un) dispozitiv de rabotat

planing jig (mas-un, OM) dispozitiv de strângere la raboteză planing knife cuțit de geluit / de rindeluit (pt. lemn)

planing machine maşină de rindeluit; (mas-un) maşină de rabotat, raboteză, şeping (mai rar)

planing surface $(\mathrm{OM})$ placă de alunecare, glisieră

planing tool daltă, cuțit de rindea (pt. lemn); (mas-un) cuțit de rabotat / de raboteză / de şeping

planish $(\mathrm{TH})$ a egaliza; a îndrepta; a nivela (plan); a aplatiza; a turti; a netezi; a poliza; a finisa; a plana; a lamina (plan)

planished sheet (met) tablă polizată la luciu

planisher (mas-un) polizor; (met) calibru finisor

planish extra-bright (mas-un) a lustrui fin

planishing $(\mathrm{TH})$ netezire; (met) calibrare de finisare (la laminare)

planishing hammer (met) ciocan planator / de netezire / de îndreptare / de aplatizare / de întindere

planishing machine (met) maşină de netezire / de îndreptare / de aplatizare / de întindere

planishing pass (met) pas de trecere / finisare, calibru de lustruit la laminarea profilelor fine

planishing roll (met) cilindru de îndreptare / de finisare (la laminare)

planishing rolling mill (met) laminor finisor / netezitor

planishing stand (met) cajă finisoare / pentru netezire

planisphere (geogr) planisferă

plank (silv) scândură groasă, dulap, blană, lemn de molid; (constr) platformă; a căptuşi cu scânduri; a podi; a pardosi; (metr, fiz) unitate de măsură pentru acțiune (energie în timp) în sistem MKS, sau pentru moment unghiular: 1 planck $=1$ joule secondă $(\mathrm{J} \cdot \mathrm{s})$

plank floor(ing) (constr) podea, duşumea (de scânduri)

planking scânduri; podea; duşumea; $(\mathrm{TH}, \mathrm{OM}$, constr) îmbrăcăminte; acoperire, căptuşire; căptuşeală (şi de lemn); (nav) bordaj de lemn

Planck length (metr, fiz) unitate de lungime pentru cea mai mică distanță semnificativă în legile fizicii: 1 Planck length $\sim 4,051 \cdot 10^{-35} \mathrm{~m}$

plank log (silv) buştean de gater

plank sheer (nav) copastie inferioară

Planck time (metr, fiz) unitate de timp egală cu timpul necesar unui foton să parcurgă o lungime Plank cu viteza luminii: 1 Planck time $\sim 1,351 \cdot 10^{-43} \mathrm{~s}$

plankton (biol) plancton

planned (ec, adm) planificat, intenţionat

planned economy $(\mathrm{ec})$ economie planificată 
planned obsolenscence (ec) planificarea articolelor care se demodează uşor

planner $(\mathrm{TH})$ planificator; proiectant

planned outage (met, mas-un) oprire / întrerupere de funcționare, planificată

planning sistematizare; planificare

planning and design work studiu de proiect

planning permission aprobare a cadastrului

plano(-)concave plan-concav

plano(-)convex plan-convex

plan of site, plan showing position (constr, mas) plan de ansamblu

plano-miller (mas-un) maşină de frezat longitudinal cu masa mobilă (tip raboteză)

plano-type surface grinding machine (mas-un) maşină de rectificat suprafețe plane, tip portal

plant plantă; $(\mathrm{TH})$ instalație, utilaj, fabrică, uzină, secție, echipament, exploatare, mecanism, maşinărie, aparat, aparatură; inventar; complex; agregat; (met) fier vechi din circuitul de fabricație; (agr, bot, silv) a planta, a sădi, a cultiva; (iht, agr) a creşte (peşte)

plant accident accident de muncă

plant acid (chim) acid vegetal

plantation (agr, silv) plantare, sădire; plantație

plant-breeding station (agr) stațiune de selecție plant chemistry (chim) fitochimie

plant code number (auto) numărul de cod al fabricii

plant conditions $(\mathrm{TH}$, mas) regim / condiții de exploatare

plant designer inginer proiectant (pentru linii tehnologice, secții etc.)

plant engineer inginer de exploatare / de producție / de întreținere (pentru linii tehnologice, secții etc.)

planter (agr) plantator, maşină de plantat

plant feeder (zool) animal fitofag

plant for trimming sheets (met, mas-un) instalație pentru tăierea tablelor

plant-hire rate $(\mathrm{ec})$ tarif de închiriere a instalațiilor

planting (agr, silv) sădire, plantare; (agr) semănat

plant item (ind, constr) maşină, utilaj, instalație (relativ mare)

plant laboratory (ind, metr) laborator uzinal

plant leasing (ec) închiriere pe termen lung a unor instalații sau clădiri complet echipate

plantlet (bot, agr) plăntuță

plant load factor $(\mathrm{TH}$, ind) factor de utilizare (la maşini-unelte, cuptoare, centrale electrice etc.)

plant management (ec) conducere a unei uzine

plant out (agr, silv) a sădi spațiat; a răsădi plant practice (edu, ind) practică în producție; metodă / experiență practică

plant remains (bot, alim, mediu) resturi de plante plant-returned scrap (met) fier vechi / deşeuri metalice din circuitul (intern) de fabricație

plant setter (agr) maşină de răsădit / de repicat

plant stock $(\mathrm{TH})$ utilaj; echipament; (mas, ec) inventar (de secție / uzină)

plant supervision (metr) control de fabricație la nivel de secție / uzină

plant unit agregat

plant wax (chim, agr) ceară naturală

plant yard / depot (ind, constr) magazie / depozit de materiale si utilaje

plan view $(\mathrm{PV})(\mathrm{OM})$ vedere în plan, proiecție orizontală (în desen tehnic)

plaque $(\mathrm{OM}$, constr) placă (de metal, faianță), plachetă, tăbliță

plash baltă, băltoacă; a stropi, a împroşca (cu apă sau alt lichid); a împleti nuiele

plashy (geogr) mocirlos, mlăştinos, cu bălți (d. teren)

plasma (fiz) plasmă, gaz ionizat; heliotrop; (minrl) calcedon verde

plasma arc cutting (met) tăiere cu jet de plasmă plasma arc weld surfacing $(\mathrm{TH})$ încărcare prin sudare cu jet de plasmă (pe suprafețe, pentru reconditionare, formarea acoperirilor cu destinație specială)

plasma etching (met) curățare cu jet de plasmă

plasma gas (fiz) gaz ionizabil / plasmagen

plasma-jet cutting (met, TH) tăiere cu jet de plasmă

plasma-jet spraying process (met, $\mathrm{TH}$, fiz) (proces de) acoperire prin pulverizare cu jet de plasmă

plasma-jet torch (met) arzător cu jet de plasmă plast (plast) (fam) material plastic, plastic

plaster (constr) mortar, tencuială, ipsos, g(h)ips; a tencui, a gipsa, a pava (un drum); gips; plasture; (med) a pune în ghips, a pune un plasture; a mânji, a murdări

plaster bandage (med) pansament ghipsat

plaster binder (ind chim) liant plastic

plaster concrete (constr) beton cu ipsos

plasterer (constr) tencuitor

plastering (constr) tencuire, tencuială

plastering smoothing machine (constr, mas-un) maşină de drişcuit / de netezit tencuiala

plastering trowel (constr, $\mathrm{OM}$ ) mistrie (de tencuit)

plaster-mould casting (met) turnare în forme de gips

plaster of Paris (constr) ipsos; (minrl) alabastru plaster stone (minrl) $\mathrm{g}(\mathrm{h}) \mathrm{ips}$ 
plastic (mec, materiale) plastic, maleabil, ductil, deformabil, (din) material plastic, material plastic; sugestiv, clar, limpede (d. substanțe) artificial; (sg şi pl) tehnica scupturii; (fam) elastic; (ec) (fam) carte de credit; (fig) sugestiv, supus

plastic alloy (met, TH) aliaj maleabil / ductil

plastic art (artă) artă plastică

plastic bronze (met, T) bronz moale / pentru lagăre de alunecare / prelucrabil prin deformare (la rece)

plastic cable (el, plast) cablu izolat cu material plastic

plastic-cased battery (auto) acumulator în carcasă din material plastic / compozit polimeric

plastic clay (met) argilă plastică / pentru modelare / plastică pentru ceramică

plastic cold working (met, $\mathrm{TH}$ ) deformare / formare / fasonare / profilare la rece

plastic collapse load (mec, OM) sarcină de rupere plastică

plastic cord (OM, plast) cordon / cablu din material plastic

plastic deformation (mec, OM) deformație plastică

plastic effect $(T V, c)$ dedublare a imaginii, efect plastic / stereoscopic

plastic-faced hardboard (ind chim) placă melaminată (de fibră)

plastic fiber(s) (plast, ind chim) fibre din materiale plastice / polimeri / polimerice

plastic film (plast, ind chim, OM) peliculă plastică / ductilă / din material plastic

plastic fire-clay (met) argilă refractară, plastică

plastic flow / yield (mec, materiale) curgere plastică (la solide)

plastic flow persistence (materiale, mec) deformație plastică remanentă / ulterioară / persistentă

plastic foam (plast) spumă / burete din plastic

plastic forming (alim, mas-un, met, plast) formare prin deformare plastică

plastic hinge $(\mathrm{OM})$ articulație plastică

plasticine (ind chim) plastilină

plasticitate (mec) a deforma plastic

plasticity (mec, TH) plasticitate, deformabilitate, maleabilitate, ductilitate

plasticity index (mec, TH) index de plasticitate

plastic sulphur (chim) sulf amorf / plastic

plasticize (alim, ind chim) a înmuia, a plastifia

plasticizer (agent) plastifiant, plastificator, agent de plastifiere

platicizer migration (plast, ind chim) migrarea / deplasarea plastifiantului

plasticizing (alim, ind chim) plastifiere (prin amestecare, încălzire şi / sau adaos de agenți de plastifiere) plastic layer strat plastic

plastic limit (mec, materiale) limită de plasticitate plastic material (plast) material plastic, plastic

plastic moment of strength (mec, materiale) modul de rezistență plastică

plastic pipe (OM, plast) țeavă / conductă din material plastic

plastic range (materiale) zonă / regim / interval / domeniu de deformare plastică / de plasticizare

plastic range test (materiale, metr) test / încercare pentru determinarea intervalului de plas-ticitate

plastic refractory clay (met) argilă plastică, refractară

plastics (ind chim, plast) materiale plastice

plastics foil (ind chim, plast) folie / film / foaie de material plastic

plastic shaping (met, TH) fasonare plastică

plastics plating (ind chim, met) acoperire (a materialelor metalice) cu material plastic

plastics processing machine (mas-un, plast) mașină / utilaj de prelucrat materiale plastice

plastic refractory clay (ind chim, termo) argilă plastică refractară

plastic state stare plastică

plastic strain (mec) deformare / deformație plastică

plastic sulphur (chim) sulf amorf / plastic

plastics welding (ind chim, TH) sudare a materialelor plastice (fără a specifica procedeul)

plastic theory $(\mathrm{mec})$ teoria plasticității

plastic-viscous flow (fiz, mec) curgere plasticvâscoasă

plastic yield / flow (mec) curgere plastică

plastification (ind chim, alim) plastifiere

plastificator (alim, ind chim) maşină de plastifiat / de masticat, malaxor; masticator

plastifier (ind chim) plastifiant

plastifying screw (OM, alim, ind chim) melc de plastifiere

plastisol adhesive (plast, chim) adeziv plastisol / obținut prin dispersia unui polimer într-un plastifiant

plast material (plast, ind chim) material plastic

plasto-elastic properties (materiale, mec) proprietăți plasto-elastice

plastomer (materiale, metr, mec) plastometru (aparat de măsurat proprietăți mecanice (de curgere) a termoplasticelor (topitură sau solid) prin trecere forțată printr-un orificiu

plate-and-frame filter-press $(\mathrm{OM}$, alim) filtrupresă cu rame

plateau tavă; platou; (constr) planşeu; (fiz) palier; (mat) palier al unei curbe

plateau duration (autom, electr) durată / lățime a palierului unui impuls 
plate axis (c) axe ale imaginii

plate battery (el) baterie anodică / de placă / A plate bending rolls / machine (met, mas-un) maşină de îndoit tablă

plate cap (el) bornă anodică / de placă

plate circuit (el) circuit anodic

plate clippings (met) deșeuri de tablă

plate clutch (auto, OM) ambreiaj / cuplaj monodisc plate column (ind chim) coloană cu talere

plate conveyor (alim, ind alim) transportor cu plăci articulate

plate cooler (alim, termo) răcitor cu plăci

plate coupling $(\mathrm{OM})$ cuplaj cu lamele / disc(uri)

plate covering (constr) acoperire cu plăci / cu tablă

plate current (el) curent anodic

plate cutter / cutting machine (met, mas-un) maşină pentru tăiat tablă

plated (met) acoperit, cu acoperire galvanică, placat, îmbrăcat

plated bar $(\mathrm{OM})$ bară plată (de metal)

plate detection $(\mathrm{el})$ detecție anodică

plate determination (alim, ind chim) calcul / determinare a numărului de talere

plate doubler (met, mas-un) maşină de dublat / placat tablă

plate dryer (ind chim, alim) uscător cu discuri / cu plăci

plate-edge bevelling / planning machine (met, mas-un) maşină de rabotat / de tăiat margini de tablă

plate-edge preparation (met) pregătirea marginilor de tablă (pentru sudare, profilare etc.)

plate efficiency (el) randament anodic

plate electrode (el, chim) electrod cu / în plăci

plate evaporator (alim, ind chim) evaporator $\mathrm{cu}$ plăci

plate extruder head (plast, mas-un, OM) cap de extrudare pentru plăci

plate feeder (alim, ind chim) alimentator cu plăci

plate fill / packing $(\mathrm{OM})$ garnitură / umplutură în plăci (suprapuse)

plate filter (OM, alim) filtru cu plăci; (el) filtru anodic

plate fin $(\mathrm{OM}$, metr) lamelă, nervură, placă

plate frame (el) ramă a plăcii de acumulator; $(\mathrm{OM})$ cadru de tablă

plate freezer (alim, termo) congelator cu plăci

plate / strip fuse (el) siguranță fuzibilă, lamelară

plate gauge (metr) spion; (met) calibru pentru grosimea tablei

plate girder $(\mathrm{OM}$, constr, mec) grindă cu inimă plină, grindă continuă

plate gland $(\mathrm{OM}$, constr, mec) suport de tablă plate glass (ind chim) sticlă în plăci

plate gripping tongs (met, $\mathrm{OM}$ ) cleşte pentru tablă

plate heater / pasteurizer (alim, termo) pasteurizator cu plăci

plate-heating furnace (met, termo) cuptor pentru încălzirea tablelor

plate ice (alim) gheață în lamele / în plăci

plate-insulator $(\mathrm{OM}$, termo) izolator în formă de placă / taler

plate iron (met) tablă (groasă) de oțel

plate jig (mas-un, $\mathrm{OM}$ ) dispozitiv de ghidare în formă de placă (şi la găurire)

plate keel $(\mathrm{OM})$ pană / paralelă; (nav) chilă orizontală

platelet $(\mathrm{OM})$ lamă, lamelă

platelet alpha (met) fază alfa, grosier aciculară

plate leveller (met, mas-un) maşină / dispozitiv de îndreptat tablă (groasă)

plate levelling / straightening machine (met, mas-un) maşină de îndreptat tablă

platelike, plate-like $(\mathrm{OM})$ lamelar; plat; în formă de plăci

platelike powder (materiale) pulbere lamelară / în paiete / în solzi

plate load (el) sarcină anodică / de placă, rezistență anodică / de sarcină; (mec) sarcină (aplicată) pe placă

plate lug ureche a plăcii de acumulator; (met) platbandă

plate marking (met) marcarea tablei

plate mill (met) laminor pentru tablă groasă

plate mill stand (met) cajă a laminorului de tablă groasă

platen (OM) placă; (alim, termo) plită; masă

platens $(\mathrm{OM}$, el) plăci de contact (şi la maşina de sudat prin presare)

plate out a întinde; a egaliza; a netezi; a aplatiza

plate panel of metal (met) foaie de tablă

plate planner (met, mas-un) maşină de rabotat margini de tablă

plate polishing machine (met, mas-un) maşină de polizat tabla

plate powder (ind chim) praf de curățat vesela

plate precipitator (alim, ind chim, mediu) filtru electrostatic, cu plăci

plate preparation (met) pregătire / teşire a marginilor (tablei) (pentru sudare)

plate out (materiale, OM, fiz) a aplatiza, a egaliza, a întinde

plater tinichigiu

plate rack $(\mathrm{OM})$ sabot cu placă, lagăr cu talpă, rastel (şi pt. vase)

plate rail (OM, transp) bară / şină plată

plate rim $(\mathrm{OM})$ bordură de tablă 
plate roll (met) cilindru pentru laminarea tablelor groase

plate rolling (met) laminarea tablelor groase

plate-rolling mill / train (met) laminor de tablă groasă

plate scrap (met) deşeuri de tablă

plate-shaped $(\mathrm{OM})$ în formă de placă

plate-shearing attachment / machine (mas-un) foarfece / maşină de tăiat tablă

plate shears (met, OM) foarfece de tablă / pentru tăierea tablelor

plate sheet (met) tablă (în general semifabricat din oțel)

plate shop atelier de tinichigerie

plate slab (met) bramă; sleb; platină

plate speciman (OM, metr) probă / epruvetă plană

plate spring $(\mathrm{OM})$ arc lamelar / în foi

plate stand (met) cajă a laminorului de tablă groasă

plate steel (met) tablă groasă

plate stem (nav) etravă fasonată / din tole

plate strake (nav) şir de table de bordaj, filă de bordaj

plate tank (alim, ind chim) cuvă de răcire (la care una sau mai multe laturi sunt constituite din evaporatoare cu plăci)

plate testing machine (metr, met) maşină de testat / de încercat tabla

plate thickness (met) grosime a tablei / a plăcii

plate turner (met, mas) răsturnător de tablă

plate-type clutch (OM) cuplaj / ambreiaj cu discuri / cu lamele

plate-type condenser (alim, ind chim) condensator cu şicane / cu plăci / cu discuri

plate-type evaporator (alim, ind chim) evaporator cu talere, vaporizator cu plăci

plate valve (hidr, OM) supapă plată / cu taler / cu disc / cu scaun plat / plan

plate vibrator $(\mathrm{OM}$, mas) vibrator cu placă

plate welding (met, $\mathrm{TH}$ ) sudare a tablelor groase

plate wheel $(\mathrm{OM})$ roată-disc (plină) / fără brațe

platework (OM, TH) ansamblu / construcție / confecție din tablă (şi sudată), lucrare de tinichigerie

plate working machine (met, mas-un) maşină de prelucrat / îndrpetat tablă / plăci

platform (cf, met) platformă, peron, rampă de încărcare; (met, ind) post de comandă la utilaje mari; (constr) podium, piedestal, terasă, platou, planşeu;

platform balance / weightening machine (met, ind) pod-basculă pentru cântărire

platform conveyor (alim, ind chim) transportor cu bandă cu plăci articulate platform for the operator (mas, ind) platformă de servire / de comandă

platform scales (metr, OM) cântar cu platane

platform truck (transp) vagon sau camion platformă

platform underpass (cf) pasaj inferior

plating (constr) pavare; (met, TH) acoperire (şi cu plăci); placare, metalizare; aurire; argintare; acoperire galvanică; (nav) bordaj metalic; (OM) strat; căptuşire

plating bath (met, chim) baie de galvanizare / de acoperire (metalică)

plating-out test (met, metr) test / încercare la aplatizare

platinic compound (chim) compus platinic / al platinei tetravalente

platinisation; platinising (met, $\mathrm{TH}$ ) platinare, acoperire cu platină

Platinum (Pt) (chim) platină

platinum foil (met) folie de platină

platinum foil rolling mill (met) laminor pentru folii de platină

platinum-platinum-rhodium couple (met, metr) termocuplu platină-platină-rodiu

platinum sponge (met) platină spongioasă

Platonic year, great year (metr, astronomie) unitate de măsură pentru timp, anul lui Platon: 1 Platonic year 25800 ani

platymeter (metr, fiz) platimetru, aparat pentru măsurarea capacităţii şi permitivității

play (OM) joc; interstițiu; spațiu liber; rost; a juca (şi d. o piesă, în sens nedorit)

playback redare, reproducere

play for expansion (termo, constr, cf) joc pentru compensarea dilatării / expansiunii termice, rost de dilatare

play the market $(\mathrm{ec})$ a specula hârtii de valoare în vederea unui profit imediat

play movement (cf, termo) rost de dilatare (şi între şine)

play of piston (OM, auto, nav, termo) joc al pistonului

play-out (OM, T, chim) efilare / subțiere (a unui strat), a unei acoperiri

play the market $(\mathrm{ec})$ a specula

plea pretext; protest; cerere; (jur) proces, acțiune juridică

please turn over vă rugăm întoarceți foaia

pleat cută dublă, plată; a încreți; a plisa; a cuta; a plia; a gofra (textile, hârtie, folii, table subțiiri)

pleated cutat; plisat; ondulat (d. textile, hârtie, folii, table subțiri)

pleated tub (OM) țeavă flexibilă / ondulată, burduf, tub ondulat 
pleated filter (OM, alim, hidr) filtru cutat / plisat pleating plisare, gofrare

pleating machine (mas-un) maşină de pliat / de gofrat

pledge (ec) gaj, garanție, obligație; promisiune; a făgădui, a promite, a garanta

pledged goods $(\mathrm{ec}, \mathrm{TH})$ mărfuri în garanție

plentiful abundent; din plin

plenty abundență

plenum (OM, hidr) de refulare, refulat

plenum chamber / space (OM, hidr) cameră spațiu de refulare / de distribuire a aerului

plethron, $(p l)$ plethra (metr) unitate din Grecia Antică pentru măsurarea distantei sau ariei: 1 plethron $\sim 31 \ldots 33 \mathrm{~m}$

plexiglass (plast) plexiglas

plf (metr, OM, T) simbol pentru pounds per linear foot $(\mathrm{lbm} / \mathrm{ft})$, unitate de măsură pentru sarcină / forță / masă liniară în inginerie: 1 plf = $1,488164 \mathrm{~kg} / \mathrm{m}$; (metr) abreviere pentru a ,per linear foot": 1 plf $=3,280840$ pe metru $(/ \mathrm{m})$; v. per linear foot

pli (metr, OM, T) abreviere pentru pounds per linear inch (livre pe inch / țol liniar); pentru masă: 1 pli $=17,85797 \mathrm{~kg} / \mathrm{m}$; pentru livre-forță: (pounds of force per linear inch): 1 pli = $175,1268 \mathrm{~N} / \mathrm{m}$

pliability (TH) pliabilitate; flexibilitate (d. semifabricate subțiri, textile etc.)

pliable pliabil (d. semifabricate subțiri, textile etc.)

pliant flexibil; pliant; cutabil; pliant

plicate în cute, cutat, pliat

plied yarn (textile, plast) fir dublat / răsucit

pliers $(\mathrm{OM})$ cleşte (şi plat / de îndoit sârmă)

pliers flat nose $(\mathrm{OM})$ clesste plat

plinth (constr) plintă, bază de coloană, soclu; (OM, mas-un) bază de coloană

plodder (alim, ind chim) presă cu melc / cu şnec (şi pt. săpun, paste fãinoase)

plot (agr, constr) parcelă, lot de pământ; (fiz) grafic, diagramă; (nav) schemă, punere / trasare pe hartă; a desena un plan, a reprezenta grafic, a trasa o curbă prin puncte, a pune pe hartă, a trasa, a schița

plottable evaluabil, estimabil, posibil de trasat

plot of function (mat) grafic al unei funcții

plotmat (birotică, metr) dispozitiv automat de trasat curbe

plot scale scara unui desen (tehnic)

plotted point punct trasat / desenat marcat

plotter, printer $(\mathrm{OM}, \mathrm{c})$ dispozitiv de trasat curbe / de desenat, înregistrator grafic

plotter unit (metr, topografie) unitate de măsură pentru distanță: 1 plotter unit $=25 \mu \mathrm{m}$ plotting (constr) fragmentare, parcelare; reprezentare grafică; cartografiere; trasare; marcare; construcția unei curbe (din date măsurate); lucru pe hartă

plotting board indicator de scară; (pe desen, hartă etc.) (mas-un) indicator de avans transversal; masă de desenat / de trasat

plotting head (electr, c) cap de trasare

plotting plate (OM, electr, c) ecran / placă / masă de trasare

plotting scale scară (pt. desen şi hărți)

plough (agr) plug, a ara; (el) sabot subteran colector de curenți telurici, priză mobilă de curent; (T) a brăzda, a zgâria (asemănător arăturii)

ploghing (agr) arătură, brazdă; (T) brăzdare (ca de plug)

pluck (out) a smulge, a scoate

plug (OM) tampon, dop, cep, pană, ic, obturator, ştift, cocoş; a astupa (cu dop); (el) patron, buşon, fişă (de conectare), priză; rotor; (met) dorn, poanson, fund de convertizor; (auto) cablu de alimentare (pt. priză)

plugboard (mas, autom) tablou de conexiuni, de programare / de distribuție / de comandă

plug box (el) priză de contact / de curent; doză / cutie de conexiune

plug braking (el, mec) frânare prin schimbarea fazelor cu curent invers (la mașini asincrone)

plug centre $(\mathrm{OM})$ dop cu gaură de centrare

plug cock / valve $(\mathrm{OM})$ robinet / supapă de trecere / cu cep, ventil cu cep / cu scaun conic

plug connector (el) conector cu fişe

plug contact (el) contact cu fişe, conector, priză de curent

plug device / socket (el, OM) priză de curent / de contact

plug door $(\mathrm{OM})$ panou / uşă de vizitare

plug drawing (met) tragerea țevilor pe dorn / pe mandrină

plug filter (OM) filtru-cartuş

plug flow (el) curgere în blocuri / prin buşoane

plug fuse (el) siguranță cu patron fuzibil

plug gauge (metr) calibru-tampon

plugging (el) frânare prin contracurent; blocare; închidere a apelor; (mediu) colmatare; (TH, hidr) astupare / înfundare (dorită sau nu, a unei țevi); (met) înfundarea / închiderea / obturarea orificiului de scurgere

plugging chart (el, electr) diagramă de conexiuni plugging chisel daltă / dorn de perforare

plugging of pores (materiale) blocare / astupare a porilor

plug batch (nav) capac izolant (de cală frigorifică) 
plug hole (mas-un, OM) gaură de golire / de evacuare / de scurgere; (nav) orificiu de scurgere (pe fundul bărcii)

plug-insulator corp izolant al bujiei

plug lines (met, plast) striuri / rizuri / urme de tragere (pe semifabricate trase, laminate, extrudate etc.)

plug of a cock (OM) cep de robinet plug-on pin (OM, electr) picioruş / ştift de fişă plug-on trip (OM, electr) regletă cu fişe

plug-ramming machine (constr, mas) maşină de compactat pământul; (met) maşină de ştampat fundul la un convertizor

plug receptacle (el) priză (de contact)

plug resistance (el) rezistență cu fişe

plug restored indicator / shutter (OM, hidr) clapetă cu ridicare / revenire automată

plug rheostat (el) reostat cu fişe

plug rolling mill (met) laminor perforator (pt. țevi)

plug scratches (met, plast) striuri / rizuri / urme de tragere (defecte pe semifabricate trase, laminate, extrudate etc.)

plug screw (OM) şurub de închidere

plug screw thread gauge (OM, metr) calibru (normal) tampon filetat / de piuliţe

plug socket / device (el) priză de curent /de contact

plug tap (mas-un) tarod de finisat / intermediar

plug tester (auto, metr) dispozitiv / aparat pentru încercat bujii

plug-type cut-out (el) siguranță cu patron fuzibil

plug up (OM) a astupa cu dop / cu cep

plug valve $(\mathrm{OM})$ robinet cu cep (drept)

plug welding $(\mathrm{TH}, \mathrm{met})$ sudare fără electrod

plum (alim) prună; stafidă; (agr, bot) prun (pom)

plumb vertical, (fir cu plumb), drept; (chim, el) a plumbui, a acoperi cu plumb; (constr) a controla verticala; a sonda adâncimea

plumbagine, plumbago (chim) grafit

plumbaginous grafitat (şi d. compozite)

plumbago crucible (met) creuzet de grafit

plumb-bob (wire) (constr) fir cu plumb

plumber (met) turnător de plumb; (constr) instalator (de apă şi canal)

plumber-fitter (TH, ind) lăcătuş-instalator

plumber' pliers (OM) cleşte pentru țevi de gaz

plumber's solder (met, TH) (aliaj cu) staniu / cositor pentru lipire moale

plumber's wiped joint (OM, TH) proeminență / guler de (la) lipitură

plumbic; plumbiferous (materiale) care conține plumb plumbing (met) plumbuire; prelucrare a plumbului; (constr, ind) verificare a verticalității (cu firul cu plumb); lucrări de instalație de apă şi canal, țevărie

plumbism (med) saturnism

plumb level (metr, constr) nivelă cu fir cu plumb plumb line (metr, constr) (linie) verticală, fir cu plumb; (mat) perspectivă perpendiculară

plumb point punct de nadir

plumb stern (nav) etravă verticală

plumbum (Pb) (chim) plumb

plume pană (de pasăre); fulg (şi la particule de uzură, formă a materialului de adaos la compozite etc.)

plummer (OM) lagăr pe capră

plummer block (nav) palier de arbore port-elice plummet greutate; (constr) fir cu plumb

plunge (hidr) a plonja; a aluneca de-a lungul unui ghidaj

plunge cylinder (OM, hidr) cilindru tip plunjer

plunge milling (mas-un) frezare de / cu adâncime (mare)

plunger (el) cursor de scurtcircuitare, miez mobil; (nav) scafandru; sondă; (OM) bară, dop de presiune, piston (plonjor), plunjer, buton de translație; (met) bară pentru astuparea gurii de descărcare

plunger armature stud (OM) buton / tastă de reținere

plunger cam $(\mathrm{OM})$ camă cu bolț

plunger case (OM, hidr) cilindrul plunjerului

plunger die $(\mathrm{OM}, \mathrm{TH})$ poanson

plunger disk / follower (OM, hidr) disc de piston / de plunjer (la distribuitoare)

plunger feeder (OM, hidr) alimentator cu piston plonjor / cu plunjer

plunger guide (OM, hidr) ghidaj de plunjer / de plonjor

plunger moulding press (mas-un) presă cu piston de injecție

plunger pin (OM, hidr) tijă (şi a plunjerului), ştift de fixare cu arc

plunger piston (OM, hidr) piston (tip) plunger / plonjor

plunger pump / set (OM, hidr) pompă cu piston plunger relay (el) releu cu miez mobil

plunger slide (OM) bolț alunecător / plonjor

plunger tester (metr, fiz) aparat pentru determinarea rezistenței la plesnire

plunger-type instrument (metr, OM) aparat care conține un plunjer (acționat hidraulic sau de o bobină) ca parte principală de măsurare

plunger valve (OM, hidr) supapă cu plunjer / cu piston 
plural (gram) plural; multiplu; numeros plurality pluralitate; (şi pol) număr mare plurality dies (mas-un) cap de filetat universal, filieră cu piepteni

plus (semnul) plus, pozitiv; cantitate pozitivă

plush (textile) pluş

plus limit $(\mathrm{OM})$ abatere superioară

plus material (agr, alim, ind) refuz / rest de sită

plus mesh (met, constr, ind chim) pulbere care nu trece prin sită, refuz

plus post (el) bornă pozitivă

plus tolerance $(\mathrm{OM})$ abatere pozitivă

Plutonium (Pu) (chim) plutoniu

pluvial (meteo, geogr) pluvial

ply placaj, inserție textilă (în benzi de transport); (plast) strat de țesătură; cută, pliu; (nav) a executa călătorii regulate (între anumite porturi)

-ply (metr) un sufix care indică numărul de cutări / straturi într-o piesă; 4-ply înseamnpă cu 4 straturi

ply belting (OM, ind) covor / bandă de cauciuc cu inserție de pânză

plying (el, compozite, electr) dublare a firelor; pliere; cablare a firelor răsucite; care se pliază

play orientation (materiale) orientarea planelor de laminare (la compozite, laminate) pentru obținerea unor proprietăți superioare

ply twist $(\mathrm{TH}$, el, electr) răsucire concomitentă cu dublarea / pliere / pentru cablare

plywood (constr) placaj; foaie de furnir

plywood sheet (constr) foaie de furnir

ply yarn (met, plast, electr) fir dublat şi/sau răsucit / cablat

PM, pm (metr) abreviere pentru post meridiem (în latină) pentru ,după prânz” / după ora 12.00: ora 4:30 pm este aceiaşi cu ora $16: 30$

PMPO (metr) abreviere pentru ,,peak music power output" unitate de măsură utilizată de producătorii de aparatură electronică de amplificare pentru a evalua puterea efectivă la ieşire a amplificatorilor (de sunet), definițiile existente fiind greu de exprimat în unităti SI

PN (metr, hidr) simbol pentru „nominal pressure" presiune nominală (în conducte, rezervoare), presiunea măsurată în conducte, în bari, la $20^{\circ} \mathrm{C}$

PNC (metr) o abreviere pentru preferred noise criterion, unitate de măsură în inginerie pentru a măsura nivelul zgomotului de fond în spații închise; este similară cu cea anterioară, criteriu de zgomot (noise criterion - NC); valorile PNC sunt cu $10 \ldots 15 \%$ mai mici față de măsurătorile nivelului sonor în decibeli pneudraulic $(\mathrm{OM})$ amortizor (cu) aer-ulei pneumatic pneumatic pneumatically actuated valve (OM, hidr) supapă acționate pneumatic

pneumatic amplifier (assembly) (mec, mas) (grup-) amplificator pneumatic de presiune pneumatic control (autom) comandă pneumatică pneumatic controller (hidr, autom) regulator pneumatic de poziție / de poziționare

pneumatic conveying (alim, ind chim) transport pneumatic (şi pt. pulberi, făină etc.)

pneumatic drive (OM, hidr, autom) acționare pneumatică

pneumatic elevator (alim, met, OM) elevator pneumatic

pneumatic expanding mandrel (mas-un, OM) dorn pneumatic de strângere / de prindere

pneumatic hammer (met, constr, OM) ciocan pneumatic

pneumatic-hydraulic actuator (hidr, OM, autom) sistem de / cu acționare (combinată) pneumohidraulică, schimbător de presiune pneumohidraulic

pneumatic moulding machine (met) maşină pneumatică de formare / de format

pneumatic press (mas-un) presă acționată pneumatic

pneumatic programmer (autom, hidr) programator pneumatic

pneumatic rammer (met, OM) mai / dispozitiv pneumatic de îndesat (amestecul de formare)

pneumatic rapper (met) ciocan pneumatic de dezbătut piese turnate

pneumatic riveting hammer / machine (met, mas-un) ciocan / maşină pneumatic( $\breve{a})$ de nituit

pneumatic shot blasting machine (met, masun) maşină pneumatică de sablat

pneumatics (fiz) ştiința care se ocupă cu proprietătile mecanice ale gazelor

pneumatic system (fiz, mas) sistem pneumatic pneumatic tool (mas-un) sculă pneumatică

pneumatic time delay unit (metr, hidr) temporizator pneumatic

pneumatic timer (metr, hidr) temporizator pneumatic

pneumatic unloading device (termo, $\mathrm{OM}$ ) dispozitiv de mers în gol (la compresoare)

pneumatic variable speed control (termo, $\mathrm{OM}$ ) dispozitiv automat de variație a vitezei compresorului functie de consumul de aer

PNU (metr, med) abreviere pentru protein nitrogen unit, o măsură a potențialului compuşilor utilizați în alergiile pielii; 1 PNU este definită ca $0,01 \mathrm{~g} \mu$ phosphotungstic acid-precipitable protein nitrogen (azot din proteine, precipitabil cu acid sulfo-wolframic); este înlocuită cu bioequivalent allergy units (BAU), definită prin testarea pielii cu preparate de referință 
poach (ind chim) a înălbi, a decolora

pocket casetă; (met) pori de gaze, retasură dispersă; $(\mathrm{OM})$ buzunar (şi de lagăr), locaş, adâncitură, sac, buncăr, gol, suflură, cavitate, rezervor pocket for a spring $(\mathrm{OM})$ locaş pentru arc pocket of ore (met) cuib / lentilă de minereu pod bit / drill (mas-un) burghiu-lingură

point (cf, met) macaz, ac, schimbător de cale; (el) punct de contact / de legătură; diviziune, extremitate; (nav) cap, promontoriu; (mat) punct, poziție, moment; (nav) poziție, cart (gradație a rozei compasului egală cu $11^{\circ} 15^{\prime}$ ); virgulă; peniță, punct, vârf, tăiş, loc; a ascuți, a îndrepta, a viza, a puncta; punctiform, ascuțit; point (pt) (metr) unitate de măsură pentru unghiuri, şi pentru exprimarea direcției pe busole: 1 point este $1 / 32$ dintr-un cerc: 1 point $=11^{\circ} 15^{\prime}$ sau $\pi / 16$ radiani; point (pt) (metr, topografie, tipografie) unitate de măsură pentru lungime: 1 point reprezintă cel mai mic element de tipar care poate fi realizat, $\sim 1 / 64$ inch; 1 point (standardizat în US şi UK) $\cong 0,35 \mathrm{~mm}$; în Europa: 1 point $=1$ Didot point $=0,377 \mathrm{~mm}$; în US, Adobe software a introdus 1 big point $(\mathrm{bp})=$ $0,3527778 \mathrm{~mm}$; 1 point (în standardul german) $=0,25 \mathrm{~mm}$; point (pt) (metr) un procent, $1 \%$, un punct procentual; point (pt) (metr) unitate de măsură pentru masă (pt. pietre prețioase): 1 point $=2 \mathrm{mg}$; point (pt) (metr, sport) unitate pentru cantitate, egală cu 1 ; point (pt) (metr, sport) punct, marcare, gol etc., unitate folosită pentru a exprima cea mai mică schimbare a scorului; point (pt) (metr) o altă denumire pentru mil $(=0,001$ inch), unitate utilizată pentru măsurarea grosimii hârtiei: 1 point $=25,4 \mu \mathrm{m}$; point (pt) (metr) punct, unitate de măsură pentru greutatea specifică a unui lichid (vin, bere etc.) ca raport între greutatea specifică a lichidului şi greutatea specifică a apei pure: 1 „point” reprezintă o creştere cu 0,001 peste 1 ; exemplu: un lichis cu greutatea specifică de 1,048 este descris ca având 48 puncte; point (metr) unitate medievală de măsurat timpul: 1 point $=1 / 5$ ore, sau 12 minute

point-and-click (c) poziționare şi apăsare (pt. mouse şi cursor) (comenzi particularizate)

point at issue chestiune controversată

point contact (mec) contact punctiform

point counter (metr, fiz, electr) contor de vârfuri (Geiger-Müller)

point discharge (el) descărcare între vârfuri

point-down method (met) metodă de laminare pe muchie, a oțelului hexagonal

pointed $(\mathrm{OM})$ ascuțit pointed corrosion (met, $\mathrm{T}$, chim) coroziune în puncte / punctiformă

pointed drill (mas-un) burghiu plat

pointed hand vice / vise (mas-un, $\mathrm{OM}$ ) menghină cu fălci înguste

pointedly $(a d v)$ (în mod) explicit, deschis, net

pointed nose $(\mathrm{OM}$, metr) vârf ascuțit / fără racordare

pointed pin $(\mathrm{OM})$ tijă cu vârf / ascuțită, ştift ascuțit (la unul sau ambele capete)

pointed step drill (mas-un) burghiu plat profilat

pointed tool (mas-un) cuțit cu vârf ascuțit / cu rază de racordare zero sau foarte mică

pointed tooth $(\mathrm{OM})$ dinte cu vârf ascuțit (şi la deplasare pozitivă exagerată)

point electrode (el, met) electrod cu vârf / punctiform / pentru sudare în puncte

pointer (inf) indicator de adresă; (OM, metr) furcă de lanț, (ac) indicator (şi cu săgeată)

pointer instrument (cf, OM) aparat / dispozitiv de manevră a macazului; (metr) aparat cu citire directă / cu ac indicator

pointer knob (OM, metr) buton indicator

pointer of index (mas-un, metr) indicator de compas de reglaj / de divizare

pointful la subiect; oportun

point hardening (met) călire parțială / locală (la otel)

pointing (constr, met) umplere a unor goluri sau defecte de zidărie, rostuire; (el, metr) precalibrare; $(\mathrm{TH})$ ascuțire, punctare

pointing error (metr) eroare de vizare / de citire pointing machine (mas-un) maşină de ascuțit (şi vârful de burghiu)

pointing mark semnul punct

pointing of the laser beam (fiz, met) focalizare a unui fascicul laser

pointing tool (mas-un) port-cuțit de strunjit conic pointing up the joints egalizare a rosturilor (d. suduri, construcții)

point in space-time, event eveniment; punct în spatiu-timp

point lattice (mat, fiz) rețea de puncte

pointless fără sens; inoportun; fără legătură cu subiectul

point lever (cf, met) pârghie de macaz

pointlike (fiz, T) în formă de punct; punctiform

point load (mec, T) sarcină concentrată / aplicată într-un punct

point lock (metr, OM) fixator de ac; (cf, OM) încuietor de macaz

point matching method (mat) problemă cu valori la limită / cu condiții de graniță / în anumite puncte 
point-observer (fiz) observator punctual point of accumulation, accumulation / cluster point (mat) punct de acumulare, limită point of application (mat, fiz) punct de aplicare / de aplicație

point of connection (el, OM) punct / loc de legătură / de îmbinare

point of contact / of osculation / of tangency (mat) punct de contact / de tangență

point of contrary flexion / flexure (mat) punct de inflexiune (al ujnei curbe)

point of control ( $\mathrm{TH}$, ind) punct de control / de reglare / de verificare

point of drill (mas-un) muchie transversală a burghiului

point of the earth (el) punct de legare la pământ, legătură la pământ

point of engagement / of attack punct de atac (al sculei); (OM) punct de angajare / de intrare în angrenare (a doi dinți)

point of fall (mat, fiz) punct de cădere / de bază

point of the feeler $(\mathrm{OM}$, metr) vârf al palpatorului

point of flammability punct de inflamabilitate (d. materiale, lubrifianți, fluide hidraulice etc.)

point of fracture $(\mathrm{mec})$ punct de rupere

point of frog (cf) vârf al inimii de încrucişare (la şine)

point of ignition (termo) punct / temperatură de aprindere (d. lubrifianti, combustibili etc.)

point of impact (mec) punct de impact / de lovire / de ciocnire; (auto) locul impactului

point of incidence (fiz, mec) punct de incidență

point of inflection (mat, mec) punct de încovoiere / de inflexiune / de schimbare a curburii

point of intersection (cf) punct de încrucişare / de întretăiere; (mat) punct de intersecție

point of junction of members (mec) nod al unei construcții cu zăbrele

point of load $(\mathrm{mec})$ punct de aplicare a sarcinii

point of lubrication $(\mathrm{OM}, \mathrm{T})$ punct / loc de lubrifiere / de ungere

point of make-out (ec) punct de echivalare (a costurilor antecalculate cu cele postcalculate)

point of maximum load (mec) limită / rezistență la / de rupere, punct de încărcare / de sarcină maximă

point of partition punct despărțitor / separator

point of pouring (met) temperatură de turnare, loc / groapă de turnare

point of rest (fiz, mec) punct de repaus; (nav, transp) punct de depozitare a mărfurilor în tranzit

point of rupture (mec) punct de rupere point of self-oscillation (autom, el) prag de amorsare a oscilației / de auto-oscilație

point of separation (chim, met) punct de separare / de tranzitie

point of solidification (chim, met) temperatură / punct de solidificare

point of support (constr, met) zid de sprijin; (mec) loc de încastrare, ' punct de reazem

point of take-off (TH, hidr) loc / punct de priză / de evacuare

point of transition (met, chim) punct critic / de transformare

point of view punct de vizare (la aparate optice) / de vedere

point of weld $(\mathrm{OM})$ punct de sudură

point of zero moment (mec) punct zero al momentelor

point of zero charge (mec) punct zero al încărcării (şi la corpuri imersate)

point out a releva; a preciza; a evidenția, a reliefa, a scoate în refief / evidentă

point paper hârtie de desen; hârtie milimetrică

point precisely (metr, autom) a regla fin / precis

point pressure (met, $\mathrm{TH}, \mathrm{mec})$ presiunea de contact a electrodului (la sudare)

point rail (cf, OM) ac de macaz / de conducere

point recorder înregistrator prin puncte

point releasing $(\mathrm{cf})$ deblocare a macazului

point roughly (metr, autom) a regla grosier / aproximativ

points (cf) macaz, schimbător de cale; punct(e) de suspensie

point set (mat) multime de puncte

pointshaped punctiform

point size corp / mărime de literă

point source sursă punctiformă

points rating method $(\mathrm{ec})$ metodă de evaluare a unei activități sau produs prin punctaj

point to point (configuratie) punct cu punct

point-to-point numerical control (mas-un) control numeric pas-cu-pas (şi la deplasare între două poziții fără o preferință asupra căii sau vitezei), control pozițional

point-up bricking (met, constr) rostuire, curățire a rosturilor (de zidărie)

point welding (met, TH) sudare în puncte point wise pe / în puncte, punctual, local

poise poziție; echilibru; a stabiliza; a echilibra; a suspenda; a tine; poise (P, Ps, Po) (metr, hidr, T) unitate de măsură în sistemul CGS pentru vâscozitate dinamică; în sistemul SI, unitatea de măsură este $\mathrm{Pa} \cdot \mathrm{s} ; 1$ poise $=0,1 \mathrm{~Pa} \cdot \mathrm{s}$ poise beam (el, metr) pârghie / braț de cursor poised echilibrat; stabilizat 
poiser (chim) soluție-tampon, oxireducătoare poiseuille (PI) (metr) unitate de măsură în sistem MKS, neacceptată în sistem SI pentru vâscozitatea dinamică: 1 poiseuille $=1 \mathrm{~Pa} \cdot \mathrm{s}=$ 10 Poise

Poiseuille flow (hidr, T) curgere laminară / Poiseuille

poise weight (mec, OM) cursor, călăreț, greutate de echilibrare

poising action (chim) acțiune de tamponare (prin reacție de oxido-reducere)

poising agent agent-tampon (de oxido-reducere)

poising solution (chim) soluție-tampon oxireducătoare

poising tool $(\mathrm{OM})$ dispozitiv de echilibrat balansul

poison (chim, med) otravă

poisoning (chim, med) otrăvire; intoxicare; (c) ardere / degradare a ecranului fluorescent

poisonous (chim, med) toxic; otrăvitor

poisonous substance (chim, med) substanță toxică

Poisson'number / ratio (mec) coeficientul lui Poisson, coeficientul contracției transversale

poke a împinge; a băga; (met, termo) a alimenta focul

poke hole (met, termo) groapă / gaură / orificiu de sondaj / de investigare / de alimentare a focului (la furnal, cuptoare, cazane etc.)

poker, poking bar (termo, OM) vătrai

poke welding (met, TH) sudare manuală în puncte polar (fiz) polar; diametral opus, care se află în raport de polaritate

polar adsorption (chim, T) adsorbție polară polar angle (geom) unghi polar; anomalie; azimut polar bond (chim) legătură polară

polar coordinates in plane (geom) coordonate polare în plan

polar equation (mat) ecuație în coordonate polare (şi a unei curbe plane)

polarity (el, fiz, chim) polaritate

polarisation (fiz) polarizare

polarise (fiz, chim) a polariza; a premagnetiza

polar line (mat) polară; (mec) rază polară

polar link(age) (fiz, chim) legătură polară

polar molecule (fiz, chim) moleculă polară

polar moment of inertia (mec) moment polar de inerție

polar solvent (chim) solvent polar

polarized effect (fiz) efect de polarizare / polarizat

polar zone (geogr) zonă polară

pole prăjină; oişte (la vehicule); unitate de lungime; 1 pole $=5,029 \mathrm{~m}$; (geogr) polul Pământu- lui; (el) pol; dinte; stâlp de linie electrică); (nav) pol, baliză; capră, suport; (OM) stâlp, țăruş, jalon, baliză; a sprijini, a propti; (el) a magnetiza, a polariza; (metr) unitate de măsură pentru suprafață, egală cu un pătrat cu latura de o prăjină: 1 square pole $=1$ pole of area $\cong 25,29285$ $\mathrm{m}^{2}$; (metr) pole; v. unit magnetic pole

pole arc (geom) arc polar / de pol

pole arm (OM, constr) braț / traversă a(1) unui stâlp

pole ax(e) (alim, OM) secure; satâr, cuțit, bardă (de măcelărie)

pole change (el) inversiune de polaritate / de poli pole changer (el) inversor de poli

pole changing (el) comutare de poli; schimbare a numărului de poli (la un motor)

pole changing control (el) reglare a (turației) prin schimbarea numărului de poli

pole core (el) miez magnetic polar / al polului

pole earth wire (el) conductor de legare la pământ / de coborâre a(l) paratrăsnetului

polegada (metr) unitate de măsură pentru lungime, inch / țol portughez: 1 polegada $=2,777 \mathrm{~cm}$ pole gap (el) întrefier polar

pole guy (OM, constr) ancoră a unui stâlp (electric) pole horns (el, OM) coarne / extremități ale pieselor polare

pole piece / shoe (auto, OM) papuc de pol; (el) piesă polară

pole pitch (el, fiz) pas / interval polar

pole with line stays (OM, constr) stâlp de întindere / ancorat

police station $(\mathrm{adm})$ secție de poliție

policy politică; tactică; metodă; (ec) poliță (de asigurare)

policy formation (ec) stabilire a politicii / a liniei (unei firme)

policy holder titular al unei polițe de asigurare

policy statement (ec) declarație / dare de seama asupra politicii firmei

poling (met) perşaj; (el) inversare a conductoarelor / a liniilor

polish $(\mathrm{TH})$ lustru; luciu; polizare; lustruire; satinare (a hârtiei); a lustrui; a poliza; a şlefui; a satina

polished $(\mathrm{TH})$ lustruit, polizat, şlefuit

polished plastering (constr) tencuială netezită

polished rod $(\mathrm{OM})$ tijă / bară lustruită

polished section (met) secțiunea şlefuită a probei; (OM) şlif

polished sheet (met, metr) tablă lustruită / laminată la rece

polished specimen (met) probă metalografică lustruită 
polisher (constr, hidr, mas-un) maşină de polizat / de lustruit, amestec pentru lustruit; (mas-un) placă de lustruire, şlefuitor

polishing $(\mathrm{TH})$ lustruire; netezire, şlefuire, polizare, poleire

polishing bit (mas-un) burghiu de finisare

polishing buff (mas-un) disc de lustruit

polishing clamp (mas-un) bucşă de lustruit

polishing cloth (mas-un) pâslă de lustruit

polishing cold rolling mill (met) laminor netezitor / finisor la rece

polishing composition (mas-un, chim) substanță de lustruit / amestec / compoziţie

polishing compound (mas-un, chim) compus de polisare (de lustruire)

polishing cone (mas-un) dorn conic de lustruit

polishing disk (mas-un) disc de lustruit (şi pt. probe metalografice)

polishing file (mas-un) pilă de şlefuit

polishing hammer $(\mathrm{OM})$ ciocan de netezit

polishing house (met) caja laminorului netezitor / finisor

polishing lathe (mas-un) strung de polizat

polishing machine (mas-un) maşină de lustruit / de polizat / de şlefuit

polishing material (met) material de lustruire; lustru de piele

polishing medium (mas-un, chim) solutie / mediu de lustruire

polishing oil (mas-un, chim) ulei de lustruit

polishing pass (met) trecere de finisare (la laminare) polishing paste (mas-un, chim) pastă de lustruit polishing pickling (met, $\mathrm{TH}$ ) decapare de lustruire polishing plate (mas-un) placă de polizat / lustruit

polishing powder (mas-un, chim) praf / pudră de şlefuit / de lustruit

polishing roll (met) cilindru netezitor (la laminare)

polishing tool (mas-un) sculă / dispozitiv de lustruit; (met) planator

polishing wheel (mas-un) disc abraziv de lustruire fină

pollex (poll) (metr) (în latină - deget), utilizat în loc de inch în botanică

pollutant (mediu, chim) factor poluant

polluted air (mediu, chim) aer impurificat / poluat polluted water (mediu, chim) apă poluată

pollution îmbâcsire; (mediu) poluare, murdărie; (fiz) contaminare; (met, OM, T) impurificare (a aunui aliaj, a unui lubrifiant etc.)

pollution load (mediu, ind) grad de impurificare / poluare

Polonium (Po) (chim) poloniu

polyacetal, POM (ind chim, plast) poliacetal polyacethylene (plast) policetilenă

polyacrylate (plast) poliacrilat

polyacrylicacid (plast, ind chim) acid poliacrilic

polyad (chim) polivalent

polyaddition (plast, chim) (reacție de) poliadiție

polyamide, $\mathbf{P A}$ (plast) poliamidă

polyamide(-)imide, PAI (plast, ind chim) poliamidimidă

polyamide resin (plast, ind chim) răşină poliamidică polyamidic fibers (plast) fibre poliamidice

polyaminiamide (plast) poliaminoamidă

polyaryletherketone, PAEK (plast, ind chim) poliarilcetonă

polybenzylmethacrylate (plast, ind chim) polibenzilmetacrilat

polybisphenol carbonate (plast, ind chim) policarbonat-bifenol

polyblends (ind chim, OM) amestec de polimeri polybutadiene (plast, ind chim) polibutadienă

polybutadiene oxide (plast, ind chim) oxid de polibutadienă

polybutadiene-styrene (plast, ind chim) polibutadienstiren

polybutene (plast) polibutilenă, polibutenă

polybutylene terephthalate, PBT (plast, ind chim) polibutilentereftalat

polycaprolactam (plast) policaprolactamă

polycaprolactone (plast, ind chim) policaprolactonă

polycarbonate, PC (ind chim, plast) policarbonat polychlorinated propylene, chlorinated polypropylene (plast, ind chim) polipropilenă clorurată

polychlorocarbon (plast) hidrocarbură clorurată

polychloroprene (plast, ind chim) policloropren, cauciuc policloroprenic

polychromatic (fiz) policrom(atic)

polychrome; polychromic (fiz) policrom

polychromy (fiz) policromie; (textile, tipografie) imprimare multicoloră

polycondensation (chim, plast) policondensare

polycrystalline (met, fiz) policristalin

polydiallylphthalate (plast, ind chim) polidialiltfalat

polydiene rubber (plast) cauciuc polidienic

polydispersed (materiale) (amestec) cu particule de mărimi diferite

polyester (plast, ind chim) poliester

polyester alkyd, PAK (plast, ind chim) poliester alchidic

polyester fibres (plast) fibre poliesterice

polyester laminate (ind chim) material poliesteric stratificat

polyester (PET) resins (plast, ind chim) răşini poliesterice 
polyester(s) (PEs) (plast, ind chim) poliester(i) polyether (plast, ind chim) polieter polyetheretherketone, PEEK (plast, ind chim) polieteretercetonă

polyetherimide, PEI (ind chim, plast) polieterimidă

polyethylene, PE (plast, ind chim) polietilenă

polyethyleneglycol, PEG (plast, ind chim) polietilenglicol

polyethyleneimine, PEI (plast, ind chim) polietilenimină

polyethylene oxide (plast, ind chim) oxid de polietilenă

polyethyleneterephthalate, PET (plast, ind chim) polietilentereftalat

polyethylene-vinyl acetate, PVA (plast, ind chim) polietilen-vinil acetat

polyfluorocarbons (plast, ind chim) hidrocarburi polifluorurate, polimeri fluorurați

polyfluoron (plast, ind chim) denumire comercială pentru politrifluorcloretilenă

polyfluoroprene (plast) polifluoropren

polyfurnace (ind chim, termo) cuptor de polimerizare

polyglicol (chim) glicol, poliglicol

polyglicol solution (chim) soluție de apă şi glicol

polygonal (geom) poligonal

polygonal path (geom) linie frântă / poligonală

polygon connection (el) conexiune în poligon (a unei înfăşari polifazate)

polygon hob (mas-un) freză-melc de prelucrat piese cu mai multe laturi / alezaje poligonale

polygonice (alim, termo) gheață poligonală / în forma de poligon

polygon of forces $(\mathrm{mec})$ poligon al forțelor

polyhalocarbons (plast, ind chim) hidrocarburi polihalogenate

polyhalide (plast, ind chim) polihalogenură polyhedral (geom) poligonal, poliedric polyhedron (geom) poliedru

polyimide, PI (plast, ind chim) poliimidă

polyisobutylene (PIB) (plast, ind chim) poliizobut(il)enă

polyisocyanate (plast, ind chim) poliizoceanat polyisoprene (plast, ind chim) poliizopren polymer (plast, chim) polimer

polymer alloy (plast, ind chim) aliaj polimeric polymer blend (plast) amestec de polimeri polymeric amide fibre (plast, ind chim) fire / fibre poliamidice, nailon ( $\mathrm{fam}$ )

polymeric compound (plast) compus polimeric polymerization (plast, chim) polimerizare polymerization accelerator (plast, chim) accelerator de polimerizare polymerization activator (plast, chim) activator / initializator de polimerizare

polymerization degree (plast, chim) grad de polimerizare

polymerization furnace (plast, ind chim, termo) cuptor de polimerizare

polymerization inhibitor / retarder (plast, chim) inhibitor / încetinitor de polimerizare

polymerization modifier (plast, chim) modificator de polimerizare

polymerize (plast, chim) a polimeriza

polymerized / polymer oil (ind chim, T) ulei polimerizat

polymerized vinyl chloride (plast) policlorură de vinil

polymerizer (plast, ind chim) autoclavă / instalație de polimerizare

polymer matrix composite (plast, $\mathrm{OM}$ ) compozit cu matrice polimerică

polymethacrylate, PMA (plast, ind chim) polimetacrilat

polymethacrylonitrile (plast, ind chim) polimetacrilonitril

polymethylene (plast) polimetilenă

polymethylmethacrylate, PMMA (plast, ind chim) polimetilmetacrilat de metil

polymolecular layer (chim, T) strat polimolecular

polymorph (fiz) polimorf

polymorphic / polymorphous transformation (fiz) transformare polimorfă

polynom(ial) (mat) polinom(ial)

polynomial equation (mat) ecuație algebrică / polinomială

polynomial ring (mat) inel de polinoame

polynuclear aromatics (plast, chim) hidrocarburi aromatice, policiclice

polyolefin PE, PP (plast, ind chim) poliolefină

polyphenylene oxide, PPO (plast, ind chim) oxid de polifenilen

polyphenylene sulfide, PPS (plast, ind chim) polifenilensulfonă

polyphenilensulphure, PPSU (ind chim, plast) polifenilensulfură

polyphenylmethylsiloxane, PPMS (plast, ind chim) polifenilmetilsiloxan

polypropylene, $\mathbf{P P}$ (plast, ind chim) polipropilenă polypropylene glycol-propylene oxide, PPGPPO (plast, ind chim) polipropilenglicolpropilenoxid

polyreaction (chim) reacție de polimerizare

polysaccharide (chim) polizaharidă

polysiloxane (plast, ind chim) polisiloxan

polystage amplifier (metr, autom) amplificator cu mai multe etaje / multiplu / în cascadă 
polystage switch (el, OM) întrerupător în trepte polystyrene, PS (plast, ind chim) polistiren; general purpose $\sim$, GPPS polistiren de uz general; high impact $\sim$, HIPS polistiren rezistent la impact; modified medium impact $\sim$ MIPS polistiren modificat, cu rezistență medie la impact

polysulphide (plast) polisulfură

polysulfone, PSU (plast, ind chim) polisulfonă

polysulfone resin (plast, ind chim) răşină polisulfonică

polytetrafluoroethylene, PTFE (plast, ind chim) politetrafluoretilenă, teflon (denumire comercială DuPont)

polyurhea (plast, ind chim) poliuree

polyurethane, PUR (plast, ind chim) poliuretan

polyurethane foam (plast, ind chim) spumă poliuretanică

polyurethane rubber (plast, ind chim) cauciuc poliuretanic

polyurethanes (plast, ind chim) poliuretani

polyvalency (chim) polivalență

polyvalent (element) polivalent

polyvinyl (chim) polivinil

polyvinyl acetals (chim) acetali polivinilici

polyvinyl acetate, PVA (plast, ind chim) acetat de polivinil, polivinilacetat

polyvinyl alcohol, PVAL (chim) alcool polivinilic

polyvinyl benzylchloride (plast, ind chim) polivinil-clorbenzil

polyvinyl butyral, PVB (plast, ind chim) polivinil butiral

polyvinyl carbazole (ind chim, plast) polivinilcarbazol

polyvinyl chloride, PVC (chim, plast) clorură de polivinil, policlorură de vinil

polyvinyl chloride resin (ind chim, plast) răşină policlorvinilică

polyvinyl ethers (ind chim, plast) polivinil eteri

polyvinyl formal, PVFM (plast, ind chim) polivinil formal

polyvinylidene fluoride (PVF) (plast, ind chim) polifluorură de viniliden

polyvinyl plastics (ind chim, plast) materiale plastice polivinilice

polyvinyl stearate (plast, ind chim) stearat de polivinil

polyvinylalcohol, PVA (plast, ind chim) alcool de polivinil

polyvinylpyridine, PVP (plast, ind chim) polvinil-piridină, polipiridină de vinil

PVC (plast) abreviere pentru polyvinyl chloride polyplant (ind chim) instalație de polimerizare polyplast (plast, chim) polimer

polypin (metr, alim) unitate de măsură pentru volum (de bere sau băuturi alcoolice) 1 polypin of beer (UK) 18,2 ..20,5 1, 1 metric polypin of beer $=20 \mathrm{l}$; polypin este denumirea unei mărci înregistrate (Biovision $\mathrm{GmbH}$ ) pentru polimerul utilizat pentru acoperirea recipientelor

pomace (alim) tescovină de mere; turtă de oleaginoase

pomace breaker-spreader (alim) mărunţitoraruncător de tescovină

pomade (chim) alifie; unguent; pomadă

PON (metr, ind chim, auto) abreviere pentru pump octane number (cifră octanică la pompă)

pond, Dutch pound (metr) livră olandeză: 1 pond (Olanda) $=500 \mathrm{~g}=1$ German pfund; pond (p) (metr) unitate metrică de măsură pentru forță (mai rar utilizată): 1 pond $=1$ gram weight $=980,665$ dyne

pond (constr, hidr) piscină; (hidr, geogr) bazin, lac, eleșteu

ponderous greu; $(\mathrm{OM})$ masiv; cu dimensiuni mari; cu pondere

pontoon (constr) cheson; (hidr, nav) ponton, bac; ambarcațiune cu fund plat

pontoon crane (nav, transp) macara (montată pe) ponton

pontoon dock (nav) doc-ponton

pony cal mic, ponei; (metr) a small glass for liquor; 1 pony (US) 29,6 ml; (metr) pahar mic de bere: în Australia, 1 pony of beer $\sim 140$ ml; 1 pony keg (US, pentru bere) 29,34 1

pony axle $(\mathrm{OM})$ osie alergătoare

pony motor (mas) motor auxiliar de pornire / de lansare

pony routher (met) cajă degrosisoare (de laminor) pony routhing (met, $\mathrm{TH}$ ) întindere preliminară (de laminare)

pony routhing mill (met) calibru pregătitor (de laminor)

pony routhing stand of rolls (met) cajă pentru cilindrii pregătitori (la laminor)

pood (metr) v. pud

pool piscină; (hidr, geogr) iaz; lac de acumulare, zonă adâncă în albie, bazin, baltă; (ec) cartel, trust; (met) puț de cercetare, baie de sudare; (nav) rezervor; zăcământ, rezervor, groapă

pool furnace (met) cuptor cu vatră

poop (nav) dunetă, pupă; (el) impuls; (nav) a inunda pupa, a se sparge pe puntea dunetei (d. valuri)

poop anchor (nav) ancoră pupa

poop deck (nav) punte pupa

pooped (nav) cu pupa spălată de valuri 
poor audibility (fiz) audibilitate redusă / slabă poor coal cărbune de calitate inferioară poor combustion (termo, chim) ardere incompletă

poor conductor (el) conductor cu conductibilitate electrică redusă

poor contact (el) contact slab / slăbit / defectuos poor electrical connection (auto) legătură / conectare defectuoasă a circuitului electric

poor gas (met, termo) gaz sărac / uscat poor-gas firing (termo, met) încălzire cu gaz sărac poor in inertia (mec) cu inerție redusă poor mixture (termo) amestec (gazos) sărac poor oil (ind chim) ulei de calitate inferioară poor ore (met) minereu sărac

poor penetration (met, TH) sudură nepătrunsă / incompletă

poor quality (de) calitate mediocră

poor restart $(\mathrm{TH})$ reluare defectuoasă (la trecere, de laminare, la sudare)

poor restart at the root (met, $\mathrm{TH}$ ) reluare defectuoasă la prima trecere (la sudare)

poor restart at the toe (met, $\mathrm{TH}$ ) reluare defectuoasă la ultima trecere (la sudură)

poor return $(\mathrm{ec})$ beneficiu slab

poor sealing (OM) etanşare slabă / defectuoasă

poor solder (met) aliaj (de lipit) cu conținut redus de staniu

poor vacuum (fiz) vid redus / puțin înaintat

poor visibility (av, nav) vizibilitatea rea (gradul

2: obiectele se disting până la 500 m) (în navigație)

poor weld (met, OM) sudură incorectă / de calitate necorespunzătoare) / cu defecte

pop pocnet, pocnitură; detunătură; (alim) băutură efervescentă; a crăpa, a pocni

pop gate (met) alimentator în formă de creion, la piciorul pâlniei de turnare

pop back (auto, termo) retur de placare, explozie în carburator

pop-off (met) răsuflătoare (la turnare)

pop-off flask (met) cutie de formare cu răsuflătoare

poppet (mas-un, OM, hidr) sabot de apăsare, păpuşă mobilă, bilă apăsată de un arc; (nav) montant de falsbord / de parapet, pontil de lansare; (termo) supapă cu disc / cu taler

poppet head (mas-un) păpuşă mobilă / de centrare

poppet sleeve (mas-un) manşon / ax al păpuşii mobile

poppet type pressure control valve (hidr, OM) dispozitiv / supapă de reglare a presiunii cu element plonjor / cu plunjer poppet valve (OM, hidr) supapă cu scaun plat (eventual cu bilă), supapă de aerisire; supapă fixă cu tijă / cu scaun oblic / în formă de ciupercă / supapă cu tijă şi taler

poppet-valve distribution (hidr, OM) distribuție cu supape

poppet-valve gear (auto, termo) mecanism de distribuție cu supape

popping pressure (hidr) presiune de deschidere a unei supape de siguranţe (şi la fluide compresibile)

populate a ocupa; a popula

population $(\mathrm{TH})$ lot, populație

population mean $(\mathrm{TH})$ media unui lot / a unei populații

population variation $(\mathrm{TH})$ (intervalul de) variație a unui lot / a unei populații

porcelain (ind chim) porțelan

porcelain crucible (ind chim) creuzet de portelan

porcelain cup (ind chim, OM, el) izolator-clopot de portelan

porcelain dish (ind chim) farfurie de porțelan, capsulă de porțelan

porcelain evaporating dish (alim, chim) capsulă de porțelan

porcelain jar / mortar (alim, chim) mojar de porțelan

porcelain pot mill (ind chim, alim) moară cu bile de porțelan

porcelain spark(ing) plug (auto) bujie cu izolator de porțelan

porcelain tank $(\mathrm{OM})$ recipient de porțelan

porch (constr) tindă, portic, portal; tambur, verandă; terasă; (el) palier de negru / al impulsului de stingere

porcupine boiler (termo, OM) boiler cu un sistem central din care pleacă tuburi închise la capete (ca nişte țepi)

pore (el) parte neizolată a unui conductor; $(\mathrm{TH})$ por

pore bridging (materiale) blocare / închidere a porilor

pore conductivity (electr) conducție lacunară (la semiconductoare)

pore filler (met, constr) umplutură pentru astupat porii

pore forming (met) formare a porilor

pore forming material (met) agent de formare a porilor, material porofor

pore fluid pressure (fiz) presiune a fluidelor din pori

pore pressure (hidr, met) presiune interstitială, presiune a fluidelor din pori

pore ratio (materiale) indice de porozitate 
pore size (materiale) dimensiune / mărime a porului / a porilor

pore size distribution (materiale) morfologia porilor; distribuție a porilor după mărime

pore space (materiale) volum al porilor; spațiu poros; porozitate

pores per inch, ppi (metr, materiale) măsură a porozității pentru produse tip spumă sau pentru filtre, pori pe inch / tol

pore volum (materiale) volum al porilor / golurilor pork (alim) carne de porc

pork-scraps (alim) jumări

poron (plast, materiale) policlorură de vinil (microporoasă)

porosimeter (metr, materiale) porozimetru

porosity porozitate; (metr) în industria hârtiei porozitatea se măsoară prin timpul necesar ca $100 \mathrm{~cm}^{3}$ de aer să treacă printr-o suprafață de 1 inch pătrat de hârtie la o diferență standard de presiune; unitatea de măsură este square inch seconds per deciliter (secunde ori inch pătrat pe decilitru) $\left(s \cdot i^{2} / d l\right)$, numită şi Gurley unit, în SI units, $1 \mathrm{~s} \cdot \mathrm{in}^{2} / \mathrm{dl}=6,4516$ secunde pe metru de coloană de aer $(\mathrm{s} / \mathrm{m})$

porosity curve / function (materiale) curbă / functie de porozitate

porosity log (materiale) diagramă de porozitate; curbă a diferentei de potențial

porous poros; spongios

porous barrier (alim, ind chim) perete separator poros

porous bearing $(\mathrm{OM}, \mathrm{T})$ lagăr (din material) poros

porous cast iron (met) fontă poroasă

porous chrome hardening (met, $\mathrm{TH}$ ) cromare dură, poroasă

porous diaphragm $(\mathrm{OM}$, alim) diafragmă poroasă

porous iron (met) fier spongios, burete de fier porous limestone (geol) calcar poros

porous medium (alim, chim, met) mediu poros

porous membrane $(\mathrm{OM})$ membrană poroasă; filtru poros

porous-metal bearing $(\mathrm{OM}, \mathrm{T})$ lagăr din aliaj / material metalic poros

porous rubber (ind chim) cauciuc poros

porous spot (met) regiune poroasă dintr-o piesă turnată (defect)

porous stratum (geol) strat poros / de rocă poroasă

porous structure (materiale) structură poroasă

porous weld (met, OM) cusătură poroasă, rost poros (la sudură) (defect)

porpoise oil (alim, chim) untură de delfin port $(\mathrm{TH})$ orificiu, gaură, deschidere; (met) capul cuptorului; (nav) port; babord (al navei); iluminator; sabord (deschidere în bordajul lateral); (el) poarta, acces; (nav) a pune cârma la babord

portability (inf) portabilitate, uşurință de modificare a unui program; $(\mathrm{TH})$ portabilitate, proprietate de a fi deplasabil / portabil

portable portabil; mobil; transportabil; deplasabil (d. un modul, un aparat etc.)

portable belt conveyor $(\mathrm{OM})$ transportor mobil cu bandă; bandă mobilă

portable boiler (cf, termo) cazan de locomotivă port conection (hidr, OM) orificiu de conectare portable fuel container (auto, OM) canistră de combustibil

portable grinder (met, mas-un) polizor mobil / portabil

portable hardness meter (metr, materiale) durimetru portabil

portable hoist (nav, OM) vinci portabil; (met, OM) troliu de intervenție transportabil

potable installation (ind) instalație portabilă

portable lathe (mas-un) strung portabil

portable motor (el, mas) motor transportabil / mobil

portable mould (OM, mas-un) matriță amovibilă

portable oscillating circular saw (OM, mas-un) ferăstrău circular-pendular (deplasabil), de tăiat şine şi profiluri

portable saw (OM, mas-un) ferăstrău deplasabil portable service set (ind, met) trusă de serviciu portable set (ind) set / ansamblu portabil

portable spot welder (mas-un) maşină portabilă de sudare prin puncte

portable standard meter (metr) aparat portabil care poate compara valorile măsurate cu cele standard

portable swing circular saw (mas-un) ferăstrău circular-pendular, deplasabil

portable terminal (c, autom) terminal portabil (cu o tastatură şi un dispozitiv de afişare / înregistrare)

portable welding boot (met) cabină portabilă de sudare

port aft (nav) pupa babord

portal (constr) portal, intrare principală; (auto, hidr) deschidere de eşapament, orificiu de scurgere / de descărcare; (mas, transp) macara portal; (met, cf, hidr) portal de tunel

portal crane (mas, transp) macara portal portal frame (OM, constr) (cadru) portal portal structure (OM, constr) stâlp portal 
portative (mas, OM) portativ, portabil portative force (mec, hidr, T) forță portantă port charges (nav, ec) taxe portuare port cover $(\mathrm{OM})$ clapetă de protecție port door (termo) uşă de acostament (a unui antrepozit frigorific)

port-end(s) (met) cap / gură de gaze şi aer (la cuptor Siemens-Martin)

port engine (nav, mas) motor babord

porter hamal; (mec, constr) grindă de rezistență port facilities (nav, mas) instalații portuare portfolio mapă, biblioraft; (ec) portofoliu, listă cuprinzând investițiile unei firme

portfolio of products $(\mathrm{ec})$ gamă de produse (ale unei firme)

portofolio selection $(\mathrm{ec})$ alegere a unei game de produse

porthole (OM, nav) hublou

portion parte; porțiune; cotă-parte; porție; fragment; a împărți; a porționa

portion of line (hidr, OM) piesă / portiune de conductă

portion of sphere (geom) calotă sferică

portion passing through screen (termo) cădere a cărbunelui prin grătar

Portland cement (chim, constr) ciment (hidraulic) Portland

Portland-Pozzolan cement (chim, constr) amestec de ciment (hidraulic) Portland cu constitueți pozzolano

port light (nav) lumină portuară, lumină distinctivă babord; lumină din babord, lumina roşie

port of call (p.o.c.) (nav) port de escală

port of delivery (nav, transp) port de livrare (a încărcăturii); port de repredare a navei (la terminarea navlosirii)

port of departure (nav, transp) port de plecare (a navei)

port of discharges (pt., disch.) (nav, transp) port de descărcare

port of distress (nav) port de refugiu

port of entry (nav, ec) port de sosire (a navei), port de import, port vamal

port of intake / loading / shipment (nav, transp) port de încărcare

port of registry (nav) port de ataş / de înregistrare / de înmatriculare

ports (autom, c, inf) porți / căi de intrare / de ieşire

portrait portret; imagine; poză; fotografie; (c) aşezare a paginii pe înălțime

port way (OM) canal (la maşini-unelte)

posistor, positive temperature coefficient resistor (el, termo, fiz) pozistor, rezistență cu coeficient de temperatură pozitiv, conductor rece position poziție; ordin; rang; situație; loc; serviciu; (nav) poziție (a navei), punct (termen referitor la locul navei); a regla; a potrivi; a poziționa

positional adjustment (autom, mas) reglare a poziției

positional notation (inf) sistem de notatie numeric; (mat) scriere poziționată a numerelor

position control servo (autom) servomecanism de comandă a poziţiei

position coupling key (OM, autom) cheie / comutator de legătură între poziții

positioner; positioning device (OM, electr) dispozitiv de pozitionare / de fixare a poziției, manipulator

position error (metr, autom) eroare de pozitiie; deviație (la reglarea proporțională)

position finder (autom, electr) indicator de poziție

position finding / fixing orientare în teren; determinare a pozitiei (unui punct, unui loc etc.) în teren, pe hartă, pe o schiță; (nav) stabilire a poziției unei nave în deplasare, determinare a punctului (navei); (fiz) radiogoniometrie

position function (fiz) funcție de punct / de loc; (mat) funcție de poziție

positioning (autom, metr) poziționare, reglare / corectare a poziției (și față de o sculă)

positioning action $(\mathrm{OM})$ acționare rigidă, reglare cu cuplaj rigid

positioning relay (el, electr, autom) releu de poziționare / de execuție

positioning scale (metr, autom) scală de reglare

positioning screw (mas-un, OM) şurub pentru assezarea piesei în pozitia cerută

position lever (mas-un) manetă pentru fixarea poziției (saniei șepingului în raport cu culisa) position light (auto) lumină de poziție; (nav) lumină distinctivă; lumină de siaj

position mark (mas-un, TH) marcă / semn care indică poziția de utilizare

position of equilibrium (mec) pozitie de echilibru

position of fracture (mec, OM) poziție a ruperii / a fisurării, locul de rupere / de distrugere (al cusăturii sudate, al unui element de maşină etc.)

position of load (mec) poziție a sarcinii

position sector switch (mas, autom) selector de poziție

position sensor (mas-un, metr) senzor de pozitie position servo(mechanism) (autom, $\mathrm{OM}$ ) servomecanism reproducător de poziție; servomecanism / regulator de urmărire

position vector (mat, fiz) rază vectoare, vector de poziţie 
positive

post-acceleration

positive (fiz, mat) pozitiv; (mas-un) imobil (opritor, limitator etc.); rigid (d. o îmbinare), fără alunecare relativă a elementelor transmisiei (la transmiterea mişcării); copie fotografică pozitivă; (mat) (semnul) plus; cantitate pozitivă

positive adsorbtion (fiz, chim) adsorbție pozitivă positive allowance (mas-un, OM) joc, toleranță (de ajustare, de uzură, funcțional)

positive battery terminal (auto, el) bornă pozitivă baterie

positive blower (auto, mas) suflantă cu rotoare angrenate (Roots), ventilator cu refulare forțată a aerului; suflantă cu capsulă

positive cash flow (ec) flux pozitiv de numerar (intrările depăşind ieşirile)

positive closing (mec, hidr) închidere forțată

positive clutch / coupling (OM) cuplaj cu transmiterea mişcării fără alunecare rotativă a elementelor cuplate

positive cooling (termo) răcire suplimentară / forțată

positive crankcase ventilation (PCV) (auto, mas) ventilație forțată a carterului

positive cut-off perdea totală (până la stratul impermeabil) (în hidrotehnică)

positive deviation (autom, metr) abatere superioară, deviație pozitivă

positive dihedral (geom) diedru pozitiv

positive displacement compressor (termo) compresor volumetric

positive displacement meter (metr, hidr) contor volumetric

positive displacement pump (OM, hidr) pompă de refulare / volumetrică

positive distortion (autom, electr) distorsiune pozitivă / în formă de butoi (d. semnale)

positive drive $(\mathrm{OM})$ acționare fără alunecare; antrenare forțată / fără alunecare

positive electrode (fiz) electrod pozitiv, anod

positive feed (mas-un) avans forțat / mecanic; (alim, ind chim) antrenare / alimentare forțată

positive feedback / regeneration (autom) reacție pozitivă, feedback cu amplificare

positive gain factor (autom) factor de multiplicare pozitiv

positive glow (fiz) lumină anodică / pozitivă

positive-going threshold voltage (el, autom) tensiune a pragului superior

positive governing (autom) comandă / reglare directă

positive intermittent taking-up motion (autom) (regulator cu) mişcare pozitivă intermitentă

positive lens (fiz, opt) lentilă convergentă / pozitivă positive live (el, fiz) aflat sub tensiune pozitivă positively $(\mathrm{OM}) \mathrm{cu}$ transmiterea mişcării fără alunecare relativă (a elementelor conduse în raport cu cele conducătoare)

positively controlled (autom) cu comandă /cu reglare printr-o transmisie care nu admite alunecare relativă (a elementelor conduse față de cele conducătoare)

positive motion $(\mathrm{OM})$ mişcare transmisă printrun mecanism fără alunecare relativă (între elementul conducător şi cel condus)

positive mould (met, plast, $\mathrm{OM}$ ) matriță pozitivă

positive-negative three-level action (hidr) reglare cu trei poziții şi zonă moartă (la distribuitoare etc.)

positive opening (OM, hidr) deschidere forțată

positive picture phase / polarity (fiz) polaritate pozitivă a semnalului de imagine

positive pressure (hidr) suprapresiune, presiune pozitivă

positive range (hidr, metr) parte pozitivă (a scării unui aparat de măsurat); (OM) (rapoarte de transmisie pozitive: $\mathrm{i}>1$ )

positive reversing $(\mathrm{OM})$ inversare forțată a sensului de mişcare

positive seat (mas) poziție de repaus

positive sequence polyphase system (el) sistem polifazat direct / de succesiune directă

positive solvent effect (OM, chim) efect pozitiv al solventului

positive speed gear box $(\mathrm{OM})$ cutie de viteze $\mathrm{cu}$ serii de rotație demultiplicatoare (rapoarte de transmisie pozitive: $\mathrm{i}>1$ )

positive stop (OM) limitator / opritor fix

positive stop screw pitch gauge (metr) calibru de filet (în care şabloanele pot fi rotite cu un anumit unghi)

positive suction pump (OM, hidr) pompă cu înălțime de aspirație pozitivă

positive temperature coefficient resistor, posistor (fiz, electr) pozistor, rezistență cu coeficient de temperatură pozitiv, conductor rece

positive terminal (el) bornă pozitivă; pol plus

positive valence (chim) valență pozitivă

possess a poseda, a avea (și proprietăți mecanice etc.); a ocupa

possession (poss.) (ec) proprietate, drept de proprietate, posesiune, folosință; bunuri

possibility posibilitate, eventualitate

post post; poştă; (constr) stâlp, par, pilon; montant; (el) ştift (al unei fişe), contact, picioruş; a plasa, a amplasa, a aşeza; a afişa (un anunț); a expedia prin poştă

post-acceleration (mas, autom) postaccelerare 
postage (transp, ec) tarif poştal; francare; cost al expediției prin poştă

postage stamp marcă poştală, timbru

postassembly seal $(\mathrm{OM})$ etanşare montată după asamblarea recipientului / sistemului de etanşat post bracket bearing $(\mathrm{OM})$ lagăr în consolă post-calculated cost (ec) cost postcalculat post-chlorination (chim, mediu) postclorurare (tratare a apei cu clor, după filtrare)

postcure (plast, ind chim) post tratament, tratament post-vulcanizare / după vulcanizare post drill (mas-un) maşină de găurit, cu coloană poster plancardă, afiş, poster

poster advertising afiș de reclamă

posterior probability $(\mathrm{TH})$ probabilitate aposteriori / bazată pe experiență

postexpouse (fiz, ind chim) expunere suplimentară / ulterioară

post-fermentation (alim) fermentare ulterioară post guiding $(\mathrm{OM})$ bucşă de ghidare precisă (după un ghidaj inițial mai puțin precis)

post hanger $(\mathrm{OM})$ suport pentru suspendarea lagărului fixat pe un montant

postheating încălzire ulterioară unui proces tehnologic (la sudare pentru detensionare etc.)

post insulate (el) a izola după asamblare

post office box (POB) căsuță poştală

post-paid (p.p., PP) francat

postpone a amâna; (met) a încărca (prin împingere)

postponement amânare (a unei reacții, a unui proces etc.)

post test (ec) testare ulterioară a unei campanii de comercializare

post tool holder (mas-un) port-cuțit simplu / cu reglarea înălțimii / suport al corzii sculei

postulate (mat) postulat; axiomă

postulational fundamentat pe postulat, axiomatic post up (sum) (ec) a reporta (o sumă)

postweld cleaning $(\mathrm{TH}, \mathrm{OM})$ curățarea (mecanică) a cusăturii sudate (de zgură, stropi etc.)

pot $(\mathrm{OM})$ oală; borcan; cutie; recipient; (chim, met) creuzet, deflector la canalul de fum; cazan de alambic; a conserva, a pune în cutii de conserve; a pune (o plantă) în ghiveci; (metr) unitate tradițională pentru măsurarea volumui în țări europene, comparabilă cu litrul; 1 pot (Elveția) $=$ 1,5 1, 1 pot $($ Belgia $)=1,51$ pentru solide, 1 pot (Belgia) $=0,51$ pentru lichide, 1 pot (Danemarca $)=0,9671,1$ pot $($ Norvegia $)=0,9651$; (metr, fiz) unitate de măsură pentru volum, în Australia: 1 unit pot of beer (Queensland şi Victoria) $=285 \mathrm{ml}, 1$ unit pot of beer (de bere) $($ Australia de Vest) $=575 \mathrm{ml}$; (metr) unitate tradițională pentru volum, în Jersey (Channel Islands): 1 pot $\cong 1,9751$ (pt. lapte)

potable water (alim, mediu) apă potabilă

pot annealing (met) recoacere în cutii (a pieselor turnate)

pot-annealing furnace (met) cuptor pentru recoacerea în cutii (a pieselor turnate) / cu creuzete potash soap (chim) săpun de potasiu / moale potash water glass (chim) silicat de potasiu; sticlă solubilă de potasiu

potassium (K) (chim) potasiu

potassium hydroxide (chim) hidroxid de potasiu potato (alim, bot) cartof

potato pulp (alim) pulpă de cartof

potato spirit (alim) alcool / spirt de cartof

potato starch (alim) amidon de cartofi

potch (ind chim) a înălbi, a decolora (d. țesături, materiale plastice etc.)

pot cooling (met) răcire în creuzet

pot core (el, met) miez semirotund / în formă de oală

potence file (mas-un) pilă lată mare

potent (alim) tare, alcoolic (d. băuturi)

potential posibilitate; (el, fiz, ec) potențial; (gram) (modul) potențial; latent; nedezvoltat; posibil

potential barrier (el, electr) barieră de potențial pot cooling (met) răcire în creuzet

potential correction (el, electr, autom) derivație temporară, corecție de potențial

potential diagram (fiz, mec) diagramă a energiei potenţiale

potential difference (p.d., PD) (el, fiz) diferență de potential, tensiune electrică

potential distribution (el, fiz) distribuție de potențial

potential divider (el) divizor de tensiune, potențiometru

potential drop / fall (el, fiz) cădere de potențial $/$ de tensiune

potential electrode (el, metr) electrod de măsură a potențialului electric

potential energy $(\mathrm{mec})$ energie potențială / acumulată

potential equalizer (el, autom) stabilizator de tensiune

potential equation (mat, fiz) ecuație verificată de potențial (la ecuații cu derivate parțiale)

potential field (mat, fiz) câmp potenţial potential flow (hidr) curgere / debit potențial(ă) potential function (fiz) funcție de forță / armonică, potențial

potential head / pressure (hidr) presiune statică potential hole / pot / trough / well (fiz) groapă de potențial 
potential of Hydrogen, pH (chim, fiz, metr) unitate logaritmică de măsură a acidității sau bazicității soluțiilor; pH unei soluții este o măsură a concerației de ioni de hidrogen, adică logaritmul negativ al concentrației, măsurată în moli pe litru; valorile $\mathrm{pH}$ variază între 0 şi 14; apa pură la $25^{\circ} \mathrm{C}$ are $\mathrm{pH} \sim 7,0$; un $\mathrm{pH}<7$ indică aciditate, iar $\mathrm{pH}>7$ indică alcalinitate

potentiometer (el, electr) potențiometru, rezistență variabilă, rezistor variabil, compensator, divizor de tensiune

potentiometer circuit (el, metr) circuit potențiometric; (metr, autom) circuit compensator

potentiometer rheostat $(\mathrm{el}, \mathrm{metr})$ reostat potentiometric în punte

potentiometer-type transducer (metr, el) traductor de tip potenţiometric / cu contact alunecător / glisant

potentiometric analysis (metr, fiz) analiză electromecanică / potențiometrică

potentiometric measurement (metr, electr) măsurare prin compensare / potențiometrică

potentiometric trimmer (metr, electr) potențiometru ajustabil

pot furnace / kiln (met) cuptor cu creuzet

pothead (cable) (el) capăt / manşon terminal, cutie terminală (pentru cabluri)

pothead entrance filting (el, OM) element armătură de fixare / de strângere în manşonul terminal al cablului

pothead joint(ing) sleeve (el) manşon de legătură (pt. cabluri)

pothead tail (el, OM) porțiune de cablu în manta de plumb (între mufa de ramificație şi linia aeriană)

pot kiln / furnace (met) cuptor cu creuzet

pot lead (met) grafit de / în creuzet

pot life (chim) durată de păstrare în bidon (a unui adeziv etc.)

pot melting process (met) proces de topire în creuzet

pot plunger (hidr, mas-un) piston de transfer / de injecție (pt. plastice)

pot roasting (met) calcinare în oală

potsherd ciob (din materiale casante: sticlă, portelan etc.)

potsherd powder (ind chim) cioburi măcinate sub formă de praf

pot steel (met) oțel de creuzet

pot still (alim, termo) alambic simplu / cu încălzire directă

Pottasium, Kalium (K) (chim) potasiu, caliu, kaliu potted capacitor (el, electr) condensator turnat / izolat prin turnare de răşină pottery (ind chim) olărie, faianță; (produse de) ceramică

potting $(\mathrm{OM}, \mathrm{el})$ etanşare / izolare prin turnare sau comprimare a unui material la partea terminală (a conductei, cablului)

potting compound (OM, hidr, el) compound / masă izolantă turnabilă

pottle (metr) unitate tradiţională de măsură pentru volum de lichid: 1 pottle $=1 / 2$ gallon

pot-type piston $(\mathrm{OM}, \mathrm{hidr})$ piston simplu

pouce (metr) unitate tradițională de măsură pentru lungime, deget (francez), inch / tol francez: 1 pouce $\cong 2,707 \mathrm{~cm}$

pouch (alim, zool) pungă; sac mic; (mil) cartuşieră; (med) pungă sub ochi

poumar (metr, textile) acronim pentru pound per million yards (livre pe un milion de iarzi), o unitate pentru măsurarea densității firelor textile în US: 1 poumar $\sim 0,496055$ tex; v. tex

pound (mas, mec) lovitură puternică, izbitură, plesnitură; (agr) îngrăditură, țarc, ocol (pt. vite); incintă închisă; (TH) a pisa, a fărâmița; a sfărâma, a zdrobi; a bate; a ciocăni; (constr) a bătători (pământul); carceră, închisoare; (fig) greu, necaz, strâmtoare; (metr, ec) liră sterlină (unitate monetară în Marea Britanie; 1 liră $=20$ shillings sau 100 pence), liră (unitate monetară în Australia, Egipt, Irlanda etc.); pound (lb, lbm, \#) (metr) unitate de măsură pentru masă sau forță, utilizată în Roma Antica și Vestul Europei, până la adoptarea sistemului metric, livră; funt; pfund; pund: în UK există două unităti standardizate cu această denumire (pt. masă şi forță); în US se utilizează avoirdupois pound (abreviată cu $\mathbf{~ l b ~ a v ~ s a u ~ l b ~ a p ) : ~} 1$ avoirdupois pound $=453,59237 \mathrm{~g}$; simbolul lbm este pentru unitatea de masă iar lbf - pentru unitatea de forță: v. pound force; pound $(\mathbf{l b} \mathbf{t}, \mathbf{l b})$ (metr, fiz) 1 troy pound $=373,242 \mathrm{~g}$ (folosită în UK în farmacologie și bijuterie); pound (lb) (metr) unitate tradiţională pentru măsurarea masei în industria hârtiei; v. pound weight

poundal (pdl, pl) (metr) unitate britanică de măsură pentru forță, utilizată în inginerie: 1 poundal $\cong 0,138255 \mathrm{~N}$

pound cut (lb cut) (metr) unitate tradiţională pentru măsurarea concentratiei lacurilor / vopselurilor tip şerlac; în US: 1 pound cut este un lac obținut prin dizolvarea a 1 pound shellac uscat într-un galon de alcool ca solvent $(\sim 120 \mathrm{~g}$ şerlac pe litru de solvent), v. shellac

pounded ore (met, $\mathrm{TH}$ ) minereu concasat prin procedeu / proces / tehnologie uscat(ă)

pounded sugar (alim) zahăr pudră 
pound foot (lbf ft, lb ft) (metr, fiz, mec) unitate de măsură pentru moment, livră.picior: 1 pound foot $\sim 1,355818 \mathrm{~N} \cdot \mathrm{m}$

pound force (lbf, lb) (metr) unitate de măsură pentru forță în țări de limbă engleză (UK şi Commonwealth), livră-forță: 1 pound force = $4,448221615 \mathrm{~N}$

pounding (constr, hidr) sfărâmare; batere (cu maiul etc.), bătătorire; (nav) lovituri repetate de valuri

pound mass (lbm) (metr, fiz) v. pound

pound-mass/inch ${ }^{3}$ (metr, fiz) unitate de măsură pentru densitate (1 pound-mass/inch ${ }^{3}=$ $\left.2,7679 \cdot 10^{4} \mathrm{~kg} / \mathrm{m}^{3}\right)$

pound mole (lbmol) (metr, fiz, chim) unitate de măsură pentru cantitatea de substanță, livrămol: 1 pound mole $=453,59237$ moli

pound per cubic foot, $\operatorname{pcf}(\mathrm{metr}$, fiz) unitate tradițională de măsură pentru densitate în inginerie, livră pe picior cubic: $1 \mathrm{pcf}=16,01846 \mathrm{~kg} / \mathrm{m}^{3}$

pound per cubic inch, pci (metr, fiz) unitate tradițională de măsură pentru densitate, în inginerie, livră pe inch / țol cubic: 1 pci = $27679,90 \mathrm{~kg} / \mathrm{m}^{3}$

pound per square foot (p.s.f., lb/sq. ft., lbf/ft ${ }^{2}$, psf) (metr, fiz) unitate de măsură pentru presiune, livră / funt / pund / pfund pe picior pătrat: 1 psf $\cong 47,880 \mathrm{~Pa}$

pound per square inch $\left(\mathrm{lbf} / \mathrm{in}^{2}\right.$, psi, lb/sq. in.) (metr, fiz) unitate tradițională de măsură pentru presiune, livră / funt / pund / pfund pe țol pătrat: $1 \mathrm{psi}=6,8947 \cdot 10^{3} \mathrm{MPa}$

pounds of force per linear foot, plf, lbf/ft (metr, fiz, T) unitate de măsură pentru forță distribuită liniar, livre pe picior liniar: 1 plf $=$ $14,59390 \mathrm{~N} / \mathrm{m}$

pounds per square inch absolute (psia, p.s.i.a.) (mec, fiz, metr, hidr) presiune absolută, exprimată în livre pe țol pătrat

pounds per square inch gauge (p.s.i.g., psig) (metr, hidr) presiune manometrică în livre pe țol pătrat (de multe ori ca diferență de presiune între presiunea incintei şi presiunea atmosferică)

pound weight (lb wt, lb) (metr) unitate pentru măsurarea masei sau grosimii hârtiei, în US; hârtia este descrisă cu 24 pound weight dacă 1 top (500 coli) în format standard are masa de 24 pounds; pentru hârtia de corespondență formatul de bază este $43,18 \mathrm{~cm}$ x $55,88 \mathrm{~cm}$; 24-pound bond paper înseamnă o masă de 6 pounds; unitatea metrică pentru masa hârtiei este densitatea unității de arie, în grame pe metru pătrat ( $\mathrm{g} / \mathrm{m}^{2}$ sau gsm); $1 \mathrm{lb}$ wt este echi- valent cu 3,76 g/m $\mathrm{m}^{2}$ pentru hârtia de corespondență, $1,48 \mathrm{~g} / \mathrm{m}^{2}$ pentru hârtie-indicator, $2,70 \mathrm{~g} / \mathrm{m}^{2}$ pentru hârtie de calitate etc.

pour (constr, met) strat turnat; (meteo) aversă de ploaie, ploaie torențială; (met, ind chim, plast) a turna (un lichid); a revărsa; a se răspândi; a curge (în); a vărsa (în); a veni în cantități mari / în număr mare

pourable sealing compound material turnabil / de turnare / de umplere (a rosturilor) pentru etanşare

pour a bearing (met, T) a căptuși prin turnare, cu compoziție un cuzinet de lagăr

pour depressor (chim, T) aditiv anticongelant / depresant

poured short mould (met) formă neumplută (defect de turnare)

pour forth (fiz, chim) a exala, a emite, a răspândi; (fig) a da frâu liber (mâniei etc.); a da buzna pour-in-place concrete (constr) beton turnat pe loc, beton monolit

pour in (TH) a turna, a vărsa în

pour in founding (met, constr) turnare la fundație pouring (met, constr) turnare, în turnare, care toarnă; (meteo) torențial (d. ploaie)

pouring basin (met) bazin de turnare; $(\mathrm{OM})$ gură de umplere / de turnare

pouring bay (met) hală de turnare

pouring bed (met) pat de turnare

pouring car (met) cărucior / vagonet de turnare

pouring crane (met) macara de turnare

pouring defect (met, plast) defect de turnare

pouring gate (met) pâlnie / rețea de turnare; (OM) gură de umplere / de turnare

pouring head (met, plast, $\mathrm{OM}$ ) canal de turnare pouring height (met) înălțime de turnare pouring in (met, $\mathrm{TH})$ turnare

pouring-in hole (met) pâlnie a rețelei de turnare pouring jar / pot (met) cazan de topit plumb pouring ladle (met) oală / lingură de turnare pouring lip (met, OM) buză / cioc de scurgere (la oala de turnare)

pouring nozzle (alim, met) cioc de turnare (la un vas)

pouring out $(\mathrm{TH})$ scurgere; turnare; golire pouring pit (met) groapă de turnare pouring platform (met) platformă de turnare pouring position (met) poziție de scurgere / de turnare

pouring rain (meteo) ploaie torențială

pouring spout (met, OM) jgheab / gură / buză de turnare

pouring temperature (met) temperatură de turnare pouring test (met, metr) probă de fluiditate 
pouring through pencil gate (met, $\mathrm{TH}$ ) turnare directă ,în ploaie”

pour into $(\mathrm{TH})$ a turna (în ceva)

pour into cups (met) a turna în forme / lingouri

pour on (met) a completa prin turnare

pour out (met) a goli; a turna (în afară); a scurge

pour point (materiale) punct de curgere (şi la unsori) / de lichefiere / de congelare; temperatură de lichefiere / de fluaj (mai rar)

pour-point additive / depressant / reducer (chim, $\mathrm{T}$ ) aditiv anticongelant / depresant

pour-point depressant $(T$, chim) agent / aditiv de coborâre / reducere a punctului de picurare / anticongelant / depresant

pour-point test (metr, T) teste pentru determinare a temperaturii de picurare (a unui ulei lubrifiant, hidraulic, a unei unsori)

pour reversion $(T)$ instabilitate a temperaturii de picurare (la lubfrifianți)

pour stability $(\mathrm{T})$ stabilitate a temperaturii de picurare (la lubrifianți)

pous, $(p l)$ podes (metr) unitate de lungime în Grecia Antică, picior: 1 pous $\sim 30,7 \mathrm{~cm}$

powder pudră, material pulverulent; pulbere, pudră; praf; $(\mathrm{TH})$ a pudra; a pulveriza; a pisa

powder bag $(\mathrm{OM}$, mil) săculeț pentru cartuşe

powder blue (chim) oxid de cobalt

powder burning (met, TH) tăiere cu gaz, cu pulbere de fier

powder carburising (met, $\mathrm{TH}$ ) cementare / carburare în mediu solid / cu pulbere

powder coating $(\mathrm{TH}, \mathrm{T})$ acoperire cu pulbere / pulberi (şi de materiale plastice)

powder cutting (met) tăiere cu gaz, cu pulbere de fier

powder dry perfect uscat (d. materiale pulverulente)

powdered (materiale) sub formă de pulbere / de praf

powdered caustic soda (ind chim) sodă caustică praf

powdered / pulverized coal cărbune pulverizat; praf de cărbune

powdered-coal firing (termo) focar / instalație de ardere cu cărbune pulverizat

powdered coke (met) praf de cocs

powdered filter (OM, mediu) filtru de praf

powdered flux (met, $\mathrm{TH}$ ) flux pentru / de sudare

powdered fuel (termo, mas) combustibil pulverizat

powdered fuel plant (termo) instalație de cazane cu ardere a prafului de cărbuni

powdered funnel (alim, plast, met) pâlnie de turnare a prafului / pulberii (şi la sinterizare) powdered glass (ind chim) praf de sticlă powdered-iron core coil (el, materiale) bobină cu miez sinterizat / din pulbere de fier

powdered slag (met) praf de zgură, zgură măcinată fin

powdered soap (ind chim) săpun praf

powder freezing (alim) congelare prin pulverizare / prin stropire / prin aspersiune, congelare în vid a stropilor de lichid pulverizat

powder glazing (chim) praf de grafitare

powdering (alim, ind chim, met) pudrare; (mediu, ind) acoperire cu praf; prăfuire

powder-jet extinguisher (chim, $\mathrm{OM}$ ) stingător cu (jet de) pulbere

powder mechanics $(\mathrm{mec})$ mecanica pulberilor powder metallurgy (met, $\mathrm{TH}$ ) metalurgia pulberilor powder milk (alim) lapte praf

powder mixer (alim, ind chim) amestecător / mixer de prafuri / de pulberi

powder particle (materiale) particulă de pulbere (în compozite, de praf, în materiale sinterizate / granulate etc.)

powder preparation (alim, ind chim, met) pregătirea pulberii (şi ca proces tehnologic)

powder rolling (met, $\mathrm{TH}$ ) laminarea pulberilor powder sugar (alim) zahăr pudră / farin

powdery purverulent, sub formă de pulbere (d. materiale)

powder yield locus punct de curgere a pulberii

power (pr.) (mec, el) putere; energie; capacitate; eficiență, randament; exponent; grad; (metr, opt) factor de mărire (la microscop); a alimenta / a furniza putere; a acționa; a excita

power absorption (mas, el) putere absorbită / cerută

power-actuated (mas, mec) cu acționare mecanică power actuator (mas, el) motor de executie power amplification (mas, el) amplificare de putere power amplifier / booster (PA) (mas, autom) amplificator de putere

power amplifier stage (mas, autom) etaj amplificator final / de putere

power and material economy (ec) economie de putere / energie şi de materie primă / materiale power-area ratio (mec, fiz) putere pe unitate de suprafață

power-assisted control (autom, electr, hidr) reglare indirectă (mod de reglare necesitând un aport de energie exterioară sistemului reglat); servocomandă

power-assisted steering (auto, autom) servodirecție; (nav) guvernare cu transmisie mecanică power balance (mec, termo) bilanț de energie / de putere 
power brake (auto) servofrână; (cf) frână mecanică; (met) stanță / matriță de îndoit

power-breeder (reactor) (el, electr) reactor regenerator de putere

power brushing (mas-un, TH) curățire cu perie rotativă

power cable (mec, el) cablu de forță / de energie power circuit (el) linie electrică de energie

power circuit breaker (el) întrerupător / disjunctor de sarcină / de putere

power coefficient (el) coeficient de putere

power consumption (mas) putere necesară; putere absorbită, consum de putere / de energie / de forță

power control $(\mathrm{OM}$, hidr) robinet de ştrangulare; (mas-un, OM) pârghie de pornire / de cuplare

power control apparatus (autom, hidr) regulator de putere

power control lever $(\mathrm{OM})$ pârghie de pornire / de cuplare

power conversion (fiz) transformare de energie / de putere

power cord (el) cordon / şnur de legare la rețea

power craft autovehicul; vehicul motorizat (naval, terestru, aerian)

power current (el) curent tare / intens / de putere (pt. acționarea sistemului principal al unei maşini)

power curve (el, mas) curbă / caracteristică de putere

power delivery (el, mec, hidr) debitare / cedare de putere, putere debitată

power demand (ind, $\mathrm{TH}$, mas) necesar / cerere de putere

power dissipation (mas) consum de putere / de energie; disipare de putere

power divider (autom, el, hidr, mec) divizor / distribuitor de putere

power door (alim, termo) uşă cu închidere automată (a unei incinte răcite)

power door lock switch (auto, OM) încuietoare electrică (pt. uşă)

power-drag scraper (OM, mas) screpăr mecanic

power drive $(\mathrm{OM}$, mas) acționare mecanică (de putere)

power-driven (mas) acționat de motor

power-driven drum winch $(\mathrm{OM}$, transp) troliu cu tobă acționat de motor

power-driven roller (constr, mas) tăvălug / compresor rutier cu motor

power-driven roller conveyor (met) cale / transportor cu mecanism de actionare a rolelor

power-driven ship / vessel (nav) navă cu propulsie mecanică power-driven system (autom, mas) sistem automat(izat) cu antrenare / acționare mecanică

power-driven vehicle (auto) autovehicul

power-driven winch (mas, transp) troliu / macara cu motor

power economy (ind, $\mathrm{TH}$ ) gospodărire a energiei powered (mas) cu acționare mecanică / electrică / pneumatică; mecanizat

powered barge (nav) şlep motorizat

powered by a motor (mas) cu acționare de la un motor

powered controls (autom) servocomenzi

power efficiency (mas, mec, el) randament energetic

power element (of a thermostat) (metr, termo) element sensibil / sesizor al unui termostat; sistem energetic / motor al unui termostat, elementul de actionare al unui termostat (un arc, un element dilatant etc.)

power engineering (ind) energetică; rețea de protectie legată la pământ

power equipment (mas) utilaj de forță

power (exponent) (mat) exponent al unei puteri (în algebră)

power factor (p.f.) (el) factor de putere, $\cos \gamma$

power factor meter (el), metr) cosfimetru

power factor rate $(\mathrm{el}, \mathrm{ec})$ tarif pentru energie reactivă

power fail protection (el) protectie contra defectelor de alimentare (cu energie)

power failure (el, mec) cădere a tensiunii, întrerupere a alimentării (cu energie)

power feed (mas-un) avans automat / mecanic; alimentare mecanică

power fluid (hidr) fluid pentru acționare hidraulică; fluid de lucru

power flux density (fiz) putere transmisă pe unitatea de suprafață (de o undă electromagnetică), flux de putere

power frame (mas) mașină cu acționare mecanică

power frequency (el) frecvență tehnică / industrială / de retea

power fuel (ind chim, termo) combustibil, carburant powerful puternic; tare

power gain (el, autom) amplificare; câștig / spor de putere; factor de amplificare a puterii

power gas (ind chim, termo) gaz de generator / carburant / combustibil

power generation $(\mathrm{mec}, \mathrm{el})$ generare / producere de energie

power governor (autom) regulator de putere

power grid (el) rețea energetică

power hack saw (mas-un) ferăstrău alternativ pentru metale, actionat de motor electric 
power hammer (mec) ciocan mecanic, acționat cu motor

power-handling capacity (mas, el) putere absorbită / cerută / consumată

power hardware (autom, el, hidr) aparat de comutare

power-house (ind) centrală energetică / de forță; sala maşinilor (într-o centrală, uzină)

power increment (ind, mas) creştere a consumului de putere

power indicator (metr, el) wattmetru (indicator) power induction (el, fiz) zgomot indus de linii industriale de energie electrică

power input (PI) (mas) putere cerută / absorbită; consum de putere / la intrare

power input rating $(\mathrm{OM})$ putere mecanică efectivă / utilă pe arbore; putere la frână / de frânare

power installation (el) centrală energetică de forță

power interrupt (mas, inf) cădere momentană de putere la echipamentul de monitorizare (cu posibile pierderi de date)

power jet (hidr) jet propulsiv

power lead (mas, ind) alimentare cu energie electrică

powerless (mas) fără forță / putere

power-limited (autom, mas) limitat la putere

power line (el) linie principală de alimentare / electrică de energie; linie / rețea de forță; (hidr) conductă principală

power-line filter (autom, electr) filtru de rețea

power-line frequency (el) frecvență de rețea / a rețelei

power-line tower (constr, el) stâlp de linie electrică / de înaltă tensiune

power loader (transp, mas) maşină de încărcat

power loading (mec, transp) greutate / încărcare / sarcină pe unitatea de putere (a unui mijloc de transport)

power loss (auto) pierdere de putere; (el, fiz, mas) pierdere de putere / de energie

power magnet (el) electromagnet de fontă

power main (el) linie electrică de (transport de) energie

power mains linie de forță

power-making capacity (el) putere / capacitate de închidere / de anclanşare (a unui aparat electric de comutatie)

power margin (mas, mec, el) limită de putere; putere-limită; rezervă de putere

power mechanical sweeper (mas, mediu) maşină de aspirat-măturat

power network (el) rețea electrică de forță power of absortion (el, mec) capacitate de absorbție (a puterii) (d. o maşină, o rețea de curent electric etc.)

power of attorney (P/a., P/A, PA) (jur, ec) împuternicire, procură

power-off indicator (mas) indicator luminos de scoatere din circuit / de deconectare de la retea power of governor (autom) capacitate de funcționare a regulatorului

power on-off switching (el, mas) schemă de comutare a puterii închis-deschis / conectatdeconectat

power-operated (acționat) mecanic (d. un dispozitiv, element de mașină etc.)

power-operated control (autom) reglare indirectă power-operated crane macara (cu acționare) mecanică

power-operated moulding machine (met) maşină de formare mecanică

power-operated point (cf) ac / macaz electric

power-operated skip (met, OM) schip cu actionare mecanică

power operation (autom) comandă prin servomotor; (mec) acționare mecanică

power outlet (auto) priză electrică, sursă de alimentare de $12 \mathrm{~V}$

power output (el) putere la borne / debitată / de ieșire / produsă / utilă / furnizată

power output per litre (termo, auto) putere litrică power pack bloc de / aparat cu alimentare de la rețea; (hidr) grup generator de presiune hidraulică

power panel (p.p.) (el) tablou de distribuție pentru instalații electrice de forță

power per litre (auto, termo) putere specifică / volumetrică / pe litru (de com bustibil)

power per unit of displacement (auto, termo) putere litrică / rezultată din capacitatea cilindrică

power plant (mas) grup motopropulsor; (el) centrală electrică; instalație de forță, centrală energetică / de forță

power-plant gas (termo, chim) gaze arse / de evacuare

power plug (el) fişă / ştecher de rețea / de sector power press (mas-un) presă mecanică / cu mecanism de actionare cu motor; presă de poansonat; (mec, TH) forță / putere de presare power production $(\mathrm{mec}, \mathrm{el}, \mathrm{fiz})$ producere a energiei

power-propelled autopropulsat (d. mijloace plutitoare); cu propulsie / cu tracțiune mecanică power-propelled vehicle (auto, termo) vehicul motorizat 
power pump (mas, hidr) motopompă

power rating (mas) putere de regim / nominală; capacitate nominală / prescrisă

power recorder (el, metr) wattmetru înregistrator power recovery (mas, mec, el) randament al puterii

power rectifier (el) redresor de putere / de alimentare

power relay (el) releu de putere / wattmetric power required (mas, $\mathrm{TH}$ ) energie necesară power riddler (met, constr) ciur vibrator mecanic, sită vibratoare

power saw (mas-un) ferăstrău mecanic

power scraper (met, mas-un) răzuitor mecanic; dispozitiv pentru acționarea mecanică a răzuitorului

power scraper excavator (constr, met) screpăr (mecanic)

power series (mat) serie de puteri (în analiza matematică)

power set (ind, constr) agregat, utilaj

power shears / shearing machine (mas-un, met) foarfece mecanic (pt. profile, semifabricate)

power shortage el, mas) lipsă de putere; cădere a alimentării / a rețelei

power shovel (constr, mas) excavator cu lingură / cu cupă dreaptă

power shovel bucket $(\mathrm{OM})$ cupă dreaptă de excavator

power spectrum (mat, fiz) funcție spectrală

power stage (hidr, constr) treaptă de amenajare energetică a unui curs de apă; (mas, el) etaj / treaptă de putere

power station (el, ind) centrală electrică

power steering (auto, mas, autom) servodirectie

power stroke (mas-un) cursă utilă / activă

power supply (el, ind) alimentare de la rețea / cu energie; bornă / racord la rețea, sursă / racord de energie; rețea electrică

power-supply synchronization (el) sincronizare cu frecvența rețelei (de alimentare)

power-supply unit (el) bloc de / aparat cu alimentare de la rețea

power-supply voltage (el) tensiune de rețea / de linie / de alimentare

power switch (el) întrerupător general / de rețea power switchboard (el, ind) tablou de distribuție pentru instalații de forță, panou de comandă power synchro (el, mas) sincromotor de putere power system (el, ind) sistem (electro)-energetic power take off (PTO) (el, mas) priză de putere / de forță / de energie

power take-off chain $(\mathrm{OM})$ lanț de avansare / de transmisie / de acționare power transformer (el) transformator de rețea / de mare putere / de forță

power transmission (el) transport de energie electrică; (mas) transmisie de forță / de putere

power-transmission system (mec, $\mathrm{OM})$ sistem de transmisie (de putere)

power traverse (mas-un, autom) avans automat(izat)

power tunnel (hidr, constr, OM) conductă forțată; galerie hidrotehnică forțată (sub presiune)

power unit (PU) (el) bloc / sursă de alimentare, agregat / grup electrogen

power wash mill (alim, met, ind chim) cilindru spălător cu actionare mecanică

power waste $(\mathrm{el}, \mathrm{mec})$ pierdere de putere

power water (hidr) apă sub presiune

power winch $(\mathrm{OM}, \mathrm{mec})$ troliu actionat mecanic power window (auto, OM, el) geam acționat electric

power window lock switch (auto) buton de blocare actionare geamurilor

power window timer (auto, electr) timer / temporizator pentru geamurile acționate electric

power window switch (auto) comutator de acționare electrică a geamurilor

power (x) (metr, fiz, opt) unitate pentru exprimarea puterii de mărire a unui sistem optic; (metr) o măsură a puterii de focalizare a lentilelor egală cu de 40 de ori lungimea focală; (metr) termen indicând că o măsurătoare este un multiplu al unei cantități standard: exemplu: un disc 16x CD-ROM se poate roti cu o viteză unghiulară de 16 ori mai mare decaât cel ,standard"

pp (metr) abreviere pentru ,pages” (pagini)

ppb, ppq, ppt, pptr (metr) abrevieri pentru unităţi de proporții: $p p b=$ part per billion $\left(10^{-9}\right)-$ unu / o parte la un miliard, ppq = part per quadrillion $\left(10^{-15}\right)$ - unu / o parte la un miliard de milioane, şi ppt / pptr = part per trillion $\left(10^{-12}\right)-$ unu / o parte la o mie de miliarde; abrevierea ppt se folosește uneori pentru per thousand $\left(10^{-3}\right)$ unu la o mie (atenție la text)

ppcm (metr, c, TV) abreviere pentru pixeli pe centimetru

ppi (metr, c, TV) abreviere pentru pixeli pe inch ppm (metr) abrevire pentru o unitate de proporții: ppm $=$ part per million $\left(10^{-6}\right)-$ unu $/ \mathrm{o}$ parte la un milion

ppi (metr) abreviere pentru pagini pe inch / țol (pages per inch), o măsură pentru grosimea hârtiei; (metr) abreviere pentru pori pe ich / țil (pores per inch), o măsură pentru porozitatea materialelor tip spumă şi a celor pentru filtre 
practicability aplicabilitate; posibilitate de utilizare

practicable practicabil; accesibil; realizabil; (auto, constr) carosabil

practical examen practic, lecție / probă practică; aplicabil; aplicat; care îşi cunoaşte interesele; comod; concret; de fapt; economicos; folositor; practic, util; (d. cineva) practician, realist

practical application aplicație practică; utilizare; valorificare

practical correction unit (autom) unitate practică de corecție aplicabilă (în funcționare)

practical entropy (fiz) entropie virtuală

practical experience (mas, TH) experiență de exploatare

practical facts / data (ind) fapte / date / informații stabilite prin practică

practical results (ind) rezultate practice / din exploatare

practical salinity unit, PSU, psu (metr) unitate standardizată, adimensională, de măsură pentru salinitatea apei de mare; raportul între conductivitatea apei de mare şi o soluție etalon: o salinitate a apei de mare de 35 PSU are aceiaşi conductivitate cu cea a unei soluții de clorură de potasiu $(\mathrm{KCl})$ cu o concentrație masică de 3,24356\%; 1 PSU are 1/35 din conductivitatea solutiei standard

practical units (metr) unități (de măsură) în sistem practic

practice practică; metodă; procedeu; (ec) clientelă; uzanță; $(\mathrm{TH})$ folosire, utilizare, exploatare, regim de lucru / de funcționare; exercițiu; a practica, a exercita, a utiliza

Prandtl number (fiz) numărul lui Prandtl

Praseodymium (Pr) (chim) praseodim

preabsortion (fiz, chim, T) preabsorbție

preacceleration (mas, $\mathrm{cf}$ ) preaccelerare

pre-aeration (termo) ventilație preliminară

preaging (met, plast) îmbătrânire artificială; trenare (a unui proces etc.)

prealloyed powder (met) pulbere de prealiaj

preamble (autom, el) sincronizator inițial

preamplifier stage (autom) etaj de preamplificare / de intrare

prearcing time (el) timp de topire a siguranței

preassembly seal $(\mathrm{OM})$ etanşare (şi modulată) montată la asamblarea sistemului sau înainte de montarea finală

preassembly selection $(\mathrm{TH}, \mathrm{OM})$ selecționare a pieselor înainte de asamblare

preassigned dat (dinainte), prevăzut (dinainte)

prebatch signal (autom) semnal cu anticipare pentru numărare / contorizare prebending $(\mathrm{TH})$ îndoire preliminară / inițială (la formarea prin roluire a țevilor, virolelor etc.)

prebevelling pregătire inițială a marginilor (de exemplu, prelucrarea suprafețelor înclinate ale rosturilor, la sudare etc.)

preblow (met) (in)suflare preliminară / iniţială

prebreakdown current (el) curent de anticipare a străpungerii / de prestrăpungere

precalcined (ind chim, met) precalcinat

precast (constr) prefabricat (din beton)

precast bearing pile (constr, $\mathrm{TH}$ ) pilot de fundație, prefabricat

precast board / floor (constr, $\mathrm{TH}$ ) planşeu prefabricat

precast concrete block (constr) bloc de beton (prefabricat)

precast concrete components (constr) elemente prefabricate din beton

precast concrete joist shaker / shaking machine (mas-un) vibrator pentru grinzi de beton prefabricate

precast concrete manufacturing yard (constr) atelier mobil de prefabricate de beton

precast concrete pile (constr) pilot de fundație prefabricat

precast concrete product (constr, TH) (produs) prefabricat de beton

precast concrete unit (constr, $\mathrm{TH}$ ) element prefabricat de beton

precast concreting vibration table (mas-un) masă vibratoare (pt. prefabricate de beton)

precast floor beam (constr) grindă prefabricată pentru planşeu

precast (foundation) pile (constr) pilot de fundatie prefabricat

precast plant / works (constr, ind) atelier de prefabricate

precast unit (constr, ind) element prefabricat

precast unit works (constr, ind) atelier de elemente de constructie prefabricate

precast wares (constr, ind) produse prefabricate / preturnate

precaution against skidding (el) protecție contra alunecării (la maşini electrice)

precautions precauții

precede a precede

precedence întâietate; prioritate; precădere; precedență; superioritate; importanță mai mare; ierarhie

precedent precedent; anterior

preceding precedent; premergător

preceding pass (met) calibru degrosisor

precept (ec) foaie de impunere; (mat) noțiune

precession precesi(un)e; precedență; precedere 
prechamber engine (termo) motor cu antecameră precharg(ed) pressure (inflation pressure) (mas, hidr) presiune inițială (pneumatică sau hidraulică) / de preîncărcare / de umplere precheck advertising $(\mathrm{ec})$ verificare prealabilă a eficacității reclamei (înaintea apariției / lansării unui produs pe piață)

precinct limită, margine; incintă; (pol, adm) circumscripție

precious prețios, perfect; de valoare, scump; afectat, căutat (d. stil)

precious metal (chim) metal prețios

precious stone (minrl) piatră prețioasă

precipitability precipitabilitate; (chim) coeficient de precipitare; capacitate de coagulare

precipitable (chim) precipitabil

precipitant precipitant; (chim) agent de precipitare, coagulant

precipitate (fiz, chim) precipitat; depunere; sediment; a precipita; a separa solidul dintr-o soluție / suspensie, a se depune; a accelera, a grăbi (o criză etc.); (meteo, fiz) a se condesa

precipitated catalyst (chim) catalizator precipitat precipitated powder (met) pulbere precipitată precipitated sulphur (chim) sulf precipitat precipitating (fiz, chim) precipitare; sedimentare; depunere

precipitating agent (alim, chim) agent de precipitare, precipitant, coagulant

precipitating reagent (chim) reactiv precipitant precipitation (chim) precipitare; (meteo) precipitații atmosferice, cantitate de precipitații

precipitation agent (chim) agent de precipitare

precipitation analysis (chim, metr) analiză prin precipitare

precipitation by electrolysis (met, ind chim) depunere / separare / precipitare electrolitică

precipitation hardening (met) călire / durificare prin precipitare

precipitation indicator (ind chim) indicator de precipitare

precipitation number (ind chim) indice / cifră de precipitare

precipitation of defects (ind) proces de transformare a unui defect latent într-un defect perceptibil, dacă sistemul funcționează (sub sarcină), proces de accelerare a ratei defectelor

precipitation test (metr, chim) determinare a indicelui de precipitare

precipitation vat (constr, alim, mediu) decantor; bazin de sedimentare

precipitator, precipitron (ind chim, mediu) epurator / curățitor de aer (şi electrostatic); (alim) aparat pentru decantat / precipitat precipitous abrupt; prăpăstios; (hidr) montat, agitat (d. mare)

precise precis; exact; clar; corect; explicit; fidel, întocmai; limpede; minuțios, migălos; pedant, punctual; at the $\sim$ moment when exact când, exact în clipa când, exact în momentul când

precise fractionation (ind chim) rectificare / fracționare precisă

precision (metr) fidelitate, grad în care un aparat repetă rezultatele în cazul unor măsurători repetate; (TH) precizie, exactitate; caracter explicit; claritate; corectitudine; punctualitate; high $\sim$ de mare precizie

precision balance (metr, fiz) balanță analitică / de precizie

precision casting (met, plast) turnare de precizie precision check (metr) control / verificare de precizie

precision class $(\mathrm{TH}, \mathrm{OM})$ clasă de precizie

precision compound (ind) atelier / secție de precizie

precision compound table (mas-un) masă deplasabilă longitudinal şi transversal, pentru lucrări de precizie

precision error (metr, electr, c, TV) eroare obiectivă / de rezoluție

precision file equalling (mas-un) egalizare / prelucrare cu pilă de precizie

precision gauge (metr, mas-un) calibru de precizie

precision gear $(\mathrm{OM})$ dantură / angrenaj de precizie

precision grind (mas-un, TH) rectificare de precizie

precision ground tap (mas-un) tarod de precizie, cu filet rectificat

precision indexing head (mas-un) cap divizor de precizie

precision instrument (metr) aparat / etalon de măsurat / de verificare

precision lathe (mas-un) strung de precizie

precision levelling ( $\mathrm{TH}$, mas-un) nivelare de precizie; (topografie) nivelment de precizie

precision-made (OM, metr) de precizie

precision mechanics mecanică fină / de precizie

precision measurement (metr) măsurare de precizie

precision mill (met) cilindru calibrat (la laminor)

precision moulding (met, plast, $\mathrm{TH}$ ) turnare de precizie

precision of fine mechanics precizie de / pentru mecanică fină

precision of test (metr) precizie de măsurare / de testare / a parametrilor de testare 
precision plug gauge (metr) calibru-tampon de control

precision rectifying column (ind chim) coloană pentru rectificare de precizie

precision regulator (metr, autom, mas-un) regulator fin / de precizie, aparat cu precizie mare de reglare

precision tool (mas-un) sculă de precizie

precision tool-room (mas-un) sculărie de precizie precision turner (mas-un) strungar de precizie precision weighing (metr) cântărire de precizie precision-wire-drawing works (met) trefilare de precizie

precision work $(\mathrm{TH}$, ind) prelucrare de precizie

preclude a exclude; a înlătura; a preveni; a împiedica

pre-coat (chim, mediu) strat de grund / de lacuri / de material filtrant (format la suprafața filtrului)

pre-coated sand (ind chim) nisip sintetic / prelucrat

pre-coating strat de grund; formare a stratului filtrant; acoperire inițială (ca etapă pregătitoare pentru următoarea acoperire)

pre-coat sealing (ind chim, $O M$ ) material de acoperire pentru etanşarea asamblării filetate (care poate fi înlăturat la demontare)

precocity, prematureness (agr, bot) precocitate; coacere / maturizare timpurie

pre-combustion (termo, chim) precombustie

pre-combustion chamber (termo, chim) antecameră; cameră de precombustie

pre-combustion engine (termo) motor Diesel cu antecameră

pre-compressed air (termo) aer precomprimat

pre-compression (auto, termo) precompresie

pre-condition condiție preliminară / inițială; a condiționa în prealabil

pre-conditioning precondiționare (d. materiale semifabricate)

pre-consolidation (constr, $\mathrm{cf}$ ) preconsolidare (a solului)

pre-consolidation load (constr) sarcină preliminară (de consolidare)

precooler (termo, alim) răcitor preliminar; prerăcitor

precuring (ind chim) întărire preliminară, vulcanizare prematură; subvulcanizare

pre-defecation (alim) predefecare (la rafinarea zaharului)

predesigned dinainte dat, fixat înainte

predetermined stabilit dinainte, predeterminat

predicate (gram) predicat; (inf) expresie alcătuită din mai multe variabile din care poate fi obținută o propoziție adevărată sau falsă predicted rate $(\mathrm{TH}, \mathrm{mec})$ viteză teoretică / estimată

prediction control system (autom) sistem de reglare cu anticipare / $\mathrm{cu}$ avans

prediction relay (el) releu de anticipare

prediction time (autom) timp mort negativ, constantă de timp a anticipării / diferențială

predictive maintenance (mas, TH) mentenanță preventivă / corectivă care anticipează avariile (după evoluția unor parametri monitorizați, cum ar fi vibrațiile) şi încearcă să reducă riscul de apariție

predictive research cercetare pentru prognoză

predictor (autom, el) instalatie / dispozitiv de transmitere a comenzilor; instalație de comandă; extrapolator; (mat) variabilă independentă

pre-dip (ind chim, textile) impregnare preliminară predischarge (hidr, TH) descărcare prealabilă / inițială

predisposition predispoziție

pre-dissolving (alim, ind chim) predizolvare

predominant hue nuanță predominantă (şi la unsori etc.)

predrying (alim, constr, $\mathrm{TH}$ ) preuscare; uscare preliminară

preece test (met, metr) încercare / test cu sulfat de cupru

pre-empt (ec) a cumpăra în / pe baza unui drept; a dobândi un monopol în prealabil

pre-empted opportunities (ec) posibilități de prioritate (la cumpărare)

preemptive patenting brevetare de blocare, brevetare a unui produs sau proces tehnologic în scopul de a-l face inaccesibil concurenței

prefab prefabricat; (constr) casă / clădire prefabricată

prefabricated (constr) prefabricat

prefabricated house (constr) casă / clădire prefabricată

prefabricated part (constr) prefabricat

prefabricated piece / unit (constr) element prefabricat; (ind) semifabricat

prefabricated track (cf, constr) panou de cale ferată cu şine gata montate pe traverse

prefer a avansa, a promova (în serviciu); a formula, a înainta (o cerere, o revendicare etc.)

preferential adsorption ( $T$, chim) adsorpție selectivă

preferential claim $(\mathrm{ec})$ privilegiu

preferential rates (ec) tarif minimal (la vamă)

preferential share $(\mathrm{ec})$ acțiune privilegiată

preferential solvent (chim) solvent selectiv

preferment (ec, adm) promovare (în serviciu), functie superioară 
preferred preferat, preferențial

preferred noise criterion, PNC (metr) unitate utilizată pentru măsurarea nivelului zgomotului de fond în incinte închise, similară celei pentru criteriul de zgomot (noise criterion - NC), valorile măsurătorilor în $\mathrm{PNC}$ sunt în general cu $10 \ldots 15 \%$ mai mici decât cele în decibeli

preferred orientation (met, plast) orientare preferențială (a moleculelor)

prefer (to) a da întâietate; a-i plăcea mai mult (decât); a da precădere, a prefera (cuiva)

prefill valve (hidr, OM) supapă de umplere pre-filter (alim, mediu, ind) prefiltru

prefiring (met, termo) antefocar

prefix (autom) semnal de declanşare; preimpuls; prefix; număr de preselecție

prefix form / notation (inf) formă / notație prefixată; formă de scriere a unei expresii în care operatorii preced operanzii lor

prefix multiplier (metr) prefix pentru formarea multiplilor unitătilor de măsură

pre-folded filter (OM, hidr) filtru burduf

preform tabletă; brichetă; semifabricat (d. materii prime); a stabili / preforma dinainte

preforming $(\mathrm{TH})$ tabletare; brichetare; preformare; precomprimare

preforming machine (mas-un) maşina de tabletat / de preformat

preforming press (mas-un) presă de tabletat pre-grain $(\mathrm{TH})$ granulare prealabilă

pre-grinding (TH, mas-un) şlefuire prealabilă pre-grounding (alim, constr, met) presfărâmare preheat (met, termo, plast) a preîncălzi

preheater (met, termo) preîncălzitor

preheating (met, termo, $\mathrm{TH}$ ) preîncălzire

preheating furnace / chamber (met) cuptor / cameră de preîncălzire

preheating of air (met, termo) preîncălzire a aerului; preîncălzitor de aer

preheating of fuel-air mixture (termo) preîncălzire a amestecului aer-carburant

preheating plant (termo) instalație de preîncălzire

preheating table (termo) masă de preîncălzire preheating torch (met) arzător de preîncălzire (la cuptoare, la sudare etc.)

preheating zone (met) zonă de preîncălzire

prehension (chim, T) reținere (la absorbție); (OM) prindere, apucare; angrenare

preignition (auto, termo) aprindere cu bujie; preaprindere, avans de aprindere

pre-insulate (el, termo) a izola înainte de montaj prejudice against a predispune împotriva prejudice in favour of a predispune în favoarea prelifting rod (met, OM) tijă de ridicare (şi la convertizor)

preliminaries (ec, TH) preliminarii, pregătiri

preliminary preliminar, premergător, prealabil, introductiv

preliminary acceptance run $(\mathrm{TH})$ funcționare pentru receptie provizorie

preliminary ageing (alim, met, plast) maturizare / îmbătrânire preliminară / inițială

preliminary amplification (autom) preamplificare, amplificare inițială

preliminary annealing (met) recoacere preliminară

preliminary balance (ind chim, met, plast) egalizare / reglare / corecție prealabilă (a unei faze)

preliminary blast / blowing (met) purjare / suflare preliminară (la cuptor)

preliminary breaking / crushing (met, ind chim) preconcasare, concasare / mărunțire preliminară

preliminary clarification (alim, hidr, mediu) decantare / limpezire primară

preliminary compression (hidr, materiale) precompresie; comprimare prealabilă

preliminary cook (alim) fierbere preliminară

preliminary crusher (mas, constr) concasor pentru presfărâmare

preliminary design / project anteproiect

preliminary distillation (alim, ind chim) distilare preliminară, predistilare

preliminary drawing (met, $\mathrm{TH}$ ) trefilare preliminară / grosieră / inițială

preliminary heating (termo, TH) încălzire preliminară

preliminary matter, prelims elemente inițiale, toate elementele care preced prima pagină a textului unei cărți

preliminary pages coală de titlu / zero

preliminary preparation (met) preparare sumară a minereurilor

preliminary project $(\mathrm{TH})$ proiect preliminar, anteproiect

preliminary purification (met, ind chim, mediu) epurare / purificare preliminară

preliminary refining mixer (met, ind chim) amestecător / melanjor de preafinare / de rafinare preliminary roasting (met) prăjire preliminară (a minereului)

preliminary sizing (agr, alim, constr, ind chim) cernere / sortare grosieră

preliminary test (met, ind chim) test preliminar preliminary transformation (met, ind chim) transformare preliminară

preliminary treatment (met, plast, alim) tratament prealabil / preliminar 
preliminary vacuum $(\mathrm{TH})$ vacuum / vid preliminar

preliminary vaporizer $(\mathrm{OM}$, alim, mediu) prevaporizator, vaporizator preliminar

preliminary work $(\mathrm{TH})$ lucrare / operație pregătitoare

pre-load $(\mathrm{OM})$ sarcină / strângere prealabilă; preîncărcare, prestrângere (şi la asamblări cu filete) pre-loaded bearing $(\mathrm{OM}, \mathrm{T})$ rulment pretensionat pre-lubricated bearing $(\mathrm{OM}, \mathrm{T})$ rulment prelubrifiat / casetat şi cu lubrifiant

prelude introducere

premature prematur, înainte de vreme; nechibzuit; negândit

premature-closing lock-out (autom) blocare înainte de vreme a conectării (la sincronizare)

premature firing (auto, termo, chim) aprindere / ardere prematură; precombustie

premature ignition (auto, termo) aprindere prematură / timpurie, precombustie

prematureness, precocity precocitate; coacere / matur(izare) timpurie

premature shot (mas) aprindere timpurie; (met) explozie prematură

premelted iron (met) fontă de primă fuziune

premium (pm., prem.) (ec) premiu, primă; recompensă; spor / creştere a(l) unei monede peste valoarea nominală; $(\mathrm{TH})$ de calitate

premium bonus system (ec) sistem de stimulare cu primă (sistem de participare la beneficii)

premium engine oil (auto, ind chim, T) ulei de motor de calitate superioară

premium fuel (auto, ind chim) supercarburant; combustibil superior

premium (grade) gasoline (ind chim, termo) benzină de calitate superioară

premium-priced fuel (ind chim, auto) carburant de calitate superioară

premixer (alim, ind chim) dispozitiv de amestecare prealabilă, a amestecare prealabil

premixing (alim, ind chim) preamestecare, amestecare inițială

premixture (alim, ind chim) preamestec

premoulding (met) preformare; presare a brichetelor

prepack seals (OM) etanşări montate pentru umplerea golurilor sau ca suport pentru etanşarea propriu-zisă

prepaid (ec) francat; plătit anticipat

preparation $(\mathrm{TH})$ preparație; prelucrare; pregătire; preparare (concentrare) a minereurilor şi a cărbunelui; (edu, univ) pregătire; măsură pregătiroare / preliminară; remediu; (chim) preparat (şi cosmetic); (med, chim) medicament preparation by magnetic separation (alim, met) preparare / sortare / îmbogățire prin separare magnetică

preparation by screening (met, $\mathrm{TH}$ ) preparare / îmbogățire prin cernere

preparation by washing (met, $\mathrm{TH}$ ) preparare / concentrare / îmbogătire prin spălare

preparation of fuel (ind chim) preparare a combustibilului

preparation of moulding sand (met) preparare a nisipului de turnătorie

preparation of moulds (met) confecționare sau pregătire a formelor (de turnare)

preparation of ores (met) preparare a minereurilor

preparatory cut (mas-un) prelucrare intermediară / premergătoare / pregătitoare, operație (aşchietoare) necesară următoarei prelucrări

preparatory pass (met) calibru degrosisor / preliminar / pregătitor

preparation plant (met) instalație de preparare (pt. cărbuni sau minereuri)

preparatory training $(\mathrm{TH})$ instructaj / instruire preliminară

preparatory treatment (met) tratament pregătitor / preliminar

preparatory work (TH) lucru pregătitor, operatie pregătitoare

prepare a pregăti; a prepara; a confecționa; a fabrica; a executa

prepared preparat; (TH) degroşat; eboşat, pregătit (pt. o altă prelucrare)

prepared atmosphere $(\mathrm{TH})$ atmosferă artificială preparing room (plast) secție de amestecare; (alim) secție de preparare, sală de pregătire

prepatch panel (el) panou / tablou de comandă / de distributie

prepayment $(\mathrm{ec})$ francare; plată în avans

prepeening (met) ecruisare preliminară (la laminare)

prepegs (plast) amestecuri (mecanice) de materiale de ranforsare şi material de bază care urmează să fie tratate sau prelucrate pentru obținerea produsului final

pre-processing $(\mathrm{TH})$ prelucrare preliminară

pre-processor (inf, c) preprocesor; macroprocesor; program de translatare a unui text-sursă într-un alt text-sursă

pre-publication evaluation of advertising (PPE) (ec) evaluare prealabilă a publicității

prepulse (autom) preimpuls; impuls anticipat / prealabil / prioritar

pre(-)regulation (autom, metr) prereglare; reglare preliminară / brută 
prerequisite condiție necesară (pentru); premisă obligatorie

pre-roast (met) precalcinare; prăjire preliminară preroll time $(\mathrm{TH})$ timp de punere în funcțiune / de pregătire a procesului tehnologic (şi la laminoare)

prescaler (fiz, autom) demultiplicator / divizor preliminar de frecvență

prescribe a prescrie; a porunci; a ordona; a recomanda (cu argumente); (med) for a prescrie un tratament (pentru); (jur) a se prescrie; a-şi pierde valabilitatea

prescribed dat (înainte); prescris; ordonat; recomandat (cu argumente)

prescribed form formă prescrisă / recomandată

preselecting rotary line switch (electr, autom) preselector / comutator rotativ

preselective gearbox $(\mathrm{OM})$ cutie de viteze $\mathrm{cu}$ preselectie

preselector (auto) preselector de viteze; (auto, el) filtru de bandă; preselector; căutător de apeluri; (autom, metr) etaj de intrare / preamplificator

present prezent; a prezenta; a arăta; a înmâna; a depune

presentation (ec) prezentare / expunere (de produse); expoziție; (c) aspect al imaginii, prezentare virtuală

presentation manager (PM) (c) interfața cu utilizatorul care permite mutări între aplicații, fără să apară confuzii

presentation unit (c) unitate de afişare

present value method $(\mathrm{ec})$ metodă de estimare la valoarea actuală (a unei investiții)

preservation (alim, TH) conservare, păstrare, mentinere; ferire, prezervare

preservation by curing (alim) conservare prin saramurare / afumare / uscare

preservation by salting (alim) conservare prin saramurare / sărare

preservation of lumber / of wood impregnare a lemnului (contra degradării), conservare a lemnului

preservative (alim, chim) substanță conservantă, conservant; (plast, chim) anticoagulant, stabilizator al dispersiei, inhibitor de îmbătrânire

preservative / preservative coating (met, plast) acoperire de protecţie

preservative substance (alim, chim) substanță conservantă

preserve a prezerva; a apăra; a feri; (alim) conservă, a păstra, a conserva; (mat) a lăsa neschimbat, invariant

preserving by drying (alim) conservare prin uscare preset stabilit; fixat; (electr, OM) determinat; adaptor; a prestabili; a preregla

preset adjustment (autom, mas-un) reglare $\mathrm{cu}$ preselecție

preset apparatus (autom, metr) aparat cu prereglaj / cu regla preliminar

preset counter (metr, autom) contor cu preselecție / cu presetare / cu setare iniţială

preset guidance (autom) ghidare programată / preselectată

preset level (fiz, metr, autom) nivel fixat / cerut / nominal / prereglat / presetat

preset parameter (autom, metr) parametru prestabilit / reglat initial

preset range (autom, metr) domeniu predeterminat / selectat initial

presetting (met, $\mathrm{OM}$ ) montaj / instalare / fixare preliminară, prereglare

preset time (autom) timp prestabilit / fixat în prealabil

preset time counting (metr) numărare într-un interval de timp prestabilit

preset timer (autom, metr) întrerupător temporizat, cu preselectie

presetting $(\mathrm{TH})$ prestabilire; preajustare; preselecţie

preshrinking (met, plast) contracție preliminară

president (ec) președinte (al unei societăți); director general

pre-sintering (chim) presinterizare; (met) încălzire înaintea sinterizării (sub temperatura finală de sinterizare)

pre-slinging (nav) cotare prealabilă (în manipulări de mărfuri de pe sau pe o navă)

pre-soften (alim, plast) a preplastifia, a înmuia (inițial, eventual cu topire parțială)

press (mas, mec) presare, solicitare; (mec) a presa; a străpunge prin presare, a turti; a injecta; a ştemui; (met) a (se) imprima; a vârî; a introduce apăsând; a turti; a (se) întipări; (mas-un) presă (foarte general); (alim) teasc, a zemui, a stoarce (fructe etc.)

pressability (materiale) proprietatea de a putea fi presat / prelucrat prin presare

pressable (material) presabil

press agency agenție de presă / de publicitate / de informații

pressboard (ind chim) preşpan; carton presat; carton special pentru întărituri

press button (OM, c, metr) buton de apăsare, tastă press-button board (autom, mas) tablou cu butoane de comandă

press-button key $(\mathrm{TH}, \mathrm{c})$ buton / tastă cu poziție fixă 
press-button switch (el) întrerupător cu buton press cake turtă; (chim) turtă de presare; (ind chim, alim) turtă de ulei / de la filtru-presă / de (la) filtrare

press-cake breaker (alim) urluitoare / zdrobitoare de turte (de la fabricarea uleiului)

press casting (met) turnare sub presiune

press cure (ind chim, plast) vulcanizare în prese

press-cured article (ind chim, plast) articol (de cauciuc) vulcanizat în presă

press cylinder (mas-un, met) cilindru (hidraulic) al presei

press die (mas-un) poanson / matriță de presare / de imprimat

press down (mas-un) a apăsa, a presa (mişcarea elementului activ este de sus în jos)

pressductor (metr, mec, electr) traductor electromecanic de sarcină

pressed (mas-un) ştanțat, matrițat

pressed coal (met, termo) brichetă de cărbune

pressed density (ind chim) densitate a pulberilor presate (înainte de sinterizare) / în stare presată

press dust core (el, electr) miez din pulbere de fier comprimată / sinterizat

pressed for funds / money (ec) strâmtorat, lipsit de fonduri

pressed frame (met) cadru din elemente ştampate

pressed girder (cf) lonjeron ambutisat; (constr) grindă ambutisată

pressed material $(\mathrm{TH})$ material presat

pressed object $(\mathrm{OM}, \mathrm{TH})$ piesă presată

pressed on crank $(\mathrm{OM})$ manivelă montată prin presare la rece

pressed sheet $(\mathrm{OM})$ foaie / placă presată

pressed volume (mec, $\mathrm{TH}$ ) volumul materialului comprimat / comprimatului

presser (mas, OM) presă; val / rolă / valț de presare; (TH) muncitor la presă / la teasc, prespapier

presser board (in moulding) (met) placă de presiune (în turnătorie)

presser cam $(\mathrm{OM})$ camă de presare

presser wheel (OM, mas-un) disc / roată de presare; presă circulară

press filter (hidr, OM) filtru de presiune

press fit (mas, met, OM) ajustaj forțat / presat, strângere, ajustaj cu strângere; a îmbina prin presare, a cala la presă

press for corrugated sheets (met) presă pentru tablă ondulată

press forging (met) forjare sub presiune (mare), piesă forjată la presă

press form (alim, plast) formă de presare press forming (met) matrițare; (TH) formare / fasonare prin presare

press forward (mec, $\mathrm{TH})$ a avansa (prin presare)

press home $(\mathrm{TH}, \mathrm{OM})$ a presa în locaş

press house (alim) cramă (de tescuire), teasc; (plast) secție de presare

pressing (alim) tescuire; (mas-un) stantare, matrițare; satinare (a hârtiei); (TH) presare, refulare

pressing brush perie de presare (în industria uşoară)

pressing crack (met, hidr, plast) crăpătură generată de presare / de presiune

pressing machine (mas-un) presă; maşină de călcat

pressing of the tyre presare / calare a bandajului pe roți (de vagon etc.), a talonului unui pneu (auto)

pressing-on calare

pressing-on of the wheel $(\mathrm{OM})$ calare a roții, asamblare prin presare

pressing order $(\mathrm{ec})$ comandă urgentă

pressing plant (ind, $\mathrm{TH}$ ) instalație de presare (şi a şpanului)

pressing quality (materiale) proprietatea de a putea fi comprimat

pressing rod (mas-un, OM) bară / tijă de presiune / de apăsare

pressing roll (alim) valt de stors / de presare

pressing screw $(\mathrm{OM})$ şurub de presiune

pressing speed (OM, met, plast, mas-un) viteză de presare

pressing table (alim) masă a presei; masă de presare

pressing time (alim, plast) timp de presare

pressing tool unealtă de presare

pressing tool for fitting unbreakable glasses (constr, auto) dispozitiv de fixat geamuri incasabile

pressing tool for hand fixing presă / dispozitiv pentru fixat ceva (manual)

pressing with floating die (met, plast) presare cu matriță mobilă

press key (c) manipulator cu apăsare, tastă; $(\mathrm{TH})$ buton manipulator, clapă

pressman (mas-un) matrițer, ştanțator, presator; reporter; gazetar, ziarist; tipograf

press mould (plast) matriță (de presare), formă de presare

press moulding $(\mathrm{TH})$ formare / mulare prin presare, matrițare prin presare

press of business (ec) urgență a afacerilor; activitate comercială febrilă

press off (mas-un, OM, met) a demonta prin presare / prin împingere (rulmenti, role etc) 
press on a apăsa (pe), a strânge

pressostat (metr, autom) presostat; automat manometric; întrerupător manometric / pneumatic; regulator automat de presiune

press out (alim, mediu) a stoarce (pentru eliminarea fluidului); a presa

press pad (met) dispozitiv de strângere / presare a tablei

press plate (alim) masă a presei; (plast) placă / masă de presiune; presă rectilinie

press plunger (OM, hidr) plonjor / piston de presă hidraulică

press the point a insista

press process $(\mathrm{TH})$ procedeu / tehnologie de presare, proces de presare

press ram (mas-un) poanson de presat

press rod (OM, mas-un) tijă de presiune; tijă a pistonului (unei prese)

press roller (OM, alim) arbore de presare, eventual cu cilindru montat, cilindru / valț de presare

press room (mas-un) secție de ștanțare / de presare; sala maşinilor / a preselor (într-o tipografie, fabrică de țesături etc.)

press run tiraj; totalitate a exemplarelor unui tiraj

press-spahn (mas-un) preşpan

press (spot) weld (OM) sudură în puncte, prin presare

press (spot) welder / welding machine (mas-un, met) maşină / instalație de sudat în puncte prin presare

press stroke (met, mas-un) cursa presei

press-toolmaker lăcătuş matrițer

press tools (mas-un) matrițe cu poanson; mecanisme ale presei

press-to-realease operation (mas) declanşare produsă prin apăsare

press-to-set operation (TH, metr) reglare prin apăsare, până la reglare la valoarea dorită

pressure (mec, fix) presiune, apăsare; comprimare; tensiune

pressure accumulator (hidr, OM) acumulator de presiune

pressure amplification (hidr) amplificare de presiune

pressure amplifier (hidr) amplificator de presiune pressure angle (OM) unghi de presiune / de angrenare $(\alpha)$ (la roți dinţate)

pressure-actuated (OM) acționat pneumatic / hidraulic

pressure air $(\mathrm{TH})$ aer comprimat

pressure altitude presiune de altitudine

pressure angle (OM) unghi de presiune / de angrenare (la roți cu dinți evolventici) pressure arrangement (mas-un) dispozitiv de presiune (la tesături, produse în bandă)

pressure atomization pulverizare pneumatică (a lichidelor)

pressure at rest presiune statică (a terenului)

pressure balance (hidr) egalizarea presiunii

pressure blower (termo) ventilator de mare presiune

pressure boost ridicarea (bruscă) a presiunii

pressure broadening (mas-un) lărgire prin presare (cu role, cu lichid sub presiune etc.)

pressure build-up test (OM, hidr, metr) probă / test de etanşeitate (la presiune)

pressure bulb (nav, hidr) bulb / proeminență de presiune

pressure caisson (constr) cheson închis

pressure calender (OM, ind chim) calandru de presiune

pressure casting (met) turnare sub presiune

pressure castings (met) piese turnate sub presiune

pressure cell (metr, hidr) doză / traductor / senzor de presiune

pressure conduit (hidr, OM) conductă sub presiune pressure connection (OM, hidr) racord de presiune pressure contact welding (met, $\mathrm{TH}$ ) (acțiunea de) sudare prin contact, sub presiune

pressure control (mec, hidr) control / reglare a (1) presiunii

pressure control circuit (mec, hidr, autom) circuit cu comandă prin presiune, circuitul de comandă al presiunii (electric sau tot hidraulic)

pressure control hydraulic servovalve (OM, hidr, autom, auto) servodistribuitor hidraulic de presiune

pressure control valve (OM, auto, hidr) supapă / distribuitor pentru reglarea presiunii

pressure cooker (alim) fierbător / autoclavă sub presiune

pressure curve (hidr, mec) linie piezometrică (a energiei potenţiale), curbă de presiune / de compresiune, izobară (pe o diagramă)

pressure cylinder (OM, hidr) cilindru acționat sub presiune, cilindru de presiune / hidraulic

pressure decline (hidr) cădere / scădere (şi nedorită) a presiunii

pressure-dependence (mec) dependență de presiune (şi d. vâscozitate)

pressure-dependent (mec, materiale) dependent de presiune

pressure derivation (OM, hidr) derivație / ramificatiie sub presiune

pressure detector (metr, hidr) detector de presiune 
pressure diaphragm (metr, hidr) diafragmă pentru reglarea presiunii

pressure die casting (met) turnare în matriță, sub presiune

pressure difference (hidr, OM) cădere / diferență de presiune

pressure distribution $(\mathrm{OM}$, hidr, $\mathrm{T})$ distribuție de presiune

pressure droop (OM, hidr) cădere de presiune (şi prin comandă, cu alt sistem hidraulic auxiliar)

pressure drop (hidr, termo, OM) salt / cădere / diferenţă / reducere de presiune

pressure element (metr, hidr, OM) traductor de presiune

pressure engine (OM, hidr) pompă de presiune, mecanism de presare (cu tot cu motor)

pressure equalising ( $\mathrm{OM}$, hidr) egalizarea presiunii

pressure expanded joint (OM) asamblare realizată prin cresterea presiunii (într-un element flexibil tip tub, sac etc.)

pressure feed (hidr) alimentare sub presiune, transport prin / sub presiune

pressure-feed lubrication $(\mathrm{OM}, \mathrm{T}$, hidr) lubrifiere / ungere sub presiune

pressure filter $(\mathrm{OM}$, alim, hidr) filtru sub presiune, filtru-presă

pressure filter cell $(\mathrm{OM})$ unitate / modul / cameră a filtrului sub presiune

pressure filtration (alim, hidr) filtrare sub presiune

pressure finger (hidr, OM) plunjer, ac de supapă / de distribuitor

pressure flow (hidr) curgere / fluid sub presiune

pressure fluctuation (hidr, mas-un) fluctuație a presiunii

pressure gain (mec, hidr) amplificare / creștere de presiune

pressure galery (hidr, OM) conductă forțată / sub presiune

pressure gas (fiz) gaz comprimat

pressure gas producer (termo) generator de gaz sub presiune

pressure gauge (metr, hidr, OM) manometru, capsulă dinamometrică

pressure governor (metr, hidr, autom) regulator de presiune

pressure gradient (fiz, mec, hidr) gradient de presiune

pressure grease fitting $(T, O M)$ gresor cu bilă, ungător sub presiune

pressure gun $(T, O M)$ pompă de ungere cu unsoare, tecalemit pressure head (hidr) înălțime de refulare (pentru o pompă), presiune hidrostatică, cădere relativă de presiune

pressure head of water (hidr) înălțime manometrică / de pompare / piezometrică a (coloanei) de apă

pressure hose (OM, met, hidr) furtun pneumatic, furtun pentru fluid sub presiune

pressure indicator $(\mathrm{OM}$, hidr, metr) indicator de presiune, manometru

pressure-inlet nipple (OM, hidr) racord de presiune

pressure intake port (hidr) priză de presiune

pressure intensifier $(\mathrm{OM}$, hidr) multiplicator de presiune

pressure jump (hidr, T) salt de presiune

pressureless sintering (met, $\mathrm{TH}$ ) sinterizare $\mathrm{cu}$ pulbere nepresată / fără presare

pressure level (fiz) nivelul / valoarea presiunii; (OM) pârghie de presiune

pressure limit (hidr) limită de presiune; (mec) limită de strivire (în sens larg)

pressure load $(\mathrm{mec})$ sarcină de compresiune, forță (ca presiune exercitată pe suprafață)

pressure loss (mec, hidr) cădere / pierdere de presiune, pierdere de sarcină (de compresiune)

pressure lubricating / lubrication $(\mathrm{T})$ (acțiunea de) lubrifiere sub presiune

pressure lubricator $(\mathrm{T}, \mathrm{OM})$ ungător sub presiune

pressure maintenance (hidr, met, T) menținerea presiunii

pressure measurement (metr, hidr) măsurarea presiunii

pressure measuring instrument (metr, hidr, OM) aparat pentru măsurarea presiunii, manometru

pressure mechanism $(\mathrm{OM})$ mecanism de apăsare / de acționare (şi la o foarfecă)

pressure meter (metr, hidr, OM) manometru

pressure moulding (plast, TH) formare / presare în formă / în matriță

pressure of chip (mas-un) efort aplicat pe cuțit, efort de aşchiere

pressure of fluidity (hidr, autom) presiune hidraulică

pressure offset (hidr) revenire prin fluid, comandă prin presiune

pressure of rolling (met, plast) presiune de laminare

pressure of the rolls (met, plast) presiunea cilindrilor de laminare

pressure of tool (mas-un) presiune / efort de aşchiere, presiune pe tăis

pressure oil $(\mathrm{T}$, hidr) ulei sub presiune 
pressure oil feed pipe (OM, hidr) conductă de alimentare cu ulei sub presiune

pressure on foundation soil (constr) presiunea pe sol / pe fundație

pressure on the support $(\mathrm{OM})$ presiune pe reazem / pe suport

pressure per unit of area / surface (mec, hidr, T) presiune pe unitatea de suprafaţă

pressure parting $(\mathrm{OM}, \mathrm{T}$, hidr) fisurare sub presiune (cauzată de un fluid)

pressure pick-up (metr, hidr, OM) captor / indicator de presiune

pressure pin $(\mathrm{OM})$ ştift opritor / de presiune

pressure pipe (hidr, $\mathrm{OM}$ ) conductă sub presiune

pressure piston ring (auto, termo, OM) segment de presiune al pistonului

pressure pipe-line (hidr, OM) conductă sub presiune

pressure plate (OM, mas-un) placă de presiune / de ambreiaj / de apăsare, tampon, tampon limitator, element de presare / activ la o presă

pressure pulsation (pressure ripple) (hidr) variație periodică a presiunii, în sincronism cu turația / viteza sistemului (de acționare al pompei)

pressure pump (OM, hidr) pompă de presiune / de refulare

pressure rating $(\mathrm{TH}$, hidr) forța maximă (internă) pe unitatea de suprafață în condiții normale de funcționare

pressure ratio (mec, hidr) raport între presiuni

pressurer recorder (metr, hidr, OM) manometru cu înregistrator

pressurer recording gauge (metr, hidr, OM) manometru cu înregistrator

pressure reducer $(\mathrm{OM}$, hidr) drosel, supapă reducătoare de presiune

pressure recovery (hidr) randamentul de recuperare / revenire (forțată) a presiunii

presssure-reducing valve / regulator / device (OM, hidr) supapă reducătoare de presiune, dispozitiv de reducere a presiunii, regulator de presiune

pressure-regulating valve $(\mathrm{OM}$, hidr) supapă pentru reglarea presiunii

pressure-regulation characteristic (OM, hidr) caracteristică de reglare a presiunii (la supape, servovalve etc.)

pressure regulator $(\mathrm{OM}$, hidr) supapă pentru reglarea presiunii

pressure reducer $(\mathrm{OM}$, hidr) drosel pentru reducerea presiunii

pressure relay (autom, hidr) releu de presiune pressure release (hidr) degajarea / scăderea presiunii pressure releif $(\mathrm{OM}$, hidr) reducere a presiunii (unui fluid sau a presiunii de compresiune într-un contact), de tensionare (de exemplu, la piesele sudate etc.))

pressure relief line $(\mathrm{OM}$, hidr) portiune a conductei, după supapa de presiune / de reducție

pressure relief valve $(\mathrm{OM}$, hidr) supapă de reducere a presiunii

pressure reservoir $(\mathrm{OM}$, hidr) rezervor sub presiune, acumulator (hidraulic sau pneumatic)

pressure resistance $(\mathrm{OM}$, hidr) rezistență la refulare, rezistență hidraulică

pressure-responsive $(\mathrm{OM}$, hidr) (element, parametru) influențat / dependent de presiune

pressure restoration $(\mathrm{OM}$, hidr) refacerea presiunii, aducere a presiunii la o valoare stabilită

pressure rise $(\mathrm{OM}$, hidr) ridicare / creştere a presiunii

pressure roller $(\mathrm{OM}$, met, plast) cilindru / valt de presiune

pressure scale (metr, hidr) scară / treaptă / scală pentru presiuni

pressure screw (OM, met) şurub de presiune de presare

pressure sensitive adhesive (plast) adeziv sensibil la presiune

pressure separator (alim, ind chim) separator sub presiune

pressure shift (hidr) ridicare de presiune

pressure side (OM) față de apăsare; (hidr) partea de refulare (a pompei)

pressure sintering (materiale) sinterizare sub presiune

pressure spray gun (OM, ind, auto) (pistol-) pulverizator sub presiune

pressure spread (hidr) propagarea presiunii

pressure spring (OM, hidr) arc de presiune / de compresiune

pressure stage (hidr) etaj / treaptă de presiune

pressure stamp (mas-un, $\mathrm{OM}$ ) poanson

pressure step (hidr) treaptă de presiune

pressure still (ind chim) cuptor pentru cracare

pressure still distilate (ind chim) benzină cracată / de cracare

pressure stirrup $(\mathrm{OM})$ arc de presiune / de compresiune

pressure surge (hidr) undă de presiune

pressure switch (autom, hidr) întrerupător manometric / dependent / actionat de presiune

pressure tank (OM, hidr) rezervor / recipient sub presiune

pressure tap (hidr, metr, OM) orificiu într-un recipient sub presiune, necesar montării unui aparat de măsură 
pressure test (metr, hidr) încercare / test la presiune / la compresiune, probă de etanşeitate pressure thermit welding (met, $\mathrm{TH}$ ) sudare aluminotermică sub presiune

pressure-tight $(\mathrm{OM})$ etanş, fără scăpări de presiune

pressure tight joint $(\mathrm{OM})$ asamblare de etanşare (posibil prin filet, strângere etc.)

pressure tightness compactitatea unui metal / compozit de a rezista la testul de compresiune / de etanşeitate

pressure - time diagram (hidr) diagramă presiune - timp

pressure transducer (hidr, metr) traductor de presiune

pressure transient (hidr, mas) variație de scurtă durată a presiunii, regim tranzitoriu de presiune

pressured-treated $(\mathrm{TH})$ tratat sub presiune (lemn, compozit, metal)

pressure tube $(\mathrm{OM}$, metr) manometru; $(\mathrm{OM})$ conductă sub presiune / de refulare

pressure-tube joint (OM, hidr) ştuț de scurgere

pressure type carburettor (auto) carburator $\mathrm{cu}$ aer sub presiune

pressure type sandblast machine (mas-un, met) maşină de sablat sub presiune

pressure under load (load pressure) (mec) presiune determinată de o sarcină / de o forță

pressure vacuum gauge (metr, fiz) manometru de vid / de presiune sub și peste cea atmosferică; vacuummetru

pressure valve $(\mathrm{OM}$, hidr) supapă de presiune

pressure vessel $(\mathrm{OM}$, hidr) vas / recipient sub presiune

pressure water (hidr) apă pentru acționări hidraulice (sub presiune)

pressure wave (hidr, mec) undă de presiune

pressure welding (met, plast) sudare prin presare

pressurisation $(\mathrm{OM}$, hidr) etanşare, ermetizare, presurizare

pressurise $(\mathrm{OM}$, hidr) a mări presiunea, a ermetiza, a etanşa (un fluid sub presiune)

press (mas-un) presă; $(\mathrm{TH})$ a presa, a strânge, a forța; tipografie; (alim) a presa, a stoarce; a insista; a fi urgent / presant

pre-stressed reinforcement (constr) armătură pretensionată

press vulcanisation (ind chim) vulcanizare sub presiune

presswork tipărire, imprimare

Prestone cooling (termo) răcire cu apă caldă pre-store a pre-înmagazina

pre-straining (mec, met, OM) pretensionare (şi la rulmenți), deformare inițială (și dorită) pre-stress (mec, OM) pretensionare (şi de compresiune)

pre-stressed (mec) pretensionat; $(\mathrm{OM})$ element piesă / organ de maşină pretensionat(ă)

pre-stressed concrete (constr, met) beton precomprimat

pre-stressed concrete steel (constr, met) oțel pentru armarea betonului precomprimat

pre-stressing (OM, met) operație / proces de precomprimare / de pretensionare

pre-stressing force (mec, OM) forță de precomprimare / de pretensionare

presumable rezonabil; probabil

presumption prezumție; presupunere; ipoteză

presupposition presupunere

pre-tension $(\mathrm{OM})$ pretensionare (ca rezultat)

pre-tensioner seat belt (auto) centură de siguranță pretensionată

pre-tensioner seat belt assembly mechanism (auto) mecanismul sistemului pretensionat al centurilor de siguranță

pre-tensioner seat belt deployment (auto) activarea sistemului de pretensionare a(l) centurilor de siguranță

pre-tensioner seat belt system (auto) sistemul de pretensionare $\mathrm{a}(\mathrm{l})$ centurii de siguranță

pre-tensioning (OM) (acțiunea de) pretensionare, (element) care pretensionează

pretest test / încercare / preliminară

pre-treat a trata preliminar (în general)

pre(-)treatment (met, alim, ind chim) tratament preliminar; aplicare a primului strat (înaite de aplicarea adezivului)

pre-vacuum (fiz, $\mathrm{TH}$ ) vid preliminar

pre-vacuum pump $(\mathrm{OM})$ pompă de vid preliminar / primară

prevail a predomina; a fi răspândit / predominant; a triumfa (şi despre o idee)

pre-value (inf) valoare prestabilită

prevent a preveni; a împiedica; a evita

preventer (OM, electr) dispozitiv de siguranță; (nav) manevră suplimentară; dublură

preventer pin $(\mathrm{OM})$ ştift de siguranţă / de oprire / de blocare

prevention of accidents (ind) tehnica securității muncii, prevenirea accidentelor

preventive inspection $(\mathrm{ec}, \mathrm{TH})$ control preventiv

preventive maintenance (mas) întreținere preventivă; reparații preventive programate

preventive maintenance time (mas) timp de întreținere preventivă / programată

preventive mark semn de atenționare / de prevenire

preventive repair (mas) reparație preventivă 
previous anterior; precedent

previous pass (met) pas / calibru degrosisor / inițial

previous project anteproiect, sarcină de proiectare

pre-vulcanisation (ind chim) pre-vulcanizare, vulcanizare prematură (şi ca defect tehnologic)

pre-weld înainte de sudare

pre-weld cleaning (met, $\mathrm{TH}$ ) curățare a semifabricatelor înainte de sudare

pre-wetting (alim, ind chim) umezire (inițială)

price (ec) preț

priced bill of quantity (ec, constr) listă de prețuri prick (auto) perforare, întepare (a cauciucurilor); perforaţie, ac; (nav) arbore de reper (pe coastă)

pricking out (alim) repicare; înțepătură; prick out a găuri; a înțepa

prick punch (mas-un) punctator de centrare

primal primitiv (şi în logica matematică); fundamental; primar; principal

primal problem problemă directă / de bază

primaries (fiz) particule primare

primary element esențial; fond; primar, de bază, fundamental; principal; primitiv; inițial

primary air (termo, met) aer introdus în arzător / în camera de ardere

primary alpha (met) fază cu structură hexagonală compactă a titaniului, care rămâne după încălzirea unei faze alfa-beta şi dependentă de temperatura maximă de încălzire

primary alcohol (alim, ind chim) alcool primar primary aluminium block / pig (met) bloc de aluminiu primar

primary axis $(\mathrm{OM})$ arbore principal

primary blasting (met) insuflare primară

primary carbide (met) carbură primară

primary cell element (fiz) galvanic; pilă galvanică

primary cell carbon rod (fiz, TH) cărbune pentru pilă electrică; bară de carbon pentru colectare

primary cleaning (ind chim) curățare brută; (met) epurare primară

primary circuit (el, hidr) circuit primar

primaray coil (el) bobină primară; inductor

primary colours (fiz) culori primare / fundamentale / spectrale

primary crystallization (met) cristalizare primară

primary decomposition (mat) descompunere în factori primi

primary element (metr) senzor; detector; element principal sau primul care răspunde cantitativ la măsurarea unei variabile

primary failure (mas) avarie principală / primară / care nu depinde de altă avarie / cădere primary feedback (autom) reacție principală / primară / inițială, buclă principală într-un circuit cu feedback complex

primary fluid (hidr) fluid principal, fluid la intrare în dispozitivul hidraulic

primary graphite (met) grafit primar

primary industry industrie de bază

primary instrument (metr) instrument / aparat a cărui calibrare nu depinde de un alt aparat

primary layer (constr, met) strat de bază

primary measuring element (metr) componentă / element în contact direct cu substanța / piesa care trebuie măsurată

primary particle (met) grăunte primar

primary pipe (met) retasură primară / deschisă

primary product $(\mathrm{ec})$ produs brut

primary refining mixer (met) melanjor de preafinare; (alim, ind chim) amestecător primar / inițial

primary resistance (el) rezistență a primarului

primary shaft $(\mathrm{OM})$ arbore motor / conducător / de acționare (principală)

primary slimes (met) şlam primar

primary stage fază / etapă inițială (într-un proces tehnologic etc.)

primary strength $(\mathrm{mec})$ rezistență inițială

primary structure (met) structură primară

primary treatment (met, alim, ind chim) tratament / tratare primar( $\breve{a}) / \operatorname{initiial}(\breve{a})$

primary unit (fiz, OM) element inițial / indivizibil

primary valence (chim) valență principală

primary voltage (el) tensiune primară

primary winding (el) înfăşurare primară, bobinaj primar

primary winding terminal (el) borna primarului

primary wire (el) sârmă pentru primar

prime început; principal; fundamental; a arma; a umple; a aproviziona; (hidr) amorsare a pompei; (mat) număr prim; a amorsa o încărcătură de explozivi

prime contractor (constr) antreprenor principal prime costs (ec) cheltuieli directe / de productie prime formula (fiz, TH) formulă elementară / de bază

prime mover (mas) maşină de forță; motor principal

prime paint (auto, ind chim) grund

prime polynomial (mat) polinom ireductibil

primer $(\mathrm{OM})$ piston, capsulă; amorsă; focos; grund, combustibil de pornire; abecedar; inițială; (el) electrod auxiliar pentru asigurarea declanşării; (plast, met) primul strat al unei acoperiri stratificate (pt. o mai bună aderență, lipire etc.) 
primer coating (OM, ind chim, auto) acoperire cu grund

primer detonation (auto) aprindere de pornire primer valve (OM, hidr) supapă / ventil de pornire

primes (ec, TH) produse de calitate superioară / înaltă

prime steam (termo) abur umed

priming $(\mathrm{TH})$ amorsare, inițiere (a încărcăturii de explozibil), grunduire; (hidr) amorsare a pompei; (termo) antrenare a aburului umed; (plast) aplicare a unui strat inițial, înaintea adezivului propriu-zis

priming cartridge (met, mil) cartuş detonant / amorsat

priming charge (met) încărcătură de amorsare (şi la furnal)

priming coat (ind chim) strat de grund

priming cock (OM, hidr) robinet cu cep

priming level (hidr) nivel / înălțime de amorsare (a pompei)

priming of pump (hidr) amorsare / pornire a unei pompe

priming paint (ind chim) (vopsea de) grund priming plug (OM, hidr) robinet de umplere

priming powder (ind chim, met) pulbere de amorsare

priming pulse (metr, autom) impuls de amorsare

priming pump (OM, hidr) pompă de amorsare / de pornire / de injecție, pompă-injector

priming reservoir (OM, hidr) rezervor de aspirație

priming voltage (el, metr) tensiune de amorsare / de pornire

primitive primitiv, inițial, neprelucrat, de bază

primitive colour (fiz) culoare spectrală

primitive function (mat) funcție primitivă

primitive root (mat) rădăcină primitivă

primitive soap (chim) săpun de bază

principal principal

principal adjustment (mas, autom) reglare principală / de bază

principal arch / roof (met, constr) arc / boltă $\operatorname{principal}(\breve{a})$ (la cuptoare)

principal axis $(\mathrm{OM})$ arbore principal

principal axis location $(\mathrm{OM}, \mathrm{mec})$ amplasarea axei principale (şi la echilibrare)

principal fermentation (alim) fermentație principală

principal focus (fiz, opt) focar principal

principal inertia axis (mec) axă principală de inerție

principal moment of inertia (mec) moment principal de inerție principal normal stress $(\mathrm{mec})$ tensiune normală principală

principal piece (mas, OM) piesă / componentă principală

principal planes of projection $(\mathrm{OM})$ planele principale de proiecție (în desen tehnic)

principal railway (cf, met) linie principală

principle lege; teoremă; principiu

principle of action and reaction (mec) principiul acțiunii şi reacțiunii

principle of connecting / communicating vessels (fiz, hidr) principiul vaselor comunicante

principle of design principiu / criteriu de proiectare (în orice domeniu)

principle of inertia (mec) principiul inerției

principle of least action (fiz, mec) principiul minimei acțiuni

principle of least constraint (fiz, mec) principiul minimei constrângeri / rezistențe

principle of superimposed stress (mec, fiz) principiul suprapunerii tensiunilor

print amprentă; semn; urmă; $(\mathrm{OM})$ urmă de imprimare (şi defect), amprentă (la lovire, la suprasolicitarea mecanică a unui contact etc.), indentare, copie; impresiune; (fotografie, poligrafie) copie, fotografie, gravură, pozitiv, a (se) copia (uşor etc.); (poligrafie) imprimare, imprimat, publicație tipărită, tipar, tipărit, tipăritură, literă de tipar; publicație, a publica, a fi sub tipar, a se tipări, a edita; (textile) imprimeu, țesătură imprimată, a imprima; (inf) înregistrare; a amprenta; a lua amprentele digitale ale unei persoane

printed tipărit, imprimat; amprentat

printed form formular

printer (birotică, OM, electr) imprimantă

printer's ream, perfect ream (metr) unitate pentru cantitate de hârtie pentru imprimantă, top pentru imprimantă; 1 top are 480 sau 500 de coli; 1 printer's ream ( 1 top pentru imprimantă) are 516 coli

printer's error eroare de redactare / de tipar

printing plate (mas-un) şablon de ambutisare pe strung

print of test ball (met) urmă (la determinarea durității în unități Brinell)

priority prioritate

prior operation (met, mas-un) operație pregătitoare

prior structure (met) structură inițială

prior to înainte de

prior to mixing $(\mathrm{TH})$ înainte de amestecare

prism prismă, ghidaj prismatic

prismatic (geom) prismatic 
prismatic guide (mas-un, OM) ghidaj prismatic / în V

prismatic surveying instrument (metr, $O M$ ) echer cu prisme

prismatic trommel (ind chim, OM) sită rotativă prismatică

prism diopter (PD) (metr, fiz, opt) unitate utilizată în optică pentru a măsura deflexia / devierea luminii cu ajutorul unei prisme: 1 prism diopter reprezintă o deflexie de $1 \mathrm{~cm}$ măsurată la distanța de $1 \mathrm{~m}$ față de prismă

prism edge $(\mathrm{OM})$ muchie de prismă

prisoner $(\mathrm{OM})$ ştift de centrare

private particular

privation lipsă

prize premiu; $(\mathrm{OM})$ pârghie; a ridica; a deplasa cu o pârghie

probability (mat) probabilitate

probability density (function) (mat) (funcția) densitate de probabilitate

probability distribution (function) (mat) (functia de) distribuție de probabilitate

probable error (autom, metr, mas, $\mathrm{TH}$ ) eroare probabilă

probation încercare, probă (şi pentru personal)

probe (radio, fiz) antenă de cuplare; (metr, OM) cap de măsură / de măsurare, palpator, sesizor, sondă; (med) cateter, sondă, a cateteriza, a sonda; (amer) cercetare, examen, examinare; sondaj; sondare; a încerca, a sonda, a testa, a verifica, a cerceta atent, a examina, a studia

probe inlet $(\mathrm{OM})$ orificiu pentru sondă

probe-induced distortion (metr) distorsiune indusă de sondă

probe inlet $(\mathrm{OM})$ orificiu pentru luat probe / pentru instalat un aparat de măsură

probing explorare; probare; luarea probelor; sondaj (de control)

problem problemă

procedural knowledge (mas, $\mathrm{TH}$ ) cunoaşterea / învățarea capacităților şi limitărilor sistemului în diferite condiții

procedure procedură, procedeu; operație, metodă; proces tehnologic

proceeding procedeu; întâmplare; avans; referat; (ec) tranzacție

procentage procentaj, procent

procentage by weight procent masic / de masă

process proces (tehnologic), operație, procedeu, cursă de lucru / activă; a prelucra, a fabrica, a confecționa, a prepara, a utiliza, a procesa

process alloys (met) adaosuri (la elaborarea şarjei)

process annealing (met) recoacere intermediară de înmuiere / incompletă process chart $(\mathrm{TH})$ fişă tehnologică, diagrama procesului tehnologic

proces control (TH, autom) reglare industrială / de proces / tehnologică, control / comandă a unui proces tehnologic

process engineering inginerie tehnologică

processed information (inf, c) date / informatiii prelucrate

processed surface (mas-un, met) suprafață prelucrată

process fluid (TH, hidr) fluid de lucru / de tratare / de proces / tehnologic

processing fasonare (d. lemn); tratare, transformare, prelucrare, preparare; elaborare; fabricare; producere, procesare

processing alloy (met) aliaj necesar elaborării şarjei

processing industry industrie prelucrătoare

processing method $(\mathrm{TH})$ metodă de prelucrare / de procesare

processing property (materiale) proprietate tehnologică / de prelucrabilitate

process leg (autom, inf) întârziere în proces

process line (ind) linie tehnologică

process monitoring (autom, $\mathrm{TH}$ ) comanda procesului; supraveghere (uneori şi reglare) a procesului, monitorizare

process of combining with oxygen (chim) procesul de reacție / de combinare cu oxigenul, oxidare

process of deformation (met, mec) proces de deformare

process of dry cyaniding (met, chim) procedeu uscat de cianurare

process reaction rate $(\mathrm{TH})$ viteză de reacție la modificarea unui parametru tehnologic

process scrap (met, ind) deşeuri de producție process steam (termo) abur tehnologic, abur viu porcess temperature (termo, $\mathrm{TH}$ ) temperatura specifică unui proces tehnologic

process timer (autom) temporizator (într-o linie tehnologică)

process unit (TH, mas) instalație de proces / tehnologică

process variable (autom) variabilă de reglare

process with independent increments (mat) proces aditiv

proclaim a anunța (oficial); a declara; (pol) a proclama; (pol, mil) a declara / proclama (război etc.); a arăta; a califica; a categorisi; (pol, jur) a declara ilegal / în afara legii; a interzice; a trăda; a vesti

proclamation (pol, adm) proclamare; anunțare (oficială) 
procurable procurabil

produce productie, produs; rezultat; (geom) a prelungi (o linie), a genera; a crea; a produce, a construi, a fabrica, a confecționa, a prezenta, a executa, a scoate; (met) a elabora

producer (el) generator; (ec, $\mathrm{TH})$ producător, furnizor, executant

producer furnace (met) gazogen, generator de gaze

producer gas (met, termo) gaz de generator (aerian) / de gazogen

producer gas tar (met, termo) gudron de gazogen producer plant $(\mathrm{TH}$, ec) uzină producătoare / furnizoare

producer shaft (met) cuvă a generatorului de gazogen / de gaze

producer shell (el, OM) manta de generator

producible oil index (ind chim, T) factor de recuperare, coeficient de extracție

product (mat) produs, intersecție, rezultat; (TH) produs, fabricat

product control $(\mathrm{TH})$ controlul producției

production extracție, debit; prezentare; $(\mathrm{TH})$ (capacitate de) producție, fabricație; (met) elaborare production capacity $(\mathrm{TH})$ capacitate de producție production costs $(\mathrm{ec})$ cheltuieli de producție production department (ind) secție de producție production engine (auto) motor de serie

production equipment (mas, $\mathrm{TH}$ ) echipament / utilaj / instalație de producție

production estimate (mas-un) calculul timpului de prelucrare; fişă tehnologică incluzând timpi de prelucrare

production forces $(\mathrm{ec})$ forțe de producție production goods (ec, ind) bunuri / mărfuri / articole de serie mare

production index $(\mathrm{ec})$ indice de productivitate production in lots $(\mathrm{ec}$, ind) producție în serie / în loturi

production line (mas, $\mathrm{TH}$ ) linie de producție production loss $(\mathrm{TH})$ pierderi în producție production machine tool (mas-un) maşinăunealtă pentru producție de serie

production method (ind, $\mathrm{TH}$ ) metodă de exploatare / de producție / de extracție, tehnologie production plan $(\mathrm{ec}, \mathrm{TH})$ plan de producție production planning $(\mathrm{ec}, \mathrm{TH})$ planificarea producției

production programme $(\mathrm{ec}, \mathrm{TH})$ program de producție

production rate $(\mathrm{ec}, \mathrm{TH}) \mathrm{ritm}$ de producție

production schedule (ec, TH) plan de producție production technology $(\mathrm{ec}, \mathrm{TH})$ tehnologie de producție production time (ec, $\mathrm{TH})$ timp de producție / de fabricare

production trial (mas) probă de exploatare / de functionare

productive (ec, TH) productiv, eficient; (agr) fertil, roditor

productive capacity (ec, $\mathrm{TH})$ capacitate de producție, productivitate

productive discharge (hidr) debit util

productiveness $(\mathrm{ec}, \mathrm{TH})$ productivitate, randament productive of (fiz, chim, TH) care produce / determină / cauzează

productive rate $(\mathrm{ec}, \mathrm{TH})$ productivitate, randament productivity $(\mathrm{ec}, \mathrm{TH})$ productivitate

product making process $(\mathrm{TH})$ proces / metodă / procedeu / tehnologie de fabricație

product rack (met, OM) stelaj / suporți pentru profiluri / produse (finite)

product of roasting (met, chim) material prăjit

product of sets (mat) intersecție a mulțimilor

products of combustion (termo, met, chim) produse de ardere / de combustie

product rack (met, OM) stelaj pentru produse (finite, semifabricate)

product take-off $(\mathrm{OM}$, termo, hidr) ştuț / racord de evacuare

proeutectic (met) proeutectic

proeutectoid (met) proeutectoid

profession meserie, profesie, specialitate

professional meşteşugăresc, industrial, profesional proffer a oferi

profilated brick (met, constr) cărămidă profilată profile (met, OM) profil (laminat); (mas-un) a strunji / aşchia profilat, a profila prin aşchiere profile board (mas-un) şablon / cu sculă profilată profile cutter (mas-un) cuțit / freză / sculă aşchietoare profilat $(\breve{a})$

profile cutting (mas-un) aşchiere după şablon profile crowning $(\mathrm{OM})$ bombarea profilului (unui dinte de roată dințată)

profiled $(\mathrm{OM})$ sârmă profilată; $(\mathrm{OM}, \mathrm{TH})$ profilat, fasonat

profile displacement $(\mathrm{OM})$ deplasare de profil (la roți dințate)

profiled outline $(\mathrm{OM})$ contur / secțiune cu formă complicată

profiled wire (met, OM) sârmă profilată / fasonată profile-extruded $(\mathrm{OM}, \mathrm{TH})$ profilat / format prin extrudare

profile form (mas-un) şablon

profile gauge (met, metr) calibru / şablon pentru profil

profile grinder / grinding machine (mas-un) maşină de rectificat prin copiere / cu şablon 
profile grinding tool / stone (mas-un) disc abraziv profilat, moletă

profile grinded tooth (mas-un, OM) dinte rectificat / detalonat

profile housing (met) cajă de profile

profile in plane $(\mathrm{OM})$ profil (în) plan

profile iron (met) semifabricat profilat (din otel)

profile mill-cutter (met, $\mathrm{OM}$ ) cilindru pentru laminare profilată

profile milling machine (mas-un) maşină de frezat prin copiere

profile modification $(\mathrm{OM})$ modificare a profilului (la un dinte de roată dințată)

profile plane (OM) plan lateral (în desen tehnic)

profile sheet (met, plast) tablă profilată, laminat profilat

profile surface (constr) profil al terenului; $(\mathrm{OM})$ profil al suprafeței (unei piese)

profile paper hârtie milimetrică / cu pătrățele

profiler (mas-un) maşină de prelucrat prin copiere sau numai dispozitivul de copiere

profile tool steel (met, mas-un) oțel profilat pentru scule

profile turning (mas-un) strujire profilată / după şablon

profile turning lathe (mas-un) strung de copiere

profiling (mas-un) copiere, prelucrare profilată, profilare

profiling cutter (mas-un) freză / sculă profilată, cuțit profilat

profiling device (mas-un) dispozitiv de (prelucrat prin) copiere / de profilare

profiling lathe (mas-un) strung de profilat

profiling machine (mas-un) maşină de frezat prin copiere

profiling roll (OM, met, ind chim) cilindru / valt de profilare

profilograph profilograf

profilometer (metr, electr, T) profilometru, rugozimetru

profit (ec) avantaj, profit, beneficiu, câştig, venit net, a realiza beneficii, a fi avantajos; a folosi, a profita, a beneficia; (fig) folos, noimă, rost; a folosi; a profita; a fi profitabil (pentru) / de folos (cuiva)

profitability (ec) rentabilitate, profitabilitate profitability account (ec) calcul de rentabilitate profitable (ec) profitabil, rentabil

profit (by) a beneficia (de), a se folosi (de), a profita (de)

profitness (ec) rentabilitate

profit and loss account (ec) calcul de profit şi pierderi

profound profund profundity profunzime; (geogr) prăpastie, abis, hău, adâncime mare (şi fig); (fig) temeinicie, intensitate, grad înalt (de enervare etc.)

progeny (fiz) descendență prognosis prognoză, predicție

programmable (c, autom) programabil

program(me) program, plan; a programa (un computer), a planifica (producție)

$\operatorname{program}(m e)$ display (c) prezentare (pe ecran) a programului

program(m)er (inf) programator; (metr, autom) dispozitiv de programare

program(me) step (c, inf) etapă de programare, instructiune

program(ming) programare (a producției, a unui computer etc.)

program timer (autom) temporizator cu paşi succesivi / programabil pentru mai multe intervale succesive

progress progres

progress elongation (met, plast) alungire progresivă

progression (mat) progresie, dezvoltare în serie

progressive progresiv, treptat; care înaintează / merge înainte; (pol) (personalitate / persoană) $\mathrm{cu}$ vederi progresiste, progresist

progressive action acțiune progresivă

progressive ageing (met, plast) îmbătrânire progresivă

progressive assembly line (mas, TH) bandă / linie de producție; linie de asamblare pe bandă / pe flux

progressive control (autom) reglare progresivă

progressive cutting (mas-un, TH) tăiere / aşchiere progresivă

progressive development (mat) dezvoltare în serie progressive dry kiln (met, alim) uscător / cuptor de uscare cu acțiune / funcționare continuă

progressive elongation (materiale, mec) elongație progresivă

progressive failure (materiale) rupere progresivă, deteriorare treptată (şi d. un parametru de funcționare)

progressive induction seam welding (met, $\mathrm{TH}$ ) sudare progresivă cu rolă, prin inducție

progressive interlace (fiz, TV) explorare întrețesută progresivă

progressive manufacture / assembly (mas-un, $\mathrm{TH}$ ) productie / asamblare în flux continuu progressive quenching (met) călire continuă progressive scanning (fiz, c) scanare progresivă / continuă, baleiaj succesiv

progressive spot welding (met, $\mathrm{TH}$ ) sudare progresivă prin puncte (şi continue) 
progressive spring seat $(\mathrm{OM})$ reazem alunecător / glisant al arcului

progressive transmission $(\mathrm{OM})$ cutie de viteze / transmisie cu reglare continuă

progress of fatigue (met, OM) creșterea gradului de oboseală, dezvoltarea proceselor de oboseală

progress of work (constr, nav, ind) ritm de înaintare a lucrărilor / a producției

prohibited interzis

project proiect, construcție, întreprindere; a proiecta, a construi, a ieşi în afară / din rând / în relief, a proiecta (pe un plan)

projected proiectat (pe un plan)

project engineering activitate de proiectare si realizare a unui anumit proiect / produs, proiectare în inginerie

projectile (mil, OM) proiectil

projecting $(\mathrm{OM})$ proeminent; proiectare, proiectat projecting beam $(\mathrm{mec})$ grindă în consolă

projecting lug $(\mathrm{OM})$ ureche / inel (de prindere) în consolă

projecting plane plan proiectant (în desen tehnic)

project into a plane a proiecta pe un plan (în desen tehnic)

projection (mat) proiecție, valoare prezisă a unei variabile aleatoare; $(\mathrm{OM})$ ieşind, proeminență, ridicătură; proiecție, (întocmire de) proiect, proiectare, plan, ieșitură, relief

projection of pipe (OM, hidr) ştuț de țeavă

projection plane planul proiectiilor (în desen tehnic)

projection welding (met, TH) sudare în relief / cu rost mult bombat, cu arc dirijat printr-o nervură / printr-un bosaj

projection weld (met, OM) sudură cu rost bombat projector (el) reflector, proiector

project site (constr) şantier

pronock(ing) agent (chim) agent detonant

prolate (fiz) alungit

prolate spheroid (mat) elipsoid de rotație, axa mare fiind axă de revoluție

prolong a prelungi; a extinde

prolongation prelungire; extindere; (mas-un) prelungitor

prolonged prelungit (ca durată)

prolonged alternating loading (mec) sarcină / solicitare alternantă de durată

Promethium (Pm) (chim) promețiu

prominence $(\mathrm{OM})$ proeminență, ieşitură; (geogr) movilă, înălțime

promissory note $(\mathrm{ec})$ cambie, obligațiune, titlu de gaj

promote a promova; a grăbi; (chim) a accelera; a susține promote oil oxidation $(\mathrm{T}$, chim) a promova / accelera oxidarea uleiului

promoter (chim, ind, ec) promotor; activator; inițiator; accelerator; (constr) beneficiar, proprietar

promotion (fiz, chim, ec) promovare, grăbire, accelerare

prompt (fiz) instantaneu, prompt; a sugera

prompt-critical (fiz) imediat critic

prone înclinat înainte, aplecat, expus

prong $(\mathrm{OM})$ furcă, gheară, dinte, ştift

prong die (mas-un) filieră tubulară

prong of a jack (el, OM) ştift de contact (la o fişă), picioruș de contact (la circuite integrate) proof $(\mathrm{TH})$ probă, încercare, verificare; dovadă; proof (prf) (metr) unitate pentru proportiii, utilizată pentru măsurarea tăriei unui alcool distilat, inclusiv a soluțiilor medicinale; valoarea „proof” este egală cu dublul procentului volumic de alcool din soluție: exemplu: „86 proof" înseamnă $43 \%$ alcool în solutie

proof rezistent (la apă, la şoc etc.), protejat; (mat) probă, dovadă, control, verificare, demonstrație; copie, corectură, şpalt, tras; (ind chim) a cauciuca, a face impermeabil, a face rezistent la proof bar (mas-un, metr) dorn etalon, de verificare a preciziei maşinilor-unelte

proof by a reduction to a contradiction (mat) demonstrație prin reducere la absurd

proof cloth (textile, ind chim) țesătură cauciucată / impermeabilă

proofed tape (el, hidr) bandă izolantă impermeabilă

proof fabric (textile, ind chim) țesătură cauciucată / impermeabilă

proof impression (textile, poligrafie) executare a unui şpalt / a unei imprimări de probă

proofing încercare, probă; impregnare, cauciucare, impermeabilizare; verificare (a etanşeității, impermeabilității etc.), care rezistă la; (materiale) care face obiecte / țesături impermeabile / impenetrabile; $(\mathrm{OM})$ care este rezistent la

proofing mix (ind chim) amestec de cauciucare

proof limit limită de încercare / de testare (foarte general)

proof liquor (alim, metr) conținutul de alcool dintr-un lichid, exprimat ca procente de alcool într-un amestec standard

proof load $(\mathrm{OM}$, mas, metr) sarcină de probă

proof-of-concept testing (ec, TH) analiză de fezabilitate

proof pressure $(\mathrm{OM}$, hidr) presiune (statică) de încercare (mai mare decât cea maxim admisă în exploatare) 
proof pressure test $(\mathrm{OM}$, mas, metr) încercare de etanşeitate sub presiune

proof sample (metr) epruvetă, probă-martor proof spirit (chim) alcool etilic de o anumită concentrație $(57,10 \%$ volumic în UK, $48,3 \%$ volumic în US)

proof stress / voltage (el, mec, metr) tensiune de încercare / de probă

proof weight (metr, mas) încărcătură / greutate de probă

pro-oxygen(ic) agent (chim) catalizator de oxidare prop (constr) sprijin, reazem, contrafişă; (mas-un) montant suport, proptea; a propti, a sprijini, a rezema

propagate (fiz) a propaga

propagation (fiz) propagare, extindere

propagation of heat (fiz) propagarea căldurii

propagation of pressure / wave (fiz, hidr) propagarea presiunii / undei (şi de presiune); expansiune

propane (chim) propan

propel (nav, mas) a propulsa

propeller (nav, mas) propulsor, elice

propeller agitator (alim, ind chim) agitator $\mathrm{cu}$ elice

propeller area / disk (fiz) aria măturată de elice propeller axis (nav, OM) axul / axa elicei

propeller blade $(\mathrm{OM})$ pală de elice, braț de agitator

propeller efficiency $(\mathrm{OM})$ randamentul elicei

propeller fan (termo) ventilator cu elice

propeller flutter (av, nav) balansare a elicei

propeller frame $(\mathrm{OM})$ colivie de elice

propeller governor (autom, OM) regulator de pas al elicei

propeller guard (nav, OM) apărătoarea elicei propeller mixer (alim, ind chim) amestecător cu elice

propeller pitch (nav, OM) pasul elicei; $(\mathrm{OM})$ pas de filet

propeller post (nav, OM) etamboul elicei

propeller pump (OM, hidr) pompă elicoidală

propeller shaft (auto, OM) arbore de transmisie, arbore cardanic, arbore cu elice / cu ventilator, arbore port-elice

propeller-shaft tunnel (auto, OM) tunel cardanic, carcasă pentru cuplajul cardanic

propeller slip stream (hidr) jet / curent provocat de elice

propeller stirrer (alim, ind chim) agitator / amestecător cu elice

propeller thrust (hidr) tracțiunea / împingerea elicei

propeller wash (hidr) jetul / curentul elicei propelling force (mec, nav) forță de propulsie / motoare / motrice

propelling means (nav) sistem / mijloc de propulsie

propelling power (mec, OM) putere de împingere / de propulsie

propel sprocket $(\mathrm{OM}$, transp) roată de antrenare a şenilei

propenyl acohol (chim) glicerină

proper inițial, original, specific; (mat) propriu, real, exact, regulat

proper fraction (mat) fractie exactă

proper operation (mas) funcționare corectă

proper time (fiz) timp propriu

property (materiale, mas) proprietate; particularitate; caracteristică, trăsătură, însuşire; (ec) bun, avere, proprietate, avut

property damage $(\mathrm{ec}, \mathrm{TH})$ pagubă materială; (auto) avarie

property damage insurance (auto, ec) asigurare de răspundere civilă

proper value (mat) valoare caracteristică, număr caracteristic (al matricei)

propinquity proximitate, vecinătate, apropiere; asemănare, similitudine; înrudire

propintious (d. ceva) (adj) propice, favorabil, prielnic; (d. cineva) (adj) binevoitor, înțelegător, bine intentionat

propintiously $(a d v)$ (în mod) favorabil, propice preponent propunător; apărător, susținător (şi al unei idei) (şi pol)

proportion (mat) proporție, raport, relație, regula de trei simplă; raport cantitativ; parte, porțiune; a proporționa, a face proporțional; a armoniza; a potrivi, a măsura, a dimensiona, a proporționa

proportionabil care poate fi proporțional

proportional (to) proporțional (cu); (mat) proporțională

proportional control factor (autom) factor de reglare proporțional / de proporționalitate

proportional controller (autom) dozator / regulator proporțional

proportionality proporționalitate

proportionality factor (fiz, $\mathrm{TH}$ ) factor de proporționalitate

proportional limit (mec, OM) limită de proporţionalitate

proportionally ( $a d v)$ (în mod) proportional

proportional pressure-reducing valve (hidr, OM) supapă de reducere proporțională / liniară (a presiunii)

proportional representation (mat, fiz) (sistem de) reprezentare proporțională 
proportional test bar (metr) epruvetă proporțională

proportionate to (fiz) proporțional cu; (geom) simetric față de

proportion by volume (fiz) raport volumic

proportion by weight (fiz) raport masic / de greutate

proportioner (OM, alim, ind chim) dozator, dispozitiv de dozat

proportioning potrivire; măsurare; dimensionare; proporționare; dozare

proportioning tank / box (OM, alim, ind chim) rezervor de dozare

proportioning device (OM, alim, ind chim) dozator, dispozitiv de dozare

proportioning plant (alim, ind chim) instalație de dozare

proportioning pump (OM, alim, ind chim) pompă dozatoare

proportion potrivire; proporționare; măsurare; dimensionare; $(\mathrm{OM})$ mărime, dimensiune

proportion to a potrivi / proporționa $\mathrm{cu}$; a pune de acord cu, a armoniza cu

proposal propunere, sugestie; ofertă; $(\mathrm{TH})$ proiect, plan

propose a(-şi) propune, a sugera; a supune (discuției); a intenționa, a avea de gând să; a plănui, a face un plan

proposer inițiator, propunător

proposition declarație, afirmație; propunere; (mat) teoremă, propoziție; problemă, chestiune

propound a supune (spre a fi luat în considerare); a propune; a expune

propped beam $(\mathrm{mec})$ grindă în consolă

proprietary (jur, ec) (drepturi) de proprietate; particular; (d. un produs) patentat, brevetat; proprietar(i), stăpân(i); proprietate, avere, bunuri

proprietor (jur, ec) proprietar, stăpân

proprietorial de proprietate

proprietorship (jur, ec) drept de proprietate, proprietate; drept de editare

propriety conformitate, caracter potrivit / adecvat; particularitate, specific, caracteristică (d. materiale, maşini etc.); decență; bunăcuviință

propulsion (mec) propulsie, forță / maşină de propulsie, mişcare de propulsie

propulsion nozzle (OM, termo) ajutaj de propulsie

propulsive (termo) propulsiv, de propulsie; (d. un motor) cu reacție

propulsive efficiency (mas, termo) randament de tracțiune / al motorului cu reactie

propulsive effort / thrust (mec) forță de tracțiune (la propulsie) prop up (constr) a propti; a susține

propylene (chim) propilenă

propylene hydride (chim) propan

pro rata proporțional

pro-rate (amer) a repartiza / distribui proporțional

proration raționalizare; repartizare proporțională; (ec, TH) limitare artificială a productiei

prosecute a efectua, a întreprinde (o anchetă); a continua (până la capăt); a duce la bun sfârşit; (jur) a urmări în justiţie / pe cale judiciară, a da în judecată, a institui / intenta un proces

prosecution (TH) continuare, efectuare; îndeplinire; (jur) urmărire, reclamație, plângere, acuzare prosecutor (jur) procuror; acuzator, reclamant proselyte prozelit; novice; nou adept

proseminar (amer) (edu) seminar pregătitor

prospect vedere, privelişte, perspectivă, panoramă; prospecțiune; (ec) cumpărător / client în perspectivă; abonat; a prospecta (şi piaţa), a cerceta

prospective (referitor) la viitor; în perspectivă, de viitor; presupus, bănuit; aşteptat; în devenire

prospectus prospect, broşură, pliant; listă de prețuri, catalog de produse / de prezentare

prosper (ec) a prospera, a înflori; a face să prospere; a favoriza

prosperity (ec) prosperitate, dezvoltare, înflorire; succes; bogătie

prosperous prosper, înfloritor, care are succes; avut, înstărit; favorabil, prielnic

prosthesis (med) proteză

Protactinium (Pa) (chim) protactiniu

$\operatorname{protamin}(e)(\mathrm{chim})$ protaminază

protean (chim, alim) proteic; schimbător

protect (from / against) a proteja (împotriva), a (se) apăra (împotriva / de); a îngrădi, a împrejmui (împotriva); a acoperi, a îmbrăca; (pt. protejare) (ec) a accepta, a onora (o poliță)

protected $(\mathrm{OM})$ apărat, protejat; blindat; tutelat

protected cruiser (nav) crucişător uşor

protecting $(\mathrm{OM})$ de protecție, care protejează / apără

protecting cap $(\mathrm{OM})$ capac / clopot protector / de protecție, cutie / carcasă de protecție

protecting cover $(\mathrm{OM})$ capac / manta de protecție, cutie a unei siguranțe

protecting device $(\mathrm{OM})$ (dispozitiv de) siguranță, dispozitiv de protecție

protecting film $(T$, met, chim) film / peliculă de protecție

protecting piece (mas-un, OM) placă protectoare (şi din material mai moale, pt. strângerea pieselor fragile sau moi)

protecting screen $(\mathrm{OM})$ ecran de protecție 
protecting sheath (termo, met, OM) manta protectoare, înveliş de protecție (al unei țevi)

protecting sheeting (el, met) acoperire cu manta protecting tube (metr, OM) tub de protecție al elementului activ al aparatului

protection (from / against) protecție; (fiz, el) ecranare; protejare (împotriva); (TH) întărire; consolidare; fixare; apărare (împotriva); (ec) acceptare, onorare (a unei polițe); (auto, OM) protecție

protection against corrosion (chim) protecție împotriva coroziunii

protection against electric-shock hazard (el) protecție împotriva electrocutării

protection against heat (termo, met) izolație / protecție termică

protection against strong current (el) protecție împotriva curenților de înaltă tensiune

protection area (ind, $\mathrm{TH}$ ) zonă de protecție

protection by metallic casing / covering (OM) protectie prin acoperire / încasetare metalică

protection by (metallic) diffusion (met) protecție / acoperire prin difuzie a metalelor

protection by oxide film (met, chim) protejare prin peliculă de oxid

protection cell $(\mathrm{TH}$, autom) unitate / modul / cameră de protecție

protection coat (chim) acoperire de protecție

protection device (OM, el, autom) dispozitiv de protecție

protection fence (OM, constr) cutie / grilaj / gard de protecție

protection of labour $(\mathrm{TH}$, ind) protecția muncii

protection shoes (alim, met) încălțăminte de protectie

protection suit (alim, met) costum de protecție

protection survey $(\mathrm{TH})$ activitate de supraveghere a protecției în general (contra radiațiilor, de exemplu)

protection switch (el) întrerupător de protecție

protection zone $(\mathrm{TH})$ zonă de protecție / de apărare

protective $(\mathrm{OM})$ de protecție, de apărare; protector; (ec) protectionist

protective atmosphere (met, chim) atmosferă protectoare (la tratamente termo-chimice, la sudare etc.)

protective casing (met, $\mathrm{OM}$ ) manta protectoare, înveliş / carcasă de protecție

protective clothing îmbrăcăminte de protecție (pt. maşini, muncitori)

protective coat(ing) / cover(ing) $(\mathrm{OM}, \mathrm{chim})$ acoperire protectoare / de protecție, strat de protecție protective component (el, hidr, metr, autom) element / modul / subansamblu de protecție protective disk $(\mathrm{OM})$ şaibă de protecţie

protective film ( $T$, met, chim) peliculă / film / strat de protecție

protective finish (auto, ind chim) strat protector final

protective gas (TH, met) gaz de protecție / protector

protective gloves (ind chim, el) mănuşi de protecție

protective goggles (met, $\mathrm{TH}$ ) ochelari de protecție

protective ground (el) protecție prin legare la pământ

protective hat $(\mathrm{OM}$, constr) cască de protecție protective layer ( $\mathrm{T}$, met, chim) strat protector protectiveness caracter protector (d. acoperiri etc.) protective relay $(\mathrm{el})$ releu de protecție

protective resistance (el) rezistență de protecție protective shell $(\mathrm{OM})$ manta / cutie / înveliş / car-casă de protecție

protective tariff $(\mathrm{ec})$ sistem vamal protecționist, protecționism

protector protector, apărător; (el) fuzibil, siguranță; (OM) dispozitiv de siguranță, cutie / tub de protecție

proteid (chim) proteidă

protein (chim) proteină

protein nitrogen unit, PNU (metr, med) abreviere pentru protein nitrogen unit, o măsură a potenţialului compuşilor utilizați în alergiile pielii; 1 PNU este definită ca $0,01(\mu \mathrm{g})$ of phosphotungstic acid-precipitable protein nitrogen (azot din proteine, precipitabil cu acid sulfowolframic); este înlocuită cu bioequivalent allergy units (BAU), care este definită prin testarea pielii cu preparate de referință

protest (pol) protest; opoziție; obiecție; (ec) protestare (a unei polițe), a protesta (o poliță); (TH) a protesta, a nu recunoaşte ca valabil (un rezultat)

protocol $(\mathrm{TH})$ proces verbal; (pol, adm) protocol, uzanță diplomatică

proton (el, chim) proton

protophile (el, chim) acceptor de protoni protophobe (el, chim) donator / donor de protoni prototype (ind) prototip, model prim prototype test (metr) test pe prototip protoxide (chim) protoxid

protract trasare, notare pe desen / pe plan; a trasa un plan, a nota pe un plan; a extinde, a lungi; a prelungi; a amâna; a scoate; (zool) a întinde ghearele (dar şi d. un dispozitiv cu gheare) 
protracted (fiz) prelungit

protracted irradiation (fiz) iradiere prelungită / de lungă durată

protractile $(\mathrm{OM})$ (element / modul) extensibil protraction extindere; lungire; prelungire; amânare; $(\mathrm{TH})$ trasare (a unui plan), întindere, scoatere; (zool) întindere (a ghearelor etc.)

protractor transportor; (metr) raportor, măsurător de unghiuri; (mas-un, metr) echer cu brat mobil / reglabil

protractor turret (mas-un, metr) disc gradat al raportorului / indexorului

protrude a se ridica, a ieşi din rând; (OM, masun) a ieși în afară, a scoate afară, a se proiecta în afară

protruding $(\mathrm{OM})$ proeminență, protuberanță

protrusion (fiz) ieşire în afară; proiectare; (OM) ieşitură

protuberance $(\mathrm{OM})$ proeminență, protuberanță; ieşitură

protuberant $(\mathrm{OM})$ ieșit / proiectat în afară, proeminent

protuberate (fiz, OM) a ieşi / a se proiecta în afară, a fi proeminent

proud (of) mândru (de); splendid; extraordinar provable care poate fi dovedit, demonstrabil provably $(a d v)$ (în mod) demonstrabil

prove (mat) a verifica, a controla un calcul; (TH) a experimenta, a proba, a încerca, a face o încercare; a manipula, a mânui; a (se) dovedi, a demonstra, a arăta; a acționa; (jur) a legaliza, a autentifica; a atesta, a certifica proved sigur, dovedit

proven (mat, fiz) dovedit, adeverit, demonstrat

prove out a (se) confirma, a (se) adeveri, a (se) dovedi

prove unavailing a se dovedi inutil / nedovedit

provide against a lua măsuri împotriva; a opri, a împiedica

provided asigurat; prevăzut; aprovizionat; pregătit, gata; $(\mathrm{adm})$ (d. şcoli) subvenționat din fonduri locale

provided that (conj) (numai) dacă, cu condiția (ca) să

provide for a întreține; (ec, TH) a aproviziona; a asigura; a se îngriji de, a căuta, a face rost; a prevedea, a avea în vedere

providence (spirit de) prevedere; chibzuială; înțelepciune

provident econom; chibzuit; prevăzător

provide that a prevedea / stipula că

provide (with) $(\mathrm{TH}$, ec) a înzestra (cu), a asigura (cu), a aproviziona (cu), a furniza; a prevedea; (ec) a se îngriji de acoperire / bani provide with coating $(\mathrm{OM}, \mathrm{TH})$ a asigura o acoperire, a face o acoperire (şi metalică)

provide with lid / cover $(\mathrm{OM})$ a aplica un capac, a acoperi cu ceva

provide with winding (el) a înfăşura

province (adm, geogr) provincie, ținut, regiune, zonă; (fig) domeniu, sferă, competență

provincial provincial, de la țară; periferic; (fig) mărginit, îngust

proving circuit (el, autom) circuit de control

proving ground (agr, mil) teren de experiență / experimental

proving rotor $(\mathrm{OM}$, metr) rotor de verificare (la echilibrare)

provision (ec) aprovizionare, asigurare, furnizare, provizie; pregătire; (jur) dispoziție, hotărâre, prevedere, stipulare; clauză, punct

provision for / against (ec, TH) măsură (de prevedere) pentru / împotriva

provisional, provisionary provizoriu, temporar, de scurtă durată

provisional calculation / estimate (ec) antecalcul, calcul estimativ, antecalculație

provisionality $(\mathrm{TH}$, mas) caracter provizoriu, provizorat

provisionally ( $a d v$ ) (în mod) provizoriu, temporar provisioner (ec) furnizor

provisions (alim) alimente, provizii

provisory $(\mathrm{TH})$ provizoriu; condiţionat, preliminar; $v$. provisional

provocation provocare; stimulare; excitare

provocative provocator; stimulent

provocative of provocator, stimulator de

provoke a provoca, a instiga, a stârni; a cauza; a determina; a evoca

provoking provocator; supărător, neplăcut, care provoacă

provost (univ) rector

prow (nav) proră, provă

proximal, proximate (mat) proxim; apropiat; următor; cel mai apropiat; aproximativ

proximal relation (mat) relație de vecinătate

proximate analysis (ec, TH) analiză rapidă / orientativă / imediată (dar nu foarte precisă)

proximity $(\mathrm{TH}$, mat) proximitate, vecinătate; apropiere

proximity effect (el, fiz) efect de vecinătate (între conductori)

proximity stwitch (el, autom) întrerupător fără contact direct, acționat prin valoarea distanței relative între piese

proxy (ec, jur) procură; mandat, împuternicire; delegație; mandatar, împuternicit; delegat, reprezentant 
PRU (metr, med, fiz) abreviere pentru peripheral resistance unit, unitate de măsură utilizată în medicină pentru a evalua curgerea sângelui prin vasele capilare; o măsurătoare în PRU este egală cu presiunea sângelui în mmHg împărțită la debitul acestuia, în mililitri pe minut: 1 PRU $=1 \mathrm{mmHg} \cdot \mathrm{min} / \mathrm{ml}=133,3 \mathrm{~Pa} \cdot \mathrm{min} / \mathrm{ml}$ (sau, în unități SI, $\sim 8 \mathrm{GPa} \cdot \mathrm{s} / \mathrm{m}^{3}$ )

prudence prevedere, chibzuință; judecată, înțelepciune, prudență, precauție; (adm) economie, gospodărire judicioasă

prudent prevăzător, chibzuit, cu judecată, înțelept; prudent, precaut; atent, grijuliu; econom, calculat

prudential (adj) (din motive) de prudență / prevedere

prudently $(a d v)$ cu prudență, prudent, prevăzător, cu grijă, cu înțelepciune

prune (alim, agr, bot) prun, prună uscată

prune a tăia, a reteza; a scurta, a reduce; a simplifica, a face mai concis (un text etc.)

prussiate (chim) cianidă

prussic acid (chim) acid cianhidric / prusic

pry $(\mathrm{OM})$ pârghie; a ridica / desface cu ajutorul unei pârghii; curiozitate; (fig) mijloc pentru atingerea unui scop

prying curios, băgăcios

pry into $(\mathrm{TH}$, fiz, metr) a examina, a cerceta

pry open $(\mathrm{OM})$ a deschide cu ajutorul unei pârghii pseudo pseudo; fals, contrafãcut; aşa-zis pseudoplastic (mec) pseudoplastic pseudoplastic fluid (mec, hidr) fluid pseudoplastic pseudoplasticity (mec) pseudoplasticitate

psf (metr) simbol tradițional pentru pound per square foot, livră pe picior pătrat, unitate de presiune; $v$. pound per square foot,

psfa (metr) simbol traditional pentru pound per square foot absolute, care este presiunea totală inclusiv presiunea atmosferică; v. pound per square foot absolute

psfd (metr) simbol tradițional pentru pound per square foot differential, o diferență între două presiuni, niciuna dintre ele nefiind cea atmosferică; v. pound per square foot differential

psfg (metr) simbol tradițional pentru pound per square foot gauge; presiunea citită măsoară diferența dintre presiunea din incinta cu fluid sub presiuen, conectată la aparat, şi presiunea atmosferică; v. ound per square foot gauge

psi (pounds per square inch) (metr, fiz, mec) simbol tradițional pentru pound per square inch, unitate de măsură pentru presiune şi tensiune mecanică, livră pe inch pătrat (1 psi = $6,8947 \cdot 10^{3} \mathrm{~N} / \mathrm{m}^{2}$ ) psia (metr, hidr) simbol tradițional pentru pound per square inch absolute (livră absolută pe inch pătrat) - unitate de măsură pentru presiunea totală, incuzând şi presiunea atmosferică psid (metr, hidr) simbol tradițional pentru pound per square inch differential (livră diferențială pe inch pătrat) - unitate de măsură pentru diferența dintre două presiuni, niciuna nefiind cea atmosferică (pt. acționări hidraulice etc.)

psig (metr, fiz) simbol tradițional pentru pound per square inch gauge; v. pound per square inch gauge

PSU, psu (metr, chim) abreviere pentru practical salinity unit, unitate standardizată, adimensională, de măsură pentru salinitatea apei de mare; raportul între conductivitatea apei de mare şi o soluți etalon: o salinitate a apei de mare de 35 PSU are aceiaşi conductivitate cu cea a unei soluții de clorură de potasiu $(\mathrm{KCl})$ cu o concentrație masică de $3,24356 \% ; 1$ PSU are $1 / 35$ din conductivitatea solutiei standard

psychic psihic; intelectual; transcedental; intelect; senzitiv

psychologic(al) psihologic; mental

psychological test test psihologic

psychologist psiholog

psychologize a analiza din punct de vedere psihologic; a studia psihologia

psychology psihologie; mentalitate, concepție psychometry psihometrie

PTFE, polytetrafluorethylene (ind chim, plast, T) poli-tetrafluoretilenă, PTFE

P-type conductivity (el, electr) conductibilitate de tip p (la semiconductori)

pu (metr) unitate de măsură pentru lungime, în China colonială: $1 \mathrm{pu}=1,7907 \mathrm{~m}$

public (adm) public, de stat, al statului; public, pentru toți / toată lumea; municipal, orăşenesc, comunal; public, deschis, larg; renumit, vestit; eminent; lume, oameni, comunitate; spectatori, audiență, ascultători, asistență, auditoriu; (pol) popor, națiune; (ec) beneficiar, consumator

public-address (radio, adm) radiodifuzare publică, radioficare

public assistance (pol, adm) ajutor (bănesc) de stat

publication publicație, editare (de cărți, reviste); anunțare, proclamare; tipăritură, carte, lucrare publication date data publicării

public company (ec) societate / companie publică / care vinde acțiuni publicului / bursei public corporation $(\mathrm{ec})$ corporație publică public debt (ec, pol) datorie publică public good (pol, adm) binele obștesc / public 
public health (med, pol) sănătate publică publicist publicist, ziarist, gazetar; agent de publicitate; (jur) specialist în drept internațional publicity reclamă, publicitate publicize a face publicitate public opinion opinie publică

public passenger transport (transp, adm) transport public de călători

public relations (ec) serviciu de informare a publicului prin publicitate

public school (edu) liceu particular, şcoală particulară; (SUA şi Scoția), şcoală (elementară sau secundară) de stat

public road (auto, transp) drum public, cale de comunicatie

public servant (adm) funcționar public

public subscriber abonat

public telephone telefon public

public works $(\mathrm{adm}, \mathrm{TH})$ lucrări publice

public works equipment (constr, mas) echipament / utilaj de constructii, utilajul antreprenorului / al şantierului de construcții

publish (a book) a edita (o carte); a (se) tipări, a fi sub tipar; a vesti, a anunța; (adm) a declara oficial; (amer) a pune în circulație

publishable publicabil; bun de tipar

published publicat, editat, tipărit

published prices (ec) pret informativ

publisher editor; (amer) director de ziar

publishing editare, activitate editorială; (adj) editorial

publishing house editură

puce (materiale) mici impurități

puck $(\mathrm{OM})$ placă sau cilindru cu acoperire de antifrictiune, ataşat rotorilor sau statorilor ansamblului de frânare

pucker $(\mathrm{TH})$ a (se) cuta, a face cute, a (se) plia, a (se) îndoi, a strânge; cută, zbârcitură, încrețitură, rid, pliu, îndoitură (d. semifabricate / piese subțiri; dar şi defect tehnologic)

puckered încrețit, cutat, cu pliuri, gofrat (d. semifabricate / piese subtiri; dar şi defect tehnologic)

pud, pood, $(p l)$ pudi (metr, fiz) unitate tradițională rusească de măsură pentru masă: 1 pud $\sim 16,381 \mathrm{~kg}$

pudding (alim) budincă; un fel de cârnat, caltaboş

pudding rock / stone (geol) conglomerat

puddle (geogr) băltoacă, baltă; mlaștină; (geol) argilă plastică, lut; a tulbura / murdări apa sau o solutie, a frământa, a bătători; (mediu) a colmata; (met) lupă (de oțel / fier pudlat), a pudla puddle ball (met) lupă (de pudlare) puddle bar / iron (met) bară de otẹl pudlat puddled (d. apă) tulbure; mocirlos, plin de bălți (d. un teren); (d. minte) confuz, zăpăcit puddle(d) steel / iron (met) oțel pudlat puddle mill / train (met) laminor / linie de lupe puddler (met) instalație de pudlare, muncitor la pudlare

puddle rolling mill (met) laminor pentru oțel pudlat

puddle rolls (met) laminor / cilindri de pudlaj

puddle train (met) laminor de pudlaj

puddling (constr) batere, îndesare, compactare; (met) afinare în cuptor, pudlare, amestecul metalului în baia de sudare

puddling cinder (met) zgură de pudlaj

puddling furnace (met) cuptor cu reverberație pentru afinarea fontei, cuptor de pudlare / pudlat puddling pig iron (met) fontă pudlată în blocuri puddling process (met) proces / procedeu de pudlare

puddling works (met, mas) instalație de pudlare puddly (acoperit) cu băltoace, mocirlos (d. un teren)

podgy mic şi îndesat, durduliu

puerile pueril, copilăros, imatur, simplu; naiv, neserios; banal

puff suflare, suflu, adiere; nor de fum; umflătură; plapumă; (alim) aluat din foi, foi de plăcintă; a sufla, a adia; a umfla; a face reclamă; a pudra; (med) (fam) bubă

puff (pF) (metr, fiz, electr) denumire informală pentru picofarad

puff off a sufla în afară

puff out a sufla în

puff paste (alim) aluat de foi / franțuzesc

puffy durduliu, umflat, gras

pug a frământa

pug and kneading machine (ind chim, constr) malaxor, amestecător; (alim) maşină de frământat

pugging mill (constr, mas) maşină de amestecat mortar, malaxor de mortar

pug mill (ind chim, mas) maşină de amestecat, malaxor, moară cu tăvălugi / chiliană / cu role verticale

pug mill / runner (ind chim, OM, mas) malaxor / moară cu ax(e); vertical(e), tăvălug de moară / de kollergang

pugnacious bătăios; combativ; certăret

pugnacity caracter bătăios; combativitate; caracter certăret

puisssance (pol, adm) putere; autoritate

puissant (pol, adm) puternic; autoritar

puke (med) a vomita; (TH) a vărsa

pulgada (metr) unitate tradițională spaniolă de lungime, inch spaniol: 1 pulgada $\sim 23,2 \ldots 24,1 \mathrm{~mm}$ 
pull (mec, OM) (efort de) împingere / de întindere / de tractiune, tracțiune, întindere, forță (de împingere, de tracțiune); tragere; smucitură; mâner; (ec) avantaj; influență; (med) entorsă; (poligrafie) şpalt; (nav) lovitură de vâslă, a trage la rame, a vâsli; (TH) a extrage, a scoate (ceva); a detuba, a trage, a căra, a duce; a smuci; a smulge; a întinde; a extinde; a trage, a împinge; a rupe, a sfâşia; (ec, adm, pol) a-şi atrage (sprijin), a-şi asigura; a se mişca, a se urni

pull ahead of a depăşi, a întrece

pull along (mec, mas) a târî, a antrena

pull apart $(\mathrm{TH})$ a smulge, a desface, a rupe (şi în bucăți) (şi în sens nedorit, ca defect); (fig) a critica

pull away a se retrage; a scăpa; (d. vehicule) a porni, a se pune în mişcare

pull away from (transp, auto) a lăsa în urmă, a depăşi, a merge mai repede decât

pull-back $(\mathrm{TH}, \mathrm{mec})$ tragere înapoi; (fig) piedică, obstacol

pull back (mec) a trage înapoi / în direcție opusă; a face să stea pe loc; a împiedica, a opri; a antedata; a se retrage; (nav) a vâsli înapoi / invers

pull-back spring (OM) arc de rapel

pull broach (mas-un) broşă solicitată la tracțiune

pull-broaching machine (mas-un) mașină de broşat cu solicitarea la tracțiune a sculei

pull bushing (mas-un, OM) bucşă pentru fixarea capătului unei broşe

pull cable (OM, transp) cablu de tracțiune

pull crack (met) crăpătură de contracție / la tragere(defect la trefilare etc.)

pull down (constr) a demola, a dărâma; a reduce, a micşora; a degrada

pulled surface suprafață ondulată (şi defect)

puller (mas-un, OM) dispozitiv de scos piese / de demontat, extractor; (met, plast, OM) dispozitiv de scos piese din matriță; (nav) vâslaş

puller bolt (OM, mas-un) bolțul dispozitivului de demontare

puller screw $(\mathrm{OM})$ şurub de tragere

pullet (agr) găină tânără

pulley $(\mathrm{OM})$ roată de transmisie; scripete, troliu pulley block $(\mathrm{OM})$ palan, scripete pulley gear $(\mathrm{OM})$ transmisie cu roți de curea pulley groove $(\mathrm{OM})$ canalul curelei pulley hanger $(\mathrm{OM})$ suspensie cu scripete pulley hub $(\mathrm{OM})$ butucul roții de curea pulley tackle $(\mathrm{OM})$ palan, sistem de scripeți pulley tap (mas-un) tarod de filetare pulley wheel $(\mathrm{OM})$ roată de curea pulley yoke $(\mathrm{OM})$ reazem pentru roată pull in a opri; a aduna, a strânge; (fig) a câştiga (ca venit); a micşora, a reduce, a restrânge (şi cheltuieli); (cf) a trage la peron

pulling (met, $\mathrm{TH}$ ) tragere, trefilare, extragere

pulling boat (nav) barcă cu vâsle

pulling capacity (mas-un, mec) capacitate / fortă de împingere / de tragere

pulling out (mec, TH) smulgere, împingere în afară

pulling roll (met, OM, mas-un) rolă de împingere / de avansare

pulling up (mec, mas-un) împingere în sus, ridicare

pull in step (mas) antrenare în trepte; a antrena intermitent

pull-in-step range (autom) intervalul unei reglări discrete

pull-in torque (el, fiz) moment de prindere (acroşare) a unei maşini sincrone

pull-line $(\mathrm{OM})$ cablu de tracțiune

pull off $(\mathrm{TH})$ a scoate; a smulge; a realiza cu greu; (mas) a pleca, a porni; (nav) a se depărta de țărm

pull-off strip (ind) zonă de staționare (a semifabricatelor, pe un ciclu tehnologic, pe o linie tehnologică)

pull-off spring (OM) arc de rapel

pull off the road (auto) a trage pe dreapta, a ieși (intenționat) pe marginea drumului

pull on (OM) a trage (o pârghie); avantaj față de pull oneself together a-şi aduna puterile, a face un efort, a se forța; a se concentra

pull-out $(\mathrm{TH})$ a extrage, a smulge, a trage / a scoate cu forța, a trage în afară

pull upon / over avantaj față de

pull-out $(\mathrm{OM})$ parte detaşabilă

pull out $(\mathrm{TH})$ a scoate, a extrage; a smulge, a culege, a strânge; a ieşi (d. o piesă)

pull-out force (el, mas-un) forță de scoatere / de extragere

pull-out seat (auto, hidr, OM) scaun culisant

pullover (textile) pulover

pull over $(\mathrm{TH}$, ec) a ridica peste limite, a trage peste

pull-over rolling mill (met) laminor intermediar pull rod $(\mathrm{OM})$ tijă solicitată la tracțiune; (plast) tijă aruncătoare a piesei din matriță

pull rope $(\mathrm{OM})$ cablu de tracțiune

pull-shovel (constr, mas) excavator cu cupă întoarsă

pull spline $(\mathrm{OM})$ pană alunecătoare / cu arc / de cuplare

pull test (met, metr) probă / test de / la întindere

pull-test machine (metr, mas) maşină de încercat la tracțiune 
pull through a scăpa, a (se) salva (de la); a învinge; a se descurca, a răzbate

pull together a conlucra, a lucra / munci împreună; a coopera

pull-up (met, plast) întindere, întins (al sârmei, al unui fir etc.)

pull up (mec) a smulge; a smuci, a apuca; a întinde; a trage în sus, a încerca (un arc); (mas) a (se) opri, a face să stea, a sta; a merge înainte, a continua; a porni mai departe

pull-up torque (el, fiz) moment minim de demaraj / de pornire

pulmonary (med) pulmonar, de plămâni

pulp (alim) miez, pulpă (de fructe, de concentrat), terci, păsat, tăiței din sfeclă de zahăr; (ind chim) pastă de lemn, tulbureală; (met) şlam, nămol; (alim) a pisa; a face terci; a curăța de pulpă (cafeaua etc.)

pulp density (alim) densitatea pulpei / pastei (de fructe etc.)

pulp dewatering (ind chim) drenarea / scoaterea apei din pulpă de concentrat

pulp mill (ind chim) fabrică de celuloză

pulp pump (OM, alim, ind chim) pompă pentru pulpă / concentrat

pulp slurry (alim, ind chim) suspensie fibroasă, pastă mai vâscoasă

pulp thickening (ind chim, alim, met) îngroşarea pulpei / şlamului / concentratului

pulpwood (silv, ind chim) lemn pentru celuloză pulpy (alim) moale, cărnos

pulsatance (el) pulsație; (fiz) viteză unghiulară

pulsate (fiz) a pulsa, a bate (ritmic), a vibra

pulsatile (fiz, med) pulsând, care pulsează

pulsating intermitent, pulsatoriu

pulsating bending fatigue limit (mec, materiale) limită de oboseală la încovoiere în ciclu pulsatoriu

pulsating current (el) curent pulsatoriu

pulsating flow (hidr) debit pulsatoriu / intermitent

pulsating load (mec) încărcare / sarcină pulsatorie / cu şocuri (mai rar)

pulsating pressure (hidr) presiune pulsatorie

pulsating quantity (fiz) mărime pulsatorie

pulsating screen $(\mathrm{OM})$ sită vibratoare, ciur vibrator

pulsating stress / voltage $(\mathrm{el}, \mathrm{mec})$ tensiune pulsatorie

pulsation (fiz, hidr) pulsație, vibrație, fluctuație rapidă a presiunii (tensiunii etc.); (fiz) frecvență / viteză unghiulară

pulsatory (mec, el) pulsatoriu, pulsând, care pulsează

pulsatory current (el, hidr) curent pulsatoriu pulsation damping (mec, hidr) amortizare pulsatorie / a pulsațiilor (de tensiune, presiune etc.) pulse (fiz, TH) impuls, schimbare (creştere-descreştere) rapidă a unui parametru, variație regulată sau intermitentă a unui parametru în mod normal constant; pulsație, ritm; (med) puls; (fig) îndemn, impuls; a pulsa; a bate, a vibra

pulse amplifier (autom, electr) amplificator de impuls

pulse amplitude (mec, el) amplitudine / mărime a impulsului / variației

pulse analyser (metr, autom) analizor de impulsuri

pulse calibration (metr, autom) etalonarea impulsurilor

pulse clipper (fiz, autom) limitator de impulsuri pulse clipping (autom) limitare de impulsuri

pulse control (autom, mas) comandă / control / reglare prin impulsuri

pulse-decay time (mec, el, autom) perioadă de amortizare a impulsurilor

pulse duration (autom) durata impulsului / în care parametrul se modifică

pulse duty factor (autom) ritm de repetare a impulsurilor, produsul dintre durată şi frecvență pentru impulsuri

pulse generator (autom, el) generator de impulsuri (şi pneumatic)

pulse high analyser (metr, autom) analizor al amplitudinii impulsurilor

pulse limiting rate (autom) grad de limitare a impulsurilor

pulse mass spectrometer (metr, fiz) spectrometru pulsatoriu de mase

pulse of light (fiz) fulger, străfulgerare

pulse operation (autom) funcționare (regim) în impulsuri

pulse rate (fiz, autom) ritm de repetiție, produsul dintre durată şi frecvență (la impulsuri)

pulse response (fiz, autom) caracteristică de impulsuri, ecou de impulsuri

pulse signal (fiz, electr, autom) impuls

pulse spacing (fiz, autom) distanța dintre impulsuri pulse stretching (fiz, autom) coadă / trenă la impulsuri

pulse time (fiz, autom, mec) durata impulsului

pulse train (fiz) tren de impulsuri

pultrusion (plast) tehnologie de obținere a compozitelor prin împingere / injectare (controlată / dirijată) în matriță (şi încălzită)

pulverable, pulverizable pulverizabil (d. materiale solide sau fluide)

pulverization (ind chim, $\mathrm{TH}$ ) pulverizare; transformare în pulbere 
pulverize (alim) a măcina; (met) a (se) pulveriza, a (se) transforma în pulbere

pulverized coal (met) cărbune praf

pulverized-coal and gas (combined) burner

(termo) arzător combinat / mixt (cu gaz şi cărbune pulverizat)

pulverized-coal burner (termo, OM) arzător de cărbune pulverizat

pulverized-coal firing plant (termo) instalație de încălzire cu cărbune pulverizat

pulverised-coal flame (termo) flacără (de) la cărbuni pulverizați

pulverized-coal furnace (termo) focar cu moară

pulverized fuel (termo) combustibil pulverizat / praf

pulverized ore (met) minereu praf

pulverizer (alim, ind) atomizor, pulverizator, moară pentru măcinare fină

pulverizer mill (alim) instalație de morărit / de măcinat

pulverizing element (materiale) element de măcinat; $(\mathrm{OM})$ element / dispozitiv de pulverizare

pulverizing equipment (alim, ind chim) instalație de morărit / de măcinat

pulverizing process (alim, ind chim) măcinare, pulverizare, concasare fină

pulverulence pulverulență, caracter purverulent (d. materiale, pulberi etc.)

pulverous, pulverulent pulverulent, ca pulberea pumice (geol) piatră ponce; spumă de mare pumice material material poros, piatră ponce pumice slag brick (met, constr) cărămidă din zgură expandată

pumice stone slag (met) zgură spongioasă pump (OM, hidr) pompă; (hidr) a pompa pumpability $(\mathrm{T}$, hidr) pompabilitate, capacitatea unui fluid / lubrifiant de a fi pompat prin pompe, conducte, dispozitive hidraulice etc.

pumpability ( $\mathrm{T}$, hidr) aptitudine de a fi pompat, pompabilitate (şi la unsori)

pump-back (hidr) pompare înapoi, reciclu, flegmă, reflux

pump barrel (OM) cilindru / corp de pompă

pump basket $(\mathrm{OM})$ sorb de pompă

pump casing $(\mathrm{OM})$ carcasă a pompei

pumpcrete placement (constr, $\mathrm{TH}$ ) betonare sub presiune

pump cup $(\mathrm{OM})$ garnitură / manşetă / manşon / colier al pompei

pump cylinder (OM) corpul / cilindrul pompei pump delivery / discharge (hidr) debitul pompei pump dredge (nav) dragă aspiratoare

pump dry (hidr) a pompa toată apa din, a seca / usca cu pompa pumped concrete (constr) beton pompat pump handle (OM) mâner de pompă pump head (OM) cap de pompă pump house (ind) sala / casa pompelor pump gun $(\mathrm{OM}, \mathrm{T})$ pompă de ungere (şi pt. unsori)

pump impeller $(\mathrm{OM})$ rotor de pompă centrifugală pump in (hidr) a injecta, a pompa în pumping (hidr) pompare, pompaj

pumping arrangement (nav) instalație de santină

pumping and flooding board (nav) diagramă de pompare şi inundare

pumping capacity (hidr, T) capacitate de pompare pumping concrete (constr) beton pompat

pumping gear $(\mathrm{OM})$ transmisie de antrenare a pompei

pumping head (hidr) înălțimea de refulare a pompei

pumping main (OM, hidr) conductă principală de refulare

pumping plant (ind) stație de pompare

pumping power (el, mas) acționarea (şi în grup) a pompelor

pumping rate (hidr) viteză de pompare

pumping rig (ind, mediu) centrală de pompare

pumping station (ind, mediu) secție / unitate de pompare

pumping through (hidr) a pompa (fluide) prin (conducte etc.)

pump intake (OM, hidr) ştuț / racord de aspirație al unei pompe

pump into (hidr) a pompa în

pumpkin (alim, agr) dovleac, bostan

pump lever (OM) pârghie de pompă

pump main $(\mathrm{OM}$, hidr) conducta principală a pompei

pump nozzle $(\mathrm{OM})$ ştuț / racord de aspirație

pump octane number, PON (metr, ind chim, auto) cifră octanică la pompă)

pump off (hidr, mediu) a îndepărta / a scoate prin pompare, a pompa în afară

pump out (hidr) a evacua prin pompare, a scoate prin pompare

pump-out line (OM, hidr) conductă de evacuare pump output (hidr) debitul pompei

pump over (hidr) transvazare prim pompare

pump piping (OM, hidr) conductă a unei pompe pump piston (OM) piston(aş) / plunjer de pompă pump plant (mas, hidr, T) instalație de pompare pump plunger $(\mathrm{OM})$ plunjer / piston de pompă pump pressure (hidr) presiunea pompei pump priming (hidr) amorsare a pompei pump rim $(\mathrm{OM})$ plunjer de pompă 
pump regulator $(\mathrm{OM}$, hidr, autom) regulator de debit (ataşat) al pompei

pump room (ind, nav) sala pompelor pump shaft $(\mathrm{OM})$ arbore de pompă pump shell $(\mathrm{OM})$ carcasă / corp de pompă pump station (ind, mediu) stație de pompare pump storage station (ind, mediu) instalație de acumulare prin pompare

pump strainer (OM, hidr) sorb de pompă

pump suction chamber $(\mathrm{OM})$ cameră de aspirație a pompei

pump suction head (hidr) înălțime de aspirație a pompei

pump thrust (hidr) presiune a pompei (la ieşire) pump up $(\mathrm{TH})$ a pompa, a injecta, a umfla cu pompa

pump valve (OM, hidr) supapă de pompă pump well (nav) puț de pompă

punch lovitură (de pumn); (mas-un) poanson, perforator, preducea, ştanță; (met) dorn de găurit, patriță, ştanță; (constr) şpiț; (TH) a perfora, a găuri, a face o gaură, a poansona, a ştanța punch-centre (mas-un) a centra cu punctator punch drift (met) perforator punched chain $(\mathrm{OM})$ lanț $\mathrm{cu}$ zale obținute prin ştanțare

punched $(\mathrm{OM})$ perforat; găurit

punched tape (birotică, OM) bandă perforată

punched washer $(\mathrm{OM})$ şaibă brută (obținută prin ştanțare)

puncheon (met) dorn, suport, patriță; (fig) ajutor; (metr) uni-tate de măsură pentru volum de lichid: 1 puncheon (US) 264,98 1; 1 puncheon (UK) 308,34 1, 1 puncheon of wine (de vin) $\sim 308$ 1; 1 puncheon of beer (de bere) 272,5 1

puncher (met) perforator, matrițer, maşină de perforat, ştanță; ciocan pneumatic de găurit punching (mas-un) poansonare, găurire, perforare, matrițare, ștanțare

punching die (OM, mas-un) ştanță (de decupat) punching knife (OM, mas-un) cuțit de ştanţare punching machine (OM, mas-un) maşină de ştanțat / de poansonat / de găurit / de decupat punching material material de / pentru ștanțat punching pliers $(\mathrm{OM})$ cleşte de perforat punching press (mas-un) presă de ştanțat / de perforat / de debavurat

punching sheet (met) tablă ştanţată / perforată

punching slotter (mas-un) maşină de mortezat prin copiere

punching test (metr, TH) test / încercare de perforare

punch press presă de perforat / de ştanțat; (met) presă de debavurat punch through voltage (el) străpungere a tensiunii punctate, punctated (OM, materiale) punctat, cu puncte; pătat, cu perforații (ca defect)

punctation punctare; punct, pată; punctaj

punctiform punctiform

punctiform corrosion (met, chim, OM) coroziune în puncte / punctiformă

punctilious formalist; minuțios, scrupulos

punctiliousness formalism; minuțiozitate, scrupulozitate

punctual punctual, exact, precis; punctiform; ca un punct, mic

punctuality punctualitate, precizie, exactitate

punctually $(a d v)$ punctual, la punct, exact

punctuate $(\mathrm{TH})$ a puncta; a folosi semne de punctuație, a pune semne de punctuație; a sublinia, a scoate în evidenţă / relief; a întrerupe din când în când; a presăra

punctuation punctuație; (gram) semne de punctuație

punctuation mark (gram) semn de punctuație

puncture (auto) înțepătură / pană / găurire a camerei, a găuri, a străpunge (un cauciuc), a se perfora (d. un cauciuc), a înțepa, a face o gaură, a găuri, a (se) perfora, a (se) dezumfla (din cauza unei pene, unei înțepături etc.); (el) străpungere (a unei izolații), descărcare electrică disruptivă; (med) punctie, punctionare, a face o puncție (cuiva); (poligrafie) punctură, puntură

punctured perforat, punctat

punctured cable (el) cablu străpuns

pund (metr) unitate de măsură pentru masă, livra scandinavă: 1 pund $=0,5 \mathrm{~kg}$

pungency (alim) iuțeală, gust înțepător

pungent (chim) caustic, picant, ascuțit (alim); iute, înțepător, picant

punish a pedepsi

punishment pedepsire; pedeapsă

punitive pedepsitor, de pedepsire; greu, apăsător; aspru, sever

punk (silv) lemn putred sau aproape putrezit; lemn uscat; iască; lucru fără valoare; fleacuri

punnet (metr, OM) container mic cu baza pătrată sau dreptunghiulară pentru fructe sau legume; ca unitate de măsură 1 punnet $\sim 1$ dry pint (US) 1 Imperial pint (UK); v. pint punning (constr, met) batere cu maiul punt (nav) barcă plată / cu fund plat; a miza, a juca pupil (edu) elev, şcolar; discipol puppet (textile) sul, păpuşă (semifabricat, jucărie); unealtă; păpuşă, marionetă (şi fig)

puppet head (mas-un) păpuşă mobilă

purchasable (ec) de vânzare; (pol, adm) care poate fi mituit, coruptibil 
purchase (ec) cumpărare, achiziționare; cumpărătură, lucru cumpărat, venit anual (pe pământ), preț, valoare; (OM) dispozitiv de ridicat şi deplasat; (nav) palanc; (TH) apucare, strângere, punct de sprijin / reazem, a ridica cu pârghia / macaraua etc.; (ec) a cumpăra, a achiziționa; a dobândi, a căpăta, a câştiga (şi încrederea); (fig) poziție avantajată, avantaj, superioritate

purchase inspection gauge (metr) calibru de recepție la achiziție

purchaser (ec) achizitor, beneficiar, proprietar, client, cumpărător

purchasing cost (ec) cost(uri) de producție purchasing power (ec, pol) putere de cumpărare

pure autentic, pur (şi d. metale), curat, neamestecat; (d. apă) clar, limpede, curat; (d. sunete) curat, limpede, pur

pure air (mediu, chim) aer curat / pur

pure bending $(\mathrm{mec})$ încovoiere pură

puree (alim) pireu, supă pasată, a face pireu din pure lime (ind chim, constr, met) var gras

purely $(a d v)$ neamestecat, fără impurități; doar, numai, pur şi simplu; complet, în întregime

pureness (chim) puritate

pure resistance (el) rezistență pură / ohmică

pure shear(ing) stress (mec) efort de forfecare pură pure stress (mec) stare liniară de tensiuni

pure water (mediu, alim) apă curată /epurată / limpezită

purge (of, from) $(\mathrm{TH})$ a (se) purifica (de), a sufla, a (se) curăța, a epura, a purja, a limpezi; curățare, purificare, curățenie

purge cock $(\mathrm{OM}$, hidr) robinet de golire

purged (termo, fiz) purjat, dat afară; eliberat (dintr-o incintă)

purge valve (termo, hidr, $\mathrm{OM}$ ) robinet de purjare

purging (termo, mediu) purjare; purificare, curătire, epurare

purging cock (OM, hidr, termo, mediu) robinet de purjare / de nămol / de reziduuri

purging pipe (OM, hidr, termo, mediu) conductă de purjare

purging valve $(\mathrm{OM}$, hidr, termo, mediu) robinet de purjare / de evacuare

purification (mediu) curățare, limpezire, curățenie; (chim) epurare, purificare; (met) afinare, rafinare; (termo) purjare

purification process (met) proces de concentrare a minereurilor; (mediu, ind chim) proces de purificare / de curățare / de epurare

purified steel (met) oțel rafinat / afinat / pudlat purifier (ind chim, hidr, mediu) epurator purify (of / from) (chim, mediu) a (se) curăța (de), a limpezi (de), a epura; (met) a (se) purifica, a afina, a rafina; (termo) a purja

purifying (met) afinare, rafinare, purificare (şi a unui fluid)

purifying agent (ind chim) agent de purificare

purifying drum $(\mathrm{OM})$ ciur rotativ

purifying furnace (met) cuptor pentru (r)afinare purifying plant (met, mediu, ind chim) instalație de curățare / de purificare / de epurare

purifying reaction (met) efect / reacție de afinare / de purificare

purifying tower (met) epurator de gaze, scruber purifying with air (met) afinare cu aer (la furnal) purine (chim) purină

purity puritate (d. materiale, mediu), curățenie; limpezime (a lichidelor); (met) titlu, marcă la metale prețioase

purity degree (materiale, mediu) grad de puritate purl (textile) fir, franjuri, broderie; tricot links; a lucra / broda cu fir, a face franjuri, a tricota links; a murmura, a susura; (alim) bere fierbinte, cu gin şi pelin

purlieu (agr) pământ la marginea pădurii; cartier mărginaş, periferie, suburbie

purlieus împrejurimi, preajmă; margini; limite, hotare

purlin(e) (constr) pană

purlin(e) ridge (constr) coamă de şarpantă

purple purpură, roşu închis, purpuriu; (culoare) violet

purple ore (met) pirită prăjită, cenuşă de pirită

purple-red roşu ca purpura, purpuriu, roşu închis purplish, purply purpuriu

purport sens, semnificație, înțeles; conținut; explicație; that a pretinde că, a afirma, susține (că), a arăta (că)

purpose scop, țintă, obiectiv; țel; intenție, tendință; efect, rezultat, urmare, succes; voință, hotărâre, fermitate; a intenționa, a avea de gând să, a-şi fixa un scop, a avea scopul

purposeful având un scop / o țintă; practic; oportun; conştient de care vrea, hotărât; consecvent; intenționat; gândit; important

purposefulness finalitate; discernământ; tenacetate, consecvență

purposely $(a d v)$ (în mod) intenționat, dinadins, premeditat

purposive (ec, TH) corespunzător; util; oportun, intenționat; v. purposeful

purpureal purpuriu, de purpură

purr (TH, auto) funcționare liniştită / lină a motorului / maşinii, a funcționa lin / liniştit

purse pungă; portmoneu, portofel; (ec, adm) trezorerie; premiu

purse bearer $(\mathrm{ec})$ administrator financiar 
pursuance îndeplinire, executare; urmărire (a îndeplinirii)

pursuant care urmăreşte

pursuant to (prep) conform, potrivit, de acord cu, ca urmare

pursue a urmări (un scop); a persecuta, a fi în urmărirea; a căuta să realizeze / să înfăptuiască; a nu se abate de la; a ajusta, a regla, a continua (o discuție); a se ocupa cu; a studia, a cerceta

pursuer urmăritor, care urmăreşte

pursuit urmărire, căutare, continuare; scop, țintă, țel; preocupare, îndeletnicire

purvey (ec) a aproviziona cu, a furniza (alimente)

purveyance (ec) aprovizionare, furnizare, rezerve, provizii

purveyor (ec) furnizor

purview (jur) parte importantă / esențială (a unei legi); sferă de activitate, domeniu; competență pus (med) puroi

push (mec) împingere; (mas-un) buton, apăsare, presare, presiune; efort, strădanie; (fig) sprijin, protecție, influență, situație critică / dificilă, criză; (TH) a apăsa (pe), a presa, a împinge, a propulsa; a grăbi, a accelera (un proces etc.); a stimula, a înviora; a împinge, a duce; a sprijini, a susține, a da o mână de ajutor

push along / ahead (mec, TH) a împinge (după o directie), a nu se opri, a merge înainte

push and pull (mas-un) comandă la un buton (prin tragere şi apăsare)

push away $(\mathrm{TH})$ a împinge, a da la o parte

push back (mec) a împinge înapoi

push boat (nav) remorcher împingător

push broaching machine (mas-un) maşină de broşat cu brošă împinsă / solicitată la compresiune

push button (OM, mas) buton de apăsare / de comandă / de acționare / de presiune

push button control (mas) comandă prin butoane push-button switch (el, OM) întrerupător cu buton (acţionat prin împingere / apăsare)

push down (mec, OM) a apăsa / împinge (în jos), a presa

pusher (OM) pârghie, mâner de apăsare, tachet; (mas-un, met) ejector, aruncător, extractor, împingător, dispozitiv de împingere

pusher blade (constr, OM) lamă de buldozer

pusher in rolling (met) împingător, dispozitiv de împingere la laminor

pusher / pushing machine (met) împingător de cocs

pusher slide (mas-un) sanie de împingător / de extractor

pusher-type billet heating furnace (met) cuptor cu trecere continuă / cu propulsie pentru tagle pusher-type furnace (met) cuptor cu trecere continuă / cu propulsie

pusher type knockout (mas-un) dispozitiv de aruncare, cu pârghie pentru scoaterea piesei din matrită

push fit $(\mathrm{OM})$ ajustaj cu strângere

push for (pol, adm) a cere cu insistentă și urgent

push foward (TH) a împinge înainte; a (se) grăbi, a accelera; a contribui la realizarea; a încerca să răzbată

pushful energic, întreprinzător

pushing $(\mathrm{OM}, \mathrm{mec})$ împingere, împingător, de împingere; insistent, stăruitor; agresiv

pushing device (mas-un, met) dispozitiv de împingere

pushing force (mec) forță de împingere

pushing stress (mec, mas-un) efort / tensiune / presiune de împingere

push key (auto, OM) cheie de contact

push lever $(\mathrm{OM})$ a întoarce o pârghie prin apăsare

push off (TH) a împinge, a îndepărta; (ec) a desface, a scăpa (de o marfă etc.)

push on a accelera, a grăbi; a sili; a merge / înainta mai repede

push open a deschide prin apăsare (o uşă, un sertar etc.)

push out $(\mathrm{OM}, \mathrm{TH})$ a expulza, a ieşi, a (se) proiecta în afară; $(\mathrm{mec})$ a împinge în afară, a scoate; (agr, bot) a da rădăcini

push-out collet chuck (mas-un, OM) mandrină cu bucşă elastică, acționată prin apăsare dinspre interior

push piece (OM, mas) buton (de apăsare)

push-pull (mas-un, autom) (mişcare / solicitare) împinge-trage, sistem în contratimp / contrafază

push-pull circuit (el) circuit / montaj echilibrat / în contratimp

push rod (OM) tachet

push screw (OM) elice propulsoare

push through a străpunge prin, a împinge înainte; a face loc, (fig) a îndeplini, a duce la bun sfârsit; a înainta, a răzbate

push-type furnace (met) cuptor cu propulsie

push up a împinge în sus, a ridica, a urca, a face să crească (şi un preț etc.)

pushy agresiv; $v$. pushing

put a pune, a aşeza, a (am)plasa; a numi, a instala; a exprima, a spune, a formula; a pune în discutie; (fig) a evalua, a pretui, a considera, a socoti; (sport) aruncare (a greutăţii), a arunca (greutatea); (ec, la bursă) primă de livrare, primă de vânzare; a aprecia; a plasa (bani); (agr) a înfige, a împlânta; (nav) a se îndrepta

put aback (nav) a masca 
put about (nav) a întoarce, a cârmi, a pilota; (fig) a pune în circulație, a răspândi, a difuza; a ocoli

put across (nav) a duce / transporta pe malul celălalt; a transpune în fapt (o idee etc.); a materializa, a concretiza; a pune în aplicare / în practică; a lansa cu succes (o piesă de teatru etc.)

put aside a pune / lăsa la o parte; a îndepărta, a înstrăina; (ec) a strânge / economisi (resurse, bani)

putative presupus, aşa-zis; prezumtiv; probabil; aproximativ, estimativ

put away a strânge, a ascunde; a pune de o parte (şi bani); (fam) a lăsa amanet; (metr) a da (ceasul) înapoi

put-back dare înapoi (în fața unui obstacol etc.), eşec, nereuşită

put back a împinge / da înapoi; a refuza; a respinge; a înlătura; a scăpa de; (nav) a reveni în port; (adm, pol) a reintegra (în funcție); a reține, a împiedica să înainteze

put by a strânge, a ascunde; (ec)a pune de o parte (şi bani), a economisi; a evita / ocoli (un răspuns / o întrebare); a nesocoti, a nu da importanță; a trece sub tăcere

put down $(\mathrm{TH}, \mathrm{ec})$ a coborî, a reduce (un parametru etc.); (ec) a micşora(un preț, o cheltuială etc.), a înscrie / trece în contul (cuiva); a retrograda; a renunța la; a nota, a însemna, a scrie; a discredita; a doborî

put down as / for a considera / socoti drept put down to a explica prin, a pune pe socoteala put forth a (se) folosi; a arăta, a manifesta, a da dovadă de; a scoate; a pune în circulație; (agr, bot) a da muguri etc., a înmuguri; a afirma, a susține; (nav) a pleca, a porni în larg; a produce, a da naştere la; a răspândi (o teorie etc.)

put foward a pune / împinge în față / înainte; a pune în valoare; a scoate în relief; a prezenta (un plan etc.); a oferi; a pune în discuție, a dezbate (o teorie etc.); a elabora (o teorie)

put in a băga, a vârî, a introduce (în); a umple, a pune, a turna (în / înăuntru); (mas) a cupla (o transmisie intermediară), a introduce burghiul (în mandrină / în conul de prindere), a pune în functiune; a prezenta (un document), a formula (o pretentie); a pune în functie; (nav) a intra în port, a ajunge la destinație, a face o escală; (adm, jur) a înainta, a depune (o plângere etc.), (pol, adm) a instala (într-un post); a furniza (o probă etc.); a intra; (jur) a aduce (o mărturie)

put in action (mas) a pune în funcțiune

put in for a cere, a pretinde dreptul (la); (pol, adm, ec)a candida la, a-şi depune candidatura pentru

put in readiness a pune la dispoziție, a pregăti (pt. funcționare etc.) put into action a pune în mişcare, a porni

put into exploit a da în exploatare

put into gear $(\mathrm{OM})$ a porni (o transmisie şi cu roți dințate), a antrena (roți dințate), a angrena put into operation / service start (mas) a pune în funcțiune (şi pt. prima oară)

put into port (nav) a intra în port

put it into (French etc.) a spune în (franțuzeşte etc.) putlog (constr) talpă de eşafodaj

put-off amânare, întârziere; pretext, scuză, subterfugiu

put off a amâna, a întârzia cu; a scoate, a îndepărta; a evita, a ocoli, a se eschiva de la; (nav) a pleca, a porni în larg

put off from a sfătui / convinge să nu facă (ceva)

put on a porni; a începe; a lansa; a formula; (OM, mas) a monta pe; (met) a acoperi, a metaliza; a îmbrăca, a pune (o haină); (ec) a mări (un preț etc.); (adm, pol, ec) a pune în functie; a lua (o atitudine etc.); a creşte (în greutate / volum etc.)

put on a tyre (auto) a monta un pneu

put on production a produce, a intra în producție (d. un produs, proiect etc.)

put on speed (mas) a mări viteza

put on the brake(s) (auto, mas, cf) a frâna; (fig) a împiedica (pe cineva)

put on the market $(\mathrm{ec})$ a pune în vânzare, a lansa pe piață

put onto a recomanda (cuiva, pe cineva, ceva)

put option (ec, la bursă) şi primă de livrare, primă de vânzare

put smb. off with promises a duce pe cineva cu vorba

put-out eliminare; (mas-un) eliminare / evacuare a piesei prelucrate, scoatere (şi mecanizată) a unei piese dintr-o poziție de prelucrare

put out a elimina, a da afară, a scoate; a concedia; a scoate; a stinge (lumina, focul etc.); (mas) a deconecta, a decupla (un subsistem), a opri; (nav) a descărca, a ieși în larg, a pleca; a publica, a edita; (ec) a investi (bani etc.), a plasa (bani cu dobândă); (TH) a produce, a fabrica; (med) a scrânti, a luxa (un membru); a încurca, a zăpăci

put out of action / gear / operation / service (auto, mas) a scoate din viteză / din funcțiune put out (sea) (nav) a pleca din port

put over a amâna, a întârzia; (met) a acoperi, a metaliza, a placa; a pune deasupra (un strat de protecție etc.); a realiza, a duce la bun sfârşit

put pressure a porni (o instalație hidraulică), a creşte presiunea (pt. pornire); a presa

putrefaction, putrescence, putrescency putrezire, putrefacție, putregai; descompunere (d. materii organice) 
putrefy a putrezi, a se descompune; a decădea, a se corupe (d. materii organice)

putrescent intrat în putrefacție / în descompunere; rău mirositor (d. materii organice)

putrescibil putrescibil, care putrezeşte uşor

putrid putred; putrezit; în descompunere; rău mirositor (d. materii organice)

putridity putreziciune, putritudine

putter a-şi pierde vremea cu, a lucra degeaba la

putter away a irosi / pierde vremea

put through a termina, a duce la bun sfârşit (un lucru), a îndeplini; a pune în legătură (cu) (şi la telefon); (ec) a încheia (o tranzacție)

putting in readness $(\mathrm{TH})$ gata de lucru, punere la dispoziție

putting into service / operation (mas, ind) dare în exploatare, punere în functiune

put into service / operation (mas, ind) a da în exploatare, a pune în funcțiune

put to a duce la; a apropia de

put together a (re)uni, a îmbina, a combina; ( $\mathrm{TH}$, OM) a monta, a asambla; a compila; (mat, ec) a aduna, a totaliza (sume)

put to it a pune într-o situație grea / dificilă

put to land (nav) a se îndrepta spre uscat

put to sea (nav) a lansa (o navă), a ieşi / pe / în mare, a porni în larg

putty (constr) chit, mastic; a chitui

putty powder (chim) dioxid de staniu

put under lead (OM) a fixa cu plumb (un diamant), a lipi (plăcuțe aşchietoare cu aliaj de plumb)

put-up aranjat dinainte, pus la cale (dinainte)

put up (constr, ind, OM) a monta, a ridica (o piesă, o construcție etc.), a înălța; a instala (un aparat), a fixa, a construi, a clădi; a oferi, a da; a arăta; a afişa; a împacheta; a duce la magazie; a fabrica, a produce; (ec) a mări pretul la, a vinde / scoate la licitatiie, a prezenta, a investi; (adm, jur) a adresa, a face (o plângere etc.); a deschide (o umbrelă); a atârna (un tablou etc.)

put up (at) a se stabili (la), a se opri (la)

put up for a plăti pentru; (pol, adm, ec) a propune (un candidat)

put upon a înșela, a păcăli

put up (with) a se obişnui (cu), a suporta

puzzle a nedumeri, a pune în încurcătură; a încurca, a zăpăci; a complica (lucrurile); nedumerire, încurcătură; complexitate; joc de cuvinte încrucişate

puzzle lock $(\mathrm{OM})$ lacăt cu cifru

puzzlement încurcătură, zăpăceală, confuzie; (fig) enigmă, semn de întrebare

puzzle out a descurca, a descâlci (o situație etc.); a descifra, a face lumină în puzzler întrebare / problemă dificilă; (persoană, sistem) care produce confuzie / complicații

puzzling încurcat, încâlcit; enigmatic, dificil; care încurcă / face dificil

p-V diagram (termo, fiz) diagramă $\mathrm{p}-\mathrm{V}$

pycnometer (metr) picnometru

pylon (constr, el) pilon / stâlp de linie electrică, suport (de linie electrică)

pyong (metr) unitate tradițională în Korea pentru măsurarea ariei: 1 pyong $\sim 3,306 \mathrm{~m}^{2}$

pyridine base (ind chim) bază piridinică

pyridine carboxylic acid (ind chim) acid piridincarboxilic

pyridine sulphonic acid (ind chim) acid piridinsulfonic

pyridine, pyridin (ind chim) piridină

pyron (metr, fiz) unitate de măsură pentru fluxul termic al radiației solare: 1 pyron $=1$ calorie pe $\mathrm{cm}^{2}$ pe minut $=697,8 \mathrm{~W} / \mathrm{m}^{2}$

pyramid (geom) piramidă

pyramidal (geom, OM) piramidal

pyramid hardness number (metr, met) duritate Vickers

pyridine (chim) piridină

pyrite(s) (minrl, ind chim) pirită

pyrite burner gas (ind chim, met) gaz de la cuptorul de pirită

pyrite cinders (met) pirită prăjită

pyrite dross (met) cenuşă de pirită

pyrite furnace / oven / roaster / kiln (met) cuptor de prăjit pirita

pyrite dust (met) praf de pirită

pyritic process / smelting (met) topire piritică

pyritic sulphur (met) sulf de pirită

pyritous copper (minrl, met) calcopirită

pyrochemistry (chim) pirochimie

pyroelectric(al) crystals (met) cristale piroelectrice

pyroelectricity (chim, fiz) piroelectricitate

pyrogenic pirogen (d. materiale)

pyrolysis (chim) piroliză

pirometallurgy (met) pirometalurgie

pyrometer (metr, met) pirometru

pyrometric cone (mas-un, metr) con pirometric / Seger

pyrometric wire (metr, met) sârmă pirometrică

pyrometry (metr) pirometrie

pyrophoric alloy (met) aliaj piroforic

pyrophorous, $(\mathrm{pl})$ pyrophora $(\mathrm{chim})$ pirofor

pyrotechnic(al) (chim) pirotehnic

pyrotechnics (chim) pirotehnie; foc de artificii

pyrotechnist (chim) pirotehnician

pyrotechny (chim) pirotehnie

pyroxilin (chim) piroxilină 


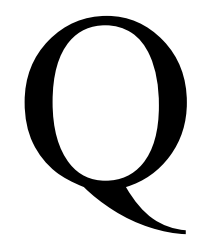

q (metr) simbol pentru quaque (în latină), ,în fiecare", termen utilizat în prescripții medicale şi rețete: exeplmu: q.8.h sau q8d înseamnă ,la fiecare 8 ore", q.2.d sau q2d - la fiecare 2 zile

Q (metr, tipografie) unitate de măsură pentru lungime: $1 \mathrm{Q}=0,25 \mathrm{~mm}$

QA (ec, TH) abreviere pentru quality assurance - asigurarea calitătiii; v. quality assurance

QC (ec, TH) abreviere pentru quality check; v. quality check

QC (ec, TH) abreviere pentru quality control; v. quality control

q.d., qd (metr, med) abreviere pentru quaque die (în latină), pentru o dată pe zi, unitate de frecvență; dar şi q.2d. sau q2d - la fiecare două zile

q.h., qh (metr) abreviere pentru quaque hora (în latină), pentru o dată la o oră, la / după fiecare oră, unitate de frecvență; dar şi în forma q.3h. sau q3h - la / după fieccare 3 ore

q.i.d., qid (metr, med) abreviere pentru quater in die (în latină), de patru ori pe zi, unitate de frecvență qian (metr) unitate tradițională de măsură pentru masă, în China: 1 qian $=5 \mathrm{~g}$

qintar (metr) unitate tradițională de măsură pentru masă, în zone arabe; 1 qintar (astăzi) $=50 \mathrm{~kg}$ qt. abreviere pentru quality; v. quality

qty. abreviere pentru quantity; v. quantity

quad (metr, fiz) unitate de măsură pentru energie: 1 quad $=10^{15}$ Btu sau $\sim 1,055$ exajoules (EJ) sau 293,07 terawatt oră (TWh)

quadbit (metr, inf) unitate de informație, egală cu 4 biți sau 1/2 byte; v. tetrad, nibble, hexit

quadra cadru, ramă, chenar

quadrable (mat) căruia i se poate face cuadratura; care poate fi redus / echivalat cu un pătrat

quadragle (geom) patrulater

quadragular (geom) patrulater, cu patru laturi, tetragonal

quadrangle (mat) patrulater; (constr, edu) curte pătrată (la colegiu)

quadrangular (geom) cadrilater, patrulater quad abreviere pentru quadrant; v. quadrant quadrant (mat) cadran, cadran (sfert de cerc), sfert de sferă, sfert de spațiu; (astronomie) cvadrant, cuadrant, sfert de arc; (mas-un) liră (la strung); (nav) sector (de cârmă), sector de cârmă; (textile) sector dințat (la maşinile de tricotat); (auto, OM) sector / segment dinţat; (matr, nav) sextant (cu limbul de $45^{\circ}$ )

quadrant (quad) (metr) unitate de măsură pentru lungime, egală cu distanța de la Polul Nord la Ecuator; în sistem metric, 1 quadrant $=10^{6} \mathrm{~m} ; 1$ quadrant (Geodetic Reference System, 1980) = $10001965,7293 \mathrm{~m}$; în principiu, 1 quadrant = 5400 mile nautice, dar 5400 mile nautice internaționale $=10000800 \mathrm{~m}$; (metr, geom) unitate de măsură pentru unghiuri, egală cu $1 / 4$ dintrun cerc, $\pi / 2$ radiani, $90^{\circ}$, sau 100 grade

quadrantal (mat) referitor la un cadran / la un sfert de cerc

quadrantal angle (geom) unghi multiplu al unghiului drept

quadrant angle of start / departure (av, mil) unghi de lansare (a rachetei); (geol) unghi de plecare; (mec) unghi iniţial (la lansare)

quadrantal component of error (metr, statistică) componentă de eroare pătratică

quadrantal error (mat, metr) eroare pătratică

quadrantal zone (geom) zonă sferică

quadrant angle of departure / start (mec) unghi inițial (la lansare)

quadrant balance (metr) balanţă pentru determinarea finetii firelor textile

quadrant davit (nav) gruie rabatabilă cu sector

quadranted împătrit, cvadruplu

quadrant electrometer (metr, el) electrometru cu cvadranți

quadrant of a circular arch (mat) sfert de cerc / de arc

quadrant plate (mas-un, OM) liră (la strung)

quadrant scales (metr, textile) balanță pentru numerotarea firelor textile

quadrant tiller (nav) eche-sector, sector al cârmei (construcții navale)

quadrat (geom) pătrat

quadrate (mat) pătrat, puterea a doua, a ridica la pătrat, a reduce o suprafață la un pătrat echivalent, a determina aria prin însumare de pătrate cuprinse în ea, a face cuadratura cercului, cu patru laturi, tetragonal; potrivit, proporțional, corespunzător, a armoniza lucrurile; a împărți în patru părți egale

quadrate with / to a cadra, a se potrivi $\mathrm{cu}$, a corespunde

quadratic (mat) pătrat, pătratic, (ecuație) pătratică / de gradul al doilea

quadratic equation (mat) ecuație de gradul al 2-lea

quadratic form (mat) formă pătratică 
quadratic formula (mat) formula rădăcinilor ecuațiilor de gradul doi / pătratice

quadratic function (mat) funcție pătratică

quadratic mean value (mat) valoare medie pătratică

quadratic term (mat) termen pătratic

quadrature cuadratură; (el) defazare la $90^{\circ}$

quadrature of the circle (mat) cuadratura cercului

quadrennial cvadrienal, de patru ani; din patru în patru ani

quadrennium (metr) unitate tradițională de timp, egală cu 4 ani

quadric (mat) cuadrică, ecuație / curbă / formă de gradul al doilea, pătratic, de ordinul al doilea

quadrilater (mat) patrulater

quadrilateral (mat) cu patru laturi, patrulater; dreptunghiular

quadrilateral mechanism (mec) mecanism patrulater

quadrilled cadrilat

quadrille paper hârtie cu pătrățele / milimetrică quadrille structure (materiale) structură reticulară quadrillion (mat) septilion; (amer) cvadrilion

quadrimester (metr, univ) unitate tradițională de timp, egală cu 4 luni

quadripartite cvadripartit; împărțit la patru; alcătuit din patru părți

quadripartition împărțire la patru

quadrivalence (chim) tetravalență

quadrivalent (chim) tetravalent

quadrumvirate (metr) (din latină) unitate de cantitate, egală cu 4

quadruple(x) cvadruplu, împătrit; compus din patru (elemente); a înmulți cu patru

quadruple-pair cable (met) cablu de oțel cu opt toroane

quadruple riveted joint $(\mathrm{OM})$ îmbinare în patru rânduri de nituri

quadruplet (metr) grup de 4 articole (şi identice); unul din articolele sau membrii unui grup / set de 4

quadword (metr, inf) unitate de informație, egală cu 4 shortwords, 8 bytes sau 64 bits; v. word quake (geol) alunecare / prăbuşire de teren, cutremur, seism; a (se) cutremura, a se clătina quake for a tremura de, a dârdâi de quake seism cutremur; a cutremura, a tremura quakeproof (constr) rezistent la solicitări seismice qualification calificare, rezervă, condiție restrictivă / prealabilă, restricție; corectiv; (pol, adm) amendament; calitate; $\sim \mathbf{s}$ (şi $p l$ ) aptitudini, calificare, competentă, competente, pricepere, (sport) calificări; însuşire; modificare; premisă; proprietate caracteristică

qualification test calificare (şi prin testare); modificare; restricție; rezervă; (ec) probă de recepție; test efectuat pe unul sau mai multe produse pentru determinarea unei anumite calități (durată de viață, compatibilitate, efect asupra mediului etc.)

qualified calificat competent, potrivit, care îndeplineşte condițiile; declarat competent / calificat qualified acceptance acceptare cu rezerve qualified accountant (ec) expert contabil (cu diplomă)

qualified expert (ec, $\mathrm{TH}$, mediu) expert autorizat qualify a (se) califica; a defini

qualimeter (metr, $\mathrm{T}$, hidr) penetrometru (pentru lubrifianți semisolizi, unsori); aparat de determinare a calității

qualitative calitativ

qualitative analysis analiză calitativă

qualitative restrictions $(\mathrm{TH})$ rezerve cu privire la calitate

quality (ec) calitate (bună), însuşire, proprietate, trăsătură caracteristică, marcă, sort, clasă de calitate; $(\mathrm{TH})$ clasă de calitate / de precizie, calitate superioară; aptitudini, bună condiție; capacitate (d. maşini, produse servicii etc.); caracter; caracteristică; fel bun; fire, însușire; marcă; merit; natură; noblețe; particularitate; posibilități; proprietate; (fig) rang (înalt), soi bun; sort (bun); trăsătură; valoare

quality assurance (QA) (ec, TH) asigurarea calității (produselor, serviciilor etc.)

quality amplifier at full charge (mas) factor de calitate în plină sarcină

quality amplifier at no charge (mas) factor de calitate (la mers) în gol

quality assurance system sistem (organizare, personal, proceduri, control) pentru asigurarea calității

quality booster (chim, T) aditiv pentru îmbunătătirea calitătii (la combustibili, lubrifianti etc.)

quality control / check (QC) $(\mathrm{TH}$, ec, metr) control al calității

quality coefficient $(\mathrm{TH}, \mathrm{ec}$, metr) caracteristică $/$ coeficient de calitate, coeficient de precizie

quality factor (mas, autom) cifră de calitate (pt. caracterizarea calității unei reglări); ( $\mathrm{TH}, \mathrm{ec})$ factor de calitate / de merit; (el, mas, mec) factor de supratensiune; factor $\mathrm{Q}$

quality forging (met) piesă forjată de calitate, forjare de calitate

quality gauge (metr, OM) dispozitiv / senzor / traductor de calitate 
quality grade (materiale, OM) marcă / grad / clasă de calitate

quality landed (nav, transp) calitate la debarcare quality management (ec) managementul calității quality manager $(\mathrm{ec})$ manager / director responsabil cu calitatea

quality of (a) fit (OM) clasă de precizie a unui ajustaj

quality of prediction (ec, TH) calitate a prevederii / estimării / a previzionării

quality of qualities calitate principală

quality of sound (fiz, muz) timbru al sunetului

quality of tolerance / of fit (OM) clasă de pre-

cizie / de toleranță / de ajustaj

quality production $(\mathrm{TH}, \mathrm{ec})$ producție de calitate superioară

quality-quantity production $(\mathrm{TH}, \mathrm{ec})$ fabricație în masă de produse superioare

quality-quantity production producție de masă de produse superioare

quality rating (antenna) (radio) coeficient / factor de calitate (al antenei)

quality specification (OM, mas) prescripții / condiții tehnice de calitate

quality survey (ec, TH) urmărire / analiză a calităţii (şi pe durata procesului tehnologic)

quality test $(\mathrm{TH}, \mathrm{ec})$ încercare / probă / încercare de calitate, control al calității

quantic cuantic

quantification, quatization cuantificare

quantitative cantitativ

quantitative analysis analiză cantitativă

quantitative determination / estimation determinare cantitativă

quantitative precipitation (chim) precipitare cantitativă

quantitative reaction (chim) reacție cantitativă

quantitative test (chim, metr) determinare / test $\operatorname{cantitativ}(\breve{a})$

quantity cantitate; mărime; dimensiune; (mat, fiz) cuantum; (fiz, chim) masă determinată; multime; (el) sarcină, cantitate de energie

quantity culture (biol, med) cultură de bacterii

quantity discharged (materiale, hidr) cantitate scursă, debit de scurgere/ la ieşire

quantity discount agreement (q.d.a.) (ec) înțelegere pentru rabat de la cantitate

quantity mark (lingv) semnul lungimii (deasupra unei vocale)

quantity meter (metr, el) amperormetru, contor de volum, debitmetru

quantity of deposit cantitate de depuneri

quantity of electricity (el, fiz) cantitate de electricitate, sarcină electrică quantity of flow (fiz, hidr) debit de apă, debit de scurgere

quantity of heat (fiz, termo) cantitate de căldură quantity of light (fiz) cantitate de lumină

quantity of magnetism (fiz) masă magnetică a unui pol

quantity of motion / of movement (mec) cantitate de mişcare, moment static

quantity of reflux (alim, ind chim) cifră de reflux (la coloanele de distilare şi rectificare), raport de reflux

quantity of waste gas (termo, auto, met) cantitate de gaze arse

quantity of waste heat $(\mathrm{TH}$, ind, mediu) cantitate de căldură pierdută

quantity of waste water (mediu, ind, met) cantitate de ape reziduale

quantity production $(\mathrm{TH}, \mathrm{ec})$ producție în serie / de masă

quantity production $(\mathrm{ec}, \mathrm{TH})$ producție de masă, productie în flux, productie în masă / în serie / pe bandă

quantity stops (TV) rastru de reglare

quantity surveyor $(\mathrm{TH})$ controlor, măsurător; (ec, TH) normator, verificator

quatization (fiz) cuantificare; (autom, alim, ind) subdivizare, dozare

quatization / quatizing error (metr, fiz) eroare de cuantificare / de discretizare / cuantică

quantize a cuantifica

quantizer (inf, autom) cuantificator, convertor analogic-numeric, traductor de mărimi

quantum, $(p l)$ quanta (metr, fizică ) unitate de măsură a energiei relative, cuantă; cuvântul descrie cantități fizice ca multipli ai unor unități discrete; exemplu: of electric charge (e) - sarcină electrică a unui singur electron

quantum of electric charge (e) (metr, fiz, el) sarcina electrică a unui singur electron

quaquaversal în formă de cupolă, în toate direcțiile, radial

quaque hora, omn. hor. (metr, med) abreviere tradițională pentru omni hora (în latină), o dată la fiecare oră, unitate de frecvență în medicină; abreviere echivalentă: q. h. (quaque hora, la fiecare oră)

quarantine flag (nav) pavilion / steag de carantină

quarrel (mat) pătrat, romb mic; (mas-un, OM) diamant / dispozitiv de tăiat geamuri

quarry (ind, constr) carieră (de piatră, de marmură, de nisip etc.), spărtură / sfărâmătură de piatră; a exploata (o carieră de piatră) carieră; (ind) deschidere de la suprafață pentru exploatarea unei 
substanțe minerale (piatră, cărbune, minereu); (fig) izvor; (fig) obiect al unei persecuții / al unei urmăriri; (fig) persoană fugărită / hăituită; persoana urmărită; (fig) sursă; vânat; pradă; a exploata în carieră, a scoate (piatră etc.)

quarry blasting (ind, constr) explozie de dislocare într-o carieră

quarry block (constr) bloc de piatră (dintr-o carieră), piatră de carieră, piatră spartă

quarry body (auto) caroserie de construcție grea (pt. utilaj de construcții în cariere de piatră), cupă / benă basculantă cu margini înclinate

quarry car (constr) vagonet (de carieră)

quarry dust (constr) faină / praf de de foraj / de carieră

quarry face (constr) față verticală de exploatare, front de exploatare (într-o carieră)

quarry floor (constr, geol) talpă a unei cariere

quarry (for) (fig) a răscoli (în căutarea), a scotoci (in căutarea)

quarry man (constr) pietrar

quarry out a extrage (din carieră)

quarry run (constr) material nesortat dintr-o carieră

quarry-run rockfill (constr, cf) (umplutură din) anrocamente brute

quarry-run stone (constr) piatră de carieră amestecată / piatră de carieră nesortată

quarry spalls (constr) piatră spartă dintr-o carieră quarry stone (constr) moloz brut, piatră brută de carieră (obținută prin spărtură), piatră de construcție, piatră spartă

quarry waste (constr) deşeuri de carieră

quart (qt) (metr, alim) unitate de măsură pentru volum, pentru vin, 1 champagne (US) $\sim 68,912$ $\mathrm{ml}, 1$ reputed quart (UK) $757,682 \mathrm{ml}$; aceste unităti de măsură au dispărut în favoarea sticlei internaționale de vin $(=750 \mathrm{ml})$; v. international wine bottle; (metr) unitate tradițională de măsură pentru volum, egală cu 1/4 dintr-un galon, sfert de galon: 1 quart $\sim 0,94635291 ; 1$ quart (US, pt. fructe etc.) $\sim 1,101221$ 1; unitate de mă-sură pentru volum, pentru lichide şi produse uscate: 1 quart (British Imperial System) $=1,13652251$; (metr, alim) unitate tradițională de măsură pentru volum: 1 quart (Scotia) 3,41 1

quarter (constr) cvartal, cartier, locuință, apartament; (alim) ciosvârtă, sfert dintr-un animal tăiat; (ec) monedă de 25 cenți; trimestru; (mat) sfert; quarter (qtr, Q) (metr, textile) unitate de lungime: 1 quarter $=22,86 \mathrm{~cm}$; quarter $(\mathbf{Q})$ (metr) unitate de măsură pentru distanță: 1 quarter $=0,25 \mathrm{~mm}$; v. Q; quarter (qtr, Q, Qr) (metr) unitate tradițională de măsură pentru masă, egală cu 1/4 hundredweight; $v$. hundredweight: 1 quarter $(\mathrm{UK})=12,7006 \mathrm{~kg} ; 1$ quarter $(\mathrm{US})=$ $11,3398 \mathrm{~kg}$; 1 quarter (informal, în US) $=226,80$ $\mathrm{kg}$ ); (metr, ec) unitate convențională de timp, egală cu 3 luni sau 1/4 dintr-un an $(90 \ldots 92$ zile); (metr, sport) unitate de măsură pentru lungime: 1 quarter $=402,336 \mathrm{~m}$; (metr) unitate informală pentru exprimarea unui sfert de oră: after 10 ora 10:15; (metr, sport) sfert (de repriză etc.), unitate de măsură pentru $1 / 4$ din timpul total al unei competiții; (metr, geom) unitate de măsură pentru unghiuri, egală cu $1 / 4$ dintr-un unghi complet de cerc; cuadrant, v. quadrant; (metr, nav) unitate de măsură pentru unghiuri, egală cu $1 / 4$ din punctul de compas: 1 quarter $=2^{\circ} 48^{\prime} 45^{\prime \prime}$ sau $\pi / 64=0,049087$ radiani; v. point; (metr, agr) unitate de măsură traditiională de măsură pentru volum (de cereale, boabe etc.): 1quarter of grain (US) $\sim 2821,1$ quarter $(\mathrm{UK})=2911$

quarterage (mil) cantonament, cazare, încartiruire, întreținere; (ec) plată / chirie trimestrială quarter bond $(\mathrm{OM})$ cot, curbă (la țevi)

quarter box bearing (OM) lagăr compus din 4 părți / sectoare

quarter deck (nav) dunetă, puntea pupa

quarter elliptic spring (auto) arc semi-cantilever quartering attachement (mas-un) dispozitiv de strunjit arbori cotiți

quartering the sample reducerea eşantionării prin metoda sferturilor

quartering way suprafață / plan de rupere

quaterly $(a d v)$ trimestrial

quarter maister (nav) timonier

quartern (metr) unitate tradițională britanică pentru masă: 1 quarten $\sim 1,5876 \mathrm{~kg}$; (metr) unitate tradițională de volum pemtru produse uscate; 1 quatern $\mathrm{UK})=2,27311,1$ quatern (US) = 2,2025 1; (metr) unitate tradițională englezească pentru cantitate egală cu 25 sau sau $1 / 4$ din 100 quartern-loaf (metr, alim) unitate tradițională englezească pentru masă (pt. pâine): 1 quaternloaf $\sim 2 \mathrm{~kg}$

quarter of year trimestru

quarter round (geom) sfert de tor

quarter twist belt drive $(\mathrm{OM})$ transmisie prin curea semi-încrucişată

quartet (metr) unitate pentru cantitate egală cu 4 quartic (mat) ecuație / curbă / suprafață / formă de gradul al patrulea, cvartică; de ordinul / gradul al patrulea

quartile (metr, statistică) unitate egală cu $25 \%$ sau 1/4 din essantionul în discuție 
quarto (metr) unitate tradițională de volum: 1 quarto (Italia) 73,6 1, 1 quarto (Portugalia) $\sim 3,461$; (metr) (brit) mărimea paginii / formatului de pagină

quarto mill (met) laminor cuarto

quartz (cristal de) cuarț

quatz glass sticlă de cuarț

quartz fiber manometer (metr) manometru cu fir de cuart

quartz glass sticlă de cuarț

quartzite brick (met) cărămidă silica

quartz sand nisip cuarțos

quartz-tube thermometer (metr, fiz) termometru cu capilar de cuart

quasi- cvasi-; aproape; semi-

quasi-conductor semiconductor

quasi-eutectic (met) cvasieutectic

quasi-rigid (mec) cvasi-rigid

quasi-smooth (hidr, T) aproape neted

quasi-static unbalance (mec) dezechilibru cvasistatic

quasi-stationary (mec) cvasistationar

quaternary alloy (met) aliaj cuaternar

quaternary eutectic alloy (met) aliaj eutectic cuaternar

quay (hidr, nav) chei; dană; dig portuar

quayage taxe de chei, cheiaj

quench a stinge (o flacără, un foc); a şterge; (met) lichid pentru răcire rapidă, baie de călire; a căli (un aliaj, un oțel etc.); a răci rapid; a şterge; a stinge (o flacără, un arc, etc.); a se stinge (d. foc); (fig) a se potoli, a se răci, a se stinge; a înăbuşi (un simţământ); a opri (o mişcare, un gest); a potoli, a stinge (setea); a răci (un metal în apă); a stăvili (o mişcare, un gest); a stinge, a înăbuşi (un metal în apă, o flacără, un indiciu etc.); a ține în frâu (un simțământ); (fig) a astupa / închide gura (cuiva), a reteza / tăia vorba (cuiva)

quench ageing (met) îmbătrânire prin călire

quench area (termo) suprafață a chiulasei, para-

lelă şi apropiată de calota pistonului; (met) zonă / suprafață călită

quench bend test încercare de încovoiere pe probe decălite

quench crack (met) fisură de călire

quenched (met) călit

quenched and subsequently tempered steel (met) oțel călit şi revenit, oțel îmbunătățit

quenched spark scânteie amortizată / stinsă

quenched steel (met) oțel călit

quencher (el) stingător de scântei; substanță extinctoare; (met) stingător de cocs

quencher car (met) vagonet de stins cocs quench frequency (autom, el) frecvență de decuplare / de întrerupere

quench hardenability (met) călibilitate, capacitate de durificare prin călire

quench hardening (met) durificare prin călire, călire bruscă

quench hot (met) călire la temperaturi înalte

quenching (el) ştergere, stingere, atenuare, încetare a conducției fără comutație; răcire; (met) călire, care se căleşte

quenching agent (met) agent de răcire / de călire

quenching and tempering (met) călire cu / urmată de revenire, îmbunătătire

quenching and tempering furnace (met) cuptor pentru îmbunătătire

quenching and tempering in air (met) călire cu / urmată de revenire în aer, îmbunătățire quenching bath (met) baie de călire

quenching car (met) vagonet de stins cocs quenching chamber (met) cameră de răcire / de călire

quenching charge (met) lot de piese pentru călire quenching crack (met) fisură de călire quenching defect (met) defect de călire quenching effect (met) efect de călire, influență a călirii

quenching hardening (met) durificare prin călire quenching machine / unit (met) instalaţie de călire

quenching medium (met) mediu de răcire / de călire

quenching of coke (met) stingere a cocsului quenching oil (met) ulei pentru călire quenching point (met) temperatură de călire quenching strain (met) deformare (cauzată) de călire

quenching stress (met) tensiune (efort) indus de călire

quenching temperature (met) temperatură de călire

quenching test (met) test de călire / de rezistență la şoc termic

quenching time (met) timp de călire

quenching zone (met) zonă de călire / care se căleşte

quench tank (met) baie de călire, rezervor / tanc / baie de răcire

query întrebare (în suspensie); chestiune (în suspensie); cerere; îndoială; cercetare; semn de întrebare (şi pe marginea unui text corectat); dubiu, îndoială; nedumerire; nesiguranță; a-şi exprima o îndoială, a se îndoi; a întreba, a pune o întrebare, a pune la îndoială / sub semnul întrebării 
query (whether / if) a interoga, a întreba (dacă) quest căutare, cercetare question întrebare, problemă question mark semn de întrebare questionnaire chestionar queue (ec) coadă (de aşteptare); (inf) şir ordonat de date, accesibil numai prin primul element queuing theory (ec) teoria de aşteptare Quevenne scale (metr, alim) scală / scară Quevenne, pentru măsurarea densității laptelui quick rapid, repede quick acces acces rapid quick acces storage / memory (c) memorie cu acces rapid

quick acting (mas) cu acționare rapidă, rapid quick acting gate valve (TH) ventil / supapă cu acționare rapidă

quick acting vice (mas-un) menghină cu acționare rapidă

quick action switch (el) întrerupător (disjunctor) rapid

quick adjusting cu ajustare (reglare) rapidă

quick advance (mas) deplasare rapidă; (mas-un) avans rapid

quick ageing (plast) îmbătrânire rapidă

quick anneal oven (met) cuptor pentru călire rapidă

quick ash (termo) cenuşă zburătoare

quick attach-dettach montare-demontare rapidă quick break întrerupere / deconectare bruscă / rapidă / instantanee

quick catch chuck (mas-un) mandrină cu prindere rapidă

quick break switch întrerupător rapid

quick change schimbare rapidă

quick change chuck (mas-un) mandrină pentru prindere rapidă; mandrină cu înlocuirea rapidă a sculelor

quick change gear (mas-un, $\mathrm{OM}$ ) transmisie cu roți dințate baladoare

quick coke (met) praf de cocs

quick cure (plast) vulcanizare rapidă

quick cutting steel (met) oțel rapid (de scule)

quick demountable $(\mathrm{TH})$ rapid demontabil, cu demontare rapidă

quick disconnect deconectare rapidă

quickening bath baie de amalgamare

quick exhaust valve (hidr, OM) supapă de evacuare rapidă

quick flashing (fiz) care pâlpâie rapid

quick gripping (mas-un, OM) prindere / strângere rapidă

quick grip vice (mas-un) menghină cu strângere rapidă a pieselor de prelucrat quick hardening cu întărire rapidă quick heating încălzire rapidă

quick indexing (mas-un) cu indexare rapidă

quick( )lime var nestins

quick look vizualizare / observare rapidă

quick make-and-break switch întrerupător / comutator rapid

quick motion mișcare (deplasare) rapidă; (masun) avans rapid

quick-operating relay / switch (el) releu instantaneu / rapid / fără temporizare

quick release (TH) scurgere / evacuare / descărcare / întrerupere / eliberare rapidă

quick release coupling (hidr, OM) cuplaj / racord rapid

quick return (stroke) (mas-un) cursă rapidă de înapoiere (de retragere)

quick setting cement ciment (soluție) cu priză rapidă

quick setting emulsion (alim, T) emulsie instabilă / cu spargere rapidă

quick silver (chim) mercur

quick silvering (chim) amalgamare / argintare (a unei oglinzi / suprafețe)

quick spindle adjusment (mas-un) ajustare (reglare) rapidă a axului principal

quick stick (plast) lipire rapidă

quick work; quickwork (nav) operă vie, carenă

quiescent (mec) în repaus; liniștit

quiescent condition (mec) stare de repaus

quiescent current (hidr, el) curent de repaus (şi la distribuitoare pilotate electric)

quiescent flow scurgerile totale ale unui sistem hidraulic

quiescent load (mec) sarcină statică / constantă

quiescent period (met) perioadă de liniștire /de oxidare (în oțelării)

quiescent pouring (met) turnare liniștită

quiescent settling decantare lentă

quiescent value valuare de repaus; (autom) valoare neperturbatoare

quiet linişte; repaus; tăcere; tihnă; (adj) ascuns, calm, cuminte, fără pretentii; imperturbabil; (ec) (care merge) lipsit de avânt (d. afaceri), (care merg) slab, mort; modest; paşnic; (d. culori) potolit, tern, spălăcit, cuminte, şters, fără strălucire; potolit, retras; secret; simplu; tăcut; tainic; tihnit; (mas) liniştit, calm, silențios, fără zgomot; a (se) linişti, a (se) potoli, a (se) calma; (met) a calma, a dezoxida; a domoli; a liniști, a potoli, a risipi, a alunga (temeri, îndoieli)

quiet gear (mas-un) angrenaj silențios

quieting (TH) liniştire; potolire; (fiz) amortizare a zgomotului, izolare acustică / fonică / sonoră; (met) calmare; calmant, liniştitor 
quieting sensitivity (autom, metr) prag de sensibilitate

quiet market (ec) piață / bursă calmă (interes redus pentru tranzacții / afaceri)

quiet run / running (auto, mas) mers silențios / lin / silenţios

quiet shifting schimbare silențioasă a vitezelor quiet steel (met) oțel calmat / dezoxidat

quiet tuning (autom, mas) acord silențios / fără zgomot / surd

quill (auto, OM) arbore gol / tubular, bucşă lungă, pană cilindrică

quill bearing $(\mathrm{OM})$ rulment cu ace

quill drive (auto, $\mathrm{OM}$ ) transmisie cu arbore tubular

quill face plate (mas-un) platou / planşaibă pe un ax suplimentar (la strunguri de masă)

quill gear (mas-un, OM) roată dințată montată pe o bucşă (în transmisiile intermediare), angrenaj cu o roată liberă

quill gears (mas-un, $\mathrm{OM}$ ) pereche de roti dințate baladoare montate pe o bucşă comună

quill rest (mas-un) păpuşa axului suplimentar al unui strung mic

quilt a capitona; a matlasa; a coase la maşină

quincena (metr) unitate de măsură pentru timp în țări de limbă spaniolă, echivalentă cu fortnight, adică două săptămâni sau 14 zile; (în latină, quince înseamnă 15 , indicând o perioadă de două săptămâni care se termină în a 15 -a zi)

quinquennium (metr) unitate tradițională de timp, egală cu 5 ani, cincinal

quintal (q) (metr) unitate de măsură pentru masă în sistem metric: 1 quintal $=100 \mathrm{~kg}$; (metr) unitate tradițională de măsură pentru masă, chintal: v. hundredweight: (Franța medievală) $=48,95 \mathrm{~kg}, 1$ quintal (Spania, astăzi) $46 \mathrm{~kg}, 1$ quintal (Portugalia) $\sim 58,75 \mathrm{~kg}$

quintet (metr) unitate pentru cantitate, egală cu 5 quintile (metr, statistică) unitate egală cu $20 \%$ (1/5) din eşantionul în discuție quintuplet (metr) grup / set de 5 articole (identice), un articol din setul de 5 articole identice quinzaine, quinzena (metr) v. quincena quintal (q.) (metr) unitate de măsură pentru masă, chital: 1 q $(\mathrm{UK})=50,8 \mathrm{~kg}, 1 \mathrm{q}(\mathrm{US})=$ $45,35 \mathrm{~kg}$

quintet cvintet

quintic (mat) ecuație / curbă de gradul al cincilea

Q unit, $\mathbf{Q}$ (metr, fiz, termo) unitate de măsură pentru energie: $1 \mathrm{Q}$ unit $=10^{18} \mathrm{Btu}, \sim 1,055$ zettajoules (ZJ)

quit a părăsi; a înceta; a abandona

quite pe deplin, în întregime

quituple a încinci, a înmulți cu cinci, a mări de cinci ori; încincit, înmulțit cu cinci

quire (qr) (metr) unitate tradițională pentru coli de hârtie; (în latină) câte patru; 1 quire era inițial format din 24 coli tăiate din 4 coli din cele mai mari ale producătorului de hârtie; astăzi 1 quire este format din 25 de coli; 1 ream of 20 quires - 500 coli, şi nu 480; v. ream

quiver (mec) a vibra, a oscila, a trepida quivering (mec) vibrație, oscilație, trepidație quoin colț; ungher (de cameră / de clădire); (TH) pană, ic; a înțepeni; a fixa cu o pană quota (ec) cotă-parte; cotă; cotizație; divident; taxă de contingentare; contingent (de mărfuri) quotation citat; citare; moto; (ec) cotare, curs (la bursă)

quatation marks ghilimele

quotation (ec) curs al zilei (la bursă); ofertă de preț făcută la cererea unui eventual cumpărător

quote a cita (un autor, un pasaj); (ec) a cota, a cere un preț

quoted price (ec) preț informativ / cerut (de vânzător)

quotient cât, coeficient

quotum cotă, parte 


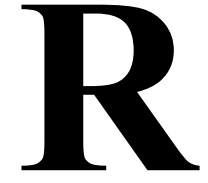

R (metr) unitate comercială de măsură pentru exprimarea eficienței izolației termice, obținută prin abrevierea unitătii $\mathrm{hr} \cdot \mathrm{ft}^{2} \cdot{ }^{\circ} \mathrm{F} / \mathrm{Btu}$ (oră picior pătrat $\left.\operatorname{grad}{ }^{\circ} \mathrm{F} / \mathrm{Btu}\right), 1 \mathrm{R}=0,17611$ metru pătrat ori grad Kelvin / Watt $\left(\mathrm{m}^{2} \cdot \mathrm{K} / \mathrm{W}\right)$; forme de scriere: R15 sau R-15; v. RSI

rabbet (const) falţ; (OM) nut, şanţ, uluc, jgheab, scobitură, îmbucătură, canal, locaş, canelură, crestătură; (met) bavură; tăietură longitudinală în lemn pentru fixarea unei scânduri; (nav) batură II; (TH) a fălțui, a cuta, a îmbina cu falț rabbet joint $(\mathrm{OM})$ îmbinare / îmbucare cu falț rabbeting $(\mathrm{TH})$ făltuire

rabbit (zool) iepure; iepure de câmp

rabbit hutch (OM, agr) cuşcă sau crescătorie de iepuri de casă

rabbitry (agr) iepuri de casă

rabbit waren (agr) crescătorie de iepuri

rabble (ind chim) agitator, amestecător; (const) racletă, răzuitoare; (met) prăjină pentru amestecat metalul topit, bară de pudlare, agitator mecanic (în cuptor), pudlare, a amesteca / răscoli cu agitatorul; (termo) vătrai rabble furnace (met) cuptor de pudlare

rabble out a grebla, a amesteca; (mec, TH) a racla, a îndepărta prin raclare

rabbler $(\mathrm{OM})$ răzuitoare; racletă; lopată

race cursă, alergare, alergări; concurs, competiție, întrecere (după), goană (după); luptă; drum al vieții; (nav) ambalare a elicei; (alim) aromă, buchet (a vinului); (hidr) bief, canal, curent rapid; (constr) rigolă; breaslă; tagmă; cale (străbătută); (OM) cale / inel de rulare (şi la rulmenți), scoc (de moară, de gater etc.), culisă; (OM, termo) mers al pistonului; caracter deosebit; caracteristică; particularitate; stil deosebit; carieră; categorie, clasă; (geogr) curent (al apei), torent; (mediu, ind) curent puternic (de apă sau de aer); curs / drum al vieții; (sport) cursă; (auto) cursă, curse; descendență; origine; gintă, stirpe; grup; neam; viță; (biol) neam, rasă, soi, specie; (fiz, astronomie) orbită (a soarelui); (textile, OM) pat al vatalei; (bot) rădăcină, soi; rădăcină; (nav, sport) regată; sex; specific; (jur) speță; a lupta (pentru); a alerga; (mas, TH) a ambala (în gol), a dezvolta o viteză periculoasă; (med) a bate prea repede (d. inimă, puls); a concura, a se duce la curse, a participa la o cursă / întrecere, a fi amator de curse; a fugi, a galopa, a goni; a juca la curse; (sport, zool) a ține cai de curse; (auto) a (se) ambala (motorul) în gol, a conduce în mare viteză, a forța; (pol, adm) a face sa treacă (un proiect) (prin parlament, etc.), a forța; a grăbi race an engine (auto) a ambala / tura un motor race (for) (fig) competiție (pentru), concurență (pentru), cursa (după)

race the engine (auto) a suprasatura motorul

raceway pistă; (el, constr) canal de cabluri; (hidr) canal sau conducta de aducție a apei la turbine; $(\mathrm{OM})$ cale de rulare (la rulmenti)

race (with) a concura (cu), a se întrece (cu), a se lua la întrecere $(\mathrm{cu})$

race boat (nav) barcă de curse

race car (auto) automobil de curse

race curse (constr) hipodrom; (sport) curse de cai racer alergător; cal de curse; (mas, nav, sport) vechicul / ambarcatiune de curse

race track (constr, sport) hipodrom; teren / pistă pentru curse

raceway (amer) $(\mathrm{OM})$ scocul morii

racing în plină fugă / cursă, în plin elan; iute, rapid, repede; (auto) autoambalat; precipitat, agitat; autoambalare, accelerare, demaraj; (sport) care participă la o cursă

racing body (auto) caroserie (de automobil) de curse

racing car (constr, sport) automobil de curse

racing path pistă de alergări

racing of engine (auto) ambalare / turare exagerată a motorului

racing yacht (nav) iaht de regate / de curse

rack $(\mathrm{OM})$ cremalieră, şină dintață, grătar, gratii, grilaj, coloană de suport, cutie de tablă, trepiedpostament; (transp) plasă pentru bagaje; stelaj, raft(uri), etajeră, poliță; eşafodaj; suport pentru scule; cuier; rastel, stativ; iesle; distrugere, nimicire; prăpăd; (mas-un, OM) lamă cu dinți; (cf, met) pat de şine, sină dințată; (agr, OM) greblă; (textile) deplasare laterală (a fonturii); (fig) caznă, chinuri; (aport, OM) dispozitiv triunghiular de aranjat bilele la începutul partidei de biliard; (meteo) drumat urmat de un nor, nor cumulus; (agr) oiță, iesle, a lega (vitele) la iesle, a pune (fân) în iesle, a epuiza, a secătui (pământul); (ind) podul sondei; (alim) rachiu de orez, a trage, a pritoci (vinul etc.); (poligrafie) regal; (constr) ruină, schelă, schelet, rampă; (mas) stand (de probă, de laborator); (sport) trap uşor, a merge în trap uşor; vitrină; a decanta; a epuiza; a întinde piei; a seca; a turna; a merge la 
culcare; a şoca, a surprinde; a aşeza, a pune (pe grătar, poliță, în cuier etc.); (fig) a stoarce, a tortura; (fig) a estorca

rack-and-gear drive (auto, OM) angrenaj cu cremalieră şi pinion

rack-and-gear jack (auto, OM) cric cu cremalieră şi pinion

rack-and-gear steering (auto, OM) cric cu cremalieră şi pinion

rack-and-lever jack $(\mathrm{OM})$ cric cu pârghie

rack and pinion $(\mathrm{OM})$ angrenaj cu cremalieră şi roată dințata

rack-and-pinion gear $(\mathrm{OM})$ transmisie cu pinion şi cremalieră

rack-and-pinion jack $(\mathrm{OM})$ cric cu cremalieră

rack-and-pinion railway (cf) cale ferată cu cremalieră

rack bar $(\mathrm{OM})$ cremalieră

rack bar sluice valve $(\mathrm{OM}$, hidr) valvă / supapă de închidere, cu comandă prin mecanism cu cremalieră

rack barrel (mas-un, OM) manşon / bucşă cu cremalieră

rack circle (auto, OM) segment / sector dințat

rack cutting machine (mas-un) maşină de tăiat dinți de cremalieră

rack cylinder (mas-un, OM) cremalieră cilindrică / cu secțiune rotundă

rack feed (mas-un) mecanism de avans cu pinion şi cremalieră

rack for bottles (alim, OM) raft / rastel pentru sticle

rack gear(ing) $(\mathrm{OM})$ angrenaj / transmisie cu pinion şi cremalieră

rack hook $(\mathrm{OM})$ piedică, cârlig de agățare, clichet racking exorbitant, excesiv; chinuitor

rack off (alim) a scoate tescovina din drojdie

rack rail(way) (cf) cale ferată cu cremalieră

rack rent (ec, agr) chirie / arendă exorbitantă

racking apparatus (alim) maşină de umplut sticle (la fabricile de bere)

racking bench / block (alim, ind chim) instalație de îmbuteliat şi agitat (sticle)

racking of wine (alim) pritocirea vinului

racking room (alim) cameră de decantare (în industria berii)

rack jack (auto, OM) cric cu cremalieră

rack mechanism $(\mathrm{OM})$ mecanism cu cremalieră

rack milling machine (mas-un) maşină de frezat cremaliere

rack operated jack $(\mathrm{OM}) \mathrm{cric} \mathrm{cu} /$ acționat prin cremalieră

rack profile standard $(\mathrm{OM})$ profil de referință (standardizat) al cremalierei rack raill $(\mathrm{OM})$ cremalieră; (cf) şină cu cremalieră

rack-shaped cutter (mas-un) cuțit-pieptene

rack steering (auto) direcție cu cremalieră

rack tool (mas-un) cremalieră ca sculă aşchietoare

rack type cutter (OM, mas-un) (sculă) cuțitcremalieră

rack work $(\mathrm{OM})$ mecanism cu cremalieră

racon (nav, av) semnal radar pentru navigaţie

rad (rd) (metr, fiz) unitate în sistemul metric pentru măsurarea dozei de radiație: 1 a rad este o doză de 0,01 Joule pe kilogram $(\mathrm{J} / \mathrm{kg})$; acronim pentru ,radiation absorbed dose”

radar (fiz) radar, radiolocator; radiolocație, radiodetecție

radar mile (metr, fiz) timpul necesar unui semnal radar să parcurgă distanța de 1 milă de la transmițător la obiect şi înapoi: 1 radar statute mile $\cong 10,8$ microseconde $(\mu \mathrm{s}), 1$ radar nautical mile $\cong 12,4$ microseconde. 1 radar kilometer $\cong 6,7$ microseconde

radar trap (metr, auto) radar pentru autovehicule radial (geom, fiz) radial cu raze

radial backlash $(\mathrm{OM})$ joc radial (între dinți)

radial engine (el) motor radial în stea

radial-ply (auto) (d. anvelopă) radial

radial ply construction (auto) aşezare radială a straturilor

radial tire (auto) anvelopa radială

radiance (fiz) radiație;strălucire, iradiere

radiant (fiz) iradiant, care radiază; strălucire; sursă de căldură sau lumină

radiation (fiz) (i)radiere, radiație, strălucire

radiation balance (fiz, chim) bilanț radiativ (în meteorologie)

radiation barrier (fiz) ecranare / barieră contra radiatiilor

radiation belt (astronomie) centură de radiație

radiation chamber (chim, fiz, OM) cameră de expunere / de iradiere

radiation capture (chim, fiz) captură radiativă

radiation catalysis (chim, fiz) cataliză prin iradiere

radiation chemestry (fiz, chim) radiochimie; studiul efectelor chimice ale radiațiilor

radiation-chemical (chim, fiz) radiochimic

radiation-chemical equilibrium (fiz) echilibru radiochimic

radiation coefficient (fiz) coeficient de radiatie radiation constant (fiz) constantă de radiație radiation counter (fiz, metr) contor de radiatii radiation damage (chim, fiz) distrugere radioactivă 
radiation damping (fiz) frecare radiativă radiation-density constant (chim, fiz) constantă a densității de radiație

radiation destruction of polymer (chim, fiz, plast) distrugere a polimerului prin radiație radiation excitation (fiz) excitare prin radiație radiation flux (fiz) flux radiant / de radiație radiation height (fiz) înălţime de radiație (a unei antene)

radiation intensity (fiz) intensitate de particule radiation detector (fiz, metr) detector de radiații radiation dose (fiz, med, biol) doză de radiaţii radiation dosimetry (fiz) dozimetrie a radiațiilor

radiation efficiency (chim, fiz) coeficient de radiație termică

radiation field (chim, fiz) câmp de radiaţie

radiation-induced (fiz, chim) produs de radiație, indus / provocat de radiaţie

radiation maze (fiz) intrare de tip labirint (a particulelor radioactive)

radiation physics (fiz) fizica radiaţiilor

radiation pattern (fiz) diagramă de radiație polară (a unei antene)

radiation rate (fiz) încărcare termică

radiation-selective (fiz) radioselectiv

radiation-sensitive (fiz) radiosensibil

radiation shield (chim, fiz, OM) blindaj / ecran

/ scut contra radiațiilor

radiation sickness (med, fiz) boala atomică / de iradiere / radiațiilor

radiation source (chim, fiz) corp radiant

radiation trap (chim, fiz) captator de radiații, intrare de tip labirint (în fizică)

radial radial, cu raze, în formă de stea; (auto) radial (d. anvelopă)

radial acceleration (mec) accelerație centrifugă radială

radial and axial ball-bearing (OM) rulment radial-axial cu bile

radial-axial bearing $(\mathrm{OM})$ rulment / lagăr radialaxial

radial axle (cf, OM) osie radială

radial bar $(\mathrm{OM})$ tijă radială

radial bearing $(\mathrm{OM})$ rulment / lagăr radial

radial boring machine (mas-un) maşină radială de găurit

radial brick (met) cărămidă radială

radial clearance $(\mathrm{OM})$ joc radial

radial cylinder engine (auto) motor în stea

radial die (mas-un) pieptene radial (al capului de filetat)

radial distribution function (fiz, mec) functie de distributie pe directia razei radial drill(ing) machine (mas-un) maşină de găurit, radială

radial engine (el, mas) motor cu ardere internă, în stea / cu cilindrii dispuşi pe o circumferință

radial facing (mas-un) strunjire a suprafeței frontale, strungire frontală

radial flow compressor (mas, termo) compresor radial

radial key (OM) cheie radială

radial load (mec, OM) sarcină / solicitare / încărcare radială (sau transversală)

radial motor / engine (el) motor în stea

radial piston motor / pump (hidr, OM) motor / pompă cu pistoane radiale

radial play $(\mathrm{OM})$ joc radial

radial pressure (hidr) presiune radială

radial range (mas) raza de acțiune

radial rib (auto, OM) nervură radială

radial roller-bearing $(\mathrm{OM})$ rulment radial cu role (cilindrice)

radial sharpened tooth (OM, mas-un) dinte $\mathrm{cu}$ plan de ascuțire radial (la freze)

radial spoke (auto, OM) spiță radială

radial stress (mec, OM) efort / tensiune radial( $\breve{a})$

radial tooth (mas-un) dinte (de freză) cu tăiş radial

radian (fiz, mat, metr) radian

radian (rad) (metr, geom) unitate de măsură pentru unghiuri: 1 radian $=1 /(2 \pi)$, sau $\sim 57,295779^{\circ}$

radian per second ( $\mathrm{rad} / \mathrm{s})$ (metr, fiz, mec) unitate de măsură pentru viteză unghiulară: 1 radian per second $=9,54930$ rotații pe minut $(\operatorname{rot} / \mathrm{min})$; v. strob

radian frequency (autom, el) viteză unghiulară

radian length (fiz) lungime în radiani

radiant heat (fiz, termo) căldură radiantă / de radiație

radiant heating (termo) încălzire prin radiație

radiant intensity (fiz) intensitate de radiație / a radiației

radiant superheater (termo) supraîncălzitor prin radiație

radiant tube bell-type annealing (met, termo) cuptor cu clopot pentru recoacere, cu tuburi radiante

radiant tube heating (met) încălzire cu tuburi radiante

radiate (fiz) a radia a emite, a emana

radiating capacity (met, termo) capacitate / putere de radiație (a unei surse de căldură)

radiating fin / flame $(\mathrm{OM}$, termo) aripioară / nervură de răcire

radiating heat (met, termo) căldură de radiație

radiating structure (met) structură micro-aciculară 
radiating surface (met, termo, OM) suprafață radiantă / de radiație

radiating vane $(\mathrm{OM}$, termo) aripioară / nervură de răcire

radiation (fiz) iradiație, strălucire

radiation absorbed dose, rad (fiz) rad (unitate de măsură a radiației de ionizare); rad (rd) (metr) unitate în sistemul metric pentru măsurarea dozei de radiație: 1 rad este o doză de 0,01 Joule pe kilogram $(\mathrm{J} / \mathrm{kg})$

radiation boiler (termo) cazan $\mathrm{cu} /$ de radiație radiation counter (fiz, metr) contor de radiații radiation dosage (fiz) doză de radiații radiation heat (fiz, termo) căldură de radiație radiation loss (termo, met) pierdere de căldură prin radiatie

radiation of heat (termo, met) radiația căldurii

radiation pyrometer (metr, met) pirometru care măsoară temperatura prin intermediul radiației corpului fierbinte

radiation unit (metr, fiz) denumire mai veche pentru becquerel

radiator (fiz, el) corp / element radiant; (termo) corp de încălzire, radiator, schimbător de căldură; (met) corp radiant

radiator mascot (auto) emblemă (pe radiator)

radiator apron (auto, OM) mască / apărătoare de radiator

radiator botton tank (auto, OM) rezervor inferior de apă, al radiatorului

radiator bracket (auto, $\mathrm{OM}$ ) suport de radiator

radiator cap (auto) capac (filetat) de radiator

radiator coolant (auto) agent de răcire a radiatorului

radiator core (auto) miez de radiator

radiator cover (auto) husă de radiator

radiator cowl (auto, $\mathrm{OM}$ ) ramă de radiator

radiator dampers (auto, OM) jaluzele de radiator

radiator drain cock / draw-off (auto, OM) robinet de golire a radiatorului

radiator draw-off plug (auto, OM) şurub de golire al radiatorului

radiator fan (auto, $\mathrm{OM}$ ) ventilator de radiator

radiator filler (auto, OM) orificiu de umplere a radiatorului

radiator filler cap (auto, OM) buşonul de umplere al radiatorului

radiator fin (auto, OM) nervură de radiator

radiator flap (auto, OM) înveliş de radiator; clapă de protecție a radiatorului

radiator frame (auto, $\mathrm{OM}$ ) cadru de radiator

radiator grill(e) (auto, $\mathrm{OM}$ ) apărătoare de radiator radiator hood / hose (auto, OM) husă de radiator radiator hose (auto) furtunul radiatorului radiator hose clamp (auto, OM) colierul furtunului de radiator

radiator louvres (auto, $\mathrm{OM}$ ) jaluzele de radiator radiator overflow (auto, $\mathrm{OM}$ ) preaplinul radiatorului

radiator overflow tube (auto, $\mathrm{OM}$ ) țeavă de preaplin a radiatorului

radiator plug (auto, $\mathrm{OM}$ ) buşon / dop de umplere al radiatorului

radiator rim (auto, OM) ramă / cadru de radiator radiator screen (auto, $\mathrm{OM}$ ) apărătoare de radiator radiator shell (auto, OM) mască de radiator radiator shutter (auto, OM) clapă de protecție a husei radiatorului

radiator standard (auto, $\mathrm{OM}$ ) suport de radiator radiator stay (auto, OM) contrafişă / tirant de radiator

radiator tie rod (auto, $\mathrm{OM}$ ) bară întinzătoare a radiatorului

radiator water lever (auto, hidr) nivelul de apă al radiatorului

radiator with detachable sections (auto, OM) radiator cu blocuri separate / demontabile; radiator modulat / format din elemente

radical radical, fundamental, esențial; (pol) radical, de convingeri radicale; (bot) fară tulpină

radical sign (mat) semnul radical

radicle radical; (bot) radiculă; (anat) semnificație inițiala

radicular (bot) radicular

radio (radio, fiz) (aparat de) radio, aparat de radiorecepție, radioreceptor, radiodifuziune; a difuza / transmite prin radio, a radiotelegrafia; (med) a trata cu radium

radioactive (chim) radioactiv

radioactive carbon-14 (chim, fiz) carbon radioactiv-14

radioactive fall-out (fiz) căderi radioactive

radioactive half life (chim, fiz) timp de înjumătățire (la substanțe radioactive)

radioactive isotope (chim, fiz) izotop radioactiv radioactivity (fiz, chim) radioactivitate radio bearing (nav, av, fiz) radionavigație radio bearing station (metr, fiz) radiogoniometru radio call (radio, fiz) semnal radio

radiocarbon (chim, fiz, metr) carbon radioactiv radiocarbon age (chim, fiz, metr) vârstă determinată prin carbon radioactiv

radiocarbon dating (fiz, geol, metr) datare a vârstei rocilor prin metoda carbonului radioactiv

radiocarbon year $\left({ }^{14} \mathbf{C}\right.$ yr, yr BP) (metr) unitate de măsură pentru evaluarea vârstei nominale a resturilor plantelor şi animalelor prin testare cu carbon radioactiv 
radio-chemestry (fiz, chim) radiochimie radio communication (fiz, radio) radiocomunicatie

radio-compas (nav, av) radio compas

radio-controlled (av, mas) dirijat de la distanță (şi d. un robot)

radioelement (chim) element radioactiv

radiogram (fiz, metr) radiogramă, radiografie

radio location (radio, fiz) radio locatie

radio locator (fiz, metr) radiolocator

radiologic (med) radiologic

radiology (med, fiz) radiologie

radioexamination (chim, metr) control / examinare cu radiatii / röentgenografic $(\breve{a})$

radio-frequency bridge (metr, electr) punte de înaltă frecvență

radiographic examination / inspection (fiz) examinare radiografică / cu ajutorul radiațiilor

radiography analysis (chim, fiz) analiză röentgenografică

radiomarker (nav, av) radiobaliză

radio range (fiz, radio, metr) radiomarker

radioreceiver (radio) aparat de radio, receptor

radioscopic (med) radioscopic

radiscopy (med, fiz) radioscopie

radiomateriology (chim, metr) analiză / examinare röentgenografică, defectoscopie cu ajutorul radiatiiilor

radiotelephone (radio, fiz) radiotelefon (termen învechit) (telefon mobil)

radiotherapeutics (med, fiz) radioterapie

radiometalography (chim, met, metr) analiză / examinare röentgenografică, defectoscopie cu ajutorul radiațiilor (mai ales la materiale metalice)

radio-shielded spark plug cap (auto) bujie ecranată contra paraziților

radio station (radio) post / statie radio

radio transmitter (radio, fiz) transmițător radio

Radium (Ra) (chim) radiu

radium therapy (med, fiz) radiumterapie

radius, $(p l)$ radii (geom) de rază (de cerc); (OM) distanță, întindere; spiță (la roată); (metr) cadran gradat, limb (al unui instrument pt. măsurarea unghiurilor)

radius arm $(\mathrm{OM})$ bară de împingere

radius bar $(\mathrm{cf})$ bielă; $(\mathrm{OM})$ tijă radială

radius crosscut saw machine (mas-un) ferăstrău basculant (şi pt. lemn)

radiusing machine (mas-un) maşină de rotunjit (pt. dinți, la roți dințate)

radius of bend (mec) rază de curbură / de îndoire / de încovoiere

radius of centre of gravity (mec) raza centrului de greutate radius of curvature (mat, $\mathrm{OM}$ ) rază de curbură

radius of gyration (mec) rază de girație / de inerție

radius of influence $(\mathrm{ec})$ zonă de influentă

radius of notch $(\mathrm{OM})$ rază de crestare, rază de racordare la fundul crestăturii (la epruvete crestate) radius of pipe bend (hidr, mas) curbură a unei țevi îndoite

radius of sphericity (mat, OM) rază de curbură

radius of travel (TH, mas) rază de deplasare

radius of turn(ing circle) (auto) rază de întoarcere / de bracare

radius planer (mas-un) raboteză de prelucrat suprafete curbe (în arc de cerc)

radius rod $(\mathrm{OM})$ bară / element $\operatorname{radial}(\breve{a})$, spiță, distantier radial

radius vector (mat, $\mathrm{mec}$ ) rază vectoare

radix, $(p l)$ radices (mat) bază (a unui sistem logaritmic); izvor, sursă; radical, rădăcină

Radon (Rn) (chim) radon; (fiz) emanație

raft (nav) plută, pod umblător, bac, ponton, masă plutitoare (de gheață etc.); grămadă, morman, mulțime; (fam) belșug, abundență

rafter (nav) podar, pontonier; căprior

rag (const) piatră (dură) de construcții, gresie (cu granulație grosieră); (geol) calcar dur; (met) crestătură (defect de forjare), bavură, grat, a cresta (calibrele cilindrilor); (textile) zdreantă, deşeu, ruptură, petic / bucată de pânză, cârpă, haine jerpelite / roase / rupte, rochie; (mas-un) a debavura, a dantura; (met) a cresta (calibrele cilindrilor); (constr) a concasa, a măcina, a sfărâma; (fig) dram, pic; (fig) fituică; (fig) idee, umbră; glumă grosolană; tărăboi, vacarm (făcut de tineri); ziar, revistă; a certa; a enerva; a glumi; a sâcâi, a necăji, a râde de, a tachina; a tulbura (o prelegere etc.)

rag-bag (fig) adunătură de tot felul de obiecte, bric-à-brac; $(\mathrm{fam})$ femeie prost îmbrăcată

rag bolt (constr) bulon de scelement; (OM) bolt de / cu cârlig, bolț de blocare / de fixare

rag breaker (ind chim) holendru pentru pastă de cârpe

rag chopper (mas, textile, ind chim) tocător (de cârpe)

rag cutter (mas, textile, ind chim) maşină de tăiat zdrențe

rag devil (mas, textile, ind chim) maşină de destrămat zdrente

ragged zdrențuit, rupt în zdrențe, jerpelit; (OM) colțuros, dințat, zimțit, neregulat, zgrunțuros, aspru, cu rugozități; nepieptănat, mițos, flocos (d. blana unui animal); neingrijit, neglijat; neglijent; necizelat 
raggedness jerpeleală, aspect zdrențăros / jerpelit; (OM) rugozitate, asprime, neomogenitate caracter inegal

ragged roll (met, OM) cilindru cu suprafață rugoasă

ragging (materiale, TH) fărâmițare, concasare, măcinare; (met) crestarea / strierea cilindrilor

rag grinder (ind chim, textile) maşină de destrămat zdrente

rag head $(\mathrm{OM})$ cap striat

ragout (alim) tocană, ostropel

rag paper (textile, ind chim, mediu) hârtie făcută din deşeuri textile

rag pulp (mas, textile, ind chim) pastă din cârpe (în ind. hârtiei)

rag pump (OM, hidr) pompă cu lanț

rag shaker (mas, textile, ind chim) maşină de scuturat (desprăfuit) zdrențe

rag shredder (ind chim, textile) maşină de destrămat zdrențe

rag stock (ind chim, textile) amestec (de cauciuc) şarjat cu fibre textile

rag sorting sortare a cârpelor (în industria hârtiei)

rag stone (geol) rocă silicioasă cenuşie cu spărtură colțuroasă

rag thrasher (mas) destrămător (în industria hârtiei, a textilelor)

rag trade (textile, fam) industria îmbrăcămintei, design pentru casele de modă

raid (mil) raid, atac, incursiune; razie, descindere, a întreprinde un atac / incursiune; a invada, a năvali

raid into (mil) a invada, a provoca panică în

rail (cf, met) şină, traversă; (const) balustradă (din bare), parapet; (nav) copastie, balustradă; (cf) a aşeza şine; (OM) cuier pentru pălării;

rail car (cf) automotor

rail chair (cf, OM) scaun pentru şină, cuzinet alunecător al şinei

railed (constr) îngrădit, împrejmuit

rail fence (constr) gard din şine şi stâlpi

rail guard $(\mathrm{OM})$ grătar de protecție

rail base (cf, met) talpa şinei

rail breaker (met, mas) sonetă pentru ruperea şinelor

rail bending press (mas-un, cf) presă de curbat şine rail conditioning unit (met, cf) agregat pentru îndreptarea și finisarea șinelor

rail corrugation (cf, met) ondularea şinelor

rail cutting machine (mas-un) maşină de tăiat şine

rail drilling machine (mas-un) maşină de găurit şine

rail end (met, cf) cap(ăt) de şină, ciupercă rail flange / foot (met, mec, cf) talpa şinei

rail head (cf) cap de linie, punct terminus; stație de descărcare

railing (const, nav) balustradă, parapet; zăbrele, barieră, grilaj de protecție

rail off (constr) a separa / despărți printr-un gard railroad (cf) cale ferată, transport feroviar

railroader (cf) muncitor feroviar; (ec, cf) propietarul unei căi ferate particulare

railroad system (cf) rețea feroviară / de căi ferate railway (cf) cale ferată; (transp, cf) a merge cu trenul, a calători

railway bed (constr, cf) terasament

railway board ( $\mathrm{cf}, \mathrm{ec}$, adm) direcția căilor ferate rail joint bar (cf, met, OM) eclisă (pentru şină) rail mill (train) (met) linie de laminare de şine railroad rolling stock $(\mathrm{cf})$ material rulant rail rolling mill (met) laminor de şine rail saw (met, mas-un) ferăstrău pentru tăierea (şi la cald) a şinelor

rail setter (mas-un) mecanism de cursă verticală a traversei (la raboteză şi la maşina de frezat longitudinal)

rail steel (met, $\mathrm{cf}$ ) oțel pentru șine

rail-structural mill (met) laminor de şine şi profiluri

railway (cf, met) cale ferată

railway axle (cf, OM) osie de cale ferată

railway material (cf, met) material pentru cale ferată

railway switch (cf, met) ac / macaz / schimbător de cale ferată

railway tyre (cf, OM, met) bandaj de cale ferată

railway wheel lathe (mas-un) strung pentru roți de cale ferată

rail with bottom-discharge tubs (cf, transp) vagon cu pâlnie de golire / cu golire de fund

raisable care se poate ridica; (mat) care poate fi anulat

rainbow (meteo, fiz) curcubeu

rainbow-hued (fiz) irizat

rainchart (geogr) hartă pluviometrică

raincoat (textile) impermeabil, manta / haină de ploaie

rainfall (meteo) precipitații, aversă, ploaie torențială rain forest (silv) pădure tropicală

rainguage (meteo, metr) pluviometru

rain glass (geogr) barometru

raininess clima ploioasă / umedă

rainless (agr) secetos, uscat

rainlessness secetă, uscăciune

rain or shine (meteo, $\mathrm{TH}$ ) indiferent de vreme / pe orice vreme; (fig) indiferent de situație, în orice conditii 
rainproof (materiale, textile) impermeabil, rezistent la ploaie

rain shower (meteo) aversă de ploaie

rain storm (meteo) vijelie,furtună

rainwater (meteo, hidr) apă de ploaie, apă provenită din precipitații

rainy (meteo) ploios, umed

raise a ridica, a înălţa, a aşeza vertical, a pune drept sau în picioare; a ridica sus (paharul, jaluzelele); a scula; a aduce la suprafață din adâncuri; a trezi interes, a stârni; a agita, aprovoca; a ridica, a monta, remonta (moralul); a evoca, a chema; (constr) a clădi, a construi un edificiu; a cresta; (mil) a înălța în grad; a spori, a urca; (ec) a strânge, a aduna bani

rainy humid day (meteo) zi ploioasă şi umedă

raised ridicat, în relief; crescut

raised quarterdeck (nav) semidunetă

raise to a higher power (mat) a ridica la o putere

raise to second power (mat) a ridica la pătrat

raise to third power (mat) a ridica la cub / la puterea a treia

raise up (OM) a trage în sus, a ridica

raise with a windlass $(\mathrm{OM})$ a ridica cu troliul

raisin (alim) stafidă

raising $(\mathrm{mec})$ ridicare, urcare, înălțare; (textile) scămoşare, operație de scămoşare; (met) extractie (de minereu)

raising block (mas-un) plăcuță (pt. reglarea înălțimii cuțitului)

raising of the dough (alim) creşterea aluatului

raising to a power (mat) ridicare la putere

rake (agr, OM) greblă; răzuitoare, răzătoare, curățitoare, raşchetă; $(\mathrm{OM})$ pieptene mare şi rar, depănătoare; vătrai, cârlig pentru foc, lopățică pentru jeratic; lopățică a crupierului (la cazinouri); a grebla, a netezi, a strânge; a scormoni, a scotoci; a răzui, a sâcâi; a cerceta atent; libertin; a se abate de la verticală; (metr, TH) deviere, abatere; (OM, mas-un) unghi de degajare

rake angle (cf, auto) unghi de declivitate; (masun) unghi de degajare (la scule)

rake classifier (const, met) sortator cu greble rake conveyer (mas, OM) transportor cu raclete rake feeder (mas) alimentator cu raclete rake mixer (ind chim, mas) amestecător cu raclete rake away a curăța cu mătura

rakeful (agr) cantitate (de fân) luată cu grebla

rake off $(\mathrm{ec})$ comision al intermediarului

rake out a extrage, a scoate la iveală, a răzui, a curăța prin răzuire, a îndepărta prin raclare

raker $(\mathrm{OM})$ racletă

rake-type cooling bank (met) pat de răcire, cu raclete rake together (agr) a strânge / aduna cu grebla raking (agr) greblare;frunze adunate cu grebla; scotocire, adunare; înclinat, în pantă; înverzit rally (pol) miting, întrunire, adunare; (mil) concentrare de trupe, regrupare a forțelor; concurs, competiție; (pol, edu) congres; (med) restabilire, revenire; (ec) nou avânt, revenire; a zeflemisi, a ironiza, a persifla; a se ralia; a reanima, a rechema la viată

ram (const) berbec (şi basculant), mai; (OM, hidr) plunjer, piston plonjor, placă / pană a vanei supapei, piston hidraulic pentru împingere; (mas-un) sanie principală; (nav) pinten, a ataca / aborda cu pintenul etravei; (const) a bătători, a bate cu maiul, a înfige cu maiul, a ştampa, a presa; (met) bloc port-poanson, mai, berbec de fontă (la forjă), împingător de cocs / de cărbuni

rambler vagabond, excursionist; vorbă lungă; (bot) plantă agățătoare

rambling rătăcitor, hoinar; incoerent, dezlânat, fără sir; întortocheat, însirat; dezordonat; neregulat; (bot) agățător; (fig) divagație, incoerență

rambling effect (fiz, TH) efect / operație / proces de împrăştiere

ram adjuster (mas-un) manetă pentru reglarea cursei saniei principale

ram cylinder (OM, hidr) cilindrul presei hidraulice

ram effect (autom, hidr) efect de presiune dinamică

ram extrusion (plast) proces de extrudare a unui amestec de pulbere cu lubrifiant, fără încălzire (şi pt. izolatoare)

ram guide (mas-un) port-cuțitul / capul berbecului (la morteză); (met) cap de aruncare centrifugală

ramification ramificație; bifurcare, răspântie; (cf) linie secundară; (fig) ramură, branşă, secție, subdiviziune; (bot) ramuri, crengi, mlădițe

ramify (bot, OM, hidr, el) a se ramifica, a se bifurca

ram jet (mas) statoreactor

rammed (constr) bătătorit, îndesat / bătut cu maiul rammel (silv) arboret; țarină; (bot) țelină; (mediu) gunoi

rammer $(\mathrm{OM})$ muncitor care lucrează cu maiul; berbec, pilon, mai, pisălog, vergea

ramose (bot) rămuros, cu multe crengi rammed bottom (met) vatră bătătorită / ștampată rammed lining (met) căptuşeală ştampată bătătorită prin îndesare

rammer (const, met) mai (pt. pavaj), berbec (de bătut piloți), berbec basculant, bătător-îndesător rammer board (met) placă de bătătorit 
ramming dolomite (met) dolomită pentru / de bătătorit / de ştampare

ramming head (met) cap de aruncare / turnare centrifugală

ramming machine (alim, met) maşină de bătut / de presat / de ştampat, maşină de percuție

ramming mass (met) masă de ştampat

ramp (constr, transp) pantă, rampă, platformă de încărcare

rampart (constr) metereze, întărituri, protecție; val de pământ; cilindru, sul

ramrod $(\mathrm{OM}$, mil) vergea, armă; îndesător; baghetă, sondă

ram up a astupa; a înfunda

ram positioning screw (mas-un, $\mathrm{OM}$ ) şurub pentru reglarea poziției saniei principale (în raport cu piesa de prelucrat)

ramshackle (const) şubred, dărăpănat, ruinat, gata să se prăbuşească, insalubru

ramshorn test (materiale, metr) test / încercare la dublă îndoire

ranch (agr) fermă, imaş, a se ocupa de creşterea vitelor

rancher (agr) fermier, proprietar de vite

rancid (alim) rânced

rancidity (alim) râncezeală; (ind chim) alterarea țiţeiului

rancid turning (alim) râncezire, rânced, care râncezeşte

rancidness (alim) râncezeală; alterare a gustului rand (constr, textile) chenar, bordură; (geogr) podiş, platou; (OM) capăt, extremitate

random întâmplare, hazard, nimereală, întâmplător, haotic; (mil) bataie a puştii; la întâmplare, aleatoriu, arbitrar; accidental; (mil) bătaie a puştii; (mat) stocastic, fără ordine; dezordonat; (luat) la întâmplare; at $\sim(a d v)$ la întâmplare, haotic

random access memory, RAM (c, inf) memorie volatilă în care se poate scrie / citi, memorie cu acces aleatoriu / direct / imediat

random accuracy errors (metr, autom, fiz) imprecizie (datorită erorilor întâmplătoare)

random analysis analiză prin sondaj

random bullit (mil) glonț rătăcit / tras la întâmplare

random coincidence coincidență întâmplătoare $/$ accidentală

random distribution (inf) distribuție aleatoare; distribuție întâmplătoare

random error (metr, autom) eroare nesistematică / întâmplătoare

random errors (metr, mat) date a căror precizie şi repetabilitate se abate de la valoarea medie (din teoria probabilităților) sau din intervalul acceptat

random expansion (termo, fiz) expansiune accidentală (în camera Wilson)

random fill (nav) garnisaj în vrac; (OM, termo) dispozitive de împrăştiere a apei într-un turn de răcire, constând din elemente de mici dimensiuni îngrămădite în vrac

random fluctuations (fiz, mas) variații / fluctuații întâmplătoare

random function (mat) funcție aleatorie (în teoria probabilităţilor)

random generator (autom) generator de semnale stocastice / aleatoare

random inspection (mas-un, metr) verificare prin sondaj

random interlace $(T V, c)$ explorare întrețesută aproximativă

randomly $(a d v)$ aiurea, la întâmplare, (în mod) întâmplător

random noise (mat) teoria reînnoirii (în teoria probabilităților); (el, autom) zgomot de fond

random number $(\mathrm{c}$, inf) număr aleatoriu

random packing (nav) garnisaj în vrac

random-position scattering (fiz) împrăştiere dezordonată / accidentală

random process (mat) proces stocastic / aleatoriu (în teoria probabilităților)

random sample (ec, $\mathrm{TH})$ probă prin sondaj

random searching (c, inf) explorare aleatorie

random slubs (textile) fire de efect cu îngroşare (la țesături)

random test (metr) test / încercare prin luarea la întâmplare a probei

random walk (fiz) mișcare haotică; mers aleatoriu random waveform (fiz) formă de undă neregulată

random web (textile, materiale) văl / țesătură obținut(ă) prin aşezarea întâmplătoare a fibrelor (şi la compozite cu fibre lungi)

random winding (el, textile) înfăşurare fără dispozitiv de conducere a firului, înfăşurare neregulată

range (chim) rând, lanț, catenă; (mat) şir, serie; interval, domeniu, imaginea unei funcții; câmp; distanță; (fiz) oscilație, amplitudine; (OM) ciur, sită, grătar de sobă; (alim) maşină de gătit; parcurs; gamă de variație / de măsurare / de produse; grosime de material; (met) penetrație, adâncime de pătrundere (după tratament); (nav) bătaie (la far), amplitudine (la maree), lungime necesară (a unei parâme), a da parâma, a naviga de-a lungul coastei, a aduce în aliniament; a alinia, a (se) situa, a (se) întinde, a oscila 
(într-un anumit domeniu), a clasifica; (metr) a regla; (auto, OM, T) plajă, interval (normal al nivelului lubrifiantului) (de pe jojă); (geol, geogr) catenă (muntoasă), lanț muntos; aliniament; anvergură; aranjament; (radio) bandă, plajă; (mil) bătaie (a tunului), tir, a regla (tirul artileriei), a avea o bătaie de, a bate (d. o armă); călătorie, excursie; (constr) camera de trecere; câmp; capacitate intelectuală; categorie, clasă; distanță; (metr) diviziune, gradație; domeniu, interval; rază de acțiune (a unui robot, a unei macarale etc.); scară; serie; sferă (de cuprindere, de interes, de cunoştințe etc.); specialitate; sortiment; (TH, metr, autom) a oscila (într-un domeniu / interval); (bot, zool) a avea răspândire, a se întinde, a creşte; a aşeza pe categorii / în grupe, a sorta (după un criteriu); a clasa, a clasifica; a înşira; a măsura; a se situa; a trece; a pune în ordine, a ordona (lucruri)

range between a fluctua, a varia între (d. un parametru)

range centre (metr, fiz, opt) punct de ochire

range correction (metr) corecție la distanță (a tirului)

range deviation (metr) abatere longitudinală

range finder (metr, constr) telemetru

range plate indicator de distanță

ranger pădurar; (adm) jandarm, grănicer; (mil) trupe de comandă, de asalt; hoinar, tâlhar, hoț; (fig) copoi

range rod (constr) jalon

range with a se număra / a fi socotit printre, a fi unul dintre; a se alinia cu

rangeability (metr) relația dintre intervalul măsurabil şi valoarea minimă posibil de măsurat; raport între valoarea maximă şi cea minimă care poate fi măsurată cu un aparat, caracteristică de aparat

range check (inf, metr) verificare dacă datele sunt într-un anumit interval

range dial (mas-un) disc de divizare, cu pasul diferit al găurilor

range drum (mas-un) tambur divizor

range light (nav) lumină de poziție

range lights (nav) lumini de aliniament

range marks (autom) repere de etalonare; (el) cercuri / repere de distanță

range of action (mas, radio) rază de acţiune; (mas) parcurs

range of adjustment (autom, metr) domeniu / interval de reglare; capacitate / gamă / limită de reglare

range of application ( $\mathrm{TH}$, metr) domeniu / interval de aplicare range of audibility (el, fiz) domeniu de audibilitate, gama de frecvente acustice

range of boiling (fiz) interval de fierbere

range of loading (mec, OM) domeniu de încărcare / de solicitare

range of ovens (met) baterie de cuptoare

range of pre-heating (termo, met) zonă / interval (de temperatură) de preîncălzire

range of proportionality (met, fiz) domeniu de proporţionalitate

range of revolutions (auto, mas-un, OM) gama de turatii

range of setting (autom, mas, metr) domeniu de reglare

range of speed (auto, OM, mas-un) gama de viteze range of spring (mas-un, OM) modificare a săgeții arcului în timpul funcționării

range of stress (mec, $\mathrm{OM}$ ) domeniu / interval de încărcare; intervalul tensiunilor (unui ciclu)

range of temperature(s) (termo) interval de temperatură

range of use (mas, OM) domeniu de aplicare / de utilizare

range ratio $(\mathrm{OM}, \mathrm{mec})$ raport dintre limitele unui ciclu (de tensiuni), coeficient de asimetrie (a unui ciclu)

ranging (mil) reglare / ajustare a tirului, ajustare a tragerilor; jalonare; clasificare, clasare, ierarhizare; (metr, autom) control al scării (unui aparat), etalonare; determinare a distantei; (masun) reglare a gamei de viteze, avansuri etc.

raging radar (fiz, nav, mil, auto) radiolocator pentru stabilirea distanței; (fiz, metr) radiolocator pentru telemetrie

rank rând, front, linie şir, clasă, tip; (mat) rang, a clasifica, a ordona după un criteriu; (inf) pozitie într-o listă ordonată

Rankine (metr, termo) o scară absolută de temperatură, scara Rankine: (zero corespunde temperaturii zero absolut şi diviziunile sunt egale cu cele din scara Fahrenheit $\left(0^{\circ} \mathrm{F}=549,69^{\circ} \mathrm{R}\right)$

rank among a se număra printre

ransom $(\mathrm{ec})$ răscumpărare

rap (mec) a desface prin ciocănire, a dezbate (în turnătorie); bucățică, mărunțiş, cantitate foarte mică

rapacious (zool) răpitor, de pradă; nesățios, răpace, vorace, apucător, hrăpăreț

rape(-seed) oil (alim, $T$, ind chim) ulei de rapiță

rape cake (agr) turtă de rapiță

rape oil (ind chim, T) ulei de rapiță

rape seed (agr) sămânță de rapiță

rapeseed methyl ester (RME) (auto, ind chim, agr) ester metilic din semințe de rapiță 
raphia (bot, textile) rafie

rapid rapid, iute; abrupt, în pantă rapidă

rapid change (mas, autom) săritură, salt, schimbare, variație rapidă (a unui parametru etc.)

rapidity rapiditate, repeziciune; iuțeală, viteză

rapidly iute, repede

rapid setting (constr) (d. ciment) cu priză rapidă

rapid advance phase (TH) fază / etapă de avans rapid (la apartură hidraulică şi maşini-unelte)

rapid analysis method (chim, met, metr) analiză rapidă

rapid approach (mas-un, hidr) abordare / alimentare / circulare rapidă; (mas-un) avans rapid, apropiere rapidă (a sculei)

rapid-charge rate (mec, el) viteză mărită de încărcare (la acumulatoare)

rapid determination (chim, metr) analiză / determinare rapidă

rapid heater (ind chim) încălzitor rapid

rapid heating (ind chim) încălzire rapidă

rapid indexing (mas-un) divizare rapidă

rapid machining steel (met) oțel rapid pentru / de scule

rapid power traverse (mas) mișcare accelerată / rapidă; (mas-un) înapoiere rapidă; mers rapid (a sculei, a saniei etc.)

rapid quenching (met) călire rapidă (cu viteză mare de răcire)

rapid-return motion (mas) mişcare accelerată / rapidă; înapoiere rapidă

rapid return phase (hidr, mas-un, OM) fază de revenire rapidă (la apartură hidraulică şi maşiniunelte)

rapid traverse (mas-un) mecanism de schimbare rapidă a poziției semifabricatului în timpul retragerii sculei

rapid steel (met) oțel rapid

rapid traverse (mas-un) deplasare rapidă, avans rapid

rapper (met) dispozitiv pentru baterea modelului

rapping (autom, mas) bătaie, detonare, funcționare cu detonatii (a motorului); (met) baterea modelului

rapping plate (met) placă pentru baterea modelului

rapport raport, relație

rare rar, neobişnuit; greu de găsit; care se întâmplă rareori; fără pereche, neasemuit, extraordinar, excelent, formidabil; (alim) crud, nefiert, nefăcut; straşnic, grozav

rarefied medium (fiz) mediu rarefiat

rarefy (fiz) a rarefia

rare earths (chim) pămâturi rare, lantanide

rarefaction (fiz) rarefiere, subțiere, răcire rarefactive (fiz) (legat) de rarefiere, rarefacție rareripe timpuriu, precoce, prematur

rarity raritate, caracter rar / excepțional, piesă rară; obiect de anticariat

rash pripit, grăbit, iute; năpraznic, impetuos, temerar, nepăsător, nesocotit

rasher (alim) feliuță, felioară

rashly $(a d v)$ în pripă, în grabă, făă chibzuială

rashness grabă; nechibzuință, nesocotință; îndrăzneală, aroganţă

rasp (mas-un) raspă, raspel, pilă; (alim, OM) răzătoare; zăngănit, scârțâit

raspberry (bot, alim) zmeură

raspberry cane (bot) tufiș de zmeură

rasper $(\mathrm{OM}$, mas) răzuitoare, maşină de răzuit, lucrător care răzuieşte; (bot) mărăciniş

rasping (TH) răzătură, pilitură, şpan; sunet enervant

raster raster, tipar de baleiaj

rat (zool) şobolan

ratability (ec, $\mathrm{TH})$ posibilitate de evaluare

ratable evaluabil, estimabil; (ec) impozabil, care poate fi taxat

ratchel (geogr) prundiş

ratchet $(\mathrm{OM})$ roată cu clichet; castaniete

ratchet clutch $(\mathrm{OM})$ ambreiaj

rare gas (chim) gaz nobil / inert

rare metals (chim) metale rare

rare mixture (auto, termo) amestec prea sărac

rasp (alim) răzătoare; (met, $\mathrm{OM})$ raşpel

rasping machine (met, mas-un) maşină de cojit / de degroşat

ratchet $(\mathrm{OM})$ roată / mecanism / dispozitiv cu clichet

ratchet-and-pawl $(\mathrm{OM})$ mecanism cu clichet

ratchet bar (mas-un, OM) cremalieră cu dinți, a unui angrenaj cu clichet

ratchet brake (auto, el) tensiune la borne; (OM) zăvor de blocare

ratchet coupling $(\mathrm{OM})$ cuplaj cu clichet

ratchet device $(\mathrm{OM})$ dispozitiv cu clichet

ratchet disk $(\mathrm{OM})$ disc de clichet, roată dințată a mecanismului cu clichet

ratchet drill (mas-un, OM) perforator cu dispozitiv de rotire cu clicheți

ratchet feed (mas-un, $\mathrm{OM}$ ) avans prin intermediul roții cu clichet

ratchet gear $(\mathrm{OM})$ mecanism cu clichet, roată cu clichet opritor

ratchet gearing $(\mathrm{OM})$ transmisie / angrenare $\mathrm{cu}$ clichet (roată şi clichet)

ratchet hob (mas-un) freză-melc pentru roți de clichet

ratchet jack $(\mathrm{OM})$ cric / vinci cu clichet 
ratchet lever $(\mathrm{OM})$ pârghia roții cu clichet ratchet mechanism (mas-un, $\mathrm{OM}$ ) mecanism cu clichet

ratchet pawl $(\mathrm{OM})$ declic, clichet

ratchet time base (el, autom) bază de timp, cu blocare

ratchet tooth $(\mathrm{OM})$ dinte de cuplare

ratchet transmission $(\mathrm{OM})$ transmisie cu clichet ratchet wheel (el) mecanism de conectare / de comutare; cu roată cu clichet $(\mathrm{OM})$ roata de cuplare, cu clichet

ratchet wheel gear (mas-un) mecanism cu roată cu clichet

ratchet wrench $(\mathrm{OM})$ cheie cu clichet / cu dinte rate grad; (ec) tarif, rată, taxă, impozit (pt. apă, lumină etc.), normă, preț (unitar), sortiment, sort, categorie, clasă; ritm; valoare, curs; proporție, procent; regim; productivitate, cantitate, raport; (fig) mers; (mat) număr proporțional, mărime proporțională, proporție, procent, calcul, viteză de variatie, derivată, rang, măsură; coeficient, rang; (mec) viteză; (metr) etalon; evaluare; porție (ec) a aprecia, a estima, a evalua, a preți; (metr) a etalona; (mat) a calcula, a socoti; a considera; a dimensiona; a clasifica; (inf, c, autom) frecvență de executare a unui ciclu de reîmprospătare la o memorie dinamică, frecvență de reîmprospătare, număr de generări pe secundă ale unei imagini (pt. reîmprospătare); (textile) raport

rate control (autom) reglare în funcție de variația unui parametru şi nu de valoarea lui absolută

rated $(\mathrm{OM}, \mathrm{TH})$ nominal, de calcul, de proiect

rated capacity (autom, el, metr) capacitate nominală; (mas) putere nominală / teoretică; (ec, TH) productivitate de calcul / nominală

rate as a fi cotat, apreciat / socotit

rated $(\mathrm{OM}$, mas, $\mathrm{TH})$ stabilit, evaluat, calculat, estimativ

rated capacity $(\mathrm{OM}$, mas, $\mathrm{TH})$ capacitate nominală, productivitate, randament

rated horse power (mas) capacitate / putere nominală (în cai-putere)

rated output $(\mathrm{ec}, \mathrm{TH})$ producție normală, randament normal

ratel (metr) v. rotl

rate of climb (fiz, mec) viteză ascensională

rate of exchange (ec) curs (de schimb)

rate of feed (mec, mas-un) viteză de avans / de alimentare

rate of shear (mec) viteză de forfecare

rate of slip $(\mathrm{mec}, \mathrm{T})$ rata / viteză de alunecare (şi relativă)

rate of surplus value (ec) rata plusvalorii rate of travel (mec, OM) viteză de deplasare, valoarea deplasării relative

rate of work (ec) gradul de exploatare al fortei de muncă

rate payer (ec) contribuabil

rate paying $(\mathrm{ec}, \mathrm{adm})$ plata impozitelor / taxelor

rate policy $(\mathrm{pol}, \mathrm{adm})$ politică tarifară

rater $(\mathrm{adm})$ evaluator, taxator, funcționar care stabileşte tarifele

rather $(a d v)$ mai bine / degrabă / curând, preferabil rated $(\mathrm{TH})$ calculat, evaluat, nominal, normat, stabilit; (ec) calculat estimativ, evaluat, stabilit; de calcul, de proiect

rated altitude (av) altitudine de restabilire (în aeronautică)

rated breaking capacity (el, electr) capacitate nominală de întrerupere / de decuplare (a unui aparat de conectare)

rated capacity (el, fiz) cantitate de electricitate a unei pile

rated capacity (mas, $\mathrm{TH}$ ) capacitate nominală, productivitate, randament

rated conditions (mas) condiții nominale de funcționare

rated consumption (mas) consum nominal estimat / stabilit (de energie / putere etc.)

rated continuous power (mas) putere continuă (pt. un timp nedeterminat), dată de un motor fără afectarea duratei de viață estimată

rated current (el) curent nominal

rated duty $(\mathrm{el})$ serviciu nominal

rated flow (hidr) debit proiectat / nominal

rated horsepower (mas, mec) puterea maximă / admisibilă de ieşire la un motor, în condiții normale de lucru, capacitate / putere nominală (exprimată în cai-putere)

rated hydraulic fluid volume (hidr) volum nominal de fluid hidraulic

rated input (mec, mas) putere nominală consumată

rated load (auto, mec) sarcină / încărcare nominală / teoretică / maximă (de proiectare)

rated making-capacity (electr, autom) capacitate nominală de închidere (a unui aparat de conectare)

rated operating conditions (mas) condiții de funcționare nominale

rated output (TH, mas) producție normală, randament normal; (el) putere de ieșire nominală; $(\mathrm{mec})$ putere produsă / debitată nominală

rated power $(\mathrm{el}, \mathrm{mec})$ putere nominală

rated pressure (hidr) presiune nominală rated qantity (el) mărime / valoare nominală rated signal (autom, hidr) semnal nominal 
rated speed (auto, mas) turație nominală rated temperature (autom) temperatură nominală sau maximă la care circuitul poate lucra un timp îndelungat, fără a-şi pierde proprietățile sau precizia

rated value (ec, fiz) valoare / mărime nominală rated voltage (el, autom) tensiune la care poate lucra un circuit un timp îndelungat fără a fi deteriorat

rate meter (fiz, metr) indicator al vitezei de numărare; contor

rate of attack (met, chim) viteză de atac / de coroziune

rate of carbon drop (met) viteză de afinare

rate of combustion (ind chim, termo, met) viteză / intensitatea de ardere / a focarului

rate of cooling (met, $\mathrm{TH}$ ) viteză de răcire

rate of corrosion (met) viteză de coroziune

rate of creep (met) viteză de fluaj

rate of crystalline growth (met) viteză de cristalizare

rate of curve (mat) alura / gradient a(l) unei curbe

rate of cutting (mas-un) viteză de aşchiere / de tăiere

rate of deposition (met) viteză de depunere (la sudare, acoperiri); viteză de sedimentare / de precipitare / de depunere

rate of discharge (met, ind chim) viteză de descărcare

rate of doing work (mas) viteză de lucru, intensitate a lucrului

rate of driving (met) viteză de trecere

rate of evacuation (of vacuum pump) (mas) viteză de pompare (a unei pompe de vid)

rate of evaporation (chim, fiz) viteză de evaporare

rate of expenditure / consumption (auto, ec) normă de consum

rate of feed (ind chim) viteză de alimentare; (met, mas-un) viteză de avans (la aşchiere, sudare etc.)

rate of filtration (chim) viteză de filtrare

rate of flame propagation (met, fiz) viteză de propagare a flăcării

rate of flow (hidr) viteză de curgere (într-un anumit timp), debit

rate of growth (met) viteză de creştere

rate of heating (met) viteză de încălzire

rate of loading (met) viteză de aplicare a sarcinii / de încărcare

rate of melting (met) viteză de topire

rate of outflow (hidr) debit de scurgere

rate of oxidation (chim) grad de oxidare

rate of pouring (met) viteză de turnare

rate of propagation (met) viteză de propagare

rate of reaction (met) viteză de reacție rate of strain (mec) viteză de deformare, deformație relativă

rate of transformation (met) viteză de transformare

rate of travel (met) viteză de trecere

rate of vertical descent (met) viteză de coborâre a încărcăturii (la furnal)

rate of wear (TH) grad de uzură, viteză de uzură rate of welding (met) viteză de sudare

rate response (metr, autom) viteză de răspuns (a unui sistem de reglare sau de măsurare)

rate time (autom, metr) timpul în care acțiunea provoacă răspunsul (proporțional) al dispozitivului / aparatului

ratification $(\mathrm{ec}, \mathrm{pol})$ ratificare

rating $(\mathrm{ec})$ evaluare, estimare, apreciere, prețuire; dimensionare, calculare; clasare; determinare; etalonare; valoare, valoare limită, productivitate, randament; (el) regim nominal; (hidr) tarare, stabilirea dependentei între două variabile; (mas-un) caracteristică nominală (a unei maşini)

rating life $(\mathrm{OM})$ durabilitate nominală (şi la rulmenți)

rating moment (autom) moment nominal

rating nut $(\mathrm{OM})$ piuliță de reglare; şurub de reglare (al balansierului)

rating plate (autom) etichetă; (mas) plăcuță cu caracteristicile tehnice

rating torque $(\mathrm{mec}, \mathrm{OM})$ cuplu de rotație nominal, moment nominal (de torsiune)

rating value (mas) valoare / caracteristică nominală

raticide (ind chim, biol) substanță de deratizare / care omoară şoarecii

ratification ratificare, omologare, validare

ratify a ratifica, a valida, a omologa, a sancționa, a contrasemna

ratio (mat) raport, proporție, relație, corelație; $(\mathrm{OM})$ raport de transmisie; rațiune, motiv, cauză

ratiocinate a raționa, a argumenta, a discuta

ratiocination raționament, argumentare, silogism, concluzie, consecință

ration rație, porție, tain; a alimenta, a aproviziona

rational rațional, logic, conform cu logica, înţelept, lucid, moderat

rationale rațiune de a fi, de a exista, analiză rațională; expunere, argumentare

rationality înțelepciune, rațiune, raționalism; minte, judecată; caracter rațional

rationalization raționalizare, raționare

ratio controller (autom) dispozitiv de menținere a unui anumit raport între două sau mai multe variabile

rationalisation (autom) raționalizare 
rationalise (ec) a raționaliza

rationalised MKS system (metr) sistemul raționalizat (de unități de măsură) MKS (metrukilogram-secundă)

ration of expansion (termo) raport de destindere ratio of compression (auto, termo) raport de compresiune

ratio of gear (mec, OM) raport de transmitere / de transmisie

ratio of intensification (OM, autom) coeficient / raport de multiplicare

ratio of iron in slag to iron in bath (met) raport între fierul din zgură şi fierul din baia metalică

ratio of load (mec) raport de sarcină / de încărcare

ratio of mixture (auto) raport de amestec; (alim, chim) dozaj, proportie de amestec

ratio of reduction by forging (met, $\mathrm{TH}) \mathrm{grad} \mathrm{de}$ refulare / de reducere prin forjare

ratio of similitude (mat) raport de asemănare

ratio of specific heat (termo, fiz) raportul între căldura specifică la presiune constantă și cea la volum constant

ratio of stroke to diameter (auto, termo) raportul cursă-alezaj

ratio of transmission (mec, OM) raport de transmitere / de transmisie

ratio separator (ind chim) separator centrifugal

rat-tail file $(\mathrm{TH})$ pilă coadă-de-soarece, pilă rotundă mică

ratlin (nav) grijea

ratoon (agr) lăstar de trestie de zahăr, frunze din inima tutunului

rat race (ec) concurență aspră / neloială; (fig) luptă pe viață şi pe moarte

ratsbane (ind chim, biol) şoricioaică, otravă de şobolani

ratten a împiedica (pe muncitor) de la lucru, a sabota

ratting (mas) oportunism, acțiuni de spărgător de grevă

rattle sunătoare, cârâitoare, pârâitoare, morişcă, zăngănit; a năuci, a buimăci, a zăpăci

rattling (h)uruit, răpăit, zăngănit, trepidație; bătaie a motorului; zgomot, gălăgie, ărăboi

rat trap capcană / cursă pentru şobolani; situație disperată; pedală dintață (la bicicletă)

rattle barrel (met, OM) tobă pentru curățarea pieselor turnate

rattle of chain (auto, OM) zgomotul lanțului

rattler (mas) moară cu tambur; (mas-un) tambur rotativ pentru lustruirea pieselor mici; (met, $\mathrm{OM}$ ) tobă de curățire

ravage a devasta, a pustii, a distruge, a ruina, a face ravagii ravel (textile) încurcătură de ițe, ațe de însăilat; capăt de ață, pieptene de netezit; a se destrăma, a se resfira, a desface, a despărți; a se degrada, a decădea, a (se) strica

raven (zool) corb; negru ca pana corbului, a prăda, a jefui, a ataca, a devora

raveling împrăştiere, desfacere; (constr, auto) deteriorarea îmbrăcămintei rutiere sub acțiunea trecerii unui vehicul

rave out (textile, plast) a desface în fibre; a descurca, a descâlci, (fig) a lămuri

ravine (geogr) râpă, viroagă; trecătoare, defileu, pas

ravioli (alim) ravioli, colțunaşi cu carne

raw (alim, ind chim, ind) crud, nefiert, necopt, nefript; brut, nelucrat, natural, neprelucrat; (agr, zool) jupuit, sângerând; simțitor, sensibil; ageamiu, novice, lipsit de experiență; (meteo) rece şi umed; necinstit, incorect

raw cast (met) brut turnat (d. o piesă etc.)

raw castings (met) piese brute turnate

raw coal (met) cărbune brut, bulgări (cu granulație mare) de cărbune

raw count (ec, agr) numărare brută

row data (c, inf) date care nu au fost încă analizate de computer

raw foundry zinc (met) zinc brut, de turnare

raw gas (met) gaz nepurificat (impur)

raw gas offtake (met, OM, constr) canal de gaz brut / de gaz nepurificat

raw hide pinion $(\mathrm{OM})$ pinion din piele crudă

raw ingot (met) lingou / bloc brut

rawb ingot (met) lingou brut

raw juice (alim) zeamă brută

raw lignite (met) lignit brut

raw material $(\mathrm{TH}$, ec, ind) materie primă, material brut / primar / de bază

rawnes (materiale) stare brută / crudă / neprelucrată; (meteo) umezeală, răceală; lipsă de îndemânare / de experiență

raw matte (met) mată

raw metal additions (met) adaos de minereu

raw ore (met) minereu brut, grămadă de minereu

raw product $(\mathrm{ec}, \mathrm{TH})$ produs / marfă brut(ă)

raw rubber (plast, ind chim) cauciuc brut

raw sheet iron (met) tablă de oțel, neprelucrată

raw slag (met) zgură primară

raw smelting (met) topitură brută

raw state $(\mathrm{TH})$ stare brută

raw state tyre $(\mathrm{TH}, \mathrm{OM})$ bandaj pentru roată in stare brută

raw oil (geol, ind chim) titei brut

raw silk (textile) borangic, mătase brută

raw spirit (alim, ind chim) alcool curat / natural raw steel (met) oțel brut 
raw stock $(\mathrm{TH})$ materie primă raw sugar (alim) zahăr brut / nerafinat raw wire (el) sârmă neizolată; (met) sârmă albă ray (fiz, mat) rază, radiație; (fiz) a radia rayed în formă de raze

raying (fiz) radiere

rayon (textile) mătase artificială, vâscoză

rayl (metr, fiz) una din cele două unități de măsură pentru impedanța sonoră; în sistemul de unități de măsură MKS, 1 rayl = 1 pascal-second pe metru $(\mathrm{Pa} \cdot \mathrm{s} / \mathrm{m})$, sau 1 Newton-secundă pe metru cub $\left(\mathrm{N} \cdot \mathrm{s} / \mathrm{m}^{3}\right)$; în unele texte denumirea se foloseşte pentru o unitate de măsură în sistemul CGS, 1 dyne-second per cubic centimeter $\left(\right.$ dyn $\left.\cdot \mathrm{s} / \mathrm{cm}^{3}\right): 1 \mathrm{CGS}$ rayl $=10 \mathrm{MKS}$ rayl

rayleigh (R) (metr, astronomie, fizi) o unitate de măsură a intensității luminoase a cerului, aurorei etc., în sistemul CGS: 1 rayleigh reprezintă intensitatea luminoasă a $10^{6}$ fotoni emişi în toate directiile pe centimetrul pătrat şi pe secundă, al receptorului; în sistem SI, 1 rayleigh $=795,775 \cdot 10^{6}$ fotoni pe metru pătrat şi steradian $\left(\mathrm{m}^{-2} \cdot \mathrm{sr}^{-1}\right)$

raylon (plast) teflon (rar, neclar)

rayotube (metr, met) pirometru fotoelectric pentru măsurarea temperaturii benzii

rayotube pyrometer (metr, met) pirometru optic cu radiație totală, şi pentru măsurarea temperaturii benzii

raze (constr) a demola, a dărâma; a distruge, a ruina, a nărui; a sterge, a rade, a suprima

razor $(\mathrm{OM})$ brici; aparat de ras, a răzui

razor blade $(\mathrm{OM})$ lamă de ras

razor edge $(\mathrm{OM}$, mas-un) tăiş de brici; muchie de cuțit (fig), situație grea / primejdioasă

r.c. (remote control) (autom, fiz) telecomandă, control de la distanță

r.c. (rough cutting) (mas-un) prelucrare de degroşare

reach întindere, rază de acțiune, sector, secțiune; (mas) lungime a brațului; (nav, geogr) bătaie, porțiune de fluviu între două coturi; a se întinde, a atinge, a ajunge (la viteze mari, la presiuni înalte etc.)

reach type tool (mas-un) port-cuțit cu coadă lungă

react (chim, met, mec) a reacționa

reactance (el) reactantă

reactant (chim) reactant

reacting force (mec) forță opusă / reactivă / de reacție

reacting spring (auto, $\mathrm{OM}$ ) contra-arc

reacting weight (chim) greutate / masă echivalentă, masă de reacțiune

reaction (chim) reacție; (fiz) contrapresiune, recul; (mec) (forță de) reacțiune reaction adhesive (plast) adeziv cu reactivitate chimică

reaction bonding (chim) legătură chimică / în urma unei reactii

reaction force $(\mathrm{mec}, \mathrm{OM})$ forță de respingere / de recul

reaction furnace (met) cuptor pentru topire reactivă (pt. metale neferoase)

reaction limit (met, chim) limită de coroziune

reaction of the abutment (mec, OM) reacțiune de reazem

reaction of support (mec, OM) forță de reacțiune, reactiune de reazem

reaction pressure (fiz, termo) contrapresiune

reaction products (chim) produse de reacție (dorite sau nu)

reaction sintering (met) sinterizare prin reacție (chimică)

reaction soldering (met, chim, $\mathrm{TH}$ ) lipire $\mathrm{cu}$ amestec de săruri care se reduc în metal

reaction time $(\mathrm{TH})$ timp de reacție al operatorului

reactivation (chim, plast, met) reactivare

reactive (ind chim, plast) reactiv, (substanță / material) cu reactivitate chimică

reactive adhesive (chim, plast) adeziv reactiv / cu reactivitate chimică

reactive diluent (ind chim, plast) diluant / dizolvant reactiv / cu reactivitate chimică

reactive jet (hidr, termo) jet reactiv

reactive polyamide (ind chim, plast) poliamidă reactivă / cu reactivitate chimică

reactive power (chim) putere de reacție / reactivă

reactivity (chim, $\mathrm{TH}$ ) reactivitate

react on a reacționa la; a acționa asupra

read citire, (timp pentru) citit, lectură, povestire; autorizație pentru o afacere / un atelier; (adj) citit, informat, inovat; a arăta, a indica (d. termometru, contor etc.); a citi (despre, de); (fig) a citi / desluşi (pe chipul cuiva); a se citi; (c) a citi conținutul unei memorii, a înregistra; (pol) a da citire (unei legi, etc.); a descifra; (fig) a explica; a ghici; a glăsui; a interpreta; a învăța readability (metr) diviziunea / fracția cea mai mică care poate fi citită pe scala unui aparat

reader (metr) indicator, dispozitiv de citire

readiness for immediate operation / use (mas) gata / pregătit pentru funcționare

reading (autom, el, metr) indicație, citire (indicație la un aparat gradat)

reading error (fiz, inf) eroare la citire / de lectură

reading glass (fiz, op) lupă de citit

reading in thausandths of an inch (mas-un, metr) cu gradații în 0,001 țol 
readjust (autom, mas, metr) a reajusta, a corecta reglarea

readjustment (mas, metr) reglare, corectare, rectificare

read-only memory (ROM) (c) memorie cu date care pot fi doar citite, nu şi modificate

read out (met, metr) dispozitiv de citire a grosimii tablei (laminate); (c) afişare a datelor citite pe display

read time (c, autom) timp de acces

ready pregătit, preparat, gata

ready built machine (mas-un, ec) maşină confectionată / asamblată ,la depozit” (în opozitie cu maşină executată după o comandă specială)

ready for operation (mas) pregătit pentru intrarea în funcțiune

ready for the road / service ( $\mathrm{TH}$, autom, transp) pregătit pentru intrarea în funcțiune

ready for use (TH, mas) gata pentru utilizare / pentru folosire

ready for work (mas, $\mathrm{TH}$ ) în stare de funcționare, gata de fi pus în funcționare

ready-made $(\mathrm{OM})$ gata pentru utilizare / pentru folosire; (textile) de gata (confectii)

ready state $(\mathrm{mec})$ stare de inerție

reagent (chim) reactiv

real axis (mat) axă reală

real iron volume (met) volum real de fier

realizable realizabil, utilizabil

realize a realiza, a înțelege, a-şi da seama

real number (mat) număr real

real power (mas) putere reală / utilă / efectivă

real surface (metr) suprafață reală (la profilometria suprafeței)

real time (c, fiz, autom) timp real (și de rezolvare a unui probleme pe computer)

real-time processing (c, autom) procesare în timp real, rezultatele putând fi folosite la reglare, la comandă etc.

ream top, stivă (de hârtie); (mas-un) a aleza, a lărgi; (met) a lărgi o excavație; ream (rm) (metr) unitate tradiţională de măsură pentru coli de hârtie; initial 1 ream $=480$ coli; recent 1 ream $=$ 500 coli; 1 short ream $=480$ coli; ream $(\mathbf{r m})$ (metr) unitate tradițională de măsură pentru arie, în industria hârtiei: 1 ream $\sim 278,709 \mathrm{~m}^{2}$

reamed hole (mas-un) orificiu alezat

reamer (mas-un) alezor; lărgitor

reamer bar (mas-un) bară pentru fixarea alezorului (la alezarea găurilor adânci)

reamer blade (mas-un) lamă de lărgitor

reamer burnisher (mas-un) alezor fin

reamer holder (mas-un, OM) port-alezor, cheie de alezor

reamer wrench (mas-un, OM) cheie pentru manipularea alezorului (de mână) reaming (mas-un) lărgirea / corectarea găurii; a fileta, a finisa filetul prin aşchiere

reaming bonch (mas-un) dispozitiv / maşină de alezat cu alezor fixat în tijă cu articulație

reaming bit (mas-un) alezor de lărgit, cap de lărgit

reaming jig (mas-un) dispozitiv de ghidare pentru alezare

reaming machine (mas-un) mașină de alezat (cu alezor, dispozitiv mecanic de alezat

ream out (mas-un, $\mathrm{TH}$ ) a aleza

ream up (met) a lărgi; a evaza

Réaumur (metr) scara Réaumur de temperaturi

reanneal (met) a recoace suplimentar

reaper file (mas-un) pilă cu dințare simplă

rear (auto, OM) din spate; (mil) ariergardă, coadă; (constr) closet; (poligrafie) pagină cu soț, verso, contra(-)pagină; de la coadă, de la sfârşit; a clădi, a construi, a înălța, a ridica; a crește (animale); a crește, a educa (copii)

rear axle (auto, mas, OM) osie / punte din spate rear axle casing (auto, OM) trompa diferențialului

rear axle casing cover (auto, OM) capacul carcasei puntii din spate

rear axle housing (auto, OM) trompa diferentialului / semi-osiei

rear axle radius rod (auto, $\mathrm{OM}$ ) brațul de forță al punții din spate

rear axle shaft (auto, OM) arbore / ax planetar

rear axle tie bar (auto) sprijinul / brațul de împingere al osiei din spate

rear center (auto) centru spate

rear center passenger's seat belt warning light (auto) semnal luminos de avertizare pentru centura de siguranță a pasagerului din mijloc spate

rear central (seat) (auto) scaun central din spate rear cargo area (auto) compartimentul de marfă rear door (auto) portieră (din) spate rear door child safety lock (auto) blocare a portierei spate pentru siguranța copiilor

rear door lock (auto) încuietoare pentru portiera din spate

rear door (left) power window switch (auto) comutator electric pentru geamul stânga-spate

rear door (right) power window switch (auto) comutator electric pentru acționarea geamului dreapta-spate

rear dump body (auto) benă / benă basculantă spre spate; caroserie de vehicul cu golirea prin spate

rear dumping (drum) basculare spre spate

rear dump truck (auto) camion cu benă basculantă spre spate

rear end (hidr, OM) capac de fund, capac-spate 
rear engine (auto) motor în spate

rear fog lights (auto) faruri de ceață (pe) spate

rear fog light indicator (auto) indicator pentru lumini (din) spate de ceață

rear hatch (auto) portbagaj; trapă din spate

rear hatch lift cylinders (auto, OM) cilindrii de ridicare a capotei portbagajului

rear hatch warning (auto) atenționare / avertizare pentru portbagaj deschis

rear hub (auto, OM) butucul roții de la spate

rear impact (auto) impact din spate

rear impact colision (auto) coliziune din spate

rear lap/shoulder belt (auto) centură de siguranță a scaunelor din spate

rear left passenger's seat belt warning light (auto) semnal luminos de avertizare pentru centura de siguranta a pasagerului din stânga-spate

rear license plate (auto) numărul de circulație de la spate

rear light (auto) lumină din spate

rear of vehicle (auto) spatele vehiculului

rear outboard (driver side) (auto) (locul) de la margine din spate; montaj auxiliar (în / pe) spate rear outboard (passenger side) (auto) (locul) de la margine din spate(le pasagerului din dreapta şoferului)

rear outboard seat (auto) scaun lateral al banchetei din spate

rear parking assit(ing) system (auto, metr) sistemul senzorilor de parcare cu spatele

rear passenger's seat belt warning light and chime (auto) semnal luminos de avertizare pentru starea centurilor de siguranță a pasagerilor din spate

rear reflector (auto) dispozitiv reflectorizant (ochi de pisică, reflector de la spate)

rear right passenger's seat belt warning light (auto) semnal luminos de avertizare pentru centura de siguranță a pasagerului din dreaptaspate

rear seat (auto) banchetă din spate

rear side $(\mathrm{TH})$ latură din spate, revers

rear spring (auto, $\mathrm{OM}$ ) arcul de la spate

rear tread (auto) ecartament spate

rear turn signal light (auto) semnalizare spate

rear-view (OM, mas) vedere din spate (în desen tehnic)

rear-view miror (auto) oglindă retrovizoare

rearward (mas) spre spate / coadă; (auto) orientat către spate

rear wheel (auto) roată din spate

rear-wheel brake (auto) frână pe roțile din spate rear window (auto) lunetă (în spate)

rear window defroster button (auto) buton pentru dejivrarea lunetei rear window wiper and washer (auto, $\mathrm{OM}$ ) spălător şi ștergător pentru lunetă

rear window wiper and washer switch (auto) buton de acționare a spălătorului și ştergătorului pentru lunetă

rear window wiper blade (auto, $\mathrm{OM}$ ) lamela ştergătorului de lunetă

reason temei, cauză, motiv; rațiune; for no fără motiv; a raționa; a discuta; a convinge; a determina; smb. out a face pe cineva să-şi schimbe părerea; by of din cauză că; it stands to that este firesc că, se înțelege de la sine că reasonable rezonabil, întelept, cuminte, chibzuit; convenabil, moderat, ieftinătate; echitabilitate, echitate, justete

reasonableness test (metr, $\mathrm{TH}$ ) test care asigură mijloace de detectare a erorilor grosolane în calcul, prin compararea rezultatelor obținute pentru limite considerate rezonabile

resonably $(a d v)$ rezonabil, chibzuit, înțelept, acceptabil, convenabil, echitabil

reason away a înlătura, a respinge prin argumente raționale / pe calea rațiunii

reason down a învinge cu argumente

reasoned întemeiat, bine motivat; chibzuit, bine gândit, întelept, rational, logic

reasoner gânditor, cugetător

reasoning rationament, judecată, capacitate de a raționa, argumentare, discuție logică; care argumentează / judecă

reason into a convinge / a determina să, a aduce la ascultare

reasonless fără rațiune / judecată; neîntemeiat; nemotivat, nejustificat

reason out a deduce / a iscodi, a izbuti să găsească prin gândire / meditație

reason adduced motivarea unei hotărâri

reason whether a se intreba dacă

reason with a discuta (în contradictoriu) cu, a purta o discuție / dezbatere cu; a aduce argu-mente, a încerca să convingă, a reflecta în sinea lui

re(-)assemble a pune din nou la laolaltă, a strânge, a aduna / a îmbina din nou; a întruni, a convoca

reassembly (mas-un) asamblare repetată

reassert a reafirma, a afirma din nou

reassertion reafirmare

reassess a reevalua, a reconsidera, a reimpune; (ec) a reimpozita

reassessment reevaluare; reconsiderare, reimpunere, reimpozitare

reassign a repartiza din nou, a încredința din nou, a redistribui

reassignment nouă repartiție / distribuire a sarcinilor, încredințare a unei sarcini noi 
reassessment $(\mathrm{ec})$ reevaluare

reassume a presupune din nou, a relua ca premisă / ca punct de pornire

reassumption nouă ipoteză / presupunere (luată ca bază)

reassurance asigurare (verbală); linişte; potolire, reasigurare

reassuring liniştitor, care(-ți) dă / conferă siguranță, reconfortant

Réaumur scale (alim, metr) scară Réaumur (de temperaturi) $\left(0^{\circ} \mathrm{C}==0^{\circ} \mathrm{R}\right.$ şi punctul de fierbere al apei $\left.=80^{\circ} \mathrm{R}\right)$

rebate (ec) rabat, reducere; (hidr, OM) rebord, prag; treaptă, ulu, scobitură, ieşitură, a reduce puterea, a îmbina

rebate plane (mas-un) rindea de fălțuit

rebabbitt a bearing (met) a turna din nou un lagăr / un cuzinet

rebar sizes (metr, constr, met) simbolizări numerice ale mărimilor barelor de armare a betonului, provinind de la (steel) reinforcing bars; numărul reprezintă mărimea diametrului barei de armare, în optimi de inch / țol (1/8 inch = $3,175 \mathrm{~mm}$ ); o bară de 1 inch în diametru se notează \#8 rebar

rebate (ec) bonificatie, rabat (comercial), reducere (a prețului), remiză; $(\mathrm{OM})$ ieşitură, palplanşă, scobitură, uluc; (arht, constr) prag, rebord, terasă, treaptă; (TH) a îmbina în falț, a îmbina prin blătuire; (cf) a lega şinele cu eclise; a face o lambă / un feder / un prag, a îmbina în; a reduce puterea; (fig) a slăbi, a toci rebating $(\mathrm{TH})$ fălțuire, îmbinare cu feder / cu prag rebating cutter (mas-un) freză de falțuri de canale rebind a lega din nou, a reface o legătură (chimică, mecanică etc.)

reboiler (alim, ind chim) schimbător de căldură de la baza coloanei de distilare, schimbător de căldură capsulat (cu un anumit mediu) care încălzeşte un alt mediu

reboring of cylinder (mas-un, termo) realezarea a unui cilindru

rebound (fiz, mec) reflectare; (mec, OM) contralovitură, recul / revenire (şi la un amortizor), reacție, şoc; (fiz) a ricoșa, a avea recul, a se intoarce, salt înapoi

rebounding (materiale) cu ricoșeu, elastic, caresi revine

rebound crusher (alim, ind chim) moară cu ciocane / cu ciocănele / percutantă

rebound hardness (materiale) duritate sclereoscopică / Shore

rebuff (mec) recul, aruncare / împingere înapoi; ripostă, răspuns viguros rebuild (const) a reconstrui, a reface, a reclădi; (mas-un, mas, OM) a reconditiona, a modifica (construcţia unei maşini, a unui elemnet de maşină etc.); a reconstitui

rebuilded tyre (auto, ind chim) pneu reşapat

rebuilding (constr, $\mathrm{TH}$ ) reconstruire, a reface, a reclădi

rebut (mec) a împinge înapoi, a respinge; (jur) a dovedi netemeinicie; a combate

rebutment combatere $(\mathrm{TH})$ refulare, respingere, răsturnare; (jur) dovedire a netemeiniciei

recalesce a se reîncălzi, a se reînfierbânta

recalescence (fiz, termo) degajare de căldură, reîncălzire, reînfierbântare

recalescence curve (fiz, termo) curbă de răcire

recalescence point (fiz, termo) punct / temperatură de transformare

recall a rechema; (pol, adm, mil) abrogare, contramandare, revocare, a abroga (o lege), a revoca (o lege), a contramanda (un ordin); (pol) destituire, rechemare; aducere aminte, amintire; (teatru) bis, bisare, chemare la rampă; (ec) metodă de testare a efectului reclamei, reamintire; (telefonie) rapel, rechemare; a retracta; a-şi călca cuvântul; a(-şi) aminti (de), a-şi reaminti, a trezi amintirea; a evoca; a retracta (o afirmație); a-şi retrage (cuvintele, banii)

recalibrate (metr, $\mathrm{TH}$ ) a recalibra, a reetalona, a reverifica

recalibration (autom, metr) reetalonare, recalibrare

recalking (mas-un) ştemuire

recarburisation (met) recarburare

recarburise (met) a recarbura, a recementa

recarburiser (met, chim) agent de recarburare / de recementare

recap $(\mathrm{OM})$ a reface capul sau învelisul; (auto, ind chim) a reşapa (anvelope); a recapitula, a revizui, a revedea

recapitulate a recapitula, a revedea

recapitulation recapitulare, revedere

recapitulatory ( $a d j)$ (cu caracter) recapitulativ

recaption (jur) reintrare în posesie / în drepturi

recapture recapturare, reluare, prindere din nou, recuperare, recâştigare, regăsire; a prinde / a apuca din nou, a recâştiga

recast modificare; (teatru) montare cu o nouă distribuție / versiune, a schimba distribuția (unui spectacol); (TH) prelucrare, re-turnare (a metalului), rearuncare; reconstituire; refacere; transformare; (met) a retopi, a corecta, a refasona, a turna din nou, a arunca din nou; a corecta (d. o topitură etc.); a reconstitui; a reface; a transforma 
recasting (met) returnare; (el) punte / cablu de racord electric; retopire (şi d. hârtie, materiale plastice etc.)

recaulking (mas-un) ștemuire

receding table (mas-un, autom) masă cu retragere automată (la cursa de înapoiere a sculei)

re-cede (jur) a retroceda

receding retragere; îndepărtare; renunțare (asupra unei hotărâri etc.), revenire; care dispare, care se îndepărtează, care se retrage

receding tide (geogr, nav) reflux

receding table (mas-un) masă cu retragere automată (la cursa de înapoiere a sculei)

receipt primire; (ec) chitanță, adeverință de plată; s ( $p l$ ) încasări, venit(uri); (med) remediu, rețetă, prescripție, ordonanță medicală; percepție, oficiu de depunere a banilor

receipt book (ec) chitanțier; (alim) carte de bucate, rețetar

receivable care poate fi primit; de primit

receive a primi, a obține, a căpăta; (ec) a încasa, a lua; a găzdui, a adăposti, a dăinui; a admite; a accepta, a recunoaşte, a confirma; (transp, mas) a cuprinde, a avea o capacitate (de)

received (ec) achitat, încasat, acceptat, admis

receive of a primi din; a lua din;

receiver (ec) primitor, persoana care primeşte / recepționează; destinatar; încasator; perceptor tăinuitor; administrator din oficiu; (jur) executor judecătoresc; (fiz) aparat de radio

receiver gauge (metr) dispozitiv (etalonat) care primeşte informația / rezultatul măsurătorii

receiver mixer (met) melanjor de fontă

receivership (jur) calitatea de executor judecătoresc

receiving $(\mathrm{ec})$ primire, recepție, acceptare, admitere (d. mărfuri etc.)

receiving bath (mas, $\mathrm{OM}$ ) bazin de recepție

receiving box (ind chim, $\mathrm{OM}$ ) recipient

receiving cone (mas-un, $\mathrm{OM}$ ) pâlnie de colectare

receiving document $(\mathrm{ec})$ proces verbal de recepție

receiving gauge (metr, $\mathrm{OM}$ ) dispozitiv de control parțial / pentru verificarea unor dimensiuni sau a relației dintre ele

receiving hopper (met) pâlnie de încărcare (la furnal, la cuptoare etc.)

receiving opening (ind chim, met) deschidere pentru încărcare, zgură de încărcare

receiving system (el, electr) receptor

receiving trial (el) încercare / probă de recepție

receptacle $(\mathrm{OM})$ container

reception (ec) recepție, recepționare, acceptare; primire; întâmpinare, mod de a întâmpina / a primi

reception test (metr, $\mathrm{TH}, \mathrm{ec})$ test / încercare la recepție (a mărfurilor) reception desk birou de recepție, dispecerat hotel receptionist recepționer, funcționar la recepție; dispecer hotel

reception room sală de recepție; salon; cameră de primire

receptive (fiz) receptiv

receptor (fiz) receptor

recess cotlon, loc / colț retras, colțişor, tainiță; firidă, nişă, alcov; ascunzişuri, adâncuri, străfunduri; (anat, bot, zool) fosă, cavitate; (geogr) golfuleț, baie, scobitură (a țărmului), reflux; (OM) şanț, canelură, adâncitură, canal (şi circular), degajare, gât, nut, falț, ieşire din angrenare; (bot, anat, zool) cavitate, fosă; (geol) cavitate; (constr) firidă, golul ancadramentului de fereastră / de uşă, nişă; interval; întrerupere, pauză; (jur) prorogare, suspendare, a intra in deliberare, a suspenda şedința; vacanță; (mas-un) a canela, a degaja, a freza şanțuri sau intrânduri, a reteza; a face o întrerupere / o pauza; a (se) ascunde întro adâncitură, a forma o cavitate în (d. materiale)

recessed înfundat, astupat, băgat înăuntru; cu adâncituri, cu scobituri

recessed part (met) partea îngropată (a unei piese turnate)

recessed square $(\mathrm{OM})$ locaş pătrat

recessing bar (mas-un, OM) bară / port-cuțit de strunjit caneluri şi praguri interioare

recessing machine (mas-un) maşină de frezat de sus

recessing tool (mas-un) cuțit de strunjit praguri şi caneluri interioare

recession retragere, plecare; recesiune, depresiune, criză; adâncire

recessive $(\mathrm{OM})$ care dă înapoi / se retrage / se îndepărtează; (fiz) regresiv, descendent

recharge (mec, fiz) a reîncărca

recharging $(\mathrm{TH})$ încărcare (şi a bateriilor) / dozare suplimentară

recheck (metr) a verifica, a controla (din nou)

rechuck (mas-un) a strânge din nou în mandrină recipient (chim, OM) vas, recipient

reciprocal (mat) invers, reciproc, mutual, echivalent reciprocal equation (mat) ecuație reciprocă

reciprocal matrix (mat) matrice inversă

reciprocal megakelvin $\left(\mathbf{M K}^{-1}\right)$ (metr, fiz) unitate de măsură utilizată în calorimetrie şi fotografie pentru a măsura lungimea de undă a luminii, mai ales pentru filtre; v. mired

reciprocal motion (mat) mişcare de du-te-vino / alternativă

reciprocal of amplification factor (el, autom) factor de amplificare

reciprocal second $\left(\sec ^{-1}\right)$ (metr, fiz) secundă ${ }^{-1}$, unitate de măsură pentru frecvență

reciprocal spiral (mat) spirală hiperbolică 
reciprocal value (mat) valoare inversă / reciprocă recipe (alim) rețetă (culinară); soluție, remediu recipience recepționare, recepție

recipient $(\mathrm{OM})$ recipient, vas; primitor, destinatar; laureat, câstigător

reciprocal reciproc; mutual, echivalent, bilateral reciprocally $(a d v)$ (în mod) reciproc, unul pe altul reciprocate a plăti cu aceeaşi monedă, a întoarce; a răspunde, a împărtăşi; a face schimb; a imprima o mişcare (oscilantă) de du-te-vino, a răspunde în acelaşi fel

reciprocate to a proceda la fel; a răspunde in acelaşi fel la

reciprocating (mec) cu mişcare rectilinie; oscilant, cu piston

reciprocating rod $(\mathrm{OM})$ bielă

reciprocation reciprocitate

reciprocity reciprocitate; caracter reciproc

reciprocating blowing engine (met) suflantă cu piston

reciprocating compressor (termo) compresor cu piston

reciprocating drill (mas, met) perforator percutant

reciprocating engine / motor (mas) motor / maşină cu piston

reciprocating feeder (mas) alimentator oscilant reciprocating (internal combustion) engine (auto, termo) motor cu ardere internă / cu mişcare alternativă / cu piston

reciprocating lever (mas-un) pârghie oscilantă; balansier

reciprocating mass $(\mathrm{mec})$ masă în mişcare alternativă

reciprocating mass balance (mec) echilibrul maselor alternante / în mişcare alternantă

reciprocating motion $(\mathrm{mec})$ mişcare alternativă / oscilantă de du-te-vino

reciprocating motion of the pistons (mas, termo) mişcare alternativă a pistonului

reciprocating pump (mas, OM, hidr) pompă cu mișcare alternativă / cu piston, pompă cu dublu efect

reciprocating rolling process (met) procedeu / proces (de laminare) în pas de pelerin

reciprocating saw (mas-un) gater (pt. lemn)

reciprocating speed (autom, hidr) frecvență de manevră alternativă

reciprocity of the displacements (mec) reciprocitatea deplasărilor

reciprocity of the work done (mec) reciprocitatea lucrului mecanic

reciprocity theorem (mat) reciproca unei teoreme, teorema reciprocă recirculate a recircula (d. un fluid, lubrifiant etc.) recirculated air (auto) aer recirculat recirculated air position (auto) poziţia pentru aer recirculat / recircularea aerului recirculating (ind chim) recirculare recirculating water (termo) apă de recirculare recirculation (ind chim, hidr) recirculare

reck (negativ sau interogativ) a privi (îndeaproape), a preocupa; a îngrijora, a supăra, a necăji; (impersonal) a conta, a avea importanță

reckless nepăsător, indiferent; nesăbuit, nechibzuit, necugetat, nesocotit; nedisciplinat, recalcitrant

recklessnes nepăsare, indiferență; nesocotință; nechibzuință, necugetare, caracter temerar

reckon a socoti, a număra, a calcula; (ec) a trece / a pune la socoteală; a evalua, a prețui; a socoti, a aprecia; a considera; a gândi; a fi socotit / considerat; a se baza pe; a depinde de; a presupune

reckoner socotitor, calculator; tabel de calcul; (metr) contor

reckon for a răspunde, de a fi răspunzător, a fi responsabil pentru, a da socoteală pentru

reckoning socoteală, socoteli

reckoning up (mat) adunare

reckon off (ec) a face (cuiva) lichidarea / socoteala reckon over $(\mathrm{ec}, \mathrm{TH})$ a verifica, a controla, a cerceta reckon upon a se bizui, a se baza, a avea încredere în

reckon with a lua în considerare

reckon up (ec) a deconta, a socoti

reclaim $(\mathrm{TH}$, mediu) ameliorare; (ind chim) cauciuc regenerat; îndreptare; recâş̧igare; recuperare; (med) vindecare, a vindeca; (constr, hidr) a executa lucrări de hidroameliorare; (mas, TH, autom) a repara, a îndrepta, a corecta, a reface, a repara, a recupera, a recâştiga; a ameliora; a domestici, a îmblânzi, a cere înapoi; (ec, TH) a face îmbunătățiri; (fig) a aduce pe calea cea bună; (agr, constr) a face îmbunătățiri / ameliorări funciare, a ameliora (un teren), a asana, a recupera (un teren); (jur) a face apel; a cere înapoi; a domestici, a îmblânzi (d. animale); a îndrepta (şi fig); a reclama; (chim) a regenera

reclaimed rubber (plast, ind chim) (cauciuc) regenerat

reclamation (ec, TH) reclamație; îmbunătățire, ameliorare, asemănăre, recuperare; (agr, zool) îmblânzire, domesticire

reclaimable (materiale) reparabil, care poate fi îndreptat / corijat / corectat; recuperabil

reclaimant (jur) reclamant

reclaim days (jur) termen de apel 
reclaimed (ind chim) îndreptat, corectat; /med) vindecat; recuperat; (agr, zool) domesticit, îmblânzit

reclamation reclamație; îmbunătățire, ameliorare; asanare; recuperare; regenerare, renovare; (agr, zool) îmblânzire, domesticire

recline a sta aplecat sau înclinat; a sta culcat / întins, a se odihni; a (se) rezema, a se sprijini, a înclina, a (se) abate de la perpendicularitate; $(\mathrm{OM})$ a rabata

reclined înclinat (d. un scaun)

reclining aplecat, înclinat; culcat, tolănit; care (se) apleacă/ (se) înclină

reclining chair scaun pliant, strapontină

reclining seat (auto) scaun rabatabil

recoal (termo) a reîncărca / a reaproviziona cu cărbuni

recognition recunoaştere, apreciere; faimă, renume recognitory cu caracter de recunoaştere

recognizable de recunoscut, care poate fi recunoscut

recognizance recunoastere; admitere; mărturisire; angajament, îndatorire; cauțiune, garanție

recognizant recunoscător, care recunoaşte ceva

recoil (fiz, mec) recul, retragere, dare înapoi, ricoşare; (mas) retragere, şoc; (el, hidr) retur, revenire; cursă inversă; (mil, OM) a avea recul; from a se da înapoi de la; a se feri de; a (se) retrage din fața; a sări înapoi

recoil acceleration $(\mathrm{mec})$ acceleratiie de recul recoil brake cylinder $(\mathrm{OM}, \mathrm{mil})$ cilindru de amortizare a unui recul (şi la artilerie)

recoil buffer $(\mathrm{OM})$ amortizor de recul (şi la tunuri), tampon cu recul

recoil buffer / wedge $(\mathrm{OM})$ pană de blocare / de frână, sabot de frână în formă de pană

recoil control $(\mathrm{OM})$ controlul / reglarea energiei absorbite de un amortizor (prin orificiile de trecere a fluidului hidraulic folosit etc.)

recoiler (met, mas) desfăşurător; (plast, textile) depănător de fir

recoil liquid (auto, ind chim) (de bandă) lichid pentru frână

recoil on / upon (mec) a ricoşa în / asupra; a se răsfrânge / reflecta / repercuta asupra; a se întoarce împotriva, a avea repercursiuni chiar asupra (autorului)

recoil snubber (OM, $T$, hidr) supape, orificii etc. care pot controla amortizarea (şi vâscoasă)

recoil spring $(\mathrm{OM})$ arc de recul

recoil strike (mec, mas-un) mişcare în sens invers

recollect a-şi aduce aminti, a-şi aminti de

re-collect a reuni, a strânge / aduna din nou; a-şi reveni (şi în fire) recolour a recolora, a colora din nou

recombination recombinare,nouă combinare recombination recombinare, combinare nouă recombine a (se) recombina, a (se) combina din nou

recommence a reîncepe, a relua, a începe din nou

recommencement reîncepere, revenire, reluare recommend a recomanda, a sfătui; (amer) (fam) favoare, propunere, recomandare

recommendable recomandabil, indicat; înțelept recommendation recomandare

recommendatory recomandare; recomandabil; demn / vrednic de a fi recomandat

recommended recomandat

recommended dietary allowance (RDA) (metr, alim, med) unități pentru a măsura cantităţile de nutrienți din alimente sau pentru suplimente (vitamine etc.); fiecare nutrient are propria unitate de măsură

recommit a comite / săvârși din nou; a reîncredința, a retrimite; (pol) a încredința din nou (un proiect de lege unei comisii spre reexaminare)

recompacting (met, plast, constr) recomprimare, represare, recompactare

recompense a răsplăti, a recompensa, a premia; recompensă, răsplată, premiu, compensație

recompose a recompune, a reconstitui

recompute $(\mathrm{ec}, \mathrm{TH})$ a verifica calculul, a recalcula reconcile a împăca; (pol, adm, ec) a aduce împăcarea / pacea / înțelegerea între, a (re)concilia, a aplana un conflict

reconcilement (re)conciliere, împăcare; (ec) aplanare (a unui conflict); înțelegere, împăcare, armonie

reconciler împăciuitor

reconciliatory conciliant, conciliator

recondition $(\mathrm{TH})$ recondiționare; (chim, autom) regenerare; (ind, $\mathrm{TH}$ ) a recondiționa, a repara, a reface, a ajusta, a restaura, a regenera, a îndrepta, a corecta, a corija, a finisa, a prelucra suplimentar

reconsider a reconsidera, a reexamina, a cumpăni / judeca din nou

reconsideration reconsiderare

reconsolidate (constr) a reconsolida, a consolida din nou (şi fig)

reconsolidation reconsolidare, nouă consolidare reconstruct a reconstrui, a reclădi, a reface, a restaura

reconstruction (constr, adm) reconstructie, refacere, restaurare

reconvene a convoca din nou, a reconvoca / întruni din nou 
reconversion reconvertire; (mil) trecere la producția (pe timp) de pace

reconvert a reconverti, a converti din nou

reconvey (jur) a retroceda

recondition (met, ind chim) recondiționare, regenerare; (met, mas) a recondiționa, a repara, a repune în stare de functionare; (mas-un, TH) a prelucra suplimentar, a finisa, a ajusta, a recondiționa

reconditioning $(\mathrm{TH}$, mas) restaurare, reparație, recondiționare

reconfigurable (c, autom) (sistem / computer) care poate fi reconfigurat

reconstruction (constr) reconstrucție

reconversion (ec) reconversie, trecerea de la un fel de producție la altul

recooling plant (termo, alim, ind) instalație de răcire cu recirculare

record înregistrare, a înregistra, a consemna, a nota, a lua notă; a imprima, a transmite, a imortaliza, a trece în istorie; document / act oficial, registru, catastif; dosar, palmares; cazier; a reține (un număr, un cod etc.)

recordable care poate fi consemnat / înregistrat; memorabil, demn de a fi consemnat / înregistrat; care poate fi înregistrat (pe disc etc.)

recorder (metr, autom) înregistrator, aparat care înregistrează și afișează valori (măsurate); (adm, jur) arhivar, magistrat (principal), grefier; secretar (care scrie procesul verbal etc.); (fiz) instalație de captare a sunetului

record format (inf, c) formatul unei înregistrări / unei date

recording (autom, c) înregistrare, imprimare; (el) bandă de imprimat (la aparate de măsură); fotografierea unei scene cu o cameră de luat vederi; relatare, povestire, narațiune; (adj) înregistrator, de înregistrare, cu scriere / imprimare / înregistrare automată

recording altimeter / barometer (metr, meteo) barograf

recording system (autom, metr) mecanism de înregistrare automată, sistem de înregistrare

recording apparatus (autom, metr, el) aparat de măsurat cu; înregistrator / înregistrare

recording attachment (el, metr) dispozitiv înregistrator

recording instrument (autom) înregistrator; (metr, autom) aparat de măsurare-înregistrare (automată)

recording meter (autom, metr) aparat înregistrator / cu înregistrare (a valorilor măsurate)

recording pressure-gauge $(\mathrm{TH})$ manometru înregistrator recording of proceedings (ec) notă, minută / proces verbal înregistrat $(\breve{a})$

recording stylus (metr) dispozitiv de trasat

recording system (metr, autom) mecansim $\mathrm{cu}$ înregistrare automată; sistem de înregistrare

records (ec) adeverință, certificat

re-count (mat) a socoti / număra din nou; renumărare, repetare a unei numărători

recoup (for) a despăgubi, a compensa (pentru); a reîmpăți; (ec) a defalca; a se reface, a-și reveni; (jur) scăzământ, reținere, scădere

recoupment $(\mathrm{ec})$ indemnizație, compensație, despăgubire

recourse resursă; scăpare, refugiu; adăpost; (jur) recurs; (ec) responsabilitate; indemnizație, compensație, despăgubire; without $\sim$ (ec) fără responsabilitate (formulă utilizată de girantul unei polițe)

recover (met, ind chim) regenerare, îmbrăcarea cilindrilor de presiune la trenuri de laminare; a redobândi, a recăpăta; a recâștiga; a recupera; a completa, a regenera, a (se) reface, a (se) restabili, a reacoperi; (mediu, TH) a utiliza (deșeuri); (TH) a extrage, a scoate, a exploata; (jur) a recupera, a redobândi, a încasa, a câş̧iga (un proces), a reintra în posesia, a primi ca despăgubire re-cover $(\mathrm{TH})$ a reacoperi, a acoperi din nou recoverable $(\mathrm{TH})$ care poate fi recuperat / recondiționat / reacoperit (la acoperiri metalice sau nu, prin sudare, rectificare, reîncărcare, revopsire, retratare etc.); (med) recuperabil, vindecabil

recovered (mediu, materiale) recuperat; (ec, jur) redobândit, recâştigat; (med) restabilit, însănătoşit, convalescent

recovered energy $(\mathrm{TH}$, ind) energie recuperată recovered oil (ind chim, mediu) ulei regenerat / recuperat

recovering tap $(\mathrm{OM})$ cârlig / dorn de instrumentație / de recuperare (a unei piese)

recovery (autom, inf) recuperare, regenerare, restabilire / revenire la o valoare dată / la valoarea inițială, restaurare după cădere (a unui sistem de calcul); ( $\mathrm{TH}$, ind chim) recuperare / exploatare secundară, extracție (de materiale), valorificare a deşeurilor, reconstituire, refacere, regenerare; sortare, selectare, selecționare; revenire; (mec, textile) revenire (elastică), relaxare; redresare; (met) coeficient de trecere a metalului în baia de zgură (la sudare); (jur) despăgubire, indemnizație, redobândire; (med) însănătoşire, vindecare; recăpătare, recâștigare; (av) redresare, revenire (la orizontală); reluare (şi din haldă) (constr) renovare; amintire

recovery of damages (jur) daune-interese 
recovery of spent pickle liquor (met, chim) regenerarea băilor / soluțiilor de decapare uzate

recovery oven (met) cuptor de cocs cu extragerea / recuperarea produselor secundare

recovery plant $(\mathrm{TH}$, mediu) instalație de recuperare / de reciclare, instalație pentru extragerea produselor secundare

recovery ratio (met, ind chim) procentaj / grad de extragere (a minereului / a materialului util)

recovery station $(\mathrm{TH})$ stație / centru de reparații recovery to original position (mas-un) întoarcere în poziție iniţială

recreate (mec) a (se) relaxa, a (se) destinde; (el) a se deconecta

re-create a crea din nou, a recrea

recreation recreere, relaxare, destindere; distracție, agrement; schimbare, transformare

re-creation recreare, recreație

recreation area / ground teren de joacă / de agrement

recross a străbate / traversa din nou

recrudesce a izbucni din nou, a reapărea, a reizbucni; (d. un focar etc.), a (se) reaprinde, a avea o recrudescență

recrudescent recrudescent, care revine; (mat) recurent

recruit (mil) recrut, recrutare; novice, nou membru, învățăcel; a recruta; a completa, a întregi; a reface, a restabili; a recupera, a redobândi, a reînnoi; (nav) a (se) aproviziona; a (se) întări, a (se) fortifica

recruitment (mil) recrutare; (ind, $\mathrm{TH}$ ) completare, adaos; restabilire; (re)împrospătare

recrystallization (chim, met) recristalizare

recrystallization annealing (chim, met) recoacere de recristalizare

recrystallization hardening (in case of aluminium alloys) (met) întărire de recristalizare (a aliajelor de aluminiu)

recrystallization temperature (chim, met) temperatură de recristalizare

recrystallization texture / structure (met) structură de recristalizare

recrystallize (chim, met) a recristaliza

rectangle (geom) dreptunghi

rectangular (fiz) rectangular, ortogonal; (mat) dreptunghiular

rectangular axis (mat) axa coordonatelor

rectangular bar (met) bară / semifabricat rectangular(ă) / dreptunghiular( $\breve{a})$

rectangular coordinates (mat) coordonate rectangulare

rectangular key $(\mathrm{OM})$ pană paralelă / dreptunghiulară (paralelipipedică) rectangular table (mas-un, OM) masă dreptunghiulară

rectangular wire (mas-un, met) sârmă cu secțiune dreptunghiulară

rectification (chim) rectificare, corectare, corijare, îndreptare; (alim, mediu, ind chim) limpezire, purificare, distilare fractionată; (el, autom) redresare, detecție; (fiz) demodulație; slăbirea liniilor (de contur)

rectifiable $(\mathrm{TH})$ corectabil, amendabil, rectificabil, care poate fi îndreptat

rectification (ind, $\mathrm{TH}$ ) rectificare, corectare, corijare, îndreptare; (el) redresare; (fiz) detectare; (chim) rectificare, purificare

rectified alcohol (ind chim) alcool rafinat

rectifier rectificator, (ind chim, mediu) corector, purificator, separator; (el) redresor; (fiz) detector (şi radio); (mas-un) strung de rectificat

rectifier unit (met) redresor (de sudare)

rectify a rectifica; îndrepta, a corecta, a remedia; a potrivi; (autom) a regla; a ajusta / regla (un aparat etc.); (chim) a rectifica, a purifica; (el) a redresa; (fiz) a detecta (unde radio etc.)

rectifying column (ind chim) coloană de redresare / rectificare

rectilineal rectiliniar (geom, mec) rectiliniu, rectiliniar, în linie dreaptă

rectilineal / rectiliniar motion $(\mathrm{mec})$ mişcare rectilinie; a slăbi, a subția (o linie); (el) a detecta

rectitude corectitudine, cinste; justețe, dreptate; caracter corect / onest; onestitate; exactitate, comportare corectă

recuperated work $(\mathrm{mec})$ lucru mecanic recuperat rectilineal $(\mathrm{mec})$ rectiliniu, rectiliniar, în linie dreaptă

rector (univ) rector

rectorate (univ) titlu sau funcție de rector

recultivate (agr) a (re)valorifica (un teren etc), a cultiva din nou

recuperate a (se) reface, a (se) restabili, a recupera, a redobândi, a recâştiga, a regenera, a reface

recuperation recuperare, redobândire, recâştigare; regenerare, refacere; (med) vindecare, însănătosire, înzdrăvenire

recuperation of current / energy (TH, el) recuperare (de curent / de energie)

recuperative furnace / oven (met) cuptor $\mathrm{cu}$ recuperare

recuperator (met, termo) recuperator, regenerator recur a reveni, a se repeta, a avea un caracter recurent / repetabil, a (se) repeta

recurrence revenire, repetare, reiterare; caracter recurent 
recurrent recurent, periodic, care revine (d. un proces, un fenomen etc.)

recurrent continued fraction (mat) fracție continuă periodică

recurently $(a d v)$ (în mod) recurent/repetat

recursion $(c$, inf) proprietate care îi permite unui program să se apeleze singur

recursion formula (mat) formulă recurentă

recursive (inf) (proces) repetitiv / iterativ (la care rezultatul unei repetări depinde de rezultatul anterior)

recut (mas-un) a tăia din nou, a dința (la pile), a finisa prin lustruire

recycle (ind chim) reciclu, recirculare, flegmă; (TH) material folosit din nou / a doua oară; a recicla un (material, un deşeu)

recyeled juice (alim) zeamă de retur

recycling (fiz) reciclare, reutilizare (a combustibilului regenerat); (hidr, $\mathrm{TH}$ ) recirculare, recirculatie

red roşu

redact a stiliza, a revizui, a redacta (pt. tipar)

redaction stilizare, revizuire, redactare (pt. publicare); reeditare, ediție nouă (revizuită)

red aniline (chim) anilină (roşie), fucsină

red antimony (minrl) stibină, antimonit

red arsenic (chim) sulfură de arsen

red asin (silv) frasin roșu

red blindness (anat) daltonism

red blood-celss / corpuscles (anat) globule roşii, hematii

red brass (met) alamă roşie

red brittleness (met) fragilitate la roşu

red burning (met) incandescență la roșu (d. oțeluri)

red cabbage (agr, alim) varză roşie

red currant (alim, bot) coacăz, coacăză

redden a înroşi, a vopsi în roşu

red duster (nav) pavilion comercial / al flotei comerciale

redecorate (constr) a(re)zugrăvi, a renova

redecoration (constr) renovare, redecorare

redeem a compensa, a îndrepta, a răscumpăra (o greșeală); a recupera; a scoate de sub amanet; a amortiza; a restitui, a reda, a da înapoi; a se folosi de; a salva; a scăpa

redeemer salvator, $(\mathrm{de})$ răscumpărător

red copper (met) cupru tehnic pur / roșu

redemption $(\mathrm{TH})$ amortizare, stingere

red hardness (met) duritate / rezistentă la roșu / la incandescență

red heat (met) incandescență la roşu, roşu incandescent, încălzit la roșu

red heating (met) încălzire până la incandescență red hematite (met, metr) hematit, blutstein red herring (alim) scrumbie afumată; mijloc de diversiune; tertip; pistă falsă

red-hot (met) încălzit la roşu

red incandescence (met) incandescență la roşu

red iron (met, metr) hematit

redistribution $(\mathrm{TH})$ redistribuție, redistribuire

red lead (chim) miniu de plumb

red lead cement/putty (ind chim) chit de miniu

red liquor (ind chim) baiț, mordant, argăseală

red litmus paper (chim) hârtie roşie de turnesol

red lead and gauze packing $(\mathrm{OM})$ garnitură de etanşare din țesătură metalică (impregnată) cu miniu de plumb

redial a forma / a face din nou (un număr de telefon, un cod etc)

red meat (alim) carne de vită, oaie sau miel

redness roşeață, roşeală; (met) încălzire la roşu, incandescenţă la roşu

re-do a reface, a face din nou

red ochre (chim) ocru, miniu de fier; (minrl) limonit

red oil (chim) oleină,acid oleic

redouble a dubla, a îndoi; a înzeci, a intensifica, a mări, a spori; a împături; a se înteți

redox (chim) oxidare şi reducere; $(\mathrm{TH}$, met) oxidoreducere

red pepper (agr, alim, bot) ardei iute, ciușcă, ardei gras, gogoşar

red plague (el, met) depozit pulverulent de oxid cupros (maro-roşcat, sub formă de pete) (specific conductorilor de cupru, acoperiți cu argint)

redraft a alcătui din nou, a reîntocmi, a realcătui redraw (met) tragere / trefilare suplimentară; (ec) a reînnoi o rată; a alcătui din nou, a reîntocmi, a realcătui; a redesena (în desen tehnic)

redraw on / upon $(\mathrm{ec})$ a emite o trată asupra

redress (autom, mas $\mathrm{TH}$ ) a restabili, a reface; a îndrepta, a corecta, a corija; a alina, a potoli; (av, el, autom) a redresa; a repara, a drege, a rectifica, a restabili, a reface; îndreptare, corectare, corijare reparare (a unei greșeli etc.); a îmbrăca din nou; (textile) a reapreta, a finisa, a îmbrăca / înveşmânta din nou; (const) a tencui; (mas-un) a finisa (şi prin lustruire); alinare, potolire, uşurare; a alina; a potoli; (teatru) a monta (o piesă) în costume noi

redressable (autom, mas) reparabil, corijabil

redressing (mas, autom) restabilire, refacere, redresare, corectare, corijare, care redresează / restabileste

red-shift (fiz) deplasare a liniilor spectrului

red-short (met) sfărâmicios la roşu

red soil (geol) pământ roşu 
redshift, red shift (z) (metr, astronomie) deplasare spre roşu, unitate pentru exprimarea distanței relative a obiectelor în univers

red-short (met) fragil la roşu / la cald, sfărâmicios (d. oțeluri)

red shortness (met) fragilitate la roşu (în timpul forjării)

reduce a reduce, a micşora, a atenua, a diminua, a scădea, a descrește; a scurta, a prescurta; a preface, a transforma; (chim) a dilua, a subția (d. o soluție, o vopsea etc.); (mil, adm) a retrograda, a coborâ în grad (în armată, poliție etc.); (mat) a aduce la acelaşi numitor, a simplifica; a converti; (TH) a detensiona, a îngusta, a limita; (fiz) a scădea (temperatura); (alim) a face cură de slăbire, a slăbi, a ține regim; (ec) a converti, a face schimb de, a schimba, a micşora (prețuri, impozite etc.); (chim) a dilua, areduce (un oxid); (med) a îndrepta, a pune la loc (un os dislocat, o articulație luxată); to writing a formula în scris; (mat) a aduce (la acelaşi numitor), a reduce, a simplifica; (mil) a cobori în grad, a retrograda; (med) a îndrepta, a pune la loc (un os dislocat, o articulație luxată)

reduced redus, micşorat, diminuat; slăbit, firav; sărăcit

reduce cost (ec) a scădea costul / cheltuielile de productie

reduced mass (fiz, mec) masă redusă

reduced quadratic (mat) ecuație pătratică redusă

reducer (chim) dezoxidant, agent reducător, substanță reducătoare; (mec, met) reductor; (mas-un, hidr, OM) manşon de reducție, reducție, supapă de reducție; (ind chim) instalatie de dezbenzinare

reduced goods (ec) solduri, mărfuri cu preț redus reduce to a constrânge la, a sili să

reduce to classes a clasifica

reduce to nothing / zero a reduce la zero

reduce the damping a compensa amortizarea

reductibillity reductibilitate

reducible reductibil, care se poate micşora

reducer sleeve $(\mathrm{OM})$ reducție cu mufă

reducer rolling (met) forjare prin laminare

reducing (met) reducere (şi de grosime)

reducing agent (chim, met) dezoxidant, agent reducător; diluant

reducing gear $(\mathrm{OM})$ demultiplicator,mecanism de demultiplicare (cu angrenaje)

reductio ad absurdum (mat) reducere la absurd / demonstrare a absurdității; aplicare exagerată a unui principiu

reducing atmosphere (met, chim) atmosferă reducătoare reducing buch $(\mathrm{OM}$, hidr) reducție cu mufă; manşon de reducție

reducing carbon (chim, met) carbon de reducere reducing coupling $(\mathrm{OM}$, hidr) racord / mufă pentru reducerea presiunii / pentru legarea a două conducte cu dimensiuni diferite

reducing die (mas-un) ştanță de tras pentru operație finală, matriță de refulare

reducing flame (met) flacără reducătoare

reducing furnace (met) cuptor de reducere

reducing gas (ind chim) gaz reducător

reducing gear (mas) (angrenaj) reductor

reducing machine (ind chim) maşină de mărunțire / de măcinare

reducing medium (chim) mediu de reducere; (chim, met) mediu / agent reducător

reducing melting (met) topire reducătoare

reducing mill (met) laminor reductor

reducing nipple $(\mathrm{OM})$ niplu de reducere / niplu de trecere

reducing piece (mas-un) manşon de reducție, reducție

reducing roasting (met) prăjire reducătoare (pt. prepararea minereului)

reducing scale (met) scară de reducere; $(\mathrm{OM})$ scară care micşorează (la un desen tehnic)

reducing slag (met) zgură reducătoare

reducing sleeve $(\mathrm{OM}$, hidr) reducție de racord

reduction (chim) reducere; (met) reducere, dezoxidare, scădere (de temperatură, presiune etc.)

reduction furnace (ind chim, met) cuptor de reducere

reduction gear (auto, OM) angrenaj de demultiplicare / reductor, demultiplicator; (hidr, mec) reductor (şi de presiune)

reduction gear box (auto, OM) reductor

reduction in / of area (materiale, mec) gâtuire, stricțiune, îngustare

reduction joint $(\mathrm{el}, \mathrm{OM})$ reducție, mufă de reducție / de reducere

reduction melting (met) topire reducătoare

reduction mill (met) laminor reducător / reductor reduction of area (hidr, materiale, OM) îngustare, contracție, gâtuire

reduction of area at fracture (materiale) gâtuire (relativă) la rupere

reduction of (cross-section) area $(\mathrm{OM})$ micşorare a sectiunii transversale

reduction of hardness (met) reducerea durităţii

reduction-oxidation (chim) reducere-oxidare, (reacție de) oxidoreducere

reduction per pass (met) reducerea secțiunii la o trecere (de laminare)

reduction print (tipografie) copie micşorată / la scară redusă 
reduction ratio (auto, metr) raport de demultiplicare; (ind chim, met) grad de mărunțire / de reducere; $(\mathrm{OM})$ raport de transmisie / de transmitere

reduction reverberatory furnace (met) cuptor cu atmosferă reducătoare

reduction smelting (met) topire reducătoare

reduction slag (met) zgură reducătoare

reduction sleeve $(\mathrm{OM})$ reducție cu mufă

reduction to a common denominator (mat) aducere la acelaşi numitor

reduction valve (auto, hidr, OM) supapă / reducătoare de presiune

reduction zone (met) zonă de reducere (la furnal)

reductive reductiv, agent reductor

reductively $(a d v)$ prin reducere, pe scurt, (ca) drept urmare

redundancy exces, surplus, excelent; prisos(ință), supraabundență; (autom, mas) redundanță; tautologie

redundancy payment $(\mathrm{adm})$ indemnizatie de șomaj redundantly supraabundent; din belşug

reduplicate a repeta; a dubla; a relua (o operatie, un proces etc.); dublat

redye $(\mathrm{TH}$, constr) a revopsi

re-echo a repeta; a relua; a reverbera (d. flacără, la un cuptor etc.)

reductor $(\mathrm{OM})$ reductor, angrenaj demultiplicator redundancy (mas, autom) redundanță; excedent, exces, prisos, prisosință; supra-abundență; (inf) exces; existență a unui număr de elemente mai mare decât cel strict necesar realizării unui scop, surplus de semnale pentru transmiterea unei anumite cantități de informație; (lingv) pleonasm, prolixitate, tautologie; surplus, surplus de comunicare / de personal / de salariați; modular (inf, c) folosire a unui număr impar de unități operaționale mai mare decât cel necesar pentru functionarea normală a unui sistem informatic; stand-by $\sim$ redundanță de rezervă

redundancy payment $(\mathrm{ec}, \mathrm{adm})$ indemnizație de şomaj (după vechimea în muncă)

redudancy in determination (mat, inf) supradeterminare

redudant suplimentar, excedentar; (OM, mas) (element) redundant; (mec) static nedeterminat; supraabundent, excesiv

redundant design (mas, autom) proiectare redundantă / cu introducerea elementelor de redundanţă (la sisteme cu grad mare de periculozitate / risc)

redundant sealing $(\mathrm{OM})$ etanşare suplimentară (care va lucra doar în cazul căderii / distrugerii altei etanşări)
Redwood second (metr, hidr) unitate de măsură pentru vâscozitate cinematică, măsurată cu vâscozimetrul Redwood, astăzi rar utilizată: vâscozitatea se exprimă în numărul de secunde necesar unui eşantion de fluid de $50 \mathrm{ml}$ să treacă prin vâscozimetrul Redwood

Redwood viscosimeter (metr, hidr) vâscozimetru Redwood

reed (bot) trestie, stuf; (auto, cf) arc lamelar; (met) retasură

reeded acoperit cu stuf sau trestie (d. un loc, un acoperiş etc.)

re-edify (constr) a reface, a reclădi, a reda, a reconstrui

re-edit a republica; a reedita

re-edition reeditare, republicare, retipărire

reed mace (bot) papură

reed stop tub de orgă, registru

re-educate (edu) a reeduca

re-education (edu) reeducare

reef (geogr, nav) recif, stâncă submarină; (geol) filon de cuarț aurifer; (nav) terțarolă; a acționa cu prudență, a fi cu băgare de seamă

reef claim (adm, geol) concesiune auriferă

reefer (nav) matelot care strânge pânzele, aspirant de marină; (textile) haină groasă la două rânduri reef tackie $(\mathrm{OM})$ pălăncel

reef knot (nav) lat, nod lat

reek a unge, a vopsi

reel (el) bobină (în general, de bandă magnetică); (ind chim) (cilindru) înfăşurător, tobă de înfăşurare; (OM) tambur de troliu, disc, (cilindru) înfăşurător, şant (la un disc etc.), tobă de înfăşurare; (met) tobă de trefilat; (nav) tambur (de parâme, de lant, de vinci), a avea mișcare de ruliu, a se clătina; sul (şi de hârtie); (textile) bobină, mosor(el) de fire, depănătoare, vârtelniță, hașpel, maşină de depănat / de sculuit, sucală, a depăna, a scului, a deşira; (med) amețeală, vertigo; clătinare, legănare; oscilare; (poligrafie) rulou, sul; (fiz, hidr) vârtej; (mas) a înfăşura, a bobina, a rula, a depăna, a desfăşura; a roti în haşpel (ind pielăriei); a se clătina; a se învârti; a merge clătinându-se / legănându-se dintr-o parte într-alta; a se roti

reel break (met) deteriorare a marginilor (tablei) reeler (met) laminor netezitor pentru tuburi

reel for strip (met, plast) maşină de înfăşurat benzi / folii / laminate

reeking fumegând; aburind; puturos, împuțit, care are un iz / miros urât

reeky afumat, plin de funingine, înnegrit de fum reelect (pol, adm) a realege

reelection $(\mathrm{pol}, \mathrm{adm})$ realegere 
reeler (textile) bobinator / muncitor care înfăşoară bobine / mosoare

re-eligible $(\mathrm{ec}, \mathrm{adm})$ eligibil din nou, calificat pentru realegere, care poate fi reales

reeling (textile) depănare, bobinare, înfăşurare, clătinare; legănat, care se învârteşte

reeling apparatus / machine (textile) dispozitiv / măsură de bobinat

reel up a desfăşura în întregime

re-embark (nav) a îmbarca din nou, a reîmbarca

re-embarkation (nav) reîmbarcare

reembody (transp) a reîncărca

re-emerge a reapărea; a ieşi din nou la iveală; a fi din nou pe tapet

re-emergence revenire la suprafaţă, reapariție, recrudescentă

re-emergent care vine la suprafață; care revine în actualitate

reeming iron (nav) patarațină

re-enforce (pol, adm) a repune în vigoare, a întări; a da puteri noi, a consolida

re-enforcement (constr, OM) întărire, întăritură, proptea

re-engage (ec) a reangaja, a reprimi; $(\mathrm{OM})$ a angrena din nou

re-engagement $(\mathrm{ec})$ reangajare

re-enlistment (ec) a se reangaja; (mil) a se înrola din nou

re-enter a reintra, a pune iar piciorul (într-o casă, o instituție) a reînscrie

re-enter for a se prezenta din nou

re-entry (av) reintrare în atmosfera terestră

reestablishmen (mas, constr) restabilire, refacere, restaurare, reintegrare

re-examination $(\mathrm{TH}, \mathrm{ec})$ reexaminare, nouă cercetare, cercetare suplimentară; (jur) interogatoriu suplimentar

re-examine (edu, $\mathrm{TH})$ a reexamina, a examina din nou; a revizui, a revedea, a reconsidera

re-export (ec) a reexporta, a exporta din nou; mărfuri reexportate

reface $(\mathrm{TH})$ a repara; a reînnoi, a rectifica; (textile) a pune revere noi la (o haină); (const) a reface fațada (unei clădiri)

reface the clutch (auto, T, TH) a îmbrăca / acoperi cu material de fricțiune, un ambreiaj

refacer (mas-un, OM) dispozitiv pentru repararea / recondiționarea suprafețelor scaunelor de supapă

refacing valve seats (mas-un) rectificarea / frezarea scaunelor de supape

refashion a reînnoi, a face ca nou; a fățui din nou, a pune la punct

refection (re)împrospătare (a forțelor etc.); (alim) gustare, mâncare, băutură răcoritoare refective înviorător, care întremează

refer (to) a refera, a reporta, a amâna; a adresa, a deferi, a aviza; a înainta; a supune (unei alte persoane sau autorități); a transmite / supune spre aprobare / avizare; (jur) a acționa pe cineva în justiție; a atribui, a pune pe socoteala; (ec) a imputa

referable stapdard gauge (mas, metr) etalon de referință

referable to referitor la; care poate fi atribuit; care poate fi referit la

referee (jur) arbitru; persoană care dă referințe; a arbitra, a fi arbitru; a funcționa / servi ca arbitru

reference (to) (jur) referire, (la) înaintare, (spre) trimitere (la o instanță superioară); competență; informație; indicație; recomandare; referință, trimitere, referire; (la) citare, menționare; raport, legătură, relație; (cu) raportare (la ceva); aviz; atribuție; atribuire; (mat) punct de referință; s $(p l)$ referințe, recomandare; persoană care dă referințe; referent; a completa cu trimiteri, a pune / ataşa referințele (la un text etc.)

reference accuracy (OM, metr) precizie / toleranță de bază / de referință

reference analysis analiză de referință / de / prin comparație

reference atmosphere (hidr) presiune nominală / de referință

reference axis (mat) axă de referință

reference book $(\mathrm{TH}$, ec) carte de referință / documentară / de consultat; material documentar, documentație (scrisă); îndreptar, ghid, îndrumar

reference centre distance $(\mathrm{OM})$ distanță de referință dintre axe (şi la un angrenaj cu roți cilindrice)

reference circle $(\mathrm{OM})$ cerc de divizare (al unei roți dințate)

reference cylinder $(\mathrm{OM})$ cilindru de divizare (la roți dințate cilindrice)

reference diameter $(\mathrm{OM})$ diametru de divizare (la roți dințate)

reference dimension $(\mathrm{OM})$ dimensiune nominală / de referință (de proiectare) (fără toleranță, deci nu poate fi folosită la control sau montaj fără specificarea toleranței

reference disk (mas-un, metr) disc-etalon pentru verificarea instrumentelor de măsurat

reference gauge (hidr) post hidrometric de bază; (mas-un, metr) calibru de control, contraca-libru

reference input (autom) mărime de referință; (TH) valoare prescrisă (de referință)

reference input current (autom, el) curent de alimentare, de referință 
reference input voltage (autom, el) tensiune de alimentare de referință

reference jet (mas, metr) ajutaj etalon

reference line (mas-un, metr) linie / poziție de zero, linie de referință

reference magnitude (mat, metr) mărime de referință / etalon

reference operating conditions ( $\mathrm{TH}$, mas) condiții de lucru / de exploatare de referință / de bază

reference peg $(\mathrm{TH})$ reper

reference plane (geom, constr) plan de referință

reference point (met, mat, mec) punct de referință, reper

reference pressure (hidr) presiune de referință (fără specificarea intervalului de variație)

reference quantity (autom, metr) mărime de referință

reference source (ec) sursă de aprovizionare

reference standard (metr) etalon (de referință)

reference temperature (auto, metr, $\mathrm{T}$, termo) temperatură de referință / de bază

referent referent; referire; referință

referred to sus-menționat, de mai sus; respectiv

referring to cu referire / privire la, în legătură cu

refer to a trimite la, a îndruma la / către / spre; a pune să se adreseze; a se referi la; a menționa; a apela la, a recurge la, a face apel la

refigure a recalcula

refile (mas-un) a pili din nou (cu pila)

refill (birotică) rezervă, piesă de schimb; mină (pt. pix); (TH, OM) a umple din nou, a reumple; a se alimenta din nou, a-şi reumple (rezervoarele etc.); (auto, met) a face plinul (de benzină sau ulei)

refilling (hidr, auto) reumplere, facere a plinului refiltered oil (mas-un, mediu) ulei recuperat refine (alim, chim) a fermenta; ( $\mathrm{TH}$, met) a (se) rafina, a înnobila, a supune recristalizării, a curăți, a distila, a înnobila, a îmbunătăți, a afina, a curăța; (şi fig) a (se) purifica, a ameliora; (mas-un) a şlefui, a cizela, a ciopli; (autom) a perfecționa, a ameliora; (fig) a perfecționa, a şlefui

refined fin; (chim) rafinat, purificat; (met) afinat; precis, exact; distins; delicat; cultivat; exagerat de subtil / de rafinat

refined cast iron (met) fontă turnată, rafinată

refined copper (met) cupru rafinat

refined iron (met) oțel afinat / pudlat, fontă rafinată

refined metal (met) metal afinat / rafinat

refined oil (alim, ind chim) ulei rafinat

refine on / upon a face speculații subtile asupra, a specula asupra (unei probleme)

refined pig iron (met) fontă brută de afinare refined steel (met) oțel de calitate superioară, oțel rafinat

refined zone (met) zonă de tranziţie (la sudură)

refine the grain (met) (proces / tratament de) finisare a grăuntelui cristalin, a finisa grăuntele cristalin (prin tratament termic etc.)

refinement (met, chim) rafinare, purificare, afinare, supunere la recristalizare; curăţire; (alim, ind chim) distilare; limpezire, tratare; prelucrare, valorificare superioară; perfecționare, desăvârşire; ameliorare; eleganță, rafinament; talent, calitate; pricepere, îndemânare

refinement of structure (met) îmbunătățirea structurii, micşorarea grăunților

refiner (met) cuptor de rafinare / de afinare; (ec) proprietar de rafinărie de petrol, rafinărie

refinery (ind chim) rafinerie, distilerie, instalație de purificare / curățare etc.

refinery cinder (met) zgură de afinare

refinery slag (met) zgură de afinare

refine upon a specula, a face speculații (subtile) asupra

refining (chim) limpezire, purificare; (met, ind chim) rafinare, (metodă / procedeu / proces de) afinare, înnobilare, curătire, epurare

refining addition / admixture (met) adaos de afinare

refining by heat-treatment (met) îmbunătăţire (prin tratament termic)

refining by melting (met) afinare (prin topire)

refining cupellation (met) proces de cupelație / de afinare

refining fire (met) vatră de afinare (a unui cuptor etc.)

refining furnace (met) cuptor de afinare / de rafinare

refining hearth (met) cuptor / vatră de afinare

refining hearth of furnace (met) cuptor de afinare

refining heat (met) temperatură / căldură de afinare

refining melt (met) şarjă de afinare

refining of waste (met) topirea lipiturii

refining period (met) perioadă de rafinare / de afinare

refining procedure (met) procedeu de rafinare / de afinare

refining process (met) proces de afinare; proces de concentrare (a minereurilor); (ind chim) proces de rafinare; (met, ind chim) proces de curățire / de purificare / de epurare

refining skimmings (met) zgură de afinare de plumb refining slag (met) zgură de la cuptorul de rafinare, zgura oxidantă / finală

refining solvent (ind chim) solvent selectiv, solvent pentru rafinare selectivă

refining stage (met) stadiu / etapă de rafinare 
refining steel by top blowing (met) afinare cu suflare deasupra băii de metal

refining temperature (met) temperatură de rafinare / de afinare

refining under a deoxidizing slag (met) rafinare / afinare sub zgură dezoxidantă

refining vat (alim) cuvă-filtru

refinish (mas-un) a finisa (prin lustruire), a ajusta

refinishing operation (mas-un) operație de refinisare

refit (mas, ind) reparație, revizie; reutilare; a renova; a repara; a reutila; a reface o asamblare; (autom) a repara, a repune în funcțiune; $(\mathrm{TH})$ a depana; (nav) a reechipa, a reutila, a rearma, reechipare, reutilare

reflate $(\mathrm{ec})$ a produce o reflație / inflație după deflație

reflation $(\mathrm{ec})$ reflație, inflație după deflație

reflect (fiz) a (se) reflecta, a (se) răsfrânge; a (se) oglindi; a dăuna, a avea efecte negative asupra

reflected daylight (fiz) lumina zilei, reflectată reflected (fiz) reflectat, oglindit, răsfrânt (şi fig)

reflecting mustrare, dezaprobare, reproş, critică; (fiz) reflectare, răsfrângere, oglindire; reflecție, imagine reflectată; care reflectă / răsfrânge / oglindeşte; (TH) reflector; care gândeşte / meditează

reflection, reflexion (fiz) reflectare, răsfrângere, oglindire; reflecție, imagine reflectată; (med) reflex; mustrare, dezaprobare, reproş, critică

reflectional (fiz) referitor la reflecție; reflectant, reflector

reflection imagine reflectată; (fiz) oglindire, răsfrângere, reflectare, reflexie; reflecție; (mat) simetrie; (şi fig) umbra; (med, artă) reflex; blam; dezaprobare; reproş; meditare; mustrare

reflection coefficient (el, opt) coeficient / factor de reflexie

reflection factor (fiz) factor / coeficient de reflexie, factor de (pierderi prin) reflexie

reflectionless fără reflecție / reflectare; negândit, făcut pe negândite

reflective care gândeşte / meditează

reflectiveness, reflectivity (fiz) (capacitate de) reflectare / oglindire; chibzuință, cumpănire, meditație

reflect light (fiz) a reflecta lumina

reflectogauge (metr, met) detector cu ultrasunete, pentru fisuri interne

reflect on a ataca, a critica; a blama; a pune sub semnul îndoielii; a aduce o atingere (reputației cuiva); a aduce reproşuri

reflect on / upon a se întoarce asupra; a medita la / asupra; a proiecta asupra; (fig) a (se) răsfrânge asupra, reflecta la / asupra, a se repercuta asupra; a se întoarce asupra

reflector (fiz) reflector; imagine reflectată; (med) reflex; reflecție, reflectare

reflectoscope (metr, met) defectoscop ultrasonic reflet reflex, lustru, irizație (mai ales la ceramică)

reflex (fiz) reflectare, răsfrângere, oglindire; reflecție, imagine reflectată; (med) reflex; independent de voință; introspectiv

reflexible (fiz) care răsfrânge / reflectă; reflexibil, care se răsfrânge / reflectă

reflexive (mat) reflexiv, recurent

refloat (nav) a repune pe linia de plutire, a ranflua; (ec) a emite din nou (un împrumut); a repune în funcțiune, a reface (o întreprindere etc.) refloating (nav) emersiune, scoatere pe uscat

reflow (hidr) a (se) revărsa, a deborda; a curge înapoi; reflux

refluence, reflux (hidr) curgere înapoi; (chim) procedeu de fierbere cu lichefierea vaporilor

refluent (hidr) care curge înapoi; care se revarsă / debordează

reflux cooler (termo) refrigerent / răcitor ascendent reflux refrigerator (termo) refrigerent / răcitor ascendent

reforest, reafforest (silv) a reîmpăduri, a împăduri din nou

reforestation (silv) reîmpădurire

reforge (met) a forja din nou; a reface, a recrea

reforging (met) reforjare

reform (ec) a reforma, a îmbunătăți, a (se) îndrepta, a corecta, a (se) corija; a reorganiza, a schimba, a preface; a stârpi, a extirpa, a înlătura; (ec, adm) reformă, îmbunătățire, ameliorare, amendare, corectare

re-form a preface, a transforma, a face încă o dată reformation transformare, prefacere; corijare, îndreptare

re-formation $(\mathrm{TH})$ re(-)formare

re-forwarding (transp) re(-)expediere

refound (met) a retopi

refract (fiz) a refracta (o rază de lumină)

refraction (fiz) refracție

refraction angle (fiz) unghi de refracție

refraction index test (ind chim, $\mathrm{T}$ ) determinarea indicelui de refractie

refractive (fiz) refringent, refractant, care reflactă lumina

refractive index (fiz) indice de refractie

refractivity (fiz) refringență, capacitate de refractare

refractometer (metr, fiz) refractometru

refractor (fiz) corp refractant, refractor

refractories (met, termo) materiale refractare 
refractoriness (materiale, termo) caracter refractar; îndărătnicie, încăpățânare, calitatea de a fi refractar

refractoriness (met, materiale) refractaritate

refractory refractar, încăpățânat, neascultător; persistent; (met, fiz, termo) (material) refractar; (termo) rezistent la temperatură (ridicată)

refractory brick (met, ind chim) cărămidă refractară

refractory cement (met, termo, ind chim) ciment refractar

refractory clay (met) argilă refractară

refractory clay brick (met, ind chim, constr) cărămidă refractară

refractory coat(ing) (termo, met) căptuşeală refractară (şi din sticlă / ceramică refractară)

refractory-lined (met, termo) acoperit / căptuşit cu material refractar

refractory lining (met, ind chim) căptuşire / acoperire refractară

refractory materials (ind chim, met) materiale refractare

refractory metal (ind chim, met) metal refractar refractory mixture (ind chim, met) amestec refractar

refractory mortar (met, termo, constr) mortar refractar

refractory patching mixture (ind chim) material / amestec refractar pentru repararea cuptoarelor

refractory products (met, chim) produse refractare

refractory quality (met, ind chim) refractaritate refractory ramming mixture (met) material / amestec refractar pentru batere / pentru ştampat refractory wall (met, constr) perete refractar

re-frame a încadra / înrăma din nou, a pune în ramă nouă; a refasona, a reface; (pol, jur) a remania, a amenda (o lege)

refrangibility (fiz) capacitate de refracție

refrangible (fiz) refringibil, refractabil

refresh a împrospăta, a înviora; a răcori; a întări, a reconforta; a (se) odihni, a (se) recrea, a (se) relaxa; a reîncărca (o baterie etc.); a (se) reface; (nav) a (se) reaproviziona

refresher (alim) băutură răcoritoare; lucru care înviorează / răcoreşte; reamintire, rememorare; (jur) onorariu suplimentar pentru avocat; recapitulativ, cu caracter de repetitie

refresher course (edu) curs recapitulativ; curs de perfecționare / reciclare

refreshment (alim) gustare, aperitiv, mâncare, alimente, băutură răcoritoare; răcorire, înviorare; împrospătare (şi a memoriei)

refrigerant răcoritor; (fiz) refrigerent; (termo, met, chim) agent frigorific / de răcire, răcitor refrigerant mixture (termo, chim) amestec refrigerent

refrigerate (alim, fiz, termo) a refrigera, a răci; a păstra la loc rece; a (se) răci, a (se) răcori

refrigerated-cargo ship (nav) navă frigoriferă

refrigerating (termo, alim) frigorific; răcire, refrigerare; congelare; care răcește / congelează / refrigerează

refrigerating capacity (termo) capacitate frigorifică

refrigerating chamber (alim, termo) cameră de răcire

refrigerating effect (termo, fiz) efect de răcire

refrigerating fluid (ind chim) fluid refrigerent / de răcire

refrigerating industry (ind) industria frigului, frigotehnie

refrigerating machine (alim, termo) frigorifer, maşină / instalație de refrigerare

refrigerating mixture (termo, chim) amestec refrigerent

refrigerating plant (termo, alim) instalație frigorifică / de răcire / de congelare

refrigerating vehicle (auto, termo) autovehiculfrigorifer

refrigeration (ind chim) răcire, refrigerare; (alim) congelare; (termo) frigotehnică, tehnica frigului

refrigeration cooling (alim) (răcire prin) refrigerare

refrigeration cycle (fiz, termo) ciclu de refrigerare (de răcire)

refrigeration plant (termo) instalație frigorifică

refrigeration surface (alim, met, termo) suprafață de răcire

refrigerator (termo) frigorifer, frigider, refrigerent (răcitor), răcitor electric

refrigeratory (termo) refrigerent, serpentină de alambic; frigorific, refrigerent

refringent (fiz) refringent

refuel (auto, met) a face plinul (de benzină, ulei), a reumple rezervorul cu combustibil; (nav) a umple din nou, a se reaproviziona cu combustibil refuelling (mas, auto) (re)alimentare cu combustibil re-fund (ec) a reînnoi (o datorie)

refund $(\mathrm{ec})$ restituire, rambursare, înapoiere, plată, despăgubire (pt. cheltuieli); a rambursa, a plăti, a da înapoi; a despăgubi, a compensa

refundable $(\mathrm{ec})$ rambursabil

refurbish (mas-un) a lustrui / poliza din nou; a da un nou luciu; a înnoi, a renova; a pune la punct, a cizela

refurnish a remobila, a mobila din nou

refusal refuz; respingere; (jur) drept de preemțiune 
refuse (mediu) gunoi, gunoi menajer, murdărie; resturi, rămăşițe; (TH, ind) deşeu, rebut; (const, mediu) moloz, dărâmături, grohotiş; (met, chim) reziduu, refuz, steril rezultat de la o instalație de epurare; a refuza, a respinge; a nu accepta; a nu consimți; a interzice; $(\mathrm{TH})$ a rebuta; (termo, mediu, chim) produse solide, rezultate după ardere

re-fuse (met, ind chim) a retopi, a topi din nou

refuse body (auto, mediu) caroserie de transportat gunoi menajer

refuse heap (ind) grămagă de steril / de deşeuri

refuse spout (cf, const) jgheab / şanț / rigolă de scurgere; (hidr) albie / rigolă de colectareevacuare, jgheab colector / evacuator

re-fusion (met) retopire

refusion soldering $(\mathrm{TH}$, met) lipire prin retopire refutable (jur) care poate fi dezmințit / respins; refutabil, negabil

refutal, refutation (ec, jur) respingere, negare, refutare; combatere

refute (jur) a dezminți, a combate; a respinge, a refuta; a infirma

regain a recâştiga, a redobândi; a recupera; a recăpăta, a ajunge din nou la; (nav) a se întoarce / reveni la țărm

regainment (ec, mas) redobândire, recâştigare; recuperare; (jur) reintrare în posesie

regard privire, ochire; privință, punct de vedere; (mat) relație; considerație, respect; băgare de seamă; atenție; legătură; deferență; a considera; a da / acorda atenție la; (fig) a ține seama / cont de, a avea în vedere; as a socoti, a considera (drept / ca); a privi, a viza, a avea legătură cu; a prețui, a privi cu respect, a respecta

regarding $\mathrm{cu}$ privire la, în privința; referitor / relativ la, cât despre, în ceea care priveşte

regardless neatent; neglijent; fără a ține seama de; indiferent la; nepăsător față de

regardlessness nepăsare, indiferență, neatenție, lipsă de grijă

regardless of fără a ține seama de, indiferent / neatent / nepăsător la / față de

regelate (termo, alim) a îngheța din nou / la loc

regelation (termo, alim) reînghețare

regenerate (ind chim) a (se) regenera, a se reface; a recupera; a reîmprospăta; a îndrepta; regenerat, reînoit; ameliorat, îmbunătățit

regeneration (mediu, ind chim) regenerare / recuperare; (chim) reacție; (autom) reacție a sistemului automatizat la factori externi (în sens dorit)

regeneration capacity (met, termo) capacitate de regenerare / de recuperare / de acumulare (a căldurii) regeneration crucible furnace (met, termo) cuptor cu creuzet, cu recuperare de căldură

regeneration of spent pickle liquor / of spent pickling solution (met, chim) regenerarea băilor / soluțiilor de decapare

regenerative $(a d v)$ regenerator, cu caracter de regenerare / reînnoire

regenerative capacity (met, termo) capacitate de regenerare / de recuperare / de acumulare (a căldurii)

regenerative chamber (met, termo) recuperator, regenerator (de abur, de căldură etc.)

regenerative circuit (hidr) circuit de recirculare a fluidului

regenerative coke oven (met) cuptor de cocs, cu regenerator

regenerative feedback (metr, autom) feedback pozitiv

regenerative furnace (met, termo) cuptor cu regenerator

regenerative reverberatory furnace (met) cuptor cu flacără şi cu regenerator

regenerator (termo, ind) acumulator / regenerator / recuperator de căldură

regerminate (agr) a reîncolți, a germina din nou regime, régime (mas, $\mathrm{TH}$ ) regim

region (geogr) regiune, zonă, provincie, ținut; domeniu, sferă; sector, raion, district (de oraş)

regional (geogr) regional, de ținut; zonal; cu caracter local

region of adhesion ( $T$, plast, fiz) regiune / zonă de adeziune / de coeziune

region of reduction (met) zonă de reducere

register registru, condică; borderou, listă, tabel; catalog, tablou; (fiz, autom, metr) numărător, contor, aparat de înregistrare, regulator; registru, reperaj, repertoar, index; (termo) registru de ventilație; (metr) aparat de înregistrare, înregistrator cantitate / temperatură etc. înregistrată de un aparat; oblon, clapetă, clapă; a (se) înregistra, a marca, a trece în registru, a consemna; a nota; a indica; a trimite / expedia (o scrisoare etc.); (mas-un) aliniere față de o poziție anterioară sau de un set de coordonate; (c) localizare a unor date în memorie, circuit de memorare, locație specială de stocare; (nav) încărcătură, caric, cargou, registru naval (de clasificare), contor de loch; (OM) clapă, clapetă, oblon; coincidență; concordanță; (ind) registru de ventilație; (poligrafie) conținut, potrivire la semne; dispozitiv de înregistrare / de memorare; (inf, telefonie) numărător, înregistrator a instala, a se înregistra (la un hotel etc.); a se înscrie

register card (ec) fișă de evidență 
registred (ec, TH) înregistrat; înscris, marcat, consemnat; înmatriculat; (d. scrisoare) recomandat, cu valoare declarată

registered design brevet, patent

registered length (nav) lungime de tonaj

registered trade-mark (ec) marcă depusă / înregistrată / de fabrică

registering înregistrator, de înregistrare, care înregistrează / marchează / consemnează; înregistrare; înscriere, trecere în registru; consemnare; expediere recomandată (a unei scrisori); (jur) transcriere

register pin $(\mathrm{OM})$ ştift de montaj / de centrare

register ton (RT) (ec, metr, nav, transp) tonăregistru, unitate de măsură pentru capacitatea de încărcare cu mărfuri a unui vas etc.: 1 register ton $\cong 2,832 \mathrm{~m}^{3} ; \mathrm{v}$. ton

registrable înregistrabil, care poate fi înregistrat; care poate fi reținut / memorat; (inf) memorabil (într-o memorie de calculator etc.)

registrar arhivar; (jur) grefier; notar; ofițer de stare civilă

registration (autom) înregistrare, contorizare registation mark (auto) placă de înregistrare, placă cu număr de circulație / de înmatriculare registration numer (auto) număr de circulatie

registry înregistrare; (adm, ec) registratură; birou, oficiu; (mas) coincidență, suprapunere (de exemplu, a găurilor); (nav) pavilion

registry book (ec) registru, condică de înregistrare; matricolă

reglable resistance (el) rezistență reglabilă

regression (mat) regresie (în statistică)

regrant (ec) a reda, a acorda din nou (o bursă etc.); redare, înapoiere

regrate $(e c)$ a stoca (mărfuri) în vederea speculării

regrater (ec) speculant, persoană care stochează mărfuri

regressive (mat, fiz) regresiv

regressiveness (mat, fiz) regresivitate, caracter regresiv

regret regret; a regreta

regrind (mas-un) a rectifica din nou, a reascuți (o sculă aşchietoare), a ascuți din nou; (alim, const) a măcina / concasa (mărunţit) repetată

regriding (mas-un) rectificare din nou

regroup a regrupa

regrowth (chim) regenerare, nouă creştere; (agr, biol, mediu) (agr, biol, mediu) repopulare

regrowth alpha (met) fază alfa care se dezvoltă dintr-o fază alfa deja existentă (în anumite condiții de răcire şi temperatură) (la aliaje metalice) regulable (mas, OM) reglabil, ajustabil regular normal, obişnuit, curent; uniform, regulat, ordonat; sistematic; precis; exact; riguros; corespunzător; reglementar, cum se cuvine, în conformitate cu regulile / practica; simetric, armonios

regular employment (ec) angajament / serviciu regulat; slujbă / angajare permanentă

regular engine oil $(T$, ind chim) ulei standard / normal pentru motoare

regular feed (mas-un, TH) avans / alimentare cu viteză normală

regular geometrical outline (mat, geom) contur geometric regulat

regular hand feed (mas-un) avans manual $\mathrm{cu}$ viteză mică

regular hole trecere / alezaj / gaură normal(ă) (la racord, scule, găuri pt. montat şuruburi etc.)

regularity regularitate, caracter regulat; ordine, simetrie, uniformitate; continuitate

regularisation (ec, mat) regularizare

regularisation account $(\mathrm{ec})$ cont de regularizare

regularize (autom) a regulariza, a regla; (pol, adm, jur) a regula; a reglementa; a pune în ordine, a ordona, a aranja

regular jaws (mas-un, OM) fălci fixe (la menghină) regular-lay rope $(\mathrm{OM}$, transp) cablu cu torsadare încrucișată

regular operation $(\mathrm{TH}$, mas) exploatare / funcționare normală

regular packing (fiz) aranjare / organizare regulată (şi pt. amestecuri de particule, pulberi, rețele cristaline etc.)

regular polygon (geom) poligon regulat

regular powder (met, plast) pulbere / pudră cu particule uniforme

regularly $(a d v)$ (în mod) regulat / obişnuit / curent, cu regularitate

regular salary $(\mathrm{ec})$ salariu permanent / regulat

regular sequence (mat) şir Cauchy / convergent

regular service condition (autom) condiții normale de exploatare / de serviciu

regular space (mat) spațiu regulat

regular traveller (transp) călător cu abonament, posesor de abonament (de călătorie), navetist

regulate $(\mathrm{TH}$, autom) a regla, a menține un parametru în anumite limite în ciuda variației altora, a potrivi; a adapta (la cerințe etc.)

regulate a potrivi; a pune în ordine; a dirija; a norma; (autom) a regla, a ajusta

regulating (autom, $\mathrm{TH}$ ) de reglare, reglare, care reglează / regularizează

regulating apparatus (autom, metr) aparat de reglare

regulating cock $(\mathrm{OM}$, hidr) ventil / robinet de reglare

regulating device (autom) dispozitiv de reglare regulating element (autom) element / organ de reglare / care reglează 
regulating rod (fiz) bară de reglare / de control / de comandă

regulating system (autom) sistem de reglare / de comandă

regulating valve $(\mathrm{OM}$, hidr) robinet / supapă de reglare

regulating variable (autom) mărime finală de reglare, variabilă de reglare

regulating wheel (mas-un) piatră / disc de avans (la rectificare fără vârfuri)

regulation (pol, adm) ordin, ordonanță; $\sim \mathbf{s}(p l)$ regulament (şi în UE); (adm, ec) regulament (de funcționare); statut; aranjare; întrerupere; potrivire, reglementare; organizare, ajustare; ordonare; (autom, mas) reglare, comandă, control, acordare, adaptare; (fiz) punere la punct; (hidr) reglare, regularizare; (autom, hidr) reglaj, reglare, punere la punct; (mas, autom, mat) stabilizare, adaptare, comandă; (el, metr) acordare, variație a tensiunii (la bornele unei maşini electrice între două regimuri de funcționare); (pol, adm) legiferat, stabilit (prin lege, regulament etc.); reglementar

regulation in steps (autom) reglare treptată / în trepte

regulation of electrodes (met) reglarea electrozilor (la oțelării şi cuptoare electrice)

regulation of flames (met, termo) reglarea flăcării

regulation of slag (met) reglarea / controlul zgurii regulation speed (auto, adm) viteză legală / permisă

regulation voltage (autom, metr) tensiune de reglare

regulative (autom) (adj) regulator

regulator (autom, $\mathrm{TH}$ ) regulator, egalizator, compensator, moderator; (adm) reglementator; (mas) regulator de motor; (met) registru la o uşă de aeraj (pt. reglarea debitului de aer); (metr) cronometru

regulator housing (mas, OM) carcasă de regulator

regulator valve (mas-un, OM, hidr) sertarul / supapa regulatorului

regulator with slide valve (cf, OM, autom, hidr) regulator / distribuitor / supapă cu sertar

regulatory control (autom, mas) menținerea parametrilor de ieşire în limite impuse în ciuda variației parametrilor de intrare şi a influenței lor

regulus (geom) familie de drepte liniare cu parametru; (met) cristal de metal pur

rehabilitate (jur) a reabilita, a repune (în drepturi); (constr) a reconstrui, a restaura rehabilitation restabilire, restaurare; (jur) repunere în drepturi, reabilitare; refacere, reconstrucție; (mas-un) reparație, recondiționare

rehandle a schimba mânerul (la o sculă etc.); a mânui din nou, a lua în mână din nou; a ataca / trata din nou (o problemă etc.)

reharden (met) a căli din nou, a recăli

rehardening (met) recălire

rehash a transforma, a prelucra, a înnoi; a prezenta într-o formă nouă; a readuce pe tapet; vechitură transformată

rehear (jur) a cerceta din nou, a reexamina, a face noi audieri în; a auzi din nou, a reauzi

rehearing (jur) reaudiere, reexaminare (a unui caz etc.)

rehearsal repetitiie, repetare

rehearse (teatru) a face repetiții; a repeta; a enumera, a număra din nou

reheat (termo) a reîncălzi, a reveni; a fierbe din nou

reheated steam (termo) abur reîncălzit

reheater (termo) preîncălzitor

reheating (termo, met) preîncălzire; încălzire repetată, preîncălzire (a combustibilului, a unui semifabricat), reîncălzire

reheating furnace (met) cuptor de reîncălzire / de recoacere

reheat-treated (met) retratat termic

reheat-treatment / treating (met, alim, ind chim) tratament termic repetat, tratare termică repetată

rehoboam (metr, alim) o sticlă mare de vin de 4,51 , de 6 ori volumul unei sticle obişnuite

reignite (termo) a (se) reaprinde, a (se) aprinde la loc

reimbursable (ec) rambursabil, recuperabil

reimburse (ec) a restitui, a rambursa, a plăti, a înapoia (bani); for a indemniza, a despăgubi pentru

reimbursement $(\mathrm{ec})$ rambursare, restituire, înapoiere (a unei sume de bani), returnare

reimbursement credit $(\mathrm{ec})$ credit de acceptare prin ramburs

reimplant (agr) a replanta, a planta din nou

reimport (ec) a reimporta; reimportare; mărfuri reimportante

reimpose a reimpune, a impune din nou

reimpress (textile, tipografie) a reimprima, a imprima din nou; a retipări

reimpression (tipografie) (textile, tipografie) retipărire; reimprimare; ediție nouă

rein frâu, hăț; a ține în frâu; (mas-un, OM) mâner, manetă

reincorporate (materiale, $\mathrm{TH}$ ) a reîncorpora, a reintegra, a încorpora din nou; a reintroduce 
reinforce (const) a arma (betonul); (TH, OM) a întipări, a rigidiza, a consolida, a întări, a fortifica, a ranforsa (compozite), întăritură, material de întărire / ranforsare

reinforced concrete (const) beton armat

reinforced joint (met, OM) cusătură îngroşată (de sudură), articulație rigidizată

reinforced seam (met, OM) cusătură îngroşată (la sudură)

reinforced tyre / tire (auto, OM) pneu ranforsat

reinforced weld (met, OM) cusătură de sudură convexă / îngroșată

reinforcement (auto, OM) talon (de pneu); (const) consolidare, fixare, armare / armătură a betonului, ranforsare; (hidr) armătură; (met, T) întărire (a cusăturii, la sudare, a materialului compozit etc.), întăritură, material de întărire, ranforsare; ajutor, sprijin

reinforcement bar (const) bară de armătură

reinforcement of the wheld (met, $\mathrm{OM}$ ) întărirea cusăturii de sudură

reinforcement plate $(\mathrm{TH}, \mathrm{OM})$ tablă de întărire / de rigidizare

reinforcer (materiale) întăritor, ranforsant (şi în compozite)

reinforcing (const, $\mathrm{TH}$ ) armare, sprijinire, consolidare, rigidizare

reinforcing bars / steel (const, $\mathrm{TH}$ ) oțel-beton, bare de rigidizare / de întărire (din oțel)

reinforcing filler (plast, T) fibre / umplutură cu rol de întărire / ranforsare, material de întărire / de umplutură (la compozite)

reinforcing frame (const, mas-un) cadru de rigidizare

reinforcing iron (const, met) fier-beton

reinforcing rib (const, $\mathrm{OM}$ ) nervură de întărire / de rigidizare

reinforcing ring (const, OM) cerc / inel de întărire / de rigidizare

reinforcing steel (const, met) fier-beton, oțelbeton

reins (med, anat) rinichi

reinsert a reinsera, a insera din nou; a interpune din nou

reinsersation (materiale) reinserare, reinserție, inserție nouă

reinstall a reinstala; a restabili; (jur) a repune în drepturi, a reabilita; a reintegra

reinstalment, reinstatement (pol, adm, jur) reinstalare; restabilire, repunere în drepturi

reinstate (med, $\mathrm{TH})$ a restabili; a restaura, a reface; a reinstala; a repune în drepturi, a reabilita; a reintegra

reinsurance $(\mathrm{ec})$ reasigurare reinsure (ec) a face o nouă asigurare pentru, a asigura din nou

reintegrate a reintegra

reinvest (ec) a reinvesti; (TH) a îmbrăca / acoperi din nou

reinvestment (with) (adm, pol) reinvestire (cu / pentru); restabilire; $\sim$ in repunere (în funcție), reintegrare

reissue a retipări, a republica, a scoate o nouă ediție; reeditare, retipărire, ediție nouă

reiterate a repeta, a relua, a reitera

reiteration reiterare, repetare (continuă)

reject (mas-un) a rebuta, a respinge, a refuza, a nu accepta; a arunca; a elimina, a scoate, a evacua; rebut; persoană respinsă

rejectable $(\mathrm{TH}$, ind) care poate fi aruncat / scos / respins / eliminat / dispensabil; bun de aruncat; care poate fi rebut

rejected material (met, materiale) material rebutat / respins

rejected stock $(\mathrm{TH})$ refuz de sortare

rejecter (mas-un) ejector

rejecter circuit (mas-un) circuit ejector

rejection refuz; $(\mathrm{TH})$ rebutare, respingere, refuzare, aruncare de rebut, blocare, filtrare; $(\mathrm{ec})$ neacceptare (a mărfurilor); (ec, TH) rebutare; (el) suprimare

rejection of spoilage $(\mathrm{ec})$ rebutare, respingere a produselor neconforme

reject pocket (autom, OM) casetă de rebuturi

rejector persoană care respinge / refuză / nu acceptă

rejects $(\mathrm{ec})$ rebuturi

rejig (ec) a reprofila, a reutila (pt. o nouă destinatie); a schimba destinatia (unei fabrici etc.)

rejoin a (se) alătura din nou; a reveni la; a ajunge din urmă; a reuni, a re(a)lipi, a lipi la loc; a reveni; a răspunde; $(\mathrm{TH})$ a reface o asamblare / o legătură; (d. drumuri) a se reuni, a se reîntâlni relabel (ind) a eticheta din nou / diferit

relapse (into) a reveni (la); a se apuca din nou de; recidivă, recădere

relate a relata, a povesti, a descrie, a expune; with / to a lega de, a socia cu, a raporta la, a pune în legătură cu, a stabili un raport între; a (se) înrudi, a fi în raport / relație / legătură cu; a fi înrudi cu

related to / with legat de, asociat cu, raportat la, înrudit cu; relatat, narat

relating to relativ / referitor la; în privința, în legătură cu; care are legătură cu

relation (mat) relație, raport; legătură; asociație; analogie; relatare; expunere; descriere; privință, raport, referire; narare, narațiune, povestire; 
neam, rudă, înrudire, rudenie; in $\sim$ to referitor / privitor / relativ la, în privința; cât despre, în raport cu, față de, pe lângă; $\sim \mathbf{s}(p l)$ relații, raporturi, termeni; relatare, descriere, expunere

relational cu caracter de relație; de înrudire; relațional

relationless fără relație / relații / legătură

relation of forces (pol, $\mathrm{TH}$ ) raport de forțe

relationship raport, conexiune (între două lucruri), legătură, relație; asociație; analogie; relatare; mediu înconjurător

relations of production (ec) relații de producție

relative relativ, comparativ; reciproc; respectiv, corespunzător; interdependent

relative amounts (mat) proporţie cantitativă

relative damping $(\mathrm{OM}$, hidr) amortizare relativă

relative deformation (mec, $\mathrm{OM}$, met) deformatie relativă

relative duty time (mas, $\mathrm{TH}$ ) coeficient de execuție, timp relativ de lucru / de funcționare (a unei maşini): timp execuție $_{\text {(timp }}$ execuție + timp $_{\text {repaos }}$ )

relative error (mat, metr) eroare relativă / raportată la (ceva)

relative humidity (fiz, meteo) umiditate / umezeală relativă (în procente, masa vaporilor de apă raportată la un kilogram de aer uscat)

relatively $(a d v)$ (în mod) relativ / comparativ

relatively low cost $(\mathrm{TH}, \mathrm{ec})$ cost relativ redus

relative material ratio (metr). lungime portantă relativă față de o referință (la profilometria suprafeței)

roughness profile. (metr). profil de rugozitate. (la profilometria suprafeței)

relativeness, relativity (fiz) (şi fig) relativitate, caracter relativ

relative permeability (fiz, el) permeabilitate relativă

relative prime numbers (mat) numere prime între ele

relative to relativ / referitor la

relative speed (mec) viteză relativă

relative value (mat) valoare relativă; $(\mathrm{TH})$ valoare prescrisă / de referință

relative velocity (hidr, mec) viteză relativă

relative viscosity (hidr, mec, T) vâscozitate relativă (şi d. emulsii)

relative yield (fiz) randament relativ

relativity theory (fiz) teoria relativității

relativization relativizare; (fiz) aplicare a teoriei relativității

relativize a relativiza; (fiz) a aplica teoria relativităţii (unui lucru, unui fenomen etc.)

relator narator; prezentator al faptelor / cazului

relax $(\mathrm{OM})$ a (se) relaxa, a (se) destinde; a (se) slăbi, a (se) micsora, a ceda (d. un arc, o piuliță, un nit etc.), a se destinde (d. un arc etc.); a (se) odihni; a dezlega, a desface; (el, autom) a atenua, a slăbi (d. un semnal etc)

relaxation (fiz) relaxare, destindere; revenire (repaus); (mec) relaxare a unui material; slăbire, înmuiere; repaus, destindere, odihnă; divertisment relaxation time (fiz, metr, autom) timp de relaxare / de revenire (a unui material, a unui ac indicator etc.)

relaxed (d. o persoană, un material) relaxat, destins relaxing (materiale) odihnitor; care se relaxează / extinde

relay schimb de muncitori; rezervă; (el) releu, comutator, a transmite (prin releu), retransmisie, reluare (a unei transmisii); a transmite unul de la altul (ca o ştafetă), a retransmite

re-lay a reaşeza, a aşeza din nou, a repune relay system $(\mathrm{TH}, \mathrm{ec})$ lucru în schimburi / ture releasable degajabil; (mat) rezolvabil; (OM, autom) declanşabil, care se poate declanşa; (ec) care se poate da pe piață (d. un produs)

release eliberare; scutire; emitere; (jur) punere în libertate, transmitere (a unui drept, a unei proprietăți), a ceda (un drept, o proprietate etc.); (ec) eliberare / livrare de mărfuri, chitanță, recipisă, scutire, a descărca (de o datorie etc.), a pune la dispozitie; autorizație de publicare / difuzare (în presa etc.), a autoriza difuzarea / publicarea; lansare; (auto, mas) debreiere, descărcare, reducere; (cf, OM) decuplare; (el) eliberare, deblocare, declanşare, deconectare, decuplare, întrerupere; $(\mathrm{OM})$ mecanism de declanşare / decuplare, declanşator; (fix, chim) degajare, emitere (de gaze etc.); a preda, a emite; (autom, mec) a deconecta; (chim) degajare, eliberare, a degaja; (mas) descărcare, retragere, revenire, a desface, a slăbi, a desprinde; (mec) a descărca, a declanşa, a decupla, a destinde, a debloca, a desface; (auto, OM) debreiere, $\sim$ a brake a debloca o frână; (jur) a ceda, a transfera (un drept); a lansa, a da drumul la; a autoriza publicarea / difuzarea; (mil) a lansa (paraşutişti, bombe etc.); eliberare, usurare (de o obligatie, datorie etc.); iertare; a difuza în premieră (un film etc.)

release agent (chim) agent antiaderent

release bearing for clutch $(\mathrm{OM})$ manşon / mufã de debreiere

releasee (jur, ec) cesionar

release lever (auto) pârghie de eliberare / de deplocare etc.

releaser (jur, ec) cedent

release the brake (auto) a slăbi frâna

release button (el, mas, OM) buton de declanşare 
release cock relief

release cock $(\mathrm{OM}$, hidr) robinet de decompresiune

release contact (el, mas) contact de declanşare

release disk (el, OM) disc de decuplare

released time (mas) timp de repaus

released vapors from (fiz, chim, T) vapori eliberați din

release gear (auto, OM) mecanism cu clichet, mecanism / diapozitiv de decuplare sau de declanşare

release lever (OM, autom) mâner / pârghie de declanşare, declanşator, dispozitiv de declanşare automat; (auto) pârgie de eliberare

release lucking device (mas, $\mathrm{OM}$ ) dispozitiv de blocare împotriva decuplării întâmplătoare

release magnet (el, mas) magnet de declanşare

release mechanism (mas, OM) mecanism de decuplare

release the mould (plast) deschiderea matriței pentru evacuarea gazelor

release of pressure $(\mathrm{TH}$, hidr) reducere de presiune, decompresi(un)e

release paper (ind chim) hârtie antiaderentă

release position (TH, mas) poziție ,decuplat”

releaser $(\mathrm{OM})$ declanşor, mecanism de decuplare

release retardation (el, autom) întârziere de declanşare

release screw (auto, OM) şurub de dezaerare, şurub de evacuare a aerului

release spring $(\mathrm{OM})$ arc declanşator, arc de rapel / de slăbire

release system of gear (el, OM) dispozitiv de declichetare / de declanşare

release the accelerator pedal (auto) a ridica piciorul de pe pedala de accelerație

release the catch $(\mathrm{TH}, \mathrm{mec}$, materiale) a dezăvorî

release the clutch pedal (auto, mas) a ambreia

release the tension $(\mathrm{TH}, \mathrm{OM})$ a detensiona

release the trigger $(\mathrm{TH})$ a manipula / a mânui / a actiona o manetă / un declanşator

releasing $(\mathrm{OM}$, mas) degajare, decuplare, debreiere; deconectare, eliberare; (chim) degajare

releasing cam (OM, mas-un) camă / deget de declanşare

releasing current (autom, el) curent de declanşare

releasing device $(\mathrm{OM}$, electr) dispozitiv de decuplare / deblocare, de deconectare

releasing gear $(\mathrm{OM})$ declic, angrenaj / transmisie de decuplare / de deconectare

releasing key (el, OM) cheie de deblocare

releasing lever (mas, OM) pârghie de decuplare / de debreiere releasing of brakes (cf, $\mathrm{OM}$ ) slăbirea frânelor relasing (of a relay) (el) declanşare (a unui releu)

releasing spring $(\mathrm{OM})$ arc de rapel

relevance, relevancy legătură, relație; potrivire, raport; relevanță, importanță

relevant relevant, important; pertinent, legat de problema respectivă

relf. vl. (relief valve) (OM, hidr) supapă de siguranță

reliability (mas) fiabilitate; (inf) încredere; (mat, autom) functie de încredere, coeficient de siguranță / fiabilitate; (ec) solvabilitate, certitudine, siguranță, veridicitate, autenticitate, încredere; (el, mas) siguranță / securitate în functionare

reliability assurance (mas) măsuri de asigurare a fiabilității (sau a clasei de fiabilitate)

reliability centred maintenance (mas) mentenanță centrată pe menținerea fiabilității (program de mentenantă preventivă, cu costuri minime şi asigurarea fiabilității)

reliabity control (mas) control / verificare a(l) fiabilității

reliability development / growth test (metr, mas) test(e) efectuat(e) pentru depistarea deficiențelor, prevenirea reapariției lor (deci creșterea fiabilității)

reliability growth (mas, TH) creşterea / mărirea fiabilității

reliability of operation (mas, $\mathrm{TH}$ ) securitate de / în serviciu, securitate / siguranță în funcționare, fiabilitate în funcţionare

reliability of service (auto, mas) siguranță / fiabilitate în exploatare

reliability (of transmission) $(\mathrm{OM}, \mathrm{TH})$ siguranța / fiabilitatea (transmisiei)

reliability qualification test, design approval, reliability demonstration (mas, ind) test efectuat în anumite condiții, cu anumite cerințe de fiabilitate a produselor, în vederea omologării

reliable demn de încredere, de nădejde, sigur, pe care te poți baza; (autom, OM, mas) sigur în funcționare, cu un înalt coeficient de siguranță, fiabil

reliableness soliditate; fiabilitate, caracter care conferă încredere / siguranță

reliable working (el, mas) funcționare sigură

relief uşurare; descărcare; reducere; degrevare; relief, îngroşare; destindere; (mas-un) detalonare, ridicarea cuțitului de raboteză la cursa de înapoiere; (jur) reparare, reparație, despăgubire, câştig de cauză 
relief angle (mas-un) unghi de aşezare relief annealing (met) recoacere de relaxare relief cam (mas, OM) camă de decompresiune, cama mecanismului pentru micşorarea compresiunii (arcului, în cilindrul motorului)

relief cock (auto, OM) robinet de decompresie

relief door (met) ușă de salvare

relief flow rate (fiz, hidr) debit de evacuare în aer liber (la sisteme pneumatice)

relief from taxation (ec) scutire / degrevare de impozite

relief grinding (mas-un) detalonare la maşina de rectificat

relief grinding machine (mas-un) maşină de rectificat pentru detalonat scule

relief map (geogr) hartă în relief

relief mechanism (mas-un, $\mathrm{OM}$ ) mecanism de siguranță

relief pressure valve $(\mathrm{OM}$, hidr) supapă / ventil de siguranță, de descărcare

relief road (auto, transp) rută ocolitoare, drum de descongestionare a traficului

relief slot (OM, hidr) canal de echilibrare (a presiunii)

relief valve (OM, hidr) clapetă / supapă / ventil de golire / de scurgere / de siguranță / de descărcare / de respirație

relief work (const) zidăriea; (pol, adm) activitate / acțiune pentru ajutarea şomerilor

relieve a reliefa, a releva, a scoate în relief / în evidență, a sublinia; a evidenția, a face să se remarce; (OM) a debloca; (chim) a degaja, a descărca; a reduce (şi tensiunile), a elibera, a uşura; (met) a calma; (mec, termo) a destinde, a relaxa

relieve (eccentrically) (mas-un) a detalona (excentric)

relieve of strain / tension $(\mathrm{mec}, \mathrm{OM})$ a reduce deformarea / tensiunea / efortul

relieving (mec, OM, chim) degajare, descărcare, reducere, descărcător; (el) gravare, reliefare; (mas-un) detalonare

relieving arch (const) arc de descărcare

relieving attachment / device (mas-un) dispozitiv de detalonat, (şi detaşabil) pentru strung

relieving lathe (mas-un) strung de detalonat

relight (fiz, termo) a (se) reaprinde, a aprinde din nou

re-line, reline (met, T) a recăptuşi, a căptuşi din nou, a reacoperi un cuptor / un lagăr; $(\mathrm{OM})$ a schimba materialul căptuşirii / de etanşare al presetupei, a monta cămaşa unei țevi / unui cilindru (de motor)

reline a bearing (met, $\mathrm{T}$ ) a turna din nou un lagăr / un cuzinet reline the clutch (auto, TH) a îmbrăca / a încărca din nou un ambreiaj

relining (met, termo) căptuşeală nouă (d. un cuptor, convertizor etc.)

relish (alim) savoare, gust (bun); aromă, parfum; condiment, mirodenie delicatese, bunătăti; a condimenta, a adăuga mirodenii, a face picant, a da gust (mâncării), a savura (un aliment), a avea gust bun; a fi apetisant / picant / plăcut

relishable (alim) savuros, gustos, apetisant, picant reload (cf, nav) a transborda; (mas-un, c) a reîncărca, a încărca din nou

relocate a localiza din nou, a re-aloca; a restabili (aşezarea unui obiect etc.); a da de urmă; a muta într-o locuință nouă; (adm, ec) a muta, a detaşa (d. un serviciu); a-şi schimba locuința / domiciliul; a-şi schimba locul de muncă / slujba

relocation relocalizare, găsire, precizare a aşezării; schimbare / mutare dintr-o locuință în alta, schimbare a domiciliului / locului de muncă, transfer(are)

reluct a refuza, a nu voi, a fi refractar; a nu manifesta entuziasm / bunăvoință; a face lucrurile fără chef / în silă

reluct against a (se) lupta cu / împotriva, a combate

reluctance neplăcere, repulsie, dezgust; şovăială, ezitare; împotrivire, opoziție, rezistență; (fiz, el) reluctanță (rezistența unui material la trecerea liniilor magnetice de forță)

reluctant nedoritor, fără / lipsit de tragere de inimă; şovăitor, ezitant; care se opune / se împotriveşte / rezistă

reluctive pressure transducer (metr, hidr) traductor de măsurare a presiunii, bazat pe efectul de reluctanţă a unui material

rely on / upon a se bizui / baza pe, a avea încredere în

rem (fiz, metr) rem, echivalent, röentgen, unitate de radiație / ionizare (absorbită de țesuturile umane): $1 \mathrm{rem}=0,01$ sievert $(\mathrm{Sv})$

remain ședere; rămăşiță; a rămâne; a sta, a întârzia; a zăbovi; a se menține, a rămâne (neschimbat / la fel); a continua; I yours truly rămân al dvs. sincer (ca formulă de închiriere) remain behind a rămâne în urmă

remain in force (pol, adm, jur) a rămâne în vigoare

remain in hiding a sta ascuns / camuflat

remainder rest, rămăşiță, ceea care rămâne; (ec, mat) rest, restanță; (ind chim, mediu) rest, reziduu, rămăşiță; (mat) termenul rest (al unei serii); (ec) stoc nevândut, a vinde la solduri; (jur) drept de moştenire (a unui titlu) 
remainder theorem (mat) teorema lui Bezout remaining slag (met) zgură reziduală remains $(p l)$ rămăşițe, resturi; (mediu, ind) reziduuri

remain within call / reach a rămâne in apropiere

remake a reface; lucru refăcut; reluare a unui subiect

re-man (nav) a (re)completa (d. echipaj, efectiv etc.)

remanence (fiz, el) remanență (cu referire la câmp magnetic), inducție remanentă

remanent (fiz) remanent; $(\mathrm{TH}, \mathrm{mec})$ rezidual

remanent contraction (met, mec) contracție reziduală / remanentă

remanent magnetization (el) magnetizare remanentă

remanufacture of waste papers (ind chim) prelucrarea maculaturii

remark observație, comentariu, remarcă; replică; notă, însemnare, notiță; a observa, a remarca, a băga în seamă; a declara, a spune, a afirma; a comenta; a replica; on / upon a face o remarcă / observație / un comentariu despre, asupra; a atrage atentia asupra

remarkable remarcabil, deosebit; ieşit din comun; uluitor, extraordinar

remarkableness caracter remarcabil / deosebit / excepțional / ieșit din comun

remarkably $(a d v)$ (în mod) remarcabil, deosebit (de); excepțional, uimitor; în cel mai înalt grad

remeasure (metr) a măsura din nou, a verifica măsurarea

remediable (mas, ind) remediabil; care se poate remedia; corijabil, care se poate corecta / îndrepta

remedial (med) vindecător, curativ; (autom, mas) care remediază / corectează, de îndreptare, de întreținere, de reparare

remedial maintenance $(\mathrm{TH}$, mas) mentenanță de remediere / după cum se cere / pentru înlăturarea / remedierea avariei / neprogramată

remedial measures (ec, TH) măsuri de îndreptare, remedii corective

remedy (med) remediu, medicament; (autom, mas) corectiv, măsură / mijloc de corectare / îndreptare; (jur) reparație, satisfacție, compensație, despăgubire; (TH, mas) toleranță; a remedia; a repara, a îndrepta; a corija, a corecta; (med) a vindeca

rem effect (metr, hidr) efect de presiune dinamică remelt (met) a retopi

remelted iron (met) fontă retopită / de a doua fuziune

remelted lead (met) plumb din a doua fuziune remelting (met) retopire

remelting furnace (met) cuptor pentru retopire remelting precess (met) proces de retopire remelt sugar (alim) zahăr de adaos (pt. cristalizare)

remember a-și aminti, a-şi aduce aminte de; a(şi) reaminti; a răsplăti, a da bacşiş; a memora, a învăța pe dinafară; a nu uita, a ține minte

remetal (met, T) a turna din nou compoziție pe un lagăr / cuzinet

remigration $(\mathrm{pol}, \mathrm{adm})$ repatriere

remind a aminti, a reaminti (cuiva)

reminder memento; aluzie; avertizare

remint (ec) a bate din nou (monedă); (mas-un) a ștanța din nou

remise (constr) remiză, depou; şopron; (jur) a ceda, a transfera, a înstrăina (o proprietate sau un drept)

remiss neglijent, nepăsător, indolent; (chim) diluat, dizolvat

remissable scuzabil, care poate fi iertat

remission (ec) scutire (de datorii); (jur) renunțare (la pretenții, drepturi) atenuare, diminuare, micşorare

remissive iertător; care diminuează / atenuează

remissly $(a d v)$ (în mod) neglijent; nepăsător; inexact, incorect

remissness neglijență; nepăsare; indolenţă; tărăgănare

remit a remite, a transmite; a expedia, a trimite (prin mandat); /ec) a plăti, a achita; (jur) a remite, a înainta (spre judecare), a repune în drepturi / în libertate; a scădea în intensitate; a scuti de; a (se) micşora, a domoli, a potoli; a (se) atenua

remittal (ec) anulare (a unei datorii)

remittance transmitere; expediere (prin mandat), bani expediați prin poştă; (ec) remiză

remittee persoană căreia i se remite ceva; destinatar, adresant

remittent intermitent, discontinuu; recurent

remitter remitent, expeditor (al unui mandat)

remnant rest, rămăşiță; (mediu) deşeu, reziduu, gunoi; urmă, vestigiu; bucățică, fragment, fărâmă; (ec) cupon

remodel (arh, const) a remodela, a reconstrui, a reconstitui; a reorganiza; $(\mathrm{TH})$ a reface (o lucrare), a da o soluție nouă

remodelling (mas-un) modificarea construcției (unei maşini); remodelare

remold (amer) remould (brit) a remodela, a reforma, a turna într-o formă nouă; (auto, ind chim) a reface striurile / relieful (unei anvelope) remote îndepărtat; de departe; izolat, singuratic, solitar; distant, rezervat; fără legătură / înrudire; separat; divergent; străin, necunoscut; (d. şansă) minim, slab, putin probabil; vag; prea abstract; (mas, autom, electr) dirijat / comandat de la distanță; teleghidat 
remote control (autom, fiz, el) teleghidare, telecomandă; reglare / control / manevră / comandă de la distanță; (cf) manevrare de la distanță a macazurilor şi a semnalelor; telecomandat, teleghidat

remote-control gear (autom, OM) instalații / mecanisme cu telereglare, mecanism pentru comandă la distanță

remote-controlled master switch (el, autom) întrerupător principal, telecomandat

remote-control switch (el) întrerupător de comandat de la distanţă / telecomandat

remote drive (electr, autom) telecomandă, acționare de la distanță

remote gear(-box) control (auto) comandă de la distanță, a cutiei de viteze

remote handling (autom) telecomandă

remote keyless entry (auto) deschidere cu telecomandă (a autoturismului)

remotely $(a d v)$ departe, în depărtare; de departe, din depărtare; vag, slab; în mică măsură; prea puțin (probabil)

remote manipulation manipulare de la distanță (a unei maşini, instalații, în zone periculoase / cu temperaturi înalte etc.)

remote measurement (metr, TH) măsurare de la distanţă, telemăsurare

remote setting up (metr) indicație față de la distanță, teleindicație, telereglare

remould a remodela, a re-forma, a turna într-o formă nouă, a rematrița; (auto, ind chim) a reface striurile / relieful (unei anvelope), cauciuc recondiționat / reşapat

remount a (se) urca / (se) sui din nou

removability (jur) amovibilitate; (OM, mas) mobilitate, posibilitate de înlăturare / schimbare

removable $(\mathrm{OM})$ detaşabil, mobil; amovibil; care poate fi schimbat / mutat / înlăturat; (jur) judecător amovibil

removable bottom $(\mathrm{OM})$ fund demontabil / amovibil / detaşabil (la un recipient etc.)

removable cylinder head (auto) chiulasă demontabilă / amovibilă

removable handle $(\mathrm{OM})$ mâner detaşabil / amovibil

removable ladder (OM, constr) scară mobilă

removable liner (auto, OM) bucşă / cămaşă de cilindru (amovibilă)

removable parts (mas, OM) piese de schimb / detaşabile / amovibile

removable rim (auto, $\mathrm{OM}$ ) geantă amovibilă

removal $(\mathrm{TH})$ mutare, deplasare, transportare; schimbare a domiciliului, mutare (din casă); îndepărtare, înlăturare, suprimare, evacuare, eliminare, scoatere (a deşeurilor); (el) transfer (la linii electrice); (ec, adm) destituire, concediere, demitere; transferare

removal by draining (hidr) înlăturarea prin drenare

removal justified (item / piece / unit) (articol / element de maşină / piesă) înlocuit(ă), înlocuirea fiind justificată de deteriorare (din cauza unui şoc, a uzurii etc.)

removal of cuttings (met) evacuarea materialului sfărâmat / tăit (la finisarea benzilor / profilurilor laminate)

removal of faults $(\mathrm{TH})$ înlăturarea / lichidarea defectelor

removal of nitrogen (met, chim) (tratament de) denitrurare; (chim) îndepărtarea / înlăturarea / scoaterea azotului dintr-un compus chimic)

removal of the load $(\mathrm{mec})$ descărcare / înlăturare a sarcinii

removal of shuttering (const) decofrare

removal of slag (met) scoatere / îndepărtare a zgurii

removal of stress $(\mathrm{TH})$ degajare a presiunii, detensionare

removal of work-hardening (met) eliminarea ecruisării, înmuiere

removal rate $(\mathrm{TH}$, mas) viteză / frecvență de înlocuire (exprimată și ca număr de articole / piese înlocuite într-un anumit interval de timp)

removal tool (mas-un, OM) sculă de extracție / de demontare

removal unconfirmed (item / piece / unit) (articol / piesă / unitate / modul) înlocuit(ă) nejustificat / fără a fi observat / analizat(ă) după demontare, deteriorare

removal unschedule (item / piece / unit) (articol / piesă / unitate / modul) înlocuit(ă) neplanificat (din cauza deteriorării, funcționării nesatisfăcătoare) şi care nu este prevăzut(ă) în programul mentenanței preventive

remove a muta, a mişca din loc; a înlătura, a scoate, a extrage, a (se) îndepărta, a elimina, a evacua, a curăța, a şterge; a transfera; (ec, adm) a destitui, a concedia, a demite; (pol) a aboli; (TH) a deplasa, a îndepărta, a transporta, a demonta; a suprima, a ucide; treaptă, grad, pas; distanță, interval; etapă, escală; generație, familie; mutare, transferare; (edu) promovare (la scoală), clasa intermediară; (alim) fel de mâncare; neam, spiță, stirpe; (med) a extirpa

remove air (met, $\mathrm{TH})$ a îndepărta aerul, a dezaera

remove a load (mec, TH) a înlătura o sarcină remove burrs (met) a debavura (piese turnate) 
remove by suction $(\mathrm{TH})$ a înlătura prin aspirație removed depărtat, îndepărtat; aflat la mare distanță; înlocuit, scos

remove dust $(\mathrm{TH}$, met) a înlătura praful, a desprăfui

remove faults $(\mathrm{TH})$ a înlătura / a lichida defecte / erori / greşeli

remove fins (met) a debavura

remove forms from concrete (const) a decofra

remove lead (met) a îndepărta plumbul

remover persoană care se mută / deplasează / îndepărtează; (chim) decapant, soluție pentru scos pete / îndepărtat vopseaua

remove slag (met) a evacua zgura

remove the oil (chim, mas) a curața de ulei, a degresa, a goli de ulei

remover (const, mas) utilaj de săpat; (mas-un) dispozitiv pentru scoaterea unei piese rupte (de exemplu, pentru scoaterea unui şurub prizonier)

remove ridges (met) a debavura (piese turnate)

remove rivets $(\mathrm{TH})$ a desface niturile

remove slag (met) a evacua zgura; a curăța de rugină

remove the spent grains (alim) a înlătura sâmburii din must

remove stress $(\mathrm{TH})$ a detensiona, a degaja presiunea

removing (mas, TH) demontare, înlăturare, îndepărtare

removing of the bones (alim) ciontolire, îndepărtare a oaselor

remunerate (ec) a remunera, a retribui, a plăti; (fig) a recompensa, a răsplăti

remuneration $(\mathrm{ec})$ remunerare, retribuție, retribuire, salarizare, plată, salariu; răsplată, recompensă

remunerative, remuneratory (ec) remunerator, rentabil, lucrativ, profitabil; convenabil, avantajos

rend $(\mathrm{OM}$, materiale) a (se) sfâşia, a sparge, a (se) rupe; a (se) despica, a (se) crăpa; sfâşiere, ruptură; crăpătură, despicătură

rend away from a despărți / rupe de

render a da; a reda; a expedia, a preda; a remite, a înmâna; a transmite; a face; a interpreta; a aplica, a unge, a topi; (ec) a livra, a plăti, a achita; a acorda, a atribui; a înapoia, a restitui; a face, a aduce în stare de; a contribui cu; a traduce, a interpreta; (const) a tencui; (alim) a topi (untura), a extrage prin topire; a limpezi; a acorda recompensă; (ec) plată; răsplată, recompensă

render alkaline (chim) a alcaliniza render difficult $(\mathrm{TH})$ a îngreuna / desfăşurarea unui proces

rendering dare, predare; acordare; refacere, prefacere, transformare; (ec) remitere, transmitere; (const) tencuială; (met) încărcare prin sudură; traducere, interpretare

rendering operative ( $\mathrm{TH}$, mas) punere / dare în funcțiune; dare / luare în exploatare

render into a traduce (într-o altă limbă)

render passive (met, chim) a pasiva

render proof $(\mathrm{TH})$ a proteja (de exemplu, contra focului, umezelii etc.)

render-set (const) a tencui de două ori; (cu) tencuială dublă; tencuit de două ori

rendition dare, predare; acordare; refacere, prefacere, transformare; traducere; transpunere, interpretare; (jur) extrădare

renew (const) a renova; ( $\mathrm{TH}, \mathrm{OM})$ a reconditiona, a restaura; a reface; a (se) reînnoi, a înlocui cu ceva nou; a repeta, a relua, a reitera; a continua; a reîncepe

renewable (mas, mas-un, OM) care se poate înlocui, amovibil / detaşabil, care poate fi refăcut

renewable element (hidr, OM) element filtrant regenerabil

renewable fuse (el) siguranță demontabilă / înlocuibilă

renewal, renewing reînnoire; inovație; (const) renovare; refacere, restaurare, recondiționare; repetare, reluare, reiterare

renew the air $(\mathrm{TH})$ a aerisi, a ventila

reniform $(\mathrm{OM})$ reniform, în formă de rinichi

renitence, renitency împotrivire / rezistență la forță; opoziție; caracter recalcitrant / refractar, recalcitrantă

renitent care se opune / împotriveşte forței; recalcitrant; refractar

rennet (alim) chiag (de la miel sau vițel)

Renn process (met, chim) proces Renn (de reducere directă)

renounce a ceda, a renunța la; a abandona, a nu recunoaşte; a se da bătut

renouncement renunțare; cedare; abandonare

renovate a reînnoi, a renova; (mas) a repara; (constr, artă) a restaura; a împrospăta, a înviora

renovation (constr) renovare, restaurare, reparație; (pol, adm) restaurație, reînnoire; împrospătare, înviorare

renovator inovator; înnoitor

rent $(\mathrm{OM}$, textile) ruptură, crăpătură, tăietură; falie; (textile) şliț; (OM) gaură; spărtură, fisură; dezbinare; (ec) chirie, rentă, arendă, arendare, închiriere; a închiria; a lua / da în arendă, a arenda; a fi închiriat / arendat 
rentable (ec) de închiriat / arendat

rental $(\mathrm{ec})$ arendă; cuantumul arendei / rentei funciare; închiriere, luare cu chirie; listă cu arendaşi rental library (amer) bibliotecă de împrumutat cărți (cu taxă sau abonament)

renter $(\mathrm{ec})$ persoană / organizație care ia o casă cu chirie; arendaş, persoană / organizație care ia în arendă

rent-free (ec) scutit de plata chiriei / arendei

rent-roll (ec, adm) registru al arendaşilor / impozitelor pe proprietăti funciare / veniturilor din arendă; carte funciară

renumber a renumerota, a numerota din nou, a schimba numerele (de inventar etc.)

renunciant persoană / organizație care renunță la ceva; cu caracter de renunțare la un drept etc.

renunciation renunțare (la un drept etc.)

renunciative care renunță / abandonează; referitor la renunțare

reoccupation reocupare

reoccupy a reocupa

reoperate (mas-un, $\mathrm{TH}, \mathrm{OM}$ ) a prelucra din nou, a repara prin prelucrare la altă dimensiune

reorder a rearanja, a pune din nou în ordine, a schimba ordinea; a schimba ordinul / comanda pentru, a comanda din nou; rearanjare, reordonare, reorganizare; comandă nouă; $(\mathrm{adm})$ ordin schimbat / modificat

reorganization $(\mathrm{ec}, \mathrm{adm})$ reorganizare, restructurare

reorganize (ec, adm) a reorganiza, a restructura

reorient, reorientate a reorienta, a schimba orientarea; a readapta; a schimba concepțiile / ideile (cuiva)

reorientation reorientare, schimbare a orientării / atitudinii / conceptiei

reoxidate (met, chim) a (se) reoxida, a oxida din nou

reoxidation (met, chim) reoxidare

repack $(\mathrm{OM})$ a înlocui un material de etanşare în presetupă

repaint a repicta; a revopsi, a vopsi din nou, a reface culoarea; revopsire; lucru revopsit

repair $(\mathrm{TH}$, mas) reparație, reparare, depanare (şi $p l: \sim \mathbf{s})$; de / pentru reparație, de rezervă; under în reparație; întreținere; $(\mathrm{OM})$ piesă de rezervă; stare, condiție; $(\mathrm{TH})$ a repara, a depana, a drege, a reconditiona; a remedia; a face ca nou; (constr) renovare, a renova; a se înapoia (la), a se întoarce (la), a reveni (la); a îndrepta, a remedia, a repara (o nedreptate etc.); (med) a tămădui, a vindeca

repairability (mas) capacitatea / proprietatea (unui sistem tehnic) de a fi reparat repairable (mas, OM) reparabil; care poate fi îndreptat / corijat, corijabil, corigibil

repairable item / unit (OM) piesă / unitate / modul reparabil(ă)

repair box (auto) trusă de scule pentru reparații; (mas, TH) ladă cu trusă de scule pentru reparații repair cycle (time) $(\mathrm{TH}$, mas) ciclu / timp între reparații, interval de timp din momentul demontării până în momentul remontării sau depozitării (în condiții gata de lucru)

repair equipment (auto, OM) trusă de scule pentru reparații

repairer (ind) reparator, depanator

repairing $(\mathrm{TH})$ reparație, depanare, care (se) repară

repair(ing) shop (mas-un, $\mathrm{TH}$ ) atelier / secție de reparații / de întreținere

repair kit (auto, mas-un, OM) trusă de scule pentru reparații

repairman (cf, met, ind) lăcătus de revizie / de reparații; (auto) mecanic auto

repair of castings (met) corectarea piesei turnate, încărcare prin sudură a unei piese turnate (pt. corectarea / eliminarea unui defect)

repair outfit (auto, OM) trusă de scule pentru reparații

repair part / piece (mas, mas-un, OM) piesă de schimb / de rezervă

repair service (mas, $\mathrm{TH}$ ) serviciu de întreținere

repair ship (nav) atelier plutitor

repair shop (ind, $\mathrm{TH}$ ) atelier / secție de reparații / depanare

repair size (auto, $\mathrm{TH}$ ) cotă de reparație

repair stand (auto) suport / stand de reparație / de montaj

repair tag (mas-un, mas, TH) fişă de indicare a reparațiilor de executat

repair work $(\mathrm{TH})$ lucrări de reparații

repair workshop $(\mathrm{TH}$, ind) atelier de reparații

repaper (constr) a tapeta din nou, a reface tapetul

reparation (ec) despăgubire, compensație; $(\mathrm{TH})$ remediere

repartition repartitie, repartizare, distributie

repass a trece din nou / încă o dată, a reveni, a se întoarce tot pe acolo; a relua (un proces tehnologic)

repay (to) a restitui, a da înapoi; (ec) a (se) plăti (o obligație), a (se) achita; a înapoia; (fig) a răsplăti, a recompensa, a acorda o răsplată

re-pay (ec) a plăti încă o dată, a plăti din nou repayable (ec) rambursabil, care poate fi plătit / achitat; care poate fi răsplătit

repayment $(\mathrm{ec})$ rambursare, plată, restituire, achitare; răsplată, recompensă 
repeal (jur, pol) a abroga, a revoca, a anula; a contramanda; (jur, adm) abrogare, revocare, anulare; contramandare

repealable (jur) care poate fi respins, uşor de respins; (jur, adm) revocabil, care poate fi revocat / anulat

repeat a (se) repeta, a recapitula; (inf) a repeta periodic; (ec) a reînnoi o comandă; a spune acelaşi lucru, (comandă pentru) mărfuri similare cu transportul anterior; a reveni, a se produce / întâmpla încă o dată; repetare, reluare; (edu, univ) student repetent

repeatability (metr) repetabilitate, reproductibilitate, fidelitate

repeatability error (metr) eroare de repetabilitate / reproductibilitate

repeatable repetabil, care poate fi repetat, care se poate repeta

repeated (mat) repetat

repeated bending stress strength (mec, metr) limită de rezistentă la oboseală la încovoiere alternativă

repeated bending stress test (mec, metr) încercare / test de rezistență la oboseală de încovoiere

repeated direct stress test (mec, metr) încercare / test la întindere / tracțiune repetată

repeated dynamic stress test (mec, metr) încercare / test la tensiuni dinamice repetate

repeated-impact bending strength (mec, metr) limită de rezistență la oboseală, la sarcini dinamice alternative, de încovoiere

repeated-impact strength (mec, metr) rezistență la oboseala prin loviri / impact repetat(e)

repeated-impact tension / tensile test (mec, metr) încercare / test la oboseală prin tracțiune $\mathrm{cu}$ şoc

repeated-impact test (mec, metr) încercare / test la oboseală prin impact repetat (nu se specifică)

repeated stress $(\mathrm{mec})$ sarcini / tensiuni repetate (tipul de solicitare: tractiune, încovoiere etc.)

repeated stress failure (mec, OM) rupere / distrugere (a unui element de maşină) cauzată de oboseală, în urma aplicării sarcinilor repetate (şi în domeniul oligociclic)

repeated-stress test (mec, metr) încercare / test la tensiuni repetate

repeated tension test (mec, metr) încercare / test la tracțiune / întindere repetată

repeated test (met) încercare / test repetat (pt. îndeplinirea procedurii de testare, pt. confirmarea rezultatelor sau pt. că nu a fost concludent etc.) repeated torsion test (mec, metr) încercare / test la răsucire / torsiune repetată (la cabluri electrice etc.), nu neapărat în domeniul de oboseală)

repeated-torsion test $(\mathrm{mec})$ încercare la oboseală prin răsucire / prin torsiune alternativă

repeated-transverse-stress test (mec, metr) încercare / test la încovoiere repetată (la cabluri electrice etc.), nu neapărat în domeniul oboselii)

repeater element care se repetă; (mat) fracție periodică; (autom) repetitor, amplificator, releu, emițător; (nav) repetitor (pavilion, girocompas); ceas cu repetiție; (el, electr) amplificator repeating decimal (mat) zecimală recurentă / care se repetă

repel (ec) a respinge o ofertă; a para, a arunca înapoi; (fig) a respinge, a nu accepta, a nu primi

repellent to $(\mathrm{TH})$ care respinge; respingător; (materiale) impermeabil, impenetrabil

repel to a provoca repulsie

repercussion repercusiune, urmare, consecință (şi negativă); (fiz) reverberație, reflecție, răsunet, ecou; contralovitură

repercussive cu caracter de repercusiune / de consecință

repertory repertoriu, catalog; depozit, magazie; tezaur

repetend (mat) perioadă (la fracțiile periodice), cifră care se repetă (la numere zecimale); clişeu, slogan

repetition repetiție, repetare, reluare, reiterare; (edu) învățare de pe rost

repetitional, repetitory repetat, recurent; repetitiv, cu caracter de repetiție; frecventativ

repetition lathe (mas-un) strung de copiat / de prelucrat în serii mari (piese mici)

repetition of dynamic stress $(\mathrm{mec})$ repetare a tensiunii dinamice (rezultată din şocuri repetate în functionare)

repetition of stress (mec, metr) solicitare de durată

repetition rate (autom) frecvență de repetitie de repetare / de bază; (inf) cadență / regim de repetitie; (el) procentaj de repetare

repetition work $(\mathrm{TH})$ fabricare în serie repetitive repetitiv, care se repetă, repetițional

repetitive error (autom, metr) eroare repetitivă / care se repetă

repetitive instruction (autom, inf) instrucțiune iterativă

repetitive intrument (metr) aparat echivalent / de schimb

repetitive process (inf, autom) proces iterativ / repetitiv 
repetitive-stress test (mec) încercare / test la tensiune repetitivă

rephosphorisation (met, dim) refosfatare

replace (by / with) a repune, a pune la loc, a restitui, a înapoia, a reda; a înlocui (cu), a schimba (cu)

replaceable $(\mathrm{TH}, \mathrm{OM})$ de înlocuit, înlocuibil, care poate fi înlocuit; interschimbabil

replaceable (cutting) bit (mas-un) tăiş detaşabil / demontabil / înlocuibil

replace material material de înlocuire, înlocuitor replacement înlocuire, substituire; $(\mathrm{TH})$ schimbare; aprovizionare; reînnoire, înlocuitor, piesă de schimb, rezervă; reașezare, repunere, înlocuire (şi a unei piese)

replacement engine (auto, mas, mas-un) motor de schimb

replacement instruments $(\mathrm{TH}$, metr) instrumente / aparate interschimbabile / uşor de adoptat la alte sisteme

replacement part (mas, OM) piesă de schimb / interschimbabilă / de rezervă

replacement reserve part (piece) (auto, mas, $\mathrm{OM}$ ) piesă de rezervă / de schimb

replace part (el, OM) piesă de schimb / de rezervă

replace stand (met) cajă de rezervă / de schimb

replanish a umple; a completa; a întregi; a umple din nou; (nav) a face plinul

replenishing solution (met, chim) soluție de rezervă / de înlocuire / de completare (şi la decapare)

replanishment (hidr, T) completare, întregire

replant (agr) a planta din nou, a replanta

replantation (agr) replantare

replay a rejuca, a juca din nou; (c) a relua; reluare

replenish (hidr, T) a reumple, a umple din nou; with a completa cu, a aproviziona din nou cu

replenishment (hidr, T) reumplere, completare; (ec) reaprovizionare

replevin (jur) recuperare / recăpătare / reluare a bunurilor sechestrate / ținute ca gaj, hotărâre de scoatere de sub sechestru

replevy (jur) a scoate de sub sechestru; a redobândi, a recupera, a recăpăta (bunurile sechestrate)

replica copie; machetă; reproducere; duplicat; facsimil; (mas-un) model, sablon

replicate a face o copie / reproducere după; a copia; (agr) întors / pliat către sine

replication (metr) reproductibilitate (la teste); răspuns, replică

replunge a se arunca, a plonja reply răspuns (şi scris); replică, răspuns; a răspunde, a replica; (mas) semnal de răspuns / de confirmare

reply coupon cupon (poştal) de răspuns

reply-paid cu răspuns plătit (la poştă)

repolish (mas-un) a (re)finisa prin lustruire, a poliza din nou, a lustrui din nou

repone (jur, adm) a reabilita, a reintegra (într-un post)

report (on) declarație; comunicare; raport; ştire, informare; reputație, faimă, renume; reportaj; foc de armă, detunătură, împusçătură; (autom) semnalizare; (ec) dare de seamă, proces verbal, raport, protocol; (despre / asupra) (met) detonație; zgomot de explozie; a comunica, a anunța, a referi, a raporta, a aduce la cunoștință; a relata, a expune; a indica; a face un raport / o dare de seamă asupra / despre; on, upon a informa, a da informații despre, a face un raport despre; a face un reportaj; a se prezenta (la serviciu, superiorului); a bill (pol) a face un raport asupra unui proiect de lege

reportable care poate fi raportat / relatat / comunicat

repose odihnă, calm; somn; (mec) repaus; a sprijini; a se întinde, a se bizui; a sta culcat; a se odihni; a culca, a aşeza

reposit a depune, a pune, a așeza (într-un loc sigur)

repository depozitar; (constr) depozit, magazie; antrepozit; muzeu; cavou

repot (agr, bot) a sădi o floare în alt ghiveci, a răsădi, a muta dintr-un ghiveci în altul

repoussé (TH) ştanțat, matrițat, stampat; gofrat; obiect ştanțat / matrițat / stampat / gofrat; (mas-un) piesă obținută prin ştampare; cu suprafață în relief

repoussé work $(\mathrm{TH})$ lucrătură în relief / gofrată, gofraj

repp (textile) rips

repped (textile) ripsat

represent (ec, jur) a reprezenta; a înfătişa, a prezenta; a simboliza, a semnifica, a reprezenta, a denota; a descrie; (teatru) a interpreta (un rol)

reprezentable reprezentabil, care se poate reprezenta

representation (mat) reprezentare, imaginare; relatare, expunere; reproş, mustrare; observație

representation of fasteners $(\mathrm{OM})$ reprezentarea organelor de asamblare demontabile

representative reprezentativ; caracteristic, tipic; ilustrativ; care simbolizează / reprezintă; reprezentant, imputernicit; trimis; exemplu / eşantion reprezentativ, mostră 
representative feedback control system (autom) sistem de autoreglare (cu feedback, cu buclă de reglare)

representative sampling $(\mathrm{TH})$ preluare de probe reprezentative, preluare periodică de probe

representative shape (materiale, OM) formă reprezentivă / tipică (şi la pulberi, amestecuri solide, elemente de maşini etc.)

representative value $(\mathrm{ec})$ valoare proprie

re(-)press (met, TH) a retuşa la presă; a presa după şablon, a reimprima

repressing (materiale, $\mathrm{TH}$ ) represare, recomprimare

repressuring $(\mathrm{TH}$, hidr) restabilirea / refacerea presiunii, represurizare

reprocessing reprocesare, reprelucrare, prelucrare din nou; reîmprospătare; (ind chim) regenerare; reînnoire; (met) prelucrare, utilizare, preparare, concentrare (a minereurilor)

reprieve (jur) a acorda o suspendare a sentinței; (ec) a amâna, a păsui, a acorda un termen (unui debitor); amânare, păsuire (în sens nedorit)

reprint a retipări, a reedita; retipărire, reeditare, republicare; ediție nouă; extras

reprise (ec) dobândă anuală

reprobate a dezaproba, a condamna; a respinge, a refuza

reprobation reprobare, dezaprobare

reproduce $(\mathrm{TH})$ a reproduce, a produce din nou, a copia; a se multiplica (şi d. un text), a relua, a copia, a repeta; a reînnoi, a reface, a prezenta din nou; a se reproduce, a se înmulți

reproducibility (metr) reproductibilitate (şi a testelor / condițiilor), caracter reproductibil; posibilitate de reproducere / refacere / reeditare; repetabilitate

reproducible $(\mathrm{TH})$ reproductibil, care poate fi reprodus

reproducible results $(\mathrm{TH}$, metr) rezultate reproductibile

reproducibly $(a d v)$ permițând reproducerea / repetarea; (într-un mod) reproductibil / repetabil / care permite reproducerea / repetarea

reproducing (mas-un) prelucrare după şablon; (birotică) reproducere, copiere

reproducing lathe (mas-un) strung de copiat

reproductibility $(\mathrm{TH}$, metr) reproductibilitate (şi a testelor / condițiilor)

reproductibility error (metr) eroare de reproductibilitate (d. rezultatele testelor, condiții etc.)

reproduction $(\mathrm{ec})$ reproducție; $(\mathrm{TH})$ reproducere, multiplicare, înmulțire; copie

reproductive (agr) reproducător, de reproducere / înmultire; reproductiv reprogramming (inf, c) reprogramare

reproof (materiale, hidr, T) a scoate o nouă probă; (textile) a impermeabiliza din nou, a reimpermeabiliza

reprovision (ec) a reaproviziona, a reface stocul / proviziile pentru

republication republicare, reeditare, retipărire

republish a republica, a reedita, a retipări

repudiate a respinge

repudiation respingere; (ec) rebutare; refuz de acceptare la recepționare

repulse (ec) a refuza / a respinge (o cerere); a dezminți; respingere, refuz

repulsion, repugnance (auto, mil) recul; (fiz, $\mathrm{mec})$ respingere, repulsie, recul; şoc, contralovitură

repulsive, repugnant (fiz) repulsiv, de respingere

repulsiveness (fiz) forță de respingere

repuchase (ec) a recumpăra, a re(a)chiziționa; recumpărare, re(a)chiziționare

reputable respectabil, onorabil, cinstit; care se bucură de o reputație bună

reputation reputație, renume, bun nume; celebritate

repute faimă, renume, reputație, a avea reputația de; of (good) $\sim$ reputat; of ill $\sim$ de reputație proastă, rău famat

reputed respectat; celebru; presupus, ipotetic, prezumtiv

reputed pint (alim, ec) sticlă de bere cu capacitate declarată / reglementată

reputed quart (metr) v. quart

request apel, cerere; at / on / upon la cerere; exigență, petiție, reclamație; dorință; revendicare, pretenție; întrebare, interpelare; a cere, a solicita; a pretinde; a ruga; a invita

request slip formular de cerere (şi la bibliotecă)

request stop (autom, inf) oprire arbitrară / facultativă, oprire la cerere

require a solicita; a cere, a reclama, a pretinde; a insista asupra; a necesita, a avea nevoie de; a impune, a obliga

required output (el) putere cerută (la ieșire)

required work (mas, mec) putere consumată, lucru mecanic necesar

requirement cerere, cerință, revendicare, pretenție; necesitate, nevoie, trebuință; condiție de bază, premisă; exigență; (ec, mat) condiție (necesară); (mec) solicitare; dorință, rugăminte

requisite (to) (adj) cerut, necesar, indispensabil (pentru); lucru necesar / indispensabil; condiție / premisă indispensabilă, cerință; (mat) necesar; rechizite; $\sim \mathbf{s}(p l)$ rechizite 
requisite power (el, mas) putere necesară / cerută (pt. funcționare)

requisition (ec) cerere; solicitare; comandă; exigență; rechiziţie; (ec, adm, pol) revendicare, ordonanță, ordin, prescripție oficială; a rechiziționa

rerail (cf) a repune pe şine

re-read a reciti, a citi încă o dată

re-roll (met) a finisa laminarea, a lamina din nou; a re(-)rolui, a rolui din nou (şi d. particule de uzură)

re-rolling (met) relaminare, dresare

re-route (auto, transp) a îndruma pe altă rută, a schimba ruta / traseul

re-routing (auto, transp) schimbare a rutei / traseului / itinerariului

re-run(ning) (ind chim) redistilare, recirculare; (inf) reluare a unui program, executare din nou

res, RES (metr, c) simbol pentru „resolution”, o unitate definită ca numărul de puncte sau pixeli pe milimetru într-o imagine: RES $1=$ 25,4 puncte pe inch / tol (dpi)

resale (ec) a revinde, revânzare (a unui obiect cumpărat)

rescind (jur, adm, pol) a anula, a abroga, a revoca

rescission (jur, adm, pol) anulare, abrogare, revocare

re-scrape (mas-un) a răzui din nou, a finisa prin răzuire

rescue salvare, scăpare; eliberare; ( $a d j)$ salvator, de salvare; a asalva, a scăpa de

resque corps / crew ( $\mathrm{TH}$, mil, nav) echipa de salvare

rescue work ( $\mathrm{TH}$, nav) acțiuni de salvare

resealing pressure $(\mathrm{OM}$, hidr) presiune interioară de etanşare a unei supape, după care a fost închisă, presiune internă pe elementul de etanşare, care asigură deformarea / presarea garniturii fără scurgeri

research cercetare (ştiințifică), investigare, studiu, căutare; $(\mathrm{TH})$ cercetare, explorare; a cerceta, a studia, a explora, a investiga, a ancheta

researcher, reseach worker cercetător (ştiințific), investigator

research engineer $(\mathrm{TH})$ cercetător

research institute $(\mathrm{TH})$ institut de cercetări

research method $(\mathrm{TH})$ metodă de cercetare

research octane number (RON) (auto, chim) cifră octanică determinată după metoda de cercetare; v. road octane number

research work (muncă / lucrare de) cercetare (ştiințifică) reseat a reaşeza, a reinstala, a instala din nou; a repara (un scaun); a se aşeza la loc, a-ți relua locul

reseating (mas-un) frezare / rectificare a scaunelor de supapă (la reparații, recondiționări)

resell (ec) a revinde, a vinde din nou

resemblance to / between of asemănare / similitudine cu / între; imagine, reprezentare

resemblant, resembling to asemănător, similar $\mathrm{cu}$

resemble to a semăna, a aduce cu, a fi asemănător / similar cu

resembling lye (met) leşietic

reservable care poate fi reținut / rezervat / păstrat

reservation rezervă; rezervare, reținere; restricție, limitare; (geogr, adm) rezervație naturală; rezervat; (ec) rezervă, reținere; a rezerva; (met, hidr) a menține deschis

reserve rezervă; stoc, provizii; (adj) de rezervă, de schimb; a rezerva, a reține (şi o cameră la hotel); a cumpăra, a reține (bilete etc.): for / to a pune deoparte, a păstra, a-şi rezerva pentru; a nu se pronunța, a sta / rămâne în rezervă; (sport) jucător de rezervă

reserve curency $(\mathrm{ec})$ rezerve monetare (ale unei bănci), acoperire, garanție

reserved rezervat, reținut; păstrat, pus deoparte; rezervat, reticent; închis, necomunicativ; tăcut, retras

reservedly $(a d v)$ cu (oarecare) rezerve / rețineri; cu reticență; cu prudență

reserve energy $(\mathrm{OM}, \mathrm{mec})$ capacitate (exprimată ca energie) a unui amortizor de a accepta suprasarcini /care nu au fost incluse în proiectare)

reserve of buoyancy (nav) rezervă de flotabilitate

reserve part $(\mathrm{TH}, \mathrm{OM})$ piesă de schimb / de rezervă

reserve power $(\mathrm{mec})$ rezervă de energie

reserve price (ec) preț minimal / inițial / de pornire (la o licitație, la bursă)

reserve protection (el) protecție de rezervă

reserves $(\mathrm{ec})$ rezerve, aprovizionare

reserve source of power (mas) rezervă de putere

reserve tank (auto, OM) rezervor suplimentar / auxiliar

reservoir $(\mathrm{OM})$ rezervor (de colectare), bazin; (amer) lac de acumulare (la o hidrocentrală); (ec) depozit, magazie; (geol) zăcământ, material colector, rocă colectoare; (hidr) rezervor, bazin, recipient colector, reținere; (termo) cazan; (ec) rezervă, provizii, stoc; (fig) izvor, sursă 
reservoir cap (auto, OM) buşonul rezervorului reservoir contents gauge (metr) indicator de conținut (al rezervorului)

reservoir ladle (met) oală de turnare cu dispozitiv de amestecare

reservoir magazine (autom, mas-un) buncăr vertical pentru piese brute (la alimentarea maşinilor-unelte automate)

reset (mas, autom) repunere / restabilire / corectare (automată); (autom) readucere la zero; (el) revenire; a repune, a restabili; a potrivi (un ceas); (mas) a încadra, a monta (din nou), a reaşeza; (mas-un, met) a reajusta; (inf, c) resetare, a reseta; a reinstala (si un program), a reîncadra; a tăinui (obiecte furate); a adăposti un criminal urmărit; (mas, TH) a monta, a regla (prevăzut în funcționare) (din nou)

reset action (c, autom) acțiune de resetare

reset cycle (inf) a readuce indexul ciclului la valoarea inițială, ciclu de resetare

reset time (autom, mas, mas-un) durată de reglare / de revenire / de retur / de restabilire

resettle a repune, a restabili; a potrivi (un ceas); a (se) reaşeza; a (se) reinstala; a (se) stabili din nou; a se fixa din nou

resettlement restabilire, reinstalare

re(-)setting (mas) reaşezare; (autom, metr) reglare repetată, readucere la zero

resetting (auto, autom) resetare

resetting cam $(\mathrm{OM})$ camă de reglare; (el, $\mathrm{OM})$ camă readucătoare

reshape $(\mathrm{TH})$ refacerea / reconstruirea profilului initial; a reface, a forma din nou, a remodela; a prelucra; a reorganiza; a reprofila; $(\mathrm{OM}$, mas-un) a corecta profilul transversal

resharpen (mas-un) a ascuți, a reascuți

re-shearing (met, nav) croire de precizie a tablelor, cu foarfecele

reship (nav, transp) a reîmbarca; a reexpedia reshipment (nav, transp) reîmbarcare, reexpediere reside a locui, a domicilia; (chim) a precipita reside in a caracteriza, a aparține, a fi inerent / propriu; a ține de

residence reşedință, domiciliu; domiciliere, sedere; perioadă de domiciliere; (const) locuință; (chim) sediment, depunere, precipitat

residency (amer) (med) stagiu de specializare

resident rezident; inerent, propriu (c) program permanent în memoria computerului

residential estate (const) teren parcelat / parcelabil, destinat constructiilor de locuinte: parc (de constructiii)

residentship rezidență, domiciliere; domiciliu, reşedință residual rezidual, remanent, rezidual; restant; (mat) rămas ca rest (după scădere); lăsat ca rămăşiţă; rămas nelămurit / neexplicat

residual alkalinity (alim, chim) alcalinitate finală / reziduală

residual asphalt (ind chim) asfalt rezidual residual austenite (met) austenită reziduală residual blue (fiz) lumină albastră a lui Tyndall residual carrier (fiz, autom) purtătoare reziduală de modulație

residual chlorine (ind chim) clor rezidual

residual clay (geol) argilă primară / diluvială de pantă

residual coke (met) cocs rezidual

residual deflection (autom, metr) deviaţie (de) la punctul de zero, eroare a punctului de zero

residual deformation (mec) deformare remanentă / reziduală

residual deposits (ind, mediu) depozite remanente, depozite reziduale

residual elasticity (mec) elasticitate remanentă

residual elongation (textile, materiale) alungire reziduală / remanentă

residual error (autom, metr) eroare reziduală / remanentă / experimentală

residual excitation (fiz, el) excitație remanentă

residual flux density (fiz) inducție remanentă, remanență

residual fraction (ind chim) coadă de distilare, fracțiune finală de distilare

residual fuel (termo) combustibil / carburant rezidual; (chim) carburant neevaporat după distilarea petrolului

residual gas (ind chim, met) gaz rezidual, gaz(e) remanent(e) / necondensabil(e)

residual heat (fiz, termo, $\mathrm{TH}$ ) căldură reziduală

residual magnetisation (metr, fiz) magnetizare remanentă

residual mass curve (hidr) curbă integrală a abaterilor de la normă (în hidrologie)

residual modulation (fiz, autom) nivel de zgomot al undei purtătoare

residual nucleus (mat) nucleu-produs

residual oil (ind chim) reziduu de distilare

residual pin (fiz) pastilă antiremanentă

residual plate (fiz) pastilă antimagnetică / antiremanentă

residual product $(\mathrm{TH}, \mathrm{ec})$ produs secundar residual range (fizică atomică) parcurs rezidual

residual ray (fiz) rază reziduală

residual relay (el) releu funcționând în punctul nul al fazei

residual shrinkage (materiale, $\mathrm{TH}$ ) contractie remanentă

residual soil (geol) eluviu 
residual strain (const, mec) deformare remanentă / reziduală

residual stess (const, mec) tensiune internă / remanentă / reziduală

residual stud (el) pastilă antiremanentă

residual tack (chim, T) adezivitate reziduală / uzată

residual time constant (mas, autom) constantă naturală / proprie de

residual tolerance $(\mathrm{TH})$ toleranță reziduală

residual water $(\mathrm{TH}$, mediu) apă reziduală

residuary rezidual, restant

residuary product $(\mathrm{TH}$, mediu) produs din deşeuri / reziduuri

residue, residuum $(p l)$ residual (chim) reziduu, reziduuri, sediment, depunere, precipitat; (mat) rest; (met) clasă de resturi, şlam; (TH) reziduu; rest, rămăşiță; (alim) drojdie; sediment; (ec) rămăşiță, excedent, sold

residue from combustion (auto, termo, chim, T) reziduuri de ardere / de combustie

residue oils (ind chim) reziduuri petroliere, păcură

residue on ignition (termo, chim) reziduuri la aprindere

residuum (alim, $\mathrm{TH}$, mediu) reziduu, rest, sediment, drojdie

resign a demisiona din (un post etc.); a renunța la, a abandona; to a ceda, a se resemna; from (ec, adm) a demisiona, a-şi da demisia

re-sign (ec, adm) a semna / iscăli din nou

resignation demisie; (jur) renunțare (la un drept); abandonare; resemnare

resigned resemnat; (ec, adm) demisionat, demisionar

resile (mec, $\mathrm{OM}$ ) a sări înapoi, a ricoşa, (d. un corp elastic) a-şi reveni (la forma inițială); a-şi relua forma; (fig) a-şi reveni, a se reface (după o boală etc.)

resile from (ec) a rezilia (un contract etc.), a-şi infirma / retracta / tăgădui (o decizie etc.)

resilience (auto) şoc, hop, zdruncinătură; (fiz) recul; (mec) reziliență, elasticitate; revenire

resiliency $(\mathrm{mec})$ reziliență

resilient (fiz, mec) rezilient, rezistent la compresiune fără deformare permanentă vizibilă sau rupere; elastic; (fig) optimist; plin de viață

resilient coupling (mas) cuplaj elastic

resilient gearing (el, OM) angrenaj elastic

resilient steering wheel (auto) volan de direcție, elastic

resin (ind chim) răşină; colofoniu, sacâz; smoală; catran; gudron; răşină (naturală, de brad etc.)

resinaceous (silv, chim) răşinos

resinate (ind chim) (substanță) rășinoasă, a preschimba în răşină, a polimeriza resin-cored solder (for pipes) (met) aliaj de lipit, „fludor” cu răşină (pentru țevi)

resineferous (chim) răşinos, cu conţinut de rășină, care produce rășină

resin-free (chim) lipsit de răşini, fără (conținut de) răşini

resinic (chim) răşinos, cu conținut de răşină

resinification (chim, $\mathrm{TH})$ transformare în răşină, rezinificare

resiniform (chim) de consistența / compozitia / calitatea răşinii

resinify (chim) a transforma în răşină, a rezinifica

resin matrix composite (plast) compozit cu matrice de răşină / de polimer

resinoid (chim) (substanță) rășinoasă sau similară cu o răşină

resinous (chim) răşinos, cu conținut de rășină

resintering (met, plat) resinterizare

resist a opune rezistență; a rezista, a se împotrivi; (chim) substanță de protecție, înveliş / strat protector

resistance (mas, materiale) rezistenț̆a împotrivire, opoziție; durabilitate; permanență; fixitate; (el, mec) rezistență, reostat

resistance-arc furnace (met, el, termo) cuptor electric cu arc, cu rezistență (cu închiderea circuitului prin vatră)

resistance box (el, metr) cutie de rezistențe

resistance bridge (el, metr) punte de rezistente

resistance butt welding (el, met) sudare cap-lacap, prin rezistență

resistance coil (el) bobină rezistivă

resistance coefficient (hidr, fiz, mec) coeficient de rezistență

resistance-coupled (el) amplifier amplificator $\mathrm{cu}$ rezistentă

resistance-coupling (el) cuplaj galvanic / rezistiv resistance diagram $(\mathrm{mec}, \mathrm{el})$ diagramă a tensiunilor / rezistențelor

resistance drop (el) cădere a tensiunii odată cu curentul / cu intensitatea, scădere a rezistenței electrice; (mec) scădere a rezistenței (mecanice) resistance flash(-butt) welding (el) sudare (electrică) (cap-la-cap) cu scântei / prin topire intermediară

resistance force (hidr) forță de rezistență hidrodinamică; (mec) forță de rezistență

resistance force near wall (hidr, mec) forță de rezistență lângă perete (d. pentru pulberi, la miscare în conducte)

resistance furnace (met, el, termo) cuptor cu rezistentă electrică

resistance head (hidr) presiune echivalentă / care corespunde cu rezistența în conducte resistance loss (el) pierderi ohmice / pe rezistență 
resistance moment (mec) moment de rezistență resistance movement mişcare de rezistență resistance of a machine $(\mathrm{mec})$ stare de inerție a unei maşini

resistance of motion (mec) rezistență la misçare resistance of a whole circuit (el) rezistenţă totală / a întregului circuit

resistance pyrometer (el, metr) pirometru / termometru cu rezistență

resistance seam welding (met) sudare continuă prin rezistență (cu role / în linie)

resistance thermometer (metr) termometru cu rezistență electrică

resistance to abrasion ( $\mathrm{T}$, mas-un) rezistență la uzură prin frecare / la abraziune

resistance to atmospheric corrosion (chim, T, $\mathrm{OM}$ ) rezistență la coroziune atmosferică

resistance to ageing (plast) rezistență la îmbătrânire

resistance to bending $(\mathrm{mec})$ rezistență la încovoiere

resistance to breaking $(\mathrm{mec})$ rezistență la rupere

resistance to buckling (mec) rezistență la flambaj

resistance to cold (termo) rezistență la frig / la îngheț

resistance to compression (mec) rezistență la compresiune

resistance to corrosion (met) rezistență la coroziune

resistance to crushing (mec) rezistență la strivire / la spargere / la zdrobire

resistance to deformation (mec, met) rezistență la deformare

resistance to displacement $(\mathrm{mec})$ rezistență la alunecare / la deplasare

resistance to erosion (mec) rezistență la eroziune resistance to expansion and contraction $(\mathrm{mec})$ rezistență la dilatare şi la contracție; stabilitate de volum

resistance to fatigue-corrosion (met) rezistență la oboseală şi coroziune / la oboseală în mediu corosiv / oboseală corozivă

resistance to freezing (ind chim) rezistență la solidificare (a sticlei)

resistance to heat (ind chim, met) stabilitate termică, rezistență la cald

resistance to high temperature (materiale) rezistență la temperaturi înalte

resistance to impact (mec, materiale) rezistență la şoc / la impact

resistance to motion $(\mathrm{mec}, \mathrm{TH})$ rezistentă la mers / la înaintare / la mişcare

resistance to pit corrosion (materiale, mediu) rezistență la coroziune în puncte resistance to pressure (mec, met) rezistență la presiune

resistance to repeated impact $(\mathrm{mec})$ rezistență la şoc / impact repetat

resistance to rapid change of temperature (materiale, termo) rezistenţă la şoc termic

resistance to rolling (mec, met, plast) rezistență la rostogolire / la laminare

resistance to rupture (const, mec, materiale) rezistență la rupere

resistance to shear / to shearing strain (mec) rezistență la forfecare

resistance to shock (mec, met) rezistenţă la şoc

resistance to slip $(\mathrm{mec})$ rezistentă la alunecare

resistance to sudden changes of temperature (termo) rezistență la şocuri termice (pt. metale şi ceramice)

resistance to tearing (mec, plast, textile) rezistență de / la rupere / la sfâșiere

resistance to tensile strain (mec, materiale) rezistentă la tractiune / la deformare prin tractiune resistance to thermal shocks (materiale) rezistență la şocuri termice (şi d. sticlă)

resistance to torsion (mec, materiale) rezistență la torsiune / la răsucire

resistance to wear $(T)$ rezistență la uzură

resistance to weathering (met, plast, $\mathrm{TH}$ ) rezistentă la intemperii / la coroziune atmosferică; (plast) rezistență la îmbătrânire în mediu extern / în aer (liber)

resistance wall (const) perete de rezistență

resistance welding (el, met) sudare electrică prin rezistență

resistant, resistent (fiz, $\mathrm{TH}$, materiale, $\mathrm{OM}$ ) rezistent, durabil, fix, permanent

resistant to bending (const, mec) rigid / rezistent la încovoiere

resistant to compression (mec, constr) rezistent la presiune / la compresiune

resistant to corrosion (chim) rezistent la coroziune, protejat contra coroziunii

resistant to fracture (fiz, mec) incasabil, rezistent la rupere

resistant to oil (auto, chim) inatacabil de ulei, rezistent la ulei

resistant to rupture (mec) incasabil (d. obiecte de sticlărie), rezistent la rupere

resistant to scaling (met) inoxibabil, rezistent la (oboseală prin) exfoliere

resist being rubbed off (T, fiz) a rezista la îndepărtare / la tendința de răzuire etc.

resister persoană care se opune; (pol, adm) oponent, potrivnic, adversar; (fiz) corp rezistent, forță de rezistență 
resist flow (fiz, hidr) a rezista la curgere resistibility rezistibilitate, posibilitate de rezistență; (capacitate de) rezistență / de împotrivire resisting moment (mec) moment de rezistență resistive rezistent; capabil să reziste, care poate rezista; (el) (element) rezistiv

resistive flowmeter (metr, el, hidr) debitmetru la care măsurarea debitului se face prin intermediul unui semnal electric proporțional, dat de un material conductiv, sensibil la diferenţa de presiuni

resistive pulse (el) impuls / salt al rezistenței electrice, pulsație / variaţie rezistivă

resistive pulse technique (el, autom) tehnica impulsului / saltului rezistenței electrice

resistivity (el) rezistivitate, rezistență specifică

resistor (el) rezistor, rezistență electrică

resitor furnace (met, el) cuptor electric, cu rezistență

re-size (mas-un) a prelucra din nou, la o altă dimensiune

resol (plast, chim) rezol

resoluble (chim) solubil, disociabil; (mat) rezolvabil

re-soluble (chim, materiale) redizolvabil, resolubil, care poate fi redizolvat / dizolvat din nou

resolution (const, mec, chim) descompunere (a forțelor), dezagregare, disociere, dizolvare; (fiz, metr, c) putere de rezoluție / de separare / de rezolvare; (mat) rezolvare; (chim) redizolvare; (c, TV) rezoluție / definiție / descompunere a imaginii resolution sensitivity (metr, autom) sensibilitate, cea mai mică schimbare la intrare, care produce un răspuns detectabil

resolution of a force (fiz, mec) descompunere a forței

resolution of precipitate (chim) dizolvarea precipitatului

resolvable (chim) solubil; (mat) rezolvabil

resolve hotărâre, fermitate; (mat) a rezolva; a termina; a încheia; (ec, adm, pol) a hotărâ, a decide; (chim, fiz) a dizolva (în); a separa

resolver (c, autom) rezolver; (ind chim) solvent, dizolvant

resonance (el, fiz, $\mathrm{mec})$ rezonanță

resonant frequencies (fiz) frecvențe de rezonanță resort resursă; adăpost

resources (ec) mijloace băneşti, resurse, rezerve respect raport, legătură; punct de vedere; respect; a respecta

respite răgaz; a da răgaz

respond a reacționa; a răspunde, a da un răspuns; a suferi o influență; a riposta

responding time (el, autom) timp de răspuns response (autom) răspuns; (inf, autom) răspuns, reacție, efect; (fiz, metr) indicație (a aparatului); citire, caracteristică de frecvență (de răspuns); (mas, metr) sensibilitate (la aparate şi mecanisme); (TH) reacție, comportare; sensibilitate, receptivitate

response characterisic (autom) curbă / caracteristică de răspuns; (inf) caracteristica frecvenței; (el) curbă de sensibilitate

response curve (mas, metr) caracteristică a sensibilității (aparatului); (el) curbă de răspuns / de sensibilitate

response error (mat, metr, autom) eroare de răspuns

response pressure (hidr) presiune la care sistemul (hidraulic) este actionat / la care se obține inițierea unei funcții a sistemului (hidraulic)

response time (autom, inf, el) timp de răspuns; (el) inerție, timp de stabilizare

responsibility $(\mathrm{ec})$ răspundere, garantie

responsive (mas, materiale) sensibil

responsiveness (el, metr, $\mathrm{TH}$ ) sensibilitate, capacitatea unui sistem de a răspunde rapid la variația parametrilor de intrare

rest repaus, odihnă, sprijin, pauză; (chim, mat) rest, reziduu; (const) adăpost; (ec) rest, fond de rezervă; rezemătoare, spătar (de scaun etc.); (mas-un, OM) reazem, lunetă, cărucior, suport, sanie, consolă; (mec) repaus; (mec) a fi în repaus, a se rezema, a rămâne, a se baza pe

restandardisation (metr) reetalonare; restandardizare, modificare (parțială) a unui standard

restart a porni din nou, a reporni

rest bar (for guides and guards) (met) barăsuport de ghidare (la laminoare)

rest base (mas-un) placă de bază a saniei principale (la strung)

resting (mec) în repaus; (mas) (maşină) oprit (dar care poate funcționa)

resting barrel (mas, OM) tambur fix

restitution (ec, fiz) restituire

re-stone (mas-un) a reascuți / a reface un disc abraziv

restoration (const) restaurare; $(\mathrm{TH}, \mathrm{OM})$ recondiționare

restore (ec, jur) a restitui, a înapoia, a restabili; (const) a repara, a restaura, a renova; $(\mathrm{TH}$, $\mathrm{OM})$ a recondiționa, a reface

restored waste rubber (plast, ind chim) (cauciuc) regenerat

restored waste vulcanized rubber (plast, ind chim) regenerat din deșeuri de cauciuc vulcanizat 
restoring $(\mathrm{TH})$ recondiționare, reparare; (constr) restaurare, renovare

restoring force (mec) forță de restabilire / de rapel restoring mechanism (mas, $\mathrm{OM}$ ) mecanism de readucere / de rapel

restoring spring (el) resort antagonist; $(\mathrm{OM})$ arc de readucere / de rapel

restoring torque (el, metr) cuplu antagonist

restraighten (mas-un, met) a reajusta, a reîndrepta (d. table, benzi etc.)

restrain a reține, a împiedica, a înfrâna, a restrânge; a opri; (TH) a frâna, a fixa; (auto) a proteja

restrainer (chim) inhibitor; $(\mathrm{OM})$ element de mentinere / de fixare / de blocare

restraint împiedicare; obstacol, restricție; piedică; limită; (const) încastrare; (TH, OM) limitare, delimitare, restrângere, reținere

restraint at ends (const, mas, $\mathrm{TH}$ ) prindere / fixare / încastrare la capete

restriction (transp, ec, adm) limitare, restricție; (met) contracție (rar)

restriction crack (met) fisură de contracție

restriking (mas-un) rectificare, reprelucrare, reluare a unei operații / a unei curse active (mai rar)

restrict a restrânge, a limita; a îngrădi, a delimita

restricted restrâns, limitat, îngrădit, delimitat, restrictionat

restricted area $(\mathrm{TH}$, ind) zonă cu restricții / cu acces limitat

restricted guidance (OM, mas-un) ghidare forțată

restrictor (fiz) restrictor; (metr) diafragmă de măsură; (TH, hidr) loc de ştrangulare

rest time (mas) timp de repaus

result (mat) rezultat; (mec) randament; a rezulta

resultant (mec) rezultantă (ca sumă vectorială), forță medie / rezultantă

resultant acceleration $(\mathrm{mec})$ accelerație rezultantă

resultant force $(\mathrm{mec})$ forță rezultantă / totală

resultant moment of unbalance forces (mec) rezultantă a momentelor forțelor de dezechilibru

resultant of all forces (const, mec) rezultantă a tuturor forțelor

resultant of reaction (ind chim) produs de reacție resultant unbalance force $(\mathrm{mec})$ rezultantă a forțelor de dezechilibru

resultant value (ec, mat) valoare finală / rezultantă

resultant velocity (mec) rezultanta vitezelor; viteza rezultantă

resulting moment $(\mathrm{mec})$ moment rezultant

resume a limita; a rezuma retail (sale) (ec) vânzare cu amănuntul / în detaliu retail trade $(\mathrm{ec})$ comerț cu amănuntul / cu bucată retain a reține, a lega, a aduna; (hidr) a stăvili, a zăgăzui, a bara (cursul unei ape)

retained austenite (met) austenită de călire

retainer (geol) rocă impermeabilă; (OM, masun) opritor, dispozitiv de blocare / de oprire, colivie a rulmentului, colector de ulei, piesă de fixare, suport

retainer ring $(\mathrm{OM})$ colivie rulmentului, inel de fixare / de retinere, bandaj, inel opritor

retaining clip $(\mathrm{OM})$ clema de fixare

retaining device $(\mathrm{OM})$ dispozitiv de reținere / de fixare, încuietoare

retaining nut $(\mathrm{OM})$ piuliță de fixare / de reținere

retaining pin (OM, mas-un) extractor, ştift / bolț de blocare / de reținere

retaining ring $(\mathrm{OM})$ inel de siguranță

retaining ring of rim (auto, $\mathrm{OM})$ cerc de jantă

retaining snap ring $(\mathrm{OM})$ inel elastic de fixare

retaining spring (auto, OM) arc de oprire / de fixare / de retinere

retaining washer $(\mathrm{OM})$ şaibă de siguranță / Grower, inel de siguranță

re-tap (mas-un) a trece din nou cu tarodul (la o piuliță uzată)

retard (mec, chim, fiz) a împiedica, a frâna, a opri, a reține, a întârzia, a temporiza

retardation $(\mathrm{TH}, \mathrm{mec}$, autom) întârziere, încetinire; (el) defazare, defazaj (în urmă); întârziere (de fază); (fiz) retardare; (mec) accelerație negativă, efect de frânare, reducere a vitezei; retinere retardation factor (autom, alim, chim) factor de întârziere

retarded closing of valve (auto, termo) închidere întârziată a supapelor

retarded ignition (auto, termo) aprindere întârziată

retarded motion $(\mathrm{mec})$ mişcare întârziată / încetinită

retarder (const, chim) întârzietor de priză; (met, cf) frână de încetinire a mersului vagonetelor; (chim) încetinitor, întârzietor, inhibitor, moderator, produs de frânare (care micşorează viteza de vopsire / de reactie)

retarding force $(\mathrm{mec})$ forță de decelerație / de întârziere / de frânare

retarding torque (mec) cuplu de frânare

retard the corrosion process (chim) a întârzia procesul de coroziune

retell a repeta, a repovesti, a spune din nou retention of hardness (mec) stabilitate la duritate, duritate stabilă după revenire

retention of shape (mec, plast, OM) rezistență la deformare, menținere a formei 
retention pin $(\mathrm{OM})$ ştift de siguranță / de oprire / de asamblare

retentivity (chim) retentivitate; (el) remanență; (mec) forță coercitivă; (TH) capacitate de reținere

retest (metr) retestare, testare de control, a testa din nou, a retesta

rethread (mas-un) a fileta din nou; a calibra un filet

reticle(s) (fiz) reticul, fire reticulare, rețea (și la aparate optice); (mas-un, opt) crucea vizorului reticular (fiz) reticular, în formă de rețea

reticular structure (met) structură reticulară; (el) structură de rețea / a rețelei

reticulate (fiz, plast) reticular, a reticula

reticulated (fiz) reticular, în formă de rețea

reticulated foam (plast) material / spumă reticular( $\breve{a})$

reticulated structure (materiale) structură reticulată reticulate structure (plast) structură reticulată

reticule (fiz) reticul, fire reticulare, rețea; (masun, opt) cruce a vizorului

retightening $(\mathrm{el}, \mathrm{mec})$ reîntindere, retensionare

retime (autom) a modifica momentul de declanşare a unui aparat / dispozitiv

retinol equivalent (RE) (metr) unitate de dozare pentru retinol (vitamina A) şi pentru substanțe similare ca beta carotena: 1 RE este echivalent cu 5 international units (IU) (unităţi internaționale) sau $1,5 \mathrm{mg}$ de retinol

retire (ec) a retrage efectele de pe piață; (mec) a mişca în sens invers; a se retrage (şi din activitate)

retirement retragere, abandon; (TH) scoatere din funcțiune; ieşire la pensiune, retragere din activitate

retoother (mas-un) maşină de retăiat dinţi (la pânza de ferăstrău pentru metale)

retort (chim, OM) retortă

retort furnace / oven (met) cuptor cu retortă / cu cameră

retract (mas-un, mec) mers invers; cursă de înapoiere, retragere (a unui element de maşină / a unei scule)

retractable $(\mathrm{OM})$ retractabil, pliant, escamotabil, care se poate retrage

retractile $(\mathrm{OM})$ retractabil, escamotabil

retractile spring $(\mathrm{OM})$ arc de readucere / de rapel retractility (mec) forță de restabilire / de rapel retracting spring $(\mathrm{OM})$ arc de readucere / de rapel retraction (mas-un) retragere (a unui dispozitiv) retractor (auto, OM) locaşul curelei

retractor collar (auto, mas, OM) inel / guler de cuplare a ambreiajului retractor pre-tensioner assembly (auto, OM) ansamblu cataramei de pretensionare

retransformation (met) transformare inversă retreading (auto, ind chim) reşapare, recauciucare

retreading mould (ind chim, OM) formă / matriță de reşapare

re-treatment / retreating (met, $\mathrm{TH}$ ) retratare, tratament suplimentar / repetat

retrievable amovibil, extractibil, recuperabil, remediabil, reparabil; (autom) (re)utilizabil; (inf, c) care poate fi recuperat / găsit (în memoria computerelor etc.); de regăsit; (ec), care se poate percepe, incasabil

retrieve ( $\mathrm{TH}$, mas) a extrage, a ridica, a îndrepta, a recupera, a remedia, a repara, a scăpa; a redobândi; (c) a salva, a regăsi; a dezgropa (amintiri); a (se) reabilita (d. reputați etc.), a-şi reface / restabili (reputația, etc.); (d. un câine de vânătoare) a aporta (vânatul); past $\sim$ irecuperabil; $\sim$ one's losses a recupera terenul pierdut, a se reface

retroaction (fiz) retroacțiune, acțiune ulterioară

retroactive (jur, adm) retroactiv

retrofitting (mas) modificare a echipamentului pentru a introduce schimbări făcute în echipamente similare, dar mai noi

retrogradation (plast) degradare; (ec) retrogradare

retrograde motion mişcare retrogradă; (auto, mas) mers înapoi; (cf, met) mişcare de recul (la locomotivă)

retrogression (mas, mec) mişcare de recul / de înapoiere

retrogressive movement (auto, mec) mişcare retrogradă / de recul

retrospection mirror (auto, $\mathrm{OM}$ ) oglindă retrovizoare

return întoarcere, înapoiere, restituire; (ec) intrări (provenite din vânzări), venit, câştig; (hidr) restituție (în râu, a debitului derivat); (mas) mişcare în sens invers, cursă de înapoiere, mers înapoi, rapel, revenire, readucere; $(\mathrm{mec})$ mişcare înapoi; cursă inversă; (met) galerie de ieşire a aerului; (hidr) retur, recirculare; evacuare; a (se) întoarce, a inversa, a reveni, a înapoia, a restitui; (ec) a plăti o sumă luată cu împrumut

return air (mas, hidr) aer utilizat (în utilaj pneumatic); (met) aer ieşit cuptor, aer viciat

return bend (hidr) curbă de retur / de întoarcere; îndoitură dublă; (TH, OM) cot / țeavă în forma de $\mathrm{U}$

return circuit (hidr) conductă de retur

return condenser (ind chim, alim) refrigerent cu reflux, condensator cu contracurent 
return crank $(\mathrm{OM})$ contra manivelă returned juice (alim) zeamă de retur return feeder (el) cablu de întoarcere return-flow cooler (chim, alim, termo) refrigerent cu contracurent, răcitor în contracurent return idler (const) rolă inferioară return journey (cf, nav) cursă / călătorie de întoarcere; (mas, mas-un) cursă de înapoiere, mers înapoi

return key (c) tastă de revenire (şi pt. alte funcții)

return lead (auto, el) fir de retur; (hidr) conductă de retur

return line (hidr) conductă de retur; (mas) linie de readucere

return material $(\mathrm{TH}, \mathrm{ec})$ material de returnat / refuzat / care se poate întoarce în circuitul producției

return mechanism (mas, nav) timonerie de readucere / de rapel

return motion / movement (mas) mişcare în sens invers, cursă de înapoiere, mers înapoi; (el, TH) mişcare de întoarcere

return pass (auto) mers înapoi; (mas) cursă inversă / de înapoiere, mişcare în sens invers, retur, revenire; (met) trecere în sens invers (la laminare)

return path (hidr, termo) conductă de retur; (mas) cursă / traiectorie de înapoiere

return pipe (auto, OM) țeavă / tub retur; (hidr, termo) conductă inversă / de evacuare; țeavă de preaplin, tub de versor

returns (ec) dare de seamă contabilă

return scrap (met) deșeuri de recirculație / interne return slag (met) zgură recirculată

return speed (mas-un) viteză (la cursa) de înapoiere

return spring (auto, $\mathrm{OM}$ ) resort / arc de rapel

return stroke (mas, mas-un, TH) cursă moartă / de revenire / de înapoiere / de retragere; (mec) mişcare de recul

return time (chim, metr) timp de scurgere (la pipete și biurete); (TH) timp de desfăşurare; (masun) timp de retragere (a sculei, a unei sănii etc.)

return to normal $(\mathrm{TH}, \mathrm{ec}, \mathrm{adm}$, mas) revenire la normal

return tube $(\mathrm{OM}$, hidr) conductă de retur

return valve $(\mathrm{OM}$, hidr) supapă / ventil de retinere

return wire (el) fir / conductor de întoarcere; fir neutru; (mec) linie neutră

revaluation $(\mathrm{ec})$ reevaluare

revenue ton, tonne (RT) (metr) unitate de măsură utilizată în facturarea / plata transportului pe mare a unei încărcături; mărimea unei încărcături în revenue tons este egală cu numărul de tone metrice sau numărul de metri cubi al încărcăturii (atentie la text)

reverberating / reverberatory furnace (met, termo) cuptor (cu flacără) cu reverberație

reverberatory-furnace practice (met, termo) (proces de) topire în cuptor cu flacără

reverberatory (puddling) furnace (met) cuptor (cu flacără) cu reverberație

reverberatory smelting (met) topire în cuptor (cu flacără) cu reverberație

reversal (fiz) inversiune; (mas) schimbare a sensului mişcării / de mişcare, schimbător de sens; (mas-un) inversor, inversare, reversare; (c) inversare / răsturnare de imagine; reversibil; (pol, jur) abrogare, întoarcere / schimbare totală (a curentului de opinii etc.); (jur) casare, desființre, revocare, renunțare; (poligrafie inversare; (el) legare în opoziție; (meteo, av) schimbare a direcției vântului; self- (chim) autoabsorbție, (autom)autoinversiune; load $\sim(\mathrm{mec})$ alternanță de sarcină

reversal control (autom) comandă prin inversare, comandă reversibilă

reversal development (fiz, chim) dezvoltare reversibilă (a unui fenomen, a unei reactii etc.)

reversal dip $(\mathrm{OM})$ înclinare inversă

reversal load $(\mathrm{mec})$ sarcină reversibilă

reversal of aileron effect (av) inversare a actiunii eleroanelor

reversal of damping (mec, autom) compensare a amortizării

reversal of direction (auto) schimbare a direcției / sensului de mers

reversal of phase (el) inversare a fazelor

reversal of polarity (fiz) schimbare a polarității

reversal of stroke (mas-un) schimbare / inversare a cursei

reversal of stress (mec, const) alternanță / inversare a eforturilor / tensiunilor

reversal of the magnetic needle (fiz) reîntoarcere / revenire a acului magnetizat

reversal point (mat, mas, mas-un) punct de întoarcere (la o curbă, la o cursă etc.)

reversal prism (fiz, opt) prismă de inversare (la aparate optice)

reversal processing $(\mathrm{TH})$ proces reversibil

reversal return travel (mas) cursă de înapoiere, cursă inversă; (mas, auto) mers înapoi; (telefonie) retur, revenire

reversal stage (autom) etaj inversor

reversal time (met) timp de inversare (la caupere) reverse $(\mathrm{TH})$ compensare automată (sau oprire parțială) la depăşiri accidentale (de sarcină / viteză etc.); (auto) mers înapoi, marşarier; (mas) cursă de înapoiere, mişcare inversă; (geom) latură 
opusă; inversare; (mec) recul; înfrângere; (poligrafie) contrapagină, pagină cu soț, verso; a inversa; (autom, mas) a schimba / a inversa mersul, a reversa; (TH) a învârti, a întoarce, a comuta schimba poziția; (textile) a întoarce pe dos; contrar; invers; răsturnat

reverse axle (auto) ax de mers înapoi / de marşarier; (OM) arbore de inversare a sensului de rotație (într-un angrenaj etc.)

reverse-bending (fatigue) test (met, metr) test / încercare de îndoire / încovoiere alternativă (la oboseală)

reverse drawing (met, plast) tragere inversă / inversată (etapă a tragerii când materialul poate avea curgere pe direcție opusă tragerii inițiale / dorite)

reversed frame (nav) contracoastă

reversed stress $(\mathrm{mec})$ tensiune / efort alternativ( $(\breve{a})$ reverse direction $(\mathrm{mec})$ directie inversă, sens invers reverse double-gear wheel (auto, OM) roată dublă, de mers înapoi (la cutia de viteze)

reversed stress $(\mathrm{mec})$ tensiune alternativă

reverse end for end (mas-un) a întoarce la $180^{\circ}$

reverse flow cooling (mas, termo) răcire în contracurent

reverse gear (auto) mers înapoi, marşarier; (OM) roată dințată a mersului înapoi, angrenaj pentru inversarea sensului de rotatie

reverse gear ratio (auto) raportul de transmisie al angrenajului de mers înapoi / de marşarier

reverse gear shaft (auto) ax de mers înapoi / de marşarier; $(\mathrm{OM})$ arbore pentru inversarea sensului de rotatie

reverse gear wheel (auto) roată dințată a angrenajului de mers înapoi / pentru inversarea sensului de rotație

reverse idler (gear) shaft (auto) arborele pinionului de mers înapoi

reverse lever $(\mathrm{OM})$ pârghie de inversare a sensului de mişcare

reverse motion / movement (auto) mers înapoi, marşarier; (mas) mişcare în sens contrar / opus / invers, cursă de înapoiere, revenire (a sculei, saniei port-scule etc.)

reverse order of removal $(\mathrm{TH})$ ordinea inversă a îndepărtării / scoaterii / demontării

reverse pedal (auto, OM) pedală pentru mers înapoi / invers

reverse pinion (auto, $\mathrm{OM}$ ) pinion de mers înapoi / de marşarier / de schimbare a sensului de rotatie

reverse plate $(\mathrm{OM})$ suportul inversorului sensului de rotatie

reverse the poles (el) a inversa polii reverse time, reaction time (autom, metr) timp de reacție / de răspuns (la un aparat, sistem automatizat etc.)

reverser (el, mas) reversor, inversor, schimbător de sens

reverse rotation $(\mathrm{mec})$ rotaţie în sens invers

reverse running $(\mathrm{OM})$ mers înapoi

reverse screw (mas, mas-un, OM) şurub de comandă a mecanismului de inversare

reverse shaft $(\mathrm{OM})$ arbore inversabil / de inversare reverse speed (auto) viteză de mers înapoi / în marşarier

reverse stop $(\mathrm{OM})$ fixator / opritor al mecanismului de mers înapoi

reverse torsion test $(\mathrm{mec}, \mathrm{OM})$ încercare / test la torsiune alternativă

reverse wheel (auto, OM) pinion de mers înapoi / de marşarier / de inversare a sensului de rotație

reversible (mas, mec) reversibil, cu mecanism de inversare a sensului de mişcare; (mat) reversibil, inversabil; (TH, OM) reversibil, rabatabil, rotibil, înclinabil

reversible chuck jaw (mas-un, $\mathrm{OM}$ ) falcă de universal pentru exterior şi interior

reversible Diesel engine (mas, termo) motor diesel reversibil

reversible drive $(\mathrm{OM})$ acționare reversibilă

reversible motion $(\mathrm{OM}, \mathrm{mec})$ mișcare reversibilă

reversible pawl $(\mathrm{OM})$ clichet reversibil

reversible platern plate (met) placă de model, reversibilă

reversible process (termo, chim) proces / reacție reversibil(ă)

reversible propeller (nav) elice cu pas variabil / cu pale reglabile

reversible transducer (metr) traductor la care pierderile nu depind de sensul transmiterii semnalului / energiei prin traductor

reversing (mas, mec) inversarea sensului de mişcare, schimbător de mers / al sensului de mișcare, inversare, care inversează

reversing bar $(\mathrm{OM})$ tijă a inversorului, a mecanismului de inversare a sensului de mișcare

reversing blooming mill (met) laminor blooming reversibil

reversing clutch (auto, OM) cuplaj reversibil, ambreiaj de inversare

reversing cogging mill (met) laminor bluming reversibil

reversing cogging mill train (met) linia de laminare (tip bluming) reversibilă

reversing cold rolling mill (met) laminor reversibil, pentru laminare la rece 
reversing drive $(\mathrm{OM})$ acționare cu mecanism de inversare

reversing finishing rolling mill (met) laminor finisor reversibil

reversing four-high hot (cold) rolling mill (met) laminor cuatro reversibil pentru laminare la cald (la rece)

reversing gas valve (met, OM, hidr) clapă de inversare a gazului

reversing gear $(\mathrm{OM})$ mecanism / angrenaj de inversare a mişcării / rotației

reversing-gear lever $(\mathrm{OM})$ pârghie pentru inversare a sensului mişcării

reversing-gear valve (met, termo) registru / şubăr de inversare (la cuptoare)

reversing handle $(\mathrm{OM})$ pârghie de inversare a mişcării

reversing hoop rolling mill (met) laminor reversibil pentru benzi (în rulouri)

reversing latch $(\mathrm{OM})$ clichet pentru inversarea sensului de mişcare

reversing lever $(\mathrm{OM})$ manetă de comandă a inversorului, pârghie pentru inversarea sensului de mişcare

reversing mechanism $(\mathrm{OM})$ mecanism pentru inversarea sensului de mişcare; (mas-un) dispozitiv de filetat la maşina de găurit

reversing mill (met) (cajă de) laminor reversibil

reversing mill stand (met) cajă de laminor reversibil

reversing mill strand / train (met) cajă / tren / linie de laminor reversibil

reversing motion $(\mathrm{mec})$ mişcare de inversare de sens / inversă

reversing motor (mas) motor reversibil

reversing motor planer (mas-un) raboteză cu mecanism de acționare cu motor reversibil

reversing plate mill / train (met) laminor de table reversibil

reversing point (mas) punct de inversare (a unei curbe)

reversing rolling mill (met) laminor reversibil

reversing rolling mill stand (met) cajă de laminor reversibil

reversing roughing rolling mill (met) laminor reversibil degrosisor

reversing screw $(\mathrm{OM})$ şurub de comandă a mecanismului de inversare, şurub de schimbare sensului de mişcare

reversing shaft $(\mathrm{OM})$ arbore reversibil / de inversare a rotaţiei

reversing shape mill (met) laminor reversibil de profiluri

reversing stip mill (met) laminor reversibil de table / benzi reversing strip rolling mill (met) laminor reversibil pentru benzi

reversing the rolls (met) inversarea sensului de laminare

reversing three-high rolling mill (met) laminor trio reversibil

reversing train (met) linie de laminor reversibil

reversing two-high hot (cold) rolling mill (met) laminor duo reversibil, pentru laminare la cald (la rece)

reversing two-high plate rolling mill (met) laminor duo reversibil pentru table groase

reversing two-high sheet rolling mill (met) laminor duo reversibil pentru table

reversing two-high sheet rolling stand (met) cajă de laminor duo reversibil, pentru table

reversing valve (OM, hidr) sertar / supapă pentru inversarea sensului de mişcare

revert a reveni, a se întoarce

revert scrap (met) deşeuri metalice de recirculare / interne

revertible (mat) reversibil, inversabil

revet (const, hidr) a căptuși, a îmbrăca; $(\mathrm{TH})$ a acoperi, a proteja, a căptuşi

revetment (const) întărire, consolidare, acoperire cu piatră, protejare, îmbrăcăminte (și rutieră); (TH) acoperire, protejare, căptuşire

review analiză; bilanț; inspectie; recenzie; privire generală / retrospectivă; (metr, mas) revizie, verificare, control; trecere în revistă, paradă; (poligrafie) revistă (literară, ştiințifică etc.), jurnal periodic; critică; cronică; recenzie; (mil) paradă, (trecere în) revistă; (jur) revizuire (a unui proces); recenzat; analizat; a recenza; (mas, $\mathrm{TH}$, ec) a analiza; a corecta, a inspecta; a revedea; reconsidera; a reexamina; a repeta; a face critică (literară), a fi cronicar (literar) / recenzor (la o vevistă), a recenza (un articol pt. o revistă); a expune; a povesti; a privi retrospectiv

reviewer recenzor (la o revistă, editură etc.), recenzent, critic / cronicar literar

reviewing (metr) verificare, control, revizuire; recenzare, recenzie, care face o recenzie

revision (metr, TH) revizie, verificare, control, revizuire; cercetare; ediție revăzută corectată / completată

revolution (mat) revoluție; (chim) rotație (a planului de polarizare); (mas, mec) învârtire, rotatie, rotire; revolution $(\mathbf{r}$, rev) (metr) unitate de măsură pentru unghiuri, egală cu unghiul corespunzător unui cerc, $360^{\circ}$, sau $2 \pi$ radiani

revolution axis $(\mathrm{OM})$ ax de rotire / de rotație

revolution counter (auto, autom, metr) numărător de ture, tahometru; (hidr, metr) tahimetru 
revolution in counterclockwise direction (mat, $\mathrm{TH}$ ) răsucire / rotaţie spre stânga (în sens invers acelor unui ceasornic)

revolution indicator / meter (auto, metr, hidr) tahometru; contor de rotații; numărător de ture revolution motion (mec) mişcare de revoluție revolutions per inch (mas-un) numărul de rotații al arborelui principal pentru un avans de 1 țol revolutions per minute (RPM, rpm, r/min) (mas, metr, mec, fiz) unitate de măsură pentru viteză unghiulară, rotații pe minut, turație: 1 $\mathrm{r} / \mathrm{min}=0,104720$ radiani pe secundă $(\mathrm{rad} / \mathrm{s})$

revolve (mec, mas-un) a (se) roti, a se mişca în jurul unui centru / unei axe

revolvable (mec, mas-un) turnant, rotativ

revolving (mat) rabatere; $(\mathrm{TH})$ rotativ, turnant, pivotant, rotitor, giratoriu, mişcare de rotaţie în jurul unei axe exterioare corpului

revolving bed plate (mas, OM) placă turnantă

revolving couple (mec) cuplu de rotaţie

revolving crosscut saw ferăstrău de debitat (şi pt. lemn)

revolving crystal method (chim) metodă cu cristal rotativ / turnant

revolving cylinder engine (auto) motor cu cilindri rotativi / cu cilindru rotativ

revolving cylinder roaster (met, termo) cuptor rotativ de prăjire

revolving cylindrical furnace (met) cuptor tubular, rotativ

revolving distributor (ind chim, met, alim, OM) distribuitor rotativ

revolving drier (ind chim) uscător rotativ

revolving feed plate (mas-un) disc cu roți dințate amovibile, ale mecanismului de avans (la strung)

revolving feed table (mas-un) masa mecanismului de avans circular

revolving furnace (ind chim) cuptor rotativ

revolving grate (ind chim) grătar rotativ

revolving part $(\mathrm{OM})$ piesă turnată / în rotație

revolving press (mas-un, met) presă-revolver, presă cu masă cu avans circular

revolving reverberatory furnace (met) cuptor rotativ, cu flacără

revolving screen (const, ind chim, met) ciur rotativ, sită rotativă

revolving slide rest (mas-un, OM) suport sferic

revolving top (met, ind chim) dozator / alimentator rotativ

revolving trommel (met) tambur rotativ

revolving tubular furnace / kiln (met) cuptor tubular rotativ

revolving turret (mas) turn rotitor (pt. macarale); (mas-un) cap rotativ (şi la strunguri automate)

revolving worm (mas) transportor elicoidal revs. (revolutions) (mas, metr) numărul de rotații pe unitate de timp, turație

revolutions per minute $(\mathrm{OM}$, mas) revoluții pe minut, turație

rewater (alim, hidr) apă de recirculație

reweighing (metr) recântărire

rewind (el) reînfaşurare, rebobinare (a unei benzi magnetice, a unui rotor / stator de motor electric etc.), a rebobina; (textile) reînfăşurare, a depăna; a întoarce (ceasul); (poligarfaie, textile) a rebobina

rework (mas-un, TH) a retuşa, a finisa, a reutili$\mathrm{za}$, a prelucra din nou

reworkable waste (met, textile, $\mathrm{TH}$ ) deşeuri reutilizabile

rework $(\mathrm{OM}, \mathrm{TH})$ a recondiționa, a prelucra din nou

reworking (mas-un) recondiționare a unei piese uzate, prelucrarea pentru a doua oară; prelucrare a deşeurilor sau a materiilor prime regenerate; $(\mathrm{TH})$ completarea prelucrării, finisare

reyn (metr) unitate de măsură pentru viscozitate dinamică în sistem britanic: 1 reyn $\cong 68,94757$ kilopoise, sau 6,894757 $\mathrm{kPa} \mathrm{s}$

Reynolds criterion (fiz, hidr, T) criteriul lui Reynolds

Reynolds number (chim, hidr) numărul lui Reynolds

r.h. (right hand) (auto) la dreapta; (OM) de dreapta; cu filet pe dreapta

rhe (metr, hidr) unitate de măsură a fluidității, opusul vâscozității, în sistem SI: 1 rhe $=10(\mathrm{~Pa} \cdot \mathrm{s})^{-1}$

Rhine foot, Rheinfuss, fuss (metr) unitate de măsură pentru lungime, utilizată tradițional în nordul şi vestul Germaniei, picior (din zona Rhinului)

Rhenium (Re) (chim) reniu

rheocasting (met, plast) turnare a unui material în stare semi-fluidă / parțial topit / vâscos

rheological grease ( $T$, hidr) unsoare reopectică / care îşi măreşte vâscozitatea la solicitare mecanică

rheologic(al) property (fiz) proprietate reologică / de curgere

rheology (fiz) reologie

rheopectic substance (fiz, plast) substanță cu vâscozitate dependentă de timp (de obicei crescătoare în timp), indiferent de viteza de forfecare

rheopexy (fiz) reopexie

rhm (metr, fiz) abreviere pentru roentgen-hourmeter, o unitate utilizată pentru a măsura puterea razelor / radiației gamma; o sursă de $1 \mathrm{rhm}$ produce o ionizare cu o viteză de 1 roentgen pe oră la o distanță de 1 metru de sursă

R.H.N. (Rockwell hardness number) (mec, metr) duritate Rockwell / în unităţi Rockwell 
Rhodium (Ro) (chim) rodiu

rhomb (geom) romb

rhombic (geom) rombic

rhombohedral (geom) romboedric

rhombohedral packing (mat) rețea / aranjament romboedric $(\breve{a})$

rhombus (geom) romb

rho ratio (material) coeficient de contracție

rhyolite (minr) riolit, liparit

rhythm ritm

rhythmic(al) ritmic

rhythmicity ritmicitate

rhythmic variation $(\mathrm{TH})$ pulsație, variație ritmică / periodică

ri (metr) unitate tradițională japoneză de măsură pentru distanță, leghe japoneză: $1 \mathrm{ri} \cong 3927 \mathrm{~m}$

rib (OM, alim) coastă; (OM) muchie, flanșă; nervură, renură; (met) adaos turnat, îngroșare; (cf, met) coastă (de rambleu); dungă, margine; (TH) a prevedea cu nervuri, a nervura

ribband shore (nav) pontil lateral (al saniei de lansare)

ribbed (auto, $\mathrm{OM}$ ) nervurat, cu nervuri

ribbed brake drum (auto, OM) tambur de frână, cu nervuri

ribbed conveyer belt (plast, $\mathrm{OM}$, mas) bandă de transport canelată / nervurată

ribbed flat $(\mathrm{OM})$ profil cu nervuri / nervurat

ribbed funnel (ind chim, alim) pâlnie cu nervuri (pt. filtrare)

ribbed mat (auto, ind) covor de cauciuc dungat ribbed pipe $(\mathrm{OM})$ țeavă cu nervuri / cu aripioare ribbed plate (ind chim, OM) placă cu nervuri

ribbed profile (plast, auto) profil cu canale (la anvelope)

ribbed radiator (termo) radiator cu nervuri ribbed roller (ind chim, OM) cilindru canelat

ribbed roof (met) boltă cu nervuri

ribbed tank (OM, hidr) vas cu nervuri

ribbed tube (OM, termo) țeavă cu nervuri / cu aripioare

ribbed tube radiator (termo, $\mathrm{OM}$ ) radiator cu nervuri

ribbing $(\mathrm{OM})$ nervuri, întărire cu nervuri

ribbon conveyer (mas) transportor cu bandă

ribbon drier (ind chim, alim) uscător cu bandă

ribbon folder (met) înfăşurător pentru bandă

ribbon iron (met) platbandă de oțel, oțel lat

ribbon reel (met) înfăşurător de / pentru bandă

ribbon saw (mas-un) ferăstrău-bandă, ferăstrăupanglică (şi pt. lemn)

ribbon spring $(\mathrm{OM})$ arc plan

ribbon transmission $(\mathrm{OM})$ transmisie prin bandă / cu curele

rib radiator (termo) radiator cu nervuri

rice (agr, alim) orez rice corn (agr, bot) sorg

rice cup (metr, alim) (engl) unitate de măsură pentru volum / capacitate (pt. produse lichide sau uscate): 1 rice cup (ceașcă de orez) $\cong 180$ $\mathrm{ml}$ sau 3/4 US cup

rice flour (alim, textile) făină de orez

rise in temperature (fiz) creștere a temperaturii rice oil (alim, chim) ulei de orez

rice starch (alim, chim, textile) amidon de orez

Richardson number (fiz) număr adimensional, caracteristic curgerii în fluide stratificate

rich gas (ind chim, met, termo) gaze umede / bogate / cu putere calorică mare

rich gas heating (termo) încălzire cu gaz bogat

rich in lead (met) bogat în plumb

rich mixture (auto, chim, met) amestec bogat (în combustibil)

rich slag (met) zgură bogată (în metale neferoase)

Richter scale (metr, fiz, geol) scară logaritmică pentru măsurarea intensitătii cutremurelor de pământ; v. magnitude

rick (metr, silv) unitate tradițională pentru volum, lemne de foc: 1 rick $\sim 1,208$ steri

rid eliberat, liber; a curăta, a elibera, a se debarasa, a scăpa (de ceva); get of a scăpa, a se debarasa (de ceva)

ride alee, drum (pentru călărie); plimbare călare / cu bicicleta; voiaj, drum, călătorie (cu automobilul, autobuzul, bicicleta etc.); ( $\mathrm{fam}$ ) cursă de cai / de maşini, spălătorie; a parcurge / trăbate călare; (amer) (fig) a enerva, a râcâi, a sâcâi, a scoate din sărite, a stăpâni; (fam) a deranja; (nav) a muşca (d. volte), a se mușca (d. parâme), a înfrunta valurile / furtuna; (fig) a cuprinde, a domina; on a merge călare pe, a călări

rid from / out / of a mântui din / de, a salva din (de), a scăpa din / de

ridge (metr) unitate tradițională de măsură pentru lungime: 1 ridge $=6,1722 \mathrm{~m}$

rid of a curăța de, a debarasa de, a descotorosi de, a elibera de, a scăpa de

right angle (metr, geom) unghi drept, unitate de măsură pentru unghiuri, egală cu $1 / 4$ de cerc, $90^{\circ}$ (grade hexagesimale), 100 grade (centagesimale), sau $\pi / 2$ radiani

rid a (e)libera, a scăpa de ceva, a se debarasa, a curăța

riddle $(\mathrm{OM})$ ciur, sită de separare; a cerne, a separa, a strecura, a trece prin sită

riddling (alim, const) refuz de ciur / de sită

ride at anchor (nav) a sta la ancoră

ride the clutch (auto, $\mathrm{OM}$ ) a apăsa pedala de ambreiaj, a debreia

rider (geol, mediu) strat dominant; însoțitor; (fiz, metr) călăreț (la balanțe mai vechi); rocă sterilă inclusă într-un filon; dispozitiv care stă 
călare pe o bandă, pentru golirea materialului în diverse puncte; intercalare (în manuscris) rider pin $(\mathrm{OM})$ bolț / ştift cu canal de ghidare rider strip $(\mathrm{OM})$ bandă (metalică) de protecție ridge creastă; (const) muchie / coamă de acoperiş, cărămidă de falț; coronament; (geogr) coamă, creastă, prag, creastă de munte, lanț de munți, cumpăna apelor; (met, TH) bavură, muchie, bordură, margine, profil cu bulb

ridge beam (const) grindă de coamă

ridged-back file (mas-un) pilă rombică

ridging (agr) muşuroire; (OM) aplatizare pe suprafața de lucru a dinților

ridding comfort (auto, transp) confort de călătorie riffled iron (met) fier / otel striat

riffled sheet (met) tablă striată

riffled surface table (met) masă cu nervuri pentru sortarea minereurilor

riffled tube (met, OM) țeavă cu nervuri sau caneluri elicoidale / spiralate

riffle file (mas-un) pilă fină

riffler (met) denisipar; (OM) canelură, renură (rar), riflu (de tăvălug de moară); crestătură; (mas-un) pilă pentru găuri

riffling (ind chim) epurarea pastei în denisipar (în industria); (met, TH) striere, zimtare

rifle (mil) puşcă, armă; (OM) şanţ; jgheab; canelură; (mas-un) a canela

rifle-bore, rifle-drill (mas-un) a aleza cu sculă specială (şi tip burghiu) un canal de mare lungime

rifle file (mas-un) pilă mare (şi curbată), raşpil

rifling (mas-un) tăierea canalelor elicoidale interioare; ghintuirea armelor de foc

rifling bar (mas-un) bară (cu sculă sau suport de sculă) de tăiat canale elicoidale interioare

rifling machine (mas-un) maşină de tăiat caneluri elicoidale

rift (geol, geogr) crăpătură, fisură, suprafață / plan de rupere, ruptură; defileu; (mas, OM) nervuri; (OM, met) a tăia / a spinteca un covor de bandă

rig (geogr) creastă, muchie; (mas) dispozitiv, aparat(aj), utilaj, instalație, echipament, maşină, montaj; tinută; $(\mathrm{TH})$ înzestrare; tachelaj; $(\mathrm{TH})$ a înzestra; a monta, a asambla; a arma (o pompă, o navă)

Riga last (metr, silv) unitate tradițională britanică pentru a măsura volumul de lemn / buşteni: 1 Riga last $\cong 2,265 \mathrm{~m}^{3}$ de bușteni cu secțiuen pătrată sau $\sim 1,841 \mathrm{~m}^{3}$ de bușteni rotunzi

rigger $(\mathrm{OM})$ roată de curea, dispozitiv de întins cureaua

rigging $(\mathrm{OM}$, mas) asamblare, montaj, reglare, transmisie prin (sistem de) pârghii; (nav) funii de ancorare a unui catarg, greement; sarturi, manevre, tachelaj, cordaj; (TH) instalare, montaj, dotare, dotare, echipare rigging up $(\mathrm{TH})$ montaj, montare, instalare, asamblare, amenajare, dotare

rigging up expenses $(\mathrm{ec}$, ind chim, $\mathrm{TH})$ cheltuieli de montaj

right drept; just; îndreptățit; exact; potrivit; corespunzător; bine; direct; corect; complet; (auto) la dreapta; $(\mathrm{OM})$ filet pe dreapta; a ridica; a redresa; a îndrepta; a corecta

right ahead (nav) drept în prova

right-and-left threaded (OM) (o piesă) având la unul din capete filet pe dreapta şi la celălalt filet pe stânga

right angle (geom) unghi drept

right-angled (geom) dreptunghiular

right-angle elbow pipe (mas, OM) tub cotit la $90^{\circ}$ right-angle friction gear $(\mathrm{OM})$ transmisie cu roți de frictiune conice, $\mathrm{cu}$ axe perpendiculare

right drive / driving (auto) conducere pe stânga (în UK, Australia etc.)

right-handed $(\mathrm{OM}) \mathrm{cu}$ filet / dantură pe dreapta right-handed screw $(\mathrm{OM})$ şurub cu filet pe dreapta right-handed thread screw $(\mathrm{OM})$ şurub cu filet pe dreapta

right-handed twist (mas, $\mathrm{OM}$ ) răsucire la dreapta right hand mill / milling cutter (mas-un) freză de aschiat pe dreapta

right-hand rule (el) regula mâinii drepte right-hand side (mat) membrul al doilea al unei ecuații

right-hand teeth $(\mathrm{OM})$ dantură pe dreapta right-hand thread $(\mathrm{OM})$ filet pe dreapta right-hand tool (mas-un) cutit pe dreapta right-hand twist (met, $\mathrm{OM}$ ) răsucire / torsiune la dreapta

right outside rearview mirror (auto) oglindă retrovizoare exterioară (pe partea) dreapta

right prism (geom) prismă dreaptă

right proportion (mat) egalitate, simetrie, proportionalitate

right the rudder (nav) a îndrepta cârma, a pune cârma la zero

right section (geom, OM) secțiune ortogonală right-side round iron (mas-un) cutit de canelat, sculă de nituit; (mas-un) cuțit de raionat convex right-side view $(\mathrm{OM})$ vedere din dreapta (în desen tehnic)

right triangle (geom) triunghi dreptunghic

rigid (mec, $\mathrm{OM}$ ) rigid, stabil, fix, dur, tare

rigid air screw $(\mathrm{OM})$ elice rigidă

rigid axle (auto, $\mathrm{OM}$ ) osie rigidă

rigid body (fiz) corp rigid

rigid crust (geol) crustă solidă (a globului terestru)

rigid coupling (auto, OM) cuplaj fix / rigid; (cf) cuplare rigidă / strânsă

rigid die (ind chim) formă / matriță rigidă rigid drawgear $(\mathrm{OM})$ dispozitiv rigid, de tracțiune 
rigid fixing (constr, mec, OM) capăt încastrat rigid, încastrare

rigid frame (const) cadru / schelet rigid, şarpantă rigidă

rigid free body balancing (mec) echilibrare a unui corp rigid liber

rigid guide (mas-un, OM) ghidaj fix

rigidified rubber (ind chim) cauciuc rigidizat

rigid in phase (el) stabil în fază, cu defazaj constant

rigidity (el) rigiditate dielectrică; (mec) rigiditate

rigidity modulus (mec, OM) modul de elasticitate transversal

rigidity rib $(\mathrm{OM})$ nervură de rigidizare

rigid joint $(\mathrm{OM})$ îmbinare / asamblare rigidă

rigid plastics (ind chim, plast) materiale plastice rigide; semi- materiale plastice semirigide

rigid polyvinylchloride (ind chim, plast) policlorură de vinil neplastifiată / rigidă

rigid shaft $(\mathrm{OM})$ arbore rigid

rigid suspension (auto) suspensie rigidă

rig out $(\mathrm{OM}$, mas, $\mathrm{TH})$ a demonta

rig up $(\mathrm{OM}, \mathrm{mas}, \mathrm{TH})$ a monta

rim $(\mathrm{OM})$ margine, cadru, ramă, zonă exterioară, bordură; obadă, cant, coroană; (auto) jantă; (met) crustă (a lingoului); a bordura

rim band (auto, $\mathrm{OM}$ ) bandă de protecție a camerei rim base (auto, OM) bază de jantă rim bolt (auto, OM) bolț / şurub de jantă rim brake (auto, OM) frână de jantă rim bruising (auto) deteriorarea jenții rim clamp (auto, OM) clemă de jantă rim clutch (auto, OM) ambreiaj cu benzi rim colar (auto, OM) bordură de jantă rim contour designation (auto) codul jantei rim cut (auto) tăierea anvelopei de către jantă rim diameter (auto) diametrul jantei rim drive $(\mathrm{OM})$ transmisie cu curele rime (auto) a monta anvelope

rim expander / remover (auto, OM) dispozitiv / levier de demontat jenți

rimmed steel (met) oțel necalmat

rimming ingot (met) lingou de oțel necalmat rim of the flywheel (auto, OM) coroana dințată a volanului

rim of guide blading (mas-un) coroană directoare rim of a toothed wheel $(\mathrm{OM})$ coroană dințată rim of wheel (auto, $\mathrm{OM}$ ) janta roții; $(\mathrm{OM})$ coroana roții

rim saw (mas-un) ferăstrău circular cu bandă dințată

rim size (auto) mărimea jentii

rim socket spanner / wrench (auto, OM) cheie tubulară pentru piulițele jenții

rim tool (auto, OM) sculă de demontat janta

rim width (auto) lătimea rotii, jantei rind coajă (şi de copac), pieliță de fructe

ring (const) belciug, ureche; (fiz) sunet, timbru, intonație; (mat) inel; (TH, OM) toartă, inel, ureche; a chema, a suna; (metr, silv) unitate traditională britanică pentru volum de scânduri de lemn, legate cu benzi de tablă: $1 \sim 0,566 \mathrm{~m}^{3}$

ring burner (met) arzător inelar / cu ajutaj inelar; (termo) coroană de încălzire

ring-compression coupling $(\mathrm{OM})$ manşon de cuplare / cu inel de strângere

ring conduit (hidr, OM) conductă circulară

ring core (met) miez rotund / inelar

ring cutter (mas-un) maşină / dispozitiv / sculă de tăiat inele, carotieră

ringed roof (met) boltă inelară (de cuptor)

ring eye bolt $(\mathrm{OM})$ şurub cu ochi

ring fastener $(\mathrm{OM})$ inel de fixare

ring forming machine (met, mas-un) maşină de bobinat sârmă

ring gasket $(\mathrm{OM})$ garnitură inelară

ring gearing $(\mathrm{OM})$ inel de ghidare (şi dințat), ghidaj circular țat

ring groove $(\mathrm{OM})$ canal pentru segment de piston

ring jet (hidr, termo) jet inelar

ring-joint gasket $(\mathrm{OM})$ garnitură inelară (şi metalică) de etanşare

ring kiln (met) cuptor circular

ring-lubricated bearing $(\mathrm{OM}, \mathrm{T})$ lagăr cu ungere cu inel

ring lubrication $(\mathrm{T} ; \mathrm{OM})$ lubrifiere cu inel

ring nozzle (termo, OM) injector / duză inelar(ă)

ring nut $(\mathrm{OM})$ piuliță inelară / rotundă

ring nut spanner $(\mathrm{OM})$ cheie pentru piulite rotunde

ring of wire (met) colac / inel de sârmă

ring oiling $(\mathrm{T})$ lubrifiere cu inel

ring-oiling bearing $(\mathrm{OM}, \mathrm{T})$ lagăr cu ungere cu inel

ring packing $(\mathrm{OM})$ garnitură formată din mai multe inele / pachet de inele (şi elastice)

ring pivot $(\mathrm{OM})$ pivot inelar

ring race of bearing $(\mathrm{OM})$ calea de rulare a rulmentului radial, inel de rulare (al rulmentului)

ring-shaped $(\mathrm{OM})$ inelar, în formă de inel, circular ring size (metr) mărime de inel, o unitate de măsură pentru diametrul interior sau pentru circumferința interioară a(1) unui inel; există diverse sisteme de măsurare; în US mărimea unui inel $\mathrm{n}$ are o circumferință interioară de 36,3 + $2,60 \cdot n \mathrm{~mm}$; în UK mărimile tradiționale se notează cu litere A, B, etc.; if we replace the letters by numbers $n(\mathrm{~A}=1, \mathrm{~B}=2$, etc. $)$, mărimea unui inel (UK) $\mathrm{n}$ are circumferința interioară $36,25+1,25 \cdot n \mathrm{~mm}$; conform ISO 8653 mărimea inelului este egală cu circumferința interioară în mm minus 40 
ring slip (el) inel colector / alunecător

ring spring $(\mathrm{OM})$ arc inelar, arc-taler, arc cu secțiune dublu trapezoidală

ring sticking (auto, termo, T) griparea / blocarea segmenților de piston

ring-tongue terminal $(\mathrm{OM})$ terminație rotunjită (a unei piese), cu o gaură pentru trecerea unui şurub

ring-type packing $(\mathrm{OM})$ garnitură inelară de etanşare

ring with flaps $(\mathrm{OM})$ inel cu aripi / cu nervuri

rinse ( $\mathrm{TH}$, mediu, alim, textile) clătire; a clăti; a spăla; (alim) a înghiți; a curăța

rinse out ( $\mathrm{TH}$, mediu, alim, textile) a spăla (cu înlăturarea impurităților)

rinsing $(\mathrm{TH}$, mediu, alim, textile) clătire, spălare (uşoară)

rinsing plant $(\mathrm{TH}$, mediu, alim, textile) maşină / instalație de spălat

rinsing screen $(\mathrm{OM})$ sită de spălare

rip (textile, semifabricate subțiri, folii) sfâş̧iere; curent (de fluid); tăietură; (mas-un) a canela, a cresta; a (se) rupe; a tăia; a provoca o tăietură / o sfâșiere; a despica (în lung); a (se) sfâșia

ripen a (se) coace; a (se) maturiza

ripeness (alim) maturitate, coacere

ripeness stadium (alim) stadiu de coacere / de maturare

ripening maturizare, maturare, maturație, îmbătrânire, coacere

rip open a spinteca, a despica (d. lemn, piese etc.) ripple (fiz, mec, mas) variație ciclică în jurul valorii medii

rippled $(\mathrm{OM})$ ondulat (dar şi defect)

rippled weld (met) sudură ondulată

ripping (met) prima trecere

ripping chisel $(\mathrm{OM})$ daltă de despicat, rangă

ripping surface $(\mathrm{OM})$ suprafață ondulată (şi defect); (T) (proces de) micro-deformare locală, generat de prelucrare sau în exploatare

ripple încrețire, ondulație (a apei), clipocit; (T) (proces de) micro-deformare locală, generat de prelucrare sau în exploatare

ripple weld $(\mathrm{OM}$, met) sudură ondulată

rip saw (mas-un) ferăstrău de spintecat

ripstop (hidr) soluție de proiectare mecanică pentru separarea a două circuite hidraulice

rip up (mec) a rupe, a spinteca

rise (constr, TH, fiz) rampă, ridicare / înălțare a terenului, înălțime a unei trepte, înclinare, ridicare, creştere, mărire, urcare; (şi fig) ascensiune; (mil) avansare (în grad); (mat) diferență între ordonatele a două puncte; ieşire la suprafaţă înălțare; înălțime; majorare; (fig) parvenire; proveniență; răsărit (al soarelui, lunii etc.); (ec) ridicare, creștere, urcare (a prețurilor etc.); (geol) ridicare, înălțare (a unor straturi); (geogr) ridicătură (de teren), povârniş, deal, înălțime, izvor (şi fig);(OM) săgeată; sporire; suire; sursă; (fam) furie, indignarea, vexare (ca urmare a declaratiei împotriva intereselor unei persoane); a (se) urca, a (se) ridica; (şi fig) a se agita, a se ridica (d. mare etc.); a se porni (d. vânt); a se cățăra pe; a se deştepta (dimineața); a se înălța; a se înălța, a răsări, a se arăta (d. soare, lună); a se încheia, a ridica şedinţa (d. o adunare etc.); (ec) a (se) majora, a crește, a se ridica (d. prețuri, salarii); a se revolta; a se ridica de pe un scaun, a se ridica în picioare; a da de; a zări (de la distanță); to the occasion a fi la înălțimea situației; of the curtain (teatru) ridicare a cortinei (si fig); the $\sim$ of the tide fluxul; of the temperature creştere a temperaturii; ask for a $\sim(\mathrm{ec})$ a cere o majorare a salariului; give $\sim$ to a da naştere la; take smth.'s $\sim$ in (from) a proveni din ceva

rise-and fall rest (mas-un) sanie port-cutit cu reglarea înălțimii

rise of an arch (const) săgeata unui arc

rise of the crown (met) înălțimea / săgeata bolții cuptorului

riser (met) piciorul pâlniei (de turnare), maselotă; (OM) teavă de refulare, verticală / dispozitiv cu mişcare verticală de debitare, coloană montantă, răsuflătoare

rise rate (hidr) viteză de creştere (a presiunii) (şi la deschiderea circuitului hidraulic)

rise time (hidr, mec, autom) timp de creștere / de propagare / de demarare / de accelerare / de stabilizare

rising (fiz, mec) (acțiunea de) ridicare, creştere, suiş, urcare, în ridicare

rising and falling motion (mec, mas-un, mas) mișcare alternativă pe verticală

rising casting (met) turnare prin / în sifon

rising head (met) maselotă

rising load (el) sarcină crescătoare

rising pipe $(\mathrm{OM}$, hidr) tub de refulare, încărcător, (mas-un) țeavă / coloană verticală de debitare

rising steel (met) otel incomplet dezoxidat

risk (ec) risc, pericol; primejdie; a risca; a primejdui; a periclita; a îndrăzni

risk of breakage (ind, $\mathrm{OM}, \mathrm{TH}$ ) pericol de spargere / de rupere

rive breşă; crăpătură; deschizătură; despicătură; v. rip; a (se) crăpa; a (se) despica, a rupe

rive away / off a smulge

rive from a smulge de la / din

river transport (nav, transp) transport fluvial

river vessel (nav, transp) navă fluvială

rivet $(\mathrm{OM})$ nit, a nitui, a fixa cu nituri

rivet bucker $(\mathrm{OM})$ contrabuterolă

riveted $(\mathrm{OM})$ nituit 
riveted frame $(\mathrm{OM})$ cadru / suport nituit rivet hole $(\mathrm{OM})$ gaură / alezaj pentru nit riveted joint $(\mathrm{OM})$ îmbinare / asamblare cu nituri, nituire

riveted on patch $(\mathrm{OM})$ nituit cu eclisă riveted seam $(\mathrm{OM})$ cusătură nituită, nituire riveted weld $(\mathrm{TH}, \mathrm{met})$ electronituire riveter $(\mathrm{OM}$, met) maşină / dispozitiv de nituit rivet head $(\mathrm{OM})$ cap de nit

riveting $(\mathrm{OM}$, met) nituire, asamblare prin nituire, îmbinare nituită

riveting block $(\mathrm{OM})$ dorn de nituit țevi

riveting die $(\mathrm{OM})$ căpuitor

riveting gang $(\mathrm{OM})$ nituire pe mai multe rânduri riveting hammer $(\mathrm{OM})$ ciocan de nituit riveting knob $(\mathrm{OM})$ contrabuterolă

riveting machine / press (mas-un) maşină de nituit prin presare

riveting punch $(\mathrm{OM})$ ştemuitor de nituri

riveting set $(\mathrm{OM})$ căpuitor, buterolă

riveting snap $(\mathrm{OM})$ ciocan de nituit

riveting tongs $(\mathrm{OM})$ cleşte pentru nituri

riveting tool $(\mathrm{OM})$ sculă pentru nituit

rivet joining / joint $(\mathrm{OM})$ îmbinare / asamblare $\mathrm{cu} /$ prin nituri

rivet pitch $(\mathrm{OM})$ pasul nituirii

rivet point $(\mathrm{OM})$ cap de nit

rivet resistance $(\mathrm{OM})$ rezistența nitului

rivet set $(\mathrm{OM})$ căpuitor, buterolă

rivet setter $(\mathrm{OM})$ extractor de nituri

rivet shank $(\mathrm{OM})$ corpul / tija nitului

rivet snap $(\mathrm{OM})$ ciocan de nituit

rivet spacing $(\mathrm{OM})$ distanța dintre nituri, pasul nituirii

rivet stamp $(\mathrm{OM})$ căpuitor

rivet steel (met, $\mathrm{OM}$ ) oțel pentru nituri

rivet stem $(\mathrm{OM})$ corpul / tija nitului

rivet transmitting a force $(\mathrm{OM})$ nit de rezistență

rivet wire (met, OM) sârmă pentru nituri

rivet with button head $(\mathrm{OM})$ nit cu cap semirotund

rivet with half countersunk head $(\mathrm{OM})$ nit $\mathrm{cu}$ cap semiînnecat

rms, RMS (metr) abreviere pentru root mean square, valoare medie pătratică, notație pentru a indica aplicarea metodei de calculare a radicalului mediei pătratelor valorilor date

road (auto, transp) parcurs, drum, cale şosea, stradă; (nav) radă

roadability (auto) ținută de drum, stabilitatea automobilului în mers

road building slag (met, const) zgură pentru construcția drumurilor

road clearance (auto) gardă la sol, spațiu dintre caroseria vehiculului şi şosea

road conditions (auto) condiții de trafic road grime (auto) murdărie (d. şosea)

road octane number, RON (auto, ind chim) cifră octanică la drum

road stability (auto) stabilitate a autovehiculului în mers

roadstead (nav) radă

roadway (constr, auto, cf) rambleu / coronament carosabil, stradă, drum, şosea, cale de transport, bandă de circulație, suprafață a şoselei, parte carosabilă, cale de acces

roar (fiz) zgomot

roaring (chim) efervescență, stropire, pulverizare roast (alim) a frige, a coace; (met) a calcina, a coace, a arde, a prăji

roaster (met) cuptor de calcinare / de prăjire

roaster mix (met) amestec calcinat

roast gas (chim, termo) gaz de ardere

roast heap (met) grămadă de minereu de prăjit

roasting (met) calcinare, prăjire (a minereului)

roasting blast furnace (met) cuptor cu cuvă de prăjire

roasting chamber (met) cameră de prăjire / decalcinare

roasting charge (met) şarjă de prăjire / calcinare roasting furnace / kiln (met) cuptor de prăjire / de calcinare / de ardere

roasting oven (alim) cuptor de coacere

roasting plant (met) instalație de prăjit minereu roasting process (met) proces de prăjire / de coacere / de calcinare

roasting melting (met) topire combinată cu prăjire roasting stall (met) cuptor de prăjit minereu

robot (mas, autom) robot

robotics robotică

robustness (mas, autom) insensibilitate / robustețe a unui sistem / proprietatea de a nu fi afectat de perturbatiii necontrolabile / de a fi independent față de condițiile de mediu

rock (geogr, constr) rocă, piatră brută, stâncă; (mec) poziție instabilă; a (se) balansa, a oscila, a vibra rock breaker / crusher (mas, constr, ind chim) concasor

rock drill $(\mathrm{OM}$, mas) perforator de rocă, perforator cu aer comprimat

rocked tube (met) țeavă laminată la rece în pas de pelerin

rocker $(\mathrm{OM})$ balansier, culisă, bielă, pârghie oscilantă, culbutor

rocker actuated engine (termo) motor cu culbutoare

rocker actuator (auto) culbutor de supapă

rocker arm $(\mathrm{OM})$ brat oscilant / basculant, pârghie basculantă, culisă, pârghie de comandă

rocker arm bonnet (auto, OM) capac de culbutor rocker arm bracket (auto, $\mathrm{OM}$ ) suport de culbutor rocker arm cover (auto, OM) capac de culbutor 
rocker arm shaft (auto, $\mathrm{OM}$ ) ax de culbutor rocker arm support (auto, OM) suport de culbutor rocker bar heating furnace (met) cuptor cu propulsie, pentru încălzit țevi

rocker bearing $(\mathrm{OM}, \mathrm{OM})$ lagăr basculant / oscilant

rocker conveyer (OM, transp) transportor cu cupe rocker oscillating base $(\mathrm{OM})$ reazem oscilant rocker panel $(\mathrm{OM})$ prag

rocking (OM, mas-un) mişcare alternativă / oscilantă / de du-te-vino, basculare

rocking-arc furnace (met) cuptor basculant cu arc rocking arm $(\mathrm{OM})$ braț oscilant / basculant rocking distributor (met) distribuitor oscilant (şi la furnal)

rocking furnace (met) cuptor basculant

rocking lever (OM, met) pârghie basculantă / oscilantă, culbutor

rocking runner / spout (met, OM) canal / jgheab oscilant / basculant

rocking screen / sieve $(\mathrm{OM})$ ciur / sită oscilant( $(\breve{a})$ rocking trough $(\mathrm{OM})$ jgheab oscilant / vibrator rocking-type furnace (met) cuptor basculant

Rockwell hardness (number) (metr, met) duritate Rockwell / în unități Rockwell

Rockwell hardness (RH-) (metr, met) unitate de măsură pentru duritatea materialelor metalice: scara B (RHB) - penetratorul este o bilă de oțel, scara C (RHC) - penetratorul este un con de diamant

Rockwell hardness test (materiale, metr) test de duritate Rockwell

Rockwell hardness tester (metr, mas) maşină / tester pentru determinarea durității Rockwell

Rockwell point / unit (materiale, metr) unitate de duritate Rockwell

rock wool (ind chim, termo) azbest

$\operatorname{rod}(\mathrm{OM})$ ac, tijă, bară, deget, bielă, ştangă, riglă, vergea, baghetă de sticlă, miră (de nivelmetru), nuia, tirant, dorn; prăjină; rod (rd) (metr) unitate tradiţională de măsură pentru lungime, prăjină: $1 \mathrm{rod}=5,0292 \mathrm{~m}$; rod (rd) (metr) unitate de măsură pentru arie, egală cu o prăjină pătrată: 1 rod of area $\cong 25,29285 \mathrm{~m}^{2}$

roede (metr) unitate tradiţională olandeză de măsură pentru lungime sau pentru arie: 1 roede $=$ $10 \mathrm{~m} ; 1$ square (linear) roede $=100 \mathrm{~m}^{2}$

roentgen, röntgen (R) (metr, fiz) unitate în afara sistemului metric, pentru a măsura capacitatea de ionizare a unei radiații: 1 roentgen este egal cu o descărcare de 258 microcoulombi pe kilogram de aer

rod cutter (mas-un) maşină / sculă de retezat bare rod drawing bench / drawing machine (met, mas-un) banc / maşină de tras bare rod gear $(\mathrm{OM}$, nav) transmisie prin sistem de pârghii, timonerie

rod mill (alim, ind chim) moară cu vergele, concasor cu cilindri; (met) laminor pentru bare

rod packing $(\mathrm{OM}$, auto) garnitura jojei / tijei de nivel

rod reel (met, OM) înfăşurător (pentru sârmă)

rod-rolling mill (met) laminor de profiluri grele (tip bară)

rod rolling (mill) train (met) linie de laminor pentru profiluri grele (tip bară)

rod rounds $(\mathrm{OM})$ baghetă rotundă

rod-shaped $(\mathrm{OM})$ în formă de bară

rod wire (met) sârmă laminată (şi pt. recondiționări prin sudare), sârmă-semifabricat

röentgen (fiz) unitate röentgen

röentgen-hour-meter (metr, fiz) o unitate de măsură a puterii razelor / radiației gama; o sursă de $1 \mathrm{rhm}$ produce ionizarea cu o viteză de 1 röentgen pe oră la o distanţă de 1 metru de sursă

Röentgenium (Rg) (fiz) röentgeniu

Röentgen rays (fiz) radiație $X$

roll (alim, OM) tăvălug, sul (pt. ambalare), corn, chiflă; (ec) registru, rol; (OM) tambur cu cuțite, sul de hârtie, rolă (şi de sudare), valț; (met) cilindru (şi de laminor), rulou (şi de tablă); (nav) bandă, ruliu, ondulație; (inf) listă; a rula; a (se) (ră)suci; a rolui, a lamina, a (se) rostogoli, a mandrina, a înfaşura, a netezi

rollability (met) laminabilitate, capacitate de a fi laminat

roll-a-car hydraulic jack (OM, hidr) cric hidraulic pentru manevrarea maşinii / utilajului în atelierul de reparații

roll adjustement (met) reglarea cilindrilor de laminare

roll axis (nav) axă de ruliu

roll back (mas) a rula înapoi

roll balance (met) echilibrare a cilindrilor de laminare

roll barrel (met, OM) tăblie a cilindrului de laminare

roll bearing (met, $\mathrm{OM}, \mathrm{T}$ ) lagăr pentru cilindrul de laminare

roll bending (met, $\mathrm{OM}, \mathrm{mec}$ ) încovoierea cilindrului (de laminare)

roll bending machine (met, mas-un) maşină de îndoit tablă

roll body (met, OM) tăblie a cilindrului (de laminare)

roll body length (met, $\mathrm{OM}$ ) lungime a tăbliei cilindrului (de laminare)

roll camber (met, $\mathrm{OM}$ ) profilul / convexitatea tăbliei cilindrului (de laminare)

roll campagn (met, mas) durata de lucru / de funcționare a cilindrului (la laminare) 
roll changing (met, $\mathrm{TH})$ schimbarea / înlocuirea cilindrilor

roll compacting (met, plast, ind chim) compactare cu ajutorul cilindrilor / prin laminare (între cilindri)

roll compaction (met, plast, ind chim) compactare cu ajutorul cilindrilor / prin laminare / prin rulare (între cilindri)

roll cone (mas-un, OM) con al dispozitivului de copiere, la prelucrarea roților dințate

roll conveyer (OM, transp) transportor cu role

roll cooling device (met, termo) dispozitiv pentru răcirea cilindrilor

roll crown (met) convexitatea cilindrilor

roll crusher (alim, ind chim) concasor cu valțuri

roll designing (met) calibrare (a cilindrilor de laminare)

roll doctor $(\mathrm{OM})$ valț de curățire / răzuitor

roll down (to) (met, $\mathrm{TH}$ ) a lamina, a mandrina, a reduce (la)

roll drafting (met, ind chim) calibrarea cilindrilor

rolled dimeter (met) diametrul la care se laminează (la produse circulare)

rolled edge (met) muchia laminatului

rolled-in scale (met) arsură incrustată în timpul laminării

rolled-in scraps (met) incrustaţie de aşchii în timpul laminării

rolled iron (met) oțel laminat

rolled joint $(\mathrm{OM})$ asamblare (nedemontabilă) prin roluire / presare a unei piese tubulare deformabile (cu un dispozitiv expandabil cu role etc.)

rolled material (met) produs / material laminat

rolled mill edge (met) muchie de laminat

rolled piece (met) produs laminat

rolled pipe (met, OM) țeavă trasă

rolled section / shape (met) profil laminat

rolled slab (met) bramă, sleb

rolled steel (met) laminate, otel laminat

rolled-steel channel (met) profil $\mathrm{U}$

rolled thread $(\mathrm{OM})$ filet obținut prin rulare

rolled tube (met, $\mathrm{OM}$ ) țeavă laminată

rolled-up steel for concrete (met, const) oțelbeton în colaci

rolled-up stock (textile, ind chim) semifabricat în suluri (şi d. hârtie)

roller (alim, OM) tăvălug, sul, corn; (const, OM) rolă (de șenilă, de transportor cu bandă), compresor, cilindru compresor, şofer / operator pe maşină cu cilindru-compresor; (hidr) vârtej / amestecător / mixer cu ax orizontal, cilindru (corp) al stavilei cilindrice, vârtej cu ax orizontal; (OM, met) cilindru de laminor, rolă de conducere / de ghidare / de rulment, rolă (de transportor cu bandă, de şenilă etc.), scripete mic, rulou, sul, valt, rotită, rulou (la mobile, la transport); (met) rulou (şi de tablă), laminorist, cilindru de laminor; (ind chim, mas-un) maşină de rulat; (textile) cilindru de laminare / netezire; (med) sul / rolă de bandaj, bandaj lung rulat; (alim) făcăleț; (metr) greutate culisantă pe tija gradată a cântarului; (nav) rolă, val brizant; (poligrafie) rulou, val (de imprimare); (agr) tăvălug

roller / ball bearing steel (met) oțel de rulmenți roller back rest (mas-un, OM) lunetă fixă cu role

roller beam (met, $\mathrm{OM}$ ) arbore al cilindrului

roller bearing $(\mathrm{OM})$ rulment (radial), lagăr de rostogolire

roller bearing crankshaft (auto, OM) arbore cotit cu rulmenti cu role

roller-bearing drop hanger $(\mathrm{OM})$ lagăr suspendat (cu rulment) pentru scripete

roller-bearing pillow block $(\mathrm{OM})$ crapodină cu role, lagăr cu rulment cu role şi suprafață exterioară sferică

roller-bearing with shoulders $(\mathrm{OM})$ rulment radial cu role, cu umeri

roller bed (met, OM) cale / transportor cu role

roller cage $(\mathrm{OM})$ colivia rulmentului cu role (cilindrice) sau ace

roller chain $(\mathrm{OM})$ lant articulat / cu eclise / cu role / Gall

roller-chain sprocket $(\mathrm{OM})$ roată de lanț cu role Gall

roller-chain track (const, OM, transp) șenilă

roller coater (plast, ind chim, OM) rolă de suprafață / de acoperire

roller coiler (met, mas-un) maşină de bobinat bandă, înfăşurător (de benzi / de rulouri)

roller conveyer (OM, transp) transportor cu role roller cooling bank / bed (met) pat de răcire cu role

roller core $(\mathrm{OM})$ ax al valțului / cilindrului

roller crusher (alim, constr, ind chim) concasor cu valțuri

roller delivery bed (met) cale cu role pentru evacuare

roller drier (alim, constr, ind chim) uscător cu cilindri

roller face $(\mathrm{T}, \mathrm{OM})$ suprafața de rulare / de rostogolire

roller feed (mas-un) avans / alimentare prin mecanism cu role

roller for moving equipment $(\mathrm{OM}$, mas) rolă glisantă, rolă care asigură rularea / avansul / mişcarea unui echipament

roller gear $(\mathrm{OM})$ transmisie / cale cu role, acționată prin angrenaje

roller guide (mas-un) sanie pe role, ghidaj pe role roller-hearth furnace (for coils) (met) cuptor cu vatră mobilă (pt. rulouri de sârmă) 
roller lapping (met) înfăşurare pe cilindrii de laminare

roller level dent (met, mas-un) amprentă / deteriorare cauzată de rolele maşinii de îndreptat

roller leveller (met, mas-un) maşină cu role, pentru îndreptat table

roller link-block $(\mathrm{OM})$ culisă cu role

roller lubrication $(\mathrm{T}, \mathrm{OM})$ ungere cu role

roller mill (alim, ind chim) moară cu valțuri, maşină de măcinat

roller mixer (alim, ind chim) malaxor cu role

roller path (met, mas-un) şină de rulare, ghidajul căii cu role

roller pawl $(\mathrm{OM})$ clichet cu rolă

roller pin $(\mathrm{OM})$ ax al rolei (de dimensiuni relativ mai mici)

roller race $(\mathrm{OM})$ calea de rulare / inelul unui rulment cu role

roller reel (met, OM) înfăşurător cu role

roller riveting machine (mas-un) maşină de prelucrat nituri prin rulare

roller scale (met) arsură / țunder de laminare

roller slide (mas-un, OM) sanie / ghidaj cu role

roller's side (met) partea de introducere / de intrare în laminor

roller stands (met, OM) suportul / suporții / cadrul căii cu role

roller straightener / straightening machine (met, mas-un) maşină de îndreptat cu role

roller support (OM) suport / reazem cu role, suport pentru rulment

roller table (mas-un, OM) masă / cale cu role

roller tappet $(\mathrm{OM})$ tachet cu rolă

roller thrust bearing $(\mathrm{OM})$ rulment axial cu role (cilindrice)

roller towel (textile) prosop-rulou / rulant

roller track $(\mathrm{OM}$, constr, ind) bandă, culoar / şină de rulare; (met) cale cu role (la laminor)

roller train keeper / side plate (met, $\mathrm{OM}$ ) grindă purtătoare a rolelor

roller-type heating furnace (met) cuptor Martin, basculant

roller-type jack (auto, OM) cric pe role

roller-type feed-in table (met, ind) alimentator cu căi cu role, transportor de alimentare cu role

roller-type valve lifter $(\mathrm{OM})$ ridicător de supapă, cu rolă

roll feed alimentare cu hârtie sul (birotică)

roll-feed press (mas-un) presă cu alimentare cu rulouri

roll force (met) forță de laminare

roll for cold-milling (met, OM) cilindru de laminat la rece

roll-forging (met, $\mathrm{TH}$ ) forjare prin laminare

roll for hot-milling (met, OM) cilindru de laminat la cald roll-forming of strips (met, $\mathrm{TH}$ ) formare de profiluri din benzi

roll gap (met) deschidere / distanţă între cilindri (de laminare)

roll grinding (met, $\mathrm{TH})$ rectificarea cilindrilor

roll grinder / grinding machine (met, mas-un) maşină de rectificat cilindri

roll heat-treating furnace (met, termo) cuptor pentru tratamentul termic al cilindrilor

roll housing (met) cajă de laminor

rolling $(\mathrm{OM})$ rostogolire, desfăşurare, rulare; zgomot de rostogolire; care se rostogoleşte, care rulează, care se bălăbănește; care trece / se scurge (d. ani etc.); (met) laminare, forjare între valturi; (nav) (cu) ruliu, cu / de hulă; (const) compactare cu cilindru compresor / tăvălug, tăvălugire, laminare, cilindrare (a drumurilor); (cf) clătinare, legănare, mişcare de legănare a locomotivei; (c, TV) înclinare transversală (a camerei); (av) tonou; (poligrafie) ungere cu cerneală; (ind pielăriei) vălțuire; (geogr) cu coline, deluros

rolling barrel (met, OM) tobă de curățat piese de turnătorie

rolling billet (met) semifabricat, țaglă, bramă pentru laminare

rolling chock (nav) chilă de ruliu

rolling contact $(\mathrm{OM} ; \mathrm{T})$ contact $\mathrm{cu} /$ de rostogolire rolling crusher (mas, alim, ind chim) concasor cu valțuri

rolling defect (met) defect de laminare

rolling direction (met, mec) directia de laminare / de rostogolire

rolling down (met) laminare de finisare / finală

rolling edge (on rolled materials) (met) muchia laminatului

rolling face (met) suprafața de lucru (la laminor)

rolling friction $(\mathrm{T})$ frecare de rostogolire

rolling friction couple (met, OM) moment de frecare (la laminare sau la rostogolire)

rolling ingot (met) lingou pentru laminare

rolling-in tool (met, OM) dispozitiv de lărgit tevi

rolling horse-power (met) putere de laminare (în cai-putere)

rolling margin (met) toleranță de laminare

rolling mill (met) laminor, linie de profiluri mijlocii la laminare

rolling mill crew (met) echipă de laminare

rolling mill drive (met, mas) antrenarea / acționare a laminorului

rolling mill engineering (met) tehnica / tehnologia / ingineria laminării

rolling mill for circular shapes (met) laminor pentru profiluri rotunde

rolling mill for light section (met) laminor pentru profiluri uşoare

rolling mill forman (met) maistru laminorist 
rolling mill for medium-sized produsts (met) laminor pentru produse mijlocii

rolling mill for motor car sheets (met) laminor pentru table de caroserie şi ambutisare adâncă

rolling mill for rounds (met) laminor pentru profiluri rotunde

rolling mill for semi-finished products (met) laminor pentru semifabricate

rolling mill for sheet bar (met) laminor pentru platine

rolling mill for steel strips (met) laminor pentru benzi de oțel

rolling mill for (tramways) rails (met) laminor pentru şină (de tramvai)

rolling mill furnace (met) cuptor de / pentru laminor

rolling mill operator (met) laminator, laminorist, muncitor / operator pentru laminare

rolling mill product (met) (produs) laminat

rolling-mill stand (met) cajă de laminor

rolling-mill superintendent (met) inginer laminorist (tehnolog)

rolling-mill train (met) linie de laminare

rolling mill with diagonal rolls (met) laminor cu cilindri tronconici, pentru laminarea țevilor rolling moment (nav, mec) moment de ruliu

rolling motion (nav, mec) înclinare laterală, ruliu, mişcare de rostogolire

rolling movement (nav, mec) mişcare de legănare, şerpuire, ruliu, mişcare de rostogolire

rolling off / out (met, $\mathrm{TH}$ ) laminare

rolling of sectional iron (met) laminare de profiluri

rolling press $(\mathrm{OM}$, mas-un) calandru, presă cu cilindri

rolling pressure (met, mec) presiune de laminare

rolling process (met, mec) procedeu / proces de laminare, $(\mathrm{OM}, \mathrm{T})$ proces de rostogolire

rolling program(me) / schedule (met) program de laminare

rolling resistance (met, T) rezistență la rostogolire / la laminare

rolling skin (met) strat de oxizi (format) la laminare

rolling slab (met) bramă pentru laminare

rolling speed $(\mathrm{T}, \mathrm{OM})$ viteză de rostogolire; (met) viteză de laminare

rolling stand (met) cajă de laminor

rolling stock (cf) material rulant, parc de vagoane; (met) (stoc de) material pentru laminat

rolling surface $(\mathrm{OM}, \mathrm{T})$ suprafață de rostogolire / de rulare

rolling temperature (met, ind chim) temperatura de laminare

rolling texture (met) structura / textura materialului laminat rolling thread cutter (mas-un, OM) dispozitiv de prelucrat filete prin rulare

rolling tolerance (met) toleranță la laminare rolling track $(\mathrm{OM})$ cale de rulare (şi la rulmenți); (T) urmă a rostogolirii

rolling train (met) linie de laminor

rolling train for heavy products (met) linie de laminor pentru profiluri grele

rolling truck (met) cărucior cu role

rolling-up device $(\mathrm{OM})$ dispozitiv de rulare

rolling width (met, OM) lățime de laminare (a semifabricatului sau a zonei active a cilindrului de laminare)

roll in steps (met) cilindru laminor, cu tăblie în trepte

roll-jaw crusher (alim, ind chim) concasor $\mathrm{cu}$ valțuri şi fălci

roll lift (met) ridicare a cilindrului (pt. reglare)

roll mandrel (met, OM) dorn de perforat

roll mark (met) semn la cilindru (pt. montaj)

roll mill (alim) valț, moară cu valțuri; (met, ind chim) laminor

roll neck (met, $\mathrm{OM}$ ) fus de cilindru

roll neck bearing (met, OM) lagăr al fusului de cilindru

roll-nip adjustment (metr, met, ind chim) reglare a distanței dintre cilindri (şi de laminare)

roll off (mec, ind) a desfăşura, a derula (o bandă, o suprafață)

roll on (met) a mandrina, a văltui; (ind) a desfăşura, a derula (un sul, un rulou de tablă etc.)

roll opening (met) deschidere / distanță dintre cilindri

roll out (met, plast) a lamina, a mandrina

roll-out table (OM, mas) masă cu role pentru deplasarea semifabricatelor sau a produselor finite din zona de lucru

roll over a răsturna, a întoarce prin rostogolire; a răsuci; a se întoarce pe partea cealaltă

rollover (auto) răsturnare (a vehicolului)

roll-over board (met) placă basculantă, de bătătorit

roll-over furnace (met) cuptor basculant

roll packing machine (mas-un, textile, hârtie) maşină de ambalat în suluri

roll pass (met) operație, trecere (prin calibru)

roll pass design (met) calibrare, proiectare a calibrelor

roll pass dressing machine (met) maşină pentru calibrarea cilindrilor

roll piercing mill (met) laminor de țevi / cu cilindri oblici

roll pick-up (met, OM) dispozitiv de prindere

roll pressure (met, mec) presiune / efort de laminare 
roll(ed) product (constr) produs de concasare, (met, plast) produs laminat

roll rack (met, OM) stativ / stand / suporți pentru cilindri

roll ratchet $(\mathrm{OM})$ clichet cu rolă

roll ring (met) inel între calibre (la laminare)

roll roofing (const) carton asfaltat

rolls $(\mathrm{OM})$ valțuri de concasor

roll scale (met) țunder, arsură de laminare

roll separating force (met, mec) forță specifică de laminare, forța de separare a cilindrilor

roll shell (met) cămaşa / tăblie a cilindrului

roll smoothing (met, plast, textile) netezire cu cilindru / cu valt

roll spider (OM, met) butuc al cilindrului / al valțului

roll split $(\mathrm{OM}$, met) deschidere / distanţă dintre cilindri

roll spindler (OM, met) axă cilindrului / a valțului

roll stand (met) cajă de laminor

roll straightener (met) maşină de îndreptat cu role

roll sweep (met) profilul / convexitatea tăbliei cilindrului

roll system (met, OM) sistem / pereche de cilindri de laminare

roll table (transp, OM) transportor / masă / cale cu role

roll tape (measure) (metr) ruletă

roll train (met, transp) transportor / cale cu role

roll trolley attachement (met, OM) dispozitiv de demontare a cilindrilor

roll turning lathe (mas-un, met) strung pentru prelucrarea arborilor mari şi a cilindrilor de laminor

roll-type crusher (constr, alim, ind chim) concasor cu valțuri

roll up $(\mathrm{TH})$ a rula, a înfăşura, a face sul, a rostogoli (d. hârtie, benzi etc.)

roll welding (met, $\mathrm{TH}$ ) sudare cu role

rolly oil (ind chim) emulsie de țitei, țiței emulsionabil

RON (auto, ind chim) abreviere pentru road octane number - cifră octanică la drum; v. road octane number; abreviere pentru research octane number - cifră octanică determinată (după o anumită metodă, în laborator) v. research octane number

rood (metr, constr) prăjină, unitate tradițională de măsură pentru lungime şi arie (pt. teren): 1 rood = 5,029 m; fâșie îngustă de pământ cu lățime de 22 de iarzi şi lungime de 55 de iarzi (parcelă urbană pt. locuință): 1 rood 1011,714 m²

roof (constr) acoperiş, tavan, a acoperi (o casă); (met) boltă a cuptorului; a acoperi; (nav) plafon, ruf; a acoperi, a înveli, a căptuşi; (fig) a adăposti

roof brick (met, constr) cărămidă pentru bolta cuptorului

roof carrier (auto, OM) portbagaj extern

roof rack (auto) antenă

roof rails (auto) plafon

room (constr) cameră, încăpere, sală, cămară; (cf, nav) compartiment (şi naval)

roominess (auto) spațiozitate

room temperature (mediu) temperatura camerei / ambiantă / normală de interior

roomy vast, spațios, încăpător

root (mat) rădăcină, radical, bază, a extrage rădăcina; (met) rădăcină (a cusăturii sudate); (OM) rădăcină (la cusătura de sudură), vârf (pt. sudură), ieşire a filetului, picior al dintelui $\left(\mathrm{d}_{\mathrm{b}}\right)$ (la o roată dintată); (fig) esență, fond (al unei probleme etc.), izvor, fundament, rădăcină, sursă; (bot) ghiveci de flori; întemeietori ai unei familii; (geogr) piciorul / poalele muntelui; (lingv) rădăcină; străbuni, strămoși; (muz) sunet fundamental, notă fundamentală a unui acord; țigară, trabuc; a da ajutor / sprijin, a sprijini; a cotrobăi, a scotoci; a face o intervenție; a implanta; a se înrădăcina, a prinde rădăcini; (fig) a înțepeni, a pironi, a țintui; a pune o pilă; a râma (d. porc); a susține; a ține cu; (sport) a aplauda, a încuraja (jucatorii unei echipe); a favoriza pe cineva; a fura

root circle / cylinder (OM) cerc / cilindru de bază (la roți dințate)

root cone $(\mathrm{OM})$ conul de picior al danturii conice root deviation (mat) abatere pătratică medie root diameter $(\mathrm{OM})$ diametru interior al filetului, diametru al cercului de bază la roți dinţate $\left(\mathrm{d}_{\mathrm{b}}\right)$, diametrul minim de picior al roții melcate (rar)

root gap (met, OM) rost între marginile pieselor de sudat, mărime / deschidere a rostului / a interstițiului

root layer (met) primul strat al cusăturii (din mai multe straturi de sudură), sudură la rădăcină

root mean square (rms) (metr) valoare medie pătratică, notație utilizată pentru a indica aplicarea metodei de calculare a radicalului mediei pătratelor valorilor date

root mean square method (metr) metoda mediei pătratice

root mean square deviation of the assessed profile (metr) abatere medie pătratică a profilului evaluat (la profilometria suprafeței)

root-mean square error (mat) eroare pătratică medie

root mean square slope of the assessed profile (metr) pantă medie pătratică a profilului evaluat (la profilometria suprafeței) 
root-mean square value (mat) valoare pătratică medie; (el) valoare eficace

root of thread $(\mathrm{OM})$ baza / fundul filetului

root of tooth $(\mathrm{OM})$ piciorul dintelui

root radius (met, OM) raza cusăturii la rădăcină

(la sudură); $(\mathrm{OM})$ raza de racordare la piciorul dintelui (la roți dințate) $\left(\rho_{\mathrm{f}}\right)$

root reinforcement (met, $O M$ ) îngroşare la rădăcină a cusăturii sudate

root test (mat) criteriu de convergență Cauchy rope funie, frânghie; (met) cablu (şi de oțel); (nav) manevră, odgon, parâmă (vegelată, metalică sau din fibre sintetice), parâmă de legare la cheu; a lega cu o frânghie / o funie etc.; (metr) altă denumire pentru rood, unitate de măsură pentru lungime, prăjină; v. rood

rope brake $(\mathrm{OM})$ frână cu cablu

rope bridge (transp) pod suspendat (pe cabluri)

rope clamp / clip / cramp (OM) dispozitiv de prindere a funiei / cablului, fixator de cablu, clemă de cablu

rope conveyer (transp) transportor pe cablu

rope conveyer hot bed (met) pat de răcire cu transportor cu cablu

rope drive / transmission $(\mathrm{OM}, \mathrm{mec})$ acționare / transmisie prin cablu

rope-drive pulley $(\mathrm{OM})$ roată pentru cablu (la transmisii)

rope gearing $(\mathrm{OM})$ transmisie prin cablu (profilat) rope grease $(\mathrm{T}$, met) unsoare pentru cabluri rope guard $(\mathrm{OM})$ apărătoare pentru cablu rope guide $(\mathrm{OM})$ ghidaj pentru cablu rope hoist $(\mathrm{OM})$ troliu / palan pe cablu rope pull $(\mathrm{OM}$, transp, el) întindere a cablului rope pulley $(\mathrm{OM})$ roată pentru cablu, scripete rope setter $(\mathrm{OM})$ pârghie pentru aşezarea curelei / cablului pe roată

rope sheave $(O M)$ şaibă de cablu

rope spinning machine (mas-un) maşină de răsucit cabluri

rope tackle block $(\mathrm{OM})$ sistem cu scripeți

ropeway (transp) funicular

rope winch (transp) troliu pe cablu

ropy (materiale) cleios, lipicios, vâscos, ductil rose bit (mas-un) adâncitor conic, tăiș în formă de rozetă

rose countersink (mas-un) teşitor cu cap sferic

rose cutter (mas-un) freză cu cap semi-sferic, pentru prelucrarea matrițelor

rose reamer (mas-un) alezor de capăt

rose steel (met) oțel cementat foarte dur

rosette rozetă

rosette-shape path (of electrons) (fiz) traiectorie / orbită specifică electronilor

rosette-type strain gauge (metr) sistem de aranjare a mărcilor tensometrice, cu trei mărci, dispuse în stea (rozetă) (de obicei, câte două la $90^{\circ}$ și a treia la $45^{\circ}$ față de una din cele două)

rosin (chim) sacâz, colofoniu, gumă, smoală, catran, gudron, răşină

rot putregai, descompunere; a putrezi, a se descompune, a se dezintegra, a fi supus eroziunii eoliene (d. materiale)

rotameter (hidr, OM, metr) debitmetru cu flotor rotary placă turnantă, dispozitiv cu mișcare de rotație; de rotație, rotativ, turnant, circulant, pivotant; giratoriu; prin rotatie; (textile) mașină de tricotat cu acționare mecanică

rotary attachment (mas-un, OM) masă / dispozitiv rotativ( $\breve{a})$

rotary autoclave (alim, ind chim) autoclavă rotativă

rotary bending (mec, OM) încovoierea unei piese în rotatie

rotary blower (met, termo) suflantă rotativă, turbosuflantă

rotary-blower-type supercharger (termo) turbosuflantă de înaltă presiune

rotary-body-type gas producer (met) generator de gaz, cu cuvă rotativă

rotary boring clamp (OM, mas-un) braț de rotire (şi la maşina de găurit)

rotary breaker (met) concasor conic, cu girație, pentru sfărâmat minereu

rotary bridge crane (constr, met) macara / pod rulant( $\breve{a}) \mathrm{cu}$ brat rotitor

rotary calciner (met, ind chim) cuptor rotativ (la fabricarea cimentului şi varului)

rotary casting (met, $\mathrm{TH})$ turnare centrifugală

rotary compressor $(\mathrm{OM}$, termo) suflantă cu piston rotativ, compresor centrifugal

rotary convertor (el) convertizor rotativ, comutator electric (prin rotire), grup convertizor rotary core bit (mas-un) carotieră

rotary crane (mas, transp) macara pivotantă

rotary crusher (ind chim) concasor conic, cu mișcare de rotatie

rotary cup $(\mathrm{OM})$ cupă rotativă

rotary current (el) curent alternativ trifazat

rotary current transformer (el) transformator de curent alternativ

rotary cutter (mas-un) carotieră, maşină / dispozitiv de tăiat / de aşchiat rotativ

rotary cutting (mas-un, TH) tăiere / aşchiere inelară

rotary-cut veneer $(\mathrm{TH}, \mathrm{OM})$ furnir derulat / tăiat în spirală de pe lemn rotund

rotary diafragm $(\mathrm{OM})$ diafragmă care se închide sau se deschide prin mişcări de rotație rotary digester (alim, ind chim) fierbător rotativ rotary disk filter $(\mathrm{OM}$, alim, mediu) filtru (celular) cu discuri rotative 
rotary disk valve (hidr, OM) supapă / robinet cu cep îngust, actionat prin rotire

rotary drier (alim, ind chim) uscător cu mişcare de rotație / rotativ

rotary drilling bit (mas-un, constr) perforator rotativ

rotary drum $(\mathrm{OM})$ tobă / tambur $\operatorname{rotativ}(\breve{a})$

rotary drum filter $(\mathrm{OM}$, hidr) filtru cu tambur rotativ

rotary drum mixer (const, mas) betonieră; (ind chim, alim) amestecător cu tambur

rotary drying kiln (alim, ind chim) uscător rotativ cu tambur

rotary dry vacuum pump (alim, fiz) pompă de vid, rotativă, uscată

rotary dump-type separator (alim, agr, ind chim) separator cu tobă rotativă, descărcător rotativ

rotary feeder $(\mathrm{OM})$ dispozitiv rotativ de alimentare, roată transportoare (de alimentare); (poligrafie) alimentator rotativ

rotary field (fiz) câmp rotitor

rotary file (mas-un) pilă rotundă

rotary filter $(\mathrm{OM}$, hidr) filtru rotativ

rotary force $(\mathrm{mec})$ forță de rotire, forță cu direcție variabilă / rotațională

rotary furnace (met) cuptor cu vatră rotitoare

rotary gang slitter (mas-un) foarfece cu discuri, de tăiat tablă în benzi

rotary gas-blower (termo, ind) suflantă rotativă

rotary grate-type gas producer (met) generator de gaz cu grătar rotativ

rotary grinding machine (mas-un) maşină de rectificat plan, cu masă rotativă

rotary hammer-type breaker (constr, ind) concasor cu ciocane articulate

rotary indexing table (mas-un, $\mathrm{OM}$ ) masă rotativă de indexare

rotary jig $(\mathrm{OM})$ dispozitiv de ghidare, turnant rotary kiln (ind chim, met) cuptor (tubular) rotativ rotary melting furnace (met) cuptor rotativ pentru topire

rotary mixer (constr, mas) betonieră, amestecător rotativ

rotary motion / movement (mec) mişcare de rotație

rotary oscillation $(\mathrm{OM}, \mathrm{mec})$ oscilație datorată rotirii unei piese sau oscilație cu aceeaşi lege de variație (dependentă de poziţia unui punct pe un cerc)

rotary oven (met) cuptor rotativ

rotary piercing (met, $\mathrm{TH})$ perforare / laminare cu cilindri oblici (pentru țevi)

rotary piercing rolling mill (met, $\mathrm{TH}$ ) laminor cu cilindri oblici / Manesmann / perforator, pentru țevi

rotary pan (alim) cuvă rotativă rotary piston blowing engine (met) suflantă cu piston rotativ

rotary piston drive (autom, hidr) servomotor cu piston rotativ

rotary piston engine (mas, termo) motor $\mathrm{cu}$ piston rotativ

rotary pulger pump $(\mathrm{OM}$, hidr) pompă cu pistonaşe (acționate prin rotirea axului pompei)

rotary preforming press (mas-un) presă de tabletare, cu masă rotativă

rotary press presă cu masă rotativă

rotary pump (OM, hidr) pompă centrifugă

rotary reverberatory furnace (met) cuptor rotativ, cu flacără

rotary screen $(\mathrm{OM})$ sită cu mișcare circulară

rotary screwing chuck (mas-un) cap de filetat rotativ

rotary scrubber (met, ind chim, mediu) epurator centrifugal de gaze

rotary selector (el, OM) selector / buton de reglare rotativ

rotary shears (mas-un) foarfece rotativ

rotary sintering kiln (met, ceramice) cuptor tubular rotativ de sinterizare / de aglomerare

rotary slide valve (OM, hidr) supapă cu cep rotativ / cu plunjer rotativ

rotary slide valve engine (mas) motor $\mathrm{cu}$ supapă rotativă

rotary suction filter $(\mathrm{OM})$ filtru rotativ cu vid / de aspiratie

rotary switch (el) întrerupător / comutator acționat prin rotire

rotary sweeper $(\mathrm{OM})$ cap rotativ de spălat

rotary table (mas-un) masă rotativă

rotary-table sandblast machine (met, mas-un) suflantă de sablat, cu masă rotativă

rotary-tower crane (met) macara rotitoare / pivotantă

rotary vacuum pump $(\mathrm{OM})$ pompă rotativă de vid

rotary valve (OM, hidr) vană / supapă rotativă

rotary vane compressor (mas, OM) compresor rotativ volumetric

rotary vice $(\mathrm{OM})$ menghină / dispozitiv $\operatorname{rotativ}(\breve{a})$ rotate a (se) roti, a (se) învârti, a pivota, a alterna (producția agricolă sau de alt fel)

rotate the entire circle $(\mathrm{OM}$, mas) a face o rotire completă $\left(\right.$ de $\left.360^{\circ}\right)$

rotating $(\mathrm{OM}, \mathrm{mec})$ (acțiunea de) pivotare, rotativ, rotitor, turnant, care se rotește / pivotează

rotating autoclave (alim, termo) autoclavă rotativă rotating axle $(\mathrm{OM})$ osie rotativă

rotating bar fatigue test $(\mathrm{OM}$, metr) test / încercare de oboseală cu o bară în rotatie

rotating barrel $(\mathrm{OM})$ tambur rotativ

rotating beacon (el, mas) baliză rotitoare 
rotating-beam testing machine (mas, metr) maşină de încercat la oboseală prin rotire

rotating-bending fatigue strength (materiale, mec, metr) rezistență la oboseală prin încovoiere rotativă

rotating-bending fatigue test (materiale, metr) încercare / test la oboseală prin încovoiere rotativă

rotating buddle (met) vatră rotativă

rotating crane (mas, transp) macara cu mişcare de rotație

rotating crystal method (fiz) metodă cu cristal rotativ / turnant

rotating cylindrical kiln (met) cuptor tubular rotativ

rotating device $(\mathrm{OM})$ dispozitiv de întoarcere / de rotire / cu mişcare de rotație

rotating dredger (nav) dragă cu cupe rotative

rotating electrical machine (el, mas) maşină electrică rotativă (prea general)

rotating field (fiz) câmp rotitor

rotating furnace (met) cuptor rotativ

rotating (gun) ring (mas, mil) turelă (cu arme)

rotating-hearth furnace (met) cuptor cu vatră rotativă

rotating kiln (met) cuptor rotativ

rotating screen $(\mathrm{OM})$ sită rotativă

rotating shaft $(\mathrm{OM})$ arbore în / cu mișcare de rotație

rotating shears (mas-un, OM) foarfece rotativ

rotating table $(\mathrm{OM})$ placă turnantă, masă rotativă (şi la maşini-unelte)

rotating table press (mas-un) presă cu masă rotativă

rotating top (met) pâlnie rotitoare / rotativă (la furnal)

rotating tool (mas-un) sculă rotitoare

rotating tool with parallel shanks (mas-un) sculă rotitoare / rotativă cu cozi cilindrice

rotating viscosimeter (metr, T) vâscozimetru rotativ

rotation (mec) rotație, rotire; (c, inf) acțiune de rotire a elementelor grafice în jurul unei axe (în desen virtual / asistat de computer); repetare periodică / ciclică; alternare; girație

rotational field (fiz) câmp rotațional

rotational inertia $(\mathrm{mec})$ moment de inerție

rotational motion $(\mathrm{mec})$ mişcare de rotație

rotational resistance $(\mathrm{mec}, \mathrm{T})$ rezistență la mişcare de rotatie

rotational speed $(\mathrm{mec})$ viteză unghiulară

rotational symmetric $(\mathrm{OM}$, geom) cu simetrie de rotație / de revoluție

rotation angle (mec, OM) unghi de rotire

rotation cooling (met, ind chim) răcire prin recirculare / în circuit rotation drum $(\mathrm{OM})$ tobă rotativă

rotation gear $(\mathrm{OM})$ mecanism de rotire (şi cu roți dințate)

rotation of axes $(\mathrm{OM})$ rotația axelor (şi la planetare, diferențiale etc.)

rotations per minut $(\mathrm{OM}, \mathrm{mec})$ rotatii pe minut rotative moment $(\mathrm{mec})$ moment de inertie, moment de torsiune (mai rar)

rotative speed $(\mathrm{mec}, \mathrm{TH})$ turatie

rotary flow (hidr) mişcare de rotație (a unui fluid) rotl, rotel, rottle, ratel, arratel (metr) unitate tradițională arabă de măsură pentru masă, corespunzătoare livrei romane, livrei franceze si livrei engleze: 1 rotl $\sim 450 \ldots 530 \mathrm{~g}, 1$ rotl (Siria, Palestina) $\sim 2,5 \ldots 2,8 \mathrm{~kg}$

rotor $(\mathrm{OM})$ rotor; (el) indus, corp de rotație rotor blade $(\mathrm{OM})$ pală / paletă de rotor rotor body (OM, el) corp de rotor / de indus rotten putred, descompus (şi d. lemn) rotting (constr) edificiu rotund, rorondă; putrezire (d. lemn, semănături etc.)

rotund (geom, OM) rotund; gras, plin, plinut; umflat; emfatic; bombastic; răsunător

rough asprime; dificultate; schiță; stare brută; (poligrafie) ciornă; (auto) maşină care a fost lovită cel puțin o dată; $(\mathrm{OM})$ caia / cui de potcoavă, brut, cu asperități mari, neprelucrat, rugos, aspru, grosolan (după prelucrare), grosier; colturos; zgomotos; aproximativ; estimatic; accidentat, bolovănos, pietros (d. teren, drum etc.); alterat, aspru, răguşit (d. glas, voce) (TH) a degroşa, a eboşa; a schița; aspru, rău (d. vreme); (fig) bădăran, grosolan; (fig) dificil, dur, greu

rough accomodation condiții de cazare nesatisfăcătoare

rough adjustement (metr, mas) reglare / ajustare grosolană

roughage (agr) furaj grosier / grosier / ordinar; (alim) alimente greu digerabile, hrană indigestă

rough-and-tumble dezordonat, în dezordine, neregulat; învălmășeală; amestec

rough analysis analiză brută / fără mare precizie rough approximation (mat) aproximație grosieră / brută

rough attempt încercare primară / primitivă, schiță primordială; ciornă; proiect în stare brută / incipientă

rough bar (met) lingou

rough bloom (met) lupă forjată

rough bore (mas-un, $\mathrm{OM}$ ) alezare de degroşare, alezaj cu rugozitate mare

rough bottom $(\mathrm{OM}$, hidr) fund neregulat / $\mathrm{cu}$ asperități / denivelări)

rough bulk appearance $(\mathrm{OM})$ aparență rugoasă (generală)

rough burning (met, ind chim) ardere incompletă 
rough calculation (mat) calcul estimativ / aproximativ

rough-cast schițat în linii mari, abia schițat; (const) tencuit brut, tencuială brută, a tencui brut; (textile) scămoşat; (met) brut-turnat; a schița

rough circle (geom) cerc aproximativ / imprecis / prost desenat

rough cleaning (ind chim, met, mediu) epurare / purificare / curățare preliminară

rough coal (met) cărbuni inferiori

rough coat (const) grund (de tencuială), primul strat de tencuială / mortar

rouh copy ciornă, concept, formă brută (a unui text); copie neprelucrată (în fotografie etc.)

rough-cutting tool (mas-un) sculă / cuțit de degroşare

rough diamond diamant neşlefuit

rough down (met) a lamina

rough draft schiță (provizorie); (ante)proiect; ciornă; a schița

rough drill (mas-un) găurire de degroşare

rough-dry (d. textile) uscat dar necălcat; a usca (textile) fără a le călca

rough edge margine crestată (la o carte; defect)

roughed out (mas-un) degroşat, prelucrat în prealabil

roughen (mas-un) formare artificială a asperităților (pt. acoperiri ulterioare etc.); a înăspri, a face / deveni aspru; (TH) formare de asperităţi, a degroşa; (met) a decapa, a aspri o suprafață, a eboşa; (const) a buciarda; (poligrafie) a face aspru, a decapa

roughened surface (on glass) (ind chim) pete de ardere (pe sticlă, defect)

roughener (met, OM) matriță de preforjat, (cajă de) laminor de grosisor

roughening of concrete (const) buciardare

rougher (met) cajă degrosisoare

rough estimate (ec) deviz estimativ / aproximativ; estimație brută / grosieră / aproximativă, evaluare aproximativă; la prima vedere

rough face (mas-un) a degroşa (o suprafață frontală)

rough file (mas-un) pilă aspră / de degroşare

rough fit $(\mathrm{OM})$ ajustaj cu toleranță mare / de precizie scăzută

rough-forge (met) a preforja, a forja grosier

rough-forged (met) forjat brut, preforjat

rough-form (mas-un) a prelucra inițial cu cuțit profilat

rough grazing (agr) (păscut în) păşune naturală

rough-grind (mas-un) a rectifica (fază de degroşare), a ascuți (sumar, neglijent), a face polizarea / ascuțirea (unei scule)

rough grinding (mas-un) rectificare grosieră / de degroşare rough groove (met) calibru degrosisor

rough guess aproximație; apreciere estimativă; a aprecia estimativ, a aproxima

rough-hew, rough-hewn a tăia (piatră, lemn etc.) grosolan; a prelucra brut; a schița, a dăltui provizoriu

rough in $(\mathrm{TH})$ a grundui

roughing ( $\mathrm{TH}$, mas-un) degroșare, creșterea asperității, asprire (a unei suprafețe); (plast) asperizare

roughing and finishing mill (met) laminor degrosisor şi finisor

roughing caliber (met) calibru degrosisor

roughing cut (mas-un) aşchiere de degroşare, eboşare, trecere de degroşare

roughing cutter (mas-un) sculă / freză de degroşare

roughing diamond pass (met) calibru romboidal, de degroşare (la laminoare)

roughing-down mill (met) laminor degrosisor

roughing file (mas-un) pilă aspră / de degroşare

roughing flat (met) laminare de brame

roughing grindstone (mas-un) piatră / disc de rectificare grosieră, piatră aspră

roughing lathe (mas-un) strung de degroşare / de eboşare

roughing mill (met) laminor degrosisor

roughing milling cutter (mas-un) freză de degroşare

roughing-mill stand (met) cajă degrosisoare

roughing pass (mas-un) trecere / operație de degroşare; (met) calibru degrosisor

roughing reamer (mas-un) alezor de degroşare

roughing roll (met) cilindru degrosisor (la laminare)

roughing stand (met) cajă degrosisoare

roughing tap (mas-un) tarod de degroşare

roughing tool (mas-un) sculă / cuțit pentru degroşare

roughing train (met) linie de laminor degrosisor rough lapping (mas-un) rodare / lepuire de degroşare

roughly $(a d v)(\mathrm{ec}, \mathrm{mat})$ aproximativ, estimativ, cu aproximație mare

rough-machine (mas-un) a degroşa, a eboşa, a prelucra grosier / aspru

rough-machining prelucrare de degroşare, eboşare (şi prin aşchiere)

rough makeshift aranjament provizoriu / primar / expedient

rough metal (met) metal brut

roughness (mas-un, $\mathrm{OM}, \mathrm{T}$ ) rugozitate, asprime, asperitate; caracter accidentat / bolovănos / pietros (al unui drum etc.); stare brută / neprelucrată; asprime (a vremii, a părului, a unei suprafețe etc.); rigoare; caracter nepoliticos / grosolan; 
nepolitețe; lipsă de politețe; tratament aspru / sever; maltratare; stare incipientă / informă; lipsă de rafinament / de prelucrare; aproximație, caracter estimativ / aproximativ / provizoriu; dezordine, lipsă de aranjare

rough nut $(\mathrm{OM})$ piuliță brută / grosolană

rough out (constr, $\mathrm{TH}$ ) a netezi, a tăia, a scoate, a săpa, a dăltui

rough passage (nav) traversare (pe o mare) agitată rough pierced tube blank (met) semifabricat pentru țevi

rough plane rindea de degroşare; (mas-un) a degroşa prin rabotare

rough rice (alim) orez nedecorticat

rough rolled slab (met) bramă laminată grosier

rough rolling (met) laminare de degroşare

rough rule (mat) regulă aproximativă / de aproximare

rough size (met) dimensiunea piesei brute / neprelucrate

rough state $(\mathrm{TH})$ stare brută / neprelucrată; lipsă de rafinament / prelucrare; dezordine, nearanjare, stare primară (şi ciornă)

rough surface $(\mathrm{OM}, \mathrm{T})$ suprafață aspră / rugoasă / cu asperități / neprelucrată

rough-surface colloid mill (alim, ind chim) moară coloidală, cu rotor striat

rough tooth $(\mathrm{OM})$ dinte neprelucrat, dinte $\mathrm{cu}$ rugozitate mare

rough toothed file (mas-un) pilă grosolană

rough translation traducere brută / nestilizată / neprelucrată; ciornă, primă formă a unei traduceri

rough turn (mas-un) a degroşa la strung, a degroşa prin strunjire

rough turning (mas-un) strunjire de degroşare

rough vacuum (fiz) vid slab / preliminar / puțin înaintat

rough walling (met) zidul de bază al unui cuptor rough washer $(\mathrm{OM})$ şaibă grosolană / neprelucrată

rough weather (meteo) timp / vreme urât(ă)

rough weld (face) $(\mathrm{OM}, \mathrm{TH})$ suprafață rugoasă a sudurii

rough work (ec, TH) muncă grea / brută / care te solicită mult / care necesită forță / care cere multă putere; ciornă, concept; proiect preliminar; (met) a ebosa, a prelucra brut

rough-wrought (ind) semi-preparat, semi-prelucrat, prelucrat provizoriu; pregătit pentru finisare / definitivare

roulade (alim) ruladă (de carne)

rouleau, $(p l)$ rouleaux fişic / top de monede roulette ruletă; (mat, geom) curbă generată; (const) rulou (al zugravului); (OM, alim) rozetă pentru dantelarea timbrelor / aluatului rouletted (d. timbre) dantelat

round cerc, circumferință; tură, turneu, rond; ciclu, rând; ocol, ocolire; rundă, repriză; circular, rotund; în cerc, ciclic; rotunjit; felie, feliuță; de jur împrejur; complet; (mat) (d. cifre) rotunjit, complet, întreg, (d. calcule) aproximativ, estimativ, în cifre rorunde; sincer, deschis; aspru, brutal; continuu; a (se) rotunji, a tăia rotund, a deveni rorund; a completa, a rotunji; a încon-jura, a ocoli; (auto, cf) a lua un viraj; a (se) întoarce, a (se) învârti, a se răsuci, a (se) întregi, a se completa; a merge pe teren; a se răspândi; (nav) a înconjura, a dubla (un cap); ( $a d v)$ în cerc, în jur, de jur împrejur; (metr, sport) rundă, repriză (în box runda are 3 minute); go a se învârti

round about din toate părțile, în apropiere, în vecini

roundabout ocolit, indirect; întortocheat; $(a d v)$ pe ocolite; cale ocolită, ocol; (auto) sens giratoriu round about $(a d v)$ (de jur) împrejur, prinprejur roundabout traffic system (auto) sens giratoriu roundabout way ocolire; (auto) sens giratoriu round arch (const) arc semicircular

round bar (iron / steel) (met) oțel / semifabricat (din oțel) rotund, bară rotundă

round bar peeling plant (met, mas-un) instalație de decojit bare rotunde

round bar spiral spring $(\mathrm{OM})$ arc spiralat / elicoidal cu secțiune rotundă

round bar straightening plant (met, mas-un) instalație de îndreptat semifabricate / bare rotunde round beam $(\mathrm{OM})$ grindă cu sectiune rotundă round belt $(\mathrm{OM})$ curea rotundă (în secțiune) round billet (met) semifabricat rotund (şi pt. laminarea tevilor)

round bloom (met) lingou rotund

round blunt scraper (mas-un) răzuitor rotund cu vârf teşit

round-bottom(ed) $(\mathrm{OM}) \mathrm{cu}$ fund rotund / rotunjit; (chim) balon cu fund rotund

round brackets (mat) paranteze rotunde round-branch box (el) doză de derivație round-chamber kiln (met) cuptor circular round charging machine (met, alim, ind chim) alimentator cu mișcare de rotatie

round column drill (mas-un) maşină de găurit cu coloană rotundă

round-cornered $(\mathrm{OM})$ cu muchii rotunjite

round die (mas-un) filieră rotundă / pentru filet rotund

rounded $(\mathrm{OM})$ rotunjit $\mathrm{cu}$ racordare, întregit, completat

round-edge (un)equal angles steel (met) oțelcornier cu aripi (in)egale și muchii rotunjite rounded thread $(\mathrm{OM})$ filet cu vârf rotund / bombat 
rounded weld (OM, met) cusătură de sudură circulară / inelară

roundel $(\mathrm{OM})$ rondelă, obiect rotund, disc; cerc; tavă rotundă; (const) fereastră rotundă

round faced tool (mas-un) cuțit / sculă cu tăiş rotunjit

round figure(s) (mat) cifră rotundă, număr rotund / întreg; cifră aproximativă (pe ghicite), evaluare / apreciere estimativă; măsurare / estimare / apreciere din ochi / pe ghicite

round groove (met) calibru rotund

round head $(\mathrm{OM})$ cap semirotund

roundheaded $(\mathrm{OM})$ cu cap semirotund

roundheaded screw $(\mathrm{OM})$ şurub cu cap semirotund

roundhouse (cf) depou; (nav) ruf, sala cabinelor round in (nav) a brața în vânt, a ocoli

rounding $(\mathrm{OM}$, mat) racordare, rotunjire, arc, curbă, racordare, care racordează

rounding corner tool (mas-un) sculă de rotunjit / de racordat colțuri

rounding error (mat, inf) eroare de rotunjire

rounding off $(\mathrm{OM})$ rotunjire, racordare

rounding off cutter(s) (mas-un) freză de rotunjit

rounding off the edges (mas-un, OM) rotunjirea muchiilor / marginilor

round ingot (met) lingou rotund

rounding tool (mas-un) cuțit de rotunjit

round iron (met) oțel rotund

roundish rotunjor, aproape / aproximativ rorund

round key $(\mathrm{OM})$ pană-disc

round kiln (met) cuptor rotund

roundlet cerculeț

roundly $(a d v)$ rotund, circular; în cerc, de jur împrejur; direct, sincer, fără menajamente; în cifre rotunde; în general, fără prea multe detalii; (în mod) energic, viguros, îndrăzneț; temeinic, serios

roundness $(\mathrm{OM})$ rotunjime, circularitate; sfericitate; rotund, cerc; caracter circular / sferic; (fig) aproximație, exactitate relativă; apreciere / evaluare în linii mari / grosso modo / în cifre rotunde; fluență, caracter curgător; cursivitate; sinceritate (exagerată / brutală); vorbire deschisă / fără menajamente; caracter direct / categoric / fără echivoc

round-nosed tool (mas-un) cuțit cu vârf rotunjit round-nose iron (mas-un) cuțit convex de raionat round-nose pliers $(\mathrm{OM})$ cleşte cu vârfuri rotunjite / curbate

round notch $(\mathrm{OM})$ crestătură cu fundul rotunjit (şi la epruvete pt. teste de rezilienţă)

round nut $(\mathrm{OM})$ piuliță rotundă

round number (mat) număr întreg / rotunjit

round off the angles a rotunji colțurile

round-off (mas-un) rotunjire a muchiilor / colțurilor (prin aşchiere) round-off error (mat, inf) eroare de rotunjire roun off $(\mathrm{TH})$ a rotunji (şi prin aşchiere), a tăia rotund, a obține un cerc / o rondea prin tăiere / decupare

round out $(\mathrm{TH})$ a netezi, a rotunji (prin eliminare de material)

round pass (met) calibru rotund de laminare / de trefilat sârmă

round pliers $(\mathrm{OM})$ clește cu vârfuri curbate

rounds (met) semifabricate rotunde / cu secțiune circulară, oțel rotund

round screw die for Briggs taper thread (masun) filieră rotundă pentru filet conic Briggs

round screw die for metric (screw) thread (mas-un) filieră rotundă pentru filet metric

round seam $(\mathrm{OM})$ cusătură circulară / închisă (de sudură, de nituire)

round section $(\mathrm{OM})$ profil circular

rounds for reinforced concrete (met, constr) otelbeton cu secțiune rotundă

round steel (bar) (met) semifabricat rotund (din oțel)

round table conference (conferință la) masă rotundă

round-the-clock service serviciu / funcționare permanent $(\breve{a})$

round thread $(\mathrm{OM})$ filet rotund

round timber (const) lemn rotund / neecarisat, buştean

round tongs $(\mathrm{OM})$ clește cu vârfuri curbate

round trip ocol, înconjur, călătorie în circuit; (amer) călătorie dus-întors

round-trip ticket bilet dus-întors

roundwire (met) sârmă rotundă

roustabout (amer) muncitor portuar (necalificat); (nav) marinar fără calificare / brevet; (ec) muncitor / lucrător necalificat, salahor

route drum, cale, itinerar; a dirija, a îndruma; a repartiza

route sheet $(\mathrm{TH})$ fişă tehnologică

routine rutină; ordine stabilită; practică împământenită; dibăcie, pricepere; (c, inf) secvență de program (are), care se repetă, subprogram; obişnuit, curent, normal, ordinar; regulat, şablon; de rutină (d. activități etc.); banal; de fiecare zi, zilnic, cotidian

routine business (ind, ec) treburi / afaceri curente routine inspection (ind) control tehnic la locul de prelucrare, inspecție / verificare de rutină / obișnuință

routinely $(a d v)$ (în mod) curent, obişnuit, banal, cotidian; zilnic, făcut / repetat în fiecare zi

routine maintenance (mas, ind, auto) întreținere curentă, revizie preventivă

routine order (mas, ind, auto) instrucțiuni curente de întreținere 
routine test (metr) încercări / teste curente / regulate / incluse în programul normal / obişnuit routine work serviciu curent / de rutină; îndatoriri / treburi curente

routine works control (ind, transp) control curent în exploatare

routing (transp) drum, traseu, curs, directie; (masun) prelucrarea pieselor cu profil complicat

routing machine (mas-un) maşină de frezat cu şablon

routinism caracter rutinier / banal; banalitate

routinist muncitor / funcționar care face treburile de mântuială (în virtutea obişnuinței)

route the lap / shoulder belt through the restraint (auto) a trece centura de siguranță prin sistemul de siguranță

row (mat) progresie, serie; (TH) şir, linie, rând; străduță, şir de case; (nav) a vâsli, a lopăta; a trece / traversa pe cineva cu barca, vâslit; (sport) canotaj; plimbare cu barca

row boat (nav) barcă / şalupă cu rame / cu vâsle

row engine (termo) motor cu cilindri în linie

rowens (amer) (agr) (lot de) pământ lăsat să se odihnescă; (agr) otavă

rowing machine (sport, mas) aparat pentru exersat vâslitul; barcă mecanică

rowlock (nav, OM) furchet

row of nozzles $(\mathrm{OM}, \mathrm{T}$, met) şir de duze

row of rivets $(\mathrm{OM})$ linie / şir de nituri

row of tuyères (met) şir de duze la un inel de vânt

row over (nav) a traversa / trece cu barca

row up (nav) a merge cu barca în susul apei

row-vector (mat) vector coloană

royal foot (metr) unitate de măsură pentru lungime, pied de roi (în francez $\breve{a}$ - picior regal), pentru încălțăminte; v. Paris foot

royal jelly (alim) lăptişor de matcă

royal mast (nav) arboret (al rândunicii)

royal post $(\mathrm{OM}$, nav) pivot central / principal

royal yard (nav) vergă (de rândunică)

rpm (metr) abreviere pentru revolutions per minute; v. revolutions per minute

$\mathbf{R}_{\text {SI }}$, RSI (metr, termo) un simbol pentru R-value - valoare a isolației termice, în unităț SI: metru pătrat Kelvin pe Watt $\left(\mathrm{m}^{2} \cdot \mathrm{K} / \mathrm{W}\right): \mathrm{R}_{\mathrm{SI}} 1$ $=\mathrm{R} 5,678\left(\mathrm{hr} \cdot \mathrm{ft}^{2} \cdot{ }^{\circ} \mathrm{F} / \mathrm{Btu}\right)$ sau $\mathrm{R}$-value 1 $\left(\mathrm{hr} \cdot \mathrm{ft}^{2} \cdot{ }^{\circ} \mathrm{F} / \mathrm{Btu}\right)=\mathrm{R}_{\mathrm{SI}} 0,17611\left(\mathrm{~m}^{2} \cdot \mathrm{K} / \mathrm{W}\right) ; \mathrm{v} . \mathbf{R}$

RT (metr) simbol pentru register ton, refrigeration ton, dar şi pentru revenue ton; v. register ton; $v$. refrigeration ton, $v$. revenue ton

rub $(T)$ frecare, uzură prin frecare, a freca, a roade, a uza; a transforma; a reduce; a măcina; (TH) a poliza, şlefui, a lustrui; a şterge, a curăţi prin frecare; a lustrui; a fricționa (şi fig); against / on / over (T) a se freca de, a se uza (prin frecare); piedică, obstacol, impediment; greutate, dificultate; (fig) imperfecțiune, greşeală; (mas-un) piatră de tocilă, piatră de ascuțit; (fam, fig) dificultate, greşeală, greutate, impediment, imperfecțiune, obstacol, piedică; (sport) inegalitate de teren; (metr, T) pas al aparatului pentru determinarea rezistenței la frecare; (mas-un) piatră de ascuțit, (piatră de) tocilă; esență (a unei conversații), poantă a unei glume; ( $\mathrm{fam})$ a omori, a ucide pe cineva; (textile) a se uza (d. haine etc.); a copia un model (cu grafit); (med, fiz) a fricționa; v. rubber, rubbing

rub against / on / over a se freca (de)

rub away a uza prin frecare; a scoate / îndepărta prin frecare; a şterge

rubbed surface suprafată netedă / şlefuită

rubber (ind chim, birotică) gumă, radieră, cauciuc; obiect din cauciuc; $(p l)$ galosii; $(\mathrm{OM})$ sabot de frână, frotor; a cauciuca, a impregna cu cauciuc

rubber band (OM) bandă (transportoare) de cauciuc, cureluşă elastică, elastic

rubber bearing $(\mathrm{OM})$ lagăr / reazem de cauciuc rubber belt(ing) (OM, plast) curea / bandă din cauciuc (pt. transportoare)

rubber belt track $(\mathrm{OM})$ şenilă de cauciuc

rubber-bonded-to-metal (OM) cauciuc lipit de metal

rubber boots cizme de cauciuc

rubber buffer (OM) tampon / burduf de cauciuc rubber carpet $(\mathrm{OM})$ covor de cauciuc

rubber cheque (ec) cec fără acoperire

rubber-coated (ind chim, OM) cauciucat, gumat, acoperit cu cauciuc

rubber-coated fabric (textile, ind chim) țesătură cauciucată

rubber coating (ind chim) cauciucare

rubber compounding (ind chim) stabilirea retetei pentru cauciuc, rețetă pentru cauciuc

rubber cone belt $(\mathrm{OM})$ curea trapezoidală de cauciuc

rubber conveyer belt (OM, plast) curea de cauciuc pentru transportor

rubber covering (ind chim, $\mathrm{OM}$ ) acoperire / căptuşire cu cauciuc

rubber crumb (ind chim, mediu) granule / deşeuri de cauciuc

rubber dollar (ec) dolar devalorizat (de inflație)

rubbered fabric (Textile, ind chim) țesătură cauciucată

rubber finger burete pentru umezit degetul

rubbered tape $(\mathrm{OM})$ bandă / cureluşă de cauciuc

rubber fendering tampon / amortizor de cauciuc rubber gasket $(\mathrm{OM})$ garnitură de cauciuc 
rubber goods (ind chim) articole / produse din cauciuc

ruuber hose (OM, hidr) furtun / tub de cauciuc rubber-impregnated belt $(\mathrm{OM})$ curea impregnată cu cauciuc / cauciucată

rubber-impregnated fabric (textile, ind chim) țesătură impregnată cu cauciuc / cauciucată

rubber industry (ind chim) industria cauciucului rubber insulation (el) izolație de cauciuc

rubberize (ind chim) a cauciuca, a impregna cu cauciuc

rubberized $(\mathrm{OM})$ cauciucat, impregnat cu cauciuc (d. textile etc.)

rubberized asphalt (ind chim) amestec cauciuc + bitum

rubberized belt $(\mathrm{OM})$ curea cauciucată

rubber joint $(\mathrm{OM})$ garnitură / piesă intermediară din cauciuc

rubber-lined (OM, ind chim) căptuşit / acoperit cu cauciuc

rubber mat (OM, ind) covor de cauciuc

rubber mould (OM, ind chim) formă de cauciuc

rubber-mounted suspension (OM) suspensie pe cauciuc

rubberneck car (auto, transp) autocar (pt. turişti)

rubber packing $(\mathrm{OM})$ garnitură (de etanşarea) de cauciuc

rubber packing gasket / ring $(\mathrm{OM})$ garnitură de cauciuc

rubber pad $(\mathrm{OM})$ tampon de cauciuc, sabot de frână din cauciuc, pernă de cauciuc

rubber partition $(\mathrm{OM})$ despărțitură printr-o piesă de cauciuc

rubber patch (auto, OM) petic de cauciuc

rubber shock absorber (OM) amortizor de şocuri din cauciuc

rubber seal $(\mathrm{OM})$ etanşare / garnitură din cauciuc

rubber shackle block (OM) bloc de cauciuc pentru fixarea arcului

rubber sheet (ind chim) foaie de cauciuc, pânză cauciucată

rubber sleeve $(\mathrm{OM})$ manşetă / mufă / manşon de cauciuc

rubber spring shackle $(\mathrm{OM})$ cauciuc de fixare a arcului

rubber stopper (OM) buşon / dop / limitator de cauciuc

rubber stamp ştampilă de cauciuc; a ştampila; a aproba, a aviza, a parafa (în mod mecanic / automat)

rubber substitute (materiale, ind chim) înlocuitor de cauciuc

rubber suspension $(\mathrm{OM})$ suspensie pe cauciuc rubber tape (el, OM) bandă izolantă cauciucată rubber tree / plant (bot) arbore de cauciuc, specie de arbust decorativ rubber trimmings (ind chim, mediu) deşeuri de cauciuc

rubber tube (OM) furtun / tub de cauciuc

rubber tube connection / coupling $(\mathrm{OM})$ îmbinare / racord pentru furtun de cauciuc

rubber tubing $(\mathrm{OM})$ tub de cauciuc

rubber tyre (auto, OM) anvelopă de cauciuc

rubber universal joint (OM) legătură / cuplaj cardanic $(\breve{a})$, din cauciuc

rubber-weather-strip (ind chim, OM) profil / bandă de cauciuc pentru etanşarea găurilor

rubbery (materiale) de cauciuc, asemănător cauciucului; cauciucat; elastic; de consistența cauciucului

rubbing frecare, polizare; (med) frecție, frecționare; frecător, fricativ

rubbing alcohol (med, chim) alcool / spirt pentru frectie

rubbing bar (nav) chilă falsă

rubbing part $(\mathrm{OM}, \mathrm{T})$ piesă în frecare

rubbing speed viteză de alunecare (rar)

rubbing surface $(\mathrm{T})$ suprafață de frecare

rubbing velocity of bearing $(\mathrm{OM}, \mathrm{T})$ viteza de alunecare a unui lagăr, viteza periferică

rubbish (ind, mediu) gunoi; deşeuri (de orice fel), moloz; steril, rocă de calitate inferioară; a arunca la gunoi; (fig) a critica (aspru)

rubbish bin (OM, mediu) ladă / cutie de gunoi

rubbish cart (OM, mediu) tomberon; (transp, mediu) autogunoieră

rubbish hip (mdiu) morman de gunoi

rubbishing, rubbishy plin / acoperit de gunoi; fără valoare, de nimic, de aruncat (la gunoi), de dat la coş

rubble (constr) moloz, dărâmături; (constr, geol) pietriş, prundiş; balast

rubble ice (alim) gheață sfărâmată

rubble walling / work (constr) zidărie din piatră brută / neprelucrată

rubbly sfărâmicios; sfărâmat; ca pietrişul

rubbly culm coke (met) cocs mărunt

rubefy (med, chim) a înroşi, a irita (pielea)

rub fastener rezistență la frecare

rubellite turnalină roşie

Rubidium (Rb) (chim) rubidiu

rub in (T) a freca; (fig) a insista asupra, a readuce în discuție

rub into (T) a face să pătrundă prin frecare / fricționare

rub off a jupui (de piele, de un strat superficial)

rub off the rust (met) a curăța rugina

rub proofness $(\mathrm{T})$ rezistență la frecare (mai rar)

rubric rubrică; alineat, paragraf; (agr) pământ roşu rubricate a însemna cu roşu; a despărți în coloane / capitole / secțiuni

rubric of a table coloană / rubrică de tabel 
rubsen oil (agr, ind chim) ulei de rapiță ruby (minrl) rubin

rudaceous (materiale) denditric, conglomeratic (d. structura aliajelor turnate)

rudder direcție; (nav) cârmă, vâslă, lopată; (fig) principiu călăuzitor / conducător

rudder blade (nav) pană a cârmei

rudder chain (nav) lanț de siguranță al cârmei

rudder head (nav) cap al axului cârmei

rudder heel (nav) călcâi al cârmei

rudder hole (nav) etambou al cârmei

rudder main piece (nav) ax al cârmei

rudder moment (nav) moment de evoluție

rudder plate (nav) pană a cârmei

rudder post (nav) etambou al cârmei

rudder stop (nav) limitator de cârmă

rudder tiller (nav) eche

rudder torque (nav) moment de redresare

rudder trunk (nav) etambou de cârmă, puț al cârmei

ruddle cretă roşie

rude aspru, grosolan; brut; (fig) brusc, puternic, vehement, violent (d. lovituri, pasiuni etc.); crud, feroce; fără maniere, grosolan, insolent, mojic, necivilizat, necuviincios, nepoliticos, prost crescut, obraznic; neprelucrat; primitiv; rudimentar; sever; robust, sănătos, viguros, voinic (d. oameni, plante etc.)

rudeness asprime; caracter brusc / grosolan; caracter neaşteptat; caracter primitiv / rudimentar; ferocitate; grosolănie, insolență, proastă creştere, lipsă de maniere, mojicie, nepolitețe, obrăznicie; primitivism; severitate; vehemență; violență

rug (textile) pătură, covor, carpetă pled; perucă

ruggedness rigiditate, rezistență; robustețe, asprime; aspect neuniform; asperitate (a unei suprafete); asprime, duritate, severitate (a caracterului), caracter colturos; rigiditate

ruggerized $(\mathrm{OM}$, materiale) rigidizat, întărit mecanic

rugosity rugozitate

ruin ruină; distrugere, năruire; $\sim \mathbf{s}(p l)$ ruine, dărâmături; a (se) ruina; a dărâma, a nărui, a distruge; a sărăci; a decădea, a scăpăta; a cădea, a se prăbuși (cu zgomot)

ruination ruinare, dărâmare, dărăpănare; distrugere, ruină

ruinous (ec) ruinător, distrugător, dezastruos; ruinat, pierdut, decăzut

ruinousness (ec) caracter ruinător / distrugător / falimentar

rule regulă; lege; normă, prescripție; formulă; dispoziție; (jur) hotărâre judecătorească, ordonantăă decizie; linie; riglă (gradată); by după regulile stabilite, conform regulii; $\sim \mathbf{s}(p l)$ regulament; (poligrafie) linie care desparte coloanele, interlinie; liniuță, pauză (în punctuație); a linia, a trage linii pe; a guverna, a conduce; a hotărâ, a declara; (jur) a decide, a hotărî, a dispune; (ec) a cota, a se menține

rule absolute (jur) regulă absolută / obligatorie / generală

ruled liniat; (autom) reglat, condus de

ruled paper hârtie riglată / liniată, hârtie milimetrică

ruled surface (geom) suprafață riglată

rule foot (metr, OM) riglă gradată în țoli

ruleless dezordonat; (mas, autom) dereglat, deranjat; în dezordine

rulemeter (metr) echer cu brat mobil

rule of court (jur) decizie / sentință a tribunalului

rule off a trage o linie sub / dedesubt; (ec) a încheia un cont

rule of the parallelogram of forces (mec) regula paralelogramului pentru forțe

rule of the road (auto, jur) legea circulatiei, regulament de circulație rutieră; (nav) reglementare a curselor vaselor

rule of three (mat) regula de trei simplă

rule of thumb regulă empirică

rule out a exclude, a elimina; (jur) a interzice; a bifa

ruler conducător; linie, riglă

ruling conducător; de conducere / guvernământ; curent, actual; predominant; (mat) generatoare (pt. suprafețe riglate), liniere (a hârtiei etc.); (autom) guvernare (a unui proces), conducere; (jur) ordonanță / decizie / hotărâre judecătorească

ruling out (ec, mat) excludere, eliminare

ruling prices $(\mathrm{ec})$ prețuri curente (pe piață), prețul pieței

rum (alim) rom; (amer) băutură alcoolică

rum baba (alim) savarină

rumble a bubui, a hurui; a hodorogi; a murmura; bubuitură, bubuit, huruit; gălăgie

rumble barrel (met, OM) tobă de curătat rumble seat $(\mathrm{OM}$, auto) scaun rabatabil rumbler (mas-un) tambur rotativ pentru lustruirea pieselor mici, tobă pentru curățare

rumble-tumble zdruncinătură; hop; rablă ruminant (agr, zool) rumegător

ruminate (zool) (d. rumegătoare) a rumega rumination (zool) rumegare; (fig) reflectare, meditaţie

rummage a răscoli, a scotoci, a răvăşi; a căuta peste tot; răvăşire, răscolire, scotocire; $(\mathrm{adm})$ căutare, percheziție (vamală); vechituri

rummage sale (ec) vânzare / licitație de vechituri; bazar 
rumour zvon, ştire, veste; a răspândi zvonuri despre

rumple (d. textile, folii etc.) a mototoli, a şifona; a ciufuli, a zburli

rumpled (d. textile, folii etc.) şifonat, mototolit; ciufulit

rumpling (d. textile, folii etc.) mototolire, boțire; (met) prima trecere

rump steak (alim) friptură din pulpă de vacă

rum-shop (alim, ec) magazin de băuturi spirtoase

run (transp, auto, cf) parcurs, direcție, drum, distanță, traseu; cursă, mers (şi al furnalului), trecere (la laminare), funcționare, mişcare, fugă, alergare; (TH, ind) lot, serie; etapă, materie primă în curs de prelucrare, regim de lucru, serie, dema-raj, ciclu (de functionare a unei instalații / maşini), circuit, curent, flux; (hidr, geogr) albie, curent; situare geografică; (nav) trecere, distanță parcursă, pasă, marş; tiraj; (iht) banc de peşti, bătaie, reproducere a peştilor; plimbare, alergare; (poligrafie) tiraj; întindere, directie, dispunere; şir, succesiune, curs, mers (al evenimentelor); (ec) cerere (a cumpărătorilor, pieței); (mec) plan înclinat; acces liber (la o bibliotecă etc.); vizită scurtă; tendință, modă; a alerga, a fugi; a căuta să scape; a (se) grăbi; a curge, a se scurge; a se prelinge; a şiroi; a rula; a (se) roti; a funcționa, a merge (d. maşini); a deveni, a (se) face; a conduce, a dirija (și circulația); a îndruma; a administra; a ține (un hotel etc.); a acționa, a porni (o maşină); a tipări; (hidr) a curge (d. un fluid de lucru); (inf, c) a începe rularea unui program, comandă de începere a unui program; (nav) a naviga, a pluti, a fila; (med) (d. o rană) a supura, a puroia; (d. culori) a se şterge, a ieşi; (fig) a merge, a se desfăşura; a se menține, a dura, a ține, a dăinui; (d un text) a spune, a suna; (jur) a fi în vigoare, a-şi păstra efectul / valabilitatea; a circula; (agr) (d. plante) a se cățăra, a se târî; a se mișca în continuu, a nu se mai opri; (d. ciorapi) a se rupe, a i se duce firul / firele; (d. timp) a se scurge, a trece; a urmări; a turna; a topi (unt etc.); a fuziona; a vârî, a băga, a înfige; a face (carieră etc.), a îndeplini (un comision etc.); a trage, a trasa (o linie etc.); a introduce prin contrabandă, a face contrabandă; a străbate, a parcurge (o distanță); (sport) a totaliza puncte; run, American run (metr) unitate de măsură pentru densitate, utilizată pentru jurubițe de lână în US

run against a da de, a se ciocni de, a se lovi de run aground / ashore (nav) a pune pe uscat run a machine (mas, ind) a lucra la / a exploata o maşină runaway (mil, adm) fugar, dezertor, evadat; (pol) transfug; creştere impetuoasă; impetuos; (d. succes) facil

run away a părăsi; a pleca; a se îndepărta de ceva repede; a se ascunde

runaway speed (el) viteză de ambalare

run away with a învinge, a înfrânge, a întrece; a folosi, a întrebuința, a uza

run-back $(\mathrm{OM}$, hidr) curent invers, teavă de scurgere, conductă de retur

run back a alerga / fugi înapoi; a se înapoia, a reveni, a se întoarce; (auto) a da înapoi, a merge în marșarier; $(\mathrm{TH})$ a deplasa înapoi (o sanie a unei maşini-unelte, o sculă etc.)

run back over a trece în revistă, a revedea; a recapitula, a relua punct cu punct

run board (mas-un) platformă pentru deservirea unei maşini

run by gravity (mec, $\mathrm{TH})$ curgere gravitațională / prin cădere liberă

rundlet (metr, alim) unitate tradițională de măsură pentru capacitate (pt. lichide, vin etc.): 1 rundlet $\sim 68,11$

run down (d. un mecanism) a (se) opri, a înceta să funcționeze; (el) (d. o baterie) a se descărca; (OM) (d. arcuri) a (se) destinde; a (a)luneca; a scufunda, a afunda; a epuiza (d. resurse); (hidr, alim) a distila, a scurge, a descărca peste / prea mult; a se opri

run-down reducere numerică; analiză detaliată, detaliere, intrare în amănunte, despicarea firului în patru; scăpătat, în declin, decăzut, în decădere; distrus

run-down pipe (OM, termo) ț̦eavă / conductă de evacuare

run-down tank (OM, hidr) rezervor de recepție run dry (d. un curs de apă) a seca; ( $\mathrm{T}$, mas) a funcționa neuns / fără ungere

run empy (mas) a merge / a functiona în gol

rung (constr, OM) treaptă (de scară); (OM) traversă, spiță de roată, braț (al unei roți de mână); (nav) varangă

run full of (nav) a intra în coliziune

Runge-Kutta method (mat) metodă numerică de rezolvare a ecuațiilor diferențiale, metoda RungeKutta

rung ladder $(\mathrm{OM})$ scăriță, scară mobilă

runhead $(\mathrm{OM})$ cap semirotund

run idle (mas) a merge / a funcționa în gol

run in a băga, a vârî, a introduce; a vota; (mas, $\mathrm{T})$ a roda (un motor etc.)

run-in roller table (mas-un, met) transportor / masă cu role pentru alimentare

run into a întâlni întâmplător; a da peste / de; (ec) a face datorii; a intra în coliziune, a lovi; 
a căpăta / dobândi (deprinderi etc.); a fi publicat în mai multe ediții (d. o carte)

runless stockings (textile, ind chim) ciorapi indeşirabili

runlet (geogr, hidr) pârâu

run light (el, mas) a merge în gol

run low a scădea (simțitor); a fi pe sfârşite / terminate, a se termina, a se epuiza

runnel (geogr) pârâu; (OM, hidr) canal de scurgere, rigolă; (geogr) viroagă, vâlcea

runner (sport) alergător; curier, mesager; contrabandist; (const) pod; (el) transmițător de comandă; $(\mathrm{OM})$ rotor, roată de actionare, glisieră, rolă de malaxor, rolă de alergare, talpă (de sanie); (met) canal / pâlnie / rețea de turnare, jgheab de scurgere, pâlnie de aerisire, răsuflător; (nav) macara alunecătoare, roată cu zbaturi; (agr, bot) plantă agățătoare, vlăstar, mlădiță

runner and tacker (nav, $\mathrm{OM}$ ) palanc alunecător runner basin (met) bazin de turnare runner bean (agr, bot) fasole cătărătoare runner blade $(\mathrm{OM})$ paletă de rotor

runner brick (met) cărămidă fasonată cu gaură, pentru formarea canalelor de umplere, la turnarea în sifon a lingourilor

runner gate / trumpet (met) pâlnie de turnare

runner head (met) pâlnie / cap de turnare, maselotă

runner of a turbine (termo, OM) rotor (de turbină)

runner opening (met) orificiul oalei de turnare, deschiderea orificiului oalei de turnare

runner stone (alim) piatră de moară alergătoare / rotativă / liberă

running alergător, care aleargă; cursier, de curse; succesiv, continuu; (d. apă) curgător, curent; alergare, cursă, fugă; marș; (TH, mas) funcționare, exploatare, serviciu, regim care funcționează, care merge (d. o mașină); (cf) mers, circulație (a trenurilor); (med) supurare, purulent, care supurează (d. o rană)

running account $(\mathrm{ec})$ cont curent

running a motor (el) exploatarea / functionarea unui motor

running away (auto, termo) ambalare (de motor) running back (mas) care merge înapoi (şi fig) running balance (mas, OM) echilibrare dinamică running balance indicating machine (mas, mec) maşină de echilibrare dinamică

running board $(\mathrm{OM})$ treaptă, scară (şi de vagon) running brake (auto, $\mathrm{OM}$ ) frână de picior running bridge (transp, ind) pod rulant running center (mas-un) vârf rotativ (şi la strung) running characteristic (mas, $\mathrm{OM}$ ) caracteristică de funcționare

running charge (ec, mas) cheltuieli de exploatare running conditions (mas, ind) condiţii de lucru / de functionare

running costs (ec, mas) costuri de exploatare running current (el) curent de regim running direction $(\mathrm{mec})$ direcție de mişcare running down $(\mathrm{mec}, \mathrm{OM})$ rotație datorită inerției / până la oprire, coborâre, introducere running edge of the rail (cf, met) muchie conducătoare / de ghidare a şinei

running expenses (mas, ind) cheltuieli curente de exploatare

running fit $(\mathrm{OM})$ ajustaj cu joc

running foot (metr) o altă denumire pentru linear foot - picior liniar; v. foot

running gate (met) pâlnie de turnare

running gear $(\mathrm{OM})$ mecanism de antrenare $(\mathrm{cu}$ roți dințate)

running grid stone (alim) piatră de moară alergătoare

running hand scris cursiv

running hot (auto, mas) încălzire (la pornire)

running hour (mas) timp de lucru / de functionare

running idle (mas) regim de mers în gol

running-in (mas, T) (perioadă de) rodaj, ajustare prin functionare, turnare a compoziției la un lagăr

running-in period (mas, $T$ ) perioadă de rodaj

running-in test (mas, metr) încercare / test de mers în gol

running knot (nav) nod marinăresc / culant / care ştrangulează

ruuning life (mas) durată de funcționare, durabilitate

running-light current (el) curent de mers în gol running line (cf, met) linie curentă (de cale ferată, de tren)

running loss (mas) pierdere de energie în timpul functionării

running meter (metr) metru liniar

running mill-stone $(\mathrm{OM})$ piatră de moară alergătoare (la o moară)

running no-load (mas) functionare fără sarcină

running number număr de ordine

running off $(\mathrm{OM})$ coborârea curelei / lanțului de pe roată

running order (mas) în stare de funcționare

running out (mec, mas) oprire, mișcare datorată inerției

running out fire (met) cuptor de primă afinare

running-out of oil (mas, T) oprire cauzată de întreruperea lubrifiantului, funcționare fără lubrifiant, rămânere fără lubrifiant

running plate (ind, met) platformă de vizitare running repairs (mas) întrețineri / reparații curente / minore (care nu implică schimbări de piese) 
running rigging (nav) manevră curentă, greement curent

running slag (met) zgură fluidă / inferioară

running speed (mas, nav) viteză de mers / de funcționare

running stich (textile) saia, împunsătură de ac pentru plisat

running stone $(\mathrm{OM})$ piatră de moară

running surface (of rail) $(\mathrm{OM}, \mathrm{cf}$, met) suprafaţă de rulare (a şinei)

running test (mas, metr) încercare / test la parametri de functionare / în exploatare

running time (mas, transp) timp de lucru / de funcționare / de parcurgere

running torque (mas) moment de torsiune la funcționare în regim nominal

running track (sport, constr) pistă de curse / alergări

running tread $(\mathrm{cf})$ cerc de rulare al roților

ruuning water (alim, hidr) apă curentă / curgătoare / de la robinet

running work (mas) funcționare continuă

running yard (metr) yard liniar

run-off scurgere, golire, deversare, descărcare, fugă, scăpare, debit

run off $(\mathrm{TH})$ a (se) goli, a se deversa, a funcționa defectuos

run-off factor (hidr) coeficient de scurgere

run-off gutter $(\mathrm{OM}$, hidr) jgheab de scurgere

run of the fiber $(\mathrm{OM}$, hidr, materiale) orientarea fibrelor (şi la compozite)

run-off pipe (OM, hidr, materiale) țeavă de golire $/$ de scurgere

run-off slag (met) zgură de evacuare

run-off tap (OM, hidr) robinet de evacuare

run of furnace (met, termo) campania / durata de exploatare (continuă) a unui cuptor

run of piping (termo, met, hidr, OM) grup de conducte paralele

run of the grain(s) (met, plast) orientarea grăunților (şi la compozite)

run-of-the-oven-coke (met) cocs metalurgic

run of tailing (met) evacuarea deșeului

run of the rim (auto) rulare pe jantă

run-on adaos (tehnologic, de material, pt. compensarea pierderilor în transport etc.); supliment

run on a fugi / alerga mai departe, a continua să fugă / alerge; a-şi urma cursul; (d. timp) a trece, a se scurge; a zbura; (d. un text) a continua fără alineat; (ec) (d. datorii) a se aduna / acumula; a continua să crească (d. un parametru al unui proces etc.)

run-out uzură, uzare; întrebuințare; (OM) excentricitate, bătaie (a unei piese în rotație), ieşire a filetului; sfârşit de rolă / bandă / bobină; deviere de la o direcție; (OM, hidr, termo) evacuare, scurgere; (mas-un) deviere pe o direcție precisă run out a ieşi alergând / fugind; a alerga (în) afară; (nav) (d. flux) a se retrage; a (se) termina, a nu ajunge; a fi insuficient; a se scurge, a se întinde pe o suprafață (și d. apă); (mas) a nu funcționa corect; (d. o perioadă de timp) a se scurge, a expira, a se încheia; (T) a uza; of a termina / epuiza (provizii, materiale etc.)

run-out bearing $(\mathrm{OM}, \mathrm{T})$ cuzinet uzat / care nu (mai) funcționează corect

run-out device ( $\mathrm{TH}$, met, mas-un) dispozitiv de evacuare / de golire / de scurgere

run out limit (mec, mas) limită de rupere, limită peste care functionarea nu este normală

run out of fuel (auto, termo) a rămâne fără carburant

run out of true (OM, mas-un) modificarea formei din cauza uzurii, bătaia unei piese în rotație run-out table (met) cărucior de transportat rame de formare, transportor cu role pentru evacuare

run over (hidr) deversor; transvazare; (auto) a călca (cu un vehicul) peste ceva; (hidr, plast) a da pe dinafară

run short a fi pe sfârșite / terminate; a începe să se sfârşească; a fi în scădere / aproape să se termine, a fi gata să se epuizeze; a se epuiza, a se termina

run short of a se termina, a nu prea mai avea, a înceta să mai aibă (d. resurse, materii prime etc.) run slow (fiz, autom, TH) a întârzia, a fi în întârziere (şi de fază), a fi defazat în urmă

run the motor up to full speed (mas, termo) a aduce motorul la turația de lucru / de regim

run through (hidr) a se infiltra, a pătrunde; (el) a străpunge; a cheltui, a irosi; a parcurge cu privirea, a se uita la; a şterge (ceva scris)

runtiness caracter pitic / pipernicit

run true (mas-un, OM) rotație fără bătaie, avans al sculei, fără deviere de la direcția precisă

run to a atinge (un nivel, o cifră etc.), a ajunge la; (fig) a cădea în extreme; a se transforma runty pitic; (bot, agr) pipernicit, nedezvoltat run-up (mas) pornire (şi a unui motor); avânt run up a porni (şi un motor); a (se) urca; a (se) mări pe durata funcționării (d. un parametru); (iht) (d. peşti) a urca spre izvorul râului); (agr) (d. plante) a creşte repede; (ec) (d. prețuri) a urca, a creşte, a se mări; a spori brusc

runway $(\mathrm{TH}, \mathrm{OM}$, const) suprafață de rulare, pistă, cale (drum); (av) spațiu / câmp de decolare / de rulaj; (hidr) jgheab / rigolă de scurgere; (geogr) albie de râu, matcă; monorai; (mas-un) 
monoşină; (transp, ind) grindă de rulare (la macarale), cale de rulare a căruciorului de macara, cale de rulare a macaralei; (met) cale cu role, cale de rulare (pt. vagonete, cărucioare de întreținere); (fiz, radio) câmp progresiv; (nav) pasă de navigație, $\sim \mathbf{s}(p l)$ lumini de pasă navigabilă; (sport) pistă de alergare / de curse; (silv) tobogan, plan înclinat (de corhănire a buştenilor)

runway of crane (OM, transp, met) cale de rulare a macaralei

runway rail (met, $\mathrm{OM}$ ) şină de rulare (de ghidare / de conducere

rupee $(\mathrm{ec})$ rupie (monedă indiană)

rupture (el) străpungerea izolației; $(\mathrm{OM}$, materiale) rupere, fractură, ruptură, sfărâmare, spărtură, breşă; (fig) neînțelegere; (med) hernie, a produce o hernie; (chim) a desface o combinație / o legătură, a (se) rupe (şi d. o membrană, o peliculă etc.), a sparge, a (se) perfora; a (se) sfărâma, a (se) fisura

rupture constriction $(\mathrm{mec}, \mathrm{T})$ gâtuire la rupere ruptured rupt, perforat; (med) cu hernie rupture disc $(\mathrm{OM})$ disc de siguranță / de protecție (proiectat să se rupă la o anumită sarcină)

rupture disc device $(\mathrm{OM}$, hidr) dispozitiv cu disc de siguranță / de protecție (proiectat să se rupă la o anumită presiune, pt. deschiderea unei supape) rupture limit (mec, materiale) rezistentă / limită la rupere

rupture load (const) sarcină de rupere

rupture pieces (materiale) fragmente rezultate din rupere / sfărâmare etc.

rupture plane (materiale) plan de rupere

rupture strength (mec, materiale) rezistență / limită la rupere

rupture stress (mec) tensiune / efort de rupere

rupture test (materiale, metr) încercare / test la rupere

rupturing $(\mathrm{TH})$ întrerupere, rupere, străpungere, care (se) rupe

rupturing capacity / duty (mec, el) putere de străpungere / rupere

rupturing strength (mec, OM) tensiune (mecanică) / limită de rupere

rupturing voltage (el) tensiune de străpungere rural rural, de tară, rustic; țărănesc

rush afluență (bruscă), înghesuială, îngrămădeală, aglomerație, îngrămădire; (met) minereu fără valoare; (mas) pornire (grăbită), mişcare impulsivă, grabă; (bot) papură; trestie, rogoz, stuf, țipirig, rugină, pipirig; (mil) asalt, atac rapid, a lua cu asalt; (mil, pol) cursa (a înarmărilor); (meteo) rafală de vânt; salt, săritură; (geol) viitură (de petrol etc.); iureş, navală; (fig) lucru fără valoare, fleac, (lucru de) nimic; aclamație, aplauze; a merge repede / cu mare viteză, a alerga, a goni, a (se) grăbi, a accelera; a se arunca, a se năpusti; a se precipita; a năvăli (în), a invada; a țâşni; a apărea brusc, a se ivi brusc (în amintire etc.); a face repede / în grabă, a executa la repezeală; (amer) a se da bine pe lângă (cineva), a duce cu preșul / cu zăhărelul, a face curte (cuiva), a lua cu binişorul

rush at a se repezi la / asupra, a se năpusti la; a face în grabă; a se grăbi să ajungă (şi la o concluzie)

rush-bed (agr, bot) stufăriş, stufărie

rush-bottom (d. mobilă) cu fundul de trestie / papură

rushed supraaglomerat cu munca, ultraocupat; zorit, prins, hărțuit (de treburi); (d. un lucru) făcut în pripă / la repezeală, dat peste cap

rush hour (auto, transp) oră de vârf

rush job urgență, treabă / operație urgentă, lucru urgent

rush of current (el) impuls de curent

rush up a grăbi, a accelera

rushy acoperit cu / făcut din papură

rusk (alim) pesmet, biscuit

russet roşcat, roşiatic; roşu-cafeniu; culoare roşcată / roşiatică

Russian leather iuft, toval

rust (met, OM, T, chim) rugină; a (se) rugini, a (se) oxida, a face să ruginească; (agr, bot) rugina grâului; (mas) a distruge (prin lipsa de întrebuințare); (fig) a regresa, a da înapoi, a deveni lent / greoi

rust-eaten (met, OM, chim) uzat / atacat / mâncat de rugină

rusted (met, OM, chim) ruginit

rusted on (piece, nut) (OM, chim) (piesă, piuliță) blocată prin ruginire / coroziune

rust-free (materiale) inoxidabil, care nu rugineşte

rustic rustic, provincial, rural; necioplit, grosolan; lucru grosolan

rustic bridge (constr) podeț simplu, punte din bârne

rustic work (const) constructie din bârne neşlefuite

rustiness (chim, OM, TH) caracter / aspect ruginit; ruginire

rusting (chim) (proces de) ruginire / coroziune, corodare

rusting agent (chim, met) substanță / agent co$\operatorname{rosiv}(\breve{a})$

rust inhibitor (chim, T) inhibitor de coroziune, (agent / aditiv) anticorosiv

rust into (met, OM) a se întepeni din cauza ruginirii

rust layer (met, OM, chim) strat de rugină 
rustless (materiale) neruginit, neoxidat; care nu rugineşte, necorodabil, inoxidabil, care nu rugineşte (d. oțeluri în special)

rustless property (materiale) rezistență la ruginire rustless steel / iron (met) oțel rezistent la ruginire, oțel inoxidabil (termen rar folosit)

rust of cereals (agr, bot) rugina cerealelor

rust off (materiale) a (se) rugini, a (se) coroda (şi prin oxidare, mai ales pentru aliaje feroase) rust out a putrezi

rust preventative (chim) agent anticorosiv, substanţă de protecție contra ruginirii

rust preventer (chim, $\mathrm{T}$ ) agent / produs pentru împiedicarea oxidării / ruginirii, inhibitor de coroziune

rust preventing (met, chim) protecție împotriva coroziunii / ruginirii

rust preventing additive / agent / medium (met, chim) aditiv (şi pt. lubrifianți), agent / mediu de protecție împotriva coroziunii / ruginirii

rustproof (materiale, OM, T) rezistent la coroziune / la ruginire, inoxidabil

rust-proofing treatment (met, chim) tratament anticorosiv

rust-proof oil (ind chim, T) ulei anticorosiv

rust protection (materiale, $\mathrm{T}$ ) protectie contra ruginirii / oxidării

rust removal (met, TH) îndepărtare a ruginii

rust remover (mec, chim) mijloc / agent de îndepărtare a ruginii

rust-resisting (met, OM, T) rezistent la rugină / ruginire, inoxibabil (în special cu referire la oțeluri) rust-resisting property (met, OM, T) rezistență la rugină / ruginire

rust-resisting steel (met, OM, T) oțel rezistent la rugină / ruginire, oțel inoxidabil

rust spot (met, chim) pată / punct de rugină

rusty (chim, met) ruginit, oxidat; ruginiu, de culoarea ruginii; roşu-cafeniu; părăsit, uitat; învechit, demodat

rut făgaş; urmă (şi de roată etc.); $(\mathrm{OM})$ şanţ, canelură, jgheab, falţ, brazdă; (adm) rutină; închistare; (zool) (perioadă de) îmnperechere; (fig) deprindere, obicei, rutină; (fig) direcție, făgaş; a săpa, a brăzda

Ruthenium (Ru) (chim) ruteniu

rutherford (Rd) (metr, fiz) unitate practică de măsură a radioactivității, 1 rutherford $=1$ megabecquerel $(\mathrm{MBq})$ şi reprezintă 1 million de dezintegrări radiactive pe secundă

Rutherfordium (Rf) (chim) rutherfordiu rutile (chim) bioxid de titaniu în stare nativă rutted (auto, geogr) brăzdat de făgaşe (d. un deal, un drum etc.)

rutty (d. drumuri, teren etc.) brăzdat de făgaşe

$R$ value of the insulator (metr, termo) valoare a eficienței izolației termice / izolatorului termic, exprimată în $\mathrm{hr} \cdot \mathrm{ft}^{2} \cdot{ }^{\circ} \mathrm{F} / \mathrm{Btu}$

rydberg (metr, fiz) denumire veche pentru a kayser, numărul de undă în sistem CGS

rye (alim, bot) secară; (amer) (alim) whisky

rye bread (alim) pâine de secară

rye flour (alim) făină de secară

rye grass (agr) iarbă folosită ca furaj

ryepeck (nav) stâlp / țăruş de amarare 


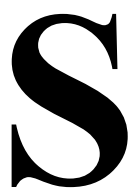

sabin (metr, fiz) unitate în afara sistemului metric de măsură a absorbției suntelor în ingineria acustică: 1 sabin este absorbția sunetului pentru o suprafață perfect absorbantă (o fereastră deschisă) de 1 picior pătrat; absorbția sunetului de materiale este dată prin coeficienti, în functie de material, frecvența sunetului etc.; rar utilizată cu numele de open window unit (owu)

sabla (zool) zibelină, (blană de) samur

sabot sabot, pantof de lemn, pantof de piele, talpă de lemn

sabotage sabotaj; diversiune; activitate subversivă; a sabota

sabulous (materiale) nisipos, granulos

sac sac, pungă; (textile) (rochie) sac; (biol) pungă

saccharates (alim, chim) zaharați

saccharification (alim) zaharificare

saccharify (alim) a zaharifica

saccarifying (alim) zaharificare

saccharimeter (alim, metr) zaharimetru, aparat pentru măsurarea conținutului de zahăr dintrun produs alimentar

$\operatorname{saccharin}(e)$, saccharinose (alim, chim) zaharină saccharine (alim, chim) de zahăr, zaharos; extrem de / foarte dulce

sacharize (alim, chim) a zaharifica

saccharobiose (alim, chim) zaharoză

saccharol (alim, chim) zaharină

saccharose (alim, chim) zaharoză

sack pungă, sac (şi de pânză); conținutul unui sac; (textile) rochie sac; sac de dormit; (metr) unitate tradițională de măsură pentru volum, pentru diferite produse; 1 sack $=3$ bushels $(\sim 105,71$ pe baza US bushel și 109,1 1 pe baza British Imperial bushel); (metr) unitate tradițională de măsură pentru masă, cu valori diferite în functie de produsul încărcat în saci: 1 sack of salt (US) (1 sac de sare $)=215$ pounds, 1 sack of cotton (US) $(1 \mathrm{sac}$ de bumbac $)=140$ pounds, 1 sack of flour (US) $(1$ sac de făină $)=100$ pounds. 1 sack of concrete (US) (1 sac de ciment) 94 pounds, 1 sack of concrete (Canada) (1 sac de ciment) $\sim 87,5$ pounds

sackcloth (textile) pânză de sac

sack elevator (mas, ind) elevator de saci

sackful (of) sac plin de / cu; cantitate mare sacking ambalare în saci; (textile) pânză de sac sack packer (alim, ind chim, mas) maşină de ambalat în saci

sacrifice sacrificare; sacrificiu, privațiune, lipsă; abnegație; a (se) sacrifica; (ec) a vinde în pierdere

sad lipsit de strălucire; şters, închis, sumbru, întunecat (d. o culoare); trist, abătut; regretabil, condamnabil (d. o greşeală); jalnic, mizerabil, fără ieşire (d. o situaţie)

saddle şa; (OM) garnitură, soclu, suport; (masun) sanie transversală, cărucior; (alim) bucată de carne de la spate, muşchi; (geogr) coamă, creastă, şa; (poligrafie) rădăcină a cotorului

saddle-backed $(\mathrm{OM})$ bombat

saddle bar (agr, ind) balot

saddle control (mas-un, autom) sistem de comandă al căruciorului / al saniei principale saddle flange $(\mathrm{OM})$ flanşă răsfrântă

saddle key (OM) pană de fricțiune / concavă saddle of mutton (alim) spate de berbec

saddle point (mat) punct de şa

saddle roof (constr) acoperiş cu două versante

saddle tank (auto) rezervor de benzină sub şa (la motociclete)

saddle with a împovăra, a îngreuna cu

sadzhen, sagene (metr) unitate tradițională de măsură pentru lungime, în Rusia: 1 sadzen = $2,1336 \mathrm{~m}$

SAE - Society of Automotive Engineers, (auto, adm) Societatea Inginerilor din Industria de Autovehicule

SAE grade (ind chim, T) clasă SAE de vâscozitate (a unui lubrifiant)

SAE number (Grade) (T) număr / cod numeric aplicat lubrifianților pentru motor, transmisii şi osii, pentru a indica intervalul de vâscozitate

safe sigur, lipsit de pericol, neprimejdios; solid; neprimejdois; în siguranță; precaut; demn de încredere; incontestabil; teafăr, sănătos; precaut, prudent; eficace; convins, încredințat; seif / casă de bani; frigider

safe against high-potential breakdown (el, autom) protejat contra întreruperii din cauza tensiunii înalte

safe allowable load (mec) sarcină admisibilă

safe back $(O M)$ fața laterală, netedă a pilei

safe bearing load $(\mathrm{OM}, \mathrm{T})$ sarcină admisibilă (pe lagăr)

safe clearance (OM) joc / interstițiu admis / care asigură funcționarea / oferă siguranță în funcționare

safe coefficient (OM, mas) coeficient de siguranță safe-covering $(\mathrm{OM})$ capac de protectie 
safe from ferit de, la adăpost de; în siguranță

safeguard garanție; ocrotire; $(\mathrm{OM})$ contraşină, dispozitiv de securitate / de siguranță, apărătoare, grilaj de protecție; a îngrădi; a proteja, a păzi; a întări

safeguard against pază / protecție împotriva; prevedere, precautie împotriva

safeguarding against breakage (OM, autom) siguranță / protecție contra suprasolicitării / ruperii

safe in operation (mas) sigur în functionare

seif-keeping siguranță, securitate; protecție, păstrare (la loc sigur)

safe load per axle $(\mathrm{OM}$, auto, cf) sarcină admisibilă pe osie

safe load $(\mathrm{OM})$ sarcină admisibilă

safely $(a d v)$ în siguranță; (în mod) sigur; ferit, adăpostit; în stare bună; fără griji / risc

safe procedure (mas, TH) măsuri de protecție, procedură sigură / care oferă siguranță

safe range of stress $(\mathrm{OM})$ limită de oboseală a materialului, interval sigur de variație a tensiunii / efortului

safety siguranță; securitate; protecție, pază

safety against buckling $(\mathrm{OM})$ stabilitate la flambaj

safety against fracture (OM) siguranță la rupere, asigurat împotriva ruperii

safety appliance (OM, autom) dispozitiv de siguranță / de securitate

safety belt (auto) centură de siguranță; (nav) centură de salvare; (silv) perdea parafoc

safety bolt $(\mathrm{OM})$ şurub de siguranță

safety brake $(\mathrm{OM})$ frână de siguranță

safety catch $(\mathrm{OM}$, mil) siguranță (la o armă, la trăgaci)

safety circuit (OM, hidr, el) circuit de siguranță

safety clutch $(\mathrm{OM})$ cuplaj de siguranță

safety coefficient (mec, el) coeficient de siguranță

safety coupler / coupling (OM) cuplă / cuplaj / legătură de siguranță

safety cut-out (el) siguranță fuzibilă; (mas) întrerupere / oprire pentru sigurantă

safety device (OM, autom) dispozitiv de protecție / de siguranță / de securitate; aparat de control

safety device monitor (fiz, autom, metr) aparat de control / de siguranță / de semnalizare a radiatiiilor, dispozitiv de protecție

safety dog (mas-un, OM) antrenor de siguranță (la strung)

safety driver $(\mathrm{OM})$ (dispozitiv de) antrenare / actionare cu șurub cu cap înecat

safety earthing (el) legare a siguranței la pământ safety education (edu) curs scurt de tehnica securităţii în muncă (în şcoli, întreprinderi etc.) safety engineering tehnica securităţii muncii safety factor (OM, el, mas) coeficient de siguranță

safety film (chim) peliculă de protecție, strat protector

safety-first precaut, prevăzător; (ind, transp) (de) siguranță înainte de orice

safety-first engineering (ind, transp) tehnica securității muncii

safety first (ind) siguranță mai înainte de orice

safety fuel (ind chim, av) benzină de aviație (cu punct de inflamabilitate de peste $40^{\circ} \mathrm{C}$ )

safety fuse (el) siguranță fuzibilă; fitil de siguranță

safety gap (auto) eclator

safety gear (OM) dispozitiv de siguranță / de protecție (şi cu angrenaj cu roți)

safety goggles $(\mathrm{TH})$ ochelari de protecție

safety glass (ind chim, ind) securit, sticlă incasabilă, geam de siguranță

safety guard (ind, TH) barieră / dispozitiv de protecție (foarte general)

safety handle $(\mathrm{OM})$ manivelă de siguranță

safety hazard (auto, ind) pericol

safety hook $(\mathrm{OM})$ carabină

safety in operation (mas) siguranță în funcționare

safety interlock (mec, el, autom) blocare / blocaj de siguranță

safety island (auto) refugiu de pietoni

safety jaw (mas-un, OM) falcă de strâns piese din aliaj de aluminiu

safety joint $(\mathrm{OM})$ manșon / racord de siguranță

safety lamp (el) lampă de siguranță

safety latch $(\mathrm{OM})$ clichet de asigurare / de siguranță

safety limit (TH, mas) limită de încărcare, limită de siguranță

safety limit switch (el) întrerupător de siguranță safety line (cf) linie de scăpare

safety lock (constr) broască de siguranță

safety margin rezervă / coeficient / limită / margine de siguranţă

safety meci chibrit

safety measures (în orice domeniu) de asigurare a securității în muncă

safety net $(\mathrm{OM})$ plasă protectoare de siguranță; (el, autom) rețea de siguranță

safety nut (OM) contrapiuliță, piuliță de siguranță safety of operation (mas) siguranța funcționării safety petcock $(\mathrm{OM})$ robinet de incendiu, hidrant safety pin $(\mathrm{OM})$ ştift / ac de siguranță safety pinion $(\mathrm{OM})$ pinion de siguranță safety plug (el) sigurantă (şi fuzibilă) 
safety precautions (ind etc.) măsuri de siguranță safety razor $(\mathrm{OM})$ aparat de bărbierit / de ras safety restraint(s) (auto) măsuri (restricție) de siguranță

safety relief valve (OM. hidr) supapă de siguranță / de descărcare

safety ring $(\mathrm{OM})$ inel de siguranță

safety rod $(\mathrm{OM})$ tijă de siguranță /de rezervă

safety securitate (mas) siguranță în funcționare

safety stop (OM, mas-un) opritor de siguranţă

safety strip (silv) perdea parafoc

safety tire / tyre (auto) pneu antiderapant

safety valve (OM, hidr) ventil / supapă de siguranță; debușeu, ieșire, scăpare

safety washer $(\mathrm{OM})$ şaibă de siguranţă

safety wire (OM) sârmă de asigurare a şuruburilor / a piulițelor contra deşurubării

safety zone (auto) refugiu de pietoni; (ind, mas) zonă de siguranță / sigură / fără pericol

safe working stress (mec, OM) solicitare / tensiune admisibilă în functionare

saffir (minrl) safir

Saffir-Simpson category (metr, meteo) clasă categorie a puterii unui uragan

saffron (alim) şofran; culoarea şofranului; de şofran, galben ca şofranul

saffron oil (alim) ulei de şofran

sag scobitură; (s)cădere; tasare; (mec) săgeată, încovoiere; a îndesa; a tasa; a face / a avea săgeată; a (se) îndoi (sub greutate, sub sarcină), a se lăsa; a atârna (d. textile); (bot, agr) a se ofili, a se trece; a se târâ, a se mişca greu; a pierde din valoare, a-şi pierde valoarea, a nu mai avea acelaşi preț; (nav) a se abate, a se îndepărta de la drumul drept; a face să se îndoaie; îndoire, îndoitură; lăsare; (ec) scădere a pretului / a valorii

sagacity perspicacitate, vioiciune, agerime, inteligență

sage înțelept; inteligent; om deştept

sage brush (agr, bot) pelin

sage-green verde-gri

sagely $(a d v)$ cu înțelepciune

S.A.G. foot, South African geodetic foot (metr) unitate de măsură pentru lungime, picior geodezic, aprobat în Africa de Sud

saggar, sagger (ind chim, OM) capsulă de porțelan

sagging $(\mathrm{OM}, \mathrm{mec})$ flexiune, deformație, îndoirea arcului, lăsare în jos; (plast) revărsare (a adezivului); (geogr) depresiune

sagging point (plast) punct de înmuiere sagital (OM) sagital, în formă de săgeată sag of belt $(\mathrm{OM})$ săgeata curelei sag of cable (el, OM) săgeata cablului

sail (el, OM) săgeata liniei / cablului; (nav) velă, vele, pânză, pânze, vas cu pânze, corabie, velier, navă cu vele, plimbare cu un vas cu pânze, a naviga (cu un vas cu pânze), a ridica pânzele, a conduce, a pilota, a cârmi, a transporta cu un vas cu pânze; aripă (de moară de vânt); a aluneca, a plana, a pluti

sailboat (nav) barcă cu pânze

sail cloth (textile, nav) pânză groasă de in / cânepă sailer, sailing ship (nav) navă rapidă (de orice tip) sail in a se amesteca, a interveni, a lua măsuri hotărâte; a se apuca de lucru cu zel

sailing (nav) navigație; sport nautic

sailing boat / ship (nav) vas cu pânze

sailing line (hidr) şenal navigabil

sailing ship / vessel (nav) corabie, vas cu pânze, velier

sailmaker ounce (smoz) (metr, textile, nav) unitate tradițională de măsură pentru masa pe unitatea de arie a pânzelor de velatură (o pânză de 36 inchi x 28,5 inchi: $1 \mathrm{smoz}=42,828 \mathrm{~g} / \mathrm{m}^{2}$

sailor (nav) marinar, matelot, matroz

sailor boy (nav) elev marinar

sailor's knot (nav) nod marinăresc

sal (chim) sare

salability $(\mathrm{ec})$ vandabilitate

salable (ec) vandabil, care are căutare

salad (alim) salată

salad cream (alim) sos de salată, dressing

salad dressing (alim) sos de salată, salată, maioneză

salad oil (alim) ulei comestibil / pentru salată

salamander (met) bloc de metal în vatra cuptorului, urs (la furnal)

salami (alim) salam

sal ammoniac (chim) țipirig, clorură de amoniu

salariat $(\mathrm{ec})(s)$ salariat

salaried $(\mathrm{ec})$ salariat, cu salariu

salary (ec) salariu

sale (ec) vânzare, licitație

saleable (ec) vandabil

sale by auction (ec) licitație publică, vânzare prin licitare / licitație

sale of work (ec) vânzare de articole pregătite în casă

sale price (ec) preț de vânzare, (preț de) sold

sale room (ec, constr) sală de licitații

sales leaflet foaie de reclamă, prospect

salesman (ec) vânzător, comisionar, agent / reprezentant comercial, angrosist

salesmanship (ec) arta de a convinge / de a vinde / de a găsi cumpărători

salespeople (ec) comercianți, vânzători 
sales resistance (ec) refuz de a cumpăra ceva, rezistență a consumatorului posibil

sales slip (ec) bon (de vânzare)

sales tax (ec) impozit pe cifra de afaceri

saleswoman (ec) vânzătoare, reprezentantă comercială, angrosistă

salicylate (chim) salicilat

salicylic acid (chim) acid salicilic

salience, saliency $(\mathrm{OM})$ proeminență, ieşitură; reliefare, scoatere în relief, subliniere, accentuare (şi fig)

salient proeminent; remarcabil; izbitor, care iese în relief, reliefat; (met, OM) proeminență (la sudură), care iese în afară; protuberanță, ieşitură, proeminență; (fig) proeminent, frapant, care iese în relief; caracteristic; dominant

salify (chim, alim) a săra, a safilia

salina (geol, geogr) salină, lac sărat, baltă sărată

saline salin, sărat, de sare; (chim) sare metalică, sare de magneziu

salinity (chim) salinitate

salinometer (chim, metr) salinometru

sallow (silv) salcie (moale), lemn de salcie; galben, pământiu; palid

sallowish cam palid, gălbui

sally ieşire bruscă, manifestare, izbucnire; replică neaşteptată; a ieşi brusc

salmanazar (metr, alim) sticlă mare pentru vin de $\sim 91$, de 12 ori volumul unei sticle obişnuite

salmiac (chim) clorură de amoniu, țipitig

salmon (alim, iht) somon; roz-portocaliu; (met) galben-oranj (culoare de revenire)

salmon trout (alim, iht) păstrăv (european sau american)

salon salon, sală (de expozitie etc.)

salse (geogr, geol) vulcan de noroi

salt (chim) sare (şi de bucătărie), clorură de sodiu; salinitate; salin, sărat, cu sare, păstrat în sare, picant (şi fig); a săra, a presăra cu sare, a păstra / conserva în saramură, a presăra cu sare; (fig) a exagera, a ridica (valoarea); (fig) farmec, gust, haz; (nav) (fam) lup de mare, marinar experimentat / cu experiență; amar (d. lacrimi); (fig) cu gust / miros de sare; (fig) piperat, sărat (d. prețuri); (fig) de duh, nostim; (as) as a brine / herring (fig) ocnă de sare, sărat ca o scrumbie; above the $\sim$ care are pâinea şi cuțitul; be worth one's $\sim$ a fi capabil; the books (ec) a falsifica / măslui registrele contabile

salt a bill (ec) a încărca nota de plată, a economisi (bani)

salt ammoniac cell (chim, el) element / pilă Leclanche

salt an account (ec) a încărca contul salt-and-pepper effect $(T V, c)$ bruiaj / perturbație parazită pe ecranul televizorului saltary (ec, autom) (dezvoltare etc.) în salturi saltation salt (brusc); salt, salturi, săritură, sărituri; saltație, schimbare (bruscă); dans, joc; (geol, geogr, hidr, mediu) deplasare prin salturi a aluviunilor de râu, debit solid (de aluviuni) deplasat prin saltație

salt away v. salt down

salt away stock (ec) a dosi / stoca / ascunde mărfuri salt bath (chim, met) baie de săruri / de sare

salt-bath case-hardening (chim, met) călire în baie de săruri

salt-bath furnace (chim, met) cuptor cu baie de săruri / de sare

salt-bath quench (chim, met) călire în baie de săruri

salt-bearing bed (geol) strat salifer

salt bridge (chim) punte de sare

salt brine (geol) apă sărată din strat; saramură, solutie salină

salt brine pump (OM; alim, chim) pompă de saramură

salt cake (chim) sulfat de sodiu (şi tehnic)

salt-cake furnace cuptor pentru sulfat de sodiu

salt cellar (alim, OM) solniță

salt content (alim, materiale) conţinut de sare

salt core (geol) sâmbure de sare (în cută anticlinală)

salt dome (geol) dom de sare

salt down (ec) a economisi (bani)

salt drum (OM, ind chim) colector / rezervor de sare cristalizată

salt drum (OM) rezervor / colector de sare cristalizată

salted sărat (d. alimente); cu sare

salt efflorescence (geol, chim) eflorescență a cristalelor de sare

saltern salină; (ind, ec) întreprindere de extractie a sării

salt extractor extractor de sare

salt fog (climă, chim) ceață salină

salt gauge (metr, chim) aparat de determinat salinitatea

salt glaze glazură de sare

salt hardening (met) călire cu răcire în soluție / baie de săruri

salt horse (alim) carne de vită sărată

saltiness (alim) gust sărat; (chim) caracter salin

salting (alim) sărare

salting evaporator (alim, chim) evaporator pen-

tru soluții de sare

saltish cam sărat (d. alimente)

salt lake (geogr) lac sărat 
Salt Lake City (geogr) capitala statului Utah, SUA saltlick (agr) bulgăre de sare (pt. vite) salt liquor (alim, chim) saramură salt marsh (geogr) mlaştină inundată periodic de apă sărată

salt meter (metr) aparat de determinat salinitatea salt mine (geol) mină / ocnă de sare, salină salt of amber (chim) acid succinic salt of Lemery (chim) sulfat de potasiu salt of phosphorus (chim) fosfat acid de sodiu si amoniu

salt of sorrel oxalate (chim) acid de potasiu

salt of tartar (chim) carbonat de potasiu

salt out (ind chim) a desalina, a desaliniza

salt-out (ind chim) desalinare, desalinizare, extragere a sării

salt pan (geol) lac mic sărat, salină

saltpeter, saltpetre (chim) salpetru, silitră, nitrat de potasiu

salt pit (geol, ind chim) puț de extracție a sării, ocnă, salină

salt plug (geol) dom / stoc de sare

salt prices (ec) (a cere) prețuri piperate, a ridica / umfla prețurile

salt removal (chim) desalinare, extrageare a unei săruri

Salt River (geogr) numele a două râuri în SUA

salt settler (ind chim) decantor de sare, instalație de desalinare / desalinizare

salt settling (ind chim, mas) decantare / sedimentare a sării

salt-settling tank decantor de sare

salt shaker (amer) (OM, alim) solniță

salt solution (alim, chim) saramură, soluție a unei săruri

salt somth. away (amer) a trage cuiva un perdaf salt somth. down $v$. salt somth. away

salt (-) spray test (chim, metr, materiale) probă / test (de coroziune) în cameră cu ceață salină

salt stains pete de sare (în ind. pielăriei)

salt works (chim) v. saltern

salt-out (chim, TH) desalinare

salt screen ecran fluorescent

saltspoon (ssp) (metr, alim) unitate de măsură pentru volum, utilizată în US, în rețete alimentare: 1 saltspoon $=1 / 4$ teaspoon $\cong 1,2 \mathrm{ml}$; . teaspoon

salt spots pete de sare (în ind. pielăriei)

saltus $(\mathrm{TH}$, autom, fiz) salt, oscilație

saltus function (mat) funcție de salt

salt water (geogr) apă sărată / de mare; marin;

(alim, chim) saramură, soluție a unei săruri

salt-water (chim) de apă sărată, marin

salt (water) spring (geogr) izvor de apă sărată salubrious salubru, favorabil sănătății, sănătos salubriousness caracter salubru

salubrity (mediu) salubritate, caracter salubru; (med) sănătate perfectă

salutary (med) folositor sănătății; salutar, folositor, util

salvage (nav) salvare, operație de salvare a unei nave, obiecte salvate, încărcătură recuperată (prin salvare), navă salvată, ranfluare, remunerație de salvare; salvare de la foc; (nav) a salva o navă, a recupera o încărcătură (prin salvare), a ranflua; (ind, mediu) a valorifica (materiale uzate)

salvaging salvare, lucrări / operațiuni de salvare / recuparare; (ind, mediu) utilizare a deseurilor salve oil (chim, med) ulei medicinal

salvia (bot) salvie

salvor (nav) persoană / navă care ajută la salvarea unui vas

Samarium (Sm) (chim) samariu(m)

same acelaşi, aceeaşi, aceiaşi, aceleaşi; aceeaşi persoană, sus-numitul; acest lucru

same as întocmai ca (şi), la fel ca (şi), precum

sameness identitate, asemănare (perfectă); uniformitate, monotonie

samlet (alim, iht) somon tânăr

sampan (nav) şampană

sample (metr) epruvetă, specimen; mostră; eşantion, şablon, probă, leră; model, tipar; probă de tipar; (mat) selecție; a proba, a încerca; a selecta, a compara; a preleva; a lua un eşantion; (alim) a degusta (vinuri)

sample division (ind) divizarea eşantionului (de verificat etc.)

sample interval (metr) interval de observare a unei variabile

sample mean medie de selecție

sample piece $(\mathrm{OM})$ model

sample point (autom) punct etalon

sample preparation (ind) pregătirea eşantionului / probei

sample quartering reducerea probei / eşantionării prin metoda sferturilor

sampler (ind) luare de probe, eşantionare; tester / aparat / sondă pentru luarea probelor, ciupitor; (textile) model (de împletit); (autom, el, c) selector

sample size volumul selectiilor

sample spoon (met, OM) lingură de luat probe sample taking luarea unei probe

sample variation (statistică) variație a eşantionului/a selectiei

sampling analiză; cuantizare; (inf) eşantionare; (materiale) eşantionare, luare a unei probe; (mas) selecție; (met) segregare; explorare; (c, TV, fiz) 
discriminare cromatică; (fiz) discriminare selectivă; (mat) proces de obținere a unei selecții; sondaj

sampling action (TH, autom, mas) corecție periodică (datorată analizei unei probe)

sampling at random luarea unei probe la întâmplare

sampling device $(\mathrm{OM})$ aparat / dispozitiv de luat probe

sampling length (metr) lungime de bază (la profilometria suprafeței)

sampling rate (metr) viteza de citire / de înregistrare a unei variabile (la un aparat de măsură)

sampling tube $(\mathrm{OM})$ carotieră, ciupitor

sanction sancțiune; aprobare, confirmare; a sancționa; a confirma, a aproba; a sprijini, a susține

sand (constr) nisip; (met) a sabla; culoarea nisipului; a presăra, a acoperi cu nisip; (constr) a amesteca cu nisip; (TH) a şlefui cu nisip / şmirghel; a umple cu nisip; (nav) a face să eşueze

sand aerating machine / apparatus (met) maşină de afânat amestecul de formare sandal cureluşă de sandală, sanda(lă)

sandal wood (silv) lemn de santal sandarac (chim) sandarac; (minrl) realgar sand asphalt (geol, constr) asfalt nisipos, nisip asfaltos

sand bag sac cu nisip; a acoperi / apăra cu saci de nisip

sand bank (geogr, hidr) banc de nisip

sand bar (geogr, hidr) prag de nisip, banc

sand bath baie de nisip

sand bed (met) pat de nisip de turnare

sand binder (met, constr) liant pentru nisip

sand(-)blast (TH, OM) sablat, sablaj, sablare; (mas-un) instalație / dispozitiuv de sablare; (met, TH) a sabla, a curăța cu nisip

sand-blast (apparatus) (met, mas) aparat de sablat / de curătăat cu nisip

sand-blast barrel $(\mathrm{OM})$ tambur de sablare

sand-blast cleaning (met, TH) sablare, curățire prin sablare

sand-blasting (met, $\mathrm{TH}$ ) sablare, curățare prin sablare / cu nisip

sand blast machine / unit (met, mas-un) aparat de sablat

sand-blast sand (met) nisip de sablaj

sand-blaster (mas-un) aparat / instalație de sablat

sand-blasting (met, $\mathrm{TH}$ ) curățire prin jet de nisip; sablare

sand-blast(ing) equipment / machine / plant (mas-un) maşină / echipament de sablat

sand-blasting shot $(\mathrm{TH})$ material (şi nisip) de sablare, împroşcare cu nisip sand-blasting work (met) (operație / tehnologie de) sablare

sand-blast sand (met) nisip de sablaj

sand blister (auto) umflătură din cauza prafului adunat în pneu

sand blow (met) incluziune de nisip

sand-blowing nozzle $(\mathrm{OM})$ ajutajul aparatului de sablat

sand boil (med) hernie de praf

sand box (cf) nisipelniță, cutie cu nisip

sandcast (met) a turna în forme de nisip sand-casting plant (met, $\mathrm{TH}$ ) turnare în forme de nisip / în amestec de formare / în nisip sand clay (geol) sol nisipos-argilos

sand cleaning (met, TH) sablare, curățare cu nisip sand conditioning (met) prepararea / pregătirea amestecului de formare / a nisipului

sand core (met) miez de amestec / de nisip

sand crusher (mas, constr, ind chim) concasor

sand crust (met) aderență / crustă de nisip

sand desintegrator (constr, mas) moară centrifugă de nisip

sand-drying oven (met) cuptor de uscat nisip

sanded acoperit / umplut cu nisip; de culoarea nisipului; înnisipat

sanded up înnisipat, plin de nisip (şi în sens nedorit) sander (mas-un) maşină de netezit cu abrazivi / de sablat / de curățat cu nisip; (cf) nisipelniță

sanders (silv) lemn de santal

sand filter (OM, mediu) filtru de nisip

sand filtering ( $\mathrm{TH}$, mediu) filtrare prin strat de nisip sand flowability (met) capacitate a nisipului de a curge (din / în formă)

sand glass clepsidră; (nav) nisipar

sand grain (materiale) granulă de nisip

sand hole / inclusion / mark (met) incluziune de nisip

sandiness caracter nisipos

sanding presărare / acoperire cu nisip; (TH) sablare; (hidr, mediu) înnisipare

sanding machine (mas-un) maşină de şlefuit / de netezit (cu praf abraziv) / de sablat (cu nisip)

sand-jet blower (met, mas-un) dispozitiv de sablat sand ladlet (constr, OM) mistrie

sand-lime brick (met) cărămidă silico-calcaroasă sand mill (constr, met, mas) malaxor de nisip sand mixer (constr, met) malaxor / amestecător de nisip

sand mould (met) formă din amestec de formare / de nisip

sand mould cast iron (met) fontă turnată în formă de nisip

sand mould casting (met, $\mathrm{TH}$ ) turnare în forme de amestec de formare 
sand moulding (met) formare cu amestec de formare / cu nisip

sand nozzle $(\mathrm{OM})$ duză de sablare

sand-paper şmirghel, glaspapir

sand-paper holder (OM) suport de şmirghel

sand permeability (constr, met) permeabilitate a nisipului

sand pin (met) cui de turnătorie

sand pit (constr, geol) carieră de nisip

sand pocket (met) incluziune de nisip

sand pores (met) porii nisipului

sand preparation (met) prepararea amestecului de formare

sand preparation plant / unit (met) instalație de preparare / pregătire a amestecului de formare

sand properties (met) caracteristicile nisipului de turnătorie

sand quality (met) calitate a nisipului

sand rock (geol) gresie

sand rolling (met, $\mathrm{TH}$ ) prelucrare / curățare prin antrenarea în miscare de rostogolire a pieselor, în toba cu nisip

sand screen (OM, constr) ciur / sită de nisip

sand separator $(\mathrm{OM})$ separator de nisip

sand slinger (met) aruncător de amestec de formare / de nisip

sandstone (geol) gresie

sand stopping (met) stavilă / opritor de zgură

sand trap $(\mathrm{OM})$ deznisipator, denisipar

sandwich (alim) sandviş; (materiale) suprapunerea a două sau mai multe materiale, material tip sandwich (în straturi); (met) pachet de table; a intercala (în straturi)

sandwich blending (materiale) amestecare în straturi suprapuse

sandwich braze (OM, met) lipitură (tare) stratificată / cu strat intermediar pentru reducerea tensiunilor interne

sandwich frame $(\mathrm{OM})$ cadru dublu / tip sandwitch sandwich panel (materiale) panou tip sandwich / stratificat

sandwich valve (OM, hidr) dispozitiv / aparat hidraulic modulat / etajat

sandy nisipos, cu nisip; de culoarea nisipului

sandy clay (constr) argilă nisipoasă

sane sănătos la minte; rațional; judicios, normal

sanforized shrunk finish (textile, TH) sanforizare, tratare a tesăturilor de bumbac pentru a împiedica contractía la spălare

sanitary (med) sanitar; inspector sanitar, igienist sanitary appliances (OM, mas, med) aparate sanitare

sanitary articles (OM, mas, med) produse / articole / obiecte sanitare sanitary castings (OM, constr) produse / piese turnate pentru instalații sanitare

sanitary engineering tehnică sanitară, ingineria instalațiilor sanitare

sanitary-engineering installation(s) (constr, ind) instalație tehnico-sanitară

sanitary service (adm, med) serviciu sanitar

sanitary sewer (hidr, mediu) canal de ape uzate

sanitation sanitație; (hidr) asanare a bălților, canalizare

sanity sănătate psihică; echilibru mintal; judecată sănătoasă

santal-wood (silv) lemn de santal

santonica (bot) pelin; santonină

sap (bot, alim) sevă, suc; a scoate / stoarce seva / sucul din, a usca; a epuiza; a slăbi

saponide (chim, T) detergent sintetic

saponifiable grease (chim, T) grăsime saponificabilă

saponifiable oil (chim, T) uleiuri saponificabile

saponifiable (chim) saponificabil

saponification (chim) saponificare; formare a săpunului

saponification agent (chim, T) agent de saponificare

saponification number / value (chim, T) indice de saponificare

saponification number test (chim, T) determinarea indicelui de saponificare

saponification rate (ind chim) viteză de saponificare

saponification ratio (chim, T) cifră de saponificare saponify (chim) a (se) saponifica

saponin(e) (chim) saponină

sapour (alim) savoare, gust

sapphir (metr) safir

sapphirine (ca) de safir, albastru (ca safirul)

sappy fracture (met) ruptură / spărtură cu grăunte fin

sappy structure (met) structură cu grăunte fin saprophyte (bot) saprofită

sarcasm sarcasm, ironie usturătoare

sarcenet (textile) mătase (pt. căptuşeală)

sardonyx (minrl) sardonix

saros (metr, astronomie) unitate de timp, utilă în predicția eclipselor de lună şi de soare: 1 saros $=6585,32$ zile

sash eşarfă, bandaj; (constr) toc / cadru mobil de fereastră

sash and casement sections (met, plast) profiluri (metalice sau plastice) pentru ferestre

sash bolt (constr, OM) închizător de geam / fereastră

sash saw (mas-un) ferăstrău cu pânză îngustă 
sash window (constr, OM) fereastră glisantă / ghilotină

satchel ghiozdan

satchel bag pungă pliată

sate a sătura

sated (with) sătul (de)

sateen (textile) imitație de satin

satellite $(\mathrm{OM})$ satelit, roată-satelit

satellite gear (OM) angrenaj cu roată-satelit, angrenaj planetar

satiability îndestulare, sațietate

satiable saturabil, care poate fi saturat

satiate a (supra)satura

satiated saturat

satiation (supra)saturare, îndopare

satiety saturare, saț; îndestulare, sațietate

satin (textile) satin, atlaz

satinet(t)e (textile) satinet, satin subțire

satin finish (mas-un) finisare cu perie (şi metalică)

satin-gloss black (chim) negru de fum

satinize (poligrafie) a satina, a netezi (d. hârtie)

satin paper hârtie satinată

satin spar (ind chim) var de calcit

satiny (ca) de satin, satinat, lucios, mătăsos

satisfaction (at / with) satisfacție, mulțumire (fa-

ță de / pentru), răscumpărare, despăgubire, compensare, compensație (pentru)

satisfactorily $(a d v)$ satisfăcător, mulțumitor, destul de bun; acceptabil; plăcut, bun

satisfactoriness caracter satisfăcător / mulțumitor, condiție satisfăcătoare / mulțumitoare, acceptabilitate

satisfiable care poate fi satisfăcut

satisfied (with / at) satisfăcut, mulțumit (de), saturat; sătul; satisfăcut (d. un criteriu)

satisfied compound (chim) compus saturat

satisfy a corespunde; a satisface, a îndeplini (o dorință, o condiție etc.); a mulțumi (pe cineva); a acoperi (o necesitate), a face față; (ec) a plăti o datorie; of / that a convinge (pe cineva) de / că; a compensa, a plăti pentru; a se convinge; a fi destul

satisfying satisfăcător, care satisface / corespunde, mulțumitor; îndestulător

satisfyingly $(a d v)$ (în mod) satisfăcător, mulțumitor; îndestulător

satsuma (agr, bot, alim) mandarin pitic

saturability saturabilitate (d. soluții)

saturable saturabil, saturant, care poate fi saturat (d. soluții)

saturate a satura, a împregna; (chim) a neutraliza

saturated saturat; (chim) neutralizat

saturated polyester (ind chim, plast) poliester saturat saturated solution (chim) soluție saturată

saturated vapor (fiz) vapori saturați

saturates steam (termo) abur saturat

saturating (care) care saturează / neutralizează

saturating capacity (fiz, chim) capacitate de absorbție / de saturare (a unei soluții)

saturating speed (ind chim) viteză de saturație / de absorbție / de îmbibare

saturation (chim, fiz) saturare, saturație, impregnare, îmbibare; concentrare; solicitare maximă; (metr) măsură a strălucirii unei culori; v. color units

saturation coefficient (chim, fiz) coeficient de saturare

saturation intensity (chim, fiz) grad de saturaţie saturation point (chim, c) punct de saturare / de saturatie

saturation pressure (fiz) presiune de saturație saturation property proprietate de impregnare saturation vat (chim, OM) cuvă de carbonatare / de saturare

saturator (chim, OM) saturator, aparat de saturat saturnism (med, chim) saturnism, intoxicație cu plumb

Saturn salt (chim) acetat de plumb

sauce (alim) sos, zeamă; suc de fructe, (amer) compot, băutură (alcoolică); (agr, bot) legumă, zarzavat; (alim) a găti cu sos, a drege, a aromatiza, a asezona; ( $f i g)$ a atenua, a micşora

sauce boat (alim, OM) sosieră

saucepan (alim, OM) cratiță, oală

saucer (alim, OM) farfurioară, suport (de pahar, taler; $(\mathrm{OM})$ pivot, talpă, călcâi

saucer-shaped (met, OM) în formă de ceaşcă

saucer-shaped furnace bottom (met) adâncitură a vetrei (la un cuptor)

sauna (constr, hidr, termo) saună, baie de abur (finlandeză)

saurel (alim, iht) stavrid

saurian (zool) saurian

saury (alim, iht) un fel de scrumbie

sausage (alim) cârnat, salam, crenvurşt, cârnăcior, caltaboş

sausage meat (alim) carne / tocătură pentru cârnați

sausage roll (alim) pateu cu carne sau tocătură de cârnați, franzeluță cu crenvurşt

saute (alim) soté, a prăji repede în grăsime

savable, saveable care poate fi salvat / recuperat, recuperabil

savage primitiv, sălbatic; necivilizat

savant savant, învățat

savart (metr, muz) unitate pentru a descrie raportul frecvențelor a două note muzicale; 
diferența între două frecvențe în savarts este egală cu de 100 de ori logaritmul raportului dintre cele două frecvențe.

save (from) a salva (de), a săpa, a păzi (de), a feri (de); a economisi, a face economie (de timp, bani etc.); a cruța, a nu irosi; a scuti de; a exclude, a excepta (de la); a recupera (de la / din); a ține, a dura, a rezista

save-all (OM, mas-un) vas / tavă pentru captarea picăturilor, dispozitiv de protecție / de recuperare; salopetă, haină de protecție

saveloy (alim) cârnat uscat, condimentat puternic, babic

saver persoană economă; lucru care permite să se economisească (timp, bani etc.); salvator

save up (ec) a strânge, a economisi (bani, resurse etc.)

saving salvator; de salvare; econom; (jur) restrictiv, de interdicție; salvare; (ec) economie, care economiseşte; (conj) dacă nu, numai că; (prep) cu excepția, exceptând, în afară de

saving in weight economie de greutate; $(\mathrm{OM})$ micşorare a greutății / masei

savingly $(a d v)$ cu economie

savings (ec) economii

savings bank (ec) casă de economii, bancă

saving that atât / numai că, atâta, doar că

savoir faire tact, comportare plină de tact

savoir vivre bună creştere, bun simț

savory (alim, bot) cimbru

savour (alim) savoare, gust / miros deosebit, aromă; urmă, iz, nuanță; a da gust, a condimenta, a asezona; a avea un gust / miros de

savour (of) (alim) a avea gust / miros (de)

savory (alim) savuros, gustos, apetisant; plăcut mirositor; agreabil; (alim) fel de mâncare / aperitiv picant

savoy (agr, bot, alim) varză creață / nemțească

savvy a pricepe, a înțelege; simț practic, pregătire, cunoștințe; pricepere, minte, judecată

saw (mas-un) ferăstrău; $(\mathrm{TH})$ a ferăstrui, a tăia / a debita cu ferăstrăul

saw arbor (mas-un, OM) ax al ferăstrăului circular, dorn al frezei de canelat

saw( )blade (mas-un, OM) pânză / lamă / disc de ferăstrău

saw bow (mas-un, OM) arc / cadru de ferăstrău

saw buck / horse capră (de tăiat lemne)

saw cutting (mas-un, TH) debitare / retezare / tăiere cu ferăstrău

saw cutting machine (mas-un) mașină de ascutit dinți de ferăstrău

sawdust (TH, mediu) rumeguş, aşchii de la operația de tăiere cu ferăstrău saw edge (mas-un) tăiş de ferăstrău

saw file (mas-un) pilă de ascuțit dinți de ferăstrău saw frame $(\mathrm{OM})$ ramă de gater

sawing $(\mathrm{TH})$ debitare cu ferăstrăul

sawing machine, saw mill (mas-un) ferăstrău mecanic, gater, instalaţie pentru cherestea, joagăr

saw $\log$ (silv) buştean pentru gater

saw nick (mas-un) tăiș de ferăstrău

sawn wood (silv) cherestea

saw off (TH) a curma, a tăia (cu desprindere), a debita

saw out (mas-un, TH) a decupa cu ferăstrăul

saw pliers $(\mathrm{OM})$ clește de rostuit dinți de ferăstrău

saw setting machine (mas-un) maşină de rostuit

I de tăiat dinți de ferăstrău

saw steel (met) oțel de ferăstrău

saw-tooth (mas-un, OM) dinte de ferăstrău

saw-tooth effect (mas-un) bavuri mici la marginea piesei (din prelucrarea prin aşchiere)

saw-tooth hob (mas-un) freză de tăiat dinți la ferăstrău circular

saw-tooth punch $(\mathrm{OM})$ poanson pentru dințarea ferăstrăului

saw-toothed (OM, mas-un) în dinți de ferăstrău saw vice $(\mathrm{OM})$ menghină pentru pânza de ferăstrău sawyer (mas) tăietor de lemne (cu ferăstrău)

say a spune, a zice, a rosti; a pronunța, a articula (cuvinte); a afirma, a susține; a promite; a admite, a presupune; a repeta; a indica, a arăta (şi d. cadranul unui aparat / ceas); a exprima; a scrie; cuvânt, vorbă; părere; drept de a vorbi

Saybolt Furol viscometer (metr, T, hidr) vâscozimetru Saybolt Furol (pt. uleiuri foarte vâscoase)

Saybolt Furol viscometer (metr, T, hidr) vâscozimetru Saybolt Furol (pt. uleiuri şi fluide mai vâscoase) (,furol” - acronim de la „fuel and road oils" - bitum lichid şi combustibil greu)

Saybolt Furol seconds (SSF, SFS) (metr, T) valoare în secunde, pentru vâscozitate cinematică, obținută cu vâscozimetre Saybolt; reprezentând timpul necesar ca $60 \mathrm{ml}$ din eşantionul de fluid să curgă prin vâscozimetru; pentru lichide foarte vâscoase (peste 500 centistokes) la $50^{\circ} \mathrm{C}, 1 \mathrm{SSF} \sim 2,120$ centistokes sau 2,120 $\mathrm{mm}^{2} / \mathrm{s}$; se mai utilizează în industria petrolului

Saybolt Universal seconds (SSU, SUS) (metr, T) valoare în secunde, pentru vâcozitatea cinematică, obținută cu vâscozimetre Saybolt; pentru lichide cu peste 50 centistokes la $37,8^{\circ} \mathrm{C} 1 \mathrm{SSU}$ $\cong 0,2158$ centistokes sau $0,2158 \mathrm{~mm}^{2} / \mathrm{s}$. se mai utilizează în industria petrolului

Saybolt universal viscometer (metr, $\mathrm{T}$, hidr) vâscozimetru Saybolt (vâscozitatea se exprimă 
funcție de timpul de scurgere al fluidului prin tuburi calibrate) (pt. lichide cu vâscozitate mai mare de 1000 centistokes)

saying spunere, rostire, anunț; care spune / afirmă / arată / presupune

say on a spune mai departe, a continua

scab (met, OM) suprapunere, pliu, peliculă, incluziune de nisip, coajă, crustă (la laminare), defect de suprafață la turnare sau laminare constând dintr-o bucată mică ataşată (sau parțial detaşată) de materialul de bază; (agr) rugină a frunzelor; a acoperi cu crustă; (constr) a scarifica

scabbard $(\mathrm{OM})$ teacă, manşon

scabbiness (met) suprafață inegală a unei piese turnate

scabble a ciopli (piatra)

scabby, scabious (met, med) acoperit cu o crustă; (agr) ruginit

scabies (med) râie, scabie

scabrous aspru (la pipăit); dificil, plin de dificultăti

scaffold (constr) schelă, schelet; eșafodaj; tribună; a eşafoda, a folosi schele (la construcții); (met) blocarea şarjei (la furnal); a se astupa, a se bloca

scaffolding (met) agățarea / blocarea şarjei (la furnal); (constr) grindă de schelărie

scaffolding beams (constr) grinzi de schelă

scaffolding (constr) eşafodaj de schelărie

scalable escaladabil, accesibil

scalar field (mat) câmp scalar

scalar quantity (fiz, mat) mărime scalară

scalar (mat, fiz) scalar, mărime scalară

scald a (se) opări, a arde, a frige; a încălzi până aproape de fierbere; a pasteuriza, a steriliza; (med) arsură (cauzată de un lichid fierbinte), râie, scabie

scalding (alim, chim) opărire

scale (TH, metr) scală / scară a unui instrument, cadran gradat; (chim, OM) vas, mojar; (mat) scară, mărime, proporție, dimensiune; (met) arsură, scorie, coajă, zgură, tunder, a arde, a forma arsură / țunder, a scoate zgura de pe, a curăța de zgură / scorie, a se acoperi de zgură; a avea o greutate de, ierarhie; linie, riglă; a urca (pe o scară), a escalada (cu o scară); a determina scara de reprezentare; a măsura cu o scară / scală, a (se) urca, a se ridica (pe scară); a corespunde, a fi corespunzător; (alim) solz (de peşte etc.), a (se) curăța de solzi, a îndepărta solzii de pe; a (se) descuama, a (se) exfolia (și din cauza oboselii materialului); (med) coajă, crustă, tartru dentar, piatră; a se coji; (metr) o măsură a rezoluției unei hărți: în general, o scară 1:n scale înseamnă că 1 unitate de distanță de pe hartă reprezintăs $n$ unități de aceiaşi mărime: scara 1:250 000 pe o hartă, înseamnă că 1 $\mathrm{cm}$ reprezintă $250000 \mathrm{~cm}(2,5 \mathrm{~km})$ pe teren scale beam (metr, OM) braț de balanță scale board (materiale) placă de furnir, placaj scale breaker (met) dispozitiv de tăiere (la laminor continuu), spărgător de arsură / de țunder scale breaker stand (met) cajă pentru desțunderizare / pentru spargerea şi îndepărtarea arsurii scale decade (metr) demultiplicare în raportul $10 / 1$

scale disk (OM, metr) cadran

scale division (metr) gradare a scării

scale down a micşora, a reduce (prețuri, dimensiuni etc.)

scale effect (constr, arhit) efect de scară (la modelare)

scale error (metr) eroare de scală

scale factor (fiz, nav) factor de scară (şi la încercări pe model)

scale-free (met) fără oxizi, fără țunder

scale handling (met) îndepărtarea / scoaterea tunderului

scale illumination (metr, el) luminare a cadranului / scalei

scale incrustation (termo) piatră de apă, tartru (d. cazane, tubulatură)

scale interval (metr) interval al scării / scalei scale mark (metr) gradație a unei scale, reper scalene (geom) scalen

scalene / scalenous triangle (geom) triunghi scalen scale of hardness (materiale) scară de duritate scale of height (metr) riglă verticală

scale of micrometer (metr, OM) manşon gradat al micrometrului

scale of reduction $(\mathrm{OM})$ scară de reducție / de reducere

scale off $(\mathrm{TH})$ a răzui

scale pit (met) groapă de colectare a țunderului (la laminor)

scale pitted surface (met) suprafață rugoasă (din cauza țunderului sau a îndepărtării lui etc.); (T) suprafață cu exfolieri (de oboseală)

scaler (autom, el) numărător de impulsuri; (fiz) demultiplicator

scale range (metr) interval de măsurare al aparatului de măsură, scală, interval al scalei

scale removal (met) îndepărtare a tunderului / a arsurii

scale removing (termo) dezincrustare (la cazane, conducte)

scale-resistant steel (met) oțel refractar scales (metr) cântar, balanță 
scale shape (metr) forma scalei

scale span (metr) lungimea scalei

scale units (metr) unități de scală / de scară (la un aparat de măsură)

scale up a ridica (prețuri etc.); (metr) a lărgi intervalul de măsurare al unui aparat

scale-up factor (metr) factor de scală / de scară

scale with line marks (metr) scală gradată (la un aparat de măsură)

scaliness (materiale) caracter solzos / filiform

scaling (met) oxidare, formare de arsură / de țun-

der, scorojire, formare de peliculă groasă de

oxizi, mai ales la temperaturi înalte, acoperire solidă din straturi anorganice aderente pentru protejat suprafețele active ale utilajului de proces; $(\mathrm{T})$ exfoliere (de oboseală)

scaling ladder $(\mathrm{OM})$ scară de incendiu

scaling loss (met) arsură, pierderi de metal prin topire / prin ardere, reziduu de la prăjire; (T) pierderi prin exfoliere (de oboseală)

scaling of paint (ind chim) cojirea vopselei

scaling system $(\mathrm{OM})$ demultiplicator

scaling tool (met, mas-un) cuțit de îndepărtat crusta

scaling unit (autom) circuit demultiplicator

scall (med) eczemă, eruptie; coajă, crustă

scallion (agr, bot) arpagic, eşalot, praz

scallop (specie de) scoică; (textile, OM) feston, a festona; tăiere în formă de feston, a zimțui, a cresta, a tăia în zigzag

scallopinig machine (mas-un) maşină de trefilat / festonat

scallops (met, ind chim) adâncituri, şanțuri (defecte de laminare); $(\mathrm{OM})$ rugozitate (vizibilă)

scallywag (agr) animal nedezvoltat / prost hrănit, vită slabă

scalp (constr) ciuruirea claselor granulometrice mari; (met) a coji, a îndepărta arsura / țunderul; a scoate coaja, a descoji; a dezgoli

scalpel (OM, med) scalpel

scalper (agr, constr) rest / reziduu pe sită; (met, mas-un) dispozitiv / maşină de cojit

scalping (mas-un, TH) eboşare, prelucrare grosieră, degroşare; (met) cojire

scalping screen (agr, constr) ciur pentru clasele granulometrice mari

scaly (d. materiale, suprafețe etc.) cu solzi, solzos, filiform; (met) cu zgură / scorie, cu coajă, cu crustă; murdar, rupt, uzat

scaly structure (materiale) structură solzoasă

scan (fiz, metr) baleiaj, exploatare; a examina atent / cu grijă; a explora (şi o imagine); (c) a scana, a baleia (o imagine etc.)

scandal scandal; calomnie(re) scandalize a scandaliza, a indigna, a ofensa; a şoca

scandalous scandalos; şocant; calomniator

scan frequency (fiz, autom) frecvență de exploatare / de scanare

Scandium (Sc) (chim) scandiu

scanned (c) scanat; (met) controlat (cu defectoscop, prin scanare, baleiere), baleiat (d. o suprafață)

scanner (c) sistem de scanare (a unei imagini), scanner; (met, metr) defectoscop; (radio) sistem de antenă rotitoare; explorator

scanning explorare, analiză, analizare; (metr, birotică) scanare

scanning beam (fiz) fascicul explorator / de scanare

scanning electron microscopy (fiz) microscopie electronică / cu baleiaj electronic

scanning speed (fiz, metr) viteză de explorare / de scanare

scansion (c) descompunere a imaginii

scant puțin, neîndestulător, insuficient; redus; restrâns; a împuțina; a micşora; a reduce (porția etc.)

scantily $(a d v)$ puțin, restrâns; neîndestulător, insuficient, rar

scantiness puținătate, insuficiență, neîndestulare; raritate, caracter rar

scantling (met) colțar mic, deșeu; mărime / dimensiune prescrisă (a lemnului etc.); (OM) stelaj pentru butoaie; cantitate mică / neînsemnată

scantlings rigle

scant of lipsit de, cu puțin

scanty limitat, mărginit, puțin, neîndestulător, insuficient; neîncăpător (d. spațiu etc.), strâmt scape (agr, bot) tulpină, lujer

scar (med) cicatrice, rană; urmă; a se cicatriza, a umple cu cicatrici / răni; prăpastie, mal abrupt, faleză, stâncă abruptă

scarce care se găseşte rar, puțin

scarcely $(a d v)$ (de-)abia, tocmai, chiar

scarcity of lipsă de, puținătate, deficit; caracter rar, raritate

scare a (se) speria, a îngrozi, a înspăimânta; a alunga scarf, $(p l)$ scarves, scarfs (textile) eşarfă, fular, batic, şal, cravată; $(\mathrm{OM})$ îmbinare cu eclise; tăietură, crestătură; a cresta; a canela; (met) a curăța (cu flacără) (un cuptor)

scarfing (met) îndepărtarea arsurii / a țunderului cu flacără

scarfing angle $(\mathrm{OM})$ unghi de teşire / de şanfrenare

scarfing machine (mas-un) maşină de şanfrenat / pentru executat şanfrene

scarfing tool (mas-un) răzuitor 
scarf joint $(O M)$ îmbinare fulger / rapidă, îmbinare în gât-de-lup, îmbinare oblică

scarf pin (OM) ac de cravată / de eşarfă

scars (met) (pete de) crustă aderentă la furnal, la cuptoare)

scarfskin (anat) epidermă

scarifier (agr, constr) scarificator, grapă cu cuțite scarify (agr, constr) a scarifica; a critica violent scarlet roşu aprins, stacojiu; (textile) stofă / haină stacojie

scarlet runner (agr, alim) fasole mare

scarp pantă abruptă

scarry (anat) plin de cicatrice; (d. teren) brăzdat cu repezişuri

scathe a vătăma, a face un rău (cuiva), a răni; a demasca; a critica virulent; vătămare, pagubă; prejudiciu

scatter (fiz, materiale, metr) dispersie, dispersare; împrăştiere, risipire, difuzare; a dispersa, a despărți, a (se) împrăştia, a (se) risipi, a răvăşi, a presăra; a irosi, a risipi, a cheltui (bani); a strica (un plan); a difuza

scatter analysis (fiz, met) analiză de dispersie scatter band (fiz, metr) domeniu / interval de dispersie

scattered (fiz, TH) împrăştiat, risipit, difuz; rar, izolat; dispersat (şi un adaos în compozite)

scattered radiation radiație de scăpărări

scattering aflat din loc în loc; aşezat la intervale regulate; care împarte / (se) împrăştie / difuzează; (fiz) dispersie; răspândire, împrăştiere

scattering coefficient (fiz) coeficient de dispersie / de împrăştiere

scattering error (metr, fiz) eroare datorită împrăştierii

scatter rug covor mic, covoraş

scatter value (mat, metr, fiz) valoare / parametru de dispersie

scavenge a sufla, a purja, a baleia; (mediu) a curăța (străzi etc.), a mătura, a strânge gunoiul de pe / din; a elinima

scavenge oil ( $\mathrm{T}$, ind mediu) ulei uzat

scavenger mediu / substanță de curățare; (met) metal reactiv pentru combinarea și îndepărtarea gazelor dizolvate sau a altor impurități; (termo) agent chimic adăugat în apa de boiler, pentru scoaterea / dezactivarea oxigenului; măturător de stradă

scavenging (met, termo) purjare, baleiaj, evacuare a gazelor arse; curățare

scavenging port (termo) fantă de baleiaj la motorul în doi timpi

scavenging stroke (termo, hidr) cursă de evacuare a pistonului scem, scfm, scfh, scfd, scim (etc.) (metr) simboluri pentru ,standard cubic centimeters per minute”, „standard cubic feet per minute”, ,standard cubic feet per hour", ,standard cubic feet per day” şi „standard cubic inches per minute”, unităţi pentru debit de gaze, termenul standard indicând că debitul este la o temperatură şi o presiune standard de 1 atmosferă; în industria gazului natural, temperatura standard este de $15,6^{\circ} \mathrm{C}$; pentru aer, temperatura standard poate fi $0^{\circ} \mathrm{C}$ sau $20^{\circ} \mathrm{C}$ şi trebuie specificată şi umiditatea relativă; debitul real este notat cu ,a" (actual - real în limba engleză), în loc de ,s” scenario scenariu (şi de accident)

scend (nav) a sălta (d. navă)

scene scenă, loc al acțiunii; priveliște, tablou, spectacol; peisaj; episod

scenery culise; (fig) decor, peisaj, privelişte, tablou scent miros, adulmecare; parfum, mireasmă; (fig) a fi pe o pistă sigură, a fi pe drumul cel bun; (fig) nas, miros, intuitie, simt; a mirosi, a adulmeca; a parfuma, a înmiresma

scentless fără miros, nemirositor, neparfumat; fără miros / simțul mirosului

sceptic, sceptical sceptic, neîncrezător

sceptically $(a d v)$ (în mod) sceptic, cu scepticism scepticism scepticism, neîncredere

shackle (metr, nav) unitate tradițională de măsură pentru lungimi ale cablurilor submarine, lanțurilor de ancoră etc.; din 1949, Royal Navy a adoptat 1 shackle $(\mathrm{UK})=1$ shot $(\mathrm{US})=27,432 \mathrm{~m}$

shade number (metr, $\mathrm{TH}$ ) unitate pentru gradul de transmitere a luminii pentru ochelari de protecție la sudare; dacă $T$ este fracția luminii vizibile transmise, numărul de umbrire (de protecție) este: $1+7\left(-\log _{10} \mathrm{~T}\right) / 3$; exemplu: dacă se transmite $1 \%$ din lumină, numărul de umbrire este 4

shaftment (metr) unitate veche englezească de măsură pentru lungime, egală cu 2 palme: 1 shaftment $=15,24 \mathrm{~cm}$

shake (metr, fizică nucleară) unitate informală pentru timp, egală aproximativ cu durata de viață a unui neutron: 1 shake $=10^{-8} \mathrm{~s}$

shaku (metr) unitate de măsură pentru lungime, arie sau volum, în Japonia, picior japonez: 1 shaku $\sim 30,30 \mathrm{~cm} ; 1$ shaku $=330,6 \mathrm{~cm}^{2} ; 1$ shaku $\cong 18,04 \mathrm{ml}$

shannon (Sh) (metr, inf) unitate binară de cantitate de informație

shed (metr) unitate foarte mică de măsură pentru arie, în fizica particulelor; 1 shed $=10^{-52} \mathrm{~m}^{2}$

schedule $(\mathrm{TH}, \mathrm{ec})$ anexă, adaos, plan, program, schemă, grafic; orar; listă, inventar; tabel; (mas) 
regim; a înregistra, a programa, a fixa, a stabili; a trece pe o listă / într-un tabel; (jur) anexa, a adăuga

scheduled planificat; prevăzut; (ec) tarifar; programat

schedule maintenance (mas, ind) mentenanță programată / planificată (inclusă în mentenanța preventivă)

schedule of prices $(\mathrm{ec})$ borderou / listă de prețuri scheduling (ec, TH) planificare (şi calendaristică) scheffel, schepel (metr) unitate tradițională de măsură pentru volum (materiale uscate), în sistemul metric: 1 German scheffel $=501,1$ Dutch schepel $=10$ l; v. skep

shekel, sheqel (metr) unitate antică, iudaică, de măsură pentru masă (şi denumire a monedei cu aceiaşi masă); 1 shekel $\sim 8,3$ g sau 1 shekel $\sim 7 \ldots 14 \mathrm{~g}$

sheng (metr) unitate tradițională de măsură pentru volum de lichid, în China: 1 sheng $=1,0351$

shetland (metr, alim) unitate de măsură pentru volum (de bere) în Australia de Vest, 1 shetland $=115 \mathrm{ml}$

shift (metr) schimb, unitate tradițională de muncă a unui operator; de obicei egală cu 8 ore

shipping ton (metr, nav) unitate tradițională de măsură pentru volum pentru încărcătura unui vas: 1 US shipping ton $=1$ freight ton $\cong 1,1326$ $\mathrm{m}^{3} ; 1$ British shipping ton $=1,1893 \mathrm{~m}^{3}$

schema, $(p l)$ schemata schemă; plan; diagramă schematic schematic, de principiu; superficial schematically $(a d v)$ (în mod) schematic schematic diagram schemă / diagramă de principiu

schematism schematism, organizare schematică schematist autor al unei scheme / clasificări schematization schematizare

schematize a schematiza

scheme plan (sistematic), proiect, schemă; sistem, aranjament; organizare; plan utopic / vizionar; a face proiecte / planuri

schist (geol) şist

schistose (geol) șiștos

schistosity (geol) şiştozitate

schistous (geol) şiştos

schlicht (mat) univalent

schlicht function (mat) funcție univalentă

Schlippe's salt (chim) tioantimoniat de sodiu, sarea lui Schlippe

schnitzel (alim) şnițel (din carne de vițel)

sho (metr) unitate tradițională japoneză de măsură pentru volum de lichide: 1 sho $=1,80391$

shock, shook (metr) unitate pentru cantitate, egală cu 5 duzine sau 60 shoe pantof, gheată (şi din piele); (anat) labă (de picior), talpă; (nav) chilă falsă, talpă, papuc; (OM) cuzinet, patină, za de şenilă, potcoavă, sabot, sabot de frânare, sanie, talpă; (mas-un) sanie; (el) sabot alunecător de contact; (constr) țiglă, talpă; (auto) (fig) cauciuc de maşină; a încălța; a pingeli; a potcovi

shoe size (metr) mărime de pantof; toate mărimile de pantof exprimă lungimea aproximativă a pantofului; în US, diferența între două mărimi consecutive pentru incălțăminte este de 8,47 mm, pantoful cu numărul $n$ are o lungime de $Z$ $+n / 3, Z$ fiind lungimea mărimii $0: Z=99,5 \mathrm{~mm}$ pentru copii şi adolescenți, $Z=91,0 \mathrm{~mm}$ pentru adolescente, $Z=201,1 \mathrm{~mm}$ pentru femei şi $Z=$ 209,6 mm pentru bărbați; în Europa, mărimea unui pantof se măsoară în Paris points $(=2 / 3$ cm); încăltămintea de schi se măsoară în mondo points (milimetri); v. Paris point

scholar om de știință, erudit; discipol

scholarly (de) savant; științific; (edu) studios, preocupat de studiu; ordonat, metodic, meticulos

scholarship învățătură; erudiție; (edu) bursă; ştiințe umaniste; ştiință de carte

school (edu) şcoală (ca instituție, clădire); (univ) facultate umanistică sau filologică; instrucție; a instrui, a da la şcoală, a scolariza; a crește, a educa; (alim, nav, iht) banc de peşti

schoolable (edu) de vârstă şcolară

schoolboard (edu, adm) consiliu de conducere al şcolii, comisie şcolară locală

school book (edu) manual

school house (edu) şcoală, clădirea şcolii

schooling (edu) scoală, învățătură, educație; școlarizare

school leaver (edu) care a abandonat şcoală; absolvent

schoolman (edu) învătător, profesor, educator schoolmastering (edu, adm) funcția de învățător / institutor / director de şcoală

school of thought școală de gândire; concepție

school report (edu) caracterizare (şcolară); carnet de note

schoolroom (edu) clasă (încăpere)

school teacher (edu) învățător, institutor

school time (edu) (ore de) şcoală, (ani de) şcoală school work (edu) muncă / activitate în clasă; temă de casă

schoolyard curtea şcolii

schooner (alim) pahar de bere (1/3 1); (amer) pahar înalt (p. bere); (metr) unitate de măsură pentru volum (de bere); 1 schooner $\sim 400 \mathrm{ml}$; în Queensland, New South Wales şi Northern Territory (Australia), 1 schooner $=425 \mathrm{ml} ; 1$ schooner $($ South Australia $)=285 \mathrm{ml}$ 
schooner-brig (nav) bric-goeletă, brigantină schoppen (metr, alim) unitate tradițională germană pentru a măsura un volum de lichid (vin etc.): 1 schoppen $=250 \mathrm{ml}$

Shore hardness (metr, materiale) duritate Shore, unitate de măsură pentru exprimarea durităţii materialelor, cu un durometru Shore

short hundredweight (metr) denumire pentru a US hundredweight sau cental (100 pounds)

short ream (metr, birotică) top tradițional de hârtie (480 de coli); 1 standard ream -500 de coli

short ton (st, tn) (metr) denumire pentru US ton; $v$. ton

short ton unit (stu) (metr) unitate de măsură pentru masă, în industria extractivă pentru a exprima masa de material valoros dintr-un minereu; 1 short ton unit $=1$ US ton $(\cong 9,072 \mathrm{~kg}) \mathrm{de}$ minereu care contine $1 \%$ material valoros

shortword (metr, inf, c) unitate de informație, în general egală cu $1 / 2$ cuvânt

shot (metr, fiz) unitate tradițională de măsură pentru volum de lichid: 1 shot $(\mathrm{US})=29,574 \mathrm{ml}$ barmanii utilizează şi 1 (larger) shot $\sim 37,0$.. 44,4 ml; (metr, nav) altă denumire pentru shackle, ca unitate de măsură pentru lungime pentru lanturi de ancoră: 1 shot (US) $=27,432 \mathrm{~m}$; v. shackle

shovel (agr, OM) brăzdar; (constr, mas, OM) cupă de excavator, excavator (în sens larg), lingură de excavator; (OM) făraş, lopată; (constr) lopată, lopățică, a curăța / săpa cu lopată; scafă; (fig) lingură; a căra cu nemiluita; (alim) a se îndopa (cu mâncare), a înfuleca; a întoarce; a ridica; (metr, constr) unitate de măsură pentru volum, în construcții, lopată: 1 cubic yard (US) $\cong 150$ standard (no. 2) lopeți de material: 1 shovel $\sim 5$ 1 şi $1 \mathrm{~m}^{3} \sim 200$ lopeți

shovel arm (OM) braț / săgeată de excavator

shovel blade (constr, $\mathrm{OM}$ ) pală, paletă

shovel crane (constr, mas) macara-excavator

shovel dipper (constr, OM) cupă de excavator

shovel dipper slide (constr, OM) clapă de cupă de excavator

shovel dipper stick (constr, OM) braț / săgeată de excavator

shovel dipper tooth (constr, OM) dinte de cupă de excavator

shovel dozer (constr, OM) autoîncărcător cu cupă

shovel dozer attachment (constr) echipament de autoîncărcător cu cupă

shovel for jewelers (OM) lopățică pentru bijutieri shovel into (constr, transp) a încărca cu lopata

shovel-man (constr) excavatorist, lucrător la terasamente / terasare

shovel-nose tool (mas-un) cutit lat shovel out (constr, transp) a descărca cu lopata shovel stowing (constr, $\mathrm{cf}$ ) rambleiere cu lopata shovel with fork equipment (constr, OM) excavator cu benă

shower (OM, hidr) duş (instalație, acțiune, proces); persoană care arată / demonstrează / expune; (meteo) ploaie repede / torentială / de vară, aversă de ploaie; (OM) stropitor; (TH) umezire prin stropire; (fig) a bombarda / inunda pe cineva (cu scrisori etc.), a copleşi; a inunda, a stropi, a uda

shower bath (constr) duş

shower of mulțime de, abundență de; răpăială (de gloanțe etc.), ploaie (de săgeți etc.); (fig) râu (de lacrimi), jerbă (de scântei etc.); of rain (hidr, meteo) aversă

shower-proof (OM, mas) rezistent la stropire / la pătrunderea picăturilor / stropilor de apă

shower unit (metr, fiz) unitate de măsură pentru lungime, pentru studiul radiației cosmice; distanța parcursă de o particulă încărcată întrun anumit material, până când energia acesteia scade la $50 \%$ din cea avută înainte de a pătrunde în material: 1 shower unit în aer $\sim 230 \mathrm{~m}, 1$ shower unit în apă $\sim 30 \mathrm{~cm}$

schtoff (metr) unitate tradițională de măsură pentru volum, în Rusia: 1 schtoff $\cong 1,231$

science ştiinţă, cunoştințe; ştiințele naturii / naturale; (fig) știință, artă, îndemânare, măiestrie

science degree titlu ştiințific

science-fiction (roman) ştiințifico-fantastic, literatură ştiințifico-fantastică

science of materials (fiz, chim, univ) ştiinţa materialelor, studiul materialelor (şi ca disciplină în universități)

science of measurement metrologie

science of metals (met) metalografie, studiul metalelor

sciential cunoscător, priceput, expert; ştiințific

scientific ştiințific, de expert; priceput; privitor la științele naturii

scientific investigation cercetare / investigare ştiințifică

scientific researcher cercetător ştiințific

scientist om de ştiință, savant; naturalist specialist în ştiințele naturii

scim (metr) v. sccm.

scintillant (fiz) scânteietor, care aruncă scântei

scintillate a scânteia, a scintila, a arunca scântei; a scili, a licări

scintillation (fiz) scânteiere, scintilație; sclipire, licărire

scion (agr) altoi; (fig) vlăstar, descendent, urmaş scissile(s) (met) deşeuri de tăiere, bandă obținută prin ştanțare; (met) foarfece mare (și tip ghilotină) 
scission (fiz, chim) scindare; ( $\mathrm{TH}$, textile, met) divizare, tăiere

scissor (TH, textile, met) a tăia cu foarfecele scissoring (met, textile, TH) tăiere cu foafecele scissor jack (auto, OM) vinci / cric compus dintrun mecanism paralelogram care are diagonala variabilă datorită unei transmisii cu șurub

scissors (mas-un) foarfece

scissors blade (mas-un, OM) lamă de foarfece

sclerometer (metr, materiale) aparat de încercat duritatea, sclerometru

scleroscope (metr, materiale) scleroscop

scleroscope hardness (metr, materiale) duritate Shore / scleroscopică

scleroscope-hardness number (metr, materiale) indice de duritate Shore

scleroscope-hardness test, sclereoscopic test (materiale, metr) încercare / test de duritate Shore

sclerous tare, dur; (anat) osos

scobs (mediu, silv) surcele, deşeuri; (met) zgură

sconce (constr, mil) întăritură, tranșee, redută şopron, colibă, adăpost, îngrăditură; a adăposti; a proteja; a îngrădi; (univ) a amenda, a penaliza (la Oxford)

scone (alim) un fel de biscuit (din făină de grâu sau de orz)

scoop (OM) lopată / lingură / cupă de excavator, paletă amestecătoare; (constr) scoatere, excavare, cancioc, groapă de fundație; (alim, OM) linguriță; (geogr) groapă, depresiune, vale; a scoate cu lopata, a săpa, a excava

scoop feeder (OM) alimentator cu cupe

scoop flight-conveyer (OM) elevator cu cupe

scoop sample (met) probă (luată) cu lingura

scoop shovel (mas, constr) excavator cu cupă

scoop up (constr) a scoate cu lopata, a săpa, a excava; a strânge, a aduna, a îngrămădi

scooter (auto) scuter

scope (fig) orizont, sferă; întindere; gamă; libertate, posibilități; (TH, fiz) câmp (şi visual, la un microscop etc.); (nav) lungime de lanț filat la apă; tintă, scop; diapazon, interval; (fiz, metr) aparat optic (foarte general)

scorch (chim, met) a prăji, a arde, a (se) pârli; a se pârjoli; (agr) a (se) ofili, a (se) veșteji, a (se) usca, a arde; arsură superficială

scorched steel (met) oțel cu structură aciculară scorcher (metr) zi caniculară / călduroasă; critică severă / aspră

scorching (fiz, met) cristalizare aciculară, formare de cristale aciculare

score urmă, semn; socoteală, însemnare; scor; situație; motiv; $(\mathrm{OM}, \mathrm{T})$ tăietură, crestătură, zgârietură; dungă; reusită, succes, victorie; a cresta, a face crestături, a tăia, a zgâria; a însemna, a marca a înregistra; a nota; a câștiga, a înregistra (un succes etc.); a critica sever; a câştiga un avantaj / încredere / credit, a realiza un succes; (T) a deteriora prin zgâriere şi adeziune; score (metr) unitate tradiţională pentru cantitate, egală cu 20; sufix pentru a forma multipli de 20: threescore (60), fivescore (100)

scoreboard tabelă de marcaj / de înregistrare scored pulley $(\mathrm{OM})$ roată de curea trapezoidală, roată cu canele (pt. curele)

score down a nota, a înregistra, a trece (pe ceva) score out a şterge, a tăia (un cuvânt, o notă) scoria, $(p l)$ scoriae (met) zgură, scorie, arsură scoriaceous (met) cu conținut de zgură scorification (met) zgurificare scorify (met) a (se) zgurifica

scoring crăpare; plesnire; (mas-un) formarea canelurilor; (met) formare de striuri; $(\mathrm{T})$ formare a zgârieturilor (relativ adânci) pe suprafețe în frecare; un fel de uzură de aderentă (cu microsmulgeri) (şi la rulmenți)

scoring knife (mas-un) cuțit de crestat scoring of barrel (termo) curățirea grătarului scotch $(\mathrm{OM})$ camă de frână, bandă adezivă; (met) tăietură, crestătură; $(\mathrm{TH})$ a cresta, a tăia

scotch block $(\mathrm{OM})$ sabot de frână

Scotch broth (alim) arpacas cu legume

scotch glue (ind chim) clei de tâmplărie

Scotch mist (meteo) ceață deasă cu burniță

scotch tape $(\mathrm{OM})$ bandă adezivă, scotch

Scots foot, Scots mile (metr) unitate traditională de măsură pentru lungime, în Scoția: 1 Scots foot $=1,0054054$ English foot $(\sim 30,645 \mathrm{~cm})$; 1 Scots mile $=1814,2 \mathrm{~m}$

scour (TH) erodare; curățare, frecare; lustru, luciu; (T) a freca, a răzui, a roade; a eroda; a alunga; a (se) lustrui; (chim) a coroda, a decapa; a băiţui; a degresa, a curăța prin frecare; a curăța (prin frecare)

scorer (OM) burete de sârmă; (met, chim) băituitor, degresor; (agr, alim) decorticator scouring frecare; corodare; roadere; (met) curățare, scoatere a ruginii; ( $\mathrm{TH}$, ind chim) atac fizic şi chimic al suprafețelor interioare ale utilajelor de proces

scouring cloth cârpă de curățat

scouring powder (chim) praf de curățat scouring water (chim) lichid de curătat scout prospector; a explora; a cerceta scouting recunoaștere; cercetare

Scoville unit (metr, alim) unitate utilizată pentru a măsura concentrația capsaicin, ingredientul „iute” din ardeii iuti; exemplu: 50000 Scoville 
units înseamnă că un extract de ardei poate fi diluat 50000 la 1 cu apă îndulcită astfel încât „iuţeala" să fie aproape nedetectabilă de limbă scow (nav) gabară; scraper-ladă

scrabble a mâzgăli, a zgâria; a strânge la repezeală; mâzgălitură; zgârietură

scrag end (alim) gât de oaie / de berbec / de vițel scraggily $(a d v)$ (în mod) neregulat, asimetric scragginess neregularitate, caracter asimetric; slăbiciune

scraggly $(a d v)$ în dezordine; crescut la întâmplare; nepieptănat

scraggy neregulat, asimetric, cu zigzaguri; nepieptănat; slab, costeliv (d. animale)

scrap bucată, bucățică, fărâmă; fragment; rămăşiţă, rest; (c) decupare de imagini; (met) alice pentru curățarea pieselor turnate, deşeuri feroase, fier vechi, a dezmembra (piese vechi), a sparge piese de fier vechi, a da la fier vechi; a arunca, a da la gunoi; (TH) a da la rebut

scrap and pig process (met) procedeu / proces de obținere a oțelului din fier vechi - fontă

scrap bailing (met, mas-un) balotarea fierului vechi / a şpanului

scrap bailing / bundling machine / press (met, mas-un) maşină / presă pentru balotarea fierului vechi / a spanului

scrap billet (met) deşeuri de țagle

scrap carburisation processs (met) procedeu / proces de obținere a oțelului din fier vechi cu aport de carbon

scrap charge (met) încărcătură de fier vechi /și la oțelării electrice)

scrap charging box handling crane (met) macara de încărcat fier vechi, cu troacă

scrap-chisel $(\mathrm{OM})$ ciocan-daltă

scrap coke (met) deşeuri de cocs

scrap crushing plant (met) instalație de măruntit fier vechi

scrap drop crane (met) macara cu berbec de sfărâmat fier vechi

scrape hârşâit; zgârietură; răzuire; strat subțire; scârtâit, scârțaitură, hârșit; necaz, nevoie; a curăța; a freca, a şterge; a zgâria; a rade, a răzui; a scârțai; a nivela (o stradă etc.)

scrape against a se atinge, a se freca de

scrape away / down / off a răzui, a înlătura (prin răzuire / frecare)

scraped edge $(\mathrm{OM})$ muchie / margine deteriorată scrape dozer (constr, mas) screper-buldozer scraped surface $(\mathrm{OM}$, constr) suprafață răzuită scrape out a racla, a curăța prin îndepărtare de material / prin răzuire

scraper (alim, OM) răzătoare; (met, OM, hidr) transportor cu raclete, racletă, răzuitor, screper, garnitură de / prin răzuire, rindea, maşină de rindeluit; dăltiță; (nav) raşchetă

scraper conveyer $(\mathrm{OM})$ transportor cu raclete scraper elevator transportor cu raclete scraper flight conveyer (OM, transp) (bandă de) transportor cu raclete

scraper loader (OM) încărcător cu raclete

scraper ring (OM, T, termo) inel / segment de piston pentru adunat uleiul de pe pereți

scrap heap (met) grămadă de gunoi / de fier vechi

scraping (chim, met) răzuire; frecare (şi nedorită), hârşâire; decapare; (met) sfărâmare a fierului vechi; (constr) săpătură cu screper

scraping cut (mas-un) prelucrare cu îndepărtare de aşchii

scraping device (OM, mas-un) răzuitor, racletă, dispozitiv de curățat (prin răzuire)

scraping excavator (constr) excavator-screper

scraping machine (mas-un) maşină de răzuit

scrapings (mas-un, mediu) pilitură, aşchii, şpan, răzuitură

scrap iron (met, ind) fier vechi, deșeuri feroase; (OM) sapă

scrap-iron process (met, $\mathrm{TH}$ ) procedeu / proces de elaborare a oțelului cu fier vechi

scrap-iron yard (met) sectie de preparare a fierului vechi

scrap lead (met, chim, mediu) deşeuri de plumb scrapman colector de fier vechi

scrap metal (met, mediu) sfărâmătură (de metal), deşeuri metalice

scrap paper (ind chim, mediu) maculatură, deșeuri de hârtie

scrappiness dezorganizare, lipsă de legătură

scrap practice (met, $\mathrm{TH}$ ) procedeu / proces / tehnologie de elaborare a otelului cu fier vechi scrap preparation plant (met) instalație de pregătire a fierului vechi

scrappy $(\mathrm{OM}, \mathrm{TH})$ făcut / alcătuit din bucăți, resturi, rămăşiţe; fragmentar; discontinuu, neregulat; nesistematic

scrap returns (met, mediu) deşeuri feroase recuperabile

scrap shears (met, mas-un) foarfece de deșeuri metalice

scrap steel (met) fier vechi (mai mult oțel)

scrap(-stock) yard (met) depozit de fier vechi

scratch $(\mathrm{OM}, \mathrm{T})$ zgârietură; (met) crăpătură, raclare; a zgâria, a face zgârieturi; a scârțâi; a răzui; a elimina, a șterge (de pe o listă etc.); a mâzgăli; a se freca, a se roade; parafă; scârțâit, hârşit; semn, însemnare; improvizat, făcut la întâmplare; scris în grabă, schițat scratch awl $(\mathrm{OM}, \mathrm{TH})$ ac de trasare 
scratch brush $(\mathrm{OM}, \mathrm{TH})$ perie de sârmă; a curăța cu perie de sârmă

scratch finish $(\mathrm{TH})$ mătuire

scratch hardness (materiale, metr) duritate Martens / prin zgâriere

scratch hardness number (materiale, metr) unitate de duritate Martens

scratch hardness tester (materiale, metr) sclerometru

scraching $(\mathrm{T}, \mathrm{OM})$ zgâriere, care zgârie

scratching test (materiale, metr) încercare / test de duritate scleroscopică

scratch out (TH, ind) a curăța prin răzuire, a răzui; a şterge (un rând dintr-un text etc.)

scratch paper (amer) (ind chim, mediu) maculatură, deşeuri de hârtie

scratch-proof (materiale) rezistent la răzuire / la zgâriere

scratch resistance (materiale) rezistență la răzuire / la zgâriere

scratch test (materiale, metr) încercarea duritate prin zgâriere

scratch up a zgâria (şi cu îndepărtare, chiar nedorită, de material)

scratchy care zgârie; (fiz) disonant, supărător, neplăcut (d. un sunet); scârțâit, hârşit; aspru (textile); iritant; adunat / strâns la întâmplare; eterogen, amestecat (d. deşeuri, piese etc.)

scrawl a mâzgăli, a scrie neciteț; măzgălitură; notiță

scrawny (amer) slab, costeliv

scream a țipa; a şuiera, a țiui; țipător (d. culori)

scree (geol, constr) pietriș, prundiș, grohotiș

screech a țipa; a face să scrâşnească; a pune (brusc) frână; (mas, OM) a scrâșni, a scârțaii; a înceta, a se opri brusc (d. o activitate); scrâşnit, scârțait

screetchy țipător, strident (d. culori)

screed vorbărie; listă / scrisoare interminabilă;

(agr) fâșie / petic de pământ; (textile) cardă manuală

screen $(\mathrm{OM}$, ind) ecran, paravan; perdea, cortină (de protecţie); mască; panou; grătar (şi pt. eliminarea impurităților); (OM) ciur, sită; diafragmă (ca dispozitiv); (nav) convoi; (fiz) a feri, a face să nu se vadă, a diafragma; a ecrana, a blinda; (agr, alim, constr) a cerne, a trece prin sită, a ciurui; a sorta; a examina, a cerceta, a supune unei probe; a proiecta (şi pe un ecran); a ascunde (o greşeală etc.); a selecta, a alege

screen adjustment (c) reglare a ecranului; (agr, alim, constr) reglare a sitei / ciurului

screen analysis (materiale, metr) analiză granulometrică / cu site screen aperture $(\mathrm{OM})$ diametru / deschidere a sitei screen bank (OM, agr, constr, ind) trusă de site screen capacity (OM, agr, constr, ind chim) capacitatea sitei

screen cleaner (met) curățitor de grătar

screen cloth (textile) pânză de sită

screened (fiz, OM) protejat, ecranat

screened-conductor cable (el) cablu cu conductor ecranat

screened ignition cable (auto) fişă de bujie antiparazitată

screened oven coke (met) sfărâmătură de cocs

screened producer coal (met) cărbune bucăți pentru generatoare de gaz

screened spark(ing) plug (auto, termo) bujie blindată

screen efficiency (agr, alim, constr, ind chim) eficiență a sitei / a sortării

screener $(\mathrm{OM})$ paravan / ecran de protecție

screen fabric (texztile) pânză de sită

screen filter $(\mathrm{OM})$ filtru de sită

screen hole (OM) ochi de ciur / de sită

screening (agr, alim, constr, ind chim) sortare, triere, cernere; sortare / clasare cu site; ferire, protejare, ecranare; selectare, alegere; examen, probă; blindaj

screening capacity (metr, ind, fiz) capacitate de sortare

screening machine (agr, alim, constr, ind chim) maşină de sortare / de cernere

screening model (fiz, TH, autom) model de sortare / de cernere

screening of grain (materiale) sortare granulometrică

screenings (materiale, mediu) rămăşițe, resturi (şi de la sortare etc.)

screening table sită plană

screening wall (met, termo) paravan de protecție contra flăcării

screenings (met, termo) cărbune mărunt, rejecție screen microscope (fiz, metr) microscop electronic cu fascicul baleiat

screen mill (alim) moară cu site

screen of bars $(\mathrm{OM}$, termo) grătar din bare

screen opening (OM, alim) ochi de ciur, mărime a ochiului de sită

screen out (alim, agr, ind chim) a cerne, a trece prin sită pentru separare

screen pipe $(\mathrm{OM})$ tub filtrant

screen rake $(\mathrm{OM}$, termo) curățitor de grătar

screen reject (materiale) refuz al unui ciur / unei site

screen separation (alim, constr, met, $\mathrm{TH}$ ) clasare / sortare cu sită / cu site, cernere 
screen-separator mill (alim, ind chim) moară cu site

screen size (metr, OM) numărul sitei

screen sizing (materiale, TH) clasificare prin sortare granulometrică

screen test (metr, OM) analiză pe site

screen washer (auto) spălător de parbriz

screen windover (agr, alim) vânturătoare cu site screen wiper (auto) ştergător de parbriz screen wire (met, OM) sârmă de / pentru sită screw (OM) şurub, elice, spirală, bulon, bolț, înşurubare, răsucire a şurubului; a (se) răsuci, a (se) înşuruba, a fixa cu şuruburi, a strânge cu ajutorul unui șurub; a se învârti; a apăsa, a presa, a îndesa (prin mişcare combinată de rotire şi de avans); (nav) elice; sul, pachet

screw and nut type steering (auto, $\mathrm{OM}$ ) direcție cu sistem cu şurub şi piuliță

screw axis (mat) axă a elicei; $(\mathrm{OM})$ axă a șurubului

screw base (OM, constr) postament cu şurub de reglare a poziţiei

screwbit (mas-un) burghiu elicoidal

screw blade (OM, nav) pală de elice

screw body $(\mathrm{OM})$ miezul / corpul şurubului

screw bolt $(\mathrm{OM})$ şurub / bolț filetat

screw box $(\mathrm{OM})$ piuliță cu caneluri interioare paralele cu axa piulitei

screw bushing $(\mathrm{OM})$ manşon filetat

screw cap $(\mathrm{OM})$ buşon/ dop filetat, piuliță olandeză screw cap fuse carrier (OM) buşon / capac / dop filetat, portfuzibil

screw capstan head $(\mathrm{OM})$ mecanism cu tijă filetată, şurub fără sfârşit

screw chaser (mas-un) pieptene de filetat

screw chuck (mas-un, OM) mandrină cu (strângere $\mathrm{cu}$ ) filet

screw clamp (mas-un, OM) menghină cu picior, clemă cu şurub

screw conveyer dryer (alim, ind chim) uscător cu transportor elicoidal

screw conveyer (alim, ind chim) transportor elicoidal cu melc

screw core $(\mathrm{OM})$ tija bulonului / şurubului / bolțului

screw coupling (OM) cuplă / cuplaj / asamblare cu şurub(uri)

screw cover (OM) piuliță-capac cu fund plat

screw crystallizing tank (alim, ind chim) cristalizor cu agitator elicoidal

screw-cutting (mas-un) filetare (prin aşchiere) screw-cutting lathe (mas-un) strung de filetat screw-cutting machine (mas-un) maşină de filetat (prin aşchiere) screw cutting tools (mas-un) scule de filetat screw die (mas-un) filieră

screw dolly (mas-un, OM) suport reglabil cu şurub screw down $(\mathrm{OM})$ a înşuruba până la refuz; (met) şurub de reglare a cilindrilor

screw-down stop valve (OM, hidr) robinet / supapă de închidere, cu ventil

screwdown mechanism $(\mathrm{OM})$ mecanism de deșurubare

screw driven (mas-un, OM) cu transmitere a mişcării prin şurub conducător, acționat prin şurub

screw driver $(\mathrm{OM})$ şurubelniță

screw driving machine $(\mathrm{OM}$, mas) şurubelniţă mecanică, dispozitiv de înşurubare

screwed $(\mathrm{OM})$ filetat, cu şuruburi, cu filet, înfiletat screw(ed) cap (OM) capac filetat

screwed end $(\mathrm{OM})(\mathrm{cu})$ mufă filetată (la robinet, aparatură hidraulică etc.)

screwed flange $(\mathrm{OM})$ flanşă filetată / cu filet, bridă filetată

screwed home $(\mathrm{OM})$ înșurubat până la fund

screwed hose connection (OM, hidr) îmbinare de furtun prin piese filetate

screwed joint (OM) îmbinare / asamblare prin / $\mathrm{cu}$ şuruburi, asamblare prin filet

screwed nipple $(\mathrm{OM})$ niplu cu filet

screwed nut $(\mathrm{OM})$ piuliță

screwed-on attachment $(\mathrm{OM})$ legătură / asamblare / ataşare prin filet

screwed pin $(\mathrm{OM})$ știft filetat

screwed pipe joint $(\mathrm{OM})$ îmbinare / asamblare de țevi cu filet

screwed pump (OM, hidr) pompă cu şurub(uri)

screwed sleeve $(\mathrm{OM})$ mufă filetată

screwed spindle $(\mathrm{OM})$ fus filetat

screwed test bar (OM, metr) epruvetă cu cap filetat

screwed tube (OM, hidr) țeavă filetată

screw elevator $(\mathrm{OM})$ elevator elicoidal / cu şu$\mathrm{rub} / \mathrm{cu}$ melc

screw extractor $(\mathrm{OM})$ dispozitiv pentru scoaterea restului de şurub rupt

screw extruder maşină de extrudat cu şurub

screw fastening (OM) fixare cu şuruburi, înşurubare, asamblare cu şurub

screw feed (mas-un, OM) avans diferențial (pe baza mişcării combinate a unor şuruburi)

screw feeder (alim, mas-un) alimentator $\mathrm{cu}$ şurub / cu melc

screw gauge (mas-un, OM) garnitură de scule pentru filetare

screw gear $(\mathrm{OM})$ roată dințată elicoidală (mai rar) cu dinți înclinați

screw-geared pulley (OM) palan cu melc 
screw gearing $(\mathrm{OM})$ transmisie cu şurub şi piuliță screw head (OM) cap de şurub screwhead file with tail (mas-un) pilă cu coadă cu fețe lise

screw-holding power $(\mathrm{OM})$ forța de strângere a şuruburilor

screw hole $(\mathrm{OM})$ gaură (şi de trecere) pentru şurub screw hook (OM) şurub cu cap ciocan / cu nas, crampon

screw hoop $(\mathrm{OM})$ şurub cu ochi / cu inel screw in $(\mathrm{OM})$ a înşuruba

screwing lathe (mas-un) strung de filetat screwing plate (mas-un, $\mathrm{OM}$ ) filieră rigidă screwing tool (mas-un) pieptene de tăiat filet screwing up $(\mathrm{OM})$ înşurubare screwings (mas-un, mediu) aşchii de filetare screw in place / into $(\mathrm{OM})$ a înşuruba în screw jack $(\mathrm{OM})$ cric / vinci cu şurub screw key $(\mathrm{OM})$ şurubelniță, cheie (simplă) pentru şuruburi

screw lag $(\mathrm{OM})$ șurub de fundație

screw line $(\mathrm{OM})$ spirală (şi la filet)

screw locking device (OM) dispozitiv contra deşurubării / de blocare

screw machine (mas-un) maşină de filetat (fără specificarea procedeului)

screw mandrel $(\mathrm{OM})$ ax filetat

screw microscope (fiz, metr) microscop cu şurub micrometric

screw nail $(\mathrm{OM})$ şurub pentru lemn

screw nicking machine (mas-un) maşină de canelat screw off $(\mathrm{OM})$ a deşuruba, a scoate şurubul / piesa filetată

screw on $(\mathrm{OM})$ a înşuruba, a înfileta

screw pitch gauge (metr) şablon filetat, calibru pentru pas de filet

screw pitch $(\mathrm{OM})$ pasul filetului / şurubului

screw plate (mas-un) filieră

screw point $(\mathrm{OM})$ vârful şurubului

screw post (nav) etambou al elicei

screw press (mas-un) presă cu şurub

screw propeller (nav) elice

screw pump (OM, hidr) pompă elicoidală / cu şuruburi

screw rack $(\mathrm{OM})$ cremalieră a angrenajului melcat screw retention $(\mathrm{OM})$ dispozitiv de siguranță contra deşurubării

screw reversing $(\mathrm{OM})$ schimbător de mers / de sens, cu şurub

screw riveting machine (mas-un) maşină de nituit, cu surub

screw shaft $(\mathrm{OM})$ ax / arbore filetat

screw shaving machine (mas-un) strung de prelucrat piulițe screw ship (nav) navă cu elice screw slip (nav) recul de elice screw slotting cutter (mas-un) freză de canelat screw slotting saw (mas-un) ferăstrău de canelat / de crestat capete de şuruburi screw spanners $(\mathrm{OM})$ cheie franceză screw spike $(\mathrm{OM})$ crampon filetat screw spindle $(\mathrm{OM})$ tijă filetată screw stay bolt (constr, OM) antretoază filetată, bolț filetat de fixare / de fundație

screw stay (constr, OM) tijă filetată de legătură screw steel (met) oțel de / pentru şuruburi screw stocks $(\mathrm{OM})$ bacuri de filetat screw stopper (OM) dop / opritor filetat screw tap (mas-un) burghiu de filetat, tarod screw terminal $(\mathrm{OM})$ bulon / bolt de fixare screw thread $(\mathrm{OM})$ filet

screw-thread gauge (fingers) (metr) calibru de filete

screw-thread measuring jaw (metr, OM) vârful micrometrului pentru măsurarea filetului

screw-thread measuring (metr, OM) măsurare a filetului

screw-thread micrometer caliper (metr, OM) micrometru cu filet

screw-thread micrometer (OM, metr) şurub micrometric

screw-thread profile $(\mathrm{OM})$ profilul filetului

screw-thread rolling machine (mas-un) maşină de filetat prin rulare

screw-threading machine (mas-un) maşină de filetat buloane / şuruburi / filet exterior

screw threads (mas-un) tarod

screw top (alim, OM) capac cu filet (la sticle sau alte ambalaje)

screw transporter $(\mathrm{OM}$, alim, hidr) transportor elicoidal

screw traverse (mas-un) deplasare prin cuplarea şurubului conducător

screw-type compressor (termo) suflantă elicoidală

screw-type kick-off (met) aruncător cu surub screw-type lubricator $(\mathrm{OM}, \mathrm{T})$ ungător cu pâlnie screw up $(\mathrm{OM})$ a înşuruba, a strânge cu piulița; a închide strâns

screw vice (mas-un, OM) menghină (cu şurub) screw washer (alim, ind chim) spălător elicoidal screw wheel $(\mathrm{OM})$ roată dințată cu dinți înclinați screwy răsucit; suspect, dubios

scribble a mâzgăli, a scrie neciteț; a murdări; mâzgălitură, scriere neciteață, scris neciteț; (fig) maculatură

scribe(r) (TH, OM) ac de trasat

scribing awl / point (TH, OM) ac de trasat 
scribing block (TH, OM) trasor paralel

scrim (textile) pânză aspră

scrimp $(\mathrm{OM})(\mathrm{TH})$ a micşora, a reduce, a îngusta; a tăia

scrimpily $(a d v)$ cu zgârcenie

scrip bucată de hârtie; notă, notiță; listă; (ec) chitanță; adeverință; certificat

script scriere (de mână), fel de scris; document, act (scris); (manu)scris original; (edu, univ) lucrare scrisă, teză; scenariu; text; a scrie / concepe un scenariu

scroll sul de hârtie; pergament; $(\mathrm{OM})$ canelură spirală, filet plan; (mat, fiz) spirală; (constr) cartuş (ornament), a împodobi cu cartuşe; parafă; listă, tabel; inventar; a face sul, a răsuci (o hârtie), a înfăşura

scroll chuck $(\mathrm{OM})$ mandrină (şi cu filet plan)

scroller shaft $(\mathrm{OM})$ arbore melcat

scroll saw (mas-un) ferăstrău de traforaj

scrub (silv, bot) arbust, tufă, tufiş, lăstăriş, arbore pitic, plantă pitică; animal pitic; a curăta cu peria, a freca / spăla cu peria; (chim, met, mediu) a epura, a curăța (un gaz) de impurități, a spăla, a îndepărta impuritățile din; pitic, mic, nedezvoltat; frecare / frecat, spălare / spălat cu peria; perie (aspră); persoană care muncește din greu / care îndeplineşte o muncă grea, salahor

scrubbed gas (chim, met) gaz epurat

scrubber (met, ind chim) scruber, instalație pentru epurarea umedă a gazelor, epurator de gaze; perie aspră

scrubbing and drying unit (met) instalație de spălat şi uscat

scrubbing filter (ind chim) filtru de gaze

scrubbing oil (ind chim) ulei de absorbție

scrubbing uniot (met, ind chim) scruber, instalație pentru epurarea umedă a gazelor

scrubby (silv, bot) cu arbuşti / tufişuri / tufe; pitic, mic, nedezvoltat; inferior

scrub out a curăța, a scoate / elimina impurități (din gaze si lichide etc.)

scrubwoman femeie de serviciu / cu ziua

scuff $(\mathrm{OM}, \mathrm{T})$ uzură prin frecare de alunecare, a uza prin alunecare

scuffing (T) (acțiunea de) uzură prin frecare, uzură de aderenţă / de la forme uşoare până la unele severe, roadere; (met) strivirea / deformarea marginilor ruloului de tablă

scuff pad / patch (OM, hidr) acoperire (şi cu cauciuc, plăci compozite etc.) a pereților rezervorului pentru prevenirea deteriorării lor

scruffy (plast, textile, met) plin de scame / zgură; murdar; dezordonat scrunch a mesteca cu zgomot; a ronțăi

scruple scrupul, considerent moral; conștiință; dram, cantitate infimă, nimica toată; gram: a nu şovăi, a nu avea scrupule; scruple (s) (metr, farmacologie) unitate de măsură pentru masă în sistemul traditional britanic (troy): 1 scrupule $\cong$ 1,2960 g; v. troy weights; în Europa: scrupule (Franța, Rusia), Italian scrupolo (Italia), skrupul (Germania) 1,1...1,3 g

scrupulosity, scrupulousness scrupulozitate, conştiinciozitate; meticulozitate

scrupulous scrupulos, cinstit, corect, conștiincios; meticulos, grijuliu

scrupulously ( $a d v)$ (în mod) scrupulos, cu scrupulozitate; conştiincios; meticulos

scrutable care poate fi analizat / cercetat

scrutater cercetător atent / meticulos

scrutineer cercetător examinator; anchetator; (ec, adm) inspector (şi al unei organizatiii internaționale)

scutinize a scruta, a cerceta / examina atent / minuțios

scrutiny cercetare atentă / minuțioasă; (pol, adm) validare a alegerilor

scud a pluti (d. nori, praf etc.), a luneca; a fi împins de vânt; fugă, alergare; plutire, lunecare; (nav) fugă înaintea vântului; (geol) intercalație de argilă / cărbune (în sol); (TH) a fălții

scuff a râcâi; a roade, a strica

scuffed ros; zgâriat; stricat

scull (nav) vâslă, ramă, lopată, barcă mică, cu vâsle, a vâsli, a rama, a lopăta; (met) crustă aderentă, urs (la furnal)

sculler (nav) vâslă, ramă, lopată, barcă mică, cu vâsle

scullery (alim) cameră de spălat vase, spălător

sculpt a sculpta

sculpture sculptură; a sculpta, a dăltui; (d. apă) a roade, a sculpta

scum (hidr, T, mediu) spumă (si de pe un lichid), depunere, crustă; (met) scorie, zgură, arsură, țunder; a face spumă

scrumble a estompa

scummer (OM) lingură de îndepărtat spuma scumming (hidr, T, alim) separarea spumei scummy (acoperit) cu spumă; ca spuma, spumos scum riser (met) cap pentru separarea spumei scum rubber (ind chim) cauciuc celular scum skimmer (met) separator de zgură scupper (nav) gaură de drenaj

scurf coajă, crustă; (met) zgură, incrustație (întrun metal)

scutch (textile, OM) volant (al bătătorului), a melița; ciocan (de pietrar) 
scuttle butoi; $\operatorname{coş}$ (cu fund îngust şi deschidere largă); torpedo, tăblia din față; (OM, constr) chepeng, deschidere, deschizătură; (nav) tambuchi, bocaport, a saborda (un vas)

scuttle ventilation (auto) ventilația torpedoului scutum $(p l)$ scuta scut; (anat, zool) rotulă, țeastă, caparace

scythe (agr) coasă, a cosi

se (metr) unitate tradițională japoneză de măsură pentru arie: $1 \mathrm{se} \sim 99 \mathrm{~m}^{2}$

sea (geogr, nav) mare (deschisă, agitată), larg, val, flux

sea anchor (nav) ancoră plutitoare / de furtună sea bank (geogr, nav) țărm de mare, coastă marină sea base (nav, mil) bază navală

sea bed (geogr) fund de de mare, fundul mării seaboard, see-coast (geogr) coastă marină, țărm de mare, coasta mării / unei țări, litoral

Seagorgium (Sg) (chim) seaborgiu

sea-borne (nav) maritim

sea breeze (nav) briză de mare / de zi

sea calf (zool) focă

sea captain (nav) căpitan de vas comercial, căpitan de cursă lungă

sea cock (nav, OM) robinet de fund

sea cow (zool) morsă, cal de mare

sea craft (nav) vase, nave, ambarcați(un)i; arta de a naviga

sea floor (nav, geogr) fund de mare

sea foam spuma valurilor; spumă de mare, piatră ponce

sea fog (nav) ceață marină

sea food (alim, iht) peşti de mare comestibili, moluşte comestibile

sea front (geogr) partea dinspre mare a unei localități, faleză

sea gauge (nav) pescaj, sondă

sea-going (nav) maritim, de mare; navigant, de navigație; care călătoreşte pe mare

sea green verde marin

seah (metr) unitate antică (ebraică) de măsură pentru volum de lichid sau de produse uscate: 1 seah $\sim 13,441$

sea inlet (nav) priză de apă; (geogr) baie, golf sea jelly (biol) meduză

seal sigiliu, pecete, ştampilă; $(\mathrm{OM}$, ec) strat izolator, plombă de garanţie, sigiliu, marcă; $(\mathrm{OM})$ dispozitiv de etanşare, închidere etanşă, etanşare, izolare; (nav) călăfătuire, a călăfătui; a etanşa, a izola, a închide ermetic, a astupa; a încheia; garanție, promisiune; a pune sigiliu / ştampila pe, a ştampila, a sigila; a ratifica, a confirma, a autentifica (şi prin aplicarea ştampilei); a adeveri, a întări; (zool) focă sealant (plast, OM) mastic, material (adeziv) elastic de etanşare

seal box (OM, hidr) sifon

sea league (nav) leghe marină (UK şi US); 1 sea league $=5554,9 \mathrm{~m}$

sealed sigilat, ştampilat; (OM) sigilat, etanş(at), izolat, astupat, închis

sealed door (constr, nav) uşă sigilată / etanşă

sealed package (alim, OM) ambalaj închis / etanş / sigilat

sealer (OM, materiale) strat / material de protecție pentru etanşare; (nav) pescador / navă de (vânat) foci

sea letter (nav) permis de navigatie

sea levee (nav, constr) dig maritim

sea level (nav) nivelul mării

seal in $(O M)$ a încapsula, a etanşa

sealing $(\mathrm{OM})$ etanşare; (textile) apretare; aplicarea unui material pe suprafaţa aderentă în vederea reducerii puterii de absorție a aderentului sealing wax ceară de sigiliu; (chim) ceară roșie sealing (el) izolare; (OM) etanşare, umplere cu material de etanşare

sealing band $(\mathrm{OM})$ bandă de etanşare

sealing bucket $(\mathrm{OM}$, hidr) nas de amorsare al sifonului deversor

sealing compound (OM, materiale) pastă de etanşare

sealing cord $(\mathrm{OM})$ şnur / cord de etanşare

sealing device (OM, hidr) dispozitiv de etanşare sealing frame $(\mathrm{OM})$ cadru de etanşare, carcasa etanşării, componentele rigide care nu participă direct la etanşare, dar fac parte din dispozitivul de etanşare

sealing gland $(\mathrm{OM})$ presgarnitură

sealing liquid $(\mathrm{OM}$, hidr) lichid de etanşare

sealing machine (alim, ind chim) mașină de capsulat

sealing material $(\mathrm{OM})$ material de etanşare

sealing presses $(\mathrm{OM})$ cleşte de plumbuit

sealing ring / washer $(\mathrm{OM})$ şaibă / inel de etanşare

sealing rod $(\mathrm{OM})$ bară de etanşare

sealing surface $(\mathrm{OM}, \mathrm{T})$ suprafață de etanșare, suprafață pe care acționează garnitura / etanşarea

sealing-off (el, OM) izolare, etanşare

seal labyrinth $(\mathrm{OM})$ labirint de ermetizare / de etanşare, labirint

sea lock (nav) ecluză maritimă

seal material (materiale, OM) material pentru etanşare

seal nipple $(\mathrm{OM})$ niplu de etanşare

seal off $(\mathrm{OM})$ a etanşa, a izola 
sealskin piele / blană de focă

seal-weld $(\mathrm{OM})$ sudură de etanşare

seal-welded (OM, met) sudat etanş

seam cusătură, tiv, tighel; dungă; creț, cută, încrețitură; îmbinare; (geol) intercalație, strat, filon; (OM) sudură, îmbinare prin sudură, cusătură sudată, locul lipiturii, falt, margine; a îmbina prin sudură / prin coasere (la curele) etc.; (met) încrețire (la laminare), crăpătură capilară, microfisură, a suda, a lipi; (textile) a coase, a tricota; (materiale, semifabricate subțiri, textile) a (se) încreți; a se rupe, a crăpa, a face crăpături / fisuri; (metr) unitate tradiţională de măsură pentru volum: 1 seam of grain (boabe) $(\mathrm{UK})=$ 290,951 ; 1 seam $(U S)=281,91$ 1; altă denumiri: quarter, soam

seaman (nav) marinar, matroz, matelot

seam bending machine (mas-un) maşină de răsfrânt margini

sea mark (nav) semn maritim, far, geamandură, semnal de navigatie costieră, reper costier

sea mile (metr, nav) milă marină (internaţională,

$=1852 \mathrm{~m}$ ); altă denumire pentru nautical mile;

v. nautical mile

seam folding machine (mas-un) maşină de fălțuit seamer (mas-un) maşină de fălțuit

seaming (textile) tivire, coasere

seaming die (mas-un) stantă de bordurat

seaming machine maşină de îndoit margini

seaming roll $(\mathrm{OM})$ rolă de îndoit margini

seam in the weld (met, TH) stratificare în cusătură seamless $(\mathrm{OM})$ fără cusătură / sudură; dintr-o singură bucată

seamless articles articole / piese dintr-o bucată / fără cusături

seamless drawn tube $(\mathrm{OM})$ țeavă fără sudură

seamless pipe $(\mathrm{TH}, \mathrm{OM})$ teavă trasă

seamless tube / tubing (met, OM, plast) țeavă laminată, fără sudură, produs fără cusătură de sudură / de lipire

seam size $(\mathrm{OM})$ grosimea cusăturii sudate seam welded $(\mathrm{OM})$ sudat cu role

seam welder (mas-un) maşină cu role pentru sudare seam welding (met, TH) sudare în cusătură continuă / în linie

seamy crăpat, fisurat; cu cusături (d. suduri, textile, curele etc.)

seance (adm, ec) şedință, întrunire

sea plane (nav) hidroavion

seaplane tender (nav, mil) (navă) portavion

sea port (nav, mil) port maritim

sea power (nav) putere maritimă / navală

sear (agr) (d. flori etc.) uscat, mort, veşted, a usca,

a veșteji, a ofili, a arde (pământul), a întări, uscare, ofilire, veştejire; (OM) manetă de tragere / de declanşare

search cercetare, examinare; căutare; a căuta; a urmări; (c) a căuta date după anumite criterii; a cerceta, a examina; a scotoci; (jur) percheziție, a perchiziţiona

searcher cercetător

searching căutare, exploatare, care caută / cercetează, (proces de) cercetare

searchlight (fiz, OM, el) proiector, reflector

searchlight beam (fiz) con de lumină

search out a căuta atent, a cerceta; a găsi, a afla search party echipă de căutare (a unei persoane) search warrant (jur) ordin de perchezitie

sea rim (nav) linia orizontului

searing dogoritor, foarte fierbinte; încins; arzător searing effect (fiz) efect luminos, radiație luminoasă; influența razelor de lumină (şi în urma unei explozii nucleare)

sea rolling (nav) hulă

seashore (geogr) tărm de mare, coastă, malul mării; litoral

sea sickness (nav, med) rău de mare

season anotimp ( 1/4 ani), sezon; timp, periodă, vreme; moment potrivit / oportun; (met, plast) a îmbătrâni; a se usca (d. lemn); (OM, T, ec) a se uza în timp (şi moral); (alim) a condimenta, a asezona, a drege, a face picant; (bot, zool) a se aclimatiza, a se adapta, a se obişnui; a se coace, a se maturiza; a se banaliza, a deveni o rutină

seasonable de sezon, al anotimpului; oportun, potrivit; făcut la timp

seasonably $(a d v)$ în mod oportun / potrivit, la timpul său, la / în momentul potrivit

seasonal de sezon, al anotimpului; (d. un muncitor etc.) sezonier; regulat, periodic

seasonal energy efficiency rating, SEER (metr) unitate de măsură pentru exprimarea eficienței / capacității instalațiilor de aer condiționat, în US și Canada, exprimată în energia pentru condiționarea aerului pe durata unui întreg sezon / anotimp, în Btu, împărțită la energia electrică consumată, în watt ore

seasonally $(a d v)$ într-un anumit anotimp; regulat, periodic

seasonal oil change (auto, T) schimbare de ulei, sezonieră

season crack (met) (proces de) fisurare intercristalină datorată coroziunii, tensiunii interne sau îmbătrânirii

season cracking (met) fisură intercristalină spontană / cauzată de îmbătrânire

seasoned călit, experimentat; (met, plast) supus îmbătrânirii; (alim) asezonat, condimentat, piperat 
seasoning (met, plast) îmbătrânire, condiționare, uscare la aer; (alim) asezonare, condimentare, condiment, ingredient; preparare, pregătire

seasoning kiln (alim, ind chim) cuptor de uscare / de condiționare

season ticket (cf) abonament

seat loc (de stat), scaun, bancă, canapea; bilet; tăblie a scaunului; (auto) banchetă; (OM) (suprafață de) reazem, loc, locaş (de sprijin), scaun (de ventil / de supapă etc.); reședință; fund, spate, dos; a (se) aşeza; a avea o capacitate de, a avea locuri pentru (un număr de persoane); a pune un scaun / scaune; a situa, a plasa, a aşeza (într-un loc); a așeza, a sprijini, a rezema; (o piesă etc.) a se aşeza, a lua loc, a se instala

seat adjustment (OM) reglarea scaunului (la supape, robinete etc.)

seat adjustment height (auto) reglarea scaunului pe verticală

seat and ball $(\mathrm{OM})$ scaun cu bilă (la o supapă etc.)

seatback (auto) spătar

seatback recliner (auto) spătar rabatabil

seat belt (auto) centură de siguranță (pt. scaun)

seat belt locking (auto) blocarea centurilor de siguranță

seatbelt pre-tensioner assembly (auto) ansamblu de pretensionare a centurilor de siguranță

seat belt restraint system (auto) sistem centuri de siguranță

seat belt retractor (auto) cataramă de cuplare

seat belt warning light and chime (auto) semnal luminos şi sonor de avertizare a prezenței centurii de siguranță

seat cover (auto) husă

seat cushion (auto) perna spătarului

seated properly $(\mathrm{OM}$, auto) rezemat pe toată suprafața portantă

seat for loose poises (metr, OM) taler de greutăți

seat frame (OM, auto) rama scaunului (în general la armături, supape etc.)

seat grinding $(\mathrm{OM}, \mathrm{TH})$ rodare, şlefuire (a unui scaun de supapă etc.)

seating instalare pe scaun(e), locuri de stat jos, scaune, bănci; (constr) fundație; locaş, (suprafață de) reazem; soclu, suport; batiu; montare; ajustare

seating nipple (OM, hidr) niplu de racordare seating position (auto) amplasare a scaunului seating surface $(\mathrm{OM}, \mathrm{T})$ suprafaț̆ de reazem seat of valve (OM) locaş / scaun de supapă / de ventil

seat rail (auto) glisieră de scaun

seat slide mechanism (auto) mecanism de alunecare a scaunului seat slide adjustment lever (auto) pârghia de ajustare a scaunului

seat strap (auto) cureaua scaunului

seat temperature (auto) temperatura scaunelor

seat warmer (auto, termo) încălzire scaune

seat warmer switch (auto) buton de încălzire a scaunelor

sea wall (nav) dig de mare

seawards $(a d v)$ spre / către mare

seawater bronze (met, nav) bronz rezistent la apă de mare

seaway (nav) mare (deschisă), larg, canal maritim, cale maritimă, drum maritim

sea weed (biol, bot) plantă marină, algă marină, iarbă de mare

seaworthy (nav) în bună stare de navigabilitate / pentru navigație / capabil să navigheze

sea wrack (bot) algă cafenie

sec (alim) (vin) sec

secant (geom) secant(ă)

secant lines (mat) drepte secante

secand modulus (materiale) modul de elasticitate, secant

secant plane (mat) plan secant

secaturs $(\mathrm{OM})$ foarfece de grădină / grădinar

secession $(\mathrm{ec}, \mathrm{adm})$ separare / retragere formală

secessional (ec, adm) separatist, de separare, de retragere

seclude (from) a (se) izola (de), a (se) separa (de)

secluded izolat; retras; depărtat

seclusion izolare; retragere, loc retras / izolat

second (metr, fiz) secundă; moment; secundar; al doilea; următor; ajutor; (ec, adm) adjunct; înlocuitor, suplinitor; (nav) ofițer secund; (cf) clasa a doua; a fi secundul / ajutorul (cuiva); a ajuta, a seconda, a sprijini; a promova, a întări; a fi ajutor / secund; $(a d v)$ în al doilea rând; second (s, sec, ") (metr) unitate fundamentală de timp în toate sistemele de unități de măsură; din 1967, secunda s-a definit caperioada de timp a frecvenței de $9192631770 \mathrm{~Hz}$, a radiației emise de atomul de cesiu-133; second, aresecond (", s, sec) (metr, geom) unitate de măsură pentru unghiuri, secundă: 1 second $=1 / 60$ arcminut; second (", s, sec) (metr, geogr) o unitate de longitudine, utilizată în astronomie: 1 second of longitude = 15 arcsecunde; second (", sec) (metr) unitate de măsură pentru vâscozitatea unui fluid, definită prin timpul necesar unei anumite cantităţi de fluid să curgă printr-un anumit vâscozimetrzu; v. Saybolt second (US), v. Redwood second (UK), v. Engler degree în Europa continentală; second (s, sec) (metr, av, termo) unitate de măsură pentru a exprima eficiența 
combustibilului pentru rachete prin raportul dintre forța de impingere dezvoltată de o rachetă şi greutatea combustibilului (la $1 \mathrm{~g}$ ) consumat pe secundă; numită şi „specific impulse” - impuls specific, deşi impulsul specific real se măsoară în unități de viteză, fiind raportul dintre forța de împingere şi masa combustibilului consumat pe secundă; second (s, ") (metr, astronomie) unitate de măsură pentru timpul sideral; v. sidereal day

second annealing (met) recoacere secundară / suplimentară

secondarily $(a d v)$ (în mod) indirect, mijlocit, (de abia) în al doilea rând

secondary secundar; subordonat; minor; inferior; dependent; derivat; următor; (al) doilea; (el, adm) subaltern; reprezentant, trimis, împuternicit, ajutor, adjunct, înlocuitor

secondary air (met) aer secundar / fals (la cuptoare)

secondary aluminum (met) aluminiu secundar secondary axis $(\mathrm{OM})$ axa secundară

secondary beam (mec, constr) grindă alăturată / de întărire / suplimentară

secondary bending moment (mec, OM) moment încovoietor de ordinul II / parazitar

secondary cell (el) acumulator

secondary cementite (met) cementită secundară secondary cleaning (alim, ind chim) curățare secundară / ulterioară

secondary constituent (met, chim) constituent / metal secundar

secondary cooling zone (met) (la turnarea continuă) zona secundară de răcire

secondary crushing (constr, ind chim) concasare secundară, reconcasare

secondary crystallization (met) cristalizare secundară

secondary damage (mas) avarie / distrugere rezultată dintr-o avarie / distrugere anterioară / iniţială

secondary drive $(\mathrm{OM})$ arborele actionat

secondary effect efect secundar

secondary flame (met, termo) flacără secundară secondary fluid (hidr) fluid secundar (şi restituit la ieşirea din multiplicatorul de presiune)

secondary force (mec, mas) forță suplimentară secondary gear (OM, mas-un) pinion al arborelui cu came

secondary hardening (met) durificare secundară / de revenire

secondary hardness (met) duritate de revenire secondary ingredient (met) component secundar la aliaje secondary jaw crusher (mas, constr) concasor cu fălci, secundar, granulator

secondary latch (auto) cealaltă încuietoare

secondary loop (autom, inf) buclă interioară într-un sistem cu mai multe bucle

secondary metal (met) metal secundar / recuperat secondary pipe (met) retasură secundară

secondary production $(\mathrm{ec}, \mathrm{TH})$ producție anexă / auxiliară

secondary reinforcement (constr, OM) armătură auxiliară

secondary salt (chim) sare secundară

seondary school (edu) şcoală secundară, liceu

secondary shaft $(\mathrm{OM})$ arbore intermediar

secondary spectrum (fiz) spectru secundar

secondary spring $(\mathrm{OM})$ arc secundar

secondary standard (metr) etalon de ordinul II

secondary stress (mec, OM) efort secundar / suplimentar; tensiune suplimentară / secundar secondary tensioning $(\mathrm{OM})$ reglare ulterioară a pretensionării

secondas hand (metr) ac secundar (la un ceas etc.) second best al doilea; de calitatea / categoria a doua

second-class de calitatea / categoria a doua; inferior (d.un vagon etc.) de clasa a doua; inferior $(a d v)$ (transp, cf) (cu) clasa a doua

second cousin $(s)$ văr de-al doilea, vară de-a doua second curvature (mec, $\mathrm{OM})$ torsiune, curbură de gradul doi

second cut (mas-un) dințare superioară la pile second-cut file (mas-un) pilă semifină

second-day-foot (sdf), day-second-foot (dsf) (metr, hidr, meteo) unitate de măsură pentru volumul de apă: 1 second-day-foot (US) este volumul de apă acumulat într-o zi de o cădere de apă / debit de 1 cubic foot per second picior cubic pe secundă; $\sim 2446,58 \mathrm{~m}^{3}$

second-degree (adj) (med) (d. arsuri etc.) de gradul al doilea

second drying (alim, ind chim) uscare suplimentară

seconder (ec, adm, pol) sprijinitor, susținător (al unui proiect etc.)

second estate (ec, constr) imobil / clădire de mâna a doua

second phase in the system (fiz) a doua fază din sistem

second floor (constr) etajul al doilea (în UK, în Europa); etajul întâi (în US)

second-foot (metr, fiz) denumire neoficială pentru cubic foot per second - picior cubic pe secundă, unitate de măsură pentru debit volumic

second gear (auto) viteza a doua 
second-guess a critica (pe cineva), a da un sfat (cuiva) (mult) prea târziu

second-hand (d. obiecte) uzat, folosit, vechi; (d. informații etc.) indirect, de la a doua mână; $(a d v)$ de ocazie; de la a doua mână; indirect second hand (OM, metr) secundar (al ceasului) second-in-command (mil) loctiitor de comandant; (nav) secund; director adjunct

second intermediate rolls (met) cilindri intermediari (la laminare)

second lieutenant (mil) al doilea locotenent secondly $(a d v)$ în al doilea rând; pe de altă parte second motion shaft $(\mathrm{OM})$ arbore de transmisie, intermediar / secundar

second nature a doua natură

second-operation drawing (mas-un) a doua etapă la ambutisare adâncă / tragere / trefilare

second-operation machine ( $\mathrm{TH}$, mas-un) maşină de executat operații ulterioare / auxiliare second person (gram) persoana a doua second power (mat) puterea a doua second product $(\mathrm{ec}, \mathrm{TH})$ produs secundar second-rate de calitate / clasa / categorie a doua; inferior; de mărimea a doua; indirect, mijlocit seconds (ec) mărfă de calitatea a doua seconds counter (metr, fiz) cronometru seconds (TH) rebut, rebuturi (în orice domeniu) second sight clarviziune, a doua vedere, o a doua examinare

second tap (mas-un) tarod N 2 / intermediar second to inferior față de secpar (metr, astronomie) parsec

secrecy izolare; singurătate; caracter ascuns / secret / tainic; discreție; tendințade a fi secretos / ascuns

secret secret, ascuns; tainic; nedivulgat; confidențial; (d. cineva) retras; ascuns; (d. un loc etc.) retras, izolat; ferit; singuratic; $(s)$ secret, taină; (fig) secret, cheie (a succesului etc.), mister secret agent agent secret; spion

secretaire secretar, măsuță de scris (din limba franceză)

secretarial (adm, ec) de secretar/secretariat

secretariat (adm, ec) secretariat (serviciu, birou) secretary (ec, adm, pol) secretar; secretară; ministru; (OM, mobilă) secretar (al unei organizatiii etc.); secretar, birou de scris

secretary bird (zool) pasăre-secretar

secretary general (adm, pol) secretar şef, secretar general, consilier (într-o delegație / ambasadă)

Secretary of Defense (pol, adm) ministru al apărării (în SUA)

Secretary of State (pol, adm) secretar de stat, ministru (în UK); ministru de externe (în SUA)
Secretary of State for Foreign Affairs (pol, adm) ministru al Afacerilor Externe (în UK)

Secretary of State for Home Affairs (pol, adm) ministru al Afacerilor Interne (în UK)

Secretary of the Air Force (pol, adm) ministru al Aviaţiei (în SUA)

Secretary of the Army (pol, adm) ministrul Forțelor Armate (în SUA)

secretaryship (pol, ec) functia, obligatiile / calificarea de secretar; (pol, adm) funcția, rangul, obligațiile etc. de ministru

secrete (from) a ascunde, a tăinui (de); a feri (de); a ține într-un loc secret; (biol) a secreta, a produce prin secretie; a se ascunde

secrete a separa; a secreta

secretion (chim) secretare; (med, biol) secretie secretive ascuns; rezervat, discret; reticent; (biol) secretor

secretively $(a d v)$ în secret / taină, pe ascuns

secretiveness rezervă, caracter ascuns / misterios / secretos

secretly $(a d v)$ în secret / taină, pe ascuns

secret service (adm, pol) serviciu secret; (mil) serviciu de spionaj

sect sectă; grup(are); (edu) şcoală; (OM) secțiune, parte

sectarian sectar, de sectă; sectar, de sectă; partizan; limitat, mărginit, sectar; dogmatic

sectarianism sectarism

sectile (mas-un, $\mathrm{TH}$ ) prelucrat prin aşchiere

section (met) oțel profilat, tronson, cvartal, secție; (nav) (bloc-) secție; (OM, TH) secțiune transversală; secționare, tăiere; tăietură; parte, porțiune; fâşie; segment; profil; (poligrafie) paragraf, capitol, parte, fascicul; sectie; raion (de mărfuri etc.); (constr) oțel profilat; tronson; (med) secțiune; a secționa; a împărți, a diviza; a împărți în secțiuni; section (sec) (metr) unitate tradițională de măsură pentru arie în US şi Canada de Vest, 1 section $=1$ square mile; v. square mile

sectional $(\mathrm{OM})$ demontabil, care poate fi sectionat sectional secționat, împărțit în secțiuni; tehn demontabil, transversal, profilat, (fig) (d. păreri etc.) divizat, împărțit; diferit

sectional area $(\mathrm{OM})$ sectiune transversală

sectional die (mas-un) matriță / ştanță din mai multe piese, matriță cu calibre succesive

sectional form $(\mathrm{OM})$ secțiune profilată (d. semifabricate etc.)

sectional groove (met) calibru de profilare

sectional iron / steel (met) fier / oțel semifabricat profilat

sectionalism interese sectare; spirit de gaşcă 
sectional plane (OM, geom) plan de secțiune sectional steam boiler (termo) cazan secționat / din mai multe bucăți

sectional view vedere laterală din profil, secțiune (în desen tehnic)

sectional view $(\mathrm{OM})$ vedere din profil / laterală (în desen tehnic)

sectional wire $(\mathrm{OM})$ sârmă profilată

section cutter (mas-un) cuțit de retezare / de debitare

section engineer (ind chim) şef de şantier

section gang (ind chim) echipă de întreținere a unui sector

section groove (met) calibru de profilare (la laminare)

sectioning secționare (proces tehnologic, dar si în desen tehnic)

section iron (met) oțel profilat

section mark (poligrafie) paragraf, semn de paragraf

section mark (poligrafie) (semn de) paragraf, semnul $\S$

section mill (met) laminor de profiluri

section modulus (mec, OM) moment de rezistență (al secțiunii)

section of groove (met) secțiune / formă / profil al calibrului (la laminare)

section of shaped steel (met) sectiunea profilurilor laminate / profilului laminat

section pit (termo) cameră de aspirație

section rolling (met) (procesul de) laminare de profiluri

section rolling mill (met) laminor de profiluri

sections (met) profiluri

section shape $(\mathrm{OM})$ profilul sectiunii (d. piese, semifabricate)

section shearing machine (met, mas-un) foarfece de tăiat profiluri

section steel (met) profil (de oțel), oțel / semifabricat profilat

section straightening machine (met) maşină de îndreptat profiluri

section tube (met, OM, plast) țeavă / tub profilat $(\breve{a})$

sector $(\mathrm{OM})$ sector (şi de roată dințată)

sector sector; zonă; parte, porțiune; (geom) arc de cerc; (constr) baraj în sectoare; $(\mathrm{OM})$ culisă

sector for hand brake lever segment dinţat pentru levierul frânei de mână

secular secular, laic; lumesc; de secole / veacuri; străvechi; care se întâmplă o dată într-un secol

secularism vederi / conceptii laice; doctrina separării bisericii de stat / învățământ

secularity caracter secular / laic; secularism secularization secularizare; laicizare

secularize a seculariza (averi etc.); a laiciza

secure a îmbina, a fixa, a asigura

secure sigur; liniştit; ferit de primejdii etc.; (d. un pod etc.) solid, trainic; (TH) care nu prezintă (nici un) risc; sigur, în siguranță; într-un loc sigur (de unde nu poate fugi / aluneca, cădea etc.); garantat; asigurat; from a asigura (împotriva); a apăra, proteja, a feri (de / împotriva); a întări, a fortifica (un oraş etc.); a întări, a consolida; a fixa; a asigura (cu dispozitive de protectie); a face rost de (bilete etc.); a cumpăra; a se asigura de; a câştiga, a reputa, a dobândi (victoria); a realiza, a îndeplini (scopul); asigură (o asamblare)

secure by bolts $(\mathrm{OM})$ a fixa prin bolturi

secure in position (OM, mas) a fixa într-o anumită poziție

securely $(a d v)$ cu rezistență suficientă, fix, fixat; (TH) asigurat în siguranță, la adăpost, ferit; la loc sigur; din sursă sigură

securely closed (auto) închis corespunzător / în sigurantă (d., portiere, portbagaj, etc.)

securement asigurare

secure of sigur / încredințat de; încrezător în (victorie etc.)

secure rotationally a asigura contra rotirii

secure to a fixa de

securing ring $(\mathrm{OM})$ inel de fixare

securit (ind chim) (geam) securit

security siguranță, securitate; siguranță, încredințare, convingere, certitudine; (pol) siguranță, securitate; pază; protecție; apărare; garanție; zălog; in for (ec, pol, adm) ca / drept garantie pentru; (ec) garantie; cautiune; (ec) garant, chezaş, girant, (mil) contraspionaj

security against breakage (OM, mas) siguranță contra suprasolicitării / la rupere

security against buckling (OM) siguranță (prin piese adiționale, formă etc.) stabilitate la flambaj

security against failure (OM, mas) siguranț̆ la rupere

Security Council Consiliul de securitate security risk suspect, persoană dubioasă (căreia nu i se pot încredința funcții de stat)

secy., sec'y prescurtare de la secretary

SED (metr, med, anat) simbol pentru standard erythemal dose, unitate pentru a măsura cantitatea de radiaţie ultravioletă care înroseşte pielea, primită de o persoană aflată în soare sau la bronzare artificială; 1 SED este o doză de $100 \mathrm{~J} / \mathrm{m}^{2}$ pentru piele; 1 SED este echivalent cu $27,778 \mathrm{~mW} / \mathrm{m}^{2}$ pe piele 
sedan (auto) sedan, berlină

sedan chair lectică; palachin

sedate liniştit, calm, netulburat; serios, grav, demn sedatine (chim) antipirină

sedation (med) linişte; calmare, potolire, liniştire (după administrarea de sedative)

sedative (med, chim) sedativ

sedentarily $(a d v)$ (într-un mod) sedentar

sedentariness caracter sedentar

sedentary sedentar, stabil; care nu face mişcare;

(zool) fixat într-un anumit loc

sedge (bot) rogoz

sedgy (acoperit) cu (mult) rogoz; (ca) de rogoz

sediment (chim, termo, hidr) etc. sediment, pre-

cipitat; (geol) nămol, noroi; sediment; depunere; (alim) drojdie; reziduu (în alimente)

sediment sediment; depunere; depozit

sedimental sedimentat, depus, depozitat

sedimentary sedimentar; de sedimente

sedimentary rock (geol) rocă sedimentară

sedimentation (geol, chim, alim, hidr, termo) sedimentare, depunere, depozit(are)

sedimentation analysis (materiale, metr) analiză granulometrică prin sedimentare

sedimentation constant (geol, chim, alim, hidr, termo) constantă de sedimentare

sedimentation chamber (ind chim, alim) cameră de sedimentare

sedimentation equilibrium echilibru de sedimentare

sedimentation method (ind chim, alim) metodă de sedimentare

sedimentation plant (ind chim, alim) instalație de sedimentare

sedimentation rate (ind chim, alim) viteză de sedimentare

sedimentation size analyser (ind chim, alim, metr) analizor pentru o mărime de sedimentare (de obicei înălțime sau grosime)

sedimentation test (materiale, metr) analiză granulometrică prin sedimentare

sedimentation velocity (ind chim, alim) viteză de sedimentare / de depunere

sediment bowl (OM, ind chim, alim) pahar de sedimentare

sediment box (mediu, met) decantor de noroi

sediment filter press (mas, alim, ind chim) presă pentru sediment filtrat

sediment trap (mas, alim, ind chim) decantor

sedition răzvrătire, revoltă

seditionary de răzvrătire, răzvrătitor

seditious, seditionary înclinat spre răzvrătire

seduce a seduce, a ademeni (o fată); a corupe; a ademeni; a duce pe căi greșite; $\sim$ smb from his duty a abate pe cineva de la datorie, a corupe pe cineva; $\sim$ smb into doing smth a ademeni / îndemna pe cineva să facă ceva (rău); a ispiti, a atrage; a fermeca

seducement, seduction seducere, seductie; ademenire; corupere

seducer seducător, ademenitor, ispititor

seducible care poate fi sedus / corupt

seduction seducere, ademenire; corupere; seducție; farmec; (putere de) atracție; ispită

seductive seducător, ademenitor, ispititor

seductively $(a d v)$ (în mod) seducător, fermecător

seductiveness caracter seducător, fermecător

seductor seducător

sedulity silință, sârguință

sedulous silitor, sârguitor, sârguincios; harnic; stăruitor; perseverent, asiduu

sedulously $(a d v)$ cu silință / hărnicie; asiduu, cu asiduitate

sedum (bot) iarbă de şoaldină, şărpariță

see a vedea; a zări; a observa; a viziona (un spectacol); a vedea, a vizita (pe cineva, un muzeu etc.); a trece pe la (cineva); a întâlni (pe cineva); a se întâlni cu (cineva); a revedea; a-şi da seama de; a înțelege, a pricepe; a-şi imagina, a-şi închipui; a vedea, a recunoaşte, a descoperi (o calitate a cuiva etc.); a întrezări, a prevedea (ce va fi etc.); a constata, a afla; a consulta (un doctor etc.); a primi vizita (cuiva); a merge cu, a însoți, a acompania (pe cineva); a se întâlni cu; a face curte (cuiva) (d. o fată), a fi curtată, a i se face curte; a avea vedere bună, a fi văzător; a (se) vedea, a (se) întâlni; a-şi da seama, a înțelege, pricepe; a se gândi; a privi, a se uita; a cerceta; a afla

see about a avea grijă / a se îngriji de; a se ocupa de; a cerceta; a face cercetări cu privire la; a umări; a se gândi la

see after a avea grijă de; a fi atent la (bagaje etc.) seed (şi $p l$ ) sămânță sau semințe; sămânță, germen(e); început; (biol, anat) spermă; (agr) a semăna (un câmp), a însămânța, a semăna; (alim) a curăța de sâmburi, a scoate sâmburii din (stafide etc.); a planta, a sădi; (bot) a da samânță

seed, $(p l)$ seed (alim, biol) sâmbure, sămânță bob; (chim, TH) germene, sursă, nucleu de cristalizare; (fig) început; a curăța de sâmburi, a scoate sâmburii (din stafide etc.); (agr) a semăna (un câmp), a sădi, a planta; (bot) a da sămânța; (sport) a selecționa jucători

seedage (agr) semenologie, cultură seminceră, campanie de însămânțări, timpul semănatului, înmulțirea plantelor prin semințe 
seed bed (agr) răzor de sămânță seed cake (alim) prăjitură / chec cu semințe seed charge (chim) agent de precipitare seeder (agr) semănător; semănătoare seed grower (agr) cultivator de seminte seed growing (agr) semenologie, cultură seminceră

seedily prost dispus

seediness jerpeleală; aspect zdrențăros; lipsă de chef, dispoziție; mahmureală

seeding amorsare; inițiere; (agr) însămânțare, semănat, semănătură

seeding-felling (silv) tăiere de însămânțare

seeding apparatus / device (agr, OM) distribuitor (la semănătoare)

seeding machine (agr) semănătoare

seedling (agr) răsad, butaș; (silv) semințiş

seedling plant (silv) pepinieră

seed oil (agr, ali, T) ulei vegetal

seed plant (bot) (plantă) spermatofită; fanerogamă

seedsman (agr) semănător; vânzător de semințe (de plante)

seed time (agr) perioadă de însămânțare, timpul semănatului

seed vessel (bot) pericarp

seedy (bot) cu semințe, plin de semințe; (textile) cu impurități vegetale; ros, uzat

see everything through rose-coloured spectacles a vedea totul în roz

seeing vedere, văz; văzător, care vede; $(c o n j)$ având în vedere că, ținând seama de faptul că, întrucât, cum, deoarece; (prep) ținând seama de, având în vedere; datorită (cuiva etc.)

seeing as (how) seeing, seeing that seeing văzând aşa cum este

see into a cerceta, a examina; a înțelege, a înțelege adevăratul sens

see it through a rezista până la capăt

seek a căuta; a căuta să găsească / să afle; a umbla după; a cere (un sfat); a vrea să cunoască (părerea cuiva); a se mișca / a se îndrepta (în mod firesc) spre; a căuta; a cerceta

seek after / for a căuta, a urmări (ceva / pe cineva)

seek out a căuta (societatea cuiva etc.); a percheziționa (pe cineva, ceva)

seek the buttom (mediu, ind chim, alim) a (se) precipita, a (se) depune

seek to a căuta să; a se strădui să

seel a lega la (ochi); a sigila

seem a părea, a da impresia; a avea impresia; a se părea

seeming aparent; care pare; prefăcut; pretins; outwards $\sim$ judecând după aparențe / din afară / din exterior

seemingly $(a d v)$ după câte s-ar părea; aparent; (în mod) evident, clar, limpede seemlines bună-cuviință; decență

seemly potrivit, convenabil; cuvenit; cuviincios, decent; plăcut; frumos; atrăgător; $(a d v)$ cum trebuie / se cuvine, (în mod) convenabil

se of (at) a însoți, acompania (la, până la gară etc.); a face față, a rezista la (un atac etc.); a respinge

see out a ține / a rezista până la sfârşitul; a conduce (pe cineva) până la ușă, poartă, ieșire etc.; a duce până la capăt, a sfârşi cu bine (lupta etc.)

see over a examina, a studia (un raport etc.); v. see round

seep (hidr, geol, T) a pătrunde; a se prelinge, a (se) infiltra, a se strecura; spărtură, fisură (prin care trece apa etc.),

seepage (hidr, geol, T) infiltrație; scurgere; percolare

seepage area $(\mathrm{TH}$, geol, constr) arie / suprafață de infiltrație / de scurgere

seepage test (hidr, metr) probă / test de filtrare

seer văzător; clarvăzător, profet; (metr) unitate tradițională de măsură pentru masă în India şi Asia de Sud: 1 seer $=1 \mathrm{~kg}$; (metr) unitate tradițională de măsură pentru volum de produse uscate în India: 1 seer $\sim$ volumul ocupat de 1 seer of grain (de cereale, ca masă); SEER (metr) abreviere pentru seasonal energy efficiency rating, unitate de măsură pentru eficienta / capacitatea instalatiilor de aer condiționat, în US şi Canada, exprimată în energia pentru condiționarea aerului pe durata unui întreg sezon / anotimp, în Btu, împărțită la energia electrică consumată, în watt ore

seeress clarvăzătoare; femeie-profet, profetă

see round a vizita, a vedea

see-saw balans(are), legănare, legănat; scrânciob; de balans(are); încoace şi încolo; în sus şi în jos; (fig) şovăitor, ezitant; a legăna (în sus şi în jos), a da în sus şi în jos; a se legăna, a se balansa

seethe a fierbe, a clocoti

see things through rose-coloured spectacles a vedea lucrurile în roz

see-through (fiz, materiale) prin care se poate vedea, transparent (fără a indica gradul de transparență)

see through (fiz, materiale) a vedea prin; a da ajutor (cuiva), a ajuta, a sprijini, a susține (pe cineva), a scoate la liman (pe cineva); a salva; a redresa; a nu renunța la; (med) a asista până la capăt la (operație etc.); (mil, ind, adm) a lua parte de la început până la sfârşit la (război etc.); a duce până la capăt; a nu renunța la; a ghici (planurile cuiva etc.), a-şi da seama de (planurile cuiva etc.); a brick / a stone wall a 
avea o minte ageră / ascuțită, a fi perspicace (fig) a vedea şi prin zid; see smth. through a duce ceva la bun sfầşit / până la capăt; see through smb.'s game a înțelege intențiile ascunse ale cuiva, a pricepe jocul cuiva

see through a glass / darkly a distinge cu greu, a vedea ca prin ceață / ca prin sită

see through a ladder a nu vedea ceea ce este clar pentru toți

see through blue glasses a fi pesimist, a vedea totul în negru

see to a avea grijă de / a se îngriji de

Seger cone (mas-un, OM) con Seger

segment $(O M$, metr) lamelă, segment

segment parte, porțiune, bucată; (OM) segment; parte, secțiune, compartiment, diviziune, lamelă; a segmenta, a împărți în segmente; (geom) segment

segment(al) gear $(\mathrm{OM})$ segment dințat

segmental (OM, geom) segmentat, compartimentat; de segment / segmente; în formă de segment

segmental sawblade (mas-un) disc de ferăstrău, cu dinți aplicați

segmentary (adj) v. segmental

segmentation (TH, chim) segmentare

segment gear $(\mathrm{OM})$ sector / segment dințat segment tool (mas-un) cutit lateral cu tăis rotunjit segregate (met, chim) segregare; a segrega, a (se) separa, a (se) izola; (TH) a secreta; a (se) scinda; a (se) segrega;

segregated separat, izolat; segregaționist; (materiale) scindat, segregat

segregated spot (met) zonă (relativ mică) de segregare

segregation despărțire; (chim, TH) excreție, secretie; izolare; (met, geol) licuatie; scindare; (materiale, met, geol) segregare, segregație, separare

segregation by size / density (alim, ind chim, met) segregare pe criteriu de mărime / de densitate

segregation in an ingot (met) segregație în lingouri

segregation line (met) zonă de segregare (eventual îngustă)

segregation pattern (alim, ind chim, met) model / tipar de segregare

segregation process (alim, ind chim, met) proces de segregare

segregation streaks (met) benzi de segregare

Seidel (metr, alim) unitate tradițională de măsură pentru volum de lichid, în Austria: 1 Seidel (Germania de Sud) $\sim 535 \mathrm{ml}, 1$ Seidel of beer (de bere, în Austria) 300 ml, 1 Seidel of beer (Germania) $500 \mathrm{ml}$

Seignette salt (chim) sare Seignette

Seine (geogr) fluviu în Franța, Sena seine(net) năvod

seining (iht, agr) pescuit cu năvodul

seism seism, cutremur

seismal (geol) seismic

seismic(al) seismic

seismic wave (geol, fiz) undă seismică

seismograph (metr, fiz, geol) seismograf

seismologic(al) (adj) seismologic

seismology (metr, fiz, geol) seismologie

seismometer seismometru

seismometric(al) (metr, fiz, geol) seismometric seismoscope (metr, fiz, geol) seismoscop seizable care poate fi prins, apucat etc.; v. seize seize a prinde, a apuca (violent); a pune mâna pe; (jur) a lua în posesie / în stăpânire; a confisca, a popri, a sechestra; a pune stăpânire pe; a aresta; a-şi însuşi; a cuceri (o fortăreață etc.); a captura; a (se) folosi (de) (un prilej etc.); (fig) a prinde, a înțelege, a pricepe (o idee etc.); (d. panică etc.) a cuprinde, a pune stăpânire pe; a lua în captivitate / prizonier; a prinde, a pune mâna pe; (termo, alim, plast) a se lipi din cauza dilatării / umflării / gonflării cauzate de căldură, frecare sau de ambele procese; a cuceri; (fig) a sesiza, a pricepe, a-şi însuşi, a prinde (o idee etc.); a izbi, a frapa; a confisca; (OM, T) a (se) bloca, a (se) înțepeni (d. piese în contact şi/ sau în mişcare), a (se) gripa (d. un cuzinet, un piston etc.), a captura (o impuritate etc.); a cuceri (o fortăreață etc.); a pune stăpânire pe, a cuprinde (d. panică etc.); a se agăța de (un pretext etc.)

seized of / with (jur) posedând, având în stăpânire (ceva)

seized piston $(\mathrm{OM}, \mathrm{T})$ piston gripat / blocat

seize the meaning of a sesiza sensul

seized with cuprins de (teamă etc.)

seize on / upon a deveni stăpân pe, a lua în stăpânire

seize up (OM, T) a (se) gripa, a (se) bloca, a (se) îțepeni

seize upon a prinde, a apuca, a pune mâna pe; a lua în stăpânire, a deveni / se face stăpân pe

seizin (ec, jur) proprietate funciară

seizing $(\mathrm{OM}, \mathrm{T})$ (acțiune / proces de) gripare / corodare (şi cauzată de frecare), blocare, înțepenire, captură (de impurități, şi nedorită); care se gripează; care frapează / cuprinde; (ec) confiscare; (nav) legătură; (jur) sechestrare; opposite- signal contrasemnal (telefonic) de ocupat 
seizing of a mould (TH) blocare / înțepenire / gripare a matriței

seizing of piston rings (auto, T) blocare / înțepenire / gripare a segmenților (în canalele pistonului)

seizing signal (telecomunicații) semnal de ocupare / de ocupat

seizure $(\mathrm{OM}, \mathrm{T})$ rupere / distrugere prin gripare, gripare, gripaj, calare; prindere, apucare; luare în stăpânire; ocupare; (jur) confiscare, sechestrare; (nav) captură; (med) acces, atac

seizure jur confiscare; acaparare, acces, atac

Sejm (pol) Seim (Camera Deputaţilor în Polonia)

selachians selachieni

seldom $(a d v) \operatorname{rar}($ eori), arar(e); când şi când

select ales; select; de cea mai bună calitate; selectiv; dificil, mofturos, pretențios; accesibil celor puțini; a alege, a selecta, a selecționa; a tria, a sorta

select committee (adm, ec, TH) comisie specială

selecting levers $(\mathrm{OM})$ pârghiile sistemului de comandă

selection alegere, selectare, selecționare; selectie; $(\mathrm{TH})$ triere, sortare; (biol) selecție (naturală etc.); (edu) culegere, antologie

selection triere, alegere (după anumite criterii)

selection function (mat, autom) funcție de selecție

selection rule (metr, $\mathrm{TH}$, autom) regulă de selecție / de alegere

selective (metr, fiz, $\mathrm{TH}$, autom) selectiv

selective adhesion (chim, T) adeziune selectivă

selective adsorption (chim, T) absorbție selectivă

selective annealing (met) recoacere selectivă

selective assembly (OM) asamblare cu selecționare, asamblare selectivă a pieselor grupate după anumite criterii (de exemplu, după câmpul de toleranță)

selective carburising (met, chim) carburare / cementare selectivă

selective control (autom) reglaj selectiv, reglare selectivă

selective corrosion (chim, met) coroziune locală / selectivă

selective cracking (ind chim) cracare selectivă

selective crystallization (met) cristalizare selectivă

selective filter (electr, el, hidr, autom) filtru selectiv

selective fit $(\mathrm{OM})$ asamblare selectivă (a organelor / elementelor de maşini)

selective flotation (fiz, alim, met) flotație selectivă

selective freezing (fiz, alim, termo) congelare selectivă selective hardening (met) călire diferențiată / locală / selectivă / parțială

selective heating (termo) încălzire preferențială / locală / parțială

selectively ( $a d v)$ (în mod) selectiv

selectiveness caracter selectiv, selectivitate

selective plating (el, chim) acoperire / placare selectivă electrochimică (prin acoperire cu izolant a unor poțiuni din piesă / suprafață)

selective oxidation (chim, met) oxidare fracționată / selectivă / parțială

selective quenching (met) călire parțială / selectivă / locală

selective service (ec, adm) recrutare; (mil) serviciu militar

selective solvent (chim) solvent selectiv

selectivity (fiz, autom) rezoluție, selectivitate (a unui dispozitiv); (mas-un, OM) pârghie de selectare a vitezei; catalyst / solvent $\sim(\mathrm{chim})$ selectivitate a catalizatorului / solventului

selector (autom) căutător, selector; alegător, sortator

selector (autom) căutător, selector

selector gear $(\mathrm{OM})$ mecanismul selectorului (la cutia de viteze)

selector lever (OM) pârghia selectorului

Selene Selene, Luna

selenic acid (chim) acid selenic

selenite (chim, minrl) selenit

Selenium (Se) (chim) seleniu

self (filosofie) eu, sine, ego, subiect; identitate; individualitate; personalitate; (adj) identic; acelaşi; uniform; din acelaşi material etc.; one's better $\sim$ partea cea mai bună a omului; one's other alter ego, mână dreaptă, prieten apropiat; before all mai aproape dinții decât părinții, pielea mai aproape decât cămaşa; comes first în primul rând te gândeşti la tine; $\sim$ do, $\sim$ have ce-şi face omul cu mâna lui e bun făcut, cum îți aşterni, aşa vei dormi; praise is no recommendation lauda de sine nu miroase a bine

self- prefix pentru auto-, automat, în cuvinte compuse

self-abandonment uitare de sine, abnegație

self- abasement umilire de sine

self-absorbed egocentric; preocupat, cufundat în gânduri

self-absorption egocentrism; cufundare în (propriile sale) gânduri

self-abuse abuz de sine; (med) onanism, masturbare

self-acting (autom) automat(izat)

self-acting billy (textile) maşină de filat cu acțiune periodică (pt. lână deşeuri şi vigonie); selfactor 
self-acting clutch $(\mathrm{OM})$ ambreiaj / cuplaj automat self-acting control (autom) reglaj direct / automat, reglare directă, control / reglare fără energie auxiliară

self acting controller (autom) regulator direct self-acting feed avans automat, avans mecanic self-acting incline plan înclinat automotor (la exploatări miniere)

self-acting lathe (mas-un, autom) strung cu avans automat

self-acting lubricator / oiler ( $\mathrm{T}, \mathrm{OM}$, autom) ungător automat

self-acting mule (textile, $\mathrm{OM}$ ) selfactor

self-acting needle (textile, $\mathrm{OM}$ ) ac cu limbă

self-acting plane (transp, constr) plan înclinat automotor

self-acting signal (autom, electr) semnal automat

self-acting valve (OM, hidr, autom) supapă automată, distribuitor automat

self-actuated (autom) automat(izat)

self-actuated controller / regulator (autom) regulator direct

self acting feed (mas-un, autom) avans mecanic automat, alimentare automată (cu un semifabricat, cu piesa de prelucrat etc.)

self-act travel (autom, mec, mas-un, mas) mişcare automată / automatizată

self-adapting (autom, T) autoadaptabil

self-adaptive (autom) autoadaptiv, autoadaptare

self-adaptive control (autom) comandă autoadaptivă) şi la roboți)

self-addressed envelope plic cu adresă, plic de retur

self-adhesive autoadeziv, autocolant

self-adhesive tape $(\mathrm{OM}$, chim) bandă adezivă

self-adjoined autoadjunct

self-admiration autoadmirație

self-adjustable (autom) autoreglabil

self-adjusting (autom) automat, cu reglare automată, autoreglabil, care se adaptează / ajustează singur

self-adjusting bearing $(O M, T)$ lagăr oscilant

self-adjusting control (autom) reglaj automat, reglare automată

self-adjusting system (autom, OM) sistem cu autoadaptare / cu autoreglare

self-adjusting tappet $(\mathrm{OM})$ tachet $\mathrm{cu}$ reglare automată a jocului

self-adjustment (autom) autoreglare (fără a specifica cum); (OM) (cu) aşezare reglablă (la montaj, în functionare), reglare automată

self-admiration autoadmirație, narcisism

self-advertisement autoreclamă self ageing (met, plast) îmbătrânire prin stocare (şi d. lubrifianți)

self-aligning $(\mathrm{OM})$ autocentrant, (element de maşină) care se autocentrează, autocentrare

self-aligning (ball-) bearing (OM) rulment oscilant cu bile / sferic cu bile, rulment sferic (la exterior) cu bile

self-aligning bearing $(\mathrm{OM})$ rulment cu autocentrare, rulment oscilant

self-aligning radial ball-bearing $(\mathrm{OM})$ rulment oscilant radial cu bile

self-aligning radial roller-bearing $(\mathrm{OM})$ rulment oscilant radial cu role

self-aligning system (mas) sistem cu autoaliniere

self-alignment $(\mathrm{OM}$, mas) autocentrare

self-annealing (met, $\mathrm{TH})$ recoacere / revenire naturală

self-appointed (pol) autoproclamat

self-approbation, self-approval autoaprobare, automultumire

self-asserting, self-assertive care se autoafirmă; ambițios, care se ambiționează

self-assertion, self-assertiveness autoafirmare; dorința / ambiția de a se impune; încredere în sine

self-assertive care vrea / caută să se impună; ambițios; încrezător în sine

self-assurance, self-assuredness siguranță de sine; încredere în sine; suficiență

self-assured sigur de sine; încrezător în sine; suficient

self-backing electrode (nav, met) electrod continuu (care nu se consumă sau sub formă de bară, sârmă în colac etc.)

self-balanced (OM, mas, el, fiz) autoechilibrat, autostabilizat

self-balancing (OM, mas, el) autoechilibrare, autostabilizare; autoechilibrat, autostabilizat, care se autoechilibrează / se autostabilizează

self-balancing bridge (electr, autom) punte cu autoechilibrare

self-balancing device (mas, autom) dispozitiv cu autoechilibrare / cu autostabilizare

self-balancing potentiometer (metr, el) compensator automat/cu autoechilibrare

self-ballasted mercury lamp (fiz) lampă cu lumină mixtă (cu filament și cu vapori de mercur)

self-bearing autodirijare; (radio, nav) radiogoniometru de bord

self-betrayal trădare față de sine însuşi

self-bias (fiz) negativare automată, polarizare automată de grilă

self-blast circuit-breaker (termo) disjunctor cu autosuflaj / cu insuflare automată 
self-blood (med) sinucidere

self-blow alcohol lamp (fiz, chim) lampă de alcool cu / sub presiune

self-braking (OM, el) autofrânare, autoblocare; (autom, inf) blocare / oprire automată

self-cancel (inf, autom) autoanulare

slef-canceling (inf, autom) care se autoanulează, autoanulare

self-capacity capacitate proprie

self-catalysed reaction reacție autocatalizată

self-catching (OM, el) autofrânare, blocare automată, care se autoblochează

self-centering, self-centring $(\mathrm{OM})$ autocentrare, autocentrant, care se autocentreză; (mas-un)

self-centering / centring chuck (mas-un, OM) mandrină cu autocentrare, universal (de strung)

self-centering / self-centring punch (mas-un, $\mathrm{OM})$ punctator autocentrant

self-centred egocentric; egoist; $(\mathrm{OM})$ autocentrat (d. arbori, rulmenți etc)

self-charge (mec, fiz) sarcină proprie / indusă

self-charging (OM, mas-un) (cu) autoîncărcare, care se autoîncarcă

self-changing centrifuge (OM, mas) centrifugă cu încărcare automată

self-changing gear (OM, autom) mecanism de schimbare automată a angrenajelor / a vitezelor

self-check (ec, autom) autoverificare; a se autoverifica

self-checking code (inf, autom) cod cu autocontrol, cod cu detectarea erorilor

self-clamping guillotine (mas-un) mașină de tăiat, cu presare automată (pt. hârtie)

self-cleaning (autom, TH) (cu) autocurătare, autoepurare

self-cleaning bowls $(\mathrm{OM})$ bacuri cu care se curăţă automat (la leviatane, maşini de vopsit şi de finisat textile)

self-cleaning element (hidr, OM) element filtrant autolavabil

self-cleaning spark plug (auto, el) bujie cu autocurățire

self-clearing (inf, autom) autoinitializare, corectare a funcționării defectuoase a unor dispozitive de calcul

self-closing (el) autoînchidere a circuitului, care se autoînchide

self-closing butterfly valve (OM) vană-fluture cu închidere automată

self-closing valve supapă de siguranță cu închidere automată

self-clocking tracks (inf) piste cu autocadențare / cu autoritmare self-closing (el, electr, autom) autoînchidere a circuitului

self-closing $(\mathrm{OM})$ care se autoînchide, autoanclanşare, închidere automată

self-closing butterfly valve (OM, hidr) vană fluture cu închidere automată

self-closing valve (OM, hidr) supapă de siguranță cu închidere automată / care se închide automat

self-cocking (OM, mil) autoarmare, armare automată (a unei arme de foc)

self-collected stăpân pe sine, calm, stăpânit, cu sânge rece

self-colour culoare naturală / proprie (a unui material etc.); (fiz) monocromie

self-coloured (fiz) de o singură culoare, monocrom; având culoare proprie /naturală

self-command, self-control (autom) control propriu / intrinsec, autocontrol

self-communion reculegere; introspecție; (edu) autoanaliză

self-compensating (OM, electr, autom) autocompensare, care se autocompensează

self-complacence, self-complacency mulțumire de sine, automulțumire; (fig) înfumurare, îngâmfare

self-complacent mulțumit de sine; încrezut, plin de sine

self-complacently $(a d v)$ (cu un aer, pe un ton etc.) de automulțumire, plin de sine (însuşi)

self-composed, self-collected calm, cu sânge rece; stăpânit, stăpân pe sine

self-computing chart (inf, autom) nomogramă / diagramă / hartă care se autogenerează (pe măsură ce sistemul primește datele de la maşina monitorizată)

self-conceit îngâmfare, trufie

self-conceited îngâmfat, plin de sine, închipuit, fudul

self-condemnation (fiz) autocondamnare

self-condensation (fiz, termo) autocondensare, autocondensatie

self-confessed mărturisit, declarat, care recunoaşte singur (că are un viciu etc.)

self-confidence încredere (adesea exagerată) în sine / în propriile sale puteri; aplomb

self-confident (adesea prea) încrezător în sine / în propriile sale puteri

self-confidently $(a d v)$ cu (prea multă) încredere în sine; cu aplomb

self connecting (OM, el, autom) cuplare / conectare automată

self-connecting working (electr, autom) exploatare / centrală (telefonică) automată 
self-conscious care se cunoaşte pe sine; conştient; ruşinos, sfios; stângaci; timid; cu stângăcie, cu timiditate; jenat

self-consciously $(a d v)$ ruşinos, timid, cu timiditate; cu stângăcie; jenat

self-consciousness conştiență, conştiință; jenă; sfială, sfiiciune; stângăcie; timiditate

self-consistent consecvent; logic

self-consistent field (mat, fiz) câmp autoconsistent, câmp selfconsistent

self-constituted (pol, adm) autoconstituit, autointitulat, autoproclamat

self-contained (mas, autom, mil) independent, autonom, de sine stătător, cu comandă autonomă; (d. locuință etc.) izolat, separat; (d. cineva) retras, nesociabil; (OM) închis, independent (d. elemente de maşini care pot fi introduse ca module în proiecte etc.); (mil) autonom, capabil să ducă acțiuni independente

self-contained air conditioning unit aparat de climatizare monobloc, aparat preasamblat de condiționat aerul

self-contained air-cooler răcitor de aer cu agregat încorporat, răcitor de aer cu grup încorporat

self-contained cooling-unit (termo) răcitor de aer cu agregat încorporat, răcitor de aer cu grup încorporat

self-contained instrument (metr) aparat independent / autonom, cu toate elementele într-o singură carcasă, aparat multiplu

self-contained lubrication $(\mathrm{T})$ ungere prin circulația lubrifiantului sub presiune

self-contained motor drive (mas, el) actionare cu motor electric individual

self-contained press (mas-un) presă cu comandă automată

self-contained system (termo) agregat frigorific monobloc / preasamblat, instalație frigorifică automată

self-content mulțumire de sine; automultumire self-contented mulțumit de sine; automulțumit self-contradiction contradictie internă self-contradictory (adj) contradictoriu, cu contradicții interne; care se contrazice singur

self-control autocontrol, stăpânire de sine, sânge rece, calm; (mas, autom) automat(izat)

self-controlled stăpân pe sine, calm, cu sânge rece; stăpânit

self-convergence (fiz) autoconvergentă a fasciculelor de electroni (și fără reglare)

self-conviction autocondamnare

self-cooled (OM, mas) autorăcit, autoventilat, cu răcire naturală self-cooled oil transformer (el, termo) transformator în ulei cu răcire naturală

self-cooling autorăcire

self-cooling (termo, OM) autorăcire, care se autorăceşte

self-coupling (OM, el) cuplare / anclanşare automată

self-cost (ec) cost / preț de revenire

self-critical autocritic

self-criticism autocritică

self-culture (edu) cultură de autodidact; autoeducație

self-curing (plast, ind chim) autovulcanizare

self-curing adhseive (plast, ind chim) adeziv cu autoîntărire

self-curing cement (plast, ind chim) clei adeziv de / pentru cauciuc autovulcanizant

self-cutting screw şurub autofiletant

self-damping ( $O M$, autom) atenuare proprie, care are atenuare proprie

self-deceit autoînșelare, autoamăgire

self-deceiving care se înşală singur

self-deception $v$. self-deceit

self-defeating contrar propriilor sale interese; sieşi dăunător

self-defence (mil, jur) autoapărare

self-delivery rake $(\mathrm{OM})$ greblă cu descărcare automată

self-delusion autoizolare; $v$. self-deceit

self-demagnetization (fiz, materiale) demagnetizare proprie / spontană

self-denial jertfire de sine; abnegație; spirit de sacrificiu

self-denying care-şi sacrifică propriile interese; plin de abnegație

self-dependence independență; bizuire pe sine; dependență internă

self-dependent independent; care nu depinde de nimeni

self-destroyer sinucigaş; care se autodistruge

self-destruction autodistrugere; (med) sinucidere

self-detaching (OM, autom) (cu) autodecuplare, care se decuplează automat; (materiale) usor îndepărtabil / detaşabil (şi d. depuneri zgură etc.)

self-detaching hook $(\mathrm{OM})$ cârlig cu decuplare automată

self-determination (met, adm, pol) autodeterminare

self-development (adm, ec) autodezvoltare, dezvoltare proprie

self-devotion devotare, consacrare; jertfire de sine; abnegație

self-diagnosis (mas, autom, inf) autodiagnosticare 
self-diagnosis system (mas, autom, inf) sistem de auto-diagnosticare

self-diffusion (fiz) autodifuzie

self-discharge (el) autodescărcare (la acumulatoare, baterii etc.); (mas, autom) autodescărcare

self-discharging (OM, mas, mas-un, el, autom) cu autodescărcare, cu descărcare automată, care se autodescarcă

self-discharging truck (auto) autocamion cu descărcare automată

self-discharging wag(g)on (cf, met, transp) vagon cu descărcare automată

self-discipline autodisciplină

self-doffing (textile) cu efectuare / scoatere automată a levatei (în ind. textilă)

self-drive (auto, transp, ec) (d. maşini) de închiriat (fără şofer)

self-drive car (auto, transp, ec) automobil de închiriat fără şofer

self-dumping (OM, mas, autom) cu răsturnare automată, care (se) răstoarnă automat

self-dumping bucket (OM, met, constr) chiblă cu basculare / descărcare automată, schip cu basculare / descărcare automată

self-dumping cage $(\mathrm{OM})$ colivie autobasculantă

self-dumping (mas, autom) cu golire / răsturnare automată

self-educated autodidact

self-effacement (materiale) autodepreciere; menținere în umbră; modestie, autoaprecierece defavorabilă / depreciativă

self-effacing care nu atrage atenția; discret; modest; sfios, timid, v. reticent, v. retiring

self-employed care lucrează singur (fără funcționari etc.)

self-emptying (autom, transp, hidr, mas-un) cu descărcare / golire automată

self-emptying trailer (auto, transp) remorcă cu descărcare / golire automată

self-energizing brake (OM, autom) servofrână, frână automată

self-energy (fiz) (cu) energie proprie

self-equalizing (autom, TH) (cu) egalizare automată

self-esteem părere (foarte) bună despre sine; prezumție

self-evaporation (fiz) evaporare spontană

self-evident apriori, aprioric; axiomatic; care vorbeşte de la sine; clar; evident

self-examination autoexaminare; introspectie; autocritică

self-excitation autoexcitație

self-exited (el, fiz) cu autoexcitație, autoexcitat

self-exiting (el) cu autoexcitație; care se entuziasmează singur self-exiting braking (el, OM) frânare cu autoexcitatie

self-explanatory care nu are nevoie de explicații / lămuriri (pt. a fi înțeles), de la sine înțeles, evident

self-extinguishing $(\mathrm{TH}, \mathrm{ind}) \mathrm{cu}$ autoextincție, $\mathrm{cu}$ autostingere, care se stinge singur (d. un foc, materiale aprinse)

self-extinguishing effect efect de autoextinctie, efect de autostingere

self-feeder (OM, mas-un) autoalimentator, alimentator automat

self-feeding (TH) autoalimentare, (cu) alimentare automată, care se alimentează automat (d. cir-cuite hidraulice etc.); (mas-un) cu avans automat, cu încărcare automată a posturlor de lucru

self-firer (mil, OM) armă automată

self-fluxing (met) autofondant

self-fluxing sinter (met) aglomerat autofondant

self-gauging (metr, autom) cu dispozitiv de calibrare automată

self-generating $(\mathrm{TH})$ prelucrarea / generare a profilurilor fără şablon / prin rulare

self-generating transducer (metr) traductor de măsurare fără energie auxiliară, traductor generator

self-generating method $(\mathrm{TH})$ metodă de rulare / de generare (şi pt. roți dințate, suprafețe profilate etc.) (la prelucrarea roților dințate cu freză-melc)

self-governing (mas, autom) (cu) reglare automată, (sistem) care se reglează singur; (pol) autonom, cu au-toconducere; autoreglare

self-government (pol) autoconducere, autonomie; calm (rar); sânge rece, stăpânire de sine ( $r a r)$

self gripping jaws $(\mathrm{OM})$ cleşte $\mathrm{cu}$ prindere automată

self-hardening (met) autocălire, călire / durificare în aer, autocălibil, autodurificabil

self-hardening steel (met) oțel autocălibil / care se căleşte în aer

self-healing (med) autovindecare

self-heating (termo) autoîncălzire

self-help autoajutorare, folosirea propriilor (sale) forțe; autoperfecționare

self-heterodyne receiver (fiz) receptor cu autoheterodină

self-holding contact (OM, el, autom) contact de automenținere

selfhood individualitate; personalitate; egoism self-hooped pipe $(\mathrm{OM})$ tub autofretat, conductă cu autofretare / cu fixare / montare automată

self-ignition (auto, termo) autoaprindere

self-ignition engine (auto, termo) motor diesel 
self-ignition point (fiz) punct / temperatură de autoaprindere / de autoinflamare (la lubrifianți, fluide hidraulice, combustibili etc.)

self-ignition temperature (SIT) (fiz) temperatură de autoaprindere (la lubrifianți, fluide hidraulice, combustibili etc.)

self-ignition test (ind chim, metr) test de autoaprindere (pt. lubrifianți etc.)

self-importance (auto)importanță; părere foarte bună despre sine; suficiență; înfumurare

self-important care-ş̧i dă importanță, plin de sine; încrezut, înfumurat

self-imposed (rar) autoimpus, pe care şi-1 impune singur

self-indexing (autom, inf, mas-un) autoindexare, cu indexare automată, care se autoindexează care se numără automat

self-inductance (fiz) inductanță / inductivitate proprie

self-induction (el, fiz) autoinducție, selfinducție, autoinductantă

self-induction coil (el, fiz) bobină de inductanță, bobină de şoc

self-indulgence îngăduință prea mare față de sine (însuşi); slăbiciune

self-inflammable (materiale) autoimflamabil

self-inflammable mixture (chim, ind, $\mathrm{TH}$ ) amestec autoinflamabil

self-instructed carry (inf) transport autonom (de date, comenzi etc.)

self-interest propriul interes; egoism

self-interested interesat; care-şi cunoaşte / urmăreşte propriile (sale) interese; egoist

self-invariant invariant în sine, autoinvariant

self-invited neinvitat (de nimeni); nechemat; care s-a autoinvitat

selfish egoist; interesat

selfishly $(a d v)$ în mod egoist / interesat

selfishness egoism; interes

self-justification autojustificare

self-knowledge autocunoaştere, cunoaştere de sine selfless altruist; dezinteresat

selflessly ( $a d v)$ (în mod) altruist; dezinteresat

selflessness altruism; caracter dezinteresat

self-levelling level nivelă automată

self life (ind chim) stabilitatea lacurilor depozitare

self-limiting chain reaction (chim) reacție în lanț, auto-moderatoare

self-limiting fan (termo, autom) ventilator centrifug cu autoreglare

self-liquidating loan (ec) împrumut pe termen scurt garantat cu marfa (se achită automat la vânzarea mărfii) self-loading (mas, mas-un) cu încărcare automată (mil) semiautomat; automat

self-loading vehicle (auto, transp) autovehicul cu încărcare automată

self-locking (OM, autom) care se închide singur, cu închidere automată; (mas) (cu) autofrânare, (cu) autoblocare; (inf) cu blocare automată

self-locking differential $(\mathrm{OM})$ diferențial $\mathrm{cu}$ blocare automată

self-locking key $(\mathrm{OM})$ pană cu autoblocare

self-locking steering gear $(\mathrm{OM})$ direcție $\mathrm{cu}$ autoblocare

self-love dragoste de sine, narcisism; instinct de autoconservare

self-lubricating $(\mathrm{OM}, \mathrm{T}) \mathrm{cu}$ autoungere, care se autounge, cu ungere / lubrifiere automată, autolubrifiant

self-lubricating bearing $(\mathrm{OM}, \mathrm{T})$ lagăr (şi poros sau cu lubrifianți solizi incorporați) cu autoungere / autolubrifiere, lagăr cu ungere automată

self-lubricating bushing (OM, T) bucşă cu ungere automată, bucşă cu autoungere / autolubrifiere (şi datorită materialului, uneori impregnat cu lubrifianți)

self-lubricating ring $(\mathrm{OM}, \mathrm{T})$ inel $\mathrm{cu} /$ pentru autoungere

self-lubricating sleeve $(O M, T)$ bucşă cu ungere automată

self-lubrication (T) ungere / lubrifiere automată, autoungere, autolubrifiere (d. elemente de maşini cu lubrifiant incorporat, maşini şi instalații cu sistem propriu de ungere etc.)

self-lubricator $(O M, T)$ ungător automat, sistem $\mathrm{cu}$ autoungere / cu lubrifiere proprie

self-luminous (fiz, materiale) luminescent

self-luminous dial cadran luminescent

self-made făcut singur; (d. cineva) care s-a realizat prin propriile sale puteri / mijloace

self-maiming (med) automutilare

self-maintained (fiz, autom) autointreținut, automenținut; care se întreține singur (d. un foc, un proces etc.)

self-maintained discharge (inf) descărcare autoîntreținută; (inf) descărcare autonomă

self-maintaining cu automenținere, independent

self-mastery $v$. self-control

self-measuring tank (OM; hidr, ind, metr, autom, nav) rezervor / recipient / tanc cu măsurare automată

self-modulation (fiz, autom) automodulație

self-motion (mec, mas) mișcare independentă; auto-propulsie

self-motivated automotivat, motivat prin propria dorință / ambiție etc. 
self-motivated spin (fiz) moment cinetic propriu (sau intrinsec) de spin

self-movement (mec) mişcare independentă

self-moving (mas) cu autopropulsie, automat; $\mathrm{cu}$ mişcare independentă; autopropulsat

self-multiplying chain reaction reacție în lanț automultiplicatoare

self-murder (jur) sinucidere

self-murderer (jur) sinucigaş

self-mutilation (med) automutilare

self-neglect neglijență; dezordine; caracter dezinteresat; altruism

selfness egoism

self-nulling (autom, metr) revenire automată la zero

self-oil feeder (OM, T) aparat / dispozitiv de ungere automată

self-opening (OM, autom) cu deschidere automată

self-opening die head / die(s) (mas-un, OM) cap de filetat, cu deschidere automată

self-operated control (autom, mas) reglare automată / directă (fără suplimentare cu energie din exterior)

self-operated controller (autom, hidr) regulator direct

self-operated measuring unit transmițător de măsură direct (cu un singur detector)

self-operated valve (OM, hidr, autom) supapă automată

self-opinionated încrezut, închipuit, înfumurat; încăpăţânat, îndărătnic

self-optimizing (autom, TH) auto-optimizare (şi la roboți tehnologici)

self-oscillating system (autom) sistem autooscilant

self-oscillation (fiz, electr) autooscilație, oscilație proprie

self-oscillator (fiz, electr) autooscilator, oscilator autoexcitat

self-packing $(\mathrm{OM})$ autoetanşare

self-partiality supraapreciere a propriilor merite; lipsă de obiectivitate, subiectivism, părtinire

self-pity milă față de sine (însuşi); văicăreală

self-portrait (artă) autoportret

self-possessed stăpân pe sine, calm, cu sânge rece

self-possession stăpânire pe sine, calm, cu sânge rece

self-potential (fiz, ec, ind) potențial propriu

self-potential curve / log (fiz) curbă a potențialului spontan

self-potential survey (geol) prospecțiune pe baza măsurării potențialului spontan self-powered (mas, hidr) cu alimentare proprie, cu sursă proprie de energie

self-praise laudă de sine

self-preservation instinct de (auto)conservare

self-preserving $(\mathrm{TH}, \mathrm{el}$, autom) autoconservant, autoprotejant, care are autoprotecție, care se protejează (singur)

self-priming (hidr, OM, termo) cu autoamorsare (la pompe etc.)

self-priming pump (OM, hidr) pompă autoamorsantă / cu auto-amorsare

self-profit (ec, edu) profit personal

self-programming (autom, mas) autoprogramare (la roboți)

self-propagating (fiz) cu autoîntreținere, independent, care se propagă singur, care se autopropagă

self-propelled (mas) autopropulsat, cu autopropulsie

self-propelled car (cf) vagon automotor

self-propelled crane (transp, mas) automacara

self-propeller locomobile (cf) locomobilă autopropulsată

self-propelled roller (mas, constr) compresor rutier cu motor; tăvălug rutier cu motor

self-propelled ship / vessel (nav) motonavă, navă cu propulsie proprie

self-protection autoapărare, autoprotecție, autoprotejare

self-pruning (silv) elagaj natural (al pădurii)

self-pulse modulation (autom, electr) modulație prin impulsuri autoexcitate / locale

self-purification ( $\mathrm{TH}$, mediu) autoepurare, autocurățare, purificare fără intervenția (omului etc.)

self purification (ind chim, mediu) autoepurare

self-quadder (poligrafie, inf) dispozitiv / comandă de centrare a rândurilor

self-quenched counter (fiz, el, metr) contor $\mathrm{cu}$ autoextinctie

self-quenching (chim) auto extincție, (fizică nucleară) autoextinctor; (met) autocălibil

self-quenching oscillator (fiz, electr) oscilator cu autoîntreruperea trenurilor de oscilații

self-quenching (chim) autoextincție, care se stinge singur (d. un foc, o reacție)

self-quenching steel (met) oțel călit / călibil în aer

self-raising flour (amer) (alim) făină cu praf de copt

self-recorder (autom, metr) înregistrator automat

self-recording (autom, metr) cu autoînregistrare; (cu) înregistrare automată

self-recording device (metr, mas, autom) dispozitiv / mecanism cu autoînregistrare

self-recovery (ind chim, biol) autoregenerare 
self-refrigeration (termo) autorăcire

self-regard sentiment al demnității personale; grijă de sine

self-registering (autom, metr) cu înregistrare automată

self-registering anemometer (metr, fiz) anemograf

self-regulating (autom) (cu) autoreglare, autoreglabil, cu reglare automată

self-regulating control (autom, mas) reglare automată

self-regulating controlled system (mas, autom) sistem cu autoreglare

self-regulating water delivery (constr) aducție autoregularizatoare (în alimentări cu apă)

self-regulation autoreglare

self-relative addressing adresare diferențială

self-releasing $(\mathrm{OM})$ cu decuplare / declanşare / degajare automată (d. un arc, un cliclet etc.)

self-releasing casing spear $(\mathrm{OM}) \mathrm{rac} /$ sistem de prindere cu decuplare automată

self-reliance bizuire pe propriile sale puteri, încredere in propriile sale puteri, independență

self-reliant încrezător în sine / în propriile sale puteri / forțe, care se bizuie pe propriile sale forțe; independent

self-renunciation renunțare la sine; abnegație

self-repair (ind chim, biol) autoregenerare; (mas, autom) autoreparare

self-reproach reproş față de sine însuşi, autoincriminare; mustrări de conştiinţă

self-resetting (OM, autom) reanclanşare automată

self-resetting button (OM, mas) buton cu readucere / cu revenire automată

self-respect respect faţă de sine însuşi, sentiment al demnității personale

self-respecting care se respectă; care are sentimentul demnității personale

self-restoring button (OM, mas) buton cu readucere / cu revenire automată

self-restrained reținut, stăpânit; calm

self-restraint control, autocontrol; calm, reținut, stăpânit

self-retention autofrânare, autoblocare; autoreținere; automentinere (d. un proces, un fenomen)

self-revelation autodemascare; dare în vileag (a sentimentelor etc.)

self-reversal (fiz) autoabsorbție, autoinversiune; (mas, autom) autoinversare

self-righteous ( $f i g$ ) convins că numai el are dreptate; făţarnic; ipocrit; (fig) prezumțios, sigur de sine

self-righteously ( $a d v)$ (în mod) fățarnic; (în mod) ipocrit; prezumțios, sigur de sine self-righteousness (fig) siguranță de sine, prezumțiozitate; fățărnicie, ipocrizie

self-rising flour (amer) (alim) faină cu praf de copt

self-rotation $(\mathrm{OM}$, fiz) rotație proprie

self-rule, self-government (adm, pol, mas, autom) autoguvernare

self-sacrifice sacrificiu de sine

self-same (chiar) același, (chiar) aceiaşi; so many successes on the $\sim$ day atâtea succese în aceeași / într-o singură zi

self-satisfaction mulțumire de sine; automulțumire; părere foarte bună despre sine

self-satisfied mulțmit de sine; automulțumit

self-scattering (fiz) autodifuzie, autodispersie, autoîmprăștiere; care se autodifuzează / împrăştie

self-scorn dispreț față de sine (însuşi)

self-scouttering oil (textile, ind chim) ulei autolavabil

self-sealing (OM, hidr) cu autoetanşare, cu etanşare automată, care se etanşează singur, care autoetanșează (prin formă, material, reactii chimice etc.)

self-sealing air tube (termo, om, hidr) cameră / conductă de aer autoobturatoare

self-sealing coupling (OM, hidr) dispozitiv de cuplare, cu autoetanşare

self-sealing injection nozzle (OM, termo) ecluză de injecție, cu blocare automată

self-sealing (inner) tube cameră de aer cu astupare automată a găurilor

self-sealing stuffing box $(\mathrm{OM})$ presgarnitură cu etanşare automată / cu autoetanşare

self-sealing tyre (auto) pneu cu astupare automată a găurilor

self-seeker egoist; carierist; persoană care-şi urmărește propriile sale interese

self-seeking egoist; care-şi urmăreşte propriile sale interese

self-service autoservire; $(\mathrm{TH})$ autoservice; (adj) cu autoservire

self-service display case (ec, alim) vitrină pentru autoservire

self-setting $(\mathrm{OM})$ autoajustare, care se autoajustează

self-setting bearing $(\mathrm{OM}, \mathrm{T})$ lagăr cu cuzineți oscilanți

self-sheaf dropping reaper (agr, mas) secerătoare cu greble

self-shifting transmission $(\mathrm{OM})$ transmisie / cutie de viteze automată

self-slaughter (med) sinucidere

self-sown (bot) (care crește) sălbatic, neînsămânțat de om 
self starter, self-starter (auto, el) demarator automat, reostat autodemarator; (auto) vehicul cu demaror automat

self-starting (auto, el, mas, autom) demaraj automat, care demarează automat, pornire automată

self-stopping $(\mathrm{OM}, \mathrm{mec})$ autoblocare, autofrânare; (inf, autom) blocare / oprire automată

self-stopping gear (OM) mecanism / angrenaj cu autofrânare / cu oprire automată

self-stripping (textile) autocurățire, deburaj automat / continuu

self-styled autointitulat; pretins

self-sucking injector (termo, OM) injector autoaspirant

self-sufficiency (ec) autoaprovizionare, independență economică, autarhie, autonomie; selfsufficiencies $(p l),(\mathrm{adm}, \mathrm{ec})$ autoaprovizionare; îndestulare; (fig) încredere în sine; prezumție; înfumurare, îngâmfare

self-sufficient / -sufficing (ec) autarhic, autonom, independent din punct de vedere economic; care se autoaprovizionează; independent, autonom; (fig) (prea) încrezător în sine, înfumurat, îngâmfat, prezumțios

self-suggestion autosugestie

self-support independență; (de) autoîntreținere; (agr) de subzistență, independență

self-supported autonom, independent; autosusținut; automenținut

self-supporting (d. cineva) care se întreține singur, independent; (fiz) autoîntreținut, independent; (constr) autoportant; (OM, constr) care suportă singur o sarcină

self-supporting antenna tower (constr) pilon / stâlp de antenă neancorat

self-supporting insulation izolație autoportantă

self-supporting overhead cable (el, OM) cablu aerian cu autosustinere

self-supporting piston (termo) piston cu tijă, cu un singur reazem în chiulasa cilindrului

self-supporting steel stack (constr) pilon / stâlp suficient de rezistent pentru a nu avea suport lateral

self-supporting tank (OM, hidr, transp) cuvă autoportantă, tanc autoportant

self-supporting vault (constr, termo) boltă autoportantă

self-supporting wall (constr) zid autoportant

self-sustained autonom; autoîntreținut (d. un proces, un fenomen)

self-sustained discharge (fiz, el) descărcare (electrică) autonomă

self-sustained oscillation (fiz, mec) oscilație autoîntreținută self-sustained vibration (fiz, mec) autooscilaţie self-sustained vibrations (fiz, mec) autooscilații, oscilații proprii, vibrații autointreținute

self-sustaining chain reaction reacție în lanț autoîntreținută

self-sustaining independent

self-synchronizing (autom, mas) sincronizare automată

self-tapping screw (OM) şurub cu autofiletare, şurub pentru tablă

self-taught autodidact; autoinstruit; (pe care 1-a) învățat singur

self-testing autotestare; (inf, autom) testare automată a performanțelor unui echipament de calcul prin transmiterea unor probleme-test şi analizarea rezultatelor recepționate

self-threading eye (textile) ochi cu autoînşirare

self-timer autodeclanşator (la aparate fotografice), declanşator automat

self-timering descărcare (electrică) automată / spontană

self-torture autoflagelare; autotorturare

self-tuning (autom, metr) autoreglare (fină)

self-triggered program(me) program cu lansare automată

spring-type self-starter $(\mathrm{OM})$ demaror / starter / dipozitiv de pornire cu arc

self-unloading waggon ( $\mathrm{cf}$, met) vagon cu descărcare automată

self-ventilated (OM, mas) autoventilat, autorăcit self-ventilation $(\mathrm{TH})$ autoventilație

self-violence $($ fig) sinucidere

self-will încăpățânare, îndărătnicie; bun plac, samavolnicie

self-willed încăpătânat, îndărătnic

self-winding (OM) (d. ceas) cu întoarcere automată

self-wisdom părere (foarte) bună despre sine

self-wise cu o părere (foarte) bună despre sine; prezumțios; înfumurat

self worth respect de sine

sell (ec) a vinde; a desface; a face comert / negot $\mathrm{cu}$; a face reclamă; a populariza; a-şi face autoreclamă; a face vânzare; a se ocupa cu vânzarea; (d. o marfă) a se vinde; a se desface; (d. o idee etc.) a prinde, a avea succes; goods that do not $\sim($ ec) mărfuri care nu trec; $\sim$ goods retail (ec) a vinde mărfuri cu amănuntul; goods for cash (ec) a vinde mărfuri pe bani gheață; off (ec) a solda, a desface la preț scăzut

seller (ec) vânzător; lucru care se vinde / are căutare; succes de librărie, carte de succes

seller's market $(\mathrm{ec})$ (piață cu) cerere mai mare decât oferta 
selling (ec) (d. preț etc.) de vânzare / desfacere; vandabil; care are căutare; de succes; angajat ca vânzător

selling agent (ec) agent pentru vânzări

selling commission / brokerage (ec) comision asupra vânzărilor / la vânzări

selling costs (ec) cheltuieli cu vânzarea / cu desfacerea (produselor)

selling-off / out (ec) vânzare, desfacere

selling pressure (ec) afluență a ofertelor de vânzare selling price $(\mathrm{ec})$ preț de vânzare

selling rate (ec) curs de vânzare (a unei valute, a unei acțiuni etc.)

sell off (ec) a vinde cu rabat / cu pret redus

sell on (ec) a convinge, a îndupleca; a îmbia (să vândă, să cumpere)

sellotape (OM, ind chim) scotch, bandă adezivă; a lipi cu scotch

sell-out (ec) vânzare, desfacere

sell out (ec) a vinde tot (stocul etc.); a vinde la licitație; a trăda; a înşela (încrederea etc.)

sell up (ec) a vinde tot (stocul etc.); a vinde la licitație

seltzer (alim) apă gazoasă, sifon

selvage, selvedge (OM) muchie; (textile) tiv, margine, bordură

selvage $(\mathrm{OM})$ muchie, margine, bordură; cant; (textile) tiv

selvage-tension motion $(\mathrm{OM}, \mathrm{TH})$ mişcare de tensionare a marginilor

selves $(p l)$ de la self

sem. (med) prescurtare de la semicolon

SEM, scanning electron microscopy (fiz, metr) microscopie electronică / cu baleiaj electronic

semanteme semantem

semantic(al) (gram) semantic

semantics semantică, semasiologie

semaphore (auto) semafor; (mil) semnalizare cu două fanioane; a semnaliza cu semaforul / cu două fanioane

semasiological (lingv) semasiologic; semantic semasiology (lingv) semasiologie; semantică semblable aparent; asemănător, similar; potrivit, nimerit, cuvenit

semblance înfățişare (exterioară), aspect; formă; asemănare, similitudine; reproducere; copie; aparență; formă înşelătoare; under the of sub aparența

semblant aparent, înșelător; fals, contrafăcut seme (lingv) sem, semantem

semeiology semiologie, semiotică; (med) semio-

logie, simptomatologie

semeiotic (med) semiotic

semen, $(p l)$ semina (anat) spermă, sămânță semester (sem) (metr, univ, edu) semestru, unitate informală de timp, egală cu 6 luni, o jumătate de an sau o perioadă de studiu de $15 . . .21$ săptămâni

semestral semestrial

semester hour (sem hr) (metr, edu, univ) unitate pentru credite universitare, echivalentă cu 1 oră de predare pe săptămână

semi- (metr) semi, prefix pentru $1 / 2$ sau jumătate, la fiecare jumătate

semi-adder (ind chim) circuit de semiadiție

semi-annual bianual, semestrial

semiannually, twice a year $(a d v)$ de două ori de an semi-automatic (mas) semiautomat

semi-automatic advance (mas-un) avans semiautomat

semi-automatic arc welding machine (mas-un, met) maşină semiautomată de sudare cu arc electric

semi-automatic welding ( $\mathrm{TH}$, met) sudare semiautomată cu arc electric

semi-automatic clutch $(\mathrm{OM})$ ambreiaj semiautomat

semi-automatic control (autom) comandă semiautomată

semi-automatic controller (autom) regulator semiautomat

semi-automatic lathe (mas-un) strung semiautomat

semi-automatic mould (OM, mas-un) matriță semiautonată

semi-automatic multispindle lathe (mas-un) strung semiautomat multiax

semi-automatic welding ( $\mathrm{TH}, \mathrm{met})$ sudare semiautomată

semi-axis $(\mathrm{OM})$ semiosie; (geom) semiaxă

semi-axle $(\mathrm{OM})$ arbore (de) planetar

semi-basement (constr) demisol

semi-beam $(\mathrm{OM}$, constr, mec) grindă în consolă semibreve (metr, muz) unitate relativă de timp, egală cu o notă întreagă

semi-cantilever (wing) aripă cu contravântuire exterioară parțială

semi-chilled cast iron (met) fontă semi-dură

semicircle (geom) semicerc; (metr, geom) semicerc, unitate de măsură pentru unghiuri, egală cu $1 / 2$ dintr-un cerc, $\pi$ radiani sau $180^{\circ}$

semicircular (geom) semicircular

semi-coke (met) semicocs

semi-coking (met) semicocsificare

semicolon punct și virgulă

semi conductor (electr, materiale) semiconductor semi-conscious pe jumătate conştient semi-continuous semicontinuu 
semi-continuous broad strip mill (met) laminor semicontinuu pentru tablă lată

semi-continuos rolling mill (met) laminor semicontinuu

semi-continuous train (met) linie de laminare semicontinuă

semi-convergence (mat) convergență simplă

semi-cured (ind chim) semivulcanizat

semi-cycle alternanță, (mec) jumătate de ciclu (de solicitare)

semi-cylindrical (geom) semicilindric

semidetached, semi-detached (constr) casă având zid / perete comun cu alta, (d. o casă) despărțit de o altă casă printr-un zid / perete comun

semi-diameter (s.d.) (geom) rază

semi-Diesel engine (termo) motor cu cap incandescent, motor semi-diesel

semidiurnally, twice a day $(a d v)$ de două ori pe zi, la fiecare jumătate de zi

semi-drying oil (ind chim) ulei semisicativ semi-elliptical spring $(\mathrm{OM})$ arc semieliptic semi-ferritic steel (met) oțel semiferitic semifinal (sport) semifinală, de semifinală semifinalist (sport) semifinalist

semifinished ( $\mathrm{TH}$, ind) semifinit; semifabricat; semifinisat

semi-finished, semifinished ( $\mathrm{TH}$, ind) semifinisat semi-finished flat (met) oțel lat, platină, semifabricat plat (şi din oțel)

semi-finished goods (ind) articole semifabricate semi-finished material / product (ind) semifabricat

semi-finishing mill train (met) laminor pregătitor

semi-float (ind chim) cauciuc regenerat fără fibre textile

semi-fluid (materiale) semilichid, vâscos

semi-fluid consistency $(T)$ consistență semifluidă (d. unsori)

semi-fluid friction (T) frecare semifluidă

semi-gantry crane (transp, mas) macara semicapră

semi-gas firing (termo) încălzire cu semigaz

semi-girder $(\mathrm{mec})$ grindă în consolă

semi-Goliath crane (transp, mas) macara semiportal

semih (metr, med) abreviere pentru semihourly (every half hour); v. semihourly

semi-hard semidur (d. materiale)

semihourly (every half hour) ( $a d v)$ de două ori de oră, la fiecare jumătate de oră

semi-infinite (mat) semiinfinit

semi-infinite body / space (mat, fiz) semispațiu

semi-killed steel (met) oțel semicalmat semi-manufactured article / good / product (ind) semifabricat

semimechanical / semi-mechanised (ind) semiautomat, semimecanizat

semi-mild steel (met) oțel semi(-)moale

semimonthly, semi-monthly, twice a month $(a d v)$ de două ori de lună, chenzinal; ediție / revistă bilunară; bilunar, bimensual; de două ori pe lună

seminal (biol) seminal, germinal; (fig) germinal, embrionar

seminar (univ) seminar, sală de seminar

seminarian (edu) seminarist

seminarist (edu) seminarist (romano-catolic)

seminary seminar (teologic) (romano-catolic); seminar (teologic) (pt. alte confesiuni); (edu) şcoală secundară particulară pentru fete; seminar; (agr) pepinieră; focar

seminate (bot, agr) a semăna, a răspândi

semination răspândire, difuzare (a cunoştințelor etc.); (biol) (di)seminație, diseminare

semi-occlusive semioclusiv

semiology $v$. semeiology

semi-oscillation (fiz, autom, mec) alternanță, jumătate de oscilație

semiotics semiotică

semi-opaque (materiale) semi-transparent

semi-pasty slag (met) zgură vâscoasă

semi-plant (ind, TH) instalaţie semiindustrială

semi-portal crane (transp, mas) macara semiportal

semiprecious semiprețios (d. metale, pietre)

semi-product (ind) semifabricat

semiquaver (metr, muz) (notă) şaisprezecime, unitate relativă de timp, egală cu 1/16 dintr-o notă întreagă

semi-radial drilling machine (mas-un) maşină de găurit radială, semi-universală

semi-rigid (mec, fiz) semirigid

semi-rigid plastic (plast) material plastic semirigid (cu modul de elasticitate aparent de $\sim 70 \ldots 700 \mathrm{MPa})$

semi-rimming (met) semi-calmat

semi-rimming steel (met) oțel semi-calmat

semi-rotary actuator (OM, hidr) motor / sistem de actionare oscilant / balansier

semi-rotary pump (OM, hidr) pompă semirotativă

semis (ind) (produse) semifabricate, materiale semifinite / semifinisate

semi shrouded $(O M)$ semideschis

semi-sintered (materiale) semiaglomerat, semisinterizat

semi-smooth-cut file (mas-un) pilă semifină 
semi-solid consistency consistență semi(-)solidă (d. unsori)

semi-solid substance (fiz) substanță semi(-)solidă semisphere (geogr) emisferă semispherical (geogr) semisferic

semi-stable (ind chim) emulsie de bitum semistabilă

semisteel (met) fontă cu structură fin-perlitică / oțelită

semi-suspended roof (met, constr, termo) boltă semisuspendată (a unui cuptor)

semi-synthetics produse semisintetice

semite semitic

semitic semitic; limbi semitice

semitism semitism

semitone (muz, metr, fiz) semiton, unitate pentru a descrie raportul între frecvențele a două note, cu două variante; a) - două note diferă pritr-un semiton dacă cea mai înaltă are frecvența $16 / 15=1,0667$ ori frecvența celei mai joase; b) - sinonim pentru jumătate de pas în scări monocromatice standard, raportul frecventelor fiind $2^{1 / 12}=1,0595$

semi-traverse axis $(\mathrm{OM})$ axă reală

semitropical (geogr) subtropical

semi-ultra accelerator (fiz) accelerator semiultrarapid

semivowel (lingv) semivocală

semi-water gas (termo) gaz de apă, sărac

semiweekly $(a d v)$ de două ori pe săptămână; care apare de două ori pe săptămână, bisăptămânal; publicație bisăptămânală

semiweekly newspaper revistă cu apariție de două ori pe săptămână

semolina (alim) griş

sempstress (textile) cusătoreasă

semsem sesame (alim)

sen (ec) monedă în Indonezia, Japonia, Kampuchia

senary format din şase părți / elemente

senate (pol, univ) senat

senator (pol) senator

senatorial (adm, pol) senatorial, de senat, al senatului, având dreptul de a participa la alegerile pentru senat

senatorship (adm, pol) calitate de senator; durata mandatului de senator

send a trimite, a expedia; a transmite; a adresa; a arunca, a azvârli; a face, a îndrepta; a trage; (radio, TV) a transmite, a difuza; a aduce întro anumită stare; a face; a porunci; a remite; (fiz, radio) a emite; impuls, avânt; (nav) forță, impuls (al valurilor)

send after a chema, a trimite după send along a trimite (mai repede)

send away a trimite (în altă parte) (la studii, la specializare etc.); a da afară, a goni; a izgoni

send away for (ec) comanda prin poştă (produse) send down a reduce, a scădea, a micşora (prețuri, temperatura etc.); a trimite în jos (fumul etc.); a trimite, a distribui (unităților etc. în subordine); (univ) a exmatricula (pt. conduită proastă); (ec, adm) a trimite un mesaj / un ordin etc. unei unităţi etc. în subordine

sender trimițător; expeditor; transmițător; (fiz) emițător de impulsuri; manipulator; (OM) buton sender manipulator

send for a chema (doctorul etc.), a trimite după; (ec) a comanda (o marfă), a face o comandă de send forth (bot) a da (frunze etc.), a produce; (fiz) a emite (raze etc.), a emana

send forward a transmite

send in a da, a prezenta (o declarație, demisia etc.); for a expune, a prezenta (la o expoziție) send-off impuls, avânt; (bune) urări (la despărțire, la numirea cuiva într-o funcție etc.); recenzie laudativă

send off a trimite, a expedia (o scrisoare etc.); a alunga, a da afară; a conduce, a însoți (pe cineva care pleacă)

send out a expedia; a distribui; v. send forth

send out a emite

send up a trimite în sus

Senegal (geogr) stat în Africa; the fluviu în Africa

Senegalese (geogr) senegalez

senescence (anat) bătrânețe, senilitate

senescent (anat) care îmbătrâneşte

senile senil; bătrân

senility senilitate; bătrânețe

senior senior; mai în vârstă; bătrân, persoană mai în vârstă; (univ) student în ultimul an; persoană importantă / marcantă

seniority vârstă mai mare; vechime mai mare în muncă / în serviciu

senna (bot) siminichie; (med) foi de siminichie sennit (nav) tresă, salamastră, parâmă împletită sensation (med, anat) senzație; senzație, simțire, sentiment; senzație, impresie; vâlvă, emoție

sensational senzațional, de senzație; extraordinar; (anat) senzorial, senzitiv; senzual

sensationalism goană după senzațional; senzualism

sensationalist autor de cărți de senzație; senzualist; persoană dornică de senzațional sensationalize a trata ca pe ceva senzațional sensationally ( $a d v)$ (în mod) senzațional sensation-monger colportor de ştiri senzaționale 
sense (anat) simț; $(p l)$ minte, judecată, luciditate; simț (al umorului etc.); simț, sentiment (al datoriei etc.); conştiință; judecată; înțelepciune; rost; sens, înțeles, accepțiune; sens, direcție; orientare; tendință; (fig) sens, esență (a unui enunț etc.); (fig) dispoziţie, stare de spirit, puls; a simți, a-şi da (vag) seama de / că; a pricepe, a înțelege; (d. aparate) a înregistra, a detecta; a examina după un criteriu

sensed within a distance of (auto) sesizat / observat / detectat până la o distanță de

senseful plin de sens / înţeles / semnificaţie

senseless ( $a d j)$ fără sens / înțeles; necugetat, nesăbuit; prost; prostesc; nebunesc; nesimtitor; căzut în nesimțire; leşinat

senselessly $(a d v)$ (în mod) necugetat, prostește senselessness lipsă de sens / înțeles; nesăbuință; prostie; nebunie; nesimțire, lipsă de simțire; (stare de) nesimțire; leșin

sense of direction $(\mathrm{TH})$ sens, orientare

sense of rotation (mec, OM) sens de rotatie

sense organ (anat) organ senzorial

sensibility sensibilitate; simțire; emotivitate; sensibilitate (a unui aparat); acuitate a simţurilor; $\sim \mathbf{s}(p l)$ susceptibilitate

sensible rațional, cu judecată; inteligent; practic; logic; cuminte; mare, considerabil, apreciabil, sensibil (la un stimul, cum ar fi lumina etc.); perceptibil, perceput prin simțuri; simțitor; emotiv

sensible heat (termo) căldură proprie / percepută; (metr) căldură care determină o schimbare a temperaturii (sesizabilă de un aparat)

sensible heat (air) cooler (termo) aerorăcitor fără dezumidificare, răcitor de aer cu (transfer de) căldură sensibilă

sensible heat ratio (termo) coeficient de căldură sensibilă (al unui răcitor de aer)

sensible horizon orizont aparent

sensible of conştient de, care-şi dă seama de

sensibly $(a d v)$ (în mod) apreciabil, considerabil; (în mod) rațional; inteligent; înțelept

sensing (fiz, metr, autom) detectare, analiză, care detectează / analizează; (inf) citire, care cireşte (d. un subprogram etc.)

sensing bulb (metr, termo) bulb / rezervor termostatic, element sensibil al unui termometru

sensing component element sensibil

sensing device / element (metr, fiz) captor, detector, element sensibil, traductor /ca modul intr-un aparat)

sensing element (metr, fiz) element sensibil sensing head (metr) cap de măsurare / explorator, (cap) palpator sensing member (metr, fiz) element sensibil sensing probe (metr) cap (de măsurare) sensitivation sensibilizare

sensitive de precizie; sensibil; simțitor; impresionabil; emotiv; (anat) (d. piele etc.) sensibil; prea sensibil, susceptibil; supărăcios; (OM) de precizie, precis; (mas-un) cu avans manual; (fiz) fin, sensibil

sensitive adjustment (autom, OM, metr) ajustare / reglareprecisă / fină

sensitive bulb (metr) parte sensibilă a unui termometru

sensitive drill machine (mas-un) maşină de găurit cu avans manual, maşină de găurit de precizie

sensitive region (metr) interval de sensibilitate; regiune / zonă sensibilă

sensitive time perioadă de funcționare (d. maşini, aparate etc.)

sensitive to heat sensibil la căldură (d. materiale, aparate, elemente de mașini etc.)

sensitive control (autom, OM) comandă manuală, reglare sensibilă; (mas-un) comandă manuală, comandă precisă

sensitive drilling machine (mas-un) maşină de găurit, cu avans manual

sensitive element $(\mathrm{OM})$ sondă, element sensibil (într-un aparat de măsură)

sensitive (hand) feed (mas-un) avans manual

sensitively $(a d v)$ cu sensibilitate; cu susceptibilitate; (TH, metr) cu precizie

sensitiveness sensitivity sensibilitate

sensitiveness of the reading (metr) precizia indicațiilor unui instrument de măsurat

sensitiveness to percussion sensibilitate la şoc (d. materiale, maşini)

sensitiveness to tapping sensibilitate la şoc / la batere (d. materiale, maşini)

sensitive part $(\mathrm{OM})$ piesă de siguranță (şi cu durabilitate limitată) a cărei rupere nu afectează serios funcționarea / repornirea sistemului

sensitive plant (bot) plantă sensibilă, senzitivă

sensitive to corrosion (materiale) sensibil la coroziune

sensitive to heat (d. materiale, aparate, elemente de maşini etc.) sensibil la căldură

sensitive to overheating (met, plast) sensibil la supraîncălzire

sensitive to red light (plast) sensibil la lumina roşie

sensitive to shock (materiale) sensibil la şoc

sensitivity (metr, autom) sensibilitate, finețe, precizie; (ec) reacție la recompense şi penalizări; sensibilitate 
sensitivity area (metr, autom, mas) interval / zonă de sensibilitate (pt. un parametru etc.)

sensitivity control (metr, autom) reglarea sensibilității (d. aparate)

sensitivity of deflection (mec) sensibilitate a deviației

sensitivity switch (metr) comutator de sensibilitate

sensitivity to ageing (materiale) sensibilitate la îmbătrânire (inclusiv lubrifianți, vopseluri etc.)

sensitivity to hardening (met, plast) sensibilitate la călire / la durificare

sensitivity to percussion (materiale) sensibilitate la şoc / la lovire

sensitivity to temperature (alim, materiale) sensibilitate la temperatură

sensitivity to welding cracks (met, plast) sensibilitate la fisurare în timpul sudării

sensitisation, sentivization (amer) sensibilizare

sensitize a sensibiliza

sensitized stainless steel (met) oțel austenic inoxidabil, mai sensibil la medii agresive din cauza depunerii carburii de crom la marginea grăunților

sensor (OM, fiz, metr) traductor, senzor

sensorial v. sensory

sensory (anat) senzorial

sensual senzual; v. sensory

sensualism senzualitate; senzualism

sensualist senzual, persoană senzuală; senzualist

sensualistic senzual

sensuality senzualitate; lascivitate; lubricitate

sensuous senzual, senzorial; care apelează la simțuri; estetic

sensuously $(a d v)$ prin simțuri; cu simțurile; estetic sensuousness senzualitate, sensibilitate senzorială; plăcere estetică

sent trimis, expediat

sentence (jur) sentință, verdict, a condamna; (gram) propoziție, frază; maximă

sentence (gram) propoziție, frază; raționament; afirmație; maximă; (inf) propoziție, frază; (jur) sentință, verdict, a condamna, a da o sentință

sententious sentențios; emfatic; plictisitor; plin de sentințe

sententiously $(a d v)$ sentențios, emfatic

sentience simțire; facultatea de a simți, sensibilitate

sentient simtitor; conștient

sentiment sentiment, simțământ; simțire; atitudine; dispoziție; punct de vedere; sensibilitate; patos; participare; sentimentalism

sentimental (d. cineva) sentimental; emotiv; duios; (fig) dulceag sentimentalism sentimentalism

sentimentalist sentimental, persoană sentimentală sentimentality sentimentalitate; sentimentalism sentimentalize a se comporta ca un sentimental, a sentimentaliza

sentinel (metr, mas) aparat de supraveghere; marcă; semn; (inf) simbol separator (la limbaje de programare); v. sentry; stand $\sim$ a sta de pază

sentinel pyrometer (metr, termo) con Seger / pirometric

sentinel plant (ind, met) instalație de rezervă sentry (mil) santinelă; strajă; pază; keep a sta de pază / strajă

sentry box (mil) gheretă (a santinelei)

sentry-go (mil) serviciul de gardă

Seoul (geogr) capitala Coreii de Sud, Seul

Sep. prescurtare de la September

sepal (bot) sepală

sepalous (bot) cu sepale

separability separabilitate, caracter separabil

separable $(\mathrm{OM})$ demontabil, separabil

separate separat; împărțit; diferit, deosebit, special, distinct, individual, particular; independent, autonom; izolat, retras, despărțit; a separa, a despărţi; a alege; apune de o parte; a sorta; a izola, a detaşa, a desprinde; a clasifica; (poligrafie) a despărți (cuvinte) în silabe; a împărți, a diviza; a (se) despărti, a se separa, a se izola, a se detaşa, a se desprinde; a divorța; $(\mathrm{OM})$ a demonta; (chim) a descompune

separate applicatin adhesive (plast, chim) adeziv cu aplicare separată

separate as a flocculent $(\mathrm{TH})$ a separa cu agent de flocurare (d. minereuri)

separate drive (mas) acționare individuală / separată

separate end-condition (fiz) condiții speciale la extremități

separate in flakes (ind chim) a coagula sub formă de fulgi / solzi

separate individual, separat

separate into layers a separa în straturi

separate into parts a separa în părți / elemente (componente)

separate lubrication $(T)$ ungere locală / separată (pt. un subansamblu)

separate lubricator $(\mathrm{T}, \mathrm{OM})$ ungător pentru ungere locală

separately controlled $(\mathrm{OM})$ cu comandă individuală

separate out a sorta, a scoate

separate phase (ind chim) fază separată (deja)

separate plant (ind) instalație separată / independentă 
separate tar (ind chim) a degudrona separate ventilation (ind) ventilație separată separating care (se) separă, separator separating agent (alim, ind chim) agent de precipitare / de separare, precipitant

separating bath (alim, ind chim) baie de separare

separating bowl $(\mathrm{OM})$ coş / rotor al centrifugei separating capacitor (alim, ind chim, termo) condensator de separare

separating capacity $(\mathrm{TH})$ capacitate de separare / de sortare (la centrifugă, la separator)

separating column (alim, ind chim) coloană de separare

separating cylinder $(\mathrm{OM})$ cilindru separator separating dam (constr, hidr) dig de separatie separating device (OM, alim, ind chim) separator separating factor (OM, alim, ind chim) factor de separare

separating filter (OM, alim, ind chim) filtru de separare

separating flask (OM, alim, ind chim) separator florentin

separating funnel (OM, alim, ind chim) pâlnie de separare

separating line linie de delimitare / de separare; (OM, constr, met) rost de delimitare / de separare

separating machine (alim, ind chim) maşină de separat / de porționat

separating of grease (chim) sinereza unsorii consistente

separating plate (textile) antibalon (la maşina de filat cu inele); (OM) placă separatoare

separating point (TH, mat) punct despărțitor

separating process $(\mathrm{TH})$ proces / procedeu / metodă de separare

separating screen $(\mathrm{OM})$ sită de separare / de sortare

separating shears (mas-un) foarfece de debitat / de tăiat

separating strength $(\mathrm{TH})$ rezistență la separare, rezistență la smulgere (d. materiale, componenți etc.)

separating sump (constr, alim, mediu) bazin de limpezire / de separare / de decantare

separating tank (constr, alim, mediu, OM) bazin /tanc de decantare, decantor

separating thread (textile) fir de separare (la tesături, compozite etc.)

separation despărțire, separare; alegere; sortare; izolare; detaşare, desprindere; clasificare; (poligrafie) despărțire în silabe (a cuvintelor); împărțire, divizare; despărțire, separație; divorț separation allowance (jur) diurnă, pensie după divort

separation by dilution $(\mathrm{TH})$ separare prin diluare separation coefficient $(\mathrm{TH})$ coeficient de separare

separation efficiency (alim, ind chim, met) eficiența separarării

separation factor $(\mathrm{TH})$ factor de separare

separation joint (OM, constr) rost de separare (în construcții şi la sudură)

separation machine (ind chim, alim, constr, met) maşină / instalație de separare

separation of crystals (chim, met) separare a cristalelor

separation of graphite (met) grafitizare separation of mixtures (ind chim, fiz) separare a amestecurilor

separation process $(\mathrm{TH})$ proces / procedeu / metodă de separare

separation sharpness $(\mathrm{TH})$ precizia / acuratețea procedeului de separare

separation size $(\mathrm{TH}$, fiz) mărime / dimensiune de separare / de la care se separă (d. particule, picături care trebuie separate)

separation strength (materiale) rezistență la smulgere / la separare

separatist (pol) separatist

separator $(\mathrm{OM})$ separator; (agr) sită, trior; (ind chim, mediu) aparat de separare / epurare

separator box (OM, hidr, fiz, mediu) capcanăseparator

separator disk $(\mathrm{OM})$ disc de separare, discseparator

separator drain valve (OM, hidr, mediu) supapă de epurare / de separare, epurator

separator for dust (ind, mediu) separator de praf, ciclon colector, filtru de praf

separatory $(\mathrm{OM})$ separator, despărțitor

separatrix (poligrafie) semn de despărțire

sepia, $(p l)$ sepiae (zool) sepia; (chim) sepia; (de culoare) sepia

sepsis (med) septicemie, stare septicemică

sept clan (în Irlanda)

September septembrie

septennium (metr) unitate de timp, egală cu 7 ani septentrional (geogr) septentrional, nordic

septet(te) (muz) septet; (metr) unitate pentru cantitatea de 7 (articole identice etc.)

septic (med) septic

septic(a)emia (med) septicemie

septic tank (hidr, constr, mediu) fosă septică

septuagenarian septuagenar

septum, $(p l)$ septa (anat) sept; (OM) perete despărțitor; membrană 
septuple, septuplet (metr) grup de 7 articole (în special identice); grup de 7 persoane

sepulchral sepulcral; mormântal, de mormânt sepulchre mormânt; cavou; înmormântare sepulture înmormântare, îngropăciune; mormânt; cavou

seq. prescurtare de la sequel - următorul, următoarea şi sequentes, sequentia - următorii, următoarele; v. sequel, sequentes, sequentia

sequel urmare, continuare; consecință, rezultat sequela, $(p l)$ sequelae (med) sechelă

sequence succesiune, şir, ordine, înşiruire; secvență; in în succesiune, la rând, unul după altul; v. sequel; secvență; episod

sequence circuit (hidr, autom) circuit de servocomandă

sequence valve (OM, hidr) supapă de succesiune

sequence of events derularea / succedarea / succesiunea evenimentelor

sequence of operation $(\mathrm{TH})$ proces tehnologic, succesiunea operațiilor tehnologice

sequence of passes (met) succesiunea trecerilor (la laminare)

sequence of tenses (gram) corespondență / concordanţă a timpurilor

sequencer (autom, inf) ordonator

sequencing succesiune (în timp), care se succed (în timp); (proces) secvențial, cu ordine de succedare, unul după altul

sequent următor; rezultat, care rezultă; v. sequel sequentia, sequentes $(p l)$ următorii, următoarele sequential consecvent; care urmează (după altul); continuu; secvential

sequential life test (metr, mas, materiale) test de durabilitate în care numărul de epruvete / căderi nu este dinainte stabilit; concluziile şi deciziile depind de datele acumulate; (rezultatele pot fi: a) criteriile de acceptabilitate sunt îndeplinite, b) nu sunt îndeplinite şi c) rezultate încă neconcludente și testul trebuie continuat)

sequentially $(a d v)$ (în mod) consecvent; consecutiv; obey $\sim$ (inf) a executa în mod secvential / una după alata (în prelucrarea datelor)

sequential scanning (fiz, autom) explorare continuă / secvențială

sequester (jur) a sechestra; a confisca; a izola, a îndepărta; a separa; from a se izola de, a se retrage din

sequestered (d. viață, locuri etc.) retras, liniştit

sequestrate a sechestra; a confisca

sequestration (jur) sechestrare, confiscare, sechestru; retragere; izolare; (med) izolare, carantină

sequin (textile) paletă, fluturaş sequoia (silv) arbore (de) seq(u)oia

ser (metr) v. seer

ser. (mat) prescurtare de la series; $\mathbf{v}$. series

sera $(p l)$ de la serum; v. serum

Serb sârb; (limba) sârbă; sârb(esc)

Serbia (geogr) Serbia

Serbian (adj) sârb, sârbesc

Serbo-Croatin sârbo-croat

sere uscat; (bot) ofilit,veştejit, veşted (d. plante)

serendipity însuşirea de a găsi obiecte interesante / de valoare

serene senin; liniştit

serenely $(a d v)$ senin, cu seninătate

serenity senin, liniște; seninătate

Sereth (geogr) râu în România, Siret

serge (textile) serj

sergeant (mil) mil sergent; (jur) aprod; (adm) ofițer de poliție, polițist; comisar (grad inferior inspectorului de poliție)

sergeant-at-arms, serjeant-at-arms (adm) aprod, supraveghetor al ordinii (în unele instituții)

sergeant major (mil) grad intermediar între subofițer şi ofițer; plutonier major

sergeant of the guard (mil) sergent ajutor al comandantului gărzii

serial în serie; (mat) curent, înseriat; roman serial / în serie; (film) serial; serie de articole

serial development (mat) dezvoltare în serie

serialize a publica / transmite în serie; a aranja / dispune în serie / serii

serially $(a d v)$ consecutiv, succesiv; în serie

serially connected (el, hidr) legat în serie

serially ordered set (mat) mulțime ordonată

serial number $(\mathrm{OM})$ număr de uzină, cod de produs cu număr distinct pentru fiecare produs serial production (ind, $\mathrm{TH}$ ) productie în / de serie serial testing (metr, $\mathrm{TH}$ ) încercare în serie

serial transmissions (mec, $\mathrm{OM}$ ) transmisii legate în serie

seriate(d) de serie; periodic; aşezat unul după altul / în ordinea succesiunii

seriatim în serie; unul după altul; punct cu punct seriation aşezare în serie, înseriere

sericultural (agr) sericicol

sericultural (agr) sericicultură

sericulturist (agr) sericicultor

series, $(p l)$ series $(\mathrm{TH})$ (în) serie, şir, rând; succesiune, gamă; (poligrafie) garnitură (de litere); secvenţă; suită; scară; înlănțuire; in în serie; în lanț; (poligrafie) garnitură (de litere); (mat) serie, şir, progresie; (el) legare în serie (a amorselor)

series-arc welding $(\mathrm{TH}$, med) sudare $\mathrm{cu}$ electrozi legați în serie 
series cascade action (autom) acțiune în serie a unui parametru de intrare asupra modulelor (înseriate) ale unui circuit de comandă / reglare

series connected (mec, el, autom) legat în serie series copper refining (met) (procesul / tehnologia de) afinare / rafinare succesivă a cuprului series expansion (mat) serii / şiruri divergente series flow control valve (OM, hidr) regulator de debit în serie

series (of fabricated products) (ind, $\mathrm{TH}$ ) serie de fabricatie

series of measurements (metr) şir de măsurări

series-parallel arrangement (mec, autom, el) conexiune de grupări în serie şi în paralel

series ratio (hidr) factor serie, număr de componente montate în serie

serif picioruş, cârlig (de literă)

serio-comic(al) serios şi comic / glumeț totodată; tragi-comic

serious serios; sobru; grav; solemn; aşezat, ponderat; sever, rigid; pozitiv, real, adevărat; sincer; grav; periculos; cu care nu e de glumit; important; (d. o lucrare etc.) serios, profund, adânc

serious injury (med) rană gravă, răni grave seriously $(a d v)$ (în mod) serios; cu seriozitate; serios; grav (bolnav etc.)

serious-minded (d. cineva) cu intenții / preocupări serioase; serios

seriousness seriozitate; caracter serios / grav; gra-vitate; importanță

serjeant(-at-arms) (adm) supraveghetor al ordinii (în instituții); (jur) aprod

sermon predică; predică, lecție, morală

sermonize a predica; a tine o predică / predici; a face morală

serology (biol, chim) serologie

serous (biol) seros

serous membrane (biol) membrană seroasă

serpent (zool) şarpe; şarpe, viperă, năpârcă

serpentine (geol) serpentin( $\breve{a})$; de şarpe; (fig) ca de şarpe; şerpuit; cu multe cotituri; întortocheat; sinuos

serpentry şerpi; crescătorie de şerpi; serpentină; şerpuită

serpigo (med) lupus

serra, $(p l)$ serrae (iht) peştele ferăstrău

serrate a tăia în zigzag; (bot) serat

serrated (bot) serat

serrated hub $(\mathrm{OM})$ butuc cu caneluri

serrated wheel hub $(\mathrm{OM})$ butuc de roată, canelat

serrating $(\mathrm{TH})$ zimțare

serration $(\mathrm{OM})$ dantură, zimțuri serration hob (mas-un) freză melc de prelucrat arbori canelați

serried strâns; înghesuit; compact; umăr la umăr serum, $(p l)$ sera (anat, med) ser, limfă; (alim) zer

serval (zool) serval

servant servitor, slujitor, slugă; your humble al dvs. (prea) devotat (formulă folosită uneori în scrisorile oficiale); functionar

serve a munci / lucra la / pentru; (fig) a sluji (patria etc.); a servi; a fi folositor; a fi de ajutor (cuiva); a servi (masa etc.); a da; a aduce; a servi (un musafir, un client); a deservi (populația etc.); a aproviziona; a trata (pe cineva); a se comporta / se purta cu; (fig) a trece prin; a-şi face (ucenicia etc.); a deservi (două circumscripții etc.); a funcționa la / în; (adm) a fi funcționar etc. la / în; a corespunde (unui scop etc.); a servi (unui scop etc.); a fi; a sluji; a funcţiona; (mil) a-şi face serviciul militar / armata; a fi militar, marinar etc.; a fi de folos / folositor; a fi de ajuns / suficient; a fi favorabil / prielnic; as occasion s când se va ivi prilejul / ocazia; a servi (la masă etc.); (sport) serviciu

serve as a servi de/drept/ca, a fi folosit ca

serve for serve as a fi bun de / pentru

serve out a i-o plăti (cuiva)

server persoană care servește / slujește; servitor; slujitor; (OM, alim) tavă, platou

serve up a servi (la masă)

service serviciu; slujbă; funcție; muncă; lucru, a fi angajat, ajutor, sprijin; favoare; folos; (fig) dispozitie, ordin, ordine; (mil) (gen de) armă (infanterie etc.); (ec) servire, deservire; serviciu, servire (la masă); serviciu (de cafea etc.); (sport) serviciu; (jur) înştiințare; aviz; publicare; (TH) serviciu; deservire, reparatii curente, exploatare, regim; (adm) a deservi (un district etc.); (TH) a întreține (o maşină etc.); a face revizia şi reparațiile curente (unei maşini etc.); exploatare; regim (de lucru); întreținere, reparatii curente; deservire, a repara; (termo) a alimenta cu combustibil

serviceable folositor, util; (d. haine etc.), rezistent, durabil; (mas) care se poate repara / întreține, care este gata de a intra în funcțiune (după efectuarea reparațiilor, testelor etc.)

serviceable life (mas, OM) durată de funcționare

serviceableness folos, utilitate; durabilitate, rezistentă, trăinicie

service brake $(\mathrm{OM})$ frână de picior / de serviciu service bridge (OM, constr) pasarelă / estacadă de serviciu 
service ceiling (constr) plafon practic service condition(s) (mas) condiții de funcționare / de exploatare / de utilizare service dress (textile) ținută de serviciu service entrance (constr) intrare de serviciu; intrare pe din dos / din spate

service factor (mas) factor de utilizare / de funcționare a utilajului (exprimat ca timp efectiv de exploatare raportat la timpul total al utilajului)

service gallery (ind) platformă de deservire

service gangway (constr) pasarelă

service instructions regulament de funcționare

service interruption ( $\mathrm{TH}$, mas) avarie, deranjament, pană, întrerupere în funcționare, instrucțiuni de lucru (d. maşini, utilaje etc.)

service lead (el) branşament electric

service life (OM, mas) durata de viață (a unei lucrări, a unei piese sau a unui subansamblu), durabilitate

service load (mas) sarcină utilă, sarcină din exploatare / în funcțiune

serviceman (mil) militar; soldat, ostaş

service part $(\mathrm{OM})$ piesă de schimb

service performance (mas, OM, materiale) performanțe în funcționare

service pit (met) canal de reparație

service platform (ind) platformă de deservire

service port (hidr, OM) orificiu de ieşire

service position $(\mathrm{OM})$ poziție de functionare

service pressure (hidr) presiune de serviciu / de lucru

service road (constr) drum provizoriu / de şantier service section (ind) secție de exploatare

service shop (ind) atelier pentru reparatii curente

service speed (mas) viteză de funcționare / de lucru

service stairs (constr) scară de serviciu

service station (auto) stație service de întretinere; (ind) atelier de reparații; (amer) stație de benzină

service stress condiți de lucru; (mec) tensiuni / eforturi în funcționare

service test (mas) încercare în exploatare

service time (OM, mas) durată de viață

service tools (OM, mas-un) scule folosite pentru lucrări de reparații

service water (OM, hidr, mediu) apă de exploatare / industrială / tehnică

service woman (mil) femeie care face parte din fortele armate

servicing (ind, TH) întreținere; deservire; mânuire

servient (adm) subordonat; dependent serviette şervețel (de masă)

servile servil, slugarnic; linguşitor; captiv servilely $(a d v)$ (în mod) servil, slugarnic servility servilism, slugărnicie, servilitate serving porție; bucată (de tort etc.); (OM) înveliş (protector), garnitură de etanşare; îmbrăcăminte; (el) izolație

servitor servitor; însoțitor

servitude servitute; obligație, constrângere servo (autom, mas) servomecanism, servomotor servo-amplifier (autom) servoamplificator servo-assisted brake $(\mathrm{OM}$, autom) servofrână servo-assisted steering (OM, autom) servodirectie

servobrake (OM, autom) servofrână

servo circuit (autom, hidr) circuit cu buclă închisă / cu autoreglare, servocircuit

servo-clutch $(O M$, autom) servoambreiaj

servo-control (OM, autom) servomecanism

servo-controlled (OM, autom) servocomandat

servo-drive (OM, autom) actionare prin servomotor

servo-engine (autom, mas) servomotor

servo-loop (autom) circuit de reglare automată

servo-lubrication ( $T$, autom) ungere centrală, cu reglare automată

servo-mechanism (OM, autom) servomecanism servomotor (autom, mas) servomotor

servo operated valve (autom, $O M$, hidr) ventil cu servomotor

servorudder (nav, autom) servocârmă

servospeed control (autom, mas) servocomandă a vitezelor

servo-steering (autom, OM, hidr) servodirecție servosystem (autom, mas) sistem de reglaj, servosistem

servo unit (autom, mas) servomecanism

servovalve (hidr, OM, autom) servovalvă

sesame (bot, alim) susan

sesame-oil (alim) ulei de susan

sesquioxide (chim) sescrioxid

session (pol) sedintă, sesiune (a parlamentului etc.); conferință; (univ) an universitar / academic; (amer) semestru; (edu) an școlar, școală, lecții, cursuri, curs, lecție; oră; şedință (de lucru, în orice sferă de activitate); bătaie de cap; întrevedere neplăcută, discuție

sessional de şedință / sesiune; care are loc în fiecare perioadă etc.

sester (metr) unitate britanică veche de măsură pentru volum (de miere): 1 sester $\sim 7,51$

sestet (metr) o altă denumire pentru sextet, o unitate pentru cantitate de 6; (muz) un ansamblu de 6 instrumente 
set set; garnitură; echipament; aparat; agregat; ansamblu; serie; sortiment; aşezare; poziție (a capului etc.); trusă; (sport) (tenis) set; (fig) curent, tendință, (a opiniei publice etc.), direcție (a unui curent etc.); (ec) scrisoare (comercială etc.); (alim) serviciu (de cafea etc.), garnitură; grup, cerc; așezat; fixat; complet; bine stabilit; a aşeza; a pune; a întinde; a îndruma; a impune; a potrivi (la un montaj); a stabili (o pozitie a unei maşini, o dată etc.); a monta (o piesă, piatră prețioasă etc.); a înțepeni; a situa; a aranja; a fixa (o piesă, o dată etc.); (OM, TH) a recondiționa; a pune (în libertate etc.); in order a pune în ordine; a ordona, a aranja; a pune în ordine, a regla; a face să meargă / funcționeze (ceasul etc); a indica, a arăta; a repara (un mecanism); a ajusta, a regla, a acorda, a potrivi; (agr) a sădi (o plantă), a semăna, a însămânța, a planta, a pune, a aşeza (cloșca pe ouă); a introduce; avârî, a băga, a înfinge (un țăruş etc.), a împlânta; a ascuți (coasa etc.); a îndrepta, a dirija; a întoarce; a răsuci; a trasa; a pregăti, a aranja (scena etc.); a găti, a înfrumuseța, a împodobi; (tipografie) a culege o pagină; (teatru) a monta; a presăra (cu); a determina (poziția) cu busola; a întinde (o cursă); a pune / îndemna (să facă); a pune pe cineva pe urmele cuiva; (d. vânt, curenți de apă) a începe; (d. faimă, zvon) a se stinge; (fig) (d. aştri) a dispărea; (fig) a ațața, a da importanță (unei probleme); (adm) a pune, a aplica (ștampila etc.); a strânge din (dinți); (ec) a fixa, a stabili (valoarea, prețul etc.); a dispune; a da (o sarcină, un exemplu etc.); (muz) a pune pe note, a scrie partitura pentru; (poligrafie) a culege, a zețui; (mai rar) (nav) a întinde, a desfăşura (velele); aşi face (părul), a (se) coafa; a introduce (o modă, un stil etc.); a pune în circulație (idei etc.); a face să nu mai funcționeze, a opri (un mecanism etc.); (zool) (d. păsări) a sta pe ouă, a cloci; (d. ciment etc.) a se întări, a se solidifica; (alim) (d. lapte etc.) a se coagula, a se prinde, (d. albuşul de ou) a se coagula; (d. față) a căpăta o expresie rigidă; (d. o culoare etc.) a se fixa; a prinde; a prinde formă; a se contura; a se modela; (d. soare, lună etc.) a apune, a asfinți; a porni, a pleca, a se duce, a merge; a se îndrepta, a se dirija, a avea direcția (spre nord etc.); (textile) (d. o haină etc.) a sta, a şedea, a veni bine; (bine, rău etc.); (bot) (d. un răsad etc.) a prinde; a se dezvolta; (med) a pune la loc (un braț luxat), (d. un os rupt) a se suda, (d. un cadavru) a întepeni; (d. privire etc.) fix; nemișcat; rigid; stabilit (dinainte), prestabilit; fixat dinainte; premeditat; intenționat; of $\sim$ purpose premeditat, cu premeditare, dinadins; (d. un discurs etc.) redactat, pregătit etc. dinainte; (d. vreme) neschimbat, stabil; ferm, hotărât, neclintit; (d. soare etc.) care a apus / asfințit, apus de soare; (d. cineva) construit, clădit; consistent; solidificat; întărit; (alim) (d. lapte) coagulat; gata, pregătit; direcție, sens; mers, curs; tendință, înclinație; puls; (constr) (d. ciment) a face priză; (geogr, constr) contur, configurație (a unui teren etc.); trăsături; caracteristici; poziție (a capului); postură; ținută; (teatru) decor; grup (de persoane); societate, companie; număr; (fig) clică, gaşcă, bandă; grup (de obiecte); colecție; serie; număr; sport set; (mat) ansamblu, serie, mulțime; (bot, agr) răsad, lăstar, plantă; be dead on doing smth. a fi ferm hotărât să facă ceva; make a dead $\sim$ on smb. (fig) a ataca brusc pe cineva

set about a se apuca de; a începe, a porni cu; apuca să lucreze; a tăbărî (pe cineva), se năpusti asupra (cuiva); a face (pe cineva) să înceapă (ceva); a răspândi, a împrăștia (un zvon)

set a day a fixa o $z$

set a dish on the table (alim) a servi, a pune o mâncare pe masă

set a dog an smb. a slobozi un câine asupra cuiva set a dog barking a stârni / asmuți un câine set a file (mas-un, TH) a recondiționa o pilă set against a pune / a îndrepta spre / către; a opune; a ațâța / răscula / ridica împotriva; a compara cu

set a hen (agr) a pune o găină pe cuibar

set alight a aprinde

set apart a pune de o parte, a rezerva; a păstra; a despărți, a separa

set a person against another a ațața o persoană împotriva alteia

set a problem a pune / ridica o problemă

set a sail (nav) a desfășura o pânză

set a scene (teatru) a monta un decor

set aside v. set apart; a înlătura, a da de o parte; a respinge; a anula

set about doing smth. a se apuca să facă ceva

set about smb. ( $\mathrm{fam}$ ) a ataca pe cineva

set an example a da un exemplu

set a task a trasa o sarcină

set at normal a conecta (normal)

set a violin (muz) a acorda o vioară

set-back piedică, obstacol; oprire (în dezvoltare etc.); (mil) recul

set-back (mec) contralovitură; (fizică nucleară) corectare automată a excesului de reactivitate, repunere, restabilire; (el, hidr) curent turbinar; dare înapoi, pas înapoi; obstacol; oprire (în dezvoltare etc.); piedică; (mil) recul 
set back a împiedica, a opri; a reține; a împiedica / opri dezvoltarea; a stânjeni; a da înapoi (ceasul); a opune rezistență, a reacționa; a curge înapoi; a se retrage; a stânjeni; (fig) a costa (pe cineva)

set-back scale (metr) scală cu aşezare în poziție de zero

set beside a compara cu, a pune alături de set bolt $(\mathrm{OM})$ şurub de ajustare, bolț de fixare set by a pune de o parte; a economisi set collar (OM) inel de fixare

set down a pune / aşeza jos; a descărca; a lăsa (jos); a pune / aşterne pe hârtie; a nota, a însemna; a trece într-un registru etc. (pe cineva), a înregistra; a micşora, a potoli, a domoli (zelul etc.), a se lăsa (în jos); a se aşeza

set down as a considera / socoti (pe cineva) ca / drept

set down to a atribui, a pune pe seama; a urma, a trebui să

set fire to a da foc la

set forth a declara; a expune; a lămuri, a explica; a arăta; a lăuda, a recomanda; a face cunoscut; a proclama, a vesti; a specifica, a menționa (într-un contract etc.); a porni, a pleca (la drum), a începe (o călătorie, o expediție etc.)

set free $(\mathrm{OM})$ a decupla; a acționa; a decupla; a elibera; a manipula; a mânui

set hammer (OM) ciocan de nituit / căpuitor

set in a-şi face apariția, a veni; (hidr, fiz) a se amorsa; (d. un anotimp etc.) a începe, a se instala

set in action (mas) a pune în functiune

set in air (plast, ind chim) întărire la / în aer (d. adezivi etc.)

set in motion (mec, mas) a porni

set in operation (mec, mas) a pune în exploatare set lap joint $(\mathrm{OM})$ îmbinare cu margini suprapuse

set noise (el, autom) zgomot de amplificare

set of curves (mat) familie de curbe

set of exchange (ec) scrisoare de schimb

set-off compensație, compensare; evidentiere; declanşare; marcare; înfrumusețare; separare; despărțire

set off a scoate în relief / în evidență, a reliefa; a contrasta, a pune în contrast; a marca; a semnala; a lansa; a declanşa; a marca; a înfrumuseța; a împodobi; a compensa, a contracara; a despărți, a separa; (poligrafie) a copia (după tipărire), (d. cerneală umedă) a se întinde, a păta; a porni la drum, a începe (o călătorie); (mil) a lansa (o rachetă etc.); a declanşa; against a forma un contrast (față de); (fig) a izbucni (în râs etc.) set off a debt (ec) a compensa o datorie

set off a gain against a loss (ec, adm, pol) a pune în balanţă un câştig cu o pagubă, a compensa un câştig cu o pagubă

set off against a face un contraszt (față de)

set off one's assets / goods (ec) a(-şi) pune în valoare mărfurile / bunurile, a(-şi) prezenta în condiții cât mai bune mărfurile

set-off paper (ind chim) hârtie maculatură

set-off reel (ind chim) sul de maculatură anticopiativă

set-off sheet (ind chim) hârtie maculatură

set off the course (nav) a se abate de la drum (d. o navă)

set of furniture garnitură de mobilă

set of gauge blocks set de cale plan paralele

set of instruments (metr, OM) set / trusă / garnitură de scule

set of mixing rollers (alim, ind chim) malaxor cu valțuri / cu role

set of passes (met) numărul de treceri în cajă / la laminarea profilurilor

set of pulley $(\mathrm{OM})$ palan

set of rolls (met, OM) garnitură / set de cilindri (de laminare); (alim, OM) set de tăvălugi (pt. o moară etc.)

set of tools $(\mathrm{OM}$, mas-un) trusă de scule

set of utensils (OM, mas-un) trusă de scule

set of weights (metr, $\mathrm{OM}$ ) garnitură de greutăți

set one's hands to a pune o semnătură pe un act; a se pune pe (treabă, lucru)

set one's heart/mind to a-şi pune în cap să obțină

set one's shoulder to the wheel (fig) a pune umărul

set one's wits to a question a căuta răspuns la o problemă

set oneself against a se împotrivi/a se opune cu dat

set oneself to a se apuca de

set on fire a aprinde

set on to a pune să, a îndemna să / la; a asmuți (un câine) (la cineva); a pune în mişcare

set opinions convingeri ferme

set out a delimita; a preciza; a defini; a marca; (constr) a jalona, a picheta, a marca; (ec) a expune (spre vânzare etc.); a etala; a expune, a prezenta (motive etc.); (bot) a planta, a sădi; (ec, adm) a fonda, a întemeia (o casă de comerț); a stabili (un record); (tipografie) a spația; a aranja, a rândui; a echipa (pe cineva); (nav) a se îmbarca; a porni, a pleca (la drum); a instaura (un cult, o tendință etc.)

set out a curve (mat) a trasa o curbă 
set out in pursuit of smb. a porni în urmărirea cuiva

set out one's ideas clearly a-şi orândui ideile set pen to paper a se aşterne pe scris set phrase expresie des folosită

set piece operă (literară, de artă) de efect, folosind un stil convențional; focuri de artificii dispuse într-o anumită formă; element de decor

set pin $(\mathrm{OM})$ ştift de montaj

set point (autom, metr) valoare prescrisă / de referință, punct de reper / fixat

set right (autom, metr) a rectifica, a corecta prin reglare (d. aparate etc.)

setscrew (OM) şurub opritor; (av, nav) elice cu pas reglabil

set( )screw (nav) elice cu pas reglabil; (OM) ştift filetat (şi transversal, pentru fixarea unei piese pe un arbore)

set-screw spanner $(\mathrm{OM})$ cheie pentru şuruburi de reglare

set smb. doing smth. a îndemna / pune pe cineva să facă ceva

set smb. on his way a îndruma pe cineva pe calea cea bună

set smile (fig) zâmbet rece

set socket (el) priză (fixă)

set solid (constr, plast) a se întări, a deveni solid, a se solidifica

set spark (autom, mas-un) avans fix

set speech discurs bine pregătit

set speed (auto) viteză setată (de croazieră, la sistemul de control automat al vitezei)

sett (constr) pavea (la drumuri); (nav) coțadă

settee divan (mic); canapea; banchetă

setter (zool) prepelicar; (OM) reglor, mecanism de reglare; stimulare; (ind) (muncitor-) reglor; (autom) stimulator; (pol) instigator; ațațător

setter on stimulare; ațâțător; instigator

setter-up (TH, ind) ajustor

set the clock (metr) a potrivi un ceas / un cronometru

set the course (nav) a trasa ruta

set the fashion (textile, artă) a da tonul (în modă), a stabili moda

setting punere, aşezare, aranjare etc.; poziție, situație; cadru, decor; mediu; (teatru) decor, montare; $(\mathrm{OM})$ fixare, montură, montare (a unei pietre prețioase), lagăr metalic (în mecanica fină); (metr, OM, mas) ajustare; reglare, instalare; (constr, ind chim) solidificare, priză (şi la adeziv, ciment etc.), întărire (a unui amestec); apus, (de soare), asfințit; (constr) zidărie, tencuială; (fiz, hidr) direcție (a unui curent etc.); (chim, alim) coagulare; (textile) desime, ceapraz; fundare setting angle (OM, fiz, mas-un) unghi de atac (al unui tăiş de sculă etc.)

setting bath (alim, ind chim, met) baie de precipitare / de depunere / de coagulare

setting device (OM, autom) dispozitiv de reglare

setting-free degajare (dintr-o prindere etc.)

setting gauge (metr, $\mathrm{TH}$ ) calibru / şablon de reglare

setting going (mas) punere în functiune

setting heat (alim, ind chim) căldură de hidratare

setting in motion (mas) punere în funcțiune

setting-in of oscillations (autom, electr) amorsare a oscilatiiilor

setting jaw $(\mathrm{OM})$ falcă de menghină

setting lever $(\mathrm{OM}$, el) pârghie de comutare

setting of carburetor (auto) reglare a carburatorului

setting of concrete (constr, chim) priză a betonului

setting off (ind, mediu) murdărie

setting out pichetare, trasare

setting piece $(\mathrm{OM})$ piesă pentru prinderea sculei setting point (alim) temperatură de congelare

setting spindle $(\mathrm{OM})$ fus filetat de reglare

setting strength (chim) capacitate de priză (d. adezivi, beton etc.)

setting strip $(\mathrm{OM}, \mathrm{T})$ plăci aplicate pe menghina de maşină

setting temperature (chim, termo) temperatură de priză (a cimentului, a adezivului)

setting time timp de priză (a cimentului, a adezivului etc.)

setting up (ind chim) prevulcanizare; (mas) instalare

setting-up department / shop (ind) atelier de reglare

setting-up joint (OM, mas, constr) rost de montaj

setting-up piece $(\mathrm{OM})$ piesă folosită la aşezarea sculei

setting-up time (mas, autom) timp de stabilizare setting-up truck (met, mas) cărucior de montaj

settle a stabili, a instala, a (se) aşeza; a coloniza; a stabiliza, a face stabil; a fixa; a întepeni; a pune ordine în (afaceri etc.); a aranja, a căpătui (pe cineva); a lăsa să se limpezească (un lichid), a lăsa să se aşeze; a risipi (îndoieli); a linişti (nervii etc); a hotărî, a fixa, a stabili (un termen etc.); a aplana (o ceartă etc.), a împăca; a achita, a plăti (o datorie etc.); a aloca, a fixa (o rentă etc.); a face de petrecanie (cuiva); a se stabili; a se aşeza (într-un loc); a se instala; a se cocța; (d. o boală etc.) a se localiza; (d. un lichid) a se limpezi; (meteo) (d. zăpadă etc.) a se aşeza, 
(d. vânt) a porni, a începe să bată; (d. un vas etc.) a se scufunda; a aranja lucrurile (cu cineva); a achita, a plăti; a (se) linişti, a se domoli; (d. pământ etc.) a se tasa, a se bătuci, a se îndesa; a rezolva; a (se) stabili; a hotărâ; a reglementa; (ec) a plăti, a achita; a (se) aşeza; a se sedimenta; laviță cu speteaza înaltă

settled (meteo) (d. vreme) stabil, frumos, senin; (d. o stare) neschimbat, invariabil; fix, fixat (d. cineva, d. un aranjament etc.) stabilit, aranjat; colonizat; (d. o idee) fix, înrădăcinat; permanent; stabil; calm; aşezat; stabilit; decantat, stabilizat

settle down a stabili, a fixa; a coloniza; a aşeza; (autom, mas) a regla, a (se) stabiliza, a regula, a rezolva; a se stabili; a se aşeza; a se instala; a se linişti, a se domoli; a-şi calma nevii; tehn a se depune, a decanta; a se limpezi; (d. vreme) a deveni stabil, a se face frumos / senin

settle down (alim, ind chim, mediu, hidr) a decanta, a (se) sedimenta

settle down to a se dedica, a se consacra

settled (d. cineva) aranjat, stabilit; (fiz, OM) aranjat, constant, determinat, fixat, rezolvat, stabilit, stabil; calm; colonizat; (fiz, termo) fix, invariabil, neschimbat, stabil (d. o stare); fix, înrădăcinat (d. o idee); frumos, senin, stabil (d. vreme); permanent

settled production $(\mathrm{ec}$, ind) producție stabilizată settled solution (alim, ind chim, mediu) soluție decantată

settle for a accepta, a se împăca cu

settle in a obişnui, a deprinde, a face să se obişnuiască; a se acomoda, a se desprinde, a se obişnui; a se simți în largul lui

settle into a se obişnui cu, a se deprinde cu, a se acomoda cu

settlement stabilire (într-o țară etc.); colonizare; aşezare (omenească); colonie; instalare (într-o locuință etc.); (TH) depunere, sedimentare; lăsare în jos, coborâre; (constr) tasare (a pământului); amplasare; amplasament; reglare; (pol, $\mathrm{adm}$ ) reglementare; rezolvare, soluționare; fixare, stabilire, hotărâre (a unui termen etc.); (ec, pol) înțelegere, tranzacție, acord; (jur) domiciliu legal

settle off a adormi (pe cineva)

settlement $(\mathrm{TH})$ depunere, aşezare, sedimentare settlement joint (constr) rost de tasare

settlement rate (alim, ind chim, mediu) viteză de sedimentare

settle on / upon a alege (până la urmă), a se decide în privința; a se hotărî în privința (cuiva, a ceva), a lăsa (drept) moştenire (cuiva) settle oneself to a se pregăti de (somn etc.)

settle out (alim, ind chim, mediu) a (se) sedimenta; a (se) separa

settler (alim, ind chim, mediu, OM) cuvă / butoi de limpezit; separator; lovitură hotărâtoare

settler butoi de limpezit, decantor, bazin de decantare / de limpezire

settle up (ec) a achita ceea care este de plată

settle upon a se hotărî / se decide în privința; a alege (până la urmă); a lăsa (drept) moştenire (cuiva)

settling (alim, ind chim, mediu) depunere a materialului mai greu, sedimentare (gravitațională), decantare

settling area $(\mathrm{OM})$ secțiune a decantorului

settling basin / tank (OM) bazin / tanc de decantare / de limpezire, decantor

settling bath $(\mathrm{OM})$ baie de decantare

settling bowl $(\mathrm{OM})$ rezervor de decantare

settling box $(\mathrm{OM})$ cutie de decantare

settling capacity (alim, ind chim, mediu, OM) capacitate a decantorului

settling cask (alim, ind chim, mediu, OM) cuvă de limpezire

settling centrifuge (alim, ind chim, mediu, $\mathrm{OM}$ ) centrifugă de decantare

settling chamber (ind, mediu) cameră de desprăfuire, desprăfuitor

settling cone $(\mathrm{OM})$ pâlnie de decantare (de apă grasă)

settling down (alim, ind chim, mediu) depunere, precipitare

settling filter $(\mathrm{OM})$ filtru decantor

settling head (met) maselotă

settling out (alim, ind chim, mediu) depunere, precipitare

settling rate viteză de sedimentare / de depunere settling room spațiu sau încăpere de decantare

settling speed (alim, ind chim, mediu) viteză de sedimentare

settlings (alim) sedimente, drojdii

settling tank (ind chim, termo, mediu) batal, decantor, decantor de cenuşă

settling time (autom) timp de răspuns / de stabilizare, (alim, ind chim, mediu) timp de depunere, timp de liniştire

settling under its own weight (constr, mediu) tasare / depunere / sedimentare sub greutatea proprie

settling velocity (alim, ind chim, mediu) viteză de sedimentare

settling velocity for nonspherical particle (fiz) viteză de sedimentare pentru particule nesferice / non-sferice 
set-to luptă, încăierare, ciocnire

set to a se apuca de (lucru); a începe să

set to an angle of $(\mathrm{OM})$ a aşeza sub un unghi de set to exact size (OM, mas-un) a regla la dimensiunea exactă

set to work (mas) a pune în funcțiune

set-up tinută, poziție, postură; (mas, materiale, ec) structură, organizare, alcătuire; sistem; ridicare, instalare, montare; operația de reglare, amenajare; aranjat

set up a ridica, a înălța; a pune în poziție verticală; a stabili, a aranja; a căpătui; a organiza; a iniția; a înființa, a institui; a întemeia, a fonda; a cauza, a provoca (o reactie, o boală etc.), a determina; a aproviziona; a furniza (cuiva); (med) a restabili, a însănătoşi, a înzdrăveni (pe cineva); a remonta, a reface; a scoate (un strigăt etc.); a dezvolta prin exerciții fizice (corpul); (TH, OM) a monta; a amenaja (un parc etc.); (tipografie) a culege o pagină; (mas, autom) a regla, a fixa, a monta (o mașină); a înălta (un drapel); a ridica (o statuie); a aşeza (un obiect) la vedere; (inf) aranjare a datelor în vederea rezolvării unei probleme; (fiz, mec, mas) condiții inițiale (în modelare, simulare etc.)

set up a MS (tipografie) a culege

set up as a începe să practice meseria de; a se da drept, a face pe, a pretinde că este

set-up production $(\mathrm{ec}, \mathrm{TH})$ creştere a producției set up production (ec, $\mathrm{TH})$ a crește producția set-up scale (metr) scară / scală fără punct zero set-up time (chim, autom, mas) timp de stabilire / de reglare / de fixare / de stabilizare

set-value control (autom, mas) reglare $\mathrm{cu} / \mathrm{la}$ valoare constantă

set wheel grinding (mas-un) rectificare cu disc abraziv, fără deplasare longitudinală

seven şapte; şeptar; seven (metr) unitate de măsură pentru volum (pt. bere în New South Wales şi alte regiuni din Australia): 1 seven of beer este un pahar de $200 \mathrm{ml} ; 1$ seven $=1$ butcher (în Australia de Sud) $=1$ glass (în alte regiuni din Australia)

sevenfold $(a d v)$ înșeptit, de şapte ori

seven-leagued (în basme) de şapte poşte

seven seas, the $(p l)$ oceanele lumii

seventeen şaptesprezece

seventeenth al şaptesprezecilea, a şastesprezecea parte (dintr-un întreg)

seventh al şaptelea; şeptime; (metr, muz) septimă, unitate în muzică pentru a descrie raportul între frecvențele a două note: două note diferă printro septime dacă nota mai înaltă are frecvența de 15/8 frecvența celei mai joase seventhly $(a d v)$ (în) al şaptelea rând seventieth al şaptezecilea; a şaptezecea parte seventy şaptezeci

sever a (se) despărți, a separa; a dezbina; a rupe, a desface; a tăia, a reteza, a diseca, a secționa (capul, o piesă, etc.); from a se despărți, a se separa de, a se desface de

severable separabil; divizibil

several mai mulți /mai multe; câțiva; diferiți; diverşi; times de mai multe ori, în mai multe rânduri; fiecare; diferit; separat; respectiv, corespunzător; jur (d. un bun etc.) individual, particular, al său (propriu); (pron) mai mulți, mai multe; of them mai mulți dintre ei, unii dintre ei

severance ( $\mathrm{TH}$, fiz) separatie, desprindere

severalize a separa, a despărți; a distinge

severally $(a d v)$ (în mod) separat; distinct; în parte; individual

severalty caracter particular / individual, trăsătură / caracteristică particulară; (jur) proprietate individuală

severance despărțire, separare; tăiere, retezare; (ec) reziliere a contractului de muncă

severance pay $(\mathrm{ec})$ compensație pentru concediere

severe sever (d. un proces, de exemplu, de uzare etc.), aspru; strict; rigid; riguros; (d. o pierdere etc.) serios, grav, greu; (d. vreme etc.) aspru; (d. vânt etc.) tăios; crunt, cumplit; (d. stil etc.) sever, sobru; (d. o remarcă etc.) tăios, sarcastic, caustic, muşcător, aspru; (fotografie) contrast

severe agitation (mec, $\mathrm{TH})$ agitare / amestecare severă / puternică

severily $(a d v)$ (în mod) sever, cu severitate / asprime, aspru; (în mod) grav, serios; grav bolnav severing $(\mathrm{TH}, \mathrm{mec}$, fiz) separare, scindare, secționare

severity severitate (a unui proces de deteriorare, de exemplu, de uzură), asprime; seriozitate; gravitate; (mas) severitate / gravitate a (unei avarii)

severity of injury (med) gravitate a rănii / a rănirii

sew (textile) a (se) coase (cu ață), a prinde cu ață; a coase la un loc, a lucra cu acul, a prinde cu ață; (poligrafie) a broşa, a lega (prin coasere); (nav) a andoca (o ambarcație); a drena (un iaz etc.); a eşua; (hidr, agr) a seca, a usca, a drena (un iaz etc.)

sewage (constr, mediu) canalizare, canal pentru ape uzate; ape menajere / uzate, apă reziduală / uzată; murdărie; deşeuri

sewage farm (agr) câmp de irigație 
sewage pump (OM, hidr) pompă de canalizare sewage treatment (chim, mediu) tratarea apelor reziduale

sewage-treatment plant (mas, mediu) instalație de limpezire a apelor uzate

sewer (textile) cusător, cusătoreasă; (constr, mediu) canal colector (pt. canalizare) / de canalizare, canal principal de ape uzate; a canaliza

sewerage (constr, mediu) canalizare; lucrare de canalizare

sewerage net (constr, mediu) sistem / rețea de canalizare

sewerage system (constr, mediu) sistem de canalizare

sewer casting (met, constr) piesă turnată / armătură din fontă pentru canalizare

sewer pipe (OM, mediu) conductă de canal sewer system (constr, mediu) canalizare sewing (textile) cusut, coasere, ață de cusut, care coase

sewing machine (mas, textile) maşină de cusut sewing needle (OM, textile) ac de cusut sewing thread (textile) ață de cusut sewn belt $(\mathrm{OM})$ curea cusută

sex sex; the $\sim$ femeile, sexul frumos; sexualitate; viață sexuală / amoroasă; (med) probleme sexuale; preocupări de ordin sexual

sexadecimal number, hexadecimal number (mat, c) număr în baza 16

sexagenarian sexagenar

sexagesimal (metr) aparținând unui sistem hexagesimal, hexagesimal; al şaizecilea

sexavalence (chim) hexavalență

sexed (zool, bot) sexuat, cu sex

sexennial de şase ani; care are loc la şase ani

sexivalent (chim) hexavalent

sexless asexuat, fără sex; rece din punct de vedere sexual

sextant (nav, metr) sextant

sextarius (metr) unitate romană de măsură pentru volum de lichid: $1 \sim 530 \mathrm{ml}$

sextern şase foi de hârtie

sextet(te) sextet, grup de şase instrumente etc.; (metr) unitate pentru cantitate, egală cu 6

sextodecimo (poligrafie) 160, coală împăturită în 16 sextolet sextolet

sextuple sextuplu, înşesit, de şase ori mai mare; sextuple, sextuplet (metr) grup de 6 articole (şi identice), grup de şase persoane

sexual sexual

sexuality sexualitate; senzualitate

sexualize a diferenția ca sex; a acorda un sex (obiectelor neînsuflețite)

sexually $(a d v)$ din punct de vedere sexual sexy sexy, erotic; excitant; cu sex-appeal, cu vino-ncoace

Seychelles, the (geogr) insule în Oceanul Indian Seym, the (pol) Seim, seimul polonez; dieta poloneză

SF prescurtare de la science fiction; V. science fiction; (metr) simbol pentru square foot $\left(\mathrm{ft}^{2}\right)$; $v$. square foot

SFM (metr) un simbol pentru surface feet per minute, o unitate de măsură pentru viteza de rotație a unei scule / maşini rotitoare (strung, ferăstrău etc.); termenul surface foot este echivalent cu linear foot; v. linear foot, foot

s.g., SG (specific gravity) (metr, materiale) simboluri pentru greutate / masă specifică (mărime adimensională); se scrie "1,134 SG" pentru raportul între greutățile specifice sau densitățile a două materiale de 1,134 (dacă nu se specifică al doilea material, se subînțelege greutatea specifică ca raport între densitatea materialului și cea a apei)

shabbily (îmbrăcat etc.) sărăcăcios; zdrențăros; $(a d v)$ (în mod) meschin; zgârcit; cu zgârcenie

shabbiness (textile) uzură, uzare, ponosire (a hainelor); caracter sărăcăcios / zdrențăros (al hainelor); dărăpănare; meschinărie; zgârcenie

shabby (textile) uzat, jerpelit; ponosit; zdrentăros; neîngrijit; lăsat în paragină; sărăcăcios; meschin; zgârcit; josnic, ticălos, murdar; urât

shabby-genteel care încearcă să-şi ascundă sărăcia shabby-looking cu înfățişare sărăcăcioasă

shack (constr) cocioabă, colibă, bojdeucă; baracă

shackle (OM) ochi / verigă de lanț, brățară, carabină, eclisă, jug, cercel, brățară, inel (de legătură), verigă; $(p l)$ cătuşe; $\sim \mathbf{s}(p l)(f i g)$ lanţuri, impedimente, piedici, restricții, constrângeri; (nav) cheie (de lanț); a pune cătuşe (cuiva); (fig) a încătuşa, a opri, a stânjeni

shackle bolt $(\mathrm{OM})$ bolt cu cercel / cu inel de prindere

shackle of cable $(\mathrm{OM})$ cheie de transmisie

shack up a trăi împreună, a conviețui (fără să fie căsătoriți)

shad (iht) specii de scrumbie

shadberry (bot, silv) specie de păr pădureț

shaddock (bot) un fel de grapefruit

shade umbră; răcoare; put into the $\sim(f i g)$ a pune în umbră, a umbri, a eclipsa; (artă, c, TV) nuanță; colorit; tentă; (fig) umbră; lucru ireal; spirit; iluzie; abajur; (fiz) degradare a culorii; a $\sim$ of un pic / o idee de, putin; a umbri, a feri de lumină (cu ajutorul perdelelor etc.); a pune la umbră / la 
răcoare; a învălui în umbră; a întuneca; a ascunde; (artă) a haşura (în desen); a (se) nuanța; a (se) schimba puțin / treptat

shade away / down (autom, mas) a se atenua (d. un semnal); a se estompa

shade (dark) nuanţă de culoare

shaded umbros; umbrit; cu abajur; întunecos; închis

shadeful umbros

shade into a-şi schimba nuanța în

shadeless fără umbră; deschis; (d. pălării) fără boruri; inexpresiv; fără nuante, nenuantat

shadelessness lipsă (totală) de umbră; inexpresivitate; lipsă de nuante

shade of blackness (fiz, c) grad de înnegrire

shader apărător, protector; umbrar

shadiness caracter umbros / tenebros

shading (autom, electr) umbrire; umbre; haşurare; retuşare; retuş; umbră, urmă; nuanţă

shading reglarea / comanda nivelului zgomotului; (fiz) înnegrire (în analiza spectrală)

shading cone (fiz) con de umbră

shadoof (OM) cumpănă (de fântână)

shadow umbră (a unui obiect); pată; (fig) umbră, duh, spirit; nălucă, fantomă; fantasmă; (fig) acolit; (fig) pic, idee; a fila, a urmări pas cu pas, a spiona

shadow cabinet (pol) cabinet fantomă

shadow effect (fiz) efect de umbră

shadower agent (secret), spion; care face umbră / are efect de umbră / de umbrire, care ascunde; paravan; umbrar

shadowgraph siluetă; umbră chinezească; (fiz) radiografie

shadowing (fiz) umbrire, ecranare, efect de ecran; eclipsă

shadowless fără umbră; deschis, descoperit

shadow lines (met) structură în benzi / în linii

shadow-proof opac (d. materiale, lichide)

shadow show umbre chinezești

shadow test (fiz, med) schiascopie

shadowy umbros; umbrit; întunecat, posomorât, ursuz; obscur, neclar, neînțeles; vag; închipuit, imaginat; iluzoriu

shadow zone (fiz) zonă de umbră

shady umbros; umbrit; (ec) (d. o tranzacție etc.) suspect, dubios, necurat; (alim) (d. un ou) stricat, clocit

shaft $(\mathrm{OM})$ osie, ax, arbore, fus, valt, mâner al unei unelte etc., coadă, săgeată, ac; (textile) iță înțepătură, împunsătură; lance, suliță; rază; scânteiere; sclipire; fulger; scăpare; cabină (de lift); hulubă; (OM, constr) stâlp, coloană; bară; trunchi; (constr) puț; (met) cuvă (rar) shaft alley (nav) tunel al axului elicei

shaft angle (OM) unghiul dintre arbori (la angrenaje conice) $(\Sigma)$

shaft balancing (OM, mec) echilibrare dinamică, prin redistribuirea masei pe arbore

shaft bearing (OM) lagăr de osie / pe arbore

shaft boring machine (mas, constr) maşină de săpat / de exploatare

shaft collar (OM) guler, umăr (de arbore)

shaft extension (OM, hidr, mas-un) capăt de arbore (şi pt. montaj)

shaft foundation (constr) fundație cu chesoane deschise

shaft furnace (met) cuptor cu cuvă

shaft hole of a hammer (OM) ochi al ciocanului, gaură pentru montarea mânerului ciocanului

shaft horse (agr, zool) cal rotas / de hulube

shaft horse power (mec, OM) putere la arborele de ieşire / condus (exprimată în cai-putere), putere livrată unei pompe / unui compresor (exprimată în cai-putere)

shafting $(\mathrm{OM})$ transmisie; (nav) linie de arbori; (arhit, constr) coloane ornamentale

shaft intersection (mat, geom, OM) punct de intersecție a axelor

shaft kiln (met) cuptor vertical

shaft lining (met) căptuşire a cuvei (convertizorului, cuptorului etc.); (OM, TH) recondiționare a unui arbore prin (re)acoperire (prin sudare sau alt procedeu)

shaft neck $(\mathrm{OM})$ fus al arborelui

shaft of hammer $(\mathrm{OM})$ coadă de ciocan

shaft of rivet $(\mathrm{OM})$ tijă / corp a(l) nitului

shaft of tool (mas-un, OM) corp al cuțitului / sculei

shaft on roller-bearings (OM) fus / arbore pe rulmenți

shaft top (met) gură de alimentare (la partea superioară) (la cuptor, la furnal)

shaft tunnel (nav) tunel al liniei de arbori

shaft turning lathe (mas-un) strung de prelucrat arbori

shafty (textile) (d. lână, produse din lână) aspru

shag (textile) blană aspră, stofă păroasă; (agr) tutun prost, mahorcă

shagged (out) frânt, stors

shagginess caracter păros / hirsut

shaggy păros; mițos; flocos; hirsut; (d.păr) aspru; zburlit; țepos; (d. cineva) nepieptănat; neîngrijit; sălbatic

shagreen (piele de) şagrin; (poligrafie) (hârtie) şagren

shah (pol) şah (al Iranului etc.)

shaitan arab; om hain; (geogr) furtună de nisip 
shakable (agr) (d. fructe) gata să cadă; care poate fi convins / înduplecat

shake (fiz, mas) a scutura; a zgâlțâi; a zgudui, a zdruncina, a bate, a vibra, a scutura; a agita (un lichid etc.); a clătina din (cap); a arăta cuiva pumnul, a amenința pe cineva cu pumnul; (fig) a zdruncina (credința etc.); a zgudui (tinutul etc.); a slăbi; a clătina (convingeri etc.); a pune doage la (un butoi); a agita (sabia etc.), a roti; a strânge (mâna), a apuca de (mână); (fig) a zdruncina nervii (cuiva); a demonta; a distruge (pe cineva); a doborî; a tremura; a (se) clătina, a se cutremura; a se zgudui; a se zgâlțâi; with cold a tremura de frig; a vibra; a se clătina; a ameți; a şovăi, a ezita; muz a face titluri; tremur(are); freamăt; scuturătură; zgâlțaitură; zguduire, zguduitură, zdruncin(ătură); (muz) tril; shake (dans); zguduire; crăpătură, fisură

shakedown pat / culcuş improvizat; (amer) şantaj; (nav, av) probă finală, test final (al navei / avionului)

shake down a scutura (fructe din pom); (constr) a dărâma, a demola; a stoarce bani de la

shake off a se descotorosi de, a se dezbăra de

shake-out (met) dezbatere; a dezbate formele

shake-out machine (OM, mas) centrifugă; (met) maşină de dezbătut forme

shakeproof (mas, metr) protejat contra vibrațiilor

shaker $(\mathrm{OM})$ sită vibratoare, scuturător

shaker conveyer $(\mathrm{OM})$ jgheab oscilant / vibrator

shaker leader (OM) jgheab de alimentare vibrator

shaker machine (OM, mas) vibrator

shaker motion $(\mathrm{TH})$ mişcare de agitare

shaker screen (OM, agr, alim, constr) sită vibratoare / oscilantă

shake table (OM, agr, alim, constr) masă vibratoare

shake-up scuturătură, scuturare; (pol) epurare a aparatului de stat; mutare, transferare; improvizatie

shake up a scutura, a clătina, a agita; a amesteca (scuturând); (fig) a clătina; a zgudui; (fig) a şoca; a supăra; a tulbura

shakily $(a d v)$ clătinându-se, nesigur; cu voce tremurată; cu o mână tremurătoare

shakiness (mas, constr) lipsă de stabilitate / echilibru; tremur

shaking tremurat; tremurător, care tremură; tremurând; care se clatină; nesigur; tremur(are) etc.; (v. shake); (med) friguri, malarie; (mas) trepidație; scuturare; vibrare; (met) (operație de) dezbatere shaking apparatus (mas, alim, ind chim) agitator shaking barrel / drum (met, OM) tobă pentru curățarea pieselor turnate

shaking chute / conveyer (OM) jgheab oscilant shaking down $(\mathrm{TH})$ agitare a băii

shaking feeder (mas, agr, alim, constr, ind chim) vibrator cu rol de alimentare, alimentator / dozator oscilant / vibrator

shaking grate $(\mathrm{OM})$ grătar vibrator

shaking grizzly / screen $(\mathrm{OM})$ sită vibratoare / oscilantă, ciur vibrator

shaking sieve $(\mathrm{OM})$ sită vibratoare

shaking table $(\mathrm{OM})$ masă oscilantă / vibratoare

shaky tremurat; tremurător; (d. cineva) neputincios, bicisnic; (med) infirm, bolnav; slab; slăbit; instabil, nesigur; (autom) instabil, oscilant; (d. un argument etc.) şubred, care nu stă în picioare; feel $\sim$ a se clătina pe picioare, a fi dărâmat / doborât / fără vlagă

shale (geol) marnă, şist argilos / bituminos, rocă argiloasă în lamele

shale oil (ind chim) ulei (obținut) din şist bituminos

shale rock (geol) rocă şistoasă

shall (gram) formă tare, forme slabe, prezent şi conditional prezent, verb auxiliar (pt. formarea viitorului I, la pers I $s g$ şi $p l$ ) voi; vom; o / am să; o / avem să; (în propoziții interogative, pt. formarea viitorului I, la pers a II-a $s g$ şi $p l$ ) vei; veți; o / am să; o / aveți să; (posibil şi la persoana I sg şi $p l$ ) voi; vom; o/am să; o/avem să; (pt. formarea viitorului II, la pers I $s g$ şi $p l$ ) voi; vom; have returned mă voi fi întors; verb auxiliar-modal (pt. formarea viitorului, la pers I şi a II-a, $s g$ şi $p l$, exprimând necesitatea, obligația, caracterul logic, promisiunea din partea vorbitorului) (categoric) vei; o/ai să; (categoric) va; o/are să; (categoric) veți; o/aveți să; (categoric) vor; o/au să; they be told about it li se vor aduce la cunoştință acestea (negreșit); verb modal (în propoziții enunțiative / în texte cu caracter juridic, statute, proclamatii etc.) trebuie; (adesea, nu se traduce, redându-se prin viitor); the fine $\sim$ not exceed one pound amenda nu va depăşi o liră; (în propoziții interogative, la pers I $s g$ şi $p l$ ) să; trebuie să; I open the window? (trebuie) să deschid fereastra?

shallop (nav) luntre; barcă; şalupă

shallow (geogr) (d. un râu etc.) puțin adânc; mic; (fig) superficial, de suprafață, fără adâncime; gol; deşert; $\sim \mathbf{s}(p l)$ loc puțin adânc; (nav) vad

shallow (nav, met) zonă puțin adâncă

shallow-brained (d. cineva) surperficial, limitat, mărginit; de nimic 
shallow hardening (met) călire superficială (şi ca defect: călire prea puțin adâncă)

shallow-hardening steel (met) oțel pentru călire superficială

shallow-hearted, shallow-brained (d. cineva) aspru; fără inimă; nesimțitor

shallowly $(a d v)$ cu superficialitate, (în mod) superficial

shallowness lipsă de adâncime; (fig) lipsă de adâncime / profunzime, superficialitate

shallow pass (met) calibru gol, trecere goală / în gol

shallow weld (OM) cusătură (de sudură) incompletă (şi ca defect)

shaly (geol) şistos, argilos

sham prefăcut, simulat; fictiv; împrumutat; fals, imitat, contrafăcut; falsificat; diamond diamant fals; a simula (boala etc.); illness a simula o boală, face pe bolnavul, a se preface bolnav; a imita, a maimuțări; a simula; a se preface; simulare, impostură, înșelăciune, ipocrizie; (om) fățarnic; prefăcut; pungaş, escroc

shamble a merge târşâind picioarele; (mers) târşâit

shambles (alim) abator, za(1)hana; măcel; (teatru) scenă a unui măcel

shame ruşine, pudoare, simțul ruşinii / pudoarei; ocară; necinste; pată (rușinoasă); a face de ruşine; a necinsti; a pângări; a profana; a se rușina, a-i fi ruşine

shamefaced ruşinos; sfios; modest; timid; ruşinat; discret; rezervat

shamefacedly $(a d v)$ ruşinat; ruşinos

shamefacedness ruşine (falsă); sfială; timiditate

shameful ruşinos; infam; condamnabil, reprobabil; odios; scandalos

shamefully $(a d v)$ (în mod) ruşinos, scandalos

shamefulness ruşine; infamie

shameless neruşinat, neobrăzat, fără ruşine

shamelessly $(a d v)$ (în mod) neruşinat; fără rușine

shamelessness neruşinare, neobrăzare

shammer simulant, prefăcut, ipocrit; farsor

shammy piele de capră neagră, şamoa

shampoo (ind chim) şampon; spălatul capului; a spăla cu şampon

shamrock (bot) trifoi alb (emblema Irlandei), trifoi mărunt, măcrişul iepurelui

Shanghai (geogr) Şanhai, oraş în China

shank (anat) picior, gambă, tibie, fluierul piciorului; (bot) tulpină, tijă; codiță (de floare); (OM) mâner (de unealtă), coadă (de lingură etc.); (poligrafie) corp de literă

shank (OM) furcă; coadă a unei scule / a unei pârghii shank bone (anat) tibie

shank cutter (mas-un) freză cu coadă

shanked $(\mathrm{OM})$ cu coadă (d. scule etc.)

shank end mill (mas-un) freză (maşină) pentru scule cu coadă

shanker (med) şancru

shank ladle (met) oală de turnare cu furcă

shank milling cutter (mas-un) freză cu coadă / deget

shank of anchor (nav) fus de ancoră

shank of bit (mas-un, OM) antrenor al burghiului

shank plug $(\mathrm{OM})$ dop filetat, cu cap pătrat

shank-type cutter (mas-un) freză cu coadă

Shannon, the (geogr) râu în Irlanda

shannon (inf) unitate binară de informație

shannon nat unit, natural unit (metr, inf) unitate de informație, similară cu shannon, dar utilizând logaritmul natural (cu baza e) în locul celui în baza 2

Shansi (geogr) provincie în China, Şansi

shan't prescurtare de la shall not

shanty (constr) cocioabă, bordei; (nav) cântec marinăresc

shape formă; chip; configurație; conformație; figură; put / get smth. into a aranja / organiza ceva cum trebuie; put / get smth. out of $\sim$ a strica ceva, a strica forma; take $\sim$ a căpăta formă / contur; a se contura, a se concretiza, a se materializa; a prinde viață; (fig) chip, formă, imagine; (ind, TH) model, mostră, tipar; aspect, înfățişare; ținută; a da formă; a modela; a inventa, a născoci; a produce; a da naştere la (ceva) / (cuiva); a aranja, a (o)rândui, a aşeza, a pune în ordine; a îndrepta, a dirija; a crea, a făuri; a se potrivi, a fi potrivit / bun / nimerit; (fig) a prinde viață; a se contura; a se dezvolta; (OM) configurație, formă; model; profil; (TH) a fasona, a forma, a modela, a profila; a se concretiza

shaped brick (met, constr) cărămidă fasonată

shaped castings (met) piese turnate

shape characterisation caracterizarea formei (şi pt. amestecuri de particule, pulberi)

shape defect $(\mathrm{OM}, \mathrm{TH})$ defect de formă

shape descriptor (ind, materiale) descriptor / parametru de caracterizare a formei (şi pt. amestecuri de particule, pulberi)

shaped gear $(\mathrm{OM})$ roată dințată cu formă specială (de exemplu, cu butuc mai lung etc.)

shaped grinding wheel (mas-un) disc de rectificat profiluri

shape memory alloy (met) aliaj cu memorie (a formei)

shaped part $(\mathrm{OM})$ piesă fasonată 
shaped plate (met) tablă fasonată shaped roll (met, OM) cilindru profilat shaped section $(\mathrm{OM})$ secțiune profilată shaped wire (met, OM) sârmă profilată shapeless amorf, inform; diform; fără formă shapelessness lipsa oricărei forme; urâțenie; diformitate

shapeliness frumusețe (a unei forme etc.); grație; simetrie

shapely bine porporționat / legat, simetric; armonios; frumos; plăcut

shape mill (met) laminor de profiluri

shape of a groove $(\mathrm{OM})$ profil / formă a(l) canalului; formă a calibrului (de laminare)

shape parameter $(\mathrm{OM})$ parametru de formă

shaper (mas-un) maşină de rabotat

shaper and planer tool (mas-un) cuțit de raboteză

shape roll (met) cilindru de laminat profiluri shape rolling mill (met) laminor pentru profiluri shaper work (mas-un, TH) prelucrare / operație la şeping

shape shears (met) foarfece de profiluri

shape wave (met) ondulație (defect de laminare)

shaping $(\mathrm{TH})$ formare, fasonare, modelare, profilare; (mas-un, TH) rabotare, prelucrare pe şeping

shaping groove (met) calibru de profilare

shaping machine (mas-un) şeping

shaping mill (met) laminor degrosisor / de profilare

shaping pass $(\mathrm{TH})$ şablon, calibru de formare; (met) trecere de finisare

shaping roll (met) cilindru de finisare

shaping stand (met) cajă de laminor degrosisor

shaping tool (mas-un) sculă de formare, cuțit pentru şeping, cuțit pentru prelucrare plană

shaping unit (constr, met, mas) circuit / agregat de formare

shard (zool) elitră (la insecte zburătoare); ciob, hârb; fărâmă

share (agr, OM) brăzdar, fier lat; parte; porțiune; participare, cantitate, component; parte; proporție; contribuție; aport; (ec) acțiune; cotă-parte; a impărți, a divide, a diviza; a distribui; with a împărți cu, a împărtăşi cu, a se bucura de (ceva) $\mathrm{cu}$ (cineva)

share bone (anat) os pelvian

shareholder (ec) actionar

share-out (ec) împărțire (a câştigului)

share out a împărți (câştigul etc.), a distribui

shareware (c) soft care poate fi copiat (făă taxă)

shark (zool) rechin; (fig) rechin, om rapace, tâlhar, bandit; (amer) cunoscător, expert; a devora, a înghiți; (fig) a fura, a escroca, a face escrocherii

shark on / upon (fig) a suge (pe cineva), a stoarce, a jecmăni (pe cineva)

sharkskin piele de rechin; (piele de) şagrin

sharp (OM) ascuțit, tăios, ascuțit; (fig) tăios, incisiv, mușcător; ironic; sarcastic; usturător, înțepător; (fig) precis, exact; (d. o pantă etc.) brusc, abrupt; intens; brusc; (d. gust) iute, picant, acru; aspru; (d. sunete) ascuțit, pătrunzător, strident; (d. simțuri, intelect etc.) fin, pătrunzător; ager; (d. cineva) abil, şiret; (d. o acțiune) necinstit, de pungaş / escroc; energic, viguros; surd, mut (d. o vocală etc.); (muz) diez; înalt; (poligrafie) clar; (d. lucru) făcut repede / la iuțeală; (fig) coțcar, tâlhar, escroc; $(a d v)$ (la ora ...) precis, fix, exact; brusc, dintrodată; subit; a potlogări, a pungăşi, a înşela

sharp-cornered (OM) cu vârfuri/colțuri ascuțite sharp-cut limpede, clar, distinct

sharp-edged (OM, mas-un) (cu tăiş) ascutit, tăios sharp edged (mas-un, $\mathrm{OM}$ ) cu muchii ascuțite / vii

sharpen a ascuți; a (se) intensifica; a (se) ascuți vârful; a da la tocilă; (fig) a (se) ascuți (d. contradicții, minte etc.), a spori; a înrăutăți; a face mai ager

sharp end $(\mathrm{OM})$ vârf (ascuțit), capăt ascutit

sharpener ascuțitor, tocilar; (mas-un) maşină de ascuțit; tocilă; ascuțitoare (de creion)

sharpening a new $(\mathrm{TH})$ reascuțire

sharpening (mas-un) ascuțire

sharpening stone (mas-un) piatră / disc de ascuțit sharper trişor, jucător (de cărți) necinstit; pungas, escroc

sharp-eyed cu ochi(i) ageri, cu vederea pătrunzătoare

sharp gas (met, ind chim) gaz exploziv / detonant

sharp lane change (auto) schimbare bruscă a benzii de circulație

sharply $(a d v)$ aspru, cu asprime; tăios; (în mod) clar, distinct; brusc, pe neaşteptate

sharpness ascuțime, caracter ascuțit / tăios; asprime, severitate; duritate; (metr) exactitate, precizie; (med) durere ascuțită / acută; agerime, perspicacitate; dibăcie, abilitate; ascuțiş, tăiş; (c, TV) claritate (a imaginii)

sharpness of tuning (autom, metr) precizie de reglare

sharp-nosed (OM) cu nas / capăt ascuțit (d o piesă etc.); cu nasul / mirosul fin; șicanator; critic

sharp(-pointed) object $(\mathrm{OM})$ obiect ascutit

sharp sand (materiale) nisip cu margini ascuțite 
sharp-set bine ascuțit; (TV, c) reglat (sub raportul clarității); (poligrafie) reglat la clar

sharp-sighted, sharp-eyed perspicacitate

sharp slags (met) pojghiță / peliculă de oxizi la suprafața metalului topit

sharp turn (auto) întoarcere îngustă, bruscă

Shatt-al-Arab, the (geogr) fluviu în Asia, Șatt el Arab

shatter a (se) sfărâma, a (se) fărâmița, a (se) zdrobi; a (se) sparge; (fig) a distruge (sănătatea etc.), a nimici, a ruina; a zdruncina (nervii); a nărui, a spulbera (speranțe etc.); a se strica; a se distruge

shatter box $(\mathrm{OM})$ sită vibratoare

shatter-brained nebun, țicnit; nebunesc, nesăbuit shatter-crack (met) fisură capilară, microfisură shatter-proof (OM, materiale) incasabil

shattering cutremurător; zdrobitor; dărâmător; strident; asurzitor; zguduire; (met) rupere a benzii (la laminare)

shave a (se) rade, a (se) bărbieri, a tunde; a tăia, a reteza; a răzui; a reduce puțin (prețuri); a trece foarte aproape (fără să atingă); ras, bărbierit; apropiere; (OM) răzuitoare, cuțitoaie shave hook $(\mathrm{OM})$ răzuitor în formă de inimă shaven $(a d j)$ tuns, ras, bărbierit

shaver bărbier, frizer; aparat de ras; brici

shaver (mas-un) răzuitor, șever

shaving bărbierit; aşchie; surcea

shaving (mas-un) aşchie, răzuire, aşchiere, şeveruire

shaving brush pămătuf de ras / de bărbierit

shaving cream (ind chim) cremă de ras

shaving cutter (mas-un) şever (sculă)

shaving lathe (mas-un) strung scurt, de prelucrat piulițe

shaving machine (mas-un) maşină de prelucrat tip şever

shaving stock (mas-un) adaos de prelucrare la şeveruire

shaving tool (mas-un) cuțit de prelucrare (pt. severuire), sever

shaw (silv) desiş, hățiş

shawl (textile) şal; eşarfă; broboadă

shay trăsură

she ea; dânsa; cea care; (zool) femelă

sheaf, $(p l)$ sheawes (agr) snop; mănunchi; legătură; (fiz) fascicul, mănunchi, legătură; teanc; pachet

shear a tunde (cu foarfecele); (TH) a tăia, a reteza, a mărgini, a tivi; a tăia părul, lâna etc. de pe; tuns(oare); tundere; (mec) forfecare; (mas-un) foarfece; (mec) forfecare, efort de forfecare; a tăia (cu un foarfece), a forfeca shear angle (mec, materiale) unghi de forfecare shear approach (roller) table (met, OM) transportor (cu role) de alimentare, amplasat în faţa foarfecelor de tăiat

shear blade (OM, mas-un) lamă de forfecare / de foarfece; textile, OM) spată de urzit

shear blade slide (mas-un, OM) sanie a foarfecelor mecanice

shear centre (mec, T, OM) centru / punct de forfecare

shear edge (met, materiale) margine tăiată / ruptă (la table, folii etc.)

shearer (agr) tunzător (de oi); (mas-un) foarfece mecanic

shear for cutting the split ends (mas-un, met) foarfece pentru tăierea capetelor / maselotelor

shearing foarfece; (mec) (acțiune / proces de) forfecare; tăiere cu foarfece; alunecare internă (în materiale); (textile) tundere, tuns

shearing bolt $(\mathrm{OM})$ bolț de forfecare (ca element de sigurantă)

shearing chip (TH, materiale, mas-un,) aşchie de forfecare

shearing crack $(\mathrm{OM}, \mathrm{TH}, \mathrm{mec})$ fisură produsă de (tensiune / efort de) forfecare

shearing cross section $(\mathrm{OM})$ sectiune de forfecare shearing disk (agr, OM) disc cu picuri la o combină pentru tăiere în plan vertical

shearing force (mec, OM) forță de forfecare / de tăiere, forță de destrămare (la folii, textile etc.)

shearing knife (mas-un, alim, ind) cuțit de foarfece / de forfecat (carne, table, hârtie, piele etc.)

shearing limit (mec, OM) limită de rezistență la forfecare

shearing load (mec, OM) forță / sarcină de forfecare / tăietoare

shearing machine (constr, geol) combină care taie în plan vertical; (mas-un) foarfece mecanic

shear(ing) modulus (mec, materiale) modul de forfecare, modul de elasticitate transversal

shearing modulus of elasticity (mec, materiale) coeficient / modul de elasticitate transversal

shearing off (mas-un, TH) retezare, tăiere, debitare (prin forfecare)

shearing pin $(\mathrm{OM})$ ştift de forfecare

shearing rate $(\mathrm{mec})$ viteză de forfecare

shearing resilience (mec, materiale) reziliență de / la forfecare

shearing resistance (mec, materiale) rezistență la forfecare

shearings (met, textile, plast) deșeuri / rămăşițe rezultate prin tăiere

shearing section (OM) secțiune de forfecare, sectiune (supusă la un efort) de forfecare 
shearing specimen (OM, metr, materiale) epruvetă pentru încercarea la forfecare

shearing strain $(\mathrm{mec})$ deformare cauzată de tensiune / efort de forfecare

shear(ing) strength (mec, materiale) rezistență la forfecare

shearing stress (mec, OM) tensiune / efort de forfecare

shearing test (OM, metr, materiale) încercare test la forfecare

shearing-test apparatus (metr, materiale) aparat de forfecat / de tăiat (în mecanica rocilor)

shearing waves (mec) unde de forfecare; (fiz) unde transversale

shear knife (mas-un) lamă / cuțit de foarfece

shear legs (constr, OM) capră, trepied; (nav) bigă improvizată, capră

shearling (agr) oaie care a fost tunsă o dată, cârlan shear lip (mec, materiale) deplasare / alunecare la / prin forfecare, rupere ductilă cu forfecarea materialului

shear modulus (mec, materiale) modul de elasticitate transversal, modul de forfecare

shear of a lipsi de, a priva de (un drept etc.)

shear off (TH) a forfeca, a tăia / a debita cu foarfecele

shear pin $(\mathrm{OM})$ ştift de siguranţă (solicitat la torsiune / la forfecare)

shear plane (mec, materiale) plan de forfecare / de alunecare

shear rate (mec, materiale) viteză de forfecare

shears $(\mathrm{OM})$ foarfece (mare), foarfece de tuns; (constr, OM) capră, trepied

shear stability (mec, hidr, T) stabilitate la forfecare (d. fluide, lubrifianți etc.)

shear steel (met) oțel sudat, pudlat

shear strain (mec) deformare la forfecare

shear strength (mec, materiale) rezistență de rupere la forfecare

shear stress (mec) tensiune / efort de forfecare

shear test (metr, mec) încercare / test la forfecare (pt. un material - pe epruvete, pt. o piesă etc.)

shear thickening (plast) îngroşare la forfecare (şi la adezivi)

shear thinning (plast) subțiere la forfecare / la sfâşiere (şi la adezivi)

shear thrust (mec) efort / sarcină / forță de forfecare (şi laterală)

shear tool (mas-un) cutit de finisare / de forfecare she-ass (zool) măgăriță

sheat fish (iht) somn

sheath, $(p l)$ seaths $(\mathrm{OM})$ teacă, toc; cutie; manta, înveliş, cămaşă, manşon, husă; (mat) închidere; (anat) membrană, înveliş; (fiz) pătură; înveliş; v. sheathe sheathe (TH) a acoperi, a capitona, a căptuşi, a dubla, a înveli (şi cu table), a placa, a proteja cu un înveliş; (el) a arma un cablu; a băga în cutie; a băga în toc / în teacă (sabia, etc.); (nav) a dubla bordajul

sheath eddies (el) curenți turbionari în mantaua unui cablu

sheathed electrode (el, met) electrod învelit

sheathing (constr) podea, duşumea; (el) armare; $(\mathrm{OM})$ căptuşire, acoperire, cămaşă

sheathing (OM, termo) cămaşă a unui cilindru

sheath knife (OM) cuțit (cu lamă fixă) purtat în teacă

sheave (OM) scripete, roată de curea / de cablu, disc; (mas-un) moletă

sheave groove $(\mathrm{OM})$ şanț / canal de curea trapezoidală / de cablu

sheave hole (OM, constr) ferestruică

shebang chestie, afacere, treabă; situație

she-bear (zool) ursoaică

she-cat (zool) pisică, mâță

shed (constr, met) hală, atelier; şopron; magazie; remiză; baracă; (agr) staul, şură, grânar; atelier; (av) hangar; (el) izolator-clopot; (textile) rost; a arunca; a cădea (d. frunze etc.); a-i cădea părul (d. un animal); (fiz) a difuza, a emana; (fig) a emana, a iradia, a răspândi, a revărsa (lumină etc.); a lăsa sa cadă; a lepăda; a năpârli (d. un animal); (anat, med) a pierde (dinții, părul etc.); a răspândi; a vărsa (lacrimi etc.)

she-elefant (zool) femelă de elefant

shee-metal tube $(\mathrm{OM})$ burlan de tablă

sheen (fiz) strălucire; sclipire; lucire, luciu; strălucitor; nespus de frumos

sheeny (fiz) strălucitor; lucitor; scânteietor

sheep ( $s g$ şi $p l$ ) (zool, agr) oaie

sheep breeding / farming (agr) creșterea oilor, ovicultură

sheep cheese (alim) brânză de oaie

sheep cote (agr) stână, târlă

sheep dog (zool, agr) câine ciobănesc, dulău (de stână)

sheepfold (agr) stână, târlă; țarc

sheepish sfios, timid, ruşinos; fricos; prostut, bleg sheepishly $(a d v)$ sfios, timid, cu sfială / timiditate; cu frică; prosteşte, ca un prost

sheepishness sfială, sfiiciune, timiditate, ruşinare; frică; înfățişare de om prost / bleg

sheep leather şevretă

sheepman (agr) crescător / negustor de oi, cioban, păstor

sheep run (agr) păşune (întinsă) pentru oi

sheepshank (nav) picior de câine (nod)

sheepskin piele de oaie; pergament (din piele)

sheer a devia, a se abate; (nav) a se legăna, a se clătina; a se încovoia; deviere, abatere; (nav) evitare, 
selatură (a punții), ambardee, evitare pe ancoră; (mec) curbură, încovoiere, deviere; (textile) transparent, diafan; curat, pur; nediluat; absolut, complet, total; vertical; perpendicular; (geogr) abrupt, râpos; $(a d v)$ perpendicular; vertical; cu desăvârşire complet(amente), perfect, absolut

sheers $(p l)$ (nav) bigă improvizată

sheerlegs (OM, constr) trepied; (nav, transp) bigă, macara-foarfece

sheer strake $(O M)$ centură, şirul tablelor centurii (la recipiente, ansamble sudate)

sheet (nav) velă, pânză, şcotă; (textile) cearşaf; foaie, coală (de hârtie); (OM, fiz, materiale) pânză, strat, pătură, înveliş, placă; (mas, TH) schemă, diagramă, tabel; (met) foaie de tablă (subțire); perdea (de apă, fum etc.); a acoperi cu un cearşaf; a întinde un strat (de vopsea etc.) peste; (TH) a înveli; a placa

sheet (met) tablă, foaie de tablă (subțire); (OM) pânză de ferăstrău, placă

sheet anchor (nav) ancoră de rezervă / de siguranță

sheet bar $(\mathrm{OM})$ platină

sheet-bar reheating furnace (met) cuptor de reîncălzit țagle

sheet-bar (rolling) mill (met) laminor pentru tagle sheet-bar shears (met) foarfece pentru țagle sheet-bar stacker (met) stivuitor pentru țagle sheet-bar train (met) linie de laminare pentru țagle sheet bending machine (met) maşină de îndoit tablă

sheet bend (nav) nod de şcotă (simplu)

sheet billet (met) semifabricat pentru table / pentru laminare

sheet blowing method (met, plast) metodă de formare prin suflare a foilor

sheet brass (met) tablă de alamă

sheet case $(\mathrm{OM})$ carcasă / manta / învelitoare din tablă

sheet cleaning machine (met) maşină de curățat table

sheet clippings (met) deşeuri de tablă

sheet copper (met) tablă de cupru

sheet doubler (met) maşină de placat / de dublat tablă

sheeted acoperit cu un cearşaf / o husă; întins (ca un cearşaf); (fig) continuu, neîntrerupt

sheet gauge (metr, met) calibru pentru grosimea tablei

sheet glass (ind chim) sticlă plană, foaie de sticlă

sheet greasing machine (met, mas-un) maşină de uns table

sheet hook double (OM) cârlig-foarfece

sheeting (met, OM) căptușeală / îmbrăcăminte de tablă, blindaj, placare, acoperire; (ind chim) intercalare de maculatură (la fabricarea hârtiei) sheeting process (met, plast) tragere în foi, laminare sheet-iron (met) tablă de otel, tolă

sheet iron (met) tolă, tablă de metal

sheet-iron casing / shell (met) manta de tablă de oțel

sheet-iron for deep stamping (met) tablă de / pentru ambutisare adâncă

sheet-iron lining $(\mathrm{OM})$ manta / carcasă de tablă

sheet-iron pipe $(\mathrm{OM})$ burlan de tablă

sheet-iron shears $(\mathrm{OM})$ foarfece de / pentru tablă

sheet lead (met) tablă de plumb

sheet leveling machine (met, mas-un) maşină de îndreptat tablă

sheet lighting (fiz) fulger de căldură; (meteo) fulger îndepărtat

sheet metal (ind chim) ranforsare (cu fire metalice, fibre, plasă etc.) (la compozite, pneuri etc.)

sheet-metal (met) tablă

sheet-metal case $(\mathrm{OM})$ carcasă de tablă

sheet-metal casing $(\mathrm{OM})$ înveliş / manta de tablă

sheet-metal cover $(\mathrm{OM})$ capac de tablă

sheet-metal for deep drawing (met) tablă de pentru ambutisare adâncă

sheet-metal pipe $(\mathrm{OM})$ tub de tablă, burlan

sheet-metal plate (met) foaie de tablă

sheet-metal strip (met) platbandă (metalică)

sheet-metal-testing apparatus (met, metr) aparat de încercat / testat tabla

sheet-metal work (TH) lucrare de tinichigerie

sheet mill (met) laminor de tablă

sheet mill stand (met) cajă la laminorul de tablă

sheet mill train (met) linie de laminat tablă, tren de laminare

sheet music (muz) partituri pe foi volante

sheet pack (met) legătură / pachet de tablă, tablă în pachete

sheet-pack heating furnace (met, termo) cuptor de încălzit tabla în pachete

sheet panel / plate (met) foaie de tablă

sheet pile (met) stivă de table; (constr) palplanşă sheet piler (met, mas) dispozitiv de stivuit / stivuitor de table

sheet plate (met) foaie de tablă (plană)

sheet polishing machine (met, mas-un) maşină de polizat / de lustruit tablă

sheet roll (met) cilindru de laminat tablă

sheet rolling (met, $\mathrm{TH})$ laminare a tablei

sheet rolling mill (met) laminor de tablă

rului de tablă

sheet rolling train (met) linie de laminat tablă

sheet rolls (met, plast, $\mathrm{OM}$ ) valț / rolă de tragere în foi

sheet (rolling-mill) stand (met) cajă a laminorului de tablă

sheet scraps (met) deşeuri de tablă

sheet shears (met) foarfece de tablă 
sheet size (met) format de coadă (la rulouri de tablă, la laminare la rece a benzilor lungi etc.)

sheet steel (met) tablă de oțel, subțire

sheet-steel straightening unit (met, mas-un) maşină de îndreptat table de oțel

sheet stock-yard (met) depozit de tablă

sheet straightening unit (met, mas-un) maşină de îndreptat table

sheet strip (met) bandă, tablă în benzi

sheet strip cold rolling mill (met) laminor de benzi la rece

sheet thickness (met) grosime a tablei

sheet tin (met) tablă de staniu

sheet zinc (met) tablă de zinc

sheet with good bend properties (met) tablă pentru fălțuire

she-fox (zool) vulpe (femelă)

she-goat (zool) capră

sheik(h) (pol) şeic

shekels gologani, bani

sheldrake, shelldrake (zool) gâscă de peșteră

shelf $(\mathrm{OM})$ raft, poliță; etajeră; stelaj; to put on the $\sim \mathbf{a}$ a pune la dosar/index; (fig) a trece pe linie moartă; (fig) (ec) a da afară, a concedia; a pensiona, a scoate la pensie; (geogr) stâncă, prag, recif; (geol) rocă din culcuş, zonă terigenă, platformă continentală

shelf life (plast, ec) durată de conservare / de stocare (a unui adeziv, pe raft a unui produs în magazin etc.)

shell (TH, OM, met) cămaşă, manta, înveliş, teacă, cuzinet, capsă; (alim, met) cuvă; pojghiță, strat, peliculă; scoarță, coajă, înveliş; crustă; găoace; cochilie; valvă; (zool) țeastă, carapace, scoică, elitră; (fig) loc / punct vulnerabil; (met) carcasă / înveliş de tablă; (fiz, agr) strat, pojghităă, peliculă; (mil) obuz; şrapnel; (nav) corp de navă, cocă, căpățână de macara, peşte de loh; (fiz) strat, pătură; (el) cuvă; (sport) schif; (constr, hidr) umplutură (în corpul barajului de pământ); a (des)coji, a curăța de coajă; a decortica; (mil) a bombarda; a supune tirului artileriei; a se coji; a se jupui; a (se) dezghioca; (d. coajă etc.) a se desprinde, a cădea

$\operatorname{shellac}(\mathbf{k})$ (ind chim, mobilă) şe(r)lac, lac natural obținut din dizolvarea unei răşini secretate de insecte din Asia în alcool tehnic; a acoperi / trata cu şe(r)lac (în industria mobilei)

shell and tube exchanger (termo) schimbător de căldură tubular

shell and tube / coil condenser (termo) condensator tubular cu manta

shell-and-tube cooler (termo, alim) răcitor tubular cu manta shell auger (mas-un) burghiu scoică / cilindric shellback (nav) lup de mare, marinar cu experienţă

shell core (met) miez tubular

shell drill (mas-un) zencuitor cu alezaj / cu coadă demontabilă, adâncitor cu gaură, burghiu cu alezaj conic

shell end mil with plai bore and tenon drivel (mas-un) freză cilindro-frontală

shelled (alim, materiale, TH) cu crustă

shell end cutter (mas-un) freză frontală, cu gaură

shell end mill (mas-un) freză frontală cu alezaj / cu coadă demontabilă

shell fish (zool) crustaceu, testaceu

shelling cojire; descojire; decorticare; $\sim \mathbf{s}(p l)$ coajă, coji, pleavă, boabe / semințe decorticate / curăţate; culegerea scoicilor

shell mould (met, plast) formă-coajă / subțire

shell of blast furnace (met) căptuşeală de zidărie / manta la cuptoare

shell out (ec) (fam) a ieși cu (banii), a scoate (banii) pe masă, a plăti

shell plate (met) tablă de învelit

shell-proof (mil) blindat, apărat împotriva obuzelor

shell reamer (mas-un) alezor cu alezaj conic

shell rings $(\mathrm{OM})$ virole de cazan

shell-shaped $(\mathrm{OM})$ concoidal, în formă de scoică

shell-sheet (met) tablă de învelit

shell shock (mec) şoc cauzat de o explozie; (med) contuzie cauzată de suflul unei explozii

shell-shoked (med) contuzionat de suflul unei explozii

shell skin plate (met, OM) îmbrăcăminte / manta / înveliş de tablă

shell snail (zool) moluscă (terestră), melc

shelly (d. un teren) cu (multe) scoici; ca scoica; ca de scoică

shelter adăpost, acoperiş; ascunziş, refugiu, loc ferit; azil; apărare, protecție; umbrar; şopron; paravan; (agr) şură, grânar; (mil) a apăra, a proteja, a feri; a găzdui; a da casă (cuiva); a (se) adăposti, a oferi adăpost; a se ascunde

shelter belt (silv) perdea / centură de protecție (din copaci, pădure); paravânt

sheltered adăpostit, apărat; (ec, pol) protecționist

sheltering effect (fiz) efect de ecranare

shelterless lipsit de / fără adăpost

shelter pit adăpost individual

shelve a pune / aşeza pe raft / poliță; (fig) a pune la dosar (un plan etc.); a amâna (o discuție etc.); (fig) a destitui, a concedia, a da afară; a suspenda din serviciu; a prevedea cu rafturi / polițe; a se înclina / se povârni lin / treptat 
shelves $(O M)$ rastel, rafturi

shelving (OM) (care are / cu) rafturi, polite; stelaj

shelvy (geogr) cu bancuri şi recife; ieşit în afară care atârnă

she-monkey (zool) maimuță (femelă)

shepherd (agr) cioban, păstor, mocan, baci; (zool, agr) câine ciobănesc; (agr) a paşte (oile), a păstori (turma)

shepherd dog (zool, agr) câine ciobănesc

shepherdess (agr) ciobăniță, păstoriță

shepherd's knot (bot) sclipeți

shepherd's pie (alim) musaca de cartofi

shepherd's purse (bot) traista ciobanului

sherardize (met) a şerardiza

sherbet (alim) suc de fructe (rece), şerbet

sheriff $(\mathrm{adm})$ şerif, aprox. prefect, şef de poliție

(al unui district); (jur) prim-preşedinte (al unui comitat, în Scoția)

sheriffdom $(\mathrm{adm})$ funcția de serif; $\mathrm{v}$. sheriff

sherry (alim) vin de Xeres

sherry cobbler (alim) băutură din vin de Xeres, lămâie şi zahăr

shield (OM) scut, ecran, paravan, armătură, blindaj, ecranare, apărătoare; (fotografie, hidr, OM) diafragmă; a apăra, a feri a proteja; a ascunde, a tăinui; (fiz, TH) a ecrana; a blinda; the other side of the $\sim(f i g)$ reversul monedei, celălalt aspect al problemei; (fig) scut, apărător

shielded (OM, fiz) ecranat, protejat; acoperit

shielded arc-electrode (met, fiz) electrod în manta shielded arc welding (met, TH) sudare $\mathrm{cu}$ arc electric, în gaz / gaze protector / protectoare

shielded ball-bearing $(\mathrm{OM})$ rulment cu bile, protejat

shielded carbon arc welding (met, $\mathrm{TH}$ ) sudare cu arc electric în gaz protector (dioxid de carbon)

shielded electrode (met, TH, el) electrod învelit / protejat

shielded spark plug (auto) bujie blindată

shielding (OM, fiz) stăvilire, protecție, înveliş metalic, ecranare,; care protejează / ecranează

shielding action (OM, fiz) efect de ecranare / de protecție

shier (zool) cal sperios

shift a (se) (stră)muta, a schimba, a transfera; a deplasa; a întoarce; a schimba direcția; a comuta; a muta, a transfera; a decala; (cf, nav) a transborda; (mat) a translata; one's lodging a-şi schimba locuinta / domiciliul, a se muta; $\sim$ the sails (nav) a schimba direcția pânzelor; a ucide; a schimba, a înlocui; (bot) a transplanta, a răsădi; a schimba (hainele); a mânca/a bea (tot); a-şi schimba locul / domiciliul etc., a se muta; a se deplasa; a se transfera; a se mișca; a se întoarce; a (se) feri, a se da în lături / într-o parte; (auto) a schimba viteza, a cupla (o viteză); (d. o scenă etc.) a se schimba; (d. vânt etc.) a-şi schimba direcția; (fig) a o scoate la capăt; a se descurca; for a living a-și câștiga existența; aşi schimba hainele, a se schimba; schimbare; mutare; deplasare; schimb (al muncitorilor); work in $\sim \mathbf{s}$ a lucra în schimburi; on the night $\sim$ în schimbul de noapte; pretext, subterfugiu, chichiță; scuză; for a drept scuză / pretext; expedient; make a se descurca (cumva); a se strădui; a se zbate; (textile) cămaşă de noapte (pt. femei); rezolvare; mijloc, mod, metodă; deplasare, mutare; comutare; post / schimb de lucru; schimbare; schimb

shift about a-şi schimba locul într-una

shift angle (metr, OM) unghi de deviere, eroare unghiulară

shift bar (auto, OM) tijă a schimbătorului de viteză shift claw $(\mathrm{OM})$ furcă a schimbătorului de viteze

shift dog (auto, OM) gheară a de schimbătorului de viteză

shift down (auto) a schimba viteza în jos, a reduce viteza

shifted phase (fiz) fază decalată

shifter (el) comutator, unitate de decalare; pârghie de cuplare; (cf) locomotivă de manevră

shifter cylinder $(\mathrm{OM}$, hidr) cilindru mecanismului de decuplare (la acționare pneumatică)

shifter feeler $(\mathrm{OM})$ furcă a dispozitivului pentru mutarea curelei

shifter fork $(\mathrm{OM})$ furcă de decuplare

shifter lever (OM) pârghie a mecanismului de inversare, pârghie de comutare

shifter rod $(\mathrm{OM})$ bară de cuplare

shiftily $(a d v)$ (în mod) nesincer, prefăcut; cu ipocrizie; (în mod) nehotărât

shiftiness ingeniozitate; prefăcătorie, ipocrizie

shifting mobil, mişcător, schimbător; nestatornic; siret, șmecher

shifting $(\mathrm{OM})$ cuplare, ambreiere; (mec) alunecare cauzată de forța tăietoare, dislocație; (inf) deplasare (a poziției ocupate de fiecare bit al unui sistem binat într-o locatie de memorie); deplasare; decalare; (mat) translație; (nav) transbordare, deplasare a mărfii în magazie, manevră de schimbare a danei

shifting beam $(\mathrm{OM})$ bară de susținere

shifting board (constr, nav) separație, perete de stivare

shifting bolt $(\mathrm{OM})$ bolt cu inel pentru remorcare $/$ tractare

shifting coupling $(\mathrm{OM})$ ambreiaj, muflă decuplabilă 
shifting device $(\mathrm{OM})$ dispozitiv de cuplare şi decuplare a curelei

shifting eye $(\mathrm{OM})$ inel de manevră / de prindere shifting fork (OM) furcă a schimbătorului de viteză

shifting gauge (OM, metr) trasator paralel

shifting handle $(\mathrm{OM})$ manetă pentru schimbarea vitezelor

shifting head (mas-un) păpuşă mobilă

shifting-jay clutch / coupling (OM) ambreiaj cu gheare, cuplaj cu dinți

shift key (c) tastă pentru majuscule; cheie / clapă de comutare

shifting screw $(\mathrm{OM})$ șurub de schimbare a mersului shifting spanner $(\mathrm{OM})$ cheie franceză

shift into reverse (auto) a acționa marşarierul / viteza de marşarier

shiftless leneş, moale; slab, fără vlagă; nedescurcăreț; netot, prost, bleg; lipsit de iniţiativă; ineficace

shiftlessly lene; moliciune; lipsă de resurse; ineficacitate

shift lever (auto, OM) schimbător de viteze; pârghie de comutare

shift lock $(\mathrm{OM})$ organ de fixare

shift-lock override (auto) eliberarea de urgență a sistemului de blocare a schimbătorului de viteză

shift lock system (auto) sistemul de blocare a schimbătorului de viteză

shift of butts $(\mathrm{OM})$ decalare a îmbinărilor

shift off a scăpa de; a se dezbăra de, a se descotorosi de; a-şi declina (răspunderea)

shift off responsibility / task a scăpa de o răspundere / sarcină (trecând-o altuia), a pasa o răspundere / o sarcină

shift of workers (ec, ind) schimb, tură

shift pattern (auto) schimbător de viteze

shift pattern indicators (auto) indicatori (simbolizări) pentru schimbătorul de viteze

shift position indicator (automatic transaxle only) (auto) indicator al schimbătorului de viteze (numai la cutie automată de viteze)

shift up (auto) a schimba viteza în sus

shifty ingenios, plin de resurse; şmecher, pişicher

shilling (metr, ec) şiling (monedă de diverse valori: în Anglia 1/20 de liră sau 12 pence)

shilly-shally a ezita, a şovăi, a fi nehotărât; ezitare, şovăire, nehotărâre; şovăitor, şovăielnic; $(a d v)$ (într-un mod) şovăitor

shim $(\mathrm{TH})$ adaos, bailag; (mec) inerție; (OM) lamelă, suport, element / pană de fixare, garnitură de reglare, inserție; (constr) pană de fixare; a bate pene, a împăna shimmer (fiz) a licări, a sclipi, a luci, a pâlpâi; licărire; sclipire; lucire; pâlpâit

shimmery (fiz) licăritor, lucitor, pâlpâitor

shimming $(\mathrm{OM})$ reglare cu garnituri / şaibesubțiri shimmy tremur(at); (auto) oscilatie a rotilor, balansare / trepidare a autovehicolului din cauza denivelărilor drumului, șimiu; (fiz, mas) oscilație, clătinare, vibrație / trepidație anormală

shimmy of the front wheels (auto) legănat al părții din față a autovehicolului, oscilație / şimiu a(l) roților din față

shim plates $(\mathrm{OM})$ şaibe / adaosuri de tablă

shims $(\mathrm{OM})$ discuri de egalizare, distanțiere de montaj / de reglare

shim up $(\mathrm{OM})$ a aşeza în poziție, a corecta prin adaosuri / garnituri de reglare / şaibe / distanțiere, a folosi distanțiere pentru reglare / montare

shin (OM) eclisă; (anat) tibie, fluierul piciorului; a se cățăra pe (o frânghie etc.); a lovi (pe cineva) cu piciorul (în fluierul piciorului)

shinbone shin (anat) tibie, fluierul piciorului shindig zaiafet, bairam, petrecere

shindy scandal, tărăboi, gălăgie, larmă; încăierare; kick up a a face scandal / tărăboi

shine a străluci; a luci; a lumina; a străluci, a se remarca, a se evidenția; (fig) a fi eminent; a face să strălucească / să lucească; a sclipi; a lustrui (ghete etc.), a poliza; strălucire, lumină (a soarelui etc.); iradiere (a soarelui etc.); luciu; lustru; (fig) strălucire, splendoare, măreție, farmec; (amer) simpatie (pentru cineva); (fig) în orice condiții, indiferent de situație

shiner stea, luceafăr; corifeu; briliant; (anat) ochi învinețit, vânătaie; văcsuitor de ghete, lustragiu; (constr) sindrilă, sită, draniță, olan, tiglă; a înveli cu şindrilă / țiglă; a tăia (părul) foarte scurt (părul cuiva); pietriş, prundiş; galeți

shingling (met) îndepărtare a țunderului

shingling rolls (met, $\mathrm{OM}$ ) cilindri de degroşare

shingly (constr) învelit / acoperit cu şndrilă / țiglă; cu pietriş, cu prundiş

shining strălucitor, lucitor, luminos; care străluceşte / luceşte; (fig) strălucitor; (d. cineva) strălucit; eminent; remarcabil

shining coal (met, termo) cărbune bituminos

shiny strălucitor; lucitor; lucios, cu luciu; (meteo) senin, cu soare, însorit (d. vreme)

ship (nav) navă, vas, vas cu trei catarge, corabie, vapor, bastiment, echipaj; on board $\sim$ pe / la bord; (amer) avion, dirijabil; (nav) a îmbarca; a lua la bord; a expedia (cu vaporul); a transporta (pe cale maritimă), a fixa (catargul etc.), a se îmbarca, a se angaja ca marinar; (gram) sufix care exprimă calitatea, condiția etc.): 
friendship - prietenie, kinship - înrudire, rudenie, leadership - conducere

ship agent (nav, ec) agent maritim de navlosire

shipa boat (nav) barcă de serviciu

shipa journal (nav) jurnal de bord

shipas breadth (nav) lățime a navei

shipas sheathing (nav, met) tablă navală

shipas skin (nav) table ale bordajului exterior

shipas waterline (nav) linie de plutire

shipas winch (nav) vinciu al bărcilor

ship biscuit (nav, alim) pesmet marinăresc

shipboard (nav) vas, navă, bord; on pe vas, la bord

shipboard plane (nav, av) avion îmbarcat

ship boat (nav) şalupă de bord

ship bottom (nav) fund al navei

ship boy nav elev marinar, mus

ship-broker (nav, ec) agent maritim

ship builder (nav, ind) constructor de nave

ship building (nav, ind) constructii navale

shipbuilding dock (nav) doc de construcții navale

shipbuildin hall (nav) hală de construcții navale shipbuilding plate (met, nav) tablă de constructii navale

shipbuilding yard (nav) şantier naval

ship caisson (nav) cheson

ship cargo (nav) a încărca (un vas, o navă)

ship depth (nav) înălțime a bordului

shipless (nav) fără nave, gol (d. un port etc.)

shiplet (nav) corăbioară

ship-lifting device (nav) utilaj de / pentru ridicarea vaselor

shipload (nav) încărcătură a navei, caric

shiplock (nav) ecluză navigabilă

shipman (nav) marinar, căpitan, muncitor de port / pe navă

shipmaster (nav) comandant de navă (comercială)

shipmate tovarăş/camarad de navă

shipment (nav) transport naval; nav navlu; încărcare; expediere; încărcătura

ship of the line (nav) vas de linie

ship owner, shipowner (nav) armator, proprietar de vas / vase

shipper (mas) încărcător; (OM) furcă de comandă, dispozitiv de mutare; (ec) expeditor

shipper rod $(\mathrm{OM})$ tijă a dispozitivului de mutare

shipping (nav) navigație, expediere, transport naval, flotă comercială, vase, nave, îmbarcare; naval, maritim

shipping bill (nav) permis de încărcare

shipping company (nav) companie armatorială, întreprindere de transporturi pe apă

shipping container (nav) cisternă de transport shipping ore (nav, met) minereu transportat pe cale maritimă

shipping room (nav) spațiu de încărcare, cală

shipping slip (nav) conosament

shipping ton (metr, nav) unitate de măsură pentru volumul încărcăturii unui vas, tonă de încărcare: 1 shipping ton $(\mathrm{UK})=1,17 \mathrm{~m}^{3}, 1$ shipping ton (US) $=1,11 \mathrm{~m}^{3}$

shipping weight (nav) greutate brută

ship plate (nav, met) tablă de / din oțel pentru constructii navale

ship repairing dock (nav) doc de reparații

ship salvage (nav) ranfluare

ship's breath (nav) lătime a navei

ship scraper (nav) dragă

ship's crew (nav) echipaj (de navă / vas)

ship-shape (nav) în perfectă ordine

ship's number (nav) indicativ / denumire a(l) navei

ship's papers $(p l)$ (nav) actele de bord

ship's people (ca $p l$ ) (nav) echipaj

ship's register (nav) carte tehnică a navei; societate de clasificare a navei

ship's sheathing / skin (nav) bordaj / înveliş etanş al navei

ship's side (nav) bord / flanc al navei

ship's time (nav) oră a bordului, oră a fusului orar ship's wake / track (nav) siaj al navei

ship's warrant (nav) navicert amendat

ship's water line (nav) linie de plutire a navei

ship's winch (nav) vinci de bord / de navă

shipway (nav) cală de lansare

shipwork (nav) construcții naval, muncă de bord

shipwreck (nav) epavă, naufragiu, rămășițe din nava distrusă, naufragiat; (fig) spulberare (a sperantelor etc.); nimicire; ruină; distrugere; (nav) a naufragia, a provoca naufragiul (unui vas), a face să naufragieze, a eșua; (fig) a spulbera; a nimici, a distrugere, a eşua, a fi distrus / nimicit

shipwright (nav) constructor de nave, marangoz, tâmplar de vapoare

shipyard (nav) şantier naval, cală de lansare

shire (adm) comitat, district

shirk (from) a se eschiva, a se sustrage (de la); a se eschiva/a se sustrage de la (îndeplinirea unei obligații etc.); a neglija; eschivare, sustragere

shirr (textile, plast) a plia, a cuta, a face pliuri în (stofă, folii etc.); (alim) a coace (ouă în coajă) în forme cu unt; (textile, plast) pliuri, cute

shirt (textile) cămaşă (bărbătească), bluză cu mânecă lungă (pt. femei), șemizetă, cămașă de noapte (bărbătească), bluză; give smb. a wet a pune pe cineva să muncească din greu; $(\mathrm{OM}$, termo) cămaşă (de cilindru / de piston) 
shirt-front (textile) plastron

shirt-sleeve simplu; neceremonios; (de) plebeu; de rând; comun; umil, modest; in one's $\sim \mathbf{s}$ în cămašă, fără haină

shirty $(a d v)$ cu arțag / draci; cu capsa pusă

shive bucată, fărâmă, fragment; aşchie; (textile) deşeuri

shiver sfărâmătură; ciob; țandără

shivery care se sparge uşor, fragil; care tremură; înfiorat; înfrigurat; (d. vreme) rece

shivy impurificat; murdar

shoal mulțime, grămadă; gloată; (iht) banc (de peşti); a veni, a se mişca, a se deplasa cârduricârduri; (geogr, hidr) banc de nisip, traversadă, zonă cu bancuri de fund, fund mic, loc puțin adânc; (d. apă) a scădea, a se micşora, a se împuțina; a se înnămoli

shoal water (nav, geogr) apă joasă / puțin adâncă shoat (zool, agr) purcel

shock (mec) şoc, lovire, lovitură, izbitură, zdruncinare, ciocnire; (agr) cruce de snopi; căpiță; claie (de păr); a aşeza în căpițe; (med) şoc, atac, comoție, şoc electric, atac de paralizie, apoplexie; a şoca; a uimi peste măsură; a ului; a dezgusta; a scârbi; a revolta, a ofensa, a scandaliza, a indigna; (mec) a izbi, a lovi (puternic), a zdruncina, a zgudui; a (se) ciocni

shock-absorbent, shock absorbing (OM) antişoc, amortizant, fără trepidație

shock absorber (OM) amortizor de şocuri

shock-absorber spring $(\mathrm{OM})$ arc de tampon / de amortizor

shock-absorbing plate / slab placă de amortizare

shock absorption (OM) amortizare a socurilor shock bending test (metr, materiale, OM) încercare / test de încovoiere cu şoc

shock brigade (mil, ind) brigadă de şoc

shock chilling (termo, alim) refrigerare foarte bruscă (şoc); zvântare rapidă (tip şoc)

shock coefficient (mec, OM) coeficient de impact

shock cord tesătură ranforsată (tip şnur / coardă, bandă) pentru amortizarea şocului (şi pentru centuri de siguranță)

shock damper $(\mathrm{OM})$ amortizor de şocuri

shock effect (mec) efect de şoc

shock elasticity (mec) reziliență

shocker persoană/lucru care şochează

shock excitation (mas, el) excitație prin şoc

shock-headed cu părul zburlit / vâlvoi

shocking (d. o ştire etc.) îngrozitor; paralizant; zguduitor; şocant, scandalos; revoltător, respingător; ruşinos; grozav de

shockless $(\mathrm{OM})$ fără trepidație shockless jolt machine (met, mas-un) maşină de format prin scuturare, $\mathrm{cu}$ amortizarea şocului shock load (mec, OM) sarcină dinamică / aplicată cu şoc / la impact

shock-mount base (el, OM) soclu elastic / cu arc

shock pressure (hidr, fiz) suprapresiune datorată loviturii de berbec

shockproof (materiale, OM) antişoc, rezistent la şoc

shockproof plug (el, OM) fişă protejată contra atingerilor accidentale

shockproof polystyrol (plast) polistiren rezistent la şoc

shock-resistance (mec, hidr) rezistentă la şoc

shock-resistant (materiale, OM) rezistent la şoc

shock stress (mec, OM) tensiune / efort la şoc / cauzat $(\breve{a})$ de şoc

shock strut (OM) suport cu amortizor de şocuri

shock tactics (mil, ec) tactică de şoc

shock troops (mil) trupe de şoc

shock wave (mec, hidr) undă de şoc

shock worker muncitor de şoc, operator în caz de avarii / pentru situații speciale

shoddiness proastă calitate, calitate inferioară

shoddy (lucru, piesă etc.) prost, de calitate proastă / inferioară; ieftin; falsificat; (textile) fibre de calitate inferioară, cu scamă; (ind chim) cauciuc uzat/prost/inferior

shoddy (ind chim) cauciuc îmbătrânit / regenerat shoe pantof, papuc; (amer) gheată; labă; potcoavă; $(\mathrm{OM})$ sabot (şi de frână), za de şenilă, talpă, sanie, cuzinet, papuc, patină; (el, OM) sabot alunecător de contact; (nav) chilă falsă, talpă, papuc; (constr) țiglă; (auto) (fig) cauciuc de mașină;a potcovi; a încălța; a pingeli

shoeblack văcsuitor, lustragiu

shoe brake $(\mathrm{OM})$ frână cu sabot / saboți

shoe buckle $(\mathrm{OM})$ cataramă (la pantofi)

shoe cream (ind chim) cremă de ghete, vacs

shoe drill (agr, mas) semănătoare cu brăzdare

shoe horn $(\mathrm{OM})$ limbă de pantofi, încălțător

s-hook (OM) cârlig curbat în formă de $\mathrm{S}$

shoe lace / string (textile) şiret de pantofi / de ghete; on $\mathbf{a} \sim$ (a începe etc.) cu un capital foarte mic, de la mai nimic

shoe leather (ind chim, ind uşoară) piele pentru pantofi

shoe polish (ind chim) cremă de ghete / de pantofi

shoer potcovar

shoeshine lustruit, văscuit

shoe thread (ind chim) cremă de ghete ață de cizmărie, fir smolit

shoo hâş! (pt. a goni păsările); a speria; a goni (păsările); (d. păsări) a fugi, a pleca 
shoot a împuşca, a omorî prin împuşcare; a trage, a (se) descărca (d. o armă) (în); a arunca, a ținti (o săgeată); (mediu) grămadă (de gunoi), a arunca, a azvârli (gunoi etc.); (fiz) a arunca (raze); a se revărsa, a împrăştia (lumină etc.); a trage repede (zăvorul etc.); (sport) a marca (un gol), a şuta, a juca golf etc.; a străbate, a traversa; a fotografia; (constr) a împuşca (un perete etc.), a degaja un teren prin explozie controlată; a goli, a deşerta; a împestrița; a colora într-altfel; a dunga; (astronomie) a lua altitudinea; a trage (cu arma etc.) (în); a vâna (cu puşca); a trece iute / în zbor; (d. stele) a cădea; a se ivi brusc, a apărea pe neaşteptate; a țâşni; a se proiecta; (bot) a încolți; a miji; (med) a durea; a zvâcni; (fotografie, cinematografie) a lua un instantaneu, a fotografia, a face un film, a filma; a vâna (cu puşca); (bot) mlădiță, vlăstar, mugur(e), boboc; (partidă de) vânătoare; (mil) tir, tragere la țintă; (mil, constr) împuşcătură; (geol) gangă; (OM) glisieră, cale de alunecare, uluc; scoc; zbor (de săgeață etc.); a gelui, a rindelui (lemn)

shoot along a se ivi brusc / pe neaşteptate; a țâş̧i shoot at a căuta să atingă/să realizeze; a ținti la; a năzui la

shoot away, shoot off a reteza printr-un foc de armă (un braț etc.)

shoot down a doborî (prin împușcare), a împuşca; (fig) a spune nu la, a respinge

shoot for a urmări; a căuta să obțină

shoot forth (bot) a încolți; a înmuguri; a da (muguri)

shooting (mil) tragere, foc; vânătoare cu arme de foc; dreptul de a vâna; permis de vânătoare; (med) durere acută şi bruscă; filmare; (ind) împuşcare; (geol) prospecțiune

shoot out (d. păsări) a-şi lua zborul brusc; a țâşni, a ieşi în afară, a se proiecta în afară; (bot) a da (muguri etc.); a împrăştia, a arunca (scântei etc.); a țuguia, a strâmba (buzele, în semn de dispreț); a scoate (limba)

shoot up (d. flăcări etc.) a se ridica, a se înălta; a țâşni, a izbucni; (d. copii etc.) a se înălța, a crește repede / văzând cu ochii; (mil) a deschide focul, a începe să tragă

shooting (constr) (îm)puşcare; declanşare a aparatului de fotografiat

shooting box (constr) cabană de vânătoare

shooting brake (auto) autoturism combi / station; (TV) car de televiziune / de reportaj

shooting cameră cameră de luat vederi

shooting flow curgere rapidă

shooting gallery (sport, constr) pavilion de tir sportiv, tir (pt. amuzament) shooting iron (OM, mil) armă (de foc)

shooting star stea căzătoare, meteorit

shooting stating (geol) stație seismologică

shooting war (pol, mil) război real / adevărat

shoot off (mil, med) a reteza (un braț etc.) printr-un foc de armă

shop (ec) magazin, prăvălie, dugheană, debit (de tutun, de băuturi spirtoase); (ind) atelier (de fabrică, mecanic etc.); a face / merge după cumpărături

shop (ind) atelier mecanic, secție

shop accident (ind) accident de exploatare

shop assistant (ec) vânzător / vânzătoare (întrun magazin)

shop conditions $(p l)$ (mas, TH) condiții de lucru (într-un atelier, sectie etc.)

shop data (ind, mas) date de exploatare

shop drawing (TH, mas-un) desen de execuție / tehnologic, desen de execuţie specific operației de prelucrare

shop equipment (ind, mas-un) utilaj de atelier, pentru reparații

shop fabrication ( $\mathrm{TH}$, ind) realizarea de subansamble în atelier pentru montare ulterioară pe şantier

shop floor (constr) nivel al atelierului

shop for steel structures (ind) atelier / secție pentru constructiii metalice

shop girl (ec) vânzătoare (într-un magazin)

shopkeeper (ec) negustor, comerciant, neguțător

shopkeeping (ec) comerț, negoț, negustorie

shoplifter hoț din magazine

shoplike (ec) negustoresc, mercantil, de proastă calitate

shopman (ind) muncitor (de reparații / de mentenanță); (ec) lucrător în comerț

shop manual (mas) manual de reparații şi mentenanță

shopocracy (ec) proprietari de magazine, (personal cu răspundere din) administrația magazinului, negustori, negustorime

shop pan $(\mathrm{OM})$ cutie de oțel pentru depozitarea pieselor

shopper (ec) cumpărător, client

shopping (ec) (mers la) cumpărături, târguieli

shopping bag (ec, ind chim, textile) sacoşă / pungă (pt cumpărături)

shoppy (ec) comercial, (de) vânzătoare; legat de comerțul cu bucata; profesional; de specialitate; cu multe magazine; (de) mic-burghez; servil; prefăcut

shop replaceble assembly (mas, OM, TH) ansamblu care poate fi înlocuit şi testat inițial doar în atelier / în hală 
shop-soiled (ec) care şi-a pierdut aspectul de marfă, degradat (în magazin)

shop steward (ec, adm) delegat de atelier; reprezentant al muncitorilor; delegat sindical

shop-walker (ec) supraveghetor (într-un magazin universal)

shop welding (met, $\mathrm{TH}$ ) sudare în atelier / în secție shop window (ec) vitrină

shore (geogr) țărm, mal, coastă; uscat; off în larg; in la țărm, (mai) aproape de coastă / țărm; on pe țărm / coastă, pe uscat; $(\mathrm{OM})$ proptea; reazem, suport; (constr) pop (pt. armarea galeriilor, şanțurilor etc.); a propti; a sprijini

shore țărm, litoral; (TH) a propti, a sprijini; (nav) pontil de sprijinire a mărfii stivuite

Shore (materiale, metr) duritate Shore

Shore (dynamic indentation) test (materiale, metr) încercare / test dinamic(ă) pentru determinarea durității de tip Shore

shore boat (nav) şalupă de coastă / de țărm, vas de cabotaj

shore dinner (alim) masă pescărească

shore fast (nav) parâmă dată (de) la uscat

Shore hardness (materiale, metr) duritate Shore

Shore hardness number (materiale, metr) indice / valoare de duritate Shore

shoreless nețărmuit, fără hotar(e)

shore line (geogr, hidr) linia malului, (linie de) litoral

shoreman locuitor de pe coastă; pescar de coastă; barcagiu; hamal de port

Shore sleroscope (metr) scleroscop Shore

shore up (OM, constr) a rezema, a propti, a sprijini

shorewards $(a d v)$ spre / către țărm/coastă

shoring (OM, constr) susținere (de lemn), zidire, cofraj de lemn

shorn tuns

short scurt; redus; restrâns; puțin; concis; succint; rezumat; diminutiv; (ec) deficit; scurtătură; lipsă; termen scurt, pentru puțină vreme; scurtime; (el) scurtcircuit; (lingv) prescurtare, formă prescurtată, vocală / silabă scurtă; casant; urgent; brusc, imediat; exclusiv; mai încoace, dincoace; a time age nu de mult, de curând; (d. cineva) scund, mic, mic de statură; insuficient; deficitar; incomplet; fall $\sim$ a nu ajunge, a nu fi îndeajuns / suficient, a fi insuficient; a nu corespunde, a nu fi corespunzător; a nu fi la înălțime; a dezamăgi, a dezminți aşteptările; a nu-şi atinge scopul; run a (se) termina, a (se) isprăvi; a (se) epuiza; a nu ajunge; (d. un răspuns etc.) scurt; tăios; sec; aspru; (alim) (d. o prăjitură etc.) fraged; care se topește în gură, sfărâmicios, (d. o băutură) tare; $(a d v)$ brusc, deodată, pe neaşteptate; stop / pull up a (se) opri brusc; cut smb. a tăia cuiva vorba, a întrerupe pe cineva; for $\sim$ pe scurt; prescurtat; in pe / în scurt, în câteva cuvinte; ca să nu (mai) lungim vorba; lipsă, deficit; $\sim \mathbf{s}(p l)$ (textile) şort, pantaloni scurți; $\sim \mathbf{s}(p l)$ cămaşă (bărbătească) scurtă; (cinematografie) film de scurt metraj; $\sim \mathbf{s}(p l)$ resturi; rămăşiţe; rebut; $\sim$ s (ec) mărfuri / hârtii de valoare fără acoperire; s $(p l)$ (agr) tărâță (fină) de grâu; a way off la o distanță mică; go the est way a merge pe drumul cel mai scurt; for $\mathbf{a} \sim$ while pentru puțin timp; give $\sim$ weight a cântări în minus; be on time a fi şomer parțial; be of cash (fam) a fi în lipsă de fonduri; cut $\sim$ a tăia scurt; make work of a se debarasa rapid de, a expedia repede; come $\sim$ of one's duty a nu-şi face datoria; $\sim$ tempered irascibil; in $\sim$ în rezumat, pe scurt; the long and the $\sim$ of it is that în două cuvinte; of cu exceptia

shortage lipsă; penurie; criză; (ec) manco, insuficiență, deficit

shortage material(s) (ind) materiale deficitare

short annealing (met, TH) recoacere rapidă / cu ciclu scurt

short arc (met, el, TH) arc scurt de sudare

short bill (TH) documentare lipsă, lipsă a documentării; (ec) trată pe termen scurt

short block (OM) butuc scurt

shortbread (alim) prăjitură sfărâmicioasă din aluat fraged

short breaking (plast) fribilitate, rupere scurtă

short-brittle (met) fragil (şi la roşu), casant

shortcake (alim) prăjitură sfărâmicioasă din aluat fraged; un fel de tort (cu cremă şi fructe)

short-change (ec) a nu da restul cuvenit cuiva (care a plătit o bancnotă mare)

short circuit (el) scurtcircuit

short-circuit brake $(\mathrm{OM}$, el) frână cu scurt-circuit

short-circuiter (autom, el) scurtcircuitor, care scurtcircuitează

short-circuit rotor (el) rotor în scurtcircuit

short-circuit to ground (el) scurtcircuit la pământ shortcoming ( $\mathrm{TH}, \mathrm{OM}$, ind) defect, deficiență, neajuns; (ec) lipsă, deficit

short credit (ec) credit pe termen scurt

short cut drum scurt / de-a dreptul, scurtătură; (textile) cută, încrețitură, pliu; (ec, TH) metodă rațională

short-cut method (mat, metr) metodă rapidă / simplificată (în orice domeniu)

short cutting of the vine (agr) tăiere a viței la cap ras

short-cycle annealing (met) ciclu scurt de recoacere 
short-cycling (mec) pendulare rapidă; (termo) funcționare în cicluri scurte, a unui circuit frigorific

short-dated pe termen scurt

short dead-end (cf) linie moartă

short-distance transporter (transp) transportor la mică distanță

shorten a (se) scurta, a face (mai) scurt, a reduce, a (se) micşora; a se contracta; a reduce; a prescurta (cuvinte etc.); (fig) a micşora, a diminua, a slăbi; (alim) a face fărâmicios / fraged (aluatul); (el) a scurtcircuita; a deveni (mai) scurt

short ends $(p l)$ scurtături; (mediu, ind) resturi (de lemn, de tablă etc.)

shortening scurtare; prescurtare; tăiere; (alim) grăsime pentru frăgezirea aluatului

shorten sail (nav) a reduce velatura; (fam) (fig) a o lua mai domol

shorten the hand / arm of smb. (fig) a îngrădi / limita puterea cuiva

shorten the range (mil) a scurta tirul; (metr, autom) a reduce intervalul (de actionare, de răspuns etc.)

shorter short story schiță (literară)

short fiber(ed) (cu) fibre scurte (la compozite)

short-fiber asbestos (materiale) azbest cu fibre scurte

short fiber (materiale) fibră scurtă (în compozite etc.)

short-focus lens (fiz) lentilă cu distanță focală mică

short for prescurtat pentru / din; poreclă pentru

short-grained (materiale) cu granule fine, cu grăunți fini

short-haired cu părul scurt

shorthand (birotică) stenografie

short-handed (ec) care duce lipsă de mână de lucru / de personal

shorthead (zool) (animal) brahicefal

short-headed (zool) (adj) brahicefal

shorthorn (zool, agr) rasă de vite cu coarnele scurte; (fig) nou venit, novice, ageamiu

short-hose (textile, sport) pantaloni (scurți) de golf, pantaloni golf

shortie (textile) chiloți; pantaloni scurți, pantalonaşi; (cinematografie) film de scurt metraj; pitic, om mic de statură

shorting (el) scurtcircuitare; (ec) scurtcircuitare (a unui furnizor, distribuitor etc.); scurtare

shortish cam scurt, destul de scurt

short life (ec, ind) (cu) durată scurtă de viață (a unui produs / element de maşină)

short-life intermediates (chim, met, plast) compuşi intermediari instabili / cu durată scurtă de viață / existență

short-link chain (OM) lanț cu zale scurte short list (ec, adm) listă preferențială (a celor care solicită o functie)

short-lived de scurtă durată; efemer; de viață; care nu trăiește mult

shortly $(a d v)$ în câteva cuvinte, pe scurt; concis; curând, peste puțin timp; degrabă; îndată, imediat; brusc, pe neaşteptate; abrupt; scurt, tăios; cu asprime

short mark semn pentru sunet scurt (în fonetică)

shortness concizie; (fiz, materiale) fragilitate, friabilitate, imperfectiune; rupere scurtă; scurtime; (ec, TH) cantitate (prea) mică de resurse materiale; (fig) scurtime; slăbiciune; statură mică; blue (met) fragilitate la albastru / de revenire; cold- (materiale) fragilitate / rupere la rece; corrosive fragilitate corosivă; hot(met) fragilitate la cald / la roșu, rupere la cald / la roşu; impact $\sim$ fragilitate la impact / la şoc; red $\sim$ fragilitate la roşu (în timpul forjării)

shortness of memory lipsă de memorie, memorie slabă

short of mai puțin decât / ca, sub; căruia îi lipseşte (ceva); fără; care duce lipsă de; neavând suficiente (mijloace etc.); nu tocmai / prea (cu adj); lipsit de; inferior; cu excepția (unui material etc.)

short of fuel (auto, mas) lipsă de combustibil

short oil (ind chim) ulei parțial polimerizat

short order minut, comandă rapidă (la restaurant); in repede şi fără osteneală

short paid (d. o scrisoare etc.) francat insuficient

short pin (OM, hidr) stift (scurt) presat pentru înfundarea unei găuri

short-poured mould (met) formă incomplet umplută cu metal lichid

short radius (geom) apotemă a unui poligon regulat

short-range (mas, fiz) cu rază mică de acțiune (la roboti, manipulatoare, macarale etc.); care nu reclamă mult timp

short residuum (ind chim, alim) reziduu $\mathrm{cu}$ interval îngust de fierbere (şi la distilare în vid)

short-run casting (met) umplere incompletă

short-run demand $(\mathrm{ec})$ cerere de scurtă durată (pe piață)

shorts (materiale) material(e) care nu trec(e) prin sită, reziduu de cernere; (textile) cămaşa scurtă (bărbătească), chiloți bărbăteşti, pantaloni scurți, şort; rămăşițe; rebut(uri); resturi; $(\mathrm{TH}$, ec) sortiment scurt; tărâțe de grâu (fine); (fig) sume mici de bani, bunuri personale

short sale (ec) vânzare în alb (fără precizarea prețului)

short scanning (fiz, metr) explorare de scurtă durată (la control nedistructiv) 
short shipped (ec) expediat( $\breve{a})$ în minus (d. marfă) short short story schiță; povestire / relatare foarte scurtă (cu final neaşteptat)

short shrift (fig) neacordarea atenției cuvenite, expediere (a unui subiect etc.)

short sight, short-sightedness (anat) miopie; (fig) lipsă de prevedere, mărginire, obtuzitate

short sighted (anat) miop; (fig) lipsit de prevedere, mărginit, obtuz

short-spoken concis; laconic; tăios, aspru, nepoliticos

short-staffed (ec) cu personal incomplet, având lipsă de personal

short steps paşi mărunți (pt. rezolvarea unei probleme)

short story nuvelă, povestire

short strock (materiale) pastă cu fibre scurte

short-stroke (mas-un, termo) (cu) cursă scurtă

short-stroke engine (mas, termo) motor cu cursă scurtă

short-stroke press (mas-un) presă cu cursă scurtă short subject (cinematografie) film de scurt metraj

short temper caracter irascibil, irascibilitate, fire aprinsă / nestăpânită

short tempered irascibil, supărăcios, iute (la mânie); arțăgos

short term (pe) termen scurt

short test bar (materiale, metr) epruvetă scurtă

short-time duty / service (mas) functionare / regim de scurtă durată / temporar(ă)

short-time testing method (mas, OM, metr) metodă de încercare de scurtă durată / rapidă

short ton (sh.t, sh.tn., s.t.) (metr) unitate de măsură pentru masă, tonă engleză / scurtă / mică; 1 short ton $=907,18 \mathrm{~kg}$

short-waisted scurt în talie; cu talie ridicată

short wave (fiz) undă scurtă

short weight lipsă de / la greutate / de masă

short winded (med) cu respirație scurtă, care gâfâie, cu dispnee; scurt, concis

short-witted sărac cu duhul, lipsit de spirit

shot (textile, hârtie) cu ape, moarat; dungat, vărgat; multicolor; distrus, la pământ; împuşcat; (cinematografie, fotografie) cadru de film (dintr-o succesiune), secțiune (de film), filmare, filmat, tras, înregistrat (pe peliculă), secvență, fotografie; (ec) socoteală, plată; notă de plată; ghiulea; (sg și $p l$ ) (met) alice; (mil) țintaş, trăgător, foc de armă, împuşcătură; lovitură, a încărca (o armă); (ind) explozie, împuşcare a unei găuri; (nav) cheie de lanț; (sport) şut, încercare; şansă (med) doză (pt. o injecție); a pune plumb la (undiță); (plast) doză / şarjă de injectare shot-blast cleaning (met, TH) curățire cu curent de alice

shot blasting (met, TH) împroşcare / curăţare cu alice metalice

shot-blast unit (met, mas-un) instalație de curățat cu alice

shot copper (met) granule de cupru

shot defect (met) picătură de transpirație (la segregare inversă)

shote (zool) purcel

shot gun puşcă de vânătoare

shot-lubrication system ( $\mathrm{T}$, OM, hidr) sistem de ungere sub presiune

shot peening prelucrare cu alice metalice

shot-stopped reaction (chim, T) reacție frânată încetinită

shot-stopping agent (chim, T) întrerupător / inhibitor al polimerizării

shot-stopping of chain (chim, T) întrerupere a reacție

shot tank (ind, chim, OM) bazin de granulare shotting (met, TH) formare de alice (pt. curățat) shot welder (met, mas-un) maşină de sudat în puncte

shot welding (met, TH) sudare electrică (în puncte) prin impulsuri

should (gram) condiționalul prezent de la shall; (pt. formarea cond prez si trecut, pers I $s g$ și $p l$ ) aş; am; I $\sim$ design aş proiecta; we $\sim$ design am proiecta; I $\sim$ have designed aş fi proiectat; we $\sim$ have designed am fi proiectat; I $\sim$ help him if I could 1 -aş ajuta dacă aş putea; (pt. formarea viitorului în trecut, pers I $s g$ și $p l$ ); voi; vom; o / am să; o / avem să; I told him I remember his advice i-am spus ca nu-i voi uita sfatul; (pt. formarea subjonctivului analitic) să; it is necessary that you $\sim$ tell her trebuie să-i spui ei; the occasion arise dacă se iveşte prilejul / ocazia; (arată obligatia morală / socială, adesea, recomandarea) ar trebui, s-ar cuveni să, ar fi cazul să, s-ar cădea să; ar fi bine să; ar fi de dorit să; you $\sim$ see her off to the station ar trebui / ar fi cazul s-o conduci la gară; you $\sim$ see the play ar trebui să vezi piesa; he $\sim$ have helped them ar fi trebuit / ar fi cazul să-i ajute (arată probabilitatea logică) ar trebui să; după toate posibilitătile, probabil; it be in ar trebui / trebuie să fie în sertar, probabil că este în; (în întrebările retorice si exclamatiile, exprimă surprinderea, dezaprobarea etc.) (traduceri contextuale); I think so cred şi eu, bineînțeles, desigur

shoulder (anat) umăr; (textile) umăr (pt. haine), umeraş; (OM) umăr (la o piesă etc.), banchetă, prag, guler; (constr) eclisă de cuplare; a da la 
o parte cu umărul, a împinge; a pune pe umăr (o armă etc.); (fig) a-şi lua, a-şi asuma (răspunderea etc.)

shoulder anchor position (auto) poziție a ancorei umărului (la centura de siguranță)

shoulder belt (auto, OM) centură pentru umăr (în diagonală)

shoulder blade (anat) omoplat

shoulder boards (mil) epoleți

shouldered $(\mathrm{OM})$ cu praguri, cu umeri, în trepte (d. elemente de maşini)

shoulder hole $(\mathrm{OM})$ gaură în trepte

shouldering $(\mathrm{OM}, \mathrm{TH})$ prelucrare a unui prag / a unui umăr (la un element de mașină etc.)

shouldering file (mas-un) pilă lată subțire de prelucrare a pragurilor

shoulder of mutton (alim) jigou, pulpă de berbec shoulder rebord $(\mathrm{OM})$ umăr / guler răsfrânt (la un element de maşină etc.)

shoulders (met) etalaj (la furnal)

shoulder screw $(\mathrm{OM})$ șurub cu partea nefiletată mai mare decât cea filetată

shoulder slip (med) luxație a umărului

shoulders of unworked grease $(T)$ unsoare "aruncată" lateral fată de directia de mișcare, care formează ,umeri”, praguri (pe calea de rulare a rulmenților etc.)

shoulder stick (transp) călător pe blat / fără bilet shoulder strap (textile) epolet, bretele, umeraşe (la o cămaşă de femeie)

shoulder yoke (OM) cobiliță

shouldn't (gram) contras din should not

shout strigăt; tịpăt; rând (la băutură); a striga (la); a țipa (la); a striga; a rosti strigând

shout down a face / sili să tacă (prin strigăte); a striga mai tare decât

shout for a sprijini / susține călduros (pe cineva)

shouting strigăte, vociferări; aclamații, urale

shove (mec, fiz, autom, metr) a devia; (mec) a disloca, a împinge, a lovi, a deplasa, a mișca, a urni, a izbi, a devia, a deplasa; a îndesa, a vârî, a băga; a trânti; a pune, a aşeza; a înghionti; a îmbrânci; a strămuta; (mec) împingere, mişcare, urnire, trântire; îndesare, vârâre, băgare, lovire, izbire; deviere, deplasare, aşezare, punere; înghiontire; ghiont; îmbrâncire; brânci; strămutare

shove about a împinge încoace şi încolo

shove around (adm) a da ordine (cuiva), a trimite încoace și încolo, a nu lăsa (pe cineva) să respire

shove aside a împinge într-o parte, a da la o parte shove away a respinge; a da la o parte

shovel (OM) lopată, scafă, lopățică, făraş; (agr, OM) brăzdar; (constr, OM) cupă de excavator; a ridica, a întoarce, a săpa cu lopata, a curăța cu lopata; (alim) a înfuleca; a se îndopa cu (mâncare); a căra mult (fără rost)

shovel arm (constr, OM) braț de excavator

shovel blade $(\mathrm{OM})$ paletă, pală

shovel crane (constr, transp) macara-excavator

shovelful (constr) lopată (plină)

shovel into (constr, met) a încărca cu lopata

shovel (constr, OM) lopată, cupă, excavator

shoveller (zool) rață lopătar

shovel out (constr) a scoate cu lopata

shovel with fork equipment (constr, mas) excavator cu benă

shovel-nose tool (mas-un) cuțit lat

shoveling buckets (termo, OM) cupe de turbine shove off (nav) a împinge, a îndepărta, a desprinde (o barcă) de țărm / de chei / de navă

shoving (mec) împingere

show a arăta; a indica (drumul etc.); a etala, a expune; a da dovadă de, a demonstra, a dovedi (bunăvoință etc.); a arăta, a înfățişa, a prezenta; a duce, a conduce; a îndruma; a arăta, a clarifica, a lămuri; (d. un aparat) a arăta, a indica; a înregistra; a sublinia; a atrage atenția asupra; a-şi arăta, a-și manifesta (supărarea etc.); a da în vileag; a scoate la lumină; a acorda (o favoare etc.); a se arăta; a se dovedi; a se vedea; a se ivi; a apărea; a-și face apariția; a arăta (bine, frumos etc.); a avea o înfățişare (frumoasă etc.); (teatru) a juca (într-un rol); manifestare (de mânie etc.); izbucnire, acces; spectacol; privelişte, tablou; reprezentație; expoziție; vitrină; arătare; by of hands (pol, amd, ec) (a vota) prin ridicare de mâini; aspect, înfățişare; aparență; impresie; (fig) semn, urmă; paradă, pompă, fast; treabă, chestie; afacere; şansă; posibilitate; (mil) campanie; bătălie, luptă

show around (adm, ec) a conduce / însoți prin birouri, incintă etc. (un vizitator, un nou angajat); a însoți / conduce prin; a face (cuiva) cunoștință cu

show biz, show business (artă, ind) industria divertismentului / spectacolelor

show boat (artă) teatru plutitor

show business (teatru, TV, cinematografie) actorie, industria diverstismentului / spectacolului show case (ec) vitrină (de magazin, muzeu etc.) show-down arătare a cărților (de joc); (fig) dare în vileag, demascare; aplanare (a certei)

show down a arăta, a pune pe masă (cărțile)

shower (persoană, aparat etc.) care arată / indică / expune, demonstrează etc.; (meteo) aversă ploaie torențială / repede / de vară; of $(f i g)$ ploaie (de săgeți etc.), râu (de lacrimi), răpăială 
(de gloanțe etc.); mulțime, abundență (de); jerbă (de scântei etc.); duş; a inunda, a uda, a stropi; (fig) a inunda; a bombarda (pe cineva, cu scriesori etc.), a copleşi; (alim) umezire prin stropire

shower bath (constr) (sală / cameră de) duş

shower jet (hidr, termo) jet perdea

shower of sparks (met) ploaie de scântei, scânteiere

shower water (agr, alim, mediu) apă de stropit

showery (meteo) ploios, cu averse, cu caracter de aversă

show girl dansatoare de revistă

showily (îmbrăcat) țipător, fără gust

show in a conduce înăuntru

showiness strălucire; ostentație; pompă, fast; excentricitate, bizarerie

showing expunere, arătare; indiciu; prezentare / arătare, expunere (de modele etc.); performanță; meci reuşit; spectacol reuşit; declarație; recunoaștere; demonstrare; make a good $\sim($ amer $)$ a face figura buna, a se prezenta bine; make a poor $\sim$ a se prezenta prost, a face o figură proastă; on this astfel privind faptele / lucrurile; map $\sim$ altitudes cote de relief; be $\sim$ signs of worry a da semne de îngrijorare / de nelinişte

show-leg day (meteo) zi mohorâtă / posomorâtă / închisă

showman proprietar de circ, de menajerie etc.; saltimbanc, măscărici, clovn

showmanship arta de a organiza spectacole / petreceri publice; $(\mathrm{ec})$ arta de a prezenta mărfuri show-me sceptic, neîncrezător

show number (poligrafie) exemplar de probă show-off $(f i g)$ aere, fandoseală; fandosit; pozeur show off a etala; a arăta în mod ostentativ; a se făli cu, a se mândri cu; a scoate în evidență (frumusețea etc.); a-şi da aere, a face pe grozavul, a se grozăvi

show of hands (pol, adm, ec) vot deschis, votare prin ridicare de mâini

show out a conduce afară (din casă etc.)

show over a conduce prin, a arăta (cuiva)

show place punct de atracție turistică

show room sală de expoziție

show round, show around a arăta (cuiva, ceva), a trece în revistă; (d. un vizitator, un nou angajat etc.) a conduce prin, a însoți prin (birouri, incintă etc.); a face (cuiva) cunoștință cu

show-through (fiz) transparență, expunere directă show through a fi transparent

show up a face să se vadă clar, a arăta limpede; a da în vileag; a demasca; a face să se simtă prost; a face de ocară; a se vedea clar / foarte bine show window (ec) vitrină (de magazin)

showy atrăgător; de efect; frumos, prezentabil; țipător, bătător la ochi

shredder mașină de destrămat material fibros

shred (textile) fâşie, petic, zdreanță, cârpă, bucată; a rupe în bucăți, a sfâşia; tear to $\sim \mathbf{s}$ a rupe în bucăți, a (s)fâșia; tear an argument to $\sim$ s (fig) a arăta totala netemeinicie a unui argument; (fig) fărâmă, grăunte, pic (de adevăr etc.)

shrew (zool) şoarece de câmp

shrewd ager, perspicace; fin, subtil; iscusit; şiret, viclean, şmecher; (meteo) (d. frig etc.) tăios, aspru; violent; crunt

shrewdly $(a d v)$ cu agerime, cu perspicacitate; fin, subtil; cu şiretenie/viclenie

shrewish arțăgos, gâlcevitor, rău de gură

shriek a țipa: a scoate un țipăt strident/țipete stridente $\sim$ with laughter a râde cu hohote; a rosti țipând; țipăt, sunet strident

shrill ascuțit, strident, țipător, pătrunzător; zgomotos, gălăgios; insistent, supărător, plictisitor

shrill-tongued / -voiced cu voce ascuțită / stridentă shrimp (zool) crevete; ghemotoc, prichindel, pitic, persoană scundă

shrink (textile) a (se) strâmta, a (se) scurta, a intra la apă / la spălat; a (se) contracta; (d. scânduri etc.) a se (s)coroji; a se zbârci, a (se) încreți; a (se) strânge; a (se) retrage; a (se) strâmba; a (se) micşora, a se împuţina, a scădea; a da înapoi, a se sustrage; $\sim$ from a se da înapoi de la, a se codi, a ezita (să facă ceva); $(\mathrm{OM}, \mathrm{TH})$ a freta; (amer) (med) psihiatru; (met) contracție, scurtare, a forma retasură; retragere; micşorare; retractare; uscare

shrinkage (met) retasură, contractare, strângere; strâmtare; (s)corojire; ( $\mathrm{TH}$, materiale) contractie; fretare; reducere; (textile) îngustare prin intrare la apă; (plast) contractare, contracție (după turnare, matrițare, răcire etc.)

shrinkage allowance (met, plast) adaos de contractie / de contractare

shrink away a se sustrage; a se împrăștia; se micşora, a scădea văzând cu ochii

shrink from no task a nu refuza nici o sarcină

shrinkage by burning (materiale) contractie la ardere

shrinkage cavity (met) retasură; (plast) cavitate de contracție / de contractare

shrinkage crack (materiale) fisură de contracție

shrinkage distorsion (met, plast) deformare de contractie

shrinkage fault (met) retasură (defect)

shrink(age) fit (OM) ajustaj presat la cald / cu strângere 
shrinkage from drying (plast, constr) contracție de uscare

shrinkage groove (met, OM) crestătură la rădăcina sudurii

shrinkage hole (met) fisură de contracție, retasură shrinkage in / from drying (materiale) contracție prin / după uscare

shrinkage in firing (termo) contracție la ardere (la materiale ceramice)

shrinkage in high (met) contracție verticală / în înălțime

shrinkage in length (met, plast) contracție în lungime

shrinkage jig (plast, OM) dispozitiv de răcire cu contracție / pentru preluarea contracției

shrinkage joint (materiale) rost lărgit de răcire

shrinkage limit (materiale, TH) limită de contractie

shrinkage-pipe preventing agent (met, chim) substanță de protecție contra retasurilor / de prevenire a formării retasurilor tubulare

shrinkage porosity (materiale, $\mathrm{TH}$ ) porozitate de contractie (d. materiale sinterizate etc.)

shrinkage rule (met, metr) scară / riglă de contracție

shrinkage strain (termo, materiale, mec) tensiune (rar) / deformare de contracție

shrinkage stress (termo, materiale, mec) tensiune / efort cauzat( $\breve{a})$ de contractie

shrinkage value / allowance (met, $\mathrm{TH}$ ) adaos de contracție

shrink away a se sustrage; a se împrăştia; a se micşora, a scădea văzând cu ochii

shrink forming $(\mathrm{TH})$ formare / dare a formei prin contracție (prin răcire) / prin comprimare

shrink from no (task etc.) a nu refuza nicio (sarcină etc.)

shrink gauge (met) adaos de contractie; (metr, TH) aparat / senzor de detectare / măsurare a contractiei

shrinking contracție; (met) formarea retasurilor; intrare la apă

shrinking behaviour (met, plast, ceramice) comportare la contracție

shrink(ing) head (met) maselotă

shrink(ing) head casing (met) maselotieră

shrink(ing) hole (met) retasură; (plast, ceramice) pori (cauzați) de contracție

shrink link (OM) scoabă de strângere montată la cald

shrinking market (ec) piață în regres / în scădere

shrinking-on (met, OM) fretare, montare prin presare la cald

shrink in the wash (textile) a intra la spălat shrink measure (met) măsură de contracție

shrink on (OM, TH) a cala la cald, a freta, a monta prin fretare

shrink(-)proof (met) necontractabil

shrink(-)proofing (met, plast) tratare anticontractantă; (material, element de maşină) care rezistă la contracție (rezultată din procesul tehnologic sau exploatare)

shrink-ring (met, OM) fretă, inel / piesă inelară / exterioară la asamblare (prin presare) la cald

shrink type joint (TH, OM) asamblare / ajustaj presat la cald

shrink up a se strâmta; a se zgârci; (fig) a se retrage

shrivel a freta; a se contracta; a se zbârci; a (se) încreți; a se ofili; a contracta; a zbârci

shrivelling (materiale) încrețire, cutare (a suprafețelor, foliilor, semifabricatelor subțiri etc.)

shroud giulgiu, lințoliu; înveliş; (textile) văl; (nav) sart; a înfăşura în giulgiu / lințoliu; (fig) a înveli, a ascunde, a tăinui

shroud (OM) înveliş, manta, carter, carcasă; (nav) duză de elice; a înveli, a acoperi

shrouded impeller (OM, termo) rotor închis / blindat / încasetat

shrouded pinion $(\mathrm{OM})$ roată dințată cu borduri / cu umeri / cu discuri laterale

shrouded / shielded spark(ing) plug (auto) bujie blindată

shrouding (OM) manta, înveliş, (element) care înveleşte / înfăşoară

shrouding wire (OM) sârmă de rigidizare

shrub (silv, bot) arbust, tufă

shrubbery (silv, bot) arbuşti, tufe, tufăriş

shrubby (silv, bot) cu arbuști / tufe

shrug a ridica din (umeri); ridicare (a umerilor, din umeri)

shrug off a uita de, a lăsa deoparte (supărarea etc.); a nu-i (mai) păsa de

shrunk $(\mathrm{TH})$ a cala; London- (textile) țesătură de lână cu contracție reziduală mică

shrunken (OM) micşorat, contractat, scurtat, strâns; strâmtat; încrețit (d. textile, folii, table subțiri etc.); sustras

shrunk finish (met, plast, ceramice, materiale sinterizate) stabilizare dimensională, fixare a dimensiunilor prin contracție în timpul finisării; (TH) fixare a dimensiunilor prin contractie în timpul finisării; (TH, OM) stabilizare dimensională

shrunk fit (OM) (asamblare prin) fretare, ajustaj cu strângere (mare), obținut prin fretare / prin asamblare la cald

shrunk on $(\mathrm{OM})$ montat la cald / prin fretare 
shrunk-on collar (OM) fretă

shrunk-on crank $(\mathrm{OM})$ manivelă montată la cald shrunk on joint (met, OM) ajustaj presat la cald, asamblare la cald

shrunk-on ring $(\mathrm{OM})$ inel de strângere, montat la cald

shuck (bot, agr) coajă; păstaie, coajă; (zool) crustă (de rac etc.), carapace, cochilie; lucru de nimic / fără valoare

shudder a se cutremura, a se înfiora, a tremura (de frig, frică etc.); cutremur(are), tremur, fior(i)

shuffle târşire, (mers) târşit; şovăire, şovăială, ezitare; amestecare (a cărţilor de joc); dat (al cărților); truc, chichiță, pretext; scuză (puțin inteligentă etc.); a târşâi, a târî (picioarele); a amesteca, a încurca, a zăpăci (lucruri); a muta dintr-un loc în altul; a târşâi picioarele; a se eschiva; a minți; a căuta să scape prin minciuni, trucuri etc.; a se muta (repede) dintr-un loc în altul, a-şi schimba locul; a se vânzoli, a se suci; a amesteca / face / da cărțile; a ezita, a şovăi

shuffle off a scăpa de, a se descotorosi de; a pleca târşâind picioarele; a scoate în grabă (hainele)

shuffle off on / upon a arunca (răspunderea) asupra

shuffle on a îmbrăca în grabă, a-şi pune repede (haina)

shuffling (mers) târşâit; (d. cineva) nehotărât, şovăitor; târşâire (a picioarelor); amestecare, dat (al cărților); încurcătură, talmeş-balmeş, harababură

shufty ochire, ocheadă, aruncătură de ochi

shun a evita, a ocoli; a se feri de; a se abține de la

shunt (cf, transp) linie secundară, a manevra, a trece pe altă linie, a gara; (el) şunt, element de şuntare / în paralel / în derivatie / de scurgere, a şunta, a deriva, alega în derivație / în paralel; (mas, hidr) deviație ramificare; linie paralelă; a nu da curs (unui proiect etc.); a amâna, a opri; a întrerupe; a se muta; a trece dintr-un loc în altul

shunt calibration (el, metr) etalonare / calibrare prin legarea în paralel a unei rezistențe determinate

shunt circuit (el) circuit paralel

shunt connection (el, hidr) şuntare, legare în paralel / în derivație, comutare de şuntare

shunted across (el, mec, hidr) şuntat, legat în paralel / în derivație

shunting (el, hidr) circuit în derivație

shunted instrument (el, hidr, metr) aparat de măsurat, şuntat

shunter (cf, met) locomotivă de manevră, manevrant de vagoane, acar

shunt feeder (el, ind, hidr) alimentator în paralel / cu mai multe puncte de alimentare shunting (cf) instalație de triaj / de manevră, a manevra (vagoane), a tria (vagoane), a schimba macazul; (el, hidr) şunt, şuntare, legătură / legare în paralel / în derivație; (ec) arbitraj între burse, cumpărare cu o valută şi vindere cu o alta

shunting engine / locomotive (cf) locomotivă de triaj / de manevră

shunting line (cf) linie de manevră

shunting point (cf) ac de manevră, macaz

shunting table (cf, met) panou cu schema gării de triaj / de manevră

shunting track $(\mathrm{cf})$ parcurs de manevră

shunting train (cf) garnitură de manevră

shunting yard (cf) (gară / stație de) triaj

shunt limit-switch (autom, mas-un) întrerupere / întrerupător de cap de cursă

shunt loading (mec) sarcină transversală

shunt motor (el) motor electric (cu excitație) în derivație

shunt off (el, hidr) a şunta, a deriva

shunt onto a siding (el, hidr, transp) a ocoli printr-o derivație

shunt ration (el) constantă a şuntului

shunt regulation (el, metr, autom) reglare a şuntului

shunt resistance (el) rezistență de şuntare / în paralel / în derivație

shunt switch (cf) macaz; (el) întrerupător şuntat

shunt tripping (el) declanşare în funcție de tensiunea prin bobina în derivație (tip de releu)

shunt-wound electric motor / machine (el, mas) motor / maşină electric(ă) (cu excitaţie) în derivatie

shut a (se) închide; a zăvorî; a astupa (un orificiu, urechile etc.); (TH, ind) a întrerupe, a decupla, a închide (intrarea, admisia etc.), a împiedica, a opri, a stăvili; a închide (gura, umbrela etc.), a prinde, a încercui; a strânge; a se închide (într-o casă etc.); (d. o uşă etc.) a se închide; (bot) (d. flori etc.) a se închide; închis; zăvorât; închidere shut away (OM, el, termo, hidr) a izola, a feri shut cock (OM, hidr) robinet de închidere shut-down, shutdown (TH, OM, mas) pană, avarie, cădere, defect de exploatare, scoatere (şi din funcțiune), repaus (în funcționare), defect de funcționare (având ca rezultat oprirea); (mas) întrerupere a funcționării / a producției, oprire a exploatării, sistare, oprire, deconectare, blocare; (ec) închidere a unei întreprinderi

shut down a lăsa (în jos) (un transperant etc.); a închide, a trânti (capacul etc.); (ec) a închide (o întreprindere); (TH, mas) a închide, a întrerupe; a decupla 
shutdown period for servicing / maintenance (mas) perioadă / (interval de) timp de staționare pentru deservire / mentenanță

shut-in (amer) (adj) (med) bolnav; închis; izolat shut in a închide; a zăvorî; a pune sub lacăt / cheie; a înconjura, a împrejmui; a împiedica (lumina etc.)

shut-in pressure (hidr) presiune statică în incintă închisă

shut off a despărți, a separa, a izola; a exclude; a opri; a zăvorâ; (el) a întrerupe; a tăia; (mas) a întrerupe funcționarea

shut(-off) cock (OM, hidr) robinet de închidere

shut-off device (OM, el, autom) element / dispozitiv de închidere

shut-off mechanism (OM) mecanism de oprire / de închidere

shut-off nozzle (OM, termo, hidr) duză cu obturator

shut-off valve (OM, hidr) ventil / supapă / robinet de închidere

shut oneself away a se izola (de lume)

shutout, lock-out oprirea / interzicerea accesului muncitorilor în fabrică

shut out a interzice accesul / intrarea / pătrunderea (cuiva); a înlătura, a exclude (o posibilitate); a împiedica (vederea)

shutter oblon; volet; jaluzea; (constr) cofraj; (el) întrerupător; tehn închizător; ventil; (fotografie) obturator; diafragmă

shutter (constr, OM) cofraj, oblon, jaluzea; (OM, hidr) obturator, diafragmă, ventil (de închidere), clapetă, închizător, vană; (el) întrerupător

shutter disk (OM) disc obturator / de închidere

shuttering (constr) cofraj; (OM, hidr, fiz) care închide / obturează

shuttering boards (constr) scânduri de cofraj

shuttering vibration (constr) vibrare exterioară (pe cofraj)

shutting off $(\mathrm{TH})$ închidere; separare; obturare

shuttle (textile, OM) suveică; (mec) mişcare alternativă / oscilantă; pendulator; (fiz) tub pneumatic; (amer) (cf, transp) tren suburban; a pendula, a oscila; (av) navetă spațială; (sport) fluturaş pentru badmington

shuttle box (textile, OM) casetă a suveicii

shuttle car (el, mas) electrocar

shuttlecock (sport) volant (minge cu pene pt. badminton)

shuttle valve (hidr) selector de circuit, supapă / distribuitor cu plunjer cu mişcare alternativă / oscilantă

shuttling motion / movement (mec) mișcare alternativă oscilantă shut up a (se) închide (strâns); a zăvorî; a astupa (ermetic etc.); a închide, a întemnița; a face să tacă (pe cineva), a reduce la tăcere; (d. uşă etc.)

shy (d. cineva etc.) timid, fricos, sfios, ruşinos, rezervat; sălbatic; fricos; (zool) (d. cai) sperios, cu nălucă; a azvârli, a arunca (o piatră etc.); azvârlire, aruncare; încercare; (fig) remarcă ironică / batjocoritoare / usturătoare; $\sim$ of (d. cineva) precaut, prudent față de / în privința, a sări în lături; a tresări, a se speria; persoană timidă / fricoasă

shyer sperios, care este timid / sperios etc.

shy of care ezită / şovăie să (spună ceva etc.); care se fereşte de; fight $\sim$ a se feri să, a căuta să nu; lipsit de; căruia nu-i ajunge (ceva)

si (muz) (nota) si

siack $(\mathrm{OM})$ joc exagerat

sial (geol) sial

Siam (geogr) stat în Asia, Siam - azi Thailanda

Siamese siamez, din Siam; siamez; (limba) siameză; (zool) pisică siameză

Siamese twins (anat, med) gemeni, frați siamezi / surori siameze; (fig) prieteni nedespărțiți

Siberia (geogr) Siberia, regiune în Rusia

Siberian (geogr) siberian

sibiling frate / soră (de mamă / de tată)

sic sic, întocmai

S.I., SI abraviere pentru sistemul internațional al unităților

siccative (chim) sicativ, care usucă

siccative oil (ind chim) ulei sicativ

Sicillian (geogr) sicilian; sicilian; dialect sicilian

Sicily (geogr) Sicilia, regiune în Italia

sick căruia îi e greatắ; a asmuti (un câine); feel a-i fi / veni greață, a-i veni să vomite; be a vomita; (amer) bolnav, indispus; take $\sim$ a se îmbolnăvi; (d. un pat etc.) pentru (oameni) bolnavi; (d. un concediu etc.) de boală; având o culoare bolnăvicioasă; galben, palid; (fig) bolnăvicios, nesănătos; (fig) tulburat; abătut; dezgustat; amărât; bolnav sufletește; alienat; deranjat, stricat, deteriorat; (agr) (d. sol) neproductiv; wheat- care nu mai produce grâu (cât ar trebui); ship (nav) navă care necesită reparații

sick bay (nav, med) infirmerie de navă

sick bed (med) pat de suferință / pentru bolnav

sick call (med) chemare a unui doctor la bolnav sicken a dezgusta, a scârbi; (amer) a se îmbolnăvi; a da semne de boală; a-i fi greață, a simți scârbă (de); (bot) (d. plante) a se ofili, a se veșteji

sickening care produce scârbă / dezgust / greață; dezgustător, revoltător 
sickeningly $(a d v)$ provocând dezgust / greață; (în mod) revoltător

sicken of a-i fi greață / silă / scârbă de

sick-flag (nav) pavilion de carantină

sick for care tânjeşte după

sick-headache (med) migrenă, durere de cap însoțită de greață

sick humour umor negru

sickle (agr, OM) seceră

sick leave (med, mil) permisie / concediu de boală

sickle man (agr) secerător

sickle-shaped $(\mathrm{OM})$ în formă de seceră

sickliness (med) stare morbidă / patologică; stare bolnăvicioasă

sick list (med, adm) lista bolnavilor; be on the a lipsi din cauză de boală

sickly bolnăvicios, suferind; bicisnic, neputincios; slab; (d. surâs) slab, şters; pierit; (d. climă) nesănătos; care produce greață; scârbos, respingător; sentimental

sickness (med) boală, maladie, greață

sick of sătul / plictisit de

sick tin (met, chim) ciuma staniului

sidathene (plast) polietenă, polietilenă (denumire comercială)

side parte, latură; față; fațetă; by unul lângă altul, alături; from every $\sim$, from all $\sim$ s din toate părțile, de pretutindeni; (poligrafie) pagină; margine (a unei pagini); (fig) asepect, latură (a unei chestiuni etc.); two $\sim$ s to the event două aspecte (ale evenimentului); (geogr) pantă, versant, povârniş, coastă, țărm, mal; (nav) bord, coastă, secție; departament; (adm) sector (într-o instituție); (alim) jumătate (de but etc.); (jur) parte (într-un proces etc.); (sport) echipă; (anat) coastă; linie, descendență; punct de vedere, opinie, conceptie (într-o discutie); (OM) perete (al unei cutii / piese etc.); (fig) parte; win smb. over to one's $\sim$ a câştiga pe cineva de partea sa; take $\sim$ s a se declara de partea cuiva; (teatru) rol; lateral; dintr-o parte; secundar; minor; adiacent; (d. privire) chiorâs

side $(\mathrm{OM})$ latură, parte (laterală), margine, față, fațtăa (geom) latură (de poligon, de unghi), catetă, față a unui poliedru; (mat) parte a unei ecuații, membru (al unei egalități), generatoare; lateral; secundar; (nav) bord (de navă); accesoriu side airbag (auto) airbag lateral

side and face cutter (mas-un) freză-disc, freză cilindro-frontală

side arm (constr, OM) traversă, consolă a unui stâlp

side arms (mil) arme albe (baionetă etc.)

side bar (OM) eclisă, lonjeron, bară longitudinală side-blown converter (met) convertizor $\mathrm{cu}$ insuflare laterală

sideboard bufet; (cf, OM) perete lateral (la vagoane descoperite)

side-bracke (OM, auto) frână ataşată / montată pe roată

side-bracket bearing $(\mathrm{OM})$ lagăr cu flanşă flanşat / cu prindere laterală

side break (el, OM) întrerupător cu cuțite / lamele laterale

sideburns favoriți; perciuni

side by side (mat) membru cu membru; unul lângă altul

side car (auto) atas (de motocicletă)

side carriage (mas-un) sanie laterală

side casting îndepărtare; (met, TH) turnare laterală

side chain (chim, plast) catenă laterală

side chain chlorination (chim, plast) reactie de clorurare în catena laterală

side chain compound (chim, plast) compus cu catenă laterală

side chain halogenation (chim, plast) reactie de halogenare în catena laterală

side chain notrogen (chim, plast) (reacție cu fixare de) azot în / din catena laterală

side clearance $(\mathrm{OM})$ joc lateral / între flancuri (şi la roți dințate)

side collision (auto) coliziune laterală

side crank $(\mathrm{OM})$ manivelă fixată la capătul unui arbore

side-cut, side draw (alim, ind chim) fracțiune evacuată în partea laterală a coloanei de distilare

side-cut fuels, side draw (ind chim) fracțiune de combustibil, evacuată în partea laterală a coloanei de distilare

side-cut shear (mas-un) maşină de şanfrenat / de tivit

side cutting edge (mas-un) tăiş secundar (la scule)

side cutting pliers $(\mathrm{OM})$ clește-patent $\mathrm{cu}$ tăiș secundar

sided (în cuvinte compuse) cu latură / laturi: four- cu patru laturi

side discharge tippler (alim, mas-un, met) basculator lateral

side dish (alim) fel de mâncare în plus (pe lângă friptură)

side door (constr) uşă laterală / de serviciu, uşă din spate

side drum $(\mathrm{OM})$ tobă mică

side dump body $(\mathrm{OM})$ benă cu basculare laterală

side dumping (TH) basculare / descărcare laterală

side effect (fiz, chim) efect secundar / obținut pe lângă cel de bază 
side face $(\mathrm{OM})$ profil, față laterală; (arhit, constr) fațadă laterală

side file (mas-un) pilă pentru muchiile laterale ale dinților de ferăstrău

side frame $(\mathrm{OM})$ cadru de prindere (laterală), cadru lateral

side gauge / tube (metr, hidr) manometru montat lateral (pt. presiune statică)

side glance ocheadă; căutătură piezişă; mențiune în treacăt, aluzie

side guard (met, mas-un, OM) ghidaj lateral, protecție laterală

side-guard manipulator (met, mas-un) dispozitiv de deplasare (laterală) şi de răsturnare, manipulator cu protecție laterală

side guide (met, $\mathrm{OM}$ ) şină de ghidare

side guide wheel $(\mathrm{OM})$ rolă / roată / rotiță (laterală) de conducere

side head (mas-un) sanie laterală; $(\mathrm{OM})$ suport lateral

side hill (amer) (geogr) povârniș, pantă

side-impact collision (auto) impact lateral

side impact sensor (auto, metr) senzor de impact lateral

side issue problemă / chestiune secundară; aspect secundar (al problemei)

side jet (hidr, termo) jet lateral

side / sister keelson (nav) carlingă laterală

side kingston valve (OM, hidr) priză de apă, laterală

side lamp (auto) lanternă laterală

side land (agr) hotar, hat, răzor

side lap weld $(\mathrm{OM})$ sudură / cusătură de sudură laterală

side lay (mas-un, OM) opritor lateral

side leakage $(\mathrm{OM}$, hidr, $\mathrm{T})$ dispersie pe flancuri, pierderi laterale (şi de fluid)

sidelight (auto, mas) lanternă / lumină laterală; (fig) informații suplimentare (care aruncă lumină asupra unei probleme)

side-line, side line (cf, ind) linie secundară / laterală; (ec) linie colaterală (într-o tehnologie etc.), articol adițional / suplimentar; (sport) linie de tuşă; loc pentru spectatori; a împiedica (pe cineva) să participe (în mod) activ (la o competiție etc.)

sideling $(a d v) \mathrm{v}$. sidelong

side-loader (OM, constr) schip de betonieră

sidelong (OM, geom) oblic; înclinat; pieziș

side member $(\mathrm{OM})$ lonjeron, bară laterală

side mill (mas-un) freză disc / cilindro-frontală

side milling (mas-un) prelucrare a suprafetei perpendiculare pe axa frezei / a suprafeței frontale side-milling cutter (mas-un) freză disc / cilindro-frontală

side motion (mec) mişcare / balansare laterală

side mounting $(\mathrm{OM}$, hidr) fixare laterală

side neck $(\mathrm{OM}$, hidr) tub lateral

side note notă marginală (pe o pagină)

side of a line (mat) semiplan

side of ship (nav) bordaj, bord (al navei)

side of thread $(\mathrm{OM})$ flanc de filet

side panel (constr, OM) perete lateral

side planer (mas-un) raboteză universală

side planing machine (mas-un) raboteză cu port-cuțite laterale

side-plate press (mas-un) presă cu pereți laterali side plating (nav) bordaj lateral (metalic)

side play (OM, constr) joc lateral / între flancuri (la roți dinţate)

side pressure (mec, constr) presiune laterală

sider (el, OM) jug (statoric sau rotoric) al unei maşini electrice

side rail (cf, met) contrașină; $(\mathrm{OM})$ lonjeron, bară laterală

side rake (mas-un) unghi de înclinare a tăişului (şi la cremaliere)

side-ram press (mas-un) presă hidraulică cu cilindri verticali şi orizontali

side reaction (chim) reacție secundară

sidereal day (metr) unitate de timp, utilizată în astronomie, egală cu perioada de timp în care Pământul face o rotație relativ la stele; din afara sistemului solar, Pământul face 366,242 rotații într-un an (pe durata unei revoluții în jurul soarelui; se numără doar 365,242 din cauză că o rotație este anulată de sensul de rotatie în jurul soarelui; ziua siderală este perioada medie între două treceri succesive prin dreptul aceleiaşi stele şi este mai mică decât ziua solară cu 1/366,242: 1 sidereal day $=23$ ore, 56 minute şi 4,09054 secunde

sidereal hour (metr, astronomie) oră siderală: 1 sideral hour $=1 / 24$ sideral day; $v$. sideral day

sidereal minute (metr, astronomie) minut sideral: 1 sideral minute $=1 / 60$ sideral hour $=$ 59 minute şi $50,17 \mathrm{~s}$; v. sideral hour

sidereal second (metr, astronomie) secundă siderală: 1 sideral second $=1 / 60$ sideral minute $=0,997270 \mathrm{~s}$

side relief angle (for cutting-off tool) (mas-un) unghi de aşezare a suprafetei laterale (și la scule de debitat / retezat)

siderite (met, minrl) siderit

siderosis, $(p l)$ sideroses (med) sideroză

side run-off (ind chim) fractiune evacuată la partea laterală a coloanei de distilare 
side run-out (mec, OM) bătaie laterală / frontală siderurgical (met) siderurgic siderurgical cement (met) ciment metalurgic / de furnal

siderurgy (met) siderurgie

side scattering (fiz) împrăştiere laterală

side scene (teatru) culise

side screen (auto) parbriz / geam lateral

side seal(ling) (OM) etanşare laterală

side seam (textile, ind) cusătură laterală (şi la curele, folii etc.)

side seat bancă laterală; scaun longitudinal

side seep(age) (geol, constr) infiltrație laterală

side shearing (met, TH) tăierea marginilor cu foarfece

side shear(s) $(\mathrm{OM})$ foarfece de şanfrenat / de tivit side sheet $(\mathrm{OM})$ ecran lateral (şi de protecţie) side show (teatru) completare (la spectacol); intermezzo; problemă secundară / adiacentă

side sill (constr, OM) lonjeron, grindă longitudinală

side skirt of fender (auto) partea laterală a aripii side-slip, slideslip alunecare laterală / într-o parte; (auto) derapaj, derapare; (av) glisadă, zbor pe aripă; (nav) derivă laterală, cală transversală; copil nelegitim; (bot) ramură (de copac)

side slip a aluneca într-o parte; (auto) a derapa; a glisa, a face o glisadă

side slipping alunecare / glisare laterală; (auto) derapare laterală

side span (met, ind) travee laterală

side-splitting $(\mathrm{OM})$ care se desface în / pe lateral

side-step a se da / păşi într-o parte; a se da la o parte din calea; a evita

side-step gating (met, plast) turnare prin rețea etajată (metalul / materialul curge prin alimentatoare situate la înălțimi diferite)

side spring $(\mathrm{OM})$ arc longitudinal / lateral

side strain (met) bombare, ondulare, defect de laminare la rece (deformare a marginii semifabricatului)

sideswipe a lovi într-o parte / lateal

side terminal (el) bornă / terminal lateral( $\breve{a})$

side thrust (OM, hidr) joc lateral, presiune / forță / împingere / deplasare laterală

side-thrust effect (mec) efect de deplasare laterală

side tipper (mas, auto) basculantă / vehicul cu basculare laterală

side tipping bucket $(\mathrm{OM})$ cupă / benă de descărcare laterală

side tone (fiz) zgomot de fond, efect local, sunet / zgomot secundar side tool (mas-un) cuțit lateral

side-track (cf) linie laterală, a trece pe o linie de rezervă, a gara; (fig) a abate, a devia

side track (cf, TH, ind) linie de aşteptare / de garare

side trimmer (met, mas-un) foarfece de tăiere a marginilor

side-valve(d) engine (termo) motor cu supape laterale

side view vedere laterală / din profil / dintr-o parte (în desen tehnic)

side wall, sidewall $(\mathrm{OM})$ perete lateral; (auto) flanc de anvelopă

sidewall coring / sampling ( $\mathrm{TH}$, mas-un) carotaj lateral (la formare, aşchiere)

sidewalk (constr) trotuar

sideward(s) oblic, într-o parte, pe o parte, pietiş;

v. sideways

sideway (TH, nav) deplasare / derivă laterală / de ruliu

sideways într-o parte; pe o parte; pieziş, oblic

side weld (met, OM) cusătură laterală de sudură

side wind (meteo) vânt lateral; influență indirectă / străină / din afară

sidewise $\mathrm{v}$. sideways

side with a fi de partea; a simpatiza cu; (pol) a sprijini (un partid etc.)

siding (cf) linie secundară / de rezervă / de garare / de aşteptare, macaz, ac; $(\mathrm{OM})$ perete lateral

siding lines (cf) triaj

siding track (cf) linie secundară / de garare / de aşteptare

sidle, sidle along a merge înclinat (într-o parte); a merge speriat / ruşinat / sfios etc.

Sidney (geogr) oras în Australia, Sidney

Siegbahn unit (metr, fiz) o altă denumire pentru X unit, o unitate de măsură pentru lungime, utilizată pentru a descrie lungimile de undă ale radiației $X$; v. $\mathbf{X}$ unit

siege asediu, împresurare; lay $\sim$ to a asedia, a împresura; raise the $\sim$ a ridica asediul; a asedia, a împresura

Siemens (S) (metr) unitate SI pentru a măsura conductanța, susceptanța și admitanța, acestea fiind, respectiv, invesul rezistenței, reactanței şi impedanței; siemens este inversul unității ohm; conductanța, susceptanța sau admitanța în siemensi se obține împărțind 1 la valoarea rezistenței, reactanței sau impedanței (exprimate în ohmi)

Siemens-Martin furnace (met) cuptor SiemensMartin

Siemens-Martin plant (met) (secție de) oțelărie Siemns-Martin 
Siemens-Martin process (met) proces SiemensMartin (de obținere a oțelului)

Siemens-Martin steel (met) oțel (obținut prin proicedeu) Siemens-Martin

Siemens regenerative furnace (met) cuptor Siemens-Martin

Siemens-unit (met) unitate Siemens

sienna (culoare) siena

sierra (amer) sierra, lanț de munți

sierra Nevada (geogr) lanț muntos în California şi Spania

siesta siestă, odihnă de după-amiază

sieve (alim, constr) ciur, sită; a cerne, a trece prin sită / prin ciur, a ciurui; (agr) coş împletit; sieve (metr) unitate tradiţională de măsură pentru finețea unei site din sârmă; valori mari în sieve corespund unor site mai fine; în sistemul metric, finețea unei site în sieve este dat de diametrul deschiderilor, în milimetri sau microni

sieve analysis (metr, materiale) analiză granulometrică

sieve diameter (alim, constr) diametru de ciur / de sită

sieveas mesh $(\mathrm{OM})$ ochi de sită

sieve bottom (alim, constr) fund de sită

sieve bucket (nav, OM) cupă de draglină, perforată

sieve cloth (ind) țesătură pentru site

sieve dragline bucket (nav, OM) cupă de draglină perforată

sieve fraction (metr, materiale) fracțiune granulometrică

sieve frame $(\mathrm{OM})$ cadru de sită

sieve mesh $(\mathrm{OM})$ mărirea găurilor unui ciur / a unei site

sieve number (ind) numărul sitei, în unități sive; $\mathrm{v}$. sieve

sieve out (alim, constr) a cerne

sieve plate / tray $(\mathrm{OM})$ taler reticular / perforat / de sită

sieve plate / tray column / tower (OM) coloană reticulară / de talere de sită

sieve residue $(\mathrm{TH})$ reziduu pe / de sită

sievert (Sv) (metr, fiz) o unitate SI pentru măsurarea dozei efective (sau ,echivalente) de radiatii primită de o persoană sau altă viețuitoare; doza echivalentă, în sievert, este egală cu doza reală, măsurată în gray, multiplicată cu un factor de calitate care este mai mare pentru radiatii mai periculoase: 1 doză efectivă de 1 sievert necesită 1 gray de radiație gama sau beta, şi numai 0,05 gray din radiație alfa sau de neutroni

sieve set $(\mathrm{OM}$, alim, constr) garnitură de site sieve shaker $(\mathrm{OM})$ scuturător de sită sieve test (metr, materiale) analiză prin cernere sieve texture $(\mathrm{OM})$ structură de sită

sieve tray $(\mathrm{OM})$ taler reticular

sieving $(\mathrm{TH})$ sortare; cernere; strecurare

sieving analysis analiză pe site

sieving machine (alim, constr) maşină de cernut sieving process $(\mathrm{TH})$ metodă / procedeu / proces de cernere

sieving test (materiale, metr) analiză pe site siffle fluiera

sift a cerne, a trece prin sită / prin ciur, a ciurui; a separa granulometric; a da prin sită / ciur; a strecura; a examina, a analiza, a studia; a alege, a selecta; a presăra (zahăr etc.); (d. zăpadă etc.) a se cerne

sifter (met) ciocan de selectare; $(\mathrm{OM})$ sită; ciur sifting (alim, agr, constr, ind) cernere; trecere prin sită / prin ciur; sortare; strecurare

sifting cylinder (alim, OM) trior, cilindru de sortare

sifting drum $(\mathrm{OM}$, alim) sită circulară / tubulară sifting machine (alim, constr) mașină de cernut sigh a suspina, a ofta (după); (d. vânt) a suspina; a geme; a şopti suspinând; suspin, oftat

sight vedere, privire; uitătură, căutătură; (lungă) (anat) prezbiție; short (med) miopie; at / on la vedere; at / first $\sim$ la prima vedere; in $\sim$ vizibil, care se vede; la orizont; (fiz) văz, vedere; the sense of $\sim$ simțul văzului, vedere; apariție, înfățişare; prezență; locuri care merită văzute; puncte turistice de atractie; (TH, metr) vedere, câmp de vizibilitate (al aparatului); (OM) vizor; (nav) observație astronomică; (constr, ind) viză; (mil) etc. cătare; grămadă, mulțime (de bani etc.); a vedea, a zări; (mil) a pune cătare la (o armă); a ochi, a tinti, a observa; a urmări

sight vedere; câmp de vizibilitate; vizor; a viza; a face vizarea (la un aparat optic reticulat etc.)

sight bar (constr) alidadă

sight case $(\mathrm{OM})$ carcasă a vizorului

sight check(ing) / control ( $\mathrm{TH}$, metr) control / verificare vizual( $\breve{a})$

sight discharge (OM, hidr) ştuț de scurgere, cu geam / cu vizor

sight distance (anat, metr) rază vizuală; vizibilitate

sighted (în cuvinte compuse) cu vederea short$\sim$ miop

sight entry (ec) declarație vamală provizorie

sight-feed lubricator / oilier (met, OM, T) ungător cu picurare

sight gauge $(\mathrm{OM})$ jojă de control

sight glass $(\mathrm{OM}$, hidr, $\mathrm{T})$ dispozitiv de picurare al ungătorului, vizor, lanternă, indicator vizual de nivel; felinar 
sight graticule (OM, opt) punct de reper; vizor sight hole (met, OM) gură de vizitare, orificiu de observare, fereastră de control / de observare sighting $(\mathrm{TH})$ reperare, vizare sighting device $(\mathrm{OM}$, mil) dispozitiv de vizare sighting disk (OM, opt) disc de vizare sighting level (constr, metr) nivelă cu bulă de aer sighting line (fiz, chim, TH) diagramă, grafic sighting mark semn (şi de marcare)

sighting mark error (metr) eroare de vizare (la aparate optice)

sighting telescope (metr) lunetă de vizare

sighting the objects (metr) vizare a reperelor (la aparate optice)

sighting tube (metr, OM) tub (ceramic, de direcționare) pentru pirometrul optic

sightless (anat) orb, nevăzător; care nu se vede, invizibil; urât, slut, hâd

sight level (metr, OM) nivelă longitudinală

sight line (metr, opt) linie de vizare / de reper; (opt) directie a privirii

sightliness frumusețe, farmec

sightly plăcut la vedere, frumos, atrăgător

sight-mount $(\mathrm{OM})$ vizor

sight-mount housing $(\mathrm{OM})$ carcasa vizorului

sight opening (met, OM) gură / orificiu / gaură de control

sight out (opt) a viza, a se uita printr-un vizor sigma literă din alfabetul grec $(\sigma, \Sigma)$; (metr) denumire neoficială pentru deviația standard, simbolizată cu $\sigma$

sigma phase (met) fază sigma

sight-read vedere, a citi (un text) pentru prima oară

sight rule $(O M)$ riglă / talpă / suport al dispozitivului de vizare; (constr) alidadă

sight-see a vizita locurile interesante, obiectivele turistice etc.

sight-seeing vizitare a obiectivelor turistice; plimbare; go $\sim$ a vizita obiectivele turistice, a face turul oraşului etc.

sightsman ghid (turistic)

sigil sigiliu, pecete

sigilate a sigila

sigmatism (lingv) sigmatism

sigmatron (fiz) sigmatron

sigmoid sigmoid

sign semn, urmă; marcă, indiciu; indicație; (med) simptom; (adm, ec, jur) a semna, a-şi pune semnătura pe, a iscăli; a însemna, a marca (cu un semn); a exprima printr-un semn; firmă; tăbliță (de firmă / cu caracteristici tehnice), emblemă; (mat) simbol; a (în)semna; a semnaliza; a marca; semn zodiacal; (metr) măsură informală pentru unghiuri: 1 sign $=1 / 12$ dintrun cerc sau $30^{\circ}$

signal semnal; semnalizator; (chim) indicator; (metr, opt) aparat optic; (fig) semnal, semn; ( $p l$ (mil) transmisiuni; a semnala; a anunța, a vesti; a face semnale (cuiva, cu ceva); a semnaliza; folosit ca semnal / pentru semnalizare; remarcabil; însemnat, important; (inf, ec, adm) informație de schimbare a ceva; a anunța; a semnala; a emite; a transmite

signal board (mas) tablou / panou de semnalizare signal box (cf) punct de blocare, post de manevră signal code (inf, mil, autom) cod de semnale signal converter (autom, electr) traductor de semnal

signal / signaling $(\mathrm{TH})$ semnalizare

sighnal handling (autom, metr, mas-un) prelucrare a semnalului

signal input (autom, mas) mărime / parametru de comandă

signaliser ( $\mathrm{TH}$, autom) semnalizator, aparat / dispozitiv de semnalizare

signalize a semnala; a atrage atentia asupra; a scoate în evidență, a sublinia; a distinge

signaller (mil, nav, av) radiotelegrafist signal-light foc de semnalizare; semnal luminos; (cf, auto) semafor; (nav, av) baliză (luminoasă)

signal-light (opt, autom) lumină de semnalizare, semnal luminos / optic

signal limiter (autom) limitator de semnal

signallizer (fiz, autom) semnalizator; aparat de semnalizare

signally $(a d v)$ eminamente; (în mod) vizibil; vădit; categoric; evident

signalman (mil, nav) semnalizator (persoană, operator)

signalment (adm) semnalizare; (şi $p l, \sim$ s) semnalment(e), (pt. poliție)

signal to go ahead / to carry on (autom) semnal de pornire / de executare / de continuare

signal-to-noise ratio (autom, hidr, fiz) raport semnal-zgomot

signal word (inf, mil) parolă, cuvânt de ordine signatory semnatar, parte semnatară; (adj) semnatar, care a semnat

signature (jur, ec, adm) semnătură; iscălitură; (poligrafie) signatură; semnătură, urmă

signature tune (radio, TV, fiz) semnal sonor sign away (jur) a semna transferul (proprietății etc.) / renunțarea la un (proprietate etc.)

signboard $(\mathrm{OM}, \mathrm{ec})$ firmă (la magazin)

signed (mat) cu semn ataşat (+ sau -); marcatic signed minor (mat) complement algebric signer (pol, adm, jur) semnatar 
signet semn de recunoaştere; sigiliu; ştampilă; pecete

signet ring inel cu sigiliu

sign for $(\mathrm{ec}, \mathrm{adm})$ a semna de primire pentru, a primi formal / cu forme legale

sigh handling (autom, fiz) prelucrare a semnalului

significance, significancy semnificație, sens, înțeles, tâlc; importanță, însemnătate

significant semnificativ; plin de / cu înțeles; expresiv; semnificativ, important, însemnat (mat, fiz) determinat, nealeatoriu

significant conditions stări / condiții caracteristice

significantly $(a d v)$ (în mod) semnificativ, cu înțeles

signification sens, semnificație, înțeles (al unui cuvânt)

significative, significant determinat; expresiv; important; însemnat; nealeatoriu; plin cu / de înteles; semnificativ

significative of având înțelesul / semnificaţia / sensul de

signify a însemna, a avea sensul / înțelesul / semnificația de; a face cunoscut, a declara (intenții etc.); a fi un semn / indiciu de; a trăda; a avea o semnificație / un sens (de); a avea importanță / însemnătate

signify a semnifica, a însemna

sign in a se înregistra (la hotel etc.)

sign language limbaj al semnelor / gesturilor / mimic

sign manual (jur, adm) semnătură proprie (a unui functionar important etc.)

sign of equality semnul egalității ( $=$ )

sign off a renunța la (un drept etc.); a transfera, a ceda; (radio, TV) a anunta închiderea emisiunii; a încheia o scrisoare (cu semnătură etc.)

sign-off signal (autom) semnal de final / de închidere

sign on a se angaja, a fi angajat; (radio, TV) a începe emisiunea

sign on behalf of somebody (jur) a semna în numele cuiva

sign per pro (jur) a semna prin procură

sign post (auto) indicator rutier, semn

signum (mat) funcția semn (având valori 1, 0 sau -1)

sign up (ec, adm) a angaja (într-o funcție); a înscrie (la un curs etc.); $(a d v)$ a se angaja (ca muncitor etc.)

silage (agr) siloz; a însiloza; cereale însilozate

silane (plast) silan

silastic (plast) cauciuc siliconic silcar (materiale) amestec de carburi de siliciu şi dioxid de siliciu

silchrome (met) silcrom

silence linişte, tăcere; pace; (fig) tăcere; uitare; pass into a fi dat uitării, a fi uitat; (fig) a face să tacă, a reduce la tăcere, a înăbuşi (glasul conştiinței etc.)

silenced (mas) amortizat; silenţios; fără zgomot; cu zgomot redus

silencer (auto) silențiator, amortizor de zgomot, tobă de eşapament; argument decisiv / hotărâtor; replică tăioasă / usturătoare

silencer-filter type air intake (auto) filtru de aer cu amortizor de zgomot la admisie

silencing (fiz, mas) atenuare / amortizare a zgomotului

silent tăcut, liniştit; taciturn, necomunicativ; mut; rezervat; reticent; nezgomotos; mut; tăcut; fără sunet; afon; aton; liniștit; fără zgomot; (TH) silențios

silent chain drive $(O M)$ transmisie prin lant, silențioasă / fără zgomot

silent discharge (el) descărcare electrică lentă

silent film film mut / fără sonor

silent gear change (auto, mas-un) schimbare silențioasă a vitezelor

silently $(a d v)$ în tăcere, pe tăcute, fără zgomot

silent mesh $(\mathrm{OM})$ angrenare fără zgomot / silențioasă

silent / sleeping partner (ec) comanditar; partener / asociat puțin cunoscut (şi care nu ia parte activă la afaceri)

silent running (mas) mers silențios, funcționare silențioasă

silent shift(ing) (auto, mas-un) schimbare silențioasă a vitezelor

Silesia (geogr) regiune în Polonia şi Cehia, Silezia

silex (minrl) cremene, silex

silhouette siluetă, imagine; a proiecta / a înfățișa ca siluetă / imagine

silica (chim) dioxid de siliciu, cuarț, silice; (minrl) cremene

silica aerogel (chim) silicagel cu structură poroasă fină

silica-alumina refractories (met, chim) refractare alumino-silicioase / silico-aluminoase

silica brick (met) cărămidă silica

silica glass, fused silica, vitreous silica (ind chim) sticlă obținută prin topirea dioxidului de siliciu

silica sand (geol, constr, ind chim) nisip cuartos silicate (chim) silicat

silicate area / inclusion (met) incluziune de nisip 
silicated (chim) silicic, combinat / rezultat al reactiei cu acid silicic

silicate inclusions (met) incluziuni de silicaţi silicate slag, siliceous slag (met) zgură silicioasă / acidă

silicating / silication / silicatisation (chim) silicatizare

siliceous (chim) silicios, care conține siliciu; (minrl) cuarțos

siliceous flux (met) adaos de material silicios

silico-manganese steel (met) oțel silico-manganos, oțel aliat cu siliciu-mangan

siliceous refractories (met) refractare silicioase

silicic (chim) silicic

silicide (chim) siliciură

silicification, silification (chim) silicalizare, silicifiere

silicify (chim) a silicifia

Silicon (Si) (chim) siliciu

silicon brass (met) alamă cu siliciu / silicioasă

silicon bronze (met) bronz cu siliciu / silicios

silicon carbide (chim, met) carbură de siliciu, carborund

silicon dioxide (chim) dioxid de siliciu

silicone (chim) silicon

silicone (plastic) (plast) silicon, polimer cu siliciu (şi oxigen), material plastic siliconic

silicone polymer (SI) (plast, ind chim) polimer siliconic

silicone rubber (plast) cauciuc siliconic

siliconising (met) mărirea conținutului de siliciu, cementare cu siliciu

silicon-killed steel (met) oțel calmat cu siliciu

silico(n)-manganese (alloy) steel (met) aliaj / otel aliat cu siliciu-mangan

silicon-molybdenum steel (met) oțel (aliat cu) siliciu-molibden

silicon nitride (chim) nitrură / azotură de siliciu

silicon oxide (chim) oxid de siliciu

silicon steel (met) oțel aliat cu siliciu / silicios

silicon-steel sheet (met) tablă de oțel (aliat cu siliciu) pentru electrotehnică, tablă silicioasă

silicon sulphide (chim) sulfură de siliciu

silicoorganic compounds (chim) compuşi organici ai siliciului

silicosis (med, ind) silicoză

silification (chim) silicatizare

silk (fiz) absorbant de lumină; mătase; $\sim \mathbf{s}(p l)$ (textile) mătăsuri, îmbrăcăminte de mătase; (ca) de mătase; mătăsos; îmbrăcat în mătase

silk breeder (agr, textile) sericicultor

silk fiber (textile) fibră de mătase

silken (ca) de / din mătase; (fig) mătăsos, catifelat; dulce; mieros; minunat, extraordinar silk grass (bot) negară

silk grower (agr) sericicultor

silk gum (textile) sericină

silkiness caracter mătăsos / catifelat; onctuozitate; (fig) caracter mieros

silk mill (textile) fabrică de mătăsuri, filatură de mătase

silk screen (constr) decorare prin site

silkweed ceară de albine

silkworm (zool) vierme de mătase

silky de mătase; ca de mătase; catifelat; lucios; (fig) mieros; dulceag; insinuant

silky fracture (met) fractură mătăsoasă

sill (constr) pervaz; prag (de uşă etc.), talpă inferioară, bară de susținere; cosoroabă (la acoperiș), centură, grindă de fundație; (met) prag de uşă (la cuptor Siemens-Martin); (el) bază; suport

sillabub (alim) (băutură din) lapte covăsit cu vin şi zahăr; (fig) stil pompos

sillily $(a d v)$ prosteste, (în mod) prostesc / stupid

silliness prostie; caracter prostesc / stupid; prostie, neghiobie, faptă etc. prostească

sill of a framework (constr, OM, mas) prag de legătură

sill timber (cf) traversă de lemn

silly (d. cineva) prost, neghiob, tont, nătâng, netot; absurd / ridicol; do a $\sim$ thing a face o prostie / o gafă / o boacănă; năuc(it), zăpăcit, amețit (în urma unei lovituri etc.); (fig) sărac cu duhul; nevinovat, inocent; slab, neputincios, neajutorat, bicisnic

silo (agr, constr) siloz, bunker; a însiloza

silo capacity (agr, constr) capacitate a silozului

siloing (agr, constr) însolozare

siloxanes (chim) siloxani

silt (geol, geogr) nămol, aluviune, a (se) înnămoli (un canal etc.); a se astupa, a se înfunda

silt (mediu, ind) mâl; nămol; şlam; a colmata

silt exclusion (mediu, ind) decantare / evacuare a mâlului / nămolului / şlamului

silting (mediu, ind) înfundare (şi cu nisip, a unei conducte)

silting up (mediu, ind) colmatare

silumin (met) silumin, aliaj Al-Si

silvan (silv) de pădure, silvic, forestier; rustic

silver argint; monedă / bani / monede / bani (de argint); argintărie, veselă / vase de argint; de argint; (d. păr etc.) cărunt; argintiu; argintat; (chim) a arginta (oglinzi etc.); (fig) a arginta, a albi, a încărunți (părul etc.)

Silver, Argentum (Ag) (chim) argint

silver acetate (chim) acetat de argint

silver birch (bot) mesteacăn (alb) 
silver brazing (met, OM) lipire tare cu (aliaj de) argint

silver brazing alloy (met, OM) aliaj de argint pentru lipire tare

silver bromide (chim) bromură de argint

silver bronze (met) bronz aliat cu argint

silver coating (chim, $\mathrm{T}$ ) argintare, acoperire cu argint

silverer argintar

silver fir (bot) brad alb / argintii

silver fish (iht) peştişor auriu; tarpon; numeroase alte specii de peşti lucitori

silver foil (met) foiță / folie de argint

silver fox (zool) vulpe argintie

silver grass (bot) ierbăluță

silver-grey gri-argintiu

silver-haired cu părul argintiu / cărunt

silvering (chim, TH) argintare, care (se) argintează

silverly argintiu, de culoarea argintului; (ca) de argint; (cu sunet) argintiu

silvern argintos, (ca) de argint

silver nitrate (chim) nitrat de argint

silver paper, silver foil (artă) foiță de argint

silver-plate (OM, alim) argintărie, veselă de argint; (chim, $\mathrm{TH})$ a arginta

silver plating (chim, $\mathrm{TH}$ ) argintare, acoperire cu argint

silver sand (geol, ind chim) cuarțos

silversmith argintar

silver solder (met) aliaj de lipit cu argint

silver soldering (met, $\mathrm{TH}$ ) lipire cu aliaj de argint

silver steel (met) oțel aliat cu argint

silver-tongued elocvent, cu darul vorbirii

silverware (OM, alim) tacâmuri de argint, argintărie

silver wedding nuntă de argint

silver work $(\mathrm{TH})$ argintărie, orfevrărie

silvery ca argintul, (ca) de argint; (d. râs etc.) argintiu

silvery argintat; argintiu

silvery pig iron (met) fontă cenuşie

silviculture (silv) silvicultură

sima (met) aliaj sima Si-Mg

simian (zool) maimuță (antropoidă); de maimuță

similar (to) asemănător, analog (cu); similar; la

fel (cu); identic; (mat) omogen (cu); (geom) asemenea; obiect asemănător / similar

similar similar; asemănător; asemenea

similarity (between) similitudine (între); asemănare; omotetie; analogie (între)

similarly $(a d v)$ în mod asemănător/similar

simile comparație

similitude similitudine similitude law (fiz, mec, hidr) lege de similitudine

similitudine înfățişare, chip, formă; in man's după (chipul şi) asemănarea omului; asemănare, similitudine; comparație; alegorie; pildă; parabolă

simmer (alim, ind chim) a tine (supa etc.) sub punctul de fierbere; (d. un lichid) a fierbe la foc mic; a fi pe punctul de a fierbe; with a fierbe, a clocoti (de); fierbere la foc mic

simper zâmbet prostesc / afectat; a zâmbi / surâde prosteşte / afectat

simperingly $(a d v)$ zâmbind prosteşte

simple simplu, necomplicat; inteligibil; uşor, lesnicios; natural; modest; neartificial; neprefăcut; fără podoabe / zorzoane; beauty frumusețe naturală; (mat) simplu, indivizibil; pur, neamestecat, curat; inferior; fără valoare; (d. cineva) simplu, cinstit, sincer, neprefăcut; deschis; simplu, de rând; lipsit de cultură, incult; necompus; elementar; rudimentar; primitiv; nevinovat, inocent; neînsemnat, neimportant; nesemnificativ; uşor de tras pe sfoară; credul, lesne, crezător; prost; necondiţionat; absolut; (om) credul, naiv; (bot, med) buruiană de leac, plantă medicinală; obiect simplu, substanță simplă etc.; (lingv) cuvânt simplu; (gram) propoziție simplă; om de rând; om de origine modestă / umilă; a căuta / strânge buruieni de leac

simple-acting engine (mas, termo) motor $\mathrm{cu}$ simplu efect

simple beam (mec) grindă simplu rezemată

simple body (mec, OM) corp simplu

simple bond (chim) legătură simplă

simple construction (mec, OM) construcție static determinată

simple expansion (termo) detentă simplă

simple flexure (mec) încovoiere simplă

simple fraction (mat) fracție simplă

simple-harmonic (fiz) o singură undă

simple-harmonic motion (mec) mişcare sinusoidală

simple-hearted naiv, credul; sincer, deschis

simple indexing (mas-un) divizare / indexare simplă

simple interest (ec) dobândă simplă

simple kelly bushing (mas-un) dispozitiv simplu, de antrenare

simple linear polymer (ind chim, plast) polimer liniar

simple machine (mas-un) unealtă / maşină simplă / de bază (de prelucrat, foarte general)

simple-minded sincer, deschis; prost, stupid, nătâng; slab de minte; smintit, nebun 
simple-mindedness naivitate, credulitate; sinceritate; prostie, stupiditate; sminteală, nebunie

simple motion (mec) mişcare simplă

simpleness, simplicity simplitate

simple protein (chim) proteină

simple pump (OM, hidr) pompă cu acțiune simplă

simple sentence (gram) propoziţie simplă

simple Simon prost, nătăfleață, gogoman

simple soldering iron $(\mathrm{OM})$ ciocan de lipit

simple stress (mec) stare de tensiune simplă

simple support $(\mathrm{mec})$ reazem simplu

simpleton naiv, credul; prostănac, prost, imbecil, nătâng

simplex (mat) simplex; (mas) fără redundanţă

simplex pump (OM, hidr) pompă simplex

simplicity caracter simplu, simplitate; lipsă de afectare / de prefecătorie / de podoabe etc.; naturalețe; naivitate, creduliate; prostie, stupiditate, imbecilitate

simplification (mat, TH) simplificare

simplifier simplificator

simplify a simplifica; a uşura

simplifying convention (OM, ind) convenție de reprezentare simplificată (în desen tehnic)

simply supported beam (mec) grindă simplu rezemată

simulacrum, $(p l)$ simulacra simulacru; prefăcătorie; pretext

simulate a simula; a afecta; a imita; a modela, a lua înfățişarea de

simulated (d. diamante etc.) fals, artificial; (mat, inf) simulat

simulation machetă; copie; simulare (şi pe computer), prefăcătorie; reproducere analoagă a condițiilor; simulacru; imitare

simulator simulator, (instalație) model

simultaneity (fiz, TH) simultaneitate, concomitență

simultaneous (fiz, TH) concomitent, simultan

simultaneously ( $a d v)$ (în mod) simultan, concomitent

simultaneousness, simultaneity simultaneitate

sin păcat; (as) black as negru ca păcatul; (as) ugly as $\sim$ urât de mama focului; fall into $\sim$ a cădea în păcat, a păcătui; the seven deadly $\sim$ s cele şapte păcate capitale; mare greşeală; insultă; ofensă; sacrilegiu; crimă; a păcătui; a face un păcat; liable to păcătos, supus păcatului

Sinai Mount (geogr) Muntele Sinai

Sinai Peninsula (geogr) Peninsula Sinai

since $(a d v)$ de atunci (încoace); de când; din clipa când; din vremea când; de pe vremea când; (conj) întrucât, deoarece, fiindcă, pentru că sincere sincer, deschis, fățiş, fără dedesubturi; cinstit; credincios; (devotament etc.) adevărat, real, neprefăcut

sincerely $(a d v)$ (în mod) sincer, cu sinceritate; (în mod) deschis, pe față; yours $\sim, \sim$ yours (formulă de încheiere la scrisori) cu stimă / respect, al dvs.

sincerity sinceritate; cinste, onestitate; in all cu toată sinceritatea, cu mâna pe inimă / conştiință

sinciput (anat) sinciput; vertex

sine (mat) (funcția) sinus

sine fără; minus

sinecure (ec) sinecură

sinecurist (ec) sinecurist

sine curve (mat) sinusoidă

sine die $(a d v)$ sine die (în latină), fără termen

sine qua non condiție sine-qua-non (în latină) / obligatorie

sinew (anat) tendon; (fig) putere fizică, forță (musculară), muşchi, rezerve de energie, izvor de putere

sine wave (fiz) undă sinusoidală

sinewless fără putere, slab

sinewy (anat, alim) (d. carne) cu tendoane; musculos, puternic, viguros; (d. stil etc.) viguros

sinful păcătos; imoral; idiot, inutil, zadarnic

sinfully $(a d v)$ în păcat; cu păcat; (în mod) idiot / tâmpit, prosteşte

sinfulness păcat, păcătuire

sing a cânta (un cântec, din gură etc.); a întoarce foaia, a schimba placa; a coborî tonul; a o lăsa mai moale; a intona; a psalmodia; a slăvi, a lăuda; to dumb (fig) a nu crâcni, a nu mai crâcni, a nu (mai) scoate o vorbă; low (fig) a vorbi prudent; small a o lăsa mai moale; make smb. small a mai tăia nasul cuiva; (d. albine etc.) a zumzăi; (d. păsări) a cânta; a ciripi; (d. greieri) a țârâi; a cânta; (d. vânt, gloante etc.) a şuiera; (d. izvor) a murmura, a susura; (d. urechi) a vâjâi; a scrie versuri; (d. o melodie etc.) a se cânta (uşor etc.)

sing., sg (gram) prescurtări pentru singular

singable care poate fi cântat; uşor de cântat; melodios

Singapore (geogr) Singapore, stat în Asia

singe a pârli; a arde uşor; to one's reputation a-şi păta numele / renumele /reputaţia

singe a gaza

singer cântăreț; pasăre cântătoare; (fig) bard, rapsod, poet, cântăreț

singing canto; cântare, cântat; cântare; intonare; interpretare; freamăt; foşnet (al pădurii etc.)

singing bird (zool) pasăre cântătoare 
singing school (edu) şcoală de canto

single unic, mono, singur; singular; separat; individual; cu o singură parte; a alege; a selecta, a selecționa; a distinge; necăsătorit, celibatar; (d. paturi etc.) de / pentru o singură persoană; (d. suflet) sincer, deschis; cinstit; (OM) cu o singură parte / etapă / trecere; bilet simplu, bilet pentru o (singură) călătorie; s $(p l)$ (bancnote de) un dolar / o liră; a remarca; a distinge; (agr) a rări (porumbul etc.)

single acting $(\mathrm{OM}, \mathrm{el}) \mathrm{cu}$ acțiune simplă

single-acting compressor (mas, termo, OM) compresor cu un singur etaj

single-acting cylinder $(\mathrm{OM})$ cilindru cu simplă acțiune

single-acting hand pump (OM, hidr) pompă manuală, cu simplu efect

single-acting intensifier (OM, hidr) multiplicator de presiune, cu simplu efect

single-acting press (mas-un) presă cu acțiune simplă

single-acting pressing (mec) compresiune unilaterală

single-acting pump (OM, hidr) pompă cu simplu efect

single-acting shock absorber (OM, hidr) amortizor într-un singur sens

single-arc welding (met, TH) sudare cu electrozi legaţi în circuite separate

single-axle $(\mathrm{OM})$ cu o singură osie

single bar $(\mathrm{OM})$ cu un singur braț

single-barrelled (mil, OM) (d. puşcă) cu o singură țeavă

single-beam traveling crane (met, transp) pod rulant mono-grindă

single bed pat de o singură persoană

single bevel $(\mathrm{OM})$ rost de sudură cu o singură teşitură / cu teşire pe o singură parte, rost jumătate $\mathrm{V}$

single-bevel butt joint $(\mathrm{OM})$ sudură cap-la-cap (cu rost) în $1 / 2 \mathrm{~V}$

single block (OM) palan simplu

single-block brake $(\mathrm{OM})$ frână cu un singur sabot

single-bolt cutter (mas-un) maşină / sculă de filetat (care prelucrează un singur şurub / bolț)

single breasted (textile) (d. haină) la un singur rând (de nasturi)

single-bucket excavator (constr, mas) excavator cu graifăr

single cascade acting (autom) (sistem de control / de reglare) liniar / cu subansamblele legate în serie

single casting (met, TH) turnare individuală single-cavity moulding (met, mas-un) matriță cu o cavitate

single-channel method (fiz, autom, $\mathrm{TH}$, ind) sistem / metodă cu o singură cale / cu un singur canal (de control, de turnare etc.)

single coil spring $(\mathrm{OM})$ arc cu o singură spiră, arc elicoidal (cilindric) simplu

single color (fiz) monocrom

single column planer (mas-un) raboteză cu un singur montant

single cord $(\mathrm{OM})$ monocord (d. fire, cabluri etc.)

single crystal (fiz, materiale) monocristal

single-curve gear $(\mathrm{OM})$ roată dinţată cu profil în evolventă

single cut (mas-un, TH) aşchiere cu o singură trecere, o singură operație de aşchiere

single-cut file (mas-un) pilă cu dantură simplă

single cutter (mas-un) freză simplă

single-cutting drill (mas-un) burghiu cu taiş simplu

single-cutting tool (mas-un) cutit cu tăiș simplu single cylinder $(\mathrm{OM}$, termo, hidr) monocilindru

single-cylinder blower (OM, termo) suflantă monocilindrică

single-cylinder engine (OM, termo) motor monocilindric

single cylindred (OM, termo, hidr) cu un singur cilindru

single daylight press (mas-un) presă cu un singur etaj

single-deck (nav) cu o singură punte

single decker (av) avion monoplan

single-disk clutch $(\mathrm{OM})$ ambreiaj monodisc

single-disk thrust bearing (OM) lagăr axial unilateral

single dividing method (mas-un) metodă simplă de divizare

single drive (mas, hidr, el) (cu) acționare individuală

single droplet (fiz) picătură izolată / singură (în studiul fluidelor)

single-edge cutting-tool (mas-un) cuțit / sculă aşchietoare cu un singur tăiş

single-effect evaporation (fiz, alim) vaporizare simplă

single ended wrench $(\mathrm{OM})$ cheie simplă

single-engined (mas) cu un singur motor

single-entry bookkeeping (ec) contabilitate simplă

single-eyed (anat) chior; onest; franc, deschis

single eye-glass (opt) monoclu

single file şir indian

single-fillet weld (OM, met) cusătură de colț unilaterală 
single-flame (termo) cu o singură flacără single-flange ring $(\mathrm{OM}$, hidr) inel cu o singură flanşă

single flexure (mec) încovoiere pură

single fluid intensifier (OM, hidr) multiplicator de presiune monofluid

single-flute drill (mas-un) burghiu cu o singură canelură

single force (mec, OM) forță concentrată

single-geared crack shaper / sheping (mas-un, $\mathrm{OM}$ ) acționat cu angrenaj şi culisă

single-handed (anat) ciung; făcut fără ajutor din afară, făcut de un singur om; singur, fără ajutor

single head $(\mathrm{OM})$ cheie simplă, dispozitiv simplu, cu un singur cap (activ / de lucru)

single-electrodewelding (met, $\mathrm{TH}$ ) sudare cu un singur electrod

single-head welding (met, $\mathrm{TH}$ ) sudare $\mathrm{cu}$ un singur cap

single-head wrench $(\mathrm{OM})$ cheie fixă, cu un singur capăt (de lucru)

single-hearted onest; franc, deschis

single-hole nozzle (auto, termo) jiclor / ajutaj cu un singur canal / orificiu

single-impression mould (met, mas-un, plast) matriță cu o cavitate

single-jet nozzle (auto, termo) jiclor cu o singură gaură

single-lap joint $(\mathrm{OM})$ îmbinare / asamblare printr-o singură suprapunere

single-leg (OM) monopicior, cu / pe un singur picior / suport

single-leg construction gentry crane (mas, transp) macara semicapră

single-lever control $(\mathrm{OM})$ comandă cu o singură pârghie

single-line rolling mill (met) laminor cu o singură linie de laminare

single-line spectrum (fiz) spectru cu o singură linie

single load $(\mathrm{OM}, \mathrm{mec})$ sarcină individuală, o singură sarcină / forță

single-loader $(\mathrm{OM})$ încărcător individual (pt. o singură piesă etc.)

single lubricator $(\mathrm{OM}, \mathrm{T})$ ungător pentru ungere locală (într-un singur loc)

single-minded onest; franc, deschis

single-mindedness onestitate; franchete; unitate de intentie / de scop

single motor un singur motor

singleness unitate de intenție / de scop; celibat

single-noded (fiz) cu un singur nod

single-operating welding machine (mas-un, met) convertizor de sudură pentru un singur post single out a alege, a selecționa, a selecta (un singur element, prin excludere etc.); a remarca; a distinge

single particle (fiz, met) grăunte elementar, particulă izolată / singulară

single-part drawing $(\mathrm{OM})$ desen de execuție (pt. o singură piesă)

single-part production (ind, $\mathrm{TH}$ ) producție de piese-unicat /cel mult serie mică şi foarte mică), confecționare individuală /

single-pass condenser (ind chim, alim) condensator cu o singură trecere

single-pass dryer (ind chim, alim) uscător cu o singură trecere

single-pass exchanger (termo) schimbător de căldură cu un singur pas

single-pass operation $(\mathrm{TH})$ proces monociclic, operație tehnologică cu o songură trecere

single-pass welding (TH, met) sudare cu o singură trecere / pe un singur rând

single pattern (met, plast) model nedemontabil dintr-o bucată

single point cutter (mas-un) freză / sculă cu un singur dinte

single-phase alternating current (el) curent alternativ monofazat

single-phase (el) cu o singură fază

single-phase current (el, mas) curent monofazat

single-phase motor (el) motor monofazat

single-picked sheet (met) tablă decapată

single-piece $(\mathrm{OM})$ o bucată, dintr-o bucată, monobloc

single-piece rim (auto) jantă dintr-o bucată

single-plane / static balancing machine (mec, mas, metr) maşină de echilibrat static / într-un singur plan

single-ply belt $(\mathrm{OM})$ curea dintr-un strat

single point recorder (autom) înregistrator cu o cale

single-point tool (mas-un) cuțit cu un singur vârf single-pulley (OM) scripete simplu

single-pulley drive $(\mathrm{OM})$ acționare cu o singură roată (conducătoare) de curea

single-purpose machine (mas-un) maşină-unealtă specială / specializată pentru o singură operație / piesă etc.

single-range instrument (metr) aparat de măsurat cu domeniu unic

single-reinforcement (met, TH) îngroșare pe o singură parte a cusăturii sudate

single-riveted joint $(\mathrm{OM})$ îmbinare / asamblare într-un singur rând de nituri

single-roll breaker $(\mathrm{OM}$, constr) concasor cu un singur valt / cilindru 
single-roll crusher (OM, constr) moară cu un singur cilindru

single-row ball bearing (OM) rulment $\mathrm{cu}$ un singur rând de bile

singles (met) table laminate separat

single-shaft pug mill (alim, constr, ind chim) malaxor cu un singur ax

single-shear rivet $(\mathrm{OM})$ nit supus acțiune de forfecare

single-shell rotary dryer (alim, ind chim) uscător rotativ, cu un tambur

single shot intensifier (OM, hidr) multiplicator de presiune, cu acțiune simplă

single-sintering technique (met, plast) tehnică / tehnologie simplă de sinterizare

single-slag process (met) procedeu / proces de topire cu o singură zgură

single-span (TH) cu o singură trecere; (constr) cu o singură travee (şi d. un atelier, o secție etc.)

single-span tuning (metr, autom, mas) deservire / acord / reglare prin comandă unică

single sphere drag (fiz, alim) coeficient de tragere pentru o singură sferă (particulă sferică) (Şi în modelare)

single spindle machine (mas-un, OM) maşinăunealtă cu un singur arbore

single-stage (autom, OM) cu o singură treaptă (d. reductoare, compresoare, pompe, aparate etc.)

single-stage compressor (termo) compresor $\mathrm{cu}$ un singur etaj

single-stage evaporation (alim, ind chim) evaporare cu un singur etaj / cu o singură treaptă

single-stage evaporator (alim, ind chim) evaporator cu o treptă

single-stage pump (OM, hidr) pompă cu un singur etaj

single-stand (rolling) mill (met) laminor $\mathrm{cu} \mathrm{o}$ singură cajă

single-stand process (met) proces / procedeu de turnare continuă / în linie

single start $(\mathrm{OM})$ cu un singur început (şi $\mathrm{d}$. filete / melci etc.)

single start thread $(\mathrm{OM})$ şurub / melc cu un singur început

single-step (OM, mas, TH) un singur etaj, (cu) un singur pas, cu o singură treaptă (d. un proces, o piesă etc.)

single-step compressor (termo) compresor $\mathrm{cu}$ un singur etaj

single-strap butt joint $(\mathrm{OM})$ îmbinare / asamblare cap-la-cap, cu o singură eclisă

single-strap lap joint $(\mathrm{OM})$ îmbinare / asamblare prin suprapunere, cu o singură eclisă

singlet (textile) flanelă (de corp) single test (metr, OM) încercare / test separat $(\breve{a})$ pentru fiecăre piesă, test izolat

single thread (OM) filet cu un singur început single-thread screw $(\mathrm{OM})$ şurub cu un singur început

single-thread worm (OM) melc simplu (cu un singur început)

single-throw crankshaft $(\mathrm{OM})$ arbore cotit

single ticket (transp) bilet simplu, bilet pentru o (singură) călătorie

single track (cf) cale / linie feroviară simplă

single tyre press (ind chim, mas-un) presă individuală pentru prelucrat un singur pneu

single upright machine (mas-un) maşinăunealtă cu un singur montant

single-valued (chim) monovalent

single-V-butt joint (OM) îmbinare / asamblare în $\mathrm{V}$ (şi de sudură)

single-V groove $(\mathrm{OM})$ crestătură / rost (de sudură etc.) în $\mathrm{V}$

single-way furnace (met, termo) cuptor $\mathrm{cu}$ un singur arzător

single weight $(\mathrm{OM})$ greutate / masă pe bucată single wire $(\mathrm{OM}, \mathrm{el})$ monofilar (d. un cablu, fir etc.)

single working beam $(\mathrm{OM})$ balansier cu un singur braț

singling (ind chim) obținerea stibiului brut

singly $(a d v)$ singur, fără ajutor (din afară); (în mod) individual, separat; unul câte unul

sing of a cânta despre; a slăvi

sing out a fluiera; a striga; a chema; a rosti, a transmite, a repeta (un ordin etc.) cu voce tare / strigând

sing-song lectură, interpretare, recitare etc. monotonă; vorbire tărăgănată; melopee; lălăit, lălăială; concert improvizat; cor de amatori; monoton; tărăgănat; melopeic; a rosti / cânta monoton

singular neobişnuit, ciudat, straniu; original; bizar, rar, singular; particular; singur, unic; (mat) (număr) singular

singularity particularitate; ciudățenie, originalitate; exemplar unic; (mat, fiz) singularitate

singularize a distinge, a remarca, a evidenția; a individualiza; a particulariza; a se distinge (de alții)

singularly $(a d v)$ (în mod) ciudat, bizar, straniu; deosebit / extraordinar de, cu totul; singur, fără ajutor din afară; (gram) la singular

sing up a cânta mai tare/puternic

sinister stâng, din partea stângă; sinistru, prevestitor de rău, de rău augur; funest; $\sim$ to dezastruos pentru; nefericit, nenorocit 
sinistro-gyrate (d. scriere) sinistrogir

sinistrous, sinister criminal, funest, de rău augur (d. un gând); to dezastruos / nefericit pentru

sink (nav, fiz) a (se) (s)cufunda; a (se) afunda; a (se) da la fund; a se duce la fund; a se lăsa (în jos); a cădea; (constr) (d. un zid) a se prăbuşi, a se nărui, (d. temelie) a se lăsa, a se slăbi, a săpa (o groapa, un puț etc.); (d. foc etc.) a slăbi, a începe să se stingă; (d. apă etc.) a scădea, a se micşora; a se împuțina (d. apă etc.); (d. soare etc.) a apune, a asfinți; a coborî; a se afunda (în zăpadă etc.); (fig) (ec) (d. prețuri etc.) a scădea, a se micşora, a se ieftini, a stinge (o datorie), a achita (o datorie), a investi, a aloca (fonduri); (d. furtună etc.) a se potoli, a se domoli, a scădea în intesitate; (fig) (d. cineva) a slăbi (văzând cu ochii), a se stinge; (fig) a înrăutăți, a i se apropia moartea / sfârşitul (d. cineva), a i se strânge (d. inima), a fi pe moarte, a se stinge (d. cineva); a coborî (pe scara socială etc.); (d. glas, voce etc.) a slăbi, a coborî; through (d. apă etc.) a pătrunde prin; (pol, ec) a determina scăderea (nivelului de trai etc.) a înfunda; a vârî / băga în pământ; a îngropa; a înfinge (un par etc.); a apleca, a lăsa (capul pe piept etc.), a sprijini; a renunța la; a lăsa la o parte; a aplana (o ceartă etc.); a înrăutăţi; (fig) a distruge, a ruina; (fig) a-i sări din piept (d. inimă); a coborî; $(\mathrm{OM})$ a instala, a strunji un şanț (pe o piesă); (geol, constr) a se tasa; a se adânci; a ascunde; a pătrunde; a intra; a se prăbuşi, a (se) îngropa; (birotică, poligrafie) a străbate prin hârtie; (geol, ind) a coborî un foraj, a fora, a adânci un foraj (pt. petrol, apă etc.); (fam) a înghiți, a mânca; (constr) chiuvetă, hazna; (hidr, constr) scurgere din puț, puț de scurgere, canal de scurgere; (mas, el, hidr) derivație, ramificație, şunt; (ec) alocare, destinație a fondurilor / a resurselor; (OM) gol interior (într-o piesă etc.); (met) baie de decapare; (mat) ieşire, sursă negativă; (teatru) trapă (a scenei); (fig) cloacă, mocirlă

sinkage scufundare; (alim) pierdere de masă prin spălare; (auto) împotmolire (a roților etc.)

sink bolt $(\mathrm{OM})$ şurub cu cap înecat

sink current (el) curent absorbit

sinker (constr, met) perforator pneumatic; plumb (la undiță); (textile) platine; monedă falsă (şi fig); (amer) dolar de argint

sinker lifting bar (OM, auto) presă de platine

sinkhead (met) maselotă

sinkhole (constr) canal (de scurgere), hazna; (geol) ponor, dolină, relief carstic

sink hole (met) retasură / suflură de tasare; (geol) pâlnie de eroziune, dolină, ponor sink in (d. lichide) a pătrunde, a intra (într-un corp solid); (fiz) a scufunda; a afunda; a imersa; (fig) a avea efect, a găsi ecou

sinking care se scufundă etc.; (d. o senzație etc.) de slăbiciune, de leşin; (ec) amortizare, de amortizare, care se amortizează; (hidr) (s)cufundare; afundare; agravare; adâncire; (ec, adm, TH) avansare; (constr, geol, ind) săpare; adâncire (a unui puț)

sinking fund (ec) capital de amortizare

sinking-funds (ec) fond(uri) de amortizare

sinking head (met) maselotă

sinking of the subsoil (constr, geol) tasare (a solului)

sinking pump (OM, hidr) pompă verticală de evacuat apă

sinking rolling mill (met) laminor reducător / reductor

sink into a cufunda / afunda în; a vârî / băga în; a înfige în; a muşca din; (d. apă etc.) a pătrunde în; a fi absorbit de; a se pierde în; (d. cuțit etc.) a pătrunde adânc în; (d. imagine etc.) a se imprima în, a se întipări în (memorie etc.); a se cufunda în (somn, uitare); a cădea în (nesimțire etc.)

sinless fără păcat; nevinovat, neprihănit

sinlessness nevinovăție, inocență, curățenie; sfintenie

sinner păcătos; ticălos, nemernic, netrebnic

Sinn Fein (pol) mişcare şi societate revoluționară irlandeză (întemeiată în 1005)

sinter (met) zgură, țunder, scorie; $(\mathrm{TH})$ produs sinterizat; concrețiune; (geol) travertin; (met, ind chim, TH) a aglomera, a sinteriza, a arde, a prăji; a aglutina

sinter cake (met) turtă pentru sinterizare

sintered sinterizat (d. materiale)

sintered carbide alloy (met) aliaj din carburi sinterizate

sintered-carbide cutter (met, OM, mas-un) freză / sculă de aşchiere cu plăcuțe din (aliaj din) carburi sinterizate

sintered compact $(\mathrm{OM})$ piesă sinterizată, semifabricat sinterizat

sintered density (materiale, fiz, TH) densitate după sinterizare

sintered electrical contact material (materiale, el) material sinterizat pentru contacte electrice

sintered flux (met, TH) flux ceramic sinterizat (pentru sudură)

sintered hard metal / alloy (met) aliaj dur sinterizat

sintered hearth bottom (met) vatră sinterizată (la un cuptor etc.) 
sintered iron (met) fier sinterizat

sintered material in layers (materiale) material sinterizat în straturi

sintered metal (met) metal / aliaj sinterizat

sintered metal filter (materiale, $\mathrm{OM}$ ) filtru din metal / aliaj sinterizat

sintered part $(\mathrm{OM})$ piesă sinterizată

sintered sample (materiale, metr) epruvetă sinterizată

sintered steel (met, OM,) oțel sinterizat, piesă din otel sinterizat

sintering (TH) aglomerare, (acțiune / proces de) sinterizare, care se sinterizează

sintering atmosphere (met, plast, ceramice) atmosferă / mediu de sinterizare

sintering box (met, plast, ceramice, OM) nacelă / cutie de sinterizare

sintering coal (met) cărbune cocsificabil

sintering furnace cuptor de sinterizare / de agomerare

sintering machine / plant (mas-un, TH) maşină / instalație de sinterizare / de aglomerare

sintering point (fiz, termo, $\mathrm{TH}$ ) punct de sinterizare

sintering press (mas-un) presă de sinterizare

sintering process (materiale, $\mathrm{TH}$ ) proces de sinterizare / de aglomerare

sintering rate $(\mathrm{TH})$ viteză de sinterizare

sintering strand (met, OM) bandă de aglomerare

sintering technique $(\mathrm{TH})$ procedeu / tehnică de sinterizare / de aglomerare

sintering temperature (termo, materiale, $\mathrm{TH}$ ) temperatură de sinterizare / de aglomerare

sintering time (TH) durată de sinterizare

sintering under pressure $(\mathrm{TH})$ (proces de) sinterizare sub presiune

sintering with a liquid phase $(\mathrm{TH})$ (proces de) sinterizare cu o fază lichidă

sinuosity $(\mathrm{OM})$ circumvolutie, sinuozitate

sinuous sinuos; cotit; şerpuit; ondulat; întortocheat; (d. cineva) întortocheat, încurcat, încâlcit; neaşteptat, pe care nu te poți bizui; care nu are un drum drept în viață

sinuously $(a d v)$ (în mod) sinuos; cotit; serpuit

sinus (anat, med) sinus, sinuzită

sinusitis (med) sinuzită

sinusoidal wave (fiz) undă sinusoidală

Sion (geogr) munte lângă Ierusalim

-sion sufix tradus deseori cu -sie, -siune; exemple: obsession obsesie, procession procesi(un)e

Sioux, $(p l)$ Sioux și Siux (amer) indian din tribul Sioux

sip a sorbi, a înghiți; of a sorbi din, a bea câte puțin din; sorbitură, înghițitură siphon (OM, hidr) sifon (sticlă, aparat), sifon deversor, țeavă de aspirație; a sifona, a evacua prin sifonare

siphonage, siphoning ( $\mathrm{TH}$, hidr) sifonare

siphon body $(\mathrm{OM})$ corp de sifon

siphon bottle $(\mathrm{OM})$ (sticlă de) sifon

siphon conduit $(\mathrm{OM})$ colector în sifon

siphon gauge (OM, hidr, metr) manometru $\mathrm{cu}$ tub în U

siphon lubricator $(\mathrm{OM})$ ungător cu fitil

siphon main $(\mathrm{OM})$ colector în $\mathrm{V}$

siphon off (TH, chim) a evacua / scurge apa prin sifonare, a decanta cu un sifon; (alim) a sifona

siphon tap (met) autodescărcare a cuptorului

siphon trap (OM, hidr) sifon

sipid (alim) savuros

sippet bucată, fărâmă; (alim) bucată de pâine prăjită (înmuiată în sos etc.), frigănea

sir (ca vocativ, neurmat de nume) domnule, stimate domn(ule)

Siracusa (geogr) port în Italia, Siracuza

sire (ca vocativ) sire, maiestate; strămoş, străbun; (zool) animal de prăsilă, reproducător; (d. cai) a procrea, a da naştere

siren sirenă; vampă, femeie fatală; $(\mathrm{OM})$ sirenă, fluier

siriasis $(p l)$ siriases (med) insolație

sirloin(steak) (alim) muşchi (de vacă) (gătit)

sirocco (meteo) siroco

sirup (alim) sirop

sirupy (alim) siropos

sisal (textile) sisal

siskin (zool) scatiu

sissified efeminat

sissy surioară; băiat / bărbat efeminat; homosexual; timid; fricos

sissyish efeminat; alienat

sister soră; surată; surioară; soră, călugăriță; infirmieră, soră; (med) infirmieră șefă; băiat / bărbat efeminat; homosexual

sister-german soră bună

sisterhood calitatea / situatia de soră; înrudire ca soră; (med) comunitate de infirmiere

sister hook (OM) cârlig bicor / cu cablu dublu

sister-in-law, $(p l)$ sisters-in-law cumnată

sister-like (ca) de soră; ca o soră

sisterly $(a d v)$ (ca) de soră; ca o soră

Sistine Chapel, the Capela Sixtină

Sisyphus mit mitul lui Sisif

sit a aşeza; a rezema; a sprijini; a şedea, a fi / sta aşezat; a poza, a fi model; a fi în şedință, a se întruni, a se reuni; (d. păsări) a sta, a fi cocoțat (pe cracă etc.); (d. cloşcă) a sta pe ouă, a cloci; (d. haine) a sta, a şedea, a veni (bine etc.); 
(d. comportare etc.) a sta, a şedea (frumos etc.); a se potrivi (d. comportarea unui material etc.); a sta pe; a se ține pe (cal etc.); a face să se aşeze; a se aşeza, a sta jos, a lua loc; loc, serviciu, slujbă; (textile) croială, ajustare (d. haine); SIT (metr) prescurtare de la self-ignition temperature - temperatură de auto-aprindere

sit about / around a tăia frunză la câini, a sta cu brațele / mâinile încrucişate (când alții lucrează)

sit back a nu face nimic, a sta cu mâinile încrucişate, a tăia frunză la câini

sit by a nu lua nici o măsură, a nu face nimic

sit down a se aşeza, a sta jos, a lua loc; a şedea; (av) a ateriza; a face să se aşeze

sit down for a asedia, a împresura (o cetate etc.) sit-down strike (ec) greva brațelor încrucişate

sit down under a se împăca cu; a răbda fără să se plângă de

site loc, poziție, situație; loc, aşezare; (ind) loc de montaj, şantier, amplasament; on la locul de muncă, pe şantier, pe teren; (geogr) pantă, coastă, povârniş

sited aşezat, situat, dispus (în cuvinte compuse)

site of breaking (OM, mas) ruptură, loc al ruperii site of fracture / of rupture spărtură, rupere, spargere, loc al ruperii / spargerii

site plan (ind) plan de ansamblu

site road (constr, transp) drum de şantier

site welding (met, $\mathrm{TH})$ sudare pe şantier / la (locul de) montaj

sit for a se prezenta la (un examen); (pol) a reprezenta (o circumscripție electorală), a fi reprezentantul (unei circumscripții electorale)

sith, since de atunci (încoace)

sit-in (ec, pol) grevă italiană; (pol) (protest social prin) ocuparea locurilor (dintr-un local etc.)

sit in a avea grijă de un copil / de copii (în absența părinților)

sit in for (ec, adm, pol) a fi membru; a lua parte la; a participa la

sit in on (ec, adm, pol) a fi prezent fără a lua parte activă la

sitio (metr) unitate de măsură pentru arie, denumire tradițională pentru square legua (în Mexic şi sud-estul US); 1 sitio $~ 1800$ ha; v. square legua

sit on a fi membru; a examina, a cerceta, a investiga; (fig) a înăbuşi, a suprima, a reprima

sitting (ec, adm, pol) şedință, adunare, întrunire; aşezat, care stă jos; în şedință

situate $(\mathrm{OM})$ a situa, a şeza, a plasa; a încadra

situated (OM, mas, constr) situat, aşezat, plasat

situation situație; poziție; aşezare (a unui oraş, a unei piese); amplasare; situație, stare (financiară); slujbă, serviciu; (mas, constr) amplasament situation of proximity valoare aproximativă, aproximație

sit up a şedea în picioare / drept, a nu se culca; a sta până târziu

six şase; grup de câte şase (obiecte sau persoane)

six-angled (geom) hexagonal

six-bladed fan (termo) ventilator cu şase pale

six-cylinder engine (termo) motor cu şase cilindri

sixfold de şase ori, înşesit

sixfold polymer (chim) hexamer

six-high mill (met) laminor sixto

six-in-line (termo, auto) (cu) şase cilindri în linie

six-roller mill (met) laminor sexto

six-stand mill / train (met) laminor / linie de laminare cu şase caje / sexto

sixteen şaisprezece

sixteen-cylinder engine (termo, auto) motor $\mathrm{cu}$ 16 cilindri

sixteenth al 16-lea, a şaisprezecea parte (dintrun întreg)

sixth al saselea; sesime, a sasea parte; sixth (metr, muz) sexta, unitate utilizată pentru a descrie raportul dintre frecvențele a două note; două note diferă prin 1 minor sixth (1 sixta minoră) dacă nota mai înaltă are frecvența exact $8 / 5$ din frecvența notei mai joase; două note diferă prin 1 major sixth (1 sixtă majoră) dacă nota mai înaltă are frecvența egală cu $5 / 3$ din frecvența celei joase

six-throw crankshaft (OM, auto) arbore cotit cu şase paliere

sixtieth şaizecilea; a şaizecea parte

sixty şaizeci

six-wheel lorry (auto, transp) autocamion cu şase roți

size mărime; măsură; dimensiune sau dimensiuni, proportiii; volum; categorie; calibru; format; of a $\sim$ de aceeaşi mărime, de aceleaşi dimensiuni; (textile) mărime, talie, număr, apret; (poligrafie) corp de literă; (TH, chim) clei; statură, talie; a aranja / clasa / clasifica după mărime; a aprecia; (metr) a etalona; a sorta; (TH, metr) a calibra; (TH) a lipi, a încleia; (OM, mas) a potrivi, a ajusta; (ind, ec, mediu) a standardiza

sizeable mare, voluminos, de mărime considerabilă

size block (OM, metr) cală plan paralelă

size class (auto) clasă, măsură (şi pt. componente)

size composition (alim, constr, met, materiale) compoziție granulometrică

size degradation ( $\mathrm{TH}$, materiale) dezintegrare, mărunțire, sfărâmare, degradare prin sfărâmare size distribution (materiale, metr) distributie granulometrică 
sized (materiale, metr) granulat

size factor $(\mathrm{OM})$ factor de mărime / dimensional size grade $(\mathrm{OM})$ ordin de mărime (d. piese produse în seturi dimensionale etc.)

size grading (materiale, metr) compoziție granulometrică

size measurement (materiale, metr) măsurare a dimensiunii (şi la pulberi, amestecuri etc.)

size segregation (materiale, $\mathrm{TH}$ ) segregare granulometrică / după mărime

sizing $(\mathrm{OM})$ dimensionare, ajustare; (plast, $\mathrm{TH}$ ) etanşare, apretare prin aplicarea unui material elastic, înainte de aplicarea adezivului; (textile) apretare, încleiere; (TH, OM) aşezare / clasare / dispunere după mărime, prelucrare fină; (metr) calibrare, clasare, măsurare; (fig) parte, tain

size of jaw (OM) deschiderea cheii / fălcilor (unui dispozitiv de prindere / fixare, unei mandrine de prindere pt. prelucrare etc.)

size of mesh (metr) numărul sitei

size of pore (materiale) dimensiunea porilor (şi la un filtru etc.)

size of section $(\mathrm{OM})$ mărime a secțiunii

size of the hole $(\mathrm{OM})$ diametru (nominal) al alezajului

sizer $(\mathrm{OM})$ sită

size reduction $(\mathrm{TH})$ sfărâmare, mărunțire, măcinare, reducere a dimensiunii (particulelor etc.)

size test $(\mathrm{OM}$, metr) încercare / test de rezistență a încleierii

size up a măsura; a aprecia, a evalua, a stabili aproximativ

size variation $(\mathrm{TH})$ abatere de la dimensiunea nominală, variație dimensională

sizing aşezare, dispunere după mărime; parte; (TH) dimensionare; calibrare; clasare; (mas-un) finisare / prelucrare la dimensiuni finale; (constr) sortare (după granulație); încleiere (şi la textile); (metr) sortare după dimensiuni, calibrare; preliminary $\sim(\mathrm{TH})$ cernere grosieră; medium (materiale) clasare / sortare intermediară; equal friction method duet $\sim(\mathrm{OM})$ dimensionare a conductelor prin metoda frecării egalizate; fluidized-bed (ind chim) clasificare în strat fluidizat

sizing analysis (materiale, metr) analiză pe site

sizing chisel (OM, mas-un, metr) cuțit combinat cu un calibru potcoavă

sizing die (OM, mas-un, metr) matriță de calibrare

sizing drum (OM, mas-un, metr) cilindru de sortare; ciur rotativ (ind hârtiei)

sizing facility (OM, mas-un, metr, autom) dispozitiv de calibrare automată

sizing glue (ind chim) lac de lipit sizing gum (ind chim) substanţă de încleiere sizing jigging screen sită vibratoare de sortare sizing of grain (materiale, metr) sortare granulometrică

sizing process (textile) apretare

sizing roller (ind chim, textile) valț / cilindru de aplicat masa de încleiere / apretul

sizing rolling mill (met) laminor de calibrare / finisor

sizing screen (materiale, OM) ciur / sită de sortare

sizing stop (OM, metr) opritor de calibrare

sizing test (materiale, metr) analiză granulometrică

sizing tool (mas-un, metr) cuțit combinat cu calibru potcoavă

sizing trip (OM, mas-un) mecanism de decuplare a avansului

sizy lipicios, cleios (d. materiale pt. încleiere, lipire)

sizzle sfârăitură (de ulei încins); trosnitură; pocnitură; a sfârâi; a trosni; a pocni

skate $(\mathrm{OM})$ patină, piesă alunecătoare; a patina

skating (sport) patinaj

skating rink (sport, constr) patinoar

skeg (nav) călcâi de chilă / de etambou

skein (OM) filet (rar); (textile) scul, jurubiță, ghem; (metr, textile) scul, unitate variabilă ca mărime (masă sau lungime) în funcție de tipul de fire şi de producător; în industria textilă este o unitate de măsură pentru lungimea firelor: 1 skein $=1$ lea (300 iarzi)

skein dyeing (textile, TH) vopsire în sculuri

skein examiner (textile, metr) controlor de jurubite / de sculuri

skein method of tensile test (textile, metr) metodă de determinare a sarcinii de rupere în scul

skein strength of yarn (textile, metr) rezistență la rupere a firului în jurubiță / în scul

skein test (textile, metr) probă de rezistență în scul skeleton (OM, constr) carcasă, schemă, schelet (metalic), structură; osatură; (nav) carcasă (a unui vas); cu gratii; (textile) ajurat

skeleton crystal (fiz) cristal imperfect

skeleton diagram (mas) schemă cinematică

skeleton key $(\mathrm{OM})$ şperaclu

skeleton spanner $(\mathrm{OM})$ cheie de robinet

skeliering (met) deformare (la încălzire)

skelp (met) fâşie de tablă

skelp (rolling) mill (met) laminor de platbande / de benzi pentru tevi

skelp steel (met) platbandă de oțel

skelp storage (met) magazie / depozit de platbande, table 
skep, skæppe, skjeppe (metr) unitate tradițională de măsură pentru volum (materiale uscate), în nordul Europei; 1 skep (UK) $\sim 1$ bushel, 1 skæppe (Danemarca) 17,407 1, 1 skjeppe (Norvegia) $\sim 17,3701 ; 1$ schepel (Olanda), 1 scheffel (Germania)

sketch desen, schiță; schemă; (fig) fragment; a desena, a schița; a proiecta

sketch board planşetă de desen

sketchily $(a d v)$ sumar, schițat, în linii mari; vag; fără amănunte

sketchiness caracter sumar; lipsă de finisare; superficialitate

sketchy sumar, schițat; nefinisat; vag; incomplet; superficial

skew oblic; înclinat, pieziş; nesimetric; ( $a d v)$ în mod) oblic, nesimetric; oblicitate; a aşeza oblic; a înclina; (fig) a denatura

skew bevel gear $(\mathrm{OM})$ roată dințată hiperboloidală; roată conică cu dinți înclinați

skew distribution repartitie metrică

skewed direcție oblică, înclinat, oblic

skewed rollers $(\mathrm{OM})$ role înclinate

skewing $(\mathrm{OM})$ poziție înclinată

skew iron cuțit oblic de rindea

skewness $(\mathrm{TH}, \mathrm{T})$ înclinare, oblicitate (şi ca parametru de rugozitate); caracter

skewness of assessed profile (metr) factor de asimetrie a profilului evaluat (la profilometrie)

skew-roller table (met, mas) cale cu role înclinate

skew rolling mill (met) laminor cu cilindri oblici / Mannesmann

skew spanner $(\mathrm{OM})$ cheie cu coadă aşezată sub un unghi față de axa deschiderii

skew spur wheel $(\mathrm{OM})$ angrenaj melcat / cu melc skew surface $(\mathrm{OM})$ suprafață deformată / neuniformă (şi ca defect)

skew-symmetric $(\mathrm{OM})$ asimetric

skid $(\mathrm{OM})$ talpă, sanie, patină, piron, sabot (de frână); (auto) piedică la roată, derapare, patinare, alunecare; (nav) şină de alunecare, talpă de lansare (a unei nave), tălpice; a derapa, a face să derapeze; a frâna, a bloca (o roată); a cala (un cilindru); a glisa

skid board (TH) cală de roată

skid chain (auto) lanț antiderapant

skid-defied antiderapant (d. pneuri etc.)

skid-defied tyre (auto) anvelopă antiderapantă

skidding (mec, T) patinare, derapare, glisare; alunecare; transport pe sanie / pe ghidaje de alunecare / pe sanie

skiddy (mec, T, OM) care poate derapa / aluneca skidlid cască de protecție (a motocicliştilor)

skid mark (auto) urmă de frânare (pe drum, pe sabot) skid pan (auto, OM) sabot de oprire / de frână skid platform $(\mathrm{OM})$ capră de încărcare

skid-proof (auto) antiderapant

skid-runners (nav) cală de lansare

skid shoe $(\mathrm{OM})$ sabot de frână, tachet opritor

skid transfer (mas-un) transfer prin alunecare

skilful dibaci, îndemânatic; abil, priceput, iscusit; expert

skilfulness îndemânare, dibăcie, pricepere; experiență; cunoştințe

skill îndemânare, dibăcie; abilitate, pricepere, iscusință; măiestrie, artă; competență (tehnică); meserie; calificare

skilled calificat, competent; meșter; $\sim$ in priceput în / la, experimentat în

skilled furnace (met) cuptor cu creuzete

skilled worker muncitor calificat

skillet (met) tighel; creuzet; tigaie, cratiță

skilling (constr) şopron

skillless neîndemânatic; nepriceput, fără experiență

skim (alim) a smântâni (laptele), a lua spuma; șlefuire; (met) a curăţa, a îndepărta zgura / spuma / țunderul; (constr) a nivela terenul; a prinde o pojghiță / crustă subțire; a face de mântuială

skim coat (OM) strat / acoperire de cauciuc

skim coulter (agr) antebrăzdar, antetrupiță

skim gate (met) separator de zgură

skimmed milk (alim) lapte degresat

skimmer (met) prag pentru reținerea zgurii; separator (şi de zgură); (constr) plug nivelator, greder; (alim) lingură de spumă / de luat spumă; racletă, răzuitoare; (fig) cititor superficial; a (stră)luci

skimmer gate (met) separator de zgură, colector de spumă (la turnare)

skimmer plug (OM, constr) nivelator, greder, racletă

skimmer shovel (mas, constr) excavator nivelator skim milk (ind chim) latex decantat / stratificat; (alim) lapte smântânit / degresat

skimming luare, îndepărtare; (alim) îndepărtarea spumei, smântânire (a laptelui); (constr) nivelare (a terenului); (met) îndepărtare a zgurii; formare a pojghiței; spumă îndepărtată / luată; (a)lunecare; plutire; contact superficial

skimming basin (met) bazin de turnare cu opritor de spumă

skimming door (met, OM) orificiu de evacuare / de îndepărtare a zgurii

skimming gate (met) separator de zgură (şi la reteaua de turnare)

skimming (met, hidr, T) îndepărtare a spumei

skimming ladle (met) oală pentru zgură

skimming machine (mas) centrifugă 
skimming plate (met, OM) gură de evacuare a zgurii

skimming spoon (met, alim, OM) lingură de scos spumă

skimmings (met) zgură

skim off a îndepărta (zgura / spuma)

skimp a reduce; a da / împărți cu zgârcenie / economie

skimpiness zgârcenie; economie; insuficiență

skimpy redus; insuficient; puțin; neîndestulător; zgârcit; econom

skim the market (ec) a asigura succesul unui produs pe piaţă (înainte de apariția concurenței)

skin înveliș; (anat) piele; blană (de animal); s $(p l)$ piei, blănuri, blănărie, pielărie; (met, T) crustă fină, film, peliculă, strat superficial / acoperitor, strat de oxizi de laminare; pieliță; (textile) pânză subțire, lână tăbăcărească; (nav) înveliş (etanş al navei), bordaj, cocă; a (se) jupui; a curăța de coajă, a decoji; (med) a se cicatriza

skin decarburisation (met, chim) decarburare superficială

skin-deep superficial, la suprafața pielii; (fig) de suprafață, superficial

skin depth (met) adâncime de pătrundere, profunzime

skin-dried mould (met) formă de turnare, uscată superficial

skin effect (fiz, hidr, T) efect pelicular / superficial

skin friction $(\mathrm{T})$ frecare superficială

skin hardened (met) durificat superficial, cementat

skin hardness (materiale, mec) duritate superficială

skin hole (met, plast, ceramice) porozitate superficială

skin mill (met) laminor de ecruisat oțel

skinned acoperit cu piele; (anat) jupuit, cu pielea zdrelită

skinner (ind ușoară) cojocar, pielar, blănar; escroc

skinniness slăbiciune; aspect costeliv

skinning (el, TH) dezizolare, curățare a izolației; (auto, chim) deşapare, desprindere a anvelopei uzate; (T) care formează o peliculă

skin of a casting / of metal part (met) pojghiță / crustă de turnare

skin pass(ing) (met) trecere de finisare / de dresare / de ecruisare / de netezire

skin-pass mill stand (met) cajă de finisare / de netezire

skin-pass rolling (met) trecere / laminare de finisare / de netezire, netezire prin laminare skin-pass rolling mill (met) laminor de finisare / de netezire / netezitor

skin-pass stand (met) cajă de finisare / de netezire skin plate / plating (met, OM) tablă de etanşare, îmbrăcăminte / căptuşeală de tablă

skin-reddening (med, anat) (în)roşire a pielii

skin rolling (met) trecere / laminare de finisare / de netezire, netezire prin laminare

skin runners (nav) cale de lansare

skin shrinkage (met) contracția crustei

skin temperature $(\mathrm{OM}$, termo) temperatura suprafeți

skin to skin aderență

skin weld $(\mathrm{OM})$ sudură de suprafață

skip salt, săritură (mică), hop; (met) benă / găleată / vagonet basculant (de încărcare); elevator cu plan înclinat; a sălta, a sări; a trece peste, a omite; a face să sară; (c) a schimba, a şterge din memorie; (fig) a divaga

skip bridge (met) platformă de încărcare

skip bucket (met) găleată / cupă basculantă a skipului

skip car (met) (cărucior-) schip (la furnal); vagonet basculant

skip charger (constr, met) maşină de încărcat cu schipuri

skip charging / filling (met) încărcare a furnalului cu vagonete basculante / cu schipuri

skip-charging gear (met) instalație de încărcat cu schipuri (şi la furnal)

skip dump track (met) şine de conducere a skipului

skip filling (met) încărcare a furnalului cu schipul

skip hoist (met, mas) ascensor cu plan înclinat / basculant / cu skip

skip loader (met, mas) maşină de încărcat cu schipuri

skipper (nav) comandant (de costier, de pescador), căpitan (de vas comercial); (fig) comandant, conducător, şef

skipping (auto) funcționare a motorului $\mathrm{cu}$ impulsuri, rateuri la aprindere

skip welding (met, $\mathrm{TH}$ ) sudare în pas de pelerin

skirt (textile) fustă; $(\mathrm{OM}$, termo) manta / cămaşă a pistonului; a ocoli, a evita (o problemă)

skirting (constr) plintă, bordură; bordurare

skirting board (constr) şipcă de bordură; (nav) brâu de acostare

skirt round a ocoli

skirt slot $(\mathrm{OM}$, termo) fantă de cămaşă / manta de piston

skittle away a risipi; a neglija, a omite, a scăpa, a lăsa să-i scape 
skive (mas-un) piatră abrazivă / ferăstrău / bandă cu praf de diamant; a lustrui, a poliza; a răzui (piei); a tăia pieziş

skived tape $(\mathrm{OM}, \mathrm{TH})$ con / conicitate obținut $(\breve{a})$ prin îndepărtare de straturi fine dintr-o piesă cilindrică

skiving tool (mas-un) cuțit tangențial de finisat

skock (metr) unitate tradițională suedeză pentru cantitate, egală cu 60

skot (metr) unitate veche de măsură pentru luminanță (slabă) (utilizată în Germania, pt. niveluri de luminanță pe durata bombardamentelor): 1 skot este strălucirea unei suprafețe, produsă de 0,001 lux (de lumină)

skull (zool) berbec; (met) urs (la furnal)

skull at the converter mouth (met) lipitură la gura convertizorului

skull cracker (met, constr) berbec

sky cer

sky-blue azuriu, de azur

sky blue azur, senin

sky diver (mil, sport) paraşutist

skylight (constr) luminator, lucarnă

sky sail (nav) contrarândunică

skyscraper (constr) zgârie-nori

slab (constr) dală, lespede, placă, margine; tablou; placă; foaie; bucată, felie, parte (dintr-o masă solidă); (alim) tabletă (de ciocolată) (met) sleb, bramă, semifabricat de dimensiuni mari, pentru prelucrare ulterioară, la laminoare; a lamina brame / sleburi; (inf) grup de 12 biți; (el) tablou, placă; (constr) lăturoi, lătunoi, a acoperi cu lespezi / dale, a pava (cu dale)

slab billet (met) țaglă, platină, semifabricat

slabbing (met) laminarea sleburilor / bramelor; (mas-un) frezarea suprafeței paralele cu axa frezei

slabbing cutter (mas-un) freză radială cilindrică, cu lungime mare

slabbing mill for rolling armor plate (met) laminor de blindaje

slabbing mill (met) laminor de brame

slabbing mill (met) laminor slebing / pentru laminarea bramelor / sleburilor

slabbing-mill roll (met) cilindru de brame si platine

slabbing(-mill) stand (met) cajă de laminor pentru sleburi / brame

slabbing-mill train (met) linie de laminor slebing / pentru brame / sleburi

slabbing pass (met) calibru pentru brame / sleburi

slabbing roll (met) cilindru de laminor de brame / sleburi slabbing rolling mill (met) laminor de brame / sleburi, slebing

slab bloom (met) bramă

slabby coal cărbune care se rupe în lespezi

slab cogging rolling mill (met) laminor pentru sleburi / brame, slebing

slab conditioning (met) tratament superficial (mecanic) al slebului / bramei

slab copper (met) cupru în plăci

slab-heating furnace (met) cuptor adânc pentru brame

slab ingot (met) lingou pentru brame

slab mill (mas-un) laminor pentru sleburi / pentru brame, slebing

slab milling machine (mas-un) maşină de frezat plan

slab pile (met) pachet / stivă de brame / de sleburi

slab pusher (met) împingător de brame / sleburi (şi la cuptor)

slab reheating furnace (met) cuptor pentru reîncălzit brame / sleburi

slab rubber (ind chim) cauciuc în plăci

slabs (constr) plăci de pardoseală; (ind chim) cauciuc / semifabricate în plăci

slab shears (met) foarfece de brame

slab-sided (TH, OM) cu pereți laterali; înalt şi slab

slab side press (mas-un) presă cu pereți laterali

slab turn-over device (met) dispozitiv pentru răsturnat sleburi / brame

slab wax (ind chim) parafină în plăci

slab weigher (met) dispozitiv de cântărit sleburi slab zinc (met) zinc în plăci

slack $(\mathrm{TH})$ slab; slăbit; destins, moale; fără coeziune; încet, lent; lipsit de energie; nefixat bine, fixat slab; (d. cineva) delesător, indolent, neglijent; cu joc (şi cauzat de slăbirea unei strângeri); joc (şi exagerat); încetinire; porțiune întinsă (a unei frânghii) (mec) săgeată datorită greutății proprii; (met) praf de cărbune; $(\mathrm{ec})$ (d. comerț) slab, care lâncezește, mort; (ec) (perioadă de) acalmie, inactivitate; (nav) mare staționară (între flux şi reflux); (textile, ind) salopetă; praf de cărbune; a (se) slăbi; a ceda; a se înmuia; a se destinde; a încetini; a lăsa joc (şi nedorit, între piese); (ind chim) a se stinge (d. var)

slack adjuster (mas-un) dispozitiv de eliminare a jocurilor

slack barrel (ind chim, OM) butoi pentru materiale pulverulente

slack business (ec) lipsă de afaceri, stagnare a comertului 
slack chain $(\mathrm{OM})$ lanț slăbit / neîntins; (chim) catenă liberă

slack / small coal (met) cărbune slab / mărunt, praf de cărbune

slacken (fiz, mec) a (se) slăbi (intensitatea), a relaxa; a se lăsa; a elibera; a încetini (viteza etc.); a (se) micşora, a (se) diminua; a destinde; a stagna (d. comerț etc.); a lâncezi; (d. var) a se stinge

slackening (mec) slăbire, destindere, relaxare; care slăşeşte / se relaxează) (d. materiale, asamblări etc.); încetinire; liniştire

slack hours (auto) ore de trafic redus

slack in the screw (mas-un) cursa moartă a şurubului conducător

slacking indolență, delăsare, incorectitudine în activitate

slack in the screw (OM, mas-un) cursă moartă a şurubului conducător

slack lime (ind chim) var stins

slackness (OM) jocul lagărului; (ec) stagnare

slack of the steering wheel (auto) joc al volanului de direcție

slack side $(\mathrm{OM})$ ramură condusă / netensionată (la transmisia cu lanţuri)

slack time stagnare; acalmie

slack water (nav) staționarea mareei; apă moartă, apă stătătoare

slade (agr, OM) talpă a plugului, plaz; (silv) luminiş, dumbravă; (agr) pământ mocirlos

slag (met) zgură, scorie, țunder, arsură; cenuşă; a forma zgură / țunder

slag accumulation (met) acumulare a zgurii

slag adhering to the converter nose (met) depunere de zgură la gura convertizorului

slag basin (met) decantor de zgură

slag-bearing (met) cu conținut de zgură

slag bed (met) pat de zgură

slag blanket (met) strat de zgură

slag breaker (met) concasor de zgură

slag brick (met) cărămidă de zgură

slag bridge (met) apărător la gura de evacuare a zgurii

slag buggy (met) vagonet de zgură

slag cake (met) zgură de creuzet

slag catcher (met) oală de zgură

slag cement (met) ciment de zgură

slag chamber (met) cameră de zgură

slag composition (met) constituție / compoziție a zgurii

slag concrete (met) beton cu ciment de zgură

slag cotton (met) vată de zgură

slag crusher (met) concasor de zgură

slag-crushing mill (met) moară de zgură slag crust (met) crustă de zgură

slag dam (met) prag de reținere a zgurii (la oale, la cuptor)

slag deposit (met) formare a zgurii

slag discharge (met) evacuare a zgurii

slag dump (met) haldă de zgură

slag element (met) ciment de / din zgură

slag enclosure (met) incluziune de zgură

slag flow (met, $\mathrm{OM}$ ) vană / deschidere / orificiu de zgură

slag fluidity (met) fluiditate a zgurii

slag-forming (met) formare a zgurii

slag-forming constituent (met) agent de zgură

slagfree (met) fără zgură, lipsit de zgură

slag from roasting (met) zgură de prăjire

slag furnace (met) cuptor de topit zgură

slagging (met) evacuare a zgurii

slagging agent (met) agent zgurifiant

slag globule (met) granulă de zgură

slag granulation (met) granulare a zgurii

slag gravel (met) zgură concasată

slag grinding plant (met, mas-un) concasor / moară pentru zgură

slaggy (met) cu conţinut de zgură, cu / de zgură

slaggy patch (met) pată de zgură

slag hearth (met) cuptor de reducere

slag hole (met) orificiu de evacuare a zgurii

slag inclusion (met) incluziune de zgură

slag iron (met, $\mathrm{OM}$ ) rangă de spart zgură

slag ladle and car (met, cf, transp) vagonet de / pentru evacuare a zgurii

slag ladle (met) oală de zgură

slag ladle car (met) cărucior / vagonet cu oală pentru zgură

slag lead (met) plumb strâns la curătirea cuptorului / din zgură

slagless (met) fără zgură

slag line (met) nivel de zgură (în cuptor, în oală)

slag lump (met) bulgăre de zgură

slag-making material (met, chim) agent zgurifiant

slag mill (met) moară de zgură

slag muck (met) haldă de zgură

slag notch (met) orificiu de evacuare a zgurii

slag occlusion (met) incluziune de zgură

slag of liquation (met) zgură din lipitura de cuptor

slag-off (met) îndepărtare a zgurii

slag off (met) a îndepărta / evacua zgura (fără specificarea procedeului)

slag overflow (met) jgheab de scurgere a zgurii

slag patch (met) pată de zgură

slag pocket (met) opritor / colector de zgură

slag penetration (met) coroziune de zgură

slag pit (met) groapă de zgură 
slag pocket (met) opritor / colector / cameră de zgură

slag Portland cement (constr, met) ciment Portland cu zgură

slag pot (met) oală pentru zgură

slag puddling (met) pudlare cu zgură

slag ratio (met) indice de bazicitate al zgurii (raport masic $\mathrm{CaO} / \mathrm{SiO}_{2}$ )

slag removal (met) îndepărtare a zgurii

slag riser (met) separator de zgură

slag roaster (met) prăjire însoțită de zgurificare

slag runner (met) jgheab pentru evacuarea zgurii

slag sample (met) probă de zgură

slag sand (met) nisip de zgură

slags dump (met) haldă, bocşă de zgură

slag separation (met) separare a zgurii

slag settler (met) decantor de zgură / de cenuşă

slag skimmer (met) lingură de reținere a zgurii

slag / slagging off (met) îndepărtare de zgură

slag smelting (met) topire a zgurii

slag specimen (met) probă de zgură

slag spout (met) jgheab pentru evacuarea zgurii

slag stone (met, constr) cărămidă de zgură

slag tap (met) evacuare a zgurii

slag tapped out (met) zgură evacuată

slag tapping (met) evacuare a zgurii

slag trap (met, OM) canal de turnare cu două niveluri (pt. separarea zgurii), colector de zgură, în trepte

slag treatment (met) tratarea zgurii

slag wadding (met) vată de zgură

slag wool (met) lână / vată de zgură

slag working (met) formarea zgurii

slake (ind chim) a stinge (varul); (d. frânghii, cabluri etc.) a se slăbi, a se detinde; a se lăsa

slake clay (met) lipitură

slake (ind chim) a stinge varul

slaked lime (ind chim) var stins, hidroxid de calciu

slaking (ind chim) stingere / dizolvare a varului

slaking pit (ind chim, met) groapă de var

slaking slag (met) zgură fărâmicioasă

slalom (sport) slalom (şi fig)

slam a trânti, a izbi (uşa); a se închide cu zgomot; zgomot (la trântirea uşii etc.), izbitură

slant (mat) pantă, înclinație, înclinare, oblicitate, bară de fracție; povârniş; tendință; (meteo, nav) vânt variabil (ca direcție şi forță); a se înclina; a fi înclinat / pieziş; (fig) a falsifica, a denatura; a prezenta tendențios

slant collision (auto) coliziune în pantă

slant distance distanță reală

slanted, slanting (OM, auto) înclinat (şi d. parbrize); (geogr, auto) în pantă; oblic, abrupt (d. un drum etc.)

slant high (OM) înălțime a feței laterale

slant impact (auto) impact în pantă slanting abrupt, în pantă; oblic; înclinat; care se înclină; în diagonală

slanting arrangement / position $(\mathrm{OM})$ poziție oblică / înclinată

slanting hole $(\mathrm{OM})$ gaură oblică (față de o suprafață sau o axă)

slant range $(\mathrm{OM}$, geom) distanță oblică

slant rolling mill (met) laminor cu cilindri oblici

slantwise (OM) înclinat, oblic; pieziş, într-o parte

slapdash neatenție; lipsă de griji; caracter brusc / neaşteptat; grabă; necugetat; la repezeală, improvizat; $(a d v)$ la întâmplare, în pripă, necugetat

slapjack (alim) clătită

slash (med) tăietură, rană; crestătură; bară de fracție; (c) tasta pentru bara înclinată ( / ); (textile) şliț, tăietură; felie; a tăia, a reteza (la întâmplare), a cresta; a ciopărți

slasher (OM) aparat de tăiat / de încheiat (şi curele late)

slashing (ec) reducere masivă; încheiere, coasere, prindere (a curelei late, cu cusături oblice)

slat $(\mathrm{OM})$ canal / nut de pană; stinghie / şipcă de lemn

slat conveyer $(\mathrm{OM})$ transportor cu plăci articulate / cu bandă articulată

slate (geol) gresie, şist; (placă de) ardezie; (cu) structură lamelară; (constr) a acoperi cu plăci de gresie / ardezie

slat-packing column / tower (ind chim, alim) coloană cu umplutură în formă de grătar

slaty, slatelike (fiz) fibros; şistos; în plăci; stratificat; ca de ardezie; cenuşiu închis

slaty fracture $(\mathrm{TH})$ rupere / ruptură fibroasă

slaughter-house (alim) abator

slaughter-house with refrigerating room (alim) abator frigorific

slaughtering (alim) tăierea vitelor, sacrificare

slave ( $\mathrm{TH}$, autom) (dispozitiv / computer) aflat cub comanda sau controlului altuia / auxiliar / secundar

slay bătător; (textile) vatală; (fig) a distruge, a nimici; a lovi; a măcelari; a omorî, a ucide; (fam) a câștiga afecțiunea / afecțiunea cuiva, a face impresie bună

sled $(\mathrm{OM})$ sanie, sabot, glisieră, patină a capului de cruce; (nav) sanie de lansare (de pe cală); a merge prin alunecare, a transporta cu sania

sledge $(\mathrm{OM})$ tachet, sanie; (met) baros / ciocan de forjă; a merge prin alunecare, a transporta cu sanie

sledge hammer (met) ciocan de forjă, baros

sledge runner $(\mathrm{OM})$ talpă de sanie, partea activă a unui ghidaj de alunecare

sleek lucios; neted; alunecos; onctuos; lustruit; zgârietură cu muchii netede; (TH) a finisa, a lustrui, a netezi 
sleeker S (met, OM) unealtă (şi cârlig) pentru formele de turnătorie, netezitor, planator

sleeking lustruire, netezire

sleep hibernare; somn, somnolență, toropeală; (fig) somn veşnic; a adormi, a fi adormit, a dormi peste noapte; a avea paturi pentru a dormi; (fig) a dormi (somnul de veci); (fig) a dormi; (fig) a nu fi activ, a nu funcționa, a lâncezi, a nu lucra; a hiberna

sleeper (cf) traversă (de lemn); (constr) grindă de lemn

sleep grade (auto) drum înclinat

sleeping patent brevet neaplicat

sleet (meteo) ploaie şi zăpadă, lapoviță

sleet formation (alim) formare a crupelor

sleeve $(\mathrm{OM})$ manşon, bucşă, mufă, cilindru, tambur, cuzinet, niplu, cămaşă; (met) orificiu de golire al oalei; (el) bucşă de jac

sleeve back-up roll (met, $\mathrm{OM}$ ) cilindru de sprijin pentru manta, cilindru de sustinere

sleeve bearing $(\mathrm{OM})$ lagăr monobloc cu bucşăcuzinet

sleeve brick (constr, met) bloc / cărămidă cu goluri, cărămidă cu orificiu (la oala de turnare)

sleeve connection $(\mathrm{OM}$, hidr) racord cu manşon

sleeve coupling (OM) cuplaj / cuplare / prindere cu manşon

sleeve joint $(\mathrm{OM})$ mufă, îmbinare prin mufe

sleeveless $(\mathrm{OM})$ fără bucşă

sleeve nut $(\mathrm{OM})$ manșon / mufã cu filet interior

sleeve pipe $(\mathrm{OM})$ mufă, bucşă, țeavă filetată

sleeve valve $(\mathrm{OM}$, hidr) sertar cilindric, robinet / supapă cu sertar

sleeve-valve engine motor fără supape, motor cu distributie cu sertar

sleight $(\mathrm{OM})$ sanie, glisieră

sleight runners (OM, sport) schi / tălpic de sanie

slender subțire, zvelt, cu raport mare între lungime şi secțiunea transversală

slenderness zveltețe, subțirime (şi d. elemente de maşini)

slenderness ratio $(\mathrm{OM})$ coeficient de zveltețe

slew rate (autom) limitare a vitezei de variatie a parametrului de ieşire

slewing $(\mathrm{OM})$ turnant, rotativ

slewing bracket $(\mathrm{OM})$ braț articulat

slewing gear mecanism de rotire

slewing speed (OM, mec, mas) viteză de rotație

slice (geol, alim etc.) felie (subțire), bucată (subțire); (OM, alim) cuțit de pește; a tăia felii; (fig) bucată, parte, porțiune; (fig) a brăzda, a spinteca, a tăia (apa, etc.)

slicing lathe (mas-un) strung de retezat / debitat slick $(\mathrm{TH})$ a finisa

slicker solder (met, OM) aliaj moale de lipit

slidable mobil, alunecător, care poate aluneca slide alunecare; lamelă (la microscop); (OM) ghidaj, piesă şlefuită / alunecătoare (şi tip sertar, plunjer); a face să alunece; a (a)luneca; a scăpa; a se strecura

slide-bar (OM) glisieră, bară de ghidaj

slide-bar bracket $(\mathrm{OM})$ port-glisieră

slide bars $(\mathrm{OM})$ ghidaje ale saniei, glisieră

slide base $(\mathrm{OM})$ bază / placă glisantă

slide bearing $(\mathrm{OM})$ lagăr de alunecare

slide bed (mas-un, OM) sanie longitudinală

slide-block $(\mathrm{OM})$ culisor, glisor, galet

slide-box (OM) cutie de distribuție (a vitezelor, la o transmisie etc.)

slide button (auto) buton de deschidere (d. trapă)

slide caliper (metr, OM) calibru reglabil, subler

slide caliper rule (metr, OM) şubler

slide carriage (met, mas-un) sanie de glisare / alunecătoare

slide catch $(\mathrm{OM})$ închizător baionetă

slide contact $(\mathrm{OM}$, el) contact alunecător, cursor

slide conveyer (mas-un, OM) ghidaj al căruciorului / saniei

slide-crank $(\mathrm{OM})$ culisă manivelă, manivelă glisantă

slide down a aluneca în jos

slide drawing press (mas-un) presă de tras, cu masă mobilă

slide fastener (OM, textile) fermoar

slide fit (OM) ajustaj alunecător / cu joc

slide gauge (OM, metr) calibru reglabil, subler

slide guide spring $(\mathrm{OM}$; metr) arc de reglare

slide lock $(\mathrm{OM})$ închizător-baionetă

slide main face $(\mathrm{OM}$, hidr) oglindă / suprafață netedă a sertarului

slide of vernier calipers (metr, $\mathrm{OM}$ ) cursor al şublerului

slide off $(\mathrm{OM}$, mas) a demonta prin alunecarea pieselor una față de alta

slide on a (OM, mas) monta pe un arbore

slide plate $(\mathrm{OM})$ sanie, glisieră, placă alunecătoare

slider $(\mathrm{OM})$ cursor inelar, culisou, glisor

slide rail (met, OM) şină de ghidare

slide rest (mas-un) sanie port-cutit

slide rod (OM, hidr) tijă de sertar / de plunjer

slide rule (metr, OM) riglă de calcul, şubler

slide-rule caliper (metr, OM) calibru reglabil, şubler

slide scale $(\mathrm{OM})$ scară mobilă / din module glisante

slide shoe (OM) sabot alunecător

slide shut-off valve (OM, hidr) robinet cu sertar cu plăci, supapă de închidere cu element alunecător

slide spring $(\mathrm{OM})$ arc pentru contact alunecător, zăvor alunecător 
slide surface (OM, hidr) oglindă / suprafața netedă a sertarului

slide the seat (auto) a împinge scaunul (prin alunecare)

slide valve (OM, hidr) cutie / supapă de distribuție, distribuitor (cu plunjer)

slide-valve air pump (OM, hidr) pompă de aer, cu sertar

slide valve casing $(\mathrm{OM}$, hidr) cameră / bucşă a sertarului

slide valve chest $(\mathrm{OM}$, hidr) distribuitor, cameră de distributie cu sertare

slide-valve damper (OM, hidr) amortizor cu vană glisantă / cu plunjer

slide-valve distribution (termo, OM, hidr) distribuție cu sertar

slide-valve face (OM, hidr) suprafață a sertarului / a plunjerului supapei

slide valve for chimneys (termo) registru de fum

slide valve gate $(\mathrm{OM}$, hidr) corpul sertarului

slide-valve gear (OM, hidr) distribuție cu sertar plan / cu sertar scoică

slide valve lead (OM, hidr) oglindă a sertarului plan

slide-valve plate (OM, hidr) patină / placă (de alunecare) a sertarului

slide-valve reciprocating pump (OM, hidr) pompă (cu piston sau plunjer) cu distribuție cu sertare

slide valve rod $(\mathrm{OM}$, hidr) tijă de sertar

slide valve-chest $(\mathrm{OM})$ cutie de distribuție, distribuitor (si hidraulic)

slide wall (OM, constr) perete glisant

slideway (OM, hidr) ghidaj, culisă

slideway grinder (mas-un) maşină de rectificat plan / ghidaje

slide / sliding window (OM, constr) fereastră glisantă

slide wire (metr, OM, el) fir calibrat

slide-wire bridge (electr, metr) punte cu fir de contact, punte Wheastone

slide-wire resistance (el) reostat cu cursor

slide with two grooves $(\mathrm{OM})$ ghidaj cu şanțuri bilaterale de ghidare

sliding (T, OM) alunecare, alunecător, ajustabil, care alunecă; (constr) (rupere prin) alunecare, alunecare a construcției; (geol) alunecare de teren; cross- coupling (Oldham coupling) (OM) cuplaj Oldham

sliding agent $(\mathrm{T})$ lubrifiant (pt. ghidaje)

sliding and screw cutting lathe (mas-un) strung universal pentru filete și suprafete cilindrice

sliding and surfacing lathe (mas-un) strung de prelucrat suprafețe cilindrice și frontale / cu avans longitudinal şi radial sliding angle $(\mathrm{T})$ unghi de alunecare / de frecare sliding bar $(\mathrm{OM})$ glisieră, bară / tijă de ghidare sliding base $(\mathrm{OM})$ reazem glisant, bază / placă glisantă, postament cu glisieră

sliding / slide bearing $(\mathrm{OM}, \mathrm{T})$ lagăr de alunecare sliding bed lathe (mas-un) strung cu lungime reglabilă a carului / a patului

sliding block $(\mathrm{OM})$ galet, culisor, glisor

sliding-block linkage $(\mathrm{OM})$ mecanism bielămanivelă

sliding bow (el) contact alunecător, arc colector de curent (în tracțiune electrică)

sliding caliper (OM, metr) calibru reglabil, subler sliding carriage $(\mathrm{OM})$ glisieră

sliding change gear (OM) (transmisie cu) schimbător de viteze cu roți baladoare

sliding clutch member $(\mathrm{OM})$ element glisant al cuplajului / ambreiajului

sliding coil (el, OM) bobină cu cursor

sliding / slide contact $(\mathrm{OM}$, el) contact alunecător / glisant; cursor

sliding cylindrical valve (OM, hidr) sertar / plunjer cilindric

sliding damper (OM, hidr) şuber, registru, vană-ghilotină, amortizor cu mişcare liniară

sliding door (constr) uşă glisantă

sliding drill head (mas-un) sania maşinii de găurit

sliding electrode $(\mathrm{OM}$, el) electrod reglabil / glisant

sliding feather key $(\mathrm{OM})$ zăvor alunecător

sliding fit (OM) ajustaj alunecător / cu joc

sliding flange $(\mathrm{OM})$ inel / flanşă mobil(ă) / alunecător / alunecătoare

sliding friction $(\mathrm{T})$ frecare de alunecare

sliding gauge (metr, OM) şubler, calibru reglabil

sliding gear $(\mathrm{OM})$ roată dințată baladoare alunecătoare pe arbore

sliding gear type gearing mechanism $(\mathrm{OM})$ cutie de viteze / de avansuri cu roți baladoare

sliding gearbox $(\mathrm{OM})$ cutie de viteze $\mathrm{cu}$ tren balador

sliding head $(\mathrm{OM})$ patină a capului de cruce; (mas-un) cărucior al păpuşii port-sculă

sliding head( )stock (mas-un, OM) păpuşă portpiesă, cu sanie

sliding housing needle valve (OM, hidr) vană supapă cu carcasa mobilă

sliding jack $(\mathrm{OM})$ cric pe cărucior / pe glisieră

sliding jaw (OM) falcă a cursorului, cioc al cursorului (la şubler)

sliding key $(\mathrm{OM})$ pană culisantă / glisantă / alunecătoare

sliding lathe (mas-un) strung de prelucrat suprafețe cilindrice lungi / fără şurub conducător 
sliding lever $(\mathrm{OM})$ pârghie alunecătoare; $(\mathrm{OM}$, electr) cheie glisantă

sliding lever bar (OM) bară de cheie glisantă sliding locking bolt $(\mathrm{OM})$ zăvor (alunecător) sliding / slipping motion (mec, T) mişcare de alunecare / de glisare

sliding nut $(\mathrm{OM})$ piuliță conducătoare, piuliță care alunecă (nefixată)

sliding pinion $(\mathrm{OM})$ pinion balador

sliding plane (mec, T) plan de alunecare

sliding plate (met) placă mobilă pentru model

sliding plug $(\mathrm{OM})$ cursor

sliding post $(\mathrm{OM}$, textile, ind chim) dispozitiv de conducere a firului

sliding punch (mas-un) poanson alunecător pe glisiere / pe ghidaj

sliding regime (mas) regim lent variabil / pulsant

sliding resistance $(\mathrm{mec}, \mathrm{T})$ rezistență la alunecare

sliding ring $(\mathrm{OM})$ cursor inelar

sliding roof $(\mathrm{OM})$ capac (mare) alunecător / culisant / glisant; (auto) acoperiş culisant

sliding sash (constr, OM) cercevea culisantă, geam culisant

sliding scale (metr) scală alunecătoare

sliding scale price (ec) preț ajustabil

sliding scraper (mas, OM) screper pe patine

sliding seat (OM) scaun culisant (şi la armături)

sliding share $(\mathrm{OM}$, agr) brăzdar-patină

sliding shutter (OM, hidr) robinet de închidere cu sertar / cu plunjer

sliding sleeve $(\mathrm{OM})$ manşon culisant

sliding-sleeve engine (termo) motor cu mansoane culisante, motor fără supape

sliding speed $(O M, T)$ viteză de alunecare

sliding spring key $(\mathrm{OM})$ pană alunecătoare (şi $\mathrm{cu} \operatorname{arc})$

sliding surface $(T)$ suprafață de frecare (de alunecare)

sliding table (mas-un) masă glisantă, cu mişcare de alunecare

sliding universal joint $(\mathrm{OM})$ cardan culisant, culisă, articulație tip culisă, cuplaj cardanic, si cu deplasare axială prin culisare (arbore şi arbore tubular)

sliding velocity (mec, $O M, T)$ viteză de alunecare sliding vane compressor (OM, termo) compresor rotativ cu lamele / cu palete

sliding vane pump (OM, hidr) pompă cu palete

sliding wheel $(\mathrm{OM})$ roată alergătoare, roată liberă pe arbore

sliding window sash (constr, OM) cercevea glisantă

slight mic, slab (d. un efort, o solicitare etc.); neînsemnat; puțin; slab, subțire, zvelt; sărăcăcios; fragil; slab, fără putere; neputincios; superficial (d. o analiză cercetare etc.); neglijent; uşor; lin; a desconsidera, a nu respecta; a nesocoti; a neglija; a nu fi politicos; nesocotire; neglijare; desconsiderare; dispret

slight acid (chim) slab / uşor acid, acid slab

slight curve (mat, geom) curbă cu rază mare de curbură

slight decline (in price) (ec) uşoară scădere (a prețurilor)

slight impression (T) urmă uşoară / puțin adâncă

slightly $(a d v)$ puțin, întrucâtva, cam

slightly acid (chim) slab / usor acid

slightly alkaline (chim) slab / uşor alcalin

slightly soluble (chim) uşor solubil

slight performance reduction (auto, TH) functionare slabă / puțin sub performanțe, reducere usoară / mică a performantei / performantelor

slight reduction $(\mathrm{TH}$, fiz) reducere mică / uşoară

slim subțire, slab; zvelt; insuficient; a pierde în greutate, a slăbi

slim file (mas-un) pilă de ferăstrău

slim object $(\mathrm{OM})$ obiect subțire

slim tool (mas-un) unealtă subțire

slime (ind chim) bitum lichid; (met, mediu) slam; nămol; noroi; murdărie; (chim, T) strat superficial moale, vâscos sau semi(-)solid (şi ca rezultat al coroziunii, al aderenței), turbulență

slime blanket / layer (el, TH) strat de nămol (la electroliză)

slime formation (met) formare a şlamului / nămolului

slime pit (met, OM, mediu) cutie de decantare, decantor / bazin de slam

slime pump (met, OM, mediu) pompă de şlam / de nămol

slime separator (met) separator de şlam / de nămol; (hidr, mediu) deznisipator

slime sludge (ind, mediu) noroi vâscos, şlam

slime sponge (met) burete de şlam

slime spot (alim, ind chim) pată de mucegai (pe hârtie)

slime table / washer, slimer (alim, met) masă pentru spălarea noroiului

slime thickener (met) decantor de şlam

slime yield (alim, met, ind chim, mediu) randament al procesului de spălare

slimy vâscos; lipicios; cleios; acoperit de șlam / de noroi; nămolos

slimy precipitate (alim) precipitat mucilaginos

slimy wine (alim) vin băloşit

slinch (metr) unitate de măsură pentru masă, inventată de US National Aeronautics and Space Administration (NASA); 1 slinch $\cong 175,1268$ kg, denumită şi mug, snail; v. mug, snail 
sling (OM) lanț / cablu de siguranță (la ridicarea unor obiecte); a arunca; a lansa; a atârna; a suspenda

slinger moulding machine (met, mas-un) maşină de format prin aruncare

slinger pressure (plast) presiune de injectare slink (zool) avorton, (d. animale) a lepăda (pui); a se furișa, a se strecura

slip alunecare; (el) alunecare (la motoare asincrone), diferență de turație; scăpare; greşeală; praf de rectificat; (ec) fișă, borderou, anexă; (nav) cală de lansare / de construcție, bazin de stationare; (mec, OM) glisare, a aluneca, a glisa; a (se) strecura

slip bands (fiz, met) benzi de alunecare

slip bolt $(\mathrm{OM})$ zăvor tip bolț, bolț alunecător

slip bushing $(\mathrm{OM})$ bucşă de ghidare amovibilă / alunecătoare (şi la dispozitive de găurit)

slip casting (met) turnare de barbotină

slip clutch (auto, OM) ambreiaj cu alunecare (pt. limitarea momentului)

slip coefficient (mec, OM) coeficient de recul

slip correction factor (mec, alim, ind chim, mediu) factor de corecție al alunecării (şi la sedimentare)

slip coupling (OM) cuplaj de / cu alunecare

slip crack (met) crăpătură / fisură de alunecare / de clivaj (la cristale, grăunți cristalini)

slip direction (mec, OM, T) direcție de alunecare slip down (mec) a aluneca (în jos)

slip foward (mec, materiale) a avansa prin alunecare (d. o desprindere între grăunții cristalini etc.)

slip gauge (metr, OM) cală plan-paralelă, etalon de lungime

slip hook cârlig cu cioc de papagal

slip in a (OM) introduce (prin alunecare)

slip jacket (met) ramă de formare

slip joint $(\mathrm{OM})$ cardan culisant, articulație culisantă, culisă, asamblare telescopică, rost de dilatatie

slip lines (met) benzi de alunecare

slip meter (metr, el) aparat de măsurat alunecarea maşinilor electrice

slip of propeller / of generator / of asynchrons (fiz) alunecare a elicei / a generatorului / a motorului asincron

slip-on attachement $(\mathrm{OM})$ asamblare cu mufă şi cep

slip-on flange $(\mathrm{OM})$ flanşă liberă / detaşabilă / alunecătoare

slip out $(\mathrm{OM})$ a aluneca în afară

slip over (OM) a glisa, a aluneca (pe / peste)

slip plane (OM, T) suprafață / plan de alunecare

slippage (mec, OM) alunecare, patinare (şi nedorită); (hidr) debit de fluid care scapă pe lângă piston; (ec) timp pierdut slipped thread (OM) filet forțat

slipper (OM) berbec, cap de cruce, sabot de frână, patină a capului de cruce

slipper clutch $(\mathrm{OM})$ ambreiaj

slipper path $(\mathrm{OM}, \mathrm{met})$ ghidaj inelar, cale de alunecare; (mas-un) inel de ghidare (la strung carusel)

slippery (a)lunecos

slippery road (auto) drum alunecos

slipping (TH) alunecare, culisare, patinare; alunecător, care alunecă; (met) prăbuşirea şarjei (la furnal)

slipping cam $(\mathrm{OM})$ camă de mers în gol / pentru cursa de retragere / de revenire

slipping / slip clutch $(\mathrm{OM})$ ambreiaj de / prin / cu alunecare

slipping / sliding motion (mec) mişcare de alunecare

slipping of driving wheels $(\mathrm{OM})$ patinarea roților (conduse) (la transmisii prin frictiune)

slipping of the yarns (textile, el, OM, TH, materiale) alunecare a firelor (și la inserții, în compozite, la site etc.)

slipping plane (fiz) plan de alunecare

slipping strength (mec, T) rezistență la alunecare slipping surface $(\mathrm{T})$ suprafată de alunecare

slip plane (mec, T) plan de alunecare

slippage (mec, $\mathrm{T}$, fiz) alunecare

slip points (cf, met) macaz de încrucişare, legături între linii

slip region / zone zonă de / cu alunecare

slip ring (el, OM) inel colector / alunecător / de contact

slips (OM, mas-un) bacuri

slip seal $(\mathrm{OM})$ etanşare pentru mişcare de alunecare / de translație

slip sheet (TH, OM) foaie de acoperire, interlinie, foaie provizorie de acoperire pentru a transporta ceva (şi adeziv)

slip speed (el, mas) turație de alunecare

slip surface $(T)$ suprafată de alunecare

slip through (mec, fiz, T) a se strecura (prin alunecare)

slip velocity $(\mathrm{OM}, \mathrm{mec}, \mathrm{T})$ viteză relativă de alunecare

slipway (nav) şină de cale, cală de construcție şi lansare

slip whirl (nav, OM) agitator de barbotină

slit (OM, materiale) despicătură, deschizătur, fantă, diafragmă, gură de încărcare, fisură, renură, şant, crestătură; (mat) tăietură; (TH) a canela; a tăia; a despica; a spinteca; a crăpa; a trefila

slit and tongue joint $(\mathrm{OM})$ asamblare cu uluc şi pană (şi la flanşe)

slit / slotted diaphragm (fiz) fantă de lumină 
slit end (OM) cap(ăt) crestat

slit nosed (OM) cu cap(ăt) crestat

slit nut $(\mathrm{OM})$ piuliță crestată / despicată / secționată / spintectă

slit orifice (OM, mas-un) filieră în formă de fantă

slitted $(\mathrm{OM})$ crestat, canelat, împărțit în mai multe părți (şi identice), modulat

slitter (mas-un) freză de canelat; (met, ind hârtiei etc.) foarfece cu discuri (pt. semifabricate lungi şi subțiri)

slitting $(\mathrm{OM})$ canelură, crestătură; (met) crăpare, despicare

slitting cutter (mas-un) freză de canelat

slitting machine (mas-un) maşină de retezat diamante

slitting mill (met, mas-un) ferăstrău (şi cu discuri) pentru table / metale

slitting shears (met, mas-un) foarfece cu discuri pentru tablă subțire

slitting unit (met) agregat pentru tăierea longitudinală / fâșierea benzii de tablă

slitting wheel (mas-un) disc abraziv de retezat

slit width $(\mathrm{OM}$, fiz) lărgime a intrefierului / fantei / fisurii)

sliver (met) ruptură, pliu (la laminare), crustă (la turnare); aşchie; ciob; (textile, plast) şuviță (de fibre); a sparge

slm, slpm (metr, hidr) simboluri pentru standard liters per minute - litri pe minut, unitate de măsură pentru debit volumic

slop (ind chim, T) produs petrolier necorespunzător; a vărsa (un lichid); a transvaza; a deversa; a da pe afară

slope (mec) plan înclinat, pantă; $(\mathrm{OM})$ înclinare; oblicitate; a (se) înclina; a teși; (cf) a taluza

slope angle (mec) unghi de înclinare

sloped (constr) taluzat; înclinat

slope-intercept form of the ecuation of a straight line (mat) ecuația dreptei prin tăieturi (de forma $\mathrm{y}=\mathrm{a} \cdot \mathrm{x}+\mathrm{b})$

slope line (cf) linie de taluz

slopes (met) înclinare la vatra cuptorului Martin

sloping (constr, cf) taluzare; (OM) în pantă; oblic, înclinat; povârnit (d. teren); (met) erupție (la convertizor)

sloping apron $(\mathrm{OM})$ apărătoare înclinată, disipator / radiator înclinat (de căldură); $(\mathrm{T})$ deflector înclinat, pentru / de lubrifiant

sloping back wall (met) peretele înclinat din spate (la cuptoare Siemens-Martin)

sloping bench (constr) rampă înclinată; (agr, alim, constr) rampă pentru animale vii

sloping bottom (met, OM) fund înclinat (la cuptoare etc.) sloping bottom tank (OM, hidr, alim, mediu) recipient / rezervor / tanc cu fund conic / înclinat sloping clamp (OM, mas-un) menghină oblică sloping edge (constr) creastă / muchie a taluzului

sloping ground (constr) teren înclinat

sloping hearth furnace (met) cuptor (electric) cu deplasare gravitațională a sarcinii

sloping hoop channel (met, OM) jgheab de ghidare pentru bucle (la laminoare)

sloping loop channel (met) jgheab înclinat în buclă (între cuptor și laminor)

sloping position $(\mathrm{OM})$ poziție înclinată

sloping radiator (termo, $\mathrm{OM}$ ) radiator înclinat

sloping surface (OM, constr) suprafață înclinată

sloping wall (constr, cf) perete / zid pe taluz

sloping windshield (auto) parbriz înclinat

sloppy umed, apos murdar; plin de noroi; neglijent slops (alim, ind, mediu) ape (reziduale) de spălare; (ind chim, mediu) reziduuri petroliere

slot $(\mathrm{OM})$ crestătură, scobitură (şi alungită), gaură longitudinală, urmă, dâră, semn, crăpătură (lungă şi îngustă), deschizătură (la un automat etc.), canal, canelură, renură, şanț, tăietură, rost, spațiu, gură de încărcare, deschidere (mică şi lungă), fantă, renură; orificiu pentru introdus monede (la un automat), jgheab, rigolă, uluc; (auto) locas special; (el) crestătură pentru bobinaj, ancoşă; (constr, hidr) canal, fantă, rigolă, şanț, jgheab, uluc; (textile) dâră, semn, urmă; (met) gaură longitudinală, scobitură alungită; urmă (de animal); (av) volet cu fantă; (TH) a canela, a degroșa, a face una sau mai multe fante / deschideri (mici), a cresta, a tăia, a scobi, a slitui, a nutui; a rindelui, a degroşa prin rindeluire / cu rindeaua (lemnul); (constr) a face fante / a face slituri

slot aerial (radio, fiz) antenă cu fantă

slot and crank, slot-and-crank $(\mathrm{OM})$ manivelă cu eclisă

slot and feather, slot-and-feather $(\mathrm{OM})$ asamblare cu nut și feder, asamblare cu lambă şi uluc slot and key, slot-and-key (OM) asamblare cu pană alunecătoare

slot array (fiz) rețea cu fante radiante (la ghiduri de unde)

slot borer (mas-un) burghiu de / pentru găuri longitudinale

slot-boring machine (mas-un) maşină de găurit găuri alungite / lungi

slot conduit (OM, el, termo) tub izolant

slot cutter (mas-un) freză de canelat, freză de crestat capetele la şuruburi, freză (deget sau disc) pentru canale de pană 
slot depth (OM, mas-un) adâncime a crestăturii / canalului

slot die extruder (mas-un) dispozitiv de extrudare / extruder cu filieră plată

slot diffuser (OM, hidr) difuzor liniar / longitudinal

slot drill (mas-un) burghiu lung

slot driller (mas-un) maşină de găurit longitudinal / orizontal

slot-fed dipole (fiz, el) dublet simetrizat printrun cablu coaxial despicat

slot for air inlet $(\mathrm{OM}, \mathrm{el})$ canal / fantă pentru aer de ventilație (şi la maşini electrice)

slot guide (mas-un, OM) canal / culisă de ghidare

slot jet (hidr) jet plan

slot machine (mas) automat cu fantă pentru monede (pt. vândut bilete, bomboane etc.)

slot mesh (OM) ochi dreptunghiular (la sită)

slot mesh screen $(\mathrm{OM})$ sită cu ochiuri dreptunghiulare

slot meter (metr, el) contor electric cu plată anticipată

slot mill (mas-un) freză pentru canale / de canelat slot milling cutter (mas-un) freză pentru canelat slot milling machine / miller (mas-un) maşină / dispozitiv de frezat canale de pană / caneluri

slot punched screen $(\mathrm{OM})$ sită ştanțată, cu ochiuri dreptunghiulare

slot quadrant (mas-un, OM) sector cu locaşuri pentru ştifturi de fixare

slot radiator (fiz) fantă radiantă (a unui ghid de unde)

slot ripple frequency (el, fiz) frecvență de ancoşă / de crestătură

slotted adjustment plate (OM, mas-un) selector (în mecanisme de comandă)

slotted aileron (av, OM) eleron cu fantă

slotted arm $(\mathrm{OM})$ culisă oscilantă

slotted armature (el) rotor cu crestături / cu fante / cu poli înecați / îngropați

slotted bolt $(\mathrm{OM})$ şurub cu cap crestat

slotted circular nut $(\mathrm{OM})$ piuliță rotundă, cu canale (frezate) pentru cheie

slotted countersink head screw $(\mathrm{OM})$ şurub cu cap înecat

slotted crank plate $(\mathrm{OM})$ culisă cu canal (de ghidare)

slotted / slit diafragm (fiz, met) fantă de / pentru unde / raze / radiații (şi Roentgen) (la aparate pt. control nedistructiv); (OM, fotografie) diafragmă cu fantă

slotted disk (OM) disc cu fantă / fante

slotted frame (OM) corp / cadru al culisei slotted guide aerial (OM, radio) antenă cu fante radiante

slotted head $(\mathrm{OM})$ cap crestat / canelat

slotted hole (OM, mas, textile) fantă, crestătură, şliț; (constr) şliț; (met, OM) gaură / canal alungit(ă) / longitudinal( $\breve{a})$

slotted line section porțiune de măsurare a unui ghid de unde

slotted liner (alim, ind chim) coloană prevăzută cu fante / şlițuri

slotted link $(\mathrm{OM})$ culisă cu o singură piatră / fantă (de ghidare)

slotted measuring section porțiune de măsurare a unui ghid de unde

slotted nut $(\mathrm{OM})$ piuliţă canelată / crenelată

slotted oil piston / scraper ring (OM, termo) segment raclor, canelat

slotted oil scraperring $(\mathrm{OM}$, termo) raclare $\mathrm{cu}$ segment (raclor) canelat

slotted pan head screw (OM) şurub cu cap bombat crestat

slotted pin $(\mathrm{OM})$ ştift crestat

slotted pipe (OM, hidr, mediu) filtru cu fante / cu şlițuri

slotted piston skirt (OM, termo) cămaşă crestată / secționată, de piston

slotted raised countersunk head screw (OM) şurub cu cap semiînecat crestat

slotted screen $(\mathrm{OM})$ sită cu ochiuri dreptunghiulare

slotted shutter (constr) încuietoare cu şliț; (OM, fotografie) obturator-perdea

slotted table (OM, mas-un) masă cu canale (pt. fixarea / prinderea piesei de prelucrat)

slotted wing (fiz) aripă cu fantă

slotted weld $(\mathrm{OM})$ cusătură de sudură, cu şant

slotter (mas-un) maşină / dispozitiv de mortezat

slotter ram (mas-un) cap de mortezat

slotting scobire; (OM) canelură, crestătură, tăietură longitudinală (pe bucşe elastice etc.); (mas-un) canelare, mortezare, scobire, dăltuire slotting cutter (mas-un) freză de canelat slotting cutter with plane bore and key drive (mas-un) freză disc pentru canale de pană

slotting file (mas-un) pilă de canelat

slotting machine (mas-un) maşină de mortezat

slotting milling cutter (mas-un) freză pentru canelat

slotting milling machine (mas-un) maşină de mortezat / de frezat caneluri

slotting / slot tool (mas-un) cuțit de mortezat, cuțit / sculă de canelat

slot washer (OM) şaibă elastică, crestată / tăiată, şaibă elastică despicată (şi tip Grower) 
slot weld $(\mathrm{OM})$ cusătură de sudură, cu şanț slot welding (met, $\mathrm{TH}$ ) sudare în găuri alungite slot winding slot winding (fiz, el; OM) bobinaj / înfăşurare în ancoşă / în crestătură

slow cu acțiune lentă, cu întârziere, cu viteză mică (d. maşini, procese etc.); care cere mult timp; greoi, greu; cu efect întârziat; care întârzie, care rămâne în urmă (d. ceas), care nu e în pas cu moda / cu vremea; (ec) care stagnează, mort (d. afaceri etc.); care trece greu, neinteresant, plictisitor (d. timp etc.); (med) cu acțiune lentă, cu efect întârziat (d. un medicament etc.); (d. cineva) delăsător, demodat, fără spor, inactiv, încet (la minte), greoi (la minte), lenes, încet, lent, mocăit, neglijent; fără viață, mort (d. un oraş etc.); gradat, treptat, lent (d. o creştere, un proces etc.); înăbuşit (d. foc); încet; lent; încet (d. foc, creştere etc.); învechit; a încetini (mersul unei maşini, un proces tehnologic etc.), a merge (mai) încet; a întârzia (creşterea etc.); $(a d v)$ lent, încet, în urmă, fără grabă, agale, alene; , but steady încet, dar sigur; (as) as a snail / a tortoise / molasses (moale) ca un mormoloc, încet ca melcul / ca o broasca țestoasă; at a pace încet, la pas; at a slow trot în trap uşor; be a slow study a-şi învăța greu rolul (d. un actor); be $\sim$ in / on the uptake a fi greoi, a fi greu de cap, a întelege greu lucrurile, a nu-i merge mintea, a nu-l duce capul; be $\sim$ in coming a întârzia, a veni încet; dead $\sim$ foarte încet (d. maşini); go $\sim$ a conduce cu prudență (o maşină); a fi prudent; a funcționa încet, a lucra încet, a merge încet; a nu se grăbi, a nu se pripi; a o lua domol / încet; fast-operate- -release relay $(\mathrm{OM}$, autom, el) releu cu acționare rapidă şi revenire temporizată; have a $\sim$ wit a fi greu de cap; be $\sim$ to anger a nu fi iute la mânie, a se înfuria / se supăra greu; knob -motion control (OM, autom) buton de acord fin; be going a rămâne în urmă (d. un ceas etc.); not to be $\sim$ to defend oneself a nu şovăi când e vorba să se apere, a riposta prompt; run $\sim($ mas, el) a fi defazat în urmă, a fi în întârziere (de fază), a întârzia; and sure încet dar sigur; and steady wins the race cu răbdarea treci şi marea, graba strică treaba, încetul cu încetul se face oțetul

slow acting (TH, mas) cu mers încet / lent, (care acționează) cu viteză mică, cu turație joasă

slow-acting (mas) cu mers încet, cu turație joasă; (chim) cu acțiune lentă

slow-acting / slow-action accelerator (chim, plast) accelerator cu acțiune lentă slow-acting relay (el, autom) releu temporizat slow beating (TH) măcinare grasă (ind. hârtiei) slow-break / slow-speed / slowing interrupter (el, autom) întrerupător cu declanşare lentă / temporizată

slow burning (termo, chim) ardere încetinită / lentă / la temperatură redusă

slow-burning (termo) cu ardere lentă, care arde lent

slow combustion (termo) ardere / combustie lentă slow cooking (alim, ind hârtiei) fierbere lentă slow-curing resin (chim) răşină cu întărire lentă slow down (mec, mas) a frâna, a încetini; a micşora viteza; a deveni (mai) încet / lent, a încetini viteza, a merge mai încet, a micşora (viteza), (fizică nucleară) a modera, a reduce (viteza); a tergiversa; a amâna

slow drift of image (TV, c) deplasare a imaginii (defect de stabilitate)

slow electron electron lent

slow filter (OM, alim, hidr) filtru lent

slow fission (fizică nucleară) fisiune cu neutroni lenți

slow-fission neutron reactor (fizică nucleară) reactor cu neutroni lenți

slow frequency drift (fiz, electr, autom) alunecare gradată / lentă de frecvență, derivă lentă / înceată de frecvență

slow goods (ec) mărfuri cu circulare / vânzare lentă slow goods traffic (ec) circulație / vânzare lentă a unor bunuri

slowing (mec, fiz, ec, TH) încetinire, care încetineşte / merge / funcționează mai lent / încet

slowing down (fizică nucleară) moderare; (mas, autom) temporizare; (mec) încetinire, frânare

slowing-down length (cf, transp) lungime de încetinire

slowing-down power (fizică nucleară) putere de încetinire

slowing-down time timp de încetinire

slowing interrupter (el, autom) întrerupător cu declanşare lentă, întrerupător temporizat

slowing period / time (mas, OM) timp de mişcare în virtutea inerției / de încetinire

slowly-cooled steel (met) oțel răcit lent

slow match (ind, geol) fitil (pt. declanşarea unei explozii)

slow motion (mec, mas) mişcare lentă, mers lent / încet

slow-motion control knob (autom, metr) buton de acord fin / de reglare fină (implicit cu mişcare lentă), buton de acord cu vernier

slow-motion device (autom, mas) încetinitor, dispozitiv de încetinire

slow-motion hand wheel (metr, OM) rotită de mână pentru aşezare / reglare precisă 
slow-motion shooting luare de vederi cu încetinitorul, turnare / filmare cu încetinitorul

slowness încetineală, tărăgănare

slow neutron (fizică nucleară) neutron lent (termic)

slow off the mark care o porneşte încet, greu de urnit (din loc)

slow-operated (autom, mas) care operează / funcționează lent / temporizat, care este acționat lent

slow-operated relay (el, autom) releu cu acțiune lentă / temporizat

slow-operating relay (el, autom) releu cu acțiune lentă

slow oxidation (materiale, chim) oxidare lentă

slow-paced care se scurge alene (d. timp); încet (d. mers); interminabil (d. timp)

slow reactor (fizică nucleară) reactor cu neutroni lenți, reactor lent

slow-release / slow-releasing relay (el, autom) releu cu acțiunare lentă / temporizată / întârziată

slow-running (mas) lent, care merge / functionează lent

slow-running engine (mas, termo) motor lent

slow-running jet (termo) jiclor de mers lent / încet

slow-running screw (OM, mas) şurub de reglat mersul în gol

slow run of furnace (met, termo) mers lent al cuptorului

slow scan (fiz, metr) scanare lentă (la un profilometru, un microscop electronic etc.)

slow scan television (SSTV) (fiz, TV) semnal TV transmis mult mai lent decât la transmisia standard

slow set cement (constr, ind chim) ciment cu priză lentă

slow setting (ind chim) priză lentă (d. adezivi, ciment etc.); ruptură lentă (d. emulsie de bitum)

slow setting cement ciment cu priză lentă

slow speed (mas) viteză / turație mică / lentă

slow-speed (mas) caracterizat prin / cu viteză / turație mică / lentă (d. elemente de maşini, maşini, procese etc.)

slow-speed engine (mas, termo) motor lent

slow-speed / slow-break / slowing interrupter (el, autom) întrerupător temporizat / lent / cu acționare întârziată, întrerupător cu declanşare lentă

slow spiral drill (mas-un) burghiu spiral, cu unghi de înclinare mic al canalelor elicoidale

slow stock (ind hârtiei) pastă grasă

slow storage (c) memorie / memorare / stocare lentă (a datelor)

slow-up (auto, mec) încetinire, decelerație slow up a încetini, a micşora (viteza)

sludge (mediu) noroi, nămol, mizerie; (ind, mediu) reziduuri lichide; (met) şlam; (ind chim, TH) uzat(ă) (d. o soluție care, după folosire are reziduuri)

sludge box (OM, alim, ind, mediu) cutie / bazin de decantare

sludge chamber $(\mathrm{OM}$, alim, ind, mediu) bazin de decantare, decantor

sludge clarification (ind, mediu) sedimentare / depunere / limpezire a amestecului cu şlam / noroi etc.

sludge deposition (el) depunere de noroi (la acumulatoare şi în galvanizare)

sludge dewatering / draining $(\mathrm{TH}$, mediu $)$ deshidratare / drenare a noroiului / a şlamului / a reziduurilor

sludge digestion (mediu, chim) fermentare a nămolului (provenit din ape uzate)

sludge extractor (OM, ind, mediu) separator / colector de noroi / de reziduuri

sludge filter (OM, ind, mediu) filtru de nămol

sludge water (ind chim, mediu) amestec de gudroane acide cu apă

sludge formation (ind chim, mediu) formare a nămolului / a reziduului solid / a unui precipitat sludge inhibitor (ind chim, mediu) inhibitor de formare a nămolului / a unui reziduu solid / a unui precipitat

sludger (ind chim, OM, mediu) separator de nămol / de reziduuri

sludge removal $(\mathrm{TH}$, chim, mediu) înlăturare / îndepărtare a noroiului / precipitatului / reziduului (şi la acumulatoare şi galvanizare)

sludge washing $(\mathrm{TH}$, mediu) spălare a noroiului / şlamului etc.

sludging ( $\mathrm{TH}$, ind, mediu) sedimentare (şi de noroi / reziduu), depunere, depuneri de fund, care se depune / murdăreste (în sens nedorit)

sludging test (metr, alim, ind chim) probă / test pentru determinarea vitezei de sedimentare

sludging value (metr, alim, ind chim, mediu) indice de sedimentare

slug $(\mathrm{OM})$ miez, bară, bloc, melc; eboşă, semifabricat, reglet; (chim) inhibitor; (mil) glont cilindric; (poligrafie) interlinie, rând de tipar monolit; (zool) limax, melc fără casă; ( fam) leneş, trântor, pierde-vară; (fig) gogoașă; (fig) ins, tip; (fig) lovitură de pumn; (fig) un dolar; a lovi puternic; (metr) unitate de măsură pentru masă, în sistemul britanic foot-pound-second (picior-pfund-secundă): $1 \mathrm{slug}=14,59390 \mathrm{~kg}$

slug flow (fiz, hidr, plast) curgere difazică (intermediară între curgerea ondulată şi cea în blocuri); a lovi puternic 
slugged relay (autom, el) releu de întârziere / cu acționare temporizată

slugging (met) sudare cu adaos de sârmă în rostul de sudare; (hidr) şoc hidraulic

sluggish (materiale) gros, vâscos, inert, lent; (autom) cu sensibilitate redusă

sluggish lubricant / oil (ind chim, T) lubrifiant / ulei vâscos

sluggish market (ec) piață inactivă / cu activitate lentă

sluggish servomechanism (autom, OM) servomecanism cu acțiune lentă

slug tuner (autom, metr, elctr) cilindru / miez de acordare cu reglaj

slug-up ending (metr, TH) test / încercare de aplatizare / de refulare

sluice (hidr, constr) scurgere, ecluză, spărtură; a spăla; a se scurge

sluice valve (OM, hidr) robinet / vană / supapă de scurgere / de spălare

sluiceway (alim, ind chim, met, mediu) canal pentru reziduuri / nămol

sluicing (TH) spălare (cu / în curent mare de apă); golire a apei dintr-un rezervor

sluicing channel (OM, hidr) canal de golire / de fund

sluicing pipe (OM, hidr) țeavă / conductă de spălare / de golire

sluing (mec, OM) pivotare, rabatere, oscilare, rotire; pivotant, rabatabil, oscilant, turnant, rotativ

slump (constr, geol) tasare; (TH) refulare, (ec) criză / depresiune economică, scădere bruscă (a acțiunilor, a cursului), a aluneca

slumpability (fiz, hidr, constr) proprietate de autonivelare (a unui fluid, a unui material vâscos sau a unei unsori etc.)

slumflation (ec) depresiune / criză economică cu inflatie

slur a păta, a murdări; (birotică) a se estompa, a tipări / a scoate la imprimantă murdar; a dubla; (textile, plast) a încreți; a trece repede peste; (met) a vopsi formele; (lingv) articulare / pronunție greșită / nedesluşită, a articula neclar, a articula prost (cuvinte, etc.), a bolborosi, a îngâna cuvinte; (muz) legato, a lega (note etc.); (poligrafie) mânjire, murdărie, murdărire provocată de cerneală, pată, tipar dublat, a mânji, a murdări, a păta, a tipări murdar; a acoperi / ascunde (greșeli etc.); a dubla; a nu ține seama de; a trece neatent / repede peste; a lăsa la o parte; (fig) a defăima, a discredita

slurry pastă; (met, mediu) nămol, şlam; barbotină (la turnătorie); (alim, ind chim) suspensie, nămol, soluție reziduală slurry dryer (alim, ind chim) uscător de suspensii slurry filter cake (mediu, ind) nămol filtrat (în brichete)

slurry mixer (alim, ind) amestecător de suspensie tip nămol

slurry polymerization (ind chim, mediu) polimerizare cu catalizator în pastă / în suspensie

slurry tank (ind chim, met, mediu) decantor de noroi / de nămol etc.

slurry thickener (met, mediu) decantor de şlam slush nămol; (T) unsoare, a unge; a acoperi cu ulei pentru protecție anticorosivă; (meteo) lapoviță; (constr) a umple cu mortar rosturi / goluri

slucher (transp, OM) screper

slushing oil (ind chim, T) unsoare consistentă

slushing compound (ind chim, T) unsoare consistentă (anticorosivă) sau numai component consistent al ei

slush moulding (plast) piesă formată (şi) din suspensie de răşină policlorvinilică

slush pulp (alim, ind chim) pastă lichidă

slush stock (alim, ind chim) pastă îngroşată

sm (metr) simbol utilizat în UK, pentru statute mile - milă engleză / terestră: 1 statute mile = 1609,344 m; v. statute mile

smack (nav) pescador

small mic; mărunt; minuscul; neînsemnat, neimportant; slab; subțire; uşor; puțin; redus; încet; cu voce joasă, şoptit; partea mică / subțire (a unui obiect); în bucăți mici; banal, cotidian, mărunt, mic, neînsemnat, zilnic (d. griji etc.); (d. cineva) de rând; (fig) josnic, limitat, mărginit, meschin, mic, plouat, ticălos, netrebnic (d. o persoană); (d. cineva) modest, neînsemnat; modest, slab, redus (d. venit); (d. cineva) sărac, umil, ruşinat, jenat; scurt (d. timp); (d scriere etc.) mărunt, mic; (metr) unitate de capacitate (în industria berii): 1 small $(\mathrm{UK})=0,2481$ şi 1 small $(\mathrm{US})=0,2361$

small aggregate crusher (mas, ind chim) granulator

small bead (fiz, materiale) globulă, mărgea, particulă aproape sferică

small bell (met) clopot / con mic de şarjare (şi la furnal)

small bisiness (ec) afacere / întreprindere mică small calorie, gram calorie, $1^{\circ}$ calorie (metr, termo) calorie mică, unitate de măsură în sistemul de unități CGS pentru energie calorică, egală cu cantitatea de căldură necesară să crească temperatura a 1 gram de apă cu $1^{\circ} \mathrm{C}$, la presiune de 1 atmosferă (temperatura apei s-a ales între $14,5 \ldots 15,5^{\circ} \mathrm{C}$ ); 1 small calorie $=4,1858 \mathrm{~J}$ small / slack coke (met) praf de cocs, cocs mărunt small converter (met) convertizor mic 
small craft (nav) nave mici, ambarcațiune mică small cupola furnace (met) cubilou de capacitate mică

small drilling lathe (mas-un) strung mic, de găurit small duty pipe still (termo) cuptor tubular cu capacitate redusă

small end $(\mathrm{OM})$ picior de bielă, capul mic al bielei

small end bush(ing) (OM) bucşă de bielă

small end mill(ing) cutter (mas-un) freză-deget

small end of connecting rod $(\mathrm{OM})$ picior de bielă

smallest cel mai mic, minim

small face( )plate (OM) flanşă / placă de antrenare small forging furnace (met) cuptor de forjă mică

small-gauge track (cf) ecartament îngust

small-gauge wire $(\mathrm{OM})$ sârmă subtiire

small gold leaf / foil (met, artă) foiță de aur

small in diameter $(\mathrm{OM})$ de calibru mic, de diametru mic

small ironware (met) articole mărunte de fier / metalice, feronerie

small leaf (met, artă) foiță metalică

small loan company (ec) societate finantatoare / specializată în acordarea de credite rambursabile în rate, pentru achiziționarea unor bunuri de folosinţă îndelungată

small-lot / small-scale production (ec) productie de serie mică

small mallet $(\mathrm{OM})$ ciocan de mână

small nail $(\mathrm{OM})$ cui tecs

small of stock $(\mathrm{OM})$ gât al balonului de sticlă

small (operation) plant (ec, ind) întreprindere mică, atelier meşteşugăresc

small pile (ind) stivă mică

small part (fiz, materiale) particulă mică

small plate (mas-un) plăcuță (la scule aşchietoare)

small roller $(\mathrm{OM}, \mathrm{mas})$ rolă de conducere / de transportor

small-scale / small-lot production / manufacture $(\mathrm{ec}, \mathrm{TH})$ producție în serie mică

small-scale test (metr, OM, nav) încercare / test pe model

small-section rolling mills (met) laminor de profiluri fine / uşoare

small sections (met, plast) profiluri fine / mici / uşoare

small-shank tap (mas-un) tarod cu coadă normală small shapes (met, plast) profiluri uşoare small shot (OM, materiale) alice mici small-sized coke (met) cocs granulos / mărunt small-sized scrap (auto, constr) criblură; (met) sfărâmătură mică de cocs

small slide (mas-un) săniuță, sanie mică small smoothing iron (mas-un) aşchie de / la finisare

small tools $(\mathrm{OM})$ scule mărunte / manuale / de lăcătușerie

smalt (ind chim) smalț, email

smart aspru (d. un caracter etc.); aspru, dureros, sever, usturător (d. o lovitură etc.); tare; rapid; iute; (med) durere acută / ascuțita, usturime; descurcăreț, deștept, ingenios, inteligent, isteț, priceput, abil (d. cineva); elegant; inteligent, prompt, spiritual (d. un răspuns, etc.); modern, şic; vioi; (fig) zeflemitor, impertinent; a arde; a ustura; a întepa (d. fum etc.); a produce durere; a simți durere, a suferi (d. cineva)

smart money (ec) amendă, bani pentru rezilierea contractului

smash prăbusire; ruină; ciocnire; accident; a se duce de râpă; a distruge; a (se) ciocni; a sfărâma; (TH) a netezi, a îndrepta, a aplatiza, a turti, a zdrobi; (mec, mas) a trânti, a izbi

smashing (ec) dezastru economic, crah; faliment smear pată de ulei; strat subtire, neregulat de vopsea; murdărie, grăsime, lichid unsuros; (med) frotiu; pată (de grăsime, de ulei); (textile) pată grasă; pătare; (T) a unge, a gresa, a lubrifia, a uza prin proces de aderență (la rulmenți cu ungere insuficientă etc.); (fig) defăimare, atacare / distrugere a reputatiei cuiva, a defăima; a mânji a păta; a mâzgăli; a murdări; (poligrafie) a murdări (la tipărire); (fig) a murdări, a păta (numele etc.); (fig) a cumpăra pe (cineva), a mitui; (fig) a lovi foarte tare

smearing $(\mathrm{T})$ proces de uzare prin micro-aderențe; (c, TV) efect de prelungire neregulată a liniilor orizontale

smearing-out destindere; ( $\mathrm{T}$, materiale) (proces de uzare de) desfacere (si la contacte greu solicitate, cu ungere insuficientă sau deficitară)

smeary murdar, mânjit; soios; unsuros

smectic film (fiz) peliculă de lichid condensat

smell (anat) miros, simt al mirosului; (alim, chim) substanță mirositoare, aromă, parfum, miros (plăcut, neplăcut, urât); duhoare; mireasmă; mirosire; a adulmeca (d. animale) (şi fig); a avea miros / simtul mirosului, a fi înzestrat cu miros; a avea un miros (plăcut etc.); a duhni, a puti; a mirosi (o floare etc.); a mirosi (d. animale); (fig) a mirosi, a presimti; (fig) a simti; iz de

smelt (chim, met, $\mathrm{TH}$ ) topire, metal topit, topitură; a topi, a turna (un metal), a extrage metalul prin topire din minereu

smeltable (chim, met) fuzibil, care se poate topi smelt down (chim, met) a fluidiza, a (re)topi smelted enamel (ind chim) email vitrificat / întărit (şi ca defect)

smelter (met) topitor, cuptor de topit; turnătorie 
smelter coke (met) cocs metalurgic

smeltery (met) topitură

smelting (met, TH) topire, elaborare (a şarjei), topitură, turnare

smelting capacity (met, mas) capacitate de topire smelting flux electrolysis (met, el) electroliză a metalelor topite

smelting furnace (met) cuptor de topire

smelting hearth (met) vatra cuptorului

smelting interval / range (met, materiale) interval de topire

smelting losses (met, materiale) pierderi prin topire

smelting of slimes (met, TH) topire a şlicului / a şlamului

smelting operation (met, $\mathrm{TH}$ ) operație de topire smelting ore (met) minereu de afinare

smelting plant (met, mas) instalație de topit, uzină metalurgică

smelting point (fiz, chim, met) punct / temperatură de topire

smelting pot (met, termo) creuzet / oală pentru topire

smelting practice (met, $\mathrm{TH}$ ) elaborare a șarjei

smelting process (met, $\mathrm{TH}$ ) proces de topire

smelting zone (met) zonă de fuziune la furnal

smidgen (metr, alim) volum foarte mic de material, utilizat în retete culinare, vândut în pliculețe mici: 1 smidgen $\sim 0,15 \mathrm{ml}$

smirch pată, a păta; a murdări

smite (metr, alim, med) cantitate mică de ceva în rețete culinare, un pic; a bate; a birui, a învinge (un duşman etc.); a cuceri (d. o femeie etc.); a distruge; a doborî; a da gata (d. femeie, etc.); (fig) (fam) a înfrânge (un duşman etc.); a izbi, a lovi, a pocni(cu arma, cu pumnul etc.); a nimici; a omorî, a ucide

smith (met) forjor; a forja

smithery (met) fierărie

smith forge (met) forjă

smith forging (met) forjare

smith forging hammer (met) ciocan de forjare

smith hammer forging (met) piesă forjată liber

smithing (met, $\mathrm{TH}$ ) forjare

smith's anvil (met, OM) nicovală de forjă

smith's hammer (met, OM) ciocan de forjă

smith's hearth (met, OM) forjă de fierar

smith's tongs (met, OM) clește de forjă

smith's vice (met, OM) menghină de forjă

smithy (forge) (met) forjă, fierărie

smog (mediu, ind) ceață de fum (poluantă)

smoke (mediu, ind) fum, aburi (grosi), funingine; (meteo) ceață, negură; țigaretă, țigară; (fiz) vapori; (alim) a afuma (carne, etc.), a pune la afumat, a pune / usca la fum; (ind) a afuma, a scoate fum, a emite / face fum, a fumega; a murdari cu fum; a fuma (tutun etc.), a fi fumător; (fig) vorbe goale, minciuni; (fig, fam) a mirosi, a simți (ceva), a adulmeca, a bănui smoke black (chim) negru de fum smoke damper (termo) registru de tiraj smoke deflector (termo, OM) deflector de fum smoke detector (termo, metr) detector de fum smoked meats (alim) afumături smoke dust (termo, mediu) praf de cenuşă smoke-fire crevices (met) crăpături de preîncălzire (defect)

smokeless fără fum

smokeless fuel (termo) combustibil fără fum smokeless furnace (termo) focar fără fum smoke separator (termo, OM) separator de fum smoke slide-valve (termo) registru de tiraj smokestack (termo) cos de fum smoke streamer / plume (termo) coloană de fum smoke tube (termo, OM) teavă / conductă de fum smoke-tube boiler (termo) cazan cu țevi de fum smoking (alim, $\mathrm{TH}$ ) afumare

smoking-fire crevices (ceramice) crăpături de preîncălzire (defect)

smoking room (alim, termo) afumătoare

smoky flame (termo) flacără fumegândă

smolder (termo) a arde încet

smoldering (termo) ardere înăbuşită

smoldering zone (termo) zonă de ardere înăbuşită

smoot (metr) (rar) unitate de măsură pentru lungime, inventată în 1958: $1 \mathrm{smoot}=170,18 \mathrm{~cm}$ smooth caracter neted; lustruire; netezime; netezire; neted, plan; lustruit, şlefuit; egal, omogen, fără încrețituri; (nav) acalmie; calm, linistit; fără întreruperi; netezime; (alim) dulce (d. vin); (plast, textile, hârtie) fără cute, fără încrețituri; (mas) egal, fără întreruperi, lin, omogen (d. functionarea / mersul unei maşini etc.); (constr) întins, neaccidentat, neted, plan (d. un teren); lin, liniştit, lucios, neted, calm (d. suprafață etc.); (anat) fără riduri (d. piele); liniștit, calm, egal (d. cineva); fluent, lin, curgător (d. vorbire, etc.); lins (d. păr, blană); dulce, insinuant, plăcut, mieros, moale (d. voce); pleşuv, chel; ras, bărbierit, spân, fără barbă (d. obraz, etc.); (fig) competent, foarte atractiv, foarte plăcut, rafinat; $(\mathrm{TH})$ a nivela, a şlefui, a netezi, a egaliza, a plana; a rindelui, a gelui (d. lemn); (mas-un) a rabota, a poliza; (met) a calma; $(\mathrm{OM})$ a îndulci (o curbă etc.); (fig) a acoperi (o greșeală etc.); (textile) a călca (rufe, țesături), a întinde, a netezi, a face neted (stofe etc.); a descreți (fruntea); (fig) a micsora, a diminua, a domoli, a linişti, a potoli, a calma (pasiuni, supărări etc.); a face (mai) uşor; (fig) a facilita, a înlesni, a uşura (o acțiune etc.); (fig) a pune la punct, a rafina, a scuza (o greşeală etc.) 
smooth curve (mat) curbă cu înclinare / pantă mică

smooth cut (mas-un) dințare / tăiere / aşchiere fină smooth drum $(\mathrm{OM})$ tambur cu suprafață netedă smoothed curve (mat) curbă aplatizată

smoothered arc furnace (met) cuptor electric cu arc direct

smoother(s) (mas-un) netezitor, planator (pt. textile, semifabricate subțiri tip table, folii etc.); (autom, el) filtru de netezire (a semnalului / curentului)

smooth file pilă de şlefuit

smooth fracture (met) fisură fină / intergranulară

smooth grinding (mas-un, TH) lustruire, rectificare fină / cu luciu

smoothing (autom) aplatizare, liniarizare; (constr) netezire, drișcuire; (el) atenuare / amortizare a unei oscilații; (mas-un, TH) finisare (fină / finală)

smoothing coefficient / factor ( $\mathrm{TH}$, autom) coeficient de aplatizare / de liniarizare / de ajustare / de filtrare (a unui semnal) / de netezire

smoothing drift $(\mathrm{OM}, \mathrm{TH})$ dorn de finisare

smoothing-iron (el, OM, textile) fier de călcat

smoothing plane iron (mas-un) cuțit plan de rindeliure fină

smoothing plane $(\mathrm{OM}, \mathrm{TH})$ rindea de netezit (pt. lemn)

smoothing planer (mas-un) raboteză pentru ajustare / pentru prelucrare fină

smoothing roll (OM, TH) cilindru de îndreptare / de netezire

smoothing rolling mill (met, ind chim, plast, textile) laminor netezitor, cilindri de îndreptare / de netezire

smoothing tool (mas-un) cuțit / unealtă / sculă de finisare

smooth-jawed vice (mas-un, OM) menghină cu fălci netede

smooth motion (mas, OM) mers liniștit / continuu, mişcare lină

smoothness $(\mathrm{OM})$ planeitate, netezime; suprafaţă şlefuită

smooth operation (mas) functionare silențioasă / liniştită / lină

smooth out $(\mathrm{TH})$ a netezi, a întinde (textile, semifabricate subtiri, folii etc.)

smooth pipe (OM, hidr) țeavă / conductă (cu suprafată interioară) netedă

smooth planing $(\mathrm{TH})$ planare, netezire, îndreptare (pt. textile, semifabricate subtiri, folii etc.); ajustare cu rindeaua (pt. lemn)

smooth roll (met, OM) cilindru neted; (alim, $\mathrm{OM}$ ) tăvălug neted smooth running (mas) mers lin / fără şocuri / liniștit

smooth running balance (mas) mers lin în echilibru, echilibru la mers lin

smooth surface $(\mathrm{OM})$ suprafață netedă

smooth-surface colloid mill (mas, alim, ind chim) moară coloidală, cu rotor / cilindru neted

smooth thread (OM) filet neted / rectificat

smooth tread bandă netedă de rulare

smother (ind, TH) a stinge incendiul prin înăbuşire

smoulder (termo) a arde înăbuşit / încet / fără flacără

smouldering (termo) ardere înăbuşită / fără flacără (şi proces nedorit)

smouldering zone (termo) zonă de ardere înăbuşită (şi în sens nedorit)

smoz (metr, textile, nav) simbol pentru sailmaker ounce, unitate tradițională de măsură pentru masa pe unitatea de arie a pânzelor de velatură (o pânză de 36 inchi x 28,5 inchi: 1 $\mathrm{smoz}=42,828 \mathrm{~g} / \mathrm{m}^{2} ; \mathrm{v}$. sailmaker ounce

smudge fire (alim) aparat de produs fum

smuggle a face contrabandă

smut (termo) funingine; (bot, agr) mălură (la cereale)

smut coal cărbune pudră / fin

snaft frame (nav) jug al axului cârmei

snag ciot (de lemn); (ec) dificultate, obstacol; (plast, compozite) umflătură; agățare; (mas-un) a degroşa (cu o sculă abrazivă); a curăța brut

snagging (met, $\mathrm{TH}$ ) debavurare

snagging grinder (mas-un) maşină de degroşare (fără a specifica procedeul de aşchiere)

snail (OM) melc, spirală; (zool) melc; (metr) o altă denumire pentru slinch; v. slinch

snail countersink (mas-un) teșitor-spirală

snailing (met) aspect melcat / şerpuit / spiralat al suprafetei alamei

snake (zool) şarpe; (TH) a şerpui, a încolăci în spirală

snaker (OM, mas-un) matriță / ştanță de îndoit snakes (met) pete albe (defect de laminare)

snake track $(\mathrm{OM}$, transp) şenilă flexibilă

snaky sinuos; șerpuit; $(\mathrm{OM})$ în serpentină

snap mușcătură; pocnitură; (OM, textile) fermoar; ruptură; plesnitură; $(\mathrm{OM})$ agrafă, încuietoare, buterolă; trosnirea arcului (la sudare); (inf, c) dispozitiv grafic la computer, care comandă alinierea obiectelor la punctele indicate; instantaneu; a muşca; a pocni; a se rupe

snap-action (el, autom) salt (şi al curentului de ieşire)

snap-action valve (OM, hidr) supapă cu acțiune / acționare rapidă, regulator / supapă de presiune cu declic 
snapback timing (metr, autom) metodă de reducere la zero

snap die(s) $(\mathrm{OM})$ căpuitor

snap fastener (OM, hidr) racord / cuplaj rapid (de obicei cu bilă)

snap flask (met, OM) ramă de formare cu balamale, cutie de formare demontabilă

snap flask (met, OM) ramă de formare demontabilă / cu balamale

snap gauge (metr, OM) calibru potcoavă

snap hammer $(\mathrm{OM})$ căpuitor, ciocan de nituit

snap head $(\mathrm{OM})$ ciocan căpuitor, cap de închidere a nitului

snap hook (auto, OM) inel de siguranță la cârlig; $(\mathrm{OM})$ şaibă de siguranţă cu gheară de fixare; carabină

snap in / into $(\mathrm{OM})$ a înclicheta

snap-lever oiler $(\mathrm{T}, \mathrm{OM})$ ungător cu arc

snap out (OM) a decupla (brusc, cu un arc etc.)

snappy return (OM, mas-un) întoarcere în poziția inițială sub acțiunea arcului

snap ring $(\mathrm{OM})$ inel elastic de prindere / de fixare (de forma literei $\mathrm{C}$ )

snap riveting set $(\mathrm{OM})$ căpuitor (de nituri)

snap set $(\mathrm{OM})$ căpuitor

snapshot dump $(\mathrm{OM})$ amortizor dinamic selectiv (şi ca module amplasate în mai multe locuri)

snap switch (OM, el) comutator cu resort

snap tool $(\mathrm{OM})$ căpuitor

snare capcană, cursă, laț

snarling test (metr, materiale) încercare / test a(l) sârmei pentru determinarea ductilității şi elasticității

snarl yarn fir cu efect de cârcel (la compozite, textile)

snatch block $(\mathrm{OM})$ mufă de palan

snatching $(\mathrm{OM}, \mathrm{mec})$ şocuri (la cuplarea ambreiajului)

sneak a se furişa

sneak current (el) curent vagabond / parazit

Snellen fraction (metr, opt, anat) un raport care măsoară acuitatea vizuală a unei persoane pentru obiecte aflate la distanță (exemple: 20/20, 20/100); numitorul este distanța la care obiectul este cuprins într-un unghi de 1 arcminut, numărătorul fiind distanța la care persoana identifică corect acelaşi obiect; distanţa standard este de 6 $\mathrm{m}$, de aceea există fractiii de forma 6/30; raportul se poate exprima și în procente; de exemplu „20\% vision” este echivalent cu 20/100

snide fals; contrafăcut, monedă falsă

sniff gas (ind chim) amestec de clor, aer și hidrogen (format la electroliză)

sniffing valve $(O M)$ valvă / supapă de aerisire snips $(\mathrm{OM})$ foarfece de tinichigerie

snit (metr) unitate de măsură pentru volum (pt. băuturi tari) în US: 1 snit $=88,7 \mathrm{ml}$

snout cioc, bot; vârf; $(\mathrm{OM})$ ajutaj

snow (meteo) zăpadă, a ninge, a înzăpezi; (c, TV) imagine cu purici, efect de ninsoare; (nav) tip de velier

snow chain (auto, OM) lanț antiderapant / de iarnă / de zăpadă

snowflakes (met, plast) fulgi (defect)

snow load (constr) sarcină produsă de zăpadă

snow white (chim) alb de zinc

snow tyre (auto, OM) anvelopă de zăpadă / de iarnă / antiderapantă

snowy road (auto) drum cu zăpadă / înzăpezit

snub nod într-o scândură (de lemn); (nav) a opri nava pentru ancorare, a fila brusc lanţul de ancoră; (mas) a opri brusc

snubber, snubbing equipment $(\mathrm{OM}$, hidr) dispozitiv mecanic sau hidraulic de restricționare a mişcării

snubber chain (auto, OM) lanț de siguranță

snubber valve (OM, hidr) supapă cu rezistență hidraulică (prin formă sau deschideri variabile)

snug comod; confortabil; călduros; (OM) nas

snug bolt $(\mathrm{OM})$ şurub cu cap ciocan

snug fit $(\mathrm{OM})$ ajustaj glisant

soak (ind chim) a fierbe în leșie; (TH) (în)muiere; udare; a uda; a limpezi; a îmbiba; a înmuia; a umecta; a impregna; a macera

soakage $(\mathrm{TH})$ îmbibare, impregnare (cu un lichid, d. materiale plastice, poroase etc.)

soak cleaning $(\mathrm{TH})$ degresare la cald

soaked with oil (materiale, T) îmbibat cu ulei (d. materiale poroase)

soaker (met) cuptor adânc de încălzire; (ind chim) cameră de reactie

soak in a îmbiba, a înmuia

soaking înmuiere; impregnare; (alim) macerare; îmbibare; (chim) reacție; (met) încălzire, egalizare (a temperaturii), menținere la o temperatură dată

soaking furnace (ind chim) cuptor de menținere la o temperatură dată / de înmuiere / de egalizare a temperaturii

soaking pit (ind chim) groapă / tank (adânc) de macerare; (met) cuptor (adânc) de recoarece

soaking-pit furnace (met) cuptor adânc pentru tratament termic (şi pt. recoacere de înmuiere) soaking time (met, plast) durată de menținere (pt. înmuiere), timp de încălzire în profunzime soaking zone (met, plast) zonă de încălzire / de înmuiere / de egalizare (a temperaturii) / de menținere la temperatură înaltă 
soak test (metr, plast) test de înmuiere / de îmbibare (a materialelor plastice de etanşare)

soam (metr) altă denumire pentru seam; v. seam soap (ind chim) săpun soap bar (ind chim) calup de săpun soap base (chim) bază de săpun soap blender (ind chim, OM) malaxor de săpun soap boiling (ind chim, TH) fierbere a săpunului soap-boiling kettle / pan, soap cauldron (ind chim, OM) cazan de fiert săpun

soap-bubble solution (metr, chim) soluție (necorosivă) de săpun folosită la depistarea găurilor / porilor

soap-bubble test (metr, chim) test cu solutie (necorosivă) de săpun pentru depistarea găurilor / porilor

soap chip (ind chim) talaş de săpun, săpun în fulgi

soap-cooling frame / press (ind chim, mas-un) formă / presă de răcit săpun

soap copper (ind chim, OM) cazan de fiert săpun soap crutcher (ind chim, OM) malaxor de săpun soap-cutter / soap-cutting machine (ind chim, mas-un) maşină de tăiat săpun

soap die (ind chim, OM) ştanță de săpun soap-drawn wire (met, OM, TH) sârmă trefilată cu lubrifiere cu săpun

soap dryer (ind chim, mas) uscător de săpun

soap-drying plant (ind chim, mas) instalație de uscat săpun

soap fat (ind chim) grăsime de saponificare

soap flakes (ind chim) fulgi de săpun

soap flaking machine (ind chim, mas-un) maşină de fabricat fulgi de săpun

soap frame $(\mathrm{OM})$ formă de săpun

soap grain miez de săpun

soap grease $(T$, ind chim) unsoare consistentă de săpun

soap hardness (chim) duritatea apei față de săpun soap kettle (ind chim, OM) cazan de fiert săpun soap mill (ind chim, $\mathrm{OM}$ ) valț de săpun soap milling (ind chim, TH) pilotare a săpunului soap-mixing tank (ind chim, OM) malaxor de săpun

soap mould (ind chim, OM) matriță de săpun soap oil ( $T$, ind chim) ulei de saponificare

soap-oil dispersion $(T$, ind chim) dispersie de săpun în ulei

soap-packing / soap wrapping machine (ind chim, mas-un) maşină de împachetat săpun soap paste (ind chim) pastă de săpun

soap plodder (ind chim, mas-un) maşină de pilotat săpun

soap powder (ind chim) praf / pudră de săpun soap press (ind chim, mas-un) presă de săpun soap roller mill (ind chim, $\mathrm{OM}$ ) valț de săpun soap slab (ind chim) placă de săpun soap solution (ind chim)soluție de săpun soap stamping press (ind chim, mas-un) presă de ştanțat săpun

soap tablet (ind chim) bucată de săpun

soap test of grease (metr, chim) test / analiză pentru determinarea conținutului de săpun în unsori

soap thickener ( $T$, chim) agent de îngroşare a săpunului (din unsori)

social insurance $(\mathrm{adm})$ asigurări sociale

social overheads (adm) servicii edilitare

social security benefits $(\mathrm{ec}, \mathrm{adm})$ ajutor social

social security taxes (ec, adm) impozite de / pentru asigurări sociale

society (ec) societate, asociație, companie, firmă socket (cf) scoabă de traversă; (OM, hidr) pană, diblu, montură, cutie, ştuț (de racordare), racord (și tubular), mufă, manşon, bucșă, clichet; (el) dulie, fasung, soclu, priză, jac

socket adapter $(\mathrm{OM}$, el) fişă (electrică) intermediară

socket-and-spigot joint (OM) îmbinare cu cep şi mufă

socket(ed) pipe, socket tube $(\mathrm{OM})$ țeavă manşonată / cu mufă din corp

socketed stanchion $(\mathrm{OM})$ reazem pendular

socket fitting $(\mathrm{OM})$ îmbinare / fixare cu mufă

socket head $(\mathrm{OM})$ cap de cheie frontală

socket joint $(\mathrm{OM})$ îmbinare cu mufă

socket key / wrench $(\mathrm{OM})$ cheie tubulară

socket mandrel $(\mathrm{OM})$ dorn cu pâlnie

socket of jack (el) bucşă de jac

socket outlet adapter (el) fişă de derivație (dublă sau multiplă)

socket outlet and plug (el) fişă şi priză de curent

socket / faucet pipe / tube $(\mathrm{OM})$ țeavă cu mufă / cu manșon / manşonată

socket power unit (el) bloc / aparat de alimentare de la retea

socket screw $(\mathrm{OM})$ şurub cu locaş hexagonal

socle (el, OM) soclu, postament

soda (alim) apă gazoasă; sifon; (chim) sodă calcinată, carbonat de calciu

soda ash (chim) sodă calcinată, carbonat de sodiu anhidru

soda crystals (chim) sodă cristalizată, carbonat de sodiu cristalizat

soda lye (chim) soluție de sodă caustică / de hidroxid de sodiu, leşie de sodă

soda lye wash (chim, TH) spălare cu soluție de sodă caustică / hidroxid de sodiu / leșie de sodă 
soda nitrate (chim) nitrat de sodiu

soda salt (chim) sodă calcinată, carbonat de sodiu soda soap (chim) săpun de sodiu

soda solution (chim) soluție / leşie de sodă

soda wash (chim, TH) spălare cu hidroxid de sodiu

soda water (alim) apă gazoasă

soda waterglass (chim) silicat de sodiu, sticlă solubilă

sodion (chim) ion de sodiu

Sodium, Natrium (Na) (chim) sodiu, natriu

sodium base ( $T$, chim) bază de sodiu

sodium butadiene rubber (plast, ind chim) cauciuc sodiu-butadienic

sodium chloride (alim, chim) sare de bucătărie, clorură de sodiu

sodium dioxide (chim) peroxid de sodiu sodium hydrate (chim) hidroxid de sodiu sodium hydrogen carbonate (chim, alim) bicarbonat de sodiu, dicarbonat de sodiu

sodium lye (chim) leşie de hidroxid de sodiu

sodium rubber (ind chim) cauciuc polimerizat cu sodiu

sodium salt (chim) clorură / sare de sodiu

soft suplu, moale; maleabil; neted; catifelat; uşor; (alim) nealcoolizat (d. băuturi); (c, inf) soft(ware); (c, TV) neclar, făă contrast (d. o imagine)

soft annealing (met, $\mathrm{TH})$ recoacere de înmuiere, decălire

soft bearing (above resonance) balancing machine (mec) maşină de echilibrat cu lagăre flexibile (peste frecvența de rezonanță)

soft bobbins (termo, OM) țevi moi (şi sub formă de serpentine)

soft caramel (alim) caramel moale

soft-carbon steel (met) otel cu continut redus de carbon, oțel moale

soft clinker (met) zgură vâscoasă

soft coal (met, termo) lignit

soft copy (c, TV) imagine (nepermanentă)

soft currency (ec) valută neconvertibilă / nestabilă / instabilă / fluctuantă / volatilă

soft-drawn wire sârmă trefilată când este în stare moale

soften (met) a înmuia, a calma, a potoli, a recoace, a reveni; (plast) a plastifia, a înmuia, a face suplu softened înmuiat; (met) recopt parțial

softened water (chim) apă dedurizată

softener (ind chim, med) emolient; plastifiant; produs / agent / instalatie de înmuiere; (termo, chim) dedurizator

softening agent emolient; agent de înmuiere; înmuiere; plastifiere; (met) recoacere parțială; care se înmoaie; (chim) reducere / dedurizare a durității apei (implicit a depunerilor solide) softening anneal(ing) (met) recoacere de înmuiere softening behaviour (materiale) comportare la înmuiere / la plastifiere (şi d. unsori)

softening drum (alim, ind chim, OM) tambur tobă de umezire / înmuiere / plastifiere

softening factor / value (metr, ind chim) coeficient la / de înmuiere

softening furnace (met, ind chim) cuptor de rafinare preliminară

softening machine (mas, textile, ind chim) maşină de înmuiat / pentru înmuiere / plastifiere

softening point (fiz) punct / temperatură de înmuiere

softening point test (metr, materiale) test pentru determinarea temperaturii de înmuiere

softening range (materiale) interval de înmuiere (mai ales pt. materiale plastice)

softening value $(\mathrm{TH}$, materiale) coeficient de înmuiere

soft flow (mec, materiale, TH) curgere uşoară (în matriță etc.)

soft goods (ec) mărfuri de folosință scurtă

soft ground (geol, constr) teren / sol slab

soft gum răşină moale, cauciuc vulcanizat moale soft iron (met) fier moale / Armco / pur soft light lumină odihnitoare / plăcută soft money (ec) monedă de hârtie softness (textile) moliciune; (meteo) blâdete a climei softness index (ind chim, TH) indice de fluiditate / de plastifiere

soft oscillations (mec, autom) oscilații uşoare

soft rubber (ind chim) cauciuc moale

soft rubber plug (el, OM) fișă incorporată în izolația plastică a unui cablu

soft-sized $(O M)$ semi-înecat

soft soap (ind chim) săpun lichid / moale

soft soil (geol, constr) sol / teren moale

soft solder (met) aliaj de lipit moale (cu Pb şi Sn)

soft soldering $(\mathrm{OM}, \mathrm{el}, \mathrm{TH})$ lipire moale

soft spots (met) puncte de cementare incompletă, puncte "moi" (defect de cementare)

soft steel (met) otel moale

soft-tempered (met) recopt pentru înmuiere (d. oțel)

software (c, inf) program, set de programe, bănci de date

software addaptability (c, inf) adaptabilitate a soft-ului

software bug (c, inf) eroare de programare

software error failure (c, inf, autom) cădere / întrerupere / functionare incorectă a sistemului din cauza soft-ului

software flexibility (c, inf, autom) flexibilitate a soft-ului 
software license (c, inf, ec) licență de program / de utilizare a soft-ului

software maintenance (c, inf) întreținere a softului, dezvoltare şi documentare a soft-ului

software package $(\mathrm{c}$, inf) pachet de soft / de programe

soft water (chim) apă moale / dedurizată / nedurificată (care nu conţine săruri de calciu şi magneziu), apă din care s-au evacuat impurități

soft wire (met) sârmă moale

softwood (silv) lemn (de esență) moale

softwood timber (silv) lemn de răşinoase / de esență moale

soil (geol, constr) sol, teren, pământ, fundație; pată; murdărie; a murdări; a impurifica; a păta

soil cutting / excavation (constr) excavare

soil stability (geol, constr) stabilitate a solului

sol (chim, fiz) soluție coloidală, gel; o suspensie de particule de dimensiuni coloidale în lichid, care are, în mare, proprietățile lichidului

sol (metr) unitate de timp pe Marte, egală cu ziua medie marțiană, aşa cum ar apărea unui observator aflat pe planetă: 1 sol $=24$ ore 39 minute $35 \mathrm{~s}$, sau $\sim 1,0275$ zile terestre

solder (met) aliaj pentru lipire moale, a lipi (cu aliaj moale); (OM) punct de sudură

solderability (met, plast) capacitate de lipire

solderable (met, plast) apt de lipit, posibil de a fi lipit, care poate fi lipit

solder bar (met, plast, $\mathrm{TH}$ ) vergea pentru lipituri

soldered joint $(\mathrm{OM})$ îmbinare prin lipire

soldered seam $(\mathrm{OM})$ cusătură lipită

soldered twisted joint (OM, plast) îmbinare (a conductelor) prin lipire cu răsucire

solder embrittlement (met) fragilizare prin pătrunderea sudurii / lipiturii (defect)

solderer sudor (mai rar)

solder eye (el, OM) terminal / contact cu gaură prin care trece şi de care va fi lipit conductorul

solder glass (materiale, $\mathrm{TH}$ ) sticlă cu punct de topire mai scăzut $\left(\sim 410^{\circ} \mathrm{C}\right)$ pentru lipirea sticlelor cu punct de topire mai ridicat

solder in $(\mathrm{TH})$ a lipi

soldering (TH, OM) lipire (moale, cu aliaj metalic), care se lipește

soldering acid / fluid (chim, TH) soluție de acid (clorhidric) pentru decapare (înainte de o lipire moale)

soldering apparatus (mas) aparat de lipit soldering bit (OM, el) letcon, ciocan de lipit soldering crucible (met) creuzet, oală de topit (în general pt. aliaje mai moi)

soldering embrittlement (met) fragilizare după lipire soldering fat / paste (ind chim, TH) pastă de lipit / decapantă pentru lipire ulterioară

soldering fluid / acid / water (ind chim, TH) soluție / lichid de decapare (înainte de lipire); (chim) apă tare

soldering flux (ind chim, TH) flux / adaos decapant, fondant (pt. lipire)

soldering hammer / iron $(\mathrm{OM})$ ciocan de lipit soldering in hot air (met) lipire cu / în aer cald soldering iron $(\mathrm{OM})$ ciocan de lipit soldering lamp (OM) lampă de lipit soldering lug $(\mathrm{OM})$ ochi de lipit

soldering material (materiale, $\mathrm{TH}$ ) material de adaos pentru lipit

soldering metal (met) aliaj de lipit (inclusiv $\mathrm{Pb}$, Sn, pentru lipituri moi)

soldering method $(\mathrm{TH})$ procedeu / metodă de lipit

soldering paste (ind chim, TH) pastă de lipit soldering pin $(\mathrm{OM})$ vârf al ciocanului de lipit soldering pliers $(\mathrm{OM})$ clește de sudură soldering point $(\mathrm{OM})$ punct de lipire soldering salt (chim, TH) sare de curățat pentru lipire metalică, sare de lipit

soldering terminal $(\mathrm{OM})$ clemă de lipit soldering tin (met) (aliaj de) staniu de lipit, (fam) cositor

soldering tool $(\mathrm{OM})$ dispozitiv de lipit soldering tweezers $(\mathrm{OM})$ cleşte de lipit soldering with filler metal cladded workpiece (TH, OM) lipire cu piese placate cu aliaj soldering with flux (TH, OM) lipire cu flux soldering with soldering iron $(\mathrm{TH}, \mathrm{OM})$ lipire cu ciocan de lipit

solderless $(\mathrm{OM})$ fără lipitură

solder on $(\mathrm{TH})$ a lipi de / pe

solder sleeve (TH, OM) tub / bucşă contractabilă la căldură, cu material de lipit şi flux incorporate

solder stick vergea din aliaj de lipit solder together a alipi, a lipi două piese sole (met) vatră, fund (de cuptor etc.); (constr) temelie, fundament; unic, exclusiv

sole agent $(\mathrm{ec})$ reprezentant exclusiv

sole exporter (ec) exportator exclusiv

sole flue (met) canal sub vatră

solenoid (fiz, el) solenoid, bobină fără miez

solenoid valve (fiz, el, hidr, OM) supapă a cărui ac / plunjer este acționat de un solenoid

sole owner (ec) proprietar unic

sole-plate (constr, OM) placă de bază / de fundație; (cf) placă sub şină / de bază

sole plate frame (constr, met) cadru de fundație sole right (jur, ec) drept exclusiv 
sole weight $(\mathrm{OM})$ greutate / masă proprie (atenție la unități de măsură)

soliciter (jur) jurisconsult, avocat consultant; (ec) agent comercial; (adm, jur) solicitant, petitionar solid robust, masiv; plin, compact; $(\mathrm{OM})$ nedemontabil; rezistent; durabil; $(\mathrm{mec})$ corp solid; solid, în stare solidă; (mat) neîntrerupt în spațiu, tridimensional

solid angle (geom) unghi solid

solid angle elemnet (geom) element de unghi solid solid axle $(\mathrm{OM})$ osie plină / masivă, arbore plin solid bearing $(\mathrm{OM})$ lagăr monobloc

solid binder (constr) liant solid

solid body (fiz) corp solid

solid bottom die(s) (mas-un, OM) ştanţă de tras, cu aruncător pentru scoaterea pieselor

solid-bottom mould (met) lingotieră cu pod

solid brick (constr, met) cărămidă plină

solid broach (mas-un) broşă integrală / dintr-o bucată

solid carbon dioxide (chim) zăpadă carbonică, gheață uscată

solid core (el, met) miez masiv

solid coupling $(\mathrm{OM})$ cuplaj rigid

solid cryogen cooling (fiz) răcire cu fluide criogenice

solid contraction / shrinkage (met, plast) contractie în stare solidă

solid curve (geom) curbă în spațiu / din linie continuă

solid cylinder (geom, OM) cilindru plin

solid die (mas-un) filieră dintr-o singură bucată

solid diffusion (met, TH) difuzie în fază solidă

solid drawn tras fără sudură / fără cusătură de sudură / dintr-un semifabricat

solid drill steel (met, mas-un) oțel pentru burghiu plin

solid expansion thermometer (metr, termo) termometru cu corp solid de dilatare (de obicei bimetalic)

solid filter aid (OM, materiale) auxiliar de filtrare solid

solid friction $(T)$ frecare solidă / uscată

solid-friction clutch $(\mathrm{OM}, \mathrm{T})$ ambreiaj uscat

solid fuel (termo) combustibil solid

solid gauge (metr, OM) calibru limitator simplu

solid ground $(\mathrm{OM}, \mathrm{TH})$ obținut prin rectificare dintr-o piesă brută masivă

solid harmonic (mat) functie armonică sferică

solid head (termo, OM) cap al bielei de tip închis

solid height of spring $(\mathrm{OM})$ înălțimea arcului solidification, solidifying (fiz, materiale) solidificare (proces şi rezultat) solidification contraction (materiale) contracție la solidificare

solidification curve (met) curbă de solidificare solidification heat (termo, materiale) căldură latentă de solidificare

solidification period (met, plast) interval de solidificare

solidification point / temperature (met, fiz) punct / temperatură de solidificare

solidification point test (metr, materiale) test pentru determinarea punctului de solidificare

solidification range (metr, materiale) interval de solidificare

solidification shrinkage $(\mathrm{TH}$, materiale) contracție a materialului solidificat / de solidificare

solidification temperature (materiale, fiz) temperatură de solidificare

solidified mattle (met) crustă de mată

solidify (fiz, materiale) a (se) solidifica

solidifying (fiz, materiale) solidificare, care se solidifică

solidifying heat (fiz, materiale) căldură de solidificare

solidifying point of oil $(\mathrm{T})$ punct de congelare / de îngheț al uleiului

solidifying point (fiz, materiale) punct de solidificare

solidifying range ( $\mathrm{TH}$, materiale) interval de solidificare

solid inclusion $(\mathrm{TH})$ incluziune solidă

solid injection (plast) injecție / injectare sub presiune

solid-injection Diesel engine (termo) motor diesel cu injecție directă

solidity (mec) soliditate, rigiditate

solid jaw (OM, mas-un) falcă fixă

solid jet $(\mathrm{OM}$, plast, hidr) jet continuu

solid key $(\mathrm{OM})$ pană fixă

solid line linie plină / continuă (în desen tehnic)

solid lubricant $(\mathrm{T}$, ind chim) unsoare consistentă, lubrifiant solid

solid milling cutter (mas-un) freză monobloc

solid mineral fuel (ind chim, termo) combustibil mineral solid

solid of rotation / revolution (geom) corp de rotaţie

solid oil ( $T$, ind chim) unsoare consistentă (rar)

solid phase (met, chim) fază solidă; depunere; precipitat; reziduu (solid)

solid-phase sintering (met, ceramice) sinterizare în fază solidă

solid piston $(\mathrm{OM})$ piston masiv

solid pulley $(\mathrm{OM})$ disc / roată de transmitere (monobloc / masivă) 
solid residue from evaporation (alim, ind chim, mediu) reziduu uscat la evaporare

solid residue alim, ind, mediu) reziduu solid

solid rivet $(\mathrm{OM})$ nit masiv / plin

solid rubber (plast) ebonită

solids content alim, ind chim, mediu) conținut de substanță solidă

solids flow alim, ind chim, mediu) curgerea solidelor (pulverulente etc.)

solids handling pump (OM, hidr, mediu) pompă de noroi / de şlam / de reziduuri

solid section $(\mathrm{OM})$ secțiune totală (şi în desen tehnic)

solid shaft $(\mathrm{OM})$ arbore masiv / plin

solid shrinkage (met, plast) contracție a materialului în stare solidă

solid shrinkage strain (materiale, TH) tensiune de contractie

solid skin of the blank (met) crustă solidă a bramei (la turnarea continuă)

solid slag (met) zgură compactă

solid sleeve $(\mathrm{OM})$ cuplaj cu manşon

solids loading ratio raport al părților solide întrun amestec

solid solution (met) soluție solidă

solid space volum

solid sphere (geom) sferă plină; $(\mathrm{OM})$ bilă

solid spherical harmonic (mat) functie armonică sferică

solid spindle (OM) arbore / ax plin / masiv (şi principal)

solid state (fiz) stare solidă

solid state method of powder preparation (alim, ind chim, met, $\mathrm{TH}$ ) metodă de preparare a pulberilor în stare solidă

solid state reaction (met, chim) reacție în stare solidă

solid state welding (fiz, TH) sudare fără depăşirea punctelor de topire ale materialelor de bază de sudat

solid steel (met) oțel calmat

solid tap (mas-un) tarod masiv / neregalabil

solid three-dimensional structure (materiale) structură tridimensională

solid tool (mas-un) cuțit integral / masiv / monobloc / dintr-o bucată

solid-type end mill (mas-un) freză cu coadă

solidus (curve) (met) curbă de solidificare; (mat) linie de fractie oblică

solidus line (met) curbă de solubilitate

solid-webbed (constr) cu inima plină

solid wheel $(\mathrm{OM})$ roată nedemontabilă / masivă $/$ monobloc

solid wrench $(\mathrm{OM})$ cheie fixă soliquid (fiz) dispersie de particule solide în lichid solox (ind chim) alcool denaturat

solubility (fiz) solubilitate

solubility curve (met) curbă de solubilitate

solubility-temperature curve (met) curbă de so-

lubilitate în funcție de temperatură

solubility test (met, $\mathrm{TH}$ ) test de solubilitate

solubilization (chim, fiz) solubilizare

solubilize a dizolva, a solubiliza, a face solubil

solubilizer (chim) solvent

soluble solubil; (mat) rezolvabil

soluble castor oil (ind chim) ulei de ricin sulfonat

soluble glass (chim) sticlă solubilă

soluble in fat (chim) solubil în grăsime

soluble iron carbide (met) carbon de călire

soluble matter loss (alim, ind chim) pierderi de material solubil / prin dizolvare

solublenes $(\mathrm{TH})$ solubilitate (d. substanțe)

soluble oil $(T$, ind chim) ulei emulsionabil în apă (amestec de răcire sau de aşchiere)

soluble resin (chim) răşină solubilă

soluble silicate (chim) silicat solubil

soluble starch (chim) amidon solubil

solus offer (ec) ofertă singulară (pt. un singur produs sau serviciu)

solute (chim) substanță dizolvată

solution (chim) soluție, dizolvare

solution adhesive (chim, plast) adeziv în soluție

solution coating (ind chim) lăcuire

solution concentration (chim) concentrație a soluţiei

solution heat (chim, fiz) căldură de dizolvare

solution heat-treatment (met) tratament termic prin dizolvarea metalelor de adaos; tratament prin topirea și dizolvarea elementelor de aliere într-o fază solidă şi răcire rapidă

solution mill / mixer (plast, mas) malaxor pentru soluție (şi de cauciuc)

solution of alum and salt (chim) soluție sărată de alaun

solution of alkali (chim) soluție alcalină

solution power (chim, fiz) putere de dizolvare

solution ratio (chim) raport / rație a unei soluții

solution standardisation (chim, metr) titrare a unei soluții

solution stripping $(\mathrm{TH}$, chim) curățare chimică

solutizer (chim) accelerator de dizolvare

solvability (chim) solubilitate; (ec) solvabilitate; (mat) rezolvabilitate

solvable (chim) solubil; (ec) solvabil; (mat) rezolvabil

solvate (chim) (complet) solvatat

solvation (chim) solvatare, înmuiere / dizolvare cu un solvent 
solve (chim) a dizolva; (mat) a rezolva, a soluționa solvency (ec) solvabilitate

solvent (chim) solvent

solvent action (chim) actiune / proces de solventare / de dizolvare

solvent activated adhesive (chim, plast) adeziv cu (re)activare prin / cu solvent

solvent activation (chim, plast) activarea solventului

solvent base adhesive (chim, plast) adeziv pe bază de solvent

solvent-born adhesive (chim, plast) adeziv pe bază de solvent

solvent cleaning (chim, TH) curățare / degresare cu solvent

solvent extract (alim, ind chim) extract (selectiv) cu solvent

solvent extraction (alim, ind chim, $\mathrm{TH}$ ) extractie (selectivă) cu solvent, solventare extractivă

solvent free (chim, plast) fără solvent

solvent free adhesive (chim, plast) adeziv fără solvent

solvent mixture (chim) amestec de solventi

solvent polymerization (ind chim) polimerizare în solutie / cu solvent

solvent power (chim) capacitate / putere de dizolvare / de separare (cu solvenți)

solvent quality (chim) calitate a solventului

solvent recovery (chim, $\mathrm{TH}$ ) recuperare a solventului

solvent reactivation (chim, plast) reactivarea solventului

solvent selectivity (alim, ind chim) selectivitate a solventului

solvent strength (chim) concentratia solventului solvent treatment (ind chim, TH) solventare, rafinare / tratare cu solventi selectivi

solving agent (chim) solvent, dizolvant

-some (metr) sufix adăugat unui număr pentru a crea o unitate de cantitate; exemplu: a foursome - un grup de 4

sonar (fiz, metr) radiolocator ultrasonic sub apă sonde (OM, metr) sondă, aparat de luat probe sone (metr, ind, fiz) unitate pentru estimarea subiectivă a intensității sunetului în zone industriale cu motoare, exhaustoare, ventilatoare etc.; 1 sone este intensitatea acustică a unui zgomot cu frecvența de $1 \mathrm{kHz}$ şi puterea acustică de 40 decibeli și este echivalent cu 40 de foni

sonic altimeter (fiz, metr) ecometru

sonic method (fiz, metr) metodă acustică

sonic testing (fiz, metr, materiale) încercare / testare acustică

sonometer (fiz, metr) sonometru soot (termo) funingine; negru de fum; calamină; (met) țunder, arsură; a acoperi cu funingine soot and white wash (c, TV) imagine cu contrast foarte puternic

soot formation (termo, mas) formare de funingine / de calamină; (met) formare de țunder / de arsură

sooting of the spark plug (auto, termo) ancrasare a bujiei

soot pit (termo) cenuşar

sorbent (agent) (chim) (agent) adsorbant

sorbing agent (chim) sorbent

sorbite (met) sorbită

sorbitic cast iron (met) fontă sorbitică

sorbitic pearlite (met) perlită sorbitică

sorghum syrup (alim) sirop de sorg

sort $(\mathrm{TH}, \mathrm{OM})$ clasă de calitate, gen, fel, tip, serie; (ec) sortiment, calitate; (TH) a sorta, a tria, a clasifica; a alege; a aranja; a separa (după un criteriu)

sortable (OM, materiale) sortabil, care poate fi triat / clasificat / sortat

sorter (OM, mas) sortator, clasor (dispozitiv sau maşină)

sorters board $(\mathrm{OM})$ masă de sortare

sorting (inf, TH) sortare, triere, rearanjare, clasificare

sorting belt (alim, OM) bandă de sortare

sorting carrier (alim, OM) bandă transportoare pentru sortare

sorting device (alim, constr, ind chim, OM) separator, sortator

sorting drum (alim, constr, ind chim, OM) sortator cu tambur

sorting machine (alim, constr, ind chim) mașină de sortat

sorting plant / unit (alim, constr, ind chim) instalație de sortare

sorting programme (inf) program de triere / de aranjare

sorting table (alim, constr, ind chim, OM) masă de sortare

sort out $(\mathrm{TH})$ a sorta (şi prin eliminare)

sosoloid (chim) soluție (coloidală) solidă

sotka (metr) unitate rusească de măsură pentru suprafață: 1 sotka $=1 \mathrm{ar}=100 \mathrm{~m}^{2}$

sough (OM, constr, mediu) canal / jgheab de scurgere / de drenare

sound $(\mathrm{TH})$ de bună calitate, întreg, impermeabil, fără defecte, întemeiat, sănătos, solid, în bună ordine, robust, intact, logic; (fiz) sunet, ton; (nav) brat de mare, sondare, strâmtoare (îngustă), a se afunda (d. o navă în curs de încărcare), a se atinge de fund, a măsura adâncimea (apei); 
(agr) nevătămat, sănătos, făă cusur (d. fructe etc.); (iht) băşica (de peste); (med) cateterism, sondaj, tubaj, a sonda, a cateriza; (fig) conținut, înțeles, ton, vorbă / vorbărie goală, sens; răsunet; (nav, med) sondă; voce, glas; zgomot; adânc (d. somn); adevărat, de nădejde, de onoare (d. un prieten etc.); bun, temeinic, solid (d. o părere etc.); clar, precis (d. judecată etc.); corect, util, folositor, recomandabil (d. un sfat etc.); îndreptățit, legal (d. un titlu etc.); sănătos, zdravăn (d. trup etc.); rațional, sănătos, logic (d. minte etc.); (ec) stabil, solid, sigur; (fig) straşnic, zdravăn (d. un eveniment etc.); complet; din plin; tare; (d. orologiu) a bate (orele); a da (alarma); a declara; a exprima; a face cunoscut; a vesti; a face să (ră)sune; a proclama; a (ră)suna; (fonetică) a rosti, a pronunța; (metr, TH) a sonda; a suna (d. telefon, un aparat etc.); (fig) a sonda, a părea, a căuta să afle, a cerceta, a suna (ciudat etc.), a dojeni (pe cineva), a-şi spune părerea in mod liber; infra- (fiz) infrasunet

sound-absorbent, sound-absorbing (fiz, materiale) fonoabsorbant

sound absorption (fiz, materiale) absorbție acustică / fonică

sound absorptivity (fiz, materiale) absorbție a sunetului

sound casting (met) turnare fără defecte / corectă, piesă turnată corect

sound detector (fiz) detector de sunete sound effects $(p l)$ (fiz, TV, radio) efecte sonore sound engineer (fiz, TV, radio, muz) inginer de sunet

sound film, sound motion picture (cinematografie) film sonor

sound generator (fiz) sursă de sunet

sound-man (fiz, TV, radio) maestru de sunet

sound meter (metr, fiz) sonometru

soundness condiție / stare bună; factor de calitate; justețe; sănătate; siguranță; soliditate / trăinicie (a argumentării etc.); (met) structură corespunzătoare / fără defecte (a aliajului)

sound pressure (fiz) presiune de sunet

soundproof, sound-proof (fiz) izolat acustic / fonic

sound-ran (fiz) goniometru acustic

sound reduction (fiz) izolație acustică

sound signal (fiz, ind) semnal acustic / sonor

sound the horn (auto) a claxona

sound track (fiz) pistă sonoră

sound transmission (fiz) transmisie sonoră, conductibilitate fonică

sound transmission class (STC) (metr) grupă / clasă de conductibilitate sonoră / fonică, o ierarhizare în clase, a capacității materialelor de constructiii de a opri transmisia sunetelor nedorite şi exprimă pierderea transmisiei sonore, în decibeli, atunci când sunetul trece printr-un anumit material

sound wave (fiz) pistă / undă sonoră

sour (alim, ind chim) acru, acid; a acri, a acidula

source sursă; izvor; (el) terminal; (inf) programsursă; (ec) sursă (de aprovizionare, de energie etc.)

source-free fără sursă (de energie) (d. aparate etc.) source data (inf) date de bază (şi la proiectare, în orice domeniu)

sour crude (ind chim) țitei / petrol cu o mare cantitate de sulf

source field (el) câmp inductor

source language (c, inf) limbaj-sursă, limbaj simbolic al unui procesor

source of energy (el, hidr, fiz) sursă de energie

source of error (metr, autom, inf) sursă de eroare

source of power (el, hidr, fiz) sursă de putere / de energie

source of supply (ec) sursă de aprovizionare

source point (fiz, termo etc.) sursă punctiformă (în modelare etc.)

source program(me) (inf, c) program original / inițial

source voltage (el, metr) tensiune de comandă / de excitatie

sour gas (ind chim) gaz natural cu o mare cantitate de hidrogen sulfurat

sour gasoline (ind chim, auto) benzină acidă

sour milk (alim) lapte acru

souring (alim, chim) râncezire, oțețire, acrire sourness (alim, chim) acreală, aciditate, gust acru sours (alim) baie de acrire / de coagulare

sour sulfur (chim, T) sulf activ

south (geogr) sud

South Africa (geor) Africa de Sud

South African geodetic foot (S.A.G. ft) (metr) unitate de măsură pentru lungime: 1 South African geodetic foot $=30,47972654 \mathrm{~cm}$

southern (geogr) de sud, sudic

sovpren (plast) neopren, sovpren (denumiri comerciale)

sow (met) lupă de fier, urs (la cuptor, la furnal), crustă aderentă solidificată, groapă de zgură; (agr) a semăna, a însămânța

sow back (met) umflare a vetrei

sow block (mas-un, OM) mandrină de prins piese sferice

soya-bean oil (alim) ulei de soia

s.p. (standard pitch) $(\mathrm{OM})$ pas normal al filetului 
space (fiz, mat, mec) spațiu, distanță, volum; loc (gol / vacant), interval; pauză; zonă; domeniu; a spația; a distanța

space angle (geom) unghi solid

space at closed intervals $(\mathrm{OM})$ a amplasa piese la distanță mică între ele

space beam (constr) traversă intermediară

space between the fire bars (termo) spațiu liber între barele grătarului

space coordinate (mat) coordinate spațiale

space-centred cubic lattice (met, fiz) rețea cubică centrată / cu volum centrat

space curve (geom) curbă în spațiu

spaced butted $(\mathrm{OM})$ pus cap-la-cap cu rost (la sudură)

space diagonal (constr, mec) diagonală (d. ferme, grinzi cu zăbrele)

space factor (constr, met) coeficient de umplere

space heater (termo) radiator (şi electric) cu convecție

space integral (mat) integrală de volum

space lattice form (fiz) formă a rețelei în spațiu (cristalografie)

space model (mat) model spațial / tridimensional / 3D (şi în modelare)

space point (mat) punct în spațiu / în 3D

spacer $(\mathrm{OM})$ şaibă / inel distanțier(ă), distanțier, piesă intermediară; (c) tastă de interval

space radiation (fiz) radiație spațială

space restriction fără spațiu; $(\mathrm{OM})$ restricție de spațiu / de gabarit

space ring $(\mathrm{OM})$ inel distanțier / de distanțare

space saving (ind, mas, $\mathrm{TH}$ ) economie de spațiu

space sleeve (OM) țeavă / cămaşă / bucşă distanțieră

space saving (OM, ec, adm) economie de spațiu, (soluție de organizare / piesă) care nu ocupă spațiu mult

space sharing (c) distribuție a spațiului în memorie space temperature (fiz) temperatură a unui spațiu închis / a unei incinte climatizate

space truss (constr, mec) fermă spatială

space width $(\mathrm{OM})$ lățime a golului (la angrenaje); interval, spațiu, golul între dinți (e)

space width normal $(\mathrm{OM})$ spațiul dintre dinți în plan normal $\left(e_{n}\right)$

space width transverse $(\mathrm{OM})$ spatiul dintre dinți în plan frontal $\left(e_{t}\right)$

spacing $(\mathrm{OM})$ amplasarea pieselor la o anumită distanță; (met) pas (la calea cu role); (fiz) interval, distanță; spațiere; (autom) repaus, timp de separare

spacing accuracy (OM, mas-un) precizie a pasului / a divizării spacing clamp / clip (OM) colier / clemă distanțier(ă)

spacing contact $(\mathrm{el}, \mathrm{OM})$ contact de întrerupere / de separare

spacing current (el, autom) curent de repaus / de pauză / între semnale

spacing error (OM) eroare de montaj / de distanţare / de păsuire / de pas

spacing key (c) tastă de spațiu / de banc

spacing means / piece (OM) distanțier, piesă de distanțare

spacing of lattice (fiz) constantă a rețelei

spacing of the rivets $(\mathrm{OM})$ pas al nituirii

spacing piece $(\mathrm{OM})$ distanțier, piesă distanțieră

spacing ring $(\mathrm{OM})$ inel de distanțare / distanțier

spacing storp rest (autom, metr) deviație în poziție de repaus / de zero

spacious spațios

spade (OM) cazma; a săpa cu cazmaua

spade bolt $(\mathrm{OM})$ şurub cu cap aplatizat şi gaură pentru trecerea cheii / barei de strângere

spaghetti (el, plast) tub izolant; (alim) spaghete

spall (met, T) aşchie (şi de piatră), fragment; a (se) coji, a (se) exfolia; a crăpa; (T) a aşchia, a detaşa material de pe suprafață (mai mult în sens nedorit, sub formă de solzi / foițe, fulgi etc.) (şi proces de uzare prin oboseală)

spalling (met) crăpătură, fisurare, cojire, exfoliere; (T) spalling (proces de uzare de oboseală), exfoliere de oboseală

spalling resistance (met, termo, ceramice) rezistență la şocuri termice

spalling test (metr, materiale) încercare / test la sfărâmare / la fisurare / de fragilitate

spalls (met) desprinderi (de la cilindrii de laminare); (T) particule de uzură, produse prin spalling / exfoliere de oboseală)

spalt fragil, casant

span (constr, met) deschidere a unui pod / între stâlpi, lonjeron; (el) domeniu, a șunta; (mas) rază de acțiune a unui utilaj / a unei macarale; (mat) înfăşurătoare liniară; a cuprinde; a măsura; (metr) interval (de măsurare a unui calibru), distanță între două repere coardă; (metr) unitate tradițională de măsură pentru lungime: 1 span $=9$ inchi $\sim 22,9 \mathrm{~cm}$

span control (el, autom, metr) regulator de domeniu / de interval

spangle $(\mathrm{OM})$ buclă, lamelă

spangles (met) flori de zinc (şi defect)

span length (constr, el, met) distanță între stâlpi

spanner (OM) cheie de / pentru piulițe

spanner (for concrete iron) (OM) cheie de / pentru fier beton 
spanner hook $(\mathrm{OM})$ cheie cu dinte spanner set box $(\mathrm{OM})$ trusă de chei spanner wrench $(\mathrm{OM})$ cheie pentru piulițe span of control (autom, metr) domeniu / interval de control / de reglare; (ec) mulțime a subordonaților unui director

spar (OM, constr) lonjeron, bară; travesă, căprior; stinghie

spare (OM, mas) piesă de schimb

spare current source (mas, ind, transp) sursă de energie (electrică) de rezervă

spare element (mas, OM, el) piesă de schimb, element de maşină / modul electric / electronic, considerat înlocuibil în caz de deteriorare

sparedeck (nav) spardec, punte continuă deasupra punții principale

spare part (OM, mas) piesă de schimb

spare part number $(\mathrm{OM})$ număr / cod al piesei de schimb

spare parts $(\mathrm{OM}$, mas) piese de schimb

spare-parts deposit (OM, ind) depozit de piese de schimb

spare-parts list (OM, ind) catalog de piese de schimb

spare-parts store (OM, ind) depozit de piese de schimb

spare piece $(\mathrm{OM}$, mas) piesă de schimb

spare set $(\mathrm{TH})$ agregat de rezervă

spare stand (met) cajă de rezervă

spare time (mas, TH) timp disponibil (al maşinii, operatorului etc.)

spare tyre (auto, OM) anvelopă de schimb / de rezervă

spare wheel (auto, OM) roată de rezervă

spare-wheel cover (auto, OM) husă pentru roata de rezervă

spare-wheel safety lock (auto, OM) încuietori de roată de rezervă

spar flange (OM) talpă a lonjeronului

sparger $(\mathrm{OM})$ pulverizator

sparging (alim, $\mathrm{T}$ ) barbotaj

spargingly soluble greu / puțin solubil (d. o substanță)

spark scânteie (la bujie, la sudare); a scânteia; a scăpăra; (fiz) a fulgera

spark adjustment (auto) reglare a avansului

spark advance (auto) avans de aprindere

spark arrester, blow-out catcher (el, fiz) cameră de scântei, parascântei

spark before contact (el) scânteie la închiderea contactului

spark blow-out (el) stingător de scântei

spark breakdown (el) descărcare disruptivă /cu scântei spark catcher (el) extinctor de scântei spark collector (el) grătar parascântei spark-condensing chamber (el, fiz) cameră parascântei

spark control (auto) reglare a aprinderii

spark discharger gap (auto, el) eclator

spark erosion (fiz) eroziune prin / cauzată de scânteiere

spark fuse (fiz, el) amorsă de scânteie

spark gap, sparking gap (el) zonă a arcului, distanță disruptivă / de străpungere; eclator; (fiz) distanţa dintre electrozi (şi la analiza spectrală)

spark ignition (auto) aprindere cu bujie

sparking (el) scânteiere (la sudare), aprindere (prin scânteie), descărcare

sparking alloy (met) aliaj pirofor

sparking ball (el) electrod sferic

sparking coil (el) bobină de inducție

sparking contact (el) contact de scurtcircuitare / de stingere a arcului

sparking plug (el, auto) bujie

sparking plug ignition (el, auto) aprindere cu bujie

sparking retard (auto) întârziere la aprindere

spark killer (el) stingător de scântei

sparkle luciu; (alim) a face spumă, spumos, a fi spumos (d. vin), a degaja bule (de aer) (şi la emulsii)

sparkless (el) fără scântei

sparkless breaking (el) întrerupere fără scântei sparkling switch (el) comutare fără scântei sparkling wine (alim) vin spumos

spark metal working process (met, $\mathrm{TH}, \mathrm{el})$ proces metalurgic prin electroeroziune

sparkover impulse voltage (el) tensiune disruptivă de şoc / de impuls

sparkover (el) descărcare disruptivă

spark plug (auto, el) bujie

spark-plug body (el, OM) corp al bujiei

spark-plug bore / hole (OM) gaură / locaş de bujie spark-plug cable(s) protecting tube (auto, $\mathrm{OM}$ ) tub de protectie a fișelor de bujie

spark-plug fouling (auto) ancrasare / uzare a bujiei

spark-plug gap (auto) distanță a disruptivă a bujiei

spark-plug ignition (auto) aprindere cu bujie

spark-quench(er) (el) circuit eliminator de scântei, parascântei

spark starting (auto, el) pornire cu scântei

spark test (metr, auto) încercare / test cu bujie; (met, TH, metr) test de scânteiere (la sudare)

spark timing (auto) reglare a distribuției / a aprinderii 
spark wear (T, el) uzură prin scânteiere / prin ardere a contactelor (electrice sau la sudură); ardere a contactelor

spark welding (met, TH, el) sudare electrică cu arc electric (cu scântei)

sparry gypsum (constr) gips, ipsos

spar varnish lac pentru bărci

spasmodically $(a d v)(\mathrm{TH})$ spasmodic, prin şocuri spat (metr, geom) unitate de măsură a unghiului solid al sferei: 1 spat $=4 \cdot \pi$ steradiani; (metr, astronomie) unitate de măsură pentru lungimi foarte mari: 1 spat $=1$ terametru $(\mathrm{Tm})=10^{12} \mathrm{~m}$ spatial spațial, în spațiu

spatial distribution (OM, mas, arhit) repartizare în spațiu

spatial grid / lattice (fiz) rețea (şi cristalină) spațială

spatial truss (constr) fermă spațială

spatter strop; pată de noroi; (met) erupție, împroşcare; stropi, stropitură (la sudare)

spatterability $(\mathrm{TH})$ capacitate de împroşcare / de stropire (la turnare, sudare etc.)

spattering (met, TH) împroşcare, erupție (proces nedorit)

spatter loss (met, TH) pierderi prin stropi / prin stropire

spattle, spatula (med) spatulă; (constr, OM) şpaclu spavin (met) argilă refractară, şamotă

speak a conversa; a cunoaşte (o limbă); a enunța; a exprima; a hămăi, a începe sa latre (d. câini); (nav) a intra în legătură, a semnaliza (cu un alt vas), a trimite semnale (unui alt nas, în port etc.); a pronunța; (muz) a răsuna; a rosti, a spune, a sta de vorbă, a vorbi; a şti; (fig) a trăda speak about / of a cuvânta despre, a vorbi despre speak, (on, upon) a ține o conferința (despre), a vorbi public (despre)

spear lance; suliță; harpon, cange; țeapă, țepuşă; (OM) dorn de apucare, furcă; lăncier, sulițaș; ostie (de prins peşte); (ind petrolieră) rac de instrumentatie, sper, ghimpar; a prinde (pește) cu ostia; a străpunge cu lancea

spearmint (alim, bot) mentă

spear pointed drill (mas-un) burghiu plat

special special; specific; determinat; particular; obişnuit

special acceptance acceptare cu rezerve / parțială special account $(\mathrm{ec})$ cont special

special body (auto) caroserie specială

special cast iron (met) fontă de calitate, pentru turnătorie

special driving conditions (auto) conditiii speciale de conducere

special engineer (ind) inginer specialist

special equipment (ind) echipament special

specialist (ind) specialist specialisation specializare (în orice domeniu)

special jaw $(\mathrm{OM}, \mathrm{T})$ falcă aplicată

special key for resetting to zero (metr) cheie specială de reducere la zero

specially-built (ind, mas, OM) construit (în mod) special (pentru)

specially-killed steel (met) oțel superior calmat special piece $(\mathrm{OM})$ piesă specială

special pig iron (met) fontă (brută) (cu destinație) specială

special steel casting (met) piesă turnată din oțel superior

specialty specialitate

species (biol, bot, zool) specie

specific specific, caracteristic

specific adhesion (fiz) adeziune specifică

specific adsorption potential (fiz, T) capacitate / potențial specific(ă) de adsorbție

specific adsorptive capacity (fiz, T) capacitate specifică de adsorbție

specification specificație; condiții tehnice speciale; caiet de sarcini; (inf) documentație pentru soft; descriere a unei invenții

specification of a patent revendicările unui patent

specifications (mas, ind) specificatie / specifcații, prescripții tehnice; (auto) specificații tehnice specifications for delivery (ec) condiții de livrare

specifications for / of quality conditii tehnice de calitate (d. produse şi servicii)

specifications for / of sale (ec) condiții de vânzare / de livrare

specification sheet $(\mathrm{TH}$, inf, c) foaie de date

specific capacity (mas) capacitate specifică, putere / productivitate specifică

specific charge (mec, el) încărcătură specifică (unui proces, unei rețele)

specific consumption (ind, $\mathrm{TH}$ ) consum specific specific electric resistance (el) rezistivitate electrică

specific elongation (mec, materiale, metr) (a)lungire relativă

specific energy energie specifică

specific energy of flow (hidr) energie specifică a curentului

specific energy of position (fiz, mec) energie specifică de poziție

specific energy of shock (mec) energie specifică a şocului

specific fuel consumption (auto, nav, mas) consum specific de combustibil

specific gravity, s.g., SG (metr, materiale) greutate / masă specifică (mărime adimensională); „1,134 SG” este raportul între greutățile specifice sau densitățile a două materiale, de 1,134 
(dacă nu se specifică al doilea material, se subînțelege greutatea specifică ca raport între densitatea materialului şi cea a apei)

specific gravity of the air (fiz) greutate / masă specifică a aerului, densitate relativă a aerului specific heat (fiz, termo) căldură specifică specific heat at constant pressure (fiz, termo) căldură specifică la presiune constantă

specific heat at constant volume (fiz, termo) căldură specifică la volum constant

specific heat capacity (fiz, termo) căldură specifică

specific humidity (fiz) umezeală specifică

specific kinetic energy (mec, fiz) energie cinetică specifică

specific oil consumption (mas, T, auto) consum specific de ulei

specific pressure (hidr) presiune specifică / caracteristică

specific resistance (el, mec) rezistență specifică / caracteristică

specific surface $(\mathrm{T})$ suprafață specifică / caracteristică (unui procedeu de obținere, unui regim de lucru etc.)

specific surface diameter $(T)$ diametrul specific al suprafaței (şi pt. particule, pulberi etc.)

specific thermal capacity (OM, termo, materiale) capacitate termică specifică

specific viscosity $(T$, fiz) vâscozitate specifică

specific volume (fiz) volum specific

specific weight (materiale) greutate / masă specifică, densitate relativă

specific weight of air (fiz) greutate / masă specifică / relativă a aerului, densitate relativă a aerului

specified prescris, fixat

specified criterions (ind, TH) condiții date / specificate / impuse

specified length $(\mathrm{OM}, \mathrm{TH})$ lungime prescrisă / fixată / impusă

specify a specifica; a preciza; a determina; a enunța; a enumera

specimen (metr, OM) epruvetă, probă, mostră; model, exemplar; eşantion

specimen holder (metr, OM) cap de prindere (pt. epruvetă)

specimen of ore (met, metr) probă de minereu

speck particulă; (alim) bob; pată (defect la hârtie, materiale plastice)

specled cu aspect granular; pătat; împestrițat; tărcat

speck of dust (mediu) fir de praf

specks (plast) particule de impurități

specky pătat (d. materiale plastice)

specpure (fiz, metr) spectroscopic pur (d. materiale) specs (ind, mas, OM) condiții de recepție spectacles (opt) ochelari; safety $\sim$, protecting (ind) ochelari de protecție

spectacles lenses (opt) lentile de ochelari spectral (opt) spectral

spectral absorbtion (fiz) absorbție spectrală spectral analysis (fiz) analiză spectrală spectral centroid (fiz) centru de greutate spectral spectral colour (fiz) culoare spectrală spectral decomposition (fiz) descompunere a spectrului

spectral density (fiz) distribuție / densitate spectrală

spectral doublets (fiz) dubleți spectrali

spectral energy distribution (fiz) distribuție spectrală de energie

spectral hue (fiz, TV, c) nuanță de culoare spectrală dominantă

spectral line (fiz) linie spectrală

spectral lines (fiz) linii spectrale

spectral position (fiz) lungime de undă efectivă

spectral purity (fiz) monocromie, puritate spectrală

spectral range (fiz) regiune / interval spectral(ă)

spectral reflectance (fiz) putere reflectoare spectrală, reflectanță

spectral-response characteristic (fiz) caracteristică sensibilitate-lungime de undă a unui tub fotoelectric; (autom) caracteristică spectrală

spectral sensitivity (fiz) sensibilitate spectrală

spectral series (fiz) serie / serii spectrală

spectral term (fiz) termen spectral

spectral tristimulus values (fiz) componente tricromatice spectrale

spectrograph (fiz, metr) spectrograf

spectrometer (fiz, metr) spectrometru

spectrometric analysis (fiz, metr) analiză spectrală / spectografică

spectrometry (fiz, metr) spectrometrie

spectroscope (fiz) spectroscop

spectroscopy (fiz, metr) spectroscopie

spectrum, $(p l)$ spectrums (fiz, metr) spectru; (mat) functie de densitate (spectrală)

spectrum analyser (fiz, metr) analizor spectral spectrum analysis (fiz, metr) analiză spectrală specular (fiz) lucios; reflectant; cu efect de oglindire

specular cast iron (met) fontă oglindă

specular pig iron (met) fontă oglindă

speculate $(\mathrm{ec})$ a specula

speculum (met) bronz cu conținut ridicat de zinc (pt. acoperiri galvanice)

speech discurs; alocuțiune; conferință; cuvinte; darul vorbirii; mod de a se exprima; limbă (vorbită), limbaj (al unui popor etc.); articulare, pronunție, rostire; vorbire; (fig) vorbe, zvon 
speech sound (fonetică) fonem, sunet al vorbirii speed (fiz, mec) viteză; (fiz) fotosensibilitate; grabă, iuțeală, rapiditate, repeziciune; (OM, mas, mec) turație, viteză; (fig) reuşită, succes; a accelera; a activa; a activiza; (fig) a ajuta (pe cineva, cuiva); a da drumul (unei săgeți, etc.); a face exces de viteză; a facilita (votarea, un proiect, etc.); a goni, a (se) grăbi, a iuți, a merge repede; (fig) a înflori, a-i merge (bine), a prospera; a sprijini, a susține (un proiect, etc.), a uşura (o votare pt. un proiect etc.); a trece în zbor, a zbura; a-şi lua bun rămas de la (cineva); a ura drum bun / sănătate (cuiva)

speed-act (TH, mas-un) avans

speed at continuous rating ( $\mathrm{TH}$, mas-un) avans / regim cu viteză continuă

speed at outlet (mec, hidr) viteză de / la ieşire speedboat (nav) şalupă / vedetă / barcă rapidă speed brake $(\mathrm{OM})$ frână centrifugă

speed change (OM, auto, mas) schimbare a vitezelor, cutie de viteze

speed-change box (OM, mas-un) cutie de viteze / de avansuri

speed-change gear box (OM, mas-un) cutie de viteze / de avansuri

speed-change lever (auto, OM) manetă a schimbătorului de viteze, schimbător de viteze

speed control mechanism (OM) mecanism de / pentru schimbarea vitezelor

speed control (OM, mas, autom) reglare a vitezei speed controller / governor / regulator (OM, mas, autom) regulator de viteză

speed control mechanism (auto, mas-un) mecanism de schimbare a vitezei

speed counter / indicator (auto, metr) vitezometru

speed dressing (ind chim, met) soluție de băițuit / de decapat

speed drill (mas-un) burghiu din oțel rapid

speeder $(\mathrm{OM})$ transmisie multiplicatoare, multiplicator, accelerator; (OM, mas, autom) regulator de viteză

speed factor (fiz, mec) coeficient / factor de viteză

speed gear $(\mathrm{OM})$ angrenaj multiplicator

speed governor (mas, autom) regulator de viteză

speed-increaser drive $(\mathrm{OM})$ transmisie multiplicatoare

speed increasing gear pair $(\mathrm{OM})$ angrenaj multiplicator

speed increasing ratio $(\mathrm{OM})$ raport (de transmisie) de multiplicare

speed index plate (mas-un) tăbliță cu vitezele axului de lucru

speed indicator (metr, auto) indicator de viteză speeding up (mec, auto) accelerație, accelerare speeding up force (mas, auto) forță de pornire / de accelerare

speed lathe (mas-un) strung rapid

speed lever $(\mathrm{OM})$ pârghie de regulator de viteze speed lathe (mas-un) strung rapid

speed limit (TH, auto) viteză admisă, limită de viteză

speed-limiting device $(\mathrm{OM}$, autom) limitator de viteză

speed meter (metr, auto) contor de rotații, vitezometru

speed of combustion (chim, termo) viteză de ardere / de combustie

speed of entering (fiz, hidr) viteză de intrare

speed of fall (fiz, hidr) viteză de cădere

speed of growth (fiz, TH) viteză de amorsare / de cresstere (și a cristalelor)

speed of melting (chim, met) viteză de topire

speed of pouring (met) viteză de turnare

speed of propagation (fiz, hidr) viteză de propagare

speed of progression (fiz) viteză de progresare / de avansare

speed of response (fiz, autom, chim) viteză de reacție / de răspuns

speed of revolutions (fiz, mec) viteză de rotație (şi în rotații pe minut sau pe secundă)

speed of rotations (mas, mec) turație, viteză unghiulară

speed of running-in (mas, T) viteză de rodaj

speed of the piston (auto, termo) viteză medie a pistonului

speed of turnover (ec) viteză de rotatie a stocurilor

speedometer (auto, metr) vitezometru, tahometru speedometer cable (OM, electr) cablul de la vitezometru

speedometer flexible shaft (metr, OM) arbore flexibil pentru aparate de măsurat viteza

speed pulley $(\mathrm{OM})$ roată / con în trepte (la cutii de viteze)

speed range (OM, mas-un) etajare a turatiilor, gamă a turațiilor

speed ratio $(\mathrm{OM})$ raport de transmitere

speed reducer / reducing gear $(\mathrm{OM})$ reductor de viteză / de turație

speed reducing gear pair $(\mathrm{OM})$ raport (de transmisie) de reducere (a unei perechi de roți dinţate)

speed reducing ratio $(\mathrm{OM})$ raport (de transmisie) de reducere

speed reduction unit $(\mathrm{OM})$ reductor de viteză / de turație 
speed regulating (autom) (proces de) reglare a vitezei, care reglează viteza

speed regulation (autom, mas) reglare a vitezei / turației

speed regulator (autom, OM) regulator de viteză / de turație

speeds (mas-un) viteză / viteze de aşchiere, $(\mathrm{OM})$ vitezele unei cutii de viteze

speed sensing door lock system (auto, OM, autom) sistem automat de blocare a portierelor în timpul mersului

speed shifting mechanism (auto, mas) mecanism de schimbare a vitezei

speed train (cf) tren rapid / accelerat

speed trial (auto, mas, nav) probă de viteză

speed up (auto, mas, nav) a accelera, a mări viteza

speed-up system $(\mathrm{TH}$, mas, ec) sistem de exploatare maximă

speed variator $(\mathrm{OM})$ variator de viteză, continuu

speed variator with expansion cones (OM) variator cu conuri deplasabile

speedway (auto, constr) autostradă, pistă de încercări

speedy (mec) accelerat

speiss (met) mată (la neferoase)

spell a semnifica; a însemna; a avea drept rezultat; (fig) a implica, a meni, a presupune; (edu) a se ortografia (d. un cuvânt), a ortografia, a pronunța (un cuvânt) literă cu literă; (amer) (mână de) ajutor; alternare; farmec; descântec; (fig) farmec, fascinatie, vrajă; interval (scurt); odihnă; pauză, răstimp; recreație, repaus; (ec) durată a schimbului (de lucru), schimb (al muncitorilor etc.); perioadă (de timp); (mil) schimbare (a gărzii etc.); schimbare; (med) (fam) un atac (al unei boli); (fig) a atrage după sine (o nenorocire etc.); (şi fig) a fermeca

spellerising (met, TH) sfărâmare a tunderului cu cilindrii de laminor

spelter (met) zinc comercial

spelter solder (met) aliaj dur de lipit alamă

spend a cheltui (tot); a (se) consuma (în întregime); a (se) întrebuinta; a se consuma; (iht) a depune icre; (geol) a fi bogat, a produce mult (d. un zăcământ etc.); a-şi cheltui energia / puterile; a fi cheltuitor; a se epuiza; a irosi; a isprăvi (bani, etc.); a se istovi; (meteo) a se linişti, a se potoli (d. furtună etc.); a petrece (timpul); a risipi; a sacrifica; a secătui; a (se) termina (d. bani etc.); a toca (o avere etc.); a se uza (şi moral); (fig) a fi mâna spartă

spent $(\mathrm{TH})$ uzat, consumat, epuizat, inert, folosit; (ec) cheltuit;

spent gas (met, ind chim, termo) gaze reziduale spent grains (alim) tescovină de struguri spent oil (OM, T, termo) ulei uzat spent pickle liquor, spent pickling solution (ind chim, met, TH) soluție reziduală / uzată de la decapare

spent steam (termo) abur uzat

spent sugar-beet pulp (alim) tăiței din borhot (industria zahărului)

spew revărsare; (plast) bavură

SPF (metr, anat) abreviere pentru "sun protection factor" - factor de protecție solară, o caracteristică a cremelor / loțiunilor protectoare împotriva arsurilor de soare sau pentru bronzare; numărul indică de cîte ori mai mult timp o persoană se poate expune la soare dacă foloseşte crema comparativ cu timpul expunerii la soare fără cremă de protecție, cu efecte echivalente; o cremă cu SPF 15 arată că o persoană care poate sta in soare 10 minute fără protecție va putea sta 150 de minute dacă utilizează o astfel de cremă

sphere (geom) sferă; (OM) bilă; (metr) unitate de măsură a unghiului solid al sferei: 1 sphere = $4 \cdot \pi$ steradiani; (metr, astronomie) unitate de măsură pentru lungimi foarte mari: 1 spat $=1$ terameter $(\mathrm{Tm})=10^{12} \mathrm{~m}$; v. spat

spherical (geom) sferic, al sferei

spherical aberration (fiz) aberație de sfericitate, aberație sferică

spherical angle (geom) unghi sferic / solid

spherical ball-bearing (OM) rulment sferic $\mathrm{cu}$ bile, rulment oscilant cu bile

spherical bearing $(\mathrm{OM})$ (lagăr cu) cuzinet sferic / oscilant

spherical boiler $(\mathrm{OM}$, ind hârtiei) fierbător sferic

spherical bushing (OM) cuzinet sferic

spherical buoy (nav) geamandură sferică

spherical cap (geom) calotă sferică

spherical circle (geom) cerc absolut, cercul mare al sferei

spherical cone (geom) sector sferic

spherical coordinates (mat, fiz) coordonate polare în spațiu, coordonate sferice

spherical cutter (mas-un) freză sferică

spherical degree (metr) unitate de măsură a suprafeței relative a sferei, grad sferic: 1 spherical degree $=1 / 720$ din aria totală a sferei

spherical dephlegmator $(\mathrm{OM}$, ind chim) deflegmator sferic

spherical harmonic (mat) funcție sferică de suprafată

spherical helix (geom) curbă situată pe o sferă ale cărei meridiane le taie sub acelaşi unghi

spherical joint (OM, hidr) articulație sferică / tip nucă, racord cu rotulă

spherical lens (opt) lentilă sferică 
spherical mounting (OM, hidr) fixare / montare oscilantă, cu articulație sferică

spherical particle (met) particulă globulară / sferică

spherical plug valve (OM, hidr) robinet / supapă cu sferă / cu ventil sferic

spherical powder (met) pulbere globulară

spherical roller bearing $(\mathrm{OM})$ rulment cu rolebutoi

spherical seat washer $(\mathrm{OM})$ rondelă / şaibă (cu o suprafață sferică)

spherical sector (geom) sector sferic

spherical segment (geom) segment sferic

spherical shell $(\mathrm{OM})$ capsulă / învelitoare globulară / sferică, înveliş sferic

spherical solid harmonic (mat) funcție armonică sferică

spherical shutter (OM, hidr) obturator sferic / cu bilă

spherical surface (OM, geom) suprafață cu curbură constantă, pozitivă

spherical surface harmonic (mat, geom) funcție sferică / armonică de suprafață

spherical thrust bearing (OM) lagăr axial cu bile, crapodină cu bile, rulment axial oscilant (şi cu role butoi)

spherical turning (mas-un, TH) strunjire a suprafețelor sferice

spherical valve (hidr, OM) ventil / supapă / robinet cu bilă

spherical vault (constr, arhit, met) boltă sferică, cupolă, dom (şi de cuptor)

spherical zone $(\mathrm{OM})$ fus sferic, zonă sferică (a unei piese)

sphericity (geom, OM) sfericitate

spheridian, steradian (geom, metr) unitate pentru unghi solid

spheroid (geom) sferoid, elipsoid

spheroidal (geom) sferoidal; (met) globular, nodular

spheroidal cast iron (met) fontă cu grafit nodular spheroidal cementite (met) cementită globulară spheroidal graphite (met) grafit nodular / sferoidal spheroidal graphite cast iron (met) fontă cu grafit nodular

spheroidal pearlite (met) perlită globulară

spheroidal structure (met) structură nodulară / globulară / sferoidală

spheroidisation (met) globulizare, nodulizare

spheroidised pearlite (met) perlită globulară

spheroidising (met) nodulizare, globulizare

spheroidising annealing (met) recoacere de globulizare

spheroidite (met) perlită globulară

spherule (materiale) sferulă, picătură, globulă, bilă (mică), granulă sferică spherulitic-graphite cast iron (met) fontă moale / cu grafit globular

s.p.i. (strokes per inch) (mas-un) curse pe avans de un țol

spice (alim) mirodenie, aromă, condiment

spider (OM) (suport în) cruce, membrană de centrare, suport rotativ

spider box (el, OM) priză multiplă

spider coupling (OM) cuplaj elastic cu bandă de oțel

spider handle $(\mathrm{OM})$ roată de mână cu brațe

spider line (fiz) fir reticular

spider lines (fiz) reticul, rețea reticulară

spider pin (OM) fus / ax de satelit

spider wheel $(\mathrm{OM})$ roată cu spițe

spiegel, spiegeleisen, spiegel iron (met) fontă (silicioasă) oglindă

spigot (OM) lagăr axial, capăt lărgit al țevii, cep (şi de butoi), robinet (cu cep)

spigot and socket joint $(\mathrm{OM})$ îmbinare / asamblare a tuburilor cu mufe

spigot bearing $(\mathrm{OM}, \mathrm{T})$ lagăr de ghidare, solicitat cu efort mic

spigot edge $(\mathrm{OM})$ proeminență / muchie de centrare

spigot joint $(\mathrm{OM})$ îmbinare cu mufe / cu proeminență inelară de centrare

spigot pilot location (OM, hidr) sistem de centrare

spigot point $(O M)$ cep, capăt bombat de şurub

spigot shaft $(\mathrm{OM})$ ştift / cep de centrare

spike (cf) crampon; (OM) dorn, cui lung, ştif, pană, pivot; (autom, el) efect tranzitoriu de scurtă durată; a bate în cuie, a pironi

spike knot nod transversal (în lemn)

spike nail $(\mathrm{OM})$ piron

spike train (el, autom) tren / serie de impulsuri, curent iterativ

spile cep (mic); (constr) dulap de sprijinire, par, pilot înfipt, palplanşă

spill (hidr) revărsare; (met) defect metalic (în general), ruptură, pliu (la laminare); sudură incompletă / întreruptă, nepătrundere (defect de sudură); (fiz) accident de contaminare cu substante toxice sau radioactive; a revărsa; a da pe afară; a vărsa, a răsturna

spillage (hidr) pierderi prin scurgere / prin debordare

spillage sand (met) amestec de formare / nisip recirculat

spilling (hidr) împrăştiere

spill-over (hidr) a deversa peste

spill pipe (hidr, OM) racord de golire, țeavă / conductă de preaplin, deversor, ștuț de scurgere spills (met) sufluri, defecte interne (la turnare)

spill valve (hidr, OM) supapă de golire / de preaplin 
spill water $(\mathrm{TH}, \mathrm{alim})$ apă excedentară

spin (mec) învârtire, răsucire, rotire; torsiune; a învârti; a roti; (fiz) (moment de) spin; (inf, c) întârziere cu un pixel (la prelucrarea imaginii); (mas-un) patinare; $(\mathrm{TH})$ a centrifuga; a presa (prin rulare); a învârti; a roti; (metr, fiz) unitate de măsură pentru moment unghiular în fizica particulelor, unitate de spin: 1 spin unit $\cong$ $105,45727 \cdot 10^{-36} \mathrm{~J} \cdot \mathrm{s}$

spin bath (alim, ind chim) baie de coagulare / de precipitare

spin casting (met, $\mathrm{TH})$ turnare centrifugală

spin chiller (ind chim, alim) răcitor cu tambur agitator / rotitor

spindle axă; (OM) fus, osie, pivot, arbore, tijă, fuzetă; (mas-un) şurub de menghină, pinolă; (textile) fus, ax, tijă; (bot) vrej, lujer; (metr, textile) fus, unitate tradițională de măsură pentru lunimea firelor; 1 spindle of cotton yarn (fus de bumbac) $=13,826 \mathrm{~km}, 1$ spindle of jute (fus de fibră de iută) $=13,167 \mathrm{~km}$

spindle bearing $(\mathrm{OM})$ lagăr / pivot al fusului

spindle box (mas-un) păpuşă fixă / a axului principal

spindle connecting rod $(\mathrm{OM})$ bară de legătură de directie

spindle control lever (OM, mas-un) manetă / pârghie de cuplare şi decuplare (a arborelui principal)

spindle device (met, $\mathrm{OM}$ ) bară de cuplare

spindle frame (mas-un) păpuşă port-sculă (la maşini orizontale de frezat)

spindle guide bearing $(\mathrm{OM})$ lagăr de ghidare

spindle head (mas-un) păpuşă port-sculă

spindle head stock (mas-un) păpuşă fixă

spindleless shuttle (textile, OM) suveică fără fus

spindle nose (mas-un) cap (anterior) al arborelui principal

spindle press (mas-un) presă cu şurub

spindle shuttle (OM, textile) suveică cu fus

spindle sleeve (mas-un) pinolă, ax al păpuşii mobile, manşon al arborelui principal (la maşini de găurit)

spindle speed change (OM) cutie de viteze, $\mathrm{cu}$ fusuri

spindle speed function (mas-un, autom) funcție pentru turație (în comanda numerică a maşinilor-unelte)

spindle stop (OM) ax opritor

spine $(\mathrm{OM})$ ac, creastă, canelură; cotor (de carte)

spined pin (OM) ştift crestat

spined spanner $(\mathrm{OM})$ cheie inelară, cu caneluri

spine grinder / grinding machine (mas-un) maşină de rectificat caneluri spine hub $(\mathrm{OM})$ butuc canelat

spinel ferrite (met) ferită cu structură spiralată

spin hardening (met) călire / durificare prin centrifugare

spin in $(\mathrm{OM}, \mathrm{TH})$ a mandrina o țeavă, a monta prin răsucire (forțată)

spinneret (plast, OM) filieră, duză (la maşini de prelucrat fibre)

spinning (mec, fiz, OM) care se răsucește / se întoarce, care se învârteşte, rotitor; (av) coborâre în vrie; ( $\mathrm{TH}$, mas-un) fasonare prin presare la drucbanc; (textile) filare, filatură, care toarce, de tors, torcător; $(\mathrm{OM})$ piesă fasonată la drucbanc

spinning bath (ind chim, plast) baie de filare / de coagulare

spinning boiler (ind chim, alim) cazan rotativ de fierbere

spinning box / pot (ind chim, plast) centrifugă / oală de filare

spinning lathe (mas-un) strung de presat (prin rulare / rotire a unui dispozitiv, a unor role etc.)

spinning machine (mas-un) maşină de răsucit / de filetat; (textile, plast) maşină de filat

spinning riffler (alim) riflu de întoarcere / de rotire

spinning temperature (textile, plast) temperatură de filetare (la cald)

spinning top $(\mathrm{OM}, \mathrm{mec})$ pendul giroscopic

spinode (mat) punct de întoarcere (al unei curbe)

spin-on filter (OM, hidr) filtru amovibil

spin out $(\mathrm{TH}$, alim, ind chim) a centrifuga

spin velocity (mec, fiz) viteză de spin / de rotație

spiral (geom) spirală; (TH) elicoidal

spiral bevel gear (OM) angrenaj conic cu dinți elicoidali / curbi, roată conică cu dantură curbă (în spirală)

spiral chute $(\mathrm{OM})$ jgheab / canal elicoidal

spiral classifier (alim, ind) clasor / sortator elicoidal

spiral coil (alim, ind chim) serpentină elicoidală

spiral coil of pipe (alim, termo) (țeavă în) serpentină

spiral condenser (alim, ind chim) condensator spiral

spiral condensing tube (alim, termo) serpentină de răcire / de condensare

spiral conveyer (alim, ind chim) transportor elicoidal

spiral cut reamer (mas-un) alezor cu dinți elicoidali

spiral dividing-head (mas-un) cap divizor universal (pt. frezări elicoidale)

spiral drill (mas-un) sfredel / burghiu elicoidal 
spiral drilling machine (mas-un) perforator rotativ, cu burghiu elicoidal

spiral gear $(\mathrm{OM})$ roată dințată cu dinți elicoidali / curbi

spiral geared planer (mas-un) raboteză cu acționare prin melc sau cremalieră cu dinți înclinați

spiral gearing $(\mathrm{OM})$ angrenaj elicoidal, angrenare cu dinți înclinați

spiral head (mas-un) cap divizor universal pentru caneluri elicoidale

spiral heat exchanger (termo) schimbător de căldură elicoidal / în spirală

spiral line (mat, geom) linie / curbă elicoidală, spirală

spirally welded tube (met, OM, TH) țeavă / conductă cu sudură elicoidală

spiral milling cutter (mas-un) freză cu dinți elicoidali

spiral point (mat) focar (la ecuații diferențiale)

spiral spring $(\mathrm{OM})$ arc elicoidal

spiral thread (OM) filet elicoidal

spiral thoothing $(\mathrm{OM})$ dințare / angrenare cu dinți înclinați, dantură înclinată / elicoidală

spiral tube (alim, ind chim, termo) serpentină de țeavă

spiral walk (OM) pas al melcului / al spirei (de arc, de filet etc.)

spiral welded pipe (met, OM) țeavă sudată elicoidal / în spirală

spiral wheel $(\mathrm{OM})$ roată melcată

spiral worm (OM, termo) serpentină de țeavă, melc (elicoidal)

spiral wrap $(\mathrm{OM}$, el) înfășurare în spirală a unui material, pe un miez

spire (geom, OM) spirală, spiră; săgeată, fleșă

spirit (ind chim) alcool, spirt; benzină, carburant

spirit gauge (alim, metr) alcoolmetru

spirit level (constr, metr) nivelă cu bulă de aer

spirit of salt (chim) acid clorhidric

spirit of wine (alim) distilat de vin

spirituous (alim) spirtos, alcoolizat

spit (alim) frigare, a pune pe frigare; (met, TH) a tropi, a împroșca (la sudură); (geogr) banc de nisip, limbă de pământ, ieşind al țărmului; (OM, constr) cazma, hârleț; chip leit; (nav, metr) sondă de control al mărfurilor ambalate; a cerne; (anat, med) expectorare, expectorație, scuipare, scuipat, salivă, a expectora, a scuipa (sânge etc.); (meteo) bură, fulguială, ninsoare / ploaie slabă, ploiță, a fulgui, a ninge slab, a ploua slab, a bura spitting (met) împroşcare, stropire (la cuptoare, la sudare)

splash (TH) împroşcare, stropire; pată; a pulveriza; a stropi; (met) stropi, picături (de metal); a (se) împroşca, a (se) murdări, a stropi, a păta (cu apă, cu noroi etc.); (metr) minilinguriță, unitate de măsură pentru volum (pt. materiale solide si lichide), utilizată în rețete culinare, aproximativ egală cu 1/8 dintr-o linguriță: 1 splash $\sim 0,6 \mathrm{ml}$; (fam) apă gazoasă, sifon, pudră de / pentru față; lipăit (al paşilor); pată (de culoare, lumină etc.); (meteo) picătură, strop (de ploaie etc.), pleoscăit, răpăit (al ploii), a pleoscăi, a răpăi (d. ploaie); (fam) (fig) senzație; (fig) apă, lac, ocean; (fig) un pahar cu apă; a se bălăci, a bălăci (picioarele), a lipăi / merge împroșcând (în dreapta şi în stânga); (fig) a împodobi, a presăra, a smălța (câmpul etc.); a publica la loc de frunte (într-un ziar etc.); (poligrafie) a pulveriza; (fig) a scălda (în lumină etc.); a stropi; a țâşni; a vărsa (un lichid); (fig) a atrage atenția prin a face ceva, a face cuiva publicitate; (fig) a se îmbăia, a se scălda

splash apron (auto, TH) apărătoare împotriva stropirii / împroşcării (cu noroi, cu apă, cu stripi de material topit etc.)

splash lubrication $(\mathrm{T})$ ungere / lubrifiere prin barbotare

splash packing (OM, T) dispozitiv de dispersare / de împrăștiere / de stropire (a apei / a lubrifiantului etc.)

splash proof $(\mathrm{OM})$ protejat contra stropirii

splash ring inel (OM, T) (inel) deflector de ulei I de ungere

splasher (OM, mas-un) cutie de protecție contra stropilor

splashing $(\mathrm{OM}, \mathrm{T})$ barbotare

splash lubrication (T) lubrifiere prin barbotare / împroşcare (datorită antrenării fluidului de către piesele care trec prin baia de lubrifiant)

splash-proof (el, $\mathrm{TH})$ protejat contra stropirii

splashings (met) stropituri de metal

splay (mas-un, OM) refulare a capătului de şurub, teşit, evazat (d. tuburi, țevi); a sprijini; a propti; (TH) a teşi; a evaza; a lărgi

splaying (constr, OM) rost

splash (into) a cădea bâldâbâc / pleosc (în)

splice (OM) îmbinare, jantă, racord, prelungitor (şi cu rol de adaptor), lipitură; a îmbina capla-cap (şi la sudură), a racorda; (el) conexiune directă a firului; matisare

splice-bar (OM) eclisă de îmbinare cap-la-cap

splice box $(\mathrm{OM})$ manşon de legătură

splice housing $(\mathrm{OM})$ carcasă reglabilă / care se poate adapta modificării poziţiei pieselor interioare

splice piece $(\mathrm{OM})$ eclisă

splice plate $(\mathrm{OM})$ eclisă (plată) de îmbinare cap la cap (şi la sudură), guseu

splicer (mas-un) presă de lipit

splice web $(\mathrm{OM}$, constr) îmbinare a grinzii verticale 
splicing (TH) matisare, înnădire; îmbinare cu eclise; întărire

splicing ear / ring (el, OM) inel de conexiune splicing sleeve $(\mathrm{OM})$ manșon de legătură splicing tape $(\mathrm{OM})$ bandă adezivă

spline (OM) canal de pană, canelură, şanț, nut, golul dintre caneluri, renură, nervură; (mat) curbă spline

spline a keyway (mas-un) a executa un canal de pană

spline and keyway miller / milling machine (mas-un) maşină de frezat canale de pană

spline and keyway milling cutter (mas-un) freză pentru canale de pană

splined (OM) cu caneluri

splined arbor / shaft (OM) arbore canelat (şi la interior)

splined hub $(\mathrm{OM})$ butuc canelat

splined pin $(\mathrm{OM})$ ştift crestat

splined spanner (OM) cheie inelară, cu caneluri

splinegrinder / grinding machine (mas-un) maşină de rectificat caneluri

spline hob (mas-un) freză-melc de prelucrat arbori canelați

splined joint (OM) asamblare cu pană / cu caneluri

spline shaft $(\mathrm{OM})$ arbore canelat

spline shaft hob (mas-un) freză-melc de prelucrat arbori canelați

spline shaft milling cutter (mas-un) freză profilată, de prelucrat arbori canelați

splining tool (mas-un) cuțit de canelat

splint (OM) şplint, cui spintecat

splint coal (met, termo) huilă cu flacără lungă

splinter (met, mas-un) aşchie, şpan; (fiz) a (se) cliva; fragment; țandără

splintering (TH) aşchiere, acțiune de tăiere, împărțire a unei piese (de obicei în părți identice)

splinter off $(\mathrm{TH})$ a tăia / secționa prin aşchiere, a aşchia

splinter-proof $(\mathrm{OM}$, mil) protejat contra schijelor / aşchiilor

splinter-proof glass (ind chim) sticlă securit

splint pin $(\mathrm{OM})$ şurub prizonier, (şurub cu) şplint

split $(\mathrm{OM})$ ruptură; separație; sciziune; scindare; despicare; crăpare; (alim) băutură amestecată / răcoritoare; (met, plast) fisură longitudinală; (OM) canelat, crestat, tăiat, împărțit, divizat, despărțit (intenționat sau nu); a despica; a tăia, a (se) desface; a dezbina; a (se) scinda, a (se) crăpa, a sparge, a fractura; a frânge; a (se) rupe, a (se) întredeschide; a împărți, a diviza, a dezintegra (în bucăți mai mari); (chim) a disocia, a descompune; a dezagrega; (fiz) a dezintegra, a cliva; (metr) unitate de măsură pentru volum, pentru băuturi tari: 1 split $=177,4 \mathrm{ml}$; sticlă mică de vin $(\sim 1 / 4$ din volumul unei sticle standard $=187,5 \mathrm{ml}$ )

split adjusting collar (OM) inel secționat, de / pentru ajustare

split axle (OM) arbore secționat

split bearing $(\mathrm{OM})$ lagăr demontabil / din mai multe bucăți (şi identice)

split bushing $(\mathrm{OM})$ bucșă secționată

split casing $(\mathrm{OM})$ carcasă demontabilă / din mai multe bucăți

split cavity (met, plast, OM) submatriță, modul de matriță

split chuck (mas-un, OM) mandrină de prindere a piesei, în mai multe locuri

split core box (met) cutie de miez, din două (sau mai multe) bucăți

split cotter $(\mathrm{OM})$ şplint

split die (met, plast) matriță demontabilă / din mai multe bucăți / părți

splitery fracture (fiz) spărtură de clivaj

split flywheel $(\mathrm{OM})$ volant demontabil / din mai multe bucăti

split folding rear seat (auto, OM) deblocare a banchetei (din) spate, banchetă spate fracționabilă / din bucăți

split fractions (mat) fracții ordinare

split gear $(\mathrm{OM})$ roată dințată demontabilă sau din mai multe bucăți

split mould (OM, mas-un) matriță modulată

split (muff) coupling (OM) cuplaj cu manşon secționat

split nut $(\mathrm{OM})$ piuliță din două sau mai multe părți

split off (mas-un, TH) a aşchia (şi cu aşchii mari), a împărți, a despica, a spinteca, a separa, a ciopli; (fiz) a (se) dezintegra, a (se) scinda

split pattern (met) model de turnătorie demontabil, din bucăți / modulat

split pin (OM) ştift / şplint de siguranță, cui spintecat

split-pin extractor $(\mathrm{OM})$ extractor de şplint

split-pin pliers $(\mathrm{OM})$ cleşte de / pentru tragerea şplintului

split / slotted piston skirt (OM) cămaşă secționată de piston

split (point) (el, hidr) punct de ramificare

split pulley $(\mathrm{OM})$ roată de transmisie asamblată / modulată / din bucăţi

split rim (auto, $\mathrm{OM}$ ) jantă modulată

split rotor (el) rotor divizat / modulat

splits (materiale) fisuri, crăpături

split section of a bearing (OM, nav) parte componentă a unui cuzinet de lagăr, format prin montarea mai multor părți de acelaşi fel 
split shipment (nav, transp) partidă de mărfuri împărțite pentru a putea fi expediată cu mai multe nave

split-skirt piston (OM) piston cu cămaşă / manta despicată

split sleeve $(\mathrm{OM})$ bucşă despicată

split source (el, hidr) sursă divizată

splitter (ind chim) autoclavă pentru scindarea grăsimilor; (termo, OM) placă de scindare / de distribuție, distribuitor de aer (şi la cicloane); (hidr, OM) plăci dispuse în coturi de conducte pentru minimalizarea căderii de presiune şi uniformizare a curgerii, paletă directoare, separator de ieşire

splitting descompunere; disociere; scindare, dezagregare; (fiz) clivaj, (sub)divizare; despicare; (OM) furcă pentru mutarea curelei, despărțire / demontare a unei piese în părți (egale), demontare în părți componente (d. un modul, un subansamblu etc.); (met) fisurare; (T) spargere a emulsiei; crăpat; despicat; ramificat; scindat

splitting air current (termo, ind) ramificare a curentului de aer / de gaze (la climatizare, la cicloane în ciorchine)

splitting key (el) separator electric

splitting of chain (chim) rupere a catenei / a lanțului molecular

splitting off (TH) spintecare, care despică / desparte (în două sau mai multe părți)

splitting out (TH) spintecare (cu separare), separare

splitting product (chim) produs de disociere

splitting resistance (TH, materiale) rezistență la despicare

splitting up (TH) dezagregare; descompunere; clivaj; dezagregare; împărțire; divizare; dezintegrare

splitting wheel $(\mathrm{OM})$ roată dințată segmentată, disc sectionat

split up (TH) a fisura, a despărți, a demonta în bucăți; a cliva; a crăpa

splutter (hidr) stropire, împroşcare, bolborosire; a stropi, a bolborosi; (mas) a pârâi

spoil (ec) profit; comoară; (constr, nav) dragare, excavație; (ind, mediu) gangă, steril, haldă (de steril), material excavat, rocă sterilă; pagubă, stricăciune; premiu (la un concurs etc.); tezaur (literar etc.), trofeu; (fig) victimă, jertfă, pradă; a (se) strica, a (se) defecta; a cocoli, a răsfăța; a deposeda; a desperechea (un serviciu, o serie, o colecție); (şi fig) a deteriora (un obiect etc.), a distruge (o foaie de hârtie, o glumă, un efect etc.); a face prădăciuni, a jefui (un ținut etc.); a se altera, a se învechi, a nu mai fi bun / de folos (d. hrană etc.) spoilage (TH, ind) rebut; deşeu; (alim) alterare, degradare

spoiled (OM) stricat; (materiale) degradat; (alim, chim) alterat

spoiled castings (met) piesă turnată la temperatură (prea) mică, rebut de turnare spoiling alterare; stricare; degradare spoils (ind hârtiei) maculatură spoil sheet (ind hârtiei) foaie (de hârtie) / folie stricată / murdară / degradată

spoke $(\mathrm{OM})$ treaptă, spiță

spoke centre $(\mathrm{OM})$ butuc cu spițe

spoke copying machine (mas-un) maşină de copiat pentru confecționarea pieselor de revoluție, din lemn

spoked wheel $(\mathrm{OM})$ roată cu spițe spoke flywheel (OM) volant cu spițe spoke key $(\mathrm{OM})$ cheie de spițe spoke nipple $(\mathrm{OM})$ piuliță pentru spițe spoke wheel $(\mathrm{OM})$ roată cu spițe spoke wire $(\mathrm{OM})$ sârmă de / pentru spițe sponge burete; buretos, spongios ( $\mathrm{d}$, materiale plastice); a absorbi; a (se) îmbiba

sponge iron (met) fier spongios

sponge metal (met) metal / aliaj spongios

sponge out a şterge cu buretele

sponge rubber (plast, ind chim) cauciuc spongios / buretos / celular, burete de cauciuc

sponging (ind chim, termo) proces de trecere în stare spongioasă / poroasă / buretoasă (la materiale de etanşare, din cauza absorbției de fluide şi a variaţiei temperaturii)

sponginess stare spongioasă (d. materiale plastice)

sponging agent (chim) agent porogen

spongious; spongy spongios, buretos, poros (d. materiale plastice)

spongy cast iron (met) fontă poroasă

spongy material material poros / spongios

spongy surface suprafață spongioasă / fragilă

spontaneous spontan; automat; natural

spontaneous coagulation (alim, ind chim) autocoagulare, coagulare spontană

spontaneous combustion (termo) combustie / ardere spontană

spontaneous crystallization (fiz, met) cristalizare spontană

spontaneous fermentation (alim, mediu) fermentație / fermentare naturală

spontaneous firing (materiale, termo, ind) autoaprindere, aprindere spontană

spontaneous ignition temperature (materiale, termo) temperatură / punct de autoaprindere

spontaneous inflammation (materiale, termo) autoinflamare 
spool (el, met, plast) bobină, rolă, rulou; mosor; dispozitiv de înfăşurat, vârtelniță; (hidr, OM) plunjer; (mas) tambur de cablu (la macara); a înfăşura, a bobina

spool chain $(\mathrm{OM})$ lant de troliu

spooler (el) mecanism / dispozitiv de bobinaj

spool gear $(\mathrm{OM})$ roată dințată de lățime mare

spooling (el, met, plast, textile) bobinare, depănare, derulare

spool shut-off valve (OM, hidr) robinet / supapă cu cep cilindric

spool valve (OM, hidr) distribuitor / supapă cu cep / sertar cilindric

spool wire (el, met) sârmă de bobinaj

spoon lingură; (met) lingură pentru luat probe lichide; netezitor pentru suprafața cusăturii de sudură

spoon bit (mas-un) burghiu lingură

spoonful (metr, alim) unitate de măsură pentru volum, (cantiate care încare într-o) lingură

spoon sample (met) probă luată cu lingura (din cuptor, convertizor, oală)

spoon scraper (mas-un) răzuitor de suprafețe curbe

spoon (test) specimen (met) probă / epruvetă turnată cu lingura

spot (mas-un) antegăurire; (fiz, c) urmă, pată, punct / element de imagine (şi pe ecran), spot; poziție; punct a (se) păta, a strica; a recunoaşte spot analysis (materiale, metr) analiză în picături

spot annealing (met) recoacere locală

spot cash (ec) plată imediată în numerar

spot check control prin sondaj

spot corrosion (met, chim) coroziune punctiformă / în puncte

spot cure (ind chim, plast) vulcanizare locală

spot deal / transaction (ec) operație cu mărfuri disponibile

spot drilling (mas-un) centruire, gaură mică de ghidare (a sculei următoare)

spot face $(\mathrm{OM})$ suprafața de reazem a bosajului spotfacer (mas-un) sculă / cuțit de prelucrat suprafața de reazem a bosajului

spot goods (ec) mărfuri disponibile

spot hardening (met) călire locală a suprafeței

spot market (ec) piață cu plata în numerar / cu mărfuri disponibile / cu ofertă imediată

spot measuring (metr) măsurare la întâmplare

spot of light (fiz) indicator / spot luminos, spot luminos (la aparate optice)

spot price (ec) pret pentru mărfuri disponibile

spot reconditioning (TH) reparare / recondiționare pe loc / fără demontare

spots (ec) mărfuri disponibile

spot segregation (met) segregare locală spot spacing $(\mathrm{OM})$ pasul la sudarea în puncte, distanța între punctele sudate

spotted împestrițat; tărcat; pestriț; pătat

spot test (materiale, metr) probă de analiză (în picături)

spotting apariție de pete, pătare

spotting tool (mas-un) sculă / cuțit de centrare

spot weld $(\mathrm{OM})$ cusătură de sudură în / prin puncte; a suda prin / în puncte

spot-welded $(\mathrm{OM})$ sudat prin puncte

spot-welder, spot-welding machine (met, maun) maşină de sudare prin puncte

spot welding $(\mathrm{TH})$ (procedeu / metodă de) sudare electrică prin / în puncte

spout $(\mathrm{OM})$ nas, cioc, camă, ajutaj, piesă terminală, bucşă, duză, manşon terminal, deversor; (met) canal / jgheab de turnare; buză de golire la un vas; (fiz) deschidere / fantă (pt. unde); a erupe; a împroşca (cu fluid); a prevedea cu o scurgere, a avea o scurgere

sprag brake $(\mathrm{OM})$ frână cu saboți

spray picături; lichid pulverizat; duş; pulverizator; ceață fină (şi de lubrifiant); duză; (hidr) jet, spray; a pulveriza, a stropi (fin); a iriga; a uda; a difuza

spray adhesive (plast) adeziv (aplicabil) prin pulverizare

spray arrester $(\mathrm{OM}$, el) placă contra împroşcării (cu acid, la cumulatoare), placă deflectoare (pt. fluid împroșcat)

spray booth / chamber (ind, TH) cabină pentru vopsire prin pulverizare

spray carburettor (auto) carburator cu jiclor

spray catcher $(\mathrm{OM}, \mathrm{T})$ separator / captator de picături

spray condenser (termo) condensator cu stropire

spray cooler (alim, ind chim) răcitor prin stropire

spray cooling (termo, alim) răcire prin stropire / prin pulverizare

spray disk $(\mathrm{OM})$ disc de pulverizare

spray-dried rubber praf de cauciuc depus prin pulverizare şi uscare

spray-dryer (mas) uscător cu / prin pulverizare

spray-drying $(\mathrm{TH}$, alim, ind chim) uscare prin pulverizare

sprayed cathode $(\mathrm{el}, \mathrm{TH})$ catod cu pulverizare

spray(ed) deposit (materiale, $\mathrm{TH}$ ) material strat depus / acoperire prin pulverizare

sprayed metal coating (met, $\mathrm{TH}$ ) acoperire metalică obținută prin pulverizare

sprayer (OM) pulverizator, stropitor, injector; (met) pistol de pulverizare pentru acoperiri metalice; (auto) jiclor; (OM, hidr) distribuitor sprayer carburettor (auto) carburator cu jiclor / prin injecție 
sprayer valve (OM) supapă de pulverizare spray evaporator (alim, ind chim) evaporator cu pulverizare

spray-gun (auto, ind chim) maşină de torcretat, pistol pentru vopsit prin pulverizare

spraying (auto, ind chim) (acțiune / proces de) stropire, pulverizare, care pulverizează / stropeşte

spraying apparatus $(\mathrm{OM})$ pulverizator

spraying carburettor (auto) carburator cu jiclor

spraying chamber (ind chim, auto) cabină / cameră pentru vopsire prin pulverizare / de pulverizare / de stropire

spraying nipple (auto, termo) jiclor de / pentru pulverizat combustibil

spraying nozzle $(\mathrm{OM})$ duză / ajutaj de pulverizare

spraying pistol $(\mathrm{OM})$ pistol de vopsit

spraying washer fluid (auto, $\mathrm{TH}$ ) pulverizare a lichidului de spălare

spray jet (OM) pulverizator, duză / ajutaj de pulverizare

spray lubrication $(\mathrm{T})$ ungere prin barbotare / prin pulverizare / prin împroșcare

spray metal coating (met, $\mathrm{TH}$ ) acoperire prin pulverizare cu metal

spray nozzle $(\mathrm{OM})$ duză de pulverizator, ajutaj de injectie

spray-nozzle tube $(\mathrm{OM})$ țeavă / recipient cilindric cu ajutaj de stropit, spray

spray oil (ind chim, biol) ulei insecticid

spray on a stropi; a aplica prin pulverizare, a pulveriza pe, a împrăştia pe

spray painter $(\mathrm{OM}$, ind chim) pulverizator de soluție / de cauciuc / de vopsea

spray painting (TH, ind chim) vopsire cu pulverizator de vopsea / prin pulverizare

spray pipe (OM, T) țeavă de stropire (şi cu scop de ungere)

spray pyrolysis (ind chim, alim) piroliză prin pulverizare

spray quenching (met, TH) călire prin stropire / prin pulverizare

spray ring $(\mathrm{OM}, \mathrm{T})$ inel stropitor / de ungere

spray shield (met, TH) acoperire (de protecție) executată prin pulverizare

spray tower (met, mediu) scruber / turn de spălat gaze / de stropit

spray-type tower cooler (met, ind chim) turn de răcire prin stropire

spray unit $(\mathrm{TH}, \mathrm{met})$ instalație de metalizare / de acoperire prin stropire / prin pulverizare

spray valve $(\mathrm{OM})$ supapă de injecție

spread (fiz) dispersie (a valorilor, particulelor etc.); distribuție; întindere; extindere; răspândire; lărgire; împrăștiere; expansiune; dezvoltare; abatere; spațiu; (ec) diferență între prețul de fabrică și cel de vânzare, diferență (între două tarife), profit; (alim) aliment care se poate unge pe pâine; amploare, (av) anvergură (a aripilor etc.); anvergură (d. un fenomen etc.); ( $\mathrm{fam}$ ) ospăț, banchet, petrecere, bairam, chef, zaiafet, festin; (textile) cuvertură de pat, față de masă, plapumă; învelitoare; desfacere, desfăşurare (a aripilor etc.); (med, fiz) difuzare, propagare; (TH) expansiune, extensiune, extindere; întindere (a aripilor etc.); lărgime; (met, TH) lărgire; lățire; (constr) deschidere, lățime (unei bolți), răspândire a betonului; articol în ziar, ziar; a (se) extinde, a prelungi (pe o perioadă de timp, în spatiu); a (se) întinde; a se lăbărța; a (se) răspândi, a (se) împrăştia (d. o boală, o ştire, un miros etc.); a (se) lărgi; a acoperi; a (se) propaga (d. boli, un fenomen etc.); (ind chim) a cauciuca (şi țesături); a arăta; a aşterne (masa, îngrăşământ, un covor etc.); a (se) desface, a (se) desfăşura (d. aripi, o acțiune etc.); (bot) (d. flori) a se deschide; a (se) difuza (d. stiri etc.); a etala; a împrăştia, a presăra, a distribui (îngrăşământ, etc.); a întinde (masa, aripile, un covor etc.); a pune (masa, îngrăşământ etc.); a exala (un miros); a căuta să facă impresie; a-și da aere; a face pe nebunul, a se grozăvi; a vorbi prea pe larg; smth. on the records a consemna / nota ceva într-o minută / într-un proces verbal

spread coating goods (ind chim) articole cauciucate

spreader $(\mathrm{OM})$ distribuitor; întinzător; dispozitiv de lărgire, dispozitiv de împrăştiere; (plast, masun) maşină de cauciucat / de aplicat prin întindere (cu lamă / racletă), aplicator (şi de adeziv); (met) cajă lărgitoare; alimentator; derulator

spreader calender $(\mathrm{OM})$ calandru de fricțiune / de întins substante vâscoase (tip cauciuc, materiale plastice) pe țesături

spreader mark (met) urmă de alunecare (la laminare, tragere, extrudare)

spreading $(\mathrm{TH})$ întindere, difuzare, dispersare, împrăştiere; lățire; (plast) cauciucare a tesăturilor (la maşina de cauciucat); dispozitiv de alimentare; (constr) răspândire / împrăştire a betonului; care (se) răspândeşte / (se) difuzează / (se) distribuie etc; v. spread

spreading chest (ind chim, OM) masa încălzită a maşinii de cauciucat

spreading coefficient (fiz, chim) coeficient de difuziune

spreading device (textile) dispozitiv de lățire; (ind chim) dispozitiv de împrăștiere

spreading knife (ind chim, OM) cuțit de întins amestecul de cauciuc pe tesătură 
spreading lens (fiz) lentilă divergentă spreading machine (textile) maşină puitoare spreading mix (ind chim, textile) amestec de cauciuc pentru impregnarea țesăturilor spreading of a beam (fiz) împrăştiere / dispersie / lărgire a unui fascicul

spreading process (fiz) proces de propagare; (ind chim, textile) proces / procedeu de impregnare

spreading shop (ind chim) atelier de cauciucat țesături

spread of adhesive (plast) împrăştiere / depunere a adezivului; a împrăştia / depune adeziv

spread on a întinde, a vopsi, a unge; a împrăştia / presăra pe

spread out a întinde peste; a împrăştia în afară

spread over a împrăştia peste / pe; a presăra peste / pe; a acoperi; a întinde peste / pe

spreadsheet (inf) soft pentru analiaza informatiilor tabelate

spread velocity (fiz) viteză de propagare / de difuziune / de împrăş̧iere

sprig (OM) cui mic (fără floare), țintă; a bate / a prinde în cuie; a tintui

spring primavară; salt; săritură; sursă; izvor; (mec) elasticitate, caracter elastic; flexibilitate; cişmea; (nav) spărtură, crăpătură (în vas); (geol, higr) izvor; (fig) elasticitate, flexibilitate; (fig) izvor, obârșie, origine, sursă, temei; ( $f i g)$ cauză, pricină; (fig) zori, auroră; de primăvară, primăvăratic; (OM) arc, resort; (mec, OM) a arunca, a țassni, a (se) arcui, a se îndoi elastic, a sălta, a sări (peste) (un zid, o piesă etc.); a anunța brusc (o ştire etc.); a apărea, a se ivi, a răsări; a crăpa; a găuri; a plesni; a face să plesnească; a dezvălui brusc; a exploda, a face explozie, a face sa explodeze (o mină); (hidr) a izvorî (d. un râu etc.), a țâşni (d. un jet etc.); a da pe față (un fapt); (bot) a înmuguri, a răsări, a încolți (d. o plantă etc.); a se ridica brusc în picioare; a se scoroji, a se strâmba (d. o scândură etc.); (jur) (fig) a obține eliberarea cuiva din închisoare pe cauțiune, a amnistia, a evada; (fig) a începe lucrul / treaba; act $\mathbf{a} \sim(\mathrm{mec})$ a acţiona un resort

spring action (mec) arcuire, acțiunea unui arc

spring activation $(\mathrm{OM})$ acționare $\mathrm{cu}$ arc

spring adjusting collar (OM) inel elastic de fixare

spring a leak (OM, hidr) a avea o gaură (d. o conductă, un recipient etc.); (nav) a avea o gaură de apă (d. navă), a face o spărtură (în vas)

spring a surprise on smb. a face cuiva o surpriză

spring at a sări la (cineva) (şi fig), a se năpusti asupra (cuiva) (şi fig), a se repezi la (cineva) spring from (fig) a izvorî din, a porni de la, a-şi avea cauza în, a-şi avea izvorul în, a-și avea obârşia în

spring into existence a apărea brusc, a se ivi, a se naşte

spring off a sări în afară (d. un arc etc.)

spring out (c, poligrafie) a sări un rând (la culegerea unui text)

spring to one's feet a sări (brusc) în picioare

spring to smb.'s defence a sări (repede) în apărarea cuiva

spring up like a mushroom (fig) a apărea ca ciupercile, a apărea peste noapte

spring-and-fall gasoline (ind chim, auto) benzină pentru sezonul de primăvară şi de toamnă

spring application (OM) apăsare cu arc (a clichetului etc.), aplicaţie cu arc inclus

spring a question on smb. (fig) a cere ceva pe neaşteptate, a pune cuiva o întrebare neaşteptată, a întreba ceva pe neaşteptate

spring assembly (OM) set / grup(are) de arcuri

spring attachment $(\mathrm{OM})$ mecanism de întindere cu arcuri

springback $(\mathrm{mec}) \mathrm{recul} /$ revenire elastic $(\breve{a})$

spring balance (metr, OM) dinamometru (cu arc), balanță cu arc / cu resort, balanță ,romană”

spring bank (OM) grup(are) de arcuri

spring bar $(\mathrm{OM})$ bară telescopică / elastică, curea (în orlogerie)

spring barrel / drum (OM) locaş (cilindric) / pahar de / pentru arc

spring beam (OM) opritor cu arc, dispozitiv de strângere pentru legarea lamelelor de arc

spring bed somieră

spring blade $(\mathrm{OM})$ lamă / foaie / lamelă de arc

spring block $(\mathrm{OM})$ placă-suport a arcului

spring bolt (OM) bulon / bolț de / cu arc

spring-bolt lock $(\mathrm{OM})$ broască / zăvor cu închidere automată (cu arc)

spring boot $(\mathrm{OM})$ husă / pahar de arc

spring bow divider(s) (OM) compas cu arc

spring box $(\mathrm{OM})$ cutie / carcasă de arc

spring bracket / carrier (OM) suport de arc

spring brass (met) alamă pentru arcuri

spring breakage $(\mathrm{OM})$ rupere / defectare a arcului spring buckle $(\mathrm{OM})$ cercel / inel / buclă / spiră (rar) de arc (de tractiune)

spring buffer (OM) tampon de / cu arc, amortizor cu arc

spring bushing $(\mathrm{OM})$ bucşă de / pentru arc spring cage $(\mathrm{OM})$ manşon elastic / spintecat (şi pt. rulmenti), carcasă a arcului

spring ca(l)lipers (OM, metr) compas de grosime, cu arc 
spring camber / elongation (OM) săgeată a arcului

spring cap $(\mathrm{OM})$ rondelă / husă de arc spring carrier / bracket $(\mathrm{OM})$ suport de arc spring catch $(\mathrm{OM})$ zăvor de arc spring catcher $(\mathrm{OM})$ arc de prindere spring centre band / clamp (OM) bridă centrală de arc / de prindere a arcului în foi spring centre bolt (OM) bulon central de arc, bolț pentru centrarea / ghidarea arcului spring center clamp $(\mathrm{OM})$ bridă centrală de arc (la arcuri foi)

spring cereals (agr) cereale de primăvară

spring chair $(\mathrm{OM})$ patină a arcului

spring chaplet (met, OM) suport (elastic) pentru miez(uri)

spring chuck (OM, mas-un) cleşte cu arc, dispozitiv de prindere cu fălci, cu arc intermediar, între ele şi locaşul lor

spring clamp (OM) dispozitiv de strângere cu arc, bridă cu arc

spring clean(ing) curățenie de primăvară

spring clip (OM) clemă elastică / acționată cu arc, bridă de arc

spring coiling machine (mas-un, OM) maşină de înfăşurat / de executat arcuri

spring collar $(\mathrm{OM})$ rondelă elastică / de arc

spring collet $(\mathrm{OM})$ mandrină cu bucşă elastică

spring compass $(\mathrm{OM}$, metr) compas cu vârfuri cu arc (pt. metal)

spring-compression gease cup $(\mathrm{OM}, \mathrm{T})$ ungător cu arc / cu resort; (OM, el) contact arcuitor

spring contact (mec, OM) contact elastic/arcuit / cu arc

spring contact strip $(\mathrm{OM}, \mathrm{el})$ bandă / lamelă de contact arcuită

spring control (OM, metr) reglare cu arc antagonist

spring coupling (plate) (auto, OM) legătură a arcului de suspensie, cuplaj elastic / cu arcuri

spring coupling plate (auto, OM) legătură a arcului de suspensie, placă de prindere / de fixare / de legare a arcului

spring crop (agr) cultură de primăvară

spring cushion (OM) amortizor cu arc

spring deflection (OM) săgeată de încovoiere a arcului

spring dividers (OM, metr) compas cu arc(uri)

spring dowel pin (OM) bulon central de arc, piesă pentru centrarea / ghidarea arcului

spring drum (OM) locaş (cilindric) / pahar de arc

spring dust cover (OM) husă / carcasă (subțire) de protectie pentru arc spring dynamometer (OM, metr) dinamometru cu arc

spring ejector (mas-un, OM) ejector / aruncător cu arc

spring elongation / camber (mec, OM) săgeată a arcului

spring equilibrator $(\mathrm{OM})$ egalizor de arc, sistem de echilibrare cu arc(uri)

spring equinox echinocțiu de primăvară

spring eye (auto, OM) ochi / ureche de arc (pt. fixare)

spring eye bolt (OM) bolț / ax pentru urechea arcului

spring eye bush $(\mathrm{OM})$ bucşă de arc

spring gaiter $(\mathrm{OM})$ apăătoare / husă de arc

spring fastening $(\mathrm{OM})$ fixare a arcului, fixare / montaj cu arcuri

spring fever (med) astenie / oboseală / febră de primăvară, febră de fân, rinită spasmodică

spring finger (OM, textile) deget presor al furcii spring flesher (ind pielăriei) cuțit de blanşiruit (piei)

spring force (OM) forță a arcului, forță pe arc

spring fork (auto, OM) furcă pe arcuri

spring fracture $(\mathrm{OM})$ rupere a arcului

spring frame of seat $(\mathrm{OM})$ ramă a scaunului, suspendată pe arcuri (la supape etc.)

spring gaiter $(\mathrm{OM})$ husă / apărătoare de arc

spring governor (OM, autom) regulator cu arc

spring hammer (OM, mas-un) ciocan de forjă cu arc, poanson cu arc

spring hanger (OM) suspensie / suport (agățător) de / cu arc

spring hawser (nav) garlin de furtună

spring hook (OM) cârlig / ochi de arc (solicitat la tracțiune)

spring housing $(\mathrm{OM})$ carcasă de arc

springiness (mec, OM) elasticitate, capacitate / putere de arcuire, elasticitate (şi a unui arc)

springing arcuire; (constr, arhit) (început de) boltă, zid de sprijin, impostă

springing away (mas-un) deviere a cuțitului sub presiunea aşchiei

springing board (sport, $\mathrm{OM}$ ) trambulină

springing of the stand (met) arcuirea cajei

spring in tension (OM) arc tensionat

spring jack $(\mathrm{OM})$ clichet; (el, $\mathrm{OM})$ jac cu arc

spring latch $(\mathrm{OM})$ clichet $\mathrm{cu}$ arc

spring lay rope (nav, $\mathrm{OM}$ ) parâmă mixtă (de sârmă şi vegetală)

spring leaf / plate $(\mathrm{OM})$ foaie de arc, lamelă dintr-un arc în foi

spring-leaf opener / spreader (OM) dispozitiv pentru îndepărtarea foilor de arc 
spring leg $(\mathrm{OM})$ picior / suport arcuit spring link (OM) articulație cu arc

spring load (mec) sarcină / forță elastică (proporțională / dependentă de deplasare), sarcină a arcului / pe arc

spring loaded (OM, autom) regulator $\mathrm{cu}$ arc, aplicare a unei forte prin intermediul unui arc, încărcare prin arc

spring-loaded check valve (OM, hidr) supapă de sens unic, cu arc

spring-loaded valve (OM, hidr) supapă / cu închidere prin resort / $\mathrm{cu}$ arc

spring-load valve (OM, hidr) supapă / ventil cu închidere cu arc

spring lock $(\mathrm{OM})$ broască / zăvor cu închidere automată (cu arc)

spring lubricator $(\mathrm{OM}, \mathrm{T})$ ungător cu arc

spring manometer (OM, hidr, metr) manometru cu arc

spring mechanism $(\mathrm{OM})$ mecanism $\mathrm{cu}$ arc

spring needle $(\mathrm{OM})$ ac cu cârlig / cu arc

spring needle circular machine (textile) maşină circulară de tricotat cu ace cu cârlig

spring off $(\mathrm{OM})$ a sări în afară (cu ajutorul unui arc, din cauza unui arc etc.), a tâşni, a ieşi brusc (d. o piesă etc)

spring offset (OM, hidr) revenire prin / cu arc

spring of sulphur water (geol) izvor de apă sulfuroasă

spring onion (bot, agr) ceapă ciorească, ceapă de iarnă

spring out a sări în afară; a sări (un rând de text)

spring packing $(\mathrm{OM})$ garnitură de etanşare elastică / cu arc(uri)

spring pad $(\mathrm{OM})$ placă-suport pentru arc

spring pin $(\mathrm{OM})$ bolț de arc, şplint elastic spring-pivot seat $(\mathrm{OM})$ reazem (liber) cu / de arc spring plate $(\mathrm{OM})$ foaie de arc, şaibă Grower / elastică (de siguranță)

spring ploughing (agr) arătură de primăvară

spring plunger (hidr, OM) piston / plunjer $\mathrm{cu}$ arc(uri)

spring point / switch (cf) macaz cu arc(uri); (OM, el) întrerupător / comutator cu arc(uri)

spring pole $(\mathrm{OM})$ tijă de suspensie a arcului

spring pressure (mec, OM) presiune exercitată de arc / a arcului

spring-pressure gauge (metr, $\mathrm{OM}$ ) manometru cu arc

spring protecting $(\mathrm{OM})$ husă / carcasă de arc spring pull (OM, mas) tracțiune cu / prin arc spring rate $(\mathrm{OM})$ constantă de arc, forța necesară deformării unitare, săgeată de încovoiere a arcului (raportată la unitatea de sarcină) spring reaction (mec) efect de arcuire, reacțiune a arcului

spring return $(\mathrm{OM}$, mas) mişcare de înapoiere sub acțiunea arcului, revenire prin arc

spring ring $(\mathrm{OM})$ inel elastic, siguranță inelară elastică, arc inelar, inel-resort; (cf, OM) inel de fixare a bandajului (roții)

spring roll $(\mathrm{OM}$, ind hârtiei) valț / cilindru cu resort / arc

spring rye (agr, bot) secară de primăvară

spring saddle $(\mathrm{OM})$ bridă / suport de arc

spring safety hook $(\mathrm{OM})$ cârlig (asigurator) cu arc

spring safety valve (OM) supapă asigurată / de siguranță cu arc

spring sag $(\mathrm{OM})$ săgeată de încovoiere a arcului spring scale (metr, OM) dinamometru cu arc, scară de măsurat presiunea exercitată de arc

spring set $(\mathrm{OM}$, hidr) scaun arcuit / cu arc(uri), suport pentru arc(uri)

spring screw cutting tool (mas-un) cutit gât-delebădă pentru filetat (interior) (cu apăsare prin arc)

spring seat $(\mathrm{OM})$ reazem liber de arc, scaun arcuit / cu arc / elastic (de supapă)

spring shackle (OM) cercel / ureche / cârlig de arc, bridă de arc

spring shackle bolt $(\mathrm{OM})$ bolț de arc cu ureche / cu cârlig

spring shock absorber (OM) amortizor cu arc spring spoke steering wheel (auto) volan de direcție cu spițe arcuite / elastice

spring squeak (OM) scârțâit de arc

spring steel (met) oțel de / pentru arc

spring stirrup $(\mathrm{OM})$ clamă / bridă de arc

spring stop (auto, cf, OM) tampon de / cu arc; (mas-un) ştift / opritor cu arc(uri)

spring surprises on smb. a face surprize cuiva a provoca surprize cuiva

spring suspension $(\mathrm{OM})$ cercel / cercei de arc, inel / cârlig de prindere a arcului, suspensie pe / cu arcuri

spring switch / point (cf) macaz cu arc

spring tension (OM) forță de arcuire / de apăsare asupra arcului (la arcuri de compresiune etc.), forță de tensionare a arcului, efort / tensiune în arc / în materialul arcului

spring tensioning screw (OM, hidr) şurub de reglare a (tensionării) arcului

spring testing machine / rig (OM, metr) maşină / stand de încercat / testat arcuri

spring tide (meteo, hidr) apele primăverii; (nav, geogr), flux subit şi violent, maree puternică, (fig) potop, revărsare 
spring tie bolt (OM) bulon central / de centrare / de ghidare al arcului

spring timber (silv) lemn de primăvară

spring tool (mas-un) cuțit gât-de-lebădă / elastic spring tool holder (mas-un, OM) port-cuțit gâtde-lebădă / elastic

spring tooth $(\mathrm{OM})$ dinte flexibil

spring-tooth cultivator (agr, $\mathrm{OM}$ ) cultivator $\mathrm{cu}$ dinți flexibili

spring-tooth harrow (agr, OM) grapă cu dinți flexibili

spring trap $(\mathrm{OM})$ zăvor cu arc, dispozitiv de prindere / de închidere cu arc, locaş de arc

spring-type self starter $(\mathrm{OM})$ demaror $\mathrm{cu}$ arc

spring U-bolt / clamp $(\mathrm{OM})$ bridă de arc în formă de U

spring valve $(\mathrm{OM})$ supapă cu arc

spring vollet $(\mathrm{OM})$ bucşă elastică

spring washer $(\mathrm{OM})$ şaibă elastică / de siguranţă / Grower, inel de siguranță, şaibă arcuitoare

spring water apă de izvor

spring well (constr, arhit) fântâna arteziană; izvor; (fig) izvor, obârşie, origine, sursă

spring wheat (alim) grâu de primăvară

spring wire (met, OM) sârmă de arc(uri)

spring with upset end $(\mathrm{OM})$ arc cu capăt refulat

spring wood (silv) lăstăriş, lemn de primăvară

spring wool (agr) lână tunsă primăvara

springy elastic, care se arcuieşte

sprinkle (meteo) bură, burniță, fulguială (de zăpadă), ploaie rară / măruntă, ploaie trecătoare, a bura, a ploua mărunt / cu picături rare; stropitură; a stropi; a presăra, a răspândi; a împrăștia; a se cerne; a umidifica; a pulveriza (un lichid); (ec) a cheltui, a risipi (bani)

sprinkle (of) pic (de), strop (de)

sprinkle (on) a împrăştia (pe); a (se) presăra (pe) (d. nisip, o pulbere etc.)

sprinkler maşină de stropit; aspersor; stropitor sprinkle (with) a pulveriza (cu), a stropi (cu)

sprinkling stropire; umezire; (agr) ploaie artificială, irigare; (fig) aparență; (fig) pospai, spoială

sprinkling milk cooler (alim) răcilor de lapte prin pulverizare

sprinkling can (OM, agr) stropitoare

sprinkling device $(\mathrm{OM}$, agr) dispozitiv de stropit, aspersor

sprinkling plant (mas, agr) instalație de aspersiune / de stropire / de irigare

sprinkling system (mas, agr) sistem de pulverizare

sprinkling tower-cooler (ind) turn de răcire cu / prin picurare sprocket (inf) poziție, situație; $(\mathrm{OM})$ roată / pinion de lanț, dinte de roată de lanț, tambur de transport

sprocket chain $(\mathrm{OM})$ lanț articulat, de transmisie, lanț Gall / cu bucşe şi role

sprocket cutter (mas-un) freză(-disc) profilată, pentru roți de lant

sprocketed tape $(\mathrm{OM})$ bandă cu perforații de antrenare

sprocket feed (c, OM) avans / antrenare a benzii / hârtiei cu perforații de antrenare

sprocket gear $(\mathrm{OM})$ transmisie cu lant

sprocket hob (mas-un) maşină de frezat, freză pentru roți de lanț (care prelucrează prin metoda rulării / rostogolirii)

sprocket hole (c, OM, metr) perforație de numărare / de antrenare / de ghidare

sprocket shaft $(\mathrm{OM})$ arbore al roții de lanț

sprocket wheel $(\mathrm{OM})$ coroană / roată de lanț (şi pt. antrenarea şenilei)

sprocket wheel cutter (mas-un) freză-disc de prelucrat roți de lanț

sprocket winch $(\mathrm{OM})$ mecanism de ridicat / vinci (cu lant)

sprout (agr, bot) germen, mugur; a germina; a încolți

spruce (molid) molid

sprue (alim, met, ind chim) pâlnie / canal / cupă (de turnare); (plast) canal central de injecție

sprue bush (alim, met, ind chim, plast) bucşă de alimentare, duză a matriței

sprue cup (alim, met, ind chim) bazin de turnare sprue cutter (met, plast) aparat / dispozitiv de tăiat rețeaua de turnare

sprue ejector (met, plast) aruncător al culeei de injecție

sprue hole / opening (alim, met, ind chim, plast) gură / pâlnie de turnare

sprue-opening gate (alim, met, ind chim) gură de umplere

sprung arch (met) arcul bolții (la cuptor)

sprung mass $(\mathrm{OM})$ masă suspendată

spud $(\mathrm{OM})$ placă de presiune; (mas-un) braț al maşinii de găurit

spue (TH) bavură, formare în presă cu melc spume (hidr, T) spumă; a spuma; a face spumă spun-blend amestec de celofibră

spun cotton bumbac filat, fir de bumbac

spun casting (met) turnare centrifugală

spun / fiber glass (ind chim) fibră de sticlă

spun-iron pipe (met) tub de fontă, turnat centrifugal

spur (cf) linie / cale ferată terminus; (constr) contrafort; (OM) proptea, gheară, dinte, pinten 
spur cable (el) cablu scurt de derivație / de ramificatie

spur differential $(\mathrm{OM})$ diferențial cu angrenaje cilindrice cu dinţi drepți

spur gear $(\mathrm{OM})$ roată dințată cilindrică, cu dinți drepţi

spur-gear differential $(\mathrm{OM})$ diferențial $\mathrm{cu}$ angrenaje cilindrice cu dinţi drepți

spur gear drive $(\mathrm{OM})$ angrenaj cu roți cilindrice cu dinți drepți

spur gearing $(\mathrm{OM})$ angrenaj cilindric (cu dinți drepți), angrenarea roților cilindrice cu dinți drepți; dantură dreaptă

spur gear pair (OM) angrenaj cilindric cu dantură dreaptă

spur gear planer (mas-un) maşină de mortezat / raboteză pentru prelucrat roți cilindrice cu dinți drepți

spurious fals; aparent

spurious coupling (auto, OM, el) cuplare greşită spurious error (mas, TH) eroare cauzată de funcționarea incorectă a aparatului sau de operator

spurious event eveniment fictiv / aparent / întâmplător / parazit

spurious oscillation (mec, autom, fiz) oscilație parazită

spurious signal (fiz, autom) semnal accidental / perturbator

spur pinion $(\mathrm{OM})$ roată dinţată / pinion cilin$\operatorname{dric}(\breve{a})$ cu dinți drepți

spur rack $(\mathrm{OM})$ cremalieră cu dinţi drepți

spurt (hidr) jet (de împroşcare); suflu; (meteo) rafală de vânt; creştere; sporire; a țâşni; a împroşca; a spori; a creşte

spur teeth grommet ochet cu dinți

spur wheel $(\mathrm{OM})$ roată cilindrică cu dinți drepți (şi pt. curele dințate)

spurious coupling $(\mathrm{OM})$ cuplaj greşit, cuplare greşită

spur rack type cutter (mas-un, OM) sculă de danturare de tip cremalieră cu dinți drepți

spurt vână, jet; țâşnitură; izbucnire; a arunca (un fluid); a țâşni; a pulveriza; a stropi

sputter izbucnire; bolboroseală; a pulveriza; a stropi; (TH) a metaliza cu pistol / cu pulverizator

sputtering (fiz) pulverizare catodică, dislocare a atomilor superficiali prin bombardare cu particule cu mare energie

spy hole (OM, met) gură de vizitare, vizor, fereastră de observare

squally cu rafale, vijelios

squander risipă; a risipi

squarable (mat) integrabil square (constr) piață; (mat, geom) pătrat, a ridica la pătrat, în unghi drept; echer, şablon; (ec) a lichida o datorie; $(\mathrm{TH})$ a mărgini, a împrejmui, a tivi, a tăia în pătrate, a egaliza, a netezi, a ciopli; square (sq) (metr, constr) unitate tradițională de măsură pentru suprafață (pt. materiale de construcții, de acoperișuri, scânduri etc.): 1 square $\cong 9,290 \mathrm{~m}^{2}$

square accounts (ec) a pune ordine în socoteli, a lichida o datorie

square bale (ind, agr) balot paralelipipedic

square bar iron (met) bară pătrată de oțel, profil pătrat

square-bar spiral spring $(\mathrm{OM})$ arc elicoidal $\mathrm{cu}$ secțiune dreptunghiulară

square bevel (met, OM) margine fără teşitură / fără pregătire (la sudură)

square block (metr) unitate de măsură pentru arie: 1 square block $\sim 1 \ldots 2$ ha

square bloom (met) blum cu secțiune pătrată square brackets paranteze drepte

square broach (mas-un) alezor pătrat, broşă pătrată

square butt joint (OM) îmbinare cap-la-cap, fără teşirea marginilor

square-cap screw $(\mathrm{OM})$ şurub de constructie, cu cap pătrat

square centimeter $\left(\mathbf{c m}^{2}\right)$ (metr) centimetru pătrat, unitate de măsură pentru suprafață în sistemul de unități CGS: $1 \mathrm{~cm}^{2}=10^{-4} \mathrm{~m}^{2}$

square chain $\left(\mathbf{c h}^{2}, \mathbf{s q}\right.$ ch) (metr) unitate tradițională britanică de măsură pentru suprafață, 1 square chain $\cong 405,69 \mathrm{~m}^{2}$

square cogging $(\mathrm{OM})$ îmbinare cu prag drept

square deal (ec) tranzacție corectă

square degree (sq deg) (metr) unitate de măsură pentru unghi solid: 1 square degree $=(\pi / 180)^{2}$ sau 0,0003046174 steradiani

square drawn bar (met) bară trasă pătrată

square-edge joint $(\mathrm{OM}$, met) asamblare sudată a flanşei / a bordurii

square-edge timber (silv) lemn ecarisat square head screw (OM) şurub cu cap pătrat squared paper hârtie milimetrică

square engine (termo) motor cu cursa egală cu diametrul / alezajul cilindrului

squareface flatter $(\mathrm{OM})$ ciocan planator

square file (mas-un) pilă pătrată

square foot $\left(\mathbf{f t}^{2}, \mathbf{s q} \mathbf{f t}\right)$ (metr) picior pătrat, unitate tradițională de măsură pentru suprafață; 1 $\mathrm{ft}^{2}=0,09290304 \mathrm{~m}^{2}$

square gouge (mas-un) daltă cu tăiş lateral

square grid / lattice / net (fiz) rețea cu ochiuri pătrate, caroiaj cu linii perpendiculare 
square-head bolt $(\mathrm{OM})$ bulon / bolț cu cap pătrat square-headed $(\mathrm{OM})$ cu patru muchii, cu cap pătrat, cu secțiune pătrată

square-headed bolt / screw (OM) şurub cu cap pătrat

square hole $(\mathrm{OM})$ gaură pătrată

square inch (sq.in., in ${ }^{2}$ ) (metr) unitate de măsură pentru suprafață; 1 in $^{2}=6,4516 \mathrm{~cm}^{2}$

square ingot (met) lingou cu secțiune pătrată

square key $(\mathrm{OM})$ pană pătrată

square kilometer $\left(\mathbf{k m}^{\mathbf{2}}\right)$ (metr, geogr) kilometru pătrat, unitate de măsură pentru suprafață: 1 $\mathrm{km}^{2}=10^{6} \mathrm{~m}^{2}$

square-law function (mat) functie polinom de gradul doi / parabolică

square-loop ferrite (met, fiz) ferită cu buclă de histerezis rectangulară

square-mesh screen $(\mathrm{OM})$ sită cu ochiuri pătrate square meter $\left(\mathbf{m}^{2}\right)$ (metr) metru pătrat, unitate de măsură SI pentru suprafață

square mile (mi ${ }^{2}$, sq mi) (metr, geogr) milă pătrată, unitate tradițională de măsură pentru suprafață: 1 square mile $=2,589988 \mathrm{~km}^{2}$

square mile (sq.ml., $\mathbf{m l}^{2}$ ) (metr, nav, geogr) milă pătrată, unitate de suprafață: 1 land $\mathrm{ml}^{2}$ (milă terestră pătrată $)=2,5899 \mathrm{~km}^{2}, 1$ sea ml (milă marină pătrată) $=3,4343 \mathrm{~km}^{2}$

squareness $(\mathrm{OM})$ perpendicularitate (și referitor la toleranța la perpendicularitate)

square nose tool (mas-un) cuțit lat, de / pentru finisare

square nut $(\mathrm{OM})$ piuliță pătrată

square pass (met, metr) calibru pătrat, de laminare

square reamer (mas-un) alezor cu sectiune pătrată

square rod (rd', sq rd) (metr) prăjină pătrată, unitate tradițională de măsură pentru suprafață; 1 square $\operatorname{rod}=25,2929 \mathrm{~m}^{2}$

square root (mat) rădăcină pătrată

square root of minus one, imaginary unit, i (mat) număr imaginar-unitate: $i=\sqrt{-1}$, unitate imaginară

square roughing(-out) pass (met) calibru pregătitor / degrosisor pătrat

square rule (metr) echer

squares (met) semifabricat cu secțiune pătrată (şi de oțel), pătrat

square screw thread $(\mathrm{OM})$ filet pătrat

square section (met, metr) profil pătrat

square shaft $(\mathrm{OM})$ arbore pătrat

square shank $(\mathrm{OM})$ caneluri dreptunghiulare de ghidare

square sieve $(\mathrm{OM})$ sită / ciur cu ochiuri pătrate square socket wrench $(\mathrm{OM})$ cheie pătrată tubulară

square steel (met) semifabricat pătrat de oțel, oțel pătrat

square stern (nav) pupă dreaptă (fără boltă)

square stroke engine (termo) motor cu cursa egală cu alezajul cilindrului

square T-nut $(\mathrm{OM})$ piuliță pentru canale în $\mathrm{T}$ square thread $(\mathrm{OM})$ filet pătrat square thread tool (mas-un) cuțit de filetat square threaded screw $(\mathrm{OM})$ şurub cu filet pătrat square timber (silv) lemn ecarisat

square tool (mas-un) cuțit lat (cu plăcuță pătrată)

square-up table $(\mathrm{OM}, \mathrm{TH})$ masă de montaj

square washer $(\mathrm{OM})$ şaibă pătrată

square yard (sq yd., $\mathbf{y d}^{2}$ ) (metr) yard pătrat, unitate de măsură pentru suprafață: $1 \mathrm{yd}^{2}=$ $0,83612736 \mathrm{~m}^{2}$

squaring (mas-un) strunjire a suprafețelor frontale; (fiz) transformare în formă dreptunghiulară; (mat) ridicare la pătrat, cuadratură

squaring machine (mas-un) şeping

squaring shears (met, mas-un) foarfece de retezat / de tăiat (şi capete)

squaring tool (mas-un) cuțit de canelat pentru raboteză

squash (alim) terci, suc de fructe, dovleac; a (se) zdrobi; a terciui; a înăbuşi; a (se) turti

squat îndesat; turtit; scurt şi gros; (nav) apupare la viteză / la marş, a staționa cu pupa la chei

squeak zgomot strident

squeaking of the body / of the brakes / of the springs (mas) scârțâit al caroseriei / al frânelor / scârtâit al arcurilor

squeak of tyres (auto) scârțait de cauciucuri

squeegee (mas-un) unealtă cu muchie de cauciuc pentru netezire sau stropire şi răspândire de materiale lichide; (plast, ind chim) inserție de cauciuc, cauciucare / gumare a unei rețele / inserții; a stoarce

squeezable comprimabil; care poate fi stors / comprimat

squeeze apăsare, presare, strângere; comprimare; presiune; stoarcere; (fam) (fig) constrângere; (fam) (fig) şantaj, smulgere, stoarcere (de bani); (fam) dificultate, greu, greutate, strâmtoare; (fam) îmbrăţişare; (fig) îmbulzeală, înghesuială; strângere (a mâinii etc.); strângere, îngustare (d. un drum etc.); (geol, constr) tasare (a terenului); a strânge; a presa; a comprima; a stoarce; (met, plast) a deforma plastic, a ambutisa, a apăsa, a băga, a comprima; a sfărâma; (mec, mas-un) a strânge (prea tare); (alim) a frământa (d. aluat 
etc.), a scoate (sucul); a furişa, a vârî, a strecura (mâna, printr-o deschizătură etc.), (d. o lămâie etc.) a (se) stoarce (uşor etc.), a strivi, a tescui (d. struguri); (fig) a constrânge; a-şi face loc (prin, în etc.); (fig) a face presiuni asupra (cuiva); a îmbrăţişa călduros, a strânge mâna, a strânge (în brațe); (fig) a obține cu forța (bani, mărturii); a răzbate (prin, în etc.); (poligrafie) a refula cerneala la marginile elementelor tipăritoare; (fig) a sili, a smulge, a stoarce (bani, mărturii)

squeeze board (met) placă de presare; (alim) placă de stoarcere prin presare

squeeze film $(\mathrm{OM}, \mathrm{T})$ peliculă subțire de fluid vâscoelastic (folosită ca lubrifiant, amortizor sau etanşare)

squeeze-film lubrication $(\mathrm{T})$ lubrifiere cu pelicule aderente la suprafețele solide sau cu peliculă portantă (la sarcini cu variații mari), care poate fi ruptă / întreruptă

squeeze head $(\mathrm{OM})$ placă de presiune

squeeze into (TH) a (se) băga cu forța (în)

squeeze moulding (met) formare (cu îndesare) prin presare

squeeze moulding machine (met, mas-un) maşină de format prin presare

squeeze out (TH) a strânge, a presa (cu eliminare de material în afară); a stoarce; a ieși din îmbinare (şi d. un adeziv, o garnitură etc.)

squeeze out of (alim, plast) a ieşi cu forța / înghesuind din, a stoarce / strânge (un ambalaj) pentru a scoate conținutul (cremă, frişcă etc.)

squeeze-out time (ind chim) timp de întărire (a amestecului de etanşare)

squeeze / squeezing press, squeezer (mas, alim) presă de stors

squeezer (OM, alim) storcător, (met, mas-un) maşină de forjat prin presare

squeeze roll(s) $(\mathrm{OM})$ role / cilindri de presare (şi la lipirea foliilor / ambalajelor)

squeeze section (met, fiz) secțiune ştrangulată / îngustată

squeeze through (TH) a-şi croi drum (prin mulțime, printre particule, prin filtru etc.)

squeeze-type core making machine (met) presă pentru miezuri

squeeze (with a forging hammer) presare $\mathrm{cu}$ ciocanul de forjă

squeezing (termo) comprimare, compresie; stoarcere (şi prin presare)

squeezing apparatus $(\mathrm{OM}$, alim) aparat de stoarcere

squeezing mangle(s) / roll(s) (OM, alim, ind chim, textile) valț(uri) de stoarcere squeezing out $(\mathrm{TH})$ stoarcere (pt. eliminarea unui fluid etc.)

squeezing press (mas-un) presă de stoarcere squeezing roll $(\mathrm{OM})$ valț / cilindru de stoarcere squeezing test (materiale, OM, metr) încercare / test la strivire

squelching (mas. autom) reglaj silențios

squid (el) fişă dublă (la panou de conexiuni)

squirrel-cage motor (el) motor cu rotorul în scurtcircuit

squirrel-cage rotor (el) rotor în colivie de veveriță squirt (OM, med) seringă; izbucnire; țâşnitură; a împroşca, a pulveriza, a spăla prin jet de lichid, a stropi, a țâşni (d. lichide), a uda

squirt gun $(\mathrm{OM}, \mathrm{T})$ pompă de gresat

squirting process $(\mathrm{TH})$ (proces de) extrudare

squirt (out) (ind) a evacua, a spăla cu jet de lichid / prin stropire

SRS (Supplemental Restraint System), Supplemental Inflatable Restraints (auto) SRS, sistem suplimentar de protectie, sistemul de airgaburi (al autovehicolului)

SRS components (supplementary restraints system) (auto, autom, electr) componente suplimentare ale sistemului suplimentar de protecție / pentru airbaguri

SRS Control Module (auto, autom, electr) modulul SRS de control

s.s. (spindle speed) viteza axului principal

ss (metr) abreviere pentru $1 / 2$ sau semi, din semis (în latină)

SSR air bag warning light (auto) semnal luminos de semnalizare pentru SRS / airbaguri

SSU, SUS, Saybolt Universal second (metr, fiz, hidr, T) simboluri pentru o unitate de măsură pentru vâscozitate (utilizată mai mult în US); valoare în secunde, pentru vâcozitatea cinematică, obținută cu vâscozimetre Saybolt; pentru lichide cu peste 50 centistokes la $37,8^{\circ} \mathrm{C}$ $1 \mathrm{SSU} \cong 0,2158$ centistokes sau $0,2158 \mathrm{~mm}^{2} / \mathrm{s}$. se mai utilizează în industria petrolului

s.t. (short ton) (metr) tonă mică, unitate de măsură pentru masă: 1 short ton $=907,2 \mathrm{~kg}$

stab (TH) a perfora; a găuri; a străpunge; (med) durere acută / ascuțită, junghi, rană (lăsata de cuțit etc.), săgetare, (d. durere) a fi ascuțit (ca o lovitură de cuțit), a răni (cu un cuțit etc.);(fam) încercare, tentativă, şansă; lovitură (de cuţit etc.); a băga, a înfige, a vârî (cuțitul etc.); a (se) înjunghia, a străpunge (cu un pumnal, etc.); (alim) a tăia, a înjunghia, a sacrifica (vite)

stability stabilitate; (constr) capacitate portantă a terenului; (metr) constanță a caracteristicilor unui aparat; (TH, OM, mas) siguranță de 
basculare / contra basculării / răsturnării; (materiale) stabilitate (mecanică sau chimică); durabilitate; viabilitate; rezistență (în general); echilibru; constanță; rigiditate; fixitate; soliditate, tărie (a caracterului); (ec) stabilitate; stăruință; statornicie; trăinicie

stability computation $(\mathrm{OM})$ calcul de rezistență (în general static), calcul de / pentru stabilitate

stability conditions (mas, fiz, mec, autom) condiții de stabilitate

stability diagram (autom, mas) diagramă / curbă de stabilitate

stability factor (mas, fiz, mec, autom) factor de stabilitate

stability field (mas, fiz, mec, autom) domeniu de stabilitate

stability limit (mas, fiz, mec, autom) limită de stabilitate, stabilitate critică

stability moment (mas, fiz, mec, autom) moment de stabilitate

stability of shape (OM) indeformabilitate, stabilitate a formei

stability polygon (mec) poligon închis al forțelor

stability ratio coeficient / factor de stabilitate (la coagulare, sedimentare, a formei, a unui sistem de reglare etc.)

stability to light (plast) stabilitate la lumină

stabilization (materiale, mas) stabilizare

stabilization column / tower (alim, ind chim) coloană de stabilizare

stabilization currency (ec) stabilizare valutară

stabilizator (alim, ind chim) anticoagulant, agent de stabilizare

stabilize a stabiliza; a egaliza; a fixa; a consolida; (nav) a asigura stabilitatea navei, a stabiliza (un vas)

stabilized stabil; stabilizat; constant

stabilized conditions (mas, autom) regim stabil / stabilizat

stabilizer stabilizator; (met) component de stabilizare

stabilizing (mas, autom) stabilizare; mentinere la o valoare / la un parametru constant; care (se) stabilizează

stabilizing / stress-relief anneal(ing) (met, TH) recoacere de detensionare / de stabilizare

stabilising bath (ind chim, alim) baie de stabilizare

stabilising plant (ind chim, alim) instalatie de stabilizare

stabilizing treatment (materiale) tratament de stabilizare (a structurii sau a dimensiunilor)

stable ( $\mathrm{TH}$, mas) stabil, durabil, egal, constant, stationar, ferm, fix, solid, trainic; (sport) cai (de curse) din acelaşi grajd; (constr) grajd (de cai); (agr) grajd, staul (de vite), a ține în grajd / în staul; constant, ferm, hotărât, statornic (d. cineva, etc.); rezistent, hotărât

stable arc (el) arc stabil (la sudare)

stable component / element (mec) element static / stabil

stable compound (chim) compus stabil

stable currency $(\mathrm{ec})$ monedă stabilă

stable emty (mec, mas, transp) echilibru / stabil

fără sarcină / fără încărcătură

stable equilibrium (mec) echilibru stabil

stable hydrocarbon (chim) hidrocarbură stabilă

stable loaded (OM, mas) încărcat sub sarcină (constantă), echilibrat / stabil sub sarcină

stableness stabilitate; $v$. stability

stable operation (mas) regim / funcționare sta$\operatorname{bil}(\breve{a})$

stable phase (met, chim) fază stabilă

stable process $(\mathrm{TH})$ proces stabil / staţionar

stable state (fiz, termo) stare stabilă / staționară

stack (ind) grup de semifabricate, grămadă; (met) cuvă (de cuptor sau de furnal); (constr, termo) coş de fum / de tiraj; (inf) serie ordonată de date, cu acces numai la ultima, stivă, zonă a memoriei alocată pentru stocare temporară; (ec, ind) stivă de marfă; a îngrămădi; a stivui; (agr) căpităă, claie, șiră, stog, a așeza în căpiță / în claie; (mat) fascicul; (fam) grămadă, morman (de lemne etc.), șuvoi; grămadă; (fig) mulțime, noian, potop; (ind, TH) stivă; (nav) puț de navă, stivă de marfă (în magazia navei); (termo, auto) (fam) țeavă de eşapament a unei maşini; stack (stk) (metr) unitate tradițională britanică pentru cărbune sau lemne de foc, 4 yarzi cubi: 1 stack equals $\cong 3,058 \mathrm{~m}^{3}$

stack band (met, OM) bandaj / centură de consolidare a cuvei (la furnal, la cuptor)

stack brickwork (met) zidărie a cuvei (la furnal, la cuptoare)

stack casting (met, plast) turnare în ciorchine

stack cutting (met, mas-un, plat) tăiere / decupare în pachete (a tablelor, semifabricatelor gen laminate, folii etc.)

stack damper (met) şuber

stack draught (met, termo) tiraj de coş

stacker (mas) stivuitor; (constr, met) transportor mobil pentru formarea haldelor de material stack gas (ind chim, met, termo) gaze arse / de coş stacking ( $\mathrm{TH}$, ind) stivuire, aşezare în stive stacking conveyer (constr, met, mas) transportor (mobil) de stivuire / de formare a stivelor stack kiln (ind chim, met) cuptor de calcinare / de prăjire 
stack lining (met) căptuşeală a cuvei (la furnal, la cuptoare mari)

stack mould (met, plast) rețea de turnare în ciorchine / etajată

stack moulding (met) formare în rame suprapuse

stack of sheets (met) pachet de table

stack of stampings (el) pachet de tole

stack oxygen cutting (met, TH) tăiere cu oxigen, în pachet, a tablelor

stade, stadion, stadium, $(p l)$ stadia (metr) unitate de măsură pentru distanță, în Grecia Antică (lungimea stadionului), stadie: 1 stadion $\sim 200 \mathrm{~m}$; pentru stadionul Olympia, 1 stadion $\cong 192,3 \mathrm{~m}$; la Atena 1 stadion $\cong 185,0 \mathrm{~m}$; in the 1 stadium (Roma antică) $\sim 185,00 \mathrm{~m}$

stadia line (fiz, metr) fir reticular

staff, $(p l)$ staves (ec, adm, edu) personal, conducere (a unei întreprinderi, organizații etc.), echipă, (plural colectiv), cadre; (OM) ax (de orlogerie), baston, băț; (textile) distanță dintre două suporturi ale trenului de laminare; $(\mathrm{TH}$, constr, metr) miră de nivel, riglă; (poligrafie) portativ; (mil) stat major; (fig) ajutor, reazem, sprijin, toiag; be on the $\sim(\mathrm{ec}, \mathrm{adm}$, edu $)$ a face parte din conducere / din personal, a fi încadrat, a fi unul din colaboratori

staff college (mil, edu) şcoală superioară de război staff costs (ec) cheltuieli cu personalul (inclusiv salarii)

staff department (ec, adm) departament central, sectie coordonatoare

staff gauge (OM, metr) tijă (de control) de adâncime, jojă

staffing (ec, adm, mil) angajare, completare (de personal, de cadre)

staff-pattern (ec, adm) model (optim) de utilizare a salariaților

staff reduction (ec, adm) reducere de personal

stage scenă; estradă; stare, stadiu; etapă, treaptă, perioadă; stagiu; (cf, met) platformă; etapă / fază de lucru; (autom) etaj; (constr) a eşafoda / monta o schelă; (hidr) etaj de pompă, amplificator hidraulic într-un distribuitor

stage crushing (TH) concasare în trepte / în etape staged pump (OM, hidr) pompă etajată / cu elemente în serie

stage evaporator (ind chim, alim) evaporator în trepte / în etape

stage heating (ind chim) vulcanizare în trepte; (alim, termo, met) încălzire în etape / în trepte

stage piece $(\mathrm{OM}$, constr) perete / piesă intermediar( $\breve{a})$

stage process $(\mathrm{TH})$ proces / procedeu (tehnologic) în trepte (succesive) stagflation (ec) inflaţie cu stagnare a economiei stagger $(\mathrm{TH})$ dispunere / amplasare / aşezare în trepte / în zigzag, grupare în şah; bălăbănire, clătinare, clătinat; (av) decalaj (al aripilor); dispunere în trepte; (TH) a amplasa / monta / aşeza în zigzag / în trepte; a oscila; a eşalona; a decala, a se bălăbăni, a (se) clătina, a descumpăni, a distribui, a repartiza a eşalona; (fig) a ezita, a face să ezite / să şovăie, a nu fi sigur, a şovăi, a nu şti ce să facă, a trezi îndoieli (cuiva)

staggered (TH, fiz) alternat, decalat, în zigzag, în trepte, în eşichier

staggered bank of tubes (termo) fascicul de țevi / de tuburi amplasate în linie alternată / în şah / în zigzag

staggered deliveries (ec, $\mathrm{TH}$ ) livrări eşalonate

staggered feed (mas-un) avans intermitent

staggered intermittent (fillet) weld $(\mathrm{OM})$ cusătură (de sudură) întreruptă / intermitentă / în zigzag

staggered joint (met, OM) asamblare în zigzag (d. aşezarea niturilor / şuruburilor, a cusăturii de sudură, a formei cusăturii la curele / țesături etc.)

staggered roll (met, $\mathrm{OM}$ ) cilindru de laminor $\mathrm{cu}$ tăblia în trepte

staggered rolling mill (met) laminor duo $\mathrm{cu}$ caje aşezate în zigzag

staggered rolling train (met) linie de laminor în trepte

staggered row of rivets / bolts / screws (OM) şir / rând de nituri / bolțuri / şuruburi în zigzag

staggered tooth cutter (mas-un) freză cu dinți în zigzag / cu tăişuri în cruce

staggered weld (met, OM) cusătură (de sudură) în zigzag

staggered welding $(\mathrm{TH}$, met) sudură cu electrod decapat

staggering $(\mathrm{TH})$ decalare, eşalonare

staging (met) cajă (de laminor)

stagnation (mec, ec, TH) stagnare; (fig) nemişcare, inertie, stare pe loc

stagnation point (termo) punct mort; (ind chim, fiz) moment de stagnare (a unei reactiii, a unui proces etc.)

stagnation pressure (fiz, hidr) presiune (teoretică) dezvoltată la oprirea curgerii (fără pierderi de energie) / dinamică / de retenție

stain (ind chim) bait; decapant; colorare, culoare, colorant, vopsea, mordant; pată; murdărie; (met) pată, adâncitură (defect de suprafață, cauzat în general de coroziune, atac chimic, oxidare); (fig) întinare, ocară, pată, ruşine; (fig) pic, puțin, strop; a păta, a mânji, a murdări; (TH) a colora; 
a decapa; a vopsi, a băițui; (fig) a mânji, a murdări, a păta; (poligrafie) a tipări în culori

stained $(\mathrm{TH})$ colorat colorat (d. hârtie, textile etc.); pătat, murdărit; vopsit, băițiit; (met) oxidat, degradat chimic în pete (d. semifabricate metalice); (fig) pătat; (fig) stigmatizat

stained glass (ind chim) sticlă colorată; (artă) vitraliu

stained paper (ind chim) hârtie marmorată

stained sheet (met) tablă cu pete / pătată (corodată)

stained wool (textile) lână îngălbenită

staining (met) întunecare (la culoare din cauza coroziunii), ruginire, pătare (ca rezultat al coroziunii); (birotică) penetrare a cernelii; (ind chim, textile) băițuire, colorare, vopsire; (fiz, termografie) capacitate de colorare a filtrului

staining power (metr) capacitate de colorare (la teste de poluare) / de formare a petelor; (textile) capacitate de a forma pete

staining solution (metr, chim) colorant de microscop

stainless (met) inoxidabil, rezistent la coroziune; curat; (fig) fără pată

stainless-clad steel (met) otel placat cu material inoxidabil (eventual oțel inoxidabil)

stainlessness, stainless property (met) inoxidabilitate (d. oțeluri etc.)

stainless steel (met) otel inoxidabil / rezistent la coroziune

stain-proof (met, plast) rezistent la pătare

stain remover (chim) substanță de scos pete

stain repellant finish (ind chim) finisare de protejare la pătare

stain superficially (ind chim) a vopsi în strat subțire, a păta superficial (nu în profunzime)

stair (OM, constr) treaptă (de scară)

staircase function(ing) $(\mathrm{TH}$, mas) functionare în trepte

stairs (constr) scări, scară

stair-stepped (mas, autom) în trepte (d. semnale, functionare etc.)

staker (mas, transp) elevator pe şine

staking tool set (mas-un) utilaj de nituit

staking tool (mas-un) stanță pentru îndoirea marginilor

stale vechi, perimat, expirat (şi d. cecuri, datorii); stătut, îmbâcsit (d. aer)

stalk (constr, met) coş înalt de fum, profil vertical

stalk-like structure (fiz, met, geol) structură bazaltică / columnară

stall oprire; stagnare; impas; (constr) despărțitură, boxă; stand (de expoziție); a cala, a opri (un motor); a bloca; a compartimenta

stalled motor (auto, mas) motor blocat / oprit stalling work capacity (mas) parametru de lucru critic / minim

stamp timbru; ştampilă; semn; (TH, mas-un) matrițare, ștanțare, matriță, ștanță, poanson (de perforat / de marcat), marcă, imprimare (mecanică), amprentă; (mec) a (se) întipări, a (se) imprima; a poansona, a marca; a bătători; a îndesa; a matrița; (alim) a sfărâma, a pisa

stamp down (TH) a imprima, a ştanța, a presa

stamp duty / tax (ec, adm) taxă de timbru

stamped component $(\mathrm{OM})$ piesă ş̧anțată

stamped nut $(\mathrm{OM})$ piuliță ştanțată în matriță

stamper $(\mathrm{OM})$ maşină de marcat, matriță

stamping (poligrafie, TH) întipărire, tipar; (masun, met) poansonare, marcare, matrițare, ștanțare, presare (în matriță)

stamping die (OM) matriță, ștanță

stamping hammer (mas-un, OM) poanson / ciocan de perforat / de matritat / de ștanțat

stamping lubricator $(\mathrm{T})$ pompă de uns, tecalemit stamping press (mas-un) presă de matrițat / de ştanțat

stamping quality sheet (met) tablă de ambutisare stamping room / shop (ind, TH) sectie / atelier de matrițare / de ştanțare / de produse matrițate / ștanțate

stamping tool (mas-un, OM) matriță de imprimat în relief

stamping trim (mas-un) deşeuri de la matriţare stamp on (ind) a marca (un produs etc.)

stamp screen $(\mathrm{OM})$ placă de pisare / de (s)fărâmare

stanch, stauch $(\mathrm{OM})$ etanş, ermetic; de bună calitate

stanchion (constr, met, OM) montant, stâlp de susținere

stand $(\mathrm{OM})$ montant, suport, batiu, cadru, stativ, piedestal, picior, postament, trepied, soclu, consolă, etajeră, cuier, raft, rastel, stelaj, rezistentă; (TH) oprire, stagnare, încetare; parcare; (met) cajă (de laminor); (nav) stationare a navei, a naviga; (silv) arboret; (fig) atitudine, poziție; postură; ținută; (constr) capră de lemn, soclu; (agr) desime, recoltă (pe o anumită porțiune); (muz, sport) estradă, platformă; (sport) tribună; haltă, oprire, popas; pauză; împotrivire, opunere; opoziție; încetare; întrerupere; loc (ocupat de cineva); (auto, adm) loc de staționare, stație (pt. automobile, taxiuri etc.), (loc de) parcare; (artă) șevalet; (ec) sezon (comercial) mort, (perioadă de) stagnare, stand (pt. mărfuri, la o expoziție etc.), tarabă, tejghea; (metr, ind) stand (de încercări / de testare); (pol) tribună; (fam) magazin, poziție; (TH) a sta, a rezista, a suporta, a se menține, a staționa; a se afla, a se găsi; a se aşeza; a așeza drept, a așeza în picioare / vertical, a 
pune drept / în picioare; a avea în vedere, a cumpăni (şansele etc.); a nu ceda (în fața); a se deplasa, a merge; a dura; (fig) a face cinste (cuiva), a oferi (o băutură etc.); a fi (intr-o anumită stare sau situație); a se împotrivi (cuiva), a se opune (cuiva); a se înălța (d. clădiri); a (se) menține (d. un contract, o poziție etc.); a nu merge mai departe, a se opri; a-şi păstra prețul / valoarea, a-şi mentine prețul / valoarea

stand-alone (autom, mas) autonom

standard standard; normă; probă; epruvetă; (de) referință; (metr) etalon de măsură; nivel; grad; (OM) coloană, montant; normal, standardizat (d. elemente de maşini, materiale, metode etc.); standard (std) (metr) unitate tradiţională de volum pentru lemn finisat, în nordul Europei: 1 standard $=165 \cong 4,672 \mathrm{~m}^{3}$

standard atmosphere (metr) atmosferă standard standard (cross) section (OM, met) profil normat / standardizat

standard air (mediu) aer în conditii normale standard, atmosferă standard

standard atmosphere (fiz, metr) atmosferă standard (760 mm coloană de mercur, $65 \%$ umiditate relativă şi $20^{\circ} \mathrm{C}$ )

standard bore (OM) alezaj unitar

standard calibration (metr) etalonare, calibrare standard / după proceduri standard(izate)

standard capacity (mas, termo) putere / capacitate normală / standard

standard cell element etalon

standard condition condiție normală / standard / standardizată

standard conditions (ind, $\mathrm{TH}$ ) conditii normale / standard

standard cubic meter (metr, ind chim, termo) unitate de măsură pentru masă pentru gaze, egală cu masa $1 \mathrm{~m}^{3}$ la presiunea de 1 atmosferă şi temperatura de $0^{\circ} \mathrm{C}$ sau $20^{\circ} \mathrm{C}$; v. normal cubic meter; v. sccm

standard deviation (metr, $\mathrm{TH}$, mat) deviatie / abatere normală / medie pătratică / standard; standard deviation (sd) (metr) unitate de măsură pentru a descrie dispersia sau împrăştierea datelor

standard dimension (TH, OM) dimensiune normală / standard / normată

standard drill (mas-un) mașină standard obişnuită, de găurit, verticală cu coloană

standard electrode potential (el, met) potential de electrod normal / etalon / standard

standard environmental condition (mediu) conditii de mediu normale / standard

standard equipment (ind, mas) echipament normal / conventional / standard standard erythemal dose, SED (metr) unitate de măsură utilizată pentru a măsura cantitatea de radiaţie ultravioletă care înroşeşte pielea, de către o persoană aflată la soare sau în sala de bronzare artificială: 1 SED este o doză de 100 $\mathrm{J} / \mathrm{m}^{2}$ pe suprafața pielii; radiația care înroșește pielea are lungime de undă în jurul valorii de $300 \mathrm{~nm} ; 1$ SED pe oră este echivalent cu $27,778\left(\mathrm{~mW} / \mathrm{m}^{2}\right)$ pe suprafața pielii

standard fit (OM) ajustaj standardizat (obținut din toleranțe standardizate

standard gauge (metr) calibru etalon

standard gravity (g, grav) (metr, fiz) gravitatie standard, accelerație gravitațională standard, definită conventional la $9,80665 \mathrm{~m} / \mathrm{s}^{2}$

standard grease worker (metr) dispozitiv standard de solicitare mecanică a unsorii

standard instrument (metr) aparat etalon

standardisation standardizare

standardisation of scientific investigation standardizare a investigațiilor / metodelor ştiințifice / testării / de cercetare

standardise a standardiza

standard jib (mec, OM) săgeată normală

standard load (mec, OM) încărcare normală / standard

standard module (OM) modul standardizat standard of comparison (metr) scară etalon standard of measurement (metr) etalon

standard of reference (metr) scară etalon standard part (OM) piesă standardizată / normată, piesă executată după normă de firmă

standard pressure (hidr, metr) presiune normală / standard / normalizată

standard reference atmospheric conditions (ANR) (mediu, laborator) condiții ale atmosferei normale de referință (ARN)

standard refractories (met) refractare standard / obişnuite

standard round test bar (OM, metr) bară rotundă etalonată

standard sample (OM, metr) etalon, probăstandard, epruvetă standard, eşantion-standard

standards and calibration laboratory (metr) laborator metrologic

standards committee comitet de standardizare standard screen (metr, agr, alim) sită etalonată standard shape (inf) format standardizat; (OM) formă standardizată / normată

standard sieve (OM, metr) sită etalonată

standard size (OM) dimensiune etalonată, dimensiune standard

standard solution (metr, chim) soluţie etalon / titrată

standard specification(s) (mas, TH) condiții tehnice standardizate (şi normate), normă 
standard specimen, test bar, test piece (metr, $\mathrm{OM})$ epruvetă standard

standard static load (mec, metr) sarcină statică normală / standard / normată / impusă de norme

standard temperature (metr, fiz) temperatură normală / standard(izată) / impusă prin norme standard test bar (OM, metr) epruvetă standard standard test încercare / test standardizat(ă) / în condiții standardizate / obişnuite / normate, test / încercare cu norme / condiții impuse

standard thread $(\mathrm{OM})$ filet standardizat

standard tool (mas-un) unelte / scule / dispozitive (şi manuale) obişnuite / standard(izate) / normale pentru o anumită operație / normate pentru maşini-unelte şi procese de prelucrare

standard tooth $(\mathrm{OM}$, metr) dinte normal / (cu modul) standardizat

standard type tipizat

standard volume (metr, fiz, chim) unitate utilizată pentru măsurarea volumului gazelor: 1 standard volume este volumul ocupat de 1 kilomole de gaz, la temperatură standard $\left(0^{\circ} \mathrm{C}\right)$ şi la presiune standard (1 atmosferă sau $101,325 \mathrm{kPa}$ ): 1 standard volume $=22,414 \mathrm{~m}^{3}$

standard weight (fiz, metr) greutate / masă standard / normată

stand $100 \%$ overload (mas) a suporta o supraîncărcare de $100 \%$

stand-by, standby (mas, OM) (de) rezervă, gata de a lucra; în aşteptare, auxiliar; (inf, autom, el) stare de aşteptare

stand-by column (ind chim, alim) coloană auxiliară, gata de lucru

stand-by loss (mas) pierderi în gol, pierderi în stationare

stand-by plant (ind, TH) instalații de rezervă

stand-by power (mas, el, mec) putere de rezervă

stand-by pump (OM, hidr) pompă de rezervă

stand-by ventilator (termo, ind) ventilator de rezervă

stand-by unattended time (ind, mas) timp inactiv standing stabilitate, rezistență (statică); durată; situație; reputație; fix; imobil; invariabil; permanent; staționar; oprit

standing balance (mec) echilibru static / stabil standing bath (ind chim, met) baie uzată / epuizată / fără efect

standing losses (el, mas) pierderi în gol / la mers în gol; putere necesară de menținere a echipamentului gata de funcționare

standing start (auto) pornire din oprit

standing time (TH, mec, mas) timp de oprire / de menținere / de aşteptare

standing vice $(\mathrm{OM})$ menghină cu picior

standing wave (fiz) undă staționară stand of rolls (met) cajă de laminor / pentru cilindri stand out a ieşi în relief

standpipe (OM, hidr) tub de refulare, conductă de legătură la furtun; (hidr, metr) tub piezometric

standstill oprire; stagnare

stand support (OM) talpă a carcasei

stand test(ing) (metr, OM) încercare / testare pe stand

stand(s) $(\mathrm{OM})$ ansamblu al batiului, suporți etc.; (met) cajă, (caje)

stang (metr) unitate tradițională galeză de măsură pentru suprafată: 1 stang $=0,2709$ ha

stanine (metr) unitate în statistică, utilizată în teste educationale: notele testelor sunt normalizate astfel încât să aibă o medie de 5 şi o deviație standard de 2: datele sunt apoi împărțite în 9 clase, numite stanine, cu procentele: 4, 7, $12,17,20,17,12,7$ şi 4 ; denumirea este o contractie pentru ,standard of nine"

stanniol (alim, met) staniol, folie de staniu sau aliaj al lui

stannous compound (chim, met) compus stanos / al staniului bivalent

staple (constr) nişă, târnăcop; $(\mathrm{OM})$ scoabă, clemă, element de asamblare în U, ureche, ochi, ochet, brățară; (ind chim) fibră tăiată; a stivui; a fixa (cu cleme etc.); principal; de larg consum staple commodity (ec) produs principal; resursă principală, marfă de bază

staple knee (OM) articulație dublă

staple plate $(\mathrm{OM})$ placă de zăvor

staple rayon (ind chim) celofibră

stapling elevator (mas, transp) elevator de stivuit stapp (metr, fiz, med) unitate utilizată pentru a exprima efectele accelerației sau decelerației asupra corpului omenesc: 1 stapp reprezintă o accelerație de $1 \mathrm{~g}$ pentru o perioadă de 1 secundă sau $9,80665 \mathrm{~m} / \mathrm{s}^{2}$ pentru 1 secundă

star (fiz) fascicul, stea; asterisc; stelat

star antimony (chim, met) stibiu rafinat

star bit (mas-un, OM) floare de burghiu în stea

starch (chim) amidon

starch ester (chim) ester de amidon

starch ether (chim) eter de amidon

starch glue (chim) clei de amidon

starch sugar (alim) dextroză

star coupling $(\mathrm{OM})$ articulaţie cardanică, cuplaj cardanic

star-delta connection (el) conexiune stea triunghi star drill (mas-un, OM) burghiu cu tăiş în cruce star feed (mas-un) avans prin angrenarea unei roți stelate

star gauge (metr, OM) calibru tampon, în formă de stea

star handle $(\mathrm{OM})$ roată de mână cu brațe 
star knob $(\mathrm{OM})$ buton în formă de stea star pinion $(\mathrm{OM})$ roată de lanț (conducătoare) star stop $(\mathrm{OM}$, el) limitator în stea start început; începere; avantaj; (mec) mișcare bruscă, origine a mişcării; $(\mathrm{TH})$ pornire, plecare; (metr, autom) poziție de zero, demaraj, smucitură; (sport) avans, avantaj, linie de pornire, start, a lua startul, a porni; debut; linie de plecare; (av) decolare; (auto, mas) demaraj; salt; săritură; tresăltare; tresărire; izbucnire, manifestare, scăpare (a spiritului); (TH) a începe, a porni, a pleca, a acționa, a lansa, a amorsa, a manipula, a demara (d. o maşină, un proces etc.), a (se) pune în mişcare, a porni (d. o maşină, un motor etc.), a produce; a se arunca; a debuta; (av) a decola; (textile) a desface, a destrăma, a dezlega (o cusătură etc.); (ec, adm) a fonda, a întemeia, a înființa (o societate etc.); a împinge, a ajuta, a lansa (pe cineva); a începe (masa, lucrul etc.); a izgoni; a se mişca brusc; a da naştere la; a porni (treaba etc.); a ridica (o problemă, o piedică etc.)

startability (mas, auto) pornire / demarare uşoară start and stop lever (OM) maneta de pornire şi oprire

start button (OM) buton de pornire

starter (OM, auto) buton de contact / de demarare / de pornire; (mas, auto) starter, demaror, dispozitiv / motor de pornire; a porni o maşină; (sport) concurent de start; debut, început; inventator (de calomnii etc.); lansare; persoana care pleacă / porneşte

starter battery (mas, auto) acumulator de pornire starter carburettor (mas, auto) carburator de pornire

starter clutch (OM) cuplaj al manivelei de pornire

starter formula (mat) formulă iniţială / de inițiere (pt. integrare numerică)

starter gear $(\mathrm{OM})$ pinion de demarator

starter motor (auto, mas) motor de pornire

starter ring gear $(\mathrm{OM}$, auto) coroană dințată de demarator

start from a porni de la

starting (el) amorsare, aprindere, demaror / starter direct / cu tensiune totală; $(\mathrm{TH}$, mas) demarare, pornire, punere în funcțiune / în exploatare, cuplu / moment de pornire

starting acceleration (mec, mas) accelerație la pornire

starting-air valve (OM, hidr) ventil (pneumatic) de pornire

starting arrangement $(\mathrm{OM}$, mas) mecanism de pornire

starting cam $(\mathrm{OM})$ camă de pornire

starting cock (OM, hidr) robinet de pornire starting compressor (termo, mas) compresor de pornire

starting crank jaw $(\mathrm{OM})$ gheară a manivelei de pornire

starting crank (OM) pârghie de pornire

starting current (el) curent de pornire

starting device (OM) dispozitiv de pornire; (el) starter, demaror

starting diameter $(\mathrm{OM})$ diametru inițial / de la care se pleacă (şi în proiectare)

starting distance (auto) distanță de accelerare

starting engine (mas) motor de pornire

starting gear (OM, mas) mecanism de pornire

starting handle $(\mathrm{OM})$ manivelă de pornire

starting jet (auto, termo) jiclor de pornire

starting length (auto, mas) porțiune / lungime de pornire

starting lever $(\mathrm{OM})$ levier / pârghie de pornire

starting loss (mas, $\mathrm{TH})$ pierderi la pornire

starting material (ind, TH) material de bază / inițial, materie primă

starting moment / torque (mec, mas) cuplu / moment de torsiune, de pornire

starting output (mec, mas) putere de pornire starting point (fiz, $\mathrm{TH}$ ) punct de pornire

starting point of meshing $(\mathrm{OM})$ punctul de început al angrenării

starting position $(\mathrm{TH}$, mas) poziție la pornire starting pulley (OM, mas)roată de pornire starting push button $(\mathrm{OM})$ buton de pornire starting relay $(\mathrm{el})$ releu de pornire

starting resistance (mas) rezistență la pornire; (T, OM) forță inițială (la pornire), necesară formării peliculei de lubrifiant într-un lagăr

starting section (met) secțiune inițială (la laminare, la forjare etc.)

starting the engine (auto, mas) pornire a motorului

starting torque (OM, hidr, mec, mas) cuplu de pornire, moment de răsucire / torsiune la pornire starting under load (mas) pornire în / sub sarcină starting-up lansare; (mas) demarare, pornire starting-up charge (met) încărcătura de pornire a furnalului

starting-up connection (el) schemă de pornire

starting valve (OM, hidr) ventil / supapă de pornire

starting without shock (mas, auto) pornire fără şoc starting work (mas) lucru mecanic de pornire

start light (mec, mas) pornire fără sarcină; a porni fără sarcină

start-stop distorsion (mas, autom) distorsiune aritmică (la pornire)

start-stop pressure control (hidr, autom) reglare a debitului prin pornire-oprire, în funcție de presiune 
start time (mas) timp de pornire / de demarare / de accelerare

start(-)up (mas) pornire, demaraj, punere în functiune / în exploatare

start up a porni; a demara, a pune în funcțiune / în exploatare

star-up boiler (termo) încălzire a cazanului star-up time (TH, mas) timp de pornire / de demarare

starvation $(\mathrm{T})$ starvare

starve (auto, mas) a opri din lipsă de combustibil; (T) a îndepărta lubrifiantul din zona de lucru, a starva, a lipsi contactul de lubrifiant (din cauze diverse)

starved joint (OM, plast) asamblare / lipire cu adeziv insuficient / care a fost evacuat din zona de lipire (defect)

starving (termo) subalimentare; (T) starvare (lipsă de lubrifiant în zona contactului)

star voltage (el) tensiune pe fază / simplă

star wheel $(\mathrm{OM})$ roată de lanț / dințată pentru clichet, roată de mână, cu brațe

star-wheel idler $(\mathrm{OM})$ roată planetară

stat- (metr, fiz, el) prefix care indicând că sistemul electric este calculat, executat și exploatat, utilizându-se sistemul de unități CGS (centimetru-gram-secundă), în prezent înlocuite cu unități SI (metru-kilogram-secundă); v. ,stat" units; echivalența unor unități pentru sisteme electrice: intensitatea curentului electric: 1 statampere $=3,3356 \cdot 10^{-10} \mathrm{~A} ;$ sarcină electrică: 1 statcoulomb $=3,3356 \cdot 10^{-10} \mathrm{C}$; capacitanță: 1 statfarad $=1,1126 \cdot 10^{-12} \mathrm{~F}=1,1126 \mathrm{pF}$; inductanță: 1 stathenry $=8,9876 \cdot 10^{11}$ henry; rezistență electrică: 1 statohm $=8,9876 \cdot 10^{11} \mathrm{ohmi}$; potential / tensiune electric $(\breve{a}): 1$ statvolt $=$ $299,79 \mathrm{~V}$; putere: 1 statwatt $=10^{-7} \mathrm{~W}$

state poziție, stare; situație; structură; constituție; formă; regim; condiție; constituție; caracter, natură, caracteristică; (pol, adm) stat, guvern, statal, de stat; oficial; ceremonie; fast; loc de cinste / de onoare; alai; măreție, pompă; rang, vază; specific; stare socială bună; a indica; a declara; a afirma; a specifica; a preciza; a formula; a determina; a defini; a enunța; a fixa; a exprima; a explica; a stabili; a aminti; a constata; a declara; a expune (un caz etc.); a încunoștința; a indica; a înștiința; a menționa; a pomeni; a preciza, a specifica; a spune

state bond (ec) obligatiune de stat

stated enunțat; declarat; (mat) enunțat (în logica matematică); exprimat; fătiș; fix; formulat; mărturisit; regulat; stabilit; (pol, ec, jur) stipulat stated point $(c$, inf) virgulă fixă state equation (fiz) ecuație de stare

statement (inf) instrucțiune; (mat) propozitie; enunț (şi al unei probleme / teme de proiectare); declarație; comandă; $(\mathrm{TH})$ formulare, specificare (a unei condiții, restricții etc.)

statement of accont (ec) extras de cont statement of assets and liabilities (ec) bilant, raport al activului şi pasivului

state of aggregate (fiz) stare de agregare

state of equilibrium (mec, termo) stare de echilibru

state of fusion (materiale, fiz) stare de topire state of inertia (fiz, mec) stare de inerție state of material as supplied (ec) stare de livrare state of motion (fiz, mec) stare de mişcare state of rest (fiz, mec) stare de repaus state point (fiz, termo) stare / punct de echilibru state space (fiz) mulțime a stărilor (probabile)

static, statical (mec) static

static accuracy (fiz, mec, termo) precizie sau toleranță a unui parametru în stare / regim stabilizat $(\breve{a})$

statical (determinare) statică

statically determinate (mec) static determinat statically indeterminate $(\mathrm{mec})$ static nedeterminat

statical test (mec, metr) încerare statică, test(are) în conditii cvasi-statice

static ball indentation test (materiale, metr) încercare / test cu indentare cu bilă, pentru determinarea durității Brinell

static coefficient of friction ( $T$, fiz) coeficient de frecare statică

static current (el) curent de repaus

static deflection (mec, OM) săgeată la încovoiere statică

static design (OM, mas) calcul / proiectare la sarcină statică / constantă

static determinate (mec) static determinat

static discharge head (fiz, hidr) înălțime statică de refulare

static electricity (mec, fiz) energie statică

static endurance test (metr, OM, mas) încercare / test la durabilitate sub sarcină constantă (pt. a stabili influența timpului)

static flow (hidr, T) curgere laminară

static friction (mec, T) frecare de aderență / statică / de repaus

static load (mec, mas, OM) sarcină statică

static load rating $(\mathrm{OM})$ sarcină statică de bază (la rulmenți)

static mechanic testing machine (OM, metr) maşină de încercări mecanice statice static model (fiz, inf) model static 
static opening (OM, hidr, termo) gură / deschidere de aspirație

static over-voltage (el, plast) supratensiune electrostatică

static pressure / head (fiz, hidr) presiune statică statics of fluids hidrostatică

static seal $(\mathrm{OM})$ etanşare fixă

static stability $(\mathrm{mec})$ stabilitate statică

static strength (mec, materiale) rezistență la solicitare statică

static suction head (hidr) înălţime statică de aspirație (şi la pompe)

static temperature (termo, metr) temperatură a fluidului (în condiții de viteză relativă nulă între fluid şi senzor sau compensând orice mişcare relativă)

static test (metr, OM) încercare / test în condiții statice (de solicitare)

static torque $(\mathrm{OM})$ moment de torsiune la care frâna este încă activă

static value (autom, mas) valoare de repaus

static unbalaned (OM, mas) neechilibrat static

static weighing (metr, hidr, transp) cântărire prin tarare a unui fluid (diferenta între tancul plin şi tancul gol, după evacuarea fluidului)

station statie; post; bază; loc; (el) centrală; (cf) gară; depozit vamal

stationary (fiz) staționar, fix; (mec, mas) în repaus; (pol) conservator

stationary axle $(\mathrm{OM})$ osie fixă

stationary blade $(\mathrm{OM})$ paletă / muchie fixă

stationary bushing $(\mathrm{OM})$ bucşă fixă

stationary coupling (OM) cuplare / cuplaj fix $(\breve{a})$ $/ \operatorname{rigid}(\breve{a})$

stationary fit $(\mathrm{OM})$ ajustaj cu strângere

stationary forehearth (met) (ante-) creuzet staționar

stationary furnace (met) cuptor fix / staționar

stationary hoist $(\mathrm{OM})$ troliu fix

stationary jaw (OM) falcă fixă (a menghinei)

stationary motion (mec, mas) mişcare în regim staţionar

stationary part $(\mathrm{OM})$ piesă fixă

stationary phase (fiz) fază staționară

stationary plate $(\mathrm{OM}, \mathrm{TH})$ placă port-cochilă fixă

stationary platen $(\mathrm{OM})$ placă fixă a matriței

stationary stay (mas-un) lunetă fixă

statinary value (mas, autom) valoare de repaus, valoare staționară

stationary wave (fiz, el) undă staționară

station milling (mas-un) prelucrare la maşina de frezat cu masă rotativă

statistical (mat) statistic

statistical design (mat) calcul statistic; $(\mathrm{OM}$, mas) proiectare cu date / metode statistice

statistical error (mat, metr) eroare statistică statistical quality control (mat, metr) control statistic al calitătii

statistical straggling (mat, metr) dispersie / împrăştiere statistică

statistical thermodynamics (fiz) termodinamică statistică

statistics (mat) statistică

stator (el, mas) stator

stator yoke (el, OM) jug de stator

statuary bronze (met) bronz ornamental / pentru statui $(90 \% \mathrm{Cu}+6 \% \mathrm{Sn}+3 \% \mathrm{Zn}+1 \% \mathrm{~Pb})$

„stat" units (metr, fiz) unităţi de măsură în sistemul de unități CGS (centimetru-gram-secundă), în prezent înlocuite cu unităţi SI (metrukilogram-secundă)

status (jur) statul legal, apartenență, cetățenie; situație; condiție; loc; poziție (a cuiva); poziție, rang, situație; stare (a lucrurilor); stare / condiție socială

status bar (inf) bară de stare, linie cu informații care apare în subsolul unei ferestre sau pe ultima linie a ecranului

status byte (inf) octet de stare

status information (ec, TH, mas, inf) informație de stare; (inf) reprezentare codificată a stării unui echipament sau program

status inquiry (ec) cerere de informații asupra situației financiare (a unei firme)

status nascens (chim, fiz) stare născândă

status register (inf, mas) registru / fişier (care păstrează valorile indicatorilor) de stare

status signal (inf) semnal de stare; semnal generat de un dispozitiv, indicând starea lui curentă

status word (inf, c) totalitate a parametrilor care caracterizează executarea unei sarcini pe un anumit procesor

statute (ec) statut; (fiz, el) lege; (pol, adm) lege, ordonanță, regulament

statute book (jur) cod (de legi)

statute law (jur) drept scris, jurisprudență

statute measures (jur) măsuri legale

statute mile (metr) unitate de măsură pentru lungime, milă engleză: 1 statute mile $=1609,34 \mathrm{~m}$

statute of limitation(s) (jur) lege privitoare la prescripție

statute-barred debt (jur, ec) datorie prescrisă

statutory (jur) prevăzut / stabili de lege; conform statutului, statutar; (ec, adm) reglementar

statutory plan / planning (ec, ind) plan / proiect de amenajare aprobat

statutory undertaker (constr, adm) concesionar de servicii publice

stauffer lubricator $(\mathrm{T}, \mathrm{OM})$ gresor / ungător cu pâlnie

staunch, stanch $(\mathrm{OM})$ etanş, ermetic, de bună calitate; (med) a opri o hemoragie; loial 
stave (alim, OM) doagă (de butoi), a desfunda (un butoi), a pune doage la (un butoi); (muz, poligrafie) portativ; şipcă, stinghie; (literatură) strofă, verset

stave in a (se) desfunda, a face o gaură in, a se sparge, a sparge; a (se) strica

stave off a amâna, a împiedica, a opri, a preveni (un dezastru etc.); a îngrădi; a întârzia; a restrânge

stave holder (OM) cric / vinci cu şurub

staving (met, mas-un, termo) lărgire / evazare a unui capăt de țeavă

stay (OM, constr) reazem, stâlp, suport, coloană, picior, montant, ancoră, tirant, contrafort, suport, pauză; (fig) ajutor, sprijin; amânare; băgare de seamă; dificultate, greutate, obstacol; păsuire; piedică; precautie, prudență; rămânere, ședere, oprire, vizită (într-un oraş etc.); (TH, OM) a ancora, a fixa, a sprijini, a sta, a opri, a suspenda; (nav) staționare a navei, strai, a stationa (d. navă); (nav, constr) a ancora; a aplana (o ceartă); a aştepta; a continua; a domicilia, a locui; a face o întrerupere / o pauză; a împiedica, a opri (cursul evenimentelor etc.); a înfrâna; (edu) a-i întări (încrederea, etc.); a întârzia; a se odihni (rar); a (se) opri; (jur) a păsui, a amâna; a potoli, a astâmpăra (foamea, setea); a preveni; a rămâne, a reține; a retrage (mâna etc.); a sta (pe loc); a suspenda; (fig) a sta, a rezista, a dura stay block (nav) bloc de ancoră / de ancorare

stay bolt (constr, OM) şurub distanțier / de întindere / de fixare / de asamblare a recipientelor sub presiune / de menținere a distanței între piese

stay bracket $(\mathrm{OM})$ lagăr în consolă

stay clamp $(\mathrm{OM})$ clemă de fixare

staying $(\mathrm{OM})$ ancorare, care stă

staying time (el, mas, $\mathrm{TH}$, autom, transp) timp de mentinere / de oprire / de stationare

stay on (auto) a rămâne aprins

stay pin $(\mathrm{OM})$ bolt de lanț articulat

stay rod $(\mathrm{OM})$ şurub distanțier, zăbrea

stay wire $(\mathrm{OM})$ sârmă de ancorare

stb (metr, ind) simbol pentru stock tank barrel;

v. stock tank barrel

steadfast ferm, neclintit; constant, fix, permanent; durabil

steadily falling (fiz, electr, autom) scăzând în mod continuu

steadily rising (fiz, electr, autom) crescând în mod continuu

steadiness continuitate; uniformitate; fixitate; permanență; rigiditate; rezistență; durabilitate

steadite (met) eutectic fosforos, steadită

steady fix; rigid; staționar; uniform; stabil; regulat; neîntrerupt, continuu; aşezat; calm; constant; cuminte; ferm; tare; serios; sigur; solid; (masun) lunetă; (OM) proptea, reazem, suport; (fig) credincios, statornic; înțelept; (met) a calma; a uniformiza, a egaliza; a stabiliza, a consolida, a face stabil, a întări, a se mişca regulat, a sprijini; a-și menține / ține echilibrul; a calma, a domoli, a potoli, a linişti (nervii); a da stabilitate (cuiva)

steady background (fiz, autom) nod staționar

steady conditions (mec, mas) stare de inertie, condiții stabile

steady current (el) curent constant / stationar

steady field (el, fiz) câmp uniform (în spațiu); câmp constant (în timp)

steady flow (hidr) curgere staționară / uniformă / stabilizată

steadying (fiz, el, electr, autom) netezire, stabilizare (a unui semnal, a unui regim)

steady load (mec) sarcină permanentă / constantă / statică

steady market $(\mathrm{ec})$ piață stabilă

steady pin (OM) ştift de montaj / de poziționare

steady point punct fix / staționar (pe o curbă a funcționării unui sistem etc.)

steady position (fiz, mas) poziție de echilibru; (mec, el) stare de repaus

steady rest (mas-un) lunetă

steady source (el, fiz) sursă constantă / stabilizată steady / stationary state (fiz, mas) regim stationar, stare staționară / permanentă de echilibru

steady-state (mas) stabil, stabilizat, permanent

steady-state conditions (hidr, mas) condiții de functionare uniformă / stabilă

steady-state flow (hidr) curgere staționară / uniformă

steady-state model (fiz) model în regim stabilizat (în care timpul nu este o variabilă)

steady-state motion miscare stationară

steady-state optimization (fiz) optimizare realizată pe un model în regim stabilizat (în care timpul nu influențează)

steady-state oscillation (mec, autom) oscilație staționară

steady-state regime (mas) regim staționar / cu parametri constanți

steady-state supply pressure range (hidr) domeniu / interval de variație a presiunii stationare, de alimentare

steady (state) value (mas, $\mathrm{TH}$, autom) valoare staționară

steady-state vibration (fiz, mas) vibrație în regim stabilizat / stabilizată / descrisă de funcții periodice

steady stress (mec, OM, mas) tensiune / efort la functionare în regim normal

steady value (mas, el) valoare de repaus

steak (alim) muşchi 
steak-pot roast (alim) (carne de la) ceafă

steal (fam) chilipir; (fam) ciordeală, lucru furat, ciordit; (fam) lucru cumpărat pe un preț de nimic, afacere; (amer) (fam) coțcărie, furt, potlogărie, preț scăzut; (fam) târg; a arunca (pe furiş) (şi fig); (fig) a câştiga, a cuceri, a răpi, a fura (inima etc.); (ec, adm, jur) a delapida, a fura, a sustrage; a se furişa, a se strecura; a răpi; a şterpeli

steam (termo) abur, vapori (şi de apă); a aburi, a înmuia (în abur); a face aburi; (ind chim) a trata cu aburi

steam admission (termo) admisie a aburului steam-admission port (termo) cameră de admisie (a aburului)

steam-admitting pipe (OM, termo) țeavă / conductă de admisie a aburului

steam apparatus (alim, termo, OM) cazan cu abur, autoclavă

steam atomiser (termo, alim, ind chim) pulverizator cu abur

steam attemperation (termo) reducere a temperaturii aburului supraîncălzit prin injectare de apă

steam bath (termo) baie de abur

steam binding (termo) blocaj / restrictie de circulare a fluidului, cauzată de formare rapidă sau de o acumulare de vapori sau abur

steam blast (termo) suflantă de aer, acționată cu abur

steam bleeding (termo) priză de abur, scurgere de abur

steam bleeding valve (termo, OM) supapă pentru priză de abur

steam blower (termo, OM) suflantă de aer, acționată cu abur

steam boiler (termo, OM) cazan de abur, boiler

steam-boiler battery (termo) baterie de cazane cu abur

steam-boiler fittings (termo, OM) armături pentru cazane de abur

steam-brake valve (termo, OM) supapă de frânare a aburului

steam bubble (termo) bulă de abur

steam case (termo) manta de abur

steam cleaning $(\mathrm{TH})$ curățire prin jet de abur

steam coal (termo) cărbune necocsifical folosit la cazane, cărbune industrial

steam cock (termo, OM) robinet de abur cu cep

steam coil (termo, OM) serpentină de abur

steam collector (termo, OM) colector de abur steam compression (termo) compresie a aburului steam condenser (alim, ind chim, termo) condensator de abur

steam conduit (OM, termo) conductă de abur steam consumption (termo, $\mathrm{TH}$ ) consum de abur steam cooking (alim, ind chim) fierbere cu abur steam cooler (alim, ind chim, termo) răcitor de abur

steam cooling (alim, ind chim, termo) răcire prin vaporizare; (termo) răcire a aburului steam cure (termo, ind chim) vulcanizare cu abur steam cured concrete (constr) beton tratat în abur steam descaling sprayer (termo, met) pulverizator cu abur pentru îndepărtarea țunderului (la laminare)

steam desiccator (termo, alim, ind chim) desicator de abur

steam distributing valve (termo, OM) supapă / distribuitor pentru abur

steam distribution (termo) distributie a aburului steam distributor (termo, OM) distribuitor de abur steam drive (termo, mas) actionare cu abur steam drum (termo, OM) tambur al cazanului steam dryer (termo, OM) uscător de abur, desicator de abur

steam drying (termo, $\mathrm{TH}$ ) uscare cu abur

steam drying apparatus (termo, $\mathrm{OM}$ ) aparat / dispozitiv de uscare cu abur

steam drying cylinder (termo, $\mathrm{OM}$ ) cilindru de uscat cu abur

steam ejector (termo, OM) ejector cu abur, suflător cu jet de abur

steam emulsification ( $\mathrm{TH}$, hidr) emulsionare cu abur

steam engine (mas, termo) motor cu abur

steam-escape pipe (termo, OM) țeavă / conductă de purjare

steam extraction valve (termo, OM) supapă pentru priza de abur

steam film (termo) peliculă de vapori

steam-flow meter (termo, metr) contor de abur

steam for heating (termo) abur de încălzire

steam-free water (termo) apă fără bule de vapori

steam gate valve (termo, OM) robinet cu sertar pentru închiderea aburului

steam gauge (metr, termo) manometru de abur

steam-generating heat (termo) căldură de producere a aburului

steam-generating plant (termo, ind) instalație generatoare de abur

steam generation (termo, ind) formare a aburului steam generator (termo, ind) generator de abur steam hammer (termo, OM) ciocan cu abur steam-heated dryer (termo, OM) uscător cu abur steam heating (termo, ind) încălzire cu abur steam-heating line (termo) conductă de abur pentru încălzire

steam hose furtun pentru abur

steaming (met, TH) perioadă de încălzire la generator; spălare / tratare cu abur, aburire, antrenare cu abur 
steaming-out (termo, TH) aburire, spălare cu abur steaming pan (alim) cazan de aburire

steaming period (met) perioadă de încălzire (la generator de abur)

steam inlet (termo, OM) admisie a aburului

steam installation (termo) instalație de generare de abur

steam intake (termo) admisie a aburului

steam jacket (termo, met) manta de abur / de încălzire

steam jet (termo) manta de abur; (hidr, termo) jet de abur

steam-jet blower (termo, met) suflantă cu jet de abur (la furnal)

steam line (termo, OM) conductă de abur

steam main (termo, OM) conductă (principală) de abur

steam out (termo, TH) a aburi

steam outlet (termo, TH) evacuare a aburului

steam-outlet pipe (termo, OM) țeavă / conductă de priză de abur

steam packing (termo, OM) garnitură de etanşare a aburului

steam pipe conductă de abur

steam-pipe expansion loop (termo, OM) compensator de dilatare pentru conductă de abur (sub formă de buclă / spiră)

steam piping (termo, OM) conducte de abur, ansamblul conductelor pentru abur

steam point (fiz, termo) punct de fierbere

steam power (termo, mec, mas) putere a aburului

steam press (mas-un, termo) presă cu (acționare $\mathrm{cu}$ ) abur

steam pressure (termo) presiune a aburului

steamproof rezistent / etanş la abur

steam purity (termo) puritate a aburului (exprimată şi în ppm)

steam quality (termo) calitate a aburului (exprimată prin procentul de vapori şi apă din amestec)

steam separator (termo, OM) separator de abur, oală de condens(at)

steam sluice valve (termo, $\mathrm{OM}$ ) robinet $\mathrm{cu}$ sertar, pentru abur

steam space (termo, OM) spațiu pentru abur

steam sterilising (alim, ind chim, $\mathrm{TH}$ ) sterilizare cu abur

steam superheater (termo, ind) supraîncălzitor de abur

steam tension (fiz) presiune / tensiune de vapori steam test (metr, termo, materiale, $\mathrm{OM}$ ) încercare / test la abur / la vapori

steam throttling (termo) laminare a aburului

steamtight $(\mathrm{OM})$ etanş la abur

steam tracing (termo, OM) dispunere a unei conducte cu abur în serpentină în jurul unei linii de transportat fluide, pentru a preveni înghețarea sau condensarea

steam trap (termo) separator de abur, oală de condensat

steam tube (termo, OM) țeavă / tub / conductă de abur

steam turbine (termo, mas) turbină cu abur

steam-turbine drive (termo, mas) actionare cu turbină cu abur

steam valve (termo, $\mathrm{OM}$ ) robinet / ventil pentru abur

steam velocity (termo) viteză a aburului

steam vent (termo, $O M$ ) ieşire a aburului

steam void (termo) bulă de abur

steam vulcanisation (ind chim) vulcanizare $\mathrm{cu}$ abur

steam vulcaniser (ind chim) instalație de vulcanizare cu abur

steel (met) oțel; a căli, a oțeli

steel ageing (met) îmbătrânirea oțelului

steel-armour (met) blindaj de / din oțel

steel-armoured (met) blindat cu oțel

steel-armouring (met) blindare cu oțel

steel-backed bearing $(\mathrm{OM})$ lagăr cu suport din oțel

steel-ball (met) bilă de oțel

steel-ball cleaning (met, $\mathrm{TH}$ ) curăţare cu jet de alice din otel

steel ball penetrator (metr, OM) penetrator $\mathrm{cu}$ bilă de oțel

steel ballast (nav) lest de oțel

steel band conveyer $(\mathrm{OM})$ transportor cu bandă de oțel / metalică

steel bar (met, OM) bară de oțel (şi laminată)

steel-belt-apron conveyer $(\mathrm{OM})$ transportor $\mathrm{cu}$ eclise

steel bender (constr) fierar-betonist

steel-block coupling (OM) cuplaj cu saboți metalici / din otel

steel body (OM, met) corp (masiv) din oțel

steel casing (met, OM) carcasă / manta / înveliş din oțel

steel casting (met) turnare a oțelului, piesă turnată din oțel

steel concrete (constr, met) beton armat

steel construction (constr) construcție metalică / din oțel

steel creep / flow (met, materiale) fluaj / curgere a oțelului (atenție: în limba română creep se traduce prin fluaj - curgere la temperatură ridicată şi sub sarcină, flow - curgere la temperatură normală)

steel cutting (met, TH) tăiere / (prelucrare prin) aşchiere a oțelului

steel cylinder (ind chim, OM) butelie de oțel

steel die (met, OM) matriță din oțel 
steel dog (constr, OM) scoabă (de oțel)

steel drill (mas-un) sfredel, burghiu (din otel)

steel drop forgings (met) piese din oțel, forjate în matriță

steel edge cutting-off tool (mas-un) cuțit pentru retezat / debitat

steel-faced wrought-iron armour plate (met) tablă pentru blindaje

steel flat (met) platbandă, tablă / semifabricat plat din oțel

steel flow (met) curgere a oțelului (nu neapărat la temperatură înaltă)

steel forging (met, $\mathrm{TH}$ ) forjare a oțelului

steel forgings (met) piese din oțel forjat (liber)

steel for mechanical engineering (met) oțel pentru construcții de maşini

steel for reinforced concrete (met, constr) otel pentru armarea betonului

steel founder (met) muncitor la turnătoria de oțeluri

steel foundry (met) turnătorie de oțel, oțelărie

steel-frame superstructure (constr) construcție $\mathrm{cu}$ schelet metalic

steel girder (constr, met) grindă de oțel

steel grade (met) calitate / marcă de oțel

steel-grey (culoare) (culoare) gri-fer

steel grid (constr) grilaj de / din oțel

steel grit (constr) alice de / din oțel

steel-hardening oil (met, ind chim) ulei pentru călirea oțelului

steel-hauling truck (met) melanjor, vagon de transportat oțel lichid

steel hoop (met) bandă (laminată) de oțel, buclă din rulou de tablă de oțel

steeling (met) oțelire

steel ingot (met) lingou de oțel

steel insert (met, OM) adaos interior / inserție / armătură de oțel

steel jack (met, OM, mas, mil) armătură, blindaj, înveliş (din oțel)

steel jacket (met, ind chim, OM) manta / armătură / blindaj / înveliş de oțel

steel lacing $(\mathrm{OM})$ bandaj metalic (de întărire)

steel ladle (met) oală de turnare a oțelului

steel line (met, OM) cablu de oțel

steel maker (met) oțelar

steel making plant (met) oțelărie

steel melting (met) topire a otelului

steel-melting aggregate (met) utilaj de obținere a otelului lichid

steel melting furnace (met) cuptor de topire a otelului

steel melting plant / shop (met) oțelărie

steel mill / plant (met) oțelărie

steel mix cast iron (met) fontă oțeloasă / cu adaos de oțel / cu masă fin perlitică steel mould (met) lingotieră

steel pig (met) fontă de afinare

steel pilling (met) planşă de oțel, tablă groasă de / din oțel

steel pipe (met, OM) conductă / țeavă / tub de oțel steel pit (met) por (defect)

steel plant (met) oțelărie

steel plate (met, nav) tablă de / din oțel

steel-plate lining (met, nav) blindaj, armătură / înveliş metalic (în special din oțel) (la o navă, la furnal etc.)

steel plating (met) placare cu oțel

steel-pouring laddle (met) oală de turnare

steel-pouring laddle car (met) cărucior / vagonet cu oală de turnare pentru oțel

steel powder (met) pulbere de oțel

steel product (met) produs de / din oțel

steel product(s) for pressure purpose(s) (met) produs(e) din oțel pentru recipiente sub presiune steel quality (met) calitate a otelului

steel rack (ind) rampă de scule / de utilaje

steel ratio of concrete (constr) coeficient de armare

steel refining (met) afinare a oțelului (lichid)

steel reinforcement (met) adaos interior de oțel, căptuseală / armătură de otel (si la recipiente)

steel reinforcement in concrete (met, constr) armătură de otel pentru beton

steel rod (met) bară de oțel

steel roll (met) cilindru de otel

steel roller chain (met, OM) lanț cu role de oțel steel rolls (met) cilindri de oțel (şi pt. laminare)

steel rope $(\mathrm{OM})$ cablu de otel

steel sample (met) probă de oțel

steel scrap (met) deșeuri de otẹl

steel section (met, OM) oțel profilat, profil de oțel steel sheet (met) tablă de oțel, tolă, planșă de oțel

steel-sheet casing (met) carcasă / manta / înveliş de tablă de otel

steel-sheet pilling (met, constr) perete de tablă groasă

steel shell (met, OM) carcasă / manta de oțel

steel shell bushing / bearing $(\mathrm{OM})$ cuzinet $\mathrm{cu}$ cămaşă de / din oțel

steel shot (met) otel granulat, alice de / din otel

steel-side bar chain $(\mathrm{OM})$ lant articulat

steel-skeleton construction (constr) constructie cu schelet metalic

steel sleeper (met, cf) traversă metalică / de oțel

steel spoke $(\mathrm{OM})$ spiță de oțel

steel stack (constr) coș metalic

steel strip (met) platbandă / bandă de oțel

steel structure (met) structură / construcție metalică / de oțel

steel suitable for quenching (met) oțel călibil

steel tension rod (constr) tirant de oțel 
steel tie (cf) traversă metalică

steel tube (met) tub / țeavă de oțel

steel wide strip (met) bandă lată

steel wire (met) sârmă de oțel

steel-wire brush $(\mathrm{OM})$ perie din sârmă de oțel

steel-wire rope (constr, met) cablu din sârmă de oțel

steel-wire stay (constr, met) tirant pentru / de fier-beton

steel with high strength at elevated temperature (mec, met) otel refractar / rezistent la temperaturi ridicate

steel work (ind, OM) construcție / piese din oțel

steel worker (met) oțelar

steel works (met) oțelărie

steel works blower (met) suflantă de oțelărie

steely (met) oțelit, de oțel

steep abrupt; (geogr) mal, râpă, prăpastie; (alim) a opări; (TH) a scufunda (într-un lichid), a se uda, a se umezi, a introduce (într-o soluție), a impregna, a îmbiba, a fierbe sub presiune, a înmuia

steep-angle bearing $(\mathrm{OM})$ rulment cu role conice (mai rar)

steep curve (mat, OM) curbă cu rază mică (de curbură)

steep head (OM) cap tronconic al nitului

steep in dye (ind chim) înmuiere în vopsea

steeping (TH) înmuiere, umezire

steeping fluid (alim, ind chim) fluid / lichid pentru înmuiere

steeping in dye $(\mathrm{TH}$, ind chim) înmuiere / cufundare în vopsea

steeple head $(\mathrm{OM})$ cap tronconic al nitului, cu înălțimea egală cu diametrul tijei

steepness of sides / slopes of a curve (mat) gradient al pantelor unei curbe

steep pitch $(\mathrm{OM})$ pas mare, înclinare mare

steer a conduce, a pilota, a guverna, a cârmi

steerable dirijabil, guvernabil, care poate fi condus / dirijat

steerage way (nav) viteză de guvernare

steering (auto) comandă a direcției

steering angle (auto) unghi de bracaj

steering arm (auto) arbore / coloană de direcție, pârghie de comandă a direcției

steering arm shaft (auto, OM) ax al pârghiei de comandă a direcției

steering axle (auto, OM) ax de directie

steering box (auto, OM) casetă de direcție, carcasă a mecanismului de directie

steering by rack and pinion (auto, $\mathrm{OM}$ ) direcție cu cremalieră şi pinion

steering column (auto, $\mathrm{OM}$ ) coloană de direcție steering column bracket (auto, OM) suport al coloanei de direcție

steering-column gear change (auto, OM) schimbător de viteze pe coloana direcției

steering-column gear control (auto, $\mathrm{OM}$ ) comandă a schimbătorului de viteze pe coloana direcției

steering column tube (auto, OM) tub al coloanei de directie

steering connecting rod (auto, OM) bară de directie / de comandă

steering control (auto, OM) control al direcției

steering cross rod (auto, OM) bară transversală de directie

steering cross rod jaw (auto, OM) furcă de la bara transversală de direcție

steering damper (auto, $\mathrm{OM}$ ) amortizor de direcție steering device (auto, OM) dispozitiv de directie / de conducere

steering drag rod (auto, OM) bară a longitudinală a directiei

steering engine (nav) servomotor de cârmă

steering gear mecanism de conducere / de direcție, comandă a direcției, direcție; (nav) transmisie a cârmei

steering gear arm (auto) pârghie a mecanismului de direcție

steering-gear backlash (auto) joc al casetei de direcție

steering gear box (auto, OM) casetă de direcție

steering gear clearance (nav) joc al mecanismului de guvernare; (auto) joc al (mecanismului) de direcție

steering gear connecting rod (auto) bară de comandă de directie

steering gear (female) nut (auto, OM) piuliță a pârghiei de comandă a directieiei

steering-gear housing (auto, OM) casetă de direcție

steering gear lock (auto, OM) dispozitiv de blocare a direcției

steering-gear nut (auto, OM) piuliță de la caseta de directie

steering-gear worm (auto, OM) şurub / melc de la caseta de direcție

steering geometry (auto, OM) geometrie design al directiei

steering guide rod (auto, OM) bară de direcție

steering knuckle (auto) fuzetă

steering knuckle arm (auto) pârghie de comandă a directiei

steering knuckle bush (auto) bucșă de fuzetă steering-knuckle pivot (auto, OM) ax / pivot al fuzetei 
steering knuckle tie-rod (auto, OM) bară transversală de direcție

steering-knuckle type of steering (auto, OM) direcție cu fuzete

steering leads (nav) transmisie a cârmei

steering lever (OM, mas, auto) pârghie de comandă, pârghie a mecanismului de directie

steering machine (nav) maşină / instalaţie de cârmă

steering mechanism (OM, mas, auto) mecanism de direcție

steering pillar (auto, OM) coloană de direcție

steering pin (auto, OM) pivot de direcție

steering position (nav) post de guvernare

steering program(me) (c, inf) program director, subprogram, subrutină

steering rack (auto, OM) cremalieră (a sistemului) de direcție

steering rake (auto) înclinare a coloanei de direcție

steering (reduction) ratio (auto) raport de demultiplicare a direcției

steering rod (auto) bară de direcție / de comandă

steering routine $(\mathrm{c}$, inf) program director

steering shaft (auto, OM) arbore de direcție

steering stub (auto, OM) fuzetă

steering swivel bolt (auto, OM) pivot al fuzetei

steering swivel bush (auto, OM) bucşă a fuzetei

steering tie rod (auto) bară transversală de direcție

steering wheel (auto, OM) roată / volan (de direcție)

steering-wheel arm (auto, OM) spiță a volanului de direcție

steering-wheel lock (auto, OM) dispozitiv de blocare al directiei

steering-wheel play / tilting (auto) joc al volanului de direcție

steering-wheel rim (auto, OM) coroană a volanului de directie

steering-wheel shaft (auto, OM) arbore de direcție steering-wheel spider (auto, OM) spițe ale volanului de direcție

steering-wheel spindle (auto, OM) arbore de direcție

steering-wheel tilting (auto) joc / reglare a(l) volanului de direcție

steering wheel torque (auto, mec) moment de torsiune pe volan

steering worm (auto, $\mathrm{OM}$ ) şurub / melc de direcție steering-worm gear (auto, OM) angrenaj al casetei de directie

steering-worm sector (auto, OM) sector al direcției cu şurub / cu melc, sector dințat de direcție stein (metr) unitate de măsură pentru volum (pt. bere), în Germania: 1 stein $\sim 0,51$

steinkast (metr) v. stone's throw

stellite (met, mas-un) aliaj dur (pe bază de cobalt), rezistent la uzură, coroziune şi la temperaturi ridicate; a încărca cu stelit

stem (bot) trunchi (şi de lemn), tulpină, tijă; (el, electr) picior / tijă de lampă, picior / picioruş de componentă electronică; (nav) etravă; (OM) tijă, ax, ştift, coadă, ghidaj pentru roata de mână, plunjer; a opri

stem bearing $(\mathrm{OM})$ lagăr(e) de ghidare a axului

stem layer (met) strat de abur (la răcirea cu apă a semifabricatelor)

stemplate (nav) scară de etravă

stem rotation (hidr, mec, OM) rotire a plunjerului cu mişcare liniară din cauza unor componente ale forței hidraulice

stem spider $(\mathrm{OM})$ nervuri de lagăr

stencilling $(\mathrm{TH})$ marcare, imprimare cu şabloane

stenell (constr) tipar; (mas-un, TH) sablon, material pentru executarea şablonului, a forma cu şablonul, a matrița

stent întindere; limită; evaluare; impunere; a întinde; a evalua; a limita; a restrânge; a impune

step (auto) scară; (OM, mas, autom, el) fază, etapă, pas, timp, treaptă, prag, salt (de semnal, de sarcină etc.) tranziție, etaj; (constr) terasare; step (metr) unitate tradițională pentru lungime, pas: 1 step $=0,5$ pace $\sim 76,2 \mathrm{~cm}$; (mil, metr) 1 shorter step (US) $=57,15 \mathrm{~cm}$; step, full step (metr, muz) pas, unitate utilizată pentru a descrie raportul frecvențelor între două note; două note diferă printr-un pas dacă frecvența celei mai înalte este $2^{1 / 6}=1,12246$ din frecvența celei mai joase

step action (mas) acțiune în trepte

step-back welding (met) sudare în pas de pelerin / cu revenire / cu întoarcere

step bearing $(\mathrm{OM})$ lagăr axial, crapodină în trepte, pivot (în trepte)

step brazing ( $\mathrm{TH}, \mathrm{OM})$ lipire (tare) în straturi succesive, cu aliaje cu temperaturi de topire din ce în ce mai scăzute

step-by-step (ind, TH) treaptă cu treaptă, în trepte, gradat (d. procese etc.)

step-by-step drilling (mas-un, TH) găurire în trepte sau cu scoaterea periodică a burghiului din gaură

step-by-step / stepping / stepper motor (mas) motor în trepte, motor pas-cu-pas

step change (fiz, autom) schimbare / modificare în trepte / cu salt 
step chuck (mas-un, OM) mandrină cu suprafață de strângere în trepte

step control (mas, autom) reglare în trepte

spet disturbance (autom, el) perturbare în cascadă

step down (mas, mec, el) a reduce, a micşora (şi tensiunea electrică)

step-down gear $(\mathrm{OM})$ reductor în trepte, angrenaj demultiplicator / reductor

step-down transformer (el) transformator coborâtor de tensiune / reductor; (met) transformator de reductie

step-down twisting test (mec, metr, OM, materiale) încercare / test la torsiune în trepte (descrescătoare)

step function (mat) funcție constantă, în trepte pe porțiuni

step gating, stepped side gate (met) canal pentru alimentare suplimentară a maselotei cu metal lichid

step gauge (metr, OM) calibru în trepte

step-grate furnace (termo) focar cu grătar în scară

step hanger $(\mathrm{OM})$ suport pentru scară, balustradă step hardening-quenching (met, TH) (durificare prin) călire în trepte

step joint $(\mathrm{OM})$ îmbinare / asamblare cu prag step-ladder $(\mathrm{OM})$ scară pliantă

stepless control (autom, mas) reglare continuă step out a se scurge, a se revărsa, a ieși în afară stepped (OM, fiz, autom) (variabil) în trepte stepped anneal(ing) (met, TH) recoacere în trepte

stepped cones $(\mathrm{OM})$ conuri în trepte (la variatoare)

stepped control (autom, OM) control / reglare în trepte / în praguri

stepped cutter (mas-un) freză cu dinți profilați în trepte

stepped foundation (constr) fundație în trepte stepped gauge (metr, OM) calibru în trepte

stepped gear $(\mathrm{OM})$ con cu roți dințate, transmisie în trepte, angrenaj în trepte

stepped hole $(\mathrm{OM})$ gaură / alezaj în trepte

stepped pinion $(\mathrm{OM})$ con de pinioane (la cutia de viteze)

stepped quenching (met) călire în trepte

stepped roll(er) (met, OM) cilindru cu tăblia în trepte

stepped shaft $(\mathrm{OM})$ arbore cu tronsoane de diferite diametre

stepped teeth reamer (mas-un) alezor în trepte, alezor conic cu dinți în trepte

stepped transmission $(\mathrm{OM})$ transmisie în trepte stepped variation of speed $(\mathrm{OM}, \mathrm{mec})$ variație în trepte a vitezei

stepped wheel gear(ing) $(\mathrm{OM})$ angrenaj în trepte, transmisie cu con de pinioane

step per tooth $(\mathrm{OM})$ supraînălțare pe dinte

stepping în trepte, eşalonat, (parametru) care evoluează în trepte

stepping control (mas, autom, metr, TH) control în trepte / pas cu pas

stepping motor (el) motor pas-cu-pas

stepping wheel $(\mathrm{OM})$ roată de cuplare / cu clichet step polymerization (ind chim) polimerizare în trepte

step pulley $(\mathrm{OM})$ roată (de curea) în trepte

step response (time) (autom) timp de răspuns la schimbarea instantanee a parametrului de intrare

steps trepte, paşi, etape; (OM) cuzineți de lagăr

step size (OM) mărime a pasului; (mas-un) mărime a avansului

step soldering $(\mathrm{TH})$ procedeu / tehnologie de executare a unei asamblări lipite prin lipiri succesive, cu aliaje care se topesc la temperaturi din ce în ce mai joase

step tap (mas-un) tarod în trepte

step (-)up (el) transformare ridicătoare de tensiune, ridicarea tensiunii prin transformare; a ridica tensiunea; (OM, mas) a crește turația

step-up cure (ind chim) vulcanizare în trepte / treptată

step-up gear(ing) $(\mathrm{OM})$ angrenaj multiplicator de turație (în trepte), transmisie multiplicatoare (în trepte)

step-up in performance (mas) creştere a puterii / a unui parametru de performantă (a sistemului / maşinii)

step valve $(O M$, hidr) supapă în trepte

stepwise cooking (alim, TH) fierbere în trepte

stepwise polymerization (ind chim) polimerizare în trepte

stepwise screening (materiale, $\mathrm{TH}$ ) sortare în trepte

steradian (mat) steradian, unghi solid; steradian (sr) (metr) unitate standard pentru a măsura unghiuri solide; o sferă are $4 \cdot \pi$ steradiani; 1 steradian $\cong 0,079577$ dintr-o sferă; 1 steradian $=$ 3282,806 square degrees; $v$. square degree

stere (st) (silv, metr) unitate de măsură pentru volum (pt. lemn), ster, metru cub (de lemne)

steric (fiz) spațial

sterile (met, ind, mediu) steril

sterilization (med, alim) sterilizare

sterilize (med, alim) a steriliza

sterilized (med, alim) sterilizat 
sterling veritabil; bun; standard; de bună calitate; monedă de $\sim 10$ lire sterline

stern (nav) la cârmă, pupa

stern anchor (nav) ancoră de (la) pupa

stern frame (nav) (cadru) etambou

stern-heavy (nav) apupat, încărcat la pupa

stern pipe (nav) nară pupa

sternpost (nav) etambou

sternpost shaft (nav) arbore etambou

sternway (nav) viteză înapoi

stew (aliM) a fierbe înăbuşit

sthene (sn) (metr, fiz) unitate de măsură pentru forță, în sistem ,,metru-tonă-secundă”, utilizată în inginerie, în Europa; 1 sthene $=10^{3} \mathrm{~N}$

stibium (Sb) (chim) stibiu

stick băț; $(\mathrm{OM})$ bară, manivelă, mâner, stâlp, vergea, electrod (de sudură); a (se) lipi (de ceva), a adera, a aplica; a înfige; stick (stk) (metr) unitate de măsură pentru capacitate sau masă, unt; 1 stick (US) $\cong 113 \mathrm{~g}, 1$ stick $~ 118$ ml; stick (stk) (metr) băț, unitate de măsură pentru distanță, în special pentru rețele electrice: 1 stick $(\mathrm{US})=3,048 \mathrm{~m}$

stick electrode welding (met, $\mathrm{TH}$ ) sudare cu electrod învelit (gravitaţională)

sticker (chim) adeziv; (inf) etichetă; (alim) etichetă gumată; (auto) foaie tip stick, abțibild

stricker break (met) fisură / rupere la suprafață (din cauza lipirii la laminare)

stickiness adezivitate, proprietatea de a se lipi / de a fi lipicios, putere de lipire

sticking (TH) blocare, împungere; perforare; lipire / sudare (defect la turnarea continuă, la laminare, la recoacerea tablelor în pachet); înghețare a electrodului; (el) ardere a contactelor; (OM, hidr) înțepenire

sticking of blank (met) lipirea / ataşarea bramei (la turnarea continuă)

sticking of drill-pipe (OM, hidr) înțepenire a garniturii (pe o conductă)

sticking of piston rings $(\mathrm{OM}, \mathrm{T}$, termo) înțepenire / gripare a segmenților de piston

sticking of the valve (termo, auto, T) gripare / gumare a unei supape

sticking-piece (alim) muşchi de la ceafã

sticking tape (ind chim) bandă adezivă

sticking together of the fibers (ind chim) lipire a fibrelor

sticking valve $(\mathrm{OM}$, termo) supapă gripată / gumată

stick limit (materiale, TH) limită de aderență stick region (met) zonă de aderență (de adeziune) stick to a (se) lipi pe / de

stick together a se lipi stick weld $(\mathrm{OM})$ îmbinare / sudură / asamblare prin puncte, lipire în / prin puncte sticky lipicios, cleios (d. materiale)

sticky clay (geol) argilă lipicioasă; (ind chim) clei de lipit

sticky limit (materiale, TH) limită de aderență

sticky sand (geol, constr) nisip argilos

sticky slag (met, termo) zgură vâscoasă

sticky tape (ind chim, OM) bandă adezivă, (el) bandă izolantă / de lipit

stiff rigid, compact, tare, solid, gros, dens, consistent, inflexibil

stiffen a rigidiza, a consolida, a întări

stiffened (constr, OM) întărit, rigidizat

stiffener (OM) placă / cornier / guseu de rigidizare, element de rigidizare (şi pt. prevenirea flambajului), eclisă; (chim, plast) element / agent de rigidizare / de întărire

stiffening (OM, constr) (acțiune de) rigidizare / întărire, ranforsare

stiffening bar $(\mathrm{OM})$ bară de rigidizare / care rigidizează

stiffening frame $(\mathrm{OM})$ cadru de rigidizare

stiffening girder $(\mathrm{OM})$ grindă de rigidizare

stiffening iron plate $(\mathrm{OM})$ placă de rigidizare, nervură de întărire, eclisă (metalică)

stiffening joint (OM) legătură / asamblare de rigidizare / care rigidizează

stiffening plate $(\mathrm{OM})$ placă de întărire / de rigidizare / de consolidare, eclisă

stiffening rib $(\mathrm{OM})$ nervură de rigidizare

stiffening sheet $(\mathrm{OM})$ tablă de întărire / de rigidizare

stiffening wall (constr) perete / zid de rigidizare

stiffness rigiditate (forță sau moment pe unitatea de lungime), inflexibilitate

stiffness coefficient (mec, OM) coeficient de rigiditate

stiffness testing (OM, metr) testare a rigidității

stiff saw (mas-un) ferăstrău coadă-de-vulpe

stifle (zool) articulație / încheietură a genunchiului (la cai, câini etc.), genunchi; a se asfixia; (şi fig) a (se) înăbuşi, a muşamaliza (o afacere), a stinge (focul, o mişcare socială etc.); (fiz, muz) a înăbuşi (sunetul); a stinge (focul); a se sufoca; a sugruma

stifle frequencies (fiz) a înăbuşi frecvențele

Stilb (sb) (metr, fiz) unitate de măsură pentru luminozitate, stilb: $1 \mathrm{stilb}=10^{4}$ candela $/ \mathrm{m}^{2}$

still (adj) liniştit, fără zgomot, nemişcat, calm, silentios; fotografie de publicitate; $(\mathrm{OM}$, alim, ind chim) alambic, aparat de distilat, distilator, distilerie; calm, linişte; (cinematografie) secvență, cadru; $(a d v)$ încă (în propoziții afirmative); 
(conj) totuşi; (TH) a picura, a distila, a rafina; a curăți, a purifica; a (se) linişti, a se potoli; sit / lie / keep $\sim$ a păstra linişte; stand $\sim$ a sta nemișcat; the $\sim$ small voice glasul conștiinței; (artă) life natură moartă; it is true totuşi este adevărat

still air cooling (termo, ind) răcitor de aer, cu circulatie naturală

still air frezzing (alim) congelare în atmosferă calmă (fără circulație forțată de aer)

stillpot (alim, hidr, mediu) bazin de decantare / de limpezire

still-room (alim) distilerie

still shell (OM, alim, ind chim) manta a distilatorului / a cazanului de distilare

Stillson wrench (auto, OM) cheie tubulară (rar)

still steam (alim, ind chim) vapori de distilare

stimulate a activa, a excita; a stimula; (fig) a împodobi, a încuraja, a îndemna, a stimula

stimulation activare, excitare, excitatie, impuls, stimul; stimulare; (fig) îmbărbătare, îmboldire, încurajare, stimulare

stimulus stimulent, activator; şoc; impuls

sting $(\mathrm{OM})$ ac, bold, vârf ascuțit; (bot) ac, perișor iritabil, țep; (zool) dinte veninos (al unui şarpe); (med) durere ascuțită, usturime, a răni, a bășica, a ustura; (fig) imbold, îndemn, provocare; împunsătură; înțepătură; mușcătură, pișcătură, urzicătură; (fig) bani furați, bunuri furate; (fig) a îmboldi, a îndemna, a stimula, a răni, a durea; a împunge, a înțepa; a înțepa, a urzica (d. urzici etc.); a pişca (d. muşte etc.); a încărca nota de plată

stink duhoare, miros greu / urât, putoare; (fam) reacție puternică de mânie / de protest, a avea o proasta reputație; a duhni, a mirosi greu / urât, a puți (fam) a fi de proasta calitate

stint cantitate; hotar; limită, limitare, reducere, restrângere; măsură, parte, porție, rație; (ind) schimb; a (se) restrânge; a limita; a fi econom, a face economie la; a limita, a reduce, a restrânge (porții etc.); a se zgârci la

stipulate a stipula, a fixa, a preciza, a stabili

stipulated load (el, OM) sarcină prescrisă / recomandată

stipulation (ec) stipulație, clauză, condiție

stir mişcare, agitație, agitare, amestecare, circulație; ghiont, împinsătură; mestecare; nelinişte, senzație, tulburare; umblet; vâlvă; (fig) puşcărie; a (se) mișca, a pune în mişcare, a (se) clinti, a (se) urni; a zdruncina; a zgudui; a agita, a amesteca, a tulbura (un lichid); a scutura; (agr) a afâna (pământul); (fig) a fi activ / ocupat, a se căzni, a se strădui, a depune eforturi; a avea loc; a clătina; a deplasa; a deranja; a ieşi la iveală / la lumină; a începe să circule / să se miște / să umble; (fig) a încuraja, a iniția, a întreprinde; (fig) a înflăcăra, a stârni (imaginația etc.), a mişca (inima etc.); a se întâmpla; a muta; a neliniști; a scormoni (focul); (fig) a stimula; a trezi; a se trezi (din somn)

Stirling cycle (termo) ciclu Stirling

stir thoroughly a amesteca bine

stirrer $(\mathrm{OM}$, mas, alim, ind chim) amestecător, agitator, paletă de amestecat

stirrer bar (termo) vătrai de agitare; (met) lance / bară de agitare

stirring $(\mathrm{TH})$ agitare, amestecare; activ; agitat; emoționant; excitant; înviorător; mișcător; neliniştit; ocupat; stimulator; tulburător; (agr) a doua arătură

stirring apparatus $(\mathrm{OM})$ dispozitiv / aparat de amestecare / de agitare, amestecător, agitator

stirring by air injection (alim, ind chim, mediu) agitare / amestecare cu ajutorul jetului de aer

stirring crystallizer (ind chim) cristalizor $\mathrm{cu}$ amestecător

stirring device (OM, alim, ind chim) amestecător, aparat de amestecare

stirring implement (met) dispozitiv / vătrai de pudlare

stirring machine / mechanism (mas, om) agitator, dispozitiv (cu acționare proprie) de agitare / de amestecare; (met) utilaj de pudlat

stirring motion (mec, $\mathrm{TH}$, hidr) mişcare de amestecare / de agitare, curgere / mişcare turbulentă

stirring motion stirring paddle (OM) pală amestecătoare

stirring paddle $(\mathrm{OM})$ pală de amestecător / de agitator

stirring pole (alim) făcăleț; (ind chim) tijă de agitare

stirring tank (om, alim, ind chim) rezervor $\mathrm{cu}$ amestecător

stirring test probă prin / de agitare / amestecare stirring up (ind chim, met) agitare a băii

stirring wing $(\mathrm{OM})$ pală amestecătoare / agitatoare / de amestecător / de agitator

stirrup $(\mathrm{OM})$ brățară, jug, cercel, piesă de agățare / de atârnare (în general)

stir up (termo) a ațața focul; (TH) a agita, a amesteca

sticher mașină de cusut / de prins table / curele

stitching (textile, ind) prindere cu copci / agrafe / prin coasere; (TH, plast) sudare a termoplasticelor prin presare cu role-electrod de inducție

stitching hook $(\mathrm{OM})$ agrafã

stitching wire $(\mathrm{OM})$ sârmă de legat

stich welding (met, TH) sudare continuă, automată prin puncte (care nu se suprapun)

stochastic variable (mat) variabilă aleatoare 
stock (ec, TH) stare, capital de bază, provizie, inventar, depozit, material, materie primă, stoc, rezerve, cantitate de marfă, magazie, bun(uri), stâlp, parc de mașini; (mas-un, OM) adaos de prelucrare, păpuşă, talpa echerului; (met) piesă brută, eboşă, țaglă; (nav) traversă de ancoră, ax de cârmă; a furniza, a depozita, a stoca, a păstra (şi în depozit)

stockage (ec, TH) stocare, înmagazinare

stock anvil (met) nicovală ajutătoare

stock bin (constr, met) buncăr

stock car (auto, ind) automobil de serie

stock column (met) coloană de material încărcat (la furnal)

stock die (mas-un) placă de filetat, clupă

stocked depozitat, păstrat, stocat

stockehold (nav) compartiment al maşinilor

stocker (termo) fochist

stock-exchange (ec) bursă

stock exchange quotation (ec) cotă a bursei, cotă la bursă

stock feed (mas-un) avansul barei, alimentare cu semifabricate tip bară

stock feeder (mas-un, ind chim) dispozitiv de alimentare, alimentator

stocking (actiunea de) stocare / înmagazinare (şi a datelor)

stocking cutter (mas-un) cuțit de degroşat

stocking door (termo) uşa focarului; (constr) uşă a magaziei

stocking tool (mas-un) cuțit de degroşare

stock left for machining (mas-un) adaos de prelucrare

stockless anchor (nav) ancorament

stock number (ind, ec) număr de fabricatie / de inventar

stock of tools magazia de scule (şi la maşiniunelte cu comandă-program)

stockpile (constr, met) stoc (excedentar sau mai mare decât cel normal / uzual), haldă, stoc, rezervă, depuneri pe fund, a acumula, (constr, met) a depozita în haldă

stockpiling (met, TH) depozitare în haldă / în stoc

stock room (constr, TH) magazie, depozit mic (de materii prime)

stock rudder (nav) ax al cârmei

stocks (ec) acțiuni, hârtii de valoare, fonduri; (nav) calaje

stock shears (mas-un, met) foarfece de profiluri (laminate) grele

stock size (OM) dimensiuni ale pieselor finite depozitate

stock soap (ind chim) bază de săpun

stock stop (mas-un) limitator al avansului de material stock-taking (ec, inf) inventariere, preluare a inventarului

stockyard (ind) teren de depozitare, de exemplu, pentru piese mari turnate

stroichiometric conditions (chim) conditii necesare apropierii (în practică) de echilibrul stoichiometric

stroichiometric equilibrium (chim) echilibru stoichiometric

stoke (met, termo) a alimenta / umple cu combustibil

stoke (amer), stokes (brit) (St) (metr, T) unitate pentru vâscozitate cinematică, în sistem; 1 stokes $=1 \mathrm{~cm}^{2} / \mathrm{s}$; în sistem SI vâscozitatea cinematică se măsoară în $\mathrm{m}^{2} / \mathrm{s}$

stoker (met, termo) dispozitiv de alimentare a focarului / cuptorului şi de evacuare a produselor de ardere

stock tank barrel (stb), petroleum barrel (metr, ind) unitate de măsură pentru volum, în industria petrolului: 1 stock tank barrel $\sim 158,9871$, petrolul fiind la o temperatură de $15,556^{\circ} \mathrm{C} ; 1$ stock tank barrel $\sim 0,15899$ standard $\mathrm{m}^{3}(\mathrm{scm})$, petrolul fiind la $15^{\circ} \mathrm{C}$

stone piatră (şi abrazivă); stone (st) ( $s g$ şi $p l)$ (metr) unitate tradițională britanică pentru masă, utilizată mai mult pentru persoane şi animale: 1 stone $\sim 6,35029 \mathrm{~kg}$

stone coal antracit

stone crusher (mas, constr, ind chim) concasor stone mill (alim) moară cu pietre

stone plug (auto) bujie cu izolator de porțelan

stone's throw (metr) distanță scurtă, aruncătură de piatră; 1 stone's throw $\sim 50 \mathrm{~m}$

stoneware (OM, chim) articole de ceramică de laborator, rezistente la coroziune

stoneware floor (constr) pardoseală de gresie ceramică

stoneware tile (constr) flisă / bucată de gresie

stoning (mas-un) ascuțire (şi manuală) a unei scule pe roată / pe disc abraziv(ă)

stool (OM) scaun (fără spetează), scăunel, taburet, reazem, bancă mică, capră, rezemătoare de picioare; (bot, agr) rădăcină, butaş, stolon, trunchi, tulpină, a face butaşi; (met) fund de lingotieră; (anat, med) evacuare a materiilor fecale, scaun, a avea scaun

stop (OM) stop, oprire, opritor, fixator, diafragmă, limitator, întrerupere, pauză; (cf) haltă, oprire; (mas-un) limitator de cursă; a opri, a stopa, a frâna, a termina, a închide, a încuia, a sta, a întrerupe, a reține, a scoate din funcțiune, a înceta, a staționa; (metr) unitate a expunerii relative, utilizată în fotografie; două expuneri 
diferă prin 1 stop dacă una este caracterizată prin dublul luminii celeilalte; pe multe camere deschiderea pentru 1 stop este multiplicată cu $\sqrt{2}$ din cea precedentă

stop and license plate light (auto) lanternă / lumină de stop şi de spate (şi la plăcuța de înmatriculare)

stop and tail light (auto) lanternă / lumină de stop şi de spate

stop block $(\mathrm{OM})$ bloc de tamponare

stop bolt $(\mathrm{OM})$ şurub de oprire

stop button (OM) buton de oprire

stop chain (auto, OM) lanț de siguranță

stop-cleat of rudder (nav) limitator de cârmă

stop cock $(\mathrm{OM}$, hidr) robinet / ventil de închidere / de oprire (cu cep)

stop cock box (OM, hidr) carcasă a ventilului / robinetului de închidere

stop device $(\mathrm{OM})$ opritor, dispozitiv de oprire / de frânare; (mas-un) dispozitiv de prindere

stop dog (mas-un) opritor, limitator / de cursă cu reglare de precizie a poziției

stop drill (mas-un) burghiu cu inel opritor

stop gear (OM, mas-un) mecanism de oprire / de blocare

stop knob (OM, mas-un) buton de oprire

stop lamp (auto) lumini / faruri de stop(uri) / de oprire

stop lamp fail (auto) defectare / nefunctionare a luminilor de stop(uri) / oprire

stop lamp fail display (auto) afişaj pentru avertizare în cazul defectării luminilor de stop(uri) / oprire

stop lever $(\mathrm{OM})$ pârghie / manivelă de oprire stop location (mas-un, mas) poziţie de oprire

stop nut $(\mathrm{OM})$ piuliță limitatoare / de oprire / de limitare a cursei şurubului, piuliță cu material compresibil ataşat pentru menținerea strângerii / etanşării fără şaibe

stoppage (mec, mas) (acțiunea de) stopare

stop pawl (mas-un, OM) clichet (simplu) de oprire

stopper (alim, chim) dop (şi de plută); (OM) opritor, limitator, organ de închidere, a bloca, a zăvorî; (met) dop (la oala de turnare)

stopper bell (met) clopot de încărcare (la furnal) stopper end (met) dop (la oala de turnare)

stopper ladle (met) oală de turnare cu descărcare prin fund / pe la partea inferioară

stopper rod (met) tijă pentru astuparea orificiului de descărcare (la oala de turnare)

stopper screw $(\mathrm{OM})$ şurub de închidere / de oprire stop piece (OM) opritor (simplu)

stop pin $(\mathrm{OM})$ ştift de oprire / de limitare stopping (mec, mas) (acțiune de) oprire, frânare, care opreşte

stopping agent (chim) inhibitor (al unei reacții)

stopping device (OM) dispozitiv de oprire / de frânare

stopping distance (mec, auto, mas) distanţă / parcurs de frânare

stopping lever $(\mathrm{OM})$ manetă / pârghie de oprire stopping off (fiz, el, mec) izolatie, protectie (care opreşte trecerea căldurii, curentului etc.) (foarte general)

stopping point (fiz) punct de oprire / critic stopping potential (el) tensiune de stingere stopping time (mas) timp de oprire / de frânare stop plate $(\mathrm{OM})$ placă opritoare / limitatoare stop screw (OM) şurub de oprire / de limitare stop switch $(\mathrm{OM}, \mathrm{el})$ întrerupător

stop up (met, TH) a astupa, a strangula, a opri (turnarea) (şi ca defect tehnologic)

stop valve (OM, hidr) robinet / valvă / supapă / ventil de închidere / de oprire

storage (c, inf) memorare, memorie; (ec, $\mathrm{TH})$ depozitare, înmagazinare, stocare, păstrare; depozit; rezervor; (hidr) acumulare, reținere; (el) încărcare a acumulatorului

storage battery (el) baterie de acumulatoare

storage bin / bunker / hopper (alim, constr, met) buncăr

storage cell (el) acumulator

storage compartment (auto) compartiment de depozitare

storage device (c, inf) dispozitiv de înmagazinare / de memorare (a datelor)

storage energy (mec, hidr) energie înmagazinată / acumulată

storage hopper (mas-un) buncăr, magazie (şi de scule la maşini cu comandă-program)

storage life (materiale, $\mathrm{OM}$ ) durată de stocare / de depozitare

storage space (c, inf) spațiu de memorare (a datelor) / de depozitare, magazie

storage tank (OM, hidr, alim) rezervor de depozitare / de colectare / de păstrare

storage time $(\mathrm{TH}, \mathrm{T})$ timp de depozitare / de păstrare (d. elemente de maşini, lubrifianți etc.)

storage yard (constr) depozit, platformă / teren de depozitare, magazie (nepretențioasă)

store (c) memorie; (TH, ind) rezervor, depozit, magazie, magazin; (c, ind) a înmagazina (şi date), a memora, a acumula, a depozita

stored înmagazinat. depozitat, aprovizionat; (c, inf) înregistrat / stocat (în memorie); (auto) plasat (la airbag), depozitat

stored energy (mec, hidr) energie înmagazinată 
stored energy welder (mas-un, TH) maşină de sudat prin impulsuri / de sudat cu energie acumulată

stored energy welding (met, $\mathrm{TH}$ ) sudare cu energie înmagazinată, sudare cu acumulare de energie

stored heat (termo, met) căldură înmagazinată / acumulată

storehouse (ec) depozit / magazie de mărfuri store keeping (ec) înmagazinare, depozitare store-keeper (ec) magazioner store magazine (ec) depozit, magazie de mărfuri store-room (constr) spațiu / camere depozitare stores (ec, ind) provizii, materiale depozitate store up (ec, ind) a depozita, a înmagazina, a depune, a lega; (ec) a stoca, a face provizii

storey, story; $(p l)$ (brit) storeys, (amer) stories (metr, constr) unitate informală de măsură pentru distanţa între două etaje consecutive ale unei clădiri; 1 story $\sim 3,0 \ldots 3,6 \mathrm{~m}$ la clădiri înalte şi 1 story $\sim 2,75 \mathrm{~m}$ la clădiri rezidențiale storing (ec, TH) (acțiune de) depozitare / păstrare storing damage (materiale, $\mathrm{OM}$ ) degradare prin depozitare (şi necorespunzătoare)

storing damages (materiale, $\mathrm{OM}$ ) defecte de depozitare (în industria alimentară şi uşoară)

story furnace (met) cuptor vertical cu etaje, pentru prăjire

stout (fiz) solid, rezistent, tare, durabil, stabil

stove (alim, ind chim) cuptor, etuvă, uscător

stove drying $(\mathrm{TH})$ uscare în etuvă

stove enamel (ind chim) email cu uscare în etuvă

stove finish (ind chim) lac de uscare în cuptor

stove lid (met) placă de amorsare a vetrei, placă de concentrare

stove pipe $(\mathrm{OM})$ burlan nituit

stove plate (met, OM) placă de armare a vetrei (unui cuptor etc.)

stow (nav) a stivui. a amara, a pune la post (o ancoră)

stowage (ec) stocare, umplere, stivuire (şi la nave)

stowage factor (nav) indice de stivuire

stow away (ind) a ambala, a împacheta

STP, stp (metr) abreviere pentru presiune şi temperatură standard $\left(0^{\circ} \mathrm{C}\right.$ şi 1 atmosferă sau $101,325 \mathrm{kPa})$

straddle milling (mas-un, $\mathrm{TH}$ ) prelucrare / frezare simultană, cu două freze-disc

straight cinste, corectitudine; drept, vertical; (sport) linie dreaptă; culoare (la pocher); (fig) persoană directă, cinstit; corect; just; precis; de încredere, de nădejde; direct; drept; echitabil; exact; fățiş; (ec) (vândut) la un preț fix (indiferent de cantitate); rectiliniu, în linie dreaptă (alim) (amer) sec, simplu, fără apă (d. o băutură); sigur; sincer; (fig) heterosexual, normal; (fig) onest, plictisitor; ( $a d v)$ (a vorbi etc.) deschis, fără menajamente, verde; imediat, numaidecât; direct, drept, cinstit, fără înconjur, pe faţă, drept, sincer; (a ochi etc.) cu precizie / precis / exact; de-a dreptul; (rar) îndată, numaidecât, pe dată, pe loc, fără întârziere, imediat; ticket (pol) program politic fără modificări; thinking gândire logică; game joc corect; in a line în linie dreaptă; away / off imediat, pe loc, (de)îndată; keep on a merge drept înainte; a issue ( $\mathrm{fam}$ ) un caz simplu

straight arm (OM) braț drept; (anat) braț drept

straight armed pulley $(\mathrm{OM})$ roată (şi de curea) cu spițe drepte

straight-arm mixer amestecător cu braț drept

straight-away cut (mas-un) tăiere / aşchiere rectilinie

straight bevel gear (OM) angrenaj cu roți conice, cu dinți drepți

straight boring (mas-un) alezarea suprafețelor cilindrice (cu un singur diametru)

straight carbon steel (met) oțel-carbon, oțel nealiat

straight chain (chim) catenă normală / liniară, lanț molecular liniar

straight cup wheel (mas-un) piatră / disc de rectificat tip oală

straight cut (mas-un) tăiere plană

straight cut saw teeth (mas-un) ferăstrău dințat pentru tăiere plană

straighten (constr, TH) a îndrepta (d. centură, table etc.)

straightener (mas-un, OM, ind) dispoziv / maşină / instalație de îndreptare

straighteness liniaritate

straightening $(\mathrm{TH})$ acțiune / proces de îndreptare; care îndreaptă / face plan

straightening and sizing machine (met) maşină de îndreptat şi de debitat la dimensiuni

straightening die (met, OM) matriță de îndreptat

straightening machine (met) maşină de îndreptat

straightening mechanism (met) mecanism de îndreptare (la turnarea continuă)

straightening of hole (mas-un, $\mathrm{TH}$ ) corectare a unei găuri / unui alezaj

straightening-out $(\mathrm{TH})$ (acțiune / proces de) îndreptare (şi finală)

straightening plate $(\mathrm{OM})$ placă de îndreptat

straightening press (mas-un) presă de îndreptat 
straightening roll (met, OM) cilindru de îndreptat

straightening rolls (met) maşină de îndreptat cu role, cilindri / role de îndreptare

straightening speed (met) viteză de îndreptare straightening tongs (mas-un) cleşte de îndreptat straightening tool (mas-un) matriță / ştanță / sculă de îndreptat (sârme, table etc.)

straightening vane (hidr, OM) supapă de reducere a turbulenței fluidului

straight extruder nozzle (OM, plast, met) cap de extrudat drept

straight faced tool (mas-un) cuțit / sculă cu tăiş drept

straight file (mas-un) pilă cu vârf teşit / drept

straight flat-lap weld (OM, met) cusătură de sudură de colț concavă

straight-flow furnace (met) cuptor cu mers continuu

straight flute drill (mas-un) burghiu cu caneluri / canale drepte

straight fluted reamer (mas-un) alezor cu dinți drepți

straightforward direct, simplu

straight-frame truck (auto, transp) autocamionplatformă

straight-glued joint $(\mathrm{OM})$ îmbinare cu clei

straight grinding machine (mas-un) maşină de rectificat plan

straight-in grinding (mas-un) rectificare (a pieselor cilindrice) fără avans longitudinal

straight-line rectiliniu, cu producție în flux; (mat) (linie) dreaptă

straight-line chart nomogramă

straight-lined (geom) rectiliniu

straight-line lapping ( $\mathrm{TH}$, mas-un) lepuire rectilinie

straight-line spot welding (met, TH) sudare prin puncte în şiruri liniare

straight-manganese steel (met) oțel austenitic manganos

straight mineral oil (chim) ulei mineral fără aditivi / adaosuri

straight-pane sledge (met, $\mathrm{OM}$ ) baros

straight resin (chim) răşină nemodificată

straight-run distillation (ind chim) distilare primară (a petrolului)

straight-shank cutter / drill (mas-un) freză / burghiu cu coadă cilindrică

straight stem (nav) etravă dreaptă

straight-through boiler (termo) cazan cu circulație forțată / directă a apei

straight tool (mas-un) cuțit drept, sculă dreaptă / simplă straight toothed (milling) cutter (mas-un) freză cu dinți drepți

straight turning (mas-un) strunjire cu avans longitudinal

straight T-weld $(\mathrm{OM})$ sudură în T (de colț) continuă

straight-way cock $(\mathrm{OM}$, hidr) robinet cu o trecere cu cep

straight-way flanged gland cock (OM, hidr) robinet drept, cu cep, cu flanşe cu presgarnituri, fără devierea fluidului

strain (mec, OM) tensiune, efort, deformare, deformație, alungire, solicitare, sarcină, a deforma, a tensiona, a solicita; (mas-un, TH) a canela, a degaja la un strung, $(\mathrm{TH}$, alim, ind chim, mediu) a filtra sub presiune, a trece prin sită, a strecura

strain age-embrittlement (materiale) fragilitate din cauza eforturilor de lungă durată / prin îmbătrânire sub sarcină

strain age-embrittlement test (materiale, metr) încercare / test la fragilitate şi la deformare

strain ageing (met, materiale) îmbătrânire prin deformare / prin procedee mecanice

strain age(ing) hardening (met, $\mathrm{TH}$ ) durificare prin deformare (mecanică) şi/sau îmbătrânire

strain annealing (met, TH) recoacere după deformare

strain at failure (mec, $\mathrm{OM}$ ) deformație la rupere

strain beyond elastic limit (mec, materiale) tensiune / efort peste limita elastică (a materialului)

strain clamp $(\mathrm{OM})$ clemă de ancorare

strain coefficient (reciprocal of modulus of elasticity) (materiale, mec) coeficient de lungire / de dilatare (inversul modulului de elasticitate)

strain checking $(\mathrm{OM}, \mathrm{mec})$ verificare a deformațiilor

strained wire (met) sârmă trasă / trefilată

strain energy (mec) energie de deformare

strainer (constr, mec, OM) întinzător, bolt de întindere, epurator, sită; (met) curățitor de piese turnate; (termo, hidr, OM) (filtru cu) sită, (element de) filtru grosier, sorb

strainer core (met) miez perforat

strain ga(u)ge (metr, OM, electr) extensometru, tensometru, marcă tensometrică, tensorezistor

strain hardenability (met) capacitate / aptitudine de ecruisare / de durificare prin procese mecanice / prin deformare

strain hardened steel (met) oțel ecruisat / durificat mecanic

strain hardness / hardening (met) ecruisare 
straining (alim) strecurare; (mec) (acțiune / proces de) deformare, tensionare

straining apparatus (alim, ind chim) instalație de limpezire

straining clamp $(\mathrm{OM})$ clemă de întindere

strainless (OM, mec) nedeformat

strain magnitude (materiale, mec) modul de elasticitate, mărime a deformării

strain-measuring instrument (metr, mec, electr) instrument / aparat de măsurat deformaţii, extensometru, tensometru

strainmeter (metr, mec, electr) instrument / aparat de măsurat deformații

strain rate (mec) viteză de deformare

strain resistance (materiale, mec) rezistență la deformare

strain rod $(\mathrm{OM})$ bară de conducere

strain rods press (mas-un) presă cu coloane

strain roll (OM) rolă / valț de întindere / de îndreptare

strain sensibility (el) sensibilitate la deformare a caracteristicilor unui conductor

straky striat

strand (el) liță, bară / conductor / filament conductor, conductor monofilar neizolat, a cabla; (TH) vână, sârmă, fascicul, toron (de cablu), inimă a cablului, a împleti; (nav) a (se) pune pe uscat, a se rupe parâma

strand casting (met) turnare continuă

stranded (el) toronat, cablat

stranded cable (OM) cablu torsadat

stranded conductor (met) bramă, profil, sleb produs prin turnare continuă

stranding (el) toronare; (mas-un) răsucire; (nav) naufragiu, punere pe uscat, eşuare

stranding wire (OM, el) sârmă pentru cabluri

strand of chain $(\mathrm{OM})$ ramură a transmisiei cu lanț, lungimea lanțului între scripeți

strand roll (met) cilindru al cajei intermediare

strands of wire fascicul de sârme

strange străin; disjunct; straniu; neobişnuit, ciudat

strangling (materiale, OM, hidr) gâtuire

strap (constr) centură, brâu, cordon; (OM) fretă colier de excentric, eclisă, placă de presiune; (mec, OM) centură / bară la sistem de grinzi, bandă / fâşie de legat, curea, bandă, etrier, scoabă, clemă, zonă îngustă, chingă, cercel, distanțier rigid / semi-rigid

S-trap (OM; hidr) obturator hidraulic în formă de $\mathrm{S}$

strap band (OM) eclisă

strap bolt (OM) bolț cu cârlig / cu nas, prezon / surub filetat la ambele capete care poate fi îndoit în formă de U (pt. montarea țevilor, cablurilor etc.)

strap brake $(\mathrm{OM})$ frână cu bandă

strap iron (met) fier balot

strap joint $(\mathrm{OM})$ rost dintre eclise

strap key (el, OM) contactor cu lamelă elastică

strap(ped) joint $(\mathrm{OM})$ îmbinare / asamblare cap-la-cap cu eclise

strapped weld $(\mathrm{OM})$ sudură cap-la-cap, cu eclisă

strap rail (met) şină lată

strap saw (mas-un) ferăstrău-bandă

strategical materials (mil, ec) materiale strategice (cum ar fi crom, platină, cobalt etc.)

strategy strategie, comportare, linie / tendintă de comportare (pe termen mai lung)

stratification (materiale) stratificare; (met) exfoliere

stratified stratificat, stratiform (d. materiale)

stratified plastics (ind chim, plast) materiale plastice stratificate

stratify $(\mathrm{TH})$ a (se) stratifica, a (se) aşeza / (se) sedimenta în straturi

stratum, $(p l)$ strata, stratums strat; (geol) formațiune, strat, poziție de zăcământ; pătură; (fig) pătură (socială)

straw pai(e), fir de pai; păios, de paie

straw cellulose / pulp (ind chim) celuloză de / din paie

straw file (mas-un) pilă aspră

straw poll (pol) vot preliminar (de sondaj)

stray (el) dispersie electrică, zgomot parazit, fugă; (fiz) difuz; (mat) parazitar, auxiliar, secundar; (agr) animal rătăcit (de turmă etc.); copil rătăcit / vagabond / al nimănui; (jur) succesiune fără succesori; care merge la întâmplare; fără şir (d. gânduri); fără țel; hoinar; întâmplător, ocazional; izolat; (luat) la întâmplare (d. un exemplu, un eşantion etc.); rătăcit; rătăcitor; răzleț; răzlețit; a se abate, a se depărta; (fig) a se abate (de la), a se depărta (de subiect etc.); a devia; a (se) rătăci; a (se) răzleți

stray capacitance (el) capacitate de dispersie, capacitate parazită

stray coupling (el) cuplaj greşit / parazit, cuplaj secundar

stray current (el) curent vagabond

stray current corrosion (chim, el) coroziune cauzată de curenți vagabonzi / de scurgere

stray discharge (el) descărcare (electrică) secundară

stray electron (fiz) electron vagabond

stray emission (fiz) emisie vagabondă (la magnetron)

stray field (el, fiz) câmp de dispersie / de scăpări 
stray flux (fiz) flux de dispersie

stray light (fiz, teatru, cinematografie, TV) lumină difuză (folosită în studiouri pentru atenuarea contrastelor)

stray line (fiz) lungime moartă; (nav) porțiune a saulei lochului ordinar (cuprinsă între barcă şi primul semn de astar)

stray losses (el) pierderi suplimentare

stray mark (nav) semn de lăsătură (pe saula lochului)

stray pick-up (autom) captare de semnale parazite / perturbatoare

stray power (el, fiz) putere de dispersie, putere pierdută

stray radiation (fiz) radiaţie de scăpări, radiație parazită

stray signal (fiz, autom) semnal aleatoriu / parazit

streak calitate; caracteristică, trăsătură; curent; dâră; fâşie; rând; semn distinctiv; linie; şuviță; (fiz, met) striatie, bandă; (met) incluziune filiformă (defect la lingouri); serie neîntreruptă, succesiune, înlănțuire (de evenimente); (geol) apofiză, filon; (textile) dungă (de altă culoare); (nav) filă de bordaj din lemn; (fiz) rază (de lumină); (inf) şir de caractere; (fiz, c, TV) urmă / fâşie de culoare (contrastantă), pată (de culoare); (metr, minrl) urmă / dungă colorată lăsată de un minereu pe o placă de porțelan nesmălțitlăsată; (TH, poligrafie) a stria, a produce dungi; a se mişca repede

stream (hidr, geol) curent, curs de apă, apă curgătoare, fluviu, râu, a curge, torent (de lavă); (hidr, termo) jet de curent, curent (de apă, de aer); (nav) curent de maree, a ancora, a lăsa la apă (de la bordul navei), a naviga în curent; curs; (ec) flux de productie; (inf) lant, suită; (edu) nivel (de pregătire sau performanță) (al elevilor din aceeaşi clasă); potop (de cuvinte); şiroaie (de lacrimi); şuvoi (de lichid), torent; a arbora, a desfăşura (un steag etc.); a da drumul la, a emana, a emite; a fâlfâi, a flutura (d. un steag, plete etc.); a ieşi; (fiz) a (se) împrăştia, a (i)radia, a izvorî, a (se) răspândi, a răzbate (d. lumină etc.); a se revărsa, a se scurge (d. mulțime); a se scurge; $(\mathrm{TH})$ a spăla

stream anchor (nav) ancoră de curent / pupa stream barker (mas-un) cojitor hidraulic stream current (geogr, nav) curent maritim streamer (el) filament

stream gold (geol) aur de râu

steam-liner (nav) navă cu forme carenate streamlined (fiz, hidr) aerodinamic, (profil) hidrodinamic streamline flow (fiz, hidr) curgere laminară, curent longitudinal

steamline regime regim laminar (de curgere)

streamline resistance of a ship (nav) rezistență la înaintare a unei nave (în aer şi în apă)

streamlining (hidr, nav, fiz) formă a unui corp pentru reducerea rezistenței la mișcare în fluide stream of liquid (hidr) jet / curent de lichid stream of water (T, hidr) jet de apă

steam through (geogr, hidr) a curge prin ceva, a străbate curgând (d. fluide)

steam tube (fiz, hidr) tub (imaginar) format de liniile de curent

streck (metr, geom, mil) unitate de măsură utilizată în armata suedeză pentru unghiuri: 1 streck $=1 / 17,5^{\circ}$ sau 3,429 minute de arc (moa), sau 1,0159 mil (terminologie NATO); v. mil

street $(\mathrm{adm})$ stradă

street elbow (hidr, termo, OM) cot de teavă cu filet exterior la un capăt şi filet exterior la celălalt capăt

stremma (metr) a traditional Greek unit of area, now redefined $=1000 \mathrm{~m}^{2}$

strength (fiz, mec) forță, intensitate, rezistență, putere, tărie

strength at elevated / at high temperature(s) (mec, OM) rezistență la temperaturi înalte

strength at low temperatures $(\mathrm{mec}, \mathrm{OM})$ rezistență la temperaturi joase / la îngheț / la frig

strength at pulsating load $(\mathrm{mec}, \mathrm{OM})$ rezistență (la rupere) la oboseală pulsatorie / la sarcini pulsatorii

strength calculation $(\mathrm{OM})$ calcul de rezistență

strength cast iron (met, mec) fontă de înaltă rezistență

strength coefficient $(\mathrm{OM}, \mathrm{mec})$ coeficient / factor de rezistență / de siguranță

strengthen (OM, constr) a întări, a consolida, a fixa, a rigidiza

strengthening (OM, constr) (proces de) consolidare, concentrare, rigidizare, întărire; (mec, met) durcisare, durificare, ecruisare

strengthening rib $(\mathrm{OM})$ nervură de rigidizare strengthening ring (OM, constr) inel de rigidizare (şi la construcții sudate), inel de strângere strengthening screw $(\mathrm{OM})$ şurub de consolidare strength factor (materiale, $\mathrm{OM}$ ) factor de rezistență, valoare a rezistenței

strength in compression (materiale, mec, $\mathrm{OM}$ ) rezistență la compresiune

strength in shear (mec, OM) rezistență la forfecare

strength in torsion $(\mathrm{mec}, \mathrm{OM})$ rezistență la răsucire / la torsiune 
strength of acid (chim) tărie / concentrație a acidului

strength of compression (mec, OM) rezistență la compresiune

strength of current (el, fiz) intensitate a curentului

strength of field (el, fiz) intensitate a câmpului

strength of the film rezistență a peliculei / filmului (acoperirii sau de lubrifiant)

strength of (the) materials (materiale, mec) rezistența materialelor

strength of the solution (chim) tărie / concentrație a unei soluții

strength property (materiale) caracteristică de rezistență

strength test (metr, materiale, OM) încercare / test de rezistență

strength tester (metr, OM, electr, materiale) dinamometru, aparat de măsurat rezistenţa

strength under shock (mec) rezistență la impact / la şoc

strength weld (met, OM) sudură de rezistență

stress (mec, OM) sarcină, solicitare, încărcare, deformare (mai rar), greutate, forță, tensiune, efort; a solicita; $(\mathrm{TH})$ stres, solicitare psihică

stress amplitude (mec) amplitudine a unei sarcini / tensiuni variabile staționare, amplitudine (ca tensiune / efort) a unui ciclu (de oboseală)

stress analysis (mec, OM) analiză a tensiunilor / eforturilor

stress application cycle (mec, OM) ciclu de aplicare a tensiunii / a efortului

stress calculation $(\mathrm{OM}, \mathrm{mec})$ calcul al tensiunii / efortului

stress crack (mec, met) fisură cauzată de tensiuni (şi interne)

stress circle, Mohr's stress circle (mec) cerc al tensiunilor, cercul lui Mohr, reprezentare bidimensională a stării de tensiuni într-un punct

stress concentration (mec, OM) concentrare concentrator de tensiuni

stress concentration factor (mec, OM) factorul concentratorului de tensiuni (la calcul la oboseală)

stress corrosion (met, chim, mec, T) coroziune sub sarcină

stress corrosion cracking (met, mec) (proces de) fisurare din cauza coroziunii sub sarcină stress cycle (mec, OM) ciclu (de tensiuni) stress-deformation diagram (mec, materiale) curbă / diagramă tensiune-deformație

stress diagram (mec, OM) diagramă de eforturi stress distribution $(\mathrm{OM}, \mathrm{mec})$ distribuție a tensiunilor / eforturilor stressed (mec, OM) tensionat, sub efort, solicitat (mecanic); (med) stresat (d. persoane)

stressed collar (mec, OM) inel / bucşă solicitată (la efort) / tensionată

stressed working stands (met) cajă tensionată

stress ellipse (mec) elipsa tensiunilor (şi la oboseală)

stress-equalising anneal(ing) (met) recoacere pentru egalizarea tensiunilor interne

stress-free anneal(ing) (met) recoacere de detensionare

stress from fluid flow (ind chim, hidr, met, $\mathrm{OM}$ ) tensiuni induse de curgerea fluidului

stress in boom (mec, constr) tensiune / efort în talpa grinzii / construcției

stress intensity factors (mec, materiale, OM) factori introduşi de intensitatea tensiunilor (care joacă un rol important în inițierea şi propagarea fisurii de oboseală)

stress limit (OM) limită (de efort / de tensiune), fără a preciza tipul de solicitare

stress mark (gram) semn de exclamație

stress measuring device (metr, materiale, OM) extensometru, aparat de măsurat eforturi sau tensiuni

stress measurement (metr, materiale, OM) măsurare a eforturilor sau tensiunilor

stress of second order (mec, OM) tensiune / efort de ordinul doi

stress raiser (mec, OM) concentrator de tensiune datorat schimbării formei (piesei)

stress ratio (mec, $\mathrm{OM}$ ) coeficient de asimetrie al ciclului (raportul între tensiunea minimă şi cea maximă a ciclului)

stress relaxation $(\mathrm{mec}, \mathrm{OM})$ relaxarea tensiunilor stress relief (met, $\mathrm{TH})$ detensionare, îndepărtare a tensiunilor

stress relief annealing (met, $\mathrm{TH}$ ) recoacere de detensionare

stress relief treatment (met, $\mathrm{TH}$ ) (tratament de) detensionare

stress relieving (met) stabilizare, (tratament de) detensionare (şi prin încălzire şi răcire lentă)

stress revealing (met) detensionare

stress-revealing annealing (met, $\mathrm{TH}$ ) recoacere / revenire de detensionare

stress rupture test (metr, materiale, $O M$ ) încercare / test de tracțiune până la rupere

stress-strain characteristic (mec, metr, materiale) caracteristică tensiune-deformare (şi la dinamometre)

stress-strain curve / diagram / relationship (mec, materiale, metr) curbă / diagramă / relație / dependență tensiune-deformare 
stress testing machine (metr, mas) maşină pentru încercare la rezistență

stress transmission (constr, mec) transmitere a tensiunilor (într-o construcție)

stress under impact (mec, materiale, $\mathrm{OM}$ ) tensiune / efort cauzat $(\breve{a})$ de impact

stretch (materiale, mec) (a)lungire, întindere, extensie; (OM) sector, secțiune; a dilua; a întinde, a lungi, a alungi, a trage, a extinde; a strânge; a încorda; (fam) a exagera, a minți; abuz; interval de timp mai lung; porțiune; (nav) drum drept; efort, încordare; a (se) lărgi, a (se) mări (o mănuşă); a (se) întinde; a culca; (zool) a desface (aripile); a se încorda; a fi situat

streched steel (met) oțel tras

streched wire (met) sârmă trasă / trefilată

stretcher (constr) cărămidă așezată în lungul zidului, targă, strângător

stretcher leveller (met, mas-un) maşină de îndreptat / de dresat prin întindere

stretcher levelling (met, TH) îndreptare prin întindere

stretcher lines (mec, materiale) linii de curgere / Hartmann

stretcher strain (mec, materiale) linie / deformație de curgere

stretcher-strain marks (mec, materiale) urme ale liniilor de alunecare / de curgere

stretcher strains (mec, materiale) linii / deformații de curgere

stretch forming $(\mathrm{TH})$ formare a unei piese prin ambutisare cu mentinerea / presarea marginilor

stretching (materiale, mec) (acțiune / proces de) alungire, întindere, care se alungeşte / se întinde

stretching caliber (met) calibru de întindere

stretching device $(\mathrm{OM})$ dispozitiv de întindere, întinzător

stretching machine (met, mas-un) maşină de îndreptat / de dresat prin întindere

stretching pass (met, OM) calibru de întindere

stretching resistance $(\mathrm{mec}, \mathrm{OM})$ rezistență la tracțiune / la întindere

stretching roll (met) laminor întinzător

stretching-strain limit (materiale, mec) limită de curgere

stretching tool (OM, mas-un) matriță / ştanță de îndreptare

stretching weight $(\mathrm{OM})$ greutate de întindere

stretching wire (OM, constr) cablu de ancoraj / de întindere

stretch out a oferi, a întinde

stretch test (metr, materiale) test / probă / încercare de / la întindere stretch yarn fir supraelastic

strew a aşterne, a presăra, a împrăştia

stria, $(p l)$ striae, striations $(\mathrm{OM})$ striu, striație, striuri, striații; canelură; (geol) striații lăsate de ghețari

striate $(\mathrm{TH})$ a canela, a stria; striat, vărgat

striation $(\mathrm{TH})$ striere, striație

strickle (OM) şablon, (met) gabarit, a forma cu şablonul

strickle moulding (met, TH) formare cu / după şablon

strict precis, exact, strict; absolut; aspru; drastic; exigent; inflexibil; întreg; perfect; pretenţios; riguros; sever

striction (materiale, mec) gâtuire; stricțiune

striction line curbă de gâtuire; (mat) curbă de stricțiune (la suprafețe riglate)

stricture (OM) gâtuire (şi la piese, rezultată din solicitare sau ca formă), îngustare, strâmtare; (jur) condamnare fără apel; (med) contractare, strictură; critică aspră / severă; gâtuire

stride pas; fel de a merge, mers; pas (ca distanță intre picioarele desfăcute la mers); pas lung / mare; a călca / merge / păşi / umbla cu paşi mari; a călca / păşi peste (un sanț etc.); a măsura; a sta pe, a încăleca (pe) (o cracă etc.); (mil, metr) altă denumire pentru pace, pas, unitate de măsură pentru lungime; v. pace

strident strident, tăios, ascuțit; care iese mult în afara unui grup / unei mulțimi

strike (ec) grevă, a înceta lucrul, a face (grevă, o afacere etc.); a încheia (un târg etc.); (poligrafie) culegere fără împlinire; (geol) descoperire (a unui zăcământ), direcție / orientare a stratului, a da de un zăcământ, a detecta; ( $f i g$ ) lovitură (norocoasă), noroc, succes; lovitură; (fig) doză de droguri; ( $f i g$ ) refuz de a lucra / de a se juca; (TH) a lovi, a bate, a izbi, a atinge, a imprima (în relief) pe materiale metalice, plastice, pe piele etc.), a stampa, a demonta; a ciocni; a pătrunde (prin); a pocni; ( $T$, chim) strat intermediar depus electrochimic; (met, TH) crater / micro-crater local sau zonă retopită, cauzat(ă) de atingerea electrodului cu piesa; a amuti; a aprinde (prin frecare sau lovire), a se aprinde (d. chibrit); a o apuca, a se îndrepta, a o lua (într-o anumită directie); (el) a arde (fuzibilul); (muz) a bate (toba), a atinge (clape etc.), a ciupi (strune); (nav) a atinge fundul, a se ciocni de (o stâncă etc.) (d. o navă), a se lovi (de chei, de stâncă, de un recif, de fund), a coborî (o pânză, pânzele pavilionul), a descrucişa (a coborî o vergă pe punte), a prinde (cu cangea cu harponul etc.), a lovi (cu cangea, cu harponul etc.); a 
bate, a suna (d. ceas); a bate (monedă); a bate (fierul etc.); (meteo) a trăsni; (agr, bot) a da (rădăcini), a prinde rădăcini (d. plante); (mil, edu) a ridica (tabăra); a țaşni; a trece repede; a zbura; a da, a trage (o lovitură) (cuiva); a da de, a descoperi, a găsi; a nimeri peste, a da peste; a lăsa în jos; a se lovi (de); (fig) a frapa, a impresiona, a face o (anumită) impresie asupra (cuiva), a izbi, a impresiona ochiul / prin (căldură etc.); (fig) a cere cuiva ajutor; (fig) a întâlni întâmplător, a da peste; (fig) a părea (cuiva); a bate la (ochi); (metr) unitate tradițională britanică de măsură pentru volum /cu valoare variabilă): 1 strike $\sim 731$

strike-bound (ec) imobilizat (din cauza unei greve) strike breaker (ec) spărgător de grevă

strike committee (ec, adm) comitet de grevă

strike pay $(\mathrm{adm})$ alocație acordata greviştilor pentru grevă

strike off (constr) reglare, aşezare la acelaşi nivel a fundațiilor unei clădiri; a răzui, a înlătura

striker (met, OM) sabot de deformare la laminare oscilantă, cu forjare

striker clutch / fork (auto, OM) furcă a schimbătorului de viteze

striker spring (OM) resort, arc de impact

strike the horn severely (auto) a claxona prin lovirea butonului claxonului

strike through (chim, fiz) migrare / exsudare (şi a unui adeziv)

striking (OM) percutor; (constr) decofrare, desfacere a eşafodajelor; (el) amorsare, activare, aprindere (a unui arc); extraordinar; frapant; izbitor; percutant; remarcabil; grevist, (aflat) în grevă

striking back of the flame (termo) întoarcerea flăcării, retur al flăcării

striking by surprise (mil) lovitură (militară) prin surprindere

striking current (el) curent de amorsare, curent de aprindere; (fiz, el) intensitate de răspuns (a unui fuzibil)

striking distance (el) lungime a arcului electric, lungime a scânteii

striking face $(\mathrm{OM}, \mathrm{mec})$ suprafață de lovire (la ciocan, poanson etc.)

striking face of a hammer (OM) muchie (de lovit) a ciocanului

striking fault (geol) falie longitudinală

striking force (mec) forță de izbire / de lovire

striking gear(ing) (el) mecanism de amorsare / de aprindere; $(\mathrm{OM})$ dispozitiv pentru mutarea curelei

striking hammer (OM, constr) berbec de sonetă, ciocan de imprimantă striking lever (OM) braț bătător, levier al cutiei de viteze, braț / pârghie de bătaie / de lovire; (textile) pârghie de bătaie

striking off (constr) aşezare la acelaşi nivel a fundațiilor unei clădiri, reglare, umplere a rosturilor

striking surface mixture (ind chim) pastă de chibrituri, pastă fosforică

striking velocity (mec, TH) viteză de lovire / de şoc

striking wheel $(\mathrm{OM})$ roată numărătoare (în orologerie)

striking work (OM) clopoțel (la ceasornice), sonerie

string (textile) sfoară, şiret; (nav) odgon; a lega, a întinde, a încorda

string drive $(\mathrm{OM})$ acționare prin curele cu sectiune rotundă

stringer (OM, constr) grindă longitudinală, diagonală, lonjeron; (fiz) obturator longitudinal; (met) impuritate nemetalică (rezultată dintr-o incluziune deformată / laminată etc.)

stringer plate (nav) tablă lacrimară

stringiness (mec) filare, filamentare (d. un adeziv, un compozit etc.)

stringy alpha (met) fază alfa, alungită şi distorsionată (fără spargerea sau recristalizarea grăuntelui), rezultată după prelucrare mecanică nedirecționată

strip şipcă (de lemn); (mec) deformare, bandă, fâşie, panglică, deburaj; a dezbrăca; a deforma; a toci; (constr) a decofra, a scoate; a descoperi; a dezgoli; a goli; (met) bandă, a scoate lingoul din lingotieră, a stripa; (el) a scoate izolația

strip breakage (met, plast) rupere a benzii (la laminare)

strip board şipcă (de lemn)

strip crown (met, plast) bombare a benzii (defect de laminare)

strip cutting-off machine (mas-un) foarfece pentru tăierea / debitarea benzii (de tablă, de material plastic)

strip down (OM) a demonta; (met) a scoate zidăria (unui cuptor, unei oale de turnare etc.)

strip electrode welding (met, $\mathrm{TH}$ ) sudare cu electrod (tip) bandă

strip end stop (mas-un) opritor automat la apropierea sfârşitului benzii-semifabricat

strip flatness (materiale) plani(e)tate a benzii (laminate)

strip for forming tube (met) bandă de oțel pentru fabricarea țevilor (şi prin sudură)

strip iron (met) fier-balot, oțel în bandă

strip mill (met) laminor de benzi 
strip off a şterge, a curăţa (şi semifabricate în industria metalurgică); (met) a stripa

strip-off (met, TH) stripare

strip of lead (met) fâşii de plumb

stripped surface (met) suprafață stripată / curățată

stripper (met, mas-un) instalație de stripare; (el) sculă / unealtă de îndepărtat izolația

stripper crane (met, transp) pod rulant cu striper, macara striper

stripper plate (met, OM) placă-pieptene de extras modelul

stripper punch (met, OM) poanson de extragere (la laminare)

stripping (el) dezizolare, curățarea izolației; (met) stripare, curățare a unei piese turnate

stripping attachment (met, mas-un, OM) dispozitiv de scoatere, presă de montare, curătitor, striper

stripping brush $(\mathrm{OM})$ perie curățitoare

stripping crane (met, transp) macara striper (pt. scoaterea lingourilor), pod rulant pentru stripare

stripping curve (met) curbă de stripare

stripping of alcohol (ind chim, alim) dezalcoolizare

stripping oil (ind chim, alim) ulei absorbant

stripping plant (met) hală / instalație de stripare

stripping plate (met, $\mathrm{OM}$ ) placă-pieptene de extras modelul

stripping-plate machine (met, mas-un) maşină de format, cu extragerea modelului cu placăpieptene

stripping plate moulding machine (met, masun) maşină de format cu placă-pieptene de extragere a modelului

stripping process (met) procedeu de formare cu extragere a modelului prin / cu placă-pieptene, proces de stripare (a lingourilor)

stripping pump (nav, OM, hidr) pompă de golire / de curățare

stripping ring (OM, termo)segment de raclare

stripping still (ind chim, met) coloană de stripare

stripping tongs (el, OM) cleşte de curățat izolația / de dezizolat; (met, OM) cleşte de scoatere a lingoului

strip rolling mill (met) laminor de platbande / îngust

strips (met) bandă / benzi de / din otel

strip steel (met) oțel lat, platbandă de / din oțel

strip steel rolling mill (met) laminor pentru benzi de oțel

strip stock (met) fâşie de tablă, stoc de tablă în benzi strip straightening machine (met, mas-un) mașină de îndreptat benzi

strip uncoil (met, OM) desfăşurător de bandă strip winder (met, OM) înfăşurător de tablă / de bandă

strip with holes (met) bandă / tablă perforată

strive a face tot posibilul (să); a se forța (să); a năzui (să); a se strădui (să); a tinde (să)

strive after a căuta sa dobândească (ceva); a năzui la / spre; a tinde către / spre; a urmări (ceva / pe cineva)

strive after an end a se strădui să atingă un țel

strive against a se împotrivi (cuiva), a se lupta împotriva, a lupta împotriva, a rezista (cuiva / la ceva)

strive for a căuta sa obtină (ceva), a se certa pentru (ceva), a disputa (ceva), a lupta pentru, a se strădui sa obțină (ceva)

strive for an end a se strădui sa atingă un țel strive with one another for smth. a-şi disputa ceva cu alții, / cu altul, a fi in competiție / în concurenta cu ceilalți, a fi in lupta cu ceilalți, a se întrece cu alții pentru a obține ceva

strob (metr, fiz) unitate în sistem metric, pentru viteză unghiulară: 1 strob $=1 \mathrm{rad} / \mathrm{s}=9,54930$ $\mathrm{rot} / \mathrm{min}$

strobe (metr, fiz) a selectiona / controla prin metoda stroboscopului

stroboscope (metr, fiz) stroboscop

stroboscopic tachymeter / tachometer (metr, fiz) tahometru stroboscopic

stroke (mas-un, hidr, mas) cursă, timp (pt. o cursă), lovitură, bătaie, mers (d. un mecanism, o maşină); izbitură; atac; efort; (med) atac cerebral; atingere (cu mâna); bătaie (a ceasului), mişcare (ritmică); (textile) bătaie; (termo, nav) cursă (a pistolului); (metr) diviziune a scării / scalei; (fig) idee, lovitură, mişcare, străfulgerare (genială etc.); (poligrafie) linie; (nav) şef de rame, bătaie (a vâslei etc.), stil / cadență de rămare, a da cadența de ramare (cuiva); trăsătură (de condei); mângâiere; a dezmierda

stroke adjustment (OM, autom) reglare a cursei (la maşini-unelte, motoare, prese etc.)

stroke-bore ratio (auto, termo) raport cursăalezaj

stroke capacity (auto, termo, hidr) cilindree

stroke counter (metr, mas-un) contor de curse

stroke decrease (OM, termo, autom, mas-un) reducere a cursei

stroke indicator (OM, termo, autom, mas-un) indicator al lungimii cursei

stroke limitor (OM, termo, autom, mas-un) limitator de cursă

stroke of engine (termo, mas) cursă a motorului 
stroke of piston (OM, termo, auto, hidr) cursă a pistonului

stroke ratio (OM, termo, auto, hidr) raport între cursă şi diametru

stroke setting crank (mas-un, OM) manetă / manivelă pentru reglarea cursei

stroke timer (mas-un, autom) aparat pentru reglarea automată a numărului de curse

stroke volume $(\mathrm{OM}$, termo, hidr) cilindree, capacitate cilindrică

strong tare; puternic, rezistent (d. o armată, o per-soană etc.), rigid, durabil, trainic, rezistent; aspru, tare, vulgar (d. limbaj etc.); (fig) (d. cineva) autoritar, cu mână forte / de fier; (alim, chim) concentrat, tare (d. ceai, cafea etc.), (cu gust) înțepător, iute, usturător; cu miros tare;

(fig) drastic, tare (d. măsuri); (constr) fortificat, întărit (d. un castel etc.); neînmuiat, tare (d. un sunet); (gram) neregulat, tare (d. verbe); puternic, tare (d. lumină, miros etc.); (OM) întărit, robust (d. un element de maşină, proiectare etc.); strâns; tare; (mil) de o anumită forță (numerică), tare (d. o armată etc.); viguros (d. stil); puternic, violent, intens (d. un sentiment etc.); (d. cineva) zdravăn, vânjos, viguros, tare, robust, musculos, puternic (fiziceşte); ( fam $\mathrm{cu}$ energie, cu tărie, grozav, straşnic; drinks (alim) băuturi alcoolice; prices (ec) prețuri ferme / în creştere; one's point punctul tare (al cuiva); a proof o dovadă convingătoare; the $\sim$ cei puternici, cei sănătoși

strong acid (chim) acid tare

strong base (chim) bază tare

Strong-Cobb Unit (SC) (metr) unitate de forță, pentru a exprima duritatea în industria farmaceutică, pe o scară cu 30 de unități: 1 StrongCobb unit $\sim 7 \mathrm{~N}$

Strong-Cobb test machine (metr, mas) maşină / dispozitiv de măsurat duritatea tabletelor în industria farmaceutică

strong intensity (fiz) intensitate mare

strongly damped (mec, autom) puternic amortizat

Strontium (Sr) (chim) stronțiu

strontium unit (SU) (metr, fizică nucleară, med) unitate pentru a măsura concentrația radioactivă a radioizotopului stronțiu 90 din corp sau din mediu: 1 strontium unit este o concentrație de 1 picocurie pe gram de calciu ( $\mathrm{pCi} / \mathrm{g} \mathrm{Ca}$ ), în sistem SI reprezintă 37 becquerel pe kilogram $(\mathrm{Bq} / \mathrm{kg})$, adică, 37 de dezintegrări atomice pe kilogram şi pe secundă

strop (TH) a şlefui, a ascuți

strowger selector / switch (el, electr) selector pas-cu-pas

structural structural (d. materiale, sisteme etc.) structural adhesive (plast) adeziv structural structural analysis (metr, materiale) analiză structurală

structural annealing (met, $\mathrm{TH}$ ) recoacere structurală / pentru modificarea structurii

structural arrangement (materiale) aranjament structural, distribuția de structuri

structural bond (chim, OM) îmbinare / legătură structurală

structural change schimbare structurală

structural composition (materiale) compoziție structurală

structural constituent / component (materiale) constituent / component structural

structural defect (met, materiale) defect de structură

structural design (OM, mas, constr) soluție constructivă de ansamblu (eventual modulată)

structural dimensions (materiale, constr) dimensiuni ale structurii

structural element (chim) element structural

structural formula (chim) formulă structurală

structural fracture (fiz, met) ruptură / fisurare / rupere a structurii

structural frame (constr) schelă, cadru de structură

structural hardening alloy (met) aliaj cu durificare structurală / a structurii

structural iron (constr, met) armătură de oțel pentru constructii

structural material (constr) material pentru / de constructii

structural member (constr, OM) element de construcție, grindă

structural mill (met) laminor de profiluri

structural part (OM, constr) element / piesă de constructie

structural rigidity (constr, OM, mas) rigiditate a structurii

structural shape (met) oțel profilat, produs laminat structural shapes (constr, met) laminate / semifabricate profilate, profiluri

structural steel (constr, met) otel-beton, fierbeton, semifabricat din oțel de construcții, oțel profilat (standardizat)

structural steel rolling mill (met, mec) laminor de profiluri din oțel

structural steel section (met, mec) sectiunea profilului / semifabricatului

structural-steel shape (met, mec, constr) profil laminat, semifabricat profilat

structural strength (mec, constr) rezistență a structurii (metalice) / a construcției

structural tongs $(\mathrm{OM})$ clește de nituri

structural transformation (met) transformare structurală 
structural viscosity (plast, hidr) vâscozitate plastică

structural weight (cvonstr, OM, chim) greutate / masă proprie a structurii / construcției

structural wrench $(\mathrm{OM})$ cheie mecanică fixă structure (constr) structură, edificiu, construcție, clădire; (met, TH) structură, alcătuire, formare

structure analysis (metr, materiale, constr, mas) analiză de structură

structure factor (constr, OM, materiale) factor de structură

structureless (materiale) amorf, fără ordine interioară

structure sensitive (materiale) sensibil la structură, dependent de structură

strut (av) lonjeron; (constr, OM) bară, riglă, traversă, sprijin, contrafişă, stâlp, bară de grindă (solicitată la compresiune); (el) suport; (mec, $\mathrm{OM}$ ) grindă solicitată la flambaj, flambaj; a sprijini, a propti, a (se) deforma la flambaj

strut frame (constr) grindă cu zăbrele, fermă cu contrafişe

strut jack $(\mathrm{OM}$, constr) vinci de strângere

strut pile (constr) pilot solicitat la compresiune

strutting (constr) întărire, consolidare, rigidizare, antretoază

stu (metr) v. short ton unit

stub (silv) butuc, buturugă, ciot; (mas-un, OM) piesă de lungime mică, ax scurt

stubbie (alim) sticlă tradițională de bere, în Australia, de $375 \mathrm{ml}$

stubbs steel (met) otel rotund calibrat

stub end loss / waste / wastage (met, TH) pierderi de electrozi (la capete)

stub file (mas-un) pilă lată scurtă pentru suprafețe mari

stub tooth $(\mathrm{OM})$ dinte cu înălțime mică / scurtat stud stâlp, pilastru; (auto) deget / bolț de directie; (autom, el) buton de comandă, conector (și de terminale); (cf) scoabă de traversă; (el) contact; (OM) ştift, nas, ştuț, bolț, opritor, prezon, şurub prizonier, şurub cu ochi / cu ochet, cep, diblu, buton, cui, a îmbina cu şuruburi etc.; (met) suport de miez

stud arc welding (met, TH) sudare prin încălzire cu arc electric (produs între un electrod şi piesă) şi apoi presare a pieselor de asamblat stud bolt $(\mathrm{OM})$ şurub prizonier, prezon, bolt stud chain (nav, $O M$ ) lanț cu zale, de punte studded link $(\mathrm{OM})$ verigă, za (şi de lanț) studding (met) sudare a prezoanelor stud driver (mas-un, OM) dispozitiv de înfiletat şuruburi

Student's t-distribution (mat, statistică) distribuție Student $t$ stud hole $(\mathrm{OM})$ gaură prin care trece un şurub / un bolt / un stift, gaură / alezaj de trecere stud nut $(\mathrm{OM})$ piuliță

stud of hub (auto) bulon de roată / de butuc stud removing jig (mas-un, OM) dispozitiv de ghidare pentru scoaterea şuruburilor rupte

stud setter (mas-un) dispozitiv de înşurubat şuruburi prizoniere

stud wheel plate $(\mathrm{OM})$ mecanism de inversat sensul de mişcare

study studiu, studiere, examinare; a studia, a examina, a cerceta, a investiga

stuff (materiale) material, substanță, masă de etanşare, pastă, steril; a umple, a astupa, a etanșa, a călăfătui; (T) a lubrifia

stuffing (alim) umplutură; de umplutură (d. un material într-un compozit etc.) care umple; (auto) capitonaj, tapițerie; $(\mathrm{OM})$ garnitură de etanşare

stuffing box $(\mathrm{OM})$ îmbinare etanşă, presetupă, cutie / bucşă de etanşare, presgarnitură

stuffing box flange (OM) flanşă a presgarniturii stuffing box gland $(\mathrm{OM})$ cutie de garnitură, garnitură (numai materialul ei)

stuffing box packing $(\mathrm{OM})$ garnitură de etanșare / de presetupă

stuffing box ring $(\mathrm{OM})$ inel de etanşare

stuffing box stud (OM) şurub prizonier de / pentru presetupă

stuffing gland $(\mathrm{OM})$ presetupă (şi cu membrană)

stuffing of the fissures (constr) astupare / umplere a fisurilor

stump (silv) ciot, butuc, buturugă

stump mandrel (mas-un, OM) dorn (unilateral) de fixat în mandrină

stunde (metr) unitate de măsură în Elveția pentru lungime: 1 stunde $=4800 \mathrm{~m}$

stunning hammer / hachet (alim, OM) ciocan de sacrificare

sturdiness stabilitate; constanță; vigoare; tărie

sturdy (mas-un, OM) masiv, solid, rezistent, rigid

sturgeoon (metr, fiz) unitate de măsură pentru reluctanța magnetică - opusul inductanței: 1 sturgeon $=1$ amper pe weber $(\mathrm{A} / \mathrm{Wb})$

style stil; (TH) aspect, tip, construcție, model

stylus (mas-un) cutit; (metr) stilou, peniță, vârf (de înregistrator), palpator (foarte mic, de exemplu, la profilometre cu contact etc.)

styrene (plast) stiren; vinil-benzen

styrene-butadiene copolymer rubber (SBSR) (plast, ind chim) cauciuc copolimer stiren butadienă - stiren

styrene-butadiene rubber (SBR) (plast) cauciuc butadien-stiren(ic) 
s.u., servo unit (OM, autom) servomecanism sub $(\mathrm{OM})$ mufã de reducere, reducție, manşon de reductie

subassembly (OM) element, organ (de maşină), piesă detaşabilă, bloc, (sub)ansamblu, modul sub-base $(\mathrm{OM}$, hidr, mas-un) placă de bază subcontractor $(\mathrm{ec})$ furnizor intermediar, furnizor de piese auxiliare

subcooled (fiz, met) subrăcit

subcooled boiling (alim, met, termo) fierbere locală

subcooling (fiz, met) subrăcire

subcooling condenser (termo) condensator $\mathrm{cu}$ subrăcire

subcritical (fiz, mec) subcritic

subcritical annealing (met) recoacere subcritică de recristalizare

sub-crust (constr) strat de bază

sub-cutaneous blowhole (met, plast) suflură / por superficial( $\breve{a})$

subdivide a subîmpărți, a subdivide

subdivision (ec) subdiviziune; (nav) compartiment, compartimentare

subjective fatigue $(\mathrm{TH})$ oboseală subiectivă (a operatorului) din cauze psihologice, stres, conflicte de muncă etc.

sub-grain (fiz, met) subgrăunte (al structurii)

subgroup (mat) subgrup

subject obiect, subiect, materie, obiect (de studiu); temă; (med) bolnav, caz, pacient; (pol, adm) cetățean; individ, om, persoană; împrejurare, ocazie; motiv, prilej; noțiune fundamentală / de bază; specialitate (d. un profesor, un medic, un inginer etc.); (gram) subiect; (filosofie) subiect, substanță, sine, eu; (mat) variabilă independentă, a supune (în logica matematică); cucerit; a cuceri, a îngenunchea; a pune dedesubt; a supune; tender problema dificilă / grea / spinoasă / delicată

subjected to supus / expus la; pasibil de; cu conditia; sub rezerva; a aduce sub influenta

subject-index repertoar; (edu) indice de materii

subject matter obiect, subiect, materie, temă, conținut, fond

subject to oxidation (materiale) supus / expus oxidării

sublayer (materiale, OM) substrat

sublet (ec) a subarenda, a subînchiria

sublevel subnivel

sublimate (materiale, fiz) sublimat

sublimation (fiz) sublimare

sublimation heat (materiale, fiz) căldură de sublimare

sublime (materiale, fiz) a sublima

submerge (hidr, nav) a (se) scufunda, a afunda, a imersa; a inunda submerged acoperit; (met, TH) sub flux (la sudare, afinare în convertizor a oțelului etc.); (hidr) cufundat, imersat

submerged arc-welding (met, $\mathrm{TH}$ ) sudare sub flux / cu arc acoperit de flux

submerged coil condenser (alim, ind chim) condensator cu serpentină înecată / cufundată

submerged condenser (termo) condensator înecat submerged fermentation (alim) fermentație submersă

submerged lubrication $(\mathrm{OM}, \mathrm{T})$ ungere în baie de ulei / în carter

submerged orifice (OM, hidr) diafragmă / orificiu cufundat $(\breve{a}) / \operatorname{imersat}(\breve{a})$

submerged piston pump (OM, hidr) pompă submersibilă

submerged tank (OM, hidr, constr) rezervor subteran / îngropat

submergence (geogr, meteo) inundație, revărsare; (nav) imersiune

submersible (OM, hidr) imersibil, submersibil

submersible pump (OM, hidr) pompă imersibilă

submultiple (mat) submultiplu

subnormal subnormal, sub standard (d. produse)

sub-optimization (inf, autom) optimizare partială / a unui modul / a unei funcții

subordonate (pol, adm, ec) a aşeza sub, a subordona

subordonation (pol, adm, ec) subordonare

subpermanent magnetism (nav, fiz) magnetism semipermanent

sub-plate (OM, hidr, mas-un) placă de bază sub-plate valve (OM, hidr) aparat (hidraulic) / supapă pe / în placa de bază

subpress (mas-un) presă de ştanțări intermediare subpunch (mas-un) perforare prealabilă (pt. lărgire, finisare a găurilor etc.)

subroutine (c, inf) subprogram

subscale $(T$, chim) oxizi (poroşi / solzoşi etc.) formați sub suprafață din cauza difuziei oxigenului spre interior

subscript indice (inferior), index; (c) comandă pentru introducere de indici inferiori

subscription (ec) subscripție, cotizație, abonament

subsequent următor, subsecvent, ulterior, care urmează după

subsequent processing / treatment $(\mathrm{TH})$ prelucrare ulterioară, tratament ulterior

subset (mat) submulţime; subansamblu

subside (chim) a (se) precipita, a (se) depune; (constr) a se tasa, a se lăsa (d. pământ), a se denivela; a cădea la fund (d. un sediment), a scădea, a coborî nivelul; (mas, OM) a slăbi, a ceda 
subsidence (constr) tasare, scufundare, denivelare; (constr, geol) depresiune, prăbuşire, subsidență, tasare; (meteo) alunecare descendentă; (OM, mas) cedare, slăbire; depunere (a unui sediment); descreştere, domolire, micşorare, scădere, potolire ( $\mathrm{d}$ un proces, un fenomen); precipitare

subsidence ratio (autom) raport de amortizare

subsidiary subsidiar, auxiliar

subsidiary stress $(\mathrm{mec})$ tensiune suplimentară

subsiding tank (OM, mediu, ind) bazin decantor subsieve analysis (materiale, metr) distribuție granulometrică a pulberii nereținute de sită standard de $44 \mu \mathrm{m})$

subsieve fraction (materiale, metr) fractie granulometrică (care trece, de obicei, printr-o sită de $44 \mu \mathrm{m})$

subsieve powder (materiale) pulbere fină

substance (fiz, chim, met) componentă, conținut, masă, substanță, material, natură

substance engaging in flow (fiz, hidr, T) substanță antrenată în curentul de fluid / care curge (odată cu fluidul)

substancial damage $(\mathrm{TH})$ avarie / distrugere / deteriorare substanțială, care necesită reparații costisitoare şi cronofage

substandard subetalon, substandard (d. un produs, o măsurătoare etc.)

substitute (chim) înlocuitor, surogat, substitut; $(\mathrm{OM})$ rezervă, piesă de schimb; a substitui, a înlocui

substitute material (materiale) material înlocuitor, înlocuitor / de substituție

substitute steel (mas-un) cuțit cu tăiș aplicat; (met) oțel-înlocuitor (uneori echivalent) (al altui oțel sau a altui material)

substitution (mat, chim) substituție, înlocuire, substituire

substitutional element (chim, met) element de aliere, care poate înlocui alt element de aliere sau, parțial, elementul de bază

substitution method (chim, met) metodă de substitutie

substitution product $(\mathrm{TH})$ produs de substitutie substrate (met, chim, T) substrat, strat suport (la acoperiri)

substructure (constr) infrastructură, structură inferioară

subsurface (constr, geol) subsol, subteran; (OM, T) zonă / volum de sub suprafață

subsurface pump (OM, hidr) pompă de fund / de adâncime

subsurface structure (constr, geol) structură a subsolului

subsystem subsistem (foarte general) subtense (geom) coardă corespunzătoare unui unghi, latura opusă unui unghi

subterfuge subterfugiu, mijloc auxiliar

subtract (mat) a scădea; a scoate din

subtraction / substractive (mat) scădere

subtraction / substractive (mat) scădere

subtraction sign (mat) semnul de scădere, semnul minus

subtrahend (mat) scăzător

sub-zero refrigeration (alim, fiz, termo) răcire la temperaturi joase / sub $0^{\circ} \mathrm{C}$ sau ${ }^{\circ} \mathrm{F}$ (atenție la text)

sub-zero treatment (met) tratament la temperatură joasă / sub $0^{\circ} \mathrm{C}$

succeed a urma, a reuşi

succeedent (mat) succesor

success succes, reuşită

succession succesiune, şir

succession of passes (met) succesiune a trecerilor / calibrelor de laminare

successive succesiv

successive approximation(s) (mat) aproximare succesivă, aproximări succesive

successor (mat) succesor, următor

succint succint, concis

suck $(\mathrm{TH}$, ind $)$ a absorbi, a suge, a aspira, a sorbi (şi aer)

sucker rod $(\mathrm{OM})$ tijă (și de pompă)

suck off $(\mathrm{TH}$, ind) a aspira, a scoate prin aspirare

sucking off $(\mathrm{TH}$, ind) aspirație, evacuare prin aspirare

sucking-off section / plant $(\mathrm{TH}$, ind) instalație de aspirație

sucking pump (OM, hidr) pompă aspiratoare

sucking room (OM, hidr, termo) cameră de aspirație

suck up (OM, hidr) a aspira, a suge, a absorbi

sucrose (chim, alim) zaharoză

suction (OM, hidr, fiz, termo) admisie, aspirare, aspirație

suction air aer aspirat

suction apparatus (termo, OM) deflector (la un coş de fum), dren, drenaj, aspirator de aer, aspirator, dispozitiv de aspirație

suction casting (met, plast) turnare sub vid

suction conduit $(\mathrm{OM}$, hidr) conductă de aspirație

suction connection $(\mathrm{OM}$, hidr) conductă / racord de aspirație / de absorbție

suction draghead (nav) capul elidei (la dragă)

suction dredge(r) (nav) dragă aspiratioare

suction dredging (nav, $\mathrm{TH}$ ) dragare prin aspirare

suction dryer (alim, ind chim) uscător prin aspirare / prin absorbție 
suction effect (fiz) efect de aspirare / de aspirație / de absorbție

suction ejector (mas-un, OM) ejector de aspirație suction filter (OM, termo) filtru cu vid / cu (de) aspirație / de admisie

suction gas producer (termo, ind chim) generator de gaz cu aspirare de aer

suction head (hidr) înălțime de aspirare, cap de aspirare

suction hole (OM, hidr) gură / orificiu de aspirare / de aspirație

suction hood (OM, hidr, termo) sorb, hotă de aspiratie

suction hose sorb, furtun de aspirație / de vid (şi din materiale plastice)

suction inlet (OM, hidr, termo) orificiu de aspirație / de admisie

suction ladder (nav, OM) elindă

suction lift (hidr, OM) înălțime de aspirație a unei pompe

suction line (OM, hidr) linie / conductă de aspirație / de admisie

suction main (OM, hidr) conductă / țeavă de admisie; (met) conductă de aspirație

suction manifold (OM, hidr) colector de aspirație / de admisie

suction noise (OM, hidr, termo, auto) zgomot la aspirare / la admisie

suction nozzle (OM, hidr, termo, auto) ajutaj / orificiu / trompă de aspirare / de admisie

suction pipe (OM, hidr, termo, auto) conductă / țeavă de admisie / de aspirare

suction piping (OM, hidr, termo, auto) conducte / ansamblu de conducte de aspirare / de admisie

suction port (OM, hidr, termo, auto) gură / orificiu de aspirare

suction pressure (hidr, termo) presiune de aspirare / de admisie

suction pump (OM, hidr, termo, auto) pompă de admisie / de aspirare

suction screen $(\mathrm{OM}$, hidr, termo, auto) filtru de / la admisie / aspirare

suction stroke (OM, hidr, termo, auto) cursă de aspirație (la acționări cu piston)

suction stub (OM, hidr) ştuț / racord de aspirație suction tube (OM, hidr, termo, auto) teavă / conductă de admisie / de aspirație

suction valve (OM, hidr, termo, auto) supapă de admisie / de aspirație

suction vortex (fiz) vârtej la aspirare

sudden alteration of cross section (OM) modificare bruscă a secțiunii transversale a unei conducte

sudden shut-down (mas, ind) întrerupere de urgență, oprire / întrerupere bruscă

sudden stop oprire bruscă suds (alim, ind chim) decocție, spumă, clăbuc de săpun

suds lubrication $(T)$ ungere cu clăbuc de săpun / cu spumă

suds trough (mas-un, OM) tavă a strungului

suet (alim) seu

suffer a suferi, a suporta

sufficient suficient

suffocate a (se) sufoca, a (se) înăbuşi

sugar (alim) zahăr

sugar content (alim) conținut de zahăr

sugar-beet knife / stripper (alim, mas-un) cuțit pentru sfeclă de zahăr

sugar-beet washer (alim, mas) spălător pentru sfeclă de zahăr

sugar-juice (alim) zeamă de (sfeclă de) zahăr

sugar of milk (chim, alim) lactoză

sugar rafinery (alim) fabrică / rafinărie de zahăr suit $(\mathrm{ec})$ proces, acțiune, a adapta, a corespunde, a (se) potrivi

suitability for calitatea / proprietatea de a fi potrivit pentru

suitable to / for convenabil; potrivit cu / pentru

suitable for tropics (materiale, $\mathrm{OM}$; mas) rezistent la clima tropicală

suitor administrator; petiționar, solicitant; (jur, adm) pretendent, reclamant

sulfonated oil (alim, ind chim) ulei tratat cu acid sulfuric (pt. a-l face emulsionabil)

Sulfur, Sulphur (S) (chim) sulf

sulfurised oil (ind chim, T) ulei cu sulf activ (pt. creşterea sarcinii portante)

sulk (constr) a sprijini cu o capră

sull (met, chim) rugină, strat de oxid feros

sullage (met) zgură de oală

sullage head / piece (TH) adaos de turnare (la sticlărie, materiale plastice); (met) maselotă

sullage pipe (met, plast, $\mathrm{OM}$ ) pâlnie răsuflătoare sulling (chim, met) oxidare după decapare

sully a (se) murdări, a (se) păta, a (se) mânji (d suprafete etc.); a întuneca

sulphamide (chim, med) sulfamidă

sulphate (chim) sulfat

sulphate-carbonate ratio (chim, termo) raport între sulfați şi carbonați

sulphated oil (chim) ulei sulfatat

sulpha(tisa)tion, sulphating (chim, met) (proces de) sulfatare

sulphide (chim) sulfură

sulphide embrittlement (chim) fragilitate la hidrogen sulfurat

sulphite (chim) sulfit

sulphizing (met, chim) sulfizare

sulphone (chim) sulfonă

sulphur content (chim, met) conținut de sulf (în unsori, oteluri etc.) 
sulphur dioxide (chim) dioxid de sulf sulphureous (chim) sulfuros

sulphuretted hydrogen (chim) hidrogen sulfurat sulphuric acid (chim) acid sulfuric

sulphurised oil (ind chim, T) ulei conținând sulf activ

sulphur pock marks (chim) pete sulfuroase sulphur print (met, chim) amprentă Baumann sulphur removal (met, chim, $\mathrm{TH}$ ) desulfurare sulphurisation (chim) sulfurare

Sulfur soap (T, chim) săpun pe bază de sulf

sum (ec, mat) sumă, total; rezultat; esență, fond; problemă de aritmetică; a socoti, a calcula, a aduna; a rezuma

summability (mat) sumabilitate

summable function (mat) funcție însumabilă summarization (mat, ec) însumare, centralizare, rezumare

summarize a rezuma, a centraliza; a recapitula summarized (ec, mat) însumat, centralizat, rezumat

summarizing table (ec) tabelă centralizatoare summarizing tolerance $(\mathrm{OM}$, mas-un) toleranță totală / însumată

summary sumar; concis; rezumat; recapitulare; conspect; expunere sumară / scurtă

summary offence (jur) contravenție

summation totalizare, însumare; total, sumă; rezumat

summer beam (constr, OM) talpă a grinzii

summer vară; (fig) (perioadă de) înflorire; de vară, văratec

summer gasoline (ind chim, auto) benzină de vară summer school (edu) şcoală / cursuri de vară summer time vară, timpul verii, timp de vară ora standard în lunile de vară

summer type diesel fuel (auto, ind chim) combustibil / carburant biodiesel de vară

summing amplifier (autom, electr) amplificator sumator

summing(-)up (ec) totalizare; apreciere generală a unei situații, retrospectivă; care însumează

summit vârf, creștet; pisc; (fig) culme, apogeu; (pol, adm) întâlnire la nivel înal

summit talks (pol, adm, ec) discuții la nivel înalt

summon a soma; (jur) a cita, a convoca; a invita; a aduna

summons, $(p l)$ sommonses (jur) citație, mandat, somație; (adm, ec) avertisment, proces verbal, apel, chemare (a autorităților); convocare

sump (OM, mediu) colector de apă

sump drain plug $(\mathrm{OM})$ buşon de golire a băii de ulei

sump hole (OM, hidr) orificiu de golire sum rule regulă de sumare, regula sumelor sum total (ec) sumă globală sum up a însuma, a aduna; a rezuma, a face un rezumat; a recapitula

sun (fiz) soare, lumina soarelui / naturală; a lumina, a radia, a străluci

sun-and-planet gear $(\mathrm{OM})$ mecanism / angrenaj planetar, transmisie planetară

sun bath (fiz) baie de soare

sun beam (fiz) rază de soare

sun bow (fiz) curcubeu

sunburn (med) arsură de soare, bronzare; a (se) bronza, a fi ars de soare

sun check (mediu, materiale) crăpătură din cauza soarelui (d. lemn, umateriale plastice etc.)

sundown apus de soare, asfințit

sundries lucruri diverse; (ec) cheltuieli diverse

sun-dry (materiale, textile) a usca la soare

sundry diferit; divers, felurit; amestecat

sunfast (textile, plast) rezistent la acțiunea luminii solare, care nu se decolorează la soare

sunflower (agr, alim) floarea-soarelui

sunflower oil (alim) ulei de floarea-soarelui

sun gear $(\mathrm{OM})$ roată dințată centrală la transmisii planetare

sun glass (fiz, opt) lentilă convergentă

sun glasses (fiz, opt, OM) ochelari de soare

sunglass holder (auto, OM) loc / toc pentru ochelari

sun glow zori, auroră; amurg, crepuscul; coroană / căldură / arşiță solară

sunken (s)cufundat, afundat; coborât; (TH, OM) înecat, îngropat, înfundat, scobit, adânc

sunk hinge balama îngropată

sunk key $(\mathrm{OM})$ pană îngropată

sunk pin $(\mathrm{OM})$ ştift cu cap înecat

sunk screw $(\mathrm{OM})$ şurub cu cap înecat

sunk well foundation (constr) fundatie cu chesoane deschise

sunk wreck (nav) epavă scufundată

sunlamp (fiz) lampă cu cuarț / cu (raze) ultraviolete

sunless neluminat de soare; (fiz) umbrit; fără lumină naturală

sun light (fiz) lumina soarelui / naturală

Sun mass, solar mass (metr, astronomie) unitate de măsură pentru a exprima mase foarte mari (ale corpurilor cerești), masă a Soarelui: 1 Sun mass $\sim 1,9891 \cdot 10^{30} \mathrm{~kg}$

sunny expus la soare, însorit

sun-proof $(\mathrm{OM})$ care nu lasă să treacă / pătrundă razele soarelui; care nu se decolorează la soare, rezistent în lumina soarelui

sun ray rază de soare; $(p l)$ sun rays lumină ultravioletă, raze ultraviolete

sunrise răsărit de soare; (fig) răsărit, început 
sunroof (auto) trapă

sunshade (auto) parasolar

sun shake crăpătură din cauza soarelui (la lemn) sunset apus de soare; amurg; (fig) asfințit, declin sunshine lumină de soare; vreme senină; (fig) prosperitate

sunstroke (med) insolatie

sun-struck (med) lovit de insolație

sunvisor (auto) parasolar

sunward (bot, constr, termo) îndreptat / orientat spre soare (şi d. instalații de captare a energiei solare)

sun-wheel $(\mathrm{OM})$ roată dințată centrală $(\mathrm{la} \quad$ o transmisie planetară)

super extra, (produs) de calitate superioară; (ec) superintendent; excesiv; extrem de; în exces

superabound (with) a (supra)abunda (în), a fi din abundență

superabundance (supra)abundență, belşug; prisos; exces

superabundant (prea) abundent, îmbelşugat, supra(-)abundent

super-accelerator (fizică nucleară) accelerator ultrarapid

superadd a supraadăuga, a mai adăuga

superaddition supraadăugare

superageing mix (ind chim) amestec de cauciuc, cu rezistență mare la îmbătrânire

superalloy (met) superaliaj (cu un det de proprietăti superioare aliajelor uzuale)

superannuate $(\mathrm{ec}, \mathrm{adm})$ a pensiona, a scoate la pensie

superannuated pensionat; învechit, demodat, perimat; uzat

superannuation pensionare; pensie; învechire, perimare; uzare (mai ales morală)

super-atomic bomb (fizică nucleară, mil) bombă termonucleară

superb superb, excelent; de prim rang; luxos; impozant, impunător

supercarburization (met, chim) carburare / cementare excesivă (şi ca defect)

supercentrifuge (alim, med, OM) ultracentrifugă, supercentrifugă

supercharge (termo) a supraalimenta; (mec, el) a supraîncărca, a suprasolicita

supercharged engine / motor (termo) motor cu compresor / supraalimentat

supercharger (termo) compresor de supraalimentare

supercharging (termo) supraalimentare, supracompresi(un)e (la motoare)

supercharging jet (hidr, termo) jet cu supraalimentare super chopper (OM, autom) selector mecanic ultrarapid

supercompressibility (fiz) supercompresibilitate a gazelor (care nu respectă legea lui Boyle)

superconductivity (fiz) supraconductivitate

superconductor (fiz, materiale) supraconductor supercool (fiz, termo, TH) a subrăci, a suprarăci supercooling (chim, met) răcire rapidă, subrăcire supercritical (fiz, mec) supracritic

super cut (mas-un, TH) dinţare dublu fină la pile superelevation (auto, cf) supraînălțare (la curbe) supererogate a face mai mult decât i se cere, a face exces de zel

supererogation exces de zel

supererogatory făcut în plus; peste limita oligației; superfluu, de prisos, nedorit

superficial superficial, de suprafață; artificial; (metr) adjectiv utilizat pentru conversia unei unități de lungime într-o unitate de suprafață; aici sinonim cu square - pătrat; superficial foot $=$ square foot, superficial yard $=$ square yard; în Australia şi Noua Zeelandă superficial foot se traduce prin super foot; $v$. super foot

superficial carburization (met, chim) carburare / carbonizare superficială

superficial cementation (met, chim) cementare superficială

superficial current (hidr, geogr) curent de suprafață

superficial expansion (termo, OM) dilatare superficială

superficial (face) hardening (met) durificare călire superficială

superficialism superficialitate, neseriozitate, netemeinicie

superficiality superficialitate; artificialitate; lucru făcut superficial

superficial layer $(T$, met) strat superficial

superficial measures (ec, pol, adm, ind) măsuri superficiale

superficies (materiale, OM) suprafață, arie; exterior; aparență, înfățișare

superfine $(\mathrm{OM})$ superfinisat, foarte fin, extrafin; de calitate superioară

superfine file pilă fină

superfines (materiale) pulbere cu particule sub $10 \mu \mathrm{m}$

superfinishing $(\mathrm{TH})$ superfinisare, şlefuire fină superfinishing machine (mas-un) maşină pentru superfinisare

superfinish surface $(\mathrm{OM}, \mathrm{TH})$ suprafață superfinisată

superfluidity (fiz, TH) superfluiditate (d. materiale topite, fluide etc.) 
superfluity superfluitate, caracter superfluu; prisos, excedent; exces

superfluous superfluu, de prisos; inutil; suplimentar, excedentar

superfluously $(a d v)$ (în mod) superfluu, inutil

super foot (metr) unitate britanică de măsură pentru suprafață, picior pătrat; în Australia şi Noua Zeelandă, unitate de măsură pentru volum pentru lemn sau buşteni: 1 super foot are volumul unei scânduri cu arie de un picior pătrat şi grosime de 1 inch; în America de Nord aceaiaşi unitate de volum se numeşte board foot

super-frequency (fiz, mec) frecvență suprainaltă / supracritică

superheat (fiz, termo) supraîncălzire; a supraîncălzi, a crește temperatura aburului peste punctul de saturație

superheated (fiz, termo) supraîncălzit (şi d. abur) superheated steam (termo) abur supraîncălzit

superheater (termo) supraîncălzitor, sistem de țevi (în partea superioară a boilerului) pentru supraîncălzirea aburului

superheat horn (termo) curbă de supraîncălzire (pe diagrama Carnot, în formă de corn)

superheating (termo, met) (acțiune / proces de) supraîncălzire

superhybrid material(s) materiale compozit(e) din polimeri, fibre și particule

superimpose a suprapune, a pune unul este altul; a supratipări

superimposed $(\mathrm{TH})$ suprapus (defect la ştanțare)

superimposing $/ \mathrm{TH}, \mathrm{c}, \mathrm{TV}$ ) suprapunere (şi de imagine), care se suprapune

superimposition (fiz) suprapunere

superincumbent suprapus; atârnat deasupra; (fig) apăsător, împovărător

superinduce on / upon a adăuga la, a introduce în plus / peste; a sprijini, a susține

superintend (ec) a gospodări, a supraveghea, a administra, a conduce

superintendence $(\mathrm{ec})$ supraveghere, administrare, conducere

superintendent $(\mathrm{TH}$, adm, ec) supraveghetor, conducător tehnic, şef de exploatare, administrator, director

superintendent engineer $(\mathrm{TH}$, ind, ec) inginer şef superior (to) superior; mai bun, mai rezistent (decât); excelent; de calitate superioară; extraordinar, puțin obişnuit; (poligrafie) (literă) de sus, de deasupra (rândului); (ec, adm) superior, director, șef, comandant

superior alloy steel (met) oțel înalt aliat

superior bound (mat) margine superioară (a unui interval) superiority superioritate

superjacent aflat deasupra, pe deasupra

superlative suprem, excelent; fără egal; (gram) superlativ

superlattice (fiz) suprarețea

super lock system (auto) suprasistem de blocare, sistem de blocare cu asigurare suplimentară

super-marginal care depăşeşte limitele stabilite

supermarket (ec) supermarket, magazin universal (şi cu autoservire)

supernatant liquor (alim, mediu, ind) lichid limpezit (deasupra solidelor sedimentate, în sedimentare gravitaţională)

superphosphate (chim) superfosfat

superplasticity (materiale) superplasticitate, capacitatea unor materiale de a se alungi uniform şi foarte mult la temperaturi ridicate fără a se rupe

superpose (fiz) a suprapune (oscilații, franje etc.), a interfera; a etaja, a supraetaja

superposed suprapus; etajat, supraetajat

superposed circuit (el, elctr, autom) circuit fantomă / circuit suprapus / circuit virtual

superposition (mat) superpoziție; (fiz, met) suprapunere

superpressure (mec, hidr) suprapresiune

superprofit (ec) supraprofit

super-proton (fizică nucleară) hiperon

super-refractories (met, termo) suprarefractare

super-regeneration (chim) suprareactie

super-retroaction (fiz) suprareactie

supersaturate (chim) a suprasatura

supersaturated solution (chim) soluție suprasaturată

supersaturated steam (termo) abur suprasaturat supersaturation (termo) supersaturare (a aburului); (chim) suprasaturație

super season a maturiza

super seasoning îmbătrânire (d. materiale plastice)

superscribe a grava, a înscrie; a scrie (adresa pe plic); a pune (şi adresa); a menționa

superscript (mat) indice superior, exponent

superscription înscripție; adresă (pe plic); antet; legendă (pe diagrame)

supersede (by) a înlocui (prin / cu); a înlătura, a da la o parte; a elimina, a îndepărta

supersession înlocuire; înlăturare; eliminare, îndepărtare

supersonic (fiz, av) supersonic, ultrasonic

supersonic dispersed oil (ind chim, TH) ulei dispersat cu ultrasunete

supersonics (fiz) ultraacustică, supersonică (parte a fizicii) 
superstrong metal (steel) (met) metal (oțel) cu rezistență ridicată

superstructure (cf) suprastructură a căii ferate; (OM, constr) suprastructură, şasiu turnant, suprastructură

superstructure of furnace (met) partea superioară a cuptorului

supertax (ec) suprataxă, impozit pe supraprofit

super(-)tension (mec, el) supratensiune, tensiune maximă

supervene a surveni, a interveni

supervenient următor; în plus, suplimentar, adițional; complementar

supervention urmare, consecință

supervise $(\mathrm{ec}, \mathrm{adm}, \mathrm{TH})$ a supraveghea, a controla (pt. avizare, acceptare etc.), a inspecta, a dirija, a conduce, a aproba (la nivel superior), a superviza

supervising staff (ec, adm, TH) personal de supraveghere / de dirijare (a lucrărilor)

supervision (ec, adm, TH) supraveghere, control, inspecție, avizare (la nivel mai înalt); conducere, dirijare

supervisor (mas-un, TH, ec) maistru, conducător de lucrări, supraveghetor, controlor, administrator

supplant (ec, adm, TH) a înlocui

supplantation (ec, adm, TH) înlocuire; înlăturare

supplanter $(\mathrm{ec}, \mathrm{adm}, \mathrm{TH})$ înlocuitor

supple $(\mathrm{OM})$ suplu, flexibil, maleabil, mlădios

supplement supliment, adaos; (mat) complementar, suplementar; completare, anexă, ediție specială; a completa, a suplimenta, a adăuga

supplememtary, supplemental suplimentar; aditional; în plus

supplememtary benefit (ec) beneficiu suplimentar de stat (în UK)

supplementary air intake (auto, termo) intrare / admisie de aer suplimentar

supplementary gear set $(\mathrm{OM}$, mas) cutie de viteze, suplimentară / auxiliară

supplementary heat (met, termo) căldură suplimentară

supplementary load $(\mathrm{el}, \mathrm{mec})$ sarcină suplimentară

supplementary means (ec, TH) material(e) / mijloace auxiliar(e)

supplementation (mat) suplementare, complementare; suplimentare; adăugare

suppletion suplimentare; adăugare

supplier (ec) furnizor, sursă

supplies (alim) alimente; furnituri (de birou etc.); (ec, TH) provizii, aprovizionări, resurse (de materii prime etc.) supply (with) (ec) credit, fond(uri), stare, ofertă, procurare, livrare, aprovizionare, furnizare, rezervă, stoc; înlocuire, suplinire; înlocuitor, suplinitor; $(\mathrm{TH})$ alimentare, conductă de alimentare, livrare, furnizare, aprovizionare; suplinitor; a aproviziona (cu), a furniza, a alimenta (cu un fluid de lucru, semifabricate etc.), a livra (şi energie), a aduce; a procura; a da; a oferi, a acoperi (necesități); a suplini, a umple (goluri etc.), a completa (lipsuri etc.); a înlocui (cu); $(a d v)$ cu suplețe, flexibil

supply and demand $(\mathrm{ec})$ cerere şi ofertă

supply base (constr, ec) depozit, bază de aprovizionare

supply circuit (el, alim, hidr) circuit de alimentare supply current (el) curent de alimentare

supply flow (hidr) debit de alimentare / de intrare supply network $(\mathrm{TH}, \mathrm{el})$ rețea de alimentare supply of current (el, ind) furnizare de curent supply of energy (el, ind) sursă de energie, alimentare cu energie (şi electrică)

supply of gas (ind) alimentare cu gaz, sursă de gaz

supply pipe $(\mathrm{OM}$, ind) conductă de alimentare supply plant (ind, ec) uzină furnizoare supply port (hidr, OM) orificiu de alimentare supply pressure (hidr) presiune furnizată de motorul hidraulic

supply pump (OM, hidr) pompă de alimentare supply valve (OM, hidr) supapă / robinet de admisie / de aspirație

support (OM) suport, reazem, consolă, sprijin, postament, susținere; (mat) reprezentant, mulțime suport; ajutor; susținător (şi de familie); întreținere, subzistență; a susține, a sprijini, a rezema, a propti, a consolida; a încuraja, a dovedi, a corobora; a suporta; a ajuta; a adeveri, a confirma; a întreține (o discuție etc.); a duce supportable suportabil, tolerabil; admisibil; care poate fi susținut (d. o lucrare etc.)

support costs (ec) totalitatea cheltuielilor cu exploatarea unui utilaj (echipament de testare, monitorizare, piese de schimb, mentenanță, facilităti, calificare a personalului etc.) exclusiv cele pentru manoperă şi plata personalului auxiliar

support die block (met, OM) bloc port-pastilă (la forjă, la matrițare)

supported sprijinit, suportat, proptit, rezemat, susținut

supported film adhesive (plast) adeziv film cu / pe suport

supporter (pol, ec) suport; susținător, partizan, adept; (OM) suport, reazem, proptea 
supporting susținere, proptire, purtător (OM) susținător, care susține / sprijină / reazemă, de sprijin / reazem / suport / susținere; secundar, cu rol secundar

supporting area $(\mathrm{OM}, \mathrm{mec}$, constr) suprafață / arie de susținere / de rezemare / de reazem

supporting arm $(\mathrm{OM})$ suport tip consolă

supporting beam (OM, constr) grindă de susținere / de suport

supporting bearing (OM) lagăr de susținere / de reazem

supporting bracket $(\mathrm{OM})$ suport / consolă de reazem

supporting capacitty capacitate portantă, capacitate de încărcare

supporting document (ec) act justificativ

supporting element (OM, constr) element portant / de susținere

supporting flange $(\mathrm{OM})$ flanşă de suport

supporting force $(\mathrm{OM}, \mathrm{mec}$, constr) forță pe reazem / de susținere

supporting frame $(\mathrm{OM})$ cadru-suport, schelet purtător, cadru de sprijin, batiu (şi de maşină)

supporting gas (fiz) gaz purtător

supporting journal $(\mathrm{OM}, \mathrm{T})$ lagăr de reazem de sprijin

supporting mass $(\mathrm{OM}, \mathrm{mec})$ masă / bloc de rezistență

supporting pin (OM) fus, cep / ştift de reazem

supporting pivot $(\mathrm{OM})$ pivot de rezemare, pivot-suport

supporting plate $(\mathrm{OM})$ placă de reazem

supporting point $(\mathrm{mec})$ punct de reazem

supporting power (mec, OM) capacitate portantă, capacitate de încărcare / de susținere, forță / putere de sustentație

supporting reaction (mec, $\mathrm{OM}$ ) reactiune în reazem

supporting ring $(\mathrm{OM})$ inel de reazem / de susținere

supporting rod $(\mathrm{OM})$ bară de suport / de întărire supporting saddle $(\mathrm{OM})$ cuzinet de reazem

supporting shackle $(\mathrm{OM})$ cercel / inel de sustinere / de suspendare

supporting shoe $(\mathrm{OM})$ cuzinet / sabot de reazem supporting strand $(\mathrm{OM}, \mathrm{mec})$ cablu purtător / de susținere

supporting surface $(\mathrm{OM}, \mathrm{mec})$ suprafața portantă, platformă de susținere, suprafață de sprijin / de reazem

supporting table (OM) masă / platformă de sprijin / de depunere

supporting truss (OM, constr) fermă (metalică) de sprijin support plate $(\mathrm{OM}$, mas-un, $\mathrm{TH})$ placă-suport, placă de reazem

support pressure $(\mathrm{OM}, \mathrm{mec})$ presiune pe reazem support rod (auto, OM) tijă de suport

support without failure (OM, mas) a rezista / suporta fără a se rupe / fără a se defecta

supposably supozabil; de presupus

supposably $(a d v)$ de presupus; probabil; după toate probabilitățile

suppose a presupune, a bănui, a crede; a implica; a trage după sine; a trebui să; a face o presupunere

supposed presupus, pretins, aşa-zis

supposedly $(a d v)$ după cum se presupune; prin supoziție

supposing presupunând, care presupune, dacă, în cazul când / că

supposition presupunere; supoziție, ipoteză; bănuială; prezumție; sens, înțeles, semnificație (pt. un cuvânt, simbol etc.)

suppositional ipotetic, presupus

suppress a înăbuşi, a reprima; (pol) a interzice; (ec) a confisca; a suprima; a pune capăt, a face să dispară; a reține; a stăpâni; a ascunde; $(\mathrm{TH})$ a atenua vibrațiile, a frâna, a închide

suppressed range (metr, autom) interval fără zero (al unui parametru)

suppression înăbușire, reprimare; (hidr) reținere; ascundere

suppressive (pol, adm) represiv

suppressor frână (şi fig)

supranational (pol, adm, ec) supranațional, suprastatal

supremacy (pol, ec) supremație, poziție dominantă, preponderență

supreme suprem; cel mai mare / înalt etc.; critic, dificil, extrem, greu; fatal; ultim

supremium (mat) cel mai mic majorant

surcease a înceta; încetare

surcharge (mec, el, hidr) sarcină suplimentară, suprasarcină, supraîncărcare; (adm) amendă, suprataxă; a supraîncărca (şi un acumulator), a supraalimenta (şi un motor); (adm) a amenda, a cere suprataxă pentru

surcharged steam (termo) abur nesaturat

surcoat (textile) bluză de vânt, vindiac

surd (mat) număr irațional

sure sigur; convins; cert; de nădejde

sure-enough (amer) real, adevărat; sigur

surely $(a d v)$ (în mod) sigur; în siguranță; cu încredere; cert, categoric, fără îndoială; cu siguranță, cu precizie

sureness siguranță, certitudine; convingere fermă; fermitate, hotărâre 
surety (ec) aval; (TH) siguranță, securitate surf (nav) brizanți, resac, deferlare, val surface suprafață, arie; zonă, regiune; (OM) față, parte de sus, exterior; superficial; aparență; (av) plan; superficial, de / la suprafață; $(\mathrm{TH})$ a lustrui (o suprafață), a polei; (nav) a aduce a suprafață (un submersibil); (poligrafie) a satina, a velina; (constr) (d. drumuri) a îmbrăca, a pietrui

surface action (fiz) acțiune de suprafață / superficială, efect superficial / pelicular

surface-active (fiz, chim) tensoactiv, activ de / la suprafață

surface-active agent (chim, T) agent tensoactiv / cu acțiune la suprafață

surface activity (fiz) activitate superficială

surface adsorbtion $(\mathrm{T})$ adsorbție superficială

surface analyser (metr, T, fiz) profilometru, profilograf

surface attraction (fiz) atracție la suprafață

surface bearing $(\mathrm{OM})$ reazem plat

surface boiling (fiz, materiale) fierbere de suprafață / locală

surface brightness (fiz) strălucire de suprafață

surface broaching (mas-un, $\mathrm{TH}$ ) prelucrare a suprafețelor prin broşare

surface carburising (met, chim) carburare / cementare (superficială / de suprafață)

surface cementation (met, chim) cementare (superficială)

surface charge (el, mec, fiz) sarcină / încărcare pe suprafață, sarcină superficială

surface checking (OM, metr) verificare a suprafeței (din punct de vedere al rugozității, dar şi a defectelor metalurgice)

surface chill (termo) răcitor de / la suprafață

surface cleaning $(\mathrm{TH})$ curățare a suprafeței (la lipire, sudare etc.)

surface coating $(\mathrm{OM}, \mathrm{TH})$ acoperire superficială, strat de acoperire a suprafeței

surface combustion (termo) ardere pe / la suprafață

surface condition (mas-un, $\mathrm{OM}$, met, $\mathrm{T}$ ) calitate a suprafeței (și referitor la rugozitate), stare / structură a suprafeței / a stratului superficial

surface constraint (mec) tensiune superficială

surface contact (mec, T) contact superficial / direct între două suprafețe, contact pe o suprafață

surface converting (met, el, TH) călire superficială (şi cu curenți de înaltă frecvență)

surface cooler (termo, mas) răcitor prin suprafață / prin stropire

surface corrosion (chim, materiale) coroziune superficială / de suprafață surface crack (OM) crăpătură / fisură de suprafață; (met) fisură superficială

surface decarburization (met, chim) decarburare superficială (şi defect)

surface defect (met, mas-un, OM) defect de suprafață

surface discharge (el, fiz) descărcare superficială

surface effect (fiz) acțiune superficială, efect de suprafață, efect pelicular

surface element (mat, mec) element de suprafață (şi în modelare)

surface energy (fiz) energie de suprafață / care caracterizează suprafața

surface evaporation (fiz) evaporare superficială / la suprafață

surface fall (geogr) depresiune de teren

surface feet per minute, SFM (metr, mas-un) unitate de măsură pentru viteza de rotație a unei scule rotitoare (la strung etc.), picioare pe minut (la aşchiere etc.)

surface film (fiz) peliculă superficială

surface finish $(\mathrm{TH}, \mathrm{OM}, \mathrm{T})$ calitate / stare / structură a suprafeței

surface finishing (TH, OM) finisare a suprafeței

surface foot (metr) similar cu picior liniar; v. linear foot

surface forces $(\mathrm{TH}, \mathrm{OM}, \mathrm{T})$ forte superficiale / de suprafață

surface formation ( $\mathrm{TH}, \mathrm{OM}, \mathrm{T})$ formare / generare a suprafeței

surface friction $(\mathrm{OM}, \mathrm{T})$ frecare de suprafață

surface gauge (metr, $\mathrm{OM}$ ) trasator paralel

surface grinder (mas-un, TH) maşină de rectificat plan

surface grinding (mas-un, TH) rectificare plană surface grinding machine (mas-un) maşină de rectificat plan

surface hardening ( $\mathrm{TH}$, materiale) durificare întărire superficială; (met) călire superficială

surface hardness (materiale, mec) duritate superficială

surface harmonic (mat) funcție sferică

surface imperfection (TH, OM) defect de suprafață

surface integral (mat) integrală de suprafață

surface-inactive agent (chim, T) agent inactiv de suprafaţă

surface irregularity $(\mathrm{OM})$ abatere de la forma ideală / cerută (defect), neregularitate a suprafetei

surface lathe (mas-un) strung frontal

surface layer (mec, T, OM) strat superficial / de suprafață 
surface layer welding $(\mathrm{TH}$, met) încărcare prin sudură (pt. recondiționare, acoperire etc.)

surface leakage (el) scurgere / curent / fugă superficială / de suprafață

surface loading (mec) sarcină pe suprafață surface mapping (constr) ridicare topografică surface milling (mas-un, TH) frezare plană surface milling machine (mas-un) freză pentru frezare plană

surface modification (mec, fiz, hidr, TH) modificare de suprafață / a suprafeței

surface normal (geom) normală la suprafață

surface of failure $(\mathrm{OM}, \mathrm{T})$ suprafată de ruptură / a rupturii / de alunecare / deteriorată

surface of fracture (met) casură, suprafată (caracteristică) rupturii / fisurii

surface of guide (mas-un, OM) suprafață de ghidare

surface of revolution (mat, geom) suprafață de rotație / de revoluție

surface of separation (fiz) suprafață de separare

surface of the water (hidr) suprafață / oglindă a apei

surface plate (mas-un, OM) placă de control de îndreptare, masă de verificare

surface pore (met, T) por de suprafață

surface pore (mec, el) potenţial de suprafață

surface preparetion $(\mathrm{TH})$ pregătire a suprafetei (la lipire, sudare etc.)

surface pressure (fiz) presiune / tensiune superficială

surface profile (metr, T) profilul suprafeței. (la profilometria suprafetei)

surface protection $(\mathrm{OM}$, chim) protecție a suprafeței

surface quality $(\mathrm{OM}, \mathrm{T})$ calitate a suprafeței surface ray (fiz) undă de sol, fascicul terestru surface reaction (chim) reacție de suprafață surface roughness $(\mathrm{OM}, \mathrm{T})$ rugozitate a suprafeței

surface roughness test(ing) (metr, OM, T) determinare a parametrilor rugozității

surface scratching test (met, plast, $\mathrm{T}$, metr) test de duritate prin zgâriere

surface screw (mas-un, OM) şurub al mecanismului avansului transversal

surface speed (mas-un) viteză (circumferențială) de aşchiere

surface stress (mec, fiz) tensiune superficială / la suprafață

surface structure (met, fiz) structură superficială

surface tear (mec, materiale) fisură superficială (prin forfecare / sfâşiere)

surface temperature (termo) temperatură a suprafeței / la / pe suprafață surface tempering (met, TH) călire superficială (eventual cu revenire)

surface tension (met, fiz, hidr) tensiune superficială / la suprafață

surface-tension force (fiz) forță capilară, forță generată de tensiunea superficială

surface thermal damage $(\mathrm{OM}, \mathrm{T}, \mathrm{TH})$ defect termic de suprafață

surface-to-air (mil) sol-aer, antiaerian

surface treating (met, plast, chim, $\mathrm{TH}$ ) tratare superficială / a suprafeței

surface treatment (met) tratament superficial; (TH) prelucrare a suprafeței (foarte general)

surface under pressure (mec, hidr) suprafață de presiune

surface viscozity (hidr, T) vâscozitate a peliculei superficiale

surface waviness $(\mathrm{OM})$ ondulație a suprafeței

surface waviness high value $(\mathrm{OM})$ valoare maximă a ondulației suprafeței

surface waviness width value $(\mathrm{OM})$ valoare a lungimii ondulației suprafeței (măsurată între două vârfuri consecutive)

surface work $(\mathrm{OM}$, fiz, chim) actiune superficială / pe suprafaţă, efect superficial / pelicular

surface zone (fiz, OM) zonă marginală / de suprafață

surfacing (mas-un, TH) strunjire a suprafeței frontale; $(\mathrm{TH})$ căptuşire, strat de suprafață, nivelare, netezire / tratare a suprafețelor; (met) încărcare a suprafetelor prin sudură (reconditionare prin sudură) / prin pulverizare etc.; (nav) ieşire la suprafață (şi a unui submarin)

surfacing feed (mas-un) avans transversal la strunjire plană

surfacing lathe (mas-un) strung frontal

surfacing motion (mas-un) avans (automat) la strung

surfacing pressure (fiz) presiune superficială

surfacing screw (mas-un, OM) şurub al mecanismului de avans transversal

surfactant (chim, T) agent tenso-activ, (aditiv) detergent

surfeit supraabundență, surplus; exces; îmbuibare, lipsă de cumpătare (la mâncare şi băutură); prisos; saț; a (se) îmbuiba; a (se) îndopa; a suprasatura

surfy (nav) cu brizant / resac

surge (el) supraintensitate / supratensiune tranzitorie, curent tranzitoriu anormal; (nav) valuri mari de hulă, distanță de câştigare sau pierdere a vitezei, resac, a se ridica pe valuri, a fi aruncat pe valuri, a fila un cablu; $(\mathrm{TH})$ a merge neregulat (şi d. un motor) 
surge back and forth $(\mathrm{OM}, \mathrm{mec})$ a vibra alternativ, a oscila

surgeless liniştit, lin (d. funcționarea unei maşini) surge pressure (el) tensiune de şoc; (hidr) presiune de vârf

surge protection (el) protecție împotriva supratensiunii

surge protector (el, electr, autom) dispozitv de protecție intercalat între computer / aparat şi sursa de putere

surge pump (OM, hidr) pompă cu membrană

surge tank (hidr) recipient / compensator tampon, castel de apă, cameră de echilibru, rezervor de egalizare

surgical soap (ind chim, med) săpun medicinal

surjection (mat) surjecție, aplicație surjectivă

surmisable presupus; ipotetic; prezumtiv

surmise presupunere, ipoteză, bănuială; a presupune; a ghici, a bănui

surmount a învinge; a surmonta (o dificultate etc.), a trece peste, a depăşi (în înălțime); a escalada

surmountable surmontabil, care poate fi trecut / depăşit

surmounting învingere, depăşire, care trece peste

surname nume de familie; a supranumi

surpass a întrece, a depăşi; a fi superior

surpassing excepțional, fără pereche; care întrece / depăşeşte / este superior

surplus excedent, surplus, suplimentar; excedentar, în surplus

surplus gas (met, ind chim) gaz în exces

surplus heat (termo) exces / surplus de căldură

surplus of power (mas, mec, el) exces de putere / de forță / de energie

surplus production $(\mathrm{ec})$ supraproducție

surplus value (ec) plusvaloare

surprise surpriză, surprindere; cadou, dar; nepregătire; a surprinde, a lua prin surprindere / pe neaşteptate

surprised surprins, mirat

surprisedly $(a d v)$ cu surprindere, surprins

surrender (mil) predare, capitulare, a ceda, a se preda

surrogate $(\mathrm{adm})$ loctiitor; supleant; (ind, $\mathrm{TH}$, materiale) înlocuitor, surogat

surround (constr) a înconjura, a împrejmui, a îngrădi; a încercui, a închide

surrounding înconjurător, care înconjoară; ambiant; împrejmuitor

surrounding air mediu, aer înconjurător

surroundings circumferință, împrejurimi, vecinătate; mediu înconjurător, ambianță

surtax (ec) suprataxă; a impune o suprataxă

surveillance (adm, ec, TH) supraveghere; control, inspecție, observare sistematică survey control; (geol) prospecți(un)e, ridicare geologică; trecere în revistă; examen, examinare, cercetare, studiu, studiere; inspecție, inspectare; anchetă; sondaj; (fiz) control; (agr) hotărnicire, cadastru, măsurare de teren; ridicare topografică; (constr, OM) releveu; (mas) revizie; expertiză; cuprindere cu privirea; a ridica (o hartă), a supraveghea; a privi, a cuprinde cu privirea (un peisaj etc.); a inspecta, a cerceta, a studia; a examina; a măsura (un teren), a face un releveu, a face o expertiză; a trece în revistă

survey foot (metr) picior cadastral / de cadastru, unitate mai veche de măsură pentru suprafață, utilizată în US: din 19591 survey foot a fost înlocuit cu international foot $=30,48 \mathrm{~cm}$, dar este încă utilizat în măsurători cadastrale

surveying (adm, ec, TH) control, inspecție, inspectare, executarea unei expertize, topografie, releveu, prospecțiune

surveying instrument (metr) aparat / instrument de control, monitor

surveying panel planşetă topografică, monitor al unui soft topografic

survey of heights (constr) nivelare

surveyor controlor, supraveghetor; inspector; topometru; geodez; topograf

surveyor's rod $(\mathrm{OM})$ baliză, jalon

surveyor's tape (OM, metr) ruletă

survivability (mas) capacitate a unui sistem de a funcționa satisfăcător în mediu ostil

survival supraviețuire; rămăşiţă

survival probability (ind, $\mathrm{TH}$ ) probabilitate de funcționare / de supraviețuire / de viață (a unei piese, a unui ansamblu etc.)

survive a supraviețui, a rămâne în viață

surviving care supraviețuieşte

survivor supraviețuitor

survivor curve (TH, mas) curbă de supraviețuire (de fiabilitate) (a unui lot de piese, maşini etc.)

SUS (metr, hidr, T) simbol pentru Saybolt Universal Second - unitate de măsură pentru vâscozitate; v. Saybolt Universal Second

susceptibility susceptibilitate, sensibilitate

susceptibility to ageing (materiale) susceptibilitate / sensibilitate la îmbătrânire

susceptibility to corrosion (materiale, chim) tendinţă de coroziune, sensibilitate la coroziune

susceptibility to flakes susceptibilitate la flocurare

susceptibility to grain coarsing (met) susceptibilitate / tendință la granulație mare

susceptibility to hardening (met) susceptibilitate / sensibilitate la călire

susceptibility to quench cracking (met) susceptibilitate la fisurare la călire 
susceptibility to welding cracks (materiale, $\mathrm{TH}$ ) susceptibilitate la fisurare la sudare

susceptible susceptibil; (exagerat de) sensibil; impresionabil

susceptible of susceptibil de; pasibil de; care permite / îngăduie să / o interpretare

susceptive susceptibil; receptiv

susceptivity susceptibilitate; receptivitate

suspect (of) a suspecta, a bănui (de); a se îndoi (de); that a-şi imagina, a crede (că); a fi bănuitor; suspect, bănuit (că / de)

suspectable suspect, care poate fi suspectat / bănuit

suspend (ec, adm) a suspenda (şi din serviciu), a atârna, a agăța; a sista, a opri; a amâna; a exclude

suspended suspendat (şi din serviciu), atârnat, agățat; oprit; în suspensie (d. particule solide într-un fluid)

suspended arch (met, constr) boltă din cărămizi / blocuri refractare suspendate de / cu agățătoare metalice

suspended centrifuge (mas) centrifugă suspendată

suspended ladder (OM, constr) scară suspendată

suspended matter (fiz) substanțe în suspensie

suspended particles / solids (fiz) particule în suspensie (într-un fluid, lichid sau gaz)

suspended pipe $(\mathrm{OM})$ conductă suspendată

suspended rudder (nav, OM) cârmă suspendată

suspended screen $(\mathrm{OM})$ sită suspendată

suspend work (ec) a suspenda lucrul

suspense suspensie; întrerupere; nesiguranță nehotărâre; aşteptare, suspanse

suspension atârnare, agățare; încetare, oprire, întrerupere; (chim) suspensie; (mec, OM) suspensie, sprijinire, rezemare, suspendare; amânare; (adm, mil) suspendare, scoatere din activitate; eliminare

suspension bracket $(\mathrm{OM})$ suport / brățară de suspendare

suspension bridge (constr) pod suspendat suspension cable $(\mathrm{OM})$ cablu de suspendare suspension chain $(\mathrm{OM})$ lanț de suspendare suspension clamp $(\mathrm{OM})$ clamă / clemă de suspendare, placă de suspendare (la linii electrice)

suspension clip (mas-un, auto, OM) brățară de suspendat conducte

suspension device $(\mathrm{OM})$ dispozitiv de suspendare / de suspensie

suspension hook (OM) cârlig de suspensie / de suspendare

suspension lug $(\mathrm{OM})$ nas /cârlig de atârnare suspension pin $(\mathrm{OM})$ ştift / bolț de suspendare / de suspensie

suspension pivot $(\mathrm{OM})$ pivot de suspensie / de suspendare

suspension points (gram) puncte de suspnsie, puncte-puncte

suspension shaft $(\mathrm{OM})$ arbore de suspensie

suspension strand (el, OM) cablu de suspensie

suspension tower (el, OM) stâlp de susținere / de suspendare (a unui cablu etc.)

suspension wire $(\mathrm{OM}, \mathrm{el}) \mathrm{fir} / \mathrm{cablu}$ suspendat

suspensive (OM) suspendat, atârnat; (ec, adm) nerezolvat, în suspnsie

suspicion suspiciune, bănuială; presupunere; neîncredere

suspicious care bănuiește, suspicios față de, neîncrezător, bănuitor

sustain a susține, a sprijini, a propti; a menține; a prelungi; a încuraja; a face față; a rezista la; a confirma, a adeveri, a întări

sustained susținut, de durată, prelungit; neîntrerupt, continuu

sustained load strength (mec, materiale) rezistență la sarcini de lungă durată

sustained oscillation (fiz, mec) oscilație întreținută

sustenance întreținere, subzistență

sustentation menținere, întreținere (a vieții)

suture (med) catgut, cusătură, sutură, a coase, a sutura; (bot) sutură

suture sizes (metr) mărimi ale catgutului, în unităţi tradiţionale sau în sistem metric, care includ în simbol şi alte caracteristici decât diametrul, cum ar fi rezistența la tracțiune

svedberg (S) (metr, fiz) unitate de timp, utilizată pentru a măsura eficiența sedimentării în centrifugi de mare viteză: 1 svedverg $=10^{-13} \mathrm{~s}$

sverdrup (metr, fiz) unitate de măsură pentru debit volumic, utilizată în hidrologie şi oceanografie: 1 sverdrup $=10^{6} \mathrm{~m}^{3} / \mathrm{s}$

swab pămătuf, mătură; tampon; (met) a vopsi forma; (nav) coadă de punte; a mătura, a curăța (cu mătura / pămătuful etc.)

swag (mec) săgeată de încovoiere; a se apleca într-o parte, a se încovoia

swage (met, OM) matriță de forjat, a forja; (mas, OM, T) a îngusta, a gâtui, a ștrangula

swage block (met) placă perforată

swaged forging (met) piesă forjată în matriță, forjare în matriță

swage nipple (OM, hidr) niplu cu reducție, reducție-niplu

swager, swedging machine (met, mas-un) maşină de forjat / de matrițat la cald 
swaging, swedging $(\mathrm{TH})$ forjare în matriță, matrițare (la cald); strângere / asamblare a țevilor prin comprimare (şi micşorare a diametre-lor)

swaging hammer (met, $\mathrm{OM}$ ) ciocan de matrițat swaging machine (met, mas-un) maşină de forjat radial

swallow a înghiți, a îngurgita; (zool) rândunică swallow-tailed $(\mathrm{OM})$ cu coadă bifurcată, în coadă de rândunică

swamp (geogr) mlaştină, baltă, smârc; a (se) (s)cufunda, a (se) afunda; a inunda, a îneca; (nav) a se umple cu apă (d. o barcă etc.); (fig) a se prăbuși

swamped mooring (nav) corp mort

swampy (geogr) mlăştinos, mocirlos

swarf (mas-un, met) aşchie, şpan, resturi de tablă

swarfless (TH) fără aşchiere / șpan

swarm a se urca pe, a urca, a escalada; roi de albine, a roi; (fig) mulțime; a înghesui

swash plate $(\mathrm{OM})$ disc pendular

swathe legătură; bandaj; a lega, a înfaşura, a bandaja; a cuprinde, a înconjura

sway (mec, OM) a (se) legăna, a mişca încoace şi încolo, a (se) balansa; a mânui (o sculă); a influența; (ec, adm) a conduce, a guverna; a se înclina, a se aplica (şi d. balantă); a şovăi, a ezita, a fi nehotărât; legănare, balansare, dute-vino

sweapt volume (hidr, termo) volum aspirat / deplasat (la pompe, cilindri hidraulici, motoare etc.)

swear a declara solemn / sub (prestare de) jurământ; a depune (un jurământ); a înjura (pe cineva); a (se) jura (să, că); a jura; a ocări (pe cineva); a presta (un jurământ); a pune să jure

sweat (anat) sudoare, transpirație; efort (al muncitorului), muncă grea; umezeală; $(\mathrm{TH})$ a asuda, a transpira, a exsuda; a (se) aburi; a (se) condensa (fără a forma picături, pe zid); (constr) condens (şi pe zid)

sweat cooling (termo) răcirea unui corp poros prin trecerea forțată a fluidului prin el

sweated joint (mas, OM) îmbinare lipită (cu aliaj de lipit)

sweating (constr) transpirație la beton; (hidr) picurare a apei prin infiltratie; (termo) exsudare (la cazane); (materiale) asudare, transpirare, transpiratie

sweat roll $(\mathrm{OM}$, termo) cilindru răcitor

sweat shirt (textile) tricou de bumbac, cu mânecă lungă

sweep măturare, măturat; curățare; mișcare; (hidr) curent, şuvoi; (fiz) relatare, baleiaj, explorare, analiză; (mas-un) lungime / deschidere a brațului, rază (de acțiune); cuprins; (constr) spațiu de deschidere (al ușii etc.), zonă de învârtire (a unui buton, a manivelei etc.); (OM) braț, cot, curbură, sinuozitate, balansor de pompă; (nav) vâslă, lopată; a baleia; a mătura; a spăla, a căra; a trece; a merge (peste); a șterge (praful); a se mişca repede; a se întinde, a se extinde; (met) şablon

sweep-cutting saw (mas-un) ferăstrău mecanic pentru decupat

sweeper (auto, constr, mediu) măturător, măturătoare, maşină de măturat

sweeping iute, repede; impetuos, năvalnic; înins, larg, mare; complet, cuprinzător; măturare

sweepingly $(a d v)$ repede, rapid, iute; năvalnic; fără alegere

sweepings (mediu) gunoaie, gunoi; (textile, mediu) deşeuri

sweep moulding (met, $\mathrm{TH}$ ) formare cu şablon sweep-out (TH) spălare (prin injecție cu apă); (fiz) a baleia, a curăța, a explora; (mat) a genera (o suprafață), a mătura

sweep out a mătura, a curăța (prin măturare), a înlătura (prin măturare); (fiz) a baleia, a mătura (un ecran, o suprafață); (mat) a genera (o suprafață); (TH) a spăla (prin injecție cu apă)

sweep over $(\mathrm{TH})$ a unge, a vopsi

sweet (alim) dulce, zaharat; prietenos; plăcut mirositor, parfumat; melodios; (d. mâncare) proaspăt; dulceață, gust dulce; bomboană

sweetening (ind chim) îndulcire a benzinei cracate; (alim, chim) îndulcitor, substanță care îndulceşte, edulcorant

sweet gas (ind chim) gaz natural / metan fără hidrogen sulfurat

sweet marjoram (alim, agr) măghiran

sweet mash (alim) plămadă dulce

sweetmeat (alim) bomboană

sweetness (alim) dulceață, gust dulce; (fig) caracter agreabil, farmec; parfum, miros plăcut; prospețime; suavitate

sweet oil (ind chim) țiței neagresiv / îndulcit / dezodorizat; (alim) ulei de măsline

sweet pepper (agr, alim) ardei gras / dulce

sweet potato (agr, alim) batată, cartof dulce

sweets (alim) dulciuri, vinuri dulci

sweet water (geogr) apă dulce; (ind chim) apă glicerinoasă

sweetwort (bot) plantă plăcut mirositoare

swell intensificare; (constr) înfoliere; (nav) (valuri de) hulă; (OM, mas, plast) prag, bordură, umăr, colier, nervură, guler, bombare, umflătură, umflare, umplutură, ridicătură, convexitate; a (se) umfla, a mări, a intensifica; a crește, a (se) ridica; (termo) creştere bruscă a volumului de abur din amestecul apă-abur de sub nivelul apei; (nav) hulă, furtună; (muz) sunet (de orgă), a urca (o notă); (fam) ștab; cută (a scoarței pământului); 
(fam) elegant; (fam) (d. artişti) de prim rang; (fig) straşnic, minunat; a face să răsune

swelling umflătură; umflare; creştere; (plast) expansiune, expandare; $(\mathrm{TH})$ dilatare (nu neapărat cauzată de căldură); gâlmă; proeminență; ieşitură; arcuire (la sârmă)

swelling agent (plast, ind chim) agent de expandare / de umflare

swelling binder (ind chim) liant care se umflă (prin umectare)

swelling capacity (materiale) aptitudine / capacitate de umflare / de expandare

swelling heat (chim) căldură de umflare

swelling out (materiale) umflare, înfoliere

swell into a preface (în), a schimba (în)

swell up a (se) umfla, a (se) expanda

swept area $(\mathrm{OM}$, nav, TH) suprafață spălată

swept capacity (mas) capacitate cilindrică

swept volume (auto, termo) cilindree, capacitate cilindrică

SWG (metr, el) abreviere pentru Standard Wire Gauge, o unitate tradiţională de măsură pentru diametrul (sau aria sectiunii transversale) a unui fir / conductor; în scala American Wire Gauge (AWG), un fir 0000 este un fir cu diametrul de 0,46 inch si un fir calibrat 36 are un diametru de $0,005 \mathrm{inch}$; alte diametre se obțin prin interpolare; un fir calibrat $n$ gauge are diametrul de $0,00592^{((36-n) / 39)}$ inch; în sistemul metric, metric wire gauge number - numărul firului calibrat este egal cu de 10 ori diametrul firului; exemplu: un fir calibrat de 8 are $0,8 \mathrm{~mm}$

swift (fiz) rapid, repede; iute, grăbit; (fig) susceptibil

swifter (nav) cingătoare de cabestan

swiftness (mec, TH) viteză, rapiditate, iuțeală

swill spălătură; a (se) spăla

swim a înota; a pluti, a merge plutind; a face să plutească; a inunda; (med) senzație de amețeală, vertij, leșin

swimmer înotător; $(\mathrm{OM})$ plutitor, flotor; plută

swimming (nav) pe apă, pe linia de plutire

swimmng costume (textile) costum de baie

swimmimg pool (constr) bazin de înot, piscină, ştrand, băi publice

swimsuit (textile) costum de baie

swine (agr) porc, colectiv de porci, porcine

swine breeding (agr) creştere a porcilor / porcinelor

swine fever (agr) pestă porcină

swing (mec) impuls, vibrație, vibrare, balansare, legănare, (mişcare de) du-te-vino; învârtitură tur; (mas-un) înălțime a vârfurilor la strung, turnant; (cf, met) balansare a locomotivei; (fiz, mec, autom) oscilație, impuls, pendulare, elongație, deviație, amplitudinea oscilației; a oscila, a (se) balansa, a (se) întoarce, a (se) roti, a (se) răsuci, a (se) legăna, a pendula, a se clătina; a schimba direcția; a agita; a agăța, a atârna (nav) girație, balansare, învârtire pe loc, a evita pe ancoră, a gira (pt. determinarea deviatiiilor), a face girații / se învârti în jurul ancorei; (mil) a face o întoarcere, a schimba directia; a (se) da în leagăn; a spânzura, a fi spânzurat; ritm, cadență, mişcare cadențată; (fig) toi, punct culminant; (amer) a duce la bun sfârşit / până la capăt; (metr) unitate informală pentru un ciclu de muncă (numărul de zile de muncă și cele libere); exemplu: a swing of 10 days poate avea 7 zile de lucru la rând, urmate de 3 zile libere

swingable $(\mathrm{OM}, \mathrm{mec})$ oscilant, pivotant, pendular, rotitor

swing arm $(\mathrm{OM})$ braț oscilant

swing axle $(\mathrm{OM})$ ax oscilant

swing bar (nav, OM) palonier

swing beam $(\mathrm{OM})$ grindă / pârghie oscilantă

swing bearing $(\mathrm{OM})$ lagăr oscilant

swing bolt $(\mathrm{OM})$ şurub articulat

swing bridge (transp) pod rotitor / turnant / mobil / de transbordare

swing-bucket elevator (transp, mas) transportor cu cupe basculante

swing channel $(\mathrm{OM})$ jgheab / scoc oscilant

swing check valve (hidr, OM) robinet / ventil pivotant / articulat / rabatabil / cu obturator articulat, ventil de reținere (şi cu clapetă)

swing cut-off saw ferăstrău circular pendular

swing diameter (mec) diametru util (la echilibrare)

swing door (constr) uşă batantă

swing drill (mas-un) maşină de găurit pivotantă

swingeing $(\mathrm{ec}, \mathrm{adm})$ drastic, sever (d. reduceri bugetare etc.)

swingeing taxes $(\mathrm{ec}, \mathrm{adm})$ impozite exorbitante

swing excavator (mas, constr) excavator $\mathrm{cu}$ rotire totală $\left(360^{\circ}\right)$

swing gear $(\mathrm{OM})$ mecanism de pivotare / de basculare

swing-hammer crusher (mas, alim, ind chim, constr) concasor / moară cu ciocane / ciocănele

swing-hammer mill (mas, alim, ind chim, constr) moară cu ciocane / ciocănele

swinging (mec) oscilare, rabatere, basculare, balansare, legănare, rotire, pivotare, răsucire; (fiz) oscilație momentană a frecvenței; (mec) vibrație, pendulare; (nav) evitare; (OM) pivotant, turnant, rotitor, rotativ, basculant, rabatabil

swing(ing) crane (mas, transp) macara rotitoare / pivotantă 
swinging door (constr) uşă batantă swinging fork $(\mathrm{OM})$ furcă oscilantă

swinging half-axle (auto, OM) semiax oscilant, arbore planetar

swinging lever (OM) braț pivotant; (mas-un, OM) pârghie basculantă

swinging load $(\mathrm{mec})$ sarcină variabilă in intervale mici de timp / oscilantă

swinging machine (mas, agr, alim) maşină vibratoare

swinging motion (mec) mişcare oscilatorie / de pendulare

swinging oscillation $(\mathrm{mec})$ pendulare

swinging sieve (ind chim, met, OM) sită oscilantă / vibratoare

swinging spout (OM, ind) distribuitor oscilant swing in production (ec) fluctuație (periodică) in producție

swing jaws $(\mathrm{OM})$ falcă oscilantă (şi la concasor) swing joint $(\mathrm{OM})$ articulație tip nucă, articulație / îmbinare mobilă (pt. repozitionarea tevilor) swingle (textile) meliță, a melița, a bate

swing lever balansier; (el) braț / pârghie / armătură basculan( $\breve{a})$

swing line $(\mathrm{OM})$ cablu de manevră

swing link guide (OM, mas-un) ghidaj oscilant

swing loader încărcător cu cupă rotitoare / cu descărcare laterală

swing on the dial (metr) deviație (a indicatorului) pe cadranul scării

swing out a bascula, a rabate

swing-out table (mas, mas-un) masă pivotantă / basculantă

swing over (mec) a bascula, a rabate

swing pipe (hidr) teavă rabatabilă / articulată / cu poziție variabilă în rezervor

swing-roof arc furnace (met) cuptor (cu arc) cu boltă pivotantă

swing round $(\mathrm{mec})$ a se întoarce (complet, cu $180^{\circ}$ ), a face o întoarcere completă

swing sieve $(\mathrm{OM})$ sită vibratoare

swing support (OM, mas) lagăr oscilant / de basculare

swing table (mas, mas-un, OM) masă pivotantă / basculantă / rabatabilă

swing tool (mas-un) cutit turnant (la strung automat), dispozitiv (mic) de polizat

swing tray elevator (mas, transp) elevator $\mathrm{cu}$ platouri / plăci basculante

swing-type arc furnace (met) cuptor cu arc, cu boltă pivotantă

swing upward (auto) a se deschide în sus (d. uşa portbagajului)

swinish (agr) porcin, referitor la porc swipe (mec) a lovi / da cu putere, a pocni; lovitură puternică; $(\mathrm{OM})$ troliu, pârghie

swirl (hidr) vârtej, anafor, turbion; (hidr) a (se) roti, a se învârti, a face / forma vârtejuri, a se învolbura; (nav) dâră, siaj; nor de fum

swirling burner (termo) arzător turbionar

swirling flow (hidr) curgere turbionară

swirling motion (fiz, hidr) turbionare, mişcare turbionară

swirling of metal (met) agitare a băii (de metal topit)

swish a fâsâi, a foșni; a murmura; fâsâit, foșnet, foşnitură

Swiss welding method (met,TH) (metodă / proces / procedeu de) sudare spre stânga

switch bețişor, nuia; (cf) ac, macaz, schimbător de cale, a manevra, a trece de pe o linie pe alta; (el) conjunctor, întrerupător, disjunctor, comutator, selector, a conecta, a lega, a comuta, a schimba sensul curentului; (auto, mas) contact, a cupla, a schimba viteza / directia, a ambreia; (ec) operație comercială prin intermediul unei terțe părți

switchable (el, OM) comutabil (d. un întrerupător etc.)

switch-and-lock movement (el) dispozitiv de deblocare, funcționare şi blocare

switch arc (el) arc electric de întrerupere / de comutare

switchblade (el, OM) cuțit / lamă de întrerupător; cuțit (de buzunar) cu arc

switchboard (auto) tablou de bord; (el, autom) tablou de distribuție / de măsurare și control, pupitru de comandă

switchboard plant (el) instalatie de distributie

switch box (el, OM) cutie de distribuție, cutie / casetă a întrerupătorului

switching characteristic (hidr, el) caracteristică de comutare

switch clock (el, autom) întrerupător cu temporizator

switch damper (cf, OM) amortizor de macaz / pentru întrerupător (mecanic)

switch desk (mas, ind) pupitru de comandă

switch fork (OM) furcă conducătoare / de întrerupere / de comutare

switch frame (el, OM) cadru cu selectoare

switch fuse (el) siguranță separatoare / întrerupătoare

switch gear (el, OM) aparataj electric / electromecanic) de conexiuni; (OM) dispozitiv / mecanism de întrerupere / comutare / conectare

switchgear oil (el, ind chim) ulei de întrerupătoare 
switch gear distribution (junction) box (el, OM) doză de legătură, cofret / cutie de protecție pentru întrerupător, cutie de distribuție

switch gear oil (el, ind chim) ulei pentru întrerupătoare

switch group (el, autom) (set de) comutatoare de reglare

switch hook (el, OM) tijă de manipulare a separatorului, cârlig de comutare

switch in (auto) a anclanşa; (el) a pune în circuit, a conecta

switching (el) (acțiunea de) comutare, distribuție, conexiune, care conectează / comută

switching arrangement (el, hidr) schemă de montaj / de conexiuni

switching bar (OM, mas, met) bară de cuplare

switching characteristic (OM, mas, hidr) caracteristică de comutare

switching clock (el, autom) temporizator (cu comutare)

switching in (el) anclansare, conectare, închidere; (mat) interpolare, inserție

switching key (auto, OM) cheie de contact; (OM, mas) cheie de cuplaj / de pornire

switching mechanism mecanism de cuplare (electric sau mecanic)

switching member (OM) organ / element de cuplare

switching off (el) deconectare, deschidere; (mas) decuplare (electrică sau mecanică)

switching on (el) conectare, închidere, anclanşare

switching out (el) întrerupere, deconectare, deschidere, declanşare

switching over (el, OM) comutare

switching point (OM, hidr, el, mas) loc / punct de ramificație / de derivație / de conexiune

switching power (hidr, el) putere de comutare

switching pressure (hidr) prag (de presiune) de comutare

switching relay (autom, el) releu declanșator / de comandă / de comutare / de schimbare

switching starter (el) demaror stea-triunghi

switching surge (el) supratensiune tranzitorie de comutatie

switching time (autom, hidr) perioadă / timp de comutare / de întrerupere; (inf) timp de preluare și trimitere a unui mesaj, timp de salvare (la întrerupere accidentală)

swtching track (cf) linie de manevră

switching yard (cf) gară de triaj

switch key (auto, mas) cheie de contact

switch lever (auto, OM) levier al schimbătorului de viteză; (cf, OM) pârghie a macazului / a acului switch lock (cf, OM) fixator de ac, încuietor de macaz

switch off (el) a tăia, a întrerupe, a deschide (curentul, circuitul, contactul), a deconecta; (mas) a întrerupe

switch-off position (el, mas) poziție de deconectare

switch on (el) a închide circuitul / contactul, a conecta; (mas) a cupla, a anclanşa

switch-on position (el, hidr, mec) poziție de cuplare / de închidere (a circuitului) / de conectare

switch operated by crank (OM) întrerupător (actionat) cu manivelă

switch out (el, hidr, mec) a deconecta, a declanşa, a întrerupe

switch over (el, mec) a comuta, a schimba (canalul, întrerupătorul etc.)

switch plant (autom, el, hidr) instalație de distribuție / de comandă

switch plug (el) priză de curent

switch plug box (el) dulie de priză de curent

switch point (cf) ac de macaz; (inf) parametru de comandă a alegerii unui subansamblu sau a unei ramuri de program

switch point on railroad (cf, mas) inimă de încrucişare / de macaz / de schimbător de cale

switch position (mas, el) poziție de cuplare

switch releasing (cf) deblocarea macazurilor

switch room (el, mas) cameră de cuplare / de comandă / de distribuție

switch seat (auto) scaun rotativ

switch selling (ec) comercializare (spre) "lider" (prin publicitate făcută unui produs ieftin, care atrage atentia asupra celorlalte produse)

switch shaft (el, OM) bară a brațului port-perie (la maşini electrice)

switch spring (OM) clichet; (el) jac

switch step (mas) treaptă de cuplare

switch system (autom, el) schemă de conexiuni, sistem de întrerupere / de comutare

switch tender, switchman (cf) acar

switch train (el, autom) grup de întrerupătoare (cu anclanşare simultană)

switch yard (cf) triaf; (el) instalație de întrerupere / de comutare în aer liber

swivel $(\mathrm{OM})$ centru de rotatie, îmbinare articulată, pivot, ax, element cu rotație liberă pe un arbore / stift etc., za de lanț, vârtej, suport pivotant; (mas-un) lira roților de schimb; (nav) tambur de lanț de troliu, cârlig, verigă, ochi (de cablu); a (se) roti, a (se) învârti, a oscila, a pendula, a pivota; a ataşa / prinde cu un cârlig; a face să se învârtească 
swivel arm $(\mathrm{OM})$ braț pivotant

swivel axis $(\mathrm{OM})$ ax oscilant

swivel bridge (met, transp) pod turnant

swivel carriage (mas-un) sanie pivotantă

swivel chair (med, edu, mobilă) scaun rotitor / pivotant (şi de stomatolog)

swivel chute $(\mathrm{OM})$ transportor pivotant, jgheab rotativ

swivel connection / joint (OM, hidr) îmbinare / legătură articulată, racord pivotant

swivel coupling (OM, hidr) racord / cuplaj turnant / pivotant

swivel eye (OM) ochi / ochet de articulaţie

swivel fitting (hidr, OM) racord / armătură care nu se poate roti în serviciu, dar se poate roti pentru adaptare pozițională la montaj

swivel head (mas-un, OM) cap revolver / turnant, dispozitiv de torsiune / de rotire / de răsucit

swivel hook (mas, OM) cârlig rotitor; (nav) cârlig cu vârtej

swivel joint $(\mathrm{OM})$ articulatie tip nucă / cardanică, îmbinare articulată; (hidr, OM) racord care se poate roti în funcționare (sub presiune)

swivelling $(\mathrm{OM})$ rotire, întoarcere, articulație, articulare, asamblare articulată; (fiz, mec) oscilant, rabatabil, pendular, pivotant, care pivotează, rotativ, turnant

swivelling cover $(\mathrm{OM})$ capac pivotant

swivelling link / piece $(\mathrm{OM})$ articulație rotativă, piesă articulată, cu mișcare de rotație

swivel pin (auto, OM) pivot de fuzetă, ax / ştift de rotație

swivel plate $(\mathrm{OM})$ disc / placă turnat(ă) / pivo$\operatorname{tant}(\breve{a})$

swivel rawlook $(\mathrm{OM})$ furchet

swivel socket wrench $(\mathrm{OM})$ cheie tubulară articulată / cardanică

swivel union $(\mathrm{OM})$ mufă / asamblare cu carabină de rotire

swivel vice (OM, mas-un) menghină turnantă / pivotantă

swivel wheel $(\mathrm{OM})$ roată pivotantă

swollen umflat; mărit

swoop (on / upon) a se abate, a devia; deviere, abatere de la directie

sword sabie, spadă; (OM, mas-un) lamă, cuțit

sword lily (bot) gladiolă

sword-shaped în formă de sabie, gladiolat

swording (met) desfacere a sudurilor (la table legate în pachete)

sworn broker (ec) curier autorizat

SWU (metr, fizică nucleară) simbol pentru separative work unit, unitate utilizată pentru centrale nucleare, pentru a descrie energia nece- sară îmbogăţirii uraniului (creşterii concentrației de uraniu 235); 4,5 SWU sunt necesare pentru a îmbogăţi $1 \mathrm{~kg}$ de uraniu

sycomore (bot) sicomor, smochin

sykose (alim, chim) zaharină

syllable silabă; (fig) cuvânt, vorbă, sunet

syllabus, $(p l)$ syllabi (univ, edu) programă analitică; expunere, conspect; plan (de învățământ), orar

syllogism silogism

syllogistic silogistic

syllogize a argumenta logic / prin silogisme

sylphon (OM, mas-un) membrană armonică, tub ondulat, silfon, burduf, tub-armonică

sylviculture (silv) silvicultură

sylviculturist (silv) silvicultor

symbiosis (biol) simbioză

symbol emblemă, simbol, semn, notație, simbol grafic; (inf) semnal de corectare, entitate care desemnează un obiect sau o stare

symbolic address (autom) adresă simbolică

symbolic(al) (mat) simbolic, operatorial, funcțional

symbol for fluid logic device (hidr) simbol grafic pentru componente (hidraulice) de logică fluidă

symbol for hydraulic and pneumatic components (hidr) simbol grafic pentru componente pneumatice şi hidraulice

symbolically ( $a d v)$ (în mod) simbolic

symbolism simbolism

symbolize a simboliza, a reprezenta cu ajutorul simbolurilor; a fi un simbol; a recurge la simboluri, a se servi de simboluri

symbol per second (sym/s) (metr, radio) simboluri pe secundă, unitate pentru viteza de transmistere a semnalelor radio, în special între sateliți şi stațiile terestre; informația poate fi transmisă în biți, care au doar valoarea 1 sau 0 ; creșterea vitezei de transmitere se face utilizând simboluri, care au mai multe stări, deci fiecare simbol poate include câtiva biți de informație; se utilizează multipli: 1 $\mathrm{ksym} / \mathrm{s}=10^{3}$ simboluri pe secundă, $1 \mathrm{Msym} / \mathrm{s}$ $=10^{6}$ simboluri pe secundă

symbol weight (mec, fiz) greutate / masă echivalentă

symmetric(al) (geom, OM) simetric

symmetrical about an axis (geom, OM) simetrie axială

symmetrical fractional-slot winding (el) înfăşurare cu număr fracționar de crestături pe pol şi fază, înfăşurare simetrică cu crestături fractionare 
symmetrically loaded (mec, OM) încărcat simetric (şi cu o sarcină mecanică)

symmetrical with respect to rotation $\mathrm{cu}$ (geom, OM) simetrie de rotație / de revoluție

symmetrisation simetrizare

symmetry (geom, OM) simetrie

symmetry axis (geom, $\mathrm{OM}$ ) axă de simetrie

symmetry breaking (geom, OM) deviere de la simetrie, distrugerea simetriei

symmetry plane (geom, OM, fiz) plan de simetrie

symmetry tolerance (mas-un, OM) toleranță la simetrie

sympathetic strike (ec, pol) grevă de solidaritate / de solidarizare

symposium, $(p l)$ symposia simpozion

symptom simptom; semn, indiciu, manifestare

symptomatic simptomatic

symptomatically $(a d v)$ (în mod) simptomatic

synchro-angle (el) unghi de sincronizare

synchronic(al) (fiz, el) sincron(ic), simultan

synchronism sincronism (mai mult electric); izocromatism; simultaneitate, concomitentă

synchronization (mas, TH) sincronizare (electrică sau mecanică)

synchronize a (se) sincroniza, a ordona (în timp); a stabili simultaneitatea; a coincide în timp, a fi sincronizat / simultan / concomitent; (d. cea-suri şi aparate) a arăta acelaş lucru

synchronizing (mas, autom) intrare în sincronism, sincronizare

synchronizing bridge (transp, met) pod de reglare (la bandă)

synchronizing cicuit (el, autom, electr) circuit de sincronizare

synchronous, synchronic (mec, el) sincron, în fază

synchronous motor (el) motor sincron

synchronous timer (metr, autom) cronometru sincron (şi de comandă)

synergism sinergie (efectul total a doi agenți acționând simultan este mai mare decât suma efectelor lor, când acționează separat); exemplu de sinergie: $(\mathrm{T})$ coroziune sub sarcină, fretting

syndet (ind chim, T) abreviere pentru detergent sintetic (şi ca aditiv)

syndic (jur) jurisconsult; (ec, adm, edu) reprezentant, împuternicit (al unei instituții); membru al unui comitet (la univ. Cambridge)

syndicate a sindicaliza, a uni într-un sindicat; sindicat (patronal); organizatie care vinde articole mai multor ziare, concomitent

syndrome (med) sindrom

sinergy (fiz) sinergie, sinergism; v. synergism syneresis $(\mathrm{T})$ pierdere de lichid lubrifiant dintr-o unsoare din cauza contractării sau a rearanjării structurale

synfil (ind chim) fibră sintetică

synonym (lingv) sinonim

synonymous identic, sinonim, sinonimic, $\mathrm{cu}$ acelaşi înțeles / rol / functie

synopsis, $(p l)$ synopses sinopsis, rezumat, centralizator, tabel sinoptic; punctaj

synoptic(al) sinoptic

syntactical ambiguity (c, inf) ambiguitate sintactică, existența a minim două instrucțiuni distincte pentru aceeaşi propoziţie

syntax (c, inf) sintaxă (a unui limbaj de programare)

synthesis, $(p l)$ syntheses sinteză

synthesis chemistry (chim) chimie de sinteză

synthesis gas (ind chim) gaz de sinteză

synthesize (chim) a sintetiza (și fig)

synthesizer (persoană etc.) care face o sinteză

synthetic(al) sintetic, artificial

synthetic fiber (ind chim, plast) fibră sintetică / artificială

synthetic fuel (ind chim) combustibil sintetic / artificial

synthetic lubricant (ind chim, T) lubrifiant sintetic

synthetic oil (ind chim, T) ulei sintetic

synthetic product (ind chim) produs sintetic

synthetic relationship $(\mathrm{TH})$ relație bazată pe observare / rezultate experimentale

synthetic resin (ind chim) răşină sintetică

synthetic rubber (plast, ind chim) cauciuc sintetic

synthetics (plast, ind chim) materiale plastice, produse / materiale sintetice

synthetic size (ind chim) clei / adeziv sintetic synthetic sodium butadiene rubber (plast, ind chim) cauciuc sintetic sodiu-butadienă

synthetize (chim) a sintetiza

syntony concordanță

syphon, siphon (hidr, OM) sifon

syringe (OM, med) seringă; (agr, OM, hidr) pompă pentru irigații

syringing $(\mathrm{TH}$, med) injectare, injecție, care injectează

syrup (alim) sirop, zeamă de zahăr, melasă distilată

syrupy (alim) siropos

systalsic (hidr) sistalsic; care pulsează

system sistem, aranjament complex şi ordonat; metodă, sistem de organizare; regim; (el) rețea / sistem electric(ă); (cf) rețea de căi ferate; (met) formațiune, (ec) ansamblu de elemente 
interconectate organizate coerent în jurul unui scop; (mat) familie, metodă, mulțime, şir; organism; (muz) distribuire a partiturilor, pupitru, nomenclatură; (pol) regim, sistem, orânduire; rețea (hidrologică, feroviară, de comunicații, electrică, rutieră); (geol) sistem, formație, formațiune geologică; (c) sistem de calcul, calculator electronic; (ec) sistem de organizare

system activation (autom, ec, mas) activare a sistemului

system analysis analiză (organică) a sistemului

systematic sistematic, metodic, organizat

systematically $(a d v)$ (în mod) sistematic; metodic, (în mod) organizat, în ordine

systematic error (metr, inf, autom) eroare sistematică

systematics sistematică

systematist sistematician, clasificator; v. systemizer, systematizer

systematization sistematizare

systematize, systemize a sistematiza; a clasifica, o ordona, a pune în ordine

systematizer, systemizer sistematician, clasificator

systematizing sistematizare; care sistematizează system bleeding (termo, hidr) purjare a instalației (şi hidraulice)

system capacity (c) capacitate maximă de prelucrare a unui sistem de calcul

system centre (constr, mec) nod; (c) nod de rețea

system cleaning ( $\mathrm{TH}$, ind) curățare a instalației (hidraulice etc.)

system components componente ale sistemului

system crash $(c)$ căderea bruscă şi completă a unui sistem de computere

system designation (OM, mas) număr (şi parțial) de identificare a unui ansamblu şi care apare şi în numerotarea subansamblelor lui (şi în desen tehnic)

system dispatching centre (ind, ec) centru de dispecerat al unui sistem

system draining (hidr, ind) golire (a unei instalații hidraulice)

system effectiveness (mas) fiabilitate / eficiență a unui sistem

system engineering ingineria sistemelor (proiectare, instalare şi exploatare a unui sistem în condiții optime)

system error (mas, autom) eroare de sistem

system draining (hidr) golire a instalatiei

system filling (hidr) umplere a instalației (hidraulice) system-flow chart (ec, adm, TH) organigramă generală

system flushing $(\mathrm{TH}$, ind) clătire / spălare a instalației

systemic (anat) somatic; sistemic; privind întregul organism / sistem

system interconnection / tie (c) interconectare / interconexiune a rețelelor / sistemelor, funcționare în paralel a rețelelor

systemizer sistemalist, care sistematizează

systemless fără sistem(ă); nesistematic; nestructurat

system of coordinates (mat) sistem de coordonate

system of crystallization (fiz, materiale) sistem de cristalizare

system of fits (metr, OM) sistem de ajustaje / de toleranțe (care pot forma ajustaje)

system of measuring (metr) sistem de măsurare, sistem de unități de măsură

system of reference sistem de referintă

system of units sistem de unități de măsură

system organization (c) arhitectură a unui sistem de calcul

system point (constr, mec) nod

system program(m)ing (inf, autom) programare generală, programarea sistemului

system pressure (hidr) presiune a instalatiei

system progeam(me) (c, inf) program de bază

system recovery time (ind, mas) timp de recuperare a sistemului (după avarie)

system registration database (SRDB) (c, inf) bază de date de înregistrare la nivel de sistem

system reliability (ind, mas) fiabilitate a sistemului

systems analyst / designer / man (c, inf) analist de sisteme, specialist în sisteme informatice

systems integration (ind, mas) integrare a sistemului în unul mai complex

system-sensitive relay (el, autom) releu palpator al sistemului

system simulation simulare a (funcționării) unui sistem (şi dinamică)

system software (c, inf) soft de sistem / de bază, totalitatea programelor de calcul cu care este echipat calculatorul

system specification (mas, T) caracteristici / specificații (tehnice) ale sistemului

system / unit (functional) test (metr, mas) probă / test de funcționare (a sistemului)

system voltage (el) tensiune de rețea / de linie / între faze

system with power amplification (autom, mas) sistem cu amplificator de putere 


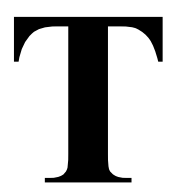

T (metr) abreviere informală pentru trillion (amer) $=10^{12}$; (metr, meteo) simbol pentru numărul lui Dvorak, o evaluare subiectivă a puterii ciclonului tropical pe baza imaginii aparente din satelit, $\mathrm{T}$ variind între $\mathrm{T} 1,0$ și $\mathrm{T} 8,0$ în trepte de 0,5 ; de la T2,5 - furtună tropicală, peste T4,0 - uragan, taifun; (metr, fiz) simbol pentru Tesla; v. Tesla

tab gaică, agățătoare; (mas-un, OM) umăr (la şaiba de sigurantăa), ureche; prelungire (în consolă) a unei mese (de aparat, de maşină-unealtă); (autom) durată de cădere, trenă, coadă (de semnal), declanşator al butonului de apăsare; butonieră; (amer) socoteală, calcul; contramarcă, contor; (inf) a aranja în tabel, întocmire a unui tabel, a întocmi un tabel

tabacosis (med) tabagism, intoxicație tabagică

tabasco (alim) paprica, boia de ardei, sos picant

tabbing, tabulation (inf) tabulare, reprezentare tabelară; (mat) tabelare

tabby (constr) amestec de pietriş-nisip, var şi apă

table (mas, TH) masă, planşaibă (la strung carusel), platou, placă, masă rotativă, oglinda apei, tabelă, planşă, talpă a unei grinzi, suprafață plată, tablier, podea; (inf, c) tabel, listă, tablou; tarif; indicator; podiş, platou; (constr) temelie, fundație, a împreuna, a îmbuca (grinzi etc.); a depune (pe o masă), a scrie / grava pe o tăbliță / placă; (nav) a întări, a căptuşi, a dubla (o pânză)

table arm (mas-un) consolă de susținere a mesei de lucru

tableau, $(p l)$ tableaux pictură, tablou; registru oficial

table bracket / supporting arm (mas-un, OM) consolă, suportul mesei (la maşina de frezat)

table bushings ( $\mathrm{OM}$, mas-un) lagărele mari / ale mesei rotative

table chair scaun cu spetează

table circular saw (mas-un) ferăstrău circular cu masă / cu platou

table classifier (alim, agr, ind chim) masă de sortare / de clasare

table cloth față de masă

table concentrate (met) concentrat de minereu prin spălare

table concentration (met) lucrare de executare a vetrei, prepararea minereului prin spălare

table-cut (mas-un) tăiat în fațete / fețe

tabled (mas-un) (tăiat) în fațete / fețe table / reversing dog (mas-un) limitator de cursă, camă pentru inversarea mişcării saniei mesei

table feed (mas-un) avans al mesei

table flap (mas-un) tăblie rabatabilă (a mesei)

table fork (mas-un) furculiță

tableful (alim) obiectele de pe masă; mâncăruri / mâncare de pe masă

table furniture serviciu de sufragerie

table-knife cuțit de masă / de mărunțit mâncarea

table land (geogr) podiş, platou

table-like în plăci, lamelar

table look up (inf, c) extragerea valorii corespunzătoare unei poziții dintr-un tabel, căutare întrun tabel

table napkin şervețel, şervet de masă

table of contents tablă de materii, conținut, cuprins, sumar; index

table of correction (metr) tabel de etalonare / de corecție (pt. aparate de măsură)

table of fares (ec) listă de prețuri; tarife

table of logarithms (mat) tabelă / tabel de logaritmi

table of multiplication (mat) tabla înmulțirii

table oil (alim) ulei de masă / de salată

table relief (mas-un) retragere / descărcare (a piesei prelucrate) a mesei (şi la maşina de prelucrat roți dințate)

table reversing dog (mas-un) limitator de cursă / camă pentru inversarea mişcării saniei mesei

table roller (mas, met) cale / transportor cu role, platou simplu

table saddle (mas-un) sanie a mesei

table salt (alim) sare fină / de masă

table section (met) sector de cuptoare / de spălare a minereurilor

table search (inf) căutare într-un tabel, a căuta in tabel

table slate (constr) ardezie

tablespoon, tablespoonful (tbsp, tblsp, Tsp, T) (metr, alim) unitate de măsură pentru volum, utilizată în rețete culinare, lingură: 1 tablespoon $(\mathrm{US}) \cong 14,8 \mathrm{ml}, 1$ tablespoon (Canada) $\cong 14,2 \mathrm{ml})$. In Britain, 1 tablespoon $(\mathrm{UK})=14,2 \ldots 17,6 \mathrm{ml}$, în sistem metric, 1 tablespoon $=15 \mathrm{ml}$ în UK, Canada şi Noua Zeelandă, 1 tablespoon $=20 \mathrm{ml}$ în Australia; (metr) unitate de măsură pentru volum, utilizată în baruri, în US: 1 tablespoon $\cong 11,1 \mathrm{ml}$

table stop (mas-un) opritor al mesei

table supporting arm (mas-un) consola / suportul (mesei maşinii de frezat etc.)

tablet tăbliță, placă (scrisă); carnet de notițe, blocnotes; bucată de săpun; pastilă, tabletă

tablet compound $(\mathrm{TH})$ amestec de tabletat / de brichetat 
tablet compressing / compression machine (alim, ind chim, mas) maşină / instalație de tabletat

tablet forming (alim, ind chim, mas) tabletare, pastilare, (procesul de) formare a tabletelor / pastilelor

tableting (alim, ind chim, mas) tabletare (ambalare sau formare a pastilelor / calupurilor etc.)

table top tăblie (superioară) a mesei; (mas-un) partea superioară a mesei (de prelucrat/ de aşezat semifabricatul)

table-top (alim) pentru masă / mâncare, de folosit la masă

table vibrator (agr, alim, constr) masă vibratoare

table-ware (alim) veselă şi tacâmuri

table water (alim) apă minerală de masă

table ways / slides (mas-un, OM) ghidaje / glisiere ale mesei

table wine (alim) vin de masă

table work (met) lucrare de executare a vetrei, prepararea minereului prin spălare

tabling depunere (şi a unui proiect de lege); capacitate (a unui restaurant etc.); (nav) întărire, căptuşire, dublare (a unei pânze); (constr) îmbucare, împreunare (a grinzilor)

taboo tabu, interdictie; interzis, prohibit, tabu; a interzice, a prohibi, a pune sub interdicție; a pune în caractină; a boicota

tabouret taburet, scăunel; tambur, tobă mică; gherghef (pt. broderie)

tabular, tabulated (c, inf) tabelar, tabular, în / sub formă de tabel; (TH) lamelar, în plăci; în formă de tablou / de tabel sinoptic

tabularize a tabula, a aranja în tabel / în diagramă; a netezi

tabularly $(a d v)$ în formă tabelară / de tabel; (în mod) tabularizat

tabular (ec) standard etalon / standard mediu; medie (aritmetică) a prețurilor

tabular value valoare tabulară / din tabel

tabulate a tabula, a prezenta / aranja în formă tabelară / de tabel, a intabula; a doza; a netezi, a da o formă netedă; a cataloga

tabulation (în)tabulare; trecere în tabel; netezire tabulation of mixture (alim, constr, ind chim, $\mathrm{TH})$ dozare a amestecului

tab washer (OM, mas-un) şaibă de blocare cu ciocuri / cu gheare / de siguranță, cu umeri

tacheometer, tachometer, tachymeter (metr) tahometru

tacheometry, tachometry, tachymetry (metr) tahometrie

tachograph (auto, metr) tahograf, tahometru înregistrator

tachometer drive (auto) mecanism de antrenare a vitezometrului / a tahografului tachometer recorder (metr, auto) tahograf, înregistrator de viteze

tachy adeziv, aderent, lipicios (şi d. lubrifianți, adezivi etc.)

tacit tacit, implicit, subînțeles

tacitly $(a d v)$ (în mod) tacit, implicit, subînțeles

tack prindere, luare; pradă; cantitate de vânat sau de peşte; (met, OM) cui (cu cap rotund), ştift, tintă, cui scurt, cuișor, clemă, sudură de prindere, pioneză, buton; cui de cizmărie; (textile) saia, însăilare, însăilătură, împunsătură (de ac), a însăila, a împunge cu acul, a prinde provizoriu cu ață; a țintui, a prinde în pioneze, a fixa în ținte; a înlănțui, a lega, a uni; a alipi, a ataşa; a adăuga (un apendice); a spăla; a leviga; a capsa; (nav) voltă, frânghie care leagă colțul de jos, funie (în colțul pânzei), rută, curs, traseu, schimbare de rută / traseu, a schimba ruta / direcția, a vira, a pluti în zigzag; hrană; vâscozitate (d. vopsea etc.); a-și schimba atitudinea / concepțiile / părerea; a adopta o nouă tactică; (fig) cale, drum

tack bolt $(\mathrm{OM})$ bolț de legătură

tack claw (OM) unghie de capră (pt. scos cuie)

tack-driver (mas) maşină de bătut ținte / cuie, pistol de împuşcat cuie / ținte

tack-hammer (mas-un) ciocan cu ghiară (pt. bătut şi scos cuie), teslă (mică)

tackifying agent (chim) agent de mărire a aderentei

tackiness adezivitate, caracter adeziv / lipicios, vâscozitate

tacking rivet $(\mathrm{OM})$ nit provizoriu pentru montaj tackle uneală, sculă, instrument; (alim, ind chim) garnitură de măcinare; scripete, palan(c), troliu; utilaj, echipament, scule, înzestrare; accesorii; (met, plast) vârtelniță, dispozitiv de înfăşurat (mai ales fire); a aborda, a deschide (o temă); (nav) a lega funii, a fixa (scripeți); (fig) a ataca / aborda (o problemă)

tackle block (nav) bloc de palan

tackle fall (nav) capăt liber al cablului palanului tackle hook (mas, met) cârlig de macara tackle pulley $(\mathrm{OM})$ roată de scripete

tackle rivet $(\mathrm{OM})$ nit provizoriu

tackle reveting (met, OM) nituire pentru / de montaj

tackle weld (met) sudură de prindere / provizorie

tackle welded (constr, met) sudat provizoriu / pentru poziționare / pentru prindere inițială

tacky cleios; lipicios; vâscos; inferior, prost

tacky slag (met) zgură aderentă

tack weld (constr, met) sudură de prindere

tack welding (constr, met) (acțiunea / operația / procesul de) sudură de prindere 
taclocus (mat) loc geometric al punctelor de contact (pt. o familie de curbe)

taconite taconit

tacpoint (mat) punct de contact (pt. o familie de curbe)

tact tact; timp; cadență, măsură; tact, delicatețe; abilitate, diplomație; pipăit, simț tactil

tactful plin de tact, abil, cu tact, diplomat

tactic tactică

tactical tactic; dibaci, îndemânatic, abil

tactics tactică

tactile tactil, referitor la simțul pipăitului; (fig) palpabil, tangibil

tactility caracter tactil; tangibilitate

tactless lipsit de tact, fără tact; inabil

tactlessly $(a d v)$ fără tact

tactlessness lipsă de tact / de abilitate, inabilitate

tact period perioadă de recurență

tael, tahil (metr) unitate tradițională de măsură pentru masă, în Asia de Est: 1 tael ( 37,8 g; 1 tael (Japonia) $=37,51 \mathrm{~g}$

taffeta, taffety (textile) tafta

taffrail (mas-un) grilaj de protecție, îngrădire, balustradă; (nav) coronament, partea superioară a bolții pupei

tafia (alim, chim) spirt / alcool obținut din distilarea trestei de zahăr

tag capăt liber care atârnă; capăt metalic (al unui şiret); etichetă ataşată (pe un colet); (zool) vârf al cozii (unui animal); capăt; bucată (şi de sfoară); ureche (şi de gheată etc.); agăţătoare, gaică; index, semn; (el) picioruş de lipit; cuvântare de încheiere; citat banalizat, ( $\mathrm{fam}$ ) clişeu; replică; sfârşit de replică; epilog, morală (la sfârşitul unei piese); (mas-un) etichetă, tăbliță; (met) clemă de lipit, vârful ciocanului de lipit, lamă de racord; a marca, a eticheta, a prevedea cu o etichetă / cu un vârf metalic; a ataşa (şi un capăt de metal); a anexa, a adăuga; a urma îndeaproape (pe cineva); a înflori, a împodobi

tag-end rămăşiță, (ultim) rest, capăt, căpețel

tagged (fiz) marcat (şi radioactiv); etichetat; (el) prevăzut cu cleme de lipit; (inf) caracterizat

tagger (met) tablă / foaie (foarte) subțire; (el) vârf, papuc, bornă

tagging (met) ascuțirea / formarea unui vârf ascuțit la semifabricatul de trefilat; marcare; marcaj

taglock buclă încâlcită (la compozite fibroase)

tag together a potrivi cu

tail (nav) coadă (de macara), persistența ecoului; (autom) trena (coada) impulsului; (OM) coadă, partea de la coadă / din spate / terminală; escortă; revers (al monedei); (anat) coadă, colț (al ochiului); (zool) coadă de animal / de pasăre; a pune coadă (la un obiect; (amer) a urmări (îndeaproape); a lega, a ataşa, a adăuga; a veni în urma; (agr, alim) a curăța de cozi; (jur) drept de succesiune limitat, limitarea succesiunii, limitat din punct de vedere al moştenirii

tail after a urmări îndeaproape

tail and stop light (auto) lanternă de spate şi de stop

tail arm (mas-un, cstr) contrafişă, diagonală

tail away a se împrăștia, a se răsfira, a se rări (și numai la capete, d. compozite, fibre, fire etc.); a putrezi treptat

tail block (mas-un) păpuşă mobilă (la capete)

tail board (OM, hidr) clapă, perete frontal / rabatabil, clapetă, prag deversant / de scurgere

tail centre (mas-un) vârful păpuşii mobile (la un strung)

tail cone (OM, hidr, termo) con de ajutaj

tail diffuser (alim) difuzor terminal

tailed cu coadă, cu terminație

tail end (OM) extremitate a arborelui; coadă, capăt extrem; fund, spate; sfârşit, încheiere

tailet codiță

tail fraction (ind chim) cozi de distilare, fracțune terminală / de coadă

tail gas (ind chim, met, termo) gaz rezidual

tail gate $(\mathrm{OM})$ capac din spate, capac de descărcare din spate; (hidr, met) poartă aval, galerie de refugiu, ecluză de golire

tail hammer (mas-un) ciocan cu arc / cu pedală

tail house (TH, mediu) fabrică / secție de prelucrare a deşeurilor

tailing rămășiță, rest; (agr, alim) pleavă, drojdie; sediment (nedorit, neutilizabil); (met, mediu) deșeu(ri), reziduu(ri) (provenit(e) de la concentrarea minereurilor)

tailing-out efilare, subțiere graduală a straturilor (şi la compozite)

tailings (ind, mediu) reziduuri, cozi, steril, rocă sterilă, deșeuri, resturi

tailless fără coadă / terminație

tail light (auto) lumină din spate, stop; (cf) lumină / felinar de semnal

tail of a forge hammer (met) coada ciocanului (şi de forjă)

tail of a piece $(\mathrm{OM})$ coada unei piese; (met) capăt (al benzii laminate)

tail on a ataşa / adăuga ca apendice / supliment / la coadă / la capăt / la sfârșit; a face coadă; a sta la coadă

tailor croitor; a croi, a face haine / croitorie, a exercita meseria de croitor

tailored ajustat (si d. haine), pe corp

tailored version execuție specială / la comandă

tailoring (nav, met) croitorie, croială, care croieşte; decupare a tablelor (după şablon, tipar) 
tailor-made oil (ind chim, T) ulei mineral nestandardizat / special

tailor mades țigări de fabrică

tail piece sfârșit, parte finală, încheiere; şipcă de încheiere, coada moriştii hidrometrice; (masun, OM) coadă, finală, baghetă; (poligrafie) vignetă de sfrşit de capitol

tail pipe (auto) țeavă de evacuare din spate / de eşapament; (ind chim, OM) coloană pierdută, sorb, niplu / țeavă de golire / de evacuare

tail post (nav) etambou

tail pulley (mas, OM) tambur de întoarcere

tails (met) şlam, bucăți / capete mici de tablă; (ind chim) cozi de distilare, reziduuri; resturi (textile, din foi de aluat, din table) (după croire)

tail signal (cf) semnal de la coada trenului

tail spindle (mas-un) vârf al păpuşii mobile

tailstock (mas-un) păpușă mobilă

tailstock centre (mas-un) vârful păpușii mobile

tailstock sleeve (mas-un) manşonul / axul păpuşii mobile

tailstock slide (mas-un) sanie a păpuşii mobile

tailstock slindle sleeve (mas-un) pinolă / manşon a(l) a păpuşii mobile

tail water (mediu, TH) apă uzată / reziduală

tail wind (nav) vânt prielnic / favorabil

taint (med) a (se) infecta; (mediu) a polua; (fig)

a (se) molipsi, a păta; a (se) strica; a se contamina, a se altera; (med) infectie, molipsire, contagiune; boală latentă; (mediu, med) contaminare; pătare; corupție, imoralitate

tainted degradat, stricat, alterat; pătat

taining (plast) decolorare, ieşire a culorii

taintless nepătat; curat

take captură; (ec) încasări; a primi, a lua; a accepta; a adopta; a obține; a duce, a conduce; a consuma, a mânca, a bea; a presupune, a socoti; a alege; a apuca, a pune mâna pe, a prinde; a folosi; a atrage; a necesita; a capta (apa); a îngheța (râul); a ocupa, a cuceri, a captura; a respira; a cumpăra; a închiria, a reține, a angaja (locuri etc.); a cuprinde, a avea o capacitate de, a primi; a înțelege, a pricepe, a interpreta, a considera (ca); a necesita, a cere, a reclama; a încasa, a lua, a câştiga, a căpăta, a primi; a avea succes, a reusi, a prinde; a avea efect; (d. foc) a se aprinde; a se întinde; (nav) a prinde vântul (d. o pânză, vele); a pune stăpânire pe; a face; a prinde; (mat) a scădea; a urma, a merge pe (un drum etc.); a conduce, a însoți; a resimți; a pune; a încânta, a fermeca; a fotografia; taken ocupat (d. mese în restaurante); be taken in a trap a cădea în cursă; be taken in the act a fi prins asupra faptului; be taken ill a cădea bolnav take a bath a face o baie takeable de luat, care poate fi luat / prins

take account of a ține seamă de

take advantage of a utiliza; a folosi; a întrebuința; a valorifica; a profita de

take after a semăna cu

take aim a ochi, a ținti

take a journey a face o călătorie

take along a lua cu sine

take a look / glance a arunca o privire

take apart (OM, TH) a separa, a despărți, a demonta; a descompune; a desface (în bucăţi)

take aside a duce deoparte / la o parte

take a step a face un pas; ( $\mathrm{fam}$ ) a lua o măsură

take a taxi a lua un taxi

take away a îndepărta; a fura, a răpi; a retrage, a lua, a duce de acolo / de aici; a sustrage (un document etc.); a lua, a duce cu sine (pe cineva); a retrage (un copil) de la scoală; a face un prost serviciu; a tăia (respirația); a înlătura, a suprima

take-away belt (OM, alim) bandă transportoare de descărcare

take back a lua înapoi, a retrage, a scoate; a duce înapoi, a conduce înapoi

take care of a îngriji; a întreține; a avea grijă de

take current (el) a absorbi curent din retea

take delivery (of goods) a recepționa / a prelua / a ridica (marfa)

take down a coborî, a da jos; (OM, TH) a demonta; (constr) a demola, a dărâma; a nota, a lua notițe; a înregistra, a consemna; a umili

take effect a intra în vigoare; a fi eficace

take finishing cut (mas-un) a finisa, a strunji de finisare

take for a lua drept, a confunda cu, a considera

take from a lua (din / de la, cu împrumut), a împrumuta de la; a scoate; a extrage; a reduce, a micşora, a scădea din, a diminua (valoarea, meritul)

take great pleasure in a-i face mare plăcere (să facă ceva)

take heavy cut (mas-un) a degroşa, a prelucra prin formarea de aşchii de mare secțiune

take hold of a prinde; a apuca (şi a ține)

take-home pay (ec) salariu net

take-in înșelăciune, escrocherie

take in a băga înăuntru, a lua înăuntru; a înmagazina, a băga în magazie / hambar; a lua în gazdă; a cuprinde, a îngloba, a include; a întelege (situaţia), a-şi da seama de, a pricepe, a sesiza; a strâmta, a îngusta (şi haine); a primi (un ziar), a fi abonat; (nav) a se aproviziona cu; a adăposti (pe cineva); a trage pe sfoară

take in service a pune în funcțiune

take in tow a remorca

take into a lua, a băga în, a primi (în) 
take into account a ține seamă de; a lua în calcul / în considerare

take measurement of (metr) a măsura

take-nut (mas-un) piuliță pentru eliminat jocul axial (şi la arborele principal)

take-off avânt, elan; start, plecare; trambulină, lansare; decolare; suprimarea purtătoarei de sunet, prelevare (de debit, de probe etc.); întrerupere, oprire; (met) desfăşurare (a benzii, a sârmei etc.)

take off a pleca; a ridica, a scoate; a lua; a îndepărta, a da la o parte, a înlătura; a abate, a distrage (atenţia etc.); a separa; a opri; a întrerupe; (met) a desfăşura (bandă, sârmă); a scădea, a reduce, a micssora, a reduce (d. un preț); a elimina, a şterge de pe listă; a suprima; a imita; a parodia, a caracteriza; a decola, a-şi lua zborul; a-şi lua avânt / elan; a se domoli, a se potoli (şi d. vânt); a jupui; (av) a decola; a dezbrăca, a scoate (o haină); a duce (pe cineva undeva); (nav) a lua (pasageri) pe bord; a lăsa mai ieftin

take office a prelua o functie

take-off the receiver a ridica / a deconecta receptorul (casca)

take off the slag (met) a scoate zgura

take on a-şi asuma, a(-şi) lua asupra sa; a primi, a accepta (o sarcină etc.); a dobândi (o calitate, formă etc.), a căpăta; a prinde (un accent); a ambarca (pasageri); a duce mai departe, a conduce (mai departe); a întreprinde; a-și asuma (o responsabilitate); a se măsura (cu cineva)

take on lease (agr, ec) a arenda, a lua în arendă

take-out (alim) semipreparat culinar, mâncare semipreparată, mâncare la pachet

take out (med) a scoate (un dinte); a scoate la plimbare; a invita, a duce (la teatru, la restaurant); (TH) a scoate (din functiune), a extrage; a excepta; a elimina; a ieşi la suprafață; a obține, a scoate (un act); a smulge

take out a factor (mat) a da / a scoate factor comun

take out dents (in a metal part) (met) a îndrepta, a egaliza, a elimina (rizuri)

take out of service a bloca; a imobiliza; a scoate din funcțiune / din exploatare

take over a conecta, a introduce în circuit; a prelua (un serviciu etc.); a trece (pe cineva dincolo de un râu etc.), a transborda; a muta la

take part in a participa la, a lua parte la

take place a avea loc, a se petrece

take possession of a prelua (ceva); a ocupa

take preparatory / roughing cut (mas-un) a degroşa

taker primitor; antreprenor

take readings (mas-un, metr) a nota indicațiile (unui instrument de măsurat) taker-in înşelător, amăgitor; escroc

take roughing cut (mas-un) a degroşa

take speed (met, plast) viteză de înfăşurare / derulare a benzii (d. tablă, material plastic, hârtie etc.)

take stock / (an) inventory a face inventarul, a inventaria, a prelua un inventar

take the level a nivela

take to a duce la, a transporta la; a-şi asuma; a-şi atribui; a se îndrepta spre, a fugi către / în; a apuca, a lua; a se consacra

take to pieces a descompune; a demonta în bucăți; a desface

take-up (TH, OM) ambreiaj, ambreiere, reglaj, compensare; înfăşurare, rulare

take up a ridica (de jos), a aduna, a strânge (de pe jos); a sălta; a scoate; a lua, a îmbarca (pasageri etc.); a apuca (în mână), a înhăța; (ec) a onora (o poliță), a percepe (impozit etc.); a absorbi, a amortiza; a înfăşura (bobina, rola); a rula; a accepta, a primi (o provocare); a se apuca de; a lua, a se instala, a ocupa (o cameră etc.); a relua, a reîncepe; a înțelege, a interpreta; $(\mathrm{TH})$ a regla, a compensa; a se ameliora, a se îmbunătăţi (şi d. vreme etc.); a culege; a bea; a relua (un refren); a lua în mână (o afacere); a adopta (un copil)

take-up a bill (ec) a onora o trată / o notă de plată

take up any slack (auto, mas) a prelua o anume greutate

take up any position (mas-un) a ocupa orice poziție take-up assembly / unit / device (mas, mas-un) dispozitiv / ansamblu / unitate de înfăşurare / de bobinare

take upon oneself a lua asupra sa, a-şi asuma

take-up real (mas) rolă de rebobinare

take-up roller (mas, plast, ind chim) valț / rolă / cilindru de înfășurare

take-up speed (mas, plast, ind chim, met) viteză de înfaş̧urare (pe un valț / o rolă / un cilindru etc.)

take-up spindle (mas) rolă de rebobinare valț, cilindru etc.

take up the backlash (mas-un) a elimina jocul excesiv

take up the bearing (mas-un, OM, T) a regla un lagăr, a elimina jocul (nedorit) din lagăr, a elimina jocul din lagăr

take-up spindle (mas) rolă de rebobinare

taking scoatere; prelevare; extragere; luare, apucare; capturare; ocupare; prindere; (jur) sustragere; ridicare (topografică); alcătuire, schițare; atractiv, captivant; (med) contagios, molipsitor, infecțios; s $(p l)$ (ec) încasări, venituri, sume încasate;

taking-back (ec, jur) retractare; (mas) retragere 
taking-down coborâre, dare (în) jos; consemnare, notare, înregistrare; (constr) demolare; (ec) consemnare, înregistrare

taking off (met, plast) desfăşurare (a sârmei, a firului, a benzii); îndepărtare (de material superficial, fără specificarea tehnologiei); (alim) jupuirea pieilor

taking of idle / reactive / wattless current (el) consum de putere reactivă

taking of power (ec, mec) absorbție / consum de putere

taking of samples $(\mathrm{TH})$ luarea probelor

taking of steam (met, termo) prelevare / priză de abur

taking-out scoatere; ieşire, deblocare; extracție

taking out velocity ( $\mathrm{TH}$, met, mas-un) viteza de scoatere (a unui semifabricat, a piesei deja prelucrate etc.)

taking-over (ec, TH) recepție; luare în posesie / în stăpânire; preluare

takings (ec) încasări, sume încasate, venituri

taking the mean (mat, metr) măsurare / calculare a valorii medii

taking the root (mat) extragerea rădăcinii (de obicei pătrată, atenție la text)

takings (ec) încasări

taking-up preluare, adoptare; (met, plast) înfăşurare (a sârmei, a firului, a benzii); (auto) amortizare, absorbție (a unui şoc)

taking-up catch $(\mathrm{OM})$ clichet ridicător / de prindere

taking-up pressure surface (hidr) suprafață de presiune

talc (chim) talc

talky, talcose, talcous (chim) de / cu talc, ca talcul

tac(um) powder pudră de talc

talangwah (tw), square wah (metr) unitate de măsură pentru arie (teren), în Tailanda: 1 talangwah $=4 \mathrm{~m}^{2}$

talbot (metr, fiz) unitate de măsură pentru energie luminoasă, denumită şi lumen secundă $(\operatorname{lm} \cdot s)$; pentru lumina cu lungimea de undă de $555 \mathrm{~nm}$ (sesizată de ochi), 1 talbot $=1,464 \mathrm{~mJ}$; pentru alte lungimi de undă 1,1 talbot = $1,464 \cdot V(l) \mathrm{mJ}, V(l)$ - „luminous efficiency” eficiența luminoasă sau un factor de sensibilitate relativă a ochiului la lungimea de undă 1

talent talent, dar; aptitudine; persoană talentată; (metr) unitate antică de măsură pentru masă în estul Mediteranei: 1 Hebrew sacred talent (din Biblie) $\sim 30 \mathrm{~kg}$. 1 Greek talent $\sim 25,8 \mathrm{~kg}$

talented talentat, dotat

talentless lipsit de talent, netalentat

tale quale (t.q., TQ) (ec, TH) aşa cum se prezintă (marfa) talk a vorbi, a se exprima; a vorbi (o limbă); convorbire; conversație, discuție; vorbire; comentariu; conferință; prelegere, lecție, curs

talkable (despre) care se poate discuta

talk about a vorbi / discuta despre

talker vorbitor, orator

talkfest întrunire (neoficială) pentru discuții, discuție liberă

talking point argument, bază de discuție

talking-to mustrare, admonestare

talk over a discuta despre; a dezbate (asupra unui subiect, unei teme)

talks (ec, pol) negocieri, tratative

talk to / with a vorbi (cu cineva, cuiva); a conversa, a discuta cu

tall înalt, de statură mare / înaltă; zvelt, subțire; (fig) exagerat, fantastic; exccesiv, greu de conceput; de necrezut

tallness înălțime, statură înaltă

tallow (alim) seu, grăsime animală, a produce grăsime; a unge cu grăsime / seu, a gresa

tallow chandelery fabricarea lumânărilor, meserie de lumânărar

tallower (agr, alim) animal din care se scoate seu / grăsime; lumânărar

tallow melting plant (alim) instalatie de topire a seului / a grăsimilor animale

tallow oil (alim) oleomargarină; (met) ulei de călire tally pontaj, jeton (de prezență), punctaj, însemnare, înregistrare (cu puncte); etichetă (ataşată de bagaj, pe un pachet etc.); a ponta; (mas-un) etichetă, tăbliță, număr; (ec) duplicat (al unei facturi etc.), copie; (inf, mat) calcul, a calcula, a număra, a socoti; a puncta; a eticheta; a concorda, a corespunde; a ataşa, a aplica o etichetă (pe un pachet etc.); a face înregistrări; a controla (mărfuri); element similar, corespondent, omolog, replică; -sheet (ec) borderou; with a corespunde, a coincide cu (o factură etc.); with the invoice a corespunde cu factura (d. mărfuri etc.)

tally sheet (ec) borderou; foie de pontaj

tally-shop magazin unde se vând mărfuri în rate / pe credit

tally system / trade (ec) comerț / vânzări pe credit pe termen scurt

tally with a corespunde $\mathrm{cu}$, a se potrivi $\mathrm{cu}$; a concorda cu

talon talon; gheară; contramarcă; cupon

talus (constr) taluz

tambour (OM) tobă, tambur, cilindru

tame domol; regulat; neted; domesticit, îmblânzit; (agr) cultivat; (fig) slab, fără energie, inofensiv (d. acțiuni, lucruri); a (se) domestici, a (se) îmblânzi; a dresa, a supune

tame acquiescence acord tacit

tame down a se atenua; a se potoli, a se liniști 
tamp (met, constr, TH) a bate (şi piloți), a bătători, a îndesa, a ştampa, a astupa (o gaură)

tamp down a îndesa (în jos)

tamped concrete (constr) beton comprimat tamper (constr) pilon (pt. compactat pământul), reflector, mai, bătător

tempering (with) (ec) falsificare (de conturi, cecuri, registre etc.), modificare (a registrelor etc.); cumpărare, mituire (a martorilor)

tamper-proof (jur) sigur, inviolabil; ferit de primejdie, aflat în siguranță; de siguranță, care nu poate fi deschis / violat

tamper with (TH) a se atinge de; a deschide, a viola (corespondenta); a falsifica; a modifica, a corecta, a face schimbări în; a sustrage, a se atinge (de bani); a mitui, a corupe (martori); a strica (un mecanism, un aparat etc.)

tamping (met) îndesare, bătătorire, ștampare; compactare (a materialelor în vrac)

tamping clay (met) masă refractară pentru ștampare

tampion (TH) tampon, dop mare

tampon tampon, a tampona

tan (silv) scoarță / coajă de stejar (şi măcinată); (chim) tanin; argăseală, tanant; culoare cafenie; a argăsi, a tăbăci; a băițui; (anat) bronz (al pielii); a argăsi, a tăbăci; a (se) bronza (d. piele)

tan (metr) unitate tradițională de măsură pentru masă în China: 1 tan sau 1 dan $=50 \mathrm{~kg}$; (metr) unitate tradițională de măsură pentru arie, în Japonia: 1 tan $\cong 991,7 \mathrm{~m}^{2}$

tan-chord angle (mat) unghi format de tangentă şi coardă (în punctul de contact)

tandem (OM) tandem; în cascadă, în serie; dublu; apropiat; montaj în tandem a rulmenților sau a altor elemente; (el) cascadă; (legat) în tandem

tandem arrangement (met, OM, mas) dispoziție / aranjament în tandem (şi d. rulmenți)

tandem axle (OM, auto, met) osie tandem, puntea din spate tandem

tandem blower engine (mas, termo, met) suflantă în tandem

tandem calender (ind chim, plast) calandru dublu

tandem cold reduction mill (met) laminor tandem pentru laminare la rece

tandem / dual compressor (mas) compresor în tandem / jumelat

tandem engine (mas, termo) maşină / motor (în) tandem

tandem knife switch (el) întrerupător cu două cuțite / pârghii

tandem mill (met) laminor tandem

tandem network (el) rețea în stea

tandem operation (TH) lucru / operații în serie / în tandem tandem pump (mas, hidr) pompă (în) tandem tandem rolling mill (met) laminor tandem tandem submerged arc welding (met) sudare automată sub strat de flux, cu doi electrozi în tandem

tandem truck axle (auto, OM) osie / puntea din spate tandem

tandem turbine (mas) turbină-tandem

tandem wiper (auto) ştergător de parbriz, dublu

tang zgomot puternic; a zdrăngăni; (mas-un) aripă / limbă de antrenare, coadă (la scule); (met) cârlig (la unelte)

tangelo, $p l$ tangelos (agr, bot, alim) hibrid de mandarină şi grape-fruit

tangency (mat) tangentă, tangență

tangent (mat) tangentă, tangent, tangențial

tangent arc (mat) arc tangent

tangent cone (mat) con tangent (la o sferă etc.), con format de tangente

tangent deformation (mec) deformare tangențială / pe direcție tangențială

tangent galvanometer (el, metr) aparat / traductor de măsurat curentul electric, cu ajutorul devierii unui ac magnetic în câmpul electromagnetic generat de curent, busolă de tangente

tangential (mat, geom) tangențial

tangential acceleration (mec) accelerație tangențială

tangential bearing (OM) reazem tangențial (bombat)

tangential casting (met) turnare tangențială / pe direcție tangențială (prin centrifugare)

tangential component (mec) componentă tangențială / periferică

tangential conversion (mas-un) debitare tangențială

tangential / cross-flow fan (mas, termo) ventilator tangential

tangential feed worm gear hob (mas-un) avans tangențial pentru freză-melc conică pentru roți elicoidale / melcate

tangential flow turbine (mas, termo) turbină cu admisie tangentială

tangential force (mec) forță tangențială

tangential key / wedge $(\mathrm{OM})$ pană tangențială

tangentially $(a d v)$ (în mod) tangențial

tangential path $(\mathrm{mec})$ tangentă la traiectorie

tangential plane (mat) plan tangent / de contact

tangential pressure diagram $(\mathrm{mec})$ diagrama eforturilor tangentiale

tangential section (mec) secțiune tangențială

tangential stress $(\mathrm{mec})$ tensiune tangențială / de forfecare / pe direcție tangențială

tangential thrust (OM) împingere / sarcină (tangențială) a arcului; (mec) efort tangențial / de forfecare, presiune orizontală / laterală 
tangential (viscous) force component $(\mathrm{T}) \mathrm{com}$ ponenta / forța vâscoasă (într-un fluid) a forței

tangential wheel (mas) rotor de turbină cu admisie tangențială

tangential-flow turbine (mas) turbină cu admisie tangențială

tangent key / wedge (mas, OM) pană tangențială

tangent law (mat) teorema tangentelor

tangent line (mat) tangentă

tangent plane (mat) plan tangent

tangent point (mat) punct de tangență

tangent wedge $(\mathrm{OM})$ pană tangențială

tangerine (alim) mandarină

tangerine oil (alim) ulei de mandarine

tangibility, tangibleness tangibilitate, caracter tangibil / palpabil; realitate

tangible tangibil, palpabil, real, material; clar

tangle nod; (fig) încurcătură, încâlcire, încâlceală, amestec (şi de microfibre în compozite sau de lanțuri moleculare în polimeri); dezordine; zăpăceală; blocare a traficului (în circulație); dispută, ceartă; a amesteca; a (se) încâlci, a (se) încurca, a se întortochia; a zăpăci; be in a $\sim$ a fi dezorientat

tangled încâlcit, încurcat (d. fire, o afacere etc.)

tangle up a (se) încâlci, a (se) încurca; a strica, a deteriora

tangly încurcat, încâlcit; amestecat; confuz

tan house, tannery tăbăcărie

tank tanc, automobil blindat, cisternă, castel (de apă), lac / iaz mic; (nav) barcaz, barcă mare, şalandă, şlep-tanc (pt. aprovizionare cu apă sau combustibil); recipient, bazin, bac, bidon, chiuvetă, rezervor, tanc, cuvă, baie; cabină de înregistrare, izolată fonic; (mat) prescurtare de la hiperbolic tangent (tangentă hiperbolică)

tank accessories (auto, nav, termo) armătura / armăturile / accesoriile rezervorului / recipientului / tancului

tankage (OM, hidr) capacitate (a unui rezervor etc.); reziduuri, deşeuri (pe fundul unui tanc, rezervor, recipient etc.)

tankage capacity (nav) capacitate de tancare / a unui tanc / a unui rezervor etc.

tank apparatus (mas, metr) aparat(e) de presiune (ataşat(e) unui recipient sub presiune)

tankard (alim) cană cu capac

tank boiler (termo) cazan cilindric cu teavă de flacără, boiler

tank bottom (alim, ind chim, termo) fund de recipient / de tanc / de rezervor / de creuzet (la turnarea sticlei)

tank bottoms (alim, auto, ind chim, termo) reziduuri / depuneri de fund (într-un rezervor / tanc / recipient) (solide sau/şi lichide) tank breathing (alim, auto, ind chim, nav, termo) respirație / aerisire a rezervorului

tank capacity (alim, auto, ind chim, nav, termo) capacitate de tancare / a rezervorului / a recipientului etc.

tank car; tank wag(g)on (cf) (vagon) cisternă

tank crystallization (alim, ind chim) cristalizare în rezervor / în recipient

tank crystallizer (alim, ind chim) cristalizator, recipient / tanc de cristalizare

tank engine (cf) locomotivă-tender

tanker autocisternă, vagon-cisternă; (nav) navăcisternă, navă-tanc (şi petrolier)

tanker trade transport al mărfurilor lichide

tank farm / battery parc de rezervoare, depozit de petrol (în mai multe rezervoare / tancuri)

tank filler cap (OM, hidr) ştuţ de umplere (a rezervorului / tancului etc.)

tank furnace (ind chim) cuptor tip recipient

tank-furnace crown (ind chim, met, termo) boltă / capac al cuptorului tip recipient

tank gauge (metr, hidr) aparat de măsurat nivelul / presiunea etc. într-un recipient / tanc

tank lining (ind chim, termo) căptuşeală de rezervor / de cuvă / de baie (electrolitică)

tank lorry / truck (auto) autocisternă

tank oxygen (ind chim, TH) oxigen în butelii

tank pad (constr, OM) postament / suport de rezervor / de recipient

tank plant (constr, OM) instalație de alimentare din rezervor / recipient (cu combustibil, lubrifiant, apă etc.)

tank plate (met) oțel de blindaje (pt. recipiente / tancuri etc.)

tank potential / voltage (el) tensiunea băii electrolitice

tank railing (OM, ind chim, nav) balustradă a rezervorului

tank resistance (el) rezistența băii electrolitice

tank shell (alim, ind chim, nav, OM) mantaua rezervorului / recipientului

tank ship / vessel (nav) navă-cisternă, tanc petrolier, petrolier

tank sizing (metr) determinare a capacității unui tanc / rezervor / recipient

tank spacing (constr, nav, ind chim) distanță / spațiu între rezervoare, amplasare a rezervoarelor / recipientelor / tancurilor

tank top plating (nav) punte de dublu-fund

tank trailer (auto) remorcă-cisternă

tank vessel / ship (nav) navă-tanc

tank voltage (el, chim) tensiunea băii electrolitice

tank wagon (cf) vagon-cisternă

tan liquor, tan ooze, tan pickle (ind chim) lichid tanant / pentru argăseală 
tannate (chim) tanat

tannic acid (chim) acid tanic

tanner tăbăcar

tannin (chim) tanin, acid tanic

tanning; tawing (TH, ind chim) tăbăcire, argăsire (a pieilor)

tan pit (industria pielăriei) baie de argăseală

tantalite (chim) tantalit

Tantalum (Ta) (chim) tantal

tantalum bronze (met) bronz cu tantal

tantalum carbide (chim, met) carbură de tantal

tap (mas-un) tarod, filieră, burghiu de filet, a fileta; (met) gură de evacuare, curgere (a metalului topit), a evacua parțial o topitură; (el) derivație, ramificație, racord, priză; (OM, mas-un) dorn, sculă de instrumentație, racord, derivație (şi pt. aparate de măsură în hidraulică), deri-vație, robinet, ventil, cep (și de robinet, butoi etc.) canea, priză, lovitură / bătaie uşoară; a ramifica; a deriva; a preleva; a da cep; a evacua treptat; a goli; a acoperi; a (se) scurge; a găuri, a face gaură în; a face o tăietură / incizie în; a tăia, a străpunge; a trage, a scoate, a face să curgă; a intercepta, a supraveghea (convorbiri); a lovi / bate ușor, a atinge; a bate la mașină; bătaie uşoară (şi cu vârful degetului)

tap and reamer milling cutter (mas-un) freză de canelat tarozi şi alezoare

tap a screw thread $(\mathrm{OM})$ a înşuruba, a asambla prin înfiletare

tap bar (met) bară de astupat orificiul de descărcare (a unei oale cu aliaj topit etc.)

tap bolt scoabă de traversă, pană de fixare; (OM) şurub / bulon cu cap, prezon, cep, diblu

tap borer / screw (mas-un) tarod

tap catcher (met) dorn de prindere

tap cinder (met) zgură finală / de pudlare

tap density (constr, ind chim, metr, met) densitatea materialului îndesat / presat / ştampat

tap down (mas-un) refulare cu ciocan

tap drill (mas-un) tarod, sculă de filetat (la interior)

tap drill size hole (mas-un) dimensiunea găurii de filetat

tape lant de măsură, panglică / bandă (şi de oțel, de magnetofon), ruletă, cureluşă, panglică, bandă, fâşie; şiret; a izola, a acoperi prin bobinare cu bandă / panglică; (el) a izola; a înfăşura cu bandă; a bobina; a lega cu panglică / sfoară / șnur; a măsura cu ruleta; (fig) a repera; a cunoaşte, a descoperi

tape armouring (ind chim, OM) armătură (întăritură / întărire din bandă (metalică)

tape clatter huruit / bătaie / păcănit a(l) benzii (şi de transportat) tape covering (el, hidr, plast) bandă izolatoare / de etanşare

tape length $(\mathrm{OM})$ lungime a benzii / curelei

tape line (metr) ruletă / panglică de măsurat

tape (line) measure (metr) ruletă

tape-machine aparat morse / de telegraf / cu bandă de înregistrare (şi tip magnetofon) / maşină / aparat de înregistrat cu bandă

tape measure (metr) bandă / panglică de măsurat, ruletă

taper conicitate; lumânare; secțiune cu tranziție conică, formă conică (ascuțită); a da / avea formă conică / ascuțită, a se termina într-un vârf ascuțit; a subția; a ascuți; a micşora; conic, tronconic, conoform; îngustat spre vârf; (el, autom) acțiune cu tranziție progresivă

taper angle (OM, mas-un) unghi de teşire (la piese de revoluție), conicitate, unghi de conicitate

taper attachment (OM) îmbinare cu mufă (şi cep), îmbinare / asamblare pe con

taper bolt $(\mathrm{OM})$ şurub conic

taper boring (mas-un) alezare a suprafetei conice

taper bridge reamer (mas-un) alezor pentru găuri (conice) de nit

tape record (mas, metr) aparat de înregistrare cu bandă, înregistrare pe bandă (magnetică, de magnetofon)

tapered $(\mathrm{OM})$ conic, cu formă conică, în formă de con

tapered bearing $(\mathrm{OM}, \mathrm{T})$ lagăr cu cuzinet conic

tapered collar $(\mathrm{OM})$ pană (înclinată) cu inel / cu ochi / cu nas, colier (de strângere / fixare) cu suprafață conică; (mas-un) inel (cu secțiune) înclinată sau conică / tronconic

tapered cotter $(\mathrm{OM})$ pană conică / înclinată

tapered drum (ind chim, OM, mas) tambur conic, tobă conică

tapered end (OM) capăt (ascuțit) conic

tapered gear(ing) $(\mathrm{OM})$ angrenaj conic

tapered hobbing cutter (mas-un) freză-melc conică, de tăiat / prelucrat dinți (și la roți conice, melcate)

tapered journal (OM, T) fus / lagăr (tron)conic

tapered machine handle (mas, OM) mâner conic

tapered milling cutter (mas-un) freză conică

tapered package $(\mathrm{OM})$ format conic, pachet conic (de garnituri)

tapered pass (met, metr) calibru conic

tapered pin $(\mathrm{OM})$ cui / ştift conic

tapered plug (OM, el) bușon / dop conic

taper(ed) reamer (mas-un) alezor conic

tapered reduction bushing (mas) bucşă conică de reducere 
tapered ring $(\mathrm{OM})$ inel conic / tronconic tapered roller-bearing $(\mathrm{OM})$ rulment $\mathrm{cu}$ role conice

tapered roller (OM, mas-un) rolă conică (şi de rulment etc.)

tapered sleeve / socket $(\mathrm{OM})$ con, piesă / bucşă conică, suport conic

tapered steering-wheel hub (auto) butuc (conic) de la volanul direcției

tapered top $(\mathrm{OM})$ capăt conic de arbore, fus conic, vârf conic de şurub / de arbore

tapered washout plug (hidr, mas, OM) dop filetat (şi conic) de închidere a gurii de spălare

taper fit (OM, mas-un) ajustaj conic, montaj / asamblare pe con

taper flat file (mas-un) pilă lată cu vârf ascuțit

taper gauge (mas, met, metr) calibru conic

taper hole (hidr, mas-un, OM) gaură conică, orificiu conic (de golire)

tapering (OM) conicitate; care este / devine conic, conic, ascutit la vârf, de formă conică

tapering pass (met, metr) calibru conic întrerupt / cu degajări

taper journal (OM) fus / lagăr conic

taper of groove (met) conicitate a calibrului de laminare

taper of key (mas, OM) strângere / înclinare a penei (înclinate)

taper out subțiere graduală, efilare (şi la compozite stratificate)

taper pin $(\mathrm{OM})$ ştift (conic) de pană

taper-pin reamer (mas-un, OM) alezor conic (pt. găuri de ştift conic)

taper pipe tap (mas-un, OM) tarod pentru filetgaz conic

taper reamed (mas-un) alezat conic, alezat cu suprafață (interioară) conică

taper reamer (mas-un) alezor conic

taper / reducing pipe (hidr, OM, termo) țeavă / racord / conductă / tub de reducție / cu formă (tron)conică

taper roller- / rolling-bearing $(\mathrm{OM})$ rulment $\mathrm{cu}$ role conice

taper-roughing reamer (mas-un) alezor conic pentru degroşare

taper-seat valve (hidr, OM) supapă cu scaun / ventil conic

taper shank (mas-un) coadă conică

taper-shank reamer (mas-un) alezor conic / cu coadă conică (atenție la text)

taper shank twist drill (mas-un) burghiu spiral / elicoidal, cu coadă conică

taper sleeve (mas, OM) bucşă conică de reducere, manșon conic, con, piesă conică taper square file (met, OM) pilă plată boantă taper(-sunk) key (OM) pană (înclinată) de antrenare

taper tap (mas-un) tarod de degroşare, dorn pentru țevi

taper thread $(\mathrm{OM})$ filet conic

taper turning (mas-un) strunjire conică

taper-turning attachment (mas-un) riglă / dispozitiv de strunjit conic

taper-turning lathe (mas-un) strung pentru prelucrarea suprafețelor conice

taper washer (mas-un) zencuitor

taper wedge $(\mathrm{OM})$ pană de reglare (cu ajutorul unei suprafețe conice; deseori montate câte două)

taper weld (met) îmbinare / sudare a țevilor cu mufă; sudură în partea conică a flanşei / conductei / tevii

tapestried tapisat; tapetat; a tapisa, a tapeta

tapestry tapiserie, goblen; tapet care imită goblenul; a tapisa, a decora, a tapeta

tapestry weaver decorator care lucrează tapiserii / goblenuri

tapestry work tapiserie, goblenuri; tapițerie, tapetare

\section{tapestry worker tapițer}

tape unit (alim, met, mas, ind chim) derulor de bandă, ansamblu de derulare a benzii / foliei / hârtiei de ambalat etc.

tape warping urzire în benzi (la compozite cu fire lungi, țesături, plase etc.)

tape weave (met, ind chim, plast) fluctuație / oscilație laterală a benzii

tap extension (mas-un) prelungitor de tarod, tijă prelungitoare a tarodului

tap funnel (OM, hidr, ind chim) pâlnie de separare tap grinding machine (mas-un) maşină de ascutit tarozi

tap handle (mas-un) cheie / clupă pentru tarozi

tap holder (mas-un) mandrină de găurit / pentru tarozi, dispozitiv (conic) de prindere / fixare a tarodului

tap( )hole (met) gură de scurgere a zgurii, orificiu de golire; (OM, hidr) supapă de evacuare

tap-hole gun (met) maşină / instalație de astupat orificiul de golire (şi la turnarea continuă)

tap-hole material (met) material refractar pentru astupat orificiul de golire (şi la turnarea continuă)

taping (el, hidr, OM, TH) izolație / etanşare acoperire prin bobinare cu bandă / cu panglică tap ladle (met) oală de turnare

tap-making machine (mas-un) maşină de prelucrat ghiventuri / tarozi

tapped (mas-un, OM) filetat, cu filet (conic) 
tapped fixing / mounting hole (OM) gaură cu filet conic pentru fixare / montare

tapper tap (mas-un) tarod de maşină pentru piulițe (conice)

tappet (nav) pisălog; gheara manivelei de pornire, nas; (OM) deget, camă, antrenor, excentric, tijă, tachet, graifăr

tappet adjusting screw $(\mathrm{OM})$ şurub de reglat tachetul

tappet clearance (OM) joc de tachet; (OM, hidr) joc / ajustaj al supapei / al ventilului

tappet gear (mas-un) distribuție cu came

tappet guide (OM, mas-un) ghidaj de tachet, joc al supapei / al ventilului

tappet lever (OM) pârghie oscilantă, culbutor

tappet rod (OM) tijă / arbore de tachet

tappet spanner (hidr, OM) cheie pentru reglarea ventilelor

tapping derivație, scurgere; intermitent; (el) priză, legături de racordare (la linii electrice); (mas-un) filetare; (met) evacuarea metalului sau a zgurii, golire; incizie

tapping attachment (mas-un) dispozitiv de găurit / de filetat

tapping bar (met) rangă / dorn de destupat cuptorul / furnalul / canalul / orificiul de evacuare a materialului topit

tapping bushing (mas-un) dispozitiv de ghidare (folosit la filetare)

tapping capacity (mas-un) diametrul maxim al găurii care poate fi filetată (la maşina-unealtă respectivă)

tapping chuck (mas-un) mandrină specială pentru prinderea pieselor filetate cu tarodul

tapping contact contact intermitent

tapping die (mas-un) filieră, cap de filetat

tapping head (mas-un) cap de filetat, dispozitiv de filetat cu tarod

tap(ping) hole (met) gură / orificiu de scurgere / de golire / de descărcare (a zgurii, a metalului topit)

tapping-hole drilling (met) deschiderea (prin golire) a orificiului de scurgere / golire (a zgurii, a metalului topit) prin găurire / batere repetată

tapping lauder / spout (met) canal / jgheab de scurgere / de golire (a zgurii, a metalului topit) (la furnal)

tapping machine (mas-un) maşină de filetat piulițe (cu tarod)

tapping noise (TH) zgomot de bătaie / de ciocănire / de lovire repetată

tapping platform (met) pat de turnare

tapping point $(\mathrm{TH})$ punct / loc de priză / de derivație tapping sample (met) probă de metal lichid, luată în timpul elaborării sau turnării

tapping slag (met) zgură evacuată odată cu metalul / aliajul topit

tap pipe (hidr, OM) țeavă (filetată) de scurgere / de golire / de evacuare

tap remover (mas-un) dispozitiv de scos tarozi rupți

tap root (agr, bot) rădăcină pivotantă

tap screw / borer (mas-un) tarod

tap set (mas-un) set de tarozi

tap setting (el, hidr) reglare / aşezare a prizelor (de curent electric sau de alimentare cu un fluid)

tap spout (met) jgheab de scurgere

tap switch (el) întrerupător în trepte

tap the slag (met) a îndepărta / a evacua zgura

tap volume (met) volum ocupat de materialul tasat / ştampat

tap water apă de (la) robinet, apă din conductă

tap with ground relief (mas-un) tarod cu dinți detalonati (prin rectificare)

tap wrench (mas-un) cheie / clupă de tarozi sau de robinet

tar (ind chim) smoală, gudron, catran; a gudrona, a unge cu smoală / gudron

tar board (constr) carton asfaltat / gudronat

tar camphor / white (chim) naftalină

tar coating (chim) gudronare

tardily $(a d v)$ târziu, tardiv, cu întârziere; agale, alene, încet, lent, fără grabă / zor

tardiness zăbavă, întârziere, încetineală

tardy (adv) întârziat, tardiv, (venit) cu întârziere; leneş, indolent, apatic, moale

tar dolomite brick (met) cărămidă de dolomită gudronată

tare .(bot) neghină; (ec, metr) dara, tară, greutate proprie; a tara; a determina tara

tare allowance toleranță pentru tară, reducere pentru tară

tarefa (metr) unitate tradițională de măsură pentru arie, în Beazilia: 1 tarefa $\geq 3000 \mathrm{~m}^{2}$

tare weight greutate brută / cu tară; tară

tar-fired furnace (ind chim, termo) focar de ardere a gudronului

tar for steel making purposes (ind chim, met) gudron utilizat în oțelării (şi pt. impregnarea cărămizilor, dopului de la turnarea continuă)

target (fiz, el) anticatod; țintă; țel; sarcină; normă; obiect de încercare / de măsurare; (cf) semnal de zi; $(\mathrm{TH})$ şuber, clapetă, registru

target angle unghi de înclinare (dorit, de exemplu, la un reglaj)

target date termen de predare (a unui proiect, a unei lucrări etc.) 
target figure (ec) sarcină / cifră de plan, normă target price (ec) preț de referință (stabilit ca obiectiv la negocieri)

tariff (ec) tarif, taxă; listă de prețuri / tarife; a tarifa, a evalua; a include în tarif

taring device (metr, TH) dispozitiv de cântărire $/$ de tarare

tarlatan (textile) tarlatan, muselină

tarn (geog) iezer, lac de munte, tău

tarnish pată;pierderea lustrului; a întuneca; (met) film de oxizi, a acoperi / a dubla cu un strat metalic, a reveni (în tratamente termice), a(-şi) pierde lustrul / luciul, a lipsi de strălucire, a face să-şi piardă luciul, a lua lustrul / luciul, a deveni mat la culoare; (fig) a defăima, a calomnia, a întina / păta reputația (cuiva)

tarnishing (met) mătuire, patinare

tarnish on glass (ind chim, met) metalizare / mătuire a sticlei

tarpaulin (nav) prelată (impermeabilă) de bocaport; prelată, foaie de cort

tarragon (alim) tarhon

tarred gudronat (d. carton)

tarred dolomite refractory (met) cărămidă refractară din dolomită gudronată

tarry de aspectul gudronului; (drum) gudronat, bituminat, bituminos; a întârzia, a zăbovi, a pierde vremea (de pomană); a şovăi, a ezita; at, in a locui, a sălăşlui, a trăi (la, în); mânjit cu smoală / catran

tarrying (mas-un) pauză (la sfârşitul cursei mesei)

tar seal (australian) a acoperi (drumurile) cu gudron / produse gudronate

tar spraying gudronare (prin pulverizare)

tart acru, acrişor, astringent, acidulat; picant; înțepător; (alim) tartă cu fructe sau gem; (amer) tort (cu foi); (fig) muşcător, aspru, caustic; rigid, acerb

tartar tartru

tartar emetic (chim) emetic, tartar stibiat / antimoniat

tartness astringență; acreală; gust acru / înțepător, aciditate; (fig) causticitate, spirit muşcător

tartrate (chim) tartrat

tar weight greutate brută, tară

tar white / camphor (chim) naftalină

tart wine (alim) vin aspru

tary oil (ind chim) țiței asfaltos / răşinos

task lucru (impus), corvoadă, treabă; sarcină; (inf) grup de instrucțiuni; problemă; misiune; temă lecție (pt. acasă); obligație, îndatorire; a pune la treabă / lucru; a da de lucru (cu dat), a impune o sarcină / o muncă / un lucru (cu dat); a repartiza / a fixa / a distribui o sarcină / o misiune (cuiva); a pune la (grea) încercare; a chinui, a solicita (memoria etc.); (nav) a pune la probă / la încercare; a testa

task master $(\mathrm{TH}, \mathrm{ec})$ distribuitor de sarcini, conducător, şef; supraveghetor; normator, pontator task wage(s) (ec) salariu în acord, plată

task work (ec) lucru în acord, muncă în acord / cu bucata

task worker (ec) muncitor / lucrător în acord taste gust, simțul gustului; savoare, miros, aromă; (fig) urmă, pic, picătură, nuanță, undă; ( for) înclinație, preferință, predilecție, tendință pentru, gust (pentru); bun gust, rafinament, finețe; (fig) mostră, probă, dovadă; a gusta (un aliment), a gusta (din), a încerca (o mâncare), a degusta (băutură); a simți / percepe / distinge gustul la, a avea gust, $(\sim$ of $)$ a avea un anumit gust, a avea gust / miros / iz de (ceva); a savura; a lua, a pune în gură; a consuma

tasteful cu gust bun, savuros, gustos, plăcut la gust; (fig) de bun gust, elegant

tasteless fără gust, insipid; fad; searbăd, (fig) anost, plicticos, nesărat, fără haz; lipsit de tact / diplomatie; de prost gust

tastelessness caracter searbăd / insipid; (fig) lipsă de gust / eleganță; prost-gust

taster (alim) degustător (de vinuri etc.); redactor / consilier / recenzent / lector de editură

tat a înnoda, a lega

tatami (metr) unitate tradițională de măsură pentru suprafețe interioare de case, în Japonia, egală cu aria unui tatami $\sim 90 \mathrm{~cm} \times 180 \mathrm{~cm}$ $\left(\sim 1,62 \mathrm{~m}^{2}\right)$

tau $(\tau)$ litera $t$ în alfabetul grecesc

taunt dojană; ironie, zeflemea; (nav) (d. catarg) zvelt, foarte înalt; a certa; a dojeni; with a imputa, a reproşa; a zeflemisi

taunt-masted (nav) (d. un vas) cu catarge înalte taurine (agr, alim) taurin; bovin

taut (d. o funie, un fir etc.) încordat, întins, strâns; (nav) în bună stare

tauten a întinde, a încorda (un cablu, un fir); (nav) a întinde (o parâmă, o pânză etc.)

tautness (mas-un) grad de întindere

tautomer (chim) tautomer, compus organic cu structură recurentă / repetitivă, izomer

tautomerization (chim) reacție chimică de formare a izomerului, tautomerizare

tawed (industria pielăriei) argăsit / tăbăcit cu alaun / piatră acră

tawer (industria pielăriei) tăbăcar, argăsitor

tawery (industria pielăriei) tăbăcărie

tawniness (industria pielăriei) tăbăcărie, argăsire, culoare de piele tăbăcită

tawny maro-roşcat, roşiatic, de culoarea pielii tăbăcite 
tax (ec) taxă, tarif; impozit, dare; contribuție; a impozita, a impoza, a taxa, a evalua; a impune fiscal; a pune impozit (pe); (jur) a stabili (daune, amenzi); (fig) a pune la încercare, a solicita, a încerca; (amer, fam) a fixa prețul taxability (ec) impozabilitate, caracter impozabil taxable (ec) impozabil, supus impozitelor, contribuabil

\section{taxableness $\mathrm{v}$. taxability}

taxably (ec) ( $a d v)$ (în mod) impozabil, în conditii de impunere / de impozabilitate

taxation (ec) taxare, evaluare, impunere fiscală, fiscalizare, fiscalitate; impozit, dare; (jur) acuzație, învinuire, vină

tax collector $(\mathrm{ec})$ perceptor; administrator sau inspector financiar

tax deductible (ec) scutit de impozitul pe venit / profit (atenție la text); care poate fi plătit înainte de scăderea impozitului pe venit

tax dodger (ec) evazionist fiscal

taxer (ec) agent fiscal

tax exemption (ec, jur) scutire de taxă / de impozit(e), exceptare de la plata taxei / impozitului

tax for (ec) a învinovăti / a învinui / a acuza de

tax-free (ec) scutit de taxă / impozit; neimpozabil

tax-gatherer $v$. tax collector

taxi taxi, maşină de piață; a merge / a călători cu taxiul

taxi-cab v. taxi

taxi driver şofer de taxi

taxiing (auto) drum / mers cu taxiul; luare a unui taxi; cursă cu taxiul; (av) rulare pe pistă (sau pe apă) înainte de decolare sau la aterizare; tur de pistă

taximan $v$. taxi driver

taximeter (metr) aparat de taxare pe taxi

taxing (ec) impunere, impozitare; taxare pe aparatul de taxare a taxiului

taxing district (ec) (amer) circumscriptie fiscală / financiară

taxi rank statie de taxiuri

taxistrip (av) pistă de rulare

taxiway pistă (de rulare)

taxless $v$. tax-free

tax liabilities (ec) obligații fiscale

taxology v. taxonomy

taxon, $(p l)$ şi taxa (biol) taxon, unitate sistematică, element de clasificare; grup taxonomic; gen sau specie

taxonomic(al) taxonomic, cu caracter de / relativ la clasificare

taxonomy taxonomie, stiința clasificării

tax-payer (ec) contribuabil

tax return (ec) declarație de venituri / de impunere tax with $v$. tax for tax year (ec) an fiscal / financiar (începe la 1 sau 6 aprilie în UK, la 1 ianuarie sau 1 iulie în US etc.)

Taylor series (mat) seria Taylor

Taza (metr) unitate de măsură pentru volum sau capacitate: 1 Taza $($ Spania $)=0,000236588 \mathrm{~m}^{3}$

T-bar (constr, mec, met) semifabricat / grindă în T (de obicei din oțel, pt. construcții metalice)

T-beam (constr, mec, met) grindă (cu profil secțiune) în $\mathrm{T}$

T-bend (hidr, OM) teu (la conducte)

T-bolt (mas-un, OM) şurub cu cap ciocan

T-bulb steel (constr, met, nav) otel / semifabricat (profilat) în $\mathrm{T}$ cu cap îngroşat tip naval, oțel-bulb (profilat)

tce (metr, fiz, termo) simbol pentru tonne of coal equivalent, unitate de măsură pentru energie, utilizată în industria energetică: 1 tce reprezintă energia degajată prin arderea unei tone (metrice) de cărbune, echivalentă cu 29,308 GJ sau 8,141 MWh

tea (bot) (frunze, plante de) ceai; (alim) ceai (băutură), fiertură, infuzie, tizană, zeamă (de carne etc.); a bea ceai; a trata cu ceai

tea biscuit (alim) biscuit / prăjiturică pentru ceai tea board (alim) tavă de servit ceai

tea caddy (alim) cutie de ceai

tea cake (alim) prăjitură pentru ceai, brioșă (cu unt) teach (edu) a preda (carte / învățătură); a învăța (pe alții), a instrui; a da lecții; a deprinde, a învăța (cu); a face să înțeleagă / să deprindă; a dezvăța, a dezobişnui (de un lucru); a fi profesor; a exercita profesia didactică; a fi instructiv

teach-in conferință urmată de discuții / dezbateri teaching line materie, specialitate, disciplină (pe care o predă un profesor)

teaching staff (edu) corpul didactic

teacupful (metr, alim) unitate tradițională britanică de măsură pentru volum, pentru fluide, în rețete culinare, linguriță (de ceai): 1 teacupful $\sim 137,7 \mathrm{ml}$

tead nip stopper (TH, OM) dispozitiv de strângere a cablului din fire de oțel

tea equipage (alim) serviciu de ceai

tea grower (agr) plantator / cultivator de ceai

tea leaf (bot, agr) frunză de ceai; ( $p l$, tea leaves) (infuzie de) ceai slab

team (TH, ec) grupă, echipă (de muncitori), brigadă; (agr) atelaj (de vite), (pereche de) vite înhămate / înjugate; a înjuga, a înhăma

teaming (constr) lucrare angajată de un antreprenor; lucru în echipă, formare e unei echipe

team mate coleg de echipă

team up with a se alia / a se uni / a se înhăita cu team work (ec) lucru în echipă / în colectiv / pe bandă rulantă; muncă în echipă; cooperare, conlucrare, colaborare; eforturi comune 
tea-pot ladle (met) oală de golire prin sifon tear lacrimă; (mec) ruptură; rupere; întrerupere; (mas-un, T) uzură (prin sfâşiere), roadere, uzare, tăietură, deșirare (la textile, compozite fibroase etc.); defect (la o stofă); (met) fisură a (se) rupe, a smulge; a lua cu de-a sila; a crăpa, a físura, a întrerupe; a (se) sfâşia (haine, pânză); a tăia; a (se) smulge; a se rupe (din cauza uzurii), a se destrăma (d. textile, compozite cu fibre lungi etc.); a se uza (repede); to pieces a rupe / a sfâşia în bucăți, a face bucăți / praf; ( at) a trage, a apuca (de); (fig) a distruge, a strica, a face praf, a dezbina, a despărți, a împărți în două (tabere)

tearable deşirabil, care se rupe uşor (d. fire, folii, materiale plastice, textile etc.)

tear at a trage de, a rupe, a sfâşia

tear-and-wear (met, T) uzură (prin tragere şi sfâşiere)

tear apart test încercare / test la desprindere (a îmbinărilor lipite / sudate în puncte, a foliilor din materiale plastice etc.)

tear asunder a rupe, a străpunge rupând, a sfâşia în bucăți

tear down a da jos, a smulge, a scoate, a rupe (de pe perete etc.)

tear gas (chim) gaz lacrimogen

tearing metoda secționării; (met) tăierea marginilor (la laminare); sfâșiere a imaginii / a unei țesături; sfâşiere, rupere, smulgere, îndepărtare; v. tearable: care sfâşie / rupe istovitor, epuizant; chinuitor; puternic, extrem, culminant; to be in a $\sim$ fashion a fi turbat / furios la culme; go fine a se îmbraca bine / elegant; (fam) scos din pepeni; (d. glas) strident, ascuțit; imoral, stricat

tearing initiation (mec, plast) inițierea sfâşierii tearing length (mec, met) lungime de rupere (prin sfâşiere sau forfecare)

tearing-off (met, plast) izolare (şi prin secționare, (s)fâssiere etc.)

tearing resistance (met) rezistență la apariția crestăturilor / fisurilor la / de margine

tearing strength (mec, plast) rezistență la sfâşiere tearing strength test (met, plast) încercare la rupere prin sfâşiere / smulgere

tear-off (d. pagină) detaşabil; perforat

tear off a rupe, a sfâşia, a smulge, a detaşa prin sfâşiere; perforat, detaşabil (şi d. o foaie)

tear open (mec) a deschide prin rupere / sfâşiere (la recipiente pt. medicamente etc.)

tear-out (c) rupere / deşirare a unei imagini; (mec) smulgere, scoatere cu forța / forțată

tear out a detaşa, a rupe, a scoate forțat, a smulge (o foaie etc.); a sustrage, a fura tear plate (met) placă cu urme de smulgeri / sfâşieri (pe margine)

tear-proof (met, plast, T) rezistent la uzură, rezistent la sfâşiere / la forfecare; indeşirabil (d. fire, textile, compozite cu fibre lungi etc.)

tear propagation (mec, met, plast) propagarea sfâşierii

tear resistance (mec, met, plast) rezistență la sfâsşiere / rupere (d. table, folii, textile etc.)

tear-shaped în formă de lacrimă

tear-sheet pagină / foaie / filă ruptă dintr-o revistă, carte etc.

tear strength (mec, met, plast) rezistență la sfâşiere (folii şi stratificate, țesături etc.)

tear up a rupe (şi prin sfâşiere, forfecare) în bucăți, a face bucăți; a smulge; (agr) a smulge din rădăcini, a dezrădăcina; (constr) a scoate (pavajul); a întoarce pe dos

tease a pluşa tesătura; a desface; a destrăma, a defibra materiale textile, a scămoşa, a pieptăna, a dărăci, a melița; a scărmăna material fibros; a sâcâi, a hărțui, a tracasa, a plictisi

teasel darac, maşină de dărăcit; (textile) a dărăci, a pieptăna, a lânoşi

teasl(I)er (mas) dărăcitor, lucrător la darac / care dărăceşte lâna

teasel frame (mas, textile) ramă / cadru / batiu de darac

teaser reclamă, anunț publicitar, reclamă anonimă (pt. stârnirea curiozității); (fig) problemă / chestiune dificilă / spinoasă

tea spoon (alim) linguriță de ceai / de cafea

teaspoonful (cantitate care încape într-o) linguriță de ceai / cafea; teaspoon, teaspoonful (tsp, t) (metr, alim) unitate de măsură pentru volum, utilizată în rețete culinare, linguriță (de ceai): 1 teaspoon (US) $\sim 4,9 \mathrm{ml}, 1$ teaspoon (Canada) $4,74 \mathrm{ml}, 1$ teaspoon-ful $(\mathrm{UK}) \cong 3,55$ $\mathrm{ml}, 1$ medical teaspoonful $(\mathrm{UK}$, în medicină $)=$ $5 \mathrm{ml}$; în sistem metric (Canada, Australia și Noua Zeelandă), 1 teaspoonful $=5 \mathrm{ml}$; (metr) unitate de măsură pentru volum, utilizată în baruri, în US: 1 teaspoon $\cong 3,7 \mathrm{ml}$

teat (mas-un) adaos turnat; (OM) fus (de ghidare), cep, bosaj, pivot

teat drill (mas-un) burghiu cu fus de centrare / de ghidare

tea tray tavă pentru (servit) ceai

tebi- (Ti-) (metr, inf, c) prefix binar, pentru $2^{40}=$ 1099511627776 ; contractie de la „terabinary”

Technetium (Tc) (chim) tehnețiu

technetronic influențat de tehnica modernă, tehnotronic

technic $v$. technical 
technical tehnic; formal; $(p l)$ terminologie tehnică; detalii / amănunte tehnice

technical adviser $(\mathrm{TH})$ consilier tehnic

technical assistance (TH) asistență tehnică

technical atmosphere (at) (metr, mec, fiz, hidr) unitate de măsură pentru presiune, atmosferă tehnică: 1 technical atmosphere $\cong 98,0665 \mathrm{kPa}$

technical conditions / specifications $(\mathrm{TH}, \mathrm{mas})$ condiții / specificații tehnice

technical control control tehnic

technical expression termen tehnic

technicality chestiune de specialitate / măruntă / de amănunt, parte / latură tehnică (a unei probleme); amănunt / detaliu; tehnicitate; ( $p l$, technicalities) terminologie / tehnică specială technical journal revistă tehnică

technically $(a d v)$ (din punct de vedere) tehnic

technicalness tehnicitate, caracter tehnic; (înaltă) specializare, înaltă calificare; tehnicizare

technical office $(\mathrm{TH})$ birou de proiectare

technical officer / official (TH) inginer proiectant (fără a preciza specializarea)

technical order(s) (mas-un, $\mathrm{TH}$ ) prescripții tehnice technical regulation(s) / requirement(s) (masun, $\mathrm{TH}$ ) condiții tehnice

technical revision (mas, TH) revizie tehnică

technical staff personal tehnic

technician (TH) tehnician

technics v. technique tehnică, tehnologie, stiințe tehnice

technique tehnică, tehnologie; procedeu; metodă (tehnică)

technique of least squares (mat, TH) tehnica metoda celor mai mici pătrate

technocracy tehnocrație

technocrat tehnocrat, adept al puterii tehnicii în societatea modernă

technocratic tehnocratic, referitor la puterea / influența tehnicii în societatea modernă

technological tehnologic, tehnic

technological restraint $(\mathrm{TH})$ restricție / condiție / condiționare / limitare tehnologică

technologist $(\mathrm{TH})$ tehnolog, tehnician de înaltă calificare, specialist în tehnică

technology tehnologie; tehnică, ştiințe tehnice / aplicate

technology of metals (met) tehnologia metalelor tectiform (constr) în formă de acoperiş

tectonic (geol) tectonic; (constr, arhit) arhitectonic, de construcție

tectonics (geol) tectonică; ştiința construcțiilor

tectorial acoperitor, învelitor; care înveleşte sau acoperă

ted (agr) a întoarce, a afâna (fânul) tedder (agr, mas) maşină de întors fânul tedge (met) pâlnie de turnare

tedious plictisitor, anost, plicticos; obositor, supărător, incomod; $(a d v)$ încet, dificil, care ia mult timp

tediously $(a d v)$ (în mod) plictisitor / obositor

tediousness plictiseală, caracter plicticos / plictisitor; încetineală obositoare, tărăgănare, zăbavă, tărăgăneală; oboseală

tee (constr, OM) profil / semifabricat (în) T, teu; (hidr) racord în $\mathrm{T}$ (cu trei căi); a deriva; a ramifica; litera t; to a $\sim$ exact, precis; obiect în formă de T; $(\mathrm{TH})$ în formă de T

tee across a (se) bifurca, a (se) ramifica, a monta în punte (el, în telefonie)

tee (bar / iron) (OM, met) profil $\mathrm{T}$

tee-conduit, T-piece / -pipe (OM, hidr) teu (de conducte)

tee-head bolt with nip (OM, mas-un) şurub cu cap ciocan, cu nas

tee joint (constr, met, OM) teu de derivație, îmbinare în $\mathrm{T}$

teem (met) a turna, a umple (forma)

teem downhill (met) a turna direct

teemer (met) turnător (muncitor), instalație de turnare

teeming (met) turnare (şi din oală, în lingotieră)

teeming bay (met) hală de turnare

teeming ladle (met) oală de turnare (si cu dop / cu sertar)

teeming lap (met) pojghiță la suprafața metalului topit

teeming nozzle (met) pahar / ajutaj de scurgere teeming platform (met) platformă de turnare teeming rate (met) viteză de turnare

teeming temperature (met) temperatură de turnare teem off (met) a turna (dintr-o oală în alta etc.)

tee piece (hidr, OM) teu (la conducte)

tee rest (mas-un) suport (pt. mână) în (formă de)

tee slotting tool (mas-un) cuțit de raboteză pentru canale în $T$

tee-steel bar (met, constr) profil / bară / semifabricat-bară în (formă de) T, din oțel

teeth (mas-un) tăierea dinților, danturare, dințare, dinți, dantură; a dantura; a zimțui

teething (mas-un) tăierea / formarea/ prelucrarea dinților (şi prin aşchiere), (procedeu / tehnologie de) danturare

tee together (el, hidr) a lega în paralel

tee-welding $(\mathrm{OM}$, met) sudură de colț (şi în puncte) tee with side outlet $(\mathrm{OM}$, hidr) teu cu ramificație (laterală)

teflon (plast) denumire comercială pentru politetrafluoretilenă (PTFE) 
teleadjusting (autom) telereglare, reglare de la distanță

telebreaking (autom) întrerupere comandată (de la distanță) / telecomandată

telecamera (electr, opt) cameră de televiziune; aparat / cameră pentru telefotografie

telecast (TV) a televiza, a transmite la televizor

telecommunication telecomunicații

teleferic teleferic

telegram telegramă

telescope jack $(\mathrm{OM})$ cric telescopic

telescope mount (OM, mas) suport / montaj telescopic

telegraph telegraf; semafor; a telegrafia

telegraphic telegrafic; pe scurt, sumar (d. o prezentare etc.)

telegraph money order mandat telegrafic

telegraphy telegrafie, telegrafiere

telemechanics telemecanică

telemeter (metr) telemetru

telemetry telemetrie

telephone, $(\mathrm{fam})$ phone telefon; a telefona, a da un telefon; by $\sim$ prin telefon, telefonic; on the

$\sim$ telefonic, prin telefon; ring up smb. on the

$\sim$ a suna pe cineva la telefon; be on the $\sim$ a fi la telefon; $\sim$ box cabină telefonică; exchange centrală telefonică, număr de telefon

telephone book carte de telefon

telephone booth / box cabină telefonică

telephone call convorbire telefonică

telephone line linie telefonică; cablu telefonic

telephone number număr de telefon

telephonic telefonic

telephony telefonie

telescope telescop; lunetă; sac de voiaj (din două părți îmbinate); (TH) a (se) telescopa (şi d. cilindri hidraulici); (cf) a (se) ciocni de, a intra în, a (se) strivi; a rezuma

telescopic (mas-un, OM) telescopic; făcut prin telescop; (astronomie) vizibil numai prin telescop; care poate fi telescopat, care intră unul în altul; rabatabil

telescopic funnel (nav) coș de vapor rabatabil / care poate fi telescopat

telescopic jack (OM) cric telescopic

telescopic leg (el, OM) picior / contrafișă / cric telescopic $(\breve{a})$

telescopic observation (fiz) observare / observație prin telescop

telescopic pipe / tube (hidr, OM) tub / țeavă / conductă telescopic $(\breve{a})$

telescopic series (mat) serie de forma

$$
\sum_{n=0}^{\infty} 1 /[(k+n)(k+n+1)]
$$

telescopic shaft (mas-un, OM) arbore / ax telescopic

telescopic shock absorber (cf, OM) amortizor telescopic (obținut şi prin gruparea în paralel a arcurilor elicoidale concentrice)

telescopic shock course (OM) cursă telescopică (a arcului amortizor / a amortizorului de şocuri) (şi la grupări de arcuri)

telescopic tube $(\mathrm{OM})$ tub / teavă telescopic( $\breve{a})$

telescoping (met, hidr) telescopicitate (la rulouri de tablă şi la cilindri hidraulici cu pistoane telescopice)

teleswicthing (autom) comutare telecomandată, telecomutare

televiewer (TV) telespectator

televise (TV) a televiza, a transmite la televiziune / la televizor

television (TV) televiziune; TV

televisional (TV) televizat, transmis prin televiziune; (prezentat) la televiziune

television set (TV) televizor (aparat)

television viewer $v$. televiewer

televisor $v$. television set

tell a indica (verbal), a arăta, a spune, a zice; a povesti, a relata; a vorbi; a comunica, a anunța, a informa de / despre, a pune la curent cu; a exprima; a învăţa, a deprinde, a obişnui (cu un lucru); a descrie, a prezenta, a înfătișa, a expune; a dezvălui, a proclama; a ghici, a discerne, a simți, a vedea; a recunoaşte, a identifica; a şti, a prevedea, a prezice, a garanta; (d. ceas) a indica, a arăta; a bate (ora); a porunci, a ordona, a comanda (să); a invita, a ruga (să); a socoti, a număra; of, about a povesti, a spune despre; a fi sigur; a actiona, a-şi produce efectul asupra; a anunța (o veste); a număra; from a deosebi de (on) a-şi produce/face efectul

tellable care poate fi spus / povestit; demn de a fi povestit; comunicabil

tell off a repartiza, a desemna; a indica, a numi; (fig) a-l pune la locul lui / în banca lui

tell on a influenta, a afecta, a avea influență / a acționa / a-şi produce efectul asupra, a avea efect / urmări asupra

telltale (device) (metr) indicator de nivel (în afara rezervorului); aparat / dispozitiv de înregistrare / de semnalizare / de control; contor; ceas de control; (nav) axiometru, indicator al pozitiei cârmei

telltale board (mas) tablou / panou indicator / de control

telltale pointer (metr) ac indicator

tellurate (chim)sare telurică

telluric teluric, terestru, pământesc 
telluride (chim) compus al teluriului cu un element electropozitiv

tellurite (chim) (minrl) compus al teluriului

Tellurium (chim) telur, teluriu (Te)

tellurous (chim) (minrl) teluros, legat de teluriu

tellurium bronze (met) bronz cu teluriu

tellurium copper (met) aliaj $\mathrm{Cu}-\mathrm{Te}$

telpher (mas, el) palan electric cu cărucior

temper (chim, met) amestec, combinație; (met) duritate (şi maximă / care nu poate fi crescută după un tratament termic sau deformare), tărie, consistență, călirea / revenirea oțelului, grad de călire; caracter, fire, temperament; dispoziție (trecătoare), toană, toane, capriciu; calm, liniște, echilibru; (met) a căli, a oțeli, a detensiona, a tempera, a ameliora, a reveni (a reîncălzi după călire), a recoace, a modera; a amesteca; (alim, ind chim, plast) a întări, a frământa, a malaxa, a aduce la consistența dorită; a umidifica, a muia; a tempera, a potoli, a linişti, a calma, a alina; a reglementa, a regula, a pune în ordine; a adapta; a se potoli, a se tempera; a deveni moderat sau conciliant / înțelegător

temperable (met) călibil, care poate fi călit, uşor de călit; (alim, ind chim) uşor de amestecat, care poate fi bine amestecat; miscibil

temperament $\mathrm{v}$. temper amestec, compoziție; structură, stare

temperamental temperamental, de caracter, constitutional; caracteristic pentru un anumit temperament; instabil, uşor influențabil

temperance temperanță, sobrietate, cumpătare

temperate (met) temperat, revenit, tratat termic (prin revenire); moderat; sobru, cumpătat

temperate distribution (mat) funcție de repartiție cu creştere lentă, distribuție temperată (în teoria probabilităților)

temperateness moderație, temperanță

temperate zone (met) zonă temperată / revenită

temperature (fiz, termo) temperatură, căldură; (med) temperatură, febră

temperature alarm (met, plast, termo) semnalizare de supraîncălzire / de depăşire a temperaturii (dorite)

temperature balance (fiz, termo) echilibru de temperaturi, bilanț termic

temperature bath (met) baie de revenire (care se menține la o anumită temperatură)

temperature bulb (metr) bulb de termometru

temperature coefficient (termo, T) coeficient de temperatură

temperature colour scale (met) scară a temperaturilor după culoare (la tratamente termice, la oțeluri) temperature-compensated device (autom, termo) dispozitiv stabilizat termic / cu compensare termică

temperature-compensating device (autom, termo) dispozitiv pentru compensare termică

temperature constancy (fiz) constantă de temperatură

temperature control (autom, termo, metr) controlul / reglarea temperaturii

temperature control knob (auto) buton pentru controlul temperaturii

temperature controller / control apparatus / equipment (autom, termo) regulator de temperatură, echipament / inslație / sistem de control al temperaturii

temperature conversion (metr) conversia temperaturii (dintr-un sistem de măsurare în altul)

temperature correction (fiz, autom, metr) corectie de temperatură

temperature cycle stressing (met) solicitare termică ciclică (și cu şocuri periodice), solicitare (mecanică) variabilă cauzată de variația ciclică a temperaturii

temperature delay / leg (fiz, termo) inerție termică temperature dependance (fiz, termo) dependență de temperatură

temperature detector (metr) traductor de temperatură, termometru

temperature difference (fiz, termo, T) diferență de temperatură

temperature distribution (fiz, termo, $\mathrm{T}$ ) distribuție de temperaturi

temperature drop (fiz, hidr, termo, T) cădere / gradient / diferență de temperatură

temperature effect (fiz, termo, $\mathrm{T}$ ) efect al temperaturii, efect termic

temperature error (metr, met) eroare de temperatură

temperature factor (mec, fiz, termo, T) factor de temperatură

temperature fall (fiz, termo, T) (s)cădere / diferență de temperatură

temperature field / pattern (fiz, termo, met) câmp de temperatură

temperature fluctuations (fiz, termo, $\mathrm{T}, \mathrm{TH}$ ) variații de temperatură

temperature function (fiz, termo, T) functie de temperatură (care satisface ecuația căldurii)

temperature fuse (termo, el, ind chim) siguranţă termică

temperature gauge (metr) indicator / senzor de temperatură

temperature gradient (fiz, termo, $\mathrm{T}$ ) gradient de temperatură 
temperature-gravity curve (fiz, T) curbă de variație a densității în funcție de temperatură, curbă temperatură-densitate

temperature - (specific) gravity graph (fiz, termo) nomogramă de temperatură - densitate / de variație a densității în funcție de temperatură temperature-humidity index $(\mathrm{TH})$ indice / factor al efectelor (dăunătoare) ale temperaturii şi umiditătii

temperature increase (fiz, termo, T) creştere / ridicare a temperaturii

temperature indication (fiz, metr) indicarea temperaturii

temperature indicator (met, metr) indicator de temperatură, creion termic

temperature interval / range (met) interval de temperatură

temperature lag (fiz, met, plast, termo, met) inerție termică

temperature limit limită de temperatură

temperature loss (fiz, ind chim, met, plast, termo) pierdere de căldură

temperature measurement / measuring (metr) măsurarea temperaturii (metodă şi rezultat)

temperature measuring apparatus / instrument (metr) aparat pentru măsurarea temperaturii

temperature of combustion (, fiz, auto, termo) temperatură de combustie / de ardere

temperature of inflammability ( $\mathrm{TH}, \mathrm{fiz}$, termo) temperatură de inflamabilitate

temperature of quench(ing) (met) temperatură de călire

temperature of reaction (chim, plast, met) temperatură de reactie

temperature of saturation (alim, ind chim, plast, met) temperatură de saturație

temperature of self-ignition (chim, met) temperatură de autoaprindere

temperature of solidification (chim, fiz, met) temperatură de solidificare

temperature overshoot (chim, met) exces / depăşire de temperatură

temperature plug (metr) termocuplu

temperature-pressure curve (fiz, T, TH) curbă de variație a presiunii în functie de temperatură, curbă temperatură-presiune

temperature range (termo, ind chim) domeniu / interval de temperatură

temperature recorder (metr, autom) termometru înregistrator, termograf

temperature regulation reglarea temperaturii

temperature regulator (autom) regulator de temperatură

temperature relay (autom) releu de temperatură / termic temperature-resistant termorezistent (materiale plastice, ceramice, aliaje)

temperature-responsive / -dependent (material / proces / fenomen) dependent de temperatură, sensibil la temperatură

temperature rise (fiz, termo, ind chim) ridicare / creștere a temperaturii

temperature rundown (met, ind chim) scăderea controlată a temperaturii

temperature setting (auto) setarea temperaturii temperature stability (autom, fiz, termo) stabilitate termică / a temperaturii

temperature strain (fiz, met, plast) deformație termică / din cauza temperaturii, tensiune indusă de temperatură / de variația temperaturii

temperature stress (mec) solicitare de temperatură / datorată temperaturii

temperature switch (autom, el, termo) regulator (cu întrerupător sau comutator) de temperatură temperature-time factor (plast, $\mathrm{T}$, hidr) factor de temperatură-timp (si la vâscozitate)

temperature variation variație de temperatură

temperature-viscosity curve (fiz, T) curbă de variație a vâscozității în funcție de temperatură, curbă temperatură-vâscozitate

temper brittleness (met) fragilitate de revenire temper carbon (met) arderea carbonului, grafit de recoacere, carbon de revenire

temper-carbon nodule (met) cuib / nodul de grafit de recoacere

temper casting (met) fontă maleabilă

temper (drawing) colour (met) culoare de revenire

tempered (met) revenit; (TH şi fig) călit, oțelit; temperat

tempered glass (ind chim) sticlă călită şi revenită tempered hardness (met) duritate după revenire (a unui aliaj metalic)

tempered steel (met) oțel revenit

tempered super hardboard (ind chim, plast) placă extradură (d. compozite polimerice cu fibre)

temper etch (met) atac prin oxidare la cald (pt. analiză metalografică a probelor)

temper furnace (met) cuptor de revenire

temper graphite (met) grafit de recoacere

temper hardening (met) călire cu revenire (ulterioară), durificare după / prin revenire

temper heat of iron (met) temperatură / căldură (energie) de revenire la albastru

tempering temperare; (met) revenire (după călire), răcire lentă, detensionare; încălzirea sticlei sub punctul de topire

tempering agent (met) substanță / agent de revenire (poate fi şi de călire) 
tempering air (met) aer de răcire (la tratament termic de revenire)

tempering bath (alim, ind chim) baie de întărire a gelatinei; (met) baie de revenire (după călire / cementare)

tempering brittleness (met) fragilitate la revenire tempering charge (met) şarjă de revenire (la un cuptor)

temper(ing) colour (met) culoare de revenire tempering compound (met) substanță de călire tempering flame furnace (met) cuptor de reverberație pentru călire şi revenire (cu flacără)

tempering furnace (met) cuptor de revenire (după călire)

tempering heat (met) căldură de / necesară la revenire

tempering liquid (met) lichid pentru tratament de revenire

tempering medium (met) mediu de revenire tempering oil (met) ulei de / pentru (tratament de) revenire

tempering operation (met) operație de revenire tempering process (met) proces / procedeu de revenire (după călire)

tempering quality (met) capacitatea unui aliaj de a reveni / de a suporta o revenire

tempering range (met) domeniu / interval (de temperatură) de revenire

tempering shortness (met) fragilitate la revenire tempering steel (met) oțel îmbunătătit (călit și revenit)

tempering temperature (met) temperatură de revenire

tempering water (TH, met) apă de stins incendii / var

temper mill (met) laminor pregătitor

temper pass rolling (met) dresare, laminare la presiune mică

temper pass rolling mill (met) laminor de dresare

temper rolling (met) laminare inițială / primară, dresare

temper scale (met) țunder (format la revenire)

temper screw (mas-un, OM) şurub de reglare / de slăbire

temper stand (met) cajă pregătitoare / pentru dresare

temper troostite (met) troostită de revenire

tempest furtună, vijelie, uragan; (d. mare) a se zbuciuma, a se agita; a vui, a vâjâi

tempestuous furtunos, vijelios, sălbatic, violent; impetuos

tempilstick (metr, met) creion de temperatură cu reacție vizibilă într-un anumit interval de temperatură

template (OM, metr) model, şablon, leră, calibru; (met) a forma cu şablonul template casting (met) turnare cu şablon template follower (mas-un) şablon de copiere / de copiat

template gauge (metr) calibru pentru filet exterior template guide (mas-un) ghidarea sculei după şablon

template moulding (met) formare cu şablonul template pipe (mas, OM) fiting, piesă de racord templates in lockmaking (met) stanță de decupat cu ghidaj

temple (mas-un) placă de presiune / de reținere templet (constr) pană (a acoperișului); (mas, masun) şablon, model, tipar, calibru, placă de reazem, leră, florar; (met) a forma după şablon templet curve florar

templet milling (mas-un) frezare după şablon / prin copiere

templet pipe (mas-un, OM) fiting, tub profilat, racord

tempo ritm

temporal temporar, vremelnic, trecător; de timp; temporal, referitor la tâmplă

temporally $(a d v)$ în timp

temporarily $(a d v)$ temporar

temporary temporar, provizoriu; improvizat; auxiliar; vremelnic, efemer, trecător

temporary bridge legătură temporară / provizorie

temporary bottom (met) dop temporar (la oala de turnare)

temporary current surge (el) şoc scurt de curent

temporary file (c) fişier temporar

temporary earth (el) instalație temporară de legare la pământ

temporary hardness (met, plast) duritate temporară

temporary line fault (el) punere la pământ trecătoare / temporară

temporary repair (mas) reparație curentă

temporary result $(c$, mat) rezultat intermediar

temporary set (mec, plast) deformare elastică / temporară

temporary storage memory (c) memorie intermediară / de stocare temporară

temporary working storage (c) memorie temporară / de lucru

temporization ( $\mathrm{TH}$, autom) temporizare (si nedorită, a unui proces tehnologic etc.); tărăgănare, amânare (veşnică), şovăială, ezitare, codeală

temporize a căuta să câştige timp, a tărăgăna; (autom) a temporiza; a amâna, a întârzia, a zăbovi; a ezita, a şovăi, a se codi; a se adapta vremurilor şi împrejurărilor 
temporizer persoană care temporizează / întârzie / amână; obstrucționist, persoană care face obstrucții; (autom) temporizator

ten nota zece; grup de zece

tenable trainic; durabil, solid; utilizabil, folositor, util; justificabil, care poate fi susținut / apărat; destoinic, capabil, bun

tenacious tenace, dârz, stăruitor, perseverent; persistent; lipicios, adeziv, aderent; (TH) tenace, rezistent la rupere

tenaciousness $\mathrm{v}$. tenacity

tenacity (met, mec) tenacitate, vâscozitate, adezivitate, aderentă, caracter lipicios; perseverență; persistență; soliditate, durabilitate

tenant (agr) (țăran / fermier) care ia în arendă o parcelă de moşie; fermier-arendaş; chiriaş, locatar; a arenda, a lua cu arendă; a închiria, a lua cu chirie

tenantable gata de a fi închiriat sau arendat; (d. casă) locuibil

tenantless de închiriat, liber, fără locatar

tend a tinde; a se apropia mult; a duce, a se îndrepta; a (se) întinde într-o anumită direcție, a dirija, a îndruma, a îndrepta; (nav) a evita (la ancoră); a conduce, a întovărăşi; a mâna (vite, oi); (med) a veghea, a avea grijă de (un bolnav etc.); a se interesa de, a-i păsa de; (TH) a supraveghea, a controla, a dirija (o maşină, un aparat)

tendency înclinare, înclinație; direcție; sens; tendință, năzuință, aspirație, pornire; efect rezultat, scop

tendency to corrode (met, plast, hidr) tendință de corodare

tendency to cracking (met, plast, ceramice) tendință de fisurare (a unui material)

tendency to edge cracking (met, plast) tendință de fisurare a marginilor (la laminare)

tendency to flow (met) capacitate de fluidizare, fuzibilitate; (plast) tendintă de curgere

tendency to fracture (mec) fragilitate, friabilitate

tendency to rupture (mec) tendinţă de rupere

tendency to rust (mec, chim) tendință de oxidare / de ruginire (la aliaje feroase)

tendency to ward corrosion (chim) tendință la coroziune

tendentious tendențios, cu tendință

tender (cf) tender; operator; mecanic; remorcă; (ec) ofertă; propunere; (jur) sumă depusă, depozit (pt. o datorie etc.); (ec) mijloc de plată, anexă, deviză, ofertant, monedă; (nav) barcă de serviciu, navă-bază, bază plutitoare; (ind chim) lot de țiței; delicatețe, atenție, considerație; a oferi; a propune, a supune (o ofertă); a furniza; a prezenta, a înmâna; a întinde, a da (demisia, o cerere); (amer) a organiza, a da (o masă în cinstea cuiva etc.); a decerna, a conferi (premii, distinctii); a provoca, a produce, a aduce (o jignire, o mutilare); a (în)muia, a face moale; slab; delicat; nerezistent; moale; gingaş, plăpând, calm, blajin; cu grijă / mănuşi / delicatete; (d. constituție, sănătate etc.) firav, șubred, plăpând, slab; sensibil, delicat, bolnăvicios; (d. o situație) delicat, dificil; impresionabil

tender clause (ec) clauză a ofertei

tenderer (ec, jur) ofertant, persoană care-şi ia angajamentul de a respecta clauzele fixate

tender for (ec) a cere, a solicita (un împrumut etc. în anumite conditii)

tenderize (alim) a frăgezi (carnea)

tenderloin (alim) (amer) (filé) de muşchi

tenderness frăgezime, delicatețe; blândețe; sensibilitate; grijă, prudență, chibzuială

tender of payment (ec) ofertă de plată

tender ship / vessel (nav) navă instabilă

tender subject problemă spinoasă / grea / dificilă; subiect delicat

tendinous vânos, cu vine; cu tendoane; (fig) atos tendon (alim) tendon (la carne)

tendril (agr, bot) cârcel, lujer; cătărător, urcător

tend to a fi înclinat / aplecat să, a se înclina spre / către; a fi îndreptat, a se îndrepta spre / către; (fig) a avea o înclinaţie / tendință / pornire spre / către; a tinde spre / către; a avea tendința de a / să, a tinde să

tend upwards (ec, fiz) a tinde să crească (d. prețuri, parametri etc.)

tenement proprietate / moşie arendată; casă / proprietate închiriată; casă de raport; apartament în locuințe ieftine / într-o casă de raport; (jur) privilegiu permanent, posesiune permanentă

tenemental arendabil, de închiriat, care se poate închiria / arenda

tenet teorie; doctrină; învățătură, dogmă, teză, principiu (de bază); (fig) părere, opinie

tenfold înzecit, de zece ori (mai mult)

tenne maro, castaniu

tenner (bancnotă de) zece lire; (amer) (bancnotă de) zece dolari; (cifra) zece

tennis (sport) tenis

tennis ball (sport) minge de tenis

tennis court teren de tenis

tennis ground $v$. tennis court

tennis net (sport) plasă pe terenul de tenis, plasă de tenis

tennis racket (sport) rachetă de tenis

tennis shoes (sport) pantofi / încălțăminte de (jucat) tenis; ( $\mathrm{fam}$ ) tenişi

tenon (cf) scoabă de traversă; (OM) pană de fixare, călcâi, prezon, știft, gheară de fixare; a îmbina cu cep; (constr) cep, îmbinare, fus, diblu tenon joint (constr, OM) îmbinare cu cep 
tenon saw (mas-un) ferăstrău de mână cu spinare pentru metale sau pentru tăiat cepuri

tenor curs, scurgere, trecere, direcție; succesiune; conținut / sens general; tendință; v. temper

tenour conținut (al unui document); (ec) scadență (a unei cambii); copie, duplicat

tense încordat, întins, tẹapăn; (fig) iritat, agitat, încordat, sub tensiune; (gram) timp (al verbelor)

tenseness încordare, întindere, rigiditate

tensible tensionabil

tensided (mat) decagonal, cu zece fețe

tensile extensibil, care se poate întinde; (fiz, mec) ductil, rezistent la întindere / tracțiune / rupere la tractiune; solicitat la efort mecanic (fără a specifica tipul efortului sau implicit, de tractiune); tensionat

tensile bending test (mec) încercare de rupere la tensiune prin / de încovoiere

tensile breaking strength $(\mathrm{mec})$ sarcină de rupere, rezistență la rupere prin tracțiune

tensile elongation (mec) (a)lungire la întindere / la tractiune

tensile fatigue test (mec) încercare la oboseală la tracțiune (fără specificarea solicitării variabile, atentie la text)

tensile force (mec) forță / sarcină de tractiune / de întindere

tensile impact stress (mec) tensiune / efort cauzat de solicitare la rupere prin lovire / prin şoc, tensiune rezultată la şoc

tensile-impact test (mec, plast, ceramice) încercare / test de rupere prin cădere / prin impact

tensile limit (mec) limită de rezistență la tracțiune (poate fi limită de curgere sau de rupere, fortă / sarcină limită; atenție la text!)

tensile load (mec) sarcină / forță / încărcare / solicitare de / la tractiune

tensile properties (mec) proprietăți mecanice (determinate, de obicei, la tractiune)

tensile-reinforcing bar (constr, mec) bară de armare / de întărire, solicitată la tracțiune

tensile shock test (met) încercare / test de rupere la tracţiune prin şoc (pt. orice material)

tensile state (mec) stare de tensiuni

tensile steel (met) oțel cu rezistență ridicată la tracțiune

tensile strain (mec) deformație de / la întindere / tractiune

tensile strength $(\mathrm{mec})$ rezistență la tractiune / la întindere / la rupere prin tractiune

tensile stress (mec) efort / de tractiune / de întindere

tensile-stress intensity $(\mathrm{mec})$ intensitatea efortului unitar la tracțiune tensile test (mec) încercare / test la întindere / la tracțiune; probă de rezistență la rupere prin întindere / tracțiune

tensile-test across the rolling (mec, met, plast) încercare la tracțiune pe direcție transversală / perpendiculară pe cea de laminare

tensile-test bar / piece / specimen (mec) epruvetă pentru încercare la tracțiune

tensile-test(ing) machine (mec) maşină de încercat la tracțiune, maşină-dinamometru

tensile yield (mec) cedare elastică, relaxare

tensile yield limit / stress (mec) limită de curgere la tracțiune

tensility caracter extensibil; (fiz, mec) ductilitate

tensimeter (metr) aparat de măsurat presiuni diferentiale de vapori

tensiometer (metr) tensometru, extensometru

tension (fiz) tensiune, efort (şi în lichid); (mec) tensiune, efort, elasticitate, întindere, încordare; extensibilitate; tractiune; (el) tensiune, intensitate, voltaj; tensiune (a firului); (plast) extensie / extensiune a firului; a întinde, a tensiona

tensional (fiz, $\mathrm{TH}$ ) de tensiune, referitor la tensiune / întindere / încordare; (constr) structural, de structură

tensional bar / member (mec, constr, OM) tirant, bară tensionată

tensional load (constr, mec) sarcină de tracțiune / de întindere

tensionally connected (mas, mec) cu contact forțat, montat tensionat

tensional member (mec, constr, OM) tirant / element (de fermă metalică) / bară tensionat( $\breve{a})$ la întindere / tractiune, element / bară de preluare a sarcinii pe direcție axială

tension bar (mec, constr, OM) tirant, bară tensionată; (cf) bară de tensionare a sabotului

tension bridge pod suspendat / în formă de arc

tension bridle (met) dispozitiv de întindere (cu bridă / inel / bucşă) (şi la maşina de încercat la tractiune)

tension brittleness (mec, met) fragilitate cauzată de tensiuni interne

tension carriage (ind chim, mas, OM) cărucior / dispozitiv glisant pentru întinderea benzii de cauciuc (şi la transportoare de capacitate mare)

tension clamp (constr, OM) clemă de ancorare

tension crack (mec) fisură / crăpătură din cauza tensionării (şi de tracțiune)

tension-cracking (mec, termo) fisurare / crăpare din cauza tensiunii / solicitării mecanice

tension disk (mas, met, plast, ind chim, textile, $\mathrm{OM}$ ) disc de frânare (a firului) 
tension dynamometer (metr) dinamometru de măsurare a tensiunii de întindere

tension-elongation curve (mec) curba tensiune -elongație / deformație relativă (obținută de obicei prin tracțiune)

tensioner (mas) întinzător, dispozitiv de întindere

tension impact $(\mathrm{mec})$ tensiune cauzată de şoc / de lovire

tensioning device (mas, ind chim, met) dispozitiv de întindere (a firului / benzii etc.)

tensioning device for light wires (mas-un) clemă-broască de întins, întinzător de sârmă, cleşte de tras sârmă; (met) cleşte de trefilat

tensioning measuring (metr, OM) măsurarea tensiunii / a tensionării (de exemplu, la rulmenți, la arcuri etc.)

tension load (mec) solicitare / sarcină la tracțiune, forță de tracțiune

tension member (mas, OM) tirant, tijă; (mec) element / bară solicitat( $\breve{a})$ la tracțiune

tension of the strip (met, plast) întinderea / tensiunea / tracțiunea din bandă (la laminare dar şi în benzile de trasportoare)

tension pulley (mas-un, OM) rolă de întindere, întinzător de curea / de bandă

tension regulator $(\mathrm{el})$ regulator / stabilizator de tensiune

tension release (mec) detensionare, detentă

tension rod (auto) tijă de acționare a frânei mecanice; (cf) bară de sabot; (constr, mas-un) bară solicitată la tracțiune, tirant de consolidare

tension roll (ind chim, mas, met, plast, textile) valț / rolă / cilindru de întindere de întindere (a benzii laminate, a foliei, a hârtiei etc.)

tension roller $(\mathrm{OM})$ rolă de întindere

tension screw (OM) şurub de întindere

tension specimen epruvetă / probă de încercare la tractiune

tension spring $(\mathrm{OM})$ arc de tracțiune

tension stress (mec) tensiune / efort de întindere

tension test (mec) încercare / test la întindere / la tractiune

tension testing machine (mec) maşină de încercări la întindere / la tracțiune

tensity $\mathrm{v}$. tenseness

tensometer (metr, opt, el) tensometru, instrument de măsurat alungirea la rupere, traductor de (a)lungire, externsometru

tensometer sensing element (metr) palpator element sensibil la întindere / la (a)lungire, extensometru, traductor pentru sesizarea modificării lungimii

tensor tensor; tensorial

tensor field (fiz) câmp tensorial tent cort; şopron; a locui în cort, a campa; (med) tampon, fitil, meşă; (med) a pune meşă / tampon la (o rană), a ține (o rană) deschisă cu meşa; (alim) vin roşu (de Malaga)

tentacle (zool) tentacul, antenă, corn(uleț) (de melc); (bot) fir exterior, glandă cu tulpină

tentacled (zool) (înzestrat) cu tentacule

tentacular (zool) tentacular

tentaculate $v$. tentacular

tentative de probă / încercare; empiric; experimental; provizoriu, temporar; tentativă, încercare; probă, experiență

tentative experiment experiență / probă / încercare / experiment preliminar(ă) / empiric(ă)

tentative inquiry (ec) cerere de ofertă / de informații pentru luare de contact

tentative offer (ec) ofertă pentru începerea negocierilor

tentative specifications (mas, mas-un) condiții tehnice provizorii / preliminare

tentative standard (specifications) (mas-un) proiect de standard

tent cloth pânză de cort

tenter ramă de întins / de uscat şi întins; a întinde / a atârna cu cârlige (pt. uscare)

tenth al zecelea, zecime, a zecea parte

tenth gauge (metr) calibru de zecimi

tenthmeter (brit), tenthmetre (amer) (fiz, metr) a zecea milionime dintr-un milimetru (unitate de măsură pentru lungime foarte mică), denumire vecehe pentru an angstrom: 1 tenth-meter $=10^{-10} \mathrm{~m}$

tenth-rate foarte prost, de proastă calitate, mizerabil, de mâna a şaptea

tent peg țărus pentru cort

tent pole par, țăruş pentru cort

tent rope frânghie / funie pentru fixarea cortului

tent-stitch cusătură (paralelă) în diagonală

tenuity (fiz) rarefiere (a aerului); subțirime, fluiditate; (fig) insuficiență, sărăcie, penurie; simplitate extremă

tenuous subtire, subtiratic; ( $i g$ ) micut, insuficient; simplu; subtil, fin

tenuous atmosphere (fiz) atmosferă rarefiată

tenure arendă; (jur) (drept de) posesiune / stăpânire; termen de posesiune / stăpânire; ocupare, deținere (a unui post); durata exercitării deținerii (unei funcții)

tenurial (jur) legat de dreptul de posesiune sau de deținere a unui titlu; legat de titularizare; titularizat, titular

tepefaction (fiz, termo) încălzire moderată / uşoară

tepefy (fiz, termo) a (se) încălzi moderat / uşor 
tepid călduț

tequila (alim) techila, băutură alcoolică din America Latină

tera- (T-) (metr) prefix în sistemul metric pentru $10^{12}$, trilion

terabecquerel (TBq) (metr, fiz) unitate de măsură pentru radioactivitate: $1 \mathrm{TBq}=10^{12} \mathrm{dez}$ integrări atomice pe secundă sau 27,027 curie

teraflops (Tflops) (metr, c) unitate pentru puterea de calcul: 1 teraflops $=10^{12}$ operații în virgulă mobilă

teragram ( $\mathbf{T g})$ (metr, astronomie, fiz) unitate de măsură pentru mase mari: 1 teragram $=10^{12} \mathrm{~g}$ sau 1 megatonă

teragram/liter (metr) teragram/litru, unitate de măsură pentru densitate: 1 teragram/liter = $10^{12} \mathrm{~kg} / \mathrm{m}^{3}$

teragram/second (metr, fiz) teragram/secundă, unitate de măsură pentru debit masic: 1 teragram $/$ second $=10^{9} \mathrm{~kg} / \mathrm{s}$

terahertz (THz) (metr, fiz) unitate de măsură pentru frecvență, terahertz: $1 \mathrm{THz}=10^{12} \mathrm{~Hz}$

terajoule (TJ) (metr, fiz) unitate de măsură în sistem metric, pentru energie, utilizată în industria energetică: $1 \mathrm{TJ}=10^{12} \mathrm{~J}$

teraliter (metr) (metr) teralitru, unitate de măsură pentru volum / capacitate: 1 teraliter $=10^{9} \mathrm{~m}^{3}$

terameter (Tm) (metr) unitate de măsură în sistem metric, pentru lungime, teranetru: $1 \mathrm{Tm}$ $=10^{12} \mathrm{~m}=10^{9} \mathrm{~km}$

teranewton (metr) teranewton, unitate de măsură pentru forță: 1 teranewton $=10^{12} \mathrm{~N}$

terannual (metr) (adj) de 3 ori pe an, la fiecare 4 luni

terapascal (metr) terapascal, unitate de măsură pentru presiune 1 terapascal $=10^{12} \mathrm{~Pa}$

terastokes (metr) terastokes, unitate de măsură pentru viscozitate cinematică: 1 terastokes $=$ $100000000 \mathrm{~m}^{2} / \mathrm{s}$

terawatt (TW) (metr) (metr, fiz) unitate de măsură pentru putere, în sistem metric: 1 terawatt hour $=10^{12} \mathrm{~W}$

terawatt hour (TW'h) (metr, fiz) unitate de măsură pentru energie, în sistem metric: 1 terawatt hour $=3,6$ petajoule $(\mathrm{PJ})$

Terbium (Tb) (chim) terbiu, pământ rar

terce treime, a treia parte

terebrate a perfora, a găuri

terebration (TH) pătrundere; perforare; găurire, scobire (şi ca defect)

tergiversate $\mathrm{v}$. temporize

tergiversation v. temporization; şovăială, ezitare, codeală; eschivare, pretext, subterfugiu, tertip; nestatornicie, inconsecvență term (mat) termen, membru, parte, factor, expresie; trimestru; condiție; perioadă, durată, termen (pt. funcție sau întemnițare etc.); (ec) scadență (a unei cambii), dată (limită), ultima zi; capăt, sfârşit; (jur) sesiune judecătorească, a califica, a considera; (edu, univ) trimestru; (univ) semestru $(p l)$ termeni, condiți, clauze, preț, condiții (materiale), acord, înțelegere, compromis, tranzacție, raporturi, relații; termen, element, unitate (de măsură); (fiz) nivel energetic; limită, graniță, noțiune; denumire; notare; (lingv) termen, cuvânt; $(p l) \sim \mathbf{s}$ denumire, nume, expressie, exprimare, $\bmod / \mathrm{fel} \mathrm{de}$ a vorbi, limbaj; (arhit) ornament sculptural; a desemna; a numi; a nota; a denumi; a se intitula, a se numi, a-şi spune, a se da drept (ceva); to come to $\sim \mathbf{s}$ a ceda; make $\sim \mathbf{s} /$ come to $\sim \mathbf{s}$ with smb. a cădea de acord cu cineva; bring to $\sim \mathbf{s}$ a impune condiții; not on any $\sim \mathbf{s}$ cu nici un preț; technical $\sim$ termen tehnic; in $\sim \mathbf{s}$ of law (jur) în termeni juridici; the $\sim \mathbf{s}$ of the treaty (pol, ec) clauzele tratatului; during his of office în timpul activității sale

term by term termen cu termen

terminability (mat) proprietate de a fi mărginit

terminable limitat în timp; urgent, presant, grabnic; determinabil, susceptibil de a fi definit / limitat / încheiat (în timp)

terminableness limitare în timp, urgență, caracter urgent / presant; determinare, definire, specificare

terminal capăt; sfârşit; (mat) ultim, final; (cf) stație terminus / de capăt; (el) bornă, terminal, conexiune, papuc de cablu, picioruş de contact, pol; (OM) ştift; aparat terminal; (nav) chei de descărcare, port de destinație; (inf) (echipament) terminal / destinat comunicării între utilizator şi sistemul de calcul; hotarnic, de hotar; terminal, de încheiere; definitiv, ultim; (med) fatal, mortal, letal, fără vindecare, necruțător; (cf) terminus, ultim, gară / stație terminus; trimestrial; punct final / terminal; (amer) cap de linie; (av) aerogară; v. termination

terminal amplifier (el, telefonie, radio, autom) amplificator final / de ieşire

terminal binding post / screw (el, OM) bornă filetată / cu şurub (şi lipită)

terminal block / box (el) cutie / placă cu borne / terminală

terminal bond (el) legătură terminală

terminal cable (el) cablu terminal

terminal clamp (el, OM) bornă pentru papuc de cablu

terminal conditions (fiz, mec) condiții limită 
terminal current (el) curent la borne

terminal job (ec) muncă / funcție fără viitor / perspective (şi de avansare)

terminal lead / wire (el) fir de conexiune, conductor legat la bornă

terminal loss (el) pierdere finală / la consumatorul final

terminal lug (el, OM) ureche de placă (bornă), ştift de conexiune / de lipire

terminal pad (el) suprafață de conectare (a unui circuit integrat)

terminal pair (el, electr) pereche de borne

terminal panel (el) panou / tablou terminal $\mathrm{cu}$ borne

terminal pin (el, OM) ştift / picioruş de conexiune / de contact

terminal plate (el, electr) placă / cutie / terminal cu borne

terminal point $(\mathrm{TH})$ extremitate; capăt; v. terminal

terminal post (el) ştift de soclu, bornă polară de baterie / de acumulator

terminal products produse finite

terminal screw (el, OM) şurub de bornă, şurub de strângere

terminal state stare finală

terminal switch (el, hidr, OM, mas-un) întrerupător de capăt de cursă

terminal valve (hidr, OM) tub final, supapă finală / de capăt

terminal voltage (el) tensiune la borne

terminal with wing nut $(\mathrm{el}, \mathrm{OM})$ bornă cu piuliță fluture / cu aripioare

terminate a delimita, a mărgini, a (se) termina; a limita, a stabili / a fixa sfârșitul / încheierea; a fixa marginea / granița / limita; a (se) încheia, a (se) sfârși, a pune capăt la; a restrânge

terminating (el) legătură cu izolator de întindere; (mat) finit, cu număr finit de cifre / de termeni

terminating decimal fraction (mat) fracție zecimală exactă

termination terminare; terminație; încheiere; capăt; sfârşit; extremitate, limită; concluzie, rezultat, consecință; (gram) terminație, desinență, sufix; (TH) mecanism / dispozitiv final / terminal / marginal

termination reaction (ind chim, plast) reacție de încetare a cresterii catenei

terminative de încheiere, final; conclusiv; definitiv, absolut

terminer (jur) hotărâre, decizie

terminological terminologic, referitor la terminologie terminological inexactitude inexactitate terminologică; terminologie inexactă; îndepărtare de adevăr

terminology terminologie, nomenclatură; ştiința terminologiei (tehnice)

term in parentheses (mat) expresie / termen între paranteze

terminus punct extrem / final, punct terminus terminus of a vector (mat, fiz) vârf al unui vector term leasing (ec) închiriere pe termen stabilit termless fără termen; nelimitat; nemărginit, fără limită; fără termen (final), fără dată fixă (de încheiere); necondiţionat; independent, neatârnat; inexprimabil, (de) nespus; inefabil

term of a sum (mat) termenul unei sume term of an equation (mat) termen al unei ecuații term of delivery (ec) termen / condiție / clauză de livrare

term of guarantee $(\mathrm{ec}, \mathrm{TH})$ termen de garanție term of second degree (mat) termen de gradul al doilea

term of validity (alim, TH) termen de valabilitate

terms (ec, TH) condiții; clauze

term shift amânare

terms of reference $(p l)$ coordonate individuale / factori (pt. o hotărâre, un raport etc.); (edu) program(ă) cadru; definire (a scopului) și proportiilor unei anchete etc.; coordonate esențiale; termeni de bază; repere

terms of supply / of delivery (ec, TH) condiții de livrare

terms of trade (ec) balantă comercială externă, raport între exporturi şi importuri

termoregulation (autom, termo, metr) reglarea temperaturii, termoreglare, reglare pe baza variatiei temperaturii

termosetting (ind chim, plast) (reacție chimică, ireversibilă, de) termofixare (d. materiale plastice termorigice)

terms of delivery / of supply (ec) condiții de livrare / de primire / de receptie

terms of sale (ec) condiții de vânzare

term time (edu) trimestru; perioada cursurilor, during în timpul cursurilor / anului şcolar

termwise (mat) termen cu termen

tern triadă, grup de trei; (zool) rândunică de mare

ternary (met) ternar; care se referă la numărul trei; triadă; grupare de trei elemente; (chim) compus / corp ternar

ternary alloy (met) aliaj ternar

ternary steel (met) otel ternar

ternary system (met) sistem ternar (la un aliaj) 
ternate (bot) ternar, aşezat în triade / în grupuri de câte trei

terne (met) aliaj de $\mathrm{Pb}-\mathrm{Sn}$ (pt. acoperire contra coroziunii), a acoperi cu un astfel de aliaj

terne pipe (mas-un, met) tub / conductă acope$\operatorname{rit}(\breve{a})$ cu aliaj $\mathrm{Pb}-\mathrm{Sn}$

terne plate (met) tablă cositorită / mată / acoperită cu aliaj de staniu

terned (mas-un) acoperit cu plumb

terpene (chim) terpenă

terpolymer (ind chim) trimer, terpolimer

terra ( $\mathrm{rar})$, tera (metr) terra, tera prefix pentru puterea a doisprezecea a lui zece (unităti), $10^{12}$

terrace (constr) terasă, dig, zăgaz, stăvilar; alee, stradă, șir de case (cu vegetație bogată); (geol) terasă; acoperiş neted / plat

terrace (constr) terasă, acopreiş plat / neted; dig, zăgaz, stăvilar; alee, stradă (cu vegetație multă / bogată); (geol) terasă

terraced house (arhit, constr) casă cu etajele retrase

terraced roof (arhit, constr) acoperis plat / terasat

terra cota, terracota (constr) teracotă

terrain (geogr, agr) teren; sol; pământ; regiune, teritoriu

terrene pământesc, terestru; suprafața pământului; glob terestru

terrestrial terestru, pământesc; de pe uscat; (fig) lumesc, prozaic; pământean, locuitor al pământului

terrestrial current (el, fiz) curent teluric

terret $(\mathrm{OM})$ inel pentru hățuri

terrible teribil; îngrozitor; groaznic; înspăimântător; colosal, enorm, uriaş; formidabil, extraordinar, nemaipomenit; violent; aspru

terricoline, terricolous (biol) care trăieşte în pământ / în sol

terrigenous terigen, produs de sol / pământ

territorial teritorial, referitor la teritoriu; (adm) funciar; cadastral; referitor la pământ

territorial waters $(p l)$ ape teritoriale

territory teritoriu; (amer) teritoriu, posesiune; (fig) domeniu, sferă (de activitate etc.)

tertian (metr, hidr) unitate tradițională de măsură pentru volum de lichid: 1 tertian $~ 3181$

tertiary al treilea (ca ordine sau grad); (geol) terțiar; om terțial; (chim) de gradul al treilea; $(p l)$ tertiares (geol) terțiar, eră terțiară; culoare amestecată

tertiary creep (mec, met, plast) fluaj terțiar accelerat

tertium quid terț, al treilea element, element intermediar

tervalence (chim) trivalență

tesla (T) (metr, fiz) unitate de măsură SI pentru densitate de flux magnetic sau intensitate a câmpului magnetic: 1 tesla reprezintă densitatea unui flux magnetic de 1 weber pe metru pătrat

test test; criteriu; probă, încercare, experimen$\mathrm{t}(\mathrm{are})$; sondă pentru explorare; (chim, tehn) probă, încercare, examen, verificare; control; (fig) piatră de încercare; semn distinctiv; dovadă / probă concludentă; of, $\sim$ for (chim) reactiv (pentru), cupelație, scoaterea metalelor prețioase din aliaje; cercetare, examinare; (zool) carapace; (bot) coajă dură (a unei semințe), a încerca; a proba; a face proba; a pune la probă / la încercare; a controla, a verifica; a experimenta; a testa; a examina, a cerceta, a analiza; (chim) a determina (cu ajutorul reactivului), a cupela, a separa (metalele prețioase); a face probe / analize / verificări etc.

testable care se poate experimenta / testa / verifica / cerceta; (jur) apt pentru a testa / a face testament, apt pentru a depune mărturie

test at constant load (mec) încercare sub / la sarcină constantă

testate (jur) testat, succesoral, lăsat / rămas prin testament; testator

test bar (met, metr, OM) epruvetă, probă (pt. încercări, testare)

test bench (met) stand pentru încercări; $(\mathrm{TH})$ banc de probă

test beam grindă de încercare / de testare

test bed / bench / block banc / stand de încercare / de probă

test by sound (metr) a verifica prin sondare acustică / cu ultrasunete

test car (auto) automobil / vehicul de probă; prototip

test case (jur) speță / caz care generează jurisprudență

test certificate buletin de testare / de încercare / cu rezultatele testelor / încercărilor

test cock (hidr, termo) robinet de luat probe

test conditions (mec) conditiii de testare

test cube epruvetă cubică, cub de încercare

test data (metr) rezultate experimentale / ale testelor, caracteristici de încercare

test desk pupitru / masă de etalonare / de verificare / de testare / de încercare

test drive (auto) parcurs de probă / cursă de probă; a testa / a încerca la drum / într-o cursă de probă

test engine $(\mathrm{TH})$ prototip, motor de încercare tester experimentator, persoană care face probe / analize / experiente; laborant; instalatie / dispozitiv / mecanism / aparat pentru experiențe / teste, tester

test environment atmosferă (condiționată), de încercare, mediul în care se vor face testele 
test equipment / facility (metr) echipament / stand / instalație / dispozitiv / utilități de testare / de încercare

tester cercetător, verificator, tester, aparat de control / de verificare / de încercare / de testare

test floor banc de probă

test for / of convergence criteriu de convergență al rezultatelor testelor / încercărilor

test for / of divisibility (mat) criteriu de divizibilitate

test for parallelism (mas-un, OM) verificarea paralelismului (axelor)

test frame masă de verificare

test furnace (termo) cuptor de încercare / de testare / de laborator

test gauge instrument de probă, aparat etalon, manometru de control

test gear (OM) aparat de încercat / de testat; angrenaj de referință pentru testarea materialelor pentru roți dințate

test glass eprubetă (din sticlă)

test grid grilă / rețea de control

test hole sondă de explorare

testification atestare; (jur) (depunere de) mărturie

testifier martor

testify (jur, TH) a confirma; a declara, a sta / a depune mărturie, a atesta, a declara (ca martor), a depune mărturie; a întări prin jurământ, a declara solemn, a face o declarație solemă; a susține sus şi tare; a manifesta (o dorință etc.)

testify to (jur) a depune o mărturie / a face o depoziție / declarație pentru / în favoarea; (fig) (TH) a dovedi, a confirma, a arăta

testily $(a d v)$ cu încăpățânare / îndărătnicie; morocănos, tâfnos, ciufut; cu tâfnă

testimonial certificat, atestat; dovadă; declarație; depoziție; măsurătoare; verificare, încercare, probă

test indicator (metr, OM) indicator, braț de palpare, pârghie

testing (met) luarea unei probe, verificare, încercare, test (în curs de desfăşurare), testare; probă, care (se) testează

testing acids (chim) acid titrat (pt. metale prețioase)

testing apparatus aparat de încercare / de verificare / de testare

testing bench banc de probă

testing certificate $(\mathrm{TH})$ certificat de încercare

testing department laborator / departament de încercări şi analize

testing field (auto) teren / poligon de încercare a automobilelor; (TH) domeniu de testare

testing for brittle behaviour (met, plast, alte materiale) încercare la rupere fragilă testing fixture (mas, OM) dispozitiv de fixare a epruvetei de încercat

testing in boiling fluid(s) încercare în lichid(e) în fierbere

testing instrument (metr) aparat / utilaj de verificare, de încercare / de testare

testing laboratory laborator de încercare

testing machine (met, TH) maşină / stand de încercat

test(ing) method metodă de încercare

testing) methodology (TH) metodologie de testare / încercare

testing of hardness (mec, materiale solide) încercare pentru determinarea duritătii

testing of load verificarea / controlul sarcinii

testing of material(s) (met) încercarea materialelor, defectoscopie

testing plant (metr, mas) instalație experimentală pentru încercări

testing plate placă de control

testing point punct de încercare / de verificare

testing position stație de încercare; poziția în care se testează

testing pressure presiune de încercare

testing room laborator de încercări şi analize

testing sieve sită de laborator / de control

testing-sieve shaker scuturător mecanic al sitei de laborator

testing technique tehnica măsurării / de testare

testing time timp de testare

testing voltage (el) tensiune de încercare

testing without replacement $(\mathrm{TH})$ testare fără înlocuirea unităților căzute

testing with replacement $(\mathrm{TH})$ testare cu înlocuirea unităților căzute, până la durata stabilită de testare

test in-situ (TH) încercare / testare pe / la locul de funcționare / in-situ

test in the field încercare pe teren

test item / object / specimen mostră; eşantion / probă de încercare; epruvetă

test limits (mec) conditiii / intervale de încercare / de testare

test liquor (chim) soluție normală; grad pentru măsurarea alcoolului

test load (TH) sarcină de încercare / de probă

test mark marcă de verificare, reper de ajustare

test material material de încercare / de testat

test-mixer cilindru gradat

test mixture amestec de probă / de încercare

test model model de încercare / experimental

test mould (met) formă (de turnare) pentru epruvetă

test of convergence criteriu de convergență 
test of thermal shock (mec, termo) încercare la soc termic

test out a încerca, a verifica în practică, a selecta prin încercări (şi eliminări ale pieselor defecte)

test paper (chim) hârtie indicatoare / de turnesol / reactiv; lucrare / probă scrisă (preliminară), teză; lucrare de control

test piece piesă / probă de încercat, epruvetă; (TH) vas de luat probele de metal; (muz) piesă impusă (la concurs)

test plant (metr) instalație experimentală / de cercetări, stand de încercări

test point punct de testare

test pressure (mas-un, hidr, mas) presiune de încercare / de probă

test probe sondă (de luat probe / eşantioane)

test prod (mas-un) emițător de comenzi, element de recepție

test program(me) program de încercări

test rack suportul probei, dispozitiv de încercare test reading rezultatul unei încercări

test report (metr) proces verbal / buletin / raport de încercare

test result rezultatul încercării

test rod (met) epruvetă (tip bară)

test room (mas-un) laborator (cu utilaj) de încercare; (TH) cameră de probă / încercare / verificare / experimentare

test routine program de încercări

test run (auto) cursă de încercare / de probă, probă de mers; desfăsurarea testului / probei

tests by progressive load testare / încercare prin creşterea progresivă / în trepte a sarcinii

test sample mostră, eşantion, probă de încercat

test sequence secventă de test (dintr-un ansamblu programat cu parametri variabili)

test sheet tablă de încercat / de testat (din rulou, pt. ambutisare etc.)

test sieve analysis analiză pe site / granulometrică test specimen (met) epruvetă

test spoon (met) lingură de luat probe

test-stand (met) lingou de probă; stand de încercări

test table masă / banc de încercări sau de probă

test tube eprubetă; cultură de bacterii; (chim) clorometru

test-tube brush perie de eprubete

test-tube centrifuge centrifugă de laborator / de eprubete

test-tube clamp cleme de eprubete

test-tube holder suport de eprubete

test-tube stand stativ de eprubete

testudinate arcuit, boltit

test unit dispozitiv / instalație de control, de încercare test value valoare de încercare / măsurată / experimentală, rezultatul încercării

test weight greutate etalon

test weld (met) cusătură de sudură de probă (şi pt. atestarea sudorilor)

thether pripon; sferă (a cunoştințelor etc.); resurse intelectuale; a priponi (un animal)

tether strap hook (auto) încuietoare; cârligul curelei

tetrad numărul patru (din limba greacă), grup de patru; cvartet; cvatuor; (metr) o arie pătrată de $2 \mathrm{~km} \times 2 \mathrm{~km}$; (metr) unitate pentru cantitate, egală cu 4; (metr, inf, c) unitate pentru informația digitală: 1 tetrad $=4$ bits sau $1 / 2$ byte; alte denumiri: v. nibble, quadbit, hexit

tetradrachma (metr) unitate de măsură pentru masă (veche): 1 tetradrachma (Biblical Greek) $=0,0136 \mathrm{~kg}$

tetragon (mat, geom) patrulater; pătrat

tetragonal tetragonal; (geom) patrulateral; pătrat tetragonal system sistem pătratic / tetragonal

tetragonal thread $(\mathrm{OM})$ filet trapezoidal

tetrahedron, $(p l)$ tetraedra (mat, geom, minrl) tetraedru, piramidă triunghiulară

TEU (metr, nav, transp) abreviere pentru ,twentyfoot equivalent unit”, unitate de măsură pentru încărcătura unei nave, mai ales în containere: 1 TEU reprezintă capacitatea unui container cu 20 picioare în lungime, 8 picioare în lățime şi 8 picioare în înălțime, 1 TEU $\cong 12$ register tons sau $34 \mathrm{~m}^{3}$

TeV (metr) simbol pentru teraelectronvolt: 1 $\mathrm{TeV}=10^{12}$ electronvolți

tew a presa, a muia

tex (metr, textile) unitate în sistem metric, pentru a măsura densitatea unui singur fir / a unei singure fibre: 1 tex este densitatea de 1 gram pe kilogram şi kilometru de fir sau 1 miligram pe metru $(\mathrm{mg} / \mathrm{m})$

texrope (mas-un, OM) curea trapezoidală (cu inserție textilă)

texrope drive $(\mathrm{OM})$ acționare / transmisie antrenare prin curea trapezoidală sau rotundă (cu inserție textilă)

text text; citat; temă, subiect; (poligr) caractere gotice, zaț

text book manual (şcolar), carte de şcoală; culegere de texte biblice

textile fabrics produse / materiale textile

textile insertion inserție textilă

textile laminate textolit

textile oil ( $\mathrm{T})$ ulei textil

textile soap (chim, textile) săpun textil, săpun care nu pătează tesăturile 
textiles (textile, ind chim) țesături, textile, materii textile (pt. com-pozite)

textolite textolit

texture structură (şi metalografică dar şi pentru polimeri); (T, chim) textură (şi a unsorii); (textile) țesătură (a unei stofe); context; structură (a unei cărți, a unui articol.); (anat) țesut; (geol) construcție, compoziție (a unei roci)

texture defect defect de structură / de textură (la aliaje, polimeri şi compozite cu fibre orientate)

T-girder (constr, mec) grindă (cu secțiune) în $T$

Thallium (TI) (chim) taliu

than (conj) decât, ca; $(a d v)$ v. then

thank v. thanks a multumi, a exprima mulțmiri / recunoştință față de (cineva)

thanks $(p l)$ mulțumiri; mulțumită; recunoştință; expresia recunoştinței; many $\sim$ mii de multumiri; I owe you many îti rămân profund îndatorat; no $\sim$ are needed! n-ai / n-aveți pentru ce!, pentru puțin / nimic; cu plăcere; to give / to express / to offer $\sim$ (to somebody for something) a exprima mulțumiri / a mulțumi (cuiva, pt. ceva); to get small / much $\sim$ for smth a fi răsplătit prost pentru ceva; (interj) mulțumesc, mersi; very much multumesc foarte mult

thanks to mulțumită, datorită (cu dat)

that $(p r, p l)$ those (demonstrativ) acela / aceea; ( fam) ăla / aia; (în vorbirea indirectă) acesta, aceasta, (fam) ăsta / asta; aceasta, asta, lucrul ăsta; (relativ) care; (relativ circumstanțial, adesea se omite) în care; când; unde; (relativ la ac) pe care; (adj) acela, ace(e)a; (fam) ăla, aia; (de scop) ca, pentru ca; numai (ca) să, în scopul de a (sau cu gen); (consecutiv) încât;

thatch paie; stuf (pt. acoperiş); acoperiş de paie sau stuf; acoperiș de frunze; (fig) coamă / claie (de păr); a face un acoperiş de paie sau stuf la; a acoperi cu paie sau stuf

thatching knife (constr) cuțit pentru stuf

thaw dezgheț, dezghețare, decongelare, topire (a zăpezilor), dizolvare; a (se) dezgheța, a (se) topi gheața; a se muia, a se dizolva; a se încălzi

thawing (alim) (acțiunea de) decongelare, dezgheț(are)

thawless (d. gheață etc.) care nu se topește

thaw out a dezgheța, a topi, a lichefia

thaw out a frozen radiator (auto) a dezgheța un radiator

thaw point (fiz) punct de rouă, temperatură de condensare

thaw rigor (alim, plast) contracție în urma decongelării

thawy fuzibil, care se poate topi

T-head cylinder (hidr, OM) cilindru cu supape laterale theft insurance asigurare împotriva furtului

theca, $(p l)$ thecae (bot) parte a plantei care serveşte de receptacul; (zool) parte a unui organ

theft-alarm system (auto) sistem de alarmă în caz de furt / anti-furt

theft proof antifurt, de siguranță

theine (chim) cafeină, teină, 1,3,7-trimetil-xantină thematic tematic

thematically (din punct de vedere) tematic ( $a d v)$ thematic catalogue catalog tematic / pe materii theme temă; subiect, obiect (de descuție etc.); compoziție; lucrare; eseu; disertație; (gram) rădăcină, radical, temă; (amer) retroversiune, traducere în limbă străină

then $(a d v)$ atunci; pe atunci; în / pe vremea aceea; by până atunci, cam pe atunci; since $\sim$ de atunci (încoace); (every) now and $\sim$ când şi când, din când în când; what ? ei şi?, şi ce-i cu asta?; now... ... când..., când ...; ba..., ba...; now hot $\sim$ cold când cald, când rece; apoi, pe urmă, după aceea; pe lângă asta, pe deasupra, în plus; pe urmă, la urma urmelor / urmei; în acest caz, atunci; pe de altă parte; aşadar, prin urmare, în consecință, deci; de (pe) atunci, din vremea aceea

then and there $v$. there and then

thence $(a d v)$ de-acolo, din locul acela; altundeva, în altă parte; (conj) v. then

thenceforth $(a d v)$ de atunci înainte; ulterior, în continuare

thenceforward $(a d v) v$. thenceforth

theobromine (chim) teobromină

theorem (mat, fiz) teoremă, lege

theorem of conservation of areas (mec) teorema conservării ariilor

theorem of conservation of momentum (mec) teorema conservării impulsului

theorem of kinetic energy $(\mathrm{mec})$ teorema energiei cinetice

theorem of mean value (mat) teorema mediei theorem of momentum (mec) teorema impulsului theorem of residues (mat) teorema reziduurilor theoretic $\mathrm{v}$. theoretical

theoretical teoretic; (pur) speculativ

theoretical air (fiz, termo) aer teoretic necesar (pt. ardere etc.)

theoretical concept noțiune / concept teoretic(ă)

theoretical efficiency randament teoretic, eficacitate teoretică

theoretical efficiency of screen (agr, alim, met) randamentul teoretic al sitei

theoretically ( $a d v)$ (în mod) teoretic

theoretically dry absolut uscat

theoretical mechanics $(\mathrm{mec})$ mecanică teoretică 
theoretical model model teoretic

theoretical size $(\mathrm{mec}, \mathrm{OM})$ dimensiune teoretică / ideală

theoretical stress-concentration factor (mec, $\mathrm{OM}$ ) coeficient de formă, teoretic

theoretical throat (of weld) (met, OM) grosime (nominală) a sudurii

theoretic(al) value valoare teoretică

theoretical versus actual consumption eficacitate, randament, raport între consumul teoretic şi cel real (cu referire şi la putere / energie consumată)

theoretical yield $(\mathrm{TH})$ randament teoretic

theoretician teoretician

theoretics ( $p l$ ca $s g$ ) teorie, latură / parte teoretică

theorician $v$. theoretician; $v$. theorizer

theorist $\mathrm{v}$. theoretician

theorize a face teorii; a face speculații, a specula, a filosofa

theorizer persoană care face teorii / speculaţii

theorizing teoretizare; generare a unor teorii / speculații

theory teorie; doctrină; învățătură; speculație (filosofică); teoretizare

theory of chances / of probability (mat) calcul al propabilităților, teoria probabilităților

theory of combinations (mat) analiză combinatorie

theory of games teoria jocurilor

theory of plastic hinges (mec) teoria articulațiilor plastice

theory of probability (mat, mec, nav) calculul teoriei probabilităţilor

theory of queues / of congestion / of waiting lines (mat, ec) teoria fenomenelor / proceselor de aşteptare

theory of sets teoria multimilor

theory of similarity (mec, fiz) teoria similitudinii

therapeutic terapeutic

therapeutics ( $p l$ ca $s g$ ) terapeutică

therapy (med) terapie

therblig (metr, ind) unitate de măsură pentru activități fizice (tipuri de mişcări şi timp afectat acestora) în industrie: therblig reprezintă una din cele 18 activități normate, identificate de pshiholigii americani Frank B. Gilbreth şi Lillian Moller Gilbreth: search - căutare, find - găsire, select - selectare, grasp - apucare, hold - (men)ținere, position - poziționare, assemble - asamblare, use - utilizare, disassemble - dezasamblare, inspect - control (inspectare), transport loaded - deplasare cu de greutăți, transport unloaded - deplasare fără greutăți, pre-position for next operation - pregătire pentru următoarea operație, release load - descărcare greutate, unavoidable delay - întârziere care nu poate fi evitată, avoidable delay - întârziere care poate fi evitată, plan - planificare şi rest for overcoming fatigue - odihnă pentru a preîntâmpina oboseala

there $(a d v)$ acolo; aici; iată, uite;

thereabouts $(a d v)(\mathrm{cam})$ pe acolo; prin preajmă / împrejurimi; nu departe de acolo; cam / aproximativ atât; cam aşa ceva

thereafter $(a d v)$ după aceea, ulterior, pe urmă; în consecință, prin urmare

there and then $(a d v)$ atunci, pe loc, pe dată, chiar atunci

thereat $(a d v)$ în legătură cu aceasta; (legat) de aceasta; la aceasta / asta

thereby $(a d v)$ prin aceasta; din aceasta; cu aceasta; astfel, în acest chip / mod, drept urmare; despre aceasta; în legătură cu aceasta

therefor $(a d v)$ pentru aceasta

therefore $(a d v)$ de aceea, din / pentru acest motiv; deci, aşadar, prin urmare, astfel, în consecință

therefrom $(a d v)$ de acolo; de aici

therein ( $a d v)$ aici; acolo; dinăuntru; din el, din ea; în această privință, în ceea ce privește acest lucru thereinafter $(a d v)$ (jur) mai departe / jos thereinbefore $(a d v)$ (jur) mai sus / înainte thereof $(a d v)$ din aceasta / el / ea

thereon $(a d v)$ deasupra, pe el etc.; de aceasta

thereout $(a d v)$ din aceasta / aceea; de acolo

therethrough $(a d v)$ prin aceasta, prin acest mijloc

thereto $(a d v)$ la aceasta; în plus, în afară de aceasta

theretofore $(a d v)$ până atunci, înainte de asta

thereunder $(a d v)$ dedesubt, mai jos; sub aceasta

thereunto $(a d v) v$. thereto

thereupon $(a d v)$ la care; după care; (literar) despre aceasta, în legătură cu aceasta

therewith $(a d v)$ (o dată) cu aceasta, totodată; v. thereupon

therewithal $(a d v)$ v. therewith

therm termic; prescurtare de la thermometer; (fiz) baie caldă; (metr, fiz, termo) calorie mare, (amer) calorie mică; therm (thm) (metr) unitate comercială pentru măsurarea energiei calorice: 1 therm $=10^{6}$ Btu; 1 therm (US, 1968) $=105,4804 \mathrm{MJ} ; 1$ therm $(\mathrm{UE}, 1979)=10^{6} \mathrm{IT}$ $\mathrm{Btu}=105,5060 \mathrm{MJ}$

thermal termic; caloric; termal; cald, fierbinte

thermal activation (alim, chim) activare termică

thermal ageing (alim, met, plast) îmbătrânire / maturare / tratare termică

thermal ageing test încercare de / la îmbătrânire termică

thermal agitation (fiz) agitație termică 
thermal analysis analiză termică

thermal arrest (alim, fiz) punct de oprire a congelării, palier de stabilizare a temperaturii de congelare

thermal balance (fiz, termo) bilanț / balanță termic( $\breve{a})$, echilibru termic

thermal balance sheet (fiz, termo, ind chim) bilanț termic

thermal black (chim) negru de fum termic

thermal boundary layer (fiz) strat limită termic, condiție de margine a temperaturii (în metoda elementului finit)

thermal burden rating (fiz, termo) sarcină termică nominală

thermal capacity (fiz, termo) căldură specifică, capacitate / valoare termică

thermal coefficient of expansion (fiz, met) coeficient de dilatație / dilatare termică

thermal compression / thermocompression bonder $(\mathrm{TH})$ aparat pentru sudare prin comprimare termică, liant pentru asamblare prin compresie termică

thermal condition (fiz, termo, mas, met) regim termic

thermal conductibility / conductivity / conduction (fiz, termo) conductibilitate / conductivitate termică

thermal conductibility vacuum gauge (metr, termo) manometru termic de vid / cu difuzie termică

thermal conductor (fiz, termo) conductor de căldură

thermal content (chim, termo) entalpie, conținut de căldură

thermal contraction (fiz, met, plast) contracție termică

thermal controller (metr, autom, termo) termoregulator

thermal convection (fiz) convecție termică

thermal conversion (chim, met) transformare termică

thermal converter (mas, metr) convertizor termic, termocuplu

thermal crack (mas-un, met, plast) fisură provocată de tratamentul termic / de temperatură

thermal cracking (ind chim) cracare termică

thermal cracking process (chim) proces de cracare termică

thermal critical point (met) temperatură critică

thermal cross / junction (metr, termo) cuplu termo-electric, termocuplu

thermal cross linking (ind chim, plast) reticulare termică (a lanţurilor moleculare)

thermal curing (plast) întărire la cald thermal current (fiz, termo) flux de căldură; curent termo-electric

thermal curve (met, plast) curbă de răcire

thermal cut-out (autom, el, termo) întrerupător / releu / declanşator termic

thermal cycling (mec) solicitare la şocuri termice, solicitare termică ciclică

thermal decomposition (chim, alim) disociație / descompunere termică

thermal deformation / strain (mec, met, plast) deformație termică

thermal degradation plastifiere termică (la cauciuc), degradare termică (în general)

thermal diagram diagramă termică

thermal differential (fiz) cădere de temperatură, variație de căldură / temperatură

thermal diffusion (fiz) difuzie termică, termodifuzie

thermal diffusion process (fiz) proces de difuzie termică

thermal diffusion relaxation (fiz, termo) pierderi de căldură prin difuzie termică

thermal diffusivity difuzibilitate termică, coeficient de difuzivitate termică

thermal dilatation (fiz,termo) dilatație termică

thermal dissociation (chim) disociație termică

thermal duty (termo, mas) sarcină termică

thermal effect (fiz, mec, termo) efect termic

thermal efficiency (termo) randament termic

thermal endurance (materiale) stabilitate termică de durată

thermal energy (fiz) energie termică

thermal equilibrium (fiz, termo) echilibru termic

thermal equivalent of work (mec) echivalent termic al unitătii de lucru mecanic

thermal expansion (fiz) dilatație / dilatare termică

thermal expansivity (met) tendință de dilatare termică

thermal extension (fiz, OM) (a)lungire (dar şi în sens de dilatare) termică / din cauza încălzirii sau a temperaturii (ridicate)

thermal fatigue oboseală termică / provocată de căldură / de cicluri termice

thermal gradient (mec, termo, $\mathrm{T})$ gradient de temperatură / termic

thermal heat (fiz, termo, met) cădere / variație de entalpie

thermal inertia (fiz, termo) inerție termică

thermal instrument (metr) aparat (de măsurat) electrotermic

thermal-insulating jacket (termo, met) cămaşă termoizolantă

thermal-insulating lining (termo, met) căptuşeală termoizolantă 
thermal insulation izolație termică

thermal insulator (termo, ind) termoizolant

thermal insulator pugging (termo. constr, met) umplutură termoizolatoare

thermal lag(ging) (fiz, plast, ind chim, termo) efect termic de retardare, de întârziere, timp termic mort, histerezis termic

thermal limit (termo) limită termică (la circuite electrice, carcase etc.), sarcină termică maximă, temperatură limită

thermal losses (termo) pierderi de căldură / de energie termică

thermal loss power (el, termo, met, ind chim) pierdere de putere sub formă de căldură / prin efectul termic al curentului

thermally attacked rubber (ind chim) cauciuc degradat termic

thermally foamed plastics materiale plastice spumate prin procedeu termic

thermally-operated (mas, autom) cu funcționare termică, care funcționează pe baza variațiilor de temperatură sau de căldură

thermally sensitive (fiz, autom, metr) termosensibil, sensibil la temperatură

thermally stimulated current (el, termo) curent indus termic

thermal neutrons (fiz) neutroni aflați în echilibru termic cu mediul înconjurător

thermal ohm (metr, termo, materiale) denumire informală pentru unitatea de măsură pentru rezistența termică, în sistem SI, kelvin pe watt $(\mathrm{K} / \mathrm{W})$ sau grad Celsius pe watt $\left({ }^{\circ} \mathrm{C} / \mathrm{W}\right)$, ohm termic; rezistența termică a unui izolator termic este valoarea $\mathrm{R}$ (R-value) în unități SI, împărţită la grosimea materialului, în metri

thermal overload (capacity) relay (el, termo) releu termic de suprasarcină

thermal overload (termo) suprasarcină termică

thermal palling (mec, met, ind chim) fisurare datorită oscilațiilor de temperatură

thermal polymerization (ind chim, plast) polimerizare termică

thermal potential potential termic

thermal power (termo) putere calorifică / calorică

thermal power plant / station centrală termică

thermal process (met, chim) proces termic / caloric, transformare termică

thermal radiation (termo) radiație termică

thermal radiator (termo) radiator termic

thermal rating (termo, el) sarcină termică admisibilă / nominală (şi la circuite electrice)

thermal reactor (fiz) reactor termonuclear

thermal reclaiming process (ind chim) procedeu / proces de regenerare termică (şi a cauciucului) thermal-regulating device, thermal regulator (auto, termo) regulator termic, termoregulator thermal resistance termorezistență; (termo) (coeficient de) rezistență termică

thermal retardation (met, plast) durată de menținere (la tratamente termice)

thermal safety rezistentă la căldură

thermal shield (met, termo, ind chim) / scut / protecție termic $(\breve{a})$

thermal shock (met, termo) şoc termic

thermal shock resistance (met, termo) rezistență la şoc(uri) termic(e)

thermal shock test (met, termo) încercare la şoc termic

thermal softening (ind chim, plast) înmuiere provocată de căldură / de încălzire; termoplastifiere; (termo) dedurizare termică

thermal spalling (met, plast) exfoliere la căldură / cauzată de căldură

thermal spring (termo) sursă de căldură; apă / izvor termal $(\breve{a})$

thermal stability $(T$, chim) stabilitate termică

thermal stability under load $(T$, mec, met) stabilitate termică sub sarcină

thermal still (alim) cazan de distilare

thermal storage (termo) acumulare a căldurii

thermal storage water heat (termo) încălzitor cu apă / boiler prin acumulare de apă caldă

thermal stress (materiale, termo) tensiune termică / cauzată de câmpul termic sau e variația acestuia

thermal stress crack (met, plast, T) fisură provocată de tensiune termică / de câmpul termic

thermal system (termo) rețea termică

thermal transmission (met) schimb / transfer / transport / transmitere de căldură, transmisie termică

thermal transmittance (fiz, termo) coeficient global de transfer de căldură, transmitanță termică

thermal treatment (alim, met, ind chim) tratament termic

thermal unit (metr) calorie, unitate de / pentru căldură / energie termică

thermal utilisation factor (termo) factor de utilizare termică / al energiei calorice

thermal value of fuel oil (auto, termo) putere calorică a unui combustibil lichid

thermal value test (metr) determinarea puterii calorice

thermal waste (termo) deșeu termic, căldură pierdută în procesul tehnologic

thermal wave (termo) undă termică

thermal yield (termo, mas) randament termic

thermel (fiz, el, termo) element termoelectric, termoelement

thermic termic, caloric; referitor la căldură (rar) 
thermie (th) (metr, fiz, termo) unitate în sistem metric (metru-tonă-secundă), pentru măsurarea energiei calorice în inginerie: 1 thermie este cantitatea de energie necesară unei tone de apă să-şi crească temperatura $c u 1{ }^{\circ} \mathrm{C}: 1$ thermie $=4,1868 \mathrm{MJ}$

termistor (autom, el) termistor, element semiconductor cu rezistența dependentă exponențial de temperatură

thermit(e) (met) termit

thermit fusion welding (met) sudare aluminotermică

thermit(e) mixture (met) termit pentru sudare

thermite mould (met) formă pentru sudare alumino-termică

thermite pressure welding (met) sudare aluminotermică, sub presiune

thermite process (met) alumino-termie, procedeu alumino-termic (şi de sudare)

thermite reaction (chim, met) reacție aluminotermică (între aluminiu și oxidul de fier)

thermite welding (met) sudare alumino-termică

thermoammeter (el, metr) termo-ampermetru, ampermetru termic / cu termocuplu

thermochemical termochimic

thermochemical calorie ( cal $_{\text {th }}$ ) (metr, chim) calorie termochimică, 1 thermochemical calorie $(1935)=4,184$ J, 1 International Steam Table calorie $=4,1868 \mathrm{~J}$

thermochemical treatment (met, ind chim) tratament termochimic

thermocompression / thermal compression bonder (met, plast) aparat de sudare prin compresie termică; (ind chim) liant care devine activ la compresie termică

thermoconvection (fiz, termo) termoconvecție, convecție a căldurii

thermoconverter (termo) convertor de energie termică în energie electrică (şi tip termocuplu)

thermocouple (metr) termocuplu, termoelement, cuplu termo-electric

thermocouple element (metr) termocuplu (cu referire la partea activă)

thermocouple instrument (metr) aparat cu termocuplu

thermocouple jonction (met, metr) lipitură / joncțiune / loc cald a(l) termocuplului

thermocouple thermometer (metr) termometru / pirometru cu termocuplu

thermocouple vacuum gauge (metr) vacuummetru termoelectric

thermodiffusion (fiz) difuziune termică / termodifuziune

thermodynamic termodinamic thermodynamic activity (fiz) activitate termodinamică

thermodynamic(al) equilibrium (fiz) echilibru termodinamic

thermodynamic(al) laws (fiz, termo) legile termodinamicii

thermodynamic(al) process (fiz) transformare / proces termodinamic $(\breve{a})$

thermodynamics termodinamică

thermodynamic system sistem termodinamic

thermoelastic coefficient (mec, fiz) coeficient de termoelasticitate

thermoelasticity (mec, fiz) termoelasticitate, interdependența câmp termic - stare de tensiuni

thermoelectric cooling; thermoelectric refrigeration (fiz) răcire prin efect Peltier

thermoelectric effect (fiz) efect termo-electric

thermoelastic effect (mec, fiz) efect de termoelasticitate / termo-elastic

thermoelectric heating (fiz, el) încălzire cu curent electric (și prin efect Joule)

thermoelectric pressure-gauge $(\mathrm{OM}$, hidr) manometru termoelectric

thermoelement (metr) termocuplu, termoelement thermofeeling (metr) termopalpator, element sensibil termic

thermoforming (plast) formare la cald

thermography termografie

thermo-hardening (plast, chim) termoreactiv

thermo-insulating material (constr, met, ind chim) material termoizolant

thermo-insulating plywood (constr) placaj termoizolant

thermojunction (fiz, termo) suprafață de contact termo-electric, termocuplu

thermolith (met) termolit, liant pentru cărămizi refractare

thermolysis (chim, termo) termoliză, descompunere termică

thermomechanical treatment (met) tratament termo-mecanic

thermometal (metr, met) bimetal / bandă bimetalică cu sensibilitate termică

thermometer (metr) termometru

thermometer bulb (metr) rezervor / bulb de termometru

thermometer probe (metr) senzor / element sensibil termic / termoelectric / de temperatură, sondă pirometrică

thermometer resistance / resistor (el, termo) rezistentă termometrică

thermometer tube (metr) tub termometric

thermometric fluid (fiz, termo) lichid termometric 
thermometric / thermometer well (OM, termo) locaş al termometrului

thermometry termometrie

thermonegative endoterm

thermo-nuclear (fiz) termonuclear

thermo-nuclear bomb bombă termonucleară

thermophil(e) (biol) termofil, care creşte / se dezvoltă la temperaturi înalte; bacterie etc., care se dezvoltă la temperaturi înalte

thermopile (el) pilă termoelectrică

thermoplastic termoplastic, care poate fi plastifiat la căldură; substanţă termoplastică / care se plastifiază la căldură, polimer / material plastic / termoplastic

termoplegia (med) termoplegie, şoc termic

termopollution (mediu, termo) poluare termică (a mediului ambiant)

thermoregulator (fiz, $\mathrm{TH}$, autom) termoregulator, termostat

thermos bottle / flask (alim) termos

thermosetting (chim) (d. materiale plastice) plastifiabil, prin încălzire; proces termochimic pentru obținerea materialelor plastice termorigide; proces termic de rigidizare a legăturilor intermoleculare

thermosiphon ( $\mathrm{TH}$, termo) termosifon; circulație termică / a apei calde în sistem sifon

thermosiphon (water) cooling (auto) răcire (a apei) prin termosifon

thermostable (fiz) termostabil, stabil la căldură

thermostat (autom) termostat, termoregulator

thermphore (termo, ind chim, alim) termofor, (agent) purtător de căldură, agent termic

thermphore process (ind chim, met) procedeu / proces termic

termopile (el, termo) baterie / pilă termoelectrică, termopilă

thermoplasticising (ind chim, termo) termoplastifiere (d. polimeri termoplastici)

thermoplasticity (ind chim, termo) termoplasticitate (d. polimeri termoplastici)

thermoplastic (plast, ind chim) material / polimer termoplastic

thermoplastics (ind chim) termoplaste, materiale termoplastice, polimeri termoplastici

thermopolymerization (ind chim) termopolimerizare

thermopositive (chim) exoterm

thermoprobe (metr, met) termosondă

thermoregulator (autom, termo) regulator de temperatură, regulator termic, termoregulator

thermorelay (el, termo) releu termic, termoreleu

thermoresistent, thermotolerant (fiz, mec) termo-rezistent, stabil / rezistent la căldură

thermos bottle / flask termos thermosetting (chim) fixarea unor proprietăți prin încălzire (mai ales la materiale plastice termorigide), (plastic) termorigid

thermosetting plastics (plast) materiale (plastice) termorigide

thermo-siphon cooling (termo) răcire prin termosifon

thermo(-)siphon water cooling (termo) răcirea apei prin termosifon

thermostability (fiz, plast) stabilitate termică

thermostable (met, plast) rezistent la temperatură, refractar, termostabil

thermostat (autom) termostat, termoregulator; termostatic

thermostat bulb / phial (metr, termo) senzor / element sensibil al termostatului

thermostatically controlled valve (hidr, termo) ventil termostatic, supapă acționat termic

thermostatic bath (alim, ind chim) baie de termostatare

thermostatic control (autom) reglaj termostatic, reglare a temperaturii

thermostatic throttle / throttling valve (hidr, OM, termo) supapă / ventil de strangulare termostatic

thermoswitch (autom, el, termo) termocontact, comutator termic (acţionat de un anumit prag de temperatură)

thermowell (OM, metr) ştuț / tub / teacă de termocuplu

thesis pl theses teză (de doctorat etc.); disertație; (edu) compoziție, lucrare scrisă, teză

theta theta (majusculă $\Theta$, literă mică $\theta$ ), thita, a opta literă a alfabetului grecesc

thews $(p l)$ muschi, tendoane; (fig) nervi; fortă, vigoare, energie (fizică sau morală), tărie (de caracter); inteligență, capacitate mintală

thick gros; dens; des; compact; consistent; tulbure; vâscos (d. fluide); ticsit, înțesat, îndesat, aglomerat; din belşug / abundență; (d. pahar) murdar; gras, lipicios; (d. întuneric) adânc, beznă; (d. glas) adânc, profund, gros; îngroşat, răgușit; parte mai groasă (a degetului, a unui obiect); (fig) mijloc, centru, inimă, toi

thicken a (se) întări, a (se) îngroşa, a (se) îndesa, a (se) concentra; a (se) îndesi; a se înmulti, a spori; (fig) a se complica

thick-eyed (med) miop

thicked oil (T) ulei oxidat / îngroşat

thickened with (chim, alim, T) îngroşat cu

thickener (chim, alim) agent de îngroşare, aglutinant; (alim, ind chim) cuvă de decantare, concentrator

thickening îngroşare a suspensiilor de praf / de substanță utilă în apă, îngroşare, concentrare, închegare; (ind chim) aglutinant 
thickening agent / substance (alim, ind chim) agent de îngroşare; (T) agent de mărire a vâscozității, agent de îngroşare (în unsori)

thickening time începutul prizei / îngroşării thick extract (alim, ind chim) extract concentrat thick-film lubrication (T) ungere cu lichid gros, lubrifiere cu peliculă groasă

thick-grown (agr) acoperit cu iarbă deasă

thickly în straturi groase, gros, dens, compact; în succesiune rapidă

thickly coated (alim, ind chim, T) acoperit cu strat / peliculă gros / groasă

thick metal plate (met) tablă (de metal) groasă

thick mud (met) nămol, șlam

thickness grosime; consistență; densitate, strat, pătură; (met; T) vâscozitate (a zgurii, a unui lubrifiant); desime; (OM) grosime (a dintelui, ca arc pe cercul de divizare); (metr) compas de grosime; (fig) (prostie, obtuzitate); neclaritate, încâlceală (la vorbă)

thickness gauge (met, metr) şubler micrometric, calibru de grosime

thickness (measuring) gauge (metr, mas-un) şubler de măsurat grosimi, calibru de grosime

thickness of armour (met) grosimea blindajului

thick of a bed / layer (TH) grosime a stratului

thickness of coat (met, auto, T) grosimea acoperirii / stratului aplicat

thickness of chip (met, mas-un) grosimea aşchiei / şpanului

thickness of cutting (mas-un) grosime a aşchiei

thickness of deposit (alim, ind chim) grosime a stratului / a sedimentului / a depunerii

thickness of film grosimea stratului / filmului / peliculei / foliei (aplicabile)

thickness of head (OM) înălțimea capului (dintelui) (h) (la roți dințate)

thickness of layer grosime a stratului

thickness of plate (met, plast) grosime a tablei / a plăcii

thickness of profile (met, OM, plast) grosime / lățime a profilului

thickness of sheet (met) grosime a tablei

thickness of wall (mas, met, ind chim, OM) grosime a peretelui

thick nut (OM) piuliță (specială) înaltă

thick place îngroşare, porțiune / zonă groasă / îngroşată (şi pe un fir, placă etc.)

thick plank (silv) scândură groasă, dulap, blană (de lemn)

thick register (audio) registru grav / de jos

thickset (agr) (plantat) des; tufiş des; gard viu des; (textile) pânză groasă de salopetă

thick sheet (met) tablă groasă; (plast) placă groasă thick-sown (agr) semănat des / în rânduri strânse

thick-wall(ed) (constr, mas, OM, met) cu pereți groşi

thick-walled pipe (OM, hidr) țeavă / tub cu pereți groşi

thick wall of blast furnace (met) zidărie exterioară, la cuptoare

thief (chim, el) catod auxiliar

thief hatch / hole (met, ind chim) orificiu de măsurat / de luat probe

thief sampling luare / recoltare de probe

thigh (anat) coapsă (partea interioară)

thigh-bone (anat) femur

thigh boot cizmă care urcă mai sus de genunchi

thimble (mas-un, OM) ciocănel, papuc de cablu, cârlig de fixare, cartuş de extracție, bucşă, manşon, mufă, cuplă; (met) oală pentru zgură; (metr, OM) tambur (şi de micrometru); degetar

thimbleful înghițitură mică; strop; (fig) nimic, o nimica toată; (metr) unitate informală de volum foarte mic: 1 thimble $\cong 1 \mathrm{~cm}^{3} ; \mathbf{a} \sim$ of matter from a neutron star would weigh 100 million tons un volum mic dintr-o stea neutrinică ar cântări 100 de milioane de tone

thimble hook (mas) cârlig cu ochet (pt. cablu) / cu căuş

thin subtire; (d. lichid) fluid, slab, diluat, apos; (d. aer) rarefiat, rar; răsfirat; (d. oameni) slab, uscățiv, deşirat; slăbănog; (d. obiecte) subțire, subțirel; slab; (d. pretext etc.) slab, şubred, cusut cu ață albă; neconvingător, superficial; (d. glas) slab, subțire; (d. vegetație, păr, populație) rar, rărit, puțin abundent / numeros; a (se) subția, (d. lichid) a dilua, a rări (părul, vegetația etc.); (d. mulţime) a se împrăştia, a se rări; (d. loc) a se goli

thin bedded stratificat în benzi subțiri

thin boards (constr, plast) scânduri / plăci subtiri

thin-coated (met, plast) cu acoperire / înveliş subtire

thin-covered electrode (met) electrod cu înveliş subtire

thin extract (alim, ind chim) extract fluid

thin film (plast, T) peliculă fină / subțire

thin-film dryer (alim, ind chim) uscător cu strat subțire

thin-film evaporator (mas) evaporator cu peliculă subțire

thin-film rust preventive (met, ind chim, $\mathrm{T}$ ) ulei anticorosiv (aplicat în peliculă subțire) (pe suprafața metalică)

thin flame (termo) flacără ascuțită / îngustă 
thing lucru; obiect; articol; $(p l)$ obiecte, articole, serviciu (de masă, de ceai etc.); haine, îmbrăcăminte, veşminte; acțiune, gest, fapt, lucru; punct, detaliu; (fig) persoană, ființă, creatură; obsesie, fobie

thin gas mixture (chim) amestec gazos rarefiat

thin-gauge plate (met) tablă subțire

think a gândi, a se gândi la, a medita (la), a reflecta (la); a concepe, a imagina, a-şi închipui; a înțelege, a pricepe, a cugeta; a crede, a fi de părere; a socoti

thinkable imaginabil, de conceput / închipuit / imaginat; posibil

think about $v$. think of

think again a se răzgândi, a se gândi mai bine

think aloud a se gândi cu voce / glas tare

think back a-şi (re)aminti; a se întoarce înapoi cu gândul; a privi / a se gândi la trecut

think big a avea ambiții mari; a gândi lucrurile în mare; a avea planuri grandioase

think fit a socoti / a considera / a crede potrivit / nimerit; a socoti că se cuvine

thinking gânditor, cugetător; chibzuit, cuminte, înțelept; gândire, cugetare, părere, opinie; to my după părerea mea

think of a se gândi / a reflecta / a medita la; a medita asupra; a-şi imagina; a-şi închipui; a-şi aminti, a-și aduce aminte de; a intenționa să, a avea intenția să, a-1 bate gândul să; a judeca, a considera; a avea o părere / impresie despre

think on $v$. think of

think out a concepe, a imagina; a elabora (în minte); a chibzui

think-so presupunere / supoziție (neîntemeiată), închipuire, părere

think-tank (pol, ec, TH) grup (consultativ) de experți

think through a reconsidera, a considera / a privi / a studia în ansamblu, a (re)examina în întregime / din cap în coadă

think up $v$. think out

thin layer film (plast, T) film / peliculă subtire

thinly $(a d v)$ subțire, în straturi subțiri; rar, risipit, dezlânat; de-abia, foarte puțin, sumar

thinly bedded în straturi subțiri, lamelar, în / cu benzi fine

thinner (ind chim) diluant, solvent, tiner, dizolvant; mai subțire

thinning (ind chim) diluare; (met) fluidizare

thinning agent (ind chim) diluant

thinning out (mas, T) (proces de) subțiere până la dispariție a unui strat (prin uzare, diluare, dizolvare etc.)

thin nut $(\mathrm{OM})$ piuliță cu înălțime mică / joasă thin plate / sheet (met) tablă subțire

thin pulp (met) pulpă decantată (la flotație)

thin rule linie fină

thin-section castings (met) piesă turnată, cu pereți subțiri

thin sheet (met) tablă subțire

thin sheet rolling mill (met) laminor pentru tablă subțire

thin-skinned ingot (met) lingou cu crustă subțire de metal înghețat / solidificat

thin-sown semănat rar / la intervale mari

thin-spun (textile) (țesut) rar

thin-wall bearing $(\mathrm{OM}, \mathrm{T})$ cuzinet $\mathrm{cu}$ perete subtire

thin-walled $(\mathrm{OM})$ cu pereți subțiri

thin-walled blast furnace (met) furnal cu pereți subțiri; (ind chim) cuptor cu pereți subțiri insuflare de aer / gaze pentru reacție

thin-walled castings (met) piese turnate cu pereți subțiri

thin-walled pipe / tube $(\mathrm{OM})$ țeavă / tub cu pereți subțiri

thio acid (chim) tioacid

thionyl (chim) tionil, sulfinil

thiosulphate (chim) tiosulfat

thiourea (chim) tiouree

third (al) treilea, trei; treime; (jur) terț, terță persoană; (auto) viteza a treia; (edu) notă de trecere (la limită); $(p l)$ (ec) mărfuri / marfă de calitatea a treia; (metr, muz) terță, unitate de măsură pentru a descrie raportul frecvențelor a două note; două note diferă printr-o terță minoră (minor third) dacă nota mai înaltă are frecvența de $6 / 5$ ori mai mare decât frecvența celei joase; două note diferă printr-o terță majoră (major third) dacă nota mai înaltă are frecvența de 5/4 ori mai mare decât frecvența celei joase; third ("') (metr) unitate de măsură pentru timp: 1 third $=1 / 60 \mathrm{~s}$ (simbolul "' este rar utilizat)

third best nu prea bun, de calitatea / mâna a treia, de proastă calitate; fără valoare; lucru nu prea bun / de proastă calitate / de calitatea / (fam) mâna a treia

third class (cf etc.) de clasa a treia, cu (clasa) a treia; (ec) de calitatea a treia

third gear (auto) viteza a treia

third grade (amer) (edu) clasa a treia (primară)

third grader (amer) (edu) elev în clasa a treia primară

third-octave (metr, fit) unitate pentru interval de frecvente, descriind o bandă de frecvenț cu frecvența cea mai mare de $2^{1 / 3}=1,260$ ori mai mare decât frecvența cea mai joasă 
third party (ec) terț, persoană aflată în afara raporturilor contractuale directe

third-rate (ec, TH) de calitatea / mâna a treia; inferior; prost, slab

thirds (ec) (mărfuri de) calitatea a treia

third tap (mas-un) tarod de finisare / N3

third wheel pinion $(\mathrm{OM})$ roată dințată intermediară

thirst (şi fig) sete; a-i fi sete, a fi însetat; to a dori fierbinte (să); a ține mult (să)

thirteen treisprezece

thirthteenth al treisprezecelea; treisprezecime, a treisprezecea parte

thirty treizeci

this, $(p l)$ these ( $p r$. demonstrativ de apropiere) acesta, aceasta, ăsta, $(\mathrm{fam})$ asta, acela, aceea

thistle (bot) ciulun, scai, scaiete

thistly (agr) plin de scaieți / ciulini / spini; (fig) spinos; țepos; ascuțit

thither ( $a d v)$ acolo, într-acolo; mai îndepărtat; a se îndrepta într-acolo

thixotropic (fiz) (d. un lichid, un gel) thixotropic, lichefiabil prin agitație

thixotropy ( $\mathrm{T}$, fiz) tixotropie, capacitatea de lichefiere (a unui gel); înmuiere la solicitare / forfecare (d. fluide) şi revenire / creştere a consistentei / vâscozitătii la anularea solicitării / forfecării

thole (constr, arhit) cupolă; (nav) furchet, furcă de vâslă

thole pin (nav, OM) cui de furchet

Thomas converter (met) convertizor Thomas

Thomas low-carbon steel (met) oțel Thomas, otel cu continut redus de carbon

Thomas meal (met) zgură măcinată din convertizor Thomas

Thomas pig iron (met) fontă de convertizor Thomas

Thomas process (met) procedeul Thomas (de obținere a oțelului)

Thomas slag (met, ind chim) zgură Thomas (îngrăşământ fosforat)

Thomas steel (met) otel Thomas

Thomas steel plant / works (met) oțelărie cu convertizoare Thomas

thong curea (şi de piele)

thoracoscopy (med) toracoscopie, radioscopie pulmonară / a toracelui

thorax, $(p l)$ thoraces (anat) torace, piept

Thorium (Th) (chim) toriu

thorn (şi fig) spin, țeapă, ghimpe; cârlig / dorn de instrumentație; (bot) porumbar, mărăcine (Prunus spinosa)

thorn bush (bot) tufiş de mărăcini; mărăciniş thornless (bot) fără spini thorny țepos, cu țepi; (fig) spinos; dificil, greu thoron toron

thorough minuțios; meticulos; amănunțit, detaliat; complet; profund; exact; scrupulos; conștiincios, aprofundat, serios, vast; ferm, nestrămutat, categoric, deplin; desăvârşit, perfect, eminent; adevărat

thorough bend (mec, met) săgeată de încovoiere

thorough-brace (amer) (auto) curea cu care se leagă capota motorului automobilelor tip sport

thorough cut $(\mathrm{TH})$ străpungere, găurire

thorough drying (ind chim, constr) uscare completă

thoroughfare arteră principală (de circulație), magistrală; stradă principală / frecventată; trecere, pasaj, trecătoare; (drept de) trecere

thorough-going complet, total; categoric, radical; care duce lucrurile / care merge până la capăt; care nu se oprește la jumătatea drumului; fără compromisuri; întreprinzător, intrepid

thorough heating (met, termo) încălzire pătrunsă / până în miez

thoroughly $(a d v)$ complet, cu totul, în întregime; până la capăt / sfârșit; profund, amănunțit, detaliat, în tot amănuntul; desăvârşit, perfect

thorough mixing (alim, ind chimic, $\mathrm{TH}$ ) amestecare completă

thoroughness totalitate, întregime; caracter total / complet; aprofundare, caracter aprofundat / profund; perfecțiune, desăvârşire

thorough repair reparație capitală / generală

those ( $p r$ şi adj demonstrativ) ( $p l$ ) de la that

Thou (metr) altă denumire pentru mil: 1 Thou = 0,001 inch $(0,0254 \mathrm{~mm})$

though (conj) deși, cu toate că; chiar dacă; $(a d v)$ totuşi, cu toate acestea

thought gând, idee, cugetare, reflecție; (capacitate de) gândire, cugetare, cuget, meditație; părere, opinie, idee; noțiune, concepție; intenție, plan, gând; atenție, grijă, considerație; întristare, mâhnire, îngrijorare; (fam) pic, idee, strop, lecuță; gândit

thoughtful gânditor, cugetător; meditativ, contemplativ, dus pe gânduri; serios, profund, adânc; cugetat, (bine) gândit; preocupat, atent, grijuliu

thoughtfulness meditare, gândire, chibzuială; chibzuință, înțelepciune; atenție, considerație, grijă, solicitudine

thoughtless nechibzuit, nesocotit, fără cap / minte; fără griji, nepăsător; egoist, neatent față de alții; prost, neghiob, aiurit

thoughtlessness nechibzuință, nesocotință, lipsă de cap / înțelepciune; pripeală; nepăsare, lipsă de atenție, de grijă 
thought-out (bine) gândit, chibzuit, socotit, înțelept; făcut cu socoteală

thought-provoking fertil, incitant, stimulativ, care stimulează / stârnește gândirea

thousand (num cardinal) o mie; (ordinal) al miilea, o mie; mie; imensitate; cantitate imensă; sobor; by $\sim$ s cu miile, mii şi mii

thousandfold înmiit; de o mie de ori

thousandth al miilea, o mie; a mia parte, o miime; a miia oară

thrashing speed (fiz, mec, mas) viteză critică

thread (el, mec) fir de cablu, (textile) fir tors, filament, fibră, tort; (OM) filet (de şurub), spira filetului; ( $f i g$ ) fir, firicel, ață; a băga ață în (ac); a înşira (mărgele etc.); a străbate, a pătrunde (prin); a trece cu greu prin / peste (obstacole); (TH) a fileta (un şurub); a ghintui (o țeavă); in a (se) înşuruba în; through aşi croi drum cu greu prin, a se furişa, a se strecura (prin); (metr, textile) unitate traditională de măsurare a lungimii firului de bumbac: 1 thread $=137,16 \mathrm{~cm}$

thread angle (OM) unghiul (la vârf) / (al profilului filetului)

thread base (OM) bază / fund de filet

thread beam (fiz) fascicul filiform

thread bottom $(\mathrm{OM})$ baza filetului

thread brake (textile, mec) frâna firului, frânare a firului, dispozitiv de tensionare a firului

thread-building / -bulging machine (mas-un, metr) maşină de presat filete / de obținut filete prin rulare

thread calliper(s) (mas-un) calibru de filet

thread chaser (mas-un, metr) pieptene de filetat, tarod de calibrare

thread chasing dial; thread indicator (mas-un) ceas / indicator de filet (la strung)

thread cutter (mas-un) cuțit de filet, tăietor de fir

thread cutting (mas-un) filetare (prin aşchiere)

thread-cutting lathe (mas-un) strung de filetat

thread-cutting / -generating machine (mas-un) maşină de filetat / de generat filete (şi prin rulare, presare etc.)

thread-cutting tool (mas-un) cuțit de tăiat filete

thread depth $(\mathrm{OM})$ înălțime / adâncime (mai rar în limba română) a filetului

thread diameter $(\mathrm{OM})$ diametrul (exterior al) filetului, diametrul nominal al filetului

thread dimensions $(\mathrm{OM})$ dimensiunile filetului

threaded $(\mathrm{OM})$ filetat

threaded cap (OM) buson / dop filetat

threaded connection $(\mathrm{OM})$ îmbinare / asamblare cu filet / filetată

threaded coupling (mas, OM, hidr) cuplaj filetat / cu filet (mai ales la tevi), asamblare filetată threaded end of the stud (mas-un) cap de filetat threaded flange (OM, hidr) flanşă filetată

threaded hook $(\mathrm{OM})$ cârlig cu filet

threaded joint (OM) îmbinare / asamblare filetată / cu filet

threaded-nose cap / plug (OM) dop filetat

threaded piece (mas-un, OM) piesă filetată / cu filet

threaded pipe / tube (OM, hidr) țeavă filetată / cu filet

threaded plug $(\mathrm{OM})$ dop / bușon filetat

threaded ring $(\mathrm{OM})$ inel cu filet

threaded sleeve $(\mathrm{OM})$ mufă cu filet interior / filetată

threaded spindle $(\mathrm{OM})$ fus filetat

threaded tube $(\mathrm{OM})$ teavă / tub filetat $(\breve{a})$

threader (mas-un) maşină de filetat (şuruburi)

thread-forming device (mas-un, plast) dispozitiv de formare a filetului / a firului

thread gauge (metr) calibru / şablon de filet

thread-generating / -cutting machine (mas-un) maşină de filetat prin generare / prin aşchiere

thread grinding (mas-un) rectificarea filetului

thread-grinding machine (mas-un) maşină de rectificat filete

thread groove $(\mathrm{OM})$ degajare a filetului

thread head $(\mathrm{OM})$ vârf de filet

thread indicator (mas-un, metr) ceas / indicator de filet (la strung)

threading (mas-un) filetare

threading die (mas-un) cap / bac de filetat, filieră

threading machine (mas-un) maşină de filetat

threading opening die (mas-un) cap de filetat, cu deschidere automată

threading roll (mas-un) rolă de filetat, rolă a maşinii de filetat prin rulare

threading tap (mas-un) tarod de filetat găuri

threading tool (mas-un) cuțit de filetat

thread into $(\mathrm{OM})$ a înşuruba (în)

threadlike ca firul / ața; fibros, filamentos

thread-mark filigran (pe bancnote)

thread micrometer (metr) micrometru de / cu filet

thread milling (mas-un) frezare a filetului

thread milling-cutter (mas-un) freză de filetat

thread milling machine (mas-un) maşină de frezat filete

thread nipple (OM) niplu filetat

thread of the current (el, hidr) linie de curent

thread of the screw $(\mathrm{OM})$ filet al unui şurub

thread on $(\mathrm{OM})$ a înşuruba (a deşuruba), a înşira, a aşeza în rând, a acționa o transmisie cu şurub

thread pitch $(\mathrm{OM})$ pas al filetului / şurubului 
thread-pitch diameter $(\mathrm{OM})$ diametrul mediu al unui filet

thread plug (mas-un, OM) dop filetat

thread plug gauge (metr) calibru de filet interior

thread producing machine (mas-un) maşină de filetat

thread profile (mas-un, OM) profil de filet

thread protecting cap $(\mathrm{OM})$ capac protector, $\mathrm{cu}$ filet, manşon / teacă de protecție a filetului

thread roll (mas-un) rola maşinii de filetat prin rulare

thread rolling (mas-un) (proces de formare la rece prin) rulare a filetului

thread rolling-die (mas-un) matriță de filetat prin rulare

thread rolling machine (mas-un) maşină de rulat filete

thread-shaped filiform, ca un fir, în formă de fir; în formă de spirală / de filet

thread side (OM) flanc de filet

threads per unit (mas-un, OM) număr de spire de filet / al începuturilor de filet

thread stop (mas-un) opritor de avans la filetare / (la găurile înfundate etc.)

thread system (mas-un, OM) sistem de filete

thread templet (mas-un) şablon de filet

thread tolerance unit $(\mathrm{OM})$ toleranța filetului

thread tool (mas-un) cutit de filetat

thread tool gauge (mas-un) şablon / calibru pentru cutite de filetat

threadworm (med, zool) trichină

thready fibros

threat of / to amenințare de

threaten a amenința, a anunța ceva rău, a fi amenintător; a constitui un pericol

threatening amenințător, acre amenință; (cu caracter) de amenințare

three trei

three-action / three-term controller (autom) regulator cu acțiune proporțională, integrală și diferențială, regulator PID

three-colour(ed) tricolor

three-component $(\mathrm{TH})$ cu trei elemente

three-component alloy (met) aliaj ternar

three-component system (met) sistem ternar / cu trei componente (metalice)

three-cornered (mat) triunghiular; în trei colțuri; în trei; între trei concurenți

three-cornered scrapper (mas-un) răzuitor cu trei tăişuri / cu secțiune triunghiulară

three-cylinder inverted engine (mas) motor cu trei cilindri, în stea

three-D, 3D tridimensional, în relief, în spațiu, stereoscopic three-decker (nav) vas cu trei punți; corabie cu trei rânduri de baterii; (constr) clădire cu trei nivele

three-dimensional; 3D (v. three-D) corporal, spațial, tridimensional

three-dimensional cross slide system (mas) sistem mecanic pe glisiere (cu mişcare spațială)

three-dimensional curve, 3D-curve curbă spațială / în spațiu

three-dimensional geometry (geom) geometrie în spațiu

three-dimensional lattice (plast, fiz) rețea spatială

three-dimensional pantograph engraving machine (mas-un) maşină de frezat prin copiere cu pantograf

three-dimensional / 3D polymer (chim) polimer tridimensional / cu rețea spațială a lanţurilor moleculare

three-dimensional profiling (mas-un) prelucrarea suprafețelor profilate

three-dimensional space (mat) spatiu tridimensional

three-faced (mat) triedru, cu trei fețe

three-field system (agr) sistem de agricultură / cultură în trei asolamente

three-figure cu trei cifre

threefold triplu, de trei ori, întreit

three-furnace process (met) proces triplex (la furnal)

three groove chucking reamer (mas-un) alezor de maşină cu trei dinți

three-groove drill (mas-un) burghiu cu trei caneluri / canale

three-head milling machine (mas-un) maşină de frezat, cu trei arbori principali

three-high bar mill (met) laminor trio pentru laminarea oțelului profilat

three-high blooming bloomer / mill (met) laminor trio pentru lingouri

three-high blooming-mill train (met) laminor trio pentru blumuri, laminor degrosisor cu trei cilindri

three-high cogging mill (met) laminor degrosisor cu trei cilindri

three-high finishing rolling mill (met) laminor finisor trio

three-high finishing train (met) linie de laminor finisor trio

three-high finishing stand (met) cajă de laminor finisor trio

three-high hot rolling mill (met) laminor trio la cald

three-high housing (met) caja / cadrul laminorului trio 
three-high mill (met) laminor trio

three-high mill stand (met) caja laminorului trio three-high plate mill (met) laminor trio pentru tablă

three-high rail mill (met) laminor trio pentru şine three-high reversing mill (met) laminor trio reversibil

three-high rolling mill (met) laminor trio

three-high rolling-mill train (met) linie de laminor trio

three-high rolling stand (met) cajă de laminor trio

three-high rolling train (met) linie de laminor trio

three-high rougher (met) laminor degrosisor trio three-high shape mill train (met) laminor trio pentru profiluri

three-high stand (met) cajă de laminor trio

three-jaw chuck (mas-un) universal / mandrină cu trei fălci

three-jawed (mas-un) cu trei fălci

three-knife trimmer maşină de tăiat cu trei cuțite (simultan)

three-lane (d. arteră de circulație) cu trei benzi (de circulație)

three-legged (d. scăunele) cu trei picioare

three lipped drill (mas-un) burghiu cu trei tăişuri three-master (nav) vas / corabie cu trei catarge three membered (mat) trinom, cu trei termeni three-pair (constr) la etajul al doilea

three-part alloy (met) aliaj ternar

three-part flash (met) ramă de formare din trei părți

three-phase (el, fiz) trifazat, din / cu trei faze

three-phase alternating current (el) curent alternativ trifazat

three-phase arc smelting furnace (met, el) cuptor de topire cu arc electric trifazat

three-phase commutator motor (el) motor trifazat cu colector

three-phase motor (el) motor trifazat

three-phase system (el) sistem trifazat

three-phase transformer (el) transformator trifazat

three-piece din trei părți / bucăți

three ply (d. furnir) cu trei straturi, triplu; dublat în trei fire; furnir triplu;

three ply wool (textile) lână cu firul în trei (şuvițe)

three-point suspension $(\mathrm{OM})$ suspensie în trei puncte

three-position (TH) cu trei poziții

three-position relay / switch (el) releu / comutator cu trei poziții three-quarter elliptic spring $(\mathrm{OM})$ arc pe trei sferturi eliptic

three-quarter floating axle $(\mathrm{OM})$ arbore planetar, trei-sferturi flotant

three-quarter hard annealing (met) recoacere $3 / 4$ sau tare

threeroll(er) gringing mill (alim, ind chim) breioză, maşină cu role / cu valțuri, de frecat / de omogenizat amestecuri

three-roll unbender (met) maşină de îndreptat cu trei role

three sided cu trei laturi

three-speed (auto) cu trei viteze

three-speed gear box $(\mathrm{OM})$ cutie de viteze cu trei trepte

three-speed transmission (auto, mas, OM) schimbător de viteze / transmisie cu trei trepte

three-square triunghiular

three-stage, three-step (OM, hidr, termo) cu trei trepte (distribuitoare, cutii de viteze, reductoare), cu trei etape; (el) cu trei faze

three-storied (constr) cu trei etaje

three-term (mat) cu trei termeni

three-throw crankshaft $(\mathrm{OM})$ arbore cotit cu trei paliere

three-valved (TH) (d. un robinet, o supapă etc.) cu trei căi / faze; (cf) cu linie triplă; (el) (d. un comutator) cu trei faze / directii

three-way cu trei căi (şi d. distribuitoare)

three-way pipe (hidr, OM) conductă cu trei ramificații, teu

three-way switch (el) comutator cu trei poziții

three-way $\operatorname{tap}(\mathrm{OM}$, hidr) robinet cu trei căi

three-way valve $(O M$, hidr) supapă cu trei căi

three-wheeled (OM) cu trei roti

three-wheeler (auto) automobil cu trei roți

three-wheel pump (hidr) pompă cu trei rotoare

three-wire (el) cu trei conductoare / fire / sârme

thremmatology (biol) creştere artificială; (agr) ştiinţa creşterii animalelor şi plantelor, agrozootehnie

thresh (agr) a treiera

thresher (mas, agr) treierător; treierătoare, batoză; maşină de treier(at)

threshing (agr) treierat, treieriş; v. thresher

threshing floor (agr) arie de treier(at)

threshing machine $v$. thresher

threshold (constr, met) prag de uşă, poartă, uşă, pridvor; (autom, fiz) valoare de prag, prag

threshold adjustment (autom, metr) reglare la valoare limită / de prag; (fig) prag, început, punct de plecare

threshold control (autom, metr) reglare la limită / critică / de prag 
threshold limit (autom, el) valoare de prag, condiție limită

threshold of coagulation (alim, ind chim) limită de coagulare

threshold of response / of sensivity (autom, metr) prag de sensibilitate, sensibilitate limită

threshold sensitivity (autom, metr) sensibilitate de prag, cea mai mică variație a parametrului de intrare pentru care se obține variația semnalului de ieşire

threshold switch (TH) întrerupător la valoare limită / cu prag

threshold value (autom) valoare de prag / de treaptă

thrice de trei ori

thrifallow (agr) a ara a treia oară înainte de însămânțare / semănat

thrift economie, cumpătare, chibzuială; frugalitate; (înv) prosperitate, înflorire; succes; (agr) creştere viguroasă, brazdă, gazon

thrift account (ec) (amer) cont de economii; cont (curent) / depozit de bancă

thrift box puşculiță

thriftily $(a d v)$ cu economie / chibzuială / chibzuință; cumpătat, cu moderație

thriftlessness risipă, cheltuială; nechibzuință, nesocotință

thrifty econom, chibzuit, socotit; cumpătat, moderat; bine administrat / gospodărit; (amer) înfloritor, prosper; folositor; profitabil, rentabil

thrive a se căpătui; (bot, zool) a creşte puternic / viguros, a merge bine; a face avere, a se îmbogăți; a înflori; a-i merge bine; a prospera

thriving înfloritor, prosper; viguros

throat $(\mathrm{OM})$ gât (la flanşe), orificiu de intrare, lungimea brațului în consolă; (hidr) zonă îngustă / îngustată (la sifon deversor, tub Venturi etc.); (met) gură de încărcare a furnalului; (anat) gâtlej, gât; strungă, trecătoare, defileu; (alim, constr, ind chim, met) gură de încărcare / alimentare (şi la furnal, cuptor etc.); deschidere maximă; (nav) gât de ancoră

throat armour (met) blindaj de protectie contra loviturilor

throat capacity rază de acțiune utilă (a maşinii de sudat); (met) capacitate de încărcare la gura furnalului

throat clearance (mas-un) lungimea brațului în consolă, distanța între suprafaţa frontală a pietrei de rectificat şi masă (la maşina verticală de rectificat plan)

throat depth (constr) adâncime a unui şanț / jgheab; (mas-un) lungime / deschidere a braţului în consolă

throat dust (met) praf de la gura furnalului throat of blast furnace (met) platformă de încărcare a furnalului

throat opening (met) deschiderea / mărimea gurii de încărcare a furnalului

throat platform (met) platformă de încărcare a furnalului

throat seam (met, OM) cusătură de colț (sudată)

throat spacing (met) deschiderea între console (la maşina de sudat)

throat-stopper (met, autom) dispozitiv de închidere automată la gura furnalului

throat-stopper winch (met) troliul conului de la gura furnalului

throat temperature (met) temperatura la gura furnalului

throb (met, fiz) pulsație; (med) palpitație, bătaie (a inimii); tremur, agitație; fior; a pulsa, a bate, a palpita; (fig) a tremura / a vibra / a palpita de emoție

throttle (OM, hidr) drosel, regulator, clapetă, clapă (de închidere), fluturaş, supapă de reglare a debitului; (auto) volet, fluturaş, supapă de reglaj / fără admisie; gâtlej; a sugruma, a înăbuși, a strânge de gât; a se sufoca; a respira / a răsufla greu; a muri de astmă; a ştrangula (o sectiune, un curent de fluid etc.)

throttle back (auto) a reduce accelerația; a lăsa motorul la ralanti

throttle-clack valve $(\mathrm{OM}$, hidr) clapetă de ştrangulare (a debitului)

throttled-down (auto) (d. motor) lăsat la ralanti

throttle diaphragm / disk $(\mathrm{OM})$ diafragmă de laminare (a curgerii)

throttle down (OM, hidr) a ştrangula, a reduce (debitul de gaz)

throttle effect (fiz) efect de laminare / de îngustare / de ştrangulare / Joule-Thomson

throttle governing $(\mathrm{OM}$, hidr) reglare prin ştrangulare / reducere / gâtuire (a unei secțiuni)

throttle handle / grip / lever (mas, met) manetă de gaze

throttle jet (OM, hidr) ajutaj de ştrangulare

throttle opening (mas) admisie cu ştrangulare

throttle pedal (auto) (pedală de) accelerație, accelerator

throttle plant for wetting instalație de laminare pentru umezire

throttle regulator $(\mathrm{OM}$, hidr) regulator prin ştrangulare, drosel

throttle steam (termo) abur laminat

throttle valve (auto) clapetă de accelerație; (OM, hidr) supapă-fluture, supapă de ştrangulare / de reglare a debitului, drosel, fluturaş, fluture

throttle with slide valve (hidr, OM) regulator cu sertar / cu supapă alunecătoare / cu supapă cu plunjer 
throttling (OM, hidr) ştrangulare, îngustare, laminare, încetinire, frânare, reducere, închidere prin supapă / vană-fluture

throttling coefficient $(\mathrm{TH})$ factor de proporționalitate / de îngustrare

throttling controller (hidr, OM) regulator $\mathrm{cu}$ drosel / prin ştrangulare

throttling range / zone (TH) interval / zonă de proporționalitate / de îngustrare (a secțiunii)

through (constr, alim, ind chim) fracțiunea trecută prin sită; (prep) prin, printre, peste; prin intermediul / mijlocirea, din pricina, din cauza; de la, din; mulţimită, datorită, grație; (amer) (temporal) inclusiv, până la; de la un capăt la celălalt, dintr-o parte în cealaltă; direct; (d. tren, bilet, drum, zbor etc.) direct; (TH) continuu, de trecere, traversant; terminat, gata, sfârşit

through base (mas) placă de fundație, cu jgheab - colector de ulei

through beam (cf) grindă continuă / plină; (constr) grindă de susținere

through bore (mas-un, OM) gaură pătrunsă / străpunsă

through carburising (met) cementare carburare totală / în miez

through carrige / coach (cf) vagon direct

through coal $(\mathrm{TH})$ cărbune brut / netăiat

through communication (cf) (inter)comunicaţie între vagoane

through connection $(\mathrm{TH})$ transfer, tranzit; (cf) legătură

through corrosion (met) coroziune pătrunsă

through cracks (met) crăpături străpunse, fisuri pe toată grosimea piesei (turnate, tratate etc.)

through feed (mas-un) avans continuu pe toată lățimea / lungimea piesei

through feed grinding (mas-un) rectificare cu avans continuu / longitudinal

through-going shaft $(\mathrm{TH}, \mathrm{OM})$ arbore transversal

through hardening (met) călire pătrunsă / totală / pe toată grosimea piesei / în miez

through hole (mas-un, OM) gaură fără fund / pătrunsă / străpunsă

through insulator (el) izolator de trecere

through joint (el) bornă / clemă de legătură

throughout $(a d v)$ pretutindeni, peste tot (locul); de la un capăt la celălalt; în toate privințele, complet; în întregime; (prep) de la un capăt la celălalt al, peste tot (cuprinsul); (temporal) în tot cursul, de-a lungul

through-out productivitate

through pin $(\mathrm{OM})$ ştift pătruns / tubular through(-)put (ind) cantitate de material trecut (prin instalație); materii (prime) şi materiale introduse în procesul de fabricație; materiale prelucrate; produs, rezultat; (c) output (al unui computer)

through(-)put capacity $(\mathrm{TH}, \mathrm{ec})$ debit, randament, capacitate de productie

through quenching (met) călire integrală / pătrunsă / în miez

through quenching and subsequent tempering (met) îmbunătătiire integrală / pătrunsă

through(-)put rate $(\mathrm{TH})$ viteză de trecere prin instalație

through rate $(\mathrm{TH}, \mathrm{ec})$ condiții de plată pentru transport direct

through repeater (el, autom) amplificator intermediar

through road (ind) drum direct; cale de trecere

through route arteră principală, magistrală, cale directă de acces

through station (cf) stație în care trenul nu opreşte

through-stone (constr, arhit) piatră / cărămidă ieşită în afară (prin zid)

through ticket (cf) bilet direct (fără transbordare)

through traffic (cf) circulație de tranzit; tranzit

through train (cf) tren direct; tren care circulă fără oprire

through-type furnace (alim, met, plast) cuptor cu trecere continuă

through welding (met) pătrundere completă (la sudură)

through-way valve (mas, OM, hidr) ventil / supapă de trecere

throw aruncare, azvârlire, lansare, aruncătură, azvârlitură, şoc, cursă, deplasare, împingere; (TH) anvergură, amplitudine, întindere, cursă (a pistonului); (amer) încercare; (ec) preț de unitate / bucată; unitate cu care se vinde un articol (pereche, duzină, bucată etc.); a (se) arunca, a (se) azvârli, a zvârli (jos); a lansa (un proiectil, o piatră etc.); a răspândi, a împrăştia; a pune jos, a lepăda, a abandona, a părăsi; (d. animale) a-şi lepăda (pielea), a făta, a naşte; (amer) (fam) a abandona (intenționat), a renunța (la o cursă etc.); roata olarului

throw about a arunca încoace şi încolo / în toate părțile / peste tot

throw aside a da la o parte, a înlătura

throwaway (amer) afiş / manifest / reclamă (care se distribuie pe stradă etc.); lucru care se aruncă după folosire / întrebuințare; de aruncat, care se aruncă după folosire / întrebuințare; (d. un bun / 
produs) de folosință imediată; efemer; secundar; şoptit, în surdină; atenuat; degajat

throw away a arunca (departe / cât acolo), a azvârli (la gunoi); a irosi, a risipi (zadarnic); a rata, a pierde (un prilej), a lăsa să-i scape (o şansă); a atenua, a nu sublinia

throwaway society (ec) societate de consum (caracterizată prin aruncarea la gunoi imediat după întrebuințare a unor obiecte sau materiale refolosibile)

throw-back (mec) mişcare înapoi, întoarcere, recul; (fig) regres, întoarcere înapoi; (biol) regres atavic, atavism

throw back a respinge; a arunca înapoi / îndărăt; a împinge înapoi; a da / a împinge în lături sau pe spate (pălărie, perdele etc.); (d. oglindă) a reflecta, a răsfrânge; (biol) a se întoarce la un tip anterior

throw-down bătaie, înfrângere, insucces; aruncare (a unui obiect etc.)

throw down a runca în jos / de sus în jos; a lăsa / a pune jos; a depune; a doborî, a dărâma, a da jos; (chim) a precipita; a depune, a face să se precipite; (amer) a dejuca, a contracara; a respinge; a face să cadă (un plan etc.)

thrower aruncător; olar

thrower ring (mas-un, T) inel de ungere, ineldeflector de ulei

throw in a arunca în, a introduce în; a azvârli înăuntru; a adăuga, a pune în plus (de bună voie, de la sine); a abandona

throwing-about (ec) risipă, irosire a banilor

throwing-away aruncare, azvârlire (la gunoi); îndepărtare, eliminare; ratare, pierdere (a unui prilej), irosire

throwing-back aruncare înapoi, înapoiere; retragere, răsfrângere, oglindire; întârziere, tergiversare (a unei lucrări etc.)

throwing-down aruncare, azvârlire (în jos); (mil) depunere (a armelor); renunțare (la un plan etc.); dărâmare, doborâre; demolare

throwing-aut jet, țâşnire, emitere; respingere (a unui proiect etc.); v. throwing-down

throwing-over părăsire, abandonare

throwing-up (med) aruncare în aer; (med) vomare, vomitare, vărsătură; scoatere în relief, subliniere, reliefare; $v$. throwing-down

throw in gear $(\mathrm{OM})$ a cupla, a intra în angrenare (d. un dinte)

throwing out aruncare / azvârlire (în afară)

throwing power (met, chim) acțiune în profunzime (la acoperiri); putere de pătrundere

throw in the first gear (speed) (auto) a schimba în viteza întâi throw in lever (auto, OM) pârghie de cuplare / de ambreiaj

throw into (met) a sufla în, a insufla

throw into gear (OM, auto, mas-un) a cupla (o treaptă de viteză), a angrena, a intra în angrenare

throw key (auto, mas) cheie de contact / de cuplaj / de pornire

throw lathe (mas-un) strung manual / cu comandă manuală

thrown from aruncat / azvârlit din

throw of crank $(\mathrm{OM})$ rază de manivelă

throw off a arunca (la o parte); a părăsi, a abandona / a se lăsa de (un obicei etc.); a dezbrăca, a arunca (hainele); (mec) a arunca, a proiecta, a lansa; (fiz) a emite

throw of governor (autom, hidr) deviație a regulatorului (de debit sau de presiune)

throw-out (auto) debreiere, decuplare (automată) $(\mathrm{TH})$ ejector, aruncător; (el) întrerupător, disjunctor automat; (mas-un, OM) ejector; $(p l)$ (com) deşeuri, rebuturi; articole cu defect(e)

throw out a arunca / a da / a scoate afară; a scoate în afară / în relief; a sublinia, a emite, a răspândi (raze, căldură, miros etc.); a defosa, a arunca (o carte de joc); a deranja, a întrerupe (de la lucru); a lansa (o provocare); (jur) a emite, a respinge; a scoate; (mas) a decupla, a dezangrena, a arunca în afară

throw a bill (jur) a emite o ordonanță de neurmărire, a anula un mandat de urmărire;

throw out of gear (mas, OM) decuplare, dezanclanşare, debreiere, ieşire din angrenare (şi nedorită)

throw-out bearing (of the clutch) (OM) rulment / lagăr de debreiere / de decuplare (a ambreiajului)

throw-out the clutch $(\mathrm{OM})$ a debreia, a decupla un ambreiaj

throw-out lever (mas, OM) pârghie de decuplare / de debreiere

throw-out mechanism (mas) mecanism / dispozitiv de decuplare

throw-out of action (mas-un) a decupla, a opri, a ieşi din procesare (defect)

throw-out of engagement (mas-un) a decupla, a scoate din angrenare

throw-out of motion (mas) a opri (o maşină)

throw-out of sleeve (of a gear clutch) (mas, OM) bucşă de debreiere / de decuplare (a unui cuplaj dințat)

throw-over contact (el) contact de comutare

throw-over gear (mas, OM) mecanism de inversare, transmisie intermediară 
throw-over plug (el) fişă de comutație / de contact throw-over relay (el) releu cu două poziții / basculant / de comutare

throw over a abandona, a părăsi

throw overboard (fig) a arunca peste bord; a se descotorosi / a se debarasa de; a lepăda, a arunca; a abandona, a părăsi; a renunța la

throw together a reuni, a pune laolaltă; a strânge (în grabă) laolaltă, a aduce împreună; (fig) a scrie / a compune în grabă

throw up (met) a arunca în sus; a ridica (cu putere) în sus; a înălța / a clădi / a consrui în grabă; a abandona, a renunta la; a-și da demisia din; a abdica de la; (med) a voma, a vomita, a vărsa (mâncarea)

thrum (textile) capătul firului; fir gros; smoc, ciucure; fragment, părticică

thrust (constr) împingere a terenului; $(\mathrm{OM})$ distanțier; (mec) lovire, şoc, forță / presiune axială / centrică, împingere laterală, tracțiune, contrapresiune, apăsare, compresiune, reacție, contrareacție; $(\mathrm{OM})$ opritor, cui de blocare, limitator, fixator; (geol) şariaj; împingere, îmbrâncitură, îmbrânceală, lovitură; înțepătură, împunsătură fandare, atac; (fig) înțepătură, împunsătură, aluzie răutăcioasă, atac; ghimpe; a împinge; a înfige; ( into) a (se) vârî (cu forța) în; a (se) băga în, a înfinge în; a (se) împinge (înăuntru); a scoate; ( through) a-și croi / a-şi face / a-și deschide (drum etc.) prin; a împinge, a face să treacă prin; a se îmbrânci, a se înghesui

thrust back a împinge (violent) înapoi; a băga cu de-a sila la loc; a trânti (uşa etc.)

thrust ball bearing $(\mathrm{OM})$ (lagăr cu) rulment axial cu bile

thrust bearing $(\mathrm{OM})$ lagăr axial, crapodină, pivot de fus

thrust block (mas-un, OM) lagăr canelat / în pieptene, crapodină, lagăr-pieptene, cuzinet de reazem

thrust bolt $(\mathrm{OM})$ şurub / bolt de presiune

thrust collar (OM) inel de sprijin, guler de oprire (pe direcție axială)

thrust down a împinge în jos

thruster (mas-un, hidr, OM) dispozitiv hidraulic pentru transformarea mişcării de rotație în mişcare rectilinie

thrust frame (mas) cadru de împingere

thrust-hoe (agr) săpăligă

thrusting (mec) înfigere; împingere

thrust journal (OM) fus cu umeri

thrust line curbă de presiune

thrust load (mas-un, OM, mec) presiune axială, sarcină / forță / încărcare axială

thrust nut (mas-un, OM) piuliță de presare thrustor (TH, autom) servomotor

thrust out (mec, TH) a împinge / a scoate (în) afară (şi prin împingere)

thrust pin $(\mathrm{OM})$ reazem de arc

thrust plate (cf) disc de lovire a tamponului; (OM) disc de ambreiaj, placă opritoare / de presiune, cuzinetul crapodinei

thrust race $(\mathrm{OM})$ lagăr axial

thrust ring $(\mathrm{OM})$ inel opritor / limitator de capăt

thrust screw $(\mathrm{OM})$ şurub de strângere; (met) şurub de forță / de presare

thrust shaft $(\mathrm{OM})$ arbore de împingere

thrust side of thread (OM) flanc activ al filetului

thrust strip (mas-un, OM) placă de reazem (şi pe direcție axială)

thrust through a străpunge cu, a băga prin; (cu prep) a-şi croi drum prin, a răzbate prin

thrust up a împinge în sus, a ridica brusc

thrust washer $(\mathrm{OM})$ disc / şaibă de presiune, inel de presiune / de reazem

thud bufnitură, zgomot înăbuşit, lovitură / pocnitură surdă; a bufni, a pocni / a face un zgomot surd; a cădea cu bufnitură

thuja (bot) tuia

Thulium (Tu) (chim) tuliu; pământ rar

thumb (anat) degetul mare (de la mână); (OM, mas-un) camă; a mânui stângaci / cu stângăcie; a murdări, a mânji; (amer) a solicita, a cere (arătând cu degetul mare); (metr) deget, altă denumire pentru inch; v. inch; tol (din limba germană), 1 inch (tol) $=25,4 \mathrm{~mm}$

thumb cleat $(\mathrm{OM})$ tachet

thumb head (mas-un, OM) cap zimțat / fluture al şurubului

thumb nut $(\mathrm{OM})$ piuliță-fluture, piuliță moletată, piuliță răsucită cu degetul mare

thumb rule regula mâinii drepte (pt. determinarea sensului curentului electric etc.)

thumb screw (cf) şurub cu eclise; (OM) şurub de presiune / cu piuluță-fluture / cu cap striat / moletat / zimțat

thumb( )tack piuneză

thumbwheel (auto) buton de reglare

thump zgomot surd / înăbușit

thunder (şi fig) tunet, bubuit / bubuitură de tunet; ropot (de aplauze); furtună (cu descărcări electrice)

thunder and lightning tunete şi fulgere; furtună; (textile) varietate de postav gri-fer

thunderbeat a trăsni, a lovi (d. trăsnet)

thunder-proof care rezistă la trăsnet; dispozitiv contra trăsnetelor, paratrăsnet; înzestrat cu paratrăsnet

thurm (geol) cută mică, falie; dislocare de strat 
thurrough (reg) (agr) brazdă (de arătură) thurruck (agr) şanț de scurgere thus $(a d v)$ astfel, aşa, în acest fel / mod / chip thwart a contracara; a pune bețe în roate (cu dat); a se împotrivi, a sta împotrivă; a zădărnici; a da peste cap (planuri, socoteli etc.); a dejuca; a înfrânge, a învinge; a întretăia, a se încrucişa cu; a merge de-a curmezişul, a traversa, a merge pieziş; (fig) a alerga încoace şi încolo; ( with) a fi în contrast / contradicție / opoziție cu; refractar, recalcitrant, îndărătnic; contrar, potrivnic; împotrivire, opotiție, obstacol, piedică; (nav) bancă de lopătar

twartship (nav) ( $a d v)$ transversal; de-a curmezişul; (adj) transversal

thwartship bunker (nav) buncăr transversal

tibia (anat) tibie

tick a ticăi, a face tic-tac; (d. păsări etc.) a ciuguli, a da cu ciocul; a ciocăni; (d. ceas) a bate (minutele, secundele); a bifa, a însemna; a puncta; ticăit, tic-tac, bătaie a ceasului; clipă, clipită, moment, secundă; s $(p l)$ buline, picățele; semn mic, bifă, bifare; bucățică, părticică; (ec) credit, veresie, datorie; cont, socoteală; a lua pe datorie; a da / vinde pe datorie / credit; a cere credit (pt. o marfă etc.); a cere să ți se treacă în cont (o datorie etc.); (zool) căpuşă; bătaie a ceasului; (ec) cont, datorie; (textile) dos de pernă, față (de saltea sau pernă); (fig) punct (pe i); (fig) credit; (fig) moment; (metr) unitate informală de timp, egală cu un ciclu de ceas, bătaie de ceas; 1 tick of a computer's system (un ciclu al computerului) $=0,01 \mathrm{~s}$ (numit şi jiffy; (metr, sport) cea mai mică unitate de timp, măsurată la o competiţie, de obicei $0,1 \mathrm{~s}$ sau $0,01 \mathrm{~s}$; (metr, ec) unitate folosită la bursă pentru a exprima cea mai mică schimbare măsurabilă a unui indice bursier sau a valorii unei acțiuni: exemplu: la bursa din Chicago (Chicago Board of Trade) 1tick (pt. prețul produselor agricole $)=1 / 4$ cent $(\$ 0,0025)$ pe bushel

ticked cu picățele, cu buline

ticker (OM) întrerupător periodic / vibrator; balansier (la ceas); ceas (de buzunar, de mână); (el) contact intermitent, ruptor rapid; telegraf (înregistrator automat), vibrator; (ind, c) buzzer - avertizare sonoră; (fig) curaj, inimă, vigoare

ticket tichet, bilet (de intrare / de călătorie); etichetă; bon, tichet (de cantină etc.); bilet / loz de loterie; (ec) etichetă (cu prețul); legitimație de comisionar; afiş, aviz, anunţ; adeverință, dovadă, recipisă; certificat, diplomă, brevet; (ec) ofertă în plic închis (la licitaţie); carte de vizită; (amer) proces-verbal de contraventie (la circulație); (ec) a eticheta (o marfă), a pune prețul la (o marfă), a marca (prețul); (amer) a da / a elibera (cuiva) un bilet de călătorie; a trimite în călătorie; (ec) a depune (o ofertă) în plic închis (la licitație)

ticket agent agenție / casă de bilete

ticket clerk / collector (cf) controlor (de bilete), conductor

ticketing (ec) etichetare, marcare (a prețurilor, a mărfurilor); (vânzare prin) ofertă închisă

ticket inspector controlor de bilete (în autobuze, trenuri etc.)

ticket office (amer) casă de bilete

ticket window (cf) ghişeu de bilete

ticking (textile) nanchin, dril, pânză de saltea

ticking-off bifare, punctare; marcare, însemnare; (fam) (fig) săpuneală, perdaf, refec, dojană

ticking over (auto, av) mers la ralanti

tickler (mas) pompă de carburator, gresor, ac de transfer / de îngustare

tick off a bifa, a puncta, a însemna; a pune (pe cineva) la punct / la locul lui

tick out a înregistra (un mesaj, la telefon etc.); a transmite, a expedia (o telegramă); a lansa (un mesaj)

tick over (auto) a funcționa în gol, a merge în la ralanti

tid (agr) vreme sau situație prielnică; dispoziție, chef, poftă; toană; (zool) uger; (agr) căpiţă / grămadă mică / morman de fân

TID (metr, med) abreviere din limba latină pentru ter in die, de trei ori pe zi, unitate de frecvență în prescripții medicale

tidal (nav) referitor la / legat de maree / flux; asemănător fluxului; ca un flux

tidal air (med) aer respirat; (cantitate de) aer care se inspiră și se expiră

tidal basin (nav) doc plutitor

tidal boat (nav) vas care circulă în functie de flux şi reflux

tidal chart (nav) hartă a mareelor

tidal day, lunar day (metr) unitate de timp egală cu perioada medie dintre două treceri succesive ale lunii prin dreptul meridianului: 1 tidal day $\cong 24$ ore şi 50,272 minute

tidal dock v. tidal basin

tidal flow trafic / circulație în direcții opuse în diverse perioade ale zilei

tidal harbour (nav) port închis

tidal river (geogr, nav) fluviu, estuar în care pătrunde fluxul

tidal service (nav) serviciu naval legat de flux şi reflux

tidal shore (geogr, nav) coastă expusă mareei

tidal town port / oraş cu flux şi reflux

tidal wave (nav) val de flux 
tide maree, flux şi reflux, flux; (nav) a porni profitând de reflux; (fig) a urma cursul evenimentelor, a se da după vremuri, a fi oportunist; a produce / a marca / a face o cotitură; (poetic) torent, revărsare, şuvoi, avalanşă; mare, ocean; (fig) soartă (schimbătoare), mers / curs schimbător, vicisitudine (a soartei); ( $\mathrm{fam}$ ) (interval de) timp; zi; schimb (de douăsprezece ore), timp de lucru (în industrie etc.); sezon, perioadă, anotimp (al sărbătorilor etc.); (nav) a se lăsa dus de flux sau reflux; a fi supus mareei; a surveni, a se întâmpla, a se petrece; (d. maree) a duce, a purta, a transporta; a face să treacă peste (o dificultate etc.)

tide away a se potoli, a se linişti, a scădea, a slăbi (treptat)

tide back (nav) a se retrage odată cu refluxul

tide current (nav) curent provocat de flux sau reflux

tided supus mareelor, cu flux şi reflux

tide dial (nav, metr) hidrometru / limnimetru cu cadran, miră hidrometrică

tide driven acționat de energia mareelor

tide duty (nav) taxă de cheiaj

tide gate (nav) poartă de cap amonte (la ecluză); (geogr, nav) loc foarte expus mareelor; gură a bazinului de evaporare

tide gauge (nav, hidr) hidrometru, limnimetru; maregraf, miră de maree

tide harbour v. tidal harbour

tide hour (nav) timp al portului

tide in (nav) a intra în port odată cu fluxul

tidelands oil (amer) țiței extras din platoul continental

tideless (nav) fără maree / flux

tide lock (nav) ecluză de maree

tide mark (nav) limita fluxului sau refluxului; v. tide gauge

tide on a face progrese, a înainta, a progresa

tide out (nav) a ieşi din port odată cu refluxul / purtat de reflux

tide over a învinge / a birui / a trece (un obstacol), a sări (un hop)

tide power energia mareelor

tide predictor (nav, geogr) instrument pentru calcularea orarului fluxului şi refluxului

tide-rock (nav, geogr) stâncă acoperită de flux şi dezgolită de reflux

tide stream (geogr, nav) flux

tidewater (geogr) apă supusă mareelor; apă a flixului sau refluxului; țărm de mare; (nav) costier, de litoral

tide wave (nav) val de flux / de maree

tide way (geogr, nav) teren / canal expus fluxului / mareei; (hidr) sens al curentului tie legătură; nod; îmbinare; nod; fundă; cravată; (amer) şiret de pantofi / de ghete; pantofi cu şireturi, ureche (de cizmă); (OM) tirant, colier, scoabă; clamă; piesă de ancorare; (constr, cf) traversă; (nav) atârnătoare de vergă; troță; (fig) obligație, sarcină, răspundere; (constr) tirant, ancoră; (mas-un) grindă solicitată la tracțiune; (met, constr) sârmă de legat, bandă; (textile) cravată, fată de pernă, pilotă; a lega (cu sfoară, şiret etc.); a fixa; a asambla; a îmbina; a înnoda; a şnurui; (fig) a obliga, a sili, a constrânge; $(\mathrm{cf})$ a pune traverse la; $(\mathrm{TH})$ a ancora; a fixa cu cârlige / scoabe; (sport) a egala (pe adversar), a ajunge la egalitate cu (echipa adversă etc.); a face remiză / meci nul, a remiza; (fig) a se obliga, a se lega

tie bar (mec, mas-un, OM) bară de legătură / transversală de directie; (constr) tirant, bară de ancorare; vergea metalică / hobană de ancorare

tie-bar joint (mec, constr) nod, articulație (la grinzi sau ferme metalice)

tie beam (constr) grindă de legătură / de ancorare, chingă, căprior(i)

tie bolt (constr, OM, mas) şurub / bolț de fundație / de ancorare / de legătură / de îmbinare

tie cutting machine (mas-un) maşină de tăiat traverse (şi de cale ferată)

tied legat; terminat cu rezultat nedecis

tied foundry (met) turnătorie pentru producția de bază a uzinei

tie hook $(\mathrm{OM})$ balama cu cârlig

tie-in (ec) anunt publicitar / subsidiar, vânzare condiționată, articol fără căutare (băgat pe gâtul consumatorului)

tie line (met) linie / lipsă de miscibilitate / de separare clară (în cristalografie)

tie loan (ec) împrumut condiţionat / cu clauză restrictivă

tie member (constr, mas, mec) tirant

tie on $(\mathrm{TH})$ a înşuruba, a asambla prin înşurubare; a ataşa, afixa, a lega (de ceva)

tie piece (mas-un, OM) tirant, tendor, traversă, piesă / bară de legătură, pană

tie piece between uprights (met, mas-un) traversă superioară a presei cu două coloane, grindă principală

tie plate (cf) placă sub şină, placă de cale; (constr, met, OM) platbandă; placă de bază / de fundație / de reazem / de ancorare; contraplacă

tier rând; strat; şir; (constr) etaj, cat, strat (suprapus); (constr, OM) armătură; întăritură; piesă de sustinere; (nav) paniol; rând de marfă (și în magazia unei nave); a aranja în stive; a înşirui, a aranja / a aşeza în / la şir; a fi / a sta în şiruri / rânduri / straturi; a avea etaje / caturi, a fi 
etajat; a se stratifica, a se etaja; a se (o)rândui în şiruri / straturi / etaje

tierce (mat) treime, a treia parte; (metr) unitate de măsură britanică pentru capacitate(din limba franceză - treime): 1 tc (tierce) $=1$ petroleum barrel $\sim 1591$

tiering attachment (mas) dispozitiv ataşat / demontabil, de ridicat (la o maşină, instalaţie etc.)

tiering truck (mas) cărucior de ridicat, stivuitor

tie rod (mas, OM) tijă de legătură, bielă (şi de tracțiune) / cuplată, bulon de ancorare, bară de legătură / transversală, de direcție; diagonală; întinzător; (constr) tirant

tie to (şi fig) a lega / a fixa / a ataşa de; (fig) a îngrădi prin, a face să se încadreze în (reguli etc.); a se lega de

tie together a lega împreună / laolaltă, a îmbina

tie-up (amer) (ec, pol) coaliție, uniune, alianță; (ec) stagnare (a lucrului)

tie up a ocupa în mod inutil, a lega, a fixa; (fig) a încătuşa, a lega; a înfăşura, a înveli, a ambala; a lega de anumite condiţii; (ec) a depune, a consemna (o sumă)

tie water (chim) apă legată (în structura materialului)

tie welding (met) sudare cap-la-cap, cu eclisă

tiff (minrl) calcită

tiffany (textile) tifon, tul de mătase; sită de mătase

tight strâns; dens; impermeabil; ermetic; etanş; mic; compact, îndesat, consistent; solid, rezistent; bine clădit / lucrat; impermeabil; (bine) înțepenit, fix; (d. sfoară etc.) bine întins; încodat, strâns; (d. nod, şurub etc.) (bine) strâns; (d. haine, încălțăminte) strâmt; (OM) (prea) ajustat, fest, fără joc, bine reglat; (fig) rar, sărac, slab, deficitar; (ec) (d. piață) într-o stare critică, în criză; ferm, tare, bine, cu fermitate

tight beam (fiz) fascicul dens / strâns

tight coiling table (met, OM) masă / dispozitiv pentru înfăşurarea strânsă a benzii în rulou

tight contact (el) contact strâns / bun

tight cure (ind chim, plast) vulcanizare completă

tighten $(\mathrm{TH})$ a (se) întinde; a strânge (o curea, o sfoară etc.); a încorda; a ştemui; a etanşa; a fixa; a închide (ermetic); a înăspri, a întări, a intensifica; (fig) a se întinde, a se încorda, a se contracta; a se strânge

tightener tensor, întinzător; şnur, şiret; (mas-un, $\mathrm{OM}$ ) rolă / roată de întindere, întinzător

tightener pulley $(\mathrm{OM})$ fulie / roată de întindere (şi la curele)

tightening (mas-un, OM) (garnitură de) etanşare; strângere; încordare, întindere; înăsprire, intensificare tightening agent for brickwork (constr, met) liant de zidărie, agent / material de / pentru etanşarea zidăriei

tightening device (mas-un, OM) dispozitiv de întindere

tightening key $(\mathrm{OM})$ pană de reglare; cheie de acordor

tightening rails (OM, mas-un) sania dispozitivului de întindere

tightening screw (OM) întinzător, bolț / şurub de întindere

tightening sheet (hidr, OM) tolă antifiltrantă / de etanşare

tightening taper / wedge $(\mathrm{OM})$ pană de reglare

tightening up device întinzător (de cablu etc.)

tighten up a întinde, a trage (un cablu)

tight fit $(\mathrm{OM})$ ajustaj cu strângere / forțat / blocat / fix / strâns

tight fitting $(\mathrm{TH})$ închis ermetic; bine ajustat

tightish cam strâmt, strâmtuț; cam prost / dificil / critic

tight fitting screw $(\mathrm{OM})$ şurub de etanşare tight joint (mas-un, OM) îmbinare / cusătură etanşă

tightly inflated tyre (auto) pneu complet umflat tightness (met) compactitate, etanşeitate; impermeabilitate; închidere ermetică; densitate; tensiune, încordare; atmosferă încordată; apăsare, opresiune

tightness of money (ec) lipsă de bani (de pe piață)

tightness test probă de etanşeitate

tightness weld (met) sudură compactă / etanşă

tight nut $(\mathrm{OM})$ piuliță de întindere / de strângere

tight pulley $(\mathrm{OM})$ şaibă / rondea fixă

tight riveting $(\mathrm{OM})$ nituire de etanşare

tight stowage $(\mathrm{TH}$, nav) stivuire compactă

tight thread (OM) filet de etanşare / etanş

tilde tildă, semnul

tile (constr) tiglă, tub de argilă, placă de teracotă (şi pt. sobă) / de faianță / de gresie, cărămidă cu goluri, olan; (met) capac de pământ (pt. creuzete); (constr) cahlă; a acoperi / a înveli cu țiglă, a acoperi / a căptuşi / a pardosi cu plăci de ceramică

tile burner fabricant de țigle

tile colour cărămiziu, culoare cărămizie

tile-coloured cărămiziu, de culoarea cărămizilor / olanelor / tiglelor

tile-drain (agr, constr) dren / tub / țeavă de argilă arsă / olan (pt. drenaj, irigații etc.); a drena / a canaliza cu olane

tile dust (constr, met) cărămidă măcinată / sfărâmată 
tile earth (constr, TH) argilă pentru țiglă / olane tile field teren argilos (ca materie primă pentru fabricarea țiglelor / olanelor)

tile floor (constr) pardoseală din plăci de ceramică tile in (constr) a înveli, a îmbrăca în olane / țigle; a acoperi cu țigle / olane

tile kiln (constr, termo) cuptor pentru țigle / olane; cărămidărie

tile marker v. tile burner

tile making (ind chim) confecționare / fabricare a țiglelor / olanelor / plăcilor de ceramică

tile-packed column (ind chim, alim) coloană cu plăci de umplutură / cu umplutură în formă de plăci

tiler (constr) meseriaş / muncitor care pune țigle / olane pe acoperişuri / care pardoseşte sau acoperă pereții cu plăci de ceramică; v. tile kiln; v. tile burner

tile roof (constr) acoperiş de țigle / olane

tilery fabrică de olane şi plăci de ceramică

tile shard (constr) ciob de țiglă / olan

tile-works v. tilery

tiling (constr) învelire / acoperire cu țigle / olane; acoperis de tigle / olane; tigle / olane pentru acoperiş; pardosire / căptuşire cu plăci de ceramică; pardoseală de ceramică / cu plăci ceramice / cu placi de gresie

till (temporal) până la; (spațial) până la / în; lângă; (conj) până (ce) / să; (agr) a ara, a lucra, a cultiva (pământul); (teren) de argilă cu blocuri; (geogr) argilă eratică (cu blocuri)

tillable (agr) arabil, cultivabil

tillage (agr) arătură; pământ arat; munca câmpului; plugărit; cultivare, cultură

tillage ground / land teren cultivat / lucrat / arat

tiller (OM) mâner, manetă, bielă, tirant; (agr) agricultor, plugar; muncitor / lucrător agricol; cultivator (mașină agricolă); (agr) lăstar, mlădiță; puiet, copac tânăr; (nav) fusul cârmei, cârmă; a încolți, a scoate colți

tiller chain (nav) lanț al cârmei, lanț de guvernare

tiller rope (nav) odgon / cablu al cârmei; odgon / cablu de guvernare

tiller steering (mas) direcție comandată prin leviere

till money (ec) total al încasărilor (unui magazin), bani din casă / încasări

tilt (mec) înclinare, înclinație, aplecare, pantă, clină, deviere, abatere, basculare; lovitură; coviltir; (nav) pânză de corabie (întinsă ca umbrar); (OM, met) a teşi; a bascula; a (se) răsturna; a întoarce; a înclina, a apleca; a aşeza pe / într-o parte; a trânti jos; a da peste cap; a lua apărarea; a se clătina; a se legăna; a se balansa; a cădea; a acoperi cu un coviltir / cu o foaie de cort etc.

tiltable (OM) basculant, care poate fi înclinat, rabatabil, orientabil

tiltable furnace (met, ind chim) cuptor basculant tilt button (auto) buton de înclinare (d. o trapă)

tilt deck (constr) platformă basculantă

tilted oblic, înclinat

tilted turret (mas-un) cap revolver înclinat

tilter (met) dispozitiv de răsturnare / de întoarcere / de basculare, răsturnător (de rulouri, la laminoare)

tilth (agr) plugărit, arat, munca câmpului, strat arabil, adâncime a arăturii

tilt hammer (mas) ciocan cu arc / cu pedală (şi de forjă)

tilting (constr) (TH) basculare, răsturnare; inversare; rabatere; vărsare a conținutului; rabatabil; înclinabil; înclinat; aplecat, basculant

tilting bearing $(\mathrm{OM})$ lagăr oscilant, reazem rabatabil

tilting bracket (mas) consolă basculantă

tilting car (cf, met) vagon / cărucior rabatabil / basculant

tilting cart (cf) vagon basculant / dumcar

tilting charging bucket (mas, met) cupă basculantă, de încărcare

tilting converter (met) convertizor basculant tilting device (mas, met) dispozitiv de basculare

tilting effort (mec, OM) efort tensiune de / la răsturnare

tilting electric furnace (met) cuptor electric, basculant

tilting equipment (mas) dispozitiv / sistem de basculare

tilting fingers (mas, met) dispozitiv cu degete pentru întoarcere / răsturnare (a blocurilor rulourilor), răsturnător cu cârlige

tilting force (mec) forță / sarcină de răsturnare

tilting furnace (met, ind chim) cuptor basculant

tilting gear (mas) mecanism de înclinare (la un proiector, reflector etc.) (cu angrenaje)

tilting gear(ing) (met) dispozitiv / mecanism de basculat / de răsturnat (cu angrenaje)

tilting head moulding press (mas) presă de vulcanizat (cu cap basculant)

tilting ladle (met) oală de turnare, basculantă

tilting load (mec) sarcină (forță, moment) de răsturnare

tilting mechanism (mas) mecanism de basculare tilting milling head (mas-un) cap de frezat orientabil / pivotant / înclinabil

tilting moment (mec) moment de răsturnare

tilting motion (mec) mişcare basculantă, basculare 
tilting over (met) răsturnare (şi a rulourilor) tilting pass (met) calibru de răsturnare (la laminare), spațiu necesar răsturnării (unui rulou)

tilting platform (cf, met) rampă basculantă, platformă turnantă

tilting position $(\mathrm{TH})$ poziție de basculare

tilting screw (metr) şurub de reglare pentru citirea unghiului vertical

tilting skip (met) skip (cu răsturnare)

tilting steering wheel (auto) volan de direcție, basculant

tilting switch (el) comutator / întrerupător basculant

tilting table (mas, TH, mas-un) masă rabatabilă / basculantă / înclinabilă

tilting tank / vessel (OM, ind chim) recipient / rezervor / tanc basculant

tilting time (autom, mas) timp de declanşare / de relaxare / de revenire (la pozitiie)

tilting-type mixer (mas, constr) betonieră basculantă

tilting winch (mas) troliu de răsturnare

tilt over (mas, mas-un) a răsturna, a bascula, a da peste cap

tilt steering (auto) volan ajustabil

tilt up in front (mec) a bascula / a răsturna în față; a face să basculeze; a ridica într-o parte; a redresa

timber lemne; cherestea; material lemnos; a sprijini, a propti

timber carriage (auto) remorcă de transportat buşteni

timber-claim (ec, jur, silv) concesiune forestieră

timbered de cherestea / lemn; lemnos; păduros, împădurit

timber frame / framing (constr) (perete) de paiantă cu cadre de lemn

timbering împădurire; vegetație arborescentă; bogăție naturală în păduri; lemnărie, cherestea, lemn de construcție

timber land (amer) ținut împădurit, zone de păduri (folosite pt. cherestea)

timber merchant (ec) cherestegiu, comerciant de cherestea

timber partition (constr) perete de lemn; palplanşă

timber ship (nav) navă / corabie de lemn

timber trade $(\mathrm{ec})$ comert de cherestea, cherestegerie

timber tree (constr) arbore de construcție

timber work (constr) construcție de lemn; lemnărie (a unei construcții)

timber yard fabrică / depozit de cherestea time timp; perioadă; termen; tact; durată; vreme; soroc; in the course of $\sim \mathrm{cu}$ vremea / cu timpul, în decursul timpului; is money timpul costă bani / este prețios; will tell / show vom vedea, timpul va dovedi adevărul; all the $\sim$ tot timpul; to have $\sim$ on one's hand a dispune de timp, a avea timp disponibil; to kill $\sim$ a omorî vremea, to spend one's $\sim$ in talking a-şi pierde timpul cu vorba / vorbind; to take one's $\sim$ a nu se grăbi, a o lua încetişor; presses / is pressing ne presează timpul, e urgent; to be pressed for a fi grăbit, a nu avea timp de pierdut; to fritter / to potter away / to waste one's a-şi pierde / a-şi irosi vremea zadarnic; truth is the daughter of $\sim$ cu timpul adevărul iese ca undelemnul la suprafață; liber / disponibil; răstimp, (interval de) timp; existență, viață; dată, rând, oară; ocazie, prilej; a regla; a împărți; a fixa în timp; a stabili (termenul pentru, momentul; a alege, a potrivi momentul; a hotărî data; a se adapta (vremurilor etc.); a se acomoda cu, a se da după; a face să fie oportun, a face la timpul potrivit; a acorda (un termen); a cronometra, a măsura; a regla, a potrivi (ceasul etc.); (metr) formă de exprimare a timpului pe durata unei zile; formatul ISO 8601 pentru exprimarea timpului: HH:MM, sau HH:MM:SS, HH - numărul orei (de la 00 la 23), MM - numărul minutelor (de la 00 la 59), şi SS . numărul secundelor (de la 00 la 59); se acceptă şi fără separare: HHMMSS; în US se utilizează notația 1:23 am (ante meridian) pentru 01:23, şi $1: 23 \mathrm{pm}$ (post meridian) pentru 13:23; miezul nopții poate fi 00:00 pentru ziua care începe sau 24:00 pentru ziua care se termină

time allowed in advance (TH) timp acordat / prevăzut / estimat (din proiect)

time and motion study (TH) studiu al mişcărilor şi duratei (pt. operații manuale, normare)

time-band averaging $(\mathrm{ec}, \mathrm{TH})$ calcul al mediei costului manoperei pe unitatea de timp

time bargain (ec) tranzactie / afacere cu termen time-base oscillation (mec) oscilație basculantă / de basculare (cu intervale de timp impus)

time behaviour (materiale) comportare în / dependentă de timp

time belt fus orar

time-board tablou de pontaj

time book v. time sheet; (cf) mersul trenurilor

time card (mas-un, TH) fişă de cronometraj

time charter (nav) navlosire pe termen; charter pe timp scurt

time check (metr) cronometru, verificare a timpului (de lucru etc.) 
time circuit (autom, el) circuit de temporizare

time clerk (ec, $\mathrm{TH})$ pontator, cronometror, normator

time clock (metr) ceas de control, cronometru; ceas de pontaj

time closing contract (ec) contract cu închidere la termen limită

time constant (fiz, mec) constantă de timp

time consuming (adj) care necesită / reclamă / consumă mult timp, care constituie o risipă de timp, cronofag

time-consuming lag (mas-un, TH) timp de prelucrare / procesare

time / timed control reglare în timp; reglare a planului / programului de timp; (autom) comandă cu program / cronometrică, regulator cu program

time curves of swelling pressure (ind chim, plast) curbe ce reprezintă presiunea de umflare în functie de timp

time-cycle control (autom) reglare programată / după program

timed (autom, mas) sincron, sincronizat; programat (în timp)

time-deformation curve (plast, met) curbă a variației deformației în timp

time delay (autom, TH) interval de întârziere, temporizare

time-delay connection (TH autom, mas) conectare înceată / întârziată / temporizată

time-delay device ( $\mathrm{TH}$, autom) temporizator, releu de timp, circuit de întârziere / de temporizare

time-delay relay (el, autom) releu temporizator / temporizat / cu actionare întârziată

time deposit (ec) depozit pe termen lung; depunere pe termen

time derivative (mat, fiz) derivată în raport cu timpul

time detector (metr, autom) ceas de control

time element (el, autom) dispozitiv de temporizare; (fiz) interval de timp (şi elementar)

time-elongation curve (plast, met) curbă elongație-timp

time exposure (mec) expunere îndelungată

time factor (plast) factorul timp (în special de constrângere); (ec, TH) termen-limită, datălimită; trecerea / scurgerea timpului în defavoarea cuiva

time for completion $(\mathrm{TH}, \mathrm{ec})$ termen / durată de execuție (a unei lucrări)

time freight (transport, nav) transport / încărcătură / fraht de mare viteză; navlu pe timp; coletărie de mare viteză

time fuse (el, autom) siguranță cu întârziere / temporizată time grading eşalonare în timp

time in starting (auto, mas) timp de demaraj

time-inverse invers proporțional cu timpul; (autom, el) dispozitiv de protectie la care timpul de deschidere descreşte dacă tensiunea (curentul) crește

time it out (fiz, met, autom) a tărăgăna, a tergiversa, a (pre)lungi (timpul)

time jitter fluctuatie în timp

timekeeping (fiz, metr) cronometrie, cronometraj; (ec) pontaj; mers exact / regulat (al ceasului)

time lag (autom, metr) (timp de) întârziere, decalaj, timp între aplicarea semnalului și indicația aparatului; rămânere în urmă, temporizare

time lag / -limit / delayed action (autom, mas) acțiune întârziată (a unui întrerupător, releu etc.), temporizare (şi prevăzută)

time lag device (autom, mas) dispozitiv cu acțiune întârziată, temporizator

time-lag error (metr, autom) eroare de temporizare

time lapse / period durată, perioadă, interval de timp

time law dependență de timp

time lead avans temporal / în timp

timeless nedatat, fără dată; inoportun, nepotrivit

time limit (ec, TH) limită de timp, termen (de predare a unei lucrări, proiect), scadență

time-limit relay $(\mathrm{mec})$ releu temporizat

time load withstand strength $(\mathrm{mec})$ stabilitate la sarcină / la încărcare de durată

time-loan / -money (ec) împrumut pe termen

timely $(a d v)$ actual, de actualitate; oportun

time marching (mat) tehnică de rezolvare a ecuatiilor diferentiale care au derivate de timp

time mark marcarea timpului

time meter (metr) cronometru

time of burning (TH) durată de ardere (a fitilului / a capsei electrice cu întârziere)

time of cure (constr, ind chim) durată de tratare a betonului; (plast, ind chim) durată a vulcanizării / a întăririi

time of delivery $(\mathrm{ec})$ termen de livrare

time of dwell (met, plast, mas-un, hidr) timp / durată de menținere a presiunii

time of etching (met) durata atacului (pt. probe metalografice)

time of exposure (fiz, metr, TH) timp de expunere; (met, ind chim) timp de menținere (în cuptor / reactor etc.)

time off timp / moment de sfârșit / de terminare / de încheiere (a unei acțiuni / operații / proces tehnologic etc.)

time of fusing (met) timp de topire 
time of heat (met, plast, ind chim, alim) durată de menţinere a temperaturii

time of operation (mas) durată de funcționare / de lucru / de execuție a unei operații sau a unui set de operații intercondiționate

time of queezing (alim, mas, plast) durată de compresiune / de comprimare / de stoarcere

time of recovery (mas, med) durată de recuperare / de restabilire

time of (s)melting (met, ind chim) durată de topire

time of vibration (fiz, mec) perioada vibrației

time of welding (met) durată a sudării, timp de sudare

time out of repair (mas-un, $\mathrm{TH}$ ) timp pierdut din cauza reparației

time payment (amer) plată în rate

time per charge (met) timp de trecere (prin cuptor), durata unei şarje

time piece (metr) cronometru; ceas(ornic)

time-program(me) control (mas, mas-un, autom) control / reglare după program

time-proof durabil, rezistent în timp; trainic

time quenching (met) călire reglabilă / întreruptă, călire dependentă de durata de menținere şi cea de răcire

timer (autom, el) distribuitor de aprindere, traductor, releu / regulator de timp / cu program, temporizator; (auto) distribuitor de aprindere

time(r) switch (autom, el) întrerupător comandat electronic

time release (autom) declanşare temporizată

time sampling eşantionare / cuantificare în timp

time-saving device aparat de uz casnic

time scale scara timpului

time schedule (constr, $\mathrm{TH}, \mathrm{ec}$ ) program de constructie / de executare a lucrărilor

time sequence $(\mathrm{TH})$ succesiune / desfăşurare în timp, secvență de timp

time setting range (metr, autom) domeniu de reglare a temporizării

time sharing (ec) operatie de leasing constând în închirierea / folosirea simultană de utilaje mai multor clienți / parteneri (în „timpi partajați”); (autom) divizare a timpului, repartiție temporală, distribuție în timp

time-sheet foaie de prezență; fişă de pontaj; (nav) program de descărcare

time signal semnal pentru ora exactă

time-stained (plast) îngălbenit / pătat de vreme; (met) patinat

time standard (TH) normă de timp

time study $(\mathrm{TH})$ cronometraj; normare inițială / de probă time switch ( $\mathrm{TH}$, autom) comutator automat (programat dinainte)

timetable (cf) mersul trenurilor; $(\mathrm{TH}, \mathrm{ec})$ orar; program; ordine de zi, agendă

time-taking care cere / consumă (mult) timp

time-temperature curve (met, ind chim) curba timp-temperatură

time-temperature tolerance (alim) corelație timp - temperatură (efect combinat al duratei şi temperaturii de depozitare asupra calității alimentelor congelate); (TH) toleranța referitoare la abaterea combinată timp - temperatură

time-temperature transformation curve (met) curbă / diagramă timp - temperatură - transformare, diagramă TTT, curbă de transformare izotermică / în S

time the ignition (auto, termo) a regla, a potrivi aprinderea

time-wage rate tarif orar

time work (ec) muncă (plătită) cu ora / ziua

time worker muncitor (plătit) cu ora / ziua

time yield randament în / raportat la timp

time zone (metr) fus orar, unitate reprezentând diferența în timp dintre o anumită locație şi timpul universal: diferența este pozitivă dacă timpul local este mai avansat decât timpul universal şi negativă dacă timpul local este în urmă față de timpul universal; (metr) fus orar, unitate informală pentru a exprima diferența de longitudine între două locuri pe Pământ; 1 fus orar cuprinde o deschidere de $15^{\circ}$ în longitudine

timing (termo) distribuție a gazelor (în timp), coordonare în timp, sincronizare, reglare în timp / a unui ceas; reglarea timpului; cronometrare; contorizare; potrivire în timp; îndeplinire / executie la timp; (sport) cronometraj, cronometrare; ( $\mathrm{TH}$, auto) reglare a aprinderii; (fotografie) calcul al timpului de expunere; (autom) temporizare

timing adjustment (autom, auto, termo) reglare a momentului de aprindere

timing angle (mas-un) unghi de reglare a avansului, în timp

timing chain (auto) lanț de distribuție

timing control (autom) reglare a timpului / a temporizării

timing device (autom) dispozitiv de sincronizare; (metr) mecanism de măsurare a timpului / de temporizare

timing error (mas, autom, metr) eroare de temporizare / de sincronizare

timing gear (mec, autom, OM) distribuție sincronizată / temporizată 
timing relay (el, autom) releu de temporizare de timp

timing screw (mas, OM) şurub de reglare a balansierului

Timken bearing (OM) rulment Timken / cu role conice

Timperley transporter (mas) macara Timperley

Tin (Sn) (chim) (şi Stannum) staniu; cositor

tin (met) tablă cositorită / galvanizată; (alim, OM) cutie de conservă, bidon, cană, gamelă, căniță, tinichea, formă de copt, veselă, vase (de cositor sau tablă); (alim) a pune (în) conserve, a face conserve din, a conserva (în cutii); de cositor; de tablă; slab, prost, de proastă calitate; a cositori, a spoi; a acoperi cu staniol; (metr, alim) unitate informală de măsură pentru volum, utilizată în rețete culinare: 1 tin $=227 \mathrm{ml}$

tin and temper (met) aliaj de staniu cu cupru tin-base alloy (met) aliaj pe bază de staniu tin-bearing (material) (met, T) (aliaj) pe bază de staniu pentru lagăre; bogat în cositor / staniu

tin box (alim, OM) cutie de tablă (moale), cutie de conservă

tin bronze (met) bronz cu staniu

tincal (chim) borax (natural) brut

tin can (nav) distrugător, contratorpilor

tin canister $(\mathrm{OM})$ bidon, canistră; cutie de tablă

tin case $(\mathrm{TH})$ cutie de tablă, bidon

tin coat(ing) (met) acoperire cu staniu

tin concentrate (met) concentrat de staniu

tin concentrate smelting (met) topirea minereului concentrat de staniu

tin-copper plating (met, T) placare cu staniu şi cupru

tin cow (alim) lapte condensat / în cutii de conserve; conservă de lapte

tinct vopsea; culoare

tincture (chim, med) tinctură; culoare, vopsea; (arte) nuanță, ton; (fig) spoială, lustru, cunoştințe superficiale, a da o spoială (de); with a vopsi cu

tinder box brichetă

tinder-like (uscat) ca iasca; uşor inflamabil

tin desease (chim) ciuma staniului

tin filing machine (alim, TH) maşină de umplut cutii de tablă / de conserve

tin filings (met) pilitură / aşchii de staniu; pilitură de cositor

tin( )foil (alim, met) folie / foiță de staniu, staniol

tin-free (met) fără staniu

tin-free bearing metal (met, T) babbit / aliaj antifrictiune fără staniu

tinge colorație, nuanță; tentă, ton; to have $\sim$ of blue / a blue a bate în albastru; a avea o nuanță albăstrie; (fig) nuanță, iz; vopsea; (ec) primă, premiu, gratificație; with a colora, a vopsi în / cu; a da o nuanță; (fig) a da o spoială / un aspect / un iz

tingle a țiui, a zbârnâi, a zumzăi, a bâzâi, a suna; (med) a furnica, a da / a produce o mâncărime; a tremura, a palpita; țiuit, bâzâit, zumzăit, zbârnâit

tin leaf (met) foaie de staniu, staniol

tinless bronze (met) bronz fără staniu

tin liquor (TH) baiț, mordant (de cositor)

tin metal (met) staniu metalic

tin metal sheet (met) tablă de staniu

tinned (met) cositorit, stanat; (alim) conservat (în cutii metalice / cutii de conserve)

tinned cow $v$. tin cow

tinned food (alim) conserve

tinned goods $(p l)$ conserve

tinned loaf (alim) pâine coaptă în formă

tinned plate / sheet (met) tablă cositorită

tinned wire (met) sârmă cositorită

tinner tinichigiu

tinner's hammer ciocan de tinichigerie

tinner's shears foarfece de tinichigerie

tinner's snips foarfecă de tablă

tinnery (ind chim) industria cositorului

tinning (met) cositorire, stanare

tinning bath (met) baie de cositorire / de stanare tinning line / plant / unit (met) linie / instalație de cositorire / de stanare / de acoperire cu staniu sau aliaje de staniu

tinning metal (met) aliaj cu conţinut de $\mathrm{Sn}$ şi $\mathrm{Pb}$ tinning plant (met) atelier de cositorit

tinning pot / stark / vat (met) baie / creuzet de cositorire / de stanare

tinning solution (met) lichid de cositorire

tinny cu / de cositor; ca de tinichea; care sună ca o tinichea; metalic; (artă) (d. colorit) aspru, dur, metalic, sec

tin opener $(\mathrm{OM})$ deschizător de conserve

tin ore (minrl) casiterit, minereu de cositor

tin pan (alim) formă pentru copt; farfurie de tablă

tin pest / plague (chim, met) ciuma cositorului (proces de deteriorare prin coroziune)

tin pickling (met) atac cu acizi după cositorire / stanare

tin plate (met) tablă galvanizată, tablă cositorită / de cositor / albă / stanată; tinichea; a cositori

tin-plate cold rolling mill (met) laminor la rece pentru tablă cositorită / albă / stanată

tin-plate rolling mill (met) laminor pentru tablă cositorită / albă / stanată

tin-plate waste (met) deşeuri de tablă cositorită / albă / stanată

tin plated (met) acoperit cu staniu 
tin plate ink (ind chim, met) vopsea / cerneală de tipărit pentru / pe tablă

tin plating (met) cositorire, placare cu $\mathrm{Sn}$

tin pot (met) cuvă de cositorire; oală de tablă; cutie de tinichea; (nav, mil) cuirasat; $(\mathrm{TH})$ baie de cositor

tin powder (met) pulbere / praf de staniu

tin printing (met) tipar pe tablă, întipărire pe tablă

tin pyrite (chim, minrl) pirită staniferă

tin refuse (met) deşeuri de cositor

tins (alim) conserve

tin salt $v$. tin liquor

tinsel beteală, paiete; lamé brocart; (met) sârmă plată; sclipitor; superficial, amăgitor; care îți ia ochii; prefăcut; a împodobi cu beteală; a găti

tinsel cord (met) sârmă laminată pentru liță; (el) cordon flexibil

tin sheet(ing) (met) tablă subțire de staniu sau aliaj al lui; tablă cositorită / galvanizată

tin shop atelier de tinichigerie

tin slab (met) placă de staniu (semifabricat)

tinsmithing (met) atelier de stanare / de cositorire

tin solder (met) aliaj (de cositor) de lipit, pe bază de staniu

tin stone (minrl) casiterit

tin strip (met) (plat)bandă de staniu sau aliaj al lui, bandă stanată / cositorită

tin-strip rolling mill (met) laminor pentru benzi stanate / cositorite

tin strongly mixed with lead (met) aliaj $\mathrm{Sn}-\mathrm{Pb}$ (în proporție $1: 1$, cu mult $\mathrm{Pb}$ )

tin stuff (minrl, met) minereu de cositor brut

tint tentă; culoare, colorit, colorație; nuanță; ton; hașură; a colora; a nuanța; a da culoare (unui tablou etc.)

tin tack $(\mathrm{OM}$, met) cuişor, țintă colorată (de tapiterie) (din aliaj de staniu)

tinted glasses ochelari (cu lentile) de soare

tinting nuanțare, gradare a culorilor; (poligrafie) tonare

tintless incolor; nenuantat, negradat

tinto (agr) soi de vin spaniol

tint of passage culoare de tranzitie

tintometer (metr, plast) calorimetru, tintometru, aparat de măsurat culoarea / colorimetru

tints of the rainbow (fiz) culorile curcubeului

tin ware obiecte de cositor sau tinichea

tin works (met) uzină / atelier de prelucrare a staniului; topitorie de cositor; fabrică de tablă cositorită

tiny micuț, mititel

tiny crack (met, materiale) microfisură (subțire sau moale) tin-zinc plating (met) acoperire / placare cu staniu şi zinc

tip (OM) duză, ajutaj, jiclor, vârf, extremitate, capăt, plăcuță, pastilă; (met) cioc / bec al suflaiului / al arzătorului (la sudare sau tăiere cu flacără); (cf, met) culbutor de vagoane; loc de aruncat gunoaie; atingere uşoară; cap (şi al unui dinte la o roată dințată); (anat) lob al urechii; bombeu, vârf (la pantofi); vârf, capăt metalic, măciulie (la baston, umbrelă etc.); (textile) colț (de basma etc.); înclinatie, înclinare, aplecare; loc de descărcare (pentru gunoi etc.); lovitură / atingere ușoară; ( fam) ciubuc, bacșiș; mic dar / cadou bănesc; (la bursă sau fig) pont (vândut cuiva); informatie / indicatie confidentială; sfat discret; a scutura; a teşi; a atinge / a lovi uşor; a (se) răsturna, a (se) deșerta, a face să se basculeze; a pune vârf la; a reteza vârful; a tunde; a (se) înclina; a (se) apleca; a face să se încline; a culbuta; a face să cadă, a doborî; a se întoarce într-o parte; a da bacşiş / ciubuc; a dărui, a face cadou (bani etc.); (la bursă etc.) a sfătui / a informa discret, a vinde un pont (sigur); a arunca, a azvârli, a da; sfat; driving $\sim \mathbf{s}$ (auto) sfaturi pentru şoferi

tip barrow (constr, mediu) tomberon; (met) cărucior basculant

tip car (cf) vagon basculant

tip cart (met, TH) cărucior basculant / culbutor; tomberon

tip circle $(\mathrm{OM})$ cercul de cap $\left(\mathrm{d}_{\mathrm{a}}\right)$ (al unei roți dințate)

tip cleaning (met) curățarea electrodului (la maşina de sudat în puncte)

tip clearance $(\mathrm{OM})$ joc radial, joc de cap, exterior (la roți dințate), toleranță radială

tip cylinder $(\mathrm{OM})$ cilindrul de cap (al unei roți dinţate)

tip diameter $(\mathrm{OM})$ diametrul de cap (al unei roți dințate) $\left(\mathrm{d}_{\mathrm{a}}\right)$

tip down a doborî, a da jos, a dărâma

tip electrode (met, el) electrod de sudură

tip lorry (auto) autocamion cu benă basculantă, autobasculantă

tip off a avertiza, a preveni; a vinde un pont

tip of thread (OM) vârf al filetului

tip out a deşerta, a răsturna, a goli; a se deşerta (prin răsturnare)

tip over a face să (se) basculeze, a (se) răsturna; a trece peste; $v$. tip out

tippable care primeşte bacşiş; corupt, care poate fi mituit

tipped (mas-un) cu plăcuță de aliaj dur, aplicată pe tăiş, încărcat / acoperit cu metal / aliaj dur

tipped fill (cf, constr) rambleu executat uscat, umplutură executată uscat 
tipped solid cutter (mas-un) freză cu dinți placați cu (plăcuțe din) carburi dure

tipper (auto) camion basculant; (cf, met) culbutor, dispozitiv de basculare / de răsturnare / culbutare; muncitor (basculator / culbutor); persoană care dă bacşiş; v. tip car

tipper seal (OM, met) obturator / închizător basculant

tippet (textile) eşarfă, capişon, glugă; (capă de) blană; a se dezice

tipping basculare, descărcare; răsturnare; (met, constr) fixare / încărcare cu sudură (şi pt. recondiţionare); basculant, culbutant; straşnic, grozav, formidabil

tipping angle (mec) unghi de basculare tipping body (mas) benă basculantă tipping bracket $(\mathrm{OM})$ consolă basculantă tipping bucket (mas) benă apucătoare, schip, găleată basculantă, graifăr; (met) skip (la furnal)

tipping car (cf, met) vagonet basculant

tipping device / equipment (mas) dispozitiv de basculare, culbutor

tipping force (mec) efort / forță de răsturnare

tipping furnace (met) cuptor basculant

tipping gearing (met) dispozitiv / mecanism de basculare

tipping gradient (mec) pantă critică

tipping grate $(\mathrm{TH})$ grătar oscilant

tipping hopper (agr, ind chim) jgheab / buncăr / siloz basculant

tipping (met) basculare, descărcare

tipping ladle (met) oală de turnare basculantă

tipping lever $(\mathrm{OM})$ pârghie basculantă

tipping mechanism (mas) mecanism de basculare

tipping motion (mec) basculare, mişcare basculantă

tipping platform / stage (cf, met) rampă basculantă, descărcător basculant

tipping seat $(\mathrm{OM})$ strapontină

tipping trough (mas) jgheab basculant

tipping truck camion basculant

tipping (wag)gon v. tip car

tipple (mas) basculator, culbutor, basculare; (alim) băutură alcoolică / spirtoasă

tip relief $(\mathrm{OM})$ rotunjire / flancare a capului (de dinte)

tip surface (OM) suprafața capului dintelui / de vârf a angrenajului

tipsy cake (agr) budincă / prăjitură cu rom etc.

tiptop (d. persoane) perfecțiune întruchipată, culme a perfecțiunii; $(p l)$ cremă, caimac; $(f i g)$ (d. lucruri) cremă, tot ce e mai bun; excelent, admirabil, superior

tip truck v. tip lorry tip vortex (mec, fiz) vârtej / efect marginal (şi la cicloane)

tip wag(g)on v. tip car

tire (auto) anvelopă, pneu, cauciuc; cerc (de fier) la roată; bandaj, obadă (de roată); (cf, mas) şină de roată (şi de pod rulant); oboseală, surmenaj; a obosi, a extenua, a epuiza; (fig) a (se) plictisi, a se sătura (de ceva); ( of, $\sim$ with) a se plictisi / a se sătura (de); a fi dezgustat de; a cercui, a pune cerc la (o roată); a schimba / a pune cauciuc(uri) la (automobil, bicicletă)

tire blow-out (auto) explozie de pneu

tire bolt (auto) şurub pentru fixarea jenții / roții

tire confection machine mașină de confecționat anvelope

tired (mas) obosit, slăbit; of, with ostenit, extenuat, istovit, epuizat din cauza; plictisit (de), sătul (de); dezgustat (de)

tiredness oboseală (fizică); istovire, extenuare, epuizare, surmenaj; (fig) plictiseală; saturație; dezgust

tireless neobosit, inepuizabil, neostenit; (d. eforturi etc.) neobosit, neîncetat, susținut; (d. o roată) fără cerc / bandaj; (auto) fără anvelope / pneuri / cauciucuri

tire lever (mas, OM, auto) pârghie de montat anvelope

tire mill (cf, met) laminor de bandaje (de roți)

tire out a istovi, a epuiza, a extenua

tire press (cf, mas-un) presă de montat bandaje (de roată)

tire pressure (auto) presiunea aerului în cameră / pneu

tire pressure monitoring system (TPMS) (auto) sistem de monitorizare a presiunii în pneuri

tire puncture (auto) pană de cauciuc

tire shoe (auto) sabot de cauciucuri

tiresome obositor, istovitor; plictisitor, plicticos; nesuferit, exasperant, supărător

tiresomeness caracter obositor / istovitor; caracter plictisitor, plictiseală; caracter enervant / supărător

tire trouble (auto) pană de cauciuc

tire tube (auto) cameră de aer

tire valve (auto, OM) valvă / ventil de cameră / la cauciuc

tirewoman cameristă; garderobieră

tiring v. tiresome (amer) cercuire, bandajare (a roții); (auto) montare a pneurilor (la maşină, bicicletă etc.)

tiring house $v$. tiring room

tiring room cabină, garderobă

tirl a tremura, a se cutremura; (d. vânt) a se schimba brusc; a roti, a învârti; a dezgoli; învârtire, rotire; vârtej 
tiro începător, novice; ageamiu

T-iron (met) grindă de fier / oțel în T

tisane (alim) tizană, infuzie, (tip de) fiertură

tisic(k) (med) ftizic, tuberculos

tissue tesătură, stofă fină / subțire; voal; (biol) țesut; (fig) textură, împletitură, urzeală; țesătură; păienjeniş (de minciuni etc.); a țese, a urzi, a împleti

tissued țesut, urzit, împletit

tissue paper hârtie de mătase, foiță

titan v. titanium

titanate (chim) titanat, sare de titaniu / a acidului titanic

titanic (chim) titanic, referitor la titaniu

titanic oxide (chim) oxid de titan

Titanium (Ti) (chim) titan(iu)

titanium carbide (chim, met) carbură de titan

titanium steel (met) oțel cu titan

tithe (metr) unitate tradițională pentru proporții: 1 tithe $=1 / 10$

tithing (metr) unitate veche britanică de măsură pentru arie: 1 tithing $\sim 5$ ha

title (poligrafie etc.) titlu, capitol, secțiune; $(p l)$ titluri, generic; demnitate, grad, rang; (jur) titlu, drept, calitate, vocație, document, act doveditor al unui drept, a îndreptăti, a da drepturi; (chim) titlu, titru (la un aliaj, o soluție); a intitula, a denumi; (poligrafie) a pune titlul (pe cotorul unei cărți); (chim) a titra

titled (învestit) cu titluri, titrat

title deed (jur) titlu / act de proprietate; act / document / titlu doveditor al unui drept

titrant (chim) solutie de titrare

titrable acidity (chim) aciditate titrabilă

titrant (chim) soluție / agent de titrare

titrate (chim) a titra, a doza

titrated (chim) titrat

titrated solution (chim) soluție titrată

titrating $\mathrm{v}$. titration

titration (chim) titrare, dozare volumetrică

titre (chim) titru (al unei soluții); titlu, titru (al unui aliaj)

titter a se legăna, a se hâțâna

tittle liniuță (ca semn de prescurtare); punct(uleț); (fig) amănunt meschin, fleac, bagatelă; iotă

titular titular, nominal; onorific, onorar; cuvenit (unei funcții); legat de titlu / funcție / post; titular (suplinit de altcineva)

titulary $(a d v)$ în virtutea unui titlu; (doar) cu numele, de formă, (în mod) nominal

titulary v. titular

T joint (OM) îmbinare în T; teu (armătură)

T junction (OM) ramificație / racord în T; drum / intersecție în formă de T; (el) joncțiune în T

TMC ft (metr, hidr) abreviere pentru ,thousand million cubic feet" -1000 de milioane de picioare cubice, unitate de măsură pentru volum, utilizată în hidrotehnică: $1 \mathrm{TMC} \mathrm{ft}$ $28,31710^{6} \mathrm{~m}^{3}$

TMC ft/day (metr, hidr) abreviere pentru ,thousand million cubic feet per day" - 1000 de milioane de picioare cubice pe zi, unitate de măsură pentru debit volumic, utilizată în hidrotehnică: $1 \mathrm{TMC} \mathrm{ft/day} \sim 327,74 \mathrm{~m}^{3} / \mathrm{s}$

TME (metr) abreviere pentru Technische Mass Einheit (în germană) (engineering mass unit unitate de masă în inginerie): 1 TME este masa accelerată la $1 \mathrm{~m} / \mathrm{s}^{2}$ de o forță de $1 \mathrm{kgf} ; 1 \mathrm{TME}$ $=1$ metric slug $($ brit $)=9,80665 \mathrm{~kg}$

T network (inf, c) rețea / filtru

TNT (chim) tinitrotoluen, trotil

to (metr) unitate tradițională de măsură pentru volum, în Japonia: 1 to 18,0391

toad's eye (chim, minrl) casiterit

toadstool ciupercă otrăvitoare; ciupercă mare

to-and-fro $(a d v)$ încoace şi încolo; (mişcare) de du-te-vino; forfotă, agitație

to-and-fro motion (mec) mișcare de du-te-vino

to-and-fro bend test $(\mathrm{mec})$ încercare la îndoire alternativă

toast (alim) pâine prăjită, pesmete; felie de pâine prăjită; $(p l)$ frigănele; toast, închinare (a paharului); persoană sărbătorită / pentru care se toastează / lucru pentru care se toastează; obiect al admirației generale; a (se) prăji, a (se) rumeni (pâinea), a se încălzi la loc; a toasta pentru (cineva sau ceva)

toaster (alim) grătar / tigaie pentru prăjit pâinea, aliment (de) prăjit; persoană care propune toasturi / care prezidează un banchet / care toastează

tabacco (bot, agr) tutun; tutun (de pipă); tabac (de prizat sau mestecat)

TNT (chim, mil) simbol pentru trinitrotoluen (substantă explozivă)

tobacco-coloured de culoarea tutunului

tobacco cutter (agr, mas-un) maşină de tăiat tutun; cuțit de tăiat tutun

tobacco-cutting machine $v$. tobacco cutter

tobacco pipe lulea, pipă

to-be viitor; făgăduit; în perspectivă

to-come viitor, din viitor; care va să vină; viitor, ziua de mâine; devenire

tocopherol (chim) vitamina E uleioasă (extrasă din seminte etc.)

tod (înv) tufiş; (metr) unitate de măsură pentru masă (veche, pentru lână) $(1$ tod $=12,7$ kg); a avea masa de 1 tod

tod (metr) unitate tradițională de măsură pentru masă: 1 tod $\cong 12,7 \mathrm{~kg}$

today astăzi, (ziua de) azi; în zilele noastre; zilele / vremurile / timpurile noastre 
toe (mas-un, OM) crapodină, lagăr axial, pivot, vârf curbat / bombat; (anat) deget de la picior; vârf (al piciorului, pantofului, ciorapului); extremitate inferioară; capăt de jos; bază; parte anterioară / dinainte; a lovi / a atinge cu vârful piciorului; (fig) a fi disciplinat; a se supune / a se integra disciplinei / regulilor; toe (metr) simbol pentru tonne of oil equivalent, unitate de măsură pentru energie, utilizată în industria energetică; 1 toe reprezintă energia disponibilă prin arderea a aproximativ 1 tonă de țitei: 1 toe $\cong 41,868 \mathrm{GJ}$

toe basin (hidr) puț de amortizare

toe cap (OM) bombeu, (vârf) bombat (de pantof etc.)

toe change (auto) schimbare a unghiului de convergență (a roților)

toe clip cureaua pedalei, curea de pedală (la bicicletele de curse)

toe crack (met) fisură în cusătura de sudură, extinsă şi în materialul de bază

toe-in (auto) convergența roților

toe in (auto) (d. roți) a avea convergență; (fam) a călca înăuntru

toe-in angle (auto) unghi de convergență a roților

toe it a dansa; a călca; a păşi

toe nail $(\mathrm{OM})$ cui bătut oblic; (anat) unghie (de la picior)

toe out (auto) (d. roți) a avea convergență negativă; ( fam $)$ a călca în afară

toe-out (auto) convergență negativă a roților

toft mică gospodărie (agricolă / țărănească); casă cu curtea ei; vatră, cămin, coş, fum; deluşor

toftman (agr) mic agricultor / fermier; (țăran) proprietar al unei gospodării; gospodar

tog cioc; (metr) unitate de măsură în sistem metric pentru a descrie proprietățile de izolare termică a unei țesături / folii; dacă fluxul termin prin tesătură este If the flow of heat through the cloth is $1 \mathrm{~W} / \mathrm{m}^{2}$, atunci valoarea caracteristică izolației termice în tong este de 10 ori diferența de temperatură, în ${ }^{\circ} \mathrm{C}$ sau $\mathrm{K}$, între cele două suprafete ale tesăturii: 1 tog $=0,1 \mathrm{~m}^{2} \cdot \mathrm{K} / \mathrm{W}$

together împreună; $(a d v) \sim$ with împreună / laolaltă cu, (temporal) concomitent / simultan / în acelaşi timp cu; to act $\sim$ a acționa împreună / de comun acord / concomitent; laolaltă, unul cu altul, unul față de celălalt; unul după altul, la rând, în şir, consecutiv; fără întrerupere, necontenit; puse / puşi cap la cap, adunate / adunați; (nav) toți odată

toggle $(\mathrm{OM})$ placă de distanțare, sistem / mecanism cu pârghii cotite; declanşator; întrerupător ,„închis-deschis” / cu două poziții; (nav) cavilă de parâme; $(\mathrm{TH})$ piron, cârje; sistem / mecanism cu pârghii cotite; (nav) a prevedea cu cavilă de parâme

toggle bolt (mas-un, OM) şurub / bolț cu inel

toggle brake $(\mathrm{OM})$ frână cu leviere articulate

toggle clamp (mas-un) dispozitiv de strângere, cu articulatie

toggle joint $(\mathrm{OM})$ articulație tip nucă sferică / cu rotulă, pârghie articulată

toggle-joint press (met, mas) presă cu genunchi

toggle-joint riveting machine (mas) maşină de nituit cu sistem de pârghii / cu genunchi

toggle lever (mas, OM) pârghie cotită; pârghie articulată; (el) întrerupător / comutator basculant

toggle lever press (mas) presă cu pârghie cotită / articulată

toggle-lever tongs (met) cleşte de apucat, cu brațe curbate / cotite

toggle link (mas) pârghie intermediară a sistemului de pârghii cotite

toggle pin v. toggle

toggle press (mas) presă cu pârghii cotite / cu genunchi

toggle switch (mas-un) presă cu articulație; (OM, el) întrerupător cu manetă, manetă de întrerupător, ruptor

toil muncă (grea); a munci; a trudi

toil along a înainta cu greu / a se târî de-a lungul toile (textile) pânză / stofă (pentru îmbrăcăminte); tipar de îmbrăcăminte (pe muselină), patron, mulaj

toilet paper hârtie igienică / de toaletă

toilet powder pudră de toaletă (folosită după baie)

toilet roll sul de hârtie igienică

toiletry (amer) articole de toaletă

toilet service / set trusă / garnitură / serviciu de toaletă

toilet soap săpun de toaletă

toilet sponge burete de baie

toilet ware (ec) articole de toaletă; articole / obiecte pentru baie

toilet water apă de toaletă

to/in all appearances după toate probabilitățile

toing and froing du-te-vino, agitație; (mec, mas) mişcare într-o parte şi într-alta; pendulare (permanentă)

toise (metr) unitate tradițională franceză pentru lungime, comparabilă cu unitatea britanică numită fathom: 1 toise (pe uscat) $=1,949 \mathrm{~m}$ şi 1 brasse $($ pe mare $) \cong 1,624 \mathrm{~m}$

token semn, indiciu, simptom; simbol; dovadă; (inf) pachet de date; simbolic; semnifictiv; for a $\sim$ ca semn (de recunoaştere) / dovadă; a denota, a simboliza, a dovedi, a fi semn / simbol de 
tokenism (efectuare a unui) efort simbolic; (efort) minim necesar; linie de minimă rezistență

token money (ec) monedă fiduciară / divizionară; circulație fiduciară

token payment (ec) plata simbolică

token strike grevă de avertisment

tola (metr) unitate tradițională de măsură pentru masă în India şi Asia de Sud: 1 tola 11,664 g.

tolerable tolerabil, admisibil, suportabil, acceptabil; bunişor, bunicel; mediocru, pasabil

tolerableness caracter suportabil / tolerabil; intensitate / măsură suportabilă; ( fam) calitate bunicică / bunişoară; calitate acceptabilă; caracter acceptabil / satisfăcător

tolerably tolerabil, suportabil; acceptabil; relativ / destul de suportabil

tolerance (om, metr) toleranță (şi dimensională de formă etc.); (autom, metr) eroare / abatere / deviație admisă; îngăduință, indulgență

tolerance end-measuring rod with spherical ends (met, metr) etalon vergea limitativ, cu capete sferice

tolerance in size $(\mathrm{OM})$ toleranță de dimensiune

tolerance limits (metr, OM) limite de admisibilitate / admisibile / ale câmpului de toleranță

tolerance on fit $(\mathrm{OM})$ toleranță de ajustaj

tolerance unit (metr, OM) unitate de toleranță, a unitate relativă de lungime, utilizată în inginerie: dacă diametrul unui arbore este $\mathrm{D}$ [mm], o unitate de toleranță este $0,001 \mathrm{D}+$ $0,45(\mathrm{D})^{1 / 3}$; toleranța reală poate fi astfel exprimată în unități de toleranță

tolerance zone $(\mathrm{OM})$ câmp / zonă de toleranță

tolerate a tolera; a suporta; a îndura, a răbda; a permite, a îngădui, a accepta

toleration tolerare; v. tolerance

tolite (chim) trinitrotoluen, TNT

toll taxă rutieră; impozit; dare; taxă; vamă; a percepe / a încasa dări / taxe

tollable (ec) impozabil, supus la taxe / impozite

tollage (ec) impozitare, taxare

toll bridge pod cu plată / cu taxă de trecere / pentru folosirea căruia se percepe taxă

toll road autostradă cu plată / pentru folosirea căreia se percepe taxă

toll service (auto, cf) trafic suburban

toluen(e), toluol (chim) toluen

toluidine (chim) toluidin

toman (metr) unitate antică de cantitate, egală cu 10 000, utilizată în Turcia şi Iran

tomato, $(p l)$ tomatoes (bot, agr, alim) (pătlăgea) roșie, tomată

tomato sauce (alim) sos tomat, bulion

tombac(k) (met) tombac (aliaj $\mathrm{Zn}-\mathrm{Cu}$ )

tommy (OM) bară de manipulare, ştift de montaj, cheie, şurubelniță, șurub; (alim) pâine, pită alimente date angajaților cu plată; plată în alimente

tommy bar nut $(\mathrm{OM})$ piuliță cu bară (transversală) de manipulare; bară de manipulare

tommy nut $(\mathrm{OM})$ piuliță cu gaură transversală / pătrunsă

tommy screw $(\mathrm{OM})$ șurub de strângere

tommy shop bufet, cantină (în fabrică, cantină etc.); brutărie, franzelărie; gustare, sandviș (cu care pleacă muncitorii la lucru)

tomorrow $(a d v)$ mâine; month de mâine întro lună

ton grămadă, cantitate mare / imensă; ton (tn, T, t) unitate tradițională de măsură pentru masă: 1 ton $(\mathrm{US}$, Canada $)=1$ short ton $(\mathrm{USt})=907,185$ $\mathrm{kg}, 1$ ton $(\mathrm{UK})=1$ long ton $(\mathrm{Ukt})=1016,047$ $\mathrm{kg}$; metric ton, tonne (t) (metr) unitate de măsură în sistem metric, pentru masă: 1 metric ton $=1000 \mathrm{~kg}$; ton, register ton $(\mathbf{R T}, \mathbf{r T})$ (metr) unitate tradițională pentru măsurarea capacității / volumului de încărcare a unei nave comerciale: 1 merchant marine ton $\cong 1$ register ton $=2,8316 \mathrm{~m}^{3}$; ton, displacement ton (DT, dT) (metr) unitate de volum pentru măsurarea deplasamentului unei nave (volumul de apă de mare, dislocuit de navă sau volumul navei aflat sub linia de plutire): 1 displacement ton $\cong$ $0,9911 \mathrm{~m}^{3}$; ton, freight ton (FT), US shipping ton (metr) unitate tradițională de volum pentru măsurarea încărcăturii unei nave, a unui tren sau camion etc.: 1 freight ton $\cong 1,1326 \mathrm{~m}^{3}$, totuşi „freight ton” poate însemna 1 tonă (metrică), volumul nefiind specificat; unitatea de 40 picioare cubice este deseori numită şi measurement ton (MTON), unii transporatori consideră $1 \mathrm{MTON}=1$ tonă (metrică) de încărcătură $=1000 \mathrm{~kg} ; 1$ British shipping ton $=1,1893 \mathrm{~m}^{3}$; ton (tn, T) (metr, fizică nucleară) unitate de măsură pentru energia degajată prin explozie (în special nucleară): 1 ton este cantitatea de energie degajată prin explozia a 1 short ton of $\mathrm{TNT}=4,184 \mathrm{GJ}$; ton (RT) (metr) unitate de putere, utilizată în industria frigului: 1 ton of refrigeration este puterea necesară înghețării a 1 short ton of water (1 tonă scurtă de apă) la $0^{\circ} \mathrm{C}$ în 24 ore: $1 \mathrm{RT}=.12000 \mathrm{Btu}$ pe oră $(\mathrm{Btu} / \mathrm{h}$, Btuh), echivalent cu $3,516853 \mathrm{~kW}$; ton (metr) 100 în argoul britanic (100 pounds, viteză de 100 mile pe oră, scor de 100 la darts sau cricket)

tonal (muz) tonal; intermediate value (fiz, c) treaptă de gradare a luminozității, treaptă de luminozitate; graduation of $\sim$ intensities gradație de intensitate de ton (sonor sau de culoare) 
tonal frequency (fiz) frecvență acustică, joasă frecvență

tonal generator (fiz, muz) generator de ton

tonal pattern (fiz) spectru acustic

tonal range (fiz) registru sonor

tønde (metr) denumire daneză pentru baril: 1 tønde $\cong 1391$

tonde land (metr) unitate tradiţională daneză pentru suprafață de teren: 1 tønde land $\cong 5516$ $\mathrm{m}^{2}=0,5516$ ha

tone (muz) ton, sunet, intonație; modulație; timbru (al vocii); ton / mod / fel de exprimare; (gram) accent; (artă) nuanță de culoare, nuanțare; (med) vigoare, vlagă, energie; (fig) ton, atitudine, inițiativă; nivel, caracter general; (med) tonus; a (se) nuanța; a acorda (un instrument muzical); (metr, muz) ton, altă denumire pentru pas, pentru descrierea raportului dintre frecvențele a două note

tonelada (metr) unitate tradițională de măsură pentru masă: 1 tonelada $($ Spania $) \cong 919,9 \mathrm{~kg}, 1$ tonelada (Portugalia) $\cong 793,15 \mathrm{~kg}$

tone with a se armoniza, a se potrivi cu

tone down a (se) atenua, a diminua, a (se) potoli; a nuanța; (fig) a coborî tonul

toneless fără glas / voce; (d. culori) fără strălucire / lustru / luciu, şters, tern; (fig) inexpresiv, lipsit de expresie

tone spectrum (fiz) spectru acustic

tone up a întări, a intensifica (d. sunete); a sublinia, a accentua; a se reface, a-şi reveni; a se înzdrăveni

ton (explosives), explosive(s) ton (metr) unitate de măsură pentru energie degajată prin explozie: 1 ton (explosives) $=4184 \mathrm{MJ}$

ton-force (metr) tonă-forță, unitate de măsură pentru forță: 1 ton-force $($ metric) $=9806,65$ $\mathrm{N} ; 1$ ton-force $($ short $)=8896,443230521 \mathrm{~N} ; 1$ ton-force (long) $=9964,016418171 \mathrm{~N}$

ton-force (long)/square foot, long ton-force/ square foot (metr) tonă-forță (mică)/picior pătrat: 1 ton-force (long)/square foot = $107251,78011595 \mathrm{~Pa}$

ton-force (long)/square inch (metr) tonă-forțăinch pătrat, unitate de măsură pentru presiune: 1 ton-force (long)/square inch = 15444256,336697 $\mathrm{Pa}$

ton-force (short)/square foot (metr) tonăforță/picior pătrat, unitate de măsură pentru presiune: 1 ton-force (short)/square foot $=$ $95760,517960678 \mathrm{~Pa}$

ton-force (short)/square inch (metr) tonă-forță (mică)/inch pătrat, unitate de măsură pentru presiune 1 ton-force (short)/square inch = $13,789514 \mathrm{MPa}$ tong hold (met) capăt de semifabricat forjat, pentru prins cu cleştele

ton-hour (refrigeration) (metr) unitate de măsură pentru energie termiocă: 1 ton-hour $($ refrigeration $)=12660670,23144 \mathrm{~J}$

tongs cleşte; ( fam) pantaloni (de salopetă)

tongs cooling tank (met) tanc pentru răcirea cleştelui

tongue (met) calibru reliefat al cilindrului (de laminor); (el) terminal aplatizat (pentru conectare); (OM) limbă, ac, clichet, macaz; (anat) limbă; (fig) grai, vorbire, glas; limbă (vorbită), limbaj; limbă de pământ; limbă de pantofi; limbă de clopot; ac de cântar / balanță; lamă de cuțit; (cf) ac de macaz; oişte; (OM) limbă, feder, lamă de cuțit; (agr, OM) oiște; (el) indus; (fig) avocat; a vorbi, a grăi, a rosti; a linge, a atinge cu vârful limbii; (TH) a uni / asambla prin îmbinare cu lambă şi uluc; a atinge cu vârful limbii; (fig) a flecări

tongue-and-groove joint (OM) îmbinare cu canal şi pană; îmbinare cu lambă şi uluc; (met) calibru de refulare închis (la laminare)

tongued key $(\mathrm{OM})$ cheie pentru pene (şi înclinate sau cu nas)

tangued (lock) washer (OM) şaibă de siguranță / de blocare cu nas / cu cioc

tongue file (mas-un) pilă rotundă mică

tongue flame (chim) flacără oxihidrică

tongue roll (met) cilindru superior / de presiune

tongue plate (auto) plăcuță

tonguing plane (constr) rindea pentru lambă şi uluc

tonight ( $a d v)$ diseară, astă seară; la noapte; seara sau noaptea asta

ton-kilometer (cf) tonă-kilometru

ton (long)/cubic yard, long ton/cubic yard (metr) tonă engleză (mare)/ yard cubic, unitate de măsură pentru densitate: 1 ton (long)/cubic yard $=1328,93918 \mathrm{~kg} / \mathrm{m}^{3}$

ton (metric)/day, metric ton/day (metr) tonă/zi, unitate de măsură pentru debit masic sau producție în unitatea de timp: 1 ton (metric)/day = $0,011574074 \mathrm{~kg} / \mathrm{s}$

ton (metric)/hour (metr) tonă/oră, unitate de măsură pentru debit masic: 1 ton (metric) / hour $=0,27777 \mathrm{~kg} / \mathrm{s}$

ton (metric)/minute (metr) unitate de măsură pentru debit masic: 1 ton $($ metric) $/$ minute $=$ $16,666666 \mathrm{~kg} / \mathrm{s}$

ton (metric)/second (metr) tonă/secundă, unitate de măsură pentru debit masic sau productie în unitatea de timp: 1 ton (metric) $/$ second $=1000 \mathrm{~kg} / \mathrm{s}$

ton-mile (ec, nav) tonă-milă, unitate de măsură pentru mărfurile transportate 
tonnage (met) spațiu de încărcare; (nav) tonaj; taxă de tonaj / în funcție de tonaj; (termo) putere frigorifică; capacitate de încărcare

tonnage deck (nav) punte de tonaj

tonnage hatch / opening (nav) deschidere de tonaj

tonnage oxygen (chim, ind chim) oxigen tehnic tonnage oxygen plant fabrică de oxigen tehnic

tonne, metric ton (MT, t) (metr) tonă metrică europeană (1 MT = 1000 kg)

tonneau (metr) tona tradițională franceză: 1 tonneau / traditional French ton $\cong 979 \mathrm{~kg}, 1$ tonneau 1440 l; (metr, alim) în comerțul cu vin 1 tonneau este o încărcătură de 100 de lăzi sau 1200 sticle de vin, de 9001

ton of force (tnf, tn) (metr) tonă-forță, unitate tradițională de măsură pentru forță, 1 tnf (US) $\cong 8,8964 \mathrm{kN}$ şi $1 \mathrm{tnf}(\mathrm{UK}) \cong 9,9640 \mathrm{kN}$

ton per square inch (tnf/in ${ }^{2}$, tsi) (metr) unitate de măsură pentru presiune în inginerie: 1 tsi $(\mathrm{US})=13,790 \mathrm{MPa}, 1$ tsi $(\mathrm{UK}) \cong 15,444 \mathrm{MPa}$

ton (refrigeration), refrigeration ton (metr) unitate de măsură pentru putere frigorifică: 1 ton $($ refrigeration $)=3516,85284 \mathrm{~W}$

ton register (metr) unitate de măsură pentru volum, tonă-registru: 1 ton register $=2,831684659 \mathrm{~m}^{3}$

ton (short)/cubic yard, short ton/cubic yard (metr) tonă (scurtă) pe yard cubic, unitate de măsură pentru densitate: 1 ton (short)/cubic yard $=1186,552842515 \mathrm{~kg} / \mathrm{m}^{3}$

ton (short)/hour, short ton/hour (metr) tonă (mică / scurtă) pe oră, unitate de măsură pentru debit masic sau producție în unitatea de timp: 1 ton (short) $/$ hour $=0,251995761 \mathrm{~kg} / \mathrm{s}$

too $(a d v)$ prea, foarte; de asemenea, şi; de altfel, de alminteri, pe de altă parte; pe deasupra, în plus, mai mult decât atât

too coarse grain (constr, met, agr) bulgări mari, refuz de ciur, granule mari

tool (mas-un) cuțit, unealtă, sculă, instrument; (fig) instrument, mijloc, unealtă; agent, coadă de topor; (TH) maşină-unealtă, sculă, unealtă; a prelucra cu o sculă / unealtă, a uzina, a lucra cu o sculă; a ciopli (piatră)

tool and cutter grinder (mas-un) maşină (universală) de ascuțit

tool angle (mas-un) unghi de ascuțire (a sculei); unghi de cuțit

tool bag trusă / set de scule / cu unelte

tool bit (mas-un) cuțit aplicat, cuțit mic aplicat fixat în port-cuțit

tool bit holder (mas-un) port-cuțit intermediar

tool block / holder (mas) port-cuțit

tool box cutie / ladă de scule / cu unelte

tool cabinet dulăpior de scule tool carrier (mas-un) sanie port-cuţit

tool case trusă de scule

tool chart (mas-un) schema reglării unei maşiniunelte

tool clearance angle (mas-un) unghi de aşezare (şi la scule aşchietoare)

tooth depth (OM) înălțimea dintelui (h) (unei roți dințate)

tool dimension offset (autom, mas-un) corecție a dimensiunii sculei (în comanda numerică)

tool dresser (mas) ascutitor de scule

tool dressing (mas-un, T) ascuțire şi rodare a sculelor

tooled (mas-un) prelucrat (folosind scule) (fără a preciza procedeul sau tehnologia)

tool edge (mas-un) muchie aşchietoare, tăiş

tool engineering $(\mathrm{TH})$ sculărie, sculărit, uzinaj; fabricare şi/sau proiectare a sculelor

tool equipment echipament / trusă / set de scule

tool for stretching wheels (mas-un) dispozitiv de forjare a roților

tool gauge (mas-un) şablon de sculă

tool grinder (mas-un) maşină / dispozitiv (şi demontabil) de şlefuit / de polizat / de rectificat scule / de ascuțit (unelte)

tool grindery / grinding department (mas, ind) atelier de ascuțit scule

tool-grinding machine (mas-un) maşină de ascuțit scule, polizor

tool head (mas-un) port-cuțit, sanie port-cuțit (la maşini-unelte)

tool holder (mas-un, OM) dispozitiv de prindere a sculelor; v. tool head

tool-holding strap (mas-un, OM) placă de presiune pentru fixarea cuțitului

tool hole (mas-un, OM) locaş / alezaj pentru fixarea sculei

tool hook (ind) cârlig de foraj

tool house (ind) sculărie, atelier de sculărie

tooling (TH, ind) prelucrare (a pieselor), uzinare, uzinaj; dăltuire, sculptare, modelare, cizelare (a pietrei cu dalta); ornamentație gofrată, gofraj (pe coperțile cărților); (mas-un) ansamblu de scule montate pentru prelucrarea unui lot de piese, scule; sculărie

tooling allowance (mas-un) adaos / toleranță de prelucrare (mai ales la aşchiere)

tool joint racord de prăjini; racord special

tool kit / outfit / set trusă de scule

tool layout (mas-un) schemă de reglare a unui strung / a unei maşini unelte

tool lifter (mas-un) dispozitiv de ridicare automată a cuțitului, la cursa de înapoiere

toolmaker (ind) lăcătuş, sculer

toolmaker's file (mas-un) pilă de precizie / de sculer 
toolmaker's lathe (mas-un) strung pentru lucrări de sculărie

toolmaker's shop sculărie

tool-making turner strungar de precizie

tool-man lăcătuş, sculer

tool marks (mas-un) urme lăsate de o sculă pe o suprafață prelucrată

tool offset (mas-un) decalaj al axului unei maşini-unelte cu comandă numerică

tool outfit trusă de scule

tool post suport pentru sculă; (mas-un) portcuțit, sanie port-cuțit (la maşini-unelte)

tool pan (mas-un) cavitate pentru scule

tool path freedrate (mas-un) viteză de avans tangențială (în comanda numerică)

tool point (mas-un) vârf de cuțit

tool-post (mas-un) suport pentru scule, portcuțit, sanie port-cuțit

tool-post grinder (mas-un) dispozitiv de rectificat, fixat în port-cutitul saniei

tool post rocker (mas-un) garnitură sferică a port-cuțitului

tool pressure (mas-un) efort de tracțiune la broşare, presiunea exercitată de sculă

tool resistance (mas-un) rezistență a cuțitului

tool rest (mas-un) sanie port-cuţit (şi de strung)

tool roll ambalaj de scule

tool room $(\mathrm{TH})$ atelier de sculărie

tool-room lathe (mas-un) strung pentru lucrări de sculărie

tool-set trusă de sculărie / de scule

tool-setter (mas-un) ajustor, reglor

tool setting gauge (mas-un) şablon de aşezat cutite / unelte

tool-setting time (mas-un) timp de reglare (a maşinii-unelte, a sculei)

tool set (mas-un) garnitură / set de scule sau dispozitive pentru prelucrarea unui lot de piese

tool set-up (mas-un) reglarea unei maşini-unelte / scule

tool shop atelier de sculărie; v. tool house

tool slide (mas-un) sanie port-cuțit

toolsmith (met, mas-un) forjor specializat în confecționarea şi repararea sculelor, sculer

tool stand (mas-un) măsuță / stelaj pentru scule

tool steel (met) oțel de scule

tool storage room (mas-un) magazie / depozit de scule

tool thrust (mas-un) forță de aşchiere (pe directie axială)

tool wag(g)on (cf) vagon de montaj

tool work $(\mathrm{TH})$ fabricare a sculelor; sculărie

tooth, $(p l)$ teeth (anat) dinte, măsea; dinte de pieptene; $(\mathrm{OM})$ dinte (la roți dințate, de furcă, de ferăstrău etc.), pieptene, crestătură; (mas- un) pieptene de filetat; a tăia /genera dinți (şi la roți), a dantura; a muşca din; a apuca / a prinde cu dinții; a mesteca; (TH) a dința, a face dinti la (o roată etc.); a se angrena

tooth-and-pinion jack (OM) cric cu cremalieră

tooth brush periuță de dinți

tooth calliper (mas-un, metr) şubler / calibru de roți dinţate

tooth chamfering machine (mas-un) maşină de frezat / de rotunjit capetele frontale ale dinţilor tooth construction (mas-un, $\mathrm{OM}$ ) danturare, dințare, dantură, generare a dintelui (la roți dințate)

tooth cutting machine (mas-un) maşină de prelucrat roți dințate / de danturat

toothed (mas-un, OM) dințat; cu dinți

toothed bar (OM, mas-un) cremalieră

toothed barrel (metr, OM) casetă dințată / danturată, a arcului care actionează un ceas / aparat

toothed chain (OM) lanț fără zgomot

toothed clutch $(\mathrm{OM})$ cuplaj cu gheare / dintat

toothed coupling (OM, mas-un) cuplaj dințat

toothed-disk mill (OM, mas-un) moară cu roți dințate

toothed flywheel $(\mathrm{OM})$ volant cu coroană dintată

toothed gear $(\mathrm{OM})$ transmisie prin angrenare / prin roți dințate, angrenaj; roată dintată

toothed quadrant (OM) segment dinţat / sector

toothed sector $(\mathrm{OM})$ sector dintat

toothed wheel $(\mathrm{OM})$ roată / coroană dințată

tooth face (mas-un, OM) lățime / grosime a dintelui, față de degajare (la scule)

tooth flank $(\mathrm{OM})$ flancul dintelui (la o roată dințată)

toothing $(\mathrm{OM})$ dantură, coroană dințată; (masun) tăiere a dinților, dințare, danturare; zimțuire; (TH) angrenare, angrenaj (la roțile dintate); (arhit) cărămizi proeminente folosite la îmbucarea zidurilor; îmbucătură, îmbucare

toothing of face / of surface $(\mathrm{OM})$ dantură plană (la roata plană de referință a unui angre-naj conic, la cremalieră)

toothing plane rindea dințată

toothing with negative addendum modification $(\mathrm{OM})$ danturare / dantură cu scurtarea capului dintelui (unei roți dințate)

toothing with no addendum modification (mas-un, OM) danturare / dantură fără scurtarea capului dintelui; dantură nemodificată

toothing with positive addendum modification (mas-un, OM) danturare cu supraînălțarea capului dintelui

tooth-like $(\mathrm{OM})$ dințat; în formă de dinte; dentiform

tooth of milling cutter (mas-un) dinte de freză 
tooth paste pastă / cremă de dinți tooth pitch $(\mathrm{OM})$ pasul dinților / danturii tooth point (mas-un, OM) vârful dintelui tooth profile $(\mathrm{OM})$ profilul dintelui (la o roată dințată)

tooth rest (mas-un) sprijinul dintelui unei freze folosit, la ascuțirea frezei

tooth ripple $(\mathrm{OM})$ arbore canelat / cu canelură evolventică

tooth rolls (alim, constr, mas-un) cilindri nervurați / rifluiți (la un concasor / o moară)

tooth-rounding hob (mas-un) freză-melc de rotunjit capetele dinților

tooth space chord (OM) gol (dintre dinți), coarda golului între dinţi

tooth thickness $(\mathrm{OM})$ grosimea dintelui (fără a specifica pe care cerc este măsurată) (s)

tooth thickness half angle $(\mathrm{OM})$ semi-unghiul grosimii dintelui $(\psi)$

tooth thickness on the tip cylinder (OM) grosimea dintelui pe cilindrul de cap (s)

tooth top (mas-un, OM) vârful / capul dintelui

top (constr) acoperiş, tavan, cap; (chim) distilate uşoare; (geogr) vârf, culme, creştet, coamă, creastă, pisc; parte de sus / superioară; grad maxim / extrem; (fig) culme, pisc, rang superior, frunte; (auto) capotă; (met) gură de încărcare a furnalului; (textile) marginea unei țesături; (OM) parte superioară, capac; (poligrafie) cap (de pagină), margine de cap (la carte); partea de sus (la o hartă); (nav, geogr) punct maxim (al fluxului); (nav) gabie; (din partea) de sus; superior; din / de la vârf; maxim, cel mai mare

top and bottom ram (mas-un) piston / berbec superior şi inferior (la presă)

topaz topaz (şi culoare)

topazolite (minrl) piatră prețioasă galbenă sau verde, tip de granat

top beam coronament superior

top belt conveyer (alim, constr, ind) transportorbandă, cu încărcare pe covorul superior

top blade (mas-un) lamă superioară (la foarfecă)

top block $(\mathrm{OM})$ scripete superior

top blowing (met) afinare cu suflare deasupra băii de metal / oțel topit (în convertizor)

top bolt $(\mathrm{OM})$ şurub / bolț cu filet pe toată lungimea / filetat până sub cap

top boom (constr) talpă superioară (a unei grinzi), parte superioară (a unei ferme)

top box (met) parte superioară a ramei de formare; cutia superioară de formare; (cf) cutia / acoperişul vagonului

top bracket gasoline (ind chim, auto) benzină cu cifră octanică înaltă top capping (auto, ind chim) înlocuire a benzii de rulare, reşapare

top cast (met) a turna direct / pe sus

top casting (met) turnare directă / pe sus

top charging (met) încărcare a furnalului, pe sus / pe la partea superioară

top-charging hoist (met) elevator pentru încărcare (şi la furnal)

top chisel $(\mathrm{TH})$ daltă de fierărie; daltă de forjă

top circle / line (OM) cerc exterior / de cap (la roți dințate)

top-closing device (met) dispozitiv de închidere automată la gura furnalului

top coat (met, OM, T) strat de acoperire; (textile) pardesiu; acoperire (la partea) superioară

top copy original, primul exemplar, exemplarul unu (copia)

top dead centre, TDC (mas, termo) punctul mort superior

top die (mas-un, plast, met) patriță, poanson

top discard (met) maselota lingoului

top-dress (agr) a răspândi / a împrăştia îngrăşăminte la suprafața ogorului / arăturii

top dressing (agr) tratament superficial; gunoire la / de suprafață; împrăştiere / răspândire a îngrăşămintelor pe suprafața arăturii; (constr) îmbrăcăminte (exterioară) a drumului

top-driven centrifuge (alim, mas) centrifugă cu mecanism de acționare la partea superioară

top edge $(\mathrm{OM})$ muchia de sus / superioară

top end vârf; creştet; parte superioară

top end (of an ingot) (met) maselotă a lingoului top face (mas-un) față de degajare (a unei scule)

top feed(ing) alimentare pe la partea superioară

top fermentation (alim) (proced de) fermentare la / din partea superioară

top fiber fibră superioară

top fin (met) bavură sub masoletieră / de capăt

top flange $(\mathrm{OM})$ talpă superioară

top force poanson superior

top frame / girder (constr) cadru de acoperiş, cadru superior / de sus

top freezing (met) formare de crustă (la lingouri)

topgallant (nav) arboret; (fig) vârf, culme

topgallant mast (nav) arboretul zburătorului

topgallant sail / yard (nav) zburător

top gas (chim, met) gaz de furnal

top gas main (met) conductă (principală) de gaz de furnal

top gate (met) pâlnie / orificiu de turnare

top gear priză directă (şi de putere); (auto) viteză maximă

top grade (de) calitate superioară

top(-)hat furnace (met) cuptor cu hotă / clopot 
top-heavy (nav) supraîncărcat la partea superioară / pe punte; cu vârful mai greu; instabil (din cauza încărcării la partea superioară) top-hole de prima calitate

topiary art (agr) horticultură / grădinărie ornamentală, arta tunderii şi aranjării arbuștilor și arborilor în scopuri decorative / ornamentale

topic temă; problemă; topic; subiect (de discuție); expunere, argumentație

topical actual, de (mare) actualitate; (de interes) local

top-icing (alim) răcire prin gheață depusă la partea superioară a unui recipient cu produse

top land (termo) prag de sus / de foc al pistonului top layer strat superior

top leaf of spring (OM, cf) foaie principală de arc, lamă superioară de arc

top light (nav) lumină de semnalizare (la catargul din mijloc)

top line of the tooth (mas, OM) dreapta de vârf (la cremalieră)

top-loading belt (met, ind chim, alim) covorul superior (folosit la încărcare, la banda transportoare)

top loading capacity (mas, ind chim) capacitate maximă (de încărcare)

top management (ec) management de top, conducere superioară,

top manager (ec) director general, top-manager

top mark (nav) semn de geamandură

topmast (nav) arbore gabier

topmast fid (nav) cavilă, cavilieră

topmost cel mai din vârf, cel mai de sus; cel mai important

top of blast furnace (met) gură de încărcare a furnalului

top of burner (termo) ajutaj / duză de arzător

top-of-form margine de sus a hârtiei, poziție a primului rând tipărit

top of piston (mas, OM, termo) cap de piston

top of pole vârf de stâlp

topographer topograf

topographic(al) topografic

topography topografie

topological product (mat) produs cartezian / topologic

topology topologie

topometry topometrie

top opening (met) gură de încărcare

top overhaul (mas-un) reparație capitală

top part moulding box (met) parte superioară a ramei de formare

topping file (mas-un) pilă lată cu vârf teşit şi cu fețe laterale teşite

topping roll (met) cilindru superior (la laminor) topping up completare

top pivot (mas-un, OM) fus cu umeri, pivor superior / de la partea de sus

top plate (OM)placă / eclisă superioară; (ind chim) taler superior

top platform (met) platformă de încărcare (şi la furnal)

topple a răsturna; a rostogoli

top plug (OM) dop superior

top-pour (met) a turna direct / pe sus

top pouring (met) turnare directă / pe sus

top-pour ladle (met) oală de turnare cu cioc scurt

top pressure (met) presiunea cilindrului superior (la laminare), presiune superioară (la laminare)

top prices (ec) prețuri maxime

top rail (cf, constr) traversă fixă, grindă de legătură

top rake (mas-un) unghi de degajare (la scule)

top ram press (mas) presă cu piston superior

top rest / slide (mas-un) sanie superioară

top roll(er) (met) cilindru superior / de presiune; (alim) tăvălug / valț superior; (ind chim, masun) rolă de presare / apăsare

top-roll pressure (met) presiunea exercitată de cilindrul de presiune / superior

top rope (nav) parâmă de ridicare (sau coborâre) a arborelui gabier

tops (alim, ind chim) fracțiuni uşoare (la distilare) topsail (nav) gabier, vela gabier

top section parte superioară

top shear blade (met, mas-un) lamă superioară (de foarfecă)

top side latură / față / suprafață superioară; (nav) bord deasupra apei, bord liber; (alim) strat exterior al fripturii de vacă; $(a d v)$ (nav) pe puntea (superioară); sus (de tot); la vârf; la cel mai înalt nivel; în poziția cea mai avantajoasă / favorabilă

topsides (nav) operă moartă (a navei)

top sizing încleiere la suprafață

top slide (mas-un) sanie superioară (şi la strungrevolver)

top soil (agr) stratul superior / suprafața unui teren

top speed viteză maximă; v. top gear

top stairs of a blast furnace (met) scara platoului de încărcare a furnalului

top stratum strat superior / de acoperire

top temperature (met) temperatură la gura furnalului

top tether (auto) dispozitiv de ancorare

top up a umple, a completa; (met) a regenera baia de decapare

top view vedere în plan, proiectie orizontală / verticală, vedere de sus 
top with gum $(\mathrm{OM})$ cauciucat, gumat, închidere cu capac cauciucat

top yeast (alim) drojdie de suprafață

torch torță; lampă / lanternă de buzunar (termo); arzător, flacără; (met) lampă de lipit, bec de sudare, suflai

torch brazed (met) lipit tare cu flacără

torch brazing (met) lipire tare cu flacără

torch cutting (met) tăiere cu flacără / cu gaz / autogenă

torch deseaming (met) curățare cu flacără / prin ardere

torch hardening (met) călire superficială cu flacără

torch head (met) bec / cap de sudură (oxiacetilenică)

torching aprindere întârziată; formare a flăcării

torchon paper hârtie grofată

torch welded (met) sudat cu flacără / cu gaz / autogen

tore, torus (geom) tor

toric în formă de torus, tor, convex

Torino number (metr) o scară arbitrară (din 1999) pentru evaluarea probabilităţii ca o cometă sau un asteroid să lovească Pământul, cu 0 - obiect care sigur nu va lovi Pământul sau este prea mic pentru a cauza pagube semnificative, şi 10 - obiect care va lovi sigur Pământul şi este suficient de mare să producă catastrofe şi schimbarea climei

torn surface (mas-un, T) suprafață inegală / cu urme de gripare; (TH, T) suprafaţă rugoasă (şi după o montare sau exploatare incorectă)

toroid cameră de vid, toroidală; (mat) toroid; figură toroidală / în formă de torus

toroidal (geom, OM) toroid(al), în formă de torus, tor, convex

toroidal coil (el) bobină toroidală

torpedo torpilă; petardă; (mil) mină; a torpila, a ataca cu torpile; (fig) a torpila, a submina, a distruge, a nărui; a paraliza (o acțiune)

torpedo-boat destroyer (nav) contratorpilor torpedo body (auto) caroserie ultra-aerodinamică (la automobilele de curse)

torpedo bomber (av) bombardier torpilor

torpedoing (nav, mil) torpilare

torpedo man (nav, mil) torpilor, servant pe torpilor

torpedo-net (nav, mil) plasă împotriva torpilelor torpedo plane $v$. torpedo bomber

torpedo tubs (nav, mil) tub lanstorpile

torpid adormit, toropit; amorțit, înțepenit; (fig) indolent, apatic, inactiv

torpidity somnolență, toropeală; amorțeală, întepenire; indolență, apatie, inactivitate torque (mec) moment / cuplu / efort de torsiune; a supune cuplului de torsiune, a răsuci

torque arm $(\mathrm{OM})$ levier de comandă a frânei (acționat prin răsucire)

torque converter (el, mec) convertizor / variator de cuplu / al cuplului de torsiune

torque gauge (metr) indicator de cuplu, traductor pentru moment de torsiune

torque indicator handle wrench (metr) cheie dinamometrică

torque load (mec, OM) sarcină de torsiune / de răsucire, solicitare la torsiune, moment de torsiune (aplicat)

torque member (OM, metr) piesă care limitează momentul de torsiune

torquemeter, torsiometer, torsion(al) (strain) indicator, torsion meter (metr) torsiometru, traductor pentru moment de torsiune

torque motor (el) motor cu cuplu constant; (mas-un) servomotor pentru mişcări de întoarcere de scurtă durată

torque reaction (mec) moment de torsiune reactiv

torque screw driver $(\mathrm{OM}$, metr) şurubelniță cu limitarea efortului / sarcinii (moment sau forță) de înşurubare

torque stand (metr) banc / stand de probă pentru cuplu / moment de torsiune

torque tube $(\mathrm{OM})$ tub pentru arborele unui cuplaj cardanic, arborele tubular al unui cuplaj dublu cardanic

torquing of nuts (mas-un, OM) înşurubarea piulițelor cu moment de răsucire maxim

torr (metr, fiz) torr (unitate de măsură pentru presiune): 1 torr $=133,32236 \mathrm{~Pa}$

torr (Torr) (metr, fiz) unitate de măsură pentru presiune, în inginerie pentru presiuni foarte mici, aproape de vid: 1 torr $=1 \mathrm{mmHg}$ (milimetru coloană de mercur) $=1 / 760$ atmosfere

torrefaction (ind chim, $\mathrm{TH}$ ) calcinare, prăjire (a minereului), torefiere, ardere

torrefy $(\mathrm{TH})$ a torefia, a arde, a calcina, a prăji (minereuri)

torrent torent; aversă, ploaie torențială

torrential torențial; iute; învolburat

torrid torid, fierbinte

torridity căldură toridă, arșiță

torridness $\mathrm{v}$. torridity

torse (mat) suprafaț̆ desfăşurabilă

torsimeter; torsiometer (mec) torsiometru, aparat de măsurat elemente de torsiune

torsion (mec) răsucire, torsiune, întoarcere, sucire torsional (mec) de torsiune

torsional buckling (mec) flambaj prin torsiune torsional couple (mec) cuplu de torsiune 
torsional deflection / deformation (mec, OM) deformație de / la răsucire / torsiune

torsional elasticity (mec) elasticitate de torsiune torsional-endurance limit (mec, OM) rezistență la oboseală (prin răsucire alternată sau de alt tip)

torsion fatigue $(\mathrm{mec})$ rezistență la oboseală, la solicitare de torsiune (fără a specifica tipul de ciclu de solicitare)

torsional flexion încovoiere cu torsiune

torsional flexural buckling (mec) flambaj cu răsucire

torsional force $(\mathrm{mec})$ sarcină / forță de torsiune / de răsucire

torsional load (fiz, mec, OM) sarcină de torsiune / de răsucire

torsional moment (mec) moment de torsiune / de răsucire

torsional oscillation (mec) oscilație torsională

torsional oscillation damper $(\mathrm{OM})$ amortizor de oscilații torsională

torsional resilience (mec) reziliență la torsiune

torsional rigidity / stiffness (mec) rigiditate la torsiune (în piese solicitate)

torsional shearing stress (mec) tensiune de forfecare la torsiune

torsional spring rate $(\mathrm{mec}, \mathrm{OM})$ rigiditate la torsiune (exprimată ca moment de torsiune funcție de deplasarea unghiulară)

torsional stabiliser $(\mathrm{OM})$ stabilizator de torsiune (sub formă de bară, arc-bară de torsiune) torsional strain $(\mathrm{mec})$ deformare de / la răsucire torsional strain indicator (metr) torsiometru, traductor pentru torsiune / deformare la torsiune

torsional strength $(\mathrm{mec})$ rezistență la răsucire / torsiune

torsional stress (mec) solicitare / efort / tensiune de răsucire / de torsiune

torsional suspension (OM) suspensie / amortizor pentru oscilații torsionale

torsional test (mec, metr) probă / test / încercare la torsiune

torsional vibration (mec, OM) vibrație / oscilatie torsională

torsional-vibration testing machine (mas, metr) maşină de încercat la vibrații de torsiune

torsion angle (auto) unghi de viraj; (mec) de rotire (la deformare), unghi de torsiune

torsion-bar / spring (OM) bară de torsiune

torsion-bar suspension $(\mathrm{OM})$ suspensie pe bare torsionale

torsion coefficient coeficient de torsiune

torsion couple (mec) cuplu de torsiune

torsion dynamometer (mas-un, metr) dinamometru de torsiune torsion-endurance test (mec, $\mathrm{OM}$ ) încercare la oboseală prin răsucire / prin torsiune

torsion failure $(\mathrm{mec})$ rupere la răsucire, căderea cauzată de tensiune

torsion-free (mec) fără torsiune

torsion impact (mec) şoc de torsiune

torsion indicator (metr) torsiometru

torsionless (fiz) fără torsiune / răsucire

torsion load (mec) sarcină de răsucire / de torsiune

torsion meter (mec, metr) torsiometru / traductor tensiometric / de torsiune

torsion modulus (mec) modul de elasticitate la torsiune

torsion moment (mec) cuplu motor, moment de torsiune

torsion pendulum (fiz) pendul de torsiune / rotativ torsion rod $(\mathrm{OM})($ arc-)bară de torsiune

torsion shear test $(\mathrm{OM})$ încercare la forfecare prin torsiune

torsion spring $(\mathrm{OM})$ bară de torsiune; (mas) arc solicitat la torsiune

torsion suspension (mas, OM) suspensie cu arc spiral

torsion test (met) încercare / test la răsucire / la torsiune

torsion-testing machine maşină de încercat la torsiune / la răsucire

torsion viscosimeter (metr, T) vâscozimetru cu măsurarea momentului de torasiune / rotatie torsion wire (mec) sârmă cu torsiune / răsucită tort (jur) prejudiciu

tortious (jur) dăunător, care aduce un prejudiciu; care prejudiciază; vinovat

tortuosity sinuozitate; întortochere

tortuous (mec) îndoit, şerpuit, şerpuitor, sinuos, întortocheat

torus, $(p l)$ tori (mat) tor; (arhit) tor, toron, mulură convexă a unui profil semicircular (la baza unei coloane); profil jumătate rotund; (geom) tor, corp geometric format prin rotirea unei curbe închise; protuberanță, umflătură, convexitate, ieşitură (rotundă)

to some degree $(a d v)$ în oarecare măsură

toss a arunca, a azvârli; a scutura, a zgudui, a clătina; a legăna puternic; (d. valuri) a sălta, a legăna; a se mişca încoace şi încolo; a se agita, a se bălăbăni; a se legăna încoace şi încolo; (nav) a tanga, a sălta pe valuri; aruncare / azvârlire (în sus); zdruncinătură, zguduire; scuturare; distanță a aruncării

toss overboard (nav) a arunca peste bord

tot (metr, alim) unitate de măsură pentru volum de lichior: 1 tot $(\mathrm{UK}) \cong 23,7 \mathrm{ml}$

tour (metr, ind) altă denumire pentru schimb în industria petrolului, având, de obicei, 8 ore 
tovar (metr) unitate tradițională de măsură pentru masă, în Bulgaria: 1 tovar $\sim 128 \mathrm{~kg}$

tower weights (metr) sistem de unități de măsură pentru masă, în monetăria britanică medievală, bazat pe tower pound (pfund al Turnului Londrei, unde se afla monetăria): 1 tower pound $\sim 349,91 \mathrm{~g}$

total complet; general; întreg; total; sumă; absolut, deplin; categoric; a însuma, a face totalul; a totaliza; a aduna; a fi egal cu

total acidity (chim, T) aciditate totală

total acid number (chim, $\mathrm{T}$ ) indice de aciditate totală

total alkalinity (chim, T) alcalinitate totală

total amount sumă / cantitate totală / globală

total angle of transmission (OM) unghiul total al transmisiei $(\Sigma)$ (şi pentru angrenaje conice, transmisii conice de fricțiune)

total aromatics (chim, T) hidrocarburi total aromatice

total attenuation (mec) mărime a amortizării, atenuare totală

total available alkali (chim) conţinut total de alcalii

total base number (chim) indice de alcalinitate totală

total blast-nozzle area (met) secțiunea gurii de vânt (la furnal)

total break-time $(\mathrm{TH}$, ec) timp total de întrerupere

total characteristic caracteristică totală / echivalentă / generală

total carbon (chim, met) carbon total / echivalent (atenție la contextul în care este utilizat)

total carburisation (met) cementare / carburare totală

total connections (el) putere totală racordată; toate circuitele

total contact ratio $(\mathrm{OM})$ grad de acoperire total $\left(\varepsilon_{\gamma}\right)$ (la angrenaje cu roți dințate cu dantură înclinată)

total correction (autom) corecție globală (totală)

total creep (met, OM) deformare prin fluaj

total derivative (mat) derivată totală

total differential (mat) diferențială totală

total drag (mec) rezistență totală/ însumată

total draught laminaj total

total effect (mec, fiz) efect global / rezultantă (pentru forțe, vectori etc.)

total equation (mat) ecuație cu diferentiale totale / exacte

total exhaust energy (termo) energie totală la ieşire

total expansion / extension (met, mec) (a)lungire totală total force (mec) forță rezultantă / totală

total hangover time timp de revenire în poziția iniţială

total hardness of the water (chim) duritatea totală a apei

total hardening (met) călire / durificare totală

total head (hidr) înălțime / cădere totală (a unei coloane de fluid)

total heat (termo) căldură totală

total heat content (fiz, termo) conținut total de căldură, entalpie

total heat value (fiz, termo) putere calorifică superioară

total height of profile (metr) înălțime totală a profilului. (la profilometria suprafeței)

total increment creştere totală

total internal reflection (fiz) reflecție internă totală (fără refractie)

total interrupting time $(\mathrm{TH}$, mas) durată totală de întrerupere

totality totalitate; întreg, întregime

totalisation totalizare

totalising scale (alim, constr, ind chim, metr) dispozitiv pentru cântărirea continuă a materialelor în vrac

totalizator totalizator

totalize a totaliza

totalizer totalizator

total latent heat (fiz, termo) căldură latentă totală

total length (constr) lungime de constructie / constructivă / totală

total lift (mec) forță ascensională totală

total load greutate brută; (mec, mas) încărcare totală, sarcină / rezultantă totală

total load at fracture (mec) sarcină rezultantă / totală de rupere

total loss $(\mathrm{TH}, \mathrm{ec})$ pierdere totală / globală

totally ( $a d v)$ total(mente), în întregime; cu desăvârşire

totally bounded complet mărginit

totally continuous (mat) absolut continuu

totally enclosed complet (în)capsulat (şi d. un motor electric, un rulment etc.)

total number număr / cantitate total( $\breve{a})$

total operating time $(\mathrm{TH}$, mas) durată totală de functionare

total output (mec, ec) putere / producție totală, randament total

total pore volume (met, compozite) volumul total poros / al porilor

total porosity (met, compozite) porozitate totală

total pressure $(\mathrm{mec})$ presiune totală

total production producție totală

total radiation pyrometer (metr, met, termo) pirometru cu radiație totală 
total range (metr) scală totală, domeniu total (şi de măsurare)

total recall (psihologie) memorie perfectă, capacitate de a-și aminti clar / perfect toate amănuntele unei întâmplări

total reduction (met, plast) reducere totală (după câteva treceri, şi la laminare, profilare); (OM) raport total de transmisie

total refrigeration (alim, termo) capacitate frigorifică nominală (în condiții standard)

total reservoir storage (alim, hidr, OM) capacitate totală a rezervorului

total resisting effort (mec, hidr, OM, ind chim, alim) rezistență totală la înaintare; efort total de rezistență

total rule linie de total

total sensitivity (metr) sensibilitate totală (la aparate)

total shrinkage (met, plast) contracție totală

total strain / tension (mec) tensiune totală

total solid concentration (alim, mediu, hidr, ind chim) concentrația totală de impurități dizolvate sau în suspensie (dintr-un fluid)

total tolerance (mas-un, OM) toleranță totală

total turnover (ec) cifră de afaceri totală / globală

total tuyére area (met) secțiunea gurii de vânt

total upset (mas-un) scurtare a pieselor prin refulare

total view vedere de ansamblu (desen tehnic)

total weight masă / greutate totală (atenție la context)

tote box (mas-un) ladă din tablă de oțel (pentru păstrarea şi deplasarea pieselor într-un atelier mecanic); (amer) cutie, cutiuță; lădiță

tote up a trece în revistă, a înşira, a înşirui, a socoti

totter a se clătina; a se bălăbăni; a merge clătinându-se; (d. o construcție) (şi fig) a fi şubred, a fi gata să se prăbuşească; clătinare; bălăbăneală

tottering care se clatină / se bălăbăneşte; şubred, dărăpănat; nesigur, instabil

tottering contact $(\mathrm{el})$ contact intermitent

totterry care se clatină, (care este) pe punctul de a se prăbuşi; care merge nesigur / clătinânduse; instabil, nesigur, şubred

totting (mat) adunare, socoteală, total; sumă; totalizare; adițiune; punere la socoteală (a unor defecte); adunare a greşelilor; (mediu) adunare / strângere / colectare / recuperare a obiectelor reutilizabile / refolosibile din gunoaie, strângere a cârpelor / fierului vechi etc.

touch (mat) tangență; contact; atingere; pipăit, simțul pipăitului; (fig) pecete personală, caracteristică, notă specifică; cașet; semn, indicație; nuanță; acces, atac (al bolii); diferență mică; a atinge (cu mâna etc.); a ataca; a apăsa (pe sonerie etc.); a face să se atingă / ciocnească; a ajunge până la, a atinge; a da cu mâna de; (fig) a egala, a ajunge din urmă; a se măsura / compara cu; a pipăi; a avea de-a face cu; a impresiona, a face impresie asupra; a influența; a modifica; a produce un efect asupra; (fig) a se referi la, a aborda, a atinge (o problemă etc.); a privi (îndeaproape), a afecta, a atinge; a avea legătură cu; a contura; a marca; a retuşa; a colora, a nuanța; (d. ger etc.) a vătăma, a ataca, a altera, a strica, a dăuna; (geom) a fi tangent la; a se atinge, a fi / a veni în contact; a se ciocni, a se lovi; at (nav) a acosta la / în

touchable palpabil, pipăibil, care poate fi atins

touching atingere, contact(are), care (se) atinge / (se) ating; care se contactează

touching film peliculă de tuşare (a contactului)

touching point (mat, geom) punct de tangență / de contact

touching up retus(are); tuşare; ajustare

touch-mark semnul / marca fabricantului (pe tacâmuri)

touch-needle (metr, met) ac de aur sau argint folosit ca etalon pentru testarea titlului aliajelor touch-pitch (met) rafinat

touch spark (el) scânteie de (între)rupere (şi la comutatoare, contractoare etc.)

touch-type electrode (met) electrod pentru sudare cu "electrod rezemat"

touch-up retuş, retuşare; înviorare, împrospătare (a culorilor)

touch up (mas-un) a da / a face ultima şlefuire, a rectifica (tăişul) la piatra abrazivă, a finisa; a retuşa, a face / a aduce unele retuşuri; a lustrui, a da un nou lustru; a împrospăta, a înviora (culorile); (fig) a șlefui, a îmbunătăți, a ameliora

tough dur; tare, solid; rezistent; rigid; tenace; (fig) viguros, robust, rezistent, vânjos; încăpățânat, inflexibil; insistent, persistent; dificil, greu

tough at sub-zero $(\mathrm{mec})$ tenace la rece $/ \mathrm{sub} 0^{\circ} \mathrm{C}$

tough copper (met) cupru laminat la rece / deformabil

toughen (materiale) a se întări; a se solidifica; (alim) a (se) învârtoşa (d. aluat, creme etc.)

toughener (ind chim) substanță pentru întărirea aliajelor / materialelor plastice / compozitelor toughish cam tare / aspru / dur; cam greu / dificil / spinos

toughness (mec, OM) rezistență, compactitate, vâscozitate, tenacitate, reziliență; fragilitate; duritate, asprime; soliditate; rezistență, persistență; vigoare, forță; dificultate, greutate 
toughness test (metr, materiale) încercare de reziliență

tough-rubber sheating manta izolantă / izolație de cauciuc (dur / rigid)

tour $(\mathrm{TH})$ schimb de lucru; călătorie, voiaj (de agrement); excursie, plimbare; cursă; turneu; rond, tur; rând (la serviciu); întoarcere, mişcare circulară; fel, procedeu, manieră; a călători, a voiaja, a face călătorii; a se întoarce, a reveni; a cutreiera, a colinda (o țară); a face un turneu prin (provincie etc.)

tourbillion (hidr) vârtej

tourmaline (minrl) turmalină (piatră semiprețioasă)

tourniquet uşă turnantă

tow cablu / odgon de remorcare / de remorcă; (nav) remorcher; remorcă, edec; (textile) fuior; deşeuri; câlți; (auto, nav) a remorca; to take in $\sim$ (şi fig) a remorca, a trage după sine; (fig) a fi condus / călăuzit, a fi purtat de acolo până acolo; a trage, a târî (după sine); a merge / a fi remorcat

towage (nav) remorcare, remorcaj; tragere la edec towage astern (nav) remorcare înapoi

towards (prep) spre, către, în direcția; față de, referitor la, privitor la, în legătură cu; pentru, în scopul de a; (temporal) aproape de, spre, către

tow a vessel (nav) a remorca o navă

tow away (auto) a remorca

tow-bar (auto) bară de remorcare

tow boat (nav) remorcher

tow cable (auto, nav) cablu de remorcare

tow coupling (auto) dispozitiv de remorcare

towed (auto) remorcat, tractat

towed carrier / vehicle (auto) remorcă

towed ship / vessel (nav) navă remorcată

towel prosop, ştergar; a (se) şterge cu prosopul

towelling (textile) material / pânză de prosop

tower turn; turlă; (constr, OM) suport, pilon, stâlp, coloană; (mil) turelă; (fig) sprijin, reazem, apărător, protector; tură (piesă la şah), a se înălța, a se ridica

tower bottoms (ind chim) gudroane, reziduuri de distilare

tower (building) crane (mas) macara-turn

tower dryer (met, alim, ind chim) turn / coloană / cuptor de uscare vertical

tower evaporation (alim, ind chim) evaporare / vaporizare în coloană

tower evaporator / concentrator (alim, ind chim) coloană / turn de concentrare

tower furnace (termo) focar cu turn; (met) cuptor vertical

tower packing / filling (alim, ind chim) umplutură a coloanei tower scrubber (ind chim, met) scruber, turn de spălare a gazelor

tower skirt (ind chim, $\mathrm{OM}$ ) virolă (inferioară) a coloanei

tower washer (ind chim, mediu) coloană de spălare, scruber

tow-hook (auto) cârlig de remorcă

towing (auto) remorcare

towing crane (nav) macara de remorcat

towing device (mas) dispozitiv de remorcare

towing engine (nav) vinci de remorcă

towing gear (mas, nav) instalație de remorcare

towing hook (auto, mas) cârlig de remorcare / de tractiune

towing hook $(\mathrm{OM}$, mas) ochi / cârlig de remorcă / de tracțiune

towing rope (auto, nav) cablu de remorcare

town oraş; centrul oraşului, centru, oraş; (amer) comună; urban, orăşenesc; municipal; de oraş; citadin, de la oraş

town councillor / counsellor consilier municipal

town gas (ind chim) gaz de uz casnic / de oraş / de iluminat

town hall primărie

town mains (sistem de) canalizare a oraşului; conductele principale dintr-un oraş

town management gospodărie comunală; urbanism, urbanistică; administrația locală

town mayor primar, preşedintele Consiliului municipal, districtual sau orăşenesc

town planner (arhit) urbanist; sistematizator

town planning urbanism, urbanistică; sistematizare (a oraşelor)

town water apă de conductă; apă din rețeaua urbană

tow packing $(\mathrm{OM})$ garnitură de etanşare din câlți de cânepă

towing point $(\mathrm{OM}$, nav, auto, mec) punct de aplicare a forței de remorcare

township (twp) (metr) diviziune teritorială, unitate tradițională pentru suprafață de teren, în US şi Canada, pentru urbanizare, incluzând 36 de arii pătrate şi drumuri de acces: 1 township $(\mathrm{US})=6$ mile pătrate $\cong 93,24 \mathrm{~km}^{2}, 1$ township $($ Canada $) \cong 95,00 \mathrm{~km}^{2}$

tow linkage (OM, auto) armătură / piesă pentru cuplarea remorcii (la autovehicule)

town planning urbanism

township (metr) unitate de măsură pentru suprafață: 1 township $=93239571,972096 \mathrm{~m}^{3}$

tow off a remorca

tow packing $(\mathrm{OM})$ garnitură de etanşare din câlți (şi de cânepă)

tow pole / rod $(\mathrm{OM})$ bară de remorcat 
tow-rope hoop (OM) ochi de remorcă tow ship / vessel (nav) navă-remorcher toxic (chim, med) toxic toxicity toxicitate toxicological (med) toxicologic

toxicology (med) toxicologie

toxin (med) toxină

toz (metr) simbol pentru troy ounce, unitate tradițională pentru masă, pentru metale pretioase: 1 troy ounce $\cong 31,1035 \mathrm{~g}$

t.p.i., tpi (threads per inch) (OM, metr) abreviere pentru ,threads per inch" - numărul de spire pe un țol

T-piece / pipe (OM) teu (la conducte)

T plate (mas-un) placă cu secțiune în $\mathrm{T}$

trace traseu; curbă; urmă (de picior); indiciu; (mec, fiz) traiectorie; semn, rămăşiță; (fig) grăunte, urmă, pic (de adevăr etc.); făgaş, cărare, potecă; (punct de) intersectie; proiectie; a trasa; a urmări; a marca (cu substanțe); a schița, a desena; a scrie cu migală; a copia (prin transparență), a calchia; a găsi urme / semne de; a urmări (în trecut)

traceable detectabil; decelabil; căruia i se poate da de urmă, care poate fi urmărit; care poate fi trasat / desenat / schițat

trace a fault a căuta un defect

trace amount (chim, fiz) cantitate infimă, marcatoare / indicatoare

trace curves a construi / a trasa o curbă prin puncte trace elements (chim, fiz) elemente trasoare trace information (c, inf) flux informațional trace in full size (nav) a trasa (corpul navei sau elemente componente) în mărime reală

traceless fără urmă / urme, nedetectabil, care nu poate fi urmărit / trasat

trace of a line urma dreptei, proiecție a dreptei pe un plande coordonate (şi în desen tehnic)

trace of a plane urma unui plan (desen tehnic)

trace of a surface (geom) curba de intersectie a suprafeței cu planul coordonatelor

trace out a proiecta

trace press (alim, mas-un, plast) presă cu melc / de extrudare

tracer indicator, trasor; (mas-un) trasator, dispozitiv de copiat; urmăritor; instrument de desenat / tras linii; desenator; (mil) proiectil / cartuş trasor

tracer agent (chim) trasor, indicator (şi radioactiv)

tracer contact (mas-un) contact al punctatorului tracer finger deget sesizor, senzor, vârf de testare / de palpare, trasor

tracer method / technique (fiz, metr) metoda atomilor marcați / trasatori tracers (chim) trasori, marcatori, trasatori (indicatori ai deplasării aluviunilor şi în metalurgie, în pereții furnalului pentru controlul grosimii lor)

tracer stylus (metr) palpator

traces (chim) elemente nedozabile

trachyte (minrl) trahit

tracing trasare; pichetaj; copiere pe hârtie (prin transparență, calchiere, decalcare), punctare; schiță, desen; plan decalcat; înregistrare (a unui aparat); urmărire; (adj) (d. glonte, substanță) trasor; (chim) trasare / marcare

tracing cloth pânză de calc

tracing for troubles cercetare / căutare a cauzei avariei / penei / defectării

tracing paper hârtie de calc / copiat

tracing point (mas-un) trasator

tracing table (mas) măsuță de şablon (la maşina de frezat prin copiere)

tracing up plate (mas-un) placă / platou de îndreptat

track urmă (şi de uzură, de zgîriere etc.); pistă de curse, autodrom; (mas, OM, nav) întinzător de lanț; (cf) linie / cale ferată, şină; ecartament, double $\sim$ linie ferată dublă; (el) conductor de circuit imprimat; (inf) pistă, parte a unei memorii masive; (OM) cale, canal, şenilă (la tractor, la tanc etc.), glisieră; dâră (de sânge etc.), urmă (de paşi etc.); făgaş; drum, potecă, cărare; curs; traseu, traiectorie, direcție; (nav) rută regulată, trecătoare navigabilă îngustă, rotire a elicei, dâră / urmă lăsată de vapor; (TH) şenilă, drumul unui tractor cu şenile; a urma; a urmări (o țintă); a se afla în sincronism; a descoperi, a scoate la iveală / lumină (pe baza unor urme); (d. vehicule) a avea un ecartament de; lose $\sim$ of a pierde urma

trackage (mas-un, cf, met) (rețea de) cale ferată, şină; (amer) (cf) rețea feroviară

track alignment gauge (mas, auto, cf) dispozitiv de verificat alinierea roților

track arm (auto, mas) levier de comandă a direcției

track a target a urmări o țintă

track ball (c) bilă de mouse

track beam (mas, met) şină de rulare / de ghidare / de conducere

track block $(\mathrm{OM})$ verigă, za (la lant,, şenilă etc.)

track boat (nav) şalandă de canal

track bolt $(\mathrm{OM}, \mathrm{cf})$ bolț de eclisă (şi pentru îmbinarea şinelor), șurub de îmbinare

track chain $(\mathrm{OM})$ şenilă

track chart (geogr, nav) hartă a căilor maritime / a rutelor navigabile 
track clearer (cf) curățitor de cale

track-connecting tool / connective fixture (mas, $\mathrm{OM}$ ) întinzător de lanț

track crossing $(\mathrm{cf})$ intersectie a liniilor, trecere peste calea ferată

track curve (mec) traiectorie

track down a depista / a detecta defecte; a descoperi, a da de urma; a încolți

track drive sprocket roată dințată de antrenare a şenilei

tracked (mas, mil) cu șenile

tracked aggregate / plant utilaj pe şenile

tracked vehicle vehicul cu șenile / cu antrenare prin lant

track excavator (mas) excavator pe şine

track gauge (cf) ecartament

track hopper (met, ind chim) pâlnie de încărcare

tracking autotransport, camionaj; (cf) montarea liniei ferate; trasare; urmărire; (autom) reglaj exact

tracking circuit (autom, mas-un) circuit de urmărire

tracking controller (autom, mas-un) regulator de al sistemului de urmărire / de copiere

tracking device for leaks (autom, hidr) circuit / dispozitiv pentru detectarea scăpărilor / scurgerilor (de gaze, fluide)

tracking down seat of interference / trouble (TH) localizarea defectelor / deranjamentelor

tracking error (autom, mas-un, metr) eroare de urmărire (din cauza întârzierii de răspuns), eroare de sincronizare

tracking point (mas-un) ac trasor, trasator

tracking symbol (c) simbol de urmărire (care indică coordonatele)

tracj laying (cf) montare a şinelor / căii / liniei; (auto) cu şenile

track-laying vehicle autovehicul $\mathrm{cu}$ șenile / cu antrenare prin lant

trackless trolley (amer) (transp, el) troleibuz, (fam) troleu

track link $(\mathrm{OM})$ patină de şenilă

track maintenance service (cf, met) întreținere a căilor ferate (şi uzinale)

trackman (cf) lucrător de cale

track of bearing $(\mathrm{OM})$ cale de rulare a bilelor de rulment

track of depression (alim, mas) traiectorie a depresiunii (şi în ciclon)

track pin $(\mathrm{OM})$ bolț de lant

track plotter (metr, c) trasator, plotter

track put on rear wheels of trackwheel vehicles (auto) lant antiderapant (pentru roata de tractiune a vehiculelor)

track rail (cf, mec) şină (şi de cale ferată) track rod $(\mathrm{OM})$ bară de conexiune

track runway rail (mas, met) şină de rulare / de ghidaj / de conducere

track shoe $(\mathrm{OM})$ element / sabot de şenilă, za (de lanț), verigă; gheată cu crampon

track spacing (cf) ecartament / spațiu dintre linii

track spike (OM) crampon (şi de şină)

track spreader $(\mathrm{OM})$ întinzător de lanț

track-type tractor (auto, mas) tractor pe senile

trackwalker (amer) (cf) revizor de cale / linie

trackway (amer) v. track pavaj, caldarâm, parte carosabilă

track wheel $(\mathrm{OM}, \mathrm{cf})$ roată alergătoare / liberă (şi la locomotive)

track width (cf) ecartament

tractability capacitatea / proprietatea de a fi tractat / maniabilitate; (şi fig) maleabilitate

tractable maniabil; uşor de mânuit, maleabil; usor de prelucrat; (fig) docil, supus, blând, maleabil

tractate tratat, lucrare (d. un subiect)

traction tractiune; întindere; tragere; trefilare; (med) contracție, contractare; atracție; (amer) transport public / în comun

tractional (fiz, $\mathrm{TH})$ referitor la tracțiune, de tractiune

tractional load (mec) sarcină de tracțiune

tractional resistance (mec) rezistență la tracțiune

traction clutch (mas, OM) ambreiaj al mecanismului de deplasare / de ridicare (la macarale)

traction engine (cf) locomobilă, motor de tracțiune

traction flange (mec) bridă / inel de tractiune / de tractare

traction force (mec) forță de tracțiune

traction motor motor de tractiune

traction test test / încercare la tracțiune

traction wheel ( $\mathrm{TH}$, auto) roată conducătoare / de tractiune

tractive (mec) de tracțiune, tirant

tractive force (mec) forță de tracțiune (şi la cârligul de macara); (el, fiz) forță de atracție (magnetică)

tractive effort / force / load on starting (mas) efort / forță / sarcină de tracțiune la demaraj / la pornire

tractor tractor; tractor de sudare; (c, birotică) dispozitivul de deplasare a hârtiei la imprimantă; motor de tracțiune; (mas) instalație de tractiune; echipament de tractiune / remorcare

tractor cultivator (agr) tractor prăşitor

tractor ditcher / ditching shovel (mas, constr) excavator cu cupă întoarsă (pentru şanțuri și canale înguste) 
tractor drag bucket (mas, constr) excavator cu cupă întoarsă

tractor-drawn tractat, tras (şi de un tractor)

tractor-drawn bottom-dump trailer (agr, auto) remorcă cu descărcare prin fund

tractor driver / operator tractorist

tractor elevator (mas) elevator montat pe tractor

tractor loader (mas) excavator, autoîncărcător cu cupă

tractor revolving crane (mas) macara pivotantă pe tractor

tractor roller $(\mathrm{OM})$ rolă / roată de şenilă

trade profesie (manuală); meșteşug; meserie; măiestrie, îndeletnicire; (ec) afaceri, comerț, negoț, tranzactie (comercială); the $\sim(\mathrm{com})$ comercianți, furnizori autorizați, clientelă, clienți, cumpărători; (amer) material, stofă; (peiorativ) vechituri, zdrențe; (nav) călătorie cu destinație precisă; rută / cursă regulată; (minrl) steril, rocă sterilă, gangă; urmă, călcătură; direcție; drum, cărare, potecă; (fam) unealtă, sculă; magazin, trafic comercial; a face comerț; a transporta mărfuri (pe mare); $(\sim$ in) a face comerț $(\mathrm{de}, \mathrm{cu})$; ( $\sim$ with) a face negustorie / afaceri cu, a face schimb de, a schimba cu; a negocia; comercial, de comert; mercantil, negustoresc

trade agreement $(\mathrm{ec})$ acord comercial

trade balance (ec) balantă comercială

trade bank (ec) bancă comercială

trade cycle $(\mathrm{ec})$ alternare a perioadelor de prosperitate şi criză, flux şi reflux (al condițiilor economice)

trade discount (ec) scont comercial

trade disease (med) maladie / boală profesională

trade disputes $(p l)$ conflicte industriale / de muncă / comerciale

trade edition ediție comercială / obișnuită

trade expensives (ec) cheltuieli administrative / de comercializare

trade-in (ec) cumpărarea unui bun de folosință îndelungată cu înapoierea celui vechi firmei producătoare şi achitarea unei diferențe de preț sau schimbare a unui articol vechi cu unul nou

trade journal revistă de specialitate

trade-mark / name (TH, ec) marca fabricii, marcă înregistrată; semn distinctiv

trade mark punch (mas-un) poansonarea mărcii de fabrică

trade name v. trade mark, nume de marcă

trade off (ec) a face troc cu / schimb de; a schimba (prin bună înțelegere); a negocia / a vinde în compensatie / contrapartidă

trade-off (ec) schimb în natură, troc; comerț / negot în compensație / contrapartidă

trade plates (auto) numere auto provizorii, numere de atelier (folosite înaintea înscrierii în circulatie) trade price (ec) preț de gros / en-gros / cu ridicata trader (ec) comerciant, negustor (angrosist); afacerist, om priceput la afaceri; (nav) vas comercial, navă care face curse regulate (pe aceeaşi rută)

trade representative $(\mathrm{ec})$ ataşat comercial

trade route rută comercială, drum comercial

trade school (edu) şcoală profesională, liceu industrial; şcoală de (arte şi) meserii; şcoală comercială

trade show vizionare / prezentare (comercială) a unui film (în vederea achiziționării)

trade terms $(\mathrm{TH}$, ec) condiții de livrare / de recepție

trade-union sindicat (muncitoresc)

trade unionism mișcare sindicală, sindicalism

trade unionist sindicalist; membru de sindicat

trading (ec) comert, trafic; comercial, de comert

trading capital (ec) capital comercial, fond de rulare / de rulment

trading company (ec) companie / societate comercială

trading down (ec) comert cu produse ieftine și de calitate inferioară (pt. a asigura volumul de vânzări)

trading estate (arhit, ec) zonă destinată construcțiilor industriale şi comerciale, zonă comercială; construcții pentru firmele industriale şi comerciale; (aprox) spații economice

trading house (ec) magazin universal, antrepozit, casă de comert

trading in futures $(\mathrm{ec})$ a face comert la termen

trading port (nav, ec) port comercial

trading-post $(\mathrm{ec})$ punct comercial

trading stamp (ec) cupon, tichet (de rabat / reducere) oferit clientului (pt. cumpărarea altor articole)

trading town (ec) oras comercial

trading up (ec) comerț cu produse scumpe și de calitate superioară (pt. a asigura prestigiul firmei)

trading vessel (nav) navă / vas comercial(ă)

traffic trafic, exploatare, circulație; mişcare (a vehiculelor); bewarw of $\sim$ ! atentie la circulatie!; (ec) comerț; navigație comercială; negoț, comert, trafic comercial; trafic / comert ilicit / ilegal; comunicații; referitor la circulație

traffic accident accident de circulatie

traffic circle (amer) (auto) sens giratoriu

traffic departament (cf) (serviciu) de mişcare; (inf, ind) serviciu de exploatare

traffic indicator (auto) indicator de circulație

traffic intensity intensitate a circulației (mărfurilor, informației etc.)

traffic jam (auto) ambuteiaj, blocare / gâtuire a circulației; încurcătură de circulație 
trafficless pustiu, gol, deşert; necirculat

traffic lights $(p l)$ (auto) stop, semafor / semafoare pentru dirijarea circulației

traffic manager (cf) impiegat de mişcare; şeful biroului de mişcare

traffic officer agent de circulație

traffic sign (auto) semn / indicator de circulatie

traffic ticket (amer) (auto) proces verbal de contraventie

traffic unit (TU) (metr, telecomunicații) altă denumire pentru erlang, o măsură adimensională pentru densitatea de trafic în telecomunicații: 1 TU este un apel-secundă pe secundă sau un apel-oră pe oră etc.

traffic violator contravenient la legea circulației traiectory (fiz, mec) traiectorie, orbită traiectory path track $(\mathrm{mec})$ urma traiectoriei

T rail (met) şină / grindă în $T$

trail urmă, dâră (de sânge, fum etc.); pistă; drum, potecă, cărare; coadă, dâră de fum / de lumină; marcaj (pe munte); trenă, sir, rând, alai, procesiune; (bot) lăstar târâtor; a remorca; a se întinde; along / after / behind a târî, a trage după sine; a sfida, a avea o atitudine de sfidare; a remorca, a urmări; v. trace a călca / a păşi (pe iarbă etc.); a (se) târî (pe jos); a târî picioarele; a merge încet

trail behind (mas) întârziere (de fază), defazare (în urmă)

trailer remorcă (de camion, tramvai etc.); (auto) rulotă; (el) port-perie; (ec) reclamă (la sfârșit de program); (agr, biol) plantă târâtoare / agățătoare; codaş, persoană care rămâne în urmă

trailer block (c) bloc adițional (al unei memorii) trailer bogie (cf) boghiu purtător

trailer brake valve (auto) ventil / supapă al frânei de remorcă

trailer coupling (auto, OM) cuplaj de remorcă, dispozitiv de remorcare

trailer label (c) etichetă / marcaj / reper de oprire / de sfârşit (de program etc.)

trailer towing (auto) tractare de remorcă

trail flying bridge (mas) pod rotativ

trailing (mas-un) frecare a cutitului la cursa de înapoiere; remorcat; din spate; târâre, târâire; atârnare, târâre pe pământ; rămânere în urmă, decalaj; sfârşit / final neconcludent / în coadă de peşte; încheiere neconvingătoare; lăsare baltă; care atârnă / se târăște pe jos; care rămâne în urmă; rămas neterminat / în coadă de pește; care urmează să continue

trailing axle (mas, OM) osia din spate, osie purtătoare

trailing cable $(\mathrm{TH})$ cablu suspendat trailling edge (el) curbă descendentă a amplitudinii (pulsației etc.)

trailing lead (el, mas) cablu trenant / remorcat (pentru alimentarea utilajelor mobile actionate electrice)

trailing shaft $(\mathrm{OM})$ prelungirea osiei

trailing wheel (mas, OM) roată alergătoare / condusă; roată liberă (nemotrice)

train (cf) (garnitură de) tren; (el, autom) tren de impulsuri; (met) tren laminor, linie de laminare; (OM) (tren de) angrenaj(e), transmisie cu mai multe angrenaje; trenă, suită; echipaj; şir, rând, lant;; înlănțuire; (fig) curs, mers; cale; (geogr) curs de râu; sanie; (edu) a (se) instrui, a învăța, a (se) pregăti; a (se) forma; a (se) educa, a face educatic; a îndruma; a (se) exersa, a face exercitii; a (se) antrena; a (se) angrena; a califica, a stila (pe cineva); (agr) a dirija (creșterea unei plante), a trage pe spalier; a trage, a târî (după sine); a urmări, a urma (un filon)

trainable (edu) susceptibil, de educație / disciplinare; (d. un animal) care poate fi dresat

train diagram (cf) graficul trenurilor

train dispatcher (cf) dispecer, impiegat de mişcare

trained educat, învățat, instruit; calificat, cu experiență, versat, exersat, deprins; stilat

trained (in a profession) calificat (într-o profesie)

trainee (edu) elev la o şcoală specială; elev (al unui maestru); sportiv care se antrenează

trainer instructor, antrenor

train ferry (nav) feribot

train guard (amer) (cf) conducător / şef de tren

training (edu) instruire; învățământ (specializat); calificare; antrenare; formare (şi profesională), pregătire, cultivare, exersare, perfecționare

training evaluation evaluarea calificării / specializării (personalului)

training school $v$. teacher training college (edu) şcoală profesională

traning ship (nav) navă-şcoală

train load (mec) sistem de sarcini mobile, sarcină mobilă, aplicată în mai multe puncte

trainman (amer) (cf) muncitor feroviar; $(p l)$ personalul trenului

train master $v$. train guard

train-mile (cf) milă parcursă (de un tren, ca unitate de măsură pt. traficul feroviar)

train of barges (nav) convoi de barje / de şlepuri, dană de şlepuri

train of events suită / înlăntuire / lant de evenimente; concurs de împrejurări; context (situațional)

train of gears (mas-un, OM) sistem (tren) de angrenaje, angrenaj, tren de roți dințate

train of ideas / thought înlăntuire / lanț / suită / ordine de idei 
train (of rolls) (met) linie de laminare train of stands (met) caje de laminare în linie train-oil (alim, iht) ulei / untură de peşte train rope cablu de remorcare train service (cf) serviciu / birou de mişcare train staff (cf) personalul trenului

train work $(\mathrm{TH})$ angrenaj; mecanism de ceasornic (tren de angrenaje)

trait trăsătură, linie; caracteristică, trăsătură; particularitate, specific

tram tramvai, linie de tramvai; roabă; (mas-un) şubler de trasat; (met) vagonet, cărucior; (textile) fir de mătase dublu răsucit; a duce / a transporta cu tramvaiul

tram car vagon de tramvai

tram driver manipulant, vatman

tram line linie de tramvaie; şină de tramvai

tramlines (met, plast) dungi / urme longitudinale (defect de laminare)

trammels (mas-un, metr) şubler de trasat

tram rail (met, transp) şină de tramvai

tramroad (amer) v. tramway (met, cf) linie de vagonet

tramway (transp) linie de tramvai, tramvai

tranche (ec) tranşă, porție, cotă (de venituri, acțiuni etc.)

tranquil flow (hidr) curgere liniştită

transact (ec) a negocia, a trata (o afacere); a se tocmi pentru; a încheia, a executa, a îndeplini; a face (treburi etc.); with a face afaceri cu, a perfecta tranzacții cu

transaction (ec) tranzacție; afacere; operație comercială; negociere, conducere a afacerilor; gestiune; efectuare, încheiere, îndeplinire (a unor treburi); $(p l)$ procese verbale, acte, lucrări (ale şedinţelor unei academii etc.)

transactor (ec, pol) negociator, persoană care încheie / face o tranzacție

transaxle (auto) schimbator de viteze

transaxle forks (auto) furcile schimbătorului de viteze

transaxle shift lever (auto) mâner al schimbătorului de viteze

transcend a depăşi (limitele), a trece (dincolo) de; $(f i g) \sim$ in a întrece, a depăşi într-o privință; a fî superior, a se ridica deasupra celorlalți, a excela

transcendental equation (mat) ecuație transcendentă / transcedentală

transcontinental transcontinental, care traversează continentul (de la un capăt la altul)

transcribe a transcrie, a copia; a reproduce (o stenogramă); (lingv) a transcrie fonetic

transcriber traducător, copist, persoană care transcrie transcript copie, transcriere (şi a unei stenograme); reproducere

transcription transcriere, copiere, copie; reproducere, transcripție

transcrystalline (met) intercristalin

transcrystalline corrosion (chim, met) coroziune transcristalină / intercristalină

transducer (autom, el, metr) traductor, convertor; captator; (OM) organ de transmisie / de transfer; (fiz, el, TH) convertizor, dispozitiv de transformare a variațiilor unei mărimi în variații ale alteia

transducer losses (autom, el, metr) pierderi prin / în traductor

transducer pulse delay (autom, el, metr) întârziere a semnalului între intrarea și ieșirea din traductor

transect a tăia, a secționa; a face o secțiune în transection secțiune, tăietură

transfer (autom, mat) transfer, trecere, mutare; schimbare; deplasare; transformare; salt, transmitere, translație; (inf) mutare / transferare a datelor, lansare forțată în executie a unui program; (jur) remitere, predere, transfer, transmitere, (act de) cedare / de cesiune; (bilet de) transbordare / corespondență; (edu) mutare (în altă clasă etc.); calchiere, copiere; transpunere (a unui desen, a culorilor); $(p l)$ abtibilduri, poze de copiat; (ec) transfer, virament, a vira o sumă; (nav) transbordare, a transborda; a transporta; a transfera, a deplasa; a muta; (jur) a remite, a transmite, a transfera, a preda; a calchia, a copia, a transpune (un desen etc.)

transferability transmisibilitate, caracter transmisibil; posibilitate de transferare / mutare / deplasare; capacitatea de a fi transferabil

transferable transferabil, transmisibil; (jur) negociabil, care poate fi cedat / cesionat; (ec) care poate face obiectul unei tranzacții; transportabil; susceptibil de calchiere / copiere / decalcare / transpunere

transfer account (ec) cont de virament

transfer arm (mas-un) pârghie de transport al piesei de la un ax la altul (la strungul automat) transfer bin (alim, met) pâlnie / siloz de transfer transfer book (ec, jur) registru de transfer al / de transferare a proprietăților, acțiunilor etc.

transfer box $(\mathrm{OM})$ cutie intermediară de viteze, transmisie intermediară

transfer car vagonet / cărucior de alimentare / de transferare / de transport (a pieselor mari)

transfer chain (mas, OM) lanț de transport, transportor cu lanț 
transfer company (amer) societate de transport care asigură transbordarea pasagerilor (între gări apropiate etc.)

transfer contact (el, autom) contact de comutare / de basculare / cu două poziții

transfer container (ind chim, alim) rezervor / cisternă de transfer; (nav) container de transvazare

transfer crane (mas, nav) macara de transbordare transference (jur, ec) transmitere, transferare, cedare (a unei creanțe etc.)

transfer gantry (mas) macara-capră, macara portal transfer gear (met) mecanism de transfer al semifabricatelor (şi cu angrenaje)

transfer ladle (met) oală pentru transportul / transferul materialului topit / a metalului lichid

transfer lag întârziere; timp mort de transmisie / de transfer

transfer line $(\mathrm{TH})$ linie automată de producție transfer / transition motion (mec) translație

transfer mould (met, plast) matriță de formare prin transfer

transfer moulding (met, plast) formare / presare / turnare prin transfer

transfer of energy (mas, fiz) transfer de energie transfer of force (mas) transmisie de forță

transfer of heat (termo, met) cedare / schimb / transfer / transmisie de căldură

transfer of metal (met) transfer de metal (şi topit)

transfer order (ec) dispoziție de transfer / de virament

transfer paper hârtie de calc; document / act scris pe hârtie de calc; copie; (poligrafie) hârtie litografică

transfer pipe (mas, OM, hidr) conductă / țeavă de transfer al fluidului

transfer plunjer (alim, mas-un, hidr, OM) piston / plunjer de transfer

transfer rate $(\mathrm{TH}$, autom, c) viteză de transfer

transfer ratio raport / factor de transfer

transfer reaction (chim) reacție de creştere a catenei

transfer relay (el) releu de transfer / comutator (şi intermediar)

transferrer transmițător; v. transferor; (poligrafie) muncitor litograf

transfer resistance (el) rezistență de trecere / de transfer

transferring $(\mathrm{TH}, \mathrm{ec})$ transfer; cedare; virament

transfer roll (met) cilindru de avans; $(\mathrm{OM})$ rolă de transportor; (alim, plast) valț de transfer

transfer service serviciu de legătură / transbordare / de mutare / de trasferare

transfer switch (el) comutator / întrerupător de derivație transfer table (mas-un) cărucior, platformă mobilă (la nivelul pardoselii); (cf) (amer) transbordor

transfix a străpunge, a perfora; a imobiliza, a paraliza

transfixion străpungere, perforare; $(\mathrm{TH})$ imobilizare, paralizare

transform (mat) rezultat / produs al transformării, imagine, reprezentare, transformată; a schimba; a preface; a reprezenta; a reconstrui; a aplica; a metamorfoza; a reforma, a reorganiza; (chim, fiz) a converti, a transmuta, a transforma

transformable transformabil, care poate suferi schimbări / transformări structurale; (el) convertibil; susceptibil de transformare / reformare

transformation (ec) convertire; conversie; (mat) transformare, aplicație, reprezentare; (fiz) schimbare de formă; (met) transformare (de fază); prefacere, modificare, reformare; reformă, reorganizare; (chim) transmutaţie; metamorfoză

transformation apparatus (autom, metr) aparat / dispozitiv de transformare

transformation of coordinates (mat) transformare de coordonate

transformation of energy (met, mec, chim) transformare de energie

transformation point (met) punct de transformare, punct critic / de oprire a unui proces

transformation range (met) domeniu / interval de transformare, zonă critică

transformation ratio (mas, $\mathrm{OM}$ ) raport de transmitere

transformation temperature (met) temperatură de transformare

transformative transformativ, transformațional; referitor la transformare sau convertire; care se poate transforma / schimba; v. transform

transformed beta (met) structură beta transformată (la aliaje metalice)

transformer (el) transformator

transformer booster (el) transformator ridicător de tensiune

transformer coil (el) bobină de transformator transformer oil (el, T) ulei de transformator

transformer plate / sheet / stamping (el) tolă de transformator

transformer ratio (mas) raport de transmitere, raport de transformare

transformer-sheet steel (met, el) oțel de tole (pentru transformatoare)

transformer station (el) stație de transformare

transformer welder (el, met) transformator de sudură 
transforming $(\mathrm{TH})$ (proces de) transformare, modificare comutare, transvazare; care (se) transformă / modifică / schimbă

transfuse (alim, plast) a injecta; a face o transfuzie (şi de sânge); a traversa; with a îmbina cu, a impregna cu; (fig) a insufla, a inculca, a transmite, a inspira

transfusing, transfusion (med) transfuzie; transvazare; (med) injecție intravenoasă; (fig) insuflare, inculcare, transmitere

transgranular corrosion (chim, met) coroziune intergranulară

transgress a depăşi (atribuțiile, competența); a acoperi; a încălca, a viola, a nu respecta; (jur) a contraveni la lege; a (în)călca legea / regulile / convențiile; a greşi

transgression depăşire, exces; (jur) infracțiune, încălcare (a legii etc.); contravenție, greşeală

transgressive (jur) culpabil, vinovat (de un delict sau contravenție), vinovat care dovedește o vină / vinovăție

transgrid action (fiz) penetranță, factor de pătrundere

transient (fiz, chim, el, mec) (fenomen / proces) tranzitoriu / momentan / de scurtă durată; trecător, pasager, efemer; vremelnic; întâmplător, accidental, ocazional; (amer) în tranzit; (el) supratensiune / supracurent inițial( $\breve{a})$; (TH) şoc de conectare; (amer) pasager, trecător / în tranzit; (TH) tranzitoriu

transient behaviour regim de tranziție / instabil, comportare instabilă

transient component (chim) componentă volatilă / de tranziție / intermediară (instabilă)

transient creep (met, plast) fluaj tranzitoriu, curgere tranzitorie

transient current / flow (hidr, T) curgere tranzitorie, curent tranzitoriu

transient distribution (hidr, termo, T) distribuție nestaționară / în regim tranzitoriu

transient effect / phenomenon (fiz, TH) efect / fenomen tranzitoriu

transient fault (TH) defect cu disparitie spontană

transient function (mat, mec, el) funcție de şoc, functia delta a lui Dirac

transient heat flow (termo) transfer de căldură în regim tranzitoriu / nestabilizat

transient moment (mas, mec) moment caracteristic regimului tranzitoriu

transient period (fiz, autom, mas, TH) perioadă de tranziţie (şi d. un regim de funcționare)

transient process (fiz, chim, $\mathrm{TH}$ ) proces tranzitoriu / nestaționar / de tranzit

transient protection (el, $\mathrm{TH})$ protectie împotriva supratensiunii / a proceselor tranzitorii transient stage / state (fiz, TH) stare tranzitorie / intermediară / compusă / nestaționară

transient time (fiz, autom, TH) perioadă tranzitorie, timp de stabilizare

transient voltage (el) supratensiune, tensiune tranzitorie, tensiune de soc

transinformation (c, inf) informație transferată / transmisă

transire (ec) autorizație vamală pentru tranzitarea unor mărfuri

transistor (electr) tranzistor

transit tranzit, trecere, traversare; parcurs; trecere la meridian; (fiz) derivă, deplasare, decalaj; in / for în / de tranzit; transport, pasaj, traversare; drum; a parcurge; a tranzita, a traversa; a trece; (mat) a intersecta, a străpunge

transit compass (fiz, metr) teodolit cu busolă

transit duty (ec) taxă de tranzit

transit failure blocare a tranzitului

transit freight încărcătură în tranzit

transition tranzitie; transformare; transfer; trecere; discontinuitate; salt; evoluție; schimbare; perioadă / etapă / stadiu de tranziție; caracter intermediar, modulație; (fiz) schimbare a stării

transitional de tranziție / trecere; (cu caracter) intermediar

transition curve (cf, hidr) curbă / linie de racordare; (mat, av) curbă de trecere

transition fit (mas-un, OM) ajustaj intermediar / aderent

transition flow (hidr) curgere tranzitorie

transition form / shape formă de tranziție / intermediară

transition function (mat) functie de transfer

transition heat (chim, met) căldură de transformare

transition lattice rețea de tranziție / instabilă

transition / transfer motion (mec) (mişcare de) translatie

transition piece (mas, OM) piesă de tranziţie / de racordare / intermediară

transition point (met) punct de tranziție / de separatie / de trecere

transition range interval de tranziție

transition stage stare tranzitorie / de tranziție / nestaționară

transition steel (met) oțel de tranziție

transition temperature (met, chim) temperatură / interval de tranziție (şi în care reziliența se modifică brusc)

transition time (fiz) timp de parcurs al electronilor; timp de tranziție / de propagare

transition zone (constr, materiale, met) zonă de tranziție (a compoziției, granulației, proprietăților etc., în materiale) (şi la sudură, zona între materialul de bază și cel de adaos) 
transitiveness / transitivity (fiz) transitivitate transitory tranzitiv, tranzitoriu; $v$. transient transitory regime $(\mathrm{TH}$, mas) regim tranzitoriu transit path (mas, mas-un) ghidaj

tranzit permit $(\mathrm{ec})$ document de tranziție (al mărfurilor)

transit time (autom, $\mathrm{T}$, met, metr) timp de tranziție / de tranzit / de propagare / de trecere / de întârziere (între intrare - ieşire)

tranzit visa viză de tranzit (pe paşaport)

translatable traductibil, care se poate traduce (un text, un semnal etc.)

translate a traduce, a tălmăci; a face o traducere / tălmăcire; as a interpreta ca; a înțelege; a lua (drept / ca); a metamorfoza, a schimba, a transpune; (ec) a descifra, a decodifica; (mec) a imprima unui corp o mişcare de translație; (inf) a translata, a schimba forma datelor; (TH) a face translația, a imprima / a da o mişcare de translație; (TV) a retransmite, a relua; (fam) a transforma / modifica (hainele etc.), a cârpi, a recondiționa

translation (fiz, TH) (mișcare de) translație; (met) dislocare paralelă; (inf) convertire / translatare a datelor; traducere; interpretare; lucrare tradusă, versiune; descifrare; decodificare; explicare, explicatie; (TV) retransmisie, reluare

translational referitor la traduceri; de traduceri; (TH, fiz) de translație

translational motion (mec) (mișcare de) translație translation by amount transfer cantitativ; decalare, deviaţie (cu o anumită cantitate / valoare)

translation motion / movement (fiz, mec, $\mathrm{TH}$ ) mişcare de translatie

translation surface $(\mathrm{TH}$, mec, $\mathrm{T})$ suprafață de translație

translator (autom, el) traductor / convertor analogic-numeric; (inf) program de convertire a instrucțiunilor dintr-un limbaj în altul; (TV) aparat de retransmitere / reluare

translatory motion / shift (mec) (mişcare de) translație

translatress traducătoare; translatoare

transliterate (autom) a converti, a traduce (un semnal)

translocation deplasare, mutare din loc în loc; dislocare; (bot, agr) deplasare a substanțelor în organismul plantei

translucence, translucency (fiz) transluciditate; caracter diafan / translucid; transparență

translucent (fiz, plast) translucid, transparent translucid $v$. translucent

transmigrant migrator; aflat în tranzit; care străbate o țară; srăin / persoană care străbate o țară în tranzit (în drum spre alta); turist în tranzit transmigrate (fiz, TH) a emigra, a migra dintr-o țară în alta; a migra (şi printr-un material)

transmigration transmigrație

transmissibility (fiz) transmisibilitate

transmissible transmisibil

transmission (mas, OM) transmisie (mai ales mecanică, şi reductor), angrenaj, reducție; transmitere; (radio) emisie, transmisie; emisiune

transmission band (mas, OM, radio) bandă de transmisie

transmission / strap $(\mathrm{OM})$ curea de transmisie

transmission cable (el) cablu de transportat energie electrică

transmission case (mas-un, OM) carterul / carcasa cutiei de viteze / a reductorului; $(\mathrm{TH}$, auto) cutie de transmisie

transmission chain $(\mathrm{OM})$ lanț de transmisie

transmission control lever (mas-un) pârghie de comandă a cutiei de viteze / a transmisiei

transmission drive (mas) actionare prin transmisie, transmisia principală / de acționare

transmission dynamometer (metr) torsiometru, dinamometru (ataşat unei transmisii)

transmission efficiency $(\mathrm{TH}, \mathrm{mec})$ randament de transmisie

transmission fabric (textile, OM) țesătură / țesături pentru curele de transmisie

transmission gear (mas, OM) transmisie cu angrenaje

transmission gearbox (mec, $\mathrm{OM}$ ) cutie de viteze transmission gear case (mas-un, OM) carcasă de angrenaje, carterul cutiei de angrenaje

transmission gear(ing) (OM) transmisie cu angrenare (fără a specifica dacă este reductoare sau multiplicatoare)

transmission housing (OM) carcasa cutiei de viteze / transmisiei cu anhrenaje

transmission line (el) linie electrică, linie de înaltă tensiune; (TH) transmisie complexă, transmisii în linie

transmission lock (mas-un) fixator / siguranță a cutiei de viteze

transmission lubricant (mas, T) lubrifiant pentru mecanisme de acționare / transmisii

transmission mechanism / machinery $(\mathrm{OM})$ (mecanism de) transmisie

transmission main shaft $(\mathrm{OM})$ arborele principal de transmisie

transmission loss $(\mathrm{TH}$, mas, $\mathrm{OM}, \mathrm{T})$ pierderi într-o transmisie (mecanică, de semnal etc.)

transmission of load (mec) transmitere de sarcină / de putere

transmission oil (OM, T) ulei de transmisie transmission pulley (mec, OM) roată de transmisie (şi de curea) 
transmission ratio $(\mathrm{OM})$ raport de transformare / de transmitere; (el) raport de transformare

transmission rod (mas) bară de transmisie transmission rope (mas) cablu de transmisie transmission shaft $(\mathrm{OM})$ arbore de transmisie / de reductor

transmission-speed (fiz, chim) viteză de propagare (a unui proces / fenomen)

transmission-speed of brake action (OM) viteză de propagare a frânării

transmission time (autom, TH, mas) timp de propagare / de transmitere / de tranzit

transmission unit (fiz) unitate de transmisie a sunetelor; (aprox) decibel; (OM) sistem mecanic / unitate / subansamblu cu transmisie

transmissive transmițător, care transmite; transmis, transmisibil

transmissivity (fiz) permeabilitate; transmisivitate

transmit (el) a transmite; a emite; a radio; (inf) transfer al informației; a conduce, a face să treacă (curentul electric etc.); (radio) a transmite, a emite; a difuza; (jur) a transmite ca moştenire / pe cale ereditară, a lăsa moştenire

transmittable transmisibil, care poate fi transmis / înmânat; (jur) transmisibil, transferabil; care poate fi transmis / cedat altei persoane

transmitted load $(\mathrm{mec})$ sarcină indirectă / propagată

transmitter traductor, (fiz) emițător, transmițător; telecomandă; mediu de propagare / de transmitere; sesizor; expeditor; manipulator; microfon; (radio) post / stație de radio / emisie

transmitter centre cover (auto) capacul central al telecomenzii

transmitter key telecomandă

transmitter-receiver $v$. transceiver

transmitting aerial (radio) antenă de emisie

transmitting tower turn de transmisie

transmutation transmutație; transformare, conversi(un)e, convertire; schimbare, modificare

transmute a transmuta; into a transforma, a preface, a schimba în

transmuter (chim etc.) agent / element / factor de transmutare / transmutatie; element / factor / agent de transformare

transnational $(a d j)$ transnațional, supranațional, care depăşește granițele / limetele naționale (d. societăţi, trusturi internaționale); v. transnational company

transnational company / corporation (ec) societate transnațională, concern / trust transnațional / multinațional / internațional

transom (bar) (constr) bară, riglă, traversă, tronson; (nav) cadru transversal de etambou, osatură pupa; bară transversală; (arhit) impostă; (nav) oglinda / cadrul pupei

transonic (fiz, av) supersonic, transsonic, referitor la viteze apropiate de cea a sunetului

transparence, transparency (fiz) nebulozitate, transparență; (metr) calitate a unui aparat de măsură de a nu altera valoarea mărimii măsurate; limpezime, claritate; (hârtie) transparentă; (c) transparență a fondului unei imagini

transparent transparent; străveziu; (fig) evident, clar, transparent, vizibil, diafan; inefabil; sincer, franc, deschis, neprefăcut

transparent drawing paper hârtie de calc

transparently $(a d v)$ (în mod) transparent, în transparență; (fig) (în mod) vizibil / evident / clar / transparent; în mod inefabil; (în mod) sincer / deschis / franc, fără prefăcătorie

transparentness $v$. transparency

transparent packing (alim, plast) ambalaj transparent

transparent plate (fiz, metr) placă transparentă

transpierce a străpunge, a perfora

transpire a transpira, a asuda, a năduşi; (d. un secret etc.) a se afla, a deveni de notorietate publică; a se strecura, a se furișa; a se infiltra; a elimina prin transpirație, a exuda

transplant a transplanta; (fig) a muta, a transfera, a strămuta; (med) a grefa, a transplanta; a face grefe / transplanturi; a se preta la transplantare; (agr) puiet transplantat; (med) transplant, grefă, transplantare

transponder (radio) dispozitiv de recepțietransmisie automată

transport transport, transportare; cărăușie; (ec) livrare; (nav) vas de transport; a transporta; a duce, a căra; v. transplant

transportability posibilitate de a fi transportat / cărat / deplasat; transportabilitate

transportable deplasabil, transportabil; uşor de transportat / cărat; portabil; portabil; care poate fi transportat

transportation transport; v. transport; mijloc de transport; (amer) speze de transport; foaie de drum; bilet de călătorie

transportation bucket (met) cupă de transport

transportation cost (ec, transp) cost (mai rar preț) al transportului

transportation device $(\mathrm{TH})$ dispozitiv de transport (şi la maşini-unelte cu magazie de scule)

transportation haulage equipment instalație de transport de ridicare

transportation insurance (ec) asigurare contra riscurilor de transport

transportation loss $(\mathrm{ec}, \mathrm{TH})$ pierdere de / la transport 
transportation means mijloace de transport transport box $(\mathrm{OM}, \mathrm{TH})$ container transport charges $\mathrm{v}$. transportation

transporter (mas, transp) transportor, conveior, bandă transportoare; antreprenor, agent de transport / cărăuşie

transporter bridge (nav, constr) pod de transbordare

transport facilities ( $\mathrm{TH}$, transp) utilități / mijloace de transport (şi într-o hală)

transporting appliance utilaj de transport

transporting bridge $(\mathrm{TH}$, mas) pod rulant / de transport

transport line linie de transport

transport screw (OM, alim, ind chim) şurub / melc transportor

transport service (ec) serviciu de expediție / de transport

transport unit (mas) utilaj de transport

transport vessel v. transport; (nav) navă de transportat mărfuri

transport worker (ec) muncitor din transporturi; funcționar la o întreprindere de transport; funcționar din transporturi

transpose (mat) a transpune, a permuta, a trece un termen dintr-o parte în alta a semnului egal (cu semn schimbat); a modifica, a schimba (ordinea etc.); (muz) a transpune; a transcrie

transpose (of a) matrix (mat) transpusa unei matrici

tranposing repaginare; transpunere; transmutare transposition repaginare; (mat) transpunere, transpoziție, (per)mutare; strămutare, schimbare; inversiune, trecere; trecerea unui termen dintr-o parte în alta a semnului egal (cu semn schimbat); schimbare de poziție (şi de linii electrice, cabluri etc.)

transposition point (el, OM, hidr, mas) punct de suprapunere / de încrucişare (şi a liniilor electrice, a conductelor etc.)

transship (nav) a transborda; a face o transbordare transshipment (nav) transbordare

trans-sonic $v$. transonic

transuranic (chim, fiz) (d. un element chimic) transuranic, cu număr atomic / greutate atomică superioară uraniului

transversal transversal, oblic

transversal extruder head (mas-un) cap de extrudare montat în unghi drept față de axul principal al maşinii

transversal forging (met) forjare / refulare perpendiculară pe direcția fibrajului

transversal planer (mas-un) maşină de rabotat transversală (şeping) transversal waves (fiz) unde transversale transverse (cf, mec, constr) traversă, linie transversală, oblic

transverse arch kiln (met) cuptor continuu cu camere

transverse $v$. transversal

transverse axis $(\mathrm{OM})$ ax $(\breve{a})$ transversal $(\breve{a})$

transverse base pitch $(\mathrm{OM})$ pasul frontal pe cercul de bază (la dantură înclinată) $\left(\mathrm{p}_{\mathrm{bt}}\right)$

transverse base thickness $(\mathrm{OM})$ grosime a dintelui pe cilindrul de bază în plan frontal $\left(\mathrm{s}_{\mathrm{bt}}\right)$ (la roți dințate cu dantură înclinată)

transverse beam (mec, constr) grindă / bară transversală, traversă; grindă de coamă

transverse bending resilience $(\mathrm{mec})$ deformație remanentă la încovoiere / transversală

transverse-bending test probă / test / încercare de încovoiere transversală

transverse bulkhead (nav) perete despărțitor transversal

transverse contact ratio $(\mathrm{OM})$ grad de acoperire în plan frontal $\left(\varepsilon_{\alpha}\right)$ (la roți dinţate cu dantură înclinată)

transverse contraction (met, plast) contractie transversală

transverse crack (met) crăpătură transversală

transverse cross (-)bar (mas-un, constr) traversă, bară / grindă transversală

transverse diameter $(\mathrm{OM})$ diametrul secțiunii transversale

transverse expansion (mec) dilatare / dilatație transversală

transverse facial crack (met, plast) crăpătură / fisură transversală de suprafață

transverse fillet weld (met) cusătură frontală (în sudură) / cu umplere a rostului prin misccare transversală a electrodului față de lungimea cusăturii

transverse force (mec, OM) forță tăietoare / de forfecare

transverse frame (nav) coastă-cadru (varangă, coaste laterale şi grinda punții)

transverse joint (met, OM) îmbinare transversală, rost transversal

transverse lap (met, plast) cută / încrețitură transversală (şi defect de laminare)

transverse load $(\mathrm{mec})$ sarcină transversală

transversely v. transversally $(a d v)$ (în mod) transversal

transversaly corrugated ondulat transversal

transversely jointed chain $(\mathrm{OM})$ lanț cu articulație în cruce

transverse joint (met, OM) îmbinare transversală, rost transversal 
transverse magnet (fiz, el) magnet cu poli laterali

transverse module $(\mathrm{OM})$ modul frontal (la roți dințate cu dinți înclinați $)\left(\mathrm{m}_{\mathrm{t}}\right)$

transverse motion / movement (mas-un) avans transversal; (mec) mişcare transversală / perpendiculară (față de o linie / axă de referință)

transverse oscillation (mec) oscilație transversală transverse pitch $(\mathrm{OM})$ pas transversal (al nituirii); pas frontal $\left(\mathrm{p}_{\mathrm{t}}\right)$ (la roți dințate)

transverse planing machine (mas-un) şeping

transverse prestressing (mec) precomprimare / pretensionare transversală

transverse pressure angle $(\mathrm{OM})$ unghi de angrenare în plan frontal $\left(\alpha_{t}\right)$ (de obicei pe cercul de divizare)

transverse pressure angle at a point $Y(O M)$ unghiul de angrenare / de presiune în punctul $\mathrm{Y}\left(\alpha_{\mathrm{Yt}}\right)$ în plan frontal, unghiul frontal de angrenare în punctul $\mathrm{Y}$ al profilului (dintelui) (la dantură cilindrică, înclinată)

transverse profile $(\mathrm{OM})$ profil transversal; profil în plan frontal

transverse rib $(\mathrm{OM})$ nervură transversală

transverse rigidity (mec, met) rigiditate transversală / perpendiculară pe direcția de laminare

transverse sampling (met, plast) prelevare a probei pe direcția transversală (şi la laminare)

transverse section $(\mathrm{OM})$ secțiune transversală / frontală / perpendiculară pe axa roții dințate

transverse slide (mas-un) sanie transversală

transverse space width $(\mathrm{OM})$ spațiul / golul între dinți în plan frontal $\left(e_{t}\right)$

transverse spring $(\mathrm{OM})$ arc transversal

transverse strain (mec) dilatatie / deformare transversală

transverse strength $(\mathrm{mec})$ rezistență la lunecare / la forfecare

transverse stress (mec) efort / tensiune de încovoiere (mai rar)

transverse surface $(\mathrm{OM})$ suprafață frontală (şi la roți dințate / de fricțiune etc.)

transverse system ship (nav) navă cu osatură transversală

transverse table (cf) platformă rulantă, transportor de vagoane

transverse tangent length $(\mathrm{OM})$ lungimea (cota) peste $\mathrm{N}$ dinți, pe direcție frontală pe dinte / în plan frontal $\left(\mathrm{W}_{\mathrm{nN}}\right)$

transverse test (met, plast, metr) probă / test / încercare de încovoiere (pe direcție transversală a fibrajului sau a laminării)

transverse testing machine maşină de îndoit (pentru încercări) transverse test specimen epruvetă transversală / de încercare la forțe transversale sau la încovoiere

transverse tooth thickness $(\mathrm{OM})$ grosime a dintelui în plan frontal $\left(\mathrm{s}_{\mathrm{t}}\right)$

transverse trim (auto) structură

transverse vibration $(\mathrm{mec})$ vibrație transversală transverse wave (fiz) undă transversală (care vibrează perpendicular pe direcția propagării)

trap cursă, capcană; laț; trapă, chepeng; captator, captor, separator, uşă de aerare; (OM) închizător, clichet; (met) sifon (la turnare), tub de drenaj, obturator; -door trapă; (inf) deviere, oprire a unui program și lansare a unui program de depanare / de tratare a devierii; (fiz) dislocație, monoclină, monoclinal; (geol) piatră / rocă şistoasă; piatră (şistoasă) pentru drumuri; a prinde în capcană / cursă / laț, a instala capcane în (pădure etc.), a capta; a colecta; (TH, hidr) a prevedea cu sifon, a bloca (o particulă, o mişcare etc.); (fig) a întinde o cursă; set a a întinde o cursă

trap circuit (autom) circuit de blocare

trap door (OM, ind chim) trapă de vizitare, uşăghilotină, trapă, chepeng

trapeze (geom) trapez

trapezium; trapezoid (geom) trapez, patrulater oarecare

trapezoidal trapezoidal, în formă de trapez

trapezoidal belt $(\mathrm{OM})$ curea trapezoidală

trapezoidal thread $(\mathrm{OM})$ filet trapezoidal

trapezoidiform trapezoidal

trapped oil / lubricant $(\mathrm{OM}, \mathrm{T})$ ulei colectat / captat

trapped oxide (met) incluziune de oxid

trap (separating) vessel (termo) oală / vas de condens(at), separator, cursă, capcană, trapă, captator (de condens)

trapped slag (met) incluziune de zgură

trappy v. treacherous; primejdios, periculos

trash (TH) rebut; rămăşițe; gunoi, brac; resturi de crăci sau trestii; fără valoare; ratat, nimic, zero, obiect fără nici o valoare / importanță; vechituri; (bot) ramuri ale unui copac

trash can (amer) cutie / ladă de gunoi

trashiness lipsă de valoare, valoare mică

trash rack (mec) grătar (la priză)

trash-rack bar bară a grătarului de reținere

trashy de nimic / duzină; fără valoare; (ec, TH) de proastă calitate

trass (minrl) tras, tuf vulcanic, folosit la fabricarea cimentului

trauma, $(p l)$ traumata (med) traumă, traumatism traumatism v. trauma 
travel călătorie, voiaj; (constr) drum, galerie; trecere; pasaj; (mas, mas-un, mec) avans, cursă, deplasare, mişcare, traiectorie, elongație; (TH) circuit; a călători, a face o călătorie; a se mişca, a se deplasa; (fiz) a migra (electroni, atomi, dislocaţii etc.); a se propaga, a se răspândi; a parcurge, a străbate (un ținut etc.); a împinge înainte; a aluneca,

travel agency agenție / birou de voiaj / turism travel agent birou turistic / de turism; agent / persoană care ține un birou de voiaj / turism

travel bureau $v$. travel agency

traveller (mas) pod rulant, macara rulantă / mobilă; $(\mathrm{OM})$ roată / rolă alergătoare; călător; voiajor; pasager; (ec) comis voiajor; voiajor comercial; cursor (la rigla de calcul)

traveller's cheque (ec) cec de călătorie

travelling călătorie, care călătoreşte; (mec) mişcare, deplasare; care se mişcă / deplasează, mobil, deplasabil, ambulant

travelling apron $(\mathrm{OM})$ bandă de transport la conveier, masă de transport / transportoare

travelling band conveyer (mas) transportor $\mathrm{cu}$ bandă

travelling-belt screen (alim, agr, ind chim) sită cu benzi

travelling-bracket crane (mas) macara-consolă rulantă, pod rulant cu macara

travelling-bridge (mas) pod rulant

travelling crab (mas) cărucior de macara

travelling crane (met, transp) macara mobilă, pod rulant cu macara

travelling crane girder (mas, mec) grindă de pod rulant

travelling distance (mas) rază de actiune (la macarale, poduri rulante etc.)

travelling fire grate (met) grătar mobil (la cuptor cu vatră mobilă)

travelling furnace (met, ind chim) cuptor cu vatră mobilă

travelling gantry crane (mas) macara-capră mobilă

travelling gate hoist (mas, nav) pod rulant al batardoului de reparație

travelling grate (met, termo) grătar mobil

travelling grizzly (agr, ind chim) ciur cu bare mobile

travelling head planer (mas-un) raboteză cu cap mobil (şi masă fixă)

travelling head shaper (mas-un) şeping cu avans transversal

travelling hoist (mas) cărucior mobil, de macara travelling hopper (met) cărucior de aducere / de alimentare / de distribuție travelling ladder (constr) scară culisantă / rulantă travelling load (mec) sarcină mobilă

travelling motor hoist (mas) cărucior de macara, cu motor

travelling paddle mixer (alim, ind chim) amestecător cu paletă mobilă

travelling platform platformă mobilă

travelling rest / stay (mas-un) lunetă mobilă

travelling reversal $(\mathrm{mec})$ schimbarea sensului de mers / de mişcare

travelling roll (mas-un, met) rolă de susținere (la maşina de îndreptat)

travelling rope cablu de foraj

travelling spindle (mas-un) arbore principal (la maşina orizontală de alezat)

travelling speed (TH, transp) viteză de mers / de transport / de trecere

travelling stay (mas-un) lunetă mobilă

travelling tripper (mas, $\mathrm{OM}$ ) cărucior de descărcare (la transportor cu bandă)

travelling wave (fiz) undă călătoare (ale cărei particule se deplasează în direcția propagării undei)

travelling wheel $(\mathrm{OM})$ roată alergătoare / baladoare / liberă pe arbore

travelling winch (mas, OM) cărucior de macara

travel rope cablu de tragere

travel sick (nav) care suferă de / are rău de voiaj / călătorie

travel sickness (med, nav, transp) rău de voiaj / călătorie

travel stroke cursă activă (la motor, maşiniunelte, prese etc.)

travel through a parcurge, a traversa (prin)

travel up a merge în sus

travel-weary obosit de drumuri / călătorii

traversable mobil; deplasabil; (d. un ținut, un drum etc.) care se poate traversa / străbate; practicabil, utilizabil

traversal linie transversală de intersectie

traverse traversare; pasaj, trecere (şi de-a curmezișul); loc de traversare; (mil, TH) parapet; piedică; (jur) piedică; opoziție, obstacol; (constr) traversă; (mas-un) avans transversal; (OM, mas) cursă (a unei piese); (geom) linie transversală; (nav) rută în zigzag; ( $a d j$ ) oblic, transversal; cruciş; a traversa, a parcurge, a încrucişa; a străbate; a trece prin; a trece în revistă; a cerceta atent / în profunzime; a examina atent; a pune de-a curmezişul, a merge în curmeziș, a tăia de-a curmezișul; (jur) a nega, a tăgădui, a refuta; a face opoziție; a se împotrivi, a se opune; a obiecta; a contrazice; (fig) a parcurge, a examina (un subiect) 
traverse drill (mas-un) maşină de găurit cu deplasarea laterală a burghiului / a piesei de prelucrat

traverse feed (mas-un) avans transversal

traverse force $(\mathrm{mec})$ forță transversală

traverse gears (OM, mas-un) transmisie cu roți dinţate cu deplasare rapidă a saniei / a mesei

traverse lever for head across rail (mas-un) manetă de comandă a mecanismului de deplasare rapidă a saniei pe ghidajele traversei

traverse method of grinding (mas-un) rectificare cu mişcare alternativă a pietrei sau a piesei

traverse motor (mas-un) motor de deplasare rapidă a mesei / a saniei principale

traverse profile profil transversal

traverser (cf, OM) transbordor, traversă; v. travelling / traversing crane

traverse sight line profil transversal

traverse table $v$. traverser

traverse transfer (met) pod transportor cu lant

traversing crane (mas) pod rulant cu macara

traversing column (mas-un) coloană deplasabilă

traversing gear (mas, OM) mecanism de pivotare / de basculare / de deplasare transversală (cu angrenaje)

traversing standard (mas-un) montant deplasabil traversing wheel (mas-un) roată alergătoare / de rulare

travertin(e) (minrl) travertin

trawl dragă, traul năvod; (nav) a trage pe fund (o plasă); a pescui cu plasa / traulul

trawler (nav) trauler; dragă; pescar care foloseşte traulul

trawl-line (amer) traul, plasă mare de pescuit; (aprox) talian

trawl-net (nav) traul, năvod

tray (TH) tavă, tăvităă, taler, fund, bază, formă concavă, farfurie, chiuvetă, placă, cupă; baie; covată, copaie; scoc; compartiment (de cufăr etc.); (nav) platformă de încărcare; (metr) tavă, cutie, unitate informală pentru volum de fructe (căpşuni etc.), în US, care include 6 containere mai mici: 1 tray $\sim 6,61$

tray column (ind chim) coloană cu taler(e)

tray downspout (mas, hidr, OM, mediu) conductă deversoare, țeavă de preaplin

tray dryer (alim, ind chim) uscător cu rafturi / cu tăvi

tread pas; zgomot de paşi; talpă (de pantof); (T) suprafață / bandă de rulare (şi a pneului) / de rostogolire / de frecare / de alunecare; (cf) ecartament; (constr) treaptă (a unei scări), înveliş de traptă; loc pentru pus piciorul; loc de păşit; (nav) lungime a chilei; pas, mers, umblet, călcătură; (zgomot) de paşi; (distanță de un pas); a merge / a trece peste; a pune piciorul pe; a călca, a păşi, a merge

trad away (fig) a călca strâmb; a greşi; a face lucruri incorecte (d. un operator)

tread board (constr) treaptă (de scară), suprafața superioară a treptei

tread butt splicing machine (met, plast) maşină de îmbinat cap-la-cap

tread circle $(\mathrm{OM})$ cerc de rulare / de rostogolire al roților (dințate sau de lanț)

treading (ind chim) reşapare

treading contact contact cu pedală

treadle $(\mathrm{OM})$ pedală (de bicicletă, de maşină de cusut etc.); manivelă cu pedală, a mişca / a acționa / a împinge cu o pedală / cu ajutorul pedalei; work the $\sim$ a acționa pedala

treadle drive (mas) acționare cu pedală

treadle hammer (mas) ciocan cu pedală

treadle operation (mas) funcționare cu comandă la pedală

treadle press (mas) presă de picior / cu comandă la pedală

tread tool (mas-un) cuțit de filetat

tread wear (auto, mas) uzură a benzii de rulare

treasure comoară, tezaur; hold a tezauriza; (fig) comoară, lucru de preț; a păstra ca pe o comoară

treasure house tezaur (muzeistic); v. treasury

treasurer vistiernic; (ec) econom, administrator, gestionar; trezorier, casier (al unei societăți)

treasure ship (nav, înv) galion

treasure up a tezauriza, a acumula, a strânge, a aduna

treasury visterie, trezorerie, tezaur (de stat); (ec) casierie; antologie; tezaur (literar); (fig) comoară / sursă de informații; enciclopedie

treasury bill (ec) bon de tezaur

treasury note (ec) bancnotă (de o liră sau o jumătate de liră)

treat $(\mathrm{TH})$ a prelucra, a uzina; a aplica un strat acoperitor; a prepara; (materiale) a trata (un metal, un aliaj, un material plastic etc.), a îmbunătăți; a se purta cu, a trata; a considera, a socoti, a lua drept (o glumă etc.); (med) a trata, a îngriji; a trata, a dezbate, a discuta, a analiza (un subiect etc.); (chim, TH) a trata, a îmbogăți (un minereu); to a trata cu, a da, a oferi, a servi (cuiva); for a negocia, a purta negocieri, a duce tratative, a trata pentru; with a negocia, a trata $\mathrm{cu} ; \sim$ of a trata despre; desfătare, bucurie, plăcere, încântare; tratație

treatable (ind chim, met) tratabil, care poate fi tratat; vindecabil 
treat by Eloxal process (met) a eloxa

treated steel (met) oțel tratat (termic sau termochimic)

treated timber (cf, constr) lemn impregnat

treater $(\mathrm{ec}, \mathrm{pol})$ negociator

treating prelucrare, uzinare, preparare; (met) tratament termic; (chim) tratare

treating compound (ind chim) amestec de impregnare / pentru tratare

treatise tratat / lucrare de specialitate; $\sim$ on tratat asupra, broşură (de / despre)

treatment tratament, tratare, prelucrare, impregnare; purtare (față de cineva), fel de a trata, primire, tratament; tratare, model / fel de a trata (un subiect etc.); ( $\mathrm{TH}$, chim) tratare, prelucrare, îmbogățire (a minereului); (med) tratament, cură, îngrijire

treat with copper (met) a arămi

treat with rubber (ind chim) a cauciuca, a guma, a aplica o acoperire de cauciuc

treaty $(\mathrm{ec}, \mathrm{pol})$ tratat, contract, acord, convenție, înțelegere; negocieri, tratative

traty port (nav) port deschis

treble triplu, de trei ori, întreit; număr triplu; a (se) tripla, a (se) întrei

treble back gears (mas-un, OM) transmisie intermediară cu trei angrenaje

tree (bot) arbore, copac; (met, plast) urmă de alunecare (defect de laminare)

treeing (met) creşterea dendritei (la solidificarea oțelului)

tree-like arborescent; (met) dendritic

treenail (constr) scoabă de traversă; crampon; (OM) pană de fixare, cui de lemn, cep, diblu; (nav) pană de lemn, ic

tree resin (ind chim) gudron rezultat din distilarea lemnului

trees (met) dendrite

tree trunk (silv) trunchi de copac

trefoil (bot) trifoi; în formă de trifoi, trilobat

trek călătorie, drum; escală, haltă; emigrare, mutare dintr-un tinut într-altul; a călători, a emigra; (fig) a o şterge; a pleca

trellis (met) zăbrele, gratii, spalier, rețea, grătar de recuperator / regenerator; împletitură de nuiele, lesă; a acoperi cu împletitură de nuiele sau grătar de zăbrele; (agr) a pune (viţă, pomi etc.) pe spalier

tremble a tremura; a vibra; a trepida; a dârdâi; (fig) a-i fi teamă; a fi îngrijorat / neliniştit, a tremura; tremur, freamăt, palpitare, vibrație

trembling (c) tremurare / vibrare a imaginii; tremur, tremurat, tremurătură; fior; freamăt; tremurător, tremurând trembling poplar plop tremurător

trembly tremurător; fricos, speriat, care are tremurici, care tremură mereu; timid, intimidat tremendous groaznic, îngrozitor, înspăimântător; (fam) colosal, imens, extraordinar, uimitor; formidabil; fantastic, grozav, straşnic, nemaipomenit

tremendously $(a d v)$ teribil, îngrozitor, înspăimântător; (în mod) extraordinar / uluitor; (fam) grozav / teribil / straşnic de

tremendousness caracter îngrozitor / înfricoşător / extraordinar / neobişnuit; enormitate, imensitate

tremor trepidare, vibrare, oscilare

trench săpătură, şanț, groapă, canal de scurgere, jgheab; tranşee

trenchancy caracter tăios / tranşant / ferm; fermitate, energie; causticitate

trenchant ascuțit, tăios; (fig) tăios, muşcător; tranşant, energic, hotărât

trenchantly $(a d v)$ (în mod) tranşant / categoric / hotărât / viguros; (în mod) incisiv / muşcător / penetrant

trench coat trenci, haină de ploaie, fulgarin

trencher (alim) fund de lemn (pt. tăiat carne etc.)

trenching machine (constr, mas) maşină de spălat şanțuri

trend direcție; tendință; înclinare; orientare; v. tendency; $\sim$ to, towards a fi îndreptat orientat spre / în direcția; (fig) a tinde către

trendily $(a d v)$ (fam) după ultima modă / ultimul strigăt (al modei), foarte elegant / modern / la modă

trendiness elegantă, modernitate, stil ultramodern, rafinament; îmbrăcare în pas cu moda

trendy (fam) foarte modern / elegant / la modă; îmbrăcat după ultimul strigăt (al modei); ultramodern, ultraelegant

trepan (mas-un) maşină de găurit

trepanning tool (mas-un) cuțit pentru canale circulare

trepidation $(\mathrm{TH})$ trepidație; tremur; agitație, îngrijorare, tulburare

trespass (jur) a încălca legea, a comite un delict sau o contraventie; a încălca / a viola o proprietate (particulară); a călca granița unei proprietăți; (jur) delict, contravenție, încălcare a legii; violare, încălcare (a unei proprietăți etc.); abuz, ofensă

trespass against a leza; a dăuna, a face rău; a încălca, a viola, a nu respecta; a ofensa; a greşi împotriva

trespasser (jur) persoană care violează / încalcă o proprietate; braconier (rar); contravenient; delicvent; păcătos 
trespass on / upon v. trespsss against; a abuza de, a încălca limitele

tress cârlionț, buclă, coadă, cosiță, plete; (met) creșterea dendritelor

trestle (constr) estacadă; postament; capră; piedestal; şarpantă; schelet; schelă, suport

trestle bridge (nav, constr) pod-estacadă, podcapră / din capre

trestle-table $(\mathrm{OM})$ masă aşezată pe capre de lemn; masă demontabilă

trestle-tree (nav) crucetă

trestle work (constr) picioare de pod (capre)

tret (ec) supliment, masă / marfă suplimentară adăugată drept compensație pentru pierderile de la transport

triable (jur) care poate fi tradus în justiție; de competență judecătorească; care poate fi încercat; care merită să fie încercat

triacetate (chim) triacetat

triad triadă, grup de trei; (chim) element trivalent; (metr) unitate de cantitate, egală cu 3

triadic triadic, în formă de triadă; alcătuit din trei elemente

triage triaj; triere; sortare

trial (jur) judecată, proces; experiență; (TH) încercare, probă, verificare, experimentare; on a de probă, pe încercate; supus la încercare; (jur) proces (penal), judecată; dare în judecată; judecare (a unei spețe); (adj) de probă / încercare; experimental

trial and error metoda aproximărilor succesive; (pedagogie) metoda învățării din greşeli

trial-and-error method metodă de selecție / de aproximație empirică (prin încercări și eliminări ale erorilor)

trial-and-error solution soluție aproximativă / empirică

trial balance (ec) balanță de verificar / a sumelor

trial-balance book (ec) registru de solduri

trial court (jur) (amer) instanță inferioară; (tribunal de) primă instanță

trial cut (mas-un) trecere de încercare

trial installation / plant / stand instalație de probă / pentru încercări

trial judge (jur) (amer) judecător de la prima instanță / instanța inferioară

trial lawyer (amer) (jur) avocat pledant

trial load (mas-un, TH) sarcină de probă

trial of strength încercarea puterilor (între două persoane)

trial period (TH) perioadă de probă / încercare

trial run (TH) mers / parcurs / funcționare / cursă de probă; (auto, nav) cursă / drum de probă / de verificare; (fig) experiență, probă, experiment, verificare trial strech (auto) pistă de încercare

trial trip călătorie de probă; (nav, auto) v. trial run

triangle (geom) triunghi; (OM) echer / cruce pentru tijă de pompe

triangle of equal legs (geom) triunghi isoscel

triangular (mat) triunghiular; (pol) tripartit

triangular compasses (geom) compas $\mathrm{cu}$ trei picioare (pt. marcarea triunghiurilor)

triangular belt $(\mathrm{OM})$ curea trapezoidală

triangular file pilă triunghiulară

triangularity (geom, OM) triunghiularitate, formă triunghiulară

triangularly $(a d v)$ în formă de triunghi, ca un triunghi

triangular prism (geom) prismă triunghiulară

triangular pyramid (geom) piramidă (cu baza) triunghiulară

triangular scraper (mas-un, met) răzuitor triunghiular

triangular thread $(\mathrm{OM})$ filet triunghiular

triangulate $v$. triunghiular; a da formă de triunghi, a forma un triunghi

triatomic (chim) triatomic, cu molecula alcătuită din trei atomi; cu trei atomi sau trei radicali care pot fi înlocuiți

triaxial (OM, mas) triaxial, cu trei axe

tribasic (chim) tribazic

triblet dorn, montură; (mas-un) mandrină pentru prelucrat tuburi, cercuri etc.

tribo-acoustics (fiz, T) tribo-acustică

tribo-chemical wear mechanism $(\mathrm{T})$ mecanism / proces tribo-chimic (de uzură)

tribochemistry (chim, T) tribochimie, chimia proceselor rezultate din frecare si uzură

tribocorrosion (chim, T) tribocoroziune

triboelectricity (fiz, T) electricitate produsă prin frecare

tribolayer $(\mathrm{T})$ tribostrat, strat superficial, rezultat al mişcării relative şi uzurii

tribological behaviour ( $T$ ) comportare tribologică

tribological characteristic $(\mathrm{T})$ caracteristică tribologică

tribological parameter $(\mathrm{T})$ parametru tribologic

tribological process $(\mathrm{T})$ proces tribologic

tribology $(\mathrm{T})$ tribologie

triboluminescence $(T)$ triboluminescență, luminescență produsă prin frecare

tribometer, tribotester (metr, T) tribometru, stand pentru determinarea caracteristicilor tribologice

tribomodel $(\mathrm{T})$ tribomodel, model de laborator pentru teste tribologice

tribomodelling $(\mathrm{T})$ tribomodelare 
tribo-oxidation (chim, T) tribo-oxidare, proces de oxidare, cauzat de mişcarea relativă a corpurilor, de frecare, uzură şi câmpul termic rezultat

tribosystem $(\mathrm{T})$ tribosistem

tributariness caracter tributar; situația de a fi tributar; caracter auxiliar / subsidiar / ajutător; (biol) caracter secundar / subsidiar / inferior

tributary auxiliar, subsidiar, ajutător, tributar; (biol) secundar, inferior; (geogr) afluent

tribute (ec) redevență acordată proprietarului unei mine; cotă parte / participare la beneficii (pentru muncitori)

tricar (auto) automobil / motocicletă de transport (cu trei roți)

trice clipă; moment; (nav) a ridica (o velă)

trichina $\mathrm{pl}$ trichinae (med) trichină

trichinosis (med) trichinoză

trichloride (chim) triclorură

trichromatic (fiz) tricromatic, tricolor

trick artificiu, expedient; şiretlic, şmecherie; subterfugiu, chichiță; iluzie, înşelare, festă (pe care ți-o joacă simțurile); secret, taină; obicei, nărav, manie, tic; manierism; (nav) schimb / serviciu / rând la timonă; a înşela, a păcăli, a trage pe sfoară; (sport) a dribla, a fenta; shot trucaj (la o filmare)

trickiness caracter înşelător / perfid / dubios; complicație, caracter complicat (al unui mecanism etc.)

trickle (TH) scurgere (în cantitate mică), șuviță, dâră, firicel (de fluid), prelingere (a unui fluid), şiroi (de apă etc.), picurare, prelingere, scurgere lentă / înceată; cantitate mică / redusă, pic, picătură; a se scurge (încet), a picura, a se prelinge; a se strecura, a pătrunde (picătură cu picătură / încetul cu încetul); a se infiltra; a lăsa / a face să picure / să se prelingă / să cadă picătură cu picătură; a picura, a pica

trickle along (hidr) a se prelinge / a se scurge pe lângă / de-a lungul

trickle charge $(\mathrm{TH})$ sarcină de încărcare / de compensare / de întreținere / tampon; (el) încărcare intermitentă a acumulatorului

trickle down $(\mathrm{TH})$ a curge în picături, a picura, a se prelinge

trickle in a se infiltra

trickle out $(\mathrm{TH})$ a se scurge încet în afară (d. un fluid); a se scurge / a se prelinge picătură cu picătură; (fig) a ieşi încetul cu încetul la iveală

trickle scale (met) arsură încrustată la laminare (defect)

trickle through a se strecura; a (se) infiltra

trickling percolare, picurare

trickling cooler (alim, termo, ind chim) răcitor cu stropire cu apă trick lock lacăt / încuietoare cu cifru

tricky şmecher; înşelător, amăgitor; abil, descurcăreț; complicat, delicat, spinos

triclinic (d. un cristal) cu trei axe oblice inegale

tricolour tricolor; în trei culori; (steag) tricolor

tricoloured tricolor; în / cu trei culori

tricot (textile) tricot; tricou, cămaşă tricotată

tricuspid / three-cusped hypocycloid (mat) hipocicloidă cu trei puncte de întoarcere / a lui Steiner tridentate cu trei dinţi sau colţi

tridimensional (fiz, mat) tridimensional; cu trei dimensiuni; în relief

tried încercat, probat, experimentat; pus la încercare; cu experiență, încercat

triennial (metr) la fiecare 3 ani, o dată la 3 ani

triennium (metr) unitate tradițională de timp, egală cu 3 ani

trier persoană care încearcă; om insistent / perseverent; (jur) judecător, magistrat

tri-ferrous carbide (met) cementită

trifle away a risipi, a arunca / a azvârli pe fereastră; a cheltui de pomană

trifurcate trifurcat, cu trei ramuri; a (se) împărți în trei ramuri, a se trifurca

trifurcating box (el) cutie terminală pentru cabluri trifazate

trifurcation trifurcare, trifurcație, împărțire în trei ramuri

trig $(\mathrm{OM})$ opritor, piedică de roată (şi de clichet); frână; a opri, a împiedica, a frâna, a propti; a ține în ordine, a ține curat; a îngriji, a dichisi; a umple, a îndesa, a ticsi; corect, exact, pus la punct; voinic, viguros; sănătos

trigger (chim) centru de initiere a reactiei în lanț; (mec, OM) dispozitiv / mecanism de închidere mecanică / de declanşare, dispozitiv de blocare (şi a unei roți), clichet, trăgaci, cocoş, piedică (de siguranță), manetă; (chim) centru de inițiere a reacției în lanț; (autom, el) circuit basculant, multivibrator bistabil (inf) procedură declanşată automată la apariția unei condiții prestabilite, a lansa (imediat) un program; a declanşa, a actiona un clichet; a pune în mişcare; a impulsiona, a activa, a acti-viza; a da un impuls (cuiva)

trigger action (TH, chim) acțiune de inițiere / de declanşare; declanşare

trigger-action relay (autom, el) releu declanşator

trigger circuit (autom, el) circuit de declanșare / basculant

triggering declansare, basculare; (hidr) comandă a unui distribuitor / a amorsării unui ventil; (TH) imprimare a unui anumit ritm; care se declanşează ritmic / periodic 
trigerring level (ec) nivel de la care se face reaprovizionarea stocului; (autom) nivel de declanşare / de basculare

trigerring magnet (autom, el) magnet de declanşare

trigger molecule (chim) moleculă activatoare

trigger sear $(\mathrm{OM})$ braț de tragere / de declanşare

trigger pair circuit (autom, el) multivibrator bistabil, circuit flip-flop

trigger relay (el, autom) releu ireversibil / basculant / de declanşare

trigger spring $(\mathrm{OM})$ arc declanşator

trigonal system (fiz) sistem romboedric

trigonometrical (mat) trigonometric

trigonometric function (mat) funcție trigonometrică

trigonometric / polar form of a complex number (mat) forma trigonometrică a unui număr complex

trigonometric ratios (mat) funcții trigonometrice / circulare

trigonometry (mat) trigonometrie

trihalid (chim) trihalogenuri

trihedral (geom) triedric, triedru

trihedral angle (geom) triedru

trihedron, $(p l)$ trihedra (geom) triedru

trilaminar alcătuit din trei straturi

trilateral trilateral

trilemma raționament / judecată cu trei premise; (fam) dilemă grea, alegere între lucruri / alternative (neplăcute)

trilliard, sextillion (amer), 1000 trillion (brit) (metr) triliard, unitate de cantitate egală cu $10^{21}$

trilobate (bot) trilobat; $(\mathrm{T}, \mathrm{OM})$ trilobat, cu trei lobi (d. un lagăr etc.)

trim (met) debavurare, ajustare; (mas-un) a degroşa (cu rindeaua); a teşi, a rotunji (muchii); (nav) asietă, înclinare longitudinală a navei, orientare, diferență de pescaj, echilibru, bună repartizare a încărcăturii sau balastului; $(\mathrm{TH})$ echilibrare, balansare, egalizare; (bună) rânduială, ordine, aranjament, dispozitie; pregătire, formă, dispoziție (pt. luptă, râs etc.); (amer) (constr) căptușeală de scânduri; a egaliza, a nivela; a ajusta, a regla; a îndrepta; a pune în ordine, a rândui, a aranja; a tivi, a bordura; a curăța; a debavura; a orna, a ornamenta, a împodobi, a garnisi; (constr) a finisa; (mas-un) a degroşa (şi lemn), a teși / a rotunji margini, a îndrepta un disc abraziv; a tăia; a mărgini; a înconjura; a potrivi, a reteza (mustața, un fitil etc.); a ciopli, a netezi, a da la rindea; (nav) a echilibra încărcătura (unui vas), a orienta, a îndrepta (într-o direcție); (fig) a muştrului, a scutura, a certa; îngrijit; curățel, dichisit; pus la punct; (TH) în bună stare (de funcționare), în ordine

trimaran (nav) trimaran

trim by the bow (nav) aprovare

trim compensation (nav) compensare față de axa longitudinală

trimer (chim) trimer; corpus trimeric

trimeric (chim) trimeric

trimerous alcătuit din trei părți, tripartit

trimester (metr) trimestru, unitate de timp, egală cu 3 luni sau 1/4 ani; (metr, univ) trimestru (academic), de 14 săptămâni

trimestr(i)al trimestrial

trimmer personal de îngrijire / supraveghere a utilajelor, persoană care potriveşte / aranjează sau împodobeşte; maşină de tăiat din trei părți, trimer, rectificator; foarfecă mare de grădină; (fig) oportunist; persoană şovăielnică / lipsită de fermitate; (constr) tălpoaie

trimmers (mas-un) foarfece

trim gear $(\mathrm{OM})$ angrenaj de compensare

trim in a ajusta, a potrivi

trimming (mas-un) debavurare, curățare, îndreptare a discului abraziv; reglaj fin, ajustarea acordului; bordură, margine; balansare; echilibrare, egalizare; călcare, aburire (d. textile); punere în ordine; egalizare; aranjare, rânduială; (agr) curățire (a crengilor, copacilor); potrivire, ajustare, nivelare, aliniere; tăiere; podoabă, ornament, garnitură (la îmbrăcăminte), împodobire, ornamentatie; (alim) asezonare, condimentare; ( $p l$ ) garnitură (la un fel de mâncare); mustrare, corectie; (nav) echilibrare (a calei sau încărcăturii), orientare a velelor; (fig) oportunism, politică şovăielnică / ezitantă; (constr) armătură; $(p l)$ bucățele, firimituri, resturi, fragmente; pilitură (de fier)

trimming die (met) matriț̆ de debavurat

trimming file (met) pilă de mână

trimming lathe (mas-un) strung de debavurat / de retezat

trimming machine (mas-un) presă / maşină de debavurat

trimming press (mas-un, met) presă de debavurat trimmings (met) pilitură de fier, resturi mici de la debavurare; fragmente (de hârtie, de lemn)

trimming shears (mas-un) foarfece de şanfrenat (margini)

trimming tank (nav) tanc de asietă

trim off (mas-un, met) a debavura

trimolecular (chim) trimolecular

triommel (OM, alim, ind chim, $\mathrm{TH})$ tambur de separare

trinitrate (chim) trinitrat 
trinomial (mat) trinom, trinomial, (polinom, relatie) cu trei termeni

trinitrocellulose (chim) trinitroceluloză; fulmicoton

trinitrotoluene (chim) trinitrotoluen, TNT

trio (metr) unitate tradiționale pentru cantitate, egală cu 3

trio mill / rollers (met) laminor trio

trip traseu; (mas, el) decuplare, declanşare, cursă, declanşator; (OM) mecanism / dispozitiv de decuplare / de declanşare, întrerupător, clichet, dispozitiv de dezagăţare; excursie (scurtă), călătorie, plimbare / voiaj de agrement, itinerar; parcurs, distanță parcursă, drum; călătorie (cu avionul); piedică (pusă cuiva); pas greşit, poticneală, poticnire; (fig) greşeală, pas greşit, acțiune greşită; (cf, met) parc de vagoane / vagonete; (la pescuit) pradă, cantitate de peşte prins; a declanşa; a târî; a merge cu paşi mărunți; a se poticni, a se împiedica (la mers sau la vorbă); (fam) a greşi, a face o greşeală; (nav) (d. ancoră) a derapa, a lăsa (ancora) să plutească în apă; a face o excursie / o scurtă călătorie; a pune piedică (cuiva); a face să se poticnească / să se răstoarne; a răsturna

trip across a traversa cu paşi mărunți

trip action (autom) instabilitate (şi la un amplificator magnetic)

trip along a merge cu paşi mărunți de-a lungul

tripartite triplu; din trei părți; tripartit

trip block (mas-un) limitator pentru decuplarea avansului automat

trip cam (mas) camă / opritor de cuplare

trip coil (el, autom) bobină de declanşare (şi la distribuitoare pilotate electric)

trip computer (auto) computer de bord

trip dog (mas) limitor de cursă, declanşator; (masun) camă a mecanismului de decuplare

tripe (alim) drob; măruntaie, mațe; burtă; (fam) fleacuri, prostii; maculatură, marfă de la foc

trip-free (release) (autom, el) declanşare liberă, autodeclanşare

trip gear (mas, OM) mecanism cu clichet

trip hammer $(\mathrm{TH})$ ciocan mecanic

triphase (el, fiz, met) trifazic, trifazat, cu trei faze

trip in (TH) a ambreia (o piesă)

triple (mat) multime cu trei elemente; triplu; triplet; de trei ori, întreit; a (se) tripla; a creşte de trei ori, a întrei; triple, triplet (metr) grup de 3 articole, în special identice

triple action dies / press (mas-un) stanță / presă cu triplă acțiune

triple bolt cutter (mas-un) maşină / dispozitiv de filetat, cu trei axe principale triple bond (chim) legătură triplă (şi a carbonului în compuşi organici)

triple burner (termo) arzător triplu

triple-cylinder mixer (alim, ind chim) malaxor cu trei cilindri

triple-effect evaporator (alim, ind chim) evaporator cu trei trepte / corpuri

triple geared (mas-un) cu transmisie cu trei angrenaje / cu angrenaje, în trei trepte

triple helical gear $(\mathrm{OM})$ roată dințată cu dinți în W (simbolizată şi cu litera $\mathrm{Z}$ )

triple indexing centres (mas-un) cap divizor triplu / cu trei axe

triple integral (mat) integrală triplă / de volum

triple-layer nickel coating (met) nichel triplex, acoperire formată din trei straturi cu nichel

triple-plunger pump (OM, hidr) pompă cu trei pistoane

triple point of water (fiz, metr) punctul triplu al apei, unitate de măsură pentru temperatură: 1 Triple point of water $=273,16 \mathrm{~K}$

triple-riveted joint $(\mathrm{OM})$ îmbinare cu trei rânduri de nituri

triple socket $(\mathrm{OM})$ cruce cu mufe (fiting)

triplet trei gemeni, tripletă; (OM, el, hidr) (distribuitor) cu trei căi / poziții; (mas-un) basculator

triple-thread screw (OM) şurub cu trei începuturi

triple valve (OM, hidr) valvă / supapă triplă / cu trei căi

trip lever (mas, OM) pârghie de declanşare / cu manetă / cu declic

triplex (mas-un, OM) triplu, sticlă securit, triplex, cu trei cilindri, cu acțiune triplă; v. triple time

triplex board $(\mathrm{TH})$ carton triplex

triplex glass (ind chim, auto, constr) geam de siguranță / triplex / din două straturi de cristal / sticlă şi un strat intermediar de material plastic

triplex process (hidr, $\mathrm{TH}$ ) procedeu / tehnologie triplex (pt. geamuri, folii rezistente la şoc etc.)

triplex pump (OM, hidr) pompă triplex

triplicate v. triple; v. tripartite; triplicat, exemplarul al treilea; a redacta în trei exemplare

triplication, tripling triplare

trip loading point (mec, nav) punct de încărcare triply $(a d v)$ triplu, întreit

trip mechanism (mas) mecanism de declanşare, mecanism de conectare / de comutare

tripmeter mode (auto, metr) contor de parcurs, mod în care contorul de parcurs este activat, buton de activare / anulare a contorului de parcurs 
trip mill (met) laminor de benzi de oțel tripod (OM, constr) trepied, capră de ridicat; masă / scaun cu trei picioare; cu trei picioare

trip (-)out ejecție

trip paddle $(\mathrm{OM})$ paletă / pedală oscilantă

tripper (mas) mecanism de deschidere a fundului cupei unui excavator, clapă basculantă

tripping (mas) demarare; (el) declanşare / acționare (a unui releu); (nav) derapare a ancorei; piedică (pusă cuiva); pas uşor; poticneală; pas greşit; călcătură strâmbă; agil, care se mişcă uşor şi repede

tripping cam (mas-un) camă a mecanismului de decuplare / de declanşare

tripping chain (mas, met) lanț de basculare

tripping device (autom) declanşator automat, declanşor

tripping gear mecanism de decuplare; (mas) dispozitiv de răsturnare-basculator (cu angrenaje)

tripping lever $(\mathrm{OM})$ manetă de declanşare, pârghie de declanşare

tripping relay (el) releu de declanşare

tripping spring $(\mathrm{OM})$ arc declanșator

tripping voltage (autom, el) tensiune de declanşare

tripple action press (mas-un) presă cu triplă acțiune

trip-releasing catch $(\mathrm{OM})$ clichet de declanşare trip rod (mas-un) tija mecanismului de decuplare

trip spindle (el) arbore port-perii, arbore de conexiune

trirectangular triortogonal (d. sisteme de referință)

trireme (nav) triremă

trisect a tăia în trei părți, a triseca

trisection (TH, OM) împărțire / secționare în trei părți egale

trisulphide (chim) trisulfură

trisulphides (chim) trisulfuri

tritiation (chim) tritiare, indroducere a tritiului în locul hidrogenului

tritium (T) (chim) triti(um), hidrogen (supra)greu / greu radioctiv

triton (chim, fiz) nucleu de tritiu (cu un proton şi doi neutroni)

triturable $(\mathrm{TH})$ care poate fi triturat / mărunțit / măcinat

triturate (OM, alim, constr, ind chim) a măcina / pisa fin, a pisa, a zdrobi; a tritura; a mesteca bine / intens; a mastica perfect

triturating, trituration triturare, măcinare fină

trituration triturare, măcinare (fină), sfărâmare, fărâmițare, pisare (în mojar); mărunțire (și până la pulbere); (anat) masticație, mestecare

triturator persoană care triturează / sfărâmă în mojar; masticator, persoană care mestecă / mastichează (bine); instrument de triturare / măcinare; pisălog / pistil pentru mojar

triumvirate (metr, pol, adm) triumvirat, unitate pentru cantitate, egală cu 3

triune triunic, triunitar, alcătuit din trei părți îmbinate

trivalence (chim) trivalență

trivalent trivalent

trivalve trivalv, cu trei valve / valvule

trivet trepied; scaun sau obiect cu trei picioare

trivial banal

trochoid (mat, geom) (curbă) trohoidă (inclusiv epicicloida şi hipocicloida), curbă descrisă de un cerc care se rostogolește pe o curbă, trohoid, spiral, generat de curbe care se îmbină

trochoidal (mat, $\mathrm{TH}$ ) trohoid, în formă de spirală

troctlite (minrl) troctolit

troke (în scotiană) schimb, troc; mărunțisuri; legături de familie

troland (Td) (metr, fiz, opt) unitate folosită în fotometrie pentru a măsura cantitatea de lumină primită de retină; iluminanța retinală în troland, este egală cu luminanța unei lumini care cade direct pe retină, măsurată în candela pe metru pătrat $\left(\mathrm{cd} / \mathrm{m}^{2}\right)$, inmultită cu aria pupilei deschisă la lumină, în $\mathrm{mm}^{2}$ : 1 troland $=1$ microcandela $(\mu \mathrm{cd})$

trolley $(\mathrm{OM})$ troleu, rolă de contact, cărucior; (mas) pisică, cărucior de macara

trolley-beam track (mas, met) cale de rulare a căruciorului de macara

trollley bus (auto) troleibuz

trolley car (amer) tramvai; troleibuz

trolley hoist (mas) cărucior de macara

trolley pole (mas) bară de ghidare, bară de luare de curent cu rolă / de troleu

trolley runway (mas, met) cale de rulare a căruciorului de macara

trolley shoe (mas, OM) cursor, sabot, piesă alunecătoare

trolley track (amer) şină de tramvai

trolley-travel gearing (mas) mecanism de rulare a căruciorului de macara (cu angrenaj)

trolley-travel rail (mas) şină de rulare a căruciorului de macara

trolley wheel $(\mathrm{TH})$ rolă de contact / curent al troleului

trolley wire (el) troleu, fir de contact / cale / troleu

trommel (alim, ind chim) ciur rotativ, tambur, tobă

trommel crystallizer (alim, ind chim) cristalizator cu tambur

trommel screen (alim, ind chim) ciur rotativ (cilindric / conic)

trompe $(\mathrm{TH}$, hidr) suflantă hidraulică 
troop mulțime (de oameni); (mil) trupă, baterie (de artilerie), escadron, detaşament, $(p l) \sim \mathbf{s}$ soldați, trupe; ceată, grup, bandă; (agr, zool) turmă; herghelie; cireadă, cârd; a mărșălui; a merge buluc / de-a valma; a se aduna, a se strânge

troop away a se îndepărta, a se abate

troostite (met) troostită

troostite-sorbite (met) troostitic-sorbitic

tropenas (side-blown) converter (met) convertizor cu insuflare laterală

tropical tropical

tropicalised, tropic-proof $(\mathrm{TH})$ rezistent la / în climat tropical

tropopause (meteo, geol) granița deintre troposferă și stratosferă; tropopauză

troposphere (geogr) troposferă

trotyl (chim) trotil

trouble $(\mathrm{TH})$ pană, avarie, defect, cădere, defectare, deranjament (a unui sistem); necaz, supărare, neplăcere; nenorocire; strâmtoare, ananghie; încurcătură; griji, nevoi; osteneală, deranj, bătaie de cap; efort, sforțare, strădanie, străduință; dificultate, greutate; (med) afecțiune, tulburări, maladie, boală; durere; neplăcere; a tulbura, a deranja; a incomoda; a face să se deranjeze / să se ostenească; a face să se tulbure, a tulbura (apa etc.); ( fam) a traduce în fața justiției, a da în judecată (pentru achitarea datoriilor); a se deranja, a se osteni, a-şi da osteneala; a se neliniști, a se îngrijora, a-şi face griji

trouble finder $(\mathrm{TH})$ dispozitiv de determinat defecte, detector de defecte

trouble-free operation (TH) functionare normală / fără defecte

trouble-free use $(\mathrm{TH})$ utilizare fără probleme

trouble-gang echipă de intervenție / de depanare

trouble hunter / man / shooter (TH) depanator

trouble hunting / shooting / tracking $(\mathrm{TH}) \mathrm{de}$ fectoscopie, depanare, căutare / depistare / localizare a defectelor

trouble in calibration (metr) eroare de etalonare

trouble in the hearth (met) mers neregulat al cuptorului

trouble location (TH) localizare a defectelor; depanare

trouble-proof tyre (auto) pneu fără pană / care nu-şi întrerupe rularea la înțepare etc.

troubleshoot (amer) a depana, a repara; a detecta şi înlătura / remedia defecțiuni tehnice

trouble shooter (amer) (TH) depanator; tehnician care detectează defectele / penele

trouble shooting $(\mathrm{TH})$ căutarea cauzei defectelor, localizarea defectelor; depanare; detectare a defectiunilor tehnice

troublesome supărător, neplăcut; care tulbură / stingherește / jenează; enervant, supărător, care deranjează; chinuitor; obositor, dificil, anevoios; care îți dă bătaie de cap

troublesomeness caracter dificil, supărător sau obositor

trouble time $(\mathrm{TH})$ timp / durată de deranjament trouble tone $(\mathrm{TH})$ semnal (acustic) de deranjament / de avarie

trough $(\mathrm{OM}$, constr) recipient de mortar, cadă, troacă, jgheab (şi de sedimentare), jgheab de scurgere, rigolă, troc, albie, rezervor, bazin, copaie, scoc, uluc, covată, canal; scobitură, adâncitură; (geol) sinclinal; (meteorogie) depresiune, zonă depresionară

trough belt (OM) bandă concavă de transport

trough casting (met) turnare cu cuvă refractară intermediară

troughed core box (met) cutie de miezuit cu găuri pătrunse

trough feeder (mas, constr, ind, agr) alimentator cu jgheab

trough floor $(\mathrm{TH})$ platelaj în formă de jgheab

trough grate $(\mathrm{TH})$ grătar-albie

trough iron / steel (met) semifabricat / profil U (din oțel)

trough truck (cf) vagon-cisternă

trout, $(p l)$ trout (alim) păstrăv

trout-coloured pătat, cu picățele

trout farm (alim, iht) păstrăvărie

troutlet, troutling (alim) păstrăv mic, păstrăvior trouty (alim, iht) ca păstrăvul; din familia păstrăvului

trowel (met) lingură de turnare; făraş de grădină; (constr) mistrie, paletă, a netezi cu mistria

troy (metr) carat

troy / fine ounce (tr.oz.) (metr) uncie, unitate de masă pentru metale prețioase: $1 \mathrm{tr} . \mathrm{oz}=155,52$ carate metrice $=31,1035 \mathrm{~g}$

troy pound (metr, farmacologie) unitate britanică de măsură pentru masă: 1 troy pound = $373,242 \mathrm{~g}$

troy weights (metr, farmacologie) un sistem tradițional britanic, de unități de măsură pentru masă, bazat pe troy pound, astăzi rar utilizat

truancy neglijare a îndatoririlor; absenteism; chiul, fit, absențe (de la şcoală sau serviciu)

truant (edu) absent nemotivat; care chiulește, chiulangiu

truck autocamion, remorcă; (cf) vagon, vagonet, cărucior de bagaje, boghiu, vagon platformă / de marfă; (mas, OM) cărucior de macara / pentru bagaje, şasiu, parte rulantă / mobilă, aparat de rulare, rulou, tăvălug, valț; roată; (nav) butonul giruetei, scripete în vârful catargului; cadru, ladă; (ec) troc, schimb (de mărfuri / în natură); (ec) plată în natură (pentru muncitori); (fam) raporturi, relații, legături, contact(e); 
(amer) (sl) zdrențe, vechituri, resturi; prostie, absurditate, stupiditate; (amer) legume, zarzavaturi (pentru piață); a face troc / schimb (în natură) / de ceva cu cineva, a face schimb de, a schimba (ceva, pe altceva); (amer) a face grădinărie / grădinărit, a cultiva legume / zarzavaturi; a face comert ambulant cu / de; a transporta cu vagon-platformă sau cu camionul

truckage, trucking camionaj, transport de marfă cu camionul, cărăuşie; camioane, căruțe

truck chassis (auto) şasiu de autocamion

trucker (amer) camionagiu; şofer de camion; grădinar (de legume, zarzavaturi)

truck farm (agr) grădină de zarzavaturi / legume

truck farmer (amer) legumicultor, zarzavragiu; grădinar, cultivator de legume

truck farming (amer) legumicultură

truck fleet parc de camioane

truck frame (cf, OM) cadru de boghiu; şasiul boghiului

truck garden (amer) v. truck farm

truck gardener (amer) v. truck farmer

truck gardening (amer) v. truck farming

truck house magazie de mărfuri

trucking $\mathrm{v}$. truckage

trucking house $v$. truck house

truck ladle (met) oală de turnare, cu cărucior

truckle rotiţă; pat pe role; a împinge / a mişca pe rotile

truck load (cf, met) (încărcătura unui) vagon; vagonet sau cărucior

truckman v. trucker

truck-mounted crane (mas) macara automobilă truck tipper (cf, met) răsturnător de vagoane

truck tyre (auto) anvelopă de autocamion

true adevărat, veritabil; drept; autentic; real, conform cu realitatea, exact; original, nefalsificat; fidel, devotat, credincios, loial; constant; de nădejde; sincer, cinstit, onest; autentic, conform cu originalul; corect, precis; tipic; legal, legitim; (TH) rectificat, ajustat; rectiliniu, drept; regulat, bine potrivit; $(a d v)$ adevărat, într-adevăr, exact; (mas-un) a ajusta, a rectifica, a netezi, a îndrepta

true annealing (met) recoacere totală / deasupra punctului $\mathrm{A}_{3}$

true a wheel to shape (mas-un) a îndrepta o piatră de rectificat cu obținerea formei necesare

true boiling point (fiz, $\mathrm{TH}$ ) punct real de fierbere

true dielectric (el, fiz) dielectric perfect

true emulsion $(\mathrm{T})$ emulsie stabilă

true equilibrium (mec) echilibru stabil

true fluids (fiz) fluide reale (diferite de cele ideale) / ne newtoniene trueing $(\mathrm{TH})$ îndepărtare, redresare

trueness adevăr, caracter adevărat; veridicitate, autenticitate; fidelitate, loialitate, credință; sinceritate, lealitate; legalitate, legitimitate

true porosity porozitate reală

true specific weight greutate specifică reală

true time timp adevărat / real

true to dimensions conform cu dimensiunile, la dimensiuni exacte

true to gauge cu dimensiuni conform calibrului

true to measure / to size (TH) conform dimensiunilor prescrise

true to pattern (met) conform modelului

true to scale la aceeaşi scară

true to shade matriță care corespunde mostrei

true to shape corespunzător formei (teoretice / proiectate)

true to size conform dimensiunilor

true up (mas-un) a îndrepta, a rectifica

truffle (alim) trufã

truffle-bed (agr) teren cu trufe

truffled (alim) umplut / garnisit cu trufe

truffle-grower (agr, alim) crescător / cultivator de trufe

truffle-growing (agr) creșterea / cultura trufelor

trug şiştar, găleată, doniță (de lemn); coşuleț făcut din bețe (pentru grădinărit); (metr) coş puțin adânc, de diferite forme şi dimensiuni, pentru a transporta flori; 1 trug of grain (US) $($ doniță pentru cereale $)=23,4931$

truing (mas-un) ajustare, reglare, îndreptare

truing attachment / device / tool (mas-un) dispozitiv de îndreptat / de reascuțit discuri / pietre de rectificat

truing tool (mas-un) dispozitiv de îndreptat discuri / pietre de rectificat

truly $(a d v)$ cu adevărat, într-adevăr; (ca formulă de încheiere a scrisorilor) devotat, sincer; exact, precis; just, drept

truly turned (mas-un, OM) prelucrat cu mare precizie prin strunjire

trumpet trompetă, țeavă, pâlnie, (met) picior de turnare central (la turnare prin sifon)

trumpet bell (met) pâlnie de turnare

trumpet cooler (met) răcitor cu tevi

"trumpet" pouring (met) turnare prin sifon

truncate a trunchia; a tăia; a reteza vârful; a scurta, a reduce, a micşora; (fig) a deforma; a masacra (un text etc.); (mat, inf) eliminarea cifrelor (şi zecimalelor) nesemnificative în obținerea unui rezultat corect / acceptat

truncated trunchiat; retezat; scurtat

truncated cone (mat) trunchi de con truncated pyramid (mat) trunchi de piramidă truncately $(a d v)$ în formă de trunchi, trunchiat 
truncation trunchiere, retezare la vârf; (fig) deformare, masacrare, distorsiune (a unui text); scurtare, reducere, micşorare

trundle (mas-un, OM) rolă, rotiță, rotiță de mobilă; cărucior; a (se) rostogoli; a face să se învârtească / să se rostogolească; a împinge (o roabă etc.); a se da de-a rostogolul / de-a dura

trunk corp de coloană, arteră principală de circulație (şi uzinală), magistrală; (mas, OM) corp, batiu, pivot de coloană; (mec) corp, trunchi, linie de joncțiune, tulpină; (hidr) conductă principală; trunchi; (bot) trunchi, tulpină; butuc; $(p l)$ pantaloni scurți, chiloți (de baie); (anat) arteră principală; $(\mathrm{TH})$ coş; jgheab, uluc; căuş, covățică; trompă (de elefant); cufăr (de voiaj), geamantan mare; (amer) (auto) portbagaj; $(s l)$ felinar

trunking (constr) canal de cabluri; grupare, formare de grupuri

trunk line (cf) linie principală; (el) linie / circuit principial $(\breve{a})$

trunk lock $(\mathrm{OM})$ lacăt cu arc / cu clapă, clanță

trunk-nail (OM) cui cu cap ornamentat / împodobit

trunk pipe-line (hidr) conductă magistrală

tunk piston $(\mathrm{OM}$, termo) piston cu cap concav

trunk road drum principal; şosea principală

trunnion (OM, mas) ax de rotație, cruce cardanică, fus, ştift, cep, pivot

trunnion bearing $(\mathrm{OM})$ lagăr de ax

trunnion bed (mas-un, OM) locaş al fusului

trunnion block (OM, auto) blocul articulației cardanice

trunnion cross $(\mathrm{OM})$ cruce cardanică

trunnion ring (mas, OM) centură cu fusuri de basculare

truss teanc; legătură; mănunchi; maldăr; ciorchine; (constr) grindă cu zăbrele, fermă de acoperiş; (nav) troță de vergă; a rigidiza, a întări, a consolida (prin ferme); a înmănunchia; a lega strâns / împreună / laolaltă; a lega cu mâinile la spate; (constr) a întări / a consolida prin ferme / grinzi; (metr) unitate tradițională de măsură pentru masă: 1 truss $\sim 25,4 \mathrm{~kg}$

truss bolt (mas, OM) bolț de ancorare

trussed arch (constr) arc cu zăbrele

trussed bridge (constr) pod cu zăbrele

truss frame ( $\mathrm{TH}$, mec, constr) dispozitiv de suspendare; (constr) căpriori

truss girder (mec, constr) grindă cu zăbrele, grindă cu contrafișă

trussing structură în zăbrele; v. truss frame

trussing of frame (mas) ranforsare / întărire a cadrului / a batiului truss joint (mec) nod de asamblare (la grinzi cu zăbrele)

truss rod (OM, constr) bulon / bară de ancorare

truss up v. truss; a lega, a fixa, a potrivi (îmbrăcămintea)

truss wings (mec) grindă cu zăbrele

trust (in) încredere (în); crezare, crezământ; (situație de) răspundere, respectabilitate (înaltă); datorie, îndatoriri, obligații; (fig) speranță, nădejde; (ec) credit; on pe credit; (ec şi fig) depozit, (lucru dat în) păstrare, sumă depusă; grijă, pază; (jur, pol) tutelă; administrație prin tutelă, procură; (ec) trust; a acorda încredere, a avea încredere în, a se încrede în; a se bizui pe; to, with a încredința, a lăsa în seama / grija / păstrarea; (ec) a face / a acorda credit, a da pe credit; a spera; a îndrăzni, a avea curaj; $\sim$ in, $\sim$ into, $\sim$ on, $\sim$ to a se încrede, a-şi pune încrederea / speranța / nădejdea în, a se bizui pe trust company (ec) societate / întreprindere de gestiune; fundație; bancă comercială

trust deed (jur) procură, mandat

trusted de încredere / nădejde; pe care te poți bizui trustee (ec) curator; epitrop; tutore; administrator; mandatar; membru în consiliul de administrație al unei societăți

trustful încrezător, plin de încredere; credul; v. trustworthy

trustification (ec) cartelare, coalizare (a societăților pe acțiuni) într-un trust

trustily $(a d v)$ (în mod) fidel, cu credință / fidelitate

trustiness fidelitate, loialitate, credință; onestitate, cinste

trustingly $(a d v)$ încrezător, confident, cu încredere, fără şovăială / îndoieli

trustless nesigur, nestatornic; pe care nu te poti bizui; nedemn de încredere; neîncrezător bănuitor, suspicios

trust to a se încrede (exagerat, prea mult) în; a avea (prea multă) încredere în; a se bizui (în mod exagerat / gresit) pe

trustworthily $(a d v)$ într-un mod care inspiră încredere; de o manieră care-ți dă siguranță / inspiră încredere

trustworthiness încredere, $(\mathrm{ec})$ solvabilitate, verosimilitate, certitudine, exactitate, veridicitate corectitudine, adevăr; v. trustiness

trustworthy demn de încredere; credincios, loial, fidel; cinstit, onest; veridic, exact

trusty fidel, credincios, statornic; devotat; detinut cu comportare bună (şi se bucură de privilegii)

truth, $(p l)$ truths adevăr; corectitudine; validitate; realitate; veracitate, verosimil; conformitate, 
exactitate, fidelitate; realism; (TH) ajustare precisă, precizie / finețe de ajustare / la instalare; out of $\sim$ prost / greşit ajustat; dereglat (mas-un, $\mathrm{OM}$ ) coaxialitate, concentricitate

truthful sincer, franc, deschis; (reprodus) fidel / exact / corect; v. trustworthy

truthfully $(a d v)$ (în mod) veridic / realist; fidel, întocmai, corect, exact

truthfulness sinceritate, franchete, loialitate; bună credință; realism; asemănare, fidelitate; exactitate (a unui portret etc.); v. truth

try (hidr, mec, TH) încercare; probă; experiență; tentativă; a proba; a face proba; a încerca; a experimenta; a face experiente; a examina, a verifica; a revizui; a pune la încercare; a gusta, a degusta; a se strădui, a căuta (să), a-şi da osteneala; (chim, mediu) a curăți, a purifica; a rectifica; (fig) a îndrepta, a corija (prin încercări repetate); a pune / supune la (grea) încercare; a obosi, a chinui; a deprima, a slăbi, a necăji; (edu) a examina, a interoga, a întreba, a asculta; (jur) a judeca (un proces, un acuzat), (amer) a pleda (într-un proces); a rezolva, a decide, a hotărî (o chestiune); (TH) a lustrui; a gelui, a da la rindea; a extrage prin topire; a topi (seu etc.); a purifica

try cock (mas) robinet de luat probe

try gauge $(\mathrm{TH})$ etalon; contracalibru

try hole (met) orificiu pentru sonda de măsurare a nivelului superior al încărcăturii unui furnal

trying probă, încercare; obositor, penibil, dificil, supărător, jenant, stânjenitor; sâcâitor, plictisitor, enervant, iritant

trying-on probă, probare (a hainelor)

trying plane $(\mathrm{TH})$ rindea, gealău; cuțitoaie

try-on încercare / tentativă de înşelătorie; cacialma, bluff, încercare de mistificare

try on a proba; a încerca (o haină); (sl) a începe, a întreprinde, a iniția; a proba / a încerca / a experimenta pe

try-out probă (tehnologică); încercare, încercări; (sport) joc / meci / concurs de verificare / selectie; (teatru) reprezentație de probă; avanpremieră

try out a incerca; a examina; a experimenta; a proba, a verifica (în fața publicului etc.)

trypsin (chim) tripsină

trysail (nav) raudă, velă aurică

try square (TH, metr) echer al tâmplarului / dulgherului (cu o latură metalică)

try with the plummet a verifica verticala (cu fir cu plumb)

t.s. (tensile strength) (mec) limită de rezistență la tractiune

T-section, T-steel bar (met) profil T din oțel
T-shaped în formă de T

T-shirt (textile) tricou sport (fără guler), maiou cu mânecuțe

T-slot (mas-un, OM) canal în T (pt. fixarea pieselor cu şuruburi cu nas)

T-slot cutter (mas-un) freză de prelucrat canale în $\mathrm{T}$

T-square (met) (profil) teu

tsubo (metr) unitate informală pentru arie, în Japonia, pentru a măsura interiorul clădirilor; 1 tsubo $\cong 3,3 \mathrm{~m}^{2}$, aproape aria a două tatami

t'sun (metr) unitate de măsură pentru lungime, în China: 1 t'sun $\cong 3,58 \mathrm{~cm}$; (metr, med) unitate relativă pentru lungime, utilizată în acupunctură: 1 t'sun este distanța dintre articulațiile de mijloc ale degetului mijlociu sau lăţimea unui deget, valori diferite în funcție de persoană; denumită şi anatomical Chinese inch (ACI) - inch / tol chinezesc anatomic sau body inch - inch / țol corporal

TTT - curve (met) diagramă timp - temperatură - transformare / TTT / curbă de transformare izotermă, curbă în $\mathrm{S}$

tub (met) vagonet de minereu; cadă cu doage de lemn, butoi, găleată, doniță; vadră; (TH) cuvă, benă, bazin, rezervor; cadă, baie, albie; ghiveci (pentru plante mari), putină, ciubăr; butoi, poloboc; (sport, nav) barcă, ambarcațiune de antrenament; a spăla, a îmbăia, a face baie; a așeza / a pune (o plantă) în hârdău / ladă, a pune / a turna (ulei) într-un recipient etc.; (sport) a antrena (canotorii), a se antrena într-o barcă de antrenament; tub (metr) unitate veche britanică pentru masă pentru unt: 1 tub $=38,10 \mathrm{~kg}$; tub (metr) container puțin înalt şi cu arie mare, pentru lichide, de diverse valori: exemple: 1 tub of herring (Newfoundland, tub de heringi) $=72,74$ 1 şi 1 tub of salt (tub de sare) $\sim 81,831$

tubby (gras) ca un butoi; bondoc; dolofan; (muz) cu sunet înfundat / dogit

tube (auto) cameră de aer; tren subteran, metrou; țeavă, burlan, conductă; țeavă de carton, tub; tub electronic; (radio, TV) tub, lampă; tub (de vopsea, pastă etc.); (anat) tub, canal; tract, trompă; ( $\mathrm{fam}$ ) metrou (la Londra); tubular, în formă de tub; a prevedea cu tuburi; (med) a tuba; a drena; a merge cu / a lua metroul

tube beader (mas-un) dispozitiv de lărgit țevi tube bend (OM, hidr) cot de țeavă / de conductă tube bender (mas-un) dispozitiv de îndoit țevi

tube bit (mas-un) burghiu de găuri adânci / de găurit țevi de tun

tube blank (met) țaglă / semifabricat pentru țevi tube boiler (termo) cazan tubular 
tube cleaner (met) ciocan de îndepărtat pietre din cazan, turbină / dispozitiv de curățat cazane; ştergător de țeavă, destupător tube clip (hidr, OM) brățară de fixat conducte tube closing $(\mathrm{OM})$ capac / dop de țeavă, obturator; închidere a unui tub / a unei conducte tube compensator (OM, termo) liră de dilatație tube conveyer tub transportor

tube cooler (met, termo) răcitor tubular

tube cutter (mas-un) dispozitiv / maşină de tăiat tevi

tube diameter (OM) diametrul țevii (la interior) tube-drawing bench (met) banc de tras tevi tube-drawing with a plug tragerea țevilor pe mandrină

tubed-expander (mas) mandrină de țevi

tubed-expanding machine (met, mas-un) mașină de lărgit tevi

tube extruder (mas, met) maşină de extrudat tuburi / tevi

tube fittings (OM, hidr) fitinguri, armături

tube flanging (mas-un) mandrinarea tuburilor

tube furnace (met) cuptor tubular

tube grinder (ind chim, mas) moară tubulară

tube heater (termo, ind chim) cuptor tubular, autoclavă de vulcanizat camere

tube-in-sheet evaporator (alim, ind chim) evaporator-placă cu tuburi interioare

tube lighter (OM, auto) levier de montat pneuri

tube-man functionar de la metrou

tube mill (met) laminor de țevi; (ind chim) moară tubulară

tube-mill liner căptuşeala morii tubulare

tube-mill shell (met, ind chim) corp / manta de moară tubulară

tube mould (mas-un) matriță de camere de aer

tube of steam gauge (mas, metr) țeavă de manometru de abur

tube-on-sheet evaporator (alim, ind chim) evaporator-placă cu tuburi exterioare

tube piercing bench (mas-un, met) banc împingător, de tras țevi

tube pin $(\mathrm{OM})$ știft tubular

tube plate / sheet / wall $(\mathrm{OM})$ placă tubulară

tube plug $(\mathrm{OM})$ dop de teavă

tube plug ram bară de astupat / destupat tevi

tuber (met) extruder pentru tevi; (bot) tubercul; excrescență; (fam) barabulă, cartof

tube radiator (termo) radiator tubular / cu țevi

tubercle (bot, med) tubercul

tubercular (med) tuberculos; (bot, med) tubercular tubercular corrosion (met) coroziune în puncte tuberculate tubercular, în formă de tubercul tuberculation (bot, agr) formare / creștere a tuberculilor tuberculin test (med) intradermo-reacție / test la tuberculină, IDR, diagnostic cu tuberculină tuberculin-tested (alim) (d. lapte) verificat, de la vaci imune la tuberculoză

tuberculization (med) tuberculizare

tuberculized (med) tuberculizat, ftizic, tuberculos tuberculosis (med) tuberculoză, (fam) TBC

tube resistance (hidr) rezistenţă hidraulică a tubului / tevii / conductei

tube rolling (met) laminare de țevi

tube rolling mill (met) laminor de tevi

tuberous root (bot) rădăcină tuberculară

tube sheet $(\mathrm{OM})$ placă tubulară

tube sinking (met) tragerea tevilor pe mandrină

tube space (termo, hidr) spațiu intern tubular

tube spacing (termo, hidr) distanța dintre tuburi, dispoziție a tuburilor

tube station stație de metrou

tube still (termo, ind chim) cuptor tubular

tube-still heater (alim, termo) preîncălzitor tubular

tube strip (met) bandă / tablă pentru țevi

tube turn (OM, hidr) cot / curbă de țeavă

tube wall placă tubulară, perete tuburi / țevi

tube-welding machine / plant (mas) maşină / instalație de sudat țevi după generatoare

tube-well puț american, fântână (adâncă) tubulară

tube wrench $(\mathrm{OM})$ cheie de teavă

tubiform $v$. tubular

tubing cuvelaj, tubaj; (OM, hidr) tub, conductă, țeavă, tubing (industria petrolului), instalație / sistem de țevi, furtun; țevărie, țevi, conducte

tubing connection $(\mathrm{OM}$, hidr) piesă de legătură pentru furtun / între țevi / între conducte

tubing machine (mas) extruder de profilat tuburi, maşină de extrudat tuburi

tub of butter (alim) dispozitiv (tubular) de bătut untul

tubular (OM) tubular; cilindric

tubular axle $(\mathrm{OM})$ osie tubulară

tubular beam (OM, constr) grindă tubulară

tubular bearing $(\mathrm{OM})$ rulment cu role-butoi, lagăr tubular (mult mai lung decât diametrul lui)

tubular boiler (termo) cazan tubular (de calorifer) / cu țevi de vaporizare

tubular brick (constr, met) cărămidă găurită / celulară

tubular bridge (TH, cf) pod de formă tubulară

tubular chassis (mas, auto) şasiu tubular; (mas) cadru tubular

tubular condenser (termo) condensator tubular tubular connecting rod $(\mathrm{OM})$ bielă tubulară tubular cooler (alim, ind chim) răcitor tubular tubular core (met) miez gol în interior 
tubular cross bearer / member (constr) traversă tubulară

tubular drill lingură de lăcărit

tubular dryer (alim, ind chim) uscător tubular, uscător-tambur

tubular expantion loop (OM, termo) compensator (tip buclă) tubular de dilatare

tubular frame (constr) ramă / cadru tubular(ă); (mas) cadru tubular / din țevi (sudate)

tubular girder (constr) grindă tubulară

tubular heat-exchanger (termo) schimbător de căldură, tubular / cu țevi

tubular heater (termo) încălzitor tubular / cu țevi

tubular pivot (mas) fus tubular

tubular radiator (termo) radiator tubular, răcitor tubular cu manta

tubular recuperator (met, termo) recuperator de căldură / de gaze tubular

tubular rivet (met, $\mathrm{OM}$ ) nit tubular

tubular shaft (mas-un, OM) arbore tubular

tubular spirit level (metr) nivelă cu bulă

tubular steel scaffolding (constr) schelă din țevi de oțel

tubular wrench $(\mathrm{OM})$ cheie tubulară

tubulated $v$. tubular

tubulature (nav, met, termo) tubulatură, tevărie

tubule $(\mathrm{OM})$ tubuleț; tub mic; țeavă subțire

TUC prescurtare de la Trades Union Congress tubus $(\mathrm{OM})$ tub, ştuț

tub wheel (mas-un) piatră abrazivă / disc abraziv tip oală

tuck pensă; cută; pliu; îndoitură; (nav) boltă pupa; creț, încrețitură, pliseu; (nav) bolta pupei; a plisa, a încreți; a face o cută / un pliu la; a scurta (o haină etc.); a îndoi, a strânge; a băga, a vârî; a ascunde, a pune bine / deoparte (într-o cutie etc.)

tuck frame (nav) coastă a boltei pupa

tuck in a îndoi / a băga / a vârî înăuntru (marginea unei haine, a unui cearşaf etc.); a înveli bine (pe cineva) cu plapuma etc.; a îndesa, a vârî cu de-a sila (cămaşa în pantaloni etc.)

tuck-net plasă mică (a pescarului) pentru scoaterea peștilor dintr-un năvod

tuck-shop (alim) patiserie, patibar; cofetărie mică tuft mănunchi, fascicul (şi de țevi)

tug zdruncinătură, zvâcnitură, smucitură; (mec) şoc, smucitură; (nav) remorcher; v. tug-boat; (OM) curea; şleau; ştreang; (edu) bursier; (nav) a remorca; a trage, a trage după sine (cu greu); a trage / a apuca de (mânecă etc.)

tug-boat (nav) remorcher

tugged (nav) remorcat

tulip lalea

tulipist (agr) cultivator de lalele

tulip root (agr) mălură / tăciune care atacă ovăzul tulip(-shaped) valve $(O M)$ supapă în formă de lalea

tumble basculare; cădere, tumbă; (fig) dezordine, învălmăşeală, talmeş-balmeş; a vălțui; (fam) a ghici, a înțelege; a face o tumbă; a cădea; a se prăvăli; (fig) a se prăbuşi, a se nărui; (amer) a cădea de acord / la învoială, a consimți; a fi de aceeaşi părere; a se înțelege; a trânti (jos), a răsturna; a rostogoli, a da de-a dura; a răvăşi, a deranja; a ciufuli; a şifona, a boți

tumble-about şubred, care se clatină; care nu e fix, care are un joc (nedorit)

tumble-down dărăpănat, pe jumătate ruinat; în stare proastă

tumble down a se prăbuşi; a se rostogoli, a se da de-a dura / de-a rostogolul; v. tumble

tumble on a da peste, a nimeri / găsi din întâmplare tumbler (el) întrerupător electric basculant; (mas) manetă, mecanism de inversare, culbutor, basculator; (met) tobă de curățat piese turnate; cheie, şaltăr; pahar (mare) fără picior (bombat); pocal; pahar gradat; tumbler (metr, alim) altă denumire pentru US cup

tumbler bracket (mas-un, OM) cadru basculant al roții dințate intermediare (din cutia de viteze de tip Norton)

tumbler drier maşină rotativă de călcat rufe

tumbler file (mas-un) pilă mare cu secțiune ovală şi vârf ascuțit

tumblerful (metr, alim) cească, altă denumire pentru breakfast cup, o unitate de volum, utilizată în retete culinare

tumbler gear (mas) basculator, culbutor, mecanism de basculare; $(\mathrm{OM})$ roată dințată basculantă

tumbler gear lever (mas-un) mâner inversor (la strung) (acționat prin angrenaje)

tumbler gear / gearing mechanism (mas-un) cutie de avansuri / de viteze cu roată dintată basculantă (tip Norton)

tumbler gear segment (mas-un) inversor (la strung), cadru cu mâner al inversorului (la strung) (cu acționare prin angrenaje)

tumbler lever (mas-un) pârghie a roții dințate basculante (în cutia de viteze tip Norton)

tumbler shaft (mas-un, OM) arbore cu came

tumbling (mas-un, met) curățare în tambur / în tobă, tobare

tumbling barrel (TH, met) tobă de curățat piese turnate

tumbling drum (mas-un, met) tambur / tobă de curăţare (a pieselor turnate)

tumefy a (se) tumefia, a (se) umfla; a provoca o tumefiere / o umflătură

tumkey (ec, TH) livrare la cheie 
tumour (med) tumoare, tumoră, umflătură

tun (alim) putină, butoi mare, poloboc; a turna, a pune în butoi; a păstra în butoi; (metr, alim) unitate de volum utilizată pentru vin şi alte lichide (din limba franceză): 1 tun $\sim 953,93$ 1; v. ton, tonneau

tuna, $(p l)$ tunas sau tuna (iht, alim) ton; carne de ton (şi conservată)

tunable (autom, metr) acordabil, cu reglaj fin, reglabil; care se poate acorda / regla; v. tuneful

tunable range interval / domeniu de reglare tun( )dish (met) oală intermediară de turnare tun fermentation (alim) fermentare în putină tune (muz) melodie, cântec, sunet, ton; acord, armonie; (fig) acord, armonie, (bună) înțelegere; dispoziție, stare de spirit, toane (bune); sumă; cantitate; mărime; (autom, metr) a acorda / regla (în general, fin); (muz) a acorda (un instrument); a sincroniza; with a se armoniza / a se acorda / a se potrivi cu; a fi în ton cu; for a fi dispus, a avea dispozitie pentru; (TH) a pune la punct, a regla, a ajusta tuned acordat, reglat

tuneless nemelodios; nearmonios; discordant; (d. glas) fără viață / vlagă; mort; lipsit de sonoritate; $(\mathrm{TH})$ nereglat

tuned manifold; exhaust tune up (auto) reglare a eșapamentului (astfel încât unda caracteristică fluxului de gaze să prezinte un nod la ieşire)

tune out a (se) dezacorda, a (se) deregla; a ieși din intervalul de reglare a dezorganiza, a deranja, a tulbura

tuner acordor (de piane); (radio) acordare, acord tune up (TH) reglare de / la performanță optimă tungstate (chim) wolframat, tungstenat

Tungsten (W) (chim) wolfram; tungsten tungsten brass (met) alamă cu wolfram tungsten bronze (met) bronz cu wolfram tungsten carbide (met) carbură de wolfram tungsten electrode (el, met) electrod de wolfram tungsten disulphide (chim, T) disulfură de wolfram tungsten steel (met) oțel (cu) wolfram tungstic (chim) tungstenic, wolframic tungstic acid (chim) acid wolframic / tungstenic tuniness $v$. tunefulness

tuning $(\mathrm{TH})$ reglaj, ajustare, acordare, acord, punere la punct; a pune la punct

tuning coil (TV, radio, autom) bobină de acord, condensator variabil

tuning control (mas, autom) reglare precisă / fină tuning drift (autom, metr) derivă / deviație a punctului de acord / de reglare

tuning fork diapazon

tuning knob buton de acord tuning of carburettor (auto) reglaj al carburatorului

tuning out dezacordare; dereglare

tuning property selectivitate

tuning range $(\mathrm{OM}$, metr) domeniu / interval de reglare

tuning screw şurub de reglare / de acord(are)

tuning sharpness precizie de acord, selectivitate

tuning (-)up punere la punct, reglare

tunnel (cf) tunel; galerie; pasaj; trecere; (met) picior vertical / canal de turnare; a săpa un tunel prin

tunnel cooler (alim, termo) tunel de refrigerare, răcitor tip tunel

tunnel dryer (alim, termo) uscător-tunel

tunnel drying oven (met, ind chim, alim) cuptor tubular, tunel de uscare, canal de uscare

tunnel freezer (alim, termo) tunel de congelare, cogelator tip tunel

tunnel furnace; tunnel kiln (ind chim, termo) cuptor-tunel / cu canale

tunneling săpare / străpungere a unui tunel; (sistem de) tuneluri

tunnel into (constr) a săpa (un tunel) în

tunnel-net (agr) vârşă, plasă de pescuit

tunnel trough (constr) a săpa un tunel prin / în

tunnel-type radiator (termo) răcitor cu ajutaj / prin desprindere

tunnland (metr) unitate tradițională de măsură pentru suprafață de teren, în Suedia: 1 tunnland $=4936,4 \mathrm{~m}^{2}$

tup (met) berbec (de spart fontă), ciocan, ciocan greu, baros; (agr, zool) berbec (necastrat); (d. berbec) a mârli, a se împerechea cu (o oaie)

-tuple (metr) sufix adăugat unui număr pentru a forma unități de cantitate; exemplu: a 7-tuple contine 7 obiecte

tur (zool) zimbru

turbid tulbure, ( $f i g)$ nebulos, confuz, vag; încurcat, complicat

turbidity culoare tulbure, tulbureală; ( $f i g)$ nebulozitate, caracter vag / confuz; complicație, caracter încurcat / complicat

turbidity unit (metr) v. NTU

turbidly $(a d v)$ în mod tulbure, nebulos; încurcat, complicat

turbidness $v$. turbidity

turbillion (hidr) (rar) vârtej, turbion

turbinal în formă de vârtej; (anat) în formă de cornet; care se învârtește ca titirezul

turbination (mec, fiz) mişcarea în formă de vârtej turbine (termo) turbină

turbine alternator (el) turboalternator

turbine blade (mas) paletă de rotor de turbină hidraulică / cu abur 
turbine blower (mas) turbosuflantă turbine bucket (mas) paletă rotitoare de turbină turbine casing (mas) carcasă de turbină turbine chamber (mas) cameră de admisie a turbinei hidraulice

turbine cylinder (mas) cilindru de turbină turbine-driven cu turbină, acționat de turbine turbine engine (mas) turbină

turbine housing (mas) carcasă de turbină turbine nozzle (mas, OM, termo) ajutajul turbinei cu abur

turbine pipe line (mas) conductă de turbină turbine pump (mas) turbo-pompă

turbine shaft (mas) arbore de turbină turbine stirrer (mas) amestecător de turbină turbine wheel (mas, termo) rotor de turbină turbo air-blower (termo) turbosuflantă de aer turbo-alternator (el) turbo-alternator turbo blade (mas) paletă de turbină turbo-blower (mas) turbosuflantă, turbocompresor

turbocharger intercooler (auto) răcire uniformă, răcire cu turbosuflantă

turbocharger unit (auto) turbină, turbosuflantă (la motoare diesel)

turbo-compressor $(\mathrm{TH})$ turbocompresor

turbo-dynamo (el) turbodinam, grup turbogenerator

turbo gas-exhauster (mas) turboexhaustor

turbo-generator (el) turbogenerator

turbo-jet (engine) (av) turboreactor

turbo-prop (av) turbopropulsor

turbo pump (mas) turbopompă

turbo(-)compressor (mas) turbocompresor

turboexhauster (mas) turboexhaustor

turbosupercharger (mas) turbină de supraalimentare, turbosuflantă

turboventilator (mas) torboventilator, ventilator centrifug

turbulator / turbulence promotor (hidr, termo) generator de turbulență

turbulence vânt în rafale, vârtej de aer atmosferic; (mas, hidr) turbionare, turbulență; nesupunere; impetuozitate; vehemență, violență; v. tumult

turbulence reduction method (met) procedeu de reducere în pat fluidizat

turbulent turbulent

turbulent current (hidr) curent turbionar

turbulent flow (hidr, T) curent turbulent, curgere turbulentă

turbulent layer dryer (alim, termo, ind chim) uscător cu strat turbulent

turbulent motion mişcare turbulentă

turbulent state regim turbulent

turfed (acoperit cu) gazon turkey (agr, alim) curcan, curcă; carne de curcan; (amer, $s l$ ) fiasco, eşec, cădere; a spune lucrurilor pe nume

Turkey (geogr) Turcia

turkey poult (zool, agr) curcănaş, pui de curcă

turkey stone (mas-un) piatră de ascuțit manuală, în formă de bară

turn înclinare, viraj; (OM) serpentină, spiră de filet, rotație, învârtire, învârtitură, tur, cot; rotație, rotire; schimbare de direcție; întoarcere; girație; (fig) întorsătură, cotitură, schimbare; (med) criză, moment greu (al unei boli); (mil) întoarcere; şerpuitură, meandră, cot, cotitură; variație, schimbare; (mec) întoarcere înapoi, mișcare înapoi, schimbare totală de direcție; (fig) înclinație, înclinare, aplicare, pornire (pentru / spre), talent (la), dispoziție (pentru); (literar) formă, structură, înfățişare; turnură de frază; plimbare, tur; rând, schimb, tură; serviciu (adus cuiva); ajutor (prietenesc); prilej, ocazie; folos, câş̧ig, profit, beneficiu; scop, intentie; (fam) soc, spaimă; lovitură; (nav) voltă; (el) spiră; (OM) strung; zăvor (la fereastră); (mas-un) a strunji, a (se) roti, a aleza; (mas, OM) a rula, a functiona, a merge, a (se) învârti; (auto) a vira; (alim) a se strica, a se acri; a întoarce; a se răsuci; a învârti; a face să se întoarcă / să se învârtească / să se răsucească; a învârti, a răsuci (un buton, un robinet etc.); a întoarce (pe partea cealaltă / cu fața în sus); a întoarce (în altă direcție); a devia; a abate (din drum); a îndrepta, a dirija; (fig) a se întoarce din drum, a face cale întoarsă; a îndrepta (atenția etc.); a întoarce (capul, privirea); a răsturna, a întoarce (cu susul în jos); into, to a (se) preface în, a (se) preschimba în, a (se) transforma în; a face să devină; (ec) a converti, a preschimba în (bani lichizi etc.); a ocoli, a întoarce; (alim) a (se) acri, a (se) covăsi, a strica (laptele); a ajunge la (un moment etc.), a împlini / a atinge o vârstă de; (TH) a (se) strunji, a fasona; a presa, a modela, a rotunji; (fig) a cizela; a da o formă la; a traduce în altă limbă; a se învârti, a se răsuci; a se roti; a se întoarce, a se învârti (printr-un loc, către cineva etc.); to a se îndrepta către, a o lua spre; a se adresa la, a consulta pe; a recurge la; a se preface în; a trece în / la; a deveni; (d. vânt, curent); a se muta; a se inversa; a deveni, a se face, a se preface, a se transforma / a se schimba în; a se învârti (de amețeală); (metr) altă denumire pentru revoluție, rotație sau pentru o unitate de măsură pentru unghiuri, egală cu $360^{\circ}$

turnability (mas-un) aptitudine la / pentru strunjire, aşchiabilitate 
turn about (mas, OM) a răsturna, a bascula, a întoarce; (nav) a gira; a face / a executa o întoarcere

turn against a se întoarce împotriva (cu gen); a se arăta ostil față de; (şi fig) a se revolta, a se răscula, a se ridica împotriva

turn and turn about alternentă, schimb, schimbare; trecere la rând

turn around a roti, a se învârti; $v$. turn round

turnaround time $(\mathrm{TH}, \mathrm{ec})$ timp între primirea unei sarcini şi apariţia rezultatelor, timp de întoarcere

turn aside a abate, a devia, a face să devieze; a para; a se ăndepărta, a se retrage

turn away a întoarce (într-o parte); (ec) a concedia; v. turn aside

turn back (mas-un, OM) a slăbi (un şurub sau o piuliță); a face să se întoarcă, a întoarce înapoi; a izgoni, a alunga; a da afară; a răsfrânge, a îndoi; a lăsa în jos; a-şi sufleca; a se întoarce din drum, a face cale întoarsă

turn-bench $(\mathrm{TH})$ polizor, (roată de) tocilă

turn bench (mas-un) strung de banc / de masă

turn bridge (mas) pod mobil / turnant

turnbuckle (mas-un, OM) întinzător cu filet, piuliță de strângere

turn buckle (TH) conexiune, cuplaj

turn button (mas-un) închizător rotativ, comandă cu buton pentru întoarcere

turn-cap $(\mathrm{TH})$ căciulă rotitoare a unui coş de fabrică

turn clockwise $(\mathrm{TH})$ a învârti în sensul acelor de ceas, a învârti la / spre dreapta

turn cock $(\mathrm{TH}, \mathrm{hidr})$ robinet de închidere

turn-down (d. guler) răsfrânt, lăsat / întors în jos; refuz, respingere, refuzare (a unei oferte / propuneri); guler răsfrânt; v. turn-over

turn down v. turn back; a îndoi (colțul unei pagini), a vira; a întoarce; a micşora, a face mai mic (lumina); (met, termo) a reduce (flacăra); a respinge, a refuza (o propunere, pe cineva); (mil) a reforma; a umili, a înjosi; a fi răsfrânt / îndoit / întors / lăsat în jos, a fí căzut

turn-down collar guler răsfrânt (şi la piese)

turned bolt (mas-un) şurub prelucrat (la strung)

turned commas ghilimele

turned-down position (met) poziție de turnare

turned-off (mas) blocat, care nu se poate roti

turner (mas-un) strungar, mecanism / dispozitiv / subansamblu pentru rotirea capului revolver; (met) manipulator

turner's lathe (mas-un) strung

turner's shop (mas-un) atelier de strungărie; strungărie; obiecte / piese strunjite

turnery (mas-un) (atelier de) strungărie turn finish (mas-un) a finisa prin strunjire / la strung

turn finishing (mas-un) strunjire de finisare, prelucrare finală prin strunjire

turn half way to the right / left (auto) a întoarce jumătate la dreapta / la stânga (şi d. volan)

turn hollow (mas-un) a aleza, a strunji interior

turn home (mas-un, OM) a înşuruba până la refuz / pe toată lungimea filetului

turn-in interiorul supracopertei / cămăşii de la o carte

turn in a îndoi înăuntru; a băga / a face să intre înăuntru; a preda (echipamentul militar, sportiv etc.); a demisiona din, a părăsi de bună voie (un serviciu); a fi întors / răsucit spre înăuntru; a intra; (fam) a se duce la culcare, a se culca; a se întoarce (acasă), a reveni

turn in and out a se încolăci, a şerpui

turning virare; serpentină; cotitură; (mas-un, mec) strunjire, prelucrare la strung, rotire; (mec) girație, pivotare; răscruce, răspântie, încrucişare de drumuri; rotație; (astr, mec) (mişcare de) revoluţie; strunjire; v. turnery

turning along (mas-un) strunjire longitudinală

turning and boring lathe / mill (mas-un) strung carusel / vertical

turning angle (auto) unghi de bracaj; (nav) unghi de girație; (mas-un) unghi de atac al tăişului cuțitului de strung

turning arbor (OM) ax de antrenare

turning arbor of a hammer shaft (met) cep de fixare la berbec

turning back întoarcere, înapoiere, revenire

turning bridge $\mathrm{v}$. turn bridge

turning chisel (TH, mas-un) cuțit de strung

turning circle (cf) curbă de cale ferată, cerc de rotație; (auto) diametru al cercului de rotire / de întoarcere (actionare prin rotire)

turning couple moment de rotaţie, cuplu

turning down rabatere (în geometrie)

turning fixture (mas-un) dispozitiv de strunjire

turning force forță de torsiune / de răsucire

turning gear (mas, met) mecanism / dispozitiv de întoarcere

turning gauge (mas) tambur rotativ

turning graver / knife (mas-un) cuțit de strung

turning handle (mas-un) maneta mecanismului de întoarcere

turning head lamp far turnant

turning joint (OM) articulație rotativă

turning knife (mas-un) cuțit de strung

turning lathe (mas-un) strung

turning length (mas-un) lungime de prelucrat (prin strunjire) 
turning lock $(\mathrm{OM})$ închizător baionetă turning machine (mas-un) strung turning mill (mas-un) strung carusel / vertical turning moment (mec) cuplu motor / activ, moment de torsiune, moment de rotație turning movement (mec) mişcare de rotire turning out (mas-un) strunjire în interior, alezare; ieşire, dare afară, scoatere; $(\mathrm{TH})$ lărgire a unei găuri (cu burghiul)

turning over răsfoire; răsturnare

turning paste masă de strunjire

turning pin (OM) pivot, ştift de rotire / de articulație

turning piston $(\mathrm{OM})$ piston rotativ

turning point moment hotărâtor / decisiv / crucial; (punct de) cotitură; moment de criză

turning point (of a curve, of a differential equation) (mat) punct de extrem (al unei curbe), punct de ramificare (la ecuații diferențiale)

turning radius (mec) rază de pendulare / de rotire / de bracare

turning rolls (dispozitiv cu role) pentru sudarea pieselor cilindrice

turnings (mas-un) aşchii (de strunjire)

turning saw (mas-un) ferăstrău circular; $(\mathrm{TH})$ ferăstrău cu coardă

turning shop (mas-un) atelier de strungărie

turning tool (mas-un) cuțit de strung

turning vane $(\mathrm{OM})$ placă deviatoare / deflectoare / de ghidare, deflector; (hidr) supapă cu acționare prin rotire

turning work (mas-un) lucru la strung

turn into a (se) transforma / a (se) preface / a (se) preschimba în; a traduce în; a se face, a deveni (lichid)

turn-key (mas, el, auto) cheie de contact

turn knob (mas) buton rotitor

turn of a coil (OM, el) spiră (şi a unei bobine, a unui arc etc.)

turn off (cf) schimbător de cale de dreapta; (mas-un) a strunji o suprafață cilindrică; a opri (prin rotire), a opri (apa etc.); a închide (un robinet); a stinge, a închide (lumina etc.); from a abate (de la); a face să devieze (de la); v. turn out; a repudia; (cf) a gara, a trage (pe o linie); a se abate din drum; a-şi schimba drumul, a coti; to a o lua / a o apuca la / spre (dreapta etc.); a înceta lucrul, a intra în grevă; a părăsi (drumul etc.); a se abate din / de la; (d. stradă) a coti, a face colt cu

turn of speed (mas, auto) rapiditate, capacitate de a intra repede în viteză; mers rapid, iuțeală, rapiditate, agilitate turn on (autom, el) a închide circuitul, a conecta, a anclanşa; a deschide, a da drumul la (apă etc.); a aprinde (lumina, radioul etc.); a pune să facă ceva; a fi răsturnat, a cădea pe spate; v. turn upon; a se îndrepta / a se întoarce / a se abate spre / către; a se năpusti asupra; a ataca; a se lega / a se agăța de; a-i căuta pricină (cuiva); a depinde / a atârna de

turn on edge (met, mas-un) a întoarce / a aşeza pe muchie, a teşi / a rotunji muchiile

turn-on point (el, hidr) punct de conectare / de întoarcere

turn on the blast (met) a pune în funcțiune / a porni furnalul

turn(-)out (el, hidr) branşament, bifurcație; adunare, asistență, auditoriu; (mil) ținută, uniformă; grevă; (cf) ramificație, bifurcație, branşament; linie de garaj; (ec) producție globală

turn out a ieși, a se elimina, a scoate din circuit; (mas-un) a strunji; (OM) a deşuruba; a întoarce / a scoate (picioarele) în afară; a izgoni, a alunga, a da afară; a evacua (un chiriaş); a concedia; a pune în stare de alarmă; a mâna (vitele) la câmp; a produce, a fabrica, a confecționa, a face; a întoarce pe dos (buzunarul etc.); a goli (un sertar etc.); a face (curățenie generală) în; v. turn off; a ieşi / apărea în public / în lume; (fig) a ieși la iveală; a se arăta, a se dovedi, a se sfârşi / ieşi (bine, rău etc.); a se întâmpla; a deveni, a se face, a se transforma / se preface în; a se da jos din pat, a se scula (de dimineață)

turn-over $(\mathrm{TH})$ răsturnare, întoarcere; culbutare; tur; randament; ciclu; (ec) cifră de afaceri, fluctuație a forței de muncă / a muncitorilor, circulație a mărfurilor, ritm de vânzare; (el) schimbare a polarității; randament; producție; (mas) pivot, turnant, rotativ; (gastr) ruladă cu dulceață de mere; răsfrângere, îndoitură (a ciorapului etc.); articol (de ziar) cu continuarea pe altă pagină; (mas-un, OM) rabatabil, basculant, pivotant; a răsturna; a forța un filet

turn over a întoarce (o pagină), a răsfoi; (fig) a rumega (în minte), a medita / a chibzui asupra; a întoarece pe toate părțile; (agr) a răsturna, a întoarce (brazda etc.); a preda, a transfera, a transmite; a da pe mâna (cuiva); (ec) a realiza, a dobândi, a câştiga; a avea o cifră de afaceri de; a capota, a se răsturna

turnover board (met) placă rabatabilă de model (la turnătorie)

turnover job (mas, TH) (operație de) reparație capitală

turnover moulding machine (met) maşină de format cu placă rabatabilă 
turnover rate (ec) viteză de circulație a banilor/ a mărfurilor

turnover-table jolter (met) maşină de format prin scuturare, cu placă rabatabilă

turnover tax (ec) taxă / impozit pe cifra de afaceri turn plate (OM, mas-un) placă turnantă

turn roughly (met, mas-un) a degroşa (prin strunjire)

turn round $(\mathrm{mec})$ a se învârti, a se roti; a întoarce, a (se) răsuci; a duce de nas; a răsuci pe / după; a se mişca; v. turn over, turn on

turnscrew şurubelniță

turn signal indicators (auto) indicatori de semnalizare a virajului / a întoarcerii

turn slightly on edge (mec) a teşi

turnsole (agr, alim) floarea-soarelui; (chim) turnesol

turnstile $(\mathrm{OM})$ roată manuală, cu brațe

turn-table placă turnantă; (mas-un) masă turnantă, disc turnant, masă rotativă; platformă turnesol, platan

turn-table pit (mas, mas-un) groapă / spațiu de / pentru placa turnantă

turn-table plate (mas, mas-un) placă turnantă, disc

turn-table press (mas-un) presă-revolver

turn the handle half way to the left and right (auto) a roti volanul spre stânga şi dreapta (jumătate stânga şi jumătate dreapta)

turn to a întoarce, a îndrepte spre / către

turn to diameter (mas-un) a strunji până la diametrul cerut

turn to profit (ec) a folosi; a valorifica; a utiliza; a aduce pe profit

turn up a ridica în sus (gulerul etc.); a sufleca; a răsfrânge; a căuta în dicționar (un cuvânt); a agăța, a înhăța, a aresta; a renunța la; (jur) a achita din lipsă de dovezi; (agr) a întoarce (brazda etc.); a desteleni; a dezgropa; a ridica (un fitil), a face mai mare (flacăra etc.); a fi ruinat; a se răsfrânge, a se îndoi în sus; a-şi face apariția; a se ivi, a se prezenta, a sosi (pe neaşteptate); a ieși la iveală, a se găsi, a fi regăsit; (d. un prilej etc.) a se ivi, a se întâmpla, a surveni; v. turn out

turn-up bed pat pliant

turn upside down (mas, mas-un) a răsturna, a bascula

turpentine (chim) terebentină; (amer) a extrage terebentină din

turpeth mineral (minrl) calomel, sulfat galben de mercur

turquoise (minrl) peruzea, turcoază

turquoise blue albastru de peruzea, culoarea turquoise / turcoaz turquoise green verde de peruzea / turcoază, verde-albăstrui

turret (mas-un) cap / strung revolver, turlă, turn; foişor, turnuleț; (mil, av, nav) turelă

turret bushing (mas-un) cap revolver (la strungrevolver)

turret drill (mas-un) maşină de găurit, cu cap revolver

turreted (arhit) crenelat, cu turnulete, foişoare; prevăzut cu turelă / turele

turret head (mas-un) cap revolver

turret lathe (mas-un) strung revolver

turret layout (mas-un) schemă de reglat şi demontat scule (la capul revolver)

turret machine (mas-un) strung revolver

turret operation (mas-un) (operație de) prelucrare cu cap revolver

turret plate (mas-un) cap-revolver, cu masă pentru scule

turret slide (mas-un) sania / căruciorul capuluirevolver

turret ship (nav) cuirasat

turret steps (constr) $(p l)$ scară în spirală

tutela, $(p l)$ tutelae (jur) tutelă

tutelage (jur) tutelă; supraveghere, pază; (edu) învățământ, educație

tutelar tutelar, ocrotitor, păzitor

tutenag(ue) (met) aliaj de zinc, cupru şi nichel

tutor (edu) profesor (particular); preceptor, meditator; asistent / îndrumător (al studenților); (amer) (edu, univ) profesor suplinitor; (jur) tutore; supraveghetor; îndrumar, îndrumător, ghid, carte (de instrucțiuni); a instrui, a medita, a pregăti, a învăța; (fig) a dăscăli, a mustra, a dojeni; a supraveghea, a avea în supraveghere

tutoress (edu) profesoară; învățătoare, institutoare; preparatoare, meditatoare; (univ) asistentă preparatoare; (jur) tutore

tutorial de preceptor / meditator / repetitor; tutelar, de tutore; (univ) practic, de seminar; $(p l) \sim \mathbf{s}$ (edu, univ) lucrări practice (de seminar sau laborator)

tutorial system (univ) sistem de învățământ bazat pe îndrumare nemijlocită

tutorship slujbă / funcție / rang de tutore

tutory (jur) tutelă

tutty (met) burete de cuptor, lipitură (la furnale)

tuyére $(\mathrm{OM})$ duză; (met) gură de vânt, conductă de aer / de vânt, oxid de zinc depus pe peretii furnalului / cuptorului

tuyére arc cooler (met) carcasa gurii de vânt (la furnal)

tuyére arch (met) cadrul gurii de vânt (la furnal) tuyére belt (met) centura gurilor de vânt (la furnal) 
tuyére block (met) răcitor de la gura de vânt (la furnal)

tuyére bottom / plate / zone (met) fundul convertizorului, cu duzele de suflare

tuyére box (met) cutie de vânt, a convertizorului tuyére cap / latch (met) clapetă la vizorul racordului de aer la cuptor

tuyére cooler (met) răcitor la gura de vânt (la furnal)

tuyére hole (met) gaura gurii de vânt

tuyére latch (met) clapetă la vizorul racordului de aer la cuptor

tuyére level / zone (met) zona gurilor de vânt (la furnal)

tuyére nozzle / snout (met) ajutajul gurii de vânt

tuyére opening (met) gură de vânt

tuyére outlet (mas) orificiul de ieşire al unui ajutaj

tuyére pipe (mas) tubul ajutajului

tuyére plate / plug (met) fundul convertizorului cu duzele de suflare

tuyére zone (met) bloc de duze

tuyéres (met) zona gurilor de vânt, bloc de duze (la furnal, convertizor)

twaddle gauge (metr) densimetru, areometru

Twaddle scale (metr, fiz) o scală a gravității specifice, scara Twaddle

twaite (shad) (iht) scrumbie europeană

tweed (textile) tuid, tweed; $(p l)$ costum de golf

tween; tween deck (nav) întrepunte

tweezer a smulge / a scoate / a îndepărta cu penseta

tweezers (med) pensetă, cleştişor; (poligrafie) cleștiță; trusă (medicală)

T weld (met) sudură în $T$

T welding (met) sudare în $T$

twelfth al doisprezecelea; (mat) doisprezecime

twelfth (metr, muz) doisprezecime, unitate pentru a descrie raportul între frecvențele a două note: două note diferă printr-o doisprezecime dacă frecvența celei înalte este de 3 ori frecvența celei joase

twelfth part (mat) a douăsprezecea parte; douăsprezecime

twelve doisprezece; duzină; grup de douăsprezece persoane; (poligrafie) format de douăsprezece file (douăzeci şi patru de pagini)

twelvefold de douăsprezece ori mai mare / mai numeros; $(a d v)$ de douăsprezece ori (mai mult)

twelvemonth (metr) perioadă de 12 luni, denumire veche britanică, pentru an

twentieth douăzecilea; (mat etc.) douăzecime

twenty douăzeci; grup de douăzeci

twentyfold de douăzeci de ori mai mare sau mai numeros; $(a d v)$ de douăzeci de ori mai mult twice dublu, de două ori; repetat; îndoit twice-normal (chim) dublu normal twilight slab luminat; obscurl crepscular twin bifilar (d. un cablu), jumelat, identic, dublu; geamăn, (frate) geamăn, (soră) geamănă; (lucru) pereche; tiz, omonim; geamăn, pereche; (TH) jumelat, îngemănat, dublu; bifilar; omonom, omonimic; a da naştere la gemeni; with (fig) a face / a fi pereche cu; a îngemăna, a uni, a lega

twin bearing (mas-un, OM) lagăr geamăn

twin cylinder engine (auto, mas) motor $\mathrm{cu}$ cilindri în $\mathrm{V}$

twin-deck bus (auto) autobuz cu imperială

twin door (constr) uşă dublă

twine sfoară; şnur; (textile) tort, mănunchi de fire; împletire, răsucire; întrețesere; împletitură (și la compozite cu fibre lungi); cos împletit; a împleti, a răsuci; a înfăşura; a încolăci, a îmbrățişa; a cuprinde; a şerpui, a undui; a tăia, a despărți; a desface; a se despărți

twined răsucit, împletit (laolaltă); înfăşurat, încolăcit; șerpuitor, unduitor

twin-engined (av etc.) bimotor, cu două motoare twiner împletitor, răsucitor; (textile) dispozitiv / maşină de răsucit fïre

twin girder (mec) grindă-cheson

twin compressor (termo) compresor dublu / jumelat

twin-hull(ed) boat / vessel / ship (nav) catamaran

twin ignition (auto) dublă aprindere

twin-jaw crusher / breaker (mas, constr) concasor cu fălci cu dublu efect / cu fălci oscilante

twinkle (fiz) scintilație; licărire, scânteiere, scăpărare; licăr; clipire, clipit; clipă, moment, clipită; tresărire, mişcare bruscă; a clipi (şi din ochi); a licări, a pâlpâi; a scăpăra, a scânteia; a se aprinde; $(\mathrm{TH})$ a face să scânteieze

twinkler semnalizator intermitent

twin milling cutter (mas-un) freză cuplată, garnitură / set de două freze

twinned electrode (el) electrod dublu / cu două vergele

twinning îngemănare, împerechere, îmbinare (a două elemente), legare, unire; naştere a doi gemeni; (minrl, geol, fiz) formare a unor cristale duble / îngemănate

twin pump (hidr) pompă duplex / dublă

twin roller crusher concasor $\mathrm{cu}$ doi cilindri / cu două valțuri

twin rolling mill (mas, met) laminor duo / cu doi cilindri

twin rudder (nav) cârmă dublă (cu două pene)

twin screw (mas, OM) elice dublă (şi la filete sau melci, dar şi la nave) 
twin set (textile) set (pulover şi jachetă) twinship îngemănare; asemănare, similitudine twin spindle machine (mas-un) maşină-unealtă cu doi arbori principali

twin track (cf) (amer) linie ferată dublă

twin wheels (mas-un, OM, auto) roți jumelate / duble / îngemănate / pereche

twin wire (el) conductor bifilar / cu vână dublă, pereche de conductoare

twin-piston engine (hidr, termo) motor cu pistoane duble

twin-roll crusher (constr, mas) concasor cu două valțuri

twin-rolling mill (met) laminor duo, cu valțuri

twine sfoară, şnur; (mas-un) a împleti, a cabla

twip (metr, c) unitate de măsură pentru lungime, utilizată în grafica pe computer, pentru controlul rezolutiei elementelor de imagine: 1 twip $\cong$ $17,639 \mu \mathrm{m}$ : twip este un acronim pentru ,twentieth of a point" - 1/20 dintr-un punct, dacă punctul - ca unitate de măsură este 1/72 inch

twirl învârtire, rotire (rapidă); vârtej, volbură; cârliont; a răsuci; a (se) învârti / a (se) roti repede / într-un vârtej; cârlionț; dublură la cheie

twist (mas, OM) cablaj, cablare, răsucire, pasul şurubului, încovoiere, torsiune, torsadare, contorsionare, deformare, strâmbare, pas al elicei / pas al şurubului; v. twirl; îndoitură; cotitură, cot; (alim) pâine împletită, colac; cornet / pungă de hârtie (răsucită); (textile) frânghie, sfoară, şnur, fir răsucit; specific, particularitate, caracteristică, pecete; înșelăciune, amăgire; cornet / pungă de hârtie (răsucită); (alim) pâine împletită, poftă de mâncare, apetit; a răsuci; a torsiona; a deforma, a împleti, învârti, a cabla; a îndoi, a contorsiona; a (se) încolăci; a strâmba; a stoarce (rufe); (fig) a înşela, a păcăli, a trage pe sfoară; (nav) a întoarce pe loc (d. navă); a chinui; (fig) a spânzura, a pune în ștreang; v. twirl, twine

twist-and-contraction meter (mec, metr) torsiometru, aparat pemtru măsurarea torsiunii şi contracției

twist-belt drive (mas, OM) transmisie cu curea încrucişată

twist cabler (mas-un) maşină de dublat şi răsucit fire / cabluri

twist drill (mas-un) sfredel / burghiu spiral / elicoidal

twist drill grinding gauge (mas-un) şablon de verificat ascuțirea burghiului elicoidal

twisted strâmb; (mec, OM) torsionat, răsucit; diform; răsucit, contorsionat

twisted cable (mec, constr) cablu torsadat / răsucit twisted-toothed spur gear $(\mathrm{OM})$ roată cilindrică cu dinți înclinați (mai rar)

twister persoană care răsuceşte etc.; v. twiner; escroc; minciună gogonată; dificultate, lucru dificil; problemă spinoasă / complicată; cuvânt greu de pronunțat; (alim) pâine împletită; (aprox) mucenic; covrigar

twist flute $(\mathrm{OM})$ canelură elicoidală

twist gear (met, plast) roată de torsiune, roată (schimbătoare) a laminajului

twisting torsiune; torsionare; cablare, răsucire, toronare

twisting couple (mec, OM) cuplu de torsiune, de răsucire

twisting device (mas-un) dispozitiv de torsionare

twisting force (mec, OM) forţă de torsiune / de răsucire

twisting guide $(\mathrm{OM})$ manşon / ghidaj cu canale elicoidale

twisting machine (met) maşină de cablat, maşină de răsucit

twisting moment (mec) cuplu motor, moment de torsiune / de răsucire

twisting resistance $(\mathrm{mec}, \mathrm{OM})$ rezistență la torsiune

twisting stick (OM) întinzător, bolț de întindere

twisting strain (mec) deformare de răsucire / de torsiune

twisting stress $(\mathrm{mec})$ tensiune de răsucire, efort de torsiune

twisting strength (mec) solicitare / rezistență la torsiune / la răsucire

twisting test (mec) test / încercare la răsucire

twistless fără torsiune, netorsionat, nerăsucit (d. fire, cabluri etc.)

twist off ruperea cusăturii longitudinale; (masun, $\mathrm{OM}$ ) a forta filetul, a deteriora filetul prin strângere excesivă; schimbare a direcției; încetare a răsucirii

twist rope cablu de torsiune / torsadat

twist test $(\mathrm{mec})$ încercare la răsucire

twist tester (mec) torsiometru

twitter v. tweet; vorbărie; agitație, freamăt, nervozitate; a fi agitat / nervos / în agitație; a fremăta, a trepida (de emoție)

two doi, două; (grup de) doi / două

two-armed lever $(\mathrm{OM}, \mathrm{mec})$ pârghie cu două brațe, pârghie de gradul întâi

two-arms lever $(\mathrm{OM})$ pârghie cu două brațe

two-axle full trailer (auto) remorcă cu două osii

two-axle semi-trailer (auto) semiremorcă cu două osii

two-beaked anvil (met) nicovală de banc cu două vârfuri

two-bladed (OM, mas-un) cu două lame / pale / tăişuri / muchii etc. 
two-bladed fan (mas) ventilator cu două pale two-blade propeller (nav) elice bipală two-colour (termo, auto) bicolor, în două culori two-cycle engine $(\mathrm{TH})$ motor în doi timpi two-daylight press (mas) presă cu două etaje two-decker (nav) vas cu două punți; tramvai sau autobuz cu imperială

two-diameter piston (OM, hidr) piston în trepte / diferential

two-dimensional; 2D $(\mathrm{TH})$ bidimensional (fără relief), în / cu două dimensiuni (în plan)

two-dimensional profiling (mas-un) prelucrare bidimensională a profilurilor / profilurilor

two-dimensional state of stress (mec) stare de tensiune bidimensională, stare plană de tensiuni two-edged (TH) (şi fig) cu două tăişuri two-engine(d) bimotor

two-equal force (mec) cuplu de forțe two-eyed cu doi ochi; (TH) binocular two-figure (număr) cu două cifre

twofold dublu, îndoit, în două straturi; răsucit în două (d. fire); (textile) din două fire; $(a d v)$ îndoit, dublu, de două ori pe atât

two-flute drill (mas-un) burghiu cu două canale two-handled cu două mânere, cu două toarte two-high blooming mill (train) (met) laminor duo pentru lingouri, bluming

two-high cogging-mill (met) laminor duo, linie de laminare pentru lingouri

two-high cogging-mill train $(\mathrm{mec})$ laminor duo, linie de laminare pentru lingouri

two-high cold finishing rolling mill (met) laminor finisor duo la rece de laminare

two-high cold stand (met) cajă duo la rece

two-high dressing rolling mill (met) laminor duo pentru dresare

two-high equalising rolling mill (met) laminor duo pentru egalizarea tablei

two-high finishing stand (met) cajă finisoare duo two-high finishing stands in train (mec) linie finisoare de laminare duo, laminor finisor duo (cu caje în linie)

two-high finishing(-mill) train (mec) linie finisoare de laminare duo, laminor finisor duo

two-high intermediate roll train (met) linie mijlocie duo, tren de laminare duo

two-high hot rolling mill (met) laminor duo (de prelucrare) la cald

two-high hot stand (met) cajă de laminor duo la cald

two-high mill (met) laminor duo / cu doi cilindri (cu axele în plan vertical)

two-high non-reversing mill (met) laminor duo ireversibil two-high piercing mill (met) laminor perforator duo (pt. țevi)

two-high plate rolling mill (met) laminor duo pentru tablă

two-high plate rolling stand (met) cajă de laminare duo pentru tablă

two-high plate rolling train (met) linie de laminare duo pentru tablă

two-high reversing blooming mill / train (met) laminor duo reversibil pentru lingouri

two-high reversing rolling mill (met) laminor duo reversibil

two-high reversing plate rolling train (met) laminor duo reversibil

two-high reversing stand (met) cajă de laminor reversibil

two-high reversing stand of rolls for roughing (met) cajă pentru laminor întinzător duo reversibil

two-high rolling mill (met) laminor duo

two-high rolling stand (met) cajă de laminor duo two-high roughing stands in trains (met) linie degrosisoare duo (de laminare)

two-high section rolling mill (met) laminor duo de profiluri

two-high section stand (met) cajă pentru lamnor duo de profiluri

two-high sheet-mill train (met) linie de laminare duo, laminor duo pentru tablă subțire

two-high sheet-rolling mill (met) linie de laminare duo, laminor duo pentru tablă subțire

two-high skin-pass rolling mill (met) laminor duo pentru dresare

two-high stand (met) cajă de laminor duo

two-high stand with repeated passing (met) cajă de laminor duo, cu treceri repetate (ale aceluiaşi semifabricat)

two-high strip rolling mill (met) laminor duo, pentru benzi

two-high strip stand (met) laminor duo, pentru dresare

two-high universal mill (met) linie universală de laminare, duo laminor universal duo

two-high universal mill train (met) linie universală de laminare duo, laminor universal

two-high universal stand (met) cajă pentru laminor duo, universal

two-independent ignition (termo) aprindere dublă two-jawed (mas, mas-un) cu două fălci

twoleaved, twoleafed, twosheeted (mat, plast, met) cu / din două foi / plăci (subțiiri)

two-level controller (autom) regulator $\mathrm{cu}$ acțiune în două trepte

two-level storage (c) memorie cu două niveluri de acces 
two-lipped end mill (mas-un) freză cu coadă, cu două tăișuri

two-masted (nav) cu două catarge

two movable jaw crusher (mas, constr) concasor cu cu fălci mobile, cu dublu efect

two-oar (nav) ambarcațiune / barcă cu două vâsle

two-part (mas-un, OM) demontabil, compus din două piese

two-part bearing (OM) lagăr demontabil / din două piese

two-pedal control (mas) comandă cu două pedale two-phase (el) bifazat; cu două faze

two-phase flow (fiz, met) curgere bifazică

two-phase system sistem bifazat

two-piece (OM) din două piese / părți / bucăți

two-pin (el) fişă dublă

two-pin driven nut (mas-un, OM) piuliță rotundă cu două găuri radiale

two-ply dublat în două fire, în două straturi; duplex, dublat

two-ply belt (mas, OM) curea dublă

two-ply board (TH) carton duplex

two-ply yarn (textile) fir răsucit în două

two-point bit (mas-un) burghiu cu două tăişuri

two-point / twin ignition (termo, auto) dublă aprindere

two-pole (el) cu doi poli; bipolar

two-position action (autom, hidr) regulator ,tot sau nimic" / bipozițional

two-ribbed nut (OM, mas-un) piuliță rotundă, cu nervuri radiale

two-roll (TH, mas) cu două valțiri / role, cu doi cilindri

two-row ball-bearing / roller-bearing $(\mathrm{OM})$ rulment cu două rânduri de bile / de role (cilindrice)

two-row(ed) cu două linii / căi (de rulare etc.)

two-seater (auto) maşină / automobil sport / cu două locuri

two-shaft mixer with blades (alim, ind chim) amestecător cu palete, cu doi arbori

two-sheet (mat) cu două pânze (în geometrie)

two-shoe brake (OM) frână cu doi saboți

two-sided diedru, cu două laturi; bilateral; (fig) complex, complicat, cu multe fatete

two-sided clad steel (met) otel duplex / placat pe ambele părți

two-slag practice / process (met) procedeu cu două zguri / cu zgură secundară, topire cu zgură secundară

two-span bridge (met, constr) pod cu două deschideri

two-spark ignition (termo) aprindere cu scântei duble two-speed (auto, mas) (d. motor) cu două viteze two-stage, two-state, two-step (autom, OM, hidr) cu două trepte / etaje, dublu etajat

two-stage reduction gear (autom, OM, hidr) reductor cu două trepte

two-stage regulator (autom, OM, hidr) regulator de presiune cu două trepte de reducere a presiunii

two-stage resing (plast, ind chim) răşină cu întărire în două trepte (tip novolac)

two-stage / two-state / two-step (action) control (autom, OM, hidr) reglare cu / în două trepte / etaje, reglare cu două poziții / „tot sau nimic" / bipozițională

two-stage screening (constr, alim, ind chim) sortare / cernere în două trepte

two-stage regulator (autom, OM) reductor / regulator cu două trepte

two-stand rolling mill (met) laminor cu două caje

two-stand vertical continuous casting machine (met) maşină / instalaţie de turnare continuă verticală

two-step în două trepte / etape / faze

two-step cure (ind chim) vulcanizare / întărire

two-stroke / two-cycle engine (termo) motor în doi timpi; în doi timpi

two-throw $(\mathrm{OM})$ (d. vibrochen) cu două coturi

two-throw crankshaft (mas, OM) arbore cotit cu două coturi / paliere

two-way bilateral; bidirecțional; bifurcat; cu două (poziții, direcții etc.); (TH, hidr) cu două căi / canale; duplex; (d. circulație etc.) în două sensuri

two-way breeches piece (OM, hidr) furcă, conductă bifurcată; (hidr) filon bifurcat

two-way cock / tap / valve (OM, hidr) robinet supapă cu două căi / poziții

two-way earthing (el) dublă punere / legare la pământ

two-way soaking pit (met) cuptor adânc cu două arzătoare

two-way street arteră de circulație / stradă cu două sensuri de circilatie / cu circulația în ambele sensuri

two-way switch (el) comutator cu două căi / poziţii

two-way tap / valve (OM, hidr) robinet / supapă cu două căi / cu două poziții

two-way traffic circulație în ambele sensuri

two-way valve v. two-way cock

two-width key $(\mathrm{OM})$ pană cu secțiune în trepte

two-wing door (constr) us̆ă cu două canaturi / dublă

two-wire (el, $\mathrm{TH})$ bifilar

twyer (TH, met) gură de vânt (la furnal) 
tying (mec) legare

type clasă; tip; caracter tipic; formă; sortiment; model; prototip; simbol; gen, soi, speță; clasă; (poligrafie) (şi $p l) \sim \mathbf{s}$ caracter, literă de tipar; a bate la calculator un text, a dactilografia; (c) a tasta (un text etc.); a tipiza, a fi un exemplu tipic de; a atribui unui tip, a stabili tipul / clasa (unui individ); (med) a caracteriza; (med) a determina grupa sanguină

type analysis (chim) analize pe grupe structurale type-height (c, poligrafie) înălțime a literei type mould (met) aparat de turnat

type of duty (TH, mas) caracteristică a funcționării, caracteristică de sarcină

type of manufacture (ec, TH) execuţie, tip de producție

type of structure (met) felul structurii

type tests încercări de / pe prototip

types mod de execuţie

typical (of) tipic, caracteristic, reprezentaiv (pentru); tip, model

typically $(a d v)$ (în mod) tipic / caracteristic / specific; într-un mod cu totul propriu

typical value valoare proprie

typification tipizare; reprezentare tipică; simbolizare

typify a personifica, a întruchipa; a simboliza, a reprezenta; a fi tipic / caracteristic / reprezentativ pentru; a fi prototipul; a tipiza, a caracteriza

typing dactilografiere, dactilografie

typographical error greşeală de tipar / culegere / cules

typography tipografie

typp (metr, textile) abreviere pentru thousand yards per pound, unitate utilizată pentru a descrie densitatea firelor: 1 typp 2,015907 metri pe gram, şi $n$ typp corespunde unei densități a firului de 2,015907/n metri

tyre (auto) anvelopă, cauciuc, pneu; şină de roată; (cf) bandaj de roată

tyre bead (auto) talon / talpă de anvelopă

tyre break / blow-out (auto) explozie de pneu / cauciuc

tyre casting (auto) carcasă (şi de pneu)

tyre cement (auto) soluție de lipit camere sau anvelope

tyre chain (auto) lanț antiderapant de pneu

tyre claps / clip (auto, OM) inel de fixare a bandajului

tyre cord (auto) pneu cu inserție / cu carcasă de cord; cord, fir cablat pentru anvelope; (textile) cord / suport textil pentru anvelope / pneuri

tyre cover (auto) anvelopă tyre curing press; tyre vulcaniser (ind chim) presă de vulcanizat anvelope

tyre failure (auto) pană de pneu / de cauciuc

tyre flap (auto) bandaj de jantă / geantă, bandă de protecție a jenții

tyre gauge (auto, metr) manometru de control pentru presiunea de umflare

tyre heater (ind chim) autoclavă de vulcanizat anvelope

tyre inflator (auto) pompă / dispozitiv de umflat pneuri / cauciucuri

tyre ingot (met) lingou de oțel pentru bandaje

tyre inner tube (auto) cameră de aer / de pneu

tyre iron / lever (auto) levier de montat pneuri / anvelope

tyre locking ring (auto, OM) inel de blocare a bordurii jenții

tyre mill (met) laminor de bandaje (pt. roți)

tyre mould ( $\mathrm{TH}$, ind chim, auto) matriță / menghină pentru vulcanizat anvelope

tyre noise (auto) zgomot de pneu, la rulare; uruitul cauciucurilor

tyre outer cover $v$. tyre cover

tyre patch (auto) petic de cameră / anvelopă / pneu

tyre patch kit (auto) trusă pentru pus petece auto la camere / pneuri

tyre press (auto) presă de anvelopă

tyre pressure gauge (metr, auto) manometru de control (pt. presiunea din pneuri); v. tyre gauge

tyre pump $v$. tyre inflator

tyre puncture / failure (auto) pană (de cauciuc)

tyre recapping machine (ind chim) maşină de reșapat anvelope

tyre reclaim (ind chim, auto) (cauciuc) regenerat din anvelope

tyre removing and replacing machine (auto, mas) dispozitiv de demontat şi montat pneuri

tyre repair kit $v$. tyre patch kit

tyre section (auto) profil al anvelopei

tyre soling (auto, ind chim) reşapare completă a pneului / anvelopei

tyre steel (met) otel de bandaje de roți

tyre stock (ind chim) amestec (de cauciuc) pentru anvelope

tyre texture (auto) cord de anvelope; v. tyre cord

tyre tread (auto) bandă de rulare (la anvelope)

tyre turning lathe (mas-un) strung de bandaje (de roți)

tyre valve (auto) valvă / venti / supapă a pneului / camerei

tyre vulcaniser / curing press (mas, ind chim) presă de vulcanizat anvelope

tyrolite (met) zgură de cupru 


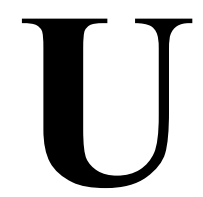

u (metr, fiz, chim) simbol pentru unified atomic mass unit, în sistem SI; v. unified atomic mass unit; $\mathbf{u}$ (metr, c) înlocuire de uz general pentru litera grecească $\mu$, în simbolul pentru micron sau alte subunități de măsură micro-, mai ales în softuri care nu au inclus în limbaj acest simbol; U (metr, termo) unitate comercială de măsură pentru conductanța termică (flux termic); U este conductanța printr-un izolator, măsurată în Btu, pe gromise în inch, pe oră şi pe picor pătrat de suprafață, când diferența de temperatură între suprafețele izolatorului este $1{ }^{\circ} \mathrm{F}$; $\mathrm{U}$ factor este numeric egal cu inversul valorii $R ; \mathrm{v}$. $R$ value, U factor; $\mathbf{U}$ (metr) unitate de măsură pentru a măsura înălțimea glisierelor pe care se pot monta componente electronice, radio, video şi de calculator: $1 \mathrm{U}=44,45 \mathrm{~mm}$

ua, au (metr) simboluri pentru astronomical unit

Ubbelohde drop (ind chim, metr, T) point punct de picurare Ubbeholde

U-beam, U-iron (constr, mec) grindă (în formă de) $U$

uberous (alim, agr) cu mult lapte, (vacă) care dă lapte mult

ubiety localizare, loc stabilit; (nav) ancorare într-un loc

ubiquitous ubicuu, omniprezent, prezent peste tot, care poate fi găsit oriunde

ubiquity ubicuitate, omniprezență, calitatea de a fi ubicuu / omniprezent

U-boat (nav) submarin

U-bolt (hidr, OM) buclă de ancoraj, bridă de arc, şurub în formă de $U$

U-clip (OM) bridă elastică / de arc

udometer (metr, meteo) pluviometru

U factor (metr, termo) unitate comercială de măsură pentru conductanța termică (flux termic); conductanța printr-un izolator, măsurată în Btu, pe groime în inch, pe oră şi pe picior pătrat de suprafață, când diferența de temperatură între suprafețele izolatorului este $1^{\circ} \mathrm{F}$, numeric egal cu inversul valorii $R$; $v$. $R$ value

U (-form) expansion loop (OM, termo) compensator de dilatare în formă de $\mathrm{U}$

U-frame (constr, OM) ramă cu profil U uglification urâțire

uglify a urâți

uglily $(a d v)$ (în mod) urât, scârbos

ugly urât; hidos; neplăcut; neatrăgător

UHF, uhf (ultra-high frequency) (fiz) frecvență ultra înaltă

UI (metr) simbol alternativ pentru international unit (IU): unité international (în franceză), unitate internațională (în română)

U iron / bar (OM, met) profil U

uld, ulp (metr, c) unități pentru precizia datelor într-un computer; simbolul ulp este pentru „unit in the last place” - cel mai mic increment al unei variabile care poate fi înregistrat de computer; uld este simbol pentru ,unit in the last digit" - o schimbare cu 1 a celei mai mici zecimale a datelor reprezentate zecimal

ule (bot) arbore de cauciuc

ullage (auto, OM) spațiu gol al rezervorului (pt. a sigura loc de expansiune în timpul transportului); cantitate de lichid necesară pentru compensarea scurgerilor / completarea la ambalare

ullaging (metr, auto, ind chim, hidr) măsurare a golului rezervorului / recipientului

ulmic acid (chim) acid ulmic

ulterior ulterior, subsecvent, de mai târziu, posterior; ascuns, abscons

ultimacy calitatea de a fi ultimul, caracter ultim / final, caracter fundamental / de bază

ultimate ultim; extrem; terminal; la limită; de bază, final; fundamental, esențial; primar; elementar; maxim

ultimate analysis (metr, chim) analiză elementară; (met, metr) analiză completă a tuturor elementelor

ultimate bending strength (mec, OM) limită de rezistență la încovoiere, rezistență la rupere la încovoiere

ultimate carrying capacity (mec, mas, OM) sarcină de rupere, portanță maximă

ultimate composition (met, ind chim) compoziție chimică de bază / ultimă

ultimate damping (autom, fiz, mec, OM) amortizare finală / la limită

ultimate decision decizie definitivă

ultimate deviation (metr, autom, mas) deviație / abatere limită

ultimate effect ( $\mathrm{TH}$, mas) postacțiune, efect terminal

ultimate elongation (mec, materiale) (a)lungire la rupere

ultimate equilibrium (mec) echilibru limită ultimate jet (hidr, termo) jet periferic 
ultimate load (mec, mas, OM) încărcare limită / de rupere, sarcină limită / de rupere

ultimately $(a d v)$ la sfârşit, în fine, în cele din urmă, (până) la urmă; esențialmente, în fond, în ultimă instanță

ultimate output $(\mathrm{TH})$ coeficient de extracție / de exploatare final; (ec, ind) producție maximă / limită

ultimate position (el, mas-un) ultima poziţie, poziție finală

ultimate production (ec) producție finală / totală / cumulativă

ultimate resistance (mec, OM) rezistență finală / la rupere, limită la rupere

ultimate strain of the compressed concrete (constr) deformație la rupere a betonului comprimat

ultimate strength (mec, materiale, OM) rezistență / limită la rupere, forță de / la rupere, limită de curgere (rar)

ultimate stress (mec, OM) efort / tensiune la rupere, rezistență la rupere (rar), sarcină maximă

ultimate structure (met) structură finală (la / după turnare)

ultimate tensile strength (mec, materiale, $\mathrm{OM}$ ) rezistență / limită de rupere la tracțiune

ultimate vacuum (fiz) vid limită / maxim

ultimate value valoare finală

ultimate yield ( $\mathrm{TH}$, ind) randament total, producție / extracție cumulativă

ultimo / last month (din) ultima lună

ultimatum $(p l)$ ultimata (pol, mil) ultimatum

ultra (pol) extremist, ultra; extrem; care întrece limitele

ultracentrifuge (ind, mas) ultracentrifugă

ultrafilter (alim, ind chim, OM) ultrafiltru, filtru fin

ultrafiltration (alim, ind chim, $\mathrm{TH}$ ) ultrafiltrare, filtrare fină

ultrafine extrafin (d. materiale, produse etc.)

ultrafine particle (fiz, alim) particulă extrafină / foarte fină

ultra-flat (materiale, OM) extraplat

ultra-high frequency (UHF) (fiz) frecvență foarte înaltă

ultra high vacuum (fiz) vid foarte înaintat

ultraistic (cu caracter) extremist

ultralight superuşor

ultralight alloy (met) aliaj superuşor / ultrauşor (d. aliaje de aluminiu, de magneziu etc.)

ultralow drift amplifier (autom, metr) amplificator cu derivă / deviație / abatere foarte mică ultramicroscopic(al) (fiz, metr) ultramicroscopic ultraphotic lights (fiz) raze invizibile ultra(-)red (fiz) infraroşu

ultrashort (fiz) foarte scurt, ultrascurt ultrashort wave (fiz) undă ultrascurtă

ultrasoft (materiale, textile) foarte moale; (c) soft de calitate superioară

ultrasonic (fiz, av) supersonic, ultrasonic, supraacustic

ultrasonically-assisted machining (mas-un) prelucrare cu ultrasunete sau cu scule obişnuite, dar supuse vibrațiilor pentru a obține o calitate superioară a prelucrării

ultrasonic bonding (met, plast, $\mathrm{TH}$ ) sudare / lipire / asamblare (mecanică) cu ajutorul ultrasunetelor

ultrasonic cleaning $(\mathrm{TH})$ curățare cu ultrasunete

ultrasonic coagulation coagulare cu ultrasunete

ultrasonic cutting (mas-un, $\mathrm{TH}$ ) tăiere / prelucrare (cu detaşare de micro-aşchii) cu ultrasunete

ultrasonic densimeter (metr, fiz) densimetru cu ultrasunete

ultrasonic density sensor (metr, fiz) senzor de densitate cu ultrasunete

ultrasonic detection (metr, fiz) defectoscopie, detectare a defectelor cu ultrasunete

ultrasonic detector (metr, fiz) detector de ultrasunete

ultrasonic drilling (mas-un) găurire cu ultrasunete ultrasonic (echo) sounding (metr, materiale, geogr) sondaj ultrasonic

ultrasonic fault / flaw detection (met, metr) defectoscopie cu ultrasunete / ultrasonică

ultrasonic drilling (mas-un, TH) găurire cu ultrasunete

ultrasonic flowmeter (metr, hidr, OM, fiz) debitmetru cu senzor de ultrasunete / ultrasonic

ultrasonic frequency (fiz) frecvență ultrasonică (peste $\sim 15 \ldots 20 \mathrm{kHz}$ )

ultrasonic image (fiz) imagine rezultată din inspecție cu ultrasunete

ultrasonic inspection / testing (metr, fiz) control cu / prin ultrasunete

ultrasonic machining (mas-un, TH) prelucrare cu ultrasunete

ultrasonic material dispersion $(\mathrm{TH}, \mathrm{T})$ dispersare cu ultrasunete (de exemplu, pentru formare de suspensii sau emulsii)

ultrasonic rays (fiz) radiații ultrasonice

ultrasonic receiver (fiz) receptor ultraacustic / ultrasonic / pentru ultrasunete 
ultrasonics (fiz) fizica ultrasonică, tehnologie asociată cu producerea şi utilizarea ultrasunetelor

ultrasonic soldering (met, plast, $\mathrm{TH}$ ) lipire $\mathrm{cu}$ ultrasunete

ultrasonic tester (metr, materiale, fiz) aparat cu ultrasunete

ultrasonic testing (metr, materiale, fiz) testare / verificare cu ultrasunete

ultrasonic thickness gage (metr, materiale, fiz) dispozitiv ultrasonic de măsurare a grosimii pieselor metalice (table subțiri, țevi etc.)

ultrasonic transducer (metr, fiz) traductor $\mathrm{cu}$ ultrasunete

ultrasonic vibration (fiz) vibrații ultrasonice cu frecventa peste $20 \mathrm{kHz}$

ultrasonic welding (met, plast, $\mathrm{TH}$ ) sudare / lipire cu ultrasunete

ultrasonic wave (fiz) undă ultrasonoră

ultra(-) sound (fiz) ultrasunet

ultraspherical polynomial (mat) polinom a lui Gegenbauer

ultra thin (chim, fiz, T) (strat) foarte subțire

ultraviolet (fiz) ultraviolet

ultraviolet absorber (fiz) substanță care absoarbe energie în regiunea UV a spectrului

ultraviolet absorption (fiz) absorbție în ultraviolet / a spectrului UV

ultraviolet degradation (plast, fit, chim, mediu) degradare din cauza expunerii la raze ultraviolete

ultraviolet light (fiz) lumină ultravioletă, raze ultraviolete

ultraviolet radiation (fiz) radiație ultravioletă

ultraviolet rays (fiz) raze ultraviolete

ultraviolet spectrophotometry (fiz, metr) spectrometrie cu ultraviolete (la determinarea concentratiei de solutii, gaze)

ultraviolet spectrum (fiz) spectru ultraviolet ultra vires $(\mathrm{adm}, \mathrm{ec})$ extrastatutar, peste limitele competenței, în afara atribuțiilor, care depăşeşte puterea / competența, abuziv; a comite un abuz de putere

um (metr, c) (rar) simbol utilizat pentru micrometru, acceptat în soft-uri care nu au litera grecească $\mu$ în sistemul de scriere şi citire a datelor

umber (geol) pământ / lut ocru / roşiatic, pământ / lut ars; (culoare) ocru; ocru, roşiatic; a colora în ocru / roşiatic

umbilical (med, anat) ombilical; (geom) sferic umbilical connection cuplare flexibilă a maşinilor, roboților la sursa de putere sau de control umbra (fiz) umbră totală, zonă / con de umbră, penumbră

umbrage (silv) umbră,frunziş, umbrar; aluzie, indicație; îndoială, suspiciune, bănuială; a se supăra

umbrageous umbros; răcoros, adăpostit; întune$\cos$

umbrageousness hipersensibilitate, susceptibilitate

umbrella umbrelă

umbrella aerial (fiz, radio) antenă tip umbrelă umbrella-shaped $(\mathrm{OM})$ în formă de umbrelă umpirage (ec, sport) arbitraj, arbitrare, functie sau autoritate de arbitru

umpire (ec, sport) arbitru, judecător, mediator; a arbitra (un diferend), a funcționa ca un arbitru

umpire analysis (ec, sport) analiză de arbitraj / de expertiză

umpireship (ec, sport) funcție / profesie de arbitru

unabated neabătut, nepotolit; neclintit, inflexibil

unabatedly $(a d v)$ fără încetare; (în mod) inflexibil

unabating persistent, susținut, care persistă, care este / rămâne neabătut / inflexibil

unabbreviated, unabridged neprescurtat, neabreviat, fără tăieturi, integral (d. texte)

unabiding efemer, trecător, instabil

unable incapabil, neputincios

unableness incapacitate, neputinţă

unabolishable de nedesființat, stabil, sigur, remanent

unabrogated neabrogat, rămas (încă) în vigoare unabsolved neabsolvit, neiertat

unabsorbent hidrofug, neabsorbant (d. materiale)

unacademic (univ) neacademic

unaccented, unaccentuated neaccentuat; nesubliniat, fără apăsare / subliniere

unacceptability caracter inacceptabil / imposibil, inacceptabilitate

unacceptable, unaccepted (de) neacceptat, inacceptabil, intolerabil

unaccessible inaccesibil, de neatins, la care nu se poate ajunge

unaccessibleness inaccesibilitate, caracter inaccesibil, imposibilitate (de realizare)

unacclimated, unacclimatized (agr) neaclimatizat, prost aclimatizat

unaccommodated nearanjat, necazat, neinstalat; (ec) neaprovizionat, prost aprovizionat

unacommodating incomod, inconfortabil, lipsit de confort; neprimitor, inospitalier, neospitalier unaccompanied neînsotit, singur 
unaccomplishable irealizabil, nerealizabil, imposibil de făcut / realizat

unaccomplished nedesăvârşit; (pol, adm, ec) neperfectat (d. un contract, un tratat etc.); nerealizat, nefăcut; imperfect, cu imperfecțiuni

unaccountability caracter inexplicabil / nejustificabil, lipsă de justificare / de motivare

unaccountable inexplicabil, de neînțeles, fără explicații; nejustificat, nemotivat

unaccountableness caracter inexplicabil / nejutificat; iresponsabilitate; absurditate; nesăbuință

unaccounted for netrecut în, neînregistrat, care nu figurează (într-un registru); neexplicat; nejustificat, fără justificare

unaccounted-for loss (termo) pierderi de căldură / de energie / de materiale (exprimate în procente)

unaccredited neacreditat (d. un laborator, un aparat, un produs etc.)

unaccustomed to neobişnuit cu / să, nedeprins cu / să

unaccustomedness to neobişnuință cu / pentru, lipsa deprinderii de a; lipsă de experiență în

unachievable irealizabil, nerealizabil, imposibil de făcut / realizat; de neexecutat

unachieved neterminat; neisprăvit; nerealizat

unacknowledged (ec) neconfirmat (d. plăți, vărsăminte); fără răspuns (la un mesaj); neacreditat; fără indicare a sursei / bibliografiei (întrun text); nerecunoscut, neconsacrat

unacquaintance with ignoranță / necunoaştere a; neștiință în privința

unaquirable de nedobândit, imposibil de achiziționat / de obținut

unacquired (ec) (rămas) nedobândit / neachiziționat

unadaptable inadaptabil, greu adaptabil

unadapted neadaptat

unaddressed (scrisoare) fără adresă

unadhesive (materiale) neaderent, lipsit de adezivitate / aderență

unadjudged (jur) nejudecat, nesoluționat (d. un diferend); în litigiu; neatribuit (d. un premiu); nerezolvat

unadjusted (ec, adm, pol) nereglat, nesoluționat; neaplanat (d. un diferend etc.)

unadmiring of indiferent de / la, insensibil la / faţă de

unadmissible inadmisibil, inacceptabil

unadmitted neadmis

unadmonished neprevenit; neadmonestat, care nu a fost admonestat

unadvantageous (ec, $\mathrm{TH})$ neavantajos, nefavorabil unadvertised (ec) căruia nu i se face / nu i s-a făcut reclamă (d. un produs, un serviciu)

unadvisable nerecomandabil; nerațional; refractar la sfaturi; nesăbuit; imprudent

unadvisableness nesăbuință, caracter nerecomandabil / imprudent

unadvised nesfătuit, neavizat, neinformat; greşit; absurd, nerațional

unaffected (metr, autom, OM) insensibil, neafectat (d. aparate, maşini etc.); simplu, sincer direct, natural (d. persoane)

unaffected zone (met, $\mathrm{TH}$ ) zonă neafectată termic (la sudare)

unaffiliated $(\mathrm{ec}, \mathrm{adm})$ neafiliat, neînregistrat unaffirmed neafirmat, nesustinut

unaggressive lipsit de agresivitate, inofensiv, neagresiv (d. materiale, fenomene, procese, persoane)

unagreable to incompatibil $\mathrm{cu}$, care nu concordă cu

unaided lipsit de ajutor, fără ajutor

unaired neaerisit, lipsit de aer; stătut, înăbuşitor (d. aer)

unalienable (jur) inalienabil, de neînstrăinat

unaligned nealiniat; neangajat, neutru

unalloted disponibil (d. timp, fonduri etc.)

unalloyed (met) nealiat, pur

unalloyed steel (met) oțel nealiat

unalterability, unalterableness (mat, autom, inf) invariabilitate (a proprietăților unui material), caracter inalterabil / nealterabil

unalterable de neschimbat / nemodificat; neabătut; consecvent; constant; fidel

unalterably $(a d v)$ invariabil, (în mod) ferm, cu consecvență, constant

unaltered neschimbat, nemodificat; permanent

unaltering care nu se schimbă, neschimbat, neschimbător; statornic, constant, permanent

unamazed by deloc surprins / uimit de, calm, indiferent față de

unambiguity, unambiguousness (metr) precizie; (mat) lipsă de ambiguitate / echivoc, univocitate; claritate, caracter categoric / precis

unambiguous (mat) neechivoc, neambiguu, precis; fără echivoc; clar

unamenable recalcitrant, dificil; nesupus; inflexibil; (jur) iresponsabil

unamendable incorigibil, de necorectat / îndreptat, refractar la educație

unamended nemodificat; fără amendamente unamplified (fiz, autom, metr) neamplificat unanalysable neanalizabil, care nu se pretează la analiză 
unanalytical neanalitic unanimity unanimitate unanimous unanim unanimously $(a d v)$ (în mod) unamin unanimousness unanimitate, caracter unanim unannealed malleable iron (met) fontă malea-

bilă, nerevenită

unannexed neanexat

unannounced neanunțat

unanswerable fără răspuns, la care nu se poate răspunde; incontestabil, categoric

unansewrableness caracter irefutabil unanswered (rămas) fără răspuns unanticipated neanticipat, neprevăzut, neaşteptat

unapparent inaparent; neevident, vag, neclar unappealable (jur) fără drept de apel, definitiv unapplied neaplicat; nefolosit, neutilizat unapplied for nesolicitat unappreciated neapreciat unapprehended neînțeles, care nu a fost prins / fixat

unapprehensive neinteligent, lipsit de inteligență; obtuz

unapprehensive of nepăsător / indiferent față de unapprehensiveness lipsă de inteligență / de înțelegere, opacitate, obtuzitate; nepăsare unapprised of neprevenit de, ignorând unapproachable de care nu tepoți apropia, care nu este abordabil, inaccesibil, inabordabil

unapproachableness inaccesibilitate, caracter inabordabil

unapproache neatins, care nu poate fi atins, care nu a fost abordat, neabordat

unappropriated neînsuşit; nealocat, nerepartizat; nepotrivit

unappropiated fund $(\mathrm{ec})$ fond neutilizat / fără destinație specială / precisă

unapproved neaprobat (d. un proiect etc.), care nu a primit aprobarea; neautorizat

unapt inapt, incapabil; nepotrivit, impropriu unaptness nepotrivire, caracter inoportun; incapacitate; inaptitudine

unarmed (TH) neîntărit, neînarmat

unarmed cable (el) cablu fără armătură unarrested neîncetat, fără oprire, continuu unartificial neartificial, natural; simplu unascertainable neverificabil; nedeterminabil unascertained neverificat, neconstatat, neatestat; nerecunoscut

unascertained fact fapt neverificat / neconstatat unascertained goods mărfuri neverificate / neidentificate unassailability inatacabilitate, caracter inatacbil; caracter discutabil / incontestabil unassailable invulnerabil; incontestabil, indiscutabil, irefutabil

unassayed neîncercat, neaprobat, neverificat unasserted neafirmat; nesusținut

unassessed neevaluat, care nu a fost impus, neimpus (d. o conditie de proiectare etc.)

unassignable care nu poate fi determinat $\mathrm{cu}$ precizie, greu de precizat; (ec, jur) netransferabil, inalienabil

unassigned nerepartizat, nedistribuit, neatribuit unassisted neasistat, neajutat; (mas, ind, transp) autonom

unassisted discharge (el) descărcare electrică autonomă

unassociated (ec) fără asociaţi, neasociat; fără legătură cu, nelegat de

unassumed, non-assumed nearogat; neasumat; nebănuit; care nu este fals; non-fictiv; nepresupus, nepretins

unassuming modest, fără pretenții; cuminte; care nu presupune, fără să presupună

unassured nesigur, îndoielnic; (ec, TH) neasigurat

unattached $(\mathrm{OM})$ nelegat, neataşat, neprins, nefixat; neînsoțit; (mil) în disponibilitate; (pol) independent (d. un ziarist)

unattainable inaccesibil, de neatins (ca valoare, ca număr la un calculator / program)

unattained nepătat, nemurdărit, neatins; (fig) imparțial, nepărtinitor; imaculat; stand-by time (mas) timp inactiv

unattemptable care nu poate fi încercat

unattended autonom, neasistat; nesupravegheat unattended operation (mas, autom) functionare autonomă / neasistată / nesupravegheată (şi d. roboți, mapipulatoare etc.)

unattended pumping station (hidr, ind) stație de pompare automată

unattentive to neatent la

unattenuated neatenuat, nemicşorat, nediminuat unattenuating (fiz, autom) care nu se atenuează unattested nedovedit, neconfirmat; (jur) necoroborat; neatestat

unaudited (ec, TH) neverificat (de cenzori / de auditori)

unauthenticity lipsă de autenticitate, caracter neautentic

unauthorized (ec, jur) neautorizat, nepermis, fără împuternicire / autorizație, ilicit

unauthorized requisitioning (pol, mil) rechiziție abuzivă 
unavailability, unavailableness indisponibilitate (şi d. maşini, operator etc.), lipsă, absență; (ec) lipsă de lichiditate (a unui capital); inutilitate; ineficacitate

unavailable care nu este disponibil / accesibil, neaccesibilă, inaccesibilă, indisponibil, nedisponibil; inutilizabil; ocupat, de neprocurat

unavailable energy (el, mec, $\mathrm{TH})$ energie pierdută / neutilizabilă / indisponibilă

unavoidable obligatoriu; inevitabil; care nu poate fi prevenit / evitat; ineluctabil

unavoidable energy $(\mathrm{el}, \mathrm{mec}, \mathrm{TH})$ energie primară, care nu poate fi consumată decât instantaneu

unavoidableness inevitabilitate

unavoidably $(a d v)$ (în mod) inevitabil

unawakened netrezit, adormit; latent, în stare latentă

unawarded nerăsplătit, nerecompensat

unaware luat prin surprindere; uimit, surprins; neatent; în necunoştință de cauză; inconştient unawareness neştiință, ignoranță

unawares pe neaşteptate, prin surprindere; fără voie; incoştient

unbacked nesusținut; (OM, constr) nesprijinit, fără sprijin, fără reazem; (OM, T) neplacat, neacoperit

unbaked (alim, constr) necopt, crud, nefăcut

unbalance (mec, mas) dezechilibru, defect de echilibrare; (autom, mas) dezacordare, neadaptare; a (se) dezechilibra, a scoate din echilibru, a face labil / instabil

unbalanced (OM, el, mas) neechilibrat, ieşit din echilibru, lipsit de echilibru; (autom, metr) necompensat; (geom, OM) nesimetric, asimetric; instabil; nereglat; neuniform

unbalanced account (ec) cont nesoldat

unbalanced carburattor (auto, termo) carburator neechilibrat (fără țeavă de egalizare)

unbalanced detector (metr, autom, mec) detector de dezechilibru/de nesimetrie

unbalanced load (mec, OM) sarcină neechilibrată unbalanced section (el) secțiune / zonă necompensată / dezechilibrată, modul necompensat

unbalanced three-phase load (el) sarcină trifazată, neechilibrată

unbalance factor (el, mec) coeficient de dezechilibru / de asimetrie

unbalance moment (mec, OM, mas) moment / cuplu de dezechilibru

unbalance reduction ratio (URR) (mec) raport de reducere a dezechilibrului (RRD)

unbalance vector (mec) vector de dezechilibru unbale (ec, transp) a despacheta (baloturi de marfă) (şi de pe o navă)

unballast (nav) a delesta

unballasted instabil, nestabil; (cf) nebalastat; (nav) delestat, debalastat, nelestat, nebalastat unbandage a scoate bandajul (de pe o roată etc.) unbank a ațâța (focul)

unbar (OM) a descuia, a trage zăvorul, a debloca

unbarked necojit (d. lemn şi semifabricate metalice)

unbearing $(\mathrm{OM}, \mathrm{mec})$ care nu suportă / ține; (agr, zool) sterp

unbeatable imbatabil, de neînvins

unbefitting nepotrivit, care nu se cuvine

unbeknown necunoscut; obscur, neştiut

unbelted (OM, constr) fără curea / centură (de întărire) (şi la recipiente); (auto) (pasager) fără centura de siguranță legată

unbend a îndrepta, a dezdoi; a întinde, a desface; a slăbi, a (se) relaxa, a (se) înmuia

unbendable, unbending (OM) rigid, țeapăn, care nu poate fi îndoit, inflexibil, lipsit de flexibilitate

unbender (mas-un, OM, TH) maşină / dispozitiv de îndreptat

unbendingness fermitate; inflexibilitate; intransigență

unbeneficial neavantajos; neprielnic care nu este binefăcător / folositor; neprofitabil; neutil, inutil unbenefitted (ec) fără beneficiu unbenefitting (ec) care nu benefiază de unbenign neprielnic, nefavorabil; rău unbent neîndoit, dezdoit

unbia(s)sed drept, nepărtinitor, imparțial; (mat) nedeplasat, absolut corect, fără eroare sistematică, fără asimetrie (în statistica matematică); (mec) echilibrat, cu centru de greutate stabil (d. o piesă, un ansamblu etc.); absolut corect; fără prejudecăți

unbia(s)sed error (mat, autom) eroare aleatoare / nesistematică

unbia(s)sed ferrite (met) ferită nepremagnetizată / fără premagnetizare

unbia(s)sed sample (mat) selecție obiectivă

unbidden neaşteptat; spontan; neinvitat, nepoftit; nerugat

unbind a dezlega; a desface (o lipitură); a desprinde

unbitt (nav) a desface (o parâmă) de la babà unbleach (textile, ind chim) a nu înălbi

unbleached (textile, ind chim) neînălbit, nealbit 
unblended (plast, ind chim) neamestecat, fără ingrediente; pur, curat

unblended octane number (ind chim, auto) cifră octanică fără tetraetil de plumb

unblighted (agr) nears de soare, nestricat de ploaie, neatacat de rugină (d. cereale); (fig) neumbrit

unblock $(\mathrm{TH}, \mathrm{OM})$ a debloca

unblock (un account) (ec) a debloca (un cont)

unblocking (OM, el) deblocare (a unui dispozitiv, releu etc.); (inf) descompunere a unui bloc (de date) în înregistrările componente

unblocking potential (el) potențial de blocare

unblown nesuflat (de vânt)

unblown engine (termo, auto) motor fără supraalimentare

unboiled (alim, ind chim) nefiert, crud

unbolt (OM) a deşuruba, a deschide, a dezăvorî, a scoate (un bolț, un şurub)

unbonded strain gauge (metr) marcă tensometrică nelipită (ataşată mecanic de capetele piesei care se deformează)

unbound (fiz) nelegat, liber

unbounded (mat, fiz) nemărginit, nelimitat; fără limite

unbounded particle (chim, fiz) particulă liberă / nelegată

unborrowed $(\mathrm{ec})$ neîmprumutat; original

unbottomed (OM) fără fund (montat, încă); (fig) pe care nu te poți bizui

unbought (ec) aflat în stoc, nevândut, nevandabil, care nu se cumpără / nu se vinde

unbound (fiz, chim, OM) dezlegat, desfăcut, eliberat

unbounded nemărginit, nelimitat, fără limite / margini; enorm, colosal, uriaş

unboundedness (mat) caracter nemărginit / fără limite (şi în modelări)

unbox a scoate din cutie, a despacheta din lăzi, a dezambala

unbrace a dezlega, a desface

unbraced $(\mathrm{OM})$ nerigidizat (cu brățări / inele etc.), fără legături

unbraced length $(\mathrm{OM})$ lungime liberă (a consolei a barei etc.)

unbreakable $(\mathrm{OM})$ incasabil, rezistent la rupere, care nu se poate rupe

unbreakable glass (ind chim) sticlă incasabilă

unbreathable (mediu, med, ind) nerespirabil, irespirabil (d. aer)

unbribable incoruptibil, cinstit, care nu poate fi corupt / mituit unbridge (constr) a arunca un pod în aer, a dărâma un pod (în mod voit); (fig) a distruge / rupe / desface o legătură

unbroken întreg; nespart, neatins, intact; neîntrerupt, neîncetat, continuu (d. un proces, un fenomen etc.); refractar; sălbatic

unbrokeness continuitate, caracter neîntrerupt; permanență

unbroken line linie continuă / neîntreruptă (şi în desen tehnic)

unbroken sequence (c, inf) secvenţă (de instructiuni) neîntreruptă

unbuild (constr) a dărâma

unbuilt (constr) neconstruit, neridicat, neclădit

unburden a descărca

unburdening descărcare, care (se) descarcă

unburnable care nu arde, ignifug (d. materiale)

unburned fuel (termo) combustibil nears

unburned lime (ind chim) var nears

unburnt brick (constr) cărămidă crudă / nearsă

unburnt product (constr, ceramice) produs crud / nears

unbushed bearing (OM) lagăr fără cuzinet / monobloc

unbusinesslike (ec) necomercial, contrar regulilor comertului, care nu are simtul afacerilor, nepriceput în afaceri; nepractic; incorect, necinstit (d. un procedeu)

unbushed bearing $(\mathrm{OM})$ lagăr fără cuzinet

unburnt gas (met) gaz de afinare

uncage a elibera, a nu constrânge; $(\mathrm{OM})$ a nu avea colivie (d. un rulment, un rotor etc.)

uncaged liber; $(\mathrm{OM})$ (rulment) fără colivie

uncalculated necalculat, neintentionat, fără voie; improvizat

uncalibrated (metr) necalibrat, neetalonat (d. un aparat de măsură

uncalled for nedorit, indezirabil; supărător; nepotrivit, inoportun

uncap $(\mathrm{OM})$ a demonta un capac, a deschide, a descoperi (ceva)

uncapsizable $(\mathrm{OM}$, constr) care nu poate fi răsturnat, care nu se poate răsturna

uncaring nepăsător; neglijent

uncase (OM) a desface / scoate din cutie / din carcasă

uncased (OM) fără cutie / carcasă, neînchis, descoperit

uncatalogued necatalogat, care nu apare în catalog (d. un produs etc.); neclasificat

uncatalysed reaction (chim) reactie necatilizată / fără catalizatori

uncate $(\mathrm{OM})$ în formă de cârlig, încârligat 
unceasing neîncetat, continuu; asiduu, susținut, neîntrerupt

uncemented (constr) necimentat; (met) necementat

uncentral periferic, necentral, situat departe de centru

uncentring (OM, mas) descentrare (cu referire şi la corpuri / piese în rotație)

uncertain nesigur; îndoielnic; dubios; ezitant; schimbător, inconstat

uncertain market (ec) piață nesigură

uncertainty incertitudine; nesiguranță; (mat) nedeterminare; dubiu, îndoială; neîncredere; nestatornicie, inconsecventă

uncertainty principle (fiz) principiul relativitătii

uncertificated (edu) fără certificat / diplomă, netitrat

uncertified necertificat; neatestat, neomologat (d. un proces tehnologic, un produs, o metodă de testare etc.)

unchallengeable indiscutabil, categoric, care nu poate fi contestat, (de) necontestat

unchallanged incontestabil; indiscutabil, irefutabil, de necombătut; necontestat, mai presus de îndoială

unchamfered (OM) neşanfrenat, fără teşitură, fără teşire

unchamfered butt joint (OM) îmbinare / asamblare cap-la-cap, fără teşirea marginilor (de sudură, lipitură etc.)

unchangeable, unchanging neschimbător, constant; imuabil; inalterabil

unchangeableness caracter constant; constanță, stabilitate; imuabilitate, caracter imuabil / inalterabil

unchangeably $(a d v)$ (în mod) constant, invariant

unchanged neschimbat; nemodificat; intact

unchanging constant, invariabil, care nu se modifică, care nu se schimbă

uncharacteristic necaracteristic, atipic; neobişnuit

uncharged (el, mec) neîncărcat, descărcat; (jur) care nu este pus sub acuzare

uncharged for (ec, adm) franco, gratuit, netaxat pentru

uncheated neînşelat, neindus în eroare; care știe ce face conştient

unchecked fără oprire, fără contenire; fără încetare; necontenit; nestăvilit; (mas) neverificat, necontrolat; (ec) nebifat (pe o listă)

uncia (metr) denumire pentru fracția a 1/12 (în limba latină) uncircumspect imprudent, lipsit de precauție / prudență; necircumspect; care riscă

uncircumstantial lipsit de amănunte; vag, imprecis, neprecizat

unclaimed (jur) nerevendicat, nereclamat, necerut

unclaimed goods (ec) mărfuri neridicate (din antrepozite)

unclaimed rivet $(\mathrm{OM})$ nit brut / fără cap

unclamp (OM) a slăbi o strângere (cu clemă), a desface o asamblare (cu clemă, brățară etc.)

unclarified neclarificat, nelimpezit (d. un fluid, o idee etc.)

unclasp (OM) a descuia, a deschide

unclassable, unclassible neclasificabil, de neclasificat, care nu se poate clasifica, care nu se poate integra într-o categorie / clasă

unclassifiable imposibil de clasificat, care nu se pretează a fi clasificat

unclean, uncleaned murdar; neîngrijit; impur

uncleanable care nu se poate curăta

uncleanliness murdărie, lipsă de curățenie

uncleanness murdărie, neîngrijire, lipsă de curățenie, lipsă de puritate

unclear (fiz, TV) neclar, lipsit de claritate; impur; murdar; obscur; (fig) de nepătruns, neclar uncleared (ec) nevămuit, care nu a trecut prin vamă, neachitat, nelichidat, neplătit; (OM) necurățat, nedesfundat (d. țevi), lipsit de claritate, nelimpezit (d. lichide); (agr) nedefrişat, nedesțelenit

unclimbable inaccesibil, care nu poate fi urcat / escaladat (d. un munte, dar şi fig)

unclipped, unclipt netuns, netăiat, nescurtat (d. fire, păr, iarbă); neperforat (d. un bilet, un semifabricat etc.)

unclog (OM, hidr, mediu) a destupa, a degaja

unclose (OM) a (se) desface, a (se) deschide; (fig) a dezvălui

unclosed $(\mathrm{OM})$ neînchis, deschis, care nu se închide; descoperit; expus

unclosed magnet (fiz) magnet deschis

unclothe (TH) a dezbrăca, a scoate o acoperire / o manta (la cuptoare, la lagăre etc.)

unclothed (termo, met) neîmbrăcat, fără acoperire, fără manta (la cuptoare, cazane etc.)

unclotted (alim) necoagulat, neînchegat

uncoagulated (alim) necoagulat, neînchegat

uncoated $(\mathrm{OM}, \mathrm{T})$ neacoperit, fără acoperire

uncoated welding rod (OM, TH) electrod / vergea de sudat / pentru sudare, neacoperit(ă)

uncogent neconvingător; lipsit de logică

uncoil (el, met) a derula, a desfăşura, a depăna (o bobină, un rulou, un colac de sârmă etc.) 
uncoiled desfăcut, desfăşurat, întins (d. o spiră, un rulou de bandă etc.)

uncoiler, uncoiling device (met, plast, OM) desfăşurător, derulător

uncoined nebătut în monede (d. aliaje); (fig) original

uncoiling (el, me, TH) desfăşurare, debobinare, derulare

uncollated necolaționat; neconfruntat; neverificat

uncollected neadunat, nestrâns; în dezordine; impulsiv

uncollectibility (ec, TH) imposibilitate de a încasa / de a colecta

uncollective (ec, adm) de neîncasat, care nu poate fi încasat

uncoloured lipsit de culoare, cu culori pale / şterse; palid; necolorat

uncombinable (chim) care nu se poate combina, dificil de combinat

uncombined (chim, met) necombinat; pur, în stare pură

uncombined carbon (chim, met) carbon necombinat / liber / nelegat

uncomfortable incomod(at), lipsit de confort, neconfortabil

uncomfortableness lipsă de confort / comoditate, caracter incomod

uncomfortably $(a d v)$ neconfortabil, inconfortabil, incomod; dezagreabil, neplăcut

uncommercial (ec) necormercial, cu comert slab

uncommissioned (ec) neangajat, fără serviciu; voluntar; nesolicitat, necomandat

uncommissioned to nesolicitat / neangajat/ nedelegat să / pentru

uncommon neobişnuit, extraordinar; deosebit; rar; neuzual ( $\mathrm{d}$ un proces tehnologic etc.); it is no $\sim$ thing that nu e ceva neobişnuit $\mathrm{ca}$, nu e un lucru neobişnuit ca

uncommonness caracter ieșit din comun, lucru neobişnuit

uncommonly $(a d v)$ extraordinar, grozav; nemaipomenit, neobişnuit, straşnic

uncommunicated necomunicat, neanunțat, (ținut) secret

uncommunicative necomunicativ, rezervat, tăcut, taciturn

uncommunicativeness lipsit de comunicativitate, caracter necomunicativ

uncompelled nesilit, necontrâns

uncompensated (el, mec, autom) necompensat, decompensat; (ec) nedespăgubit, necompensat (pt. o pagubă, un prejudiciu etc.) uncompleted nedus până la capăt; lăsat neterminat; imperfect

uncompliant inflexibil; inadaptabil; dificil uncomplicated simplu, fără complicații; clar

uncomplying (ec, adm) nesupus, insubordonat, care nu se subordonează; care nu se adaptează cerințelor

uncompounded necompus, simplu, necompoundat (d. materiale); fără complicații; neaditivat, nemodificat

uncompound oil ( $\mathrm{T}$, ind chim) ulei mineral neaditivat / nemodificat

uncomprehended neînțeles

uncomprehending neînțelegător, lipsit de înțelegere; necuprinzător, neîncăpător; care nu (se) înțelege, incapabil să înțeleagă

uncomprehensible (de) neînțeles, obscur

uncomprehensive incomplet; neînțeles

unconceived neconceput; negândit

unconcern nepăsare, indiferență, lipsă de interes unconcerned nepăsător, indiferent; lipsit de grijă

unconciliating, unconciliatory neconciliant, care nu este conciliant; sever

unconclusive neconcludent

unconditional (mat, inf) necondiționat, fără condiții, absolut

unconditional inequality (mat) inegalitate valabilă pentru orice valori ale variabilelor unconditional jump / transfer instruction (inf) instrucțiune de salt / de transfer necondiționat unconditionally $(a d v)$ (mat) necondiționat, fără rezerve / condiții

unconditional transfer transfer neconditionat

unconditioned necondiționat, total, absolut, fără conditii / rezerve

unconfined nelimitat spațial, liber

unconfirmed neconfirmat

unconformability, unconformableness neconformitate; (T) neconformabilitate (a unui contact, a cuzinetului cu arborele lagărului etc.); (geol) stratificare discordantă (în geologie)

unconformability of dip (el, autom, fiz, TH) neconformabilitate / discordanță unghiulară

unconformability of lap (autom, telecomunicaţii, inf) discodanță de suprapunere / transgresivă (a unui tren de semnale etc.)

unconformable independent; refractar; $(\mathrm{T})$ necormabil (d. un contact)

unconformable to care nu este în conformitate $\mathrm{cu}$, incompatibil cu

unconformably to $(a d v)$ (în mod) neconform cu; altfel, dimpotrivă, cu totul altfel; fără paralelism; nonconformist 
unconformity to necomformitate cu, nepotrivire cu / la, lipsă de conformitate cu / la; poziție discordantă, discordanță, dezacord cu; (materiale) discontinuitate (la compozite stratificate etc.)

uncongealable (alim, ind chim) care nu îngheață / nu poate fi înghețat, necongelabil

uncongealed (alim, ind chim) necongelat, neînghețat, necoagulat

uncongenial neprietenos; dezagreabil

uncongenial to nefavorabil pentru, ostil față de; impropice pentru

unconnected with / to neconectat cu / la, fără legătură cu, nelegat de; irelevant pentru, lipsit de importanță pentru

unconscientious lipsit de conştiinciozitate, neconştiincios

unconscientiousness lipsă de conştiinciozitate, superficialitate

unconscionable lipsit de scrupule, neprincipial; excesiv, exorbitant; scandalos, uluitor, de necrezut; incredibil

unconscionableness lipsă de scrupule / principii; caracter excesiv / exorbitant; caracter scandalos / uluitor / de necrezut

unconscious of inconştient de, care nu-şi dă seama de; involuntar, (făcut) neintenționat / din greşeală; subconştient

unconsenting to care nu consimte la, refractar la unconsidered nechibzuit, lipsit de înțelepciune unconstrained neconstrâns, neîngrădit, nelimitat unconstraint $(\mathrm{OM}$, mas, $\mathrm{TH})$ lipsă de constrâneri (la mecanisme, în funcționare, în exploatare etc.); libertate, lipsă de constrângeri, spontaneitate

unconsumed neconsumat, nefolosit (şi în întregime); neterminat, neepuizat

uncontaminated (mediu) nepoluat, necontaminat

uncontemplated neaşteptat, neprevăzut; neplanificat, neintenţionat

uncontested necontestat

uncontinuous discontinuu, lipsit de continuitate; întrerupt (din loc în loc)

uncontradictable incontestabil, irefutabil

uncontradicted ferit de contrazicere, necombătut

uncontrasty picture (c, TV) imagine fără contrast uncontrability (mas, autom) imposibilitate de a controla (d. o maşină, un proces etc.)

uncontrollable necontrolabil, nereglabil

uncontrollable expenses (ec) cheltuieli care nu pot fi influențate / modificate uncontrollableness (autom, mas) necontrolabilitate, incontrolabilitate, imposibilitate de a controla / de a regla (d. maşini, aparate, procese)

uncontrolled (mas, autom) necontrolat, neverificat; (fiz, geol) nestăpânit

uncontrolled blow-out (mas, ind, geol) erupție / explozie necontrolată

uncontroversial care nu ridică controverse, indiscutabil, clar

uncontroverted necontestat; necontroversat

uncontrovertible necontestabil, indiscutabil, irefutabil; neîndoios, neîndoielnic

unconventional neconvențional; neuzua; neobişnuit; original; neformalist

unconventionality neconformism, lipsă de convenționalism; originalitate, nonconformism

unconverted neconvertit; netransformat (dintr-o unitate de măsură în alta etc.)

unconvertible into $(\mathrm{ec})$ neconvertibil în, de nepreschimbat în

unconvinced neconvins, plin de îndoială

unconvincing neconvingător, care nu convinge

uncookable (alim) de negătit, care nu poate fi gătit, nefăcut, crud, necopt

uncooked (alim) nefript, negătit, nefiert, necopt, crud

uncooperative (ec, edu, adm) care nu vrea să ajute / să coopereze / să colaboreze; refractar, dificil, ostil

uncoordinated necoordonat, lipsit de coordonare

uncord (OM, transp) a dezlega, a desface din legături

uncork (alim, met) a destupa (un dop), a scoate (un dop)

uncorked (alim, met, hidr) destupat, fără dop

uncorrected necorectat, necorijat, neîndreptat

uncostly $(a d j, a d v)$ fără valoare, ieftin

uncountability (mat) nenumărabilitate (în teoria mulțimilor)

uncountable (mat) nenumărabil, care nu poate fi numărat

uncounted (mat) nenumărabil, fără număr; enorm, imens, incomensurabil

uncouple (autom, OM) a debreia, a decupla, a scoate un şurub, a deconecta, a desface; a despacheta

uncoupled $(\mathrm{OM})$ decuplat, detaşat, desfăcut; (auto) debreiat

uncoupling $(\mathrm{OM})$ debreiere, decuplare, deşurubare, deconectare, care (se) decuplează / (se) deconectează

uncoupling device (OM) dispozitiv / modul / subansamblu de decuplare / de debreiere / de deconectare / de detaşare 
unconvenanted (pol, ec) neconvenit, nestipulat în contract

uncover $(\mathrm{OM})$ a dezveli, a scoate un capac; (TH) a (se) descoperi, a nu acoperi; (geol, ind) a decoperta (un zăcământ etc.); a dezvălui, a da în vileag; a ridica de pe (d. un voal, o husă etc.); a-şi scoate (pălăria etc.)

uncovered (OM) descoperit, dezvelit, neacoperit; (geol) decopertat; dezvăluit, dat în vileag

uncovered cable (OM, el) cablu neizolat / blanc uncoverd sales (ec) vânzări de mărfuri nedisponibile

uncreasable (textile) neşifonabil, care nu se mototolește, care nu se șifonează

uncreate a distruge; a nimici; a stârpi

uncreated (de) necreat, (de) neînfăptuit

uncredit neconfirmat, neacreditat

uncritical indulgent, care nu aduce critici; (fiz, mec) necritic

uncropped (agr) netuns, necules

uncross a desface; a despărți, a descrucișa

uncrossed necontrariat; neşters, neradiat, nebifat; neîncrucişat (d. picioare, fire etc.), nebarat; neradiat, neşters; nestrăbătut (d. un ţinut etc.)

uncrushable (textile) care nu se mototoleşte, neşifonabil

unction (hidr, T) onctuozitate, ungere (cu unsoare), unsoare, unguent; apetit, poftă; (fig) glas mieros; (med) unguent

unctuosity, unctuousness $(\mathrm{T})$ onctuozitate, caracter onctuos / maleabil / plastic, lipicios (d. lubrifianți)

unctuos gras, grăsos; (T) onctuos, uns, unsuros, uleios; slinos, grețos

uncured (ind chim, plast) nevulcanizat (d. cauciuc), neîntărit, nematurat, netratat; neîngrijit

uncurl (OM, TH) a desface (bucle, spire), a descâlci, a se desfăşura, a se descolăci

uncurrent (ec) (bani) scoşi din circulație, care nu circulă, care nu au curs

uncushioned (OM, mas) neprevăzut cu sistem de atenuare, neatenuat, fără pernă de amortizare; necapitonat

uncushioned motion (mec, OM) mişcare neatenuată

uncustomary neobişnuit, care nu se întâlneşte frecvent

uncustomed (ec) nevămuit, netrecut prin vamă, de contrabandă (d. mărfuri)

uncut $(\mathrm{OM})$ netăiat, neşlefuit, brut (şi d. pietre prețioase), neprelucrat prin aşchiere, netrunchiat, nedebitat (d. un semifabricat); întreg

undamaged $(\mathrm{OM}$, mas) intact, nedeteriorat, nevătămat, în perfectă stare, fără avarii undamped $(\mathrm{TH})$ neamortizat, susţinut, întreținut (d. oscilații, vibrații etc.); (fiz) continuu (d. radiații etc.), întreținut

undamped oscillation (mec, fiz) oscilație neamortizată / întreținută

undamped wave (fiz) undă cu amplitudine constantă / întreținută / neatenuată

undated nedatat, fără dată; ondulat, vălurit

undebased nestricat, nealterat; curat, neamestecat

undebugged programme $(c$, inf) program netestat / nepus la punct / nedevirusat

undecagon (geom) endecagon, poligon $\mathrm{cu} 11$ laturi

undecayed intact, nedegradat, în bună stare; neputrezit (d. lemn); (alim) sănătos (d. fructe etc.); (fiz) neamortizat, cu vibrații ( $r a r$ )

undecaying durabil; care nu decade; (fiz, autom) care nu descreşte, care nu scade (d. oscilații etc.)

undecided nehotărât, indecis, şovăitor

undeciphrable nedescifrabil, greu de descifrat

undeciphred nedescifrat

undecisive nedecisiv, nehotărâtor

undeclared (adm, ec) nedeclarat; ascuns

undecomposable (fiz, chim) care nu poate fi descompus

undecomposed (OM) nedescompus (în părți componente)

undecorticated rice (alim) orez nedecorticat

undefaced nedesfigurat, intact

undefended (mil, ind) lipsit de protecție / apărare, neapărat, neprotejat; nepăzit

undefinable greu de definit, (de) nedefinit, indefinisabil, inefabil, nedefinibil

undefined (mat) nedefinit, nedeterminat

undelayed promp, instantaneu, neîntârziat, imediat, rapid, fără întârziere; neamânat

undelivered (ec, adm) nelivrat, nepredat, nefurnizat; nepredat (expeditorului) (d. un colet, o scrisoare etc.)

undemanding lipsit de exigență / pretenții, nepretențios; modest, simplu; care nu solicită / cere prea mult

undemolishable (constr) indestructibil, nedemolabil

undemonstrable (mat) nedemostrabil, de nedemostrat, care nu poate fi demonstrat

undemonstrated (mat) nedemonstrat

undemonstrative neexpansiv, simplu; temperat, care nu face mult caz, la locul lui, (antonim pentru zgomotos) 
undeniable (de) netăgăduit, incontestabil, irefutabil; care nu poate fi negat

undependable inconstant; care nu prezintă încredere / siguranță; (TH) nefiabil, nesigur; v. unreliable

under (prep) sub, în, dedesubt; $(a d v)$ sub; a învinge; a se băga sub (ceva); inferior, (din partea) de jos; subordonat, în subordine; (de) pe lângă; age minor; arms (mil) sub arme, înrolat (în armată); march (mil) în marş; the sun în lume; $\sim$ rose în secret; $\sim$ deliberation (jur) în deliberare; the leadership of $\sim$ (pol) sub conducerea (unui lider, unui partdi etc.); be vow (jur) a fi sub jurământ; repair (mas) în reparație; discussion (problema etc.) în discuție

underbead crack (met) fisură în zona afectată termic a sudurii, dar care nu se extinde în materialul de bază

underbid, underquote (ec) a oferi un preț mai mic decât alt ofertant / prețul pieții, a oferi condiții mai bune / mai avantajoase, a sublicita, ofertă foarte avantajoasă / la preț redus

underbidder (ec) ofertant care oferă sub prețul pieței / concurentei

under bond (ec) în garanție (şi d. mărfuri păsrate în antrepozit, până la plata taxelor vamale)

under-bonnet light (auto, el) lumina de sub capota motorului

undercapacity (mas, el) putere / capacitate insuficientă, subcapacitate

undercarriage (auto, OM) şasiu, dispozitiv / aparat de rulare

undercharge ( $\mathrm{TH}$, transp) a încărca mai puțin / incomplet / insuficient / sub valoarea prescrisă (un vagon, un recipient etc.); încărcătură incompletă; în minus; (ec) a plăti sub tarif, a socoti mai puțin, plată / socoteală în minus / economicoasă, a plăti sub tarif

undercharge goods or services (ec) a cere un preț mai mic decât cel curent, pentru mărfuri sau servicii

underclad $(\mathrm{OM})$ acoperit / îmbrăcat / căptuşit prea subțire / sub valoarea impusă / normată, neîncărcat la valoarea stabilită

undercoat (met, plast) strat intermediar între acoperire şi substrat; (auto, ind chim) strat protector de vopsea, a acoperi (şi caroseria) cu strat protector de vopsea

undercool (met) a subrăci, a suprarăci

undercooling (met, termo, TH) subrăcire, suprarăcire, răcire insuficientă undercooling capacity (met) capacitate de subrăcire

undercritical (fiz, met) subcritic

undercure (ind chim plast) subvulcanizare, întărire insuficientă, maturare insuficientă; (constr) tratare insuficientă a betonului armat

undercurrent (el) curent minim

undercurrent relay (el) releu de curent minimal undercurrent release (autom, el) declanşare / eliberare / deblocare la curent minim

undercut (mas-un) unghi de degajare (la scule aşchietoare), degajare interioară (pt. filete); (met) spațiu neumplut la baza rostului (la o sudură) crestătură marginală, conicitate inversă; $(\mathrm{OM})$ subtăiere (şi la danturare, la prelucrare), degajare interioară, tăietură la bază; (ec) a oferi / vinde mai ieftin / la prețuri mai mici decât concurența, a da sub preț, a sublicita, a se angaja cu salariu / tarif mai mic decât cel obişnuit; (alim) muşchi filé; (mas-un) a tăia pe dedesubt

undercut for wrenching bolts and nuts $(\mathrm{OM})$ degajare pentru manevră de cheie (la asamblări cu șurub și piuliță)

undercut sides (mas-un, OM) degajări laterale (la discuri de rectificat, la piese etc.)

undercutting $(\mathrm{OM}, \mathrm{TH})$ subtăiere (şi la danturare)

undercutting of involute $(\mathrm{OM})$ subtăiere a evolventei (dintelui unei roți dințate etc.)

undercutting tool (mas-un) cuțit de strunjit plan / de teşit

underdamping (mec, autom) amortizare slabă, subatenuare

underdeveloped slab dezvoltat, subdezvoltat, nedezvoltat

under(-)development subdezvoltare

underdo a face pe jumătate, a nu termina (ceva început), a nu încheia, a lăsa pe jumătate nefăcut; (alim) a frige / prăji puțin / doar pe jumătate (d. carne), a lăsa (friptura etc.) în sânge underdone (alim) nefăcut, crud, nefiert, nefript underdose (alim, ind chim) doză insuficientă, a doza incomplet / insuficient

underdriven (mas) antrenat de un motor la nivelul solului

underestimate (ec, adm, TH) subevaluare, subapreciere, subestimare; a subevalua; a subaprecia; a subestima

underestimation subevaluare, subapreciere, subestimare

under-excitation (el) subexcitație

underexpose (fiz) a subexpune

underexposure (fiz) subexpunere 
underface the mould (met) a pudra forma de turnare

underfeed $(\mathrm{TH})$ alimentare (pe) la partea inferioară; (mas-un) avansare prea lentă (la un semifabricat)

underfeed furnace (termo) focar cu alimentare la partea inferioară / cu împingere pe dedesubt underfeeding (alim) subnutriție; (TH) subalimentare

underfed (med) subnutrit, prost hrănit; (mas-un) cu avans prea mic

underfill (met) sudură la care materialul de adaos va fi sub suprafața pieselor sudate, neumplere (a profilului sau a calibrului), umplere insuficientă

underfilling (met, TH) lipsă / insuficiență de material

underfinished $(\mathrm{OM})$ insuficient prelucrat / finisat

underfired (ind chim) insuficient arsă (d. ceramice, sticlă)

underfloor (constr) (aşezat) sub duşumea / pardoseală

underfloor motor (mas) motor sub nivelul halei underfoot sub picioare; pe jos, pe pământ

underflow (autom, hidr) debit insuficient; (inf) depăşire negativă; (met) pulpă (de metale neferoase)

underframe $(\mathrm{OM})$ schelet, cadru, şasiu (de maşină, vagon etc.)

under-freight (nav) a subnavlosi (un vas)

undergauge $(\mathrm{OM})$ subdimensional, în afara intervalului de calibrare / de toleranță

undergirder $(\mathrm{OM}$, constr) subgrindă

undergo a trece prin, a suferi (transformări)

undergrate blast (termo) insuflare de aer sub grătar

undergrate burning (termo) ardere cu insuflare de aer sub grătar

underground (constr, transp) metrou; îngropat, (în) subteran, sub pământ, din / sub pământ, de sub pământ; (cf, transp, el) tren electric subteran; (fig) subpământean; (pol) tainic, clandestin, ilegal, în ilegalitate; (fig) în secret, în taină, pe ascuns

underground cable (el) cablu îngropat / subteran

underground collector (el, OM) sabot / colector subteran de curenți telurici

underground corrosion (chim, mediu) coroziune în sol

underground distribution chamber (el, met, constr) subsol de cabluri (electrice) underground floor (constr) demisol

underground fuel storage-tank (OM, constr) rezervor subteran de combustibil

underground hydrant (OM, constr) hidrant subteran

underground link box (el, met) cutie de distribuție subterană

underground pipe (OM, constr) conductă subterană

underground press (pol) tipografie / presă clandestină; (OM, mas-un) presa experimentală

underground structures (met, constr) structuri subterane, tuneluri, pasaje

underground utilities (ind, adm, constr) utilități / rețele subterane (electrice, telefonice, de apă, de canalizare, de gaze)

underground water (geol, hidr) apă subterană / de adâncime, pânză (de apă) freatică

underground water packing $(\mathrm{OM}$, constr) etanşare contra apei freatice

underground work (constr) constructie subterană

underground working (geol, ind) exploatare subterană

underhair (zool) puf

underhand weld $(\mathrm{OM})$ cusătură de jos / depusă în poziție de jos (în sus)

under hot running conditions (auto, met) în condiții de temperatură înaltă, de regim

under(-)inflated (auto, OM) insuficient umflat, umflat puțin (d. pneuri)

under(-) inflated tyre (auto, OM) pneu insuficient umflat

under-inflation (auto) umflare insuficientă / slabă (d. pneuri)

undeinvoiced $(\mathrm{ec}$ ) facturat la un preț inferior valorii mărfii

underinvoicing (ec) facturare la un preț inferior valorii mărfii

under-jaw (mas-un, OM) falcă de jos / inferioară a mandrinei

underlap (ind, TH) înfăşurare / suprapunere pe dedesubt (şi a unei benzi, ca defect)

underlay $(\mathrm{OM}, \mathrm{fiz})$ strat de bază, substrat; a sustine cu ceva montat dedesubt, a introduce sub, a pune dedesubt

underlayer $(\mathrm{OM}, \mathrm{T})$ strat inferior, substrat

underlease (ec) subînchiriere, subarendare; a subînchiria, a subarenda

underlessee (ec) subchirias, subarendas

underlessor (ec) chiriaş care subînchiriază, arendaş care subarendează

underlet (ec) a închiria, a arenda sub valoarea reală; a subînchiria, a subarenda 
underletter (nav, ec) subnavlositor (de vas)

underlie a sta / fi la baza, a se afla dedesubtul, a fundamenta; a susține (un proiect, o propunere), a întemeia

underline, underscore a sublinia (o idee sau un text), a întări, a reliefa, a scoate în relief, a releva

underline cursor (c, metr) cursor care se deplasează sub o scară / sub un interval (acceptat)

underload (mec, OM, mas) sarcină / încărcare parțială / incompletă; a încărca / solicita insuficient / sub valoarea stabilită, a subîncărca, a subsolicita

underloading (OM, mec, mas) sarcină / solicitare insuficientă / sub o anumită valoare

underlying de bază; fundamental, de dedesubt, inferior, de la baza

underlying company $(\mathrm{ec})$ sucursală, filială

underman (nav) a echipa cu prea puțini oameni undermentioned citat / mentionat mai jos / ulterior

undermine (ec, pol, mil) a submina, a slăbi

undermining pitting (met) formare a porilor superficiali, coroziune punctiformă sub suprafață / superficială (defect)

undermost cel mai de jos, cel mai mic

undernourished (alim, med) malnutrit, subnutrit

undernourished (alim, med) malnutriție, subnutriție, hrană proastă

underpaid (ec) plătit insuficient / prost / sub tarif underpan (auto, OM) podea a caroseriei

underpass (constr) pasaj inferior / subteran; trecere denivelată, intersectie

underpart (OM, mas) parte inferioară / de jos

underpath (constr) pasaj subteran / inferior / denivelat

underpay (ec) a plăti insuficient / sub tarif / prost

underpin (constr) a subzidi, a sprijini, a propti, a rezema, a pune temelia la

underpinning (constr) subzidire (a pereților), sprijinire; (hidr) prindere, luare, captare, care captează

underpower relay (autom, el) releu de sarcină nulă / minimal de curent

underpressure (fiz, hidr) subpresiune, vid (nu prea avansat), presiune scăzută / sub cea atmosferică

underpressure flow (hidr) curgere la subpresiune underprice (ec) preț derizoriu / scăzut

underproduce (ind, $\mathrm{TH}$ ) a produce în cantitate insuficientă, a fi în deficit cu producția, a nu produce la capacitatea necesară underproduction subproducție

underproof spirit (alim) alcool subgradat

underquenching (met) subrăcire, subcălire, călire slabă (fără obținerea parametrilor preconizați)

underquote (ec) a subevalua, a subestima, a subpreți, a impune (la) mai puțin (un imobil etc.), a oferi condiții mai avantajoase / bune (decât concurența); a oferi la un preț mai mic decât alt ofertant

underrate (ec) a subevalua; a subestima; a subprețui; a impune mai puțin (pt. un preț etc.)

underream (mas-un) a lărgi

undereamer (mas-un) lărgitor

undereamer dogs (mas-un, OM) bacuri ale lărgitorului

under repair mas) în reparație / revizie

underippe (agr) crud, necopt, imatur

underrun (inf) terminare a unui program înainte de timpul prevăzut; (ec) livrare la o calitate inferioară celei stabilite; (mas) functionare sub parametrii prevăzuți, a funcționa sub parametrii prevăzuti

underrunning voltage (el) tensiune secundară (la un transformator), tensiune joasă / minimă underscoring subliniere, accentuare

undersea (nav) ( $a d j$ ) submarin, sub / în mare

underwater pressure gauge (metr) aparate de măsurat presiunea apei de mare (la adâncimea de coborâre)

undersell (ec) a vinde la un pret mai mic (decât alții) / sub preț, a vinde la un preț mai mic decât valoarea mărfii

underseller (ec) (vânzător) care vinde sub preț underset (TH, constr) a susține, a sprijini, a propti (o zidărie, o schelărie); (nav, geogr) (curent) submarin / contrar celui de la suprafață, contrar sensului vântului

underside $(\mathrm{OM})$ partea opusă a cusăturii / electrodului, parte / față inferioară / de dedesubt undersign a subsemna, a subscrie la

undersigned subsemnat, care semnează mai jos undersintered $(\mathrm{OM})$ subsenterizat

undersize $(\mathrm{OM})$ cotă (de reparație, finală etc.) inferioară celei normale, dimensiune mai mică decât / sub cea nominală, limită inferioară a dimensiunii; (ind chim) material care trece prin sită

undersized mic; necrescut, nedezvoltat, sub dimensiune / valoare

undersize part $(\mathrm{OM})$ piesă de schimb cu dimensiuni de reparatie (posibil diferite de cele inițiale) underslung $(\mathrm{OM})$ suspendat 
underslung spring (auto, OM) arc montat sub osie

underslung worm $(\mathrm{OM})$ melc montat sub roata melcată

undersoil subsol

under( )speed (auto, OM) viteză redusă (sub o anumită valoare, dorită / recomandată etc.)

understeering (auto) subvirare (derivă mai mare de virare la roțile din față, comparativ cu cele din spate)

understaffed $(\mathrm{ec}) \mathrm{cu}$ personal insuficient, care duce lipsă de personal

understand a înțelege; a deduce; a subînțelege; a afla

understandable de înțeles, logic, inteligibil, uşor de înțeles

understanding înțelegere; acord; (adj) înțelegător, care înțelege / pricepe; perspicare, inteligent, deştept, înțelept, logic

understate a spune numai pe jumătate (ceva); a micşora, a diminua, a reduce (din importanță)

understatement adevăr spus doar pe jumătate, afirmație modestă / moderată

understeer (auto) a fi greu manevrabil la întoarceri, a lua prost curbele, tendinţa de a lua prost curbele, nemanevrabilitate, lipsă de manevrabilitate

understock (mas, auto) a alimenta (şi cu combustibil) pe la partea inferioară; (ec) a furniza în stocuri prea mici

unserstratum (geol, OM) strat inferior, substrat understressed $(\mathrm{OM})$ solicitat sub limita admisibilă

understressing $(\mathrm{OM}, \mathrm{mec})$ solicitare repetată sub limita de oboseală pentru a îmbunătăți comportarea la oboseală

undersurface sub suprafață (a apei, a unei piese etc.)

undertake (ec) a întreprinde, a iniția, a face; a lua; a prelua; (metr, TH) a încerca, a experimenta, a proba; a presupune, a afirma, a lua drept bună

undertaker antreprenor, întreprinzător

undertaking (ec) întreprindere (comercială, industrială etc.), acțiune, inițiativă, antrepriză (de construcții); angajament, promisiune, obligație luată, sarcină

undertenancy (ec) subînchiriere, calitate de subchiriaş, contract de subînchiriere

undertenant $(\mathrm{ec})$ subchiriaş, subarendaş

under the application of force (T) când se aplică o forță

undertint nuanț̆ slabă, culoare ștearsă / estompată undertow (nav, geogr) curent de fund / submarin, resac, contracurent

undertype (el) generator dinam, de tip inferior

undervaluation subevaluare, subapreciere; depreciere

undervalue subapreciere, subestimare, subevaluare; a deprecia, a aprecia la o valoare inferioară, a subaprecia, a subestima, a subevalua

undervoltage protection (el, autom) protecție de / la tensiune minimă

undervoltage tripping (el, autom) declanşare la tensiune nulă

undervulcanization (ind chim) subvulcanizare, vulcanizare incompletă (defect tehnologic)

underwater sub apă; submarin

underway $(a d v)$ în curs, în / dinmers, inițial, început, în (plină) desfăşurare

underway project proiect în curs / în derulare / în executare

underweight (OM) greutate / masă redusă / sub cea permisă / recomandată / prescrisă / normală

underwork a nu prea lucra, a lucra insuficient, a lucra de mântuială, a lucra ieftin, a face / executa la repezeală; muncă necalificată / inferioară

underwrite a semna, a scrie dedesubt / sub; a subscrie; (ec) a garanta, a gira, a scoate o poliță de asigurare, a sprijini (financiar); a asigura (şi împotriva riscurilor maritime); a întreține

underwriter (ec) asigurator, agent de asigurare, girant, garant; prețuitor; emitent (al unui titlu) underwriting (nav, ec) asigurare maritimă; (ec) subscriere (a unei polițe de asigurare), garantare (împotriva unui risc), garanție de emisiune, subscripție forfetară

undesirable nedorit, indezirabil; intrus

undesirable element (chim, met) element nedorit, impuritate nedorită

undesirableness inoportunitate

undesired nedorit; inoportun

undesirous lipsit de entuziasm; pasiv, apatic, indiferent; refractar; care se opune

undestroyed intact, nedistrus

undetachable nedetaşabil, de nedezlipit, de nedespărțit

undetected nedescoperit, nedetectat

undetected failure (materiale, $\mathrm{OM}$ ) fisură nedectabilă / nedetectată

undeterminable greu de precizat / de determinat; de neconvins

undetermined (mat) nedeterminat, nedefinit; nehotărât, şovăielnic 
undeveloped nedesfăşurat (în geometrie); (chim, met) nedezvoltat (şi d. un proces)

undeviated (from) nedeviat (de la); neabătut (de la)

undeviating (from) nedeviat (de la), neabătut (de la); care nu deviază (de la), care nu se abate; de neabătut (de la / din)

undiferentiated nediferențiat; luat de-a valma

undiffused (fiz) directă, difuză (d. lumină)

undigested (alim) nedigerat; neasimilat; brut, crud

undigestible (alim, med) indigest

undiluted nediluat; integral; (alim) curat (d. vin); (chim) concentrat (d. un acid, o soluție etc.)

undiminished întreg, deplin; plin; integral; nediminuat

undirected (mat) neorientat, nedirijat; neîndrumat; dezorientat, nedirecționat

undiscernible imperceptibil, invizibil, care nu poate fi perceput

undiscerning lipsit de discernământ / de perspicacitate

undischarged nedescărcat; (jur) nereabilitat

undischarged debt $(\mathrm{ec})$ datorie neachitată

undiscountable (ec) cont fără (taxă de) scont

undiscouraged nedescurajat, neabătut

undiscovered nedescoperit, de negăsit

undiscriminating (autom, inf) neselectiv, care nu distinge / nu alege, care nu face distincție; lipsit de exigențe, nepretențios

undiscussed (rămas) nediscutat

undispatched netrimis, neexpediat

undispersed (fiz, materiale) nedispersat (d. un fascicul de raze, un material de adaos într-un compozit etc.); intact

undisposed of (ec) nevândut, neînchiriat

undissolved (ind chim, met) nedizolvat, netopit

undistorted (fiz, OM) nedistorsionat (d. profiluri, semnale etc.), fără distorsiuni; (OM) nedeformat

undistorted output (electr, fiz) putere maximă de ieşire nedistorsionată (a unui amplificator)

undistributed nedistribuit, nerepartizat

undisturbed (fiz, mas, el) neperturbat, nederanjat; netulburat

undisturbed surface suprafață neafectată (mecanic, chimic etc.)

undistillable (alim, ind chim) nedistilabil

undistorted fără distorsiune, nedistorsionat (d. un proces, un semnal etc.); (met) nedeformat

undiversified nediversificat; lipsit de diversitate; nenuanțat; monocrom; (OM, el) monocord undo (TH, OM) a demonta, a deşuruba, a desface, a decupla, a dezlega, a deşira, a descoase, a strica, a distruge; (c, inf) a se întoarce la operația anterioară; (fig) a corupe, a distruge, a nenoroci, a ruina; (textile) a descoase, a desface, a deşira (tricot); (mil) a nimici

undoable care nu se poate face / îndeplini; imposibil; (OM) nedetaşabil, care nu se poate (des)face

undock (nav) a coborî de pe bac, a scoate (nava) din doc, a ieşi din doc

undocumented, nedocumentat, lipsit de instructiuni de folosire (şi la soft)

undoing (OM, mas) desfacere, dezlegare, distrugere, stricare; (fig) corupere, distrugere, ruinare; distrugere; nimicire

undone (OM, mas) desfăcut, dezlegat, distrus, stricat, neterminat; nefăcut; (fig) corupt, distrus, nenorocit, ruinat, stricat; nedesăvârşit; nimicit; come a se desface (d. păr, şireturi), a se desface, a se desprinde (d. un nasture); leave smth. $\sim$ a lăsa ceva făcut

undoped oil (ind chim, T) ulei neaditivat / nedopat

undoubted indiscutabil, neîndoielnic; incontestabil; de necontestat

undoubting încrezător, care nu se îndoieşte, care nu pune la îndoială

undrainable (constr, agr) nedrenabil

undrained (constr, agr) nedrenat

undrawn (ec) neîncasat; $(\mathrm{TH})$ netras (d. semifabricate metalice); netrasat (d. o linie în desen tehnic)

undressed casting(s) (met) piesă turnată brută / necurățată

undried neuscat

undrilled neinstruit (d. un operator etc.); (OM) neperforat, negăurit

undrinkable (alim) nepotabil, care nu este de băut, de nebăut

undriven rivet $(\mathrm{OM})$ nit brut / fără cap

undue necorespunzător, nepotrivi; inoportun; exagerat

undue fatigue (ind) oboseală excesivă (a operatorului, a materialului etc.)

undulate (fiz, mec) a ondula, a executa o mişcare ondulatorie

undulated (fiz) ondulat; încrețit (d. suprafețe, folii, table etc.)

undulating (fiz) ondulator, care ondulează, care are o mișcare ondulatorie

undulation ondulare, ondulație, mişcare ondulatorie, unduire 
undulatory (fiz) ondulatoriu undyed $(\mathrm{OM}, \mathrm{TH})$ nevopsit

unearned (ec) nemuncit (d. un câştig) uneasily $(a d j, a d v)$ stânjenit, stingherit, incomodat; jenat, cu jenă; agitat; neliniștit, tulburat uneasy instabil, stânjenit; neliniştit; stingherit; incomod; jenant; greu, dificil; agitat; încurcat; înfrigurat; jenat; nerăbdător; nestatornic; speriat; tulburat; $v$. uneasily; make oneself $\sim$ a se agita, a se frământa, a nu se linişti

uneatable (alim) necomestibil

uneconomic (ec) neeconomic, neeconomicos, nerentabil

uneconomical neeconomicos, costisitor

unedge (textile, met) netivit, nebordurat

unedited inedit; needitat, nepublicat

unedifying needificator, neconvingător

uneducated needucat

uneffaced neşters, intact

unelastic, inelastic (materiale, OM) neelastic, inelastic

uneliminated neeliminat

unelucidated neelucidat, nelămurit

unemployable care nu poate fi angajat; incapabil

unemployed $(\mathrm{ec}$ ) inactiv, neproductiv (şi d. fonduri), fără lucru; şomer; neutilizat, nefolosit

unemployment (ec, adm, pol) şomaj; $(\mathrm{TH})$ nefolosire, neutilizare

unemployment benefit / compensation / relief (ec, adm) ajutor de şomaj

unemployment fund (ec, adm) fond de asigurare împotriva şomajului

unemptied (hidr, transp) negolit, nedescărcat (încă), plin

unenclosed neîngrădit; (OM, mas) fără dispozitiv de protecție, neprotejat, (angrenaj) fără carter, neînchis, fără carcasă

unended neterminat

unending (mat) infinit, fără sfârşit, nemărginit, fără limite, interminabil

unendorsed (ec) neandosat; nesprijinit; nevalidat; nesacționat

unenduring $(\mathrm{T})$ care suportă greu (uzura); (autom, fiz) de scurtă durată, tranzitoriu (d. un fenomen, un proces etc.)

unenforceable (ec, jur) neexecutoriu (d. un contract)

unenforced (ec, jur) neaplicat (d. lege), care nu este în vigoare

unengaged neangajat; neocupat; liber, disponibil; (OM, el) necuplat, neintrat în angrenare (d. dinții roților dințate), fără contact

unenlightened nelămurit, în dubiu, care nu a primit explicații suficiente unenriched (met) neîmbogățit

unentangled neîncâlcit, neîncurcat (d. fire textile sau lanțuri moleculare, fire / fibre în compozite)

unentered neînregistrat, neînscris; unde nu se intră; neintrat

unentreprising neîntreprinzător, lipsit de inițiativă

unequable inegal, neregulat

unequal inegal, neegal; neechivalent; disproporționat; incapabil; neregulat, lipsit de regularitate

unequal angle (met, mec) cornier cu aripi inegale

unequal angle iron (met, OM) oțel cornier cu aripi inegale

unequality (mat, inf) inegalitate, lipsă de egalitate

unequalled neegalat; inegalabil; fără pereche

unequal leg angles (met, OM) oțel cornier cu aripi inegale

unequalled-legthed $(\mathrm{OM})$ de lungime inegală

unequally $(a d v)$ în mod inegal

unequally loaded (el, OM) inegal încărcat, cu sarcină repartizată neuniform

unequally spaced reamer (mas-un) alezor $\mathrm{cu}$ pas neuniform al dinților

unequally spaced teeth (mas-un, OM) dantură $\mathrm{cu}$ pas neuniform

unequally spacing (mas-un, OM) amplasare la intervale neegale

unequal-side angle iron (met, $\mathrm{OM}$ ) oțel cornier cu aripi inegale

unequal-sided $(\mathrm{OM}) \mathrm{cu}$ laturi inegale / neegale

unequal spacing (mas-un, OM) amplasare la intervale neegale

unequipped (mas) neechipat, nepregătit, neadaptat împrejurărilor

unequivocal neechivoc, fără echivoc / ambiguitate; clar

unerasable memory / storage (c) memorie permanentă / care nu poate fi ştearsă

unerring ferit de greşeală, infailibil; fără greşeală, corect; exact, precis

unerringly cu precizie; fără greşeală; infailibil unerringness infailibilitate; siguranță; precizie unessayed neîncercat; (textile) neprobat unessential neesențial; de mai mică importanță unestablished ajutător, auxiliar (d. personal); nestabilit

unetched (met, chim) neatacat (şi d. probele pregătite pt. analiză metalografică), necorodat, nedecapat

unevaporeted (fiz) neevaporat 
uneven inegal, neuniform; variabil; neregulat; (mat) impar, fără soț (d. numere, pagini); (TH) cu asperităţi, zgrunţuros; (constr) (teren) accidentat

uneven fracture $(\mathrm{OM})$ ruptură neplană / neregulată

uneven heating (met, termo) încălzire inegală / neuniformă

unevenly $(\mathrm{OM})$ cu asperități, inegal

unevenness neuniformitate; denivelare (a fundației, terenului, suprafeței); asprime, asperitate (a suprafeței); caracter neregulat / accidental

unevenness asperitate (şi la o suprafaţă)

unevenness of the ground denivelare (a solului)

uneven page pagină fără soț

uneven ramming (met) îndesare neuniformă (la formare)

uneven road surface (auto) suprafață denivelată de drum

uneven running (mas) functionare neuniformă / inegală

uneven wear $(\mathrm{OM}, \mathrm{T})$ uzură inegală / neuniformă uneven weld $(\mathrm{OM})$ sudură neuniformă unexamined neexaminat, neverificat

unexecuted neexecutat; neîndeplinit; nerealizat (d. un proiect etc.)

unexecuted deed (jur) act nevalidat

unexemplified neexemplificat, fără exemple

unexpansive (materiale, OM) nedilatabil, care nu se dilată

unexpectant of care nu aşteaptă, care nu se aşteaptă la

unexpected neprevăzut; neaşteptat (d. cheltuieli, rezultate, fenomene); brusc; surprinzător

unexpectedly $(a d v)$ pe neaşteptate, brusc, dintro dată; (în mod) surprinzător

unexpectedness caracter neaşteptat / brusc / subit / surprinzător

unexperienced lipsit de experiență; crud, necopt; care nu a mai fost încercat / experimentat, neexperimentat

unexplainable inexplicabil, imposibil de explicat

unexplained neexplicat, (rămas) nelămurit; indescifrabil

unexplicit neexplicit, neclar, obscur

unexploded neexplodat; încă valabil / actual (d. o teorie)

unexploited neexploatat

unexplored neexplorat, necercetat; neabordat (încă)

unexplosive neexploziv

unexposed ascuns, neexpus unextended neextins, fără extindere, nedezvoltat unfaded (agr, bot) neofilit, neveştejit; proaspăt unfading (agr, bot) care nu se ofileşte, care nu veştejeşte; (textile, plast) care nu se decolorează; trainic, durabil; peren

unfailing constant, consecvent; care nu se strică, care nu se defectează, care nu cade / nu are defectări (d. o maşină etc.): care nu te lasă la nevoie; consecvent, credincios, de nădejde, statornic (d. o persoană)

unfailingly $(a d v)$ (în mod) constant, consecvent, neabătut

unfailingness constanță, consecvență, caracter statornic / neabătut

unfair nedrept, nejust, injust; necinstit, lipsit de onestitate; nesportiv, nedemn

unfair competition (ec, sport) competiție neloială unfair hole (mas-un, OM) gaură înfundată

unfairness nedreptate, lipsă de justețe / de dreptate; lipsă de sportivitate, caracter nedemn

unfamiliar nefamiliar, nu prea bine cunoscut; neobişnuit, ieşit din comun; straniu

unfasten $(\mathrm{OM})$ a deşuruba, a slăbi, a separa, a deschide (prin deşurubare, desfacere etc.), a detaşa

unfastening $(\mathrm{OM})$ slăbire (a unei asamblări, a unei legături etc.), deşurubare

unfavourable nefavorabil, (prea) puțin favorabil, impropice

unfavourably $(a d v)$ (în mod) nefavorabil

unfavoured nefavorizat, neprivilegiat

unfeasible nerealizabil, irealizabil, nerealizat; nepractic, impracticabil

unfelt insensibil, impalpabil, nesimțit, care nu se face simțit

unfenced neprotejat; neîngrădit; (OM, mas) fără carter, fără instalație / sistem de protecție

unfertilized (agr) neîngăşat, nefertilizat (d. teren)

unfilled neumplut

unfilled $\operatorname{cog}(\mathrm{cf})$ armătură de susținere neumplută cu rambleu

unfilled order (ec, autom, inf) comandă neexecutată

unfilled resin (ind chim) răşină fără umplutură

unfilled section $(\mathrm{OM}, \mathrm{TH})$ secțiune transversală incompletă (la profiluri laminate, la matrițare)

unfinished fără finisare, nefinisat, brut (d. o piesă etc.); neterminat, incomplet (d. un proces tehnologic etc.); necompletat unfinished bolt $(\mathrm{OM})$ șurub grosolan / brut unfinished goods (ind) semifabricate 
unfired neincendiat; (constr) nears (d. cărămidă) unfired pressure vessel (OM, hidr) vas / tanc rezistent la presiune internă, cauzată de arderea unor substanțe sau de căldură

unfit nepotrivit; necorespunzător; neadecvat; inoportun; a face incapabil de muncă

unfit for use inutilizabil

unfitness, unfittingness caracter nepotrivit / impropiu / inoportun

unfitted nepotrivit, impropiu

unfitting nepotrivit, neconvenabil, impropiu; care nu se potrivește; inoportun

unfix / infix (OM) a despărți, a desface, a detaşa, a dezechilibra

unfixed $(\mathrm{OM}$, mas) nefixat, mobil, nereparat

unflagging neslăbit; nediminuat, nemicşorat, neatenuat; total, întreg; continuu, neîntrerupt, susținut, neabătut

unflowed fără defect

unfluxible (met) care nu formează zgură

unfold a îndrepta cute / îndoituri / încrețituri (la table subtiri, folii etc.); a (se) desfăsura; a aşterne; a (se) desface (cute etc.); a întinde, a extinde; a (se) dezvolta; a dezvălui, a (se) arăta, a se releva; a duce / întreprinde (o activitate), a fi în curs de defăşurare, a se desfăşura, a se petrece

unfolded necutat, neîncrețit

unforesecable imprevizibil, (de) neprevăzut, imposibil de prevăzut

unforesceableness imprevizibilitate, caracter imprevizibil / impredictibil

unforeseeing neprevăzător, imprudent, lipsit de prevedere / de precautie

unforeseen neprevăzut; care depăşeşte aşteptările; neaşteptat

unforeseen expenses $(\mathrm{ec})$ cheltuieli neprevăzute

unformed neformat (încă), imatur, crud; nedezvoltat

unfreezable care nu îngheață / nu este supus înghețului; necongelabil, greu de congelat; (nav) (mare / apă) liberă de ghețuri

unfrequent nefrecvent, rar

unfrozen dezghețat; neînghețat, necongelat; (nav) liber de ghețuri

unfunded (ec) neconsolidat (financiar etc.)

unfurnished nemobilat; fără mobilier / mobilă

unfused (met, el) netopit (d. flux, la sudură, d. o siguranță electrică fuzibilă etc.)

ungauged neetalonat; netarat (d. un aparat de măsură)

ungear a decupla, a scoate din angrenare, a debreia, a deconecta; (auto) a scoate din viteză unglue a (se) dezlipi ungraded de calitate inferioară, sub parametrii mărcii / standardului

ungraded iron (met) fontă / oțel de calitate inferioară

ungrease $(O M, T)$ a degresa

ungreasing (alim, OM, T) degresare

unguarded fără dispozitiv de protecție, neprotejat

ungovernable (mas, ec, TH) imposibil de guvernat / de condus; refractar, nedisciplinat (d. un operator, personal etc.)

ungraduated (edu, univ) fără diplomă (universitară), fără grad / titlu universitar, fără studii superioare; negradat, neprogresiv; (fiz, chim, $\mathrm{OM}$ ) negradat (d. un recipient)

unguarded nepăzit, lipsit de pază; luat prin surprindere / pe neaşteptate

unguardedness neatenție, lipsă de atenție; imprudență, lipsă de precauție

unguided neghidat, nedirectionat

unhandy neîndemânatic, stângaci; incomod, supărător, care deranjează; (nav) nemanevrabil, nemaniabil, greu de manevrat

unhang a scoate, a da jos (ceva deja agățat)

unhardened (met, $\mathrm{T}$ ) nedurificat, necălit

unharmed nevătămat, neatins (d. persoame); (rămas) intact; nedeteriorat ( $r a r$ )

unharmonious nearmonios, lipsit de armonie; neproportional, prost proporționat

unhealthful $v$. unhealthy

unhealthily $(a d v)$ (în mod) nesănătos, insalubru, bolnăvicios

unhealthiness caracter nesănătos / bolnăvicios; sănătate precară; caracter insalubru, lipsă de salubritate

unhealthy bolnăvicios, insalubru, nesănătos

unheard prea încet pentru a fi auzit, neauzit

unheated neîncălzit, fără încălzire

unheeding neatent, fără grijă, negrijuliu; nepăsător

unicoloured (fiz, textile) monocolor, monocrom, de o singură culoare

unidentified neindentificat

Unidentified Flying Object, UFO obiect zburător neidentificat, OZN

unidimensional (mat) unidimensional, cu o singură dimensiune

unidirected cu aceeaşi direcție, cu acelaşi sens (d. vectori etc.)

unidirectional unidirecțional, care are o singură direcție / un singur sens

unidirectional rotation $(\mathrm{mec}$, fiz) rotire într-un singur sens 
unifiable care poate fi unit / unificat

unification unire; uniformizare; (ec) unificare; normare; standardizare

unified unificat

unified atomic mass unit, u (metr, fiz, chim) simbol pentru unified atomic mass unit, în sistem SI

unified field theory (fiz) teoria unificată a câmpurilor (gravitațional şi electromagnetic)

unifined screw thread $(\mathrm{OM})$ (sistem de) filet standardizat, cu unghiul la vârf de $60^{\circ}$

unifilar (el, plast) cu un singur fir, monofilar, unifilar

uniflow (hidr) echicurent, unicurent

uniflow boiler (termo, OM) cazan cu echicurent / unicurent

uniflow compressor (termo) compresor cu echicurent

uniflow furnace (met, termo) cuptor cu un singur arzător

uniflow steam engine (termo) motor cu echicurent de abur

uniflow (type) condenser (termo) condensator cu curent paralel / cu echicurent

uniflow type heat exchanger (termo) schimbător de căldură cu echicurent / cu curent paralel

uniform (textile) uniformă (îmbrăcăminte); egal, uniform, identic, omogen, constant, echidistant; a uniformiza, a omogeniza, a unifica

uniform accelerating motion (mec) mişcare uniform accelerată

uniform approximation (mat) aproximare uniformă / Cebâșev a functiilor continue

uniform combustion (termo) ardere uniformă / constantă

uniform convergence (mat) convergență uniformă

uniform cargo (nav, transp) încărcătură unitară / omogenă

uniform corrosion (chim, OM) coroziune uniformă

unhelped neajutat, neajutorat

unhelpful nefolositor, (prea) putin util, de prea puțin folos; inutil

unhesitating sigur (pe sine); care nu ezită, lipsit de / fără rezerve

unhewn necioplit, netăiat, brut

unhindered nestânjenit, neîmpiedicat; ferit de piedici / obstacole

unhinge a scoate din balamale; $(\mathrm{OM})$ a dezechilibra

unhook a (se) desprinde din cârlig, a (se) separa, a da jos din cui / din cârlig, a scoate din cârlig / din cui; (textile) a se descopca, a se descopcia, a se desface din agrafe / copci (d. o rochie etc.), a descopcia, a descoperi (o rochie); a se desface, a se desprinde, a (se) deshăma (d. atelaj); (fam) a șterpeli, a subtiliza

unhooked desfăcut, descheiat, neprins (şi în cârlig)

unhurt teafăr, nevătămat (d. perosane); (OM) intact, nelovit, neatins

uniaxial (OM) monoax, cu un singur ax, uniaxial; (mat) monoaxial

unicellular (biol) monocelular, unicelular; (el) cu o singură celulă

uniform (edu, mil, ec) uniformă (îmbrăcăminte); (adj) armonios; consonant; constant; echidistant; (mat) egal, identic; (mat, materiale) omogen; uniform; la fel; neschimbat; unitar; a omogeniza; a unifica; a uniformiza; undress $\sim(\mathrm{mil})$ uniformă de mică ținută; in full $\sim$ (mil) în mare ținută

uniform approximation (mat) aproximare Cebîşev / a funcțiilor continue

uniform cargo (transp) încărcătură unitară

uniform combustion (termo) ardere uniformă

uniform diffuser (fiz) difuzor de lumină ortotrop / uniform

uniform decreasing motion (mec) mişcare uniform decelerată

uniform field (mat, fiz) câmp uniform / omogen uniform flow (hidr) curgere uniformă

uniform intensity beam (fiz) fascicul de raze paralele / de intensitate uniformă

uniformity, uniformness uniformitate, omogenitate (a structurii unui material etc.); constanță, caracter unitar / uniform

uniformization uniformizare, omogenizare ( $\mathrm{rar}$ ) uniform line linie omogenă / linie uniformă uniformly $(a d v)$ (în mod) uniform, armonios, omogen, unitar

uniformly accelerated $(\mathrm{mec})$ uniform accelerat uniformly accelerated motion $(\mathrm{mec})$ mişcare uniform accelerată

uniformly bounded (mat) egal mărginit (la ecuații diferențiale)

uniformly decreasing motion (mec) mişcare uniform decelerată / încetinită

uniformly distributed load (mec) sarcină uniform distribuită

uniformly heated (termo) încălzit uniform, cu tempetarură uniformă

uniformly retarded motion (mec) mişcare uniform întârziată

uniformly variable motion (mec) mişcare uniform variată 
uniform mix (materiale) amestec uniform / omogen uniform motion $(\mathrm{mec})$ mișcare uniformă uniform quality $(\mathrm{TH})$ calitate uniformă / (cu variaţii mici ale atributelor produsului)

uniform raw material $(\mathrm{TH})$ materie primă omogenă, material de bază, uniform (ca structură, compoziție etc.)

uniformly retarded motion $(\mathrm{mec})$ miscare uniform întârziată

uniform space (mat) spațiu uniform

uniform spectrum random noise (fiz, autom) zgomot alb, zgomot aleatoriu cu spectru uniform

uniform strength beam $(\mathrm{mec})$ grindă de egală rezistență

uniform-thickness (OM) de grosime constantă uniform-thickness piston ring (termo, $\mathrm{OM}$ ) segment de piston, de grosime uniformă (poate fi şi conic-centrat)

uniform wave-length condenser (fiz, electr) condensator pentru variația liniară a lungimii de undă

unify a unifica, a uni, a aduce laolaltă; a uniformiza, a omogeniza, a armoniza

unilateral unilateral, într-un singur sens

unilateral conductivity (termo) conductivitate unilaterală / într-un singur sens

unilateral hole $(\mathrm{OM})$ alezaj cu dimensiune nominală, care coincide cu dimensiunea minimă admisibilă

unilateral system (OM, metr) sistem asimetric de tolerante

unilateral tolerance (OM, metr) câmp de tolerantă, la care una din limite este chiar valoarea nominală, cealaltă putând fi pozitivă sau negativă

unilinear monoliniar

unimaginable inimaginabil

unimaginative lipsit de imaginaţie; îngust la minte, obtuz

unimaginativeness lipsă de imaginație, obtuzitate, mărginire (în gândire)

unimolecular film / layer (fiz, chim, T) strat monomolecular

unimpaired (OM, mas) neavariat, scăpat fără avarii

unimportance lipsă de importanță / de însemnătate

unimportant neimportant, lipsit de importanță; irelevant

unimprovable (ec, adm, pol, jur) neamendabil, care nu poate fi îmbunătățit / corijat / îndreptat

unimproved neameliorat, cu nimic îmbunătățit / ameliorat, neîmbunătățit unincorporated (ec) neînregistrat (d. o firmă, un produs), neconstituit, neautorizat; neincorporat, neintegrat (d. un ingredient într-un amestec)

uninflammable (materiale) neinflamabil, ignifug

uninflated neumflat, dezumflat; slăbit, slab

uninfluenced neînfluențat; neprevenit, neavertizat

uninformed neinformat; prost informat; ignorant, neştiutor; incult; care nu este la curent cu uninhabited nelocuit; nepolupat; părăsit

uninjured nevătămat

uninstalled (OM, mas, autom, el) neinstalat, nemontat

uninsulated conductor (el) conductor neizolat

unintelligible neinteligibil, incomprehensibil, de neînțeles

unintelligibleness caracter neinteligibil / de neînteles / indescifrabil, ininteligibilitate, incomprehensibilitate

unintelligibly ( $a d v)$ (în mod) neinteligibil, incomprehensibil, de neînţeles

unintentional neintenționat, (făcut) fără voie, involuntar, instinctiv

unintentional activation (fiz, chim) activare neintenționată / din greşeală

uninteresting neinteresant, lipsit de interes, fără interes

unintermitting neîntrerupt, fără intermitențe, neintermitent

uninterrupted neîntrerupt, necontenit, neîncetat, continuu, fără încetare

uninterrupted duty (mas) serviciu / funcționare neîntrerupt $(\breve{a})$

uninterruptedly ( $a d v)$ (în mod) neîntrerupt, încontinuu, fără încetare

uninterruptedness caracter neîntrerupt / susținut / continuu; permanență, constanță

uninterruptible power source (el, hidr) sursă de putere neintreruptă / continuă

uninvited neinvitat; nesolicitat, necerut; nechemat, inoportun

union (ec, adm, pol) asociație; sindicat; societate; unire; unificare; acord, înțelegere, convenție; (mat) reuniune; (OM) asamblare (filetată, prin lipire etc.), îmbinare, (piesă de) legătură; (ec) uniune (economică); azil de muncă; căsătorie, mariaj; (adj) sindical, unionist

union agreement (ec, pol) acord asupra tarifelor vamale, acord unional / la niveld de uniune (economică)

union body $(\mathrm{OM})$ racord, ştuț, piesă de asamblare / de racordare, corp intermediar (de legătură) 
union card (adm) carnet / legitimație de sindicalist union chuck (mas-un, OM) mandrină de fixat burghiul / pentru maşina de găurit

union elbow (OM) racord olandez

union flange $(\mathrm{OM})$ flanşă de legătură

union gate (autom) poartă SAU

unionized (fiz) neionizat

union hose joint $(\mathrm{OM})$ racord de / pentru furtun

unionism (pol) unionism, federalism, concepții unioniste; (ec, adm) sindicalism, concepții favorabile sindicalizării

unionist (pol) unionist; (ec, adm) sindicalist, partizan al sindicalizării

unionize a sindicaliza, a uni într-un sindicat

union joint hose (OM, hidr) furtun cu racord de îmbinare

union nipple (OM, hidr) niplu de racordare / de legătură

union out $(\mathrm{OM})$ desfacere a racordului / a legăturii

union nut $(\mathrm{OM})$ piuliță olandeză / de cuplare

union pipe (OM, hidr) tub / conductă / țeavă de legătură

union regulations $(\mathrm{ec}, \mathrm{adm})$ prevederi din statutul unui sindicat; reguli sindicale, regulament sindical

union shop (ec, adm, jur) întreprindere sindicalizată / care impune sindicalizarea angajaților, întreprindere cu contract colectiv de muncă, contract colectiv de muncă

union socket $(\mathrm{OM})$ mufă dublă

union station (amer) (cf) gară centrală

union suit (textile, ind) (amer) salopetă, combinezon de lucru

uniphase (el) monofazic

unipivot $(\mathrm{OM})$ pivot (unic), rezemat pe un singur pivot

unipivot bearing $(\mathrm{OM})$ lagăr (unic) pentru pivot unipolar (fiz) unipolar, omopolar, cu un singur pol; (el) care prezintă unipolaritate

uniprocessing (c, inf, autom) procesare cu o singură unitate de calcul

unique (mat) unic, univoc; remarcabil, neobişnuit; ciudat, straniu

unique existence (mat) existență unică

unique feature particularitate / caracteristică / trăsătură unică (de construcție / de design etc.)

uniqueness unicitate, caracter unic / ieşit din comun; ciudățenie, caracter straniu

uniqueness theorem (mat) teoremă de unicitate

unique selling proposition (ec) propunere de vânzare în premieră, produs / serviciu nou / cu grad mare de originalitate, ofertă excepțională uniselector (OM, el, autom) selector cu mişcare unică / unidirecțional, selector rotativ

unison (el, mec) în sincronism

unistrand $(\mathrm{OM}$, el) cu un singur fir / cablu / toron

unit (metr) unitate (de măsură), (o) bucată; (OM) ansamblu, element (de bază), agregat, instalatie; subansamblu, bloc, modul; factor;

unit of blood (metr, med) unitate de măsură pentru volum, pentru sânge uman etc., egală cu $450 \mathrm{ml}$

unit of alcohol (metr, alim) unitate de măsură pentru conținutul de alcool din băuturi, conținutul volumic de alcool dintr-un litru de băutură este egal cu procentul de alcool: vinul are 12 unităţi pe litru (sau 12\%vol alcool)

unit of energy (metr, fiz) o altă denumire pentru kilowatt·oră în UK, denumită oficial Board of Trade unit (Btu)

unit call (UC) (metr, telecomunicații) o unitate adimensională a densității de trafic în telecomunicații, care reprezintă 100 apeluri-secundă pe oră sau $1 / 36$ erlang

unit case (metr) unitate convențională de vânzare a băuturilor nealcoolizate în US, egală cu 5,678 1

unit (magnetic) pole (metr, fiz) unitate în sistem CGS penrtu a măsura forța unui pol magnetic; 1 unit magnetic pole respinge un pol identic la o distanță de $1 \mathrm{~cm}$ în vid cu o forță de 1 dyne: 1 unit magnetic pole $\cong 125,6637$ nanowebers (nWb) sau 12,566 37 maxwells (Mx)

unit area (metr, geom) unitate de arie, suprafață unitară

unitary unitar; omogen; uniform

unitary matrix (mat) matrice-unitate

unit ball (geom) sferă cu rază unitară

unit bore system $(\mathrm{OM})$ sistem de toleranțe tip alezaj unitar

unit cast (met) turnat dintr-o bucată

unit casting (met) turnare dintr-o dată / şarjă

unit cell (materiale, fiz) celulă elementară (şi la compozite, la modelarea comportării materialelor complexe etc.)

unit charge (mec) sarcină elementară; (el) unitate de sarcină electrică

unit circle (mat, trigonometrie) cerc cu raza egală cu unitatea

unit clearance $(\mathrm{OM}, \mathrm{T})$ joc relativ / unitar

unit compressive stress (mec, $\mathrm{OM})$ tensiune / efort unitar(ă) de compresiune

unit construction (constr, mas, OM) construcție unitară 
unit cost (ec) cost pe unitate / pe produs unit crystal (fiz) monocristal

unit deformation (mec, OM) deformație specifică (raportată la unitatea de lungime) unit distance piece $(\mathrm{OM})$ piesă de spațiere, distanțier; (c, inf) element tip spațiu liber unit drive $(\mathrm{OM}$, mas) acționare individuală unite a (se) lega; a (se) cupla; a (se) uni, a îmbina; a (se) amesteca; a unifica; a reuni, a aduce laolaltă; a (se) asocia, a colabora, a coopera united unit; unificat; unic; comun; asociat; federalizat; unitar

unitedly $(a d v)$ (în mod) unic, în deplină uniune; de comun acord, în comun; (în mod) unitar, în asociere / asociatie; în armonie

unit element (autom) element tip; element unitate

unit fiber stress $(\mathrm{mec})$ tensiune unitară în fir în fibră

unit form (mat) formă primitivă (a unei funcții pătratice); (TH, ind, OM) formă standardizată / normată

unit function (autom, mat) functia unitate a lui Heaviside, funcție treaptă (în tehnica impulsurilor)

unit furniture mobilă modulată / din module / din piese detaşabile

unit hardness (metr, materiale) unitate de duritate

unit impulse (metr, autom) impuls unitate; (el, mat) distribuție delta, funcția delta a lui Dirac

unit interval (metr, autom) unitate de interval, pas

unit loading (mec, OM) sarcină / încărcare unitară

unit of area (metr, geom) unitate de arie / de suprafață

unit of energy (metr, fiz) unitate de energie unit of fit (OM) unitate de câmp de toleranță unit of hardness (metr, materiale) unitate de duritate

unit of length (metr, geom) unitate de lungime unit of mass (metr, fiz) unitate de masă unit of measure / measurement (metr) unitate de măsurare / de măsură

unit of output (metr, fiz, hidr) unitate de debit unit of power (metr, fiz) unitate de putere unit of space / of volume (metr, fiz, geom) unitate de volum

unit of weight (metr, fiz) unitate de greutate unit operating factor $(\mathrm{ec}, \mathrm{TH})$ factor al timpului de lucru

unit operations $(\mathrm{TH})$ operații unitare unit plane (mec, fiz) plan cristalografic cu indici Miller

unit planes (mec) plane principale

unit power (metr, fiz) unitate de putere

unit pressure (metr, fiz) unitate de presiune

unit price (ec) preț unitar / pe produs

unit pump (OM, hidr) motopompă

unit quantity cantitate unitară; (el) sarcină elementară, unitate de sarcină electrică

unit resistance (el) rezistivitate; (hidr, OM) rezistență specifică

unit sensitivity (metr) sensibilitate pentru modificarea cu o unitate pe scala aparatului

unit set (mat) mulțime cu un singur element

unit shaft system $(\mathrm{OM})$ sistem de tolerante, tip arbore-unitar

unit square (geom, metr) pătrat cu latura de o unitate

unit step (autom, inf) salt / treaptă unitate / uni$\operatorname{tar}(\breve{a})$

unit strain (mec) deformație unitară / pe unitatea de lungime

unit stress (mec) efort / tensiune unitar( $\breve{a})$, sarcină specifică

unit symbol (metr) simbol al unității de măsură

unit system of manufacture ( $\mathrm{TH}$, ind) sistem de fabricare bazat pe tipizarea / normarea pieselor

unit type drill head (mas-un) cap de găurit standard

unit value valoare unitară

unit vector (mat, fiz) versor, vector unitate

unit volume (metr, fiz, chim) unitate de volum / volumetrică

unit weight (fiz, metr) greutate specifică

unity unitate; numărul unu; unire; consens, înțelegere reciprocă; acord, armonie

unity of command and direction (ec) principiu de organizare şi conducere conform căruia un salariat trebuie să primească ordine de la un singur superior (principiul unității de management)

univalence (chim) monovalență, valență unică univalent (chim) monovalent, univalent

universal universal, (de uz) general

universal attraction law (fiz) legea atracției universale

universal ball joint $(\mathrm{OM})$ cardan sferic (şi cu bile)

universal beam mill (met) laminor universal

universal bevel $(\mathrm{OM})$ echer reglabil (universal)

universal category categorie / clasă universală

universal chuck (mas-un, OM) universal cu fălci 
universal connection iron (met, OM) platbandă de legătură

universal coupling / joint (OM) cardan sferic, cuplaj cardanic

universal coupling device $(\mathrm{OM})$ dispozitiv universal de cuplare

universal gas constant (fiz) constanta gazului universal

universal grinding machine (mas-un) maşină universală de rectificat

universal indexing head (mas-un, OM) cap divizor universal

universality universalitate

universal joint $(\mathrm{OM})$ asamblare a doi arbori necoaxiali (unul poate fi pivotant față de axa lui), articulație / cuplă cardanică, cuplaj cardanic (şi tip nucă)

universal joint bushing (OM) bucşă de cardan / a crucii cardanice

universal-joint drive (OM) transmisie / cuplaj cardanic $(\breve{a})$

universal joint fork (OM) furcă de cardan / cardanică

universal joint housing $(\mathrm{OM})$ carcasă a cardanului / a cuplajului cardanic

universal joint shaft $(\mathrm{OM})$ arbore cardanic / articulat sferic

universal key $(\mathrm{OM})$ cheie universală (pt. asamblări filetate)

universal lathe (mas-un) strung universal

universal lay (el) cablaj direct / paralel

universal maintenance standards (mas) standarde / norme (generale / universale) de întreținere / de mentenanţă (privind operații nerepetitive)

universal mill (met) laminor universal

universal milling machine (mas-un) maşină universală de frezat

universal mill plate (met) oțel lat

universal motor (el, mas) motor electric universal (de curent continuu sau alternativ)

universal output transformer (el) transformator de uz general, cu mai multe înfăşurări pe secundar

universal pick (constr, OM) târnăcop obişnuit / universal

universal pliers / tongs $(\mathrm{OM})$ cleşte universal / obişnuit / şi tip patent

universal screw wrench $(\mathrm{OM})$ cheie franceză

universal spanner $(\mathrm{OM})$ cheie universală

universal square (OM, metr) echer normal / universal / obişnuit

universal standard data $(\mathrm{TH})$ date standard / norme pentru normarea operațiilor universal switch (el) întrerupător normal / obişnuit

universal three-high rolling mill (met) laminor universal trio

Universal Time (UT, Z) (metr) timp universal, (denumire anterioară - Greenwich Mean Time, cu abrevierea GMT): timpul standard la lon-gitudine $0^{\circ}$

universal tractor (agr, mas) tractor universal

universal two-high rolling mill (met) laminor universal duo

universe populație (în statistica matematică); cosmos; univers

universe means (mat) valoare medie

university (univ) universitate; (adj) universitar, academic, superior

university education (edu, univ) studii superioare / universitare, învățământ superior, pregătire universitară

university extension (class / scheme) (edu) curs (popular) organizat de o universitate

university man (edu) universitar, titrat, diplomat universitar, cu studii superioare

univis oil (ind chim, T) ulei cu indice mărit de vâscozitate

unjustifiably $(a d v)$ (în mod) nejustificabil, imposibil de justificat; fără nici o scuză / justificare / motiv

unjustified nejustificat, nedreptățit

unjustness injustețe; nedreptate, caracter nedrept / nejustificat

univocal univoc; clar, neambiguu, ferit de ambiguitate

univocally $(a d v)$ (în mod) univoc; clar, neambiguu, fără ambiguitate

univocity (mat) univocitate

unjoin (OM) a despărți, a separa, a desface

unjoint a diseca, a dezmembra

unjust nedrept, injust, nejust

unjustifiable (de) nejustificat, imposibil de justificat; de neiertat; nepermis, inadmisibil

unkey $(\mathrm{OM})$ a scoate o pană

unkilled (met) necalmat (d. oțel)

unknotted fără noduri (d. o parâmă, o sfoară, fire etc.)

unknowable incogniscibil, imposibil de aflat / de cunoscut

unknowing neştiutor, care nu ştie, neavizat, nepus la curent

unknown necunoscută; tip, ins, necunoscut, obscur, neştiut; modest

unlabel(l)ed (fiz) nemarcat; (inf) fără etichetă; neetichetat; (ec) fără preț afişat 
unlabel(l)ing (mas) care nu etichetează (un produs etc.), care scoate etichete (de pe ambalaje refolosobile)

unlace a desface (fire, legături)

unladen (nav) neîncărcat, fără încărcătură / caric; gol

unladen weight (transp) greutate / masă neîncărcată

unlatch (OM) a debloca, a deszăvorî; a declanşa unlawfulness (jur) ilegalitate, caracter ilegal / ilicit

unleaded gasoline (ind chim, auto) benzină neetilată, fără plumb

unlearn a uita carea învățat; a se dezvăța de

unlearned incult, ignorant

unless (conj) dacă nu; în afară de cazul când

unlettered (edu) analfabet

unlevelness neuniformitate

unlicensed neautorizat, fără licență

unlike ( altfel decât; (adj) neasemănător, deosebit;(el) de semne contrare; (mat) diferit de, neegal, neasemenea, cu numitori diferiți; diferit de; charges (el) sarcini / încărcări de semne contrare; signs (mat) semne contrare: plus

unlik(e)able supărător, greu de suportat

unlike currents (fiz, el) curenți de polarități opuse, curenți de semne opuse

unlikelihood improbabilitate, neverosimil(itate)

unlikely neverosimil, greu de crezut; $(a d v)$ (prea) puțin probabil, cu puține şanse; ( $a d v, a d j)$ improbabil

unlikeness to lipsă de asemănare cu, neasemănare cu, deosebire mare fată de

unlike poles (fiz, el) poli cu polarități opuse, poli de semne contrare

unlimited nelimitat, fără limită / margini, infinit, nemărginit

unlimitedly $(a d v)$ fără limite / măsură, (în mod) nemăsurat / nelimitat, enorm de mult, foarte mult, extrem de mult

unlimitedness caracter nelimitat / nemăsurat / nemărginit; nemărginire

unline (TH) a scoate / îndepărta o căptuşeală / o acoperire

unlined necăptuşit; neacoperit; neplacat

unlink a desface (o legătură etc.), a deznoda

unlisted necatalogat; (ec) (preț) neinclus pe listă; netrecut pe listă (d. un număr de telefon etc.); (c, inf) nelistat

unlit neaprins, stins, care nu arde

unload (mec, OM) a ridica / înlătura o sarcină; a descărca (o marfă, un aparat), a goli, a debarca; a preda, a remite; (ec) a vinde în cantități mari, a inunda piața

unloaded (mec, OM) descărcat, neîncărcat, nesolicitat

unloaded characteristic (mas, el) caracteristică de mers în gol

unload running (mas, el) mers în gol

unloaded sag (el, OM) săgeată (a unei linii electrice, a unui lanț) fără sarcină / sub greutate proprie

unloaded start demaraj fără sarcină; pornire în gol / fără sarcină

unloaded weight (transp) greutate / masă neîncărcată

unloader (OM) dispozitiv de descărcare, descărcător; (hidr) evacuator; (mas, autom, el) dispozitiv de scoatere de sub sarcină / de limitare automată a sarcinii / de echilibrare a sarcinii la pornire; derivație de demaraj / de pornire, scurtcircuitor de pornire

unloading (transp, mec, OM) descărcare; neîncărcare, care nu este încărcat, care (se) descarcă (d. o sarcină mecanică, un element de maşină, o marfă etc.)

unloading auger (OM) transportor elicoidal pentru descărcare

unloading bridge / crane (mas, transp) pod / macara de descărcare

unloading device (OM) dispozitiv de descărcare, descărcător

unloading dock (nav) doc / dană de descărcare unloading opening (OM) pâlnie / deschidere de descărcare

unloading plant (mas, transp) instalație de descărcare

unloading ramp / wharf (constr, transp) rampă de descărcare

unlock $(\mathrm{OM})$ a deszăvorî, a deschide, a descuia unlock button (auto, OM) buton de deblocare unlocking $(\mathrm{OM})$ descuiere, deschidere, deszăvorâre, deblocare, declanșare (a unui mecanism); (ec) eliberare / deblocare de fonduri unlooked at neglijat, nebăgat în seamă, uitat unloose $(\mathrm{OM})$ a slăbi (o legătură, o strângere) unlubricated $(\mathrm{T})$ neuns, nelubrifiat unlubricated friction $(\mathrm{T})$ frecare uscată / fără fluid / fără ungere

unmachinable (materiale) neprelucrabil (prin aşchiere)

unmake a distruge, a face să dispară; a demite, a declasa; a retrogada; a modifica

unmanageable $(\mathrm{ec}, \mathrm{TH})$ greu / dificil de condus / de controlat / de manevrat / de organizat 
unmanufactured (materiale) neprelucrat, în stare brută, neconfecționat, brut

unmark (metr) a şterge reperul / marcarea, a nu marca / însemna

unmarked nemarcat, fără marcă; neremarcat, neobservat

unmarketable / unmarchatable (ec) nevandabil, greu de vândut / de comercializat

unmarred corect, fără defect (d. un produs)

unmatched fără pereche; desperecheat, neasortat, nepotrivit; (inf) înregistrare fără corespondent / omolog; (OM) neadaptat, nepotrivit; necomparabil

unmate (mec, el) deconectare / dezangajare / decuplare a conectorilor / pieselor

unmeaning fără / lipsit de inteligență; stupid, fără sens; fad, plat, neinteresant

unmeant neintenționat

unmeasured nemăsurat; fără măsură, exagerat

unmelted (materiale) netopit

unmendable imposibil de reparat, prea stricat ca să poată fi reparat, ireparabil, stricat rău (d. elemente de maşini, aparate, maşini)

unmentionable nedemn de a fi menționat, imposibil de menționat

unmentioned nementionat

unmetalled $(\mathrm{OM})$ nemetalizat; fără metal; fără armătură metalică; (constr) (drum) nepavat, nepietruit, nemodernizat

unmethodical fără metodă, lipsit de metodă, nemetodic; dezordonat, (făcut) la întâmplare

unmingled pur, neamestecat, neprefăcut; nealterat, neatacat

unmissed neobservat, neluat în seamă, neremarcat; neregretat (de nimeni)

unmistakable neîndoielnic; neechivoc; clar; evident, care nu poate fi confundat; sigur, precis

unmistakably $(a d v)$ fără posibilitatea de confuzie, (în mod) clar, evident; sigur, cu siguranță, fără îndoială, mai presus de orice îndoială

unmitigated total, întreg, complet; nedinimuat; v. undiminished

unmixed neamestecat, pur (rar)

unmodified nemodificat, neschimbat; nealterat, neabătut; constant

unmodified resin (ind chim) răşină nemodificată

unmonitored control system (autom) sistem de reglare în buclă deschisă

unmoor (nav) a pleca de la ancoră / de la geamandură, a dezlega nava

unmorgaged (ec, jur) neipotecat, liber de ipotecă unmotivated nemotivat, nejustificat unmoved record (c, metr) înregistrare permanentă

unnavigable (nav) nenavigabil, nepotrivit pentru navigație

unnail a scoate cuie

unnecessarily ( $a d v)$ (în mod) nenecesar / inutil, zadarnic, fără (nici un) rost; de prisos, superfluu, degeaba

unnecessary inutil, zadarnic, fără rost; de prisos, superfluu, făcut degeaba; nedorit

unnecessary alarm (auto) alarmă nedorită / suplimentară / nenecesară / inutilă

unnegotiable (pol, ec, adm) nenegociabil, nonnegociabil, nesupus negocierii; de neschimbat; ferm, categoric

unnotched specimen (metr, OM) epruvetă necrestată

unnoted neorservat; obscur, neînsemnat; neimportant

unnoticeable neobservabil, imperceptibil, care nu poate fi observat (uşor), care trece neobservat; infim, infinitezimal

unnoticed (care a trecut) neobservat

unnumbered nenumerotat; fără număr de ordine unobjectionable ireproşabil; perfect (corect); care nu lasă nimic de dorit

unobservable (care a trecut) neobservat, neobservabil

unobserved neobservat

unobserving nepăsător față de; negrijuliu; care nu (se) observă

unobstructed neastupat; liber; neîmpiedicat; neobstrucționat, fără obstacol, neînfundat; liber de obstrucții

unobstructive $(\mathrm{OM})$ care nu poate fi împiedicat / obstrucționat / astupat

unobstrusive cu dimensiuni exterioare mici, cu gabarit redus

unobtainable care nu poate fi obținut

unoccupied time (ec, $\mathrm{TH}$ ) timp de neocupare (a forței de muncă, a utilajului), timp nefolosit / de mers în gol

unofficial neoficial; neprotocolar, neceremonios unofficially $(a d v)$ (în mod) neoficial; neprotocolar, neceremonios, fără protocol

unoil degresare, îndepărtarea uleiului, fără ungere (cu ulei)

unoperated position (mas, autom) poziție de repaus / în care maşina nu lucrează / nu poate functiona

unorganized neorganizat, nesistematizat; (adm, ec) neconstituit

unoriginal lipsit de originalitate, neoriginal; banal; comun 
unoriginality lipsă de originalitate, neoriginalitate, banalitate

unorthodox feature of a design (OM, mas) aspect neobişnuit de proiectare

unoxidable, unoxidizable (materiale, chim) inoxidabil, care nu oxidează / rugineşte

unoxidized (materiale, chim) neoxidat

unpack a despacheta; a descărca; a separa; a desface ambalajul

unpacked goods (ec, ind) mărfuri neambalate

unpacking $(\mathrm{TH})$ descărcare, despachetare, dezasamblare; (inf) despachetare a înregistrărilor, izolare a informației utile în raport cu cea de control, recuperare a datelor originale dintr-o rețea de stocare

unpaged nepaginat, fără (număr de) pagină trecută

unpaid (ec) neplătit, prost plătit; nerentabil

unpaired (mat) impar

unparalleled incomparabil; nepotrivit, neparalel

unpatented nebrevetat, nepatentat

unpaved (constr) nepavat, nepietruit, fără pavele (d. un drum)

unpay (ec) neplată

unpeeled (alim) necojit, cu coajă (d. fructe), necurățat (de coajă)

unperceivable imperceptibil, (de) neobservat, greu de observat

unpersuadable de neîndeplinit, de neexecutat, de neconvins

unperturbed neperturbat (d. un sistem, un semnal, un proces etc.)

unpick a descoase, a desface

unpicked descusut, desfăcut; (agr) necules (d. fructe); neales, neselectat

unpickled spot (met) zonă / pată nedecapată unpigmented rubber cauciuc fără ingrediente

unpin a scoate acele / ştifturile din, a desface din ace / ştifturi, a elibera, a lăsa liber

unplaced nevândut, neplasat

unplait a despleti, a desface

unpleasant neplăcut, dezagreabil; supărător; grețos

unplug (el) a deconecta, a scoate fişa / ştecherul (din priză)

unpointed $(\mathrm{OM})$ neascuțit, bont, fără vârf; tocit, care nu taie (d. cuțite, scule etc.)

unpoised neechilibrat, lipsit de echilibru

unpolarized (fiz) nepolarizat

unpolished nelustruit, neşlefuit, nepolizat, mat; grosolan

unposted neexpediat

unpractical nepractic, lipsit de simț practic; neeconomic unpractised nepracticat, neexersat; neexperimentat, lipsit de experiență

unprecedented fără precedent, nemaipomenit

unpriced fără preț, neprețuit, neevaluat

unprized fără valoare, neapreciat; insuficient prețuit / socotit, subestimat, subevaluat

unprocessed neprelucrat, brut, crud, în stare brută unprocurable de negăsit, de neobținut, de neprocurat, care nu se poate procura / obține (d. piese de schimb, resurse etc.)

unproductive (ec, $\mathrm{TH}$ ) neproductiv; (agr) lipsit de fertilitate, arid; steril; nerodnic; infructuos

unprofessional (cu caracter) neprofesional; (de) amator

unprofitable neprofitabil, nelucrativ, nerentabil, neavantajos

unprofitableness lipsă de rentabilitate, nerentabilitate; inutilitate

unprovability (mat) proprietatea de a nu putea fi demonstrat

unprofitably $(a d v)$ (în mod) nerentabil, neprofitabil; inutil, zadarnic

unprolific sterp, steril, nerodnic, neroditor; (agr) lipsit de fertilitate, nefertil, infertil

unpromising care nu (pare a) promite nimic; lipsit de prespective / viitor; neatractiv

unprompted neforțat, spontan

unprosperous neînfloritor, deloc prosper, lipsit de prosperitate; neprielnic, nefavorabil

unprotected fără apărare / protecție; $(\mathrm{OM})$ neprotejat, fără carter

unprovable (de) nedemonstrat, nedemonstrabil, care nu poate fi dovedit / demonstrat

unproved, unproven nedemonstrat (şi în logica matematică)

unprovided (ec, mas, $\mathrm{TH}$ ) neaprovizionat, neprevăzut cu

unproblishable nepublicat, de nepublicat, care nu merită să fie publicat

unpublished inedit, nepublicat, netipărit (d. un articol etc.)

unqualified necalificat; neinstruit; inconpetent, necompetent; incapabil; fără calificative / calificare; simplu; fără modificatori sau determinanți

unquantized (fiz, ec) necuatificat

unquenchable (met) necălibil

unquenched (met) necălit

unquestionable indiscutabil, incontestabil, în afară de orice discuție; mai presus de orice îndoială, care nu poate fi suspectat / pus la îndoială

unquestioned necontestat, incontestabil 
unquestioning care nu pune întrebări; discret, mut, încrezător

unquotable care nu poate fi citat

unquote a închide ghilimelele, a încheia citatul

unquoted nemenționat, nepomenit, necitat; (ec) necotat la bursă

unrated (ec) neevaluat; netaxat; neimpus; neimpozabil

unratifed (pol) neratificat (d. un tratat)

unravel (textile, plast, el) a descurca, a dezlega, a descâlci (fire); a (se) deşira; (fig) a lămuri, a clarifica, a rezolva, a soluționa

unreacted nereacționat, care nu a reacționat la; care nu a avut o reacţie chimică

unreactive (chim) nereactiv

unreactiveness inerție (chimică)

unreactive polyamide (chim) poliamidă nereactivă

unread necitit

unreadable ilizibil, de necitit, neciteț; (inf) care nu poate fi citit

unreadiness lipsă de pregătire; lipsă de promtitudine / serviabilitate; rea voință; încetineală

unready nepregătit, care nu este gata; lipsit de promtitudine; nehotărât, ezitant

unreal ireal, nereal; imaginar, fantezist, fantastic; nefiresc, nemaipomenit, de necrezut

unreality irealitate, nerealitate, absență a realității, caracter imaginar; născocire

unrealizable irealizabil, de neînfăptuit, de nerealizat, imposibil de realizat; ireal

unreasonable irațional, nerațional, lipsit de rațiune; cu care nu se poate discuta, lipsit de logică, care nu poate fi convins (cu argumente); inexplicabil, de neînţeles

unreasonableness lipsă de rațiune / judecată / înțelepciune; iraționalitate, caracter nerațional; lipsit de înțelegere, obtuzitate; caracter inexplicabil / de neînțeles

unreasonably $(a d v)$ (în mod) nerațional, irațional, neînțelept, făă rațiune / înțelepciune; (în mod) nejustificat / inexplicabil / de neînțeles, fără motiv / justificare

unreceipted (ec) neachitat, pentru care nu s-a emis chitanță

unreciprocated la care nu s-a răspuns, care nu se bazează pe reciprocitate

unreclaimed (agr) înțelenit, necultivat, rămas în paragină

unrecognizable neidentificabil, care nu poate fi identificat / recunoscut, de nerecunoscut, imposibil de recunoscut, total schimbat unrecognized nerecunoscut, neindentificat unreconcilable (ec, adm) ireconciliabil, de neîmpăcat

unrecorded (adm, ec, jur) neînregistrat (în acte / registru), neînscris; neîndeplinit, neexecutat; (ec) nerăscumpărat, neachitat

unrecoverable nerecuperabil, irecuperabil; ireversibil

unrecoverable deformation (mec, $\mathrm{OM}$ ) deformaţie ireversibilă / permanentă

unrecoverable information (inf) informație permanentă / ireversibilă / nerecuperabilă

unrecoverable error $(\mathrm{TH}$, autom) eroare ireparabilă; (inf) eroare nerecuperabilă

unrecoverable losses $(\mathrm{TH}$, ind) pierderi nerecuperabile

unreel (textile, OM) depănător, derulator; desfăşurător, dispozitiv de derulare; a (se) derula, a (se) desfăşura (un fir)

unredeemable neamortizabil

unrefined nerafinat, nesupus recristalizării

unrefined oil (alim, ind chim) ulei nerafinat

unregarded nerespectat

unregistered (ec, adm) neînregistrat, neînmatriculat (d. un autoturism etc.); nerecomandat, simplu (d. o scrisoare)

unregulated nesistematizat; (el, autom) neregularizat; (pol, jur) nereglementat, nelegiferat; (fiz) sursă de putere nestabilizată strict / neregularizată

unrelated fără legătură (cu ceva), irelevant, nerelevant

unreliability caracter inconstant, caracter care nu prezintă încredere / garanție / siguranță; (mas) non-fiabilitate, lipsă de fiabilitate; neseriozitate

unreliable inconstant; care nu prezintă încredere / garanție / siguranță; (OM, mas) nefiabil; pe care nu te poți baza, în care nu poți avea încredere; neserios; nesigur

unremarked neobservat; necomentat, trecut sub tăcere

unremembered uitat, dat uitării

unremembering uituc, care nu îşi aduce aminte

unrenumerated $(\mathrm{ec})$ nerenumerat, neplătit

unrenewed rămas nereînoit

unrepaid (ec) nerambursabil, neînapoiat; nerăsplătit, nerecompensat; nepedepsit

unrepresented (pol, adm) nereprezentat, fără reprezentant

unrequested necerut, nesolicitat; spontan; a vorbi neîntrebat

unresisted flow (hidr) curgere fără pierderi / fără rezistențe (hidraulice) 
unresisting care nu opune rezistență, care nu se împotriveşte; docil, supus, maleabil

unresolved nerezolvat, fără soluție; nehotărât, indecis

unresponsive placid, rece, apatic, indiferent; care nu reacționează, cu care nu poți comunica; (autom) care nu răspunde / nu reacționează la (parametrii de intrare)

unresponsively $(a d v)$ indiferent, cu indiferență, (în mod) pasiv, fără a reacționa într-un fel, neoferind posibilitatea de comunicare

unresponsiveness indiferență, placiditate, apatie; lipsa oricărei reacții; imposibilitate de comunicare

unrestrained nerestricționat, fără restricții (în proiectare, modelare etc.); spontan

unrestricted fără condiții / restricții

unretentive care nu reține nimic, cu memorie slabă (d. o persoană)

unrewarded $(\mathrm{ec})$ nerăsplătit

unrewarding (ec) nerentabil, nerenumerativ, prost plătit; care nu aduce satisfacții, care nu este răsplătit / recompensat

unrifled (OM, mil) neghintuit; (alim, OM) nerifluit (d. tavălugi de moară)

unrig (nav) a dezechipa, a dezafecta (un vas, o instalație marină)

unrighteous inechitabil, nedrept; nejust, injust, incorect

unrip (textile) a descoase, a desface (prin deşirare)

unripe (alim) necopt, crud (d. fructe etc.); imatur; lipsit de înțelepciune; (fig) necopt

unrivalled fără rival / adversar

unrivet $(\mathrm{OM})$ a scoate / a tăia nituri

unriveting $(\mathrm{OM})$ scoatere / tăiere a niturilor

unroll (met, plast, textile) derulare; desfăşurare; depănare; a derula, a desface un rulou (de tablă, de folie, de hârtie etc.)

unrolling derulare (a unui cablu, a unui rulou etc.); v. unroll

unrolling device $(\mathrm{OM})$ derulator, dispozitiv de derulare

unround colțuros, nerotunjit; lipsit de armonie

unsafe nesigur, periculos, primejdios; care nu prezintă garanții

unsafe fuel (termo, av) combustibil inflamabil / cu gard mare de risc / care nu oferă siguranţă

unsafety nesiguranță, insecuritate, lipsă de siguranță / securitate; fără siguranță

unsalable (ec) nevandabil

unsalaried $(\mathrm{ec})$ nesalariat, neplătit, fără salariu unsalted (alim) nesărat, proaspăt, neconservat, fără sare, fără gust unsalted butter (alim) unt nesărat / proaspăt / neconservat

unsalvageable nerecuperabil, irecuperabil (d. materiale, informatii etc.); (c) care nu poate fi salvat (d. un fişier, un program etc.)

unsanitary (med, constr) insalubru, nesănătos

unsaponifiable (chim) nesaponificabil

unsaponifiable grease (chim) unsoare nesaponificabilă

unsatisfactorily ( $a d v$ ) (în mod) nesatisfăcător, necorespunzător; insuficient, în insuficientă măsură, în prea mică măsură

unsatisfactoriness caracter nesatisfăcător / necorespunzător; insuficiență, caracter insuficient / neîndestulător

unsatisfactory nesatisfăcător, necorespunzător, inadecvat; insuficient, neîndestulător

unsatisfied nesatisfăcut, nemulțumit

unsatisfiedness nesatisfacere, nemulțumire

unsatifying nesatisfăcător, nemulțumitor; neconvingător; neîndestulător

unsaturable (chim) nesaturabil, insaturabil

unsaturated (chim) nesaturat

unsaturated polyester (chim) poliester nesaturat

unsaturated side chain (chim) catenă laterală nesaturată

unsaturated solution (chim) soluție nesaturată

unsaturation (chim) nesaturare, nesaturație

unsaved (c, inf) nesalvat

unsawn (materiale) netăiat cu ferăstrăul

unscanned necercetat (cu privirea sau un aparat optic); (c, metr) nescanat, nebaleiat

unscattered (fiz) neîmprăştiat, nerisipit

unscented fără miros / parfum, nemirositor

unscheduled neprevăzut (în plan, proiect etc.), neplanificat; neprogramat; netrecut pe o listă

unscheduled maintenance (mas) mentenanță / reparație / reglare / întreținere neplanificată

unschooled (edu) fără educaţie / cultură; neștiutor, ignorant

unscientific neştiințific

unscientifically $(a d v)$ în mod neştiințific

unscraped $(\mathrm{OM}, \mathrm{T})$ nezgâriat

unscreened (el, OM) nearmat, neecranat; (mil, fiz) neblindat; (alim, ind chim) nesortat, necernut; (constr) expus, neadăpostit; $(\mathrm{OM})$ neprotejat

unscrew (OM) a deşuruba, a desface un şurub / o piuliță

unscrewing $(\mathrm{OM})$ deșurubare, care se deșurubează

unseal a rupe un sigiliu; $(\mathrm{OM})$ a deschide, a desface, a dezafecta o etanşare 
unsealed (transp, jur) desigilat, cu sigiliul rupt; (OM, hidr) neetanşat (din proiect sau ca defect); desfăcut (d. un plic)

unseam (textile, ind) a descoase, a desface cusături

unsearchable de necercetat; impenetrabil, misterios, secret

unsearchableness impenetrabilitate, caracter inscrutabil / impenetrabil (al unui fenomen)

unseasonable inoportun, venit / apărut la un moment inoportun; nepotrivit, deplasat; şocant; de prost gust

unseasonableness inoportunitate, caracter inoportun / nepotrivit; gust îndoielnic

unseasonably $(a d v)$ (în mod) inoportun, la moment nepotrivit; cum nu trebuie, (în mod) greşit, nepotrivit

unseasoned (alim) necondimentat, fără gust / savoare, fad, nesărat, nou, neînvechit (d. vin); verde, crud (d. lemn); fără experiență (d. o persoană), nedeprins

unseat a răsturna, a arunca jos (şi dintr-un post), a scoate din funcție, a destitui

unseatworthy (nav) nepotrivit pentru călătorie pe mare, în stare proastă de navigabilitate, care nu poate pleca în cursă / ieşi în larg

unseconded nesecondat, nesusținut, nesprijinit

unsecured $(\mathrm{OM}$, mas) neasigurat (mecanic), prost închis, fixat nesigur; (ec, TH) fără garanție, negarantat, fără siguranță (în funcționare)

unsedentary neaşezat, nomad, instabil, migrator; nesedentar

unseen nevăzut, invizibil; neoservabil, (care a trecut) neobservat; (traducere) la prima vedere, improvizat

unsegregated (materiale) desegregat, nesegregat unsent (transp) neexpediat, netrimis (d. scrisori, o marfã etc.)

unsent for nesolicitat pentru, nechemat pentru, după care nu s-a trimis; nepoftit la

unserviceable inutilizabil, nefolositor, nepractic; pe care nu te poți bizui, nesigur, nestatornic

unserviceableness inutilitate, caracter inutilizabil

unset (metr, autom) aducere la starea inițială / la zero

unset concrete (constr) beton neîntărit

unsettle (mas, OM) a dezechilibra, a răsturna, a întoarce pe dos, a tulbura, a dezorganiza

unsettled (constr) netasat, neîntărit (d. beton); (fiz) nesedimentat, nedepus, tulbure (d. amestecuri lichide, suspensii etc.); (ec) neachitat, neplătit, nerambursat, neonorat;instabil, supus fluctuațiilor; $(\mathrm{OM})$ dezechilibrat, răsturnat, inconstant, inconsecvent, variabil, supus schimbării, schimbător; nehotărât, indecis; dubios, îndoielnic

unsettledness nesiguranță, stare nesigură / schimbătoare; nehotărâre, şovăire

unsew (textile) a descoase

unshaken nezdruncinat, ferm, neclintit

unshapely inform, diform, fără formă (clară), strâmb

unsharp neclar, cu contur imprecis, fără contrast (d. imagini)

unsharpness neclaritate; imprecizie a contururilor (d. imagini)

unsheltered neprotejat, neadăpostit, neocrotit, în aer liber

unsheltered industry (pol, ind) industrie neprotejată de importul produselor similare

unshielded (fiz, OM) neecranat, neprotejat $\mathrm{cu}$ ecran / cu apărătoare, descoperit

unshielded metal arc welding (met, TH) sudare cu arc electric neprotejat / neacoperit

unshift (mec, OM) împingere înapoi, neschimbabil, fix, imobil

unshiftable $(\mathrm{OM})$ care nu poate fi schimbat / mutat, fix, imobil

unship (nav, transp) a debarca (pasageri), a descărca (marfă)

unshrinkable (materiale) necontractabil, fără contracție, care nu intră la apă

unshut neînchis, deschis

unsifted necernut ( $d$ nisip etc.); neverificat (d. informații), neexaminat bine

unsigned (mat) fără semn (în algebră)

unsilt (constr, mediu) a decolmata (o canalizare, un canal), a curăți

unsinkable (nav) care nu se poate scufunda, nesubmersibil, insubmersibil

unsinkability (nav, materiale) proprietate de a nu putea fi scufundat, nescufundabilitate, insubmersibilitate

unsized (OM) neîncleiat; (textile) neapretat

unskilful neîndemânatic, inabil, lipsit de îndemânare, stângaci, greoi, nepriceput

unskilled (lucrător) necalificat, fără calificare

unskimmed (alim) nesmântânit, cu caimac, de pe care nu s-a luat caimacul (la lapte şi produse din lapte)

unslaked lime (met, ind chim) var nestins

unslip $(\mathrm{OM})$ a elibera, a dezăvorî

unsmooth $(\mathrm{OM}, \mathrm{TH})$ care nu e neted

unsolder $(\mathrm{OM}, \mathrm{TH})$ a dezlipi

unsoldered joint $(\mathrm{OM})$ legătură nelipită (corect) 
unsoldering $(\mathrm{OM}, \mathrm{TH})$ dezlipire (d. lipituri tari, între piese metalice)

unsolicited benevol, nesolicitat; necerut; (făcut) spontan, din proprie inițiativă

unsolid $(\mathrm{OM}$, constr) şubred, care nu e solid; firav, netrainic, lipsit de soliditate

unsolvability (ec) insolvabilitate; (mat) propritate de a nu putea fi rezolvat

unsolvable (mat) de nerezolvat, fără soluție / rezolvare; inextricabil

unsolved nerezolvat, nesoluționat, nedescifrat unsorted (materiale, inf) nesortat, neordonat unsorted sawn wood (silv) cherestea nesortată unsound (fiz, OM) fragil, casant; defectuos, greşit, imperfect, stricat, cu defecte; nesănătos; nerațional, irațional; nejustificat; greșit (conceput)

unsound castings (met) piese turnate greşit unsoundness lipsă de înțelepciune, caracter nerațional / greşit, bază greşită

unsown, unsowed (agr) nesemănat, neînsămânțat

unspecialized nespecializat, fără specializare unspecific nespecific, necaracteristic, atipic unspecified nespecificat, neprecizat

unspectacular care nu face impresie; simplu, neprotocolar

unspent necheltuit; neatins, intact, neutilizat

unsplinterable glass (ind chim) geam tip securit

unsplit (OM) dintr-o bucată, masiv

unspoiled nealterat, nestricat, intact; pur; necorupt

unspontaneous nespontan, lipsit de spontaneitate; contrâns, făcut la comandă

unspotted (materiale, $\mathrm{OM}$ ) nepătat, fără pete unsprung (montat) fără arcuri / fără suspensie cu arcuri, nearmat (d. un declanşator)

unsprung mass $(\mathrm{OM})$ masă nesuspendată (pe arcuri)

unspun (textile, met, plast) deşirat (de pe bobină), desfăcut (d. un fir, un ghem etc.)

unsquared neecarisat, nedecojit (d. lemne de construcție)

unstability instabilitate

unstable (cu echilibru) instabil, nestabil, labil, astabil; şubred, nesigur

unstable balance (fiz, mec) echilibru instabil / labil

unstable lubrication (T) ungere / lubrifiere instabilă / discontinuă

unstable position (mec, mas) poziție instabilă

unstable running (mas) funcționare / mers instabil( $\breve{a}) /$ neuniform $(\breve{a})$ unstable state (mas) regim instabil / nestabil; (fiz) stare instabilă

unstainable care nu se poate colora / păta, care nu prinde culoare / pete

unstamped netimbrat, nemarcat, nefrancat, netaxat, neştampilat

unstated nemenționat; (ec, adm, jur) nestipulat

unstatutable nestatutar, nediplomatic, lipsit de diplomație, în contradicție cu statutul, contrar regulamentului

unsteadfast (mec) instabil, uşor de dezechilibrat, inconstant

unsteadfastness instabilitate, inconstanță

unsteadily $(a d v)$ fără stabilitate, fără/ echilibru, (în mod) instabil, inconstant, inconsecvent, nestatornic; fără siguranță, nesigur, şovăielnic

unsteadiness (mat) variabilitate; instabilitate; lipsă de stabilitate / echilibru; inconstanță, inconsecvență, nestatornicie

unsteady variabil, neregulat, labil, instabil, nestabil, nestaționar, neuniform, inconstant, inconsecvent

unsteady feed (mas-un) avans / alimentare neuniform( $\breve{a}) / \operatorname{periodic}(\breve{a})$

unsteady flow (hidr) curgere nestaționară

unsteady motion (mec) mişcare neuniformă / nestaționară

unsteady state (fiz, termo) stare nestaționară / neuniformă / variată; (mas) regim nepermanent / variabil / instabil

unsteady-state flow (hidr, T) curgere nestaționară / neuniformă / variată

unsteady traffic (auto) trafic instabil (cu variatii de viteză şi densitate de autovehicule)

unstirred care nu a fost mişcat din loc; calm, impasibil, nemişcat; netulburat

unstitch (textile, OM) a descoase (o cusătură), a desface (copci, capse etc.)

unstop $(\mathrm{OM})$ a deschide, a desfunda, a debloca, a elibera de un obstacol

unstoppable de neoprit, imposibil de oprit; imparabil, imposibil de parat

unstopped destupat, deschis; neoprit

unstrained (mec) relaxat, destins; nefortat, necontractat, nedeformat; neconstrâns, lipsit de constrângere; nestrecurat, nefiltrat

unstrap (OM) a desface (curele, legături etc.), a descheia (nasturi); a dezlega (un pachet etc.) unstressed $(\mathrm{mec})$ nesolicitat, fără tensiuni

unstressed casting (met, plast) turnare fără tensiuni interne

unstressed member (constr, mec, OM) element (de grindă / de fermă) nesolicitat (cu efort nul) 
unstretch a slăbi, a destinde (un cablu)

unstrung destins, neîncordat; slăbit

unstuck dezlipit, desprins, desfăcut

unstudded chain (nav, OM) lanț de ancoră cu zale fără pod

unstudied nestudiat, necercetat, neaprofundat; natural, firesc, neprefăcut; nepreparat; neînvățat, neinstruit, ignorant, neşcolarizat

unsubscribed nesemnat (d. un act); (ec) (capital) nesubscris

unsubsidized (pol, adm, ec) nesubvenționat, nestipendiat; care nu primeşte subvenții / subsidii / stipendii

unsubstantial lipsit de substanţă, nesubstanțial; caracter firav; superficialitate, inconsistență

unsubstantially $(a d v)$ (în mod) nesubstanțial; firav, şubred; (în mod) inconsistent, superficial

unsubstantiated nedovedit, nesusținut de argumente / fapte, necoroborat cu dovezi, nefondat, neîntemeiat

unsuccess, unsuccessfulness nereuşită, eşec

unsuccessful neizbutit, nereuşit, eşuat: care a dat greș / a eşuat; (ec) falimentar

unsugared (alim) neîndulcit, fără zahăr

unsuitability, unsuitableness incapacitate; caracter inadecvat / impropriu; inoportunitate

unsuitable nepotrivit, necorespunzător, inadecvat

unsuitably $(a d v)$ (în mod) nepotrivit / necorespunzător, inadecvat, (aşa) cum nu trebuie

unsupervised nesupravegheat

unsupportable insuportabil, intolerabil

unsupported $(\mathrm{OM})$ fără suport, nerezemat, nesusținut, nesprijinit; neconfirmat, neîncurajat

unsupported film adhesive (plast) adeziv film / peliculă, adeziv fără suport inactiv

unsupported length (mec, OM) distanță între reazeme, lungime liberă, consolă

unsure nesigur (pe sine), şovăielnic, ezitant

unsurmountable de netrecut, de neînvins, insurmontabil

unsurpassable (imposibil) de netrecut, de neînvins

unsurpassed (imposibil) de netrecut / de neînvins, insurmontabil, nepotrivit

unsusceptible to insensibil la

unsusceptible of incapabil de, susceptibil de

unsuspectedly $(a d v)$ pe negândite, (în mod) neaşteptat

unsuspecting, unsuspicious încrezător; nebănuitor, care nu bănuieşte

unsustainable neconvingător, de nesusținut; lipsit de valabilitate unswayed nedominat; neguvernat; neafectat unsweetened (alim) fără zahăr, neîndulcit unswept nemăturat

unsymmetrical $(\mathrm{OM})$ asimetric, nesimetric unsymmetry factor $(\mathrm{OM})$ factor de asimetrie (de formă a piesei, pt. caracterizarea unei solicitări variabile etc.)

unsystematic nesistematic, dezorganizat

untack $(\mathrm{OM})$ a desface, a scoate; a desprinde, a detaşa; a elibera, a pune în libertate untained (alim) nealterat, proaspăt, nestricat untaken neluat untapped neabordat, nefolosit, intact, virgin untapped resources $(\mathrm{ec}, \mathrm{pol})$ resurse neexploatate / nefolosite / neutilizate / neexplorate untarnished (ind chim) negudronat

untasted (alim) negustat; din care nu s-a gustat untaught (edu) needucat, ignorant, neştiutor untaxable (ec) neimpozabil, nesupus impozitării, netaxabil

untaxed (ec) neimpozitat, neimpus, scutit de impozit / taxă

unteach a dezvăța

unteachable (edu) slab / prost / incapabil la învățătură; needucabil, imposibil de educat

untechnical netehnic, nespecializat

untempered (met) nerecopt, nerevenit

untenability imposibilitate de a apăra; inconsistență, lipsă de valabilitate (d. o teorie), imposibilitate de a fi susținut

untenable care nu poate fi apărat; care nu poate fi susţinut, uşor de combătut; de neconceput

untenantable nelocuibil, de nelocuit, impropriu de locuit; care nu se poate închiria

untenanted neocupat, liber, gol, fără chiriaș; (agr) nearendat, nedat în arendă; fără ocupanți untended nepăzit, nesupravegheat; neîngrijit untested netestat, neîncercat, nesuspus la probe unthinkable inimaginabil, de neconceput, imposibil de conceput

unthinking nechibzuit, care nu se gândeşte la nimic; zăpăcit, pripit; lipsit de atentie, neatent unthinkably $(a d v)$ fără să se gândească, (în mod) necugetat; neatent

unthought of neaşteptat, neprevăzut, negândit; uitat, lăsat în părăsire; nepremeditat, neintenționat, nedorit

unthread a descâlci, a descurca, a deşuruba

unthrifty risipitor, cheltuitor, nechibzuit

untidily $(a d v)$ (în mod) dezordonat, neglijent; fără grijă, la întâmplare, cum se nimereşte untidiness neglijență, lipsă de grijă / de îngrijire; murdărie 
untidy neglijent, dezordonat; neîngrijit, în dezordine

untie $(\mathrm{OM})$ a desface, a dezlega, a deznoda; a rezolva

untied dezlegat, deznodat, desfăcut; nelegat

untight $(\mathrm{OM})$ neermetic, neetanş

until (prep) până la, până ce; v. till

untile (constr) a da jos acoperişul, a descoperi o casă, a lua olanele de pe casă

untillable (agr) nearabil, necultivabil

untimeliness caracter prematur, aparaţie prea timpurie

untimely prematur, prea timpuriu, fãcut prea devreme

untirable (de) neobosit, nesupus obosenii

untiring neobosit, neodihnit, inepuizabil; care nu oboseşte

untitled fără titlu

unto (prep) spre, către înspre; (destinație) la; relația față de; aproape de

untold nespus; imens, colosal; incalculabil, nemăsurat

untorn nerupt, nesfâşiat; întreg, intact

untouchable de neatins; mai presus de orice critică; incoruptibil

untouched neatins, intact; nestricat

untoward dificil, nedisciplinat, refractar; care nu poate fi condus

untowardness nesupunere, lipsă de loialitate; caracter / aspect nefavorabil / puțin propice

untraceable căruia nu i se poate da de urmă; nedetectabil, imposibil de găsit

untracked fără drum, fără pârtie, fără potecă; nedepistat, rămas nedescoperit; nedepistat, căruia nu i s-a dat de urmă (d. un criminal, o substanță etc.)

untrained (edu) neinstruit, neexperimentat, neînvățat; (sport) neantrenat

untramelled neîmpiedicat, liber, nestingherit

untransferable netransferabil

untranslatable intraductibil, imposibil de tradus

untranslated netradus; în original

untransportable netransportabil, care nu poate fi transportat (d. o marfă, un bolnav etc.)

untraversed nestrăbătut, netraversat

untreated (materiale) netratat, fără tratament termic

untreated gasoline (ind chim, auto) benzină neetilată

untried neîncercat, neexperimentat; nesupus la încercare; neverificat

untrimmed nearanjat; nepus în ordine, dezordonat, în dezordine; nepotrivit, neîngrijit untrue, untruthful neprecis, imprecis; neadevărat, care nu corespunde adevărului, fals; incorect, inexact; mincinos

untruly $(a d v)$ fals; într-o lumină falsă; incorect, inexact

untrustworthiness lipsă de probitate; falsitate; neloialitate; caracter dubios / îndoielnic; inexactitate, incorectitudine

untruth lipsă de precizie, imprecizie; neadevăr, minciună; falsitate; rea credință

untruthfully ( $a d v)$ fals, neveridic, (în mod) neverificat, fără verificare prealabilă

untruthfulness falsitate, lipsă de veridicitate / adevăr, caracter mincinos / fals

untruth of alignment $(\mathrm{OM})$ abatere de la alniere

untuck a desface pliuri, a întinde o cută / o îndoitură (d. folii, textile etc.)

untunable (mas, OM) imposibil de reglat (fin)

untune (mas, OM) a deregla, a nu regla

untuned nereglat, dezacordat, dereglat (d. un aparat, o maşină etc.)

untuning dezacordare, dereglare (d. un aparat, o maşină etc.)

untwine a desface, a destinde, a deznoda, a descurca, a descâlci

untwist a dezrăsuci

untwisting $(\mathrm{mec})$ rotire inversă; dezrăsucire (d. fire)

untypical nespecific, netipic, atipic

Ununbium (Uub) (chim) ununbiu

ununderstandable (de) neînțeles, neinteligibil, ininteligibil

Ununhexium (Uuh) (chim) ununhexiu

Ununoctium (Uuo) (chim) ununoctiu

Ununpentium (Uup) (chim) ununpentiu

Ununquadium (Uuq) (chim) ununquadiu

Ununseptium (Uus) (chim) ununseptiu

unurged spontan, făcut din proprie inițiativă voluntar

unusable inutilizabil, de nefolosit, inutil

unused nefolosit; neuzitat; neconsumat, intact

unused to nedeprins $\mathrm{cu}$, neobişnuit $\mathrm{cu}$

unused time (mas, OM) timp nefolosit, durată de neutilizare

unusual neobişnuit, ieșit din comun; extraordinar; excepțional; nefiresc, nenatural

unusualness caracter neobişnuit / excepțional / extraordinar / ieşit din comun

unusual service conditions condiții grele / speciale / neobişnuite de lucru

unutilized (rămas) nefolosit, neutilizat

unvalued neglijat; neimportant, neînsemnat, lipsit de importanță 
unvarnished fără / lipsit de lustru / luciu / strălucire; neprefăcut, simplu, natural, firesc; neterminat; nedesăvârşit

unvarying invariabil, care nu variază

unveil a dezvălui

unvendable (ec) nevandabil, care nu este de vânzare, necormercial(izat)

unverifiable neverificabil, greu / imposibil de verificat

unversed in neversat, neexperimentat în, lipsit de rutină; nespecializat în

unviolated (jur) neviolat, neîncălcat (d. lege); intact, neatins, (exact) aşa cum era

unvouched for negarantat, neconfirmat

unvulcanized (ind chim) nevulcanizat

unvulcanized rubber (ind chim) cauciuc nevulcanizat

unwanted nedorit, indezirabil; inutil, care nu este necesar, de prisos

unwarily $(a d v)$ cu prea multă încredere, prea încrezător, (în mod) naiv; (în mod) imprudent

unwariness credulitate, naivitate; imprudență, lipsă de precauție

unwarned neprevenit, neavertizat, neînștiințtat

unwarrantable inexplicabil, fără explicație; nejustificabil

unwarranted nejustificat; nemotivat, gratuit, nefondat, nesusținut, neîntemeiat; (ec, jur) fără garanții, care nu prezintă garanții (suficiente), negarantat

unwary (prea) încrezător; naiv, credul; imprudent, lisit de precauție; neavizat, neştiutor

unwashed nespălat

unwatched nepăzit, nesupravegheat, care funcționează fără supraveghetor / fără personal de deservire

unwatered (agr) neudat, nestropit, fără apă, fără irigație; (alim) curat, fără adaos de apă (d. vin); fără ape, nemarmorat

unwatering asanare, drenaj, secare, evacuare / scoatere a apei

unwatering conduit $(\mathrm{OM}$, hidr, mediu) conductă de drenaj / de secare / de evacuare / de scoatere a apei

unwearable neobosit, inepuizabil; $(\mathrm{T})$ care nu se uzează (rar), care se uzează greu

unweighted neponderat

unweighted arithmetic average (mat) medie aritmetică neponderată

unweldable (met, plast) nesudabil

unwell (med) bolnav, indispus

unwholesomeness caracter insalubru, lipsă de salubritate unwieldiness masivitate, caracter greoi; lipsă de abilitate, stângăcie

unwieldy masiv, greoi; care se mişcă greu; stângaci

unwillingly $(a d v)$ fără voie; din greşeală; din neatenție; cu neplăcere / rea voință

unwillingness lipsă de dorință; caracter refractar / dificil; nesupunere; ostilitate, caracter ostil / neprietenos

unwind a (se) desfăşura, a derula, a depăna, a desface, a (se) dezveli, a debobina, a (se) descolăci

unwinder (textile, el, ind chim) depănător, derulator (de bandă, de fir etc.)

unwinding ( $\mathrm{TH}$, textile, el, ind chim) desfăşurare, derulare, depănare

unwisdom, unwiseness lipsă de înțelepciune, prostie; nechibzuință, nesocotință, imprudență; ignoranță, stupiditate

unwise nechibzuit, lisit de înțelepciune, imprudent; temerar, greşit

unwisely $(a d v)$ (în mod) nechibzuit, neînțelept, imprudent; greşit

unwished for nedorit la; indezirabil, supărător pentru

unwitnessed fără martor

unwitting neștiutor, neavizat; nevinovat, inocent, fără nici o vină

unwontedness caracter neobişnuit / extraordinar / ieşit din comun

unworkable neprelucrabil; impracticabil; inaplicabil, de nefolosit; nepractic, fără sorți de izbândă

unwarkableness caracter nepractic / neprelucrabil / impracticabil; imposibilitate de prelucrare / de exploatare; nerentabilitate

unworked nelucrat; neprelucrat; nefasonat unworked penetration $(T)$ penetrație a unei unsori, măsurată fără a fi supusă unei solicitări unworn neuzat; în stare (încă) bună

unworthiness lipsă de merit

unwound derulat, desfăcut, deșirat (d. fire, rulouri etc.)

unwounded (med, anat) nerănit, neatins

unwrap a desfăşura; a despacheta; a depăna unwrinkled neridat, fără riduri; neted, proaspăt unwrought neprelucrat, brut, nelucrat, neşlefuit unyielding ferm, care nu cedează; inflexibil, rigid; (met) care nu curge

unyoke a separa, a despărți

unyoked liber, neconstrâns, eliberat

up $(a d v)$ (în) sus, (drept) în sus; vertical, în aer, ridicat; (prep) spre, înspre, până la, către, în; împotriva, contra, în susul, de-a lungul; (adj) 
(de jos) de sus, în sus, în ascensiune, care urcă; în creştere, în ridicare; înalt, superior; ridicat, înălțat, construit, în picioare; (d. o persoană) în picioare, treaz, sculat, (fig) terminat, încheiat, sfârşit; (constr) în reparație, accidentat, în lucru; (s) urcuş, suiş; ridicătură de pământ, movilă; (fig) succes, reuşită, izbândă; (ec) mărire / ridicare a prețurilor; stroke lovitură / cursă de jos în sus

up against (prepoziție indicând opoziția, conflictul etc.) de față de, cu

up-anchor (nav) a ridica ancora

up-and-coming, up-and-doing (amer) energic, întreprinzător, vioi; promițător, de viitor

up and down în sus şi în jos, înainte şi înapoi

up-and-down motion (mas-un) mişcare în sus şi

în jos; (nav) la piv (lanțul de ancoră este vertical)

up-and-down stroke (mas-un) cursă dublă / de du-te-vino

up-and-up în progres, tot mai bine, spre bine; de succes, la înălțime; (amer) cinstit, onest, curat

up arrow $(\mathrm{OM})$ săgeată pe verticală (a unui conductor aerian)

upbear a susține, a sprijini; a ridica, a înălța

upburnst izbucnire, explozie

up-coiler înfăşurător

up-converter (el, elctr) amplificator de frecvență

up cut dințare superioară (la pile)

update a moderniza, a aduce la $\mathrm{zi}$, a pune de acord (o lucrare) cu ultimele teorii sau realizări, a procura informații la zi; (c) a aduce la zi, a a updata (d. informație, hard etc.)

updating actualizare (a informației), updatare

up-down counter (metr) contor / numărător reversibil

updraft / updraught carburettor (auto, termo) carburator cu curent ascendent

updraft-ceramics kiln (termo) cuptor pentru ceramice, cu flacără directă

updraft-type furnace (met, termo) cuptor cu flacără ascendentă

up-edge (mas-un, OM) a aşeza pe muchie / pe fața frontală

up-end a ridica în picioare (un butoi etc.), a se ridica (în picioare)

upender (mas) manipulator

upend forging (met) forjare pe directia fibrajului upending (met) refulare

uperization (alim) sterilizare cu abur supraîncălzit

up feed (mas-un) avans vertical / de urcare upgrade (constr) rampă, pantă, urcuş, suiş; ascendent, care urcă; în pantă; a urca o pantă; a promova; (mas-un) limită superioară; (ec) a urca (d. prețuri), a se înviora (d. afaceri), a promova (un salariat); (inf) a schimba componente sau programe pentru a creşte calitatea unui sistem operational

upgrade line (cf) linie de cale ferată în pantă, linie de rampă

upgrading (c) operație de schimbare a sistemului vechi (pt. rezultante mai performante), upgradare; (ind chim) întărire, concentrare, înnobilare, îmbunătățire; (ec) promovare, fondare a unei întreprinderi

upgrading treatment (met) afinare

upgrowing în creştere, care creşte, în dezvoltare upgrowth dezvoltare, evoluție; excrescență

up-heaval prefacere, schimbare (totală), transformare; răsturnare; (pol) mişcare (socială), revoluție

uphill în urcuş; dificil, greu, anevoios; ascendent; $(a d v)$ în sus, în susul (pantei etc.)

up-hill casting (met) turnare prin sifon

up-hill furnace (met) cuptor de topitorie cu vatră înclinată

uphold a susține, a afirma cu convingere; a sprijini; a aproba; a încuraja; a confirma

upholder sprijinitor, susținător, partizan, adept

upholster a capitona, a tapița

upkeep (cheltuieli de) întreținere

upkeep cost (ec) cost / cheltuieli de întreținere upland water (meteo, hidr) apă din zăpezi topite uplift (fiz) ridicare, înălțare, ascensiune; (hidr) forță arhimedică, subpresiune; (mec) forță ascensională

uplift pressure (hidr) subpresiune, contrapresiune

upmaking paginație

upon (prep) pe (dinamic)

upper superior, (de) deasupra, de sus, din vârf, parte superioară

upper beam (auto) fază mare

upper bed strat superior

upper bell (met) con / clopot de şarjare (la furnal)

upper blade (OM, mas-un) cuțit superior, lamă superioară (la foarfece)

upper block scripete superior

upper boiler (termo, OM) tambur / capac superior al cazanului

upper bosh line (met) pântece al furnalului upper bridge (ind) pod / eşafodaj de deservire upper case majusculă 
upper chord (constr) talpa de sus / centura superioară a fermei

upper classman (univ) (amer) student în anul III sau IV, student în ultimul an

upper crust scoarță, crustă

upper cylinder lubrication $(\mathrm{OM}, \mathrm{T})$ lubrifiere a părții de sus a cilindrului

upper dead centre (termo) punct mort superior

upper deck (constr) tăblier superior de pod; (nav) punte superioară, covertă, punte de manevră

upper deviation (autom, fiz, OM) abatere superioară (şi a câmpului de toleranță)

upper die (met, OM) poanson, contramatriță, patriță, semimatriță superioară

upper end of electrode $(\mathrm{OM})$ parte superioară a electrodului, cap de electrod

upper end piece $(\mathrm{OM})$ eclisă superioară la îmbinarea cap-la-cap, piesă la capătul superior upper feed furnace (met) cuptor cu alimentare la partea superioară

upper fired furnace (met) cuptor cu ardere în partea superioară

upper flange $(\mathrm{OM})$ flanşă superioară; talpă superioară (la o grindă)

upper half-plane semiplan superior / pozitiv

upper harmonic (fiz) armonică superioară

upper layer $(\mathrm{OM})$ strat superior / de deasupra

uppermost cel mai înalt, cel mai de sus, cel mai ridicat, superior; predominant; deosebit, ieşit din comun; $(a d v)$ în / la vârf

upper part $(\mathrm{OM}$, constr) parte superioară (şi a convertizorului)

upper range value / limit valoare / limită superioară (a intervalului / domeniului de măsurare)

upper roll (met, plast, OM) cilindru superior

upper shell of blast furnace (met) con de închidere (la furnal)

upper side latură superioară; față, suprafață; (textile) față a unei țesături

upper story / storey (constr) ultimul etaj, mansardă

upper valve (OM, termo, hidr) supapă ridicătoare

upper valve gear housing (auto, termo, OM) capac de chiulasă

upper works (nav) operă moartă (parte a navei aflată deasupra liniei de plutire), suprastructură

upper yield stress (mec) tensiune la limita superioară de curgere

upraise shaft (constr, ind) puț / gaură săpat(ă) de jos în sus upright $(\mathrm{OM})$ montant, drept, vertical; pe verticală; (mas-un) coloană, consolă; (fig) cinstit, onest, integru, corect; (mat) perpendiculară, verticală; lucru drept / îndreptățit

upright drilling machine (mas-un) maşină de găurit verticală / cu montant / cu coloană

upright frame (OM) montant, cadru (în plan) vertical

upright freezer (alim, termo) congelator vertical upright horizontal welding (met, $\mathrm{TH}$ ) sudare orizontală

uprighting machine (mas-un) maşină de găurit de precizie (cu masă rotativă)

uprighting tool (mas-un) dispozitiv de găurit axe sau arbori

uprightly $(a d v)$ cinstit, onest, cu onestitate

uprightness verticalitate, caracter vertical; perpendicularitate; (fig) corectitudine, integritate, onestitate, cinste

uprise a se ridica, a se înălța; răsărit; (fiz) ascensiune (a unui balon, a unei particule etc.); (geogr) urcuş, coastă; (adm, mil) ridicare, avansare (în rang); (OM, hidr) conductă verticală

uprunning (met) turnare în sifon

unps (and downs) accidente de teren

upset refulare; aplatizare; (met) a aplatiza, a îngroşa; a răsturna, a face să se răstoarne, a deranja, a rula (filete), a modifica diametrul sau o dimensiune prin deformare mecanică, a forma un cap de nit / de şurub; a înfrânge, a învinge; a da (un plan) peste cap

upset bolt $(\mathrm{OM})$ şurub cu cap forjat prin refulare

upset butt-welding $(\mathrm{OM})$ sudare cap-la-cap

upset clamp $(\mathrm{OM})$ clemă de strângere cu corp îndoit

upset cutter (mas-un) cuțit de mortezat pentru degroşare profundă

upset drill pipe (hidr, OM) conductă cu racord special refulat din corpul ei

upset end $(\mathrm{OM})$ cap / capăt refulat / îngroşat

upset forging (met) refulare

upset leg (met) adaos de refulare

upset metal (met) metal / aliaj refulat

upset pass (met, OM, metr) calibru de refulare

upset price (ec) curs de deschidere (la bursă), pret informativ / de pornire / cerere

upsetter (met) maşină de refulare

upsetting (met) întărire, refulare, îngroşare (şi la conducte), (tehnologie de) formare a capului unui nit / şurub

upsetting die (met, OM) matriță de refulat / pentru refulare 
upsetting factor (met, TH) factor / coeficient de refulare

upsetting machine (met, mas-un) maşină de refulat

upsetting welding sudare cu refulare

upsetting with electric resistance $(\mathrm{TH})$ refulare prin încălzire cu rezistență electrică

upset welding (met, TH) sudare cap-la-cap, cu refulare

upshift (metr) derivă pozitivă, decalaj în sens pozitiv

upshot final, rezultat; concluzie, consecință, urmare, repercursiune; corolar

upshot furnace (ind chim) cuptor vertical

upside (OM, met, constr) parte de sus, susul, parte superioară

upside-down întors (şi pe dos), răsturnat, inversat (ca poziție), cu susul în jos; dezordonat, în dezordine / neregulă; $(a d v)$ cu susul în jos, invers, în mare dezordine

upsitting indiferență, nepăsare

upstairs $(a d v)$ sus (pe scări), la etaj; (adj) de sus, de la etaj; (constr) partea de sus a casei, etajul / catul de sus

upstanding drept; voinic; cu ținută frumoasă; (fig) onest, cinstit, integru; sincer, deschis

upstay a susține, a sprijini

upstream amonte, curent amonte, în susul apei; (fig) (care merge) contra curentului; (adj) care urcă în susul râului

upstroke (TH) cursă ascendentă (şi la o maşinăunealtă)

upstroke of piston (termo) cursa ascendentă a pistonului

upsweep of the frame (OM) curbură a ramei / a şasiului

upswept (fiz) ridicat / înălțat în sus, luat pe sus, tras în sus (d. aer, într-un ciclon etc.)

upswing (fiz) (amer) urcare, ascensiune, ridicare, suiş

uptake (biol, fiz) absorbție, absorbire; asimilare; (met) canal vertical / ascendent (la furnal); (OM) ştuț; (fig) înțelegere, asimilare; be slow in / on the $\sim$ a fi greu de cap; be quick in / on the $\sim$ a le prinde din zbor,a-i merge mintea

uptake factor (biol, fiz) factor de absorbție

uptake of boilers (termo, OM) canal / conductă vertical(ă) (la un boiler, un schimbător de căldură etc.)

uptake rate (ind chim, biol) viteză de absorbție upthrow (fiz, hidr) deplasare ascendentă

up till now $(a d v)$ până acum, până astăzi; v. up to now up till then până atunci / în ziua aceea

up time timpul de utilizare directă sau de disponibilitate a unui echipament

up to (în) spre, până la

up-to-date modern, la modă; modernizat; actual, nou, conform ultimelor progrese / noutăți ale tehnicii, (adus) la zi; a aduce la zi, a moderniza

up-to-dateness caracter modern, modernitate, noutate; eleganță

up to now $(a d v)$ până acum, până azi / în zilele noastre

up to size $(\mathrm{OM}) \mathrm{cu} /$ la dimensiune nominală

up-to-the-minute de ultimă oră, foarte modern

uptown partea de sus a oraşului; centru (de oraş); (amer) suburbii, periferie, cartier de locuințe rezidențiale, suburban, de la periferie; $(a d v)$ în / spre centru; (amer) spre periferie; central

upturn înăltare, ridicare; sporire; progres, propăşire; a ridica, a înălța, a îndrepta în sus

uptwist a răsuci mult

uptwisting răsucire / torsiune mare

upward ascendent, care se ridică / înalță, care merge în sus, de ridicare / înălțare, îndreptat în sus; efect de absorbție / de admisie / de aspirație

upward compatibility (c) capacitate a unui computer / echipament de a funcționa cu programe mai noi

upward current classifier (alim, ind chim, mediu) sortator cu curent ascendent

upward draft (termo, hidr) efect de absorbție / de admisie / de aspirație

upward force (fiz, mec) forță ascensională, portanță

upward motion / movement (fiz, mas) mişcare ascensională, cursă ascendentă

upward pull (fiz, hidr) efect de absorbție / de admisie / de aspiratie; (termo) tiraj

upwards $(a d v)$ în sus, spre partea superioară

upwards of $(a d v)$ peste, mai bine / mult de

upward stroke (auto, OM) cursa ascendentă a pistonului

upward velocity (fiz) viteză de ascensiune / de ridicare

upward vertical weld $(\mathrm{OM})$ cusătură verticală de sudură, depusă de jos în sus

uranate (chim) uranat

uranide (chim) element transuranic

Uranium (U) (chim) uraniu

urate (chim) urat, sare a acidului uric

urban urban, orășenesc 
urbane civilizat, urban; rafinat

urbanification (adm) urbanizare

urbanism (adm, arhit) urbanism, sistematizare urbană

urbanist (constr, arhit) arhitect urbanist; sistematizator, specialist în urbanistică / sistematizarea orașelor

urbanization (constr, arhit) transformare urbană, urbanizare

urbanize (constr, arhit) a urbaniza

urban renewal (amer) (constr, arhit, adm) demolare şi sistematizare a cartierelor vechi / sărace

urban sprawl dezvoltare exagerată a metropolelor, expansiune urbană

urea (ind chim) uree

urea-formaldehyde resin (UF) (ind chim) răşină ureo-foraldehidică

urge îndemn, impuls; stimulent; chemare, apel; solicitare; stimulent; a forța (și o mașină etc.), a suprasolicita, a determina, a impune; a recomanda (insistent); a îndemna; (ec) a insista; a mâna (caii etc.); a sili; a (supra)solicita; have / get an $\sim$ to do smth. a avea / a-l cuprinde dorința sa facă ceva

urgency urgență, caracter urgent / imperios / presant / necesar; presiune, insistență

urgent important, de primă importanță; (absolut) necesar; imperios, presant; urgent; insistent

urge on a insista asupra / pentru; (pol, adm) a presa pentru

urna (metr) a Roman unit of volume equal to about 12,751

usability, usableness utilitate, aptitudine, aplicabilitate, posibilitate de utilizare / folosire / întrebuințare, caracter utilizabil

usable utilizabil, care poate fi utilizat / folosit, util, folositor

usable flank (OM) flanc activ / utilizabil (şi la dantură)

usable length $(\mathrm{OM})$ lungime utilă

usable range $(\mathrm{el}, \mathrm{mec})$ domeniu / sector / interval util

usable reservoir storage (auto, OM, hidr) capacitate utilă a rezervorului, rezervă (şi de apă)

usable storage capacity (hidr, OM) capacitate utilă de înmagazinare (d. rezervoare, recipiente etc.)

usably $(a d v)$ (într-un mod) utilizabil, practicabil, practic, util

usage folosire, utilizare, întrebuințare; uzaj, uz; uzanță; obicei usance uzanță; $(\mathrm{ec})$ termen obişnuit de plată

USB (c) abreviere pentru Universal Serial Bus - interfață serială bidirecțională ataşabilă pentru periferice de viteză mică (tastatură, mouse, scaner, imprimantă etc.), port / intrare USB

USB port (auto, c) port USB la computerul de bord

use utilizare, folos, folosire, exploatare, întrebuințare; utilitate, valoare; v. usability; datină, obicei; (ec) profit; valoare; scop, tel, tintă; practică (curentă); a folosi, a utiliza, a întrebuința, a uza; a (se) consuma, a lua din; a se comporta cu, a se purta cu; a se comporta fată de, a se purta față de; a trata (pe cineva); have the $\sim$ of smth. a avea acces la ceva, a avea dreptul / permisiunea de a folosi ceva; in $\sim$ în uz, (care este) folosit; out of $\sim \operatorname{scos} \operatorname{din} u z$, neîntrebuințat, neutilizat; unfit for $\sim$ inutilizabil, care nu se potriveşte (pentru); instructions / directions for $\sim$ (mas) instrucțiuni de utilizare / de folosire / de exploatare; ready for (mas, c, metr) gata pentru utilizare; outnumber $\sim \operatorname{scos}$ din uz, neuzitat; prior $\sim$ posesiune anterioară (a unei invenții brevetate); readiness for $\sim$ (mas, c) (starea de a fi) pregătit / gata pentru functionare / utilizarea; have no for smth. a nu avea nevoie de ceva, a avea o părere proasta despre ceva; have no $\sim$ for smb. a avea o părere proasta despre cineva; go out of $\sim$ a cădea în desuetitudine (d. un cuvânt, expresie, obicei), (mas, TH) a ieşi din uz (prin uzură morală, uzură, defectare etc.); make $\sim$ of a folosi (ceva), a se folosi de (ceva, cineva); joint $\sim$ (mas, autom, c) utilizare conjugată / în comun; directions for $\sim$ regulament / indicații / specificații de folosire / de utilizare

U-section (met, constr) profil U

used $(\mathrm{OM})$ folosit, utilizat, întrebuințat; vechi, de ocazie (d. un produs etc.)

used air (termo) aer uzat / evacuat

used-car lot (amer) centru de desfacere a automobilelor de ocazie

used fuel (auto, mas, chim) combustibil utilizat / uzat

used oil (auto, mas, chim) lei uzat / degradat în functionare

used sand (met) amestec de formare utilizat

used to a obişnui să, a avea obiceiul să; deprins / obişnuit cu / să

used-up purtat, uzat, utilizat, folosit până la epuizare / consumare, epuizat, sfârșit; obosit, epuizat (d. o persoană) 
use up a (se) consuma (şi complet), a (se) epui$\mathrm{za}, \mathrm{a}$ (se) termina (resurse etc.)

used waste paper (ind chim, birotică) maculatură

used water (ind, hidr, mediu) apă uzată / menajeră

use factor (TH, mas) coeficient / factor de utilizare

useful folositor, util; utilizabil; net; eficace; bun, valoros; capabil, de nădejde

useful area $(\mathrm{OM})$ secțiune / suprafață utilă useful capacity $(\mathrm{OM}$, mas) capacitate utilă

useful current curent efectiv / util

useful cross section $(\mathrm{OM})$ secțiune transversală utilă

useful effect lucru / efect util, acțiune utilă, randament

useful efficiency $(\mathrm{mec})$ putere utilă

useful effort (mec) randament

useful head (mec, hidr) presiune utilă

useful heat (mec, termo) căldură efectivă / utilă

useful hight of cupola (met) înălțime utilă a cubiloului

useful horsepower (mec, mas) putere utilă (exprimată în cai-putere)

useful life (mas, OM) durată de exploatare / de funcționare / de utilizare, durată utilă de viață

useful lift (mas, mec) putere de ridicare, forță de ridicare / aerodinamică

useful load (mas, transp) sarcină / greutate / încărcătură utilă

usefully ( $a d v)$ (în mod) util, folositor, cu folos

usefulness utilitate, caracter util / folositor

useful output (mas) putere utilă / la ieşire, productivitate, efort util

useful power (mas) putere utilă

useful resistance (el) rezistență utilă

useful section $(\mathrm{OM})$ secțiune utilă

useful voltage (el) tensiune utilă

useful volume (OM, termo, transp) volum util

useful weight $(\mathrm{OM}$, transp) greutate / masă utilă

useful work (OM, termo, transp) putere utilă / efectivă, lucru mecanic util

useless nefolositor, inutil, lipsit de valoare, fără nici o valoare; fără (nici un) efect

uselessly $(a d v)$ (în mod) inutil, nefolositor, fără rost

uselessness inutilitate; lipsă de valoare / de efect useless rock (ind) steril

user (el, ec) consumator, utilizator, abonat; (jur) drept de uzufruct

user friendly (c) atribut al unor programe usor de utilizat use ratio (materiale, $\mathrm{TH}$, mas) factor de utilizare use up a epuiza, a folosi până la epuizare, a consuma complet, a termina; a uza

U-shaped piece (OM) piesă cu cot dublu

ushering inaugurare, începere, introducere (a unui element nou)

US shipping ton (metr, nav, transp) altă denumire pentru freight ton, unitate tradițională de volum pentru măsurarea încărcăturii unei nave, a unui tren etc.: 1 freight ton $=1$ US shipping ton $\cong 1,1326 \mathrm{~m}^{3}$, totuşi poate însemna 1 tonă (metrică), volumul nefiind specificat.

using (mas, materiale) utilizare, folosire, exploatare, întrebuințare, care foloseşte / utilizează

U-slot piston (auto, OM) piston cu fantă în V

USP unit (metr) unitate utilizată în US pentru a măsura efectul vitaminelor sau medicamentelor, determinată pentru fiecare substanță, pentru aprecierea efectelor biologice; în majoritatea cazurilor USP unit este egală cu international unit (IU); v. international unit

U-steel (met, constr) profil U din oțel, oțel U

usual obişnuit, uzual, curent, de uz curent; as ca de obicei; as is but $\sim$ după cum se obişnuieşte; as per $\sim$, as usual ca de obicei; out of the $\sim$ / common road / run iesit din comun; neobişnuit, (fig) pe căi nebătătorite / neumblate; dish up the $\sim$ arguments in a new form a face variații pe aceeași tema, a prezenta / da argumente vechi într-o formă nouă; terms (u.t.) (ec, TH) condiții obişnuite / uzuale

usually $(a d v)$ (în mod) obişnuit, de obicei, (în mod) curent

usualness caracter obişnuit / normal / curent; curență

usual practical units (el) unități practice uzuale usual type $(\mathrm{OM})$ tip uzual

utensils (OM, mas-un) sculă, unealtă, ustensile

utilizable $\mathrm{v}$. usable

utilizable utilizabil, folosibil

utilizable discharge (transp) încărcătură utilizabilă / utilă; (hidr) debit instalat;

utilization (mas, materiale, TH) utilizare, folosire, exploatare, întrebuințare; v. use

utilization of waste heat (met, termo) recuperare a căldurii evacuate

utilization ratio / factor (mas, materiale, $\mathrm{TH}$ ) factor de utilizare (în special la utilaje cu exploatare intermitentă)

utilization time (mas) timp de utilizare

utilize a utiliza, a folosi, a întrebuința; v. use utilitarianism utilitarism 
utility utilitate, caracter utilitar / folositor; (adm) serviciu public utilitar, întreprindere de servicii publice; (constr) clădire, edificiu; (ec) avantaj, profit, utilitate; (c) computer de uz general (poate include sisteme de control pentru producție, abur, apă, încălzire etc.)

utility programme (c, inf) algoritm, program, instrucțiuni de utilizare

utility sofware (c) bibliotecă de programe de uz general din calculator

utility refuse (ind, $\mathrm{TH}$ ) deşeuri recuperabile / refolosibile

utility type $(\mathrm{OM})$ universal, cu destinație generală / universală

utility vehicle / car (auto) mașină / vehicul utilitar

utility waste (ind, $\mathrm{TH}$ ) deşeuri recuperabile / refolosibile

utilizable, usable utilizabil, folosibil

utilization utilizare, folosire

utilize a folosi, a utiliza

utmost (adj) cel mai îndepărtat, extrem, ultim, maxim(um) (posibil), suprem, de la margine, de limită; $(s)$ grad ultim, limită extremă, efor suprem, punct suprem; to the $\sim$ la maximum, în cel mai înalt grad, la culme; with the willingness cu cea mai mare plăcere, din toată inima; get the $\sim$ out of smb. / smth. a profita la maxim de cineva / de ceva, a scoate cât mai mult de la cineva / din ceva, a scoate tot ce se poate de la cineva / din ceva, a scoate totul de la cineva / din ceva

utter a rosti, a pronunța; a exprima, a spune; a fabrica bani falşi, a falsifica bani; total, complet utterance capăt, sfârşit, extremitate; declarație, enunt, exprimare; glas, voce; rostire

utterly $(a d v)$ total, complet, completamente, absolut, cu totul, pe-de-a-ntregul, din plin; foarte, peste măsură de, excesiv de, extrem de, din cale afară de, extraordinar; ruined complet ruinat; la pământ

U-tube (hidr, OM) tub în formă de U

U-tube manometer (metr, hidr, OM) manometru cu tub în formă de $U$

uviol glass (fiz, ind chim) sticlă uviol / transparentă la ultraviolet

uviol lamp (fiz) lampă cu ultraviolete

U-washer (OM) şaibă în formă de potcoavă 


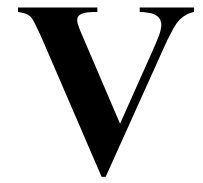

V (metr, el) simbol pentru volt, unitate de măsură în sistem SI pentru tensiune electrică

VAC (metr, el) simbol tolerat pentru tensiune electrică în circuite de curent alternativ (AC) circuit; SI nu admite alterarea simbolurilor cu informații suplimentare, recomandând $\mathrm{AC} 12 \mathrm{~V}$ în loc de 12 VAC, dar notația este tolerată

vacancy (fiz) gol, vid, vacanță, lacună; (ec) post / loc liber; spațiu / loc gol; lapsus

vacant (fiz) vacant, neocupat, liber; gol; neatent, absent

vacantness gol; post / loc liber; spațiu / loc gol; neatenție, absență, lipsă de atenție

vacant terminal (el) contact de rezervă / auxiliar vacate a lăsa vacant, a elibera; a anula

vacating $(\mathrm{adm}, \mathrm{ec})$ demisionar, care părăseşte funcția; eliberare, lăsare liberă a unui post

vacation aplicație; aptitudine; carieră; chemare, înclinație; menire; meserie, ocupație, profesie; talent, vocație; (ec) eliberare (a unui loc / post); (amer) vacanță, concendiu, a pleca în vacanță / concediu

vocational de meserie, profesional

vacation pay $(\mathrm{ec})$ plată a concediului, concediu plătit

$\operatorname{vaccin}(\mathbf{e})(\mathrm{med}) \mathrm{vaccin}$

vaccinate (med) a vaccina

vaccinated (med) vaccinat

vaccination (med) vaccinare

vacillate a se clătina, a nu avea echilibru; a osci-

la, a se legăna; a fluctua; a ezita

vacillating care se clatină, şubred; oscilant; fluctuant; ezitant

vacillation clătinare; oscilație; ezitare

vacuity absență, lipsă; neatenție, lipsă de atenție; lipsă de idei / de gândire

vacuometer (fiz, metr) vacuummetru

vacuous space (fiz) vacuum, vid, spaţiu vidat

vacuum (fiz) vacuum, vid; gol, lipsă; lapsus; a curăța cu aspiratorul

vacuum air pump (OM, fiz) pompă de vid

vacuum analyser (metr, fiz, OM) vacuummetru, manometru de vid

vacuum arc melting (met) topire cu arc electric, sub vid vacuum arc remelting (met) retopire $\mathrm{cu}$ arc (electric) a deşeurilor metalice, sub vid

vacuum augmenter (fiz, OM) dispozitiv / aparat pentru creşterea vidului

vacuum bag (plast, OM) pernă sub / de vid

vacuum booster pump (alim, ind chim) pompă de vid preliminar

vacuum bottle / flask $(\mathrm{OM})$ termos, sticlă termoizolantă

vacuum brake $(\mathrm{OM})$ presă / frână acționată de vid (în repaus)

vacuum brazing / soldering $(\mathrm{OM})$ lipire tare în cuptor cu vid

vacuum breaker $(\mathrm{OM})$ dispozitiv cu vid pentru scoaterea gazelor sau prevenirea întoarcerii curentului de fluid

vacuum casting (met, $\mathrm{TH}$ ) turnare sub vid vacuum chamber (OM, fiz) cameră de vid vacuum coating (met, $\mathrm{TH}$ ) acoperire în / sub vid vacuum clean a curăța cu aspirator de praf vacuum cleaner $(\mathrm{OM})$ aspirator de praf vacuum casting (met, $\mathrm{TH}$ ) turnare sub vid vacuum concrete (constr) beton vacuumat vacuum condenser (el) condensator cu / în vid vacuum control (hidr) reglare prin depresiune vacuum-controlled advance (auto) avans controlat / comandat prin depresiune

vacuum-controlled / -operated clutch (OM, auto) ambreiaj controlat prin depresiune

vacuum-controlled retard adjustment (auto) avans de aprindere comandat / reglat prin depresiune

vacuum-controlled spark adjustment / timing (auto, termo) avans de aprindere comandat prin depresiune

vacuum cooling plant (termo) instalație de răcire, cu vid

vacuum crystallizer (ind chim) cristalizator $\mathrm{cu}$ vid

vacuum degassing (met) afinare (a oțelului sau a altui aliaj sau metal), în vid, degazare în vid vacuum deposit(ion) (met, $\mathrm{TH}$ ) depunere în vid vacuum desiccator (alim, ind chim) exsicator / desicator cu vid

vacuum distillation (alim, ind chim) distilare în vid vacuum dryer (termo) uscător cu vid

vacuum drying oven / cupboard (ind chim, met, termo) cuptor / etuvă de uscare în vid vacuum ejector (mas-un, $\mathrm{OM}$ ) ejector cu vid vacuum evaporator (alim, ind chim) vaporizator $\mathrm{cu} /$ în vid 
vacuum extraction still (alim, ind chim) aparat de extracție în vid

vacuum filter $(\mathrm{OM})$ filtru cu vid, termos, sticlă termoizolantă

vacuum filtration (alim, ind chim) filtrare în vid

vacuum flash vaporizer (ind chim) vaporizator cu detentă

vacuum flask $(\mathrm{OM})$ balon pentru vid

vacuum forming (plast, $\mathrm{TH}$ ) formare în vid (prin vidarea spațiului dintre semifabricat şi matriță)

vacuum furnace (met) cuptor $\mathrm{cu} / \mathrm{sub}$ vid

vacuum furnace brazing (met, plast, $\mathrm{TH}$ ) lipire în cuptor, sub / în vid

vacuum fusion (metr, fiz) metodă de determinare a conţinutului de gaze prin vidare; (met) topire sub vid

vacuum gauge (metr, fiz, OM) manometru de depresiune / pentru vid, vacuummetru, indicator de vid

vacuum governer (autom, fiz) regulator de vid

vacuum grease ( $T$, ind chim) unsoare consistentă pentru vid

vacuum-grown crystal (fiz) cristal crescut în vid vacuum heating (ind chim, met) încălzire sub vid vacuum heat treatment (met) tratament termic sub vid

vacuum hose $(\mathrm{OM})$ furtun (şi de cauciuc) pentru vid

vacuum impregnating $(\mathrm{TH})$ impregnare în vid

vacuum indicator (metr, fiz) indicator de vid

vacuum jacketed flask $(\mathrm{OM}, \mathrm{fiz})$ vas Dewar

vacuum lead-timer (autom, OM) regulator de avans prin vid / vacuummetric

vacuum melting (met, $\mathrm{TH}$ ) topire sub / în vid

vacuum melting plant (met) instalație de topire sub vid

vacuum metallizing (met, $\mathrm{TH}$ ) metalizare / depunere metalică în vid

vacuum metallurgy (met) metalurgie sub vid

vacuummeter (metr) vacuummetru, manometru de vid

vacuum mixer (alim, ind chim) amestecător cu vid

vacuum-operated (autom, hidr) comandat prin depresiune

vacuum oven (termo) cuptor / etuvă cu vid

vacuum pipe (OM, hidr) conductă / țeavă de admisie sau de aspirație / de vid

vacuum plating $(\mathrm{TH})$ acoperire prin depozitare în vid (a unei pelicule) vacuum pneumatic conveyer (transp, OM) transportor pneumatic cu vid

vacuum power brake (autom, $\mathrm{OM}$ ) servofrână prin depresiune

vacuum pressing $(\mathrm{TH})$ presare sub vid

vacuum production $(\mathrm{TH}, \mathrm{fiz})$ obținere a vidului

vacuum pump $(\mathrm{OM})$ pompă de / pentru vid

vacuum refining (met, $\mathrm{TH}$ ) rafinare în / sub vid

vacuum relief valve (OM, termo) supapă de aerisire

vacuum seal (ind chim, OM) etanşare / garnitură la / pentru vid

vacuum servo (autom, OM) servomecanism cu acționare prin vid

vacuum servo brake (autom, OM) servofrână cu vid

vacuum shaper (ind chim) formator cu vid

vacuum shutter / framer (constr) cofraj vacuummetric

vacuum sintering (met, $\mathrm{TH}$ ) sinterizare sub vid

vacuum sintering bell (met) clopot pentru sinterizare sub vid

vacuum space (met, TH) spațiu vidat, cameră $\mathrm{cu} / \mathrm{sub}$ vid

vacuum spectrograph (metr, fiz) spectrograf cu vid

vacuum still (alim, ind chim) cazan / aparat de distilare în vid

vacuum switch (el, fiz) întrerupător cu vid

vacuum system(s) (ind) sistem (de camere) care poate fi vidat

vacuum tank $(\mathrm{OM})$ rezervor de vid

vacuum thermocouple (metr, fiz) termocuplu pentru vid

vacuum tight (OM, materiale) impermeabil / etanş / ermetic la vid

vacuum topping (alim, ind chim, $\mathrm{TH}$ ) distilare în vid

vacuum trap $(\mathrm{OM})$ rezervor de vid

vacuum tray dryer (alim, ind chim) uscător cu tăvi, cu / în vid

vacuum treatment (met) tratament în vid (şi al oțelului)

vacuum tube (el) tub electronic cu vid / vidat

vacuum valve $(O M)$ supapă de / pentru vid; (electr) tub electronic vidat

vacuum vaporizer (fiz, OM) vaporizator cu vid vade-mecum ghid, agendă, aide-mémoire, memento

vagarious inconstant

vagary inconstanță; nestatornicie; caracter fantezist / aiurit / fluşturatic; ciudățenie; capriciu, excentricitate; inconstanță; trăsnaie 
vagon (metr) unitate tradițională de măsură pentru masă, în state din fosta Yugoslavie: 1 vagon $=10$ tone

vague neclar, imprecis; nehotărât, nedecis; nedesluşit; vag

vaguely $(a d v)$ (în mod) neclar, imprecis, nedecis, vag, neclar

vagueness caracter vag / nedesluşit / neclar; neclaritate, lipsă de claritate; lipsă de hotărâre; imprecizie, lipsă de precizie

vaguish destul de vag, cam vag, relativ vag, cam imprecis, destul de imprecis, nu prea precis, cam relativ, destul de relativ

vain inutil; infructuos, nerodnic, steril; de prisos; prostesc, stupid; orgolios

vainness inutilitate, lipsă de valoare; caracter infructuos / nerodnic, sterilitate; prostie, stupiditate

valence, velency (chim) valență

valence angle (chim, fiz) unghi de valență

valence band (chim, fiz) bandă (de energie) de valență

valence bond (chim) legătură de valență

valence-bond band (chim, fiz) bandă de valență

valence bridge (chim, fiz) punte de valență

valence electron (el) electron de conducție; (chim) electron de valenţă; (el, fiz) electron de valență / periferic

valence forces forțe de valență

valence isomerism (chim, fiz) izomerie de valenţă

valence link(age) (chim) legătură de valență

valence orbital (chim, fiz) orbită de valență

valence shell (chim, fiz) înveliş (al electronilor) de valență

valid valid; valabil; în vigoare; acceptat, autorizat; serios, întemeiat, justificat; a valida; a legaliza; a examina validitatea

validate a valida, a confirma

validation (jur) legalizare; $(\mathrm{TH})$ validare, confirmare a valabilității; (inf) confirmare a corectitudinii unei instrucțiuni

valid contract (ec) contract în vigoare

valid digit (inf) cifră exactă / corectă

validity, validness corectitudine, valabilitate, validitate (şi a unui model); seriozitate, temei, justificare

valise valiză

valley (T) vale a unui profil de suprafață / între două asperități; (geogr) vale

valley value valoare a minimului într-un interval valorise a valoriza; a prețui; a preciza; a aprecia valoarea valorization (ec, pol) subvenționare de către stat valorize (ec, pol) a subvenționa vânzările pentru menținerea prețurilor

valour, valor, virtue ethics bravură, curaj, dârzenie

valuable valoros, prețios, de (mare) preț; lucru / obiect de valoare / de preț

valuate a pretui, a evalua, a estima

valuation (ec) evaluare, estimare, prețuire, valoare, apreciere; (mat) valoare, normă, metrică

valuator $(\mathrm{ec})$ prețuitor, persoană care face un deviz, calculator

value $(\mathrm{ec})$ valoare, preț, prețuire, apreciere, cheltuieli, estimare, deviz, cost, tarif; putere; a evalua, a aprecia, a estima; (mat) valoare, mărime, cantitate; (chim) indice; (fig) standard, etalon (valoric); importanță, însemnătate;

value-added tax, VAT (ec) impozit de valoare netă / reală, taxă pe valoarea adăugată (TVA)

valued evaluat, apreciat; prețuit, valoros

valueless fără / lipsit de valoare; neînsemnat; neimportant, lipsit de importanță; inutil

valuelessness lipsă de valoare

value engineering (ec, TH) analiză valorică (inclusiv pe baza criteriilor inginereşti şi de preț)

valuer (ec) evaluator, taxator, expert, prețuitor

valuta (ec) valută, curs, schimb

valve (constr) canat, batant; (hidr, OM) ventil, supapă, clapă robinet, valvă, sertar

valve action / effect (hidr) efect de supapă

valve actuator (OM, hidr) dispozitiv de poziționare a ventilului / a supapei, mecanism de acționare a supapei / a distribuitorului (mecanic, electromagnetic etc.)

valve adjuster $(\mathrm{OM})$ dispozitiv de reglare a supapei / a ventilului; (auto, autom) regulator de aprindere

valve adjustment (auto, termo) reglare a supapei / a supapelor (unui motor)

valve area (hidr, OM) secțiune de trecere / nominală a supapei / a ventilului

valve barrel (OM, hidr) cilindru al sertarului / al supapei

valve body (OM, hidr) corp al supapei

valve bounce / flutter (hidr) trepidatie a ventilului, vibrație ,flutter” (oscilații dezordonate ale clapetei compresorului la închidere / deschidere)

valve box $(\mathrm{OM}$, hidr) cameră / cutie a supapelor, bloc hidraulic

valve bucket $(\mathrm{OM}$, termo, hidr) piston de supapă

valve buckle (hidr, OM) cadru de sertar / de supapă 
valve burning (auto) ardere a supapelor valve bush (hidr, OM) bucşă / cămaşă pentru supapă / sertar

valve bushing (hidr, OM) bucşare a supapei, bucşă pentru supapă

valve cage $(\mathrm{OM}$, hidr) locaş al ventilului / al supapei

valve cap (hidr, OM) capac de ventil, clapă de supapă, capac al reductorului de presiune

valve case (hidr, OM) locaş pentru supapă, cameră a supapelor

valve casing (hidr, OM) cutie de sertar, carcasă a supapei, cameră a sertarului

valve casting (met) cutie de distribuție / de sertar (şi la turnare continuă)

valve chamber (hidr, OM) cameră a supapelor, bloc hidraulic

valve chatter (hidr, termo) zgomot de supape

valve chest (hidr, termo) cameră a supapei / supapelor

valve clearance (hidr, OM) joc / ajustaj al supapei

valve cone (hidr, OM) scaun conic al ventilului / al supapei

valve collet / stem key (hidr, OM) siguranță a supapei

valve cone (hidr, OM) scaun conic de supapă / de ventil

valve-control mechanism (hidr, OM) distribuție cu supape, mecanism de guvernare a supapei

valve core / inside (auto, OM) ventil de aer (la pneuri)

valve cover (hidr, OM) capac / cap / taler de ventil / de supapă

valve cylinder (hidr, OM) cilindru (şi mobil) al supapei

valved $(\mathrm{OM})$ cu supapă, cu supape

valve diameter (hidr, OM) diametru (şi nominal) al supapei, diametru al scaunului supapei

valve disk / head / poppet (hidr, OM) taler / disc / cap / ciupercă de supapă

valve displacement (hidr, OM) deplasare a supapei

valve distribution (hidr, OM) distribuție cu supape / cu robinete

valve door (hidr, OM) disc de închidere, tip alunecător

valve dust cap (hidr, OM) buşon de la supapa camerei de aer

valve face (hidr, OM) suprafața de lucru a unei supape (fin prelucrată sau oglindă), suprafața pe care alunecă plunjerul

valve flap / hood (hidr, OM) clapă a supapei valve follower (auto, hidr, OM) tachet de supapă

valve for superheated gases (met, OM) sertar/ supapă de gaze supraîncălzite

valve fouling (auto, hidr, OM) ancrasare a supapei

valve fracture (hidr, OM) rupere a supapei / a ventilului / a sertarului

valve gear (hidr, OM) mecanism (actionat) cu supape, mecanism de acționare al supapei / supapelor

valve grinder (mas-un) maşină de rectificat supape / aparatură hidraulică

valve grinding compound (OM, mas-un) amestec / pastă pentru rectificarea / rodarea supapelor

valve guide (hidr, OM) ghidaj de supapă

valve guide bush (hidr, OM) bucşă pentru ghidarea supapei sau a plunjerului

valve guide cleaner (hidr, OM) sculă de curățat ghidajul supapei

valve guide puller $(\mathrm{OM})$ extractor pentru bucşa de ghidare a supapei

valve head (hidr, OM) cap / taler de supapă

valve holder (OM) suport / soclu de supapă

valve hood / flap (hidr, OM) clapă de supapă

valve in head (auto, hidr, OM) supapă în cap

valve-in-head engine (auto, OM) motor cu supape în cap

valve lag (hidr, OM) întârziere a supapei

valve lap / overlap (hidr, OM) încrucişare / suprapunere a timpilor de deschidere a supapei / supapelor / distribuitoarelor (într-un bloc hidraulic etc.)

valve lash $(\mathrm{OM}$, hidr, nav) joc de supapă

valve leakage (hidr, OM) scurgere prin supapă, neetanşeitate a supapei

valveless (hidr, OM) fără supape sau ventil(e)

valveless engine (hidr, $\mathrm{OM}$ ) motor fără supape

valveless pump (hidr, OM) pompă fără supape

valve lever (hidr, OM) culbutor de supapă

valve lift / stroke (hidr, OM) cursă a ventilului / a supapei

valve lifter (auto, hidr, OM) cleşte de scos supape, tachet de supape

valve lifter adjustment (auto, hidr, OM) reglare a tacheților de la supape

valve-lifting plunger (hidr, $\mathrm{OM}$ ) tachet hidraulic de supape

valve mechanism (hidr, OM) comandă prin supape, mecanism de acționare cu supape

valve neck / throat (hidr, OM) gât al supapei

valve needle (hidr, OM) ac de supapă, plunjer subțire 
valve of bottle / cylinder (hidr, OM) ventil de butelie / de cilindru (pt. gaze comprimate)

valve oil (hidr, $\mathrm{OM}$ ) valvolină

valve opening (hidr, OM) deschidere / orificiu al supapei

valve-operating mechanism $(\mathrm{OM}$, hidr) mecanism cu supape / acționat prin supape

valve overlap (auto, hidr) suprapunere a timpilor de deschidere a supapelor

valve pet cock (hidr, OM) robinet de scurgere / de golire / de evacuare

valve piece (hidr, OM) con de închidere a supapei, piesă a supapei

valve piston (hidr, OM) piston cu supapă (de aspirație), plunjer al supapei

valve plate (hidr, OM) placă port-supape / supapă / port-clapetă, placă a ventilului

valve play (OM, auto, term, hidr) jocul supapei, mişcarea de ,du-te-vino” a supapei

valve plug (hidr, OM) tijă (şi demontabilă) a supapei, obturator hidraulic cu supapă

valve plunger / tappet (hidr, OM) tachet / plunjer de supapă

valve poppet / disk / head (hidr, OM) con / taler / cap / ciupercă de supapă

valve port (hidr, OM) canal de supapă, secțiune de trecere a supapei

valve push rod (auto, $\mathrm{OM}$ ) tijă de tachet a supapei

valve reamer (mas-un, OM) freză pentru scaune de supapă

valve refacer (mas-un) dispozitiv pentru prelucrarea suprafețelor active ale supapelor (şi pe un strung)

valve refacing (mas-un, $\mathrm{TH}$ ) rectificare / recondiționare a suprafețelor active ale supapei

valve regulator (hidr, OM) regulator cu supapă

valve relay (el) releu electronic pentru acționarea supapei

valve rocker (termo) culbutor, mecanism de acționare a supapei (prin balansare, rotire etc.)

valve remover $(\mathrm{OM})$ cleşte de demontat supape, ridicător de supape

valve reseater / reseating machine (mas-un) maşină de recondiționat aparatură hidraulică

valve reseating $(\mathrm{TH})$ recondiționare a suprafeței de aşezare a supapei / a ventilului

valve retainer (hidr, OM) farfurie / suport de arc de supapă

valve ring (hidr, OM) inel de supapă

valve-rocker arm / lever (OM) culbutor de supapă

valve-rocker arm cover (OM) capac de chiulasă (care poate include culbutorul) valve-rocker shaft $(\mathrm{OM})$ ax de culbutor

valve rod (hidr, OM) tijă de sertar / de supapă

valve-rod clearance (OM, auto, hidr, termo) joc al tijei supapei

valve rubber (ind chim, OM) cauciuc pentru aparatură hidraulică (cu rezistență mecanică şi compatibilitate cu fluidul vehiculat)

valve scorching (auto, OM) ardere a supapelor

valve seat (hidr, OM) scaun al ventilului / al supapei

valve-seat angle (hidr, OM) unghiul scaunului supapei / ventilului

valve seating (hidr, OM) scaun / lăcaş al supapei, suprafaţă de aşezare a ventilului

valve-seat grinder / refacer (mas-un, OM) dispozitiv de rodat / de rectificat scaunul supapei

valve-seat refacer, valve-seat renewing device (mas-un, OM) dispozitiv de recondiționare a scaunului supapei / ventilului

valve setting (hidr, OM) distribuție (prin supape)

valve shaft / stem (hidr, OM) tijă a supapei

valve sleeve (hidr, OM) bucşă de supapă, sertar cilindric, robinet cu sertar

valve spanner (auto, hidr, OM) cheie de reglat supape

valve spindle (hidr, OM) tijă (şi filetată) de supapă / de ventil / de sertar

valve spring (auto, hidr, OM) arc de supapă

valve-spring cap / retainer / washer (hidr, OM) taler de sprijin al arcului supapei

valve-spring lifter (auto, hidr, OM) ridicător al arcului supapei, dispozitiv de demontat arcul supapei

valve-spring remover (hidr, OM) dispozitiv de demontat arcul de supapă

valve-spring surge (hidr, OM) vibrația arcului de supapă

valve-spring washer (hidr, OM) taler de sprijin al arcului supapei

valve steel (met, termo) oțel de supape

valve stem (hidr, OM) tijă de supapă

valve-stem guide (hidr, OM) ghidaj de supapă

valve-stem guide bearing (hidr, OM, termo) bucşă / lagăr / cuzinet de ghidare a supapei pentru abur

valve sticking (hidr, OM) gripare / înțepenire / gumare a supapei

valve stroke / lift (hidr, OM) cursă a ventilului / a supapei

valve tappet / plunger (auto, hidr, OM) tachet de supapă

valve tappet guide (auto, hidr, OM) ghidaj al tachetului de supapă 
valve throat (hidr, OM) gât de supapă

valve timing (hidr, OM) distribuție cu supape

valve train (auto, hidr, OM) comandă a supape-

lor, supape în serie (una după alta)

valve travel (hidr, OM) cursă a ventilului / a supapei

valve trim (hidr, OM) mecanism al ventilului / robinetului (ansamblul pieselor interne ale unui ventil / robinet)

valve voltage drop (electr) cădere de tensiune în tubul electronic

valve with shutters (hidr, OM) vană / robinet cu închidere tip jaluzea

valve wrench (auto, hidr, OM) cheie de reglat supape, cheie de robinet

vamistor (el) rezistență de precizie

vamp cârpire; petic

van (auto) autodubă, camion de mobilă, furgonetă; (cf) vagon de marfă (acoperit); (fig) avangardă, partea din față

vanadic, vanadous (chim) vanadic, referitor la vanadiu sau la acidul vanadic

vanadinite (chim) vanadinit

Vanadium (V) (chim) vanadiu

vanadium steel (met) oțel (aliat) cu vanadiu

van der Waals'forces (fiz) forțe van der Waals

vane (fiz) dioptru; (OM) paletă, lopată, aripă, pală, ventilator, cursor, vizor; (hidr) vană, morișcă; morișcă de vânt, giruetă

vane chamber (OM, termo) spațiu între palete, camera paletelor

vane compressor (termo) compresor cu palete

vane piston $(\mathrm{OM})$ piston rotativ cu palete

vane pump $(\mathrm{OM}$, hidr) pompă cu palete

vane setting $(\mathrm{OM})$ poziție / poziționare a palelor

vane spindle $(\mathrm{OM})$ arbore al palelor

vane-type fluid meter (metr, OM, hidr) contor hidraulic cu rotor cu pale

vane-type pump (OM, hidr) pompă cu pistoane rotative

vane-type relay (el, OM) releu cu paletă

vane valve $(O M$, hidr) robinet / supapă cu pană

vane wheel $(\mathrm{OM}$, termo) roată cu cupe / cu palete (şi la turbine Pelton), rotor de turbină; (nav) roată cu zbaturi

vanilla (alim) vanilie

vanish a dispărea, a se şterge, a se estompa, a deveni invizibil; (mat) a se apropia de zero, a tinde la / spre zero, a (se) anula, a fi egal cu zero; (fiz, fonetică) detentă, sunet final (în descreştere), sunet tranzitoriu; into thin air a dispărea, a se face nevăzut (d. un lucru); (fig) a se topi; in a wink a dispărea într-o clipă; tend to $\sim$ a tinde să dispară; $\sim$ identically (mat) identic nul vanish identically (mat) identic nul

vanishing (fiz) dispariție; (mat) anulare

vanishing of thread $(\mathrm{OM})$ ieşire a filetului

vanishing point (mat) punct de anulare / de fugă

vanity mirror (auto) oglindă (în parasolar)

vantage avantaj; catch at the / a $\sim$ a prinde pe picior greşit; take at $\mathbf{a} \sim$ a prinde pe picior greşit; have / hold smb. at a $\sim$ a avea un avantaj asupra cuiva

vantage ground poziție avantajoasă / dominantă / favorabilă

vantage point $v$. vantage ground

vapid fără gust, insipid; şters, estompat; monoton

vapor (amer), vapour (brit) (fiz) abur, vapori, abureală, aburire, încețoșare

vaporescence caracter vaporescent, (fiz) evaporare, vaporizare

vaporific, vaporiform (fiz) vaporos, sub formă de vapori

vaporimeter (fiz, metr) vaporimetru

vaporisability (fiz) capacitate de vaporizare

vaporizable, vaporable (fiz) vaporizabil, evaporabil

vaporization (fiz) vaporizare, evaporare

vaporization heat (fiz, termo) căldură de vaporizare / de evaporare

vaporization loss (alim, fiz) pierderi prin vaporizare / prin evaporare

vaporization temperature (fiz) temperatură de vaporizare / de evaporare

vaporization cooling $(\mathrm{TH}$, fiz) răcire prin vaporizare (prin jet de vapori)

vaporize (fiz, termo) a (se) vaporiza, a (se) evapora

vaporizer (alim, termo, ind chim) vaporizator

vaporizing chamber (ind chim) cameră de vaporizare / de amestec

vaporizing tube (termo, OM) țeavă / conductă de vaporizare

vaporous vaporos; uşor ca aburul; cețos, încetoşat

vapour (brit) (fiz, termo) vapori, abur; abureală, aburire, încețoşare; (met) vapori de metal; (meteo, TH) ceață, negură, pâclă; a se evapora, a se vaporiza; (fig) beție; nebunie

vapourability capacitate de vaporizare

vapour barrier / seal $(\mathrm{OM}$, met, termo) barieră antivapori, ecran de etanşare / de etanşeizare împotriva aburului / vaporilor

vapour bath baie de vapori

vapour bubble (fiz, chim) bulă de abur / de vapori 
vapour chamber (termo) camera de vapori a separatorului

vapour compression (termo) presiune a aburului secundar

vapour concentration (fiz, termo) procent de vapori, umiditate absolută

vapour condensation (fiz, termo) condensare a vaporilor

vapour condensation cooled (fiz, termo) răcit cu vapori (de apă) condensați

vapour condenser (termo) condensator de abur (şi secundar)

vapour cooling (termo) răcire a aburului

vapour corrosion inhibitor (termo, ind chim) inhibitor de coroziune (în fază de vapori)

vapour cure (constr) tratare cu abur a betonului; (ind chim) vulcanizare cu abur

vapour degreasing ( $\mathrm{TH}$, ind chim) degresare $\mathrm{cu}$ vapori de solvent

vapour deposition (TH, T) acoperire prin vaporizare (şi în vid)

vapour eliminator (termo) separator de abur / de vapori

vapourer vaporizator, spray

vapour escape (termo) scăpare / pierdere de abur / de vapori

vapour expansion chamber (fiz, termo) cameră cu detentă / cu ceață / Wilson

vapour galvanizing (met) zincare / acoperire în vapori de zinc

vapour-gas mixture (ind, $\mathrm{TH}$ ) amestec de gaze şi vapori

vapour hold(-)up (termo) captare a aburului

vapour hood $(\mathrm{TH})$ hotă de tiraj

vapour laden (meteo, ind) (d. atmosferă, mediu) încărcat cu vapori, umed

vapour line (alim, termo, ind chim, OM) conductă de abur / de vapori

vapour-liquid equilibrium (fiz, termo) echilibru vapori-lichid, echilibrul fazelor

vapour / gas lock (auto) pungi de gaze formate în conducta de benzină, dop de vapori

vapour locking (auto) întrerupere a debitului de benzină din cauza pungilor de gaze

vapour outlet (termo) ieşire a aburului

vapour oxygen blast (met) insuflare $\mathrm{cu}$ abur şi oxigen

vapour particle (termo) picătură de abur

vapour permeability (materiale, OM) permeabilitate la vapori / la abur

vapour phase (fiz, chim) fază de vapori

vapour-phase chlorination (ind chim) clorurare în fază de vapori vapour-phase cracking (ind chim) cracare de vapori, cracare în fază gazoasă

vapour-phase hydrogenation (ind chim) hidrogenare în fază de vapori

vapour-phase inhibitor (ind chim) inhibitor în fază de vapori

vapour-phase nitration (ind chim, met) nitrare / nitrurare în fază de vapori

vapour phase process (fiz, termo) proces în fază de vapori

vapour pipe / line (alim, termo, ind chim) conductă de abur / de vapori

vapour pressure presiune de evaporare; (fiz) presiune / tensiune de vapori; (termo) presiunea aburului

vapour pressure curve (termo) curbă a presiunii aburului / vaporilor

vapour pressure thermometer (metr, termo) termometru cu vapori

vapour-pressure test determinarea tensiunii de vapori

vapour(-)proof, vapourtight (termo) etanş la abur / la vapori

vapour seal (fiz, TH, OM, termo) barieră antivapori, ecran de etanşeizare față de abur / de vapori

vapour space (ind, termo, T) spațiu / cameră de vapori

vapor state (fiz) stare de vapori

vapour tension (fiz) presiune / tensiune de vapori; (termo) presiune a aburului

vapour-tight etanş la abur

vapour trail (termo, av) urmă / dâră de condensare

vapour transfer / transmission (termo) difuzi(un)e a aburului, transfer / transmitere a(1) vaporilor (şi) prin difuzie

vapour tube (termo, OM) țeavă / conductă de abur

vapour uptake (alim, met, termo) admisie / intrare a aburului / a vaporilor, priză de abur

vapoury aburit; încețoşat; vaporos; gazos

var (metr, el) acronim pentru volt-amperereactive - volt-amper reactiv, unitate de măsură pentru puterea electrică reactivă livrată de un curent alternativ

vara (metr) unitate tradițională de măsură pentru lungime, în țări de limbă spaniolă sau portugheză: 1vara $($ Texas, US) $=84,667 \mathrm{~cm}, 1$ vara $($ California) $=83,82 \mathrm{~cm}, 1$ vara $($ Mexic) $=$ $83,802 \mathrm{~cm}, 1$ vara (America de Sud) $=86,4$ $\mathrm{cm}, 1$ vara $($ Spania $)=83,587 \mathrm{~cm} ; 1$ vara $($ Portugalia $) \cong 110 \mathrm{~cm}$ 
var-hour meter (el, metr) var-oră metru, contor pentru energie reactivă

variability, variableness (mat) variabilitate; caracter variabil

variable variabil, schimbător; inconstant; (mat) variabilă; (parametru) variabil; (inf) construcție care re prezintă într-un limbaj de programare valoarea unei date; nestatornic (d. o persoană)

variable address (inf) adresă variabilă

variable admission (auto, termo) admisie variabilă

variable compression (auto, termo) comprimare / compresie variabilă

variable condenser (el) condensator variabil

variable decreasing motion mișcare variabilă, decelerată / întârziată

variable-delivery pump pompă cu debit variabil

variable eccentric (mas-un, mas, $\mathrm{OM}$ ) excentric reglabil

variable expansion (met) dilatare variabilă / neuniformă

variable feed-back (autom) reactie feed-back neproporțională

variable feed case (mas-un) cutie de avansuri

variable force fortă variabilă

variable increasing motion mişcare accelerată variabilă

variable inlet (auto, termo) admisie variabilă

variable load $(\mathrm{mec})$ sarcină variabilă

variable moment of inertia (mec) moment de inerție variabil

variable motion mișcare variabilă / neconstantă

variable number număr de ordine

variable pitch blades aripi / pale cu pas variabil (ventilatoare, elici etc.)

variable-pitch propeller (nav) elice cu pas reglabil

variable quantity cantitate / mărime variabilă; (mat) variabilă

variable speed belt cone $(\mathrm{OM})$ roată conică la un variator cu curele

variable speed controller / device $(\mathrm{OM})$ variator de viteză / de turație

variable-speed motor motor cu turație variabilă

variable-stroke engine (termo) motor cu cursă variabilă / reglabilă

variable-voltage welding set (el, met) post de sudură cu tensiune variabilă

variably $(a d v)$ (în mod) variabil, schimbător

variance diversitate; (amer) permisiune de abatere de la regulă; excepție; permis; îngăduință; grade de libertate, numărul gradelor de libertate; (mat) dispersie

variant variantă; diferit, altfel; facultativ, la alegere variate (mat, $\mathrm{TH}$ ) variabilă / mărime aleatoare

variate in standard measure (mat) variabilă normată

variate transformation (mat) transformarea variabilei aleatoare, schimbare de variabilă

variation (OM, mas-un) abatere (de la o dimensiune nominală), variație, schimbare, deviație, deviere; (nav) declinație magnetică

variational bazat pe variație, cu caracter de variație, care variază

variation in dimension $(\mathrm{OM})$ variație în dimensiune

variation in temperature (termo, $\mathrm{TH}$ ) variatie de temperatură

variation of enthalpy (fiz, termo) variație a entalpiei

variation of field intensity (fiz) variație a intensității câmpului

variation of the speed (mec, auto) variatie a vitezei, schimbare de viteză

variation of voltage (el) variație de tensiune

variations (mat) aranjamente

variation with modificare în functie de

varied variat; divers, diferit; multiplu; variabil

variedness varietate, diversitate

variety soi; diversitate, multiplicitate; varietate, sort, variantă; tip, specie

variety reduction reducere a gamei de produse

variety meat (alim) organe de animale

variform multiform, divers, de formă diferită / variabilă

variometer (electr) bobină de inductanță mutuală reglabilă, inductor reglabil; (metr) variometru

variometer rotor (fiz) bobină mobilă a variometrului

various deosebit; diferit; distinct; variat; divers(ă), diverși, diverse; mulți, multe; numeroşi, numeroase

varnish (ind chim) lac, smalț. email, emailare, lăcuire; a lăcui, a lustrui; (poligrafie) firnis; (fig) lustru, spoială; a împodobi, a înfrumuseța; (fig) a da un lustru / o spoială; a vernisa

varnish and paint shop (auto, mobilă etc.) atelier de vopsit şi lăcuit

varnish coat (ind chim) lăcuire; (el) izolație de email

varnish coating acoperire cu lac, (acțiunea de) lăcuire

varnished (ind chim) vopsit, lăcuit (d. mobilă, table etc.)

varnished cable (el, ind chim) cablu emailat

varnish for ingot moulds (met) lac / vopsea pentru lingotiere 
varnish for sheet-metal / plate (met, ind chim) lac / vopsea pentru table

varnishing (met) vopsire a lingotierei; lăcuire, vopsire

varnishing by dipping ( $\mathrm{TH}$, ind chim) vopsire / glazurare prin cufundare

varnishing by dusting ( $\mathrm{TH}$, met) vopsire / glazurare prin pudrare

varnishing by pouring $(\mathrm{TH}$, ind chim) vopsire / glazurare prin turnare

varnish oil (ind chim) ulei pentru lacuri

varnish paint (ind chim) vopsea pe bază de ulei varnish pot (OM, ind chim) recipient pentru lac / vopsea

varnish remover (ind chim) solvent / decapant pentru lacuri

varnish resin răşină pentru lacuri

varnish spreader dispozitiv de lăcuit

varve strat de depuneri succesive de mâl / noroi

varved depus în straturi succesive

vary a (se) schimba; a (se) modifica; a varia, a face să varieze; a diferi; a (se) diversifica; a se abate, a devia; a face să difere, a face să se deosebească; a prezenta într-o formă nouă (o piesă, o maşină etc.); a (se) schimba

varying (mat) variabil; care se schimbă, variat, care variază, divers, variabil; variație, variere, schimbare

varying capacity (hidr) debit variabil; (el, mas) capacitate variabilă

varying duty / load (el, mec) sarcină variabilă

varying speed (auto) alternări de viteze

varying-speed motor (el) motor cu turație variabilă

varying terms (ec) condiții variabile / diferite (de contractare, de vânzare, de proiectare etc.)

varying voltage control (el) reglare cu tensiune variabilă

vase vază, vas (pt. flori), vas ornamental

vaseline (ind chim) vaselină

vaseline oil (ind chim) ulei pentru vaselină, parafină lichidă

vase-shaped, vasiform vasiform, în formă de vază

vat $(\mathrm{OM})$ benă, cupă, cadă, cuvă, cisternă, alambic, cazan, baie; $(\mathrm{OM}$, agr) ciubăr, putină, troacă; (nav) vas, barcaz, şalandă, barcă, bac; (textile) a prepara o baie reducătoare

VAT (ec) abreviere pentru value-added tax - taxă pe valoarea adăugată; v. value-added tax

vatful (constr, ind chim) conținut al unei căzi / băi (de spălare, de vopsire etc.)

vat rate (ec) cotă de TVA vault grotă, peşteră; salt, săritură (constr) boltă, arcadă, pivniță, subsol, galerie subterană; (met) boltă (de cuptor), a bolti, a sări peste; visterie, trezorerie, tezaur, casă de bani

V-beam (fiz) fascicul în $\mathrm{V}$

V-belt; vee-belt $(\mathrm{OM})$ curea trapezoidală

V-belt cord $(\mathrm{OM})$ cord pentru curele trapezoidale

V-belt drive (OM) acționare / transmisie cu curele trapezoidale

V-belt pulley $(\mathrm{OM})$ roată de curea trapezoidală

V-belt transmission (OM) transmisie cu curele trapezoidale

V-block suport în $\mathrm{V}$

V-block vice (mas-un) menghină cu fălci de centrare (în $\mathrm{V}$ )

V-butt weld $(\mathrm{OM})$ cusătură de sudură în V

V-cylinders (auto, termo) cilindri în $\mathrm{V}$

VDC (metr) simbol uzual pentru volt direct current - volt în circuit de curent continuu; în sistem SI se admite scrierea „DC 12 V”, dar producătorii şi utilizatorii scriu deseori „12 VDC"

V-drill (mas-un) burghiu lat

veal (alim) carne de vițel

veal broth (alim) supă concentrată / bulion de / din carne de vițel

vector (mat, fiz) vector, vectorial

vector bundle (mat, fiz) spațiu fibrat vectorial

vector space (mat, fiz) spațiu liniar, spațiu vectorial

vector calculus (mat) calcul vectorial

vector field (mat, fiz) câmp vectorial

vectorial (mat, fiz) vectorial; orientat

vectorial expression / relation (mat, fiz) expresie / relație vectorială

vectorial polymerization (ind chim) polimerizare orientată

vector equation (mat, fiz) ecuație vectorială, ecuație în care necunoscuta este un vector

vector generator (c) dispozitiv / soft care comandă deplasarea spotului pe ecran (generează segmente de dreaptă orientate); (mat, fiz) generator de vectori

vector group (el) grupă de conexiuni (a înfăşurărilor unui transfomator trifazat)

vector length (mat, fiz) lungime / modul a(l) unui vector

vector meson (fiz) mezon vector vector potential (mat, fiz) potențial vectorial vector product (mat, fiz) produs vectorial vector quantity (mat, fiz) vector, mărime vectorială 
vector radius (mat, fiz) rază vectoare vector space (mat, fiz) spațiu vectorial vector sum (mat, fiz) sumă de vectori / vectorială

vector triple product (mat, fiz) dublu produs vectorial (a trei vectori)

vedette (nav) navă de pază

V-edge (metr, OM) riglă de verificare cu muchie triunghiulară

vedro (metr) vadră, unitate tradițională de măsură pentru volum, în Rusia: 1 vedro $\sim 12,301$, 1 vedro $($ Bulgaria $)=1$ dekaliter $=101$

vee (litera) $\mathrm{V}$; în formă de $\mathrm{V}$ (d. elemente de maşini)

vee-belt $(\mathrm{OM})$ curea trapezoidală

vee-belt wrapping machine (met) maşină de înfăşurat, cu curele trapezoidale (la ieşire din laminorul de benzi la rece)

vee-engine (termo, auto) motor în $\mathrm{V}$

vee slide (mas-un, OM) ghidaj în (formă de) V / prismatic

vee thread $(\mathrm{OM})$ filet triunghiular

vee weld $(\mathrm{OM})$ cusătură de sudură cu rost în $\mathrm{V}$

vegetable (alim) vegetal; plantă, legumă

vegetable diet (alim) regim vegetarian / vegetal

vegetable fat (alim) grăsime vegetală

vegetable fibber (agr, textile) fibră vegetală

vegetable garden (agr, alim) grădină de legume / zarzavaturi

vegetable gum (ind chim) clei vegetal, răşină naturală

vegetable marrow (bot, alim) dovlecel

vegetable oil (alim) ulei vegetal, untdelemn

vegetable oil methyl ester (VME) (auto, chim) ester metilic din ulei vegetal

vegetables (bot, agr, alim) legume, verdeață, zarzavat

vegetable silk (textile) mătase vegetală

vegetal (bot) vegetal; plantă, vegetală

vehicle (auto, transp) vehicul, mijloc de transport / de circulație; (chim) agent purtător, liant; mod, mijloc, modalitate

vehicle break-in process (auto) rodaj al autovehiculului / motorului

vehicle hoist (auto) elevator hidraulic pentru maşini

vehicle operation (auto) rulare a vehiculului

vehicle spring (auto, $\mathrm{OM}$ ) arc (de suspensii) pentru maşini / vehicule

vehicle weight (auto) masa (auto)vehicolului (în $\mathrm{kg}$ etc.)

vehicular care transportă, (adj) transportor

vehicular transport (auto, transp) transport auto / cu un autovehicul vehicular radar (auto, metr) radiolocator de trafic rutier

V-eight engine (termo) motor cu opt cilindri, (montați) în $\mathrm{V}$

veil (textile) văl, voal; a voala, a estompa (o imagine); a ascunde

veiled acoperit cu voal; ascuns; deghizat

veiling ascundere; deghizare, camuflare

veilless fără voal; fățiş, deschis; descoperit, gol

vein (geol) filon, vână; (anat) venă, vână; (bot, zool) nervură (aunei frunze etc.); (fig) dispoziție, toană, ton; (TH) a face nervuri, a stria, a ramifica, a canela; a marmora

vein fissure (met) fisură (mai mult lungă), fantă

veining structure (met) substructură, figură / structură rezultată după coroziune

vein rock (geol) rocă filoniană

veiny, veined (ind chim) fibros, cu fibre; (OM) cu nervuri, cu striuri

vellum (ind chim) hârtie pergament; de pergament, ca pergamentul

vellum paper hârtie pergament

velocimeter (metr) tahimetru, vitezometru

velocity (mec) viteză, iuțeală

velocity at the surface (mec, T, hidr) viteză superficială

velocity diagram (mec) diagramă de viteze

velocity distribution (hidr, fiz, T) distribuție a vitezelor

velocity gradient (hidr) gradient al vitezei

velocity head / pressure (hidr) înălțime cinetică, presiune dinamică

velocity of deformation (met) viteză de deformare

velocity of discharge (mec, hidr) viteză de scurgere / de descărcare

velocity of exit (met, hidr, TH) viteză de / la ieșire

velocity of filtration (alim, ind chim) viteză de filtrare

velocity of flapping (mec) viteză de şoc / de lovire

velocity of flow (hidr, T) viteză de (s)curgere

velocity of impact $(\mathrm{mec})$ viteză în momentul ciocnirii / impactului, viteză de impact

velocity of light (fiz) viteza luminii

velocity of outflow (hidr, termo, T) viteză de scurgere / de ieşire / de evacuare / de descărcare

velocity of propagation (fiz, hidr) viteză de propagare

velocity of roll periphery (met, plast) viteză periferică a cilindrilor (de laminare) 
velocity of rotation (mec, OM) viteză de rotație, viteză unghiulară

velocity of scanning (metr, inf, c) viteză de scanare / de exploare / de baleiere

velocity of sliding $(\mathrm{OM}$, mec, $\mathrm{T})$ viteză de alunecare

velocity of sound (fiz, av) viteză a sunetului

velocity of transformation (met) viteză de transformare

velocity of wave (fiz) viteză de propagare a unei unde

velocity pressure (mec, hidr, T) presiune dinamică

velocity range (mas, auto, OM) gamă a vitezelor, interval de / pentru viteză

velocity space (fiz) spațiu al vitezelor

velocity stage / step (auto, OM, mas-un) treaptă de viteze

velocity triangle $(\mathrm{mec})$ triunghi al vitezelor

velours (textile) pâslă, fetru

velvet (textile) catifea, velur; de catifea, cu aspect de catifea, catifelat

vend $(e c)$ a vinde, a scoate la vânzare

vendee (jur, ec) cumpărător

vender, vendor (ec) vânzător

vendibility $(\mathrm{ec})$ vandabilitate, caracter vandabil

vendible (ec) vandabil

vending machine (mas, ec) automat pentru vânzarea dulciurilor

vendue (amer) (ec) licitație publică

veneer (mobilă) furnir; a furnirui

veneering (mobilă) furniruire

veneering wood (silv, mobilă) lemn de placaj / de furnir

vent ieşire, scăpare; $(\mathrm{OM})$ colector de evacuare, răsuflătoare, duză, ventil (de aer), supapă, orificiu de ventilare, canal / clapă de aerisire; auto, termo) eşapament; a aerisi, a ventila, a da drumul la, a lăsa să izbucnească; (constr, termo) coş (de tiraj), horn, burlan de coş; (termo) clapă de fum; (auto) duză de răcire ventage $(\mathrm{OM})$ răsuflătoare, clapă de aerisire vent cock $(O M$, hidr) robinet de aerisire vent control (auto) control / comandă pentru ventil(e)

vent control lever (auto, OM) buton / pârghie de reglare a fantei de evacuare a aerului

vent( )hole (met) răsuflătoare, gură / orificiu de ventilație; (OM) supapă (de aer, de gaz)

ventiduct $(O M$, ind) conductă de ventilație

ventil $(\mathrm{OM}$, termo) clapă de reglare a aerului, ventil (şi la pneuri)

ventilate a ventila; a aera; a climatiza; a aerisi ventilated totally-enclosed motor (el) motor ventilat, complet închis

ventilating duct $(\mathrm{OM}$, ind) canal / conductă de ventilație; (termo) fantă de ventilație / pentru aer de răcire

ventilating fan $(\mathrm{OM}$, termo) ventilator

ventilating grate (constr) grătar de ventilație

ventilating pipe $(\mathrm{OM}$, ind) conductă de ventilație / de aspirație, tub de aerisire

ventilating shaft (constr, met) puț de aerisire

ventilation system (ind, termo) sistem de ventilație

ventilating tube $(\mathrm{OM}$, termo) conductă de ventilație / de aerisire

ventilating valve (OM, hidr) ventuză, supapă de ventilație

ventilation (ind, $\mathrm{TH}$ ) aeraj, ventilație, aerisire, climatizare, condiționare a aerului, ventilație; (fig) discuție publica; self- autoventilație

ventilation by extraction (ind, termo) ventilație prin aspiratie

ventilation ejector $(\mathrm{OM})$ ejector pentru aer

ventilation loss(es) (el) pierderi prin frecare $\mathrm{cu}$ aerul / prin ventilație

ventilation pipe $(\mathrm{OM}$, termo, hidr) conductă de ventilație / de aerisire

ventilation plant $(\mathrm{TH})$ instalație de aeraj / de ventilație / de aerisire / de climatizare

ventilation rate (ind, constr) viteză / grad de schimbare / de reînnoire / de împrospătare a aerului

ventilation shaft (ind) cămin de aeraj / de ventilație

ventilation system (auto) sistem de ventilare / ventilație

ventilator (termo, OM) ventilator; (met) exhaustor

ventilator blade (auto, $\mathrm{OM}$ ) pală de ventilator

ventilator pulley (auto) roata de ventilator, roată care acționează ventilatorul

ventilatory referitor la / de ventilație

venting (ind) ventilare; (met) răsuflătoare (în forme)

venting property / quality to air (materiale, $\mathrm{OM})$ permeabilitate la aer

venting quality transparență (în fotografie)

venting screw $(\mathrm{OM})$ şurub de aerisire / de dezaerare / de evacuare a aerului

venting screw $(\mathrm{OM})$ şurub / dop filetat de aerisire / de evacuare a aerului

venting system (ind) sistem de aerisire / de ventilare

ventipane (auto, OM) clapă de aerisire 
ventless $(\mathrm{OM})$ fără supapă, fără ventil

vent peg $(\mathrm{OM}$, alim) cep, vrană

vent pipe conductă de aerisire / de ventilație / de respirație; (met) armătură centrală de miez

vent plug (auto, OM) dop de închidere (la acumulatoare); (OM) dop de aerisire

ventral $(\mathrm{OM})$ ventral, axial, ventral; (anat) abdominal

ventral fins (pl) (iht) aripioare ventrale

ventral rupture (med) hernie abdominală

vent rod (in moulding) (met, OM) ac / tijă de aerisire la forme (în turnătorie)

venture risc, hazard, aventură; (ec) acțiune (comercială), speculație, afacere riscantă; (amer) (ec) societate pe acțiuni, companie; a risca, a se aventura, a îndrăzni

venturi, Venturi $(\mathrm{OM})$ difuzor de aer

Venturi meter (metr, hidr) debitmetru Venturi / cu tub Venturi), venturimetru, fluometru Venturi

Venturi tube (metr, OM, hidr) tub Venturi; (met) pâlnie de aeraj

vent valve $(\mathrm{OM}$, hidr) ventil / robinet de aerisire, supapă / ventil de respirație / de aerisire / de răsuflare

veracious adevărat; veridic; demn de încredere veracity adevăr; veridicitate; sinceritate

verdancy (mediu) verdeață, vegetație verde; verde crud, culoare verde (proaspătă); (fig) simplitate, naivitate

verdant verde, proaspăt; nevinovat

verdigris (chim) cocleală, patină pe suprafața cuprului

verditer (chim) carbonat bazic de cupru

verifiable verificabil, uşor de verificat, care poate fi verificat / confirmat / coroborat

verifier (metr) verificator, aparat etalon de verificare, aparat de luat probe

verge chenar; $(O M)$ vergea, tijă, bordură (şi de drum), margine, limită; a (se) mărgini, a se îndoi; (metr) denumire veche, britanică şi franceză, pentru yard (virga - băț în limba latină); v. yard

verglas (meteo) polei

veridical veridic, cu aparență de adevăr

verification verificare, control; dovadă

verificatory (cu caracter) de verificare / control

verifier (autom) verificator; (metr) aparat etalon

/ de verificare; aparat de luat probe; (TH) controlor

verifier operator $(\mathrm{TH})$ operator al verificatorului

verify a verifica; a controla; a examina; a cerceta; a inspecta; a confirma, a dovedi verifying care verifică / controlează / examinează; care inspectează; care confirmă verisimilar verosimil; veridic; probabil

verisimilitude caracter verosimil; veridicitate; probabilitate

veritable veritabil, adevărat

veritableness caracter veritabil

veritably $(a d v)$ într-adervăr, cu adevărat

verity adevăr, realitate; veridicitate; afirmație adevărată; sinceritate, onestitate, cinste

vermian vermiform, vermicular; ca viermii

vermicelli (alim) fidea

vermicular, vermiform (alim, agr) viermănos, cu viermi, ros de viermi

vermiculate vermiform; (alim, agr) viermănos, mâncat de viermi

vermilion culoare roşu aprins, purpuriu; a împurpura

verminate (alim, agr) a face viermi, a fi infestat de paraziți

vermination (agr, med) dezvoltare a viermilor / paraziților, infestare cu paraziți

vermouth (alim) vermut

vernier (metr, OM) vernier

vernier adjustment (metr) reglaj / reglare micrometric( $\breve{a}) / c u$ şurub micrimetric

vernier cal(l)iper(s) (metr, OM) şubler cu vernier

versatileness, versatility caracter multilateral, multilateralitate; suplețe; elasticitate, adaptabilitate, caracter adaptabil, mobilitate; versatilitate; inconstanţă

versed cosine (mat) funcția covers $(x)=1-\sin x$

versed sine (mat) funcția vers $(x)=1-\cos x$

vershok, verchok, $(p l)$ vershki (metr) unitate tradițională de măsură pentru lungime, în Rusia: 1 vershok $=4,445 \mathrm{~cm}$

version versiune; variantă; ciornă; rude $\sim$ versiune brută / preliminară, traducere inițială

versionist traducător

version number (inf, c) număr asociat unui fişier în scopul identificării acestuia

verso spate; verso

verso page pagină cu soț / de stânga / verso

verst, versta, vehrsta, $(p l)$ vehrsty (metr) verstă, unitate tradițională de măsură pentru lungime, în Rusia: 1 verst $=1066,8 \mathrm{~m}$

vertex punct culminant; vârf; culme; (fiz) nod al unei unde

vertex angle (geom) unghi opus / la vârf

vertex distance at large end (mas-un, $\mathrm{OM}$ ) distanță de la vârf până la baza mare a conului primitiv 
vertex distance at small end (mas-un, OM) distanță de la vârf până la baza mică a conului primitiv

vertex feed (mas-un) alimentare axială

vertical linie verticală, verticală; vertical

vertical angles (mat) unghiuri opuse la vârf ( $r a r$ )

vernier cal(I)iper(s) with internal and external measuring faces (metr, OM) şubler de interior şi exterior

vernier control (metr) reglaj de precizie / cu vernier

vernier coupling (OM, mas-un) cuplaj care asigură îmbinarea arborilor în orice poziție relativă

vernier depth gauge (metr) şubler de adâncime vernier division diviziune de vernier (la şubler) vernier gear-tooth (cal(l)iper) (metr) şubler cu vernier pentru măsurarea corzii peste dinți la roți dințate

vernier slide gauge (metr, $O M$ ) şubler cu vernier

versable $(\mathrm{OM})$ care se învârteşte, învârtitor, de învârtit; mlădios, flexibil, suplu

versatile multilateral; universal; (OM) (uşor) adaptabil; versatil; elastic; mobil; inconstant; adaptabil, elastic, mobil (spiritual); nestatornic versatile multi-logic logică multiplă flexibilă versatilely $(a d v)$ (în mod) elastic, adaptabil, inconstant, schimbător; multilateral; cu (multă) mobilitate, care trece / trecând uşor de la una la alta, care se adaptează / adaptându-se uşor; schimbător, inconstant

vertical axis (geom, OM) axă verticală

vertical axis freedom (mec) libertate a axei verticale

vertical band dryer (alim, ind chim) uscător cu bandă verticală

vertical beam (OM, constr) montant

vertical bearing $(O M, T)$ lagăr vertical, pivot

vertical boring and turning mill (mas-un) strung carusel / vertical

vertical boring mill (mas-un) maşină de găurit verticală

vertical brace (constr) antretoază verticală

vertical casting (met) turnare în poziție verticală

vertical chamber oven (met) cuptor vertical cu cameră

vertical clearance înălțime de gabarit, gabaritul podului la nivelul maxim de navigație

vertical component (mec, OM) componentă verticală

vertical continuous casting machine (met) maşină / agregat de turnat continuu, vertical

vertical deflection deviație pe verticală vertical distance between ship bottom and channel bed (nav) adâncimea apei navigabile vertical down welding sudare de sus în jos vertical drilling machine (mas-un) maşină de găurit verticală

vertical eddy vârtej / turbion cu axă verticală vertical edgeing rolls (met) cilindri verticali de refulare

vertical elevation altitudine; înălțime (față de nivelul mării)

vertical filling clasare / umplere pe verticală vertical fillet weld sudură verticală de colt vertical-flue $(\mathrm{TH})$ canal vertical de fum

vertical-flue (by-product coke) oven (met) cuptor cu cameră orizontală (şi canal vertical de încălzire)

vertical-flued regenerative oven (met) cuptor de cocsificare cu recuperarea produselor auxiliare

vertical format (c) punere în pagină verticală

vertical heating furnace (met) cuptor adânc pentru tratament termic

vertical ingot heating furnace (met) cuptor adânc de lingouri

vertical integration (ec) integrare verticală (a producției cu sursele de aprovizionare şi $\mathrm{cu}$ piețele de desfacere

vertical joint îmbinare / legătură verticală

vertical journal $(\mathrm{OM})$ fus vertical, crapodină

vertical kiln (alim, ind chim) cuptor vertical

vertical lathe (mas-un) strung vertical / carusel

vertical lift bridge (constr) pod ridicător; (nav) pod de ranfluare

vertical line (linie) verticală; perpendiculară (rar); perspectivă perpendiculară

vertical magnet (met) magnet de ridicare

vertical milling machine (mas-un) maşină de frezat verticală

vertical plane (geom, OM) plan vertical (şi la desen tehnic)

vertical planer (mas-un) raboteză verticală, morteză

vertical plano-milling machine (mas-un) maşină de frezat longitudinală, cu mai multe axe principale (verticale)

vertical position poziție verticală; verticalitate vertical post pilon; montant vertical

vertical power rod (mas-un, $\mathrm{OM}$ ) ax al avansului vertical

vertical projection proiecție verticală, elevație (şi în desen tehnic)

vertical pump (OM, hidr) pompă verticală

vertical return (termo, OM) coloană (verticală) de retur (la încălzire centrală) 
vertical roll unit (met) cajă cu cilindri verticali vertical screen (agr, alim, constr, ind chim) sortator / sită vertical(ă)

vertical scrubber (mas) scruber vertical

vertical section $(\mathrm{OM})$ secțiune în plan vertical; secțiune verticală (şi în desen tehnic)

vertical shaft $(\mathrm{OM})$ arbore vertical

vertical shaper (mas-un) morteză

vertical side plate (constr, OM) grindă de ghidare, verticală

vertical steam engine (termo) mașină cu aburi, verticală

vertical stripes (textile) dungi verticale

vertical tensile method (metr, $\mathrm{TH}$ ) metodă prin / cu tracțiune / întindere verticală

vertical tube heat exchanger (termo, OM) schimbător de căldură cu tuburi verticale

vertical turret lathe (mas-un) strung vertical, cu masă rotitoare, strung revolver tip carusel

vertical-type alkaline cleaning (TH) curățare cu alcalii în cameră verticală

vertical up welding (met, $\mathrm{TH}$ ) sudare urcătoare / de jos în sus

vertical weld $(\mathrm{OM})$ cusătură de sudură, verticală

vertical welding (met, $\mathrm{TH}$ ) sudare verticală verticillate, verticillated $(\mathrm{OM}, \mathrm{fiz})$ dispus inelar verticity (hidr) învârtire / rotire în jurul axei proprii, capacitate de a fi în mișcare de rotatie

vertiginous amețitor; amețit; inconstant; vertiginos; rotativ, de rotaţie

very $(a d v)$ adevărat; veritabil; real; chiar, foarte; tocmai, aidoma; prea; precis, exact

very high frequency (VHF) (fiz) frecvență foarte înaltă $(30 \ldots 300 \mathrm{kHz})$

very low-carbon steel (met) oțel $\mathrm{cu}$ conținut foarde redus de carbon

very low frequency (VLF) (fiz) frecvență foarte joasă $(10 \ldots 30 \mathrm{kHz})$

very open-grained pig iron (met) fontă cu structură macrogranulară

very soft picture (c, TV) imagine fără contrast

vessel $(\mathrm{OM})$ bazin, rezervor, vas, chiuvetă, recipient; (nav) vas, navă, ambarcațiune, vapor; (met) convertizor, recipient

vessel slag (met) zgură de convertizor

vessel ton (metr) unitate de măsură pentru volumul încărcăturii unei nave, care presupune că 100 de picioare cubice din volumul navei sunt echivalente cu 1 tonă, tonă litrică

vest (ec) a investi, a plasa, a face investitiii; a împuternici; a aparține (cuiva); a reveni (cuiva)

vestiary (constr, ind, edu) vestiar vestibule (constr) vestibul, anticameră, antreu, hol, portic, prag

vestibule training (edu, TH) pregătire de scurtă durată în atelier; metodă de instruire în afara locului de muncă asupra unor echipamente perfecționate

vet veterinar, agent veterinar; a examina, a trata, a verifica; (fig) a cerceta, a cenzura

veto, $(p l)$ vetoes (pol) veto; (amer) veto (prin tergiversare); opoziție, împotrivire; interdicție, interzicere

vetting routine (c, inf) subprogram de validare vetting run $(\mathrm{c})$ rulare de validare / de verificare vex a supăra, a irita, a contraria; a jigni, a vexa, a ofensa, a nelinişti, a alarma; a contesta, a tăgădui; a dezbate, a discuta

vexation supărare, iritare, contrariere; ofensă, jignire, vexație; neplăcere, dezagrement; persecuție, persecutare, şicană; (jur) daună

vexatious supărător, enervant, iritant, contrariant; ofensator, jignitor, vexant, plictisitor

vexed supărat, iritat, enervat; ofensat, jignit; (nav) agitat (d. mare), cu valuri mari

vexed question chestiune / problemă controversată / disputată; controversă, chestiune litigioasă

V-four engine (termo) motor cu 4 cilindri în $\mathrm{V}$

V gear (OM) angrenaj (cu dinți) în $\mathrm{V}$; angrenaj de fricțiune cu canale (în $\mathrm{V} /$ trapezoidale)

V groove (OM) canal în formă de $V /$ trapezoidal, a tăia un canal în $\mathrm{V}$, a executa un rost în $\mathrm{V}$ (la suduri)

V-guide (OM) ghidaj trapezoidal / în V / prismatic

viability viabilitate

viaduct (constr) viaduct

vial (OM, chim) flacon; (OM, med) fiolă, sticluță pentru medicamente

vibrant (mec, OM) vibrant, care vibrează, în vibrație, vibrator; oscilant, în oscilație; (fiz) cu rezonanță (despre sunet)

vibrate (fiz) a vibra, a oscila, a face să vibreze / să oscileze; a trepida, a se legăna, a se agita, a se mișca

vibrated concrete (constr) beton vibrat

vibratility (OM, mas) capacitate / posibilitate de a vibra

vibrating, vibratory $(\mathrm{OM})$ vibrator, care vibrează, oscilator, oscilant; vibrant

vibrating ball mill (alim ind chim) moară vibratoare cu bile

vibrating conveyer (OM, transp) transportor vibrator 
vibrating diagram $(\mathrm{OM}$, fiz) membrană vibratoare

vibrating grizzly $(\mathrm{OM})$ grătar oscilant cu bare

vibrating plate / compactor $(\mathrm{OM})$ placă vibratoare (la un compactor, compresor etc.)

vibrating roller (OM, termo) compresor vibrator

vibrating screen / sieve $(\mathrm{OM})$ sită vibratoare, ciur vibrator

vibrating shoe $(\mathrm{OM})$ sabot vibrator

vibrating slab $(\mathrm{OM})$ placă vibratoare

vibrating table $(\mathrm{OM})$ masă vibratoare

vibrating tamper (constr, OM) bătător / mai vibrator

vibration (mec) trepidație; vibrație; vibrare; oscilație

vibrational (adj) vibrator, vibrativ, referitor la vibrații

vibrational chracterises $(\mathrm{mec})$ caracteristici ale vibrațiilor / oscilațiilor

vibration absorber $(\mathrm{OM})$ amortizor de vibrații

vibration absorption $(\mathrm{OM})$ absorbție a vibrației / trepidației

vibration amplitude (mec) amplitudine a vibrației

vibration conveyer $(\mathrm{OM})$ transportor cu vibrații vibration damper (OM, autom) atenuator amortizor de vibrații

vibration damping (OM, autom) amortizare / atenuare de vibrații

vibration damping layer $(\mathrm{OM})$ strat amortizor (pt. vibrații, trepidații)

vibration detector (metr, fiz) detector de vibratii

vibration direction (fiz) direcție (de propagare) a oscilației / vibrației

vibration frequency (fiz) frecvență a vibrației / oscilației

vibration frequency meter (metr, fiz) osciloscop, vibrometru

vibration isolator (OM, constr, autom) izolator de vibrații / trepidații

vibration-measuring apparatus, vibration meter (metr, fiz) aparat pentru măsurarea vibrațiilor, vibrometru

vibration( )meter (metr, fiz) vibrometru

vibration mill (alim, ind chim) moară vibratoare

vibration node (fiz) nod de vibrații, punct nodal

vibration pick-up (metr, fiz) traductor cu element piezoelectric (pt. captarea vibratiilor)

vibration proof $(\mathrm{OM}$, mas) protejat la vibrații, rezistent la vibrații

vibration screen / sifter $(\mathrm{OM})$ sită vibratoare vibration sensitivity (OM, autom, electr) sensibilitate la vibrații, eroare la vibrații

vibration slab $(\mathrm{OM})$ placă vibratoare

vibration strength $(\mathrm{mec})$ rezistență la vibrații

vibration stress $(\mathrm{OM}$, mas) solicitare vibratorie

vibration table (OM) masă vibrantă / vibratoare

vibration test (metr, OM, mas) încercare / test la vibrații

vibration transducer (metr, fiz) traductor de vibrații, vibrometru

vibration transducer plane (metr, fiz) planul traductorului de vibrații

vibrator $(s, a d j)$ vibrator, oscilator

vibrator blade $(\mathrm{OM})$ paletă / muchie / lamă vibratoare

vibrator needle $(\mathrm{OM})$ ac vibrator

vibrator reed $(\mathrm{OM})$ lamă vibratoare / vibrantă

vibrator screen (agr, alim, ind chim) sortator vibrator, sită vibratoare

vibrator with plate $(\mathrm{OM})$ vibrator cu placă

vibratory (adj) vibrator; vibrant

vibratory compactation (constr, met) compactare / îndesare prin vibrare / vibrații

vibratory feeder $(\mathrm{OM})$ dispozitiv de alimentare cu vibrator

vibratory movement $(\mathrm{mec})$ mişcare vibratorie

vibratory separation $(\mathrm{TH}$, agr, alim, ind chim) sortare / separare prin vibrare

vibratory shock load $(\mathrm{OM}$, mas) sarcină cu şocuri (repetabilă)

vibratory soil compactor (OM, constr) mai compactor pentru teren

vibratory spring $(\mathrm{OM})$ arc oscilant

vibratory stress (mec, OM) tensiune oscilantă / cauzată de vibrații / oscilații

vibratory test (metr, OM, mas) test / încercare la vibrații

vibratory testing machine (metr, mas) maşină de testat la vibratii

vibrometer (metr, fiz) vibrometru

vibroplate $(\mathrm{OM})$ placă vibratoare

vibroscope (fiz, metr) vibroscop

vibro-record (metr) înregistrare a vibrațiilor / oscilațiilor

vicarious delegat; făcut ca locțiitor; făcut în locul altuia; făcut pentru altul; indirect; interimar; mandatar; prin delegat / mandatar; provizoriu

vicarious liabilities (adm, ec) obligații ale altuia (preluate de cineva)

vicariously $(a d v)$ prin delegat / delegație; prin procură; prin mandatar; prin substituire, prin înlocuire; în locul altcuiva; indirect 
vice (mas-un, OM) dispozitiv (foarte general), menghină; defect, imperfecțiune, lipsă; viciu, corupție; (fig) a forța, a constrânge, a sili; a înşuruba

vice bench $(\mathrm{OM})$ banc cu menghină

vice body $(\mathrm{OM})$ corp al menghinei

vice-chairman (ec, adm, univ) vicepreşedinte (al unei companii, unei organizaţii, al unei conferințe etc.)

vice clamps / jaws (mas-un, OM) fălci de menghină / la un dispozitiv de prindere

vice-dean (univ) prodecan

vice-minister (pol, adm) ministru adjunct, loctiitor de ministru

vicenary (mat) legat de cifra 20; care se petrece o dată la 20 de ani, care durează două decenii

vice on swivel base $(\mathrm{OM})$ menghină turnantă / pivotantă

vice-presidency (ec, adm) (funcție de) vicepreşedinte

vice-presideent (ec, adm) vice-președinte

vice-principal (edu) director adjunct (de școală)

vicinity vecinătate; apropiere; proximitate

vicious vicios, stricat, cu vicii, corupt; $(\mathrm{OM})$ defectuos, incorect, deficient; greşit, prost (şi d. un proiect); (d. aer) viciat, stricat, nesănătos, impur

vicious circle cerc vicios

vicious spiral (ec) spirală / cursă de salarii şi prețuri, spirală a inflanției

Vickers hardness (materiale, metr) duritate Vickers

Vickers hardness number (HV, VHN), Vickers pyramid number (VPN) (metr, materiale) valoare a duritătii Vickers, ca raport între forța aplicată de un indentor piramidal şi suprafața urmei de indentare; soft-ul dedicat al durimetrului Vickers face acest calcul, dar există și tabele de conversie între media diagonalelor urmei şi suprafața amprentei

Vickers hardness test (metr, materiale) test pentru determinarea durității Vickers a unui material

Vickers unit (metr, materiale) unitate Vickers pentru duritate, unitate de măsură a durității superficiale a unui material; sunt acceptate $\mathrm{N} / \mathrm{mm}^{2}, \mathrm{kgf} / \mathrm{mm}^{2}$

victim victimă

victual a se aproviziona (pt. hrana echipajului şi a pasagerilor unei nave); a aproviziona cu mâncare; a (se) hrăni

victualler (alim, ec) furnizor de alimente; (nav, mil) cantinier, vas de aprovizionare

victualling aprovizionare cu alimente victualling bill (alim, transp) certificat vamal pentru transportul proviziilor / alimentelor victualling ship (nav) vas de aprovizionare victualling yard (nav) doc pentru provizii victuals (alim) alimente; provizii, hrană, mâncare vide infra (în limba latină) vezi mai jos video (electr) (aparat) video / care vizualizează (ceva); (fiz) frecvență video; (amer) televiziune video disk (c, elctr) disc de stocat informație care poate fi vizualizată

video frequency (fiz) frecvență video

videophone (electr) telefon cu imagine, videofon video signal (electr) semnal video, videosemnal video tape (electr) bandă / înregistrare video video supra vezi mai sus (în limba latină) vidimus (jur) legalizare (în limba latină); schiță; rezumat; sumar; extras (dintr-un registru)

viertel (metr) unitate tradițională de măsură pentru volum în țări europene: 1 danish viertel $($ Danemarca $) \cong 7,741,1$ viertel $($ Elveția $)=151$; (metr) unitate de măsură pentru volum, pentru vin, în Austria: 1 viertel $=1 / 41=250 \mathrm{ml}$

view (anat, $\mathrm{OM}$ ) vedere; vizionare; proiectie; privire; observare, considerare, examinare, cercetare, scrutare; perspectivă, privelişte; imagine, poză, fotografie; plan, secțiune; atenție, memorie; punct de vedere, opinie, concepttie, mod / fel de a vedea lucrurile; considerație; scop, tel, obiectiv; a privi, a vedea; a cerceta; (edu, TH) a examina, a studia; a inspecta, a vizita (un recipient); a considera, a socoti; a percepe, a discerne, a zări; at first $\sim$ la prima vedere; at one $\sim$ dintr-o privire; on a closer $\sim$ la o examinare mai atentă; point of $\sim$ punct de vedere; have in $\sim$ a avea în vedere; in $\sim$ of având în vedere (că); bird's-eye privire panoramică; view smb. with a friendly eye a privi pe cineva cu ochi buni; view a question in the right light a examina o problemă dintrun punct de vedere just

viewable care merită văzut; vizibil

viewer spectator; supraveghetor; inspector; observator; (TV) telespectator; cercetător, examinator

view finder $(\mathrm{OM})$ dispozitiv de vizare, vizor

viewing privire, observare

viewing angle (anat, OM, metr) unghi vizual / de observație

viewing slit / slot $(\mathrm{OM})$ antă de vizare / de observare

viewing system (metr, opt) sistem optic de control viewing window $(\mathrm{OM})$ fereastră de observare / de vizitare

viewpoint punct de vedere; considerație, opinie; atitudine; părere 
viewport $(\mathrm{OM})$ vizor

view room (ind) loc, serviciu de control tehnic vigesimal (mat) referitor la numărul 20; referitor la perioada de două decenii; din 20 în 20

vigilance vigilență; atenție, grijă; circumspecție, precauție; pază

vigneron (agr) podgorean, viticultor

vigorous viguros, puternic; robust; energic; curajos, hotărât

vigorous oxidation (chim) oxidare energică / rapidă

vigour vigoare, putere, forță; vitalitate, energie, robustețe; eficacitate; efect, influență

VI improver ( $T$, ind chim) (aditiv) care îmbunătățeşte indicele de vâscozitate (simbolizat în limba română cu IV)

village sat, comună; (amer) orăşel, târg, localitate

villager țăran, sătean

vimineous format din fire subțiri (d. textile, compozite, site etc.)

vinaceous (alim) privitor la vin, de vin; de culoarea vinului; roşu ca vinul

vinaigrette (alim) sos de salată, undelemn şi oțet; (OM, alim) sticluță pentru oțet

vincible lesne de învins, care poate fi învins; rezolvabil, care poate fi rezolvat / remediat, remediabil

vinculum $(p l)$ vincula (mat) linie de legătură; acoladă; legătură

vindicability caracter justificabil / scuzabil, justificabilitate

vindicable justificabil, motivabil, care poate fi justificat / apărat

vindicate a justifica, a motiva; a pretinde, a reclama; a revendica; a reabilita; a dezvinovăți; a apăra

vindication justificare, motivare; dezvinovăţire, reabilitare; revendicare, reclamare

vindicative justificator, care motivează / justifică / susține; cu caracter de apărare

vindicator apărător, susținător; protector

vine (bot, agr) viță de vie, lujer / cîrcel de vie

vine arbour (agr) boltă de viță-de-vie

vine-borer (agr, zool) insectă / parazit care distruge via

vine bud (agr, bot) mugur de viță-de-vie

vine culture, vine growing (agr) viticultură

vine estate (agr) podgorie, vie

vine fretter, vine grub (agr, zool) păduche de viță-de-vie

vinegar (alim) oțet (de vin), a acri, a (se) oțeți (şi d. vin)

vinegar essence (alim) esență de oțet

vinegarish (alim) acru (ca oțetul) vinegar of lead (chim) apă / acetat de plumb

vinegar of wood (ind chim) oțet din lemn / de surcele

vinegar plant (chim) ciupercă de oțet

vinegar works (chim, alim) fabrică / instalație de producere a oțetului

vinegary (alim, chim) ca oțetul, de oțet, acetic, acru, oțețit

vine knife (agr, OM) cosor de vie

vine leaf (agr, bot) frunză / foaie de viță-de-vie

vine plot, vineyard (agr) vie, podgorie

vine prop (agr, OM) arac de vie

vinery (alim) fabrică de vinuri; (agr, constr) seră cu viță-de-vie

vine shoot (agr, bot) butaş / lăstar de viță-de-vie vine stock (agr) butaş / butuc de viță-de-vie

vinewed putregăios, putrezit, mucegăit

viniculturist (agr) podgorean, viticultor

vinificator (alim) instalație pentru fabricarea vinului, vinificator

vinometer (alim, metr) alcoolmetru, aparat pentru măsurarea alcoolului din vin

vinous (alim) de vin, ca vinul

vinous fermentation (alim) fermentatie alcoolică / a vinului

vinous flavour (alim) miros de vin, buchet al vinului

vinous spirit (alim) spirt de vin

vintager (agr) culegător de struguri, vier

vintner (agr) podgorean, negustor / comerciant de vinuri

vintry (alim, constr) cramă, pivniță de vinuri

viny (agr) referitor la vița-de-vie, ca vița; (alim) de vin, referitor la vin, vinicol, vinifer, bogat în vinuri

vinyl (chim) vinil, vinilin; (fig) discuri de muzică, plastic

vinyl carbazole (chim) vinilcarbazol

vinyl chloride (chim) clorură de vinil

vinyl sulphide (chim) tioeter vinilic, sulfură vinilică

vinyl plastics (ind chim) vinilplaste, materiale plastice vinilice

vinyl resin (chim) răşină vinilică

violaceous (de culoare) violaceu, vioriu, violet

violent violent, intens, puternic, tare (d. un fenomen, un proces etc.); sălbatic; aspru; brutal; furios, vehement; irascibil; (d. culori) țipător, viu, aprins

violent proof (metr, OM) probă forțată (la solicitare maximă)

violescent bătând în violet

violet-coloured (colorat în) violet, vioriu 
violle (metr, fiz) unitate veche de măsură pentru intensitate luminoasă: 1 violle $=20,17$ candela (intensitatea luminoasă a $1 \mathrm{~cm}^{2}$ de platină strălucind la temperatura de topire de $1769^{\circ} \mathrm{C}$

viosterol, calciferol (alim, chim) vitamina $\mathrm{D}$

virgate (metr) unitate veche britanică de măsură pentru arie (de teren): 1 virgate $\sim 12$ ha, v. yardland, yard of land

virgin metal (met) metal nativ / primar

virgin pressure (mec, OM, hidr) presiune inițială

viridian (chim) oxid de crom albastru-verzui; culoare albastră-verzuie / verde-albăstruie

virtual virtual, efectiv, real, de fapt; posibil

virtual load $(\mathrm{OM}, \mathrm{el}, \mathrm{T})$ sarcină virtuală

virtual value (mat) valoare medie pătratică, valoare eficace / eficientă

virtue calitate; merit, valoare; iscusință, capacitate; forță, eficacitate, putere, acțiune; proprietate, însuşire

virulence virulență; (chim) agresivitate; (chim, med, mediu) toxicitate, caracter toxic / dăunător / periculos; sarcasm

virulent virulent; (chim) agresiv; (chim, med, mediu) malign, toxic; periculos, primejdios; sarcastic

virus (c) virus; (med) virus

visa (pol, adm) viză; a viza (un paşaport)

vis-à-vis $(a d v)$ vizavi, față în față; față de, cu privire la; omolog, partener egal; v. face to face, with regard to, in relation to

visbreaker (ind chim) instalație / agent de reducere a vâscozității

visbreaking (chim, T) (acțiunea de) reducere a vâscozității

viscera (alim) măruntaie

viscid vâscos, cleios (d. fluide)

viscidity (fiz) vâscozitate (rar)

viscoelastic damping (mec) amortizare vâscoelastică

viscoelastic flow (mec, hidr, TH, T) curgere vâscoelastică

viscoelasticity (mec) vâscoelasticitate

viscometer, viscosimeter (metr, T) vâscozimetru

viscoplastic behaviour (mec, plast) comportare vâscoplastică

viscose (textile) vâscoză

viscosity, viscousness (fiz, T) vâscozitate; frecare internă (în fluide); forță de coeziune

viscosity breaker (ind chim, alim) instalație / agent de reducere a vâscozităţii viscosity conversion chart (metr, T) diagramă pentru convertirea vâscozității dintr-o unitate în alta

viscosity curve $(T)$ curbă de vâscozitate

viscosity factor $(T)$ factor de vâscozitate

viscosity friction $(\mathrm{T})$ frecare internă (de obicei într-un fluid)

viscosity grade (VG) (metr, T, ind chim, auto) grad de vâscozitate, comercial acceptat pentru clasificarea lubrifianților; gradul de vâscozitate se notează VG xx, în care xx este vâscozitatea cinematică medie, în centistoke

viscosity-gravity chart ( $T$, metr, fiz) monogramă viscozitate-densitate

viscosity increase ( $T$ ) creştere a vâscozității

viscosity index $(\mathrm{T})$ indice de vâscozitate (notat cu VI, dar este des utilizat cu simbolizarea din limba engleză IV)

viscosity index alignment chart ( $T$, ind chim) monogramă pentru determinarea indicelui de vâscozitate

viscosity index blending value (alim, ind chim) indice de vâscozitate al amestecului

viscosity index chart $(\mathrm{T}, \mathrm{m}$ metr) monogramă pentru determinarea indicelui de vâscozitate

viscosity index improver ( $\mathrm{T}$, ind chim) aditiv pentru îmbunătățirea indicelui de vâscozitate

viscosity meter (metr, $T$ ) vâscozimetru

viscosity number $(T$, metr) indice de vâscozitate

viscosity-temperature chart ( $T$, metr) diagramă vâscozitate-temperatură

viscosity-temperature coefficient $(T$, fiz) coeficient de vâscozitate-temperatură

viscosity-temperature rating $(\mathrm{T})$ gradient (pe diagrama) vâscozitate-temperatură

viscosity test $(T$, metr) test pentru determinarea vâscozității

viscosity breaking (hidr, T) reducere a vâscozității

viscosity characteristic (of the fluid) (hidr, T) caracteristică de vâscozitate (a unui fluid) (de obicei funcția dependenței vâscozității de temperatură, dar nu numai)

viscous vâscos, lipicios, cleios (d. fluide)

viscous damper (OM, hidr) amortizor hidraulic / cu fluid vâscos

viscous damping $(\mathrm{OM}$, hidr) amortizare vâscoasă viscous fermentation (ind chim, alim) fermentație vâscoasă

viscous flow ( $T$, fiz, plast) curgere vâscoasă (laminară)

viscous fluid (fiz, T) fluid vâscos 
viscous friction $(\mathrm{T})$ frecare vâscoasă

viscous liquid ( $\mathrm{T}$ ) lichid vâscos

viscous loss $(T)$ pierderi prin frecare internă (în fluid, în lubrifiant, în pastă etc.)

viscousness vâscozitate ( $\mathrm{rar}$ )

viscous resistance $(T$, hidr, fiz, plast, $T H)$ rezistență a mediului / fluidului vâscos

viscous slag (met, termo) zgură vâscoasă

visibility, visibleness vizibilitate

visible vizibil; evident, vădit; neîndoielnic, aparent

visible reading (metr) citire directă

visible signal (metr, mas, cf, opt) semnal optic

visible spectrum (fiz, opt) spectru vizibil

visible warning device (mas, cf, opt) avertizor optic

visibly $(a d v)$ (în mod) vizibil / clar, (în mod) evident / vădit

vision privelişte, spectacol; imagine; viziune, imagine fictivă; ficțiune; perspicacitate, pătrundere (psihoilogică); a-şi imagina, a visa; (metr) acuitate vizuală, exprimată de obicei prin fracția / raportul Snellen; v. Snellen fraction

visit vizită; (ec, adm, mil) inspecție, cercetare, descindere; a vizita; a cerceta, a inspecta

visitable (metr, OM) care poate fi cercetat / inspectat / vizitat (d. un recipient, etc.)

visitation (nav) control vamal, percheziționare (a unui vas)

visitatorial de vizită, de inspecție

visiting card carte de vizită

visiting professor (univ) profesor invitat, lector străin (aproximativ)

visor $(\mathrm{OM})$ vizor; vizieră de protectie

visorless fără vizor / vizieră, neapărat / neprotejat de vizor / vizieră (d. un operator, un sudor etc.)

visual vizual, de vedere, optic, vizibil; elocvent, ilustrativ, demonstrativ

visual aids (edu) material didactic (auxiliar)

visual alarm (ind, transp) semnal optic de alarmă

visual angle (anat, opt, metr) unghi vizual / de vedere

visual appearance of grease $(\mathrm{T}, \mathrm{opt})$ aparența vizuală a unsorii

visual distance (anat, opt, metr) distanță vizuală

visual examination (anat, opt, metr) examinare / cercetare vizuală

visual field (anat, opt, metr) câmp vizual

visualisation vizualizare

visual inspection (opt, metr) control vizual

visuality vizualitate, caracter vizual, caracter vădit / evident / vizibil visualization vizualizare; imagine vizuală / clară / precisă; preconizare

visualize a vizualiza; a-şi reprezenta în mod clar; a avea reprezentarea / imaginea; a preconiza; a-şi face o imagine / idee clară despre

visually $(a d v)$ (în mod) vizual, vizibil

visual observation observare, privire

visual ray (anat, opt) rază vizuală

visual signal (ind, transp) semnal optic

visual warning device (ind, transp) dispozitiv pentru avertizare optică

vita glass (fiz) stică de cuarț (care permite trecerea razelor ultraviolete)

vital (biol) vital, referitor la viață; (ec, adm) arzător, presant, urgent; de importanță vitală, esential; (ind, chim etc.) primejdios, periculos, fatal, mortal

vitality vitalitate; viabilitate, caracter viabil / durabil

vitally $(a d v)$ (în mod) vital

vital part (anat, OM) parte vitală / esențială

vitamin (alim, chim) vitamină

vitellin(e) (chim) vitelin

vitellus (alim) gălbenuș de ou

vitiated (mediu) viciat, stricat, poluat

vitiated air (mediu) aer viciat / stricat / poluat

viciation viciere (a unui rezultat); (jur) invalidare, viciere, anulare; corupere; (mediu) stricare, poluare, viciere (d. aer etc.)

viticulture (agr) viticultură

viticulturist (agr) viticultor, podgorean

vitiosity caracter vicios; stricăciune

vitreous sticlos, vitros (d. materiale amorfe)

vitreous body / humour (anat) corp sticlos / vitros

vitreous coating $(\mathrm{TH}, \mathrm{OM})$ acoperire cu sticlă / cu ceramice

vitreous copper (minrl) calcozină

vitreous degeneration (med, anat) degenerescență vitroasă

vitreous electricity (fiz) electricitate (statică) pozitivă / sticloasă

vitreous enamel (ind chim) acoperire (a suprafeței metalice) cu sticlă de alcali-boro-silicați / cu porțelan

vitreous enamel (ind chim) acoperire (a suprafeței metalice) cu sticlă de alcali-boro-silicați / cu porțelan, smăltuire, emailare

vitreous fracture (materiale, OM) spărtură / fractură / ruptură sticloasă / vitroasă

vitreous humour (anat) umoare sticloasă / vitroasă

vitreous silica (ind chim) sticlă (amorfă) de oxid de siliciu 
vitreous silver (chim, minrl) argentit, sulfură de argint

vitreous slag (met) zgură sticloasă

vitreous state stare sticloasă / vitroasă (d. materiale plastice, ceramice în special)

vitreous texture (materiale) structură sticloasă / vitroasă

vitreousness, vitrescence vitrozitate, caracter sticlos / vitros

vitrescent care se poate transforma în sticlă / în formă sticloasă

vitrifacture fabricare a sticlei

vitrifiable vitrificabil, care se poate transforma în fază sticloasă / în sticlă

vitrification, vitrifaction vitrificare, emailare, smălțiire, glazurare; (met) obținere a zgurii sticloase

vitrified $(\mathrm{OM})$ vitrificat, glazurat

vitrified bond (ind chim) liant ceramic (pe bază de caolin şi feldspat)

vitrified ceramics (ind chim) ceramice vitrificate

vitrified process (ind chim, $\mathrm{TH}$ ) proces tehnologic pentru obținerea discurilor de rectificat cu liant ceramic

vitrified / vitrite wheel (mas-un) disc de rectificat cu liant ceramic

vitriform (materiale) vitriform, vitros, sticlos, ca sticla

vitrify (ind chim, TH) a vitrifica; a sinteriza; a transforma în sticlă

vitrifying vitrificare, vitrifiere (d. ceramice, materiale plastice)

vitrifying point (ceramice, plast) punct / temperatură de vitrificare

vitrify resitor (el) rezistență / rezistor vitrificat $(\breve{a})$

vitriol (chim) vitriol, acid sulfuric, sulfat

vitriolate (chim) a vitriola, a trata cu acid sulfuric

vitriolation (ind chim, $\mathrm{TH}$ ) vitriolare, tratare cu acid sulfuric

vitriolic (chim) vitriolic, de vitriol, de / cu acid sulfuric

vitriolic acid (chim) acid sulfuric

vitrite wheel (mas-un) disc de rectificat cu liant ceramic

vivid viu, vioi; strălucitor, intens, viu (d. culori)

vizar, vizor $(\mathrm{OM})$ vizor

V-mixer (met) melanjor în $\mathrm{V}$

V-notch (metr, OM) crestătură în V

vocabulary vocabular, glosar; (inf) listă a codurilor de instructiuni (inclusiv cuvinte rezervate)

vocation vocație; ocupație, meserie, profesie; carieră; înclinatie, aptitudine, talent, aplicație vocational profesional, de meserie, vocațional

vodka (alim) vodcă

vogue vogă, modă

voguish la modă, după ultima modă; elegant

voice voce; opinie, părere, glas; (pol) vot, a pro-

clama; a alege, a vota pentru; cuvânt; a rosti, a articula (cuvinte), a pronunța; a exprima, a enunța; a anunța

void (spațiu) gol / fără aer, vid, nul; fără efect; lacună, lipsă, loc liber; neocupat; pustiu, nelocuit; (fiz) loc vacant, liber; (met) retasură, cavitate; (c) defect de imprimare; (ec) a rezilia, a anula (un contract); (hidr, transp) a goli, a deşerta; a face gol; (jur) nul şi neavenit, lovit de nulitate, a lipsi de efect; fără valoare, ineficace, van; (fig) a evacua, a elimina

voidable care poate fi golit; (jur) anulabil, care poate fi lovit de nulitate; evacuabil

voidage volumul porilor, porozitate; (hidr, geol) epuizare, golire

voidance golire, deşertare; (jur) anulare, desființare; expulzare, eliminare, scoatere, îndepărtare; (fig) subterfugiu, pretext, chichiță

void column (ind chim) coloană fără umplutură

void contract (ec) contract reziliat

voided of (fiz, hidr) golit, vidat; lipsit de; (agr, constr) lăsat gol / liber / în paragină

voider (alim) coş de debarasat masa

void factor (materiale, OM) coeficient de porozitate

void fraction (mec, metr) fracție a golului (profilometrie) / a porilor (într-un volum)

void hole (met) gol, retasură, por mare

void index (materiale) indice de porozitate

voidless concrete (constr) beton fără goluri / fără pori

void ratio (materiale) (coeficient de) porozitate (şi procentual)

void seal $(\mathrm{OM}, \mathrm{TH})$ etanşare a golurilor / cavităților

void set (mat) mulțime vidă

voids index (materiale) indice de porozitate

void spacing (materiale) distribuție a porilor / a golurilor

voids porosity ratio (materiale) coeficient de porozitate / de goluri (şi procentual)

void(s) space / volume (materiale, metr) volum al golurilor (şi în topografia 3D a suprafeței) / al porilor

void volume (materiale) spațiu poros, volum al porilor; (metr, T) volum de gol (în topografia 3D a suprafeței) 
void water (geol, chim) apă interstițială / asociată / legată

voile (textile) (pânză de) voal

volatile (fiz, chim) volatil, schimbător; (fig) nestatornic, schimbător, uşuratic

volatile alkali (chim) amoniac, sare volatilă

volatile content (materiale) conținut de materii volatile

volatile disposition capriciu, dispoziție trecătoare, moft(uri)

volatile matter (fiz) substanță volatilă

volatile memory / storage (c) memorie nepermanentă / volatilă / pierdută la deconectare

volatile oil (chim) ulei eteric

volatile salt (chim) carbonat de amoniu

volatile wit minte iute / minte vioaie, spirit, umor

volatility, volatileness (fiz, chim) volatilitate, caracter volatil / eteric; (fiz) proprietate de a se evapora uşor; (c) volatilitate / pierdere a memoriei la deconectare; (fig) caracter schimbător / uşuratic; inconstanță; nestatornicie; (c) pierdere a continutului memoriei la disparitia tensiunii de alimentare, volatilitate a memoriei

volatility test (metr, fiz) test pentru determinarea volatilității; (metr, chim) determinare a compoziției fracționare

volatilizable (chim, fiz) volatilizabil

volatilization (fiz) volatilizare

volatilization loss(es) $(\mathrm{TH}$, ind chim) pierderi (tehnologice, la depozitare) prin volatilizare / evaporare

volatilize (chim, fiz) a (se) volatiliza, a (se) vaporiza, a se evapora

volatilizing roasting (met, $\mathrm{TH})$ prăjire cu sublimare

volcanic vulcanic, eruptiv; ( $f i g$ ) vulcanic, aprins, furtunos, impetuos, înfierbântat, năvalnic

volcanic ash (geol) cenuşă vulcanică

volcanic bomb (geol) nucleu vulcanic, bombă vulcanică

volcanic gases (geol, chim) gaze vulcanice

volcanic glass (minrl) obsidian, piatră vulcanică

volcanic lava (geol) lavă

volcanic neck (geol) coş vulcanic

volcanic rock (geol) rocă eruptivă / vulcanică

volcanic tuff / tuffa (geol) tuf vulcanic

volcanic explosivity index (VEI) (metr, geol) indice de explozivitate / activitate vulcanică, indice pentru evaluarea severității unei erupții vulcanice, cu valori între 0 şi 8 ; un indice $x$ corespunde unui volum expulzat de lavă de cel puțin $10^{3+x} \mathrm{~m}^{3}$ volcanic glass obsidiană, piatră vulcanică

volition (putere de) voință, act de voință, hotărâre

volitive volitiv

volt (V) (metr, el, fiz) volt, unitate de măsură în sistem SI, pentru potențial electric / tensiune electrică

voltage (el, fiz) tensiune, voltaj, tensiune electromotoare, diferență de tensiune / de potențial (exprimată în volți)

volt ampere $(\mathbf{V} \cdot \mathbf{A})$ (metr, el, fiz) volt-amper, unitate de sarcină / încărcare electrică pentru circuite de curent alternativ

voltage adapter switch comutator adaptor de tensiune

voltage adjustment switch comutator adaptor de tensiune

voltage amplification (el, electr) amplificare a tensiunii

voltage anti-node / loop antinod (al undei) de tensiune

voltage breakdown (el) străpungere cauzată de tensiune

voltage breakdown test (metr, el) test pentru determinarea tensiunii de străpungere a izolației

voltage connection (el) montaj în tensiune

voltage control (el, autom) reglarea tensiunii

voltage-controlled capacitor (electr) condensator a cărui capacitate este reglată prin tensiune

voltage dependent (el) (rezistență) dependentă de tensiune

voltage drop (el) cădere de tensiune

voltage equalizer (el, autom) stabilizator de tensiune, circuit de corectie al tensiunii

voltage feed (radio, fiz) excitare a antenei întrun ventru al tensiunii

voltage regulator (VR) (electr) baretor, regulator de tensiune

voltage tapping switch (el, autom) comutatoradaptor de tensiune

voltage level (el) nivel / valoare a(l) tensiunii

voltage of the circuit (el, mas) tensiune de regim / de lucru

voltage on outside lines (el) tensiune de linie, tensiune între faze

voltage-operated (autom, el) acționat de tensiune (un releu, un întrerupător etc.)

voltage ratio (el) raport de transformare (al unui transformator)

voltage-ratio box (el, metr) divizor multiplu de tensiune (şi pt. aparate de măsură)

voltage regulator (el, autom) regulator de tensiune 
voltage relay (el, autom) releu de tensiune voltage stabiliser / standardizer (el, autom) stabilizator de tensiune

voltage standard (chim) element (electrochimic) normal; (el) etalon de tensiune

voltage step up (el) transformator ridicător de tensiune

voltage surge (el) (sursă de) tensiune de şoc, supratensiune

voltage tap(ping) (el) priză de tensiune

voltage to neutral (el) tensiune față de nul / de neutru / pe fază

voltage to earth / to ground (el) tensiune față de pământ

voltage transformer (el) transformator (de tensiune)

voltage-variable (electr) diodă semiconductoare a cărei capacitate depinde de tensiune

voltage withstand test (el, metr) test / încercare pentru determinarea rigidității dielectrice, probă / test de străpungere

voltaic (el) voltaic, galvanic, conducător

voltaic arc (el) arc electric / voltaic

voltaic battery / pile (el) element galvanic / voltaic, pilă electrică

voltaic current (el) curent galvanic

voltaic wire (el) fir (de curent) conducător

voltameter (el, metr) voltametru, aparat pentru măsurarea cantității de electricitate

voltammeter (el, metr) voltapermetru (cu conexiuni separate pentru măsurarea tensiunii şi intensității curentului)

volt-ampere (el, metr) volt-amper, unitate de măsură utilizată pentru măsurarea puterii în circuite de curent alternativ

volt-ampere-hour meter (el) contor de energie electrică (aparentă) (pt. circuite cu cuernt alternativ)

volt-ampere meter (el, metr) volt-ampermetru

volt-ampere reactive (el, metr) var, volt-amper (reactiv) (unitate de măsură a puterii reactive)

voltaplast (el) aparat galvanic

volt efficiency (el, mas) randament de tensiune

voltmeter (el, metr) voltmetru

voltmeter multiplier (el, metr) voltmetru $\mathrm{cu}$ rezistențe adiționale în serie

volt-ohmmeter (el, metr) volt-ohmmetru

volt-ohm-milliammeter (el) aparat de măsură pentru tensiune, rezistență şi intensitate a curentului electric, dar pentru intervale diferite, analizor de circuite, multimetru

volt root mean square (el) volt efectiv; (fiz) amplitudine, nivel (a unui semnal de audiofrec- vență); capacitate, conținut, spațiu; (c) porțiune definită a unui disc magnetic, suport de informații montat pe un periferic; (poligrafie) tom

volt efectiv volume (mat, $\mathrm{TH}$ ) volum; (poligrafie) volum; (fiz, telecomunicații) volum (al intensității unui sunet de audiofrecvență)

volume volum, conținut, cantitate, masă (rar), spațiu, capacitate, dimensiuni, mărime; (fiz) intersitate (la radiaţii); volum / tom (de carte); (inf) suport de informație, montat pe un periferic, porțiune definită a unui disc magnetic; a strânge, a îngrămădi, a se umfla, a creşte, a spori în volum

volume batcher (ind, $\mathrm{OM}$ ) dozator volumic

volume batching (ind, TH) dozare volumică

volume change (materiale, $\mathrm{OM}$ ) variație a volumului

volume charge (fiz) sarcină electrică distribuită spațial / într-un volum

volume concentration (materiale) concentrație în volum

volume constancy (materiale, fiz) constanţă a volumului

volume control (el, metr) potențiometru, volumetru

volumed strâns la un loc / într-un volum; voluminos, enorm, întins

volume-defined chamber (ind, fiz) cameră cu volum variabil

volume density (materiale, metr) densitate de / în volum

volume change (materiale, $\mathrm{OM}$ ) variație a volumului

volume discount $(\mathrm{ec})$ bonificație la volum / la cantitate (achiziționată / vândută)

volume elasticity (fiz, mec) elasticitate volumică / de volum

volume energy (fiz) energie volumică

volume expansion (materiale, $\mathrm{OM}$, termo) dilatare / creştere volumică; (c) expandare dinamică

volume filling (fiz) umplere până la un anumit volum

volume factor (materiale, fiz, OM) factor de volum

volume fraction (materiale) fracțiune (exprimată) în volum

volume governor (alim, ind chim, OM) dozator

volume integral (mat) integrală de volum, integrală triplă

volume indicator (fiz, metr) indicator de volum, decibelmetru, sonometru

volumenometer (metr, hidr, OM) debitmetru

volume of air (fiz, ind, $\mathrm{TH}$ ) volum de aer 
volume of blast (met) debit de vânt (la cuptoare, la furnal)

volume of pores (materiale) volum al porilor volume of revolution (mat) corp de rotație volume of sound (fiz) sonoritate, audiție, intensitatea sunetului, volum sonor

volume of voids (materiale) volum al porilor volume percent (materiale) procent volumic volume pipette (metr, $\mathrm{OM}$ ) pipetă gradată

volume regulator $(\mathrm{OM}$, hidr, autom) regulator de debit, volumul (maxim) care poate fi controlat de regulatorul de debit / de drosel

volume relation (materiale) raport volumic

volume shape coefficient (materiale, $\mathrm{OM}$ ) coeficient (volumic) de formă

volume shrinkage (materiale) contracție volumică volume stability (materiale, OM) stabilitate volumică, constantă de volum

volumeter (metr, fiz) decibelmetru, volu(m)metru, debitmetru

volumetric(al) volumic, volumetric

volumetric unit (vu) (metr) unitate de măsură pentru volum: 1 volumetric unit $=5,663 \mathrm{~m}^{3}$, utilizată în US în industria lemnului pentru rumeguş şi alte produse secundare sau deşeuri lemnoase

volumetric weight (metr, transp) masă volumică, o măsură a mărimii pachetelor / bagajelor în transportul aerian, pentru taxarea acestora; masa unui pachet / bagaj, în $\mathrm{kg}$, este $l \cdot w \cdot h / 6000, l, w$, and $h$ fiind dimensiunile pachetului / bagajului, în $\mathrm{cm}$; calculul presupune o densitate de numai $1 / 6 \mathrm{~g} / \mathrm{cm}^{3}$, masa volumică se utilizează doar pentru pachete / bagaje uşoare / voluminoase

volumetrically $(a d v)$ (din punct de vedere) volumetric

volumetric analysis (metr, fiz) analiză volumetrică

volumetric average boiling point (termo, fiz) temperatură medie volumetrică de fierbere

volumetric calibration (metr, fiz) etalonare volumetrică

volumetric capacity (OM, hidr) capacitate volumică, volum

volumetric contraction (materiale) contracție volumică

volumetric correction factor (chim) factor de corecție a soluției titrate

volumetric deformation (materiale) deformare volumică (în tot volumul)

volumetric efficiency (OM, hidr) coeficient volumic, factor de volum, grad de umplere, eficiență volumică volumetric expansion expansiune / dilatare volumică

volumetric flask (chim, OM) balon cotat / gradat

volumetric flow rate (hidr) debit volumic (d. lichide şi gaze)

volumetric molar concentration (chim) concentrație volumică molară

volumetric solution (chim) soluție titrată

volume unit (vu) (metr, inf) unitate de măsură în telecomunicatii pentru a descrie volumul de semnale radio sau TV, care poartă informații complexe (muzică etc.), volumul unui semnal, în unităţi de volum, este egal cu numărul de decibeli cu care depăşeşte un semnal / nivel de referință $(1 \mathrm{~mW}$ de putere într-un circuit cu o impedanță de $600 \mathrm{ohm})$

volume weight (fiz, materiale) greutate / masă specifică

voluminous $(\mathrm{OM})$ voluminos, mare, de mari dimensiuni, gros; (format) din mai multe volume; abudent, îmbelşugat

voluminously $(a d v)$ în mare cantitate, din belşug, abundent

voluminousness caracter voluminos / amplu, volum mare; amploare, întindere; grămadă, masă

voluntary waste (ec, $\mathrm{TH})$ distrugere / pierdere / risipă intenţionată

volute (mat, OM) con, spirală (și la pompe centrifugale), melc, volută; (OM, termo) cameră spiralată; (zool) melc, cochilie; (arhit) (ornament) in spirală, volută

volute chamber (termo, OM) melc, cameră spiralată (la turbine)

volute pump (OM; hidr) pompă elicoidală

volute spiral spring $(\mathrm{OM})$ arc elicoidal conic

volution (mat) spirală; (anat) circumvoluți(un)e

vortex, $(p l)$ vortices (hidr, nav) turbion, vârtej; la cicloane, punctul în care se formează vârtejul interior (în care curenții au viteze diferite $\mathrm{cu} \sim 180^{\circ}$ )

vortex disturbance (fiz, hidr) distorsionare a vârtejului

vortex field (mat, fiz) câmp de vârtejuri / turbionar / rotațional

vortex flow (hidr) curgere turbionară

vortex generation (fiz, hidr) generare / formare a vârtejului (la cicloane), turbionare

vortex field (fiz) câmp de vârtejuri / turbionar / rotaţional

vortex flow (fiz, hidr) curgere turbionară / cu vârtejuri

vortex line (hidr) linie de vârtej

vortex motion (hidr) mişcare turbionară 
vortex nucleus (hidr) nucleu de vârtej vortex pump (OM, hidr) pompă turbionară vortex region (hidr) regiune / zonă cu vârtejuri, domeniu cu vârtejuri

vortex resistance (hidr, nav) rezistență turbionară

vortex sheet (hidr) strat cu vârtejuri

vortex surface (hidr, nav) suprafață de vârtejuri

vortex tube (hidr) tub de vârtejuri

vortex wheel turbină

vortical vortivular, referitor la vârtej, volbură

vortices (hidr) minivârtejuri într-o curgere a unui fluid (datorate variației locale a presiunii)

vorticity (hidr, fiz) turbion; turbionare

vorticity field (hidr, fiz) câmp turbionar

vorticular (fiz, hidr) în vârtejuri, rotațional

vote (pol) vot, sufragiu, scrutin; votare; drept de vot

vote for (pol, ec, adm) a vota, a da votul pentru

votometer (metr, mas, inf) maşină automată pentru numărarea voturilor

vortrap (ind, mediu) epurator turbionar

vouch mărturie; depoziție; încredințare, asigurare; a afirma; a garanta; a dovedi; a confirma; a întări (o afirmație), a susține, a gira

voucher (ec, adm, jur) act justificativ, anexă, document, girant, garant, act de garantie, chitanță, bon; certificat, adeverință, dovadă; (jur) martor, mărturie

vouch for a garanta pentru, a răspunde pentru / de

vouchsafe a da, a acorda, a nevoi să acorde; a garanta

vouchsafement asentiment, încuviințare, consimțire

vox, $(p l)$ voces voce, opinie

voyage călătorie (şi pe apă), croazieră; a străbate, a călători, a face o călătorie (pe mare)

VPH (Vickers pyramid hardness) (metr, materiale) simbol acceptat pentru duritate Vickers, determinată cu indentor piramidal

V-rope (OM) curea trapezoidală

V-rope pulley $(\mathrm{OM})$ roată de / pentru curele trapezoidale

vs. (versus) (prep) în raport cu, în funcție de, în contra, împotriva

V shape $(\mathrm{OM})(\mathrm{cu})$ formă în $\mathrm{V}$

V-shaped, V-type (cu formă) în V, în formă de $\mathrm{V}$, conic, în formă de pâlnie

V-shaped belt $(\mathrm{OM})$ curea trapezoidală

V-slot $(\mathrm{OM})$ canelură în $\mathrm{V}$

v.s.m. (variable speed motor) (mas, el, electr) motor cu viteză / turație variabilă
V-stand (constr, OM) montant cu degajare în $\mathrm{V}$

V-threaded (OM) cu filet ascuțit / triunghiular

V-toothed gear (OM) angrenaj / transmisie cu roți dinţate în $\mathrm{V}$

V-type engine (auto, termo) motor cu cilindri (montați) în V

vuggy (materiale) poros; (anat) cavernos

vulcanizate (ind chim) vulcanizat

vulcanization (ind chim) vulcanizare

vulcanization on mandrel (ind chim) vulcanizare pe dorn

vulcanization accelerator (ind chim) accelerator de vulcanizare

vulcanization bath $(\mathrm{OM}$, ind chim) cadă de vulcanizare

vulcanization by high frequency heating (ind chim) vulcanizare cu curenți de înaltă frecvență

vulcanization on drum (ind chim) vulcanizare pe tambur

vulcanization on mandrel (ind chim, $\mathrm{TH}$ ) vulcanizare pe dorn

vulcanization optimum (ind chim, TH) optim de vulcanizare

vulcanization rate (ind chim) viteză de vulcanizare

vulcanization solution (ind chim) soluție de vulcanizare

vulcanization workshop (ind chim) atelier de vulcanizare

vulcanize (ind chim) a vulcaniza

vulcanized (ind chim) vulcanizat

vulcanized asbestos (ind chim) azbest vulcanizat

vulcanized caoutchouc (ind chim) cauciuc vulcanizat

vulcanized fibre (ind chim) fibră vulcanizată

vulcanized joint (ind chim, OM) înnădire vulcanizată (la covorul unei benzi de cauciuc)

vulcanized rubber (ind chim) cauciuc vulcanizat

vulcanized-rubber cable (ind chim, el) conductor izolat în cauciuc vulcanizat

vulcanized-rubber scrap (ind chim) deşeuri de cauciuc vulcanizat

vulcanizer (ind chim, OM) aparat / dispozitiv de vulcanizat

vulcanizing boiler / heater / pan (ind chim, termo) autoclavă pentru vulcanizare

vulcanizing mould (ind chim, OM) matriță de vulcanizat

vulcanizing oven (ind chim, termo) cuptor de vulcanizare 
vulcanizing press (ind chim, termo, mas-un) presă de vulcanizat

vulgar ordinar; obişnuit; comun; the $\sim$ oameni de jos, oamenii de rând, plebea

vulgar errors greşeli omeneşti / obişnuite

vulgar establishment (nav) stabiliment mediu al portului pentru mareea înaltă de sizigii, interval mediu al mareei înalte la sizigii

vulgar fraction (mat) fracție ordinară

VU meter (metr, fiz) volummetru, decibelmetru

v.v. (vice-versa) viceversa v/v (metr, fiz, chim, farmacologie) abreviere pentru ,by volume” - (concentrație) în volum; exemplu: $2 \%$ v/v descrie un volum de substanţă de $2 \%$ din volumul total al soluţiei sau amestecului

V-welding (met, TH) sudare în V

V-welding with binder (met, $\mathrm{TH}$ ) sudare (cu rost) în $\mathrm{V}$

V-wheel drive (OM, T) transmisie cu roți de fricțiune, cu canale în $\mathrm{V}$

vying with în concurență cu, rivalizând cu; rivalitate, luptă, concurență 


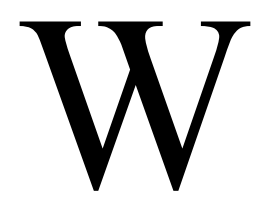

W (metr, fiz, termo) simbol pentru watt - unitate de măsură pentru putere, în sistem SI

wabbler (met) treflă (la valțuri, la cilindri de laminare etc.)

wad (OM) tampon, dop de câlți; (textile) sul (de stofă); teanc, pachet ghemotoc; (med, textile) vată; a tampona, a astupa cu un tampon, a face sul, a face cocoloș; a vătui

wadded umplut cu vată, vătuit

wadding (textile, med) vată; (textile) lână, păr, puf; tampon; umplere, căptuşire (cu vată etc.); care umple / căptuşeşte cu vată / puf

wadding of glass (ind chim) vată de sticlă

wadge teanc, pachet, sul

wad punch (mas) preducea cu mâner

wafer $(\mathrm{OM})$ placă subțire, plăcuță, disc subțire, element (subțire) de filtru, microplăcuță, capsulă, casetă, gofră; (alim) vafă, vafelă, caşetă, capsulă; timbru imprimat; (electr) tabletă (la semiconductoare)

wafer core $(\mathrm{OM})$ miez în formă de placă

wafer loudspeaker (radio) difuzor plat

wafer socket (electr) soclu / suport plat (de tub electronic)

wafer switch (electr, el) comutator cu ploturi

wafer-type temperature detector $(\mathrm{OM}$, termo, metr) termometru sandwich (metale şi izolatoare în foi subțiri)

wafery (alim) crocant, fărâmicios, brutărie pentru vafe

waffle (alim) vafă

waft flag (nav) pavilion de avarie

wag a mişca încoace şi încolo / în sus şi în jos

wage (ec) salariu, plată (săptămânală sau zilnică), parte din profit care revine muncitorilor / angajaților

wage costs (ec) cheltuieli cu salarii

wage cut $(\mathrm{ec})$ reducere a salariilor

wage earner (ec) salariat, angajat, muncitor

wage floor (ec) nivel de bază al salariului

wage(s) freeze (ec) înghețare a salariilor

wage(s) fund $(\mathrm{ec})$ fond de salarii

wage rate $(\mathrm{ec})$ tarif de salarizare

wages funds $(\mathrm{ec})$ fonduri de salarizare

wage scale (ec) schemă / plan de salarizare

wage worker (ec) salariat, angajat wagle $(\mathrm{OM}, \mathrm{mec})$ legănare, clătinare, bălăbănire, mişcare, agitare; a se clătina, a se legăna, a se bălăbăni, a tremura, a mişca, a agita

waggly $(\mathrm{OM}, \mathrm{mec})$ care se clatină / se leagănă, instabil, nesigur

waggon (OM, transp) car, cărucior, vagonet; (auto) (auto)camion, autovehicule industriale, remorcă basculantă; (cf) vagon, boghiu, vagon de marfă, vagon-platformă; (transp) furgon, a transporta (cu unul din mijloacele de mai sus)

waggonage (transp, cf) transport, vagonaj

waggon belt unboarder (cf, mas) descărcător cu bandă pentru vagoane

waggon body (cf, OM) corp / cutie de vagon

waggon bogie (cf, OM) boghiu de vagon

waggon coupler $(c, O M)$ cuplă de vagoane

waggon fitted with brake pipes (cf) vagon $\mathrm{cu}$ conductă de trecere pentru frâne

waggon hoist (cf, transp, mas) ascensor / ridicător de vagoane / autovehicule

waggon moving device (cf, OM) rangă cu articulație pentru deplasat vagoane

waggon park (cf) parc de vagoane

waggon pinch bar (cf, OM) rangă / pârghie cu articulație pentru deplasat vagoane

waggon shunting (cf) triere a vagoanelor

waggon trippler (cf, met) culbutor de vagoane

waggon washing station (cf) staţie de spălat vagoane

waggon way (cf) cale de transport

waggon works (cf, ind) uzină de vagoane

waggon yard (cf) parc de vagoane

wah (metr) unitate tradițională de măsură pentru lungime, în Tailanda: $1 \mathrm{wah}=2 \mathrm{~m}$

wainscot (constr) lambriu, panel, a lambrisa, a placa cu panel

wainscot(t)ing (constr, silv) placare cu lemn, lambriu, lambrisare

waist mijloc, parte de mijloc, centru; (mas-un, OM) îngustare, gâtuire, centură; (textile) mijloc, talie (a rochiei etc.), corsaj; (nav) punte superioară centru; (ind pielăriei) glene

waistcoat (textile) vestă

waist line (auto) linie centrală / mijlocie, linie de aşteptare (pe autostradă)

wait aşteptare, expectativă; pândă; capcană; păzitor, paznic; a aştepta, a fi / sta în aşteptare; a fi de serviciu; (ec) a servi (ca vânzător), a fi vânzător; (alim) a amâna, a întârzia cu (masa), a servi la (masă); (edu) a asista la, a lua parte la, a participa la (o ceremonie); a aştepta (rândul, prilejul, ordinul); a fi gata / pregătit; at $\sim$ în aşteptare; at / on table a fi ospătar, a 
servi la masă; in the wings a fi gata să ia locul cuiva, (şi fig) a-şi aştepta rândul în culise, a aştepta să-i vină rândul, a aştepta un moment favorabil; $\sim$ smb.'s convenience a fi / sta la dispoziția cuiva, a aştepta până când cineva găseşte ca e convenabil / potrivit / de cuviință să facă ceva; it out a aştepta până trece ceva; lie in $\sim$ for smb. (mil) a aştepta pe cineva în ambuscadă; one's turn a aştepta să-i vină rândul, a-şi aştepta rândul

wait and see a sta în expectativă, a aştepta să vezi (cum se desfăşoară lucrurile)

wait-and-see policy (pol, ec) politică de expectativă / rezervată

wait at a servi la

waiter chelner, ospătar; persoană care aşteaptă, solicitant; tavă

wait for a aştepta ceva

waiting $(\mathrm{TH}, \mathrm{adm})$ aşteptare, expectativă, serviciu, care aşteaptă; de serviciu; (mat, inf); aşteptare (în statistica matematică); (inf) stare de aşteptare; upon servire a cuiva

waiting line / queue (Th, inf, c, autom) linie / şir de aşteptare, coadă

waiting list (ec) listă de solicitanți / de cumpărători, listă de aşteptare

waiting room (constr, adm) sală de aşteptare

waiting time $(\mathrm{TH}$, ind, ec, inf) timp de aşteptare

wait on (d. succes etc.) a însoți (pe cineva); a fi la ordinele cuiva; (edu) a fi la dispoziția (cuiva); a urma după; a avea grijă de

wait on / upon a sta la dispoziție

wait state (c, inf) fază în timpul executării unui program în care microprocesorul aşteaptă ca memoria să răspundă la cererile lui

waive (jur) a renunța la; a abandona; a amâna

waiver (jur) (declarație de) renunțare, excepție, derogare (de la lege)

wake (nav) siaj de elice, jet de curent al elicei; făgaş, urmă; a se trezi, a se dezmorți, a nu dormi, a deveni activ, a se pune în mişcare, a face să se mişte; (fig) a stârni, a agita

wake interference flow $(T)$ curgere cu siaje interferate din cauza rugozității / ondulației suprafeței

wake light (nav) lumină din pupa

waken a veghea, a fi treaz; a stârni, a isca, a aprinde (focul); a înteți

waken to a trezi la acțiune

waking trezire, deşteptare; treaz, deştept, nedormit, atent, vigilent; (fig) real, adevărat

wale urmă, semn; (nav) centură / brâu de acostare; manşetă (textile)
Wales (geogr) Țara Galilor (în UK); (metr, geogr) unitate de măsură pentru suprafață, egală cu $\sim 20760 \mathrm{~km}^{2}$

walk plimbare, pas, ieşire, drum, alee, rond, tur; (constr) coridor, culoar; a merge (pe jos), a se plimba, a străbate, a parcurge; (ec) ritm lent (al producției); carieră, profesie; domeniu, sferă (de preocupări), preocupare, competență walk down ( $\mathrm{TH}$, ind) pierderi cumulative walkie-talkie (radio) aparat portativ de emisierecepție

walk-in freezer (termo) cameră de congelare

walking beam $(\mathrm{OM})$ balansier

walking beam furnace (met) cuptor basculant, cu vatră păşitoare

walking excavator (constr, mas) excavator păşitor

walk-out grevă; plecare de la o întrunire, ieşire din organizație (ca protest)

walk out a ieşi (afară), a pleca; a face grevă; a pleca (de la o întrunire), a ieşi (dintr-o organizație)

walkway (constr) coridor / culoar circular, alee; (nav) pasarelă; potecă

wall (constr) perete, zid, gard (de piatră), întăritură, a zidi, a astupa (o deschizătură); (hidr) dig; (geogr) stancă de netrecut, stanca masiva, val (de nepătruns); (fig) zid (de apă, de stâncă etc.), zid (de nepătruns)

wall beam (constr) grindă de centură

wallboard (ind, constr) placă de fibră / aglomerată

wall bracket $(\mathrm{OM})$ suport / pentru consolă; (constr) scoabă de zidărie, contrafort; (el) armătură de lampă de perete, aplică

wall-bracket crane (mas, transp) macara-consolă

wall bushing insulator (el, OM) izolator de trecere

wall channel (constr) trecere prin zid, străpungere (într-o instalație electrică, de încălzire etc.)

wall-clamp (constr) ancoră / armătură de zid; (el, OM) brățară de țeavă, clemă de perete

wall column (constr) coloană, pilastru

wall cornice (constr) cornişă a peretelui

wall creeper (bot) planta agățătoare

wall dowel (constr) diblu

wall drill (mas-un) maşină de găurit (fixată) de perete

walled (constr) cu ziduri, zidit, înconjurat de ziduri, întărit

wall from (constr) a despărți printr-un zid / perete 
wall hook $(\mathrm{OM}$, el) brățară / clemă de țeavă, prinsă în perete, cârlig fixat în perete walling (constr) (susținere) cu ziduri, zidire walling scaffold (constr) schelă

walling-up (met) zidire / căptuşire cu material refractar

wall jib crane (mas, transp) macara pivotantă

wallknot (nav) nucă

wall lamp holder (el) dulie

wall lining (met) căptuşeală (de materiale refractare)

wall machine (mas-un) maşină de perete

wall mounting $(\mathrm{OM})(\mathrm{cu})$ montare pe perete, care se montează pe perete

wall of compass towl (termo) perete de cazan

wall of (the) rivet hole (met, OM) perete al unei găuri de nit

wall outlet (el) priză de perete

wall painting (artă) frescă, pictură murală

wall rue (bot) ruginiță

wall panel (el) panou de perete

wall paper (constr) tapet

wall planer (mas-un) raboteză de perete

wall plate (constr) cosoroabă

wall plug (el) priză / fişă de perete

wall plug with movable contact pins (el) fişă de perete cu contacte elastice

wall rubler (plast) flanc (de anvelopă)

wall socket (el) doză cu fişă

walls of bore hole (mas-un) perete / suprafață a(l) găurii prelucrate; (ind) pereți de puț

wall rubber (auto) flanc de anvelopă

wall switchboard (el) tablou de distribuție de perete

wall thickness $(\mathrm{TH})$ grosimea peretelui (la țevi, tuburi, piese)

wall-tube insulator (el) izolator de trecere

wall-type socket (el) priză de perete

wall-up (constr, met) a zidi, a susține prin zidire

walnut nucă; (silv) lemn de nuc; culoare marocastanie

walnut oil (alim) ulei de nucă

wan (metr) unitate pentru cantitate, în China, egală cu 10000

wander a devia, a se abate; a cutreiera (munți etc.), a rătăci prin (munți etc.); a delira; a se încurca; a-şi pierde firul gândurilor; a vorbi fără şir; (amer) a pierde drumul, a se rătăci

wander about a cutreiera prin, a hoinări prin, a rătăci prin; a umbla prin, a călători fără tịntă, a rătăci, a umbla de colo până colo

wander about the streets a bate străzile, a rătăci pe străzi wander away (zool) a se rătăci; a se răzleți (de turmă etc.)

wander forth a se duce in lumea întreaga; a se îndrepta agale / alene spre

wander from a se abate de la / din, a se depărta de

wander from proper conduct a nu se purta corect, a nu se purta cum trebuie

wander from the beaten track (şi fig) a părăsi cărarea bătuta, a se abate de la drumul obişnuit

wander from the point / the subject a se abate / îndepărta de la subiect

wander in a intra în treacăt, a trece întâmplător (pe la cineva)

wandering mers la întâmplare (şi în statistica matematică); peregrinare; rătăcire; ambulant; (anat) deplasat (d. rinichi etc.); (fig) rătăcit, aiurind, delirant; rătăcitor; şerpuit, cotit, neregulat (d. un râu etc.)

wandering sequence (met, $\mathrm{OM}$ ) sudare cu cusătură întreruptă, la care lungimea porțiunilor sudate şi nesudate sunt variabile

wander in one's mind a avea mintea rătăcita; (fig) a vorbi aiurea; a-şi pierde mintea

wander off $v$. wander from

wander off the point / subject a face digresiuni, a se abate de la subiect

wander plug (el, OM) fişă mobilă

wander through a şerpui prin

wander year (univ) (amer) an de călătorii (după absolvire)

wane (la piese din lemn) teşitură; (d. lumină) a scădea în intensitate, a slăbi; (fig) a fi în declin, a se micşora, a slăbi; declin, decreştere, micşorare, scădere

waney (silv) nod într-o scândură, teșitură

want nevoie; lipsă; necesitate; necesar; (ec, adm) cerere; ananghie; insuficiență; sărăcie; (fig) strâmtorare; a avea (neapărată) nevoie de; a dori, a vrea, a căuta; a cere; (la aspectul continuu) a nu corespunde, a nu fi corespunzător, a nu fi prezent, a fi in culpa, a fi lipsă, a lipsi; a dori; a duce lipsă de, a-i lipsi (cele de trebuință), a fi lipsit de; a fi neapărata nevoie de / să; a necesita; a pofti; a reclama; a fi sărac strâmtorat; a suferi de, a suferi din lipsă de; a-i trebui, a trebui să

want ad (amer) ofertă de serviciu

wantage lipsă, deficit, necesar, cerere; (ec) deficit

wantage rod $(\mathrm{OM})$ tijă / jojă de măsurat nivelul lichidului într-un rezervor 
want of spare parts (auto, ind) lipsă / cerere de piese de schimb

ward (constr) secție (de spital etc.), pavilion, sală; (pol) circumscripție electorală; (adm) cartier, district; tutelă; loc sigur / ferit; (med) a interna (în spital); a para, a respinge, a înlătura (un pericol)

warden (ec) custode, îngrijitor, administrator, supraveghetor

warding apărare, protecție, pază

wardrobe (mobilă) garderobă, şifonier, dulap de haine

wardroom (nav) careul ofițerilor

ware (ec) produse finite / fabricate (şi de olărit)

warehouse (ec, ind) depozit de materiale / mărfuri; (ec) magazin mare, depozit de mărfuri, magazie, antrepozit

warehousing (ec, ind) depozitare, înmagazinare

warehouse keeper (ec, ind) magazioner

war flag (nav, mil) pavilion de război

warhead (mil) focos (el) vârf de sarcină

warily $(a d v)$ cu grijă / precauție / prudență, precaut

wariness grijă, precauție, prudență

warm cald, călduros, care ține de cald, încălzit; (termo) încălzire, a încălzi, a aprinde, a dezmorți; (fiz) cu radioactivitate mică / slabă; (alim) a încălzi

warm-air feed (auto) alimentare cu aer cald

warmer (plast) valț preîncălzitor; (termo) aparat de încălzit / de încălzire, termofor

warmhouse (agr, constr) seră

warming (met, termo) încălzire, care încălzeşte

warming(-up) mill (plast, ind chim, textile) valț cu preîncălzire

warming-up (termo) încălzire, reîncălzire; a încălzi, a reîncălzi

warming-up period ( $\mathrm{TH}$, ind) perioadă de (pre)încălzire

warmish călduț, destul de călduros

warm-up (termo) (pre)încălzire; (auto) activare (a bujiilor)

warm up (termo, auto) a (se) (pre)încălzi (şi d. un motor etc.), a reîncălzi, a face (mai) cald, a deveni (mai) cald; (alim) a încălzi, a fi pus la încălzit; (auto, mas) a activa (bujii etc.)

warn (jur) a cita, a anotifica; a încunoştința, a înştiința (oficial)

warn against / of a preveni, a avertiza, a pune în gardă împotriva; a înştiința, a încunoştința, a notifica asupra; (jur) a cita

warn off a îndepărta prin amenințări / avertizări, a ține la distanță prin ameninţări / avertizări warning înştiinţare; prevenire; avertizare, avertisment, alarmă; semnalizare, semn, indiciu; alertă; înştiințare, încunoştințare (ec) preaviz; de avertizare, care avertizează

warning agent (chim, fiz) substanță semnalizatoare / de semnalizare / avertizoare

warning and indicator lights (auto) lămpi / lumini de avertizare şi atenționare

warning beep (c, autom, mas) semnal sonor şi / sau luminos, produs din cauza unei erori sau avertizări

warning circuit (el, autom) circuit de semnalizare / de avertizare

warning flasher (auto) semnalizator (intermitent) (luminos şi / sau sonor) de atenționare

warning gauge (metr) limitator de umplere; dispozitiv de avertizare / de semnalizare

warning lamps lampă / bec de semnalizare

warning light (auto) semnal luminos de avertizare

warning signal (metr, mas) semnal de alarmă / de avertizare; (cf) semnal de atenţie

warn off a îndepărta, a ține la distanță prin avertizare, a avertiza (pe cineva), a obliga (pe cineva) să nu facă ceva

warp (mec) deformație, deformare, strâmbare, scorojire, sucire, deviere; denaturare, pervertire; (geogr, mediu) nămol aluvionar; (nav) parâmă / odgon de manevră / de remorcă, a trage (de parâme); (textile, compozite) urzeală, a urzi; (met) spiră (a colacului de sârmă), buclă de semifabricat; (mec) a (se) încovoia, a (se) strâmba, a (se) (ră)suci, a (se) deforma, a (se) scoroji; a (se) denatura, a (se) abate, a devia

warpage (mec) deformare, strâmbare; (autom, electr) distorsiune

warp defect (textile, plast) defect de urzeală / de aranjare (a fibrelor, la țesături, compozite fibroase)

warped $(\mathrm{OM})$ îndoit, strâmb, răsucit, încovoiat, deformat

warping (d. lemn) scorojire; (mec) distorsiune, deformare, încovoiere, strâmbare (d. straturi etc.); (nav) remorcare (pe ancoră), tractare

warping chock (nav, OM) urechi de ghidare

warrant motiv, justificare; drept; (ec, jur) împuternicire, procură (de percheziție etc.), mandat, ordin (de percheziție etc.), garant, garanție; autoritate morală; cădere; cauțiune, chezăşie; recipisă dată celui care depune; (ec) (recipisă) varrant; a garanta (pt. ceva, cineva); a justifica; a îndreptăți, a asigura; (jur) a da dreptul la 
(o procedură), a împuternici (o procedură), a justifica, a permite (o procedură); that a jura că, a putea sa jure că, a fi sigur că, (fig) a pune mâna în foc că; be ed in asking a fi îndreptătit să întrebe

warrantable (jur) legitim, îndreptățit, permis, care poate fi garantat / justificat

warantee (ec, jur) împuternicit, persoană căruia i se dă o imputernicire / o garanție

warrant for payment (ec, jur) ordonanță de plată

warranter, warrantor (ec, jur) garant

warrant of attorney (jur) procură

warrant officer (mil) grad intermediar între subofițer şi ofițer, subofițer

warranty (auto, mas) garanție; (jur, ec) condiție, clauză (într-un contract); justificare, temei; (adm, ec, jur) autorizație, permis

warranty rights $(\mathrm{ec})$ drepturi prin garanția (produsului)

warranty test (ec, TH, metr) probă / test de / la recepție

warren truss (constr, mec) grindă cu zăbrele, fermă (construcție metalică)

wash spălare, udare, înmuiere, stropire, rude date la spălat / spălare; (chim, met) leşie, apă de spălat; (nav) curent respins de elice, remuu, siaj, mustăți, valuri de însoțire prova, pană a ramei; (geogr, mediu) aluviuni; (textile) care se poate spăla, lavabil; a spăla, a curăța, a decanta, a limpezi, a stropi, a uda; (met) defect de turnare (prin dilatarea şi distrugerea suprafeței modelului de nisip), acoperire a formei înainte de turnare; ( $\mathrm{TH}$, ind chim) a trata cu leșie, a leșia, a placa; (textile) a (în)albi; (mas-un) operație de introducere a lichidului pentru îndepărtare a aşchiilor (la găurire adâncă); (ind, mediu) apă rezultată după spălare, zoaie, lături

washability (textile) lavabilitate, rezistență la spălare (şi d. lubrifianți)

washable (textile) lavabil, care se poate spăla

wash against a se lovi / izbi de țărm (d. valuri), a scălda

wash away $(\mathrm{TH})$ îndepărtare prin spălare; a îndepărta prin spălare, a spăla, a curăța prin spălare

wash basin (OM, constr) chiuvetă, lighean

wash board (constr) plintă, pervaz

wash by squirting $(\mathrm{TH}$, ind, mediu) a spăla prin jet de lichid

wash channel (mas-un, OM) canal de alimentare a lichidului de spălare (la filtru-presă)

wash column $(\mathrm{TH}$, ind) turn de spălare, scruber washed spălat, curățat

washed electrode (met) electrode cu înveliş subtire

washed-out (textile, plast) decolorat (din cauza spălatului), îndepărtat prin spălare

washer (ind) spălător (şi de gaze, cu sau fără lichid), amestecător; (OM) şaibă, disc (de etanşare / de distanțare), distanțier, rondelă

washer fluid (auto) lichid de spălare

washer fluid level (auto) nivel al lichidului de spălare

washer head (OM) cap cu guler / cu umăr

washer pintle (mas-un, OM) şaibă / inel de pivot

washer pump (auto, $\mathrm{OM}$ ) pompă a spălătorului de parbriz

washery slag (met) haldă de zgură

washfastness (textile) rezistență (a culorilor) la spălare, lavabilitate

wash heating furnace (met) cuptor cu încălzire până la topirea arsurii

washing (ind chim, mediu, TH) purificare, limpezire, spălare (cu jet de apă), spălat; eroziune; (textile) rufe spălate / de spălat; care spală, care limpezeşte; (adj) spălător, purificator

washing cylinder (constr, met) ciur rotativ, cilindru de spălare

washing fastness (textile, T) rezistență la spălare (d. culori ale țesăturilor, materiale plastice, lubrifianți etc.)

washing heat (met) căldură de topire / de curățare (pt. îndepărtarea arsurii şi a altor defecte, cu flacără)

washing in counter-current $(\mathrm{TH})$ spălare în contra-curent

washing liquor (alim, ind chim) lichid / soluție de spălare

washing machine (mas, textile) maşină de spălat (rufe, vase etc.)

washing material (textile) material de / pentru spălat

washing oil (ind, OM, mas, ind chim) ulei de spălare

washing pipe $(\mathrm{OM})$ țeavă / conductă de spălare

washing pit (auto, OM) canal de spălat

washing plant $(\mathrm{TH}$, ind, mediu) instalație uzină / secție de spălat / pentru spălare

washing power $(\mathrm{TH})$ capacitate de spălare

washings (ind chim, met, alim, mediu) ape de spălare

washing speed $(\mathrm{TH})$ viteză de spălare

washing tank $(\mathrm{OM})$ rezervor de spălare

washing tower / column $(\mathrm{OM})$ coloană de spălare 
washing water (chim, met) apă de spălare wash liquid (ind chim, alim) lichid de spălare wash off $(\mathrm{TH})$ a spăla; a clăti, a îndepărta prin spălare

wash-out (ec) marfă de calitate necorespunzătoare; (hidr) erodare locală; spălare, spălătură; (fig) anulare, amânare

wash out $(\mathrm{TH})$ a spăla, a șterge, a curăța prin spălare, a îndepărta prin spălare; (textile) a clăti, a (se) decolora (prin spălare); a desfun$\mathrm{da}$, a face inpracticabil, a duce cu sine (d. ape etc.); (fig) a anula, a renunța la (un plan etc.); a ieşi la spălat

washout resistance $(T)$ rezistență la spălare (d. un lubrifiant)

washout thread (mas-un, OM) ieşire a filetului wash over a inunda

wash-proof (materiale, $\mathrm{OM}$ ) rezistent la spălare wash rack (auto, OM) grătar / rampă de spălare wash tank $(\mathrm{OM}$, hidr) rezervor / bazin de spălare

wash tower (met) scruber, turn de spălare a gazelor

wash water (hidr, mediu, ind) apă de / pentru spălare

washy apos, slab, diluat (d. o soluție etc.); fără putere, slab; (fig) insipid, searbăd; vag, nedesluşit

wasp (zool) viespe

wastage (TH, ind, mediu) deseu(ri), pierderi, risipă, irosire, rebuturi, pierdere a greutăţii prin uscare, pierdere de timp; (T) proces de uzare; scurgere, pierdere (a unui lichid); produs secundar; (ec) cheltuială inutilă

waste pierdere (inutilă), irosire; (constr, mediu) moloz, dărâmături, grohotiş; (ec, ind) produs secundar, deşeu(uri), rebut(uri), reziduu(ri); (TH) pierdere, risipă (de resurse, de energie etc.) deşeu, spărtură; de aruncat, (hidr, ind, mediu) apă reziduală (din activități industriale sau domestice); (poligrafie, ind chim) hârtie maculatură; (OM, hidr) conductă de deversare / conductă de scurgere; (fiz) deşeuri, slăbire (a intensității unui câmp, unui parametru etc.); (med) emaciere, slăbire, a emacia (corpul etc.), a muri (d. cineva); (ind, mediu) haldă de steril; (şi $p l$ ) întindere pustie, pustietate; ofilire; (agr) (şi $p l$ ) pământ necultivat / sterp, pârloagă, a face (pământul) neroditor; rostogol; (ind, constr) surpătură din spatele frontului (de excavare); uzat, inutil, steril, deteriorat, degradat; irosit; nefolositor, (bun) de aruncat (la gunoi); (mediu) de scurgere (a reziduurilor etc.); gol, degradat, deteriorat, necultivat, pustiu, sterp (d. terenuri etc.); a (se) irosi (degeaba), a (se) pierde (inutil) (d. timp, resurse etc.), a risipi, a nu folosi (cum trebuie) (talentul, banii etc.); a epuiza; a distruge, a strica, a deteriora; (ec) a cheltui (inutil), a fi risipitor; a slăbi, a emacia, a şubrezi; a se micşora, a se reduce, a se împuțina; a rămâne nefolosit / necultivat; (agr, ind, mediu) a deteriora, a face neroditor (pământul etc.); a face ravagii în; a irosi (timp etc.); a nimici; a se ofili (d. cineva); (sport) a pierde din greutate

waste acid (ind chim) acid epuizat (prin reacție chimică)

waste away a slăbi (d. o persoană); v. waste

waste basket (amer) (OM, mediu) coş de hârtii / de gunoi

waste casting (met, TH) turnare defectuoasă, rebut de la turnătorie

waste channel (OM, constr, hidr) canal de scurgere / de evacuare

waste cleaner / cleaning machine (mas) mașină de curăţat / de îndepărtat deşeuri

waste copper (met) deşeuri de cupru

wasted energy (mas, TH) lucru mecanic de mers în gol, energie pierdută / irosită

waste disposal (mediu, ind) eliminare / distrugere / îndepărtare / evacuare a deşeurilor

waste dump (met, ind) haldă

waste ends (ind) capete de bandă / de fire / de semifabricate (de orice fel) etc.

waste foil (mas-un) bandă rămasă după ştanțarea şi decuparea pieselor

waste fuel-gas dryer (termo, TH) uscător de gaze de ardere

wasteful risipitor, cheltuitor; extravagant

wasteful resistance (el, electr) rezistență (electrică), rezistență de pierderi

wastefully $(a d v)$ fără chibzuială / economie; (în mod) extravagant

wastefulness risipă, extravaganță

waste gas (met, ind chim, termo) gaze de ardere / arse / reziduale / de furnal

waste gas cap (met, ind chim, termo) calotă de gaze de ardere / reziduale / de furnal

waste-gas duct / flue (termo, OM) canal / conductă de gaze de ardere / de fum

waste-gas recircutating heating (termo, met) încălzire cu / prin recircularea gazelor arse waste grinder (plast) moară de deşeuri

waste head (met) maselotă

waste heat (termo, TH) căldură evacuată / pierdută / reziduală

waste-heat boiler (termo) cazan recuperator 
waste-heat flue (met, termo) canal pentru gaze de ardere

waste heating (met, termo) încălzire cu gaze de ardere (arse)

waste-heat loss (termo) pierdere prin căldură evacuată

waste-heat recovery (termo, ind) recuperare a căldurii (evacuate)

waste heat utilisation (termo, ind) utilizare a căldurii recuperate

waste iron (met) fier vechi

waste liquor recovery (chim, met) recuperare a soluțiilor de tratare / de decapare

waste land (agr) pământ / teren necultivat

waste lubrication $(\mathrm{T})$ ungere prin picurare sau folosirea unui element de transfer al lubrifiantului, cum ar fi un fitil (din material textil, poros etc.)

waste material deşeu, rebut, material irosit / consumat prea din abundență

waste metal (met) deseu metalic

waste of electric energy (el) pierderi / risipă de energie electrică

waste of heat (termo, TH) pierderi de căldură

waste of metal (met) pierderi de metal (prin ardere, la topire)

waste oil ( $\mathrm{TH}, \mathrm{T}$, ind, auto) ulei uzat

waste oil regeneration ( $\mathrm{TH}$, ind chim) regenerare a uleiului uzat

waste pack lubrication ( $\mathrm{T}$ ) ungere / lubrifiere cu fitil

waste pack oil cup (T, OM) ungător cu fitil

waste paper (mediu, ind chim) maculatură, deșeuri de hârtie, hârtie aruncată la cos / consumată fără rost

waste-paper basket (OM) (amer) coș de hârtii

waste pickle liquor (met, chim) soluție de decapare uzată / epuizată

waste pile (ind, mediu) grămadă de deşeuri

waste pipe / conduit (OM, hidr, mediu) conductă de ape uzate / de descărcare / de evacuare / de golire / de preaplin / de deversare / de scurgere

waste product (ind) deşeu, rebut

waster ( $\mathrm{TH}$, ind) rebut (și de turnare), material pierdut; cheltuitor, risipitor

waster casting (met) rebut / deşeu din turnare / de turnătorie

waste recovery (ec, $\mathrm{TH}$, mediu) recuperare / valorificare a deșeurilor sau a reziduurilor

waste rubber (ind chim, auto) deșeuri de cauciuc waste sheet (met) tablă rebutată, resturi de tablă waste-steam heating (termo) încălzire cu abur recuperat waste-steam pipe (mas, OM) conductă de evacuare a aburului uzat

waste top gas of (a cupola) furnace (met) gaze de cubilou

waste tratement $(\mathrm{TH}$, mediu) tratament de procesare / prelucrare a reziduurilor

waste utilisation (ind, $\mathrm{TH}$ ) utilizare a deșeurilor / a rebuturilor

waste valve (OM, hidr) supapă de golire / de drenare / de evacuare (a reziduurilor)

waste vulcanised rubber (ind chim, ind) deșeuri de cauciuc vulcanizat (tehnologice sau din piese uzate din cauciuc)

waste water (hidr, mediu) ape reziduale / de scurgere / uzate

waste water chlorination (mediu, hidr, chim) clorurare a apelor uzate

waste water clarification (mediu, hidr, ind) decantare a apelor uzate

waste-water purifying plant (mediu, hidr, ind) instalație de tratare a apelor reziduale / uzate

waste-wax process ( $\mathrm{TH}$, met) procedeu / proces de turnare cu / în ceară pierdută

waste way (hidr) sistem de evacuare a apelor mari wastway operation of the turbine (hidr, $\mathrm{TH}$ ) funcționare a turbinei ca descărcător de debit waste weir (hidr, constr, OM) deversor

waste withdrawal (fiz, ind chim, mediu) eliminare / distrugere a deşeurilor

wasting of energy (ec, TH, ind) risipă de energie

watch (metr, fiz) ceas, cronometru; pază; supraveghere; atenție; (nav) cart, bord (echipaj), ceas de bord; $(\mathrm{TH})$ a controla, a supraveghea, a păzi, a observa, a se uita la, a urmări, a fi atent la / cu; (metr, nav) cart, unitate tradițională de timp de lucru, de obicei de 4 ore pe mare sau pe uscat (pt. echiajul unei nave etc.); (metr) altă denumire pentru shift - schimb; v. shift

watch buoy (nav) geamandură de veghe

watch dog (ind chim) dispozitiv de semnalizare; (inf) controlor de secvență

watch for a fi în aşteptarea, a aştepta pe

watchful for atent la, vigilent

watchfully $(a d v)$ cu atenție, vigilent

watchfulness atenție, vigilenţă

watching $(\mathrm{TH})$ control, supraveghere, observare; care supraveghează / controlează / observă

watching gauge glass $(\mathrm{OM})$ vizor de sticlă, lanternă, ochi de observatie

watch lathe (mas-un) strung de mare precizie / de ceasornicar / de mecanică fină

watch officer (nav) ofițer de cart

watch out a fi atent, a avea grijă 
watch out for a se uita după

watch over a feri, a păzi, a proteja (ceva)

watch spring $(\mathrm{OM})$ arc de ceas

watch strap $(\mathrm{OM})$ curea de ceas

water (şi $p l$ ) apă, ape, mare, maree; (adj) (agr) de stropit; (OM, hidr) hidraulic; (chim) hidric; (constr, hidr) hidrotehnic; pentru apă; (biol, zool) acvatic, de apă; (TH) a spăla (cu apă), a inunda cu apă, a iriga, a umezi, a stropi; (agr) a iriga; (adj) hidraulic, hidrotehnic, de / cu / pentru apă, hidric, de stropit, acvatic; $(\mathrm{OM})$ a lăcrima, a picura (d. o conductă fisurată, un furtun spart etc.); (geogr, hidr) nivel al apei; (nav) a lua apă, a face plinul de apă; (artă) acuarelă; (geogr, nav) maree; (anat) năduşeală, sudoare, transpirație, lacrimi, salivă, urină, a lăcrima, a se umezi (d. ochi etc.), a-i lăsa gura apă a urina; (agr, zool) a adăpa (animale); (textile) a marmora (mătasea); (geogr) a scălda, a uda (d. râuri etc.); (rar) a subția, a dilua (cu apă); fresh- (adj) de apă dulce; salt- (adj) de apă sărată, marin; high (textile) extrem de scurt, foartte scurt (d. pantaloni etc.); in deep $\sim($ fig) la strâmtoare, încurcat, care a dat de greu; milk-and- (fig) fără caracter, moale, slab; (alim) fără gust, insipid, slab (d. o băutură); on the $\sim$ pe mare; on this side of the $\sim$ (geogr) (fam) în Europa; out-of- (nav) la suprafață (d. submarine)

water-absorbing (fiz) higroscopic, (material) care absoarbe apă

water-absorbtion (fiz) absorbție de apă

water-absorbtion capacity (materiale) capacitate de absorbtie a apei

water-absorbtion characteristics $(T$, chim, fiz, plast) caracteristici ale aborbției apei (d. lubrifianți, materiale plastice)

water adsorbtion adsorbție de apă

water affinity (fiz, materiale) proprietatea de a absorbi apă, afinitate pentru apă, hidrofilitate, capacitate de umezire / umezitoare, umiditibilitate

waterage (transp) transport pe apă; (nav) navlu water bag (plast, alim) cameră de fierbere water-base foam (hidr, T) spumă apoasă water basin (constr, OM) bazin de apă water bath (constr, OM) baie de apă

water-bearing (geol, materiale) acvifer, care are apă

water bed $(\mathrm{OM})$ saltea de cauciuc (cu apă); (geol) strat acvifer

water-binder ratio (constr, ind chim) raport apă-liant water bird (zool) pasăre de apă

water blister (med) flictenă, veziculă

water boat (nav) navă-cisternă (şi de apă)

water boots $(\mathrm{OM}$, ind chim) cizme de cauciuc (rezistente la apă)

waterborne (nav) în stare de plutire, plutitor, de apă, maritim; (transp) transportat pe apă (d. mărfuri); (med, mediu) transmis prin apă (d. boli)

water borne adhesive (plast) adeziv pe bază de apă / apos

water bottom (nav) dublu fund; (hidr) pernă de apă; fund de apă (în amestecuri imiscibile)

water bottle / can $(\mathrm{OM}$, alim) cană / sticlă / bidon de apă

water catching (ind, hidr) captare de apă

water calorimeter (metr, hidr, fiz) calorimetru cu apă, pentru măsurarea puterii radio-frecvențelor

water-cement ratio (constr) raport apă-ciment water-chamber (auto, OM) cameră de apă water chlorination (mediu, hidr, alim) clorurare a apei

water chlorination plant (ind, mediu) instalație de clorurare a apei

water closet (constr) WC

water cock / tap $(\mathrm{OM}$, hidr) robinet de apă

water column (fiz, hidr) coloană de apă; water column (WC) (metr) presiune a unei coloane de apă, notație pentru presiuni (atenție la unitățile de măsură); v. inch of water, centimeter of water, millimeter of water

water column height (fiz, hidr, metr) înălțime a coloanei de apă, şi ca exprimare a valorii unei presiuni (atenție la unitatea de măsură)

water conditioning (ind, mediu, $\mathrm{TH}$ ) tratare / condiţionare a apei

water consumption (adm, TH) consum de apă

water content conținut de apă (d. un material, un produs, o soluție etc.)

water-cooked reclaim $(\mathrm{TH}$, ind chim) (cauciuc) regenerat prin fierbere cu apă

water-cooled (materiale, $\mathrm{OM}$, termo, met) răcit cu apă

water-cooled bearing $(\mathrm{OM}, \mathrm{T})$ lagăr răcit cu apă water-cooled engine (auto, termo) motor cu răcire cu apă

water-cooled exhaust manifold (auto, OM) colector de evacuare / echaustor / țeavă / conductă / dispozitiv de evacuare, răcit(ă) cu apă

water-cooler (OM, termo) răcitor cu apă; (ind, termo) instalație de răcire a apei

water cooling (ind, $\mathrm{TH}$ ) răcire cu apă 
water cooling tower (met, ind chim, termo) turn de răcire a apei

water-corrosion resistance $(\mathrm{T}$, chim) rezistența la coroziunea apei (d. lubrifianți)

water course, water-course (constr, hidr) canal pentru scurgerea apei; (geogr) curs de apă, râu, fluviu, pârâu subteran; (hidr) curent

water crack (met) crăpătură de călire, la răcirea cu apă

water cross-section (hidr) secțiune transversală prin curentul de apă

water cure / curing (ind chim) vulcanizare cu apă fierbinte; (med) cură cu apă minerală, hidroterapie

water deaeration (termo, hidr) dezaerisire a apei, eliminarea gazelor / aerului din apă

water decomposition (chim) descompunere a apei

water depth (geogr, nav, hidr) adâncime a apei

water-depth gauge (metr, OM, hidr) indicator de nivel al apei

water-descaling unit (met) instalație de desțunderizare cu apă (sub presiune)

water-digestion reclaim (ind chim) cauciuc regenerat prin fierbere cu apă

water discharge (hidr) debit de apă

water distillate (alim, ind chim) distilat apos

water distributor (OM, hidr) distribuitor de apă

water down (alim, ind) a subția / îndoi / dilua cu apă; (pol, adm) (fig) a atenua, a modera (o declarație)

water drag (hidr, nav) rezistență hidrodinamică; (nav) dragare a unei ape

water drainage (agr, constr) drenare a apei

water drinker băutor de apă (şi minerală)

water drinken (adj) antialcoolic, nebăutor (de alcool) (d. o persoană)

water-drip cooler (alim, ind chim, OM, met) dispozitiv de răcire prin stropire cu apă

water-driven (hidr, OM, mas) acționat hidraulic water drop (fiz, hidr) picătură / strop de apă

water economiser (OM, hidr, ind) economizor / recuperator de apă

watered diluat / subțiat cu apă (d. soluții etc.), cu apă

water ejector (nav, $\mathrm{OM}$ ) ejector hidraulic

water emulsion (alim, T, TH) emulsie pe bază de apă

water emulsion inhibitor (alim, $\mathrm{T}$, ind chim) inhibitor antiemulgator

water exchange (anat, med) metabolism hidric

water extract (alim, ind chim) extract apos

water factor / number (metr, T) factor de corectie al vâscozimetrului water fall (geogr) cascadă

water fastness (plast, compozite, textile) rezistenţă la apă

water faucet $(\mathrm{OM}$, hidr) robinet de distribuție (de apă)

water-film condenser (termo) condensator pelicular

water-film pipe (precipitator) (fiz, OM, alim, ind chim) electro-filtru umed

water filter (OM, hidr) filtru de apă

water filtration (alim, ind chim) filtrare a apei

water finishing (mas-un, TH) finisare cu apă /

prin răcire cu apă

water flashing (TH) spălare cu apă (multă)

water forecooler / precooler (alim, ind chim) prerăcitor cu apă

water for fire fighting (ind) apă de stins incendii

water for radiator (termo, auto) apă de răcire (pt. radiator)

water furrow (constr, agr) şanț de scurgere a apei water gas (ind chim, fiz) gaz de apă, abur, vapor de apă

water-gas welding (met, $\mathrm{TH})$ sudare cu gaz de apă

watergate (nav, constr) ecluză; (hidr) zăgaz

water gate valve $(\mathrm{OM}$, hidr) vană / supapă Ludlo

water gauge $(\mathrm{OM})$ vizor de sticlă (ca subansamblu, inclusiv piese de prindere, garnituri etc.); (metr, OM, hidr) apometru, indicator de nivel (pt. apă), contor pentru apă, acvametru; (hidr) coloană de apă (într-un aparat de măsură etc.)

water-gauge cock $(\mathrm{OM}$, hidr) robinet cu indicator de nivel

water-gauge glass $(\mathrm{OM})$ sticlă / geam de nivel al apei (sau al altui fluid)

water( )glass (ind chim) sticlă solubilă / lichidă, silicat de sodiu lichid; (OM) indicator de nivel pentru apă sau alt fluid

water-granulated slag (met) zgură granulată în / cu apă

water guard (mas-un, OM, el) deflector / apărătoare de apă, cutie de protecție împotriva stropirii / împroşcării cu apă

water hammer (hidr) lovitură de berbec, berbec hidraulic

water hardening / quenching (met, TH) călire / durificare cu apă

water hardness (chim) duritate a apei

water( )head (hidr, metr) înălțime a coloanei de apă; (geogr) izvoare ale unui râu

water header (termo, OM) distribuitor / colector de apă 
water heater (termo) boiler, încălzitor de / pentru apă

water heating (alim, termo) încălzire a apei (fără a preciza cum), încălzire cu apă

water horsepower (whp, Whp) (metr, hidr) calputere de apă, unitate de măsură pentru putere, utilzată pentru pompe de fluid, în special în US 1 water horsepower $=746,043 \mathrm{~W}$, puțin mai mare decât 1 horsepower - cal putere

water hose $(\mathrm{OM})$ furtun (de cauciuc, de material plastic) de / pentru apă

water ice (alim) înghețată (de fructe); (termo) gheață hidrică / cu apă

water imbibition (materiale, geol) îmbibare / absorbție de apă

water inch (metr, hidr) unitate tradițională de măsură pentru debit de apă, egală cu debitul de apă care cade gravitaţional printr-un orificiu circular, având diametru de $1 \mathrm{inch}$; variante: 1 water inch $\cong 6,624 \mathrm{l} / \mathrm{min}$ (nivelul apei rămâne constant la 1/12 inch deasupra deschiderii, 1 water inch $=500$ picioare cubice pe zi $\sim 9,832 \mathrm{l} / \mathrm{min}$ (altă poziționare a orificiului față de nivelul apei)

water incrustation (termo) crustă / piatră de cazan, depunere în apă

wateriness (materiale, ind, mediu) caracter apos, abudență de / în apă, umiditate

water inflow (geol, termo, ind chim) aflux de apă

water infusion (ind chim, $\mathrm{TH}$ ) injecție / injectare cu apă

watering (ind, agr) stropire cu apă, udare, inundare, irigație, irigare; (nav) descărcare; (ind chim, poligrafie) moarare (a hârtiei); (c, TV) moarare (a unei imagini)

watering can $(\mathrm{OM})$ stropitoare

watering car (auto) autostropitoare (de străzi); (met) vagonet de stins cocs

watering ditch (agr, constr) canal d eirigare

watering hose (OM, hidr, ind) furtun de stins incendii, furtun de udat

watering place stațiune balneară / cu ape minerale

watering plant (agr, $\mathrm{OM}$ ) aspersor

water injection (ind) pompare / introducere / injectare de apă

water injection air hammer (constr, hidr, OM) ciocan pneumatic, cu spălare cu apă

water inlet / intake (hidr, OM) priză de apă, conductă / racord de intrare a apei

water inlet of radiator (auto, OM) racord de intrare a apei în radiator

water-in-oil emulsion (T, TH) emulsie apă-în-ulei water intake point (OM, hidr, ind) punct de priză a apei

waterish apos, umed (d. materiale)

water jacket, water-jacket (mas, termo, OM) cămaşă / manta de apă, de răcire

water jacket cylinder (auto, termo, OM) cilindru cu cămaşă de apă

water jacketed furnace (met) cuptor cu manta de răcire cu apă

water jacketed producer (ind chim) generator cu manta de apă

water jet (hidr, termo) jet de apă

water-jet condenser (ind chim) condensator $\mathrm{cu}$ jet / în curent de apă

water-jet ejector (mas, hidr, OM) ejector cu apă

water-jet elevator (transp, $\mathrm{OM}$ ) elevator în / cu curent de apă

water-jet pump (OM, hidr) pompă cu curent de apă, ejector cu apă, trompă de apă

water jump (hidr) salt hidraulic

water landing speed (av, nav) viteză de amerizare

waterless (materiale) anhidru, fără apă

waterless gas-holder (ind chim) rezervor de gaz uscat

water level (constr, metr) cumpănă, nivelă; (hidr) nivel al apei

water level float $(\mathrm{OM}$, hidr) flotor cu indicarea nivelului de apă

water level regulator (valve) $(\mathrm{OM}$, hidr) regulator / supapă de nivel de apă

water lily (bot) nufăr

water line (hidr) nivel (al apei, al altui lichid); (OM, hidr) conductă de apă, apeduct, (nav) linie de plutire

water load (hidr) sarcină hidrodinamică

water logged (nav) plin cu apă; (OM, materiale) cufundat / înecat în apă (şi doar pe jumătate), înnămolit, îmbibat cu apă; (fig) beat pulbere

water main $(\mathrm{OM}$, hidr) conductă principală de apă

waterman (nav) lucrător pe şlep

watermark (poligrafie) filigran, pată / timbru de apă; (metr, OM, hidr) indicator / semn al nivelului apei

watermarking (poligrafie) filigranare

watermark post (meteo, metr, OM) fluviometru, sondă

watermarks (nav) scară de pescaj

water meadow (geogr) luncă, câmpie inundabilă

watermelon (alim, bot) pepene verde

water meter (metr, OM, hidr) apometru, contor de apă 
water mill, watermill (alim, agr, hidr) moară de apă

water nozzle (OM, hidr) ajutaj de stropit / de udare

water of capillarity (fiz) apă capilară

water of combustion (termo, chim) apă de combustie / rezultată din combustie / din ardere

water of condensation (termo, ind chim) apă de condensare

water of crystallization (ind chim) apă de cristalizare

water of hydratation (alim, ind chim) apă de hidratare

water-oil emulsion $(\mathrm{TH}, \mathrm{T})$ emulsie apă-ulei (fără specificarea raportului fazelor)

water-oil ratio (TH, T) raport apă-ulei

water-outlet device (OM, hidr) dispozitiv de evacuare a apei

water outlet of radiator (auto, OM, hidr) racord de ieşire a apei din radiator

water parting (geogr) cumpănă a apelor

water pearl ash glass (ind chim) sticlă solubilă potasică

water permeability (fiz) permeabilitate a apei (d. materiale)

water per ton of rolled products (met) (consum de) apă pe tona de produse laminate

water pillar (cf) coloană de apă

water pillow (hidr) pernă de apă

water pipe $(\mathrm{OM}$, hidr) conductă de apă

water plane (geogr) luciul / oglinda apei; (av) hidroavion

water plant (ind, mediu) uzină de apă

water polo (sport) polo

water pollution (hidr, mediu) poluare / contaminare / impurificare a apei

waterpower (fiz, hidr) energie / putere hidraulică

waterpower station (ind, mediu) stație / amenajare hidroelectrică

water power utilization (ind) folosire a energiei / puterii hidraulice

water pox varicelă, vărsat de vânt

water precooler / forecooler (alim, termo) prerăcitor cu / de apă

water preheater (alim, termo) preîncălzitor cu / de apă

water pressure (fiz, hidr) presiune hidrostatică, presiune a apei (într-un sistem hidraulic etc.)

waterproof impermeabil, hidrofug (d. materiale, elemente de maşini); (textile) manta / haină de ploaie, impermeabil; (OM) etanş, ermetic, protejat contra apei; a impermeabiliza waterproof adhesive (ind chim) adeziv impermeabil la apă

waterproof brick (constr) cărămidă impermeabilă (la apă)

waterproof cloth / fabric (textile, ind chim) țesătură impermeabilă

waterproof concrete (constr) beton impermeabil (la apă)

waterproof glue (ind chim) clei / lipici impermeabil la apă

waterproof grease (T, ind chim) unsoare rezistentă la (spălare cu) apă

waterproofing (material) hidrofug; (OM, constr, ind chim) etanşare, impermeabilizare, hidrofugare, hidroizolație, (garnitură) de etanşare

waterproofing agent (ind chim) agent / substanţă de impermeabilizare

waterproof membrane (chim, OM) membrană impermeabilă

waterproof paper (ind chim) hârtie impermeabilă

waterproof-paper roof (constr) acoperiş cu carton asfaltat

water pump (OM, hidr) pompă de apă

water pump impeller (auto, OM) rotor al pompei de apă

water-purification plant (ind, mediu) instalație de purificare a apei

water purifier (termo, mediu) epurator de apă

water purifying (termo, mediu) epurare a apei

water-quenched (met, OM) călit în apă

water quenching / hardening (met, TH) călire în apă

water quenching followed by tempering (met, TH) călire în apă, urmată de revenire

water ram (hidr) berbec hidraulic, lovitură de berbec / de apă

water rate $(\mathrm{ec}, \mathrm{adm})$ plată / taxă pentru apă, taxă municipală pentru apă

water refrigerant (termo) instalație de răcire cu apă, refrigerent cu apă

water removal (hidr, $\mathrm{TH}$ ) evacuare a apei

water repellency (materiale) proprietate de a respinge apa; caracter hidrofug / hidrofob

water-repellent (chim, materiale) impermeabil, hidrofug, hidrofob, care respinge apa

water-repellent coating (ind chim) peliculă / acoperire impermeabilă / hidrofugă / hidrofobă / care respinge apa

water requirements (alim, ind, $\mathrm{TH}$ ) necesar de apă (tehnologică)

water resistance (materiale) rezistență la apă (a unui lubrifiant, material plastic etc.) 
water resistant rezistent la apă (absorbție sau penetrare) (d. lubrifianți, materiale plastice etc.)

water resistant bond $(\mathrm{OM})$ lipitură / asamblare prin lipire rezistentă la apă

water resisting (materiale) rezistent la apă

water retaining (materiale) hidrofil, care reține apa

water ring $(\mathrm{OM})$ inel de etanșare (nu numai pt. apă)

water saturated (fiz) saturat cu apă (d. un material, o soluție, roci, sol etc.)

water scale (termo) piatră de cazan, crustă

water screen $(\mathrm{TH}, \mathrm{met})$ perdea de apă

water seal (hidr, OM) închidere / închizător hi$\operatorname{draulic}(\breve{a})$; etanşare prin apă

water sealed bearing $(\mathrm{OM})$ lagăr cu etanşare hidraulică

water sealed producer (ind chim) generator de gaz cu închidere hidraulică

water seep(age) (constr, mediu, ind) infiltrare a apei

water seeping (constr, mediu, ind) filtrare a apei (printr-o țesătură)

water separator / trap (OM, termo) separator / decantor de apă

water settler (alim, ind) decantor de apă

watershed (geogr) cumpănă a apelor; (hidr, OM, constr) bazin de recepție; (fig) moment hotărâtor, cumpănă

watershed management (hidr, constr) regularizare a scurgerii prin amenajări în bazinul de recepție

watershoot (constr, OM) conductă / canal de scurgere

waterside (geogr) partea dinspre apă, marginea apei, mal, tărm, coastă; (nav) de coastă, de țărm, costier, portuar, de port

water slurry (chim) suspensie apoasă

water snail (OM, transp) elevator elicoidal cu apă

water-soak (ind) a înmuia în apă

water soda (ash)glass (ind chim) sticlă solubilă sodică

water softener (chim) agent de dedurizare a apei water softening (ind chim, TH, mediu) dedurizare a apei

water solubility (chim) solubilitate în apă

water-soluble (chim) solubil în apă (d. lubrifianti, substante solide etc.)

water source (ind, geol) sursă de apă

water spray (auto, OM) împroşcare cu apă (d. autovehicule, rulmenți etc.)

water sprayer (auto) autocisternă stropitoare; (OM) dispozitiv de stropire cu apă water spout (meteo) trombă de apă, rupere de nori, ploaie torențială; (constr, OM) gură de burlan, burlan (de scurgere a apei de pe acoperiş), uluc, jgheab

water-spray granulated slag (sand) (met) zgură granulată cu apă

water spraying nozzle (mOM, hidr) ajutaj de pentru pulverizare a apei

water spreader $(\mathrm{OM}, \mathrm{hidr})$ distribuitor de apă water spinkled bosh (met) etalaj răcit / stropit cu apă (la furnale)

water spinkler $(\mathrm{OM})$ stropitoare, dipozitiv de stropire

water spinkler tank (auto) autocisternă stropitoare

water still (ind) instalație de distilat apă

water station (ind, adm, mediu) uzină de apă waterstop $(\mathrm{OM})$ garnitură de etanşare (în general) water storage basin (ind, constr, mediu) bazin de acumulare / de stocare (a apei)

water stored for fire fighting (ind) rezervă de apă contra incendiilor / de stins incendii water supply (ind, adm) alimentare cu apă, (sistem de) distribuție a apei în conducte

water-supply network / system (ind, adm) rețea de alimentare cu apă

water souchy (alim) peşte fiert în zeamă proprie water table (geogr) oglinda apei; (constr) şanț (la marginea drumului)

water tank (auto) rezervor de apă; (nav) tanc water tap / cock (OM, hidr) robinet de apă

water test (metr, hid, OM) încercare hidraulică, test de etanşeitate (cu apă) (d. conducte, recipiente etc.)

water thrower (hidr, OM) inel de obturare a apei watertight (hidr, materiale, OM) etanş, impermeabil, ermetic, hidrofug; (fig) cât se poate de clar, fără fisuri, impecabil, impermeabil, ireproşabil, neechivoc; $\sim$ s cizme de cauciuc

watertight air caisson / case (hidr, nav) cheson etanş (cu aer)

watertight bulkhead (nav) perete (de navă) etanş watertight core $(\mathrm{OM})$ nucleu / miez de etanșare watertight cover $(\mathrm{OM})$ capac etanş (la trecerea apei)

watertight diaphragm $(\mathrm{OM}$, hidr) diafragmă / mască de etanşare, perdea / voal de etanşare watertight door (nav, OM) uşă / poartă (de navă) etanşă

watertight facing $(\mathrm{OM})$ mască etanşă

watertight facing arch (termo, constr) boltă de etanşare (la cuptoare etc.)

watertight facing (OM, hidr) mască de etanşare 
watertight lamp holder (el, OM) dulie etanşă / impermeabilă

water tightness (ind chim, materiale, constr) impermeabilitate la apă

watertight packing $(\mathrm{OM})$ garnitură impermeabilă la apă

watertight wrist watch ceasornic de mână etanş la apă

watertight packing $(\mathrm{OM})$ garnitură impermeabilă

watertights (ind chim, ind) cizme de cauciuc

water to carbide acetylene generator (ind chim) generator de acetilenă ,apă peste carbid”

water tower (constr, hidr) castel de apă; (amer) extinctor, dispozitiv de stins incendiu

water trailer (auto) remorcă-cisternă cu apă

water transport (nav) transport pe apă

water treatment (mediu, ind) tratare / epurare a apei

water through (ind, constr) jgheab / canal de apă

water truck (auto) autocisternă

water tube (mas, termo) tub de apă (la cazan acvatubular)

water-tube boiler (termo, OM) cazan acvatubular

water-tube header boiler (termo) cazan cu cameră de apă, cazan nesecționat

water uptake (hidr, ind) absorbție de apă

water used in brake $(\mathrm{OM}$, hidr) apă de frână hidraulică

water utilization (ec, met, adm) gospodărire / economie a apelor / a apei

water value (metr, T) factor de corectie al vâscozimetrului

water valve (hidr, OM) supapă hidraulică (în special pentru apă)

water vapours (fiz, termo) vapori de apă, abur

water-vapour permeability (plast) permeabilitate la vapori de apă / la abur

water wave (geogr, nav) val (de mare); $(\mathrm{TH})$ deformare la rece

waterway (nav) canal / semnal navigabil, rigolă lacrimară, jgheab, cale de apă navigabilă

waterway bar (nav) cornier lăcrimar

waterway mouth $(\mathrm{OM}$, hidr) gură de intrare a unei conducte de apă

water wet umezit (cu apă)

water wheel $(\mathrm{OM}$, hidr) roată hidraulică; (agr) roată de grădinărit

water whirlpool (hidr) vârtej de apă

water willow (silv) salcie

water witch (fig) sirenă; undină

water worker (nav, transp) docher water works (ind) uzină de apă, sistem hidraulic, sistem de alimentare / pompare cu apă watery fluid (rar); (fiz, chim) apos, diluat, slab, cu multă apă; (zool, geogr, bot) de apă, acvatic, marin; lichid; umed, ud; (fig) searbăd, insipid, fără gust

water-yielding (geol) acvifer

watt (W) (metr, el, mec) watt, unitate de măsură pentru putere, în sistem SI

wattage (el, mas, ind) putere electrică activă, energie (rar) / putere (exprimată) în wați

watt component (el) componentă wattică / activă (a curentului electric alternativ)

watt consumption (mas, el) consum (de putere) în wați

wattful current (el) curent activ / wattat

watt hour (W·h) (metr, el, mec, termo) wattoră, unitate de măsură pentru putere, în sistem metric: 1 watt hour $=3,6 \mathrm{~kJ}$

watt-hour capacity (el) capacitate / energie în wați-ore, energie acumulată în wați-ore

watt-hour constant of a meter (metr, el) constantă a unui contor de energie

watt-hour efficiency (el) randament energetic / al energiei

watt-hour meter (metr, el) watt-oră-metru, contor de energie activă

wattle nuia, vergea, vargă; împletitură, gard de nuiele; (zool) bărbie (la unele păsări), moț (la curcan); a confectiona / împliti din nuiele, a împrejmui / îngrădi cu gard de nuiele

wattless (el) dewattat, reactiv (d. un element dispozitiv electric)

wattless component (el) componentă reactivă

wattmeter (metr, el) wattmetru

watt-second (el, metr) watt-secundă, unitate de măsură pentru energie

watt year (W·yr) (metr, fiz, încălzire globală) watt-an, unitate de măsură pentru energie, în sistem metric, egală cu energia livrată cu o putere de 1 watt timp de 1 an; 1 watt year $\cong$ 31,5569 MJ

wave (fiz, hidr, el) undă; semn, mișcare; (nav, hidr) brizant, val, talaz; creț; fluturare a mâinii, semn cu mâna; ondulație (a părului etc.); val (de căldură, de teamă, de violență etc.); a (se) ondula, a (se) văluri, a (se) undui, a (se) încreți; a agita, a (se) mișca (ondulatoriu); a exprima (ceva) printr-un semn (cu mâna), a face (cuiva) (semn) cu mâna (să se miște); a face valuri / valuri-valuri; a fâlfâii, a flutura (d. un steag etc.); wave, wavelength (metr, fiz, radio, opt) undă, lungime de undă, o unitate relativă de măsură 
pentru lungime, egală cu o anumită lungime de undă, în funcție de domeniul în care este utilizată: lungime de undă radio, lungime de undă luminoasă etc.

wave absorption (fiz) absorbție de unde wave aerial (fiz) antenă Beverage / aeriană wave action (hidr, nav) acțiune a valului wave attack (hidr, nav, constr) atac al valului wave back (el) întoarcere a undei de şoc de înaltă tensiune

wave band (fiz) bandă / gamă de frecvență

wave bobbins $(\mathrm{OM})$ țevi ondulate

wave caused by a rising stage (hidr) undă de retenție / de ridicare a nivelului

wave conditions (nav, hidr) regim de valuri

wave crest (hidr, nav) creastă de val

wave damping (hidr, nav, fiz) amortizare a valului / a undei

wave decay (fiz, hidr) stingere a valurilor, amortizare a undelor (pe direcția de propagare)

wave decay distance (fiz, hidr) distanță / drum de amortizare a valului / a undei

wave-director circuit (fiz) element director (de antenă)

wave disjunction (hidr) dislocare a valului

wave equation (fiz) ecuație a undelor

wave erosion (hidr, geol) erodare produsă de valuri

wave filter (fiz) filtru pentru lungimi de undă

wave flume (nav, constr) canal de încercări cu valuri

wave form (fiz) sub formă de undă

wave front (hidr, nav) front de val

wave function (fiz) funcție de undă

wave generating area (geogr, nav) zonă de formare a valurilor

wave generation (hidr) generare a valurilor; (fiz) generare a valurilor / oscilațiilor

wave generator (fiz, hidr) generator de valuri / de unde

wave group (fiz, autom) tren de unde

wave group-velocity (hidr, fiz) viteză de grup a valurilor / a undei

wave heating (fiz, termo) încălzire prin unde electro-magnetice / cu curenți de înaltă frecvență

wave hollow (hidr, nav) gol de val

wave hydraulics (hidr, nav) hidraulica valurilor wave interference (fiz, el) interferență a undelor

wave interference error (fiz) efect Heiligtag, eroare cauzată de interferența undelor

wavelength (fiz) lungime de undă; (hidr, nav) lungime de undă a valului wavelength meter (metr, fiz) aparat de măsurat lungimi de undă

wavelength scale (fiz, metr) scală a lungimilor de undă

waveless (nav, hidr) fără valuri, liniştit, calm; (fiz) neondulat (d. un semnal), fără oscilații (d. un proces, un fenomen), fără ondulații (d. o suprafață)

wavelet (fiz) undă; hidr) val mic; creț, încrețitură (la semifabricate, piese subțiri etc.), ondulație (de mică amplitudine, pe suprafețe ale unui fluid sau pe suprafața unui solid)

wave-like ca un val, ca valurile; (fiz) ondulatoriu

wave lull (hidr, nav) acalmie între două valuri

wave-making resistance (hidr, nav) rezistență la valuri

wave mechanics (fiz) mecanică / fizică ondulatorie

wavemeter (metr, fiz) aparat de măsurat lungimi de undă sau frecvențe, undametru

wave motion (fiz, hidr) mişcare ondulatorie

wave normal (fiz) vector unitar, perpendicular pe frontul de undă, componenta pozitivă fiind în direcția de propagare

wave number (fiz) număr de undă, invers al lungimii de undă

wave packet (fiz, autom) pachet / grup de unde

wave-particle duality (fiz) dualism undăcorpuscul / undă-particulă

wave-profile (hidr, nav) profil al valului; (fiz) profil / formă a undei (pe direcția de propagare)

wave propagation (fiz, hidr) propagare a undelor / a valurilor

waver (poligrafie) val intermediar (la maşinile de tipărit); a tremura (d. voce, o flacără etc.), a pâlpâi (d. o flacără etc.), a se schimba, a fluctua

waver between a şovăi între, a ezita între, a oscila între

wave reflection (fiz, hidr) reflectare a undelor / valurilor

wave refraction (fiz, hidr) refractie a undelor / valurilor

waveringly $(a d v)$ tremurător, tremurat, şovăitor, nedecis

wavery tremurat, tremurător, pâlpâitor (d. o flacără); (fig) şovăitor, nedecis, nehotărât, nesigur, schimbător

wave rump (hidr) spargere a valului

waves amplitude (hidr, nav) amplitudine a valurilor; (fiz) amplitudine a undelor

waves crest (hidr) creastă de val

wave-shape (fiz) în formă de undă, ondulatoriu, variabil periodic (d. un proces) 
wave-shape analysis (mat) analiză Fourier

wave simulation (mat, fiz) simulare (matematică) a valului / a undei

wave spectrum (fiz, hidr) spectru de valuri / de unde

wave soldering $(\mathrm{TH})$ (metodă / proces de) lipire în electronică, prin mişcare ondulatorie a pieselor într-o baie de lipire

waves records (hidr, fiz) înregistrări de valuri / de unde

wavesteepness (hidr, nav) curbură a valului (înălțimea totală împărțită la lungimea de undă)

wave theory (fiz) teoria undelor

wave train (el, autom, fiz) tren de unde

wave train frequency (fiz, autom) frecventă de grup / a trenului de unde

wave transformation (hidr, fiz) transformare a valului / a undei (prin refracție, reflexie, difracție, interferență etc.)

wave trough (fiz, hidr, nav) talpă / concavitate de val, minim al unei unde

wave velocity (fiz, hidr) viteză de propagare a undei / a valului

waviness $(\mathrm{OM})$ ondulație (a suprafeței prelucrate); (fiz) caracter ondulatoriu

waviness profile (metr) profil de ondulație (la profilometria suprafeței)

wavy $(\mathrm{OM})$ ondulat, zimțat, striat, vălurit, de forma valurilor; sinuos, şerpuitor

wavy flow (fiz, hidr) curgere turbulentă

wavy fracture (met) ruptură lamelară

wavy surface $(\mathrm{OM}, \mathrm{TH})$ suprafață ondulată (a unui semifabricat, a unei piese etc.)

wax (chim) parafină, ceară, plastelină, lumânare de ceară; (amer) (alim) sirop gros; a cerui, a da cu ceară

wax-bearing (crude) oil (chim) țiţei parafinos

wax cloth (ind chim, textile) muşama

wax-coated paper (alim, ind chim) hârtie cerată izolantă / impermeabilă

wax coating $(\mathrm{TH})$ ceruire; ungere cu ceară

wax dope (ind chim, $\mathrm{T}$ ) aditiv anticongelativ, depresant

waxed board (ind chim) carton cerat / parafinat

waxen de / din ceară, ceruit, ca ceara; plastic, moale

waxing ( $\mathrm{TH}$, mobilă) ceruire

wax oil (ind chim) țiței parafinos

wax paper (ind chim) hârtie / pânză cerată

wax pattern (met) model de ceară

wax precipitation / settlement (ind chim) depunere de ceară / de parafină

wax removal $(\mathrm{TH}$, uind chim) deparafinare waxy (ca) de ceară, ceruit, cerat

way (autom) cale de sortare, traseu de comandă; (constr) cale, drum, stradă, alee (rar), ramură, braț (al unei intersecții rutiere); (OM) canal, canelură; (nav) viteză (de marş), cale, rută, drum parcurs, direcție, marş (al navei), inerție a navei; (TH) metodă, mijloc, domeniu, braț; cale; sferă (de activitate), competență; sector; mod, fel, manieră, fel de a fi; privință, punct de vedere; condiție, stare; preajmă, vecinătate; cale (de urmat) (în sens abstract); (c, inf) cale de sortare; condiție; datină

waybill (cf, transp) foaie de expediție, fraht, scrisoare de trăsură; listă de călători / colete; itinerar, traseu (turistic etc.)

way circuit (el, transp) fir de cale pentru troleibuz

way of cock (OM, hidr) gaură de cep de robinet, traseul fluidului prin robinet

ways and means căi şi mijloace, metode

way train (cf, transp) (amer) tren personal

weak fără forță / putere; slab; diluat, slab, apos, subtire (d. lichide); (med) bolnav, bolnăvicios, delicat, lipsit de putere / vlagă, slab, slăbit; prost, nepriceput, incapabil; neputincios; (fiz) slab, fără intensitate, difuz (d. lumină); slab, nerezistent, puțin rezistent, necorespunzător (d. un material); insuficient, neîndulestulător, puțin (numeros); neaccentuat; (om) lipsit de fermitate, care nu face față, care nu şi-a revenit; descărcat (d. baterii); (sport) incapabil, nepriceput, prost, slab (d. un jucător etc.); lipsit de fermitate, moale, nehotărât, slab, şovăitor (d. un om, caracter) neconvingător, slab, șubred, vulnerabil (d. un argument etc.); (gram) slab (d. vocale); subțire (d. voce etc.)

weak acid (chim) acid diluat / slab

weak base (chim) bază slabă / diluată

weak-brained $v$. weak-minded

weak convergence (mat) convergență slabă

weaken (mas, OM) a (se) slăbi, a (se) micşora, a ceda (un arc, o piuliță); (fiz) a (se) reduce, a (se) atenua; (met) a reveni; a reîncălzi după călire, a decăli

weakening $(\mathrm{OM})$ slăbire (a unei piese, a unei asamblări)

weakening ratio (el, metr) raport / procent de şuntare

weak-eyed (anat) cu vedere slabă

weak form (fonetică) formă slabă

weak gas (chim) gaz sărac

weak-headed $v$. weak-minded

weak-hearted blajin, bun la inimă; fricos, laş; milos; slab de înger 
weak-kneed ( $f i g$ ) fără caracter, lipsit de caracter, moale, slab; slab de picioare

weak interaction (fiz) interacțiune slabă

weak-minded fără caracter, imbecil, lipsit de caracter; nehotărât, prost, slab la minte; şovăitor

weak-mindedness imbecilitate, lipsă de fermitate / de hotărâre, prostie, slăbiciune a minții, şovăială, şovăire

weak mixture (auto, ind chim) amestec (combustibil) slab / sărac (calitativ)

weakness (med) stare de slăbiciune, debilitate; neputință; (anat) infirmitate; punct slab, parte slabă; defect

weakness zone (met) zonă a reducerii rezistenței (la sudură, dar nu numai)

weak picture (c, TV) imagine slabă / necontrastantă / fără contrast

weak-sighted (anat) miop, cu vederea slabă

weak-spirited fricos, slab de înger

weak weld $(O M)$ sudură / cusătură slabă / nerezistentă

weak-willed cu voință slabă, influențabil

weal bunăstare, bogăție, avere

wealth avere, bogăție (naturală etc.); belșug, îndestulare; abundenţă; număr mare; (fig) număr mare, bogăție, abundență (de exemple etc.)

wealthy bogat; prosper; valoros, prețios

weapon (mil şi fig) armă, mijloc de luptă

weaponless (mil și fig) neînarmat, lipsit de / fără apărare

wear a purta, a fi îmbrăcat / încălțat cu; fel de a se îmbrăca, modă, ponosire, purtat (al haine-lor); purtare; (OM, T) uzură (rezultat), uzare (proces), frecare (rar), roadere; a (se) uza (prin frecare); a toci, a roade; a epuiza; a se ponosi, a se strica; a rezista, a fi rezistent; a deveni, a face; (textile) confecții; (nav) a face volta sub vânt; a avea (o anumita înfățișare, un nume); a avea (întipărit) pe față; a face o gaură de prea mult frecat / purtat / ros; a istovi; a fi la modă

wearability $(T)$ rezistență / comportare la uzură, (textile) comportare la purtat / la utilizare

wearable care se poartă, care se poate purta; $(\mathrm{T})$ care se poate uza / roade

wear allowance $(\mathrm{OM}, \mathrm{T})$ adaos de uzură, uzură admisă

wear away a mânca, a roade; a distruge; a eroda; a dispărea; a fi ros / mâncat; (T) a (se) uza prin îndepărtare de material

wear by rubbing $(\mathrm{T})$ uzură prin frecare

wear down $(\mathrm{OM}, \mathrm{T})$ a uza, a roade, a strica; (textile) a uza, a roade, a strica (d. îmbrăcăminte); a eroda, a subtia (prin uzură, roadere etc.); a rezista mai mult decât; a învinge până la urmă; a obosi; a (se) slăbi (treptat), a se subția (treptat); a înfrânge (prin perseverență) (rezistența cuiva etc.); a plictisi; wear smb. down a elimina / slăbi treptat, prin efort perseverent (opoziţia, convingerile cuiva etc.), a enerva / obosi pe cineva, a învinge treptat prin presiune morală (opoziția, convingerile cuiva etc.); wear smth. down a toci / uza prin apăsare / frecare continuă (d. o piesă, o anvelopă etc.)

wearer $(\mathrm{OM}, \mathrm{T})$ suport; (textile) purtător al unei haine etc.

wear hardening (mec, met, $\mathrm{T}$ ) ecruisare / durificare prin frecare sub sarcină

wear hardness ( $T$, materiale) rezistență la uzură wear in $(\mathrm{T}, \mathrm{OM}, \mathrm{TH})$ a ajusta prin rodare / prin funcționare, a roda

wear-in $(\mathrm{T}, \mathrm{OM}, \mathrm{TH})$ ajustare prin rodare / prin funcționare, rodaj, rodare

wearing (textile) de / pentru purtat; plictisitor obositor; (OM, T) uzat, ros, care (se) uzează / (se) roade; uzare (proces), roadere, frecare ( $r a r)$

wearing face (mas-un, T) suprafață de rectificat / de frecare / care se uzează

wearing limit (mec, OM, T) limită de uzură

wearing parts $(\mathrm{OM})$ piese supuse uzurii, piese de uzură

wearing plate (auto, $\mathrm{OM}$ ) disc de fricțiune

wearing quality $(\mathrm{OM}, \mathrm{T}$, materiale) rezistență la uzură, calitate de a rezista la uzare

wearing resistance (materiale, T) rezistență la uzură

wearing ring $(\mathrm{OM}, \mathrm{T})$ inel de compensare a uzurii, inel de uzură (la supape etc.)

wearing strip $(\mathrm{OM}, \mathrm{T})$ placă / plăcuță de reglare pentru compensarea uzurii; (el, T) dungă / urmă de uzură (la contacte și perii de cărbune) wearing surface $(O M, T)$ suprafață de uzură / de frecare / care se uzează

wear(ing) test $(\mathrm{OM}, \mathrm{T})$ test de uzură

wear intensity $(T)$ intensitate a uzurii (pierdere masică / volumică raportată la sarcină şi drumul parcurs)

wear life $(\mathrm{OM}, \mathrm{T})$ durabilitate la uzură, durată în care are loc uzura

wear loose $(\mathrm{OM}, \mathrm{T})$ slăbire / modificare (a contactului, a formei pieselor, a strângerii etc.) din cauza uzurii

wear off (T) a înlătura, a îndepărta (prin frecare, uzare etc.), a uza prin frecare (cu îndepărtare de material), a se şterge, a (se) micşora (d. asperități); a (se) atenua, a face să slăbească, a (se) micşora, a slăbi 
wear of pipes (hidr, T, OM, termo) uzură / eroziune a conductelor / țevilor

wear of the lining (met; OM; T) uzură a căptuşelii (unei piese, unui cuptor etc.); (T) uzură a acoperirii (la cuzineți)

wear on the brushes (el, T) a (se) uza (d. perii, la maşini electrice)

wear out $(\mathrm{T}, \mathrm{OM})$ a (se) uza (prin pierdere de material), a (se) epuiza, a (se) roade; (textile, plast) a îmbătrâni prin purtare; (textile) a purta / folosi până se strică; a obosi, a plictisi (pe cineva)

wear-out (T, mas) creştere a ratei de cădere / de defectare odată cu creşterea numărului de subansamble / de unități

wear oxidation, fretting $(\mathrm{T}, \mathrm{OM}$, chim) uzură tip fretting (cauzată de acțiunea simultană a vibrațiilor cu amplitudine mică în contact şi a reacțiilor chimice în zona contactului)

wear-preventive additive (ind chim, $\mathrm{T}$ ) aditiv anti-uzură

wear-proof, wear-resistance (materiale, OM, T) re-zistență la uzură, rezistent la uzură

wear rate $(\mathrm{T})$ viteză / rată de uzură

wear-resisting, wear-resistant, wear-proofing (materiale, T, OM) rezistent la uzură

wear-resisting alloy steel (me, T) oțel aliat, rezistent la uzură

wear-strip $(\mathrm{OM}, \mathrm{T})$ placă / piesă de reglare (pt. compensarea uzurii)

wear surface $(O M, T)$ suprafață de uzură / de frecare

wear test (metr, T) test de uzură

wear-testing machine (metr, $T$, mas) maşină de testat la uzură

weary foarte obosit, epuizat, frânt (d. cineva); obositor, plictisitor

weary of sătul de, plictisit de

weather (meteo) stare atmosferică, timp, vreme (şi urâtă, furtună), frig umed; a altera (prin influența climatului); a aerisi, a aera, a usca la aer; (nav) a dubla în vânt, a înfrunta (o furtună); (constr) a înclina un acoperiş; (plast) a (se) decolora (prin expunere la aer), a rezista fiind expus la aer / mediu / intemperii

weatherability (materiale) rezistență la intemperii

weather anchor (nav) ancoră din vânt

weather a storm $(\mathrm{TH})$ a aera, a ventila, a aerisi, a climatiza

weather-beaten bătut de furtuni / de vânt, bronzat (d. față, piele); (fig) călit, cu experiență, încercat, oțelit, trecut prin multe; dărăpănat; decolorat, degradat; extenuat, frânt (d. o persoană); în voia (tuturor) vânturilor; sleit; stors; (T, OM) uzat (în timp)

weatherboard (constr) şindrilă, olan, draniță; (nav) copastie

weather bord (nav) bord de vânt

weather-bound (nav) reținut / întârziat din cauza vremii / timpului nefavorabil(e), care nu poate pleca din cauza vremii

weather change (meteo) schimbare a vremii

weather conditions (meteo) condiții meteo(rologice) / atmosferice, starea timpului

weather deck (nav) punte descoperită

weather- de / la intemperii

weather-beaten bătut de furtuni, bătut de vânt bronzat (d. față, piele); (fig) călit

weather-wise (pol, ec) care cunoaşte pulsul (opiniei publice etc.)

weather-bound (transp) care nu poate pleca din cauza vremii

weather exposure (OM, materiale) expunere la intemperii / în aer liber

weather exposure test (metr, materiale) încercare / test prin expunere la intemperii / în aer liber weather-fastness (materiale) rezistență la intemperii, nealterabilitate la intemperii

weather forecast (meteo) prognoză a timpului, buletin meteo(rologic)

weather gauge (metr, fiz, meteo) barometru

weathering (materiale, fiz, chim) efect al agenților atmosferici, deteriorare / dezagregare din cauza vremii (şi asupra materialelor plastice); (geol) alterare; (nav) venire în vânt

weathering ageing (chim, plast, met) îmbătrânire în atmosferă / din cauza intemperiilor

weathering test (metr, materiale) încercare climatică, test de rezistență la intemperii

weather permitting dacă va fi timp frumos / vreme bună / favorabilă, dacă va permite vremea

weather permitting clause (ec, transp) clauză a timpului nefavorabil

weatherproof, weather resistant (materiale, OM) rezistent la intemperii / la condiții climatice, care apără de vânt / de ploaie / de intemperii (d. îmbrăcăminte); (fig) călit, oțelit, încercat; a feri de vreme rea, a face impermeabil

weather report (meteo) buletin meteorologic

weather resistance (materiale) rezistență la intemperii / la condiții climatice

weather stained decolorat, pătat (de soare şi de timp) (d. mase plastice, vopsele și tesături) weather station (meteo) stație meteorologică 
weather a storm $(\mathrm{TH})$ a aera, a ventila, a aerisi, a climatiza

weather stripping (constr, OM) garnitură (tip bandă) de etanşare a ferestrei

weave (textile) legătură, încrucişare, armură (la țesături), țesut; (fiz) vibrație, oscilație, instabilitate laterală (a unei benzi magnetice); (OM) instabilitate laterală a benzii / curelei; a merge schimbându-şi mereu direcția, a şerpui; a-şi croi (drum), a-şi face (drum); (textile) a croşeta (dantele), a (se) împleti (şi fig), a lucra la război, a țese, a se întrepătrunde (şi fig); a lega; a pune; (fig) a pune la cale (un complot); a şerpui (d. drumuri), (zool) (d. păianjen) a țese (pânza); (fig) a ticlui, a țese, a compune (pe baza unei sugestii)

weave into a strecura, a introduce (şi idei)

weaver (textile) țesător (operator sau maşină), dispozitiv / mașină de țesut

weaving oscilații transversale ale electrodului sau arzătorului la sudare; (textile) țesut, croșetat, împletit, legat; care țese; (c, TV) instabilitate a imaginii

weaving departament (textile) secție de țesătorie

weaving machine (textile, mas) maşină de țesut weaving mill (textile) țesătorie

weaving room (textile) atelier de țesătorie

web (textile) tesătură, pânză, voal, fir, împletitură, urzeală, chingă, pătură subțire de fibre; rețea; (constr) inimă de grindă / de şină / de profil, muchie transversală, batardou, buiandrug, perete de separație, perete separator / perete temporar; (OM) disc de roată, fir, brat, bară; (nav) perete despărțitor / separator, nervură; împletitură (de fire, sfori etc.); (poligrafie) bandă (de hârtie); (met) secțiune subțire (la turnare, forjare) care uneşte porțiuni mai groase; (anat) sclerotică, albul ochiului; (zool) pânza (de păianjen), membrană, membrană palmară; miez; (bot, zool) pieliță (fig) rețea, țesătură

webbed reticulat, reticular; (zool) membranat; (bot, zool) palmat

webbing (textile) țesătură, şiret, şnur, bandă, cordon (din materiale textile / fibroase); (efect de) pânză de păianjen, țesere sau scămoşare (şi la pulverizarea adezivilor)

web breaking (ind, $\mathrm{TH}$ ) rupere a benzii de hârtie / a foliei etc.

weabby cu păienjeniş, ca pânza de păianjen

weber (Wb) (metr, fiz) weber, unitate de măsură SI, pentru flux magnetic

web frame (nav) coastă întărită web girder (mec, constr) grindă continuă / cu inimă plină

webless continuum (mat) continuu nereticulat

web member (constr) bară de umplutură, montant fals

web of crank (mas, OM) braț de arbore cotit

web of curves (mat) rețea de curbe

web of paper (birotică) sul de hârtie

web of the rail (cf, OM) inimă a lonjeronului

web of wheel (OM) butuc / disc de roată

web plate (OM, met) inimă a unei grinzi sudate / nituite, guseu

web plate joint (constr, OM) rost de îmbinare a unei grinzi

web saw (silv, mas-un) gater

web stiffener (constr) rigidizarea inimii grinzii sudate / nituite

web thickness (OM, constr) grosime a inimii (unei grinzi)

wed a se căsători; (fig) a îmbina, a uni

wedding agent (chim, alim, T) agent emulgator

wedge (mas, OM) pană, falcă, ic, a împăna, a fixa cu pană / pene; (mat) produs; (nav) catarg; a despica cu ic / pană

wedge angle (OM) unghi al penei (înclinate)

wedge belt $(\mathrm{OM})$ curea trapezoidală

wedge bolt (OM) pană de reglare, cu cep filetat; (mas-un, OM) şurub conic, de fixare a fălcilor

wedged (OM) împănat, fixat (cu pană), blocat, tinut locului

wedged-point nail (OM) cui cu vârf lat (în formă de pană)

wedged-rail anchor (cf, OM) clemă cu pană

wedged ratchet $(\mathrm{OM})$ clichet cu pană

wedge for fastening helve to the hammer (OM) pană de fixare a cozii ciocanului

wedge-friction gear (OM) transmisie cu roți de fricțiune, cu canale trapezoidale

wedge-friction wheel (OM) roată de frictiune cu canale trapezoidale

wedge gib $(\mathrm{OM})$ pană, ştift, ic

wedge grip (mas-un, OM) gheară de prindere, falcă, bac

wedge hammer $(\mathrm{OM})$ ciocan de bătut pene

wedge in a se strecura / furişa înăuntru; a interveni

wedge lock $(\mathrm{OM})$ lacăt cu pană

wedge-notched friction wheel $(\mathrm{OM})$ roată de fricțiune, cu canale trapezoidale

wedge on $(\mathrm{OM})$ a cala / îmbina cu pană

wedge oneself in a-şi face loc, a se înghesui

wedge out $(\mathrm{OM})$ a scoate / a demonta (o pană)

wedge piece $(\mathrm{OM})$ pană, piesă cu rol de pană 
wedge plug $(\mathrm{OM})$ obturator cu pană

wedge shape (met) secțiune conică / înclinată (la o bandă)

wedge-shaped $(\mathrm{OM})$ în formă de pană

wedge-schaped belt $(\mathrm{OM})$ curea trapezoidală

wedge slide (mas-un, OM) sanie cu ghidaje în coadă-de-rândunică

wedge type breechblock (OM) închizător / dispozitiv de fixare cu pană

wedge up $(\mathrm{OM})$ a fixa cu cale / cu pene

wedging $(\mathrm{OM})$ calare, împănare, asamblare cu pană

wedging of the stock (met) agățare a şarjei la furnal (defect / greşeală de proces tehnologic)

wedging out $(\mathrm{OM}, \mathrm{T})$ subțiere a unui strat (si la compozite, acoperiri etc.)

wedging out (geol) efilare, subțiere graduală a unui strat geologic

wedging with chipping (auto, constr) împănare cu criblură

Wednesday miercuri

weed (textile) îmbrăcăminte, haine; (bot) bălărie, neghină, buruiană; banderola de doliu; (fig) cal prăpădit, gloabă, mârțoagă; (fig) lungan, om înalt si slab, prăjină, sfrijitură, slăbănog; (fig) țigară, tutun, trabuc; (agr) a plivi, a prăşi

weed-grown (agr, bot) năpădit / plin de buruieni weed hook (textile, OM) croşetă

weed out (agr) a plivi, a prăşi, a rări; (fig) a elimina, a înlătura, a scoate, a îndepărata, a curăța (de lucruri de prisos)

week (wk) (metr) săptămână, unitate tradițională de timp, egală cu 7 zile

weekday (ec) zi lucrătoare / de lucru, zi din săptămână (fără duminică și / sau sâmbătă)

weekend weekend, sfârşit de săptămână (duminică şi / sau sâmbătă); a-şi petrece sfârşitul de săptămână / week-end-ul

weekly $(s, a d v)$ săptămânal, hepdomadar (d. o publicație)

weeknight noapte a unei zile lucrătoare

weeny mititel, foarte mic, abia perceptibil

weep $(\mathrm{TH})$ a elimina umezeala, a curge, a se prelinge, a picura, a exuda, a transpira; a supura; a se aburi (d. sticlă)

weepage (OM, hidr, T) scurgere de fluid (şi la elemente etanşate)

weeper $(\mathrm{OM}$, hidr, $\mathrm{T})$ orificiu de scurgere / de picurare / de evacuare, picurător

weeping (nav) lăcrimar(e); ( $\mathrm{TH}$, hidr, constr) picurare, infiltrare, infiltraţie

weeping out (termo, ind) condensare în picături weft (textile) țesătură
Weierstrass approximation (mat) aproximare Weierstrass (aproximare a unei funcții printrun polinom de al cărui grad depinde mărimea erorii de aproximare)

weigh (metr) a (se) cântări; a socoti; a compara; (ec) a evalua, a estima, a aprecia; (OM, metr) cântar, cântărire; (nav) a vira / ridica ancora

weigh batching $(\mathrm{TH}$, alim, ind chim) dozare gravimetrică

weighbridge (hidr) pod-basculă

weigh down a obosi (din cauza greutății), a încovoia, a încărca, a împovăra; (fig) a apăsa, a covârşi, a chinui

weighed sample (metr) cantitate de substanță cântărită

weigher cantaragiu; (OM, metr) cântar tip basculă

weigh hopper (met) cântar cu buncăr

weigh in (chim) a cântări o substanță pentru o experiență

weigh in with a interveni (într-un proces tehnologic etc.)

weighing (metr) cântărire, care cântărește

weighing batcher (ind chim, alim) dozator cu cântar; $(\mathrm{TH})$ buncăr gravimetric

weighing cell (metr, fiz) celulă / traductor de cântărire / de masă

weighing lever (metr, fiz, OM) balanță simplă; $(\mathrm{OM})$ basculă

weighing lever with movable jockey (metr, OM) cântar roman

weighing line (nav) parâmă de virare

weighing machine (metr) cântar, basculă

weigh off / out a cântări

weigh out a cântări, a vedea cât cântăreşte; a îm-părți, a distribui (după cântărire)

weight (fiz, TH) greutate (şi etalon), încărcătură, sarcină, obiect greu; masă; pondere; însemnătate; (sport) categorie (în funcție de greutate), halteră; a îngreuna, a cântări, a stabili greutatea, a încărca; (ec) a evalua, a estima, a aprecia; (fig) gravitate, seriozitate; influență, înrâurire, apă-sare; cuvânt greu; a apăsa; a orienta, a îndrepta, a dirija

weight average boiling point (fiz) temperatură medie gravimetrică de fierbere

weight brake $(\mathrm{OM})$ frână cu contragreutate weight by volume (fiz) greutate volumetrică weight concentration (materiale) concentrația în unități de greutate / de masă, concentrație masică

weight deviation ( $\mathrm{OM}$, ind, alim) abatere de la greutate / de la masă 
weight distribution (auto, mec, transp) distribuție a greutății / masei

weight distribution balance (auto) repartiție a greutății pe osii

weighted avantajos, părtinitor

weighted approximation (mat) aproximație pon-derată

weighted average (mat) medie ponderată

weight filling (alim, ind chim) umplere până la o masă / greutate dată

weighted function (mat) funcție ponderată

weihted lever $(\mathrm{OM})$ pârghie cu contragreutate

weihgted mean (mat) medie ponderată

weighted mean value (mat) valoare a mediei ponderate

weight empty (auto) greutate / masă proprie / fără încărcătură

weight equalizer $(\mathrm{OM})$ contragreutate

weight feed (alim, ind chim) dozare în funcție de greutate / de masă

weight feeder (ind chim, alim) alimentator cu dozare prin cântărire

weight flow (hidr, alim, ind chim) debit masic

weight good(s) / cargo (transp) mărfuri grele

weight governor / controller (OM, autom) regulator cu greutate

weight holder (metr, OM) braț / suport pentru greutăți

weightily ( $a d v, f i g)$ cu greutate, cu autoritate, considerabil

weight in air of a given volume of a material (metr) greutatea / masa (în aer) a unui volum dat de material

weight increase creştere a greutăţii

weighting (ec) potențial al pieței, spor de salariu, compensație; ponderare; apreciere; evaluare; (TH) cântărire, ajustare prealabilă, care cântăreşte

weighting material (ind) material de îngreunare / umplutură, lest (şi pt. nave)

weihgt in working order (of a locomotive) (cf) greutate / masă în serviciu / în funcționare (a unei locomotive)

weight lever (cf, OM) braț de macaz cu contragreutate; $(\mathrm{OM})$ braț de balanță, pârghie de cântar

weightless (fiz) imponderabil, fără masă (ca ipoteză)

weightlessness (fiz) condiție în care observatorul din sistem nu detectează accelerație sau forță gravitațională, stare de imponderabilitate weight loss (fiz, transp) pierdere de greutate / de masă / de sarcină weight loss in hydrogen (met) pierderi în hidrogen

weight of chassis (auto) tonaj de şasiu

weight of engine per power-unit (horse-power) (mas, termo, auto) greutate a motorului pe unitatea de putere (cal-putere)

weight of load (mec, transp) greutate / masă a încărcăturii

weight of locomotive in service (cf) greutate în serviciu a unei locomotive

weight of unit volume (OM, materiale) greutate / masă pe unitate de volum

weight per brake horsepower (auto, OM) greutate / masă specifică, pe (unitatea de putere) cal-putere al sistemului de frânare

weight percent (met) procent de masă / de greutate (rar)

weight rate (hidr, alim, ind chim) debit masic

weight ratio of components / of constiutents raport masic al componenților (la compozite, aliaje etc.)

weight saving construction (constr) construcție uşoară / cu masă / greutate redusă

weight set (metr, OM) set de greutăți de cântărire

weight voltametru (el, metr) voltametru de masă (cu cântărire), coulomb-metru

weigh up a-şi forma o părere despre, a caracteriza; a înțelege, a pricepe

weigh with a avea importanță / greutate, a conta pentru / în ochii

weir (hidr, constr) deversor, dig, stăvilar, zăgaz, baraj, prag

weir box (hidr, constr) deversor

weir coefficient (hidr, constr) coeficient de debit al deversorului

weir hydroelectric dam power station (hidr, constr) hidrocentrală cu baraj

weir notch (hidr, constr) deschidere deversantă

welcome bun venit!; a ura bun venit, a întâmpina (cu bucurie), a saluta; a primi (şi o idee)

welcome to căruia i se permite, care poate să, care nu are decât să; care poate dispune, care se poate folosi de

weld $(\mathrm{OM})$ sudură, cusătură de sudură / sudată; a (se) suda, a (se) uni, a (se) lega, a omogeniza; (fig) a (se) lega, a (se) omogeniza, a (se) suda, a (se) uni

weldable $(\mathrm{TH})$ sudabil, care se poate suda (d. materiale)

weldableness sudabilitate (d. materiale, semifabricate)

weldable steel (met) oțel sudabil 
weld all around $(\mathrm{OM})$ sudură pe contur închis / pe circumferință

weld bead $(\mathrm{OM})$ cusătură de sudură

weld decay (met) coroziune intergranulară a sudurii

weld defects $(\mathrm{OM}, \mathrm{TH})$ defecte de sudare / de sudură

weld deposit (met) material metalic / aliaj depus prin sudură

welded $(\mathrm{OM})$ sudat, în stare sudată

welded body $(\mathrm{OM})$ corp / piesă sudat $(\breve{a})$

welded break $(\mathrm{OM})$ ruptură în zona sudurii, crăpătură de sudură

welded butt joint $(\mathrm{OM})$ cusătură de sudură capla-cap

welded chain $(\mathrm{OM})$ lant cu zale sudate

welded connection (OM) asamblare sudată / prin sudură

welded construction (OM, constr) construcție sudată

welded dome body (termo, OM) manta sudată a domului de abur

weld edge $(\mathrm{OM})$ margine a cusăturii de sudură

welded joint $(\mathrm{OM})$ asamblare prin sudură, îmbinare / cusătură sudată

welded-neck flange (OM) flanşă sudată (la gât)

welded pipe / tube (OM) țeavă / conductă sudată

welded seam (met, OM) cusătură sudată / de sudură

welded strain gauge (metr, TH) marcă tensometrică ataşată prin sudură (în puncte)

welded structure (OM, constr) constructie sudată, ansamblu sudat

welded tube $(\mathrm{OM})$ țeavă / tub sudat( $\breve{a})$

welded wire fabric (met, OM) plasă sudată

weld electrically (met, $\mathrm{TH}$ ) a suda electric

welder (met, TH) sudor, aparat de sudat

welder's goggles $(\mathrm{OM}, \mathrm{TH})$ ochelari de sudor (pt. protecție)

welder's helmet $(\mathrm{OM}, \mathrm{TH})$ mască de sudor

weld face $(\mathrm{OM})$ față a sudurii / a cusăturii, suprafața exterioară a cusăturii

welding $(\mathrm{TH}$, met) (acțiune / operație / proces de) sudare, care sudează

welding alternator (el, $\mathrm{TH})$ alternator pentru sudare electrică cu arc

welding appliance (el, TH) aparat / dispozitiv de sudat / pentru sudare

welding arc-voltage (el, met, $\mathrm{TH})$ tensiune a arcului de sudare

welding bath (met, $\mathrm{TH}$ ) baie de sudare

welding blowpipe $(\mathrm{OM}, \mathrm{TH})$ arzător, suflai de sudare welding carbon (OM) electrod de cărbune pentru sudare

welding cast-iron (met) fontă sudabilă

welding current (el, $\mathrm{TH}$ ) curent de sudare

welding department ( $\mathrm{TH}$, met, ind) atelier de sudare

welding dynamo (el) dinam de sudare

welding electrode (OM, met) electrod de sudare

welding flame (met, TH) flacără de sudare

welding flux (met, chim) flux de sudare

welding goggles (TH, OM) ochelari (de protecție) pentru sudură

welding ground $(\mathrm{OM}$, met) contraelectrod pentru sudură

welding handle (OM, met) pistol de sudare

welding heat (met, TH, termo) căldură dezvoltată pe durata sudării

welding helmet (OM, met) mască de sudor / pentru sudare

welding joint $(\mathrm{OM})$ cusătură sudată, sudură; asamblare prin sudură

welding leads (el) cabluri de sudare

welding machine (met, mas) maşină / utilaj de sudare

welding material (materiale, met) material de sudare

welding outfit (met, mas) maşină / utilaj / agregat de sudare

welding pass (met, $\mathrm{TH}$ ) trecere de sudare

welding pole (el, met) pol de sudare

welding powder (met, $\mathrm{TH}$, chim) flux pentru / de sudare

welding pressure (met, $\mathrm{TH}, \mathrm{mec}$ ) presiune de sudare

welding procedure (met, $\mathrm{TH}$ ) tehnologie / procedură / metodă de sudare

welding procedure(s) sheet / specifications (met, TH) fișă tehnologică a operatiiilor de sudare

welding range (el, met, $\mathrm{TH}$ ) intervalul de reglare a intensității curentului de sudare

welding rate $(\mathrm{TH})$ viteză de sudare

welding rectifier (el) redresor de / pentru sudare

welding rod $(\mathrm{OM}$, met, $\mathrm{TH})$ vergea / electrod de sudare

welding seam $(\mathrm{OM})$ cusătură de sudare / de sudură welding set (met, mas) agregat de sudură welding shop (met) atelier de sudare

welding steel (met) oțel sudabil

welding steel wire (met) sârmă (plină) de oțel, pentru sudare

welding strain $(\mathrm{OM}, \mathrm{TH})$ deformație cauzată de sudură 
welding stress $(\mathrm{OM}, \mathrm{mec})$ tensiune reziduală cauzată de sudură

welding symbol $(\mathrm{OM})$ simbol al sudurii / al rostului (de) sudat (în desen tehnic)

welding timer (el, met) temporizator al duratei de sudare

welding torch (OM, met) suflai / arzător de sudură

welding transformer (el, met, $\mathrm{TH}$ ) transformator de / pentru sudare

welding-up of blow-holes (met, TH) (corectare prin) sudarea suflurilor gazoase

welding $\mathbf{V}(\mathrm{OM})$ rost în V / cu pregătirea marginilor în $\mathrm{V}$

welding voltage (el, met) tensiune de sudare / necesară sudării

welding wire (OM, met) sârmă de / pentru sudare

welding with addition of metal powder (met, $\mathrm{TH})$ sudare cu electrod nefuzibil cu pulbere metalică

welding without preheating (met, $\mathrm{TH}$ ) sudare fără preîncălzire / la rece

welding without pressure (met, TH) sudare fără presare / prin topire

welding with postheating (met, $\mathrm{TH}$ ) sudare cu încălzire ulterioară

welding with preheating (met, TH) sudare cu preîncălzire / la cald

welding zone $(\mathrm{OM})$ zona sudurii / de sudare (pe semifabricate care urmează să fie sudate) / de influență a sudurii (pe piesa deja asamblată)

weld iron (met) aliaj feros sudabil

weld junction / line (OM, TH) margine de fuziune (la sudură)

weldless $(\mathrm{OM})$ fără sudură (la țevi, piese etc.)

weldless (drawn) pipe (OM) țeavă / conductă fără sudură

weldless tube (OM) țeavă / tub fără sudură

weldment (OM, constr) ansamblu sudat, construcție sudată

weld metal (met, TH) material metalic de adaos, la sudură, metal depus (prin sudură), material / piesă metalic(ă) sudat(ă)

weld metal excess (met, OM) îngroşare excesivă a sudurii

weld-metal test specimen (metr) probă / epruvetă de metal depus (pt. încercări mecanice)

weld on (met, TH, OM) a încărca / recondiționa / fixa prin sudare

weld on site (OM, constr, mas) cusătură de sudură, executată la locul de montaj

weld period (met, $\mathrm{TH})$ durată de sudare weld position $(\mathrm{OM})$ poziție a cusăturii (pe ansamblu / pe piesă)

weld profile $(\mathrm{OM})$ contur al sudurii

weld quality $(\mathrm{OM})$ calitate a sudurii

weld quench effect (met, TH) influența vitezei de răcire asupra cusăturii sudate, efect de călire la / după sudare

weld reinforcement $(\mathrm{OM}, \mathrm{TH})$ îngroșare a cusăturii (pt. mărirea rezistenței)

weld section (OM) secțiune a sudurii, formă a rostului în plan normal pe lungimea cusăturii

weld size (met, OM) rost / secțiune transversală a sudurii

weld structure (met, OM) structură a metalului / materialului depus la sudare / cusăturii sudate

weld surface defect (met, OM) defect de suprafață, al sudurii

weld throat dimension $(\mathrm{OM})$ grosime a cusăturii sudate

weld through (met, TH) a suda, a topi prin sudare

weld torch dressing (met, $\mathrm{TH}$ ) finisare / ajustare cu flacără (oxiacetilenică)

weld up (met, TH, OM) a încărca / a recondiționa prin sudare

weld with back sealing run $(\mathrm{OM})$ cusătură de sudură, cu completare la rădăcină

weld zone (met, OM) zonă de sudură / de continuare, obținută prin sudură, zonă a sudurii (pe un ansamblu sudat)

welfare bunăstare, prosperitate, bine; (pol, adm) asistență socială, ajutor social; (amer) (ec, $\mathrm{adm}$ ) beneficiu suplimentar

welfare fund (ec, adm) fond de asigurări sociale well $(\mathrm{OM})$ cavitate, scobitură, cameră, canal; (hidr) puț de apă, sursă, izvor, fântână, put, bazin, a se ridica (d. apă); (constr) casă a scărilor, cutie de ascensor; (met) creuzet; $(s)$ bine, fericire; (fig) izvor; (jur) (la tribunal) banca apărării; călimară; $(a d v)$ bine, favorabil, mult, din plin, pe bună dreptate; (adj) bine, sănătos, în stare satisfăcătoare, bun, satisfăcător, oportun, necesar, mulțumitor, cum trebuie, cum era de așteptat; foarte bine, remarcabil, mai mult decât satisfăcător; potrivit, nimerit, în ordine; as la fel de bine, de asemenea; do $\sim$ a reuşi, a prospera, a fi îndreptățit să

well-balanced (OM, mas, ec) echilibrat; judicios; cumpănit; rezonabil, adecvat, corespunzător

wellbase rim (auto, OM) jantă cu adâncituri well-becoming bun, potrivit, just, corespunzător 
well bedded bine stratificat (şi la compozite) wellbeing (med, anat) sănătate (bună); bunăstare, prosperitate

well callipers (metr, OM) compas / calibru de interior / pentru găuri

well-chosen ales / selectat cu grijă; nimerit, potrivit, bine ales / selectat

well-conditioned drept, corect; echilibrat; (ec, adm) (acord / contract) semnat în condiții satisfăcătoare

well-defined bine definit, clar; (mat) univoc, neechivoc

well-deserved binemeritat

well-doing caritabil, care face fapte bune; prosper, înfloritor; succes; (med) sănătate (înfloritoare)

well-done (alim) bine făcut / fript (d. carne)

well-earned binemeritat, pe deplin meritat

well end extremitate anterioară

well-established bine stabilit, ferm, precis; $\mathrm{cu}$ tradiție, cu vechime, cu bună reputație

well-formed corect / logic (construit); (tehnologic) bine făcut

well-found (mas, TH) prevăzut cu aparatura necesară

well from a curge din, a țâşni din

well-grounded in expert, versat, priceput la, bine pregătit pentru

well-handled bine făcut, făcut cu grijă; bine organizat / plănuit; bine condus

well-informed bine documentat / informat, cu o cultură vastă

well-kept (mas) bine întreținut

well-known binecunoscut, vestit, renumit

well-made bine făcut, bine lucrat / executat

well-meaning bine intenționat

well-ordered bine întreținut; aranjat; pus în ordine, bine organizat, sistematic

well-ordered set (mat) mulțime bine ordonată

well-over a se revărsa

well-point (hidr) izvor, sursă

well pump (OM, hidr) pompă de adâncime / submersibilă

well-read (edu) citit, cult, bine instruit

well-rounded bine făcut; (edu) multilateral, complet; $(\mathrm{OM})$ rotunjit, finisat

well-set bine făcut / întocmit, ajustat, potrivit

well sinker (ind) sondor

well-thought-of respectat de toată lumea, care se bucură de prestigiu

well-thought-out bine gândit, judicios

well-timed oportun, spus / făcut la momentul potrivit / când trebuie well-tried verificat, care a dat rezultate bune, încercat / testat cum trebuie

well-type manometer (metr, hidr) manometru cu două coloane, $\mathrm{cu}$ diametre mult diferite

well up a se umfla, a crește; a erupe

well water (geol, hidr) apă de izvor

well-worn uzat, tocit, banalizat, perimat

welt $(\mathrm{OM})$ margine, ramă, manșetă, falț, bordură; (textile) manşetă, bordură; lovitura de bici; (ind pielăriei) ramă (la încălțăminte); (anat) semn (pe piele); a bate cu biciul, a biciui

west (geogr) apus, vest; occident; vestic, apusean, occidental; West (pol) Vest, Occident

westerlies (geogr, nav) vânturi de vest

westerly $(a d j, a d v)$ de vest, vestic, dinspre vest

western (geogr) ( $a d j$ ) de / din vest, vestic; occidental, vestic, apusean

weston cadmium cell (el, fiz) pilă / element cu cadmiu / tip Weston

westward $(s)$ direcție vestică / spre apus; (adj) îndreptat spre vest / apus; $(a d v)$ spre apus

westwardly $(a d j, a d v)$ vestic, de vest, dinspre vest, spre vest

wet ud; jilav; umed, hidrofil, lichid; umezit; umectat; (meteo) ploios, de ploaie; a umezi; a uda; a umecta; a înmuia; (hidr) a iriga, a stropi wetability (fiz) capacitate de a (se) umezi / de a absorbi apă

wet-air pump (OM, termo) pompă de aer umed

wet assay (met, metr) test pentru determinarea unui component prin metodele umede (flotatie, dizolvare etc.)

wet back (termo) cu răcire (a mantalei, a tubului de ardere etc.)

wet basis (materiale, agr, ind chim, met) continut de umezeală / de apă, la unitatea de masă sau de volum al materialului umed / în materialul umed

wet bonding (plast, $\mathrm{TH}$ ) lipire umedă

wet boring (mas-un, TH) perforare / găurire cu lichid de răcire

wet brakes (auto) frână udă

wet breaking strength (textile, plast) rezistență la rupere în stare udă

wet-bulb temperature (termo) cea mai joasă temperatură a unui corp ud, expus în curent de aer, temperatura de saturație adiabatică, temperatură în stare umedă

wet-bulb thermometer (metr, OM, termo) termometru umed

wet classification ( $\mathrm{TH}$, agr, alim, ind chim) separare / sortare umedă

wet classifier (alim, ind chim) separator umed 
wet cleaning $(\mathrm{TH})$ curățire / purificare umedă / cu apă; (ind, TH) preparare a minereurilor pe cale umedă; (ind, mediu) purificare umedă

wet condenser (chim) condensator umed

wet corrosion (met, chim) coroziune (a metalului, aliajului, materialului plastic etc.) în mediu umed

wet contact (el) contact parcurs de curent continuu, contact umed (cu mercur)

wet crusher / crushing mill (ind chim) moară umedă de sfărâmat

wet cylinder liner (auto, termo, OM) cămaşă umedă de cilindru

wet distillation ( $\mathrm{TH}$, alim, ind chim) distilare cu vapori de apă

wet dock (nav, constr) bazin de maree, doc

wet drawing (met, plast, TH) trefilare umedă

wet drawn wire (met) sârmă trefilată în mediu umed

wet drilling (mas-un, TH) găurire cu lichid de răcire, perforare prin injecție de apă

wet elongation (plast) alungire în stare umedă

wet film (chim) peliculă umedă

wet filter (OM) filtru umed / umezit / umectat

wet galvanising (met, $\mathrm{TH}$ ) zincare / galvanizare cu flux topit

wet grinder (mas-un) maşină de rectificat umed / cu răcire

wet grinding (chim, alim, TH) măcinare umedă; (mas-un) rectificare cu lichid

wet installed fastener (OM) organe de asamblare, montate în stare umedă, care prin uscare asigură etanşeitatea

wet liner / sleeve (OM, termo) cămaşă (de cilindru) răcită cu lichid / umedă

wet milling (alim, ind chim, TH) măcinare umedă

wet mixer (constr, mas) betonieră (cu) malaxor

wet mixer for solutions (ind chim, mas) malaxor umed pentru soluții (de cauciuc)

wetness (termo) umiditate, procent de apă în abur, peliculă de apă pe suprafețe încălzite; (meteo, mediu) umezeală

wetness tester (metr, fiz) aparat de măsurat umiditatea

wet-pan mill (alim, ind chim) amestecător, malaxor, maşină de amestecat şi plastifiat / de frământat

wet process $(\mathrm{TH})$ proces / procedeu umed wet processing $(\mathrm{TH})$ prelucrare în stare umedă wet pudlling (met, $\mathrm{TH})$ pudlare în stare lichidă wet purification $(\mathrm{TH}$, ind, mediu) purificare / curăţire umedă wet rolling barrel (met, OM) tobă rotativă (pt. curățire umedă a pieselor turnate)

wet separation ( $\mathrm{TH}$, alim, ind chim) separare / sortare umedă

wet slag (met) zgură fluidă

wet sleeve cylinder (auto, OM) cilindru cu cămaşă umedă

wet snow (meteo) zăpadă umedă / aproape de temperatura de îngheț

wet spinning (plast, $\mathrm{TH}$ ) tehnologie de filamentare / filare (prin extrudare) în baie de lichid

wet steam (termo) abur umed

wet stick (plast, $\mathrm{TH}$ ) lipire umedă

wet storage holder (ind chim, OM) rezervor de gaze, cu etanşare hidraulică

wet strengh (mec, plast) rezistență la rupere în stare umedă / înmuiată

wet surface-active agent (fiz, $\mathrm{T}$, ind chim) agent tensioactiv

wettability (materiale) higroscopicitate, umidibilitate, capacitate de umezire / de umectare

wetted surface $(\mathrm{OM})$ suprafață udată / umedă

wetting (TH, T, OM) umezire, umectare, udare, care udă / umezeşte / umectează

wetting agent (ind chim) agent de udare / umezire / de înmuiere / de umectare; (fiz, T) agent tensioactiv

wetting fluid (fiz) fluid hidrofil

wetting hysteresis (plast) histerezis de umezeală

wetting liquid (ind chim) lichid de umezire / umezitor / umectant

wetting of flux (met, TH) capacitate de umezire a fluxului topit (la sudare)

wetting-out agent (ind chim, textile) agent de înmuiere

wetting power / property (fiz) capacitate de umezire / de udare

wettish cam ud / umed / jilav (d. suprafețe, vreme etc.)

wet ton (metr, ind, mediu) tonă umedă / de material în stare umedă, unitate de măsură pentru nămoluri, sterile, compost şi amestecuri similare, în care materialul solid este amestecat cu apă

wet tons (termo) necesar de frig pentru evacuarea căldurii latente, sarcină de refrigerare datorată căldurii latente

wet tube mill (alim, ind chim) moară tubulară pentru măcinare umedă

wet tumbler (met, OM) tobă rotativă pentru curățire umedă 
wet tumbling (TH) frecare umedă (rar)

wet vacuum distillation (alim, ind chim) distilare în vid cu vapori de apă

wet vapour (termo) abur umed, vapori umezi wet washing / scrubbing (TH) curățare / purificare umedă

wey (metr) unitate veche britanică de măsură pentru lungime, cu valoare variabilă de-a lungul timpului: 1 wey $\sim 1,5 \mathrm{~cm}$

wg (water gauge) (hidr, metr) (aparat de măsură cu) coloană de apă

whale oil (alim) untură de balenă

wharf, $(p l)$ warves (nav) chei (şi de descărcare), platformă de depozitare, debarcader, ponton, a depozita mărfuri pe chei

wharfage (ec, nav) taxă de dană / de chei / de platformă, folosirea unui debarcader / chei de descărcare

wharf revolving crane (mas, transp, nav) macara portuară rotitoare

what (pron) ce?, ce fel?, cum? cât?; (pron, adj) ce, ceva, cât, cîtă, câti, câte; if şi dacă; use is it? La ce foloseşte? La ce bun?; and so $\sim$ ? Ei, şi?; come $\sim$ may / will fie ce-o fi; $\sim$ for? Pentru ce? De ce?; though chair dacă; with ... and ... atât din cauza ..., cât şi din cauza

whatever (adj) oricare, fiecare; orice, fiece; (după any) oarecare; (pron) (interogativ) ce, orice, indiferent de, indiferent de ceea ce; none $\sim$ nici măcar unul; nothing absolut nimic

what with datorită (cuiva), din cauza, din pricina; în legatură cu; what with one thing and another una peste alta; what with ... and (what with) ... atât din cauza, ... cât şi din cauza ...; what with one thing and another astfel; what with .. and (what with) ... ba cu ..., ba cu ...; what is the matter with? ce a pătit? Ce se întâmplă cu?, ce i s-a întâmplat?, ce s-a întâmplat $\mathrm{cu}$ ?; what with one thing and ano-ther cu încetul, cu una cu alta; what with ... and mai din ... mai din

what you see is what you get (c, inf, birotică) functie de previzualizare (ceea ce se vede pe ecran este ceea ce se va tipări)

wheat (alim, bot, agr) grâu

wheat bran (alim, agr) tărâțe de grâu

wheat ear (agr, alim) spic de grâu

wheaten (agr, alim) de / din grâu

wheat flour (alim) făină de grâu

wheat flour paste (alim) amidon de grâu

wheat germ (agr, bot, alim) germene al bobului de grâu

wheat grass (agr, bot) pir wheat land (agr) pământ bun de cultivat grâul

wheat meal (alim) făină de grâu

wheat rust (agr, bot) rugina grâului

wheat separator (alim, agr, OM) trior / separator de grâu

wheel $(\mathrm{OM})$ roată de orice fel (dințată, de curea, de mână etc.), rotilă, rotiţă; (transp, $\mathrm{OM}$ ) bicicletă; învârtire, rotire, rotație, cerc (hidr) rotor (rar), rotor de morişcă hidrometrică; (nav) timonă, cârmă, timonier, pilot; (cf) roată alergătoare (la lomotivă şi vagoane); (pol, adm) (fam) cap, lider, şef; a căra, a transporta, a împinge pe rotile, a se mișca pe roți / rotile; (auto) volan, a rula; a (se) învârti, a se roti; a duce cu bicicleta, a duce cu roaba, a împinge (o masă pe rotile etc.); a se întoarce (brusc)

wheel (a)round / about a schimba direcția (brusc) wheel aligner / alignment gauge (auto, metr, electr) dispozitiv / aparat de verificat geometria roților

wheel axle (mas, OM) osie cu roți

wheel balancing device (cf) balansier de roată alergătoare

wheelband $(\mathrm{OM})$ bandaj de roată

wheelbarrow (constr, OM) roabă

wheel base (auto, OM) distanță dintre axe; (cf) distanță dintre osii, ampatament

wheel blank (mas-un) semifabricat pentru obținerea roții dințate

wheel brakes with shoes $(\mathrm{OM})$ frână cu saboți

wheel brush (mas-un) perie-disc

wheel camber / caster (auto) unghiul de cădere a roților

wheel clasping tyre (cf, OM) bandaj pentru roți de tren

wheel clearance (OM) joc / ajustaj cu joc al roții; (nav) joc al timonei; (auto) joc necesar ca roata să nu atingă caroseria

wheel-cutter (mas-un) freză disc-modul

wheel cylinder (auto, OM) cilindru de frânare a roților / pentru roți

wheel drag (auto, cf, OM) sabot de frână, tachet opritor

wheel dresser (mas-un) dispozitiv de ascuțire a pietrei / discului de rectificat

wheeled (OM) (prevăzut) cu roți / rotile, pe roți

wheeled scraper (auto, ind) screper pe roți

wheel flange (OM) flanșă / guler al unei roți, pentru fixare / asamblare

wheelhouse (nav) timonerie

wheeling ciclism; învârtire, rotire; (constr) stare a drumului / şoselei

wheel pin (auto) rotirea roții / roților 
wheel $\operatorname{rim}(\mathrm{OM}, \mathrm{cf})$ bandaj de roată

wheel speed transducer (metr, auto) vitezometru, traductor de viteză (la sisteme cu roți)

wheel stud (auto, OM) prezon de roată

wheel track (auto) ecartament

wheel turning lathe (mas-un) strung pentru roți

wheel tyre (TH, OM) bandaj de roată; (auto) pneu, anvelopă (de roată)

wheel wrench (auto, OM) cheie de roată

when $(a d v)$ când, în timp ce; $(c o n j)$ când, îndată ce, de când?, până când?, apoi, (pe) când, în timp ce, cu toate că, deşi, ori de câte ori, (atunci) când, în timp ce; (numai) dacă, (numai atunci) când; când (de fapt), cu toate că, de vreme ce, din moment ce; till ? până când; since $\sim$ ? de când?

whence $(a d v)$ de unde, (acolo) unde, de aici; (conj) de unde; (s) obârşie, origine; comes it that? cum se întâmplă că?

whenever (conj) când (anume); (indiferent de momentul) când, în momentul când, oricând, când (anume) (a fost, este sau va fi), indiferent de momentul) când, (indiferent de clipa) când, in clipa când, in clipa în care, ori de câte ori; you want când vrei, oricând vrei

where $(a d v)$ (interogativ) unde? încotro?; (relativ) în care, unde; (conj) unde, (acolo) unde, pe unde, de unde; încotro; în ce fel, în ce măsură; care; (atunci) când; (acolo) unde; $(s)$ loc

whereabouts ( $a d v$ şi conj) (interogativ) (pe) unde (?), prin ce parte (?), în ce direcție (?), (cam) pe unde; $(s)$ loc, poziție (aproximativă)

whereafter (conj) după care

whereas (conj) pe de altă parte, când, de fapt, dar; deşi, cu toate că; având în vedere (faptul că), ținând seama de (faptul că), dat fiind că, întrucât, pe când, în timp ce

whereat $(a d v)$ la care, dup care; de ce, pentru ce; unde, în care, şi (imediat) după aceea

whereaway (conj) unde, încotro

whereby $(a d v)$ (interogativ) cu ce? prin ce mijloc?; (relativ) cu care, din care, prin care / cine / ce, cum, pe ce cale, prin ce mijloace, în $\mathrm{ce}, \mathrm{cu}$ ajutorul căruia

wherefore $(s)$ motiv, pricină, cauză; $(a d v)$ de ce, pentru ce, din ce cauză, pentru care motiv? (interogativ); pentru care, în vederea căruia

wherefrom $(a d v)$ (relativ, interogativ) de unde?, din ce?, din care?, de unde, din ce, din care

wherein $(a d v)$ unde, în care, în ce (anume)

whereon $(a d v)$ (relativ, interogativ) pe ce (anume)?, pe care? la ce (anume)?, unde (anume)?, pe ce, pe care whereupon $(a d v)$ la care, după care; şi (imediat) după aceea

wherever $(a d v)$ unde, încotro, acolo (unde), oriunde, indiferent unde, oriunde, în orice loc

wherewith $(a d v)$ (interogativ) cu ce?, cu care?, prin ce?, prin care?, cum?, în ce fel?

wherry (nav) barcă, luntre, şalupă, iolă

whet $(\mathrm{TH})$ a şlefui, a ascuți

whether (conj) dacă, fie că... fie că..., atât... cât

whetstone (mas-un) corp / disc / piatră abra$\operatorname{ziv}(\breve{a})$ (de ascuțit sau de şlefuit)

whetting material $(\mathrm{TH})$ material abraziv

whey (alim) zer

which (pron, adj) (interogativ, relativ) care?, pe care?, ce?, care, pe care, ceea ce, ce; (conj) care

whiff (meteo) adiere, boare, rafală de vânt; miros, iz; fum, rotocol de fum; inhalare, a sufla, a îndepărta, a mătura (şi d. vânt); a fuma pipă; a adia, a mirosi urât, a duhni

while (conj) pe când, în timp ce, cât timp; pe câtă vreme, dar, însă; deşi, cu toate că, atât cât; (s) răstimp, durată, interval, strădanie, timp, interval de timp, perioadă scurtă; câtva / ceva timp; a trece, a petrece; a omorî timpul / vremea; after a după un timp; a long / good $\sim$ mult timp; once in a $\sim$ din când în când

whiles a-şi petrece (plăcut) timpul

whinstone (geol) bazalt, rocă bazaltică

whip $(\mathrm{OM})$ scripete, troliu, braț / aripă de moară de vânt; a înfăşura, a înveli, (TH) a răsuci, a învârti; (alim) albuş bătut spumă, a bate albuşul / laptele etc.; a se mişca repede; a tivi, a coase pe margine; (nav) a patrona

whipped cream (alim) frişcă

whipping (constr) înfăşurare, învelire; (OM) bătaie, oscilație, învârtire / răsucire a unui mecanism / a unui arc; (nav) patronare; iute, rapid, fulgerător; biciuire; curele, funii; înfrângere

whipping crane (mas, transp) macara oscilantă, cu braț mobil în plan vertical

whipping of shaft $(\mathrm{OM}, \mathrm{mec})$ săgeată de încovoiere a arborelui

whippy (OM) elastic, ca un arc

whip( )saw (mas-un) fierăstrău cu coadă / cu „,coadă de vulpe” (pt. lemn)

whirl (fiz, mec) vârtej, învârtire, răsucire, rotire; a (se) învârti, a (se) roti, a se răsuci, a fi prins într-un vârtej, a se mişca repede, a merge repede; (fig) nebunie, vâltoare (a vieții etc.), vâr-tej, (stare de) zăpăceală, zbucium; (fig) a ameți, a se întuneca, a se zăpăci, a trece valvârtej; a goni (d. un vehicul); a (se) învârteji 
whirl away (fiz, mec) a duce departe (şi repede) whirl core (hidr) inimă a vârtejului

whirl gate (met) maselotă cu alimentare tangențială

whirl-gate feeder (met, OM) alimentator tangențial pentru maselotă

whirl core (fiz, hidr) nucleu de vârtej

whirl disturbance (meteo) perturbatie (atmosferică) turbionară

whirling motion (mec, hidr) mişcare turbionară

whirling runner (met, OM) separator de zgură

whirling speed (mec, OM) viteză critică

whirlpool (hidr) vârtej

whirl sintering $(\mathrm{TH})$ sinterizare în strat fluidizat

whirlybird (av) elicopter

whirr (mas, fiz) bâzâit, zumzet, zbârnâit, huruit; a bârâi, a zumzăi, a zbârnâi, a vibra, a hurui

whirring (mas, fiz) bâzâitor, zumzăitor, huruitor

whisk (mas, OM) mişcare rapidă; (fiz, materiale) mănunchi de fire; pămătuf, şomoiog; a (se) îndepărta (repede), a scutura, a scoate, a trece repede; (alim) a bate cu telul

whiskered cu mustăti (d. fibre, fire etc.)

whisker(s) fibre scurte (la compozite); (met) bavură

whiskey (alim) whisky fabricat în US sau Irlanda

whistle (mas) fluier, fluierat, şuierat; a fluiera, a şuiera; (autom, electr) dispozitiv de atenționare sonoră

whistler (met) răsuflătoare (la turnare)

whistling buoy (nav) geamandură cu sirenă

white (culoare) alb, deschis, de culoare deschisă; argintiu; (alim) albuş; (fig) puritate, nevinovăție, curățenie; (constr) a vărui, a zugrăvi (mai ales în alb); (textile, plast) a albi (rufe, folii etc.); (textile) rochie albă; (spațiu) alb; (om) alb; (anat) albeață, albul ochiului; (TV, c) culoare obținută prin compunerea celor trei culori fundamentale; material alb; (alim) (fig) înghețată de vanilie, gin, pâine albă, vin alb; (fig) morfină; (pol) alb; argintiu, bălai (rar), cu părul blond (rar), cărunt; (fig) (fam) care nu are nimic de ascuns, cinstit; (alim) cu multă frișcă, cu mult lapte (d. cafea)

white alloy (met, T) babbit, compoziție antifricțiune pentru lagăre (pe bază de $\mathrm{Sn}-\mathrm{Pb}$ )

white annealing (met, $\mathrm{TH}$ ) recoacere la alb

white ant (zool) termită

white ash (silv) frasin alb / american

white birch (silv) mesteacăn alb

white bread (alim) pâine albă white breakage (alim) casare fosfatică

whitecap (hidr, nav) creastă de spumă (la salt hidraulic sau la valuri), berbec (hidraulic)

white cast iron (met) fontă albă (de turnătorie)

white cedar (silv) tuie

white-collar (adm) (fig) „guler alb”, funcționăresc, de birou; (edu, univ) intelectual

white copper (met) argentan, alpaca, maillechort

white damp (chim) monoxid de carbon

white film (alim, mediu) mucegai

whitefish (alim, iht) peşte alb / cu carene albă

white frost promoroacă, chiciură

white glass (ind chim) sticlă mată / lăptoasă

white-heart malleable cast iron (met) fontă maleabilă cu miez / inimă alb(ă)

white heat (met) încălzire până la incandescență la alb

white(-)hot (met, OM) încălzit la alb-incadescent

white incandescence (met) incandescență la alb white iron (met) tablă cositorită

white light (fiz) lumină albă; lumina zilei

white-like albicios, alburiu

white lime (ind chim) var alb / gras

white line (c, poligrafie) linie / rând gol

white meat (alim) carne albă (de pasăre, viţel, piept de pui)

white metal (met, T) aliaj / compoziție metalică antifricțiune (pt. lagăre, pe bază de $\mathrm{Sn}-\mathrm{Pb}$ ), babbit, aliaj alb

white mineral oil (ind chim, med) ulei de parafină / medicinal

whiten a (se) albi, a (se) înălbi, a deveni alb; a păli; (constr) a vărui, a zugrăvi; a pudra; (alim) a curăța de carne

whiteness albeață; (med, anat) paloare, paliditate; (fig) puritate

whitening (ind chim) albire, vopsea albă, cremă albă de ghete; care albeşte

white page pagină albă (într-o carte)

white pepper (alim) piper alb

white pickling (met) atac secundar, decapare suplimentară

white pig iron (met) fontă albă (brută)

white poplar (silv) plop alb

white rope (nav) parâmă albă / negudronată

white rust (met) strat de oxid de zinc

white slag (met) zgură albă, zgură de la topire / oxidantă / reducătoare

whitesmith (ind, auto) tinichigiu

white spirit (ind chim) solvent narta, terebentină de petrol 
whitestone (minrl) granulit

white vitriol (chim) vitriol alb, sulfat de zinc

whitewash (constr, ind chim) lapte de var, var stins, văruit, a vărui; a zugrăvi; (ind chim) lapte demachiant, cremă de față; (textile) albire, înălbire; (mobilă) lăcuire; (fig) a căuta să treacă cu vederea, a muşamaliza, a acoperi

whitewashing (constr) văruire

white water (ind chim, met) apă de recirculație

white zinc (chim) oxid / alb de zinc

whiting (ind chim) lapte de var, cretă

whitish alburiu, albicios

whittle a ciopli, a tăia cu cuțitul (în lemn)

whittle away (ec) a reduce (şi costul); (mas) a ajusta, a slăbi, a micşora (și o putere)

whittle (mas-un) cuțit pentru prelucrat lemnul

Whitworth thread (OM) filet în toli / Whitworth

whiz(z) (mas) șuierat, zbârnâit, bâzâit; (amer) expert, maestru, specialist; (TH) a şuiera, a vâjâi, a zbârnâi; a centrifuga, a stoarce prin centrifugare

whizzer (ind chim, alim) centrifugă (de uscare)

whizzing $(\mathrm{TH})$ centrifugare

who (pron) (interogrativ, relativ) cine?, pe cine?, cine, pe cine, care, pe care (relativconjunctiv) aceea care, aceea ce, acel ce, acela care, cea care, cea ce, cel care, cel ce; Who's Who - anuar de celebrități, indice biografic

WHO prescurtare de la World Health Organization - Organizația Mondială a Sănătății

whoever (pron) (pe) oricine, (pe) oricare, acela care / ce, cel care / ce

whole tot, trotal, întreg, complet, integral, plin; nevătămat, teafăr; aşa cum este, în întregime; unitate; aşa cum este, în întregime, întreg (în postpoziție); bun, de sânge (d. frați); nu mai puțin de; on the $\sim$ cu totul, în general, în ansamblu, în genere; upon the $\sim$ cu totul, în general; as a $\sim$ în general; in (the) în întregime, în total $(\mathrm{rar})$; on / upon the $\sim$ în mare, în linii mari, în total

whole blood (zool) cal pur-sânge, rasă pură; descendenţă din aceeaşi părinţi

whole-coloured (fiz, textile, plast) de o singură culoare, monocrom, uni

whole depth $(\mathrm{OM})$ înălţime a dintelui pe suprafața conului frontal exterior (la roți dințate conice)

whole flour (alim) făină integrală

whole grain (agr, alim) cereale integrale

whole-hearted (d. cineva) apropiat, cald, cordial; deplin, maxim (d. atentie, interes), (d. cineva) deschis, din toată inima; serios (d. muncă), (d. cineva) sincer, temeinic (d. muncă), uni

whole-heartedly $(a d v)$ cordial, cu căldură, din toată inima, serios

whole-heartedness (deplină) bună-credință, (deplină) onestitate, (deplină) sinceritate, căldură (sufletească), cordialitate, seriozitate

whole hip roof (constr) acoperiș cu patru versanți

whole-length (artă, arhit) în mărime naturală (d. un portret, un model etc.); integral

whole marking (mas-un, OM) contact perfect pe toată suprafața / la verificare cu vopsea (și pt. pata de contact, la angrenaje dințate)

wholemeal (alim) fãină integrală

whole milk (alim) lapte integral

whole multiple (mat) multiplu întreg

wholeness caracter complet, deplinătate, integritate; plenitudine; totalitate

whole note (metr) notă întreagă, unitate relativă de timp în muzică, numită şi semibreve

whole number (mat) număr întreg

wholesale (ec) vânzare cu ridicata, angro, en gros, cu ridicata; în masă, fără deosebire, la întâmplare; total, integral, deplin

wholesale electroplating plant (el) instalație de productivitate mare, pentru depuneri galvanice

wholesale price (ec) preț cu ridicata

wholesaler (ec) angrosist

whole step, whole tone (metr) măsură întreagă, ton, denumiri alternative pentru step - pas, măsură, o unitatea de măsură în muzică pentru a exprima raportul frecvențelor a două note

wholesome (med) bun (pt. sănătate), sănătos; salubru; folositor; (alim, med) nutritiv, hrănitor; robust, viguros

whole-time (ec) care ocupă tot timpul cuiva, cu normă întreagă, cu program complet de lucru, programat pentru întreaga săptămână / zi de lucru

whole-timer (ec, adm) salariat / angajat cu normă întreagă; muncitor sau funcționar care lucrează săptămâna / ziua întreagă (de lucru), muncitor / funcționar permanent

whole-tyre reclaim (ind chim) (cauciuc) regenerat (numai) din anvelope

wholly $(a d v)$ cu totul, în întregime, total, întreg, complet, cu totul, întru totul, pe de-a-ntregul, totalmente; excluisv; in cable în cabluri (d. o rețea)

whom (pron) (interogativ, relativ) (dativul şi acuzativul de la who, folosit în scris şi în vorbirea îngrijită) cui, pe cine, căruia, pe care 
whorl (OM, el) spiră, parte dintr-o spirală; (textile, OM) rotiță a fusului

whose (pron) cui, al cui, al cărui, de a cărui, a cărei, ale căror; for $\sim$ benefit? în folosul cui?

whosoever (pron) (absolut) oricine, (absolut) toți cei care; $v$. whoever

why $(a d v)$ pentru ce? de ce?, pentru ce / care; (conj) de ce, pentru ce; $(s)$ motiv, cauză; not? de ce nu?; so? de ce aşa? de ce asta?

wick $(\mathrm{OM})$ fitil, muc; tampon (medical)

wicked rău, neascultător, primejdios, periculos, vătămător, care face rău; (miros) urât, insuportabil

wicket $(\mathrm{OM})$ portiță, ghişeu, (hidr, $\mathrm{OM})$ vană (plană) cu ridicare

wick (feed) lubricator $(\mathrm{OM}, \mathrm{T})$ ungător cu fitil

wicking (fiz, hidr) pătrundere / distribuire a unui lichid pe principiul vaselor capilare

wick oiling $(\mathrm{OM}, \mathrm{T})$ ungere cu fitil

wide larg, vast, spațios, lat, mare, cuprinzător, întins, deschis; considerabil, apreciabil, sensibil; (ec) nestabil, instabil, fluctuant, schimbător (d. preț)

wide angle type joint $(\mathrm{OM})$ articulație cardanică cu unghi mare de înclinare a arborelui

wide bottom flange rail (cf, OM) şină cu talpă lată

wide end up mould (met) lingotieră cu baza mare sus

wide-faced pulley (mas-un, OM) roată-tambur, roată / rolă de transmisie de mare lățime

wide-flanged (met) profil cu talpă lată

wide-flange(d) beam $(\mathrm{OM}, \mathrm{mec})$ grindă cu profil cu talpă lată, profil greu

wide-flanged structural steel I beam $(\mathrm{OM}$, mec) profil I cu talpă lărgită

wide flat steel (met) platbandă, oțel lat

wide-gauge (cf) ecartament larg

wide-gauge railway (cf) cale ferată cu ecartament larg

widely $(a d v)$ la (o) mare depărtare; în mare măsură, considerabil, sensibil; foarte mult; peste tot, pe o mare suprafață

wide-meshed (OM) cu găuri mari (la site)

widen a (se) extinde; a mări; a (se) lărgi; a dezvolta; a (se) dilata; a amplifica; a (se) lăți (d. un drum, un orificiu etc.), a (se) face mai larg, a întinde, (și fig) a crește, a întinde; (fig) a lărgi (sfera de interese etc.)

widen by blasting (ind, constr, geol) a mări / lărgi prin explozie / prin împuşcare

wide neck(ed) bottle (OM) sticlă cu gâtul larg

widener (mas-un) lărgitor, extensor widening (TH) lărgire (şi a țevilor), extindere

widening out $(\mathrm{TH})$ lărgire (în afară)

wide of depărtat de, departe de adevăr / realitate

wide-open $(\mathrm{OM})$ con cu conicitate mare; larg deschis

wide-range (fiz) cu / de bandă largă; cuprinzător (d. frecvență etc.)

wide rubber belt $(\mathrm{OM})$ curea lată din cauciuc

wide-spread larg răspândit

wide strip (met) tablă lată

wide strip (rolling) mill (met) laminor de tablă lată

widia (alloy) (met, mas-un) aliaj (tip) widia

width (constr, OM) lățime, lărgime; întindere; (fig) amploare

width across corners $(\mathrm{OM})$ diametrul cercului circumscris hexagonului piuliței sau şurubului

width across flats $(\mathrm{OM})$ deschiderea cheii; diametru al cercului înscris în hexagonul piuliței sau al capului şurubului

width between centres (mas-un, OM) distanța dintre vârfuri / între axe

width indicator (auto) indicator de lățime pe aripă

width of base of rail (width of rail base) (cf, met) lăţime a piciorului şinei

width of bay (constr) lungime de panou

width of groove (met) lățime a calibrului de laminare

width of opening $(\mathrm{OM})$ dimensiune a deschiderii / orificiului

width of pass (mas-un, OM) distanța între două reazeme vecine

width of transition interval $(\mathrm{TH}, \mathrm{OM})$ lățime a interstiţiului

width of the vault (constr) deschiderea boltiii

width over flats of hexagonal nut $(\mathrm{OM})$ deschidere a cheilor fixe (pe laturile hexagonului) wield $(\mathrm{TH})$ a mânui (o unealtă)

wiggle (mec) a oscila în direcție longitudinală

wiggly şerpuit, cotit, sinuos

wig-wag signal (el) semnal oscilant / în zigzag

wild loc sălbatic, pustiu; (zool, bot) sălbatic, nedomesticit; necivilizat, primitiv; la întâmplare, negândit, nejudecat; (fig) a-ntâia; (geogr) bântuit de furtuni / vânturi, furtunos (d. un tărm); care creşte / trăieşte în natură; care nu e la subiect, fără legătură cu subiectul; crud, crunt, feroce, fioros (d. oameni sau animale); desfrânat,dezmățat, furios (la culme), apucat, barbar (d. oameni); (fig) extraordinar, grozav; fantastic, fantezist (d. idei, planuri etc.); imprudent (d. acțiuni); în neorânduială, despletit (d. păr) 
wild cat (ec, adm) întreprindere riscantă, grevă neoficială / fără aprrobarea sindicatului; (cf) tren care circulă în afara oraşului, tren special / suplimentar; (nav) barbotină; (OM, mas) neverificat, necontrolat

wild cherry (bot) vişin sălbatic

wildeat (nav) barbotină

wild lead (met) blendă de zinc

wild twist (textile, mec) torsiune neuniformă / severă

wild wear $(\mathrm{T}, \mathrm{OM})$ uzură severă / intensă

wild wheat (agr, alim, bot) grâu moale

will voință, conștiință; dorință; atitudine; hotărâre, voie; intenție; (jur) testament, a lăsa prin testament; ( $v$ auxiliar pt. formarea viitorului la persoanle 1 şi 2, sg şi $p l$ ): vei, veți, va, vor, o să, ai să, are să, aveți să, au să; (amer) (pt. formarea viitorului la toate persoanele): voi, vei, va, vom, veți, vor, o / să am, o /ai să, o / are să, o / avem să, o / aveți să, o / au să; a determina; ( $v$ defectiv modal) a vrea, a fi hotărât să; ( $v$ defectiv modal) a consimți; a vrea; a face; a hotărî, a intenționa, a avea de gând; a ordona; $\mathbf{a} \sim$ of his own un om voluntar; where there's a there's a way a voi înseamnă a putea; ill rea-voinţă; good $\sim$ bunăvoință; at $\sim$ după plac, poți să-l modifici după plac/voie; mention smb. in one's $\sim$ a trece pe cineva în testament; $\sim$ smb. to do smth. a determina pe cineva să facă ceva

willable de dorit, dezirabil

willful voluntar; încăpățânat; voit, deliberat, intenționat

willfully ( $a d v)$ cu încăpățânare; (în mod) premeditat, intentionat, dinadins

willfulness încăpățânare, premeditare, intenție, bună ştiință

willing dispus, gata, pregătit; benevol, voluntar; harnic; de voință, volitiv

willing to binevoitor / favorabil față de

willingly $(a d v)$ de bună voie, nesilit; (în mod) spontan

willingness bunăvoință, amabilitate, asentiment, consimțire; aprobare

will-less lipsit de / fără voință, fără caracter

Wilson chamber (metr, fiz) cameră de ionizare / Wilson cu ceață / cu expansiune

wimble (mas-un) burghiu cu coadă

win victorie, câştig, succes, profit; a câştiga, a învinge; a exploata a dobândi; (TH) a extrage, a tăia

win back a recâştiga, a lua înapoi

winch $(\mathrm{OM})$ troliu, vinci, manivelă, cric, macara, mulinetă (la o undiță, un troliu etc.); (nav) tambur, argat, gruie, vinci, a ridica cu vinciul; (met, OM) vârtelniță, înfăşurător (la trefilare, textile); a ridica cu un vinci; (textile, plast) bazin / cadă de vopsire cu vârtelniță

winch barrel (nav) tambur de vinci winch drum $(\mathrm{OM})$ tambur de troliu winch dyeing machine (textile, plast) maşină de vopsit cu vârtelniță

Winchester bushel (metr) denumire tradiţională britanică pentru ceea ce este astăzi US bushel; v. bushel

Winchester quart (metr) unitate informală de măsură pentru volum, în UK, pentru chimicale înmagazinate în recipiente / sticle cilindrice lungi: 1 Winchester $=2,51$

winch rope $(\mathrm{OM}$, met) cablu de oțel pentru troliu

winch wheel $(\mathrm{OM})$ roată de activare a unui palan

wind $(\mathrm{OM})$ troliu, cot; (meteo) vânt, adiere, boare, furtună; aer; (anat, med) suflu, răsuflare, respirație, gaze intestinale, vânt(uri), a îngreuna respirația (cuiva); (textile) înfășurare a semitortului / firului la maşini de filat, a pupiniza; (fig) fleacuri, prostii, vorbe goale, apă de ploaie; $(\mathrm{TH})$ apăsare (pe un mâner), îndoire, curbare, încovoiere, şerpuitură, cot, meandră, strâmbare (a lemnului); suflu; a înfăşura; a înveli, a ridica; (el) a bobina, a înfă-şura, a încolăci; a învârti, a roti, a (ră)suci, a întoarce (un meca-nism, un arc), a depăna (un scul, o rolă de sârmă), a ridica / urca / scoate cu macaraua, a se răsuci, a (se) învârti, a (se) încolăci, a fi răsucit, a șerpui, a coti, a fi cotit, a face meandre, a fi expus la vânt / la aer, a expune la aer / la vânt, a pune la aer / la vânt, a aerisi; (ec) a rula (bani); (nav) a pilota, a cârmi, a face volta în vânt; a se scoroji (d. lemn); a înveli; a lăsa sa respire, a lăsa să se odihnească (calul etc.); the (muz) suflători, instrumente de suflat; fair $\sim$ vânt prielnic; in the 's eye, in the teeth of the împotriva vântului; sail down / before the $\sim$ a naviga cu vântul în spate; find out how the $\sim$ blows / lies $(\mathrm{fam})$ a simți dincotro bate vântul; there is smth. in the $\sim$ (fam) pluteşte ceva în aer; take the $\sim$ out of smb.'s sails a lua apa de la moara cuiva, a i-o lua cuiva înainte; the four $\sim \mathbf{s}$ (geogr) cele patru puncte cardinale; lose / recover one's $\sim$ a-şi pierde / recăpăta respirația; break wind (med) a scăpa un vânt; be troubled with $\sim$ (med) a avea gaze; $\sim$ into a ball a face ghem; $\sim$ on a reel a înfăşura pe o bobină; side (fig) influență din afară / indirectă / străină 
windage (av, nav) (grad de) deviere (din cauza vântului); (OM) joc, spațiu liber; (med) contuzie; (fiz) rezistența aerului; (el) frecare cu aerul, ventilație; (nav) parte expusă vântului

windage loss $(\mathrm{el} ; \mathrm{OM})$ pierderi prin frecare $\mathrm{cu}$ aerul / prin ventilație

windbag $(\mathrm{OM})$ rezervor de aer

wind-blown (constr, meteo) bătut / suflat de vânt

wind box / chest (met) cutie de aer / de vânt

wind break $(\mathrm{OM})$ paravânt

wind chill temperature index (WCTI) (metr, meteo, med) indice de frig şi vând, o măsură a efectului combinat al frigului şi al vântului asupra corpului uman; din 2001, versiunea US: WCTI $=35,74+0,6215 \cdot \mathrm{T}-35,75 \cdot \mathrm{V}^{0,16}+$ $0,4275 \cdot \mathrm{T} \cdot \mathrm{V}^{0,16}$, cu $\mathrm{T}-$ temperatura în ${ }^{\circ} \mathrm{F}, \mathrm{V}$ viteza vântului în mile pe oră; versiunea canadiană: WCTI $=13,12+0,6215 \mathrm{~T}-11,37 \mathrm{~V}^{0,16}$ $+0,3965 \cdot \mathrm{T} \cdot \mathrm{V}^{0,16}, \mathrm{cu} \mathrm{T}$ - temperatura în ${ }^{\circ} \mathrm{C}, \mathrm{V}$ - viteza vântului în $\mathrm{km} / \mathrm{h}$

wind driven (ind, mediu) eolian, acționat de vânt

wind driven electric power station (ind, mediu) centrală electrică eoliană

wind driven generation (el) generator eolian

wind engine (mas, el) motor eolian, moară de vânt winder (metr) cheie de întors un ceas / arc; (textile) maşină de bobinat, depănător

windfallen doborât de vânt

wind flower (bot) anemonă

wind furnace (met) furnal, cuptor cu suflare de aer

wind gauge, wind-gauge (metr, fiz, meteo) anemometru, anemograf

winding şerpuit, cotit, sinuos, întortocheat; cotit(ură), sinuozitate, meandră, spirală; (el) bobinaj, înfăşurare, spiră

winding axle of winch $(\mathrm{OM})$ arbore / ax de troliu winding bench (el, mas) maşină de bobinaj

winding (coils) (el) bobină, înfăşurare / bobinare (a spirelor)

winding cylinder $(\mathrm{OM})$ tambur înfășurător

winding factor (el, TH) factor de bobinaj

winding form (el, OM) şablon de bobinaj

winding machine (el, mas, textile) maşină de înfăşurat / de bobinat

winding motion (el, mec, textile) mişcare de înfăşurare

winding motor (mas) motor de troliu

winding off $(\mathrm{TH})$ desfășurare, derulare (a unui cablu, a unei bobine etc.)

winding-off device (mas, el, met, textile) dispozitiv de înfăşurare / de derulare winding-pipe (termo, OM) serpentină

winding pitch (el) pas de înfăşurare

winding road (auto) drum şerpuit

winding room (el) secție / atelier de bobinare winding rope (mas, OM) cablu de înfăşurare winding speed (TH, met, transp, el) viteză de înfăşurare / de ridicare

winding spool (el, textile) bobină de înfăşurare

winding tackle (nav, OM) palan de punte

winding terminal (el) bobină de înfăşurare

winding tube (termo) serpentină

winding type current transformer (el) transformator de curent, fără înfăşurare primară / primar

winding-up gear (plast, met, el) transmisie de înfăşurare

winding-up roller $(\mathrm{OM})$ cilindru de înfăşurare winding wire (el) sârmă / fir de înfăşurare / de bobinaj

wind instrument (muz) instrument de suflat windlass $(\mathrm{OM})$ ax de troliu; (nav, $\mathrm{OM}$ ) vinci (de ancoră), troliu, tambur; (textile) vârtej

windlass rope (met, OM) cablu de oțel pentru troliu

windless (meteo) fără vânt

wind load (mec, constr) sarcină datorată vântului

windmill (agr) moară de vânt; (mas, el) motor eolian

wind motor (mas) motor eolian

wind off $(\mathrm{TH})$ a (se) desfăşura, a (se) derula, a desface o bobină, a debobina

wind on (met) a (in)sufla (în furnal)

window (constr, OM) fereastră, ferestruică, orificiu, geam, deschizătură, ecran, chenar; (c, inf) fereastră (a unei imagini afişate), porțiune rectangulară a unui ecran, separată de restul acestuia şi folosită pentru afișarea simultană a mai multor imagini sau texte; (fiz) fantă; (adm) ghişeu; (ec) vitrină; (agr, mas) secerătoare

window bench (constr, OM) pervaz de fereastră, parapet

window blinds (constr, OM) rulouri de fereastră window bolt / case (constr, OM) toc / pervaz de fereastră

window box (agr, OM) ghiveci, jardinieră

window catch (constr, OM) zăvor de fereastră

window crank (auto, $\mathrm{OM}$ ) manivelă pentru geamul portierei

window dresser (ec) vitrinier; (fig) mistificator

window dressing (fig) mistificare

window envelope (birotică) plic cu fereastră (cu decupaj pentru adresă)

window fastening (constr, OM) cremonă 
window flanning (constr, OM) cadru de fereastră window frame (auto, OM) ramă / cadru de geam; (constr) cercevea, toc de fereastră

window-frame aerial (fiz) antenă-cadru pentru fereastră

window frost flori de gheață (pe geam, sticlă)

window glass (ind chim, constr) geam, sticlă pentru geam

window glass run channel (auto, OM) culisă laterală pentru geam

window grating (constr) gratii la ferestre

window head (constr, OM) cheie de fereastră, buiandrug

window ledge (constr, OM) talpă a ramei de fereastră

window opening (constr) deschidere a ferestrei window pane (constr, OM) geam (de fereastră) window post (constr, OM) stâlp de fereastră

window raiser (auto, OM) dispozitiv de ridicat geamul

window regulator (auto, OM) mecanism de manevrat geamul

window sash (constr) toc / ramă / batant de fereastră, cercevea

window screen (constr, OM) plasă la fereastră

window shade (amer) (constr, OM) jaluzele

window shopping (ec) inspectare a vitrinelor, vizită prin magazine (fără a cumpăra)

window shutter (constr, OM) oblon

window sill (constr, OM) talpă de fereastră, pervaz, parapet

window strap (auto, OM) curea de geam

window valve (constr, OM) batant de fereastră

window crank (auto) manivelă

window opening and closing (auto) deschidere şi închidere geamuri

wind pressure (meteo, constr, mec) presiune a vântului

window-shop a se uita la vitrine (adesea fără intenția de a cumpăra)

window shopper persoană care se uită la vitrine (adesea fără intentia de a cumpăra)

window shopping uitat (pe) la vitrine

window tint (auto, OM) parbriz / geam colorat

window valve (constr, OM) batant de fereastră, cercevea

wind-power station (el) centrală electrică eoliană wind-sail mânecă de aerisire / de vânt (la nave)

windscreen (auto, OM) parbriz

windscreen cleaner / wiper (auto, OM) ştergător de parbriz

windscreen wiper arm (auto) brațul ştergătorului de parbriz wind set-up (meteo) intensificare a vântului

wind's eye (nav, meteo) direcție a vântului

windshield (cf, OM) paravânt; (auto, OM) apărătoare de vânt

windshield defrosting and defogging (auto) sistem de dejivrare şi dezaburire a parbrizului windshield deicer button (auto, OM) buton al dispozitivului de dejivrare a parbrizului

windshield heater (auto, termo) sistem de încălzire a parbrizului

windshield washer (auto, OM) spălător de parbriz windshield washer fluid reservoir (auto, $\mathrm{OM}$ ) rezervor lichid de spălat parbrizul

windshield wiper(s) (auto, OM) ştergător / ștergătoare de parbriz

wind shutter (OM, constr) jaluzea

wind sleeve (meteo) con de vânt

wind statistics (nav, meteo, mat) statistică a regimului vântului

wind tunnel (metr, hidr) tunel aerodinamic (de încercare)

wind-up încheiere, înfăşurare, bobinare, rulare; $v$. wind up

wind up (TH) a înfasşura (complet), a bobina, a ridica, a rula, a învârti, a răsuci, a încolăci; (metr) a răsuci un ceas; a termina, a încheia; a întoarce, a fi întors (d. un ceas etc.); (muz) a întinde corzile unei viori (răsucind cheia); a enerva, a exaspera; a termina (o scriesoare, un discurs etc.); (ec) a lichida (o afacere, o întreprindere etc.), a dizolva (o societate, o companie)

wind up the rope (mas, OM) a înfăşura cablu (pe tambur)

wind-velocity (metr, fiz) indicator anemotahometru

wind velocity (meteo) viteză a vântului

wind volume (met, $\mathrm{TH}$ ) cantitate / volum de aer insuflat

wind wall on the mouth of a (blast) furnace (met) manta de captare a gazului (la furnal)

windward (side) (nav) bord în vânt, opus vântului, din vânt, în vânt; (constr, OM) parte expusă la vânt

wind ware flume (hidr, metr) canal de încercare pentru valuri, prevăzut cu curent de aer

windy (meteo) vântos, bătut de vânt; (fig) gol, fără conținut, fricos

wine (alim) vin, băutură, lichior

wine brown-breacking, wine brownness (alim) brumificarea vinului

wine cask (alim, OM) budană

wine cellar (alim, constr) cramă, pivniţă pentru vin wine clarification (alim, $\mathrm{TH}$ ) limpezire a vinului 
wine distillate (alim) distilat de vin

wine district (agr) zonă vinicolă

wine glass (alim, OM) pahar de / pentru / cu vin wine from second (third) pressing (alim) vin de presa a doua (a treia)

wine from the first / free running must (alim) vin din must fiert natural

wine gallon (metr, alim) galon de vin, unitate veche britanică de măsură pentru volum: 1 wine gallon $=231$ cubic inches (inch cubi); unitate oficială de măsură pentru volum, în US, numită acum US liquid gallon; $v$. US liquid gallon

wineglass (metr, alim) pahar de vin, unitate neoficială de măsură pentru lichide, utilizată în US, numită şi gill: 1 wineglass $\cong 118,3 \mathrm{ml}$

wineglassful (metr) unitate de măsură pentru volum, utilizată în UK pentru recipiente de alimente: 1 wineglass $\sim 71,0 \mathrm{ml}$

wine grower (agr) viticultor

wine(-)growing (agr) viticultură

wine industry (alim) industria vinului

wine mo(u)ld (alim) floare a vinului

wine-preparation (alim) vinificație

wine-press (alim, OM) teasc de struguri

wine-stone (alim) tartru (de vin)

wine-venting (alim, $\mathrm{TH}$ ) vânturare a vinului wing (zool) aripă; (av) aripă, grup de aviaţie (de 3 escadrile); (OM, nav, mil, sport) aripă, flanc; parte; (constr) aripă (de clădire) canat, batant de fereastră / de uşă, coridor lateral, a construi (o aripă de clădire); (sport) atac pe extremă; fel de a zbura; (nav) muradă, a deplasa mărfurile spre muradă; (mil) regiment; sfầrlează de vânt; zbor; (fig) braț, mână; a da aripi / a da avânt (cuiva); a grăbi (pe cineva); a împăna (o să-geată); a răni în aripă

wing area (av) suprafață a aripii

wing callipers (metr, $\mathrm{OM}$ ) compas sferic

wing duet (hidr, OM) canal la rotorul pompei / turbinei

winged $(\mathrm{OM})$ cu palete, cu aripi(oare)

winged edge $(\mathrm{OM})$ pană cu aripă / cu nas

winged head $(\mathrm{OM})$ cap / capăt tip fluture

winged nut $(\mathrm{OM})$ piuliță-fluture

winged screw $(\mathrm{OM})$ şurub-fluture

wing fillet $(\mathrm{OM})$ racord, piesă, ştuț de racordare

wing lamp (auto) lanternă de aripă

wing nut $(\mathrm{OM})$ piuliță-fluture

wing span (av) anvergura aripii

wing stay (auto, OM) suport de aripă

wing-tip hand grip (mas) mâner cu aripioare

wing walls (hidr, constr) perete de aripă (la o ecluză) wingy cu aripi

winkers (auto) semnalizatoare

winning câştigător, învingător; atrăgător, captivant; (fig) a acționa / proceda infailibil, a merge la sigur

winning expenses (ec, $\mathrm{TH}$, alim, ind chim) cheltuieli de extracție

winnow (agr) a vântura (cereale); a spulbera, a împrăştia, a risipi; (fig) a cerne, a cerceta cu grijă, a verifica, a despărți, a deosebi, a alege, a selecta, a selecționa

winnover (agr) vânturător, vânturătoare

winter (meteo) iarnă; (zool) a ierna, a hiberna; (agr) a îngriji (animale) pe durata iernii

wintercrop / corn (agr) cultură de toamnă

winter cover / funt (auto, OM) husă / mască de radiator

winterize $(\mathrm{OM}, \mathrm{T})$ a adapta la condiții de iarnă (d. maşini, lubrifianți etc.)

winter oil (auto, T, ind chim) ulei / lubrifiant de / pentru iarnă

wintertime (meteo) vreme / timp de iarnă

winter type disel fuel (auto, ind chim) combustibil / carburant biodiesel de iarnă

winter weat (agr, alim) grâu de toamnă wintry (meteo) hibernal, de iarnă winy (alim) ca vinul, cu gust / miros de vin wipe (TH) ştergere, curăţare, frecare; (c) a şterge (şi pe ecran), a curăța, a freca, a face curat wipe away a îndepărta (şi prin ştergere)

wipe down a curăța / şterge cu o cârpă umedă wiped galvanised wire (met) sârmă galvanizată / zincată electrolitic

wiped galvanising (met, TH) galvanizare / zincată electrolitică

wiped joint $(\mathrm{TH}, \mathrm{OM})$ lipitură obținută prin picurare şi mişcare mecanică de întindere a materialului topit

wipe off / out (chim, fiz, c) a şterge, a înlătura / a elimina prin ştergere (şi de pe monitor); (fig) a scăpa de, a lichida, a achita (o datorie)

wipe out a distruge, a desființa, a îndepărta cu totul, a rade, a şterge bine, a curăța pe dinăuntru

wipe over (med) a unge; (ind) a vopsi

wiper (el, OM) perie de contact (de cărbune), cursor; (mas-un, OM, T) pieptene de ungere, raclet ştergător, raclet(ă); (auto, OM) ştergător (de parbriz); (textile) prosop, cârpă de praf

wiper blade (auto, OM) ștergător (de parbriz)

wiper lubrification $(\mathrm{T})$ ungere / lubrifiere prin picurare

wiper shaft (el) arbore port-perie, ax al periilor 
wiper speed (auto) viteză a ştergătoarelor de parbriz

wipe up a şterge (şi cu cârpa uscată)

wiping action ( $\mathrm{TH}$, ind chim) (tehnologie / procedeu / proces de) lipire prin picurare şi mişcare mecanică de întindere a materialului topit

wiping cycle (auto) ciclu de ştergere (la ştergătoare)

wire (el, OM) sârmă, fir, conductor, conductă (nav) parâmă de sârmă; (el) a bobina, a întinde fire (electrice), a conecta; (mec) a cupla, a lega / fixa (cu sârmă), a îngrădi cu sârmă; (textile) fir, ață; a înştiința printr-o telegramă

wire ammeter (metr) ampermetru termic

wire armouring (constr, OM) armătură / plasă de sârmă

wire back-tie (constr) tirant de fier-beton

wire-bar (el, OM) conductor-bară; (met) semifabricat pentru obținerea sârmei

wire basket $(\mathrm{OM})$ coş / sită metalică / din sârmă

wire braided hose $(\mathrm{OM})$ furtun cu împletitură din sârmă metalică

wire brush $(\mathrm{OM}$, met) perie de sârmă

wire cable (met, OM) cablu de sârmă (de oțel)

wire carrier (el, OM) suport de conductor

wire cart (el, OM) cărucior de transportat cabluri

wire centre (el) inimă / miez de cablu

wire cloth (constr, met) plasă / țesătură de sârmă

wire coil (el) spirală de sârmă; (met) colac de sârmă

wire-coiling machine (mas) maşină de bobinat sârmă

wire-communication (electr, inf) comunicații prin cablu

wire-core (el) miez al sârmei; sârmă pentru miez de cablu

wire-core coil (el) bobină cu miez de sârmă

wire-core reinforcement $(\mathrm{OM})$ inserție / întărire de sârmă

wire covering machine (plast, mas) maşină de acoperit / cauciucat cabluri

wire cutter(s) $(\mathrm{OM})$ clește / foarfecă de tăiat sârmă

wire drawer (met, OM) banc de trefilat sârmă

wire drawing (met, $\mathrm{TH})$ trefilare

wire drawing bench (met, $\mathrm{OM}$ ) banc de trefilare

wire drawing grease (met, ind chim) unsoare pentru trefilare

wire drawing plant (met, mas-un) utilaj de trefilat sârmă

wire drawing tongs (mas-un, $\mathrm{OM}$ ) cleşte de tras sârmă wire-drawn (met, plast) tras (în fire), trefilat wire drill (mas-un) burghiu din sârmă calibrată wire drum $(\mathrm{OM})$ tambur de colaci de sârmă wire fault (el, met) defect de sârmă / de fir wire filter cloth (ind chim, T) țesătură de sârmă pentru filtru

wire forming machine (mas-un) presă de îndoit pentru fasonarea sârmei

wire fuse (el) siguranță fuzibilă

wire gauge (metr, met) calibru pentru sârmă

wire gauze (met, constr) țesătură / pânză metalică

wire-gauze electrode (el, OM) electrod din pânză metalică, grilă

wire-gauze packing (constr, OM) umplutură reticulară

wire-glass (constr, ind chim) sticlă / geam armat(ă) cu plasă de sârmă

wire grating / grid (constr, OM) grătar / grilaj de sârmă

wire grip (el, OM) clemă-broască de întins, întinzător de sârmă; (mas-un, OM) cleşte de trefilat

wire haulage rope $(\mathrm{OM})$ cablu de tracțiune

wirehook $(\mathrm{OM})$ clemă de sârmă

wire hurdle (constr) îngrăditură de sârmă

wire ingot (met) lingou de / pentru sârmă

wire (leading) roll $(\mathrm{OM})$ valț de tragere (la prelucrarea hârtiei, pânzei)

wireless (fiz, radio) (de / prin / la) radio, fără fir

wireless apparatus (fiz, radio) radioaparat(aj)

wireless direction finder (nav, fiz) far de radiolocație

wireless station (fiz, radio, mil) stație radio (emisie şi recepție)

wireless transmitter (autom, radio) aparat emisie-recepție fără fir, radio

wire line (el) conductor / linie de cablu; (met, mas) linie de trefilat sârmă; $(\mathrm{OM})$ cablu de oțel / de palan

wire loop (cf) buclă de cale ferată; (met) buclă de sârmă

wireman (el) instalator, electrician

wireman's tent (met, $\mathrm{TH}$ ) cort de sudare

wire mesh (constr, hidr) rețea / plasă metalică

wire mesching (met) țesătură / sită metalică

wire mill (met) laminor de sârmă

wire milling (met, $\mathrm{TH}$ ) laminare a sârmei

wire-nail $(\mathrm{OM})$ cui de sârmă

wire net (el) rețea electrică; (mas, el) plasă / rețea de sârmă

wire netting (met) țesătură / plasă / rețea de sârmă 
wire of sieve $(\mathrm{OM})$ sită de sârmă

wire pass (met, metr, OM) calibru de / pentru sârmă

wire pickler (el) flux de decapat fire (electrice sau cele pt. sudare)

wire pin $(\mathrm{OM})$ cui de sârmă

wire plant (el) instalație electrică

wire pliers (mas-un, OM) clește de trefilat

wire plug (el, OM) fişă (de cablu)

wire reel (el, OM) tambur de sârmă

wire(-reinforced) glass (ind chim) sticlă armată cu plasă (metalică)

wire rod (met) talpă de sârmă, semifabricat rotund, subțire, metalic, material de adaos sub formă de sârmă (la recondiționări)

wire-rod-mill train (met) laminor de sârmă

wire-rod pass (met) calibru de sârmă

wire-rod rolling mill (met) laminor de sârmă

wire-rod rolling train (met) linie de laminat sârmă

wire rolling mill (met) laminor de sârmă

wire rope (mas, OM) cablu de oțel / de sârmă

wire-rope cableway (mas, transp) macara funiculară

wire-rope centre $(\mathrm{OM})$ inimă / miez de cablu

wire-rope pulley $(\mathrm{OM})$ roată de transmisie pentru cablu

wire-rope sheave $(O M)$ roată / şaibă pentru cablu de oțel

wire-rope stay $(\mathrm{OM})$ ancoră / opritor pentru cablu de oțel

wire ropeway (mas, transp) funicular, teleferic

wire rope with hemp centre $(\mathrm{OM})$ cablu din sârmă, cu miez de cânepă

wire screen (met) sită din sârmă

wire shaft $(\mathrm{OM})$ arbore flexibil

wire shears (mas-un, OM) foarfece de sârmă wire sheating (constr, met) armătură din sârmă wire shot $(\mathrm{OM})$ alice de sârmă

wire skinner (el) cleşte de dezizolat

wire spiral $(\mathrm{OM})$ spirală de sârmă

wire spiral reinforced hose (OM, hidr) furtun cu inserție de sârmă în spirală

wire spokes wheel (auto, OM) roată cu spițe de sârmă

wire spring $(\mathrm{OM})$ arc spiral

wire stich $(\mathrm{OM})$ agrafă (pt. hârtie)

wire stiching machine (mas) maşină de cusut cu sârmă (în poligrafie)

wire strainer (el) liță, sită de sârmă

wire strand (met, OM) fascicul / mănunchi de sârmă, toron de sârmă

wire stranding (met, $\mathrm{TH}$ ) torsadare, cablare wire stretch roll $(\mathrm{OM})$ valț de întindere (a sitei, a sârmei etc.)

wire stripper (mas-un, OM, el) dispozitiv / cuțit pentru îndepărtarea izolației de pe cablu

wire table $(\mathrm{OM})$ masă a sitei

wire trench (el, constr) şanț de cablu subteran

wire turn (el, OM) spiră de sârmă

wire twisting device (met, OM) dispozitiv de răsucit sârmă

wire type soldering tab (met, OM) vârf al ciocanului de lipit

wire welding machine (met, mas) maşină de sudare cu sârmă

wire wheel $(\mathrm{OM})$ roată cu spițe din sârmă

wire wheel brush (mas-un) perie-disc din sârmă

wire winding $(\mathrm{OM})$ spiră de sârmă

wire wool $(\mathrm{OM}$, alim) burete de sârmă (pt. curătat vesela)

wire working machine maşină de prelucrat sârmă

wirewound (metr, el) cu înfăşurare, de tip bobină, bobinat

wirewound barrel (met, OM) cilindru / buton / bucşă / manşon înfăşurat în sârmă

wirewound resistance / resistor (el) rezistență bobinată

wire-wound rheostat (el) reostat bobinat

wirewrapped rubber hose $(\mathrm{OM})$ furtun blindat / cu insertie de sârmă

wiring (el, autom) legare / cuplare / racordare la rețea, traseu de linie, conexiune, cablare, cablaj, instalație electrică, montaj, circuit, schemă, traseu de linie, cuplare / legare / racordare la rețea; (mec) cuplare; (auto) circuit(e)

wiring diagram (autom, el) schemă de montaj / de conexiuni (electrice)

wiring die (mas-un, OM) matriță de bordurat cu sârmă / de bercluit (tablă)

wiring harness (auto, el) cablu electric

wiring in circuit (el) instalație în tuburi izolante

wiring machine (mas-un) presă de bordurat, cu introducere a sârmei

wiring press (mas-un) presă de bordurat / de bercluit

wiring scheme (el, mas) schemă de conexiuni / de montaj

wiring tool (mas-un) matriță de îndoit marginile, cu introducerea sârmei

wiry $(\mathrm{OM})$ ca sârma, (ca) de sârmă, subțire şi flexibil, sârmos

wisdom înțelepciune, judecată, cumințenie, sagacitate; experiență a vieții; lucru înțelept; (edu) ştiință, învățătură, cunoştințe 
wise chip, fel, mod, manieră; înțelept, cu judecată, chibzuit, cu judecată, prevăzător, serios, cuminte, aşezat; ştiutor, cunoscător, avizat, informat; in no în nici un fel; in some într-o oarecare măsură, într-un anumit fel; alert, care cunoaşte mersul evenimentelor; a furniza cuiva date / informații pertinente

-wise (gram) arată direcția sau poziția / modul caracteristic, cu privire la, în ceea ce priveşte (în cuvinte compuse)

wisely $(a d v)$ (în mod) înțelept, cu înțelepciune, cu judecată; chibzuit, cuminte

wise up (amer) a informa, a încunoștința, a ști, a cunoaşte; a pricepe

wish dorință. plăcere; urare; a dori, a vrea; a ura wish for a-şi dori (ceva)

wishing dorință, vrere; urare; care doreşte / vrea wishy-washy (alim) fără gust, searbăd, fad; slab, apos; (fig) insipid, incolor, fără miez / conținut, şovăitor, neprecis, nehotărât, ezitant

wisp (fiz) mănunchi, legătură; funie, smoc

wispy (fiz) în mănunchi, înmănunchiat

with (prep) (arată instrumentul, mijlocul) cu; printre; de; împreună cu, laolaltă, alături de, de partea; având, care are; prin, datorită; în sprijinul; ca şi, la fel cu; cu, față de, în ceea ce priveşte, cât priveşte, privitor la, de; (rar) contra, împotriva; de, din cauza; cu; la; în ciuda, cu toate că; în grija, în sarcina; deal a avea treabă cu; child însărcinată; the object of în scopul de, cu, față de

withal $(a d v)$ în plus, în afară de acestea, pe lângă acestea, de asemenea, pe de altă parte, la acestea

with double tracks (cf) cu cale dublă

withdraw (TH) a (se) (re)trage, a scoate; (ec) a retrage, a scoate (bani); a retracta

withdraw from a se retrage din, a ieşi din, a renunța la

withdrawable (OM, mas) demontabil

withdrawal (constr, hidr) montare-demontare (la constructii provizorii); (TH) retragere, dare înapoi; retractare

withdrawal fork $(\mathrm{OM})$ furcă a dispozitivului de mutare (a curelei)

withdrawal lever $(\mathrm{OM})$ pârghie de comandă a ambreiajului / de mutare a curelei

withdrawal mechanism (met, $\mathrm{OM}$ ) mecanism de tragere (la turnarea continuă)

withdrawing device (mas-un, met) dispozitiv de descărcat, extractor

withdrawing rate (met) viteză de scoatere / de tragere (la turnarea continuă) withdrawing roll (met) cilindru de antrenare

wither a (se) veşteji, a (se) ofili, a (se) usca; (fig) a slăbi, a emacia, a îmbătrâni, a reduce la tăcere

witheredness / withering of grapes (agr, alim) stafidire a strugurilor

withering care veştejeşte / ofileşte / usucă; (fig) distrugător

with fixed ends (mec, OM) încastrat

withhold a refuza; a se abține de la; a renunța la; a reține, a opri (şi plăți); a ascunde

withhold from a se abține de la

withholding reținere

within (prep) în, înăuntrul, în interior; în casă; în cuprinsul, în raza, în cadrul, în limitele / limita; din interior; în, până (în), nu mai târziu de, la nu mai mult de, între; $(s)$ parte anterioară; $(a d v)$ înăuntru, în interior, acasă; hearing în raza auditivă (a cuiva); it is true limits este adevărat într-o anumită măsură; a distance pe o distanță, până în distanța de with navigation (auto, inf) cu sistem de navigație, cu GPS

with one accord (pol, adm) unamim, în unanimitate

with one arm $(\mathrm{OM})$ cu un singur brat

without (prep) afară de, afară din, fără, dincolo de, depăşind cadrul de; $(a d v)$ în afară, în exterior, la exterior, pe dinafară, la suprafață, afară, în aer liber, pe stradă; lipsit de, care nu are; (conj) fără ca să, afară numai dacă; from $\sim$ dinafară

without current (el) fără curent

without failure (OM, mas) fără a se deteriora, fără a se defecta, fără a cădea

without rupture $(\mathrm{OM})$ fără a se rupe, fără a apare ruperea, fără rupere

with safety (mas, TH) fără niciun risc, fără riscuri, în siguranţă

with solid web $(\mathrm{OM})$ cu inimă (miez) plin(ă), masiv

withstand a rezista, a se opune, a se împotrivi with two (three) steps $(\mathrm{OM})$ cu două (trei) trepte witness martor (şi ocular), mărturie, probă, dovadă; a fi martor, a asista la, a observa; a dovedi; (jur) martor, a afirma / atesta ca martor

witness against / for (jur) a depune mărturie împotriva / pentru

witness sample (metr, OM) probă / epruvetă martor

witness point (mec) punct de reper

wizen (bot, silv) a veşteji, a (se) ofili, a (se) usca; a seca

wK (worked) (TH) prescurtare pentru prelucrat 
wKe (cold worked) $(\mathrm{TH})$ prelucrat la rece wKh (hot worked) $(\mathrm{TH})$ prelucrat la cald wobble (mas, OM) mişcare neuniformă, bătaie, oscilare, a funcționa cu impulsuri / neuniform

wobble meter (metr, fiz, mec) aparat de înregistrat vibrații

wobbler (met) treflă (la cicluri de laminare)

wobbler shaft $(\mathrm{OM}$, mas) arbore cu came

wobbling (mas, OM) funcționare neuniformă /

cu şocuri, bătaie, mişcare a unui disc cu supra-

față frontală neperpendiculară pe axă

wobbly care şchioapătă, nesigur, şovăitor, nestabil; inegal

wolfram (W) (chim) wolfram, tungsten

wolframite (chim) wolframit

wonder uimire, mirare, surprindere; a se întreba

wonder at a se mira de, a fi uimit / surprins de

wont obişnuit (rar); (edu) obicei, obişnuință, deprindere; a fi deprins / obişnuit, a obişnui

wonted to obişnuit / deprins să

wont to a obişnuui / deprinde să (facă ceva), a se deprinde, a se obişnui să (facă ceva)

wood (silv) pădure, lemn, material lemnos, lemne de foc; de / din lemn; (alim) butoi (de lemn)

wood alcohol (auto, ind chim) metanol; alcool metilic

Wood('s) alloy (met) aliaj Wood (Bs $+\mathrm{Pb}+\mathrm{Sn}$ $+\mathrm{Cd})$

wood beam (OM, constr) grindă de lemn

wood bit (mas-un) burghiu pentru lemn

woodblock (constr, silv) pavea de lemn, butuc, buştean

wood borer (zool, silv) gândac de scoarță

wood-boring drill (mas-un) burghiu pentru lemn; (zool, silv) carii

wood box / case (OM) ambalaj de lemn; cutie

wood chip $(\mathrm{TH})$ aşchie de lemn

wood chips $(\mathrm{TH})$ talaş

wood chisel $(\mathrm{OM})$ daltă de lemn

wood coal (termo) cărbune de lemn, lignit

wood covering $(\mathrm{OM})$ căptuşeală de lemn

wood drill (mas-un) burghiu pentru lemn

wood dust (ind, TH) rumeguş, făină de lemn

wood dye (chim) colorant vegetal

wooden (silv, mobilă, $\mathrm{OM}$ ) din lemn, de lemn, lemnos

wooden beading material $(\mathrm{OM})$ grătar de lemn wooden building (constr) constructie din lemn wooden container $(\mathrm{OM})$ ambalaj de lemn wooden dowel (OM) cui / diblu de lemn wooden frame $(\mathrm{OM})$ cadru de lemn wooden gauge (met, OM) tipar / şablon de lemn (şi la turnătorie) wooden hammer $(\mathrm{OM})$ ciocan pentru lemn wooden mast (constr) stâlp de lemn wooden nail $(\mathrm{OM})$ cui de lemn wooden peg (constr) stâlp de lemn wooden plate $(\mathrm{OM})$ placă de lemn wooden pole (constr) stâlp de lemn wooden shield (ind chim) protecție a lemnului wooden slepper (cf, OM) traversă de lemn wooden stake (constr) stâlp de lemn wooden tank $(\mathrm{OM})$ rezervor de lemn wooden edge $(\mathrm{OM})$ pană de lemn wood fiber (ind) fibre / fibră de lemn wood flour (ind, mobilă) rumeguş, fãină de lemn wood frame (constr, OM) cadru / grindă de lemn wood impregnation (ind chim) impregnare a lemnului

wood joint $(\mathrm{OM})$ îmbinare în lemn

wood lath $(\mathrm{OM})$ şipcă

wood lining (OM, constr) căptuşeală de lemn wood material (silv) material lemnos

wood milling cutter (mas-un) freză pentru lemn wood packing piece $(\mathrm{OM})$ piesă lemnoasă de umplutură, lemn de căptuşit

wood panclling $(\mathrm{OM}$, constr) căptuşeală / acoperire de / din lemn

wood pattern shop (met, silv) tâmplărie de modelărie

woodpile stivă (de lemne)

wood pitch (silv, chim) răşină naturală

wood planing machine with cutter holder (masun) maşină de rindeluit, cu disc port-cuțit

wood plug (OM) cep de lemn

wood power (ind, $\mathrm{TH}$ ) rumeguş, făină de lemn

wood pulley $(\mathrm{OM})$ roată de lemn, pentru curea wood pulp (ind chim) celuloză / pastă de lemn

wood rafting plutire a lemnului

wood-refuse (ind, mediu) deşeuri de lemn

wood resin (silv, chim) răşină, colofoniu, sacâz

Woodruff key $(\mathrm{OM})$ pană semirotundă, panădisc

Woodruff key cutter (mas-un) freză pentru pene Woodruff / semirotunde / disc

wood sanding machine (mas-un) maşină de rindeluit-răzuit

wood saw (mas-un) fierăstrău pentru lemn

wood scraps (ind, mediu) deşeuri / pierderi de lemn

wood screw $(\mathrm{OM})$ şurub pentru lemn, hol-şurub wood shavings (ind, mediu) talaş

wood shoring (constr, OM) cofraj de lemn

wood spirit (ind chim) alcool metilic

wood splinters (ind, mediu) țăndări / aşchii de lemn 
wood stack stivă (de lemne, de semifabricate din lemn)

wood store, wood-store (constr) depozit de lemn wood structure (silv) structură a lemnului wood tin (minrl) casiterit

wood turner (ind, $\mathrm{TH}$ ) strungar (pt. lemn)

wood turning lathe (mas-un) strung pentru lemn

wood-waste (ind, mediu) deşeuri de lemn

wood wool lână de lemn

wood wool making machine (mas) maşină de fabricat lână de lemn

woodwork (constr, OM) construcție / piesă / piese de lemn, tâmplărie, dulgherie, parte din lemn

woodworker (ind, TH) tâmplar, dulgher, strungar în lemn; tâmplărie, parte din lemn

wood working (mobilă) prelucrare a lemnului

woody (silv) cu păduri, împădurit; de pădure; de lemn, lemnos

woody structure (materiale) structură în straturi / şistoasă / ca de lemn

woof (textile) fir de bătătură

woofer (el, autom) amplificator de frecvente / tonuri joase

wool (textile) lână, fir / stofă / îmbrăcăminte de lână

wool-and-cotton union (textile) amestec textil de lână şi bumbac

wool fat (chim) lanolină

wool grower (agr) crescător de oi

woolen (textile) de / din lână

woolens (textile) confecții din lână

wool scouring-and-drying set (textile, mas) agregat de spălat şi uscat lâna

wooly cu lână, lânos; pufos; (fig) confuz, neclar, încurcar, vag; (amer) grosolan, aspru; îmbrăcăminte de lână, pulover de lână, tricotaj

word cuvânt, promisiune; vorbă, ştire, veste; ordin; (metr, c) unitate de informație la tastarea unui text; viteza de tastare se exprimă în words per minute (wpm) - cuvinte pe minut, cuvântul fiind considerat ca având 5 caractere (inclusiv spații); (metr, c, inf) cuvânt, unitate pentru informație, reprezentând deseori datele procesate cu o singură instrucțiune, mărimea unui cuvânt în bits fiind $\mathrm{o}$ caracteristică a computerului

word book dicționar, vocabular, glosar

word-for-word cuvânt cu cuvânt, literal

wording (mod de) exprimare (în scris), redactare, formulare; legendă (sub o figură)

wordlessly fără cuvinte; mut, tacit world wide $(a d v)$ in lumea intreaga

World Wide Web (WWW, Web) (c, inf) un sistem urias de informatii legate între ele ca intr-o pinza de paianjen

work funcționare, funcțiune, acțiune, lucrare, lucru; faptă; (ec, adm) sarcină, obligație (şi de serviciu), muncă, activitate, treabă, preocupare, ocupație, însărcinare, datorie; produs, operă; lucru de mână; $(\mathrm{OM})$ piesă (şi de prelucrat), produs, rezultat, fabricat; a munci, a exploata, a lucra, a avea de lucru, a fi în activitate; (TH) a prelucra, a fabrica, a modela, a da (o anumită formă), a confecționa, a funcționa, a merge, a mişca, a pune în mişcare, a acționa, a manipula, a produce; (fiz) a determina, a cauza (şi o schimbare); (nav) a obosi (nava), a naviga (cu vele); (fiz) lucru mecanic; (fig) a fi bun, a izbuti, a reuşi, a avea efect, a fi eficace; (textile) a lucra, a tricota, a broda, a coase, a împleti; (alim) a bate untul, a face să fermenteze

workable $(\mathrm{TH})$ prelucrabil (d. materiale, senmifabricate)

workableness, workability aplicabilitate; utilitate, folos; (TH) capacitate de a fi prelucrat / de a se prelucra, uzinabilitate, prelucrabilitate (în general sau cu un anumit procedeu, de exemplu, prin aşchiere), aptitudine la fasonare; (constr, mec) lucrabilitate

work annealing (met) recoacere intermediară (pt. prelucrare prin aşchiere)

work area (mas-un) suprafață de lucru / de prelucrat

work bench $(\mathrm{OM})$ banc / masă de montaj / de lucru, masă de tâmplărie

work between centres (mas-un, $\mathrm{TH}$ ) prelucrare cu prindere între vârfuri

workbook manual, îndreptar, (broşură cu) instrucțiuni (de folosință / de funcționare); culegere de exerciții; agendă, blocnotes

workboot bocanc, sabot (la locul de muncă)

work by (ec) contract; (ec, contr) antrepriză

work carrying head (mas-un, OM) dispozitiv / cap de prindere

work centre arm head (mas-un, OM) contrasuport, brat

work centres (mas-un) vârfuri pentru aşezarea semifabricatului

workday $(\mathrm{ec})$ zi de lucru / de muncă

work done $(\mathrm{TH})$ realizare, randament (rar), lucru mecanic

work down (mas-un) prelucrare (cu trecere) la o dimensiune mai mică

work drawing $(\mathrm{OM})$ desen de execuție 
work driving arm (mas-un, OM) bolț de antrenare

worked $(\mathrm{OM})$ prelucrat, lucrat; (textile) brodat

worked penetration ( $T$, ind chim) penetrație după solicitare (mecanică) (d unsori)

worked rubber (ind chim) cauciuc plastifiat (prelucrat)

worked state (OM, materiale, $\mathrm{TH})$ (în) stare prelucrată

worked state tyre $(\mathrm{TH})$ bandaj în stare prelucrată, pentru roți

worker (ec) muncitor, lucrător, mână de lucru

worked-hardened steel (met) oțel ecruisat

work force (ec) forță / mână de lucru

work hardening (mec, $\mathrm{TH})$ ecruisare, durcisare

work hardness (met) duritate la / după ecruisare

workhead (mas-un, OM) păpuşă a piesei (şi la maşini de rectificat)

workhead transformer (el) transformator de adaptare

work-in $(\mathrm{adm}, \mathrm{ec})$ ocupare forțată a unei fabrici de către muncitori

work in a introduce, a insera, a fi inserat, a (se) strecura

working (mas) regim de lucru, funcționare, exploatare, lucru; activ, muncitor, harnic; lucrător, de lucru, (în) care (se) lucrează, în activitate, care (mai) lucrează, care funcționează, în functiune, în vigoare; (met) elaborare (a şarjei), mers (al furnalului); (TH) prelucrare, muncă, forță, activitate, exploatare, serviciu, funcționare, regim de funcționare, în funcționare, activ, care acţionează; (agr) cultivare, cultură

working agent (termo) agent de lucru

working beam $(\mathrm{OM})$ balansier

working bench $(\mathrm{OM})$ masă de lucru

working by cart (constr, OM) transportor cu roabă

working capacity (ec) capacitate de muncă / de lucru / utilă, randament

working capitol (ec) fond / capitol de rulare, fond de rulment

working characteristic (mas) caracteristică de functionare, regim de lucru

working condition (mas, $\mathrm{TH}$ ) condiție / regim de lucru

working current (el, autom) curent de regim / de actionare

working curve (autom, mas) curbă caracteristică

working cycle (termo) ciclu (termodinamic); (mas, mas-un) ciclu motor, fază activă

working day, workday (ec) zi de muncă / lucru working depth of tooth $(\mathrm{OM})$ înălțime utilă (de angrenare) a dintelui

working drawing (OM, mas-un, $\mathrm{TH})$ desen de execuție, desen tehnologic / specific operației de prelucrare

working efficiency $(\mathrm{ec})$ productivitate a muncii working element $(\mathrm{OM})$ organ de lucru

working expenses (ec, ind, $\mathrm{TH})$ cheltuieli de exploatare / de prelucrare

working face (mas, mas-un) suprafață de lucru

working flank (OM) flanc de lucru (al unui dinte la o roată dințată)

working gauge (mas-un) calibru de lucru

working gear $(\mathrm{OM})$ transmisie de acționare

working the heat (met, $\mathrm{TH}$ ) elaborare a şarjei (prin dirijarea căldurii / temperaturii)

working hours (mas) timp de lucru / de exploatare / de functionare

working instruction (mas, $\mathrm{TH}$ ) instrucțiuni de exploatare / de utilizare

working joint (constr) rost de lucru

working knowledge cunoştințe practice

working length (mas-un) lungime utilă / de lucru

working level (WL) (metr, fiz, med) nivel de expunere, unitate de măsură a expunerii la radiații ale radonului, reprezentând o concentrație de produse de dezintegrare a radonului, cu durată scurtă de viață, într-un litru de aer, a cărui emisie rezultantă este de $1,3 \cdot 10^{5} \mathrm{MeV}$ sau $20,8 \mathrm{~nJ}$

working level months (WLM) (metr, fiz, med) luni de expunere, unitate de măsură pentru expunerea cumulativă la radiații: 1 working level months reprezintă o expunere la 1 working level pentru 170 ore; v. working level

working life (ind, transp) durată de funcționare de viață / de utilizare (d. o piesă, o asamblare, o maşină etc.), durabilitate

working line (mec) direcție de acțiune a unei sarcini; (nav) parâmă de legare

working load (mec, mas) sarcină utilă de lucru / de regim, admisibilă

working loss (mec) pierdere a lucrului mecanic working man $(\mathrm{ec})$ muncitor, lucrător

working material (ind, $\mathrm{TH}$ ) materie primă, material de prelucrat

working medium (termo) agent de lucru

working methode metodă de lucru / de exploatare, procedeu (şi de prelucrare)

working motion $(\mathrm{mec})$ mișcare de lucru / principală (şi la maşini-unelte)

working of heat (met, termo) dirijare a cuptorului 
working operation (mas-un) operație / cursă de lucru, cursă utilă

working order (mas) stare / capacitate (bună) de funcționare

working-out elaborare amănunțită, calcul exact (d. proiectare); epuizare, exploatare masivă

working part $(\mathrm{OM})$ parte activă / de lucru, element de lucru / activ

working parts (mas-un, TH) faze în procesul de prelucrare

working party (ec, TH) comisie / comitete de lucru

working piece (mas-un, Om) semifabricat, piesă de prelucrat

working pit (auto, met) canal de inspecție

working place (mas-un, constr, ind) loc / spațiu de lucru

working plane (mec, mas-un) suprafață activă de lucru

working point (mec) punct de aplicare a forței; (autom) punct de funcționare

working points $(\mathrm{cf})$ mers în trepte

working position (mas-un) poziţie de lucru

working pressure (hidr, mas) presiune de lucru / de regim / de serviciu

working pressure angle $(\mathrm{OM})$ unghi de angrenare / de presiune pe cercul de rostogolire $\left(\alpha_{\mathrm{w}}\right)$

working programme (ec, $\mathrm{TH}$, constr) plan de lucru

working radius (mas) rază de acțiune

working resistance (mas-un, materiale) rezistență în prelucrare (la aşchiere, ambutisare etc.)

working roll (met, OM) cilindru de lucru / activ / care lucrează

working scheme (mas, TH) schemă a reglării, schemă a procesului de prelucrare, fişă tehnologică

working service (mas) durată de exploatare / de serviciu; durabilitate ( $r a r)$

working shift (ec, ind) schimb / echipă de muncitori

working shoes (ind) încălțăminte de protecție

working space (ind, mas) spațiu de lucru (al unei maşini)

working stand(s) (met) cajă / caje care lucrează

working standard (metr) etalon de lucru / de verificare

working steam (termo) abur viu / direct

working storage (c, inf) memorie de lucru

working stress $(\mathrm{mec}, \mathrm{OM}, \mathrm{T})$ tensiune utilă, efort unitar care solicită ceva

working stroke (mas-un) cursă utilă / de lucru working surface (OM, mas-un) suprafață de lucru

working table (mas-un, OM) masă-suport pentru semifabricat

working temperature (termo, T) temperatură de regim / în exploatare

working tension (el) tensiune de sarcină; (mas, mec) presiune de lucru

working time (mas) durată / timp de funcționare / de serviciu

working transverse pressure angle $(\mathrm{OM})$ unghiul de angrenare frontal pe cercul de rostogolire $\left(\alpha_{\mathrm{wt}}\right)$ (d. roți dințate cu dinți înclinați)

working up (TH) prelucrare, fasonare (la lemn) working voltage (el) tensiune utilă / efectivă / de regim / de lucru

working volume (transp, $\mathrm{TH}$ ) volum util

working week (ec) săptămână de lucru

working winch $(\mathrm{OM})$ troliu de manevră

working with (an acid) a basic slag (met) topire sub zgură (acidă) bazică

working woman (ec, ind) muncitoare, lucrătoare, operatoare

work into a introduce, a insera, a strecura (şi într-un text)

work in with a se încadra în muncă pe lângă / $\mathrm{cu}$

work life timp de lucru / de reglare (a unei maşini, timp de asamblare

workman (ec, ind) muncitor, meseriaş, lucrător

workmanship (TH, edu) calificare, abilitate profesională, calitate a execuției, pricepere, meşteşug; (TH) execuție, executare; lucrare, lucrări

work of / for acceleration (mec) lucru mecanic de accelerare

work of (for) braking (mec) lucru mecanic de frânare

work of (for) deformation (mec, $\mathrm{TH}$ ) lucru mecanic de deformare

work off (ind) a extrage

work of friction (mec, T) lucru mecanic de frecare / consumat prin frecare

work of ideal cycle (mec) lucru mecanic fără pierderi / pentru un ciclu ideal

work of resistance (mec, T) lucru mecanic rezistent

work on arbour (mas-un, $\mathrm{TH}$ ) prelucrare pe dorn work order $(\mathrm{adm}, \mathrm{ec})$ fişă / dispoziție / ordin de lucru

work on a solicita; a prelucra (şi un text)

work-out (sport) antrenament, încălzire; (ec) termen / durată / perioadă de probă / încercare 
work out a corespunde, a fi conform / corespunzător; a calcula (un rezultat), a rezolva o problemă; a se aplica, a da un rezultat; a exersa, a face exerciții; $(\mathrm{TH})$ a prelucra (şi prin aşezarea piesei pe un dorn); a revizui, a îmbunătăți, a elabora în amănunt; (adm) a redacta un document; a realiza, a efectua, a duce la bun sfârşit

work out $(\mathrm{TH})$ a sfârşi, a termina de prelucrat (o piesă), a elabora, a prelucra

work out for (OM, TH, mas) a fi bun / corespunzător pentru

work out at / to a se ridica la, a totaliza (o sumă)

workpeople (ec, ind) muncitori

work performed during expansion (termo) lucru mecanic de expansiune

work piece (mas-un, OM) piesă de prelucrat, semifabricat

work proceeding $(\mathrm{TH}$, ec) grafic de lucru / de muncă, metodă de lucru

work progress slip (ec) caiet de sarcini, notă de însoțire

work rest (mas-un, OM) suport al piesei (şi la rectificare fără vârfuri)

work roll (met, OM) cilindru activ / de lucru

workroom (ind, constr) cameră de lucru, atelier, laborator

works (ind) uzină, ateliere, fabrică

works council (adm, ec) comitet de întreprindere (format din reprezentanți ai muncitorilor şi ai conducerii)

works engineer (ind) inginer de exploatare

work scrap (met) fier vechi; (ind) deşeuri din circuitul de fabricație

work shift (ec, ind) schimb de muncitori

workshop (ind) atelier / secție într-o uzină (şi de reparații); (ec) întreprindere; (constr) şantier; (edu, univ) grupă (de studenți, seminar, cerc

workshop lorry / truck (auto) atelier mobil

workshop wag(g)on (cf) vagon atelier

works management $(\mathrm{ec}, \mathrm{adm})$ administrație a uzinei / a şantierului

works manager (ec) manager / director de uzină

worksheet (inf, birotică) pagină / format / formular (şi virtuală) de lucru

work softening (materiale) înmuiere la prelucrare / la deformare, scădere a limitei de curgere din cauza deformării (la cald sau la rece)

works organisation $(\mathrm{ec})$ organizație economică în industria prelucrătoare, organizare a uzinei / a şantierului

work's test certificate (metr, adm) certificat de încercări la nivel de uzină

work table $(\mathrm{OM})$ masă de lucru work the ship (nav) a manevra nava

work throught $(\mathrm{TH})$ a prelucra complet, a transforma

work together (pol, ec) a coopera, a colabora

work up a (se) urca, a face să avanseze / înainteze, a urni, a finisa; a da o formă, a modela; a dezvolta, a elabora; a cerceta / studia temeinic; a promova, a face să crească; a dobândi cu greu work up to a se apropia de, a ajunge la (o valoare etc.); a se pregăti

work voltage (el) tensiune de lucru

workweek, work week (metr, ec) săptămână de lucru, unitate de timp de $35 . .40$ de ore de lucru, repartizate într-o săptămână, conform legii; (metr) unitate egală cu numărul de zile lucrătoare dintr-o săptămână (4...6 zile de lucru)

workwoman (ec, ind) muncitoare, lucrătoare

world lume; pământ, omenire, oameni; loc de existentă; cercuri; cosmos; (stare de) existență; (biol) regn, lume; sferă; sistem planetar; societate; treburi lumeşti; univers; viață; (adj) mondial, universal, a / al / ale lumii

world market (ec) piață mondială

World Health Organization Organizația Mondială a Sănătății

worm (alim, OM) serpentină (de alambic); (zool) vierme, omidă, larvă; (mas-un, OM) melc (într-un angrenaj), şnec, spirală, şurub fără sfârşit, canal elicoidal; a se târâ, a merge greu, a înainta ca un vierme

worm and steering roller / gear (auto, OM) casetă / mecanism de direcție cu şurub şi deget (sau piuliță / rolă)

worm and sector steering gear (transmission) (auto, OM) transmisie cu melc şi sector dinţat

worm and wheel $(\mathrm{OM})$ angrenaj melc-roată melcată

worm and wheel drive (mas, $\mathrm{OM}$ ) actionare cu angrenaj melcat

worm baring gear (mas, OM) angrenaj cu melc pentru întoarcerea volantului

worm chain block $(\mathrm{OM})$ palan cu melc

worm condenser (ind chim) condensator cu serpentină

worm conveyer / conveyor (alim, mas, transp) transportor elicoidal

worm cutter (mas-un) freză-melc

worm drive $(\mathrm{OM})$ angrenaj melcat, acționare elicoidală

worm drive of rear axle (auto, $\mathrm{OM}$ ) actionare melcată a punții din spate

worm-driving gear $(\mathrm{OM})$ angrenaj melcat (cu melc la intrare), reductor melcat

worm-eaten wood (silv) lemn cariat 
worm-elevator (mas, alim, transp) elevator / transportor elicoidal / cu melc

worm feed (mas-un, alim) alimentator cu şurub / cu melc

worm gear $(\mathrm{OM})$ angrenaj melc-roată melcată, angrenaj melcat; (auto, OM) direcție cu angrenaj melcat / cu şurub fără sfârşit (rar); (alim) transmisie cu şnec / cu melc

worm gear drive $(\mathrm{OM})$ transmisie / acționare $\mathrm{cu}$ angrenaj melcat

worm gearing $(\mathrm{OM})$ transmisie elicoidală / melcată

worm gear pair $(\mathrm{OM})$ angrenaj melc-roată melcată

worm-gear spindle (mas-un, OM) fus filetat, şurub de transmisie

worm gear steering (auto) direcție cu melc / cu angrenaj melcat

worm grinder / grinding machine (mas-un) maşină de rectificat şuruburi şi melci

worm hob (mas-un) freză-melc

worm hobbing machine (mas-un) maşină de frezat roti melcate

worm hole (met) sufluri tubulare sau răsucite (şi la / după sudare) (defecte)

worm in a pătrunde, a se strecura (greu)

worm milling-cutter (mas-un) freză-disc de prelucrat şuruburi-melc

worm milling machine (mas-un) maşină de frezat şuruburi-melc

worm press (mas-un) presă cu şurub

worm rack $(\mathrm{OM})$ cremalieră a melcului (din angrenajul melcat)

worm reducer $(\mathrm{OM})$ reductor melcat

worm screw $(\mathrm{OM})$ șurub fără sfârşit / de mişcare, melc

worm sector (OM, auto) sector dințat din caseta de direcție

worm shaft $(\mathrm{OM})$ arbore al melcului

worm thread $(\mathrm{OM})$ filet al melcului

worm thread cutter (mas-un) freză-melc

worm wheel $(\mathrm{OM})$ roată melcată

worm-wheel drive (mas, OM) transmisie / acționare melcată

worm with involute profile $(\mathrm{OM})$ melc cu profil evolventic (la dinte)

wormy vermiform, vermicular, (ca) de vierme; (agr, bot) viermănos, cu viermi; învechit, perimat, scos din uz, demodat

worn (T, OM) uzat, tocit; (auto) (d. centură) legată, fixată; (textile) ponosit, purtat, uzat; v worn-out; time blazat, de veacuri, (fig) demodat, învechit, afectat de timp / vreme, ros, secular, venerabil; toil- epuizat, extenuat, istovit, surmenat; travel- istovit / obosit de drum; war- (mil, ec) care a suferit de pe urma războiului, distrus / epuizat din cauza războiului; banalizat, perimat (d. expresii); all out complet epuizat, frânt (de oboseală) (d. o persoană); be $\sim$ to a frazzle a fi frânt de oboseală (d. o persoană); be worn to rags (textile) a ajunge numai zdrente; care- ros de griji; shop v. wellworn; travel- ros de pe urma călătoriilor (d. haine); weather- v. weather-beaten; wellros, uzat, ponosit (d. haine)

worn bearing $(\mathrm{OM}, \mathrm{T})$ lagăr uzat

worn car (auto) automobil la a doua mână (folosit, dar încă folosibil)

worn component $(\mathrm{OM}, \mathrm{T})$ piesă / componentă uzată

worn engine (mas, $T$ ) motor uzat

worn-in $(\mathrm{T}, \mathrm{OM})$ rodat (rar)

worn-off $(T, O M$, textile) uzat

worn-out $(T, O M)$ uzat (prin îndepărtare de material), tocit, epuizat (d. o soluție tehnologică, un fluid tehnic etc.), scos din uz; demodat, doborât, epuizat, extenuat, foarte obosit, frânt (d. o persoană); învechit, perimat; v. worn

worry îngrijorare, grijă, nervozitate; a (se) supăra, a da bătaie de cap, a (se) îngrijora, a deranja, a nu lăsa în pace, a se enerva

worry at a se chinui (cu o problemă), a încerca să rezolve (o problemă)

worry out a plictisi, a nu lăsa în pace; a rezolva o problemă, a invinge (o dificultate)

worse mai rău, mai prost, mai slab

worsen a (se) înrăutăți, a (se) agrava; a prezenta într-o lumină nefavorabilă

worst cel mai rău, cel mai prost

worsted (textile) (stofă din) lână pieptănată

wort (alim) plamadă dulce

wort (beer) (alim) must (de bere) (dulceag)

worth (ec și fig) valoare, preț; (ec) cantitate corespunzătoare unui preț, număr corespunzător unui preț; care dispune de (bani), care valorează / merită; (mat) valoare (în teoria jocurilor); (fig) care merită, vrednic de (amintit etc.)

worthful vrednic, valoros, pretios

worthily $(a d v)$ după merit, pe bună dreptate, demn worthiness demnitate, valoare, respectabilitate

worthless fără valoare, lipsit de valoare, inutil, fără rost

worthlessly $(a d v)$ (în mod) inutil

worthlessness lipsă de valoare, inutilitate

worthwhile care merită să fie făcut, care are valoare / sens, valoros 
worthy of demn de laudă, lăudabil, care merită, după merit, corespunzător, adecvat

wortle (mas-un, OM) filieră

would-be pretins, aşa-zis, imaginar, prefăcut, de paradă

wound (med) rană, plagă, rănire, cicatrice, a răni; (el) bobinat, înfăşurat; tăietură, crestătură (în lemn etc.); (agr) a sacrifica; (fig) jignire, ofensă, rană, rănire, afront; (fig) a jigni, a lovi în, a ofensa, a răni; perforating $\sim$ (med) plagă perforată; flesh $\sim$ (med) rană superficială (care nu atinge osul); up adus într-o stare de mare tensiune; space- (el) bobinat cu interval / cu spațiu, înfăşurat cu interval / cu spațiu; shunt- (el) bobinat în derivație, cu excitație în deri-vație; apply some medicine to smb.'s $\sim$ (med) a aplica un medicament pe rana cuiva; put stitches in $\mathbf{a} \sim$ (med) a coase o rană

woundable vulnerabil

woven (textile) țesut; colour- țesut din fire vopsite; hose $\sim$ around with wire (OM, auto, hidr) furtun armat, tub blindat flexibil

woven belt $(\mathrm{OM})$ curea țesută

woven fabric (textile) țesătură

woven resistor(s) (el) rezistor de încălzire cu tesătură metalică

woven rotor (el, OM) rotor bobinat, cu inele de contact

woven sheet (el, OM) bandă (de tablă) / țesătură cu rezistență electrică

woven wire tesătură de sârmă

wove paper (ind chim) hârtie velină

W-parameter (metr) parametru W (de ondulatie) (la profilometria suprafeței)

wp (waterproof) prescurtare pentru impermeabil, rezistent la apă (d, materiale, elemente de maşini)

wrack (materiale) vrac; (nav) obiect aruncat pe țărm; (bot) algă marină aruncată pe țărm, iarbă de mare; distrugere; nimicire; (păstrat in) ruină; put / bring to a nimici, a distruge; go to $\sim$ a pieri, a se distruge; $\sim$ and ruin distrugere totală, nimicire

wrap (OM) învelitoare, manta; (textile) palton, şal, fular, mata; a (se) înfăşura, a învălui; a (se) înveli, a înfofoli, a (se) acoperi; a ascunde; a ambala, a împacheta, a face un pachet; (fig) a ascunde, a acoperi, a învălui

wrap-around (inf, c) întoarcere a imaginii, a întoarce o imagine, afişare în anumite puncte ale ecranului a unor elemente grafice ale căror coordonate se află în afara suprafetei acestuia, întoarcere a imaginii, patru pagini cu ilustrații tipărite separat de text şi prinse în legătură; (poligrafie) planşse intercalate

wrappage $(\mathrm{OM})$ înveliş, învelitoare; copertă; sul, pachet, obiect împachetat

wrapped up in cufundat în muncă, absorbit de, amestecat în, implicat în

wrapped wire $(\mathrm{OM}, \mathrm{el})$ sârmă / conductor în$\operatorname{velit}(\breve{a})$

wrapper $(\mathrm{OM})$ înveliş, învelitoare; (poligrafie) supracopertă, banderolă, şuviță, rădăcină; dosar; (mas) maşină de înfăşurat; (textile) husă, halat

wrapping $(\mathrm{OM})$ garnitură de etanşare (rar); înfăşurare, armare, împachetare, învelire, material de împachetat

wrapping angle (mas-un) unghi de înfăşurare de cuprindere

wrapping machine (met, mas) maşină de înfăşurat (şi rulouri de tablă)

wrapping paper (ind chim) hârtie de ambalaj / de împachetat

wrapping up (TH) învelire, înfăşurare, bobinare wrap round a înfăşura, a înveli jur-împrejur wrap up a ambala; a ascunde wreath $(\mathrm{OM}$, constr) coroană

wreathe a împleti, a (se) răsuci, a înfăşura, a înveli, a acoperi, a învălui, a (se) încolăci, a înconjura

wreathed împletit, încolăcit

wreck (nav) epavă, eşuare, naufragiu, a face să eşueze / naufragieze; resturi, rămăşiţe; (mas) avarie, accident; ruină; a distruge (un plan); (constr) a dărâma, a demola; (TH, OM, mas) a demonta

wrekage (nav) rămăşite de vas (după naufragiu), epavă; (constr) dărâmături

wreck buoy (nav, OM) geamandură de epavă

wrecked (nav) naufragiat; (mas, nav) avariat

wrecker reparator; (auto) (amer) camion de depanare; (nav) salvator; a dărâma, a demonta, a demola; distrugător, spărgător, tehnician specializat în demolări

wrecking (constr, ind) sfărâmare, spargere, distrugere, stricare, demontare, demolare, dărâmare; (nav) tăierea navei pentru fier vechi

wreching bar $(\mathrm{OM})$ rangă

wreching car (auto, TH) automobil de depanare wrench $(\mathrm{OM})$ cheie fixă (de / pentru piuliță); smulgere, tragere, apucare (violentă), răsucire; a smulge, a scoate cu forța; (med) scrântire, luxație, a scrânti, a luxa (încheietura mâinii); a răsuci; (fig) a denatura

wrench hammer (met, OM) cheie de strâns prin lovire 
wrench sizes (metr, OM) mărimi pentru cheie (de montare / demontare a asamblărilor); în US mărimile de cheie sunt în fracții de inch sau în multipli de 1/4 inch, în sistemul metric, mărimile pentru cheie sunt în $\mathrm{mm}$

wrest a smulge (cu forța); (jur) a denatura, a interpreta (o lege) în favoarea cuiva

wriggle încovoiere, răsucire, contorsiune, şerpuitură, şerpuire, cotire; a merge şerpuit / în zigzag, a se încolăci, a se (ră)suci, a se strecura, a (se) face ghem

wriggle out of a se eschiva de la

wring $(\mathrm{TH}$, alim, textile) sucire, răsucire; stoarcere, presare; a (se) răsuci, a stoarce (rufe, fructe etc.); a căpăta cu greu; a denatura

wringer (textile, OM) storcător (de rufe)

wringing fit $(\mathrm{OM})$ ajustaj intermediar, cu joc zero până la strângere uşoară

wrinkle cută, încrețitură; a încreți; a şifona, a se cuta, a (se) încreți (d. semifabricate subțiri, folii, textile etc.)

wrinkled, wrinkly cu încrețituri, zbârcit, cutat, încrețit(d. semifabricate subțiri, folii, textile etc.); (anat) cu riduri

wrinkle-resistant (materiale) rezistent la cutare / la şifonare

wrinkling $(\mathrm{TH})$ cutare, încrețire

wrist (anat) articulația radio-carpiană, carp, încheietură a mâinii;; (textile) manşeta

wrist pin $(\mathrm{OM})$ bolț de piston / de cap de cruce

wrist pin end of the pitman $(\mathrm{OM})$ parte inferioară a bielei

writ (pol) ordonanță; (jur) citație, hotărâre judecătorească, dispoziție

write a scrie, a redacta, a compune; (inf, c) a transfera date; (ec) a completa un cec; (c) scriere (pe un suport extern); a se (auto)intitula, a-şi spune (profesor etc.); a înregistra date (în registru, într-o locatie, pe un suport etc.); a fi scriitor; (c) a transfera (din memoria internă în cea externă); serve a on smb. (jur) a înmâna cuiva o citație / o notificare / o somație; $\sim$ smth. into a document a adăuga ceva într-un act / document (o clauză etc.)

write a good (edu) a avea o scriere frumoasă write away for $(\mathrm{ec})$ a comanda în străinătate / într-o localitate îndepărtată (o carte etc.)

write back a răspunde la o scrisoare; rescriere

write clock pulse (autom, birotică, c) impuls pentru declanşarea scrierii

write down a nu aprecia favorabil, a se exprima nefavorabil la adresa (cuiva) în ziar; a califica, a considera; a înregistra (spusele cuiva etc.) write down the capital $(\mathrm{ec})$ a reduce capitalul write for a paper a colabora la un ziar

write head (electr, c) cap de imprimare / de înregistrare / de scriere (al unui dispozitiv de înregistrare a informațiilor), electromagnet folosit pentru scrierea pe bandă / disc magnetic(ă)

write-in (amer) (pol, adm) vot acordat prin scrierea numelui candidatului;

write in (ec, adm) a se adresa unei firme; (amer) (pol, adm) a adăuga (un nume) pe un buletin de vot

write in a candidate's name (adm, pol) a adăuga numele unui candidat pe un buletin de vot

write into (c, inf) a introduce / scrie în memorie write in / on water ( $f i g$ ) a clădi pe nisip

write lock-out (autom, birotică, c) interzicere / blocare a scrierii

write-off (ec) amortizare, reducere a prețului; anulare / refuz în scris; (mas, auto) (fam) rablă, hârb (d. o maşină etc.)

write off (ec) a amortiza; a anula (şi o datorie), a renunța la, a decomanda, a accepta pierderea / eşecul / întârzierea, a şterge; $v$. write away for

write off a vehicle (auto) a avaria un vehicul în aşa măsura încât nu mai are nici o valoare / încât nu merita reparat

write off for smth. a comanda ceva (la un magazin, o editură etc.)

write-off value of a car $(\mathrm{ec})$ sumă plătită de o societate de asigurare pentru o maşină grav avariată

write on a eticheta, a pune o inscripție

write oneself down a se descrie în scris

write oneself out a-şi epuiza forța creatoare (d. un scriitor, un artist etc.), a-şi epuiza ideile (d. un scriitor, un artist etc.)

write out a copia; a descifra (o stenogramă etc.); a şterge, a scoate, a elimina (dintr-un text); a transcrie, a completa; a redacta; a scrie ceva formal

write-protect notch / element (inf, c) decupare / element (tip culisă etc.) în carcasa dischetei / flesh-ului, pentru protejare la scriere (nu și la citire)

writer scriitor, autor (al unei scrisori etc.); (adm, ec) secretar; (autom, birotică) înregistrator; the $\sim$ subsemnatul (în stilul oficial)

write smb. down as a considera pe cineva drept, a descrie pe cineva ca / drept

write so. off as a desconsidera / elimina / eticheta pe cineva din discuție ca fiind

write smb. out of a script (cinematografie) a elimina pe cineva / rolul cuiva dintr-un scenariu / film făcând personajul să moară 
write smth. off as a desconsidera ceva din discuție ca fiind, a elimina / eticheta ceva din discuție ca fiind

write smth. up a face o recenzie (a unei cărți, a unei piese de teatru etc.) (intr-un periodic)

write-up recenzie favorabilă, articol favorabil; (ec) reclamă

write up a înregistra, a recenza favorabil, a scrie un articol favorabil, a face reclamă (în ziar etc.) (unui produs etc.)

write up to (ec, adm) a se adresa (în scris) (unei firme, instituții etc.)

write word (of) a comunica un mesaj (în scris) written scris; în formă scrisă; de mână (d. scris)

writhe a se contorsiona, a se zbârci, a se crispa, a (ră)suci; (fig) a denatura

writting scriere, (stil de) scris, caligrafie; lucrare, inscripție; (inf, c) introducere a informației în memorie, scriere

writting action (inf, c) proces de scriere

writtting materials (birotică) rechizite, furnituri de birou

writting-off (ec) amortizare a capitalului

writting pad / book (birotică) bloc-notes, sugativă

wrong rău, nedreptate, greşeală, eroare; greşit, incorect; eronat; fals (în logica matematică), prost, în neregulă; nepotrivit, inoportun; nefavorabil, neprielnic; imoral; urât, cum nu trebuie; (jur) delict, prejudiciu, a nedreptăți, a face o nedreptate / un rău, a jigni, a ofensa, a calomnia, a defăima

wrong dimension (OM) defect dimensional

wrongful nedrept, incorect, injust, nejust, ilegal; vinovat, culpabil

wrongfully $(a d v)$ (în mod) greşit, pe nedrept

wrongfulness rău, nedreptate, nedreptățire

wrongheadedly $(a d v)$ (în mod) greşit, aiurit, confuz

wrong manipulation ( $\mathrm{TH}$, ind) manipulare / operare greşită

wrought fasonat, lucrat, lucru elaborat cu grijă / migală; ornamentat; (met) tras (d. semifabricate melatice)

wrought alloy (met) aliaj maleabil / deformabil / tras

wrought iron (met) fier forjat / forjabil / maleabil; oțel sudabil (rar) wrought-iron pipe $(\mathrm{OM})$ țeavă din oțel forjat / tras

wrought steel (met) oțel forjat / forjabil, maleabil

wrought structure (met) structură a materialului prelucrat prin deformare

wry strâmb(at), sucit, diform; crispat, contractat; încălcit, confuz, ambiguu (d. idei); ascuns; fals; pocit; prefăcut; put a $\sim$ sense on a denatura înțelesul / sensul

wryly $(a d v)$ (în mod) strâmb, confuz, fals, ambiguu, ascuns

wT (Whitworth thread) (OM) abreviere pentru filet Whitworth

w-type engine (termo) motor în $\mathrm{W}$

w/v (metr, chim, farmacologie) abreviere pentru „weight by volume" - masă pe volum, egală cu masa (in grame) a substanței dizolvate / amestecate în $100 \mathrm{ml}$ de soluție sau amestec; exemplu: concentraţia de fluorură din pasta de dinți este de obicei $0,15 \% \mathrm{w} / \mathrm{v}$, adică $0,15 \mathrm{~g}$ de fluorură la $100 \mathrm{ml}$ de pastă de dinţi: $1 \% \mathrm{w} / \mathrm{v}$ este egal cu 1 gram pe decilitru sau $10 \mathrm{~g} / 1$

wW (waster-waster) (ind) rebut (piesă, tablă)

w/w (metr, fiz, chim, farmacologie) abreviere pentru „by weight” - procent masic, concenrația unei substanțe într-o soluție sau într-un amestec; exemplu: $2 \%$ w/w înseamnă că substanța este $2 \%$ din masa totală a soluției sau amestecului

wyde (metr, c, inf) o unitate pentru informație, egală cu 2 bytes sau 16 bits; denumire provenită din ,double byte" - 2 bytes

wye $(\mathrm{OM})$ armătură în formă de $\mathrm{Y}$ (uneori și T), cu un braț la $45^{\circ}$; litera y; unghi de întoarcere (la calea ferată); delta- connection (el) conexiune stea-triunghi

wye-delta connection (el, mas) conexiune steatriunghi

wye connection (el, mas) conexiune / cuplaj / joncțiune în stea / în Y

wye-delta connection (el, mas) conexiune / joncțiune stea-triunghi

wye junction (el, mas) conexiune în stea / în $\mathrm{Y}$, cuplaj în stea / în Y

wye level (metr, OM) nivelă cu lunetă reversibilă 


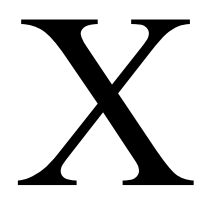

$\mathbf{x}(\mathrm{OM})$ coeficient de deplasare al danturii evolventice, în formă de X (d. elemente de maşini)

X (mat) simbol pentru abscisă; în formă de X; simbol al numeralului 10 la romani; (fiz) simbol pentru reactanță

xanthan gum (chim, alim) gumă de xantan

xanthate (chim) xantat, sare a acidului xantic

xanthene (chim) xanten, compus organic cristalin, $\mathrm{CH}_{2}\left(\mathrm{C}_{6} \mathrm{H}_{4}\right)_{2} \mathrm{O}$

xanthene dyestuffs (ind chim) coloranți xantenici

xanthic acid (chim, TH) acid xantic

xanthic acid salt (chim, TH) sare a acidului xantic (utilizată în tehnologia extracției metalelor prin flotație)

xanthine (chim, anat) xantină, $\mathrm{C}_{5} \mathrm{H}_{4} \mathrm{~N}_{4} \mathrm{O}_{2}$, precursor al acidului uric, derivat al xantinei

xanthophore (chim) cromatofor cu pigment galben

xanthophyll (chim) xantofilă, pigment carotenoid, $\mathrm{C}_{40} \mathrm{H}_{56} \mathrm{O}_{2}$, în plante verzi, identic cu luteina; pigment galben

xanthophyllic, xanthophyllous (adj) xantofilic, ca un pigment galben / carotenoid

$\mathbf{x}$-axis (mat) axa absciselor

x-bevel gear $(\mathrm{OM})$ angrenaj conic cu deplasare a danturii (cel puțin la o roată)

x-cylindrical gear (OM) angrenaj cilindric cu dantură deplasată pentru cel puțin o roată, angrenaj deplas

x-cross $(\mathrm{OM})$ încrucișat, în formă de X

x-cross member (auto, constr, OM) traversă / element în formă de $\mathrm{X}$

xen·o $\cdot$ bi·ot·ic (adj) xenobiotic, străin de corpuri sau de organisme vii (d. compuşi chimici); (s) (chim) (compus chimic) xenobiotic

xenoblast (biol) xenoblast, depunere minerală pe durata metemorfismului, fără dezvoltarea fatęetelor critaline

xenodiagnosis, $(p l)$ xenodiagnoses (med, biol) xenodiagnoză, diagnostic al unei boli infecțioase în stadii inițiale prin expunerea individului infectat sau a tesutului la un vector de laborator şi examinarea acestuia pentru identificarea microorganismului infecțios xenodiagnostic (adj) (med, biol) xenodiagnosticat

xenogamy, $(p l)$ xenogamies (bot) polenizare încrucişată, transfer de polen de la o plantă la alta xenogeneic (biol, med) obținut / derivat de la altă specie; tissue graft transplant xenogenic de țesut; antibodies (med) anticorpi xenoigenici xenolith (geol) xenolit

Xenon (Xe) (chim) xenon

xenophile (pol, edu) xenofil

xenophobe (pol) xenofob

xenophobic (pol) xenofobic

xenophoby (pol) xenofobie

xenotransplant (biol, med) ( $s$, adj) xenotransplant, rezultat al xenotranplantului

xenotransplantation (biol, med) transplant de celule / țesuturi / organe de la o specie la alta, xenotransplant

xerography (birotică, poligrafie) copiere, xerografie

xeromorphic (bot) xeromorfic, legat de adaptări structurale ale xerofitelor; v. xerophyte

xerophilous (bot) care ănfloreşte / este adaptată la un mediu uscat și cald

xerophily $(s)$ (bot) xerofilie, adaptare la habitat arid /uscat

xerophyte (bot) xerofită, plantă adaptată la un habitat arid / uscat, plantă de deşert

xerophytic (adj) xerofitic

xerophytically $(a d v)$ (în mod) la un mediu uscat și cald

xerophytism $(s)$ xerofitism

xerosere (mediu) xeroseră, succesiune de comunităti ecologice, cu origine într-un habitat uscat xerosis, $(p l)$ xeroses (med) xeroză, uscăciune / uscare anormală a pileii, ochilor etc., uscare / durificare normală a tesuturilor îmbătrânite

xerostomia (anat) xerostomie, uscăciune anormală a gurii

xerothermic (d. corpuri) xerotermic, uscat și cald / fiebinte; adaptat la un climat uscat şi cald climate (geogr) climat uscat şi cald; organisms organisme xerotermice

xerox (birotică) marcă a unui producător de aparate de copiat, aparat de multiplicat tip xerox; a xerografia, a copia / multiplica la xerox

x-frame (TH, constr, OM) cadru / ramă în formă de $\mathrm{X}$

x-gear $(\mathrm{OM})$ angrenaj cu dantură deplasată; roată deplasată, roată dințată, cu deplasare x (atenție la semnul lui $\mathrm{x}$ )

x-gear pair (OM) angrenaj deplasat (suma deplasărilor diferită de zero) 
xiphisternum, $(p l)$ xiphisterna (anat) xifistern, ultima şi cea mai mică parte a sternului; v. xiphoid

xiphoid (anat) xifoid, legat de xifistern; (OM) în formă de sabie

$\mathbf{x}$-irradiate a iradia

x-irradiating (fiz) care iradiază, care expune la radiatii $X$

$\mathbf{x}$-irradiation (fiz) iradiere cu radiații $\mathrm{X}$

$\mathbf{X}$-irradiated (fiz) iradiat cu radiații $\mathrm{X}$

Xizang (geogr) Xizang sau Tibet

x-joint (OM) îmbinare în formă de X (şi la asamblări sudate)

XL abreviere pentru extra large (foarte mare), extra long (foarte lung)

$\mathbf{x}$-minus bevel gear $(\mathrm{OM})$ angrenaj conic cu deplasare negativă a danturii (la cel puțin o roată)

x-minus worm gear $(\mathrm{OM})$ angrenaj melcat $\mathrm{cu}$ deplasare negativă (distanţa dintre axe micşorată față de cea fără deplasare)

XML (c, inf) acronim pentru Ex(tensible) $\mathrm{M}$ (arkup) L(anguage), un metalimbaj care permite elaborarea unui limbaj pentru interschimbabilitatea documentelor pe internet (World Wide Web)

XOR (mat, inf) operator logic de tip exclusiv SAU

x-plus bevel gear (OM) angrenaj conic cu deplasare pozitivă (la cel puțin o roată)

x-plus worm gear (OM) angrenaj melcat cu deplasare pozitivă (distanța dintre axe mărită față de cea fără deplasare)

x-radiation / ray (fiz) radiații X / Röentgen

x-ray, X-ray (fiz, metr, med) rază X, radiație X, radiografie röentgen, radiografiere röentgen, röentgenogramă; ( fig) a cerceta, a examina; (fiz) a cerceta / examina cu raze / radiatiie X, a fotografia cu raze $\mathrm{X}$; (med) a trata cu raze $\mathrm{X}$; give smb. a chest $\sim$ (med) a face cuiva o radiografie pulmonară; have a chest $\sim$ (med) a-şi face o radiografie pulmonară

x-ray analysis (fiz, metr) analiză spectrală cu radiaţie X / Röentgen

x-ray apparatus (fiz) aparat cu / care analizează raze / radiație X / Röentgen

x-ray background (fiz) fond de radiații $X$

$X$-ray coverage (fiz, anat, biol) arie de influență a razelor $\mathrm{X}$, distanță de acțiune a razelor $\mathrm{X}$

X-ray dermatitis (med, fiz) dermatită provocată de radiații $X$, roentgenodermatită

$X$-ray detecting (fiz, metr) detectare cu raze $X$ (a neomogenităților), defectoscopic cu raze $\mathrm{X}$, care detectează cu ajutorul radiațiilor X
X-ray detecting device (fiz, metr) dispozitiv de detectare cu raze X (a neomogenităților), dispozitiv defectoscopic cu raze $\mathrm{X}$

$\mathbf{x}$-ray diffraction (fiz) difracție a razelor $\mathrm{X}$

X-ray equipment (fiz, metr) aparat / instalație röentgen / de radiaţii X; (med, fiz, metr) / aparat / instalație radiologic( $\breve{a})$

$\mathrm{X}$-ray diffraction (fiz) difracție a radiațiilor $\mathrm{X}$

$x$-ray diffraction analyser (fiz, metr) analizor cu difracție a razelor $X$, difractometru de analiză cu raze X

x-ray diffraction instrument (fiz, metr) aparat de difracție cu radiație $X$

x-ray diffractometer (fiz, metr) difractometru cu raze $X$

x-ray diffractometry (fiz, metr) difractometrie cu raze $X$

x-ray dosimeter (fiz, metr, $\mathrm{TH}$, med) dozimetru cu raze $X /$ de radiaţii $X$

x-ray emission spectra (fiz) spectru de emisie de radiatie $X$, spectre de emisie de radiaţii $X$

x-ray equipment (fiz, med) aparat / echipament radiologic / cu radiaţie $X$

$\mathrm{X}$-ray examination (fiz, materiale, med) examen radiografie, examen radioscopic

x-ray film (fiz) film pentru radiografie (pt. suduri, în medicină etc.), film röentgen

x-ray fluorescence analysis (met) analiză röentgeno-fluorescentă

x-ray inspection / investigation (fiz, metr, materiale, med) control cu radiație / radiații X, control röentgenografic

x-ray materiology (TH, med, metr) defectoscopie cu radiație $\mathrm{X}$, röentgenodefectoscopie

x-ray metallography $(\mathrm{TH})$ metalografie (şi pt. suduri) cu raze $X$

X-ray output at full ratings (fiz, med) doză de radiații $X$ la randament maxim

x-ray pattern (fiz, metr) röentgenogramă; înregistrare tipică unei substanțe, după iradiere cu raze $X$

X-ray photographic paper (fiz, metr) hârtie fotografică Röentgen

X-ray photography / photograph / picture (fiz) radiografie (şi pt. suduri); have an $\sim$ (med) aşi face o radiografie

X-ray plate (fiz) placă Röentgen

x-ray radiation (fiz) radiații / radiație $X$

$\mathbf{x}$-rays (fiz) radiații $X$, raze $X$

x-ray spectra (fiz) spectre de radiaţie $X$

x-ray spectograph (metr, fiz) spectrograf cu radiații X 
x-ray spectometer (metr) spectrometru cu radiație X

X-ray spectroscopy (metr, fiz, materiale) spectroscopie cu radiații $\mathrm{X}$

$\mathrm{X}$-ray spectrum (fiz) spectru de radiaţii $\mathrm{X}$

x-shaped $(\mathrm{OM})$ în formă de X (d. forma unei piese, un rost de sudură etc.)

$\mathbf{x}$-shaped cross member (constr, OM, met) traversă în formă de X

X-zero addendum $(\mathrm{OM})$ dantură zero deplasată / nedeplasată

x-zero gear $(\mathrm{OM})$ angrenaj zero deplasat / cu suma deplasărilor roților în angrenare este zero (a nu se confunda cu angrenaj nedeplasat)

x-zero worm gear $(\mathrm{OM})$ angrenaj melc-roată melcată, zero deplasat

x-weld (met, OM) sudură în X (cu teşirea marginilor) / cu rost în formă de $\mathrm{X}$ sau de dublu V

$\mathbf{x}$-y function recorder (metr, $\mathrm{OM}$ ) trasator de curbe $\mathrm{x}-\mathrm{y}$

xylan (chim) xilan

xylene (chim) xilen

xylonite (chim) celuloid x-y plotting (metr) înregistrator pe două axe de coordonate; trasarea unei curbe în sistem $x-y$ x-zero bevel gear $(\mathrm{OM})$ angrenaj conic zero deplasat

x-zero gear $(\mathrm{OM})$ angrenaj zero deplasat; roată nedeplasată / fără deplasare

x-zero gear pair (OM) angrenaj zero deplasat / cu suma deplasărilor zero

x-zero worm gear $(\mathrm{OM})$ angrenaj melcat zero deplasat

$\times, \mathbf{x}, \mathbf{X}$ (metr, fiz, opt) simbol pentru unitatea puterii de mărire; exemplu: o imagine marcată cu 200x este de 200 de ori mai mare față de mă-rimea reală, iar 10x CD-ROM este un disc capabil să transfere datele de 10 ori mai repede decât viteza ,standard" de transfer

$\mathbf{X}$ unit (Xu) (metr, fiz) unitate de măsură pentru lungime, utilizată pentru măsurarea lungimii de undă a radiațiilor $\mathrm{X}$ sau gama; $1 \mathrm{X}$ unit $\cong$ $1,0021 \cdot 10^{-13} \mathrm{~m}$, astăzi exprimată mai mult în picometri (pm) sau femtometri (fm)

xylophone (muz) xilofon 


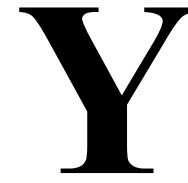

yacht (nav) iaht, a călători cu iachtul

yachting (nav) iahting, yachting, sport al ambarcaţiunilor cu vele; navigare / plimbare cu iachtul; a călători cu iachtul

y-alloy (met) aliaj de aluminiu / Y

yank smulgere (bruscă), smucitură, scoatere bruscă, zgâlțâitură; a smulge brusc, a scoate brusc, a extrage brusc, a arunca brusc; (fam) soldat american, yankeu; (fam) a aresta; (adm) (fam) a destitui pe cineva dintr-o funcție; a îmbrânci; someone around (fam) a hărțui; someone's chain a hărții; (amer) (fam) a aresta, a întemniţa

Yankee (fam) american; american din statele de nord / nord-est, yankeu

Yankee dryer (OM, textile, ind hârtiei) cilindru satinor

yankee screw driver (OM, mas-un) şurubelniță a maşinii de găurit portabilă

yard (cf) parc de vagoane, stație de triaj, depou, triaj; curte, depozit (de lemne etc.), magazie (de lemne etc.); (nav) şantier / atelier naval, atelier portuar, vergă; (metr, OM) pârghie a cântarului; (OM) balanță cu arc, braț de balanță; cimitir; (constr) curte; (amer) curte in spatele casei (cu iarbă); (agr) ocol de vite, ogradă, a vârî / aduce vitele în curte / în ocol; yard (yd) (metr) yard, iard, unitate tradițională de măsură pentru lungime, în țările de limbă engleză: astăzi 1 yard = $0,9144 \mathrm{~m}$; yard (yd) (metr) yard, unitate de măsură pentru lungime, pentru mărfuri vândute în suluri (țesături, covoare, mochetă etc.); yard (yd) (metr, constr) yard cubic unitate de măsură pentru volum: 1 yard 764,6 1) (pt. nisip, pământ excavat etc.); square yard (sq. yd., yd.) (metr) yard pătrat, unitate de măsură pentru suprafață: 1 square yard $=0,836 \mathrm{~m}^{2}$

yardage (metr) lungime / suprafață / volum exprimat în iarzi; (ec) speze de depozitare

yard arm (nav) capăt de vergă

yard-arm Derrick (nav) braț / fleșă de macara Derrick

yard bird (mil) (fam) recrut, soldat (consemnat in unitate); puşcăriaş

yard dog $(\mathrm{fam})$ persoana necioplită / nesuferită yard goods $(p l)(e c$, textile) produse textile vândute $\mathrm{cu}$ iardul / $\mathrm{cu}$ unitatea de lungime (indiferent de lățime)

yard/hour (metr, mec) yard pe oră, unitate de măsură pentru viteză: 1 yard/hour $=0,000254 \mathrm{~m} / \mathrm{s}$

yarding winch (constr, OM) troliu cu tambur dublu, montat pe un tractor

yard line (cf) linie de depou

yard locomotive (cf, ind) locomotivă de manevră / uzinală

yard master (cf) șef de stație, şef de manevră / de mişcare

yard/minute (metr) (metr, mec) yard pe minut unitate de măsură pentru viteză: 1 yard/minute $=0,01524 \mathrm{~m} / \mathrm{s}$

yard of ale (metr) unitate traditională de măsură pentru volum, în Scoția: 1 yard of ale $=1,41$

yard of land, yardland (metr) unitate tradițională britanică pentru măsurarea ariei; 1 yard of land înseamnă uneori 1 virgate $(\sim 30$ acri), uneori $1 \operatorname{rood}(1 / 4$ acri); v. virgate, rood

yard patrol (adm) gardian într-o închisoare; (mil) infanterist

yard/second (metr, mec) yard pe secundă, unitate de măsură pentru viteză: 1 yard/second $=0,9144 \mathrm{~m} / \mathrm{s}$

yard/square second (metr, mec) yard pe secundă la pătrat, unitate de măsură pentru accelerație: 1 yard/square second $=0,9144 \mathrm{~m} / \mathrm{s}^{2}$

yardstick (metr) etalon (pt. yard)

yard tackle (nav) palan de capăt de vergă

yard track (met, cf) cale ferată uzinală

yare pregătit, gata; $(a d j, a d v)$ repede, iute, activ, cu grabă

yarn (nav) fir de cablu, filată, fir, fir (la parâmele vegetale), sfilată (la parâmele vegetale); (textile) ață, fir (textil), tort; (fam) basme, istorie, născocire, poveste (lungă) (d. o călătorie); (fam) a înşira vrute si nevrute, a spune povesti; cotton yarn (textile) bumbăcel

yarn abrader (metr, $T$, textile) aparat de determinat rezistența la frecare a firelor

yarn ball (nav) colț de scotă (la o velă pătrată); (fig) făgaş, fir călăuzitor, urmă; (textile) ghem, jurubiță, a face ghem, a înfăşura; v. clew

yarn balloon, yarn of baloon (textile) balon format de fir în timpul filării pe maşina cu inele yarn beam $(\mathrm{OM}$, textile, plast) sul de urzeală yarn carrier conducător de fir (la maşini textile) yarn cleaner (textile, $\mathrm{OM}$ ) curățitor de fire yarn distributor $(\mathrm{OM}$, plast) distribuitor de fire yarn doubling machine (textile, plast) maşină de dublat fire 
yarn doubling and twisting frame (textile, plast) maşină de dublat şi răsucit fire yarn-dyed (ind chim) vopsit în fir (țesături) yarn elasticity (textile, plast) elasticitate a firului yarn fineness (textile, plast) finețe a firului yarn feeder (OM, textile) alimentator de fir yarn guide conducător de fir (la maşini textile)

yarn guide bar (OM, textile, plast) bară cu conducătoare de fir, bară cu pasete

yarn guide hook (OM, textile) cârlig conducător de fir; (OM, nav, met) cârlig / piesă de conducere a firului / a sârmei

yarn guiding arm braț conducător al firului yarn packing $(\mathrm{OM})$ garnitură de etanşare din fire textile / toarse

yarn preparation (textile, plast, $\mathrm{TH}$ ) preparație / preparare / process de pregătire a firelor textile

yarn quadrant (OM, textile, plast) sector al firelor, (metr, textile, plast) balanță de numerotat fire

yarn ring $(\mathrm{OM}$, textile, plast) inel al firelor

yarn scales (textile, metr) balanță de determinat numărul de fire

yarn separator (OM, textile, plast) separator de fir

yarn set (textile, plast) fixare / stabilizare a firelor

yarn tension (textile, mec) frână de fir, tensiune în / din fir

yarn-tension appliance (OM, textile, plast) întinzător de fir

yarn tester (metr, textile) dinamometru de fire

yarn tube (OM, textile, plast) tub pentru conducerea firului (şi metalic)

yarn waste (textile, plast) capete / resturi de fire

yarn yield (textile, plast) randament în fir (din fibră)

yaw a deriva, a aluneca; a devia; (nav) abatere bruscă de la drum, derivă, deviere, ambardee, evitare pe ancoră / pe geamandură, girare pe ancoră / pe geamandură, mascadă, a devia, a ambarda, a da ambardee, a gira / evita pe ancoră / geamandură; a (se) abate, a se abate brusc de la drum (cu revenire); deschizătură mare; prăpastie; (av) derivă, deviere, viraj unghiular în jurul axei verticale, a aluneca; (fig) a-şi da aere, a face pe grozavul, a se grozăvi; oscillatory $\sim($ av) oscilație giratorie

yawing (nav) abatere de la drum, ambardee; (av) deplasare unghiulară; răsucire, rotație; care (se) abate, care deviază

yawing angle (nav) unghi de ambardee yaw line (nav) parâmă laterală, cablu lateral yawing moment (mec) moment de forfecare (rar); (nav) moment de ambardare; (av) moment de girație, moment transversal în glisadă

yawn (mas, OM) joc, deschidere, căscare; căscat; deschizătură mare; (geogr) prăpastie, râpă; a (se) căsca, a se deschide (d. o prăpastie etc.); a căsca (de somn, plictiseală etc.); a (se) căsca, a se deschide

Y-axis (mat) axa ordonatelor, axa $\mathrm{Y}$, axa oy

Y-centering control (autom, mas, mas-un) reglare pe axa $\mathrm{Y}$, control pe axa $\mathrm{Y}$

Y-connection / grouping / network (el) cuplaj / conexiune / montaj în stea

yeanling (alim) ied, miel

year (a, y, yr) (metr) an, unitate tradițională de timp, egală cu 365 sau 366 zile, definită ca perioada necesară Pământului să facă o revoluție în jurul Soarelui, numărul întreg fiind util anului calendaristic: 1 an $\cong 365,242$ zile; Julian (a, y, yr) (metr) an iulian, unitate tradițională de timp: în medie 1 Julian year $=365,25$ de zile; sideral $\sim(\mathbf{a}, \mathbf{y}, \mathbf{y r})$ (metr) an sideral, timp necesar Soarelui să ajungă în aceaşi poziție față de stelele de pe bolta cerească: 1 sideral year $\approx$ 365,2563 zile; tropical (a, y, yr) (metr) an tropic, timpul necesar Soarelui să se întoarcă în aceiaşi poziție, în ciclul anotimpurilor: 1 tropical year $\approx 365,24219$ zile; Gregorian $\sim(\mathbf{a}, \mathbf{y}, \mathbf{y r})$ (metr) an gregorian, în medie 1 Gregorian year $=365,2425$ zile, anii obişnuiți având 365 zile, iar anii bisecți (anii divizibili cu 4, cu excepția anilor divizibili cu 400, cum sunt 2100, 2200 şi 2300 ) - 366 zile; v. leap year; one $\sim$ off un an de acum încolo, un an de atunci încolo; $\sim$ in, $\sim$ out an după an, ani de-a rândul, ani la rând; twice a $\sim$ (edu, univ) semestrial; as the $\sim$ grows old spre sfârşitul anului; towards the end of the $\sim$ spre sfârşitul anului; all the $\sim$ round tot anul, tot timpul anului; $\sim$ after $\sim$ went by trecea an după an; throughout the $\sim$ tot anul; quarter of $\sim$ trimestru; mid year (edu, univ) examen semestrial

yearbook anuar

yearly $(a d v)$ anual, de / în fiecare an, care are loc anual, an de an

yearly output (ec) producție anuală

year of assessment $(\mathrm{ec})$ an de impunere

yeast (alim) drojdie, ferment; spumă

yeast autolysis (alim, chim) autofagia drojdiilor yeast cake (alim) calup de drojdie uscată, maia, plămădeală, plămadă

yeast culture (alim) cultură de fermenți 
yeast fermentation (alim) fermentare cu drojdie / cu drojdii

yeasty (alim) de drojdie, ca drojdia, conținând drojdie; spumos, care fermentează, ca spuma

yellow galben, îngălbenit, auriu, (de) culoare galbenă; (alim) gălbenuş de ou; (TV) culoarea cu codul 4 în mira tv color; (fam) frică, laşitate, ticăloşie, laş, ticălos, fricos; (ind chim) vopsea galbenă; ziar bulevardier, bulevardier, de scandal, ieftin (d. ziare); chihlimbariu; gălbejit; îngălbenit; galben (d. rasă); a (se) îngălbeni

yellow amber (minrl) chihlimbar

yellow brass (met) alamă forjabilă / turnată / galbenă, aliaj $\mathrm{Cu}-\mathrm{Zn}$

yellow-brown (met) galben-maroniu (culoare de revenire la oțeluri)

yellow copper (met) alamă galbenă, aliaj $\mathrm{Cu}-\mathrm{Zn}$

yellow-copper ore (met) calcopirită

yellow glass bulb (auto) bec galben

yellow heat (met) incandescență / încălzire la galben (şi la tratamente termice)

yellowing (plast) îngălbenire (la materiale plastice, textile, hârtie), care (se) îngălbeneşte yellowish gălbui

yellow jack (nav, mil) pavilion de carantină, pavilion $\mathrm{Q}$

yellow metal (met) alamă forjabilă; aur

yellow pewter (met) tombac, aliaj tip tombac

yellow-white (heat) (met) incandescență (încălzire până la) alb-gălbui(e)

yellowy gălbui

yen (ec) yen (unitate monetară japoneză)

Y-engine (termo) motor cu trei cilindri, în stea

yes da, desigur

yesterday ieri

yet $(a d v)$ încă (în propoziții negative, condiționale, dubitative, interogative), pe deasupra, deja; (conj) cu toate că, cu toate acestea, totuşi (concesiv), dar; acum (în expresii), ca mai înainte, ca şi până acum, cel puțin; în continuare, încă (în propoziții negative), încă (ca posibilitate în viitor); măcar, mai (ca posibilitate în viitor); şi (în propoziții condiționale, dubitative, interogative); not încă nu; nor nici măcar; much remains to be done mai rămân încă multe de făcut; the best method $\sim$ found cea mai bună metodă găsită până acum; more încă mai mult; a more extraordinary occurrence $o$ împrejurare şi mai extraordinară

yi (metr) unitate de măsură pentru cantitate, în China: 1 yi $=100000000$

yield (ec) eficiență, beneficiu, profit, venit, câştig, a aduce beneficiu / profit (de x procente etc.), a fi profitabil, a ceda (acțiuni), a livra; (OM) cedare; (mec, materiale) curgere, fluaj (rar); (ec, $\mathrm{TH})$ grad de valorificare; ( $\mathrm{TH}$, ind) productie, debit, randament, productivitate, emisiune, efect, cedare; retragere, dare înapoi; a extrage, a scoate, a produce (şi o recoltă), a da randament, a slăbi, a curge, a ceda, a se prăbuşi, a se deschide; (agr) recoltă, cules; (fiz) debit, efect; emisie; (edu) a da, a oferi; (mil) a se preda; a răsplăti, a recompensa; not to $\sim$ an inch a nu ceda nici o palmă / nici un pic (de teren)

yield a point to smb. a ceda în fața cuiva asupra unui punct

yield a profit (ec) a produce un beneficiu / beneficii / profituri

yield capacity $(\mathrm{ec}, \mathrm{TH})$ productivitate

yield consent to smth. a-şi da consimțământul la ceva

yield curve $(\mathrm{TH})$ curbă de productivitate / de debit / deranjament; (mec) curbă deformareefort pentru un material

yield dividends (ec) a aduce dividende

yield ground a ceda terenul (şi fig)

yielding elastic, moale, flexibil, deformabil, maleabil, care curge (despre aliaje), ductil; influențabil; producere, formare, producție, productivitate, debit, randament; cedare; docilitate; $(\mathrm{mec})$ lăsare în jos, curgere, tasare, deformare

yieldingness $(\mathrm{mec})$ elasticitate, flexibilitate; $(\mathrm{TH})$ productivitate, randament; proprietatea de a curge

yielding point (mec) limită de curgere fizica; punct de început de curgere

yielding seat (mec, OM) reazem elastic / deformabil

yield interest (ec) a aduce dobândă / procente

yield limit (mec, met) limită de curgere / limită de elasticitate

yield load (met, mec) sarcină la limita de curgere / transfer

yield mix (mas, $\mathrm{TH}$ ) ansamblu al factorilor ce afectează randamentul

yield of heat (fiz, termo, T) cedare de căldură yield of ores (met) conţinut de metal în minereu yield oneself prisoner (mil, pol) a se constitui prizonier

yield palm to smb. (fig) a ceda cuiva cinstea / laurii / meritul / distincția

yield point, yield value (materiale, mec) început de curgere, limită de curgere / de fluaj, punct de rupere, punct de deformare (rar), valoare a tensiunii la care apare curgerea unui material (şi la materiale vâscoase) 
yield point at normal temperature (mec, met) limită de curgere la rece / la temperatură normală

yield point at elevated temperature (mec, materiale) limită de curgere la temperatură ridicată

yield point of torsional shear (mec, materiale) limită de curgere (a unui material) la torsiune / la forfecare

yield point of / for compression (mec) limită de curgere la compresiune

yield resistance $(\mathrm{mec})$ rezistență la curgere

yield strain (mec) deformaţie la limita de elasticitate sau de curgere

yield strength $(\mathrm{mec})$ limită de curgere

yield strength-offset $(\mathrm{mec})$ limită tehnică / aparentă de curgere (de obicei pentru o deformare permanentă de $0,2 \%$ )

yield stress (mec) efort / tensiune la curgere la deformare (de obicei la tractiune)

yield the pas to smb. (amer) a da cuiva cale liberă

yield the track to smb. (amer) a da cuiva cale liberă / întâietate

yield to a se preda (inamicului etc.); a nu rezista (la), a nu rezista (cuiva)

yield to a point a face o concesie

yield to a suggestion a asculta de o sugestie / de un sfat

yield to axial compression (mec) flambaj, deformare la compresiune axială

yield to entreaties / temptation a ceda (în fața) ispitei

yield to reason a asculta de o sugestie / de un sfat

yield torque (mec) moment de torsiune la limita de curgere

yield to superior force a ceda în fața unor forțe superioare

yield to superior numbers a ceda din cauza superiorităţii numerice (a celorlalti)

yield under pressure a ceda forțat / în fața unei presiuni

yield up a ceda la, a renunța la; a da cuiva întâietate

yield up smth. to smb. a capitula în fața cuiva, a ceda ceva cuiva

yield value (met, mec) valoarea limitei de curgere; $(\mathrm{TH})$ randament, producție (şi la unitatea de suprafață)

y/o (metr) simbol pentru ,years old" - vârstă yocto- $\left(\mathrm{y}\right.$-) (metr) prefix metric pentru $10^{-24}(\mathrm{n}=$ 8 în $\left.10^{-3 \mathrm{n}}\right)$

yogh(o)urt (alim) iaurt

yoggles (ind, met) ochelari de protecție yoke (metr) jug; (OM) furcă, basculă (mecanică fină), bridă; (cf, el) buclă de cuplaj; liră de luare / captare de curent; (constr, OM) travee, jug, etrier, colier, bridă, portal, furcă; (nav) eche rotundă; (TH) acord, joncțiune; (agr) pogon, iugăr; (el) buclă de cuplaj; a uni, a lega, a combina, a îmbina; (metr) altă denumire pentru pereche (d. animale)

yoke and eye rod ends (mas-un) îmbinare articulată pentru capete de arbore / gen furcăcontrafurcă

yoke core (el) miez de jug / de bobină

yoke end $(\mathrm{OM})$ cap de furcă

yoke lever $(\mathrm{OM})$ pârghie cu furcă, furcă

yoke of magnet (el) chiulasă / jug de magnet

yoke ring (mas-un) inel cu canal pentru furcă (de comandă)

yoked connecting rod (OM, auto) bielă în formă de furcă

yoke end $(\mathrm{OM})$ capăt de furcă

yoke hickback (el) reactie a jugului (magnetic), a colierului

yoke lever $(\mathrm{OM})$ pârghie cu furcă

yolk (of egg) (alim) gălbenuş de ou

yonside $(a d v)$ dincolo, de cealaltă parte, departe

yotta- (Y-) (metr) prefix metric pentru $10^{24}$, ca şi yocto-

yottameter (Ym) (metr, fiz, astronomie) yottametru, unitate de măsură pentru lungime: 1 yottameter $=10^{24} \mathrm{~m}$ sau $105,7 \cdot 10^{6}$ ani lumină; raza universului observabil este $\sim 200$ yottametri

young tânăr; neexperimentat, fără experiență, novice, nedeprins; (TH) de curând format / creat; (alim) pui de animal

Young('s) modulus (mec, materiale) modul de elasticitate longitudinal (al lui Young) (E)

youth tinerețe; $(\mathrm{TH}, \mathrm{ec})$ perioada inițială a unui proces / fenomen

yow (nav) ambardee

yowling deplasare unghiulară, rotație, răsucire; (nav) abatere de la drum

y.p. (yield point) (mec) limită de curgere (pt. materiale solide)

Y piece $(\mathrm{OM})$ piesă in forma de furcă /de Y

Y pipe / tube (OM, hidr) ,pantalon" / ramificație / bifurcație de țevi, conducte

Ytterbium (Yb) (chim) yterbiu

Yttrium (Y) (chim) ytriu

Y-valve (OM, hidr) ventil / supapă cu scaun oblic / conic /în formă de Y

Y-voltage (el) tensiune pe fază (la conexiuni în stea) 


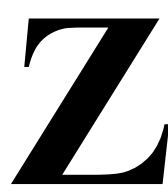

Z (metr, fiz) simbol pentru „timp universal”; de exemplu 8:43 UT se scrie 0843 Z; se pronunță şi „zulu”; (metr, fiz) simbol pentru „redshift” - o unitate relativă pentru distanţă în astronomie, $v$. redshift

zak (metr, fiz) unitate olandeză de măsură pentru volum: $1 \mathrm{zak}=1001$

z-axis (mat) axa $\mathrm{z}$

z-bit (mas-un) tăiş de burghiu (sfredel) în formă de $\mathrm{Z}$

z-coordinate coordonată (pe axa) z

zeal zel; interes; stăruință

zealous zelos, stăruitor; dornic, doritor

zed (met) oțel profilat în $\mathrm{Z}$; denumirea literei z

zee denumire a literei $z$

zenith zenit; culme, apogeu

zentner (Ztr) (metr) unitate tradițională germană pentru masă: 1 zenter $=50 \mathrm{~kg}$

zeppelin (av) zepelin, dirijabil

zepto- (z-) (metr) prefix metric pentru $10^{-21}$ (în latină - septem), însemnând $7\left(\mathrm{n}=7\right.$ in $\left.10^{-3 \mathrm{n}}\right)$

zero (mat) zero, nulă, element neutru (față de adunare); origine; (el) nul; (autom, metr) poziție / punct de zero; nimic, nulitate; (fig) un nimeni, o nulitat, o persoană nesemnificativă; a aduce la zero, a anula, a pune / regla la zero

zero-access memory / storage / store (inf) memorie cu acces rapid / cu timp de aşteptare zero, memorie rapidă

zero adjuster (mas-un, metr) dispozitiv de aducere la zero / de reglare a punctului zero

zero adjuster device (metr, autom) dispozitiv de aducere / punere la zero

zero adjusting ( $\mathrm{TH}$, metr, autom) reglare / ajustare la zero

zero adjusting device (metr) dispozitiv de reglare/de aducere la zero

zero adjustement (mas-un, metr, autom) reglare / aducere la zero; reglarea punctului de zero; (mec, autom) echilibrare la zero

zero-address instruction (inf) instrucțiune fără adresă

zero allowance (mas-un, metr) toleranță zero, fără toleranță zero axis (fiz, mat, TH) axă de coordonate; (mat, fiz, OM) axa neutră; linie / poziție de bază / de zero

zero balance (metr) poziția de zero (la aparate de măsură), semnal de zero

zero balancing (metr, autom) aducere la zero; (mec, mas) echilibrare (până) la zero

zero-base budgeting (pol, adm) alocare din buget pornind de la zero, metodă de protejare a programelor anuale prin înscrierea lor într-o ordine de priorități pe baza corelațiilor dintre beneficii şi costuri

zero-beat (metr) sincronism; (telefonie, radio) bătăi nule

zero beat indicator wavemeter (metr) undametru heterodină

zero beat reception (radio, fiz) recepție cu bătaie nulă, receptie homodină

zero bias (metr) ajustare / reglare la zero (pt. citire mai uşoară); (fiz) polarizare nulă

zero-bias junction capacity (electr, fiz) capacitate a joncțiunii la polarizare nulă (la semiconductoare), capacitate a stratului de baraj la polarizare nulă (la semiconductoare)

zero-bias tube / valve (electr) tub (electronic) cu vid pentru amplificare în clasa B, fără negativare pe grilă

zero carrier (fiz) purtătoare nulă / suprimată (în telecomunicații)

zero check / control (metr, autom) control / verificare a(l) punctului zero

zero compression (c) eliminare a zerourilor nesemnificative (la editarea pe calculator)

zero condition (fiz) stare zero

zero-conductor (el) conductor de legare la pământ / la masă / la nul

zero-control / check (metr) reglare de zero; reglare a punctului de zero

zero cross-over technique (el, autom) tehnică / metodă / principiu de întrerupere / comutare la tensiune nulă / zero

zero current (el, electr) curent nul / minim

zero cutout (el, autom) disjunctor / întrerupător de / la tensiune nulă / de zero, întrerupător de zero

zero defects fără defecte; (ec) management cu încurajarea personalului eficient

zero deviation (metr, autom) abatere / deplasare / derivă a punctului de zero

zero divergence field (mat, fiz) câmp vectorial cu divergență nulă / cu flux conservativ

zero drift $(\mathrm{TH}$, metr) deplasare / derivă a punctului de zero, derivă în timp a semnalului de zero 
zero element (mat) element neutru / de zero (al unui grup notat aditiv, în algebră)

zero elimination (c, inf) eliminare a zerourilor nesemnificative (la editarea pe calculator)

zero error (metr, fiz, radio,autom) eroare (a punctului) de zero, deplasare / derivă a punctului de zero, eroare la valoarea zero a mărimii măsurate; întârziere între emisie şi recepție (în radiolocație)

zero error / offset (metr, autom) deplasarea / de-riva punctului de zero

zero error position system (mas, TH) sistem fără eroare de poziție

zero fill (c) completare cu zerouri a unui număr zero flag (inf) indicator al valorii conținute întrun acumulator de date; (metr, autom) indicator de zero

zero frequency component (fiz, el) componentă de curent continuu

zero function (mat) funcție (de) zero, funcție nulă zero-gate-voltage current (el) curent la tensiune nulă de poartă (la semiconductoare)

zero-gravity (fiz) imponderabilitate

zero hour $(\mathrm{TH}$, mil) oră de începere a unei acțiuni

zero in on (mil) a ochi direct în / spre

zero-input terminal (el) bornă de readucere la zero; (electr, autom) bornă de ştergere

zerol bevel gear (OM) angrenaj conic tip zerol

zero lead (el) conductor / fir neutru

zero level (TH, fiz, constr) nivel zero / de referință

zero level address (inf) adresă de nivel zero, adresă imediată

zero level sensitivity (metr, fiz) sensibilitatea punc-tului de zero, sensibilitate de referință

zero line (mec, OM, mas-un) linie de bază / de referință, bază, axă neutră, linie de (nivel) zero, poziție de zero; (radio) linie zero a unei antene în diagrama polară

zero line of the vernier (metr) reper / punct de zero al vernierului (și la sublere etc.)

zero load $(\mathrm{mec})$ sarcină nulă

zero loss (ec, TH) fără pierderi

zero-loss circuit (el, electr) circuit fără pierderi

zero mark (metr) gradație zero (la un aparat de măsură), reper zero

zero marker (fiz, nav, av) radiobaliză $Z$, radiofar de marcare $\mathrm{Z}$

zero mass (mec) (de) masă nulă

zero method (autom, inf, fiz) metodă a punctului (de) zero

zero of a polynomial (mat) rădăcină a unui polinom zero offset (radio) deplasare a punctului zero; (metr, autom) derivă a punctului; întârziere între emisie şi recepție (în radiolocaţie)

zero offset control (autom, mas) reglaj / reglare $\operatorname{astatic}(\breve{a})$

zero-order reaction (autom) reacție de ordinul zero

zero output (el, autom) semnal nul de ieșire zero passage (autom, metr) trecere prin zero zero-phase modulation (el) modulație de fază (pt. momentele de trecere prin nul a curentu-lui)

zero point (metr, autom) pozitie de zero, punct zero / inițial / neutru / de referință

zero-point correction (metr, autom) corecție de zero

zero-point device / instrument (metr, autom) instrument de zero

zero-point energy (fiz) energie în punctul de zero absolut

zero point entropy (fiz) entropie în punctul de zero absolut

zero-point vibrations (mec, electr, autom, metr) oscilații de zero

zero position (metr, mas) poziție de repaus, poziție zero

zero position error (metr, autom) eroare a poziției de zero, eroare proporțională

zero potential (el) tensiune nulă; potențial zero

zero-power-factor characteristic (el) caracteristică de sarcină în curent reactiv (la mașini sincrone)

zero-power-factor saturation curve (fiz, el) curbă de magnetizare la sarcină reactivă

zero-power-lens combination (fiz) introducere a unei lentile cu putere nulă / zero

zero-power range (el, mas) domeniu de putere nulă / de putere zero / de repaus / de mers în gol zero-power resistance (fiz, electr) rezistență la disipație (de putere) nulă (la termistoare)

zero probability (mat) probabilitate nulă

zero reader (av, fiz) căutător de pistă de aterizare (în radiolocație); (inf) lector zero

zero reading (metr) citire la zero

zero resetting (autom, metr) repunere (aducere) la zero

zero reseting device (mas, mas-un, metr) dispozitiv de aducere la zero

zero resistance (electr, el) rezistență a nulului

zero rest mass (mec) masă de repaus nulă

zero-sequence component (el) componentă omopolară (a unui sistem electric trifazat nesimetric)

zero set (mat) mulțime vidă, mulțime de măsură nulă 
zero setting (metr, autom, inf) poziționare / punere la punctul de repaus / la (punctul de) zero (a unui aparat de măsură), reglare (a unui aparat de măsură)

zero setting device (autom, metr) dispozitiv de fixare a punctului zero, dispozitiv de repunere la zero

zero shift (metr, $\mathrm{TH}$ ) deplasare a punctului de zero

zero shift (metr, autom) deplasare a punctului (de) zero

zero signal direct anode current (el) curent anodic de repaus

zero state / O-state (electr, inf) stare zero / O (la circuite binare)

zero subcarrier chromaticity (fiz) cromaticitate la subpurtătoare nulă / zero, culoare corespunzătoare absenței subpurtătoarei

zero-sum game (mat, ec) joc cu sumă nulă, joc în care câştigul unui negociator compensează exact pierderea altuia

zero suppress (c, inf) eliminare a zerourilor (la calculatoare), a elimina zerorui (la afişarea unui rezultat)

zero suppression (c, inf) eliminare a zerourilor (la calculatoare)

zero terminal (el, electr) bornă de fir / de conductor neutru

zeroth order quantity (fiz, mat) mărime de ordinul zero

zero-type (fiz) tip 0

zero variation (electr, el) derivație reziduală / a punctului (de) zero; (metr, autom) abatere / derivă a punctului de zero

zero voltage (el, fiz) tensiune nulă, componentă omopolară a tensiunii

zero voltmeter (el) voltmetru de zero

zero water (chim) apă distilată

zero water level (hidr) nivel zero al apei

zero-zero (av) vizibilitate nulă

zero zone (geogr, nav, av) fus orar zero, primul fus orar

zest (alim) mirodenie, condimet, lucru picant, sare; interes, atracție deosebită, participare, energie, înclinaţie (spre)

zestful picant

zetta- (Z-) (metr) prefix metric pentru $10^{21}$

zettameter $(\mathbf{Z m})$ (metr) unitate SI de măsură pentru lungime: 1 zettameter $=10^{21} \mathrm{~m}$

Z-folded (OM) pliat în evantai (d. hârtie, folii etc.)

Z-folded paper hârtie pliată în evantai

Zhubov scale (metr) scală pentru raportarea aco-peririi cu gheață a mărilor polare zigzag (în formă de) zigzag, zigzagat; a merge în zigzag

zigzag gilled cooler $(\mathrm{OM}$, termo) radiator cu lamele în zigzag

zigzag rule (metr) metru pliant / de tâmplărie

zillion (amer) mulți, mii şi mii, noian

Zinc (Zn) (chim) zinc

zinc alloy (met) aliaj (pe bază) de zinc

zincate (chim) zincat

zincate treatment (met) tratament de zincare

zinc-base alloy (met) aliaj (pe bază) de zinc

zinc blende (chim) sulfură de zinc $(\mathrm{ZnS})$, blendă

zinc bloom (chim) oxid de zinc

zinc carbonate (chim) carbonat de zinc

zinc chloride (chim) clorură de zinc

zincify (met) a zinca

zinc-coated (met) zincat, acoperit cu zinc

zinc-coated sheet (met) tablă zincată

zinc coating (met) zincare, acoperire zincată

zinc coating furnace (met) cuptor de zincare

zinc coating kettle (met) oală, bazin de zincare

zinc coating plant (met) instalație de zincare

zincous (chim) de zinc

zinc crust (met) film / crustă / peliculă de oxid de zinc

zinc fume vapori / praf de zinc

zinc dust (met) praf de zincare / de zinc

zinc grip (met) oțel cu strat de zinc depus electrolitic

zinc gray (met) cenuşiu metalic / co de zinc

zinc impregnation (met, chim) zincare, impregnare cu zinc

zinc ingot (met) bloc / lingou de zinc

zinc mush (met) crustă (solidificată) de zinc

zinc oxide (chim) oxid de zinc

zinc phosphatising (met, chim) acoperire cu fosfat de zinc, fosfatare

zinc plate (met) tablă de zinc; a zinca, a acoperi cu zinc

zinc plated (met) zincat, acoperit cu zinc

zinc plated sheet (met) tablă zincată

zinc plating (met, chim) zincare, acoperire cu zinc, galvanizare cu zinc

zinc rich coating (met) zincare (acoperire în strat mai gros) echivalentă zincării la cald

zinc scum (met) film / crustă de oxid de zinc

zinc sheet (met) tablă de zinc

zinc soap (chim, T) săpun pe bază de zinc

zinc white (chim) oxid / alb de zinc

zinked (met) zincat

zip fermoar; pârâit; a trage un fermoar; a şuiera; a pârâi, a plesni (d. țesături, folii etc.)

zip code cod poștal 
zip-fastener (TH, textile) fermoar

zipper fermoar

zippered cu fermoar

zirconia (chim) oxid de zirconiu

Zirconium (Zr) (chim) zirconiu

zirconium carbide (chim) carbură de zirconiu

zirconium refractories (chim, $\mathrm{TH}$ ) (ceramice) refractare de zirconiu

zoll ( $s g$ şi $p l)$ (metr) unitate de măsură pentru lungime, tol / inch german: 1 zoll $=2,634 \mathrm{~cm}$, 1 zoll (Elveția) $=3 \mathrm{~cm}$

zonal, zonary zonal, de zonă, local, regional

zonal martensite (met) martensită locală

zonal segregation (met) segregație zonală / locală

zonation zonare, zonificare, împărțire în zone

zone zonă, regiune, domeniu, interval, parte, sector (c) memorie specială; a zona, a împărți pe zone

zone melting (met) topire locală

zone of action (autom, TH) bandă / zonă de acțiune, plajă de reglaj

zone of action of the tool (mas-un) zona suprafeței de prelucrat, supusă acțiunii de aşchiere a cuțitului

zone of contact (mec, T) zonă de contact; $(\mathrm{OM})$ suprafață de angrenare

zone of flame (termo, met) zona flăcării

zone of fracture $(\mathrm{mec})$ zonă de rupere

zone of fusion (met) zonă de fuziune (la furnal)

zone of incandescence (met) zona de incandescență zone of oxidation (met) zona de oxidare (la furnal)

zone of pressure (mec, $\mathrm{TH}$ ) zona de compresiune / de presiune / de presare

zone of reduction (met) zona de reducere (la furnal); (OM) zonă / porțiune de reducere (a unei secțiuni, grosimi etc.)

zone of slippage (fiz, T) zonă de alunecare

zone of vorticity (hidr, mas) zonă de turbulență (şi la cicloane)

zoning împărțire în zone; (termo) climatizare zonală

zoom uruit, bâzâit, zumzet; (c) a mări (un detaliu) mai ales la programele de calculator; a urui (şi în mers), a bâzâi, a merge cu zgomot; (ec) a se urca, a creşte vertiginos (d. prețuri)

zoom lens (fiz) transfocator

zooming (fiz, c) operație de mărire / de detaliere (a unui detaliu, a unei imagini); transfocator

zoom up (ec) a mări brusc prețurile; (c) a mări (progresiv)

Z-section (met) profil Z

„zulu” (radio) pronunțarea literei z în alfabetul internațional pentru transmisii radio

Zyglo method (metr, materiale) metodă de detectare a defectelor, cu lichide penetrante

zymometer (metr, alim) aparat de măsurat intensitatea fermentației

zymosis (alim, chim) (proces de) ferementare, fermentaţie; (med) infecție

zymotic (chim) zomotic, de ferementare, de fermentație; (med) infecțios 


\section{Irregular verbs in English}

\begin{tabular}{|c|c|c|}
\hline infinitive & past & $\begin{array}{l}\text { past } \\
\text { participle }\end{array}$ \\
\hline abide & abode & abode \\
\hline arise & arose & arisen \\
\hline awake & awoke & awoken \\
\hline be & $\begin{array}{l}\text { was, } \\
\text { were }\end{array}$ & been \\
\hline bear & bore & borne \\
\hline beat & beat & beaten \\
\hline become & became & become \\
\hline befall & befell & befallen \\
\hline beget & begot & begotten \\
\hline begin & began & begun \\
\hline behold & beheld & beheld \\
\hline bend & bent & bent \\
\hline bereave & $\begin{array}{l}\text { bereft, } \\
\text { bereaved }\end{array}$ & $\begin{array}{l}\text { bereft, } \\
\text { bereaved }\end{array}$ \\
\hline beseech & besought & besought \\
\hline beset & beset & beset \\
\hline bespeak & bespoke & bespoken \\
\hline bestride & $\begin{array}{l}\text { bestride, } \\
\text { bestrode }\end{array}$ & $\begin{array}{l}\text { bestride, } \\
\text { bestrode, } \\
\text { bestrid(den) }\end{array}$ \\
\hline bet & $\begin{array}{l}\text { bet, } \\
\text { betted }\end{array}$ & $\begin{array}{l}\text { bet, } \\
\text { betted }\end{array}$ \\
\hline betake & betook & betaken \\
\hline bethink & bethought & bethought \\
\hline bid & $\begin{array}{l}\text { bid, } \\
\text { bade }\end{array}$ & $\begin{array}{l}\text { bid, } \\
\text { bidden }\end{array}$ \\
\hline bide & $\begin{array}{l}\text { bode, } \\
\text { bided }\end{array}$ & bided \\
\hline bind & bound & bound \\
\hline bite & bit & $\begin{array}{l}\text { bitten, } \\
\text { bit }\end{array}$ \\
\hline bleed & bled & bled \\
\hline blend & $\begin{array}{l}\text { blended, } \\
\text { blent }\end{array}$ & $\begin{array}{l}\text { blended, } \\
\text { blent }\end{array}$ \\
\hline bless & $\begin{array}{l}\text { blessed, } \\
\text { blest }\end{array}$ & $\begin{array}{l}\text { blessed, } \\
\text { blest }\end{array}$ \\
\hline blow & blew & blown \\
\hline break & broke & broken \\
\hline breed & bred & bred \\
\hline bring & brought & brought \\
\hline broadcast & broadcast(ed) & broadcast(ed) \\
\hline build & built & built \\
\hline burn & $\begin{array}{l}\text { burnt, } \\
\text { burned }\end{array}$ & $\begin{array}{l}\text { burnt, } \\
\text { burned }\end{array}$ \\
\hline burst & burst & burst \\
\hline buy & bought & bought \\
\hline can & could & \\
\hline
\end{tabular}

\begin{tabular}{|l|l|l|}
\hline infinitive & past & $\begin{array}{l}\text { past } \\
\text { participle }\end{array}$ \\
\hline cast & cast & cast \\
\hline catch & caught & caught \\
\hline chide & chid & $\begin{array}{l}\text { chid, } \\
\text { chidden }\end{array}$ \\
\hline choose & chose & chosen \\
\hline cleave & cleft, clove & $\begin{array}{l}\text { cleft, } \\
\text { cloven }\end{array}$ \\
\hline cling & clung & clung \\
\hline clothe & clothed & clothed \\
\hline come & came & come \\
\hline cost & cost & cost \\
\hline creep & crept & crept \\
\hline cut & cut & cut \\
\hline deal & dealt & dealt \\
\hline dig & dug & dug \\
\hline do & did & done \\
\hline draw & drew & drawn \\
\hline dream & dreamt, \\
dreamed & $\begin{array}{l}\text { dreamt, } \\
\text { dreamed }\end{array}$ \\
\hline drink & drank & drunk \\
\hline drive & drove & driven \\
\hline dwell & dwelt & dwelt \\
\hline eat & ate & eaten \\
\hline fall & fell & fallen \\
\hline feed & fed & fed \\
\hline feel & felt & felt \\
\hline fight & fought & fought \\
\hline find & found & found \\
\hline flee & fled & fled \\
\hline fling & flung & flung \\
\hline fly & flew & flown \\
\hline forbear & forbore & forborne \\
\hline forbid & forbade & forbidden \\
\hline forecast & forecast & forecast \\
\hline forego & forewent & foregone \\
\hline foreknow & foreknew & foreknown \\
\hline foresee & foresaw & foreseen \\
\hline foretell & foretold & foretold \\
\hline forget & forgot & forgot, \\
\hline forgive & forgave & forgiven \\
\hline forsake & forsook & forsaken \\
\hline forswear & forswore & forsorn \\
\hline freeze & froze & frozen \\
\hline gainsay & gainaid & gaid \\
\hline get & got & \\
\hline
\end{tabular}


Irregular verbs in English

\begin{tabular}{|c|c|c|}
\hline infinitive & past & $\begin{array}{l}\text { past } \\
\text { participle }\end{array}$ \\
\hline gird & $\begin{array}{l}\text { girded, } \\
\text { girt }\end{array}$ & $\begin{array}{l}\text { girded, } \\
\text { girt }\end{array}$ \\
\hline give & gave & given \\
\hline go & went & gone \\
\hline grave & graved & graven \\
\hline grind & ground & ground \\
\hline grow & grew & grown \\
\hline hang & $\begin{array}{l}\text { hung, } \\
\text { hanged }\end{array}$ & $\begin{array}{l}\text { hung, } \\
\text { hanged }\end{array}$ \\
\hline have & had & had \\
\hline hear & heard & heard \\
\hline heave & $\begin{array}{l}\text { heaved, } \\
\text { hove }\end{array}$ & $\begin{array}{l}\text { heaved, } \\
\text { hove }\end{array}$ \\
\hline hew & hewed & $\begin{array}{l}\text { hewn, } \\
\text { hewed }\end{array}$ \\
\hline hide & hid & $\begin{array}{l}\text { hidden, } \\
\text { hid }\end{array}$ \\
\hline hit & hit & hit \\
\hline hold & held & held \\
\hline hurt & hurt & hurt \\
\hline inlay & inlaid & inlaid \\
\hline keep & kept & kept \\
\hline kneel & knelt & knelt \\
\hline knit & $\begin{array}{l}\text { knit, } \\
\text { knitted }\end{array}$ & $\begin{array}{l}\text { knit, } \\
\text { knitted }\end{array}$ \\
\hline know & knew & known \\
\hline lade & laded & laden \\
\hline lay & laid & laid \\
\hline lead & led & led \\
\hline lean & $\begin{array}{l}\text { leant, } \\
\text { leaned }\end{array}$ & $\begin{array}{l}\text { leant, } \\
\text { leaned }\end{array}$ \\
\hline leap & $\begin{array}{l}\text { leapt, } \\
\text { leaped }\end{array}$ & $\begin{array}{l}\text { leapt, } \\
\text { leaped }\end{array}$ \\
\hline learn & $\begin{array}{l}\text { learnt, } \\
\text { learned }\end{array}$ & $\begin{array}{l}\text { learnt, } \\
\text { learned }\end{array}$ \\
\hline leave & left & left \\
\hline lend & lent & lent \\
\hline let & let & let \\
\hline lie & lay & lain \\
\hline light & $\begin{array}{l}\text { lit, } \\
\text { lighted }\end{array}$ & $\begin{array}{l}\text { lit, } \\
\text { lighted }\end{array}$ \\
\hline lose & lost & lost \\
\hline make & made & made \\
\hline may & might & \\
\hline mean & meant & meant \\
\hline meet & met & met \\
\hline
\end{tabular}

\begin{tabular}{|c|c|c|}
\hline infinitive & past & $\begin{array}{l}\text { past } \\
\text { participle }\end{array}$ \\
\hline melt & melted & $\begin{array}{l}\text { melted, } \\
\text { molten }\end{array}$ \\
\hline mislay & mislaid & mislaid \\
\hline mislead & misled & misled \\
\hline mistake & mistook & mistaken \\
\hline $\begin{array}{l}\text { misunder- } \\
\text { stand }\end{array}$ & $\begin{array}{l}\text { misunder- } \\
\text { stood }\end{array}$ & $\begin{array}{l}\text { misunder- } \\
\text { stood }\end{array}$ \\
\hline mow & mowed & $\begin{array}{l}\text { mown, } \\
\text { mowed }\end{array}$ \\
\hline outbid & $\begin{array}{l}\text { outbade, } \\
\text { outbid }\end{array}$ & outbid(den) \\
\hline outdo & outdid & outdone \\
\hline outgo & outwent & outgone \\
\hline outgrow & outgrew & outgrown \\
\hline outrun & outran & outrun \\
\hline outspread & outspread & outspread \\
\hline outwear & outwore & outworn \\
\hline overbear & overbore & overborne \\
\hline overbid & overbid & overbid \\
\hline overcast & overcast & overcast \\
\hline overcome & overcame & overcome \\
\hline overdo & overdid & overdone \\
\hline overdraw & overdrew & overdrawn \\
\hline overeat & overate & overeaten \\
\hline overfeed & overfed & overfed \\
\hline overgrow & overgrew & overgrown \\
\hline overhang & overhung & overhung \\
\hline overhear & overheard & overheard \\
\hline overlay & overlaid & overlaid \\
\hline overleap & overleapt & overleapt \\
\hline overlie & overlay & overlain \\
\hline override & overrode & overridden \\
\hline overrun & overran & overrun \\
\hline oversee & oversaw & overseen \\
\hline overset & overset & overset \\
\hline overshoot & overshot & overshot \\
\hline oversleep & overslept & overslept \\
\hline $\begin{array}{l}\text { over- } \\
\text { spread }\end{array}$ & overspread & overspread \\
\hline overtake & overtook & overtaken \\
\hline overthrow & overthrew & overthrown \\
\hline partake & partook & partaken \\
\hline pay & paid & paid \\
\hline put & put & put \\
\hline quit & quit & quit \\
\hline read & read & read \\
\hline
\end{tabular}




\section{Irregular verbs in English}

\begin{tabular}{|c|c|c|}
\hline infinitive & past & $\begin{array}{l}\text { past } \\
\text { participle }\end{array}$ \\
\hline rebuild & rebuilt & rebuilt \\
\hline recast & recast & recast \\
\hline relay & relaid & relaid \\
\hline rend & rent & rent \\
\hline repay & repaid & repaid \\
\hline reset & reset & reset \\
\hline retell & retold & retold \\
\hline rewind & rewound & rewound \\
\hline rid & $\begin{array}{l}\text { rid, } \\
\text { ridded }\end{array}$ & $\begin{array}{l}\text { rid, } \\
\text { ridded }\end{array}$ \\
\hline ride & rode & ridden \\
\hline ring & $\begin{array}{l}\text { rang, } \\
\text { rung }\end{array}$ & rung \\
\hline rise & rose & risen \\
\hline rive & rived & $\begin{array}{l}\text { riven, } \\
\text { rived }\end{array}$ \\
\hline run & ran & run \\
\hline saw & sawed & $\begin{array}{l}\text { sawn, } \\
\text { sawed }\end{array}$ \\
\hline say & said & said \\
\hline see & saw & seen \\
\hline seek & sought & sought \\
\hline sell & sold & sold \\
\hline send & sent & sent \\
\hline set & set & set \\
\hline sew & sewed & $\begin{array}{l}\text { sewn, } \\
\text { sewed }\end{array}$ \\
\hline shake & shook & shaken \\
\hline shall & should & \\
\hline shear & sheared & $\begin{array}{l}\text { shorn, } \\
\text { sheared }\end{array}$ \\
\hline shed & shed & shed \\
\hline shine & shone & shone \\
\hline shoe & shod & shod \\
\hline shoot & shot & shot \\
\hline show & showed & $\begin{array}{l}\begin{array}{l}\text { shown, } \\
\text { showed }\end{array} \\
\end{array}$ \\
\hline shrink & $\begin{array}{l}\text { shrank, } \\
\text { shrunk }\end{array}$ & $\begin{array}{l}\text { shrunk, } \\
\text { shrunken }\end{array}$ \\
\hline shut & shut & shut \\
\hline $\operatorname{sing}$ & sang & sung \\
\hline sink & sank & $\begin{array}{l}\text { sunk, } \\
\text { sunken }\end{array}$ \\
\hline sit & sat & sat \\
\hline slay & slew & slain \\
\hline sleep & slept & slept \\
\hline slide & slid & slid \\
\hline sling & slung & slung \\
\hline
\end{tabular}

\begin{tabular}{|c|c|c|}
\hline infinitive & past & $\begin{array}{l}\text { past } \\
\text { participle }\end{array}$ \\
\hline slink & slunk & slunk \\
\hline slit & slit & slit \\
\hline smell & smelt & smelt \\
\hline smite & smote & smitten \\
\hline sow & sowed & $\begin{array}{l}\text { sown, } \\
\text { sowed }\end{array}$ \\
\hline speak & spoke & spoken \\
\hline speed & $\begin{array}{l}\text { sped, } \\
\text { speeded }\end{array}$ & $\begin{array}{l}\text { sped, } \\
\text { speeded }\end{array}$ \\
\hline spell & $\begin{array}{l}\text { spelt, } \\
\text { spelled }\end{array}$ & $\begin{array}{l}\text { spelt, } \\
\text { spelled }\end{array}$ \\
\hline spend & spent & spent \\
\hline spill & $\begin{array}{l}\text { spilt, } \\
\text { spilled }\end{array}$ & $\begin{array}{l}\text { spilt, } \\
\text { spilled }\end{array}$ \\
\hline spin & $\begin{array}{l}\text { span, } \\
\text { spun }\end{array}$ & spun \\
\hline spit & spat & spat \\
\hline split & split & split \\
\hline spoil & $\begin{array}{l}\text { spoilt, } \\
\text { spoiled }\end{array}$ & $\begin{array}{l}\text { spoilt, } \\
\text { spoiled }\end{array}$ \\
\hline spread & spread & spread \\
\hline spring & sprang & sprung \\
\hline stand & stood & stood \\
\hline stave & $\begin{array}{l}\text { staved, } \\
\text { stove }\end{array}$ & $\begin{array}{l}\text { staved, } \\
\text { stove }\end{array}$ \\
\hline steal & stole & stolen \\
\hline stick & stuck & stuck \\
\hline sting & stung & stung \\
\hline stink & $\begin{array}{l}\text { stank, } \\
\text { stunk }\end{array}$ & stunk \\
\hline strew & strewed & $\begin{array}{l}\text { strewn, } \\
\text { strewed }\end{array}$ \\
\hline stride & strode & $\begin{array}{l}\text { strode, } \\
\text { stridden }\end{array}$ \\
\hline strike & struck & $\begin{array}{l}\text { struck, } \\
\text { stricken }\end{array}$ \\
\hline string & strung & strung \\
\hline strive & strove & striven \\
\hline sublet & sublet & sublet \\
\hline sunburn & $\begin{array}{l}\text { sunburned, } \\
\text { sunburnt }\end{array}$ & $\begin{array}{l}\text { sunburned, } \\
\text { sunburnt }\end{array}$ \\
\hline swear & swore & sworn \\
\hline sweat & $\begin{array}{l}\text { sweat, } \\
\text { sweated }\end{array}$ & $\begin{array}{l}\text { sweat, } \\
\text { sweated }\end{array}$ \\
\hline sweep & swept & swept \\
\hline swell & swelled & $\begin{array}{l}\text { swollen, } \\
\text { swelled }\end{array}$ \\
\hline swim & swam & swum \\
\hline
\end{tabular}


Irregular verbs in English

\begin{tabular}{|l|l|l|}
\hline infinitive & past & $\begin{array}{l}\text { past } \\
\text { participle }\end{array}$ \\
\hline swing & swung & swung \\
\hline take & took & taken \\
\hline teach & taught & taught \\
\hline tear & tore & torn \\
\hline tell & told & told \\
\hline think & thought & thought \\
\hline thrive & $\begin{array}{l}\text { throve, } \\
\text { thrived }\end{array}$ & $\begin{array}{l}\text { thrived, } \\
\text { thriven }\end{array}$ \\
\hline throw & threw & thrown \\
\hline thrust & thrust & thrust \\
\hline tread & trod & $\begin{array}{l}\text { trodden, } \\
\text { trod }\end{array}$ \\
\hline unbend & unbent & unbent \\
\hline unbind & unbound & unbound \\
\hline underbid & underbid & underbid \\
\hline undergo & underwent & undergone \\
\hline undersell & undersold & undersold \\
\hline $\begin{array}{l}\text { under- } \\
\text { stand }\end{array}$ & understood & understood \\
\hline undertake & undertook & undertaken \\
\hline $\begin{array}{l}\text { under- } \\
\text { write }\end{array}$ & underwrote & underwritten \\
\hline
\end{tabular}

\begin{tabular}{|l|l|l|}
\hline infinitive & past & $\begin{array}{l}\text { past } \\
\text { participle }\end{array}$ \\
\hline undo & undid & undone \\
\hline unwind & unwound & unwound \\
\hline uphold & upheld & upheld \\
\hline upset & upset & upset \\
\hline wake & woke & woken \\
\hline wear & wore & worn \\
\hline weave & wove & woven \\
\hline wed & wed & wed, \\
& & wedded \\
\hline weep & wept & wept \\
\hline wet & wet & wet \\
\hline will & would & \\
\hline win & won & won \\
\hline wind & wound & wound \\
\hline withdraw & withdrew & withdrawn \\
\hline withhold & withheld & withheld \\
\hline withstand & withstood & withstood \\
\hline wring & wrung & wrung \\
\hline write & wrote & written \\
\hline
\end{tabular}


World States / Ţările lumii

\begin{tabular}{|c|c|c|c|c|}
\hline $\begin{array}{c}\text { Country name } \\
\text { Official name } \\
\text { Capital } \\
\text { Habitant (Demonym) } \\
\text { Language(s) } \\
\text { Currency }\end{array}$ & 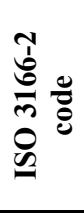 & 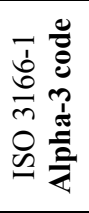 & 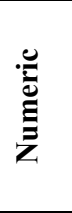 & $\begin{array}{c}\text { Țara } \\
\text { Denumire oficială } \\
\text { Capitală } \\
\text { Etnonim / Locuitor (locuri etc.) } \\
\text { Limbă oficială, limbi oficiale } \\
\text { Monedă }\end{array}$ \\
\hline $\begin{array}{l}\text { Afghanistan } \\
\text { Islamic Republic of Afghanistan } \\
\text { Kabul } \\
\text { Afghan } \\
\text { Dari (Persian), Pashto } \\
\text { Afghani (AFN) } \\
\end{array}$ & $\mathrm{AF}$ & $\mathrm{AFG}$ & 004 & $\begin{array}{l}\text { Afganistan } \\
\text { Republica Islamică Afganistan } \\
\text { Kabul } \\
\text { afgan, afgană } \\
\text { persană (Dari), Pashtu } \\
\text { afghani (AFN) }\end{array}$ \\
\hline $\begin{array}{l}\text { Åland Islands } \\
\text { Mariehamn } \\
\text { Swedish } \\
\text { Euro }(€)(\text { EUR) } \\
\end{array}$ & $\mathrm{AX}$ & ALA & 248 & $\begin{array}{l}\text { Insulele Åland } \\
\text { Marienhamn } \\
\text { suedeză } \\
\text { euro }(€)(E U R) \\
\end{array}$ \\
\hline $\begin{array}{l}\text { Albania } \\
\text { Republic of Albania } \\
\text { Tirana } \\
\text { Albanian } \\
\text { Albanian } \\
\text { Lek (ALL) }\end{array}$ & AL & ALB & 008 & $\begin{array}{l}\text { Albania } \\
\text { Republica Albania } \\
\text { Tirana } \\
\text { albanez, albaneză } \\
\text { albaneză } \\
\text { lek albanez (ALL) }\end{array}$ \\
\hline $\begin{array}{l}\text { Algeria } \\
\text { People's Democratic Republic } \\
\quad \text { of Algeria } \\
\text { Algiers } \\
\text { Algerian } \\
\text { Arabic } \\
\text { Algerian dinar (DZD) }\end{array}$ & $\mathrm{DZ}$ & DZA & 012 & $\begin{array}{l}\text { Algeria } \\
\text { Republica Algeriană Democratică şi } \\
\quad \text { Populară } \\
\text { Alger } \\
\text { algerian, algeriancă (algeriană) } \\
\text { arabă } \\
\text { dinar algerian (DA) }\end{array}$ \\
\hline $\begin{array}{l}\text { American Samoa } \\
\text { American Samoa } \\
\text { Pago Pago (de facto), Fagatogo } \\
\quad \text { (seat of government) } \\
\text { American Samoan } \\
\text { English, Samoan } \\
\text { US dollar (USD) }\end{array}$ & AS & ASM & 016 & $\begin{array}{l}\text { Samoa americană } \\
\text { Samoa americană } \\
\text { Pago Pago(de facto), Fagatogo (sediul } \\
\quad \text { oficial al guvernului) } \\
\text { engleză, samoană } \\
\text { dolar american (\$)(USD) }\end{array}$ \\
\hline $\begin{array}{l}\text { Andorra } \\
\text { Principality of Andorra } \\
\text { Andorra la Vella } \\
\text { Andorran } \\
\text { Catalan } \\
\text { Euro }(€)(E U R) \\
\end{array}$ & $\mathrm{AD}$ & AND & 020 & $\begin{array}{l}\text { Andorra } \\
\text { Principatul Andorra } \\
\text { Andorra la Vella } \\
\text { catalană } \\
\text { euro }(€)(\text { EUR) }\end{array}$ \\
\hline $\begin{array}{l}\text { Angola } \\
\text { Republic of Angola } \\
\text { Luanda } \\
\text { Angolan } \\
\text { Portuguese } \\
\text { Kwanza (AOA) } \\
\end{array}$ & $\mathrm{AO}$ & AGO & 024 & $\begin{array}{l}\text { Angola } \\
\text { Republica Angola } \\
\text { Luanda } \\
\text { angolez, angoleză } \\
\text { portugheză } \\
\text { kwanza (AOA) }\end{array}$ \\
\hline $\begin{array}{l}\text { Anguilla } \\
\text { Anguilla(British Overseas Territory) } \\
\text { The Valley } \\
\text { Anguillian } \\
\text { English } \\
\text { East Caribbean dollar (XCD) }\end{array}$ & AI & AIA & 660 & $\begin{array}{l}\text { Anguill } \\
\text { Anguilla (teritoriu britanic de peste mări) } \\
\text { The Valley } \\
\text { anguillian / anghilian, anguillian(c)ă (rar) } \\
\text { engleză } \\
\text { dolar est-caraib (BMD) }\end{array}$ \\
\hline
\end{tabular}




\begin{tabular}{|c|c|c|c|c|}
\hline $\begin{array}{c}\text { Country name } \\
\text { Official name } \\
\text { Capital } \\
\text { Habitant (Demonym) } \\
\text { Language(s) } \\
\text { Currency } \\
\end{array}$ & 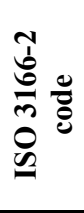 & 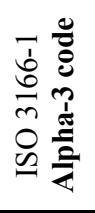 & 莺 & $\begin{array}{c}\text { Țara } \\
\text { Denumire oficială } \\
\text { Capitală } \\
\text { Etnonim / Locuitor (locuri etc.) }{ }^{*} \\
\text { Limbă oficială, limbi oficiale } \\
\text { Monedă }\end{array}$ \\
\hline $\begin{array}{l}\text { Antarctica } \\
\text { under The Antarctic Treaty } \\
\text { System }\end{array}$ & AQ & ATA & 010 & $\begin{array}{l}\text { Antarctica } \\
\text { sub Tratatele Sistemului Antartic }\end{array}$ \\
\hline $\begin{array}{l}\text { Antigua and Barbuda } \\
\text { Antigua and Barbuda } \\
\text { Saint John's } \\
\text { Antiguan, Barbudan } \\
\text { English } \\
\text { East Caribbean dollar (XCD) }\end{array}$ & $\mathrm{AG}$ & ATG & 028 & $\begin{array}{l}\text { Antigua şi Barbuda } \\
\text { Antigua şi Barbuda } \\
\text { Saint John's } \\
\text { antiguan, barbudan, antiguană, } \\
\quad \text { barbudană (rar) } \\
\text { engleză } \\
\text { dolar est-caraib (EC\$) }\end{array}$ \\
\hline $\begin{array}{l}\text { (the)Argentina } \\
\text { Argentine Republic } \\
\text { Buenos Aires } \\
\text { Argentine, Argentinian, } \\
\text { Argentinean } \\
\text { Spanish } \\
\text { Peso (ARS) }\end{array}$ & AR & ARG & 032 & $\begin{array}{l}\text { Argentina } \\
\text { Republica Argentina } \\
\text { Buenos Aires } \\
\text { angentinian, angentiniancă } \\
\text { spaniolă } \\
\text { limba spaniolă castiliană } \\
\text { peso (ARS) }\end{array}$ \\
\hline $\begin{array}{l}\text { Armenia } \\
\text { Republic of Armenia } \\
\text { Yerevan } \\
\text { Armenian } \\
\text { Armenian, Russian } \\
\text { Dram (AMD) }\end{array}$ & $\mathrm{AM}$ & ARM & 051 & $\begin{array}{l}\text { Armenia } \\
\text { Republica Armenia } \\
\text { Erevan } \\
\text { armean, armeancă } \\
\text { armeană } \\
\text { dram armean (AMD) }\end{array}$ \\
\hline $\begin{array}{l}\text { Aruba } \\
\text { Aruba } \\
\text { Oranjestad } \\
\text { Aruban } \\
\text { Dutch, Papiamento } \\
\text { Aruban florin }\left(\mathrm{AWG}^{2}\right)\end{array}$ & AW & ABW & 533 & $\begin{array}{l}\text { Aruba } \\
\text { Aruba } \\
\text { Oranjestad } \\
\text { aruban, arubaneză } \\
\text { olandeza } \\
\text { florin aruban (AWG) }\end{array}$ \\
\hline $\begin{array}{l}\text { Australia } \\
\text { Commonwealth of Australia } \\
\text { Canberra } \\
\text { Australian } \\
\text { English } \\
\text { Australian dollar (AUD) }\end{array}$ & $\mathrm{AU}$ & AUS & 036 & $\begin{array}{l}\text { Australia } \\
\text { Commonwealthul Australiei } \\
\text { Canberra } \\
\text { australian, australiancă (australian) } \\
\text { engleză } \\
\text { dolar australian (AUD) }\end{array}$ \\
\hline $\begin{array}{l}\text { Austria } \\
\text { Republic of Austria } \\
\text { Vienna } \\
\text { Austrian } \\
\text { German, locally Slovene, } \\
\text { Croatian and Hungarian } \\
\text { Euro }(€) \text { (EUR) }\end{array}$ & $\mathrm{AT}$ & AUT & 040 & $\begin{array}{l}\text { Austria } \\
\text { Republica Austria } \\
\text { Viena } \\
\text { austriac, austriacă } \\
\text { germană, local slovenă, croată şi } \\
\text { ungară } \\
\text { euro }(€)(E U R)\end{array}$ \\
\hline $\begin{array}{l}\text { Azerbaijan } \\
\text { Republic of Azerbaijan } \\
\text { Baku } \\
\text { Azerbaijani } \\
\text { Azerbaijani } \\
\text { Manat (AZN) }\end{array}$ & $\mathrm{AZ}$ & AZE & 031 & $\begin{array}{l}\text { Azerbaidjan } \\
\text { Republica Azerbaidjan } \\
\text { Baku } \\
\text { azer, azeră } \\
\text { azeră } \\
\text { manat (AZN) }\end{array}$ \\
\hline
\end{tabular}




\begin{tabular}{|c|c|c|c|c|}
\hline $\begin{array}{c}\text { Country name } \\
\text { Official name } \\
\text { Capital } \\
\text { Habitant (Demonym) } \\
\text { Language(s) } \\
\text { Currency } \\
\end{array}$ & 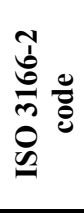 & 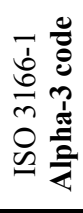 & & $\begin{array}{c}\text { Țara } \\
\text { Denumire oficială } \\
\text { Capitală } \\
\text { Etnonim / Locuitor (locuri etc.) }{ }^{*} \\
\text { Limbă oficială, limbi oficiale } \\
\text { Monedă }\end{array}$ \\
\hline $\begin{array}{l}\text { (The) Bahamas } \\
\text { Commonwealth of the Bahamas } \\
\text { Nassau } \\
\text { Bahamian } \\
\text { English } \\
\text { Dollar (BSD) }\end{array}$ & $\mathrm{BS}$ & BHS & 044 & $\begin{array}{l}\text { Bahamas } \\
\text { Commonwealth of the Bahamas } \\
\text { Nassau } \\
\text { engleză } \\
\text { dolar din Bahamas (BSD) }\end{array}$ \\
\hline $\begin{array}{l}\text { Bahrain } \\
\text { Kingdom of Bahrain } \\
\text { Manama } \\
\text { Bahraini } \\
\text { Arabic, English } \\
\text { Bahraini dinar (BHD) }\end{array}$ & $\mathrm{BH}$ & BHR & 048 & $\begin{array}{l}\text { Bahrain } \\
\text { Al-Bahrayn } \\
\text { Manama } \\
\text { arabă, engleză } \\
\text { dinar din Bahrain (BHD) }\end{array}$ \\
\hline $\begin{array}{l}\text { Bangladesh } \\
\text { People's Republic of Bangladesh } \\
\text { Dhaka } \\
\text { Bangladeshi } \\
\text { Bengali } \\
\text { Taka (BDT) }\end{array}$ & BD & BGD & 050 & $\begin{array}{l}\text { Bangladesh } \\
\text { Republica Populară Bangladesh } \\
\text { Dhaka } \\
\text { bengali } \\
\text { taka (BDT) }\end{array}$ \\
\hline $\begin{array}{l}\text { Barbados } \\
\text { Bardados } \\
\text { Bridgetown } \\
\text { Barbadian } \\
\text { English } \\
\text { Barbadian dollar }(\$)(\mathrm{BBD}) \\
\end{array}$ & BB & BRB & 052 & $\begin{array}{l}\text { Barbados } \\
\text { Bardados } \\
\text { Bridgetown } \\
\text { barbadian, barbadiană } \\
\text { engleză } \\
\text { dolar barbadian (BBD) } \\
\end{array}$ \\
\hline $\begin{array}{l}\text { Belarus } \\
\text { Republic of Belarus } \\
\text { Minsk } \\
\text { Belarusian } \\
\text { Belarusian, Russian } \\
\text { Belarusian ruble (BYR) } \\
\end{array}$ & BY & BLR & 112 & $\begin{array}{l}\text { Belarus } \\
\text { Republica Belarus } \\
\text { Minsk } \\
\text { bielarus, bielarusă } \\
\text { bielorusă, rusă } \\
\text { rublă bielarusă }\end{array}$ \\
\hline $\begin{array}{l}\text { Belgium } \\
\text { Kingdom of Belgium } \\
\text { Brussels } \\
\text { Belgian } \\
\text { Dutch, French, German } \\
\text { Euro }(€)(E U R) \\
\end{array}$ & $\mathrm{BE}$ & BEL & 056 & $\begin{array}{l}\text { Belgia } \\
\text { Regatul Belgiei } \\
\text { Ville de Bruxelles, (franceză), în } \\
\quad \text { Brussel-stad (neerlandeză) } \\
\text { belgian, belgiancă (belgiană) } \\
\text { neerlandeză (flamandă), franceză, } \\
\quad \text { germană } \\
\text { euro }(€)(\text { EUR) } \\
\end{array}$ \\
\hline $\begin{array}{l}\text { Belize } \\
\text { Belize } \\
\text { Belmopan } \\
\text { Belizean } \\
\text { English } \\
\text { Belize dollar (BZD) }\end{array}$ & $\mathrm{BZ}$ & BLZ & 084 & $\begin{array}{l}\text { Belize } \\
\text { Belize } \\
\text { Belmopan } \\
\text { engleză } \\
\text { dolar belizian (BZD) }\end{array}$ \\
\hline $\begin{array}{l}\text { Benin } \\
\text { Benin } \\
\text { Porto-Novo } \\
\text { Beninese, Beninois } \\
\text { French } \\
\text { West African CFA franc (XOF) }\end{array}$ & BJ & BEN & 204 & $\begin{array}{l}\text { Benin } \\
\text { Benin } \\
\text { Porto-Novo } \\
\text { beninez, benineză } \\
\text { franceză } \\
\text { franc central-african, CFA (XOF) }\end{array}$ \\
\hline
\end{tabular}




\begin{tabular}{|c|c|c|c|c|}
\hline $\begin{array}{l}\text { Country name } \\
\text { Official name } \\
\text { Capital } \\
\text { Habitant (Demonym) } \\
\text { Language(s) } \\
\text { Currency } \\
\end{array}$ & 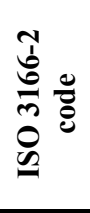 & $\begin{array}{ll}7 & 0 \\
1 & 0 \\
0 & 0 \\
0 & 0 \\
0 & \frac{1}{2} \\
0 & \frac{\pi}{2}\end{array}$ & 营 & $\begin{array}{c}\text { Țara } \\
\text { Denumire oficială } \\
\text { Capitală } \\
\text { Etnonim / Locuitor (locuri etc.) }^{*} \\
\text { Limbă oficială, limbi oficiale } \\
\text { Monedă }\end{array}$ \\
\hline $\begin{array}{l}\text { Bermuda } \\
\text { Bermuda } \\
\text { Hamilton } \\
\text { Bermudian } \\
\text { English } \\
\text { Bermudian dollar (BMD) }\end{array}$ & $\mathrm{BM}$ & BMU & 060 & $\begin{array}{l}\text { Bermude } \\
\text { Bermuda } \\
\text { Hamilton } \\
\text { engleză } \\
\text { dolar (din) Bermuda (BMD) } \\
\end{array}$ \\
\hline $\begin{array}{l}\text { Bhutan } \\
\text { Kingdom of Bhutan } \\
\text { Thimphu } \\
\text { Bhutanese } \\
\text { Dzongkha, English } \\
\text { Ngultrum (BTN) } \\
\end{array}$ & BT & BTN & 064 & $\begin{array}{l}\text { Bhutan } \\
\text { Regatul Bhutan } \\
\text { Thimphu } \\
\text { butanez, butaneză } \\
\text { dzongkha şi engleză } \\
\text { ngultrum (BTN) } \\
\end{array}$ \\
\hline $\begin{array}{l}\text { Bolivia } \\
\text { Plurinational State of Bolivia } \\
\text { Sucre (constitutional capital), La } \\
\quad \text { Paz (seat of government) } \\
\text { Bolivian } \\
\text { Spanish, Quechua, Aymara } \\
\text { Boliviano (BOB) } \\
\end{array}$ & $\mathrm{BO}$ & BOL & 068 & $\begin{array}{l}\text { Bolivia } \\
\text { Statul plurinațional al Boliviei } \\
\text { Sucre (capitala constituțională), La Paz } \\
\quad \text { (sediu al guvernului) } \\
\text { bolivian, boliviancă (boliviană) } \\
\text { spaniolă, quechua şi aymara } \\
\text { boliviano (BOB) }\end{array}$ \\
\hline $\begin{array}{l}\text { Bosnia and Herzegovina } \\
\text { Bosnia and Herzegovina } \\
\text { Sarajevo } \\
\text { Bosnian } \\
\text { Bosnian, Croatian, Serbian } \\
\text { Convertible Mark (BAM) } \\
\end{array}$ & BA & $\mathrm{BIH}$ & 070 & $\begin{array}{l}\text { Bosnia şi Herțegovina } \\
\text { Bosnia şi Herțegovina } \\
\text { Sarajevo } \\
\text { bosnian, bosniacă (bosniacă) } \\
\text { bosniacă, croată şi sârbă } \\
\text { marcă convertibilă (BAM) }\end{array}$ \\
\hline $\begin{array}{l}\text { Botswana } \\
\text { Republic of Botswana } \\
\text { Gaborone } \\
\text { Batswana } \\
\text { English, Tswana (national) } \\
\text { Pula (BWP) } \\
\end{array}$ & BW & BWA & 072 & $\begin{array}{l}\text { Botswana } \\
\text { Republica Botswana } \\
\text { Gaborone } \\
\text { borswanez, botswaneză } \\
\text { engleză, Setswana } \\
\text { pula (BWP) }\end{array}$ \\
\hline $\begin{array}{l}\text { Bouvet Island } \\
\text { (Norwegian dependency) } \\
\text { uninhabited }\end{array}$ & BV & BVT & 074 & $\begin{array}{l}\text { Insula Bouvet } \\
\text { (o dependență a Norvegiei) } \\
\text { nelocuită }\end{array}$ \\
\hline $\begin{array}{l}\text { Brazil } \\
\text { Federative Republic of Brazil } \\
\text { Brasilia } \\
\text { Brazilian } \\
\text { Portuguese } \\
\text { Real (R\$) (BRL) } \\
\end{array}$ & BR & BRA & 076 & $\begin{array}{l}\text { Brazilia } \\
\text { Republica Federativă a Braziliei } \\
\text { Brasilia } \\
\text { brazilian, braziliancă (braziliană) } \\
\text { portugheză } \\
\text { real (R\$) (BRL) }\end{array}$ \\
\hline $\begin{array}{l}\text { British Indian Ocean Territory } \\
\text { British Indian Ocean Territory } \\
\text { Diego Garcia } \\
\text { English } \\
\text { US dollar (USD) }\end{array}$ & IO & IOT & 086 & $\begin{array}{l}\text { Teritoriul Britanic din Oceanul Indian } \\
\text { Teritoriul Britanic din Oceanul Indian } \\
\text { Diego Garcia } \\
\text { engleză } \\
\text { dolar american (\$)(USD) }\end{array}$ \\
\hline
\end{tabular}




\begin{tabular}{|c|c|c|c|c|}
\hline $\begin{array}{c}\text { Country name } \\
\text { Official name } \\
\text { Capital } \\
\text { Habitant (Demonym) } \\
\text { Language(s) } \\
\text { Currency } \\
\end{array}$ & 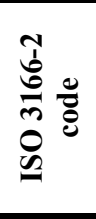 & 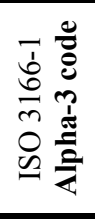 & 莺 & $\begin{array}{c}\text { Țara } \\
\text { Denumire oficială } \\
\text { Capitală } \\
\text { Etnonim / Locuitor (locuri etc.) }{ }^{*} \\
\text { Limbă oficială, limbi oficiale } \\
\text { Monedă }\end{array}$ \\
\hline $\begin{array}{l}\text { Brunei Darussalam } \\
\text { State of Brunei, Abode of Peace } \\
\text { Bandar Seri Begawan } \\
\text { Bruneian } \\
\text { Malay (Bahasa Melayu) } \\
\text { Brunei dollar (BND) }\end{array}$ & $\mathrm{BN}$ & BRN & 096 & $\begin{array}{l}\text { Brunei } \\
\text { Statul Brunei, Domiciliul Păcii } \\
\text { Bandar Seri Begawan } \\
\text { bruneian, bruneiană } \\
\text { dolar bruneian (BND) }\end{array}$ \\
\hline $\begin{array}{l}\text { Bulgaria } \\
\text { Republic of Bulgaria } \\
\text { Sofia } \\
\text { Bulgarian } \\
\text { Bulgarian } \\
\text { Lev (BGN) }\end{array}$ & BG & BGR & 100 & $\begin{array}{l}\text { Bulgaria } \\
\text { Republica Bulgaria } \\
\text { Sofia } \\
\text { bulgar, bulgăroaică (bulgară, bulgăresc, } \\
\quad \text { bulgărească) } \\
\text { bulgară } \\
\text { levă bulgară (BGN) }\end{array}$ \\
\hline $\begin{array}{l}\text { Burkina Faso } \\
\text { Burkina Faso } \\
\text { Ouagadougou } \\
\text { Burkinabé } \\
\text { French } \\
\text { West African CFA franc (XOF) }\end{array}$ & $\mathrm{BF}$ & BFA & 854 & $\begin{array}{l}\text { Burkina Faso } \\
\text { Burkina Faso } \\
\text { Ouagadougou } \\
\text { burchinez, burchineză } \\
\text { franceză } \\
\text { franc central-african (XOF) }\end{array}$ \\
\hline $\begin{array}{l}\text { Burundi } \\
\text { Republic of Burundi } \\
\text { Bujumbura } \\
\text { Burundian } \\
\text { Kirundi, French } \\
\text { Burundi franc (FBu) (BIF) } \\
\end{array}$ & BI & BDI & 108 & $\begin{array}{l}\text { Burundi } \\
\text { Republica Burundi } \\
\text { Bujumbura } \\
\text { burund(ez), burundeză } \\
\text { kirundi, franceză } \\
\text { franc burundez }(\mathrm{FBu})(\mathrm{BIF})\end{array}$ \\
\hline $\begin{array}{l}\text { Cambodia } \\
\text { Kingdom of Cambodia } \\
\text { Phnom Penh } \\
\text { Khmer or Cambodian } \\
\text { Khmer } \\
\text { Riel (banknotes and coins) (KHR) }\end{array}$ & $\mathrm{KH}$ & KHM & 116 & $\begin{array}{l}\text { Cambodgia } \\
\text { Regatul Cambodgiei } \\
\text { Phnom Penh } \\
\text { khmer, cambodgian, khmeră, cam- } \\
\text { bodgiancă (khmer, cambodgiană) } \\
\text { khmeră } \\
\text { riel (KHR) }\end{array}$ \\
\hline $\begin{array}{l}\text { Cameroon } \\
\text { Republic of Cameroon } \\
\text { Yaoundé } \\
\text { Cameroonian } \\
\text { French, English } \\
\text { Central African CFA franc (XAF) }\end{array}$ & $\mathrm{CM}$ & CMR & 120 & $\begin{array}{l}\text { Camerun } \\
\text { Republica Camerunului } \\
\text { Yaoundé } \\
\text { camerunez, cameruneză } \\
\text { franceză, engleză } \\
\text { franc central-african, CFA (XAF) }\end{array}$ \\
\hline $\begin{array}{l}\text { Canada } \\
\text { Canada } \\
\text { Ottawa } \\
\text { Canadian } \\
\text { English, French } \\
\text { Canadian Dollar }(\$)(\mathrm{CAD}) \\
\end{array}$ & CA & CAN & 124 & $\begin{array}{l}\text { Canada } \\
\text { Canada } \\
\text { Ottawa } \\
\text { canadian, canadiancă (canadiană) } \\
\text { engleza, franceza } \\
\text { dolar canadian (CAD) } \\
\end{array}$ \\
\hline $\begin{array}{l}\text { Cape Verde } \\
\text { Republic of Cape Verde } \\
\text { Praia } \\
\text { Cape Verdean } \\
\text { Portuguese } \\
\text { Cape Verdean escudo (CVE) }\end{array}$ & $\mathrm{CV}$ & CPV & 132 & $\begin{array}{l}\text { Republica Capului Verde } \\
\text { Republica Capului Verde } \\
\text { Praia } \\
\text { portugheză } \\
\text { escudo al Capului Verde (CVE) }\end{array}$ \\
\hline
\end{tabular}




\begin{tabular}{|c|c|c|c|c|}
\hline $\begin{array}{c}\text { Country name } \\
\text { Official name } \\
\text { Capital } \\
\text { Habitant (Demonym) } \\
\text { Language(s) } \\
\text { Currency }\end{array}$ & 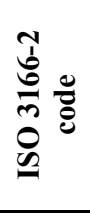 & $\begin{array}{ll}7 & 0 \\
1 & 0 \\
0 & 0 \\
0 & 0 \\
m & \frac{1}{2} \\
0 & \frac{1}{2}\end{array}$ & 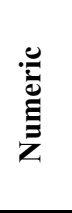 & $\begin{array}{c}\text { Țara } \\
\text { Denumire oficială } \\
\text { Capitală } \\
{\text { Etnonim / Locuitor (locuri etc.) }{ }^{*}}_{\text {Limbă oficială, limbi oficiale }} \\
\text { Monedă }\end{array}$ \\
\hline $\begin{array}{l}\text { Cayman Islands } \\
\text { Caymans Islands } \\
\text { George Town } \\
\text { Caymanian } \\
\text { English } \\
\text { Cayman Islands dollar (KYD) }\end{array}$ & $\mathrm{KY}$ & CYM & 136 & $\begin{array}{l}\text { Insulele Cayman } \\
\text { Caymans Islands } \\
\text { George Town } \\
\text { caymanian, caymaiană } \\
\text { engleză } \\
\text { dolar cayman (KYD) }\end{array}$ \\
\hline $\begin{array}{l}\text { Central African Republic } \\
\text { Central African Republic } \\
\text { Bangui } \\
\text { Central African } \\
\text { Sango, French } \\
\text { Central African CFA franc (XAF) }\end{array}$ & $\mathrm{CF}$ & CAF & 140 & $\begin{array}{l}\text { Republica Centrafricană } \\
\text { Republica Centralafricană } \\
\text { Bangui } \\
\text { sango, franceză } \\
\text { franc central-african, CFA (XAF) }\end{array}$ \\
\hline $\begin{array}{l}\text { Chad } \\
\text { Republic of Chad } \\
\text { N'Djamena } \\
\text { Chadian } \\
\text { French, Arabic } \\
\text { CFA franc (XAF) }\end{array}$ & TD & TCD & 148 & $\begin{array}{l}\text { Ciad } \\
\text { Republic of Chad } \\
\text { N'Djamena } \\
\text { franceză, arabă } \\
\text { franc central-african, CFA (XAF) }\end{array}$ \\
\hline $\begin{array}{l}\text { Chile } \\
\text { Republic of Chile } \\
\text { Santiago } \\
\text { Chilian } \\
\text { Spanish } \\
\text { Peso (CLP) }\end{array}$ & $\mathrm{CL}$ & CHL & 152 & $\begin{array}{l}\text { Chile } \\
\text { Republica Chile } \\
\text { Santiago } \\
\text { chilian, chiliancă (chiliană) } \\
\text { spaniolă } \\
\text { peso chilian (CLP) }\end{array}$ \\
\hline $\begin{array}{l}\text { China } \\
\text { People's Republic of China } \\
\text { Beijing } \\
\text { Chinese } \\
\text { Standard Mandarin (de facto) } \\
\text { Renminbi }(¥)(\mathrm{CNY})\end{array}$ & $\mathrm{CN}$ & $\mathrm{CHN}$ & 156 & $\begin{array}{l}\text { China } \\
\text { Republica Populară Chineză } \\
\text { Beijing } \\
\text { chinez, chinezoaică (chineză) } \\
\text { chineza (dialectul mandarin) } \\
\text { yuan chinezesc }\end{array}$ \\
\hline $\begin{array}{l}\text { Christmas Island } \\
\text { Territory of Christmas Island } \\
\text { Flying Fish Cove } \\
\text { Christmas Islanders } \\
\text { English (de facto) } \\
\text { Australian dollar (AUD) }\end{array}$ & $\mathrm{CX}$ & CXR & 162 & $\begin{array}{l}\text { Insula Crăciunului } \\
\text { Teritoriul Insulei Crăciunului } \\
\text { Flying Fish Cove } \\
\text { engleză (de facto) } \\
\text { dolar australian (AUD) }\end{array}$ \\
\hline $\begin{array}{l}\text { Cocos (Keeling) Islands } \\
\text { Territory of the Cocos (Keeling) } \\
\quad \text { Islands (territory of Australia) } \\
\text { West Island } \\
\text { Cocossian (Cocos Islandian) } \\
\text { English (de facto) } \\
\text { Australian dollar (AUD) }\end{array}$ & $\mathrm{CC}$ & CCK & 166 & $\begin{array}{l}\begin{array}{l}\text { Insulele Cocos } \\
\text { Teritoriul Insulelor Cocos (Keeling) } \\
\quad \text { (teritoriu al Australiei) }\end{array} \\
\text { West Island } \\
\text { engleză (de facto) } \\
\text { dolar australian (AUD) }\end{array}$ \\
\hline $\begin{array}{l}\text { Colombia } \\
\text { Republic of Colombia } \\
\text { Bogotá } \\
\text { Colombian } \\
\text { Spanish } \\
\text { Peso (COP) }\end{array}$ & $\mathrm{CO}$ & $\mathrm{COL}$ & 170 & $\begin{array}{l}\text { Columbia } \\
\text { Republica Colombia } \\
\text { Bogotá } \\
\text { columbian, columbiancă (columbiană) } \\
\text { spaniolă } \\
\text { peso columbian (COP) }\end{array}$ \\
\hline
\end{tabular}




\begin{tabular}{|c|c|c|c|c|}
\hline $\begin{array}{c}\text { Country name } \\
\text { Official name } \\
\text { Capital } \\
\text { Habitant (Demonym) } \\
\text { Language(s) } \\
\text { Currency }\end{array}$ & 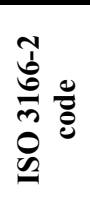 & 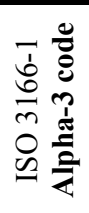 & 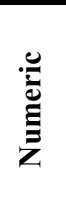 & $\begin{array}{c}\text { Ţara } \\
\text { Denumire oficială } \\
\text { Capitală } \\
\text { Etnonim / Locuitor (locuri etc.) } \\
\text { Limbă oficială, limbi oficiale } \\
\text { Monedă }\end{array}$ \\
\hline $\begin{array}{l}\text { Comoros } \\
\text { Union of the Comoros } \\
\text { Moroni } \\
\text { Comorian(s) } \\
\text { Comorian, Arabic, French } \\
\text { Comorian franc (KMF) }\end{array}$ & KM & $\mathrm{COM}$ & 174 & $\begin{array}{l}\text { Comore } \\
\text { Uniunea Comorelor } \\
\text { Moroni } \\
\text { comorez, comoreză } \\
\text { shikomor, arabă, franceză } \\
\text { franc comorez (KMF) }\end{array}$ \\
\hline $\begin{array}{l}\text { Congo } \\
\text { Republic of the Congo } \\
\text { Brazzaville } \\
\text { Congolese } \\
\text { French } \\
\text { Central African CFA franc (XAF) }\end{array}$ & $\mathrm{CG}$ & $\mathrm{COG}$ & 178 & $\begin{array}{l}\text { Congo } \\
\text { Republica Congo } \\
\text { Brazzaville } \\
\text { congolez, congoleză } \\
\text { franceză } \\
\text { franc central-african, CFA (XAF) }\end{array}$ \\
\hline $\begin{array}{l}\text { Congo } \\
\text { Democratic Republic of the Congo } \\
\text { Kinshasa } \\
\text { Congolese } \\
\text { French } \\
\text { Congolese franc (CDF) }\end{array}$ & $\mathrm{CD}$ & COD & 180 & $\begin{array}{l}\text { Republica Democrată Congo } \\
\text { Republica Democrată Congo } \\
\text { Kinshasa } \\
\text { congolez, congoleză } \\
\text { franceză } \\
\text { franc congolez }(\mathrm{CDF})\end{array}$ \\
\hline $\begin{array}{l}\text { Cook Islands } \\
\text { Cook Islands } \\
\text { Avarua } \\
\text { Cook Islander } \\
\text { English, Cook Islands Māori } \\
\text { New Zealand dollar, (Cook } \\
\text { Islands dollar) (NZD) }\end{array}$ & CK & $\mathrm{COK}$ & 184 & $\begin{array}{l}\text { Insulele Cook } \\
\text { Insulele Cook } \\
\text { Avarua } \\
\text { Cook Islander } \\
\text { engleză, māori din Insulele Cook } \\
\text { dolar neozeelandez (dolar al Insulelor } \\
\text { Cook) (NZD) }\end{array}$ \\
\hline $\begin{array}{l}\text { Costa Rica } \\
\text { Republic of Costa Rica } \\
\text { San José } \\
\text { Costa Rican; Tico } \\
\text { Spanish } \\
\text { Costa Rican colón (CRC) }\end{array}$ & CR & CRI & 188 & $\begin{array}{l}\text { Costa Rica } \\
\text { Republica Costa Rica } \\
\text { San José } \\
\text { costarican, costaricancă (costaricană) } \\
\text { spaniola } \\
\text { colón costarican(CRC) }\end{array}$ \\
\hline $\begin{array}{l}\text { Côte d'Ivoire } \\
\text { Republic of Côte d'Ivoire } \\
\text { Yamoussoukro } \\
\text { Ivorian / Ivoirian } \\
\text { French } \\
\text { West African CFA franc (XOF) }\end{array}$ & $\mathrm{CI}$ & CIV & 384 & $\begin{array}{l}\text { Coasta de Fildeş } \\
\text { Republica Coasta de Fildeş } \\
\text { Yamoussoukro } \\
\text { franceză } \\
\text { franc central-african, CFA (XAF) }\end{array}$ \\
\hline $\begin{array}{l}\text { Croatia } \\
\text { Republic of Croatia } \\
\text { Zagreb } \\
\text { Croat, Croatian } \\
\text { Croatian } \\
\text { Kuna (HRK) }\end{array}$ & HR & HRV & 191 & $\begin{array}{l}\text { Croația } \\
\text { Republica Croația } \\
\text { Zagreb } \\
\text { croat, croată } \\
\text { croată } \\
\text { kuna (HRK) }\end{array}$ \\
\hline $\begin{array}{l}\text { Cuba } \\
\text { Republic of Cuba } \\
\text { Havana } \\
\text { Cuban } \\
\text { Spanish } \\
\text { Cuban peso (CUP), Cuban } \\
\text { convertible peso (CUC) }\end{array}$ & $\mathrm{CU}$ & CUB & 192 & $\begin{array}{l}\text { Cuba } \\
\text { Republica Cuba } \\
\text { Havana } \\
\text { cubanez, cubaneză } \\
\text { spaniolă } \\
\text { peso cubanez (CUP) şi peso convertibil } \\
\text { cubanez (CUC) }\end{array}$ \\
\hline
\end{tabular}




\begin{tabular}{|c|c|c|c|c|}
\hline $\begin{array}{c}\text { Country name } \\
\text { Official name } \\
\text { Capital } \\
\text { Habitant (Demonym) } \\
\text { Language(s) } \\
\text { Currency }\end{array}$ & 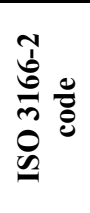 & $\begin{array}{ll}7 & 0 \\
1 & 0 \\
0 & 0 \\
0 & 0 \\
0 & \frac{1}{\pi} \\
0 & \frac{E}{2}\end{array}$ & & $\begin{array}{c}\text { Ţara } \\
\text { Denumire oficială } \\
\text { Capitală } \\
\text { Etnonim / Locuitor (locuri etc.) } \\
\text { Limbă oficială, limbi oficiale } \\
\text { Monedă }\end{array}$ \\
\hline $\begin{array}{l}\text { Cyprus } \\
\text { Republic of Cyprus } \\
\text { Nicosia } \\
\text { Cypriot } \\
\text { Greek and Turkish } \\
\text { Euro (€) (EUR) (Greek zone), Tur- } \\
\text { kish pound (TRY) (Turkish zone) }\end{array}$ & $\overline{C Y}$ & CYP & 196 & $\begin{array}{l}\text { Cipru } \\
\text { Republica Ciprului } \\
\text { Nicosia } \\
\text { cipriot, cipriotă } \\
\text { greacă şi turcă } \\
\text { euro (EUR) (€) (în zona greacă), liră } \\
\text { turcească (TRY) (în zona turcă) }\end{array}$ \\
\hline $\begin{array}{l}\text { Czech Republic } \\
\text { Czech Republic } \\
\text { Prague, Praha } \\
\text { Czech } \\
\text { Czech } \\
\text { Czech koruna }(\mathrm{CZK})\end{array}$ & $\mathrm{CZ}$ & CZE & 203 & $\begin{array}{l}\text { Cehia } \\
\text { Republica Cehă } \\
\text { Praga } \\
\text { ceh, cehoaică (cehă) } \\
\text { cehă } \\
\text { coroana cehă }(\mathrm{CZK})\end{array}$ \\
\hline $\begin{array}{l}\text { Denmark } \\
\text { Kingdom of Denmark } \\
\text { Copenhagen } \\
\text { Danish or Dane/Danes } \\
\text { Danish } \\
\text { Danish krone (DKK) }\end{array}$ & DK & DNK & 208 & $\begin{array}{l}\text { Danemarca } \\
\text { Regatul Danemarcei } \\
\text { Copenhaga } \\
\text { danez, daneză } \\
\text { daneză } \\
\text { coroană daneză (DKK) }\end{array}$ \\
\hline $\begin{array}{l}\text { Djibouti } \\
\text { Republic of Djibouti } \\
\text { Djibouti } \\
\text { Djiboutian } \\
\text { Arabic, French } \\
\text { Franc (DJF) }\end{array}$ & DJ & DJI & 262 & $\begin{array}{l}\text { Djibouti } \\
\text { Republica Djibouti } \\
\text { Djibouti } \\
\text { arabă, franceză } \\
\text { franc djiboutian (DJF) }\end{array}$ \\
\hline $\begin{array}{l}\text { Dominica } \\
\text { Commonwealth of Dominica } \\
\text { Roseau } \\
\text { Dominican } \\
\text { English } \\
\text { East Caribbean dollar (XCD) }\end{array}$ & $\mathrm{DM}$ & DMA & 212 & $\begin{array}{l}\text { Dominica } \\
\text { Commonwealth of Dominica } \\
\text { Roseau } \\
\text { dominican, dominicană } \\
\text { engleză } \\
\text { dolar est-caraib (XCD) } \\
\end{array}$ \\
\hline $\begin{array}{l}\text { Dominican Republic } \\
\text { Dominican Republic } \\
\text { Santo Domingo } \\
\text { Dominican } \\
\text { Spanish } \\
\text { Peso (DOP) }\end{array}$ & DO & DOM & 214 & $\begin{array}{l}\text { Republica Dominicană } \\
\text { Republica Dominicană } \\
\text { Santo Domingo } \\
\text { dominican, dominicancă (dominicană) } \\
\text { spaniolă } \\
\text { peso (DOP) }\end{array}$ \\
\hline $\begin{array}{l}\text { Ecuador } \\
\text { Republic of Ecuador } \\
\text { Quito } \\
\text { Ecuadorian } \\
\text { Spanish } \\
\text { US dollar (USD) } \\
\end{array}$ & $\mathrm{EC}$ & ECU & 218 & $\begin{array}{l}\text { Ecuador } \\
\text { Republica Ecuador } \\
\text { Quito } \\
\text { ecuadorian, ecuadoriancă (ecuadoriană) } \\
\text { spaniolă } \\
\text { dolar american (USD) }\end{array}$ \\
\hline $\begin{array}{l}\text { Egypt } \\
\text { Arab Republic of Egypt } \\
\text { Cairo } \\
\text { Egyptian } \\
\text { Arabic } \\
\text { Egyptian pound (EGP) } \\
\end{array}$ & EG & EGY & 818 & $\begin{array}{l}\text { Egipt } \\
\text { Arab Republica Arabă Egipt } \\
\text { Cairo } \\
\text { egiptean, egipteancă (egipteană) } \\
\text { arabă } \\
\text { liră egipteană (EGP) }\end{array}$ \\
\hline
\end{tabular}




\begin{tabular}{|c|c|c|c|c|}
\hline $\begin{array}{c}\text { Country name } \\
\text { Official name } \\
\text { Capital } \\
\text { Habitant (Demonym) } \\
\text { Language(s) } \\
\text { Currency } \\
\end{array}$ & 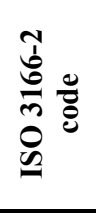 & $\begin{array}{ll}7 & 0 \\
1 & 0 \\
0 & 0 \\
0 & 0 \\
0 & \frac{1}{d} \\
0 & \frac{1}{2}\end{array}$ & 苞 & $\begin{array}{c}\text { Țara } \\
\text { Denumire oficială } \\
\text { Capitală } \\
\text { Etnonim / Locuitor (locuri etc.) }^{*} \\
\text { Limbă oficială, limbi oficiale } \\
\text { Monedă }\end{array}$ \\
\hline $\begin{array}{l}\text { El Salvador } \\
\text { Republic of EI Salvador } \\
\text { San Salvador } \\
\text { Salvadorean } \\
\text { Spanish } \\
\text { U.S. dollar (USD) }\end{array}$ & SV & SLV & 222 & $\begin{array}{l}\text { El Salvador } \\
\text { Republica EI Salvador } \\
\text { San Salvador } \\
\text { salvadorian, salvadoriană } \\
\text { spaniolă } \\
\text { dolar american }(\$)(U S D)\end{array}$ \\
\hline $\begin{array}{l}\text { Equatorial Guinea } \\
\text { Republic of Equatorial Guinea } \\
\text { Malabo } \\
\text { Equatoguinean, Equatorial Guinean } \\
\text { Spanish, French and Portuguese } \\
\text { Central African CFA franc (XAF) }\end{array}$ & GQ & GNQ & 226 & $\begin{array}{l}\text { Guineea Ecuatorială } \\
\text { Republica Guineea Ecuatorială } \\
\text { Malabo } \\
\text { ecuatorian, ecuatoriancă (ecuatoriană) } \\
\text { spaniolă, franceză, portugheză } \\
\text { franc central-african, CFA (XAF) }\end{array}$ \\
\hline $\begin{array}{l}\text { Eritrea } \\
\text { State of Eritrea } \\
\text { Asmara } \\
\text { Eritrean } \\
\text { Arabic, English, Tigrinya } \\
\text { Nakfa (ERN) }\end{array}$ & ER & ERI & 232 & $\begin{array}{l}\text { Eritreea } \\
\text { Statul Eritreea } \\
\text { Asmara } \\
\text { eritrean, eritreană } \\
\text { arabă, engleză, tigrina } \\
\text { Nakfa (ERN) }\end{array}$ \\
\hline $\begin{array}{l}\text { Estonia } \\
\text { Republic of Estonia } \\
\text { Tallinn } \\
\text { Estonian } \\
\text { Estonian } \\
\text { Estonian kroon (EEK) } \\
\end{array}$ & $\mathrm{EE}$ & EST & 233 & $\begin{array}{l}\text { Estonia } \\
\text { Republica Estoniei } \\
\text { Tallinn } \\
\text { estonian, estoniancă (estonă) } \\
\text { estonă } \\
\text { coroană estoniană (EEK) }\end{array}$ \\
\hline $\begin{array}{l}\text { Ethiopia } \\
\text { Federal Democratic Republic of } \\
\quad \text { Ethiopia } \\
\text { Addis Ababa } \\
\text { Ethiopian } \\
\text { Amharic } \\
\text { Birr (ETB) }\end{array}$ & ET & ETH & 231 & $\begin{array}{l}\text { Etiopia } \\
\text { Republica Federală Democrată a } \\
\quad \text { Etiopiei } \\
\text { Addis Ababa } \\
\text { etiopian, etiopiancă (etiopiană) } \\
\text { amharică } \\
\text { birr (ETB) }\end{array}$ \\
\hline $\begin{array}{l}\text { Falkland Islands } \\
\text { Falkland Islands (Malvinas) } \\
\text { (an Overseas Territory of the UK) } \\
\text { Stanley } \\
\text { Falkland Islander } \\
\text { English } \\
\text { Falkland Islands pound (FKP) }\end{array}$ & FK & FLK & 238 & $\begin{array}{l}\text { Insulele Falkland } \\
\text { Insulele Falkland (Insulele Malvine) } \\
\text { (un teritoriu britanic de peste mări) } \\
\text { Stanley } \\
\text { engleză } \\
\text { liră sterlină Falkland (FKP) }\end{array}$ \\
\hline $\begin{array}{l}\text { Faroe Islands } \\
\text { Faroe Islands } \\
\text { Tórshavn } \\
\text { Faroese } \\
\text { Faroese, Danish } \\
\text { Faroese króna (DKK) }\end{array}$ & FO & FRO & 234 & $\begin{array}{l}\text { Insulele Feroe } \\
\text { Insulele Feroe } \\
\text { Tórshavn } \\
\text { feroez, feroeză } \\
\text { feroeză şi daneză } \\
\text { coroană feroeză (DKK) }\end{array}$ \\
\hline $\begin{array}{l}\text { Fiji } \\
\text { Republic of the Fiji Islands } \\
\text { Suva } \\
\text { Fiji Islander, Fijian } \\
\text { English, Bau Fijian, and Hindi } \\
\text { Fijian dollar (FJD) }\end{array}$ & FJ & FJI & 242 & $\begin{array}{l}\text { Fiji } \\
\text { Republica Insulelor Fiji } \\
\text { Suva } \\
\text { fijian, fijiană } \\
\text { engleză, fijiană şi hindi } \\
\text { dolar fijian (FJD) }\end{array}$ \\
\hline
\end{tabular}




\begin{tabular}{|c|c|c|c|c|}
\hline $\begin{array}{c}\text { Country name } \\
\text { Official name } \\
\text { Capital } \\
\text { Habitant (Demonym) } \\
\text { Language(s) } \\
\text { Currency } \\
\end{array}$ & 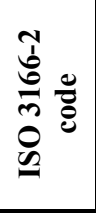 & 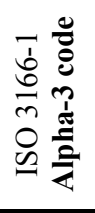 & 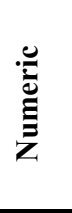 & $\begin{array}{c}\text { Țara } \\
\text { Denumire oficială } \\
\text { Capitală } \\
\text { Etnonim / Locuitor (locuri etc.) } \\
\text { Limbă oficială, limbi oficiale } \\
\text { Monedă }\end{array}$ \\
\hline $\begin{array}{l}\text { Finland } \\
\text { Republic of Finland } \\
\text { Helsinki } \\
\text { Finns, Finnish } \\
\text { Finnish, Swedish } \\
\text { Euro }(€) \text { (EUR) }\end{array}$ & FI & FIN & 246 & $\begin{array}{l}\text { Finlanda } \\
\text { Republica Finlandei } \\
\text { Helsinki } \\
\text { finlandez, finlandeză } \\
\text { finlandeză, suedeză } \\
\text { euro }(€)(E U R)\end{array}$ \\
\hline $\begin{array}{l}\text { France } \\
\text { French Repuplic } \\
\text { Paris } \\
\text { French } \\
\text { French } \\
\text { Euro }(€)(\text { EUR) } \\
\end{array}$ & FR & FRA & 250 & $\begin{array}{l}\text { Franța } \\
\text { Republica Franceză } \\
\text { Paris } \\
\text { francez, franțuzoaică (franceză) } \\
\text { franceză } \\
\text { euro }(€)(E U R) \\
\end{array}$ \\
\hline $\begin{array}{l}\text { French Guiana, Guyane } \\
\text { (an overseas region of France) } \\
\text { Cayenne } \\
\text { French } \\
\text { Euro }(€)(\text { EUR) }\end{array}$ & GF & GUF & 254 & $\begin{array}{l}\text { Guiana Franceză } \\
\text { (departament de peste mări al Franței) } \\
\text { Cayenne } \\
\text { franceză } \\
\text { euro }(€)(\text { EUR) }\end{array}$ \\
\hline $\begin{array}{l}\text { French Polynesia } \\
\text { French Polynesia (a French } \\
\quad \quad \text { overseas collectivity) } \\
\text { Papeete } \\
\text { French Polynesian } \\
\text { French } \\
\text { CFP franc (XPF) }\end{array}$ & $\overline{P F}$ & $\begin{array}{l}\text { PYF } \\
\end{array}$ & 258 & $\begin{array}{l}\text { Polinezia franceză } \\
\text { Polinezia franceză (colectivitate de } \\
\quad \text { peste mări, franceză) } \\
\text { Papeete } \\
\text { (tahitian, tahitiană) } \\
\text { franceză } \\
\text { franc CFP (XPF) }\end{array}$ \\
\hline $\begin{array}{l}\text { French Southern Territories } \\
\text { Territory of the French } \\
\quad \text { Southern and Antarctic Lands } \\
\text { Port-aux-Français } \\
\text { French } \\
\text { Euro }(€)(E U R) \\
\end{array}$ & $\mathrm{TF}$ & ATF & 260 & $\begin{array}{l}\text { Teritoriile australe şi antarctice franceze } \\
\text { Teritoriile australe şi antarctice } \\
\quad \text { franceze } \\
\text { Port-aux-Français } \\
\text { franceză } \\
\text { euro }(€)(E U R)\end{array}$ \\
\hline $\begin{array}{l}\text { Gabon } \\
\text { Gabonese Republic } \\
\text { Libreville } \\
\text { Gabonese, Gabonaise } \\
\text { French } \\
\text { Central African CFA franc (XAF) }\end{array}$ & GA & GAB & 266 & $\begin{array}{l}\text { Gabon } \\
\text { Gabonese Republic } \\
\text { Libreville } \\
\text { gabonez, gaboneză } \\
\text { franceză } \\
\text { franc central-african CFA (XAF) }\end{array}$ \\
\hline $\begin{array}{l}\text { Gambia } \\
\text { Republic of The Gambia } \\
\text { Banjul } \\
\text { Gambian } \\
\text { English } \\
\text { Dalasi (GMD) }\end{array}$ & GM & GMB & 270 & $\begin{array}{l}\text { Gambia } \\
\text { Republica Gambia } \\
\text { Banjul } \\
\text { gambian, gambiancă (rar) (gambiană) } \\
\text { engleză } \\
\text { dalasi (GMD) }\end{array}$ \\
\hline $\begin{array}{l}\text { Georgia } \\
\text { Georgia } \\
\text { Tbilisi } \\
\text { Georgian } \\
\text { Georgian } \\
\text { Lari }(m)(\mathrm{GEL})\end{array}$ & GE & GEO & 268 & $\begin{array}{l}\text { Georgia } \\
\text { Georgia } \\
\text { Tbilisi } \\
\text { georgian, georgiană } \\
\text { georgiană } \\
\text { lari }(m)(\mathrm{GEL})\end{array}$ \\
\hline
\end{tabular}




\begin{tabular}{|c|c|c|c|c|}
\hline $\begin{array}{c}\text { Country name } \\
\text { Official name } \\
\text { Capital } \\
\text { Habitant (Demonym) } \\
\text { Language(s) } \\
\text { Currency } \\
\end{array}$ & 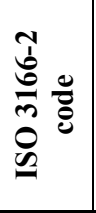 & $\begin{array}{ll}7 & 0 \\
1 & 0 \\
0 & 0 \\
0 & 0 \\
m & \frac{\pi}{\pi} \\
0 & \frac{\pi}{2}\end{array}$ & 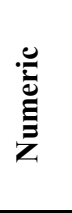 & $\begin{array}{c}\text { Țara } \\
\text { Denumire oficială } \\
\text { Capitală } \\
\text { Etnonim / Locuitor (locuri etc.) } \\
\text { Limbă oficială, limbi oficiale } \\
\text { Monedă }\end{array}$ \\
\hline $\begin{array}{l}\text { Germany } \\
\text { Federal Republic of Germany } \\
\text { Berlin } \\
\text { German } \\
\text { German } \\
\text { Euro }(€)(\text { EUR }) \\
\end{array}$ & $\mathrm{DE}$ & $\overline{D E U}$ & 276 & $\begin{array}{l}\text { Germania } \\
\text { Republica Federală a Germaniei } \\
\text { Berlin } \\
\text { german, neamţ, nemțoaică (germană) } \\
\text { germană } \\
\text { euro }(€)(\text { EUR })\end{array}$ \\
\hline $\begin{array}{l}\text { Ghana } \\
\text { Republic of Ghana } \\
\text { Accra } \\
\text { Ghanaian } \\
\text { English } \\
\text { Ghanaian cedi (GHC) } \\
\end{array}$ & $\mathrm{GH}$ & GHA & 288 & $\begin{array}{l}\text { Ghana } \\
\text { Republica Ghana } \\
\text { Accra } \\
\text { ghanez, ghaneză } \\
\text { engleză } \\
\text { cedi (GHC) }\end{array}$ \\
\hline $\begin{array}{l}\text { Gibraltar } \\
\text { Gibraltar (an British overseas } \\
\text { territory) } \\
\text { Gibraltar } \\
\text { Gibraltarian } \\
\text { English } \\
\text { Pound sterling, Gibraltar pound } £ \\
\quad \text { (GIP) }\end{array}$ & GI & GIB & 292 & $\begin{array}{l}\text { Gibraltar } \\
\text { Gibraltar (teritoriu de peste mări, } \\
\text { britanic) } \\
\text { Gibraltar } \\
\text { gibraltarian (rar), gibraltariană } \\
\text { engleză } \\
\text { liră sterlină (GBP), liră de Gibraltar } \\
\quad \text { (GIP) }\end{array}$ \\
\hline $\begin{array}{l}\text { Greece } \\
\text { Hellenic Republic } \\
\text { Athens } \\
\text { Greek } \\
\text { Greek } \\
\text { Euro }(€)(E U R) \\
\end{array}$ & GR & GRC & 300 & $\begin{array}{l}\text { Grecia } \\
\text { Hellenic Republic } \\
\text { Athens } \\
\text { grec, grecoaică (grecesc, greacă, } \\
\text { grecească) } \\
\text { greacă } \\
\text { euro }(€)(E U R)\end{array}$ \\
\hline $\begin{array}{l}\text { Greenland } \\
\text { Greenland (autonomous country } \\
\text { within the Kingdom of Denmark) } \\
\text { Nuuk (Godthåb) } \\
\text { Greenlander, Greenlandic } \\
\text { Greenlandic (Kalaallisut) } \\
\text { Danish krone (DKK) } \\
\end{array}$ & GL & GRL & 304 & $\begin{array}{l}\text { Groenlanda } \\
\text { Groenlanda (ținut autonom în Regatul } \\
\quad \text { Danemarcei) } \\
\text { Nuuk (Godthăb) } \\
\text { groenlandez, groenlandeză (groenlandică) } \\
\text { greonlandică (Kalaallisut) } \\
\text { coroană daneză (DKK) }\end{array}$ \\
\hline $\begin{array}{l}\text { Grenada } \\
\text { Grenada } \\
\text { St. George's } \\
\text { Grenadian, Greenz, Greens } \\
\text { English, Patois } \\
\text { East Caribbean dollar (XCD) }\end{array}$ & GD & GRD & 308 & $\begin{array}{l}\text { Grenada } \\
\text { Grenada } \\
\text { St. George's } \\
\text { Grenadian, Greenz, Greens } \\
\text { English, Patois } \\
\text { dolar est-caraib (XCD) } \\
\end{array}$ \\
\hline $\begin{array}{l}\text { Guadeloupe } \\
\text { Guadeloupe (Overseas region of } \\
\quad \text { France) } \\
\text { Basse-Terre } \\
\text { French } \\
\text { Euro }(€)(\text { EUR) }\end{array}$ & GP & GLP & 312 & $\begin{array}{l}\text { Guadelupa } \\
\text { Guadeloupa (regiune de peste mări, a } \\
\quad \text { Franței) } \\
\text { Basse-Terre } \\
\text { franceză } \\
\text { euro }(€)(E U R)\end{array}$ \\
\hline
\end{tabular}




\begin{tabular}{|c|c|c|c|c|}
\hline $\begin{array}{c}\text { Country name } \\
\text { Official name } \\
\text { Capital } \\
\text { Habitant (Demonym) } \\
\text { Language(s) } \\
\text { Currency } \\
\end{array}$ & 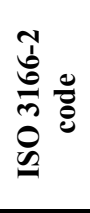 & 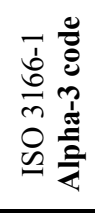 & 莺 & $\begin{array}{c}\text { Țara } \\
\text { Denumire oficială } \\
\text { Capitală } \\
\text { Etnonim / Locuitor (locuri etc.) } \\
\text { Limbă oficială, limbi oficiale } \\
\text { Monedă }\end{array}$ \\
\hline $\begin{array}{l}\text { Guam } \\
\text { Guam (an organized, unincorpo- } \\
\quad \text { rated territory of the US) } \\
\text { Hagåtña } \\
\text { Guamanian } \\
\text { English and Chamoru } \\
\text { United States dollar (USD) }\end{array}$ & GU & GUM & 316 & $\begin{array}{l}\text { Guam } \\
\text { Guam (în administrarea Statelor Unite } \\
\quad \text { ale Americii) } \\
\text { Hagåtña } \\
\text { engleză şi chamoru } \\
\text { dolar american (\$)(USD) }\end{array}$ \\
\hline $\begin{array}{l}\text { Guatemala } \\
\text { Republic of Guatemala } \\
\text { Guatemala City } \\
\text { Guatemalan } \\
\text { Spanish, } 22 \text { indigenous languages } \\
\text { Quetzal (GTQ) }\end{array}$ & GT & GTM & 320 & $\begin{array}{l}\text { Guatemala } \\
\text { Republica Guatemala } \\
\text { Guatemala City } \\
\text { guatemalez, guatemaleză } \\
\text { spaniolă, } 22 \text { limbi indigene } \\
\text { quetzal (GTQ) }\end{array}$ \\
\hline $\begin{array}{l}\text { Guernsey } \\
\text { Bailiwick of Guernsey (a British } \\
\quad \text { Crown Dependency) } \\
\text { Saint Peter Port (Saint Pierre Port) } \\
\\
\text { Enghis, French } \\
\text { Pound sterling (GBP) }\end{array}$ & GG & GGY & 831 & $\begin{array}{l}\text { Guernsey } \\
\text { Bailiwick of Guernsey (dependență a } \\
\quad \text { coroanei britanice) } \\
\text { Saint Peter Port (Saint Pierre Port) } \\
\text { engleză, franceză } \\
\text { liră sterlină (GBP) }\end{array}$ \\
\hline $\begin{array}{l}\text { Guinea } \\
\text { Republic of Guinea } \\
\text { Conakry } \\
\text { Guinean } \\
\text { French } \\
\text { Guinean franc (GNF) } \\
\end{array}$ & GN & GIN & 324 & $\begin{array}{l}\text { Guineea } \\
\text { Republica Guineea } \\
\text { Conakry } \\
\text { guineez, guineeză } \\
\text { franceză } \\
\text { franc guineez }(\mathrm{GNF}) \\
\end{array}$ \\
\hline $\begin{array}{l}\text { Guinea-Bissau } \\
\text { Republic of Guinea-Bissau } \\
\text { Bissau } \\
\text { Bissau-Guinean(s) } \\
\text { Portuguese } \\
\text { West African CFA franc (XOF) } \\
\end{array}$ & GW & GNB & 624 & $\begin{array}{l}\text { Guineea-Bissau } \\
\text { Republica Guineea-Bissau } \\
\text { Bissau } \\
\text { portugheză } \\
\text { franc central-african, CFA (XOF) }\end{array}$ \\
\hline $\begin{array}{l}\text { Guyana } \\
\text { Co-operative Republic of } \\
\quad \text { Guyana } \\
\text { Georgetown } \\
\text { Guyanese } \\
\text { Enghish } \\
\text { Guyanese dollar (GYD) }\end{array}$ & GY & GUY & 328 & $\begin{array}{l}\text { Guyana } \\
\text { Republica Cooperativă Guyana } \\
\text { Georgetown } \\
\text { guyanez, guyaneză } \\
\text { engleză } \\
\text { dolar guyanez (GYD) }\end{array}$ \\
\hline $\begin{array}{l}\text { Haiti } \\
\text { Republic of Haiti } \\
\text { Port-au-Prince } \\
\text { Haitian } \\
\text { Haitian Creole, French } \\
\text { Gourde (HTG) } \\
\end{array}$ & HT & HTI & 332 & $\begin{array}{l}\text { Haiti } \\
\text { Republic of Haiti } \\
\text { Port-au-Prince } \\
\text { haitian, haitiană } \\
\text { creolă haitiană, franceză } \\
\text { gourde (HTG) }\end{array}$ \\
\hline $\begin{array}{l}\text { Heard Island and McDonald } \\
\text { Islands } \\
\text { Territory of Heard Island and } \\
\quad \text { McDonald Islands } \\
\quad \text { (a territory of Australia) } \\
\end{array}$ & $\mathrm{HM}$ & HMD & 334 & $\begin{array}{l}\text { Insula Heard şi Insulele McDonald } \\
\text { Insula Heard şi Insulele McDonald } \\
\quad \text { (un teritoriu al Australiei) }\end{array}$ \\
\hline
\end{tabular}




\begin{tabular}{|c|c|c|c|c|}
\hline $\begin{array}{c}\text { Country name } \\
\text { Official name } \\
\text { Capital } \\
\text { Habitant (Demonym) } \\
\text { Language(s) } \\
\text { Currency }\end{array}$ & 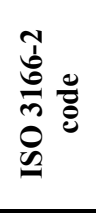 & $\begin{array}{ll} & 0 \\
1 & 0 \\
0 & 0 \\
0 & 0 \\
n & 0 \\
0 & \frac{1}{2} \\
0 & \frac{1}{2}\end{array}$ & 苞 & $\begin{array}{c}\text { Țara } \\
\text { Denumire oficială } \\
\text { Capitală } \\
\text { Etnonim / Locuitor (locuri etc.) }^{*} \\
\text { Limbă oficială, limbi oficiale } \\
\text { Monedă }\end{array}$ \\
\hline $\begin{array}{l}\text { Holy See (Vatican City State) } \\
\text { State of the Vatican City } \\
\text { Vatican City } \\
\text { Italian } \\
\text { Euro }(€)(E U R)\end{array}$ & VA & VAT & 336 & $\begin{array}{l}\text { Vatican, Statul Vatican } \\
\text { Statul Cetății Vatican } \\
\text { Vatican } \\
\text { italiană } \\
\text { euro }(€)(\text { EUR) }\end{array}$ \\
\hline $\begin{array}{l}\text { Honduras } \\
\text { Republic of Honduras } \\
\text { Tegucigalpa } \\
\text { Honduran } \\
\text { Spanish } \\
\text { Lempira (HNL) }\end{array}$ & $\mathrm{HN}$ & HND & 340 & $\begin{array}{l}\text { Honduras } \\
\text { Republica Honduras } \\
\text { Tegucigalpa } \\
\text { hondurinez, hondurineză } \\
\text { spaniolă } \\
\text { lempira (HNL) }\end{array}$ \\
\hline $\begin{array}{l}\text { Hong Kong } \\
\text { Hong Kong Special Administra- } \\
\text { tive Region of the People's } \\
\text { Republic of China }\end{array}$ & HK & HKG & 344 & $\begin{array}{l}\text { Hong Kong } \\
\text { Regiunea cu administrație specială } \\
\text { Hong Kong, a Republicii } \\
\text { Populare Chineze }\end{array}$ \\
\hline $\begin{array}{l}\text { Hongkonger } \\
\text { Chinese, English } \\
\text { Hong Kong dollar (HKD) }\end{array}$ & & & & $\begin{array}{l}\text { hongkongonez, hongkongoneză (rar) } \\
\text { chineză, engleză } \\
\text { dolar din Hong Kong (HKD) }\end{array}$ \\
\hline $\begin{array}{l}\text { Hungary } \\
\text { Republic of Hungary } \\
\text { Budapest } \\
\text { Hungarian } \\
\text { Hungarian } \\
\text { Forint (HUF) } \\
\end{array}$ & $\mathrm{HU}$ & HUN & 348 & $\begin{array}{l}\text { Ungaria } \\
\text { Republica Ungaria } \\
\text { Budapesta } \\
\text { ungur, unguroaică (ungar, unguresc, } \\
\quad \text { ungară, ungurească) } \\
\text { maghiară } \\
\text { forint, }(p l) \text { forinți (HUF) }\end{array}$ \\
\hline $\begin{array}{l}\text { Iceland } \\
\text { Iceland } \\
\text { Reykjavík } \\
\text { Icelander, Icelandic } \\
\text { Icelandic } \\
\text { Icelandic króna (ISK) }\end{array}$ & IS & ISL & 352 & $\begin{array}{l}\text { Islanda } \\
\text { Islanda } \\
\text { Reykjavík } \\
\text { islandez, islandeză } \\
\text { islandeză } \\
\text { coroană islandeză (ISK) }\end{array}$ \\
\hline $\begin{array}{l}\text { India } \\
\text { Republic of India } \\
\text { New Dheli } \\
\text { Indian } \\
\text { Hindi, English } \\
\text { Indian rupee (Rp) (INR) }\end{array}$ & IN & IND & 356 & $\begin{array}{l}\text { India } \\
\text { Republica India } \\
\text { New Dheli } \\
\text { indian, indiancă (indiană) } \\
\text { hindi, engleză } \\
\text { rupie indiană (Rp) (INR) }\end{array}$ \\
\hline $\begin{array}{l}\text { Indonesia } \\
\text { Republic of Indonesia } \\
\text { Jakarta } \\
\text { Indonesian } \\
\text { Indonezian } \\
\text { Rupiah (IDR) }\end{array}$ & ID & IDN & 360 & $\begin{array}{l}\text { Indonezia } \\
\text { Republica Indonezia } \\
\text { Jakarta } \\
\text { indonezian, indoneziancă, inodeniziană } \\
\text { indoneziană } \\
\text { rupie indoneziană (IDR) }\end{array}$ \\
\hline $\begin{array}{l}\text { Iran } \\
\text { Islamic Republic of Iran } \\
\text { Tehran } \\
\text { Iranian } \\
\text { Persan } \\
\text { Rial (IRR) }\end{array}$ & IR & IRN & 364 & $\begin{array}{l}\text { Iran } \\
\text { Republica Islamică Iran } \\
\text { Teheran } \\
\text { iranian, iraniancă (iraniană) } \\
\text { persană } \\
\text { rial iranian (IRR) }\end{array}$ \\
\hline
\end{tabular}




\begin{tabular}{|c|c|c|c|c|}
\hline $\begin{array}{c}\text { Country name } \\
\text { Official name } \\
\text { Capital } \\
\text { Habitant (Demonym) } \\
\text { Language(s) } \\
\text { Currency }\end{array}$ & 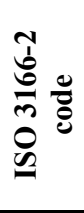 & $\begin{array}{ll} & 0 \\
1 & 0 \\
0 & 0 \\
0 & 0 \\
n & 0 \\
0 & \frac{1}{2} \\
0 & \frac{\pi}{2}\end{array}$ & 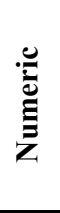 & $\begin{array}{c}\text { Țara } \\
\text { Denumire oficială } \\
\text { Capitală } \\
\text { Etnonim / Locuitor (locuri etc.) }{ }^{*} \\
\text { Limbă oficială, limbi oficiale } \\
\text { Monedă }\end{array}$ \\
\hline $\begin{array}{l}\text { Iraq } \\
\text { Republic of Iraq } \\
\text { Baghdad } \\
\text { Iraqi } \\
\text { Arabic, Kurdish } \\
\text { Iraqi dinar (IQD) }\end{array}$ & IQ & IRQ & 368 & $\begin{array}{l}\text { Irak } \\
\text { Republica of Irakiană } \\
\text { Baghdad } \\
\text { irakian, irakiană } \\
\text { arabă, kurdă } \\
\text { dinar irakian (IQD) }\end{array}$ \\
\hline $\begin{array}{l}\text { Ireland } \\
\text { Republic of Ireland } \\
\text { Dublin } \\
\text { Irish } \\
\text { Irish, English } \\
\text { Euro }(€)(\text { EUR) } \\
\end{array}$ & IE & IRL & 372 & $\begin{array}{l}\text { Republica Irlanda } \\
\text { Republica Irlanda } \\
\text { Dublin } \\
\text { irlandez, irlandeză } \\
\text { irlandeză, engleză } \\
\text { euro }(€)(\text { EUR) }\end{array}$ \\
\hline $\begin{array}{l}\text { Isle of Man } \\
\text { Isle of Man } \\
\text { Douglas (Doolish) } \\
\text { Manx } \\
\text { English, Manx } \\
\text { Pound sterling (GBP) }\end{array}$ & IM & IMN & 833 & $\begin{array}{l}\text { Insula Man } \\
\text { Insula Man } \\
\text { Douglas (Doolish) } \\
\text { manx } \\
\text { engleză, manx } \\
\text { liră sterlină (GBP) }\end{array}$ \\
\hline $\begin{array}{l}\text { Israel } \\
\text { State of Israel } \\
\text { Jerusalem } \\
\text { Israeli } \\
\text { Hebrew, Arabic } \\
\text { Shekel (凹) (ILS,NIS) }\end{array}$ & IL & ISR & 376 & $\begin{array}{l}\text { Israel } \\
\text { Statul Israel } \\
\text { Jerusalem } \\
\text { israelian, israeliană } \\
\text { ebraică, arabă } \\
\text { shekel / şekel nou (ه) (ILS,NIS) }\end{array}$ \\
\hline $\begin{array}{l}\text { Italy } \\
\text { Italian Republic } \\
\text { Rome } \\
\text { Italian } \\
\text { Italian } \\
\text { Euro }(€)(\text { EUR) } \\
\end{array}$ & IT & ITA & 380 & $\begin{array}{l}\text { Italia } \\
\text { Republica Italiană } \\
\text { Roma } \\
\text { italian, italiancă (italiană) } \\
\text { italiană } \\
\text { euro }(€)(E U R) \\
\end{array}$ \\
\hline $\begin{array}{l}\text { Jamaica } \\
\text { Jamaica } \\
\text { Kingstone } \\
\text { Jamaican } \\
\text { English } \\
\text { Jamaican dollar (JMD) } \\
\end{array}$ & $\mathrm{JM}$ & JAM & 388 & $\begin{array}{l}\text { Jamaica } \\
\text { Jamaica } \\
\text { Kingstone } \\
\text { jamaican, jamaicană } \\
\text { engleză } \\
\text { dolar jamaican (JMD) } \\
\end{array}$ \\
\hline $\begin{array}{l}\text { Japan } \\
\text { Japan } \\
\text { Tokyo } \\
\text { Japanese } \\
\text { none (national: Japanese) } \\
\text { Japanese yen (JPY, ¥) } \\
\end{array}$ & JP & JPN & 392 & $\begin{array}{l}\text { Japonia } \\
\text { Japonia } \\
\text { Tokyo } \\
\text { japonez, japoneză } \\
\text { japoneză } \\
\text { yen japonez }(J P Y, ¥)\end{array}$ \\
\hline $\begin{array}{l}\text { Jersey } \\
\text { Bailiwick of Jersey (British } \\
\quad \text { Crown dependency) } \\
\text { Saint Helier } \\
\text { English, French } \\
\text { Pound sterling (GBP) }\end{array}$ & $\mathrm{JE}$ & JEY & 832 & $\begin{array}{l}\text { Insula Jersey } \\
\text { Bailiwick of Jersey (dependență a } \\
\quad \text { coroanei britanice) } \\
\text { Saint Helier } \\
\text { engleză, franceză } \\
\text { liră sterlină (GBP) }\end{array}$ \\
\hline
\end{tabular}




\begin{tabular}{|c|c|c|c|c|}
\hline $\begin{array}{c}\text { Country name } \\
\text { Official name } \\
\text { Capital } \\
\text { Habitant (Demonym) } \\
\text { Language(s) } \\
\text { Currency } \\
\end{array}$ & 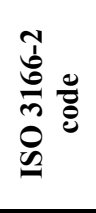 & $\begin{array}{ll} & 0 \\
1 & 0 \\
0 & 0 \\
0 & 0 \\
n & 0 \\
0 & \frac{1}{2} \\
0 & \frac{1}{2}\end{array}$ & 苞 & $\begin{array}{c}\text { Țara } \\
\text { Denumire oficială } \\
\text { Capitală } \\
\text { Etnonim / Locuitor (locuri etc.) }^{*} \\
\text { Limbă oficială, limbi oficiale } \\
\text { Monedă }\end{array}$ \\
\hline $\begin{array}{l}\text { Jordan } \\
\text { Hashemite Kingdom of Jordan } \\
\text { Amman } \\
\text { Jordanian } \\
\text { Arabic } \\
\text { Jordanian dinar (JOD) }\end{array}$ & $\mathrm{JO}$ & JOR & 400 & $\begin{array}{l}\text { Iordania } \\
\text { Hashemite Kingdom of Jordan } \\
\text { Amman } \\
\text { iordanian, iordaniancă (iordaniană) } \\
\text { arabă } \\
\text { dinar iordanian (JOD) }\end{array}$ \\
\hline $\begin{array}{l}\text { Kazakhstan } \\
\text { Republic of Kazakhstan } \\
\text { Astana } \\
\text { Kazakh, Kazakhstani } \\
\text { Kazakh, Russian } \\
\text { Tenge }(\overline{\mathbf{T}})(\mathrm{KZT})\end{array}$ & $\mathrm{KZ}$ & KAZ & 398 & $\begin{array}{l}\text { Kazahstan } \\
\text { Republica Kazakhstan } \\
\text { Astana } \\
\text { kazah } \\
\text { kazahă, rusă } \\
\text { tenge }(\overline{\mathrm{T}})(\mathrm{KZT})\end{array}$ \\
\hline $\begin{array}{l}\text { Kenya } \\
\text { Republic of Kenya } \\
\text { Nairobi } \\
\text { Kenyan } \\
\text { Swahili, English } \\
\text { Kenyan shilling (KES) }\end{array}$ & $\mathrm{KE}$ & KEN & 404 & $\begin{array}{l}\text { Kenya } \\
\text { Republica Kenya } \\
\text { Nairobi } \\
\text { kenian / kenyan, keniancă / kenyancă } \\
\quad \text { (keniană / kenyană) } \\
\text { swahili, engleză } \\
\text { şiling kenian / kenyan (KES) }\end{array}$ \\
\hline $\begin{array}{l}\text { Kiribati } \\
\text { Republic of Kiribati } \\
\text { South Tarawa } \\
\text { English, Gilbertese } \\
\text { Kiribati dollar, Australian dollar } \\
\text { (AUD) }\end{array}$ & KI & KIR & 296 & $\begin{array}{l}\text { Kiribati } \\
\text { Republica Kiribati } \\
\text { South Tarawa } \\
\text { engleză, kiribati } \\
\text { dolar kiribati, } \\
\quad \text { dolar australian (AUD) } \\
\end{array}$ \\
\hline $\begin{array}{l}\text { (North) Korea } \\
\text { Democratic People's Republic } \\
\quad \text { of Korea } \\
\text { Pyongyang } \\
\text { North Korean, Korean } \\
\text { Korean } \\
\text { North Korean won (W) (KPW) }\end{array}$ & KP & PRK & 408 & $\begin{array}{l}\text { Coreea de Nord } \\
\text { Republica Populară Democratică a } \\
\quad \text { Coreei } \\
\text { Pyongyang } \\
\text { nord-coreean, nord-coreeancă (nord- } \\
\quad \text { coreeană) } \\
\text { won nord-coreean (W) (KPW) }\end{array}$ \\
\hline $\begin{array}{l}\text { (South) Korea } \\
\text { Republic of Korea } \\
\text { Seoul } \\
\text { South Korean, Korean } \\
\text { Korean } \\
\text { South Korean won }(\mathrm{KRW})\end{array}$ & KR & KOR & 410 & $\begin{array}{l}\text { Coreea de Sud } \\
\text { Republica Corea } \\
\text { Seoul } \\
\text { coreean / sud-coreean, koreancă /sud- } \\
\text { coreancă (sud-coreană, coreană) } \\
\text { sud-coreean won (\#) (KRW) }\end{array}$ \\
\hline $\begin{array}{l}\text { Kuwait } \\
\text { State of Kuwait } \\
\text { Kuwait City } \\
\text { Kuwaiti } \\
\text { Arabic } \\
\text { Kuwaiti dinar (KWD) }\end{array}$ & KW & KWT & 414 & $\begin{array}{l}\text { Kuweit } \\
\text { Statul Kuwait } \\
\text { Kuwait City } \\
\text { kuweitian, kuweitiancă (kuweitiană) } \\
\text { arabă } \\
\text { dinar kuweitian (KWD) }\end{array}$ \\
\hline $\begin{array}{l}\text { Kyrgyzstan } \\
\text { Kyrgyz Republic } \\
\text { Bishkek } \\
\text { Kyrgyz,Kyrgyzstani } \\
\text { Kyrgyz (State), Russian (Official) } \\
\text { Som (KGS) }\end{array}$ & $\mathrm{KG}$ & KGZ & 417 & $\begin{array}{l}\text { Kârgâzstan } \\
\text { Republica Kârgâzstan } \\
\text { Bishkek } \\
\text { kârgâză, kârgâză } \\
\text { kârgâză (de stat), rusă (oficial) } \\
\text { som (KGS) }\end{array}$ \\
\hline
\end{tabular}




\begin{tabular}{|c|c|c|c|c|}
\hline $\begin{array}{c}\text { Country name } \\
\text { Official name } \\
\text { Capital } \\
\text { Habitant (Demonym) } \\
\text { Language(s) } \\
\text { Currency }\end{array}$ & 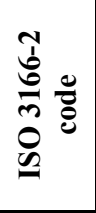 & $\begin{array}{ll}7 & 0 \\
1 & 0 \\
0 & 0 \\
0 & 0 \\
m & 0 \\
0 & \frac{1}{2} \\
0 & \frac{1}{2}\end{array}$ & 莺 & $\begin{array}{c}\text { Țara } \\
\text { Denumire oficială } \\
\text { Capitală } \\
\text { Etnonim / Locuitor (locuri etc.) } \\
\text { Limbă oficială, limbi oficiale } \\
\text { Monedă }\end{array}$ \\
\hline $\begin{array}{l}\text { Lao People's Democratic Republic } \\
\text { Lao People's Democratic } \\
\quad \text { Republic } \\
\text { Vientiane } \\
\text { Laotian, Lao } \\
\text { Lao } \\
\text { Kip (LAK) }\end{array}$ & LA & LAO & 418 & $\begin{array}{l}\text { Laos } \\
\text { Republica Populară Democrată Lao } \\
\text { Vientiane } \\
\text { laoțian, laoțiancă (laoțiană) } \\
\text { lao } \\
\text { kip (LAK) }\end{array}$ \\
\hline $\begin{array}{l}\text { Latvia } \\
\text { Republic of Latvia } \\
\text { Riga } \\
\text { Latvian } \\
\text { Latvian } \\
\text { Lats (Ls) (LVL) }\end{array}$ & LV & LVA & 428 & $\begin{array}{l}\text { Letonia } \\
\text { Republica Letonia } \\
\text { Riga } \\
\text { letonian, letoniancă (letoniană) } \\
\text { letoniană } \\
\text { lats (Ls) (LVL) }\end{array}$ \\
\hline $\begin{array}{l}\text { Lebanon } \\
\text { Republic of Lebanon } \\
\text { Beirut } \\
\text { Lebanese } \\
\text { Arabic, French } \\
\text { Lebanese pound (LBP) }\end{array}$ & LB & LBN & 422 & $\begin{array}{l}\text { Liban } \\
\text { Republica Liban } \\
\text { Beirut } \\
\text { libanez, libaneză } \\
\text { arabă, franceză } \\
\text { liră libaneză (LBP) }\end{array}$ \\
\hline $\begin{array}{l}\text { Lesotho } \\
\text { Kingdom of Lesotho } \\
\text { Maseru } \\
\text { Sesotho, English } \\
\text { Loti (LSL) }\end{array}$ & LS & LSO & 426 & $\begin{array}{l}\text { Lesotho } \\
\text { Regatul Lesotho } \\
\text { Maseru } \\
\text { sesotho, engleză } \\
\text { loti (LSL) }\end{array}$ \\
\hline $\begin{array}{l}\text { Liberia } \\
\text { Republic of Liberia } \\
\text { Monrovia } \\
\text { Liberian } \\
\text { English } \\
\text { Liberian dollar }{ }^{1}(\mathrm{LRD})\end{array}$ & LR & LBR & 430 & $\begin{array}{l}\text { Liberia } \\
\text { Republica Liberia } \\
\text { Monrovia } \\
\text { liberian, liberiancă (liberiană) } \\
\text { engleză } \\
\text { dolar liberian (LRD) }\end{array}$ \\
\hline $\begin{array}{l}\text { Libyan Arab Jamahiriya } \\
\text { Great Libyan Arab Jamahiriya, } \\
\quad \text { People's and Socialist } \\
\text { Tripoli } \\
\text { Libyan } \\
\text { Arabic } \\
\text { Dinar (LYD) }\end{array}$ & LY & LBY & 434 & $\begin{array}{l}\text { Libia } \\
\text { Marea Jamahiriye Arabă Libiană } \\
\quad \text { Populară şi Socialistă } \\
\text { Tripoli } \\
\text { libian, libiancă (libiană) } \\
\text { arabă } \\
\text { dinar libian (LYD) }\end{array}$ \\
\hline $\begin{array}{l}\text { Liechtenstein } \\
\text { Principality of Liechtenstein } \\
\text { Vaduz } \\
\text { Liechtensteiner (male), } \\
\quad \text { Liechtensteinerin (female) } \\
\text { German } \\
\text { Swiss franc (CHF) }\end{array}$ & LI & LIE & 438 & $\begin{array}{l}\text { Liechtenstein } \\
\text { Principatul Liechtenstein } \\
\text { Vaduz } \\
\text { liechtensteinian, } \\
\quad \text { liechtensteiniană } \\
\text { germană } \\
\text { franc elvețian (CHF) }\end{array}$ \\
\hline $\begin{array}{l}\text { Lithuania } \\
\text { Republic of Lithuania } \\
\text { Vilnius } \\
\text { Lithuanian } \\
\text { Lithuanian } \\
\text { Lithuanian litas (LTL), Lt }\end{array}$ & LT & LTU & 440 & $\begin{array}{l}\text { Lituania } \\
\text { Republica Lituania } \\
\text { Vilnius } \\
\text { lituanian, lituaniancă (lutuaniană) } \\
\text { lituaniană } \\
\text { litas lituanian (LTL), Lt }\end{array}$ \\
\hline
\end{tabular}




\begin{tabular}{|c|c|c|c|c|}
\hline $\begin{array}{c}\text { Country name } \\
\text { Official name } \\
\text { Capital } \\
\text { Habitant (Demonym) } \\
\text { Language(s) } \\
\text { Currency }\end{array}$ & 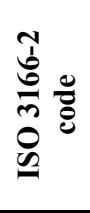 & $\begin{array}{ll}7 & 0 \\
0 & 0 \\
0 & 0 \\
0 & 0 \\
0 & \frac{1}{2} \\
0 & \frac{\pi}{2}\end{array}$ & 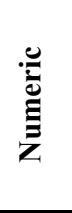 & $\begin{array}{c}\text { Țara } \\
\text { Denumire oficială } \\
\text { Capitală } \\
\text { Etnonim / Locuitor (locuri etc.) }^{*} \\
\text { Limbă oficială, limbi oficiale } \\
\text { Monedă }\end{array}$ \\
\hline $\begin{array}{l}\text { Luxembourg } \\
\text { Grand Duchy of Luxembourg } \\
\text { Luxembourg } \\
\text { Luxembourgers } \\
\text { German, French, Luxembourgish } \\
\text { Euro }(€) \text { (EUR) }\end{array}$ & LU & LUX & 442 & $\begin{array}{l}\text { Luxemburg } \\
\text { Grand Duchy of Luxembourg } \\
\text { Luxembourg } \\
\text { luxemburgez, luxemburgheză } \\
\text { germană, franceză, luxemburgheză } \\
\text { euro }(€)(E U R)\end{array}$ \\
\hline $\begin{array}{l}\text { Macao } \\
\text { Macau Special Administrative } \\
\text { Region of the People's } \\
\text { Republic of China }\end{array}$ & $\mathrm{MO}$ & $\mathrm{MAC}$ & 446 & $\begin{array}{l}\text { Macao } \\
\text { Regiunea administrativă specială } \\
\text { Macao (Àomén) a Republicii } \\
\text { Populare Chineze }\end{array}$ \\
\hline $\begin{array}{l}\text { Macanese } \\
\text { Chinese, Portuguese } \\
\text { Macanese pataca (MOP\$) (MOP) }\end{array}$ & & & & $\begin{array}{l}\text { macanez, macaneză } \\
\text { chineză, portugheză } \\
\text { pataca (macaneză) (MOP\$) (MOP) }\end{array}$ \\
\hline $\begin{array}{l}\text { Macedonia } \\
\text { Republic of Macedonia } \\
\text { Skopje } \\
\text { Macedonian } \\
\text { Macedonian } \\
\text { Macedonian denar (MKD) }\end{array}$ & MK & MKD & 807 & $\begin{array}{l}\text { Republica Macedonia } \\
\text { Republica Macedonia } \\
\text { Skopje } \\
\text { macedonean, macedonean(c)ă } \\
\text { (macedoneană) } \\
\text { macedoneană } \\
\text { denar (macedonean) (MKD) }\end{array}$ \\
\hline $\begin{array}{l}\text { Madagascar } \\
\text { Republic of Madagascar } \\
\text { Antananarivo } \\
\text { Malagasy } \\
\text { Malagasy, French, English } \\
\text { Malagasy ariary (MGA) }\end{array}$ & $\mathrm{MG}$ & MDG & 450 & $\begin{array}{l}\text { Madagascar } \\
\text { Republica Madagascar } \\
\text { Antananarivo } \\
\text { malgaş, malgaşă } \\
\text { malagaşă, franceză, engleză } \\
\text { ariary malgaş (MGA) }\end{array}$ \\
\hline $\begin{array}{l}\text { Malawi } \\
\text { Republic of Malâ̂i } \\
\text { Lilongwe } \\
\text { Malawian } \\
\text { English } \\
\text { Kwacha (D) (MWK) }\end{array}$ & MW & MWI & 454 & $\begin{array}{l}\text { Malawi } \\
\text { Republic of Malawii } \\
\text { Lilongwe } \\
\text { malawi } \\
\text { engleză } \\
\text { kwacha (D) (MWK) }\end{array}$ \\
\hline $\begin{array}{l}\text { Malaysia } \\
\text { Malaysia } \\
\text { Kuala Lumpur } \\
\text { Malaysian } \\
\text { Malay } \\
\text { Ringgit (RM) (MYR) }\end{array}$ & MY & MYS & 458 & $\begin{array}{l}\text { Malaezia } \\
\text { Malaezia } \\
\text { Kuala Lumpur } \\
\text { malaezian, malaezian(c)ă (malaeziană) } \\
\text { Malay } \\
\text { ringgit (RM) (MYR) }\end{array}$ \\
\hline $\begin{array}{l}\text { Maldives } \\
\text { Republic of Maldives } \\
\text { Malé } \\
\text { Maldivian } \\
\text { Divehi (Mahl) } \\
\text { Maldivian Rufiyaa (MVR) }\end{array}$ & MV & MDV & 462 & $\begin{array}{l}\text { Maldive } \\
\text { Republica Maldives } \\
\text { Malé } \\
\text { maldivian, maldiviană } \\
\text { divehi (mahl) } \\
\text { rufiyaa (maldiviană) (MVR) }\end{array}$ \\
\hline $\begin{array}{l}\text { Mali } \\
\text { Republic of Mali } \\
\text { Bamako } \\
\text { Malian } \\
\text { French } \\
\text { West African CFA franc (XOF) }\end{array}$ & ML & MLI & 466 & $\begin{array}{l}\text { Mali } \\
\text { Republica Mali } \\
\text { Bamako } \\
\text { malian, malian(c)ă (rar) } \\
\text { franceză } \\
\text { franc central-african, CFA (XOF) }\end{array}$ \\
\hline
\end{tabular}




\begin{tabular}{|c|c|c|c|c|}
\hline $\begin{array}{c}\text { Country name } \\
\text { Official name } \\
\text { Capital } \\
\text { Habitant (Demonym) } \\
\text { Language(s) } \\
\text { Currency } \\
\end{array}$ & 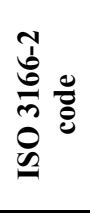 & $\begin{array}{ll}7 & 0 \\
1 & 0 \\
0 & 0 \\
0 & 0 \\
m & 0 \\
0 & \frac{\pi}{2} \\
0 & \frac{\pi}{2} \\
& \frac{1}{4}\end{array}$ & 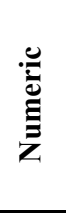 & $\begin{array}{c}\text { Țara } \\
\text { Denumire oficială } \\
\text { Capitală } \\
\text { Etnonim / Locuitor (locuri etc.) }^{*} \\
\text { Limbă oficială, limbi oficiale } \\
\text { Monedă }\end{array}$ \\
\hline $\begin{array}{l}\text { Malta } \\
\text { Republic of Malta } \\
\text { Valletta } \\
\text { Maltese } \\
\text { Maltese, English } \\
\text { Euro }(€)(\text { EUR) }\end{array}$ & MT & MLT & 470 & $\begin{array}{l}\text { Malta } \\
\text { Republica Malta } \\
\text { Valletta } \\
\text { maltez, malteză } \\
\text { malteză, engleză } \\
\text { euro }(€)(E U R)\end{array}$ \\
\hline $\begin{array}{l}\text { Marshall Islands } \\
\text { Republic of the Marshall } \\
\text { Islands } \\
\text { Majuro (Delap) } \\
\text { Marshallese } \\
\text { Marshallese, English } \\
\text { United States dollar (USD) }\end{array}$ & $\mathrm{MH}$ & MHL & 584 & $\begin{array}{l}\text { Insulele Marshall } \\
\text { Republica Insulelor Marshall } \\
\text { Majuro (Delap) } \\
\text { marshallez, marshalleză } \\
\text { marshalleză, engleză } \\
\text { dolar american (USD) }\end{array}$ \\
\hline $\begin{array}{l}\text { Martinique } \\
\quad \text { (an overseas region of France) } \\
\text { Fort-de-France } \\
\text { French } \\
\text { Euro }(€)(\text { EUR })\end{array}$ & MQ & MTQ & 474 & $\begin{array}{l}\text { Martinica } \\
\quad \text { (regiune de peste mări, a Franței) } \\
\text { Fort-de-France } \\
\text { franceză } \\
\text { euro }(€)^{2}(E U R)\end{array}$ \\
\hline $\begin{array}{l}\text { Mauritania } \\
\text { Islamic Republic of Mauritania } \\
\text { Nouakchott } \\
\text { Mauritanian } \\
\text { Arabic } \\
\text { Ouguiya (MRO) }\end{array}$ & MR & MRT & 478 & $\begin{array}{l}\text { Mauritania } \\
\text { Islamic Republica Islamică } \\
\quad \text { Mauritania } \\
\text { Nouakchott } \\
\text { (mauratinez, mauritaneză) (rar) } \\
\text { arabă } \\
\text { ouguiya (MRO) }\end{array}$ \\
\hline $\begin{array}{l}\text { Mauritius } \\
\text { Republic of Mauritius } \\
\text { Port Louis } \\
\text { Mauritian } \\
\text { English } \\
\text { Mauritian rupee }\end{array}$ & MU & MUS & 480 & $\begin{array}{l}\text { Mauritius } \\
\text { Republica Mauritius } \\
\text { Port Louis } \\
\text { mauritan, mauritană } \\
\text { engleză } \\
\text { rupie mauritană }\end{array}$ \\
\hline $\begin{array}{l}\text { Mayotte } \\
\text { Departmental Collectivity of } \\
\quad \text { Mayotte (an overseas } \\
\quad \text { collectivity of France) } \\
\text { Mamoudzou (prefecture) } \\
\text { Mahoran } \\
\text { French } \\
\text { Euro }(€)(\text { EUR })\end{array}$ & YT & MYT & 175 & $\begin{array}{l}\text { Mayotte } \\
\text { Departmental Collectivity of Mayotte } \\
\quad \text { (o colectivitate de peste mări, a } \\
\quad \text { Franței) } \\
\text { Mamoudzou (prefectură) } \\
\text { mahoran, mahorană } \\
\text { franceză } \\
\text { euro }(€)(E U R)\end{array}$ \\
\hline $\begin{array}{l}\text { Mexico } \\
\text { United Mexican States } \\
\text { Mexico City } \\
\text { Mexican } \\
\text { Spanish (de facto) } \\
\text { Peso (MXN) }\end{array}$ & MX & MEX & 484 & $\begin{array}{l}\text { Mexico } \\
\text { Statele Unite Mexicane } \\
\text { Mexico City } \\
\text { mexican, mexicancă (mexicană) } \\
\text { spaniolă (de facto) } \\
\text { peso mexican (MXN) }\end{array}$ \\
\hline
\end{tabular}




\begin{tabular}{|c|c|c|c|c|}
\hline $\begin{array}{c}\text { Country name } \\
\text { Official name } \\
\text { Capital } \\
\text { Habitant (Demonym) } \\
\text { Language(s) } \\
\text { Currency }\end{array}$ & 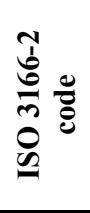 & $\begin{array}{ll}7 & 0 \\
1 & 0 \\
0 & 0 \\
0 & 0 \\
m & 0 \\
0 & \frac{1}{2} \\
0 & \frac{1}{2}\end{array}$ & 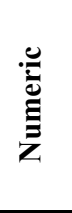 & $\begin{array}{c}\text { Țara } \\
\text { Denumire oficială } \\
\text { Capitală } \\
\text { Etnonim / Locuitor (locuri etc.) }^{*} \\
\text { Limbă oficială, limbi oficiale } \\
\text { Monedă }\end{array}$ \\
\hline $\begin{array}{l}\text { Micronesia } \\
\text { Federated States of Micronesia } \\
\text { Palikir } \\
\text { Micronesian } \\
\text { English } \\
\text { United States dollar (USD) }\end{array}$ & FM & FSM & 583 & $\begin{array}{l}\text { Micronezia } \\
\text { Micronezia } \\
\text { Palikir } \\
\text { micronezian, microneziană } \\
\text { engleză } \\
\text { dolar american (USD) }\end{array}$ \\
\hline $\begin{array}{l}\text { Moldova } \\
\text { Republic of Moldova } \\
\text { Chişinău } \\
\text { Moldovan, Moldavian } \\
\text { Moldovan (Romanian) } \\
\text { Moldovan leu (MDL) }\end{array}$ & MD & MDA & 498 & $\begin{array}{l}\text { Republica Moldova } \\
\text { Republica Moldova } \\
\text { Chişinău } \\
\text { moldovean, moldoveancă (moldoveană, } \\
\quad \text { moldovenească) } \\
\text { română (moldovenească) } \\
\text { leu moldovan / moldovenesc (MDL) }\end{array}$ \\
\hline $\begin{array}{l}\text { Monaco } \\
\text { Principality of Monaco } \\
\text { Monaco } \\
\text { Monégasque or Monegasque } \\
\text { French } \\
\text { Euro }(€)(E U R) \\
\end{array}$ & $\mathrm{MC}$ & $\mathrm{MCO}$ & 492 & $\begin{array}{l}\text { Monaco } \\
\text { PrincipatulMonaco } \\
\text { Monaco } \\
\text { monegasc, monegască } \\
\text { franceză } \\
\text { euro }(€)(E U R)\end{array}$ \\
\hline $\begin{array}{l}\text { Mongolia } \\
\text { Mongolia } \\
\text { Ulan Bator } \\
\text { Mongolian } \\
\text { Mongolian } \\
\text { Tögrög (MNT) }\end{array}$ & $\mathrm{MN}$ & MNG & 496 & $\begin{array}{l}\text { Mongolia } \\
\text { Mongolia } \\
\text { Ulan Bator } \\
\text { mongol, mongolă } \\
\text { mongolă } \\
\text { tögrög / tugrik (MNT) }\end{array}$ \\
\hline $\begin{array}{l}\text { Montenegro } \\
\text { Montenegro } \\
\text { Podgorica } \\
\text { Montenegrin } \\
\text { Montenegrin } \\
\text { Euro }(€)(\text { EUR }) \\
\end{array}$ & $\mathrm{ME}$ & MNE & 499 & $\begin{array}{l}\text { Muntenegru } \\
\text { Montenegru } \\
\text { Podgorica } \\
\text { montenegrean, montenegreană } \\
\text { montenegreană } \\
\text { euro }(€)(\text { EUR) }\end{array}$ \\
\hline $\begin{array}{l}\text { Montserrat } \\
\text { Montserrat } \\
\text { Plymouth (de jure), Brades (defacto) } \\
\text { English } \\
\text { East Caribbean dollar (XCD) }\end{array}$ & MS & MSR & 500 & $\begin{array}{l}\text { Montserrat } \\
\text { Montserrat } \\
\text { Plymouth (de jure), Brades (de facto) } \\
\text { engleză } \\
\text { dolar est-caraib (XCD) }\end{array}$ \\
\hline $\begin{array}{l}\text { Morocco } \\
\text { Kingdom of Morocco } \\
\text { Rabat } \\
\text { Moroccan } \\
\text { Arabic } \\
\text { Moroccan dirham (MAD) } \\
\end{array}$ & MA & MAR & 504 & $\begin{array}{l}\text { Maroc } \\
\text { Regatul Maroc } \\
\text { Rabat } \\
\text { morocan, marocancă (marocană) } \\
\text { arabă } \\
\text { dirham marocan (MAD) } \\
\end{array}$ \\
\hline $\begin{array}{l}\text { Mozambique } \\
\text { Republic of Mozambique } \\
\text { Maputo } \\
\text { Mozambican } \\
\text { Portuguese } \\
\text { Mozambican metical (Mtn) (MZN) }\end{array}$ & $\mathrm{MZ}$ & MOZ & 508 & $\begin{array}{l}\text { Mozambic } \\
\text { Republica Mozambic } \\
\text { Maputo } \\
\text { mozambican, mozambinancă } \\
\quad \text { (mozambicană) } \\
\text { portugheză } \\
\text { metical mozambican (Mtn) (MZN) }\end{array}$ \\
\hline
\end{tabular}




\begin{tabular}{|c|c|c|c|c|}
\hline $\begin{array}{l}\text { Country name } \\
\text { Official name } \\
\text { Capital } \\
\text { Habitant (Demonym) } \\
\text { Language(s) } \\
\text { Currency } \\
\end{array}$ & 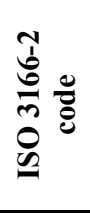 & 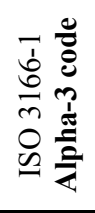 & 营 & $\begin{array}{c}\text { Țara } \\
\text { Denumire oficială } \\
\text { Capitală } \\
\text { Etnonim / Locuitor (locuri etc.) }{ }^{*} \\
\text { Limbă oficială, limbi oficiale } \\
\text { Monedă }\end{array}$ \\
\hline $\begin{array}{l}\text { Myanmar } \\
\text { Union of Myanmar } \\
\text { Naypyidaw } \\
\text { Burmese } \\
\text { Burmese } \\
\text { kyat }(\mathrm{K})(\mathrm{mmK}) \\
\end{array}$ & $\mathrm{MM}$ & MMR & 104 & $\begin{array}{l}\text { Myanmar, Birmania } \\
\text { Uniunea Myanmar } \\
\text { Naypyidaw } \\
\text { burmanez, burmaneză } \\
\text { burmaneză } \\
\text { kyat }(\mathrm{K})(\mathrm{mmK}) \\
\end{array}$ \\
\hline $\begin{array}{l}\text { Namibia } \\
\text { Republic of Namibia } \\
\text { Windhoek } \\
\text { Namibian } \\
\text { English } \\
\text { Namibian dollar (NAD) } \\
\end{array}$ & NA & NAM & 516 & $\begin{array}{l}\text { Namibia } \\
\text { Republica Namibia } \\
\text { Windhoek } \\
\text { namibian, namibiancă (namibiană) } \\
\text { engleză } \\
\text { dolar namibian (NAD) }\end{array}$ \\
\hline $\begin{array}{l}\text { Nauru } \\
\text { Republic of Nauru } \\
\text { Yaren } \\
\text { Nauruan } \\
\text { English, Nauruan } \\
\text { Usually, Australian dollar (AUD) }\end{array}$ & NR & NRU & 520 & $\begin{array}{l}\text { Nauru } \\
\text { Republica Nauru } \\
\text { Yaren } \\
\text { nauruan, nauruană (rar) } \\
\text { engleză, nauruană } \\
\text { dolar australian (AUD) }\end{array}$ \\
\hline $\begin{array}{l}\text { Nepal } \\
\text { Federal Democratic Republic of } \\
\text { Nepal } \\
\text { Kathmandu (Nepali) } \\
\text { Nepali } \\
\text { Nepali } \\
\text { Rupee (NPR) }\end{array}$ & NP & NPL & 524 & $\begin{array}{l}\text { Nepal } \\
\text { Republica Federală Democrată } \\
\text { Nepal } \\
\text { Kathmandu (Nepali) } \\
\text { nepalez, nepaleză } \\
\text { nepaleză } \\
\text { rupie nepaleză (NPR) }\end{array}$ \\
\hline $\begin{array}{l}\text { Netherlands } \\
\text { Kingdom of the Netherlands } \\
\text { Amsterdam } \\
\text { Dutch } \\
\text { Dutch } \\
\text { Euro }(€)(E U R)\end{array}$ & NL & NLD & 528 & $\begin{array}{l}\text { Țările de Jos, Olanda } \\
\text { Regatul Țărilor de Jos } \\
\text { Amsterdam } \\
\text { olandez, olandeză } \\
\text { olandeză } \\
\text { euro }(€)(E U R)\end{array}$ \\
\hline $\begin{array}{l}\text { Netherlands Antilles } \\
\text { Netherlands Antilles } \\
\text { Willemstad } \\
\text { Dutch, English, Papiamentu } \\
\text { Netherlands Antillean guilder(ANG) }\end{array}$ & AN & ANT & 530 & $\begin{array}{l}\text { Antilele Olandeze } \\
\text { Antilele Olandeze } \\
\text { Willemstad } \\
\text { antilez, antileză } \\
\text { olandeză, engleză, papiamentu } \\
\text { gulden olandez antilez (ANG) }\end{array}$ \\
\hline $\begin{array}{l}\text { New Caledonia } \\
\text { New Caledonia (Overseas } \\
\quad \text { territory of France) } \\
\text { Nouméa } \\
\text { French } \\
\text { CFP franc (XPF) }\end{array}$ & $\mathrm{NC}$ & NCL & 540 & $\begin{array}{l}\text { Noua Caledonie } \\
\text { Noua Caledonie (teritoriu de peste } \\
\quad \text { mări, al Franței) } \\
\text { Nouméa } \\
\text { franceză } \\
\text { franc CFP (XPF) }\end{array}$ \\
\hline $\begin{array}{l}\text { New Zealand } \\
\text { New Zealand } \\
\text { Wellington } \\
\text { New Zealander, Kiwi (colloquial) } \\
\text { English,'Māori } \\
\text { New Zealand dollar (NZD) } \\
\end{array}$ & $\mathrm{NZ}$ & NZL & 554 & $\begin{array}{l}\text { Noua Zeelandă } \\
\text { Noua Zeelandă } \\
\text { Wellington } \\
\text { neozeelandez, neozeelandeză } \\
\text { engleză,'Māori } \\
\text { dolar neozeelandez (NZD) } \\
\end{array}$ \\
\hline
\end{tabular}




\begin{tabular}{|c|c|c|c|c|}
\hline $\begin{array}{c}\text { Country name } \\
\text { Official name } \\
\text { Capital } \\
\text { Habitant (Demonym) } \\
\text { Language(s) } \\
\text { Currency }\end{array}$ & 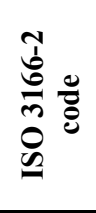 & 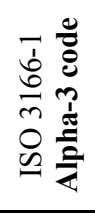 & 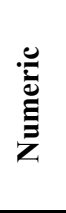 & $\begin{array}{c}\text { Țara } \\
\text { Denumire oficială } \\
\text { Capitală } \\
\text { Etnonim / Locuitor (locuri etc.) }^{*} \\
\text { Limbă oficială, limbi oficiale } \\
\text { Monedă }\end{array}$ \\
\hline $\begin{array}{l}\text { Nicaragua } \\
\text { Republic of Nicaragua } \\
\text { Managua } \\
\text { Nicaraguan } \\
\text { Spanish, Miskito } \\
\text { Córdoba (NIO) }\end{array}$ & NI & NIC & 558 & $\begin{array}{l}\text { Nicaragua } \\
\text { Republica Nicaragua } \\
\text { Managua } \\
\text { nicaraguan, nicaraguană } \\
\text { spaniolă, Miskito } \\
\text { córdoba (NIO) }\end{array}$ \\
\hline $\begin{array}{l}\text { Niger } \\
\text { Republic of Niger } \\
\text { Niamey } \\
\text { Nigerien } \\
\text { French } \\
\text { West African CFA franc (XOF) }\end{array}$ & $\mathrm{NE}$ & NER & 562 & $\begin{array}{l}\text { Niger } \\
\text { Republic of Niger } \\
\text { Niamey } \\
\text { nigerian, nigeriancă (nigeriană) } \\
\text { franceză } \\
\text { franc central-african, CFA (XOF) }\end{array}$ \\
\hline $\begin{array}{l}\text { Nigeria } \\
\text { Federal Republic of Nigeria } \\
\text { Abuja } \\
\text { Nigerian } \\
\text { English, Hausa, Igbo, Yoruba } \\
\text { Nigerian naira (\#) (NGN) }\end{array}$ & NG & NGA & 566 & $\begin{array}{l}\text { Nigeria } \\
\text { Federal Republic of Nigeria } \\
\text { Abuja } \\
\text { nigerin, nigeriancă (nigeriană) } \\
\text { engleză, hausa, igbo, yoruba } \\
\text { naira nigeriană (A) (NGN) }\end{array}$ \\
\hline $\begin{array}{l}\text { Niue } \\
\text { Niuē Fekai } \\
\text { Alofi } \\
\text { Niuean } \\
\text { Niuean, English } \\
\text { New Zealand dollar (NZD) }\end{array}$ & $\mathrm{NU}$ & NIU & 570 & $\begin{array}{l}\text { Niue } \\
\text { Niuē Fekai } \\
\text { Alofi } \\
\text { niuean, niueană (rar) } \\
\text { Niuean, engleză } \\
\text { dolar neozeelandez (NZD) }\end{array}$ \\
\hline $\begin{array}{l}\text { Norfolk Island } \\
\text { Territory of Norfolk Island (one } \\
\text { of Australia's external territories) } \\
\text { Kingston } \\
\text { English, Norfuk } \\
\text { Australian dollar (AUD) }\end{array}$ & $\mathrm{NF}$ & NFK & 574 & $\begin{array}{l}\text { Insula Norfolk } \\
\text { Insula Norfolk (teritoriu extern al } \\
\text { Australiei) } \\
\text { Kingston } \\
\text { engleză, norfuk } \\
\text { dolar australian (AUD) } \\
\end{array}$ \\
\hline $\begin{array}{l}\text { Northern Mariana Islands } \\
\text { Commonwealth of the Northern } \\
\text { Mariana Islands (a common- } \\
\text { wealth in political union with US) } \\
\text { Saipan } \\
\text { English, Chamorro, Carolinian } \\
\text { United States dollar (USD) }\end{array}$ & MP & MNP & 580 & $\begin{array}{l}\text { Insulele Mariane de Nord } \\
\text { Insulele Mariane de Nord (o uniune } \\
\text { politică cu US) } \\
\text { Saipan } \\
\text { engleză, chamorro, caroliniană } \\
\text { dolar american (USD) }\end{array}$ \\
\hline $\begin{array}{l}\text { Norway } \\
\text { Kingdom of Norway } \\
\text { Oslo } \\
\text { Norwegian } \\
\text { Norwegian (Bokmål and Nynorsk) } \\
\text { Norwegian krone (NOK) }\end{array}$ & $\mathrm{NO}$ & NOR & 578 & $\begin{array}{l}\text { Norvegia } \\
\text { Regatul Norvegiei } \\
\text { Oslo } \\
\text { norvegian, norvegiancă (norvegiană) } \\
\text { norvegiană (bokmål şi nynorsk) } \\
\text { coroană norvegiană (NOK) }\end{array}$ \\
\hline $\begin{array}{l}\text { Oman } \\
\text { Sultanate of Oman } \\
\text { Muscat } \\
\text { Omani } \\
\text { Arabic } \\
\text { Rial (OMR) } \\
\end{array}$ & $\mathrm{OM}$ & OMN & 512 & $\begin{array}{l}\text { Oman } \\
\text { Sultanatul Oman } \\
\text { Muscat } \\
\text { omanez, omaneză } \\
\text { arabă } \\
\text { rial omanez (OMR) }\end{array}$ \\
\hline
\end{tabular}




\begin{tabular}{|c|c|c|c|c|}
\hline $\begin{array}{l}\text { Country name } \\
\text { Official name } \\
\text { Capital } \\
\text { Habitant (Demonym) } \\
\text { Language(s) } \\
\text { Currency } \\
\end{array}$ & 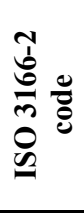 & 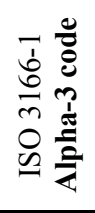 & 导 & $\begin{array}{c}\text { Țara } \\
\text { Denumire oficială } \\
\text { Capitală } \\
\text { Etnonim / Locuitor (locuri etc.) } \\
\text { Limbă oficială, limbi oficiale } \\
\text { Monedă }\end{array}$ \\
\hline $\begin{array}{l}\text { Pakistan } \\
\text { Islamic Republic of Pakistan } \\
\text { Islamabad } \\
\text { Pakistani } \\
\text { Urdu (National), English } \\
\quad \text { (Government) } \\
\text { Pakistani Rupee (Rs.) (PKR) } \\
\end{array}$ & PK & PAK & 586 & $\begin{array}{l}\text { Pakistan } \\
\text { Republica Islamică Pakistan } \\
\text { Islamabad } \\
\text { pachistanez, pachistaneză } \\
\text { urdu (națională), engleză } \\
\quad \text { (guvernamentală) } \\
\text { rupia pachistaneză (Rs.) (PKR) }\end{array}$ \\
\hline $\begin{array}{l}\text { Palau } \\
\text { Republic of Palau } \\
\text { Melekeok } \\
\text { Palauan } \\
\text { English, Palauan } \\
\text { US dollar (USD) }\end{array}$ & PW & PLW & 585 & $\begin{array}{l}\text { Palau } \\
\text { Republica Palau } \\
\text { Melekeok } \\
\text { palauan, palauană (rar) } \\
\text { engleză, palauană } \\
\text { dolar american (USD) }\end{array}$ \\
\hline $\begin{array}{l}\text { Palestinian Territory, Occupied } \\
\text { Palestine } \\
\text { Gaza, Ramallah (administrative) }\end{array}$ & PS & PSE & 275 & $\begin{array}{l}\text { Teritoriile Palestiniene Ocupate } \\
\text { Palestine } \\
\text { Gaza, Ramallah (administrative) }\end{array}$ \\
\hline $\begin{array}{l}\text { Jordanian dinar' Egyptian Pound' } \\
\text { Israeli shekel' (JOD, EGP, ILS) }\end{array}$ & & & & $\begin{array}{l}\text { dinar iordanian, liră egipteană, shekel } \\
\text { israelian'(JOD, EGP, ILS) }\end{array}$ \\
\hline $\begin{array}{l}\text { Panama } \\
\text { Republic of Panama } \\
\text { Panama City } \\
\text { Panamanian } \\
\text { Spanish } \\
\text { Balboa, U.S. dollar (PAB, USD) }\end{array}$ & PA & PAN & 591 & $\begin{array}{l}\text { Panama } \\
\text { Republica Panama } \\
\text { Panama City } \\
\text { Panamanian } \\
\text { spaniolă } \\
\text { balboa, US dolar american (PAB, USD) }\end{array}$ \\
\hline $\begin{array}{l}\text { Papua New Guinea } \\
\text { Independent State of Papua } \\
\quad \text { New Guinea } \\
\text { Port Moresby } \\
\text { Papua New Guinean } \\
\text { English, Tok Pisin, Hiri Motu } \\
\text { Papua New Guinean kina (PGK) }\end{array}$ & PG & PNG & 598 & $\begin{array}{l}\text { Papua Noua Guinee } \\
\text { Statul Independent Papua New } \\
\quad \text { Guinee } \\
\text { Port Moresby } \\
\text { engleză, tok pisin, hiri motu } \\
\text { kina (PGK) }\end{array}$ \\
\hline $\begin{array}{l}\text { Paraguay } \\
\text { Republic of Paraguay } \\
\text { Asunción } \\
\text { Paraguayan } \\
\text { Spanish, Guaraní } \\
\text { Guaraní (PYG) }\end{array}$ & PY & PRY & 600 & $\begin{array}{l}\text { Paraguay } \\
\text { Republica Paraguay } \\
\text { Asunción } \\
\text { paraguaian, paraguiancă (paraguiană) } \\
\text { spaniolă, guaraní } \\
\text { guaraní (PYG) }\end{array}$ \\
\hline $\begin{array}{l}\text { Peru } \\
\text { Republic of Peru } \\
\text { Lima } \\
\text { Peruvian } \\
\text { Spanish } \\
\text { Nuevo Sol (PEN) }\end{array}$ & $\mathrm{PE}$ & PER & 604 & $\begin{array}{l}\text { Peru } \\
\text { Republica Peru } \\
\text { Lima } \\
\text { peruvian, peruviancă (peruviană) } \\
\text { spaniolă } \\
\text { sol nou (PEN) }\end{array}$ \\
\hline
\end{tabular}




\begin{tabular}{|c|c|c|c|c|}
\hline $\begin{array}{c}\text { Country name } \\
\text { Official name } \\
\text { Capital } \\
\text { Habitant (Demonym) } \\
\text { Language(s) } \\
\text { Currency } \\
\end{array}$ & 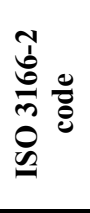 & $\begin{array}{ll}7 & 0 \\
1 & 0 \\
0 & 0 \\
0 & 0 \\
m & 0 \\
0 & \frac{1}{\pi} \\
0 & \frac{1}{2}\end{array}$ & 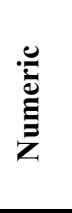 & $\begin{array}{c}\text { Țara } \\
\text { Denumire oficială } \\
\text { Capitală } \\
\text { Etnonim / Locuitor (locuri etc.) } \\
\text { Limbă oficială, limbi oficiale } \\
\text { Monedă }\end{array}$ \\
\hline $\begin{array}{l}\text { Philippines } \\
\text { Republic of the Philippines } \\
\text { Manila } \\
\text { Filipino or Pinoy } \\
\text { Filipino (based on Tagalog), } \\
\text { English } \\
\text { Peso (Filipino: piso ) (PHP) }\end{array}$ & $\mathrm{PH}$ & PHL & 608 & $\begin{array}{l}\text { Filipine } \\
\text { Republica Filipine } \\
\text { Manila } \\
\text { filipinez, filipineză } \\
\text { tagalog (filipineză), engleză } \\
\text { peso filipinez, }(p l) \text { peso filipinezi (PHP) }\end{array}$ \\
\hline $\begin{array}{l}\text { Pitcairn } \\
\text { Pitcairn Islands, Pitcairn, } \\
\text { Henderson, Ducie and Oeno Is- } \\
\text { lands (a British overseas territory) } \\
\text { Adamstown } \\
\text { English, Pitkern } \\
\text { New Zealand dollar (NZD) }\end{array}$ & PN & PCN & 612 & $\begin{array}{l}\text { Pitcairn } \\
\text { Insulele Pitcairn Islands, Pitcairn, } \\
\text { Henderson, Ducie şi Oeno (un } \\
\text { teritoriu britanic, de peste mări) } \\
\text { Adamstown } \\
\text { engleză, pitkern } \\
\text { dolar neozeelandez (NZD) }\end{array}$ \\
\hline $\begin{array}{l}\text { Poland } \\
\text { Republic of Poland } \\
\text { Warsaw } \\
\text { Pole, Polish } \\
\text { Polish } \\
\text { Złoty (PLN) } \\
\end{array}$ & PL & POL & 616 & $\begin{array}{l}\text { Polonia } \\
\text { Republic of Poland } \\
\text { Warsaw } \\
\text { polonez, poloneză } \\
\text { poloneză } \\
\text { zlot (PLN) } \\
\end{array}$ \\
\hline $\begin{array}{l}\text { Portugal } \\
\text { Portuguese Republic } \\
\text { Lisbon } \\
\text { Portuguese } \\
\text { Portuguese } \\
\text { Euro }(€)(\text { EUR) }\end{array}$ & PT & $\begin{array}{l}\text { PRT } \\
\end{array}$ & 620 & $\begin{array}{l}\text { Portugalia } \\
\text { Portuguese Republic } \\
\text { Lisabona } \\
\text { portughez, portugheză } \\
\text { portugheză } \\
\text { euro }(€)(E U R)\end{array}$ \\
\hline $\begin{array}{l}\text { Puerto Rico } \\
\text { Commonwealth of Puerto Rico } \\
\quad \text { (self-governing unincorporated } \\
\quad \text { territory of the United States) } \\
\text { San Juan } \\
\text { Puerto Rican } \\
\text { Spanish and English } \\
\text { United States dollar (USD) } \\
\end{array}$ & PR & PRI & 630 & $\begin{array}{l}\text { Puerto Rico } \\
\text { Statul liber asociat Puerto Rico (stat in- } \\
\quad \text { sular asociat Statelor Unite ale Ame- } \\
\quad \text { ricii - commonwealth, in engleză) } \\
\text { San Juan } \\
\text { portorican, portoricană } \\
\text { spaniolă, engleză } \\
\text { dolar american (USD) } \\
\end{array}$ \\
\hline $\begin{array}{l}\text { Qatar } \\
\text { State of Qatar } \\
\text { Doha } \\
\text { Qatari } \\
\text { Arabic } \\
\text { Riyal (QAR) } \\
\end{array}$ & QA & QAT & 634 & $\begin{array}{l}\text { Qatar } \\
\text { State of Qatar } \\
\text { Doha } \\
\text { quatarian, quatarian(c)ă (quatariană) } \\
\text { arabă } \\
\text { rial quatarian (QAR) }\end{array}$ \\
\hline $\begin{array}{l}\text { Réunion } \\
\text { Réunion (one of the over-seas } \\
\quad \text { départements of France) } \\
\text { Saint-Denis, Réunion } \\
\text { French }\end{array}$ & $\mathrm{RE}$ & REU & 638 & $\begin{array}{l}\text { Réunion } \\
\text { Réunion (un departament de peste } \\
\text { mări, al Franței) } \\
\text { Saint-Denis, Réunion } \\
\text { franceză }\end{array}$ \\
\hline
\end{tabular}




\begin{tabular}{|c|c|c|c|c|}
\hline $\begin{array}{c}\text { Country name } \\
\text { Official name } \\
\text { Capital } \\
\text { Habitant (Demonym) } \\
\text { Language(s) } \\
\text { Currency } \\
\end{array}$ & 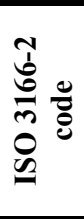 & 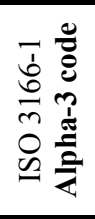 & 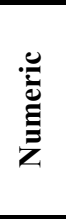 & $\begin{array}{c}\text { Țara } \\
\text { Denumire oficială } \\
\text { Capitală } \\
\text { Etnonim / Locuitor (locuri etc.) } \\
\text { Limbă oficială, limbi oficiale }^{*} \\
\text { Monedă }\end{array}$ \\
\hline $\begin{array}{l}\text { Romania } \\
\text { Romania } \\
\text { Bucharest } \\
\text { Romanian } \\
\text { Romanian } \\
\text { Leu (L) (RON) }\end{array}$ & RO & ROU & 642 & $\begin{array}{l}\text { România } \\
\text { Româmia } \\
\text { Bucureşti } \\
\text { român, româncă (românesc, } \\
\quad \text { românească, română) } \\
\text { română } \\
\text { leu }(\mathrm{L})(\mathrm{RON})\end{array}$ \\
\hline $\begin{array}{l}\text { Russian Federation, (Russia) } \\
\text { Russian Federation } \\
\text { Moscow } \\
\text { Russian } \\
\text { Russian } \\
\text { Ruble (RUB) }\end{array}$ & RU & RUS & 643 & $\begin{array}{l}\text { Rusia } \\
\text { Federația Rusă } \\
\text { Moscova } \\
\text { rus, rusoaică (rusă) } \\
\text { rusă } \\
\text { rublă (RUB) }\end{array}$ \\
\hline $\begin{array}{l}\text { Rwanda } \\
\text { Republic of Rwanda } \\
\text { Kigali } \\
\text { Rwandan, Rwandese } \\
\text { Kinyarwanda, French, English } \\
\text { Rwandan franc (RWF) }\end{array}$ & RW & RWA & 646 & $\begin{array}{l}\text { Rwanda } \\
\text { Republica Rwanda } \\
\text { Kigali } \\
\text { ruandez / rwuandez, ruandeză / } \\
\quad \text { rwuandeză } \\
\text { kinyarwanda, franceză, engleză } \\
\text { franc rwuandez (RWF) }\end{array}$ \\
\hline $\begin{array}{l}\text { Saint Barthélemy } \\
\text { Collectivity of Saint Barthélemy } \\
\text { (an overseas collectivity of France) } \\
\text { Gustavia } \\
\text { French } \\
\text { Euro }(€)(E U R)\end{array}$ & $\mathrm{BL}$ & BLM & 652 & $\begin{array}{l}\text { Saint Barthélemy } \\
\text { Colectivitatea Saint Barthélemy (co- } \\
\quad \text { lectivitate de peste mări, a Franței) } \\
\text { Gustavia } \\
\text { franceză } \\
\text { euro }(€) \text { (EUR) }\end{array}$ \\
\hline $\begin{array}{l}\text { Saint Helena } \\
\text { Saint Helena, Ascension and } \\
\text { Tristan da Cunha (a British } \\
\text { overseas territory) } \\
\text { Jamestown } \\
\text { English } \\
\text { Saint Helena pound (SHP) }\end{array}$ & $\mathrm{SH}$ & SHN & 654 & $\begin{array}{l}\text { Sfânta Elena } \\
\text { Sfânta Elena, Ascension şi Tristan da } \\
\text { Cunha (un teritoriu de peste mări, } \\
\text { britanic) } \\
\text { Jamestown } \\
\text { engleză } \\
\text { liră din Sfânta Elena (SHP) }\end{array}$ \\
\hline $\begin{array}{l}\text { Saint Kitts and Nevis } \\
\text { Federation of Saint Kitts and } \\
\text { Nevis' Federation of Saint } \\
\text { Christopher and Nevis } \\
\text { Basseterre } \\
\text { Kittitian (or, alternately, Kittian), } \\
\text { Nevisian } \\
\text { English } \\
\text { East Caribbean dollar (XCD) }\end{array}$ & $\mathrm{KN}$ & KNA & 659 & $\begin{array}{l}\text { Sfântul Kitts şi Nevis } \\
\text { Federația Sfântul Kitts şi Nevis } \\
\text { Basseterre } \\
\text { kittitian (kittian), kittitiană (kittiană) } \\
\text { engleză } \\
\text { dolar est-caraib (XCD) }\end{array}$ \\
\hline $\begin{array}{l}\text { Saint Lucia } \\
\text { Saint Lucia } \\
\text { Castries } \\
\text { Saint Lucian } \\
\text { Antillean Creole, English } \\
\text { East Caribbean Dollar (XCD) }\end{array}$ & $\mathrm{LC}$ & LCA & 662 & $\begin{array}{l}\text { Sfânta Lucia } \\
\text { Sfânta Lucia } \\
\text { Castries } \\
\text { Antillean Creole, engleză } \\
\text { dolar est-caraib (XCD) }\end{array}$ \\
\hline
\end{tabular}




\begin{tabular}{|c|c|c|c|c|}
\hline $\begin{array}{c}\text { Country name } \\
\text { Official name } \\
\text { Capital } \\
\text { Habitant (Demonym) } \\
\text { Language(s) } \\
\text { Currency }\end{array}$ & 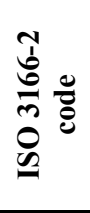 & $\begin{array}{ll}7 & 0 \\
0 & 0 \\
0 & 0 \\
0 & 0 \\
0 & \frac{1}{2} \\
0 & \frac{\pi}{2}\end{array}$ & 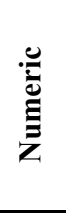 & $\begin{array}{c}\text { Țara } \\
\text { Denumire oficială } \\
\text { Capitală } \\
\text { Etnonim / Locuitor (locuri etc.) }^{*} \\
\text { Limbă oficială, limbi oficiale } \\
\text { Monedă }\end{array}$ \\
\hline $\begin{array}{l}\text { Saint Martin (French part) } \\
\text { Collectivity of Saint Martin (an } \\
\text { overseas collectivity of France) } \\
\text { Marigot } \\
\text { French } \\
\text { Euro }(€)(\text { EUR) }\end{array}$ & $\mathrm{MF}$ & MAF & 663 & $\begin{array}{l}\text { Saint Martin } \\
\text { Colectivitatea Saint Martin (o colec- } \\
\text { tivitate de peste mări, a Franței) } \\
\text { Marigot } \\
\text { franceză } \\
\text { euro }(€)(E U R)\end{array}$ \\
\hline $\begin{array}{l}\text { Saint Pierre and Miquelon } \\
\text { Territorial Collectivity of Saint } \\
\quad \text { Pierre and Miquelon } \\
\quad \text { (French part) } \\
\text { Saint-Pierre } \\
\text { French } \\
\text { Euro }(€)(E U R)\end{array}$ & PM & SPM & 666 & $\begin{array}{l}\text { Sfântul Pierre şi Miquelon } \\
\text { Saint Pierre şi Miquelon (o colectivi- } \\
\quad \text { tate de peste mări franceză) } \\
\text { Saint-Pierre } \\
\text { franceză } \\
\text { euro }(€)(E U R)\end{array}$ \\
\hline $\begin{array}{l}\text { Saint Vincent and the Grenadines } \\
\text { Saint Vincent and the } \\
\quad \text { Grenadines } \\
\text { Kingtown } \\
\text { Vincentian } \\
\text { English } \\
\text { East Caribbean dollar (XCD) }\end{array}$ & $\mathrm{VC}$ & VCT & 670 & $\begin{array}{l}\text { Sfântul Vincent şi Grenadine } \\
\text { Sfântul Vincent şi Grenadine } \\
\text { Kingtown } \\
\text { engleză } \\
\text { dolar est-caraib (XCD) }\end{array}$ \\
\hline $\begin{array}{l}\text { Samoa } \\
\text { Independent State of Samoa } \\
\text { Apia } \\
\text { Samoan } \\
\text { Samoan, English } \\
\text { Tala (WST) }\end{array}$ & WS & WSM & 882 & $\begin{array}{l}\text { Samoa } \\
\text { Statul Independent Samoa } \\
\text { Apia } \\
\text { samoan, samoan(c)ă (samoană) } \\
\text { samoană, engleză } \\
\text { tala (WST) }\end{array}$ \\
\hline $\begin{array}{l}\text { San Marino } \\
\text { Most Serene Republic of San } \\
\text { Marino } \\
\text { City of San Marino } \\
\text { Sammarinese } \\
\text { Italian } \\
\text { Euro }(€)(E U R)\end{array}$ & SM & SMR & 674 & $\begin{array}{l}\text { San Marino } \\
\text { Republica San Marino } \\
\text { City of San Marino } \\
\text { sanmarinez, sanmarineză } \\
\text { italiană } \\
\text { euro }(€)(E U R)\end{array}$ \\
\hline $\begin{array}{l}\text { Sao Tome and Principe } \\
\text { Democratic Republic of São } \\
\text { Tomé and Príncipe } \\
\text { São Tomé } \\
\text { Santomean } \\
\text { Portuguese } \\
\text { Dobra (STD) }\end{array}$ & ST & STP & 678 & $\begin{array}{l}\text { Sao Tome şi Principe } \\
\text { Democratic Republica Democratică } \\
\quad \text { São Tomé şi Príncipe } \\
\text { São Tomé } \\
\text { santomean, saotomeană (rar) } \\
\text { portugheză } \\
\text { dobra (STD) }\end{array}$ \\
\hline $\begin{array}{l}\text { Saudi Arabia } \\
\text { Kingdom of Saudi Arabia } \\
\text { Riyadh } \\
\text { Saudi, Saudi Arabian } \\
\text { Arabic } \\
\text { Riyal (SAR) }\end{array}$ & SA & SAU & 682 & $\begin{array}{l}\text { Arabia Saudită } \\
\text { Arabia Saudită } \\
\text { Riyadh } \\
\text { (arab-)saudit, (arab-)saudită } \\
\text { arabă } \\
\text { riyal (SAR) }\end{array}$ \\
\hline
\end{tabular}




\begin{tabular}{|c|c|c|c|c|}
\hline $\begin{array}{c}\text { Country name } \\
\text { Official name } \\
\text { Capital } \\
\text { Habitant (Demonym) } \\
\text { Language(s) } \\
\text { Currency } \\
\end{array}$ & 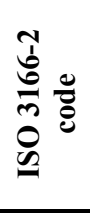 & $\begin{array}{ll}7 & 0 \\
1 & 0 \\
0 & 0 \\
0 & 0 \\
m & 0 \\
0 & \frac{1}{2} \\
0 & \frac{1}{2}\end{array}$ & 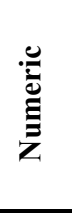 & $\begin{array}{c}\text { Țara } \\
\text { Denumire oficială } \\
\text { Capitală } \\
\text { Etnonim / Locuitor (locuri etc.) }^{*} \\
\text { Limbă oficială, limbi oficiale } \\
\text { Monedă }\end{array}$ \\
\hline $\begin{array}{l}\text { Senegal } \\
\text { Republic of Senegal } \\
\text { Dakar } \\
\text { Senegalese } \\
\text { French } \\
\text { CFA franc (XOF) } \\
\end{array}$ & SN & SEN & 686 & $\begin{array}{l}\text { Senegal } \\
\text { Republica Senegal } \\
\text { Dakar } \\
\text { senegalez, senegalez } \\
\text { franceză } \\
\text { franc central-african, CFA (XOF) } \\
\end{array}$ \\
\hline $\begin{array}{l}\text { Serbia } \\
\text { Republic of Serbia } \\
\text { Belgrade } \\
\text { Serb, Serbian } \\
\text { Serbian } \\
\text { Serbian dinar (RSD) } \\
\end{array}$ & RS & SRB & 688 & $\begin{array}{l}\text { Serbia } \\
\text { Republica Serbia } \\
\text { Belgrade } \\
\text { sîrb, sârboaică (sârbesc, sârbă) } \\
\text { sârbă } \\
\text { dinar sârbesc (RSD) } \\
\end{array}$ \\
\hline $\begin{array}{l}\text { Seychelles } \\
\text { Republic of Seychelles } \\
\text { Victoria } \\
\text { Seychellois, Seychelloise } \\
\text { Seychellois Creole, English and } \\
\text { French } \\
\text { Seychellois rupee (SCR) } \\
\end{array}$ & $\mathrm{SC}$ & SYC & 690 & $\begin{array}{l}\text { Seychelles } \\
\text { Republica Seychelles } \\
\text { Victoria } \\
\text { creolă de Seychelles, engleză şi } \\
\text { franceză } \\
\text { rupie (din Seychelles) (SCR) }\end{array}$ \\
\hline $\begin{array}{l}\text { Sierra Leone } \\
\text { Republic of Sierra Leone } \\
\text { Freetown } \\
\text { Sierra Leonean } \\
\text { English } \\
\text { Leone (SLL) } \\
\end{array}$ & SL & SLE & 694 & $\begin{array}{l}\text { Sierra Leone } \\
\text { Republica Sierra Leone } \\
\text { Freetown } \\
\text { engleză } \\
\text { leone (SLL) }\end{array}$ \\
\hline $\begin{array}{l}\text { Singapore } \\
\text { Republic of Singapore } \\
\text { City of Singapore } \\
\text { Singaporean } \\
\text { English (main), Malay (national), } \\
\quad \text { Mandarin Chinese, Tamil } \\
\text { Singapore dollar (SGD) }\end{array}$ & SG & SGP & 702 & $\begin{array}{l}\text { Singapore } \\
\text { Republica Singapore } \\
\text { City of Singapore } \\
\text { singaporez, singaporeză } \\
\text { engleză(principală), malay (națională), } \\
\quad \text { chineză (dialect mandarin), tamila } \\
\text { dolar singaporez (SGD) }\end{array}$ \\
\hline $\begin{array}{l}\text { Slovakia } \\
\text { Slovak Republic } \\
\text { Bratislava } \\
\text { Slovak } \\
\text { Slovak } \\
\text { Euro }(€)(\text { EUR) } \\
\end{array}$ & SK & SVK & 703 & $\begin{array}{l}\text { Slovacia } \\
\text { Republica Slovacă } \\
\text { Bratislava } \\
\text { slovac, slovacă } \\
\text { slovacă } \\
\text { euro }(€)(\text { EUR) }\end{array}$ \\
\hline $\begin{array}{l}\text { Slovenia } \\
\text { Republic of Slovenia } \\
\text { Ljubljana } \\
\text { Slovenian, Slovene } \\
\text { Slovene }^{1} \\
\text { Euro }(€)(\text { EUR) }\end{array}$ & SI & SVN & 705 & $\begin{array}{l}\text { Slovenia } \\
\text { Republica Slovenia } \\
\text { Ljubljana } \\
\text { sloven, slovenă } \\
\text { slovenă } \\
\text { euro }(€)(\text { EUR) }\end{array}$ \\
\hline $\begin{array}{l}\text { Solomon Islands } \\
\text { Solomon Islands } \\
\text { Honiara } \\
\text { Solomon Islander } \\
\text { Solomon Islands dollar (SBD) }\end{array}$ & SB & SLB & 090 & $\begin{array}{l}\text { Insulele Solomon } \\
\text { Insulele Solomon } \\
\text { Honiara } \\
\text { solomonian, solomoniană } \\
\text { dolar solomonian (SBD) }\end{array}$ \\
\hline
\end{tabular}




\begin{tabular}{|c|c|c|c|c|}
\hline $\begin{array}{l}\text { Country name } \\
\text { Official name } \\
\text { Capital } \\
\text { Habitant (Demonym) } \\
\text { Language(s) } \\
\text { Currency }\end{array}$ & 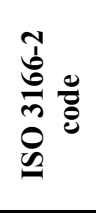 & $\begin{array}{ll}7 & 0 \\
1 & 0 \\
0 & 0 \\
0 & 0 \\
0 & \frac{1}{2} \\
0 & \frac{\pi}{2}\end{array}$ & 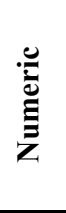 & $\begin{array}{c}\text { Țara } \\
\text { Denumire oficială } \\
\text { Capitală } \\
\text { Etnonim / Locuitor (locuri etc.) } \\
\text { Limbă oficială, limbi oficiale } \\
\text { Monedă }\end{array}$ \\
\hline $\begin{array}{l}\text { Somalia } \\
\text { Republic of Somalia } \\
\text { Mogadishu } \\
\text { Somali } \\
\text { Somali, Arabic } \\
\text { Somali shilling (SOS) }\end{array}$ & $\mathrm{SO}$ & SOM & 706 & $\begin{array}{l}\text { Somalia } \\
\text { Republica Somalia } \\
\text { Mogadishu } \\
\text { somalez, somaleză } \\
\text { somali, arabă } \\
\text { şiling somalez (SOS) }\end{array}$ \\
\hline $\begin{array}{l}\text { South Africa } \\
\text { Republic of South Africa } \\
\text { Pretoria (executive), Cape Town (le- } \\
\text { gislative), Bloemfontein (judicial) } \\
\text { South African } \\
\text { Afrikaans, English, Southern } \\
\text { Ndebele, Northern Sotho, } \\
\text { Southern Sotho, Swazi, Tsonga, } \\
\text { Tswana, Venda, Xhosa, Zulu } \\
\text { Rand (ZAR) }\end{array}$ & $\mathrm{ZA}$ & ZAF & 710 & $\begin{array}{l}\text { Africa de Sud } \\
\text { Republica Africa de Sud } \\
\text { Pretoria (executivă), Bloemfontein } \\
\text { (judiciară), Cape Town (legislativă) } \\
\text { sud-african, sud-african(c)ă } \\
\text { afrikaans, engleză, zulu, xhosa, swazi, } \\
\text { ndebele, sotho de sud, sotho de nord, } \\
\text { tsonga, tswana, venda } \\
\text { rand (ZAR) }\end{array}$ \\
\hline $\begin{array}{l}\text { South Georgia and the South } \\
\text { Sandwich Islands } \\
\text { South Georgia and the South } \\
\quad \text { Sandwich Islands (a British } \\
\quad \text { overseas territory) } \\
\text { King Edward Point (Grytviken) } \\
\text { English } \\
\text { Pound sterling (GBP) }\end{array}$ & GS & SGS & 239 & $\begin{array}{l}\text { Georgia de Sud şi Insulele Sandwich de } \\
\text { Sud } \\
\text { Georgia de Sud şi Insulele Sandwich } \\
\quad \text { de Sud (un teritoriu de peste mări, } \\
\quad \text { britanic) } \\
\text { King Edward Point (Grytviken) } \\
\text { engleză } \\
\text { liră sterlină (GBP) }\end{array}$ \\
\hline $\begin{array}{l}\text { Spain } \\
\text { Kingdom of Spain } \\
\text { Madrid } \\
\text { Spanish, Spaniard } \\
\text { Spanish } \\
\text { Euro }(€)(\text { EUR) }\end{array}$ & ES & ESP & 724 & $\begin{array}{l}\text { Spania } \\
\text { Regatul Spaniei } \\
\text { Madrid } \\
\text { spaniol, spanioloaică, spaniolă } \\
\text { spaniolă } \\
\text { euro }(€)(\text { EUR })\end{array}$ \\
\hline $\begin{array}{l}\text { Sri Lanka } \\
\text { Democratic Socialist Republic } \\
\quad \text { of Sri Lanka } \\
\text { Sri Jayawardenapura-Kotte } \\
\text { Sri Lankan } \\
\text { Sinhala, Tamil } \\
\text { Sri Lankan Rupee (LKR) }\end{array}$ & LK & LKA & 144 & $\begin{array}{l}\text { Sri Lanka } \\
\text { Republica Socialistă şi Democrată } \\
\quad \text { Sri Lanka } \\
\text { Sri Jayawardenapura-Kotte } \\
\text { srilankez, srilankeză } \\
\text { sinhala, tamila } \\
\text { rupie srilankeză (LKR) }\end{array}$ \\
\hline $\begin{array}{l}\text { Sudan } \\
\text { Republic of the Sudan } \\
\text { Khartoum } \\
\text { Sudanese } \\
\text { Arabic, English } \\
\text { Sudanese pound (SDG) }\end{array}$ & SD & SDN & 736 & $\begin{array}{l}\text { Sudan } \\
\text { Republica Sudan } \\
\text { Khartoum } \\
\text { sudanez, sudaneză } \\
\text { arabă, engleză } \\
\text { liră sudaneză (SDG) }\end{array}$ \\
\hline $\begin{array}{l}\text { Suriname } \\
\text { Republic of Suriname } \\
\text { Panamaribo } \\
\text { Surinamese } \\
\text { Dutch } \\
\text { Surinamese dollar (SRD) }\end{array}$ & SR & SUR & 740 & $\begin{array}{l}\text { Surinam } \\
\text { Republica Surinam } \\
\text { Panamaribo } \\
\text { surinamez, surinameză } \\
\text { olandeză } \\
\text { dolar surinamez (SRD) } \\
\end{array}$ \\
\hline
\end{tabular}




\begin{tabular}{|c|c|c|c|c|}
\hline $\begin{array}{c}\text { Country name } \\
\text { Official name } \\
\text { Capital } \\
\text { Habitant (Demonym) } \\
\text { Language(s) } \\
\text { Currency }\end{array}$ & 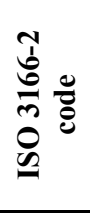 & 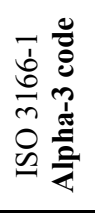 & 莺 & $\begin{array}{c}\text { Țara } \\
\text { Denumire oficială } \\
\text { Capitală } \\
\text { Etnonim / Locuitor (locuri etc.) }{ }^{*} \\
\text { Limbă oficială, limbi oficiale } \\
\text { Monedă }\end{array}$ \\
\hline $\begin{array}{l}\text { Svalbard and Jan Mayen } \\
\text { (two parts of Norway) }\end{array}$ & \multirow[t]{6}{*}{ SJ } & \multirow[t]{6}{*}{$\overline{\mathrm{SJM}}$} & \multirow[t]{6}{*}{744} & $\begin{array}{l}\text { Svalbard şi Jan Mayen } \\
\text { (teritorii aparținând Norvegiei) }\end{array}$ \\
\hline $\begin{array}{l}\text { Svalbard } \\
\text { Svalbard }\end{array}$ & & & & $\begin{array}{l}\text { Svalbard } \\
\text { Svalbard }\end{array}$ \\
\hline Longyearbyen & & & & Longyearbyen \\
\hline Norwegian & & & & norvegiană \\
\hline Norwegian krone (NOK) & & & & coroană norvegiană $(\mathrm{NOK})$ \\
\hline $\begin{array}{l}\text { Jan Mayen } \\
\text { Jan Mayen } \\
\text { Olonkinbyen (largest city) }\end{array}$ & & & & $\begin{array}{l}\text { Jan Mayen } \\
\text { Jan Mayen } \\
\text { Olonkinbyen (cel mai mare oraş) }\end{array}$ \\
\hline $\begin{array}{l}\text { Swaziland } \\
\text { Kingdom of Swaziland } \\
\text { Lobamba (royal and legislative), } \\
\text { Mbabane (administrative; } \\
\text { Swazi } \\
\text { English, SiSwati } \\
\text { Lilangeni (SZL) }\end{array}$ & SZ & SWZ & 748 & $\begin{array}{l}\text { Swaziland } \\
\text { Regatul Swaziland } \\
\text { Lobamba (regală şi legislativă), } \\
\text { Mbabane (administrativă) } \\
\text { engleză, siswati } \\
\text { Lilangeni (SZL) }\end{array}$ \\
\hline $\begin{array}{l}\text { Sweden } \\
\text { Kingdom of Sweden } \\
\text { Stockholm } \\
\text { Swedish or Swedes } \\
\text { Swedish } \\
\text { Swedish krona (SEK) } \\
\end{array}$ & $\mathrm{SE}$ & SWE & 752 & $\begin{array}{l}\text { Suedia } \\
\text { Regatul Suediei } \\
\text { Stockholm } \\
\text { suedez, suedeză } \\
\text { suedeză } \\
\text { coroană suedeză (SEK) } \\
\end{array}$ \\
\hline $\begin{array}{l}\text { Switzerland } \\
\text { Swiss Confederation } \\
\text { Berna } \\
\text { Swiss } \\
\text { German, French, Italian, Romansh } \\
\text { Swiss franc (CHF) }\end{array}$ & $\mathrm{CH}$ & CHE & 756 & $\begin{array}{l}\text { Elveția } \\
\text { Confederația Elvețiană } \\
\text { Berna } \\
\text { elvețian, elvețiancă (elvețiană) } \\
\text { germană, franceză, italiană, reto- } \\
\quad \text { romana } \\
\text { frac elvețian }(\mathrm{CHF}) \\
\end{array}$ \\
\hline $\begin{array}{l}\text { Syrian Arab Republic } \\
\text { Syrian Arab Republic } \\
\text { Damascus } \\
\text { Syrian } \\
\text { Arabic } \\
\text { Syrian pound (SYP) }\end{array}$ & SY & SYR & 760 & $\begin{array}{l}\text { Siria } \\
\text { Arab Republica Arabă Siriană } \\
\text { Damasc } \\
\text { sirian, siriancă (siriană) } \\
\text { arabă } \\
\text { liră siriană (SYP) }\end{array}$ \\
\hline $\begin{array}{l}\text { Taiwan } \\
\text { Taiwan, province of China } \\
\text { Taipei } \\
\text { Taiwanese } \\
\text { Traditional Chinese, Simplified } \\
\text { Chinese }\end{array}$ & TW & TWN & 158 & $\begin{array}{l}\text { Taiwan, taivan } \\
\text { Taiwan, province of China } \\
\text { Taipei } \\
\text { taiwanez(ă), taivanez }(\breve{a}) \\
\text { chineza tradițională, chineza } \\
\text { simplificată }\end{array}$ \\
\hline $\begin{array}{l}\text { Tajikistan } \\
\text { Republic of Tajikistan } \\
\text { Dushanbe } \\
\text { Tajikistani } \\
\text { Tajik } \\
\text { Somoni (TJS) }\end{array}$ & TJ & TJK & 762 & $\begin{array}{l}\text { Tadjikistan } \\
\text { Republica Tajikistan } \\
\text { Dushanbe } \\
\text { tadjic, tadjică } \\
\text { tadjică } \\
\text { somoni (TJS) }\end{array}$ \\
\hline
\end{tabular}




\begin{tabular}{|c|c|c|c|c|}
\hline $\begin{array}{c}\text { Country name } \\
\text { Official name } \\
\text { Capital } \\
\text { Habitant (Demonym) } \\
\text { Language(s) } \\
\text { Currency }\end{array}$ & 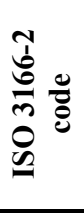 & 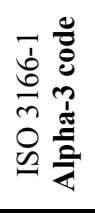 & 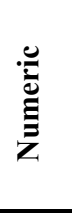 & $\begin{array}{c}\text { Țara } \\
\text { Denumire oficială } \\
\text { Capitală } \\
\text { Etnonim / Locuitor (locuri etc.) } \\
\text { Limbă oficială, limbi oficiale } \\
\text { Monedă }\end{array}$ \\
\hline $\begin{array}{l}\text { Tanzania } \\
\text { United Republic of Tanzania } \\
\text { Dodoma } \\
\text { Tanzanian } \\
\text { Swahili (de facto), English } \\
\text { (Higher courts, higher education) } \\
\text { Tanzanian shilling (TZS) }\end{array}$ & $\mathrm{TZ}$ & TZA & 834 & $\begin{array}{l}\text { Tanzania } \\
\text { United Republica Unită a Tanzaniei } \\
\text { Dodoma } \\
\text { tanzanian, tanzaniancă (tanzaniană) } \\
\text { swahili (de facto), engleză (edu, univ, } \\
\text { jur) } \\
\text { Tanzanian shilling (TZS) }\end{array}$ \\
\hline $\begin{array}{l}\text { Thailand } \\
\text { Kingdom of Thailand } \\
\text { Bangkok } \\
\text { Thai } \\
\text { Thai } \\
\text { Baht (B) (THB) }\end{array}$ & $\mathrm{TH}$ & THA & 764 & $\begin{array}{l}\text { Thailanda } \\
\text { Regatul Thailandei } \\
\text { Bangkok } \\
\text { t(h)ailandez, th(h)ailandeză } \\
\text { thai / thailandeză } \\
\text { baht (B) (THB) }\end{array}$ \\
\hline $\begin{array}{l}\text { Timor-Leste } \\
\text { Democratic Republic of Timor- } \\
\quad \text { Leste } \\
\text { Dili } \\
\text { East Timorese } \\
\text { Tetum and Portuguese } \\
\text { US Dollar (USD) }\end{array}$ & TL & TLS & 626 & $\begin{array}{l}\text { Timorul de Est } \\
\text { Republica Democrată aTimorului de } \\
\text { Est } \\
\text { Dili } \\
\text { tetum şi portugheză } \\
\text { dolar american (USD) }\end{array}$ \\
\hline $\begin{array}{l}\text { Togo } \\
\text { Togolese Republic } \\
\text { Lomé } \\
\text { Togolese } \\
\text { French } \\
\text { CFA franc (XOF) }\end{array}$ & TG & TGO & 768 & $\begin{array}{l}\text { Togo } \\
\text { Togolese Republic } \\
\text { Lomé } \\
\text { togolez, tongoleză } \\
\text { franceză } \\
\text { franc central-african, CFA (XOF) }\end{array}$ \\
\hline $\begin{array}{l}\text { Tokelau } \\
\text { Tokelau (a territory of New } \\
\text { Zealand) } \\
\text { None } \\
\text { Tokelauan } \\
\text { Tokelauan, English } \\
\text { New Zealand dollar (NZD) }\end{array}$ & TK & TKL & 772 & $\begin{array}{l}\text { Tokelau } \\
\text { Tokelau (un teritoriu al Noii zeelande) } \\
\text { nu are } \\
\text { tokelauan, tokelauană } \\
\text { tokelauană, engleză } \\
\text { dolar neozeelandez (NZD) }\end{array}$ \\
\hline $\begin{array}{l}\text { Tonga } \\
\text { Kingdom of Tonga } \\
\text { Nuku'alofa } \\
\text { Tongan } \\
\text { Tongan, English } \\
\text { Pa'anga (TOP) }\end{array}$ & TO & TON & 776 & $\begin{array}{l}\text { Tonga } \\
\text { Regatul Tonga } \\
\text { Nuku'alofa } \\
\text { tongan, tongană }(r a r) \\
\text { Tongan, engleză } \\
\text { pa'anga (TOP) }\end{array}$ \\
\hline $\begin{array}{l}\text { Trinidad and Tobago } \\
\text { Republic of Trinidad and Tobago } \\
\text { Port of Spain } \\
\text { Trinidadian, Tobagonian } \\
\text { English } \\
\text { Trinidad and Tobago dollar (TTD) }\end{array}$ & TT & TTO & 780 & $\begin{array}{l}\text { Trinidad şi Tobago } \\
\text { Republica Trinidad şi Tobago } \\
\text { Port of Spain } \\
\text { trinididadian, trinididadiană } \\
\text { engleză } \\
\text { dolar trinididadian (TTD) }\end{array}$ \\
\hline $\begin{array}{l}\text { Tunisia } \\
\text { Tunisian Republic } \\
\text { Tunis } \\
\text { Tunisian } \\
\text { Tunisian, French } \\
\text { Tunisian dinar (TND) } \\
\end{array}$ & $\mathrm{TN}$ & TUN & 788 & $\begin{array}{l}\text { Tunisia } \\
\text { Republica Tunisiană } \\
\text { Tunis } \\
\text { tunisian, tunisiancă (tunisiană) } \\
\text { tunisiană, franceză } \\
\text { dinar tunisian (TND) } \\
\end{array}$ \\
\hline
\end{tabular}




\begin{tabular}{|c|c|c|c|c|}
\hline $\begin{array}{l}\text { Country name } \\
\text { Official name } \\
\text { Capital } \\
\text { Habitant (Demonym) } \\
\text { Language(s) } \\
\text { Currency }\end{array}$ & 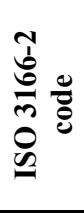 & $\begin{array}{ll}7 & 0 \\
1 & 0 \\
0 & 0 \\
0 & 0 \\
m & \frac{\pi}{\pi} \\
0 & \frac{\pi}{2}\end{array}$ & 泀 & $\begin{array}{c}\text { Țara } \\
\text { Denumire oficială } \\
\text { Capitală } \\
\text { Etnonim / Locuitor (locuri etc.) } \\
\text { Limbă oficială, limbi oficiale } \\
\text { Monedă }\end{array}$ \\
\hline $\begin{array}{l}\text { Turkey } \\
\text { Republic of Turkey } \\
\text { Ankara } \\
\text { Turkish } \\
\text { Turkish } \\
\text { Turkish lira (TRY) }\end{array}$ & TR & TUR & 792 & $\begin{array}{l}\text { Turcia } \\
\text { Republica Turcia } \\
\text { Ankara } \\
\text { turc, turcoaică (turcă, turcesc, turcească) } \\
\text { turcă } \\
\text { liră turcească (TRY) }\end{array}$ \\
\hline $\begin{array}{l}\text { Turkmenistan } \\
\text { Republic of Turkmenistan } \\
\text { Ashgabat } \\
\text { Turkmen } \\
\text { Turkmen } \\
\text { Turkmen new manat (TMT) }\end{array}$ & TM & TKM & 795 & $\begin{array}{l}\text { Turkmenistan } \\
\text { Republica Turkmenistan } \\
\text { Ashgabat } \\
\text { turkmen, turkmenă } \\
\text { turkmenă } \\
\text { manat turkmen nou (TMT) }\end{array}$ \\
\hline $\begin{array}{l}\text { Turks and Caicos Islands } \\
\text { Turks and Caicos Islands } \\
\text { Cockburn Town } \\
\text { Enghish } \\
\text { US dollar (USD) }\end{array}$ & $\mathrm{TC}$ & TCA & 796 & $\begin{array}{l}\text { Insulele Turks şi Caicos } \\
\text { Insulele Turks şi Caicos } \\
\text { Cockburn Town } \\
\text { engleză } \\
\text { dolar american (USD) }\end{array}$ \\
\hline $\begin{array}{l}\text { Tuvalu } \\
\text { Tuvalu } \\
\text { Funafuti } \\
\text { Tuvaluan } \\
\text { Tuvaluan, English } \\
\text { Tuvaluan dollar, Australian dollar } \\
\text { (AUD) }\end{array}$ & TV & TUV & 798 & $\begin{array}{l}\text { Tuvalu } \\
\text { Tuvalu } \\
\text { Funafuti } \\
\text { tuvaluană, engleză } \\
\text { dolar tuvaluan, } \\
\quad \text { dolar australian (AUD) } \\
\end{array}$ \\
\hline $\begin{array}{l}\text { Uganda } \\
\text { Republic of Uganda } \\
\text { Kampala } \\
\text { Ugandan } \\
\text { English, Swahili } \\
\text { Ugandan shilling (UGX) }\end{array}$ & $\mathrm{UG}$ & UGA & 800 & $\begin{array}{l}\text { Uganda } \\
\text { Republica Uganda } \\
\text { Kampala } \\
\text { ugandez, ugandeză } \\
\text { engleză, swahili } \\
\text { şiling ugandez (UGX) }\end{array}$ \\
\hline $\begin{array}{l}\text { Ukraine } \\
\text { Ukraine } \\
\text { Kyiv (Kiev) } \\
\text { Ukrainian } \\
\text { Ukrainian } \\
\text { Hryvnia (UAH) }\end{array}$ & UA & UKR & 804 & $\begin{array}{l}\text { Ucraina } \\
\text { Ucraina } \\
\text { Kiev } \\
\text { ucrainian, ucrainiancă (ucrainiană) } \\
\text { ucrainiană } \\
\text { grivna (UAH) }\end{array}$ \\
\hline $\begin{array}{l}\text { United Arab Emirates } \\
\text { United Arab Emirates } \\
\text { Abu Dhabi } \\
\text { Emirati } \\
\text { Arabic } \\
\text { UAE dirham (AED) }\end{array}$ & $\overline{\mathrm{AE}}$ & ARE & 784 & $\begin{array}{l}\text { Emiratele Arabe Unite } \\
\text { Emiratele Arabe Unite } \\
\text { Abu Dhabi } \\
\text { arabă } \\
\text { dirham al ARE (AED) }\end{array}$ \\
\hline $\begin{array}{l}\text { United Kingdom } \\
\text { United Kingdom of Great Bri- } \\
\quad \text { tain and Northern Ireland } \\
\text { London } \\
\text { British or Briton } \\
\text { English } \\
\text { Pound sterling (GBP) }\end{array}$ & GB & GBR & 826 & $\begin{array}{l}\text { Regatul Unit } \\
\text { Regatul Unit al Marii Britanii şi al } \\
\quad \text { Irlandei de Nord } \\
\text { Londra } \\
\text { britanic (englez), britanică } \\
\quad \text { (englezoaică) } \\
\text { engleză } \\
\text { liră sterlină (GBP) }\end{array}$ \\
\hline
\end{tabular}




\begin{tabular}{|c|c|c|c|c|}
\hline $\begin{array}{c}\text { Country name } \\
\text { Official name } \\
\text { Capital } \\
\text { Habitant (Demonym) } \\
\text { Language(s) } \\
\text { Currency }\end{array}$ & 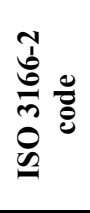 & $\begin{array}{ll}7 & 0 \\
0 & 0 \\
0 & 0 \\
0 & 0 \\
0 & \frac{1}{2} \\
0 & \frac{\pi}{2}\end{array}$ & 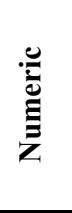 & $\begin{array}{c}\text { Țara } \\
\text { Denumire oficială } \\
\text { Capitală } \\
\text { Etnonim / Locuitor (locuri etc.) }^{*} \\
\text { Limbă oficială, limbi oficiale } \\
\text { Monedă }\end{array}$ \\
\hline $\begin{array}{l}\text { United States } \\
\text { United States of America } \\
\text { Washington, D.C. } \\
\text { American } \\
\text { Enghish (de facto) } \\
\text { United States dollar (\$) (USD) }\end{array}$ & US & USA & 840 & $\begin{array}{l}\text { Statele Unite ale Americii } \\
\text { Statele Unite ale Americii } \\
\text { Washington, DC } \\
\text { american, americancă (americană) } \\
\text { engleză (americană) } \\
\text { dolar american (\$)(USD) }\end{array}$ \\
\hline $\begin{array}{l}\text { United States Minor Outlying } \\
\text { Islands } \\
\text { (9 US insular areas in the Pacific } \\
\text { Ocean and Caribbean Sea) }\end{array}$ & UM & UMI & 581 & $\begin{array}{l}\text { United States Minor Outlying Islands } \\
\text { (9 US zone insulare în Oceanul Pacific } \\
\text { şi Marea Caraibelor) }\end{array}$ \\
\hline $\begin{array}{l}\text { Uruguay } \\
\text { Oriental Republic of Uruguay } \\
\text { Montevideo } \\
\text { Uruguayan } \\
\text { Spanish } \\
\text { Uruguayan peso (\$, UYU) (UYU) }\end{array}$ & UY & URY & 858 & $\begin{array}{l}\text { Uruguay } \\
\text { Republica Orientală Uruguay } \\
\text { Montevideo } \\
\text { uruguayan, uruguyan(c)ă (uruguyană) } \\
\text { spaniola castellană } \\
\text { peso uruguian, }(\mathrm{pl}) \text { peso uruguyeni (\$, } \\
\quad \text { UYU) (UYU) }\end{array}$ \\
\hline $\begin{array}{l}\text { Uzbekistan } \\
\text { Republic of Uzbekistan } \\
\text { Tashkent } \\
\text { Uzbekistani; also Uzbek } \\
\text { Uzbek } \\
\text { Uzbekistan som (UZS) }\end{array}$ & UZ & UZB & 860 & $\begin{array}{l}\text { Uzbekistan } \\
\text { Republica Uzbekistan } \\
\text { Taşkent } \\
\text { uzbec, uzbecă } \\
\text { uzbecă } \\
\text { sum (UZS) }\end{array}$ \\
\hline $\begin{array}{l}\text { Vanuatu } \\
\text { Republic of Vanuatu } \\
\text { Port Vila } \\
\text { Ni-Vanuatu; Vanuatuan } \\
\text { Bislama, English, French } \\
\text { Vanuatu vatu (VUV) }\end{array}$ & VU & VUT & 548 & $\begin{array}{l}\text { Vanuatu } \\
\text { Republic of Vanuatu } \\
\text { Port Vila } \\
\text { bislama, engleză, franceză } \\
\text { vatu (VUV) }\end{array}$ \\
\hline $\begin{array}{l}\text { Venezuela } \\
\text { Bolivarian Republic of Venezuela } \\
\text { Caracas } \\
\text { Venezuelan } \\
\text { Spanish } \\
\text { Bolívar fuerte (VEF) }\end{array}$ & VE & VEN & 862 & $\begin{array}{l}\text { Venezuela } \\
\text { Republica bolivariană a Venezuelei } \\
\text { Caracas } \\
\text { venezuelean, venezuelean(c)ă, } \\
\text { (venezueleană) } \\
\text { spaniolă } \\
\text { bolívar fuerte (VEF) }\end{array}$ \\
\hline $\begin{array}{l}\text { Viet Nam } \\
\text { Socialist Republic of Vietnam } \\
\text { Hanoi } \\
\text { Vietnamese } \\
\text { Vietnamese } \\
\text { đồng (VND) } \\
\end{array}$ & $\mathrm{VN}$ & VNM & 704 & $\begin{array}{l}\text { Vietnam } \\
\text { Socialist Republica Socialistă Vietnam } \\
\text { Hanoi } \\
\text { vietnamez, vietnameză } \\
\text { vietnameză } \\
\text { đồng (VND) }\end{array}$ \\
\hline $\begin{array}{l}\text { Virgin Islands, British } \\
\text { British Virgin Islands (a British } \\
\text { overseas territory) } \\
\text { Road Town } \\
\text { Virgin Islander } \\
\text { English } \\
\text { US dollar, GB Pound (USD, GBP) }\end{array}$ & VG & VGB & 092 & $\begin{array}{l}\text { Insulele Virgine Britanice } \\
\text { Insulele Virgine Britanice (un } \\
\text { teritoriu de peste mări britanic) } \\
\text { Road Town } \\
\text { engleză } \\
\text { dolar american, liră britanică (USD, } \\
\quad \text { GBP) }\end{array}$ \\
\hline
\end{tabular}




\begin{tabular}{|c|c|c|c|c|}
\hline $\begin{array}{c}\text { Country name } \\
\text { Official name } \\
\text { Capital } \\
\text { Habitant (Demonym) } \\
\text { Language(s) } \\
\text { Currency }\end{array}$ & 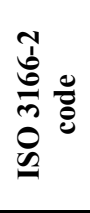 & $\begin{array}{ll}7 & 0 \\
1 & 0 \\
0 & 0 \\
0 & 0 \\
m & 0 \\
0 & \frac{\pi}{2} \\
0 & \frac{\pi}{2} \\
& \frac{1}{4}\end{array}$ & 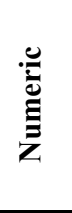 & $\begin{array}{c}\text { Ţara } \\
\text { Denumire oficială } \\
\text { Capitală } \\
\text { Etnonim / Locuitor (locuri etc.) }^{*} \\
\text { Limbă oficială, limbi oficiale } \\
\text { Monedă }\end{array}$ \\
\hline $\begin{array}{l}\text { Virgin Islands, U.S. } \\
\text { United States Virgin Islands } \\
\text { Charlotte Amalie } \\
\text { US Virgin Islander } \\
\text { English } \\
\text { US dollar (USD) }\end{array}$ & VI & VIR & 850 & $\begin{array}{l}\text { Insulele Virgine Americane } \\
\text { Insulele Virgine Americane } \\
\text { Charlotte Amalie } \\
\text { engleză } \\
\text { dolar american (USD) }\end{array}$ \\
\hline $\begin{array}{l}\text { Wallis and Futuna } \\
\text { Territory of the Wallis and } \\
\quad \text { Futuna Islands (Polynesian } \\
\quad \text { French island territory) } \\
\text { Mata-Utu } \\
\text { Wallisian, Futunan } \\
\text { French } \\
\text { CFP franc (XPF) }\end{array}$ & WF & WLF & 876 & $\begin{array}{l}\text { Wallis şi Futuna } \\
\text { Colectivitatea Insulelor Wallis şi } \\
\quad \text { Futuna (o colectivitate de peste } \\
\quad \text { mări, franceză) } \\
\text { Mata-Utu } \\
\text { wallisian(ă), futunan( } \breve{a})(\text { rar }) \\
\text { franceză } \\
\text { franc CFP (XPF) }\end{array}$ \\
\hline $\begin{array}{l}\text { Western Sahara } \\
\text { Western Sahara } \\
\text { none; the biggest city: El Aaiún } \\
\text { Sahrawi } \\
\text { Arabic (de jure), Spanish and } \\
\quad \text { French (de facto) } \\
\text { Moroccan dirham, Sahrawi Peseta }\end{array}$ & $\mathrm{EH}$ & ESH & 732 & $\begin{array}{l}\text { Sahara Occidentală } \\
\text { Sahara Occidentală } \\
\text { nu are; cel mai mare oraş: El Aaiún } \\
\text { sahravari sau sahrawian, sahrawiană) } \\
\text { arabă (de jure), spaniolă şi franceză (de } \\
\quad \text { facto) } \\
\text { diram marocan (MAD), peseta sahrawi }\end{array}$ \\
\hline $\begin{array}{l}\text { Yemen } \\
\text { Republic of Yemen } \\
\text { Sana'a } \\
\text { Yemeni, Yemenite } \\
\text { Arabic } \\
\text { Yemeni rial (YER) }\end{array}$ & YE & YEM & 887 & $\begin{array}{l}\text { Yemen } \\
\text { Republica Yemen } \\
\text { Sana'a } \\
\text { yemenit, yemenită } \\
\text { arabă } \\
\text { rial yemenit (YER) }\end{array}$ \\
\hline $\begin{array}{l}\text { Zambia } \\
\text { Republic of Zambia } \\
\text { Lusaka } \\
\text { Zambian } \\
\text { English } \\
\text { Zambian kwacha (ZMK) }\end{array}$ & $\mathrm{ZM}$ & ZMB & 894 & $\begin{array}{l}\text { Zambia } \\
\text { Republica Zambia } \\
\text { Lusaka } \\
\text { zambian, zambiancă (zambiană) } \\
\text { engleză } \\
\text { kwacha zambian (ZMK) }\end{array}$ \\
\hline $\begin{array}{l}\text { Zimbabwe } \\
\text { Republic of Zimbabwe } \\
\text { Harare } \\
\text { Zimbabwean } \\
\text { English } \\
\text { US dollar (USD) }\end{array}$ & ZW & ZWE & 716 & $\begin{array}{l}\text { Zimbabwe } \\
\text { Republica Zimbabwe } \\
\text { Harare } \\
\text { zimbabwean, zimbabwea(c)nă (rar) } \\
\text { engleză } \\
\text { dolar zimbabwean (USD) }\end{array}$ \\
\hline
\end{tabular}

* În paranteze este dat adjectivul pentru denumiri (masculine, feminine sau neutre), cu formă diferită de cea a denumirii locuitorilor.

Extras şi prelucrat din „Officially assigned code elements”, diponibil on-line (12.11.2009) la adresa http://en.wikipedia.org/wiki/ISO_3166-1 şi „Lista completă a țărilor pentru care au fost definite coduri, în ordinea alfabetică a numelui în limba engleză", diponibil on-line (12.11.2009) la adresa http://ro.wikipedia.org/wiki/ISO_3166-1 